José Miguel Belucio Pereira

\title{
UM PROCEDIMENTO DE RETROANÁLISE PARA PAVIMENTOS FLEXÍVEIS BASEADO NA TEORIA DO PONTO INERTE E EM MODELAGEM MATEMÁTICA
}

Dissertação apresentada à Escola de Engenharia de São Carlos da Universidade de São Paulo, como parte dos requisitos para a obtenção do Título de Mestre em Engenharia de Transportes.

Orientador: Prof. Dr. Glauco Tulio Pessa Fabbri

São Carlos 


\section{FOLHA DE JULGAMENTO}

Candidato: Engenheiro JOSÉ MIGUEL BELUCIO PEREIRA

Dissertação defendida e julgada em 07/05/2007 perante a Comissão Julgadora:

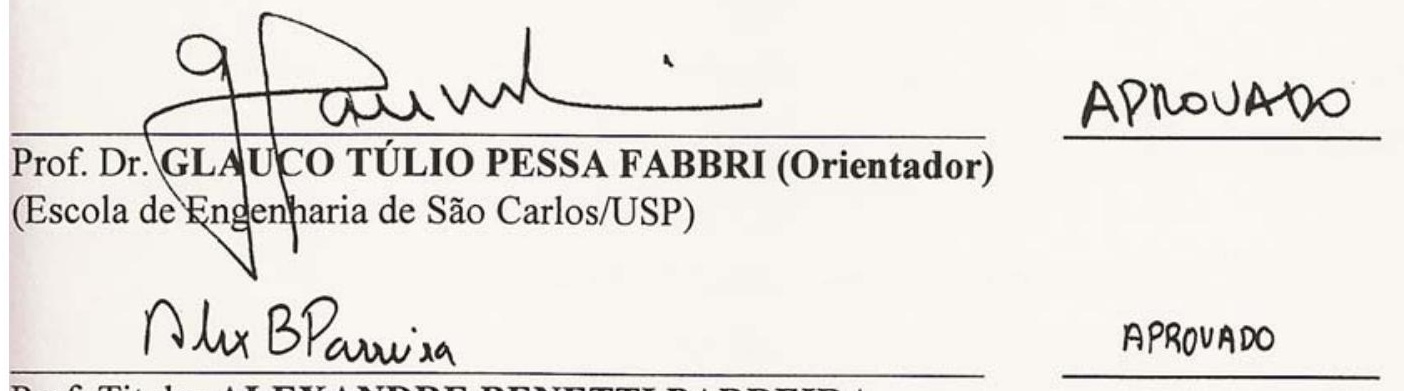

\section{Prof. Titular ALEXANDRE BENETTI PARREIRA}

(Escola de Engenharia de São Carlos/USP)

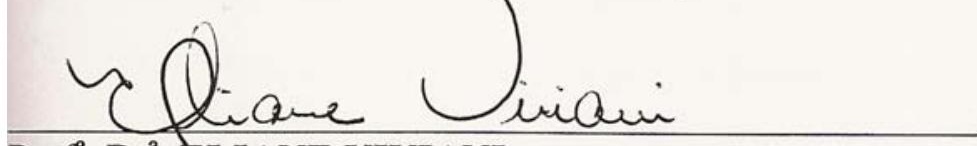

\section{APROV'ADO}

Prof ${ }^{\mathrm{e}}$. $\mathrm{Dr}^{\mathrm{a}}$. . NIANE VIVIANI

(Universidade Estadual Paulista "Julio de Mesquita Filho"/UNESP-Campus de Bauru)
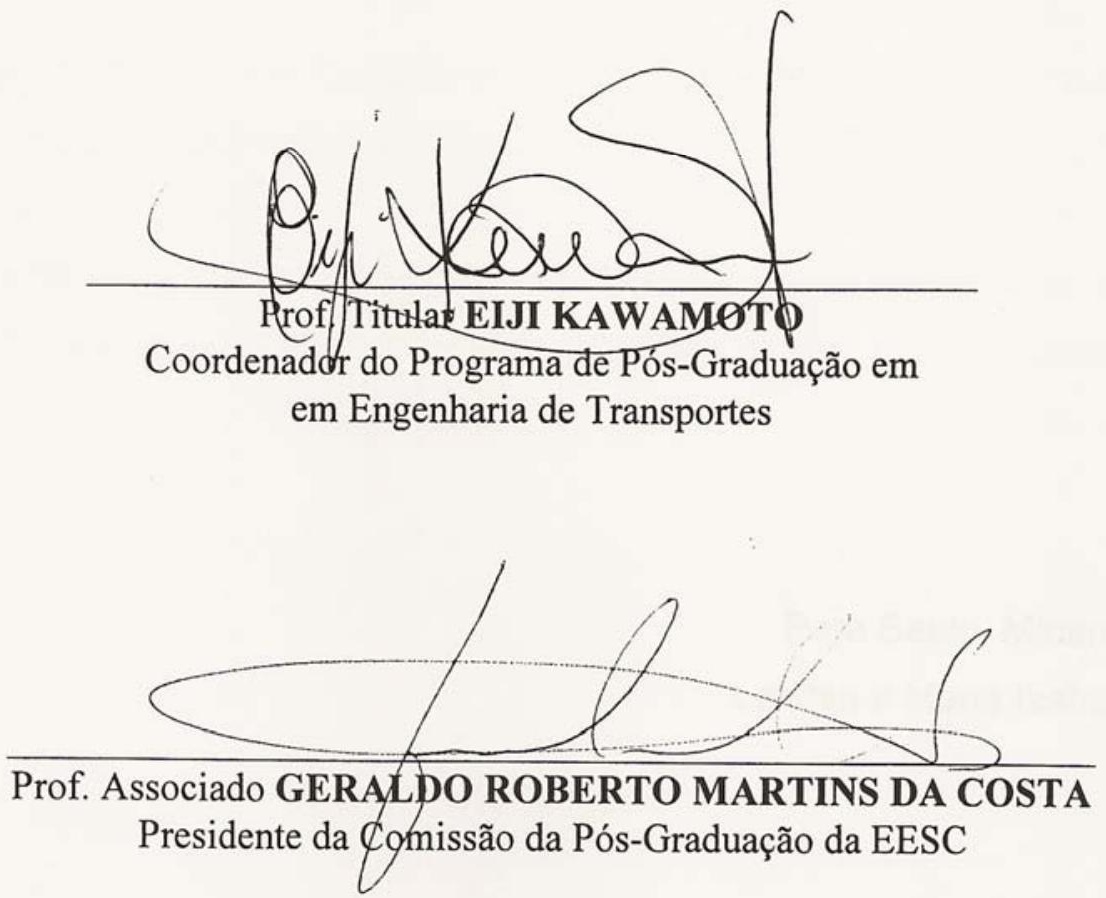
Para Saulo, Miriam,

Larissa e Maria Izabel. 


\section{Agradecimentos}

Ao Prof. Dr. Glauco Tulio Pessa Fabbri pelo apoio, confiança e imensurável contribuição.

Ao meu tio Prof. Dr. Gener Tadeu Pereira por me incentivar e auxiliar no software Statistica e em diversas etapas no desenvolvimento deste trabalho.

Ao Prof. Dr. Hans Kurt Edmund Liesenberg do Instituto de Computação da Unicamp pelo ensino e auxílio no desenvolvimento dos programas computacionais em Pascal durante minha graduação e pós-graduação.

Ao Prof. Dr. Alexandre Benetti Parreira pelo auxílio e confiança depositada em momentos importantes no decorrer deste mestrado.

A CCB-P Engenharia e Projetos S/S pela compreensão e apoio* ao desenvolvimento desta pós-graduação.

Aos amigos e amigas do Departamento de Transportes da USP - São Carlos: Gigante, Paulo, João, Heloísa e Beth.

A todos os funcionários da biblioteca central da Escola de Engenharia de São Carlos pela ajuda e exemplar disposição em todos os momentos necessários.

* O desenvolvimento desta pesquisa foi efetuado na ausência de qualquer tipo de apoio de órgão ou fundação de amparo à pesquisa em âmbito estadual ou federal. 


\section{Sumário}

Lista de Figuras...................................................................... vii

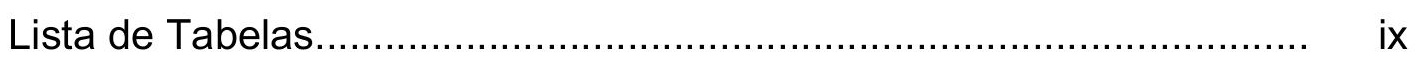

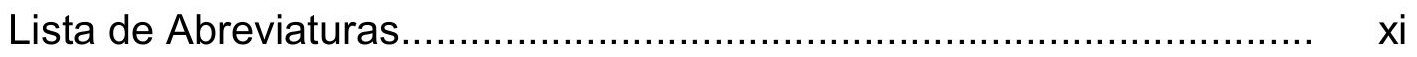

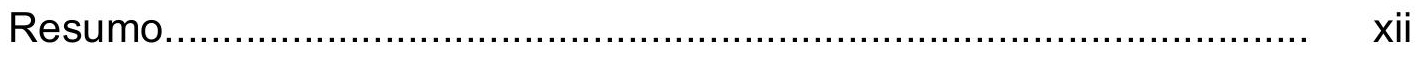

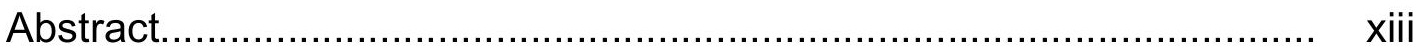

Capítulo 1 Introdução.................................................................... 1

Capítulo 2 Avaliação da condição do pavimento................................ 4

$2.1 \quad$ Avaliação subjetiva..................................................... 5

$2.2 \quad$ Avaliação objetiva....................................................... 5

2.2.1 Avaliação da irregularidade superficial............................ 5

2.2.2 Ensaios estruturais....................................................... 5

2.2.3 Atrito superficial....................................................... 10

2.2.4 Identificação dos defeitos superficiais............................ 10

2.3 Principais causas de falhas encontradas em pavimentos............................................................... 11

2.3.1 Deformação permanente.............................................. 11

2.3.2 Fadiga...................................................................... 13

2.4 Métodos de avaliação................................................... 19

2.4.1 Métodos destrutivos...................................................... 19

2.4.2 Métodos não destrutivos............................................... 21

$2.5 \quad$ Módulo de resiliência................................................... 22

$2.6 \quad$ Coeficiente de Poisson.................................................. 23

Capítulo 3 Medidas deflectométricas.............................................. 25

3.1 Introdução...................................................... 25

3.2 Equipamentos deflectométricos................................. 26

3.2.1 Carregamento estático................................................ 26

3.2.1.1 Ensaio de placa...................................................... 26

3.2.1.2 Viga Benkelman......................................................... 27 
3.2.1.3 Viga Benkelman automatizada...................................... 29

3.2.2 Carregamento vibratório............................................... 29

3.2.2.1 Dynaflect.................................................................. 30

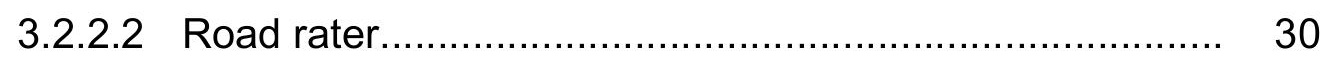

3.2.3 Carregamento por impulso........................................... 32

3.2.3.1 Dynatest FWD........................................................ 33

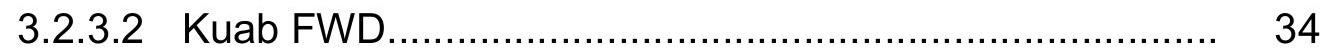

3.2.4 Outros equipamentos............................................. 36

3.3 Considerações sobre equipamentos deflectométricos..... 36

3.4 Fatores influentes em deflexões................................... 39

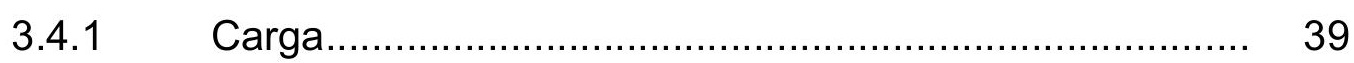

3.4.2 Clima

Capítulo 4 Retroanálise em pavimentos flexíveis............................ 42

4.1 Aspectos gerais dos métodos existentes........................ 47

4.1.1 Métodos iterativos....................................................... 47

4.1.1.1 Cálculos durante o processo........................................ 48

4.1.1.2 Utilização de banco de dados........................................ 49

4.1.1.3 Regressão estatística.................................................. 49

4.1.2 Métodos simplificados............................................... 50

4.1.2.1 Método da AASHTO................................................ 50

4.1.2.2 Método de A. S. Noureldin.......................................... 51

4.1.2.3 Método de Albernaz.................................................... 54

4.1.3 Redes Neurais Artificiais............................................. 55

$4.2 \quad$ Softwares existentes................................................ 56

4.3 Problemas encontrados em retroanálise......................... 63

4.3.1 Efeitos de espessuras das camadas.............................. 63

4.3.2 Compensação de camadas e efeitos de não linearidade 64

4.3.3 Camada rígida......................................................... 65

4.3.4 Efeitos de rigidez relativa das camadas.......................... 68

4.3.5 Efeitos de entrada de dados.......................................... 68 
Capítulo 5 A Teoria do Ponto Inerte................................................ 70

5.1 Comentários iniciais.................................................... 70

5.2 O Ponto Inerte em pavimentos flexíveis (Para bacias de deflexões obtidas com FWD)......................................... $\quad 71$

5.2.1 Caso A: O Ponto Inerte em bacias de deflexões geradas pelo FWD para pavimentos compostos por duas camadas.

5.2.2 Caso B: O Ponto Inerte em bacias de deflexões geradas pelo FWD para pavimentos compostos por três camadas.

5.3 O Ponto Inerte em pavimentos flexíveis para bacias de deflexões obtidas com a viga Benkelman

5.3.1 Caso C: O Ponto Inerte em bacias de deflexões para pavimentos compostos por duas camadas, com carga gerada pelo eixo padrão

5.3.2 Caso D: O Ponto Inerte em bacias de deflexões para pavimentos compostos por três camadas, com carga gerada pelo eixo padrão

5.4 Um algoritmo convergente para retroanálise do subleito baseado na posição do Ponto Inerte

Capítulo 6 O procedimento de retroanálise proposto 88 Considerações iniciais

Retroanálise do subleito utilizando-se a Teoria do Ponto Inerte 88 Retroanálise da Camada Equivalente 98

6.4 Análise de sensibilidade do procedimento proposto em relação à altura do pavimento 101

Capítulo 7 Comparações com outros processos de retroanálise...... 107 7.1 Exemplo 108

7.1.1 Retroanálise via Teoria do Ponto Inerte e modelagem matemática (Caso 1). 
7.1.2 Retroanálise via Método de Albernaz (Caso 1)

7.1.3 Retroanálise via redes neurais artificiais (Caso 1).......... 113

7.1.4 Retroanálise via Teoria do Ponto Inerte e modelagem matemática (Caso 2)................................................. 115

7.1.5 Retroanálise via Método de Albernaz (Caso

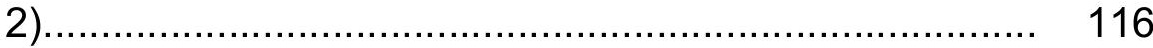

7.1.6 Retroanálise via redes neurais artificiais (Caso 2).......... 119

7.2 Resultados de comparações.......................................... 119

Capítulo 8 Conclusões e Sugestões para futuras pesquisas............ 121

Capítulo 9 Referências Bibliográficas............................................. 124

Anexo A Bacias deflectométricas teóricas utilizadas para obtenção das coordenadas $\left(R_{c}, D_{c}\right)$ do Ponto Inerte....... $C D$

Anexo B Programa desenvolvido em linguagem Pascal para obtenção das coordenadas $\left(R_{c}\right.$ e $\left.D_{c}\right)$ dos pontos inertes do conjunto de bacias deflectométricas teóricas utilizado 129

Anexo C Coordenadas $\left(R_{c}, D_{c}\right)$ do Ponto Inerte obtidas com o conjunto de bacias deflectométricas do Anexo A............. CD

Anexo D Programa desenvolvido em linguagem Pascal para avaliação do erro na retroanálise do subleito utilizandose a Teoria do Ponto Inerte

Anexo E Banco de dados de bacias deflectométricas aleatório.....

Anexo F Erro na retroanálise do subleito utilizando-se a Teoria do Ponto Inerte.

Anexo G Erro na retroanálise da Camada Equivalente.

Anexo H Programa desenvolvido em linguagem Pascal para retroanálise do subleito utilizando-se a Teoria do Ponto Inerte com utilização de uma bacia deflectométrica

Anexo I Ábacos para retroanálise do subleito. 


\section{Lista de Figuras}

Figura 2.1 - Subdivisão das avaliações de condições dos pavimentos.............. 4

Figura 2.2 - Bacia de deformação (ou deflexão)............................................... 9

Figura 2.3 - Tensões e deformações no pavimento (Manual de reabilitação de pavimentos asfálticos - DNER).

Figura 2.4 - Composição da deformação em um material (Elliot e Thornton, 1988)

Figura 3.1 - Viga Benkelman (DNER ME024-94).

Figura 3.2 - Posição de leitura inicial $L_{0}$ (DNER ME024-94)

Figura 3.3 - Viga Benkelman (www.cremape.com.br/23211 km146.htm).

Figura 3.4 - Força dinâmica típica resultante de aparelhos vibratórios (Haas, Hudson e Zaniewski 1994)

Figura 3.5 - Esquema de funcionamento do Road rater (Haas, Hudson e Zaniewski 1994).

Figura 3.6 - Road Rater (www.dot.state.ia.us/materials/paveeval.htm)...

Figura 3.7 - Princípio básico do Falling Weight Deflectometer (Haas, Hudson e Zaniewski 1994).

Figura 3.8 - Dynatest FWD 8000 (www.dynatest.com/hardware/fwd hwd.htm). 34

Figura 3.9 - KUAB FWD (http://www.erikuab.com/kuab.htm)

Figura 3.10 - Diagrama esquemático KUAB FWD (Haas, Hudson e Zaniewski 1994)

Figura 4.1 - Representações simplificadas de problemas de retroanálise.

Figura 4.2 - Aspectos comuns aos métodos computacionais para retroanálise.

Figura 4.3 - Superfícies de mesma deformação vertical em um pavimento (Noureldin 1993)

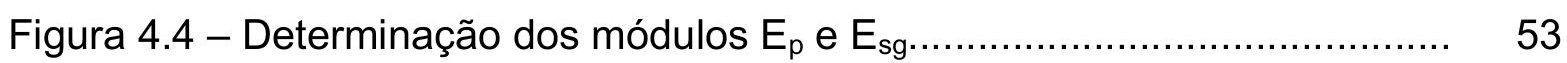

Figura 4.5 - Identificação de sistema, aproximação "forward" (Wang 1993)..... 59

Figura 4.6 - Deflexões nulas devido à camada rígida (Mahoney et al., 1993)... 66

Figura 4.7 - Estimativa da profundidade da camada rígida (Mahoney et al.,1993).

Figura 5.1 - Pavimento com duas camadas (Caso A).

Figura 5.2 - Bacias de deflexões do Caso A (Zhang e Sun, 2003). 
Figura 5.3 - Pavimentos com três camadas (Casos 1 a 6)................................ 76

Figura 5.4 - Pavimentos com três camadas (Casos 7 a 12)............................ 76

Figura 5.5 - Bacias de deflexões do Caso B (Zhang e Sun, 2003)................... 77

Figura 5.6 - Pavimento com duas camadas (Caso C)................................... 79

Figura 5.7 - Bacias de deflexões do Caso C............................................... $\quad 79$

Figura 5.8 - Pavimentos com três camadas (Casos 1 a 3)............................... 81

Figura 5.9 - Pavimentos com três camadas (Casos 4 a 6)............................... 82

Figura 5.10 - Bacias de deflexões do Caso D.......................................... 82

Figura 5.11 - Trajetória do ponto inerte para um pavimento hipotético.............. 85

Figura 5.12 - Bacia de deflexão e a trajetória do ponto inerte.......................... 86

Figura 6.1 - Cargas aplicadas pelo eixo padrão............................................ 90

Figura 6.2 - Corte AA (cotas em centímetros)............................................. 90

Figura 6.3 - Altura do pavimento x Erro relativo.............................................. 94

Figura 6.4 - Módulo resiliente real x Erro relativo............................................ 95

Figura 6.5 - Solução gráfica para a retroanálise do subleito entre 20 e $80 \mathrm{MPa} 96$

Figura 6.6 - Solução gráfica para a retroanálise do subleito entre 80 e 140 $\mathrm{MPa}$

Figura 6.7 - Solução gráfica para a retroanálise do subleito entre 140 e 200 $\mathrm{MPa}$ 97

Figura 6.8 - Altura do pavimento x Erro relativo............................................. 99

Figura 6.9 - Módulo resiliente do subleito x Erro relativo.................................. 100

Figura 6.10 - Módulo resiliente real da camada equivalente x Erro relativo....... 100

Figura 6.11 - Influência da altura do pavimento na trajetória do ponto inerte..... 103

Figura 6.12 - Influência da espessura na retroanálise do subleito.................... 106

Figura 7.1 - Solução gráfica para retroanálise do subleito............................... 110

Figura 7.2 - Solução do Exemplo 1 (Caso 1) pelo processo de Albernaz (1994).

Figura 7.3 - Configuração da rede neural utilizada para retroanálise do subleito.

Figura 7.4 - Configuração da rede neural utilizada para retroanálise da camada equivalente.

Figura 7.5 - Solução do Exemplo 1 (Caso 2) pelo processo de Albernaz (1994). 


\section{Lista de Tabelas}

Tabela 2.1 - Parâmetros para avaliação estrutural........................................... 7

Tabela 2.2 - Fator de correção sazonal........................................................ 8

Tabela 2.3 - Conceitos de degradação do pavimento em função do IGG.......... 11

Tabela 2.4 - Resumo das causas e tipos de deformações permanentes........... 12

Tabela 2.5 - Avaliação comparativa entre ensaios TC e DC............................. 15

Tabela 2.6 - Valores do coeficiente de Poisson............................................ 24

Tabela 3.1 - Características dos equipamentos FWD existentes no Brasil....... 37

Tabela 4.1 - Sumário de módulos retroanalisados......................................... 60

Tabela 4.2 - Resultados de retroanálises................................................... 61

Tabela 4.3 - Programas de retroanálise .................................................... 62

Tabela 5.1 - Características em comum dos pavimentos (Caso A).................. 72

Tabela 5.2 - Módulos resilientes para o revestimento (Caso A)......................... 72

Tabela 5.3 - Características em comum dos pavimentos (Caso B).................. 75

Tabela 5.4 - Módulos resilientes para o revestimento e a base (Caso B)......... $\quad 75$

Tabela 5.5 - Características em comum dos pavimentos (Caso C).................. 78

Tabela 5.6 - Módulos resilientes para o revestimento (Caso C)....................... 78

Tabela 5.7 - Características em comum dos pavimentos (Caso D)................. 80

Tabela 5.8 - Módulos resilientes para o revestimento e a base (Caso D).......... 81

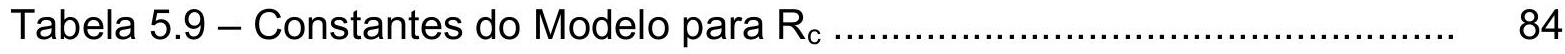

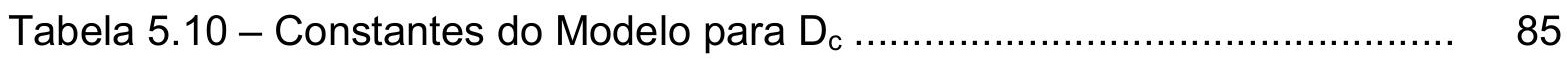

Tabela 6.1 - Fração do banco de dados para retroanalise do subleito............... 91

Tabela 6.2 - Fração do banco de dados aleatório............................................ 93

Tabela 6.3 - Distribuição de erro na retroanálise do subleito............................ 95

Tabela 6.4 - Distribuição de erro na retroanálise da camada equivalente.......... 101

Tabela 6.5 - Distribuição de erro na camada equivalente................................ 102

Tabela 6.6 - Influência da altura na retroanálise do subleito.............................. 105

Tabela 7.1 - Iterações realizadas para o exemplo............................................ 109

Tabela 7.2 - Parâmetros de cálculo do método de Albernaz............................. 111

Tabela 7.3 - Iterações realizadas para o exemplo.......................................... 115

Tabela 7.4 - Parâmetros de cálculo do método de Albernaz........................... 117

Tabela 7.5 - Quadro comparativo de resultados para o subleito....................... 119 
Tabela 7.6 - Quadro comparativo de resultados para a camada equivalente. 


\section{Lista de Abreviaturas}

AASHO - American Association of State Highway Officials

AASHTO - American Association of State Highway Transportation Officials

CBR - California Bearing Ratio

DC - Deformação Controlada

DNER - Departamento Nacional de Estradas de Rodagem

DNIT - Departamento Nacional de Infra-estrutura de Transportes

EUA - Estados Unidos da América

FHWA - Federal Highway Administration

FWD - Falling Weight Deflectometer

GPR - Ground Penetrating Radar

IGG - Índice de Gravidade Global

IGI - Índice de Gravidade Individual

LC - Limite de Contração

LL - Limite de Liquidez

LP - Limite de Plasticidade

LTPP - Long Term Pavement Performance

PAEP - Programa de Apoio ao Estudo de Pavimentos

$R$ - Raio de Curvatura

RNA - Redes Neurais Artificiais

SGP - Sistema de Gerência de Pavimentos

SHRP - Strategic Highway Research Program

TC - Tensão Controlada

TPI - Teoria do Ponto Inerte

VSA - Valor de Serventia Atual

WASHO - Western Association of State Highway Officials 


\section{Resumo}

PEREIRA, J. M. B. (2007). Um Procedimento de Retroanálise de Pavimentos Flexíveis Baseado na Teoria do Ponto Inerte e em Modelagem Matemática. Dissertação (mestrado) - Escola de Engenharia de São Carlos, Universidade de São Paulo, São Carlos, 2007.

Apresenta-se um processo de retroanálise de pavimentos flexíveis baseado na Teoria do Ponto Inerte para a retroanálise do subleito, readaptado para bacias de deflexões teóricas obtidas com o carregamento para o ensaio com a viga Benkelman. Além da retroanálise do subleito, foi desenvolvido um modelo matemático fatorial para a obtenção do módulo resiliente equivalente das camadas presentes sobre o subleito, consideradas como uma única, denominada camada equivalente. Para a readaptação da Teoria do Ponto Inerte e elaboração do modelo fatorial foram utilizados bancos de dados de bacias deflectométricas teóricas geradas pelo programa ELSYM5. Avaliou-se o erro na retroanálise do subleito e da camada equivalente para o processo proposto mediante comparações com outras metodologias semelhantes de retroanálise. A Teoria do Ponto Inerte proporciona o desenvolvimento de um algoritmo simples, convergente e de resposta única para retroanálise de subleito de pavimentos flexíveis, minimizando a influência da experiência do engenheiro na resposta do problema. O procedimento de retroanálise elaborado nesta pesquisa caracteriza-se por simplicidade, sendo de uso adequado, entre outros, para avaliações em nível de rede.

Palavras-chave: retroanálise de pavimentos flexíveis; ponto inerte de bacias deflectométricas; viga Benkelman; 


\begin{abstract}
PEREIRA, J. M. B. (2007). A Backcalculation Procedure for Flexible Pavements Based on Inertial Point Theory and in Mathematical Modeling. M. Sc. Dissertation - Escola de Engenharia de São Carlos, Universidade de São Paulo, São Carlos, 2007.
\end{abstract}

A Backcalculation Procedure for Flexible Pavements is introduced based on Inertial Point Theory for subgrade backcalculation readapted to theoretical deflection basins obtained with the load to Benkelman Beam test. Beside subgrade backcalculation, it was developed a factorial mathematical model to obtain equivalent resilient modulus from the layers presents upon subgrade, considered as unique and denominated equivalent layer. To the readaptation of Inertial Point Theory and preparing of factorial model were used theoretical deflection bowls data base generated by ELSYM5 program. The subgrade and equivalent layer modulus backcalculation were evaluated to the proposed process through others similar backcalculation methodologies. The Inertial Point Theory provides the development of simple algorithms, convergent and with unique solution for flexible pavements subgrade backcalculation minimizing the influence of engineer experience in the problem answer. The backcalculation procedure developed in this research is characterized by simplicity being of suitable use at network evaluation level among others.

Key words: backcalculation of flexible pavements; Inertial Point of deflection bowls; Benkelman beam; 


\section{Capítulo 1 - Introdução}

As atividades necessárias para fornecer e manter pavimentos em um nível adequado de serviço compreendem o processo de gerência de pavimentos. Dentro de um sistema de gerência de pavimentos é de relevante importância a reabilitação de vias, que pode ser orientada com a avaliação estrutural do pavimento.

Para a tomada de decisões sobre intervenções a serem executadas em pavimentos flexíveis deve-se considerar a caracterização da condição estrutural do pavimento, que por sua vez, pode ser acessada por processos de medidas de deflexões.

Carneiro (1966) cita que os estudos de deflexões de pavimentos pela WASHO, onde a viga Benkelman foi utilizada pela primeira vez, e posteriormente pela $A A S H O$, revelaram que o desempenho e a vida útil dos pavimentos flexíveis estão intimamente relacionados com as deflexões causadas pela passagem das rodas dos veículos.

Análises de deflexões em seções de pavimentos estruturalmente similares, sujeitos ao mesmo tipo de tráfego indicaram que as seções que exibiram maiores deflexões apresentavam pior desempenho e as menores vidas úteis. As seções com menores deflexões necessitavam de pouca manutenção e apresentavam um período de vida útil maior.

Após a obtenção destes resultados em pistas experimentais americanas, engenheiros e organizações rodoviárias passaram a empregar a viga Benkelman como instrumento de medida das deflexões de pavimentos flexíveis. 
Com os dados de medidas deflectométricas obtidas pela viga Benkelman ou equipamentos como o FWD (Falling Weight Deflectometer), pode-se obter a bacia de deflexão do pavimento em estudo, que é utilizada para a estimativa dos módulos resilientes "em serviço" das camadas do pavimento.

Este processo, denominado retroanálise, permite a avaliação estrutural do pavimento para fins de gerência de malha, dimensionamento de reforço ou ainda determinação da vida útil remanescente.

A retroanálise de pavimentos flexíveis é função das propriedades dos materiais "in situ" e das condições de contorno, o que a torna uma tarefa difícil de ser executada. Esse tipo de análise pode levar, freqüentemente, a diferentes respostas em função das simplificações adotadas na modelagem e, conseqüentemente, à não unicidade de solução.

O desenvolvimento de algoritmos de retroanálise que minimizam a influência dos valores iniciais arbitrários adotados (seed moduli) em programas computacionais conduz a resultados independentes da experiência do engenheiro, auxiliando-o na análise de materiais com comportamento resiliente pouco conhecido.

A Teoria do Ponto Inerte aliada a algoritmos simplificados aparenta tornar mínima a influência dos seed moduli no processo de retroanálise e possibilita a obtenção de resultados convergentes na retroanálise do subleito de pavimentos flexíveis.

O objetivo desse trabalho é a readaptação da Teoria do Ponto Inerte, inicialmente proposta para ser utilizada com deflexões pelo FWD, para ser utilizada com as deflexões obtidas com a viga Benkelman, assim como o desenvolvimento de um processo de retroanálise para a camada equivalente que seja simples, rápido e que produza respostas de boa qualidade, visando à unicidade de resultados e redução de influência dos seed moduli. 
Esta pesquisa é composta por oito capítulos, no Capítulo 2 estão sucintamente descritos os procedimentos utilizados para avaliação estrutural e os principais problemas encontrados em pavimentos. A apresentação e discussão sobre aparelhos deflectométricos, assim como fatores influentes nas medidas de deflexões são escopo do Capítulo 3.

A retroanálise em pavimentos flexíveis é abordada no Capítulo 4, em conjunto com os procedimentos computacionais utilizados habitualmente, assim como os fatores influentes. A Teoria do Ponto Inerte é apresentada no Capítulo 5, sendo o procedimento de retroanálise proposto descrito no Capítulo 6.

Exemplos comparativos da metodologia proposta de retroanálise com outras de mesmo gênero estão descritos no Capítulo 7. Finalizando, o Capítulo 8 descreve as conclusões e sugestões para novas pesquisas relacionadas ao tema desenvolvido. 


\section{Capítulo 2 - Avaliação da condição do pavimento}

A gerência de pavimentos é um procedimento que abrange as atividades envolvidas no propósito de fornecer e manter pavimentos em níveis adequados de serviço.

A função de um Sistema de Gerência de Pavimentos (SGP) é a de obtenção do melhor retorno possível para o capital investido, através de pavimentos seguros, confortáveis e econômicos aos usuários. A etapa inicial do desenvolvimento deste Sistema é a definição das seções de análise, com posterior levantamento da condição atual do pavimento.

O monitoramento periódico do pavimento é fundamental para o desenvolvimento do SGP, através de informações sobre as características físicas da via ao longo do tempo. As formas de avaliação da condição do pavimento são classificadas em Subjetivas e Objetivas, representadas na Figura 2.1.

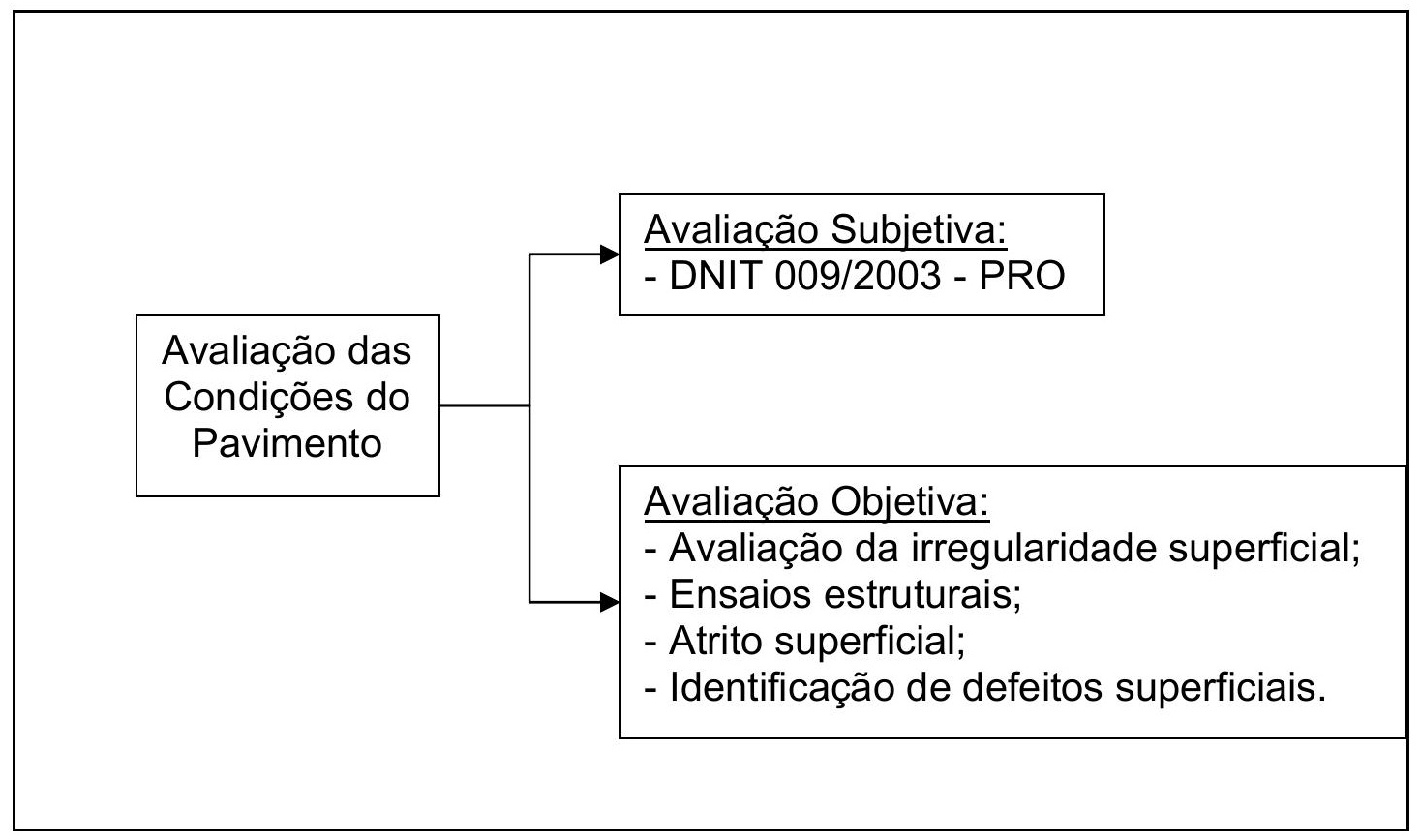

Figura 2.1 - Subdivisão das avaliações de condições dos pavimentos 
Descrições sumárias das Avaliações Subjetivas e Objetivas são apresentadas a seguir.

\section{1 - Avaliação Subjetiva}

Normalizada pela DNIT 009/2003 - PRO, compreende a determinação do Valor de Serventia Atual (VSA), sendo este valor uma medida subjetiva das condições de superfície de um pavimento feito por um grupo de avaliadores que percorrem o trecho em análise, registrando suas opiniões sobre a capacidade do pavimento no momento da avaliação quanto à suavidade e ao conforto.

\section{2 - Avaliação Objetiva}

\subsection{1 - Avaliação da irregularidade superficial}

É associada diretamente à capacidade da via em servir ao tráfego com segurança, conforto e economia. Define-se como o desvio de pontos da superfície do pavimento em relação a um plano de referência, sendo medida ao longo da trajetória dos veículos.

Os equipamentos destinados a este tipo de avaliação são perfilômetros, perfilógrafos e veículos equipados com acelerômetros. Há equipamentos tipo resposta que integram esse tipo de avaliação, chamados integradores.

\subsection{2 - Ensaios estruturais}

Durante a vida útil de um pavimento, as cargas provenientes do tráfego ocasionam deformações cuja magnitude é função da condição estrutural do pavimento. O levantamento da condição estrutural revela ao projetista a adequação da estrutura ou o seu grau de deterioração e permite a seleção e dimensionamento da alternativa mais adequada de reabilitação, visto que uma correlação quase perfeita existe entre a magnitude das deflexões e a surgência de falhas no pavimento. 
Com a difusão dos microcomputadores, a aplicação da Teoria da Elasticidade em métodos de dimensionamento de pavimentos sofreu grande impulso, gerando rapidez na obtenção de parâmetros de características estruturais dos pavimentos.

A determinação de características estruturais como: deformação vertical máxima, tensão de tração na porção inferior do revestimento e a tensão vertical de compressão no topo do subleito permitem uma avaliação estrutural criteriosa do pavimento. Essas características são utilizadas em projetos de reestruturação e em estimativas de vida útil remanescente.

Para avaliar estruturalmente um pavimento, dispõe-se de dois métodos: destrutivos e não destrutivos. Os destrutivos são realizados com coletas de corpos de prova e posterior análise em laboratório, os não destrutivos trabalham com equipamentos de medidas de deflexões recuperáveis no pavimento quando solicitado a um carregamento.

Uma abordagem mais ampla dos métodos destrutivos e não destrutivos de avaliação estrutural de pavimentos é feita nos itens 2.4 .1 e 2.4 .2 respectivamente.

Segundo a Norma DNER-PRO 011-79, ainda não são disponíveis critérios universalmente aceitos que possibilitem uma fácil tomada de decisão em relação à avaliação estrutural de pavimentos. Não existem normas que separem os campos de aplicação dos critérios deflectométricos e da resistência.

Gontijo, Guimarães e Nogueira (1994) mencionam que os procedimentos que possibilitam a avaliação estrutural de um pavimento visam, primordialmente, a definição das medidas a serem tomadas no sentido de se restaurar as boas condições de serventia, mediante o fornecimento de respostas para as seguintes questões básicas: 
- Deve ou não ser aproveitado o valor residual da estrutura do pavimento?

- Em se decidindo pelo aproveitamento do valor residual da estrutura existente, esse aproveitamento deve ser parcial ou total ?

- Estabelecida a conveniência de um aproveitamento total da estrutura primitiva deve ou não ser ela reforçada?

- Que critério é aplicável à concepção do reforço quando este último resultar necessário?

Diante das dificuldades, procura-se formular cinco casos típicos, na suposição que as situações encontradas nos subtrechos enquadrem-se em um dos casos formulados na Tabela 2.1. Para isto, são considerados os seguintes parâmetros:

$\mathrm{N}$ - Número de solicitações de eixos equivalentes ao eixo padrão (8,2 tf);

$D_{p}$ - Deflexão de projeto;

$\mathrm{R}$ - Raio de curvatura;

$\mathrm{D}_{\mathrm{adm}}$ - Deflexão admissível;

Tabela 2.1 - Parâmetros para avaliação estrutural

\begin{tabular}{|c|c|c|c|c|}
\hline Hipótese & $\begin{array}{c}\text { Dados } \\
\text { deflectométricos } \\
\text { obtidos }\end{array}$ & $\begin{array}{l}\text { Qualidade } \\
\text { estrutural }\end{array}$ & $\begin{array}{c}\text { Necessidades de } \\
\text { estudos } \\
\text { complementares }\end{array}$ & $\begin{array}{l}\text { Medidas } \\
\text { corretivas }\end{array}$ \\
\hline I & $\begin{array}{c}D_{p} \leq D_{a d m} \\
R \geq 100\end{array}$ & Boa & Não & $\begin{array}{c}\text { Apenas } \\
\text { correções de } \\
\text { superfície }\end{array}$ \\
\hline \multirow{2}{*}{ II } & \multirow{2}{*}{$\begin{array}{c}D_{p}>D_{a d m} \\
R>100\end{array}$} & $\begin{array}{c}\text { Se } D_{p} \leq 3 D_{a d m} \\
\text { Regular }\end{array}$ & Não & Reforço \\
\hline & & $\begin{array}{c}\text { Se } D_{p}>3 D_{a d m} \\
\text { Má }\end{array}$ & Sim & $\begin{array}{l}\text { Reforço ou } \\
\text { construção }\end{array}$ \\
\hline III & $\begin{aligned} D_{p} & \leq D_{a d m} \\
R & <100\end{aligned}$ & Regular para Má & Sim & $\begin{array}{l}\text { Reforço ou } \\
\text { construção }\end{array}$ \\
\hline IV & $\begin{aligned} D_{p} & >D_{a d m} \\
R & <100\end{aligned}$ & Má & Sim & $\begin{array}{l}\text { Reforço ou } \\
\text { construção }\end{array}$ \\
\hline V & - & Má & Sim & Reconstrução \\
\hline
\end{tabular}

Fonte: DNER-PRO 011-79 
A seguir, apresentam-se definições sucintas dos parâmetros descritos na Tabela 2.1.

- $D_{p}$ - Deflexão de projeto:

$$
D_{p}=D_{c} \times F_{s}
$$

Para,

$D_{c}$ - Deflexão característica obtida para a época do levantamento deflectométrico, em centésimos de milímetros.

$$
D_{c}=D_{m}+\sigma
$$

Sendo,

$D_{m}$ - Deflexão média dos valores da amostra obtida por média aritmética; e

$\sigma-$ Desvio padrão da amostra.

$\mathrm{F}_{\mathrm{s}}$ - Fator de correção sazonal, determinado com o auxílio da Tabela 2.2 .

Tabela 2.2 - Fator de correção sazonal $\left(F_{\mathrm{s}}\right)$

\begin{tabular}{|c|c|c|}
\hline \multirow{2}{*}{ Natureza do subleito } & \multicolumn{2}{|c|}{ Fator de correção sazonal $\left(\mathbf{F}_{\mathbf{s}}\right)$} \\
\cline { 2 - 3 } & Estação seca & Estação chuvosa \\
\hline Arenoso e permeável & $1,10-1,30$ & 1,00 \\
\hline Argiloso e sensível à umidade & $1,20-1,40$ & 1,00 \\
\hline
\end{tabular}

Fonte: DNER-PRO 011-79

- Raio de curvatura (R):

Nas avaliações estruturais não destrutivas, é determinada com o auxílio de equipamentos, a linha de influência longitudinal devido à deformação ocasionada pela carga aplicada à superfície do pavimento. Esta linha é denominada de bacia de deformação, ilustrada pela Figura 2.2. 


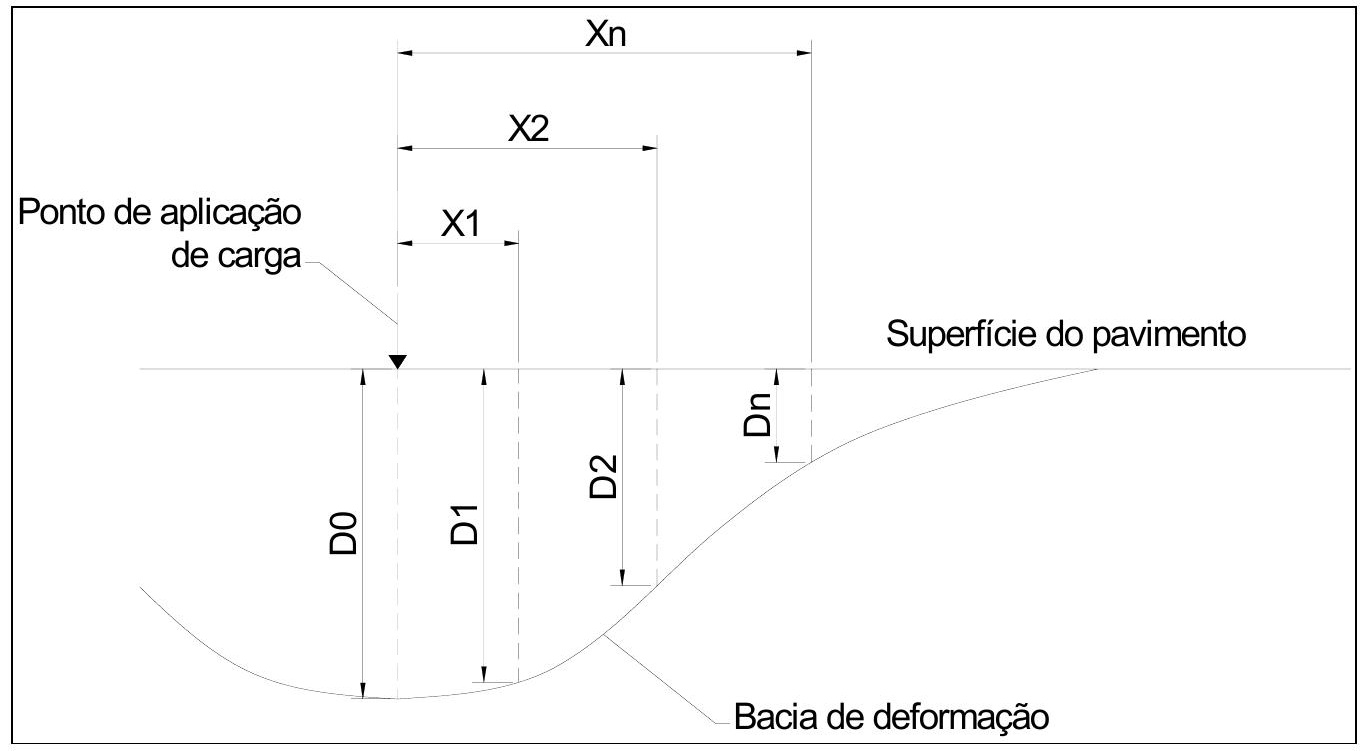

Figura 2.2 - Bacia de deformação (ou deflexão)

O raio de curvatura $(R)$ é o parâmetro mais difundido no sentido de identificação da bacia de deformação com a avaliação estrutural. É calculado pela seguinte equação:

$$
\mathrm{R}=\frac{10 \cdot X n^{2}}{2(D 0-D n)}
$$

Sendo,

$\mathrm{R}$ - em metros;

$X_{n}$ - Distância em relação ao ponto de aplicação de carga (Figura 2.2);

D0 e Dn - Deflexões em centésimos de milímetros (Figura 2.2).

Um raio de curvatura baixo indica um arqueamento severo da bacia de deformação, revelando uma condição estrutural crítica. Em geral, adota-se $n$ igual a $25 \mathrm{~cm}$ por ser a região mais crítica da bacia de deflexões.

- Deflexão admissível $\left(D_{\text {adm }}\right)$ :

Esta deflexão é dependente dos materiais constituintes do revestimento, base do pavimento e do número $\mathrm{N}$ de solicitações do eixo de carga padrão de 
8,2 tf e caracteriza-se pela deflexão à qual se deve trabalhar com valores inferiores para evitar trincas no pavimento.

Para pavimentos flexíveis, com revestimento asfáltico, bases de materiais granulares e solicitação de carga correspondente ao eixo padrão de $8,2 \mathrm{tf}$, a deflexão admissível (em $0,01 \mathrm{~mm}$ ) é fornecida pela expressão (DNERPRO 011-79):

$$
\log \left(D_{a d m}\right)=3,01-0,176 \log N
$$

\subsection{3 - Atrito superficial}

Diretamente relacionada à segurança, a avaliação do atrito superficial pneu-pavimento é obtida através de equipamentos Mu-Meter, os quais medem força de atrito em um reboque trafegando com rodas travadas a diferentes velocidades sobre pavimento molhado.

\subsection{4 - Identificação dos defeitos superficiais}

Com o registro das ocorrências inventariadas normalizadas (trincas, afundamento, exsudação, etc.) presentes no pavimento, calcula-se a freqüência relativa através da equação:

$$
f_{r}=\frac{f_{a} \cdot 100}{n}
$$

Para:

$f_{r}$ - freqüência relativa,

$f_{a}$ - freqüência absoluta e

$n$ - número de estações inventariadas.

Para cada ocorrência inventariada, calcula-se o Índice de Gravidade Individual (IGI):

$$
|G|=f_{r} \times f_{p}
$$


Sendo:

$f_{r}-$ freqüência relativa e

$f_{p}$ - fator de ponderação (valor tabelado em função do tipo de ocorrência).

O Índice de Gravidade Global (IGG) é obtido com a somatória dos valores dos Índices de Gravidade Individuais, resultando no conceito de degradação do pavimento, conforme a Tabela 2.3.

Tabela 2.3 - Conceitos de degradação do pavimento em função do IGG

\begin{tabular}{|c|c|}
\hline Conceito & Limites \\
\hline Ótimo & $0<$ IGG $\leq 20$ \\
\hline Bom & $20<$ IGG $\leq 40$ \\
\hline Regular & $40<$ IGG $\leq 80$ \\
\hline Ruim & $80<$ IGG $\leq 160$ \\
\hline Péssimo & IGG $>160$ \\
\hline
\end{tabular}

Fonte: (DNIT 006/2003 - PRO)

\section{3 - Principais causas de falhas encontradas em pavimentos}

\subsection{1 - Deformação permanente}

Deformações plásticas no revestimento, depressões e afundamentos nas trilhas de roda estão entre as deformações permanentes em pavimentos. Estes defeitos afetam a regularidade longitudinal da via, interferindo na dinâmica de cargas, qualidade de rolamento e custo operacional dos veículos, além de apresentarem risco à segurança dos usuários, já que estas deformações podem acumular água.

As principais causas de deformações permanentes são descritas na Tabela 2.4 . 
Tabela 2.4 - Resumo das causas e tipos de deformações permanentes

\begin{tabular}{|c|c|c|}
\hline Causa geral & Causa específica & Exemplo de defeito \\
\hline \multirow{3}{*}{$\begin{array}{l}\text { Associada ao } \\
\text { carregamento }\end{array}$} & $\begin{array}{c}\text { Carregamento } \\
\text { concentrado ou em } \\
\text { excesso }\end{array}$ & $\begin{array}{c}\text { Fluência plástica } \\
\text { (ruptura por } \\
\text { cisalhamento) }\end{array}$ \\
\hline & $\begin{array}{c}\text { Carregamento de longa } \\
\text { duração ou estático }\end{array}$ & $\begin{array}{c}\text { Deformações ao longo } \\
\text { do tempo (creep) }\end{array}$ \\
\hline & $\begin{array}{l}\text { Grande número de } \\
\text { repetições de carga }\end{array}$ & $\begin{array}{l}\text { Afundamento nas trilhas } \\
\text { de roda }\end{array}$ \\
\hline \multirow{2}{*}{$\begin{array}{l}\text { Não associada ao } \\
\text { carregamento }\end{array}$} & $\begin{array}{c}\text { Subleito constituído de } \\
\text { solo expansivo }\end{array}$ & $\begin{array}{l}\text { Inchamento ou } \\
\text { empolamento }\end{array}$ \\
\hline & $\begin{array}{l}\text { Solos compressíveis na } \\
\text { fundação do pavimento }\end{array}$ & Recalque diferencial \\
\hline
\end{tabular}

Fonte: Manual de reabilitação de pavimentos asfálticos - DNER

Existem dois mecanismos associados às deformações que são causados pela ação do tráfego: a densificação e a fluência plástica. A densificação relaciona-se com a diminuição do volume de vazios do material, ocasionando uma maior aproximação das partículas constituintes do mesmo.

Uma compactação adequada durante a construção das camadas do pavimento pode usualmente controlar a densificação. Em linhas gerais, quanto maior a compactação de um material, maior é sua resistência ao cisalhamento e menor a sua susceptibilidade ao ingresso de água.

A fluência plástica ocorre quando os esforços induzidos pelo carregamento excedem a resistência ao cisalhamento dos materiais ou são suficientes para induzir recalque.

Simpson, Daleiden e Hadley (1995), citam que muitos estudos têm sido realizados para investigar as possíveis causas das deformações permanentes e predizer seu desenvolvimento. As principais dificuldades encontradas nestes estudos estão associadas com a identificação da camada que mais contribui para o surgimento da deformação permanente medida na superfície do 
pavimento. Outra dificuldade é a falta de padronização para colecionar dados de afundamentos de trilhas de roda.

Do ponto de vista de dimensionamento de pavimentos, pesquisadores da Shell Oil Company sugerem a utilização da tensão vertical de compressão no topo do subleito para controlar a deformação permanente.

Um dos modelos para previsão de deformações permanentes é descrito pela equação:

$$
N=a\left(\frac{1}{\varepsilon_{v c, m}}\right)^{b}
$$

Sendo,

$N$ - número de solicitações associado ao valor limite da deformação permanente;

$\mathcal{E}_{v c, m}$ - deformação vertical de compressão no topo do subleito;

a,b - constantes obtidas de correlações entre análises mecanísticas e observações de pavimentos em serviço.

Yoder e Witczak (1975) apresentam os diferentes limites de deformação do subleito adotados pela Shell Oil Company e The Asphalt Institute para que os valores da deformação permanente sejam mínimos nas camadas. Os valores limites dependem do número de solicitações até o colapso.

\subsection{2 - Fadiga}

A aplicação repetitiva de forças que solicitam à flexão a camada de concreto asfáltico produz deformações elásticas no material em níveis de intensidade aquém dos requeridos para induzir a fratura imediata.

No Brasil, pode-se dizer que o estudo sobre fadiga de pavimentos asfálticos é recente, tendo maior abordagem a partir da década de 80 . As 
cargas do tráfego ocasionam o tracionamento das fibras inferiores da camada de revestimento e da base, originando, desta maneira, o trincamento das camadas.

A Figura 2.3 ilustra a tensão situada na parte inferior da capa $\left(S_{t}\right)$, a tensão de compressão atuante no topo do subleito $\left(S_{z}\right)$ e a deflexão vertical do revestimento $\left(D_{0}\right)$.

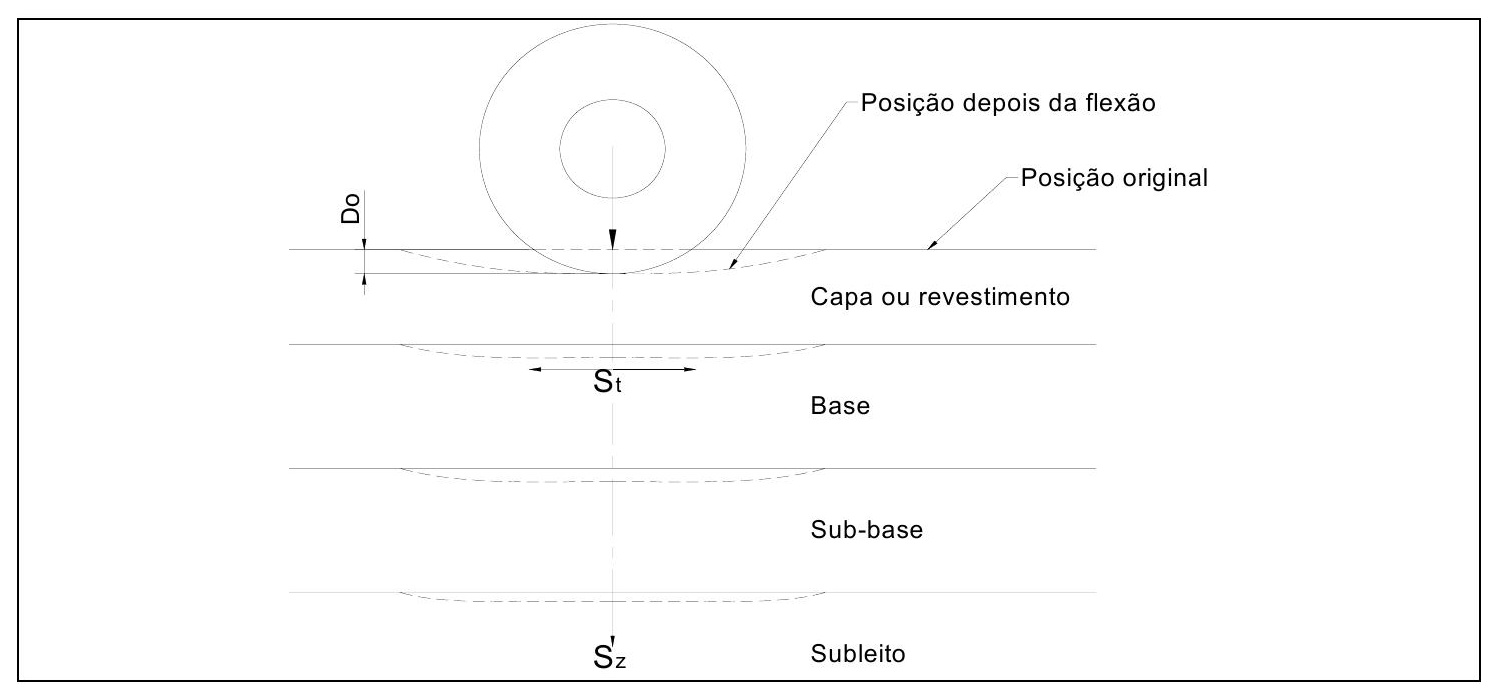

Figura 2.3 - Tensões e deformações no pavimento (Manual de reabilitação de pavimentos asfálticos - DNER 1998)

Rauhut e Kennedy (1982) citam que a forma das expressões de fadiga em uso comum é derivada de uma relação logarítmica entre tanto tensão ou deformação e o número de ciclos de carregamento até a ruptura. A relação entre o logaritmo da tensão ou deformação e o logaritmo dos ciclos de carregamento é considerada linear, resultando na seguinte equação:

$$
N_{i}=K_{1} \varepsilon_{i}^{-K_{2}}
$$

Sendo,

$\mathrm{N}_{\mathrm{i}}$ - número de solicitações para a ruptura com um carregamento que resulta em deformação elástica;

$\mathcal{E}_{i}$ - deformação calculada sobre carregamento; e 
$\mathrm{K}_{1}$ e $\mathrm{K}_{2}$ - constantes de calibração do modelo que dependem do material, condição de uso ou ensaio.

Os ensaios realizados em laboratório para se estimar a vida de fadiga dos revestimentos asfálticos podem ser classificados em dois grupos, em função da dependência direta da vida de fadiga das deformações e tensões atuantes no pavimento:

- Tensão controlada (TC): realizado através de aplicação constante da mesma magnitude de carga ao corpo de prova, ocorrendo breve período de repouso entre as aplicações. Devido ao dano progressivo ao corpo de prova, os resultados de rigidez são decrescentes.

- Deformação controlada (DC): a carga aplicada ao corpo de prova é variada continuamente para que ocorra deslocamento constante, resultando em tensões continuamente decrescentes com a aplicação de carga.

As diferenças existentes entre os ensaios de Tensão Controlada e Deformação Controlada estão sumarizadas na Tabela 2.5, obtidas por diversos pesquisadores relacionados em Monismith et al. (1990).

Tabela 2.5 - Avaliação comparativa entre ensaios TC e DC

\begin{tabular}{|l|c|c|}
\hline \multicolumn{1}{|c|}{ Variáveis } & Tensão Controlada & $\begin{array}{c}\text { Deformação } \\
\text { Controlada }\end{array}$ \\
\hline $\begin{array}{l}\text { Espessura da camada } \\
\text { de concreto asfáltico }\end{array}$ & $\begin{array}{c}\text { Comparativamente } \\
\text { espessuras espessas de } \\
\text { camada asfáltica }\end{array}$ & $\begin{array}{c}\text { Espessuras delgadas } \\
(<3 \text { polegadas })\end{array}$ \\
\hline $\begin{array}{l}\text { Definição de ruptura; } \\
\text { número de ciclos }\end{array}$ & Bem definida & $\begin{array}{c}\text { Arbitrário (50\% do valor } \\
\text { da deformação inicial) }\end{array}$ \\
\hline $\begin{array}{l}\text { Dispersão dos pontos no } \\
\text { ensaio }\end{array}$ & Menos disperso & Mais disperso \\
\hline
\end{tabular}


Tabela 2.5 - Avaliação comparativa entre ensaios TC e DC (cont.)

\begin{tabular}{|c|c|c|}
\hline Variáveis & Tensão Controlada & $\begin{array}{l}\text { Deformação } \\
\text { Controlada }\end{array}$ \\
\hline $\begin{array}{l}\text { Número de corpos de } \\
\text { prova requeridos }\end{array}$ & Menor & Maior \\
\hline $\begin{array}{l}\text { Magnitude da vida de } \\
\text { fadiga }(N)\end{array}$ & Geralmente vida menor & Geralmente vida maior \\
\hline $\begin{array}{l}\text { Efeito das variáveis da } \\
\text { mistura }\end{array}$ & Mais sensível & Menos sensível \\
\hline $\begin{array}{l}\text { Taxa de dissipação de } \\
\text { energia }\end{array}$ & Rápida & Lenta \\
\hline $\begin{array}{l}\text { Taxa de propagação de } \\
\text { trincas }\end{array}$ & $\begin{array}{l}\text { Mais rápida do que as } \\
\text { que ocorrem "in situ" }\end{array}$ & $\begin{array}{l}\text { Mais representativa das } \\
\text { condições "in situ" }\end{array}$ \\
\hline $\begin{array}{l}\text { Efeitos beneficiais do } \\
\text { tempo sem } \\
\text { carregamento }\end{array}$ & Grande efeito benéfico & Menor efeito benéfico \\
\hline
\end{tabular}

Fonte: Monismith et al., 1990

Diversos fatores influenciam a resposta da vida de fadiga de um corpo de prova de uma mistura asfáltica em ensaios de laboratório, dos quais destacam-se (Monismith et al., 1990):

- $\quad$ O tipo de compactação e rigidez do corpo de prova;

- $\quad$ O modo de ensaio (DC ou TC);

- $\quad$ O volume de vazios na mistura (deve ser o menor possível mas, não menor que 3\%).

- Altas temperaturas diminuem a vida de fadiga para pavimentos espessos e aumentam a mesma para pavimentos delgados.

Os procedimentos convencionais de laboratório para análise de fadiga de pavimentos asfálticos apresentam custos significativos e esforço considerável para sua realização, procedimentos alternativos têm sido utilizados para simplificação tanto dos ensaios quanto da análise. Por este 
motivo, expressões representativas para a estimativa da deformação de fadiga ou número de aplicações até a ruptura têm sido desenvolvidas em centros de pesquisa. Algumas expressões estão mencionadas a seguir.

A aproximação da Shell para estimar a deformação de fadiga é obtida pela equação:

$$
\boldsymbol{E}_{t}=\left(0,856 \cdot \mathrm{V}_{\mathrm{B}}+1,08\right) \mathrm{S}_{\mathrm{mix}}{ }^{-0,036} \cdot \mathrm{N}^{-0,2}
$$

Para:

$\mathcal{E}_{\text {t }}$ - Deformação elástica permissível;

$\mathrm{N}$ - Número de aplicações até a ruptura;

$V_{B}$ - Volume de asfalto (\%);

$\mathrm{S}_{\text {mix }}-$ Rigidez da mistura para um tempo particular de carregamento e temperatura.

O Instituto do Asfalto apresenta, para procedimentos simplificados, a expressão:

$$
\mathrm{N}_{\mathrm{r}}=18,4 \mathrm{C}\left[4,325.10^{-3}\left(\mathcal{E}_{\mathrm{t}}\right)^{-3,291}\left(\mathrm{~S}_{\mathrm{mix}}\right)^{-0,854}\right]
$$

Sendo os parâmetros $\mathcal{E}_{t}$ e $S_{\text {mix }}$ os mesmos descritos pela aproximação da Shell. $V_{v}$ é definido como o volume de vazios e o parâmetro $C$ é definido por:

$$
\begin{gathered}
C=10^{\mathrm{M}} \\
\left.M=4,84\left(\frac{V_{B}}{V_{V}+V_{B}}-0,69\right)\right)
\end{gathered}
$$

Von Quintus (2001) descreve uma metodologia para projetar pavimentos asfálticos de longa vida. Para a fadiga, o procedimento de projeto é baseado na limitação da deformação elástica na face inferior da camada de revestimento. É enunciada a seguinte função empírica para fadiga: 


$$
\log N_{f t}=\beta_{t} K_{1}-K_{2}\left[\log \left(\varepsilon_{t} / 10^{6}\right)-K_{3}\left[\log E / 10^{3}\right)\right]
$$

Sendo,

$N_{f t}$ - número de repetições de carga para um nível específico de fadiga;

$\varepsilon_{t}$ - deformação elástica na face inferior da camada de revestimento;

$E$ - módulo de resiliência para a mistura asfáltica (psi);

$\mathrm{K}_{1}, \mathrm{~K}_{2}$ e $\mathrm{K}_{3}$ - Parâmetros do material determinados em laboratório;

$\beta_{t}$ - fator de calibração de campo.

As curvas de fadiga obtidas em laboratório necessitam de calibração com dados obtidos em campo pois, os ensaios contêm várias simplificações, entre elas: tempo de carga determinado e carga uniforme. Outros fatores não considerados são: variação da temperatura ao longo do dia, oxidação do revestimento e distribuição transversal do tráfego.

O desenvolvimento de uma relação significativa entre os resultados de ensaio em laboratório e o desempenho real do pavimento em campo é uma das principais dificuldades encontradas no assunto de fadiga.

Existe uma grande quantidade de valores fornecidos para os fatores campo-laboratório resultante de diversas pesquisas, esta quantidade de valores diferentes aparenta ser dependente do tipo e condições de ensaio. Como exemplo, ensaios onde corpos de prova foram submetidos a altas taxas de flexão com carregamentos de formato sinusoidal, o fator campo-laboratório foi da ordem de 100; ensaios onde houve período de repouso entre as aplicações de carga os fatores utilizados foram menores que 20.

Balbo (2000) aborda as diferenças existentes entre as situações de um corpo de prova ensaiado em laboratório e do comportamento em pista, relevando a inaptidão dos modelos experimentais de fadiga em representar a realidade dos pavimentos por diversos motivos, dentre estes:

- Carregamento: as cargas reais aplicadas aos pavimentos apresentam vasta variabilidade (tipos de eixos, distância entre eixos, tamanhos de pneumáticos) enquanto que no laboratório os ensaios de deformação 
controlada devem reduzir o nível de tensão aplicada ao longo do tempo; para os ensaios de tensão controlada a carga aplicada é constante.

- Amostras de ensaios: o processo de preparo de amostras para ensaios de fadiga apresenta dispersão típica, exigindo grande número de corpos de prova para a homogeneidade da amostra. Em campo, muitos fatores colaboram para a inexistência de homogeneidade: variações no processo de usinagem, segregação de mistura entre usinagem e espalhamento, variações de qualidade do material por fornecedores distintos e compactação variável em campo.

- Temperatura do ensaio: as variações reais de temperatura de misturas asfálticas ao longo do ano na região central do Estado de São Paulo poderia ser tomada como sendo entre $10^{\circ} \mathrm{C}$ e $60^{\circ} \mathrm{C}$. Os ensaios de fadiga são inexeqüíveis para temperaturas superiores a 30 ou $35^{\circ} \mathrm{C}$, pois as amostras de pequenas dimensões e sem confinamento lateral sofrem fluência significativa, inviabilizando as aplicações de carga.

\section{4 - Métodos de avaliação}

A avaliação estrutural de pavimentos pode ser realizada através de métodos destrutivos (laboratório) e não destrutivos ("in situ”).

Normalmente, a diferença entre os métodos destrutivos e os não destrutivos diz respeito à ocorrência ou não de distúrbios físicos no material (Haas, Hudson e Zaniewski, 1994).

\subsection{1 - Métodos destrutivos}

Ocasionalmente torna-se necessário a remoção de partes da estrutura do pavimento para se determinar onde e porque os problemas estão ocorrendo através de ensaios de laboratórios.

O termo destrutivo é aplicado ao método pois a estrutura original do pavimento é destruída para a avaliação em um local particular. Em geral, este procedimento de avaliação é restrito a pavimentos que apresentam evidências 
estruturais críticas, entretanto, os métodos destrutivos estão sendo usados em pistas experimentais e formam uma importante parte no Programa Estratégico de Pesquisas Rodoviárias (SHRP - Strategic Highway Research Program) e no estudo de Desempenho de Pavimentos a Longo Prazo (LTPP - Long Term Pavement Performance).

As técnicas usadas dependem do tipo de informação desejada e geralmente envolvem uma incisão em cada camada do pavimento e remoção simples para inspeção e testes. O objetivo também pode ser a retirada de amostras não perturbadas das várias camadas.

As seguintes informações podem ser obtidas, em laboratório, de cada camada da estrutura do pavimento quando se realiza um ensaio destrutivo:

- Sub-base / base:

- Limites de Atterberg - (LL,LP e LC);

- Teor de umidade;

- Espessura;

- Uniformidade do material na camada

- Tipo de material;

- Intrusão do material de subleito nas camadas de sub-base ou base;

- Permeabilidade;

- Capacidade de suporte (CBR);

- Módulo de resiliência;

- Características tensão-deformação;

- Granulometria e outros;

- Revestimento:

- Teor de asfalto;

- Espessura;

- Módulo de resiliência e outros.

Para o Manual de Reabilitação de Pavimentos Asfálticos do DNER, as principais desvantagens dos ensaios destrutivos são: 
- Interrupção do tráfego da rodovia por um período de tempo significativo;

- Natureza destrutiva do ensaio e introdução de defeito nas seções do pavimento;

- Os ensaios não podem ser utilizados extensivamente pois, são onerosos, requerem muito tempo e mão-de-obra.

- Os resultados dos ensaios são representativos das condições do material em um ponto específico.

\subsection{2 - Métodos não destrutivos}

São realizados ensaios "in situ" com auxílio de equipamentos deflectométricos, que medem os deslocamentos recuperáveis da estrutura do pavimento com a aplicação de uma carga conhecida.

O estudo das deflexões ou das condições de deformabilidade dos pavimentos flexíveis é fundamental para a compreensão de seu comportamento, uma vez que refletem as condições estruturais das camadas que o compõem e do subleito.

A magnitude das deformações recuperáveis ou resilientes, originadas pela atuação do tráfego sobre o pavimento, é variável, depende da geometria do carregamento, do valor da carga, da pressão de inflação dos pneus, da posição do ponto de medida em relação à posição da aplicação da carga e do clima, dentre outros fatores.

Albernaz, Caldas e Oliveira (1996), citam algumas vantagens e desvantagens da metodologia não destrutiva de avaliação estrutural de pavimentos.

Vantagens:

- Elimina, ou pelo menos, minimiza a necessidade de onerosas e perigosas coletas de amostras na pista; 
- São estimados os módulos elásticos dos materiais nas condições reais de campo, dificilmente reproduzíveis em laboratório;

- Rapidez na caracterização elástica do pavimento.

Dentre as desvantagens, destacam-se:

- Os levantamentos das bacias de deflexão no campo devem apresentar elevado grau de exatidão;

- A aferição dos instrumentos e a confiabilidade dos procedimentos operacionais de medição das deflexões devem ser continuamente verificadas;

No capítulo 3 são descritas as características operacionais dos aparelhos deflectométricos utilizados nas avaliações não destrutivas.

\section{5 - Módulo de resiliência}

O módulo de resiliência $\left(M_{R}\right)$ é uma propriedade fundamental dos materiais, similar, conceitualmente, ao módulo de elasticidade, ou seja, ambos são relação entre tensões e deformações. Francis Hveem preferiu a utilização do termo resiliente sob o argumento de que as deformações nos pavimentos são muito maiores do que as de outros sólidos com os quais o engenheiro lida.

Para a Norma DNER-ME 133/94, o módulo de resiliência de misturas betuminosas é definido pela expressão:

$$
M_{R}=\left(\frac{\sigma_{t}}{\varepsilon_{t}}\right)_{T}
$$

Onde:

$\sigma_{t}$ - Tensão de tração aplicada repetidamente no plano diametral vertical de uma amostra cilíndrica; 
$\varepsilon_{\mathrm{t}}$ - Deformação específica recuperável correspondente à tensão aplicada numa dada temperatura $\mathrm{T}$.

O corpo de prova betuminoso pode ser produzido em laboratório ou retirado "in situ" por sonda.

A Figura 2.4 ilustra as deformações que podem ocorrer em um material quando solicitado por um carregamento. A deformação plástica $\left(\varepsilon_{\mathrm{p}}\right)$ é sinônimo de deformação permanente; a deformação resiliente $\left(\varepsilon_{r}\right)$ pode ser denominada de elástica ou recuperável. A adição da deformação plástica com a deformação resiliente resulta na deformação total.

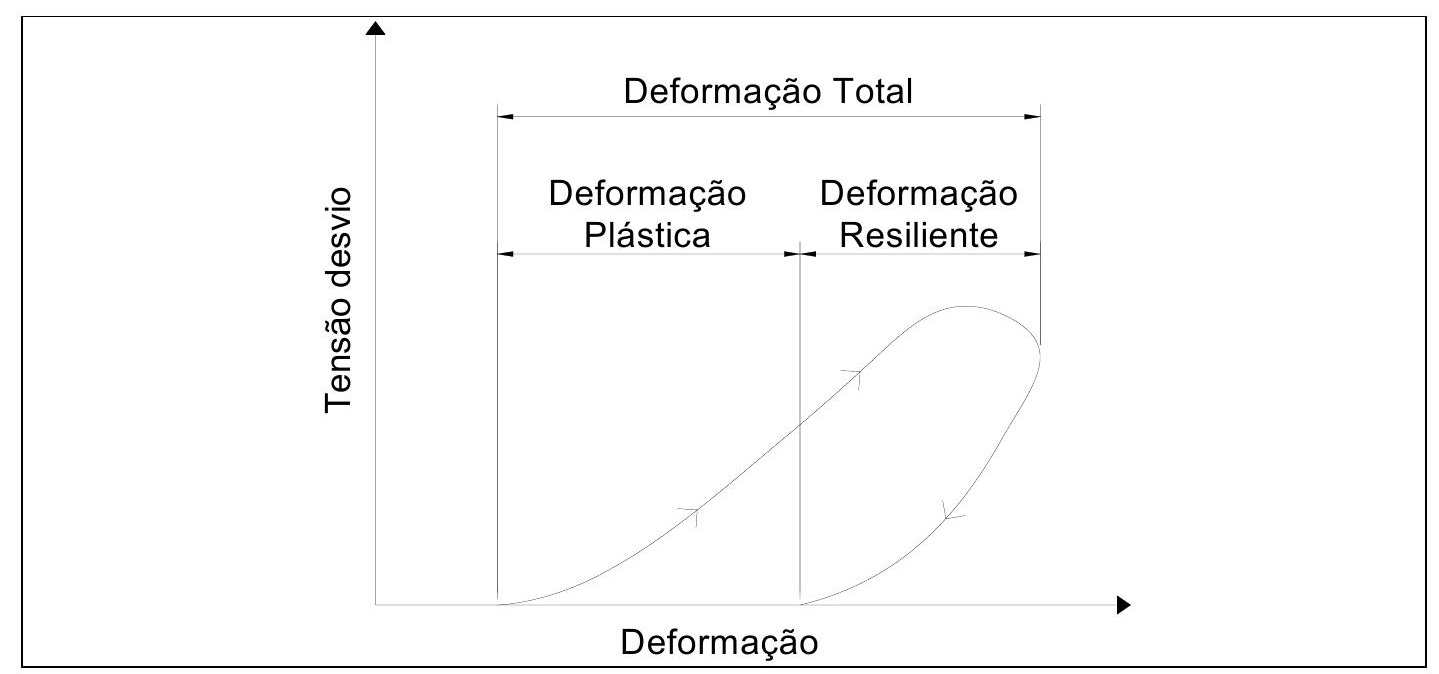

Figura 2.4 - Composição da deformação em um material (Elliot e Thornton, 1988).

\section{6 - Coeficiente de Poisson}

A abordagem mecanística de projetos de pavimentos requer informações sobre o coeficiente de Poisson $(v)$. A relação entre a deformação lateral $\left(\varepsilon_{\mathrm{L}}\right)$ e a deformação axial $\left(\varepsilon_{\mathrm{a}}\right)$ para um carregamento aplicado na direção axial define este coeficiente, ou seja:

$$
v=-\frac{\varepsilon_{L}}{\varepsilon_{a}}
$$


Durante o ensaio de módulo de resiliência, podem ser medidas as deformações laterais e axiais no corpo de prova e, conseqüentemente, determinar o coeficiente de Poisson do material.

Huang (1993) recomenda a utilização de valores usuais para o coeficiente de Poisson pois, há pouca influência dos valores deste coeficiente na resposta estrutural de pavimentos. Uma característica padrão é a preferência por utilização de valores tabelados para este coeficiente ao invés de determiná-lo experimentalmente.

A Tabela 2.6 apresenta o coeficiente de Poisson para diferentes materiais.

Tabela 2.6 - Valores do coeficiente de Poisson

\begin{tabular}{|l|c|c|}
\hline \multirow{2}{*}{ Material } & \multicolumn{2}{c|}{ Coeficiente de Poisson } \\
\cline { 2 - 3 } & Faixa & Usual \\
\hline Concreto asfáltico à quente & $0,30-0,40$ & 0,35 \\
\hline Concreto de cimento Portland & $0,15-0,20$ & 0,15 \\
\hline Material granular não tratado & $0,30-0,40$ & 0,35 \\
\hline Material granular tratado com cimento & $0,10-0,20$ & 0,15 \\
\hline Solo fino - granular tratado com cimento & $0,15-0,35$ & 0,25 \\
\hline Material estabilizado com cal & $0,10-0,25$ & 0,20 \\
\hline Areia fofa ou silte arenoso & $0,20-0,40$ & 0,30 \\
\hline Areia densa & $0,30-0,45$ & 0,35 \\
\hline Solo fino - granular & $0,30-0,50$ & 0,40 \\
\hline Argila & $0,40-0,50$ & 0,45 \\
\hline
\end{tabular}

Fonte: Huang (1993) 


\section{Capítulo 3 - Medidas deflectométricas}

\section{1 - Introdução}

As técnicas de medidas de deflexões em pavimentos com equipamentos deflectométricos são amplamente utilizadas para avaliação estrutural e retroanálise. $\mathrm{O}$ baixo custo, menor interrupção do tráfego e menores danos ao pavimento as tornam preferenciais em relação às destrutivas.

Embora as técnicas não destrutivas (medidas de deflexão) sejam priorizadas em relação aos métodos destrutivos, tal fato não minimiza a importância dos métodos destrutivos, sendo em muitos casos completamente necessária sua execução.

Historicamente, o registro mais antigo de medida de deflexões em pavimentos deve-se a Hveem, sensores foram instalados em rodovias do Estado da Califórnia (EUA) por volta de 1938 porém, estudos mais complexos iniciaram-se nos princípios da década de 50.

A locação espacial dos pontos de deflexão deve ser realizada de modo a cobrir toda a variabilidade na capacidade estrutural do pavimento. Esta variabilidade pode ser decorrente de materiais não uniformes no subleito, variação na profundidade de camada rígida ou locais com variações construtivas. Portanto, pavimentos com alta variabilidade devem ser submetidos a um grande número de medidas de deflexões. 


\section{2 - Equipamentos deflectométricos}

Haas, Hudson e Zaniewski (1994) dividem os equipamentos utilizados nas medidas de deflexão, baseando-se no tipo de carregamento aplicado ao pavimento, em três categorias:

- Carregamento estático:

- Ensaio de placa,

- Viga Benkelman,

- Viga Benkelman automatizada,

- Carregamento vibratório:

- Dynaflect;

- Road Rater.

- Carregamento por impulso:

- Dynatest FWD;

- KUAB FWD;

- Phoenix FWD.

\subsection{1 - Carregamento estático}

\subsubsection{1 - Ensaio de placa}

Denominado também como "Prova de carga", o ensaio de placa é um procedimento para medida estática de deflexão, sendo a carga aplicada por um macaco hidráulico em uma placa rígida com $762 \mathrm{~mm}$ (30 polegadas) de diâmetro sobre a superfície do pavimento.

É um ensaio lento e trabalhoso, com duração de trinta minutos a mais de uma hora, razão pela qual não é um procedimento difundido para avaliação de pavimentos. 


\subsubsection{2 - Viga Benkelman}

Desenvolvida por A. C. Benkelman em conjunto com a WASHO Road Test, este equipamento simples e de baixo custo tem sido utilizado por diversas agências rodoviárias do mundo.

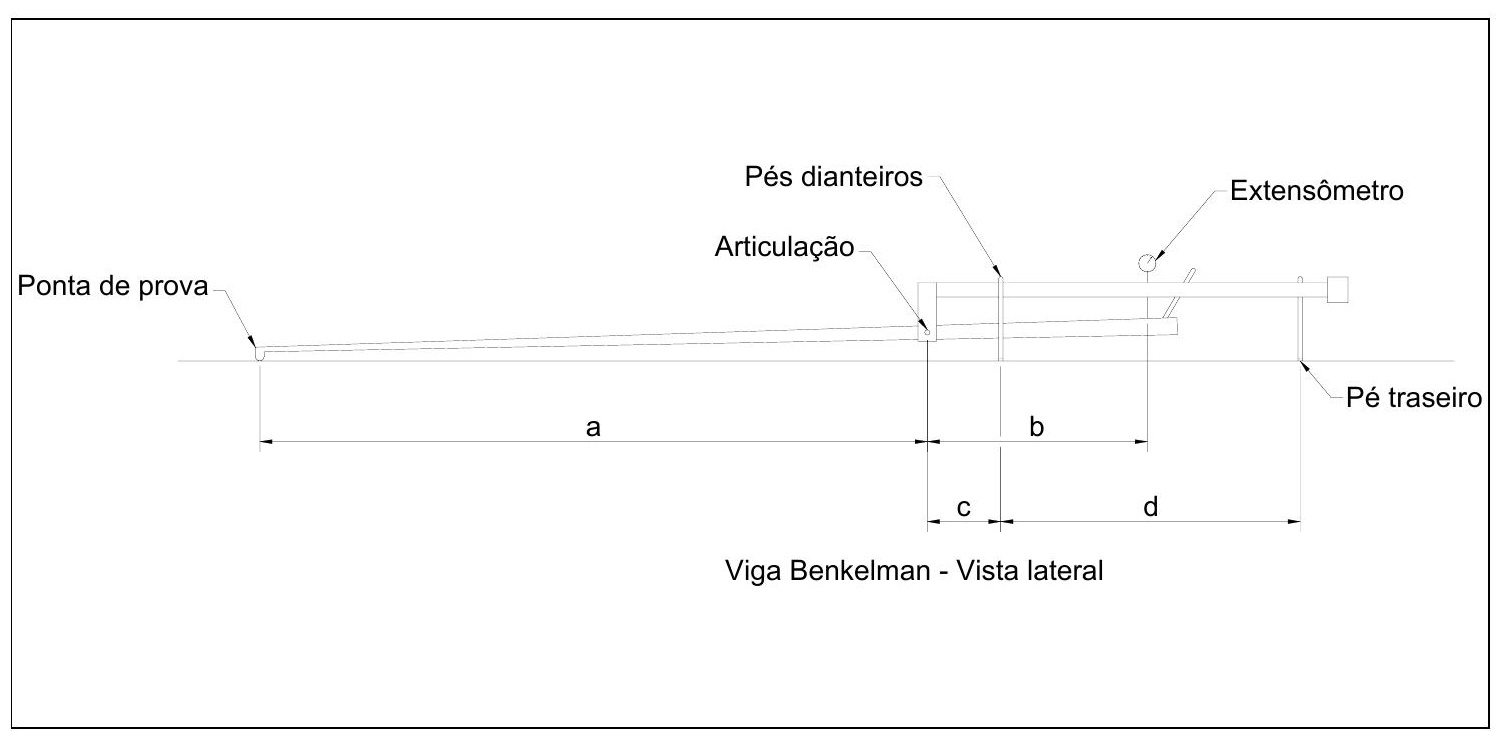

Figura 3.1 - Viga Benkelman (DNER ME024-94)

Para a execução das medidas de deflexão utiliza-se um caminhão com $8,2 \mathrm{tf}$ de carga no eixo traseiro que é simples com rodas duplas. A leitura inicial $\left(L_{0}\right)$ é feita com a ponta de prova situada entre as rodas duplas traseiras do caminhão, conforme a Figura 3.2.

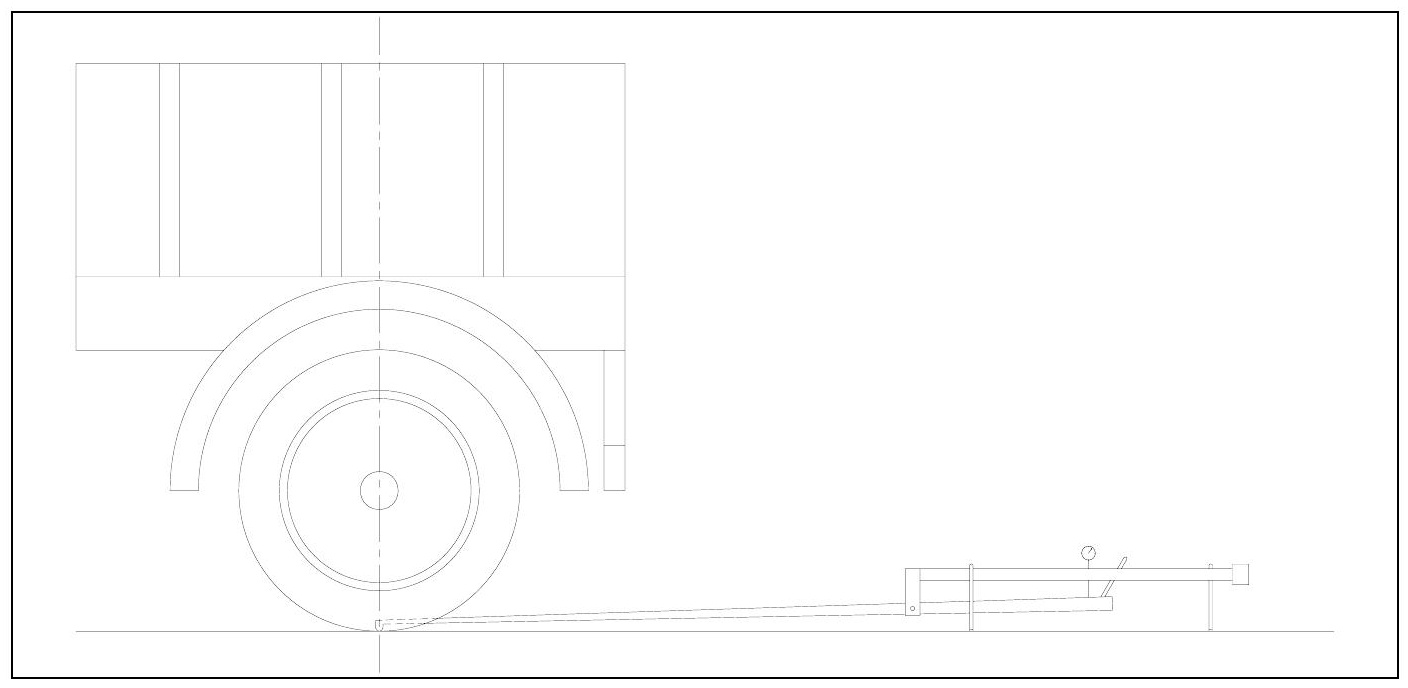

Figura 3.2 - Posição de leitura inicial $L_{0}$ (DNER ME024-94) 
Concluida a leitura inicial $\left(L_{0}\right)$, desloca-se lentamente o caminhão para frente cerca de dez metros e realiza-se a leitura final $\left(L_{f}\right)$. Caso desejado, desloca-se o caminhão para frente em distâncias preestabelecidas a fim da obtenção da deflexão em vários pontos, possibilitando o delineamento da bacia de deformação.

A deflexão $\left(D_{0}\right)$ na ponta de prova é fornecida pela expressão:

$$
D_{0}=\left[\left(L_{0}-L_{f}\right) \cdot a / b\right]
$$

Para,

$D_{0}$ - Deflexão real ou verdadeira (centésimos de milímetros);

$\mathrm{L}_{0}$ - Leitura inicial (centésimos de milímetros);

$L_{f}-$ Leitura final (centésimos de milímetros);

a - Dimensão da viga (ponta de prova à articulação, ver Figura 3.1);

b - Dimensão da viga (articulação ao extensômetro, ver Figura 3.1).

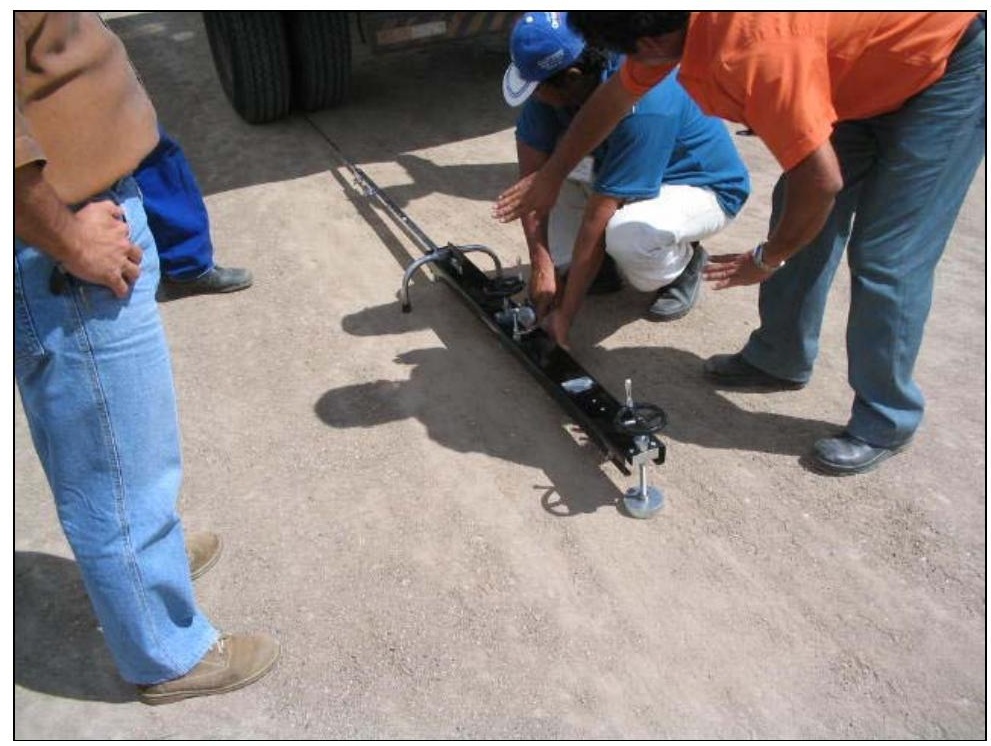

Figura 3.3 - Viga Benkelman (www.cremape.com.br/232l1 km146.htm) acesso em 22/11/05.

A operação da viga Benkelman é simples porém, relativamente lenta. $A$ sua utilização é limitada pela rigidez do pavimento, não sendo desejável os pés estarem posicionados dentro da bacia de deflexão. As cargas estáticas ou em movimento lento, utilizadas para obtenção de medidas com a viga, não 
representam as cargas reais transitórias ou por impulso na realidade impostas ao pavimento.

As características negativas previamente referidas não minimizam a importância ou a eficiência da utilização da viga Benkelman, ressalta-se o significativo número de procedimentos executados/existentes nas áreas de reabilitação de pavimentos, gerência e manutenção, baseados em deflexões obtidas com a viga.

\subsubsection{3 - Viga Benkelman automatizada}

A automatização da viga Benkelman foi elaborada objetivando acréscimo na velocidade das medidas deflectométricas. Desenvolvido na França e utilizado largamente na Europa (situação oposta na América do Norte), o deflectógrafo La Croix é a viga de deflexão automatizada comercialmente disponível. O veículo com a viga move-se a uma velocidade de $3 \mathrm{~km} / \mathrm{h}$ durante o procedimento, sendo a operação completamente automatizada.

The British Pavement Deflection Data Logging Machine é similar ao La Croix mas, fabricado no Reino Unido para os padrões britânicos. The California Traveling Deflectometer desenvolvido pelo Departamento de Transportes da Califórnia, é essencialmente uma viga Benkelman automatizada com deflexões medidas a uma velocidade de $0,8 \mathrm{~km} / \mathrm{h}$.

\subsection{2 - Carregamento vibratório}

São equipamentos caracterizados por produzir uma força sinusoidal dinâmica sobreposta a uma carga estática, conforme ilustrado na Figura 3.4. Apresentam vantagem de não requererem um ponto de referência como nos equipamentos estáticos.

Como desvantagem, nota-se que as cargas reais aplicadas aos pavimentos não estão em um estado invariável de magnitude e vibração. O uso 
de amplas cargas estáticas pode ter algum efeito no comportamento de materiais sensíveis à tensão.

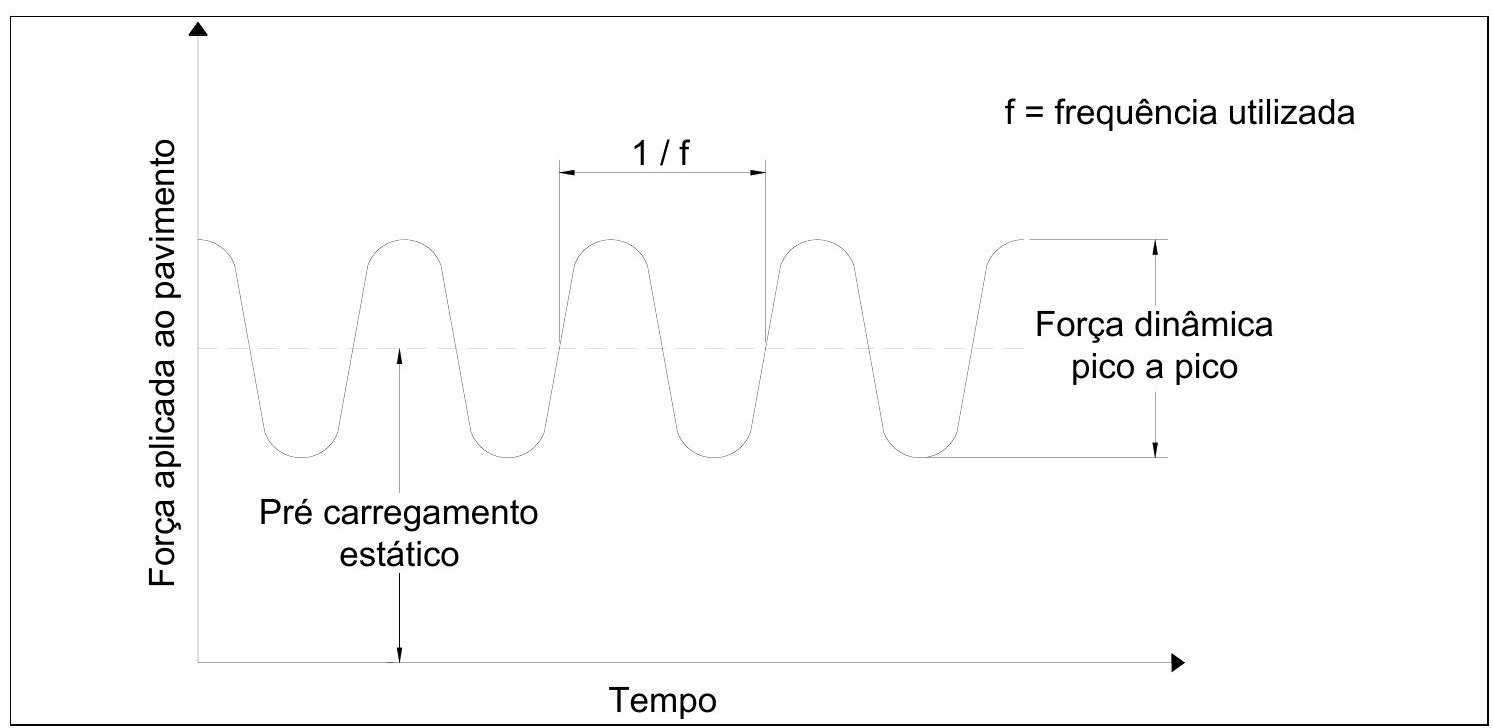

Figura 3.4 - Força dinâmica típica resultante de aparelhos vibratórios (Haas, Hudson e Zaniewski 1994).

O Dynaflect e o Road Rater são comercialmente disponíveis e amplamente utilizados em ensaios não destrutivos dentro desta categoria.

\subsubsection{1 - Dynaflect}

Consiste em um trailer rebocado por um veículo e com operação completamente controlada da cabine do motorista. A carga estática (907 a 952 $\mathrm{kg}$ ) é aplicada ao pavimento por um par de rodas rígidas de aço.

Um gerador de força dinâmico é utilizado para produzir uma força pico a pico de $453 \mathrm{~kg}$ em uma freqüência de 8 hertz. Cinco geofones alinhados em uma barra distanciados em intervalos de $30,5 \mathrm{~cm}$ medem a bacia de deflexão.

\subsubsection{2 - Road Rater}

Estão comercialmente disponíveis em uma série de modelos, contemplando cargas estáticas de 1088 a 2630 kg e cargas dinâmicas de pico 
a pico de 226 a $3628 \mathrm{~kg}$. A freqüência utilizada pode ser variada de 5 a 70 hertz, utilizando-se quatro sensores para obter a bacia de deflexão.

A carga estática é variada pela transferência do peso do carro reboque através das rodas para uma placa de carga, o carregamento dinâmico é gerado pelos cilindros hidráulicos movimentando uma massa na direção vertical (Figura 3.5). A deflexão é medida por quatro transdutores de velocidade, um localizado no centro da placa de carregamento e os outros três alinhados em intervalos de 12 polegadas.

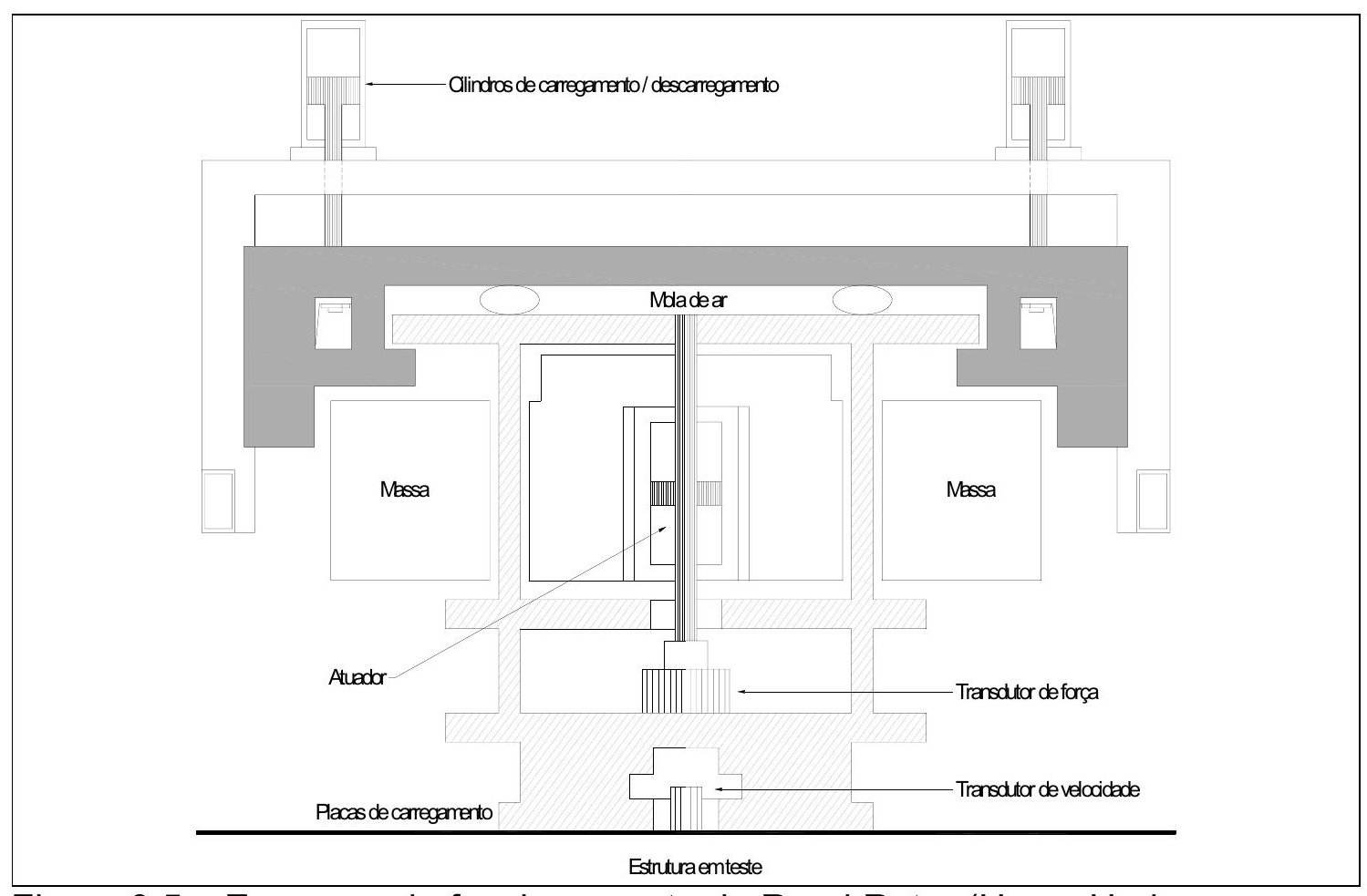

Figura 3.5 - Esquema de funcionamento do Road Rater (Haas, Hudson e Zaniewski 1994).

A Figura 3.6 ilustra este equipamento. 


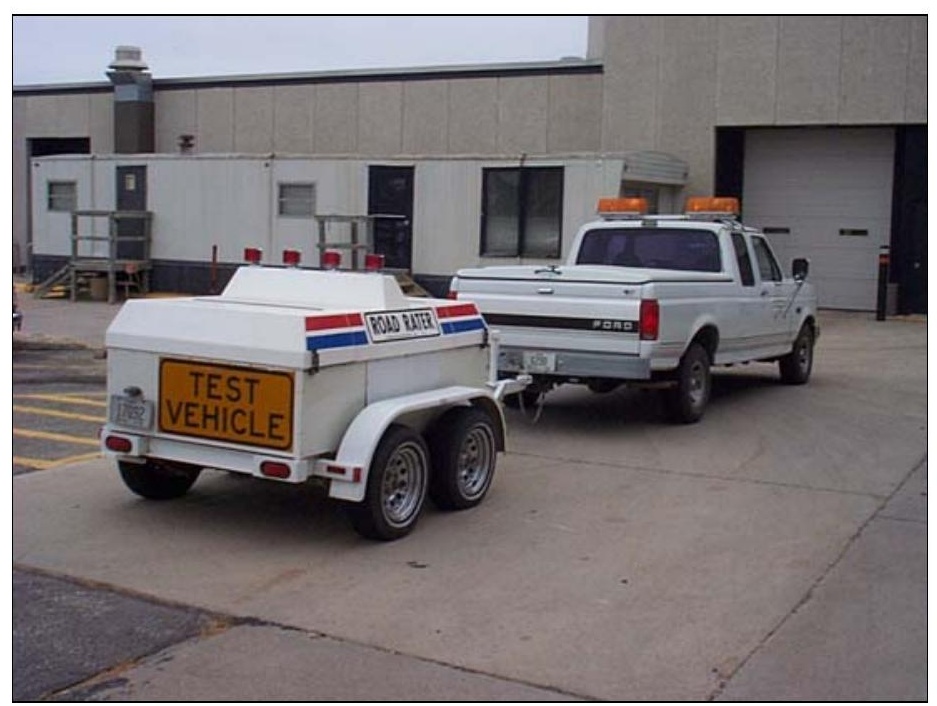

Figura 3.6 - Road Rater (www.dot.state.ia.us/materials/paveeval.htm) acesso em 22/11/05.

\subsection{3 - Carregamento por impulso}

Compreendem os equipamentos de medidas de deflexão que empregam um sistema de massa que colide em uma placa amortecida, tipicamente conhecidos como Falling Weight Deflectometer (FWD).

Para alguns pesquisadores, a força transitória de impulso criada pelo FWD em pavimentos aproxima-se mais das situações reais de cargas móveis do que as desenvolvidas pelos equipamentos estáticos e vibratórios.

Desenvolvidos na Europa, estes equipamentos tornaram-se populares nos Estados Unidos a partir de meados da década de 80 no estudo de Long Term Pavement Performance (LTPP) dentro do Strategic Highway Research Program (SHRP). 


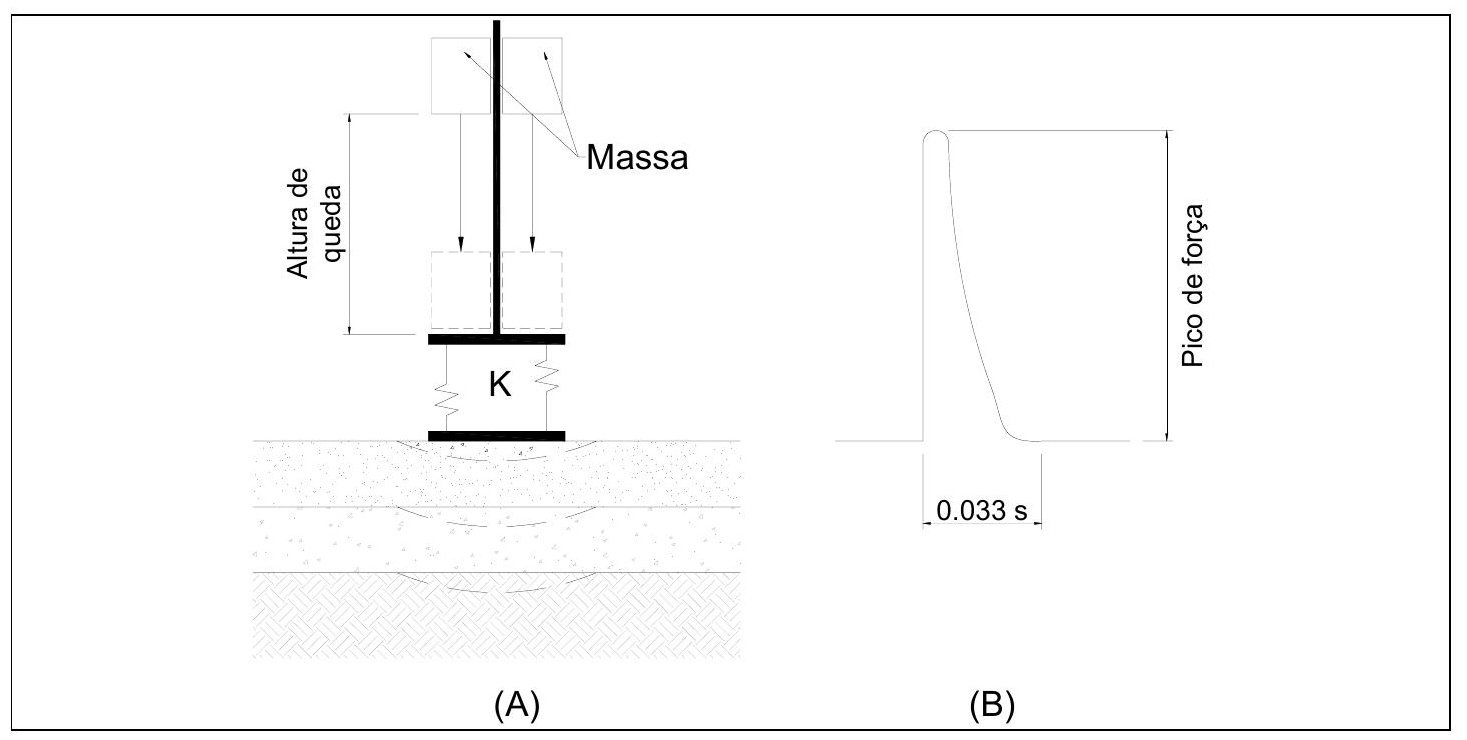

Figura 3.7 - Princípio básico do Falling Weight Deflectometer (Haas, Hudson e Zaniewski ,1994).

Na Figura 3.7 (A) é ilustrado o princípio básico de funcionamento do FWD, variações nos níveis de pico de força aplicado (Figura 3.7 (B)) são obtidos com a variação da magnitude da massa e da altura de queda desta.

\subsubsection{1 - Dynatest FWD}

O Dynatest FWD 8000 é o equipamento mais utilizado nos Estados Unidos, a força de impulso é criada por um conjunto de massas que pode ser de: $50,100,200$ ou $300 \mathrm{~kg}$, a partir do seguinte intervalo de alturas de queda deste conjunto: 2 a $38,1 \mathrm{~cm}$.

Com a variação da massa e da altura de queda, podem ser gerados valores para o pico de força de 680 a $12.247 \mathrm{~kg}$ (dependendo do modelo do FWD). A carga é transmitida ao pavimento por uma placa circular de $30 \mathrm{~cm}$ de diâmetro, sendo a duração do pulso de carga entre 25 a 30 ms. A Figura 3.8 ilustra o FWD 8000. 


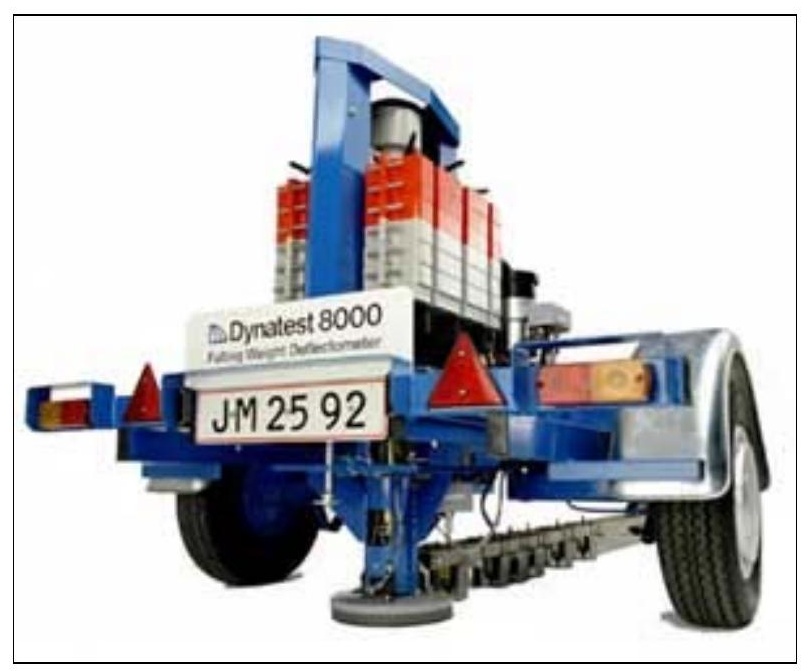

Figura 3.8 - Dynatest FWD 8000 (www.dynatest.com/hardware/fwd hwd.htm) acesso em 22/11/05.

As deflexões são medidas por sete transdutores de velocidade, sendo o primeiro localizado no centro da placa e o último podendo ser posicionado até 2,25 m do centro da placa. O equipamento é completamente automatizado, sendo operado integralmente do assento do motorista.

\subsubsection{2 - KUAB FWD}

Com origem na Suécia, a força de impulso é gerada por um sistema duplo de carga, sendo ajustável na massa e altura de queda, a amplitude da força criada pode variar de 1223 a $15875 \mathrm{~kg}$. A carga é transferida por uma placa circular segmentada de $30 \mathrm{~cm}$ de diâmetro e as medidas lidas por cinco transdutores de deflexão (sismógrafos), este equipamento também possui automatização integral. Este equipamento é mostrado na Figura 3.9.

O sistema duplo de cargas (massas 1 e 2 da Figura 3.10) cria um pulso de carga mais largo (maior tempo) do que os outros equipamentos FWD, representando melhor a duração de tensões criada por caminhões. A placa de carga segmentada fornece contato com o pavimento. 


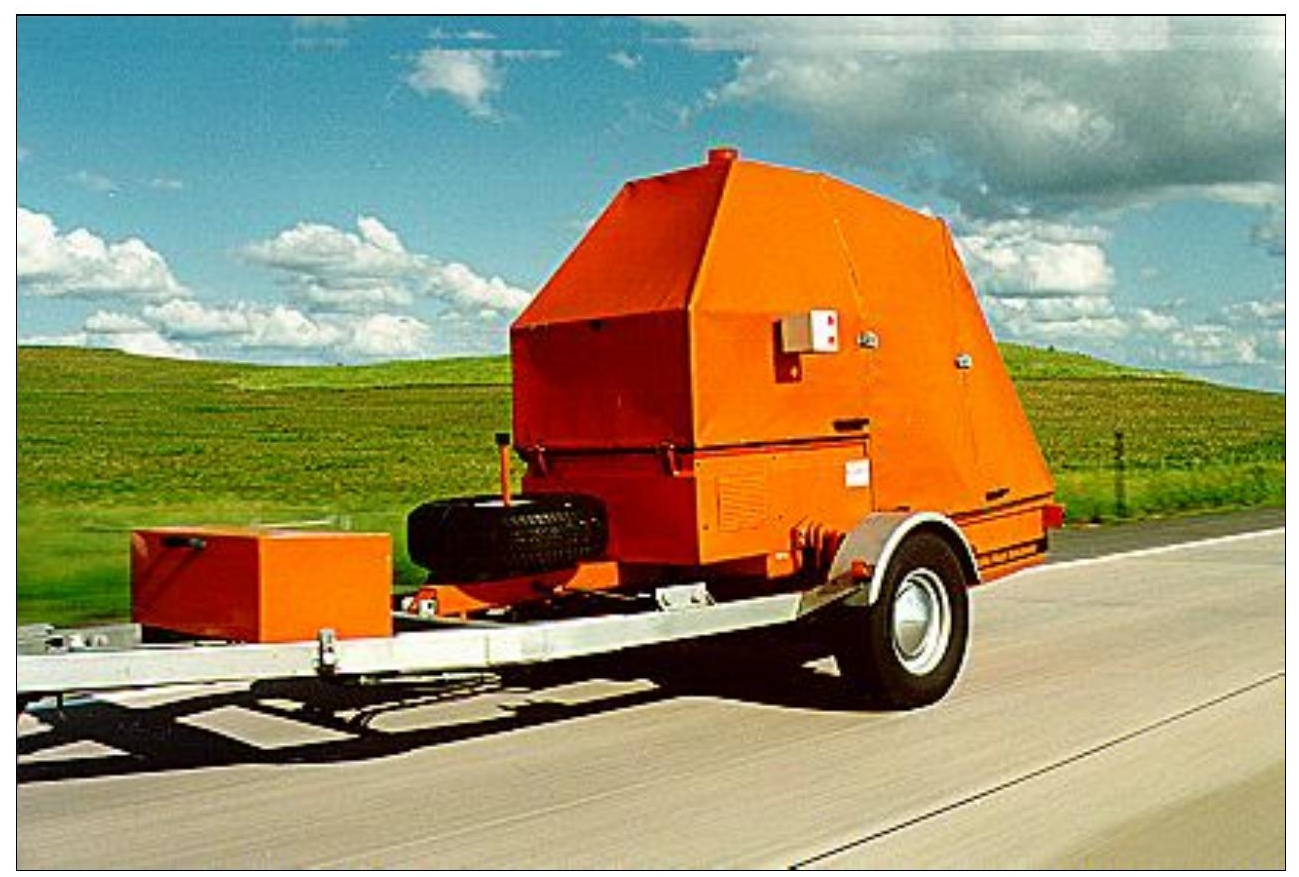

Figura 3.9 - KUAB FWD (http://www.erikuab.com/kuab.htm) acesso em 22/11/05.

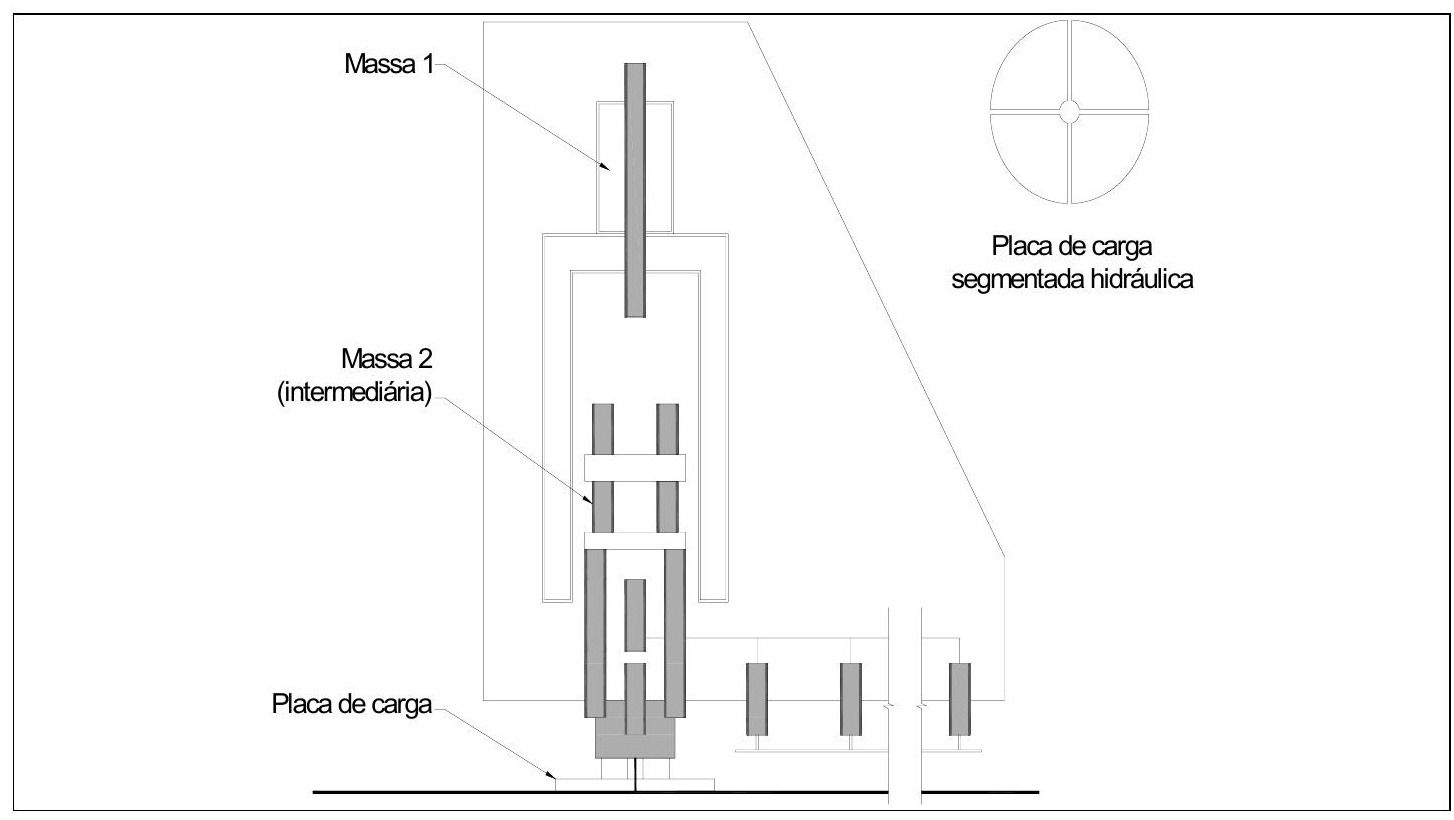

Figura 3.10 - Diagrama esquemático KUAB FWD (Haas, Hudson e Zaniewski 1994). 


\subsection{4 - Outros Equipamentos}

$\mathrm{Na}$ categoria de equipamentos caracterizados por carregamento estático podem ser citados o medidor de curvatura e o curviômetro. O medidor de curvatura não tem sido utilizado regularmente por agências rodoviárias na América do Norte; o curviômetro foi desenvolvido na França e apresenta resultados de medidas de deflexões bem correlacionados com a viga Benkelman (Haas, Hudson e Zaniewski, 1994).

O Phoenix FWD pertence aos equipamentos de aplicação de carga por impulso, sendo uma versão primitiva dos deflectômetros comercialmente disponíveis na Europa e nos Estados Unidos. Não disponível comercialmente, o Federal Highway Administration (FHWA) possui o Thumper formado por sofisticada tecnologia sendo classificado como um equipamento multimodo.

\section{3 - Considerações sobre equipamentos deflectométricos}

Smith e Lytton (1985) realizaram um estudo com a colaboração de diversas agências rodoviárias em todo o mundo, visando comparar características operacionais e satisfação do usuário com 0 uso de equipamentos não destrutivos comercialmente disponíveis.

Neste estudo, em relação ao rendimento de número de pontos testados por dia pelos equipamentos avaliados, a viga Benkelman apresentou o menor número de pontos medidos, em uma amplitude de 50 a 100 pontos diários. O deflectógrafo La Croix revelou ser o equipamento com maior rendimento, 1750 a 3250 pontos por dia. Para o restante dos outros equipamentos a amplitude situou-se entre 75 e 420 pontos diários.

As recomendações presentes no trabalho de Smith e Lytton são:

- A locação dos sensores de deflexão nos equipamentos como Dynaflect, road rater e FWD's deveria ser padronizada;

- Considerações devem ser fornecidas para padronizar o tamanho e a forma das placas de carregamento; 
- O tamanho do pneu e a pressão neste utilizada para caminhões usados como veículo de carga para a viga Benkelman deveria ser padronizado;

Tholen, Sharma e Terrel (1985) realizaram comparações de medidas deflectométricas entre FWD e os demais equipamentos (vibratórios, viga Benkelman) em várias estruturas de pavimentos na Escandinávia, revelando a significativa vantagem de utilização do FWD pelo fato de obtenção de medidas representativas do tráfego de carga em velocidades normais.

$\mathrm{Na}$ análise comparativa entre FWD's (sistema comum e sistema de duas massas) o sistema com duas massas (KUAB FWD) aparentou ter melhor precisão.

Medina et al. (1994) apresentam características, vantagens e limitações na utilização do FWD, descritas a seguir.

Tabela 3.1 - Características dos equipamentos FWD existentes no Brasil

\begin{tabular}{|c|c|c|}
\hline Características & Dynatest & KUAB \\
\hline Montagem & Trailer aberto & Trailer fechado \\
\hline Pulso de carga & $\begin{array}{l}\text { Queda de um conjunto } \\
\text { de massas }\end{array}$ & $\begin{array}{l}\text { Queda de dois } \\
\text { conjuntos de massas }\end{array}$ \\
\hline $\begin{array}{l}\text { Tempo de duração do } \\
\text { pulso }\end{array}$ & $30 \mathrm{~ms}$ & 34 a $50 \mathrm{~ms}$ \\
\hline Amortecimento & Colchões de borracha & \\
\hline Placa rígida de carga & $\varnothing 30 \mathrm{~cm}$ ou $\varnothing 45 \mathrm{~cm}$ & $\begin{array}{l}\text { Placa segmentada } \\
\text { em } 4 \text { partes unidas } \\
\text { por êmbolos }\end{array}$ \\
\hline $\begin{array}{l}\text { Ajuste à superfície do } \\
\text { pavimento }\end{array}$ & $\begin{array}{l}\text { Inclinação da placa em } \\
\text { até } 6^{\circ} \text { em relação à } \\
\text { horizontal }\end{array}$ & $\begin{array}{c}\text { Segmentação da } \\
\text { placa }\end{array}$ \\
\hline Força aplicada & $7 \mathrm{kN}$ a $111 \mathrm{kN}$ & $14 \mathrm{kN}$ a $150 \mathrm{kN}$ \\
\hline Medida de deflexão & 7 geofones & 7 sismômetros \\
\hline
\end{tabular}


Tabela 3.1 - Características dos equipamentos FWD existentes no Brasil (continuação)

\begin{tabular}{|l|c|c|}
\hline Características & Dynatest & KUAB \\
\hline Deflexão máxima & $2 \mathrm{~mm}$ & $5 \mathrm{~mm}$ \\
\hline Controle do ensaio & Automático & Automático \\
\hline Registro de temperatura & Sim & Sim \\
\hline Registro de carga & Sim & Sim \\
\hline Pontos ensaiados por dia & 500 a 700 & 500 a 700 \\
\hline
\end{tabular}

Fonte: Medina et al. (1994)

Vantagens na utilização do FWD:

- As deflexões produzidas são as que mais se aproximam das deflexões causadas por um caminhão carregado em movimento;

- A rapidez com que se pode variar a carga aplicada, além de agilizar o ensaio, permite avaliar a não-linearidade no comportamento tensão-deformação, dos materiais constituintes das camadas do pavimento;

- Acurácia e repetibilidade na medida das cargas e deflexões, em qualquer tipo de estrutura de pavimento;

- Medição e registro automático das temperaturas do ar e da superfície do pavimento e da distância percorrida entre os pontos de ensaio;

- Redução ou mesmo eliminação da necessidade de coletas de amostras para ensaios em laboratório.

Limitações na utilização do FWD:

- A existência de uma camada rígida, dependendo da profundidade, pode afetar a bacia de deflexão obtida e conseqüentemente a retroanálise dos módulos; esta limitação também se aplica a outros equipamentos não destrutivos de medidas de deflexões;

- A aceleração da carga do FWD é maior que a de uma carga de roda em movimento, de modo que a inércia da massa do pavimento pode desempenhar um papel importante para o FWD, enquanto que é desprezível para a roda em movimento; o que parece não afetar a 
boa concordância das deflexões medidas com o FWD com as medidas sob carga de roda.

- O FWD gera um sinal de carga transiente e o impulso gerado no pavimento cria ondas de corpo e ondas superficiais. Os sensores captam a velocidade vertical do movimento da superfície do pavimento e a partir da integração analógica dos sinais, obtém-se a resposta da deflexão "versus" tempo de cada sensor, sendo o tempo para completar esta operação de aproximadamente $100 \mathrm{~ms}$. Usualmente estes sinais são utilizados para extrair o pico de carga e os picos de deflexão em cada sensor de modo que a bacia de deflexões não é na verdade o que se observa durante o ensaio, pois há diferença de fase (phase lag) dos sinais dinâmicos captados pelos transdutores.

\section{4 - Fatores influentes em deflexões}

Os principais fatores que influenciam deflexões em pavimentos são: carga, clima e condições do pavimento (presença de trincas e deformações). Tais fatores devem ser cuidadosamente considerados na realização de avaliações não destrutivas.

\subsection{1 - Carga}

A magnitude e a duração do carregamento imposto ao pavimento têm grande influência nas deflexões. É desejável que o equipamento utilizado em avaliação não destrutiva tenha capacidade de aplicar a carga de projeto (4100 kgf por roda).

Nem todo equipamento não destrutivo disponível comercialmente é capaz de simular a carga de projeto, alguns podem simular a magnitude deste carregamento mas, não sua duração e freqüência. Dentro deste cenário, existe uma concordância da superioridade dos FWD's dentre os equipamentos de avaliação estrutural. 
O comportamento não linear da maioria dos materiais utilizados em pavimentação é responsável pela não proporcionalidade entre carga e deformações e extrapolações podem conduzir a erros significativos.

Equações de correlações entre medidas de diferentes equipamentos têm sido publicadas mas, em geral, não existe unicidade entre as mesmas. $\mathrm{Na}$ realidade estas são dependentes das estruturas ensaiadas, condições climáticas, modo de carregamento e metodologia de ensaio empregada. As correlações somente devem ser usadas com a devida compreensão nas quais foram desenvolvidas e com consciência de seus erros (Medina et al., 1994).

Hoffman e Thompson (1982) realizaram comparações entre deflexões medidas no estado norte americano de Illinois e apresentaram, dentre outras, as seguintes conclusões entre correlações dos equipamentos:

- Em geral, as deflexões medidas com a viga Benkelman não podem ser previstas com as deflexões do Road Rater;

- Deflexões medidas pelo Road Rater são significativamente diferentes (estatisticamente) das medidas com FWD, entretanto, as deflexões estão correlacionadas.

\subsection{2 - Clima}

Em pavimentos asfálticos as altas temperaturas diminuem a rigidez do revestimento e aumentam as medidas de deflexão. Em áreas onde o pavimento não está submetido a ciclos de congelamento / descongelamento, as deflexões máximas ocorrem geralmente nas estações úmidas; em áreas relativamente secas, o período das deflexões máximas pode ocorrer no verão quando a superfície asfáltica recebe intensa radiação solar.

A hora do dia e a estação do ano em que foram feitas as medidas são importantes para comparar e interpretá-las. Em geral, as medidas são corrigidas para uma temperatura padrão. 
No Brasil, de 1979 a 1984 o Instituto de Pesquisas Rodoviárias conduziu em 53 seções de estradas de 10 estados diferentes, um projeto denominado P.A.E.P com o propósito de elaborar novas reabilitações e métodos de projeto de recapeamento para pavimentos flexíveis.

O projeto P.A.E.P. não alcançou uma relação única entre as variações sazonais e diárias da temperatura do pavimento com as deflexões medidas pela viga Benkelman, que poderia ser utilizada em projetos de recapeamento. Somente em $4 \%$ das seções foi possível recomendar correções de temperatura para medidas de deflexão (Medina e Motta, 1989). 


\section{Capítulo 4 - Retroanálise em pavimentos flexíveis}

Em laboratórios, os ensaios especiais dinâmicos fornecem o módulo de resiliência de pavimentos (novos ou existentes). Os módulos de resiliência dos materiais ou de um conjunto de materiais também pode ser estimado a partir de procedimentos analíticos sem a necessidade de coleta de amostras em campo (avaliação não destrutiva).

Este procedimento de estimativa de módulo resiliente com base em avaliações não destrutivas é denominado retroanálise. A utilização da retroanálise está presente em diversas áreas da engenharia. Dentro do contexto específico de pavimentação, o processo de retroanálise das camadas e subleito do pavimento é baseado na interpretação da magnitude e forma das bacias de deflexão fornecidas pelos equipamentos deflectométricos.

A resposta estrutural de um pavimento à solicitação de um carregamento depende de muitos fatores, dentre eles, das relações tensão-deformação dos vários materiais que o compõem, da intensidade, do modo, da duração e da freqüência de aplicação desse carregamento e ainda de aspectos extrínsecos como temperatura, umidade, etc.

Geralmente o pavimento é representado por uma estrutura multicamada que permite a simulação do comportamento de materiais elásticos, lineares ou não, visco-elásticos e/ou plásticos, submetidos à ação de um ou mais carregamentos e utilizam processos baseados em diferenças finitas, camadas finitas ou elementos finitos para a resolução das equações.

Stolle (1989) aborda a questão da não unicidade da resposta e da importância do condicionamento inicial do problema em retroanálise de pavimentos flexíveis, utilizando dois exemplos de geometria de problemas em 
retroanálise simplificados: viga em balanço e Fundação Winkler, ilustrados na Figura 4.1.

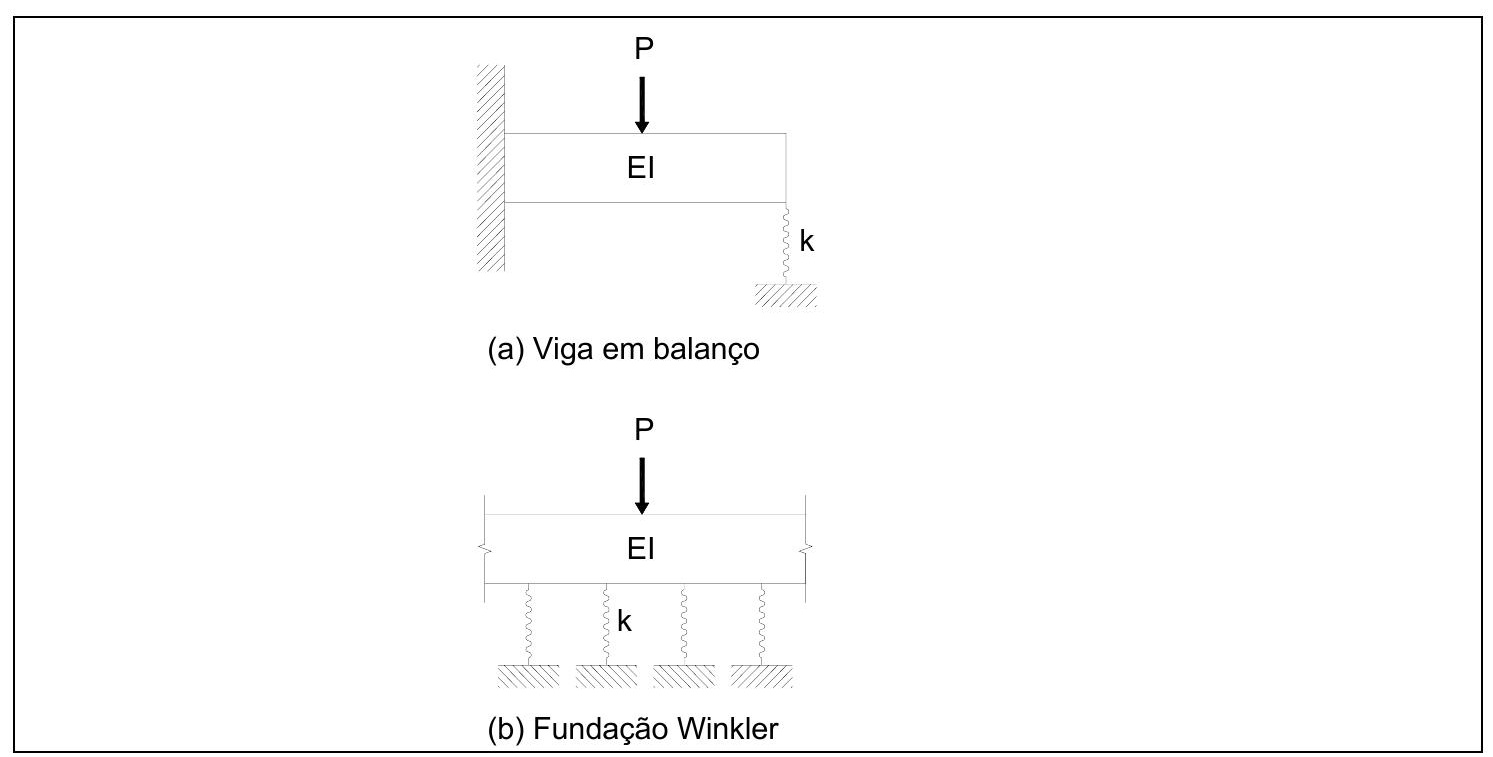

Figura 4.1 - Representações simplificadas de problemas de retroanálise

A viga representada em (a) na Figura 4.1 apresenta uma extremidade engastada e um apoio com mola de rigidez $\mathrm{k}$. A rigidez da viga é dada por El e o carregamento $P$ aplica-se ao seu ponto médio. Este sistema tem 1 grau de indeterminação e para carga e comprimento unitários, os deslocamentos no vão central $\left(d_{1}\right)$ e no apoio elástico $\left(d_{2}\right)$ em função dos parâmetros de rigidez, são dados por:

$$
\left[\begin{array}{cc}
2 d_{1} & 5 d_{2} \\
6 d_{2} & 16 d_{2}
\end{array}\right]\left\{\begin{array}{c}
E I \\
k
\end{array}\right\}=\left\{\begin{array}{l}
1 \\
5
\end{array}\right\}
$$

Para valores da rigidez $(\mathrm{EI})$ da viga muito superiores à rigidez da mola (k), a expressão (4.1) é bem condicionada. Para valores elevados de k, a expressão (4.1) torna-se mal condicionada, ou seja, uma pequena mudança nos deslocamentos pode resultar em grandes alterações nas previsões de rigidez. 
Consequentemente, se uma resolução iterativa fosse utilizada para se obter uma solução, a convergência seria lenta e mesmo que a convergência fosse precisa, o processo poderia não convergir para uma solução adequada.

Na fundação tipo Winkler representada na Figura 4.1 (b), a solução do problema por unidade de largura é obtida por:

$$
w(x)=w_{0} e^{-\lambda x} \operatorname{sen}(\lambda x+\pi / 4)
$$

Para:

$$
\begin{aligned}
& \mathrm{w}_{0}=\sqrt{2} \mathrm{P} \lambda / \mathrm{k} ; \mathrm{e} \\
& \lambda=\sqrt[4]{\mathrm{k} /(4 E I)}
\end{aligned}
$$

Devido à indeterminação associada a este problema, ou seja, apoio contínuo, o problema inverso envolve a determinação da solução para uma equação não-linear. Examinando a natureza periódica da expressão (4.2), pode ser mostrado que o problema inverso admite um valor para $\lambda$ desde que as medidas de deslocamentos respeitem, aproximadamente, $\lambda x<3 \pi / 4$.

Para $\lambda x>3 \pi / 4$, a função definida para a equação (4.2) oscila com pequenas amplitudes em relação ao eixo e o resultado para o problema inverso, envolvendo medidas de deslocamentos desta região é não único e pobremente condicionado, ou seja, a taxa de convergência para a solução é lenta e a solução em si é muito sensível a pequenas mudanças nas medidas de deflexões.

Lytton (1989) atribui o primeiro método de retroanálise a F. H. Scrivner ${ }^{1}$, que apresentou uma solução restrita para pavimentos compostos por duas camadas e com coeficientes de Poisson das camadas iguais a 0,5.

\footnotetext{
${ }^{1}$ Scrivner, F. H.; Michalak, C. H. and Moore, W. M. (1973) - Calculation of the Elastic Moduli of a Two-Layer Pavement System from Measured Surface Deflection - Highway Research Record $n^{\circ} 431$, Highway Research Board, Washington, DC.
} 
A equação utilizada por Scrivner foi desenvolvida a partir das equações de Burmister (1943):

$$
\frac{4 \pi w r}{3 p} E_{1}=1+\int_{0}^{10 r / h}(v-1) J_{0}(x) d x
$$

Onde:

$E_{1}$ - Módulo de elasticidade da camada da superfície;

w - Deflexão na superfície a uma distância radial (r) da carga aplicada (p);

h - Espessura da camada de superfície;

$\mathrm{J}_{0}(\mathrm{x})$ - Função Bessel de ordem zero;

$x=\mathrm{mr} / \mathrm{h}$, onde $\mathrm{m}$ é uma variável contínua de integração;

$v=\left(1+4 N e^{-2 m}-N^{2} e^{-4 m}\right) /\left[1-2 N(1+2 m) e^{-2 m}+N^{2} e^{-4 m}\right] ; e$

$N=\left(E_{1}-E_{2}\right) /\left(E_{1}+E_{2}\right)$.

O mesmo autor apresenta um fluxograma (Figura 4.2) de aspectos comuns encontrados na maioria dos métodos computacionais em uso para retroanálise de pavimentos.

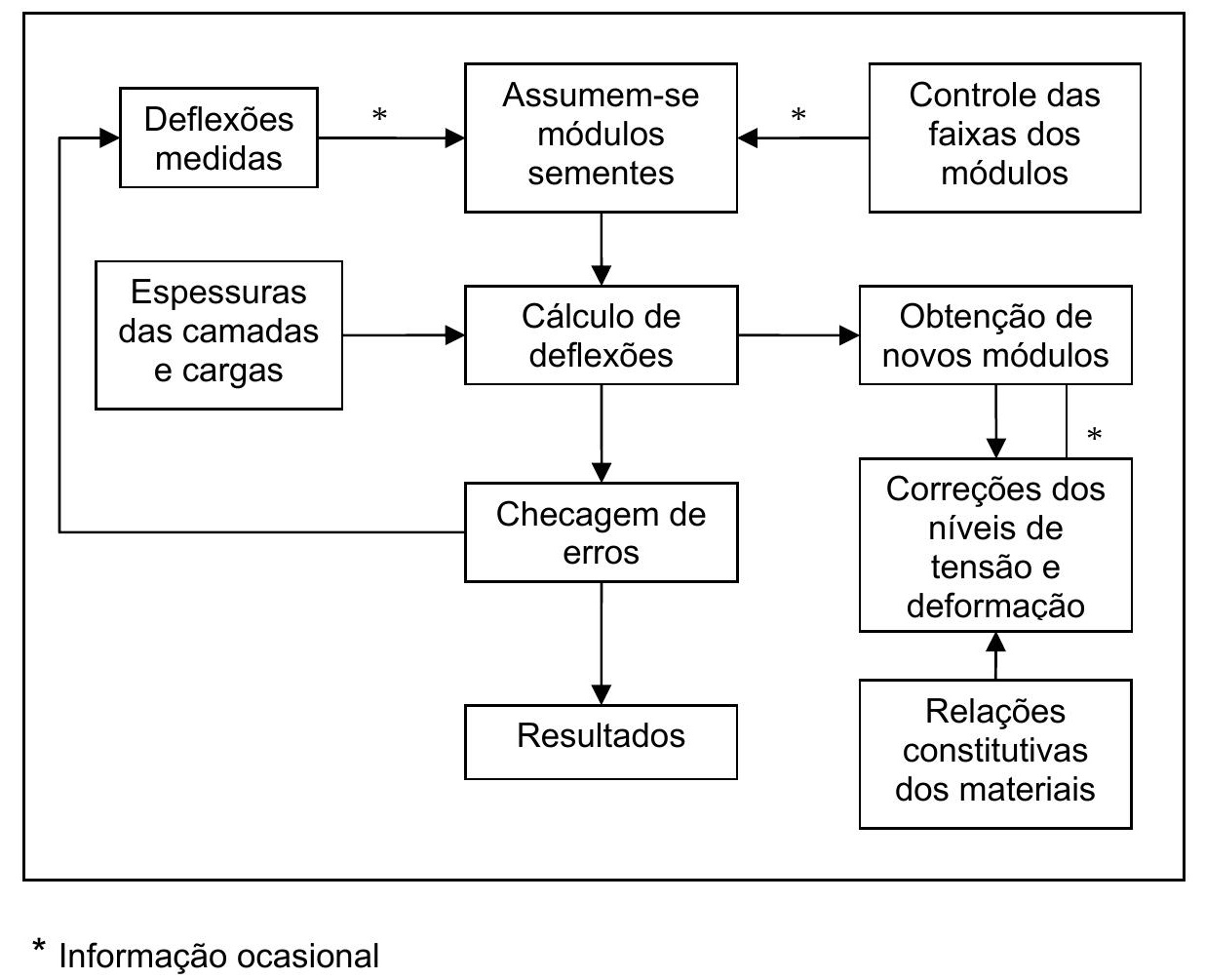

Figura 4.2 - Aspectos comuns aos métodos computacionais para retroanálise 
Irwin (2002) atribui a atual popularidade da retroanálise a três importantes avanços no campo da engenharia de pavimentos:

- A correspondência existente entre pavimentos com boas condições estruturais e as baixas deflexões e pavimentos estruturalmente debilitados com deflexões elevadas, relacionando o desempenho do pavimento com as deflexões (conceito desenvolvido entre os períodos de 1935 e 1960).

- O desenvolvimento de teorias mecanísticas que retratam as propriedades fundamentais dos materiais em relação às tensões, deformações e deslocamentos em sistemas de camadas (19401970).

- O desenvolvimento de equipamentos de medidas de deflexões portáteis, precisos e acessíveis (1955-1980).

A retroanálise em pavimentos utiliza os conceitos gerais da Teoria da Elasticidade aplicada aos sistemas em camadas, cuja formulação está baseada na teoria original de Boussinesq ${ }^{2}$ e nos estudos complementares de Barber ${ }^{3}$, Burmister ${ }^{4}$, Odemark ${ }^{5}$ e outros pesquisadores.

${ }^{2}$ Boussinesq, J. (1885) - Application des potentials à l'étude de l'equilibre et du mouvement des solides elastiques - Gauthier-Villars.

${ }^{3}$ Barber, E. S. (1940) - Discussion - HRB, Proc. - Vol. 20.

${ }^{4}$ Burmister, D. M. (1943) - The theory of stresses and displacements in layered systems and application to the design of airports runway - HRB, Proc.

${ }^{5}$ Odemark, N. (1949) - Investigations as to the elastic properties of soils and design of pavements according to the theory of elasticity - HRB, Proc. - Vol. 20. 


\section{1 - Aspectos gerais dos métodos existentes}

A obtenção dos módulos de resiliência por retroanálise das camadas componentes do pavimento baseia-se na interpretação do deslocamento da superfície do pavimento quando submetida a um carregamento (bacia de deformação).

Harichandran, Raab e Baladi (1993) classificam genericamente os métodos de retroanálise existentes em dois grupos: métodos iterativos e métodos simplificados.

\subsection{1 - Métodos iterativos}

Apresentam, em linhas gerais, os seguintes dados de entrada:

a) Coordenadas dos pontos da bacia de deflexão medidas em campo;

b) A quantidade e as espessuras das camadas do sistema;

c) O intervalo provável da variação dos módulos das camadas do pavimento e subleito;

d) A profundidade e o módulo de uma camada rígida no subleito;

e) Os valores dos módulos iniciais de cálculo (seed moduli);

f) Valores padrões para o coeficiente de Poisson.

Os métodos iterativos são compostos de formulação matemática complexa e processos de convergência, confeccionando-lhes boa precisão porém, alto tempo para processamento. São utilizadas como algoritmo nos métodos iterativos a Teoria das Multicamadas Elásticas e o Método dos Elementos Finitos.

A retroanálise pode ser processada de três maneiras distintas pelos métodos iterativos: cálculos durante o processo, utilização de banco de dados e regressão estatística. 


\subsubsection{1 - Cálculos durante o processo}

Durante a rotina de execução de um algoritmo computacional, a bacia de deslocamento medida em campo é comparada com bacias geradas iterativamente por programas de análise mecanística. O processo encerra-se quando a semelhança entre as duas bacias estiver dentro de um critério de aceitação.

O critério de aceitação, ou seja, a discrepância entre os valores medidos em campo pelos equipamentos e os valores obtidos por programas, é formado por uma função critério.

A otimização do processo consiste em minimizar o valor da função critério. A seleção da função critério pode influenciar significativamente a precisão e a eficiência do processo de otimização.

Sivaneswaran, Kramer e Mahoney (1991) apresentam as seguintes funções critério para retroanálise em pavimentos com $\mathrm{M}$ camadas e $n$ medidas de deflexão:

- Somatório das diferenças absolutas:

$$
f(E, h)=\frac{1}{n} \sum_{i=1}^{n}\left|d_{i}^{c}(E, h)-d_{i}^{m}\right|
$$

- Somatório das diferenças relativas absolutas:

$$
f(E, h)=\frac{1}{n} \sum_{i=1}^{n}\left|\frac{d_{i}^{c}(E, h)-d_{i}^{m}}{d_{i}^{m}}\right|
$$

- Somatório das diferenças quadradas:

$$
f(E, h)=\frac{1}{n} \sum_{i=1}^{n}\left[d_{i}^{c}(E, h)-d_{i}^{m}\right]^{2}
$$


- Somatório das diferenças relativas quadradas:

$$
f(E, h)=\frac{1}{n} \sum_{i=1}^{n}\left[\frac{d_{i}^{c}(E, h)-d_{i}^{m}}{d_{i}^{m}}\right]^{2}
$$

sendo,

$d_{i}^{c}(E, h)$ - deflexões calculadas na posição $i$ baseado em $E$ e $h$;

$\mathrm{E}-\left\{E_{1}, E_{2}, E_{3}, \ldots, E_{n}\right\}$ módulos desconhecidos das camadas;

$\mathrm{h}-\left\{h_{1}, h_{2}, h_{3}, \ldots, h_{n}\right\}$ espessuras desconhecidas das camadas;

$d_{i}^{m}$ - deflexão medida na posição $i$.

Cada função critério referida acima tem suas próprias vantagens e desvantagens. As funções (4.4) e (4.5) não apresentam inclinação contínua e conseqüentemente, as técnicas de otimização que utilizam informação da derivada primeira (tanto analítica ou numérica) não podem ser usadas para estimação.

Esta é a principal desvantagem pois, métodos de otimização que utilizam informação da derivada primeira possuem performance maior do que os métodos que utilizam somente valores de funções.

\subsubsection{2 - Utilização de banco de dados}

A diferença do procedimento anterior está na comparação da bacia de campo com bacias previamente calculadas e armazenadas em um banco de dados.

\subsubsection{3 - Regressão estatística}

Utilizam fórmulas obtidas por regressão estatística para o cálculo das deflexões teóricas em pontos escolhidos da bacia de deformação. A solução é alcançada quando a diferença entre as bacias teórica e medida atinge um erro pré estabelecido. 


\subsection{2 - Métodos simplificados}

Estimam-se os módulos do sistema pavimento/subleito tendo como base gráficos, tabelas e aplicações diretas de equações obtidas a partir da Teoria da Elasticidade. São úteis em análises preliminares e anteprojetos pois, devido à sua relativa simplificação, perdem precisão mas, são rápidos para processamento.

O Método da AASHTO (American Association of State Highway and Transportation Officials), o Método de A. S. Noureldin e o Método de Albernaz descritos a seguir exemplificam os Métodos simplificados.

\subsubsection{1 - Método da AASHTO (AASHTO, 1993)}

Neste procedimento simplificado de retroanálise de pavimentos, estimase o módulo resiliente do subleito $\left(M_{R}\right)$ e um módulo equivalente $\left(E_{p}\right)$ para as outras camadas componentes do sistema (revestimento+base+sub-base).

Os dados necessários na utilização do método são:

- As deflexões medidas $\left(d_{i}\right)$ localizadas em pontos a uma distância $\left(r_{i}\right)$ do ponto de aplicação de carga;

- A pressão e o raio da área de contato do carregamento;

- A espessura total do pavimento acima do subleito.

Para o cálculo do módulo do subleito utiliza-se a expressão:

$$
M_{R}=\frac{0,24 P}{d_{i} \cdot r_{i}}
$$

Recomendações da AASHTO indicam que o produto presente no denominador da expressão (4.8), seja aproximadamente igual a $70 \%$ do valor do raio do bulbo de tensões $\left(a_{c}\right)$, determinado por:

$$
\left.a_{C}=\sqrt{\left[a^{2}+\left(D \sqrt[3]{E_{p} / M_{R}}\right)^{2}\right.}\right]
$$


O módulo equivalente é obtido pela expressão (4.10) em um processo iterativo, até que o membro direito da equação seja igual à deflexão obtida sobre o ponto de aplicação de carga $\left(d_{0}\right)$.

$$
d_{0}=1,5 p a\left\{\frac{1}{M_{R} \sqrt{1+\left(\frac{D}{a} \sqrt[3]{E_{p} / M_{R}}\right)^{2}}}+\frac{\left[1-\frac{1}{\sqrt{1+(D / a)^{2}}}\right]}{E_{p}}\right\}
$$

As variáveis envolvidas no processo são:

D - espessura total das camadas sobre o subleito;

P - carga aplicada sobre a área circular;

a - raio da área circular de distribuição de carga;

$\mathrm{p}$ - pressão de contato.

O Método da AASHTO recomenda que as deflexões máximas medidas em diversas temperaturas, sejam ajustadas a uma temperatura padrão de referência $\left(20^{\circ} \mathrm{C}\right)$ para efeitos de normalização dos valores dos módulos efetivos do pavimento $\left(E_{p}\right)$ e execução de comparações dos módulos ao longo do trecho em estudo. Tal procedimento de ajuste de medidas é feito com auxílio de gráficos exibidos no guia.

\subsubsection{2 - Método de A. S. Noureldin (Noureldin, 1993)}

Baseado na análise elástica de duas camadas, este procedimento simplificado aplica-se em bacias de deformações obtidas pelo equipamento deflectométrico FWD (Falling Weight Deflectometer) com aplicação de carga de $4.082 \mathrm{~kg}(9.000 \mathrm{lb})$.

Os deslocamentos $D_{0}, D_{1}, D_{2}, \ldots, D_{6}$ emergentes no pavimento provenientes da aplicação desta carga, são captados por sete geofones distanciados a $0, r_{1}, r_{2}, r_{3}, \ldots, r_{6}$ do centro de aplicação da mesma. 
O conceito característico deste método, ilustrado na Figura 4.3, consiste na existência de uma posição única na superfície do pavimento, distanciada $r_{x}$ do ponto de aplicação de carga, cuja deflexão $D_{x}$ é exatamente a mesma deflexão de um ponto na superfície do subleito localizado no eixo vertical de aplicação da carga.

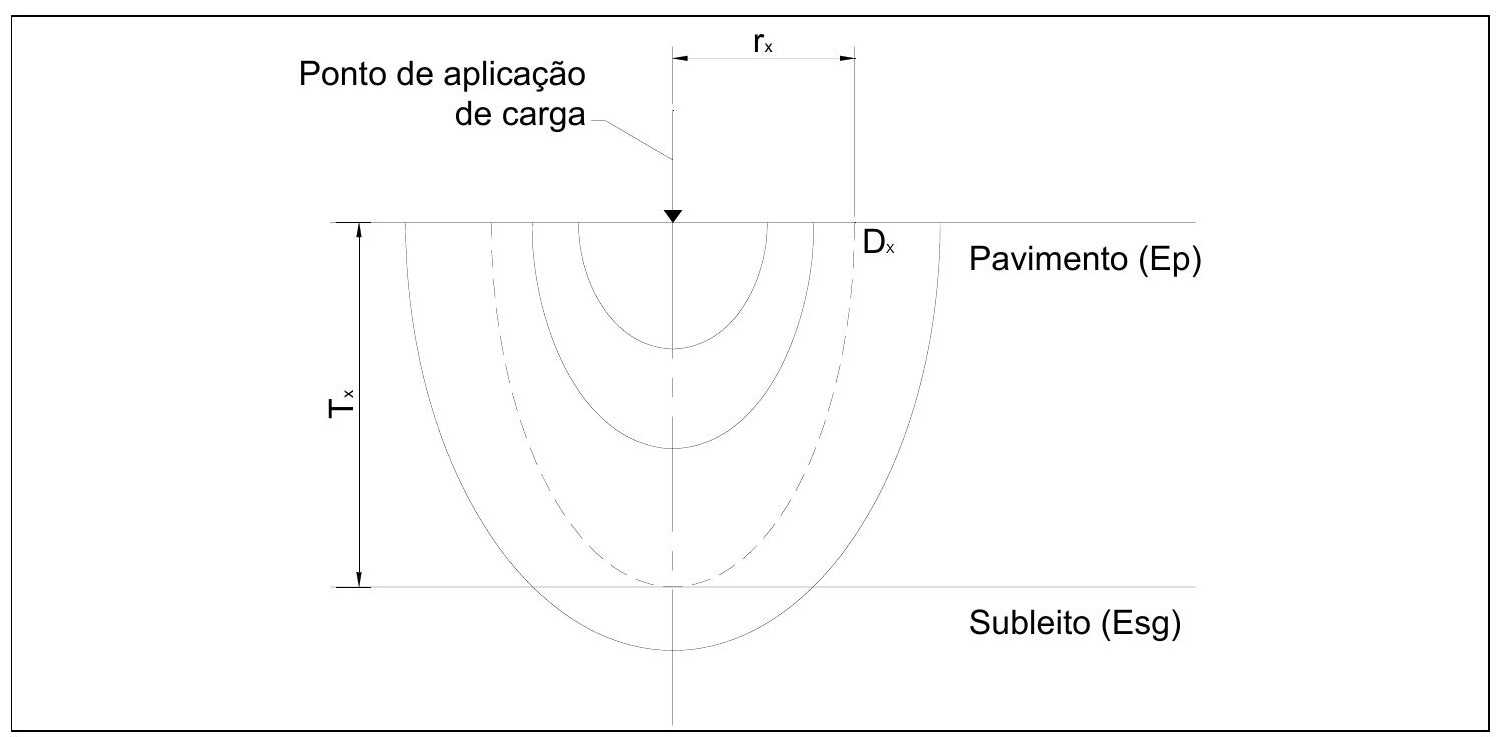

Figura 4.3 - Superfícies de mesma deformação vertical em um pavimento (Noureldin, 1993).

O procedimento para pavimentos com espessuras conhecidas é descrito pelos passos 1, 2 e 3 abaixo.

1) Determinar o módulo resiliente do subleito $\left(E_{s g}\right)$ pela expressão:

$$
E_{s g}=\frac{2,149}{r_{x} \cdot D_{x}}
$$

Para,

$r_{x}$ - distância do geofone mais externo em polegadas;

$D_{x}$ - deflexão do geofone mais externo em polegadas;

$E_{s g}$ - módulo de resiliência do subleito (psi).

2) O módulo equivalente do pavimento $\left(E_{p}\right)$ é obtido por: 


$$
E_{p}=\frac{716-\frac{2,149}{r_{x}}}{D_{0}-D_{x}}
$$

Para $D_{0}$ representando a deflexão (em polegadas) sob o eixo de aplicação de carga.

3) Determina-se a espessura total efetiva $\left(T_{x}\right)$ pela equação:

$$
T_{x}=\left[\frac{D_{0}-D_{x}}{D_{x}\left(\frac{r_{x}}{3}-1\right)}\right]^{1 / 3}\left(4 r_{x}{ }^{2}-36\right)^{\frac{1}{2}}
$$

Repetir os passos de 1 a 3 com o intervalo das deflexões de $D_{1}$ a $D_{5}$ e com o raio variando de $r_{1}$ a $r_{5}$ para a elaboração dos gráficos da Figura 4.4.

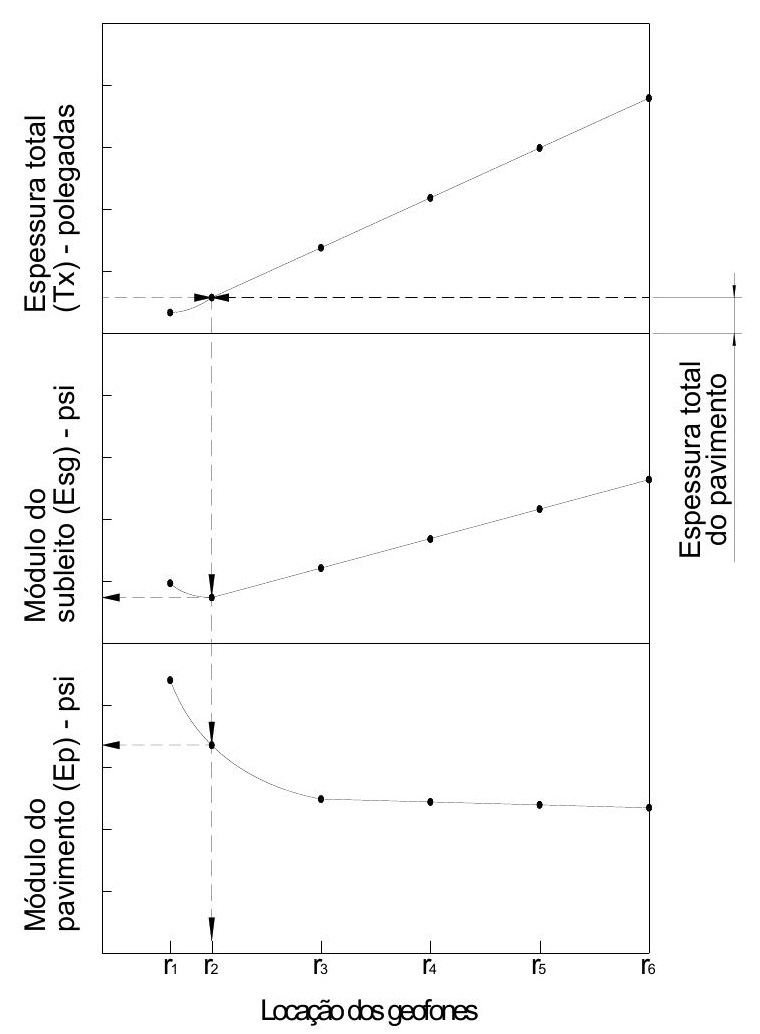

Figura 4.4 - Determinação dos módulos $E_{p}$ e $E_{s g}$

Os valores dos módulos resilientes do subleito e do pavimento são obtidos graficamente através da entrada da espessura total do pavimento e suas interseções com os gráficos obtidos pelas expressões (4.11) a (4.13), procedimento simulado pelas linhas tracejadas da Figura 4.4. 
Quando a espessura do pavimento não é conhecida, utiliza-se o maior produto entre os dados $r_{x} \times D_{x}$ existentes. Obtido o máximo valor $r_{x} \times D_{x}, 0$ procedimento é idêntico ao utilizado em pavimentos com espessuras conhecidas.

\subsubsection{3 - Método de Albernaz}

Albernaz (1994) realizou uma adaptação no Método original de Noureldin, adaptando-o para os resultados de um ensaio de viga Benkelman.

A razão desta adaptação está no predomínio do uso e grande acervo de dados obtidos com a viga no Brasil. Adotando-se o critério de igualdade das bacias de deslocamentos e com análise paramétrica pelo programa ELSYM5, as expressões resultantes são apresentadas abaixo.

1) Módulo resiliente do subleito $\left(E_{s g}\right)$ :

$$
E_{s g}=\frac{1,193}{r_{x} \cdot D_{x}}
$$

Para,

$r_{x}$ - distância radial a partir do ponto de aplicação da carga até o ponto considerado $(\mathrm{cm})$;

$D_{x}$ - deflexão correspondente ao ponto situado à distância radial $r_{x}(\mathrm{~cm})$;

$E_{s g}$ - módulo de resiliência do subleito $\left(\mathrm{kgf} / \mathrm{cm}^{2}\right)$.

2) Módulo equivalente do pavimento $\left(E_{p}\right)$ :

$$
E_{p}=\frac{142-\frac{1,193}{r_{x}}}{D_{0}-D_{x}}
$$

Para $D_{0}$ representa a deflexão (em centímetros) sob o eixo de aplicação de carga.

3) Espessura total efetiva $\left(T_{x}\right)$ : 


$$
T_{x}=1,364\left[\frac{D_{0}-D_{x}}{D_{x}\left(\frac{r_{x}}{3,3}-2,54\right)}\right]^{1 / 3}\left(4 r_{x}{ }^{2}-282,3\right)^{\frac{1}{2}}
$$

A rotina de cálculo é análoga ao Método original, compreendendo as situações de espessuras do pavimento conhecidas e não conhecidas.

Através de estudo de caso na rodovia MG-188, (Albernaz, 1994) revela que o Método de Noureldin modificado para o carregamento com a viga Benkelman, apresenta excelente potencial de aplicação em análises de pavimentos para fins de anteprojeto, análises estruturais preliminares e gerência de pavimentos.

\subsection{3 - Redes Neurais Artificiais}

Além dos processos iterativos e simplificados exemplificados anteriormente, existem técnicas mais recentes para a elaboração de retroanálise em pavimentos flexíveis tais como as redes neurais artificiais (RNAs).

As RNAs são ferramentas potentes para solucionar problemas que envolvem reconhecimento de padrões, classificação e mapeamento, estando presentes em várias pesquisas na área de engenharia de transportes.

Coutinho Neto (2000) aplicou a técnica das redes neurais artificiais para a retroanálise de pavimentos flexíveis de modo a atingir o objetivo eliminando a subjetividade na escolha dos seed moduli, redução da dificuldade e economia de tempo na realização da retroanálise utilizando-se métodos tradicionais.

$\mathrm{Na}$ pesquisa deste autor, foi utilizado um banco de dados de 35.472 bacias de deflexões geradas pelo programa ELSYM5, sendo 17.880 representando o carregamento proveniente do FWD e 17.592 simulando o carregamento com a viga Benkelman, foram elaborados modelos de regressão 
múltipla para estruturas de pavimentos compostas por duas, três e quatro camadas.

As Redes Neurais Artificiais apresentam um bom desempenho para a realização de retroanálise em pavimentos flexíveis de duas, três e quatro camadas, sendo o desempenho da Rede Neural proporcional ao tamanho da base de dados utilizada (Coutinho Neto, 2000).

\section{2 - Softwares existentes}

Segundo Sivaneswaran, Kramer e Mahoney (1991), para ser proveitoso aos engenheiros de pavimentos, um bom método de retroanálise deve possuir as seguintes características:

1) Apresentar precisão: o desempenho satisfatório do revestimento ou de qualquer outra atividade de reabilitação, depende da precisão na obtenção dos módulos das camadas. Um método de retroanálise confiável deve ser capaz de reconhecer e corrigir pequenos erros nos módulos das camadas, para desenvolver uma solução mais precisa.

2) Rapidez: decisões relevantes freqüentemente devem ser feitas rapidamente com base nos módulos retroanalisados das camadas. É importante permitir o processamento de uma grande quantidade de dados no menor tempo possível.

3) Robustez: o procedimento deve convergir para a solução correta, mesmo sobre circunstâncias difíceis. Tais circunstâncias têm origem em erros e dúvidas nas medidas resultantes de equipamentos.

Vários programas computacionais têm sido desenvolvidos para analisar os dados obtidos de equipamentos deflectométricos, especialmente para o FWD. Muitos deles foram padronizados com sufixo DEF (CHEVDEF, BISDEF), representando uma série de programas desenvolvidos pelo Corpo de Engenheiros do Exército dos Estados Unidos. 
Estes programas empregam uma técnica de procura gradiente por iteração em direção ao módulo correto das camadas. Na formulação usada nestes programas, uma aproximação sucessiva linear dos mínimos quadrados é utilizada, sendo vantajosa em relação parâmetros obtidos de modelos linearizados empiricamente.

A linearização dos parâmetros do modelo permite um sistema de equações simultâneas para ser resolvido para os módulos das camadas a cada iteração. Se os parâmetros são verdadeiramente lineares, somente uma iteração é necessária, entretanto, a linearização é somente aproximada e assim, sucessivas iterações são necessárias para se aproximar da solução correta.

O WESDEF é o último programa de retroanálise desenvolvido pelo "U.S. Army Engineer Waterways Experiment Station", sendo similar à versão prévia chamada CHVDEF. O CHVDEF usa o programa CHEV $n$-layer como subrotina. O WESDEF contém uma rotina de otimização computacional para determinar um conjunto de valores de módulos que fornecem o melhor ajuste entre a bacia de deflexão medida e a bacia de deflexão computada.

Três iterações do programa podem gerar um conjunto de valores de módulos que produzem uma bacia de deflexão dentro de uma precisão de $3 \%$. As iterações vão sendo cessadas quando a soma absoluta das diferenças percentuais entre as bacias medidas e computadas, ou alterações nos valores dos módulos previstos tornam-se menores que $10 \%$.

O EVERCALC baseia-se no programa Chevron $n$-layer e utiliza um procedimento iterativo de ajuste entre as deflexões medidas na superfície com as deflexões teoricamente calculadas na mesma. O programa encontra uma solução quando a soma dos valores absolutos das diferenças entre as deflexões medidas e teóricas da superfície atingem uma tolerância préestabelecida, geralmente $10 \%$. 
Regressões internas são utilizadas no EVERCALC para se estimar os módulos iniciais (seed moduli), estas regressões são algoritmos desenvolvidos utilizando o módulo do pavimento, carga e vários tipos de parâmetros de bacia de deflexão.

Para o programa MODULUS, que foi desenvolvido na Universidade do Texas $A \& M$, inicialmente, é computada uma série de bacias de deflexões normalizadas usando o programa BISAR (Bitumen Stress Analysis on Roads) com módulos das camadas em uma faixa de variação que contenha os módulos a serem obtidos. O número de bacias de deflexão normalizadas aumenta rapidamente com o número de parâmetros desconhecidos em retroanálise. As bacias de deflexão são armazenadas em um banco de dados para posterior comparação com as bacias medidas.

A maioria dos programas baseia-se na Teoria de Camadas Elásticas Lineares, ou em algumas variações desta Teoria para o modelo estrutural básico. Para comparar resultados gerados pelos programas, o primeiro critério usado para o cálculo da precisão é baseado na qualidade do ajuste entre as deflexões computadas e deflexões medidas.

Em muitos casos, a melhora da qualidade do ajuste entre bacias teóricas e reais não significa necessariamente que o modelo teórico obtido representa as melhores respostas do pavimento. Se a estrutura de um pavimento existente claramente viola uma hipótese fundamental da Teoria da Elasticidade, então, um bom ajuste entre as deflexões medidas e calculadas não é esperado e a qualidade do ajuste pode não ser um fator determinante para decidir se a solução é realística ou não. 
Deve-se destacar que todos os pavimentos não são na realidade perfeitamente elásticos. Ullidtz e Coetzee (1995) apud Lytton ${ }^{6}$ apontam a necessidade de experiência com materiais e deflexões para que o processo de retroanálise forneça um conjunto de módulos aceitáveis para uma dada bacia de deflexão.

Uzan (1994) expressa a opinião de que qualquer programa deve ser verificado antes do uso. Mesmo assim, não há garantias corretas para todas as condições as quais o programa não foi verificado.

Wang (1993) desenvolveu um método de retroanálise baseado no esquema de identificação de sistemas (SID - System Identification) objetivando estimar os módulos resilientes das camadas que compõem o pavimento e também as espessuras das camadas. Um esquema de identificação de sistemas utilizando aproximação "forward" e um algoritmo de ajustes de parâmetros é representado na Figura 4.5.

Em uma aproximação "forward" o modelo e o sistema a ser identificado trabalham com as mesmas entradas fornecidas e o erro de saída entre os dois processos é minimizado.

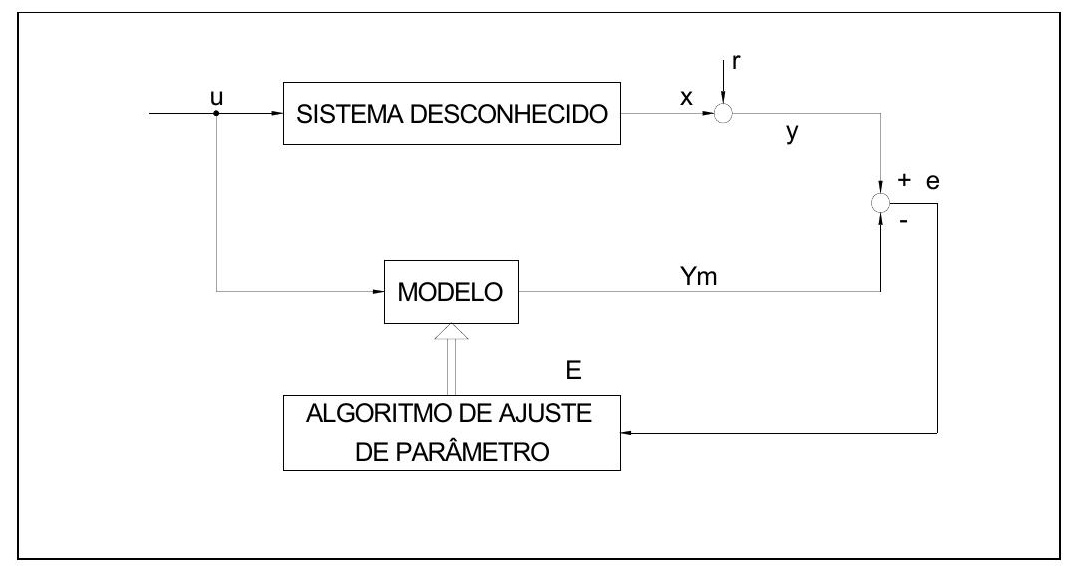

Figura 4.5 - Identificação de sistema, aproximação "forward" (Wang 1993).

\footnotetext{
${ }^{6}$ Lytton, R. L. (1988) - Backcalculation of pavement layer properties - ASTM STP1026, ASTM.
} 
O Programa elaborado por Wang denomina-se SID, sendo utilizado com as bacias deflectométricas fornecidas pelo programa BISAR. Uma seção de pavimento flexível real foi analisada para comparação dos resultados entre SID e outros programas existentes, sendo os resultados mostrados na Tabela 4.1.

Tabela 4.1 - Sumário de módulos retroanalisados $\left(\mathrm{kgf} / \mathrm{cm}^{2}\right)$

\begin{tabular}{|c|c|c|c|c|}
\hline Seção & Programa & Revestimento & Base & Subleito \\
\hline \multirow{4}{*}{1} & BISDEF & 13652 & 1776 & 809 \\
\cline { 2 - 5 } & BOUSDEF & 11470 & 1809 & 788 \\
\cline { 2 - 5 } & CHEVDEF & 12371 & 1738 & 851 \\
\cline { 2 - 5 } & ELSDEF & 14074 & 1661 & 823 \\
\cline { 2 - 5 } & MODCOMP2 & 11456 & 2350 & 739 \\
\cline { 2 - 5 } & SID & 15474 & 1527 & 809 \\
\hline \multirow{4}{*}{2} & BISDEF & 12223 & 1084 & 739 \\
\cline { 2 - 5 } & BOUSDEF & 11097 & 1070 & 697 \\
\cline { 2 - 5 } & CHEVDEF & 10605 & 1168 & 739 \\
\cline { 2 - 5 } & ELSDEF & 12244 & 1070 & 732 \\
\cline { 2 - 5 } & MODCOMP2 & 9254 & 1907 & 654 \\
\cline { 2 - 5 } & SID & 11498 & 1217 & 704 \\
\hline
\end{tabular}

Fonte: Wang (1993)

A não unicidade da solução também é destacada em Mahoney et al.(1989). Estes autores investigaram os resultados de retroanálises de bacias de deflexões, obtidas de ensaios de FWD, de cinco diferentes seções de pavimentos no Estado de Washington (EUA).

$\mathrm{Na}$ retroanálise foram utilizados cinco programas computacionais e resultados de ensaios laboratoriais. Os autores concluíram que nenhuma dessas técnicas pode ser considerada como "referência" e que elas apenas fornecem valores para comparações entre resultados.

A Tabela 4.2 apresenta os resultados encontrados por Mahoney et al. (1989). Todos os pavimentos retroanalisados eram compostos por três 
camadas e os módulos obtidos não foram ajustados para efeitos de temperatura ou de taxa de carregamento.

Tabela 4.2 - Resultados de retroanálises

\begin{tabular}{|c|c|c|c|c|}
\hline & $\begin{array}{l}\text { Método ou } \\
\text { Programa }\end{array}$ & $\begin{array}{c}\text { Revestimento } \\
\text { (MPa) }\end{array}$ & $\begin{array}{l}\text { Base } \\
\text { (MPa) }\end{array}$ & $\begin{array}{c}\text { Subleito } \\
\text { (MPa) }\end{array}$ \\
\hline \multirow{6}{*}{ 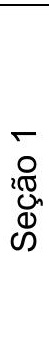 } & ELMOD & 3570 & 193 & 159 \\
\hline & ELSDEF & 3790 & 186 & 172 \\
\hline & EVERCALC & 5250 & 159 & 186 \\
\hline & ISSEM4 & 4080 & 172 & 193 \\
\hline & MODCOMP2 & 4730 & 152 & 200 \\
\hline & Laboratório & 2790 & 103 & 55 \\
\hline \multirow{6}{*}{ 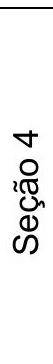 } & ELMOD & 2190 & 690 & 152 \\
\hline & ELSDEF & 4460 & 166 & 221 \\
\hline & EVERCALC & 4730 & 331 & 186 \\
\hline & ISSEM4 & 8690 & 179 & 186 \\
\hline & MODCOMP2 & 4720 & 310 & 186 \\
\hline & Laboratório & 1570 & 324 & 207 \\
\hline \multirow{6}{*}{ 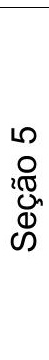 } & ELMOD & 2710 & 903 & 241 \\
\hline & ELSDEF & 800 & 841 & 276 \\
\hline & EVERCALC & 5770 & 276 & 248 \\
\hline & ISSEM4 & 7030 & 317 & 276 \\
\hline & MODCOMP2 & 4150 & 572 & 248 \\
\hline & Laboratório & 3360 & 193 & 200 \\
\hline \multirow{6}{*}{ 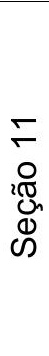 } & ELMOD & 2810 & 221 & 159 \\
\hline & ELSDEF & 4420 & 110 & 228 \\
\hline & EVERCALC & 4260 & 186 & 186 \\
\hline & ISSEM4 & 2760 & 207 & 166 \\
\hline & MODCOMP2 & 4710 & 97 & 234 \\
\hline & Laboratório & 3520 & 76 & 193 \\
\hline \multirow{6}{*}{$\begin{array}{l}\text { م) } \\
\text { o } \\
\text { జ్ } \\
\mathbb{1} \\
\infty\end{array}$} & ELMOD & 7920 & 324 & 124 \\
\hline & ELSDEF & 6890 & 48 & 344 \\
\hline & EVERCALC & 7370 & 269 & 131 \\
\hline & ISSEM4 & 6020 & 648 & 110 \\
\hline & MODCOMP2 & 6800 & 428 & 117 \\
\hline & Laboratório & 10900 & 69 & 110 \\
\hline
\end{tabular}

Fonte: Mahoney et al. (1989) 
Na Tabela 4.3 são mencionados alguns programas de retroanálise, em conjunto com o programa mecanístico utilizado e o método de processamento.

Tabela 4.3 - Programas de retroanálise

\begin{tabular}{|c|c|c|}
\hline $\begin{array}{l}\text { Programas de } \\
\text { retroanálise }\end{array}$ & $\begin{array}{c}\text { Programa } \\
\text { mecanístico } \\
\text { utilizado }\end{array}$ & $\begin{array}{c}\text { Teorias / Métodos numéricos } \\
\text { utilizados }\end{array}$ \\
\hline $\begin{array}{l}\text { CHEVDEF } \\
\text { (Bush, 1980) }\end{array}$ & CHEVRON-N & $\begin{array}{l}\text { Procedimentos numéricos } \\
\text { empíricos. }\end{array}$ \\
\hline $\begin{array}{l}\text { MODCOMP v.2.1 } \\
\text { (Irwin, 1983) }\end{array}$ & CHEVRON-N & Algoritmo de Levenberg-Marquardt. \\
\hline $\begin{array}{l}\text { LOADRATE } \\
\text { (Lytton, 1984) }\end{array}$ & ILLIPAVE & Equações de regressão estatística. \\
\hline $\begin{array}{l}\text { BISDEF } \\
\text { (Bush, 1985) }\end{array}$ & BISAR & $\begin{array}{l}\text { Procedimentos numéricos } \\
\text { empíricos. }\end{array}$ \\
\hline $\begin{array}{l}\text { ELSDEF } \\
\text { (Lytton, 1986) }\end{array}$ & ELSYM5 & $\begin{array}{l}\text { Procedimentos numéricos } \\
\text { empíricos. }\end{array}$ \\
\hline $\begin{array}{l}\text { MODULUS } \\
\text { (Lytton, 1989) }\end{array}$ & BISAR & Banco de dados. \\
\hline $\begin{array}{l}\text { DBCOMPAS } \\
\text { (Ruth, 1989) }\end{array}$ & FEACONS & $\begin{array}{l}\text { Pavimentos rígidos. } \\
\text { Método dos elementos finitos. }\end{array}$ \\
\hline $\begin{array}{l}\text { BOUSDEF } \\
\text { (Hicks, 1990) }\end{array}$ & - & $\begin{array}{l}\text { Método espessuras equivalentes e } \\
\text { equações de Boussinesq } \\
\text { modificadas. }\end{array}$ \\
\hline $\begin{array}{l}\text { ELMOD3 } \\
\text { (Dynatest, 1991) }\end{array}$ & - & Teorias de Odemark e Boussinesq. \\
\hline $\begin{array}{l}\text { ELCON } \\
\text { (Dynatest, 1991) }\end{array}$ & - & $\begin{array}{l}\text { Pavimento rígido. } \\
\text { Teorias de Westgaard (placas) e } \\
\text { Boussinesq (subleito). }\end{array}$ \\
\hline $\begin{array}{l}\text { ISSEM4 } \\
\text { (Dynatest, 1991) }\end{array}$ & ELSYM5 & $\begin{array}{l}\text { Método das espessuras } \\
\text { equivalentes e eq. de Boussinesq. }\end{array}$ \\
\hline $\begin{array}{l}\text { RETROANA } \\
\text { (Rodrigues, 1991) }\end{array}$ & - & Método das camadas finitas. \\
\hline $\begin{array}{l}\text { EVERCALC } \\
\text { (Mahoney, 1991) }\end{array}$ & CHEVRON-N & Algoritmo de Levenberg-Marquardt. \\
\hline $\begin{array}{l}\text { MICHBACK } \\
\text { (Baladi, 1993) }\end{array}$ & CHEVRON-X & Algoritmo de Newton. \\
\hline $\begin{array}{l}\text { SID } \\
\text { (Lytton, 1993) }\end{array}$ & BISAR & $\begin{array}{l}\text { Procedimentos numéricos } \\
\text { empíricos. }\end{array}$ \\
\hline
\end{tabular}


Tabela 4.3 - Programas de retroanálise (continuação)

\begin{tabular}{|l|c|l|}
\hline \multicolumn{1}{|c|}{$\begin{array}{c}\text { Programas de } \\
\text { retroanálise }\end{array}$} & $\begin{array}{c}\text { Programa } \\
\text { mecanístico } \\
\text { utilizado }\end{array}$ & $\begin{array}{c}\text { Teorias / Métodos numéricos } \\
\text { utilizados }\end{array}$ \\
\hline $\begin{array}{l}\text { OVER } \\
\text { (KUAB, 1992) }\end{array}$ & - & - \\
\hline $\begin{array}{l}\text { OVERCALC } \\
\text { (KUAB, 1992) }\end{array}$ & CHEVRON-N & Análise linear. \\
\hline $\begin{array}{l}\text { RIGOVER } \\
\text { (KUAB, 1992) }\end{array}$ & - & $\begin{array}{l}\text { Pavimento rígido. } \\
\text { Teorias de Westergaard. }\end{array}$ \\
\hline $\begin{array}{l}\text { SYPHAX } \\
\text { (Kobisch, 1990) }\end{array}$ & ECOROUTE/BASSIN & Análise linear e não linear. \\
\hline $\begin{array}{l}\text { DEFPAV (modif.) } \\
\text { (Farouki, 1994) }\end{array}$ & - & Método dos elementos finitos. \\
\hline
\end{tabular}

Fonte: Albernaz, Motta e Medina (1995)

\section{3 - Problemas encontrados em retroanálise}

Ullidtz e Coetzee (1995) descrevem concisamente alguns problemas encontrados na execução de retroanálise, apresentados nos itens a seguir.

\subsection{1 - Efeitos de espessura das camadas}

A espessura das camadas do pavimento é assumida constante na maioria das atividades de retroanálise, resultado de limitação de software ou tempo restrito para execução do trabalho.

$\mathrm{Na}$ prática, espessuras de camadas constantes em pavimentos são casos raros pois, as variações resultam de vários detalhes de construção e manutenção, mesmo sob condições de controle especiais.

Em alguns casos, a variação dos módulos retroanalisados não sofre influência significativa das espessuras das camadas. Entretanto, é desejável a utilização das espessuras corretas das camadas, para isso equipamentos como Ground Penetrating Radar (GPR) são capazes de fornecer dados de espessuras. 
Camadas de superfície com menos de $7,5 \mathrm{~cm}$ de espessura não podem ser confiantemente caracterizadas com os dados de deflexões obtidos com 0 FWD devido à geometria do carregamento e o sistema de medida (Ullidtz e Coetzee, 1995).

\subsection{2 - Compensação de camadas e efeitos de não linearidade}

Estes efeitos resultam essencialmente de modelagem incorreta da resposta estrutural do pavimento e do processo natural iterativo de retroanálise, bem como da geometria da bacia de deflexão em análise.

Um exemplo típico ocorre quando o módulo resiliente do subleito é significativamente maior do que o esperado para aquele tipo de material, enquanto o módulo da base apresenta-se baixo e o do revestimento extremamente elevado. Tal fato provavelmente ocorre com maior freqüência em subleitos mais sensíveis à tensão, onde o nível de tensão que ocorre nos sensores mais externos em um FWD é muito menor do que as tensões registradas no eixo da placa de carga.

O módulo aparente do subleito para os sensores mais externos é conseqüentemente maior do que o módulo aparente diretamente sobre a placa de carga. Se o subleito é modelado como um material elástico linear (a maioria das rotinas de retroanálise primeiramente calculam o módulo do subleito com as deflexões dos sensores externos) então, um alto valor para o módulo de resiliência é encontrado e assumido constante em todo o processo.

Na próxima iteração quando o módulo da base está sendo calculado, o alto valor do módulo do subleito é compensado por um baixo módulo para a base, de modo a ajustar as deflexões medidas nesta região da bacia de deflexão, caracterizando o efeito de compensação nos módulos resilientes das camadas.

Para evitar o efeito de compensação recomenda-se uma modelagem não linear de respostas dos materiais, fato que já está se tornando comum, 
visto que programas como ELMOD, MODCOMP3, EVERCALC e BOUSDEF podem utilizar modelos não lineares para materiais.

Se um subleito com comportamento elástico é utilizado, a inclusão de uma camada rígida pode ajudar a minimizar o problema. Esta é a razão pela qual algumas rotinas de retroanálise incluem uma camada rígida como default em alguma profundidade (geralmente 6 metros).

\subsection{3 - Camada rígida}

Por definição, camada rígida é aquela em que abaixo da mesma há pouca ou nenhuma contribuição aparente para as deflexões de superfície medidas. As camadas rígidas podem ser reais ou aparentes e possivelmente constituem-se no problema mais comum encontrado na estimativa das bacias de deflexões.

$\mathrm{Na}$ realidade pode ser constituída por rocha ou outro material rígido, observando-se o mesmo efeito em solos saturados ou em locais onde o lençol freático encontra-se próximo à superfície.

Para casos onde existe a presença de camada rígida, programas como - MODULUS, BISDEF e WESDEF possuem uma sub-rotina de cálculo específico. Uma aproximação aparente para o problema da camada rígida (caso esteja em uso um programa elástico de multicamadas) é dividir o subleito em duas ou mais camadas, permitindo ao programa atribuir proporções aos módulos para determinar o melhor ajuste.

Mahoney et al (1993) descrevem de maneira sumária a aproximação usada por Rhode e Scullion ${ }^{7}$ para a estimativa da profundidade da camada rígida, a qual é citada a seguir.

\footnotetext{
${ }^{7}$ Rhode, G. T; Scullion, T. (1990) - MODULUS 4.0: Expansion and validation of the MODULUS backcalculation system. - Research report 1123-3, Texas Transportation Institute, Texas A\&M University System, College Station.
} 
Somente a região da estrutura do pavimento situada dentro da área de tensões contribui com deflexões na superfície, não havendo deflexões além do intercepto entre a camada rígida e a zona de tensões, ou seja, além de $D_{c}$ (ver Figura 4.6) as deflexões são nulas.

Deste modo, o método assume que a profundidade na qual ocorre deflexão nula (presumidamente devido à camada rígida) está relacionada à distância de $P$ a $D_{c}$. Uma estimativa da profundidade na qual não há deflexões, pode ser feita inicialmente pela plotagem (Figura 4.7) dos pontos inversos do raio $(1 / r)$ com as correspondentes medidas de deflexões na superfície $\left(D_{r}\right)$ para se obter $r_{0}$.

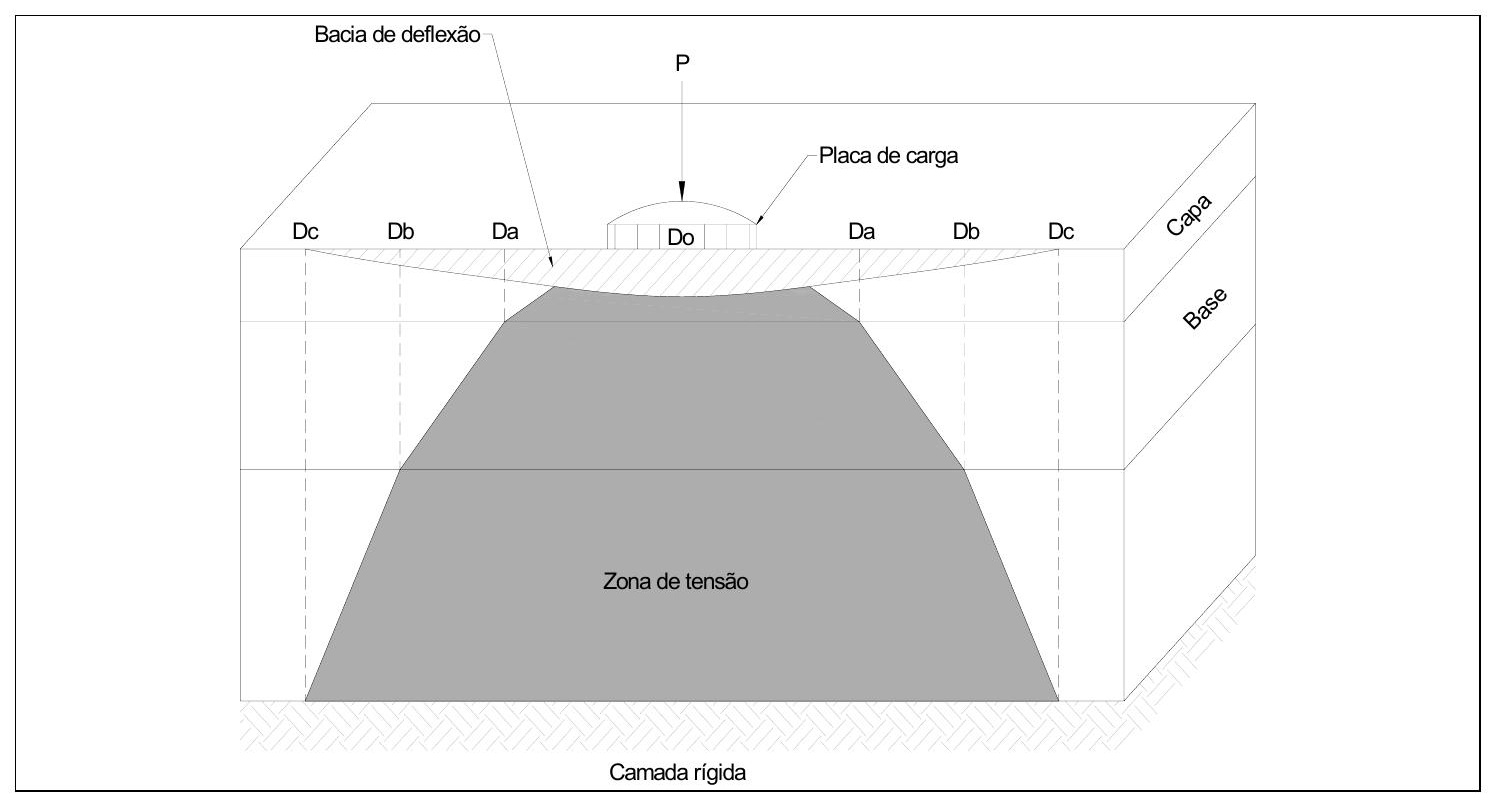

Figura 4.6 - Deflexões nulas devido à camada rígida (Mahoney et al., 1993) 


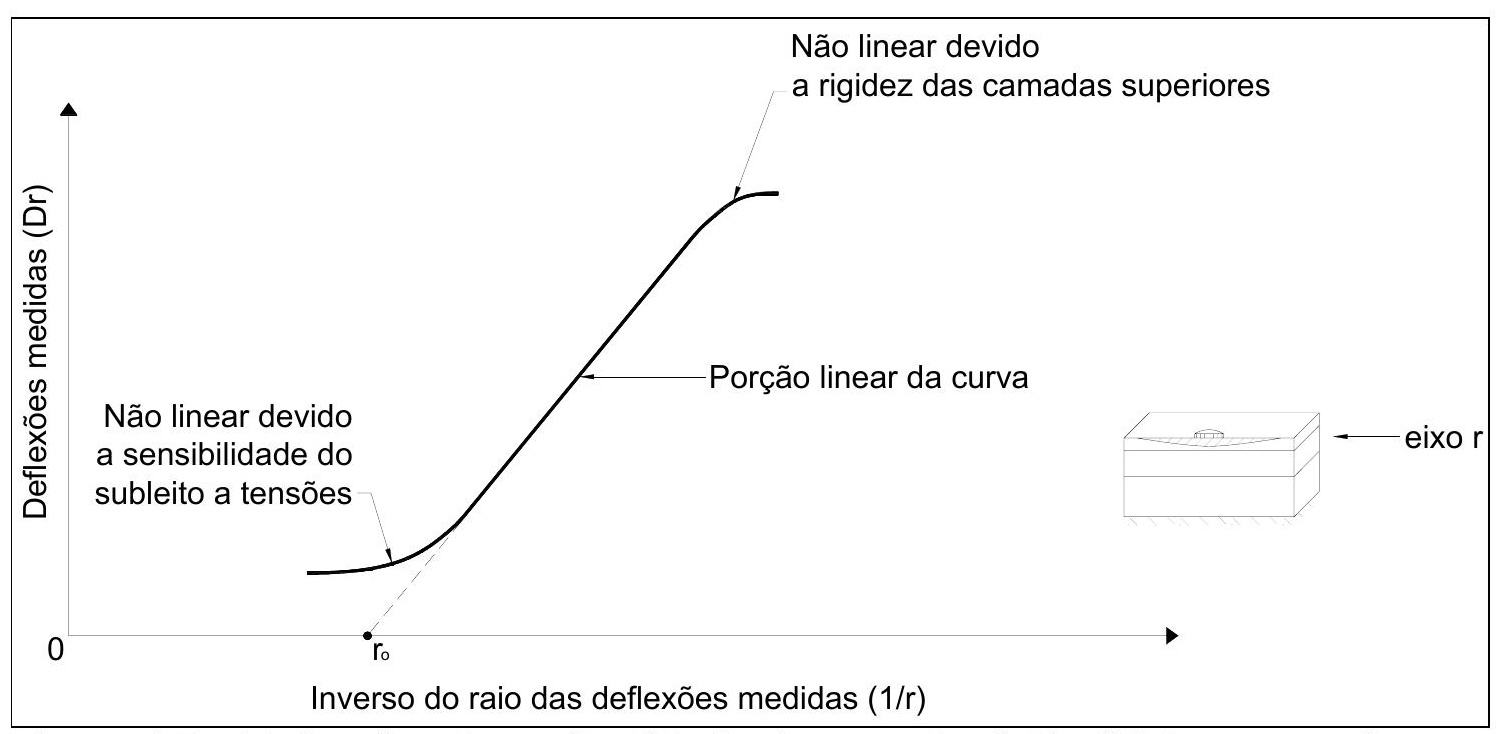

Figura 4.7 - Estimativa da profundidade da camada rígida (Mahoney et al., 1993).

A região central do gráfico é linear com ambas extremidades curvas devido a não linearidade associada ao subleito e às camadas superiores. Estendendo-se a porção linear até cruzamento com o eixo das abscissas, obtém-se o ponto $r_{0}$.

A profundidade da camada rígida não pode ser estimada diretamente de $r_{0}$. Para isto, foram desenvolvidas equações de regressão obtidas com base no programa BISAR para vários níveis dos seguintes fatores: carga de $40 \mathrm{kN}$, razões entre módulos $\left(E_{1} / E_{s g}, E_{2} / E_{s g}\right.$ e $\left.E_{\text {rig }} / E_{s g}\right)$, espessuras das camadas e profundidade da camada rígida (B) medida a partir da superfície do pavimento.

- Para espessuras de revestimento menores que $50 \mathrm{~mm}$ :

$1 / B=0,0362-0,3242\left(r_{o}\right)+10,2717\left(r_{o}\right)^{2}-23,6609\left(r_{o}\right)^{3}-0,0037$ (ICB)

- Para espessuras de revestimento de 50 a $100 \mathrm{~mm}$ :

$1 / B=0,0065-0,1652\left(r_{o}\right)+5,4290\left(r_{o}\right)^{2}-11,0026\left(r_{o}\right)^{3}+0,0004($ IDB $)$ 
- Para espessuras de revestimento de 100 a $150 \mathrm{~mm}$ :

$$
1 / B=0,0413+0,9929\left(r_{o}\right)-0,0012(\text { ICS })+0,0063(\text { IDB })-0,0778(\text { ICB })
$$

- Para espessuras de revestimento maiores que $150 \mathrm{~mm}$ :

$$
1 / B=0,0409+0,5669\left(r_{0}\right)+3,0137\left(r_{0}\right)^{2}+0,0033(\text { IDB })-0,0665 \log (I C B)
$$

Sendo,

$r_{o}$ - obtido graficamente (ver Figura 4.7) em pés ${ }^{-1}$;

ICS - Índice de Curvatura da Superfície $\left(D_{0}-D_{305} \mathrm{~mm}\right)$;

IDB - Índice de Danos da Base $\left(D_{305}-D_{610 \mathrm{~mm}}\right)$;

ICB - Índice de Curvatura da Base $\left(D_{610}-D_{914} \mathrm{~mm}\right)$.

$D_{i}$ - Deflexões na superfície normalizadas a $40 \mathrm{kN}$, distantes i do ponto de aplicação de carga.

\subsection{4 - Efeitos da rigidez relativa das camadas}

A retroanálise pode descrever a rigidez da camada de um pavimento de acordo com seu grau de influência nas deflexões. Camadas delgadas contribuem apenas com uma reduzida parcela das deflexões totais, resultando baixa precisão em valores retroanalisados obtidos.

Deve-se enfatizar que a rigidez de uma camada, ou seja, a combinação de sua espessura e módulo, precisa ser relativamente significante (comparada com outros componentes do pavimento) para influenciar nas deflexões da superfície. Caso não se verifique esta importância, as aproximações de retroanálise não obterão êxito nas identificações dos efeitos das camadas.

\subsection{5 - Efeitos de entrada de dados}

Dados de entradas em programas computacionais como módulos iniciais (seed moduli), limites inferiores e superiores para os módulos, espessuras de 
camadas, número de iterações e critério de convergência, influenciam as respostas obtidas no processo.

É possível obter diferentes módulos de uma mesma bacia de deflexões utilizando diferentes módulos iniciais ou limites, caracterizando desta maneira a não-unicidade da solução.

Lytton e Chou ${ }^{8}$ apud Huang (1993) citam que duas agências utilizando o mesmo programa computacional encontraram diferentes valores para os módulos resilientes das camadas analisadas em uma mesma seção de pavimento.

\footnotetext{
${ }^{8}$ Lytton, R. L; Chou, Y. J.; (1988) - Modulus backcalculation exercise. - Informal Report to TRB committee A2B05, Strenght and Deformation Characteristics, Transportation Research Board.
} 


\section{Capítulo 5 - A Teoria do Ponto Inerte}

\section{1 - Comentários iniciais}

O processo de retroanálise é trabalhoso, requerendo um alto grau de experiência pois os resultados encontrados são de moderada a altamente dependentes da experiência do engenheiro. Em diversos processos de retroanálise é necessária uma entrada estimada dos módulos resilientes iniciais (seed moduli) para o processamento, fato que influencia diretamente os resultados obtidos.

Alguns programas computacionais já eliminam ou minimizam a influência dos módulos resilientes inicialmente estimados, baseando-se em expressões para previsão ou resultados de ensaios de laboratório para estes valores.

O SHRP-P-655 (1993) desenvolveu um procedimento baseado no programa MODULUS para tentar assegurar o processo de retroanálise aplicado à análise de dados deflectométricos com consistência, produtividade e diretamente quando possível, sendo para isto criado um procedimento padrão (rigorosas aplicações de regras).

As etapas para se estabelecer este procedimento de retroanálise padrão foram:

1 - Identificar programas que podem ser utilizados no procedimento;

2 - Seleção limitada de um número de programas para avaliação detalhada;

3 - Avaliação detalhada dos programas selecionados em 2;

4 - Desenvolvimento do procedimento de retroanálise em torno do programa selecionado. 
Em pavimentos flexíveis, os programas MODCOMP3, MODULUS e WESDEF foram escolhidos na etapa 2 descrita anteriormente pois produzem bons resultados porém, todos apresentam pontos favoráveis e desfavoráveis, sendo o MODULUS selecionado por apresentar ligeira superioridade aos outros programas.

Nos últimos anos, métodos baseados em simulações naturais têm sido utilizados para retroanalisar módulos de camadas. Métodos baseados em redes neurais artificiais e algoritmo genético ainda situam-se em estágio de desenvolvimento e não têm sido empregados amplamente.

\section{2 - O ponto inerte em pavimentos flexíveis (Para bacias de deflexões obtidas com FWD).}

Durante a retroanálise dos módulos das camadas existentes em estruturas de pavimentos de concreto em aeroportos, alguns pesquisadores (Sun, L.; Hachiya, Y. e Yao, Z. (1995)) notaram a presença de um ponto na superfície da bacia de deflexão, cuja deflexão não variava em função dos módulos das camadas superiores, desde que o módulo do subleito e a soma das espessuras das camadas superiores permaneçam inalterados.

O adjetivo inerte, caracterizando este ponto da bacia de deflexão, provém da independência da sua localização em relação aos módulos resilientes das camadas superiores. Segundo Zhang e Sun (2003, p.04) " [...] a demonstração empírica da presença deste ponto é preferível em relação à analítica por razões de simplicidade [...] ".

A análise empírica da existência do ponto inerte em bacias de deflexão obtidas com carregamento de FWD em pavimentos flexíveis de duas (Caso A) e três camadas (Caso B), é descrita a seguir nos itens 5.2.1 e 5.2.2, de acordo com Zhang e Sun (2003).

Em seguida (itens 5.3.1 e 5.3.2), são analisadas bacias de deflexões teóricas em pavimentos de duas (Caso C) e três camadas (Caso D), com o 
intuito de observação empírica da ocorrência do ponto inerte para o ensaio com a viga Benkelman.

\subsection{1 - Caso A: Ponto inerte em bacias de deflexões geradas pelo FWD para pavimentos compostos por duas camadas.}

Para exemplificar este caso, descrevem-se oito grupos de estruturas de pavimentos teóricas com as características em comum apresentadas na Tabela 5.1:

Tabela 5.1 - Características em comum dos pavimentos (Caso A)

\begin{tabular}{|l|c|}
\hline Espessura da camada superior $(\mathrm{H})$ & $40 \mathrm{~cm}$ \\
\hline Módulo resiliente do subleito $\left(\mathrm{E}_{0}\right)$ & $30 \mathrm{MPa}$ \\
\hline Coeficiente de Poisson da camada superior e do subleito & 0,30 \\
\hline Tensão na superfície de carregamento & $1 \mathrm{MPa}$ \\
\hline Raio da placa de carregamento & $15 \mathrm{~cm}$ \\
\hline
\end{tabular}

A diferença entre os oito grupos de estruturas de pavimentos encontrase no módulo resiliente da camada superior $\left(E_{1}\right)$, conforme a Tabela 5.2.

Tabela 5.2 - Módulos resilientes para o revestimento (Caso A)

\begin{tabular}{|c|c|c|c|c|c|c|c|c|}
\hline Caso & 1 & 2 & 3 & 4 & 5 & 6 & 7 & 8 \\
\hline $\mathrm{E}_{1}(\mathrm{x} 1000 \mathrm{MPa})$ & 0,25 & 0,50 & 0,75 & 1,00 & 1,25 & 1,50 & 1,75 & 2,00 \\
\hline
\end{tabular}

A representação gráfica do Caso A é exibida na Figura 5.1. 


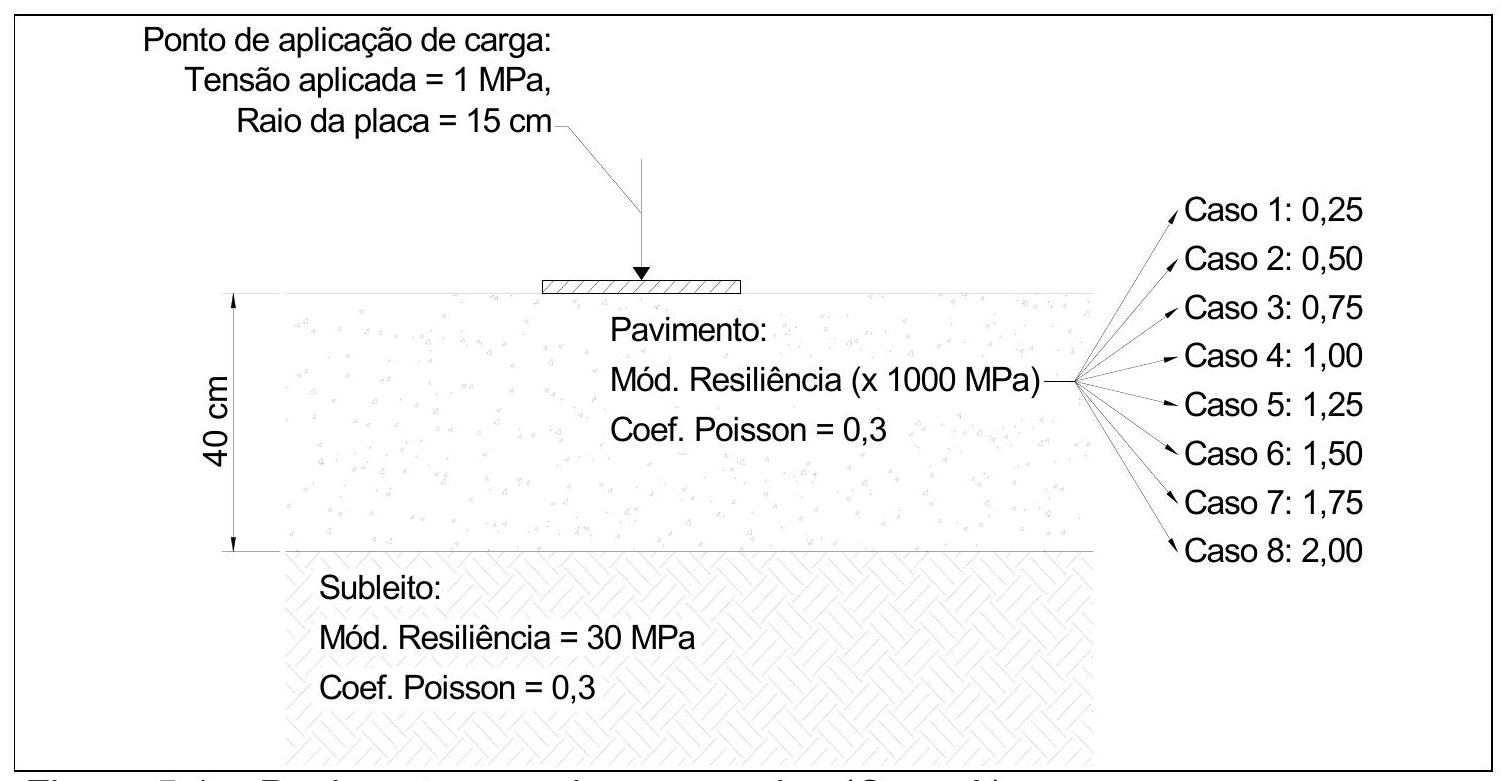

Figura 5.1 - Pavimento com duas camadas (Caso A)

As deflexões obtidas para os oito casos e suas respectivas distâncias do centro de aplicação de carga são ilustradas na Figura 5.2.

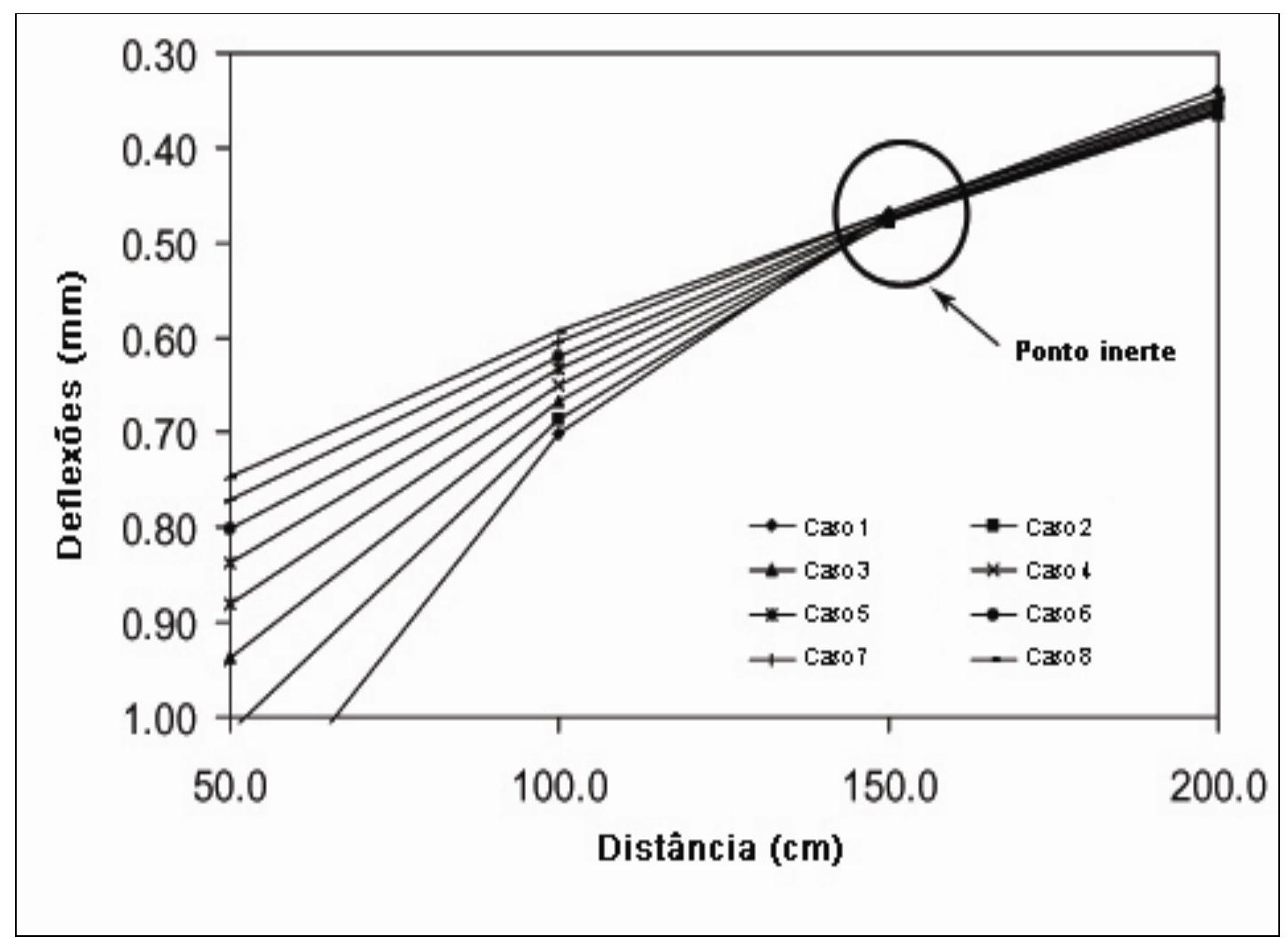

Figura 5.2 - Bacias de deflexões do Caso A (Zhang e Sun, 2003) 
Nota-se que as bacias de deflexões apresentam um ponto de intersecção em comum localizado, aproximadamente, na distância $150 \mathrm{~cm}$ por deflexão de $0,472 \mathrm{~mm}$, sendo a diferença de deflexões relativamente pequena entre as bacias neste ponto, da ordem de 3\%. Este é o ponto inerte, mencionado anteriormente, para este grupo particular de estruturas.

Dois parâmetros caracterizam a localização do ponto inerte, a distância $\left(R_{c}\right)$ e a deflexão $\left(D_{c}\right)$. Na Figura 5.2, a localização do ponto inerte (indicada em um círculo) caracteriza a posição deste ponto para o grupo de estruturas de pavimentos mencionados anteriormente, resultados de cálculos revelam que também ocorre a existência do ponto inerte em qualquer outra estrutura de pavimentos com duas camadas.

\subsection{2 - Caso B: Ponto inerte em bacias de deflexões geradas pelo FWD para pavimentos compostos por três camadas.}

A maior parte dos pavimentos é constituída por mais de duas camadas, os sistemas de três camadas apresentam o revestimento ou capa, a base e o subleito.

A análise da ocorrência do ponto inerte para um grupo de pavimentos de três camadas é análoga ao grupo de pavimentos com duas camadas, por exemplo, o revestimento e a base são tratados como uma única camada cuja espessura é a soma de suas espessuras individuais, resultando em uma estrutura simplificada de duas camadas.

Para ilustrar o Caso B, doze grupos de estruturas de pavimentos teóricos com características em comum são descritos na Tabela 5.3: 
Tabela 5.3 - Características em comum dos pavimentos (Caso B)

\begin{tabular}{|l|c|}
\hline Espessura do revestimento (caso 1 a 6) (H) & $8 \mathrm{~cm}$ \\
\hline Espessura da base (caso 1 a 6) (H) & $32 \mathrm{~cm}$ \\
\hline Espessura do revestimento (caso 7 a 12) $(\mathrm{H})$ & $15 \mathrm{~cm}$ \\
\hline Espessura da base (caso 7 a 12) $(\mathrm{H})$ & $25 \mathrm{~cm}$ \\
\hline Módulo resiliente do subleito ( $\left.\mathrm{E}_{0}\right)$ & $30 \mathrm{MPa}$ \\
\hline $\begin{array}{l}\text { Coeficiente de Poisson das camadas superiores e do } \\
\text { subleito }\end{array}$ & $1 \mathrm{MPa}$ \\
\hline Tensão na superfície de carregamento & $15 \mathrm{~cm}$ \\
\hline Raio da placa de carregamento & \\
\hline
\end{tabular}

As diferenças entre os doze grupos de estruturas de pavimentos encontram-se nos módulos resilientes do revestimento $\left(E_{1}\right)$ e da base $\left(E_{2}\right)$, conforme a Tabela 5.4 .

Tabela 5.4 - Módulos resilientes para o revestimento e a base (Caso B)

\begin{tabular}{|c|c|c|c|c|c|c|}
\hline Caso & 1 & 2 & 3 & 4 & 5 & 6 \\
\hline $\begin{array}{c}\mathrm{E}_{1}-\text { revest. } \\
(\times 1000 \mathrm{MPa})\end{array}$ & 0,50 & 0,50 & 1,00 & 1,00 & 2,00 & 2,00 \\
\hline $\begin{array}{c}\mathrm{E}_{2}-\text { base } \\
(\times 1000 \mathrm{MPa})\end{array}$ & 1,00 & 2,00 & 0,50 & 2,00 & 0,50 & 1,00 \\
\hline
\end{tabular}

\begin{tabular}{|c|c|c|c|c|c|c|}
\hline Caso & 7 & 8 & 9 & 10 & 11 & 12 \\
\hline $\begin{array}{c}\mathrm{E}_{1}-\text { revest. } \\
(\times 1000 \mathrm{MPa})\end{array}$ & 0,50 & 0,50 & 1,00 & 1,00 & 2,00 & 2,00 \\
\hline $\begin{array}{c}\mathrm{E}_{2}-\text { base } \\
(\times 1000 \mathrm{MPa})\end{array}$ & 1,00 & 2,00 & 0,50 & 2,00 & 0,50 & 1,00 \\
\hline
\end{tabular}

Fonte: Zhang e Sun (2003)

A representação gráfica do Caso B é exibida nas Figuras 5.3 e 5.4 . 


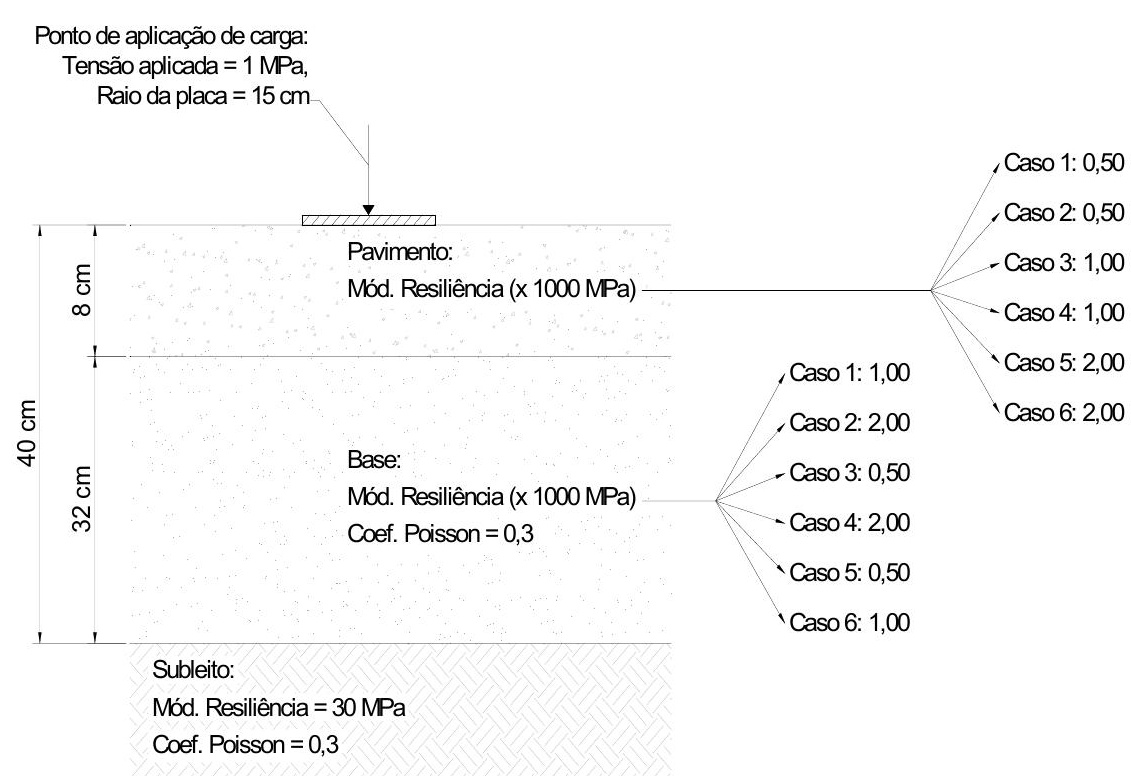

Figura 5.3 - Pavimentos com três camadas (Casos 1 a 6)

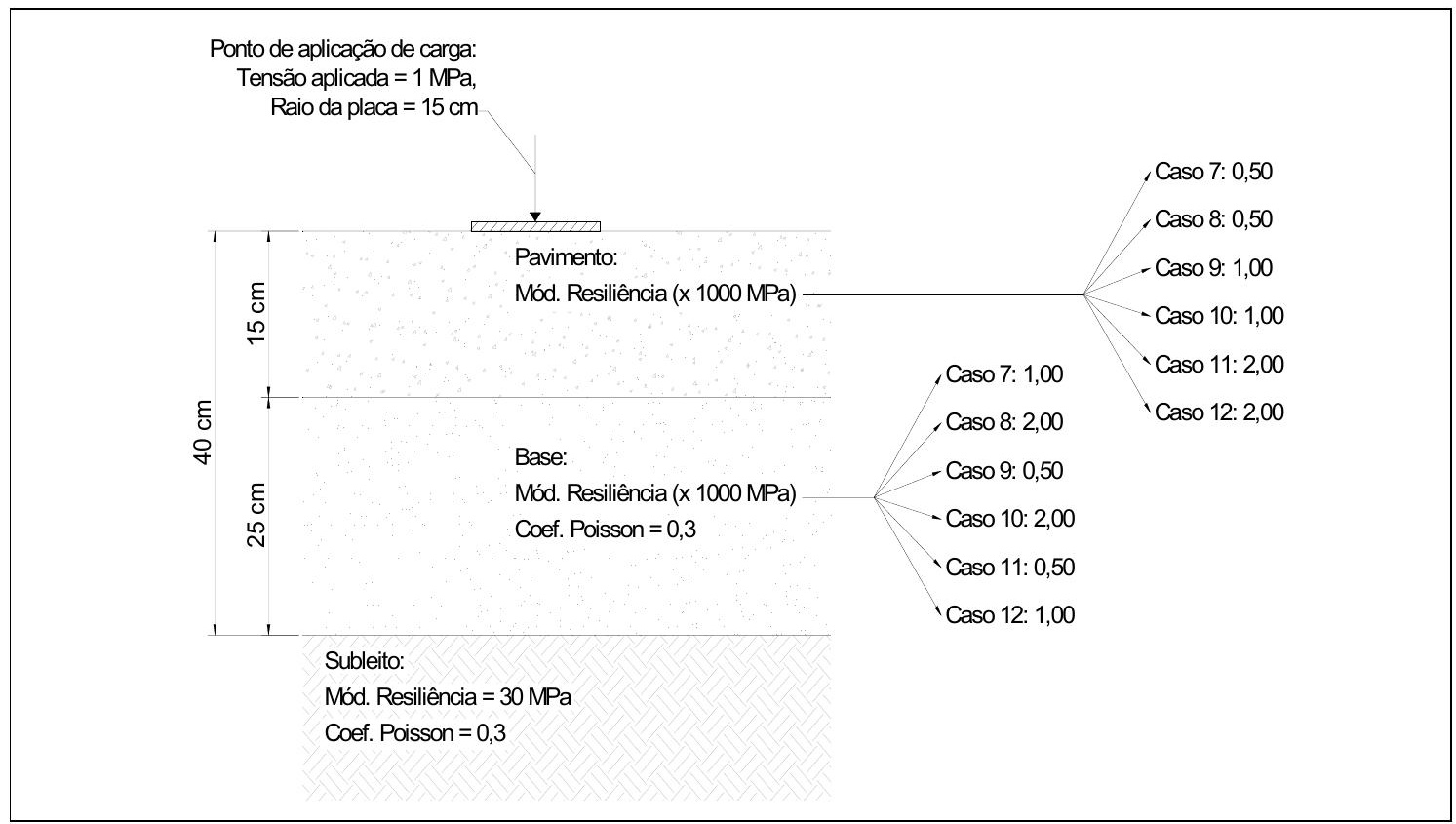

Figura 5.4 - Pavimentos com três camadas (Casos 7 a 12)

As deflexões obtidas para os doze casos e suas respectivas distâncias do centro de aplicação de carga são ilustradas na Figura 5.5. 


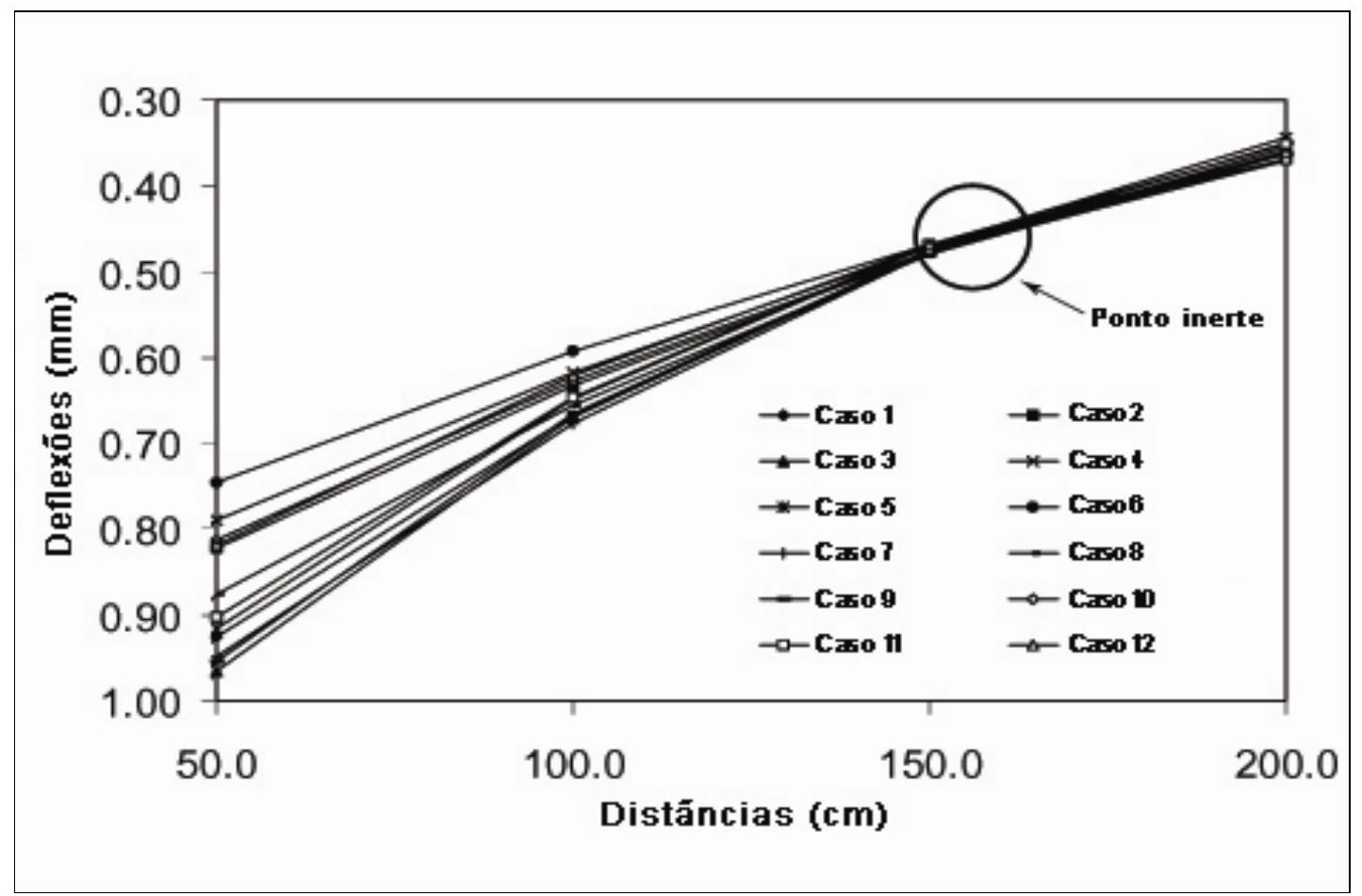

Figura 5.5 - Bacias de deflexões do Caso B (Zhang e Sun, 2003)

Ao analisar a Figura 5.5 nota-se a convergência das bacias para o ponto inerte. A característica relevante é que as coordenadas $R_{c}$ e $D_{c}$ do ponto inerte para pavimentos com três camadas são as mesmas $(150 \mathrm{~cm}, 0.472 \mathrm{~mm})$ dos pavimentos com duas camadas, ou seja, os sistemas de três camadas podem ser simplificados em sistemas de duas camadas combinando as duas camadas superiores em uma camada composta, mantendo o módulo do subleito $\left(E_{0}\right)$ inalterado e as alturas equivalentes $(\mathrm{H})$.

\section{3 - O ponto inerte em pavimentos flexíveis para bacias de deflexões obtidas com a viga Benkelman.}

Observada a presença do ponto inerte em pavimentos rígidos e flexíveis para as bacias de deflexões obtidas com carregamento proveniente de FWD, é objetivo deste item a análise empírica da ocorrência do ponto inerte em pavimentos flexíveis para as bacias de deflexões teóricas provenientes de ensaios com a viga Benkelman. 
Os valores utilizados nesta análise como o módulo de resiliência do subleito, base, revestimento, altura das camadas do pavimento e coeficiente de Poisson das camadas, possuem magnitudes representativas da realidade estrutural de projetos de pavimentos flexíveis existentes.

\subsection{1 - Caso C: Ponto inerte em bacias de deflexões para pavimentos compostos por duas camadas, com carga gerada pelo eixo padrão (8,2 tf com eixo simples e rodas duplas).}

Para este Caso C, apresentam-se seis grupos de estruturas de pavimentos teóricos com as características em comum listadas na Tabela 5.5:

Tabela 5.5 - Características comuns dos pavimentos (Caso C)

\begin{tabular}{|l|c|}
\hline Espessura do pavimento $(\mathrm{H})$ & $60 \mathrm{~cm}$ \\
\hline Módulo resiliente do subleito $\left(\mathrm{E}_{0}\right)$ & $100 \mathrm{MPa}$ \\
\hline Coeficiente de Poisson do pavimento & 0,30 \\
\hline Coeficiente de Poisson do subleito & 0,30 \\
\hline Pressão de contato na superfície de carregamento & $0,565 \mathrm{MPa}$ \\
\hline Raio de carregamento & $10,75 \mathrm{~cm}$ \\
\hline
\end{tabular}

A diferença entre os seis grupos de estruturas de pavimentos encontrase no módulo resiliente da camada superior $\left(E_{1}\right)$, conforme a Tabela 5.6.

Tabela 5.6 - Módulos resilientes para o revestimento (Caso C)

\begin{tabular}{|c|c|c|c|c|c|c|}
\hline Caso & 1 & 2 & 3 & 4 & 5 & 6 \\
\hline $\mathrm{E}_{1}(\times 1000 \mathrm{MPa})$ & 0,50 & 0,90 & 1,30 & 1,70 & 1,90 & 2,10 \\
\hline
\end{tabular}

A representação gráfica do Caso C é exibida na Figura 5.6. 


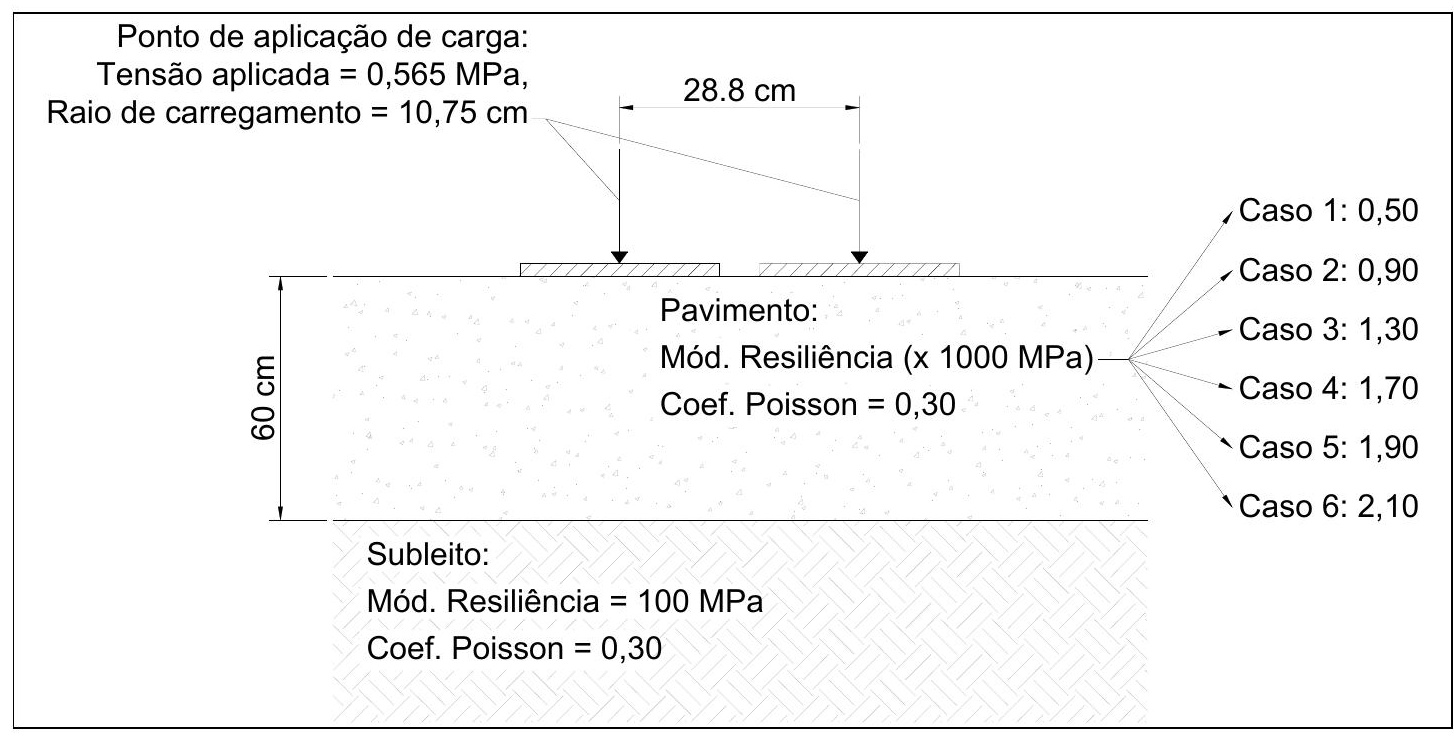

Figura 5.6 - Pavimento com duas camadas (Caso C)

As deflexões teóricas obtidas com o auxílio do programa ELSYM 5, para os seis casos e suas respectivas distâncias do centro de aplicação de carga, são ilustradas na Figura 5.7.

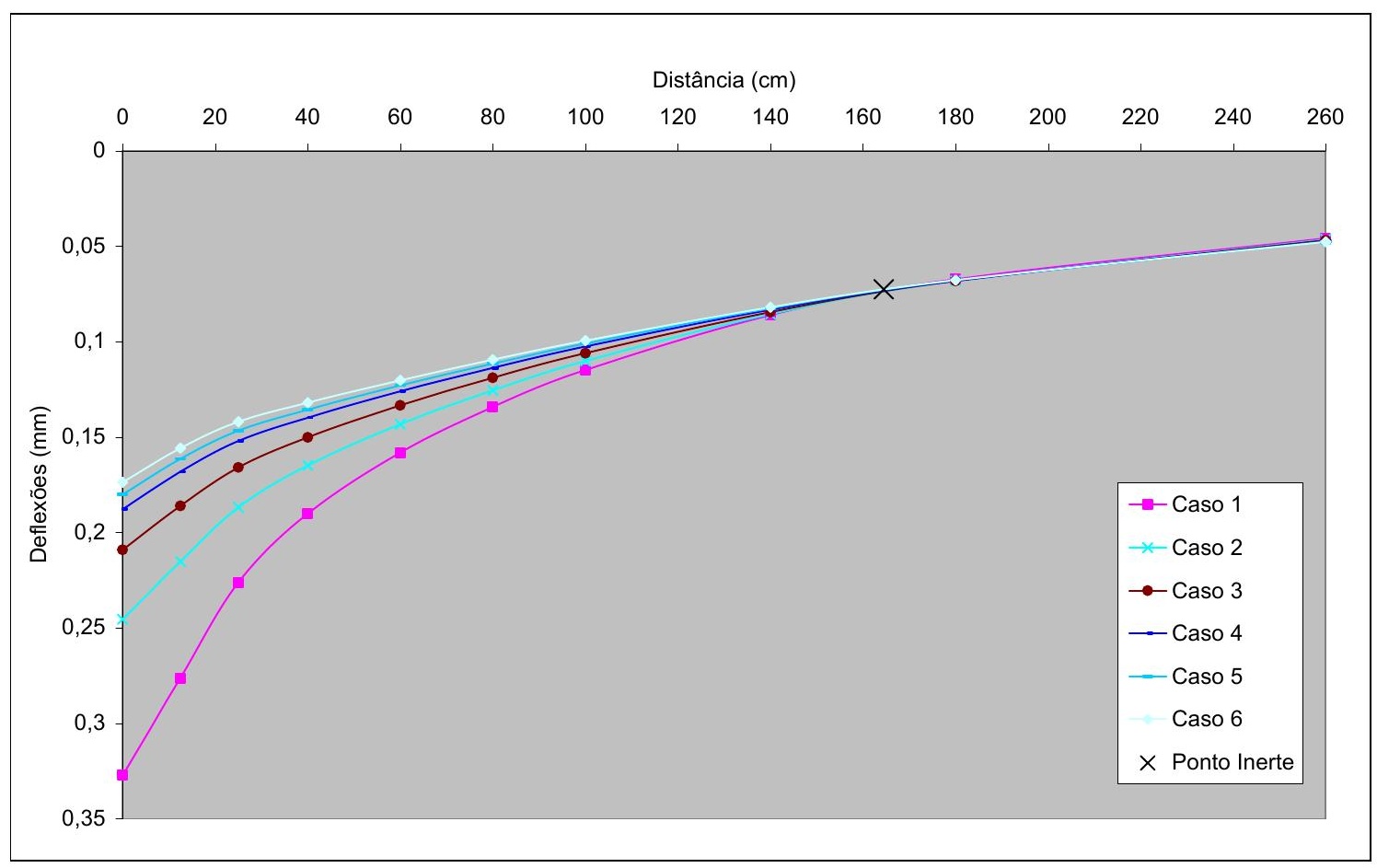

Figura 5.7 - Bacias de deflexões do Caso C. 
A intersecção das bacias no ponto de coordenadas aproximadas $(160 \mathrm{~cm}, 0.075 \mathrm{~mm})$ revela a presença do ponto inerte para o grupo de estruturas de pavimentos anteriormente descritos, quando submetidos ao carregamento padrão (8,2 tf) para análise de deflexões com a Viga Benkelman.

\subsection{2 - Caso D: Ponto inerte em bacias de deflexões para pavimentos compostos por três camadas, com carga gerada pelo eixo padrão (8,2 tf com eixo simples e rodas duplas).}

Para pavimentos compostos por três camadas, a base e o revestimento são tratados como uma única camada, apresentando um módulo de resiliência equivalente e espessura igual ao somatório das espessuras individuais destas camadas. Deste modo, a análise para um pavimento de três camadas, é semelhante à análise de um pavimento com duas camadas.

No Caso $D$ apresentam-se seis grupos de estruturas de pavimentos teóricos com características em comum listadas na Tabela 5.7:

Tabela 5.7 - Características em comum dos pavimentos (Caso D)

\begin{tabular}{|l|c|}
\hline Espessura do revestimento (casos 1 a 3) & $5 \mathrm{~cm}$ \\
\hline Espessura da base (casos 1 a 3) & $55 \mathrm{~cm}$ \\
\hline Espessura do revestimento (casos 4 a 6) & $10 \mathrm{~cm}$ \\
\hline Espessura da base (casos 4 a 6) & $50 \mathrm{~cm}$ \\
\hline Módulo resiliente do subleito (E $\left.\mathrm{E}_{0}\right)$ & $100 \mathrm{MPa}$ \\
\hline Coeficiente de Poisson do revestimento & 0,30 \\
\hline Coeficiente de Poisson da base & 0,30 \\
\hline Coeficiente de Poisson do subleito & 0,30 \\
\hline Tensão na superfície de carregamento & $0,565 \mathrm{MPa}$ \\
\hline Raio de carregamento & $10,75 \mathrm{~cm}$ \\
\hline
\end{tabular}

As diferenças entre os seis grupos de estruturas de pavimentos encontram-se nos módulos resilientes do revestimento $\left(E_{1}\right)$ e da base $\left(E_{2}\right)$, conforme a Tabela 5.8 . 
Tabela 5.8 - Módulos resilientes para o revestimento e a base (Caso D)

\begin{tabular}{|c|c|c|c|}
\hline Caso & 1 & 2 & 3 \\
\hline $\begin{array}{c}\mathrm{E}_{1}-\text { revest. } \\
(\mathrm{x} 1000 \mathrm{MPa})\end{array}$ & 2,50 & 3,50 & 4,50 \\
\hline $\begin{array}{c}\mathrm{E}_{2}-\text { base } \\
(\mathrm{x} 1000 \mathrm{MPa})\end{array}$ & 0,20 & 0,30 & 0,40 \\
\hline
\end{tabular}

\begin{tabular}{|c|c|c|c|}
\hline Caso & 4 & 5 & 6 \\
\hline $\begin{array}{c}\mathrm{E}_{1}-\text { revest. } \\
(\times 1000 \mathrm{MPa})\end{array}$ & 2,50 & 3,50 & 4,50 \\
\hline $\begin{array}{c}\mathrm{E}_{2}-\text { base } \\
(\times 1000 \mathrm{MPa})\end{array}$ & 0,20 & 0,30 & 0,40 \\
\hline
\end{tabular}

A representação gráfica do caso D é exibida nas Figuras 5.8 e 5.9.

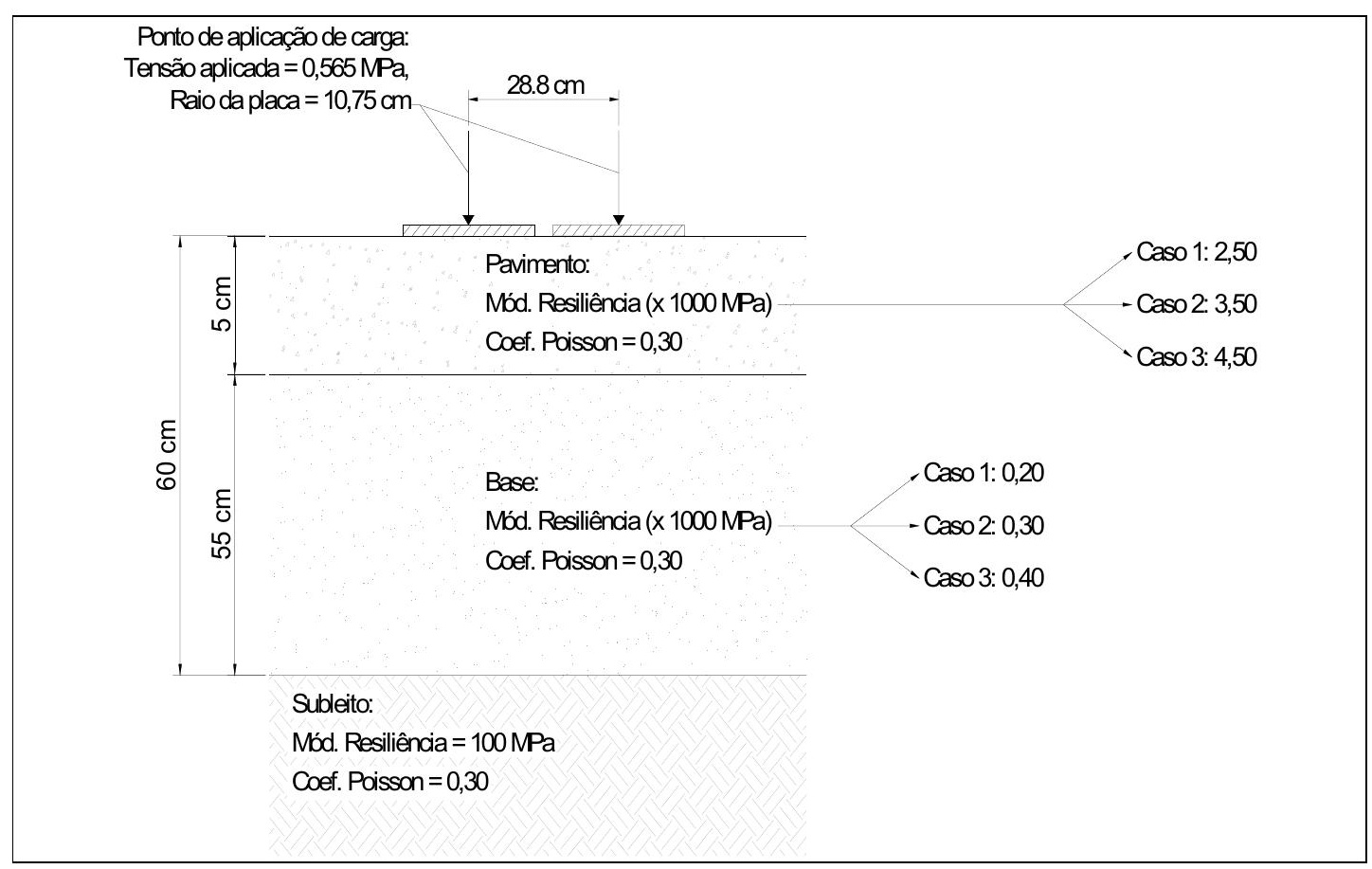

Figura 5.8 - Pavimentos com três camadas (Casos 1 a 3) 


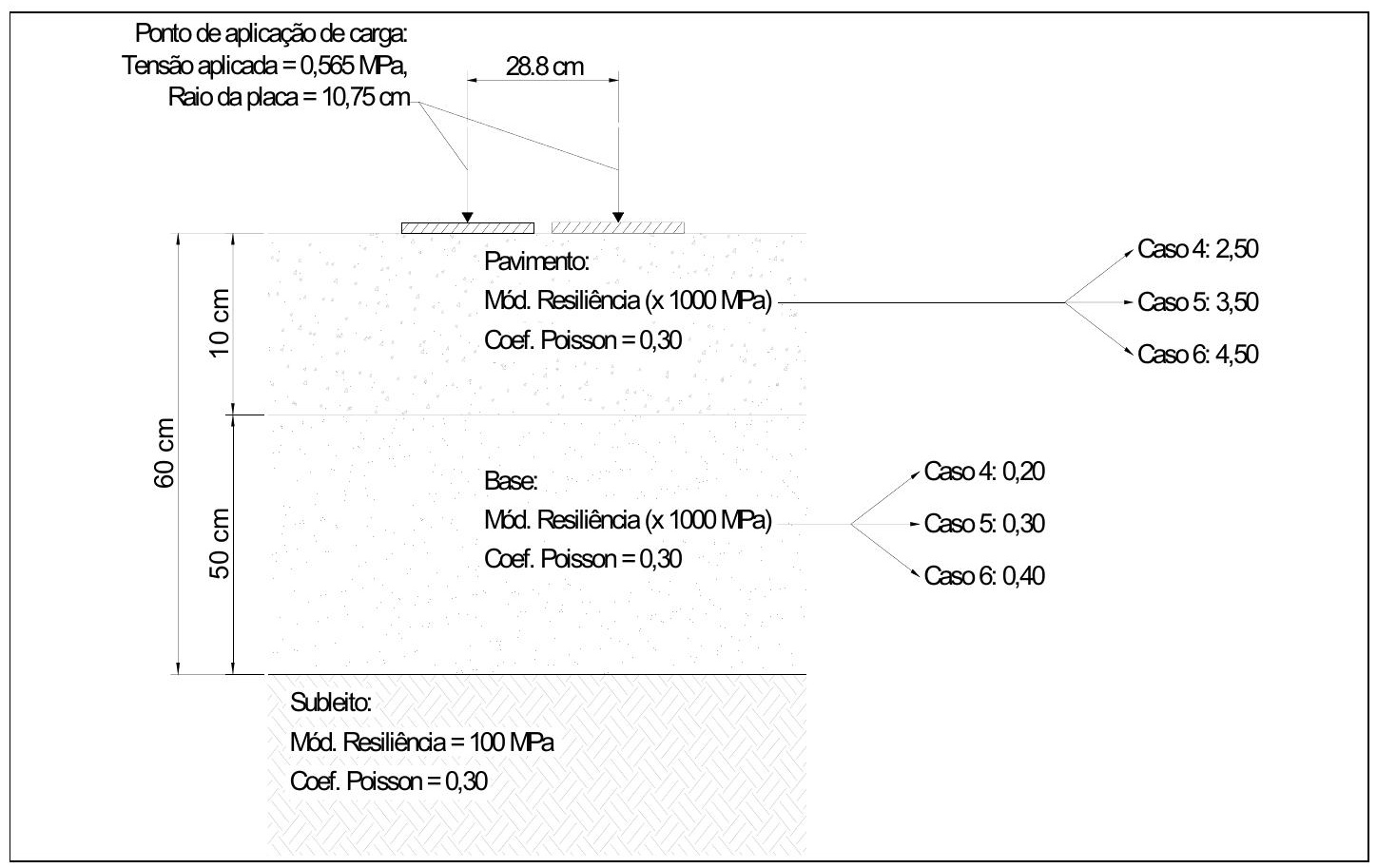

Figura 5.9 - Pavimentos com três camadas (Casos 4 a 6)

As deflexões teóricas obtidas com o auxílio do programa ELSYM5, para os seis casos e suas respectivas distâncias do centro de aplicação de carga, são ilustradas na Figura 5.10.

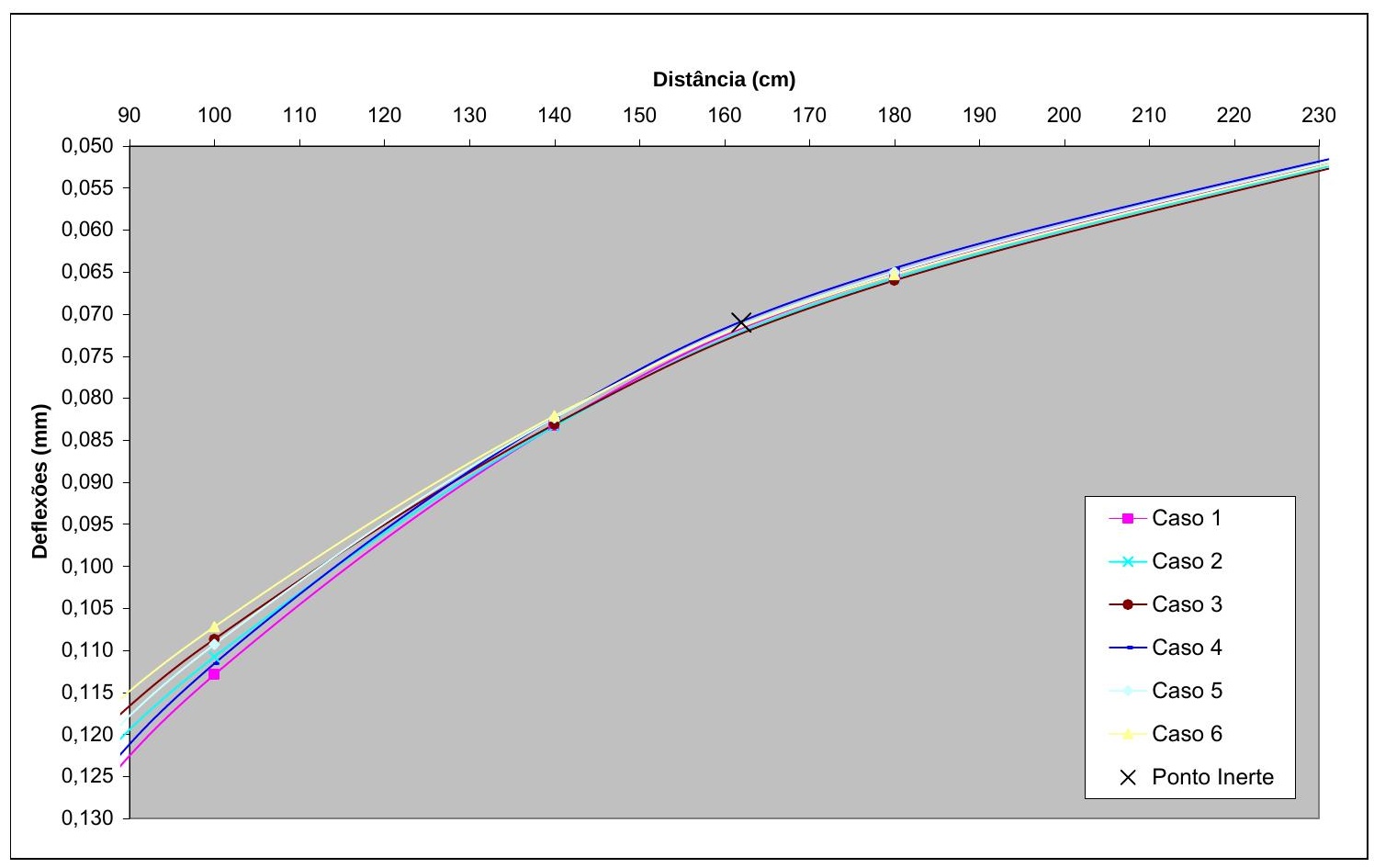

Figura 5.10 - Bacias de deflexões do Caso D. 
A análise das bacias de deflexões apresentadas na Figura 5.10 revelam a presença do ponto inerte para um pavimento de três camadas, com aproximadamente as mesmas coordenadas dos pavimentos com duas camadas $(160 \mathrm{~cm}, 0.075 \mathrm{~mm})$ para o carregamento padrão $(8,2 \mathrm{tf})$.

\section{4 - Um algoritmo convergente para retroanálise do subleito baseado na posição do ponto inerte.}

A observação da existência do ponto inerte, inicialmente em bacias de deflexão de pavimentos rígidos e posteriormente em bacias de pavimentos flexíveis, possibilitou o desenvolvimento de um algoritmo convergente para os resultados de retroanálise, minimizando significativamente o efeito de entrada de módulos iniciais.

Analisando-se separadamente os casos A e B (FWD) dos casos C e D (viga Benkelman), os pavimentos compostos por duas ou três camadas, apresentam estruturas com mesmo módulo de subleito, mesma altura equivalente e mesma posição de coordenadas (Distância x Deflexão) do ponto inerte.

Caracteriza-se deste modo, que somente dois parâmetros têm influência direta na localização das coordenadas $\left(R_{c}, D_{c}\right)$ do ponto inerte: a altura do pavimento $(H)$ e o módulo resiliente do subleito $\left(E_{0}\right)$, ou seja:

$$
\begin{aligned}
& \mathrm{R}_{\mathrm{c}}=f\left(\mathrm{H}, \mathrm{E}_{0}\right) ; \\
& \mathrm{D}_{\mathrm{c}}=f\left(\mathrm{H}, \mathrm{E}_{0}\right) .
\end{aligned}
$$

De fato, existem outros fatores que afetam o posicionamento do ponto inerte, como a carga aplicada e as condições de interface entre camadas adjacentes. Geralmente a carga do FWD é padronizada e a placa de carregamento tem um certo tamanho; para os estudos do ponto inerte Zhang e Sun (2003) consideraram um carregamento de $50 \mathrm{kN}$ e o raio da placa de carregamento de $15 \mathrm{~cm}$. 
Para o estabelecimento de relações entre os parâmetros do ponto inerte $\left(R_{c}\right.$ e $\left.D_{c}\right)$ e as informações da estrutura do pavimento $\left(H, E_{0}\right)$, os autores geraram 1280 bacias de deflexões (carga de $50 \mathrm{kN}$ em um raio de $15 \mathrm{~cm}$ ) para pavimentos com alturas entre 25 a $60 \mathrm{~cm}$ e módulos de subleito entre 25 a 100 MPa que pudessem ser encontrados em situações reais.

Utilizando regressão não linear multivariável, uma vez que as relações entre os parâmetros em questão são difíceis para serem obtidas analiticamente, Zhang e Sun (2003) apresentaram o seguinte modelo matemático que descreve a trajetória do ponto inerte para bacias de deflexões obtidas com FWD:

$$
\begin{aligned}
& R_{c}=\left[a_{1}+a_{2} \cdot\left(\frac{H}{E_{0}}\right)^{a_{3}}\right] \cdot H^{b} \cdot E_{0}{ }^{c} ; \\
& D_{c}=\left[x_{1}+x_{2} \cdot\left(\frac{H}{E_{0}}\right)^{x_{3}}\right] \cdot H^{y} \cdot E_{0}{ }^{z} .
\end{aligned}
$$

Onde, $a_{1}, a_{2}, a_{3}, b, c, x_{1}, x_{2}, x_{3}$, y e z são constantes do modelo apresentadas nas Tabelas 5.9 e 5.10 .

Conhecida a altura do pavimento $(\mathrm{H})$ a ser analisado, as coordenadas de Rc e Dc são funções somente do módulo de resiliência do subleito. Para módulos de resiliência dos subleitos situados em um determinado intervalo, a trajetória do ponto inerte para um pavimento hipotético de duas ou três camadas com uma altura $\mathrm{H}$ constante é representada pela Figura 5.11.

Tabela 5.9 - Constantes do Modelo para $\mathrm{R}_{\mathrm{c}}$ (Zhang e Sun, 2004)

\begin{tabular}{|c|c|c|c|c|c|}
\hline $\mathbf{H}(\mathrm{cm})$ & $\mathbf{a}_{\mathbf{1}}$ & $\mathbf{a}_{\mathbf{2}}$ & $\mathbf{a}_{\mathbf{3}}$ & $\mathbf{b}$ & $\mathbf{c}$ \\
\hline$<42.5$ & -87.15 & 106.4 & 0.0784 & 0.4616 & 0.1464 \\
\hline$>42.5$ & 68.31 & 100.0 & 0.2143 & 0.0909 & 0.3990 \\
\hline
\end{tabular}


Tabela 5.10 - Constantes do Modelo para $D_{c}$ (Zhang e Sun, 2004)

\begin{tabular}{|c|c|c|c|c|c|}
\hline $\mathbf{H}(\mathrm{cm})$ & $\mathbf{X}_{\mathbf{1}}$ & $\mathbf{X}_{\mathbf{2}}$ & $\mathbf{X}_{\mathbf{3}}$ & $\mathbf{y}$ & $\mathbf{z}$ \\
\hline$<42.5$ & 10.56 & 78.42 & 1.182 & -1.958 & 0.3171 \\
\hline$>42.5$ & 9.86 & 47.13 & 1.448 & -1.993 & 0.4595 \\
\hline
\end{tabular}

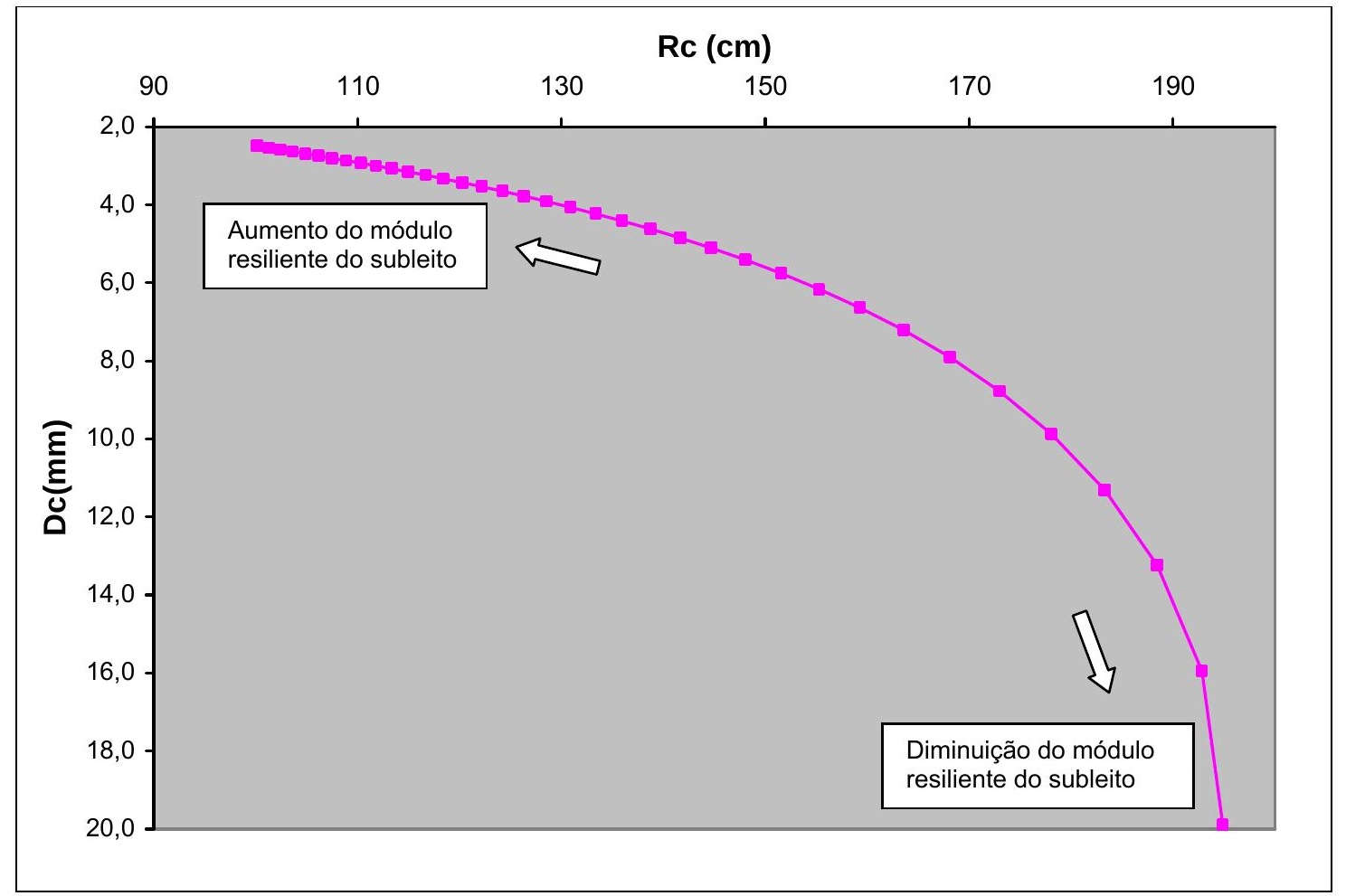

Figura 5.11 - Trajetória do ponto inerte para um pavimento hipotético

A intersecção entre uma bacia de deflexão obtida neste pavimento hipotético (para deflexões medidas $\left(D_{m}\right)$ distantes $\left(R_{m}\right)$ do ponto de aplicação de carga) com a trajetória do ponto inerte, fornece o módulo resiliente do subleito $\mathrm{E}_{0}{ }^{*}$, conforme ilustrado na Figura 5.12. 


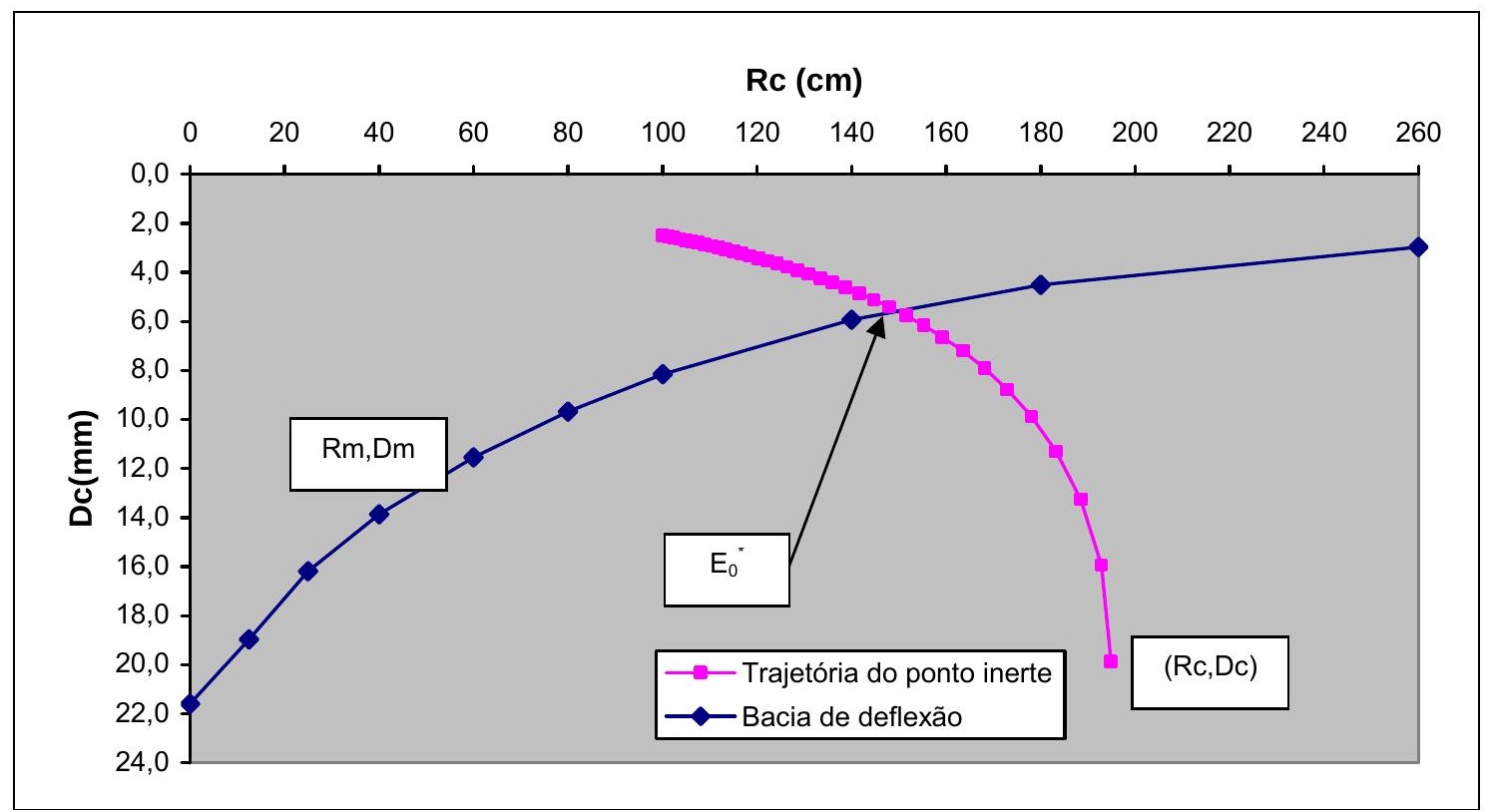

Figura 5.12 - Bacia de deflexão e a trajetória do ponto inerte

O algoritmo convergente de Zhang e Sun (2003) baseado na posição do ponto inerte para retroanalisar o subleito de pavimentos com três camadas, é descrito pelos seguintes passos:

Passo 1 - Obter $\mathrm{H}, \mathrm{H}=\mathrm{h}_{1}+\mathrm{h}_{2}$ (onde $\mathrm{h}_{1}$ é a espessura do revestimento e $\mathrm{h}_{2}$ a espessura da base).

Passo 2 - Fornecer as deflexões medidas e suas respectivas distâncias do centro de aplicação de carga. Ajustar um valor superior para o módulo resiliente do subleito $E_{0}{ }^{u}$, um valor inferior $E_{0}^{\prime}$ e um valor inicial $E_{0}$. Selecionar o critério de convergência $(\varepsilon)$ e contar $k=0$.

Passo 3 - Calcular os parâmetros Rc e Dc do ponto inerte com a altura $\mathrm{H}$ e o valor inicial de $E_{0}$ através das expressões 5.3 e 5.4 .

Passo 4 - Calcular a deflexão medida (Dm) na posição Rc baseado nos dados de deflexões medidas. 
Passo 5 - Comparar a deflexão calculada (Dc) com a deflexão medida (Dm).

Se IDc-Dml< $\varepsilon$, ir para o Passo 6.

Se Dc $>$ Dm, ajustar $E_{0}{ }^{u}=E_{0}$ e $E_{0}=\left(\left(E_{0}+E_{0}^{\prime}\right) / 2\right)$,

Ou se $D c<D m$, ajustar $E_{0}^{\prime}=E_{0}$ e $E_{0}=\left(\left(E_{0}+E_{0}{ }^{u}\right) / 2\right)$, ajustar $k=k+1$ e retornar ao Passo 3.

Passo 6 - Parada, $E_{0}^{*}=\left(\left(E_{0}{ }^{u}+E_{0}^{l}\right) / 2\right)$

A rápida convergência em qualquer caso ( $\mathrm{Dc}>\mathrm{Dm}$ ou $\mathrm{Dc}<\mathrm{Dm})$ ocorre pois, a cada iteração a região provável de $E_{0}$ é dividida pela metade. Outro destaque é a solução única para a retroanálise do subleito. Estas são as principais vantagens de métodos de retroanálise baseados no ponto inerte. 


\section{Capítulo 6 - 0 procedimento de retroanálise proposto}

\section{1 - Considerações inicias}

Esta dissertação apresenta dois objetivos para propor um procedimento de retroanálise em pavimentos flexíveis de duas ou mais camadas:

a) Verificação do modelo e readaptação dos coeficientes das expressões 5.3 e 5.4 de coordenadas do ponto inerte (Rc e Dc) do carregamento com FWD para o carregamento com o eixo padrão $(8,2$ tf) de modo a retroanalisar o subleito baseando-se na teoria do ponto inerte com bacias de deflexões medidas pela viga Benkelman.

b) Elaboração de modelo matemático para obtenção aproximada do módulo resiliente equivalente das camadas do pavimento encontradas acima do subleito (camada equivalente).

É escopo deste capítulo a descrição dos itens a e b previamente referidos.

\section{2 - Retroanálise do Subleito Utilizando-se a Teoria do Ponto Inerte}

No capítulo 5 foram apresentadas expressões de autoria de Zhang e Sun (2003) que fornecem as coordenadas do ponto inerte para o carregamento com FWD; tais expressões têm a seguinte forma:

$$
R_{c}=\left[a_{1}+a_{2} \cdot\left(\frac{H}{E_{0}}\right)^{a_{3}}\right] \cdot H^{b} \cdot E_{0}{ }^{c}
$$




$$
D_{c}=\left[x_{1}+x_{2} \cdot\left(\frac{H}{E_{0}}\right)^{x_{3}}\right] \cdot H^{y} \cdot E_{0}{ }^{z}
$$

Sendo $a_{1}, a_{2}, a_{3}, b, c, x_{1}, x_{2}, x_{3}, y$ e $z$, constantes do modelo para o carregamento com FWD descritas nas Tabelas 5.9 e 5.10 .

Para a readaptação das constantes das expressões 5.3 e 5.4 para o carregamento com o eixo padrão (8,2 tf), foram utilizadas 19.654 bacias teóricas de deflexões com auxílio do programa ELSYM5. Estas bacias de deflexões são apresentadas no Anexo A (CD-Rom) e têm as seguintes características:

- Carga aplicada: eixo padrão de 8,2 tf (2,05 tf por roda com um raio de $10,75 \mathrm{~cm})$;

- Altura de pavimento: 20 a $90 \mathrm{~cm}$, com variações de 5 em $5 \mathrm{~cm}$;

- Módulo resiliente da camada equivalente: 200 a 2000 MPa com variações de 50 em $50 \mathrm{MPa}$;

- Módulo resiliente do subleito: 20 a 200 MPa com variações de 5 em 5 MPa;

- Coeficiente de Poisson do subleito: 0,45; e

- Coeficiente de Poisson da camada equivalente: 0,30.

Os pontos de medidas de deflexão $(\mathrm{Rc})$ a partir do centro de aplicação de carga $(0 \mathrm{~cm})$ foram: $0,25,40,60,80,100,140,180,260 \mathrm{~cm}$. As Figuras 6.1 e 6.2 demonstram as condições de aplicação de carga e distâncias de medidas de deflexões.

Um programa computacional em linguagem Pascal foi desenvolvido para o fornecimento das coordenadas das intersecções (Rc e Dc) entre bacias deflectométricas, para uma mesma altura e módulo de subleito, de maneira a se obter o ponto inerte do grupo de estruturas de pavimentos em estudo. 


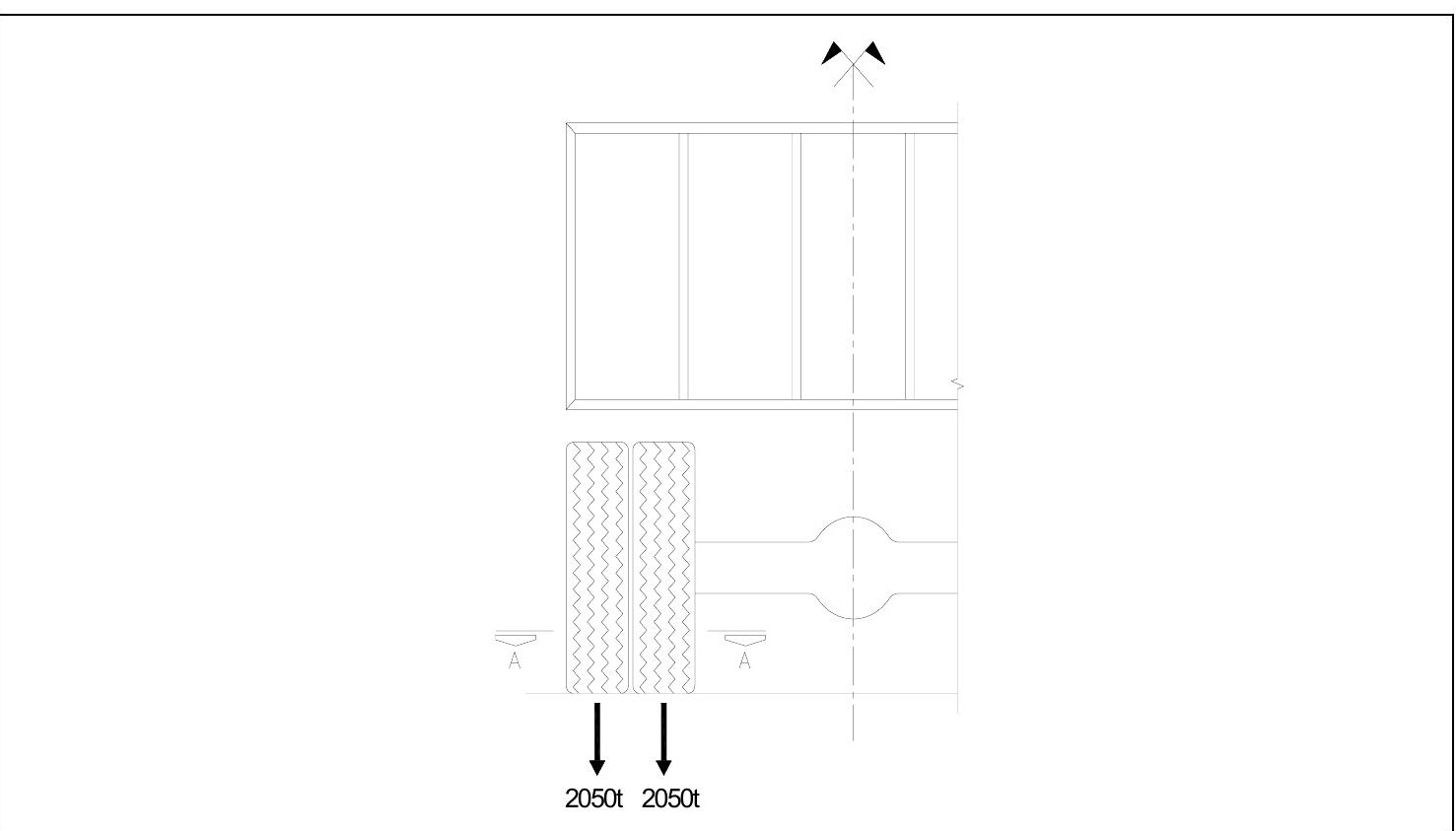

Figura 6.1 - Cargas aplicadas pelo eixo padrão

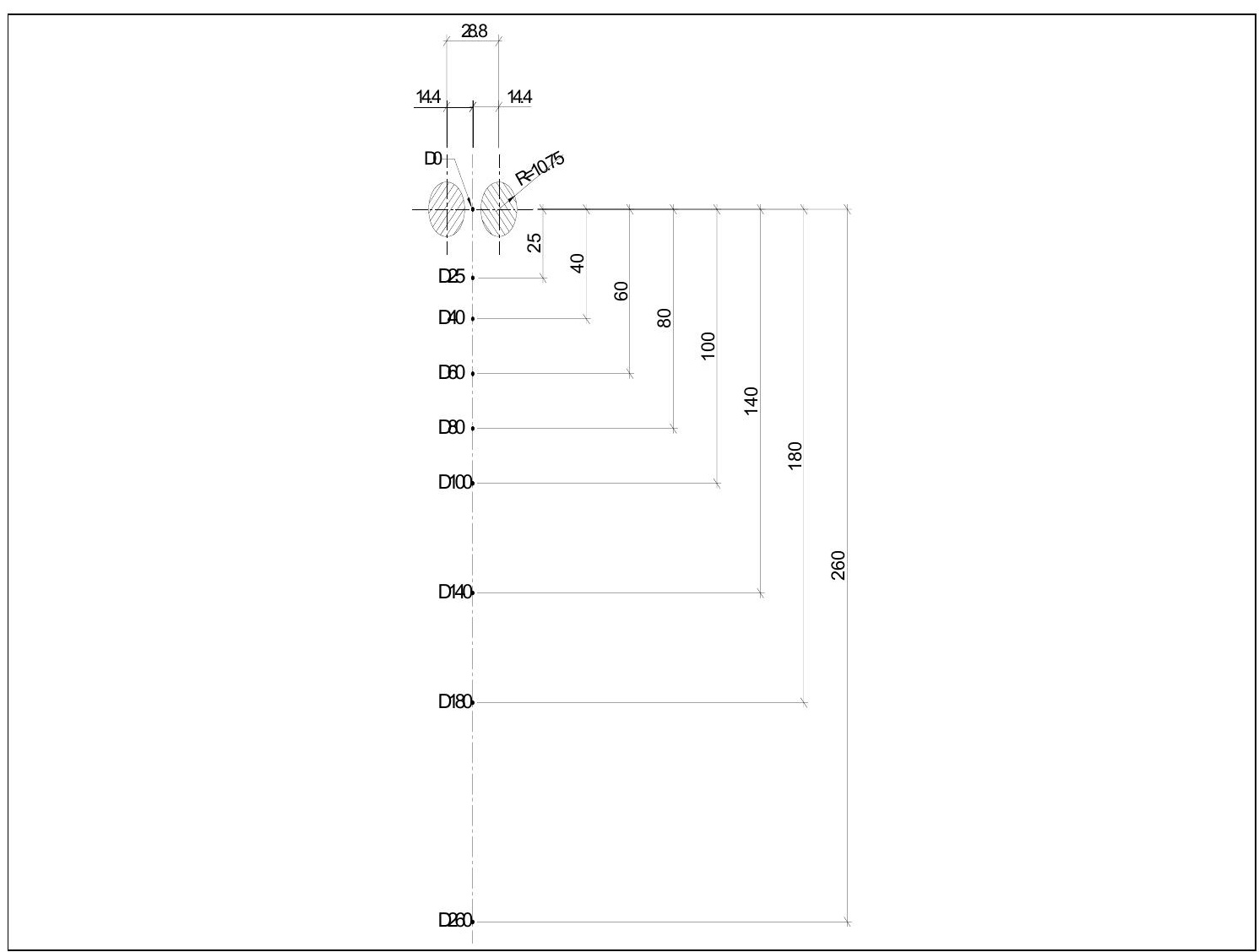

Figura 6.2 - Corte AA (cotas em centímetros)

Este programa fornece o ponto de convergência entre duas bacias de deflexões com referência na bacia deflectométrica de menor módulo resiliente 
equivalente. A Tabela 6.1 auxilia na compreensão do algoritmo utilizado, representando as deflexões teóricas geradas pelo programa ELSYM5 para o carregamento do eixo padrão, especificamente para um pavimento de $45 \mathrm{~cm}$ de altura e módulo resiliente do subleito de $130 \mathrm{MPa}$.

Tabela 6.1 - Fração do banco de dados para retroanálise do subleito

\begin{tabular}{|c|c|c|c|c|c|c|c|c|c|c|c|}
\hline \multirow[b]{2}{*}{$\underset{(\mathrm{cm})}{\mathrm{H}}$} & \multirow[b]{2}{*}{$\begin{array}{l}\text { Mceq } \\
\text { (MPa) }\end{array}$} & \multirow[b]{2}{*}{$\begin{array}{l}\text { Msub } \\
\text { (MPa) }\end{array}$} & \multicolumn{9}{|c|}{ Deflexões $\left(\times 10^{-4} \mathrm{~cm}\right)$} \\
\hline & & & D0 & D25 & D40 & D60 & D80 & D100 & D140 & D180 & D260 \\
\hline 45 & 200 & 130 & 51,33 & 27,34 & 19,65 & 14,01 & 10,69 & 8,5 & 5,87 & 4,51 & 3,15 \\
\hline 45 & 250 & 130 & 45,28 & 25,74 & 19,14 & 13,98 & 10,77 & 8,59 & 5,93 & 4,53 & 3,14 \\
\hline 45 & 300 & 130 & 41,07 & 24,54 & 18,71 & 13,93 & 10,82 & 8,66 & 5,98 & 4,55 & 3,13 \\
\hline 45 & 350 & 130 & 37,94 & 23,58 & 18,33 & 13,86 & 10,85 & 8,71 & 6,03 & 4,58 & 3,13 \\
\hline 45 & 400 & 130 & 35,49 & 22,79 & 17,99 & 13,78 & 10,86 & 8,76 & 6,07 & 4,60 & 3,13 \\
\hline 45 & 450 & 130 & 33,52 & 22,12 & 17,69 & 13,69 & 10,87 & 8,79 & 6,11 & 4,62 & 3,13 \\
\hline 45 & 500 & 130 & 31,88 & 21,54 & 17,42 & 13,61 & 10,86 & 8,82 & 6,15 & 4,64 & 3,13 \\
\hline 45 & 550 & 130 & 30,49 & 21,02 & 17,16 & 13,52 & 10,85 & 8,84 & 6,18 & 4,66 & 3,13 \\
\hline 45 & 600 & 130 & 29,29 & 20,56 & 16,92 & 13,44 & 10,84 & 8,86 & 6,21 & 4,68 & 3,14 \\
\hline 45 & 650 & 130 & 28,24 & 20,14 & 16,70 & 13,35 & 10,82 & 8,87 & 6,24 & 4,70 & 3,14 \\
\hline 45 & 700 & 130 & 27,32 & 19,76 & 16,49 & 13,26 & 10,80 & 8,88 & 6,26 & 4,72 & 3,14 \\
\hline 45 & 750 & 130 & 26,50 & 19,41 & 16,30 & 13,18 & 10,77 & 8,89 & 6,28 & 4,73 & 3,15 \\
\hline 45 & 800 & 130 & 25,75 & 19,09 & 16,11 & 13,10 & 10,75 & 8,89 & 6,30 & 4,75 & 3,15 \\
\hline 45 & 850 & 130 & 25,08 & 18,79 & 15,94 & 13,02 & 10,72 & 8,89 & 6,32 & 4,77 & 3,15 \\
\hline 45 & 900 & 130 & 24,47 & 18,51 & 15,77 & 12,94 & 10,69 & 8,89 & 6,34 & 4,78 & 3,16 \\
\hline 45 & 950 & 130 & 23,91 & 18,24 & 15,61 & 12,86 & 10,66 & 8,89 & 6,36 & 4,80 & 3,16 \\
\hline 45 & 1000 & 130 & 23,39 & 18,00 & 15,46 & 12,79 & 10,63 & 8,88 & 6,37 & 4,81 & 3,17 \\
\hline 45 & 1050 & 130 & 22,91 & 17,76 & 15,31 & 12,71 & 10,60 & 8,88 & 6,39 & 4,83 & 3,17 \\
\hline 45 & 1100 & 130 & 22,47 & 17,55 & 15,17 & 12,64 & 10,57 & 8,87 & 6,40 & 4,84 & 3,18 \\
\hline 45 & 1150 & 130 & 22,06 & 17,34 & 15,04 & 12,57 & 10,54 & 8,86 & 6,41 & 4,85 & 3,18 \\
\hline 45 & 1200 & 130 & 21,67 & 17,14 & 14,91 & 12,50 & 10,51 & 8,85 & 6,42 & 4,87 & 3,19 \\
\hline 45 & 1250 & 130 & 21,31 & 16,95 & 14,79 & 12,44 & 10,47 & 8,85 & 6,43 & 4,88 & 3,19 \\
\hline 45 & 1300 & 130 & 20,97 & 16,77 & 14,67 & 12,37 & 10,44 & 8,84 & 6,44 & 4,89 & 3,20 \\
\hline 45 & 1350 & 130 & 20,65 & 16,60 & 14,56 & 12,31 & 10,41 & 8,82 & 6,45 & 4,90 & 3,20 \\
\hline 45 & 1400 & 130 & 20,34 & 16,43 & 14,45 & 12,24 & 10,38 & 8,81 & 6,46 & 4,91 & 3,21 \\
\hline 45 & 1450 & 130 & 20,06 & 16,28 & 14,34 & 12,18 & 10,35 & 8,80 & 6,47 & 4,92 & 3,21 \\
\hline 45 & 1500 & 130 & 19,78 & 16,12 & 14,23 & 12,12 & 10,32 & 8,79 & 6,47 & 4,93 & 3,22 \\
\hline 45 & 1550 & 130 & 19,53 & 15,98 & 14,13 & 12,06 & 10,29 & 8,78 & 6,48 & 4,94 & 3,22 \\
\hline 45 & 1600 & 130 & 19,28 & 15,84 & 14,04 & 12,00 & 10,26 & 8,76 & 6,48 & 4,95 & 3,23 \\
\hline 45 & 1650 & 130 & 19,05 & 15,70 & 13,94 & 11,95 & 10,22 & 8,75 & 6,49 & 4,96 & 3,23 \\
\hline 45 & 1700 & 130 & 18,82 & 15,57 & 13,85 & 11,89 & 10,19 & 8,74 & 6,49 & 4,97 & 3,24 \\
\hline 45 & 1750 & 130 & 18,61 & 15,44 & 13,76 & 11,84 & 10,16 & 8,73 & 6,49 & 4,97 & 3,24 \\
\hline 45 & 1800 & 130 & 18,41 & 15,32 & 13,68 & 11,79 & 10,14 & 8,71 & 6,50 & 4,98 & 3,25 \\
\hline 45 & 1850 & 130 & 18,21 & 15,20 & 13,59 & 11,73 & 10,11 & 8,70 & 6,50 & 4,99 & 3,25 \\
\hline 45 & 1900 & 130 & 18,02 & 15,09 & 13,51 & 11,68 & 10,08 & 8,68 & 6,50 & 5,00 & 3,26 \\
\hline 45 & 1950 & 130 & 17,84 & 14,98 & 13,43 & 11,63 & 10,05 & 8,67 & 6,51 & 5,00 & 3,26 \\
\hline 45 & 2000 & 130 & 17,67 & 14,87 & 13,35 & 11,58 & 10,02 & 8,66 & 6,51 & 5,01 & 3,27 \\
\hline
\end{tabular}


O algoritmo utilizado adota como parâmetro de referência para comparação a bacia deflectométrica de menor módulo equivalente dentro do intervalo apresentado na Tabela 6.1, ou seja, a primeira linha de deflexões (em negrito).

Verifica-se a intersecção de todas as outras bacias de deflexões pertencentes a este intervalo com a linha em negrito. Um outro algoritmo analisado foi a intersecção de duas bacias deflectométricas consecutivas dentro do intervalo exposto na Tabela 6.1 porém, o algoritmo adotado de uma única bacia de referência (menor módulo da camada equivalente), apresentou melhor desempenho na qualidade da regressão para obtenção dos Pontos Inertes.

Para simplificação do algoritmo, uniram-se os pontos de deflexões medidas subseqüentes de uma mesma bacia de deflexão por retas, sendo as coordenadas de intersecção entre duas bacias, o ponto de cruzamento entre duas retas. O programa desenvolvido encontra-se no Anexo $B$ e seus resultados são exibidos no Anexo C presente em CD-Rom.

Com a altura do pavimento, módulo de resiliência do subleito e os parâmetros Rc e Dc de coordenadas do ponto inerte, utilizou-se o software Statistica ${ }^{\circledR} 6.0$ para uma estimativa das constantes presentes nas expressões 5.3 e 5.4. Os coeficientes readaptados encontrados para o carregamento com o eixo padrão foram:

$$
\begin{gathered}
R c=\left[-104,057+114,777\left(\frac{H}{E}\right)^{0,0158}\right](H)^{0,811}(E)^{-0,171} \\
\mathrm{R}^{2}=0,9641 \\
D c=\left[11855,85+436,84\left(\frac{H}{E}\right)^{0,0033}\right](H)^{-0,976}(E)^{-0,693} \\
\mathrm{R}^{2}=0,9819
\end{gathered}
$$


Obtidas as equações 6.1 e 6.2, utilizou-se o mesmo algoritmo de Zhang e Sun (2003) descrito no capítulo 5 para a elaboração de um procedimento de retroanálise baseado na Teoria do Ponto Inerte para a observação do erro na retroanálise do subleito de pavimentos flexíveis submetidos ao carregamento do eixo padrão.

Em linguagem Pascal, o programa para retroanalisar o subleito de bacias de deflexões teóricas obtidas com o carregamento do eixo padrão encontra-se no Anexo D. Um banco de dados composto por 17.528 bacias deflectométricas teóricas foi gerado a partir do programa ELSYM5 com as seguintes características:

- Carga aplicada: eixo padrão de 8,2 tf (2,05 tf por roda com um raio de $10,75 \mathrm{~cm}$ de aplicação de carga, ver Figuras 6.1 e 6.2).

- Altura de pavimento: 20 a 90cm com variação aleatória em duas casas decimais.

- Módulo resiliente da camada equivalente: 200 a 2000 MPa (aleatório).

- Módulo resiliente do subleito: 20 a 200 MPa (aleatório).

- Coeficiente de Poisson do subleito: 0,45

- Coeficiente de Poisson da camada equivalente: 0,30.

A Tabela 6.2 representa um segmento do conjunto de dados utilizados na elaboração dos modelos para a análise do erro da retroanálise do subleito. Este banco de dados encontra-se integralmente no Anexo E (CD-Rom).

Tabela 6.2 - Fração do banco de dados aleatório

\begin{tabular}{|c|c|c|c|c|c|c|c|c|c|c|c|}
\hline \multirow[b]{2}{*}{$\mathrm{H}(\mathrm{cm})$} & \multirow[b]{2}{*}{$\begin{array}{l}\text { Mceq } \\
(\mathrm{MPa})\end{array}$} & \multirow[b]{2}{*}{$\begin{array}{l}\text { Msub } \\
\text { (MPa) }\end{array}$} & \multicolumn{9}{|c|}{ Deflexões $\left(\times 10^{-4} \mathrm{~cm}\right)$} \\
\hline & & & Do & D25 & D40 & D60 & D80 & D100 & D140 & D180 & D260 \\
\hline 20,46 & 646,3 & 96,5 & 53,57 & 37,75 & 28,24 & 19,59 & 14,36 & 11,16 & 7,72 & 5,97 & 4,16 \\
\hline 30,49 & 1977,9 & 51,9 & 43,47 & 39,29 & 35,57 & 30,72 & 26,31 & 22,46 & 16,5 & 12,47 & 8,02 \\
\hline 71,2 & 1652,3 & 116,5 & 15,55 & 11,93 & 10,92 & 9,87 & 8,97 & 8,15 & 6,72 & 5,56 & 3,9 \\
\hline 24,62 & 1704,4 & 105 & 33,9 & 27,64 & 23,08 & 17,92 & 13,99 & 11,1 & 7,52 & 5,62 & 3,81 \\
\hline 30,84 & 566,2 & 43,8 & 73,85 & 60,3 & 51,44 & 41,25 & 33,13 & 26,86 & 18,53 & 13,8 & 9,19 \\
\hline 89,51 & 1440,6 & 147,4 & 13,11 & 9,19 & 8,17 & 7,31 & 6,65 & 6,07 & 5,08 & 4,27 & 3,09 \\
\hline 97,31 & 272,7 & 109,7 & 39,16 & 21,85 & 16,75 & 13,2 & 11,07 & 9,5 & 7,24 & 5,76 & 3,97 \\
\hline 69,67 & 1788,3 & 79,9 & 19,21 & 15,08 & 14,14 & 13,06 & 12,07 & 11,13 & 9,42 & 7,97 & 5,77 \\
\hline
\end{tabular}


Os parâmetros necessários adotados na programação baseada no algoritmo de Zhang e Sun (2003) foram:

- Tolerância de erro da deflexão entre a bacia deflectométrica analisada e a trajetória do Ponto Inerte: 0,0001;

- Limite inferior do módulo resiliente: $20 \mathrm{MPa}$;

- Limite superior do módulo resiliente: 200 MPa; e

- Número máximo de iterações: 25.

O Anexo F (CD-Rom) fornece o erro relativo na retroanálise do subleito, assim como o número de iterações necessárias para se chegar à tolerância de erro pré-estabelecida. As Figuras 6.3 e 6.4 ilustram a distribuição de erros obtida no processo em duas situações distintas: em função da altura do pavimento e em função do módulo resiliente do subleito.

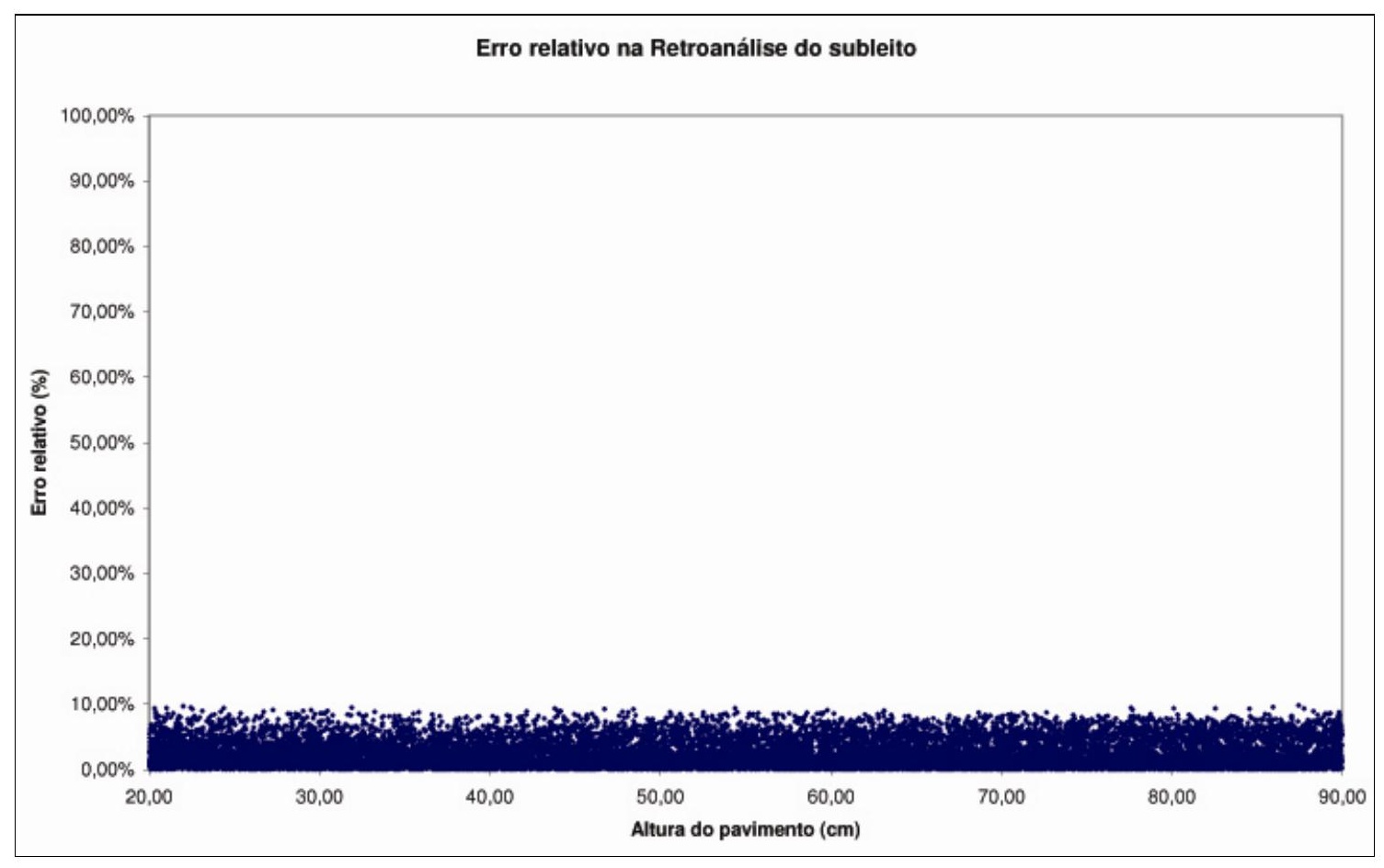

Figura 6.3 - Altura do pavimento x Erro relativo*

* Diferença absoluta em porcentagem entre o valor real e o valor calculado. 


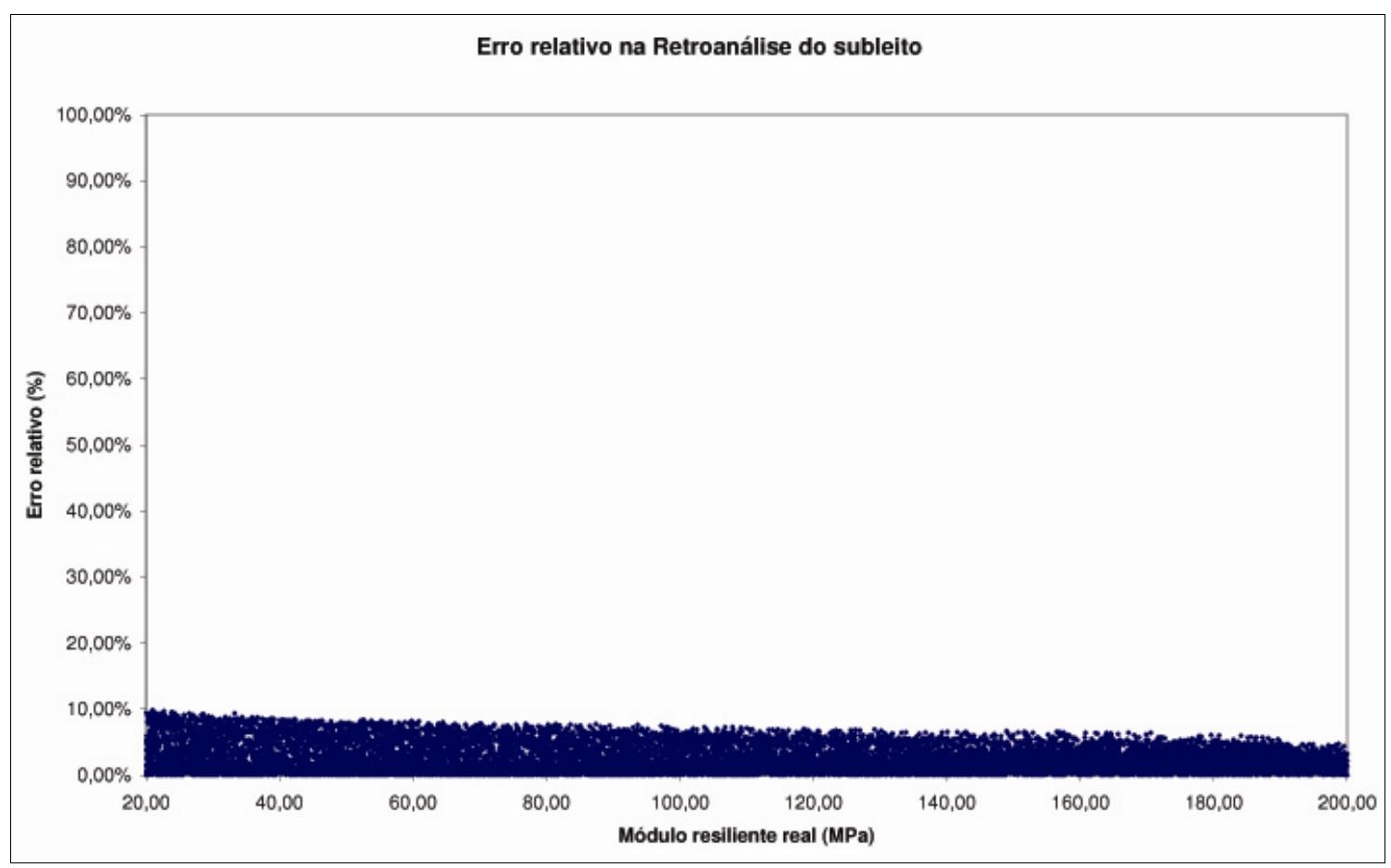

Figura 6.4 - Módulo resiliente real x Erro relativo

Ao observar as Figuras 6.3 e 6.4 percebe-se o erro relativo com distribuição uniforme, tanto em função da altura do pavimento, como do módulo real do subleito, com um máximo da ordem de 10\%, caracterizando-se desta maneira, o potencial da Teoria do Ponto Inerte para a retroanálise do subleito.

De maneira complementar, a Tabela 6.3 mostra a distribuição estatística encontrada com o emprego da Teoria do Ponto Inerte.

Tabela 6.3 - Distribuição de erro na retroanálise do subleito

\begin{tabular}{|c|c|c|c|}
\hline \multicolumn{4}{|c|}{ Distribuição do erro - Estatística descritiva } \\
\hline Erro (\%) & $\begin{array}{c}\text { Número de } \\
\text { ocorrências }\end{array}$ & $\begin{array}{c}\text { Porcentagem } \\
\mathbf{( \% )}\end{array}$ & $\begin{array}{c}\text { Porcentagem } \\
\text { acumulada (\%) }\end{array}$ \\
\hline 0,00 & 31 & 0,18 & 0,18 \\
\hline $0,00<\mathrm{a} \leq 2,00$ & 9209 & 52,54 & 52,72 \\
\hline $2,00<\mathrm{a} \leq 4,00$ & 4439 & 25,33 & 78,04 \\
\hline $4,00<\mathrm{a} \leq 6,00$ & 2474 & 14,11 & 92,16 \\
\hline $6,00<\mathrm{a} \leq 8,00$ & 1184 & 6,75 & 98,91 \\
\hline $8,00<\mathrm{a} \leq 10,00$ & 191 & 1,09 & 100,00 \\
\hline
\end{tabular}


A retroanálise do subleito de pavimentos baseada na Teoria do Ponto Inerte também pode ser feita graficamente com a utilização dos ábacos apresentados nas Figuras 6.5 a 6.7, que são constituídos por famílias de curvas obtidas com as expressões 6.1 e 6.2. Resultados mais precisos são obtidos com a utilização do programa em linguagem Pascal presente no Anexo $\mathrm{H}$.

Para a utilização da solução gráfica, traça-se a bacia deflectomética sobre o gráfico. A interseção da bacia deflectométrica com a curva de altura do pavimento a retroanalisar, fornece um ponto entre as curvas do módulo resiliente do subleito.

Os ábacos para impressão encontram-se no Anexo I deste trabalho.

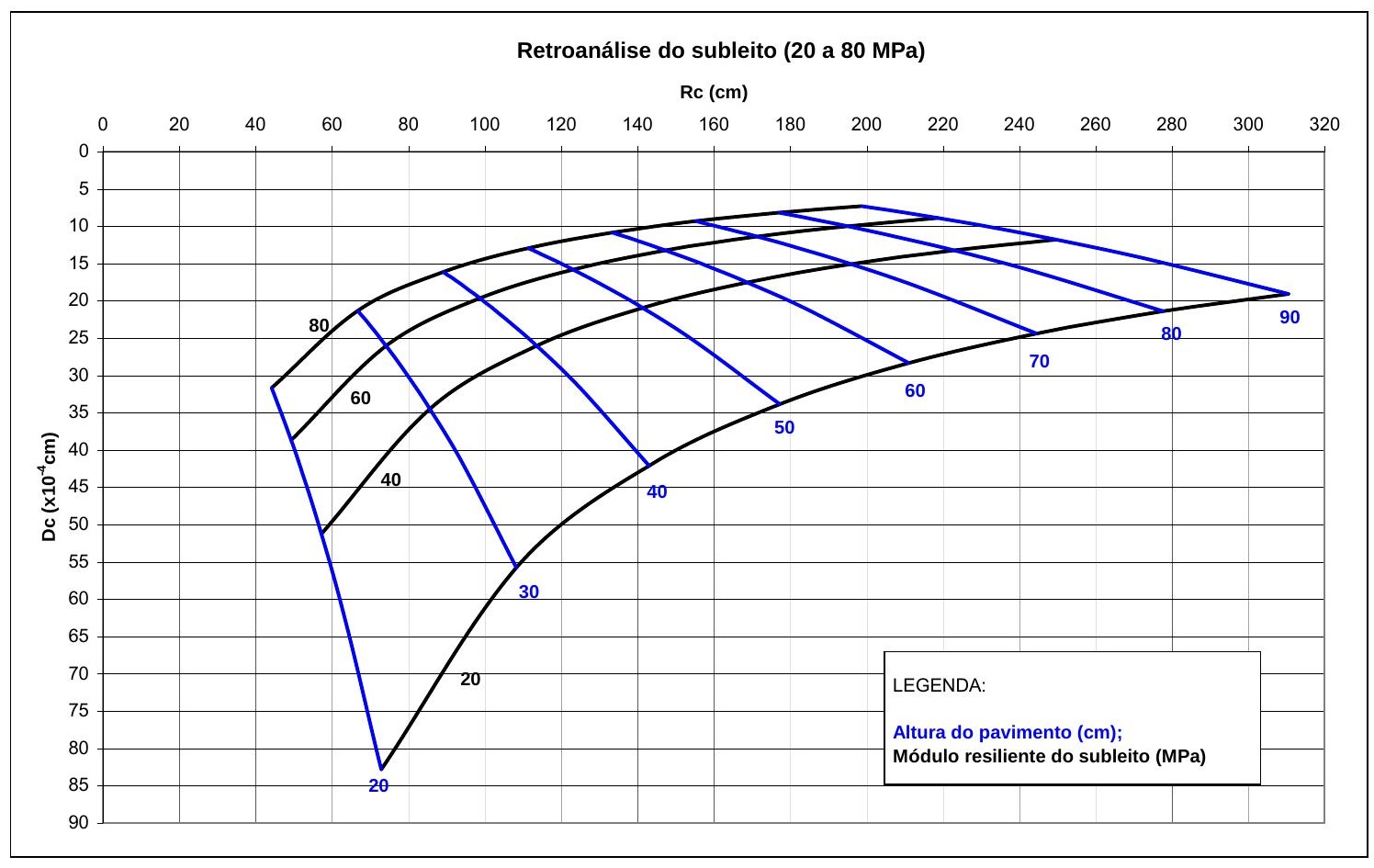

Figura 6.5 - Solução gráfica para a retroanálise do subleito entre 20 e $80 \mathrm{MPa}$ 


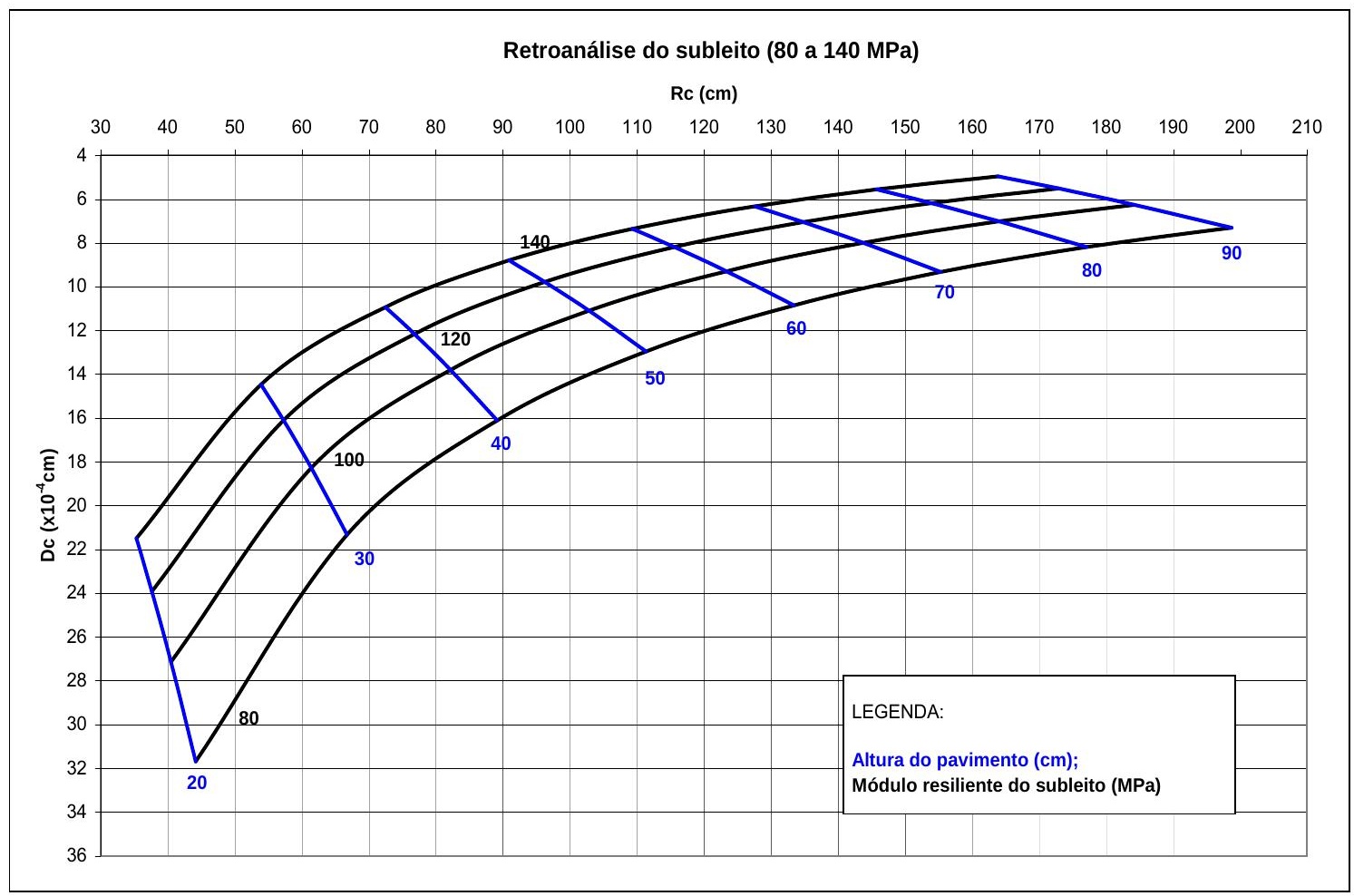

Figura 6.6 - Solução gráfica para a retroanálise do subleito entre 80 e $140 \mathrm{MPa}$

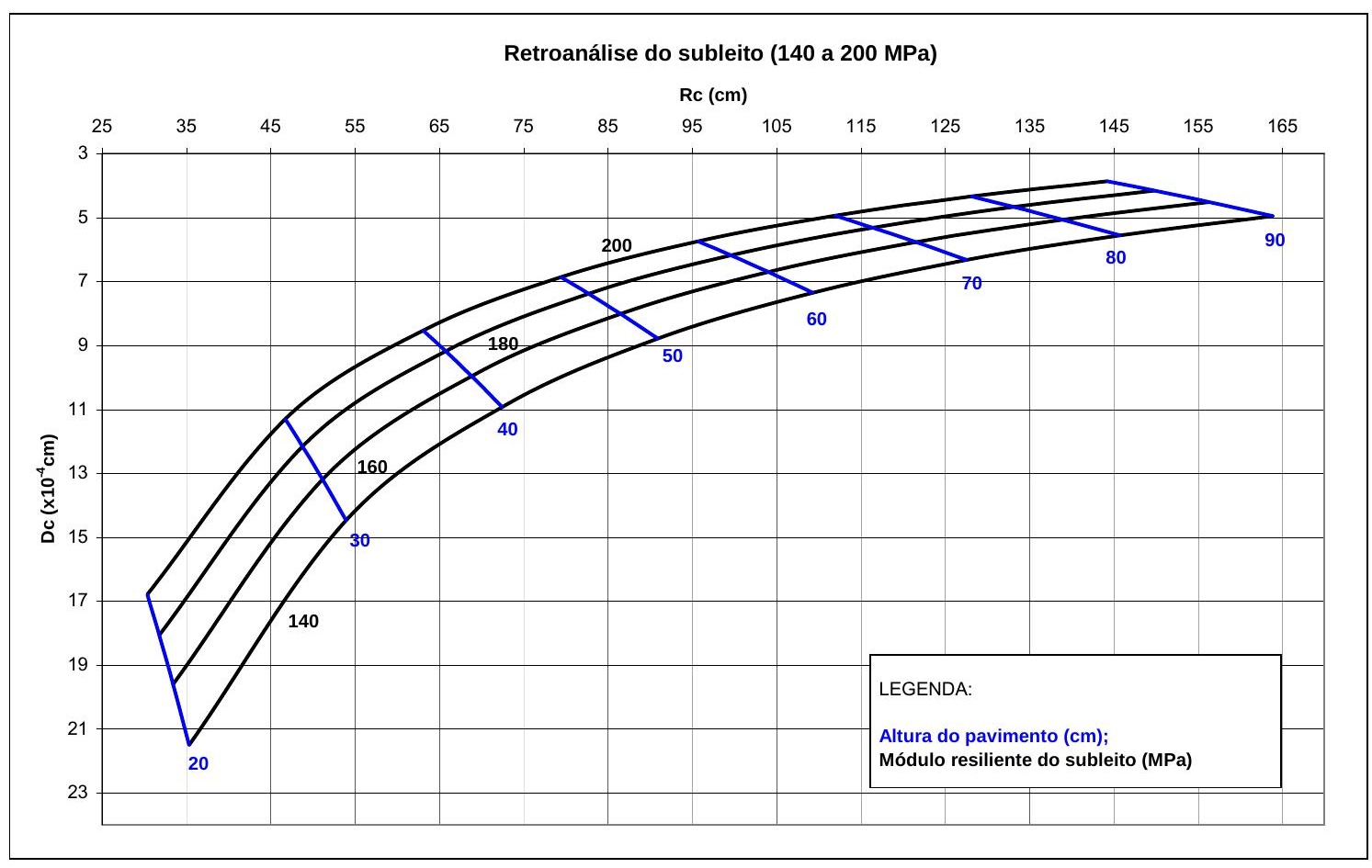

Figura 6.7 - Solução gráfica para a retroanálise do subleito entre 140 e 200 $\mathrm{MPa}$ 


\section{3 - Retroanálise da Camada Equivalente}

A camada equivalente simula ou é uma única camada acima do subleito com altura $\mathrm{H}$, tendo um único módulo resiliente, equivalente ao módulo resiliente das camadas de base, revestimento, sub-base,... para uma mesma altura $\mathrm{H}$.

Para retroanalisar a camada equivalente, utilizou-se o mesmo banco de dados de bacias deflectométricas teóricas presentes no Anexo E, ou seja, o mesmo banco de dados utilizados na avaliação do erro da retroanálise do subleito.

Para um melhor ajuste do modelo e de distribuição de simetria dos dados, optou-se na utilização do logaritmo das medidas de deflexões $\left(D_{0}\right)$, módulos resilientes da camada equivalente e módulos resilientes do subleito. Este procedimento implica em uma distribuição que se aproxima da distribuição Normal para estes parâmetros, fornecendo melhores ajustes para o modelo em estudo.

O software Statistica ${ }^{\circledR} 6.0$ possibilitou a elaboração de um modelo de regressão múltipla fatorial dos parâmetros significativos (altura do pavimento,

módulo de resiliência do subleito e deflexão no ponto $D_{0}$ ) a serem utilizados na previsão do módulo de resiliência da camada equivalente. O modelo resultante é descrito na equação 6.3 .

$$
\begin{gathered}
\log (M e q)=\frac{\log \left(D_{0}\right)+2,526 \cdot \log (H)+2,881 \cdot \log (S)-7,289-1,623 \cdot(\log (H) \cdot \log \cdot(S))}{\text { 0,58.Log}(S)+0,443 \cdot \log (H)-0,878-0,434 \cdot(\log (H) \cdot \log (S))} \\
\mathrm{R}^{2}=0,9961
\end{gathered}
$$

Sendo,

Meq: módulo resiliente da camada equivalente [MPa];

$\mathrm{H}$ : altura do pavimento [cm];

S: módulo resiliente do subleito [MPa]; e

$\mathrm{D}_{0}$ : deflexão medida $\left[\times 10^{-4} \mathrm{~cm}\right]$ entre as rodas duplas. 
A expressão (6.3) foi aplicada ao banco de dados utilizado em sua elaboração para ser verificado o erro relativo. As Figuras 6.8, 6.9 e 6.10 ilustram as distribuições de erros obtidas no processo em três situações distintas: em função da altura do pavimento, em função do módulo resiliente do subleito e em função do módulo resiliente real da camada equivalente.

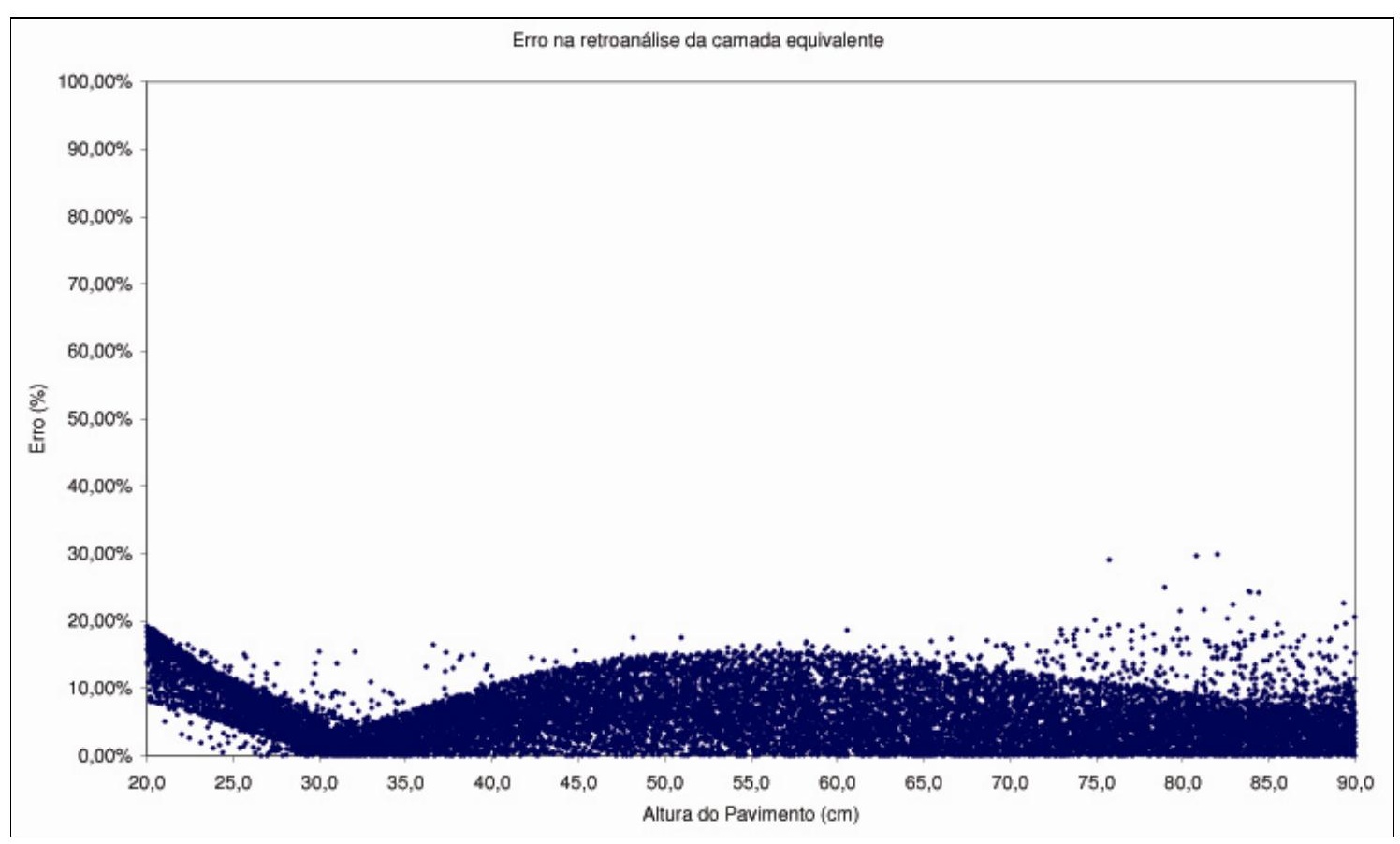

Figura 6.8 - Altura do pavimento x Erro relativo*

* Diferença Absoluta em porcentagem entre o valor real e o valor calculado. 


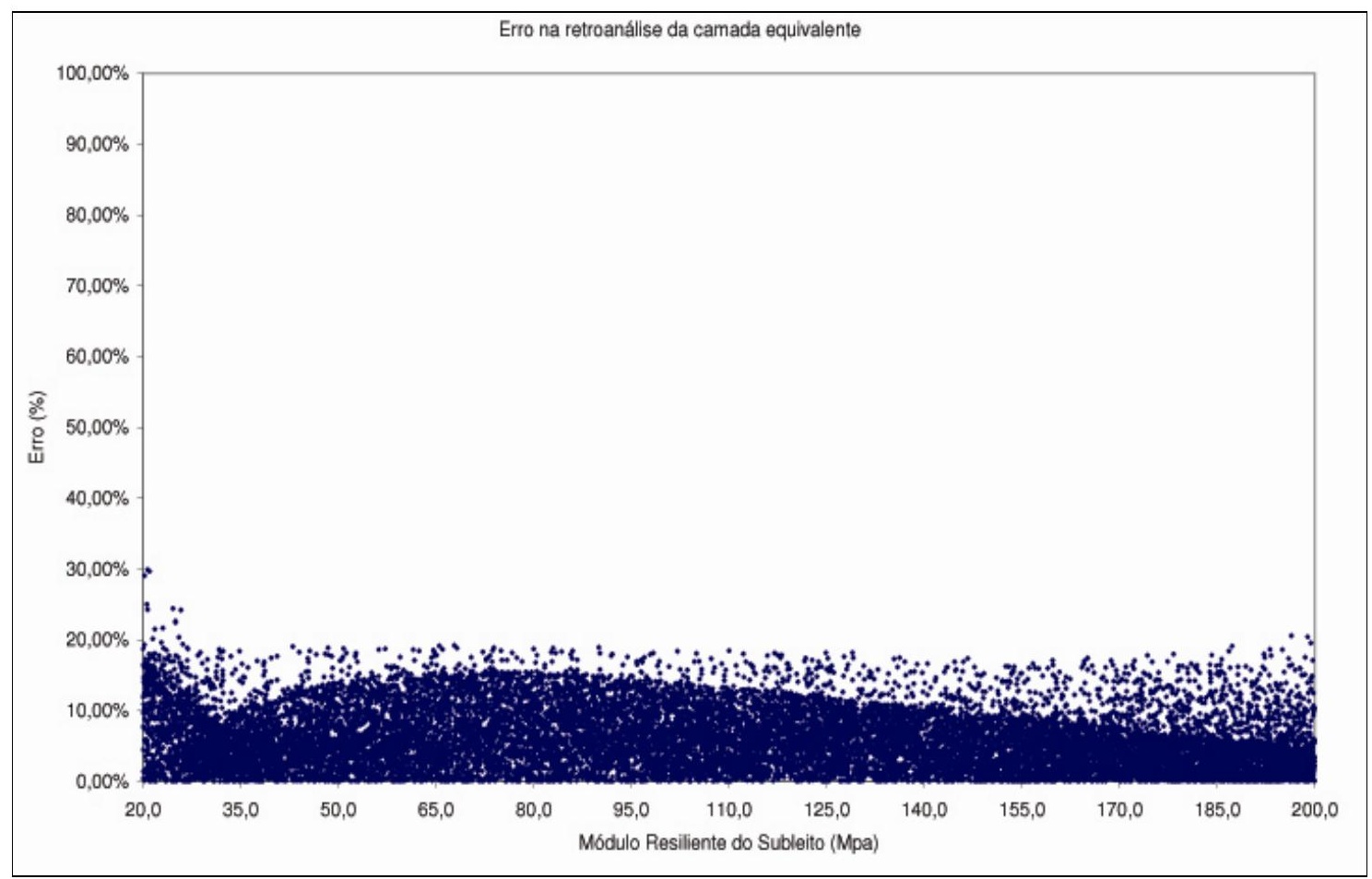

Figura 6.9 - Módulo resiliente do subleito x Erro relativo

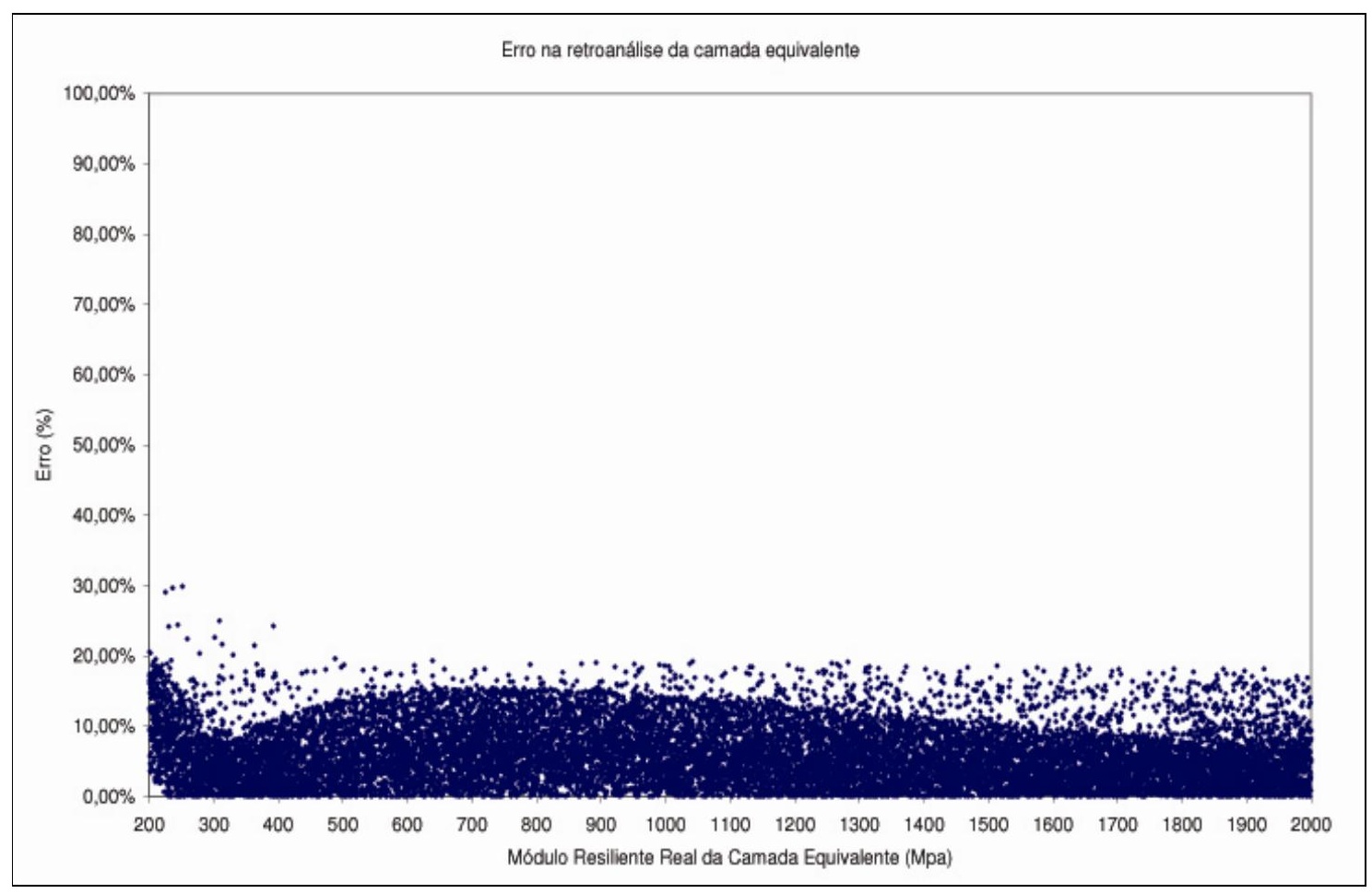

Figura 6.10 - Módulo resiliente real da camada equivalente x Erro relativo 
A Tabela 6.4 descreve estatisticamente os resultados na avaliação do erro no modelo proposto para a retroanálise da camada equivalente.

Tabela 6.4 - Distribuição de erro na retroanálise da camada equivalente

\begin{tabular}{|c|c|c|c|}
\hline \multicolumn{4}{|c|}{ Distribuição do erro - Estatística descritiva } \\
\hline Erro (\%) & $\begin{array}{c}\text { Número de } \\
\text { ocorrências }\end{array}$ & $\begin{array}{c}\text { Porcentagem } \\
\text { (\%) }\end{array}$ & $\begin{array}{c}\text { Porcentagem } \\
\text { acumulada (\%) }\end{array}$ \\
\hline 0,00 & 9 & 0,05 & 0,05 \\
\hline $0,00<a \leq 5,00$ & 8173 & 46,63 & 46,68 \\
\hline $5,00<a \leq 10,00$ & 6157 & 35,13 & 81,81 \\
\hline $10,00<a \leq 15,00$ & 2708 & 15,45 & 97,26 \\
\hline $15,00<a \leq 20,00$ & 466 & 2,66 & 99,21 \\
\hline $20,00<a \leq 25,00$ & 12 & 0,07 & 99,98 \\
\hline $25,00<a \leq 30,00$ & 3 & 0,02 & 100,00 \\
\hline
\end{tabular}

Em função da imprecisão presente no processo de retroanálise, o modelo revelado na expressão 6.3 apresenta um erro máximo relativo da ordem de $20 \%$ para $99,21 \%$ das 17.528 bacias deflectométricas teóricas utilizadas na sua obtenção, demonstrando "certo grau" de simplificação e confiança para avaliar o módulo resiliente da camada equivalente.

O Anexo G, disponível no CD-Rom anexo, revela em detalhes os erros encontrados em todos os casos analisados no processo de retroanálise da camada equivalente.

\section{4 - Análise de sensibilidade do procedimento proposto em relação à altura do pavimento}

Um dos fatores influentes no resultado da retroanálise de pavimentos flexíveis é a altura do pavimento, ou seja, a espessura das camadas existentes sobre o subleito. Estas espessuras apresentam características de não homogeneidade dentro de um mesmo trecho em estudo, resultante de disposições construtivas. 
Para que se possa avaliar a influência da espessura do pavimento no procedimento de retroanálise proposto, escolheu-se aleatoriamente uma bacia deflectométrica presente no Anexo $E$ variando-se a altura da camada equivalente. A variação de alturas da camada equivalente obedeceu a seguinte distribuição de erro descrita na Tabela 6.5:

Tabela 6.5 - Distribuição de erro na camada equivalente

\begin{tabular}{|c|c|c|c|c|c|c|c|c|}
\hline \multicolumn{9}{|c|}{ Erro relativo na altura do pavimento } \\
\hline$-30,0 \%$ & $-20,0 \%$ & $-10,0 \%$ & $-5,0 \%$ & $0,0 \%$ & $+5,0 \%$ & $+10,0 \%$ & $+20,0 \%$ & $+30,0 \%$ \\
\hline
\end{tabular}

A distribuição simétrica do erro relativo na altura para verificação do processo de retroanálise, fundamenta-se na possibilidade da origem do erro durante a obtenção da medida das camadas do pavimento ser superior ou inferior à medida real da altura do pavimento em estudo.

A bacia deflectométrica escolhida aleatoriamente no Anexo $E$, apresentando $0,0 \%$ de erro na altura equivalente, possui as seguintes características teóricas:

Altura do pavimento: $53,13 \mathrm{~cm}$;

Módulo resiliente do Subleito (MPa): 170,40;

Deflexões obtidas para o carregamento com o eixo padrão $\left(\times 10^{-4} \mathrm{~cm}\right)$ :

\begin{tabular}{|c|c|c|c|c|c|c|c|c|}
\hline $\mathbf{D}_{\mathbf{0}}$ & $\mathbf{D}_{\mathbf{2 5}}$ & $\mathbf{D}_{\mathbf{4 0}}$ & $\mathbf{D}_{\mathbf{6 0}}$ & $\mathbf{D}_{\mathbf{8 0}}$ & $\mathbf{D}_{\mathbf{1 0 0}}$ & $\mathbf{D}_{\mathbf{1 4 0}}$ & $\mathbf{D}_{\mathbf{1 8 0}}$ & $\mathbf{D}_{\mathbf{2 6 0}}$ \\
\hline 17,88 & 13,13 & 11,21 & 9,34 & 7,87 & 6,66 & 4,87 & 3,72 & 2,45 \\
\hline
\end{tabular}

Para retroanalisar o subleito, utilizou-se o programa e as condições de contorno descritas no Anexo $\mathrm{H}$. É válido lembrar que o critério de parada para a resposta do módulo resiliente do subleito é satisfeito quando o valor absoluto entre as deflexões teóricas e medidas tornam-se menores ou iguais a 0.0001 ou o número máximo de 25 iterações seja atingido.

A Tabela 6.6 descreve os resultados obtidos, sendo em sua análise revelada uma influência de pequena magnitude ao se variar a altura do pavimento em uma faixa de erro de $-30,0 \%$ a $+30,0 \%$. A presença do erro 
relativo já era esperada, visto que a região do posicionamento do Ponto Inerte para um conjunto de estruturas de pavimentos é dependente da altura do mesmo (vide expressões 6.1 e 6.2).

O procedimento proposto de retroanálise apresentou um erro relativo de $0,60 \%$ na obtenção do módulo resiliente do subleito para a altura correta do pavimento $(53,13 \mathrm{~cm})$. Nota-se um maior valor porcentual no erro relativo na retroanálise do subleito quando a espessura avaliada do pavimento é menor do que a espessura real. A Figura 6.11 auxilia no entendimento deste comportamento.

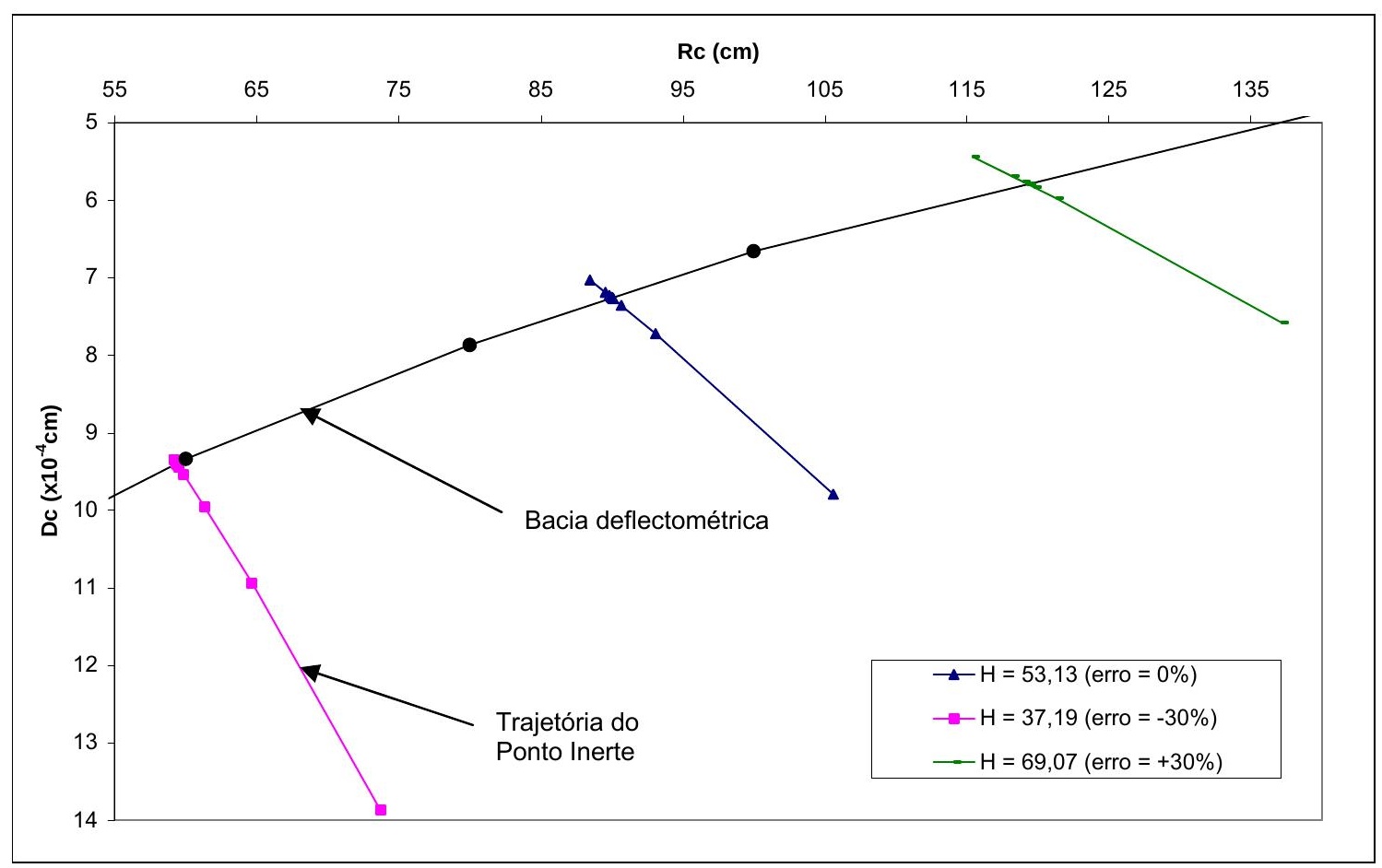

Figura 6.11 - Influência da altura do pavimento na trajetória do ponto inerte

A mudança da região de posicionamento do Ponto Inerte quando a altura do pavimento é medida corretamente e com variações de $\pm 30,0 \%$ de erro também é ilustrada na Figura 6.11.

Devido à distribuição de tensões oriundas do carregamento do eixo padrão, o módulo resiliente do subleito é obtido com maior acurácia para 
valores elevados para $R_{c}$, ou seja, os valores de deflexões distantes do ponto de aplicação de carga, representam melhor o comportamento do subleito . 
Tabela 6.6 - Influência da altura na retroanálise do subleito

\begin{tabular}{|c|c|c|c|c|c|}
\hline $\begin{array}{c}\text { Erro relativo na } \\
\text { espessura do } \\
\text { pavimento }\end{array}$ & $\begin{array}{c}\text { Espessura } \\
\text { real (cm) }\end{array}$ & $\begin{array}{c}\text { Espessura } \\
\text { avaliada (cm) }\end{array}$ & $\begin{array}{c}\text { Módulo resiliente } \\
\text { real do } \\
\text { subleito(MPa) }\end{array}$ & $\begin{array}{c}\text { Módulo resiliente } \\
\text { calculado do } \\
\text { subleito (MPa) }\end{array}$ & $\begin{array}{c}\text { Erro relativo no } \\
\text { módulo } \\
\text { resiliente do } \\
\text { subleito }\end{array}$ \\
\hline$-30,0 \%$ & \multirow{9}{*}{53,13} & 37,19 & \multirow{9}{*}{170,40} & 192,86 & $+13,18 \%$ \\
\hline$-20,0 \%$ & & 42,50 & & 181,19 & $+6,33 \%$ \\
\hline$-10,0 \%$ & & 47,81 & & 174,75 & $+2,55 \%$ \\
\hline$-5,0 \%$ & & 50,47 & & 171,63 & $+0,72 \%$ \\
\hline $0,0 \%$ & & 53,13 & & 169,37 & $-0,60 \%$ \\
\hline$+5,0 \%$ & & 55,78 & & 167,90 & $-1,46 \%$ \\
\hline$+10,0 \%$ & & 58,44 & & 167,12 & $-1,92 \%$ \\
\hline$+20,0 \%$ & & 63,75 & & 163,64 & $-4,14 \%$ \\
\hline$+30,0 \%$ & & 69,07 & & 162,12 & $-4,86 \%$ \\
\hline
\end{tabular}


Por outro lado, o módulo resiliente da camada equivalente possui dependência mais significativa das deflexões mais próximas ao centro de aplicação de carga.

Quando a espessura do pavimento adotada é menor que a espessura real, a trajetória do ponto inerte é deslocada para uma região mais próxima ao centro de aplicação de carga, apresentando desta maneira um maior erro relativo na previsão do módulo resiliente do subleito.

Para espessuras de pavimentos maiores do que a espessura real, a trajetória do ponto inerte encontra-se na parte de menores deflexões da bacia deflectométrica, sendo menor o erro na previsão do módulo de resiliência do subleito.

A Figura 6.12 ilustra o erro relativo na espessura do pavimento e o respectivo erro na previsão do módulo resiliente do subleito do procedimento proposto, com os valores extraídos da Tabela 6.6.

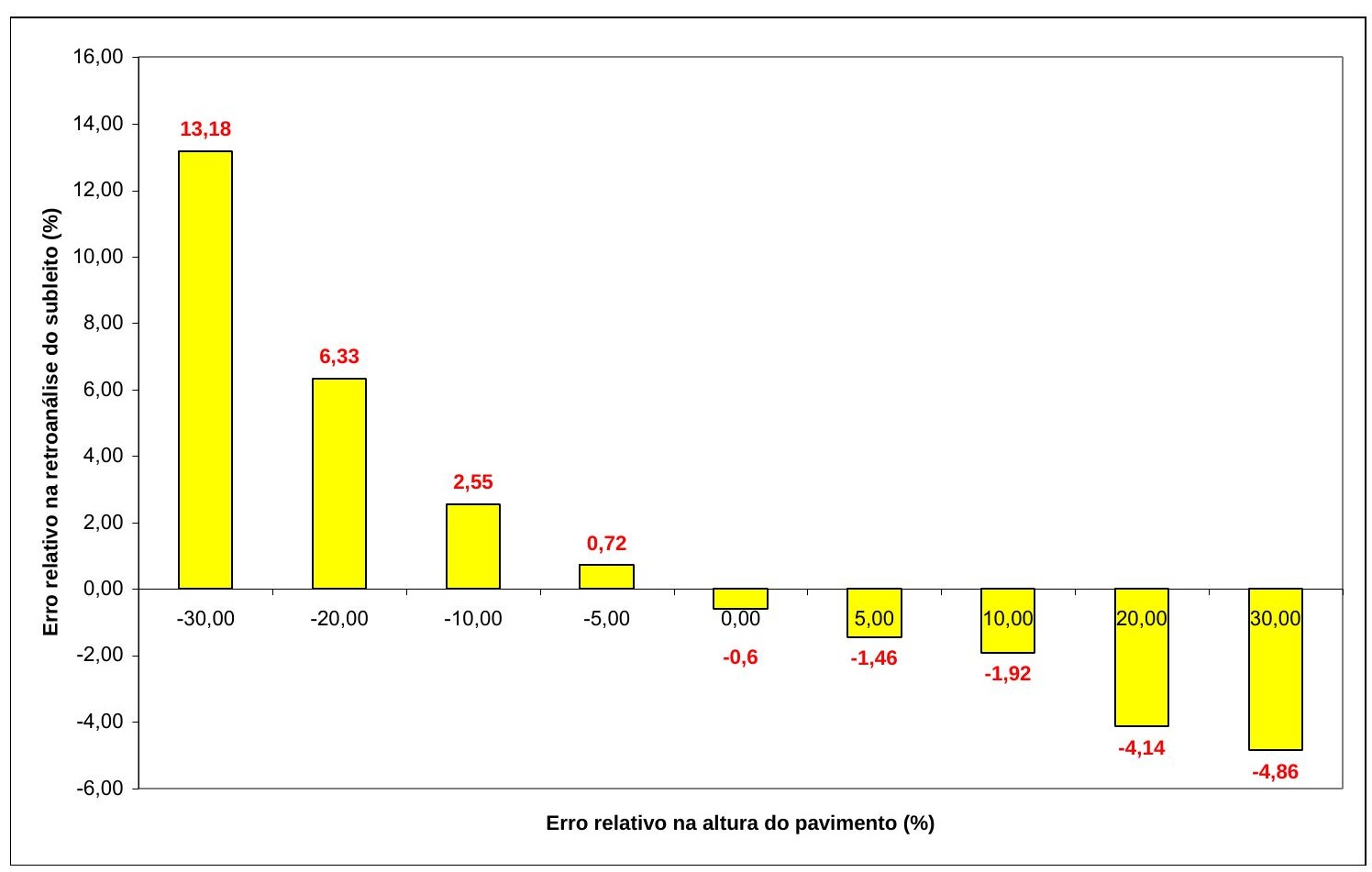

Figura 6.12 - Influência da espessura na retroanálise do subleito 


\section{Capítulo 7 - Comparações com outros processos de retroanálise}

Neste capítulo, são comparados três processos de retroanálise de pavimentos flexíveis em um único exemplo utilizando-se uma bacia teórica obtida com o carregamento do eixo padrão (8,2 tf, eixo simples e rodas duplas). A estrutura do pavimento foi simplificada em duas camadas: subleito e camada equivalente (sub-base, base, revestimento, etc.).

Os procedimentos utilizados na análise comparativa dos resultados foram:

1 - Retroanálise de pavimentos flexíveis utilizando a Teoria do Ponto Inerte e Modelagem Matemática (proposto neste trabalho);

2 - Retroanálise de pavimentos de flexíveis utilizando-se o processo de Noureldin adaptado por Albernaz (1994), descrito anteriormente em 4.1.2.3; e

3 - Retroanálise de pavimentos flexíveis com Redes Neurais Artificiais.

As deflexões da bacia teórica foram geradas pelo programa ELSYM5 para o carregamento do eixo padrão. Um aspecto a ser destacado nesta comparação de procedimentos é o da variação do coeficiente de Poisson. A adaptação de Albernaz (1994) para o processo de Noureldin considera o coeficiente de Poisson igual a 0.5 para ambas as camadas do pavimento.

A Análise pela Teoria do Ponto Inerte e modelagem matemática é baseada para valores do coeficiente de Poisson iguais a 0.45 para o subleito e 0.30 para a camada equivalente. As redes neurais artificiais foram treinadas com o banco de dados aleatórios (Anexo E), "calibradas" assim para os coeficientes de Poisson iguais a 0.45 para o subleito e 0.30 para a camada equivalente. 
Para verificação da influência do coeficiente de Poisson nos resultados da retroanálise, variou-se este parâmetro nos exemplos a seguir em dois casos:

\begin{tabular}{|l|l|l|}
\hline \multirow{2}{*}{ Caso 1} & Coeficiente de Poisson do subleito & 0.45 \\
\cline { 2 - 3 } & Coeficiente de Poisson da camada equivalente & 0.30 \\
\hline \multirow{2}{*}{ Caso 2} & Coeficiente de Poisson do subleito & 0.50 \\
\cline { 2 - 3 } & Coeficiente de Poisson da camada equivalente & 0.50 \\
\hline
\end{tabular}

Um quadro comparativo (item 7.2) com os erros encontrados em cada exemplo para os Casos 1 e 2 é apresentado no final deste capítulo.

\section{1 - Exemplo}

\subsection{1 - Retroanálise via Teoria do Ponto Inerte (TPI) e modelagem matemática (Caso 1).}

\begin{tabular}{|l|c|}
\hline \multicolumn{2}{|c|}{ Características do pavimento } \\
\hline Altura (cm) & 50,00 \\
\hline Módulo resiliente do subleito (MPa) & 113,90 \\
\hline Módulo resiliente da camada equivalente (MPa) & $1.188,40$ \\
\hline Coeficiente de Poisson do subleito: & 0,45 \\
\hline Coeficiente de Poisson da camada equivalente: & 0,30 \\
\hline
\end{tabular}

\begin{tabular}{|c|c|c|c|c|c|c|c|c|}
\hline \multicolumn{10}{|c|}{ Deflexões teóricas obtidas (x 10 } \\
\hline $\mathbf{D}_{\mathbf{0}}$ & $\mathbf{D}_{\mathbf{2 5}}$ & $\mathbf{D}_{\mathbf{4 0}}$ & $\mathbf{D}_{\mathbf{6 0}}$ & $\mathbf{D}_{\mathbf{8 0}}$ & $\mathbf{D}_{\mathbf{1 0 0}}$ & $\mathbf{D}_{\mathbf{1 4 0}}$ & $\mathbf{D}_{\mathbf{1 8 0}}$ & $\mathbf{D}_{\mathbf{2 6 0}}$ \\
\hline 22,00 & 17,58 & 15,53 & 13,33 & 11,46 & 9,86 & 7,38 & 5,68 & 3,72 \\
\hline
\end{tabular}

A Tabela 7.1 apresenta os resultados gerados com a aplicação do programa em linguagem Pascal descrito no Anexo $\mathrm{H}$. 
Tabela 7.1 - Iterações realizadas para o exemplo

\begin{tabular}{|c|c|c|c|}
\hline Iteração & Rc (cm) & Dc $\left(\times 10^{-4} \mathrm{~cm}\right)$ & $\mathrm{M}_{\mathrm{R}}-$ Subleito (MPa) \\
\hline 1 & 99,3628 & 10,3927 & 110,0000 \\
\hline 2 & 87,5308 & 8,1940 & 155,0000 \\
\hline 3 & 92,8056 & 9,1350 & 132,5000 \\
\hline 4 & 95,8907 & 9,7144 & 121,2500 \\
\hline 5 & 97,5731 & 10,0396 & 115,6250 \\
\hline 6 & 98,4537 & 10,2124 & 112,8125 \\
\hline 7 & 98,0100 & 10,1251 & 114,2187 \\
\hline 8 & 97,7907 & 10,0821 & 114,9219 \\
\hline 9 & 97,6816 & 10,0608 & 115,2734 \\
\hline 10 & 97,6273 & 10,0502 & 115,4492 \\
\hline 11 & 97,6002 & 10,0449 & 115,5371 \\
\hline 12 & 97,6137 & 10,0475 & 115,4932 \\
\hline 13 & 97,6205 & 10,0488 & 115,4712 \\
\hline 14 & 97,6239 & 10,0495 & 115,4602 \\
\hline 15 & 97,6256 & 10,0498 & 115,4547 \\
\hline 16 & 97,6265 & 10,0500 & 115,4520 \\
\hline 17 & 97,6260 & 10,0499 & 115,4533 \\
\hline
\end{tabular}

Após 17 iterações o critério de convergência é satisfeito, obtendo-se um módulo resiliente para o subleito de 115,45 MPa. O módulo de resiliência da camada equivalente é obtido pela expressão 6.3 , com os respectivos valores do exemplo:

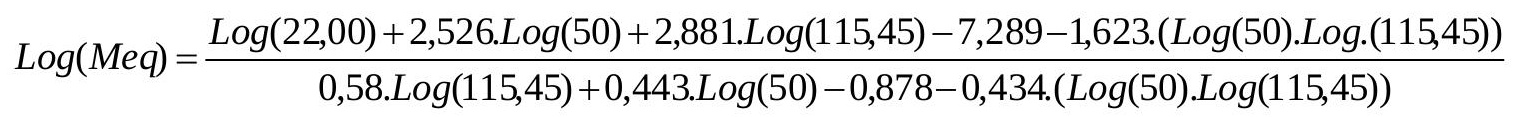

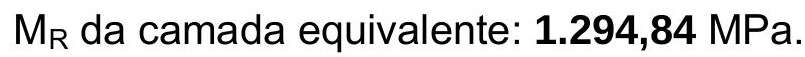


Como alternativa de cálculo para o módulo resiliente do subleito através da Teoria do Ponto Inerte, foi desenhada a bacia de deflexões no ábaco proposto, conforme ilustra a Figura 7.1, encontrando-se um valor em torno de 115,0 MPa para o módulo de resiliência do subleito.

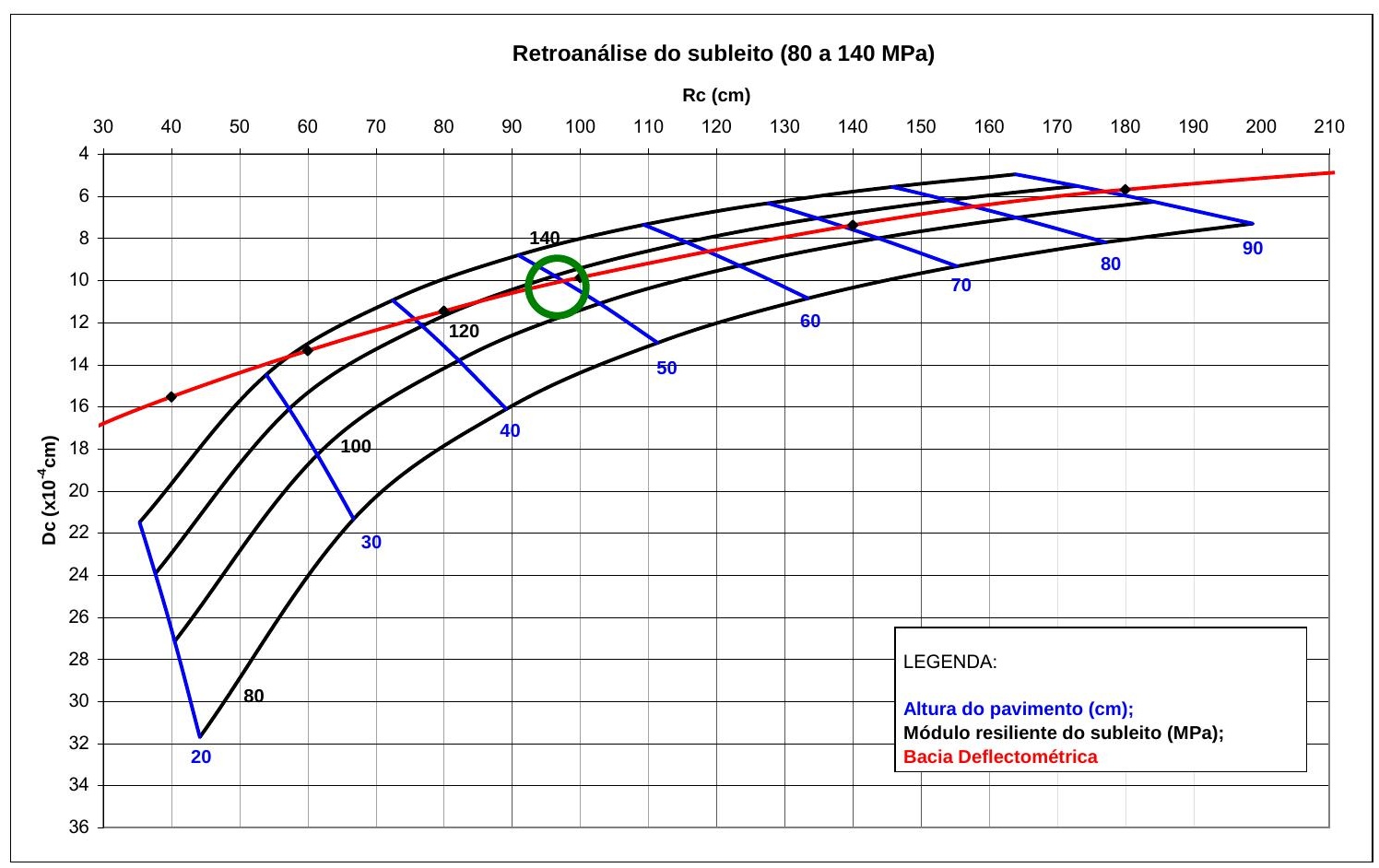

Figura 7.1 - Solução gráfica para retroanálise do subleito

\subsection{2 - Retroanálise via Método de Albernaz (Caso 1)}

\begin{tabular}{|l|c|}
\hline \multicolumn{2}{|c|}{ Características do pavimento } \\
\hline Altura (cm) & 50,00 \\
\hline Módulo resiliente do subleito (MPa) & 113,90 \\
\hline Módulo resiliente da camada equivalente (MPa) & $1.188,40$ \\
\hline Coeficiente de Poisson do subleito: & 0,45 \\
\hline Coeficiente de Poisson da camada equivalente: & 0,30 \\
\hline
\end{tabular}

\begin{tabular}{|c|c|c|c|c|c|c|c|c|}
\hline \multicolumn{10}{|c|}{ Deflexões teóricas obtidas (x 10-4 cm) } \\
\hline $\mathbf{D}_{\mathbf{0}}$ & $\mathbf{D}_{\mathbf{2 5}}$ & $\mathbf{D}_{\mathbf{4 0}}$ & $\mathbf{D}_{\mathbf{6 0}}$ & $\mathbf{D}_{\mathbf{8 0}}$ & $\mathbf{D}_{\mathbf{1 0 0}}$ & $\mathbf{D}_{\mathbf{1 4 0}}$ & $\mathbf{D}_{\mathbf{1 8 0}}$ & $\mathbf{D}_{\mathbf{2 6 0}}$ \\
\hline 22,00 & 17,58 & 15,53 & 13,33 & 11,46 & 9,86 & 7,38 & 5,68 & 3,72 \\
\hline
\end{tabular}


Os parâmetros de cálculo do processo de Albernaz calculados pelas expressões 4.14, 4.15 e 4.16 estão descritos na Tabela 7.2.

Tabela 7.2 - Parâmetros de cálculo do método de Albernaz

\begin{tabular}{|c|c|c|c|c|}
\hline Rx $(\mathrm{cm})$ & 0 & 25 & 40 & 60 \\
\hline Dx $(\mathrm{cm})$ & 0,02200 & 0,01758 & 0,01553 & 0,01333 \\
\hline Mód. do Subleito (kgf/cm $)$ & & 2714,44 & 1920,47 & 1491,62 \\
\cline { 1 - 3 } $\begin{array}{c}\text { Mód. Efetivo do Pavimento } \\
\left(\mathrm{kgf} / \mathrm{cm}^{2}\right)\end{array}$ & & 21330,32 & 17337,71 & 14084,97 \\
\cline { 1 - 3 } \cline { 4 - 6 } Esp. Efetiva do Pavimento (cm) & & 23,65 & 37,51 & 56,14 \\
\hline
\end{tabular}

A Figura 7.2 representa graficamente alguns valores da Tabela 7.2 e a obtenção do módulo resiliente do subleito e módulo efetivo do pavimento. 


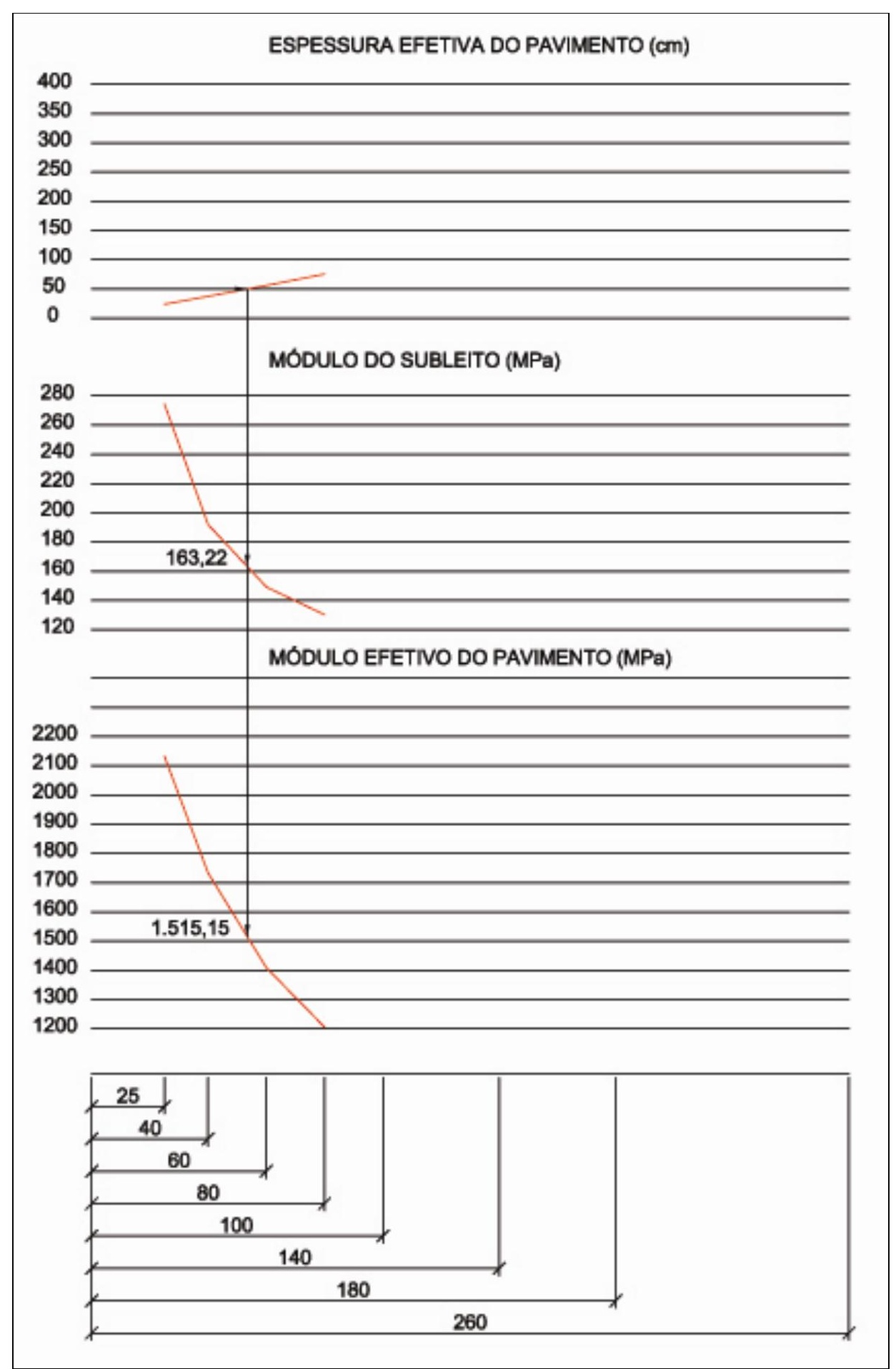

Figura 7.2 - Solução do Exemplo 1 (Caso 1) pelo processo de Albernaz (1994).

Portanto, pelo método de Albernaz tem-se para o Exemplo 1 (Caso 1): Módulo resiliente do subleito: 163,22 MPa; e

Módulo resiliente da camada equivalente: 1.515,15 MPa. 


\subsection{3 - Retroanálise via Redes Neurais Artificiais (Caso 1)}

Com o uso do software $\operatorname{EASYNN}^{\circledR}$ e a configuração da rede neural presente na Figura 7.3, o módulo de resiliência do subleito retroanalisado foi de 113,53 MPa.

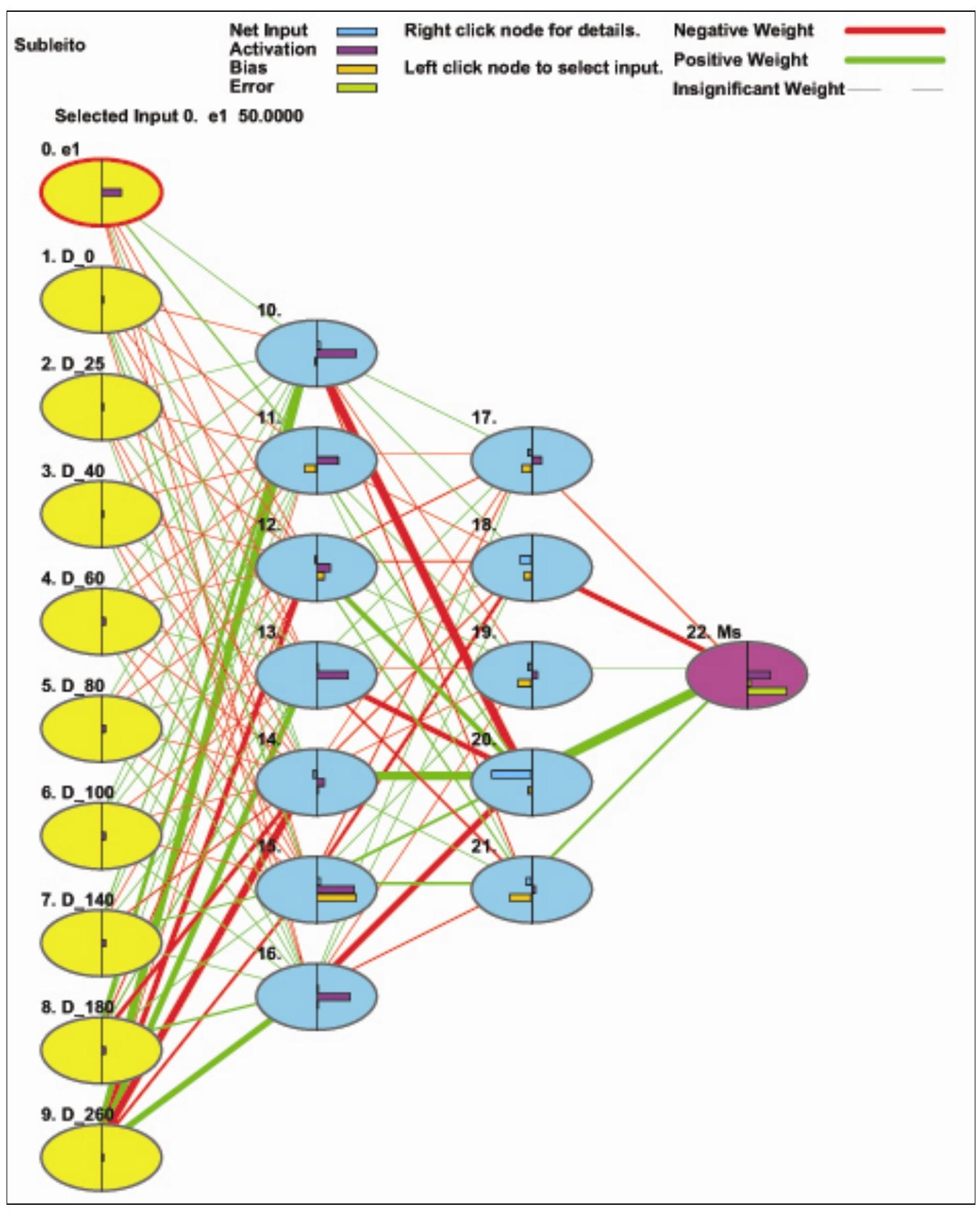

Figura 7.3 - Configuração da rede neural utilizada para retroanálise do subleito 
Para a camada equivalente, o módulo de resiliência resultante foi de 1.197,49 $\mathrm{MPa}$, sendo a configuração da rede neural utilizada vista na Figura 7.4 .

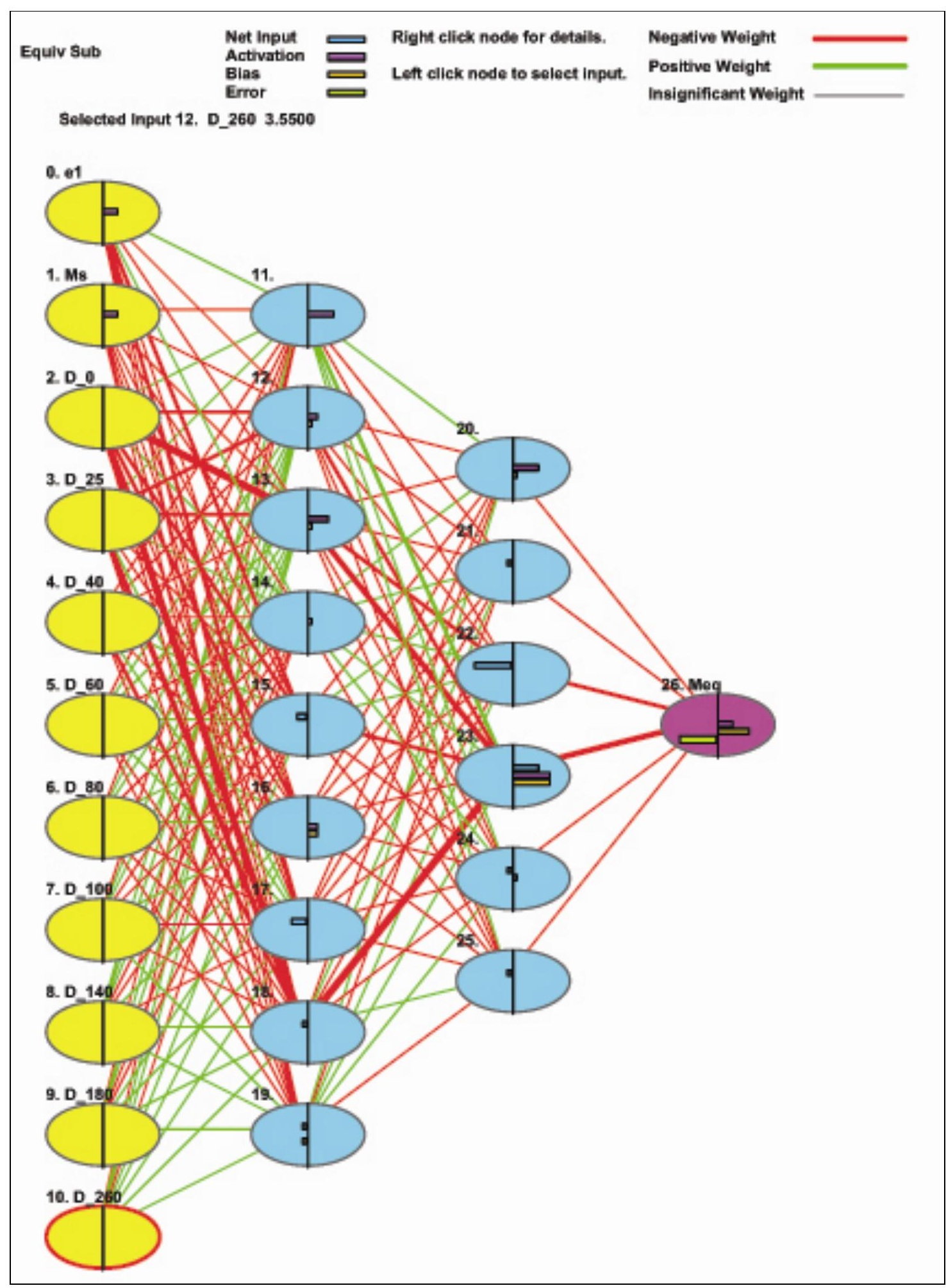

Figura 7.4 - Configuração da rede neural utilizada para retroanálise da camada equivalente. 
7.1.4 - Retroanálise via Teoria do Ponto Inerte e modelagem matemática (Caso 2).

\begin{tabular}{|l|c|}
\hline \multicolumn{2}{|c|}{ Características do pavimento } \\
\hline Altura (cm) & 50,00 \\
\hline Módulo resiliente do subleito (MPa) & 113,90 \\
\hline Módulo resiliente da camada equivalente (MPa) & $1.188,40$ \\
\hline Coeficiente de Poisson do subleito: & 0,50 \\
\hline Coeficiente de Poisson da camada equivalente: & 0,50 \\
\hline
\end{tabular}

\begin{tabular}{|c|c|c|c|c|c|c|c|c|}
\hline \multicolumn{10}{|c|}{ Deflexões teóricas obtidas (x 10-4 cm) } \\
\hline $\mathbf{D}_{\mathbf{0}}$ & $\mathbf{D}_{\mathbf{2 5}}$ & $\mathbf{D}_{\mathbf{4 0}}$ & $\mathbf{D}_{\mathbf{6 0}}$ & $\mathbf{D}_{\mathbf{8 0}}$ & $\mathbf{D}_{\mathbf{1 0 0}}$ & $\mathbf{D}_{\mathbf{1 4 0}}$ & $\mathbf{D}_{\mathbf{1 8 0}}$ & $\mathbf{D}_{\mathbf{2 6 0}}$ \\
\hline 20,22 & 16,42 & 14,62 & 12,63 & 10,92 & 9,43 & 7,08 & 5,45 & 3,55 \\
\hline
\end{tabular}

A Tabela 7.3 apresenta os resultados gerados com a aplicação do programa em linguagem Pascal descrito no Anexo $\mathrm{H}$.

Tabela 7.3 - Iterações realizadas para o exemplo

\begin{tabular}{|c|c|c|c|}
\hline Iteração & $\mathbf{R c} \mathbf{( c m )}$ & $\left.\mathbf{D c} \mathbf{( x ~ 1 0 ^ { - 4 }} \mathbf{c m}\right)$ & $\mathbf{M}_{\mathbf{R}}-$ Subleito (MPa) \\
\hline 1 & 99,3628 & 10,3927 & 110,0000 \\
\hline 2 & 87,5308 & 8,1940 & 155,0000 \\
\hline 3 & 92,8056 & 9,1350 & 132,5000 \\
\hline 4 & 95,8907 & 9,7144 & 121,2500 \\
\hline 5 & 97,5731 & 10,0396 & 115,6250 \\
\hline 6 & 96,7192 & 9,8737 & 118,4375 \\
\hline 7 & 96,3018 & 9,7933 & 119,8437 \\
\hline 8 & 96,0955 & 9,7536 & 120,5469 \\
\hline 9 & 95,9929 & 9,7340 & 120,8984 \\
\hline 10 & 95,9417 & 9,7242 & 121,0742 \\
\hline 11 & 95,9673 & 9,7291 & 120,9863 \\
\hline 12 & 95,9801 & 9,7315 & 120,9424 \\
\hline 13 & 95,9737 & 9,7303 & 120,9644 \\
\hline 14 & 95,9705 & 9,7297 & 120,9753 \\
\hline
\end{tabular}


Tabela 7.3 - Iterações realizadas para o exemplo (continuação)

\begin{tabular}{|c|c|c|c|}
\hline Iteração & $\mathbf{R c}(\mathbf{c m})$ & $\mathbf{D c}\left(\times \mathbf{1 0}^{-4} \mathbf{c m}\right)$ & MR - Subleito (MPa) \\
\hline 15 & 95,9721 & 9,7300 & $\mathbf{1 2 0 , 9 6 9 8}$ \\
\hline
\end{tabular}

Após 15 iterações o critério de convergência é satisfeito, obtendo-se um módulo resiliente para o subleito de $120,97 \mathrm{MPa}$. O módulo de resiliência da camada equivalente é obtido pela expressão 6.3 , com os respectivos valores do exemplo:

$\log (\mathrm{Meq})=\frac{\log (20,22)+2,526 \cdot \log (50)+2,881 \cdot \log (120,97)-7,289-1,623 \cdot(\log (50) \cdot \log \cdot(120,97))}{0,58 \cdot \log (120,97)+0,443 \cdot \log (50)-0,878-0,434 \cdot(\log (50) \cdot \log (120,97))}$

$M_{R}$ da camada equivalente: $1.464,32 \mathrm{MPa}$.

\subsection{5 - Retroanálise via Método de Albernaz (Caso 2)}

\begin{tabular}{|l|c|}
\hline \multicolumn{2}{|c|}{ Características do pavimento } \\
\hline Altura (cm) & 50,00 \\
\hline Módulo resiliente do subleito (MPa) & 113,90 \\
\hline Módulo resiliente da camada equivalente (MPa) & $1.188,40$ \\
\hline Coeficiente de Poisson do subleito: & 0,50 \\
\hline Coeficiente de Poisson da camada equivalente: & 0,50 \\
\hline
\end{tabular}

\begin{tabular}{|c|c|c|c|c|c|c|c|c|}
\hline \multicolumn{10}{|c|}{ Deflexões teóricas obtidas (x 10-4 $\mathbf{~ c m})$} \\
\hline $\mathbf{D}_{\mathbf{0}}$ & $\mathbf{D}_{\mathbf{2 5}}$ & $\mathbf{D}_{\mathbf{4 0}}$ & $\mathbf{D}_{\mathbf{6 0}}$ & $\mathbf{D}_{\mathbf{8 0}}$ & $\mathbf{D}_{\mathbf{1 0 0}}$ & $\mathbf{D}_{\mathbf{1 4 0}}$ & $\mathbf{D}_{\mathbf{1 8 0}}$ & $\mathbf{D}_{\mathbf{2 6 0}}$ \\
\hline 20,22 & 16,42 & 14,62 & 12,63 & 10,92 & 9,43 & 7,08 & 5,45 & 3,55 \\
\hline
\end{tabular}

Os parâmetros de cálculo do processo de Albernaz calculados pelas expressões 4.14, 4.15 e 4.16 estão descritos na Tabela 7.4 . 
Tabela 7.4 - Parâmetros de cálculo do método de Albernaz

\begin{tabular}{|c|c|c|c|c|}
\hline $\mathrm{Rx}(\mathrm{cm})$ & 0 & 25 & 40 & 60 \\
\hline $\mathrm{Dx}(\mathrm{cm})$ & 0,02022 & 0,01642 & 0,01462 & 0,01263 \\
\hline Mód. do Subleito $\left(\mathrm{kgf} / \mathrm{cm}^{2}\right)$ & & 2906,21 & 2040,01 & 1574,29 \\
\hline $\begin{array}{l}\text { Mód. Efetivo do Pavimento } \\
\left(\mathrm{kgf} / \mathrm{cm}^{2}\right)\end{array}$ & & 24810,53 & 20031,25 & 16089,15 \\
\hline Esp. Efetiva do Pavimento $(\mathrm{cm})$ & & 23,00 & 36,48 & 54,68 \\
\hline
\end{tabular}

A Figura 7.5 representa graficamente alguns valores da Tabela 7.4 e a obtenção do módulo resiliente do subleito e módulo efetivo do pavimento. 


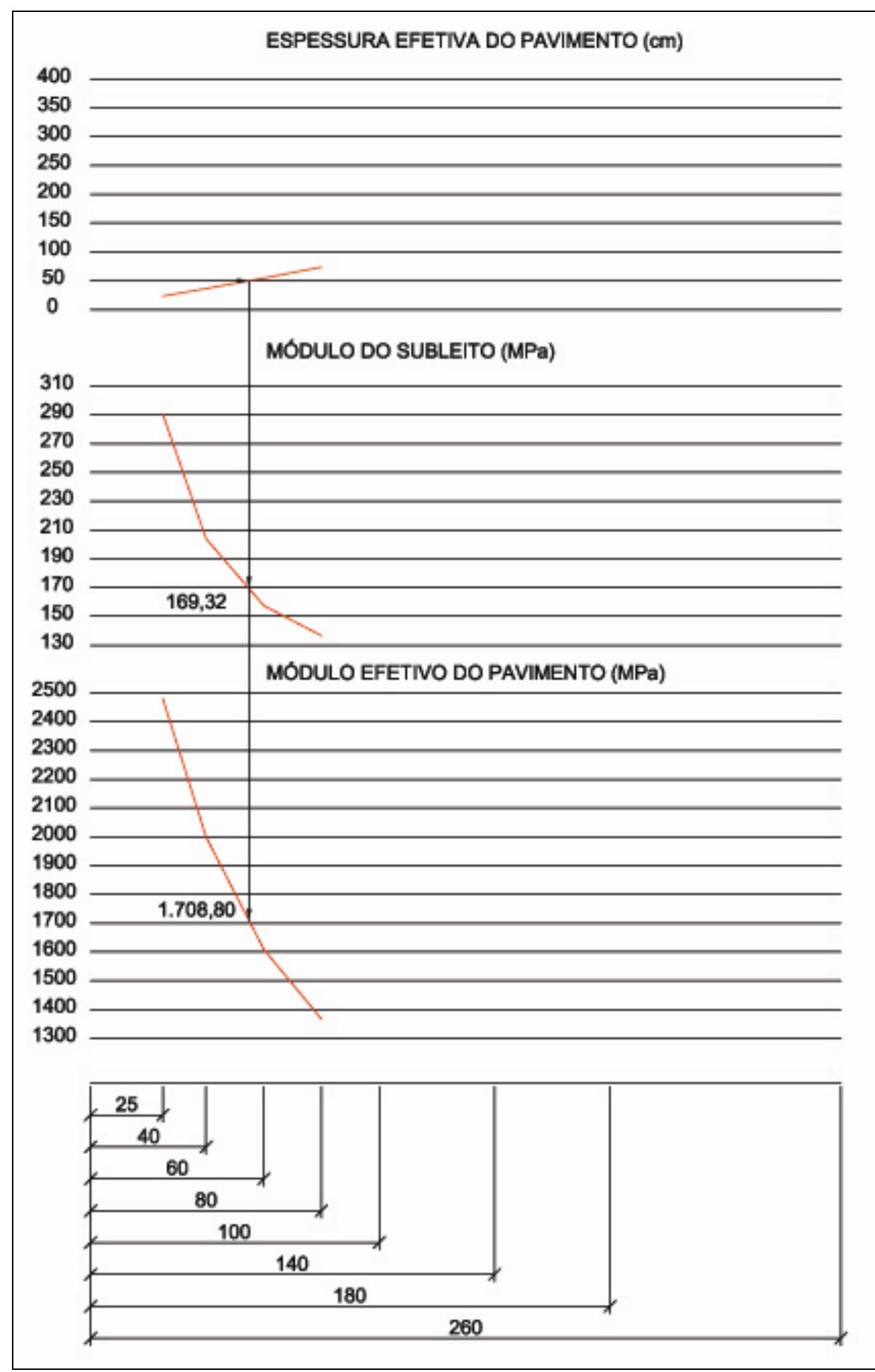

Figura 7.5 - Solução do Exemplo 1 (Caso 2) pelo processo de Albernaz (1994).

Portanto, pelo método de Albernaz tem-se para o Exemplo 1 (Caso 2): Módulo resiliente do subleito: 169,32 MPa; e Módulo resiliente da camada equivalente: 1.708,80 MPa. 


\subsection{6 - Retroanálise via Redes Neurais Artificiais (Caso 2)}

Com o mesmo procedimento e configurações de rede neural descritos no item 7.1.3, relembrando a diferença presente no valor do coeficiente de Poisson entre o banco de dados de aprendizado da rede com o da bacia teórica para o Caso 2, os valores retroanalisados foram:

- Subleito: 119,02 MPa; e

- Camada equivalente: 1.362,31 MPa.

\section{2 - Resultados de comparações}

A Tabela 7.5 descreve os resultados encontrados neste estudo comparativo para o subleito.

Tabela 7.5 - Quadro comparativo de resultados para o subleito

\begin{tabular}{|c|c|c|c|c|}
\hline \multicolumn{2}{|c|}{ Subleito } & $M_{R}$ previsto & $M_{R}$ real & Erro relativo \\
\hline \multirow{3}{*}{$\begin{array}{c}\text { Caso } 1 \\
\mu_{\text {sub. }}: 0,45 \\
\mu_{\text {cam. eq. }}: 0,30\end{array}$} & TPI & $115,45 \mathrm{MPa}$ & \multirow{3}{*}{$113,90 \mathrm{MPa}$} & $+1,36 \%$ \\
\hline & ALBERNAZ & $163,22 \mathrm{MPa}$ & & $+43,3 \%$ \\
\hline & RNA & $113,53 \mathrm{MPa}$ & & $-0,32 \%$ \\
\hline \multirow{3}{*}{$\begin{array}{c}\text { Caso } 2 \\
\mu_{\text {sub. }}: 0,50 \\
\mu_{\text {cam. eq. }}: 0,50\end{array}$} & TPI & $120,97 \mathrm{MPa}$ & \multirow{3}{*}{$113,90 \mathrm{MPa}$} & $+6,20 \%$ \\
\hline & ALBERNAZ & $169,32 \mathrm{MPa}$ & & $+48,6 \%$ \\
\hline & RNA & $119,02 \mathrm{MPa}$ & & $+4,49 \%$ \\
\hline
\end{tabular}

Para a camada equivalente, os resultados observados estão listados na Tabela 7.6. 
Tabela 7.6 - Quadro comparativo de resultados para a camada equivalente

\begin{tabular}{|c|c|c|c|c|}
\hline \multicolumn{2}{|c|}{ Camada equivalente } & $M_{R}$ previsto & $M_{R}$ real & Erro relativo \\
\hline \multirow{3}{*}{$\begin{array}{c}\text { Caso } 1 \\
\mu_{\text {sub. }}: 0,45 \\
\mu_{\text {cam. eq. }}: 0,30\end{array}$} & TPI & $1.294,84 \mathrm{MPa}$ & \multirow{3}{*}{$1.188,40 \mathrm{MPa}$} & $+8,95 \%$ \\
\hline & ALBERNAZ & $1.515,15 \mathrm{MPa}$ & & $+21,5 \%$ \\
\hline & RNA & $1.197,49 \mathrm{MPa}$ & & $+0,76 \%$ \\
\hline \multirow{3}{*}{$\begin{array}{c}\text { Caso } 2 \\
\mu_{\text {sub. }}: 0,50 \\
\mu_{\text {cam. eq. }}: 0,50\end{array}$} & TPI & $1.464,32 \mathrm{MPa}$ & \multirow{3}{*}{$1.188,40 \mathrm{MPa}$} & $+23,2 \%$ \\
\hline & ALBERNAZ & $1.708,80 \mathrm{MPa}$ & & $+43,8 \%$ \\
\hline & RNA & $1.362,89 \mathrm{MPa}$ & & $+14,7 \%$ \\
\hline
\end{tabular}




\section{Capítulo 8 - Conclusões e Sugestões para futuras pesquisas}

Dentro do contexto de dificuldades e incertezas para procedimentos de retroanálise tornam-se relevantes os processos simples e com significativa confiança para caracterização da rigidez das camadas de pavimentos tendo como base a Teoria da Elasticidade.

Com as condições de contorno representativas de condições reais de estruturas de pavimentos flexíveis utilizadas neste estudo:

- Altura do pavimento: 20 a $90 \mathrm{~cm}$;

- Módulo de resiliência do subleito: 20 a 200 MPa;

- Módulo de resiliência da camada equivalente: 200 a 2000 MPa;

- Coeficiente de Poisson do subleito: 0,45; e

- Coeficiente de Poisson da camada equivalente: 0,30.

Foi priorizada a elaboração de um procedimento de retroanálise com as principais características: resultados confiáveis e convergentes dentro de praticidade em sua aplicação.

Embora seja empiricamente comprovada a existência do ponto inerte em pavimentos flexíveis para bacias deflectométricas obtidas com carregamento do FWD ou com o carregamento com o eixo padrão (viga Benkelman), a Teoria do Ponto Inerte apresenta a característica de convergência para uma resposta única (independente do módulo de resiliência inicial adotado), com reduzido número de iterações e resultado de qualidade para retroanálise do módulo de resiliência do subleito considerando sistemas de pavimentos elástico-lineares.

A retroanálise do subleito com a utilização da Teoria do Ponto Inerte apresentou resultados significativos (erros inferiores a 10\%) mesmo com um coeficiente de Poisson diferente do utilizado na calibração do modelo. Os resultados observados nas comparações dos processos de retroanálise revelam a importância de uma caracterização de qualidade deste coeficiente 
para o material em estudo, visto que variações em seus valores conduzem a diferentes medidas de deflexões e a diferentes respostas para a retroanálise do subleito, consequentemente da camada equivalente.

O modelo matemático fatorial desenvolvido para a obtenção do módulo de resiliência da camada equivalente apresenta alta dependência da precisão do módulo de resiliência do subleito do pavimento em estudo. Seus resultados revelam uma excelente representatividade para as bacias teóricas geradas pelo ELSYM5 dentro do conjunto de dados para o qual foi calibrado.

Em relação à altura do pavimento, erros da ordem de $\pm 10,0 \%$ (toleráveis durante levantamento de alturas de pavimentos) influenciam o valor da resposta da retroanálise do subleito em cerca de 2,6\%, podendo ser considerado uma influência inexpressiva na previsão dos módulos de resiliência do pavimento em estudo.

A comparação com outros processos similares de retroanálise revela a superioridade dos resultados obtidos com redes neurais. Embora pesquisas já tenham revelado o potencial das redes em soluções de retroanálise, seu uso não está amplamente difundido em ambientes extra acadêmicos.

Para maior praticidade, além da possibilidade de utilização dos ábacos confeccionados para retroanalisar o subleito, o procedimento de retroanálise proposto foi adaptado para utilização em planilhas do Microsoft Excel ${ }^{\circledR}$, presente no CD-Rom em anexo. O algoritmo de programação utilizado é o mesmo descrito no Anexo $\mathrm{H}$, possuindo facilidade de alteração de critérios de parada (erro entre a deflexão real e a deflexão teórica) e valores dos limites do módulo de resiliência inicial, inferior e superior.

Como sugestões de futuras pesquisas na área de retroanálise de pavimentos flexíveis, considerando a abordagem realizada nesta dissertação, poderia ser promovida a divisão da camada equivalente em duas camadas (revestimento e base), visando obtenção individual dos valores dos módulos de resiliência destas camadas. 
A elaboração de um processo de retroanálise onde os valores do coeficiente de Poisson das camadas componentes do pavimento e do subleito pudessem ser inclusos forneceria maior qualidade na obtenção dos módulos de resiliência da estrutura em estudo. 


\section{9 - Referências Bibliográficas}

AASHTO (1993). Guide for Design of Pavement Structures.

Albernaz, C.A.V. (1994). Retroanálise do Módulo de Resiliência de Pavimentos Flexíveis e de Subleitos para fins de Anteprojeto, Análise Estrutural e Gerência de Pavimento. In: 28a REUNIÃO ANUAL DE PAVIMENTAÇÃO, 1994, Belo Horizonte-MG, p. 627-682.

Albernaz, C.A.V.; Motta, L.M.G.; Medina, J. (1995). Retroanálise: Uma Ferramenta Útil na Avaliação Estrutural de Pavimentos. In: $29^{a}$ REUNIÃO ANUAL DE PAVIMENTAÇÃO, 1995, Cuiabá-MT, p. 400-417.

Albernaz, C.A.V.; Caldas, J.E.F.; Oliveira, S.E. (1996). Avaliação Estrutural Simplificada de Pavimentos Através de Retroanálise. In: $30^{\mathrm{a}}$ REUNIÃO ANUAL DE PAVIMENTAÇÃO, 1996, Salvador-BA, p. 747-774.

Balbo, J.T. (2000). Fatos, Mitos e Falácias sobre os Modelos Experimentais de Fadiga. In: 32 ${ }^{\mathrm{a}}$ REUNIÃO ANUAL DE PAVIMENTAÇÃO, 2000, Brasília-DF, p. 391-404.

Burmister, D. M.; (1943). The Theory of Stresses and Displacements in Layered Systems and Applications to the Design of Airport Runaways. Highway Research Record no23.

Carneiro, F. B. L.; (1966). Benkelman Beam - Auxiliary Instrument of the Maintenance Engineer. Highway Research Record n 129, p. 28-59.

Coutinho Neto, B. (2000) Redes Neurais Artificiais como Procedimento para Retroanálise de Pavimentos Flexíveis. Dissertação de Mestrado. Universidade de São Paulo. São Carlos. SP. 
DNER (1994). Pavimento - Determinação das Deflexões pela Viga Benkelman. DNER-ME 024/94. Departamento Nacional de Estradas de Rodagem. Rio de Janeiro - RJ. CD-ROM.

DNER (1994). Misturas Betuminosas - Determinação do Módulo de Resiliência. DNER-ME 133/94. Departamento Nacional de Estradas de Rodagem. Rio de Janeiro - RJ. CD-ROM.

DNER (1998). Manual de Reabilitação de Pavimentos Asfálticos. Departamento Nacional de Estradas de Rodagem. Rio de Janeiro - RJ.

Elliott, R. P.; Thornton, S.I. (1988). Resilient Modulus and AASHTO Pavement Design. Transportation Research Record, $\mathrm{n}^{\circ} 1196$, p. 116-124.

Gontijo, P.R.A.; Guimarães, F.H.R.; Nogueira, C.L. (1994). Metodologias Brasileiras para Avaliações das Características Funcionais e Estruturais dos Pavimentos Rodoviários - O Estado da Arte. In: 28a REUNIÃO ANUAL DE PAVIMENTAÇÃO, 1994, Belo Horizonte-MG, p. 501-529.

Haas, R.; Hudson, W.R.; Zaniewski, J. (1994). Modern Pavement Management. Krieger Publishing Co. Malamar, Florida.

Harichandran, T.M.; Raab, A.R.; Baladi, G.Y. (1993). Modified Newton Algorithm for Backcalculation of Pavement Layer Properties. Transportation Research Record, $\mathrm{n}^{\circ} 1196$, p. 116-124.

Hoffman, M.S.; Thompson, M.R.; (1982). Comparative Study of Selected Nondestructive Testing Devices. Transportation Research Record, $\mathrm{n}^{\circ}$ 852, $\mathrm{p}$. $32-41$.

Huang, Y. H.; (1993). Pavement Analysis and Design. Prentice Hall, Englewood Cliffs, New Jersey. 
Irwin, L. H.; (2002). Backcalculation: An Overview and Perspective. $6^{\text {th }}$ International Conference on the Bearing Capacity of Roads, Railways and Airfields. Lisboa, Portugal.

Lytton, R. L. (1989). Backcalculation of Pavement Layer Properties. ASTM STP 1026, Philadelphia, p. 7-38.

Mahoney, J. P.; Coetzee, N. F.; Stubstad, R. N.; Lee, S.W.; (1989). A Performance Comparison of Selected Backcalculation Computer Programs. ASTM STP 1026, Philadelphia, p. 452-467.

Mahoney, J.P.; Winters, B.C.; Jackson, N.C.; Pierce, L.M.; (1993). Some Observations about Backcalculation and Use of a Stiff Layer Condition. Transportation Research Record, $\mathrm{n}^{\circ} 1384$, p. 08-14.

Medina, J.; Macêdo, J.A.G; Motta, L.M.G.; Albernaz, C.A.V.; (1994). Utilização de Ensaios Deflectométricos e de Laboratório para a Avaliação Estrutural de Pavimentos. In 28a REUNIÃO ANUAL DE PAVIMENTAÇÃO, 1994, Belo Horizonte-MG, p. 595-624.

Medina, J.; Motta, L.; (1989). Experimental Data on Climatic Factors in Pavement and Overlay Design. In: $2^{\text {nd }}$ INTERNATIONAL SYMPOSIUM ON PAVEMENT EVALUATION AND OVERLAY DESIGN, 1989, Rio de Janeiro-RJ, p. 2.1.2-2.1.27.

Monismith, C.L.; Deacon, J.A.; Craus, J.; Rao Tangella, S.C.S.; (1990). Summary Report on Fatigue Response of Asphalt Mixtures (TM-UCB-A-003A89-3). Institute of Transportation Studies - University of California, Berkeley, Fevereiro, 1990.

Noureldin, A.S.; (1993). New Scenario for Backcalculation of Layer Moduli of Flexible Pavements. Transportation Research Record, n 1384, p. 23-28. 
Rauhut, J.B.; Kennedy, T.W.; (1982). Characterizing Fatigue Life for Asphalt Concrete Pavements. Transportation Research Record, n 888, p. 47-56.

SHRP-P-655 (1993). SHRP's Layer Moduli Backcalculation Procedure. The Strategic Highway Research Program. National Academy of Science. Washington, D.C.

Simpson, A.L.; Daleiden, J.F.; Hadley, W.O.; (1995). Rutting Analysis from a Different Perspective. Transportation Research Record, n 1473, p. 9-16.

Sivaneswaran, N.; Kramer, S.L.; Mahoney, J.P.; (1991). Advanced Backcalculation Using a Nonlinear Least Squares Optimization Technique. Transportation Research Record, n 1293, p. 93-102.

Smith, R.E.; Lytton, R.L.; (1985). Operating Characteristics and User Satisfaction of Commercially Available NDT Equipment. Transportation Research Record, n 1007, p. 01-10.

Stolle, D.; Hein, D.; (1989). Parameter Estimates of Pavement Structure Layers and Uniqueness of the Solution. ASTM STP 1026, Philadelphia, p. 313-322.

Sun, L.; Hachiya, Y. e Yao, Z. (1995) Concrete Pavement Layer Moduli Based on Stable Deflection. Journal of Materials, Concrete Structures and Pavements, $n^{\circ} 526$, p. $143-149$.

Tholen, O.; Sharma, J.; Terrel, R.L.; (1985). Comparison of FWD with Other Deflection Testing Devices. Transportation Research Record, n 1007, p. 20-26.

Ullidtz, P.; Coetzee, N. F.; (1995). Analytical Procedures in Nondestructive Testing Pavement Evaluation. Transportation Research Record, $\mathrm{n}^{\circ} 1482$, p. 6166.

Uzan, J. (1994) Advanced Backcalculations Techniques. ASTM STP 1198, p. 337. 
Von Quintus, H. L.; (2001). Hot-Mix Asphalt Layer Thickness Design For Longer-Life Bituminous Pavements. Transportation Research Circular, n 503 , p. 66-78.

Wang, F.; Lytton, R.L.; (1993). System Identification Method for Backcalculating Pavement Layer Properties. Transportation Research Record, $\mathrm{n}^{\circ} 1384$, p. $01-$ 07.

Yoder, E.J.; Witckzak, M.W.; (1975). Principles of Pavement Design. John Wiley \& Sons, New York, $2^{\mathrm{a}}$ ed.

Zhang, X.; Sun, L. (2003) Backcalculation of Asphalt Pavement Moduli with Convergent Procedure and Unique Solution. Transportation Research Board2003 Annual Meeting CD-ROM.

Zhang, X.; Sun, L. (2004) Novel Method for Backcalculation of Asphalt Pavement Moduli. Transportation Research Board, n 1869, p.67-72. 
ANEXO B - Programa desenvolvido em linguagem Pascal para obtenção das coordenadas $\left(R_{c}\right.$ e $\left.D_{c}\right)$ dos pontos inertes do conjunto de bacias deflectométricas teóricas utilizado. 


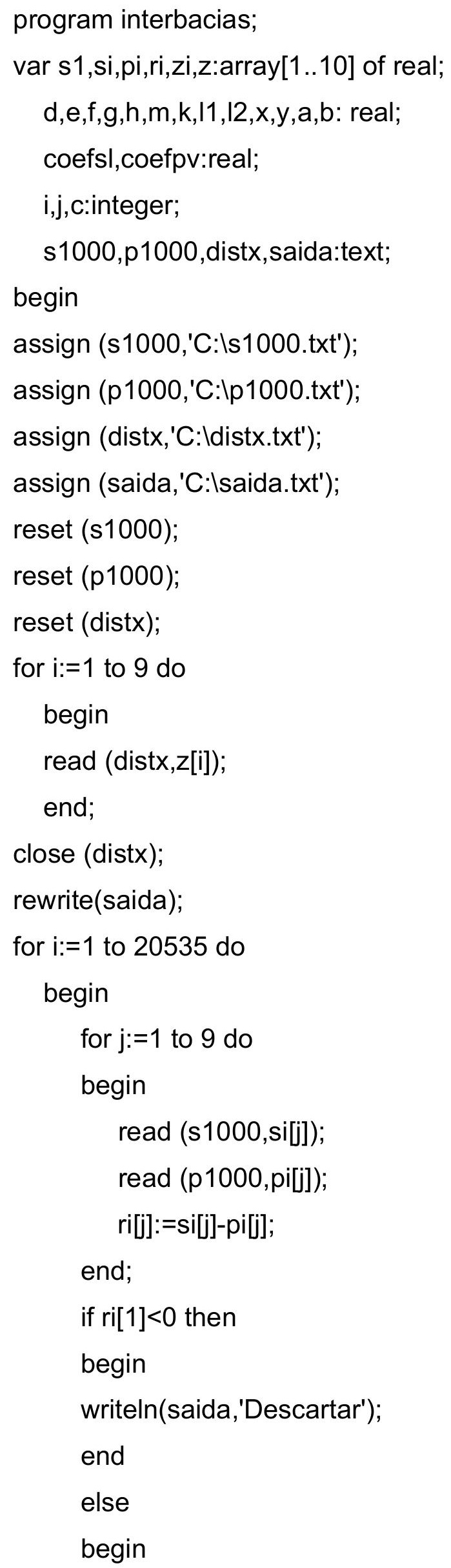




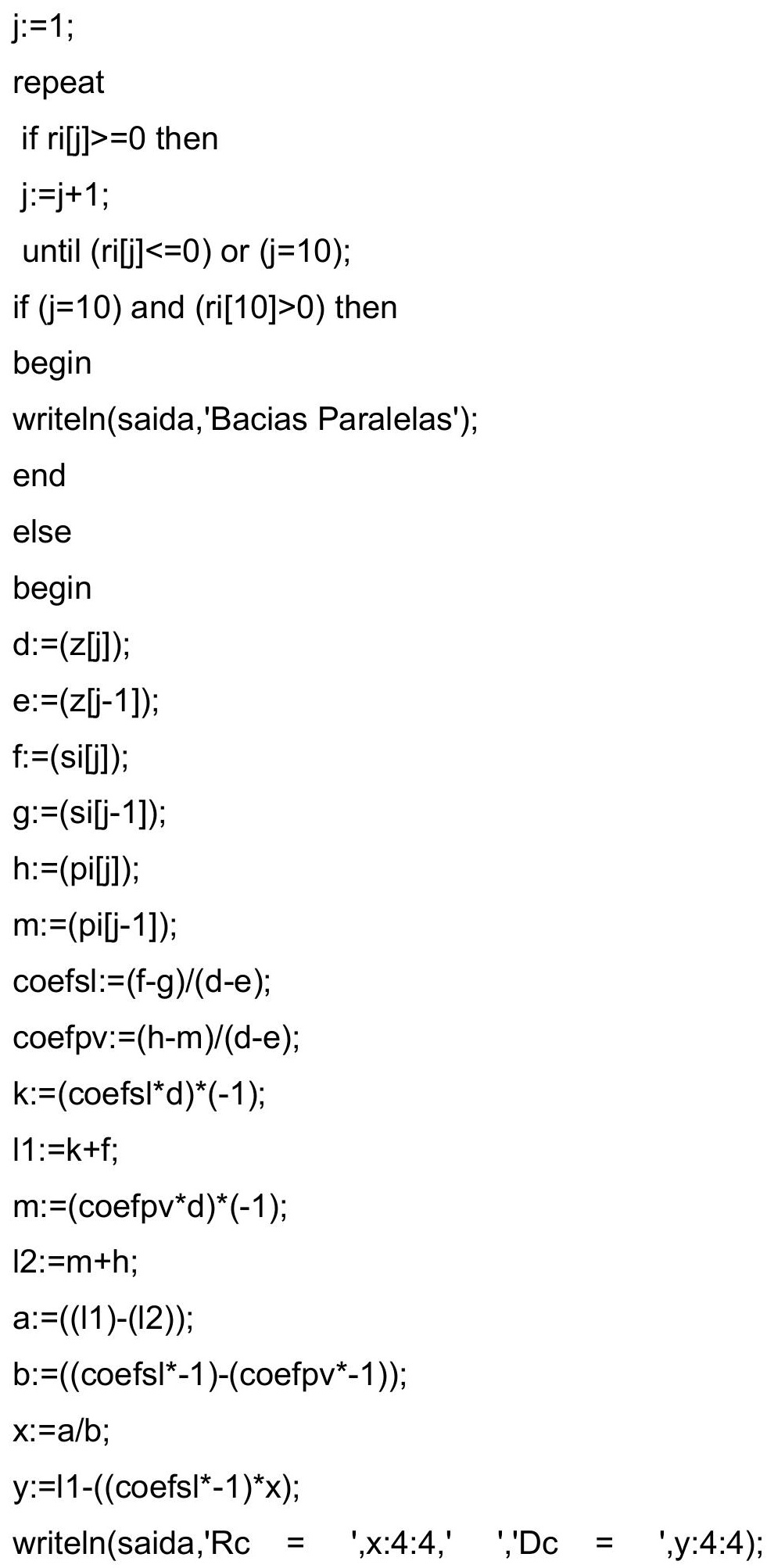


close(saida);

end. 
ANEXO D - Programa desenvolvido em linguagem Pascal para avaliação do erro na retroanálise do subleito utilizando-se a Teoria do Ponto Inerte. 


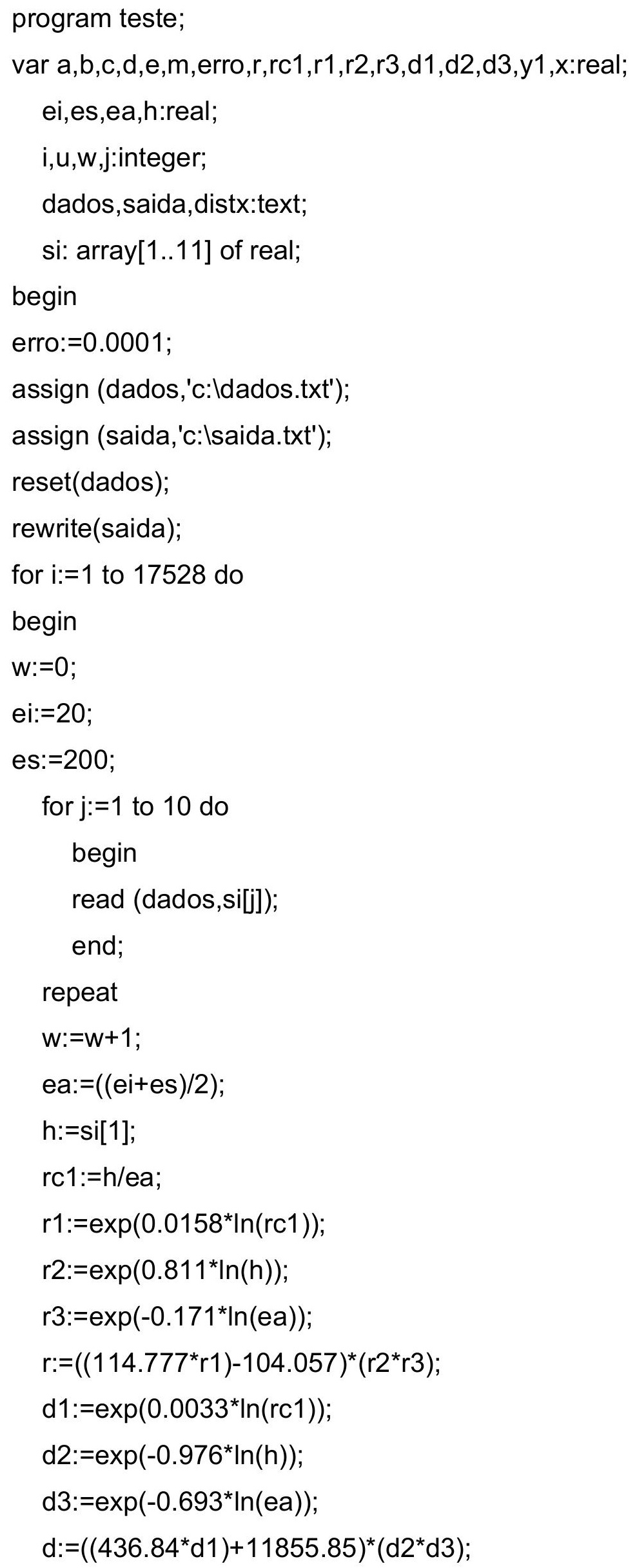


if $(r>=0)$ and $(r<=25)$ then

begin

$\mathrm{m}:=((\mathrm{si}[3]-\mathrm{si}[2]) / 25)$;

$\mathrm{y} 1:=(\mathrm{si}[2])+\left(\mathrm{m}^{*}(\mathrm{r}-25)\right)$;

end;

if $(r>25)$ and $(r<=40)$ then

begin

$\mathrm{m}:=((\mathrm{si}[4]-\mathrm{si}[3]) / 15)$;

$y 1:=(\operatorname{si}[3])+\left(m^{*}(r-25)\right)$;

end;

if $(r>40)$ and $(r<=60)$ then

begin

$\mathrm{m}:=((\mathrm{si}[5]-\mathrm{si}[4]) / 20)$;

$\mathrm{y} 1:=(\mathrm{si}[4])+\left(\mathrm{m}^{*}(\mathrm{r}-40)\right)$;

end;

if $(r>60)$ and $(r<=80)$ then

begin

$\mathrm{m}:=((\mathrm{si}[6]-\mathrm{si}[5]) / 20)$;

$y 1:=(\operatorname{si}[5])+\left(m^{*}(r-60)\right)$;

end;

if $(r>80)$ and $(r<=100)$ then

begin

$\mathrm{m}:=((\mathrm{si}[7]-\mathrm{si}[6]) / 20)$;

$y 1:=(\operatorname{si}[6])+\left(m^{*}(r-80)\right)$;

end;

if $(r>100)$ and $(r<=140)$ then

begin

m:=((si[8]-si[7])/40);

$y 1:=(\operatorname{si}[7])+\left(m^{*}(r-100)\right)$;

end;

if $(r>140)$ and $(r<=180)$ then

begin

$\mathrm{m}:=((\mathrm{si}[9]-\mathrm{si}[8]) / 40)$;

$y 1:=(\operatorname{si}[8])+\left(m^{*}(r-140)\right)$; 


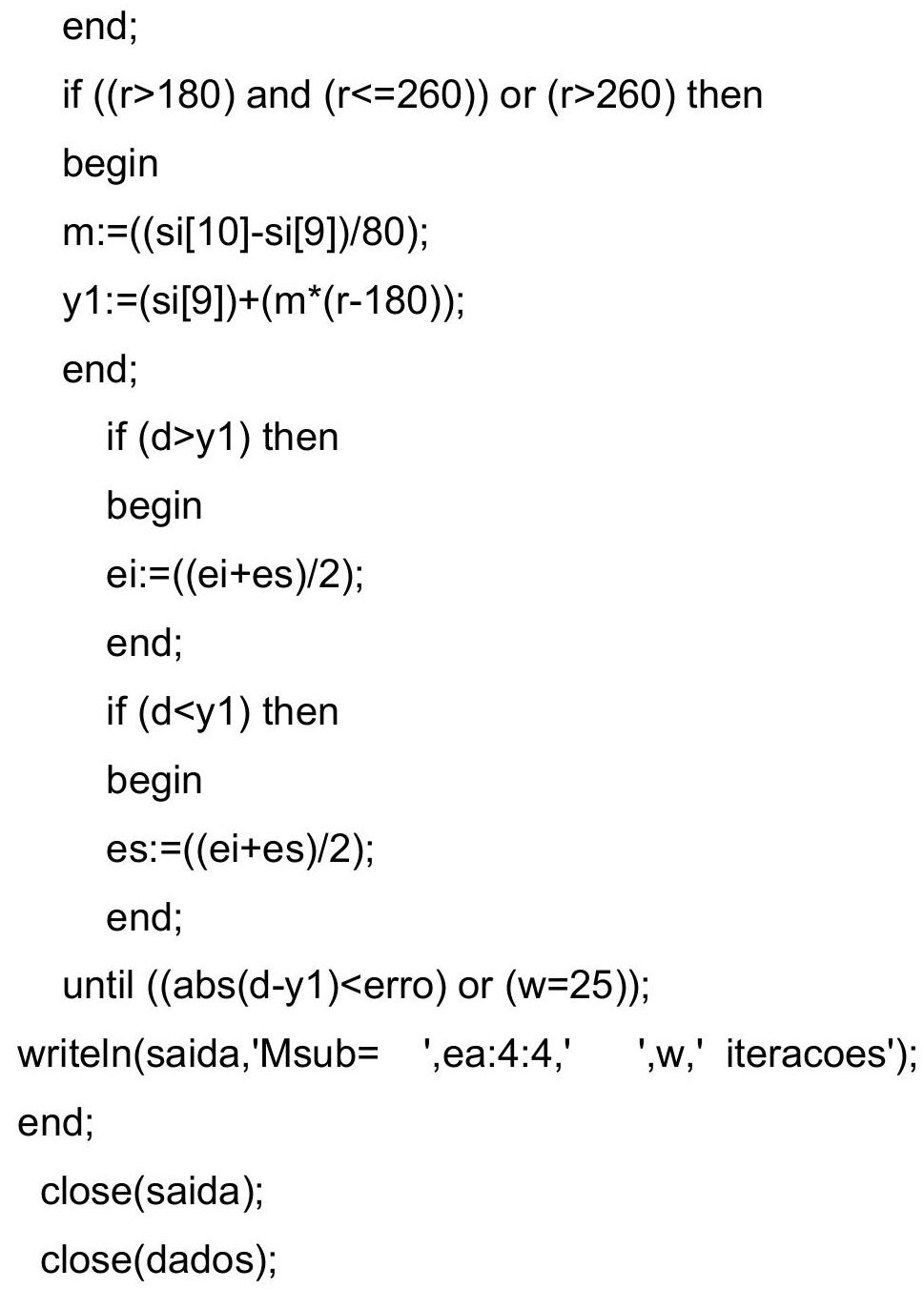


ANEXO H - Programa desenvolvido em linguagem Pascal para retroanálise do subleito utilizando-se a Teoria do Ponto Inerte com utilização de uma bacia deflectométrica. 


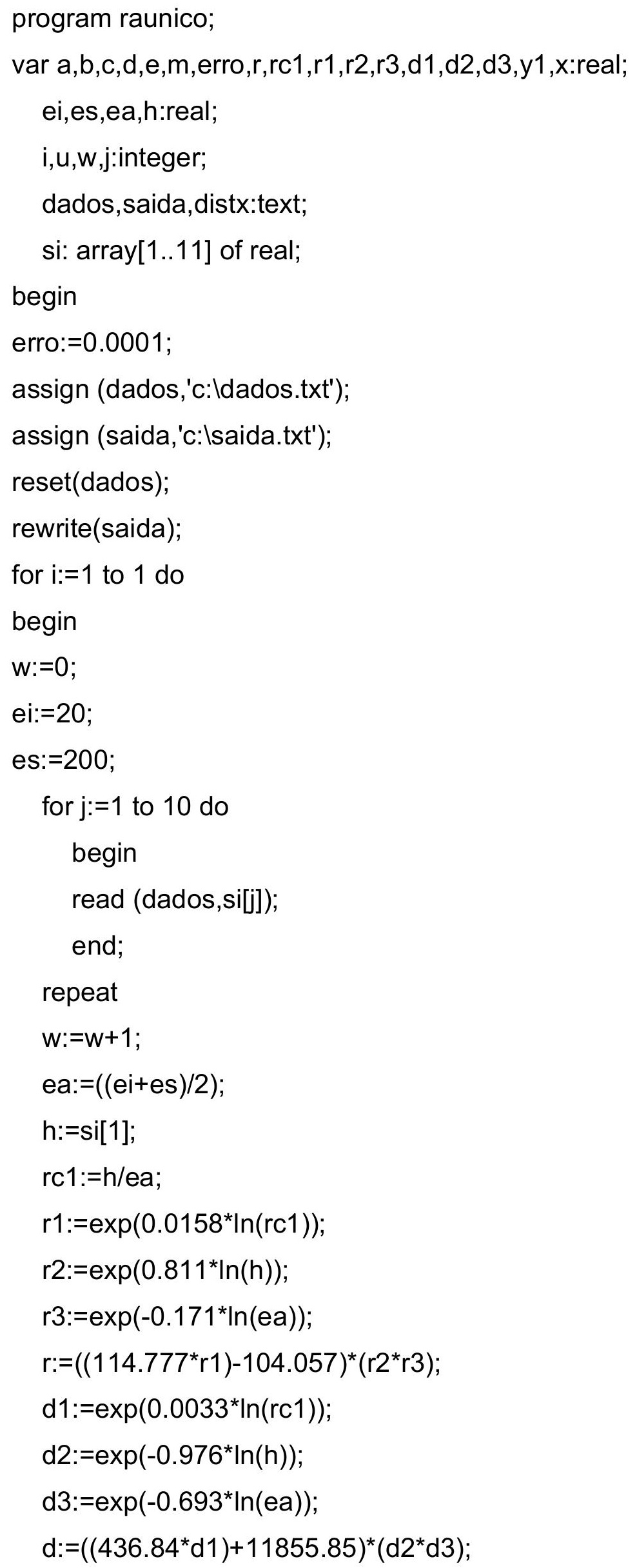


if $(r>=0)$ and $(r<=25)$ then

begin

$\mathrm{m}:=((\mathrm{si}[3]-\mathrm{si}[2]) / 25)$;

$\mathrm{y} 1:=(\mathrm{si}[2])+\left(\mathrm{m}^{*}(\mathrm{r}-25)\right)$;

end;

if $(r>25)$ and $(r<=40)$ then

begin

$\mathrm{m}:=((\mathrm{si}[4]-\mathrm{si}[3]) / 15)$;

$\mathrm{y} 1:=(\mathrm{si}[3])+\left(\mathrm{m}^{*}(\mathrm{r}-25)\right)$;

end;

if $(r>40)$ and $(r<=60)$ then

begin

$\mathrm{m}:=((\mathrm{si}[5]-\mathrm{si}[4]) / 20)$;

$y 1:=(\operatorname{si}[4])+\left(m^{*}(r-40)\right)$;

end;

if $(r>60)$ and $(r<=80)$ then

begin

$\mathrm{m}:=((\mathrm{si}[6]-\mathrm{si}[5]) / 20)$;

$y 1:=(\operatorname{si}[5])+\left(m^{*}(r-60)\right)$;

end;

if $(r>80)$ and $(r<=100)$ then

begin

$\mathrm{m}:=((\mathrm{si}[7]-\mathrm{si}[6]) / 20)$;

$y 1:=(\operatorname{si}[6])+\left(m^{*}(r-80)\right)$;

end;

if $(r>100)$ and $(r<=140)$ then

begin

$\mathrm{m}:=((\mathrm{si}[8]-\mathrm{si}[7]) / 40)$;

$y 1:=(s i[7])+\left(m^{*}(r-100)\right)$;

end;

if $(r>140)$ and $(r<=180)$ then

begin

$\mathrm{m}:=((\mathrm{si}[9]-\mathrm{si}[8]) / 40)$;

$y 1:=(\operatorname{si}[8])+\left(m^{*}(r-140)\right)$; 


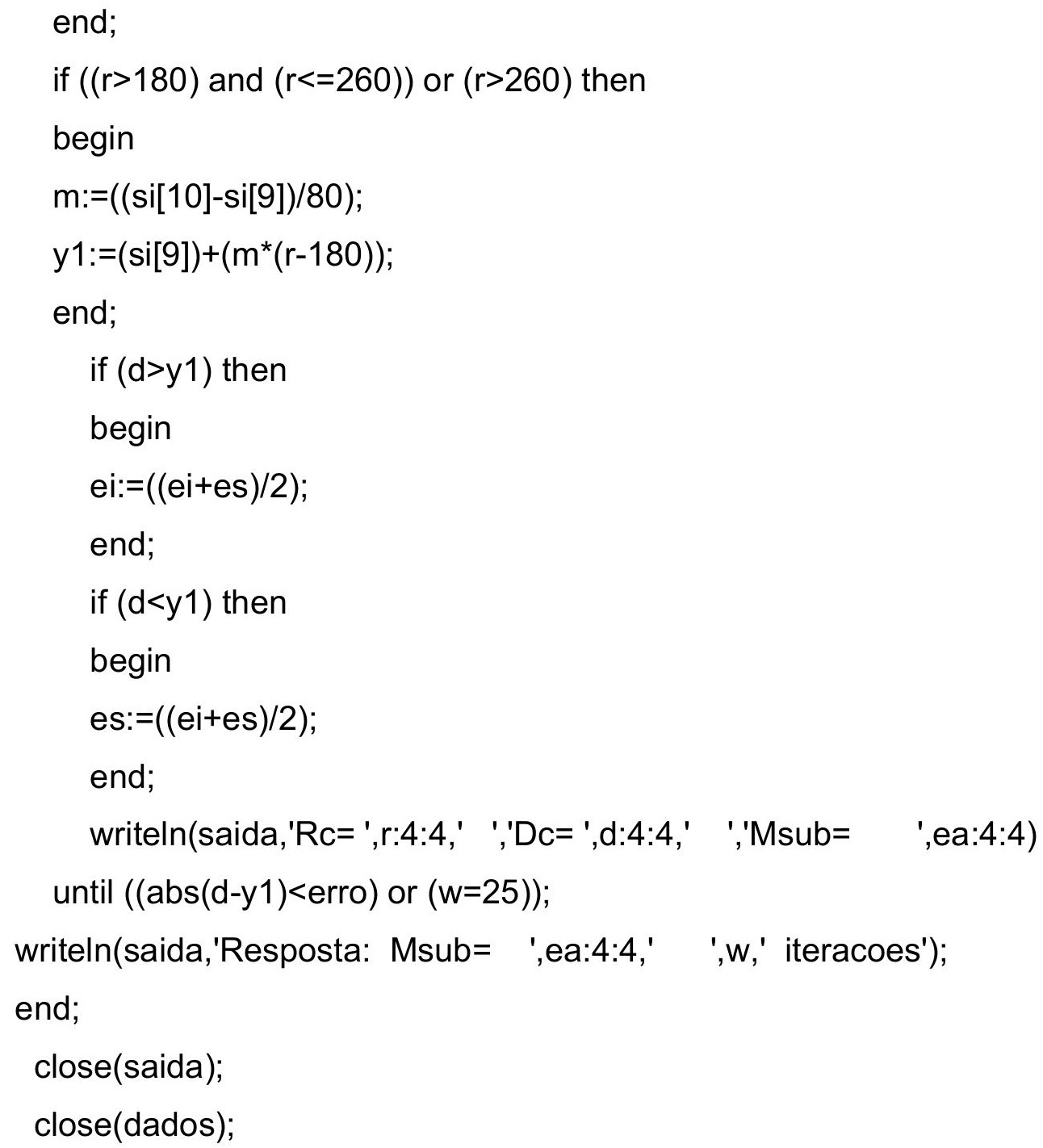


ANEXO A - Bacias deflectométricas teóricas utilizadas para obtenção das coordenadas $\left(R_{c}, D_{c}\right)$ do Ponto Inerte. 


\begin{tabular}{|c|c|c|c|c|c|c|c|c|c|c|c|}
\hline \multirow[b]{2}{*}{$\mathrm{H}(\mathrm{cm})$} & \multirow[b]{2}{*}{ Mceq (MPa) } & & & & & $\mathrm{De}$ & ões (x1 & m) & & & \\
\hline & & Msub (MPa) & D0 & D25 & D40 & D60 & D80 & D100 & D140 & D180 & D260 \\
\hline 20 & 200 & 20 & 236,37 & 175,44 & 135,06 & 95,82 & 70,67 & 54,75 & 37,46 & 28,83 & 20,01 \\
\hline 20 & 250 & 20 & 222,89 & 170,16 & 133,47 & 96,33 & 71,58 & 55,47 & 37,69 & 28,86 & 19,99 \\
\hline 20 & 300 & 20 & 212,23 & 165,52 & 131,79 & 96,55 & 72,29 & 56,11 & 37,94 & 28,90 & 19,97 \\
\hline 20 & 350 & 20 & 203,46 & 161,40 & 130,11 & 96,56 & 72,83 & 56,67 & 38,20 & 28,96 & 19,95 \\
\hline 20 & 400 & 20 & 196,05 & 157,71 & 128,47 & 96,43 & 73,25 & 57,17 & 38,46 & 29,03 & 19,94 \\
\hline 20 & 450 & 20 & 189,64 & 154,37 & 126,88 & 96,21 & 73,57 & 57,60 & 38,71 & 29,12 & 19,93 \\
\hline 20 & 500 & 20 & 184,02 & 151,33 & 125,36 & 95,92 & 73,81 & 57,97 & 38,96 & 29,20 & 19,93 \\
\hline 20 & 550 & 20 & 179,01 & 148,54 & 123,91 & 95,58 & 73,99 & 58,30 & 39,19 & 29,30 & 19,92 \\
\hline 20 & 600 & 20 & 174,52 & 145,97 & 122,52 & 95,21 & 74,11 & 58,59 & 39,42 & 29,39 & 19,92 \\
\hline 20 & 650 & 20 & 170,44 & 143,59 & 121,20 & 94,82 & 74,18 & 58,84 & 39,64 & 29,49 & 19,92 \\
\hline 20 & 700 & 20 & 166,72 & 141,37 & 119,93 & 94,42 & 74,22 & 59,05 & 39,85 & 29,59 & 19,93 \\
\hline 20 & 750 & 20 & 163,30 & 139,30 & 118,72 & 94,00 & 74,23 & 59,24 & 40,05 & 29,69 & 19,93 \\
\hline 20 & 800 & 20 & 160,14 & 137,36 & 117,56 & 93,58 & 74,22 & 59,40 & 40,24 & 29,79 & 19,94 \\
\hline 20 & 850 & 20 & 157,20 & 135,53 & 116,45 & 93,15 & 74,18 & 59,54 & 40,42 & 29,90 & 19,94 \\
\hline 20 & 900 & 20 & 154,47 & 133,81 & 115,38 & 92,72 & 74,12 & 59,66 & 40,59 & 30,00 & 19,95 \\
\hline 20 & 950 & 20 & 151,91 & 132,18 & 114,36 & 92,30 & 74,05 & 59,76 & 40,75 & 30,10 & 19,97 \\
\hline 20 & 1000 & 20 & 149,51 & 130,64 & 113,38 & 91,88 & 73,97 & 59,85 & 40,91 & 30,19 & 19,98 \\
\hline 20 & 1050 & 20 & 147,25 & 129,17 & 112,43 & 91,46 & 73,87 & 59,92 & 41,06 & 30,29 & 19,99 \\
\hline 20 & 1100 & 20 & 145,12 & 127,77 & 111,52 & 91,04 & 73,77 & 59,98 & 41,19 & 30,39 & 20,01 \\
\hline 20 & 1150 & 20 & 143,10 & 126,44 & 110,64 & 90,63 & 73,66 & 60,03 & 41,33 & 30,48 & 20,02 \\
\hline 20 & 1200 & 20 & 141,19 & 125,17 & 109,79 & 90,23 & 73,54 & 60,07 & 41,45 & 30,57 & 20,04 \\
\hline 20 & 1250 & 20 & 139,37 & 123,95 & 108,97 & 89,83 & 73,41 & 60,10 & 41,57 & 30,66 & 20,06 \\
\hline 20 & 1300 & 20 & 137,64 & 122,78 & 108,17 & 89,44 & 73,28 & 60,12 & 41,68 & 30,75 & 20,08 \\
\hline 20 & 1350 & 20 & 135,99 & 121,66 & 107,40 & 89,05 & 73,15 & 60,13 & 41,79 & 30,84 & 20,10 \\
\hline 20 & 1400 & 20 & 134,42 & 120,58 & 106,66 & 88,67 & 73,01 & 60,14 & 41,89 & 30,92 & 20,12 \\
\hline 20 & 1450 & 20 & 132,92 & 119,55 & 105,94 & 88,30 & 72,87 & 60,14 & 41,98 & 31,00 & 20,14 \\
\hline 20 & 1500 & 20 & 131,48 & 118,55 & 105,24 & 87,93 & 72,73 & 60,13 & 42,07 & 31,08 & 20,16 \\
\hline 20 & 1550 & 20 & 130,10 & 117,58 & 104,56 & 87,57 & 72,58 & 60,12 & 42,16 & 31,16 & 20,18 \\
\hline 20 & 1600 & 20 & 128,77 & 116,65 & 103,90 & 87,21 & 72,44 & 60,10 & 42,24 & 31,24 & 20,20 \\
\hline 20 & 1650 & 20 & 127,50 & 115,75 & 103,26 & 86,86 & 72,29 & 60,08 & 42,32 & 31,31 & 20,23 \\
\hline 20 & 1700 & 20 & 126,28 & 114,89 & 102,64 & 86,51 & 72,14 & 60,06 & 42,39 & 31,39 & 20,25 \\
\hline 20 & 1750 & 20 & 125,10 & 114,04 & 102,03 & 86,17 & 71,99 & 60,03 & 42,46 & 31,46 & 20,27 \\
\hline 20 & 1800 & 20 & 123,97 & 113,23 & 101,44 & 85,84 & 71,84 & 60,00 & 42,53 & 31,53 & 20,30 \\
\hline 20 & 1850 & 20 & 122,87 & 112,44 & 100,86 & 85,51 & 71,69 & 59,96 & 42,59 & 31,60 & 20,32 \\
\hline 20 & 1900 & 20 & 121,82 & 111,67 & 100,30 & 85,19 & 71,54 & 59,92 & 42,65 & 31,66 & 20,35 \\
\hline 20 & 1950 & 20 & 120,80 & 110,92 & 99,75 & 84,87 & 71,39 & 59,88 & 42,71 & 31,73 & 20,37 \\
\hline 20 & 2000 & 20 & 119,81 & 110,20 & 99,22 & 84,55 & 71,24 & 59,84 & 42,76 & 31,79 & 20,40 \\
\hline 20 & 200 & 25 & 200,27 & 144,18 & 108,91 & 76,05 & 55,80 & 43,30 & 29,84 & 23,05 & 16,02 \\
\hline 20 & 250 & 25 & 189,09 & 140,35 & 108,05 & 76,65 & 56,53 & 43,80 & 29,97 & 23,06 & 16,01 \\
\hline 20 & 300 & 25 & 180,25 & 136,93 & 107,04 & 77,01 & 57,13 & 44,27 & 30,12 & 23,08 & 15,99 \\
\hline 20 & 350 & 25 & 172,98 & 133,85 & 105,97 & 77,19 & 57,62 & 44,69 & 30,27 & 23,11 & 15,98 \\
\hline 20 & 400 & 25 & 166,83 & 131,05 & 104,89 & 77,26 & 58,02 & 45,08 & 30,44 & 23,14 & 15,97 \\
\hline 20 & 450 & 25 & 161,51 & 128,50 & 103,82 & 77,23 & 58,34 & 45,42 & 30,60 & 23,18 & 15,96 \\
\hline 20 & 500 & 25 & 156,84 & 126,16 & 102,77 & 77,14 & 58,60 & 45,73 & 30,76 & 23,23 & 15,95 \\
\hline 20 & 550 & 25 & 152,68 & 124,01 & 101,76 & 77,01 & 58,81 & 46,01 & 30,93 & 23,28 & 15,95 \\
\hline 20 & 600 & 25 & 148,95 & 122,01 & 100,77 & 76,83 & 58,98 & 46,26 & 31,09 & 23,33 & 15,94 \\
\hline 20 & 650 & 25 & 145,56 & 120,15 & 99,82 & 76,63 & 59,11 & 46,49 & 31,24 & 23,39 & 15,94 \\
\hline 20 & 700 & 25 & 142,46 & 118,41 & 98,90 & 76,41 & 59,21 & 46,69 & 31,39 & 23,45 & 15,94 \\
\hline 20 & 750 & 25 & 139,61 & 116,77 & 98,02 & 76,17 & 59,29 & 46,87 & 31,54 & 23,51 & 15,94 \\
\hline 20 & 800 & 25 & 136,98 & 115,24 & 97,17 & 75,92 & 59,34 & 47,03 & 31,68 & 23,58 & 15,94 \\
\hline 20 & 850 & 25 & 134,54 & 113,79 & 96,35 & 75,66 & 59,37 & 47,18 & 31,82 & 23,64 & 15,94 \\
\hline 20 & 900 & 25 & 132,25 & 112,42 & 95,55 & 75,40 & 59,38 & 47,30 & 31,95 & 23,71 & 15,94 \\
\hline 20 & 950 & 25 & 130,12 & 111,12 & 94,79 & 75,13 & 59,38 & 47,42 & 32,07 & 23,77 & 15,95 \\
\hline 20 & 1000 & 25 & 128,11 & 109,89 & 94,05 & 74,86 & 59,37 & 47,52 & 32,19 & 23,84 & 15,95 \\
\hline 20 & 1050 & 25 & 126,22 & 108,71 & 93,33 & 74,59 & 59,35 & 47,61 & 32,31 & 23,90 & 15,95 \\
\hline 20 & 1100 & 25 & 124,43 & 107,59 & 92,64 & 74,32 & 59,32 & 47,69 & 32,42 & 23,96 & 15,96 \\
\hline 20 & 1150 & 25 & 122,74 & 106,52 & 91,98 & 74,04 & 59,28 & 47,76 & 32,53 & 24,03 & 15,97 \\
\hline 20 & 1200 & 25 & 121,14 & 105,49 & 91,33 & 73,77 & 59,23 & 47,83 & 32,63 & 24,09 & 15,97 \\
\hline 20 & 1250 & 25 & 119,61 & 104,51 & 90,70 & 73,50 & 59,17 & 47,88 & 32,73 & 24,16 & 15,98 \\
\hline 20 & 1300 & 25 & 118,15 & 103,57 & 90,09 & 73,23 & 59,11 & 47,93 & 32,82 & 24,22 & 15,99 \\
\hline 20 & 1350 & 25 & 116,77 & 102,66 & 89,50 & 72,97 & 59,05 & 47,97 & 32,91 & 24,28 & 16,00 \\
\hline 20 & 1400 & 25 & 115,44 & 101,79 & 88,93 & 72,70 & 58,98 & 48,00 & 33,00 & 24,34 & 16,01 \\
\hline 20 & 1450 & 25 & 114,17 & 100,95 & 88,37 & 72,44 & 58,91 & 48,03 & 33,08 & 24,40 & 16,02 \\
\hline 20 & 1500 & 25 & 112,95 & 100,13 & 87,83 & 72,18 & 58,83 & 48,06 & 33,16 & 24,46 & 16,03 \\
\hline 20 & 1550 & 25 & 111,78 & 99,35 & 87,30 & 71,93 & 58,75 & 48,07 & 33,24 & 24,52 & 16,04 \\
\hline 20 & 1600 & 25 & 110,66 & 98,59 & 86,79 & 71,68 & 58,67 & 48,09 & 33,31 & 24,57 & 16,06 \\
\hline 20 & 1650 & 25 & 109,58 & 97,86 & 86,29 & 71,43 & 58,58 & 48,10 & 33,38 & 24,63 & 16,07 \\
\hline 20 & 1700 & 25 & 108,54 & 97,15 & 85,80 & 71,18 & 58,50 & 48,11 & 33,45 & 24,68 & 16,08 \\
\hline 20 & 1750 & 25 & 107,54 & 96,47 & 85,33 & 70,94 & 58,41 & 48,11 & 33,51 & 24,74 & 16,09 \\
\hline 20 & 1800 & 25 & 106,57 & 95,80 & 84,87 & 70,70 & 58,32 & 48,11 & 33,57 & 24,79 & 16,11 \\
\hline 20 & 1850 & 25 & 105,64 & 95,15 & 84,41 & 70,46 & 58,23 & 48,11 & 33,63 & 24,84 & 16,12 \\
\hline 20 & 1900 & 25 & 104,74 & 94,53 & 83,97 & 70,23 & 58,14 & 48,10 & 33,69 & 24,89 & 16,13 \\
\hline 20 & 1950 & 25 & 103,86 & 93,92 & 83,54 & 69,99 & 58,04 & 48,09 & 33,74 & 24,94 & 16,15 \\
\hline 20 & 2000 & 25 & 103,02 & 93,32 & 83,12 & 69,77 & 57,95 & 48,08 & 33,79 & 24,99 & 16,16 \\
\hline 20 & 200 & 30 & 174,77 & 122,48 & 91,10 & 62,89 & 46,03 & 35,79 & 24,80 & 19,21 & 13,37 \\
\hline 20 & 250 & 30 & 165,17 & 119,59 & 90,65 & 63,48 & 46,61 & 36,15 & 24,88 & 19,21 & 13,35 \\
\hline 20 & 300 & 30 & 157,58 & 116,96 & 90,04 & 63,88 & 47,11 & 36,50 & 24,97 & 19,22 & 13,34 \\
\hline 20 & 350 & 30 & 151,34 & 114,56 & 89,34 & 64,13 & 47,53 & 36,83 & 25,08 & 19,23 & 13,33 \\
\hline 20 & 400 & 30 & 146,05 & 112,37 & 88,61 & 64,29 & 47,89 & 37,13 & 25,18 & 19,25 & 13,32 \\
\hline 20 & 450 & 30 & 141,49 & 110,35 & 87,86 & 64,36 & 48,19 & 37,41 & 25,29 & 19,27 & 13,31 \\
\hline 20 & 500 & 30 & 137,48 & 108,48 & 87,11 & 64,38 & 48,44 & 37,66 & 25,41 & 19,29 & 13,31 \\
\hline
\end{tabular}




\begin{tabular}{|c|c|c|c|c|c|c|c|c|c|c|c|}
\hline \multirow[b]{2}{*}{$\mathrm{H}(\mathrm{cm})$} & \multirow[b]{2}{*}{ Mceq (MPa) } & & & & & & ões (x1 & m) & & & \\
\hline & & Msub (MPa) & D0 & D25 & D40 & D60 & D80 & D100 & D140 & D180 & D260 \\
\hline 20 & 550 & 30 & 133,91 & 106,75 & 86,37 & 64,35 & 48,66 & 37,90 & 25,52 & 19,32 & 13,30 \\
\hline 20 & 600 & 30 & 130,70 & 105,14 & 85,64 & 64,29 & 48,84 & 38,11 & 25,64 & 19,36 & 13,30 \\
\hline 20 & 650 & 30 & 127,79 & 103,63 & 84,94 & 64,19 & 48,98 & 38,31 & 25,75 & 19,39 & 13,29 \\
\hline 20 & 700 & 30 & 125,12 & 102,21 & 84,25 & 64,08 & 49,11 & 38,49 & 25,86 & 19,43 & 13,29 \\
\hline 20 & 750 & 30 & 122,68 & 100,88 & 83,58 & 63,95 & 49,21 & 38,65 & 25,97 & 19,47 & 13,29 \\
\hline 20 & 800 & 30 & 120,41 & 99,63 & 82,93 & 63,80 & 49,29 & 38,80 & 26,08 & 19,51 & 13,28 \\
\hline 20 & 850 & 30 & 118,31 & 98,44 & 82,29 & 63,64 & 49,35 & 38,93 & 26,18 & 19,55 & 13,28 \\
\hline 20 & 900 & 30 & 116,35 & 97,31 & 81,68 & 63,48 & 49,40 & 39,06 & 26,28 & 19,59 & 13,28 \\
\hline 20 & 950 & 30 & 114,51 & 96,24 & 81,09 & 63,30 & 49,44 & 39,17 & 26,38 & 19,64 & 13,28 \\
\hline 20 & 1000 & 30 & 112,78 & 95,22 & 80,51 & 63,13 & 49,47 & 39,27 & 26,48 & 19,68 & 13,28 \\
\hline 20 & 1050 & 30 & 111,15 & 94,25 & 79,95 & 62,94 & 49,48 & 39,37 & 26,57 & 19,73 & 13,28 \\
\hline 20 & 1100 & 30 & 109,61 & 93,32 & 79,41 & 62,76 & 49,49 & 39,45 & 26,66 & 19,77 & 13,29 \\
\hline 20 & 1150 & 30 & 108,15 & 92,43 & 78,89 & 62,57 & 49,49 & 39,53 & 26,74 & 19,82 & 13,29 \\
\hline 20 & 1200 & 30 & 106,76 & 91,57 & 78,37 & 62,38 & 49,48 & 39,60 & 26,83 & 19,86 & 13,29 \\
\hline 20 & 1250 & 30 & 105,44 & 90,75 & 77,88 & 62,19 & 49,46 & 39,67 & 26,91 & 19,91 & 13,29 \\
\hline 20 & 1300 & 30 & 104,18 & 89,97 & 77,39 & 62,01 & 49,44 & 39,72 & 26,99 & 19,95 & 13,30 \\
\hline 20 & 1350 & 30 & 102,98 & 89,21 & 76,92 & 61,82 & 49,41 & 39,77 & 27,06 & 20,00 & 13,30 \\
\hline 20 & 1400 & 30 & 101,83 & 88,48 & 76,46 & 61,63 & 49,38 & 39,82 & 27,13 & 20,04 & 13,31 \\
\hline 20 & 1450 & 30 & 100,73 & 87,77 & 76,02 & 61,44 & 49,35 & 39,86 & 27,20 & 20,09 & 13,31 \\
\hline 20 & 1500 & 30 & 99,67 & 87,09 & 75,58 & 61,25 & 49,31 & 39,90 & 27,27 & 20,13 & 13,32 \\
\hline 20 & 1550 & 30 & 98,66 & 86,43 & 75,16 & 61,07 & 49,27 & 39,93 & 27,34 & 20,17 & 13,33 \\
\hline 20 & 1600 & 30 & 97,68 & 85,80 & 74,75 & 60,88 & 49,23 & 39,96 & 27,40 & 20,22 & 13,33 \\
\hline 20 & 1650 & 30 & 96,75 & 85,18 & 74,34 & 60,70 & 49,18 & 39,99 & 27,46 & 20,26 & 13,34 \\
\hline 20 & 1700 & 30 & 95,84 & 84,59 & 73,95 & 60,51 & 49,13 & 40,01 & 27,52 & 20,30 & 13,35 \\
\hline 20 & 1750 & 30 & 94,97 & 84,01 & 73,57 & 60,33 & 49,08 & 40,03 & 27,58 & 20,34 & 13,35 \\
\hline 20 & 1800 & 30 & 94,13 & 83,45 & 73,19 & 60,15 & 49,02 & 40,05 & 27,63 & 20,38 & 13,36 \\
\hline 20 & 1850 & 30 & 93,31 & 82,90 & 72,82 & 59,98 & 48,97 & 40,06 & 27,69 & 20,42 & 13,37 \\
\hline 20 & 1900 & 30 & 92,52 & 82,37 & 72,47 & 59,80 & 48,91 & 40,07 & 27,74 & 20,46 & 13,38 \\
\hline 20 & 1950 & 30 & 91,76 & 81,85 & 72,12 & 59,63 & 48,85 & 40,08 & 27,79 & 20,50 & 13,38 \\
\hline 20 & 2000 & 30 & 91,02 & 81,35 & 71,77 & 59,45 & 48,80 & 40,08 & 27,83 & 20,54 & 13,39 \\
\hline 20 & 200 & 35 & 155,68 & 106,49 & 78,20 & 53,51 & 39,13 & 30,50 & 21,23 & 16,46 & 11,47 \\
\hline 20 & 250 & 35 & 147,22 & 104,25 & 78,00 & 54,07 & 39,60 & 30,77 & 21,28 & 16,46 & 11,45 \\
\hline 20 & 300 & 35 & 140,55 & 102,17 & 77,63 & 54,47 & 40,02 & 31,03 & 21,34 & 16,47 & 11,44 \\
\hline 20 & 350 & 35 & 135,07 & 100,25 & 77,18 & 54,75 & 40,38 & 31,29 & 21,41 & 16,47 & 11,43 \\
\hline 20 & 400 & 35 & 130,42 & 98,48 & 76,67 & 54,95 & 40,69 & 31,53 & 21,48 & 16,48 & 11,43 \\
\hline 20 & 450 & 35 & 126,41 & 96,84 & 76,13 & 55,07 & 40,97 & 31,75 & 21,56 & 16,49 & 11,42 \\
\hline 20 & 500 & 35 & 122,89 & 95,31 & 75,58 & 55,15 & 41,20 & 31,96 & 21,64 & 16,51 & 11,41 \\
\hline 20 & 550 & 35 & 119,75 & 93,88 & 75,03 & 55,18 & 41,40 & 32,16 & 21,72 & 16,53 & 11,41 \\
\hline 20 & 600 & 35 & 116,93 & 92,55 & 74,48 & 55,18 & 41,58 & 32,34 & 21,81 & 16,55 & 11,40 \\
\hline 20 & 650 & 35 & 114,37 & 91,30 & 73,94 & 55,15 & 41,73 & 32,51 & 21,89 & 16,57 & 11,40 \\
\hline 20 & 700 & 35 & 112,03 & 90,12 & 73,41 & 55,10 & 41,86 & 32,67 & 21,97 & 16,59 & 11,40 \\
\hline 20 & 750 & 35 & 109,87 & 89,00 & 72,89 & 55,04 & 41,97 & 32,81 & 22,06 & 16,62 & 11,39 \\
\hline 20 & 800 & 35 & 107,88 & 87,95 & 72,38 & 54,95 & 42,06 & 32,95 & 22,14 & 16,64 & 11,39 \\
\hline 20 & 850 & 35 & 106,03 & 86,95 & 71,88 & 54,86 & 42,14 & 33,07 & 22,22 & 16,67 & 11,39 \\
\hline 20 & 900 & 35 & 104,30 & 86,00 & 71,40 & 54,76 & 42,21 & 33,18 & 22,30 & 16,70 & 11,39 \\
\hline 20 & 950 & 35 & 102,68 & 85,10 & 70,92 & 54,65 & 42,27 & 33,29 & 22,38 & 16,73 & 11,39 \\
\hline 20 & 1000 & 35 & 101,16 & 84,24 & 70,46 & 54,53 & 42,31 & 33,39 & 22,45 & 16,76 & 11,38 \\
\hline 20 & 1050 & 35 & 99,72 & 83,41 & 70,01 & 54,41 & 42,35 & 33,48 & 22,53 & 16,80 & 11,38 \\
\hline 20 & 1100 & 35 & 98,37 & 82,62 & 69,58 & 54,28 & 42,37 & 33,56 & 22,60 & 16,83 & 11,38 \\
\hline 20 & 1150 & 35 & 97,08 & 81,86 & 69,15 & 54,15 & 42,39 & 33,64 & 22,67 & 16,86 & 11,38 \\
\hline 20 & 1200 & 35 & 95,86 & 81,14 & 68,74 & 54,02 & 42,41 & 33,71 & 22,74 & 16,89 & 11,39 \\
\hline 20 & 1250 & 35 & 94,69 & 80,44 & 68,33 & 53,88 & 42,42 & 33,78 & 22,81 & 16,93 & 11,39 \\
\hline 20 & 1300 & 35 & 93,58 & 79,76 & 67,94 & 53,75 & 42,42 & 33,84 & 22,87 & 16,96 & 11,39 \\
\hline 20 & 1350 & 35 & 92,52 & 79,12 & 67,55 & 53,61 & 42,42 & 33,89 & 22,93 & 16,99 & 11,39 \\
\hline 20 & 1400 & 35 & 91,51 & 78,49 & 67,18 & 53,47 & 42,41 & 33,94 & 22,99 & 17,03 & 11,39 \\
\hline 20 & 1450 & 35 & 90,54 & 77,89 & 66,81 & 53,33 & 42,40 & 33,99 & 23,05 & 17,06 & 11,39 \\
\hline 20 & 1500 & 35 & 89,60 & 77,30 & 66,45 & 53,19 & 42,38 & 34,03 & 23,11 & 17,09 & 11,40 \\
\hline 20 & 1550 & 35 & 88,70 & 76,74 & 66,10 & 53,05 & 42,37 & 34,07 & 23,17 & 17,12 & 11,40 \\
\hline 20 & 1600 & 35 & 87,84 & 76,19 & 65,76 & 52,92 & 42,34 & 34,11 & 23,22 & 17,16 & 11,40 \\
\hline 20 & 1650 & 35 & 87,01 & 75,66 & 65,43 & 52,78 & 42,32 & 34,14 & 23,28 & 17,19 & 11,41 \\
\hline 20 & 1700 & 35 & 86,21 & 75,15 & 65,10 & 52,64 & 42,30 & 34,17 & 23,33 & 17,22 & 11,41 \\
\hline 20 & 1750 & 35 & 85,43 & 74,65 & 64,79 & 52,50 & 42,27 & 34,20 & 23,38 & 17,25 & 11,42 \\
\hline 20 & 1800 & 35 & 84,69 & 74,17 & 64,47 & 52,36 & 42,24 & 34,23 & 23,42 & 17,29 & 11,42 \\
\hline 20 & 1850 & 35 & 83,96 & 73,70 & 64,17 & 52,23 & 42,20 & 34,25 & 23,47 & 17,32 & 11,43 \\
\hline 20 & 1900 & 35 & 83,27 & 73,24 & 63,87 & 52,09 & 42,17 & 34,27 & 23,52 & 17,35 & 11,43 \\
\hline 20 & 1950 & 35 & 82,59 & 72,79 & 63,58 & 51,96 & 42,14 & 34,28 & 23,56 & 17,38 & 11,44 \\
\hline 20 & 2000 & 35 & 81,93 & 72,36 & 63,29 & 51,82 & 42,10 & 34,30 & 23,60 & 17,41 & 11,44 \\
\hline 20 & 200 & 40 & 140,80 & 94,21 & 68,42 & 46,51 & 34,01 & 26,57 & 18,55 & 14,41 & 10,04 \\
\hline 20 & 250 & 40 & 133,21 & 92,43 & 68,38 & 47,02 & 34,40 & 26,78 & 18,59 & 14,41 & 10,03 \\
\hline 20 & 300 & 40 & 127,24 & 90,75 & 68,18 & 47,41 & 34,75 & 26,98 & 18,63 & 14,41 & 10,02 \\
\hline 20 & 350 & 40 & 122,33 & 89,18 & 67,88 & 47,70 & 35,06 & 27,18 & 18,68 & 14,41 & 10,01 \\
\hline 20 & 400 & 40 & 118,18 & 87,72 & 67,53 & 47,91 & 35,33 & 27,37 & 18,73 & 14,41 & 10,00 \\
\hline 20 & 450 & 40 & 114,60 & 86,36 & 67,14 & 48,06 & 35,58 & 27,56 & 18,79 & 14,42 & 10,00 \\
\hline 20 & 500 & 40 & 111,44 & 85,08 & 66,73 & 48,17 & 35,79 & 27,73 & 18,85 & 14,43 & 9,99 \\
\hline 20 & 550 & 40 & 108,64 & 83,88 & 66,32 & 48,24 & 35,98 & 27,90 & 18,91 & 14,44 & 9,99 \\
\hline 20 & 600 & 40 & 106,12 & 82,76 & 65,89 & 48,27 & 36,14 & 28,06 & 18,97 & 14,45 & 9,98 \\
\hline 20 & 650 & 40 & 103,83 & 81,70 & 65,47 & 48,29 & 36,29 & 28,20 & 19,03 & 14,47 & 9,98 \\
\hline 20 & 700 & 40 & 101,73 & 80,70 & 65,05 & 48,28 & 36,42 & 28,34 & 19,10 & 14,48 & 9,98 \\
\hline 20 & 750 & 40 & 99,81 & 79,75 & 64,64 & 48,25 & 36,53 & 28,46 & 19,16 & 14,50 & 9,97 \\
\hline 20 & 800 & 40 & 98,02 & 78,85 & 64,23 & 48,21 & 36,63 & 28,58 & 19,23 & 14,52 & 9,97 \\
\hline 20 & 850 & 40 & 96,37 & 78,00 & 63,83 & 48,16 & 36,71 & 28,69 & 19,29 & 14,54 & 9,97 \\
\hline
\end{tabular}




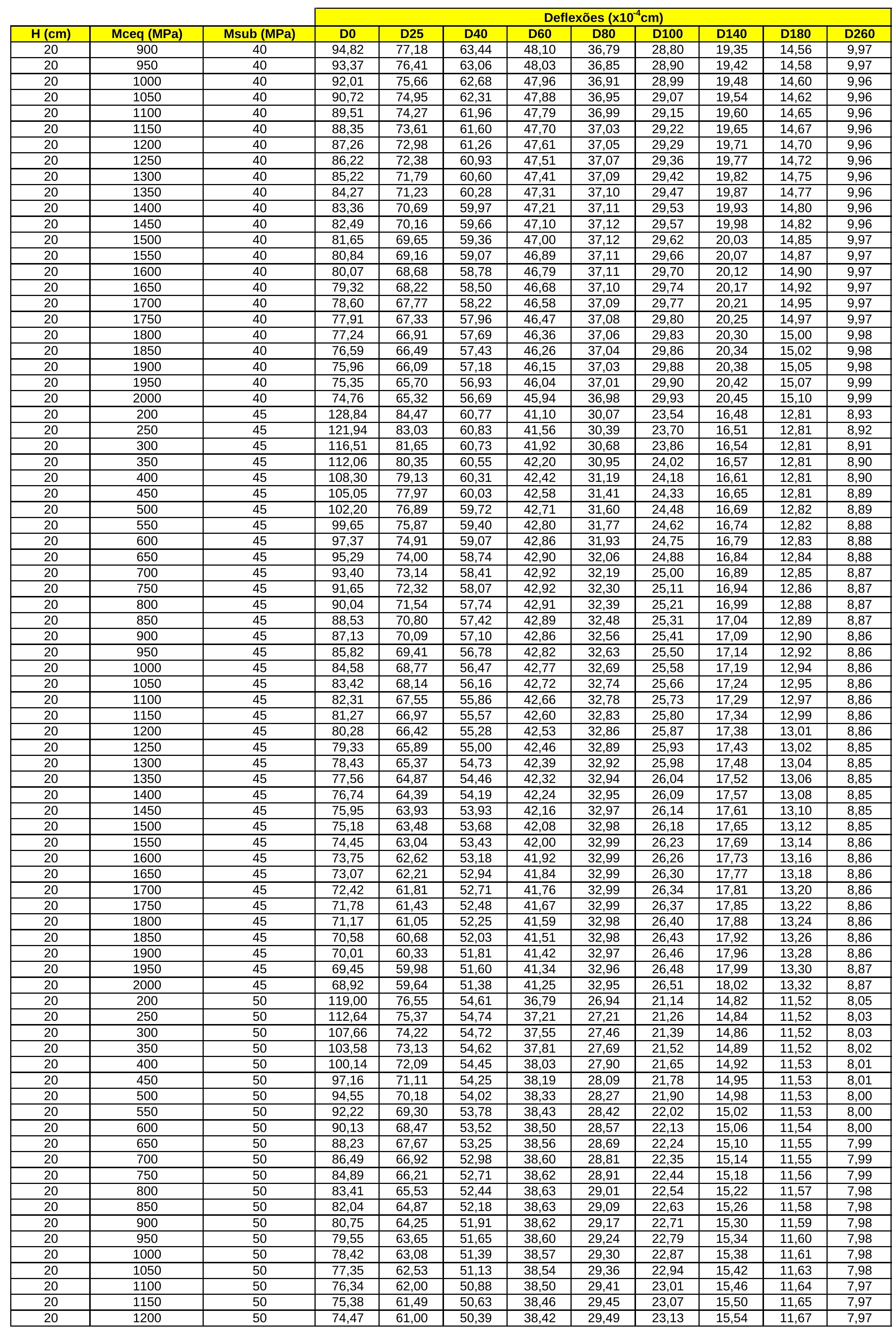




\begin{tabular}{|c|c|c|c|c|c|c|c|c|c|c|c|}
\hline \multirow[b]{2}{*}{$\mathrm{H}(\mathrm{cm})$} & \multirow[b]{2}{*}{ Mceq (MPa) } & & & & & $\mathrm{De}$ & ões (x1 & & & & \\
\hline & & Msub (MPa) & D0 & D25 & D40 & D60 & D80 & D100 & D140 & D180 & D260 \\
\hline 20 & 1250 & 50 & 73,61 & 60,53 & 50,15 & 38,37 & 29,53 & 23,19 & 15,58 & 11,68 & 7,97 \\
\hline 20 & 1300 & 50 & 72,78 & 60,07 & 49,91 & 38,32 & 29,56 & 23,24 & 15,62 & 11,70 & 7,97 \\
\hline 20 & 1350 & 50 & 71,99 & 59,63 & 49,68 & 38,26 & 29,58 & 23,30 & 15,66 & 11,71 & 7,97 \\
\hline 20 & 1400 & 50 & 71,23 & 59,20 & 49,45 & 38,20 & 29,61 & 23,34 & 15,70 & 11,73 & 7,97 \\
\hline 20 & 1450 & 50 & 70,50 & 58,79 & 49,23 & 38,15 & 29,63 & 23,39 & 15,73 & 11,74 & 7,97 \\
\hline 20 & 1500 & 50 & 69,81 & 58,39 & 49,01 & 38,09 & 29,64 & 23,43 & 15,77 & 11,76 & 7,97 \\
\hline 20 & 1550 & 50 & 69,14 & 58,00 & 48,79 & 38,02 & 29,66 & 23,48 & 15,80 & 11,77 & 7,97 \\
\hline 20 & 1600 & 50 & 68,49 & 57,62 & 48,58 & 37,96 & 29,67 & 23,52 & 15,84 & 11,79 & 7,97 \\
\hline 20 & 1650 & 50 & 67,87 & 57,25 & 48,38 & 37,90 & 29,68 & 23,55 & 15,87 & 11,80 & 7,97 \\
\hline 20 & 1700 & 50 & 67,27 & 56,90 & 48,17 & 37,83 & 29,68 & 23,59 & 15,91 & 11,82 & 7,97 \\
\hline 20 & 1750 & 50 & 66,69 & 56,55 & 47,97 & 37,77 & 29,69 & 23,62 & 15,94 & 11,84 & 7,97 \\
\hline 20 & 1800 & 50 & 66,13 & 56,21 & 47,78 & 37,70 & 29,69 & 23,65 & 15,97 & 11,85 & 7,97 \\
\hline 20 & 1850 & 50 & 65,58 & 55,88 & 47,58 & 37,63 & 29,69 & 23,68 & 16,00 & 11,87 & 7,97 \\
\hline 20 & 1900 & 50 & 65,06 & 55,56 & 47,39 & 37,57 & 29,69 & 23,71 & 16,04 & 11,89 & 7,97 \\
\hline 20 & 1950 & 50 & 64,55 & 55,25 & 47,21 & 37,50 & 29,69 & 23,74 & 16,07 & 11,90 & 7,97 \\
\hline 20 & 2000 & 50 & 64,06 & 54,94 & 47,02 & 37,43 & 29,69 & 23,76 & 16,10 & 11,92 & 7,97 \\
\hline 20 & 200 & 55 & 110,74 & 69,98 & 49,56 & 33,28 & 24,40 & 19,18 & 13,47 & 10,48 & 7,32 \\
\hline 20 & 250 & 55 & 104,83 & 69,00 & 49,73 & 33,66 & 24,63 & 19,27 & 13,48 & 10,48 & 7,31 \\
\hline 20 & 300 & 55 & 100,22 & 68,04 & 49,77 & 33,98 & 24,84 & 19,38 & 13,50 & 10,48 & 7,30 \\
\hline 20 & 350 & 55 & 96,45 & 67,11 & 49,72 & 34,23 & 25,04 & 19,49 & 13,52 & 10,48 & 7,29 \\
\hline 20 & 400 & 55 & 93,26 & 66,22 & 49,62 & 34,43 & 25,23 & 19,59 & 13,54 & 10,48 & 7,29 \\
\hline 20 & 450 & 55 & 90,51 & 65,37 & 49,47 & 34,60 & 25,40 & 19,70 & 13,57 & 10,48 & 7,28 \\
\hline 20 & 500 & 55 & 88,10 & 64,56 & 49,30 & 34,73 & 25,55 & 19,81 & 13,59 & 10,48 & 7,28 \\
\hline 20 & 550 & 55 & 85,95 & 63,80 & 49,11 & 34,84 & 25,70 & 19,91 & 13,62 & 10,48 & 7,28 \\
\hline 20 & 600 & 55 & 84,02 & 63,07 & 48,91 & 34,93 & 25,83 & 20,01 & 13,65 & 10,49 & 7,27 \\
\hline 20 & 650 & 55 & 82,27 & 62,38 & 48,70 & 34,99 & 25,95 & 20,10 & 13,68 & 10,49 & 7,27 \\
\hline 20 & 700 & 55 & 80,66 & 61,71 & 48,48 & 35,04 & 26,05 & 20,19 & 13,71 & 10,49 & 7,27 \\
\hline 20 & 750 & 55 & 79,19 & 61,08 & 48,26 & 35,08 & 26,15 & 20,28 & 13,75 & 10,50 & 7,26 \\
\hline 20 & 800 & 55 & 77,82 & 60,48 & 48,03 & 35,10 & 26,24 & 20,36 & 13,78 & 10,51 & 7,26 \\
\hline 20 & 850 & 55 & 76,55 & 59,90 & 47,81 & 35,11 & 26,33 & 20,44 & 13,81 & 10,51 & 7,26 \\
\hline 20 & 900 & 55 & 75,37 & 59,35 & 47,59 & 35,12 & 26,40 & 20,52 & 13,85 & 10,52 & 7,26 \\
\hline 20 & 950 & 55 & 74,25 & 58,82 & 47,37 & 35,11 & 26,47 & 20,59 & 13,88 & 10,53 & 7,26 \\
\hline 20 & 1000 & 55 & 73,21 & 58,31 & 47,15 & 35,10 & 26,53 & 20,66 & 13,92 & 10,54 & 7,25 \\
\hline 20 & 1050 & 55 & 72,22 & 57,82 & 46,93 & 35,09 & 26,59 & 20,73 & 13,95 & 10,55 & 7,25 \\
\hline 20 & 1100 & 55 & 71,29 & 57,35 & 46,71 & 35,07 & 26,64 & 20,79 & 13,98 & 10,56 & 7,25 \\
\hline 20 & 1150 & 55 & 70,41 & 56,89 & 46,50 & 35,04 & 26,68 & 20,85 & 14,02 & 10,57 & 7,25 \\
\hline 20 & 1200 & 55 & 69,56 & 56,45 & 46,29 & 35,01 & 26,73 & 20,90 & 14,05 & 10,58 & 7,25 \\
\hline 20 & 1250 & 55 & 68,76 & 56,03 & 46,09 & 34,98 & 26,76 & 20,96 & 14,08 & 10,59 & 7,25 \\
\hline 20 & 1300 & 55 & 68,00 & 55,62 & 45,89 & 34,94 & 26,80 & 21,01 & 14,12 & 10,60 & 7,25 \\
\hline 20 & 1350 & 55 & $\begin{array}{ll}67,27 \\
\end{array}$ & 55,22 & 45,69 & 34,90 & 26,83 & 21,06 & 14,15 & 10,61 & 7,25 \\
\hline 20 & 1400 & 55 & 66,57 & 54,84 & 45,49 & 34,86 & 26,85 & 21,10 & 14,18 & 10,63 & 7,25 \\
\hline 20 & 1450 & 55 & 65,90 & 54,46 & 45,30 & 34,81 & 26,88 & 21,15 & 14,21 & 10,64 & 7,25 \\
\hline 20 & 1500 & 55 & 65,25 & 54,10 & 45,11 & 34,77 & 26,90 & 21,19 & 14,24 & 10,65 & 7,25 \\
\hline 20 & 1550 & 55 & 64,63 & 53,75 & 44,92 & 34,72 & 26,92 & 21,23 & 14,28 & 10,66 & 7,24 \\
\hline 20 & 1600 & 55 & 64,04 & 53,41 & 44,74 & 34,67 & 26,93 & 21,27 & 14,31 & 10,68 & 7,24 \\
\hline 20 & 1650 & 55 & 63,46 & 53,08 & 44,55 & 34,62 & 26,95 & 21,30 & 14,34 & 10,69 & 7,24 \\
\hline 20 & 1700 & 55 & 62,91 & 52,76 & 44,38 & 34,57 & 26,96 & 21,34 & 14,37 & 10,70 & 7,24 \\
\hline 20 & 1750 & 55 & 62,37 & 52,44 & 44,20 & 34,52 & 26,97 & 21,37 & 14,39 & 10,71 & 7,24 \\
\hline 20 & 1800 & 55 & 61,85 & 52,14 & 44,03 & 34,47 & 26,98 & 21,40 & 14,42 & 10,73 & 7,24 \\
\hline 20 & 1850 & 55 & 61,35 & 51,84 & 43,86 & 34,41 & 26,98 & 21,43 & 14,45 & 10,74 & 7,25 \\
\hline 20 & 1900 & 55 & 60,86 & 51,55 & 43,69 & 34,36 & 26,99 & 21,46 & 14,48 & 10,75 & 7,25 \\
\hline 20 & 1950 & 55 & 60,39 & 51,27 & 43,53 & 34,31 & 26,99 & 21,49 & 14,51 & 10,77 & 7,25 \\
\hline 20 & 2000 & 55 & 59,93 & 50,99 & 43,37 & 34,25 & 26,99 & 21,51 & 14,53 & 10,78 & 7,25 \\
\hline 20 & 200 & 60 & 103,71 & 64,44 & 45,34 & 30,37 & 22,30 & 17,55 & 12,34 & 9,60 & 6,72 \\
\hline 20 & 250 & 60 & 98,18 & 63,63 & 45,54 & 30,72 & 22,49 & 17,63 & 12,35 & 9,60 & 6,70 \\
\hline 20 & 300 & 60 & 93,87 & 62,81 & 45,62 & 31,01 & 22,67 & 17,72 & 12,37 & 9,60 & 6,70 \\
\hline 20 & 350 & 60 & 90,35 & 62,01 & 45,61 & 31,25 & 22,85 & 17,80 & 12,38 & 9,60 & 6,69 \\
\hline 20 & 400 & 60 & 87,38 & 61,24 & 45,55 & 31,44 & 23,01 & 17,90 & 12,40 & 9,60 & 6,68 \\
\hline 20 & 450 & 60 & 84,83 & 60,50 & 45,45 & 31,61 & 23,17 & 17,99 & 12,42 & 9,60 & 6,68 \\
\hline 20 & 500 & 60 & 82,58 & 59,80 & 45,33 & 31,74 & 23,31 & 18,08 & 12,44 & 9,61 & 6,68 \\
\hline 20 & 550 & 60 & 80,59 & 59,12 & 45,18 & 31,85 & 23,44 & 18,16 & 12,46 & 9,61 & 6,67 \\
\hline 20 & 600 & 60 & 78,79 & 58,48 & 45,02 & 31,94 & 23,56 & 18,25 & 12,49 & 9,61 & 6,67 \\
\hline 20 & 650 & 60 & 77,16 & 57,87 & 44,85 & 32,01 & 23,67 & 18,33 & 12,51 & 9,61 & 6,67 \\
\hline 20 & 700 & 60 & 75,67 & 57,28 & 44,67 & 32,07 & 23,77 & 18,41 & 12,54 & 9,61 & 6,66 \\
\hline 20 & 750 & 60 & 74,30 & 56,72 & 44,49 & 32,11 & 23,86 & 18,49 & 12,56 & 9,62 & 6,66 \\
\hline 20 & 800 & 60 & 73,03 & 56,18 & 44,30 & 32,14 & 23,94 & 18,56 & 12,59 & 9,62 & 6,66 \\
\hline 20 & 850 & 60 & 71,85 & 55,67 & 44,12 & 32,17 & 24,02 & 18,64 & 12,62 & 9,63 & 6,66 \\
\hline 20 & 900 & 60 & 70,74 & 55,17 & 43,93 & 32,18 & 24,10 & 18,70 & 12,65 & 9,63 & 6,66 \\
\hline 20 & 950 & 60 & 69,71 & 54,70 & 43,74 & 32,19 & 24,16 & 18,77 & 12,68 & 9,64 & 6,65 \\
\hline 20 & 1000 & 60 & 68,74 & 54,24 & 43,55 & 32,19 & 24,22 & 18,83 & 12,70 & 9,65 & 6,65 \\
\hline 20 & 1050 & 60 & 67,82 & 53,80 & 43,37 & 32,19 & 24,28 & 18,89 & 12,73 & 9,65 & 6,65 \\
\hline 20 & 1100 & 60 & 66,95 & 53,37 & 43,18 & 32,18 & 24,33 & 18,95 & 12,76 & 9,66 & 6,65 \\
\hline 20 & 1150 & 60 & 66,13 & 52,96 & 43,00 & 32,16 & 24,38 & 19,00 & 12,79 & 9,67 & 6,65 \\
\hline 20 & 1200 & 60 & 65,35 & 52,57 & 42,82 & 32,14 & 24,42 & 19,06 & 12,82 & 9,68 & 6,65 \\
\hline 20 & 1250 & 60 & 64,60 & 52,19 & 42,64 & 32,12 & 24,46 & 19,11 & 12,85 & 9,69 & 6,65 \\
\hline 20 & 1300 & 60 & 63,89 & 51,81 & 42,47 & 32,10 & 24,49 & 19,15 & 12,88 & 9,70 & 6,65 \\
\hline 20 & 1350 & 60 & 63,21 & 51,46 & 42,29 & 32,07 & 24,52 & 19,20 & 12,90 & 9,71 & 6,64 \\
\hline 20 & 1400 & 60 & 62,56 & 51,11 & 42,12 & 32,04 & 24,55 & 19,24 & 12,93 & 9,71 & 6,64 \\
\hline 20 & 1450 & 60 & 61,94 & 50,77 & 41,95 & 32,01 & 24,58 & 19,28 & 12,96 & 9,72 & 6,64 \\
\hline 20 & 1500 & 60 & 61,34 & 50,44 & 41,79 & 31,97 & 24,60 & 19,32 & 12,99 & 9,73 & 6,64 \\
\hline 20 & 1550 & 60 & 60,76 & 50,12 & 41,62 & 31,94 & 24,63 & 19,36 & 13,01 & 9,74 & 6,64 \\
\hline
\end{tabular}




\begin{tabular}{|c|c|c|c|c|c|c|c|c|c|c|c|}
\hline \multirow[b]{2}{*}{$\mathrm{H}(\mathrm{cm})$} & \multirow[b]{2}{*}{ Mceq (MPa) } & & & & & $\mathrm{De}$ & ões (x1 & & & & \\
\hline & & Msub (MPa) & D0 & D25 & D40 & D60 & D80 & D100 & D140 & D180 & D260 \\
\hline 20 & 1600 & 60 & 60,21 & 49,81 & 41,46 & 31,90 & 24,65 & 19,40 & 13,04 & 9,75 & 6,64 \\
\hline 20 & 1650 & 60 & 59,67 & 49,51 & 41,30 & 31,86 & 24,66 & 19,43 & 13,06 & 9,77 & 6,64 \\
\hline 20 & 1700 & 60 & 59,15 & 49,22 & 41,15 & 31,82 & 24,68 & 19,47 & 13,09 & 9,78 & 6,64 \\
\hline 20 & 1750 & 60 & 58,66 & 48,93 & 40,99 & 31,78 & 24,69 & 19,50 & 13,12 & 9,79 & 6,64 \\
\hline 20 & 1800 & 60 & 58,17 & 48,66 & 40,84 & 31,74 & 24,70 & 19,53 & 13,14 & 9,80 & 6,64 \\
\hline 20 & 1850 & 60 & 57,71 & 48,38 & 40,69 & 31,70 & 24,71 & 19,56 & 13,17 & 9,81 & 6,64 \\
\hline 20 & 1900 & 60 & 57,25 & 48,12 & 40,54 & 31,65 & 24,72 & 19,59 & 13,19 & 9,82 & 6,64 \\
\hline 20 & 1950 & 60 & 56,81 & 47,86 & 40,40 & 31,61 & 24,73 & 19,61 & 13,21 & 9,83 & 6,64 \\
\hline 20 & 2000 & 60 & 56,39 & 47,61 & 40,26 & 31,56 & 24,73 & 19,64 & 13,24 & 9,84 & 6,64 \\
\hline 20 & 200 & 65 & 97,65 & 59,71 & 41,76 & 27,92 & 20,52 & 16,18 & 11,39 & 8,86 & 6,20 \\
\hline 20 & 250 & 65 & 92,42 & 59,03 & 41,98 & 28,24 & 20,69 & 16,25 & 11,40 & 8,87 & 6,19 \\
\hline 20 & 300 & 65 & 88,37 & 58,32 & 42,08 & 28,51 & 20,85 & 16,32 & 11,41 & 8,87 & 6,18 \\
\hline 20 & 350 & 65 & 85,07 & 57,63 & 42,11 & 28,73 & 21,01 & 16,39 & 11,42 & 8,87 & 6,18 \\
\hline 20 & 400 & 65 & 82,30 & 56,96 & 42,09 & 28,92 & 21,15 & 16,47 & 11,44 & 8,87 & 6,17 \\
\hline 20 & 450 & 65 & 79,90 & 56,32 & 42,02 & 29,07 & 21,29 & 16,55 & 11,45 & 8,87 & 6,17 \\
\hline 20 & 500 & 65 & 77,80 & 55,69 & 41,93 & 29,21 & 21,41 & 16,62 & 11,47 & 8,87 & 6,16 \\
\hline 20 & 550 & 65 & 75,93 & 55,10 & 41,82 & 29,31 & 21,53 & 16,70 & 11,49 & 8,87 & 6,16 \\
\hline 20 & 600 & 65 & 74,25 & 54,53 & 41,69 & 29,41 & 21,64 & 16,77 & 11,51 & 8,87 & 6,16 \\
\hline 20 & 650 & 65 & 72,73 & 53,98 & 41,56 & 29,48 & 21,74 & 16,85 & 11,53 & 8,87 & 6,16 \\
\hline 20 & 700 & 65 & 71,33 & 53,46 & 41,41 & 29,54 & 21,84 & 16,92 & 11,55 & 8,87 & 6,15 \\
\hline 20 & 750 & 65 & 70,05 & 52,96 & 41,26 & 29,59 & 21,92 & 16,99 & 11,57 & 8,87 & 6,15 \\
\hline 20 & 800 & 65 & 68,86 & 52,47 & 41,11 & 29,63 & 22,00 & 17,05 & 11,59 & 8,88 & 6,15 \\
\hline 20 & 850 & 65 & 67,76 & 52,01 & 40,95 & 29,66 & 22,08 & 17,12 & 11,62 & 8,88 & 6,15 \\
\hline 20 & 900 & 65 & 66,73 & 51,57 & 40,79 & 29,69 & 22,15 & 17,18 & 11,64 & 8,89 & 6,15 \\
\hline 20 & 950 & 65 & 65,76 & 51,14 & 40,63 & 29,70 & 22,21 & 17,24 & 11,66 & 8,89 & 6,14 \\
\hline 20 & 1000 & 65 & 64,85 & 50,72 & 40,47 & 29,71 & 22,27 & 17,29 & 11,69 & 8,90 & 6,14 \\
\hline 20 & 1050 & 65 & 64,00 & 50,33 & 40,31 & 29,71 & 22,32 & 17,35 & 11,71 & 8,90 & 6,14 \\
\hline 20 & 1100 & 65 & 63,18 & 49,94 & 40,15 & 29,71 & 22,38 & 17,40 & 11,74 & 8,91 & 6,14 \\
\hline 20 & 1150 & 65 & 62,42 & 49,57 & 39,99 & 29,71 & 22,42 & 17,45 & 11,76 & 8,91 & 6,14 \\
\hline 20 & 1200 & 65 & 61,68 & 49,21 & 39,84 & 29,70 & 22,46 & 17,50 & 11,78 & 8,92 & 6,14 \\
\hline 20 & 1250 & 65 & 60,99 & 48,86 & 39,68 & 29,69 & 22,50 & 17,55 & 11,81 & 8,93 & 6,14 \\
\hline 20 & 1300 & 65 & 60,32 & 48,52 & 39,53 & 29,67 & 22,54 & 17,59 & 11,83 & 8,93 & 6,14 \\
\hline 20 & 1350 & 65 & 59,69 & 48,20 & 39,38 & 29,65 & 22,57 & 17,63 & 11,86 & 8,94 & 6,14 \\
\hline 20 & 1400 & 65 & 59,08 & 47,88 & 39,23 & 29,63 & 22,60 & 17,67 & 11,88 & 8,95 & 6,13 \\
\hline 20 & 1450 & 65 & 58,49 & 47,57 & 39,08 & 29,61 & 22,63 & 17,71 & 11,90 & 8,96 & 6,13 \\
\hline 20 & 1500 & 65 & 57,93 & 47,27 & 38,93 & 29,58 & 22,66 & 17,75 & 11,93 & 8,96 & 6,13 \\
\hline 20 & 1550 & 65 & 57,39 & 46,98 & 38,79 & 29,56 & 22,68 & 17,79 & 11,95 & 8,97 & 6,13 \\
\hline 20 & 1600 & 65 & 56,87 & 46,70 & 38,64 & 29,53 & 22,70 & 17,82 & 11,97 & 8,98 & 6,13 \\
\hline 20 & 1650 & 65 & 56,37 & 46,42 & 38,50 & 29,50 & 22,72 & 17,85 & 12,00 & 8,99 & 6,13 \\
\hline 20 & 1700 & 65 & 55,89 & 46,16 & 38,36 & 29,47 & 22,74 & 17,89 & 12,02 & 9,00 & 6,13 \\
\hline 20 & 1750 & 65 & 55,42 & 45,90 & 38,23 & 29,43 & 22,75 & 17,92 & 12,04 & 9,01 & 6,13 \\
\hline 20 & 1800 & 65 & 54,97 & 45,64 & 38,09 & 29,40 & 22,77 & 17,95 & 12,07 & 9,02 & 6,13 \\
\hline 20 & 1850 & 65 & 54,53 & 45,39 & 37,96 & 29,37 & 22,78 & 17,97 & 12,09 & 9,03 & 6,13 \\
\hline 20 & 1900 & 65 & 54,11 & 45,15 & 37,83 & 29,33 & 22,79 & 18,00 & 12,11 & 9,03 & 6,13 \\
\hline 20 & 1950 & 65 & 53,70 & 44,91 & 37,70 & 29,30 & 22,80 & 18,03 & 12,13 & 9,04 & 6,13 \\
\hline 20 & 2000 & 65 & 53,30 & 44,68 & 37,57 & 29,26 & 22,81 & 18,05 & 12,15 & 9,05 & 6,13 \\
\hline 20 & 200 & 70 & 92,36 & 55,62 & 38,69 & 25,83 & 19,01 & 15,01 & 10,57 & 8,23 & 5,76 \\
\hline 20 & 250 & 70 & 87,40 & 55,04 & 38,92 & 26,13 & 19,16 & 15,06 & 10,58 & 8,23 & 5,75 \\
\hline 20 & 300 & 70 & 83,57 & 54,44 & 39,05 & 26,37 & 19,30 & 15,12 & 10,59 & 8,23 & 5,75 \\
\hline 20 & 350 & 70 & 80,46 & 53,84 & 39,10 & 26,58 & 19,44 & 15,18 & 10,60 & 8,23 & 5,74 \\
\hline 20 & 400 & 70 & 77,84 & 53,25 & 39,10 & 26,76 & 19,56 & 15,25 & 10,61 & 8,23 & 5,73 \\
\hline 20 & 450 & 70 & 75,59 & 52,68 & 39,06 & 26,91 & 19,69 & 15,32 & 10,63 & 8,23 & 5,73 \\
\hline 20 & 500 & 70 & 73,61 & 52,13 & 39,00 & 27,03 & 19,80 & 15,38 & 10,64 & 8,23 & 5,73 \\
\hline 20 & 550 & 70 & 71,86 & 51,60 & 38,92 & 27,14 & 19,91 & 15,45 & 10,65 & 8,23 & 5,72 \\
\hline 20 & 600 & 70 & 70,28 & 51,09 & 38,82 & 27,23 & 20,01 & 15,52 & 10,67 & 8,23 & 5,72 \\
\hline 20 & 650 & 70 & 68,84 & 50,60 & 38,71 & 27,31 & 20,10 & 15,58 & 10,69 & 8,23 & 5,72 \\
\hline 20 & 700 & 70 & 67,53 & 50,13 & 38,59 & 27,38 & 20,19 & 15,64 & 10,70 & 8,24 & 5,72 \\
\hline 20 & 750 & 70 & 66,33 & 49,67 & 38,46 & 27,43 & 20,27 & 15,70 & 10,72 & 8,24 & 5,71 \\
\hline 20 & 800 & 70 & 65,21 & 49,24 & 38,33 & 27,47 & 20,35 & 15,76 & 10,74 & 8,24 & 5,71 \\
\hline 20 & 850 & 70 & 64,17 & 48,82 & 38,20 & 27,51 & 20,42 & 15,82 & 10,76 & 8,24 & 5,71 \\
\hline 20 & 900 & 70 & 63,21 & 48,42 & 38,07 & 27,54 & 20,48 & 15,88 & 10,78 & 8,25 & 5,71 \\
\hline 20 & 950 & 70 & 62,30 & 48,03 & 37,93 & 27,56 & 20,54 & 15,93 & 10,80 & 8,25 & 5,71 \\
\hline 20 & 1000 & 70 & 61,44 & 47,65 & 37,79 & 27,57 & 20,60 & 15,98 & 10,82 & 8,25 & 5,71 \\
\hline 20 & 1050 & 70 & 60,64 & 47,29 & 37,65 & $\begin{array}{l}27,58 \\
\end{array}$ & 20,65 & 16,03 & 10,84 & 8,26 & 5,71 \\
\hline 20 & 1100 & 70 & 59,87 & 46,94 & 37,52 & 27,59 & 20,70 & 16,08 & 10,86 & 8,26 & 5,70 \\
\hline 20 & 1150 & 70 & 59,15 & 46,60 & 37,38 & 27,59 & 20,75 & 16,13 & 10,88 & 8,27 & 5,70 \\
\hline 20 & 1200 & 70 & 58,46 & 46,27 & 37,24 & 27,59 & 20,79 & 16,17 & 10,90 & 8,27 & 5,70 \\
\hline 20 & 1250 & 70 & 57,81 & 45,96 & 37,11 & 27,58 & 20,83 & 16,21 & 10,92 & 8,28 & 5,70 \\
\hline 20 & 1300 & 70 & 57,18 & 45,65 & 36,97 & 27,58 & 20,86 & 16,26 & 10,95 & 8,28 & 5,70 \\
\hline 20 & 1350 & 70 & 56,59 & 45,35 & 36,84 & 27,56 & 20,90 & 16,30 & 10,97 & 8,29 & 5,70 \\
\hline 20 & 1400 & 70 & 56,01 & 45,06 & 36,70 & 27,55 & 20,93 & 16,33 & 10,99 & 8,30 & 5,70 \\
\hline 20 & 1450 & 70 & 55,46 & 44,78 & 36,57 & 27,54 & 20,96 & 16,37 & 11,01 & 8,30 & 5,70 \\
\hline 20 & 1500 & 70 & 54,94 & 44,50 & 36,44 & 27,52 & 20,99 & 16,41 & 11,03 & 8,31 & 5,70 \\
\hline 20 & 1550 & 70 & 54,43 & 44,24 & 36,32 & 27,50 & 21,01 & 16,44 & 11,05 & 8,32 & 5,70 \\
\hline 20 & 1600 & 70 & 53,94 & 43,98 & 36,19 & 27,48 & 21,03 & 16,47 & 11,07 & 8,32 & 5,70 \\
\hline 20 & 1650 & 70 & 53,47 & 43,72 & 36,06 & 27,45 & 21,05 & 16,50 & 11,09 & 8,33 & 5,69 \\
\hline 20 & 1700 & 70 & 53,02 & 43,48 & 35,94 & 27,43 & 21,07 & 16,53 & 11,11 & 8,34 & 5,69 \\
\hline 20 & 1750 & 70 & 52,58 & 43,24 & 35,82 & 27,41 & 21,09 & 16,56 & 11,13 & 8,34 & 5,69 \\
\hline 20 & 1800 & 70 & 52,15 & 43,00 & 35,70 & 27,38 & 21,11 & 16,59 & 11,15 & 8,35 & 5,69 \\
\hline 20 & 1850 & 70 & 51,74 & 42,77 & 35,58 & 27,35 & 21,12 & 16,62 & 11,17 & 8,36 & 5,69 \\
\hline 20 & 1900 & 70 & 51,34 & 42,55 & 35,46 & 27,32 & 21,13 & 16,64 & 11,19 & 8,37 & 5,69 \\
\hline
\end{tabular}




\begin{tabular}{|c|c|c|c|c|c|c|c|c|c|c|c|}
\hline \multirow[b]{2}{*}{$\mathrm{H}(\mathrm{cm})$} & \multirow[b]{2}{*}{ Mceq (MPa) } & & & & & $\mathrm{De}$ & ões (x1 & & & & \\
\hline & & Msub (MPa) & D0 & D25 & D40 & D60 & D80 & D100 & D140 & D180 & D260 \\
\hline 20 & 1950 & 70 & 50,96 & 42,33 & 35,35 & 27,29 & 21,14 & 16,67 & 11,21 & 8,37 & 5,69 \\
\hline 20 & 2000 & 70 & 50,58 & 42,12 & 35,23 & 27,26 & 21,16 & 16,69 & 11,23 & 8,38 & 5,69 \\
\hline 20 & 200 & 75 & 87,70 & 52,05 & 36,03 & 24,03 & 17,71 & 14,00 & 9,86 & 7,68 & 5,38 \\
\hline 20 & 250 & 75 & 82,97 & 51,56 & 36,27 & 24,30 & 17,84 & 14,04 & 9,87 & 7,68 & 5,37 \\
\hline 20 & 300 & 75 & 79,33 & 51,03 & 36,41 & 24,53 & 17,96 & 14,09 & 9,88 & 7,68 & 5,36 \\
\hline 20 & 350 & 75 & 76,38 & 50,51 & 36,48 & 24,72 & 18,08 & 14,14 & 9,89 & 7,68 & 5,36 \\
\hline 20 & 400 & 75 & 73,91 & 49,99 & 36,50 & 24,89 & 18,20 & 14,20 & 9,90 & 7,68 & 5,35 \\
\hline 20 & 450 & 75 & 71,77 & 49,48 & 36,48 & 25,03 & 18,31 & 14,26 & 9,91 & 7,68 & 5,35 \\
\hline 20 & 500 & 75 & 69,91 & 48,99 & 36,44 & 25,15 & 18,41 & 14,32 & 9,92 & 7,68 & 5,35 \\
\hline 20 & 550 & 75 & 68,25 & 48,52 & 36,38 & 25,26 & 18,51 & 14,37 & 9,93 & 7,68 & 5,34 \\
\hline 20 & 600 & 75 & 66,76 & 48,06 & 36,30 & 25,35 & 18,60 & 14,43 & 9,95 & 7,68 & 5,34 \\
\hline 20 & 650 & 75 & 65,41 & 47,62 & 36,22 & 25,43 & 18,69 & 14,49 & 9,96 & 7,68 & 5,34 \\
\hline 20 & 700 & 75 & 64,17 & 47,19 & 36,12 & 25,49 & 18,77 & 14,55 & 9,97 & 7,69 & 5,34 \\
\hline 20 & 750 & 75 & 63,03 & 46,78 & 36,02 & 25,55 & 18,84 & 14,60 & 9,99 & 7,69 & 5,34 \\
\hline 20 & 800 & 75 & 61,98 & 46,39 & 35,91 & 25,60 & 18,92 & 14,65 & 10,01 & 7,69 & 5,33 \\
\hline 20 & 850 & 75 & 61,00 & 46,01 & 35,79 & 25,64 & 18,98 & 14,70 & 10,02 & 7,69 & 5,33 \\
\hline 20 & 900 & 75 & 60,08 & 45,64 & 35,68 & 25,67 & 19,04 & 14,76 & 10,04 & 7,69 & 5,33 \\
\hline 20 & 950 & 75 & 59,23 & 45,29 & 35,56 & 25,69 & 19,10 & 14,80 & 10,06 & 7,70 & 5,33 \\
\hline 20 & 1000 & 75 & 58,42 & 44,95 & 35,44 & 25,72 & 19,16 & 14,85 & 10,07 & 7,70 & 5,33 \\
\hline 20 & 1050 & 75 & 57,66 & 44,62 & 35,32 & 25,73 & 19,21 & 14,90 & 10,09 & 7,70 & 5,33 \\
\hline 20 & 1100 & 75 & 56,94 & 44,30 & 35,20 & 25,74 & 19,25 & 14,94 & 10,11 & 7,71 & 5,33 \\
\hline 20 & 1150 & 75 & 56,26 & 43,98 & 35,08 & 25,75 & 19,30 & 14,98 & 10,13 & 7,71 & 5,32 \\
\hline 20 & 1200 & 75 & 55,61 & 43,68 & 34,96 & 25,75 & 19,34 & 15,03 & 10,15 & 7,71 & 5,32 \\
\hline 20 & 1250 & 75 & 54,99 & 43,39 & 34,84 & 25,75 & 19,38 & 15,07 & 10,16 & 7,72 & 5,32 \\
\hline 20 & 1300 & 75 & 54,40 & 43,11 & 34,72 & 25,75 & 19,41 & 15,10 & 10,18 & 7,72 & 5,32 \\
\hline 20 & 1350 & 75 & 53,84 & 42,83 & 34,61 & 25,74 & 19,45 & 15,14 & 10,20 & 7,73 & 5,32 \\
\hline 20 & 1400 & 75 & 53,30 & 42,57 & 34,49 & 25,74 & 19,48 & 15,18 & 10,22 & 7,73 & 5,32 \\
\hline 20 & 1450 & 75 & 52,78 & 42,31 & 34,37 & 25,73 & 19,51 & 15,21 & 10,24 & 7,74 & 5,32 \\
\hline 20 & 1500 & 75 & 52,28 & 42,05 & 34,26 & 25,71 & 19,53 & 15,24 & 10,25 & 7,74 & 5,32 \\
\hline 20 & 1550 & 75 & 51,80 & 41,81 & 34,14 & 25,70 & 19,56 & 15,28 & 10,27 & 7,75 & 5,32 \\
\hline 20 & 1600 & 75 & 51,34 & 41,57 & 34,03 & 25,69 & 19,58 & 15,31 & 10,29 & 7,75 & 5,32 \\
\hline 20 & 1650 & 75 & 50,89 & 41,34 & 33,92 & 25,67 & 19,60 & 15,34 & 10,31 & 7,76 & 5,32 \\
\hline 20 & 1700 & 75 & 50,46 & 41,11 & 33,81 & 25,65 & 19,62 & 15,37 & 10,33 & 7,77 & 5,32 \\
\hline 20 & 1750 & 75 & 50,05 & 40,89 & 33,70 & 25,63 & 19,64 & 15,39 & 10,34 & 7,77 & 5,32 \\
\hline 20 & 1800 & 75 & 49,65 & 40,67 & 33,59 & 25,61 & 19,66 & 15,42 & 10,36 & 7,78 & 5,31 \\
\hline 20 & 1850 & 75 & 49,26 & 40,46 & 33,48 & 25,59 & 19,68 & 15,45 & 10,38 & 7,78 & 5,31 \\
\hline 20 & 1900 & 75 & 48,88 & 40,25 & 33,38 & 25,57 & 19,69 & 15,47 & 10,40 & 7,79 & 5,31 \\
\hline 20 & 1950 & 75 & 48,52 & 40,05 & 33,27 & 25,54 & 19,70 & 15,50 & 10,41 & 7,80 & 5,31 \\
\hline 20 & 2000 & 75 & 48,17 & 39,85 & 33,17 & 25,52 & 19,72 & 15,52 & 10,43 & 7,80 & 5,31 \\
\hline 20 & 200 & 80 & 83,56 & 48,90 & 33,71 & 22,46 & 16,57 & 13,11 & 9,24 & 7,20 & 5,05 \\
\hline 20 & 250 & 80 & 79,03 & 48,48 & 33,95 & 22,71 & 16,68 & 13,15 & 9,25 & 7,20 & 5,04 \\
\hline 20 & 300 & 80 & 75,56 & 48,03 & 34,09 & 22,92 & 16,79 & 13,19 & 9,26 & 7,20 & 5,03 \\
\hline 20 & 350 & 80 & 72,75 & 47,57 & 34,18 & 23,10 & 16,90 & 13,24 & 9,27 & 7,20 & 5,03 \\
\hline 20 & 400 & 80 & 70,40 & 47,11 & 34,21 & 23,26 & 17,01 & 13,29 & 9,28 & 7,20 & 5,02 \\
\hline 20 & 450 & 80 & 68,38 & 46,65 & 34,21 & 23,39 & 17,11 & 13,34 & 9,29 & 7,20 & 5,02 \\
\hline 20 & 500 & 80 & 66,61 & 46,22 & 34,19 & 23,51 & 17,20 & 13,39 & 9,29 & 7,20 & 5,01 \\
\hline 20 & 550 & 80 & 65,03 & 45,79 & 34,15 & 23,62 & 17,29 & 13,44 & 9,30 & 7,20 & 5,01 \\
\hline 20 & 600 & 80 & 63,62 & 45,38 & 34,09 & 23,70 & 17,37 & 13,49 & 9,32 & 7,20 & 5,01 \\
\hline 20 & 650 & 80 & 62,34 & 44,98 & 34,02 & 23,78 & 17,45 & 13,54 & 9,33 & 7,20 & 5,01 \\
\hline 20 & 700 & 80 & 61,17 & 44,59 & 33,94 & 23,85 & 17,53 & 13,59 & 9,34 & 7,20 & 5,01 \\
\hline 20 & 750 & 80 & 60,09 & 44,22 & 33,86 & 23,91 & 17,60 & 13,64 & 9,35 & 7,21 & 5,00 \\
\hline 20 & 800 & 80 & 59,09 & 43,86 & 33,76 & 23,95 & 17,67 & 13,69 & 9,37 & 7,21 & 5,00 \\
\hline 20 & 850 & 80 & 58,16 & 43,51 & 33,67 & 24,00 & 17,73 & 13,73 & 9,38 & 7,21 & 5,00 \\
\hline 20 & 900 & 80 & 57,30 & 43,18 & 33,57 & 24,03 & 17,79 & 13,78 & 9,39 & 7,21 & 5,00 \\
\hline 20 & 950 & 80 & 56,49 & 42,85 & 33,47 & 24,06 & 17,84 & 13,82 & 9,41 & 7,21 & 5,00 \\
\hline 20 & 1000 & 80 & 55,72 & 42,54 & 33,37 & 24,08 & 17,89 & 13,87 & 9,42 & 7,21 & 5,00 \\
\hline 20 & 1050 & 80 & 55,00 & 42,24 & 33,26 & 24,10 & 17,94 & 13,91 & 9,44 & 7,22 & 5,00 \\
\hline 20 & 1100 & 80 & 54,32 & 41,94 & 33,16 & 24,12 & 17,99 & 13,95 & 9,45 & 7,22 & 4,99 \\
\hline 20 & 1150 & 80 & 53,67 & 41,66 & 33,05 & 24,13 & 18,03 & 13,99 & 9,47 & 7,22 & 4,99 \\
\hline 20 & 1200 & 80 & 53,06 & 41,38 & 32,95 & 24,14 & 18,07 & 14,03 & 9,49 & 7,23 & 4,99 \\
\hline 20 & 1250 & 80 & 52,47 & 41,11 & 32,84 & 24,14 & 18,11 & 14,06 & 9,50 & 7,23 & 4,99 \\
\hline 20 & 1300 & 80 & 51,91 & 40,85 & 32,74 & 24,14 & 18,14 & 14,10 & 9,52 & 7,23 & 4,99 \\
\hline 20 & 1350 & 80 & 51,38 & 40,60 & 32,63 & 24,14 & 18,18 & 14,13 & 9,53 & 7,24 & 4,99 \\
\hline 20 & 1400 & 80 & 50,87 & 40,35 & 32,53 & 24,14 & 18,21 & 14,17 & 9,55 & 7,24 & 4,99 \\
\hline 20 & 1450 & 80 & 50,37 & 40,11 & 32,42 & 24,13 & 18,24 & 14,20 & 9,57 & 7,25 & 4,99 \\
\hline 20 & 1500 & 80 & 49,90 & 39,88 & 32,32 & 24,13 & 18,26 & 14,23 & 9,58 & 7,25 & 4,99 \\
\hline 20 & 1550 & 80 & 49,45 & 39,65 & 32,22 & 24,12 & 18,29 & 14,26 & 9,60 & 7,25 & 4,99 \\
\hline 20 & 1600 & 80 & 49,01 & 39,43 & 32,12 & 24,11 & 18,31 & 14,29 & 9,61 & 7,26 & 4,99 \\
\hline 20 & 1650 & 80 & 48,59 & 39,21 & 32,02 & 24,10 & 18,34 & 14,32 & 9,63 & 7,26 & 4,99 \\
\hline 20 & 1700 & 80 & 48,18 & 39,00 & 31,92 & 24,08 & 18,36 & 14,35 & 9,65 & 7,27 & 4,98 \\
\hline 20 & 1750 & 80 & 47,79 & 38,79 & 31,82 & 24,07 & 18,38 & 14,37 & 9,66 & 7,27 & 4,98 \\
\hline 20 & 1800 & 80 & 47,41 & 38,59 & 31,72 & 24,05 & 18,39 & 14,40 & 9,68 & 7,28 & 4,98 \\
\hline 20 & 1850 & 80 & 47,04 & 38,40 & 31,62 & 24,04 & 18,41 & 14,42 & 9,69 & 7,28 & 4,98 \\
\hline 20 & 1900 & 80 & 46,69 & 38,20 & 31,53 & 24,02 & 18,43 & 14,45 & 9,71 & 7,29 & 4,98 \\
\hline 20 & 1950 & 80 & 46,34 & 38,02 & 31,43 & 24,00 & 18,44 & 14,47 & 9,72 & 7,30 & 4,98 \\
\hline 20 & 2000 & 80 & 46,00 & 37,83 & 31,34 & 23,98 & 18,45 & 14,49 & 9,74 & 7,30 & 4,98 \\
\hline 20 & 200 & 85 & 79,86 & 46,11 & 31,65 & 21,08 & 15,58 & 12,34 & 8,70 & 6,78 & 4,76 \\
\hline 20 & 250 & 85 & 75,51 & 45,75 & 31,89 & 21,31 & 15,67 & 12,37 & 8,71 & 6,78 & 4,75 \\
\hline 20 & 300 & 85 & 72,19 & 45,36 & 32,05 & 21,50 & 15,77 & 12,40 & 8,71 & 6,78 & 4,74 \\
\hline 20 & 350 & 85 & 69,50 & 44,95 & 32,14 & 21,67 & 15,87 & 12,44 & 8,72 & 6,78 & 4,73 \\
\hline 20 & 400 & 85 & 67,26 & 44,54 & 32,19 & 21,82 & 15,96 & 12,48 & 8,73 & 6,78 & 4,73 \\
\hline
\end{tabular}




\begin{tabular}{|c|c|c|c|c|c|c|c|c|c|c|c|}
\hline \multirow[b]{2}{*}{$\mathrm{H}(\mathrm{cm})$} & \multirow[b]{2}{*}{ Mceq (MPa) } & & & & & $\mathrm{De}$ & ões (x1 & & & & \\
\hline & & Msub (MPa) & D0 & D25 & D40 & D60 & D80 & D100 & D140 & D180 & D260 \\
\hline 20 & 450 & 85 & 65,33 & 44,13 & 32,20 & 21,95 & 16,05 & 12,53 & 8,73 & 6,78 & 4,72 \\
\hline 20 & 500 & 85 & 63,64 & 43,74 & 32,19 & 22,07 & 16,14 & 12,57 & 8,74 & 6,78 & 4,72 \\
\hline 20 & 550 & 85 & 62,15 & 43,35 & 32,17 & 22,17 & 16,22 & 12,62 & 8,75 & 6,78 & 4,72 \\
\hline 20 & 600 & 85 & 60,80 & 42,98 & 32,12 & 22,25 & 16,30 & 12,66 & 8,76 & 6,78 & 4,72 \\
\hline 20 & 650 & 85 & 59,58 & 42,62 & 32,07 & 22,33 & 16,37 & 12,71 & 8,77 & 6,78 & 4,71 \\
\hline 20 & 700 & 85 & 58,47 & 42,27 & 32,01 & 22,39 & 16,44 & 12,75 & 8,78 & 6,78 & 4,71 \\
\hline 20 & 750 & 85 & 57,45 & 41,93 & 31,94 & 22,45 & 16,51 & 12,80 & 8,79 & 6,78 & 4,71 \\
\hline 20 & 800 & 85 & 56,50 & 41,60 & 31,86 & 22,50 & 16,57 & 12,84 & 8,80 & 6,78 & 4,71 \\
\hline 20 & 850 & 85 & 55,62 & 41,28 & 31,78 & 22,54 & 16,63 & 12,88 & 8,81 & 6,78 & 4,71 \\
\hline 20 & 900 & 85 & 54,79 & 40,97 & 31,69 & 22,58 & 16,68 & 12,92 & 8,83 & 6,78 & 4,71 \\
\hline 20 & 950 & 85 & 54,02 & 40,68 & 31,61 & 22,61 & 16,73 & 12,96 & 8,84 & 6,79 & 4,71 \\
\hline 20 & 1000 & 85 & 53,29 & 40,39 & 31,52 & 22,64 & 16,78 & 13,00 & 8,85 & 6,79 & 4,70 \\
\hline 20 & 1050 & 85 & 52,61 & 40,11 & 31,43 & 22,66 & 16,83 & 13,04 & 8,87 & 6,79 & 4,70 \\
\hline 20 & 1100 & 85 & 51,96 & 39,84 & 31,33 & 22,68 & 16,87 & 13,08 & 8,88 & 6,79 & 4,70 \\
\hline 20 & 1150 & 85 & 51,35 & 39,57 & 31,24 & 22,69 & 16,92 & 13,12 & 8,89 & 6,79 & 4,70 \\
\hline 20 & 1200 & 85 & 50,76 & 39,32 & 31,15 & 22,71 & 16,95 & 13,15 & 8,91 & 6,80 & 4,70 \\
\hline 20 & 1250 & 85 & 50,21 & 39,07 & 31,06 & 22,71 & 16,99 & 13,19 & 8,92 & 6,80 & 4,70 \\
\hline 20 & 1300 & 85 & 49,67 & 38,83 & 30,96 & 22,72 & 17,03 & 13,22 & 8,93 & 6,80 & 4,70 \\
\hline 20 & 1350 & 85 & 49,17 & 38,59 & 30,87 & 22,72 & 17,06 & 13,25 & 8,95 & 6,81 & 4,70 \\
\hline 20 & 1400 & 85 & 48,68 & 38,36 & 30,78 & 22,72 & 17,09 & 13,28 & 8,96 & 6,81 & 4,70 \\
\hline 20 & 1450 & 85 & 48,21 & 38,14 & 30,68 & 22,72 & 17,12 & 13,31 & 8,98 & 6,81 & 4,70 \\
\hline 20 & 1500 & 85 & 47,76 & 37,92 & 30,59 & 22,72 & 17,14 & 13,34 & 8,99 & 6,82 & 4,69 \\
\hline 20 & 1550 & 85 & 47,33 & 37,71 & 30,50 & 22,71 & 17,17 & 13,37 & 9,01 & 6,82 & 4,69 \\
\hline 20 & 1600 & 85 & 46,92 & 37,50 & 30,41 & 22,71 & 17,19 & 13,40 & 9,02 & 6,82 & 4,69 \\
\hline 20 & 1650 & 85 & 46,52 & 37,30 & 30,32 & 22,70 & 17,22 & 13,43 & 9,03 & 6,83 & 4,69 \\
\hline 20 & 1700 & 85 & 46,13 & 37,11 & 30,23 & 22,69 & 17,24 & 13,45 & 9,05 & 6,83 & 4,69 \\
\hline 20 & 1750 & 85 & 45,75 & 36,92 & 30,14 & 22,68 & 17,26 & 13,48 & 9,06 & 6,84 & 4,69 \\
\hline 20 & 1800 & 85 & 45,39 & 36,73 & 30,05 & 22,67 & 17,27 & 13,50 & 9,08 & 6,84 & 4,69 \\
\hline 20 & 1850 & 85 & 45,04 & 36,54 & 29,96 & 22,65 & 17,29 & 13,52 & 9,09 & 6,84 & 4,69 \\
\hline 20 & 1900 & 85 & 44,70 & 36,37 & 29,88 & 22,64 & 17,31 & 13,55 & 9,10 & 6,85 & 4,69 \\
\hline 20 & 1950 & 85 & 44,38 & 36,19 & 29,79 & 22,63 & 17,32 & 13,57 & 9,12 & 6,85 & 4,69 \\
\hline 20 & 2000 & 85 & 44,06 & 36,02 & 29,71 & 22,61 & 17,34 & 13,59 & 9,13 & 6,86 & 4,69 \\
\hline 20 & 200 & 90 & 76,54 & 43,62 & 29,83 & 19,85 & 14,69 & 11,64 & 8,21 & 6,40 & 4,50 \\
\hline 20 & 250 & 90 & 72,34 & 43,31 & 30,07 & 20,07 & 14,78 & 11,67 & 8,22 & 6,40 & 4,48 \\
\hline 20 & 300 & 90 & 69,14 & 42,96 & 30,23 & 20,25 & 14,86 & 11,70 & 8,23 & 6,40 & 4,48 \\
\hline 20 & 350 & 90 & 66,57 & 42,60 & 30,33 & 20,41 & 14,95 & 11,74 & 8,23 & 6,40 & 4,47 \\
\hline 20 & 400 & 90 & 64,42 & 42,24 & 30,38 & 20,55 & 15,03 & 11,77 & 8,24 & 6,40 & 4,47 \\
\hline 20 & 450 & 90 & 62,58 & 41,87 & 30,41 & 20,67 & 15,12 & 11,81 & 8,25 & 6,40 & 4,46 \\
\hline 20 & 500 & 90 & 60,97 & 41,52 & 30,41 & 20,78 & 15,20 & 11,85 & 8,25 & 6,40 & 4,46 \\
\hline 20 & 550 & 90 & 59,54 & 41,17 & 30,40 & 20,88 & 15,27 & 11,89 & 8,26 & 6,40 & 4,46 \\
\hline 20 & 600 & 90 & 58,26 & 40,83 & 30,37 & 20,96 & 15,34 & 11,93 & 8,27 & 6,40 & 4,46 \\
\hline 20 & 650 & 90 & 57,09 & 40,50 & 30,33 & 21,04 & 15,41 & 11,97 & 8,28 & 6,40 & 4,45 \\
\hline 20 & 700 & 90 & 56,03 & 40,17 & 30,28 & 21,10 & 15,48 & 12,01 & 8,28 & 6,40 & 4,45 \\
\hline 20 & 750 & 90 & 55,06 & 39,86 & 30,22 & 21,16 & 15,54 & 12,05 & 8,29 & 6,40 & 4,45 \\
\hline 20 & 800 & 90 & 54,15 & 39,56 & 30,15 & 21,21 & 15,60 & 12,09 & 8,30 & 6,40 & 4,45 \\
\hline 20 & 850 & 90 & 53,31 & 39,27 & 30,08 & 21,25 & 15,65 & 12,13 & 8,31 & 6,40 & 4,45 \\
\hline 20 & 900 & 90 & 52,53 & 38,99 & 30,01 & 21,29 & 15,70 & 12,17 & 8,32 & 6,41 & 4,45 \\
\hline 20 & 950 & 90 & 51,79 & 38,71 & 29,94 & 21,33 & 15,75 & 12,20 & 8,34 & 6,41 & 4,44 \\
\hline 20 & 1000 & 90 & 51,10 & 38,45 & 29,86 & 21,35 & 15,80 & 12,24 & 8,35 & 6,41 & 4,44 \\
\hline 20 & 1050 & 90 & 50,45 & 38,19 & 29,78 & 21,38 & 15,84 & 12,28 & 8,36 & 6,41 & 4,44 \\
\hline 20 & 1100 & 90 & 49,83 & 37,94 & 29,70 & 21,40 & 15,89 & 12,31 & 8,37 & 6,41 & 4,44 \\
\hline 20 & 1150 & 90 & 49,24 & 37,69 & 29,62 & 21,42 & 15,93 & 12,34 & 8,38 & 6,41 & 4,44 \\
\hline 20 & 1200 & 90 & 48,68 & 37,46 & 29,54 & 21,43 & 15,96 & 12,38 & 8,39 & 6,42 & 4,44 \\
\hline 20 & 1250 & 90 & 48,15 & 37,22 & 29,45 & 21,44 & 16,00 & 12,41 & 8,41 & 6,42 & 4,44 \\
\hline 20 & 1300 & 90 & 47,65 & 37,00 & 29,37 & 21,45 & 16,03 & 12,44 & 8,42 & 6,42 & 4,44 \\
\hline 20 & 1350 & 90 & 47,16 & 36,78 & 29,29 & 21,45 & 16,06 & 12,47 & 8,43 & 6,42 & 4,44 \\
\hline 20 & 1400 & 90 & 46,70 & 36,57 & 29,20 & 21,46 & 16,09 & 12,50 & 8,44 & 6,43 & 4,44 \\
\hline 20 & 1450 & 90 & 46,25 & 36,36 & 29,12 & 21,46 & 16,12 & 12,53 & 8,46 & 6,43 & 4,44 \\
\hline 20 & 1500 & 90 & 45,83 & 36,16 & 29,04 & 21,46 & 16,15 & 12,55 & 8,47 & 6,43 & 4,44 \\
\hline 20 & 1550 & 90 & 45,41 & 35,96 & 28,95 & 21,46 & 16,17 & 12,58 & 8,48 & 6,43 & 4,43 \\
\hline 20 & 1600 & 90 & 45,02 & 35,77 & 28,87 & 21,46 & 16,20 & 12,61 & 8,49 & 6,44 & 4,43 \\
\hline 20 & 1650 & 90 & 44,64 & 35,58 & 28,79 & 21,45 & 16,22 & 12,63 & 8,51 & 6,44 & 4,43 \\
\hline 20 & 1700 & 90 & 44,27 & 35,40 & 28,71 & 21,44 & 16,24 & 12,66 & 8,52 & 6,44 & 4,43 \\
\hline 20 & 1750 & 90 & 43,91 & 35,22 & 28,63 & 21,44 & 16,26 & 12,68 & 8,53 & 6,45 & 4,43 \\
\hline 20 & 1800 & 90 & 43,57 & 35,05 & 28,55 & 21,43 & 16,28 & 12,70 & 8,55 & 6,45 & 4,43 \\
\hline 20 & 1850 & 90 & 43,23 & 34,87 & 28,47 & 21,42 & 16,30 & 12,73 & 8,56 & 6,46 & 4,43 \\
\hline 20 & 1900 & 90 & 42,91 & 34,71 & 28,39 & 21,41 & 16,31 & 12,75 & 8,57 & 6,46 & 4,43 \\
\hline 20 & 1950 & 90 & 42,60 & 34,54 & 28,31 & 21,40 & 16,33 & 12,77 & 8,58 & 6,46 & 4,43 \\
\hline 20 & 2000 & 90 & 42,29 & 34,38 & 28,23 & 21,39 & 16,34 & 12,79 & 8,60 & 6,47 & 4,43 \\
\hline 20 & 200 & 95 & 73,53 & 41,37 & 28,20 & 18,76 & 13,90 & 11,03 & 7,78 & 6,06 & 4,26 \\
\hline 20 & 250 & 95 & 69,46 & 41,11 & 28,44 & 18,96 & 13,98 & 11,05 & 7,78 & 6,06 & 4,25 \\
\hline 20 & 300 & 95 & 66,38 & 40,81 & 28,59 & 19,13 & 14,06 & 11,08 & 7,79 & 6,06 & 4,24 \\
\hline 20 & 350 & 95 & 63,91 & 40,49 & 28,70 & 19,28 & 14,13 & 11,11 & 7,80 & 6,07 & 4,24 \\
\hline 20 & 400 & 95 & 61,85 & 40,16 & 28,77 & 19,41 & 14,21 & 11,14 & 7,80 & 6.07 & 4,23 \\
\hline 20 & 450 & 95 & 60,08 & 39,83 & 28,80 & 19,53 & 14,28 & 11,17 & 7,81 & 6,07 & 4,23 \\
\hline 20 & 500 & 95 & 58,54 & 39,51 & 28,81 & 19,64 & 14,36 & 11,21 & 7,81 & 6,07 & 4,23 \\
\hline 20 & 550 & 95 & 57,17 & 39,19 & 28,81 & 19,73 & 14,43 & 11,24 & 7,82 & 6,07 & 4,22 \\
\hline 20 & 600 & 95 & 55,94 & 38,88 & 28,79 & 19,81 & 14,49 & 11,28 & 7,83 & 6,07 & 4,22 \\
\hline 20 & 650 & 95 & 54,83 & 38,58 & 28,76 & 19,88 & 14,56 & 11,31 & 7,83 & 6,07 & 4,22 \\
\hline 20 & 700 & 95 & 53,82 & 38,28 & 28,72 & 19,95 & 14,62 & 11,35 & 7,84 & 6,07 & 4,22 \\
\hline 20 & 750 & 95 & 52,88 & 38,00 & 28,67 & 20,00 & 14,67 & 11,39 & 7,85 & 6,07 & 4,22 \\
\hline
\end{tabular}




\begin{tabular}{|c|c|c|c|c|c|c|c|c|c|c|c|}
\hline \multirow[b]{2}{*}{$\mathrm{H}(\mathrm{cm})$} & \multirow[b]{2}{*}{ Mceq (MPa) } & & & & & $\mathrm{De}$ & ões (x1 & & & & \\
\hline & & Msub (MPa) & D0 & D25 & D40 & D60 & D80 & D100 & D140 & D180 & D260 \\
\hline 20 & 800 & 95 & 52,02 & 37,72 & 28,62 & 20,05 & 14,73 & 11,42 & 7,86 & 6,07 & 4,22 \\
\hline 20 & 850 & 95 & 51,21 & 37,45 & 28,56 & 20,10 & 14,78 & 11,46 & 7,87 & 6,07 & 4,21 \\
\hline 20 & 900 & 95 & 50,46 & 37,19 & 28,50 & 20,14 & 14,83 & 11,49 & 7,88 & 6,07 & 4,21 \\
\hline 20 & 950 & 95 & 49,76 & 36,94 & 28,43 & 20,17 & 14,88 & 11,53 & 7,89 & 6,07 & 4,21 \\
\hline 20 & 1000 & 95 & 49,10 & 36,69 & 28,37 & 20,20 & 14,92 & 11,56 & 7,90 & 6,07 & 4,21 \\
\hline 20 & 1050 & 95 & 48,48 & 36,45 & 28,30 & 20,23 & 14,96 & 11,59 & 7,91 & 6,07 & 4,21 \\
\hline 20 & 1100 & 95 & 47,89 & 36,22 & 28,23 & 20,25 & 15,00 & 11,62 & 7,92 & 6,07 & 4,21 \\
\hline 20 & 1150 & 95 & 47,33 & 35,99 & 28,15 & 20,27 & 15,04 & 11,65 & 7,93 & 6,07 & 4,21 \\
\hline 20 & 1200 & 95 & 46,79 & 35,77 & 28,08 & 20,28 & 15,08 & 11,69 & 7,94 & 6,08 & 4,21 \\
\hline 20 & 1250 & 95 & 46,29 & 35,55 & 28,01 & 20,30 & 15,11 & 11,71 & 7,95 & 6,08 & 4,21 \\
\hline 20 & 1300 & 95 & 45,80 & 35,35 & 27,93 & 20,31 & 15,14 & 11,74 & 7,96 & 6,08 & 4,21 \\
\hline 20 & 1350 & 95 & 45,34 & 35,14 & 27,86 & 20,32 & 15,17 & 11,77 & 7,97 & 6,08 & 4,20 \\
\hline 20 & 1400 & 95 & 44,89 & 34,94 & 27,78 & 20,32 & 15,20 & 11,80 & 7,98 & 6,08 & 4,20 \\
\hline 20 & 1450 & 95 & 44,47 & 34,75 & 27,71 & 20,33 & 15,23 & 11,83 & 7,99 & 6,09 & 4,20 \\
\hline 20 & 1500 & 95 & 44,06 & 34,56 & 27,63 & 20,33 & 15,26 & 11,85 & 8,00 & 6,09 & 4,20 \\
\hline 20 & 1550 & 95 & 43,67 & 34,38 & 27,56 & 20,33 & 15,28 & 11,88 & 8,02 & 6,09 & 4,20 \\
\hline 20 & 1600 & 95 & 43,29 & 34,20 & 27,48 & 20,33 & 15,31 & 11,90 & 8,03 & 6,09 & 4,20 \\
\hline 20 & 1650 & 95 & 42,92 & 34,02 & 27,41 & 20,33 & 15,33 & 11,93 & 8,04 & 6,10 & 4,20 \\
\hline 20 & 1700 & 95 & 42,57 & 33,85 & 27,34 & 20,33 & 15,35 & 11,95 & 8,05 & 6,10 & 4,20 \\
\hline 20 & 1750 & 95 & 42,23 & 33,68 & 27,26 & 20,32 & 15,37 & 11,97 & 8,06 & 6,10 & 4,20 \\
\hline 20 & 1800 & 95 & 41,90 & 33,52 & 27,19 & 20,32 & 15,39 & 11,99 & 8,07 & 6,11 & 4,20 \\
\hline 20 & 1850 & 95 & 41,58 & 33,36 & 27,12 & 20,31 & 15,41 & 12,01 & 8,08 & 6,11 & 4,20 \\
\hline 20 & 1900 & 95 & 41,27 & 33,20 & 27,05 & 20,30 & 15,42 & 12,04 & 8,10 & 6,11 & 4,20 \\
\hline 20 & 1950 & 95 & 40,97 & 33,05 & 26,97 & 20,29 & 15,44 & 12,06 & 8,11 & 6,12 & 4,20 \\
\hline 20 & 2000 & 95 & 40,68 & 32,90 & 26,90 & 20,28 & 15,45 & 12,07 & 8,12 & 6,12 & 4,20 \\
\hline 20 & 200 & 100 & 70,79 & 39,35 & 26,73 & 17,78 & 13,19 & 10,47 & 7,38 & 5,76 & 4,05 \\
\hline 20 & 250 & 100 & 66,85 & 39,12 & 26,96 & 17,97 & 13,26 & 10,49 & 7,39 & 5,76 & 4,04 \\
\hline 20 & 300 & 100 & 63,87 & 38,86 & 27,13 & 18,13 & 13,33 & 10,51 & 7,40 & 5,76 & 4,03 \\
\hline 20 & 350 & 100 & 61,48 & 38,57 & 27,23 & 18,27 & 13,40 & 10,54 & 7,41 & 5,76 & 4,03 \\
\hline 20 & 400 & 100 & 59,50 & 38,28 & 27,31 & 18,39 & 13,47 & 10,57 & 7,41 & 5,76 & 4,02 \\
\hline 20 & 450 & 100 & 57,80 & 37,98 & 27,35 & 18,51 & 13,54 & 10,60 & 7,42 & 5,76 & 4,02 \\
\hline 20 & 500 & 100 & 56,32 & 37,69 & 27,37 & 18,61 & 13,60 & 10,63 & 7,42 & 5,76 & 4,02 \\
\hline 20 & 550 & 100 & 55,01 & 37,40 & 27,37 & 18,69 & 13,67 & 10,66 & 7,43 & 5,76 & 4,01 \\
\hline 20 & 600 & 100 & 53,83 & 37,11 & 27,36 & 18,77 & 13,73 & 10,69 & 7,43 & 5,76 & 4,01 \\
\hline 20 & 650 & 100 & 52,76 & 36,83 & 27,34 & 18,84 & 13,79 & 10,73 & 7,44 & 5,76 & 4,01 \\
\hline 20 & 700 & 100 & 51,79 & 36,56 & 27,31 & 18,91 & 13,85 & 10,76 & 7,45 & 5,76 & 4,01 \\
\hline 20 & 750 & 100 & 50,90 & 36,30 & 27,27 & 18,96 & 13,90 & 10,79 & 7,45 & 5,76 & 4,01 \\
\hline 20 & 800 & 100 & 50,07 & 36,04 & 27,23 & 19,01 & 13,95 & 10,82 & 7,46 & 5,76 & 4,01 \\
\hline 20 & 850 & 100 & 49,30 & 35,80 & 27,18 & 19,06 & 14,00 & 10,86 & 7,47 & 5,76 & 4,00 \\
\hline 20 & 900 & 100 & 48,58 & 35,55 & 27,13 & 19,10 & 14,05 & 10,89 & 7,48 & 5,76 & 4,00 \\
\hline 20 & 950 & 100 & 47,91 & 35,32 & 27,07 & 19,13 & 14,09 & 10,92 & 7,48 & 5,76 & 4,00 \\
\hline 20 & 1000 & 100 & 47,27 & 35,09 & 27,01 & 19,16 & 14,13 & 10,95 & 7,49 & 5,77 & 4,00 \\
\hline 20 & 1050 & 100 & 46,68 & 34,87 & 26,95 & 19,19 & 14,17 & 10,98 & 7,50 & 5,77 & 4,00 \\
\hline 20 & 1100 & 100 & 46,11 & 34,65 & 26,89 & 19,21 & 14,21 & 11,01 & 7,51 & 5,77 & 4,00 \\
\hline 20 & 1150 & 100 & 45,57 & 34,44 & 26,82 & 19,23 & 14,25 & 11,04 & 7,52 & 5,77 & 4,00 \\
\hline 20 & 1200 & 100 & 45,06 & 34,23 & 26,76 & 19,25 & 14,28 & 11,07 & 7,53 & 5,77 & 4,00 \\
\hline 20 & 1250 & 100 & 44,58 & 34,03 & 26,69 & 19,27 & 14,32 & 11,09 & 7,54 & 5,77 & 4,00 \\
\hline 20 & 1300 & 100 & 44,11 & 33,84 & 26,63 & 19,28 & 14,35 & 11,12 & 7,55 & 5,77 & 4,00 \\
\hline 20 & 1350 & 100 & 43,67 & 33,65 & 26,56 & 19,29 & 14,38 & 11,15 & 7,56 & 5,77 & 4,00 \\
\hline 20 & 1400 & 100 & 43,25 & 33,46 & 26,49 & 19,30 & 14,40 & 11,17 & 7,57 & 5,78 & 3,99 \\
\hline 20 & 1450 & 100 & 42,84 & 33,28 & 26,42 & 19,30 & 14,43 & 11,20 & 7,58 & 5,78 & 3,99 \\
\hline 20 & 1500 & 100 & 42,45 & 33,10 & 26,36 & 19,31 & 14,46 & 11,22 & 7,59 & 5,78 & 3,99 \\
\hline 20 & 1550 & 100 & 42,07 & 32,93 & 26,29 & 19,31 & 14,48 & 11,25 & 7,60 & 5,78 & 3,99 \\
\hline 20 & 1600 & 100 & 41,71 & 32,76 & 26,22 & 19,31 & 14,50 & 11,27 & 7,61 & 5,79 & 3,99 \\
\hline 20 & 1650 & 100 & 41,36 & 32,60 & 26,16 & 19,31 & 14,53 & 11,29 & 7,62 & 5,79 & 3,99 \\
\hline 20 & 1700 & 100 & 41,02 & 32,44 & 26,09 & 19,31 & 14,55 & 11,31 & 7,63 & 5,79 & 3,99 \\
\hline 20 & 1750 & 100 & 40,69 & 32,28 & 26,02 & 19,31 & 14,57 & 11,33 & 7,64 & 5,79 & 3,99 \\
\hline 20 & 1800 & 100 & 40,38 & 32,13 & 25,95 & 19,31 & 14,59 & 11,36 & 7,65 & 5,80 & 3,99 \\
\hline 20 & 1850 & 100 & 40,07 & 31,98 & 25,89 & 19,30 & 14,60 & 11,38 & 7,66 & 5,80 & 3,99 \\
\hline 20 & 1900 & 100 & 39,78 & 31,83 & 25,82 & 19,30 & 14,62 & 11,40 & 7,67 & 5,80 & 3,99 \\
\hline 20 & 1950 & 100 & 39,49 & 31,68 & 25,76 & 19,29 & 14,64 & 11,41 & 7,68 & 5,80 & 3,99 \\
\hline 20 & 2000 & 100 & 39,21 & 31,54 & 25,69 & 19,29 & 14,65 & 11,43 & 7,69 & 5,81 & 3,99 \\
\hline 20 & 200 & 105 & 68,29 & 37,51 & 25,40 & 16,90 & 12,55 & 9,97 & 7,03 & 5,48 & 3,86 \\
\hline 20 & 250 & 105 & 64,46 & 37,32 & 25,63 & 17,07 & 12,61 & 9,99 & 7,04 & 5,48 & 3,85 \\
\hline 20 & 300 & 105 & 61,57 & 37,08 & 25,80 & 17,22 & 12,68 & 10,01 & 7,05 & 5,49 & 3,84 \\
\hline 20 & 350 & 105 & 59,26 & 36,83 & 25,91 & 17,36 & 12,74 & 10,03 & 7,05 & 5,49 & 3,84 \\
\hline 20 & 400 & 105 & 57,35 & 36,56 & 25,98 & 17,47 & 12,80 & 10,05 & 7,06 & 5,49 & 3,83 \\
\hline 20 & 450 & 105 & 55,71 & 36,29 & 26,03 & 17,58 & 12,87 & 10,08 & 7,06 & 5,49 & 3,83 \\
\hline 20 & 500 & 105 & 54,29 & 36,02 & 26,06 & 17,68 & 12,93 & 10,11 & 7,07 & 5,49 & 3,83 \\
\hline 20 & 550 & 105 & 53,03 & 35,76 & 26,07 & 17,76 & 12,99 & 10,14 & 7,07 & 5,49 & 3,82 \\
\hline 20 & 600 & 105 & 51,89 & 35,50 & 26,07 & 17,84 & 13,04 & 10,17 & 7,08 & 5,49 & 3,82 \\
\hline 20 & 650 & 105 & 50,87 & 35,24 & 26,05 & 17,91 & 13,10 & 10,20 & 7,08 & 5,49 & 3,82 \\
\hline 20 & 700 & 105 & 49,93 & 34,99 & 26,03 & 17,97 & 13,15 & 10,23 & 7,09 & 5,49 & 3,82 \\
\hline 20 & 750 & 105 & 49.07 & 34.75 & 26,00 & 18,02 & 13,20 & 10,26 & 7.09 & 5,49 & 3,82 \\
\hline 20 & 800 & 105 & 48,28 & 34,51 & 25,96 & 18,07 & 13,25 & 10,29 & 7,10 & 5,49 & 3,82 \\
\hline 20 & 850 & 105 & 47,54 & 34,28 & 25,92 & 18,12 & 13,30 & 10,31 & 7,11 & 5,49 & 3,82 \\
\hline 20 & 900 & 105 & 46,85 & 34,06 & 25,88 & 18,16 & 13,34 & 10,34 & 7,11 & 5,49 & 3,81 \\
\hline 20 & 950 & 105 & 46,20 & 33,84 & 25,83 & 18,19 & 13,38 & 10,37 & 7,12 & 5,49 & 3,81 \\
\hline 20 & 1000 & 105 & 45,60 & 33,63 & 25,78 & 18,22 & 13,42 & 10,40 & 7,13 & 5,49 & 3,81 \\
\hline 20 & 1050 & 105 & 45,02 & 33,42 & 25,73 & 18,25 & 13,46 & 10,43 & 7,14 & 5,49 & 3,81 \\
\hline 20 & 1100 & 105 & 44,48 & 33,22 & 25,67 & 18,28 & 13,50 & 10,46 & 7,14 & 5,49 & 3,81 \\
\hline
\end{tabular}




\begin{tabular}{|c|c|c|c|c|c|c|c|c|c|c|c|}
\hline \multirow[b]{2}{*}{$\mathrm{H}(\mathrm{cm})$} & \multirow[b]{2}{*}{ Mceq (MPa) } & & & & & $\mathrm{De}$ & ões (x1 & & & & \\
\hline & & Msub (MPa) & D0 & D25 & D40 & D60 & D80 & D100 & D140 & D180 & D260 \\
\hline 20 & 1150 & 105 & 43,96 & 33,02 & 25,61 & 18,30 & 13,53 & 10,48 & 7,15 & 5,49 & 3,81 \\
\hline 20 & 1200 & 105 & 43,47 & 32,83 & 25,56 & 18,32 & 13,56 & 10,51 & 7,16 & 5,49 & 3,81 \\
\hline 20 & 1250 & 105 & 43,01 & 32,64 & 25,50 & 18,33 & 13,60 & 10,53 & 7,17 & 5,49 & 3,81 \\
\hline 20 & 1300 & 105 & 42,56 & 32,46 & 25,44 & 18,35 & 13,63 & 10,56 & 7,18 & 5,50 & 3,81 \\
\hline 20 & 1350 & 105 & 42,14 & 32,28 & 25,38 & 18,36 & 13,66 & 10,58 & 7,19 & 5,50 & 3,81 \\
\hline 20 & 1400 & 105 & 41,73 & 32,10 & 25,32 & 18,37 & 13,68 & 10,61 & 7,20 & 5,50 & 3,81 \\
\hline 20 & 1450 & 105 & 41,34 & 31,94 & 25,26 & 18,38 & 13,71 & 10,63 & 7,20 & 5,50 & 3,80 \\
\hline 20 & 1500 & 105 & 40,96 & 31,77 & 25,19 & 18,38 & 13,73 & 10,65 & 7,21 & 5,50 & 3,80 \\
\hline 20 & 1550 & 105 & 40,60 & 31,61 & 25,13 & 18,39 & 13,76 & 10,68 & 7,22 & 5,50 & 3,80 \\
\hline 20 & 1600 & 105 & 40,25 & 31,45 & 25,07 & 18,39 & 13,78 & 10,70 & 7,23 & 5,51 & 3,80 \\
\hline 20 & 1650 & 105 & 39,92 & 31,29 & 25,01 & 18,39 & 13,80 & 10,72 & 7,24 & 5,51 & 3,80 \\
\hline 20 & 1700 & 105 & 39,59 & 31,14 & 24,95 & 18,39 & 13,82 & 10,74 & 7,25 & 5,51 & 3,80 \\
\hline 20 & 1750 & 105 & 39,28 & 30,99 & 24,89 & 18,39 & 13,84 & 10,76 & 7,26 & 5,51 & 3,80 \\
\hline 20 & 1800 & 105 & 38,98 & 30,85 & 24,83 & 18,39 & 13,86 & 10,78 & 7,27 & 5,52 & 3,80 \\
\hline 20 & 1850 & 105 & 38,68 & 30,71 & 24,77 & 18,39 & 13,88 & 10,80 & 7,28 & 5,52 & 3,80 \\
\hline 20 & 1900 & 105 & 38,40 & 30,57 & 24,71 & 18,39 & 13,89 & 10,82 & 7,29 & 5,52 & 3,80 \\
\hline 20 & 1950 & 105 & 38,12 & 30,43 & 24,65 & 18,38 & 13,91 & 10,84 & 7,30 & 5,52 & 3,80 \\
\hline 20 & 2000 & 105 & 37,85 & 30,30 & 24,59 & 18,38 & 13,93 & 10,85 & 7,31 & 5,53 & 3,80 \\
\hline 20 & 200 & 110 & 66,00 & 35,83 & 24,20 & 16,10 & 11,97 & 9,52 & 6,71 & 5,23 & 3,69 \\
\hline 20 & 250 & 110 & 62,26 & 35,67 & 24,43 & 16,26 & 12,03 & 9,53 & 6,72 & 5,23 & 3,68 \\
\hline 20 & 300 & 110 & 59,46 & 35,46 & 24,59 & 16,40 & 12,08 & 9,55 & 6,72 & 5,24 & 3,67 \\
\hline 20 & 350 & 110 & 57,22 & 35,23 & 24,70 & 16,53 & 12,14 & 9,57 & 6,73 & 5,24 & 3,66 \\
\hline 20 & 400 & 110 & 55,37 & 34,99 & 24,78 & 16,64 & 12,20 & 9,59 & 6,73 & 5,24 & 3,66 \\
\hline 20 & 450 & 110 & 53,79 & 34,75 & 24,83 & 16,74 & 12,26 & 9,61 & 6,74 & 5,24 & 3,66 \\
\hline 20 & 500 & 110 & 52,42 & 34,50 & 24,86 & 16,83 & 12,31 & 9,64 & 6,74 & 5,24 & 3,65 \\
\hline 20 & 550 & 110 & 51,20 & 34,26 & 24,88 & 16,91 & 12,37 & 9,66 & 6,75 & 5,24 & 3,65 \\
\hline 20 & 600 & 110 & 50,11 & 34,02 & 24,88 & 16,99 & 12,42 & 9,69 & 6,75 & 5,24 & 3,65 \\
\hline 20 & 650 & 110 & 49,12 & 33,78 & 24,88 & 17,05 & 12,47 & 9,72 & 6,76 & 5,24 & 3,65 \\
\hline 20 & 700 & 110 & 48,22 & 33,55 & 24,86 & 17,11 & 12,52 & 9,74 & 6,76 & 5,24 & 3,65 \\
\hline 20 & 750 & 110 & 47,40 & 33,33 & 24,84 & 17,17 & 12,57 & 9,77 & 6,77 & 5,24 & 3,65 \\
\hline 20 & 800 & 110 & 46,63 & 33,11 & 24,81 & 17,22 & 12,61 & 9,80 & 6,77 & 5,24 & 3,64 \\
\hline 20 & 850 & 110 & 45,92 & 32,89 & 24,77 & 17,26 & 12,66 & 9,82 & 6,78 & 5,24 & 3,64 \\
\hline 20 & 900 & 110 & 45,26 & 32,68 & 24,74 & 17,30 & 12,70 & 9,85 & 6,78 & 5,24 & 3,64 \\
\hline 20 & 950 & 110 & 44,63 & 32,48 & 24,70 & 17,34 & 12,74 & 9,88 & 6,79 & 5,24 & 3,64 \\
\hline 20 & 1000 & 110 & 44,05 & 32,28 & 24,65 & 17,37 & 12,78 & 9,90 & 6,80 & 5,24 & 3,64 \\
\hline 20 & 1050 & 110 & 43,50 & 32,09 & 24,60 & 17,40 & 12,81 & 9,93 & 6,80 & 5,24 & 3,64 \\
\hline 20 & 1100 & 110 & 42,98 & 31,90 & 24,56 & 17,42 & 12,85 & 9,95 & 6,81 & 5,24 & 3,64 \\
\hline 20 & 1150 & 110 & 42,48 & 31,71 & 24,51 & 17,44 & 12,88 & 9,98 & 6,82 & 5,24 & 3,64 \\
\hline 20 & 1200 & 110 & 42,01 & 31,53 & 24,45 & 17,46 & 12,91 & 10,00 & 6,83 & 5,24 & 3,64 \\
\hline 20 & 1250 & 110 & 41,56 & 31,36 & 24,40 & 17,48 & 12,94 & 10,03 & 6,83 & 5,24 & 3,64 \\
\hline 20 & 1300 & 110 & 41,13 & 31,19 & 24,35 & 17,50 & 12,97 & 10,05 & 6,84 & 5,24 & 3,63 \\
\hline 20 & 1350 & 110 & 40,72 & 31,02 & 24,29 & 17,51 & 13,00 & 10,07 & 6,85 & 5,25 & 3,63 \\
\hline 20 & 1400 & 110 & 40,33 & 30,86 & 24,24 & 17,52 & 13,03 & 10,10 & 6,86 & 5,25 & 3,63 \\
\hline 20 & 1450 & 110 & 39,95 & 30,70 & 24,18 & 17,53 & 13,05 & 10,12 & 6,87 & 5,25 & 3,63 \\
\hline 20 & 1500 & 110 & 39,59 & 30,54 & 24,13 & 17,54 & 13,08 & 10,14 & 6,87 & 5,25 & 3,63 \\
\hline 20 & 1550 & 110 & 39,25 & 30,39 & 24,07 & 17,54 & 13,10 & 10,16 & 6,88 & 5,25 & 3,63 \\
\hline 20 & 1600 & 110 & 38,91 & 30,24 & 24,02 & 17,55 & 13,12 & 10,18 & 6,89 & 5,25 & 3,63 \\
\hline 20 & 1650 & 110 & 38,59 & 30,09 & 23,96 & 17,55 & 13,14 & 10,20 & 6,90 & 5,26 & 3,63 \\
\hline 20 & 1700 & 110 & 38,28 & 29,95 & 23,91 & 17,56 & 13,16 & 10,22 & 6,91 & 5,26 & 3,63 \\
\hline 20 & 1750 & 110 & 37,97 & 29,81 & 23,85 & 17,56 & 13,18 & 10,24 & 6,92 & 5,26 & 3,63 \\
\hline 20 & 1800 & 110 & 37,68 & 29,68 & 23,79 & 17,56 & 13,20 & 10,26 & 6,92 & 5,26 & 3,63 \\
\hline 20 & 1850 & 110 & 37,40 & 29,54 & 23,74 & 17,56 & 13,22 & 10,28 & 6,93 & 5,26 & 3,63 \\
\hline 20 & 1900 & 110 & 37,13 & 29,41 & 23,68 & 17,56 & 13,23 & 10,30 & 6,94 & 5,26 & 3,63 \\
\hline 20 & 1950 & 110 & 36,86 & 29,28 & 23,63 & 17,55 & 13,25 & 10,31 & 6,95 & 5,27 & 3,63 \\
\hline 20 & 2000 & 110 & 36,60 & 29,16 & 23,57 & 17,55 & 13,27 & 10,33 & 6,96 & 5,27 & 3,63 \\
\hline 20 & 200 & 115 & 63,88 & 34,29 & 23,10 & 15,37 & 11,44 & 9,10 & 6,41 & 5,00 & 3,53 \\
\hline 20 & 250 & 115 & 60,24 & 34,15 & 23,32 & 15,52 & 11,49 & 9,11 & 6,42 & 5,01 & 3,52 \\
\hline 20 & 300 & 115 & 57,51 & 33,97 & 23,48 & 15,66 & 11,54 & 9,13 & 6,43 & 5,01 & 3,51 \\
\hline 20 & 350 & 115 & 55,34 & 33,77 & 23,60 & 15,77 & 11,60 & 9,14 & 6,44 & 5,01 & 3,51 \\
\hline 20 & 400 & 115 & 53,55 & 33,55 & 23,68 & 15,88 & 11,65 & 9,16 & 6,44 & 5,01 & 3,50 \\
\hline 20 & 450 & 115 & 52,02 & 33,33 & 23,74 & 15,98 & 11,70 & 9,19 & 6,44 & 5,01 & 3,50 \\
\hline 20 & 500 & 115 & 50,69 & 33,10 & 23,77 & 16,06 & 11,75 & 9,21 & 6,45 & 5,01 & 3,50 \\
\hline 20 & 550 & 115 & 49,51 & 32,88 & 23,79 & 16,14 & 11,81 & 9,23 & 6,45 & 5,01 & 3,49 \\
\hline 20 & 600 & 115 & 48,46 & 32,66 & 23,80 & 16,21 & 11,85 & 9,25 & 6,46 & 5,01 & 3,49 \\
\hline 20 & 650 & 115 & 47,51 & 32,44 & 23,80 & 16,28 & 11,90 & 9,28 & 6,46 & 5,01 & 3,49 \\
\hline 20 & 700 & 115 & 46,64 & 32,23 & 23,79 & 16,34 & 11,95 & 9,30 & 6,46 & 5,01 & 3,49 \\
\hline 20 & 750 & 115 & 45,84 & 32,02 & 23,77 & 16,39 & 11,99 & 9,33 & 6,47 & 5,01 & 3,49 \\
\hline 20 & 800 & 115 & 45,11 & 31,81 & 23,75 & 16,44 & 12,04 & 9,35 & 6,47 & 5,01 & 3,49 \\
\hline 20 & 850 & 115 & 44,42 & 31,62 & 23,72 & 16,48 & 12,08 & 9,38 & 6,48 & 5,01 & 3,49 \\
\hline 20 & 900 & 115 & 43,78 & 31,42 & 23,69 & 16,52 & 12,12 & 9,40 & 6,48 & 5,01 & 3,48 \\
\hline 20 & 950 & 115 & 43,18 & 31,23 & 23,65 & 16,55 & 12,15 & 9,43 & 6,49 & 5,01 & 3,48 \\
\hline 20 & 1000 & 115 & 42,62 & 31,04 & 23,62 & 16,59 & 12,19 & 9,45 & 6,50 & 5,01 & 3,48 \\
\hline 20 & 1050 & 115 & 42,09 & 30,86 & 23,58 & 16,61 & 12,22 & 9,47 & 6,50 & 5,01 & 3,48 \\
\hline 20 & 1100 & 115 & 41,58 & 30,68 & 23,53 & 16,64 & 12,26 & 9,50 & 6,51 & 5,01 & 3,48 \\
\hline 20 & 1150 & 115 & 41,11 & 30,51 & 23,49 & 16,66 & 12,29 & 9,52 & 6,52 & 5,01 & 3,48 \\
\hline 20 & 1200 & 115 & 40,65 & 30,34 & 23,44 & 16,68 & 12,32 & 9,54 & 6,52 & 5,01 & 3,48 \\
\hline 20 & 1250 & 115 & 40,22 & 30,18 & 23,40 & 16,70 & 12,35 & 9,57 & 6,53 & 5,01 & 3,48 \\
\hline 20 & 1300 & 115 & 39,81 & 30,02 & 23,35 & 16,72 & 12,38 & 9,59 & 6,54 & 5,02 & 3,48 \\
\hline 20 & 1350 & 115 & 39,41 & 29,86 & 23,30 & 16,73 & 12,40 & 9,61 & 6,54 & 5,02 & 3,48 \\
\hline 20 & 1400 & 115 & 39,04 & 29,71 & 23,25 & 16,75 & 12,43 & 9,63 & 6,55 & 5,02 & 3,48 \\
\hline 20 & 1450 & 115 & 38,67 & 29,56 & 23,20 & 16,76 & 12,45 & 9,65 & 6,56 & 5,02 & 3,48 \\
\hline
\end{tabular}




\begin{tabular}{|c|c|c|c|c|c|c|c|c|c|c|c|}
\hline \multirow[b]{2}{*}{$\mathrm{H}(\mathrm{cm})$} & \multirow[b]{2}{*}{ Mceq (MPa) } & & & & & $\mathrm{De}$ & ões (x1 & & & & \\
\hline & & Msub (MPa) & D0 & D25 & D40 & D60 & D80 & D100 & D140 & D180 & D260 \\
\hline 20 & 1500 & 115 & 38,33 & 29,41 & 23,15 & 16,77 & 12,48 & 9,67 & 6,56 & 5,02 & 3,48 \\
\hline 20 & 1550 & 115 & 37,99 & 29,27 & 23,10 & 16,77 & 12,50 & 9,69 & 6,57 & 5,02 & 3,47 \\
\hline 20 & 1600 & 115 & 37,67 & 29,12 & 23,05 & 16,78 & 12,52 & 9,71 & 6,58 & 5,02 & 3,47 \\
\hline 20 & 1650 & 115 & 37,36 & 28,99 & 23,00 & 16,79 & 12,54 & 9,73 & 6,59 & 5,02 & 3,47 \\
\hline 20 & 1700 & 115 & 37,06 & 28,85 & 22,95 & 16,79 & 12,56 & 9,75 & 6,59 & 5,03 & 3,47 \\
\hline 20 & 1750 & 115 & 36,77 & 28,72 & 22,89 & 16,79 & 12,58 & 9,77 & 6,60 & 5,03 & 3,47 \\
\hline 20 & 1800 & 115 & 36,48 & 28,59 & 22,84 & 16,79 & 12,60 & 9,79 & 6,61 & 5,03 & 3,47 \\
\hline 20 & 1850 & 115 & 36,21 & 28,46 & 22,79 & 16,80 & 12,62 & 9,80 & 6,62 & 5,03 & 3,47 \\
\hline 20 & 1900 & 115 & 35,95 & 28,34 & 22,74 & 16,80 & 12,63 & 9,82 & 6,63 & 5,03 & 3,47 \\
\hline 20 & 1950 & 115 & 35,69 & 28,22 & 22,69 & 16,79 & 12,65 & 9,84 & 6,63 & 5,03 & 3,47 \\
\hline 20 & 2000 & 115 & 35,45 & 28,10 & 22,64 & 16,79 & 12,66 & 9,85 & 6,64 & 5,04 & 3,47 \\
\hline 20 & 200 & 120 & 61,93 & 32,88 & 22,09 & 14,71 & 10,96 & 8,72 & 6,15 & 4,79 & 3,39 \\
\hline 20 & 250 & 120 & 58,37 & 32,76 & 22,31 & 14,85 & 11,00 & 8,73 & 6,15 & 4,80 & 3,37 \\
\hline 20 & 300 & 120 & 55,71 & 32,60 & 22,47 & 14,97 & 11,05 & 8,74 & 6,16 & 4,80 & 3,37 \\
\hline 20 & 350 & 120 & 53,60 & 32,42 & 22,59 & 15,08 & 11,10 & 8,76 & 6,17 & 4,80 & 3,36 \\
\hline 20 & 400 & 120 & 51,86 & 32,22 & 22,67 & 15,19 & 11,15 & 8,78 & 6,17 & 4,80 & 3,36 \\
\hline 20 & 450 & 120 & 50,37 & 32,02 & 22,73 & 15,28 & 11,20 & 8,79 & 6,17 & 4,80 & 3,35 \\
\hline 20 & 500 & 120 & 49,09 & 31,81 & 22,77 & 15,36 & 11,24 & 8,82 & 6,18 & 4,80 & 3,35 \\
\hline 20 & 550 & 120 & 47,95 & 31,61 & 22,79 & 15,44 & 11,29 & 8,84 & 6,18 & 4,80 & 3,35 \\
\hline 20 & 600 & 120 & 46,93 & 31,40 & 22,81 & 15,50 & 11,34 & 8,86 & 6,18 & 4,80 & 3,35 \\
\hline 20 & 650 & 120 & 46,01 & 31,20 & 22,81 & 15,57 & 11,38 & 8,88 & 6,19 & 4,80 & 3,35 \\
\hline 20 & 700 & 120 & 45,17 & 31,00 & 22,81 & 15,62 & 11,43 & 8,90 & 6,19 & 4,80 & 3,34 \\
\hline 20 & 750 & 120 & 44,40 & 30,81 & 22,79 & 15,67 & 11,47 & 8,93 & 6,20 & 4,80 & 3,34 \\
\hline 20 & 800 & 120 & 43,69 & 30,62 & 22,78 & 15,72 & 11,51 & 8,95 & 6,20 & 4,80 & 3,34 \\
\hline 20 & 850 & 120 & 43,03 & 30,43 & 22,75 & 15,76 & 11,55 & 8,97 & 6,21 & 4,80 & 3,34 \\
\hline 20 & 900 & 120 & 42,41 & 30,25 & 22,73 & 15,80 & 11,58 & 8,99 & 6,21 & 4,80 & 3,34 \\
\hline 20 & 950 & 120 & 41,84 & 30,07 & 22,70 & 15,84 & 11,62 & 9,02 & 6,22 & 4,80 & 3,34 \\
\hline 20 & 1000 & 120 & 41,29 & 29,90 & 22,66 & 15,87 & 11,65 & 9,04 & 6,22 & 4,80 & 3,34 \\
\hline 20 & 1050 & 120 & 40,78 & 29,73 & 22,63 & 15,90 & 11,69 & 9,06 & 6,23 & 4,80 & 3,34 \\
\hline 20 & 1100 & 120 & 40,29 & 29,56 & 22,59 & 15,92 & 11,72 & 9,08 & 6,23 & 4,80 & 3,34 \\
\hline 20 & 1150 & 120 & 39,83 & 29,40 & 22,55 & 15,95 & 11,75 & 9,10 & 6,24 & 4,80 & 3,34 \\
\hline 20 & 1200 & 120 & 39,39 & 29,24 & 22,51 & 15,97 & 11,78 & 9,12 & 6,24 & 4,80 & 3,33 \\
\hline 20 & 1250 & 120 & 38,98 & 29,09 & 22,47 & 15,99 & 11,81 & 9,15 & 6,25 & 4,81 & 3,33 \\
\hline 20 & 1300 & 120 & 38,58 & 28,93 & 22,42 & 16,01 & 11,83 & 9,17 & 6,26 & 4,81 & 3,33 \\
\hline 20 & 1350 & 120 & 38,20 & 28,79 & 22,38 & 16,02 & 11,86 & 9,19 & 6,26 & 4,81 & 3,33 \\
\hline 20 & 1400 & 120 & 37,83 & 28,64 & 22,34 & 16,03 & 11,88 & 9,21 & 6,27 & 4,81 & 3,33 \\
\hline 20 & 1450 & 120 & 37,48 & 28,50 & 22,29 & 16,05 & 11,91 & 9,23 & 6,28 & 4,81 & 3,33 \\
\hline 20 & 1500 & 120 & 37,15 & 28,36 & 22,24 & 16,06 & 11,93 & 9,24 & 6,28 & 4,81 & 3,33 \\
\hline 20 & 1550 & 120 & 36,82 & 28,22 & 22,20 & 16,06 & 11,95 & 9,26 & 6,29 & 4,81 & 3,33 \\
\hline 20 & 1600 & 120 & 36,51 & 28,09 & 22,15 & 16,07 & 11,97 & 9,28 & 6,30 & 4,81 & 3,33 \\
\hline 20 & 1650 & 120 & 36,21 & 27,96 & 22,11 & 16,08 & 11,99 & 9,30 & 6,30 & 4,81 & 3,33 \\
\hline 20 & 1700 & 120 & 35,92 & 27,83 & 22,06 & 16,08 & 12,01 & 9,32 & 6,31 & 4,81 & 3,33 \\
\hline 20 & 1750 & 120 & 35,64 & 27,71 & 22,01 & 16,09 & 12,03 & 9,33 & 6,32 & 4,82 & 3,33 \\
\hline 20 & 1800 & 120 & 35,37 & 27,59 & 21,96 & 16,09 & 12,05 & 9,35 & 6,32 & 4,82 & 3,33 \\
\hline 20 & 1850 & 120 & 35,11 & 27,47 & 21,92 & 16,09 & 12,06 & 9,37 & 6,33 & 4,82 & 3,33 \\
\hline 20 & 1900 & 120 & 34,86 & 27,35 & 21,87 & 16,09 & 12,08 & 9,38 & 6,34 & 4,82 & 3,33 \\
\hline 20 & 1950 & 120 & 34,61 & 27,23 & 21,82 & 16,10 & 12,10 & 9,40 & 6,34 & 4,82 & 3,33 \\
\hline 20 & 2000 & 120 & 34,37 & 27,12 & 21,78 & 16,10 & 12,11 & 9,42 & 6,35 & 4,82 & 3,33 \\
\hline 20 & 200 & 125 & 60,12 & 31,57 & 21,17 & 14,09 & 10,51 & 8,37 & 5,90 & 4,60 & 3,25 \\
\hline 20 & 250 & 125 & 56,63 & 31,48 & 21,38 & 14,23 & 10,55 & 8,38 & 5,91 & 4,61 & 3,24 \\
\hline 20 & 300 & 125 & 54,03 & 31,34 & 21,54 & 14,35 & 10,60 & 8,39 & 5,91 & 4,61 & 3,23 \\
\hline 20 & 350 & 125 & 51,98 & 31,17 & 21,65 & 14,45 & 10,64 & 8,40 & 5,92 & 4,61 & 3,23 \\
\hline 20 & 400 & 125 & 50,29 & 30,99 & 21,74 & 14,55 & 10,69 & 8,42 & 5,92 & 4,61 & 3,22 \\
\hline 20 & 450 & 125 & 48,85 & 30,81 & 21,80 & 14,64 & 10,73 & 8,44 & 5,93 & 4,61 & 3,22 \\
\hline 20 & 500 & 125 & 47,60 & 30,62 & 21,84 & 14,72 & 10,78 & 8,45 & 5,93 & 4,61 & 3,22 \\
\hline 20 & 550 & 125 & 46,50 & 30,43 & 21,87 & 14,79 & 10,82 & 8,47 & 5,93 & 4,61 & 3,22 \\
\hline 20 & 600 & 125 & 45,51 & 30,24 & 21,89 & 14,85 & 10,86 & 8,49 & 5,94 & 4,61 & 3,21 \\
\hline 20 & 650 & 125 & 44,62 & 30,05 & 21,90 & 14,91 & 10,90 & 8,51 & 5,94 & 4,61 & 3,21 \\
\hline 20 & 700 & 125 & 43,81 & 29,87 & 21,90 & 14,97 & 10,95 & 8,53 & 5,94 & 4,61 & 3,21 \\
\hline 20 & 750 & 125 & 43,06 & 29,69 & 21,89 & 15,02 & 10,98 & 8,56 & 5,95 & 4,61 & 3,21 \\
\hline 20 & 800 & 125 & 42,38 & 29,51 & 21,88 & 15,06 & 11,02 & 8,58 & 5,95 & 4,61 & 3,21 \\
\hline 20 & 850 & 125 & 41,74 & 29,34 & 21,86 & 15,11 & 11,06 & 8,60 & 5,95 & 4,61 & 3,21 \\
\hline 20 & 900 & 125 & 41,14 & 29,17 & 21,84 & 15,14 & 11,09 & 8,62 & 5,96 & 4,61 & 3,21 \\
\hline 20 & 950 & 125 & 40,58 & 29,00 & 21,81 & 15,18 & 11,13 & 8,64 & 5,96 & 4,61 & 3,21 \\
\hline 20 & 1000 & 125 & 40,05 & 28,84 & 21,78 & 15,21 & 11,16 & 8,66 & 5,97 & 4,61 & 3,20 \\
\hline 20 & 1050 & 125 & 39,56 & 28,68 & 21,75 & 15,24 & 11,19 & 8,68 & 5,97 & 4,61 & 3,20 \\
\hline 20 & 1100 & 125 & 39,09 & 28,52 & 21,72 & 15,27 & 11,22 & 8,70 & 5,98 & 4,61 & 3,20 \\
\hline 20 & 1150 & 125 & 38,64 & 28,37 & 21,68 & 15,29 & 11,25 & 8,72 & 5,98 & 4,61 & 3,20 \\
\hline 20 & 1200 & 125 & 38,22 & 28,22 & 21,65 & 15,31 & 11,28 & 8,74 & 5,99 & 4,61 & 3,20 \\
\hline 20 & 1250 & 125 & 37,82 & 28,07 & 21,61 & 15,33 & 11,31 & 8,76 & 5,99 & 4,61 & 3,20 \\
\hline 20 & 1300 & 125 & 37,43 & 27,93 & 21,57 & 15,35 & 11,33 & 8,78 & 6,00 & 4,61 & 3,20 \\
\hline 20 & 1350 & 125 & 37,07 & 27,79 & 21,53 & 15,36 & 11,36 & 8,80 & 6,01 & 4,61 & 3,20 \\
\hline 20 & 1400 & 125 & 36,71 & 27,65 & 21,49 & 15,38 & 11,38 & 8,82 & 6,01 & 4,61 & 3,20 \\
\hline 20 & 1450 & 125 & 36,38 & 27,52 & 21,45 & 15,39 & 11,40 & 8,84 & 6,02 & 4,62 & 3,20 \\
\hline 20 & 1500 & 125 & 36,05 & 27,39 & 21,41 & 15,40 & 11,43 & 8,85 & 6,02 & 4,62 & 3,20 \\
\hline 20 & 1550 & 125 & 35,74 & 27,26 & 21,37 & 15,41 & 11,45 & 8,87 & 6,03 & 4,62 & 3,20 \\
\hline 20 & 1600 & 125 & 35,44 & 27,13 & 21,32 & 15,42 & 11,47 & 8,89 & 6,04 & 4,62 & 3,20 \\
\hline 20 & 1650 & 125 & 35,15 & 27,01 & 21,28 & 15,43 & 11,49 & 8,91 & 6,04 & 4,62 & 3,20 \\
\hline 20 & 1700 & 125 & 34,87 & 26,89 & 21,24 & 15,43 & 11,51 & 8,92 & 6,05 & 4,62 & 3,20 \\
\hline 20 & 1750 & 125 & 34,60 & 26,77 & 21,19 & 15,44 & 11,52 & 8,94 & 6,05 & 4,62 & 3,20 \\
\hline 20 & 1800 & 125 & 34,33 & 26,65 & 21,15 & 15,44 & 11,54 & 8,95 & 6,06 & 4,62 & 3,20 \\
\hline
\end{tabular}




\begin{tabular}{|c|c|c|c|c|c|c|c|c|c|c|c|}
\hline \multirow[b]{2}{*}{$\mathrm{H}(\mathrm{cm})$} & \multirow[b]{2}{*}{ Mceq (MPa) } & & & & & $\mathrm{De}$ & ões (x1 & & & & \\
\hline & & Msub (MPa) & D0 & D25 & D40 & D60 & D80 & D100 & D140 & D180 & D260 \\
\hline 20 & 1850 & 125 & 34,08 & 26,54 & 21,11 & 15,45 & 11,56 & 8,97 & 6,07 & 4,62 & 3,20 \\
\hline 20 & 1900 & 125 & 33,83 & 26,43 & 21,06 & 15,45 & 11,57 & 8,99 & 6,07 & 4,63 & 3,19 \\
\hline 20 & 1950 & 125 & 33,60 & 26,32 & 21,02 & 15,45 & 11,59 & 9,00 & 6,08 & 4,63 & 3,19 \\
\hline 20 & 2000 & 125 & 33,37 & 26,21 & 20,98 & 15,45 & 11,60 & 9,02 & 6,09 & 4,63 & 3,19 \\
\hline 20 & 200 & 130 & 58,44 & 30,37 & 20,31 & 13,53 & 10,10 & 8,05 & 5,67 & 4,42 & 3,13 \\
\hline 20 & 250 & 130 & 55,02 & 30,29 & 20,53 & 13,66 & 10,14 & 8,05 & 5,68 & 4,43 & 3,12 \\
\hline 20 & 300 & 130 & 52,48 & 30,17 & 20,68 & 13,77 & 10,18 & 8,06 & 5,68 & 4,43 & 3,11 \\
\hline 20 & 350 & 130 & 50,47 & 30,02 & 20,80 & 13,87 & 10,22 & 8,08 & 5,69 & 4,43 & 3,11 \\
\hline 20 & 400 & 130 & 48,82 & 29,86 & 20,88 & 13,96 & 10,26 & 8,09 & 5,69 & 4,43 & 3,10 \\
\hline 20 & 450 & 130 & 47,42 & 29,69 & 20,94 & 14,04 & 10,30 & 8,11 & 5,70 & 4,43 & 3,10 \\
\hline 20 & 500 & 130 & 46,21 & 29,51 & 20,99 & 14,12 & 10,35 & 8,12 & 5,70 & 4,43 & 3,10 \\
\hline 20 & 550 & 130 & 45,14 & 29,34 & 21,02 & 14,19 & 10,39 & 8,14 & 5,70 & 4,43 & 3,09 \\
\hline 20 & 600 & 130 & 44,19 & 29,16 & 21,04 & 14,25 & 10,43 & 8,16 & 5,71 & 4,43 & 3,09 \\
\hline 20 & 650 & 130 & 43,32 & 28,99 & 21,05 & 14,31 & 10,47 & 8,18 & 5,71 & 4,43 & 3,09 \\
\hline 20 & 700 & 130 & 42,54 & 28,82 & 21,06 & 14,37 & 10,50 & 8,20 & 5,71 & 4,43 & 3,09 \\
\hline 20 & 750 & 130 & 41,81 & 28,65 & 21,05 & 14,41 & 10,54 & 8,21 & 5,72 & 4,43 & 3,09 \\
\hline 20 & 800 & 130 & 41,15 & 28,48 & 21,04 & 14,46 & 10,58 & 8,23 & 5,72 & 4,43 & 3,09 \\
\hline 20 & 850 & 130 & 40,53 & 28,32 & 21,03 & 14,50 & 10,61 & 8,25 & 5,72 & 4,43 & 3,09 \\
\hline 20 & 900 & 130 & 39,95 & 28,16 & 21,01 & 14,54 & 10,64 & 8,27 & 5,73 & 4,43 & 3,08 \\
\hline 20 & 950 & 130 & 39,41 & 28,00 & 20,99 & 14,57 & 10,68 & 8,29 & 5,73 & 4,43 & 3,08 \\
\hline 20 & 1000 & 130 & 38,90 & 27,85 & 20,97 & 14,60 & 10,71 & 8,31 & 5,73 & 4,43 & 3,08 \\
\hline 20 & 1050 & 130 & 38,42 & 27,70 & 20,94 & 14,63 & 10,74 & 8,33 & 5,74 & 4,43 & 3,08 \\
\hline 20 & 1100 & 130 & 37,97 & 27,55 & 20,91 & 14,66 & 10,77 & 8,35 & 5,74 & 4,43 & 3,08 \\
\hline 20 & 1150 & 130 & 37,54 & 27,41 & 20,88 & 14,68 & 10,79 & 8,37 & 5,75 & 4,43 & 3,08 \\
\hline 20 & 1200 & 130 & 37,13 & 27,26 & 20,85 & 14,70 & 10,82 & 8,39 & 5,75 & 4,43 & 3,08 \\
\hline 20 & 1250 & 130 & 36,74 & 27,13 & 20,81 & 14,72 & 10,85 & 8,40 & 5,76 & 4,43 & 3,08 \\
\hline 20 & 1300 & 130 & 36,36 & 26,99 & 20,78 & 14,74 & 10,87 & 8,42 & 5,76 & 4,43 & 3,08 \\
\hline 20 & 1350 & 130 & 36,01 & 26,86 & 20,74 & 14,76 & 10,90 & 8,44 & 5,77 & 4,44 & 3,08 \\
\hline 20 & 1400 & 130 & 35,67 & 26,73 & 20,71 & 14,77 & 10,92 & 8,46 & 5,77 & 4,44 & 3,08 \\
\hline 20 & 1450 & 130 & 35,34 & 26,60 & 20,67 & 14,78 & 10,94 & 8,48 & 5,78 & 4,44 & 3,08 \\
\hline 20 & 1500 & 130 & 35,03 & 26,48 & 20,63 & 14,80 & 10,96 & 8,49 & 5,78 & 4,44 & 3,08 \\
\hline 20 & 1550 & 130 & 34,72 & 26,36 & 20,59 & 14,81 & 10,98 & 8,51 & 5,79 & 4,44 & 3,08 \\
\hline 20 & 1600 & 130 & 34,43 & 26,24 & 20,55 & 14,82 & 11,00 & 8,53 & 5,80 & 4,44 & 3,07 \\
\hline 20 & 1650 & 130 & 34,15 & 26,12 & 20,51 & 14,82 & 11,02 & 8,54 & 5,80 & 4,44 & 3,07 \\
\hline 20 & 1700 & 130 & 33,88 & 26,01 & 20,47 & 14,83 & 11,04 & 8,56 & 5,81 & 4,44 & 3,07 \\
\hline 20 & 1750 & 130 & 33,62 & 25,89 & 20,43 & 14,84 & 11,06 & 8,57 & 5,81 & 4,44 & 3,07 \\
\hline 20 & 1800 & 130 & 33,36 & 25,78 & 20,39 & 14,84 & 11,07 & 8,59 & 5,82 & 4,44 & 3,07 \\
\hline 20 & 1850 & 130 & 33,12 & 25,68 & 20,35 & 14,85 & 11,09 & 8,60 & 5,83 & 4,44 & 3,07 \\
\hline 20 & 1900 & 130 & 32,88 & 25,57 & 20,31 & 14,85 & 11,11 & 8,62 & 5,83 & 4,45 & 3,07 \\
\hline 20 & 1950 & 130 & 32,65 & 25,46 & 20,27 & 14,85 & 11,12 & 8,63 & 5,84 & 4,45 & 3,07 \\
\hline 20 & 2000 & 130 & 32,43 & 25,36 & 20,23 & 14,86 & 11,14 & 8,65 & 5,84 & 4,45 & 3,07 \\
\hline 20 & 200 & 135 & 56,88 & 29,25 & 19,52 & 13,01 & 9,72 & 7,75 & 5,46 & 4,26 & 3,01 \\
\hline 20 & 250 & 135 & 53,51 & 29,19 & 19,73 & 13,13 & 9,76 & 7,75 & 5,47 & 4,26 & 3,00 \\
\hline 20 & 300 & 135 & 51,02 & 29,08 & 19,89 & 13,24 & 9,79 & 7,76 & 5,47 & 4,27 & 3,00 \\
\hline 20 & 350 & 135 & 49,07 & 28,95 & 20,00 & 13,33 & 9,83 & 7,77 & 5,48 & 4,27 & 2,99 \\
\hline 20 & 400 & 135 & 47,46 & 28,80 & 20,09 & 13,42 & 9,87 & 7,79 & 5,48 & 4,27 & 2,99 \\
\hline 20 & 450 & 135 & 46,09 & 28,64 & 20,15 & 13,50 & 9,91 & 7,80 & 5,48 & 4,27 & 2,98 \\
\hline 20 & 500 & 135 & 44,91 & 28,48 & 20,20 & 13,57 & 9,95 & 7,82 & 5,49 & 4,27 & 2,98 \\
\hline 20 & 550 & 135 & 43,87 & 28,32 & 20,23 & 13,64 & 9,99 & 7,83 & 5,49 & 4,27 & 2,98 \\
\hline 20 & 600 & 135 & 42,95 & 28,16 & 20,26 & 13,70 & 10,02 & 7,85 & 5,49 & 4,27 & 2,98 \\
\hline 20 & 650 & 135 & 42,11 & 28,00 & 20,27 & 13,76 & 10,06 & 7,86 & 5,50 & 4,27 & 2,98 \\
\hline 20 & 700 & 135 & 41,35 & 27,84 & 20,28 & 13,81 & 10,10 & 7,88 & 5,50 & 4,27 & 2,98 \\
\hline 20 & 750 & 135 & 40,65 & 27,68 & 20,28 & 13,85 & 10,13 & 7,90 & 5,50 & 4,27 & 2,97 \\
\hline 20 & 800 & 135 & 40,00 & 27,52 & 20,27 & 13,90 & 10,16 & 7,92 & 5,50 & 4,27 & 2,97 \\
\hline 20 & 850 & 135 & 39,40 & 27,37 & 20,26 & 13,94 & 10,20 & 7,94 & 5,51 & 4,27 & 2,97 \\
\hline 20 & 900 & 135 & 38,84 & 27,22 & 20,24 & 13,97 & 10,23 & 7,95 & 5,51 & 4,27 & 2,97 \\
\hline 20 & 950 & 135 & 38,31 & 27,07 & 20,23 & 14,01 & 10,26 & 7,97 & 5,52 & 4,27 & 2,97 \\
\hline 20 & 1000 & 135 & 37,82 & 26,93 & 20,21 & 14,04 & 10,29 & 7,99 & 5,52 & 4,27 & 2,97 \\
\hline 20 & 1050 & 135 & 37,35 & 26,78 & 20,18 & 14,07 & 10,32 & 8,01 & 5,52 & 4,27 & 2,97 \\
\hline 20 & 1100 & 135 & 36,91 & 26,64 & 20,16 & 14,09 & 10,34 & 8,03 & 5,53 & 4,27 & 2,97 \\
\hline 20 & 1150 & 135 & 36,50 & 26,51 & 20,13 & 14,12 & 10,37 & 8,04 & 5,53 & 4,27 & 2,97 \\
\hline 20 & 1200 & 135 & 36,10 & 26,38 & 20,10 & 14,14 & 10,40 & 8,06 & 5,54 & 4,27 & 2,97 \\
\hline 20 & 1250 & 135 & 35,72 & 26,24 & 20,07 & 14,16 & 10,42 & 8,08 & 5,54 & 4,27 & 2,97 \\
\hline 20 & 1300 & 135 & 35,36 & 26,12 & 20,04 & 14,18 & 10,45 & 8,09 & 5,55 & 4,27 & 2,96 \\
\hline 20 & 1350 & 135 & 35,02 & 25,99 & 20,01 & 14,19 & 10,47 & 8,11 & 5,55 & 4,27 & 2,96 \\
\hline 20 & 1400 & 135 & 34,69 & 25,87 & 19,98 & 14,21 & 10,49 & 8,13 & 5,55 & 4,27 & 2,96 \\
\hline 20 & 1450 & 135 & 34,37 & 25,75 & 19,94 & 14,22 & 10,51 & 8,14 & 5,56 & 4,27 & 2,96 \\
\hline 20 & 1500 & 135 & 34,07 & 25,63 & 19,91 & 14,24 & 10,53 & 8,16 & 5,56 & 4,27 & 2,96 \\
\hline 20 & 1550 & 135 & 33,77 & 25,52 & 19,87 & 14,25 & 10,55 & 8,18 & 5,57 & 4,27 & 2,96 \\
\hline 20 & 1600 & 135 & 33,49 & 25,40 & 19,84 & 14,26 & 10,57 & 8,19 & 5,57 & 4,27 & 2,96 \\
\hline 20 & 1650 & 135 & 33,22 & 25,29 & 19,80 & 14,27 & 10,59 & 8,21 & 5,58 & 4,27 & 2,96 \\
\hline 20 & 1700 & 135 & 32,96 & 25,18 & 19,76 & 14,27 & 10,61 & 8,22 & 5,59 & 4,28 & 2,96 \\
\hline 20 & 1750 & 135 & 32,70 & 25,08 & 19,73 & 14,28 & 10,63 & 8,24 & 5,59 & 4,28 & 2,96 \\
\hline 20 & 1800 & 135 & 32,46 & 24,97 & 19,69 & 14,29 & 10,64 & 8,25 & 5,60 & 4,28 & 2,96 \\
\hline 20 & 1850 & 135 & 32,22 & 24,87 & 19,65 & 14,29 & 10,66 & 8,26 & 5,60 & 4,28 & 2,96 \\
\hline 20 & 1900 & 135 & 31,99 & 24,77 & 19,62 & 14,30 & 10,67 & 8,28 & 5,61 & 4,28 & 2,96 \\
\hline 20 & 1950 & 135 & 31,76 & 24,67 & 19,58 & 14,30 & 10,69 & 8,29 & 5,61 & 4,28 & 2,96 \\
\hline 20 & 2000 & 135 & 31,55 & 24,57 & 19,54 & 14,30 & 10,70 & 8,31 & 5,62 & 4,28 & 2,96 \\
\hline 20 & 200 & 140 & 55,41 & 28,21 & 18,79 & 12,53 & 9,37 & 7,47 & 5,26 & 4,11 & 2,91 \\
\hline 20 & 250 & 140 & 52,10 & 28,16 & 19,00 & 12,64 & 9,40 & 7,48 & 5,27 & 4,11 & 2,90 \\
\hline 20 & 300 & 140 & 49,66 & 28,06 & 19,15 & 12,74 & 9,44 & 7,48 & 5,28 & 4,11 & 2,89 \\
\hline
\end{tabular}




\begin{tabular}{|c|c|c|c|c|c|c|c|c|c|c|c|}
\hline \multirow[b]{2}{*}{$\mathrm{H}(\mathrm{cm})$} & \multirow[b]{2}{*}{ Mceq (MPa) } & & & & & $\mathrm{De}$ & ões (x1 & & & & \\
\hline & & Msub (MPa) & D0 & D25 & D40 & D60 & D80 & D100 & D140 & D180 & D260 \\
\hline 20 & 350 & 140 & 47,75 & 27,94 & 19,26 & 12,83 & 9,47 & 7,49 & 5,28 & 4,11 & 2,89 \\
\hline 20 & 400 & 140 & 46,18 & 27,81 & 19,35 & 12,92 & 9,51 & 7,51 & 5,28 & 4,11 & 2,88 \\
\hline 20 & 450 & 140 & 44,85 & 27,67 & 19,41 & 12,99 & 9,54 & 7,52 & 5,29 & 4,12 & 2,88 \\
\hline 20 & 500 & 140 & 43,70 & 27,52 & 19,46 & 13,06 & 9,58 & 7,53 & 5,29 & 4,12 & 2,88 \\
\hline 20 & 550 & 140 & 42,69 & 27,37 & 19,50 & 13,13 & 9,61 & 7,55 & 5,29 & 4,12 & 2,87 \\
\hline 20 & 600 & 140 & 41,78 & 27,22 & 19,52 & 13,19 & 9,65 & 7,56 & 5,30 & 4,12 & 2,87 \\
\hline 20 & 650 & 140 & 40,97 & 27,07 & 19,54 & 13,24 & 9,68 & 7,58 & 5,30 & 4,12 & 2,87 \\
\hline 20 & 700 & 140 & 40,23 & 26,92 & 19,55 & 13,29 & 9,72 & 7,59 & 5,30 & 4,12 & 2,87 \\
\hline 20 & 750 & 140 & 39,55 & 26,77 & 19,55 & 13,34 & 9,75 & 7,61 & 5,30 & 4,12 & 2,87 \\
\hline 20 & 800 & 140 & 38,92 & 26,62 & 19,55 & 13,38 & 9,78 & 7,63 & 5,31 & 4,12 & 2,87 \\
\hline 20 & 850 & 140 & 38,34 & 26,48 & 19,54 & 13,42 & 9,81 & 7,64 & 5,31 & 4,12 & 2,87 \\
\hline 20 & 900 & 140 & 37,79 & 26,34 & 19,53 & 13,45 & 9,84 & 7,66 & 5,31 & 4,12 & 2,87 \\
\hline 20 & 950 & 140 & 37,28 & 26,20 & 19,52 & 13,49 & 9,87 & 7,68 & 5,32 & 4,12 & 2,86 \\
\hline 20 & 1000 & 140 & 36,81 & 26,06 & 19,50 & 13,52 & 9,90 & 7,69 & 5,32 & 4,12 & 2,86 \\
\hline 20 & 1050 & 140 & 36,35 & 25,93 & 19,48 & 13,55 & 9,93 & 7,71 & 5,32 & 4,12 & 2,86 \\
\hline 20 & 1100 & 140 & 35,93 & 25,80 & 19,46 & 13,57 & 9,95 & 7,73 & 5,33 & 4,12 & 2,86 \\
\hline 20 & 1150 & 140 & 35,52 & 25,67 & 19,43 & 13,60 & 9,98 & 7,74 & 5,33 & 4,12 & 2,86 \\
\hline 20 & 1200 & 140 & 35,14 & 25,54 & 19,41 & 13,62 & 10,00 & 7,76 & 5,33 & 4,12 & 2,86 \\
\hline 20 & 1250 & 140 & 34,77 & 25,42 & 19,38 & 13,64 & 10,03 & 7,77 & 5,34 & 4,12 & 2,86 \\
\hline 20 & 1300 & 140 & 34,42 & 25,30 & 19,35 & 13,66 & 10,05 & 7,79 & 5,34 & 4,12 & 2,86 \\
\hline 20 & 1350 & 140 & 34,09 & 25,18 & 19,32 & 13,67 & 10,07 & 7,81 & 5,35 & 4,12 & 2,86 \\
\hline 20 & 1400 & 140 & 33,77 & 25,06 & 19,29 & 13,69 & 10,10 & 7,82 & 5,35 & 4,12 & 2,86 \\
\hline 20 & 1450 & 140 & 33,46 & 24,95 & 19,26 & 13,70 & 10,12 & 7,84 & 5,36 & 4,12 & 2,86 \\
\hline 20 & 1500 & 140 & 33,16 & 24,84 & 19,23 & 13,71 & 10,14 & 7,85 & 5,36 & 4,12 & 2,86 \\
\hline 20 & 1550 & 140 & 32,88 & 24,73 & 19,20 & 13,73 & 10,15 & 7,87 & 5,37 & 4,12 & 2,86 \\
\hline 20 & 1600 & 140 & 32,61 & 24,62 & 19,17 & 13,74 & 10,17 & 7,88 & 5,37 & 4,12 & 2,86 \\
\hline 20 & 1650 & 140 & 32,34 & 24,51 & 19,13 & 13,75 & 10,19 & 7,90 & 5,37 & 4,12 & 2,86 \\
\hline 20 & 1700 & 140 & 32,09 & 24,41 & 19,10 & 13,75 & 10,21 & 7,91 & 5,38 & 4,12 & 2,86 \\
\hline 20 & 1750 & 140 & 31,84 & 24,31 & 19,07 & 13,76 & 10,23 & 7,92 & 5,38 & 4,12 & 2,86 \\
\hline 20 & 1800 & 140 & 31,60 & 24,21 & 19,03 & 13,77 & 10,24 & 7,94 & 5,39 & 4,12 & 2,85 \\
\hline 20 & 1850 & 140 & 31,37 & 24,11 & 19,00 & 13,77 & 10,26 & 7,95 & 5,39 & 4,12 & 2,85 \\
\hline 20 & 1900 & 140 & 31,15 & 24,01 & 18,96 & 13,78 & 10,27 & 7,96 & 5,40 & 4,12 & 2,85 \\
\hline 20 & 1950 & 140 & 30,93 & 23,92 & 18,93 & 13,78 & 10,29 & 7,98 & 5,40 & 4,13 & 2,85 \\
\hline 20 & 2000 & 140 & 30,72 & 23,83 & 18,90 & 13,79 & 10,30 & 7,99 & 5,41 & 4,13 & 2,85 \\
\hline 20 & 200 & 145 & 54,04 & 27,24 & 18,11 & 12,08 & 9,04 & 7,21 & 5,08 & 3,96 & 2,81 \\
\hline 20 & 250 & 145 & 50,78 & 27,20 & 18,31 & 12,19 & 9,07 & 7,22 & 5,09 & 3,97 & 2,80 \\
\hline 20 & 300 & 145 & 48,39 & 27,12 & 18,46 & 12,28 & 9,10 & 7,22 & 5,09 & 3,97 & 2,79 \\
\hline 20 & 350 & 145 & 46,51 & 27,01 & 18,57 & 12,37 & 9,14 & 7,23 & 5,10 & 3,97 & 2,79 \\
\hline 20 & 400 & 145 & 44,98 & 26,89 & 18,66 & 12,45 & 9,17 & 7,24 & 5,10 & 3,97 & 2,78 \\
\hline 20 & 450 & 145 & 43,68 & 26,76 & 18,73 & 12,52 & 9,20 & 7,25 & 5,10 & 3,97 & 2,78 \\
\hline 20 & 500 & 145 & 42,56 & 26,62 & 18,78 & 12,59 & 9,24 & 7,27 & 5,11 & 3,97 & 2,78 \\
\hline 20 & 550 & 145 & 41,57 & 26,48 & 18,81 & 12,65 & 9,27 & 7,28 & 5,11 & 3,97 & 2,78 \\
\hline 20 & 600 & 145 & 40,69 & 26,34 & 18,84 & 12,71 & 9,30 & 7,29 & 5,11 & 3,97 & 2,77 \\
\hline 20 & 650 & 145 & 39,90 & 26,20 & 18,86 & 12,76 & 9,34 & 7,31 & 5,11 & 3,97 & 2,77 \\
\hline 20 & 700 & 145 & 39,18 & 26,06 & 18,87 & 12,81 & 9,37 & 7,32 & 5,12 & 3,97 & 2,77 \\
\hline 20 & 750 & 145 & 38,52 & 25,92 & 18,88 & 12,85 & 9,40 & 7,34 & 5,12 & 3,97 & 2,77 \\
\hline 20 & 800 & 145 & 37,91 & 25,78 & 18,88 & 12,89 & 9,43 & 7,35 & 5,12 & 3,97 & 2,77 \\
\hline 20 & 850 & 145 & 37,34 & 25,65 & 18,87 & 12,93 & 9,46 & 7,37 & 5,12 & 3,97 & 2,77 \\
\hline 20 & 900 & 145 & 36,81 & 25,51 & 18,86 & 12,97 & 9,49 & 7,38 & 5,13 & 3,97 & 2,77 \\
\hline 20 & 950 & 145 & 36,32 & 25,38 & 18,85 & 13,00 & 9,51 & 7,40 & 5,13 & 3,97 & 2,77 \\
\hline 20 & 1000 & 145 & 35,85 & 25,25 & 18,84 & 13,03 & 9,54 & 7,42 & 5,13 & 3,97 & 2,77 \\
\hline 20 & 1050 & 145 & 35,41 & 25,13 & 18,82 & 13,06 & 9,57 & 7,43 & 5,14 & 3,97 & 2,76 \\
\hline 20 & 1100 & 145 & 35,00 & 25,00 & 18,80 & 13,08 & 9,59 & 7,45 & 5,14 & 3,97 & 2,76 \\
\hline 20 & 1150 & 145 & 34,61 & 24,88 & 18,78 & 13,11 & 9,62 & 7,46 & 5,14 & 3,97 & 2,76 \\
\hline 20 & 1200 & 145 & 34,23 & 24,76 & 18,76 & 13,13 & 9,64 & 7,48 & 5,15 & 3,97 & 2,76 \\
\hline 20 & 1250 & 145 & 33,88 & 24,65 & 18,74 & 13,15 & 9,66 & 7,49 & 5,15 & 3,97 & 2,76 \\
\hline 20 & 1300 & 145 & 33,54 & 24,53 & 18,71 & 13,17 & 9,69 & 7,51 & 5,16 & 3,98 & 2,76 \\
\hline 20 & 1350 & 145 & 33,21 & 24,42 & 18,68 & 13,19 & 9,71 & 7,52 & 5,16 & 3,98 & 2,76 \\
\hline 20 & 1400 & 145 & 32,90 & 24,31 & 18,66 & 13,20 & 9,73 & 7,54 & 5,16 & 3,98 & 2,76 \\
\hline 20 & 1450 & 145 & 32,60 & 24,20 & 18,63 & 13,22 & 9,75 & 7,55 & 5,17 & 3,98 & 2,76 \\
\hline 20 & 1500 & 145 & 32,32 & 24,09 & 18,60 & 13,23 & 9,77 & 7,57 & 5,17 & 3,98 & 2,76 \\
\hline 20 & 1550 & 145 & 32,04 & 23,99 & 18,57 & 13,24 & $\begin{array}{l}9,78 \\
\end{array}$ & 7,58 & 5,18 & 3,98 & 2,76 \\
\hline 20 & 1600 & 145 & 31,77 & 23,89 & 18,54 & 13,25 & 9,80 & 7,59 & 5,18 & 3,98 & 2,76 \\
\hline 20 & 1650 & 145 & 31,52 & 23,79 & 18,51 & 13,26 & 9,82 & 7,61 & 5,18 & 3,98 & 2,76 \\
\hline 20 & 1700 & 145 & 31,27 & 23,69 & 18,48 & 13,27 & 9,84 & 7,62 & 5,19 & 3,98 & 2,76 \\
\hline 20 & 1750 & 145 & 31,03 & 23,59 & 18,45 & 13,28 & 9,85 & 7,63 & 5,19 & 3,98 & 2,76 \\
\hline 20 & 1800 & 145 & 30,80 & 23,49 & 18,42 & 13,29 & 9,87 & 7,65 & 5,20 & 3,98 & 2,76 \\
\hline 20 & 1850 & 145 & 30,58 & 23,40 & 18,39 & 13,29 & 9,88 & 7,66 & 5,20 & 3,98 & 2,76 \\
\hline 20 & 1900 & 145 & 30,36 & 23,31 & 18,35 & 13,30 & 9,90 & 7,67 & 5,21 & 3,98 & 2,76 \\
\hline 20 & 1950 & 145 & 30,15 & 23,22 & 18,32 & 13,30 & 9,91 & 7,69 & 5,21 & 3,98 & 2,76 \\
\hline 20 & 2000 & 145 & 29,94 & 23,13 & 18,29 & 13,31 & 9,93 & 7,70 & 5,22 & 3,98 & 2,76 \\
\hline 20 & 200 & 150 & 52,76 & 26,33 & 17,48 & 11,66 & 8,74 & 6,97 & 4,91 & 3,83 & 2,72 \\
\hline 20 & 250 & 150 & 49,55 & 26,30 & 17,67 & 11,77 & 8,76 & 6,98 & 4,92 & 3,84 & 2,71 \\
\hline 20 & 300 & 150 & 47,19 & 26,23 & 17,82 & 11,86 & 8,79 & 6,98 & 4,92 & 3,84 & 2,70 \\
\hline 20 & 350 & 150 & 45,35 & 26,14 & 17,93 & 11,94 & 8,82 & 6,99 & 4,93 & 3,84 & 2,70 \\
\hline 20 & 400 & 150 & 43,85 & 26,02 & 18,02 & 12,02 & 8,86 & 7,00 & 4,93 & 3,84 & 2,69 \\
\hline 20 & 450 & 150 & 42,58 & 25,90 & 18,08 & 12,08 & 8,89 & 7,01 & 4,93 & 3,84 & 2,69 \\
\hline 20 & 500 & 150 & 41,48 & 25,78 & 18,14 & 12,15 & 8,92 & 7,02 & 4,94 & 3,84 & 2,69 \\
\hline 20 & 550 & 150 & 40,52 & 25,65 & 18,17 & 12,21 & 8,95 & 7,03 & 4,94 & 3,84 & 2,68 \\
\hline 20 & 600 & 150 & 39,67 & 25,52 & 18,20 & 12,26 & 8,98 & 7,05 & 4,94 & 3,84 & 2,68 \\
\hline 20 & 650 & 150 & 38,89 & 25,39 & 18,22 & 12,31 & 9,01 & 7,06 & 4,94 & 3,84 & 2,68 \\
\hline
\end{tabular}




\begin{tabular}{|c|c|c|c|c|c|c|c|c|c|c|c|}
\hline \multirow[b]{2}{*}{$\mathrm{H}(\mathrm{cm})$} & \multirow[b]{2}{*}{ Mceq (MPa) } & & & & & $\mathrm{De}$ & ões (x. & & & & \\
\hline & & Msub (MPa) & D0 & D25 & D40 & D60 & D80 & D100 & D140 & D180 & D260 \\
\hline 20 & 700 & 150 & 38,19 & 25,25 & 18,24 & 12,36 & 9,04 & 7,07 & 4,95 & 3,84 & 2,68 \\
\hline 20 & 750 & 150 & 37,55 & 25,12 & 18,25 & 12,40 & 9,07 & 7,09 & 4,95 & 3,84 & 2,68 \\
\hline 20 & 800 & 150 & 36,95 & 24,99 & 18,25 & 12,44 & 9,10 & 7,10 & 4,95 & 3,84 & 2,68 \\
\hline 20 & 850 & 150 & 36,40 & 24,87 & 18,25 & 12,48 & 9,13 & 7,11 & 4,95 & 3,84 & 2,68 \\
\hline 20 & 900 & 150 & 35,89 & 24,74 & 18,24 & 12,52 & 9,15 & 7,13 & 4,95 & 3,84 & 2,68 \\
\hline 20 & 950 & 150 & 35,41 & 24,62 & 18,23 & 12,55 & 9,18 & 7,14 & 4,96 & 3,84 & 2,67 \\
\hline 20 & 1000 & 150 & 34,95 & 24,50 & 18,22 & 12,58 & 9,21 & 7,16 & 4,96 & 3,84 & 2,67 \\
\hline 20 & 1050 & 150 & 34,53 & 24,38 & 18,21 & 12,60 & 9,23 & 7,17 & 4,96 & 3,84 & 2,67 \\
\hline 20 & 1100 & 150 & 34,12 & 24,26 & 18,19 & 12,63 & 9,25 & 7,19 & 4,97 & 3,84 & 2,67 \\
\hline 20 & 1150 & 150 & 33,74 & 24,14 & 18,17 & 12,65 & 9,28 & 7,20 & 4,97 & 3,84 & 2,67 \\
\hline 20 & 1200 & 150 & 33,38 & 24,03 & 18,15 & 12,68 & 9,30 & 7,22 & 4,97 & 3,84 & 2,67 \\
\hline 20 & 1250 & 150 & 33,03 & 23,92 & 18,13 & 12,70 & 9,32 & 7,23 & 4,98 & 3,84 & 2,67 \\
\hline 20 & 1300 & 150 & 32,70 & 23,81 & 18,11 & 12,71 & 9,34 & 7,24 & 4,98 & 3,84 & 2,67 \\
\hline 20 & 1350 & 150 & 32,39 & 23,70 & 18,08 & 12,73 & 9,36 & 7,26 & 4,98 & 3,84 & 2,67 \\
\hline 20 & 1400 & 150 & 32,08 & 23,60 & 18,06 & 12,75 & 9,38 & 7,27 & 4,99 & 3,84 & 2,67 \\
\hline 20 & 1450 & 150 & 31,79 & 23,49 & 18,03 & 12,76 & 9,40 & 7,29 & 4,99 & 3,84 & 2,67 \\
\hline 20 & 1500 & 150 & 31,52 & 23,39 & 18,01 & 12,78 & 9,42 & 7,30 & 4,99 & 3,84 & 2,67 \\
\hline 20 & 1550 & 150 & 31,25 & 23,29 & 17,98 & 12,79 & 9,44 & 7,31 & 5,00 & 3,84 & 2,67 \\
\hline 20 & 1600 & 150 & 30,99 & 23,20 & 17,95 & 12,80 & 9,46 & 7,33 & 5,00 & 3,84 & 2,67 \\
\hline 20 & 1650 & 150 & 30,74 & 23,10 & 17,93 & 12,81 & 9,47 & 7,34 & 5,01 & 3,84 & 2,67 \\
\hline 20 & 1700 & 150 & 30,50 & 23,01 & 17,90 & 12,82 & 9,49 & 7,35 & 5,01 & 3,85 & 2,67 \\
\hline 20 & 1750 & 150 & 30,27 & 22,91 & 17,87 & 12,83 & 9,51 & 7,37 & 5,02 & 3,85 & 2,67 \\
\hline 20 & 1800 & 150 & 30,04 & 22,82 & 17,84 & 12,83 & 9,52 & 7,38 & 5,02 & 3,85 & 2,67 \\
\hline 20 & 1850 & 150 & 29,82 & 22,73 & 17,81 & 12,84 & 9,54 & 7,39 & 5,02 & 3,85 & 2,66 \\
\hline 20 & 1900 & 150 & 29,61 & 22,64 & 17,78 & 12,85 & 9,55 & 7,40 & 5,03 & 3,85 & 2,66 \\
\hline 20 & 1950 & 150 & 29,41 & 22,56 & 17,75 & 12,85 & 9,56 & 7,41 & 5,03 & 3,85 & 2,66 \\
\hline 20 & 2000 & 150 & 29,21 & 22,47 & 17,72 & 12,86 & 9,58 & 7,43 & 5,04 & 3,85 & 2,66 \\
\hline 20 & 200 & 155 & 51,55 & 25,48 & 16,88 & 11,27 & 8,45 & 6,75 & 4,75 & 3,71 & 2,63 \\
\hline 20 & 250 & 155 & 48,38 & 25,46 & 17,08 & 11,37 & 8,48 & 6,75 & 4,76 & 3,71 & 2,62 \\
\hline 20 & 300 & 155 & 46,07 & 25,40 & 17,22 & 11,46 & 8,50 & 6,76 & 4,76 & 3,71 & 2,62 \\
\hline 20 & 350 & 155 & 44,26 & 25,32 & 17,33 & 11,54 & 8,53 & 6,76 & 4,77 & 3,72 & 2,61 \\
\hline 20 & 400 & 155 & 42,78 & 25,21 & 17,42 & 11,61 & 8,56 & 6,77 & 4,77 & 3,72 & 2,61 \\
\hline 20 & 450 & 155 & 41,54 & 25,10 & 17,48 & 11,68 & 8,59 & 6,78 & 4,77 & 3,72 & 2,60 \\
\hline 20 & 500 & 155 & 40,47 & 24,99 & 17,54 & 11,74 & 8,62 & 6,79 & 4,78 & 3,72 & 2,60 \\
\hline 20 & 550 & 155 & 39,53 & 24,87 & 17,58 & 11,79 & 8,65 & 6,80 & 4,78 & 3,72 & 2,60 \\
\hline 20 & 600 & 155 & 38,70 & 24,74 & 17,61 & 11,85 & 8,68 & 6,81 & 4,78 & 3,72 & 2,60 \\
\hline 20 & 650 & 155 & 37,94 & 24,62 & 17,63 & 11,90 & 8,71 & 6,83 & 4,78 & 3,72 & 2,59 \\
\hline 20 & 700 & 155 & 37,26 & 24,50 & 17,64 & 11,94 & 8,74 & 6,84 & 4,78 & 3,72 & 2,59 \\
\hline 20 & 750 & 155 & 36,63 & 24,37 & 17,65 & 11,98 & 8,76 & 6,85 & 4,79 & 3,72 & 2,59 \\
\hline 20 & 800 & 155 & 36,05 & 24,25 & 17,66 & 12,02 & 8,79 & 6,86 & 4,79 & 3,72 & 2,59 \\
\hline 20 & 850 & 155 & 35,51 & 24,13 & 17,66 & 12,06 & 8,82 & 6,88 & 4,79 & 3,72 & 2,59 \\
\hline 20 & 900 & 155 & 35,01 & 24,01 & 17,66 & 12,09 & 8,84 & 6,89 & 4,79 & 3,72 & 2,59 \\
\hline 20 & 950 & 155 & 34,55 & 23,90 & 17,65 & 12,12 & 8,87 & 6,90 & 4,80 & 3,72 & 2,59 \\
\hline 20 & 1000 & 155 & 34,11 & 23,78 & 17,64 & 12,15 & 8,89 & 6,92 & 4,80 & 3,72 & 2,59 \\
\hline 20 & 1050 & 155 & 33,69 & 23,67 & 17,63 & 12,18 & 8,92 & 6,93 & 4,80 & 3,72 & 2,59 \\
\hline 20 & 1100 & 155 & 33,30 & 23,56 & 17,61 & 12,21 & 8,94 & 6,95 & 4,80 & 3,72 & 2,59 \\
\hline 20 & 1150 & 155 & 32,93 & 23,45 & 17,60 & 12,23 & 8,96 & 6,96 & 4,81 & 3,72 & 2,59 \\
\hline 20 & 1200 & 155 & 32,57 & 23,34 & 17,58 & 12,25 & 8,98 & 6,97 & 4,81 & 3,72 & 2,59 \\
\hline 20 & 1250 & 155 & 32,24 & 23,23 & 17,56 & 12,27 & 9,00 & 6,99 & 4,81 & 3,72 & 2,58 \\
\hline 20 & 1300 & 155 & 31,91 & 23,13 & 17,54 & 12,29 & 9,03 & 7,00 & 4,82 & 3,72 & 2,58 \\
\hline 20 & 1350 & 155 & 31,61 & 23,03 & 17,52 & 12,31 & 9,04 & 7,01 & 4,82 & 3,72 & 2,58 \\
\hline 20 & 1400 & 155 & 31,31 & 22,93 & 17,50 & 12,32 & 9,06 & 7,03 & 4,82 & 3,72 & 2,58 \\
\hline 20 & 1450 & 155 & 31,03 & 22,83 & 17,48 & 12,34 & 9,08 & 7,04 & 4,83 & 3,72 & 2,58 \\
\hline 20 & 1500 & 155 & 30,76 & 22,73 & 17,45 & 12,35 & 9,10 & 7,05 & 4,83 & 3,72 & 2,58 \\
\hline 20 & 1550 & 155 & 30,50 & 22,64 & 17,43 & 12,36 & 9,12 & 7,06 & 4,83 & 3,72 & 2,58 \\
\hline 20 & 1600 & 155 & 30,25 & 22,54 & 17,40 & 12,37 & 9,14 & 7,08 & 4,84 & 3,72 & 2,58 \\
\hline 20 & 1650 & 155 & 30,01 & 22,45 & 17,38 & 12,39 & 9,15 & 7,09 & 4,84 & 3,72 & 2,58 \\
\hline 20 & 1700 & 155 & 29,77 & 22,36 & 17,35 & 12,40 & 9,17 & 7,10 & 4,84 & 3,72 & 2,58 \\
\hline 20 & 1750 & 155 & 29,55 & 22,27 & 17,32 & 12,40 & 9,18 & 7,11 & 4,85 & 3,72 & 2,58 \\
\hline 20 & 1800 & 155 & 29,33 & 22,19 & 17,30 & 12,41 & 9,20 & 7,13 & 4,85 & 3,72 & 2,58 \\
\hline 20 & 1850 & 155 & 29,11 & 22,10 & 17,27 & 12,42 & 9,21 & 7,14 & 4,86 & 3,72 & 2,58 \\
\hline 20 & 1900 & 155 & 28,91 & 22,02 & 17,24 & 12,43 & 9,23 & 7,15 & 4,86 & 3,72 & 2,58 \\
\hline 20 & 1950 & 155 & 28,71 & 21,94 & 17,21 & 12,43 & 9,24 & 7,16 & 4,86 & 3,72 & 2,58 \\
\hline 20 & 2000 & 155 & 28,52 & 21,85 & 17,19 & 12,44 & 9,25 & 7,17 & 4,87 & 3,72 & 2,58 \\
\hline 20 & 200 & 160 & 50,41 & 24,68 & 16,33 & 10,91 & 8,18 & 6,54 & 4,60 & 3,59 & 2,55 \\
\hline 20 & 250 & 160 & 47,28 & 24,67 & 16,52 & 11,00 & 8,21 & 6,54 & 4,61 & 3,59 & 2,54 \\
\hline 20 & 300 & 160 & 45,00 & 24,62 & 16,66 & 11,08 & 8,23 & 6,54 & 4,61 & 3,60 & 2,53 \\
\hline 20 & 350 & 160 & 43,23 & 24,54 & 16,77 & 11,16 & 8,26 & 6,55 & 4,62 & 3,60 & 2,53 \\
\hline 20 & 400 & 160 & 41,78 & 24,45 & 16,85 & 11,23 & 8,29 & 6,56 & 4,62 & 3,60 & 2,53 \\
\hline 20 & 450 & 160 & 40,56 & 24,35 & 16,92 & 11,29 & 8,31 & 6,57 & 4,62 & 3,60 & 2,52 \\
\hline 20 & 500 & 160 & 39,52 & 24,24 & 16,97 & 11,35 & 8,34 & 6,58 & 4,63 & 3,60 & 2,52 \\
\hline 20 & 550 & 160 & 38,60 & 24,13 & 17,01 & 11,41 & 8,37 & 6,59 & 4,63 & 3,60 & 2,52 \\
\hline 20 & 600 & 160 & 37,78 & 24,01 & 17,05 & 11,46 & 8,40 & 6,60 & 4,63 & 3,60 & 2,52 \\
\hline 20 & 650 & 160 & 37,05 & 23,90 & 17,07 & 11,51 & 8,42 & 6,61 & 4,63 & 3,60 & 2,51 \\
\hline 20 & 700 & 160 & 36,38 & 23,78 & 17,09 & 11,55 & 8,45 & 6,62 & 4,63 & 3,60 & 2,51 \\
\hline 20 & 750 & 160 & 35,76 & 23,67 & 17,10 & 11,59 & 8,48 & 6,63 & 4,64 & 3,60 & 2,51 \\
\hline 20 & 800 & 160 & 35,20 & 23,55 & 17,11 & 11,63 & 8,50 & 6,64 & 4,64 & 3,60 & 2,51 \\
\hline 20 & 850 & 160 & 34,68 & 23,44 & 17,11 & 11,66 & 8,53 & 6,66 & 4,64 & 3,60 & 2,51 \\
\hline 20 & 900 & 160 & 34,19 & 23,33 & 17,11 & 11,70 & 8,55 & 6,67 & 4,64 & 3,60 & 2,51 \\
\hline 20 & 950 & 160 & 33,73 & 23,22 & 17,10 & 11,73 & 8,58 & 6,68 & 4,64 & 3,60 & 2,51 \\
\hline 20 & 1000 & 160 & 33,30 & 23,11 & 17,09 & 11,76 & 8,60 & 6,69 & 4,65 & 3,60 & 2,51 \\
\hline
\end{tabular}




\begin{tabular}{|c|c|c|c|c|c|c|c|c|c|c|c|}
\hline \multirow[b]{2}{*}{$\mathrm{H}(\mathrm{cm})$} & \multirow[b]{2}{*}{ Mceq (MPa) } & & & & & $\mathrm{De}$ & ões (x. & & & & \\
\hline & & Msub (MPa) & D0 & D25 & D40 & D60 & D80 & D100 & D140 & D180 & D260 \\
\hline 20 & 1050 & 160 & 32,90 & 23,00 & 17,09 & 11,78 & 8,62 & 6,71 & 4,65 & 3,60 & 2,51 \\
\hline 20 & 1100 & 160 & 32,52 & 22,89 & 17,07 & 11,81 & 8,64 & 6,72 & 4,65 & 3,60 & 2,51 \\
\hline 20 & 1150 & 160 & 32,15 & 22,79 & 17,06 & 11,83 & 8,67 & 6,73 & 4,65 & 3,60 & 2,51 \\
\hline 20 & 1200 & 160 & 31,81 & 22,69 & 17,04 & 11,85 & 8,69 & 6,74 & 4,66 & 3,60 & 2,50 \\
\hline 20 & 1250 & 160 & 31,48 & 22,59 & 17,03 & 11,87 & 8,71 & 6,76 & 4,66 & 3,60 & 2,50 \\
\hline 20 & 1300 & 160 & 31,17 & 22,49 & 17,01 & 11,89 & 8,73 & 6,77 & 4,66 & 3,60 & 2,50 \\
\hline 20 & 1350 & 160 & 30,87 & 22,39 & 16,99 & 11,91 & 8,75 & 6,78 & 4,67 & 3,60 & 2,50 \\
\hline 20 & 1400 & 160 & 30,58 & 22,30 & 16,97 & 11,92 & 8,76 & 6,80 & 4,67 & 3,60 & 2,50 \\
\hline 20 & 1450 & 160 & 30,31 & 22,20 & 16,95 & 11,94 & 8,78 & 6,81 & 4,67 & 3,60 & 2,50 \\
\hline 20 & 1500 & 160 & 30,04 & 22,11 & 16,93 & 11,95 & 8,80 & 6,82 & 4,68 & 3,60 & 2,50 \\
\hline 20 & 1550 & 160 & 29,79 & 22,02 & 16,91 & 11,97 & 8,82 & 6,83 & 4,68 & 3,60 & 2,50 \\
\hline 20 & 1600 & 160 & 29,55 & 21,93 & 16,88 & 11,98 & 8,83 & 6,84 & 4,68 & 3,60 & 2,50 \\
\hline 20 & 1650 & 160 & 29,31 & 21,84 & 16,86 & 11,99 & 8,85 & 6,86 & 4,69 & 3,60 & 2,50 \\
\hline 20 & 1700 & 160 & 29,08 & 21,76 & 16,83 & 12,00 & 8,86 & 6,87 & 4,69 & 3,60 & 2,50 \\
\hline 20 & 1750 & 160 & 28,86 & 21,67 & 16,81 & 12,01 & 8,88 & 6,88 & 4,69 & 3,60 & 2,50 \\
\hline 20 & 1800 & 160 & 28,65 & 21,59 & 16,79 & 12,02 & 8,89 & 6,89 & 4,70 & 3,60 & 2,50 \\
\hline 20 & 1850 & 160 & 28,44 & 21,51 & 16,76 & 12,02 & 8,91 & 6,90 & 4,70 & 3,61 & 2,50 \\
\hline 20 & 1900 & 160 & 28,24 & 21,43 & 16,73 & 12,03 & 8,92 & 6,91 & 4,70 & 3,61 & 2,50 \\
\hline 20 & 1950 & 160 & 28,05 & 21,35 & 16,71 & 12,04 & 8,93 & 6,92 & 4,71 & 3,61 & 2,50 \\
\hline 20 & 2000 & 160 & 27,86 & 21,27 & 16,68 & 12,04 & 8,95 & 6,93 & 4,71 & 3,61 & 2,50 \\
\hline 20 & 200 & 165 & 49,33 & 23,93 & 15,81 & 10,56 & 7,93 & 6,34 & 4,46 & 3,48 & 2,48 \\
\hline 20 & 250 & 165 & 46,24 & 23,93 & 15,99 & 10,65 & 7,96 & 6,34 & 4,47 & 3,49 & 2,47 \\
\hline 20 & 300 & 165 & 44,00 & 23,89 & 16,13 & 10,73 & 7,98 & 6,34 & 4,47 & 3,49 & 2,46 \\
\hline 20 & 350 & 165 & 42,25 & 23,82 & 16,24 & 10,81 & 8,00 & 6,35 & 4,48 & 3,49 & 2,45 \\
\hline 20 & 400 & 165 & 40,83 & 23,73 & 16,32 & 10,87 & 8,03 & 6,36 & 4,48 & 3,49 & 2,45 \\
\hline 20 & 450 & 165 & 39,64 & 23,64 & 16,39 & 10,93 & 8,06 & 6,36 & 4,48 & 3,49 & 2,45 \\
\hline 20 & 500 & 165 & 38,61 & 23,54 & 16,44 & 10,99 & 8,08 & 6,37 & 4,49 & 3,49 & 2,44 \\
\hline 20 & 550 & 165 & 37,71 & 23,43 & 16,49 & 11,04 & 8,11 & 6,38 & 4,49 & 3,49 & 2,44 \\
\hline 20 & 600 & 165 & 36,91 & 23,33 & 16,52 & 11,09 & 8,13 & 6,39 & 4,49 & 3,49 & 2,44 \\
\hline 20 & 650 & 165 & 36,20 & 23,22 & 16,54 & 11,14 & 8,16 & 6,40 & 4,49 & 3,49 & 2,44 \\
\hline 20 & 700 & 165 & 35,54 & 23,11 & 16,56 & 11,18 & 8,18 & 6,41 & 4,49 & 3,49 & 2,44 \\
\hline 20 & 750 & 165 & 34,94 & 23,00 & 16,58 & 11,22 & 8,21 & 6,42 & 4,49 & 3,49 & 2,44 \\
\hline 20 & 800 & 165 & 34,39 & 22,89 & 16,58 & 11,26 & 8,23 & 6,44 & 4,50 & 3,49 & 2,44 \\
\hline 20 & 850 & 165 & 33,88 & 22,79 & 16,59 & 11,29 & 8,26 & 6,45 & 4,50 & 3,49 & 2,43 \\
\hline 20 & 900 & 165 & 33,41 & 22,68 & 16,59 & 11,33 & 8,28 & 6,46 & 4,50 & 3,49 & 2,43 \\
\hline 20 & 950 & 165 & 32,96 & 22,57 & 16,59 & 11,36 & 8,30 & 6,47 & 4,50 & 3,49 & 2,43 \\
\hline 20 & 1000 & 165 & 32,54 & 22,47 & 16,58 & 11,38 & 8,33 & 6,48 & 4,50 & 3,49 & 2,43 \\
\hline 20 & 1050 & 165 & 32,15 & 22,37 & 16,57 & 11,41 & 8,35 & 6,50 & 4,51 & 3,49 & 2,43 \\
\hline 20 & 1100 & 165 & 31,78 & 22,27 & 16,56 & 11,43 & 8,37 & 6,51 & 4,51 & 3,49 & 2,43 \\
\hline 20 & 1150 & 165 & 31,42 & 22,17 & 16,55 & 11,46 & 8,39 & 6,52 & 4,51 & 3,49 & 2,43 \\
\hline 20 & 1200 & 165 & 31,09 & 22,07 & 16,54 & 11,48 & 8,41 & 6,53 & 4,51 & 3,49 & 2,43 \\
\hline 20 & 1250 & 165 & 30,77 & 21,98 & 16,52 & 11,50 & 8,43 & 6,54 & 4,52 & 3,49 & 2,43 \\
\hline 20 & 1300 & 165 & 30,46 & 21,88 & 16,51 & 11,52 & 8,45 & 6,56 & 4,52 & 3,49 & 2,43 \\
\hline 20 & 1350 & 165 & 30,17 & 21,79 & 16,49 & 11,53 & 8,47 & 6,57 & 4,52 & 3,49 & 2,43 \\
\hline 20 & 1400 & 165 & 29,89 & 21,70 & 16,47 & 11,55 & 8,48 & 6,58 & 4,53 & 3,49 & 2,43 \\
\hline 20 & 1450 & 165 & 29,62 & 21,61 & 16,45 & 11,56 & 8,50 & 6,59 & 4,53 & 3,49 & 2,43 \\
\hline 20 & 1500 & 165 & 29,37 & 21,52 & 16,43 & 11,58 & 8,52 & 6,60 & 4,53 & 3,49 & 2,43 \\
\hline 20 & 1550 & 165 & 29,12 & 21,43 & 16,41 & 11,59 & 8,53 & 6,61 & 4,53 & 3,49 & 2,43 \\
\hline 20 & 1600 & 165 & 28,88 & 21,35 & 16,39 & 11,60 & 8,55 & 6,63 & 4,54 & 3,49 & 2,43 \\
\hline 20 & 1650 & 165 & 28,65 & 21,27 & 16,37 & 11,61 & 8,57 & 6,64 & 4,54 & 3,49 & 2,43 \\
\hline 20 & 1700 & 165 & 28,43 & 21,18 & 16,35 & 11,62 & 8,58 & 6,65 & 4,54 & 3,49 & 2,42 \\
\hline 20 & 1750 & 165 & 28,21 & 21,10 & 16,33 & 11,63 & 8,59 & 6,66 & 4,55 & 3,49 & 2,42 \\
\hline 20 & 1800 & 165 & 28,01 & 21,02 & 16,30 & 11,64 & 8,61 & 6,67 & 4,55 & 3,50 & 2,42 \\
\hline 20 & 1850 & 165 & 27,81 & 20,94 & 16,28 & 11,65 & 8,62 & 6,68 & 4,55 & 3,50 & 2,42 \\
\hline 20 & 1900 & 165 & 27,61 & 20,87 & 16,26 & 11,66 & 8,64 & 6,69 & 4,56 & 3,50 & 2,42 \\
\hline 20 & 1950 & 165 & 27,42 & 20,79 & 16,23 & 11,66 & 8,65 & 6,70 & 4,56 & 3,50 & 2,42 \\
\hline 20 & 2000 & 165 & 27,24 & 20,72 & 16,21 & 11,67 & 8,66 & 6,71 & 4,56 & 3,50 & 2,42 \\
\hline 20 & 200 & 170 & 48,31 & 23,22 & 15,32 & 10,24 & 7,70 & 6,15 & 4,32 & 3,38 & 2,40 \\
\hline 20 & 250 & 170 & 45,26 & 23,23 & 15,50 & 10,33 & 7,72 & 6,15 & 4,33 & 3,38 & 2,39 \\
\hline 20 & 300 & 170 & 43,05 & 23,19 & 15,64 & 10,41 & 7,74 & 6,16 & 4,34 & 3,38 & 2,39 \\
\hline 20 & 350 & 170 & 41,33 & 23,13 & 15,74 & 10,48 & 7,76 & 6,16 & 4,34 & 3,39 & 2,38 \\
\hline 20 & 400 & 170 & 39,93 & 23,06 & 15,83 & 10,54 & 7,79 & 6,17 & 4,35 & 3,39 & 2,38 \\
\hline 20 & 450 & 170 & 38,76 & 22,97 & 15,89 & 10,60 & 7,81 & 6,18 & 4,35 & 3,39 & 2,38 \\
\hline 20 & 500 & 170 & 37,76 & 22,88 & 15,95 & 10,65 & 7,84 & 6,18 & 4,35 & 3,39 & 2,37 \\
\hline 20 & 550 & 170 & 36,87 & 22,78 & 15,99 & 10,70 & 7,86 & 6,19 & 4,35 & 3,39 & 2,37 \\
\hline 20 & 600 & 170 & 36,09 & 22,68 & 16,02 & 10,75 & 7,89 & 6,20 & 4,36 & 3,39 & 2,37 \\
\hline 20 & 650 & 170 & 35,39 & 22,58 & 16,05 & 10,80 & 7,91 & 6,21 & 4,36 & 3,39 & 2,37 \\
\hline 20 & 700 & 170 & 34,75 & 22,47 & 16,07 & 10,84 & 7,93 & 6,22 & 4,36 & 3,39 & 2,37 \\
\hline 20 & 750 & 170 & 34,17 & 22,37 & 16,08 & 10,87 & 7,96 & 6,23 & 4,36 & 3,39 & 2,37 \\
\hline 20 & 800 & 170 & 33,63 & 22,27 & 16,09 & 10,91 & 7,98 & 6,24 & 4,36 & 3,39 & 2,36 \\
\hline 20 & 850 & 170 & 33,13 & 22,17 & 16,10 & 10,94 & 8,00 & 6,25 & 4,37 & 3,39 & 2,36 \\
\hline 20 & 900 & 170 & 32,66 & 22,07 & 16,10 & 10,98 & 8,03 & 6,26 & 4,37 & 3,39 & 2,36 \\
\hline 20 & 950 & 170 & 32,23 & 21,97 & 16,10 & 11,01 & 8,05 & 6,27 & 4,37 & 3,39 & 2,36 \\
\hline 20 & 1000 & 170 & 31,82 & 21,87 & 16,10 & 11,03 & 8,07 & 6,29 & 4,37 & 3,39 & 2,36 \\
\hline 20 & 1050 & 170 & 31,44 & 21,77 & 16,09 & 11,06 & 8,09 & 6,30 & 4,37 & 3,39 & 2,36 \\
\hline 20 & 1100 & 170 & 31,07 & 21,68 & 16,08 & 11,08 & 8,11 & 6,31 & 4,38 & 3,39 & 2,36 \\
\hline 20 & 1150 & 170 & 30,73 & 21,58 & 16,07 & 11,11 & 8,13 & 6,32 & 4,38 & 3,39 & 2,36 \\
\hline 20 & 1200 & 170 & 30,40 & 21,49 & 16,06 & 11,13 & 8,15 & 6,33 & 4,38 & 3,39 & 2,36 \\
\hline 20 & 1250 & 170 & 30,09 & 21,40 & 16,05 & 11,15 & 8,17 & 6,34 & 4,38 & 3,39 & 2,36 \\
\hline 20 & 1300 & 170 & 29,79 & 21,31 & 16,03 & 11,16 & 8,19 & 6,35 & 4,38 & 3,39 & 2,36 \\
\hline 20 & 1350 & 170 & 29,51 & 21,22 & 16,02 & 11,18 & 8,20 & 6,37 & 4,39 & 3,39 & 2,36 \\
\hline
\end{tabular}




\begin{tabular}{|c|c|c|c|c|c|c|c|c|c|c|c|}
\hline \multirow[b]{2}{*}{$\mathrm{H}(\mathrm{cm})$} & \multirow[b]{2}{*}{ Mceq (MPa) } & & & & & $\mathrm{De}$ & ões (x. & & & & \\
\hline & & Msub (MPa) & D0 & D25 & D40 & D60 & D80 & D100 & D140 & D180 & D260 \\
\hline 20 & 1400 & 170 & 29,24 & 21,13 & 16,00 & 11,20 & 8,22 & 6,38 & 4,39 & 3,39 & 2,36 \\
\hline 20 & 1450 & 170 & 28,97 & 21,05 & 15,99 & 11,21 & 8,24 & 6,39 & 4,39 & 3,39 & 2,36 \\
\hline 20 & 1500 & 170 & 28,72 & 20,96 & 15,97 & 11,23 & 8,25 & 6,40 & 4,40 & 3,39 & 2,36 \\
\hline 20 & 1550 & 170 & 28,48 & 20,88 & 15,95 & 11,24 & 8,27 & 6,41 & 4,40 & 3,39 & 2,35 \\
\hline 20 & 1600 & 170 & 28,25 & 20,80 & 15,93 & 11,25 & 8,28 & 6,42 & 4,40 & 3,39 & 2,35 \\
\hline 20 & 1650 & 170 & 28,02 & 20,72 & 15,91 & 11,26 & 8,30 & 6,43 & 4,40 & 3,39 & 2,35 \\
\hline 20 & 1700 & 170 & 27,81 & 20,64 & 15,89 & 11,27 & 8,31 & 6,44 & 4,41 & 3,39 & 2,35 \\
\hline 20 & 1750 & 170 & 27,60 & 20,56 & 15,87 & 11,28 & 8,33 & 6,45 & 4,41 & 3,39 & 2,35 \\
\hline 20 & 1800 & 170 & 27,40 & 20,49 & 15,85 & 11,29 & 8,34 & 6,46 & 4,41 & 3,39 & 2,35 \\
\hline 20 & 1850 & 170 & 27,20 & 20,41 & 15,83 & 11,30 & 8,35 & 6,47 & 4,42 & 3,39 & 2,35 \\
\hline 20 & 1900 & 170 & 27,01 & 20,34 & 15,80 & 11,31 & 8,37 & 6,48 & 4,42 & 3,39 & 2,35 \\
\hline 20 & 1950 & 170 & 26,83 & 20,26 & 15,78 & 11,31 & 8,38 & 6,49 & 4,42 & 3,39 & 2,35 \\
\hline 20 & 2000 & 170 & 26,65 & 20,19 & 15,76 & 11,32 & 8,39 & 6,50 & 4,43 & 3,39 & 2,35 \\
\hline 20 & 200 & 175 & 47,35 & 22,55 & 14,85 & 9,94 & 7,48 & 5,97 & 4,20 & 3,28 & 2,34 \\
\hline 20 & 250 & 175 & 44,33 & 22,57 & 15,03 & 10,02 & 7,50 & 5,98 & 4,21 & 3,29 & 2,33 \\
\hline 20 & 300 & 175 & 42,14 & 22,54 & 15,17 & 10,10 & 7,52 & 5,98 & 4,22 & 3,29 & 2,32 \\
\hline 20 & 350 & 175 & 40,45 & 22,48 & 15,27 & 10,16 & 7,54 & 5,98 & 4,22 & 3,29 & 2,32 \\
\hline 20 & 400 & 175 & 39,08 & 22,42 & 15,36 & 10,22 & 7,56 & 5,99 & 4,22 & 3,29 & 2,31 \\
\hline 20 & 450 & 175 & 37,93 & 22,34 & 15,42 & 10,28 & 7,58 & 6,00 & 4,23 & 3,29 & 2,31 \\
\hline 20 & 500 & 175 & 36,94 & 22,25 & 15,48 & 10,33 & 7,61 & 6,00 & 4,23 & 3,29 & 2,31 \\
\hline 20 & 550 & 175 & 36,08 & 22,16 & 15,52 & 10,38 & 7,63 & 6,01 & 4,23 & 3,29 & 2,30 \\
\hline 20 & 600 & 175 & 35,31 & 22,06 & 15,56 & 10,43 & 7,65 & 6,02 & 4,23 & 3,29 & 2,30 \\
\hline 20 & 650 & 175 & 34,62 & 21,97 & 15,58 & 10,47 & 7,67 & 6,03 & 4,23 & 3,29 & 2,30 \\
\hline 20 & 700 & 175 & 34,00 & 21,87 & 15,60 & 10,51 & 7,70 & 6,04 & 4,23 & 3,29 & 2,30 \\
\hline 20 & 750 & 175 & 33,43 & 21,77 & 15,62 & 10,55 & 7,72 & 6,05 & 4,24 & 3,29 & 2,30 \\
\hline 20 & 800 & 175 & 32,90 & 21,68 & 15,63 & 10,58 & 7,74 & 6,06 & 4,24 & 3,29 & 2,30 \\
\hline 20 & 850 & 175 & 32,41 & 21,58 & 15,64 & 10,62 & 7,76 & 6,07 & 4,24 & 3,29 & 2,30 \\
\hline 20 & 900 & 175 & 31,96 & 21,49 & 15,64 & 10,65 & $\begin{array}{l}7,78 \\
\end{array}$ & 6,08 & 4,24 & 3,29 & 2,30 \\
\hline 20 & 950 & 175 & 31,54 & 21,39 & 15,64 & 10,68 & 7,81 & 6,09 & 4,24 & 3,29 & 2,29 \\
\hline 20 & 1000 & 175 & 31,14 & 21,30 & 15,64 & 10,70 & 7,83 & 6,10 & 4,25 & 3,29 & 2,29 \\
\hline 20 & 1050 & 175 & 30,76 & 21,21 & 15,64 & 10,73 & 7,85 & 6,11 & 4,25 & 3,29 & 2,29 \\
\hline 20 & 1100 & 175 & 30,41 & 21,12 & 15,63 & 10,75 & 7,87 & 6,12 & 4,25 & 3,29 & 2,29 \\
\hline 20 & 1150 & 175 & 30,07 & 21,03 & 15,62 & 10,77 & 7,88 & 6,13 & 4,25 & 3,29 & 2,29 \\
\hline 20 & 1200 & 175 & 29,75 & 20,94 & 15,61 & 10,79 & 7,90 & 6,14 & 4,25 & 3,29 & 2,29 \\
\hline 20 & 1250 & 175 & 29,44 & 20,85 & 15,60 & 10,81 & 7,92 & 6,15 & 4,26 & 3,29 & 2,29 \\
\hline 20 & 1300 & 175 & 29,15 & 20,76 & 15,59 & 10,83 & 7,94 & 6,16 & 4,26 & 3,29 & 2,29 \\
\hline 20 & 1350 & 175 & 28,88 & 20,68 & 15,57 & 10,85 & 7,96 & 6,17 & 4,26 & 3,29 & 2,29 \\
\hline 20 & 1400 & 175 & 28,61 & 20,60 & 15,56 & 10,86 & 7,97 & 6,19 & 4,26 & 3,29 & 2,29 \\
\hline 20 & 1450 & 175 & 28,36 & 20,52 & 15,54 & 10,88 & 7,99 & 6,20 & 4,27 & 3,29 & 2,29 \\
\hline 20 & 1500 & 175 & 28,11 & 20,43 & 15,53 & 10,89 & 8,00 & 6,21 & 4,27 & 3,29 & 2,29 \\
\hline 20 & 1550 & 175 & 27,87 & 20,36 & 15,51 & 10,91 & 8,02 & 6,22 & 4,27 & 3,29 & 2,29 \\
\hline 20 & 1600 & 175 & 27,65 & 20,28 & 15,49 & 10,92 & 8,03 & 6,23 & 4,27 & 3,29 & 2,29 \\
\hline 20 & 1650 & 175 & 27,43 & 20,20 & 15,47 & 10,93 & 8,05 & 6,24 & 4,28 & 3,29 & 2,29 \\
\hline 20 & 1700 & 175 & 27,22 & 20,12 & 15,45 & 10,94 & 8,06 & 6,25 & 4,28 & 3,29 & 2,29 \\
\hline 20 & 1750 & 175 & 27,01 & 20,05 & 15,44 & 10,95 & 8,08 & 6,26 & 4,28 & 3,29 & 2,29 \\
\hline 20 & 1800 & 175 & 26,82 & 19,98 & 15,42 & 10,96 & 8,09 & 6,27 & 4,28 & 3,29 & 2,29 \\
\hline 20 & 1850 & 175 & 26,62 & 19,91 & 15,40 & 10,97 & 8,10 & 6,28 & 4,29 & 3,30 & 2,29 \\
\hline 20 & 1900 & 175 & 26,44 & 19,83 & 15,37 & 10,98 & 8,11 & 6,29 & 4,29 & 3,30 & 2,29 \\
\hline 20 & 1950 & 175 & 26,26 & 19,76 & 15,35 & 10,98 & 8,13 & 6,30 & 4,29 & 3,30 & 2,29 \\
\hline 20 & 2000 & 175 & 26,08 & 19,70 & 15,33 & 10,99 & 8,14 & 6,31 & 4,30 & 3,30 & 2,29 \\
\hline 20 & 200 & 180 & 46,44 & 21,92 & 14,42 & 9,65 & 7,27 & 5,81 & 4,08 & 3,19 & 2,27 \\
\hline 20 & 250 & 180 & 43,45 & 21,94 & 14,59 & 9,73 & 7,28 & 5,81 & 4,09 & 3,19 & 2,26 \\
\hline 20 & 300 & 180 & 41,29 & 21,92 & 14,73 & 9,80 & 7,30 & 5,81 & 4,10 & 3,20 & 2,26 \\
\hline 20 & 350 & 180 & 39,62 & 21,87 & 14,83 & 9,87 & 7,32 & 5,82 & 4,10 & 3,20 & 2,25 \\
\hline 20 & 400 & 180 & 38,27 & 21,81 & 14,91 & 9,93 & 7,34 & 5,82 & 4,10 & 3,20 & 2,25 \\
\hline 20 & 450 & 180 & 37,14 & 21,73 & 14,98 & 9,98 & 7,37 & 5,83 & 4,11 & 3,20 & 2,24 \\
\hline 20 & 500 & 180 & 36,17 & 21,65 & 15,03 & 10,03 & 7,39 & 5,84 & 4,11 & 3,20 & 2,24 \\
\hline 20 & 550 & 180 & 35,32 & 21,57 & 15,08 & 10,08 & 7,41 & 5,84 & 4,11 & 3,20 & 2,24 \\
\hline 20 & 600 & 180 & 34,57 & 21,48 & 15,11 & 10,12 & 7,43 & 5,85 & 4,11 & 3,20 & 2,24 \\
\hline 20 & 650 & 180 & 33,90 & 21,39 & 15,14 & 10,17 & 7,45 & 5,86 & 4,11 & 3,20 & 2,24 \\
\hline 20 & 700 & 180 & 33,28 & 21,30 & 15,16 & 10,20 & 7,48 & 5,87 & 4,12 & 3,20 & 2,24 \\
\hline 20 & 750 & 180 & 32,73 & 21,21 & 15,18 & 10,24 & 7,50 & 5,88 & 4,12 & 3,20 & 2,23 \\
\hline 20 & 800 & 180 & 32,21 & 21,12 & 15,19 & 10,27 & 7,52 & 5,89 & 4,12 & 3,20 & 2,23 \\
\hline 20 & 850 & 180 & 31,73 & 21,03 & 15,20 & 10,31 & 7,54 & 5,90 & 4,12 & 3,20 & 2,23 \\
\hline 20 & 900 & 180 & 31,29 & 20,94 & 15,21 & 10,34 & 7,56 & 5,91 & 4,12 & 3,20 & 2,23 \\
\hline 20 & 950 & 180 & 30,87 & 20,85 & 15,21 & 10,36 & 7,58 & 5,92 & 4,12 & 3,20 & 2,23 \\
\hline 20 & 1000 & 180 & 30,48 & 20,76 & 15,21 & 10,39 & 7,60 & 5,92 & 4,13 & 3,20 & 2,23 \\
\hline 20 & 1050 & 180 & 30,12 & 20,67 & 15,20 & 10,42 & 7,62 & 5,93 & 4,13 & 3,20 & 2,23 \\
\hline 20 & 1100 & 180 & 29,77 & 20,58 & 15,20 & 10,44 & 7,64 & 5,95 & 4,13 & 3,20 & 2,23 \\
\hline 20 & 1150 & 180 & 29,44 & 20,50 & 15,19 & 10,46 & 7,65 & 5,96 & 4,13 & 3,20 & 2,23 \\
\hline 20 & 1200 & 180 & 29,13 & 20,41 & 15,18 & 10,48 & 7,67 & 5,97 & 4,13 & 3,20 & 2,23 \\
\hline 20 & 1250 & 180 & 28,83 & 20,33 & 15,17 & 10,50 & 7,69 & 5,98 & 4,14 & 3,20 & 2,23 \\
\hline 20 & 1300 & 180 & 28,55 & 20,25 & 15,16 & 10,52 & 7,71 & 5,99 & 4,14 & 3,20 & 2,23 \\
\hline 20 & 1350 & 180 & 28,28 & 20,17 & 15,15 & 10,54 & 7,72 & 6.00 & 4.14 & 3,20 & 2,23 \\
\hline 20 & 1400 & 180 & 28,02 & 20,09 & 15,14 & 10,55 & 7,74 & 6,01 & 4,14 & 3,20 & 2,23 \\
\hline 20 & 1450 & 180 & 27,77 & 20,01 & 15,12 & 10,57 & 7,75 & 6,02 & 4,14 & 3,20 & 2,23 \\
\hline 20 & 1500 & 180 & 27,53 & 19,93 & 15,11 & 10,58 & 7,77 & 6,03 & 4,15 & 3,20 & 2,23 \\
\hline 20 & 1550 & 180 & 27,30 & 19,86 & 15,09 & 10,59 & 7,78 & 6,04 & 4,15 & 3,20 & 2,22 \\
\hline 20 & 1600 & 180 & 27,08 & 19,78 & 15,08 & 10,61 & 7,80 & 6,05 & 4,15 & 3,20 & 2,22 \\
\hline 20 & 1650 & 180 & 26,86 & 19,71 & 15,06 & 10,62 & 7,81 & 6,05 & 4,15 & 3,20 & 2,22 \\
\hline 20 & 1700 & 180 & 26,66 & 19,64 & 15,04 & 10,63 & 7,83 & 6,06 & 4,16 & 3,20 & 2,22 \\
\hline
\end{tabular}




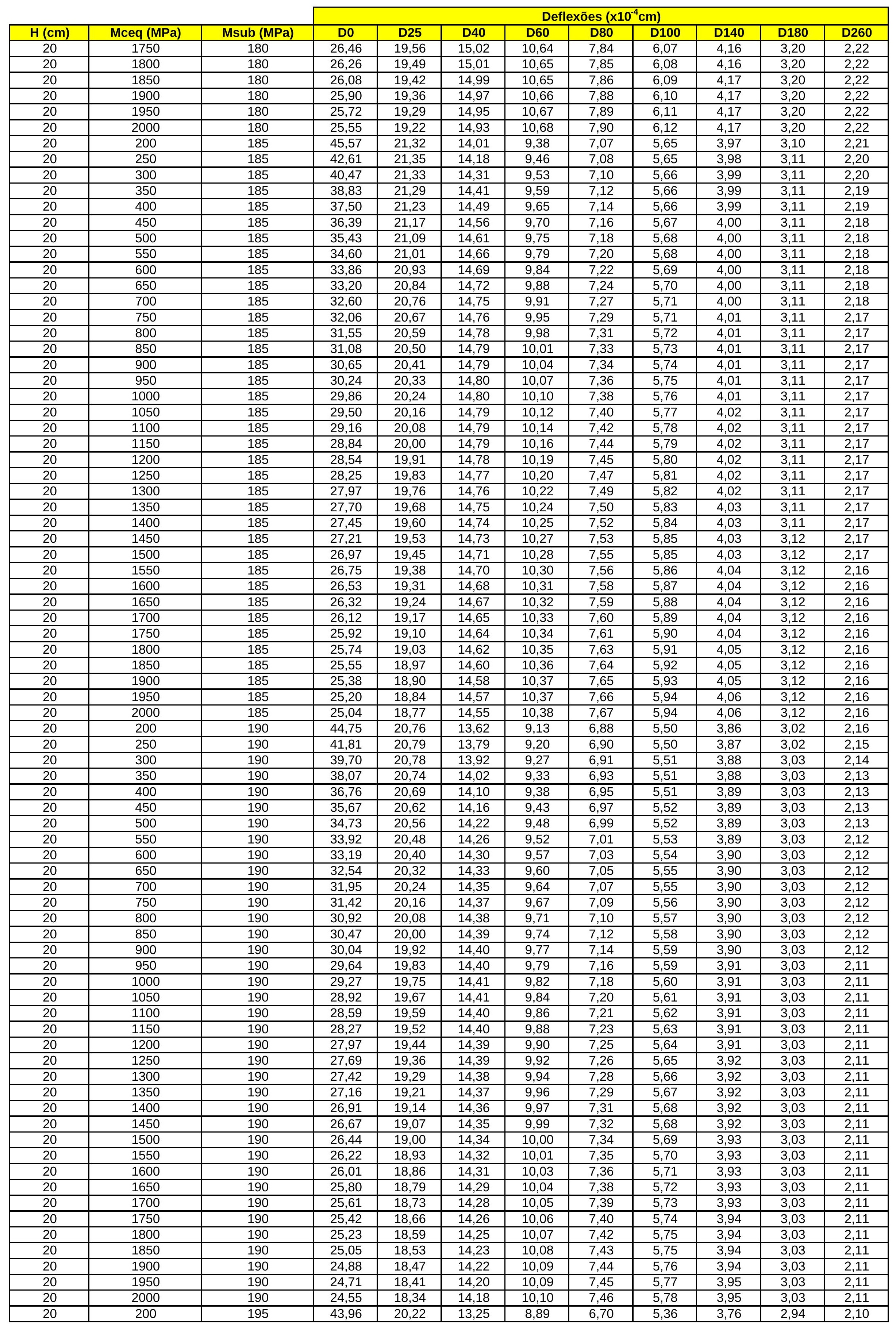




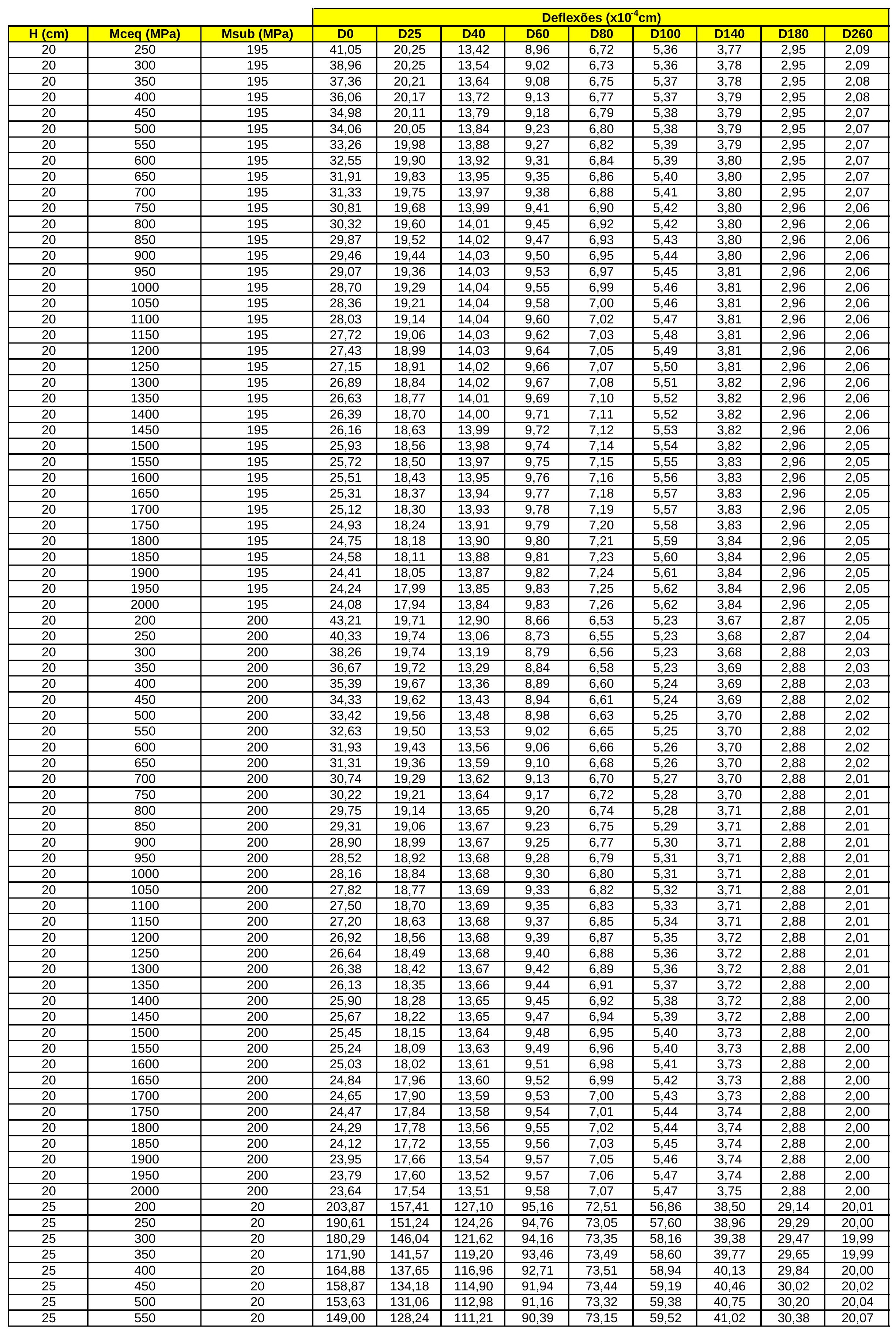




\begin{tabular}{|c|c|c|c|c|c|c|c|c|c|c|c|}
\hline \multirow[b]{2}{*}{$\mathrm{H}(\mathrm{cm})$} & \multirow[b]{2}{*}{ Mceq (MPa) } & & & & & $\mathrm{De}$ & ões (x1 & & & & \\
\hline & & Msub (MPa) & D0 & D25 & D40 & D60 & D80 & D100 & D140 & D180 & D260 \\
\hline 25 & 600 & 20 & 144,88 & 125,67 & 109,55 & 89,64 & 72,95 & 59,61 & 41,26 & 30,55 & 20,10 \\
\hline 25 & 650 & 20 & 141,16 & 123,32 & 107,99 & 88,90 & 72,73 & 59,67 & 41,48 & 30,72 & 20,13 \\
\hline 25 & 700 & 20 & 137,79 & 121,15 & 106,53 & 88,18 & 72,48 & 59,70 & 41,68 & 30,88 & 20,17 \\
\hline 25 & 750 & 20 & 134,72 & 119,13 & 105,16 & 87,48 & 72,23 & 59,70 & 41,86 & 31,03 & 20,21 \\
\hline 25 & 800 & 20 & 131,90 & 117,25 & 103,86 & 86,80 & 71,96 & 59,69 & 42,02 & 31,18 & 20,25 \\
\hline 25 & 850 & 20 & 129,30 & 115,50 & 102,63 & 86,14 & 71,69 & 59,65 & 42,17 & 31,32 & 20,29 \\
\hline 25 & 900 & 20 & 126,89 & 113,85 & 101,47 & 85,50 & 71,42 & 59,60 & 42,30 & 31,45 & 20,33 \\
\hline 25 & 950 & 20 & 124,65 & 112,30 & 100,36 & 84,88 & 71,14 & 59,54 & 42,42 & 31,58 & 20,38 \\
\hline 25 & 1000 & 20 & 122,56 & 110,84 & 99,30 & 84,28 & 70,86 & 59,47 & 42,53 & 31,70 & 20,42 \\
\hline 25 & 1050 & 20 & 120,61 & 109,46 & 98,30 & 83,69 & 70,58 & 59,39 & 42,63 & 31,81 & 20,47 \\
\hline 25 & 1100 & 20 & 118,78 & 108,15 & 97,33 & 83,13 & 70,30 & 59,31 & 42,71 & 31,92 & 20,51 \\
\hline 25 & 1150 & 20 & 117,06 & 106,90 & 96,41 & 82,57 & 70,03 & 59,21 & 42,79 & 32,03 & 20,56 \\
\hline 25 & 1200 & 20 & 115,44 & 105,71 & 95,52 & 82,04 & 69,75 & 59,12 & 42,86 & 32,13 & 20,61 \\
\hline 25 & 1250 & 20 & 113,90 & 104,57 & 94,67 & 81,52 & 69,48 & 59,01 & 42,93 & 32,22 & 20,66 \\
\hline 25 & 1300 & 20 & 112,46 & 103,49 & 93,86 & 81,01 & 69,21 & 58,91 & 42,98 & 32,31 & 20,70 \\
\hline 25 & 1350 & 20 & 111,08 & 102,45 & 93,07 & 80,52 & 68,94 & 58,80 & 43,03 & 32,40 & 20,75 \\
\hline 25 & 1400 & 20 & 109,78 & 101,45 & 92,31 & 80,04 & 68,68 & 58,68 & 43,07 & 32,48 & 20,80 \\
\hline 25 & 1450 & 20 & 108,54 & 100,50 & 91,58 & 79,57 & 68,41 & 58,57 & 43,11 & 32,56 & 20,84 \\
\hline 25 & 1500 & 20 & 107,35 & 99,58 & 90,88 & 79,12 & 68,16 & 58,45 & 43,15 & 32,63 & 20,89 \\
\hline 25 & 1550 & 20 & 106,23 & 98,69 & 90,19 & 78,67 & 67,90 & 58,33 & 43,18 & 32,70 & 20,93 \\
\hline 25 & 1600 & 20 & 105,15 & 97,83 & 89,53 & 78,24 & 67,65 & 58,21 & 43,20 & 32,77 & 20,98 \\
\hline 25 & 1650 & 20 & 104,12 & 97,01 & 88,89 & 77,82 & 67,40 & 58,09 & 43,22 & 32,83 & 21,02 \\
\hline 25 & 1700 & 20 & 103,14 & 96,21 & 88,27 & 77,41 & 67,16 & 57,97 & 43,24 & 32,89 & 21,07 \\
\hline 25 & 1750 & 20 & 102,19 & 95,44 & 87,67 & 77,01 & 66,92 & 57,85 & 43,25 & 32,95 & 21,11 \\
\hline 25 & 1800 & 20 & 101,28 & 94,70 & 87,09 & 76,61 & 66,68 & 57,73 & 43,26 & 33,01 & 21,15 \\
\hline 25 & 1850 & 20 & 100,41 & 93,97 & 86,52 & 76,23 & 66,44 & 57,60 & 43,27 & 33,06 & 21,19 \\
\hline 25 & 1900 & 20 & $\begin{array}{l}99,58 \\
\end{array}$ & 93,27 & 85,97 & 75,85 & 66,21 & 57,48 & 43,27 & 33,11 & 21,24 \\
\hline 25 & 1950 & 20 & 98,77 & 92,59 & 85,44 & 75,49 & 65,98 & 57,36 & 43,28 & 33,16 & 21,28 \\
\hline 25 & 2000 & 20 & 98,00 & 91,93 & 84,92 & 75,13 & 65,76 & 57,24 & 43,28 & 33,20 & 21,32 \\
\hline 25 & 200 & 25 & 174,34 & 130,64 & 103,59 & 76,18 & 57,47 & 44,90 & 30,50 & 23,22 & 16,03 \\
\hline 25 & 250 & 25 & 163,10 & 125,93 & 101,68 & 76,13 & 58,01 & 45,49 & 30,80 & 23,31 & 16,01 \\
\hline 25 & 300 & 25 & 154,38 & 121,91 & 99,85 & 75,88 & 58,37 & 45,97 & 31,09 & 23,41 & 16,00 \\
\hline 25 & 350 & 25 & 147,31 & 118,42 & 98,12 & 75,53 & 58,60 & 46,36 & 31,37 & 23,52 & 15,99 \\
\hline 25 & 400 & 25 & 141,39 & 115,34 & 96,50 & 75,11 & 58,74 & 46,68 & 31,63 & 23,63 & 15,99 \\
\hline 25 & 450 & 25 & 136,32 & 112,60 & 94,99 & 74,65 & 58,80 & 46,94 & 31,88 & 23,75 & 16,00 \\
\hline 25 & 500 & 25 & 131,91 & 110,12 & 93,57 & 74,17 & 58,81 & 47,15 & 32,11 & 23,87 & 16,00 \\
\hline 25 & 550 & 25 & 128,00 & 107,87 & 92,24 & 73,67 & 58,77 & 47,32 & 32,32 & 23,99 & 16,01 \\
\hline 25 & 600 & 25 & 124,51 & 105,81 & 90,99 & 73,18 & 58,70 & 47,45 & 32,51 & 24,10 & 16,02 \\
\hline 25 & 650 & 25 & 121,37 & 103,92 & 89,81 & 72,68 & 58,61 & 47,55 & 32,69 & 24,22 & 16,04 \\
\hline 25 & 700 & 25 & 118,51 & 102,17 & 88,69 & 72,19 & 58,49 & 477,63 & 32,86 & 24,33 & 16,06 \\
\hline 25 & 750 & 25 & 115,90 & 100,54 & 87,64 & 71,71 & 58,36 & 47,69 & 33,01 & 24,44 & 16,08 \\
\hline 25 & 800 & 25 & 113,50 & 99,02 & 86,64 & 71,24 & 58,22 & 47,73 & 33,15 & 24,55 & 16,10 \\
\hline 25 & 850 & 25 & 111,28 & 97,60 & 85,69 & 70,77 & 58,07 & 47,75 & 33,28 & 24,65 & 16,12 \\
\hline 25 & 900 & 25 & 109,23 & 96,26 & 84,78 & 70,32 & 57,91 & 47,76 & 33,40 & 24,75 & 16,15 \\
\hline 25 & 950 & 25 & 107,31 & 95,00 & 83,92 & 69,88 & 57,74 & 47,76 & 33,52 & 24,85 & 16,17 \\
\hline 25 & 1000 & 25 & 105,52 & 93,80 & 83,09 & 69,44 & 57,57 & 47,75 & 33,62 & 24,94 & 16,20 \\
\hline 25 & 1050 & 25 & 103,84 & 92,67 & 82,30 & 69,02 & 57,40 & 47,73 & 33,71 & 25,03 & 16,22 \\
\hline 25 & 1100 & 25 & 102,26 & 91,60 & 81,54 & 68,60 & 57,22 & 47,70 & 33,80 & 25,12 & 16,25 \\
\hline 25 & 1150 & 25 & 100,78 & 90,58 & 80,81 & 68,20 & 57,05 & 47,67 & 33,88 & 25,20 & 16,28 \\
\hline 25 & 1200 & 25 & 99,38 & 89,60 & 80,12 & 67,81 & 56,87 & 47,62 & 33,95 & 25,28 & 16,31 \\
\hline 25 & 1250 & 25 & 98,05 & $\begin{array}{l}88,67 \\
\end{array}$ & 79,44 & 67,42 & 56,69 & 47,58 & 34,02 & 25,36 & 16,34 \\
\hline 25 & 1300 & 25 & 96,79 & $\begin{array}{l}87,78 \\
\end{array}$ & 78,79 & 67,05 & 56,51 & 47,53 & 34,09 & 25,43 & 16,37 \\
\hline 25 & 1350 & 25 & 95,60 & 86,93 & 78,17 & 66,68 & 56,33 & 47,47 & 34,14 & 25,50 & 16,40 \\
\hline 25 & 1400 & 25 & 94,46 & 86,11 & 77,57 & 66,32 & 56,15 & 47,42 & 34,20 & 25,57 & 16,43 \\
\hline 25 & 1450 & 25 & 93,38 & 85,32 & 76,98 & 65,97 & 55,98 & 47,36 & 34,25 & 25,64 & 16,46 \\
\hline 25 & 1500 & 25 & 92,35 & 84,57 & 76,42 & 65,63 & 55,80 & 47,29 & 34,29 & 25,70 & 16,49 \\
\hline 25 & 1550 & 25 & 91,36 & 83,84 & 75,87 & 65,30 & 55,63 & 47,23 & 34,33 & 25,76 & 16,52 \\
\hline 25 & 1600 & 25 & 90,42 & 83,13 & 75,34 & 64,97 & 55,45 & 47,16 & 34,37 & 25,82 & 16,55 \\
\hline 25 & 1650 & 25 & 89,52 & 82,45 & 74,83 & 64,65 & 55,28 & 47,09 & 34,40 & 25,88 & 16,58 \\
\hline 25 & 1700 & 25 & 88,65 & 81,80 & 74,33 & 64,34 & 55,11 & 47,02 & 34,43 & 25,93 & 16,61 \\
\hline 25 & 1750 & 25 & 87,82 & 81,16 & 73,85 & 64,03 & 54,94 & 46,95 & 34,46 & 25,98 & 16,64 \\
\hline 25 & 1800 & 25 & 87,02 & 80,55 & $\begin{array}{ll}73,38 \\
\end{array}$ & 63,73 & 54,77 & 46,87 & 34,48 & 26,03 & 16,67 \\
\hline 25 & 1850 & 25 & 86,26 & 79,95 & 72,92 & 63,44 & 54,61 & 46,80 & 34,51 & 26,08 & 16,70 \\
\hline 25 & 1900 & 25 & 85,52 & 79,37 & 72,48 & 63,15 & 54,44 & 46,72 & 34,53 & 26,13 & 16,72 \\
\hline 25 & 1950 & 25 & 84,81 & 78,81 & 72,05 & 62,87 & 54,28 & 46,65 & 34,54 & 26,17 & 16,75 \\
\hline 25 & 2000 & 25 & 84,12 & 78,27 & 71,63 & 62,59 & 54,12 & 46,57 & 34,56 & 26,21 & 16,78 \\
\hline 25 & 200 & 30 & 153,38 & 111,91 & 87,40 & 63,37 & 47,47 & 37,03 & 25,25 & 19,32 & 13,37 \\
\hline 25 & 250 & 30 & 143,53 & 108,17 & 86,06 & 63,49 & 47,98 & 37,50 & 25,46 & 19,36 & 13,35 \\
\hline 25 & 300 & 30 & 135,92 & 104,94 & 84,73 & 63,44 & 48,34 & 37,91 & 25,67 & 19,42 & 13,34 \\
\hline 25 & 350 & 30 & 129,75 & 102,12 & 83,45 & 63,28 & 48,60 & 38,25 & 25,87 & 19,49 & 13,33 \\
\hline 25 & 400 & 30 & 124,60 & 99,61 & 82,24 & 63,05 & 48,78 & 38,53 & 26,07 & 19,57 & 13,33 \\
\hline 25 & 450 & 30 & 120,19 & 97,36 & 81,08 & 62,77 & 48,90 & 38,78 & 26,25 & 19,64 & 13,33 \\
\hline 25 & 500 & 30 & 116,35 & 95,33 & 79,99 & 62,47 & 48,97 & 38,98 & 26,43 & 19,73 & 13,33 \\
\hline 25 & 550 & 30 & 112,96 & 93,47 & 78,95 & 62,14 & 49,00 & 39,15 & 26,60 & 19,81 & 13,33 \\
\hline 25 & 600 & 30 & 109,92 & 91,77 & 77,97 & 61,80 & 49,00 & 39,29 & 26,76 & 19,89 & 13,34 \\
\hline 25 & 650 & 30 & 107,18 & 90,19 & 77,04 & 61,46 & 48,98 & 39,41 & 26,90 & 19,97 & 13,34 \\
\hline 25 & 700 & 30 & 104,70 & 88,73 & 76,16 & 61,12 & 48,94 & 39,51 & 27,04 & 20,05 & 13,35 \\
\hline 25 & 750 & 30 & 102,42 & 87,37 & 75,32 & 60,77 & 48,88 & 39,59 & 27,17 & 20,14 & 13,36 \\
\hline 25 & 800 & 30 & 100,32 & 86,10 & 74,52 & 60,43 & 48,81 & 39,65 & 27,29 & 20,21 & 13,37 \\
\hline 25 & 850 & 30 & 98,39 & 84,91 & 73,76 & 60,09 & 48,73 & 39,70 & 27,40 & 20,29 & 13,38 \\
\hline 25 & 900 & 30 & 96,59 & 83,78 & 73,03 & 59,76 & 48,63 & 39,74 & 27,51 & 20,37 & 13,40 \\
\hline
\end{tabular}




\begin{tabular}{|c|c|c|c|c|c|c|c|c|c|c|c|}
\hline \multirow[b]{2}{*}{$\mathrm{H}(\mathrm{cm})$} & \multirow[b]{2}{*}{ Mceq (MPa) } & & & & & $\mathrm{De}$ & ões (x1 & & & & \\
\hline & & Msub (MPa) & D0 & D25 & D40 & D60 & D80 & D100 & D140 & D180 & D260 \\
\hline 25 & 950 & 30 & 94,91 & 82,72 & 72,33 & 59,43 & 48,54 & 39,77 & 27,61 & 20,44 & 13,41 \\
\hline 25 & 1000 & 30 & 93,34 & 81,72 & 71,66 & 59,11 & 48,43 & 39,79 & 27,70 & 20,51 & 13,43 \\
\hline 25 & 1050 & 30 & 91,86 & 80,76 & 71,02 & 58,79 & 48,32 & 39,80 & 27,79 & 20,59 & 13,44 \\
\hline 25 & 1100 & 30 & 90,48 & 79,86 & 70,41 & 58,48 & 48,21 & 39,80 & 27,87 & 20,65 & 13,46 \\
\hline 25 & 1150 & 30 & 89,17 & 78,99 & 69,81 & 58,17 & 48,09 & 39,80 & 27,94 & 20,72 & 13,48 \\
\hline 25 & 1200 & 30 & 87,93 & 78,17 & 69,24 & 57,87 & 47,98 & 39,79 & 28,02 & 20,78 & 13,50 \\
\hline 25 & 1250 & 30 & 86,76 & 77,38 & 68,69 & 57,57 & 47,86 & 39,78 & 28,08 & 20,85 & 13,52 \\
\hline 25 & 1300 & 30 & 85,65 & 76,63 & 68,16 & 57,28 & 47,73 & 39,76 & 28,14 & 20,91 & 13,54 \\
\hline 25 & 1350 & 30 & 84,59 & 75,90 & 67,65 & 57,00 & 47,61 & 39,74 & 28,20 & 20,97 & 13,55 \\
\hline 25 & 1400 & 30 & 83,59 & 75,21 & 67,15 & 56,72 & 47,49 & 39,71 & 28,26 & 21,02 & 13,57 \\
\hline 25 & 1450 & 30 & 82,63 & 74,54 & 66,67 & 56,45 & 47,36 & 39,68 & 28,31 & 21,08 & 13,59 \\
\hline 25 & 1500 & 30 & 81,71 & 73,89 & 66,20 & 56,19 & 47,24 & 39,65 & 28,35 & 21,13 & 13,61 \\
\hline 25 & 1550 & 30 & 80,83 & 73,27 & 65,75 & 55,92 & 47,12 & 39,61 & 28,40 & 21,18 & 13,64 \\
\hline 25 & 1600 & 30 & 79,99 & 72,68 & 65,31 & 55,67 & 46,99 & 39,58 & 28,44 & 21,23 & 13,66 \\
\hline 25 & 1650 & 30 & 79,19 & 72,10 & 64,89 & 55,42 & 46,87 & 39,54 & 28,48 & 21,28 & 13,68 \\
\hline 25 & 1700 & 30 & 78,41 & 71,54 & 64,47 & 55,17 & 46,75 & 39,50 & 28,51 & 21,33 & 13,70 \\
\hline 25 & 1750 & 30 & 77,67 & 71,00 & 64,07 & 54,93 & 46,62 & 39,45 & 28,54 & 21,37 & 13,72 \\
\hline 25 & 1800 & 30 & 76,96 & 70,47 & 63,68 & 54,69 & 46,50 & 39,41 & 28,57 & 21,42 & 13,74 \\
\hline 25 & 1850 & 30 & 76,27 & 69,96 & 63,30 & 54,46 & 46,38 & 39,36 & 28,60 & 21,46 & 13,76 \\
\hline 25 & 1900 & 30 & 75,61 & 69,47 & 62,93 & 54,23 & 46,26 & 39,32 & 28,63 & 21,50 & 13,78 \\
\hline 25 & 1950 & 30 & 74,97 & 68,99 & 62,57 & 54,01 & 46,14 & 39,27 & 28,65 & 21,54 & 13,80 \\
\hline 25 & 2000 & 30 & 74,35 & 68,53 & 62,22 & 53,79 & 46,02 & 39,22 & 28,68 & 21,58 & 13,82 \\
\hline 25 & 200 & 35 & 137,63 & 98,01 & 75,54 & 54,15 & 40,37 & 31,48 & 21,55 & 16,54 & 11,47 \\
\hline 25 & 250 & 35 & 128,80 & 94,95 & 74,59 & 54,36 & 40,83 & 31,86 & 21,70 & 16,57 & 11,46 \\
\hline 25 & 300 & 35 & 121,99 & 92,29 & 73,60 & 54,42 & 41,17 & 32,20 & 21,85 & 16,61 & 11,44 \\
\hline 25 & 350 & 35 & 116,50 & 89,95 & 72,63 & 54,38 & 41,44 & 32,49 & 22,00 & 16,65 & 11,44 \\
\hline 25 & 400 & 35 & 111,91 & 87,86 & 71,69 & 54,26 & 41,63 & 32,74 & 22,15 & 16,70 & 11,43 \\
\hline 25 & 450 & 35 & 107,99 & 85,97 & 70,78 & 54,10 & 41,78 & 32,96 & 22,30 & 16,75 & 11,43 \\
\hline 25 & 500 & 35 & 104,57 & 84,26 & 69,92 & 53,91 & 41,88 & 33,15 & 22,44 & 16,81 & 11,42 \\
\hline 25 & 550 & 35 & 101,56 & 82,69 & 69,09 & 53,69 & 41,95 & 33,32 & 22,57 & 16,87 & 11,42 \\
\hline 25 & 600 & 35 & 98,86 & 81,24 & 68,30 & 53,46 & 41,99 & 33,46 & 22,70 & 16,93 & 11,42 \\
\hline 25 & 650 & 35 & 96,43 & 79,90 & 67,55 & 53,22 & 42,00 & 33,58 & 22,82 & 16,99 & 11,43 \\
\hline 25 & 700 & 35 & 94,22 & 78,66 & 66,83 & 52,98 & 42,00 & 33,68 & 22,93 & 17,05 & 11,43 \\
\hline 25 & 750 & 35 & 92,19 & 77,50 & 66,15 & 52,72 & 41,99 & 33,77 & 23,04 & 17,11 & 11,43 \\
\hline 25 & 800 & 35 & 90,33 & 76,41 & 65,49 & 52,47 & 41,96 & 33,84 & 23,14 & 17,17 & 11,44 \\
\hline 25 & 850 & 35 & 88,60 & 75,38 & 64,87 & 52,22 & 41,92 & 33,91 & 23,24 & 17,23 & 11,45 \\
\hline 25 & 900 & 35 & 87,00 & 74,42 & 64,26 & 51,97 & 41,87 & 33,96 & 23,33 & 17,29 & 11,46 \\
\hline 25 & 950 & 35 & 85,50 & 73,50 & 63,69 & 51,72 & 41,82 & 34,00 & 23,42 & 17,35 & 11,46 \\
\hline 25 & 1000 & 35 & 84,10 & 72,64 & 63,13 & 51,47 & 41,75 & 34,04 & 23,50 & 17,40 & 11,47 \\
\hline 25 & 1050 & 35 & $\begin{array}{l}82,79 \\
\end{array}$ & 71,81 & 62,60 & 51,22 & 41,69 & 34,06 & 23,58 & 17,46 & 11,48 \\
\hline 25 & 1100 & 35 & 81,55 & 71,03 & 62,08 & 50,98 & 41,61 & 34,09 & 23,65 & 17,51 & 11,49 \\
\hline 25 & 1150 & 35 & 80,38 & 70,28 & 61,59 & 50,74 & 41,54 & 34,10 & 23,72 & 17,57 & 11,51 \\
\hline 25 & 1200 & 35 & 79,27 & 69,57 & 61,11 & 50,51 & 41,46 & 34,11 & 23,79 & 17,62 & 11,52 \\
\hline 25 & 1250 & 35 & 78,22 & 68,89 & 60,65 & 50,27 & 41,38 & 34,12 & 23,85 & 17,67 & 11,53 \\
\hline 25 & 1300 & 35 & 77,22 & 68,23 & 60,20 & 50,05 & 41,30 & 34,12 & 23,91 & 17,72 & 11,54 \\
\hline 25 & 1350 & 35 & 76,28 & 67,61 & 59,77 & 49,82 & 41,21 & 34,11 & 23,96 & 17,77 & 11,56 \\
\hline 25 & 1400 & 35 & 75,37 & 67,00 & 59,35 & 49,60 & 41,12 & 34,11 & 24,01 & 17,82 & 11,57 \\
\hline 25 & 1450 & 35 & 74,51 & 66,42 & 58,94 & 49,38 & 41,03 & 34,10 & 24,06 & 17,86 & 11,58 \\
\hline 25 & 1500 & 35 & 73,68 & 65,86 & 58,55 & 49,17 & 40,95 & 34,08 & 24,11 & 17,91 & 11,60 \\
\hline 25 & 1550 & 35 & 72,89 & 65,32 & 58,17 & 48,96 & 40,86 & 34,07 & 24,15 & 17,95 & 11,61 \\
\hline 25 & 1600 & 35 & 72,13 & 64,80 & 57,80 & 48,76 & 40,77 & 34,05 & 24,19 & 17,99 & 11,63 \\
\hline 25 & 1650 & 35 & 71,41 & 64,30 & 57,44 & 48,55 & 40,67 & 34,03 & 24,23 & 18,03 & 11,64 \\
\hline 25 & 1700 & 35 & 70,71 & 63,81 & 57,09 & 48,35 & 40,58 & 34,01 & 24,27 & 18,07 & 11,65 \\
\hline 25 & 1750 & 35 & 70,04 & 63,34 & 56,74 & 48,16 & 40,49 & 33,98 & 24,30 & 18,11 & 11,67 \\
\hline 25 & 1800 & 35 & 69,39 & 62,88 & 56,41 & 47,97 & 40,40 & 33,96 & 24,33 & 18,15 & 11,68 \\
\hline 25 & 1850 & 35 & 68,77 & 62,44 & 56,09 & 47,78 & 40,31 & 33,93 & 24,37 & 18,19 & 11,70 \\
\hline 25 & 1900 & 35 & 68,17 & 62,01 & 55,77 & 47,59 & 40,22 & 33,90 & 24,39 & 18,22 & 11,72 \\
\hline 25 & 1950 & 35 & 67,59 & 61,59 & 55,47 & 47,41 & 40,13 & 33,87 & 24,42 & 18,26 & 11,73 \\
\hline 25 & 2000 & 35 & 67,03 & 61,18 & 55,16 & 47,23 & 40,04 & 33,84 & 24,45 & 18,29 & 11,75 \\
\hline 25 & 200 & 40 & 125,32 & 87,27 & 66,49 & 47,21 & 35,08 & 27,36 & 18,79 & 14,46 & 10,05 \\
\hline 25 & 250 & 40 & 117,26 & 84,71 & 65,79 & 47,47 & 35,49 & 27,68 & 18,90 & 14,48 & 10,03 \\
\hline 25 & 300 & 40 & 111,07 & 82,47 & 65,05 & 47,59 & 35,81 & 27,96 & 19,02 & 14,50 & 10,02 \\
\hline 25 & 350 & 40 & 106,09 & 80,49 & 64,29 & 47,62 & 36,06 & 28,21 & 19,13 & 14,53 & 10,01 \\
\hline 25 & 400 & 40 & 101,94 & 78,71 & 63,55 & 47,58 & 36,26 & 28,43 & 19,25 & 14,57 & 10,01 \\
\hline 25 & 450 & 40 & 98,39 & 77,09 & 62,83 & 47,50 & 36,41 & 28,63 & 19,37 & 14,61 & 10,00 \\
\hline 25 & 500 & 40 & 95,30 & 75,62 & 62,13 & 47,38 & 36,53 & 28,80 & 19,48 & 14,65 & 10,00 \\
\hline 25 & 550 & 40 & 92,58 & 74,27 & 61,46 & 47,24 & 36,61 & 28,95 & 19,59 & 14,69 & 10,00 \\
\hline 25 & 600 & 40 & 90,14 & 73,02 & 60,81 & 47,08 & 36,68 & 29,08 & 19,69 & 14,73 & 10,00 \\
\hline 25 & 650 & 40 & 87,95 & 71,86 & 60,19 & 46,91 & 36,72 & 29,20 & 19,79 & 14,78 & 10,00 \\
\hline 25 & 700 & 40 & 85,95 & 70,78 & 59,60 & 46,73 & 36,74 & 29,30 & 19,89 & 14,82 & 10,00 \\
\hline 25 & 750 & 40 & 84,12 & 69,77 & 59,03 & 46,54 & 36,75 & 29,39 & 19,98 & 14,87 & 10,00 \\
\hline 25 & 800 & 40 & 82,44 & 68,83 & 58,48 & 46,35 & 36,75 & 29,47 & 20,07 & 14,92 & 10,00 \\
\hline 25 & 850 & 40 & 80,88 & 67,93 & 57,95 & 46,16 & 36,74 & 29,54 & 20,15 & 14,96 & 10,00 \\
\hline 25 & 900 & 40 & 79,43 & 67,09 & 57,45 & 45,97 & 36,72 & 29,60 & 20,23 & 15,01 & 10,01 \\
\hline 25 & 950 & 40 & 78,08 & 66,29 & 56,96 & 45,77 & 36,69 & 29,65 & 20,31 & 15,06 & 10,01 \\
\hline 25 & 1000 & 40 & 76,81 & 65,53 & 56,49 & 45,58 & 36,66 & 29,69 & 20,38 & 15,10 & 10,02 \\
\hline 25 & 1050 & 40 & 75,62 & 64,81 & 56,04 & 45,39 & 36,62 & 29,73 & 20,45 & 15,15 & 10,03 \\
\hline 25 & 1100 & 40 & 74,50 & 64,12 & 55,60 & 45,20 & 36,58 & 29,76 & 20,51 & 15,19 & 10,03 \\
\hline 25 & 1150 & 40 & 73,44 & 63,47 & 55,18 & 45,01 & 36,53 & 29,79 & 20,57 & 15,23 & 10,04 \\
\hline 25 & 1200 & 40 & 72,44 & 62,84 & 54,77 & 44,82 & 36,48 & 29,81 & 20,63 & 15,28 & 10,05 \\
\hline 25 & 1250 & 40 & 71,49 & 62,24 & 54,38 & 44,63 & 36,42 & 29,82 & 20,69 & 15,32 & 10,06 \\
\hline
\end{tabular}




\begin{tabular}{|c|c|c|c|c|c|c|c|c|c|c|c|}
\hline \multirow[b]{2}{*}{$\mathrm{H}(\mathrm{cm})$} & \multirow[b]{2}{*}{ Mceq (MPa) } & & & & & De & ões (x1 & m) & & & \\
\hline & & Msub (MPa) & D0 & D25 & D40 & D60 & D80 & D100 & D140 & D180 & D260 \\
\hline 25 & 1300 & 40 & 70,58 & 61,66 & 54,00 & 44,45 & 36,36 & 29,83 & 20,74 & 15,36 & 10,06 \\
\hline 25 & 1350 & 40 & 69,72 & 61,11 & 53,63 & 44,27 & 36,30 & 29,84 & 20,79 & 15,40 & 10,07 \\
\hline 25 & 1400 & 40 & 68,90 & 60,57 & 53,27 & 44,09 & 36,24 & 29,85 & 20,84 & 15,44 & 10,08 \\
\hline 25 & 1450 & 40 & 68,11 & 60,06 & 52,92 & 43,91 & 36,18 & 29,85 & 20,89 & 15,48 & 10,09 \\
\hline 25 & 1500 & 40 & 67,36 & 59,57 & 52,58 & 43,74 & 36,11 & 29,85 & 20,93 & 15,52 & 10,10 \\
\hline 25 & 1550 & 40 & 66,64 & 59,09 & 52,25 & 43,57 & 36,05 & 29,85 & 20,97 & 15,55 & 10,11 \\
\hline 25 & 1600 & 40 & 65,95 & 58,63 & 51,93 & 43,40 & 35,98 & 29,84 & 21,01 & 15,59 & 10,12 \\
\hline 25 & 1650 & 40 & 65,29 & 58,18 & 51,62 & 43,23 & 35,91 & 29,84 & 21,05 & 15,62 & 10,13 \\
\hline 25 & 1700 & 40 & 64,65 & 57,75 & 51,32 & 43,07 & 35,85 & 29,83 & 21,08 & 15,66 & 10,14 \\
\hline 25 & 1750 & 40 & 64,04 & 57,33 & 51,02 & 42,91 & 35,78 & 29,81 & 21,12 & 15,69 & 10,15 \\
\hline 25 & 1800 & 40 & 63,44 & 56,93 & 50,73 & 42,75 & 35,71 & 29,80 & 21,15 & 15,72 & 10,17 \\
\hline 25 & 1850 & 40 & 62,87 & 56,53 & 50,45 & 42,59 & 35,64 & 29,79 & 21,18 & 15,76 & 10,18 \\
\hline 25 & 1900 & 40 & 62,33 & 56,15 & 50,18 & 42,44 & 35,57 & 29,77 & 21,21 & 15,79 & 10,19 \\
\hline 25 & 1950 & 40 & 61,79 & 55,78 & 49,91 & 42,29 & 35,50 & 29,75 & 21,24 & 15,82 & 10,20 \\
\hline 25 & 2000 & 40 & 61,28 & 55,42 & 49,65 & 42,14 & 35,43 & 29,74 & 21,26 & 15,85 & 10,21 \\
\hline 25 & 200 & 45 & 115,39 & 78,70 & 59,34 & 41,81 & 30,99 & 24,19 & 16,66 & 12,85 & 8,94 \\
\hline 25 & 250 & 45 & 107,95 & 76,52 & 58,83 & 42,09 & 31,35 & 24,45 & 16,75 & 12,86 & 8,92 \\
\hline 25 & 300 & 45 & 102,25 & 74,61 & 58,26 & 42,24 & 31,65 & 24,69 & 16,84 & 12,88 & 8,91 \\
\hline 25 & 350 & 45 & 97,67 & 72,90 & 57,67 & 42,32 & 31,88 & 24,90 & 16,93 & 12,90 & 8,91 \\
\hline 25 & 400 & 45 & 93,86 & 71,36 & 57,08 & 42,33 & 32,08 & 25,10 & 17,02 & 12,92 & 8,90 \\
\hline 25 & 450 & 45 & 90,61 & 69,96 & 56,49 & 42,29 & 32,23 & 25,27 & 17,11 & 12,95 & 8,89 \\
\hline 25 & 500 & 45 & 87,79 & 68,68 & 55,92 & 42,23 & 32,35 & 25,43 & 17,20 & 12,98 & 8,89 \\
\hline 25 & 550 & 45 & 85,29 & 67,50 & 55,36 & 42,14 & 32,45 & 25,57 & 17,29 & 13,01 & 8,89 \\
\hline 25 & 600 & 45 & 83,07 & 66,41 & 54,82 & 42,03 & 32,52 & 25,69 & 17,38 & 13,04 & 8,89 \\
\hline 25 & 650 & 45 & 81,06 & 65,39 & 54,31 & 41,91 & 32,58 & 25,80 & 17,46 & 13,08 & 8,89 \\
\hline 25 & 700 & 45 & 79,24 & 64,44 & 53,81 & 41,78 & 32,62 & 25,90 & 17,54 & 13,11 & 8,88 \\
\hline 25 & 750 & 45 & 77,57 & 63,55 & 53,33 & 41,64 & 32,65 & 25,99 & 17,62 & 13,15 & 8,89 \\
\hline 25 & 800 & 45 & 76,03 & 62,71 & 52,86 & 41,50 & 32,66 & 26,06 & 17,70 & 13,19 & 8,89 \\
\hline 25 & 850 & 45 & 74,61 & 61,93 & 52,41 & 41,35 & 32,67 & 26,13 & 17,77 & 13,22 & 8,89 \\
\hline 25 & 900 & 45 & 73,28 & 61,18 & 51,98 & 41,20 & 32,67 & 26,20 & 17,84 & 13,26 & 8,89 \\
\hline 25 & 950 & 45 & 72,04 & 60,47 & 51,57 & 41,05 & 32,66 & 26,25 & 17,90 & 13,30 & 8,89 \\
\hline 25 & 1000 & 45 & 70,89 & 59,80 & 51,16 & 40,90 & 32,65 & 26,30 & 17,97 & 13,33 & 8,90 \\
\hline 25 & 1050 & 45 & 69,80 & 59,16 & 50,77 & 40,75 & 32,63 & 26,34 & 18,03 & 13,37 & 8,90 \\
\hline 25 & 1100 & 45 & 68,77 & 58,54 & 50,40 & 40,59 & 32,60 & 26,38 & 18,09 & 13,41 & 8,90 \\
\hline 25 & 1150 & 45 & 67,80 & 57,96 & 50,03 & 40,44 & 32,57 & 26,41 & 18,14 & 13,44 & 8,91 \\
\hline 25 & 1200 & 45 & 66,88 & 57,40 & 49,68 & 40,29 & 32,54 & 26,44 & 18,19 & 13,48 & 8,91 \\
\hline 25 & 1250 & 45 & 66,01 & 56,86 & 49,34 & 40,14 & 32,50 & 26,46 & 18,24 & 13,51 & 8,92 \\
\hline 25 & 1300 & 45 & 65,18 & 56,35 & 49,01 & 39,99 & 32,46 & 26,48 & 18,29 & 13,55 & 8,93 \\
\hline 25 & 1350 & 45 & 64,39 & 55,86 & 48,69 & 39,84 & 32,42 & 26,49 & 18,34 & 13,58 & 8,93 \\
\hline 25 & 1400 & 45 & 63,64 & 55,38 & 48,38 & 39,69 & 32,38 & 26,51 & 18,38 & 13,61 & 8,94 \\
\hline 25 & 1450 & 45 & 62,91 & 54,92 & 48,07 & 39,55 & 32,33 & 26,52 & 18,43 & 13,64 & 8,94 \\
\hline 25 & 1500 & 45 & 62,22 & 54,48 & 47,78 & 39,40 & 32,29 & 26,53 & 18,47 & 13,68 & 8,95 \\
\hline 25 & 1550 & 45 & 61,56 & 54,05 & 47,49 & 39,26 & 32,24 & 26,53 & 18,51 & 13,71 & 8,96 \\
\hline 25 & 1600 & 45 & 60,93 & 53,64 & 47,21 & 39,12 & 32,19 & 26,53 & 18,54 & 13,74 & 8,97 \\
\hline 25 & 1650 & 45 & 60,32 & 53,24 & 46,94 & 38,98 & 32,14 & 26,53 & 18,58 & 13,77 & 8,97 \\
\hline 25 & 1700 & 45 & 59,73 & 52,85 & 46,67 & 38,85 & 32,09 & 26,53 & 18,61 & 13,80 & 8,98 \\
\hline 25 & 1750 & 45 & 59,17 & 52,48 & 46,41 & 38,71 & 32,04 & 26,53 & 18,65 & 13,83 & 8,99 \\
\hline 25 & 1800 & 45 & 58,62 & 52,11 & 46,16 & 38,58 & 31,98 & 26,53 & 18,68 & 13,86 & 9,00 \\
\hline 25 & 1850 & 45 & 58,10 & 51,76 & 45,91 & 38,45 & 31,93 & 26,52 & 18,71 & 13,88 & 9,01 \\
\hline 25 & 1900 & 45 & 57,59 & 51,42 & 45,67 & 38,32 & 31,88 & 26,51 & 18,74 & 13,91 & 9,01 \\
\hline 25 & 1950 & 45 & 57,10 & 51,08 & 45,44 & 38,19 & 31,82 & 26,51 & 18,76 & 13,94 & 9,02 \\
\hline 25 & 2000 & 45 & 56,63 & 50,76 & 45,21 & 38,06 & 31,77 & 26,50 & 18,79 & 13,96 & 9,03 \\
\hline 25 & 200 & 50 & 107,21 & 71,69 & 53,55 & 37,48 & 27,74 & 21,67 & 14,97 & 11,56 & 8,05 \\
\hline 25 & 250 & 50 & 100,25 & 69,81 & 53,19 & 37,77 & 28,07 & 21,89 & 15,03 & 11,57 & 8,04 \\
\hline 25 & 300 & 50 & 94,95 & 68,16 & 52,75 & 37,95 & 28,33 & 22,09 & 15,10 & 11,58 & 8,03 \\
\hline 25 & 350 & 50 & 90,70 & 66,67 & 52,28 & 38,05 & 28,55 & 22,28 & 15,18 & 11,59 & 8,02 \\
\hline 25 & 400 & 50 & 87,17 & 65,32 & 51,80 & 38,09 & 28,73 & 22,45 & 15,25 & 11,61 & 8,01 \\
\hline 25 & 450 & 50 & 84,16 & 64,09 & 51,32 & 38,09 & 28,88 & 22,60 & 15,33 & 11,63 & 8,01 \\
\hline 25 & 500 & 50 & 81,55 & 62,96 & 50,84 & 38,06 & 29,01 & 22,74 & 15,40 & 11,65 & 8,01 \\
\hline 25 & 550 & 50 & 79,25 & 61,92 & 50,38 & 38,01 & 29,11 & 22,87 & 15,47 & 11,68 & 8,00 \\
\hline 25 & 600 & 50 & 77,19 & 60,96 & 49,92 & 37,94 & 29,19 & 22,99 & 15,55 & 11,70 & 8,00 \\
\hline 25 & 650 & 50 & 75,34 & 60,05 & 49,49 & 37,86 & 29,25 & 23,09 & 15,62 & 11,73 & 8,00 \\
\hline 25 & 700 & 50 & 73,66 & 59,21 & 49,06 & 37,76 & 29,30 & 23,18 & 15,69 & 11,76 & 8,00 \\
\hline 25 & 750 & 50 & 72,12 & 58,42 & 48,65 & 37,66 & 29,34 & 23,27 & 15,75 & 11,79 & 8,00 \\
\hline 25 & 800 & 50 & 70,70 & 57,67 & 48,25 & 37,55 & 29,37 & 23,34 & 15,82 & 11,82 & 8,00 \\
\hline 25 & 850 & 50 & 69,38 & 56,97 & 47,87 & 37,44 & 29,39 & 23,41 & 15,88 & 11,85 & 8,00 \\
\hline 25 & 900 & 50 & 68,16 & 56,30 & 47,49 & 37,32 & 29,40 & 23,47 & 15,94 & 11,87 & 8,00 \\
\hline 25 & 950 & 50 & 67,02 & 55,66 & 47,13 & 37,20 & 29,40 & 23,53 & 16,00 & 11,90 & 8,00 \\
\hline 25 & 1000 & 50 & 65,95 & 55,06 & 46,78 & 37,08 & 29,40 & 23,58 & 16,05 & 11,93 & 8,00 \\
\hline 25 & 1050 & 50 & 64,95 & 54,49 & 46,45 & 36,96 & 29,40 & 23,62 & 16,11 & 11,96 & 8,00 \\
\hline 25 & 1100 & 50 & 64,00 & 53,94 & 46,12 & 36,84 & 29,38 & 23,66 & 16,16 & 11,99 & 8,01 \\
\hline 25 & 1150 & 50 & 63,11 & 53,41 & 45,80 & 36,71 & 29,37 & 23,69 & 16,21 & 12,02 & 8,01 \\
\hline 25 & 1200 & 50 & 62,26 & 52,91 & 45,49 & 36,59 & 29,35 & 23,73 & 16,26 & 12,05 & 8,01 \\
\hline 25 & 1250 & 50 & 61,45 & 52,42 & 45,19 & 36,46 & 29,33 & 23,75 & 16,30 & 12,08 & 8,02 \\
\hline 25 & 1300 & 50 & 60,69 & 51,96 & 44,90 & 36,34 & 29,30 & 23,78 & 16,35 & 12,11 & 8,02 \\
\hline 25 & 1350 & 50 & 59,95 & 51,51 & 44,62 & 36,22 & 29,28 & 23,80 & 16,39 & 12,14 & 8,02 \\
\hline 25 & 1400 & 50 & 59,26 & 51,08 & 44,35 & 36,10 & 29,25 & 23,82 & 16,43 & 12,17 & 8,03 \\
\hline 25 & 1450 & 50 & 58,59 & 50,67 & 44,08 & 35,98 & 29,21 & 23,83 & 16,47 & 12,19 & 8,03 \\
\hline 25 & 1500 & 50 & 57,95 & 50,27 & 43,82 & 35,86 & 29,18 & 23,84 & 16,51 & 12,22 & 8,04 \\
\hline 25 & 1550 & 50 & 57,34 & 49,88 & 43,57 & 35,74 & 29,15 & 23,86 & 16,54 & 12,25 & 8,04 \\
\hline 25 & 1600 & 50 & 56,75 & 49,51 & 43,32 & 35,62 & 29,11 & 23,86 & 16,58 & 12,27 & 8,05 \\
\hline
\end{tabular}




\begin{tabular}{|c|c|c|c|c|c|c|c|c|c|c|c|}
\hline \multirow[b]{2}{*}{$\mathrm{H}(\mathrm{cm})$} & \multirow[b]{2}{*}{ Mceq (MPa) } & & & & & $\mathrm{De}$ & ões (x1 & & & & \\
\hline & & Msub (MPa) & D0 & D25 & D40 & D60 & D80 & D100 & D140 & D180 & D260 \\
\hline 25 & 1650 & 50 & 56,19 & 49,15 & 43,08 & 35,50 & 29,07 & 23,87 & 16,61 & 12,30 & 8,05 \\
\hline 25 & 1700 & 50 & 55,64 & 48,80 & 42,84 & 35,39 & 29,03 & 23,88 & 16,64 & 12,33 & 8,06 \\
\hline 25 & 1750 & 50 & 55,12 & 48,46 & 42,61 & 35,27 & 28,99 & 23,88 & 16,67 & 12,35 & 8,07 \\
\hline 25 & 1800 & 50 & 54,61 & 48,13 & 42,39 & 35,16 & 28,95 & 23,88 & 16,70 & 12,38 & 8,07 \\
\hline 25 & 1850 & 50 & 54,13 & 47,81 & 42,17 & 35,05 & 28,91 & 23,88 & 16,73 & 12,40 & 8,08 \\
\hline 25 & 1900 & 50 & 53,65 & 47,50 & 41,96 & 34,94 & 28,87 & 23,88 & 16,76 & 12,42 & 8,09 \\
\hline 25 & 1950 & 50 & 53,20 & 47,20 & 41,75 & 34,83 & 28,83 & 23,88 & 16,78 & 12,45 & 8,09 \\
\hline 25 & 2000 & 50 & 52,76 & 46,90 & 41,54 & 34,72 & 28,79 & 23,87 & 16,81 & 12,47 & 8,10 \\
\hline 25 & 200 & 55 & 100,33 & 65,85 & 48,78 & 33,95 & 25,10 & 19,63 & 13,58 & 10,50 & 7,32 \\
\hline 25 & 250 & 55 & 93,78 & 64,22 & 48,52 & 34,23 & 25,39 & 19,81 & 13,64 & 10,51 & 7,31 \\
\hline 25 & 300 & 55 & 88,80 & 62,76 & 48,18 & 34,42 & 25,63 & 19,99 & 13,70 & 10,52 & 7,30 \\
\hline 25 & 350 & 55 & 84,82 & 61,45 & 47,80 & 34,54 & 25,83 & 20,15 & 13,76 & 10,53 & 7,30 \\
\hline 25 & 400 & 55 & 81,52 & 60,26 & 47,41 & 34,60 & 26,00 & 20,30 & 13,82 & 10,54 & 7,29 \\
\hline 25 & 450 & 55 & 78,72 & 59,17 & 47,01 & 34,63 & 26,15 & 20,44 & 13,88 & 10,56 & 7,28 \\
\hline 25 & 500 & 55 & 76,28 & 58,17 & 46,61 & 34,63 & 26,27 & 20,56 & 13,94 & 10,58 & 7,28 \\
\hline 25 & 550 & 55 & 74,14 & 57,24 & 46,22 & 34,60 & 26,37 & 20,68 & 14,00 & 10,60 & 7,28 \\
\hline 25 & 600 & 55 & 72,22 & 56,38 & 45,83 & 34,56 & 26,45 & 20,78 & 14,06 & 10,62 & 7,27 \\
\hline 25 & 650 & 55 & 70,50 & 55,57 & 45,46 & 34,51 & 26,52 & 20,88 & 14,12 & 10,64 & 7,27 \\
\hline 25 & 700 & 55 & 68,93 & 54,81 & 45,09 & 34,44 & 26,58 & 20,96 & 14,18 & 10,66 & 7,27 \\
\hline 25 & 750 & 55 & 67,50 & 54,10 & 44,74 & 34,36 & 26,62 & 21,04 & 14,24 & 10,68 & 7,27 \\
\hline 25 & 800 & 55 & 66,18 & 53,43 & 44,39 & 34,28 & 26,66 & 21,12 & 14,29 & 10,70 & 7,27 \\
\hline 25 & 850 & 55 & 64,96 & 52,79 & 44,06 & 34,19 & 26,69 & 21,18 & 14,35 & 10,73 & 7,27 \\
\hline 25 & 900 & 55 & 63,83 & 52,19 & 43,74 & 34,10 & 26,71 & 21,24 & 14,40 & 10,75 & 7,27 \\
\hline 25 & 950 & 55 & 62,77 & 51,62 & 43,42 & 34,01 & 26,72 & 21,30 & 14,45 & 10,78 & 7,27 \\
\hline 25 & 1000 & 55 & 61,77 & 51,07 & 43,12 & 33,91 & 26,73 & 21,35 & 14,50 & 10,80 & 7,27 \\
\hline 25 & 1050 & 55 & 60,84 & 50,55 & 42,82 & 33,81 & 26,73 & 21,39 & 14,55 & 10,82 & 7,27 \\
\hline 25 & 1100 & 55 & 59,96 & 50,05 & 42,53 & 33,71 & 26,73 & 21,43 & 14,59 & 10,85 & 7,27 \\
\hline 25 & 1150 & 55 & 59,12 & 49,58 & 42,25 & 33,61 & 26,72 & 21,47 & 14,64 & 10,87 & 7,28 \\
\hline 25 & 1200 & 55 & 58,34 & 49,12 & 41,98 & 33,51 & 26,72 & 21,50 & 14,68 & 10,90 & 7,28 \\
\hline 25 & 1250 & 55 & 57,59 & 48,68 & 41,72 & 33,41 & 26,70 & 21,53 & 14,72 & 10,92 & 7,28 \\
\hline 25 & 1300 & 55 & 56,87 & 48,26 & 41,46 & 33,30 & 26,69 & 21,56 & 14,76 & 10,95 & 7,28 \\
\hline 25 & 1350 & 55 & 56,19 & 47,86 & 41,21 & 33,20 & 26,67 & 21,58 & 14,80 & 10,97 & 7,29 \\
\hline 25 & 1400 & 55 & 55,54 & 47,46 & 40,96 & 33,10 & 26,65 & 21,60 & 14,84 & 10,99 & 7,29 \\
\hline 25 & 1450 & 55 & 54,92 & 47,09 & 40,73 & 33,00 & 26,63 & 21,62 & 14,87 & 11,02 & 7,29 \\
\hline 25 & 1500 & 55 & 54,33 & 46,72 & 40,50 & 32,90 & 26,61 & 21,64 & 14,91 & 11,04 & 7,30 \\
\hline 25 & 1550 & 55 & 53,76 & 46,37 & 40,27 & 32,80 & 26,58 & 21,65 & 14,94 & 11,06 & 7,30 \\
\hline 25 & 1600 & 55 & 53,21 & 46,03 & 40,05 & 32,70 & 26,56 & 21,67 & 14,97 & 11,09 & 7,30 \\
\hline 25 & 1650 & 55 & 52,68 & 45,70 & 39,84 & 32,60 & 26,53 & 21,68 & 15,01 & 11,11 & 7,31 \\
\hline 25 & 1700 & 55 & 52,18 & 45,38 & 39,63 & 32,50 & 26,50 & 21,69 & 15,04 & 11,13 & 7,31 \\
\hline 25 & 1750 & 55 & 51,69 & 45,07 & 39,42 & 32,40 & 26,47 & 21,69 & 15,06 & 11,15 & 7,32 \\
\hline 25 & 1800 & 55 & 51,22 & 44,77 & 39,22 & 32,30 & 26,44 & 21,70 & 15,09 & 11,18 & 7,32 \\
\hline 25 & 1850 & 55 & 50,76 & 44,48 & 39,03 & 32,21 & 26,41 & 21,70 & 15,12 & 11,20 & 7,33 \\
\hline 25 & 1900 & 55 & 50,32 & 44,19 & 38,83 & 32,11 & 26,37 & 21,71 & 15,14 & 11,22 & 7,33 \\
\hline 25 & 1950 & 55 & 49,90 & 43,92 & 38,65 & 32,02 & 26,34 & 21,71 & 15,17 & 11,24 & 7,34 \\
\hline 25 & 2000 & 55 & 49,48 & 43,65 & 38,46 & 31,93 & 26,31 & 21,71 & 15,19 & 11,26 & 7,34 \\
\hline 25 & 200 & 60 & 94,46 & 60,90 & 44,77 & 31,01 & 22,91 & 17,93 & 12,44 & 9,63 & 6,72 \\
\hline 25 & 250 & 60 & 88,25 & 59,47 & 44,58 & 31,29 & 23,17 & 18,09 & 12,48 & 9,63 & 6,71 \\
\hline 25 & 300 & 60 & 83,54 & 58,18 & 44,32 & 31,48 & 23,39 & 18,24 & 12,53 & 9,64 & 6,70 \\
\hline 25 & 350 & 60 & 79,79 & 57,02 & 44,02 & 31,60 & 23,58 & 18,38 & 12,58 & 9,65 & 6,69 \\
\hline 25 & 400 & 60 & 76,69 & 55,96 & 43,70 & 31,68 & 23,74 & 18,52 & 12,63 & 9,66 & 6,69 \\
\hline 25 & 450 & 60 & 74,05 & 54,98 & 43,37 & 31,73 & 23,87 & 18,64 & 12,68 & 9,67 & 6,68 \\
\hline 25 & 500 & 60 & 71,76 & 54,08 & 43,03 & 31,75 & 23,99 & 18,75 & 12,73 & 9,68 & 6,68 \\
\hline 25 & 550 & 60 & 69,75 & 53,25 & 42,70 & 31,74 & 24,09 & 18,86 & 12,78 & 9,70 & 6,67 \\
\hline 25 & 600 & 60 & 67,96 & 52,47 & 42,37 & 31,72 & 24,17 & 18,95 & 12,83 & 9,71 & 6,67 \\
\hline 25 & 650 & 60 & 66,34 & 51,74 & 42,04 & 31,68 & 24,24 & 19,04 & 12,89 & 9,73 & 6,67 \\
\hline 25 & 700 & 60 & 64,88 & 51,06 & 41,73 & 31,64 & 24,30 & 19,12 & 12,94 & 9,75 & 6,67 \\
\hline 25 & 750 & 60 & 63,54 & 50,41 & 41,42 & 31,59 & 24,35 & 19,20 & 12,99 & 9,76 & 6,67 \\
\hline 25 & 800 & 60 & 62,30 & 49,81 & 41,12 & 31,52 & 24,39 & 19,27 & 13,03 & 9,78 & 6,66 \\
\hline 25 & 850 & 60 & 61,16 & 49,23 & 40,83 & 31,46 & 24,42 & 19,33 & 13,08 & 9,80 & 6,66 \\
\hline 25 & 900 & 60 & 60,10 & 48,68 & 40,54 & 31,39 & 24,45 & 19,39 & 13,13 & 9,82 & 6,66 \\
\hline 25 & 950 & 60 & 59,10 & 48,16 & 40,26 & 31,31 & 24,47 & 19,44 & 13,17 & 9,84 & 6,66 \\
\hline 25 & 1000 & 60 & 58,18 & 47,66 & 39,99 & 31,23 & 24,49 & 19,49 & 13,22 & 9,86 & 6,66 \\
\hline 25 & 1050 & 60 & 57,30 & 47,19 & 39,73 & 31,15 & 24,50 & 19,53 & 13,26 & 9,88 & 6,66 \\
\hline 25 & 1100 & 60 & 56,48 & 46,74 & 39,48 & 31,07 & 24,50 & 19,58 & 13,30 & 9,90 & 6,67 \\
\hline 25 & 1150 & 60 & 55,70 & 46,30 & 39,23 & 30,99 & 24,50 & 19,61 & 13,34 & 9,92 & 6,67 \\
\hline 25 & 1200 & 60 & 54,96 & 45,88 & 38,99 & 30,90 & 24,50 & 19,65 & 13,38 & 9,95 & 6,67 \\
\hline 25 & 1250 & 60 & 54,26 & 45,48 & 38,75 & 30,82 & 24,50 & 19,68 & 13,42 & 9,97 & 6,67 \\
\hline 25 & 1300 & 60 & 53,59 & 45,10 & 38,52 & 30,73 & 24,49 & 19,71 & 13,45 & 9,99 & 6,67 \\
\hline 25 & 1350 & 60 & 52,96 & 44,73 & 38,30 & 30,65 & 24,48 & 19,73 & 13,49 & 10,01 & 6,67 \\
\hline 25 & 1400 & 60 & 52,35 & 44,37 & 38,08 & 30,56 & 24,47 & 19,75 & 13,52 & 10,03 & 6,68 \\
\hline 25 & 1450 & 60 & 51,77 & 44,02 & 37,87 & 30,47 & 24,46 & 19,78 & 13,55 & 10,05 & 6,68 \\
\hline 25 & 1500 & 60 & 51,21 & 43,69 & 37,66 & 30,39 & 24,44 & 19,79 & 13,58 & 10,07 & 6,68 \\
\hline 25 & 1550 & 60 & 50,68 & 43,36 & 37,46 & 30,30 & 24,42 & 19,81 & 13,62 & 10,09 & 6,68 \\
\hline 25 & 1600 & 60 & 50,16 & 43,05 & 37,26 & 30,22 & 24,40 & 19,83 & 13,65 & 10,11 & 6,69 \\
\hline 25 & 1650 & 60 & 49,67 & 42,75 & 37,07 & 30,13 & 24,38 & 19,84 & 13,67 & 10,13 & 6,69 \\
\hline 25 & 1700 & 60 & 49,19 & 42,45 & 36,88 & 30,05 & 24,36 & 19,85 & 13,70 & 10,15 & 6,69 \\
\hline 25 & 1750 & 60 & 48,73 & 42,17 & 36,70 & 29,96 & 24,34 & 19,86 & 13,73 & 10,17 & 6,70 \\
\hline 25 & 1800 & 60 & 48,29 & 41,89 & 36,52 & 29,88 & 24,32 & 19,87 & 13,75 & 10,18 & 6,70 \\
\hline 25 & 1850 & 60 & 47,87 & 41,62 & 36,34 & 29,80 & 24,29 & 19,88 & 13,78 & 10,20 & 6,70 \\
\hline 25 & 1900 & 60 & 47,45 & 41,36 & 36,17 & 29,71 & 24,27 & 19,88 & 13,80 & 10,22 & 6,71 \\
\hline 25 & 1950 & 60 & 47,05 & 41,11 & 36,00 & 29,63 & 24,24 & 19,89 & 13,83 & 10,24 & 6,71 \\
\hline
\end{tabular}




\begin{tabular}{|c|c|c|c|c|c|c|c|c|c|c|c|}
\hline \multirow[b]{2}{*}{$\mathrm{H}(\mathrm{cm})$} & \multirow[b]{2}{*}{ Mceq (MPa) } & & & & & $\mathrm{De}$ & ões (x1 & & & & \\
\hline & & Msub (MPa) & D0 & D25 & D40 & D60 & D80 & D100 & D140 & D180 & D260 \\
\hline 25 & 2000 & 60 & 46,67 & 40,86 & 35,83 & 29,55 & 24,22 & 19,89 & 13,85 & 10,26 & 6,71 \\
\hline 25 & 200 & 65 & 89,39 & 56,66 & 41,35 & 28,52 & 21,07 & 16,51 & 11,47 & 8,88 & 6,21 \\
\hline 25 & 250 & 65 & 83,46 & 55,38 & 41,23 & 28,79 & 21,30 & 16,64 & 11,51 & 8,89 & 6,19 \\
\hline 25 & 300 & 65 & 78,99 & 54,24 & 41,03 & 28,98 & 21,50 & 16,77 & 11,54 & 8,89 & 6,19 \\
\hline 25 & 350 & 65 & 75,43 & 53,20 & 40,79 & 29,11 & 21,67 & 16,90 & 11,59 & 8,90 & 6,18 \\
\hline 25 & 400 & 65 & 72,49 & 52,24 & 40,52 & 29,20 & 21,82 & 17,02 & 11,63 & 8,91 & 6,17 \\
\hline 25 & 450 & 65 & 70,00 & 51,37 & 40,24 & 29,26 & 21,95 & 17,13 & 11,67 & 8,92 & 6,17 \\
\hline 25 & 500 & 65 & 67,84 & 50,56 & 39,96 & 29,29 & 22,06 & 17,23 & 11,71 & 8,93 & 6,17 \\
\hline 25 & 550 & 65 & 65,94 & 49,80 & 39,67 & 29,30 & 22,16 & 17,33 & 11,76 & 8,94 & 6,16 \\
\hline 25 & 600 & 65 & 64,25 & 49,10 & 39,39 & 29,30 & 22,24 & 17,41 & 11,80 & 8,95 & 6,16 \\
\hline 25 & 650 & 65 & 62,73 & 48,43 & 39,11 & 29,28 & 22,31 & 17,50 & 11,85 & 8,97 & 6,16 \\
\hline 25 & 700 & 65 & 61,35 & 47,81 & 38,83 & 29,25 & 22,37 & 17,57 & 11,89 & 8,98 & 6,16 \\
\hline 25 & 750 & 65 & 60,09 & 47,23 & 38,56 & 29,21 & 22,42 & 17,64 & 11,93 & 8,99 & 6,15 \\
\hline 25 & 800 & 65 & 58,92 & 46,67 & 38,30 & 29,17 & 22,47 & 17,71 & 11,98 & 9,01 & 6,15 \\
\hline 25 & 850 & 65 & 57,85 & 46,14 & 38,04 & 29,12 & 22,50 & 17,77 & 12,02 & 9,03 & 6,15 \\
\hline 25 & 900 & 65 & 56,85 & 45,64 & 37,79 & 29,06 & 22,53 & 17,82 & 12,06 & 9,04 & 6,15 \\
\hline 25 & 950 & 65 & 55,92 & 45,17 & 37,54 & 29,00 & 22,56 & 17,87 & 12,10 & 9,06 & 6,15 \\
\hline 25 & 1000 & 65 & 55,04 & 44,71 & 37,30 & 28,94 & 22,58 & 17,92 & 12,14 & 9,08 & 6,15 \\
\hline 25 & 1050 & 65 & 54,22 & 44,28 & 37,07 & 28,87 & 22,59 & 17,96 & 12,17 & 9,09 & 6,15 \\
\hline 25 & 1100 & 65 & 53,45 & 43,86 & 36,84 & 28,81 & 22,61 & 18,00 & 12,21 & 9,11 & 6,15 \\
\hline 25 & 1150 & 65 & 52,71 & 43,46 & 36,62 & 28,74 & 22,61 & 18,04 & 12,25 & 9,13 & 6,15 \\
\hline 25 & 1200 & 65 & 52,02 & 43,08 & 36,40 & 28,67 & 22,62 & 18,07 & 12,28 & 9,14 & 6,15 \\
\hline 25 & 1250 & 65 & 51,36 & 42,71 & 36,19 & 28,60 & 22,62 & 18,11 & 12,32 & 9,16 & 6,15 \\
\hline 25 & 1300 & 65 & 50,73 & 42,35 & 35,99 & 28,53 & 22,62 & 18,14 & 12,35 & 9,18 & 6,15 \\
\hline 25 & 1350 & 65 & 50,13 & 42,01 & 35,79 & 28,45 & 22,61 & 18,16 & 12,38 & 9,20 & 6,16 \\
\hline 25 & 1400 & 65 & 49,56 & 41,68 & 35,59 & 28,38 & 22,61 & 18,19 & 12,41 & 9,22 & 6,16 \\
\hline 25 & 1450 & 65 & 49,02 & 41,36 & 35,40 & 28,31 & 22,60 & 18,21 & 12,44 & 9,23 & 6,16 \\
\hline 25 & 1500 & 65 & 48,49 & 41,05 & 35,21 & 28,23 & 22,59 & 18,23 & 12,47 & 9,25 & 6,16 \\
\hline 25 & 1550 & 65 & 47,99 & 40,76 & 35,03 & 28,16 & 22,58 & 18,25 & 12,50 & 9,27 & 6,16 \\
\hline 25 & 1600 & 65 & 47,51 & 40,47 & 34,85 & 28,09 & 22,57 & 18,26 & 12,53 & 9,28 & 6,17 \\
\hline 25 & 1650 & 65 & 47,04 & 40,19 & 34,68 & 28,01 & 22,55 & 18,28 & 12,55 & 9,30 & 6,17 \\
\hline 25 & 1700 & 65 & 46,59 & 39,92 & 34,51 & 27,94 & 22,54 & 18,29 & 12,58 & 9,32 & 6,17 \\
\hline 25 & 1750 & 65 & 46,16 & 39,65 & 34,34 & 27,87 & 22,52 & 18,31 & 12,60 & 9,34 & 6,17 \\
\hline 25 & 1800 & 65 & 45,74 & 39,40 & 34,18 & 27,80 & 22,50 & 18,32 & 12,63 & 9,35 & 6,17 \\
\hline 25 & 1850 & 65 & 45,34 & 39,15 & 34,02 & 27,72 & 22,49 & 18,33 & 12,65 & 9,37 & 6,18 \\
\hline 25 & 1900 & 65 & 44,95 & 38,90 & 33,86 & 27,65 & 22,47 & 18,33 & 12,67 & 9,38 & 6,18 \\
\hline 25 & 1950 & 65 & 44,58 & 38,67 & 33,71 & 27,58 & 22,45 & 18,34 & 12,70 & 9,40 & 6,18 \\
\hline 25 & 2000 & 65 & 44,21 & 38,44 & 33,56 & 27,51 & 22,43 & 18,35 & 12,72 & 9,42 & 6,19 \\
\hline 25 & 200 & 70 & 84,95 & 52,98 & 38,41 & 26,39 & 19,50 & 15,29 & 10,64 & 8,25 & 5,77 \\
\hline 25 & 250 & 70 & 79,27 & 51,84 & 38,34 & 26,65 & 19,71 & 15,41 & 10,67 & 8,25 & 5,76 \\
\hline 25 & 300 & 70 & 75,00 & 50,81 & 38,19 & 26,84 & 19,89 & 15,53 & 10,70 & 8,26 & 5,75 \\
\hline 25 & 350 & 70 & 71,61 & 49,87 & 37,99 & 26,98 & 20,05 & 15,64 & 10,74 & 8,26 & 5,74 \\
\hline 25 & 400 & 70 & 68,81 & 49,01 & 37,77 & 27,08 & 20,19 & 15,74 & 10,77 & 8,27 & 5,74 \\
\hline 25 & 450 & 70 & 66,45 & 48,21 & 37,54 & 27,14 & 20,31 & 15,84 & 10,81 & 8,28 & 5,73 \\
\hline 25 & 500 & 70 & 64,40 & 47,48 & 37,29 & 27,18 & 20,41 & 15,93 & 10,85 & 8,28 & 5,73 \\
\hline 25 & 550 & 70 & 62,60 & 46,79 & 37,05 & 27,20 & 20,51 & 16,02 & 10,89 & 8,29 & 5,73 \\
\hline 25 & 600 & 70 & 61,00 & 46,15 & 36,80 & 27,21 & 20,59 & 16,10 & 10,92 & 8,30 & 5,72 \\
\hline 25 & 650 & 70 & 59,56 & 45,54 & 36,56 & 27,20 & 20,66 & 16,18 & 10,96 & 8,31 & 5,72 \\
\hline 25 & 700 & 70 & 58,25 & 44,97 & 36,31 & 27,19 & 20,72 & 16,25 & 11,00 & 8,32 & 5,72 \\
\hline 25 & 750 & 70 & 57,06 & 44,44 & 36,08 & 27,16 & 20,77 & 16,31 & 11,04 & 8,34 & 5,72 \\
\hline 25 & 800 & 70 & 55,96 & 43,93 & 35,84 & 27,13 & 20,82 & 16,37 & 11,08 & 8,35 & 5,72 \\
\hline 25 & 850 & 70 & 54,94 & 43,45 & 35,61 & 27,09 & 20,85 & 16,43 & 11,11 & 8,36 & 5,71 \\
\hline 25 & 900 & 70 & 54,00 & 42,99 & 35,39 & 27,05 & 20,89 & 16,48 & 11,15 & 8,38 & 5,71 \\
\hline 25 & 950 & 70 & 53,11 & 42,55 & 35,17 & 27,00 & 20,92 & 16,53 & 11,18 & 8,39 & 5,71 \\
\hline 25 & 1000 & 70 & 52,29 & 42,13 & 34,96 & 26,95 & 20,94 & 16,58 & 11,22 & 8,40 & 5,71 \\
\hline 25 & 1050 & 70 & 51,51 & 41,73 & 34,75 & 26,90 & 20,96 & 16,62 & 11,25 & 8,42 & 5,71 \\
\hline 25 & 1100 & 70 & 50,78 & 41,34 & 34,55 & 26,85 & 20,97 & 16,66 & 11,28 & 8,43 & 5,71 \\
\hline 25 & 1150 & 70 & 50,09 & 40,97 & 34,35 & 26,79 & 20,98 & 16,69 & 11,32 & 8,45 & 5,71 \\
\hline 25 & 1200 & 70 & 49,43 & 40,62 & 34,15 & 26,73 & 20,99 & 16,73 & 11,35 & 8,46 & 5,71 \\
\hline 25 & 1250 & 70 & 48,81 & 40,28 & 33,96 & 26,67 & 21,00 & 16,76 & 11,38 & 8,48 & 5,71 \\
\hline 25 & 1300 & 70 & 48,22 & 39,95 & 33,78 & 26,61 & 21,00 & 16,79 & 11,41 & 8,49 & 5,71 \\
\hline 25 & 1350 & 70 & 47,65 & 39,63 & 33,59 & 26,55 & 21,00 & 16,81 & 11,44 & 8,51 & 5,71 \\
\hline 25 & 1400 & 70 & 47,11 & 39,33 & 33,42 & 26,49 & 21,00 & 16,84 & 11,47 & 8,52 & 5,72 \\
\hline 25 & 1450 & 70 & 46,59 & 39,03 & 33,24 & 26,43 & 21,00 & 16,86 & 11,49 & 8,54 & 5,72 \\
\hline 25 & 1500 & 70 & 46,10 & 38,75 & 33,07 & 26,36 & 20,99 & 16,88 & 11,52 & 8,55 & 5,72 \\
\hline 25 & 1550 & 70 & 45,62 & 38,47 & 32,91 & 26,30 & 20,99 & 16,90 & 11,55 & 8,57 & 5,72 \\
\hline 25 & 1600 & 70 & 45,16 & 38,20 & 32,75 & 26,24 & 20,98 & 16,92 & 11,57 & 8,58 & 5,72 \\
\hline 25 & 1650 & 70 & 44,73 & 37,94 & 32,59 & 26,17 & 20,97 & 16,94 & 11,60 & 8,60 & 5,72 \\
\hline 25 & 1700 & 70 & 44,30 & 37,69 & 32,43 & 26,11 & 20,96 & 16,95 & 11,62 & 8,61 & 5,72 \\
\hline 25 & 1750 & 70 & 43,89 & 37,45 & 32,28 & 26,05 & 20,95 & 16,97 & 11,64 & 8,63 & 5,73 \\
\hline 25 & 1800 & 70 & 43,50 & 37,21 & 32,13 & 25,98 & 20,94 & 16,98 & 11,67 & 8,64 & 5,73 \\
\hline 25 & 1850 & 70 & 43,12 & 36,98 & 31,99 & 25,92 & 20,92 & 16,99 & 11,69 & 8,66 & 5,73 \\
\hline 25 & 1900 & 70 & 42,75 & 36,75 & 31,84 & 25,86 & 20,91 & 17,00 & 11,71 & 8,67 & 5,73 \\
\hline 25 & 1950 & 70 & 42,40 & 36,53 & 31,70 & 25,80 & 20,89 & 17,01 & 11,73 & 8,69 & 5,73 \\
\hline 25 & 2000 & 70 & 42,05 & 36,32 & 31,57 & 25,73 & 20,88 & 17,02 & 11,75 & 8,70 & 5,74 \\
\hline 25 & 200 & 75 & 81,04 & 49,75 & 35,84 & 24,56 & 18,14 & 14,25 & 9,92 & 7,70 & 5,39 \\
\hline 25 & 250 & 75 & 75,57 & 48,72 & 35,81 & 24,81 & 18,33 & 14,35 & 9,95 & 7,70 & 5,38 \\
\hline 25 & 300 & 75 & 71,47 & 47,79 & 35,70 & 24,99 & 18,50 & 14,45 & 9,98 & 7,70 & 5,37 \\
\hline 25 & 350 & 75 & 68,23 & 46,94 & 35,55 & 25,13 & 18,64 & 14,55 & 10,01 & 7,71 & 5,36 \\
\hline 25 & 400 & 75 & 65,56 & 46,16 & 35,37 & 25,23 & 18,77 & 14,64 & 10,04 & 7,71 & 5,36 \\
\hline 25 & 450 & 75 & 63,30 & 45,44 & 35,17 & 25,30 & 18,89 & 14,73 & 10,07 & 7,72 & 5,35 \\
\hline
\end{tabular}




\begin{tabular}{|c|c|c|c|c|c|c|c|c|c|c|c|}
\hline \multirow[b]{2}{*}{$\mathrm{H}(\mathrm{cm})$} & \multirow[b]{2}{*}{ Mceq (MPa) } & & & & & $\mathrm{De}$ & ões (x1 & & & & \\
\hline & & Msub (MPa) & D0 & D25 & D40 & D60 & D80 & D100 & D140 & D180 & D260 \\
\hline 25 & 500 & 75 & 61,35 & 44,76 & 34,96 & 25,35 & 18,99 & 14,81 & 10,10 & 7,73 & 5,35 \\
\hline 25 & 550 & 75 & 59,64 & 44,14 & 34,75 & 25,38 & 19,08 & 14,89 & 10,13 & 7,73 & 5,35 \\
\hline 25 & 600 & 75 & 58,11 & 43,55 & 34,53 & 25,39 & 19,16 & 14,97 & 10,17 & 7,74 & 5,34 \\
\hline 25 & 650 & 75 & 56,74 & 42,99 & 34,32 & 25,40 & 19,22 & 15,04 & 10,20 & 7,75 & 5,34 \\
\hline 25 & 700 & 75 & 55,50 & 42,47 & 34,10 & 25,39 & 19,28 & 15,10 & 10,23 & 7,76 & 5,34 \\
\hline 25 & 750 & 75 & 54,37 & 41,98 & 33,89 & 25,38 & 19,34 & 15,16 & 10,27 & 7,77 & 5,34 \\
\hline 25 & 800 & 75 & 53,32 & 41,51 & 33,69 & 25,35 & 19,38 & 15,22 & 10,30 & 7,78 & 5,34 \\
\hline 25 & 850 & 75 & 52,36 & 41,06 & 33,48 & 25,33 & 19,42 & 15,27 & 10,33 & 7,79 & 5,33 \\
\hline 25 & 900 & 75 & 51,46 & 40,64 & 33,28 & 25,29 & 19,46 & 15,32 & 10,36 & 7,80 & 5,33 \\
\hline 25 & 950 & 75 & 50,62 & 40,23 & 33,09 & 25,26 & 19,49 & 15,37 & 10,40 & 7,81 & 5,33 \\
\hline 25 & 1000 & 75 & 49,84 & 39,84 & 32,89 & 25,22 & 19,51 & 15,41 & 10,43 & 7,83 & 5,33 \\
\hline 25 & 1050 & 75 & 49,10 & 39,47 & 32,71 & 25,18 & 19,53 & 15,45 & 10,46 & 7,84 & 5,33 \\
\hline 25 & 1100 & 75 & 48,41 & 39,12 & 32,52 & 25,13 & 19,55 & 15,49 & 10,49 & 7,85 & 5,33 \\
\hline 25 & 1150 & 75 & 47,75 & 38,78 & 32,34 & 25,08 & 19,57 & 15,53 & 10,52 & 7,86 & 5,33 \\
\hline 25 & 1200 & 75 & 47,13 & 38,45 & 32,17 & 25,04 & 19,58 & 15,56 & 10,54 & 7,88 & 5,33 \\
\hline 25 & 1250 & 75 & 46,54 & 38,13 & 32,00 & 24,99 & 19,59 & 15,59 & 10,57 & 7,89 & 5,33 \\
\hline 25 & 1300 & 75 & 45,98 & 37,83 & 31,83 & 24,93 & 19,60 & 15,62 & 10,60 & 7,90 & 5,33 \\
\hline 25 & 1350 & 75 & 45,44 & 37,53 & 31,66 & 24,88 & 19,60 & 15,65 & 10,63 & 7,92 & 5,33 \\
\hline 25 & 1400 & 75 & 44,93 & 37,25 & 31,50 & 24,83 & 19,60 & 15,67 & 10,65 & 7,93 & 5,33 \\
\hline 25 & 1450 & 75 & 44,44 & 36,97 & 31,34 & 24,78 & 19,60 & 15,70 & 10,68 & 7,94 & 5,33 \\
\hline 25 & 1500 & 75 & 43,97 & 36,71 & 31,19 & 24,72 & 19,60 & 15,72 & 10,70 & 7,96 & 5,33 \\
\hline 25 & 1550 & 75 & 43,52 & 36,45 & 31,04 & 24,67 & 19,60 & 15,74 & 10,73 & 7,97 & 5,33 \\
\hline 25 & 1600 & 75 & 43,08 & 36,20 & 30,89 & 24,61 & 19,60 & 15,76 & 10,75 & 7,98 & 5,34 \\
\hline 25 & 1650 & 75 & 42,67 & 35,96 & 30,75 & 24,56 & 19,59 & 15,77 & 10,77 & 8,00 & 5,34 \\
\hline 25 & 1700 & 75 & 42,27 & 35,72 & 30,60 & 24,50 & 19,58 & 15,79 & 10,79 & 8,01 & 5,34 \\
\hline 25 & 1750 & 75 & 41,88 & 35,49 & 30,46 & 24,45 & 19,58 & 15,80 & 10,82 & 8,02 & 5,34 \\
\hline 25 & 1800 & 75 & 41,50 & 35,27 & 30,33 & 24,39 & 19,57 & 15,82 & 10,84 & 8,03 & 5,34 \\
\hline 25 & 1850 & 75 & 41,14 & 35,06 & 30,20 & 24,34 & 19,56 & 15,83 & 10,86 & 8,05 & 5,34 \\
\hline 25 & 1900 & 75 & 40,79 & 34,85 & 30,06 & 24,28 & 19,55 & 15,84 & 10,88 & 8,06 & 5,34 \\
\hline 25 & 1950 & 75 & 40,46 & 34,64 & 29,94 & 24,23 & 19,54 & 15,85 & 10,90 & 8,07 & 5,35 \\
\hline 25 & 2000 & 75 & 40,13 & 34,44 & 29,81 & 24,17 & 19,52 & 15,86 & 10,92 & 8,09 & 5,35 \\
\hline 25 & 200 & 80 & 77,57 & 46,90 & 33,59 & 22,95 & 16,96 & 13,33 & 9,29 & 7,21 & 5,05 \\
\hline 25 & 250 & 80 & 72,28 & 45,97 & 33,59 & 23,19 & 17,13 & 13,42 & 9,32 & 7,22 & 5,04 \\
\hline 25 & 300 & 80 & 68,33 & 45,12 & 33,52 & 23,37 & 17,28 & 13,51 & 9,34 & 7,22 & 5,03 \\
\hline 25 & 350 & 80 & 65,22 & 44,35 & 33,39 & 23,50 & 17,42 & 13,60 & 9,37 & 7,23 & 5,03 \\
\hline 25 & 400 & 80 & 62,66 & 43,63 & 33,24 & 23,61 & 17,54 & 13,68 & 9,40 & 7,23 & 5,02 \\
\hline 25 & 450 & 80 & 60,50 & 42,97 & 33,07 & 23,68 & 17,65 & 13,76 & 9,42 & 7,23 & 5,02 \\
\hline 25 & 500 & 80 & 58,63 & 42,36 & 32,90 & 23,74 & 17,74 & 13,84 & 9,45 & 7,24 & 5,02 \\
\hline 25 & 550 & 80 & 56,99 & 41,78 & 32,71 & 23,77 & 17,83 & 13,91 & 9,48 & 7,25 & 5,01 \\
\hline 25 & 600 & 80 & 55,54 & 41,24 & 32,52 & 23,80 & 17,90 & 13,98 & 9,51 & 7,25 & 5,01 \\
\hline 25 & 650 & 80 & 54,23 & 40,73 & 32,34 & 23,81 & 17,97 & 14,04 & 9,54 & 7,26 & 5,01 \\
\hline 25 & 700 & 80 & 53,05 & 40,24 & 32,15 & 23,81 & 18,03 & 14,10 & 9,57 & 7,27 & 5,01 \\
\hline 25 & 750 & 80 & 51,96 & 39,79 & 31,96 & 23,80 & 18,08 & 14,16 & 9,60 & 7,28 & 5,00 \\
\hline 25 & 800 & 80 & 50,97 & 39,35 & 31,78 & 23,79 & 18,13 & 14,22 & 9,63 & 7,28 & 5,00 \\
\hline 25 & 850 & 80 & 50,05 & 38,94 & 31,59 & 23,77 & 18,17 & 14,27 & 9,65 & 7,29 & 5,00 \\
\hline 25 & 900 & 80 & 49,19 & 38,55 & 31,41 & 23,75 & 18,20 & 14,31 & 9,68 & 7,30 & 5,00 \\
\hline 25 & 950 & 80 & 48,40 & 38,17 & 31,24 & 23,72 & 18,24 & 14,36 & 9,71 & 7,31 & 5,00 \\
\hline 25 & 1000 & 80 & 47,65 & 37,81 & 31,06 & 23,69 & 18,26 & 14,40 & 9,74 & 7,32 & 5,00 \\
\hline 25 & 1050 & 80 & 46,95 & 37,47 & 30,89 & 23,65 & 18,29 & 14,44 & 9,77 & 7,33 & 5,00 \\
\hline 25 & 1100 & 80 & 46,29 & 37,14 & 30,73 & 23,62 & 18,31 & 14,47 & 9,79 & 7,34 & 5,00 \\
\hline 25 & 1150 & 80 & 45,66 & 36,82 & 30,57 & 23,58 & 18,32 & 14,51 & 9,82 & 7,36 & 5,00 \\
\hline 25 & 1200 & 80 & 45,07 & 36,51 & 30,41 & 23,54 & 18,34 & 14,54 & 9,85 & 7,37 & 5,00 \\
\hline 25 & 1250 & 80 & 44,51 & 36,22 & 30,25 & 23,50 & 18,35 & 14,57 & 9,87 & 7,38 & 5,00 \\
\hline 25 & 1300 & 80 & 43,97 & 35,93 & 30,10 & 23,45 & 18,36 & 14,60 & 9,90 & 7,39 & 5,00 \\
\hline 25 & 1350 & 80 & 43,46 & 35,66 & 29,95 & 23,41 & 18,37 & 14,63 & 9,92 & 7,40 & 5,00 \\
\hline 25 & 1400 & 80 & 42,98 & 35,39 & 29,80 & 23,36 & 18,37 & 14,65 & 9,94 & 7,41 & 5,00 \\
\hline 25 & 1450 & 80 & 42,51 & 35,14 & 29,65 & 23,32 & 18,38 & 14,67 & 9,97 & 7,42 & 5,00 \\
\hline 25 & 1500 & 80 & 42,06 & 34,89 & 29,51 & 23,27 & 18,38 & 14,70 & 9,99 & 7,44 & 5,00 \\
\hline 25 & 1550 & 80 & 41,63 & 34,65 & 29,38 & 23,22 & 18,38 & 14,72 & 10,01 & 7,45 & 5,00 \\
\hline 25 & 1600 & 80 & 41,22 & 34,41 & 29,24 & 23,18 & 18,38 & 14,73 & 10,03 & 7,46 & 5,00 \\
\hline 25 & 1650 & 80 & 40,82 & 34,19 & 29,11 & 23,13 & 18,37 & 14,75 & 10,05 & 7,47 & 5,00 \\
\hline 25 & 1700 & 80 & 40,44 & 33,97 & 28,98 & 23,08 & 18,37 & 14,77 & 10,07 & 7,48 & 5,00 \\
\hline 25 & 1750 & 80 & 40,07 & 33,75 & 28,85 & 23,03 & 18,37 & 14,78 & 10,10 & 7,49 & 5,00 \\
\hline 25 & 1800 & 80 & 39,72 & 33,54 & 28,72 & 22,98 & 18,36 & 14,80 & 10,11 & 7,51 & 5,00 \\
\hline 25 & 1850 & 80 & 39,37 & 33,34 & 28,60 & 22,94 & 18,35 & 14,81 & 10,13 & 7,52 & 5,01 \\
\hline 25 & 1900 & 80 & 39,04 & 33,14 & 28,48 & 22,89 & 18,35 & 14,82 & 10,15 & 7,53 & 5,01 \\
\hline 25 & 1950 & 80 & 38,72 & 32,95 & 28,36 & 22,84 & 18,34 & 14,84 & 10,17 & 7,54 & 5,01 \\
\hline 25 & 2000 & 80 & 38,41 & 32,77 & 28,25 & 22,79 & 18,33 & 14,85 & 10,19 & 7,55 & 5,01 \\
\hline 25 & 200 & 85 & 74,46 & 44,37 & 31,60 & 21,54 & 15,92 & 12,53 & 8,74 & 6,79 & 4,76 \\
\hline 25 & 250 & 85 & 69,33 & 43,51 & 31,63 & 21,77 & 16,08 & 12,61 & 8,76 & 6,79 & 4,75 \\
\hline 25 & 300 & 85 & 65,52 & 42,74 & 31,58 & 21,94 & 16,22 & 12,69 & 8,79 & 6,80 & 4,74 \\
\hline 25 & 350 & 85 & 62,51 & 42,03 & 31,48 & 22,07 & 16,34 & 12,76 & 8,81 & 6,80 & 4,73 \\
\hline 25 & 400 & 85 & 60,05 & 41,38 & 31,36 & 22,18 & 16,46 & 12,84 & 8,83 & 6,80 & 4,73 \\
\hline 25 & 450 & 85 & 57,97 & 40,77 & 31,21 & 22,25 & 16,56 & 12,91 & 8,86 & 6,81 & 4,73 \\
\hline 25 & 500 & 85 & 56,18 & 40,20 & 31,06 & 22,31 & 16,65 & 12,98 & 8,88 & 6,81 & 4,72 \\
\hline 25 & 550 & 85 & 54,61 & 39,67 & 30,90 & 22,35 & 16,73 & 13,05 & 8,90 & 6,82 & 4,72 \\
\hline 25 & 600 & 85 & 53,22 & 39,17 & 30,74 & 22,38 & 16,80 & 13,11 & 8,93 & 6,82 & 4,72 \\
\hline 25 & 650 & 85 & 51,97 & 38,70 & 30,57 & 22,40 & 16,87 & 13,17 & 8,96 & 6,83 & 4,72 \\
\hline 25 & 700 & 85 & 50,84 & 38,25 & 30,40 & 22,41 & 16,92 & 13,23 & 8,98 & 6,83 & 4,71 \\
\hline 25 & 750 & 85 & 49,80 & 37,82 & 30,24 & 22,41 & 16,98 & 13,28 & 9,01 & 6,84 & 4,71 \\
\hline 25 & 800 & 85 & 48,85 & 37,42 & 30,07 & 22,40 & 17,02 & 13,33 & 9,03 & 6,85 & 4,71 \\
\hline
\end{tabular}




\begin{tabular}{|c|c|c|c|c|c|c|c|c|c|c|c|}
\hline \multirow[b]{2}{*}{$\mathrm{H}(\mathrm{cm})$} & \multirow[b]{2}{*}{ Mceq (MPa) } & & & & & $\mathrm{De}$ & ões (x1 & & & & \\
\hline & & Msub (MPa) & D0 & D25 & D40 & D60 & D80 & D100 & D140 & D180 & D260 \\
\hline 25 & 850 & 85 & 47,97 & 37,04 & 29,91 & 22,39 & 17,06 & 13,38 & 9,06 & 6,86 & 4,71 \\
\hline 25 & 900 & 85 & 47,15 & 36,67 & 29,74 & 22,37 & 17,10 & 13,42 & 9,09 & 6,86 & 4,71 \\
\hline 25 & 950 & 85 & 46,39 & 36,32 & 29,59 & 22,35 & 17,13 & 13,47 & 9,11 & 6,87 & 4,71 \\
\hline 25 & 1000 & 85 & 45,68 & 35,99 & 29,43 & 22,33 & 17,16 & 13,51 & 9,14 & 6,88 & 4,71 \\
\hline 25 & 1050 & 85 & 45,01 & 35,67 & 29,27 & 22,30 & 17,18 & 13,54 & 9,16 & 6,89 & 4,71 \\
\hline 25 & 1100 & 85 & 44,38 & 35,36 & 29,12 & 22,27 & 17,20 & 13,58 & 9,18 & 6,90 & 4,70 \\
\hline 25 & 1150 & 85 & 43,78 & 35,06 & 28,98 & 22,24 & 17,22 & 13,61 & 9,21 & 6,91 & 4,70 \\
\hline 25 & 1200 & 85 & 43,22 & 34,77 & 28,83 & 22,21 & 17,24 & 13,64 & 9,23 & 6,92 & 4,70 \\
\hline 25 & 1250 & 85 & 42,68 & 34,50 & 28,69 & 22,17 & 17,25 & 13,67 & 9,25 & 6,93 & 4,70 \\
\hline 25 & 1300 & 85 & 42,17 & 34,23 & 28,55 & 22,14 & 17,26 & 13,70 & 9,28 & 6,94 & 4,70 \\
\hline 25 & 1350 & 85 & 41,68 & 33,97 & 28,41 & 22,10 & 17,27 & 13,73 & 9,30 & 6,95 & 4,70 \\
\hline 25 & 1400 & 85 & 41,22 & 33,73 & 28,28 & 22,06 & 17,28 & 13,75 & 9,32 & 6,96 & 4,70 \\
\hline 25 & 1450 & 85 & 40,77 & 33,49 & 28,14 & 22,02 & 17,29 & 13,77 & 9,34 & 6,97 & 4,70 \\
\hline 25 & 1500 & 85 & 40,34 & 33,25 & 28,01 & 21,98 & 17,29 & 13,79 & 9,36 & 6,98 & 4,70 \\
\hline 25 & 1550 & 85 & 39,93 & 33,03 & 27,89 & 21,94 & 17,29 & 13,81 & 9,38 & 6,99 & 4,70 \\
\hline 25 & 1600 & 85 & 39,54 & 32,81 & 27,76 & 21,90 & 17,30 & 13,83 & 9,40 & 7,00 & 4,71 \\
\hline 25 & 1650 & 85 & 39,16 & 32,60 & 27,64 & 21,86 & 17,30 & 13,85 & 9,42 & 7,01 & 4,71 \\
\hline 25 & 1700 & 85 & 38,80 & 32,39 & 27,52 & 21,81 & 17,30 & 13,87 & 9,44 & 7,02 & 4,71 \\
\hline 25 & 1750 & 85 & 38,44 & 32,19 & 27,40 & 21,77 & 17,29 & 13,88 & 9,46 & 7,03 & 4,71 \\
\hline 25 & 1800 & 85 & 38,10 & 31,99 & 27,29 & 21,73 & 17,29 & 13,90 & 9,48 & 7,04 & 4,71 \\
\hline 25 & 1850 & 85 & 37,78 & 31,80 & 27,17 & 21,69 & 17,29 & 13,91 & 9,50 & 7,05 & 4,71 \\
\hline 25 & 1900 & 85 & 37,46 & 31,62 & 27,06 & 21,64 & 17,28 & 13,92 & 9,52 & 7,06 & 4,71 \\
\hline 25 & 1950 & 85 & 37,15 & 31,44 & 26,95 & 21,60 & 17,28 & 13,94 & 9,53 & 7,07 & 4,71 \\
\hline 25 & 2000 & 85 & 36,85 & 31,26 & 26,85 & 21,56 & 17,27 & 13,95 & 9,55 & 7,08 & 4,71 \\
\hline 25 & 200 & 90 & 71,65 & 42,09 & 29,83 & 20,28 & 15,00 & 11,82 & 8,25 & 6,41 & 4,50 \\
\hline 25 & 250 & 90 & 66,67 & 41,31 & 29,87 & 20,50 & 15,15 & 11,89 & 8,27 & 6,41 & 4,49 \\
\hline 25 & 300 & 90 & 62,97 & 40,60 & 29,84 & 20,67 & 15,27 & 11,96 & 8,29 & 6,42 & 4,48 \\
\hline 25 & 350 & 90 & 60,07 & 39,95 & 29,77 & 20,80 & 15,39 & 12,03 & 8,31 & 6,42 & 4,47 \\
\hline 25 & 400 & 90 & 57,70 & 39,35 & 29,67 & 20,90 & 15,50 & 12,09 & 8,33 & 6,42 & 4,47 \\
\hline 25 & 450 & 90 & 55,70 & 38,79 & 29,55 & 20,98 & 15,59 & 12,16 & 8,35 & 6,43 & 4,47 \\
\hline 25 & 500 & 90 & 53,97 & 38,26 & 29,42 & 21,04 & 15,68 & 12,22 & 8,37 & 6,43 & 4,46 \\
\hline 25 & 550 & 90 & 52,46 & 37,77 & 29,28 & 21,09 & 15,75 & 12,29 & 8,40 & 6,43 & 4,46 \\
\hline 25 & 600 & 90 & 51,13 & 37,30 & 29,13 & 21,12 & 15,82 & 12,34 & 8,42 & 6,44 & 4,46 \\
\hline 25 & 650 & 90 & 49,92 & 36,87 & 28,98 & 21,14 & 15,89 & 12,40 & 8,44 & 6,44 & 4,45 \\
\hline 25 & 700 & 90 & 48,84 & 36,45 & 28,84 & 21,16 & 15,94 & 12,45 & 8,46 & 6,45 & 4,45 \\
\hline 25 & 750 & 90 & 47,84 & 36,06 & 28,69 & 21,16 & 15,99 & 12,50 & 8,49 & 6,45 & 4,45 \\
\hline 25 & 800 & 90 & 46,93 & 35,68 & 28,54 & 21,16 & 16,04 & 12,55 & 8,51 & 6,46 & 4,45 \\
\hline 25 & 850 & 90 & 46,09 & 35,32 & 28,39 & 21,16 & 16,08 & 12,59 & 8,53 & 6,47 & 4,45 \\
\hline 25 & 900 & 90 & 45,31 & 34,98 & 28,24 & 21,15 & 16,11 & 12,64 & 8,56 & 6,47 & 4,45 \\
\hline 25 & 950 & 90 & 44,58 & 34,65 & 28,10 & 21,13 & 16,15 & 12,68 & 8,58 & 6,48 & 4,45 \\
\hline 25 & 1000 & 90 & 43,89 & 34,34 & 27,96 & 21,11 & 16,18 & 12,71 & 8,60 & 6,49 & 4,45 \\
\hline 25 & 1050 & 90 & 43,25 & 34,04 & 27,82 & 21,09 & 16,20 & 12,75 & 8,62 & 6,50 & 4,44 \\
\hline 25 & 1100 & 90 & 42,65 & 33,75 & 27,68 & 21,07 & 16,22 & 12,78 & 8,65 & 6,51 & 4,44 \\
\hline 25 & 1150 & 90 & 42,08 & 33,47 & 27,55 & 21,04 & 16,24 & 12,81 & 8,67 & 6,51 & 4,44 \\
\hline 25 & 1200 & 90 & 41,53 & 33,20 & 27,41 & 21,02 & 16,26 & 12,84 & 8,69 & 6,52 & 4,44 \\
\hline 25 & 1250 & 90 & 41,02 & 32,95 & 27,28 & 20,99 & 16,28 & 12,87 & 8,71 & 6,53 & 4,44 \\
\hline 25 & 1300 & 90 & 40,53 & 32,70 & 27,15 & 20,96 & 16,29 & 12,90 & 8,73 & 6,54 & 4,44 \\
\hline 25 & 1350 & 90 & 40,06 & 32,45 & 27,03 & 20,92 & 16,30 & 12,93 & 8,75 & 6,55 & 4,44 \\
\hline 25 & 1400 & 90 & 39,62 & 32,22 & 26,90 & 20,89 & 16,31 & 12,95 & 8,77 & 6,56 & 4,44 \\
\hline 25 & 1450 & 90 & 39,19 & 32,00 & 26,78 & 20,86 & 16,32 & 12,97 & 8,79 & 6,57 & 4,44 \\
\hline 25 & 1500 & 90 & 38,78 & 31,78 & 26,66 & 20,82 & 16,32 & 12,99 & 8,81 & 6,58 & 4,44 \\
\hline 25 & 1550 & 90 & 38,39 & 31,56 & 26,55 & 20,79 & 16,33 & 13,01 & 8,83 & 6,58 & 4,44 \\
\hline 25 & 1600 & 90 & 38,01 & 31,36 & 26,43 & 20,75 & 16,33 & 13,03 & 8,85 & 6,59 & 4,44 \\
\hline 25 & 1650 & 90 & 37,65 & 31,16 & 26,32 & 20,71 & 16,33 & 13,05 & 8,87 & 6,60 & 4,44 \\
\hline 25 & 1700 & 90 & 37,30 & 30,96 & 26,21 & 20,68 & 16,34 & 13,07 & 8,88 & 6,61 & 4,44 \\
\hline 25 & 1750 & 90 & 36,97 & 30,77 & 26,10 & 20,64 & 16,34 & 13,08 & 8,90 & 6,62 & 4,44 \\
\hline 25 & 1800 & 90 & 36,64 & 30,59 & 25,99 & 20,60 & 16,33 & 13,10 & 8,92 & 6,63 & 4,45 \\
\hline 25 & 1850 & 90 & 36,33 & 30,41 & 25,89 & 20,56 & 16,33 & 13,11 & 8,94 & 6,64 & 4,45 \\
\hline 25 & 1900 & 90 & 36,02 & 30,23 & 25,78 & 20,53 & 16,33 & 13,12 & 8,95 & 6,65 & 4,45 \\
\hline 25 & 1950 & 90 & 35,73 & 30,06 & 25,68 & 20,49 & 16,33 & 13,14 & 8,97 & 6,66 & 4,45 \\
\hline 25 & 2000 & 90 & 35,44 & 29,90 & 25,58 & 20,45 & 16,32 & 13,15 & 8,98 & 6,67 & 4,45 \\
\hline 25 & 200 & 95 & 69,11 & 40,04 & 28,24 & 19,16 & 14,18 & 11,18 & 7,81 & 6,07 & 4,26 \\
\hline 25 & 250 & 95 & 64,25 & 39,32 & 28,30 & 19,37 & 14,31 & 11,24 & 7,83 & 6,08 & 4,25 \\
\hline 25 & 300 & 95 & 60,67 & 38,67 & 28,29 & 19,54 & 14,43 & 11,31 & 7,85 & 6,08 & 4,25 \\
\hline 25 & 350 & 95 & 57,86 & 38,07 & 28,23 & 19,67 & 14,54 & 11,37 & 7,87 & 6,08 & 4,24 \\
\hline 25 & 400 & 95 & 55,56 & 37,51 & 28,15 & 19,77 & 14,64 & 11,43 & 7,88 & 6,08 & 4,24 \\
\hline 25 & 450 & 95 & 53,63 & 36,99 & 28,05 & 19,85 & 14,73 & 11,49 & 7,90 & 6,09 & 4,23 \\
\hline 25 & 500 & 95 & 51,96 & 36,50 & 27,94 & 19,91 & 14,81 & 11,55 & 7,92 & 6,09 & 4,23 \\
\hline 25 & 550 & 95 & 50,51 & 36,05 & 27,81 & 19,96 & 14,88 & 11,61 & 7,94 & 6,09 & 4,23 \\
\hline 25 & 600 & 95 & 49,22 & 35,62 & 27,69 & 19,99 & 14,95 & 11,66 & 7,96 & 6,10 & 4,22 \\
\hline 25 & 650 & 95 & 48,06 & 35,21 & 27,56 & 20,02 & 15,01 & 11,71 & 7,98 & 6,10 & 4,22 \\
\hline 25 & 700 & 95 & 47,02 & 34,82 & 27,42 & 20,04 & 15,06 & 11,76 & 8,00 & 6,11 & 4,22 \\
\hline 25 & 750 & 95 & 46,06 & 34,45 & 27,29 & 20,05 & 15,11 & 11,81 & 8,02 & 6,11 & 4,22 \\
\hline 25 & 800 & 95 & 45,18 & 34.10 & 27,15 & 20,05 & 15,16 & 11,85 & 8,04 & 6.12 & 4,22 \\
\hline 25 & 850 & 95 & 44,37 & 33,77 & 27,02 & 20,05 & 15,20 & 11,89 & 8,06 & 6,12 & 4,22 \\
\hline 25 & 900 & 95 & 43,62 & 33,45 & 26,89 & 20,04 & 15,23 & 11,93 & 8,09 & 6,13 & 4,21 \\
\hline 25 & 950 & 95 & 42,92 & 33,14 & 26,76 & 20,03 & 15,27 & 11,97 & 8,11 & 6,13 & 4,21 \\
\hline 25 & 1000 & 95 & 42,26 & 32,85 & 26,63 & 20,02 & 15,30 & 12,01 & 8,13 & 6,14 & 4,21 \\
\hline 25 & 1050 & 95 & 41,65 & 32,56 & 26,50 & 20,00 & 15,32 & 12,04 & 8,15 & 6,15 & 4,21 \\
\hline 25 & 1100 & 95 & 41,07 & 32,29 & 26,37 & 19,99 & 15,34 & 12,07 & 8,17 & 6,15 & 4,21 \\
\hline 25 & 1150 & 95 & 40,52 & 32,03 & 26,25 & 19,97 & 15,37 & 12,10 & 8,19 & 6,16 & 4,21 \\
\hline
\end{tabular}




\begin{tabular}{|c|c|c|c|c|c|c|c|c|c|c|c|}
\hline \multirow[b]{2}{*}{$\mathrm{H}(\mathrm{cm})$} & \multirow[b]{2}{*}{ Mceq (MPa) } & & & & & $\mathrm{De}$ & ões (x1 & & & & \\
\hline & & Msub (MPa) & D0 & D25 & D40 & D60 & D80 & D100 & D140 & D180 & D260 \\
\hline 25 & 1200 & 95 & 40,00 & 31,78 & 26,13 & 19,94 & 15,38 & 12,13 & 8,21 & 6,17 & 4,21 \\
\hline 25 & 1250 & 95 & 39,51 & 31,54 & 26,01 & 19,92 & 15,40 & 12,16 & 8,23 & 6,18 & 4,21 \\
\hline 25 & 1300 & 95 & 39,04 & 31,30 & 25,89 & 19,89 & 15,41 & 12,19 & 8,24 & 6,18 & 4,21 \\
\hline 25 & 1350 & 95 & 38,59 & 31,07 & 25,77 & 19,87 & 15,43 & 12,21 & 8,26 & 6,19 & 4,21 \\
\hline 25 & 1400 & 95 & 38,16 & 30,85 & 25,66 & 19,84 & 15,44 & 12,23 & 8,28 & 6,20 & 4,21 \\
\hline 25 & 1450 & 95 & 37,75 & 30,64 & 25,55 & 19,81 & 15,45 & 12,26 & 8,30 & 6,21 & 4,21 \\
\hline 25 & 1500 & 95 & 37,36 & 30,43 & 25,44 & 19,78 & 15,45 & 12,28 & 8,32 & 6,22 & 4,21 \\
\hline 25 & 1550 & 95 & 36,98 & 30,23 & 25,33 & 19,75 & 15,46 & 12,30 & 8,34 & 6,22 & 4,21 \\
\hline 25 & 1600 & 95 & 36,62 & 30,04 & 25,22 & 19,72 & 15,47 & 12,32 & 8,35 & 6,23 & 4,21 \\
\hline 25 & 1650 & 95 & 36,28 & 29,85 & 25,12 & 19,68 & 15,47 & 12,33 & 8,37 & 6,24 & 4,21 \\
\hline 25 & 1700 & 95 & 35,94 & 29,67 & 25,02 & 19,65 & 15,47 & 12,35 & 8,39 & 6,25 & 4,21 \\
\hline 25 & 1750 & 95 & 35,62 & 29,49 & 24,92 & 19,62 & 15,47 & 12,37 & 8,40 & 6,26 & 4,21 \\
\hline 25 & 1800 & 95 & 35,31 & 29,31 & 24,82 & 19,58 & 15,48 & 12,38 & 8,42 & 6,26 & 4,21 \\
\hline 25 & 1850 & 95 & 35,00 & 29,14 & 24,72 & 19,55 & 15,48 & 12,39 & 8,43 & 6,27 & 4,21 \\
\hline 25 & 1900 & 95 & 34,71 & 28,98 & 24,62 & 19,52 & 15,48 & 12,41 & 8,45 & 6,28 & 4,21 \\
\hline 25 & 1950 & 95 & 34,43 & 28,82 & 24,53 & 19,48 & 15,47 & 12,42 & 8,46 & 6,29 & 4,21 \\
\hline 25 & 2000 & 95 & 34,16 & 28,66 & 24,44 & 19,45 & 15,47 & 12,43 & 8,48 & 6,30 & 4,21 \\
\hline 25 & 200 & 100 & 66,80 & 38,19 & 26,80 & 18,16 & 13,45 & 10,61 & 7,42 & 5,77 & 4,05 \\
\hline 25 & 250 & 100 & 62,05 & 37,52 & 26,88 & 18,36 & 13,57 & 10,67 & 7,44 & 5,77 & 4,04 \\
\hline 25 & 300 & 100 & 58,56 & 36,92 & 26,88 & 18,52 & 13,68 & 10,72 & 7,45 & 5,77 & 4,04 \\
\hline 25 & 350 & 100 & 55,83 & 36,36 & 26,84 & 18,64 & 13,78 & 10,78 & 7,47 & 5,78 & 4,03 \\
\hline 25 & 400 & 100 & 53,61 & 35,84 & 26,78 & 18,74 & 13,87 & 10,84 & 7,48 & 5,78 & 4,03 \\
\hline 25 & 450 & 100 & 51,73 & 35,36 & 26,69 & 18,82 & 13,96 & 10,89 & 7,50 & 5,78 & 4,02 \\
\hline 25 & 500 & 100 & 50,13 & 34,91 & 26,59 & 18,89 & 14,03 & 10,94 & 7,52 & 5,78 & 4,02 \\
\hline 25 & 550 & 100 & 48,72 & 34,48 & 26,49 & 18,94 & 14,10 & 11,00 & 7,53 & 5,79 & 4,02 \\
\hline 25 & 600 & 100 & 47,48 & 34,08 & 26,38 & 18,97 & 14,17 & 11,05 & 7,55 & 5,79 & 4,01 \\
\hline 25 & 650 & 100 & 46,36 & 33,70 & 26,26 & 19,00 & 14,22 & 11,09 & 7,57 & 5,79 & 4,01 \\
\hline 25 & 700 & 100 & 45,35 & 33,33 & 26,14 & 19,02 & 14,28 & 11,14 & 7,59 & 5,80 & 4,01 \\
\hline 25 & 750 & 100 & 44,43 & 32,99 & 26,02 & 19,04 & 14,32 & 11,18 & 7,61 & 5,80 & 4,01 \\
\hline 25 & 800 & 100 & 43,58 & 32,66 & 25,90 & 19,04 & 14,37 & 11,22 & 7,63 & 5,81 & 4,01 \\
\hline 25 & 850 & 100 & 42,80 & 32,35 & 25,78 & 19,05 & 14,41 & 11,26 & 7,64 & 5,81 & 4,01 \\
\hline 25 & 900 & 100 & 42,08 & 32,05 & 25,66 & 19,05 & 14,44 & 11,30 & 7,66 & 5,82 & 4,00 \\
\hline 25 & 950 & 100 & 41,41 & 31,76 & 25,54 & 19,04 & 14,47 & 11,34 & 7,68 & 5,82 & 4,00 \\
\hline 25 & 1000 & 100 & 40,77 & 31,48 & 25,42 & 19,03 & 14,50 & 11,37 & 7,70 & 5,83 & 4,00 \\
\hline 25 & 1050 & 100 & 40,18 & 31,22 & 25,30 & 19,02 & 14,53 & 11,40 & 7,72 & 5,83 & 4,00 \\
\hline 25 & 1100 & 100 & 39,62 & 30,96 & 25,19 & 19,01 & 14,55 & 11,44 & 7,74 & 5,84 & 4,00 \\
\hline 25 & 1150 & 100 & 39,10 & 30,72 & 25,07 & 18,99 & 14,57 & 11,46 & 7,76 & 5,85 & 4,00 \\
\hline 25 & 1200 & 100 & 38,60 & 30,48 & 24,96 & 18,97 & 14,59 & 11,49 & 7,77 & 5,85 & 4,00 \\
\hline 25 & 1250 & 100 & 38,12 & 30,25 & 24,85 & 18,95 & 14,61 & 11,52 & 7,79 & 5,86 & 4,00 \\
\hline 25 & 1300 & 100 & 37,67 & 30,03 & 24,74 & 18,93 & 14,63 & 11,54 & 7,81 & 5,87 & 4,00 \\
\hline 25 & 1350 & 100 & 37,24 & 29,81 & 24,64 & 18,91 & 14,64 & 11,57 & 7,83 & 5,87 & 4,00 \\
\hline 25 & 1400 & 100 & 36,83 & 29,61 & 24,53 & 18,88 & 14,65 & 11,59 & 7,84 & 5,88 & 4,00 \\
\hline 25 & 1450 & 100 & 36,43 & 29,40 & 24,43 & 18,86 & 14,66 & 11,61 & 7,86 & 5,89 & 4,00 \\
\hline 25 & 1500 & 100 & 36,06 & 29,21 & 24,32 & 18,83 & 14,67 & 11,63 & 7,88 & 5,89 & 4,00 \\
\hline 25 & 1550 & 100 & 35,70 & 29,02 & 24,22 & 18,80 & 14,68 & 11,65 & 7,89 & 5,90 & 4,00 \\
\hline 25 & 1600 & 100 & 35,35 & 28,84 & 24,13 & 18,78 & 14,68 & 11,67 & 7,91 & 5,91 & 4,00 \\
\hline 25 & 1650 & 100 & 35,01 & 28,66 & 24,03 & 18,75 & 14,69 & 11,69 & 7,92 & 5,92 & 4,00 \\
\hline 25 & 1700 & 100 & 34,69 & 28,48 & 23,93 & 18,72 & 14,69 & 11,70 & 7,94 & 5,92 & 4,00 \\
\hline 25 & 1750 & 100 & 34,38 & 28,31 & 23,84 & 18,69 & 14,70 & 11,72 & 7,95 & 5,93 & 4,00 \\
\hline 25 & 1800 & 100 & 34,08 & 28,15 & 23,75 & 18,66 & 14,70 & 11,74 & 7,97 & 5,94 & 4,00 \\
\hline 25 & 1850 & 100 & 33,79 & 27,99 & 23,66 & 18,63 & 14,70 & 11,75 & 7,98 & 5,94 & 4,00 \\
\hline 25 & 1900 & 100 & 33,51 & 27,83 & 23,57 & 18,60 & 14,70 & 11,76 & 8,00 & 5,95 & 4,00 \\
\hline 25 & 1950 & 100 & 33,24 & 27,68 & 23,48 & 18,57 & 14,70 & 11,78 & 8,01 & 5,96 & 4,00 \\
\hline 25 & 2000 & 100 & 32,98 & 27,53 & 23,39 & 18,54 & 14,70 & 11,79 & 8,03 & 5,97 & 4,00 \\
\hline 25 & 200 & 105 & 64,68 & 36,50 & 25,50 & 17,25 & 12,78 & 10,09 & 7,06 & 5,49 & 3,86 \\
\hline 25 & 250 & 105 & 60,04 & 35,88 & 25,59 & 17,44 & 12,90 & 10,14 & 7,08 & 5,50 & 3,85 \\
\hline 25 & 300 & 105 & 56,64 & 35,32 & 25,60 & 17,60 & 13,00 & 10,20 & 7,09 & 5,50 & 3,85 \\
\hline 25 & 350 & 105 & 53,98 & 34,80 & 25,58 & 17,72 & 13,09 & 10,25 & 7,11 & 5,50 & 3,84 \\
\hline 25 & 400 & 105 & 51,81 & 34,32 & 25,53 & 17,82 & 13,18 & 10,30 & 7,12 & 5,50 & 3,84 \\
\hline 25 & 450 & 105 & 50,00 & 33,87 & 25,46 & 17,90 & 13,26 & 10,35 & 7,14 & 5,50 & 3,83 \\
\hline 25 & 500 & 105 & 48,44 & 33,45 & 25,37 & 17,96 & 13,33 & 10,40 & 7,15 & 5,51 & 3,83 \\
\hline 25 & 550 & 105 & 47,08 & 33,05 & 25,28 & 18,01 & 13,40 & 10,45 & 7,17 & 5,51 & 3,83 \\
\hline 25 & 600 & 105 & 45,88 & 32,67 & 25,18 & 18,05 & 13,46 & 10,49 & 7,18 & 5,51 & 3,82 \\
\hline 25 & 650 & 105 & 44,80 & 32,31 & 25,08 & 18,08 & 13,51 & 10,54 & 7,20 & 5,52 & 3,82 \\
\hline 25 & 700 & 105 & 43,82 & 31,97 & 24,97 & 18,10 & 13,56 & 10,58 & 7,22 & 5,52 & 3,82 \\
\hline 25 & 750 & 105 & 42,93 & 31,65 & 24,86 & 18,12 & 13,61 & 10,62 & 7,23 & 5,52 & 3,82 \\
\hline 25 & 800 & 105 & 42,12 & 31,34 & 24,75 & 18,13 & 13,65 & 10,66 & 7,25 & 5,53 & 3,82 \\
\hline 25 & 850 & 105 & 41,36 & 31,05 & 24,64 & 18,14 & 13,69 & 10,70 & 7,27 & 5,53 & 3,82 \\
\hline 25 & 900 & 105 & 40,66 & 30,76 & 24,53 & 18,14 & 13,72 & 10,73 & 7,28 & 5,54 & 3,81 \\
\hline 25 & 950 & 105 & 40,01 & 30,49 & 24,42 & 18,14 & 13,76 & 10,77 & 7,30 & 5,54 & 3,81 \\
\hline 25 & 1000 & 105 & 39,40 & 30,23 & 24,32 & 18,13 & 13,79 & 10,80 & 7,32 & 5,54 & 3,81 \\
\hline 25 & 1050 & 105 & 38,83 & 29,98 & 24,21 & 18,13 & 13,81 & 10,83 & 7,33 & 5,55 & 3,81 \\
\hline 25 & 1100 & 105 & 38,29 & 29,74 & 24,10 & 18,12 & 13,84 & 10,86 & 7,35 & 5,56 & 3,81 \\
\hline 25 & 1150 & 105 & 37,79 & 29,51 & 24,00 & 18,10 & 13,86 & 10,89 & 7,37 & 5,56 & 3,81 \\
\hline 25 & 1200 & 105 & 37,30 & 29,29 & 23,90 & 18,09 & 13,88 & 10,91 & 7,38 & 5,57 & 3,81 \\
\hline 25 & 1250 & 105 & 36,85 & 29,07 & 23,79 & 18,07 & 13,90 & 10,94 & 7,40 & 5,57 & 3,81 \\
\hline 25 & 1300 & 105 & 36,41 & 28,86 & 23,69 & 18,05 & 13,91 & 10,96 & 7,42 & 5,58 & 3,81 \\
\hline 25 & 1350 & 105 & 36,00 & 28,66 & 23,59 & 18,03 & 13,93 & 10,99 & 7,43 & 5,58 & 3,81 \\
\hline 25 & 1400 & 105 & 35,60 & 28,46 & 23,50 & 18,01 & 13,94 & 11,01 & 7,45 & 5,59 & 3,81 \\
\hline 25 & 1450 & 105 & 35,22 & 28,27 & 23,40 & 17,99 & 13,95 & 11,03 & 7,46 & 5,60 & 3,81 \\
\hline 25 & 1500 & 105 & 34,86 & 28,09 & 23,31 & 17,97 & 13,96 & 11,05 & 7,48 & 5,60 & 3,81 \\
\hline
\end{tabular}




\begin{tabular}{|c|c|c|c|c|c|c|c|c|c|c|c|}
\hline \multirow[b]{2}{*}{$\mathrm{H}(\mathrm{cm})$} & \multirow[b]{2}{*}{ Mceq (MPa) } & & & & & $\mathrm{De}$ & ões (x1 & & & & \\
\hline & & Msub (MPa) & D0 & D25 & D40 & D60 & D80 & D100 & D140 & D180 & D260 \\
\hline 25 & 1550 & 105 & 34,51 & 27,91 & 23,21 & 17,95 & 13,97 & 11,07 & 7,49 & 5,61 & 3,81 \\
\hline 25 & 1600 & 105 & 34,17 & 27,73 & 23,12 & 17,92 & 13,98 & 11,09 & 7,51 & 5,62 & 3,81 \\
\hline 25 & 1650 & 105 & 33,85 & 27,56 & 23,03 & 17,90 & 13,98 & 11,11 & 7,52 & 5,62 & 3,81 \\
\hline 25 & 1700 & 105 & 33,54 & 27,40 & 22,94 & 17,87 & 13,99 & 11,12 & 7,54 & 5,63 & 3,81 \\
\hline 25 & 1750 & 105 & 33,24 & 27,24 & 22,85 & 17,85 & 13,99 & 11,14 & 7,55 & 5,64 & 3,81 \\
\hline 25 & 1800 & 105 & 32,95 & 27,08 & 22,77 & 17,82 & 14,00 & 11,15 & 7,57 & 5,64 & 3,81 \\
\hline 25 & 1850 & 105 & 32,67 & 26,93 & 22,68 & 17,79 & 14,00 & 11,17 & 7,58 & 5,65 & 3,81 \\
\hline 25 & 1900 & 105 & 32,40 & 26,78 & 22,60 & 17,77 & 14,00 & 11,18 & 7,59 & 5,66 & 3,81 \\
\hline 25 & 1950 & 105 & 32,14 & 26,63 & 22,52 & 17,74 & 14,00 & 11,19 & 7,61 & 5,66 & 3,81 \\
\hline 25 & 2000 & 105 & 31,89 & 26,49 & 22,44 & 17,71 & 14,00 & 11,20 & 7,62 & 5,67 & 3,81 \\
\hline 25 & 200 & 110 & 62,74 & 34,95 & 24,32 & 16,43 & 12,18 & 9,63 & 6,74 & 5,24 & 3,69 \\
\hline 25 & 250 & 110 & 58,19 & 34,38 & 24,41 & 16,61 & 12,29 & 9,67 & 6,75 & 5,24 & 3,68 \\
\hline 25 & 300 & 110 & 54,86 & 33,86 & 24,44 & 16,76 & 12,38 & 9,72 & 6,77 & 5,25 & 3,67 \\
\hline 25 & 350 & 110 & 52,27 & 33,37 & 24,43 & 16,88 & 12,47 & 9,77 & 6,78 & 5,25 & 3,67 \\
\hline 25 & 400 & 110 & 50,17 & 32,92 & 24,39 & 16,97 & 12,55 & 9,81 & 6,79 & 5,25 & 3,66 \\
\hline 25 & 450 & 110 & 48,40 & 32,50 & 24,33 & 17,05 & 12,63 & 9,86 & 6,81 & 5,25 & 3,66 \\
\hline 25 & 500 & 110 & 46,89 & 32,11 & 24,26 & 17,12 & 12,69 & 9,91 & 6,82 & 5,26 & 3,66 \\
\hline 25 & 550 & 110 & 45,57 & 31,73 & 24,18 & 17,17 & 12,76 & 9,95 & 6,83 & 5,26 & 3,65 \\
\hline 25 & 600 & 110 & 44,40 & 31,38 & 24,09 & 17,21 & 12,81 & 9,99 & 6,85 & 5,26 & 3,65 \\
\hline 25 & 650 & 110 & 43,36 & 31,04 & 24,00 & 17,24 & 12,87 & 10,03 & 6,86 & 5,26 & 3,65 \\
\hline 25 & 700 & 110 & 42,41 & 30,73 & 23,90 & 17,27 & 12,92 & 10,07 & 6,88 & 5,27 & 3,65 \\
\hline 25 & 750 & 110 & 41,55 & 30,42 & 23,80 & 17,29 & 12,96 & 10,11 & 6,89 & 5,27 & 3,65 \\
\hline 25 & 800 & 110 & 40,76 & 30,13 & 23,70 & 17,30 & 13,00 & 10,15 & 6,91 & 5,27 & 3,64 \\
\hline 25 & 850 & 110 & 40,03 & 29,85 & 23,60 & 17,31 & 13,04 & 10,18 & 6,92 & 5,28 & 3,64 \\
\hline 25 & 900 & 110 & 39,36 & 29,59 & 23,50 & 17,31 & 13,07 & 10,22 & 6,94 & 5,28 & 3,64 \\
\hline 25 & 950 & 110 & 38,73 & 29,33 & 23,40 & 17,32 & 13,11 & 10,25 & 6,95 & 5,28 & 3,64 \\
\hline 25 & 1000 & 110 & 38,14 & 29,08 & 23,31 & 17,31 & 13,13 & 10,28 & 6,97 & 5,29 & 3,64 \\
\hline 25 & 1050 & 110 & 37,59 & 28,85 & 23,21 & 17,31 & 13,16 & 10,31 & 6,99 & 5,29 & 3,64 \\
\hline 25 & 1100 & 110 & 37,07 & 28,62 & 23,11 & 17,30 & 13,18 & 10,34 & 7,00 & 5,30 & 3,64 \\
\hline 25 & 1150 & 110 & 36,58 & 28,40 & 23,01 & 17,29 & 13,21 & 10,37 & 7,02 & 5,30 & 3,64 \\
\hline 25 & 1200 & 110 & 36,11 & 28,19 & 22,92 & 17,28 & 13,23 & 10,39 & 7,03 & 5,31 & 3,64 \\
\hline 25 & 1250 & 110 & 35,67 & 27,98 & 22,82 & 17,27 & 13,24 & 10,42 & 7,05 & 5,31 & 3,64 \\
\hline 25 & 1300 & 110 & 35,25 & 27,78 & 22,73 & 17,25 & 13,26 & 10,44 & 7,06 & 5,32 & 3,64 \\
\hline 25 & 1350 & 110 & 34,85 & 27,59 & 22,64 & 17,24 & 13,28 & 10,46 & 7,08 & 5,32 & 3,64 \\
\hline 25 & 1400 & 110 & 34,47 & 27,41 & 22,55 & 17,22 & 13,29 & 10,48 & 7,09 & 5,33 & 3,64 \\
\hline 25 & 1450 & 110 & 34,10 & 27,23 & 22,46 & 17,20 & 13,30 & 10,50 & 7,10 & 5,33 & 3,64 \\
\hline 25 & 1500 & 110 & 33,75 & 27,05 & 22,37 & 17,18 & 13,31 & 10,52 & 7,12 & 5,34 & 3,64 \\
\hline 25 & 1550 & 110 & 33,41 & 26,88 & 22,28 & 17,16 & 13,32 & 10,54 & 7,13 & 5,35 & 3,63 \\
\hline 25 & 1600 & 110 & 33,09 & 26,71 & 22,20 & 17,14 & 13,33 & 10,56 & 7,15 & 5,35 & 3,63 \\
\hline 25 & 1650 & 110 & 32,78 & 26,55 & 22,11 & 17,12 & 13,34 & 10,58 & 7,16 & 5,36 & 3,63 \\
\hline 25 & 1700 & 110 & 32,48 & 26,40 & 22,03 & 17,10 & 13,34 & 10,59 & 7,17 & 5,36 & 3,63 \\
\hline 25 & 1750 & 110 & 32,19 & 26,24 & 21,95 & 17,07 & 13,35 & 10,61 & 7,19 & 5,37 & 3,63 \\
\hline 25 & 1800 & 110 & 31,91 & 26,10 & 21,87 & 17,05 & 13,35 & 10,62 & 7,20 & 5,38 & 3,63 \\
\hline 25 & 1850 & 110 & 31,64 & 25,95 & 21,79 & 17,03 & 13,36 & 10,64 & 7,21 & 5,38 & 3,63 \\
\hline 25 & 1900 & 110 & 31,38 & 25,81 & 21,71 & 17,00 & 13,36 & 10,65 & 7,23 & 5,39 & 3,64 \\
\hline 25 & 1950 & 110 & 31,13 & 25,67 & 21,63 & 16,98 & 13,36 & 10,66 & 7,24 & 5,39 & 3,64 \\
\hline 25 & 2000 & 110 & 30,89 & 25,54 & 21,56 & 16,96 & 13,36 & 10,67 & 7,25 & 5,40 & 3,64 \\
\hline 25 & 200 & 115 & 60,95 & 33,53 & 23,23 & 15,68 & 11,64 & 9,20 & 6,44 & 5,01 & 3,53 \\
\hline 25 & 250 & 115 & 56,48 & 33,00 & 23,34 & 15,86 & 11,73 & 9,24 & 6,46 & 5,02 & 3,52 \\
\hline 25 & 300 & 115 & 53,23 & 32,51 & 23,38 & 16,00 & 11,82 & 9,28 & 6,47 & 5,02 & 3,51 \\
\hline 25 & 350 & 115 & 50,70 & 32,06 & 23,37 & 16,11 & 11,90 & 9,33 & 6,48 & 5,02 & 3,51 \\
\hline 25 & 400 & 115 & 48,64 & 31,64 & 23,34 & 16,21 & 11,98 & 9,37 & 6,49 & 5,02 & 3,50 \\
\hline 25 & 450 & 115 & 46,92 & 31,24 & 23,30 & 16,28 & 12,05 & 9,41 & 6,50 & 5,02 & 3,50 \\
\hline 25 & 500 & 115 & 45,45 & 30,87 & 23,23 & 16,35 & 12,11 & 9,46 & 6,52 & 5,03 & 3,50 \\
\hline 25 & 550 & 115 & 44,17 & 30,52 & 23,16 & 16,40 & 12,17 & 9,50 & 6,53 & 5,03 & 3,50 \\
\hline 25 & 600 & 115 & 43,04 & 30,19 & 23,09 & 16,44 & 12,23 & 9,54 & 6,54 & 5,03 & 3,49 \\
\hline 25 & 650 & 115 & 42,02 & 29,87 & 23,00 & 16,48 & 12,28 & 9,58 & 6,56 & 5,03 & 3,49 \\
\hline 25 & 700 & 115 & 41,11 & 29,57 & 22,92 & 16,50 & 12,33 & 9,61 & 6,57 & 5,03 & 3,49 \\
\hline 25 & 750 & 115 & 40,27 & 29,29 & 22,83 & 16,52 & 12,37 & 9,65 & 6,58 & 5,04 & 3,49 \\
\hline 25 & 800 & 115 & 39,51 & 29,01 & 22,74 & 16,54 & 12,41 & 9,68 & 6,60 & 5,04 & 3,49 \\
\hline 25 & 850 & 115 & 38,80 & 28,75 & 22,65 & 16,55 & 12,45 & 9,72 & 6,61 & 5,04 & 3,49 \\
\hline 25 & 900 & 115 & 38,15 & 28,50 & 22,56 & 16,56 & 12,48 & 9,75 & 6,63 & 5,05 & 3,48 \\
\hline 25 & 950 & 115 & 37,54 & 28,26 & 22,47 & 16,56 & 12,51 & 9,78 & 6,64 & 5,05 & 3,48 \\
\hline 25 & 1000 & 115 & 36,97 & 28,02 & 22,37 & 16,56 & 12,54 & 9,81 & 6,65 & 5,05 & 3,48 \\
\hline 25 & 1050 & 115 & 36,44 & 27,80 & 22,28 & 16,56 & 12,57 & 9,84 & 6,67 & 5,06 & 3,48 \\
\hline 25 & 1100 & 115 & 35,93 & 27,58 & 22,19 & 16,56 & 12,59 & 9,86 & 6,68 & 5,06 & 3,48 \\
\hline 25 & 1150 & 115 & 35,46 & 27,38 & 22,10 & 16,55 & 12,61 & 9,89 & 6,70 & 5,07 & 3,48 \\
\hline 25 & 1200 & 115 & 35,01 & 27,17 & 22,02 & 16,54 & 12,63 & 9,91 & 6,71 & 5,07 & 3,48 \\
\hline 25 & 1250 & 115 & 34,58 & 26,98 & 21,93 & 16,53 & 12,65 & 9,94 & 6,72 & 5,08 & 3,48 \\
\hline 25 & 1300 & 115 & 34,17 & 26,79 & 21,84 & 16,52 & 12,67 & 9,96 & 6,74 & 5,08 & 3,48 \\
\hline 25 & 1350 & 115 & 33,79 & 26,61 & 21,76 & 16,51 & 12,68 & 9,98 & 6,75 & 5,09 & 3,48 \\
\hline 25 & 1400 & 115 & 33,42 & 26,43 & 21,67 & 16,49 & 12,70 & 10,00 & 6,76 & 5,09 & 3,48 \\
\hline 25 & 1450 & 115 & 33,06 & 26,26 & 21,59 & 16,48 & 12,71 & 10,02 & 6,78 & 5,10 & 3,48 \\
\hline 25 & 1500 & 115 & 32,72 & 26,09 & 21,51 & 16,46 & 12,72 & 10,04 & 6,79 & 5,10 & 3,48 \\
\hline 25 & 1550 & 115 & 32,40 & 25,93 & 21,43 & 16,44 & 12,73 & 10,06 & 6,80 & 5,11 & 3,48 \\
\hline 25 & 1600 & 115 & 32,09 & 25,77 & 21,35 & 16,42 & 12,74 & 10,08 & 6,82 & 5,11 & 3,48 \\
\hline 25 & 1650 & 115 & 31,78 & 25,62 & 21,27 & 16,40 & 12,75 & 10,09 & 6,83 & 5,12 & 3,48 \\
\hline 25 & 1700 & 115 & 31,50 & 25,47 & 21,19 & 16,39 & 12,75 & 10,11 & 6,84 & 5,12 & 3,48 \\
\hline 25 & 1750 & 115 & 31,22 & 25,33 & 21,11 & 16,37 & 12,76 & 10,12 & 6,86 & 5,13 & 3,48 \\
\hline 25 & 1800 & 115 & 30,95 & 25,19 & 21,04 & 16,34 & 12,77 & 10,14 & 6,87 & 5,13 & 3,48 \\
\hline 25 & 1850 & 115 & 30,69 & 25,05 & 20,96 & 16,32 & 12,77 & 10,15 & 6,88 & 5,14 & 3,48 \\
\hline
\end{tabular}




\begin{tabular}{|c|c|c|c|c|c|c|c|c|c|c|c|}
\hline \multirow[b]{2}{*}{$\mathrm{H}(\mathrm{cm})$} & \multirow[b]{2}{*}{ Mceq (MPa) } & & & & & $\mathrm{De}$ & ões (x1 & & & & \\
\hline & & Msub (MPa) & D0 & D25 & D40 & D60 & D80 & D100 & D140 & D180 & D260 \\
\hline 25 & 1900 & 115 & 30,43 & 24,91 & 20,89 & 16,30 & 12,77 & 10,16 & 6,89 & 5,14 & 3,48 \\
\hline 25 & 1950 & 115 & 30,19 & 24,78 & 20,82 & 16,28 & 12,78 & 10,18 & 6,90 & 5,15 & 3,48 \\
\hline 25 & 2000 & 115 & 29,95 & 24,65 & 20,75 & 16,26 & 12,78 & 10,19 & 6,91 & 5,16 & 3,48 \\
\hline 25 & 200 & 120 & 59,30 & 32,22 & 22,24 & 14,99 & 11,13 & 8,81 & 6,17 & 4,80 & 3,39 \\
\hline 25 & 250 & 120 & 54,91 & 31,73 & 22,35 & 15,16 & 11,22 & 8,85 & 6,18 & 4,81 & 3,38 \\
\hline 25 & 300 & 120 & 51,71 & 31,27 & 22,40 & 15,30 & 11,31 & 8,89 & 6,20 & 4,81 & 3,37 \\
\hline 25 & 350 & 120 & 49,24 & 30,85 & 22,40 & 15,41 & 11,38 & 8,93 & 6,21 & 4,81 & 3,36 \\
\hline 25 & 400 & 120 & 47,23 & 30,45 & 22,38 & 15,50 & 11,46 & 8,97 & 6,22 & 4,81 & 3,36 \\
\hline 25 & 450 & 120 & 45,56 & 30,08 & 22,34 & 15,58 & 11,52 & 9,01 & 6,23 & 4,81 & 3,36 \\
\hline 25 & 500 & 120 & 44,12 & 29,73 & 22,29 & 15,64 & 11,58 & 9,05 & 6,24 & 4,82 & 3,35 \\
\hline 25 & 550 & 120 & 42,87 & 29,40 & 22,23 & 15,69 & 11,64 & 9,08 & 6,25 & 4,82 & 3,35 \\
\hline 25 & 600 & 120 & 41,77 & 29,09 & 22,16 & 15,74 & 11,69 & 9,12 & 6,26 & 4,82 & 3,35 \\
\hline 25 & 650 & 120 & 40,79 & 28,79 & 22,09 & 15,77 & 11,74 & 9,16 & 6,28 & 4,82 & 3,35 \\
\hline 25 & 700 & 120 & 39,90 & 28,51 & 22,01 & 15,80 & 11,79 & 9,19 & 6,29 & 4,82 & 3,35 \\
\hline 25 & 750 & 120 & 39,09 & 28,24 & 21,93 & 15,82 & 11,83 & 9,23 & 6,30 & 4,83 & 3,34 \\
\hline 25 & 800 & 120 & 38,34 & 27,98 & 21,85 & 15,84 & 11,87 & 9,26 & 6,31 & 4,83 & 3,34 \\
\hline 25 & 850 & 120 & 37,66 & 27,73 & 21,77 & 15,85 & 11,90 & 9,29 & 6,33 & 4,83 & 3,34 \\
\hline 25 & 900 & 120 & 37,02 & 27,49 & 21,68 & 15,86 & 11,94 & 9,32 & 6,34 & 4,83 & 3,34 \\
\hline 25 & 950 & 120 & 36,43 & 27,26 & 21,60 & 15,87 & 11,97 & 9,35 & 6,35 & 4,84 & 3,34 \\
\hline 25 & 1000 & 120 & 35,88 & 27,04 & 21,52 & 15,87 & 11,99 & 9,38 & 6,37 & 4,84 & 3,34 \\
\hline 25 & 1050 & 120 & 35,36 & 26,83 & 21,43 & 15,87 & 12,02 & 9,40 & 6,38 & 4,84 & 3,34 \\
\hline 25 & 1100 & 120 & 34,88 & 26,62 & 21,35 & 15,87 & 12,04 & 9,43 & 6,39 & 4,85 & 3,34 \\
\hline 25 & 1150 & 120 & 34,42 & 26,43 & 21,27 & 15,87 & 12,07 & 9,45 & 6,40 & 4,85 & 3,34 \\
\hline 25 & 1200 & 120 & 33,98 & 26,24 & 21,18 & 15,86 & 12,09 & 9,48 & 6,42 & 4,86 & 3,34 \\
\hline 25 & 1250 & 120 & 33,57 & 26,05 & 21,10 & 15,85 & 12,10 & 9,50 & 6,43 & 4,86 & 3,33 \\
\hline 25 & 1300 & 120 & 33,17 & 25,87 & 21,02 & 15,84 & 12,12 & 9,52 & 6,44 & 4,86 & 3,33 \\
\hline 25 & 1350 & 120 & 32,80 & 25,70 & 20,94 & 15,83 & 12,14 & 9,54 & 6,46 & 4,87 & 3,33 \\
\hline 25 & 1400 & 120 & 32,44 & 25,53 & 20,86 & 15,82 & 12,15 & 9,56 & 6,47 & 4,87 & 3,33 \\
\hline 25 & 1450 & 120 & 32,10 & 25,37 & 20,79 & 15,81 & 12,16 & 9,58 & 6,48 & 4,88 & 3,33 \\
\hline 25 & 1500 & 120 & 31,77 & 25,21 & 20,71 & 15,79 & 12,18 & 9,60 & 6,49 & 4,88 & 3,33 \\
\hline 25 & 1550 & 120 & 31,45 & 25,05 & 20,63 & 15,78 & 12,19 & 9,62 & 6,50 & 4,89 & 3,33 \\
\hline 25 & 1600 & 120 & 31,15 & 24,90 & 20,56 & 15,76 & 12,20 & 9,63 & 6,52 & 4,89 & 3,33 \\
\hline 25 & 1650 & 120 & 30,86 & 24,76 & 20,49 & 15,75 & 12,20 & 9,65 & 6,53 & 4,90 & 3,33 \\
\hline 25 & 1700 & 120 & 30,58 & 24,61 & 20,41 & 15,73 & 12,21 & 9,67 & 6,54 & 4,90 & 3,33 \\
\hline 25 & 1750 & 120 & 30,31 & 24,48 & 20,34 & 15,71 & 12,22 & 9,68 & 6,55 & 4,91 & 3,33 \\
\hline 25 & 1800 & 120 & 30,05 & 24,34 & 20,27 & 15,69 & 12,23 & 9,69 & 6,56 & 4,91 & 3,33 \\
\hline 25 & 1850 & 120 & 29,80 & 24,21 & 20,20 & 15,67 & 12,23 & 9,71 & 6,57 & 4,92 & 3,33 \\
\hline 25 & 1900 & 120 & 29,55 & 24,08 & 20,13 & 15,66 & 12,24 & 9,72 & 6,59 & 4,92 & 3,33 \\
\hline 25 & 1950 & 120 & 29,32 & 23,95 & 20,06 & 15,64 & 12,24 & 9,73 & 6,60 & 4,93 & 3,33 \\
\hline 25 & 2000 & 120 & 29,09 & 23,83 & 20,00 & 15,62 & 12,24 & 9,74 & 6,61 & 4,93 & 3,33 \\
\hline 25 & 200 & 125 & 57,76 & 31,02 & 21,33 & 14,36 & 10,68 & 8,45 & 5,92 & 4,61 & 3,25 \\
\hline 25 & 250 & 125 & 53,44 & 30,55 & 21,44 & 14,53 & 10,76 & 8,49 & 5,93 & 4,61 & 3,24 \\
\hline 25 & 300 & 125 & 50,30 & 30,12 & 21,49 & 14,66 & 10,84 & 8,52 & 5,95 & 4,62 & 3,24 \\
\hline 25 & 350 & 125 & 47,88 & 29,72 & 21,51 & 14,77 & 10,91 & 8,56 & 5,96 & 4,62 & 3,23 \\
\hline 25 & 400 & 125 & 45,92 & 29,35 & 21,50 & 14,86 & 10,98 & 8,60 & 5,97 & 4,62 & 3,23 \\
\hline 25 & 450 & 125 & 44,28 & 29,00 & 21,47 & 14,93 & 11,04 & 8,63 & 5,98 & 4,62 & 3,22 \\
\hline 25 & 500 & 125 & 42,88 & 28,68 & 21,42 & 14,99 & 11,10 & 8,67 & 5,99 & 4,62 & 3,22 \\
\hline 25 & 550 & 125 & 41,67 & 28,36 & 21,37 & 15,05 & 11,15 & 8,70 & 6,00 & 4,62 & 3,22 \\
\hline 25 & 600 & 125 & 40,59 & 28,07 & 21,31 & 15,09 & 11,20 & 8,74 & 6,01 & 4,63 & 3,22 \\
\hline 25 & 650 & 125 & 39,63 & 27,79 & 21,24 & 15,13 & 11,25 & 8,77 & 6,02 & 4,63 & 3,21 \\
\hline 25 & 700 & 125 & 38,77 & 27,52 & 21,17 & 15,15 & 11,29 & 8,81 & 6,03 & 4,63 & 3,21 \\
\hline 25 & 750 & 125 & 37,98 & 27,26 & 21,10 & 15,18 & 11,33 & 8,84 & 6,04 & 4,63 & 3,21 \\
\hline 25 & 800 & 125 & 37,26 & 27,02 & 21,03 & 15,20 & 11,37 & 8,87 & 6,05 & 4,63 & 3,21 \\
\hline 25 & 850 & 125 & 36,59 & 26,78 & 20,95 & 15,21 & 11,40 & 8,90 & 6,07 & 4,64 & 3,21 \\
\hline 25 & 900 & 125 & 35,98 & 26,56 & 20,87 & 15,22 & 11,44 & 8,93 & 6,08 & 4,64 & 3,21 \\
\hline 25 & 950 & 125 & 35,40 & 26,34 & 20,80 & 15,23 & 11,47 & 8,95 & 6,09 & 4,64 & 3,21 \\
\hline 25 & 1000 & 125 & 34,87 & 26,13 & 20,72 & 15,24 & 11,49 & 8,98 & 6,10 & 4,64 & 3,21 \\
\hline 25 & 1050 & 125 & 34,36 & 25,93 & 20,64 & 15,24 & 11,52 & 9,01 & 6,11 & 4,65 & 3,20 \\
\hline 25 & 1100 & 125 & 33,89 & 25,73 & 20,56 & 15,24 & 11,54 & 9,03 & 6,12 & 4,65 & 3,20 \\
\hline 25 & 1150 & 125 & 33,44 & 25,54 & 20,49 & 15,24 & 11,56 & 9,05 & 6,14 & 4,65 & 3,20 \\
\hline 25 & 1200 & 125 & 33,02 & 25,36 & 20,41 & 15,23 & 11,58 & 9,08 & 6,15 & 4,66 & 3,20 \\
\hline 25 & 1250 & 125 & 32,62 & 25,19 & 20,34 & 15,23 & 11,60 & 9,10 & 6,16 & 4,66 & 3,20 \\
\hline 25 & 1300 & 125 & 32,24 & 25,02 & 20,26 & 15,22 & 11,62 & 9,12 & 6,17 & 4,67 & 3,20 \\
\hline 25 & 1350 & 125 & 31,87 & 24,85 & 20,19 & 15,21 & 11,63 & 9,14 & 6,18 & 4,67 & 3,20 \\
\hline 25 & 1400 & 125 & 31,53 & 24,69 & 20,11 & 15,20 & 11,65 & 9,16 & 6,20 & 4,67 & 3,20 \\
\hline 25 & 1450 & 125 & 31,19 & 24,53 & 20,04 & 15,19 & 11,66 & 9,18 & 6,21 & 4,68 & 3,20 \\
\hline 25 & 1500 & 125 & 30,88 & 24,38 & 19,97 & 15,18 & 11,67 & 9,19 & 6,22 & 4,68 & 3,20 \\
\hline 25 & 1550 & 125 & 30,57 & 24,24 & 19,90 & 15,16 & 11,69 & 9,21 & 6,23 & 4,69 & 3,20 \\
\hline 25 & 1600 & 125 & 30,28 & 24,09 & 19,83 & 15,15 & 11,70 & 9,23 & 6,24 & 4,69 & 3,20 \\
\hline 25 & 1650 & 125 & 30,00 & 23,95 & 19,76 & 15,14 & 11,71 & 9,24 & 6,25 & 4,69 & 3,20 \\
\hline 25 & 1700 & 125 & 29,72 & 23,82 & 19,69 & 15,12 & 11,71 & 9,26 & 6,26 & 4,70 & 3,20 \\
\hline 25 & 1750 & 125 & 29,46 & 23,68 & 19,62 & 15,11 & 11,72 & 9,27 & 6,27 & 4,70 & 3,20 \\
\hline 25 & 1800 & 125 & 29,21 & 23,56 & 19,56 & 15,09 & 11,73 & 9,29 & 6,29 & 4,71 & 3,20 \\
\hline 25 & 1850 & 125 & 28,97 & 23,43 & 19,49 & 15,07 & 11,73 & 9,30 & 6,30 & 4.71 & 3,20 \\
\hline 25 & 1900 & 125 & 28,73 & 23,31 & 19,43 & 15,06 & 11,74 & 9,31 & 6,31 & 4,72 & 3,20 \\
\hline 25 & 1950 & 125 & 28,50 & 23,19 & 19,36 & 15,04 & 11,74 & 9,32 & 6,32 & 4,72 & 3,20 \\
\hline 25 & 2000 & 125 & 28,28 & 23,07 & 19,30 & 15,02 & 11,75 & 9,34 & 6,33 & 4,73 & 3,20 \\
\hline 25 & 200 & 130 & 56,33 & 29,90 & 20,48 & 13,78 & 10,25 & 8,12 & 5,69 & 4,43 & 3,13 \\
\hline 25 & 250 & 130 & 52,07 & 29,46 & 20,60 & 13,94 & 10,33 & 8,15 & 5,70 & 4,44 & 3,12 \\
\hline 25 & 300 & 130 & 48,99 & 29,05 & 20,66 & 14,07 & 10,40 & 8,19 & 5,71 & 4,44 & 3,11 \\
\hline 25 & 350 & 130 & 46,61 & 28,68 & 20,68 & 14,17 & 10,47 & 8,22 & 5,72 & 4,44 & 3,11 \\
\hline
\end{tabular}




\begin{tabular}{|c|c|c|c|c|c|c|c|c|c|c|c|}
\hline \multirow[b]{2}{*}{$\mathrm{H}(\mathrm{cm})$} & \multirow[b]{2}{*}{ Mceq (MPa) } & & & & & $\mathrm{De}$ & ões (x1 & & & & \\
\hline & & Msub (MPa) & D0 & D25 & D40 & D60 & D80 & D100 & D140 & D180 & D260 \\
\hline 25 & 400 & 130 & 44,69 & 28,33 & 20,67 & 14,26 & 10,53 & 8,25 & 5,73 & 4,44 & 3,10 \\
\hline 25 & 450 & 130 & 43,09 & 28,00 & 20,65 & 14,33 & 10,59 & 8,29 & 5,74 & 4,44 & 3,10 \\
\hline 25 & 500 & 130 & 41,73 & 27,69 & 20,62 & 14,40 & 10,65 & 8,32 & 5,75 & 4,44 & 3,10 \\
\hline 25 & 550 & 130 & 40,54 & 27,40 & 20,57 & 14,45 & 10,70 & 8,35 & 5,76 & 4,45 & 3,10 \\
\hline 25 & 600 & 130 & 39,49 & 27,12 & 20,52 & 14,49 & 10,75 & 8,39 & 5,77 & 4,45 & 3,09 \\
\hline 25 & 650 & 130 & 38,56 & 26,85 & 20,46 & 14,53 & 10,79 & 8,42 & 5,78 & 4,45 & 3,09 \\
\hline 25 & 700 & 130 & 37,72 & 26,60 & 20,39 & 14,56 & 10,84 & 8,45 & 5,79 & 4,45 & 3,09 \\
\hline 25 & 750 & 130 & 36,95 & 26,35 & 20,33 & 14,58 & 10,87 & 8,48 & 5,80 & 4,45 & 3,09 \\
\hline 25 & 800 & 130 & 36,25 & 26,12 & 20,26 & 14,60 & 10,91 & 8,51 & 5,81 & 4,45 & 3,09 \\
\hline 25 & 850 & 130 & 35,60 & 25,90 & 20,19 & 14,62 & 10,94 & 8,54 & 5,82 & 4,46 & 3,09 \\
\hline 25 & 900 & 130 & 35,00 & 25,68 & 20,12 & 14,63 & 10,98 & 8,56 & 5,84 & 4,46 & 3,08 \\
\hline 25 & 950 & 130 & 34,44 & 25,48 & 20,05 & 14,64 & 11,00 & 8,59 & 5,85 & 4,46 & 3,08 \\
\hline 25 & 1000 & 130 & 33,92 & 25,28 & 19,98 & 14,65 & 11,03 & 8,61 & 5,86 & 4,46 & 3,08 \\
\hline 25 & 1050 & 130 & 33,43 & 25,09 & 19,91 & 14,65 & 11,06 & 8,64 & 5,87 & 4,47 & 3,08 \\
\hline 25 & 1100 & 130 & 32,97 & 24,90 & 19,84 & 14,65 & 11,08 & 8,66 & 5,88 & 4,47 & 3,08 \\
\hline 25 & 1150 & 130 & 32,54 & 24,72 & 19,77 & 14,65 & 11,10 & 8,69 & 5,89 & 4,47 & 3,08 \\
\hline 25 & 1200 & 130 & 32,13 & 24,55 & 19,69 & 14,65 & 11,12 & 8,71 & 5,90 & 4,48 & 3,08 \\
\hline 25 & 1250 & 130 & 31,74 & 24,38 & 19,62 & 14,65 & 11,14 & 8,73 & 5,91 & 4,48 & 3,08 \\
\hline 25 & 1300 & 130 & 31,37 & 24,22 & 19,55 & 14,64 & 11,16 & 8,75 & 5,92 & 4,48 & 3,08 \\
\hline 25 & 1350 & 130 & 31,01 & 24,06 & 19,48 & 14,63 & 11,17 & 8,77 & 5,93 & 4,49 & 3,08 \\
\hline 25 & 1400 & 130 & 30,67 & 23,91 & 19,42 & 14,63 & 11,19 & 8,79 & 5,95 & 4,49 & 3,08 \\
\hline 25 & 1450 & 130 & 30,35 & 23,76 & 19,35 & 14,62 & 11,20 & 8,80 & 5,96 & 4,49 & 3,08 \\
\hline 25 & 1500 & 130 & 30,04 & 23,61 & 19,28 & 14,61 & 11,21 & 8,82 & 5,97 & 4,50 & 3,08 \\
\hline 25 & 1550 & 130 & 29,75 & 23,47 & 19,21 & 14,60 & 11,22 & 8,84 & 5,98 & 4,50 & 3,08 \\
\hline 25 & 1600 & 130 & 29,46 & 23,34 & 19,15 & 14,58 & 11,23 & 8,85 & 5,99 & 4,50 & 3,08 \\
\hline 25 & 1650 & 130 & 29,19 & 23,20 & 19,08 & 14,57 & 11,24 & 8,87 & 6,00 & 4,51 & 3,08 \\
\hline 25 & 1700 & 130 & 28,92 & 23,07 & 19,02 & 14,56 & 11,25 & 8,88 & 6,01 & 4,51 & 3,08 \\
\hline 25 & 1750 & 130 & 28,67 & 22,95 & 18,96 & 14,54 & 11,26 & 8,90 & 6,02 & 4,52 & 3,08 \\
\hline 25 & 1800 & 130 & 28,43 & 22,82 & 18,89 & 14,53 & 11,27 & 8,91 & 6,03 & 4,52 & 3,08 \\
\hline 25 & 1850 & 130 & 28,19 & 22,70 & 18,83 & 14,52 & 11,27 & 8,92 & 6,04 & 4,52 & 3,08 \\
\hline 25 & 1900 & 130 & 27,96 & 22,58 & 18,77 & 14,50 & 11,28 & 8,94 & 6,05 & 4,53 & 3,08 \\
\hline 25 & 1950 & 130 & 27,74 & 22,47 & 18,71 & 14,49 & 11,28 & 8,95 & 6,06 & 4,53 & 3,08 \\
\hline 25 & 2000 & 130 & 27,52 & 22,36 & 18,65 & 14,47 & 11,29 & 8,96 & 6,07 & 4,54 & 3,08 \\
\hline 25 & 200 & 135 & 55,00 & 28,86 & 19,70 & 13,25 & 9,86 & 7,82 & 5,48 & 4,27 & 3,02 \\
\hline 25 & 250 & 135 & 50,80 & 28,44 & 19,82 & 13,40 & 9,93 & 7,85 & 5,49 & 4,27 & 3,01 \\
\hline 25 & 300 & 135 & 47,77 & 28,06 & 19,89 & 13,52 & 10,00 & 7,88 & 5,50 & 4,27 & 3,00 \\
\hline 25 & 350 & 135 & 45,43 & 27,71 & 19,91 & 13,62 & 10,07 & 7,91 & 5,51 & 4,28 & 2,99 \\
\hline 25 & 400 & 135 & 43,55 & 27,38 & 19,91 & 13,71 & 10,13 & 7,94 & 5,52 & 4,28 & 2,99 \\
\hline 25 & 450 & 135 & 41,98 & 27,07 & 19,90 & 13,78 & 10,18 & 7,97 & 5,53 & 4,28 & 2,99 \\
\hline 25 & 500 & 135 & 40,65 & 26,77 & 19,87 & 13,84 & 10,24 & 8,00 & 5,54 & 4,28 & 2,98 \\
\hline 25 & 550 & 135 & 39,49 & 26,50 & 19,83 & 13,89 & 10,29 & 8,03 & 5,55 & 4,28 & 2,98 \\
\hline 25 & 600 & 135 & 38,46 & 26,23 & 19,78 & 13,94 & 10,33 & 8,06 & 5,55 & 4,28 & 2,98 \\
\hline 25 & 650 & 135 & 37,55 & 25,98 & 19,73 & 13,97 & 10,37 & 8,09 & 5,56 & 4,28 & 2,98 \\
\hline 25 & 700 & 135 & 36,73 & 25,74 & 19,67 & 14,00 & 10,41 & 8,12 & 5,57 & 4,28 & 2,98 \\
\hline 25 & 750 & 135 & 35,98 & 25,51 & 19,61 & 14,03 & 10,45 & 8,15 & 5,58 & 4,29 & 2,97 \\
\hline 25 & 800 & 135 & 35,30 & 25,29 & 19,55 & 14,05 & 10,49 & 8,18 & 5,59 & 4,29 & 2,97 \\
\hline 25 & 850 & 135 & 34,67 & 25,07 & 19,49 & 14,07 & 10,52 & 8,20 & 5,60 & 4,29 & 2,97 \\
\hline 25 & 900 & 135 & 34,08 & 24,87 & 19,42 & 14,08 & 10,55 & 8,23 & 5,61 & 4,29 & 2,97 \\
\hline 25 & 950 & 135 & 33,54 & 24,67 & 19,36 & 14,09 & 10,58 & 8,25 & 5,62 & 4,29 & 2,97 \\
\hline 25 & 1000 & 135 & 33,03 & 24,48 & 19,29 & 14,10 & 10,60 & 8,28 & 5,63 & 4,30 & 2,97 \\
\hline 25 & 1050 & 135 & 32,56 & 24,30 & 19,22 & 14,11 & 10,63 & 8,30 & 5,64 & 4,30 & 2,97 \\
\hline 25 & 1100 & 135 & 32,11 & 24,12 & 19,16 & 14,11 & 10,65 & 8,32 & 5,65 & 4,30 & 2,97 \\
\hline 25 & 1150 & 135 & 31,69 & 23,95 & 19,09 & 14,11 & 10,67 & 8,34 & 5,66 & 4,30 & 2,97 \\
\hline 25 & 1200 & 135 & 31,29 & 23,79 & 19,03 & 14,11 & 10,69 & 8,37 & 5,67 & 4,31 & 2,97 \\
\hline 25 & 1250 & 135 & 30,91 & 23,63 & 18,96 & 14,11 & 10,71 & 8,39 & 5,68 & 4,31 & 2,97 \\
\hline 25 & 1300 & 135 & 30,55 & 23,47 & 18,89 & 14,10 & 10,73 & 8,41 & 5,69 & 4,31 & 2,97 \\
\hline 25 & 1350 & 135 & 30,20 & 23,32 & 18,83 & 14,10 & 10,74 & 8,42 & 5,70 & 4,32 & 2,96 \\
\hline 25 & 1400 & 135 & 29,88 & 23,17 & 18,77 & 14,09 & 10,76 & 8,44 & 5,71 & 4,32 & 2,96 \\
\hline 25 & 1450 & 135 & 29,56 & 23,03 & 18,70 & 14,08 & 10,77 & 8,46 & 5,72 & 4,32 & 2,96 \\
\hline 25 & 1500 & 135 & 29,26 & 22,89 & 18,64 & 14,08 & 10,78 & 8,48 & 5,73 & 4,33 & 2,96 \\
\hline 25 & 1550 & 135 & 28,97 & 22,76 & 18,58 & 14,07 & 10,80 & 8,49 & 5,74 & 4,33 & 2,96 \\
\hline 25 & 1600 & 135 & 28,70 & 22,63 & 18,51 & 14,06 & 10,81 & 8,51 & 5,75 & 4,33 & 2,96 \\
\hline 25 & 1650 & 135 & 28,43 & 22,50 & 18,45 & 14,05 & 10,82 & 8,52 & 5,76 & 4,34 & 2,96 \\
\hline 25 & 1700 & 135 & 28,17 & 22,38 & 18,39 & 14,03 & 10,82 & 8,54 & 5,77 & 4,34 & 2,96 \\
\hline 25 & 1750 & 135 & 27,93 & 22,25 & 18,33 & 14,02 & 10,83 & 8,55 & 5,78 & 4,34 & 2,96 \\
\hline 25 & 1800 & 135 & 27,69 & 22,14 & 18,27 & 14,01 & 10,84 & 8,56 & 5,79 & 4,35 & 2,96 \\
\hline 25 & 1850 & 135 & 27,46 & 22,02 & 18,22 & 14,00 & 10,85 & 8,58 & 5,80 & 4,35 & 2,96 \\
\hline 25 & 1900 & 135 & 27,24 & 21,91 & 18,16 & 13,98 & 10,85 & 8,59 & 5,81 & 4,36 & 2,96 \\
\hline 25 & 1950 & 135 & 27,02 & 21,80 & 18,10 & 13,97 & 10,86 & 8,60 & 5,82 & 4,36 & 2,96 \\
\hline 25 & 2000 & 135 & 26,81 & 21,69 & 18,05 & 13,96 & 10,86 & 8,61 & 5,83 & 4,36 & 2,96 \\
\hline 25 & 200 & 140 & 53,75 & 27,89 & 18,97 & 12,75 & 9,50 & 7,54 & 5,28 & 4,11 & 2,91 \\
\hline 25 & 250 & 140 & 49,61 & 27,49 & 19,10 & 12,90 & 9,57 & 7,56 & 5,29 & 4,12 & 2,90 \\
\hline 25 & 300 & 140 & 46,62 & 27,14 & 19,17 & 13,02 & 9,63 & 7,59 & 5,30 & 4,12 & 2,89 \\
\hline 25 & 350 & 140 & 44,32 & 26,80 & 19,20 & 13,11 & 9,69 & 7,62 & 5,31 & 4,12 & 2,89 \\
\hline 25 & 400 & 140 & 42,48 & 26,49 & 19,20 & 13,20 & 9,75 & 7,65 & 5,32 & 4,12 & 2,88 \\
\hline 25 & 450 & 140 & 40,94 & 26,20 & 19,19 & 13,27 & 9,80 & 7,68 & 5,33 & 4,12 & 2,88 \\
\hline 25 & 500 & 140 & 39,63 & 25,92 & 19,17 & 13,33 & 9,85 & 7,71 & 5,34 & 4,13 & 2,88 \\
\hline 25 & 550 & 140 & 38,50 & 25,65 & 19,13 & 13,38 & 9,90 & 7,73 & 5,34 & 4,13 & 2,88 \\
\hline 25 & 600 & 140 & 37,50 & 25,40 & 19,09 & 13,42 & 9,94 & 7,76 & 5,35 & 4,13 & 2,87 \\
\hline 25 & 650 & 140 & 36,61 & 25,16 & 19,05 & 13,46 & 9,98 & 7,79 & 5,36 & 4,13 & 2,87 \\
\hline 25 & 700 & 140 & 35,80 & 24,93 & 19,00 & 13,49 & 10,02 & 7,82 & 5,37 & 4,13 & 2,87 \\
\hline
\end{tabular}




\begin{tabular}{|c|c|c|c|c|c|c|c|c|c|c|c|}
\hline \multirow[b]{2}{*}{$\mathrm{H}(\mathrm{cm})$} & \multirow[b]{2}{*}{ Mceq (MPa) } & & & & & $\mathrm{De}$ & ões (x1 & & & & \\
\hline & & Msub (MPa) & D0 & D25 & D40 & D60 & D80 & D100 & D140 & D180 & D260 \\
\hline 25 & 750 & 140 & 35,08 & 24,71 & 18,94 & 13,52 & 10,06 & 7,84 & 5,38 & 4,13 & 2,87 \\
\hline 25 & 800 & 140 & 34,41 & 24,50 & 18,89 & 13,54 & 10,09 & 7,87 & 5,39 & 4,13 & 2,87 \\
\hline 25 & 850 & 140 & 33,79 & 24,30 & 18,83 & 13,56 & 10,12 & 7,90 & 5,40 & 4,14 & 2,87 \\
\hline 25 & 900 & 140 & 33,22 & 24,11 & 18,77 & 13,57 & 10,15 & 7,92 & 5,41 & 4,14 & 2,87 \\
\hline 25 & 950 & 140 & 32,69 & 23,92 & 18,71 & 13,58 & 10,18 & 7,94 & 5,41 & 4,14 & 2,86 \\
\hline 25 & 1000 & 140 & 32,20 & 23,74 & 18,65 & 13,59 & 10,21 & 7,97 & 5,42 & 4,14 & 2,86 \\
\hline 25 & 1050 & 140 & 31,74 & 23,56 & 18,59 & 13,60 & 10,23 & 7,99 & 5,43 & 4,14 & 2,86 \\
\hline 25 & 1100 & 140 & 31,30 & 23,39 & 18,52 & 13,60 & 10,25 & 8,01 & 5,44 & 4,15 & 2,86 \\
\hline 25 & 1150 & 140 & 30,89 & 23,23 & 18,46 & 13,60 & 10,27 & 8,03 & 5,45 & 4,15 & 2,86 \\
\hline 25 & 1200 & 140 & 30,50 & 23,07 & 18,40 & 13,61 & 10,29 & 8,05 & 5,46 & 4,15 & 2,86 \\
\hline 25 & 1250 & 140 & 30,13 & 22,92 & 18,34 & 13,60 & 10,31 & 8,07 & 5,47 & 4,15 & 2,86 \\
\hline 25 & 1300 & 140 & 29,78 & 22,77 & 18,28 & 13,60 & 10,33 & 8,09 & 5,48 & 4,16 & 2,86 \\
\hline 25 & 1350 & 140 & 29,44 & 22,63 & 18,22 & 13,60 & 10,34 & 8,11 & 5,49 & 4,16 & 2,86 \\
\hline 25 & 1400 & 140 & 29,12 & 22,49 & 18,16 & 13,59 & 10,36 & 8,12 & 5,50 & 4,16 & 2,86 \\
\hline 25 & 1450 & 140 & 28,82 & 22,35 & 18,10 & 13,59 & 10,37 & 8,14 & 5,51 & 4,17 & 2,86 \\
\hline 25 & 1500 & 140 & 28,53 & 22,22 & 18,04 & 13,58 & 10,39 & 8,16 & 5,52 & 4,17 & 2,86 \\
\hline 25 & 1550 & 140 & 28,25 & 22,09 & 17,98 & 13,57 & 10,40 & 8,17 & 5,53 & 4,17 & 2,86 \\
\hline 25 & 1600 & 140 & 27,98 & 21,96 & 17,92 & 13,57 & 10,41 & 8,19 & 5,54 & 4,17 & 2,86 \\
\hline 25 & 1650 & 140 & 27,72 & 21,84 & 17,86 & 13,56 & 10,42 & 8,20 & 5,55 & 4,18 & 2,86 \\
\hline 25 & 1700 & 140 & 27,47 & 21,72 & 17,81 & 13,55 & 10,43 & 8,21 & 5,56 & 4,18 & 2,86 \\
\hline 25 & 1750 & 140 & 27,23 & 21,61 & 17,75 & 13,54 & 10,44 & 8,23 & 5,57 & 4,18 & 2,86 \\
\hline 25 & 1800 & 140 & 27,00 & 21,49 & 17,70 & 13,53 & 10,44 & 8,24 & 5,57 & 4,19 & 2,86 \\
\hline 25 & 1850 & 140 & 26,77 & 21,38 & 17,64 & 13,51 & 10,45 & 8,25 & 5,58 & 4,19 & 2,86 \\
\hline 25 & 1900 & 140 & 26,56 & 21,27 & 17,59 & 13,50 & 10,46 & 8,27 & 5,59 & 4,20 & 2,86 \\
\hline 25 & 1950 & 140 & 26,35 & 21,17 & 17,53 & 13,49 & 10,46 & 8,28 & 5,60 & 4,20 & 2,86 \\
\hline 25 & 2000 & 140 & 26,14 & 21,06 & 17,48 & 13,48 & 10,47 & 8,29 & 5,61 & 4,20 & 2,86 \\
\hline 25 & 200 & 145 & 52,58 & 26,98 & 18,29 & 12,29 & 9,16 & 7,27 & 5,10 & 3,97 & 2,81 \\
\hline 25 & 250 & 145 & 48,49 & 26,61 & 18,42 & 12,43 & 9,23 & 7,30 & 5,11 & 3,98 & 2,80 \\
\hline 25 & 300 & 145 & 45,54 & 26,27 & 18,49 & 12,54 & 9,29 & 7,32 & 5,12 & 3,98 & 2,79 \\
\hline 25 & 350 & 145 & 43,28 & 25,95 & 18,53 & 12,64 & 9,34 & 7,35 & 5,13 & 3,98 & 2,79 \\
\hline 25 & 400 & 145 & 41,47 & 25,66 & 18,54 & 12,72 & 9,40 & 7,38 & 5,13 & 3,98 & 2,79 \\
\hline 25 & 450 & 145 & 39,96 & 25,38 & 18,54 & 12,79 & 9,45 & 7,40 & 5,14 & 3,98 & 2,78 \\
\hline 25 & 500 & 145 & 38,68 & 25,12 & 18,52 & 12,85 & 9,50 & 7,43 & 5,15 & 3,98 & 2,78 \\
\hline 25 & 550 & 145 & 37,57 & 24,86 & 18,49 & 12,90 & 9,54 & 7,46 & 5,16 & 3,98 & 2,78 \\
\hline 25 & 600 & 145 & 36,59 & 24,63 & 18,45 & 12,94 & 9,58 & 7,48 & 5,16 & 3,99 & 2,78 \\
\hline 25 & 650 & 145 & 35,72 & 24,40 & 18,41 & 12,98 & 9,62 & 7,51 & 5,17 & 3,99 & 2,77 \\
\hline 25 & 700 & 145 & 34,93 & 24,18 & 18,36 & 13,01 & 9,66 & 7,54 & 5,18 & 3,99 & 2,77 \\
\hline 25 & 750 & 145 & 34,22 & 23,97 & 18,32 & 13,04 & 9,69 & 7,56 & 5,19 & 3,99 & 2,77 \\
\hline 25 & 800 & 145 & 33,57 & 23,77 & 18,26 & 13,06 & 9,73 & 7,58 & 5,20 & 3,99 & 2,77 \\
\hline 25 & 850 & 145 & 32,97 & 23,58 & 18,21 & 13,08 & 9,76 & 7,61 & 5,20 & 3,99 & 2,77 \\
\hline 25 & 900 & 145 & 32,41 & 23,39 & 18,16 & 13,09 & 9,79 & 7,63 & 5,21 & 3,99 & 2,77 \\
\hline 25 & 950 & 145 & 31,90 & 23,21 & 18,10 & 13,11 & 9,81 & 7,65 & 5,22 & 4,00 & 2,77 \\
\hline 25 & 1000 & 145 & 31,41 & 23,04 & 18,04 & 13,12 & 9,84 & 7,68 & 5,23 & 4,00 & 2,77 \\
\hline 25 & 1050 & 145 & 30,96 & 22,87 & 17,99 & 13,12 & 9,86 & 7,70 & 5,24 & 4,00 & 2,77 \\
\hline 25 & 1100 & 145 & 30,54 & 22,71 & 17,93 & 13,13 & 9,88 & 7,72 & 5,25 & 4,00 & 2,76 \\
\hline 25 & 1150 & 145 & 30,14 & 22,56 & 17,87 & 13,13 & 9,90 & 7,74 & 5,26 & 4,00 & 2,76 \\
\hline 25 & 1200 & 145 & 29,76 & 22,40 & 17,82 & 13,14 & 9,92 & 7,76 & 5,27 & 4,01 & 2,76 \\
\hline 25 & 1250 & 145 & 29,40 & 22,26 & 17,76 & 13,14 & 9,94 & 7,77 & 5,28 & 4,01 & 2,76 \\
\hline 25 & 1300 & 145 & 29,05 & 22,12 & 17,70 & 13,14 & 9,96 & 7,79 & 5,28 & 4,01 & 2,76 \\
\hline 25 & 1350 & 145 & 28,73 & 21,98 & 17,64 & 13,13 & 9,97 & 7,81 & 5,29 & 4,01 & 2,76 \\
\hline 25 & 1400 & 145 & 28,42 & 21,84 & 17,59 & 13,13 & 9,99 & 7,83 & 5,30 & 4,02 & 2,76 \\
\hline 25 & 1450 & 145 & 28,12 & 21,71 & 17,53 & 13,13 & 10,00 & 7,84 & 5,31 & 4,02 & 2,76 \\
\hline 25 & 1500 & 145 & 27,84 & 21,59 & 17,48 & 13,12 & 10,01 & 7,86 & 5,32 & 4,02 & 2,76 \\
\hline 25 & 1550 & 145 & 27,56 & 21,46 & 17,42 & 13,11 & 10,03 & 7,87 & 5,33 & 4,02 & 2,76 \\
\hline 25 & 1600 & 145 & 27,30 & 21,34 & 17,37 & 13,11 & 10,04 & 7,89 & 5,34 & 4,03 & 2,76 \\
\hline 25 & 1650 & 145 & 27,05 & 21,22 & 17,31 & 13,10 & 10,05 & 7,90 & 5,35 & 4,03 & 2,76 \\
\hline 25 & 1700 & 145 & 26,81 & 21,11 & 17,26 & 13,09 & 10,06 & 7,92 & 5,35 & 4,03 & 2,76 \\
\hline 25 & 1750 & 145 & 26,57 & 21,00 & 17,20 & 13,08 & 10,07 & 7,93 & 5,36 & 4,04 & 2,76 \\
\hline 25 & 1800 & 145 & 26,35 & 20,89 & 17,15 & 13,07 & 10,07 & 7,94 & 5,37 & 4,04 & 2,76 \\
\hline 25 & 1850 & 145 & 26,13 & 20,78 & 17,10 & 13,06 & 10,08 & 7,95 & 5,38 & 4,04 & 2,76 \\
\hline 25 & 1900 & 145 & 25,92 & 20,68 & 17,05 & 13,05 & 10,09 & 7,97 & 5,39 & 4,05 & 2,76 \\
\hline 25 & 1950 & 145 & 25,71 & 20,58 & 17,00 & 13,04 & 10,10 & 7,98 & 5,40 & 4,05 & 2,76 \\
\hline 25 & 2000 & 145 & 25,51 & 20,48 & 16,95 & 13,03 & 10,10 & 7,99 & 5,40 & 4,05 & 2,76 \\
\hline 25 & 200 & 150 & 51,49 & 26,13 & 17,66 & 11,86 & 8,85 & 7,03 & 4,92 & 3,84 & 2,72 \\
\hline 25 & 250 & 150 & 47,44 & 25,78 & 17,79 & 11,99 & 8,91 & 7,05 & 4,94 & 3,84 & 2,71 \\
\hline 25 & 300 & 150 & 44,53 & 25,46 & 17,87 & 12,11 & 8,97 & 7,07 & 4,95 & 3,84 & 2,70 \\
\hline 25 & 350 & 150 & 42,31 & 25,16 & 17,91 & 12,20 & 9,02 & 7,10 & 4,95 & 3,85 & 2,70 \\
\hline 25 & 400 & 150 & 40,52 & 24,88 & 17,92 & 12,28 & 9,07 & 7,12 & 4,96 & 3,85 & 2,69 \\
\hline 25 & 450 & 150 & 39,04 & 24,61 & 17,92 & 12,35 & 9,12 & 7,15 & 4,97 & 3,85 & 2,69 \\
\hline 25 & 500 & 150 & 37,78 & 24,36 & 17,91 & 12,40 & 9,16 & 7,17 & 4,97 & 3,85 & 2,69 \\
\hline 25 & 550 & 150 & 36,70 & 24,12 & 17,88 & 12,45 & 9,21 & 7,20 & 4,98 & 3,85 & 2,69 \\
\hline 25 & 600 & 150 & 35,74 & 23,90 & 17,85 & 12,49 & 9,25 & 7,22 & 4,99 & 3,85 & 2,68 \\
\hline 25 & 650 & 150 & 34,88 & 23,68 & 17,81 & 12,53 & 9,29 & 7,25 & 5,00 & 3,85 & 2,68 \\
\hline 25 & 700 & 150 & 34.11 & 23,47 & 17,77 & 12,56 & 9,32 & 7,27 & 5,00 & 3,85 & 2,68 \\
\hline 25 & 750 & 150 & 33,42 & 23,27 & 17,73 & 12,59 & 9,36 & 7,30 & 5,01 & 3,86 & 2,68 \\
\hline 25 & 800 & 150 & 32,78 & 23,08 & 17,68 & 12,61 & 9,39 & 7,32 & 5,02 & 3,86 & 2,68 \\
\hline 25 & 850 & 150 & 32,19 & 22,90 & 17,63 & 12,63 & 9,42 & 7,34 & 5,03 & 3,86 & 2,68 \\
\hline 25 & 900 & 150 & 31,65 & 22,72 & 17,58 & 12,65 & 9,44 & 7,36 & 5,03 & 3,86 & 2,68 \\
\hline 25 & 950 & 150 & 31,15 & 22,55 & 17,53 & 12,66 & 9,47 & 7,39 & 5,04 & 3,86 & 2,68 \\
\hline 25 & 1000 & 150 & 30,68 & 22,38 & 17,48 & 12,67 & 9,49 & 7,41 & 5,05 & 3,86 & 2,67 \\
\hline 25 & 1050 & 150 & 30,23 & 22,22 & 17,43 & 12,68 & 9,52 & 7,43 & 5,06 & 3,86 & 2,67 \\
\hline
\end{tabular}




\begin{tabular}{|c|c|c|c|c|c|c|c|c|c|c|c|}
\hline \multirow[b]{2}{*}{$\mathrm{H}(\mathrm{cm})$} & \multirow[b]{2}{*}{ Mceq (MPa) } & & & & & $\mathrm{De}$ & ões (x. & & & & \\
\hline & & Msub (MPa) & D0 & D25 & D40 & D60 & D80 & D100 & D140 & D180 & D260 \\
\hline 25 & 1100 & 150 & 29,82 & 22,07 & 17,37 & 12,69 & 9,54 & 7,45 & 5,07 & 3,87 & 2,67 \\
\hline 25 & 1150 & 150 & 29,43 & 21,92 & 17,32 & 12,69 & 9,56 & 7,46 & 5,08 & 3,87 & 2,67 \\
\hline 25 & 1200 & 150 & 29,06 & 21,77 & 17,27 & 12,70 & 9,58 & 7,48 & 5,08 & 3,87 & 2,67 \\
\hline 25 & 1250 & 150 & 28,71 & 21,63 & 17,21 & 12,70 & 9,60 & 7,50 & 5,09 & 3,87 & 2,67 \\
\hline 25 & 1300 & 150 & 28,37 & 21,50 & 17,16 & 12,70 & 9,61 & 7,52 & 5,10 & 3,88 & 2,67 \\
\hline 25 & 1350 & 150 & 28,05 & 21,36 & 17,11 & 12,70 & 9,63 & 7,53 & 5,11 & 3,88 & 2,67 \\
\hline 25 & 1400 & 150 & 27,75 & 21,24 & 17,05 & 12,70 & 9,64 & 7,55 & 5,12 & 3,88 & 2,67 \\
\hline 25 & 1450 & 150 & 27,46 & 21,11 & 17,00 & 12,69 & 9,66 & 7,57 & 5,13 & 3,88 & 2,67 \\
\hline 25 & 1500 & 150 & 27,18 & 20,99 & 16,95 & 12,69 & 9,67 & 7,58 & 5,13 & 3,88 & 2,67 \\
\hline 25 & 1550 & 150 & 26,92 & 20,87 & 16,89 & 12,68 & 9,68 & 7,60 & 5,14 & 3,89 & 2,67 \\
\hline 25 & 1600 & 150 & 26,66 & 20,75 & 16,84 & 12,68 & 9,69 & 7,61 & 5,15 & 3,89 & 2,67 \\
\hline 25 & 1650 & 150 & 26,42 & 20,64 & 16,79 & 12,67 & 9,70 & 7,62 & 5,16 & 3,89 & 2,67 \\
\hline 25 & 1700 & 150 & 26,18 & 20,53 & 16,74 & 12,66 & 9,71 & 7,64 & 5,17 & 3,90 & 2,67 \\
\hline 25 & 1750 & 150 & 25,95 & 20,42 & 16,69 & 12,66 & 9,72 & 7,65 & 5,17 & 3,90 & 2,67 \\
\hline 25 & 1800 & 150 & 25,73 & 20,32 & 16,64 & 12,65 & 9,73 & 7,66 & 5,18 & 3,90 & 2,67 \\
\hline 25 & 1850 & 150 & 25,52 & 20,22 & 16,59 & 12,64 & 9,74 & 7,67 & 5,19 & 3,90 & 2,67 \\
\hline 25 & 1900 & 150 & 25,31 & 20,12 & 16,54 & 12,63 & 9,74 & 7,69 & 5,20 & 3,91 & 2,67 \\
\hline 25 & 1950 & 150 & 25,11 & 20,02 & 16,50 & 12,62 & 9,75 & 7,70 & 5,21 & 3,91 & 2,67 \\
\hline 25 & 2000 & 150 & 24,92 & 19,92 & 16,45 & 12,61 & 9,76 & 7,71 & 5,21 & 3,91 & 2,67 \\
\hline 25 & 200 & 155 & 50,46 & 25,34 & 17,07 & 11,45 & 8,55 & 6,80 & 4,76 & 3,71 & 2,63 \\
\hline 25 & 250 & 155 & 46,45 & 25,00 & 17,20 & 11,59 & 8,61 & 6,82 & 4,77 & 3,72 & 2,62 \\
\hline 25 & 300 & 155 & 43,58 & 24,69 & 17,28 & 11,70 & 8,67 & 6,84 & 4,78 & 3,72 & 2,62 \\
\hline 25 & 350 & 155 & 41,39 & 24,41 & 17,32 & 11,79 & 8,72 & 6,86 & 4,79 & 3,72 & 2,61 \\
\hline 25 & 400 & 155 & 39,63 & 24,14 & 17,34 & 11,86 & 8,77 & 6,89 & 4,80 & 3,72 & 2,61 \\
\hline 25 & 450 & 155 & 38,17 & 23,89 & 17,34 & 11,93 & 8,81 & 6,91 & 4,81 & 3,72 & 2,60 \\
\hline 25 & 500 & 155 & 36,94 & 23,65 & 17,33 & 11,99 & 8,86 & 6,93 & 4,81 & 3,73 & 2,60 \\
\hline 25 & 550 & 155 & 35,87 & 23,43 & 17,31 & 12,03 & 8,90 & 6,96 & 4,82 & 3,73 & 2,60 \\
\hline 25 & 600 & 155 & 34,93 & 23,21 & 17,29 & 12,08 & 8,93 & 6,98 & 4,83 & 3,73 & 2,60 \\
\hline 25 & 650 & 155 & 34,09 & 23,00 & 17,26 & 12,11 & 8,97 & 7,00 & 4,83 & 3,73 & 2,60 \\
\hline 25 & 700 & 155 & 33,34 & 22,80 & 17,22 & 12,14 & 9,01 & 7,03 & 4,84 & 3,73 & 2,59 \\
\hline 25 & 750 & 155 & 32,66 & 22,61 & 17,18 & 12,17 & 9,04 & 7,05 & 4,85 & 3,73 & 2,59 \\
\hline 25 & 800 & 155 & 32,03 & 22,43 & 17,14 & 12,20 & 9,07 & 7,07 & 4,85 & 3,73 & 2,59 \\
\hline 25 & 850 & 155 & 31,46 & 22,25 & 17,09 & 12,22 & 9,10 & 7,09 & 4,86 & 3,73 & 2,59 \\
\hline 25 & 900 & 155 & 30,93 & 22,08 & 17,04 & 12,23 & 9,12 & 7,11 & 4,87 & 3,73 & 2,59 \\
\hline 25 & 950 & 155 & 30,44 & 21,92 & 17,00 & 12,25 & 9,15 & 7,13 & 4,88 & 3,74 & 2,59 \\
\hline 25 & 1000 & 155 & 29,98 & 21,76 & 16,95 & 12,26 & 9,17 & 7,15 & 4,88 & 3,74 & 2,59 \\
\hline 25 & 1050 & 155 & 29,54 & 21,61 & 16,90 & 12,27 & 9,20 & 7,17 & 4,89 & 3,74 & 2,59 \\
\hline 25 & 1100 & 155 & 29,14 & 21,46 & 16,85 & 12,27 & 9,22 & 7,19 & 4,90 & 3,74 & 2,59 \\
\hline 25 & 1150 & 155 & 28,76 & 21,32 & 16,80 & 12,28 & 9,24 & 7,21 & 4,91 & 3,74 & 2,59 \\
\hline 25 & 1200 & 155 & 28,40 & 21,18 & 16,75 & 12,28 & 9,25 & 7,23 & 4,91 & 3,74 & 2,59 \\
\hline 25 & 1250 & 155 & 28,05 & 21,04 & 16,70 & 12,29 & 9,27 & 7,25 & 4,92 & 3,75 & 2,59 \\
\hline 25 & 1300 & 155 & 27,73 & 20,91 & 16,65 & 12,29 & 9,29 & 7,26 & 4,93 & 3,75 & 2,58 \\
\hline 25 & 1350 & 155 & 27,42 & 20,79 & 16,60 & 12,29 & 9,30 & 7,28 & 4,94 & 3,75 & 2,58 \\
\hline 25 & 1400 & 155 & 27,12 & 20,66 & 16,55 & 12,29 & 9,32 & 7,29 & 4,94 & 3,75 & 2,58 \\
\hline 25 & 1450 & 155 & 26,84 & 20,54 & 16,50 & 12,29 & 9,33 & 7,31 & 4,95 & 3,75 & 2,58 \\
\hline 25 & 1500 & 155 & 26,57 & 20,43 & 16,45 & 12,28 & 9,34 & 7,32 & 4,96 & 3,76 & 2,58 \\
\hline 25 & 1550 & 155 & 26,31 & 20,31 & 16,40 & 12,28 & 9,36 & 7,34 & 4,97 & 3,76 & 2,58 \\
\hline 25 & 1600 & 155 & 26,06 & 20,20 & 16,35 & 12,27 & 9,37 & 7,35 & 4,98 & 3,76 & 2,58 \\
\hline 25 & 1650 & 155 & 25,82 & 20,09 & 16,30 & 12,27 & 9,38 & 7,36 & 4,98 & 3,76 & 2,58 \\
\hline 25 & 1700 & 155 & 25,59 & 19,99 & 16,26 & 12,26 & 9,39 & 7,38 & 4,99 & 3,77 & 2,58 \\
\hline 25 & 1750 & 155 & 25,36 & 19,88 & 16,21 & 12,26 & 9,40 & 7,39 & 5,00 & 3,77 & 2,58 \\
\hline 25 & 1800 & 155 & 25,15 & 19,78 & 16,16 & 12,25 & 9,41 & 7,40 & 5,01 & 3,77 & 2,58 \\
\hline 25 & 1850 & 155 & 24,94 & 19,68 & 16,11 & 12,24 & 9,41 & 7,41 & 5,01 & 3,78 & 2,58 \\
\hline 25 & 1900 & 155 & 24,74 & 19,59 & 16,07 & 12,23 & 9,42 & 7,42 & 5,02 & 3,78 & 2,58 \\
\hline 25 & 1950 & 155 & 24,55 & 19,49 & 16,02 & 12,22 & 9,43 & 7,43 & 5,03 & 3,78 & 2,58 \\
\hline 25 & 2000 & 155 & 24,36 & 19,40 & 15,98 & 12,22 & 9,43 & 7,44 & 5,04 & 3,78 & 2,58 \\
\hline 25 & 200 & 160 & 49,48 & 24,59 & 16,51 & 11,08 & 8,28 & 6,58 & 4,61 & 3,60 & 2,55 \\
\hline 25 & 250 & 160 & 45,51 & 24,27 & 16,65 & 11,21 & 8,33 & 6,60 & 4,62 & 3,60 & 2,54 \\
\hline 25 & 300 & 160 & 42,68 & 23,98 & 16,73 & 11,31 & 8,39 & 6,62 & 4,63 & 3,60 & 2,54 \\
\hline 25 & 350 & 160 & 40,51 & 23,71 & 16,77 & 11,40 & 8,43 & 6,64 & 4,64 & 3,61 & 2,53 \\
\hline 25 & 400 & 160 & 38,78 & 23,45 & 16,80 & 11,47 & 8,48 & 6,67 & 4,65 & 3,61 & 2,53 \\
\hline 25 & 450 & 160 & 37,35 & 23,21 & 16,80 & 11,54 & 8,52 & 6,69 & 4,65 & 3,61 & 2,52 \\
\hline 25 & 500 & 160 & 36,14 & 22,98 & 16,80 & 11,59 & 8,57 & 6,71 & 4,66 & 3,61 & 2,52 \\
\hline 25 & 550 & 160 & 35,09 & 22,77 & 16,78 & 11,64 & 8,60 & 6,73 & 4,67 & 3,61 & 2,52 \\
\hline 25 & 600 & 160 & 34,17 & 22,56 & 16,76 & 11,68 & 8,64 & 6,75 & 4,67 & 3,61 & 2,52 \\
\hline 25 & 650 & 160 & 33,35 & 22,36 & 16,73 & 11,72 & 8,68 & 6,78 & 4,68 & 3,61 & 2,52 \\
\hline 25 & 700 & 160 & 32,61 & 22,17 & 16,70 & 11,75 & 8,71 & 6,80 & 4,68 & 3,61 & 2,51 \\
\hline 25 & 750 & 160 & 31,94 & 21,99 & 16,66 & 11,78 & 8,74 & 6,82 & 4,69 & 3,61 & 2,51 \\
\hline 25 & 800 & 160 & 31,33 & 21,82 & 16,62 & 11,80 & 8,77 & 6,84 & 4,70 & 3,61 & 2,51 \\
\hline 25 & 850 & 160 & 30,77 & 21,65 & 16,58 & 11,82 & 8,80 & 6,86 & 4,70 & 3,62 & 2,51 \\
\hline 25 & 900 & 160 & 30,25 & 21,49 & 16,54 & 11,84 & 8,82 & 6,88 & 4,71 & 3,62 & 2,51 \\
\hline 25 & 950 & 160 & 29,77 & 21,33 & 16,49 & 11,86 & 8,85 & 6,90 & 4,72 & 3,62 & 2,51 \\
\hline 25 & 1000 & 160 & 29,31 & 21,18 & 16,45 & 11,87 & 8,87 & 6,92 & 4,73 & 3,62 & 2,51 \\
\hline 25 & 1050 & 160 & 28,89 & 21,03 & 16,40 & 11,88 & 8,89 & 6.94 & 4,73 & 3,62 & 2,51 \\
\hline 25 & 1100 & 160 & 28,50 & 20,89 & 16,36 & 11,89 & 8,91 & 6,96 & 4,74 & 3,62 & 2,51 \\
\hline 25 & 1150 & 160 & 28,12 & 20,75 & 16,31 & 11,89 & 8,93 & 6,97 & 4,75 & 3,62 & 2,51 \\
\hline 25 & 1200 & 160 & 27,77 & 20,62 & 16,26 & 11,90 & 8,95 & 6,99 & 4,75 & 3,63 & 2,51 \\
\hline 25 & 1250 & 160 & 27,43 & 20,49 & 16,21 & 11,90 & 8,97 & 7,01 & 4,76 & 3,63 & 2,50 \\
\hline 25 & 1300 & 160 & 27,12 & 20,36 & 16,17 & 11,90 & 8,99 & 7,02 & 4,77 & 3,63 & 2,50 \\
\hline 25 & 1350 & 160 & 26,81 & 20,24 & 16,12 & 11,90 & 9,00 & 7,04 & 4,78 & 3,63 & 2,50 \\
\hline 25 & 1400 & 160 & 26,52 & 20,12 & 16,07 & 11,90 & 9,02 & 7,05 & 4,78 & 3,63 & 2,50 \\
\hline
\end{tabular}




\begin{tabular}{|c|c|c|c|c|c|c|c|c|c|c|c|}
\hline \multirow[b]{2}{*}{$\mathrm{H}(\mathrm{cm})$} & \multirow[b]{2}{*}{ Mceq (MPa) } & & & & & $\mathrm{De}$ & ões (x. & & & & \\
\hline & & Msub (MPa) & D0 & D25 & D40 & D60 & D80 & D100 & D140 & D180 & D260 \\
\hline 25 & 1450 & 160 & 26,25 & 20,01 & 16,03 & 11,90 & 9,03 & 7,07 & 4,79 & 3,64 & 2,50 \\
\hline 25 & 1500 & 160 & 25,98 & 19,89 & 15,98 & 11,90 & 9,04 & 7,08 & 4,80 & 3,64 & 2,50 \\
\hline 25 & 1550 & 160 & 25,73 & 19,78 & 15,93 & 11,90 & 9,05 & 7,09 & 4,81 & 3,64 & 2,50 \\
\hline 25 & 1600 & 160 & 25,48 & 19,68 & 15,89 & 11,89 & 9,06 & 7,11 & 4,81 & 3,64 & 2,50 \\
\hline 25 & 1650 & 160 & 25,25 & 19,57 & 15,84 & 11,89 & 9,07 & 7,12 & 4,82 & 3,64 & 2,50 \\
\hline 25 & 1700 & 160 & 25,02 & 19,47 & 15,80 & 11,89 & 9,08 & 7,13 & 4,83 & 3,65 & 2,50 \\
\hline 25 & 1750 & 160 & 24,81 & 19,37 & 15,75 & 11,88 & 9,09 & 7,14 & 4,83 & 3,65 & 2,50 \\
\hline 25 & 1800 & 160 & 24,60 & 19,27 & 15,71 & 11,87 & 9,10 & 7,16 & 4,84 & 3,65 & 2,50 \\
\hline 25 & 1850 & 160 & 24,39 & 19,18 & 15,66 & 11,87 & 9,11 & 7,17 & 4,85 & 3,65 & 2,50 \\
\hline 25 & 1900 & 160 & 24,20 & 19,09 & 15,62 & 11,86 & 9,12 & 7,18 & 4,86 & 3,66 & 2,50 \\
\hline 25 & 1950 & 160 & 24,01 & 18,99 & 15,58 & 11,85 & 9,13 & 7,19 & 4,86 & 3,66 & 2,50 \\
\hline 25 & 2000 & 160 & 23,83 & 18,91 & 15,53 & 11,84 & 9,13 & 7,20 & 4,87 & 3,66 & 2,50 \\
\hline 25 & 200 & 165 & 48,56 & 23,88 & 15,99 & 10,72 & 8,02 & 6,38 & 4,47 & 3,49 & 2,48 \\
\hline 25 & 250 & 165 & 44,63 & 23,58 & 16,13 & 10,85 & 8,07 & 6,40 & 4,48 & 3,49 & 2,47 \\
\hline 25 & 300 & 165 & 41,83 & 23,30 & 16,21 & 10,95 & 8,12 & 6,42 & 4,49 & 3,49 & 2,46 \\
\hline 25 & 350 & 165 & 39,69 & 23,04 & 16,26 & 11,04 & 8,17 & 6,44 & 4,50 & 3,50 & 2,46 \\
\hline 25 & 400 & 165 & 37,99 & 22,80 & 16,28 & 11,11 & 8,21 & 6,46 & 4,50 & 3,50 & 2,45 \\
\hline 25 & 450 & 165 & 36,58 & 22,57 & 16,29 & 11,17 & 8,25 & 6,48 & 4,51 & 3,50 & 2,45 \\
\hline 25 & 500 & 165 & 35,38 & 22,35 & 16,29 & 11,23 & 8,29 & 6,50 & 4,52 & 3,50 & 2,45 \\
\hline 25 & 550 & 165 & 34,35 & 22,15 & 16,28 & 11,28 & 8,33 & 6,52 & 4,52 & 3,50 & 2,44 \\
\hline 25 & 600 & 165 & 33,44 & 21,95 & 16,26 & 11,32 & 8,37 & 6,54 & 4,53 & 3,50 & 2,44 \\
\hline 25 & 650 & 165 & 32,64 & 21,76 & 16,23 & 11,35 & 8,40 & 6,56 & 4,53 & 3,50 & 2,44 \\
\hline 25 & 700 & 165 & 31,92 & 21,58 & 16,20 & 11,38 & 8,43 & 6,58 & 4,54 & 3,50 & 2,44 \\
\hline 25 & 750 & 165 & 31,26 & 21,41 & 16,17 & 11,41 & 8,46 & 6,60 & 4,55 & 3,50 & 2,44 \\
\hline 25 & 800 & 165 & 30,66 & 21,24 & 16,14 & 11,44 & 8,49 & 6,62 & 4,55 & 3,50 & 2,44 \\
\hline 25 & 850 & 165 & 30,11 & 21,08 & 16,10 & 11,46 & 8,52 & 6,64 & 4,56 & 3,51 & 2,44 \\
\hline 25 & 900 & 165 & 29,60 & 20,92 & 16,06 & 11,47 & 8,54 & 6,66 & 4,57 & 3,51 & 2,43 \\
\hline 25 & 950 & 165 & 29,13 & 20,77 & 16,02 & 11,49 & 8,57 & 6,68 & 4,57 & 3,51 & 2,43 \\
\hline 25 & 1000 & 165 & 28,69 & 20,62 & 15,98 & 11,50 & 8,59 & 6,70 & 4,58 & 3,51 & 2,43 \\
\hline 25 & 1050 & 165 & 28,27 & 20,48 & 15,93 & 11,51 & 8,61 & 6,72 & 4,59 & 3,51 & 2,43 \\
\hline 25 & 1100 & 165 & 27,89 & 20,35 & 15,89 & 11,52 & 8,63 & 6,73 & 4,59 & 3,51 & 2,43 \\
\hline 25 & 1150 & 165 & 27,52 & 20,22 & 15,85 & 11,53 & 8,65 & 6,75 & 4,60 & 3,51 & 2,43 \\
\hline 25 & 1200 & 165 & 27,17 & 20,09 & 15,80 & 11,53 & 8,67 & 6,77 & 4,61 & 3,51 & 2,43 \\
\hline 25 & 1250 & 165 & 26,85 & 19,96 & 15,76 & 11,54 & 8,68 & 6,78 & 4,61 & 3,52 & 2,43 \\
\hline 25 & 1300 & 165 & 26,54 & 19,84 & 15,71 & 11,54 & 8,70 & 6,80 & 4,62 & 3,52 & 2,43 \\
\hline 25 & 1350 & 165 & 26,24 & 19,72 & 15,67 & 11,54 & 8,72 & 6,81 & 4,63 & 3,52 & 2,43 \\
\hline 25 & 1400 & 165 & 25,96 & 19,61 & 15,63 & 11,54 & 8,73 & 6,83 & 4,63 & 3,52 & 2,43 \\
\hline 25 & 1450 & 165 & 25,69 & 19,50 & 15,58 & 11,54 & 8,74 & 6,84 & 4,64 & 3,52 & 2,43 \\
\hline 25 & 1500 & 165 & 25,43 & 19,39 & 15,54 & 11,54 & 8,76 & 6,85 & 4,65 & 3,53 & 2,43 \\
\hline 25 & 1550 & 165 & 25,18 & 19,28 & 15,49 & 11,54 & 8,77 & 6,87 & 4,65 & 3,53 & 2,43 \\
\hline 25 & 1600 & 165 & 24,94 & 19,18 & 15,45 & 11,54 & 8,78 & 6,88 & 4,66 & 3,53 & 2,43 \\
\hline 25 & 1650 & 165 & 24,71 & 19,08 & 15,41 & 11,53 & 8,79 & 6,89 & 4,67 & 3,53 & 2,43 \\
\hline 25 & 1700 & 165 & 24,49 & 18,98 & 15,36 & 11,53 & 8,80 & 6,90 & 4,67 & 3,53 & 2,43 \\
\hline 25 & 1750 & 165 & 24,28 & 18,89 & 15,32 & 11,53 & 8,81 & 6,92 & 4,68 & 3,54 & 2,43 \\
\hline 25 & 1800 & 165 & 24,07 & 18,79 & 15,28 & 11,52 & 8,82 & 6,93 & 4,69 & 3,54 & 2,42 \\
\hline 25 & 1850 & 165 & 23,88 & 18,70 & 15,24 & 11,51 & 8,83 & 6,94 & 4,69 & 3,54 & 2,42 \\
\hline 25 & 1900 & 165 & 23,68 & 18,61 & 15,19 & 11,51 & 8,83 & 6,95 & 4,70 & 3,54 & 2,42 \\
\hline 25 & 1950 & 165 & 23,50 & 18,52 & 15,15 & 11,50 & 8,84 & 6,96 & 4,71 & 3,55 & 2,42 \\
\hline 25 & 2000 & 165 & 23,32 & 18,44 & 15,11 & 11,49 & 8,85 & 6,97 & 4,71 & 3,55 & 2,42 \\
\hline 25 & 200 & 170 & 47,69 & 23,22 & 15,50 & 10,39 & 7,78 & 6,19 & 4,34 & 3,38 & 2,41 \\
\hline 25 & 250 & 170 & 43,79 & 22,93 & 15,64 & 10,51 & 7,83 & 6,21 & 4,35 & 3,39 & 2,40 \\
\hline 25 & 300 & 170 & 41,02 & 22,66 & 15,72 & 10,61 & 7,87 & 6,23 & 4,36 & 3,39 & 2,39 \\
\hline 25 & 350 & 170 & 38,91 & 22,41 & 15,77 & 10,70 & 7,92 & 6,24 & 4,36 & 3,39 & 2,38 \\
\hline 25 & 400 & 170 & 37,23 & 22,18 & 15,80 & 10,77 & 7,96 & 6,26 & 4,37 & 3,39 & 2,38 \\
\hline 25 & 450 & 170 & 35,84 & 21,96 & 15,81 & 10,83 & 8,00 & 6,28 & 4,38 & 3,40 & 2,38 \\
\hline 25 & 500 & 170 & 34,66 & 21,76 & 15,81 & 10,88 & 8,04 & 6,30 & 4,38 & 3,40 & 2,37 \\
\hline 25 & 550 & 170 & 33,65 & 21,56 & 15,80 & 10,93 & 8,07 & 6,32 & 4,39 & 3,40 & 2,37 \\
\hline 25 & 600 & 170 & 32,76 & 21,37 & 15,79 & 10,97 & 8,11 & 6,34 & 4,39 & 3,40 & 2,37 \\
\hline 25 & 650 & 170 & 31,97 & 21,19 & 15,77 & 11,01 & 8,14 & 6,36 & 4,40 & 3,40 & 2,37 \\
\hline 25 & 700 & 170 & 31,26 & 21,02 & 15,74 & 11,04 & 8,17 & 6,38 & 4,40 & 3,40 & 2,37 \\
\hline 25 & 750 & 170 & 30,61 & 20,85 & 15,71 & 11,06 & 8,20 & 6,40 & 4,41 & 3,40 & 2,37 \\
\hline 25 & 800 & 170 & 30,03 & 20,69 & 15,68 & 11,09 & 8,23 & 6,42 & 4,42 & 3,40 & 2,36 \\
\hline 25 & 850 & 170 & 29,49 & 20,53 & 15,64 & 11,11 & 8,25 & 6,44 & 4,42 & 3,40 & 2,36 \\
\hline 25 & 900 & 170 & 28,99 & 20,38 & 15,61 & 11,13 & 8,28 & 6,46 & 4,43 & 3,40 & 2,36 \\
\hline 25 & 950 & 170 & 28,52 & 20,24 & 15,57 & 11,14 & 8,30 & 6,47 & 4,43 & 3,40 & 2,36 \\
\hline 25 & 1000 & 170 & 28,09 & 20,10 & 15,53 & 11,16 & 8,32 & 6,49 & 4,44 & 3,41 & 2,36 \\
\hline 25 & 1050 & 170 & 27,69 & 19,97 & 15,49 & 11,17 & 8,35 & 6,51 & 4,45 & 3,41 & 2,36 \\
\hline 25 & 1100 & 170 & 27,31 & 19,83 & 15,45 & 11,18 & 8,36 & 6,52 & 4,45 & 3,41 & 2,36 \\
\hline 25 & 1150 & 170 & 26,95 & 19,71 & 15,41 & 11,18 & 8,38 & 6,54 & 4,46 & 3,41 & 2,36 \\
\hline 25 & 1200 & 170 & 26,61 & 19,58 & 15,37 & 11,19 & 8,40 & 6,56 & 4,47 & 3,41 & 2,36 \\
\hline 25 & 1250 & 170 & 26,29 & 19,46 & 15,33 & 11,20 & 8,42 & 6,57 & 4,47 & 3,41 & 2,36 \\
\hline 25 & 1300 & 170 & 25,98 & 19,35 & 15,28 & 11,20 & 8,43 & 6,59 & 4,48 & 3,41 & 2,36 \\
\hline 25 & 1350 & 170 & 25,69 & 19,23 & 15,24 & 11,20 & 8,45 & 6,60 & 4,48 & 3,42 & 2,36 \\
\hline 25 & 1400 & 170 & 25,42 & 19,12 & 15,20 & 11,20 & 8,46 & 6,61 & 4,49 & 3,42 & 2,36 \\
\hline 25 & 1450 & 170 & 25,15 & 19,02 & 15,16 & 11,20 & 8,48 & 6,63 & 4,50 & 3,42 & 2,36 \\
\hline 25 & 1500 & 170 & 24,90 & 18,91 & 15,12 & 11,20 & 8,49 & 6,64 & 4,50 & 3,42 & 2,36 \\
\hline 25 & 1550 & 170 & 24,66 & 18,81 & 15,08 & 11,20 & 8,50 & 6,65 & 4,51 & 3,42 & 2,36 \\
\hline 25 & 1600 & 170 & 24,42 & 18,71 & 15,03 & 11,20 & 8,51 & 6,67 & 4,52 & 3,42 & 2,36 \\
\hline 25 & 1650 & 170 & 24,20 & 18,61 & 14,99 & 11,20 & 8,52 & 6,68 & 4,52 & 3,43 & 2,35 \\
\hline 25 & 1700 & 170 & 23,99 & 18,52 & 14,95 & 11,20 & 8,53 & 6,69 & 4,53 & 3,43 & 2,35 \\
\hline 25 & 1750 & 170 & 23,78 & 18,43 & 14,91 & 11,19 & 8,54 & 6,70 & 4,54 & 3,43 & 2,35 \\
\hline
\end{tabular}




\begin{tabular}{|c|c|c|c|c|c|c|c|c|c|c|c|}
\hline \multirow[b]{2}{*}{$\mathrm{H}(\mathrm{cm})$} & \multirow[b]{2}{*}{ Mceq (MPa) } & & & & & $\mathrm{De}$ & ões (x. & & & & \\
\hline & & Msub (MPa) & D0 & D25 & D40 & D60 & D80 & D100 & D140 & D180 & D260 \\
\hline 25 & 1800 & 170 & 23,58 & 18,34 & 14,87 & 11,19 & 8,55 & 6,71 & 4,54 & 3,43 & 2,35 \\
\hline 25 & 1850 & 170 & 23,38 & 18,25 & 14,83 & 11,18 & 8,56 & 6,72 & 4,55 & 3,43 & 2,35 \\
\hline 25 & 1900 & 170 & 23,20 & 18,16 & 14,79 & 11,18 & 8,57 & 6,73 & 4,56 & 3,44 & 2,35 \\
\hline 25 & 1950 & 170 & 23,02 & 18,08 & 14,75 & 11,17 & 8,57 & 6,74 & 4,56 & 3,44 & 2,35 \\
\hline 25 & 2000 & 170 & 22,84 & 17,99 & 14,71 & 11,16 & 8,58 & 6,75 & 4,57 & 3,44 & 2,35 \\
\hline 25 & 200 & 175 & 46,87 & 22,59 & 15,04 & 10,08 & 7,55 & 6,01 & 4,21 & 3,29 & 2,34 \\
\hline 25 & 250 & 175 & 43,00 & 22,31 & 15,18 & 10,20 & 7,60 & 6,03 & 4,22 & 3,29 & 2,33 \\
\hline 25 & 300 & 175 & 40,26 & 22,06 & 15,26 & 10,30 & 7,64 & 6,05 & 4,23 & 3,29 & 2,32 \\
\hline 25 & 350 & 175 & 38,17 & 21,82 & 15,31 & 10,38 & 7,68 & 6,06 & 4,24 & 3,30 & 2,32 \\
\hline 25 & 400 & 175 & 36,51 & 21,60 & 15,35 & 10,45 & 7,72 & 6,08 & 4,24 & 3,30 & 2,31 \\
\hline 25 & 450 & 175 & 35,14 & 21,39 & 15,36 & 10,51 & 7,76 & 6,10 & 4,25 & 3,30 & 2,31 \\
\hline 25 & 500 & 175 & 33,98 & 21,19 & 15,36 & 10,56 & 7,80 & 6,12 & 4,26 & 3,30 & 2,31 \\
\hline 25 & 550 & 175 & 32,98 & 21,00 & 15,36 & 10,60 & 7,83 & 6,14 & 4,26 & 3,30 & 2,31 \\
\hline 25 & 600 & 175 & 32,11 & 20,82 & 15,34 & 10,64 & 7,87 & 6,15 & 4,27 & 3,30 & 2,30 \\
\hline 25 & 650 & 175 & 31,33 & 20,65 & 15,32 & 10,68 & 7,90 & 6,17 & 4,27 & 3,30 & 2,30 \\
\hline 25 & 700 & 175 & 30,63 & 20,48 & 15,30 & 10,71 & 7,93 & 6,19 & 4,28 & 3,30 & 2,30 \\
\hline 25 & 750 & 175 & 30,00 & 20,32 & 15,27 & 10,74 & 7,95 & 6,21 & 4,28 & 3,30 & 2,30 \\
\hline 25 & 800 & 175 & 29,42 & 20,17 & 15,24 & 10,76 & 7,98 & 6,23 & 4,29 & 3,30 & 2,30 \\
\hline 25 & 850 & 175 & 28,89 & 20,02 & 15,21 & 10,78 & 8,01 & 6,25 & 4,29 & 3,30 & 2,30 \\
\hline 25 & 900 & 175 & 28,40 & 19,88 & 15,18 & 10,80 & 8,03 & 6,26 & 4,30 & 3,31 & 2,30 \\
\hline 25 & 950 & 175 & 27,95 & 19,74 & 15,14 & 10,82 & 8,05 & 6,28 & 4,30 & 3,31 & 2,30 \\
\hline 25 & 1000 & 175 & 27,53 & 19,60 & 15,11 & 10,83 & 8,07 & 6,30 & 4,31 & 3,31 & 2,29 \\
\hline 25 & 1050 & 175 & 27,13 & 19,47 & 15,07 & 10,84 & 8,09 & 6,31 & 4,32 & 3,31 & 2,29 \\
\hline 25 & 1100 & 175 & 26,76 & 19,35 & 15,03 & 10,85 & 8,11 & 6,33 & 4,32 & 3,31 & 2,29 \\
\hline 25 & 1150 & 175 & 26,41 & 19,22 & 15,00 & 10,86 & 8,13 & 6,34 & 4,33 & 3,31 & 2,29 \\
\hline 25 & 1200 & 175 & 26,07 & 19,11 & 14,96 & 10,87 & 8,15 & 6,36 & 4,33 & 3,31 & 2,29 \\
\hline 25 & 1250 & 175 & 25,76 & 18,99 & 14,92 & 10,87 & 8,17 & 6,37 & 4,34 & 3,31 & 2,29 \\
\hline 25 & 1300 & 175 & 25,46 & 18,88 & 14,88 & 10,88 & 8,18 & 6,39 & 4,35 & 3,31 & 2,29 \\
\hline 25 & 1350 & 175 & 25,18 & 18,77 & 14,84 & 10,88 & 8,20 & 6,40 & 4,35 & 3,32 & 2,29 \\
\hline 25 & 1400 & 175 & 24,91 & 18,66 & 14,80 & 10,88 & 8,21 & 6,41 & 4,36 & 3,32 & 2,29 \\
\hline 25 & 1450 & 175 & 24,65 & 18,56 & 14,76 & 10,88 & 8,22 & 6,43 & 4,36 & 3,32 & 2,29 \\
\hline 25 & 1500 & 175 & 24,40 & 18,46 & 14,72 & 10,88 & 8,23 & 6,44 & 4,37 & 3,32 & 2,29 \\
\hline 25 & 1550 & 175 & 24,16 & 18,36 & 14,68 & 10,88 & 8,25 & 6,45 & 4,38 & 3,32 & 2,29 \\
\hline 25 & 1600 & 175 & 23,93 & 18,26 & 14,64 & 10,88 & 8,26 & 6,46 & 4,38 & 3,32 & 2,29 \\
\hline 25 & 1650 & 175 & 23,71 & 18,17 & 14,60 & 10,88 & 8,27 & 6,48 & 4,39 & 3,33 & 2,29 \\
\hline 25 & 1700 & 175 & 23,50 & 18,08 & 14,56 & 10,88 & 8,28 & 6,49 & 4,39 & 3,33 & 2,29 \\
\hline 25 & 1750 & 175 & 23,30 & 17,99 & 14,53 & 10,88 & 8,29 & 6,50 & 4,40 & 3,33 & 2,29 \\
\hline 25 & 1800 & 175 & 23,10 & 17,90 & 14,49 & 10,87 & 8,30 & 6,51 & 4,41 & 3,33 & 2,29 \\
\hline 25 & 1850 & 175 & 22,91 & 17,82 & 14,45 & 10,87 & 8,30 & 6,52 & 4,41 & 3,33 & 2,29 \\
\hline 25 & 1900 & 175 & 22,73 & 17,73 & 14,41 & 10,86 & 8,31 & 6,53 & 4,42 & 3,34 & 2,29 \\
\hline 25 & 1950 & 175 & 22,55 & 17,65 & 14,37 & 10,86 & 8,32 & 6,54 & 4,42 & 3,34 & 2,29 \\
\hline 25 & 2000 & 175 & 22,38 & 17,57 & 14,34 & 10,85 & 8,33 & 6,55 & 4,43 & 3,34 & 2,29 \\
\hline 25 & 200 & 180 & 46,09 & 22,00 & 14,60 & 9,79 & 7,34 & 5,85 & 4,09 & 3,19 & 2,28 \\
\hline 25 & 250 & 180 & 42,25 & 21,73 & 14,74 & 9,90 & 7,38 & 5,86 & 4,10 & 3,20 & 2,27 \\
\hline 25 & 300 & 180 & 39,53 & 21,48 & 14,83 & 9,99 & 7,42 & 5,87 & 4,11 & 3,20 & 2,26 \\
\hline 25 & 350 & 180 & 37,47 & 21,26 & 14,88 & 10,07 & 7,46 & 5,89 & 4,12 & 3,20 & 2,25 \\
\hline 25 & 400 & 180 & 35,83 & 21,05 & 14,91 & 10,14 & 7,50 & 5,91 & 4,13 & 3,20 & 2,25 \\
\hline 25 & 450 & 180 & 34,47 & 20,85 & 14,93 & 10,20 & 7,54 & 5,93 & 4,13 & 3,21 & 2,25 \\
\hline 25 & 500 & 180 & 33,33 & 20,66 & 14,94 & 10,25 & 7,57 & 5,94 & 4,14 & 3,21 & 2,24 \\
\hline 25 & 550 & 180 & 32,35 & 20,47 & 14,93 & 10,30 & 7,61 & 5,96 & 4,14 & 3,21 & 2,24 \\
\hline 25 & 600 & 180 & 31,49 & 20,30 & 14,92 & 10,34 & 7,64 & 5,98 & 4,15 & 3,21 & 2,24 \\
\hline 25 & 650 & 180 & 30,72 & 20,14 & 14,91 & 10,37 & 7,67 & 6,00 & 4,15 & 3,21 & 2,24 \\
\hline 25 & 700 & 180 & 30,04 & 19,98 & 14,89 & 10,40 & 7,70 & 6,01 & 4,16 & 3,21 & 2,24 \\
\hline 25 & 750 & 180 & 29,42 & 19,82 & 14,86 & 10,43 & 7,72 & 6,03 & 4,16 & 3,21 & 2,24 \\
\hline 25 & 800 & 180 & 28,85 & 19,67 & 14,83 & 10,45 & 7,75 & 6,05 & 4,17 & 3,21 & 2,23 \\
\hline 25 & 850 & 180 & 28,33 & 19,53 & 14,81 & 10,47 & 7,77 & 6,06 & 4,17 & 3,21 & 2,23 \\
\hline 25 & 900 & 180 & 27,85 & 19,39 & 14,77 & 10,49 & 7,80 & 6,08 & 4,18 & 3,21 & 2,23 \\
\hline 25 & 950 & 180 & 27,40 & 19,26 & 14,74 & 10,51 & 7,82 & 6,10 & 4,18 & 3,21 & 2,23 \\
\hline 25 & 1000 & 180 & 26,99 & 19,13 & 14,71 & 10,52 & 7,84 & 6,11 & 4,19 & 3,21 & 2,23 \\
\hline 25 & 1050 & 180 & 26,60 & 19,01 & 14,67 & 10,53 & 7,86 & 6,13 & 4,19 & 3,22 & 2,23 \\
\hline 25 & 1100 & 180 & 26,23 & 18,88 & 14,64 & 10,54 & 7,88 & 6,14 & 4,20 & 3,22 & 2,23 \\
\hline 25 & 1150 & 180 & 25,89 & 18,77 & 14,60 & 10,55 & 7,89 & 6,16 & 4,20 & 3,22 & 2,23 \\
\hline 25 & 1200 & 180 & 25,56 & 18,65 & 14,57 & 10,56 & 7,91 & 6,17 & 4,21 & 3,22 & 2,23 \\
\hline 25 & 1250 & 180 & 25,25 & 18,54 & 14,53 & 10,57 & 7,93 & 6,19 & 4,21 & 3,22 & 2,23 \\
\hline 25 & 1300 & 180 & 24,96 & 18,43 & 14,49 & 10,57 & 7,94 & 6,20 & 4,22 & 3,22 & 2,23 \\
\hline 25 & 1350 & 180 & 24,68 & 18,33 & 14,46 & 10,58 & 7,96 & 6,21 & 4,23 & 3,22 & 2,23 \\
\hline 25 & 1400 & 180 & 24,42 & 18,22 & 14,42 & 10,58 & 7,97 & 6,23 & 4,23 & 3,22 & 2,23 \\
\hline 25 & 1450 & 180 & 24,16 & 18,13 & 14,38 & 10,58 & 7,98 & 6,24 & 4,24 & 3,23 & 2,23 \\
\hline 25 & 1500 & 180 & 23,92 & 18,03 & 14,34 & 10,58 & 8,00 & 6,25 & 4,24 & 3,23 & 2,23 \\
\hline 25 & 1550 & 180 & 23,69 & 17,93 & 14,31 & 10,58 & 8,01 & 6,26 & 4,25 & 3,23 & 2,23 \\
\hline 25 & 1600 & 180 & 23,47 & 17,84 & 14,27 & 10,58 & 8,02 & 6,27 & 4,26 & 3,23 & 2,22 \\
\hline 25 & 1650 & 180 & 23,25 & 17,75 & 14,23 & 10,58 & 8,03 & 6,29 & 4,26 & 3,23 & 2,22 \\
\hline 25 & 1700 & 180 & 23,04 & 17,66 & 14,20 & 10,58 & 8,04 & 6,30 & 4,27 & 3,23 & 2,22 \\
\hline 25 & 1750 & 180 & 22,84 & 17.57 & 14,16 & 10,58 & 8.05 & 6,31 & 4,27 & 3,24 & 2,22 \\
\hline 25 & 1800 & 180 & 22,65 & 17,49 & 14,12 & 10,57 & 8,06 & 6,32 & 4,28 & 3,24 & 2,22 \\
\hline 25 & 1850 & 180 & 22,47 & 17,41 & 14,09 & 10,57 & 8,07 & 6,33 & 4,28 & 3,24 & 2,22 \\
\hline 25 & 1900 & 180 & 22,29 & 17,33 & 14,05 & 10,57 & 8,07 & 6,34 & 4,29 & 3,24 & 2,22 \\
\hline 25 & 1950 & 180 & 22,11 & 17,25 & 14,01 & 10,56 & 8,08 & 6,35 & 4,30 & 3,24 & 2,22 \\
\hline 25 & 2000 & 180 & 21,95 & 17,17 & 13,98 & 10,56 & 8,09 & 6,36 & 4,30 & 3,24 & 2,22 \\
\hline 25 & 200 & 185 & 45,34 & 21,43 & 14,19 & 9,51 & 7,13 & 5,69 & 3,98 & 3,11 & 2,22 \\
\hline 25 & 250 & 185 & 41,53 & 21,17 & 14,33 & 9,62 & 7,18 & 5,70 & 3,99 & 3,11 & 2,21 \\
\hline
\end{tabular}




\begin{tabular}{|c|c|c|c|c|c|c|c|c|c|c|c|}
\hline \multirow[b]{2}{*}{$\mathrm{H}(\mathrm{cm})$} & \multirow[b]{2}{*}{ Mceq (MPa) } & & & & & $\mathrm{De}$ & ões (x. & & & & \\
\hline & & Msub (MPa) & D0 & D25 & D40 & D60 & D80 & D100 & D140 & D180 & D260 \\
\hline 25 & 300 & 185 & 38,84 & 20,94 & 14,41 & 9,71 & 7,22 & 5,71 & 4,00 & 3,11 & 2,20 \\
\hline 25 & 350 & 185 & 36,80 & 20,72 & 14,47 & 9,79 & 7,25 & 5,73 & 4,01 & 3,12 & 2,19 \\
\hline 25 & 400 & 185 & 35,18 & 20,52 & 14,51 & 9,85 & 7,29 & 5,74 & 4,01 & 3,12 & 2,19 \\
\hline 25 & 450 & 185 & 33,84 & 20,33 & 14,52 & 9,91 & 7,33 & 5,76 & 4,02 & 3,12 & 2,19 \\
\hline 25 & 500 & 185 & 32,72 & 20,15 & 14,53 & 9,96 & 7,36 & 5,78 & 4,02 & 3,12 & 2,18 \\
\hline 25 & 550 & 185 & 31,75 & 19,97 & 14,53 & 10,01 & 7,39 & 5,79 & 4,03 & 3,12 & 2,18 \\
\hline 25 & 600 & 185 & 30,90 & 19,81 & 14,52 & 10,04 & 7,42 & 5,81 & 4,03 & 3,12 & 2,18 \\
\hline 25 & 650 & 185 & 30,14 & 19,65 & 14,51 & 10,08 & 7,45 & 5,83 & 4,04 & 3,12 & 2,18 \\
\hline 25 & 700 & 185 & 29,47 & 19,49 & 14,49 & 10,11 & 7,48 & 5,84 & 4,04 & 3,12 & 2,18 \\
\hline 25 & 750 & 185 & 28,86 & 19,35 & 14,47 & 10,14 & 7,50 & 5,86 & 4,05 & 3,12 & 2,18 \\
\hline 25 & 800 & 185 & 28,30 & 19,20 & 14,45 & 10,16 & 7,53 & 5,88 & 4,05 & 3,12 & 2,17 \\
\hline 25 & 850 & 185 & 27,79 & 19,07 & 14,42 & 10,18 & 7,55 & 5,89 & 4,06 & 3,12 & 2,17 \\
\hline 25 & 900 & 185 & 27,32 & 18,93 & 14.39 & 10,20 & 7.57 & 5,91 & 4.06 & 3,13 & 2,17 \\
\hline 25 & 950 & 185 & 26,88 & 18,81 & 14,36 & 10,22 & 7,60 & 5,92 & 4,07 & 3,13 & 2,17 \\
\hline 25 & 1000 & 185 & 26,47 & 18,68 & 14,33 & 10,23 & 7,62 & 5,94 & 4,07 & 3,13 & 2,17 \\
\hline 25 & 1050 & 185 & 26,09 & 18,56 & 14,30 & 10,24 & 7,64 & 5,95 & 4,08 & 3,13 & 2,17 \\
\hline 25 & 1100 & 185 & 25,73 & 18,44 & 14,26 & 10,25 & 7,65 & 5,97 & 4,08 & 3,13 & 2,17 \\
\hline 25 & 1150 & 185 & 25,39 & 18,33 & 14,23 & 10,26 & 7,67 & 5,98 & 4,09 & 3,13 & 2,17 \\
\hline 25 & 1200 & 185 & 25,08 & 18,22 & 14,20 & 10,27 & 7,69 & 6,00 & 4,09 & 3,13 & 2,17 \\
\hline 25 & 1250 & 185 & 24,77 & 18,11 & 14,16 & 10,28 & 7,70 & 6,01 & 4,10 & 3,13 & 2,17 \\
\hline 25 & 1300 & 185 & 24,49 & 18,01 & 14,13 & 10,28 & 7,72 & 6,02 & 4,10 & 3,13 & 2,17 \\
\hline 25 & 1350 & 185 & 24,21 & 17,91 & 14,09 & 10,29 & 7,73 & 6,04 & 4,11 & 3,14 & 2,17 \\
\hline 25 & 1400 & 185 & 23,95 & 17,81 & 14,06 & 10,29 & 7,75 & 6,05 & 4,11 & 3,14 & 2,17 \\
\hline 25 & 1450 & 185 & 23,70 & 17,71 & 14,02 & 10,29 & 7,76 & 6,06 & 4,12 & 3,14 & 2,17 \\
\hline 25 & 1500 & 185 & 23,47 & 17,62 & 13,99 & 10,29 & 7,77 & 6,07 & 4,12 & 3,14 & 2,17 \\
\hline 25 & 1550 & 185 & 23,24 & 17,53 & 13,95 & 10,30 & 7,78 & 6,08 & 4,13 & 3,14 & 2,17 \\
\hline 25 & 1600 & 185 & 23,02 & 17,44 & 13,91 & 10,30 & 7,79 & 6,09 & 4,14 & 3,14 & 2,17 \\
\hline 25 & 1650 & 185 & 22,81 & 17,35 & 13,88 & 10,30 & 7,80 & 6,11 & 4,14 & 3,14 & 2,16 \\
\hline 25 & 1700 & 185 & 22,61 & 17,26 & 13,84 & 10,29 & 7,81 & 6,12 & 4,15 & 3,15 & 2,16 \\
\hline 25 & 1750 & 185 & 22,41 & 17,18 & 13,81 & 10,29 & 7,82 & 6,13 & 4,15 & 3,15 & 2,16 \\
\hline 25 & 1800 & 185 & 22,22 & 17,10 & 13,78 & 10,29 & 7,83 & 6,14 & 4,16 & 3,15 & 2,16 \\
\hline 25 & 1850 & 185 & 22,04 & 17,02 & 13,74 & 10,29 & 7,84 & 6,15 & 4,16 & 3,15 & 2,16 \\
\hline 25 & 1900 & 185 & 21,86 & 16,94 & 13,71 & 10,28 & 7,85 & 6,16 & 4,17 & 3,15 & 2,16 \\
\hline 25 & 1950 & 185 & 21.69 & 16,86 & 13,67 & 10,28 & 7.85 & 6.17 & 4.17 & 3,15 & 2,16 \\
\hline 25 & 2000 & 185 & 21,53 & 16,79 & 13,64 & 10,28 & 7,86 & 6,18 & 4,18 & 3,16 & 2,16 \\
\hline 25 & 200 & 190 & 44,64 & 20,90 & 13,80 & 9,24 & 6,94 & 5,54 & 3,87 & 3,03 & 2,16 \\
\hline 25 & 250 & 190 & 40,85 & 20,65 & 13,94 & 9,35 & 6,98 & 5,55 & 3,89 & 3,03 & 2,15 \\
\hline 25 & 300 & 190 & 38,18 & 20,42 & 14,02 & 9,44 & 7,02 & 5,56 & 3,89 & 3,03 & 2,14 \\
\hline 25 & 350 & 190 & 36,16 & 20,22 & 14,08 & 9,52 & 7,06 & 5,58 & 3,90 & 3,03 & 2,14 \\
\hline 25 & 400 & 190 & 34,56 & 20,02 & 14,12 & 9,58 & 7,09 & 5,59 & 3,91 & 3,04 & 2,13 \\
\hline 25 & 450 & 190 & 33,24 & 19,84 & 14,14 & 9,64 & 7,13 & 5,61 & 3,91 & 3,04 & 2,13 \\
\hline 25 & 500 & 190 & 32,13 & 19,66 & 14,15 & 9,69 & 7,16 & 5,62 & 3,92 & 3,04 & 2,13 \\
\hline 25 & 550 & 190 & 31,17 & 19,50 & 14,15 & 9,73 & 7,19 & 5,64 & 3,92 & 3,04 & 2,12 \\
\hline 25 & 600 & 190 & 30,33 & 19,34 & 14,14 & 9,77 & 7,22 & 5,65 & 3,92 & 3,04 & 2,12 \\
\hline 25 & 650 & 190 & 29,59 & 19,18 & 14,13 & 9,80 & 7,24 & 5,67 & 3,93 & 3,04 & 2,12 \\
\hline 25 & 700 & 190 & 28,93 & 19,04 & 14,12 & 9,83 & 7,27 & 5,68 & 3,93 & 3,04 & 2,12 \\
\hline 25 & 750 & 190 & 28,33 & 18,89 & 14,10 & 9,86 & 7,30 & 5,70 & 3,94 & 3,04 & 2,12 \\
\hline 25 & 800 & 190 & 27,78 & 18,76 & 14,08 & 9,88 & 7,32 & 5,72 & 3,94 & 3,04 & 2,12 \\
\hline 25 & 850 & 190 & 27,28 & 18,62 & 14,05 & 9,90 & 7,34 & 5,73 & 3,95 & 3,04 & 2,12 \\
\hline 25 & 900 & 190 & 26,81 & 18,50 & 14,02 & 9,92 & 7,36 & 5,75 & 3,95 & 3,04 & 2,12 \\
\hline 25 & 950 & 190 & 26,38 & 18,37 & 14,00 & 9,94 & 7,39 & 5,76 & 3,96 & 3,04 & 2,12 \\
\hline 25 & 1000 & 190 & 25,98 & 18,25 & 13,97 & 9,95 & 7,41 & 5,77 & 3,96 & 3,04 & 2,11 \\
\hline 25 & 1050 & 190 & 25,61 & 18,14 & 13,94 & 9,97 & $\begin{array}{l}1,+1 \\
7,42\end{array}$ & 5,79 & 3,97 & 3,05 & 2,11 \\
\hline 25 & 1100 & 190 & 25,25 & 18,02 & 13,91 & 9,98 & 7,44 & 5,80 & 3,97 & 3,05 & 2,11 \\
\hline 25 & 1150 & 190 & 24,92 & 17,91 & 13,88 & 9,99 & 7,46 & 5,82 & 3,98 & 3,05 & 2,11 \\
\hline 25 & 1200 & 190 & 24,61 & 17,81 & 13,84 & 10,00 & 7,48 & 5,83 & 3,98 & 3,05 & 2,11 \\
\hline 25 & 1250 & 190 & 24,31 & 17,70 & 13,81 & 10,00 & 7,49 & 5,84 & 3,99 & 3,05 & 2,11 \\
\hline 25 & 1300 & 190 & 24,03 & 17,60 & 13,78 & 10,01 & 7,51 & 5,86 & 3,99 & 3,05 & 2,11 \\
\hline 25 & 1350 & 190 & 23,76 & 17,51 & 13,74 & 10,01 & 7,52 & 5,87 & 4,00 & 3,05 & 2,11 \\
\hline 25 & 1400 & 190 & 23,51 & 17,41 & 13,71 & 10,02 & 7,53 & 5,88 & 4,00 & 3,05 & 2,11 \\
\hline 25 & 1450 & 190 & 23,26 & 17,32 & 13,68 & 10,02 & 7,54 & 5,89 & 4,01 & 3,05 & 2,11 \\
\hline 25 & 1500 & 190 & 23,03 & 17,23 & 13,64 & 10,02 & 7,56 & 5,90 & 4,01 & 3,06 & 2,11 \\
\hline 25 & 1550 & 190 & 22,81 & 17,14 & 13,61 & 10,02 & 7,57 & 5,91 & 4,02 & 3,06 & 2,11 \\
\hline 25 & 1600 & 190 & 22,59 & 17,05 & 13,58 & 10,02 & 7,58 & 5,93 & 4,02 & 3,06 & 2,11 \\
\hline 25 & 1650 & 190 & 22,39 & 16,97 & 13,54 & 10,02 & 7,59 & 5,94 & 4,03 & 3,06 & 2,11 \\
\hline 25 & 1700 & 190 & 22,19 & 16,88 & 13,51 & 10,02 & 7,60 & 5,95 & 4,03 & 3,06 & 2,11 \\
\hline 25 & 1750 & 190 & 22,00 & 16,80 & 13,48 & 10,02 & 7,61 & 5,96 & 4,04 & 3,06 & 2,11 \\
\hline 25 & 1800 & 190 & 21,81 & 16,72 & 13,44 & 10,02 & 7,62 & 5,97 & 4,04 & 3,06 & 2,11 \\
\hline 25 & 1850 & 190 & 21,63 & 16,65 & 13,41 & 10,02 & 7,63 & 5,98 & 4,05 & 3,07 & 2,11 \\
\hline 25 & 1900 & 190 & 21,46 & 16,57 & 13,38 & 10,02 & 7,63 & 5,99 & 4,05 & 3,07 & 2,11 \\
\hline 25 & 1950 & 190 & 21,29 & 16,50 & 13,35 & 10,01 & 7,64 & 5,99 & 4,06 & 3,07 & 2,11 \\
\hline 25 & 2000 & 190 & 21,13 & 16,42 & 13,31 & 10,01 & 7,65 & 6,00 & 4,06 & 3,07 & 2,11 \\
\hline 25 & 200 & 195 & 43,96 & 20,39 & 13,43 & 8,99 & 6,76 & 5,39 & 3,77 & 2,95 & 2,10 \\
\hline 25 & 250 & 195 & 40,21 & 20,15 & 13,56 & 9,10 & 6,80 & 5,40 & 3,79 & 2,95 & 2,09 \\
\hline 25 & 300 & 195 & 37,55 & 19,93 & 13,65 & 9,19 & 6,83 & 5,42 & 3,79 & 2,95 & 2,09 \\
\hline 25 & 350 & 195 & 35,55 & 19,73 & 13,71 & 9,26 & 6,87 & 5,43 & 3,80 & 2,96 & 2,08 \\
\hline 25 & 400 & 195 & 33,96 & 19,55 & 13,75 & 9,32 & 6,90 & 5,44 & 3,80 & 2,96 & 2,08 \\
\hline 25 & 450 & 195 & 32,66 & 19,37 & 13,77 & 9,38 & 6,93 & 5,46 & 3,81 & 2,96 & 2,08 \\
\hline 25 & 500 & 195 & 31,56 & 19,20 & 13,78 & 9,43 & 6,97 & 5,47 & 3,81 & 2,96 & 2,07 \\
\hline 25 & 550 & 195 & 30,62 & 19,04 & 13,79 & 9,47 & 6,99 & 5,49 & 3,82 & 2,96 & 2,07 \\
\hline 25 & 600 & 195 & 29,80 & 18,89 & 13,78 & 9,51 & 7,02 & 5,50 & 3,82 & 2,96 & 2,07 \\
\hline
\end{tabular}




\begin{tabular}{|c|c|c|c|c|c|c|c|c|c|c|c|}
\hline & & & \multicolumn{9}{|c|}{ Deflexões $\left(\times 10^{-4} \mathrm{~cm}\right)$} \\
\hline $\mathrm{H}(\mathrm{cm})$ & Mceq (MPa) & Msub (MPa) & D0 & D25 & D40 & D60 & D80 & D100 & D140 & D180 & D260 \\
\hline 25 & 650 & 195 & 29,07 & 18,74 & 13,77 & 9,54 & 7,05 & 5,52 & 3,83 & 2,96 & 2,07 \\
\hline 25 & 700 & 195 & 28,41 & 18,60 & 13,76 & 9,57 & 7,08 & 5,53 & 3,83 & 2,96 & 2,07 \\
\hline 25 & 750 & 195 & 27,82 & 18,46 & 13,74 & 9,60 & 7,10 & 5,55 & 3,84 & 2,96 & 2,06 \\
\hline 25 & 800 & 195 & 27,28 & 18,33 & 13,72 & 9,62 & 7,12 & 5,56 & 3,84 & 2,96 & 2,06 \\
\hline 25 & 850 & 195 & 26,79 & 18,20 & 13,70 & 9,64 & 7,15 & 5,58 & 3,84 & 2,96 & 2,06 \\
\hline 25 & 900 & 195 & 26,33 & 18,08 & 13,68 & 9,66 & 7,17 & 5,59 & 3,85 & 2,96 & 2,06 \\
\hline 25 & 950 & 195 & 25,91 & 17,96 & 13,65 & 9,68 & 7,19 & 5,61 & 3,85 & 2,97 & 2,06 \\
\hline 25 & 1000 & 195 & 25,51 & 17,84 & 13,62 & 9,69 & 7,21 & 5,62 & 3,86 & 2,97 & 2,06 \\
\hline 25 & 1050 & 195 & 25,14 & 17,73 & 13,60 & 9,70 & 7,22 & 5,63 & 3,86 & 2,97 & 2,06 \\
\hline 25 & 1100 & 195 & 24,80 & 17,62 & 13,57 & 9,72 & 7,24 & 5,65 & 3,87 & 2,97 & 2,06 \\
\hline 25 & 1150 & 195 & 24,47 & 17,52 & 13,54 & 9,73 & 7,26 & 5,66 & 3,87 & 2,97 & 2,06 \\
\hline 25 & 1200 & 195 & 24,16 & 17,41 & 13,51 & 9,73 & 7,27 & 5,67 & 3,88 & 2,97 & 2,06 \\
\hline 25 & 1250 & 195 & 23,87 & 17,31 & 13,48 & 9,74 & 7,29 & 5,68 & 3,88 & 2,97 & 2,06 \\
\hline 25 & 1300 & 195 & 23,60 & 17,22 & 13,45 & 9,75 & 7,30 & 5,70 & 3,89 & 2,97 & 2,06 \\
\hline 25 & 1350 & 195 & 23,33 & 17,12 & 13,41 & 9,75 & 7,32 & 5,71 & 3,89 & 2,97 & 2,06 \\
\hline 25 & 1400 & 195 & 23,08 & 17,03 & 13,38 & 9,76 & 7,33 & 5,72 & 3,90 & 2,97 & 2,06 \\
\hline 25 & 1450 & 195 & 22,84 & 16,94 & 13,35 & 9,76 & 7,34 & 5,73 & 3,90 & 2,97 & 2,06 \\
\hline 25 & 1500 & 195 & 22,61 & 16,85 & 13,32 & 9,76 & 7,35 & 5,74 & 3,90 & 2,98 & 2,06 \\
\hline 25 & 1550 & 195 & 22,39 & 16,77 & 13,29 & 9,77 & 7,37 & 5,75 & 3,91 & 2,98 & 2,06 \\
\hline 25 & 1600 & 195 & 22,18 & 16,68 & 13,26 & 9,77 & 7,38 & 5,76 & 3,91 & 2,98 & 2,05 \\
\hline 25 & 1650 & 195 & 21,98 & 16,60 & 13,22 & 9,77 & 7,39 & 5,78 & 3,92 & 2,98 & 2,05 \\
\hline 25 & 1700 & 195 & 21,79 & 16,52 & 13,19 & 9,77 & 7,40 & 5,79 & 3,92 & 2,98 & 2,05 \\
\hline 25 & 1750 & 195 & 21,60 & 16,44 & 13,16 & 9,77 & 7,40 & 5,79 & 3,93 & 2,98 & 2,05 \\
\hline 25 & 1800 & 195 & 21,42 & 16,37 & 13,13 & 9,77 & 7,41 & 5,80 & 3,93 & 2,98 & 2,05 \\
\hline 25 & 1850 & 195 & 21,24 & 16,29 & 13,10 & 9,76 & 7,42 & 5,81 & 3,94 & 2,99 & 2,05 \\
\hline 25 & 1900 & 195 & 21,07 & 16,22 & 13,07 & 9,76 & 7,43 & 5,82 & 3,94 & 2,99 & 2,05 \\
\hline 25 & 1950 & 195 & 20,91 & 16,14 & 13,04 & 9,76 & 7,44 & 5,83 & 3,95 & 2,99 & 2,05 \\
\hline 25 & 2000 & 195 & 20,75 & 16,07 & 13,01 & 9,76 & 7,44 & 5,84 & 3,95 & 2,99 & 2,05 \\
\hline 25 & 200 & 200 & 43,32 & 19,90 & 13,07 & 8,76 & 6,59 & 5,26 & 3,68 & 2,87 & 2,05 \\
\hline 25 & 250 & 200 & 39,59 & 19,67 & 13,21 & 8,86 & 6,62 & 5,27 & 3,69 & 2,88 & 2,04 \\
\hline 25 & 300 & 200 & 36,96 & 19,46 & 13,30 & 8,95 & 6,66 & 5,28 & 3,70 & 2,88 & 2,04 \\
\hline 25 & 350 & 200 & 34,97 & 19,27 & 13,36 & 9,02 & 6,69 & 5,29 & 3,70 & 2,88 & 2,03 \\
\hline 25 & 400 & 200 & 33,40 & 19,09 & 13,40 & 9,08 & 6,72 & 5,30 & 3,71 & 2,88 & 2,03 \\
\hline 25 & 450 & 200 & 32,11 & 18,92 & 13,42 & 9,13 & 6,75 & 5,32 & 3,71 & 2,88 & 2,02 \\
\hline 25 & 500 & 200 & 31,03 & 18,76 & 13,44 & 9,18 & 6,78 & 5,33 & 3,72 & 2,89 & 2,02 \\
\hline 25 & 550 & 200 & 30,10 & 18,61 & 13,44 & 9,22 & 6,81 & 5,35 & 3,72 & 2,89 & 2,02 \\
\hline 25 & 600 & 200 & 29,28 & 18,46 & 13,44 & 9,26 & 6,84 & 5,36 & 3,73 & 2,89 & 2,02 \\
\hline 25 & 650 & 200 & 28,56 & 18,32 & 13,43 & 9,29 & 6,87 & 5,38 & 3,73 & 2,89 & 2,02 \\
\hline 25 & 700 & 200 & 27,92 & 18,18 & 13,42 & 9,32 & 6,89 & 5,39 & 3,73 & 2,89 & 2,01 \\
\hline 25 & 750 & 200 & 27,33 & 18,05 & 13,41 & 9,35 & 6,91 & 5,40 & 3,74 & 2,89 & 2,01 \\
\hline 25 & 800 & 200 & 26,80 & 17,92 & 13,39 & 9,37 & 6,94 & 5,42 & 3,74 & 2,89 & 2,01 \\
\hline 25 & 850 & 200 & 26,32 & 17,80 & 13,37 & 9,39 & 6,96 & 5,43 & 3,75 & 2,89 & 2,01 \\
\hline 25 & 900 & 200 & 25,87 & 17,68 & 13,35 & 9,41 & 6,98 & 5,45 & 3,75 & 2,89 & 2,01 \\
\hline 25 & 950 & 200 & 25,45 & 17,57 & 13,32 & 9,43 & 7,00 & 5,46 & 3,75 & 2,89 & 2,01 \\
\hline 25 & 1000 & 200 & 25,06 & 17,45 & 13,30 & 9,44 & 7,02 & 5,47 & 3,76 & 2,89 & 2,01 \\
\hline 25 & 1050 & 200 & 24,70 & 17,35 & 13,27 & 9,46 & 7,03 & 5,49 & 3,76 & 2,89 & 2,01 \\
\hline 25 & 1100 & 200 & 24,36 & 17,24 & 13,24 & 9,47 & 7,05 & 5,50 & 3,77 & 2,89 & 2,01 \\
\hline 25 & 1150 & 200 & 24,04 & 17,14 & 13,22 & 9,48 & 7,07 & 5,51 & 3,77 & 2,89 & 2,01 \\
\hline 25 & 1200 & 200 & 23,74 & 17,04 & 13,19 & 9,49 & 7,08 & 5,52 & 3,78 & 2,89 & 2,01 \\
\hline 25 & 1250 & 200 & 23,45 & 16,94 & 13,16 & 9,49 & 7,10 & 5,54 & 3,78 & 2,90 & 2,01 \\
\hline 25 & 1300 & 200 & 23,18 & 16,85 & 13,13 & 9,50 & 7,11 & 5,55 & 3,79 & 2,90 & 2,01 \\
\hline 25 & 1350 & 200 & 22,92 & 16,76 & 13,10 & 9,51 & 7,13 & 5,56 & 3,79 & 2,90 & 2,01 \\
\hline 25 & 1400 & 200 & 22,68 & 16,67 & 13,07 & 9,51 & 7,14 & 5,57 & 3,79 & 2,90 & 2,01 \\
\hline 25 & 1450 & 200 & 22,44 & 16,58 & 13,04 & 9,52 & 7,15 & 5,58 & 3,80 & 2,90 & 2,00 \\
\hline 25 & 1500 & 200 & 22,21 & 16,49 & 13,01 & 9,52 & 7,16 & 5,59 & 3,80 & 2,90 & 2,00 \\
\hline 25 & 1550 & 200 & 22,00 & 16,41 & 12,98 & 9,52 & 7,17 & 5,60 & 3,81 & 2,90 & 2,00 \\
\hline 25 & 1600 & 200 & 21,79 & 16,33 & 12,95 & 9,52 & 7,18 & 5,61 & 3,81 & 2,90 & 2,00 \\
\hline 25 & 1650 & 200 & 21,59 & 16,25 & 12,92 & 9,52 & 7,19 & 5,62 & 3,82 & 2,90 & 2,00 \\
\hline 25 & 1700 & 200 & 21,40 & 16,17 & 12,89 & 9,52 & 7,20 & 5,63 & 3,82 & 2,91 & 2,00 \\
\hline 25 & 1750 & 200 & 21,22 & 16,10 & 12,86 & 9,52 & 7,21 & 5,64 & 3,83 & 2,91 & 2,00 \\
\hline 25 & 1800 & 200 & 21,04 & 16,02 & 12,83 & 9,52 & 7,22 & 5,65 & 3,83 & 2,91 & 2,00 \\
\hline 25 & 1850 & 200 & 20,87 & 15,95 & 12,80 & 9,52 & 7,23 & 5,66 & 3,84 & 2,91 & 2,00 \\
\hline 25 & 1900 & 200 & 20,70 & 15,88 & 12,77 & 9,52 & 7,24 & 5,67 & 3,84 & 2,91 & 2,00 \\
\hline 25 & 1950 & 200 & 20,54 & 15,81 & 12,74 & 9,52 & 7,24 & 5,68 & 3,85 & 2,91 & 2,00 \\
\hline 25 & 2000 & 200 & 20,39 & 15,74 & 12,71 & 9,52 & 7,25 & 5,69 & 3,85 & 2,91 & 2,00 \\
\hline 30 & 200 & 20 & 179,89 & 141,89 & 118,34 & 92,42 & 72,72 & 58,16 & 39,71 & 29,72 & 20,07 \\
\hline 30 & 250 & 20 & 166,90 & 135,37 & 114,73 & 91,21 & 72,73 & 58,66 & 40,27 & 30,02 & 20,09 \\
\hline 30 & 300 & 20 & 156,94 & 130,02 & 111,55 & 89,97 & 72,55 & 58,98 & 40,75 & 30,31 & 20,12 \\
\hline 30 & 350 & 20 & 148,96 & 125,49 & 108,73 & 88,73 & 72,25 & 59,15 & 41,15 & 30,60 & 20,17 \\
\hline 30 & 400 & 20 & 142,35 & 121,59 & 106,20 & 87,54 & 71,87 & 59,23 & 41,49 & 30,86 & 20,23 \\
\hline 30 & 450 & 20 & 136,75 & 118,17 & 103,92 & 86,40 & 71,46 & 59,23 & 41,78 & 31,11 & 20,29 \\
\hline 30 & 500 & 20 & 131,93 & 115,14 & 101,84 & 85,30 & 71,02 & 59,19 & 42,02 & 31,33 & 20,36 \\
\hline 30 & 550 & 20 & 127,71 & 112,41 & 99,94 & 84,27 & 70,57 & 59,10 & 42,23 & 31,54 & 20,43 \\
\hline 30 & 600 & 20 & 123,99 & 109,95 & 98,19 & 83,28 & 70,11 & 58,98 & 42,40 & 31,74 & 20,51 \\
\hline 30 & 650 & 20 & 120,67 & 107,70 & 96,56 & 82,33 & 69,65 & 58,84 & 42,54 & 31,92 & 20,59 \\
\hline 30 & 700 & 20 & 117,68 & 105,63 & 95,05 & 81,43 & 69,20 & 58,68 & 42,66 & 32,08 & 20,66 \\
\hline 30 & 750 & 20 & 114,98 & 103,72 & 93,64 & 80,58 & 68,75 & 58,51 & 42,76 & 32,24 & 20,74 \\
\hline 30 & 800 & 20 & 112,52 & 101,95 & 92,32 & 79,76 & 68,31 & 58,33 & 42,84 & 32,38 & 20,82 \\
\hline 30 & 850 & 20 & 110,27 & 100,30 & $\begin{array}{l}91,08 \\
\end{array}$ & 78,98 & 67,88 & 58,14 & 42,91 & 32,50 & 20,89 \\
\hline 30 & 900 & 20 & 108,20 & 98,75 & 89,91 & 78,23 & 67,45 & 57,95 & 42,96 & 32,62 & 20,97 \\
\hline 30 & 950 & 20 & 106,29 & 97,30 & 88,80 & 77,51 & 67,03 & 57,75 & 43,00 & 32,73 & 21,04 \\
\hline
\end{tabular}




\begin{tabular}{|c|c|c|c|c|c|c|c|c|c|c|c|}
\hline \multirow[b]{2}{*}{$\mathrm{H}(\mathrm{cm})$} & \multirow[b]{2}{*}{ Mceq (MPa) } & & & & & $\mathrm{De}$ & ões (x1 & & & & \\
\hline & & Msub (MPa) & D0 & D25 & D40 & D60 & D80 & D100 & D140 & D180 & D260 \\
\hline 30 & 1000 & 20 & 104,52 & 95,93 & 87,75 & 76,82 & 66,63 & 57,55 & 43,03 & 32,83 & 21,11 \\
\hline 30 & 1050 & 20 & 102,87 & 94,64 & 86,76 & 76,15 & 66,23 & 57,35 & 43,05 & 32,92 & 21,19 \\
\hline 30 & 1100 & 20 & 101,34 & 93,42 & 85,81 & 75,51 & 65,84 & 57,14 & 43,06 & 33,01 & 21,25 \\
\hline 30 & 1150 & 20 & 99,90 & 92,25 & 84,90 & 74,90 & 65,46 & 56,94 & 43,06 & 33,09 & 21,32 \\
\hline 30 & 1200 & 20 & 98,56 & 91,15 & 84,04 & 74,31 & 65,09 & 56,73 & 43,06 & 33,16 & 21,39 \\
\hline 30 & 1250 & 20 & 97,29 & 90,10 & 83,21 & 73,73 & 64,72 & 56,53 & 43,05 & 33,23 & 21,45 \\
\hline 30 & 1300 & 20 & 96,10 & 89,09 & 82,42 & 73,18 & 64,37 & 56,33 & 43,03 & 33,29 & 21,52 \\
\hline 30 & 1350 & 20 & 94,98 & 88,13 & 81,66 & 72,64 & 64,02 & 56,13 & 43,01 & 33,34 & 21,58 \\
\hline 30 & 1400 & 20 & 93,91 & 87,20 & 80,93 & 72,13 & 63,69 & 55,93 & 42,99 & 33,39 & 21,64 \\
\hline 30 & 1450 & 20 & 92,90 & 86,32 & 80,23 & 71,63 & 63,35 & 55,74 & 42,96 & 33,44 & 21,70 \\
\hline 30 & 1500 & 20 & 91,95 & 85,47 & 79,55 & 71,14 & 63,03 & 55,54 & 42,93 & 33,48 & 21,75 \\
\hline 30 & 1550 & 20 & 91,03 & 84,65 & 78,90 & 70,67 & 62,72 & 55,35 & 42,90 & 33,52 & 21,81 \\
\hline 30 & 1600 & 20 & 90,17 & 83,86 & 78,27 & 70,21 & 62,41 & 55,16 & 42,86 & 33,56 & 21,86 \\
\hline 30 & 1650 & 20 & 89,34 & 83,10 & 77,66 & 69,77 & 62,10 & 54,97 & 42,83 & 33,59 & 21,91 \\
\hline 30 & 1700 & 20 & 88,55 & 82,36 & 77,07 & 69,33 & 61,81 & 54,78 & 42,79 & 33,62 & 21,97 \\
\hline 30 & 1750 & 20 & 87,79 & 81,65 & 76,50 & 68,91 & 61,52 & 54,60 & 42,74 & 33,64 & 22,01 \\
\hline 30 & 1800 & 20 & 87,07 & 80,97 & 75,95 & 68,50 & 61,23 & 54,42 & 42,70 & 33,66 & 22,06 \\
\hline 30 & 1850 & 20 & 86,38 & 80,30 & 75,41 & 68,10 & 60,95 & 54,24 & 42,65 & 33,68 & 22,11 \\
\hline 30 & 1900 & 20 & 85,71 & 79,66 & 74,89 & 67,72 & 60,68 & 54,06 & 42,60 & 33,70 & 22,15 \\
\hline 30 & 1950 & 20 & 85,07 & 79,04 & 74,39 & 67,34 & 60,41 & 53,88 & 42,56 & 33,72 & 22,20 \\
\hline 30 & 2000 & 20 & 84,46 & 78,43 & 73,89 & 66,97 & 60,15 & 53,71 & 42,51 & 33,73 & 22,24 \\
\hline 30 & 200 & 25 & 155,10 & 118,65 & 97,29 & 74,61 & 57,99 & 46,04 & 31,36 & 23,59 & 16,06 \\
\hline 30 & 250 & 25 & 143,91 & 113,51 & 94,67 & 73,93 & 58,18 & 46,53 & 31,77 & 23,77 & 16,06 \\
\hline 30 & 300 & 25 & 135,36 & 109,25 & 92,33 & 73,17 & 58,20 & 46,86 & 32,13 & 23,97 & 16,07 \\
\hline 30 & 350 & 25 & 128,51 & 105,63 & 90,22 & 72,37 & 58,11 & 47,10 & 32,45 & 24,16 & 16,09 \\
\hline 30 & 400 & 25 & 122,84 & 102,50 & 88,30 & 71,57 & 57,95 & 47,25 & 32,73 & 24,34 & 16,11 \\
\hline 30 & 450 & 25 & 118,03 & $\begin{array}{l}99,74 \\
\end{array}$ & 86,56 & 70,79 & 57,74 & 47,34 & 32,98 & 24,52 & 16,15 \\
\hline 30 & 500 & 25 & 113,88 & $\begin{array}{l}97,28 \\
\end{array}$ & 84,96 & 70,03 & 57,50 & 47,38 & 33,19 & 24,69 & 16,18 \\
\hline 30 & 550 & 25 & 110,24 & 95,06 & 83,49 & 69,30 & 57,24 & 47,39 & 33,38 & 24,85 & 16,22 \\
\hline 30 & 600 & 25 & 107,02 & 93,05 & 82,12 & 68,59 & 56,96 & 47,37 & 33,54 & 25,00 & 16,27 \\
\hline 30 & 650 & 25 & 104,14 & 91,21 & 80,85 & 67,91 & 56,67 & 47,32 & 33,69 & 25,14 & 16,31 \\
\hline 30 & 700 & 25 & 101,55 & 89,52 & 79,66 & 67,25 & 56,38 & 47,26 & 33,81 & 25,27 & 16,36 \\
\hline 30 & 750 & 25 & 99,19 & 87,96 & 78,55 & 66,62 & 56,09 & 47,18 & 33,92 & 25,39 & 16,41 \\
\hline 30 & 800 & 25 & 97,04 & 86,50 & 77,50 & 66,01 & 55,80 & 47,10 & 34,01 & 25,51 & 16,46 \\
\hline 30 & 850 & 25 & 95,07 & 85,15 & 76,52 & 65,43 & 55,51 & 47,00 & 34,09 & 25,62 & 16,51 \\
\hline 30 & 900 & 25 & 93,26 & 83,88 & 75,58 & 64,87 & 55,22 & 46,89 & 34,16 & 25,72 & 16,56 \\
\hline 30 & 950 & 25 & 91,58 & 82,68 & 74,70 & 64,33 & 54,93 & 46,78 & 34,22 & 25,81 & 16,60 \\
\hline 30 & 1000 & 25 & 90,02 & 81,56 & 73,86 & 63,81 & 54,65 & 46,66 & 34,27 & 25,90 & 16,65 \\
\hline 30 & 1050 & 25 & 88,56 & 80,49 & 73,06 & 63,30 & 54,37 & 46,54 & 34,32 & 25,98 & 16,70 \\
\hline 30 & 1100 & 25 & 87,21 & 79,49 & 72,30 & 62,82 & 54,10 & 46,42 & 34,35 & 26,06 & 16,75 \\
\hline 30 & 1150 & 25 & 85,93 & 78,53 & 71,57 & 62,35 & 53,83 & 46,29 & 34,38 & 26,13 & 16,80 \\
\hline 30 & 1200 & 25 & 84,74 & 77,62 & 70,87 & 61,89 & 53,56 & 46,17 & 34,40 & 26,20 & 16,84 \\
\hline 30 & 1250 & 25 & 83,62 & 76,75 & 70,20 & 61,45 & 53,30 & 46,04 & 34,42 & 26,27 & 16,89 \\
\hline 30 & 1300 & 25 & 82,56 & 75,91 & 69,56 & 61,03 & 53,05 & 45,91 & 34,43 & 26,33 & 16,94 \\
\hline 30 & 1350 & 25 & 81,55 & 75,12 & 68,95 & 60,61 & 52,79 & 45,78 & 34,44 & 26,38 & 16,98 \\
\hline 30 & 1400 & 25 & 80,60 & 74,36 & 68,35 & 60,21 & 52,55 & 45,65 & 34,45 & 26,43 & 17,03 \\
\hline 30 & 1450 & 25 & 79,70 & 73,62 & 67,78 & 59,82 & 52,31 & 45,52 & 34,45 & 26,48 & 17,07 \\
\hline 30 & 1500 & 25 & 78,85 & 72,92 & 67,23 & 59,44 & 52,07 & 45,39 & 34,45 & 26,53 & 17,11 \\
\hline 30 & 1550 & 25 & 78,03 & 72,24 & 66,70 & 59,08 & 51,84 & 45,26 & 34,44 & 26,57 & 17,15 \\
\hline 30 & 1600 & 25 & 77,26 & 71,59 & 66,19 & 58,72 & 51,61 & 45,13 & 34,43 & 26,61 & 17,19 \\
\hline 30 & 1650 & 25 & 76,52 & 70,96 & 65,69 & 58,37 & 51,38 & 45,00 & 34,42 & 26,65 & 17,23 \\
\hline 30 & 1700 & 25 & 75,81 & 70,35 & 65,21 & 58,03 & 51,16 & 44,87 & 34,41 & 26,68 & 17,27 \\
\hline 30 & 1750 & 25 & 75,13 & 69,76 & 64,74 & 57,70 & 50,95 & 44,75 & 34,39 & 26,71 & 17,31 \\
\hline 30 & 1800 & 25 & 74,48 & 69,19 & 64,29 & 57,38 & 50,74 & 44,62 & 34,38 & 26,74 & 17,35 \\
\hline 30 & 1850 & 25 & 73,86 & 68,64 & 63,85 & 57,07 & 50,53 & 44,50 & 34,36 & 26,77 & 17,38 \\
\hline 30 & 1900 & 25 & 73,26 & 68,11 & 63,43 & 56,76 & 50,32 & 44,37 & 34,34 & 26,80 & 17,42 \\
\hline 30 & 1950 & 25 & 72,69 & 67,59 & 63,01 & 56,46 & 50,12 & 44,25 & 34,32 & 26,82 & 17,46 \\
\hline 30 & 2000 & 25 & 72,13 & 67,09 & 62,61 & 56,17 & 49,92 & 44,13 & 34,29 & 26,84 & 17,49 \\
\hline 30 & 200 & 30 & 137,42 & 102,31 & 82,66 & 62,47 & 48,10 & 38,01 & 25,88 & 19,56 & 13,39 \\
\hline 30 & 250 & 30 & 127,49 & 98,10 & 80,69 & 62,09 & 48,36 & 38,45 & 26,19 & 19,68 & 13,38 \\
\hline 30 & 300 & 30 & 119,92 & 94,59 & 78,89 & 61,61 & 48,48 & 38,77 & 26,47 & 19,81 & 13,38 \\
\hline 30 & 350 & 30 & 113,88 & 91,59 & 77,25 & 61,08 & 48,50 & 39,01 & 26,73 & 19,95 & 13,39 \\
\hline 30 & 400 & 30 & 108,87 & 88,98 & 75,75 & 60,53 & 48,46 & 39,19 & 26,96 & 20,08 & 13,40 \\
\hline 30 & 450 & 30 & 104,63 & 86,68 & 74,37 & 59,98 & 48,36 & 39,32 & 27,16 & 20,21 & 13,42 \\
\hline 30 & 500 & 30 & 100,96 & 84,62 & 73,09 & 59,43 & 48,24 & 39,40 & 27,35 & 20,34 & 13,44 \\
\hline 30 & 550 & 30 & 97,75 & 82,76 & 71,90 & 58,89 & 48,09 & 39,46 & 27,51 & 20,46 & 13,46 \\
\hline 30 & 600 & 30 & 94,90 & 81,06 & 70,80 & 58,36 & 47,92 & 39,49 & 27,66 & 20,57 & 13,49 \\
\hline 30 & 650 & 30 & 92,35 & 79,51 & 69,77 & 57,85 & 47,73 & 39,49 & 27,79 & 20,68 & 13,51 \\
\hline 30 & 700 & 30 & 90,05 & 78,08 & 68,80 & 57,35 & 47,54 & 39,48 & 27,91 & 20,79 & 13,54 \\
\hline 30 & 750 & 30 & 87,95 & 76,76 & 67,90 & 56,87 & 47,35 & 39,46 & 28,01 & 20,89 & 13,57 \\
\hline 30 & 800 & 30 & 86,04 & 75,53 & 67,04 & 56,40 & 47,15 & 39,42 & 28,11 & 20,98 & 13,61 \\
\hline 30 & 850 & 30 & 84,28 & 74,38 & 66,23 & 55,95 & 46,94 & 39,37 & 28,19 & 21,07 & 13,64 \\
\hline 30 & 900 & 30 & 82,66 & 73,30 & 65,46 & 55,52 & 46,74 & 39,32 & 28,27 & 21,16 & 13,67 \\
\hline 30 & 950 & 30 & 81,16 & 72,28 & 64,73 & 55,09 & 46,54 & 39,26 & 28,33 & 21,24 & 13,71 \\
\hline 30 & 1000 & 30 & 79,76 & 71,32 & 64,03 & 54,69 & 46,34 & 39,19 & 28,39 & 21,32 & 13,74 \\
\hline 30 & 1050 & 30 & 78,46 & 70,42 & 63,37 & 54,29 & 46,13 & 39,12 & 28,44 & 21,39 & 13,78 \\
\hline 30 & 1100 & 30 & 77,23 & 69,56 & 62,74 & 53,91 & 45,93 & 39,05 & 28,49 & 21,46 & 13,81 \\
\hline 30 & 1150 & 30 & 76,09 & 68,74 & 62,13 & 53,53 & 45,74 & 38,97 & 28,53 & 21,52 & 13,84 \\
\hline 30 & 1200 & 30 & 75,01 & 67,97 & 61,55 & 53,17 & 45,54 & 38,89 & 28,56 & 21,58 & 13,88 \\
\hline 30 & 1250 & 30 & 74,00 & 67,22 & 60,99 & 52,82 & 45,35 & 38,80 & 28,59 & 21,64 & 13,91 \\
\hline 30 & 1300 & 30 & 73,04 & 66,51 & 60,46 & 52,48 & 45,15 & 38,72 & 28,62 & 21,70 & 13,95 \\
\hline
\end{tabular}




\begin{tabular}{|c|c|c|c|c|c|c|c|c|c|c|c|}
\hline \multirow[b]{2}{*}{$\mathrm{H}(\mathrm{cm})$} & \multirow[b]{2}{*}{ Mceq (MPa) } & & & & & & ões (x1 & m) & & & \\
\hline & & Msub (MPa) & D0 & D25 & D40 & D60 & D80 & D100 & D140 & D180 & D260 \\
\hline 30 & 1350 & 30 & 72,13 & 65,83 & 59,94 & 52,15 & 44,97 & 38,63 & 28,64 & 21,75 & 13,98 \\
\hline 30 & 1400 & 30 & 71,27 & 65,18 & 59,44 & 51,83 & 44,78 & 38,54 & 28,66 & 21,80 & 14,01 \\
\hline 30 & 1450 & 30 & 70,46 & 64,56 & 58,96 & 51,52 & 44,60 & 38,45 & 28,67 & 21,84 & 14,04 \\
\hline 30 & 1500 & 30 & 69,68 & 63,95 & 58,50 & 51,21 & 44,42 & 38,37 & 28,68 & 21,89 & 14,08 \\
\hline 30 & 1550 & 30 & 68,94 & 63,38 & 58,06 & 50,91 & 44,24 & 38,28 & 28,69 & 21,93 & 14,11 \\
\hline 30 & 1600 & 30 & 68,23 & 62,82 & 57,62 & 50,62 & 44,06 & 38,18 & 28,70 & 21,97 & 14,14 \\
\hline 30 & 1650 & 30 & 67,56 & 62,28 & 57,21 & 50,34 & 43,89 & 38,09 & 28,70 & 22,01 & 14,17 \\
\hline 30 & 1700 & 30 & 66,92 & 61,76 & 56,80 & 50,07 & 43,72 & 38,00 & 28,71 & 22,04 & 14,20 \\
\hline 30 & 1750 & 30 & 66,30 & 61,25 & 56,41 & 49,80 & 43,56 & 37,91 & 28,71 & 22,07 & 14,23 \\
\hline 30 & 1800 & 30 & 65,71 & 60,77 & 56,03 & 49,54 & 43,39 & 37,82 & 28,70 & 22,11 & 14,26 \\
\hline 30 & 1850 & 30 & 65,14 & 60,29 & 55,66 & 49,28 & 43,23 & 37,73 & 28,70 & 22,14 & 14,29 \\
\hline 30 & 1900 & 30 & 64,59 & 59,84 & 55,30 & 49,03 & 43,07 & 37,64 & 28,70 & 22,16 & 14,32 \\
\hline 30 & 1950 & 30 & 64,07 & 59,39 & 54,95 & 48,79 & 42,91 & 37,55 & 28,69 & 22,19 & 14,34 \\
\hline 30 & 2000 & 30 & 63,56 & 58,96 & 54,61 & 48,55 & 42,76 & 37,47 & 28,68 & 22,22 & 14,37 \\
\hline 30 & 200 & 35 & 124,11 & 90,13 & 71,88 & 53,65 & 41,02 & 32,32 & 22,02 & 16,71 & 11,48 \\
\hline 30 & 250 & 35 & 115,08 & 86,59 & 70,36 & 53,46 & 41,31 & 32,70 & 22,26 & 16,79 & 11,47 \\
\hline 30 & 300 & 35 & 108,25 & 83,62 & 68,94 & 53,17 & 41,48 & 33,00 & 22,48 & 16,89 & 11,47 \\
\hline 30 & 350 & 35 & 102,79 & 81,08 & 67,62 & 52,81 & 41,56 & 33,23 & 22,69 & 16,98 & 11,47 \\
\hline 30 & 400 & 35 & 98,29 & 78,85 & 66,41 & 52,42 & 41,58 & 33,41 & 22,88 & 17,08 & 11,47 \\
\hline 30 & 450 & 35 & 94,47 & 76,88 & 65,28 & 52,02 & 41,55 & 33,55 & 23,05 & 17,18 & 11,48 \\
\hline 30 & 500 & 35 & 91,17 & 75,11 & 64,24 & 51,61 & 41,49 & 33,66 & 23,21 & 17,27 & 11,49 \\
\hline 30 & 550 & 35 & 88,28 & 73,51 & 63,26 & 51,21 & 41,41 & 33,74 & 23,35 & 17,37 & 11,51 \\
\hline 30 & 600 & 35 & 85,72 & 72,06 & 62,35 & 50,80 & 41,31 & 33,79 & 23,48 & 17,46 & 11,52 \\
\hline 30 & 650 & 35 & 83,42 & 70,72 & 61,49 & 50,41 & 41,20 & 33,83 & 23,60 & 17,55 & 11,54 \\
\hline 30 & 700 & 35 & 81,34 & 69,48 & 60,69 & 50,02 & 41,07 & 33,84 & 23,71 & 17,63 & 11,56 \\
\hline 30 & 750 & 35 & 79,45 & 68,34 & 59,93 & 49,65 & 40,94 & 33,85 & 23,81 & 17,72 & 11,58 \\
\hline 30 & 800 & 35 & 77,73 & 67,27 & 59,21 & 49,28 & 40,80 & 33,85 & 23,90 & 17,79 & 11,60 \\
\hline 30 & 850 & 35 & 76,14 & 66,27 & 58,52 & 48,92 & 40,66 & 33,83 & 23,98 & 17,87 & 11,62 \\
\hline 30 & 900 & 35 & 74,67 & 65,33 & 57,88 & 48,57 & 40,51 & 33,81 & 24,05 & 17,94 & 11,65 \\
\hline 30 & 950 & 35 & 73,31 & 64,45 & 57,26 & 48,23 & 40,36 & 33,78 & 24,11 & 18,01 & 11,67 \\
\hline 30 & 1000 & 35 & 72,04 & 63,62 & 56,67 & 47,91 & 40,21 & 33,74 & 24,17 & 18,07 & 11,70 \\
\hline 30 & 1050 & 35 & 70,85 & 62,83 & 56,11 & 47,59 & 40,06 & 33,70 & 24,23 & 18,14 & 11,72 \\
\hline 30 & 1100 & 35 & 69,74 & 62,08 & 55,57 & 47,28 & 39,91 & 33,66 & 24,28 & 18,20 & 11,74 \\
\hline 30 & 1150 & 35 & 68,70 & 61,37 & 55,05 & 46,97 & 39,77 & 33,61 & 24,32 & 18,25 & 11,77 \\
\hline 30 & 1200 & 35 & 67,72 & 60,69 & 54,56 & 46,68 & 39,62 & 33,56 & 24,36 & 18,31 & 11,79 \\
\hline 30 & 1250 & 35 & 66,79 & 60,04 & 54,08 & 46,39 & 39,47 & 33,51 & 24,40 & 18,36 & 11,82 \\
\hline 30 & 1300 & 35 & 65,91 & 59,42 & 53,62 & 46,11 & 39,32 & 33,45 & 24,43 & 18,41 & 11,85 \\
\hline 30 & 1350 & 35 & 65,09 & 58,83 & 53,18 & 45,84 & 39,18 & 33,39 & 24,46 & 18,46 & 11,87 \\
\hline 30 & 1400 & 35 & 64,30 & 58,26 & 52,76 & 45,58 & 39,03 & 33,33 & 24,48 & 18,50 & 11,90 \\
\hline 30 & 1450 & 35 & 63,55 & 57,71 & 52,35 & 45,32 & 38,89 & 33,27 & 24,50 & 18,54 & 11,92 \\
\hline 30 & 1500 & 35 & 62,84 & 57,18 & 51,95 & 45,07 & 38,75 & 33,21 & 24,52 & 18,58 & 11,94 \\
\hline 30 & 1550 & 35 & 62,16 & 56,68 & 51,56 & 44,82 & 38,61 & 33,14 & 24,54 & 18,62 & 11,97 \\
\hline 30 & 1600 & 35 & 61,51 & 56,19 & 51,19 & 44,58 & 38,47 & 33,08 & 24,56 & 18,66 & 11,99 \\
\hline 30 & 1650 & 35 & 60,89 & 55,72 & 50,83 & 44,35 & 38,34 & 33,02 & 24,57 & 18,70 & 12,02 \\
\hline 30 & 1700 & 35 & 60,29 & 55,26 & 50,48 & 44,12 & 38,20 & 32,95 & 24,58 & 18,73 & 12,04 \\
\hline 30 & 1750 & 35 & 59,73 & 54,82 & 50,14 & 43,89 & 38,07 & 32,88 & 24,59 & 18,76 & 12,07 \\
\hline 30 & 1800 & 35 & 59,18 & 54,39 & 49,82 & 43,68 & 37,94 & 32,82 & 24,59 & 18,79 & 12,09 \\
\hline 30 & 1850 & 35 & 58,66 & 53,98 & 49,50 & 43,46 & 37,81 & 32,75 & 24,60 & 18,82 & 12,11 \\
\hline 30 & 1900 & 35 & 58,15 & 53,58 & 49,19 & 43,25 & 37,69 & 32,69 & 24,60 & 18,85 & 12,13 \\
\hline 30 & 1950 & 35 & 57,67 & 53,19 & 48,88 & 43,05 & 37,56 & 32,62 & 24,61 & 18,88 & 12,16 \\
\hline 30 & 2000 & 35 & 57,20 & 52,81 & 48,59 & 42,85 & 37,44 & 32,55 & 24,61 & 18,90 & 12,18 \\
\hline 30 & 200 & 40 & 113,67 & 80,67 & 63,59 & 46,97 & 35,71 & 28,08 & 19,16 & 14,58 & 10,06 \\
\hline 30 & 250 & 40 & 105,34 & 77,63 & 62,39 & 46,90 & 36,00 & 28,41 & 19,35 & 14,64 & 10,04 \\
\hline 30 & 300 & 40 & 99,06 & 75,07 & 61,24 & 46,72 & 36,19 & 28,68 & 19,53 & 14,71 & 10,04 \\
\hline 30 & 350 & 40 & 94,06 & 72,87 & 60,17 & 46,48 & 36,30 & 28,90 & 19,70 & 14,78 & 10,03 \\
\hline 30 & 400 & 40 & 89,94 & 70,94 & 59,17 & 46,21 & 36,36 & 29,08 & 19,85 & 14,86 & 10,04 \\
\hline 30 & 450 & 40 & 86,46 & 69,23 & 58,24 & 45,91 & 36,38 & 29,22 & 20,00 & 14,93 & 10,04 \\
\hline 30 & 500 & 40 & 83,45 & 67,68 & 57,36 & 45,61 & 36,37 & 29,33 & 20,14 & 15,01 & 10,04 \\
\hline 30 & 550 & 40 & 80,81 & 66,29 & 56,54 & 45,29 & 36,33 & 29,42 & 20,26 & 15,08 & 10,05 \\
\hline 30 & 600 & 40 & 78,47 & 65,01 & 55,77 & 44,98 & 36,27 & 29,49 & 20,37 & 15,16 & 10,06 \\
\hline 30 & 650 & 40 & 76,37 & 63,83 & 55,05 & 44,67 & 36,20 & 29,54 & 20,48 & 15,23 & 10,07 \\
\hline 30 & 700 & 40 & 74,48 & 62,75 & 54,36 & 44,37 & 36,12 & 29,58 & 20,58 & 15,30 & 10,09 \\
\hline 30 & 750 & 40 & 72,75 & 61,74 & 53,72 & 44,07 & 36,03 & 29,60 & 20,66 & 15,36 & 10,10 \\
\hline 30 & 800 & 40 & 71,18 & 60,80 & 53,10 & 43,77 & 35,94 & 29,61 & 20,75 & 15,43 & 10,11 \\
\hline 30 & 850 & 40 & 69,72 & 59,92 & 52,52 & 43,48 & 35,84 & 29,62 & 20,82 & 15,49 & 10,13 \\
\hline 30 & 900 & 40 & 68,38 & 59,09 & 51,96 & 43,20 & 35,73 & 29,62 & 20,89 & 15,55 & 10,15 \\
\hline 30 & 950 & 40 & 67,13 & 58,31 & 51,43 & 42,92 & 35,62 & 29,61 & 20,95 & 15,61 & 10,16 \\
\hline 30 & 1000 & 40 & 65,96 & 57,57 & 50,92 & 42,65 & 35,51 & 29,59 & 21,01 & 15,67 & 10,18 \\
\hline 30 & 1050 & 40 & 64,88 & 56,87 & 50,44 & 42,39 & 35,40 & 29,57 & 21,06 & 15,72 & 10,20 \\
\hline 30 & 1100 & 40 & 63,86 & 56,21 & 49,97 & 42,13 & 35,28 & 29,55 & 21,11 & 15,77 & 10,22 \\
\hline 30 & 1150 & 40 & 62,90 & 55,58 & 49,52 & 41,88 & 35,17 & 29,52 & 21,16 & 15,82 & 10,24 \\
\hline 30 & 1200 & 40 & 61,99 & 54,97 & 49,09 & 41,64 & 35,06 & 29,49 & 21,20 & 15,87 & 10,25 \\
\hline 30 & 1250 & 40 & 61,14 & 54,40 & 48,68 & 41,40 & 34,94 & 29,46 & 21,24 & 15,92 & 10,27 \\
\hline 30 & 1300 & 40 & 60,33 & 53,85 & 48,28 & 41,17 & 34,83 & 29,42 & 21,27 & 15,96 & 10,29 \\
\hline 30 & 1350 & 40 & 59,57 & 53,32 & 47,90 & 40,94 & 34,71 & 29,38 & 21,30 & 16,00 & 10,31 \\
\hline 30 & 1400 & 40 & 58,84 & 52,81 & 47,53 & 40,72 & 34,60 & 29,34 & 21,33 & 16,04 & 10,33 \\
\hline 30 & 1450 & 40 & 58,15 & 52,33 & 47,17 & 40,50 & 34,49 & 29,30 & 21,36 & 16,08 & 10,35 \\
\hline 30 & 1500 & 40 & 57,49 & 51,86 & 46,82 & 40,29 & 34,38 & 29,26 & 21,38 & 16,12 & 10,37 \\
\hline 30 & 1550 & 40 & 56,86 & 51,41 & 46,49 & 40,08 & 34,26 & 29,21 & 21,40 & 16,15 & 10,39 \\
\hline 30 & 1600 & 40 & 56,26 & 50,97 & 46,16 & 39,88 & 34,15 & 29,16 & 21,42 & 16,19 & 10,41 \\
\hline 30 & 1650 & 40 & 55,69 & 50,55 & 45,85 & 39,68 & 34,05 & 29,12 & 21,44 & 16,22 & 10,43 \\
\hline
\end{tabular}




\begin{tabular}{|c|c|c|c|c|c|c|c|c|c|c|c|}
\hline \multirow[b]{2}{*}{$\mathrm{H}(\mathrm{cm})$} & \multirow[b]{2}{*}{ Mceq (MPa) } & & & & & De & ões (x1 & m) & & & \\
\hline & & Msub (MPa) & D0 & D25 & D40 & D60 & D80 & D100 & D140 & D180 & D260 \\
\hline 30 & 1700 & 40 & 55,13 & 50,15 & 45,54 & 39,49 & 33,94 & 29,07 & 21,45 & 16,25 & 10,45 \\
\hline 30 & 1750 & 40 & 54,61 & 49,76 & 45,24 & 39,30 & 33,83 & 29,02 & 21,47 & 16,28 & 10,47 \\
\hline 30 & 1800 & 40 & 54,10 & 49,38 & 44,96 & 39,11 & 33,72 & 28,97 & 21,48 & 16,31 & 10,48 \\
\hline 30 & 1850 & 40 & 53,61 & 49,01 & 44,67 & 38,93 & 33,62 & 28,92 & 21,49 & 16,34 & 10,50 \\
\hline 30 & 1900 & 40 & 53,15 & 48,65 & 44,40 & 38,75 & 33,52 & 28,87 & 21,50 & 16,37 & 10,52 \\
\hline 30 & 1950 & 40 & 52,69 & 48,30 & 44,14 & 38,58 & 33,41 & 28,82 & 21,51 & 16,39 & 10,54 \\
\hline 30 & 2000 & 40 & 52,26 & 47,97 & 43,88 & 38,41 & 33,31 & 28,77 & 21,51 & 16,42 & 10,56 \\
\hline 30 & 200 & 45 & 105,24 & 73,10 & 57,02 & 41,73 & 31,58 & 24,81 & 16,95 & 12,94 & 8,95 \\
\hline 30 & 250 & 45 & 97,46 & 70,44 & 56,04 & 41,74 & 31,87 & 25,10 & 17,11 & 12,99 & 8,93 \\
\hline 30 & 300 & 45 & 91,62 & 68,21 & 55,11 & 41,64 & 32,07 & 25,34 & 17,25 & 13,04 & 8,93 \\
\hline 30 & 350 & 45 & 86,98 & 66,27 & 54,22 & 41,49 & 32,20 & 25,54 & 17,39 & 13,09 & 8,92 \\
\hline 30 & 400 & 45 & 83,17 & 64,57 & 53,38 & 41,29 & 32,28 & 25,71 & 17,52 & 13,15 & 8,92 \\
\hline 30 & 450 & 45 & 79,95 & 63,06 & 52,60 & 41,07 & 32,32 & 25,85 & 17,65 & 13,21 & 8,92 \\
\hline 30 & 500 & 45 & 77,17 & 61,70 & 51,86 & 40,84 & 32,34 & 25,96 & 17,76 & 13,27 & 8,92 \\
\hline 30 & 550 & 45 & 74,74 & 60,46 & 51,16 & 40,60 & 32,33 & 26,05 & 17,87 & 13,33 & 8,93 \\
\hline 30 & 600 & 45 & 72,58 & 59,32 & 50,50 & 40,35 & 32,31 & 26,13 & 17,97 & 13,39 & 8,93 \\
\hline 30 & 650 & 45 & 70,65 & 58,28 & 49,88 & 40,11 & 32,27 & 26,19 & 18,07 & 13,44 & 8,94 \\
\hline 30 & 700 & 45 & 68,90 & 57,31 & 49,29 & 39,86 & 32,22 & 26,23 & 18,15 & 13,50 & 8,95 \\
\hline 30 & 750 & 45 & 67,31 & 56,41 & 48,73 & 39,62 & 32,16 & 26,27 & 18,23 & 13,56 & 8,96 \\
\hline 30 & 800 & 45 & 65,85 & 55,57 & 48,19 & 39,38 & 32,09 & 26,29 & 18,31 & 13,61 & 8,97 \\
\hline 30 & 850 & 45 & 64,51 & 54,78 & 47,69 & 39,14 & 32,02 & 26,31 & 18,38 & 13,66 & 8,98 \\
\hline 30 & 900 & 45 & 63,27 & 54,04 & 47,20 & 38,91 & 31,94 & 26,32 & 18,44 & 13,72 & 8,99 \\
\hline 30 & 950 & 45 & 62,11 & 53,34 & 46,74 & 38,68 & 31,86 & 26,33 & 18,50 & 13,76 & 9,00 \\
\hline 30 & 1000 & 45 & 61,04 & 52,68 & 46,29 & 38,45 & 31,78 & 26,33 & 18,56 & 13,81 & 9,02 \\
\hline 30 & 1050 & 45 & 60,03 & 52,06 & 45,87 & 38,23 & 31,70 & 26,32 & 18,61 & 13,86 & 9,03 \\
\hline 30 & 1100 & 45 & 59,09 & 51,46 & 45,46 & 38,02 & 31,61 & 26,31 & 18,65 & 13,90 & 9,04 \\
\hline 30 & 1150 & 45 & 58,20 & 50,89 & 45,07 & 37,81 & 31,52 & 26,30 & 18,70 & 13,95 & 9,06 \\
\hline 30 & 1200 & 45 & 57,36 & 50,35 & 44,69 & 37,60 & 31,43 & 26,28 & 18,74 & 13,99 & 9,07 \\
\hline 30 & 1250 & 45 & 56,57 & 49,83 & 44,33 & 37,40 & 31,34 & 26,26 & 18,78 & 14,03 & 9,09 \\
\hline 30 & 1300 & 45 & 55,82 & 49,34 & 43,98 & 37,20 & 31,25 & 26,24 & 18,81 & 14,07 & 9,10 \\
\hline 30 & 1350 & 45 & 55,11 & 48,87 & 43,64 & 37,01 & 31,16 & 26,21 & 18,84 & 14,11 & 9,12 \\
\hline 30 & 1400 & 45 & 54,43 & 48,41 & 43,31 & 36,82 & 31,07 & 26,19 & 18,87 & 14,14 & 9,13 \\
\hline 30 & 1450 & 45 & 53,79 & 47,97 & 43,00 & 36,64 & 30,98 & 26,16 & 18,90 & 14,18 & 9,15 \\
\hline 30 & 1500 & 45 & 53,17 & 47,55 & 42,69 & 36,46 & 30,89 & 26,13 & 18,93 & 14,21 & 9,16 \\
\hline 30 & 1550 & 45 & 52,59 & 47,14 & 42,39 & 36,28 & 30,80 & 26,10 & 18,95 & 14,24 & 9,18 \\
\hline 30 & 1600 & 45 & 52,03 & 46,75 & 42,10 & 36,11 & 30,71 & 26,06 & 18,97 & 14,27 & 9,19 \\
\hline 30 & 1650 & 45 & 51,49 & 46,37 & 41,82 & 35,94 & 30,62 & 26,03 & 18,99 & 14,30 & 9,21 \\
\hline 30 & 1700 & 45 & 50,98 & 46,01 & 41,55 & 35,77 & 30,53 & 26,00 & 19,01 & 14,33 & 9,22 \\
\hline 30 & 1750 & 45 & 50,48 & 45,65 & 41,29 & 35,61 & 30,45 & 25,96 & 19,03 & 14,36 & 9,24 \\
\hline 30 & 1800 & 45 & 50,01 & 45,31 & 41,03 & 35,45 & 30,36 & 25,92 & 19,04 & 14,39 & 9,25 \\
\hline 30 & 1850 & 45 & 49,55 & 44,98 & 40,78 & 35,29 & 30,27 & 25,89 & 19,05 & 14,42 & 9,27 \\
\hline 30 & 1900 & 45 & 49,12 & 44,66 & 40,54 & 35,14 & 30,19 & 25,85 & 19,07 & 14,44 & 9,28 \\
\hline 30 & 1950 & 45 & 48,69 & 44,34 & 40,30 & 34,99 & 30,10 & 25,81 & 19,08 & 14,46 & 9,30 \\
\hline 30 & 2000 & 45 & 48,29 & 44,04 & 40,07 & 34,84 & 30,02 & 25,77 & 19,09 & 14,49 & 9,31 \\
\hline 30 & 200 & 50 & 98,27 & 66,88 & 51,67 & 37,51 & 28,29 & 22,20 & 15,20 & 11,63 & 8,06 \\
\hline 30 & 250 & 50 & 90,94 & 64,54 & 50,88 & 37,57 & 28,57 & 22,46 & 15,33 & 11,67 & 8,05 \\
\hline 30 & 300 & 50 & 85,45 & 62,55 & 50,10 & 37,54 & 28,76 & 22,68 & 15,45 & 11,71 & 8,04 \\
\hline 30 & 350 & 50 & 81,11 & 60,84 & 49,35 & 37,44 & 28,90 & 22,87 & 15,57 & 11,75 & 8,03 \\
\hline 30 & 400 & 50 & 77,55 & 59,33 & 48,64 & 37,31 & 28,99 & 23,02 & 15,68 & 11,79 & 8,03 \\
\hline 30 & 450 & 50 & 74,54 & 57,97 & 47,97 & 37,14 & 29,06 & 23,15 & 15,78 & 11,84 & 8,03 \\
\hline 30 & 500 & 50 & 71,95 & 56,75 & 47,34 & 36,97 & 29,09 & 23,26 & 15,88 & 11,89 & 8,03 \\
\hline 30 & 550 & 50 & 69,69 & 55,64 & 46,73 & 36,78 & 29,10 & 23,36 & 15,98 & 11,94 & 8,03 \\
\hline 30 & 600 & 50 & 67,68 & 54,63 & 46,16 & 36,58 & 29,10 & 23,43 & 16,07 & 11,98 & 8,03 \\
\hline 30 & 650 & 50 & 65,88 & 53,69 & 45,62 & 36,39 & 29,08 & 23,50 & 16,15 & 12,03 & 8,04 \\
\hline 30 & 700 & 50 & 64,26 & 52,82 & 45,11 & 36,19 & 29,06 & 23,55 & 16,23 & 12,08 & 8,04 \\
\hline 30 & 750 & 50 & 62,78 & 52,01 & 44,62 & 35,99 & 29,02 & 23,59 & 16,30 & 12,13 & 8,05 \\
\hline 30 & 800 & 50 & 61,42 & 51,25 & 44,15 & 35,79 & 28,97 & 23,62 & 16,37 & 12,17 & 8,06 \\
\hline 30 & 850 & 50 & 60,17 & 50,54 & 43,71 & 35,59 & 28,93 & 23,65 & 16,43 & 12,22 & 8,06 \\
\hline 30 & 900 & 50 & 59,02 & 49,87 & 43,28 & 35,40 & 28,87 & 23,67 & 16,49 & 12,26 & 8,07 \\
\hline 30 & 950 & 50 & 57,94 & 49,24 & 42,87 & 35,20 & 28,81 & 23,68 & 16,54 & 12,30 & 8,08 \\
\hline 30 & 1000 & 50 & 56,94 & 48,64 & 42,48 & 35,02 & 28,75 & 23,69 & 16,60 & 12,34 & 8,09 \\
\hline 30 & 1050 & 50 & 56,00 & 48,07 & 42,10 & 34,83 & 28,68 & 23,70 & 16,64 & 12,38 & 8,10 \\
\hline 30 & 1100 & 50 & 55,12 & 47,53 & 41,74 & 34,65 & 28,62 & 23,69 & 16,69 & 12,42 & 8,11 \\
\hline 30 & 1150 & 50 & 54,29 & 47,02 & 41,40 & 34,47 & 28,55 & 23,69 & 16,73 & 12,46 & 8,12 \\
\hline 30 & 1200 & 50 & 53,51 & 46,52 & 41,06 & 34,29 & 28,48 & 23,68 & 16,77 & 12,50 & 8,13 \\
\hline 30 & 1250 & 50 & 52,77 & 46,06 & 40,74 & 34,12 & 28,41 & 23,67 & 16,81 & 12,53 & 8,14 \\
\hline 30 & 1300 & 50 & 52,07 & 45,61 & 40,43 & 33,95 & 28,34 & 23,66 & 16,84 & 12,57 & 8,16 \\
\hline 30 & 1350 & 50 & 51,41 & 45,17 & 40,12 & 33,79 & 28,26 & 23,65 & 16,88 & 12,60 & 8,17 \\
\hline 30 & 1400 & 50 & 50,77 & 44,76 & 39,83 & 33,63 & 28,19 & 23,63 & 16,91 & 12,63 & 8,18 \\
\hline 30 & 1450 & 50 & 50,17 & 44,36 & 39,55 & 33,47 & 28,12 & 23,61 & 16,93 & 12,67 & 8,19 \\
\hline 30 & 1500 & 50 & 49,60 & 43,98 & 39,28 & 33,31 & 28,04 & 23,59 & 16,96 & 12,70 & 8,20 \\
\hline 30 & 1550 & 50 & 49,05 & 43,61 & 39,01 & 33,16 & 27,97 & 23,57 & 16,98 & 12,72 & 8,22 \\
\hline 30 & 1600 & 50 & 48,52 & 43,25 & 38,75 & 33,01 & 27,90 & 23,55 & 17,01 & 12,75 & 8,23 \\
\hline 30 & 1650 & 50 & 48,02 & 42,91 & 38,50 & 32,86 & 27,83 & 23,52 & 17,03 & 12,78 & 8,24 \\
\hline 30 & 1700 & 50 & 47,54 & 42,57 & 38,26 & 32,72 & 27,75 & 23,50 & 17,05 & 12,81 & 8,25 \\
\hline 30 & 1750 & 50 & 47,07 & 42,25 & 38,02 & 32,57 & 27,68 & 23,47 & 17,07 & 12,83 & 8,27 \\
\hline 30 & 1800 & 50 & 46,63 & 41,94 & 37,79 & 32,43 & 27,61 & 23,45 & 17,08 & 12,86 & 8,28 \\
\hline 30 & 1850 & 50 & 46,20 & 41,64 & 37,57 & 32,30 & 27,54 & 23,42 & 17,10 & 12,88 & 8,29 \\
\hline 30 & 1900 & 50 & 45,79 & 41,34 & 37,35 & 32,16 & 27,46 & 23,39 & 17,11 & 12,91 & 8,30 \\
\hline 30 & 1950 & 50 & 45,39 & 41,06 & 37,14 & 32,03 & 27,39 & 23,36 & 17,12 & 12,93 & 8,31 \\
\hline 30 & 2000 & 50 & 45,01 & 40,78 & 36,93 & 31,90 & 27,32 & 23,33 & 17,14 & 12,95 & 8,33 \\
\hline
\end{tabular}




\begin{tabular}{|c|c|c|c|c|c|c|c|c|c|c|c|}
\hline \multirow[b]{2}{*}{$\mathrm{H}(\mathrm{cm})$} & \multirow[b]{2}{*}{ Mceq (MPa) } & & & & & $\mathrm{De}$ & ões (x1 & & & & \\
\hline & & Msub (MPa) & D0 & D25 & D40 & D60 & D80 & D100 & D140 & D180 & D260 \\
\hline 30 & 200 & 55 & 92,41 & 61,69 & 47,23 & 34,05 & 25,61 & 20,09 & 13,78 & 10,56 & 7,33 \\
\hline 30 & 250 & 55 & 85,43 & 59,59 & 46,58 & 34,15 & 25,87 & 20,32 & 13,88 & 10,59 & 7,32 \\
\hline 30 & 300 & 55 & 80,24 & 57,82 & 45,93 & 34,15 & 26,06 & 20,52 & 13,99 & 10,62 & 7,31 \\
\hline 30 & 350 & 55 & 76,15 & 56,28 & 45,29 & 34,10 & 26,20 & 20,68 & 14,08 & 10,65 & 7,30 \\
\hline 30 & 400 & 55 & 72,79 & 54,92 & 44,69 & 34,01 & 26,30 & 20,83 & 14,18 & 10,69 & 7,30 \\
\hline 30 & 450 & 55 & 69,97 & 53,70 & 44,11 & 33,89 & 26,37 & 20,95 & 14,27 & 10,73 & 7,30 \\
\hline 30 & 500 & 55 & 67,54 & 52,60 & 43,56 & 33,75 & 26,42 & 21,06 & 14,36 & 10,77 & 7,30 \\
\hline 30 & 550 & 55 & 65,41 & 51,59 & 43,03 & 33,61 & 26,45 & 21,15 & 14,44 & 10,81 & 7,30 \\
\hline 30 & 600 & 55 & 63,53 & 50,67 & 42,53 & 33,45 & 26,46 & 21,23 & 14,52 & 10,85 & 7,30 \\
\hline 30 & 650 & 55 & 61,85 & 49,82 & 42,06 & 33,29 & 26,46 & 21,29 & 14,59 & 10,89 & 7,30 \\
\hline 30 & 700 & 55 & 60,32 & 49,03 & 41,61 & 33,13 & 26,44 & 21,35 & 14,66 & 10,93 & 7,31 \\
\hline 30 & 750 & 55 & 58,94 & 48,30 & 41,18 & 32,96 & 26,42 & 21,39 & 14,73 & 10,97 & 7,31 \\
\hline 30 & 800 & 55 & 57,67 & 47,61 & 40,76 & 32,80 & 26,40 & 21,43 & 14,79 & 11,00 & 7,32 \\
\hline 30 & 850 & 55 & 56,50 & 46,96 & 40,37 & 32,63 & 26,36 & 21,46 & 14,85 & 11,04 & 7,32 \\
\hline 30 & 900 & 55 & 55,41 & 46,35 & 39,99 & 32,47 & 26,32 & 21,49 & 14,90 & 11,08 & 7,33 \\
\hline 30 & 950 & 55 & 54,41 & 45,77 & 39,63 & 32,31 & 26,28 & 21,51 & 14,95 & 11,12 & 7,33 \\
\hline 30 & 1000 & 55 & 53,47 & 45,23 & 39,28 & 32,15 & 26,24 & 21,52 & 15,00 & 11,15 & 7,34 \\
\hline 30 & 1050 & 55 & 52,59 & 44,71 & 38,94 & 31,99 & 26,19 & 21,53 & 15,05 & 11,19 & 7,35 \\
\hline 30 & 1100 & 55 & 51,76 & 44,22 & 38,62 & 31,83 & 26,14 & 21,54 & 15,09 & 11,22 & 7,36 \\
\hline 30 & 1150 & 55 & 50,99 & 43,75 & 38,31 & 31,68 & 26,08 & 21,54 & 15,13 & 11,25 & 7,36 \\
\hline 30 & 1200 & 55 & 50,25 & 43,30 & 38,01 & 31,53 & 26,03 & 21,54 & 15,17 & 11,29 & 7,37 \\
\hline 30 & 1250 & 55 & 49,56 & 42,87 & 37,72 & 31,38 & 25,97 & 21,54 & 15,20 & 11,32 & 7,38 \\
\hline 30 & 1300 & 55 & 48,90 & 42,46 & 37,44 & 31,23 & 25,91 & 21,53 & 15,23 & 11,35 & 7,39 \\
\hline 30 & 1350 & 55 & 48,28 & 42,06 & 37,17 & 31,09 & 25,86 & 21,53 & 15,27 & 11,38 & 7,40 \\
\hline 30 & 1400 & 55 & 47,68 & 41,68 & 36,90 & 30,95 & 25,80 & 21,52 & 15,30 & 11,41 & 7,41 \\
\hline 30 & 1450 & 55 & 47,11 & 41,32 & 36,65 & 30,81 & 25,74 & 21,51 & 15,32 & 11,44 & 7,42 \\
\hline 30 & 1500 & 55 & 46,57 & 40,96 & 36,40 & 30,68 & 25,68 & 21,49 & 15,35 & 11,46 & 7,43 \\
\hline 30 & 1550 & 55 & 46,06 & 40,62 & 36,16 & 30,54 & 25,62 & 21,48 & 15,37 & 11,49 & 7,44 \\
\hline 30 & 1600 & 55 & 45,56 & 40,30 & 35,93 & 30,41 & 25,56 & 21,46 & 15,40 & 11,52 & 7,45 \\
\hline 30 & 1650 & 55 & 45,09 & 39,98 & 35,70 & 30,28 & 25,50 & 21,45 & 15,42 & 11,54 & 7,46 \\
\hline 30 & 1700 & 55 & 44,63 & 39,67 & 35,48 & 30,16 & 25,43 & 21,43 & 15,44 & 11,57 & 7,47 \\
\hline 30 & 1750 & 55 & 44,20 & 39,38 & 35,27 & 30,03 & 25,37 & 21,41 & 15,46 & 11,59 & 7,48 \\
\hline 30 & 1800 & 55 & 43,78 & 39,09 & 35,06 & 29,91 & 25,31 & 21,39 & 15,47 & 11,61 & 7,49 \\
\hline 30 & 1850 & 55 & 43,37 & 38,81 & 34,86 & 29,79 & 25,25 & 21,37 & 15,49 & 11,63 & 7,50 \\
\hline 30 & 1900 & 55 & 42,98 & 38,54 & 34,66 & 29,67 & 25,19 & 21,35 & 15,51 & 11,66 & 7,51 \\
\hline 30 & 1950 & 55 & 42,61 & 38,28 & 34,47 & 29,55 & 25,13 & 21,33 & 15,52 & 11,68 & 7,52 \\
\hline 30 & 2000 & 55 & 42,25 & 38,03 & 34,28 & 29,44 & 25,07 & 21,31 & 15,53 & 11,70 & 7,53 \\
\hline 30 & 200 & 60 & 87,39 & 57,28 & 43,49 & 31,15 & 23,38 & 18,34 & 12,60 & 9,67 & 6,72 \\
\hline 30 & 250 & 60 & 80,73 & 55,38 & 42,95 & 31,28 & 23,62 & 18,54 & 12,69 & 9,70 & 6,71 \\
\hline 30 & 300 & 60 & 75,78 & 53,78 & 42,40 & 31,31 & 23,80 & 18,72 & 12,77 & 9,72 & 6,70 \\
\hline 30 & 350 & 60 & 71,89 & 52,39 & 41,85 & 31,29 & 23,94 & 18,87 & 12,86 & 9,75 & 6,70 \\
\hline 30 & 400 & 60 & 68,71 & 51,15 & 41,33 & 31,23 & 24,05 & 19,01 & 12,94 & 9,78 & 6,69 \\
\hline 30 & 450 & 60 & 66,04 & 50,05 & 40,83 & 31,15 & 24,13 & 19,12 & 13,02 & 9,81 & 6,69 \\
\hline 30 & 500 & 60 & 63,74 & 49,05 & 40,35 & 31,05 & 24,18 & 19,22 & 13,09 & 9,84 & 6,69 \\
\hline 30 & 550 & 60 & 61,74 & 48,14 & 39,89 & 30,93 & 24,22 & 19,31 & 13,17 & 9,87 & 6,69 \\
\hline 30 & 600 & 60 & 59,96 & 47,30 & 39,45 & 30,81 & 24,24 & 19,39 & 13,24 & 9,91 & 6,69 \\
\hline 30 & 650 & 60 & 58,37 & 46,52 & 39,03 & 30,68 & 24,25 & 19,45 & 13,30 & 9,94 & 6,69 \\
\hline 30 & 700 & 60 & 56,94 & 45,80 & 38,63 & 30,54 & 24,25 & 19,51 & 13,36 & 9,97 & 6,69 \\
\hline 30 & 750 & 60 & 55,63 & 45,12 & 38,24 & 30,40 & 24,24 & 19,55 & 13,42 & 10,01 & 6,70 \\
\hline 30 & 800 & 60 & 54,44 & 44,49 & 37,87 & 30,27 & 24,23 & 19,60 & 13,48 & 10,04 & 6,70 \\
\hline 30 & 850 & 60 & 53,33 & 43,90 & 37,52 & 30,13 & 24,21 & 19,63 & 13,53 & 10,07 & 6,70 \\
\hline 30 & 900 & 60 & 52,31 & 43,34 & 37,18 & 29,99 & 24,18 & 19,66 & 13,58 & 10,10 & 6,71 \\
\hline 30 & 950 & 60 & 51,37 & 42,81 & 36,86 & 29,85 & 24,15 & 19,68 & 13,63 & 10,14 & 6,71 \\
\hline 30 & 1000 & 60 & 50,48 & 42,31 & 36,54 & 29,71 & 24,12 & 19,70 & 13,67 & 10,17 & 6,72 \\
\hline 30 & 1050 & 60 & 49,65 & 41,83 & 36,24 & 29,58 & 24,08 & 19,72 & 13,72 & 10,20 & 6,72 \\
\hline 30 & 1100 & 60 & 48,87 & 41,38 & 35,95 & 29,44 & 24,04 & 19,73 & 13,76 & 10,23 & 6,73 \\
\hline 30 & 1150 & 60 & 48,14 & 40,94 & 35,67 & 29,31 & 24,00 & 19,74 & 13,79 & 10,26 & 6,74 \\
\hline 30 & 1200 & 60 & 47,45 & 40,53 & 35,40 & 29,18 & 23,96 & 19,74 & 13,83 & 10,29 & 6,74 \\
\hline 30 & 1250 & 60 & 46,80 & 40,14 & 35,14 & 29,05 & 23,91 & 19,75 & 13,86 & 10,31 & 6,75 \\
\hline 30 & 1300 & 60 & 46,17 & 39,76 & 34,89 & 28,92 & 23,87 & 19,75 & 13,90 & 10,34 & 6,76 \\
\hline 30 & 1350 & 60 & 45,58 & 39,39 & 34,64 & 28,80 & 23,82 & 19,74 & 13,93 & 10,37 & 6,76 \\
\hline 30 & 1400 & 60 & 45,02 & 39,04 & 34,40 & 28,68 & 23,77 & 19,74 & 13,95 & 10,39 & 6,77 \\
\hline 30 & 1450 & 60 & 44,49 & 38,70 & 34,17 & 28,55 & 23,72 & 19,74 & 13,98 & 10,42 & 6,78 \\
\hline 30 & 1500 & 60 & 43,98 & 38,38 & 33,95 & 28,43 & 23,67 & 19,73 & 14,01 & 10,44 & 6,79 \\
\hline 30 & 1550 & 60 & 43,49 & 38,07 & 33,73 & 28,32 & 23,62 & 19,72 & 14,03 & 10,47 & 6,80 \\
\hline 30 & 1600 & 60 & 43,02 & 37,76 & 33,52 & 28,20 & 23,57 & 19,71 & 14,05 & 10,49 & 6,80 \\
\hline 30 & 1650 & 60 & 42,57 & 37,47 & 33,31 & 28,09 & 23,52 & 19,70 & 14,08 & 10,51 & 6,81 \\
\hline 30 & 1700 & 60 & 42,14 & 37,19 & 33,11 & 27,98 & 23,47 & 19,69 & 14,10 & 10,54 & 6,82 \\
\hline 30 & 1750 & 60 & 41,73 & 36,91 & 32,92 & 27,87 & 23,42 & 19,67 & 14,11 & 10,56 & 6,83 \\
\hline 30 & 1800 & 60 & 41,33 & 36,65 & 32,73 & 27,76 & 23,37 & 19,66 & 14,13 & 10,58 & 6,84 \\
\hline 30 & 1850 & 60 & 40,95 & 36,39 & 32,54 & 27,65 & 23,32 & 19,65 & 14,15 & 10,60 & 6,85 \\
\hline 30 & 1900 & 60 & 40,58 & 36,14 & 32,36 & 27,55 & 23,27 & 19,63 & 14,17 & 10,62 & 6,85 \\
\hline 30 & 1950 & 60 & 40,22 & 35,90 & 32,19 & 27,44 & 23,22 & 19,61 & 14,18 & 10,64 & 6,86 \\
\hline 30 & 2000 & 60 & 39,88 & 35,66 & 32,02 & 27,34 & 23,17 & 19,60 & 14,20 & 10,66 & 6,87 \\
\hline 30 & 200 & 65 & 83,06 & 53,48 & 40,29 & 28,70 & 21,50 & 16,87 & 11,61 & 8,92 & 6,21 \\
\hline 30 & 250 & 65 & 76,65 & 51,76 & 39,84 & 28,84 & 21,72 & 17,05 & 11,68 & 8,94 & 6,20 \\
\hline 30 & 300 & 65 & 71,91 & 50,30 & 39,37 & 28,90 & 21,90 & 17,21 & 11,75 & 8,96 & 6,19 \\
\hline 30 & 350 & 65 & 68,20 & 49,03 & 38,90 & 28,90 & 22,04 & 17,35 & 11,83 & 8,99 & 6,19 \\
\hline 30 & 400 & 65 & 65,17 & 47,90 & 38,45 & 28,87 & 22,14 & 17,47 & 11,90 & 9,01 & 6,18 \\
\hline 30 & 450 & 65 & 62,62 & 46,89 & 38,01 & 28,81 & 22,22 & 17,58 & 11,97 & 9,03 & 6,18 \\
\hline 30 & 500 & 65 & 60,44 & 45,98 & 37,58 & 28,73 & 22,28 & 17,67 & 12,03 & 9,06 & 6,18 \\
\hline
\end{tabular}




\begin{tabular}{|c|c|c|c|c|c|c|c|c|c|c|c|}
\hline \multirow[b]{2}{*}{$\mathrm{H}(\mathrm{cm})$} & \multirow[b]{2}{*}{ Mceq (MPa) } & & & & & $\mathrm{De}$ & ões (x1 & & & & \\
\hline & & Msub (MPa) & D0 & D25 & D40 & D60 & D80 & D100 & D140 & D180 & D260 \\
\hline 30 & 550 & 65 & 58,54 & 45,14 & 37,18 & 28,64 & 22,33 & 17,76 & 12,10 & 9,09 & 6,18 \\
\hline 30 & 600 & 65 & 56,86 & 44,37 & 36,79 & 28,54 & 22,36 & 17,83 & 12,16 & 9,12 & 6,18 \\
\hline 30 & 650 & 65 & 55,35 & 43,66 & 36,41 & 28,44 & 22,38 & 17,89 & 12,22 & 9,14 & 6,18 \\
\hline 30 & 700 & 65 & 53,99 & 42,99 & 36,05 & 28,33 & 22,39 & 17,95 & 12,27 & 9,17 & 6,18 \\
\hline 30 & 750 & 65 & 52,75 & 42,37 & 35,71 & 28,21 & 22,39 & 18,00 & 12,33 & 9,20 & 6,18 \\
\hline 30 & 800 & 65 & 51,62 & 41,79 & 35,38 & 28,09 & 22,38 & 18,04 & 12,38 & 9,23 & 6,18 \\
\hline 30 & 850 & 65 & 50,58 & 41,24 & 35,06 & 27,98 & 22,37 & 18,08 & 12,43 & 9,26 & 6,18 \\
\hline 30 & 900 & 65 & 49,61 & 40,73 & 34,76 & 27,86 & 22,35 & 18,11 & 12,47 & 9,29 & 6,19 \\
\hline 30 & 950 & 65 & 48,72 & 40,24 & 34,47 & 27,74 & 22,33 & 18,13 & 12,52 & 9,31 & 6,19 \\
\hline 30 & 1000 & 65 & 47,88 & 39,78 & 34,18 & 27,62 & 22,31 & 18,16 & 12,56 & 9,34 & 6,19 \\
\hline 30 & 1050 & 65 & 47,09 & 39,34 & 33,91 & 27,51 & 22,28 & 18,18 & 12,60 & 9,37 & 6,20 \\
\hline 30 & 1100 & 65 & 46,36 & 38,92 & 33,65 & 27,39 & 22,25 & 18,19 & 12,63 & 9,39 & 6,20 \\
\hline 30 & 1150 & 65 & 45,66 & 38,52 & 33,39 & 27,27 & 22,22 & 18,20 & 12,67 & 9,42 & 6,21 \\
\hline 30 & 1200 & 65 & 45,01 & 38,13 & 33,15 & 27,16 & 22,19 & 18,21 & 12,70 & 9,45 & 6,21 \\
\hline 30 & 1250 & 65 & 44,39 & 37,77 & 32,91 & 27,05 & 22,15 & 18,22 & 12,74 & 9,47 & 6,22 \\
\hline 30 & 1300 & 65 & 43,80 & 37,41 & 32,68 & 26,94 & 22,11 & 18,22 & 12,77 & 9,50 & 6,22 \\
\hline 30 & 1350 & 65 & 43,24 & 37,08 & 32,45 & 26,83 & 22,08 & 18,23 & 12,80 & 9,52 & 6,23 \\
\hline 30 & 1400 & 65 & 42,71 & 36,75 & 32,24 & 26,72 & 22,04 & 18,23 & 12,82 & 9,54 & 6,24 \\
\hline 30 & 1450 & 65 & 42,20 & 36,44 & 32,03 & 26,61 & 22,00 & 18,23 & 12,85 & 9,57 & 6,24 \\
\hline 30 & 1500 & 65 & 41,72 & 36,14 & 31,82 & 26,50 & 21,96 & 18,22 & 12,87 & 9,59 & 6,25 \\
\hline 30 & 1550 & 65 & 41,25 & 35,85 & 31,62 & 26,40 & 21,92 & 18,22 & 12,90 & 9,61 & 6,26 \\
\hline 30 & 1600 & 65 & 40,81 & 35,56 & 31,43 & 26,30 & 21,87 & 18,21 & 12,92 & 9,63 & 6,26 \\
\hline 30 & 1650 & 65 & 40,38 & 35,29 & 31,24 & 26,20 & 21,83 & 18,21 & 12,94 & 9,65 & 6,27 \\
\hline 30 & 1700 & 65 & 39,97 & 35,03 & 31,06 & 26,10 & 21,79 & 18,20 & 12,96 & 9,67 & 6,28 \\
\hline 30 & 1750 & 65 & 39,58 & 34,77 & 30,88 & 26,00 & 21,75 & 18,19 & 12,98 & 9,69 & 6,28 \\
\hline 30 & 1800 & 65 & 39,20 & 34,53 & 30,71 & 25,90 & 21,70 & 18,18 & 13,00 & 9,71 & 6,29 \\
\hline 30 & 1850 & 65 & 38,84 & 34,29 & 30,54 & 25,81 & 21,66 & 18,17 & 13,01 & 9,73 & 6,30 \\
\hline 30 & 1900 & 65 & 38,49 & 34,06 & 30,37 & 25,72 & 21,62 & 18,16 & 13,03 & 9,75 & 6,30 \\
\hline 30 & 1950 & 65 & 38,15 & 33,83 & 30,21 & 25,62 & 21,57 & 18,15 & 13,05 & 9,77 & 6,31 \\
\hline 30 & 2000 & 65 & 37,82 & 33,61 & 30,05 & 25,53 & 21,53 & 18,14 & 13,06 & 9,78 & 6,32 \\
\hline 30 & 200 & 70 & 79,26 & 50,18 & 37,52 & 26,59 & 19,89 & 15,61 & 10,76 & 8,28 & 5,77 \\
\hline 30 & 250 & 70 & 73,07 & 48,60 & 37,14 & 26,74 & 20,10 & 15,77 & 10,82 & 8,30 & 5,76 \\
\hline 30 & 300 & 70 & 68,52 & 47,26 & 36,74 & 26,82 & 20,27 & 15,92 & 10,89 & 8,31 & 5,75 \\
\hline 30 & 350 & 70 & 64,95 & 46,10 & 36,34 & 26,84 & 20,40 & 16,04 & 10,95 & 8,33 & 5,75 \\
\hline 30 & 400 & 70 & 62,05 & 45,06 & 35,94 & 26,83 & 20,51 & 16,16 & 11,01 & 8,35 & 5,74 \\
\hline 30 & 450 & 70 & 59,62 & 44,14 & 35,55 & 26,79 & 20,59 & 16,26 & 11,07 & 8,37 & 5,74 \\
\hline 30 & 500 & 70 & 57,54 & 43,29 & 35,18 & 26,73 & 20,65 & 16,35 & 11,13 & 8,40 & 5,74 \\
\hline 30 & 550 & 70 & 55,73 & 42,52 & 34,82 & 26,66 & 20,70 & 16,43 & 11,19 & 8,42 & 5,73 \\
\hline 30 & 600 & 70 & 54,12 & 41,81 & 34,47 & 26,58 & 20,74 & 16,50 & 11,24 & 8,44 & 5,73 \\
\hline 30 & 650 & 70 & 52,69 & 41,15 & 34,13 & 26,50 & 20,76 & 16,56 & 11,29 & 8,47 & 5,73 \\
\hline 30 & 700 & 70 & 51,40 & 40,54 & 33,81 & 26,40 & 20,78 & 16,62 & 11,35 & 8,49 & 5,73 \\
\hline 30 & 750 & 70 & 50,22 & 39,97 & 33,50 & 26,31 & 20,79 & 16,66 & 11,39 & 8,52 & 5,74 \\
\hline 30 & 800 & 70 & 49,14 & 39,43 & 33,20 & 26,21 & 20,79 & 16,71 & 11,44 & 8,54 & 5,74 \\
\hline 30 & 850 & 70 & 48,15 & 38,92 & 32,92 & 26,11 & 20,78 & 16,74 & 11,48 & 8,56 & 5,74 \\
\hline 30 & 900 & 70 & 47,23 & 38,44 & 32,64 & 26,01 & 20,78 & 16,78 & 11,53 & 8,59 & 5,74 \\
\hline 30 & 950 & 70 & 46,38 & 37,99 & 32,38 & 25,91 & 20,76 & 16,81 & 11,57 & 8,61 & 5,74 \\
\hline 30 & 1000 & 70 & 45,59 & 37,56 & 32,12 & 25,81 & 20,75 & 16,83 & 11,61 & 8,64 & 5,75 \\
\hline 30 & 1050 & 70 & 44,84 & 37,15 & 31,87 & 25,70 & 20,73 & 16,85 & 11,64 & 8,66 & 5,75 \\
\hline 30 & 1100 & 70 & 44,14 & 36,76 & 31,63 & 25,60 & 20,71 & 16,87 & 11,68 & 8,68 & 5,75 \\
\hline 30 & 1150 & 70 & 43,48 & 36,38 & 31,40 & 25,50 & 20,68 & 16,88 & 11,71 & 8,71 & 5,76 \\
\hline 30 & 1200 & 70 & 42,86 & 36,03 & 31,17 & 25,40 & 20,66 & 16,90 & 11,74 & 8,73 & 5,76 \\
\hline 30 & 1250 & 70 & 42,27 & 35,69 & 30,96 & 25,30 & 20,63 & 16,90 & 11,77 & 8,75 & 5,77 \\
\hline 30 & 1300 & 70 & 41,71 & 35,36 & 30,75 & 25,20 & 20,60 & 16,91 & 11,80 & 8,77 & 5,77 \\
\hline 30 & 1350 & 70 & 41,18 & 35,04 & 30,54 & 25,11 & 20,57 & 16,92 & 11,83 & 8,80 & 5,77 \\
\hline 30 & 1400 & 70 & 40,67 & 34,74 & 30,34 & 25,01 & 20,54 & 16,92 & 11,85 & 8,82 & 5,78 \\
\hline 30 & 1450 & 70 & 40,19 & 34,45 & 30,15 & 24,92 & 20,50 & 16,92 & 11,88 & 8,84 & 5,78 \\
\hline 30 & 1500 & 70 & 39,73 & 34,17 & 29,96 & 24,82 & 20,47 & 16,93 & 11,90 & 8,86 & 5,79 \\
\hline 30 & 1550 & 70 & 39,29 & 33,90 & 29,78 & 24,73 & 20,43 & 16,92 & 11,93 & 8,88 & 5,80 \\
\hline 30 & 1600 & 70 & 38,86 & 33,63 & 29,60 & 24,64 & 20,40 & 16,92 & 11,95 & 8,90 & 5,80 \\
\hline 30 & 1650 & 70 & 38,46 & 33,38 & 29,43 & 24,55 & 20,36 & 16,92 & 11,97 & 8,92 & 5,81 \\
\hline 30 & 1700 & 70 & 38,07 & 33,13 & 29,26 & 24,46 & 20,33 & 16,92 & 11,99 & 8,93 & 5,81 \\
\hline 30 & 1750 & 70 & 37,69 & 32,90 & 29,10 & 24,37 & 20,29 & 16,91 & 12,01 & 8,95 & 5,82 \\
\hline 30 & 1800 & 70 & 37,33 & 32,67 & 28,94 & 24,29 & 20,26 & 16,90 & 12,02 & 8,97 & 5,82 \\
\hline 30 & 1850 & 70 & 36,99 & 32,44 & 28,78 & 24,20 & 20,22 & 16,90 & 12,04 & 8,99 & 5,83 \\
\hline 30 & 1900 & 70 & 36,65 & 32,22 & 28,63 & 24,12 & 20,18 & 16,89 & 12,06 & 9,00 & 5,84 \\
\hline 30 & 1950 & 70 & 36,33 & 32,01 & 28,48 & 24,03 & 20,14 & 16,88 & 12,07 & 9,02 & 5,84 \\
\hline 30 & 2000 & 70 & 36,02 & 31,81 & 28,33 & 23,95 & 20,11 & 16,87 & 12,09 & 9,04 & 5,85 \\
\hline 30 & 200 & 75 & 75,91 & 47,28 & 35,10 & 24,77 & 18,50 & 14,53 & 10,02 & 7,73 & 5,39 \\
\hline 30 & 250 & 75 & 69,92 & 45,82 & 34,79 & 24,92 & 18,70 & 14,67 & 10,08 & 7,74 & 5,38 \\
\hline 30 & 300 & 75 & 65,51 & 44,59 & 34,44 & 25,01 & 18,86 & 14,80 & 10,14 & 7,75 & 5,37 \\
\hline 30 & 350 & 75 & 62,08 & 43,51 & 34,09 & 25,04 & 18,99 & 14,92 & 10,19 & 7,77 & 5,37 \\
\hline 30 & 400 & 75 & 59,30 & 42,56 & 33,74 & 25,05 & 19,09 & 15,03 & 10,25 & 7,79 & 5,36 \\
\hline 30 & 450 & 75 & 56,97 & 41,70 & 33,40 & 25,03 & 19,17 & 15,12 & 10,30 & 7,80 & 5,36 \\
\hline 30 & 500 & 75 & 54,97 & 40,92 & 33,06 & 24,99 & 19,24 & 15,21 & 10,35 & 7,82 & 5,36 \\
\hline 30 & 550 & 75 & 53,23 & 40,21 & 32,74 & 24,93 & 19,29 & 15,28 & 10,40 & 7,84 & 5,35 \\
\hline 30 & 600 & 75 & 51,70 & 39,55 & 32,43 & 24,87 & 19,33 & 15,35 & 10,45 & 7,86 & 5,35 \\
\hline 30 & 650 & 75 & 50,33 & 38,94 & 32,13 & 24,80 & 19,36 & 15,41 & 10,50 & 7,88 & 5,35 \\
\hline 30 & 700 & 75 & 49,09 & 38,37 & 31,84 & 24,72 & 19,38 & 15,46 & 10,55 & 7,90 & 5,35 \\
\hline 30 & 750 & 75 & 47,97 & 37,84 & 31,56 & 24,64 & 19,39 & 15,51 & 10,59 & 7,92 & 5,35 \\
\hline 30 & 800 & 75 & 46,94 & 37,34 & 31,29 & 24,56 & 19,40 & 15,55 & 10,63 & 7,95 & 5,35 \\
\hline 30 & 850 & 75 & 46,00 & 36,86 & 31,03 & 24,48 & 19,40 & 15,59 & 10,67 & 7,97 & 5,35 \\
\hline
\end{tabular}




\begin{tabular}{|c|c|c|c|c|c|c|c|c|c|c|c|}
\hline \multirow[b]{2}{*}{$\mathrm{H}(\mathrm{cm})$} & \multirow[b]{2}{*}{ Mceq (MPa) } & & & & & $\mathrm{De}$ & ões (x1 & & & & \\
\hline & & Msub (MPa) & D0 & D25 & D40 & D60 & D80 & D100 & D140 & D180 & D260 \\
\hline 30 & 900 & 75 & 45,12 & 36,42 & 30,78 & 24,39 & 19,40 & 15,62 & 10,71 & 7,99 & 5,36 \\
\hline 30 & 950 & 75 & 44,31 & 35,99 & 30,53 & 24,30 & 19,39 & 15,65 & 10,75 & 8,01 & 5,36 \\
\hline 30 & 1000 & 75 & 43,55 & 35,59 & 30,30 & 24,21 & 19,38 & 15,68 & 10,78 & 8,03 & 5,36 \\
\hline 30 & 1050 & 75 & 42,84 & 35,21 & 30,07 & 24,12 & 19,37 & 15,70 & 10,82 & 8,05 & 5,36 \\
\hline 30 & 1100 & 75 & 42,17 & 34,85 & 29,85 & 24,04 & 19,35 & 15,72 & 10,85 & 8,07 & 5,36 \\
\hline 30 & 1150 & 75 & 41,54 & 34,50 & 29,64 & 23,95 & 19,34 & 15,73 & 10,88 & 8,09 & 5,37 \\
\hline 30 & 1200 & 75 & 40,95 & 34,17 & 29,43 & 23,86 & 19,32 & 15,75 & 10,91 & 8,11 & 5,37 \\
\hline 30 & 1250 & 75 & 40,39 & 33,85 & 29,24 & 23,77 & 19,29 & 15,76 & 10,94 & 8,13 & 5,37 \\
\hline 30 & 1300 & 75 & 39,85 & 33,54 & 29,04 & 23,68 & 19,27 & 15,77 & 10,97 & 8,15 & 5,38 \\
\hline 30 & 1350 & 75 & 39,34 & 33,25 & 28,85 & 23,60 & 19,25 & 15,78 & 10,99 & 8,17 & 5,38 \\
\hline 30 & 1400 & 75 & 38,86 & 32,96 & 28,67 & 23,51 & 19,22 & 15,79 & 11,02 & 8,19 & 5,39 \\
\hline 30 & 1450 & 75 & 38,40 & 32,69 & 28,49 & 23,43 & 19,19 & 15,79 & 11,04 & 8,21 & 5,39 \\
\hline 30 & 1500 & 75 & 37,96 & 32,43 & 28,32 & 23,34 & 19,17 & 15,79 & 11,06 & 8,23 & 5,39 \\
\hline 30 & 1550 & 75 & 37,54 & 32,17 & 28,15 & 23,26 & 19,14 & 15,80 & 11,09 & 8,25 & 5,40 \\
\hline 30 & 1600 & 75 & 37,14 & 31,92 & 27,99 & 23,18 & 19,11 & 15,80 & 11,11 & 8,26 & 5,40 \\
\hline 30 & 1650 & 75 & 36,75 & 31,69 & 27,83 & 23,10 & 19,08 & 15,80 & 11,13 & 8,28 & 5,41 \\
\hline 30 & 1700 & 75 & 36,38 & 31,46 & 27,67 & 23,02 & 19,05 & 15,80 & 11,15 & 8,30 & 5,41 \\
\hline 30 & 1750 & 75 & 36,02 & 31,23 & 27,52 & 22,94 & 19,02 & 15,79 & 11,16 & 8,32 & 5,42 \\
\hline 30 & 1800 & 75 & 35,67 & 31,02 & 27,37 & 22,86 & 18,99 & 15,79 & 11,18 & 8,33 & 5,42 \\
\hline 30 & 1850 & 75 & 35,34 & 30,81 & 27,23 & 22,79 & 18,95 & 15,79 & 11,20 & 8,35 & 5,43 \\
\hline 30 & 1900 & 75 & 35,02 & 30,60 & 27,09 & 22,71 & 18,92 & 15,78 & 11,21 & 8,36 & 5,43 \\
\hline 30 & 1950 & 75 & 34,71 & 30,40 & 26,95 & 22,64 & 18,89 & 15,77 & 11,23 & 8,38 & 5,44 \\
\hline 30 & 2000 & 75 & 34,42 & 30,21 & 26,82 & 22,56 & 18,86 & 15,77 & 11,24 & 8,39 & 5,44 \\
\hline 30 & 200 & 80 & 72,93 & 44,71 & 32,97 & 23,17 & 17,29 & 13,58 & 9,38 & 7,24 & 5,06 \\
\hline 30 & 250 & 80 & 67,10 & 43,36 & 32,71 & 23,33 & 17,48 & 13,71 & 9,43 & 7,25 & 5,05 \\
\hline 30 & 300 & 80 & 62,84 & 42,22 & 32,41 & 23,42 & 17,63 & 13,83 & 9,48 & 7,26 & 5,04 \\
\hline 30 & 350 & 80 & 59,52 & 41,22 & 32,11 & 23,47 & 17,75 & 13,94 & 9,53 & 7,28 & 5,03 \\
\hline 30 & 400 & 80 & 56,83 & 40,34 & 31,80 & 23,48 & 17,85 & 14,04 & 9,58 & 7,29 & 5,03 \\
\hline 30 & 450 & 80 & 54,59 & 39,54 & 31,49 & 23,48 & 17,93 & 14,13 & 9,63 & 7,31 & 5,02 \\
\hline 30 & 500 & 80 & 52,67 & 38,81 & 31,19 & 23,45 & 18,00 & 14,21 & 9,67 & 7,32 & 5,02 \\
\hline 30 & 550 & 80 & 51,00 & 38,15 & 30,90 & 23,41 & 18,05 & 14,28 & 9,72 & 7,34 & 5,02 \\
\hline 30 & 600 & 80 & 49,53 & 37,54 & 30,62 & 23,36 & 18,09 & 14,34 & 9,76 & 7,36 & 5,02 \\
\hline 30 & 650 & 80 & 48,22 & 36,97 & 30,35 & 23,30 & 18,13 & 14,40 & 9,81 & 7,37 & 5,02 \\
\hline 30 & 700 & 80 & 47,03 & 36,44 & 30,09 & 23,24 & 18,15 & 14,45 & 9,85 & 7,39 & 5,02 \\
\hline 30 & 750 & 80 & 45,96 & 35,94 & 29,83 & 23,17 & 18,17 & 14,50 & 9,89 & 7,41 & 5,02 \\
\hline 30 & 800 & 80 & 44,97 & 35,47 & 29,59 & 23,10 & 18,18 & 14,54 & 9,93 & 7,43 & 5,02 \\
\hline 30 & 850 & 80 & 44,07 & 35,03 & 29,35 & 23,03 & 18,19 & 14,58 & 9,96 & 7,45 & 5,02 \\
\hline 30 & 900 & 80 & 43,23 & 34,61 & 29,12 & 22,96 & 18,19 & 14,61 & 10,00 & 7,47 & 5,02 \\
\hline 30 & 950 & 80 & 42,45 & 34,22 & 28,90 & 22,88 & 18,19 & 14,64 & 10,03 & 7,49 & 5,02 \\
\hline 30 & 1000 & 80 & 41,72 & 33,84 & 28,68 & 22,80 & 18,18 & 14,67 & 10,07 & 7,50 & 5,02 \\
\hline 30 & 1050 & 80 & 41,04 & 33,48 & 28,47 & 22,73 & 18,18 & 14,69 & 10,10 & 7,52 & 5,02 \\
\hline 30 & 1100 & 80 & 40,41 & 33,14 & 28,27 & 22,65 & 18,16 & 14,71 & 10,13 & 7,54 & 5,03 \\
\hline 30 & 1150 & 80 & 39,80 & 32,82 & 28,08 & 22,57 & 18,15 & 14,73 & 10,16 & 7,56 & 5,03 \\
\hline 30 & 1200 & 80 & 39,24 & 32,50 & 27,89 & 22,49 & 18,14 & 14,74 & 10,19 & 7,58 & 5,03 \\
\hline 30 & 1250 & 80 & 38,70 & 32,20 & 27,70 & 22,41 & 18,12 & 14,76 & 10,21 & 7,60 & 5,03 \\
\hline 30 & 1300 & 80 & 38,19 & 31,92 & 27,52 & 22,34 & 18,10 & 14,77 & 10,24 & 7,61 & 5,04 \\
\hline 30 & 1350 & 80 & 37,70 & 31,64 & 27,35 & 22,26 & 18,08 & 14,78 & 10,26 & 7,63 & 5,04 \\
\hline 30 & 1400 & 80 & 37,24 & 31,37 & 27,18 & 22,18 & 18,06 & 14,79 & 10,29 & 7,65 & 5,04 \\
\hline 30 & 1450 & 80 & 36,80 & 31,12 & 27,02 & 22,11 & 18,04 & 14,79 & 10,31 & 7,67 & 5,05 \\
\hline 30 & 1500 & 80 & 36,38 & 30,87 & 26,86 & 22,03 & 18,02 & 14,80 & 10,33 & 7,68 & 5,05 \\
\hline 30 & 1550 & 80 & 35,97 & 30,63 & 26,70 & 21,96 & 17,99 & 14,80 & 10,35 & 7,70 & 5,05 \\
\hline 30 & 1600 & 80 & 35,59 & 30,40 & 26,55 & 21,89 & 17,97 & 14,81 & 10,37 & 7,71 & 5,06 \\
\hline 30 & 1650 & 80 & 35,22 & 30,17 & 26,40 & 21,81 & 17,94 & 14,81 & 10,39 & 7,73 & 5,06 \\
\hline 30 & 1700 & 80 & 34,86 & 29,96 & 26,26 & 21,74 & 17,92 & 14,81 & 10,41 & 7,75 & 5,07 \\
\hline 30 & 1750 & 80 & 34,52 & 29,75 & 26,12 & 21,67 & 17,89 & 14,81 & 10,43 & 7,76 & 5,07 \\
\hline 30 & 1800 & 80 & 34,19 & 29,54 & 25,98 & 21,60 & 17,86 & 14,81 & 10,44 & 7,78 & 5,07 \\
\hline 30 & 1850 & 80 & 33,87 & 29,35 & 25,85 & 21,53 & 17,84 & 14,81 & 10,46 & 7,79 & 5,08 \\
\hline 30 & 1900 & 80 & 33,56 & 29,15 & 25,71 & 21,46 & 17,81 & 14,80 & 10,48 & 7,81 & 5,08 \\
\hline 30 & 1950 & 80 & 33,27 & 28,97 & 25,59 & 21,39 & 17,78 & 14,80 & 10,49 & 7,82 & 5,09 \\
\hline 30 & 2000 & 80 & 32,98 & 28,78 & 25,46 & 21,33 & 17,76 & 14,80 & 10,51 & 7,83 & 5,09 \\
\hline 30 & 200 & 85 & 70,26 & 42,42 & 31,09 & 21,76 & 16,23 & 12,75 & 8,82 & 6,81 & 4,76 \\
\hline 30 & 250 & 85 & 64,58 & 41,16 & 30,86 & 21,92 & 16,40 & 12,87 & 8,86 & 6,82 & 4,75 \\
\hline 30 & 300 & 85 & 60,43 & 40,09 & 30,61 & 22,02 & 16,55 & 12,98 & 8,91 & 6,83 & 4,74 \\
\hline 30 & 350 & 85 & 57,22 & 39,17 & 30,34 & 22,07 & 16,66 & 13,08 & 8,95 & 6,84 & 4,74 \\
\hline 30 & 400 & 85 & 54,62 & 38,34 & 30,06 & 22,10 & 16,76 & 13,17 & 9,00 & 6,86 & 4,73 \\
\hline 30 & 450 & 85 & 52,45 & 37,60 & 29,79 & 22,10 & 16,84 & 13,25 & 9,04 & 6,87 & 4,73 \\
\hline 30 & 500 & 85 & 50,60 & 36,93 & 29,52 & 22,09 & 16,91 & 13,33 & 9,08 & 6,88 & 4,73 \\
\hline 30 & 550 & 85 & 48,99 & 36,30 & 29,26 & 22,06 & 16,96 & 13,40 & 9,12 & 6,90 & 4,73 \\
\hline 30 & 600 & 85 & 47,58 & 35,73 & 29,01 & 22,02 & 17,00 & 13,46 & 9,16 & 6,91 & 4,72 \\
\hline 30 & 650 & 85 & 46,31 & 35,20 & 28,76 & 21,97 & 17,04 & 13,51 & 9,20 & 6,93 & 4,72 \\
\hline 30 & 700 & 85 & 45,17 & 34,70 & 28,52 & 21,92 & 17,07 & 13,56 & 9,24 & 6,94 & 4,72 \\
\hline 30 & 750 & 85 & 44,14 & 34,24 & 28,29 & 21,87 & 17,09 & 13,61 & 9,27 & 6,96 & 4,72 \\
\hline 30 & 800 & 85 & 43,20 & 33,80 & 28,06 & 21,81 & 17,10 & 13,65 & 9,31 & 6,98 & 4,72 \\
\hline 30 & 850 & 85 & 42,33 & 33,38 & 27,84 & 21,75 & 17,11 & 13,68 & 9,34 & 6,99 & 4,72 \\
\hline 30 & 900 & 85 & 41,52 & 32,99 & 27,63 & 21,68 & 17,12 & 13,72 & 9,38 & 7,01 & 4,72 \\
\hline 30 & 950 & 85 & 40,78 & 32,62 & 27,43 & 21,61 & 17,12 & 13,75 & 9,41 & 7,03 & 4,72 \\
\hline 30 & 1000 & 85 & 40,08 & 32,27 & 27,23 & 21,55 & 17,12 & 13,77 & 9,44 & 7,04 & 4,73 \\
\hline 30 & 1050 & 85 & 39,43 & 31,93 & 27,04 & 21,48 & 17,11 & 13,80 & 9,47 & 7,06 & 4,73 \\
\hline 30 & 1100 & 85 & 38,81 & 31,61 & 26,86 & 21,41 & 17,11 & 13,82 & 9,50 & 7,08 & 4,73 \\
\hline 30 & 1150 & 85 & 38,24 & 31,31 & 26,67 & 21,34 & 17,10 & 13,84 & 9,52 & 7,09 & 4,73 \\
\hline 30 & 1200 & 85 & 37,69 & 31,01 & 26,50 & 21,27 & 17,09 & 13,86 & 9,55 & 7,11 & 4,73 \\
\hline
\end{tabular}




\begin{tabular}{|c|c|c|c|c|c|c|c|c|c|c|c|}
\hline \multirow[b]{2}{*}{$\mathrm{H}(\mathrm{cm})$} & \multirow[b]{2}{*}{ Mceq (MPa) } & & & & & De & ões (x1 & m) & & & \\
\hline & & Msub (MPa) & D0 & D25 & D40 & D60 & D80 & D100 & D140 & D180 & D260 \\
\hline 30 & 1250 & 85 & 37,18 & 30,73 & 26,33 & 21,20 & 17,08 & 13,87 & 9,58 & 7,12 & 4,73 \\
\hline 30 & 1300 & 85 & 36,69 & 30,46 & 26,16 & 21,13 & 17,06 & 13,88 & 9,60 & 7,14 & 4,74 \\
\hline 30 & 1350 & 85 & 36,22 & 30,20 & 26,00 & 21,07 & 17,05 & 13,89 & 9,62 & 7,16 & 4,74 \\
\hline 30 & 1400 & 85 & 35,78 & 29,95 & 25,85 & 21,00 & 17,03 & 13,90 & 9,65 & 7,17 & 4,74 \\
\hline 30 & 1450 & 85 & 35,35 & 29,70 & 25,69 & 20,93 & 17,01 & 13,91 & 9,67 & 7,19 & 4,74 \\
\hline 30 & 1500 & 85 & 34,95 & 29,47 & 25,55 & 20,86 & 16,99 & 13,92 & 9,69 & 7,20 & 4,75 \\
\hline 30 & 1550 & 85 & 34,56 & 29,24 & 25,40 & 20,79 & 16,97 & 13,93 & 9,71 & 7,22 & 4,75 \\
\hline 30 & 1600 & 85 & 34,19 & 29,03 & 25,26 & 20,73 & 16,95 & 13,93 & 9,73 & 7,23 & 4,75 \\
\hline 30 & 1650 & 85 & 33,84 & 28,82 & 25,12 & 20,66 & 16,93 & 13,93 & 9,74 & 7,25 & 4,76 \\
\hline 30 & 1700 & 85 & 33,49 & 28,61 & 24,99 & 20,60 & 16,91 & 13,94 & 9,76 & 7,26 & 4,76 \\
\hline 30 & 1750 & 85 & 33,17 & 28,41 & 24,86 & 20,53 & 16,89 & 13,94 & 9,78 & 7,27 & 4,76 \\
\hline 30 & 1800 & 85 & 32,85 & 28,22 & 24,73 & 20,47 & 16,87 & 13,94 & 9,80 & 7,29 & 4,77 \\
\hline 30 & 1850 & 85 & 32,54 & 28,03 & 24,60 & 20,41 & 16,84 & 13,94 & 9,81 & 7,30 & 4,77 \\
\hline 30 & 1900 & 85 & 32,25 & 27,85 & 24,48 & 20,34 & 16,82 & 13,94 & 9,83 & 7,32 & 4,77 \\
\hline 30 & 1950 & 85 & 31,96 & 27,67 & 24,36 & 20,28 & 16,80 & 13,94 & 9,84 & 7,33 & 4,78 \\
\hline 30 & 2000 & 85 & 31,69 & 27,50 & 24,25 & 20,22 & 16,77 & 13,93 & 9,86 & 7,34 & 4,78 \\
\hline 30 & 200 & 90 & 67,85 & 40,36 & 29,40 & 20,50 & 15,29 & 12,02 & 8,32 & 6,43 & 4,50 \\
\hline 30 & 250 & 90 & 62,30 & 39,18 & 29,21 & 20,67 & 15,45 & 12,13 & 8,36 & 6,44 & 4,49 \\
\hline 30 & 300 & 90 & 58,26 & 38,19 & 28,99 & 20,77 & 15,59 & 12,23 & 8,40 & 6,45 & 4,48 \\
\hline 30 & 350 & 90 & 55,14 & 37,32 & 28,75 & 20,83 & 15,70 & 12,32 & 8,44 & 6,46 & 4,48 \\
\hline 30 & 400 & 90 & 52,62 & 36,55 & 28,51 & 20,86 & 15,79 & 12,40 & 8,48 & 6,47 & 4,47 \\
\hline 30 & 450 & 90 & 50,52 & 35,85 & 28,26 & 20,87 & 15,87 & 12,48 & 8,52 & 6,48 & 4,47 \\
\hline 30 & 500 & 90 & 48,73 & 35,22 & 28,02 & 20,87 & 15,93 & 12,55 & 8,55 & 6,49 & 4,47 \\
\hline 30 & 550 & 90 & 47,18 & 34,64 & 27,79 & 20,85 & 15,99 & 12,61 & 8,59 & 6,51 & 4,46 \\
\hline 30 & 600 & 90 & 45,81 & 34,10 & 27,55 & 20,82 & 16,03 & 12,67 & 8,63 & 6,52 & 4,46 \\
\hline 30 & 650 & 90 & 44,59 & 33,60 & 27,33 & 20,79 & 16,07 & 12,72 & 8,66 & 6,53 & 4,46 \\
\hline 30 & 700 & 90 & 43,49 & 33,14 & 27,11 & 20,74 & 16,10 & 12,77 & 8,70 & 6,55 & 4,46 \\
\hline 30 & 750 & 90 & 42,50 & 32,70 & 26,90 & 20,70 & 16,12 & 12,82 & 8,73 & 6,56 & 4,46 \\
\hline 30 & 800 & 90 & 41,59 & 32,29 & 26,69 & 20,65 & 16,14 & 12,86 & 8,76 & 6,57 & 4,46 \\
\hline 30 & 850 & 90 & 40,75 & 31,90 & 26,49 & 20,59 & 16,15 & 12,89 & 8,79 & 6,59 & 4,46 \\
\hline 30 & 900 & 90 & 39,97 & 31,53 & 26,30 & 20,54 & 16,16 & 12,92 & 8,82 & 6,60 & 4,46 \\
\hline 30 & 950 & 90 & 39,26 & 31,18 & 26,11 & 20,48 & 16,17 & 12,95 & 8,85 & 6,62 & 4,46 \\
\hline 30 & 1000 & 90 & 38,59 & 30,85 & 25,93 & 20,42 & 16,17 & 12,98 & 8,88 & 6,63 & 4,46 \\
\hline 30 & 1050 & 90 & 37,96 & 30,53 & 25,75 & 20,36 & 16,17 & 13,00 & 8,91 & 6,65 & 4,46 \\
\hline 30 & 1100 & 90 & 37,37 & 30,23 & 25,58 & 20,30 & 16,17 & 13,03 & 8,94 & 6,66 & 4,46 \\
\hline 30 & 1150 & 90 & 36,81 & 29,94 & 25,41 & 20,24 & 16,16 & 13,05 & 8,96 & 6,68 & 4,46 \\
\hline 30 & 1200 & 90 & 36,29 & 29,66 & 25,25 & 20,18 & 16,15 & 13,06 & 8,99 & 6,69 & 4,47 \\
\hline 30 & 1250 & 90 & 35,79 & 29,39 & 25,09 & 20,12 & 16,14 & 13,08 & 9,01 & 6,71 & 4,47 \\
\hline 30 & 1300 & 90 & 35,32 & 29,14 & 24,94 & 20,05 & 16,13 & 13,09 & 9,03 & 6,72 & 4,47 \\
\hline 30 & 1350 & 90 & 34,88 & 28,89 & 24,79 & 19,99 & 16,12 & 13,11 & 9,05 & 6,74 & 4,47 \\
\hline 30 & 1400 & 90 & 34,45 & 28,66 & 24,64 & 19,93 & 16,11 & 13,12 & 9,08 & 6,75 & 4,47 \\
\hline 30 & 1450 & 90 & 34,04 & 28,43 & 24,50 & 19,87 & 16,09 & 13,13 & 9,10 & 6,76 & 4,48 \\
\hline 30 & 1500 & 90 & 33,65 & 28,21 & 24,36 & 19,81 & 16,08 & 13,13 & 9,12 & 6,78 & 4,48 \\
\hline 30 & 1550 & 90 & 33,28 & 27,99 & 24,23 & 19,75 & 16,06 & 13,14 & 9,14 & 6,79 & 4,48 \\
\hline 30 & 1600 & 90 & 32,93 & 27,79 & 24,10 & 19,69 & 16,05 & 13,15 & 9,15 & 6,81 & 4,48 \\
\hline 30 & 1650 & 90 & 32,58 & 27,59 & 23,97 & 19,63 & 16,03 & 13,15 & 9,17 & 6,82 & 4,49 \\
\hline 30 & 1700 & 90 & 32,25 & 27,39 & 23,84 & 19,57 & 16,01 & 13,16 & 9,19 & 6,83 & 4,49 \\
\hline 30 & 1750 & 90 & 31,94 & 27,20 & 23,72 & 19,51 & 15,99 & 13,16 & 9,20 & 6,84 & 4,49 \\
\hline 30 & 1800 & 90 & 31,63 & 27,02 & 23,60 & 19,45 & 15,97 & 13,16 & 9,22 & 6,86 & 4,50 \\
\hline 30 & 1850 & 90 & 31,34 & 26,84 & 23,48 & 19,40 & 15,95 & 13,16 & 9,24 & 6,87 & 4,50 \\
\hline 30 & 1900 & 90 & 31,06 & 26,67 & 23,37 & 19,34 & 15,93 & 13,16 & 9,25 & 6,88 & 4,50 \\
\hline 30 & 1950 & 90 & 30,78 & 26,50 & 23,26 & 19,28 & 15,91 & 13,16 & 9,26 & 6,89 & 4,50 \\
\hline 30 & 2000 & 90 & 30,52 & 26,34 & 23,15 & 19,23 & 15,89 & 13,16 & 9,28 & 6,91 & 4,51 \\
\hline 30 & 200 & 95 & 65,66 & 38,50 & 27,88 & 19,38 & 14,44 & 11,36 & 7,87 & 6,09 & 4,27 \\
\hline 30 & 250 & 95 & 60,23 & 37,39 & 27,72 & 19,54 & 14,60 & 11,46 & 7,91 & 6,10 & 4,26 \\
\hline 30 & 300 & 95 & 56,29 & 36,46 & 27,53 & 19,65 & 14,73 & 11,55 & 7,95 & 6,11 & 4,25 \\
\hline 30 & 350 & 95 & 53,25 & 35,65 & 27,32 & 19,72 & 14,83 & 11,64 & 7,98 & 6,12 & 4,24 \\
\hline 30 & 400 & 95 & 50,80 & 34,92 & 27,11 & 19,76 & 14,92 & 11,72 & 8,02 & 6,13 & 4,24 \\
\hline 30 & 450 & 95 & 48,76 & 34,27 & 26,89 & 19,77 & 15,00 & 11,79 & 8,05 & 6,13 & 4,24 \\
\hline 30 & 500 & 95 & 47,03 & 33,68 & 26,67 & 19,77 & 15,06 & 11,85 & 8,08 & 6,15 & 4,23 \\
\hline 30 & 550 & 95 & 45,52 & 33,13 & 26,45 & 19,76 & 15,12 & 11,92 & 8,12 & 6,16 & 4,23 \\
\hline 30 & 600 & 95 & 44,20 & 32,63 & 26,24 & 19,74 & 15,16 & 11,97 & 8,15 & 6,17 & 4,23 \\
\hline 30 & 650 & 95 & 43,02 & 32,16 & 26,04 & 19,72 & 15,20 & 12,02 & 8,18 & 6,18 & 4,23 \\
\hline 30 & 700 & 95 & 41,96 & 31,72 & 25,84 & 19,68 & 15,23 & 12,07 & 8,21 & 6,19 & 4,23 \\
\hline 30 & 750 & 95 & 41,00 & 31,30 & 25,64 & 19,64 & 15,26 & 12,11 & 8,25 & 6,20 & 4,23 \\
\hline 30 & 800 & 95 & 40,12 & 30,92 & 25,45 & 19,60 & 15,28 & 12,15 & 8,28 & 6,22 & 4,23 \\
\hline 30 & 850 & 95 & 39,31 & 30,55 & 25,27 & 19,55 & 15,29 & 12,18 & 8,30 & 6,23 & 4,23 \\
\hline 30 & 900 & 95 & 38,56 & 30,20 & 25,09 & 19,51 & 15,30 & 12,21 & 8,33 & 6,24 & 4,23 \\
\hline 30 & 950 & 95 & 37,87 & 29,87 & 24,91 & 19,46 & 15,31 & 12,24 & 8,36 & 6,26 & 4,23 \\
\hline 30 & 1000 & 95 & 37,22 & 29,56 & 24,74 & 19,40 & 15,32 & 12,27 & 8,39 & 6,27 & 4,23 \\
\hline 30 & 1050 & 95 & 36,62 & 29,26 & 24,58 & 19,35 & 15,32 & 12,29 & 8,41 & 6,28 & 4,23 \\
\hline 30 & 1100 & 95 & 36,05 & 28,97 & 24,42 & 19,30 & 15,32 & 12,32 & 8,44 & 6,30 & 4,23 \\
\hline 30 & 1150 & 95 & 35,52 & 28,70 & 24,27 & 19,24 & 15,32 & 12,34 & 8,46 & 6,31 & 4,23 \\
\hline 30 & 1200 & 95 & 35,01 & 28,43 & 24,12 & 19,19 & 15,31 & 12,35 & 8,48 & 6,32 & 4,23 \\
\hline 30 & 1250 & 95 & 34,53 & 28,18 & 23,97 & 19,13 & 15,31 & 12,37 & 8,51 & 6,34 & 4,23 \\
\hline 30 & 1300 & 95 & 34,08 & 27,94 & 23,83 & 19,08 & 15,30 & 12,39 & 8,53 & 6,35 & 4,23 \\
\hline 30 & 1350 & 95 & 33,65 & 27,71 & 23,69 & 19,02 & 15,29 & 12,40 & 8,55 & 6,36 & 4,23 \\
\hline 30 & 1400 & 95 & 33,24 & 27,48 & 23,55 & 18,97 & 15,28 & 12,41 & 8,57 & 6,38 & 4,24 \\
\hline 30 & 1450 & 95 & 32,85 & 27,26 & 23,42 & 18,91 & 15,27 & 12,42 & 8,59 & 6,39 & 4,24 \\
\hline 30 & 1500 & 95 & 32,47 & 27,05 & 23,29 & 18,86 & 15,26 & 12,43 & 8,61 & 6,40 & 4,24 \\
\hline 30 & 1550 & 95 & 32,11 & 26,85 & 23,16 & 18,80 & 15,24 & 12,44 & 8,62 & 6,41 & 4,24 \\
\hline
\end{tabular}




\begin{tabular}{|c|c|c|c|c|c|c|c|c|c|c|c|}
\hline \multirow[b]{2}{*}{$\mathrm{H}(\mathrm{cm})$} & \multirow[b]{2}{*}{ Mceq (MPa) } & & & & & $\mathrm{De}$ & ões (x1 & & & & \\
\hline & & Msub (MPa) & D0 & D25 & D40 & D60 & D80 & D100 & D140 & D180 & D260 \\
\hline 30 & 1600 & 95 & 31,77 & 26,66 & 23,04 & 18,75 & 15,23 & 12,45 & 8,64 & 6,43 & 4,24 \\
\hline 30 & 1650 & 95 & 31,44 & 26,47 & 22,92 & 18,69 & 15,21 & 12,45 & 8,66 & 6,44 & 4,25 \\
\hline 30 & 1700 & 95 & 31,12 & 26,28 & 22,80 & 18,64 & 15,20 & 12,46 & 8,68 & 6,45 & 4,25 \\
\hline 30 & 1750 & 95 & 30,82 & 26,10 & 22,69 & 18,59 & 15,18 & 12,46 & 8,69 & 6,46 & 4,25 \\
\hline 30 & 1800 & 95 & 30,52 & 25,93 & 22,58 & 18,53 & 15,17 & 12,46 & 8,71 & 6,47 & 4,25 \\
\hline 30 & 1850 & 95 & 30,24 & 25,76 & 22,47 & 18,48 & 15,15 & 12,47 & 8,72 & 6,49 & 4,26 \\
\hline 30 & 1900 & 95 & 29,97 & 25,60 & 22,36 & 18,43 & 15,13 & 12,47 & 8,73 & 6,50 & 4,26 \\
\hline 30 & 1950 & 95 & 29,70 & 25,44 & 22,25 & 18,38 & 15,11 & 12,47 & 8,75 & 6,51 & 4,26 \\
\hline 30 & 2000 & 95 & 29,45 & 25,28 & 22,15 & 18,33 & 15,10 & 12,47 & 8,76 & 6,52 & 4,26 \\
\hline 30 & 200 & 100 & 63,67 & 36,82 & 26,51 & 18,37 & 13,69 & 10,78 & 7,47 & 5,78 & 4,06 \\
\hline 30 & 250 & 100 & 58,34 & 35,77 & 26,38 & 18,53 & 13,83 & 10,87 & 7,51 & 5,79 & 4,05 \\
\hline 30 & 300 & 100 & 54,49 & 34,89 & 26,21 & 18,64 & 13,96 & 10,95 & 7,54 & 5,80 & 4,04 \\
\hline 30 & 350 & 100 & 51,52 & 34,12 & 26,03 & 18,71 & 14,06 & 11,03 & 7,57 & 5,81 & 4,03 \\
\hline 30 & 400 & 100 & 49,14 & 33,44 & 25,83 & 18,76 & 14,15 & 11,10 & 7,60 & 5,82 & 4,03 \\
\hline 30 & 450 & 100 & 47,15 & 32,83 & 25,64 & 18,78 & 14,22 & 11,17 & 7,63 & 5,82 & 4,03 \\
\hline 30 & 500 & 100 & 45,47 & 32,27 & 25,44 & 18,79 & 14,28 & 11,23 & 7,66 & 5,83 & 4,02 \\
\hline 30 & 550 & 100 & 44,01 & 31,75 & 25,24 & 18,78 & 14,34 & 11,29 & 7,69 & 5,84 & 4,02 \\
\hline 30 & 600 & 100 & 42,72 & 31,28 & 25,05 & 18,77 & 14,38 & 11,34 & 7,72 & 5,85 & 4,02 \\
\hline 30 & 650 & 100 & 41,58 & 30,83 & 24,86 & 18,75 & 14,42 & 11,39 & 7,75 & 5,86 & 4,02 \\
\hline 30 & 700 & 100 & 40,55 & 30,42 & 24,68 & 18,72 & 14,45 & 11,43 & 7,78 & 5,87 & 4,02 \\
\hline 30 & 750 & 100 & 39,62 & 30,03 & 24,50 & 18,69 & 14,48 & 11,47 & 7,81 & 5,89 & 4,01 \\
\hline 30 & 800 & 100 & 38,77 & 29,66 & 24,32 & 18,65 & 14,50 & 11,51 & 7,84 & 5,90 & 4,01 \\
\hline 30 & 850 & 100 & 37,99 & 29,32 & 24,15 & 18,61 & 14,51 & 11,55 & 7,87 & 5,91 & 4,01 \\
\hline 30 & 900 & 100 & 37,27 & 28,99 & 23,99 & 18,57 & 14,53 & 11,58 & 7,89 & 5,92 & 4,01 \\
\hline 30 & 950 & 100 & 36,60 & 28,67 & 23,82 & 18,53 & 14,54 & 11,61 & 7,92 & 5,93 & 4,01 \\
\hline 30 & 1000 & 100 & 35,98 & 28,38 & 23,67 & 18,48 & 14,54 & 11,63 & 7,94 & 5,94 & 4,01 \\
\hline 30 & 1050 & 100 & 35,39 & 28,09 & 23,52 & 18,44 & 14,55 & 11,66 & 7,97 & 5,96 & 4,01 \\
\hline 30 & 1100 & 100 & 34,84 & 27,82 & 23,37 & 18,39 & 14,55 & 11,68 & 7,99 & 5,97 & 4,02 \\
\hline 30 & 1150 & 100 & 34,33 & 27,56 & 23,22 & 18,34 & 14,55 & 11,70 & 8,01 & 5,98 & 4,02 \\
\hline 30 & 1200 & 100 & 33,84 & 27,31 & 23,08 & 18,29 & 14,55 & 11,72 & 8,03 & 5,99 & 4,02 \\
\hline 30 & 1250 & 100 & 33,38 & 27,07 & 22,95 & 18,24 & 14,55 & 11,73 & 8,05 & 6,00 & 4,02 \\
\hline 30 & 1300 & 100 & 32,94 & 26,84 & 22,81 & 18,19 & 14,54 & 11,75 & 8,07 & 6,02 & 4,02 \\
\hline 30 & 1350 & 100 & 32,53 & 26,62 & 22,68 & 18,14 & 14,54 & 11,76 & 8,09 & 6,03 & 4,02 \\
\hline 30 & 1400 & 100 & 32,13 & 26,41 & 22,55 & 18,09 & 14,53 & 11,77 & 8,11 & 6,04 & 4,02 \\
\hline 30 & 1450 & 100 & 31,75 & 26,20 & 22,43 & 18,04 & 14,52 & 11,79 & 8,13 & 6,05 & 4,02 \\
\hline 30 & 1500 & 100 & 31,39 & 26,00 & 22,31 & 17,99 & 14,51 & 11,80 & 8,15 & 6,06 & 4,02 \\
\hline 30 & 1550 & 100 & 31,04 & 25,81 & 22,19 & 17,94 & 14,50 & 11,80 & 8,17 & 6,07 & 4,03 \\
\hline 30 & 1600 & 100 & 30,71 & 25,62 & 22,08 & 17,89 & 14,49 & 11,81 & 8,18 & 6,09 & 4,03 \\
\hline 30 & 1650 & 100 & 30,39 & 25,44 & 21,96 & 17,84 & 14,48 & 11,82 & 8,20 & 6,10 & 4,03 \\
\hline 30 & 1700 & 100 & 30,09 & 25,27 & 21,85 & 17,80 & 14,46 & 11,82 & 8,21 & 6,11 & 4,03 \\
\hline 30 & 1750 & 100 & 29,79 & 25,10 & 21,75 & 17,75 & 14,45 & 11,83 & 8,23 & 6,12 & 4,03 \\
\hline 30 & 1800 & 100 & 29,51 & 24,93 & 21,64 & 17,70 & 14,44 & 11,83 & 8,24 & 6,13 & 4,04 \\
\hline 30 & 1850 & 100 & 29,23 & 24,77 & 21,54 & 17,65 & 14,42 & 11,84 & 8,26 & 6,14 & 4,04 \\
\hline 30 & 1900 & 100 & 28,97 & 24,62 & 21,44 & 17,60 & 14,41 & 11,84 & 8,27 & 6,15 & 4,04 \\
\hline 30 & 1950 & 100 & 28,72 & 24,47 & 21,34 & 17,55 & 14,39 & 11,84 & 8,29 & 6,16 & 4,04 \\
\hline 30 & 2000 & 100 & 28,47 & 24,32 & 21,24 & 17,51 & 14,37 & 11,85 & 8,30 & 6,17 & 4,05 \\
\hline 30 & 200 & 105 & 61,85 & 35,28 & 25,26 & 17,46 & 13,01 & 10,25 & 7,11 & 5,51 & 3,87 \\
\hline 30 & 250 & 105 & 56,62 & 34,29 & 25,16 & 17,62 & 13,15 & 10,33 & 7,14 & 5,52 & 3,86 \\
\hline 30 & 300 & 105 & 52,84 & 33,45 & 25,01 & 17,73 & 13,26 & 10,41 & 7,17 & 5,52 & 3,85 \\
\hline 30 & 350 & 105 & 49,94 & 32,73 & 24,85 & 17,80 & 13,36 & 10,48 & 7,20 & 5,53 & 3,84 \\
\hline 30 & 400 & 105 & 47,61 & 32,09 & 24,67 & 17,85 & 13,44 & 10,55 & 7,23 & 5,54 & 3,84 \\
\hline 30 & 450 & 105 & 45,68 & 31,51 & 24,50 & 17,88 & 13,51 & 10,61 & 7,26 & 5,54 & 3,84 \\
\hline 30 & 500 & 105 & 44,04 & 30,98 & 24,32 & 17,89 & 13,58 & 10,67 & 7,29 & 5,55 & 3,83 \\
\hline 30 & 550 & 105 & 42,62 & 30,49 & 24,14 & 17,89 & 13,63 & 10,72 & 7,31 & 5,56 & 3,83 \\
\hline 30 & 600 & 105 & 41,37 & 30,04 & 23,96 & 17,88 & 13,67 & 10,77 & 7,34 & 5,57 & 3,83 \\
\hline 30 & 650 & 105 & 40,26 & 29,62 & 23,79 & 17,87 & 13,71 & 10,82 & 7,37 & 5,58 & 3,83 \\
\hline 30 & 700 & 105 & 39,26 & 29,23 & 23,62 & 17,85 & 13,74 & 10,86 & 7,39 & 5,59 & 3,83 \\
\hline 30 & 750 & 105 & 38,36 & 28,86 & 23,45 & 17,82 & 13,77 & 10,90 & 7,42 & 5,60 & 3,82 \\
\hline 30 & 800 & 105 & 37,54 & 28,51 & 23,29 & 17,79 & 13,79 & 10,94 & 7,45 & 5,61 & 3,82 \\
\hline 30 & 850 & 105 & 36,78 & 28,19 & 23,13 & 17,76 & 13,81 & 10,97 & 7,47 & 5,62 & 3,82 \\
\hline 30 & 900 & 105 & 36,08 & 27,87 & 22,98 & 17,72 & 13,83 & 11,00 & 7,49 & 5,63 & 3,82 \\
\hline 30 & 950 & 105 & 35,43 & 27,58 & 22,83 & 17,68 & 13,84 & 11,03 & 7,52 & 5,64 & 3,82 \\
\hline 30 & 1000 & 105 & 34,83 & 27,30 & 22,68 & 17,64 & 13,85 & 11,05 & 7,54 & 5,65 & 3,82 \\
\hline 30 & 1050 & 105 & 34,26 & 27,03 & 22,54 & 17,60 & 13,85 & 11,08 & 7,56 & 5,66 & 3,82 \\
\hline 30 & 1100 & 105 & 33,73 & 26,77 & 22,40 & 17,56 & 13,86 & 11,10 & 7,59 & 5,67 & 3,82 \\
\hline 30 & 1150 & 105 & 33,23 & 26,52 & 22,27 & 17,52 & 13,86 & 11,12 & 7,61 & 5,68 & 3,82 \\
\hline 30 & 1200 & 105 & 32,76 & 26,28 & 22,14 & 17,47 & 13,86 & 11,14 & 7,63 & 5,69 & 3,82 \\
\hline 30 & 1250 & 105 & 32,32 & 26,06 & 22,01 & 17,43 & 13,86 & 11,16 & 7,65 & 5,70 & 3,83 \\
\hline 30 & 1300 & 105 & 31,89 & 25,84 & 21,88 & 17,38 & 13,85 & 11,17 & 7,67 & 5,72 & 3,83 \\
\hline 30 & 1350 & 105 & 31,49 & 25,63 & 21,76 & 17,34 & 13,85 & 11,18 & 7,68 & 5,73 & 3,83 \\
\hline 30 & 1400 & 105 & 31,11 & 25,42 & 21,64 & 17,29 & 13,85 & 11,20 & 7,70 & 5,74 & 3,83 \\
\hline 30 & 1450 & 105 & 30,74 & 25,23 & 21,53 & 17,25 & 13,84 & 11,21 & 7,72 & 5,75 & 3,83 \\
\hline 30 & 1500 & 105 & 30,39 & 25,04 & 21,41 & 17,20 & 13,83 & 11,22 & 7,74 & 5,76 & 3,83 \\
\hline 30 & 1550 & 105 & 30,06 & 24,85 & 21,30 & 17,16 & 13,82 & 11,23 & 7,75 & 5,77 & 3,83 \\
\hline 30 & 1600 & 105 & 29,74 & 24,68 & 21,19 & 17,11 & 13,81 & 11,24 & 7,77 & 5,78 & 3,83 \\
\hline 30 & 1650 & 105 & 29,43 & 24,50 & 21,09 & 17,07 & 13,80 & 11,25 & 7,78 & 5,79 & 3,84 \\
\hline 30 & 1700 & 105 & 29,13 & 24,34 & 20,98 & 17,02 & 13,79 & 11,25 & 7,80 & 5,80 & 3,84 \\
\hline 30 & 1750 & 105 & 28,85 & 24,18 & 20,88 & 16,98 & 13,78 & 11,26 & 7,81 & 5,81 & 3,84 \\
\hline 30 & 1800 & 105 & 28,57 & 24,02 & 20,78 & 16,93 & 13,77 & 11,26 & 7,83 & 5,82 & 3,84 \\
\hline 30 & 1850 & 105 & 28,31 & 23,87 & 20,69 & 16,89 & 13,76 & 11,27 & 7,84 & 5,83 & 3,84 \\
\hline 30 & 1900 & 105 & 28,05 & 23,72 & 20,59 & 16,85 & 13,75 & 11,27 & 7,85 & 5,84 & 3,84 \\
\hline
\end{tabular}




\begin{tabular}{|c|c|c|c|c|c|c|c|c|c|c|c|}
\hline \multirow[b]{2}{*}{$\mathrm{H}(\mathrm{cm})$} & \multirow[b]{2}{*}{ Mceq (MPa) } & & & & & $\mathrm{De}$ & ões (x1 & & & & \\
\hline & & Msub (MPa) & D0 & D25 & D40 & D60 & D80 & D100 & D140 & D180 & D260 \\
\hline 30 & 1950 & 105 & 27,81 & 23,57 & 20,50 & 16,80 & 13,73 & 11,28 & 7,87 & 5,85 & 3,85 \\
\hline 30 & 2000 & 105 & 27,57 & 23,43 & 20,41 & 16,76 & 13,72 & 11,28 & 7,88 & 5,86 & 3,85 \\
\hline 30 & 200 & 110 & 60,18 & 33,87 & 24,13 & 16,63 & 12,39 & 9,77 & 6,78 & 5,26 & 3,69 \\
\hline 30 & 250 & 110 & 55,03 & 32,93 & 24,04 & 16,79 & 12,52 & 9,84 & 6,81 & 5,26 & 3,68 \\
\hline 30 & 300 & 110 & 51,32 & 32,14 & 23,92 & 16,90 & 12,63 & 9,91 & 6,84 & 5,27 & 3,68 \\
\hline 30 & 350 & 110 & 48,48 & 31,45 & 23,77 & 16,97 & 12,72 & 9,98 & 6,86 & 5,28 & 3,67 \\
\hline 30 & 400 & 110 & 46,20 & 30,85 & 23,61 & 17,02 & 12,80 & 10,05 & 6,89 & 5,28 & 3,67 \\
\hline 30 & 450 & 110 & 44,32 & 30,30 & 23,45 & 17,06 & 12,87 & 10,10 & 6,92 & 5,29 & 3,66 \\
\hline 30 & 500 & 110 & 42,72 & 29,80 & 23,29 & 17,07 & 12,93 & 10,16 & 6,94 & 5,30 & 3,66 \\
\hline 30 & 550 & 110 & 41,33 & 29,33 & 23,13 & 17,08 & 12,98 & 10,21 & 6,97 & 5,30 & 3,66 \\
\hline 30 & 600 & 110 & 40,12 & 28,91 & 22,96 & 17,08 & 13,03 & 10,26 & 6,99 & 5,31 & 3,66 \\
\hline 30 & 650 & 110 & 39,04 & 28,51 & 22,80 & 17,07 & 13,07 & 10,30 & 7,02 & 5,32 & 3,65 \\
\hline 30 & 700 & 110 & 38,07 & 28,14 & 22,65 & 17,05 & 13,10 & 10,34 & 7,04 & 5,33 & 3,65 \\
\hline 30 & 750 & 110 & 37,20 & 27,79 & 22,49 & 17,03 & 13,13 & 10,38 & 7,07 & 5,34 & 3,65 \\
\hline 30 & 800 & 110 & 36,40 & 27,46 & 22,34 & 17,00 & 13,15 & 10,41 & 7,09 & 5,35 & 3,65 \\
\hline 30 & 850 & 110 & 35,66 & 27,15 & 22,20 & 16,98 & 13,17 & 10,45 & 7,11 & 5,35 & 3,65 \\
\hline 30 & 900 & 110 & 34,98 & 26,85 & 22,05 & 16,94 & 13,19 & 10,48 & 7,14 & 5,36 & 3,65 \\
\hline 30 & 950 & 110 & 34,35 & 26,57 & 21,91 & 16,91 & 13,20 & 10,50 & 7,16 & 5,37 & 3,65 \\
\hline 30 & 1000 & 110 & 33,77 & 26,30 & 21,78 & 16,88 & 13,21 & 10,53 & 7,18 & 5,38 & 3,65 \\
\hline 30 & 1050 & 110 & 33,22 & 26,04 & 21,65 & 16,84 & 13,22 & 10,55 & 7,20 & 5,39 & 3,65 \\
\hline 30 & 1100 & 110 & 32,71 & 25,80 & 21,52 & 16,80 & 13,22 & 10,57 & 7,22 & 5,40 & 3,65 \\
\hline 30 & 1150 & 110 & 32,22 & 25,56 & 21,39 & 16,76 & 13,23 & 10,59 & 7,24 & 5,41 & 3,65 \\
\hline 30 & 1200 & 110 & 31,77 & 25,34 & 21,27 & 16,73 & 13,23 & 10,61 & 7,26 & 5,42 & 3,65 \\
\hline 30 & 1250 & 110 & 31,33 & 25,12 & 21,15 & 16,69 & 13,23 & 10,63 & 7,28 & 5,43 & 3,65 \\
\hline 30 & 1300 & 110 & 30,92 & 24,91 & 21,03 & 16,65 & 13,23 & 10,65 & 7,30 & 5,44 & 3,65 \\
\hline 30 & 1350 & 110 & 30,53 & 24,71 & 20,92 & 16,60 & 13,23 & 10,66 & 7,31 & 5,45 & 3,65 \\
\hline 30 & 1400 & 110 & 30,16 & 24,52 & 20,80 & 16,56 & 13,22 & 10,67 & 7,33 & 5,46 & 3,65 \\
\hline 30 & 1450 & 110 & 29,81 & 24,33 & 20,69 & 16,52 & 13,22 & 10,68 & 7,35 & 5,47 & 3,65 \\
\hline 30 & 1500 & 110 & 29,47 & 24,15 & 20,59 & 16,48 & 13,21 & 10,70 & 7,36 & 5,48 & 3,66 \\
\hline 30 & 1550 & 110 & 29,14 & 23,97 & 20,48 & 16,44 & 13,21 & 10,71 & 7,38 & 5,49 & 3,66 \\
\hline 30 & 1600 & 110 & 28,83 & 23,80 & 20,38 & 16,40 & 13,20 & 10,71 & 7,39 & 5,50 & 3,66 \\
\hline 30 & 1650 & 110 & 28,54 & 23,64 & 20,28 & 16,36 & 13,19 & 10,72 & 7,41 & 5,51 & 3,66 \\
\hline 30 & 1700 & 110 & 28,25 & 23,48 & 20,18 & 16,32 & 13,18 & 10,73 & 7,42 & 5,52 & 3,66 \\
\hline 30 & 1750 & 110 & 27,97 & 23,33 & 20,09 & 16,28 & 13,17 & 10,74 & 7,44 & 5,53 & 3,66 \\
\hline 30 & 1800 & 110 & 27,71 & 23,17 & 19,99 & 16,23 & 13,16 & 10,74 & 7,45 & 5,54 & 3,66 \\
\hline 30 & 1850 & 110 & 27,45 & 23,03 & 19,90 & 16,19 & 13,15 & 10,75 & 7,46 & 5,55 & 3,67 \\
\hline 30 & 1900 & 110 & 27,20 & 22,89 & 19,81 & 16,15 & 13,14 & 10,75 & 7,48 & 5,56 & 3,67 \\
\hline 30 & 1950 & 110 & 26,97 & 22,75 & 19,72 & 16,11 & 13,13 & 10,76 & 7,49 & 5,57 & 3,67 \\
\hline 30 & 2000 & 110 & 26,73 & 22,61 & 19,64 & 16,07 & 13,12 & 10,76 & 7,50 & 5,58 & 3,67 \\
\hline 30 & 200 & 115 & 58,63 & 32,58 & 23,08 & 15,88 & 11,83 & 9,33 & 6,48 & 5,03 & 3,54 \\
\hline 30 & 250 & 115 & 53,56 & 31,68 & 23,02 & 16,03 & 11,95 & 9,40 & 6,51 & 5,03 & 3,52 \\
\hline 30 & 300 & 115 & 49,92 & 30,93 & 22,91 & 16,14 & 12,05 & 9,47 & 6,53 & 5,04 & 3,52 \\
\hline 30 & 350 & 115 & 47,13 & 30,28 & 22,78 & 16,22 & 12,14 & 9,53 & 6,56 & 5,04 & 3,51 \\
\hline 30 & 400 & 115 & 44,90 & 29,70 & 22,64 & 16,27 & 12,22 & 9,59 & 6,58 & 5,05 & 3,51 \\
\hline 30 & 450 & 115 & 43,06 & 29,18 & 22,49 & 16,30 & 12,29 & 9,64 & 6,61 & 5,06 & 3,50 \\
\hline 30 & 500 & 115 & 41,50 & 28,70 & 22,34 & 16,33 & 12,35 & 9,70 & 6,63 & 5,06 & 3,50 \\
\hline 30 & 550 & 115 & 40,15 & 28,27 & 22,19 & 16,34 & 12,40 & 9,74 & 6,65 & 5,07 & 3,50 \\
\hline 30 & 600 & 115 & 38,96 & 27,86 & 22,05 & 16,34 & 12,44 & 9,79 & 6,68 & 5,08 & 3,50 \\
\hline 30 & 650 & 115 & 37,91 & 27,48 & 21,90 & 16,33 & 12,48 & 9,83 & 6,70 & 5,08 & 3,50 \\
\hline 30 & 700 & 115 & 36,97 & 27,13 & 21,75 & 16,32 & 12,51 & 9,87 & 6,72 & 5,09 & 3,49 \\
\hline 30 & 750 & 115 & 36,12 & 26,80 & 21,61 & 16,30 & 12,54 & 9,91 & 6,74 & 5,10 & 3,49 \\
\hline 30 & 800 & 115 & 35,34 & 26,48 & 21,47 & 16,28 & 12,56 & 9,94 & 6,77 & 5,11 & 3,49 \\
\hline 30 & 850 & 115 & 34,63 & 26,18 & 21,34 & 16,26 & 12,58 & 9,97 & 6,79 & 5,12 & 3,49 \\
\hline 30 & 900 & 115 & 33,97 & 25,90 & 21,20 & 16,23 & 12,60 & 10,00 & 6,81 & 5,12 & 3,49 \\
\hline 30 & 950 & 115 & 33,36 & 25,63 & 21,07 & 16,20 & 12,61 & 10,03 & 6,83 & 5,13 & 3,49 \\
\hline 30 & 1000 & 115 & 32,79 & 25,38 & 20,94 & 16,17 & 12,63 & 10,05 & 6,85 & 5,14 & 3,49 \\
\hline 30 & 1050 & 115 & 32,25 & 25,13 & 20,82 & 16,14 & 12,64 & 10,07 & 6,87 & 5,15 & 3,49 \\
\hline 30 & 1100 & 115 & 31,75 & 24,90 & 20,70 & 16,11 & 12,64 & 10,09 & 6,89 & 5,16 & 3,49 \\
\hline 30 & 1150 & 115 & 31,28 & 24,68 & 20,58 & 16,07 & 12,65 & 10,11 & 6,91 & 5,17 & 3,49 \\
\hline 30 & 1200 & 115 & 30,84 & 24,46 & 20,47 & 16,04 & 12,65 & 10,13 & 6,92 & 5,18 & 3,49 \\
\hline 30 & 1250 & 115 & 30,42 & 24,25 & 20,35 & 16,00 & 12,65 & 10,15 & 6,94 & 5,19 & 3,49 \\
\hline 30 & 1300 & 115 & 30,02 & 24,05 & 20,24 & 15,97 & 12,65 & 10,17 & 6,96 & 5,20 & 3,49 \\
\hline 30 & 1350 & 115 & 29,65 & 23,86 & 20,13 & 15,93 & 12,65 & 10,18 & 6,98 & 5,20 & 3,49 \\
\hline 30 & 1400 & 115 & 29,28 & 23,68 & 20,03 & 15,89 & 12,65 & 10,19 & 6,99 & 5,21 & 3,49 \\
\hline 30 & 1450 & 115 & 28,94 & 23,50 & 19,93 & 15,85 & 12,65 & 10,21 & 7,01 & 5,22 & 3,49 \\
\hline 30 & 1500 & 115 & 28,61 & 23,33 & 19,83 & 15,82 & 12,64 & 10,22 & 7,02 & 5,23 & 3,49 \\
\hline 30 & 1550 & 115 & 28,30 & 23,16 & 19,73 & 15,78 & 12,64 & 10,23 & 7,04 & 5,24 & 3,50 \\
\hline 30 & 1600 & 115 & 28,00 & 23,00 & 19,63 & 15,74 & 12,63 & 10,24 & 7,05 & 5,25 & 3,50 \\
\hline 30 & 1650 & 115 & 27,71 & 22,84 & 19,54 & 15,70 & 12,63 & 10,25 & 7,07 & 5,26 & 3,50 \\
\hline 30 & 1700 & 115 & 27,43 & 22,69 & 19,45 & 15,66 & 12,62 & 10,25 & 7,08 & 5,27 & 3,50 \\
\hline 30 & 1750 & 115 & 27,16 & 22,54 & 19,35 & 15,63 & 12,61 & 10,26 & 7,09 & 5,28 & 3,50 \\
\hline 30 & 1800 & 115 & 26,90 & 22,39 & 19,27 & 15,59 & 12,60 & 10,27 & 7,11 & 5,29 & 3,50 \\
\hline 30 & 1850 & 115 & 26,66 & 22,25 & 19,18 & 15,55 & 12,60 & 10,27 & 7,12 & 5,29 & 3,50 \\
\hline 30 & 1900 & 115 & 26,42 & 22,12 & 19,09 & 15,52 & 12,59 & 10,28 & 7.13 & 5,30 & 3,50 \\
\hline 30 & 1950 & 115 & 26,18 & 21,99 & 19,01 & 15,48 & 12,58 & 10,28 & 7,14 & 5,31 & 3,51 \\
\hline 30 & 2000 & 115 & 25,96 & 21,86 & 18,93 & 15,44 & 12,57 & 10,29 & 7,15 & 5,32 & 3,51 \\
\hline 30 & 200 & 120 & 57,21 & 31,38 & 22,13 & 15,18 & 11,31 & 8,93 & 6,21 & 4,82 & 3,39 \\
\hline 30 & 250 & 120 & 52,20 & 30,52 & 22,08 & 15,34 & 11,43 & 8,99 & 6,23 & 4,82 & 3,38 \\
\hline 30 & 300 & 120 & 48,62 & 29,81 & 21,98 & 15,45 & 11,53 & 9,06 & 6,26 & 4,83 & 3,37 \\
\hline 30 & 350 & 120 & 45,88 & 29,19 & 21,87 & 15,52 & 11,61 & 9,11 & 6,28 & 4,83 & 3,37 \\
\hline 30 & 400 & 120 & 43,70 & 28,64 & 21,74 & 15,58 & 11,69 & 9,17 & 6,30 & 4,84 & 3,36 \\
\hline
\end{tabular}




\begin{tabular}{|c|c|c|c|c|c|c|c|c|c|c|c|}
\hline \multirow[b]{2}{*}{$\mathrm{H}(\mathrm{cm})$} & \multirow[b]{2}{*}{ Mceq (MPa) } & & & & & $\mathrm{De}$ & ões (x1 & & & & \\
\hline & & Msub (MPa) & D0 & D25 & D40 & D60 & D80 & D100 & D140 & D180 & D260 \\
\hline 30 & 450 & 120 & 41,89 & 28,14 & 21,61 & 15,61 & 11,75 & 9,22 & 6,32 & 4,84 & 3,36 \\
\hline 30 & 500 & 120 & 40,36 & 27,69 & 21,47 & 15,64 & 11,81 & 9,27 & 6,34 & 4,85 & 3,36 \\
\hline 30 & 550 & 120 & 39,05 & 27,28 & 21,34 & 15,65 & 11,86 & 9,32 & 6,37 & 4,85 & 3,35 \\
\hline 30 & 600 & 120 & 37,89 & 26,89 & 21,20 & 15,66 & 11,90 & 9,36 & 6,39 & 4,86 & 3,35 \\
\hline 30 & 650 & 120 & 36,86 & 26,53 & 21,06 & 15,65 & 11,94 & 9,40 & 6,41 & 4,87 & 3,35 \\
\hline 30 & 700 & 120 & 35,95 & 26,19 & 20,93 & 15,65 & 11,97 & 9,44 & 6,43 & 4,87 & 3,35 \\
\hline 30 & 750 & 120 & 35,11 & 25,88 & 20,80 & 15,63 & 12,00 & 9,47 & 6,45 & 4,88 & 3,35 \\
\hline 30 & 800 & 120 & 34,36 & 25,58 & 20,67 & 15,62 & 12,02 & 9,50 & 6,47 & 4,89 & 3,35 \\
\hline 30 & 850 & 120 & 33,66 & 25,29 & 20,54 & 15,60 & 12,05 & 9,53 & 6,49 & 4,90 & 3,35 \\
\hline 30 & 900 & 120 & 33,02 & 25,02 & 20,41 & 15,57 & 12,06 & 9,56 & 6,51 & 4,90 & 3,35 \\
\hline 30 & 950 & 120 & 32,43 & 24,77 & 20,29 & 15,55 & 12,08 & 9,59 & 6,53 & 4,91 & 3,35 \\
\hline 30 & 1000 & 120 & 31,87 & 24,52 & 20,17 & 15,52 & 12,09 & 9,61 & 6,55 & 4,92 & 3,35 \\
\hline 30 & 1050 & 120 & 31,35 & 24,29 & 20,06 & 15,49 & 12,10 & 9,63 & 6,57 & 4,93 & 3,34 \\
\hline 30 & 1100 & 120 & 30,87 & 24,07 & 19,94 & 15,47 & 12,11 & 9,66 & 6,58 & 4,94 & 3,34 \\
\hline 30 & 1150 & 120 & 30,41 & 23,85 & 19,83 & 15,43 & 12,12 & 9,67 & 6,60 & 4,94 & 3,34 \\
\hline 30 & 1200 & 120 & 29,98 & 23,65 & 19,72 & 15,40 & 12,12 & 9,69 & 6,62 & 4,95 & 3,35 \\
\hline 30 & 1250 & 120 & 29,57 & 23,45 & 19,62 & 15,37 & 12,12 & 9,71 & 6,63 & 4,96 & 3,35 \\
\hline 30 & 1300 & 120 & 29,19 & 23,26 & 19,51 & 15,34 & 12,13 & 9,73 & 6,65 & 4,97 & 3,35 \\
\hline 30 & 1350 & 120 & 28,82 & 23,08 & 19,41 & 15,30 & 12,13 & 9,74 & 6,67 & 4,98 & 3,35 \\
\hline 30 & 1400 & 120 & 28,47 & 22,90 & 19,31 & 15,27 & 12,13 & 9,75 & 6,68 & 4,99 & 3,35 \\
\hline 30 & 1450 & 120 & 28,14 & 22,73 & 19,22 & 15,24 & 12,12 & 9,77 & 6,70 & 4,99 & 3,35 \\
\hline 30 & 1500 & 120 & 27,82 & 22,56 & 19,12 & 15,20 & 12,12 & 9,78 & 6,71 & 5,00 & 3,35 \\
\hline 30 & 1550 & 120 & 27,51 & 22,40 & 19,03 & 15,17 & 12,12 & 9,79 & 6,73 & 5,01 & 3,35 \\
\hline 30 & 1600 & 120 & 27,22 & 22,25 & 18,94 & 15,13 & 12,11 & 9,80 & 6,74 & 5,02 & 3,35 \\
\hline 30 & 1650 & 120 & 26,94 & 22,10 & 18,85 & 15,10 & 12,11 & 9,81 & 6,75 & 5,03 & 3,35 \\
\hline 30 & 1700 & 120 & 26,67 & 21,95 & 18,76 & 15,06 & 12,10 & 9,81 & 6,77 & 5,04 & 3,35 \\
\hline 30 & 1750 & 120 & 26,41 & 21,81 & 18,68 & 15,03 & 12,10 & 9,82 & 6,78 & 5,04 & 3,35 \\
\hline 30 & 1800 & 120 & 26,16 & 21,67 & 18,59 & 14,99 & 12,09 & 9,83 & $\begin{array}{c}6,79 \\
\end{array}$ & 5,05 & 3,35 \\
\hline 30 & 1850 & 120 & 25,92 & 21,54 & 18,51 & 14,96 & 12,08 & 9,84 & 6,80 & 5,06 & 3,36 \\
\hline 30 & 1900 & 120 & 25,68 & 21,40 & 18,43 & 14,93 & 12,08 & 9,84 & 6,81 & 5,07 & 3,36 \\
\hline 30 & 1950 & 120 & 25,46 & 21,28 & 18,35 & 14,89 & 12,07 & 9,85 & 6,83 & 5,08 & 3,36 \\
\hline 30 & 2000 & 120 & 25,24 & 21,15 & 18,27 & 14,86 & 12,06 & 9,85 & 6,84 & 5,08 & 3,36 \\
\hline 30 & 200 & 125 & 55,88 & 30,28 & 21,24 & 14,55 & 10,84 & 8,56 & 5,95 & 4,62 & 3,26 \\
\hline 30 & 250 & 125 & 50,94 & 29,45 & 21,21 & 14,70 & 10,95 & 8,62 & 5,98 & 4,63 & 3,25 \\
\hline 30 & 300 & 125 & 47,41 & 28,77 & 21,13 & 14,81 & 11,05 & 8,68 & 6,00 & 4,63 & 3,24 \\
\hline 30 & 350 & 125 & 44,72 & 28,18 & 21,03 & 14,88 & 11,13 & 8,73 & 6,02 & 4,64 & 3,23 \\
\hline 30 & 400 & 125 & 42,57 & 27,66 & 20,91 & 14,94 & 11,20 & 8,79 & 6,04 & 4,64 & 3,23 \\
\hline 30 & 450 & 125 & 40,80 & 27,18 & 20,79 & 14,98 & 11,26 & 8,84 & 6,06 & 4,65 & 3,23 \\
\hline 30 & 500 & 125 & 39,31 & 26,75 & 20,67 & 15,00 & 11,32 & 8,88 & 6,08 & 4,65 & 3,22 \\
\hline 30 & 550 & 125 & 38,02 & 26,36 & 20,54 & 15,02 & 11,36 & 8,93 & 6,10 & 4,66 & 3,22 \\
\hline 30 & 600 & 125 & 36,89 & 25,99 & 20,41 & 15,03 & 11,41 & 8,97 & 6,12 & 4,66 & 3,22 \\
\hline 30 & 650 & 125 & 35,89 & 25,65 & 20,29 & 15,03 & 11,44 & 9,00 & 6,14 & 4,67 & 3,22 \\
\hline 30 & 700 & 125 & 34,99 & 25,32 & 20,16 & 15,02 & 11,48 & 9,04 & 6,16 & 4,68 & 3,22 \\
\hline 30 & 750 & 125 & 34,18 & 25,02 & 20,04 & 15,02 & 11,50 & 9,07 & 6,18 & 4,68 & 3,21 \\
\hline 30 & 800 & 125 & 33,44 & 24,74 & 19,92 & 15,00 & 11,53 & 9,10 & 6,20 & 4,69 & 3,21 \\
\hline 30 & 850 & 125 & 32,76 & 24,47 & 19,80 & 14,99 & 11,55 & 9,13 & 6,22 & 4,70 & 3,21 \\
\hline 30 & 900 & 125 & 32,14 & 24,21 & 19,68 & 14,97 & 11,57 & 9,16 & 6,24 & 4,70 & 3,21 \\
\hline 30 & 950 & 125 & 31,56 & 23,96 & 19,57 & 14,95 & 11,58 & 9,19 & 6,25 & 4,71 & 3,21 \\
\hline 30 & 1000 & 125 & 31,02 & 23,73 & 19,46 & 14,92 & 11,60 & 9,21 & 6,27 & 4,72 & 3,21 \\
\hline 30 & 1050 & 125 & 30,52 & 23,51 & 19,35 & 14,90 & 11,61 & 9,23 & 6,29 & 4,72 & 3,21 \\
\hline 30 & 1100 & 125 & 30,04 & 23,29 & 19,24 & 14,87 & 11,62 & 9,25 & 6,31 & 4,73 & 3,21 \\
\hline 30 & 1150 & 125 & 29,60 & 23,09 & 19,14 & 14,84 & 11,63 & 9,27 & 6,32 & 4,74 & 3,21 \\
\hline 30 & 1200 & 125 & 29,18 & 22,89 & 19,03 & 14,82 & 11,63 & 9,29 & 6,34 & 4,75 & 3,21 \\
\hline 30 & 1250 & 125 & 28,78 & 22,70 & 18,93 & 14,79 & 11,64 & 9,31 & 6,35 & 4,75 & 3,21 \\
\hline 30 & 1300 & 125 & 28,41 & 22,52 & 18,84 & 14,76 & 11,64 & 9,32 & 6,37 & 4,76 & 3,21 \\
\hline 30 & 1350 & 125 & 28,05 & 22,34 & 18,74 & 14,73 & 11,64 & 9,34 & 6,38 & 4,77 & 3,21 \\
\hline 30 & 1400 & 125 & 27,71 & 22,17 & 18,65 & 14,70 & 11,64 & 9,35 & 6,40 & 4,78 & 3,21 \\
\hline 30 & 1450 & 125 & 27,38 & 22,01 & 18,56 & 14,66 & 11,64 & 9,36 & 6,41 & 4,79 & 3,21 \\
\hline 30 & 1500 & 125 & 27,07 & 21,85 & 18,47 & 14,63 & 11,64 & 9,37 & 6,43 & 4,79 & 3,21 \\
\hline 30 & 1550 & 125 & 26,78 & 21,70 & 18,38 & 14,60 & 11,64 & 9,38 & 6,44 & 4,80 & 3,21 \\
\hline 30 & 1600 & 125 & 26,49 & 21,55 & 18,29 & 14,57 & 11,64 & 9,39 & 6,45 & 4,81 & 3,21 \\
\hline 30 & 1650 & 125 & 26,22 & 21,40 & 18,21 & 14,54 & 11,63 & 9,40 & 6,47 & 4,82 & 3,22 \\
\hline 30 & 1700 & 125 & 25,96 & 21,26 & 18,12 & 14,51 & 11,63 & 9,41 & 6,48 & 4,82 & 3,22 \\
\hline 30 & 1750 & 125 & 25,70 & 21,13 & 18,04 & 14,47 & 11,62 & 9,42 & 6,49 & 4,83 & 3,22 \\
\hline 30 & 1800 & 125 & 25,46 & 20,99 & 17,96 & 14,44 & 11,62 & 9,43 & 6,50 & 4,84 & 3,22 \\
\hline 30 & 1850 & 125 & 25,23 & 20,87 & 17,89 & 14,41 & 11,61 & 9,43 & 6,51 & 4,85 & 3,22 \\
\hline 30 & 1900 & 125 & 25,00 & 20,74 & 17,81 & 14,38 & 11,60 & 9,44 & 6,53 & 4,85 & 3,22 \\
\hline 30 & 1950 & 125 & 24,78 & 20,62 & 17,73 & 14,35 & 11,60 & 9,44 & 6,54 & 4,86 & 3,22 \\
\hline 30 & 2000 & 125 & 24,57 & 20,50 & 17,66 & 14,31 & 11,59 & 9,45 & 6,55 & 4,87 & 3,22 \\
\hline 30 & 200 & 130 & 54,65 & 29,25 & 20,43 & 13,96 & 10,41 & 8,22 & 5,72 & 4,44 & 3,13 \\
\hline 30 & 250 & 130 & 49,76 & 28,46 & 20,40 & 14,11 & 10,51 & 8,28 & 5,74 & 4,45 & 3,12 \\
\hline 30 & 300 & 130 & 46,28 & 27,81 & 20,33 & 14,22 & 10,60 & 8,33 & 5,76 & 4,45 & 3,12 \\
\hline 30 & 350 & 130 & 43,64 & 27,24 & 20,25 & 14,29 & 10,68 & 8,38 & 5,78 & 4,46 & 3,11 \\
\hline 30 & 400 & 130 & 41,53 & 26.74 & 20,14 & 14,35 & 10,75 & 8,43 & 5,80 & 4,46 & 3,11 \\
\hline 30 & 450 & 130 & 39,79 & 26,29 & 20,03 & 14,39 & 10,81 & 8,48 & 5,82 & 4,47 & 3,10 \\
\hline 30 & 500 & 130 & 38,32 & 25,88 & 19,92 & 14,42 & 10,86 & 8,52 & 5,84 & 4,47 & 3,10 \\
\hline 30 & 550 & 130 & 37,06 & 25,50 & 19,80 & 14,44 & 10,91 & 8,56 & 5,86 & 4,48 & 3,10 \\
\hline 30 & 600 & 130 & 35,95 & 25,15 & 19,68 & 14,45 & 10,95 & 8,60 & 5,88 & 4,48 & 3,10 \\
\hline 30 & 650 & 130 & 34,98 & 24,82 & 19,57 & 14,45 & 10,99 & 8,64 & 5,90 & 4,49 & 3,09 \\
\hline 30 & 700 & 130 & 34,10 & 24,51 & 19,45 & 14,45 & 11,02 & 8,67 & 5,91 & 4,49 & 3,09 \\
\hline 30 & 750 & 130 & 33,31 & 24,23 & 19,34 & 14,44 & 11,05 & 8,71 & 5,93 & 4,50 & 3,09 \\
\hline
\end{tabular}




\begin{tabular}{|c|c|c|c|c|c|c|c|c|c|c|c|}
\hline \multirow[b]{2}{*}{$\mathrm{H}(\mathrm{cm})$} & \multirow[b]{2}{*}{ Mceq (MPa) } & & & & & $\mathrm{De}$ & ões (x1 & & & & \\
\hline & & Msub (MPa) & D0 & D25 & D40 & D60 & D80 & D100 & D140 & D180 & D260 \\
\hline 30 & 800 & 130 & 32,58 & 23,95 & 19,22 & 14,43 & 11,07 & 8,74 & 5,95 & 4,50 & 3,09 \\
\hline 30 & 850 & 130 & 31,92 & 23,69 & 19,11 & 14,42 & 11,09 & 8,76 & 5,97 & 4,51 & 3,09 \\
\hline 30 & 900 & 130 & 31,31 & 23,45 & 19,00 & 14,40 & 11,11 & 8,79 & 5,98 & 4,52 & 3,09 \\
\hline 30 & 950 & 130 & 30,75 & 23,21 & 18,90 & 14,39 & 11,13 & 8,81 & 6,00 & 4,52 & 3,09 \\
\hline 30 & 1000 & 130 & 30,22 & 22,99 & 18,79 & 14,37 & 11,14 & 8,84 & 6,02 & 4,53 & 3,09 \\
\hline 30 & 1050 & 130 & 29,73 & 22,78 & 18,69 & 14,34 & 11,15 & 8,86 & 6,03 & 4,54 & 3,09 \\
\hline 30 & 1100 & 130 & 29,27 & 22,57 & 18,59 & 14,32 & 11,16 & 8,88 & 6,05 & 4,54 & 3,09 \\
\hline 30 & 1150 & 130 & 28,84 & 22,37 & 18,49 & 14,30 & 11,17 & 8,90 & 6,06 & 4,55 & 3,09 \\
\hline 30 & 1200 & 130 & 28,43 & 22,19 & 18,39 & 14,27 & 11,18 & 8,92 & 6,08 & 4,56 & 3,09 \\
\hline 30 & 1250 & 130 & 28,04 & 22,00 & 18,30 & 14,24 & 11,18 & 8,93 & 6,09 & 4,57 & 3,09 \\
\hline 30 & 1300 & 130 & 27,67 & 21,83 & 18,21 & 14,22 & 11,19 & 8,95 & 6,11 & 4,57 & 3,09 \\
\hline 30 & 1350 & 130 & 27,33 & 21,66 & 18,12 & 14,19 & 11,19 & 8,96 & 6,12 & 4,58 & 3,09 \\
\hline 30 & 1400 & 130 & 27,00 & 21,50 & 18,03 & 14,16 & 11,19 & 8,98 & 6,14 & 4,59 & 3,09 \\
\hline 30 & 1450 & 130 & 26,68 & 21,34 & 17,94 & 14,13 & 11,19 & 8,99 & 6,15 & 4,59 & 3,09 \\
\hline 30 & 1500 & 130 & 26,38 & 21,19 & 17,86 & 14,11 & 11,19 & 9,00 & 6,16 & 4,60 & 3,09 \\
\hline 30 & 1550 & 130 & 26,09 & 21,04 & 17,77 & 14,08 & 11,19 & 9,01 & 6,18 & 4,61 & 3,09 \\
\hline 30 & 1600 & 130 & 25,81 & 20,90 & 17,69 & 14,05 & 11,19 & 9,02 & 6,19 & 4,61 & 3,09 \\
\hline 30 & 1650 & 130 & 25,54 & 20,76 & 17,61 & 14,02 & 11,19 & 9,03 & 6,20 & 4,62 & 3,09 \\
\hline 30 & 1700 & 130 & 25,29 & 20,62 & 17,53 & 13,99 & 11,19 & 9,04 & 6,21 & 4,63 & 3,09 \\
\hline 30 & 1750 & 130 & 25,04 & 20,49 & 17,45 & 13,96 & 11,18 & 9,05 & 6,23 & 4,64 & 3,09 \\
\hline 30 & 1800 & 130 & 24,81 & 20,36 & 17,38 & 13,93 & 11,18 & 9,05 & 6,24 & 4,64 & 3,09 \\
\hline 30 & 1850 & 130 & 24,58 & 20,24 & 17,31 & 13,90 & 11,17 & 9,06 & 6,25 & 4,65 & 3,09 \\
\hline 30 & 1900 & 130 & 24,36 & 20,12 & 17,23 & 13,87 & 11,17 & 9,07 & 6,26 & 4,66 & 3,10 \\
\hline 30 & 1950 & 130 & 24,15 & 20,00 & 17,16 & 13,84 & 11,16 & 9,07 & 6,27 & 4,66 & 3,10 \\
\hline 30 & 2000 & 130 & 23,94 & 19,89 & 17,09 & 13,81 & 11,15 & 9,08 & 6,28 & 4,67 & 3,10 \\
\hline 30 & 200 & 135 & 53,49 & 28,30 & 19,67 & 13,42 & 10,00 & 7,91 & 5,51 & 4,28 & 3,02 \\
\hline 30 & 250 & 135 & 48,66 & 27,54 & 19,65 & 13,56 & 10,10 & 7,96 & 5,53 & 4,28 & 3,01 \\
\hline 30 & 300 & 135 & 45,23 & 26,91 & 19,60 & 13,67 & 10,19 & 8,01 & 5,55 & 4,29 & 3,00 \\
\hline 30 & 350 & 135 & 42,62 & 26,37 & 19,52 & 13,75 & 10,27 & 8,06 & 5,56 & 4,29 & 3,00 \\
\hline 30 & 400 & 135 & 40,55 & 25,89 & 19,43 & 13,80 & 10,33 & 8,11 & 5,58 & 4,30 & 2,99 \\
\hline 30 & 450 & 135 & 38,84 & 25,46 & 19,33 & 13,85 & 10,39 & 8,15 & 5,60 & 4,30 & 2,99 \\
\hline 30 & 500 & 135 & 37,40 & 25,06 & 19,22 & 13,88 & 10,44 & 8,19 & 5,62 & 4,30 & 2,99 \\
\hline 30 & 550 & 135 & 36,16 & 24,70 & 19,11 & 13,90 & 10,49 & 8,23 & 5,63 & 4,31 & 2,98 \\
\hline 30 & 600 & 135 & 35,08 & 24,37 & 19,01 & 13,91 & 10,53 & 8,27 & 5,65 & 4,31 & 2,98 \\
\hline 30 & 650 & 135 & 34,12 & 24,05 & 18,90 & 13,92 & 10,56 & 8,30 & 5,67 & 4,32 & 2,98 \\
\hline 30 & 700 & 135 & 33,26 & 23,76 & 18,79 & 13,92 & 10,60 & 8,34 & 5,69 & 4,32 & 2,98 \\
\hline 30 & 750 & 135 & 32,49 & 23,48 & 18,68 & 13,91 & 10,62 & 8,37 & 5,70 & 4,33 & 2,98 \\
\hline 30 & 800 & 135 & 31,78 & 23,22 & 18,58 & 13,90 & 10,65 & 8,40 & 5,72 & 4,33 & 2,98 \\
\hline 30 & 850 & 135 & 31,13 & 22,97 & 18,47 & 13,89 & 10,67 & 8,42 & 5,73 & 4,34 & 2,98 \\
\hline 30 & 900 & 135 & 30,54 & 22,74 & 18,37 & 13,88 & 10,69 & 8,45 & 5,75 & 4,35 & 2,98 \\
\hline 30 & 950 & 135 & 29,99 & 22,51 & 18,27 & 13,87 & 10,71 & 8,47 & 5,77 & 4,35 & 2,97 \\
\hline 30 & 1000 & 135 & 29,47 & 22,30 & 18,17 & 13,85 & 10,72 & 8,49 & 5,78 & 4,36 & 2,97 \\
\hline 30 & 1050 & 135 & 28,99 & 22,09 & 18,07 & 13,83 & 10,73 & 8,51 & 5,80 & 4,36 & 2,97 \\
\hline 30 & 1100 & 135 & 28,54 & 21,89 & 17,98 & 13,81 & 10,74 & 8,53 & 5,81 & 4,37 & 2,97 \\
\hline 30 & 1150 & 135 & 28,12 & 21,71 & 17,89 & 13,79 & 10,75 & 8,55 & 5,83 & 4,38 & 2,97 \\
\hline 30 & 1200 & 135 & 27,72 & 21,52 & 17,79 & 13,76 & 10,76 & 8,57 & 5,84 & 4,38 & 2,97 \\
\hline 30 & 1250 & 135 & 27,35 & 21,35 & 17,71 & 13,74 & 10,77 & 8,59 & 5,86 & 4,39 & 2,97 \\
\hline 30 & 1300 & 135 & 26,99 & 21,18 & 17,62 & 13,72 & 10,77 & 8,60 & 5,87 & 4,40 & 2,97 \\
\hline 30 & 1350 & 135 & 26,65 & 21,02 & 17,53 & 13,69 & 10,77 & 8,62 & 5,88 & 4,40 & 2,97 \\
\hline 30 & 1400 & 135 & 26,33 & 20,86 & 17,45 & 13,67 & 10,78 & 8,63 & 5,90 & 4,41 & 2,97 \\
\hline 30 & 1450 & 135 & 26,02 & 20,71 & 17,37 & 13,64 & 10,78 & 8,64 & 5,91 & 4,42 & 2,97 \\
\hline 30 & 1500 & 135 & 25,72 & 20,57 & 17,29 & 13,61 & 10,78 & 8,65 & 5,92 & 4,42 & 2,97 \\
\hline 30 & 1550 & 135 & 25,44 & 20,42 & 17,21 & 13,59 & 10,78 & 8,66 & 5,93 & 4,43 & 2,97 \\
\hline 30 & 1600 & 135 & 25,17 & 20,29 & 17,13 & 13,56 & 10,78 & 8,67 & 5,95 & 4,44 & 2,98 \\
\hline 30 & 1650 & 135 & 24,91 & 20,15 & 17,05 & 13,53 & 10,78 & 8,68 & 5,96 & 4,44 & 2,98 \\
\hline 30 & 1700 & 135 & 24,66 & 20,02 & 16,98 & 13,51 & 10,77 & 8,69 & 5,97 & 4,45 & 2,98 \\
\hline 30 & 1750 & 135 & 24,42 & 19,90 & 16,90 & 13,48 & 10,77 & 8,70 & 5,98 & 4,46 & 2,98 \\
\hline 30 & 1800 & 135 & 24,19 & 19,77 & 16,83 & 13,45 & 10,77 & 8,71 & 5,99 & 4,46 & 2,98 \\
\hline 30 & 1850 & 135 & 23,97 & 19,65 & 16,76 & 13,42 & 10,76 & 8,72 & 6,00 & 4,47 & 2,98 \\
\hline 30 & 1900 & 135 & 23,76 & 19,54 & 16,69 & 13,40 & 10,76 & 8,72 & 6,01 & 4,48 & 2,98 \\
\hline 30 & 1950 & 135 & 23,55 & 19,43 & 16,63 & 13,37 & 10,76 & 8,73 & 6,02 & 4,48 & 2,98 \\
\hline 30 & 2000 & 135 & 23,35 & 19,32 & 16,56 & 13,34 & 10,75 & 8,73 & 6,03 & 4,49 & 2,98 \\
\hline 30 & 200 & 140 & 52,42 & 27,41 & 18,97 & 12,91 & 9,63 & 7,62 & 5,31 & 4,12 & 2,91 \\
\hline 30 & 250 & 140 & 47,64 & 26,67 & 18,96 & 13,06 & 9,73 & 7,67 & 5,33 & 4,13 & 2,90 \\
\hline 30 & 300 & 140 & 44,25 & 26,07 & 18,91 & 13,16 & 9,81 & 7,72 & 5,34 & 4,13 & 2,90 \\
\hline 30 & 350 & 140 & 41,67 & 25,55 & 18,84 & 13,24 & 9,88 & 7,76 & 5,36 & 4,14 & 2,89 \\
\hline 30 & 400 & 140 & 39,63 & 25,09 & 18,76 & 13,30 & 9,95 & 7,81 & 5,38 & 4,14 & 2,89 \\
\hline 30 & 450 & 140 & 37,95 & 24,68 & 18,67 & 13,34 & 10,00 & 7,85 & 5,39 & 4,15 & 2,88 \\
\hline 30 & 500 & 140 & 36,54 & 24,30 & 18,57 & 13,37 & 10,05 & 7,89 & 5,41 & 4,15 & 2,88 \\
\hline 30 & 550 & 140 & 35,32 & 23,95 & 18,47 & 13,39 & 10,10 & 7,92 & 5,43 & 4,15 & 2,88 \\
\hline 30 & 600 & 140 & 34,26 & 23,63 & 18,37 & 13,41 & 10,14 & 7,96 & 5,44 & 4,16 & 2,88 \\
\hline 30 & 650 & 140 & 33,32 & 23,33 & 18,27 & 13,42 & 10,17 & 7,99 & 5,46 & 4,16 & 2,87 \\
\hline 30 & 700 & 140 & 32,48 & 23,05 & 18,17 & 13,42 & 10,20 & 8,02 & 5,47 & 4,17 & 2,87 \\
\hline 30 & 750 & 140 & 31,72 & 22,78 & 18,07 & 13,42 & 10,23 & 8,05 & 5,49 & 4,17 & 2,87 \\
\hline 30 & 800 & 140 & 31,03 & 22,53 & 17,97 & 13,41 & 10,25 & 8,08 & 5,51 & 4,18 & 2,87 \\
\hline 30 & 850 & 140 & 30,39 & 22,29 & 17,87 & 13,40 & 10,28 & 8,11 & 5,52 & 4,18 & 2,87 \\
\hline 30 & 900 & 140 & 29,81 & 22,07 & 17,78 & 13,39 & 10,30 & 8,13 & 5,54 & 4,19 & 2,87 \\
\hline 30 & 950 & 140 & 29,27 & 21,85 & 17,68 & 13,38 & 10,31 & 8,15 & 5,55 & 4,19 & 2,87 \\
\hline 30 & 1000 & 140 & 28,77 & 21,65 & 17,59 & 13,37 & 10,33 & 8,18 & 5,57 & 4,20 & 2,87 \\
\hline 30 & 1050 & 140 & 28,30 & 21,45 & 17,50 & 13,35 & 10,34 & 8,20 & 5,58 & 4,20 & 2,87 \\
\hline 30 & 1100 & 140 & 27,86 & 21,26 & 17,41 & 13,33 & 10,35 & 8,21 & 5,59 & 4,21 & 2,87 \\
\hline
\end{tabular}




\begin{tabular}{|c|c|c|c|c|c|c|c|c|c|c|c|}
\hline \multirow[b]{2}{*}{$\mathrm{H}(\mathrm{cm})$} & \multirow[b]{2}{*}{ Mceq (MPa) } & & & & & $\mathrm{De}$ & ões (x1 & & & & \\
\hline & & Msub (MPa) & D0 & D25 & D40 & D60 & D80 & D100 & D140 & D180 & D260 \\
\hline 30 & 1150 & 140 & 27,45 & 21,08 & 17,32 & 13,31 & 10,36 & 8,23 & 5,61 & 4,22 & 2,87 \\
\hline 30 & 1200 & 140 & 27,06 & 20,91 & 17,23 & 13,29 & 10,37 & 8,25 & 5,62 & 4,22 & 2,87 \\
\hline 30 & 1250 & 140 & 26,69 & 20,74 & 17,15 & 13,27 & 10,38 & 8,27 & 5,63 & 4,23 & 2,87 \\
\hline 30 & 1300 & 140 & 26,34 & 20,58 & 17,07 & 13,25 & 10,38 & 8,28 & 5,65 & 4,23 & 2,87 \\
\hline 30 & 1350 & 140 & 26,01 & 20,42 & 16,99 & 13,23 & 10,39 & 8,30 & 5,66 & 4,24 & 2,87 \\
\hline 30 & 1400 & 140 & 25,70 & 20,27 & 16,91 & 13,20 & 10,39 & 8,31 & 5,67 & 4,25 & 2,87 \\
\hline 30 & 1450 & 140 & 25,40 & 20,12 & 16,83 & 13,18 & 10,39 & 8,32 & 5,68 & 4,25 & 2,87 \\
\hline 30 & 1500 & 140 & 25,11 & 19,98 & 16,75 & 13,15 & 10,39 & 8,33 & 5,70 & 4,26 & 2,87 \\
\hline 30 & 1550 & 140 & 24,84 & 19,85 & 16,68 & 13,13 & 10,39 & 8,34 & 5,71 & 4,26 & 2,87 \\
\hline 30 & 1600 & 140 & 24,57 & 19,71 & 16,60 & 13,11 & 10,39 & 8,35 & 5,72 & 4,27 & 2,87 \\
\hline 30 & 1650 & 140 & 24,32 & 19,58 & 16,53 & 13,08 & 10,39 & 8,36 & 5,73 & 4,28 & 2,87 \\
\hline 30 & 1700 & 140 & 24,08 & 19,46 & 16,46 & 13,06 & 10,39 & 8,37 & 5,74 & 4,28 & 2,87 \\
\hline 30 & 1750 & 140 & 23,84 & 19,34 & 16,39 & 13,03 & 10,39 & 8,38 & 5,75 & 4,29 & 2,87 \\
\hline 30 & 1800 & 140 & 23,62 & 19,22 & 16,32 & 13,00 & 10,39 & 8,39 & 5,76 & 4,29 & 2,87 \\
\hline 30 & 1850 & 140 & 23,40 & 19,11 & 16,25 & 12,98 & 10,39 & 8,40 & 5,77 & 4,30 & 2,87 \\
\hline 30 & 1900 & 140 & 23,19 & 18,99 & 16,19 & 12,95 & 10,38 & 8,40 & 5,78 & 4,31 & 2,87 \\
\hline 30 & 1950 & 140 & 22,99 & 18,88 & 16,12 & 12,93 & 10,38 & 8,41 & 5,79 & 4,31 & 2,87 \\
\hline 30 & 2000 & 140 & 22,79 & 18,78 & 16,06 & 12,90 & 10,37 & 8,41 & 5,80 & 4,32 & 2,87 \\
\hline 30 & 200 & 145 & 51,41 & 26,57 & 18,31 & 12,44 & 9,29 & 7,35 & 5,12 & 3,98 & 2,81 \\
\hline 30 & 250 & 145 & 46,67 & 25,86 & 18,31 & 12,59 & 9,38 & 7,40 & 5,14 & 3,99 & 2,80 \\
\hline 30 & 300 & 145 & 43,32 & 25,28 & 18,27 & 12,69 & 9,46 & 7,44 & 5,16 & 3,99 & 2,80 \\
\hline 30 & 350 & 145 & 40,78 & 24,78 & 18,21 & 12,77 & 9,53 & 7,48 & 5,17 & 3,99 & 2,79 \\
\hline 30 & 400 & 145 & 38,77 & 24,34 & 18,14 & 12,82 & 9,59 & 7,52 & 5,19 & 4,00 & 2,79 \\
\hline 30 & 450 & 145 & 37,12 & 23,95 & 18,05 & 12,87 & 9,64 & 7,56 & 5,20 & 4,00 & 2,78 \\
\hline 30 & 500 & 145 & 35,72 & 23,58 & 17,96 & 12,90 & 9,69 & 7,60 & 5,22 & 4,00 & 2,78 \\
\hline 30 & 550 & 145 & 34,53 & 23,25 & 17,87 & 12,92 & 9,73 & 7,64 & 5,23 & 4,01 & 2,78 \\
\hline 30 & 600 & 145 & 33,49 & 22,94 & 17,78 & 12,94 & 9,77 & 7,67 & 5,25 & 4,01 & 2,78 \\
\hline 30 & 650 & 145 & 32,56 & 22,65 & 17,68 & 12,95 & 9,81 & 7,70 & 5,26 & 4,02 & 2,78 \\
\hline 30 & 700 & 145 & 31,74 & 22,38 & 17,59 & 12,96 & 9,84 & 7,73 & 5,28 & 4,02 & 2,77 \\
\hline 30 & 750 & 145 & 30,99 & 22,13 & 17,50 & 12,96 & 9,86 & 7,76 & 5,29 & 4,02 & 2,77 \\
\hline 30 & 800 & 145 & 30,32 & 21,89 & 17,40 & 12,95 & 9,89 & 7,79 & 5,31 & 4,03 & 2,77 \\
\hline 30 & 850 & 145 & 29,70 & 21,66 & 17,31 & 12,95 & 9,91 & 7,81 & 5,32 & 4,03 & 2,77 \\
\hline 30 & 900 & 145 & 29,13 & 21,44 & 17,22 & 12,94 & 9,93 & 7,84 & 5,34 & 4,04 & 2,77 \\
\hline 30 & 950 & 145 & 28,60 & 21,23 & 17,13 & 12.93 & 9,95 & 7,86 & 5,35 & 4.04 & 2,77 \\
\hline 30 & 1000 & 145 & 28,11 & 21,04 & 17,04 & 12,92 & 9,96 & 7,88 & 5,36 & 4,05 & 2,77 \\
\hline 30 & 1050 & 145 & 27,65 & 20,85 & 16,96 & 12,90 & 9,97 & 7,90 & 5,38 & 4,05 & 2,77 \\
\hline 30 & 1100 & 145 & 27,22 & 20,67 & 16,87 & 12,88 & 9,99 & 7,92 & 5,39 & 4,06 & 2,77 \\
\hline 30 & 1150 & 145 & 26,82 & 20,49 & 16,79 & 12,87 & 10,00 & 7,94 & 5,40 & 4,07 & 2,77 \\
\hline 30 & 1200 & 145 & 26,44 & 20,32 & 16,71 & 12,85 & 10,00 & 7,95 & 5,42 & 4,07 & 2,77 \\
\hline 30 & 1250 & 145 & 26,08 & 20,16 & 16,63 & 12,83 & 10,01 & 7,97 & 5,43 & 4,08 & 2,77 \\
\hline 30 & 1300 & 145 & 25,74 & 20,01 & 16,55 & 12,81 & 10,02 & 7,98 & 5,44 & 4,08 & 2,77 \\
\hline 30 & 1350 & 145 & 25,41 & 19,86 & 16,47 & 12,79 & 10,02 & 8,00 & 5,45 & 4,09 & 2,77 \\
\hline 30 & 1400 & 145 & 25,11 & 19,71 & 16,40 & 12,77 & 10,03 & 8,01 & 5,47 & 4,09 & 2,77 \\
\hline 30 & 1450 & 145 & 24,81 & 19,57 & 16,32 & 12,75 & 10,03 & 8,02 & 5,48 & 4,10 & 2,77 \\
\hline 30 & 1500 & 145 & 24,53 & 19,43 & 16,25 & 12,73 & 10,03 & 8,03 & 5,49 & 4,10 & 2,77 \\
\hline 30 & 1550 & 145 & 24,26 & 19,30 & 16,18 & 12,70 & 10,03 & 8,04 & 5,50 & 4,11 & 2,77 \\
\hline 30 & 1600 & 145 & 24,01 & 19,18 & 16,11 & 12,68 & 10,04 & 8,05 & 5,51 & 4,12 & 2,77 \\
\hline 30 & 1650 & 145 & 23,76 & 19,05 & 16,04 & 12,66 & 10,04 & 8,06 & 5,52 & 4,12 & 2,77 \\
\hline 30 & 1700 & 145 & 23,52 & 18,93 & 15,97 & 12,63 & 10,04 & 8,07 & 5,53 & 4,13 & 2,77 \\
\hline 30 & 1750 & 145 & 23,29 & 18,81 & 15,91 & 12,61 & 10,03 & 8,08 & 5,54 & 4,13 & 2,77 \\
\hline 30 & 1800 & 145 & 23,07 & 18,70 & 15,84 & 12,59 & 10,03 & 8,09 & 5,55 & 4,14 & 2,77 \\
\hline 30 & 1850 & 145 & 22,86 & 18,59 & 15,78 & 12,56 & 10,03 & 8,10 & 5,56 & 4,14 & 2,77 \\
\hline 30 & 1900 & 145 & 22,66 & 18,48 & 15,71 & 12,54 & 10,03 & 8,10 & 5,57 & $\begin{array}{l}4,15 \\
4,15\end{array}$ & 2,77 \\
\hline 30 & 1950 & 145 & 22,46 & 18,38 & 15,65 & 12,52 & 10,02 & 8,11 & 5,58 & 4,16 & 2,77 \\
\hline 30 & 2000 & 145 & 22,27 & 18,27 & 15,59 & 12,49 & 10,02 & 8,12 & 5,59 & 4,16 & 2,77 \\
\hline 30 & 200 & 150 & 50,46 & 25,79 & 17,69 & 12,01 & 8,96 & 7,10 & 4,95 & 3,85 & 2,72 \\
\hline 30 & 250 & 150 & 45,76 & 25,11 & 17,70 & 12,15 & 9,05 & 7,14 & 4,97 & 3,85 & 2,71 \\
\hline 30 & 300 & 150 & 42,45 & 24,55 & 17,67 & 12,25 & 9,13 & 7,18 & 4,98 & 3,86 & 2,71 \\
\hline 30 & 350 & 150 & 39,94 & 24,06 & 17,62 & 12,33 & 9,19 & 7,22 & 5,00 & 3,86 & 2,70 \\
\hline 30 & 400 & 150 & 37,96 & 23,64 & 17,55 & 12,38 & 9,25 & 7,26 & 5,01 & 3,86 & 2,70 \\
\hline 30 & 450 & 150 & 36,33 & 23,26 & 17,48 & 12,43 & 9,30 & 7,30 & 5,03 & 3,87 & 2,69 \\
\hline 30 & 500 & 150 & 34,96 & 22,91 & 17,39 & 12,46 & 9,35 & 7,34 & 5,04 & 3,87 & 2,69 \\
\hline 30 & 550 & 150 & 33,78 & 22,59 & 17,31 & 12,49 & 9,39 & 7,37 & 5,05 & 3,87 & 2,69 \\
\hline 30 & 600 & 150 & 32,76 & 22,29 & 17,22 & 12,50 & 9,43 & 7,40 & 5,07 & 3,88 & 2,69 \\
\hline 30 & 650 & 150 & 31,85 & 22,02 & 17,13 & 12,52 & 9,46 & 7,43 & 5,08 & 3,88 & 2,68 \\
\hline 30 & 700 & 150 & 31,04 & 21,76 & 17,05 & 12,52 & 9,49 & 7,46 & 5,10 & 3,88 & 2,68 \\
\hline 30 & 750 & 150 & 30,31 & 21,51 & 16,96 & 12,52 & 9,52 & 7,49 & 5,11 & 3,89 & 2,68 \\
\hline 30 & 800 & 150 & 29,65 & 21,28 & 16,87 & 12,52 & 9,55 & 7,51 & 5,12 & 3,89 & 2,68 \\
\hline 30 & 850 & 150 & 29,04 & 21,06 & 16,78 & 12,52 & 9,57 & 7,54 & 5,14 & 3,90 & 2,68 \\
\hline 30 & 900 & 150 & 28,48 & 20,85 & 16,70 & 12,51 & 9,59 & 7,56 & 5,15 & 3,90 & 2,68 \\
\hline 30 & 950 & 150 & 27,97 & 20,65 & 16,62 & 12,50 & 9,60 & 7,58 & 5,16 & 3,91 & 2,68 \\
\hline 30 & 1000 & 150 & 27,48 & 20,46 & 16,53 & 12,49 & 9,62 & 7,60 & 5,18 & 3,91 & 2,68 \\
\hline 30 & 1050 & 150 & 27,04 & 20,28 & 16,45 & 12,48 & 9,63 & 7,62 & 5,19 & 3,92 & 2,68 \\
\hline 30 & 1100 & 150 & 26,62 & 20,10 & 16,37 & 12,47 & 9,65 & 7,64 & 5,20 & 3,92 & 2,68 \\
\hline 30 & 1150 & 150 & 26,22 & 19,94 & 16,29 & 12,45 & 9,66 & 7,66 & 5,21 & 3,93 & 2,68 \\
\hline 30 & 1200 & 150 & 25,85 & 19,78 & 16,21 & 12,44 & 9,66 & 7,67 & 5,23 & 3,93 & 2,68 \\
\hline 30 & 1250 & 150 & 25.50 & 19.62 & 16.14 & 12.42 & 9.67 & 7.69 & 5.24 & 3.94 & 2.68 \\
\hline 30 & 1300 & 150 & 25.16 & 19.47 & 16.06 & 1240 & 9.68 & 7.70 & 5.25 & 394 & 268 \\
\hline 30 & 1350 & 150 & 24,85 & 19,32 & 15,99 & 12,38 & 9,69 & 7,72 & 5,26 & 3,95 & 2,68 \\
\hline 30 & 1400 & 150 & 24,55 & 19,18 & 15,92 & 12,36 & 9,69 & 7,73 & 5,27 & 3,95 & 2,68 \\
\hline 30 & 1450 & 150 & 24,26 & 19,05 & 15,85 & 12,34 & 9,69 & 7,74 & 5,28 & 3,96 & 2,68 \\
\hline
\end{tabular}




\begin{tabular}{|c|c|c|c|c|c|c|c|c|c|c|c|}
\hline \multirow[b]{2}{*}{$\mathrm{H}(\mathrm{cm})$} & \multirow[b]{2}{*}{ Mceq (MPa) } & & & & & De & ões (x & & & & \\
\hline & & Msub (MPa) & D0 & D25 & D40 & D60 & D80 & D100 & D140 & D180 & D260 \\
\hline 30 & 1500 & 150 & 23,98 & 18,92 & 15,78 & 12,32 & 9,70 & 7,75 & 5,29 & 3,96 & 2,68 \\
\hline 30 & 1550 & 150 & 23,72 & 18,79 & 15,71 & 12,30 & 9,70 & 7,77 & 5,31 & 3,97 & 2,68 \\
\hline 30 & 1600 & 150 & 23,47 & 18,67 & 15,64 & 12,28 & 9,70 & 7,78 & 5,32 & 3,97 & 2,68 \\
\hline 30 & 1650 & 150 & 23,23 & 18,55 & 15,58 & 12,26 & 9,70 & 7,79 & 5,33 & 3,98 & 2,68 \\
\hline 30 & 1700 & 150 & 23,00 & 18,43 & 15,51 & 12,24 & 9,70 & 7,79 & 5,34 & 3,98 & 2,68 \\
\hline 30 & 1750 & 150 & 22,78 & 18,32 & 15,45 & 12,22 & 9,70 & 7,80 & 5,35 & 3,99 & 2,68 \\
\hline 30 & 1800 & 150 & 22,56 & 18,21 & 15,39 & 12,19 & 9,70 & 7,81 & 5,36 & 3,99 & 2,68 \\
\hline 30 & 1850 & 150 & 22,35 & 18,10 & 15,33 & 12,17 & 9,70 & 7,82 & 5,36 & 4,00 & 2,68 \\
\hline 30 & 1900 & 150 & 22,15 & 18,00 & 15,27 & 12,15 & 9,70 & 7,83 & 5,37 & 4,01 & 2,68 \\
\hline 30 & 1950 & 150 & 21,96 & 17,90 & 15,21 & 12,13 & 9,69 & 7,83 & 5,38 & 4,01 & 2,68 \\
\hline 30 & 2000 & 150 & 21,77 & 17,80 & 15,15 & 12,11 & 9,69 & 7,84 & 5,39 & 4,02 & 2,68 \\
\hline 30 & 200 & 155 & 49,56 & 25,06 & 17,12 & 11,60 & 8,66 & 6,86 & 4,78 & 3,72 & 2,64 \\
\hline 30 & 250 & 155 & 44,91 & 24,39 & 17,13 & 11,74 & 8,75 & 6,90 & 4,80 & 3,73 & 2,63 \\
\hline 30 & 300 & 155 & 41,63 & 23,85 & 17,11 & 11,84 & 8,82 & 6,94 & 4,82 & 3,73 & 2,62 \\
\hline 30 & 350 & 155 & 39,15 & 23,39 & 17,06 & 11,91 & 8,88 & 6,98 & 4,83 & 3,73 & 2,61 \\
\hline 30 & 400 & 155 & 37,19 & 22,98 & 17,00 & 11,97 & 8,94 & 7,02 & 4,85 & 3,74 & 2,61 \\
\hline 30 & 450 & 155 & 35,58 & 22,61 & 16,93 & 12,02 & 8,99 & 7,05 & 4,86 & 3,74 & 2,61 \\
\hline 30 & 500 & 155 & 34,23 & 22,28 & 16,86 & 12,05 & 9,04 & 7,09 & 4,87 & 3,74 & 2,60 \\
\hline 30 & 550 & 155 & 33,08 & 21,97 & 16,78 & 12,08 & 9,08 & 7,12 & 4,89 & 3,75 & 2,60 \\
\hline 30 & 600 & 155 & 32,07 & 21,68 & 16,70 & 12,09 & 9,11 & 7,15 & 4,90 & 3,75 & 2,60 \\
\hline 30 & 650 & 155 & 31,18 & 21,42 & 16,62 & 12,11 & 9,15 & 7,18 & 4,91 & 3,75 & 2,60 \\
\hline 30 & 700 & 155 & 30,38 & 21,17 & 16,53 & 12,12 & 9,18 & 7,21 & 4,93 & 3,76 & 2,60 \\
\hline 30 & 750 & 155 & 29,67 & 20,93 & 16,45 & 12,12 & 9,20 & 7,23 & 4,94 & 3,76 & 2,60 \\
\hline 30 & 800 & 155 & 29,02 & 20,71 & 16,37 & 12,12 & 9,23 & 7,26 & 4,95 & 3,77 & 2,59 \\
\hline 30 & 850 & 155 & 28,42 & 20,50 & 16,29 & 12,12 & 9,25 & 7,28 & 4,96 & 3,77 & 2,59 \\
\hline 30 & 900 & 155 & 27,87 & 20,30 & 16,21 & 12,11 & 9,27 & 7,30 & 4,98 & 3,77 & 2,59 \\
\hline 30 & 950 & 155 & 27,37 & 20,10 & 16,13 & 12,11 & 9,28 & 7,32 & 4,99 & 3,78 & 2,59 \\
\hline 30 & 1000 & 155 & 26,89 & 19,92 & 16,05 & 12,10 & 9,30 & 7,34 & 5,00 & 3,78 & 2,59 \\
\hline 30 & 1050 & 155 & 26,46 & 19,74 & 15,97 & 12,09 & 9,31 & 7,36 & 5,01 & 3,79 & 2,59 \\
\hline 30 & 1100 & 155 & 26,04 & 19,58 & 15,90 & 12,07 & 9,33 & 7,38 & 5,02 & 3,79 & 2,59 \\
\hline 30 & 1150 & 155 & 25,66 & 19,41 & 15,82 & 12,06 & 9,34 & 7,40 & 5,04 & 3,80 & 2,59 \\
\hline 30 & 1200 & 155 & 25,29 & 19,26 & 15,75 & 12,05 & 9,35 & 7,41 & 5,05 & 3,80 & 2,59 \\
\hline 30 & 1250 & 155 & 24,95 & 19,11 & 15,68 & 12,03 & 9,35 & 7,43 & 5,06 & 3,81 & 2,59 \\
\hline 30 & 1300 & 155 & 24,62 & 18,96 & 15,61 & 12,01 & 9,36 & 7,44 & 5,07 & 3,81 & 2,59 \\
\hline 30 & 1350 & 155 & 24,31 & 18,82 & 15,54 & 12,00 & 9,37 & 7,46 & 5,08 & 3,81 & 2,59 \\
\hline 30 & 1400 & 155 & 24,02 & 18,69 & 15,47 & 11,98 & 9,37 & 7,47 & 5,09 & 3,82 & 2,59 \\
\hline 30 & 1450 & 155 & 23,74 & 18,56 & 15,40 & 11,96 & 9,38 & 7,48 & 5,10 & 3,82 & 2,59 \\
\hline 30 & 1500 & 155 & 23,47 & 18,43 & 15,33 & 11,94 & 9,38 & 7,49 & 5,11 & 3,83 & 2,59 \\
\hline 30 & 1550 & 155 & 23,21 & 18,31 & 15,27 & 11,92 & 9,38 & 7,50 & 5,12 & 3,83 & 2,59 \\
\hline 30 & 1600 & 155 & 22,97 & 18,19 & 15,21 & 11,91 & 9,39 & 7,51 & 5,13 & 3,84 & 2,59 \\
\hline 30 & 1650 & 155 & 22,73 & 18,07 & 15,14 & 11,89 & 9,39 & 7,52 & 5,14 & 3,84 & 2,59 \\
\hline 30 & 1700 & 155 & 22,50 & 17,96 & 15,08 & 11,87 & 9,39 & 7,53 & 5,15 & 3,85 & 2,59 \\
\hline 30 & 1750 & 155 & 22,28 & 17,85 & 15,02 & 11,85 & 9,39 & 7,54 & 5,16 & 3,85 & 2,59 \\
\hline 30 & 1800 & 155 & 22,07 & 17,75 & 14,96 & 11,83 & 9,39 & 7,55 & 5,17 & 3,86 & 2,59 \\
\hline 30 & 1850 & 155 & 21,87 & 17,64 & 14,90 & 11,81 & 9,39 & 7,56 & 5,18 & 3,86 & 2,59 \\
\hline 30 & 1900 & 155 & 21,68 & 17,54 & 14,85 & 11,78 & 9,39 & 7,56 & 5,19 & 3,87 & 2,59 \\
\hline 30 & 1950 & 155 & 21,49 & 17,44 & 14,79 & 11,76 & 9,38 & 7,57 & 5,20 & 3,87 & 2,59 \\
\hline 30 & 2000 & 155 & 21,31 & 17,35 & 14,73 & 11,74 & 9,38 & 7,58 & 5,21 & 3,88 & 2,59 \\
\hline 30 & 200 & 160 & 48,72 & 24,37 & 16,58 & 11,22 & 8,38 & 6,64 & 4,63 & 3,60 & 2,56 \\
\hline 30 & 250 & 160 & 44,10 & 23,72 & 16,60 & 11,35 & 8,46 & 6,68 & 4,65 & 3,61 & 2,55 \\
\hline 30 & 300 & 160 & 40,85 & 23,20 & 16,58 & 11,45 & 8,53 & 6,72 & 4,67 & 3,61 & 2,54 \\
\hline 30 & 350 & 160 & 38,40 & 22,75 & 16,54 & 11,53 & 8,59 & 6,76 & 4,68 & 3,62 & 2,53 \\
\hline 30 & 400 & 160 & 36,46 & 22,36 & 16,49 & 11,58 & 8,65 & 6,79 & 4,69 & 3,62 & 2,53 \\
\hline 30 & 450 & 160 & 34,88 & 22,00 & 16,42 & 11,63 & 8,70 & 6,82 & 4,70 & 3,62 & 2,53 \\
\hline 30 & 500 & 160 & 33,55 & 21,68 & 16,36 & 11,66 & 8,74 & 6,86 & 4,72 & 3,63 & 2,52 \\
\hline 30 & 550 & 160 & 32,41 & 21,38 & 16,28 & 11,69 & 8,78 & 6,89 & 4,73 & 3,63 & 2,52 \\
\hline 30 & 600 & 160 & 31,42 & 21,11 & 16,21 & 11,71 & 8,82 & 6,92 & 4,74 & 3,63 & 2,52 \\
\hline 30 & 650 & 160 & 30,54 & 20,85 & 16,13 & 11,72 & 8,85 & 6,94 & 4,75 & 3,64 & 2,52 \\
\hline 30 & 700 & 160 & 29,76 & 20,61 & 16,05 & 11,73 & 8,88 & 6,97 & 4,77 & 3,64 & 2,52 \\
\hline 30 & 750 & 160 & 29,06 & 20,38 & 15,98 & 11,74 & 8,90 & 7,00 & 4,78 & 3,64 & 2,52 \\
\hline 30 & 800 & 160 & 28,42 & 20,17 & 15,90 & 11,74 & 8,93 & 7,02 & 4,79 & 3,65 & 2,51 \\
\hline 30 & 850 & 160 & 27,83 & 19,96 & 15,82 & 11,74 & 8,95 & 7,04 & 4,80 & 3,65 & 2,51 \\
\hline 30 & 900 & 160 & 27,29 & 19,77 & 15,75 & 11,74 & 8,97 & 7,06 & 4,81 & 3,65 & 2,51 \\
\hline 30 & 950 & 160 & 26,80 & 19,58 & 15,67 & 11,73 & 8,98 & 7,08 & 4,83 & 3,66 & 2,51 \\
\hline 30 & 1000 & 160 & 26,34 & 19,41 & 15,60 & 11,72 & 9,00 & 7,10 & 4,84 & 3,66 & 2,51 \\
\hline 30 & 1050 & 160 & 25,90 & 19,24 & 15,52 & 11,72 & 9,01 & 7,12 & 4,85 & 3,67 & 2,51 \\
\hline 30 & 1100 & 160 & 25,50 & 19,08 & 15,45 & 11,71 & 9,03 & 7,14 & 4,86 & 3,67 & 2,51 \\
\hline 30 & 1150 & 160 & 25,12 & 18,92 & 15,38 & 11,69 & 9,04 & 7,16 & 4,87 & 3,67 & 2,51 \\
\hline 30 & 1200 & 160 & 24,76 & 18,77 & 15,31 & 11,68 & 9,05 & 7,17 & 4,88 & 3,68 & 2,51 \\
\hline 30 & 1250 & 160 & 24,43 & 18,62 & 15,24 & 11,67 & 9,06 & 7,19 & 4,89 & 3,68 & 2,51 \\
\hline 30 & 1300 & 160 & 24,11 & 18,48 & 15,17 & 11,65 & 9,06 & 7,20 & 4,90 & 3,69 & 2,51 \\
\hline 30 & 1350 & 160 & 23,80 & 18,35 & 15,11 & 11,64 & 9,07 & 7,21 & 4,91 & 3,69 & 2,51 \\
\hline 30 & 1400 & 160 & 23,52 & 18,22 & 15,04 & 11,62 & 9,08 & 7,23 & 4,92 & 3,70 & 2,51 \\
\hline 30 & 1450 & 160 & 23,24 & 18,09 & 14,98 & 11,60 & 9,08 & 7,24 & 4,93 & 3,70 & 2,51 \\
\hline 30 & 1500 & 160 & 22,98 & 17,97 & 14,92 & 11,59 & 9,08 & 7,25 & 4,94 & 3,71 & 2,51 \\
\hline 30 & 1550 & 160 & 22,73 & 17,85 & 14,85 & 11,57 & 9,09 & 7,26 & 4,95 & 3,71 & 2,51 \\
\hline 30 & 1600 & 160 & 22,49 & 17,74 & 14,79 & 11,55 & 9,09 & 7,27 & 4,96 & 3,71 & 2,51 \\
\hline 30 & 1650 & 160 & 22,25 & 17,62 & 14,73 & 11,53 & 9,09 & 7,28 & 4,97 & 3,72 & 2,51 \\
\hline 30 & 1700 & 160 & 22,03 & 17,52 & 14,67 & 11,52 & 9,09 & 7,29 & 4,98 & 3,72 & 2,51 \\
\hline 30 & 1750 & 160 & 21,82 & 17,41 & 14,62 & 11,50 & 9,09 & 7,30 & 4,99 & 3,73 & 2,51 \\
\hline 30 & 1800 & 160 & 21,61 & 17,31 & 14,56 & 11,48 & 9,09 & 7,31 & 5,00 & 3,73 & 2,51 \\
\hline
\end{tabular}




\begin{tabular}{|c|c|c|c|c|c|c|c|c|c|c|c|}
\hline \multirow[b]{2}{*}{$\mathrm{H}(\mathrm{cm})$} & \multirow[b]{2}{*}{ Mceq (MPa) } & & & & & De & ões (x & & & & \\
\hline & & Msub (MPa) & D0 & D25 & D40 & D60 & D80 & D100 & D140 & D180 & D260 \\
\hline 30 & 1850 & 160 & 21,42 & 17,21 & 14,50 & 11,46 & 9,09 & 7,31 & 5,01 & 3,74 & 2,51 \\
\hline 30 & 1900 & 160 & 21,23 & 17,11 & 14,45 & 11,44 & 9,09 & 7,32 & 5,02 & 3,74 & 2,51 \\
\hline 30 & 1950 & 160 & 21,04 & 17,01 & 14,39 & 11,42 & 9,09 & 7,33 & 5,03 & 3,75 & 2,51 \\
\hline 30 & 2000 & 160 & 20,86 & 16,92 & 14,34 & 11,40 & 9,09 & 7,33 & 5,03 & 3,75 & 2,51 \\
\hline 30 & 200 & 165 & 47,92 & 23,72 & 16,07 & 10,86 & 8,12 & 6,44 & 4,49 & 3,49 & 2,48 \\
\hline 30 & 250 & 165 & 43,34 & 23,09 & 16,09 & 10,99 & 8,19 & 6,47 & 4,51 & 3,50 & 2,47 \\
\hline 30 & 300 & 165 & 40,12 & 22,58 & 16,08 & 11,09 & 8,26 & 6,51 & 4,52 & 3,50 & 2,46 \\
\hline 30 & 350 & 165 & 37,69 & 22,15 & 16,05 & 11,16 & 8,32 & 6,54 & 4,53 & 3,51 & 2,46 \\
\hline 30 & 400 & 165 & 35,78 & 21,77 & 16,00 & 11,22 & 8,37 & 6,58 & 4,55 & 3,51 & 2,45 \\
\hline 30 & 450 & 165 & 34,21 & 21,43 & 15,94 & 11,27 & 8,42 & 6,61 & 4,56 & 3,51 & 2,45 \\
\hline 30 & 500 & 165 & 32,90 & 21,11 & 15,88 & 11,30 & 8,46 & 6,64 & 4,57 & 3,52 & 2,45 \\
\hline 30 & 550 & 165 & 31,78 & 20,83 & 15,81 & 11,33 & 8,50 & 6,67 & 4,58 & 3,52 & 2,45 \\
\hline 30 & 600 & 165 & 30,80 & 20,56 & 15,74 & 11,35 & 8,54 & 6,70 & 4,59 & 3,52 & 2,44 \\
\hline 30 & 650 & 165 & 29,94 & 20,32 & 15,67 & 11,36 & 8,57 & 6,72 & 4,60 & 3,52 & 2,44 \\
\hline 30 & 700 & 165 & 29,17 & 20,08 & 15,60 & 11,38 & 8,60 & 6,75 & 4,62 & 3,53 & 2,44 \\
\hline 30 & 750 & 165 & 28,48 & 19,86 & 15,53 & 11,38 & 8,62 & 6,77 & 4,63 & 3,53 & 2,44 \\
\hline 30 & 800 & 165 & 27,85 & 19,66 & 15,45 & 11,39 & 8,65 & 6,80 & 4,64 & 3,53 & 2,44 \\
\hline 30 & 850 & 165 & 27,28 & 19,46 & 15,38 & 11,39 & 8,67 & 6,82 & 4,65 & 3,54 & 2,44 \\
\hline 30 & 900 & 165 & 26,75 & 19,27 & 15,31 & 11,38 & 8,69 & 6,84 & 4,66 & 3,54 & 2,44 \\
\hline 30 & 950 & 165 & 26,26 & 19,09 & 15,24 & 11,38 & 8,70 & 6,86 & 4,67 & 3,54 & 2,44 \\
\hline 30 & 1000 & 165 & 25,81 & 18,92 & 15,17 & 11,37 & 8,72 & 6,88 & 4,68 & 3,55 & 2,44 \\
\hline 30 & 1050 & 165 & 25,38 & 18,76 & 15,10 & 11,37 & 8,73 & 6,89 & 4,69 & 3,55 & 2,43 \\
\hline 30 & 1100 & 165 & 24,99 & 18,60 & 15,03 & 11,36 & 8,75 & 6,91 & 4,71 & 3,56 & 2,43 \\
\hline 30 & 1150 & 165 & 24,61 & 18,45 & 14,96 & 11,35 & 8,76 & 6,93 & 4,72 & 3,56 & 2,43 \\
\hline 30 & 1200 & 165 & 24,26 & 18,31 & 14,90 & 11,34 & 8,77 & 6,94 & 4,73 & 3,56 & 2,43 \\
\hline 30 & 1250 & 165 & 23,93 & 18,17 & 14,83 & 11,32 & 8,78 & 6,96 & 4,74 & 3,57 & 2,43 \\
\hline 30 & 1300 & 165 & 23,62 & 18,03 & 14,77 & 11,31 & 8,78 & 6,97 & 4,75 & 3,57 & 2,43 \\
\hline 30 & 1350 & 165 & 23,32 & 17,90 & 14,70 & 11,30 & 8,79 & 6,98 & 4,76 & 3,58 & 2,43 \\
\hline 30 & 1400 & 165 & 23,04 & 17,77 & 14,64 & 11,28 & 8,80 & 7,00 & 4,77 & 3,58 & 2,43 \\
\hline 30 & 1450 & 165 & 22,77 & 17,65 & 14,58 & 11,27 & 8,80 & 7,01 & 4,78 & 3,58 & 2,43 \\
\hline 30 & 1500 & 165 & 22,51 & 17,53 & 14,52 & 11,25 & 8,81 & 7,02 & 4,79 & 3,59 & 2,43 \\
\hline 30 & 1550 & 165 & 22,27 & 17,42 & 14,46 & 11,24 & 8,81 & 7,03 & 4,80 & 3,59 & 2,43 \\
\hline 30 & 1600 & 165 & 22,03 & 17,31 & 14,40 & 11,22 & 8,81 & 7,04 & 4,80 & 3,60 & 2,43 \\
\hline 30 & 1650 & 165 & 21,80 & 17,20 & 14,34 & 11,20 & 8,82 & 7,05 & 4,81 & 3,60 & 2,43 \\
\hline 30 & 1700 & 165 & 21,59 & 17,09 & 14,29 & 11,19 & 8,82 & 7,06 & 4,82 & 3,61 & 2,43 \\
\hline 30 & 1750 & 165 & 21,38 & 16,99 & 14,23 & 11,17 & 8,82 & 7,07 & 4,83 & 3,61 & 2,43 \\
\hline 30 & 1800 & 165 & 21,18 & 16,89 & 14,18 & 11,15 & 8,82 & 7,08 & 4,84 & 3,62 & 2,43 \\
\hline 30 & 1850 & 165 & 20,98 & 16,79 & 14,12 & 11,13 & 8,82 & 7,08 & 4,85 & 3,62 & 2,43 \\
\hline 30 & 1900 & 165 & 20,80 & 16,70 & 14,07 & 11,11 & 8,82 & 7,09 & 4,86 & 3,62 & 2,43 \\
\hline 30 & 1950 & 165 & 20,62 & 16,61 & 14,02 & 11,10 & 8,82 & 7,10 & 4,86 & 3,63 & 2,43 \\
\hline 30 & 2000 & 165 & 20,44 & 16,52 & 13,97 & 11,08 & 8,82 & 7,10 & 4,87 & 3,63 & 2,43 \\
\hline 30 & 200 & 170 & 47,17 & 23,10 & 15,59 & 10,52 & 7,87 & 6,24 & 4,36 & 3,39 & 2,41 \\
\hline 30 & 250 & 170 & 42,62 & 22,49 & 15,62 & 10,65 & 7,94 & 6,28 & 4,37 & 3,40 & 2,40 \\
\hline 30 & 300 & 170 & 39,42 & 22,00 & 15,61 & 10,75 & 8,01 & 6,31 & 4,39 & 3,40 & 2,39 \\
\hline 30 & 350 & 170 & 37,02 & 21,58 & 15,59 & 10,82 & 8,06 & 6,35 & 4,40 & 3,40 & 2,39 \\
\hline 30 & 400 & 170 & 35,13 & 21,21 & 15,54 & 10,88 & 8,11 & 6,38 & 4,41 & 3,41 & 2,38 \\
\hline 30 & 450 & 170 & 33,58 & 20,88 & 15,49 & 10,92 & 8,16 & 6,41 & 4,42 & 3,41 & 2,38 \\
\hline 30 & 500 & 170 & 32,29 & 20,58 & 15,43 & 10,96 & 8,20 & 6,44 & 4,43 & 3,41 & 2,38 \\
\hline 30 & 550 & 170 & 31,18 & 20,30 & 15,37 & 10,99 & 8,24 & 6,46 & 4,44 & 3,41 & 2,37 \\
\hline 30 & 600 & 170 & 30,22 & 20,05 & 15,30 & 11,01 & 8,27 & 6,49 & 4,45 & 3,42 & 2,37 \\
\hline 30 & 650 & 170 & 29,37 & 19,81 & 15,24 & 11,03 & 8,30 & 6,52 & 4,47 & 3,42 & 2,37 \\
\hline 30 & 700 & 170 & 28,61 & 19,58 & 15,17 & 11,04 & 8,33 & 6,54 & 4,48 & 3,42 & 2,37 \\
\hline 30 & 750 & 170 & 27,93 & 19,37 & 15,10 & 11,04 & 8,36 & 6,56 & 4,49 & 3,42 & 2,37 \\
\hline 30 & 800 & 170 & 27,31 & 19,17 & 15,03 & 11,05 & 8,38 & 6,59 & 4,50 & 3,43 & 2,37 \\
\hline 30 & 850 & 170 & 26,75 & 18,98 & 14,96 & 11,05 & 8,40 & 6,61 & 4,51 & 3,43 & 2,37 \\
\hline 30 & 900 & 170 & 26,23 & 18,80 & 14,90 & 11,05 & 8,42 & 6,63 & 4,52 & 3,43 & 2,37 \\
\hline 30 & 950 & 170 & 25,75 & 18,63 & 14,83 & 11,05 & 8,44 & 6,65 & 4,53 & 3,44 & 2,36 \\
\hline 30 & 1000 & 170 & 25,30 & 18,46 & 14,76 & 11,04 & 8,45 & 6,66 & 4,54 & 3,44 & 2,36 \\
\hline 30 & 1050 & 170 & 24,89 & 18,30 & 14,70 & 11,04 & 8,47 & 6,68 & 4,55 & 3,44 & 2,36 \\
\hline 30 & 1100 & 170 & 24,50 & 18,15 & 14,63 & 11,03 & 8,48 & 6,70 & 4,56 & 3,45 & 2,36 \\
\hline 30 & 1150 & 170 & 24,13 & 18,01 & 14,57 & 11,02 & 8,49 & 6,71 & 4,57 & 3,45 & 2,36 \\
\hline 30 & 1200 & 170 & 23,79 & 17,87 & 14,50 & 11,01 & 8,50 & 6,73 & 4,58 & 3,46 & 2,36 \\
\hline 30 & 1250 & 170 & 23,46 & 17,73 & 14,44 & 11,00 & 8,51 & 6,74 & 4,59 & 3,46 & 2,36 \\
\hline 30 & 1300 & 170 & 23,16 & 17,60 & 14,38 & 10,99 & 8,52 & 6,76 & 4,60 & 3,46 & 2,36 \\
\hline 30 & 1350 & 170 & 22,86 & 17,47 & 14,32 & 10,97 & 8,53 & 6,77 & 4,61 & 3,47 & 2,36 \\
\hline 30 & 1400 & 170 & 22,59 & 17,35 & 14,26 & 10,96 & 8,53 & 6,78 & 4,62 & 3,47 & 2,36 \\
\hline 30 & 1450 & 170 & 22,32 & 17,23 & 14,20 & 10,95 & 8,54 & 6,79 & 4,63 & 3,48 & 2,36 \\
\hline 30 & 1500 & 170 & 22,07 & 17,12 & 14,14 & 10,93 & 8,54 & 6,80 & 4,64 & 3,48 & 2,36 \\
\hline 30 & 1550 & 170 & 21,83 & 17,01 & 14,09 & 10,92 & 8,55 & 6,81 & 4,65 & 3,48 & 2,36 \\
\hline 30 & 1600 & 170 & 21,60 & 16,90 & 14,03 & 10,90 & 8,55 & 6,82 & 4,65 & 3,49 & 2,36 \\
\hline 30 & 1650 & 170 & 21,38 & 16,79 & 13,98 & 10,89 & 8,55 & 6,83 & 4,66 & 3,49 & 2,36 \\
\hline 30 & 1700 & 170 & 21,16 & 16,69 & 13,92 & 10,87 & 8,56 & 6,84 & 4,67 & 3,50 & 2,36 \\
\hline 30 & 1750 & 170 & 20,96 & 16,59 & 13,87 & 10,86 & 8,56 & 6,85 & 4,68 & 3,50 & 2,36 \\
\hline 30 & 1800 & 170 & 20,76 & 16,50 & 13,82 & 10,84 & 8,56 & 6,86 & 4,69 & 3,50 & 2,36 \\
\hline 30 & 1850 & 170 & 20,57 & 16,40 & 13,77 & 10,82 & 8,56 & 6,87 & 4,70 & 3,51 & 2,36 \\
\hline 30 & 1900 & 170 & 20,39 & 16,31 & 13,72 & 10,81 & 8,56 & 6,87 & 4,70 & 3,51 & 2,36 \\
\hline 30 & 1950 & 170 & 20,21 & 16,22 & 13,67 & 10,79 & 8,56 & 6,88 & 4,71 & 3,52 & 2,36 \\
\hline 30 & 2000 & 170 & 20,04 & 16,13 & 13,62 & 10,77 & 8,56 & 6,89 & 4,72 & 3,52 & 2,36 \\
\hline 30 & 200 & 175 & 46,45 & 22,52 & 15,13 & 10,20 & 7,63 & 6,06 & 4,23 & 3,29 & 2,34 \\
\hline 30 & 250 & 175 & 41,93 & 21,92 & 15,17 & 10,33 & 7,71 & 6,10 & 4,25 & 3,30 & 2,33 \\
\hline 30 & 300 & 175 & 38,76 & 21,45 & 15,17 & 10,43 & 7,77 & 6,13 & 4,26 & 3,30 & 2,32 \\
\hline
\end{tabular}




\begin{tabular}{|c|c|c|c|c|c|c|c|c|c|c|c|}
\hline \multirow[b]{2}{*}{$\mathrm{H}(\mathrm{cm})$} & \multirow[b]{2}{*}{ Mceq (MPa) } & & & & & De & ões (x & & & & \\
\hline & & Msub (MPa) & D0 & D25 & D40 & D60 & D80 & D100 & D140 & D180 & D260 \\
\hline 30 & 350 & 175 & 36,38 & 21,04 & 15,15 & 10,50 & 7,82 & 6,16 & 4,27 & 3,31 & 2,32 \\
\hline 30 & 400 & 175 & 34,51 & 20,68 & 15,11 & 10,56 & 7,87 & 6,19 & 4,28 & 3,31 & 2,31 \\
\hline 30 & 450 & 175 & 32,98 & 20,36 & 15,06 & 10,60 & 7,92 & 6,22 & 4,29 & 3,31 & 2,31 \\
\hline 30 & 500 & 175 & 31,70 & 20,07 & 15,01 & 10,64 & 7,96 & 6,24 & 4,30 & 3,31 & 2,31 \\
\hline 30 & 550 & 175 & 30,61 & 19,81 & 14,95 & 10,67 & 7,99 & 6,27 & 4,31 & 3,32 & 2,31 \\
\hline 30 & 600 & 175 & 29,66 & 19,56 & 14,89 & 10,69 & 8,03 & 6,30 & 4,32 & 3,32 & 2,31 \\
\hline 30 & 650 & 175 & 28,82 & 19,33 & 14,83 & 10,71 & 8,06 & 6,32 & 4,33 & 3,32 & 2,30 \\
\hline 30 & 700 & 175 & 28,08 & 19,11 & 14,76 & 10,72 & 8,08 & 6,34 & 4,34 & 3,32 & 2,30 \\
\hline 30 & 750 & 175 & 27,41 & 18,91 & 14,70 & 10,73 & 8,11 & 6,37 & 4,35 & 3,33 & 2,30 \\
\hline 30 & 800 & 175 & 26,80 & 18,71 & 14,63 & 10,73 & 8,13 & 6,39 & 4,36 & 3,33 & 2,30 \\
\hline 30 & 850 & 175 & 26,24 & 18,53 & 14,57 & 10,73 & 8,15 & 6,41 & 4,37 & 3,33 & 2,30 \\
\hline 30 & 900 & 175 & 25,73 & 18,35 & 14,50 & 10,74 & 8,17 & 6,43 & 4,38 & 3,33 & 2,30 \\
\hline 30 & 950 & 175 & 25,26 & 18,19 & 14,44 & 10,73 & 8,19 & 6,45 & 4,39 & 3,34 & 2,30 \\
\hline 30 & 1000 & 175 & 24,82 & 18,03 & 14,38 & 10,73 & 8,20 & 6,46 & 4,40 & 3,34 & 2,30 \\
\hline 30 & 1050 & 175 & 24,41 & 17,87 & 14,31 & 10,73 & 8,22 & 6,48 & 4,41 & 3,34 & 2,30 \\
\hline 30 & 1100 & 175 & 24,03 & 17,73 & 14,25 & 10,72 & 8,23 & 6,50 & 4,42 & 3,35 & 2,30 \\
\hline 30 & 1150 & 175 & 23,67 & 17,58 & 14,19 & 10,71 & 8,24 & 6,51 & 4,43 & 3,35 & 2,30 \\
\hline 30 & 1200 & 175 & 23,34 & 17,45 & 14,13 & 10,70 & 8,25 & 6,53 & 4,44 & 3,35 & 2,29 \\
\hline 30 & 1250 & 175 & 23,02 & 17,32 & 14,07 & 10,69 & 8,26 & 6,54 & 4,45 & 3,36 & 2,29 \\
\hline 30 & 1300 & 175 & 22,72 & 17,19 & 14,01 & 10,68 & 8,27 & 6,55 & 4,46 & 3,36 & 2,29 \\
\hline 30 & 1350 & 175 & 22,43 & 17,07 & 13,95 & 10,67 & 8,28 & 6,57 & 4,47 & 3,37 & 2,29 \\
\hline 30 & 1400 & 175 & 22,16 & 16,95 & 13,90 & 10,66 & 8,28 & 6,58 & 4,48 & 3,37 & 2,29 \\
\hline 30 & 1450 & 175 & 21,90 & 16,84 & 13,84 & 10,65 & 8,29 & 6,59 & 4,49 & 3,37 & 2,29 \\
\hline 30 & 1500 & 175 & 21,65 & 16,72 & 13,79 & 10,63 & 8,30 & 6,60 & 4,50 & 3,38 & 2,29 \\
\hline 30 & 1550 & 175 & 21,41 & 16,62 & 13,73 & 10,62 & 8,30 & 6,61 & 4,51 & 3,38 & 2,29 \\
\hline 30 & 1600 & 175 & 21,19 & 16,51 & 13,68 & 10,61 & 8,30 & 6,62 & 4,51 & 3,38 & 2,29 \\
\hline 30 & 1650 & 175 & 20,97 & 16,41 & 13,63 & 10,59 & 8,31 & 6,63 & 4,52 & 3,39 & 2,29 \\
\hline 30 & 1700 & 175 & 20,76 & 16,31 & 13,58 & 10,58 & 8,31 & 6,64 & 4,53 & 3,39 & 2,29 \\
\hline 30 & 1750 & 175 & 20,56 & 16,22 & 13,52 & 10,56 & 8,31 & 6,65 & 4,54 & 3,40 & 2,29 \\
\hline 30 & 1800 & 175 & 20,37 & 16,12 & 13,47 & 10,55 & 8,31 & 6,65 & 4,55 & 3,40 & 2,29 \\
\hline 30 & 1850 & 175 & 20,18 & 16,03 & 13,43 & 10,53 & 8,31 & 6,66 & 4,55 & 3,40 & 2,29 \\
\hline 30 & 1900 & 175 & 20,00 & 15,94 & 13,38 & 10,52 & 8,31 & 6,67 & 4,56 & 3,41 & 2,29 \\
\hline 30 & 1950 & 175 & 19,83 & 15,86 & 13,33 & 10,50 & 8,32 & 6,68 & 4,57 & 3,41 & 2,29 \\
\hline 30 & 2000 & 175 & 19,66 & 15,77 & 13,28 & 10,48 & 8,32 & 6,68 & 4,58 & 3,42 & 2,29 \\
\hline 30 & 200 & 180 & 45,78 & 21,97 & 14,71 & 9,90 & 7,41 & 5,89 & 4,11 & 3,20 & 2,28 \\
\hline 30 & 250 & 180 & 41,28 & 21,39 & 14,75 & 10,03 & 7,48 & 5,92 & 4,13 & 3,21 & 2,27 \\
\hline 30 & 300 & 180 & 38,14 & 20,92 & 14,75 & 10,12 & 7,54 & 5,95 & 4,14 & 3,21 & 2,26 \\
\hline 30 & 350 & 180 & 35,78 & 20,53 & 14,73 & 10,19 & 7,60 & 5,98 & 4,15 & 3,21 & 2,26 \\
\hline 30 & 400 & 180 & 33,92 & 20,18 & 14,70 & 10,25 & 7,64 & 6,01 & 4,16 & 3,22 & 2,25 \\
\hline 30 & 450 & 180 & 32,41 & 19,87 & 14,66 & 10,30 & 7,69 & 6,04 & 4,17 & 3,22 & 2,25 \\
\hline 30 & 500 & 180 & 31,15 & 19,59 & 14,61 & 10,33 & 7,72 & 6,06 & 4,18 & 3,22 & 2,25 \\
\hline 30 & 550 & 180 & 30,07 & 19,33 & 14,55 & 10,36 & 7,76 & 6,09 & 4,19 & 3,22 & 2,24 \\
\hline 30 & 600 & 180 & 29,13 & 19,09 & 14,50 & 10,38 & 7,79 & 6,11 & 4,20 & 3,22 & 2,24 \\
\hline 30 & 650 & 180 & 28,31 & 18,87 & 14,44 & 10,40 & 7,82 & 6,14 & 4,21 & 3,23 & 2,24 \\
\hline 30 & 700 & 180 & 27,57 & 18,66 & 14,38 & 10,42 & 7,85 & 6,16 & 4,22 & 3,23 & 2,24 \\
\hline 30 & 750 & 180 & 26,91 & 18,46 & 14,32 & 10,43 & 7,87 & 6,18 & 4,23 & 3,23 & 2,24 \\
\hline 30 & 800 & 180 & 26,31 & 18,27 & 14,25 & 10,43 & 7,90 & 6,20 & 4,24 & 3,23 & 2,24 \\
\hline 30 & 850 & 180 & 25,76 & 18,10 & 14,19 & 10,44 & 7,92 & 6,22 & 4,25 & 3,24 & 2,24 \\
\hline 30 & 900 & 180 & 25,26 & 17,93 & 14,13 & 10,44 & 7,93 & 6,24 & 4,26 & 3,24 & 2,23 \\
\hline 30 & 950 & 180 & 24,80 & 17,77 & 14,07 & 10,44 & 7,95 & 6,26 & 4,27 & 3,24 & 2,23 \\
\hline 30 & 1000 & 180 & 24,36 & 17,61 & 14,01 & 10,43 & 7,97 & 6,27 & 4,28 & 3,25 & 2,23 \\
\hline 30 & 1050 & 180 & 23,96 & 17,46 & 13,95 & 10,43 & 7,98 & 6,29 & 4,29 & 3,25 & 2,23 \\
\hline 30 & 1100 & 180 & 23,59 & 17,32 & 13,89 & 10,43 & 7,99 & 6,31 & 4,30 & 3,25 & 2,23 \\
\hline 30 & 1150 & 180 & 23,24 & 17,18 & 13,83 & 10,42 & 8,01 & 6,32 & 4,30 & 3,26 & 2,23 \\
\hline 30 & 1200 & 180 & 22,90 & 17,05 & 13,78 & 10,41 & 8,02 & 6,34 & 4,31 & 3,26 & 2,23 \\
\hline 30 & 1250 & 180 & 22,59 & 16,92 & 13,72 & 10,40 & 8,03 & 6,35 & 4,32 & 3,26 & 2,23 \\
\hline 30 & 1300 & 180 & 22,29 & 16,80 & 13,66 & 10,39 & 8,03 & 6,36 & 4,33 & 3,27 & 2,23 \\
\hline 30 & 1350 & 180 & 22,01 & 16,68 & 13,61 & 10,38 & 8,04 & 6,37 & 4,34 & 3,27 & 2,23 \\
\hline 30 & 1400 & 180 & 21,75 & 16,57 & 13,56 & 10,37 & 8,05 & 6,39 & 4,35 & 3,27 & 2,23 \\
\hline 30 & 1450 & 180 & 21,49 & 16,46 & 13,50 & 10,36 & 8,06 & 6,40 & 4,36 & 3,28 & 2,23 \\
\hline 30 & 1500 & 180 & 21,25 & 16,35 & 13,45 & 10,35 & 8,06 & 6,41 & 4,36 & 3,28 & 2,23 \\
\hline 30 & 1550 & 180 & 21,02 & 16,25 & 13,40 & 10,34 & 8,07 & 6,42 & 4,37 & 3,28 & 2,23 \\
\hline 30 & 1600 & 180 & 20,79 & 16,14 & 13,35 & 10,32 & 8,07 & 6,43 & 4,38 & 3,29 & 2,23 \\
\hline 30 & 1650 & 180 & 20,58 & 16,05 & 13,30 & 10,31 & 8,07 & 6,44 & 4,39 & 3,29 & 2,23 \\
\hline 30 & 1700 & 180 & 20,37 & 15,95 & 13,25 & 10,30 & 8,08 & 6,45 & 4,40 & 3,29 & 2,23 \\
\hline 30 & 1750 & 180 & 20,18 & 15,86 & 13,20 & 10,28 & 8,08 & 6,45 & 4,40 & 3,30 & 2,23 \\
\hline 30 & 1800 & 180 & 19,99 & 15,77 & 13,15 & 10,27 & 8,08 & 6,46 & 4,41 & 3,30 & 2,23 \\
\hline 30 & 1850 & 180 & 19,80 & 15,68 & 13,10 & 10,25 & 8,08 & 6,47 & 4,42 & 3,31 & 2,23 \\
\hline 30 & 1900 & 180 & 19,63 & 15,59 & 13,05 & 10,24 & 8,08 & 6,48 & 4,43 & 3,31 & 2,23 \\
\hline 30 & 1950 & 180 & 19,46 & 15,51 & 13,01 & 10,23 & 8,08 & 6,48 & 4,43 & 3,31 & 2,23 \\
\hline 30 & 2000 & 180 & 19,29 & 15,42 & 12,96 & 10,21 & 8,08 & 6,49 & 4,44 & 3,32 & 2,23 \\
\hline 30 & 200 & 185 & 45,13 & 21,44 & 14,30 & 9,62 & 7,21 & 5,73 & 4,00 & 3,11 & 2,22 \\
\hline 30 & 250 & 185 & 40,66 & 20,88 & 14,35 & 9,74 & 7,27 & 5,76 & 4,01 & 3,12 & 2,21 \\
\hline 30 & 300 & 185 & 37,54 & 20,42 & 14,35 & 9,84 & 7,33 & 5,79 & 4,02 & 3,12 & 2,20 \\
\hline 30 & 350 & 185 & 35,20 & 20,04 & 14,34 & 9,91 & 7,38 & 5,81 & 4,04 & 3,13 & 2,19 \\
\hline 30 & 400 & 185 & 33,36 & 19,71 & 14,31 & 9,96 & 7,43 & 5,84 & 4,05 & 3,13 & 2,19 \\
\hline 30 & 450 & 185 & 31,87 & 19,41 & 14,27 & 10,01 & 7,47 & 5,87 & 4,06 & 3,13 & 2,19 \\
\hline 30 & 500 & 185 & 30,62 & 19,13 & 14,22 & 10,05 & 7,51 & 5,89 & 4,06 & 3,13 & 2,19 \\
\hline 30 & 550 & 185 & 29,55 & 18,88 & 14,17 & 10,07 & 7,54 & 5,92 & 4,07 & 3,13 & 2,18 \\
\hline 30 & 600 & 185 & 28,63 & 18,65 & 14,12 & 10,10 & 7,57 & 5,94 & 4,08 & 3,14 & 2,18 \\
\hline 30 & 650 & 185 & 27,81 & 18,43 & 14,07 & 10,12 & 7,60 & 5,96 & 4,09 & 3,14 & 2,18 \\
\hline
\end{tabular}




\begin{tabular}{|c|c|c|c|c|c|c|c|c|c|c|c|}
\hline \multirow[b]{2}{*}{$\mathrm{H}(\mathrm{cm})$} & \multirow[b]{2}{*}{ Mceq (MPa) } & & & & & De & ões (x & & & & \\
\hline & & Msub (MPa) & D0 & D25 & D40 & D60 & D80 & D100 & D140 & D180 & D260 \\
\hline 30 & 700 & 185 & 27,09 & 18,23 & 14,01 & 10,13 & 7,63 & 5,98 & 4,10 & 3,14 & 2,18 \\
\hline 30 & 750 & 185 & 26,43 & 18,04 & 13,95 & 10,14 & 7,65 & 6,01 & 4,11 & 3,14 & 2,18 \\
\hline 30 & 800 & 185 & 25,84 & 17,86 & 13,89 & 10,15 & 7,67 & 6,03 & 4,12 & 3,15 & 2,18 \\
\hline 30 & 850 & 185 & 25,30 & 17,69 & 13,84 & 10,15 & 7,69 & 6,04 & 4,13 & 3,15 & 2,18 \\
\hline 30 & 900 & 185 & 24,81 & 17,52 & 13,78 & 10,15 & 7,71 & 6,06 & 4,14 & 3,15 & 2,17 \\
\hline 30 & 950 & 185 & 24,35 & 17,36 & 13,72 & 10,16 & 7,73 & 6,08 & 4,15 & 3,15 & 2,17 \\
\hline 30 & 1000 & 185 & 23,93 & 17,22 & 13,66 & 10,15 & 7,74 & 6,10 & 4,16 & 3,16 & 2,17 \\
\hline 30 & 1050 & 185 & 23,53 & 17,07 & 13,61 & 10,15 & 7,76 & 6,11 & 4,16 & 3,16 & 2,17 \\
\hline 30 & 1100 & 185 & 23,16 & 16,93 & 13,55 & 10,15 & 7,77 & 6,13 & 4,17 & 3,16 & 2,17 \\
\hline 30 & 1150 & 185 & 22,82 & 16,80 & 13,50 & 10,14 & 7,78 & 6,14 & 4,18 & 3,17 & 2,17 \\
\hline 30 & 1200 & 185 & 22,49 & 16,67 & 13,44 & 10,13 & 7,79 & 6,16 & 4,19 & 3,17 & 2,17 \\
\hline 30 & 1250 & 185 & 22,18 & 16,55 & 13,39 & 10,13 & 7,80 & 6,17 & 4,20 & 3,17 & 2,17 \\
\hline 30 & 1300 & 185 & 21,89 & 16,43 & 13,33 & 10,12 & 7,81 & 6,18 & 4,21 & 3,18 & 2,17 \\
\hline 30 & 1350 & 185 & 21,62 & 16,32 & 13,28 & 10,11 & 7,82 & 6,19 & 4,22 & 3,18 & 2,17 \\
\hline 30 & 1400 & 185 & 21,35 & 16,20 & 13,23 & 10,10 & 7,83 & 6,20 & 4,22 & 3,18 & 2,17 \\
\hline 30 & 1450 & 185 & 21,10 & 16,10 & 13,18 & 10,09 & 7,83 & 6,22 & 4,23 & 3,19 & 2,17 \\
\hline 30 & 1500 & 185 & 20,86 & 15,99 & 13,13 & 10,08 & 7,84 & 6,23 & 4,24 & 3,19 & 2,17 \\
\hline 30 & 1550 & 185 & 20,64 & 15,89 & 13,08 & 10,07 & 7,84 & 6,24 & 4,25 & 3,19 & 2,17 \\
\hline 30 & 1600 & 185 & 20,42 & 15,79 & 13,03 & 10,06 & 7,85 & 6,25 & 4,26 & 3,20 & 2,17 \\
\hline 30 & 1650 & 185 & 20,21 & 15,70 & 12,98 & 10,04 & 7,85 & 6,25 & 4,26 & 3,20 & 2,17 \\
\hline 30 & 1700 & 185 & 20,01 & 15,60 & 12,93 & 10,03 & 7,86 & 6,26 & 4,27 & 3,20 & 2,17 \\
\hline 30 & 1750 & 185 & 19,81 & 15,51 & 12,89 & 10,02 & 7,86 & 6,27 & 4,28 & 3,21 & 2,17 \\
\hline 30 & 1800 & 185 & 19,63 & 15,42 & 12,84 & 10,00 & 7,86 & 6,28 & 4,29 & 3,21 & 2,17 \\
\hline 30 & 1850 & 185 & 19,45 & 15,34 & 12,79 & 9,99 & 7,86 & 6,29 & 4,29 & 3,21 & 2,17 \\
\hline 30 & 1900 & 185 & 19,27 & 15,26 & 12,75 & 9,98 & 7,86 & 6,29 & 4,30 & 3,22 & 2,17 \\
\hline 30 & 1950 & 185 & 19,11 & 15,17 & 12,70 & 9,96 & 7,86 & 6,30 & 4,31 & 3,22 & 2,17 \\
\hline 30 & 2000 & 185 & 18,95 & 15,09 & 12,66 & 9,95 & 7,87 & 6,31 & 4,31 & 3,22 & 2,17 \\
\hline 30 & 200 & 190 & 44,52 & 20,95 & 13,92 & 9,35 & 7,01 & 5,57 & 3,89 & 3,03 & 2,16 \\
\hline 30 & 250 & 190 & 40,07 & 20,39 & 13,97 & 9,47 & 7,07 & 5,60 & 3,90 & 3,04 & 2,15 \\
\hline 30 & 300 & 190 & 36,97 & 19,95 & 13,98 & 9,56 & 7,13 & 5,63 & 3,92 & 3,04 & 2,14 \\
\hline 30 & 350 & 190 & 34,65 & 19,58 & 13,97 & 9,63 & 7,18 & 5,66 & 3,93 & 3,04 & 2,14 \\
\hline 30 & 400 & 190 & 32,83 & 19,25 & 13,94 & 9,69 & 7,22 & 5,68 & 3,94 & 3,05 & 2,13 \\
\hline 30 & 450 & 190 & 31,35 & 18,96 & 13,90 & 9,74 & 7,26 & 5,71 & 3,95 & 3,05 & 2,13 \\
\hline 30 & 500 & 190 & 30,11 & 18,70 & 13,86 & 9,77 & 7,30 & 5,73 & 3,96 & 3,05 & 2,13 \\
\hline 30 & 550 & 190 & 29,06 & 18,45 & 13,82 & 9,80 & 7,33 & 5,75 & 3,96 & 3,05 & 2,13 \\
\hline 30 & 600 & 190 & 28,15 & 18,23 & 13,77 & 9,83 & 7,36 & 5,78 & 3,97 & 3,05 & 2,12 \\
\hline 30 & 650 & 190 & 27,34 & 18,02 & 13,71 & 9,84 & 7,39 & 5,80 & 3,98 & 3,06 & 2,12 \\
\hline 30 & 700 & 190 & 26,62 & 17,82 & 13,66 & 9,86 & 7,42 & 5,82 & 3,99 & 3,06 & 2,12 \\
\hline 30 & 750 & 190 & 25,98 & 17,64 & 13,61 & 9,87 & 7,44 & 5,84 & 4,00 & 3,06 & 2,12 \\
\hline 30 & 800 & 190 & 25,40 & 17,46 & 13,55 & 9,88 & 7,46 & 5,86 & 4,01 & 3,06 & 2,12 \\
\hline 30 & 850 & 190 & 24,87 & 17,29 & 13,50 & 9,88 & 7,48 & 5,88 & 4,02 & 3,06 & 2,12 \\
\hline 30 & 900 & 190 & 24,38 & 17,14 & 13,44 & 9,89 & 7,50 & 5,89 & 4,03 & 3,07 & 2,12 \\
\hline 30 & 950 & 190 & 23,93 & 16,98 & 13,39 & 9,89 & 7,52 & 5,91 & 4,03 & 3,07 & 2,12 \\
\hline 30 & 1000 & 190 & 23,51 & 16,84 & 13,33 & 9,89 & 7,53 & 5,93 & 4,04 & 3,07 & 2,12 \\
\hline 30 & 1050 & 190 & 23,12 & 16,70 & 13,28 & 9,89 & 7,55 & 5,94 & 4,05 & 3,08 & 2,12 \\
\hline 30 & 1100 & 190 & 22,76 & 16,57 & 13,23 & 9,88 & 7,56 & 5,96 & 4,06 & 3,08 & 2,12 \\
\hline 30 & 1150 & 190 & 22,42 & 16,44 & 13,17 & 9,88 & 7,57 & 5,97 & 4,07 & 3,08 & 2,11 \\
\hline 30 & 1200 & 190 & 22,10 & 16,31 & 13,12 & 9,87 & 7,58 & 5,99 & 4,08 & 3,08 & 2,11 \\
\hline 30 & 1250 & 190 & 21,80 & 16,19 & 13,07 & 9,87 & 7,59 & 6,00 & 4,08 & 3,09 & 2,11 \\
\hline 30 & 1300 & 190 & 21,51 & 16,08 & 13,02 & 9,86 & 7,60 & 6,01 & 4,09 & 3,09 & 2,11 \\
\hline 30 & 1350 & 190 & 21,24 & 15,97 & 12,97 & 9,85 & 7,61 & 6,02 & 4,10 & 3,09 & 2,11 \\
\hline 30 & 1400 & 190 & 20,98 & 15,86 & 12,92 & 9,84 & 7,62 & 6,03 & 4,11 & 3,10 & 2,11 \\
\hline 30 & 1450 & 190 & 20,73 & 15,75 & 12,87 & 9,83 & 7,62 & 6,04 & 4,12 & 3,10 & 2,11 \\
\hline 30 & 1500 & 190 & 20,50 & 15,65 & 12,82 & 9,82 & 7,63 & 6,05 & 4,12 & 3,10 & 2,11 \\
\hline 30 & 1550 & 190 & 20,27 & 15,55 & 12,77 & 9,81 & 7,63 & 6,06 & 4,13 & 3,11 & 2,11 \\
\hline 30 & 1600 & 190 & 20,06 & 15,46 & 12,73 & 9,80 & 7,64 & 6,07 & 4,14 & 3,11 & 2,11 \\
\hline 30 & 1650 & 190 & 19,85 & 15,36 & 12,68 & 9,79 & 7,64 & 6,08 & 4,14 & 3,11 & 2,11 \\
\hline 30 & 1700 & 190 & 19,66 & 15,27 & 12,63 & 9,78 & 7,65 & 6,09 & 4,15 & 3,12 & 2,11 \\
\hline 30 & 1750 & 190 & 19,46 & 15,19 & 12,59 & 9,77 & 7,65 & 6,10 & 4,16 & 3,12 & 2,11 \\
\hline 30 & 1800 & 190 & 19,28 & 15,10 & 12,54 & 9,75 & 7,65 & 6,11 & 4,17 & 3,12 & 2,11 \\
\hline 30 & 1850 & 190 & 19,11 & 15,02 & 12,50 & 9,74 & 7,65 & 6,11 & 4,17 & 3,12 & 2,11 \\
\hline 30 & 1900 & 190 & 18,94 & 14,94 & 12,46 & 9,73 & 7,66 & 6,12 & 4,18 & 3,13 & 2,11 \\
\hline 30 & 1950 & 190 & 18,77 & 14,86 & 12,41 & 9,72 & 7,66 & 6,13 & 4,19 & 3,13 & 2,11 \\
\hline 30 & 2000 & 190 & 18,61 & 14,78 & 12,37 & 9,70 & 7,66 & 6,14 & 4,19 & 3,13 & 2,11 \\
\hline 30 & 200 & 195 & 43,93 & 20,47 & 13,55 & 9,10 & 6,82 & 5,43 & 3,79 & 2,95 & 2,11 \\
\hline 30 & 250 & 195 & 39,51 & 19,93 & 13,60 & 9,22 & 6,88 & 5,45 & 3,80 & 2,96 & 2,10 \\
\hline 30 & 300 & 195 & 36,43 & 19,50 & 13,62 & 9,31 & 6,94 & 5,48 & 3,81 & 2,96 & 2,09 \\
\hline 30 & 350 & 195 & 34,13 & 19,14 & 13,61 & 9,38 & 6,99 & 5,51 & 3,82 & 2,96 & 2,08 \\
\hline 30 & 400 & 195 & 32,32 & 18,82 & 13,59 & 9,43 & 7,03 & 5,53 & 3,83 & 2,97 & 2,08 \\
\hline 30 & 450 & 195 & 30,86 & 18,54 & 13,56 & 9,48 & 7,07 & 5,55 & 3,84 & 2,97 & 2,08 \\
\hline 30 & 500 & 195 & 29,63 & 18,28 & 13,52 & 9,51 & 7,10 & 5,58 & 3,85 & 2,97 & 2,07 \\
\hline 30 & 550 & 195 & 28,59 & 18,05 & 13,47 & 9,54 & 7,14 & 5,60 & 3,86 & 2,97 & 2,07 \\
\hline 30 & 600 & 195 & 27,69 & 17,83 & 13,43 & 9,57 & 7,17 & 5,62 & 3,87 & 2,97 & 2,07 \\
\hline 30 & 650 & 195 & 26,89 & 17,62 & 13,38 & 9,59 & 7,19 & 5,64 & 3,88 & 2,98 & 2,07 \\
\hline 30 & 700 & 195 & 26,18 & 17,43 & 13,33 & 9,60 & 7,22 & 5,66 & 3,89 & 2,98 & 2,07 \\
\hline 30 & 750 & 195 & 25,55 & 17,25 & 13,28 & 9,61 & 7,24 & 5,68 & 3,89 & 2,98 & 2,07 \\
\hline 30 & 800 & 195 & 24,97 & 17,08 & 13,23 & 9,62 & 7,26 & 5,70 & 3,90 & 2,98 & 2,07 \\
\hline 30 & 850 & 195 & 24,45 & 16,92 & 13,18 & 9,63 & 7,28 & 5,72 & 3,91 & 2,99 & 2,06 \\
\hline 30 & 900 & 195 & 23,97 & 16,77 & 13,12 & 9,63 & 7,30 & 5,74 & 3,92 & 2,99 & 2,06 \\
\hline 30 & 950 & 195 & 23,53 & 16,62 & 13,07 & 9,63 & 7,32 & 5,75 & 3,93 & 2,99 & 2,06 \\
\hline 30 & 1000 & 195 & 23,11 & 16,48 & 13,02 & 9,63 & 7,33 & 5,77 & 3,93 & 2,99 & 2,06 \\
\hline
\end{tabular}




\begin{tabular}{|c|c|c|c|c|c|c|c|c|c|c|c|}
\hline \multirow[b]{2}{*}{$\mathrm{H}(\mathrm{cm})$} & \multirow[b]{2}{*}{ Mceq (MPa) } & & & & & De & ões (x1 & m) & & & \\
\hline & & Msub (MPa) & D0 & D25 & D40 & D60 & D80 & D100 & D140 & D180 & D260 \\
\hline 30 & 1050 & 195 & 22,73 & 16,34 & 12,97 & 9,63 & 7,35 & 5,78 & 3,94 & 3,00 & 2,06 \\
\hline 30 & 1100 & 195 & 22,37 & 16,21 & 12,92 & 9,63 & 7,36 & 5,80 & 3,95 & 3,00 & 2,06 \\
\hline 30 & 1150 & 195 & 22,04 & 16,09 & 12,87 & 9,63 & 7,37 & 5,81 & 3,96 & 3,00 & 2,06 \\
\hline 30 & 1200 & 195 & 21,72 & 15,97 & 12,82 & 9,62 & 7,38 & 5,82 & 3,97 & 3,00 & 2,06 \\
\hline 30 & 1250 & 195 & 21,42 & 15,85 & 12,77 & 9,62 & 7,39 & 5,84 & 3,97 & 3,01 & 2,06 \\
\hline 30 & 1300 & 195 & 21,14 & 15,74 & 12,72 & 9,61 & 7,40 & 5,85 & 3,98 & 3,01 & 2,06 \\
\hline 30 & 1350 & 195 & 20,87 & 15,63 & 12,67 & 9,60 & 7,41 & 5,86 & 3,99 & 3,01 & 2,06 \\
\hline 30 & 1400 & 195 & 20,62 & 15,53 & 12,62 & 9,59 & 7,42 & 5,87 & 4,00 & 3,01 & 2,06 \\
\hline 30 & 1450 & 195 & 20,38 & 15,42 & 12,57 & 9,59 & 7,42 & 5,88 & 4,00 & 3,02 & 2,06 \\
\hline 30 & 1500 & 195 & 20,15 & 15,33 & 12,53 & 9,58 & 7,43 & 5,89 & 4,01 & 3,02 & 2,06 \\
\hline 30 & 1550 & 195 & 19,93 & 15,23 & 12,48 & 9,57 & 7,43 & 5,90 & 4,02 & 3,02 & 2,06 \\
\hline 30 & 1600 & 195 & 19,72 & 15,14 & 12,44 & 9,56 & 7,44 & 5,91 & 4,03 & 3,03 & 2,06 \\
\hline 30 & 1650 & 195 & 19,51 & 15,05 & 12,39 & 9,55 & 7,44 & 5,92 & 4,03 & 3,03 & 2,06 \\
\hline 30 & 1700 & 195 & 19,32 & 14,96 & 12,35 & 9,54 & 7,45 & 5,93 & 4,04 & 3,03 & 2,06 \\
\hline 30 & 1750 & 195 & 19,13 & 14,87 & 12,30 & 9,53 & 7,45 & 5,94 & 4,05 & 3,04 & 2,06 \\
\hline 30 & 1800 & 195 & 18,95 & 14,79 & 12,26 & 9,51 & 7,45 & 5,94 & 4,05 & 3,04 & 2,06 \\
\hline 30 & 1850 & 195 & 18,78 & 14,71 & 12,22 & 9,50 & 7,46 & 5,95 & 4,06 & 3,04 & 2,06 \\
\hline 30 & 1900 & 195 & 18,61 & 14,63 & 12,18 & 9,49 & 7,46 & 5,96 & 4,07 & 3,04 & 2,06 \\
\hline 30 & 1950 & 195 & 18,45 & 14,55 & 12,14 & 9,48 & 7,46 & 5,96 & 4,07 & 3,05 & 2,06 \\
\hline 30 & 2000 & 195 & 18,29 & 14,48 & 12,10 & 9,47 & 7,46 & 5,97 & 4,08 & 3,05 & 2,06 \\
\hline 30 & 200 & 200 & 43,37 & 20,02 & 13,21 & 8,85 & 6,64 & 5,29 & 3,69 & 2,88 & 2,05 \\
\hline 30 & 250 & 200 & 38,98 & 19,49 & 13,26 & 8,97 & 6,70 & 5,32 & 3,71 & 2,88 & 2,04 \\
\hline 30 & 300 & 200 & 35,91 & 19,07 & 13,28 & 9,06 & 6,76 & 5,34 & 3,72 & 2,89 & 2,04 \\
\hline 30 & 350 & 200 & 33,63 & 18,72 & 13,27 & 9,13 & 6,80 & 5,36 & 3,73 & 2,89 & 2,03 \\
\hline 30 & 400 & 200 & 31,84 & 18,41 & 13,25 & 9,19 & 6,84 & 5,39 & 3,74 & 2,89 & 2,03 \\
\hline 30 & 450 & 200 & 30,38 & 18,13 & 13,23 & 9,23 & 6,88 & 5,41 & 3,75 & 2,89 & 2,03 \\
\hline 30 & 500 & 200 & 29,17 & 17,88 & 13,19 & 9,27 & 6,92 & 5,43 & 3,75 & 2,90 & 2,02 \\
\hline 30 & 550 & 200 & 28,14 & 17,66 & 13,15 & 9,30 & 6,95 & 5,45 & 3,76 & 2,90 & 2,02 \\
\hline 30 & 600 & 200 & 27,25 & 17,44 & 13,11 & 9,32 & 6,98 & 5,48 & 3,77 & 2,90 & 2,02 \\
\hline 30 & 650 & 200 & 26,46 & 17,25 & 13,06 & 9,34 & 7,00 & 5,50 & 3,78 & 2,90 & 2,02 \\
\hline 30 & 700 & 200 & 25,76 & 17,06 & 13,01 & 9,36 & 7,03 & 5,51 & 3,79 & 2,90 & 2,02 \\
\hline 30 & 750 & 200 & 25,13 & 16,89 & 12,97 & 9,37 & 7,05 & 5,53 & 3,79 & 2,91 & 2,02 \\
\hline 30 & 800 & 200 & 24,57 & 16,72 & 12,92 & 9,38 & 7,07 & 5,55 & 3,80 & 2,91 & 2,01 \\
\hline 30 & 850 & 200 & 24,05 & 16,56 & 12,87 & 9,38 & 7,09 & 5,57 & 3,81 & 2,91 & 2,01 \\
\hline 30 & 900 & 200 & 23,58 & 16,41 & 12,82 & 9,39 & 7,11 & 5,58 & 3,82 & 2,91 & 2,01 \\
\hline 30 & 950 & 200 & 23,14 & 16,27 & 12,77 & 9,39 & 7,13 & 5,60 & 3,82 & 2,91 & 2,01 \\
\hline 30 & 1000 & 200 & 22,73 & 16,13 & 12,72 & 9,39 & 7,14 & 5,62 & 3,83 & 2,92 & 2,01 \\
\hline 30 & 1050 & 200 & 22,36 & 16,00 & 12,67 & 9,39 & 7,16 & 5,63 & 3,84 & 2,92 & 2,01 \\
\hline 30 & 1100 & 200 & 22,00 & 15,88 & 12,62 & 9,39 & 7,17 & 5,64 & 3,85 & 2,92 & 2,01 \\
\hline 30 & 1150 & 200 & 21,67 & 15,76 & 12,57 & 9,39 & 7,18 & 5,66 & 3,85 & 2,92 & 2,01 \\
\hline 30 & 1200 & 200 & 21,36 & 15,64 & 12,52 & 9,38 & 7,19 & 5,67 & 3,86 & 2,93 & 2,01 \\
\hline 30 & 1250 & 200 & 21,07 & 15,53 & 12,48 & 9,38 & 7,20 & 5,68 & 3,87 & 2,93 & 2,01 \\
\hline 30 & 1300 & 200 & 20,79 & 15,42 & 12,43 & 9,37 & 7,21 & 5,69 & 3,88 & 2,93 & 2,01 \\
\hline 30 & 1350 & 200 & 20,53 & 15,31 & 12,38 & 9,37 & 7,22 & 5,71 & 3,88 & 2,93 & 2,01 \\
\hline 30 & 1400 & 200 & 20,28 & 15,21 & 12,34 & 9,36 & 7,22 & 5,72 & 3,89 & 2,94 & 2,01 \\
\hline 30 & 1450 & 200 & 20,04 & 15,11 & 12,29 & 9,35 & 7,23 & 5,73 & 3,90 & 2,94 & 2,01 \\
\hline 30 & 1500 & 200 & 19,81 & 15,01 & 12,25 & 9,34 & 7,24 & 5,74 & 3,91 & 2,94 & 2,01 \\
\hline 30 & 1550 & 200 & 19,59 & 14,92 & 12,20 & 9,34 & 7,24 & 5,75 & 3,91 & 2,95 & 2,01 \\
\hline 30 & 1600 & 200 & 19,39 & 14,83 & 12,16 & 9,33 & 7,25 & 5,76 & 3,92 & 2,95 & 2,01 \\
\hline 30 & 1650 & 200 & 19,19 & 14,74 & 12,12 & 9,32 & 7,25 & 5,76 & 3,93 & 2,95 & 2,01 \\
\hline 30 & 1700 & 200 & 19,00 & 14,66 & 12,08 & 9,31 & 7,26 & 5,77 & 3,93 & 2,95 & 2,01 \\
\hline 30 & 1750 & 200 & 18,81 & 14,57 & 12,03 & 9,30 & 7,26 & 5,78 & 3,94 & 2,96 & 2,01 \\
\hline 30 & 1800 & 200 & 18,64 & 14,49 & 11,99 & 9,29 & 7,26 & 5,79 & 3,95 & 2,96 & 2,01 \\
\hline 30 & 1850 & 200 & 18,47 & 14,41 & 11,95 & 9,28 & 7,27 & 5,80 & 3,95 & 2,96 & 2,01 \\
\hline 30 & 1900 & 200 & 18,30 & 14,34 & 11,91 & 9,26 & 7,27 & 5,80 & 3,96 & 2,97 & 2,01 \\
\hline 30 & 1950 & 200 & 18,14 & 14,26 & 11,87 & 9,25 & 7,27 & 5,81 & 3,96 & 2,97 & 2,01 \\
\hline 30 & 2000 & 200 & 17,99 & 14,19 & 11,83 & 9,24 & 7,27 & 5,82 & 3,97 & 2,97 & 2,01 \\
\hline 35 & 200 & 20 & 161,59 & 128,90 & 109,92 & 88,67 & 71,74 & 58,57 & 40,75 & 30,44 & 20,22 \\
\hline 35 & 250 & 20 & 148,96 & 122,30 & 105,85 & 86,85 & 71,23 & 58,74 & 41,30 & 30,84 & 20,30 \\
\hline 35 & 300 & 20 & 139,43 & 116,97 & 102,39 & 85,14 & 70,61 & 58,74 & 41,71 & 31,21 & 20,40 \\
\hline 35 & 350 & 20 & 131,90 & 112,52 & 99,39 & 83,55 & 69,94 & 58,62 & 42,03 & 31,53 & 20,50 \\
\hline 35 & 400 & 20 & 125,75 & 108,72 & 96,74 & 82,06 & 69,25 & 58,44 & 42,28 & 31,81 & 20,62 \\
\hline 35 & 450 & 20 & 120,61 & 105,42 & 94,39 & 80,69 & 68,56 & 58,20 & 42,46 & 32,06 & 20,73 \\
\hline 35 & 500 & 20 & 116,22 & 102,50 & 92,27 & 79,40 & 67,89 & 57,94 & 42,60 & 32,28 & 20,85 \\
\hline 35 & 550 & 20 & 112,43 & 99,90 & 90,34 & 78,21 & 67,23 & 57,65 & 42,70 & 32,47 & 20,96 \\
\hline 35 & 600 & 20 & 109,12 & 97,54 & 88,59 & 77,08 & 66,59 & 57,35 & 42,76 & 32,64 & 21,07 \\
\hline 35 & 650 & 20 & 106,18 & 95,41 & 86,97 & 76,03 & 65,97 & 57,05 & 42,80 & 32,79 & 21,18 \\
\hline 35 & 700 & 20 & 103,56 & 93,45 & 85,48 & 75,04 & 65,37 & 56,74 & 42,82 & 32,92 & 21,29 \\
\hline 35 & 750 & 20 & 101,21 & 91,64 & 84,09 & 74,10 & 64,79 & 56,43 & 42,83 & 33,03 & 21,39 \\
\hline 35 & 800 & 20 & 99,08 & 89,97 & 82,80 & 73,22 & 64,24 & 56,12 & 42,81 & 33,13 & 21,49 \\
\hline 35 & 850 & 20 & 97,15 & 88,41 & 81,58 & 72,38 & 63,70 & 55,81 & 42,79 & 33,22 & 21,58 \\
\hline 35 & 900 & 20 & 95,38 & 86,96 & 80,45 & 71,58 & 63,18 & 55,51 & 42,75 & 33,30 & 21,67 \\
\hline 35 & 950 & 20 & 93,75 & 85,59 & 79,38 & 70,82 & 62,68 & 55,21 & 42,71 & 33,37 & 21,76 \\
\hline 35 & 1000 & 20 & 92,25 & 84,31 & 78,36 & 70,09 & 62,19 & 54,92 & 42,66 & 33,42 & 21,84 \\
\hline 35 & 1050 & 20 & 90,86 & 83,10 & 77,41 & 69,40 & 61,72 & 54,63 & 42,60 & 33,47 & 21,92 \\
\hline 35 & 1100 & 20 & 89,56 & 81,95 & 76,50 & 68,74 & 61,27 & 54,34 & 42,53 & 33,51 & 22,00 \\
\hline 35 & 1150 & 20 & 88,35 & 80,87 & 75,63 & 68,10 & 60,83 & 54,06 & 42,47 & 33,55 & 22,07 \\
\hline 35 & 1200 & 20 & 87,23 & 79,84 & 74,81 & 67,49 & 60,41 & 53,79 & 42,39 & 33,58 & 22,14 \\
\hline 35 & 1250 & 20 & 86,17 & 78,85 & 74,02 & 66,90 & 59,99 & 53,52 & 42,32 & 33,60 & 22,21 \\
\hline 35 & 1300 & 20 & 85,17 & 77,92 & 73,26 & 66,34 & 59,59 & 53,25 & 42,24 & 33,62 & 22,27 \\
\hline 35 & 1350 & 20 & 84,23 & 77,02 & 72,54 & 65,79 & 59,21 & 52,99 & 42,16 & 33,63 & 22,33 \\
\hline
\end{tabular}




\begin{tabular}{|c|c|c|c|c|c|c|c|c|c|c|c|}
\hline \multirow[b]{2}{*}{$\mathrm{H}(\mathrm{cm})$} & \multirow[b]{2}{*}{ Mceq (MPa) } & & & & & De & ões (x1 & m) & & & \\
\hline & & Msub (MPa) & D0 & D25 & D40 & D60 & D80 & D100 & D140 & D180 & D260 \\
\hline 35 & 1400 & 20 & 83,34 & 76,16 & 71,85 & 65,27 & 58,83 & 52,74 & 42,08 & 33,64 & 22,39 \\
\hline 35 & 1450 & 20 & 82,50 & 75,34 & 71,18 & 64,76 & 58,46 & 52,49 & 42,00 & 33,65 & 22,45 \\
\hline 35 & 1500 & 20 & 81,71 & 74,56 & 70,54 & 64,27 & 58,11 & 52,24 & 41,91 & 33,65 & 22,50 \\
\hline 35 & 1550 & 20 & 80,95 & 73,80 & 69,93 & 63,80 & 57,76 & 52,00 & 41,82 & 33,65 & 22,55 \\
\hline 35 & 1600 & 20 & 80,23 & 73,07 & 69,33 & 63,34 & 57,42 & 51,77 & 41,74 & 33,65 & 22,60 \\
\hline 35 & 1650 & 20 & 79,54 & 72,37 & 68,76 & 62,90 & 57,09 & 51,54 & 41,65 & 33,65 & 22,65 \\
\hline 35 & 1700 & 20 & 78,88 & 71,69 & 68,21 & 62,47 & 56,77 & 51,31 & 41,56 & 33,64 & 22,69 \\
\hline 35 & 1750 & 20 & 78,25 & 71,04 & 67,67 & 62,05 & 56,46 & 51,09 & 41,47 & 33,63 & 22,74 \\
\hline 35 & 1800 & 20 & 77,65 & 70,41 & 67,15 & 61,65 & 56,16 & 50,87 & 41,38 & 33,62 & 22,78 \\
\hline 35 & 1850 & 20 & 77,07 & 69,80 & 66,65 & 61,25 & 55,86 & 50,66 & 41,30 & 33,60 & 22,81 \\
\hline 35 & 1900 & 20 & 76,52 & 69,22 & 66,16 & 60,87 & 55,57 & 50,45 & 41,21 & 33,59 & 22,85 \\
\hline 35 & 1950 & 20 & 75,98 & 68,65 & 65,69 & 60,50 & 55,28 & 50,24 & 41,12 & 33,57 & 22,89 \\
\hline 35 & 2000 & 20 & 75,47 & 68,09 & 65,23 & 60,13 & 55,01 & 50,04 & 41,03 & 33,55 & 22,92 \\
\hline 35 & 200 & 25 & 140,34 & 108,45 & 90,99 & 72,12 & 57,59 & 46,58 & 32,17 & 24,08 & 16,14 \\
\hline 35 & 250 & 25 & 129,27 & 103,12 & 87,93 & 70,93 & 57,39 & 46,85 & 32,60 & 24,35 & 16,18 \\
\hline 35 & 300 & 25 & 120,95 & 98,80 & 85,29 & 69,77 & 57,08 & 46,98 & 32,96 & 24,61 & 16,23 \\
\hline 35 & 350 & 25 & 114,36 & 95,18 & 82,97 & 68,65 & 56,69 & 47,00 & 33,25 & 24,85 & 16,29 \\
\hline 35 & 400 & 25 & 108,98 & 92,08 & 80,91 & 67,59 & 56,27 & 46,96 & 33,48 & 25,07 & 16,35 \\
\hline 35 & 450 & 25 & 104,46 & 89,37 & 79,07 & 66,59 & 55,84 & 46,87 & 33,67 & 25,27 & 16,42 \\
\hline 35 & 500 & 25 & 100,60 & 86,98 & 77,40 & 65,65 & 55,40 & 46,75 & 33,82 & 25,45 & 16,49 \\
\hline 35 & 550 & 25 & 97,25 & 84,84 & 75,87 & 64,76 & 54,96 & 46,60 & 33,94 & 25,61 & 16,57 \\
\hline 35 & 600 & 25 & 94,32 & 82,90 & 74,47 & 63,92 & 54,52 & 46,44 & 34,04 & 25,75 & 16,64 \\
\hline 35 & 650 & 25 & 91,72 & 81,14 & 73,18 & 63,13 & 54,10 & 46,26 & 34,11 & 25,89 & 16,72 \\
\hline 35 & 700 & 25 & 89,39 & 79,53 & 71,98 & 62,38 & 53,68 & 46,07 & 34,17 & 26,00 & 16,79 \\
\hline 35 & 750 & 25 & 87,29 & 78,04 & 70,87 & 61,67 & 53,27 & 45,88 & 34,21 & 26,11 & 16,86 \\
\hline 35 & 800 & 25 & 85,39 & 76,65 & 69,83 & 60,99 & 52,87 & 45,69 & 34,24 & 26,21 & 16,93 \\
\hline 35 & 850 & 25 & 83,66 & 75,37 & 68,85 & 60,34 & 52,49 & 45,49 & 34,26 & 26,30 & 17,00 \\
\hline 35 & 900 & 25 & 82,08 & 74,17 & 67,93 & 59,73 & 52,11 & 45,29 & 34,26 & 26,37 & 17,06 \\
\hline 35 & 950 & 25 & 80,62 & 73,04 & 67,06 & 59,14 & 51,74 & 45,09 & 34,26 & 26,44 & 17,13 \\
\hline 35 & 1000 & 25 & 79,27 & 71,97 & 66,24 & 58,57 & 51,39 & 44,90 & 34,25 & 26,51 & 17,19 \\
\hline 35 & 1050 & 25 & 78,02 & 70,97 & 65,46 & 58,03 & 51,04 & 44,70 & 34,24 & 26,56 & 17,25 \\
\hline 35 & 1100 & 25 & 76,85 & 70,02 & 64,72 & 57,51 & 50,71 & 44,51 & 34,21 & 26,62 & 17,31 \\
\hline 35 & 1150 & 25 & 75,77 & 69,12 & 64,01 & 57,02 & 50,38 & 44,31 & 34,19 & 26,66 & 17,37 \\
\hline 35 & 1200 & 25 & 74,75 & 68,26 & 63,34 & 56,54 & 50,06 & 44,12 & 34,16 & 26,70 & 17,42 \\
\hline 35 & 1250 & 25 & 73,80 & 67,45 & 62,69 & 56,07 & 49,75 & 43,93 & 34,12 & 26,74 & 17,48 \\
\hline 35 & 1300 & 25 & 72,90 & 66,67 & 62,07 & 55,63 & 49,45 & 43,75 & 34,09 & 26,77 & 17,53 \\
\hline 35 & 1350 & 25 & 72,05 & 65,92 & 61,48 & 55,20 & 49,16 & 43,56 & 34,05 & 26,80 & 17,58 \\
\hline 35 & 1400 & 25 & 71,26 & 65,21 & 60,92 & 54,78 & 48,88 & 43,38 & 34,01 & 26,82 & 17,62 \\
\hline 35 & 1450 & 25 & 70,50 & 64,53 & 60,37 & 54,38 & 48,60 & 43,20 & 33,96 & 26,84 & 17,67 \\
\hline 35 & 1500 & 25 & 69,78 & 63,87 & 59,84 & 53,99 & 48,33 & 43,03 & 33,92 & 26,86 & 17,71 \\
\hline 35 & 1550 & 25 & 69,10 & 63,24 & 59,34 & 53,61 & 48,06 & 42,86 & 33,87 & 26,88 & 17,76 \\
\hline 35 & 1600 & 25 & 68,45 & 62,63 & 58,85 & 53,25 & 47,80 & 42,69 & 33,82 & 26,89 & 17,80 \\
\hline 35 & 1650 & 25 & 67,83 & 62,04 & 58,38 & 52,90 & 47,55 & 42,52 & 33,77 & 26,90 & 17,84 \\
\hline 35 & 1700 & 25 & 67,24 & 61,48 & 57,92 & 52,55 & 47,30 & 42,35 & 33,72 & 26,91 & 17,88 \\
\hline 35 & 1750 & 25 & 66,68 & 60,93 & 57,48 & 52,22 & 47,06 & 42,19 & 33,66 & 26,92 & 17,91 \\
\hline 35 & 1800 & 25 & 66,13 & 60,40 & 57,05 & 51,89 & 46,83 & 42,03 & 33,61 & 26,92 & 17,95 \\
\hline 35 & 1850 & 25 & 65,62 & 59,89 & 56,64 & 51,58 & 46,60 & 41,87 & 33,56 & 26,92 & 17,98 \\
\hline 35 & 1900 & 25 & 65,12 & 59,40 & 56,24 & 51,27 & 46,37 & 41,72 & 33,50 & 26,92 & 18,02 \\
\hline 35 & 1950 & 25 & 64,64 & 58,92 & 55,85 & 50,97 & 46,15 & 41,57 & 33,45 & 26,92 & 18,05 \\
\hline 35 & 2000 & 25 & 64,18 & 58,46 & 55,47 & 50,68 & 45,94 & 41,42 & 33,39 & 26,92 & 18,08 \\
\hline 35 & 200 & 30 & 125,15 & 94,02 & 77,77 & 60,74 & 48,00 & 38,57 & 26,52 & 19,90 & 13,44 \\
\hline 35 & 250 & 30 & 115,20 & 89,56 & 75,37 & 59,94 & 47,97 & 38,87 & 26,87 & 20,10 & 13,45 \\
\hline 35 & 300 & 30 & 107,73 & 85,93 & 73,28 & 59,11 & 47,83 & 39,04 & 27,17 & 20,29 & 13,48 \\
\hline 35 & 350 & 30 & 101,83 & 82,89 & 71,42 & 58,30 & 47,61 & 39,14 & 27,42 & 20,48 & 13,51 \\
\hline 35 & 400 & 30 & 97,00 & 80,27 & 69,76 & 57,51 & 47,36 & 39,17 & 27,63 & 20,65 & 13,55 \\
\hline 35 & 450 & 30 & 92,95 & 77,98 & 68,26 & 56,76 & 47,07 & 39,16 & 27,81 & 20,80 & 13,60 \\
\hline 35 & 500 & 30 & 89,49 & 75,95 & 66,90 & 56,04 & 46,78 & 39,11 & 27,96 & 20,95 & 13,65 \\
\hline 35 & 550 & 30 & 86,48 & 74,13 & 65,65 & 55,36 & 46,47 & 39,04 & 28,08 & 21,08 & 13,69 \\
\hline 35 & 600 & 30 & 83,83 & 72,48 & 64,50 & 54,71 & 46,17 & 38,96 & 28,19 & 21,21 & 13,75 \\
\hline 35 & 650 & 30 & 81,48 & 70,98 & 63,43 & 54,09 & 45,86 & 38,86 & 28,27 & 21,32 & 13,80 \\
\hline 35 & 700 & 30 & 79,38 & 69,61 & 62,44 & 53,50 & 45,56 & 38,74 & 28,34 & 21,42 & 13,85 \\
\hline 35 & 750 & 30 & 77,48 & 68,33 & 61,51 & 52,94 & 45,26 & 38,62 & 28,40 & 21,52 & 13,90 \\
\hline 35 & 800 & 30 & 75,76 & 67,16 & 60,64 & 52,40 & 44,96 & 38,50 & 28,45 & 21,61 & 13,95 \\
\hline 35 & 850 & 30 & 74,19 & 66,06 & 59,83 & 51,88 & 44,67 & 38,37 & 28,48 & 21,69 & 14,00 \\
\hline 35 & 900 & 30 & 72,74 & 65,03 & 59,06 & 51,39 & 44,39 & 38,24 & 28,51 & 21,76 & 14,05 \\
\hline 35 & 950 & 30 & 71,41 & 64,06 & 58,33 & 50,92 & 44,12 & 38,10 & 28,53 & 21,83 & 14,10 \\
\hline 35 & 1000 & 30 & 70,18 & 63,16 & 57,64 & 50,46 & 43,84 & 37,96 & 28,54 & 21,89 & 14,15 \\
\hline 35 & 1050 & 30 & 69,04 & 62,30 & 56,98 & 50,03 & 43,58 & 37,83 & 28,55 & 21,95 & 14,19 \\
\hline 35 & 1100 & 30 & 67,98 & 61,48 & 56,36 & 49,61 & 43,32 & 37,69 & 28,55 & 22,00 & 14,24 \\
\hline 35 & 1150 & 30 & 66,99 & 60,71 & 55,77 & 49,20 & 43,07 & 37,55 & 28,55 & 22,05 & 14,28 \\
\hline 35 & 1200 & 30 & 66,06 & 59,98 & 55,20 & 48,81 & 42,82 & 37,41 & 28,54 & 22,09 & 14,33 \\
\hline 35 & 1250 & 30 & 65,18 & 59,28 & 54,65 & 48,43 & 42,58 & 37,28 & 28,53 & 22,13 & 14,37 \\
\hline 35 & 1300 & 30 & 64,36 & 58,61 & 54,13 & 48,07 & 42,35 & 37,14 & 28,52 & 22,17 & 14,41 \\
\hline 35 & 1350 & 30 & 63,58 & 57,97 & 53,63 & 47,72 & 42,12 & 37,01 & 28,50 & 22,20 & 14,45 \\
\hline 35 & 1400 & 30 & 62,85 & 57,36 & 53,15 & 47,38 & 41,90 & 36,87 & 28,48 & 22,23 & 14,49 \\
\hline 35 & 1450 & 30 & 62,16 & 56,77 & 52,69 & 47,05 & 41,68 & 36,74 & 28,46 & 22,26 & 14,53 \\
\hline 35 & 1500 & 30 & 61,50 & 56,21 & 52,24 & 46,73 & 41,46 & 36,61 & 28,44 & 22,28 & 14,56 \\
\hline 35 & 1550 & 30 & 60,87 & 55,66 & 51,81 & 46,42 & 41,25 & 36,48 & 28,41 & 22,30 & 14,60 \\
\hline 35 & 1600 & 30 & 60,28 & 55,14 & 51,40 & 46,12 & 41,05 & 36,35 & 28,38 & 22,32 & 14,63 \\
\hline 35 & 1650 & 30 & 59,71 & 54,64 & 51,00 & 45,82 & 40,85 & 36,23 & 28,36 & 22,34 & 14,67 \\
\hline 35 & 1700 & 30 & 59,17 & 54,15 & 50,61 & 45,54 & 40,65 & 36,10 & 28,33 & 22,36 & 14,70 \\
\hline
\end{tabular}




\begin{tabular}{|c|c|c|c|c|c|c|c|c|c|c|c|}
\hline \multirow[b]{2}{*}{$\mathrm{H}(\mathrm{cm})$} & \multirow[b]{2}{*}{ Mceq (MPa) } & & & & & De & ões (x1 & m) & & & \\
\hline & & Msub (MPa) & D0 & D25 & D40 & D60 & D80 & D100 & D140 & D180 & D260 \\
\hline 35 & 1750 & 30 & 58,65 & 53,68 & 50,23 & 45,26 & 40,46 & 35,98 & 28,30 & 22,37 & 14,73 \\
\hline 35 & 1800 & 30 & 58,15 & 53,22 & 49,87 & 44,99 & 40,27 & 35,86 & 28,26 & 22,39 & 14,76 \\
\hline 35 & 1850 & 30 & 57,68 & 52,78 & 49,52 & 44,73 & 40,09 & 35,74 & 28,23 & 22,40 & 14,79 \\
\hline 35 & 1900 & 30 & 57,22 & 52,36 & 49,18 & 44,48 & 39,91 & 35,62 & 28,20 & 22,41 & 14,82 \\
\hline 35 & 1950 & 30 & 56,78 & 51,94 & 48,84 & 44,23 & 39,73 & 35,50 & 28,16 & 22,41 & 14,85 \\
\hline 35 & 2000 & 30 & 56,36 & 51,54 & 48,52 & 43,98 & 39,56 & 35,39 & 28,13 & 22,42 & 14,88 \\
\hline 35 & 200 & 35 & 113,68 & 83,23 & 67,97 & 52,43 & 41,08 & 32,85 & 22,53 & 16,96 & 11,52 \\
\hline 35 & 250 & 35 & 104,55 & 79,40 & 66,04 & 51,87 & 41,15 & 33,15 & 22,82 & 17,11 & 11,52 \\
\hline 35 & 300 & 35 & 97,72 & 76,28 & 64,33 & 51,27 & 41,11 & 33,34 & 23,07 & 17,25 & 11,53 \\
\hline 35 & 350 & 35 & 92,34 & 73,66 & 62,81 & 50,67 & 40,99 & 33,47 & 23,29 & 17,40 & 11,55 \\
\hline 35 & 400 & 35 & 87,94 & 71,39 & 61,43 & 50,07 & 40,84 & 33,54 & 23,47 & 17,53 & 11,58 \\
\hline 35 & 450 & 35 & 84,25 & 69,41 & 60,19 & 49,49 & 40,66 & 33,57 & 23,64 & 17,66 & 11,61 \\
\hline 35 & 500 & 35 & 81,09 & 67,65 & 59,05 & 48,92 & 40,45 & 33,57 & 23,77 & 17,78 & 11,64 \\
\hline 35 & 550 & 35 & 78,35 & 66,07 & 58,00 & 48,38 & 40,24 & 33,55 & 23,89 & 17,89 & 11,67 \\
\hline 35 & 600 & 35 & 75,93 & 64,64 & 57,02 & 47,87 & 40,02 & 33,51 & 24,00 & 17,99 & 11,71 \\
\hline 35 & 650 & 35 & 73,78 & 63,33 & 56,12 & 47,37 & 39,80 & 33,46 & 24,08 & 18,09 & 11,74 \\
\hline 35 & 700 & 35 & 71,86 & 62,13 & 55,28 & 46,89 & 39,57 & 33,39 & 24,16 & 18,18 & 11,78 \\
\hline 35 & 750 & 35 & 70,12 & 61,02 & 54,49 & 46,44 & 39,35 & 33,32 & 24,22 & 18,26 & 11,82 \\
\hline 35 & 800 & 35 & 68,54 & 59,99 & 53,76 & 46,00 & 39,12 & 33,24 & 24,28 & 18,34 & 11,86 \\
\hline 35 & 850 & 35 & 67,09 & 59,03 & 53,06 & 45,58 & 38,90 & 33,15 & 24,32 & 18,41 & 11,89 \\
\hline 35 & 900 & 35 & 65,76 & 58,13 & 52,40 & 45,17 & 38,68 & 33,06 & 24,36 & 18,48 & 11,93 \\
\hline 35 & 950 & 35 & 64,54 & 57,29 & 51,78 & 44,78 & 38,47 & 32,97 & 24,39 & 18,54 & 11,97 \\
\hline 35 & 1000 & 35 & 63,41 & 56,49 & 51,18 & 44,41 & 38,26 & 32,87 & 24,42 & 18,60 & 12,01 \\
\hline 35 & 1050 & 35 & 62,35 & 55,74 & 50,62 & 44,05 & 38,05 & 32,77 & 24,44 & 18,65 & 12,04 \\
\hline 35 & 1100 & 35 & 61,37 & 55,03 & 50,08 & 43,70 & 37,85 & 32,67 & 24,45 & 18,70 & 12,08 \\
\hline 35 & 1150 & 35 & 60,45 & 54,35 & 49,57 & 43,36 & 37,65 & 32,57 & 24,46 & 18,75 & 12,11 \\
\hline 35 & 1200 & 35 & 59,59 & 53,71 & 49,08 & 43,04 & 37,45 & 32,47 & 24,47 & 18,79 & 12,15 \\
\hline 35 & 1250 & 35 & 58,78 & 53,09 & 48,61 & 42,72 & 37,26 & 32,37 & 24,47 & 18,83 & 12,18 \\
\hline 35 & 1300 & 35 & 58,02 & 52,51 & 48,16 & 42,42 & 37,07 & 32,27 & 24,47 & 18,87 & 12,22 \\
\hline 35 & 1350 & 35 & 57,30 & 51,95 & 47,73 & 42,12 & 36,89 & 32,17 & 24,47 & 18,90 & 12,25 \\
\hline 35 & 1400 & 35 & 56,62 & 51,41 & 47,31 & 41,84 & 36,71 & 32,07 & 24,46 & 18,93 & 12,28 \\
\hline 35 & 1450 & 35 & 55,97 & 50,89 & 46,91 & 41,56 & 36,53 & 31,97 & 24,46 & 18,96 & 12,31 \\
\hline 35 & 1500 & 35 & 55,36 & 50,40 & 46,52 & 41,29 & 36,36 & 31,87 & 24,45 & 18,99 & 12,34 \\
\hline 35 & 1550 & 35 & 54,78 & 49,92 & 46,15 & 41,03 & 36,19 & 31,77 & 24,44 & 19,02 & 12,37 \\
\hline 35 & 1600 & 35 & 54,23 & 49,46 & 45,79 & 40,78 & 36,02 & 31,67 & 24,42 & 19,04 & 12,40 \\
\hline 35 & 1650 & 35 & 53,70 & 49,02 & 45,44 & 40,53 & 35,86 & 31,57 & 24,41 & 19,06 & 12,43 \\
\hline 35 & 1700 & 35 & 53,19 & 48,59 & 45,11 & 40,29 & 35,70 & 31,48 & 24,39 & 19,08 & 12,46 \\
\hline 35 & 1750 & 35 & 52,71 & 48,18 & 44,78 & 40,05 & 35,54 & 31,38 & 24,37 & 19,10 & 12,48 \\
\hline 35 & 1800 & 35 & 52,25 & 47,78 & 44,46 & 39,82 & 35,39 & 31,29 & 24,36 & 19,12 & 12,51 \\
\hline 35 & 1850 & 35 & 51,81 & 47,39 & 44,16 & 39,60 & 35,23 & 31,19 & 24,34 & 19,13 & 12,53 \\
\hline 35 & 1900 & 35 & 51,38 & 47,01 & 43,86 & 39,38 & 35,09 & 31,10 & 24,32 & 19,14 & 12,56 \\
\hline 35 & 1950 & 35 & 50,98 & 46,65 & 43,57 & 39,17 & 34,94 & 31,01 & 24,29 & 19,16 & 12,58 \\
\hline 35 & 2000 & 35 & 50,58 & 46,30 & 43,29 & 38,97 & 34,80 & 30,91 & 24,27 & 19,17 & 12,61 \\
\hline 35 & 200 & 40 & 104,66 & 74,83 & 60,40 & 46,09 & 35,86 & 28,57 & 19,57 & 14,78 & 10,08 \\
\hline 35 & 250 & 40 & 96,16 & 71,48 & 58,82 & 45,70 & 35,98 & 28,85 & 19,81 & 14,89 & 10,08 \\
\hline 35 & 300 & 40 & 89,83 & 68,75 & 57,40 & 45,26 & 36,00 & 29,05 & 20,03 & 15,00 & 10,08 \\
\hline 35 & 350 & 40 & 84,86 & 66,44 & 56,12 & 44,80 & 35,96 & 29,19 & 20,21 & 15,11 & 10,09 \\
\hline 35 & 400 & 40 & 80,80 & 64,45 & 54,96 & 44,33 & 35,87 & 29,28 & 20,38 & $\frac{10,2+}{15,22}$ & 10,11 \\
\hline 35 & 450 & 40 & 77,39 & 62,70 & 53,90 & 43,87 & 35,75 & 29,34 & 20,52 & 15,32 & 10,13 \\
\hline 35 & 500 & 40 & 74,48 & 61,15 & 52,93 & 43,43 & 35,62 & 29,37 & 20,65 & 15,42 & 10,15 \\
\hline 35 & 550 & 40 & 71,94 & 59,75 & 52,03 & 42,99 & 35,46 & 29,38 & 20,76 & 15,51 & 10,17 \\
\hline 35 & 600 & 40 & 69,71 & 58,48 & 51,20 & 42,57 & 35,30 & 29,37 & 20,86 & 15,60 & 10,20 \\
\hline 35 & 650 & 40 & 67,73 & 57,33 & 50,42 & 42,16 & 35,14 & 29,35 & 20,94 & 15,69 & 10,23 \\
\hline 35 & 700 & 40 & 65,95 & 56,26 & 49,69 & 41,77 & 34,97 & 29,31 & 21,02 & 15,76 & 10,25 \\
\hline 35 & 750 & 40 & 64,34 & 55,28 & 49,01 & 41,40 & 34,80 & 29,27 & 21,08 & 15,84 & 10,28 \\
\hline 35 & 800 & 40 & 62,88 & 54,36 & 48,37 & 41,03 & 34,62 & 29,22 & 21,14 & 15,90 & 10,31 \\
\hline 35 & 850 & 40 & 61,54 & 53,51 & 47,77 & 40,68 & 34,45 & 29,16 & 21,19 & 15,97 & 10,34 \\
\hline 35 & 900 & 40 & 60,30 & 52,71 & 47,19 & 40,34 & 34,28 & 29,10 & 21,23 & 16,03 & 10,37 \\
\hline 35 & 950 & 40 & 59,17 & 51,96 & 46,65 & 40,02 & 34,11 & 29,04 & 21,27 & 16,09 & 10,40 \\
\hline 35 & 1000 & 40 & 58,11 & 51,25 & 46,13 & 39,70 & 33,94 & 28,97 & 21,30 & 16,14 & 10,42 \\
\hline 35 & 1050 & 40 & 57,13 & 50,58 & 45,64 & 39,40 & 33,78 & 28,90 & 21,33 & 16,19 & 10,45 \\
\hline 35 & 1100 & 40 & 56,22 & 49,95 & 45,17 & 39,10 & 33,61 & 28,83 & 21,35 & 16,23 & 10,48 \\
\hline 35 & 1150 & 40 & 55,36 & 49,35 & 44,72 & 38,82 & 33,45 & 28,75 & 21,37 & 16,28 & 10,51 \\
\hline 35 & 1200 & 40 & 54,56 & 48,77 & 44,29 & 38,54 & 33,29 & 28,68 & 21,38 & 16,32 & 10,54 \\
\hline 35 & 1250 & 40 & 53,80 & 48,23 & 43,88 & 38,27 & 33,14 & 28,60 & 21,39 & 16,36 & 10,56 \\
\hline 35 & 1300 & 40 & 53,09 & 47,70 & 43,49 & 38,02 & 32,98 & 28,52 & 21,40 & 16,39 & 10,59 \\
\hline 35 & 1350 & 40 & 52,42 & 47,20 & 43,10 & 37,76 & 32,83 & 28,45 & 21,41 & 16,43 & 10,62 \\
\hline 35 & 1400 & 40 & 51,78 & 46,72 & 42,74 & 37,52 & 32,69 & 28,37 & 21,41 & 16,46 & 10,64 \\
\hline 35 & 1450 & 40 & 51,18 & 46,26 & 42,39 & 37,28 & 32,54 & 28,29 & 21,41 & 16,49 & 10,67 \\
\hline 35 & 1500 & 40 & 50,61 & 45,82 & 42,04 & 37,05 & 32,40 & 28,21 & 21,41 & 16,52 & 10,70 \\
\hline 35 & 1550 & 40 & 50,06 & 45,39 & 41,72 & 36,83 & 32,26 & 28,14 & 21,41 & 16,54 & 10,72 \\
\hline 35 & 1600 & 40 & 49,54 & 44,98 & 41,40 & 36,61 & 32,12 & 28,06 & 21,41 & 16,57 & 10,74 \\
\hline 35 & 1650 & 40 & 49,05 & 44,59 & 41,09 & 36,40 & 31,98 & 27,98 & 21,40 & 16,59 & 10,77 \\
\hline 35 & 1700 & 40 & 48,57 & 44,21 & 40,79 & 36,19 & 31,85 & 27,91 & 21,39 & 16,61 & 10,79 \\
\hline 35 & 1750 & 40 & 48,12 & 43,84 & 40,50 & 35,99 & 31,72 & 27,83 & 21,39 & 16,63 & 10,81 \\
\hline 35 & 1800 & 40 & 47,69 & 43,48 & 40,22 & 35,79 & 31,59 & 27,76 & 21,38 & 16,65 & 10,84 \\
\hline 35 & 1850 & 40 & 47,27 & 43,13 & 39,95 & 35,60 & 31,46 & 27,68 & 21,37 & 16,67 & 10,86 \\
\hline 35 & 1900 & 40 & 46,87 & 42,80 & 39,69 & 35,41 & 31,34 & 27,61 & 21,35 & 16,68 & 10,88 \\
\hline 35 & 1950 & 40 & 46,49 & 42,47 & 39,43 & 35,23 & 31,22 & 27,53 & 21,34 & 16,70 & 10,90 \\
\hline 35 & 2000 & 40 & 46,12 & 42,15 & 39,18 & 35,05 & 31,10 & 27,46 & 21,33 & 16,71 & 10,92 \\
\hline 35 & 200 & 45 & 97,37 & 68,08 & 54,38 & 41,09 & 31,79 & 25,26 & 17,29 & 13,09 & 8,96 \\
\hline
\end{tabular}




\begin{tabular}{|c|c|c|c|c|c|c|c|c|c|c|c|}
\hline \multirow[b]{2}{*}{$\mathrm{H}(\mathrm{cm})$} & \multirow[b]{2}{*}{ Mceq (MPa) } & & & & & $\mathrm{De}$ & ões (x1 & & & & \\
\hline & & Msub (MPa) & D0 & D25 & D40 & D60 & D80 & D100 & D140 & D180 & D260 \\
\hline 35 & 250 & 45 & 89,37 & 65,11 & 53,05 & 40,82 & 31,94 & 25,52 & 17,50 & 13,18 & 8,96 \\
\hline 35 & 300 & 45 & 83,43 & 62,68 & 51,85 & 40,50 & 32,00 & 25,71 & 17,68 & 13,27 & 8,96 \\
\hline 35 & 350 & 45 & 78,78 & 60,62 & 50,76 & 40,14 & 32,00 & 25,86 & 17,84 & 13,36 & 8,97 \\
\hline 35 & 400 & 45 & 74,99 & 58,85 & 49,76 & 39,78 & 31,96 & 25,96 & 17,98 & 13,45 & 8,97 \\
\hline 35 & 450 & 45 & 71,82 & 57,29 & 48,85 & 39,41 & 31,88 & 26,03 & 18,11 & 13,53 & 8,99 \\
\hline 35 & 500 & 45 & 69,10 & 55,90 & 48,01 & 39,04 & 31,79 & 26,08 & 18,23 & 13,61 & 9,00 \\
\hline 35 & 550 & 45 & 66,75 & 54,65 & 47,23 & 38,69 & 31,69 & 26,10 & 18,33 & 13,69 & 9,02 \\
\hline 35 & 600 & 45 & 64,67 & 53,51 & 46,51 & 38,34 & 31,57 & 26,11 & 18,42 & 13,76 & 9,04 \\
\hline 35 & 650 & 45 & 62,82 & 52,47 & 45,83 & 38,01 & 31,45 & 26,11 & 18,50 & 13,83 & 9,06 \\
\hline 35 & 700 & 45 & 61,16 & 51,52 & 45,20 & 37,68 & 31,32 & 26,10 & 18,57 & 13,90 & 9,08 \\
\hline 35 & 750 & 45 & 59,66 & 50,63 & 44,60 & 37,36 & 31,18 & 26,08 & 18,64 & 13,97 & 9,10 \\
\hline 35 & 800 & 45 & 58,29 & 49,81 & 44,03 & 37,06 & 31,05 & 26,05 & 18,70 & 14,03 & 9,12 \\
\hline 35 & 850 & 45 & 57,04 & 49,04 & 43,50 & 36,76 & 30,91 & 26,01 & 18,75 & 14,08 & 9,14 \\
\hline 35 & 900 & 45 & 55,89 & 48,32 & 43,00 & 36,47 & 30,78 & 25,97 & 18,79 & 14,14 & 9,16 \\
\hline 35 & 950 & 45 & 54,83 & 47,65 & 42,52 & 36,20 & 30,64 & 25,93 & 18,83 & 14,19 & 9,19 \\
\hline 35 & 1000 & 45 & 53,84 & 47,01 & 42,06 & 35,93 & 30,51 & 25,88 & 18,86 & 14,24 & 9,21 \\
\hline 35 & 1050 & 45 & 52,92 & 46,40 & 41,63 & 35,67 & 30,37 & 25,83 & 18,89 & 14,28 & 9,23 \\
\hline 35 & 1100 & 45 & 52,06 & 45,83 & 41,21 & 35,41 & 30,24 & 25,78 & 18,92 & 14,32 & 9,25 \\
\hline 35 & 1150 & 45 & 51,26 & 45,29 & 40,81 & 35,17 & 30,11 & 25,72 & 18,94 & 14,37 & 9,28 \\
\hline 35 & 1200 & 45 & 50,51 & 44,77 & 40,43 & 34,93 & 29,98 & 25,67 & 18,96 & 14,40 & 9,30 \\
\hline 35 & 1250 & 45 & 49,80 & 44,28 & 40,06 & 34,70 & 29,85 & 25,61 & 18,98 & 14,44 & 9,32 \\
\hline 35 & 1300 & 45 & 49,13 & 43,80 & 39,71 & 34,48 & 29,72 & 25,55 & 18,99 & 14,47 & 9,34 \\
\hline 35 & 1350 & 45 & 48,50 & 43,35 & 39,37 & 34,26 & 29,59 & 25,49 & 19,01 & 14,51 & 9,37 \\
\hline 35 & 1400 & 45 & 47,90 & 42,92 & 39,05 & 34,05 & 29,47 & 25,43 & 19,02 & 14,54 & 9,39 \\
\hline 35 & 1450 & 45 & 47,33 & 42,50 & 38,73 & 33,84 & 29,35 & 25,37 & 19,02 & 14,57 & 9,41 \\
\hline 35 & 1500 & 45 & 46,79 & 42,10 & 38,43 & 33,64 & 29,23 & 25,31 & 19,03 & 14,59 & 9,43 \\
\hline 35 & 1550 & 45 & 46,28 & 41,72 & 38,13 & 33,45 & 29,11 & 25,25 & 19,03 & 14,62 & 9,45 \\
\hline 35 & 1600 & 45 & 45,79 & 41,35 & 37,85 & 33,26 & 29,00 & 25,19 & 19,03 & 14,64 & 9,47 \\
\hline 35 & 1650 & 45 & 45,32 & 40,99 & 37,57 & 33,07 & 28,88 & 25,13 & 19,03 & 14,67 & 9,49 \\
\hline 35 & 1700 & 45 & 44,87 & 40,64 & 37,31 & 32,89 & 28,77 & 25,06 & 19,03 & 14,69 & 9,51 \\
\hline 35 & 1750 & 45 & 44,45 & 40,31 & 37,05 & 32,71 & 28,66 & 25,00 & 19,03 & 14,71 & 9,53 \\
\hline 35 & 1800 & 45 & 44,04 & 39,99 & 36,80 & 32,54 & 28,55 & 24,94 & 19,03 & 14,73 & 9,55 \\
\hline 35 & 1850 & 45 & 43,65 & 39,67 & 36,55 & 32,37 & 28,44 & 24,88 & 19,02 & 14,74 & 9,57 \\
\hline 35 & 1900 & 45 & 43,27 & 39,37 & 36,32 & 32,21 & 28,34 & 24,82 & 19,02 & 14,76 & 9,59 \\
\hline 35 & 1950 & 45 & 42,91 & 39,07 & 36,09 & 32,05 & 28,23 & 24,76 & 19,01 & 14,78 & 9,61 \\
\hline 35 & 2000 & 45 & 42,56 & 38,79 & 35,86 & 31,89 & 28,13 & 24,70 & 19,01 & 14,79 & 9,62 \\
\hline 35 & 200 & 50 & 91,33 & 62,54 & 49,45 & 37,04 & 28,53 & 22,62 & 15,49 & 11,75 & 8,07 \\
\hline 35 & 250 & 50 & 83,73 & 59,86 & 48,32 & 36,87 & 28,69 & 22,86 & 15,66 & 11,82 & 8,06 \\
\hline 35 & 300 & 50 & 78,12 & 57,68 & 47,30 & 36,63 & 28,78 & 23,04 & 15,81 & 11,89 & 8,06 \\
\hline 35 & 350 & 50 & 73,73 & 55,83 & 46,36 & 36,35 & 28,80 & 23,19 & 15,96 & 11,97 & 8,06 \\
\hline 35 & 400 & 50 & 70,17 & 54,22 & 45,50 & 36,06 & 28,79 & 23,29 & 16,08 & 12,04 & 8,07 \\
\hline 35 & 450 & 50 & 67,19 & 52,82 & 44,70 & 35,76 & 28,76 & 23,37 & 16,20 & 12,11 & 8,08 \\
\hline 35 & 500 & 50 & 64,64 & 51,56 & 43,97 & 35,47 & 28,70 & 23,43 & 16,30 & 12,18 & 8,09 \\
\hline 35 & 550 & 50 & 62,42 & 50,43 & 43,28 & 35,17 & 28,62 & 23,47 & 16,40 & 12,24 & 8,10 \\
\hline 35 & 600 & 50 & 60,47 & 49,40 & 42,64 & 34,88 & 28,54 & 23,49 & 16,48 & 12,31 & 8,11 \\
\hline 35 & 650 & 50 & 58,74 & 48,46 & 42,05 & 34,60 & 28,45 & 23,50 & 16,56 & 12,37 & 8,13 \\
\hline 35 & 700 & 50 & 57,18 & 47,59 & 41,49 & 34,32 & 28,35 & 23,50 & 16,62 & 12,43 & 8,14 \\
\hline 35 & 750 & 50 & 55,77 & 46,79 & 40,96 & 34,06 & 28,24 & 23,49 & 16,69 & 12,48 & 8,16 \\
\hline 35 & 800 & 50 & 54,49 & 46,04 & 40,46 & 33,80 & 28,14 & 23,48 & 16,74 & 12,54 & 8,18 \\
\hline 35 & 850 & 50 & 53,31 & 45,34 & 39,98 & 33,54 & 28,03 & 23,46 & 16,79 & 12,59 & 8,19 \\
\hline 35 & 900 & 50 & 52,23 & 44,69 & 39,53 & 33,30 & 27,92 & 23,44 & 16,84 & 12,63 & 8,21 \\
\hline 35 & 950 & 50 & 51,23 & 44,07 & 39,11 & 33,06 & 27,81 & 23,41 & 16,88 & 12,68 & 8,23 \\
\hline 35 & 1000 & 50 & 50,30 & 43,49 & 38,70 & 32,83 & 27,70 & 23,37 & 16,91 & 12,72 & 8,25 \\
\hline 35 & 1050 & 50 & 49,44 & 42,94 & 38,31 & 32,60 & 27,59 & 23,34 & 16,94 & 12,76 & 8,27 \\
\hline 35 & 1100 & 50 & 48,63 & 42,42 & 37,94 & 32,38 & 27,48 & 23,30 & 16,97 & 12,80 & 8,28 \\
\hline 35 & 1150 & 50 & 47,87 & 41,92 & 37,58 & 32,17 & 27,37 & 23,26 & 17,00 & 12,84 & 8,30 \\
\hline 35 & 1200 & 50 & 47,16 & 41,45 & 37,24 & 31,96 & 27,26 & 23,22 & 17,02 & 12,88 & 8,32 \\
\hline 35 & 1250 & 50 & 46,49 & 41,00 & 36,91 & 31,76 & 27,15 & 23,17 & 17,04 & 12,91 & 8,34 \\
\hline 35 & 1300 & 50 & 45,86 & 40,57 & 36,59 & 31,57 & 27,05 & 23,13 & 17,06 & 12,94 & 8,36 \\
\hline 35 & 1350 & 50 & 45,26 & 40,16 & 36,29 & 31,38 & 26,94 & 23,08 & 17,07 & 12,97 & 8,38 \\
\hline 35 & 1400 & 50 & 44,69 & 39,76 & 35,99 & 31,19 & 26,84 & 23,04 & 17,09 & 13,00 & 8,39 \\
\hline 35 & 1450 & 50 & 44,16 & 39,38 & 35,71 & 31,01 & 26,74 & 22,99 & 17,10 & 13,03 & 8,41 \\
\hline 35 & 1500 & 50 & 43,65 & 39,02 & 35,43 & 30,83 & 26,64 & 22,94 & 17,11 & 13,06 & 8,43 \\
\hline 35 & 1550 & 50 & 43,16 & 38,67 & 35,17 & 30,66 & 26,54 & 22,89 & 17,11 & 13,08 & 8,45 \\
\hline 35 & 1600 & 50 & 42,70 & 38,33 & 34,91 & 30,49 & 26,44 & 22,84 & 17,12 & 13,10 & 8,46 \\
\hline 35 & 1650 & 50 & 42,25 & 38,00 & 34,66 & 30,33 & 26,34 & 22,79 & 17,12 & 13,13 & 8,48 \\
\hline 35 & 1700 & 50 & 41,83 & 37,68 & 34,42 & 30,17 & 26,24 & 22,75 & 17,13 & 13,15 & 8,50 \\
\hline 35 & 1750 & 50 & 41,43 & 37,38 & 34,19 & 30,02 & 26,15 & 22,70 & 17,13 & 13,17 & 8,52 \\
\hline 35 & 1800 & 50 & 41,04 & 37,08 & 33,96 & 29,86 & 26,06 & 22,65 & 17,13 & 13,19 & 8,53 \\
\hline 35 & 1850 & 50 & 40,67 & 36,80 & 33,74 & 29,71 & 25,96 & 22,60 & 17,13 & 13,20 & 8,55 \\
\hline 35 & 1900 & 50 & 40,31 & 36,52 & 33,53 & 29,57 & 25,87 & 22,55 & 17,13 & 13,22 & 8,56 \\
\hline 35 & 1950 & 50 & 39,96 & 36,25 & 33,32 & 29,43 & 25,78 & 22,50 & 17,13 & 13,24 & 8,58 \\
\hline 35 & 2000 & 50 & 39,63 & 35,99 & 33,12 & 29,29 & 25,69 & 22,45 & 17,13 & 13,25 & 8,60 \\
\hline 35 & 200 & 55 & 86,24 & 57,89 & 45,35 & 33,71 & 25,85 & 20,46 & 14,02 & 10,66 & 7,34 \\
\hline 35 & 250 & 55 & 78,97 & 55,46 & 44,39 & 33,60 & 26,03 & 20,69 & 14,17 & 10,72 & 7,33 \\
\hline 35 & 300 & 55 & 73,63 & 53,47 & 43,50 & 33,42 & 26,13 & 20,86 & 14,30 & 10,78 & 7,33 \\
\hline 35 & 350 & 55 & 69,46 & 51,79 & 42,68 & 33,21 & 26,17 & 21,00 & 14,42 & 10,84 & 7,33 \\
\hline 35 & 400 & 55 & 66,08 & 50,33 & 41,92 & 32,98 & 26,19 & 21,11 & 14,54 & 10,90 & 7,33 \\
\hline 35 & 450 & 55 & 63,26 & 49,05 & 41,22 & 32,73 & 26,17 & 21,19 & 14,64 & 10,96 & 7,34 \\
\hline 35 & 500 & 55 & 60,85 & 47,91 & 40,57 & 32,49 & 26,14 & 21,25 & 14,73 & 11,01 & 7,34 \\
\hline 35 & 550 & 55 & 58,76 & 46,87 & 39,97 & 32,24 & 26,09 & 21,30 & 14,82 & 11,07 & 7,35 \\
\hline
\end{tabular}




\begin{tabular}{|c|c|c|c|c|c|c|c|c|c|c|c|}
\hline \multirow[b]{2}{*}{$\mathrm{H}(\mathrm{cm})$} & \multirow[b]{2}{*}{ Mceq (MPa) } & & & & & $\mathrm{De}$ & ões (x1 & & & & \\
\hline & & Msub (MPa) & D0 & D25 & D40 & D60 & D80 & D100 & D140 & D180 & D260 \\
\hline 35 & 600 & 55 & 56,92 & 45,93 & 39,40 & 32,00 & 26,03 & 21,33 & 14,90 & 11,12 & 7,36 \\
\hline 35 & 650 & 55 & 55,28 & 45,07 & 38,87 & 31,76 & 25,96 & 21,35 & 14,97 & 11,18 & 7,37 \\
\hline 35 & 700 & 55 & 53,81 & 44,28 & 38,37 & 31,52 & 25,88 & 21,36 & 15,03 & 11,23 & 7,38 \\
\hline 35 & 750 & 55 & 52,48 & 43,54 & 37,90 & 31,29 & 25,80 & 21,37 & 15,09 & 11,28 & 7,40 \\
\hline 35 & 800 & 55 & 51,27 & 42,86 & 37,45 & 31,07 & 25,72 & 21,36 & 15,14 & 11,32 & 7,41 \\
\hline 35 & 850 & 55 & 50,16 & 42,22 & 37,02 & 30,85 & 25,63 & 21,35 & 15,19 & 11,37 & 7,42 \\
\hline 35 & 900 & 55 & 49,14 & 41,62 & 36,62 & 30,64 & 25,54 & 21,34 & 15,24 & 11,41 & 7,44 \\
\hline 35 & 950 & 55 & 48,19 & 41,05 & 36,23 & 30,43 & 25,45 & 21,32 & 15,28 & 11,45 & 7,45 \\
\hline 35 & 1000 & 55 & 47,31 & 40,52 & 35,87 & 30,23 & 25,36 & 21,30 & 15,31 & 11,49 & 7,47 \\
\hline 35 & 1050 & 55 & 46,49 & 40,02 & 35,52 & 30,03 & 25,27 & 21,28 & 15,34 & 11,53 & 7,48 \\
\hline 35 & 1100 & 55 & 45,73 & 39,54 & 35,18 & 29,84 & 25,18 & 21,25 & 15,37 & 11,57 & 7,50 \\
\hline 35 & 1150 & 55 & 45,01 & 39,08 & 34,86 & 29,65 & 25,09 & 21,22 & 15,40 & 11,60 & 7,51 \\
\hline 35 & 1200 & 55 & 44,34 & 38,65 & 34,55 & 29,47 & 25,00 & 21,19 & 15,42 & 11,63 & 7,53 \\
\hline 35 & 1250 & 55 & 43,70 & 38,23 & 34,25 & 29,30 & 24,91 & 21,16 & 15,45 & 11,66 & 7,54 \\
\hline 35 & 1300 & 55 & 43,10 & 37,84 & 33,96 & 29,12 & 24,82 & 21,12 & 15,47 & 11,69 & 7,56 \\
\hline 35 & 1350 & 55 & 42,54 & 37,46 & 33,69 & 28,96 & 24,73 & 21,09 & 15,48 & 11,72 & 7,57 \\
\hline 35 & 1400 & 55 & 42,00 & 37,09 & 33,42 & 28,79 & 24,64 & 21,05 & 15,50 & 11,75 & 7,59 \\
\hline 35 & 1450 & 55 & 41,49 & 36,74 & 33,16 & 28,63 & 24,55 & 21,01 & 15,51 & 11,78 & 7,60 \\
\hline 35 & 1500 & 55 & 41,00 & 36,41 & 32,91 & 28,48 & 24,47 & 20,97 & 15,52 & 11,80 & 7,62 \\
\hline 35 & 1550 & 55 & 40,54 & 36,08 & 32,67 & 28,32 & 24,38 & 20,94 & 15,53 & 11,82 & 7,63 \\
\hline 35 & 1600 & 55 & 40,10 & 35,77 & 32,44 & 28,18 & 24,30 & 20,90 & 15,54 & 11,85 & 7,65 \\
\hline 35 & 1650 & 55 & 39,68 & 35,47 & 32,21 & 28,03 & 24,21 & 20,86 & 15,55 & 11,87 & 7,66 \\
\hline 35 & 1700 & 55 & 39,28 & 35,18 & 31,99 & 27,89 & 24,13 & 20,82 & 15,56 & 11,89 & 7,68 \\
\hline 35 & 1750 & 55 & 38,89 & 34,90 & 31,78 & 27,75 & 24,05 & 20,78 & 15,56 & 11,91 & 7,69 \\
\hline 35 & 1800 & 55 & 38,52 & 34,63 & 31,57 & 27,61 & 23,97 & 20,73 & 15,57 & 11,93 & 7,71 \\
\hline 35 & 1850 & 55 & 38,17 & 34,36 & 31,37 & 27,48 & 23,89 & 20,69 & 15,57 & 11,95 & 7,72 \\
\hline 35 & 1900 & 55 & 37,83 & 34,11 & 31,18 & 27,35 & 23,81 & 20,65 & 15,57 & 11,96 & 7,73 \\
\hline 35 & 1950 & 55 & 37,50 & 33,86 & 30,99 & 27,22 & 23,73 & 20,61 & 15,57 & 11,98 & 7,75 \\
\hline 35 & 2000 & 55 & 37,18 & 33,62 & 30,80 & 27,10 & 23,66 & 20,57 & 15,57 & 11,99 & 7,76 \\
\hline 35 & 200 & 60 & 81,89 & 53,93 & 41,89 & 30,91 & 23,63 & 18,68 & 12,80 & 9,76 & 6,74 \\
\hline 35 & 250 & 60 & 74,90 & 51,71 & 41,05 & 30,85 & 23,80 & 18,88 & 12,93 & 9,80 & 6,73 \\
\hline 35 & 300 & 60 & 69,78 & 49,89 & 40,27 & 30,72 & 23,91 & 19,05 & 13,05 & 9,85 & 6,72 \\
\hline 35 & 350 & 60 & 65,80 & 48,34 & 39,55 & 30,56 & 23,97 & 19,18 & 13,16 & 9,90 & 6,72 \\
\hline 35 & 400 & 60 & 62,58 & 47,01 & 38,88 & 30,37 & 24,00 & 19,29 & 13,26 & 9,95 & 6,72 \\
\hline 35 & 450 & 60 & 59,89 & 45,83 & 38,26 & 30,17 & 24,00 & 19,37 & 13,35 & 10,00 & 6,72 \\
\hline 35 & 500 & 60 & 57,60 & 44,78 & 37,69 & 29,97 & 23,99 & 19,43 & 13,44 & 10,05 & 6,73 \\
\hline 35 & 550 & 60 & 55,61 & 43,83 & 37,15 & 29,76 & 23,96 & 19,48 & 13,51 & 10,10 & 6,73 \\
\hline 35 & 600 & 60 & 53,86 & 42,97 & 36,64 & 29,56 & 23,91 & 19,52 & 13,58 & 10,15 & 6,74 \\
\hline 35 & 650 & 60 & 52,31 & 42,17 & 36,16 & 29,35 & 23,86 & 19,55 & 13,65 & 10,19 & 6,75 \\
\hline 35 & 700 & 60 & 50,91 & 41,44 & 35,71 & 29,15 & 23,81 & 19,57 & 13,71 & 10,24 & 6,76 \\
\hline 35 & 750 & 60 & 49,65 & 40,77 & 35,28 & 28,95 & 23,74 & 19,58 & 13,77 & 10,28 & 6,77 \\
\hline 35 & 800 & 60 & 48,50 & 40,13 & 34,88 & 28,76 & 23,68 & 19,58 & 13,82 & 10,32 & 6,78 \\
\hline 35 & 850 & 60 & 47,45 & 39,54 & 34,50 & 28,57 & 23,61 & 19,58 & 13,86 & 10,36 & 6,79 \\
\hline 35 & 900 & 60 & 46,48 & 38,99 & 34,13 & 28,38 & 23,54 & 19,58 & 13,90 & 10,40 & 6,80 \\
\hline 35 & 950 & 60 & 45,58 & 38,47 & 33,78 & 28,20 & 23,46 & 19,57 & 13,94 & 10,44 & 6,81 \\
\hline 35 & 1000 & 60 & 44,74 & 37,97 & 33,45 & 28,02 & 23,39 & 19,56 & 13,98 & 10,47 & 6,82 \\
\hline 35 & 1050 & 60 & 43,97 & 37,51 & 33,13 & 27,85 & 23,31 & 19,54 & 14,01 & 10,51 & 6,83 \\
\hline 35 & 1100 & 60 & 43,24 & 37,06 & 32,82 & 27,68 & 23,24 & 19,52 & 14,04 & 10,54 & 6,85 \\
\hline 35 & 1150 & 60 & 42,56 & 36,64 & 32,53 & 27,52 & 23,16 & 19,50 & 14,07 & 10,57 & 6,86 \\
\hline 35 & 1200 & 60 & 41,92 & 36,24 & 32,25 & 27,35 & 23,08 & 19,48 & 14,09 & 10,60 & 6,87 \\
\hline 35 & 1250 & 60 & 41,31 & 35,86 & 31,98 & 27,20 & 23,01 & 19,45 & 14,12 & 10,63 & 6,89 \\
\hline 35 & 1300 & 60 & 40,74 & 35,49 & 31,71 & 27,04 & 22,93 & 19,43 & 14,14 & 10,66 & 6,90 \\
\hline 35 & 1350 & 60 & 40,20 & 35,14 & 31,46 & 26,90 & 22,85 & 19,40 & 14,15 & 10,69 & 6,91 \\
\hline 35 & 1400 & 60 & 39,69 & 34,80 & 31,22 & 26,75 & 22,78 & 19,37 & 14,17 & 10,71 & 6,92 \\
\hline 35 & 1450 & 60 & 39,20 & 34,48 & 30,98 & 26,61 & 22,70 & 19,34 & 14,19 & 10,74 & 6,94 \\
\hline 35 & 1500 & 60 & 38,74 & 34,17 & 30,76 & 26,47 & 22,63 & 19,31 & 14,20 & 10,76 & 6,95 \\
\hline 35 & 1550 & 60 & 38,30 & 33,87 & 30,54 & 26,33 & 22,55 & 19,28 & 14,21 & 10,78 & 6,96 \\
\hline 35 & 1600 & 60 & 37,88 & 33,58 & 30,32 & 26,20 & 22,48 & 19,25 & 14,22 & 10,80 & 6,98 \\
\hline 35 & 1650 & 60 & 37,48 & 33,30 & 30,11 & 26,07 & 22,41 & 19,22 & 14,23 & 10,82 & 6,99 \\
\hline 35 & 1700 & 60 & 37,09 & 33,03 & 29,91 & 25,94 & 22,34 & 19,18 & 14,24 & 10,84 & 7,00 \\
\hline 35 & 1750 & 60 & 36,73 & 32,77 & 29,72 & 25,82 & 22,27 & 19,15 & 14,25 & 10,86 & 7,01 \\
\hline 35 & 1800 & 60 & 36,37 & 32,51 & 29,53 & 25,69 & 22,20 & 19,12 & 14,25 & 10,88 & 7,02 \\
\hline 35 & 1850 & 60 & 36,03 & 32,27 & 29,34 & 25,58 & 22,13 & 19,08 & 14,26 & 10,90 & 7,04 \\
\hline 35 & 1900 & 60 & 35,71 & 32,03 & 29,16 & 25,46 & 22,06 & 19,05 & 14,26 & 10,91 & 7,05 \\
\hline 35 & 1950 & 60 & 35,39 & 31,80 & 28,99 & 25,34 & 21,99 & 19,02 & 14,27 & 10,93 & 7,06 \\
\hline 35 & 2000 & 60 & 35,09 & 31,58 & 28,82 & 25,23 & 21,92 & 18,98 & 14,27 & 10,94 & 7,07 \\
\hline 35 & 200 & 65 & 78,12 & 50,53 & 38,91 & 28,53 & 21,74 & 17,17 & 11,78 & 8,99 & 6,22 \\
\hline 35 & 250 & 65 & 71,36 & 48,47 & 38,18 & 28,51 & 21,92 & 17,36 & 11,89 & 9,03 & 6,21 \\
\hline 35 & 300 & 65 & 66,43 & 46,79 & 37,50 & 28,42 & 22,03 & 17,52 & 12,00 & 9,07 & 6,21 \\
\hline 35 & 350 & 65 & 62,61 & 45,36 & 36,86 & 28,29 & 22,10 & 17,64 & 12,09 & 9,12 & 6,20 \\
\hline 35 & 400 & 65 & 59,52 & 44,13 & 36,27 & 28,14 & 22,14 & 17,75 & 12,18 & 9,16 & 6,20 \\
\hline 35 & 450 & 65 & 56,95 & 43,04 & 35,71 & 27,98 & 22,16 & 17,83 & 12,27 & 9,20 & 6,20 \\
\hline 35 & 500 & 65 & 54,77 & 42,07 & 35,19 & 27,81 & 22,15 & 17,89 & 12,34 & 9,24 & 6,21 \\
\hline 35 & 550 & 65 & 52,87 & 41,20 & 34,71 & 27,63 & 22,14 & 17,95 & 12,41 & 9,29 & 6,21 \\
\hline 35 & 600 & 65 & 51,20 & 40,40 & 34,25 & 27,46 & 22,11 & 17,99 & 12,48 & 9,33 & 6,22 \\
\hline 35 & 650 & 65 & 49,72 & 39,66 & 33,82 & 27,28 & 22,07 & 18,02 & 12,54 & 9,37 & 6,22 \\
\hline 35 & 700 & 65 & 48,39 & 38,98 & 33,41 & 27,11 & 22,03 & 18,04 & 12,60 & 9,41 & 6,23 \\
\hline 35 & 750 & 65 & 47,19 & 38,36 & 33,03 & 26,94 & 21,98 & 18,06 & 12,65 & 9,44 & 6,24 \\
\hline 35 & 800 & 65 & 46,09 & 37,77 & 32,66 & 26,77 & 21,93 & 18,07 & 12,70 & 9,48 & 6,24 \\
\hline 35 & 850 & 65 & 45,09 & 37,22 & 32,31 & 26,60 & 21,88 & 18,08 & 12,74 & 9,52 & 6,25 \\
\hline 35 & 900 & 65 & 44,16 & 36,71 & 31,98 & 26,44 & 21,82 & 18,08 & 12,78 & 9,55 & 6,26 \\
\hline
\end{tabular}




\begin{tabular}{|c|c|c|c|c|c|c|c|c|c|c|c|}
\hline \multirow[b]{2}{*}{$\mathrm{H}(\mathrm{cm})$} & \multirow[b]{2}{*}{ Mceq (MPa) } & & & & & $\mathrm{De}$ & ões (x1 & & & & \\
\hline & & Msub (MPa) & D0 & D25 & D40 & D60 & D80 & D100 & D140 & D180 & D260 \\
\hline 35 & 950 & 65 & 43,31 & 36,22 & 31,66 & 26,28 & 21,76 & 18,08 & 12,82 & 9,59 & 6,27 \\
\hline 35 & 1000 & 65 & 42,51 & 35,76 & 31,35 & 26,12 & 21,69 & 18,07 & 12,85 & 9,62 & 6,28 \\
\hline 35 & 1050 & 65 & 41,77 & 35,33 & 31,06 & 25,97 & 21,63 & 18,06 & 12,88 & 9,65 & 6,29 \\
\hline 35 & 1100 & 65 & 41,08 & 34,92 & 30,78 & 25,82 & 21,57 & 18,05 & 12,91 & 9,68 & 6,30 \\
\hline 35 & 1150 & 65 & 40,43 & 34,53 & 30,51 & 25,67 & 21,50 & 18,03 & 12,94 & 9,71 & 6,31 \\
\hline 35 & 1200 & 65 & 39,81 & 34,15 & 30,26 & 25,53 & 21,44 & 18,02 & 12,96 & 9,73 & 6,32 \\
\hline 35 & 1250 & 65 & 39,24 & 33,80 & 30,01 & 25,39 & 21,37 & 18,00 & 12,99 & 9,76 & 6,33 \\
\hline 35 & 1300 & 65 & 38,69 & 33,45 & 29,77 & 25,25 & 21,31 & 17,98 & 13,01 & 9,79 & 6,34 \\
\hline 35 & 1350 & 65 & 38,18 & 33,13 & 29,54 & 25,12 & 21,24 & 17,96 & 13,03 & 9,81 & 6,35 \\
\hline 35 & 1400 & 65 & 37,69 & 32,81 & 29,31 & 24,99 & 21,18 & 17,94 & 13,05 & 9,84 & 6,37 \\
\hline 35 & 1450 & 65 & 37,22 & 32,51 & 29,10 & 24,86 & 21,11 & 17,91 & 13,06 & 9,86 & 6,38 \\
\hline 35 & 1500 & 65 & 36,78 & 32,22 & 28,89 & 24,73 & 21,05 & 17,89 & 13,08 & 9,88 & 6,39 \\
\hline 35 & 1550 & 65 & 36,36 & 31,94 & 28,68 & 24,61 & 20,98 & 17,87 & 13,09 & 9,90 & 6,40 \\
\hline 35 & 1600 & 65 & 35,96 & 31,67 & 28,49 & 24,49 & 20,92 & 17,84 & 13,10 & 9,92 & 6,41 \\
\hline 35 & 1650 & 65 & 35,57 & 31,41 & 28,30 & 24,37 & 20,86 & 17,81 & 13,11 & 9,94 & 6,42 \\
\hline 35 & 1700 & 65 & 35,20 & 31,16 & 28,11 & 24,26 & 20,79 & 17,79 & 13,12 & 9,96 & 6,43 \\
\hline 35 & 1750 & 65 & 34,85 & 30,91 & 27,93 & 24,15 & 20,73 & 17,76 & 13,13 & 9,98 & 6,44 \\
\hline 35 & 1800 & 65 & 34,51 & 30,68 & 27,75 & 24,04 & 20,67 & 17,73 & 13,14 & 9,99 & 6,45 \\
\hline 35 & 1850 & 65 & 34,19 & 30,45 & 27,58 & 23,93 & 20,61 & 17,70 & 13,15 & 10,01 & 6,46 \\
\hline 35 & 1900 & 65 & 33,87 & 30,23 & 27,42 & 23,82 & 20,55 & 17,68 & 13,15 & 10,03 & 6,47 \\
\hline 35 & 1950 & 65 & 33,57 & 30,01 & 27,26 & 23,72 & 20,49 & 17,65 & 13,16 & 10,04 & 6,48 \\
\hline 35 & 2000 & 65 & 33,28 & 29,80 & 27,10 & 23,62 & 20,43 & 17,62 & 13,16 & 10,06 & 6,49 \\
\hline 35 & 200 & 70 & 74,81 & 47,55 & 36,34 & 26,48 & 20,13 & 15,89 & 10,91 & 8,34 & 5,78 \\
\hline 35 & 250 & 70 & 68,26 & 45,64 & 35,69 & 26,49 & 20,30 & 16,06 & 11,01 & 8,37 & 5,77 \\
\hline 35 & 300 & 70 & 63,49 & 44,08 & 35,08 & 26,43 & 20,42 & 16,21 & 11,10 & 8,41 & 5,76 \\
\hline 35 & 350 & 70 & 59,81 & 42,76 & 34,52 & 26,33 & 20,49 & 16,33 & 11,18 & 8,44 & 5,76 \\
\hline 35 & 400 & 70 & 56,84 & 41,61 & 33,99 & 26,21 & 20,54 & 16,43 & 11,26 & 8,48 & 5,76 \\
\hline 35 & 450 & 70 & 54,37 & 40,61 & 33,49 & 26,08 & 20,57 & 16,51 & 11,34 & 8,52 & 5,76 \\
\hline 35 & 500 & 70 & 52,27 & 39,70 & 33,02 & 25,94 & 20,57 & 16,57 & 11,41 & 8,55 & 5,76 \\
\hline 35 & 550 & 70 & 50,46 & 38,89 & 32,58 & 25,79 & 20,57 & 16,63 & 11,48 & 8,59 & 5,76 \\
\hline 35 & 600 & 70 & 48,86 & 38,14 & 32,17 & 25,64 & 20,55 & 16,67 & 11,54 & 8,63 & 5,77 \\
\hline 35 & 650 & 70 & 47,44 & 37,46 & 31,78 & 25,49 & 20,53 & 16,71 & 11,59 & 8,66 & 5,77 \\
\hline 35 & 700 & 70 & 46,17 & 36,83 & 31,40 & 25,33 & 20,50 & 16,73 & 11,64 & 8,70 & 5,78 \\
\hline 35 & 750 & 70 & 45,02 & 36,24 & 31,05 & 25,18 & 20,46 & 16,75 & 11,69 & 8,73 & 5,78 \\
\hline 35 & 800 & 70 & 43,97 & 35,70 & 30,72 & 25,03 & 20,42 & 16,77 & 11,74 & 8,76 & 5,79 \\
\hline 35 & 850 & 70 & 43,01 & 35,19 & 30,40 & 24,89 & 20,38 & 16,78 & 11,78 & 8,80 & 5,80 \\
\hline 35 & 900 & 70 & 42,13 & 34,70 & 30,09 & 24,74 & 20,33 & 16,79 & 11,82 & 8,83 & 5,80 \\
\hline 35 & 950 & 70 & 41,31 & 34,25 & 29,80 & 24,60 & 20,28 & 16,79 & 11,85 & 8,86 & 5,81 \\
\hline 35 & 1000 & 70 & 40,55 & 33,82 & 29,52 & 24,46 & 20,23 & 16,79 & 11,89 & 8,89 & 5,82 \\
\hline 35 & 1050 & 70 & 39,84 & 33,42 & 29,25 & 24,33 & 20,17 & 16,78 & 11,92 & 8,92 & 5,83 \\
\hline 35 & 1100 & 70 & 39,17 & 33,03 & 29,00 & 24,19 & 20,12 & 16,78 & 11,95 & 8,94 & 5,84 \\
\hline 35 & 1150 & 70 & 38,55 & 32,67 & 28,75 & 24,06 & 20,07 & 16,77 & 11,97 & 8,97 & 5,85 \\
\hline 35 & 1200 & 70 & 37,97 & 32,32 & 28,51 & 23,93 & 20,01 & 16,76 & 12,00 & 8,99 & 5,85 \\
\hline 35 & 1250 & 70 & 37,41 & 31,98 & 28,28 & 23,81 & 19,95 & 16,74 & 12,02 & 9,02 & 5,86 \\
\hline 35 & 1300 & 70 & 36,89 & 31,66 & 28,06 & 23,68 & 19,90 & 16,73 & 12,04 & 9,04 & 5,87 \\
\hline 35 & 1350 & 70 & 36,40 & 31,36 & 27,85 & 23,56 & 19,84 & 16,71 & 12,06 & 9,07 & 5,88 \\
\hline 35 & 1400 & 70 & 35,93 & 31,06 & 27,64 & 23,45 & 19,79 & 16,70 & 12,08 & 9,09 & 5,89 \\
\hline 35 & 1450 & 70 & 35,48 & 30,78 & 27,44 & 23,33 & 19,73 & 16,68 & 12,10 & 9,11 & 5,90 \\
\hline 35 & 1500 & 70 & 35,06 & 30,51 & 27,25 & 23,22 & 19,67 & 16,66 & 12,11 & 9,13 & 5,91 \\
\hline 35 & 1550 & 70 & 34,65 & 30,25 & 27,06 & 23,11 & 19,62 & 16,64 & 12,13 & 9,15 & 5,92 \\
\hline 35 & 1600 & 70 & 34,27 & 29,99 & 26,88 & 23,00 & 19,56 & 16,62 & 12,14 & 9,17 & 5,93 \\
\hline 35 & 1650 & 70 & 33,90 & 29,75 & 26,70 & 22,89 & 19,51 & 16,60 & 12,15 & 9,19 & 5,94 \\
\hline 35 & 1700 & 70 & 33,55 & 29,51 & 26,53 & 22,79 & 19,45 & 16,58 & 12,16 & 9,20 & 5,95 \\
\hline 35 & 1750 & 70 & 33,21 & 29,29 & 26,36 & 22,69 & 19,40 & 16,55 & 12,17 & 9,22 & 5,96 \\
\hline 35 & 1800 & 70 & 32,88 & 29,07 & 26,20 & 22,59 & 19,34 & 16,53 & 12,18 & 9,24 & 5,97 \\
\hline 35 & 1850 & 70 & 32,57 & 28,85 & 26,04 & 22,49 & 19,29 & 16,51 & 12,19 & 9,25 & 5,98 \\
\hline 35 & 1900 & 70 & 32,27 & 28,64 & 25,89 & 22,39 & 19,23 & 16,48 & 12,20 & 9,27 & 5,98 \\
\hline 35 & 1950 & 70 & 31,98 & 28,44 & 25,74 & 22,30 & 19,18 & 16,46 & 12,20 & 9,28 & 5,99 \\
\hline 35 & 2000 & 70 & 31,70 & 28,25 & 25,59 & 22,20 & 19,13 & 16,44 & 12,21 & 9,30 & 6,00 \\
\hline 35 & 200 & 75 & 71,89 & 44,94 & 34,08 & 24,70 & 18,73 & 14,78 & 10,16 & 7,78 & 5,40 \\
\hline 35 & 250 & 75 & 65,51 & 43,15 & 33,51 & 24,73 & 18,90 & 14,94 & 10,24 & 7,81 & 5,39 \\
\hline 35 & 300 & 75 & 60,89 & 41,69 & 32,97 & 24,70 & 19,02 & 15,08 & 10,33 & 7,84 & 5,38 \\
\hline 35 & 350 & 75 & 57,33 & 40,46 & 32,46 & 24,62 & 19,10 & 15,19 & 10,40 & 7,87 & 5,38 \\
\hline 35 & 400 & 75 & 54,46 & 39,39 & 31,98 & 24,53 & 19,15 & 15,28 & 10,47 & 7,90 & 5,38 \\
\hline 35 & 450 & 75 & 52,08 & 38,45 & 31,53 & 24,42 & 19,18 & 15,36 & 10,54 & 7,93 & 5,38 \\
\hline 35 & 500 & 75 & 50,06 & 37,61 & 31,11 & 24,30 & 19,20 & 15,43 & 10,61 & 7,96 & 5,38 \\
\hline 35 & 550 & 75 & 48,31 & 36,85 & 30,71 & 24,17 & 19,20 & 15,48 & 10,67 & 7,99 & 5,38 \\
\hline 35 & 600 & 75 & 46,78 & 36,15 & 30,33 & 24,04 & 19,20 & 15,53 & 10,72 & 8,03 & 5,38 \\
\hline 35 & 650 & 75 & 45,42 & 35,51 & 29,97 & 23,91 & 19,18 & 15,56 & 10,77 & 8,06 & 5,38 \\
\hline 35 & 700 & 75 & 44,20 & 34,92 & 29,63 & 23,78 & 19,16 & 15,59 & 10,82 & 8,09 & 5,39 \\
\hline 35 & 750 & 75 & 43,09 & 34,37 & 29,31 & 23,64 & 19,13 & 15,62 & 10,87 & 8,12 & 5,39 \\
\hline 35 & 800 & 75 & 42,09 & 33,86 & 29,00 & 23,51 & 19,10 & 15,64 & 10,91 & 8,15 & 5,40 \\
\hline 35 & 850 & 75 & 41,16 & 33,38 & 28,71 & 23,38 & 19,06 & 15,65 & 10,95 & 8,18 & 5,40 \\
\hline 35 & 900 & 75 & 40,32 & 32,93 & 28,43 & 23,26 & 19,03 & 15,66 & 10,99 & 8,20 & 5,41 \\
\hline 35 & 950 & 75 & 39,53 & 32,51 & 28,16 & 23,13 & 18,98 & 15,67 & 11,02 & 8,23 & 5,41 \\
\hline 35 & 1000 & 75 & 38,80 & 32,11 & 27,90 & 23,01 & 18,94 & 15,67 & 11,05 & 8,26 & 5,42 \\
\hline 35 & 1050 & 75 & 38,12 & 31,73 & 27,66 & 22,88 & 18,90 & 15,67 & 11,08 & 8,28 & 5,43 \\
\hline 35 & 1100 & 75 & 37,48 & 31,37 & 27,42 & 22,76 & 18,85 & 15,67 & 11,11 & 8,31 & 5,44 \\
\hline 35 & 1150 & 75 & 36,89 & 31,02 & 27,19 & 22,65 & 18,81 & 15,66 & 11,14 & 8,33 & 5,44 \\
\hline 35 & 1200 & 75 & 36,33 & 30,69 & 26,97 & 22,53 & 18,76 & 15,65 & 11,16 & 8,36 & 5,45 \\
\hline 35 & 1250 & 75 & 35,80 & 30,38 & 26,76 & 22,42 & 18,71 & 15,65 & 11,18 & 8,38 & 5,46 \\
\hline
\end{tabular}




\begin{tabular}{|c|c|c|c|c|c|c|c|c|c|c|c|}
\hline \multirow[b]{2}{*}{$\mathrm{H}(\mathrm{cm})$} & \multirow[b]{2}{*}{ Mceq (MPa) } & & & & & De & ões (x1 & m) & & & \\
\hline & & Msub (MPa) & D0 & D25 & D40 & D60 & D80 & D100 & D140 & D180 & D260 \\
\hline 35 & 1300 & 75 & 35,29 & 30,08 & 26,55 & 22,31 & 18,66 & 15,64 & 11,20 & 8,40 & 5,47 \\
\hline 35 & 1350 & 75 & 34,82 & 29,79 & 26,36 & 22,20 & 18,61 & 15,62 & 11,22 & 8,42 & 5,47 \\
\hline 35 & 1400 & 75 & 34,37 & 29,51 & 26,16 & 22,09 & 18,56 & 15,61 & 11,24 & 8,44 & 5,48 \\
\hline 35 & 1450 & 75 & 33,94 & 29,25 & 25,98 & 21,99 & 18,52 & 15,60 & 11,26 & 8,46 & 5,49 \\
\hline 35 & 1500 & 75 & 33,53 & 28,99 & 25,80 & 21,88 & 18,47 & 15,58 & 11,27 & 8,48 & 5,50 \\
\hline 35 & 1550 & 75 & 33,14 & 28,75 & 25,62 & 21,78 & 18,42 & 15,57 & 11,29 & 8,50 & 5,51 \\
\hline 35 & 1600 & 75 & 32,77 & 28,51 & 25,45 & 21,68 & 18,37 & 15,55 & 11,30 & 8,52 & 5,51 \\
\hline 35 & 1650 & 75 & 32,42 & 28,28 & 25,29 & 21,59 & 18,32 & 15,53 & 11,31 & 8,54 & 5,52 \\
\hline 35 & 1700 & 75 & 32,08 & 28,06 & 25,13 & 21,49 & 18,27 & 15,52 & 11,33 & 8,55 & 5,53 \\
\hline 35 & 1750 & 75 & 31,75 & 27,84 & 24,98 & 21,40 & 18,22 & 15,50 & 11,34 & 8,57 & 5,54 \\
\hline 35 & 1800 & 75 & 31,44 & 27,63 & 24,82 & 21,31 & 18,17 & 15,48 & 11,35 & 8,58 & 5,55 \\
\hline 35 & 1850 & 75 & 31,14 & 27,43 & 24,68 & 21,22 & 18,13 & 15,46 & 11,36 & 8,60 & 5,56 \\
\hline 35 & 1900 & 75 & 30,85 & 27,24 & 24,53 & 21,13 & 18,08 & 15,44 & 11,36 & 8,61 & 5,56 \\
\hline 35 & 1950 & 75 & 30,57 & 27,05 & 24,39 & 21,04 & 18,03 & 15,42 & 11,37 & 8,63 & 5,57 \\
\hline 35 & 2000 & 75 & 30,30 & 26,86 & 24,26 & 20,96 & 17,99 & 15,40 & 11,38 & 8,64 & 5,58 \\
\hline 35 & 200 & 80 & 69,29 & 42,62 & 32,09 & 23,14 & 17,52 & 13,81 & 9,50 & 7,29 & 5,06 \\
\hline 35 & 250 & 80 & 63,06 & 40,94 & 31,58 & 23,18 & 17,68 & 13,96 & 9,58 & 7,31 & 5,05 \\
\hline 35 & 300 & 80 & 58,57 & 39,57 & 31,09 & 23,17 & 17,79 & 14,09 & 9,65 & 7,34 & 5,05 \\
\hline 35 & 350 & 80 & 55,11 & 38,41 & 30,64 & 23,12 & 17,88 & 14,20 & 9,72 & 7,36 & 5,04 \\
\hline 35 & 400 & 80 & 52,33 & 37,41 & 30,20 & 23,04 & 17,93 & 14,29 & 9,79 & 7,39 & 5,04 \\
\hline 35 & 450 & 80 & 50,03 & 36,53 & 29,79 & 22,95 & 17,97 & 14,36 & 9,85 & 7,42 & 5,04 \\
\hline 35 & 500 & 80 & 48,08 & 35,74 & 29,41 & 22,85 & 17,99 & 14,43 & 9,91 & 7,44 & 5,04 \\
\hline 35 & 550 & 80 & 46,39 & 35,03 & 29,04 & 22,74 & 18,00 & 14,48 & 9,96 & 7,47 & 5,04 \\
\hline 35 & 600 & 80 & 44,92 & 34,37 & 28,70 & 22,63 & 18,00 & 14,53 & 10,01 & 7,50 & 5,04 \\
\hline 35 & 650 & 80 & 43,60 & 33,77 & 28,37 & 22,52 & 17,99 & 14,56 & 10,06 & 7,53 & 5,04 \\
\hline 35 & 700 & 80 & 42,43 & 33,22 & 28,06 & 22,40 & 17,98 & 14,60 & 10,11 & 7,56 & 5,05 \\
\hline 35 & 750 & 80 & 41,37 & 32,71 & 27,76 & 22,28 & 17,96 & 14,62 & 10,15 & 7,58 & 5,05 \\
\hline 35 & 800 & 80 & 40,40 & 32,22 & 27,48 & 22,17 & 17,94 & 14,64 & 10,19 & 7,61 & 5,05 \\
\hline 35 & 850 & 80 & 39,51 & 31,77 & 27,21 & 22,05 & 17,91 & 14,66 & 10,23 & 7,64 & 5,06 \\
\hline 35 & 900 & 80 & 38,70 & 31,35 & 26,95 & 21,94 & 17,88 & 14,67 & 10,26 & 7,66 & 5,06 \\
\hline 35 & 950 & 80 & 37,94 & 30,95 & 26,70 & 21,82 & 17,84 & 14,68 & 10,29 & 7,69 & 5,07 \\
\hline 35 & 1000 & 80 & 37,24 & 30,57 & 26,46 & 21,71 & 17,81 & 14,68 & 10,32 & 7,71 & 5,07 \\
\hline 35 & 1050 & 80 & 36,58 & 30,22 & 26,23 & 21,60 & 17,77 & 14,69 & 10,35 & 7,73 & 5,08 \\
\hline 35 & 1100 & 80 & 35,97 & 29,88 & 26,01 & 21,50 & 17,73 & 14,69 & 10,38 & 7,76 & 5,09 \\
\hline 35 & 1150 & 80 & 35,40 & 29,55 & 25,80 & 21,39 & 17,69 & 14,69 & 10,40 & 7,78 & 5,09 \\
\hline 35 & 1200 & 80 & 34,86 & 29,24 & 25,60 & 21,29 & 17,65 & 14,68 & 10,43 & 7,80 & 5,10 \\
\hline 35 & 1250 & 80 & 34,35 & 28,95 & 25,40 & 21,18 & 17,61 & 14,68 & 10,45 & 7,82 & 5,11 \\
\hline 35 & 1300 & 80 & 33,87 & 28,66 & 25,21 & 21,08 & 17,57 & 14,67 & 10,47 & 7,84 & 5,11 \\
\hline 35 & 1350 & 80 & 33,41 & 28,39 & 25,03 & 20,98 & 17,53 & 14,66 & 10,49 & 7,86 & 5,12 \\
\hline 35 & 1400 & 80 & 32,97 & 28,13 & 24,85 & 20,89 & 17,48 & 14,66 & 10,51 & 7,88 & 5,13 \\
\hline 35 & 1450 & 80 & 32,56 & 27,88 & 24,67 & 20,79 & 17,44 & 14,65 & 10,53 & 7,90 & 5,13 \\
\hline 35 & 1500 & 80 & 32,17 & 27,64 & 24,51 & 20,70 & 17,40 & 14,63 & 10,54 & 7,92 & 5,14 \\
\hline 35 & 1550 & 80 & 31,80 & 27,41 & 24,34 & 20,61 & 17,36 & 14,62 & 10,56 & 7,94 & 5,15 \\
\hline 35 & 1600 & 80 & 31,44 & 27,18 & 24,19 & 20,52 & 17,31 & 14,61 & 10,57 & 7,95 & 5,15 \\
\hline 35 & 1650 & 80 & 31,10 & 26,96 & 24,03 & 20,43 & 17,27 & 14,60 & 10,58 & 7,97 & 5,16 \\
\hline 35 & 1700 & 80 & 30,77 & 26,75 & 23,88 & 20,34 & 17,23 & 14,58 & 10,59 & 7,98 & 5,17 \\
\hline 35 & 1750 & 80 & 30,45 & 26,55 & 23,74 & 20,26 & 17,18 & 14,57 & 10,61 & 8,00 & 5,18 \\
\hline 35 & 1800 & 80 & 30,15 & 26,35 & 23,60 & 20,17 & 17,14 & 14,55 & 10,62 & 8,01 & 5,18 \\
\hline 35 & 1850 & 80 & 29,86 & 26,16 & 23,46 & 20,09 & 17,10 & 14,53 & 10,63 & 8,03 & 5,19 \\
\hline 35 & 1900 & 80 & 29,58 & 25,98 & 23,33 & 20,01 & 17,06 & 14,52 & 10,63 & 8,04 & 5,20 \\
\hline 35 & 1950 & 80 & 29,31 & 25,80 & 23,19 & 19,93 & 17,01 & 14,50 & 10,64 & 8,06 & 5,21 \\
\hline 35 & 2000 & 80 & 29,06 & 25,63 & 23,07 & 19,85 & 16,97 & 14,48 & 10,65 & 8,07 & 5,21 \\
\hline 35 & 200 & 85 & 66,96 & 40,55 & 30,31 & 21,76 & 16,44 & 12,97 & 8,92 & 6,85 & 4,77 \\
\hline 35 & 250 & 85 & 60,87 & 38,96 & 29,86 & 21,81 & 16,60 & 13,10 & 8,99 & 6,87 & 4,76 \\
\hline 35 & 300 & 85 & 56,48 & 37,67 & 29,42 & 21,82 & 16,71 & 13,22 & 9,06 & 6,89 & 4,75 \\
\hline 35 & 350 & 85 & 53,11 & 36,58 & 29,01 & 21,78 & 16,80 & 13,32 & 9,12 & 6,92 & 4,75 \\
\hline 35 & 400 & 85 & 50,42 & 35,64 & 28,61 & 21,72 & 16,85 & 13,41 & 9,18 & 6,94 & 4,75 \\
\hline 35 & 450 & 85 & 48,19 & 34,81 & 28,24 & 21,65 & 16,90 & 13,48 & 9,24 & 6,97 & 4,74 \\
\hline 35 & 500 & 85 & 46,30 & 34,07 & 27,89 & 21,56 & 16,92 & 13,54 & 9,29 & 6,99 & 4,74 \\
\hline 35 & 550 & 85 & 44,67 & 33,39 & 27,56 & 21,47 & 16,94 & 13,60 & 9,34 & 7,02 & 4,74 \\
\hline 35 & 600 & 85 & 43,24 & 32,78 & 27,24 & 21,37 & 16,94 & 13,64 & 9,39 & 7,04 & 4,74 \\
\hline 35 & 650 & 85 & 41,97 & 32,22 & 26,94 & 21,27 & 16,94 & 13,68 & 9,43 & 7,07 & 4,75 \\
\hline 35 & 700 & 85 & 40,84 & 31,69 & 26,65 & 21,17 & 16,93 & 13,71 & 9,48 & 7,09 & 4,75 \\
\hline 35 & 750 & 85 & 39,81 & 31,21 & 26,37 & 21,07 & 16,92 & 13,74 & 9,52 & 7,12 & 4,75 \\
\hline 35 & 800 & 85 & 38,88 & 30,75 & 26,11 & 20,97 & 16,90 & 13,76 & 9,55 & 7,14 & 4,75 \\
\hline 35 & 850 & 85 & 38,02 & 30,33 & 25,86 & 20,86 & 16,88 & 13,78 & 9,59 & 7,16 & 4,76 \\
\hline 35 & 900 & 85 & 37,23 & 29,93 & 25,62 & 20,76 & 16,86 & 13,79 & 9,62 & 7,19 & 4,76 \\
\hline 35 & 950 & 85 & 36,51 & 29,55 & 25,39 & 20,66 & 16,83 & 13,81 & 9,65 & 7,21 & 4,77 \\
\hline 35 & 1000 & 85 & 35,83 & 29,20 & 25,17 & 20,56 & 16,80 & 13,81 & 9,68 & 7,23 & 4,77 \\
\hline 35 & 1050 & 85 & 35,20 & 28,86 & 24,96 & 20,46 & 16,77 & 13,82 & 9,71 & 7,25 & 4,78 \\
\hline 35 & 1100 & 85 & 34,61 & 28,54 & 24,75 & 20,36 & 16,74 & 13,82 & 9,74 & 7,27 & 4,78 \\
\hline 35 & 1150 & 85 & 34,06 & 28,23 & 24,56 & 20,27 & 16,70 & 13,82 & 9,76 & 7,29 & 4,79 \\
\hline 35 & 1200 & 85 & 33,53 & 27,94 & 24,37 & 20,17 & 16,67 & 13,82 & 9,78 & 7,31 & 4,79 \\
\hline 35 & 1250 & 85 & 33,04 & 27,66 & 24,18 & 20,08 & 16,63 & 13,82 & 9,80 & 7,33 & 4,80 \\
\hline 35 & 1300 & 85 & 32,58 & 27,39 & 24,00 & 19,99 & 16,60 & 13,82 & 9,82 & 7,35 & 4,80 \\
\hline 35 & 1350 & 85 & 32,14 & 27,13 & 23,83 & 19,90 & 16,56 & 13,81 & 9,84 & 7,37 & 4,81 \\
\hline 35 & 1400 & 85 & 31,72 & 26,89 & 23,67 & 19,81 & 16,52 & 13,81 & 9,86 & 7,39 & 4,81 \\
\hline 35 & 1450 & 85 & 31,32 & 26,65 & 23,50 & 19,72 & 16,48 & 13,80 & 9,88 & 7,41 & 4,82 \\
\hline 35 & 1500 & 85 & 30,94 & 26,42 & 23,35 & 19,64 & 16,45 & 13,79 & 9,89 & 7,42 & 4,83 \\
\hline 35 & 1550 & 85 & 30,58 & 26,20 & 23,19 & 19,55 & 16,41 & 13,78 & 9,91 & 7,44 & 4,83 \\
\hline 35 & 1600 & 85 & 30,24 & 25,99 & 23,05 & 19,47 & 16,37 & 13,77 & 9,92 & 7,45 & 4,84 \\
\hline
\end{tabular}




\begin{tabular}{|c|c|c|c|c|c|c|c|c|c|c|c|}
\hline \multirow[b]{2}{*}{$\mathrm{H}(\mathrm{cm})$} & \multirow[b]{2}{*}{ Mceq (MPa) } & & & & & $\mathrm{De}$ & ões (x1 & & & & \\
\hline & & Msub (MPa) & D0 & D25 & D40 & D60 & D80 & D100 & D140 & D180 & D260 \\
\hline 35 & 1650 & 85 & 29,90 & 25,78 & 22,90 & 19,39 & 16,33 & 13,76 & 9,94 & 7,47 & 4,84 \\
\hline 35 & 1700 & 85 & 29,59 & 25,58 & 22,76 & 19,31 & 16,29 & 13,75 & 9,95 & 7,48 & 4,85 \\
\hline 35 & 1750 & 85 & 29,28 & 25,39 & 22,63 & 19,23 & 16,26 & 13,74 & 9,96 & 7,50 & 4,86 \\
\hline 35 & 1800 & 85 & 28,99 & 25,20 & 22,49 & 19,15 & 16,22 & 13,72 & 9,97 & 7,51 & 4,86 \\
\hline 35 & 1850 & 85 & 28,71 & 25,02 & 22,37 & 19,08 & 16,18 & 13,71 & 9,98 & 7,53 & 4,87 \\
\hline 35 & 1900 & 85 & 28,44 & 24,85 & 22,24 & 19,00 & 16,14 & 13,70 & 9,99 & 7,54 & 4,88 \\
\hline 35 & 1950 & 85 & 28,18 & 24,68 & 22,12 & 18,93 & 16,10 & 13,68 & 10,00 & 7,55 & 4,88 \\
\hline 35 & 2000 & 85 & 27,93 & 24,51 & 22,00 & 18,86 & 16,07 & 13,67 & 10,01 & 7,57 & 4,89 \\
\hline 35 & 200 & 90 & 64,86 & 38,68 & 28,73 & 20,52 & 15,49 & 12,21 & 8,41 & 6,47 & 4,51 \\
\hline 35 & 250 & 90 & 58,88 & 37,18 & 28,32 & 20,59 & 15,64 & 12,34 & 8,48 & 6,49 & 4,50 \\
\hline 35 & 300 & 90 & 54,59 & 35,96 & 27,92 & 20,61 & 15,75 & 12,45 & 8,54 & 6,50 & 4,49 \\
\hline 35 & 350 & 90 & 51,31 & 34,93 & 27,55 & 20,59 & 15,83 & 12,55 & 8,59 & 6,53 & 4,49 \\
\hline 35 & 400 & 90 & 48,69 & 34,04 & 27,19 & 20,54 & 15,90 & 12,63 & 8,65 & 6,55 & 4,48 \\
\hline 35 & 450 & 90 & 46,52 & 33,26 & 26,85 & 20,48 & 15,94 & 12,70 & 8,70 & 6,57 & 4,48 \\
\hline 35 & 500 & 90 & 44,68 & 32,55 & 26,52 & 20,41 & 15,97 & 12,76 & 8,75 & 6,59 & 4,48 \\
\hline 35 & 550 & 90 & 43,10 & 31,92 & 26,22 & 20,33 & 15,99 & 12,81 & 8,79 & 6,61 & 4,48 \\
\hline 35 & 600 & 90 & 41,72 & 31,34 & 25,92 & 20,25 & 16,00 & 12,86 & 8,84 & 6,63 & 4,48 \\
\hline 35 & 650 & 90 & 40,49 & 30,81 & 25,64 & 20,16 & 16,00 & 12,90 & 8,88 & 6,66 & 4,48 \\
\hline 35 & 700 & 90 & 39,39 & 30,31 & 25,38 & 20,07 & 16,00 & 12,93 & 8,92 & 6,68 & 4,48 \\
\hline 35 & 750 & 90 & 38,40 & 29,85 & 25,12 & 19,98 & 15,99 & 12,96 & 8,96 & 6,70 & 4,48 \\
\hline 35 & 800 & 90 & 37,50 & 29,42 & 24,88 & 19,89 & 15,98 & 12,98 & 8,99 & 6,72 & 4,49 \\
\hline 35 & 850 & 90 & 36,67 & 29,02 & 24,65 & 19,80 & 15,96 & 13,00 & 9,03 & 6,74 & 4,49 \\
\hline 35 & 900 & 90 & 35,91 & 28,64 & 24,43 & 19,70 & 15,94 & 13,01 & 9,06 & 6,76 & 4,49 \\
\hline 35 & 950 & 90 & 35,21 & 28,29 & 24,21 & 19,61 & 15,92 & 13,03 & 9,09 & 6,79 & 4,50 \\
\hline 35 & 1000 & 90 & 34,55 & 27,95 & 24,01 & 19,52 & 15,90 & 13,04 & 9,11 & 6,81 & 4,50 \\
\hline 35 & 1050 & 90 & 33,94 & 27,63 & 23,81 & 19,43 & 15,87 & 13,05 & 9,14 & 6,83 & 4,50 \\
\hline 35 & 1100 & 90 & 33,37 & 27,32 & 23,62 & 19,34 & 15,84 & 13,05 & 9,17 & 6,84 & 4,51 \\
\hline 35 & 1150 & 90 & 32,84 & 27,03 & 23,43 & 19,26 & 15,81 & 13,05 & 9,19 & 6,86 & 4,51 \\
\hline 35 & 1200 & 90 & 32,33 & 26,76 & 23,25 & 19,17 & 15,79 & 13,06 & 9,21 & 6,88 & 4,52 \\
\hline 35 & 1250 & 90 & 31,86 & 26,49 & 23,08 & 19,09 & 15,75 & 13,06 & 9,23 & 6,90 & 4,52 \\
\hline 35 & 1300 & 90 & 31,41 & 26,24 & 22,92 & 19,00 & 15,72 & 13,06 & 9,25 & 6,92 & 4,53 \\
\hline 35 & 1350 & 90 & 30,98 & 25,99 & 22,75 & 18,92 & 15,69 & 13,05 & 9,27 & 6,93 & 4,53 \\
\hline 35 & 1400 & 90 & 30,58 & 25,76 & 22,60 & 18,84 & 15,66 & 13,05 & 9,29 & 6,95 & 4,54 \\
\hline 35 & 1450 & 90 & 30,20 & 25,53 & 22,45 & 18,76 & 15,63 & 13,04 & 9,30 & 6,97 & 4,54 \\
\hline 35 & 1500 & 90 & 29,83 & 25,32 & 22,30 & 18,68 & 15,59 & 13,04 & 9,32 & 6,98 & 4,55 \\
\hline 35 & 1550 & 90 & 29,48 & 25,11 & 22,16 & 18,60 & 15,56 & 13,03 & 9,33 & 7,00 & 4,55 \\
\hline 35 & 1600 & 90 & 29,15 & 24,90 & 22,02 & 18,53 & 15,52 & 13,02 & 9,35 & 7,01 & 4,56 \\
\hline 35 & 1650 & 90 & 28,83 & 24,71 & 21,88 & 18,45 & 15,49 & 13,01 & 9,36 & 7,03 & 4,56 \\
\hline 35 & 1700 & 90 & 28,52 & 24,52 & 21,75 & 18,38 & 15,46 & 13,01 & 9,37 & 7,04 & 4,57 \\
\hline 35 & 1750 & 90 & 28,23 & 24,34 & 21,62 & 18,31 & 15,42 & 13,00 & 9,38 & 7,06 & 4,58 \\
\hline 35 & 1800 & 90 & 27,94 & 24,16 & 21,50 & 18,24 & 15,39 & 12,99 & 9,40 & 7,07 & 4,58 \\
\hline 35 & 1850 & 90 & 27,67 & 23,99 & 21,38 & 18,17 & 15,35 & 12,98 & 9,41 & 7,08 & 4,59 \\
\hline 35 & 1900 & 90 & 27,41 & 23,82 & 21,26 & 18,10 & 15,32 & 12,96 & 9,41 & 7,09 & 4,59 \\
\hline 35 & 1950 & 90 & 27,16 & 23,66 & 21,14 & 18,03 & 15,29 & 12,95 & 9,42 & 7,11 & 4,60 \\
\hline 35 & 2000 & 90 & 26,92 & 23,50 & 21,03 & 17,96 & 15,25 & 12,94 & 9,43 & 7,12 & 4,60 \\
\hline 35 & 200 & 95 & 62,95 & 37,00 & 27,30 & 19,42 & 14,64 & 11,54 & 7,96 & 6,12 & 4,27 \\
\hline 35 & 250 & 95 & 57,08 & 35,56 & 26,93 & 19,50 & 14,78 & 11,66 & 8,01 & 6,14 & 4,26 \\
\hline 35 & 300 & 95 & 52,88 & 34,41 & 26,57 & 19,52 & 14,89 & 11,77 & 8,07 & 6,16 & 4,26 \\
\hline 35 & 350 & 95 & 49,67 & 33,43 & 26,23 & 19,51 & 14,97 & 11,86 & 8,12 & 6,17 & 4,25 \\
\hline 35 & 400 & 95 & 47,11 & 32,59 & 25,90 & 19,48 & 15,04 & 11,93 & 8,17 & 6,19 & 4,25 \\
\hline 35 & 450 & 95 & 45,00 & 31,85 & 25,58 & 19,43 & 15,08 & 12,00 & 8,22 & 6,21 & 4,25 \\
\hline 35 & 500 & 95 & 43,21 & 31,18 & 25,29 & 19,37 & 15,12 & 12,06 & 8,26 & 6,23 & 4,24 \\
\hline 35 & 550 & 95 & 41,67 & 30,58 & 25,00 & 19,31 & 15,14 & 12,11 & 8,31 & 6,25 & 4,24 \\
\hline 35 & 600 & 95 & 40,33 & 30,03 & 24,73 & 19,23 & 15,15 & 12,15 & 8,35 & 6,27 & 4,24 \\
\hline 35 & 650 & 95 & 39,14 & 29,53 & 24,47 & 19,16 & 15,16 & 12,19 & 8,39 & 6,29 & 4,24 \\
\hline 35 & 700 & 95 & 38,07 & 29,06 & 24,23 & 19,08 & 15,16 & 12,23 & 8,42 & 6,31 & 4,25 \\
\hline 35 & 750 & 95 & 37,11 & 28,62 & 23,99 & 19,00 & 15,16 & 12,25 & 8,46 & 6,33 & 4,25 \\
\hline 35 & 800 & 95 & 36,24 & 28,22 & 23,76 & 18,91 & 15,15 & 12,28 & 8,49 & 6,35 & 4,25 \\
\hline 35 & 850 & 95 & 35,44 & 27,83 & 23,55 & 18,83 & 15,14 & 12,30 & 8,52 & 6,37 & 4,25 \\
\hline 35 & 900 & 95 & 34,70 & 27,48 & 23,34 & 18,75 & 15,12 & 12,32 & 8,55 & 6,39 & 4,25 \\
\hline 35 & 950 & 95 & 34,02 & 27,14 & 23,14 & 18,67 & 15,10 & 12,33 & 8,58 & 6,41 & 4,26 \\
\hline 35 & 1000 & 95 & 33,39 & 26,82 & 22,95 & 18,59 & 15,08 & 12,34 & 8,61 & 6,43 & 4,26 \\
\hline 35 & 1050 & 95 & 32,80 & 26,51 & 22,76 & 18,50 & 15,06 & 12,35 & 8,63 & 6,45 & 4,26 \\
\hline 35 & 1100 & 95 & 32,25 & 26,22 & 22,58 & 18,42 & 15,04 & 12,36 & 8,66 & 6,46 & 4,27 \\
\hline 35 & 1150 & 95 & 31,73 & 25,95 & 22,41 & 18,34 & 15,02 & 12,36 & 8,68 & 6,48 & 4,27 \\
\hline 35 & 1200 & 95 & 31,24 & 25,68 & 22,24 & 18,27 & 14,99 & 12,37 & 8,70 & 6,50 & 4,27 \\
\hline 35 & 1250 & 95 & 30,78 & 25,43 & 22,08 & 18,19 & 14,96 & 12,37 & 8,72 & 6,51 & 4,28 \\
\hline 35 & 1300 & 95 & 30,35 & 25,19 & 21,93 & 18,11 & 14,94 & 12,37 & 8,74 & 6,53 & 4,28 \\
\hline 35 & 1350 & 95 & 29,93 & 24,96 & 21,77 & 18,04 & 14,91 & 12,37 & 8,76 & 6,55 & 4,29 \\
\hline 35 & 1400 & 95 & 29,54 & 24,73 & 21,63 & 17,96 & 14,88 & 12,37 & 8,77 & 6,56 & 4,29 \\
\hline 35 & 1450 & 95 & 29,17 & 24,52 & 21,49 & 17,89 & 14,85 & 12,36 & 8,79 & 6,58 & 4,30 \\
\hline 35 & 1500 & 95 & 28,82 & 24,31 & 21,35 & 17,82 & 14,82 & 12,36 & 8,81 & 6,59 & 4,30 \\
\hline 35 & 1550 & 95 & 28,48 & 24,11 & 21,21 & 17,74 & 14,79 & 12,36 & 8,82 & 6,61 & 4,31 \\
\hline 35 & 1600 & 95 & 28,15 & 23,92 & 21,08 & 17,67 & 14,76 & 12,35 & 8,83 & 6,62 & 4,31 \\
\hline 35 & 1650 & 95 & 27,84 & 23,73 & 20,96 & 17,61 & 14,73 & 12,34 & 8,85 & 6,63 & 4,32 \\
\hline 35 & 1700 & 95 & 27,55 & 23,55 & 20,83 & 17,54 & 14,70 & 12,34 & 8,86 & 6,65 & 4,32 \\
\hline 35 & 1750 & 95 & 27,26 & 23,38 & 20,71 & 17,47 & 14,67 & 12,33 & 8,87 & 6,66 & 4,33 \\
\hline 35 & 1800 & 95 & 26,99 & 23,21 & 20,59 & 17,41 & 14,64 & 12,32 & 8,88 & 6,67 & 4,33 \\
\hline 35 & 1850 & 95 & 26,73 & 23,05 & 20,48 & 17,34 & 14,61 & 12,31 & 8,89 & 6,68 & 4,34 \\
\hline 35 & 1900 & 95 & 26,47 & 22,89 & 20,37 & 17,28 & 14,58 & 12,30 & 8,90 & 6,70 & 4,34 \\
\hline 35 & 1950 & 95 & 26,23 & 22,74 & 20,26 & 17,21 & 14,55 & 12,29 & 8,91 & 6,71 & 4,35 \\
\hline
\end{tabular}




\begin{tabular}{|c|c|c|c|c|c|c|c|c|c|c|c|}
\hline \multirow[b]{2}{*}{$\mathrm{H}(\mathrm{cm})$} & \multirow[b]{2}{*}{ Mceq (MPa) } & & & & & $\mathrm{De}$ & ões (x1 & & & & \\
\hline & & Msub (MPa) & D0 & D25 & D40 & D60 & D80 & D100 & D140 & D180 & D260 \\
\hline 35 & 2000 & 95 & 26,00 & 22,59 & 20,15 & 17,15 & 14,52 & 12,28 & 8,92 & 6,72 & 4,35 \\
\hline 35 & 200 & 100 & 61,21 & 35,47 & 26,00 & 18,42 & 13,87 & 10,94 & 7,55 & 5,81 & 4,06 \\
\hline 35 & 250 & 100 & 55,43 & 34,10 & 25,67 & 18,51 & 14,01 & 11,05 & 7,60 & 5,83 & 4,05 \\
\hline 35 & 300 & 100 & 51,31 & 32,99 & 25,34 & 18,54 & 14,12 & 11,15 & 7,65 & 5,84 & 4,04 \\
\hline 35 & 350 & 100 & 48,17 & 32,07 & 25,03 & 18,54 & 14,20 & 11,23 & 7,70 & 5,86 & 4,04 \\
\hline 35 & 400 & 100 & 45,67 & 31,27 & 24,73 & 18,52 & 14,26 & 11,31 & 7,74 & 5,88 & 4,04 \\
\hline 35 & 450 & 100 & 43,61 & 30,56 & 24,44 & 18,48 & 14,31 & 11,37 & 7,79 & 5,89 & 4,03 \\
\hline 35 & 500 & 100 & 41,87 & 29,93 & 24,16 & 18,43 & 14,35 & 11,43 & 7,83 & 5,91 & 4,03 \\
\hline 35 & 550 & 100 & 40,37 & 29,36 & 23,90 & 18,38 & 14,37 & 11,48 & 7,87 & 5,93 & 4,03 \\
\hline 35 & 600 & 100 & 39,06 & 28,84 & 23,65 & 18,31 & 14,39 & 11,52 & 7,91 & 5,95 & 4,03 \\
\hline 35 & 650 & 100 & 37,90 & 28,36 & 23,41 & 18,25 & 14,40 & 11,56 & 7,94 & 5,96 & 4,03 \\
\hline 35 & 700 & 100 & 36,87 & 27,91 & 23,18 & 18,18 & 14,40 & 11,59 & 7,98 & 5,98 & 4,03 \\
\hline 35 & 750 & 100 & 35,93 & 27,50 & 22,96 & 18,10 & 14,40 & 11,62 & 8,01 & 6,00 & 4,03 \\
\hline 35 & 800 & 100 & 35,08 & 27,11 & 22,75 & 18,03 & 14,40 & 11,65 & 8,04 & 6,02 & 4,04 \\
\hline 35 & 850 & 100 & 34,31 & 26,75 & 22,55 & 17,96 & 14,39 & 11,67 & 8,07 & 6,04 & 4,04 \\
\hline 35 & 900 & 100 & 33,59 & 26,41 & 22,35 & 17,88 & 14,38 & 11,69 & 8,10 & 6,05 & 4,04 \\
\hline 35 & 950 & 100 & 32,93 & 26,09 & 22,16 & 17,81 & 14,36 & 11,70 & 8,13 & 6,07 & 4,04 \\
\hline 35 & 1000 & 100 & 32,32 & 25,78 & 21,98 & 17,73 & 14,35 & 11,71 & 8,15 & 6,09 & 4,04 \\
\hline 35 & 1050 & 100 & 31,75 & 25,49 & 21,81 & 17,66 & 14,33 & 11,72 & 8,17 & 6,11 & 4,05 \\
\hline 35 & 1100 & 100 & 31,21 & 25,21 & 21,64 & 17,59 & 14,31 & 11,73 & 8,20 & 6,12 & 4,05 \\
\hline 35 & 1150 & 100 & 30,71 & 24,95 & 21,48 & 17,51 & 14,29 & 11,74 & 8,22 & 6,14 & 4,05 \\
\hline 35 & 1200 & 100 & 30,24 & 24,70 & 21,32 & 17,44 & 14,27 & 11,74 & 8,24 & 6,15 & 4,06 \\
\hline 35 & 1250 & 100 & 29,79 & 24,46 & 21,17 & 17,37 & 14,25 & 11,75 & 8,26 & 6,17 & 4,06 \\
\hline 35 & 1300 & 100 & 29,37 & 24,23 & 21,02 & 17,30 & 14,22 & 11,75 & 8,28 & 6,18 & 4,06 \\
\hline 35 & 1350 & 100 & 28,97 & 24,01 & 20,88 & 17,23 & 14,20 & 11,75 & 8,30 & 6,20 & 4,07 \\
\hline 35 & 1400 & 100 & 28,59 & 23,79 & 20,74 & 17,16 & 14,17 & 11,75 & 8,31 & 6,21 & 4,07 \\
\hline 35 & 1450 & 100 & 28,23 & 23,59 & 20,61 & 17,09 & 14,15 & 11,75 & 8,33 & 6,23 & 4,08 \\
\hline 35 & 1500 & 100 & 27,89 & 23,39 & 20,48 & 17,03 & 14,12 & 11,75 & 8,34 & 6,24 & 4,08 \\
\hline 35 & 1550 & 100 & 27,56 & 23,20 & 20,35 & 16,96 & 14,10 & 11,74 & 8,36 & 6,25 & 4,08 \\
\hline 35 & 1600 & 100 & 27,24 & 23,02 & 20,23 & 16,90 & 14,07 & 11,74 & 8,37 & 6,27 & 4,09 \\
\hline 35 & 1650 & 100 & 26,94 & 22,84 & 20,11 & 16,83 & 14,04 & 11,74 & 8,38 & 6,28 & 4,09 \\
\hline 35 & 1700 & 100 & 26,66 & 22,67 & 19,99 & 16,77 & 14,01 & 11,73 & 8,40 & 6,29 & 4,10 \\
\hline 35 & 1750 & 100 & 26,38 & 22,50 & 19,88 & 16,71 & 13,99 & 11,72 & 8,41 & 6,31 & 4,10 \\
\hline 35 & 1800 & 100 & 26,11 & 22,34 & 19,77 & 16,65 & 13,96 & 11,72 & 8,42 & 6,32 & 4,11 \\
\hline 35 & 1850 & 100 & 25,86 & 22,19 & 19,66 & 16,59 & 13,93 & 11,71 & 8,43 & 6,33 & 4,11 \\
\hline 35 & 1900 & 100 & 25,61 & 22,04 & 19,55 & 16,53 & 13,90 & 11,70 & 8,44 & 6,34 & 4,11 \\
\hline 35 & 1950 & 100 & 25,38 & 21,89 & 19,45 & 16,47 & 13,88 & 11,70 & 8,45 & 6,35 & 4,12 \\
\hline 35 & 2000 & 100 & 25,15 & 21,74 & 19,35 & 16,41 & 13,85 & 11,69 & 8,46 & 6,36 & 4,12 \\
\hline 35 & 200 & 105 & 59,62 & 34,07 & 24,82 & 17,52 & 13,18 & 10,40 & 7,18 & 5,53 & 3,87 \\
\hline 35 & 250 & 105 & 53,93 & 32,76 & 24,52 & 17,62 & 13,32 & 10,50 & 7,23 & 5,55 & 3,86 \\
\hline 35 & 300 & 105 & 49,88 & 31,70 & 24,22 & 17,66 & 13,42 & 10,59 & 7,27 & 5,56 & 3,85 \\
\hline 35 & 350 & 105 & 46,79 & 30,82 & 23,93 & 17,66 & 13,50 & 10,67 & 7,32 & 5,58 & 3,85 \\
\hline 35 & 400 & 105 & 44,34 & 30,06 & 23,66 & 17,65 & 13,56 & 10,74 & 7,36 & 5,59 & 3,85 \\
\hline 35 & 450 & 105 & 42,33 & 29,39 & 23,39 & 17,62 & 13,61 & 10,81 & 7,40 & 5,61 & 3,84 \\
\hline 35 & 500 & 105 & 40,63 & 28,78 & 23,13 & 17,58 & 13,65 & 10,86 & 7,44 & 5,62 & 3,84 \\
\hline 35 & 550 & 105 & 39,17 & 28,24 & 22,89 & 17,53 & 13,68 & 10,91 & 7,47 & 5,64 & 3,84 \\
\hline 35 & 600 & 105 & 37,89 & 27,74 & 22,66 & 17,48 & 13,69 & 10,95 & 7,51 & 5,65 & 3,84 \\
\hline 35 & 650 & 105 & 36,76 & 27,29 & 22,43 & 17,42 & 13,71 & 10,99 & 7,54 & 5,67 & 3,84 \\
\hline 35 & 700 & 105 & 35,76 & 26,86 & 22,22 & 17,36 & 13,71 & 11,02 & 7,58 & 5,69 & 3,84 \\
\hline 35 & 750 & 105 & 34,85 & 26,47 & 22,01 & 17,29 & 13,72 & 11,05 & 7,61 & 5,70 & 3,84 \\
\hline 35 & 800 & 105 & 34,02 & 26,10 & 21,82 & 17,23 & 13,71 & 11,07 & 7,64 & 5,72 & 3,84 \\
\hline 35 & 850 & 105 & 33,27 & 25,75 & 21,63 & 17,16 & 13,71 & 11,10 & 7,66 & 5,74 & 3,84 \\
\hline 35 & 900 & 105 & 32,57 & 25,43 & 21,44 & 17,09 & 13,70 & 11,11 & 7,69 & 5,75 & 3,84 \\
\hline 35 & 950 & 105 & 31,93 & 25,12 & 21,27 & 17,02 & 13,69 & 11,13 & 7,72 & 5,77 & 3,85 \\
\hline 35 & 1000 & 105 & 31,34 & 24,83 & 21,10 & 16,96 & 13,68 & 11,14 & 7,74 & 5,78 & 3,85 \\
\hline 35 & 1050 & 105 & 30,78 & 24,55 & 20,94 & 16,89 & 13,66 & 11,16 & 7,76 & 5,80 & 3,85 \\
\hline 35 & 1100 & 105 & 30,26 & 24,29 & 20,78 & 16,82 & 13,65 & 11,17 & 7,78 & 5,81 & 3,85 \\
\hline 35 & 1150 & 105 & 29,77 & 24,04 & 20,63 & 16,76 & 13,63 & 11,17 & 7,81 & 5,83 & 3,86 \\
\hline 35 & 1200 & 105 & 29,31 & 23,80 & 20,48 & 16,69 & 13,61 & 11,18 & 7,82 & 5,84 & 3,86 \\
\hline 35 & 1250 & 105 & 28,88 & 23,57 & 20,34 & 16,62 & 13,59 & 11,18 & 7,84 & 5,86 & 3,86 \\
\hline 35 & 1300 & 105 & 28,47 & 23,35 & 20,20 & 16,56 & 13,57 & 11,19 & 7,86 & 5,87 & 3,87 \\
\hline 35 & 1350 & 105 & 28,08 & 23,14 & 20,06 & 16,50 & 13,55 & 11,19 & 7,88 & 5,89 & 3,87 \\
\hline 35 & 1400 & 105 & 27,72 & 22,93 & 19,93 & 16,43 & 13,53 & 11,19 & 7,89 & 5,90 & 3,87 \\
\hline 35 & 1450 & 105 & 27,36 & 22,74 & 19,80 & 16,37 & 13,51 & 11,19 & 7,91 & 5,91 & 3,88 \\
\hline 35 & 1500 & 105 & 27,03 & 22,55 & 19,68 & 16,31 & 13,48 & 11,19 & 7,92 & 5,93 & 3,88 \\
\hline 35 & 1550 & 105 & 26,71 & 22,37 & 19,56 & 16,25 & 13,46 & 11,19 & 7,94 & 5,94 & 3,88 \\
\hline 35 & 1600 & 105 & 26,41 & 22,19 & 19,45 & 16,19 & 13,44 & 11,19 & 7,95 & 5,95 & 3,89 \\
\hline 35 & 1650 & 105 & 26,12 & 22,02 & 19,33 & 16,13 & 13,41 & 11,18 & 7,96 & 5,96 & 3,89 \\
\hline 35 & 1700 & 105 & 25,84 & 21,86 & 19,22 & 16,07 & 13,39 & 11,18 & 7,98 & 5,97 & 3,89 \\
\hline 35 & 1750 & 105 & 25,57 & 21,70 & 19,11 & 16,01 & 13,36 & 11,18 & 7,99 & 5,99 & 3,90 \\
\hline 35 & 1800 & 105 & 25,31 & 21,55 & 19,01 & 15,96 & 13,34 & 11,17 & 8,00 & 6,00 & 3,90 \\
\hline 35 & 1850 & 105 & 25,06 & 21,40 & 18,91 & 15,90 & 13,32 & 11,16 & 8,01 & 6,01 & 3,91 \\
\hline 35 & 1900 & 105 & 24,82 & 21,25 & 18,81 & 15,84 & 13,29 & 11,16 & 8,02 & 6,02 & 3,91 \\
\hline 35 & 1950 & 105 & 24,59 & 21,11 & 18.71 & 15,79 & 13,27 & 11,15 & 8.03 & 6.03 & 3,91 \\
\hline 35 & 2000 & 105 & 24,37 & 20,97 & 18,61 & 15,74 & 13,24 & 11,15 & 8,04 & 6,04 & 3,92 \\
\hline 35 & 200 & 110 & 58,15 & 32,79 & 23,75 & 16,70 & 12,55 & 9,90 & 6,84 & 5,28 & 3,70 \\
\hline 35 & 250 & 110 & 52,54 & 31,53 & 23,47 & 16,80 & 12,68 & 10,00 & 6,89 & 5,29 & 3,69 \\
\hline 35 & 300 & 110 & 48,55 & 30,52 & 23,20 & 16,85 & 12,79 & 10,09 & 6,93 & 5,30 & 3,68 \\
\hline 35 & 350 & 110 & 45,53 & 29,67 & 22,93 & 16,86 & 12,87 & 10,17 & 6,97 & 5,32 & 3,68 \\
\hline 35 & 400 & 110 & 43,12 & 28,94 & 22,68 & 16,85 & 12,93 & 10,23 & 7,01 & 5,33 & 3,67 \\
\hline 35 & 450 & 110 & 41,15 & 28,30 & 22,43 & 16,83 & 12,98 & 10,29 & 7,05 & 5,34 & 3,67 \\
\hline
\end{tabular}




\begin{tabular}{|c|c|c|c|c|c|c|c|c|c|c|c|}
\hline \multirow[b]{2}{*}{$\mathrm{H}(\mathrm{cm})$} & \multirow[b]{2}{*}{ Mceq (MPa) } & & & & & $\mathrm{De}$ & ões (x1 & & & & \\
\hline & & Msub (MPa) & D0 & D25 & D40 & D60 & D80 & D100 & D140 & D180 & D260 \\
\hline 35 & 500 & 110 & 39,49 & 27,73 & 22,19 & 16,80 & 13,01 & 10,34 & 7,08 & 5,36 & 3,67 \\
\hline 35 & 550 & 110 & 38,06 & 27,21 & 21,97 & 16,76 & 13,04 & 10,39 & 7,12 & 5,37 & 3,67 \\
\hline 35 & 600 & 110 & 36,81 & 26,74 & 21,75 & 16,71 & 13,06 & 10,43 & 7,15 & 5,39 & 3,67 \\
\hline 35 & 650 & 110 & 35,71 & 26,30 & 21,54 & 16,66 & 13,08 & 10,47 & 7,18 & 5,40 & 3,66 \\
\hline 35 & 700 & 110 & 34,73 & 25,90 & 21,34 & 16,60 & 13,09 & 10,50 & 7,21 & 5,42 & 3,67 \\
\hline 35 & 750 & 110 & 33,85 & 25,52 & 21,15 & 16,55 & 13,09 & 10,53 & 7,24 & 5,43 & 3,67 \\
\hline 35 & 800 & 110 & 33,04 & 25,17 & 20,96 & 16,49 & 13,09 & 10,55 & 7,27 & 5,45 & 3,67 \\
\hline 35 & 850 & 110 & 32,31 & 24,84 & 20,78 & 16,43 & 13,09 & 10,58 & 7,30 & 5,46 & 3,67 \\
\hline 35 & 900 & 110 & 31,63 & 24,53 & 20,61 & 16,37 & 13,09 & 10,59 & 7,32 & 5,48 & 3,67 \\
\hline 35 & 950 & 110 & 31,01 & 24,23 & 20,45 & 16,31 & 13,08 & 10,61 & 7,34 & 5,49 & 3,67 \\
\hline 35 & 1000 & 110 & 30,43 & 23,95 & 20,29 & 16,24 & 13,07 & 10,63 & 7,37 & 5,51 & 3,67 \\
\hline 35 & 1050 & 110 & 29,89 & 23,69 & 20,13 & 16,18 & 13,06 & 10,64 & 7,39 & 5,52 & 3,67 \\
\hline 35 & 1100 & 110 & 29,38 & 23,44 & 19,98 & 16,12 & 13,04 & 10,65 & 7,41 & 5,53 & 3,68 \\
\hline 35 & 1150 & 110 & 28,91 & 23,20 & 19,84 & 16,06 & 13,03 & 10,66 & 7,43 & 5,55 & 3,68 \\
\hline 35 & 1200 & 110 & 28,46 & 22,97 & 19,70 & 16,00 & 13,01 & 10,66 & 7,45 & 5,56 & 3,68 \\
\hline 35 & 1250 & 110 & 28,04 & 22,75 & 19,57 & 15,94 & 13,00 & 10,67 & 7,47 & 5,58 & 3,68 \\
\hline 35 & 1300 & 110 & 27,64 & 22,54 & 19,44 & 15,88 & 12,98 & 10,68 & 7,48 & 5,59 & 3,69 \\
\hline 35 & 1350 & 110 & 27,26 & 22,33 & 19,31 & 15,82 & 12,96 & 10,68 & 7,50 & 5,60 & 3,69 \\
\hline 35 & 1400 & 110 & 26,91 & 22,14 & 19,18 & 15,76 & 12,94 & 10,68 & 7,52 & 5,61 & 3,69 \\
\hline 35 & 1450 & 110 & 26,57 & 21,95 & 19,06 & 15,70 & 12,92 & 10,68 & 7,53 & 5,63 & 3,70 \\
\hline 35 & 1500 & 110 & 26,24 & 21,77 & 18,95 & 15,65 & 12,90 & 10,68 & 7,55 & 5,64 & 3,70 \\
\hline 35 & 1550 & 110 & 25,93 & 21,60 & 18,83 & 15,59 & 12,88 & 10,68 & 7,56 & 5,65 & 3,70 \\
\hline 35 & 1600 & 110 & 25,63 & 21,43 & 18,72 & 15,54 & 12,86 & 10,68 & 7,57 & 5,66 & 3,71 \\
\hline 35 & 1650 & 110 & 25,35 & 21,27 & 18,62 & 15,48 & 12,84 & 10,68 & 7,58 & 5,67 & 3,71 \\
\hline 35 & 1700 & 110 & 25,08 & 21,11 & 18,51 & 15,43 & 12,82 & 10,68 & 7,60 & 5,68 & 3,71 \\
\hline 35 & 1750 & 110 & 24,82 & 20,96 & 18,41 & 15,37 & 12,79 & 10,67 & 7,61 & 5,70 & 3,72 \\
\hline 35 & 1800 & 110 & 24,57 & 20,81 & 18,31 & 15,32 & 12,77 & 10,67 & 7,62 & 5,71 & 3,72 \\
\hline 35 & 1850 & 110 & 24,33 & 20,67 & 18,21 & 15,27 & 12,75 & 10,67 & 7,63 & 5,72 & 3,72 \\
\hline 35 & 1900 & 110 & 24,09 & 20,53 & 18,12 & 15,22 & 12,73 & 10,66 & 7,64 & 5,73 & 3,73 \\
\hline 35 & 1950 & 110 & 23,87 & 20,39 & 18,02 & 15,16 & 12,70 & 10,66 & 7,65 & 5,74 & 3,73 \\
\hline 35 & 2000 & 110 & 23,66 & 20,26 & 17,93 & 15,11 & 12,68 & 10,65 & 7,66 & 5,75 & 3,73 \\
\hline 35 & 200 & 115 & 56,80 & 31,61 & 22,76 & 15,95 & 11,98 & 9,46 & 6,54 & 5,05 & 3,54 \\
\hline 35 & 250 & 115 & 51,26 & 30,39 & 22,51 & 16,05 & 12,11 & 9,55 & 6,58 & 5,06 & 3,53 \\
\hline 35 & 300 & 115 & 47,33 & 29,42 & 22,26 & 16,11 & 12,21 & 9,63 & 6,62 & 5,07 & 3,52 \\
\hline 35 & 350 & 115 & 44,35 & 28,61 & 22,01 & 16,13 & 12,28 & 9,70 & 6,66 & 5,08 & 3,52 \\
\hline 35 & 400 & 115 & 41,99 & 27,92 & 21,78 & 16,13 & 12,35 & 9,77 & 6,69 & 5,09 & 3,51 \\
\hline 35 & 450 & 115 & 40,06 & 27,30 & 21,55 & 16,11 & 12,39 & 9,82 & 6,73 & 5,11 & 3,51 \\
\hline 35 & 500 & 115 & 38,43 & 26,76 & 21,33 & 16,08 & 12,43 & 9,87 & 6,76 & 5,12 & 3,51 \\
\hline 35 & 550 & 115 & 37,03 & 26,26 & 21,11 & 16,05 & 12,46 & 9,92 & 6,79 & 5,13 & 3,51 \\
\hline 35 & 600 & 115 & 35,82 & 25,81 & 20,91 & 16,01 & 12,49 & 9,96 & 6,82 & 5,15 & 3,51 \\
\hline 35 & 650 & 115 & 34,74 & 25,39 & 20,71 & 15,96 & 12,50 & 9,99 & 6,85 & 5,16 & 3,51 \\
\hline 35 & 700 & 115 & 33,78 & 25,00 & 20,53 & 15,91 & 12,51 & 10,03 & 6,88 & 5,17 & 3,51 \\
\hline 35 & 750 & 115 & 32,92 & 24,64 & 20,35 & 15,86 & 12,52 & 10,05 & 6,91 & 5,19 & 3,51 \\
\hline 35 & 800 & 115 & 32,13 & 24,30 & 20,17 & 15,81 & 12,52 & 10,08 & 6,93 & 5,20 & 3,51 \\
\hline 35 & 850 & 115 & 31,42 & 23,99 & 20,00 & 15,76 & 12,52 & 10,10 & 6,96 & 5,21 & 3,51 \\
\hline 35 & 900 & 115 & 30,76 & 23,69 & 19,84 & 15,70 & 12,52 & 10,12 & 6,98 & 5,23 & 3,51 \\
\hline 35 & 950 & 115 & 30,15 & 23,41 & 19,69 & 15,65 & 12,52 & 10,14 & 7,01 & 5,24 & 3,51 \\
\hline 35 & 1000 & 115 & 29,58 & 23,14 & 19,54 & 15,59 & 12,51 & 10,15 & 7,03 & 5,26 & 3,51 \\
\hline 35 & 1050 & 115 & 29,06 & 22,89 & 19,39 & 15,53 & 12,50 & 10,16 & 7,05 & 5,27 & 3,51 \\
\hline 35 & 1100 & 115 & 28,56 & 22,65 & 19,25 & 15,48 & 12,49 & 10,18 & 7,07 & 5,28 & 3,51 \\
\hline 35 & 1150 & 115 & 28,10 & 22,42 & 19,12 & 15,42 & 12,48 & 10,19 & 7,09 & 5,29 & 3,52 \\
\hline 35 & 1200 & 115 & 27,67 & 22,20 & 18,98 & 15,36 & 12,46 & 10,19 & 7,11 & 5,31 & 3,52 \\
\hline 35 & 1250 & 115 & 27,26 & 21,99 & 18,86 & 15,31 & 12,45 & 10,20 & 7,12 & 5,32 & 3,52 \\
\hline 35 & 1300 & 115 & 26,87 & 21,78 & 18,73 & 15,25 & 12,43 & 10,21 & 7,14 & 5,33 & 3,52 \\
\hline 35 & 1350 & 115 & 26,50 & 21,59 & 18,61 & 15,20 & 12,42 & 10,21 & 7,16 & 5,34 & 3,53 \\
\hline 35 & 1400 & 115 & 26,16 & 21,40 & 18,49 & 15,15 & 12,40 & 10,21 & 7,17 & 5,36 & 3,53 \\
\hline 35 & 1450 & 115 & 25,82 & 21,22 & 18,38 & 15,09 & 12,38 & 10,22 & 7,19 & 5,37 & 3,53 \\
\hline 35 & 1500 & 115 & 25,51 & 21,05 & 18,27 & 15,04 & 12,37 & 10,22 & 7,20 & 5,38 & 3,53 \\
\hline 35 & 1550 & 115 & 25,21 & 20,88 & 18,16 & 14,99 & 12,35 & 10,22 & 7,21 & 5,39 & 3,54 \\
\hline 35 & 1600 & 115 & 24,92 & 20,72 & 18,06 & 14,93 & 12,33 & 10,22 & 7,23 & 5,40 & 3,54 \\
\hline 35 & 1650 & 115 & 24,64 & 20,57 & 17,96 & 14,88 & 12,31 & 10,22 & 7,24 & 5,41 & 3,54 \\
\hline 35 & 1700 & 115 & 24,38 & 20,42 & 17,86 & 14,83 & 12,29 & 10,22 & 7,25 & 5,42 & 3,55 \\
\hline 35 & 1750 & 115 & 24,12 & 20,27 & 17,76 & 14,78 & 12,27 & 10,21 & 7,26 & 5,43 & 3,55 \\
\hline 35 & 1800 & 115 & 23,88 & 20,13 & 17,66 & 14,73 & 12,25 & 10,21 & 7,27 & 5,44 & 3,55 \\
\hline 35 & 1850 & 115 & 23,64 & 19,99 & 17,57 & 14,68 & 12,23 & 10,21 & 7,28 & 5,45 & 3,56 \\
\hline 35 & 1900 & 115 & 23,42 & 19,86 & 17,48 & 14,64 & 12,21 & 10,20 & 7,29 & 5,46 & 3,56 \\
\hline 35 & 1950 & 115 & 23,20 & 19,73 & 17,39 & 14,59 & 12,19 & 10,20 & 7,30 & 5,47 & 3,56 \\
\hline 35 & 2000 & 115 & 22,99 & 19,60 & 17,31 & 14,54 & 12,17 & 10,20 & 7,31 & 5,48 & 3,57 \\
\hline 35 & 200 & 120 & 55,55 & 30,52 & 21,85 & 15,27 & 11,46 & 9,05 & 6,26 & 4,83 & 3,39 \\
\hline 35 & 250 & 120 & 50,07 & 29,35 & 21,62 & 15,37 & 11,58 & 9,13 & 6,30 & 4,85 & 3,38 \\
\hline 35 & 300 & 120 & 46,20 & 28,41 & 21,39 & 15,43 & 11,68 & 9,21 & 6,33 & 4,86 & 3,38 \\
\hline 35 & 350 & 120 & 43,27 & 27,64 & 21,16 & 15,45 & 11,75 & 9,28 & 6,37 & 4,87 & 3,37 \\
\hline 35 & 400 & 120 & 40,95 & 26,97 & 20,94 & 15,46 & 11,81 & 9,34 & 6,40 & 4,88 & 3,37 \\
\hline 35 & 450 & 120 & 39,04 & 26,38 & 20,73 & 15,45 & 11,86 & 9,39 & 6,43 & 4,89 & 3,36 \\
\hline 35 & 500 & 120 & 37,45 & 25,85 & 20,52 & 15,43 & 11,90 & 9,44 & 6,47 & 4,90 & 3,36 \\
\hline 35 & 550 & 120 & 36,08 & 25,38 & 20,33 & 15,40 & 11,93 & 9,49 & 6,50 & 4,91 & 3,36 \\
\hline 35 & 600 & 120 & 34,89 & 24,94 & 20,13 & 15,36 & 11,95 & 9,52 & 6,52 & 4,93 & 3,36 \\
\hline 35 & 650 & 120 & 33,84 & 24,54 & 19,95 & 15,32 & 11,97 & 9,56 & 6,55 & 4,94 & 3,36 \\
\hline 35 & 700 & 120 & 32,90 & 24,17 & 19,78 & 15,28 & 11,99 & 9,59 & 6,58 & 4,95 & 3,36 \\
\hline 35 & 750 & 120 & 32,05 & 23,83 & 19,61 & 15,23 & 11,99 & 9,62 & 6,60 & 4,96 & 3,36 \\
\hline 35 & 800 & 120 & 31,29 & 23,50 & 19,44 & 15,19 & 12,00 & 9,64 & 6,63 & 4,98 & 3,36 \\
\hline
\end{tabular}




\begin{tabular}{|c|c|c|c|c|c|c|c|c|c|c|c|}
\hline \multirow[b]{2}{*}{$\mathrm{H}(\mathrm{cm})$} & \multirow[b]{2}{*}{ Mceq (MPa) } & & & & & $\mathrm{De}$ & ões (x1 & & & & \\
\hline & & Msub (MPa) & D0 & D25 & D40 & D60 & D80 & D100 & D140 & D180 & D260 \\
\hline 35 & 850 & 120 & 30,59 & 23,20 & 19,28 & 15,14 & 12,00 & 9,66 & 6,65 & 4,99 & 3,36 \\
\hline 35 & 900 & 120 & 29,94 & 22,92 & 19,13 & 15,09 & 12,00 & 9,68 & 6,68 & 5,00 & 3,36 \\
\hline 35 & 950 & 120 & 29,35 & 22,65 & 18,99 & 15,04 & 12,00 & 9,70 & 6,70 & 5,01 & 3,36 \\
\hline 35 & 1000 & 120 & 28,80 & 22,39 & 18,84 & 14,98 & 11,99 & 9,72 & 6,72 & 5,03 & 3,36 \\
\hline 35 & 1050 & 120 & 28,29 & 22,15 & 18,71 & 14,93 & 11,99 & 9,73 & 6,74 & 5,04 & 3,36 \\
\hline 35 & 1100 & 120 & 27,81 & 21,92 & 18,57 & 14,88 & 11,98 & 9,74 & 6,76 & 5,05 & 3,37 \\
\hline 35 & 1150 & 120 & 27,36 & 21,69 & 18,44 & 14,83 & 11,97 & 9,75 & 6,77 & 5,06 & 3,37 \\
\hline 35 & 1200 & 120 & 26,93 & 21,48 & 18,32 & 14,78 & 11,96 & 9,76 & 6,79 & 5,07 & 3,37 \\
\hline 35 & 1250 & 120 & 26,53 & 21,28 & 18,20 & 14,73 & 11,94 & 9,77 & 6,81 & 5,09 & 3,37 \\
\hline 35 & 1300 & 120 & 26,16 & 21,09 & 18,08 & 14,68 & 11,93 & 9,77 & 6,83 & 5,10 & 3,37 \\
\hline 35 & 1350 & 120 & 25,80 & 20,90 & 17,97 & 14,62 & 11,92 & 9,78 & 6,84 & 5,11 & 3,38 \\
\hline 35 & 1400 & 120 & 25,46 & 20,72 & 17,86 & 14,57 & 11,90 & 9,78 & 6,86 & 5,12 & 3,38 \\
\hline 35 & 1450 & 120 & 25,13 & 20,55 & 17,75 & 14,52 & 11,89 & 9,79 & 6,87 & 5,13 & 3,38 \\
\hline 35 & 1500 & 120 & 24,83 & 20,38 & 17,64 & 14,48 & 11,87 & 9,79 & 6,88 & 5,14 & 3,38 \\
\hline 35 & 1550 & 120 & 24,53 & 20,22 & 17,54 & 14,43 & 11,86 & 9,79 & 6,90 & 5,15 & 3,39 \\
\hline 35 & 1600 & 120 & 24,25 & 20,07 & 17,44 & 14,38 & 11,84 & 9,79 & 6,91 & 5,16 & 3,39 \\
\hline 35 & 1650 & 120 & 23,98 & 19,92 & 17,34 & 14,33 & 11,82 & 9,79 & 6,92 & 5,17 & 3,39 \\
\hline 35 & 1700 & 120 & 23,72 & 19,77 & 17,25 & 14,28 & 11,80 & 9,79 & 6,93 & 5,18 & 3,39 \\
\hline 35 & 1750 & 120 & 23,48 & 19,63 & 17,16 & 14,24 & 11,79 & 9,79 & 6,94 & 5,19 & 3,40 \\
\hline 35 & 1800 & 120 & 23,24 & 19,49 & 17,07 & 14,19 & 11,77 & 9,79 & 6,95 & 5,20 & 3,40 \\
\hline 35 & 1850 & 120 & 23,01 & 19,36 & 16,98 & 14,14 & 11,75 & 9,79 & 6,96 & 5,21 & 3,40 \\
\hline 35 & 1900 & 120 & 22,79 & 19,23 & 16,89 & 14,10 & 11,73 & 9,78 & 6,97 & 5,22 & 3,41 \\
\hline 35 & 1950 & 120 & 22,58 & 19,11 & 16,81 & 14,05 & 11,71 & 9,78 & 6,98 & 5,23 & 3,41 \\
\hline 35 & 2000 & 120 & 22,37 & 18,99 & 16,72 & 14,01 & 11,69 & 9,78 & 6,99 & 5,24 & 3,41 \\
\hline 35 & 200 & 125 & 54,39 & 29,51 & 21,01 & 14,63 & 10,98 & 8,67 & 6,00 & 4,64 & 3,26 \\
\hline 35 & 250 & 125 & 48,97 & 28,37 & 20,80 & 14,74 & 11,10 & 8,75 & 6,04 & 4,65 & 3,25 \\
\hline 35 & 300 & 125 & 45,14 & 27,48 & 20,59 & 14,80 & 11,19 & 8,82 & 6,07 & 4,66 & 3,24 \\
\hline 35 & 350 & 125 & 42,25 & 26,73 & 20,38 & 14,83 & 11,26 & 8,89 & 6,10 & 4,67 & 3,24 \\
\hline 35 & 400 & 125 & 39,97 & 26,08 & 20,17 & 14,84 & 11,32 & 8,95 & 6,14 & 4,68 & 3,23 \\
\hline 35 & 450 & 125 & 38,10 & 25,52 & 19,97 & 14,83 & 11,37 & 9,00 & 6,17 & 4,69 & 3,23 \\
\hline 35 & 500 & 125 & 36,53 & 25,01 & 19,78 & 14,82 & 11,41 & 9,05 & 6,20 & 4,70 & 3,23 \\
\hline 35 & 550 & 125 & 35,19 & 24,56 & 19,60 & 14,79 & 11,44 & 9,09 & 6,22 & 4,71 & 3,23 \\
\hline 35 & 600 & 125 & 34,02 & 24,14 & 19,42 & 14,76 & 11,47 & 9,13 & 6,25 & 4,72 & 3,23 \\
\hline 35 & 650 & 125 & 32,99 & 23,76 & 19,24 & 14,73 & 11,49 & 9,16 & 6,28 & 4,73 & 3,23 \\
\hline 35 & 700 & 125 & 32,07 & 23,40 & 19,08 & 14,69 & 11,50 & 9,19 & 6,30 & 4,75 & 3,23 \\
\hline 35 & 750 & 125 & 31,25 & 23,07 & 18,92 & 14,65 & 11,51 & 9,22 & 6,33 & 4,76 & 3,23 \\
\hline 35 & 800 & 125 & 30,50 & 22,76 & 18,76 & 14,61 & 11,52 & 9,24 & 6,35 & 4,77 & 3,23 \\
\hline 35 & 850 & 125 & 29,81 & 22,47 & 18,62 & 14,56 & 11,52 & 9,26 & 6,37 & 4,78 & 3,23 \\
\hline 35 & 900 & 125 & 29,19 & 22,20 & 18,47 & 14,52 & 11,52 & 9,28 & 6,39 & 4,79 & 3,23 \\
\hline 35 & 950 & 125 & 28,61 & 21,94 & 18,33 & 14,47 & 11,52 & 9,30 & 6,41 & 4,80 & 3,23 \\
\hline 35 & 1000 & 125 & 28,07 & 21,69 & 18,20 & 14,42 & 11,52 & 9,32 & 6,43 & 4,82 & 3,23 \\
\hline 35 & 1050 & 125 & 27,57 & 21,46 & 18,07 & 14,38 & 11,51 & 9,33 & 6,45 & 4,83 & 3,23 \\
\hline 35 & 1100 & 125 & 27,10 & 21,23 & 17,94 & 14,33 & 11,51 & 9,34 & 6,47 & 4,84 & 3,23 \\
\hline 35 & 1150 & 125 & 26,66 & 21,02 & 17,82 & 14,28 & 11,50 & 9,35 & 6,49 & 4,85 & 3,23 \\
\hline 35 & 1200 & 125 & 26,24 & 20,82 & 17,70 & 14,23 & 11,49 & 9,36 & 6,50 & 4,86 & 3,23 \\
\hline 35 & 1250 & 125 & 25,85 & 20,62 & 17,59 & 14,19 & 11,48 & 9,37 & 6,52 & 4,87 & 3,24 \\
\hline 35 & 1300 & 125 & 25,49 & 20,44 & 17,47 & 14,14 & 11,47 & 9,38 & 6,54 & 4,88 & 3,24 \\
\hline 35 & 1350 & 125 & 25,14 & 20,26 & 17,37 & 14,09 & 11,46 & 9,38 & 6,55 & 4,89 & 3,24 \\
\hline 35 & 1400 & 125 & 24,81 & 20,09 & 17,26 & 14,05 & 11,44 & 9,39 & 6,57 & 4,90 & 3,24 \\
\hline 35 & 1450 & 125 & 24,49 & 19,92 & 17,16 & 14,00 & 11,43 & 9,39 & 6,58 & 4,91 & 3,24 \\
\hline 35 & 1500 & 125 & 24,19 & 19,76 & 17,06 & 13,95 & 11,42 & 9,40 & 6,59 & 4,92 & 3,25 \\
\hline 35 & 1550 & 125 & 23,90 & 19,61 & 16,96 & 13,91 & 11,40 & 9,40 & 6,60 & 4,93 & 3,25 \\
\hline 35 & 1600 & 125 & 23,63 & 19,46 & 16,87 & 13,86 & 11,39 & 9,40 & 6,62 & 4,94 & 3,25 \\
\hline 35 & 1650 & 125 & 23,37 & 19,31 & 16,77 & 13,82 & 11,37 & 9,40 & 6,63 & 4,95 & 3,25 \\
\hline 35 & 1700 & 125 & 23,11 & 19,17 & 16,68 & 13,77 & 11,35 & 9,40 & 6,64 & 4,96 & 3,25 \\
\hline 35 & 1750 & 125 & 22,87 & 19,04 & 16,59 & 13,73 & 11,34 & 9,40 & 6,65 & 4,97 & 3,26 \\
\hline 35 & 1800 & 125 & 22,64 & 18,90 & 16,51 & 13,69 & 11,32 & 9,40 & 6,66 & 4,98 & 3,26 \\
\hline 35 & 1850 & 125 & 22,42 & 18,78 & 16,42 & 13,64 & 11,31 & 9,40 & 6,67 & 4,99 & 3,26 \\
\hline 35 & 1900 & 125 & 22,20 & 18,65 & 16,34 & 13,60 & 11,29 & 9,40 & 6,68 & 5,00 & 3,26 \\
\hline 35 & 1950 & 125 & 21,99 & 18,53 & 16,26 & 13,56 & 11,27 & 9,39 & 6,69 & 5,01 & 3,27 \\
\hline 35 & 2000 & 125 & 21,80 & 18,42 & 16,18 & 13,52 & 11,25 & 9,39 & 6,70 & 5,01 & 3,27 \\
\hline 35 & 200 & 130 & 53,30 & 28,57 & 20,23 & 14,05 & 10,54 & 8,32 & 5,76 & 4,46 & 3,14 \\
\hline 35 & 250 & 130 & 47,94 & 27,47 & 20,04 & 14,16 & 10,65 & 8,40 & 5,80 & 4,47 & 3,13 \\
\hline 35 & 300 & 130 & 44,16 & 26,60 & 19,84 & 14,22 & 10,74 & 8,47 & 5,83 & 4,48 & 3,12 \\
\hline 35 & 350 & 130 & 41,31 & 25,88 & 19,65 & 14,25 & 10,81 & 8,53 & 5,86 & 4,49 & 3,11 \\
\hline 35 & 400 & 130 & 39,06 & 25,26 & 19,46 & 14,27 & 10,87 & 8,59 & 5,89 & 4,50 & 3,11 \\
\hline 35 & 450 & 130 & 37,22 & 24,72 & 19,27 & 14,27 & 10,92 & 8,64 & 5,92 & 4,51 & 3,11 \\
\hline 35 & 500 & 130 & 35,68 & 24,23 & 19,09 & 14,25 & 10,96 & 8,68 & 5,95 & 4,52 & 3,11 \\
\hline 35 & 550 & 130 & 34,36 & 23,79 & 18,92 & 14,24 & 10,99 & 8,72 & 5,97 & 4,53 & 3,10 \\
\hline 35 & 600 & 130 & 33,21 & 23,39 & 18,75 & 14,21 & 11,02 & 8,76 & 6,00 & 4,54 & 3,10 \\
\hline 35 & 650 & 130 & 32,20 & 23,02 & 18,59 & 14,18 & 11,04 & 8,79 & 6,02 & 4,55 & 3,10 \\
\hline 35 & 700 & 130 & 31,30 & 22,68 & 18,43 & 14,15 & 11,05 & 8,82 & 6,05 & 4,56 & 3,10 \\
\hline 35 & 750 & 130 & 30,49 & 22,36 & 18,28 & 14,11 & 11,06 & 8,85 & 6,07 & 4,57 & 3,10 \\
\hline 35 & 800 & 130 & 29,76 & 22,07 & 18,13 & 14,07 & 11,07 & 8,87 & 6,09 & 4,58 & 3,10 \\
\hline 35 & 850 & 130 & 29,09 & 21,79 & 17,99 & 14,03 & 11,08 & 8,89 & 6,11 & 4,59 & 3,10 \\
\hline 35 & 900 & 130 & 28,48 & 21,52 & 17,86 & 13,99 & 11,08 & 8,91 & 6,13 & 4,60 & 3,10 \\
\hline 35 & 950 & 130 & 27,91 & 21,27 & 17,72 & 13,95 & 11,08 & 8,93 & 6,15 & 4,61 & 3,10 \\
\hline 35 & 1000 & 130 & 27,38 & 21,04 & 17,60 & 13,90 & 11,08 & 8,95 & 6,17 & 4,62 & 3,10 \\
\hline 35 & 1050 & 130 & 26,89 & 20,81 & 17,47 & 13,86 & 11,07 & 8,96 & 6,19 & 4,63 & 3,10 \\
\hline 35 & 1100 & 130 & 26,43 & 20,60 & 17,35 & 13,82 & 11,07 & 8,97 & 6,21 & 4,64 & 3,11 \\
\hline 35 & 1150 & 130 & 26,01 & 20,39 & 17,24 & 13,77 & 11,06 & 8,98 & 6,22 & 4,65 & 3,11 \\
\hline
\end{tabular}




\begin{tabular}{|c|c|c|c|c|c|c|c|c|c|c|c|}
\hline \multirow[b]{2}{*}{$\mathrm{H}(\mathrm{cm})$} & \multirow[b]{2}{*}{ Mceq (MPa) } & & & & & $\mathrm{De}$ & ões (x1 & & & & \\
\hline & & Msub (MPa) & D0 & D25 & D40 & D60 & D80 & D100 & D140 & D180 & D260 \\
\hline 35 & 1200 & 130 & 25,60 & 20,20 & 17,13 & 13,73 & 11,06 & 8,99 & 6,24 & 4,66 & 3,11 \\
\hline 35 & 1250 & 130 & 25,22 & 20,01 & 17,02 & 13,69 & 11,05 & 9,00 & 6,26 & 4,67 & 3,11 \\
\hline 35 & 1300 & 130 & 24,86 & 19,83 & 16,91 & 13,64 & 11,04 & 9,01 & 6,27 & 4,68 & 3,11 \\
\hline 35 & 1350 & 130 & 24,52 & 19,66 & 16,81 & 13,60 & 11,03 & 9,02 & 6,28 & 4,69 & 3,11 \\
\hline 35 & 1400 & 130 & 24,20 & 19,49 & 16,71 & 13,55 & 11,02 & 9,02 & 6,30 & 4,70 & 3,11 \\
\hline 35 & 1450 & 130 & 23,89 & 19,33 & 16,61 & 13,51 & 11,00 & 9,03 & 6,31 & 4,71 & 3,12 \\
\hline 35 & 1500 & 130 & 23,59 & 19,18 & 16,51 & 13,47 & 10,99 & 9,03 & 6,32 & 4,72 & 3,12 \\
\hline 35 & 1550 & 130 & 23,31 & 19,03 & 16,42 & 13,43 & 10,98 & 9,03 & 6,34 & 4,73 & 3,12 \\
\hline 35 & 1600 & 130 & 23,05 & 18,88 & 16,33 & 13,38 & 10,97 & 9,04 & 6,35 & 4,74 & 3,12 \\
\hline 35 & 1650 & 130 & 22,79 & 18,75 & 16,24 & 13,34 & 10,95 & 9,04 & 6,36 & 4,75 & 3,12 \\
\hline 35 & 1700 & 130 & 22,54 & 18,61 & 16,16 & 13,30 & 10,94 & 9,04 & 6,37 & 4,76 & 3,13 \\
\hline 35 & 1750 & 130 & 22,31 & 18,48 & 16,07 & 13,26 & 10,92 & 9,04 & 6,38 & 4,77 & 3,13 \\
\hline 35 & 1800 & 130 & 22,08 & 18,35 & 15,99 & 13,22 & 10,91 & 9,04 & 6,39 & 4,78 & 3,13 \\
\hline 35 & 1850 & 130 & 21,86 & 18,23 & 15,91 & 13,18 & 10,89 & 9,04 & 6,40 & 4,78 & 3,13 \\
\hline 35 & 1900 & 130 & 21,65 & 18,11 & 15,83 & 13,14 & 10,88 & 9,04 & 6,41 & 4,79 & 3,14 \\
\hline 35 & 1950 & 130 & 21,45 & 17,99 & 15,75 & 13,10 & 10,86 & 9,04 & 6,42 & 4,80 & 3,14 \\
\hline 35 & 2000 & 130 & 21,26 & 17,88 & 15,68 & 13,06 & 10,85 & 9,03 & 6,43 & 4,81 & 3,14 \\
\hline 35 & 200 & 135 & 52,29 & 27,70 & 19,51 & 13,51 & 10,13 & 8,00 & 5,54 & 4,29 & 3,02 \\
\hline 35 & 250 & 135 & 46,98 & 26,63 & 19,33 & 13,62 & 10,24 & 8,08 & 5,58 & 4,30 & 3,01 \\
\hline 35 & 300 & 135 & 43,24 & 25,79 & 19,15 & 13,68 & 10,33 & 8,14 & 5,61 & 4,31 & 3,01 \\
\hline 35 & 350 & 135 & 40,42 & 25,09 & 18,97 & 13,72 & 10,40 & 8,20 & 5,64 & 4,32 & 3,00 \\
\hline 35 & 400 & 135 & 38,21 & 24,50 & 18,79 & 13,74 & 10,45 & 8,25 & 5,66 & 4,33 & 3,00 \\
\hline 35 & 450 & 135 & 36,40 & 23,97 & 18,62 & 13,74 & 10,50 & 8,30 & 5,69 & 4,34 & 2,99 \\
\hline 35 & 500 & 135 & 34,88 & 23,50 & 18,45 & 13,73 & 10,54 & 8,34 & 5,72 & 4,35 & 2,99 \\
\hline 35 & 550 & 135 & 33,58 & 23,08 & 18,28 & 13,72 & 10,57 & 8,38 & 5,74 & 4,35 & 2,99 \\
\hline 35 & 600 & 135 & 32,46 & 22,69 & 18,13 & 13,70 & 10,60 & 8,42 & 5,76 & 4,36 & 2,99 \\
\hline 35 & 650 & 135 & 31,47 & 22,34 & 17,97 & 13,67 & 10,62 & 8,45 & 5,79 & 4,37 & 2,99 \\
\hline 35 & 700 & 135 & 30,58 & 22,01 & 17,82 & 13,64 & 10,63 & 8,48 & 5,81 & 4,38 & 2,99 \\
\hline 35 & 750 & 135 & 29,79 & 21,70 & 17,68 & 13,61 & 10,65 & 8,51 & 5,83 & 4,39 & 2,99 \\
\hline 35 & 800 & 135 & 29,07 & 21,42 & 17,54 & 13,57 & 10,66 & 8,53 & 5,85 & 4,40 & 2,99 \\
\hline 35 & 850 & 135 & 28,41 & 21,15 & 17,41 & 13,54 & 10,66 & 8,55 & 5,87 & 4,41 & 2,99 \\
\hline 35 & 900 & 135 & 27,81 & 20,89 & 17,28 & 13,50 & 10,67 & 8,57 & 5,89 & 4,42 & 2,99 \\
\hline 35 & 950 & 135 & 27,26 & 20,65 & 17,16 & 13,46 & 10,67 & 8,59 & 5,91 & 4,43 & 2,99 \\
\hline 35 & 1000 & 135 & 26,74 & 20,42 & 17,04 & 13,42 & 10,67 & 8,60 & 5,93 & 4,44 & 2,99 \\
\hline 35 & 1050 & 135 & 26,26 & 20,21 & 16,92 & 13,38 & 10,67 & 8,62 & 5,95 & 4,45 & 2,99 \\
\hline 35 & 1100 & 135 & 25,81 & 20,00 & 16,81 & 13,34 & 10,66 & 8,63 & 5,96 & 4,46 & 2,99 \\
\hline 35 & 1150 & 135 & 25,39 & 19,80 & 16,69 & 13,30 & 10,66 & 8,64 & 5,98 & 4,47 & 2,99 \\
\hline 35 & 1200 & 135 & 25,00 & 19,62 & 16,59 & 13,26 & 10,65 & 8,65 & 5,99 & 4,48 & 2,99 \\
\hline 35 & 1250 & 135 & 24,63 & 19,44 & 16,48 & 13,22 & 10,65 & 8,66 & 6,01 & 4,49 & 2,99 \\
\hline 35 & 1300 & 135 & 24,27 & 19,26 & 16,38 & 13,18 & 10,64 & 8,67 & 6,02 & 4,50 & 2,99 \\
\hline 35 & 1350 & 135 & 23,94 & 19,10 & 16,28 & 13,14 & 10,63 & 8,68 & 6,04 & 4,51 & 3,00 \\
\hline 35 & 1400 & 135 & 23,62 & 18,94 & 16,19 & 13,10 & 10,62 & 8,68 & 6,05 & 4,52 & 3,00 \\
\hline 35 & 1450 & 135 & 23,32 & 18,78 & 16,09 & 13,06 & 10,61 & 8,69 & 6,06 & 4,53 & 3,00 \\
\hline 35 & 1500 & 135 & 23,03 & 18,63 & 16,00 & 13,01 & 10,60 & 8,69 & 6,08 & 4,54 & 3,00 \\
\hline 35 & 1550 & 135 & 22,76 & 18,49 & 15,91 & 12,98 & 10,59 & 8,70 & 6,09 & 4,55 & 3,00 \\
\hline 35 & 1600 & 135 & 22,50 & 18,35 & 15,83 & 12,94 & 10,57 & 8,70 & 6,10 & 4,55 & 3,00 \\
\hline 35 & 1650 & 135 & 22,25 & 18,22 & 15,74 & 12,90 & 10,56 & 8,70 & 6,11 & 4,56 & 3,01 \\
\hline 35 & 1700 & 135 & 22,01 & 18,09 & 15,66 & 12,86 & 10,55 & 8,70 & 6,12 & 4,57 & 3,01 \\
\hline 35 & 1750 & 135 & 21,78 & 17,96 & 15,58 & 12,82 & 10,54 & 8,70 & 6,13 & 4,58 & 3,01 \\
\hline 35 & 1800 & 135 & 21,56 & 17,84 & 15,50 & 12,78 & 10,52 & 8,70 & 6,14 & 4,59 & 3,01 \\
\hline 35 & 1850 & 135 & 21,34 & 17,72 & 15,43 & 12,74 & 10,51 & 8,70 & 6,15 & 4,60 & 3,01 \\
\hline 35 & 1900 & 135 & 21,14 & 17,60 & 15,35 & 12,71 & 10,50 & 8,70 & 6,16 & 4,60 & 3,02 \\
\hline 35 & 1950 & 135 & 20,94 & 17,49 & 15,28 & 12,67 & 10,48 & 8,70 & 6,17 & 4,61 & 3,02 \\
\hline 35 & 2000 & 135 & 20,75 & 17,38 & 15,20 & 12,63 & 10,47 & 8,70 & 6,18 & 4,62 & 3,02 \\
\hline 35 & 200 & 140 & 51,35 & 26,89 & 18,84 & 13,01 & 9,75 & 7,71 & 5,34 & 4,14 & 2,92 \\
\hline 35 & 250 & 140 & 46,08 & 25,84 & 18,67 & 13,12 & 9,85 & 7,78 & 5,37 & 4,15 & 2,91 \\
\hline 35 & 300 & 140 & 42,38 & 25,03 & 18,51 & 13,18 & 9,94 & 7,84 & 5,40 & 4,15 & 2,90 \\
\hline 35 & 350 & 140 & 39,60 & 24,35 & 18,34 & 13,22 & 10,01 & 7,89 & 5,43 & 4,16 & 2,89 \\
\hline 35 & 400 & 140 & 37,41 & 23,78 & 18,17 & 13,24 & 10,07 & 7,94 & 5,45 & 4,17 & 2,89 \\
\hline 35 & 450 & 140 & 35,62 & 23,27 & 18,00 & 13,25 & 10,11 & 7,99 & 5,48 & 4,18 & 2,89 \\
\hline 35 & 500 & 140 & 34,13 & 22,82 & 17,85 & 13,24 & 10,15 & 8,03 & 5,50 & 4,19 & 2,89 \\
\hline 35 & 550 & 140 & 32,85 & 22,41 & 17,69 & 13,23 & 10,18 & 8,07 & 5,53 & 4,20 & 2,88 \\
\hline 35 & 600 & 140 & 31,75 & 22,04 & 17,54 & 13,22 & 10,21 & 8,10 & 5,55 & 4,20 & 2,88 \\
\hline 35 & 650 & 140 & 30,77 & 21,70 & 17,40 & 13,19 & 10,23 & 8,14 & 5,57 & 4,21 & 2,88 \\
\hline 35 & 700 & 140 & 29,90 & 21,38 & 17,26 & 13,17 & 10,25 & 8,16 & 5,59 & 4,22 & 2,88 \\
\hline 35 & 750 & 140 & 29,13 & 21,08 & 17,12 & 13,14 & 10,26 & 8,19 & 5,61 & 4,23 & 2,88 \\
\hline 35 & 800 & 140 & 28,42 & 20,81 & 16,99 & 13,11 & 10,27 & 8,21 & 5,63 & 4,24 & 2,88 \\
\hline 35 & 850 & 140 & 27,78 & 20,55 & 16,87 & 13,07 & 10,28 & 8,23 & 5,65 & 4,25 & 2,88 \\
\hline 35 & 900 & 140 & 27,19 & 20,30 & 16,74 & 13,04 & 10,28 & 8,25 & 5,67 & 4,26 & 2,88 \\
\hline 35 & 950 & 140 & 26,64 & 20,07 & 16,63 & 13,00 & 10,29 & 8,27 & 5,69 & 4,27 & 2,88 \\
\hline 35 & 1000 & 140 & 26,14 & 19,85 & 16,51 & 12,97 & 10,29 & 8,29 & 5,71 & 4,28 & 2,88 \\
\hline 35 & 1050 & 140 & 25,67 & 19,64 & 16,40 & 12,93 & 10,29 & 8,30 & 5,72 & 4,29 & 2,88 \\
\hline 35 & 1100 & 140 & 25,23 & 19,44 & 16,29 & 12,89 & 10,28 & 8,31 & 5,74 & 4,30 & 2,88 \\
\hline 35 & 1150 & 140 & 24,82 & 19,25 & 16,19 & 12,86 & 10,28 & 8,33 & 5,75 & 4,30 & 2,88 \\
\hline 35 & 1200 & 140 & 24,43 & 19,07 & 16,08 & 12,82 & 10,28 & 8,34 & 5,77 & 4,31 & 2,88 \\
\hline 35 & 1250 & 140 & 24,07 & 18,90 & 15,98 & 12,78 & 10,27 & 8,34 & 5,78 & 4,32 & 2,88 \\
\hline 35 & 1300 & 140 & 23,72 & 18,73 & 15,89 & 12,74 & 10,26 & 8,35 & 5,80 & 4,33 & 2,89 \\
\hline 35 & 1350 & 140 & 23,39 & 18,57 & 15,79 & 12,70 & 10,26 & 8,36 & 5,81 & 4,34 & 2,89 \\
\hline 35 & 1400 & 140 & 23,08 & 18,41 & 15,70 & 12,67 & 10,25 & 8,37 & 5,82 & 4,35 & 2,89 \\
\hline 35 & 1450 & 140 & 22,79 & 18,27 & 15,61 & 12,63 & 10,24 & 8,37 & 5,83 & 4,36 & 2,89 \\
\hline 35 & 1500 & 140 & 22,51 & 18,12 & 15,53 & 12,59 & 10,23 & 8,38 & 5,85 & 4,37 & 2,89 \\
\hline
\end{tabular}




\begin{tabular}{|c|c|c|c|c|c|c|c|c|c|c|c|}
\hline \multirow[b]{2}{*}{$\mathrm{H}(\mathrm{cm})$} & \multirow[b]{2}{*}{ Mceq (MPa) } & & & & & $\mathrm{De}$ & ões (x1 & & & & \\
\hline & & Msub (MPa) & D0 & D25 & D40 & D60 & D80 & D100 & D140 & D180 & D260 \\
\hline 35 & 1550 & 140 & 22,24 & 17,98 & 15,44 & 12,55 & 10,22 & 8,38 & 5,86 & 4,37 & 2,89 \\
\hline 35 & 1600 & 140 & 21,99 & 17,85 & 15,36 & 12,52 & 10,21 & 8,38 & 5,87 & 4,38 & 2,89 \\
\hline 35 & 1650 & 140 & 21,74 & 17,72 & 15,28 & 12,48 & 10,20 & 8,39 & 5,88 & 4,39 & 2,90 \\
\hline 35 & 1700 & 140 & 21,50 & 17,59 & 15,20 & 12,44 & 10,19 & 8,39 & 5,89 & 4,40 & 2,90 \\
\hline 35 & 1750 & 140 & 21,28 & 17,47 & 15,12 & 12,41 & 10,18 & 8,39 & 5,90 & 4,41 & 2,90 \\
\hline 35 & 1800 & 140 & 21,06 & 17,35 & 15,05 & 12,37 & 10,16 & 8,39 & 5,91 & 4,41 & 2,90 \\
\hline 35 & 1850 & 140 & 20,85 & 17,24 & 14,97 & 12,34 & 10,15 & 8,39 & 5,92 & 4,42 & 2,90 \\
\hline 35 & 1900 & 140 & 20,65 & 17,13 & 14,90 & 12,30 & 10,14 & 8,39 & 5,93 & 4,43 & 2,91 \\
\hline 35 & 1950 & 140 & 20,46 & 17,02 & 14,83 & 12,27 & 10,13 & 8,39 & 5,94 & 4,44 & 2,91 \\
\hline 35 & 2000 & 140 & 20,27 & 16,91 & 14,76 & 12,23 & 10,11 & 8,39 & 5,94 & 4,44 & 2,91 \\
\hline 35 & 200 & 145 & 50,46 & 26,12 & 18,21 & 12,54 & 9,40 & 7,43 & 5,15 & 3,99 & 2,82 \\
\hline 35 & 250 & 145 & 45,23 & 25,11 & 18,06 & 12,65 & 9,50 & 7,50 & 5,18 & 4,00 & 2,81 \\
\hline 35 & 300 & 145 & 41,57 & 24,32 & 17,90 & 12,72 & 9,58 & 7,56 & 5,21 & 4,01 & 2,80 \\
\hline 35 & 350 & 145 & 38,82 & 23,66 & 17,74 & 12,76 & 9,65 & 7,61 & 5,24 & 4,02 & 2,80 \\
\hline 35 & 400 & 145 & 36,65 & 23,10 & 17,59 & 12,78 & 9,70 & 7,66 & 5,26 & 4,02 & 2,79 \\
\hline 35 & 450 & 145 & 34,89 & 22,61 & 17,43 & 12,79 & 9,75 & 7,70 & 5,28 & 4,03 & 2,79 \\
\hline 35 & 500 & 145 & 33,42 & 22,18 & 17,28 & 12,79 & 9,79 & 7,74 & 5,31 & 4,04 & 2,79 \\
\hline 35 & 550 & 145 & 32,17 & 21,78 & 17,14 & 12,78 & 9,82 & 7,78 & 5,33 & 4,05 & 2,78 \\
\hline 35 & 600 & 145 & 31,08 & 21,42 & 17,00 & 12,77 & 9,85 & 7,81 & 5,35 & 4,06 & 2,78 \\
\hline 35 & 650 & 145 & 30,12 & 21,09 & 16,86 & 12,75 & 9,87 & 7,84 & 5,37 & 4,06 & 2,78 \\
\hline 35 & 700 & 145 & 29,27 & 20,79 & 16,73 & 12,73 & 9,89 & 7,87 & 5,39 & 4,07 & 2,78 \\
\hline 35 & 750 & 145 & 28,50 & 20,50 & 16,60 & 12,70 & 9,90 & 7,89 & 5,41 & 4,08 & 2,78 \\
\hline 35 & 800 & 145 & 27,81 & 20,24 & 16,48 & 12,67 & 9,91 & 7,92 & 5,43 & 4,09 & 2,78 \\
\hline 35 & 850 & 145 & 27,18 & 19,98 & 16,36 & 12,64 & 9,92 & 7,94 & 5,45 & 4,10 & 2,78 \\
\hline 35 & 900 & 145 & 26,60 & 19,75 & 16,24 & 12,61 & 9,93 & 7,96 & 5,46 & 4,11 & 2,78 \\
\hline 35 & 950 & 145 & 26,06 & 19,52 & 16,13 & 12,58 & 9,93 & 7,97 & 5,48 & 4,12 & 2,78 \\
\hline 35 & 1000 & 145 & 25,57 & 19,31 & 16,02 & 12,55 & 9,93 & 7,99 & 5,50 & 4,12 & 2,78 \\
\hline 35 & 1050 & 145 & 25,11 & 19,11 & 15,91 & 12,51 & 9,93 & 8,00 & 5,51 & 4,13 & 2,78 \\
\hline 35 & 1100 & 145 & 24,68 & 18,92 & 15,81 & 12,48 & 9,93 & 8,02 & 5,53 & 4,14 & 2,78 \\
\hline 35 & 1150 & 145 & 24,27 & 18,73 & 15,71 & 12,44 & 9,93 & 8,03 & 5,54 & 4,15 & 2,78 \\
\hline 35 & 1200 & 145 & 23,89 & 18,56 & 15,61 & 12,41 & 9,93 & 8,04 & 5,56 & 4,16 & 2,78 \\
\hline 35 & 1250 & 145 & 23,54 & 18,39 & 15,52 & 12,37 & 9,92 & 8,05 & 5,57 & 4,17 & 2,78 \\
\hline 35 & 1300 & 145 & 23,20 & 18,23 & 15,42 & 12,34 & 9,92 & 8,06 & 5,58 & 4,17 & 2,79 \\
\hline 35 & 1350 & 145 & 22,88 & 18,07 & 15,33 & 12,30 & 9,91 & 8,07 & 5,60 & 4,18 & 2,79 \\
\hline 35 & 1400 & 145 & 22,58 & 17,92 & 15,25 & 12,27 & 9,90 & 8,07 & 5,61 & 4,19 & 2,79 \\
\hline 35 & 1450 & 145 & 22,29 & 17,78 & 15,16 & 12,23 & 9,90 & 8,08 & 5,62 & 4,20 & 2,79 \\
\hline 35 & 1500 & 145 & 22,01 & 17,64 & 15,08 & 12,19 & 9,89 & 8,08 & 5,63 & 4,21 & 2,79 \\
\hline 35 & 1550 & 145 & 21,75 & 17,51 & 15,00 & 12,16 & 9,88 & 8,09 & 5,64 & 4,21 & 2,79 \\
\hline 35 & 1600 & 145 & 21,50 & 17,38 & 14,92 & 12,13 & 9,87 & 8,09 & 5,65 & 4,22 & 2,79 \\
\hline 35 & 1650 & 145 & 21,26 & 17,25 & 14,84 & 12,09 & 9,86 & 8,10 & 5,66 & 4,23 & 2,79 \\
\hline 35 & 1700 & 145 & 21,03 & 17,13 & 14,76 & 12,06 & 9,85 & 8,10 & 5,67 & 4,24 & 2,80 \\
\hline 35 & 1750 & 145 & 20,81 & 17,01 & 14,69 & 12,02 & 9,84 & 8,10 & 5,68 & 4,25 & 2,80 \\
\hline 35 & 1800 & 145 & 20,60 & 16,90 & 14,62 & 11,99 & 9,83 & 8,10 & 5,69 & 4,25 & 2,80 \\
\hline 35 & 1850 & 145 & 20,39 & 16,79 & 14,55 & 11,95 & 9,82 & 8,10 & 5,70 & 4,26 & 2,80 \\
\hline 35 & 1900 & 145 & 20,20 & 16,68 & 14,48 & 11,92 & 9,81 & 8,10 & 5,71 & 4,27 & 2,80 \\
\hline 35 & 1950 & 145 & 20,01 & 16,57 & 14,41 & 11,89 & 9,79 & 8,10 & 5,72 & 4,27 & 2,80 \\
\hline 35 & 2000 & 145 & 19,82 & 16,47 & 14,34 & 11,86 & 9,78 & 8,10 & 5,73 & 4,28 & 2,81 \\
\hline 35 & 200 & 150 & 49,63 & 25,41 & 17,62 & 12,10 & 9,07 & 7,17 & 4,98 & 3,86 & 2,73 \\
\hline 35 & 250 & 150 & 44,44 & 24,42 & 17,48 & 12,21 & 9,17 & 7,24 & 5,01 & 3,87 & 2,72 \\
\hline 35 & 300 & 150 & 40,81 & 23,65 & 17,33 & 12,28 & 9,25 & 7,29 & 5,03 & 3,87 & 2,71 \\
\hline 35 & 350 & 150 & 38,08 & 23,01 & 17,19 & 12,33 & 9,31 & 7,34 & 5,06 & 3,88 & 2,70 \\
\hline 35 & 400 & 150 & 35,95 & 22,47 & 17,04 & 12,35 & 9,37 & 7,39 & 5,08 & 3,89 & 2,70 \\
\hline 35 & 450 & 150 & 34,21 & 22,00 & 16,90 & 12,36 & 9,41 & 7,43 & 5,10 & 3,90 & 2,70 \\
\hline 35 & 500 & 150 & 32,76 & 21,57 & 16,75 & 12,37 & 9,45 & 7,47 & 5,12 & 3,90 & 2,69 \\
\hline 35 & 550 & 150 & 31,52 & 21,19 & 16,62 & 12,36 & 9,48 & 7,51 & 5,14 & 3,91 & 2,69 \\
\hline 35 & 600 & 150 & 30,44 & 20,85 & 16,48 & 12,35 & 9,51 & 7,54 & 5,16 & 3,92 & 2,69 \\
\hline 35 & 650 & 150 & 29,50 & 20,53 & 16,35 & 12,33 & 9,53 & 7,57 & 5,18 & 3,93 & 2,69 \\
\hline 35 & 700 & 150 & 28,66 & 20,23 & 16,23 & 12,31 & 9,55 & 7,60 & 5,20 & 3,93 & 2,69 \\
\hline 35 & 750 & 150 & 27,91 & 19,95 & 16,11 & 12,29 & 9,56 & 7,62 & 5,22 & 3,94 & 2,69 \\
\hline 35 & 800 & 150 & 27,23 & 19,70 & 15,99 & 12,26 & 9,58 & 7,64 & 5,24 & 3,95 & 2,69 \\
\hline 35 & 850 & 150 & 26,61 & 19,45 & 15,88 & 12,24 & 9,58 & 7,66 & 5,25 & 3,96 & 2,69 \\
\hline 35 & 900 & 150 & 26,04 & 19,23 & 15,77 & 12,21 & 9,59 & 7,68 & 5,27 & 3,96 & 2,69 \\
\hline 35 & 950 & 150 & 25,52 & 19,01 & 15,66 & 12,18 & 9,60 & 7,70 & 5,29 & 3,97 & 2,69 \\
\hline 35 & 1000 & 150 & 25,03 & 18,80 & 15,55 & 12,15 & 9,60 & 7,71 & 5,30 & 3,98 & 2,69 \\
\hline 35 & 1050 & 150 & 24,58 & 18,61 & 15,45 & 12,12 & 9,60 & 7,73 & 5,32 & 3,99 & 2,69 \\
\hline 35 & 1100 & 150 & 24,16 & 18,42 & 15,35 & 12,09 & 9,60 & 7,74 & 5,33 & 4,00 & 2,69 \\
\hline 35 & 1150 & 150 & 23,76 & 18,24 & 15,26 & 12,05 & 9,60 & 7,75 & 5,35 & 4,00 & 2,69 \\
\hline 35 & 1200 & 150 & 23,39 & 18,07 & 15,17 & 12,02 & 9,60 & 7,76 & 5,36 & 4,01 & 2,69 \\
\hline 35 & 1250 & 150 & 23,04 & 17,91 & 15,07 & 11,99 & 9,59 & 7,77 & 5,37 & 4,02 & 2,69 \\
\hline 35 & 1300 & 150 & 22,71 & 17,76 & 14,99 & 11,95 & 9,59 & 7,78 & 5,39 & 4,03 & 2,69 \\
\hline 35 & 1350 & 150 & 22,40 & 17,61 & 14,90 & 11,92 & 9,59 & 7,79 & 5,40 & 4,04 & 2,69 \\
\hline 35 & 1400 & 150 & 22,10 & 17,46 & 14,82 & 11,89 & 9,58 & 7,80 & 5,41 & 4,04 & 2,69 \\
\hline 35 & 1450 & 150 & 21,82 & 17,32 & 14,74 & 11,86 & 9,57 & 7,80 & 5,42 & 4,05 & 2,69 \\
\hline 35 & 1500 & 150 & 21,55 & 17,19 & 14,66 & 11,82 & 9,57 & 7.81 & 5,43 & 4.06 & 2,70 \\
\hline 35 & 1550 & 150 & 21,29 & 17,06 & 14,58 & 11,79 & 9,56 & 7,81 & 5,44 & 4,07 & 2,70 \\
\hline 35 & 1600 & 150 & 21,04 & 16,93 & 14,50 & 11,76 & 9,55 & 7,82 & 5,46 & 4,07 & 2,70 \\
\hline 35 & 1650 & 150 & 20,81 & 16,81 & 14,43 & 11,72 & 9,54 & 7,82 & 5,47 & 4,08 & 2,70 \\
\hline 35 & 1700 & 150 & 20,58 & 16,69 & 14,36 & 11,69 & 9,53 & 7,82 & 5,47 & 4,09 & 2,70 \\
\hline 35 & 1750 & 150 & 20,37 & 16,58 & 14,28 & 11,66 & 9,52 & 7,83 & 5,48 & 4,10 & 2,70 \\
\hline 35 & 1800 & 150 & 20,16 & 16,47 & 14,21 & 11,63 & 9,51 & 7,83 & 5,49 & 4,10 & 2,70 \\
\hline 35 & 1850 & 150 & 19,96 & 16,36 & 14,15 & 11,60 & 9,50 & 7,83 & 5,50 & 4,11 & 2,71 \\
\hline
\end{tabular}




\begin{tabular}{|c|c|c|c|c|c|c|c|c|c|c|c|}
\hline \multirow[b]{2}{*}{$\mathrm{H}(\mathrm{cm})$} & \multirow[b]{2}{*}{ Mceq (MPa) } & & & & & $\mathrm{De}$ & ões (x. & & & & \\
\hline & & Msub (MPa) & D0 & D25 & D40 & D60 & D80 & D100 & D140 & D180 & D260 \\
\hline 35 & 1900 & 150 & 19,77 & 16,25 & 14,08 & 11,56 & 9,49 & 7,83 & 5,51 & 4,12 & 2,71 \\
\hline 35 & 1950 & 150 & 19,58 & 16,15 & 14,02 & 11,53 & 9,48 & 7,83 & 5,52 & 4,12 & 2,71 \\
\hline 35 & 2000 & 150 & 19,40 & 16,05 & 13,95 & 11,50 & 9,47 & 7,83 & 5,53 & 4,13 & 2,71 \\
\hline 35 & 200 & 155 & 48,84 & 24,73 & 17,07 & 11,69 & 8,76 & 6,93 & 4,81 & 3,73 & 2,64 \\
\hline 35 & 250 & 155 & 43,69 & 23,77 & 16,94 & 11,80 & 8,86 & 6,99 & 4,84 & 3,74 & 2,63 \\
\hline 35 & 300 & 155 & 40,09 & 23,02 & 16,80 & 11,88 & 8,94 & 7,05 & 4,86 & 3,75 & 2,62 \\
\hline 35 & 350 & 155 & 37,39 & 22,40 & 16,66 & 11,92 & 9,00 & 7,10 & 4,89 & 3,76 & 2,62 \\
\hline 35 & 400 & 155 & 35,28 & 21,87 & 16,53 & 11,95 & 9,05 & 7,14 & 4,91 & 3,76 & 2,61 \\
\hline 35 & 450 & 155 & 33,56 & 21,41 & 16,39 & 11,96 & 9,10 & 7,18 & 4,93 & 3,77 & 2,61 \\
\hline 35 & 500 & 155 & 32,13 & 21,00 & 16,26 & 11,97 & 9,13 & 7,22 & 4,95 & 3,77 & 2,61 \\
\hline 35 & 550 & 155 & 30,91 & 20,64 & 16,13 & 11,96 & 9,17 & 7,25 & 4,97 & 3,78 & 2,61 \\
\hline 35 & 600 & 155 & 29,85 & 20,30 & 16,00 & 11,95 & 9,19 & 7,28 & 4,99 & 3,79 & 2,60 \\
\hline 35 & 650 & 155 & 28,92 & 19,99 & 15,88 & 11.94 & 9,22 & 7.31 & 5,01 & 3,80 & 2,60 \\
\hline 35 & 700 & 155 & 28,09 & 19,70 & 15,76 & 11,92 & 9,23 & 7,34 & 5,03 & 3,80 & 2,60 \\
\hline 35 & 750 & 155 & 27,35 & 19,44 & 15,64 & 11,90 & 9,25 & 7,36 & 5,04 & 3,81 & 2,60 \\
\hline 35 & 800 & 155 & 26,68 & 19,19 & 15,53 & 11,88 & 9,26 & 7,38 & 5,06 & 3,82 & 2,60 \\
\hline 35 & 850 & 155 & 26,07 & 18,95 & 15,42 & 11,86 & 9,27 & 7,40 & 5,08 & 3,82 & 2,60 \\
\hline 35 & 900 & 155 & 25,51 & 18,73 & 15,32 & 11,83 & 9,28 & 7,42 & 5,09 & 3,83 & 2,60 \\
\hline 35 & 950 & 155 & 25,00 & 18,52 & 15,22 & 11,80 & 9,28 & 7,44 & 5,11 & 3,84 & 2,60 \\
\hline 35 & 1000 & 155 & 24,52 & 18,32 & 15,12 & 11,78 & 9,29 & 7,46 & 5,12 & 3,85 & 2,60 \\
\hline 35 & 1050 & 155 & 24,08 & 18,14 & 15,02 & 11,75 & 9,29 & 7,47 & 5,14 & 3,85 & 2,60 \\
\hline 35 & 1100 & 155 & 23,66 & 17,96 & 14,93 & 11,72 & 9,29 & 7,48 & 5,15 & 3,86 & 2,60 \\
\hline 35 & 1150 & 155 & 23,28 & 17,78 & 14,83 & 11,69 & 9,29 & 7,49 & 5,16 & 3,87 & 2,60 \\
\hline 35 & 1200 & 155 & 22,91 & 17,62 & 14,75 & 11,66 & 9,29 & 7,51 & 5,18 & 3,88 & 2,60 \\
\hline 35 & 1250 & 155 & 22,57 & 17,46 & 14,66 & 11,63 & 9,29 & 7,52 & 5,19 & 3,88 & 2,60 \\
\hline 35 & 1300 & 155 & 22,24 & 17,31 & 14,57 & 11,60 & 9,28 & 7,52 & 5,20 & 3,89 & 2,60 \\
\hline 35 & 1350 & 155 & 21,94 & 17,16 & 14,49 & 11,56 & 9,28 & 7,53 & 5,21 & 3,90 & 2,60 \\
\hline 35 & 1400 & 155 & 21,64 & 17,02 & 14,41 & 11,53 & 9,28 & 7,54 & 5,23 & 3,91 & 2,61 \\
\hline 35 & 1450 & 155 & 21,37 & 16,89 & 14,33 & 11,50 & 9,27 & 7,55 & 5,24 & 3,91 & 2,61 \\
\hline 35 & 1500 & 155 & 21,10 & 16,76 & 14,26 & 11,47 & 9,26 & 7,55 & 5,25 & 3,92 & 2,61 \\
\hline 35 & 1550 & 155 & 20,85 & 16,63 & 14,18 & 11,44 & 9,26 & 7,56 & 5,26 & 3,93 & 2,61 \\
\hline 35 & 1600 & 155 & 20,61 & 16,51 & 14,11 & 11,41 & 9,25 & 7,56 & 5,27 & 3,94 & 2,61 \\
\hline 35 & 1650 & 155 & 20,38 & 16,39 & 14,04 & 11,38 & 9,24 & 7,57 & 5,28 & 3,94 & 2,61 \\
\hline 35 & 1700 & 155 & 20,16 & 16,28 & 13,97 & 11,35 & 9,23 & 7,57 & 5,29 & 3,95 & 2,61 \\
\hline 35 & 1750 & 155 & 19,95 & 16,17 & 13,90 & 11,32 & 9,23 & 7,57 & 5,30 & 3,96 & 2,61 \\
\hline 35 & 1800 & 155 & 19,74 & 16,06 & 13,83 & 11,29 & 9,22 & 7,57 & 5,31 & 3,96 & 2,62 \\
\hline 35 & 1850 & 155 & 19,55 & 15,96 & 13,77 & 11,26 & 9,21 & 7,58 & 5,31 & 3,97 & 2,62 \\
\hline 35 & 1900 & 155 & 19,36 & 15,85 & 13,71 & 11,23 & 9,20 & 7,58 & 5,32 & 3,98 & 2,62 \\
\hline 35 & 1950 & 155 & 19,18 & 15,76 & 13,64 & 11,20 & 9,19 & 7,58 & 5,33 & 3,98 & 2,62 \\
\hline 35 & 2000 & 155 & 19,00 & 15,66 & 13,58 & 11,17 & 9,18 & 7,58 & 5,34 & 3,99 & 2,62 \\
\hline 35 & 200 & 160 & 48,10 & 24,10 & 16,55 & 11,31 & 8,47 & 6,71 & 4,66 & 3,62 & 2,56 \\
\hline 35 & 250 & 160 & 42,98 & 23,15 & 16,43 & 11,42 & 8,57 & 6,77 & 4,69 & 3,62 & 2,55 \\
\hline 35 & 300 & 160 & 39,41 & 22,42 & 16,30 & 11,49 & 8,64 & 6,82 & 4,71 & 3,63 & 2,54 \\
\hline 35 & 350 & 160 & 36,74 & 21,82 & 16,17 & 11,54 & 8,71 & 6,86 & 4,73 & 3,64 & 2,54 \\
\hline 35 & 400 & 160 & 34,65 & 21,31 & 16,04 & 11,57 & 8,76 & 6,91 & 4,75 & 3,64 & 2,53 \\
\hline 35 & 450 & 160 & 32,95 & 20,86 & 15,92 & 11,59 & 8,80 & 6,95 & 4,77 & 3,65 & 2,53 \\
\hline 35 & 500 & 160 & 31,53 & 20,47 & 15,79 & 11,59 & 8,84 & 6,98 & 4,79 & 3,65 & 2,53 \\
\hline 35 & 550 & 160 & 30,33 & 20,11 & 15,67 & 11,59 & 8,87 & 7,02 & 4,81 & 3,66 & 2,53 \\
\hline 35 & 600 & 160 & 29,28 & 19,78 & 15,55 & 11,58 & 8,90 & 7,05 & 4,83 & 3,67 & 2,52 \\
\hline 35 & 650 & 160 & 28,37 & 19,48 & 15,43 & 11,57 & 8,92 & 7,07 & 4,84 & 3,67 & 2,52 \\
\hline 35 & 700 & 160 & 27,55 & 19,21 & 15,32 & 11,56 & 8,94 & 7,10 & 4,86 & 3,68 & 2,52 \\
\hline 35 & 750 & 160 & 26,83 & 18,95 & 15,21 & 11,54 & 8,95 & 7,12 & 4,88 & 3,69 & 2,52 \\
\hline 35 & 800 & 160 & 26,17 & 18,71 & $\begin{array}{l}0, L+1 \\
15,10\end{array}$ & $\begin{array}{l}11,52 \\
11,52\end{array}$ & 8,97 & $\frac{1, \pm L}{7,14}$ & 4,89 & 3,69 & 2,52 \\
\hline 35 & 850 & 160 & 25,57 & 18,48 & 15,00 & 11,50 & 8,98 & 7,16 & 4,91 & 3,70 & 2,52 \\
\hline 35 & 900 & 160 & 25,02 & 18,27 & 14,90 & 11,48 & 8,98 & 7,18 & 4,92 & 3,71 & 2,52 \\
\hline 35 & 950 & 160 & 24,51 & 18,06 & 14,80 & 11,45 & 8,99 & 7,20 & 4,94 & 3,72 & 2,52 \\
\hline 35 & 1000 & 160 & 24,04 & 17,87 & 14,70 & 11,43 & 9,00 & 7,21 & 4,95 & 3,72 & 2,52 \\
\hline 35 & 1050 & 160 & 23,60 & 17,69 & 14,61 & 11,40 & 9,00 & 7,23 & 4,97 & 3,73 & 2,52 \\
\hline 35 & 1100 & 160 & 23,20 & 17,51 & 14,52 & 11,37 & 9,00 & 7,24 & 4,98 & 3,74 & 2,52 \\
\hline 35 & 1150 & 160 & 22,82 & 17,35 & 14,43 & 11,34 & 9,00 & 7,25 & 4,99 & 3,74 & 2,52 \\
\hline 35 & 1200 & 160 & 22,46 & 17,19 & 14,35 & 11,32 & 9,00 & 7,26 & 5,01 & 3,75 & 2,52 \\
\hline 35 & 1250 & 160 & 22,12 & 17,03 & 14,27 & 11,29 & 9,00 & 7,27 & 5,02 & 3,76 & 2,52 \\
\hline 35 & 1300 & 160 & 21,80 & 16,89 & 14,19 & 11,26 & 9,00 & 7,28 & 5,03 & 3,76 & 2,52 \\
\hline 35 & 1350 & 160 & 21,50 & 16,75 & 14,11 & 11,23 & 8,99 & 7,29 & 5,04 & 3,77 & 2,52 \\
\hline 35 & 1400 & 160 & 21,21 & 16,61 & 14,03 & 11,20 & 8,99 & 7,30 & 5,05 & 3,78 & 2,52 \\
\hline 35 & 1450 & 160 & 20,94 & 16,48 & 13,95 & 11,17 & 8,99 & 7,30 & 5,06 & 3,79 & 2,52 \\
\hline 35 & 1500 & 160 & 20,68 & 16,35 & 13,88 & 11,14 & 8,98 & 7,31 & 5,07 & 3,79 & 2,53 \\
\hline 35 & 1550 & 160 & 20,44 & 16,23 & 13,81 & 11,11 & 8,97 & 7,32 & 5,08 & 3,80 & 2,53 \\
\hline 35 & 1600 & 160 & 20,20 & 16,11 & 13,74 & 11,08 & 8,97 & 7,32 & 5,09 & 3,81 & 2,53 \\
\hline 35 & 1650 & 160 & 19,97 & 16,00 & 13,67 & 11,05 & 8,96 & 7,33 & 5,10 & 3,81 & 2,53 \\
\hline 35 & 1700 & 160 & 19,76 & 15,89 & 13,60 & 11,03 & 8,95 & 7,33 & 5,11 & 3,82 & 2,53 \\
\hline 35 & 1750 & 160 & 19,55 & 15,78 & 13,54 & 11,00 & 8,95 & 7,33 & 5,12 & 3,82 & 2,53 \\
\hline 35 & 1800 & 160 & 19,35 & 15,68 & 13,47 & 10,97 & 8,94 & 7,34 & 5,13 & 3,83 & 2,53 \\
\hline 35 & 1850 & 160 & 19,16 & 15,57 & 13,41 & 10,94 & 8,93 & 7,34 & 5,14 & 3,84 & 2,53 \\
\hline 35 & 1900 & 160 & 18,97 & 15,48 & 13,35 & 10,91 & 8,92 & 7,34 & 5,15 & 3,84 & 2,53 \\
\hline 35 & 1950 & 160 & 18,79 & 15,38 & 13,29 & 10,88 & 8,91 & 7,34 & 5,15 & 3,85 & 2,54 \\
\hline 35 & 2000 & 160 & 18,62 & 15,29 & 13,23 & 10,86 & 8,90 & 7,34 & 5,16 & 3,86 & 2,54 \\
\hline 35 & 200 & 165 & 47,40 & 23,50 & 16,06 & 10,95 & 8,20 & 6,50 & 4,51 & 3,50 & 2,48 \\
\hline 35 & 250 & 165 & 42,31 & 22,57 & 15,95 & 11,06 & 8,30 & 6,55 & 4,54 & 3,51 & 2,47 \\
\hline 35 & 300 & 165 & 38,77 & 21,86 & 15,83 & 11,14 & 8,37 & 6,60 & 4,56 & 3,52 & 2,47 \\
\hline 35 & 350 & 165 & 36,12 & 21,27 & 15,71 & 11,18 & 8,43 & 6,65 & 4,58 & 3,53 & 2,46 \\
\hline
\end{tabular}




\begin{tabular}{|c|c|c|c|c|c|c|c|c|c|c|c|}
\hline \multirow[b]{2}{*}{$\mathrm{H}(\mathrm{cm})$} & \multirow[b]{2}{*}{ Mceq (MPa) } & & & & & De & ões (x & & & & \\
\hline & & Msub (MPa) & D0 & D25 & D40 & D60 & D80 & D100 & D140 & D180 & D260 \\
\hline 35 & 400 & 165 & 34,05 & 20,78 & 15,59 & 11,21 & 8,48 & 6,69 & 4,60 & 3,53 & 2,46 \\
\hline 35 & 450 & 165 & 32,37 & 20,34 & 15,47 & 11,23 & 8,52 & 6,73 & 4,62 & 3,54 & 2,45 \\
\hline 35 & 500 & 165 & 30,97 & 19,96 & 15,35 & 11,24 & 8,56 & 6,76 & 4,64 & 3,54 & 2,45 \\
\hline 35 & 550 & 165 & 29,78 & 19,61 & 15,23 & 11,24 & 8,59 & 6,79 & 4,66 & 3,55 & 2,45 \\
\hline 35 & 600 & 165 & 28,75 & 19,30 & 15,12 & 11,24 & 8,62 & 6,82 & 4,67 & 3,55 & 2,45 \\
\hline 35 & 650 & 165 & 27,84 & 19,01 & 15,01 & 11,23 & 8,64 & 6,85 & 4,69 & 3,56 & 2,45 \\
\hline 35 & 700 & 165 & 27,04 & 18,74 & 14,90 & 11,22 & 8,66 & 6,87 & 4,71 & 3,57 & 2,45 \\
\hline 35 & 750 & 165 & 26,32 & 18,49 & 14,80 & 11,20 & 8,68 & 6,90 & 4,72 & 3,57 & 2,44 \\
\hline 35 & 800 & 165 & 25,68 & 18,25 & 14,69 & 11,18 & 8,69 & 6,92 & 4,74 & 3,58 & 2,44 \\
\hline 35 & 850 & 165 & 25,08 & 18,03 & 14,59 & 11,16 & 8,70 & 6,94 & 4,75 & 3,59 & 2,44 \\
\hline 35 & 900 & 165 & 24,54 & 17,82 & 14,50 & 11,14 & 8,71 & 6,95 & 4,77 & 3,59 & 2,44 \\
\hline 35 & 950 & 165 & 24,04 & 17,63 & 14,40 & 11,12 & 8,72 & 6,97 & 4,78 & 3,60 & 2,44 \\
\hline 35 & 1000 & 165 & 23,58 & 17,44 & 14,31 & 11,09 & 8,72 & 6,99 & 4,79 & 3,61 & 2,44 \\
\hline 35 & 1050 & 165 & 23,15 & 17,26 & 14,23 & 11,07 & 8,72 & 7,00 & 4,81 & 3,61 & 2,44 \\
\hline 35 & 1100 & 165 & 22,75 & 17,09 & 14,14 & 11,04 & 8,73 & 7,01 & 4,82 & 3,62 & 2,44 \\
\hline 35 & 1150 & 165 & 22,38 & 16,93 & 14,06 & 11,02 & 8,73 & 7,02 & 4,83 & 3,63 & 2,44 \\
\hline 35 & 1200 & 165 & 22,03 & 16,78 & 13,97 & 10,99 & 8,73 & 7,04 & 4,85 & 3,63 & 2,44 \\
\hline 35 & 1250 & 165 & 21,70 & 16,63 & 13,89 & 10,97 & 8,73 & 7,05 & 4,86 & 3,64 & 2,44 \\
\hline 35 & 1300 & 165 & 21,38 & 16,49 & 13,82 & 10,94 & 8,73 & 7,05 & 4,87 & 3,65 & 2,45 \\
\hline 35 & 1350 & 165 & 21,09 & 16,35 & 13,74 & 10,91 & 8,72 & 7,06 & 4,88 & 3,65 & 2,45 \\
\hline 35 & 1400 & 165 & 20,81 & 16,22 & 13,67 & 10,88 & 8,72 & 7,07 & 4,89 & 3,66 & 2,45 \\
\hline 35 & 1450 & 165 & 20,54 & 16,09 & 13,60 & 10,86 & 8,72 & 7,08 & 4,90 & 3,66 & 2,45 \\
\hline 35 & 1500 & 165 & 20,28 & 15,97 & 13,52 & 10,83 & 8,71 & 7,08 & 4,91 & 3,67 & 2,45 \\
\hline 35 & 1550 & 165 & 20,04 & 15,85 & 13,46 & 10,80 & 8,71 & 7,09 & 4,92 & 3,68 & 2,45 \\
\hline 35 & 1600 & 165 & 19,81 & 15,74 & 13,39 & 10,77 & 8,70 & 7,09 & 4,93 & 3,68 & 2,45 \\
\hline 35 & 1650 & 165 & 19,59 & 15,62 & 13,32 & 10,75 & 8,70 & 7,10 & 4,94 & 3,69 & 2,45 \\
\hline 35 & 1700 & 165 & 19,37 & 15,52 & 13,26 & 10,72 & 8,69 & 7,10 & 4,95 & 3,70 & 2,45 \\
\hline 35 & 1750 & 165 & 19,17 & 15,41 & 13,20 & 10,69 & 8,68 & 7,11 & 4,96 & 3,70 & 2,45 \\
\hline 35 & 1800 & 165 & 18,97 & 15,31 & 13,13 & 10,67 & 8,68 & 7,11 & 4,97 & 3,71 & 2,45 \\
\hline 35 & 1850 & 165 & 18,78 & 15,21 & 13,07 & 10,64 & 8,67 & 7,11 & 4,97 & 3,71 & 2,46 \\
\hline 35 & 1900 & 165 & 18,60 & 15,12 & 13,01 & 10,61 & 8,66 & 7,11 & 4,98 & 3,72 & 2,46 \\
\hline 35 & 1950 & 165 & 18,43 & 15,02 & 12,96 & 10,59 & 8,65 & 7,12 & 4,99 & 3,73 & 2,46 \\
\hline 35 & 2000 & 165 & 18,26 & 14,93 & 12,90 & 10,56 & 8,64 & 7,12 & 5,00 & 3,73 & 2,46 \\
\hline 35 & 200 & 170 & 46,74 & 22,93 & 15,60 & 10,61 & 7,95 & 6,30 & 4,38 & 3,40 & 2,41 \\
\hline 35 & 250 & 170 & 41,68 & 22,03 & 15,50 & 10,72 & 8,04 & 6,35 & 4,40 & 3,41 & 2,40 \\
\hline 35 & 300 & 170 & 38,16 & 21,33 & 15,39 & 10,80 & 8,11 & 6,40 & 4,42 & 3,41 & 2,39 \\
\hline 35 & 350 & 170 & 35,53 & 20,76 & 15,27 & 10,85 & 8,17 & 6,44 & 4,44 & 3,42 & 2,39 \\
\hline 35 & 400 & 170 & 33,48 & 20,27 & 15,16 & 10,88 & 8,22 & 6,48 & 4,46 & 3,43 & 2,39 \\
\hline 35 & 450 & 170 & 31,82 & 19,85 & 15,04 & 10,90 & 8,26 & 6,52 & 4,48 & 3,43 & 2,38 \\
\hline 35 & 500 & 170 & 30,43 & 19,48 & 14,93 & 10,91 & 8,30 & 6,55 & 4,50 & 3,44 & 2,38 \\
\hline 35 & 550 & 170 & 29,26 & 19,14 & 14,82 & 10,91 & 8,33 & 6,58 & 4,51 & 3,44 & 2,38 \\
\hline 35 & 600 & 170 & 28,24 & 18,83 & 14,71 & 10,91 & 8,36 & 6,61 & 4,53 & 3,45 & 2,38 \\
\hline 35 & 650 & 170 & 27,35 & 18,55 & 14,61 & 10,90 & 8,38 & 6,64 & 4,55 & 3,45 & 2,37 \\
\hline 35 & 700 & 170 & 26,56 & 18,29 & 14,50 & 10,89 & 8,40 & 6,66 & 4,56 & 3,46 & 2,37 \\
\hline 35 & 750 & 170 & 25,85 & 18,05 & 14,40 & 10,88 & 8,41 & 6,68 & 4,58 & 3,46 & 2,37 \\
\hline 35 & 800 & 170 & 25,21 & 17,82 & 14,31 & 10,86 & 8,43 & 6,70 & 4,59 & 3,47 & 2,37 \\
\hline 35 & 850 & 170 & 24,63 & 17,61 & 14,21 & 10,84 & 8,44 & 6,72 & 4,61 & 3,48 & 2,37 \\
\hline 35 & 900 & 170 & 24,09 & 17,41 & 14,12 & 10,82 & 8,45 & 6,74 & 4,62 & 3,48 & 2,37 \\
\hline 35 & 950 & 170 & 23,60 & 17,21 & 14,03 & 10,80 & 8,46 & 6,76 & 4,63 & 3,49 & 2,37 \\
\hline 35 & 1000 & 170 & 23,15 & 17,03 & 13,94 & 10,78 & 8,46 & 6,77 & 4,65 & 3,50 & 2,37 \\
\hline 35 & 1050 & 170 & 22,73 & 16,86 & 13,86 & 10,76 & 8,47 & 6,79 & 4,66 & 3,50 & 2,37 \\
\hline 35 & 1100 & 170 & 22,33 & 16,70 & 13,78 & 10,74 & 8,47 & 6,80 & 4,67 & 3,51 & 2,37 \\
\hline 35 & 1150 & 170 & 21,97 & 16,54 & 13,70 & 10,71 & 8,47 & 6,81 & 4,68 & 3,51 & 2,37 \\
\hline 35 & 1200 & 170 & 21,62 & 16,39 & 13,62 & 10,69 & 8,47 & 6,82 & 4,69 & 3,52 & 2,37 \\
\hline 35 & 1250 & 170 & 21,29 & 16,25 & 13,54 & 10,66 & 8,47 & 6,83 & 4,71 & 3,53 & 2,37 \\
\hline 35 & 1300 & 170 & 20,99 & 16,11 & 13,47 & 10,64 & 8,47 & 6,84 & 4,72 & 3,53 & 2,37 \\
\hline 35 & 1350 & 170 & 20,69 & 15,97 & 13,40 & 10,61 & 8,47 & 6,85 & 4,73 & 3,54 & 2,37 \\
\hline 35 & 1400 & 170 & 20,42 & 15,85 & 13,32 & 10,59 & 8,47 & 6,86 & 4,74 & 3,55 & 2,37 \\
\hline 35 & 1450 & 170 & 20,16 & 15,72 & 13,26 & 10,56 & 8,46 & 6,86 & 4,75 & 3,55 & 2,37 \\
\hline 35 & 1500 & 170 & 19,91 & 15,60 & 13,19 & 10,53 & 8,46 & 6,87 & 4,76 & 3,56 & 2,38 \\
\hline 35 & 1550 & 170 & 19,67 & 15,49 & 13,12 & 10,51 & 8,46 & 6,88 & 4,77 & 3,56 & 2,38 \\
\hline 35 & 1600 & 170 & 19,44 & 15,38 & 13,06 & 10,48 & 8,45 & 6,88 & 4,78 & 3,57 & 2,38 \\
\hline 35 & 1650 & 170 & 19,22 & 15,27 & 12,99 & 10,46 & 8,45 & 6,89 & 4,79 & 3,58 & 2,38 \\
\hline 35 & 1700 & 170 & 19,01 & 15,16 & 12,93 & 10,43 & 8,44 & 6,89 & 4,79 & 3,58 & 2,38 \\
\hline 35 & 1750 & 170 & 18,81 & 15,06 & 12,87 & 10,41 & 8,43 & 6,89 & 4,80 & 3,59 & 2,38 \\
\hline 35 & 1800 & 170 & 18,62 & 14,96 & 12,81 & 10,38 & 8,43 & 6,90 & 4,81 & 3,59 & 2,38 \\
\hline 35 & 1850 & 170 & 18,43 & 14,87 & 12,75 & 10,36 & 8,42 & 6,90 & 4,82 & 3,60 & 2,38 \\
\hline 35 & 1900 & 170 & 18,25 & 14,78 & 12,70 & 10,33 & 8,41 & 6,90 & 4,83 & 3,60 & 2,38 \\
\hline 35 & 1950 & 170 & 18,08 & 14,69 & 12,64 & 10,30 & 8,41 & 6,91 & 4,83 & 3,61 & 2,38 \\
\hline 35 & 2000 & 170 & 17,92 & 14,60 & 12,59 & 10,28 & 8,40 & 6,91 & 4,84 & 3,62 & 2,39 \\
\hline 35 & 200 & 175 & 46,11 & 22,40 & 15,16 & 10,29 & 7,71 & 6,12 & 4,25 & 3,30 & 2,34 \\
\hline 35 & 250 & 175 & 41,08 & 21,51 & 15,07 & 10,40 & 7,80 & 6,17 & 4,27 & 3,31 & 2,33 \\
\hline 35 & 300 & 175 & 37,58 & 20,82 & 14,97 & 10,48 & 7,87 & 6,21 & 4,29 & 3,32 & 2,33 \\
\hline 35 & 350 & 175 & 34,98 & 20,27 & 14,86 & 10,53 & 7,93 & 6,25 & 4,31 & 3,32 & 2,32 \\
\hline 35 & 400 & 175 & 32,94 & 19,80 & 14,75 & 10,56 & 7,98 & 6,29 & 4,33 & 3,33 & 2,32 \\
\hline 35 & 450 & 175 & 31,29 & 19,39 & 14,64 & 10,58 & 8,02 & 6,32 & 4,35 & 3,33 & 2,31 \\
\hline 35 & 500 & 175 & 29,93 & 19,02 & 14,53 & 10,59 & 8,05 & 6,36 & 4,36 & 3,34 & 2,31 \\
\hline 35 & 550 & 175 & 28,76 & 18,69 & 14,43 & 10,60 & 8,08 & 6,39 & 4,38 & 3,34 & 2,31 \\
\hline 35 & 600 & 175 & 27,76 & 18,40 & 14,33 & 10,60 & 8,11 & 6,41 & 4,40 & 3,35 & 2,31 \\
\hline 35 & 650 & 175 & 26,88 & 18,12 & 14,23 & 10,59 & 8,13 & 6,44 & 4,41 & 3,35 & 2,31 \\
\hline 35 & 700 & 175 & 26,10 & 17,87 & 14,13 & 10,58 & 8,15 & 6,46 & 4,43 & 3,36 & 2,31 \\
\hline
\end{tabular}




\begin{tabular}{|c|c|c|c|c|c|c|c|c|c|c|c|}
\hline \multirow[b]{2}{*}{$\mathrm{H}(\mathrm{cm})$} & \multirow[b]{2}{*}{ Mceq (MPa) } & & & & & $\mathrm{De}$ & ões (x. & & & & \\
\hline & & Msub (MPa) & D0 & D25 & D40 & D60 & D80 & D100 & D140 & D180 & D260 \\
\hline 35 & 750 & 175 & 25,40 & 17,63 & 14,03 & 10,57 & 8,17 & 6,48 & 4,44 & 3,36 & 2,31 \\
\hline 35 & 800 & 175 & 24,77 & 17,41 & 13,94 & 10,56 & 8,18 & 6,50 & 4,45 & 3,37 & 2,31 \\
\hline 35 & 850 & 175 & 24,19 & 17,20 & 13,85 & 10,54 & 8,19 & 6,52 & 4,47 & 3,37 & 2,30 \\
\hline 35 & 900 & 175 & 23,67 & 17,01 & 13,76 & 10,52 & 8,20 & 6,54 & 4,48 & 3,38 & 2,30 \\
\hline 35 & 950 & 175 & 23,18 & 16,82 & 13,68 & 10,51 & 8,21 & 6,56 & 4,49 & 3,39 & 2,30 \\
\hline 35 & 1000 & 175 & 22,74 & 16,65 & 13,59 & 10,49 & 8,22 & 6,57 & 4,51 & 3,39 & 2,30 \\
\hline 35 & 1050 & 175 & 22,32 & 16,48 & 13,51 & 10,46 & 8,22 & 6,58 & 4,52 & 3,40 & 2,30 \\
\hline 35 & 1100 & 175 & 21,93 & 16,32 & 13,43 & 10,44 & 8,23 & 6,60 & 4,53 & 3,40 & 2,30 \\
\hline 35 & 1150 & 175 & 21,57 & 16,17 & 13,36 & 10,42 & 8,23 & 6,61 & 4,54 & 3,41 & 2,30 \\
\hline 35 & 1200 & 175 & 21,23 & 16,02 & 13,28 & 10,40 & 8,23 & 6,62 & 4,55 & 3,42 & 2,30 \\
\hline 35 & 1250 & 175 & 20,91 & 15,88 & 13,21 & 10,37 & 8,23 & 6,63 & 4,56 & 3,42 & 2,30 \\
\hline 35 & 1300 & 175 & 20,61 & 15,75 & 13,14 & 10,35 & 8,23 & 6,64 & 4,57 & 3,43 & 2,30 \\
\hline 35 & 1350 & 175 & 20,32 & 15,62 & 13,07 & 10,33 & 8,23 & 6,65 & 4,59 & 3,43 & 2,31 \\
\hline 35 & 1400 & 175 & 20,05 & 15,49 & 13,00 & 10,30 & 8,23 & 6,65 & 4,60 & 3,44 & 2,31 \\
\hline 35 & 1450 & 175 & 19,79 & 15,37 & 12,93 & 10,28 & 8,22 & 6,66 & 4,60 & 3,45 & 2,31 \\
\hline 35 & 1500 & 175 & 19,54 & 15,26 & 12,87 & 10,25 & 8,22 & 6,67 & 4,61 & 3,45 & 2,31 \\
\hline 35 & 1550 & 175 & 19,31 & 15,14 & 12,80 & 10,23 & 8,22 & 6,67 & 4,62 & 3,46 & 2,31 \\
\hline 35 & 1600 & 175 & 19,09 & 15,04 & 12,74 & 10,21 & 8,21 & 6,68 & 4,63 & 3,46 & 2,31 \\
\hline 35 & 1650 & 175 & 18,87 & 14,93 & 12,68 & 10,18 & 8,21 & 6,68 & 4,64 & 3,47 & 2,31 \\
\hline 35 & 1700 & 175 & 18,67 & 14,83 & 12,62 & 10,16 & 8,20 & 6,69 & 4,65 & 3,47 & 2,31 \\
\hline 35 & 1750 & 175 & 18,47 & 14,73 & 12,56 & 10,13 & 8,20 & 6,69 & 4,66 & 3,48 & 2,31 \\
\hline 35 & 1800 & 175 & 18,28 & 14,64 & 12,50 & 10,11 & 8,19 & 6,70 & 4,67 & 3,48 & 2,31 \\
\hline 35 & 1850 & 175 & 18,10 & 14,54 & 12,45 & 10,09 & 8,19 & 6,70 & 4,67 & 3,49 & 2,31 \\
\hline 35 & 1900 & 175 & 17,92 & 14,45 & 12,39 & 10,06 & 8,18 & 6,70 & 4,68 & 3,50 & 2,31 \\
\hline 35 & 1950 & 175 & 17,75 & 14,36 & 12,34 & 10,04 & 8,17 & 6,71 & 4,69 & 3,50 & 2,31 \\
\hline 35 & 2000 & 175 & 17,59 & 14,28 & 12,29 & 10,01 & 8,17 & 6,71 & 4,69 & 3,51 & 2,32 \\
\hline 35 & 200 & 180 & 45,51 & 21,89 & 14,75 & 9,99 & 7,49 & 5,94 & 4,13 & 3,21 & 2,28 \\
\hline 35 & 250 & 180 & 40,51 & 21,02 & 14,66 & 10,10 & 7,57 & 5,99 & 4,15 & 3,22 & 2,27 \\
\hline 35 & 300 & 180 & 37,03 & 20,35 & 14,57 & 10,18 & 7,64 & 6,03 & 4,17 & 3,22 & 2,26 \\
\hline 35 & 350 & 180 & 34,45 & 19,80 & 14,47 & 10,23 & 7,70 & 6,07 & 4,19 & 3,23 & 2,26 \\
\hline 35 & 400 & 180 & 32,43 & 19,34 & 14,36 & 10,26 & 7,74 & 6,11 & 4,21 & 3,23 & 2,25 \\
\hline 35 & 450 & 180 & 30,80 & 18,94 & 14,26 & 10,28 & 7,78 & 6,14 & 4,22 & 3,24 & 2,25 \\
\hline 35 & 500 & 180 & 29,44 & 18,59 & 14,16 & 10,30 & 7,82 & 6,17 & 4,24 & 3,24 & 2,25 \\
\hline 35 & 550 & 180 & 28,29 & 18,27 & 14,06 & 10,30 & 7,85 & 6,20 & 4,25 & 3,25 & 2,25 \\
\hline 35 & 600 & 180 & 27,30 & 17,98 & 13,96 & 10,30 & 7,88 & 6,23 & 4,27 & 3,25 & 2,25 \\
\hline 35 & 650 & 180 & 26,43 & 17,71 & 13,87 & 10,30 & 7,90 & 6,25 & 4,28 & 3,26 & 2,24 \\
\hline 35 & 700 & 180 & 25,66 & 17,46 & 13,77 & 10,29 & 7,92 & 6,27 & 4,30 & 3,26 & 2,24 \\
\hline 35 & 750 & 180 & 24,97 & 17,24 & 13,68 & 10,28 & 7,93 & 6,29 & 4,31 & 3,27 & 2,24 \\
\hline 35 & 800 & 180 & 24,34 & 17,02 & 13,59 & 10,27 & 7,95 & 6,31 & 4,32 & 3,27 & 2,24 \\
\hline 35 & 850 & 180 & 23,78 & 16,82 & 13,51 & 10,26 & 7,96 & 6,33 & 4,34 & 3,28 & 2,24 \\
\hline 35 & 900 & 180 & 23,26 & 16,63 & 13,42 & 10,24 & 7,97 & 6,35 & 4,35 & 3,28 & 2,24 \\
\hline 35 & 950 & 180 & 22,78 & 16,45 & 13,34 & 10,22 & 7,98 & 6,37 & 4,36 & 3,29 & 2,24 \\
\hline 35 & 1000 & 180 & 22,34 & 16,28 & 13,26 & 10,21 & 7,99 & 6,38 & 4,37 & 3,29 & 2,24 \\
\hline 35 & 1050 & 180 & 21,93 & 16,11 & 13,18 & 10,19 & 7,99 & 6,39 & 4,39 & 3,30 & 2,24 \\
\hline 35 & 1100 & 180 & 21,55 & 15,96 & 13,11 & 10,17 & 7,99 & 6,41 & 4,40 & 3,31 & 2,24 \\
\hline 35 & 1150 & 180 & 21,19 & 15,81 & 13,03 & 10,15 & 8,00 & 6,42 & 4,41 & 3,31 & 2,24 \\
\hline 35 & 1200 & 180 & 20,86 & 15,67 & 12,96 & 10,12 & 8,00 & 6,43 & 4,42 & 3,32 & 2,24 \\
\hline 35 & 1250 & 180 & 20,54 & 15,53 & 12,89 & 10,10 & 8,00 & 6,44 & 4,43 & 3,32 & 2,24 \\
\hline 35 & 1300 & 180 & 20,24 & 15,40 & 12,82 & 10,08 & 8,00 & 6,45 & 4,44 & 3,33 & 2,24 \\
\hline 35 & 1350 & 180 & 19,96 & 15,28 & 12,75 & 10,06 & 8,00 & 6,46 & 4,45 & 3,33 & 2,24 \\
\hline 35 & 1400 & 180 & 19,70 & 15,16 & 12,69 & 10,04 & 8,00 & 6,46 & 4,46 & 3,34 & 2,24 \\
\hline 35 & 1450 & 180 & 19,44 & 15,04 & 12,62 & 10,01 & 8,00 & 6,47 & 4,47 & 3,34 & 2,24 \\
\hline 35 & 1500 & 180 & 19,20 & 14,93 & 12,56 & 9,99 & 8,00 & 6,48 & 4,48 & 3,35 & 2,24 \\
\hline 35 & 1550 & 180 & 18,97 & 14,82 & 12,50 & 9,97 & 7,99 & 6,48 & 4,49 & 3,36 & 2,24 \\
\hline 35 & 1600 & 180 & 18,75 & 14,71 & 12,44 & 9,94 & 7,99 & 6,49 & 4,50 & 3,36 & 2,24 \\
\hline 35 & 1650 & 180 & 18,54 & 14,61 & 12,38 & 9,92 & 7,99 & 6,49 & 4,50 & 3,37 & 2,24 \\
\hline 35 & 1700 & 180 & 18,34 & 14,51 & 12,32 & 9,90 & 7,98 & 6,50 & 4,51 & 3,37 & 2,25 \\
\hline 35 & 1750 & 180 & 18,14 & 14,42 & 12,27 & 9,87 & 7,98 & 6,50 & 4,52 & 3,38 & 2,25 \\
\hline 35 & 1800 & 180 & 17,95 & 14,32 & 12,21 & 9,85 & 7,97 & 6,51 & 4,53 & 3,38 & 2,25 \\
\hline 35 & 1850 & 180 & 17,78 & 14,23 & 12,16 & 9,83 & 7,97 & 6,51 & 4,54 & 3,39 & 2,25 \\
\hline 35 & 1900 & 180 & 17,60 & 14,14 & 12,11 & 9,81 & 7,96 & 6,51 & 4,54 & 3,39 & 2,25 \\
\hline 35 & 1950 & 180 & 17,44 & 14,06 & 12,05 & 9,78 & 7,95 & 6,52 & 4,55 & 3,40 & 2,25 \\
\hline 35 & 2000 & 180 & 17,28 & 13,97 & 12,00 & 9,76 & 7,95 & 6,52 & 4,56 & 3,40 & 2,25 \\
\hline 35 & 200 & 185 & 44,95 & 21,41 & 14,36 & 9,71 & 7,27 & 5,77 & 4,01 & 3,12 & 2,22 \\
\hline 35 & 250 & 185 & 39,96 & 20,55 & 14,28 & 9,82 & 7,36 & 5,82 & 4,04 & 3,13 & 2,21 \\
\hline 35 & 300 & 185 & 36,51 & 19,89 & 14,19 & 9,89 & 7,42 & 5,86 & 4,06 & 3,14 & 2,20 \\
\hline 35 & 350 & 185 & 33,94 & 19,36 & 14,09 & 9,94 & 7,48 & 5,90 & 4,07 & 3,14 & 2,20 \\
\hline 35 & 400 & 185 & 31,94 & 18,91 & 14,00 & 9,98 & 7,53 & 5,93 & 4,09 & 3,14 & 2,19 \\
\hline 35 & 450 & 185 & 30,32 & 18,52 & 13,90 & 10,00 & 7,57 & 5,97 & 4,10 & 3,15 & 2,19 \\
\hline 35 & 500 & 185 & 28,98 & 18,17 & 13,80 & 10,02 & 7,60 & 6,00 & 4,12 & 3,15 & 2,19 \\
\hline 35 & 550 & 185 & 27,84 & 17,86 & 13,71 & 10,02 & 7,63 & 6,02 & 4,13 & 3,16 & 2,19 \\
\hline 35 & 600 & 185 & 26,86 & 17,58 & 13,62 & 10,03 & 7,65 & 6,05 & 4,15 & 3,16 & 2,18 \\
\hline 35 & 650 & 185 & 26,00 & 17,32 & 13,52 & 10,02 & 7,68 & 6,07 & 4,16 & 3,17 & 2,18 \\
\hline 35 & 700 & 185 & 25,24 & 17,08 & 13,44 & 10,02 & 7,70 & 6,10 & 4,18 & 3,17 & 2,18 \\
\hline 35 & 750 & 185 & 24,55 & 16,86 & 13,35 & 10,01 & 7,71 & 6,12 & 4,19 & 3,18 & 2,18 \\
\hline 35 & 800 & 185 & 23,94 & 16,65 & 13,26 & 10,00 & 7,73 & 6,14 & 4,20 & 3,18 & 2,18 \\
\hline 35 & 850 & 185 & 23,38 & 16,45 & 13,18 & 9,99 & 7,74 & 6,15 & 4,21 & 3,19 & 2,18 \\
\hline 35 & 900 & 185 & 22,87 & 16,27 & 13,10 & 9,97 & 7,75 & 6,17 & 4,23 & 3,19 & 2,18 \\
\hline 35 & 950 & 185 & 22,40 & 16,09 & 13,02 & 9,96 & 7,76 & 6,19 & 4,24 & 3,20 & 2,18 \\
\hline 35 & 1000 & 185 & 21,97 & 15,93 & 12,94 & 9,94 & 7,77 & 6,20 & 4,25 & 3,20 & 2,18 \\
\hline 35 & 1050 & 185 & 21,56 & 15,77 & 12,87 & 9,92 & 7,77 & 6,21 & 4,26 & 3,21 & 2,18 \\
\hline
\end{tabular}




\begin{tabular}{|c|c|c|c|c|c|c|c|c|c|c|c|}
\hline \multirow[b]{2}{*}{$\mathrm{H}(\mathrm{cm})$} & \multirow[b]{2}{*}{ Mceq (MPa) } & & & & & & ões (x1 & & & & \\
\hline & & Msub (MPa) & D0 & D25 & D40 & D60 & D80 & D100 & D140 & D180 & D260 \\
\hline 35 & 1100 & 185 & 21,19 & 15,62 & 12,80 & 9,90 & 7,78 & 6,23 & 4,27 & 3,21 & 2,18 \\
\hline 35 & 1150 & 185 & 20,83 & 15,47 & 12,73 & 9,88 & 7,78 & 6,24 & 4,28 & 3,22 & 2,18 \\
\hline 35 & 1200 & 185 & 20,50 & 15,34 & 12,66 & 9,86 & 7,78 & 6,25 & 4,29 & 3,22 & 2,18 \\
\hline 35 & 1250 & 185 & 20,19 & 15,20 & 12,59 & 9,84 & 7,78 & 6,26 & 4,30 & 3,23 & 2,18 \\
\hline 35 & 1300 & 185 & 19,90 & 15,08 & 12,52 & 9,82 & 7,78 & 6,27 & 4,31 & 3,23 & 2,18 \\
\hline 35 & 1350 & 185 & 19,62 & 14,95 & 12,46 & 9,80 & 7,78 & 6,28 & 4,32 & 3,24 & 2,18 \\
\hline 35 & 1400 & 185 & 19,36 & 14,84 & 12,39 & 9,78 & 7,78 & 6,28 & 4,33 & 3,25 & 2,18 \\
\hline 35 & 1450 & 185 & 19,11 & 14,72 & 12,33 & 9,76 & 7,78 & 6,29 & 4,34 & 3,25 & 2,18 \\
\hline 35 & 1500 & 185 & 18,87 & 14,61 & 12,27 & 9,74 & 7,78 & 6,30 & 4,35 & 3,26 & 2,18 \\
\hline 35 & 1550 & 185 & 18,64 & 14,51 & 12,21 & 9,72 & 7,78 & 6,30 & 4,36 & 3,26 & 2,18 \\
\hline 35 & 1600 & 185 & 18,43 & 14,40 & 12,15 & 9,69 & 7,78 & 6,31 & 4,37 & 3,27 & 2,18 \\
\hline 35 & 1650 & 185 & 18,22 & 14,30 & 12,10 & 9,67 & 7,77 & 6,31 & 4,38 & 3,27 & 2,18 \\
\hline 35 & 1700 & 185 & 18,02 & 14.21 & 12.04 & 9.65 & 7,77 & 6,32 & 4.38 & 3,28 & 2,18 \\
\hline 35 & 1750 & 185 & 17,83 & 14,11 & 11,99 & 9,63 & 7,76 & 6,32 & 4,39 & 3,28 & 2,18 \\
\hline 35 & 1800 & 185 & 17,65 & 14,02 & 11,94 & 9,61 & 7,76 & 6,33 & 4,40 & 3,29 & 2,19 \\
\hline 35 & 1850 & 185 & 17,47 & 13,94 & 11,88 & 9,59 & 7,76 & 6,33 & 4,41 & 3,29 & 2,19 \\
\hline 35 & 1900 & 185 & 17,30 & 13,85 & 11,83 & 9,56 & 7,75 & 6,33 & 4,41 & 3,30 & 2,19 \\
\hline 35 & 1950 & 185 & 17,14 & 13,77 & 11,78 & 9,54 & 7,75 & 6,34 & 4,42 & 3,30 & 2,19 \\
\hline 35 & 2000 & 185 & 16,98 & 13,68 & 11,73 & 9,52 & 7,74 & 6,34 & 4,43 & 3,31 & 2,19 \\
\hline 35 & 200 & 190 & 44,41 & 20,95 & 13,99 & 9,44 & 7,07 & 5,62 & 3,91 & 3,04 & 2,16 \\
\hline 35 & 250 & 190 & 39,45 & 20,11 & 13,92 & 9,55 & 7,15 & 5,66 & 3,93 & 3,05 & 2,15 \\
\hline 35 & 300 & 190 & 36,01 & 19,46 & 13,83 & 9,62 & 7,22 & 5,70 & 3,95 & 3,05 & 2,15 \\
\hline 35 & 350 & 190 & 33,46 & 18,94 & 13,74 & 9,67 & 7,27 & 5,74 & 3,96 & 3,06 & 2,14 \\
\hline 35 & 400 & 190 & 31,47 & 18,50 & 13,65 & 9,71 & 7,32 & 5,77 & 3,98 & 3,06 & 2,14 \\
\hline 35 & 450 & 190 & 29,87 & 18,12 & 13,56 & 9,73 & 7,36 & 5,80 & 3,99 & 3,07 & 2,13 \\
\hline 35 & 500 & 190 & 28,54 & 17,78 & 13,46 & 9,75 & 7,39 & 5,83 & 4,01 & 3,07 & 2,13 \\
\hline 35 & 550 & 190 & 27,41 & 17,48 & 13,37 & 9,76 & 7,42 & 5,86 & 4,02 & 3,07 & 2,13 \\
\hline 35 & 600 & 190 & 26,44 & 17,20 & 13,29 & 9,76 & 7,45 & 5,88 & 4,03 & 3,08 & 2,13 \\
\hline 35 & 650 & 190 & 25,59 & 16,95 & 13,20 & 9,76 & 7,47 & 5,91 & 4,05 & 3,08 & 2,13 \\
\hline 35 & 700 & 190 & 24,84 & 16,72 & 13,11 & 9,76 & 7,49 & 5,93 & 4,06 & 3,09 & 2,13 \\
\hline 35 & 750 & 190 & 24,16 & 16,50 & 13,03 & 9,75 & 7,50 & 5,95 & 4,07 & 3,09 & 2,12 \\
\hline 35 & 800 & 190 & 23,55 & 16,30 & 12,95 & 9,74 & 7,52 & 5,97 & 4,09 & 3,10 & 2,12 \\
\hline 35 & 850 & 190 & 23,00 & 16,10 & 12,87 & 9,73 & 7,53 & 5,98 & 4,10 & 3,10 & 2,12 \\
\hline 35 & 900 & 190 & 22,50 & 15,92 & 12.79 & 9,72 & 7.54 & 6.00 & 4.11 & 3,11 & 2,12 \\
\hline 35 & 950 & 190 & 22,03 & 15,75 & 12,72 & 9,70 & 7,55 & 6,02 & 4,12 & 3,11 & 2,12 \\
\hline 35 & 1000 & 190 & 21,61 & 15,59 & 12,64 & 9,69 & 7,56 & 6,03 & 4,13 & 3,12 & 2,12 \\
\hline 35 & 1050 & 190 & 21,21 & 15,44 & 12,57 & 9,67 & 7,56 & 6,04 & 4,14 & 3,12 & 2,12 \\
\hline 35 & 1100 & 190 & 20,84 & 15,29 & 12,50 & 9,65 & 7,57 & 6,06 & 4,15 & 3,13 & 2,12 \\
\hline 35 & 1150 & 190 & 20,49 & 15,15 & 12,43 & 9,64 & 7,57 & 6,07 & 4,16 & 3,13 & 2,12 \\
\hline 35 & 1200 & 190 & 20,17 & 15,02 & 12,37 & 9,62 & 7,58 & 6,08 & 4,17 & 3,14 & 2,12 \\
\hline 35 & 1250 & 190 & 19,86 & 14,89 & 12,30 & 9,60 & 7,58 & 6,09 & 4,18 & 3,14 & 2,12 \\
\hline 35 & 1300 & 190 & 19,57 & 14,76 & 12,24 & 9,58 & 7,58 & 6,10 & 4,19 & 3,15 & 2,12 \\
\hline 35 & 1350 & 190 & 19,30 & 14,64 & 12,17 & 9,56 & 7,58 & 6,10 & 4,20 & 3,15 & 2,12 \\
\hline 35 & 1400 & 190 & 19,04 & 14,53 & 12,11 & 9,54 & 7,58 & 6,11 & 4,21 & 3,16 & 2,12 \\
\hline 35 & 1450 & 190 & 18,79 & 14,42 & 12,05 & 9,52 & 7,58 & 6,12 & 4,22 & 3,16 & 2,12 \\
\hline 35 & 1500 & 190 & 18,56 & 14,31 & 12,00 & 9,50 & 7,58 & 6,13 & 4,23 & 3,17 & 2,12 \\
\hline 35 & 1550 & 190 & 18,33 & 14,21 & 11,94 & 9,48 & 7,58 & 6,13 & 4,24 & 3,17 & 2,12 \\
\hline 35 & 1600 & 190 & 18,12 & 14,11 & 11,88 & 9,46 & 7,57 & 6,14 & 4,25 & 3,18 & 2,12 \\
\hline 35 & 1650 & 190 & 17,91 & 14,01 & 11,83 & 9,44 & 7,57 & 6,14 & 4,25 & 3,18 & 2,13 \\
\hline 35 & 1700 & 190 & 17,72 & 13,92 & 11,77 & 9,42 & 7,57 & 6,15 & 4,26 & 3,19 & 2,13 \\
\hline 35 & 1750 & 190 & 17,53 & 13,83 & 11,72 & 9,40 & 7,56 & 6,15 & 4,27 & 3,19 & 2,13 \\
\hline 35 & 1800 & 190 & 17,35 & 13,74 & 11,67 & 9,37 & 7,56 & 6,16 & 4,28 & 3,20 & 2,13 \\
\hline 35 & 1850 & 190 & 17,18 & 13,65 & 11,62 & 9,35 & 7,56 & 6,16 & 4,28 & 3,20 & 2,13 \\
\hline 35 & 1900 & 190 & 17,01 & 13,57 & 11,57 & 9,33 & 7,55 & 6,16 & 4,29 & 3,20 & 2,13 \\
\hline 35 & 1950 & 190 & 16,85 & 13,49 & 11,52 & 9,31 & 7,55 & 6,17 & 4,30 & 3,21 & 2,13 \\
\hline 35 & 2000 & 190 & 16,69 & 13,41 & 11,47 & 9,29 & 7,54 & 6,17 & 4,30 & 3,21 & 2,13 \\
\hline 35 & 200 & 195 & 43,89 & 20,52 & 13,64 & 9,18 & 6,88 & 5,47 & 3,80 & 2,96 & 2,11 \\
\hline 35 & 250 & 195 & 38,95 & 19,68 & 13,57 & 9,29 & 6,96 & 5,51 & 3,82 & 2,97 & 2,10 \\
\hline 35 & 300 & 195 & 35,54 & 19,05 & 13,49 & 9,37 & 7,02 & 5,55 & 3,84 & 2,97 & 2,09 \\
\hline 35 & 350 & 195 & 33,00 & 18,54 & 13,40 & 9,42 & 7,08 & 5,58 & 3,86 & 2,98 & 2,09 \\
\hline 35 & 400 & 195 & 31,03 & 18,11 & 13,32 & 9,45 & 7,12 & 5,62 & 3,87 & 2,98 & 2,08 \\
\hline 35 & 450 & 195 & 29,44 & 17,74 & 13,23 & 9,48 & 7,16 & 5,65 & 3,89 & 2,99 & 2,08 \\
\hline 35 & 500 & 195 & 28,12 & 17,41 & 13,14 & 9,50 & 7,19 & 5,67 & 3,90 & 2,99 & 2,08 \\
\hline 35 & 550 & 195 & 27,00 & 17,11 & 13,06 & 9,51 & 7,22 & 5,70 & 3,91 & 2,99 & 2,08 \\
\hline 35 & 600 & 195 & 26,04 & 16,84 & 12,97 & 9,51 & 7,25 & 5,72 & 3,93 & 3,00 & 2,07 \\
\hline 35 & 650 & 195 & 25,20 & 16,60 & 12,89 & 9,51 & 7,27 & 5,75 & 3,94 & 3,00 & 2,07 \\
\hline 35 & 700 & 195 & 24,45 & 16,37 & 12,81 & 9,51 & 7,29 & 5,77 & 3,95 & 3,01 & 2,07 \\
\hline 35 & 750 & 195 & 23,79 & 16,16 & 12,73 & 9,50 & 7,31 & $\begin{array}{c}5,79 \\
\end{array}$ & 3,96 & 3,01 & 2,07 \\
\hline 35 & 800 & 195 & 23,19 & 15,96 & 12,65 & 9,49 & 7,32 & 5,81 & 3,98 & 3,02 & 2,07 \\
\hline 35 & 850 & 195 & 22,64 & 15,77 & 12,57 & 9,48 & 7,33 & 5,82 & 3,99 & 3,02 & 2,07 \\
\hline 35 & 900 & 195 & 22,14 & 15,60 & 12,50 & 9,47 & 7,34 & 5,84 & 4,00 & 3,02 & 2,07 \\
\hline 35 & 950 & 195 & 21,69 & 15,43 & 12,43 & 9,46 & 7,35 & 5,85 & 4,01 & 3,03 & 2,07 \\
\hline 35 & 1000 & 195 & 21,26 & 15,27 & 12,36 & 9,45 & 7,36 & 5,87 & 4,02 & 3,03 & 2,07 \\
\hline 35 & 1050 & 195 & 20,87 & 15,12 & 12,29 & 9,43 & 7,37 & 5,88 & 4,03 & 3,04 & 2,07 \\
\hline 35 & 1100 & 195 & 20,50 & 14,98 & 12,22 & 9,42 & 7,37 & 5,89 & 4,04 & 3,04 & 2,07 \\
\hline 35 & 1150 & 195 & 20,16 & 14,84 & 12,15 & 9,40 & 7,38 & 5,90 & 4,05 & 3,05 & 2,07 \\
\hline 35 & 1200 & 195 & 19,84 & 14,71 & 12,09 & 9,38 & 7,38 & 5,92 & 4,06 & 3,05 & 2,07 \\
\hline 35 & 1250 & 195 & 1954 & 1459 & 1203 & 936 & 738 & 5.92 & 4.07 & 3,06 & 207 \\
\hline 35 & 1300 & 195 & 19,25 & 14,46 & 11,96 & 9,35 & 7,38 & 5,93 & 4,08 & 3,06 & 2,07 \\
\hline 35 & 1350 & 195 & 18,98 & 14,35 & 11,90 & 9,33 & 7,39 & 5,94 & 4,09 & 3,07 & 2,07 \\
\hline 35 & 1400 & 195 & 18,73 & 14,24 & 11,85 & 9,31 & 7,39 & 5,95 & 4,10 & 3,07 & 2,07 \\
\hline
\end{tabular}




\begin{tabular}{|c|c|c|c|c|c|c|c|c|c|c|c|}
\hline \multirow[b]{2}{*}{$\mathrm{H}(\mathrm{cm})$} & \multirow[b]{2}{*}{ Mceq (MPa) } & & & & & $\mathrm{De}$ & ões (x1 & m) & & & \\
\hline & & Msub (MPa) & D0 & D25 & D40 & D60 & D80 & D100 & D140 & D180 & D260 \\
\hline 35 & 1450 & 195 & 18,49 & 14,13 & 11,79 & 9,29 & 7,39 & 5,96 & 4,11 & 3,08 & 2,07 \\
\hline 35 & 1500 & 195 & 18,26 & 14,02 & 11,73 & 9,27 & 7,38 & 5,96 & 4,11 & 3,08 & 2,07 \\
\hline 35 & 1550 & 195 & 18,03 & 13,92 & 11,68 & 9,25 & 7,38 & 5,97 & 4,12 & 3,09 & 2,07 \\
\hline 35 & 1600 & 195 & 17,82 & 13,83 & 11,62 & 9,23 & 7,38 & 5,98 & 4,13 & 3,09 & 2,07 \\
\hline 35 & 1650 & 195 & 17,62 & 13,73 & 11,57 & 9,21 & 7,38 & 5,98 & 4,14 & 3,10 & 2,07 \\
\hline 35 & 1700 & 195 & 17,43 & 13,64 & 11,52 & 9,19 & 7,38 & 5,99 & 4,15 & 3,10 & 2,07 \\
\hline 35 & 1750 & 195 & 17,25 & 13,55 & 11,47 & 9,17 & 7,37 & 5,99 & 4,15 & 3,10 & 2,07 \\
\hline 35 & 1800 & 195 & 17,07 & 13,47 & 11,42 & 9,15 & 7,37 & 6,00 & 4,16 & 3,11 & 2,07 \\
\hline 35 & 1850 & 195 & 16,90 & 13,38 & 11,37 & 9,13 & 7,37 & 6,00 & 4,17 & 3,11 & 2,07 \\
\hline 35 & 1900 & 195 & 16,73 & 13,30 & 11,32 & 9,11 & 7,36 & 6,00 & 4,17 & 3,12 & 2,07 \\
\hline 35 & 1950 & 195 & 16,57 & 13,22 & 11,27 & 9,09 & 7,36 & 6,01 & 4,18 & 3,12 & 2,07 \\
\hline 35 & 2000 & 195 & 16,42 & 13,14 & 11,23 & 9,07 & 7,35 & 6,01 & 4,19 & 3,13 & 2,07 \\
\hline 35 & 200 & 200 & 43,40 & 20,10 & 13,30 & 8,94 & 6,70 & 5,33 & 3,71 & 2,89 & 2,06 \\
\hline 35 & 250 & 200 & 38,48 & 19,28 & 13,24 & 9,05 & 6,78 & 5,37 & 3,73 & 2,89 & 2,05 \\
\hline 35 & 300 & 200 & 35,08 & 18,66 & 13,16 & 9,12 & 6,84 & 5,40 & 3,74 & 2,90 & 2,04 \\
\hline 35 & 350 & 200 & 32,56 & 18,16 & 13,08 & 9,18 & 6,89 & 5,44 & 3,76 & 2,90 & 2,04 \\
\hline 35 & 400 & 200 & 30,60 & 17,73 & 13,00 & 9,21 & 6,94 & 5,47 & 3,77 & 2,91 & 2,03 \\
\hline 35 & 450 & 200 & 29,03 & 17,37 & 12,92 & 9,24 & 6,97 & 5,50 & 3,79 & 2,91 & 2,03 \\
\hline 35 & 500 & 200 & 27,72 & 17,05 & 12,83 & 9,26 & 7,01 & 5,53 & 3,80 & 2,91 & 2,03 \\
\hline 35 & 550 & 200 & 26,61 & 16,76 & 12,75 & 9,27 & 7,03 & 5,55 & 3,81 & 2,92 & 2,02 \\
\hline 35 & 600 & 200 & 25,66 & 16,50 & 12,67 & 9,27 & 7,06 & 5,57 & 3,83 & 2,92 & 2,02 \\
\hline 35 & 650 & 200 & 24,82 & 16,26 & 12,59 & 9,27 & 7,08 & 5,60 & 3,84 & 2,93 & 2,02 \\
\hline 35 & 700 & 200 & 24,09 & 16,03 & 12,51 & 9,27 & 7,10 & 5,62 & 3,85 & 2,93 & 2,02 \\
\hline 35 & 750 & 200 & 23,43 & 15,83 & 12,44 & 9,27 & 7,12 & 5,64 & 3,86 & 2,93 & 2,02 \\
\hline 35 & 800 & 200 & 22,83 & 15,63 & 12,36 & 9,26 & 7,13 & 5,65 & 3,87 & 2,94 & 2,02 \\
\hline 35 & 850 & 200 & 22,29 & 15,45 & 12,29 & 9,25 & 7,14 & 5,67 & 3,88 & 2,94 & 2,02 \\
\hline 35 & 900 & 200 & 21,80 & 15,28 & 12,22 & 9,24 & 7,16 & 5,69 & 3,89 & 2,95 & 2,02 \\
\hline 35 & 950 & 200 & 21,35 & 15,12 & 12,15 & 9,23 & 7,16 & 5,70 & 3,90 & 2,95 & 2,02 \\
\hline 35 & 1000 & 200 & 20,93 & 14,97 & 12,08 & 9,22 & 7,17 & 5,71 & 3,91 & 2,96 & 2,02 \\
\hline 35 & 1050 & 200 & 20,55 & 14,82 & 12,01 & 9,20 & 7,18 & 5,73 & 3,92 & 2,96 & 2,02 \\
\hline 35 & 1100 & 200 & 20,18 & 14,68 & 11,95 & 9,19 & 7,19 & 5,74 & 3,93 & 2,96 & 2,02 \\
\hline 35 & 1150 & 200 & 19,85 & 14,55 & 11,89 & 9,17 & 7,19 & 5,75 & 3,94 & 2,97 & 2,02 \\
\hline 35 & 1200 & 200 & 19,53 & 14,42 & 11,82 & 9,16 & 7,19 & 5,76 & 3,95 & 2,97 & 2,02 \\
\hline 35 & 1250 & 200 & 19,23 & 14,30 & 11,76 & 9,14 & 7,20 & 5,77 & 3,96 & 2,98 & 2,02 \\
\hline 35 & 1300 & 200 & 18,95 & 14,18 & 11,70 & 9,12 & 7,20 & 5,78 & 3,97 & 2,98 & 2,02 \\
\hline 35 & 1350 & 200 & 18,69 & 14,07 & 11,65 & 9,11 & 7,20 & 5,79 & 3,98 & 2,99 & 2,02 \\
\hline 35 & 1400 & 200 & 18,43 & 13,96 & 11,59 & 9,09 & 7,20 & 5,80 & 3,99 & 2,99 & 2,02 \\
\hline 35 & 1450 & 200 & 18,19 & 13,85 & 11,53 & 9,07 & 7,20 & 5,80 & 4,00 & 3,00 & 2,02 \\
\hline 35 & 1500 & 200 & 17,97 & 13,75 & 11,48 & 9,05 & 7,20 & 5,81 & 4,01 & 3,00 & 2,02 \\
\hline 35 & 1550 & 200 & 17,75 & 13,65 & 11,43 & 9,03 & 7,20 & 5,82 & 4,01 & 3,01 & 2,02 \\
\hline 35 & 1600 & 200 & 17,54 & 13,56 & 11,37 & 9,02 & 7,20 & 5,82 & 4,02 & 3,01 & 2,02 \\
\hline 35 & 1650 & 200 & 17,34 & 13,46 & 11,32 & 9,00 & 7,20 & 5,83 & 4,03 & 3,01 & 2,02 \\
\hline 35 & 1700 & 200 & 17,15 & 13,37 & 11,27 & 8,98 & 7,19 & 5,83 & 4,04 & 3,02 & 2,02 \\
\hline 35 & 1750 & 200 & 16,97 & 13,29 & 11,22 & 8,96 & 7,19 & 5,84 & 4,04 & 3,02 & 2,02 \\
\hline 35 & 1800 & 200 & 16,80 & 13,20 & 11,18 & 8,94 & 7,19 & 5,84 & 4,05 & 3,03 & 2,02 \\
\hline 35 & 1850 & 200 & 16,63 & 13,12 & 11,13 & 8,92 & 7,19 & 5,85 & 4,06 & 3,03 & 2,02 \\
\hline 35 & 1900 & 200 & 16,47 & 13,04 & 11,08 & 8,90 & 7,18 & 5,85 & 4,06 & 3,04 & 2,02 \\
\hline 35 & 1950 & 200 & 16,31 & 12,97 & 11,04 & 8,89 & 7,18 & 5,85 & 4,07 & 3,04 & 2,02 \\
\hline 35 & 2000 & 200 & 16,16 & 12,89 & 10,99 & 8,87 & 7,17 & 5,86 & 4,08 & 3,04 & 2,02 \\
\hline 40 & 200 & 20 & 147,40 & 118,08 & 102,22 & 84,55 & 70,01 & 58,26 & 41,49 & 31,16 & 20,47 \\
\hline 40 & 250 & 20 & 135,19 & 111,50 & 97,92 & 82,30 & 69,06 & 58,08 & 41,92 & 31,60 & 20,62 \\
\hline 40 & 300 & 20 & 126,15 & 106,26 & 94,33 & 80,27 & 68,08 & 57,77 & 42,21 & 31,97 & 20,78 \\
\hline 40 & 350 & 20 & 119,10 & 101,93 & 91,26 & 78,44 & 67,12 & 57,39 & 42,40 & 32,27 & 20,94 \\
\hline 40 & 400 & 20 & 113,42 & 98,25 & 88,59 & 76,77 & 66,20 & 56,98 & 42,51 & 32,52 & 21,10 \\
\hline 40 & 450 & 20 & 108,72 & 95,07 & 86,24 & 75,26 & 65,31 & 56,54 & 42,57 & 32,73 & 21,25 \\
\hline 40 & 500 & 20 & 104,75 & 92,27 & 84,14 & 73,87 & 64,47 & 56,10 & 42,58 & 32,90 & 21,40 \\
\hline 40 & 550 & 20 & 101,34 & 89,77 & 82,24 & 72,59 & 63,67 & 55,66 & 42,56 & 33,05 & 21,54 \\
\hline 40 & 600 & 20 & 98,38 & 87,53 & 80,52 & 71,40 & 62,91 & 55,22 & 42,52 & 33,16 & 21,67 \\
\hline 40 & 650 & 20 & 95,78 & 85,49 & 78,95 & 70,29 & 62,18 & 54,79 & 42,46 & 33,26 & 21,79 \\
\hline 40 & 700 & 20 & 93,47 & 83,63 & 77,50 & 69,26 & 61,49 & 54,37 & 42,38 & 33,33 & 21,91 \\
\hline 40 & 750 & 20 & 91,41 & 81,92 & 76,16 & 68,29 & 60,83 & 53,95 & 42,29 & 33,39 & 22,02 \\
\hline 40 & 800 & 20 & 89,55 & 80,33 & 74,91 & 67,38 & 60,21 & 53,55 & 42,19 & 33,44 & 22,12 \\
\hline 40 & 850 & 20 & 87,86 & 78,86 & 73,75 & 66,52 & 59,61 & 53,16 & 42,08 & 33,47 & 22,21 \\
\hline 40 & 900 & 20 & 86,31 & 77,49 & 72,66 & 65,71 & 59,03 & 52,78 & 41,96 & 33,50 & 22,30 \\
\hline 40 & 950 & 20 & 84,90 & 76,21 & 71,63 & 64,94 & 58,48 & 52,41 & 41,85 & 33,51 & 22,39 \\
\hline 40 & 1000 & 20 & 83,59 & 75,01 & 70,66 & 64,21 & 57,96 & 52,06 & 41,72 & 33,52 & 22,46 \\
\hline 40 & 1050 & 20 & 82,39 & 73,87 & 69,75 & 63,52 & 57,45 & 51,71 & 41,60 & 33,52 & 22,54 \\
\hline 40 & 1100 & 20 & 81,26 & 72,80 & 68,88 & 62,85 & 56,96 & 51,37 & 41,47 & 33,51 & 22,61 \\
\hline 40 & 1150 & 20 & 80,22 & 71,79 & 68,06 & 62,22 & 56,49 & 51,04 & 41,35 & 33,50 & 22,67 \\
\hline 40 & 1200 & 20 & 79,24 & 70,83 & 67,27 & 61,61 & 56,04 & 50,72 & 41,22 & 33,49 & 22,73 \\
\hline 40 & 1250 & 20 & 78,32 & 69,92 & 66,53 & 61,03 & 55,60 & 50,40 & 41,09 & 33,47 & 22,79 \\
\hline 40 & 1300 & 20 & 77,45 & 69,05 & 65,81 & 60,47 & 55,18 & 50,10 & 40,96 & 33,44 & 22,84 \\
\hline 40 & 1350 & 20 & 76,64 & 68,22 & 65,13 & 59,94 & 54,77 & 49,80 & 40,83 & 33,42 & 22,89 \\
\hline 40 & 1400 & 20 & 75,86 & 67,43 & 64,47 & 59,42 & 54,38 & 49,51 & 40,70 & 33,39 & 22,94 \\
\hline 40 & 1450 & 20 & 75,13 & 66,68 & 63,84 & 58,93 & 54,00 & 49,23 & 40,58 & 33,36 & 22,98 \\
\hline 40 & 1500 & 20 & 74,43 & 65,95 & 63,24 & 58,45 & 53,63 & 48,96 & 40,45 & 33,32 & 23,02 \\
\hline 40 & 1550 & 20 & 73,77 & 65,26 & 62,66 & 57,99 & 53,27 & 48,69 & 40,32 & 33,29 & 23,06 \\
\hline 40 & 1600 & 20 & 73,14 & 64,60 & 62,09 & 57,54 & 52,92 & 48,43 & 40,20 & 33,25 & 23,09 \\
\hline 40 & 1650 & 20 & 72,53 & 63,96 & 61,55 & 57,11 & 52,58 & 48,18 & 40,07 & 33,21 & 23,13 \\
\hline 40 & 1700 & 20 & 71,96 & 63,34 & 61,03 & 56,69 & 52,25 & 47,93 & 39,95 & 33,17 & 23,16 \\
\hline 40 & 1750 & 20 & 71,40 & 62,75 & 60,52 & 56,29 & 51,93 & 47,68 & 39,83 & 33,12 & 23,18 \\
\hline
\end{tabular}




\begin{tabular}{|c|c|c|c|c|c|c|c|c|c|c|c|}
\hline \multirow[b]{2}{*}{$\mathrm{H}(\mathrm{cm})$} & \multirow[b]{2}{*}{ Mceq (MPa) } & & & & & & ões (x1 & m) & & & \\
\hline & & Msub (MPa) & D0 & D25 & D40 & D60 & D80 & D100 & D140 & D180 & D260 \\
\hline 40 & 1800 & 20 & 70,87 & 62,18 & 60,03 & 55,89 & 51,62 & 47,44 & 39,71 & 33,08 & 23,21 \\
\hline 40 & 1850 & 20 & 70,35 & 61,63 & 59,56 & 55,51 & 51,32 & 47,21 & 39,59 & 33,04 & 23,24 \\
\hline 40 & 1900 & 20 & 69,86 & 61,10 & 59,10 & 55,14 & 51,02 & 46,98 & 39,47 & 32,99 & 23,26 \\
\hline 40 & 1950 & 20 & 69,39 & 60,59 & 58,65 & 54,78 & 50,73 & 46,76 & 39,35 & 32,94 & 23,28 \\
\hline 40 & 2000 & 20 & 68,93 & 60,09 & 58,22 & 54,43 & 50,45 & 46,54 & 39,23 & 32,90 & 23,30 \\
\hline 40 & 200 & 25 & 128,78 & 99,86 & 85,11 & 69,22 & 56,56 & 46,58 & 32,80 & 24,60 & 16,29 \\
\hline 40 & 250 & 25 & 117,92 & 94,46 & 81,78 & 67,64 & 56,01 & 46,60 & 33,19 & 24,93 & 16,37 \\
\hline 40 & 300 & 25 & 109,86 & 90,15 & 78,97 & 66,18 & 55,40 & 46,50 & 33,48 & 25,22 & 16,47 \\
\hline 40 & 350 & 25 & 103,58 & 86,59 & 76,56 & 64,84 & 54,78 & 46,32 & 33,69 & 25,46 & 16,57 \\
\hline 40 & 400 & 25 & 98,51 & 83,55 & 74,44 & 63,61 & 54,16 & 46,10 & 33,84 & 25,68 & 16,67 \\
\hline 40 & 450 & 25 & 94,30 & 80,92 & 72,56 & 62,47 & 53,55 & 45,85 & 33,94 & 25,86 & 16,78 \\
\hline 40 & 500 & 25 & 90,73 & 78,60 & 70,87 & 61,42 & 52,96 & 45,58 & 34,01 & 26,02 & 16,88 \\
\hline 40 & 550 & 25 & 87,67 & 76,54 & 69,35 & 60,44 & 52,39 & 45,30 & 34,05 & 26,15 & 16,98 \\
\hline 40 & 600 & 25 & 85,01 & 74,68 & 67,96 & 59,53 & 51,84 & 45,02 & 34,06 & 26,27 & 17,07 \\
\hline 40 & 650 & 25 & 82,66 & 72,99 & 66,69 & 58,68 & 51,32 & 44,74 & 34,06 & 26,37 & 17,16 \\
\hline 40 & 700 & 25 & 80,58 & 71,44 & 65,51 & 57,87 & 50,81 & 44,45 & 34,04 & 26,46 & 17,25 \\
\hline 40 & 750 & 25 & 78,71 & 70,02 & 64,42 & 57,12 & 50,33 & 44,17 & 34,01 & 26,53 & 17,33 \\
\hline 40 & 800 & 25 & 77,02 & 68,71 & 63,40 & 56,41 & 49,86 & 43,90 & 33,98 & 26,59 & 17,41 \\
\hline 40 & 850 & 25 & 75,49 & 67,48 & 62,45 & 55,73 & 49,41 & 43,63 & 33,93 & 26,64 & 17,49 \\
\hline 40 & 900 & 25 & 74,10 & 66,34 & 61,56 & 55,09 & 48,98 & 43,36 & 33,87 & 26,69 & 17,56 \\
\hline 40 & 950 & 25 & 72,82 & 65,27 & 60,72 & 54,48 & 48,57 & 43,10 & 33,81 & 26,72 & 17,63 \\
\hline 40 & 1000 & 25 & 71,64 & 64,27 & 59,93 & 53,91 & 48,17 & 42,84 & 33,75 & 26,75 & 17,69 \\
\hline 40 & 1050 & 25 & 70,54 & 63,32 & 59,18 & 53,35 & 47,78 & 42,59 & 33,68 & 26,77 & 17,76 \\
\hline 40 & 1100 & 25 & 69,53 & 62,43 & 58,47 & 52,83 & 47,41 & 42,35 & 33,61 & 26,79 & 17,81 \\
\hline 40 & 1150 & 25 & 68,59 & 61,58 & 57,79 & 52,32 & 47,05 & 42,11 & 33,53 & 26,80 & 17,87 \\
\hline 40 & 1200 & 25 & 67,70 & 60,77 & 57,15 & 51,83 & 46,70 & 41,87 & 33,46 & 26,81 & 17,92 \\
\hline 40 & 1250 & 25 & 66,87 & 60,01 & 56,53 & 51,37 & 46,36 & 41,64 & 33,38 & 26,82 & 17,97 \\
\hline 40 & 1300 & 25 & 66,10 & 59,28 & 55,94 & 50,92 & 46,04 & 41,42 & 33,30 & 26,82 & 18,02 \\
\hline 40 & 1350 & 25 & 65,36 & 58,58 & 55,38 & 50,49 & 45,72 & 41,20 & 33,22 & 26,81 & 18,06 \\
\hline 40 & 1400 & 25 & 64,67 & 57,91 & 54,84 & 50,08 & 45,42 & 40,99 & 33,14 & 26,81 & 18,11 \\
\hline 40 & 1450 & 25 & 64,01 & 57,28 & 54,32 & 49,68 & 45,12 & 40,78 & 33,06 & 26,80 & 18,15 \\
\hline 40 & 1500 & 25 & 63,39 & 56,66 & 53,82 & 49,29 & 44,83 & 40,57 & 32,98 & 26,79 & 18,18 \\
\hline 40 & 1550 & 25 & 62,80 & 56,08 & 53,34 & 48,92 & 44,55 & 40,37 & 32,89 & 26,78 & 18,22 \\
\hline 40 & 1600 & 25 & 62,23 & 55,51 & 52,88 & 48,56 & 44,28 & 40,18 & 32,81 & 26,76 & 18,26 \\
\hline 40 & 1650 & 25 & 61,70 & 54,97 & 52,43 & 48,21 & 44,01 & 39,98 & 32,73 & 26,75 & 18,29 \\
\hline 40 & 1700 & 25 & 61,18 & 54,45 & 52,00 & 47,87 & 43,75 & 39,80 & 32,65 & 26,73 & 18,32 \\
\hline 40 & 1750 & 25 & 60,69 & 53,95 & 51,58 & 47,54 & 43,50 & 39,61 & 32,56 & 26,71 & 18,35 \\
\hline 40 & 1800 & 25 & 60,22 & 53,46 & 51,17 & 47,22 & 43,26 & 39,43 & 32,48 & 26,69 & 18,38 \\
\hline 40 & 1850 & 25 & 59,77 & 52,99 & 50,78 & 46,91 & 43,02 & 39,25 & 32,40 & 26,67 & 18,40 \\
\hline 40 & 1900 & 25 & 59,33 & 52,54 & 50,40 & 46,61 & 42,78 & 39,08 & 32,32 & 26,65 & 18,43 \\
\hline 40 & 1950 & 25 & 58,91 & 52,10 & 50,03 & 46,32 & 42,56 & 38,91 & 32,24 & 26,62 & 18,45 \\
\hline 40 & 2000 & 25 & 58,51 & 51,68 & 49,67 & 46,03 & 42,33 & 38,74 & 32,16 & 26,60 & 18,47 \\
\hline 40 & 200 & 30 & 115,49 & 86,97 & 73,10 & 58,61 & 47,37 & 38,72 & 27,05 & 20,30 & 13,54 \\
\hline 40 & 250 & 30 & 105,59 & 82,39 & 70,43 & 57,46 & 47,06 & 38,83 & 27,39 & 20,55 & 13,58 \\
\hline 40 & 300 & 30 & 98,26 & 78,72 & 68,15 & 56,37 & 46,68 & 38,84 & 27,66 & 20,77 & 13,64 \\
\hline 40 & 350 & 30 & 92,55 & 75,68 & 66,18 & 55,35 & 46,26 & 38,77 & 27,86 & 20,98 & 13,71 \\
\hline 40 & 400 & 30 & 87,93 & 73,09 & 64,44 & 54,40 & 45,82 & 38,66 & 28,02 & 21,15 & 13,78 \\
\hline 40 & 450 & 30 & 84,10 & 70,84 & 62,89 & 53,51 & 45,39 & 38,51 & 28,14 & 21,31 & 13,85 \\
\hline 40 & 500 & 30 & 80,85 & 68,86 & 61,49 & 52,68 & 44,96 & 38,35 & 28,23 & 21,45 & 13,92 \\
\hline 40 & 550 & 30 & 78,05 & 67,09 & 60,22 & 51,91 & 44,54 & 38,17 & 28,29 & 21,57 & 14,00 \\
\hline 40 & 600 & 30 & 75,61 & 65,50 & 59,06 & 51,18 & 44,13 & 37,98 & 28,34 & 21,68 & 14,07 \\
\hline 40 & 650 & 30 & 73,46 & 64,06 & 58,00 & 50,50 & 43,74 & 37,79 & 28,37 & 21,78 & 14,13 \\
\hline 40 & 700 & 30 & 71,55 & 62,73 & 57,01 & 49,86 & 43,35 & 37,60 & 28,38 & 21,86 & 14,20 \\
\hline 40 & 750 & 30 & 69,83 & 61,51 & 56,09 & 49,25 & 42,98 & 37,40 & 28,39 & 21,94 & 14,27 \\
\hline 40 & 800 & 30 & 68,28 & 60,38 & 55,24 & 48,67 & 42,62 & 37,20 & 28,38 & 22,00 & 14,33 \\
\hline 40 & 850 & 30 & 66,88 & 59,33 & 54,43 & 48,12 & 42,27 & 37,01 & 28,37 & 22,06 & 14,39 \\
\hline 40 & 900 & 30 & 65,59 & 58,35 & 53,68 & 47,60 & 41,94 & 36,81 & 28,35 & 22,11 & 14,45 \\
\hline 40 & 950 & 30 & 64,41 & 57,43 & 52,97 & 47,10 & 41,61 & 36,62 & 28,32 & 22,15 & 14,50 \\
\hline 40 & 1000 & 30 & 63,32 & 56,57 & 52,30 & 46,63 & 41,30 & 36,43 & 28,29 & 22,19 & 14,55 \\
\hline 40 & 1050 & 30 & 62,32 & 55,75 & 51,67 & 46,17 & 40,99 & 36,24 & 28,25 & 22,22 & 14,60 \\
\hline 40 & 1100 & 30 & 61,38 & 54,98 & 51,06 & 45,74 & 40,70 & 36,06 & 28,21 & 22,25 & 14,65 \\
\hline 40 & 1150 & 30 & 60,51 & 54,25 & 50,49 & 45,32 & 40,41 & 35,88 & 28,17 & 22,27 & 14,70 \\
\hline 40 & 1200 & 30 & 59,70 & 53,56 & 49,94 & 44,92 & 40,14 & 35,70 & 28,12 & 22,29 & 14,74 \\
\hline 40 & 1250 & 30 & 58,93 & 52,90 & 49,42 & 44,54 & 39,87 & 35,53 & 28,08 & 22,31 & 14,79 \\
\hline 40 & 1300 & 30 & 58,22 & 52,27 & 48,92 & 44,17 & 39,61 & 35,36 & 28,03 & 22,32 & 14,83 \\
\hline 40 & 1350 & 30 & 57,54 & 51,66 & 48,44 & 43,81 & 39,36 & 35,19 & 27,98 & 22,33 & 14,87 \\
\hline 40 & 1400 & 30 & 56,90 & 51,09 & 47,98 & 43,46 & 39,11 & 35,02 & 27,92 & 22,34 & 14,91 \\
\hline 40 & 1450 & 30 & 56,30 & 50,53 & 47,53 & 43,13 & 38,87 & 34,86 & 27,87 & 22,34 & 14,94 \\
\hline 40 & 1500 & 30 & 55,73 & 50,00 & 47,11 & 42,81 & 38,64 & 34,70 & 27,82 & 22,35 & 14,98 \\
\hline 40 & 1550 & 30 & 55,19 & 49,50 & 46,70 & 42,50 & 38,41 & 34,55 & 27,76 & 22,35 & 15,01 \\
\hline 40 & 1600 & 30 & 54,67 & 49,01 & 46,30 & 42,19 & 38,19 & 34,39 & 27,71 & 22,35 & 15,04 \\
\hline 40 & 1650 & 30 & 54,18 & 48,54 & 45,92 & 41,90 & 37,97 & 34,24 & 27,65 & 22,34 & 15,07 \\
\hline 40 & 1700 & 30 & 53,71 & 48,08 & 45,55 & 41,62 & 37,76 & 34,10 & 27,59 & 22,34 & 15,10 \\
\hline 40 & 1750 & 30 & 53,26 & 47,64 & 45,20 & 41,34 & 37,56 & 33,95 & 27,54 & 22,33 & 15,13 \\
\hline 40 & 1800 & 30 & 52,82 & 47,22 & 44,85 & 41,08 & 37,36 & 33,81 & 27,48 & 22,33 & 15,15 \\
\hline 40 & 1850 & 30 & 52,41 & 46,81 & 44,52 & 40,82 & 37,16 & 33,67 & 27,42 & 22,32 & 15,18 \\
\hline 40 & 1900 & 30 & 52,02 & 46,42 & 44,19 & 40,56 & 36,97 & 33,53 & 27,37 & 22,31 & 15,20 \\
\hline 40 & 1950 & 30 & 51,64 & 46,03 & 43,88 & 40,32 & 36,79 & 33,40 & 27,31 & 22,30 & 15,23 \\
\hline 40 & 2000 & 30 & 51,27 & 45,66 & 43,57 & 40,08 & 36,60 & 33,27 & 27,25 & 22,28 & 15,25 \\
\hline 40 & 200 & 35 & 105,44 & 77,32 & 64,17 & 50,81 & 40,71 & 33,07 & 22,98 & 17,27 & 11,58 \\
\hline 40 & 250 & 35 & 96,26 & 73,32 & 61,96 & 49,95 & 40,54 & 33,23 & 23,28 & 17,46 & 11,61 \\
\hline
\end{tabular}




\begin{tabular}{|c|c|c|c|c|c|c|c|c|c|c|c|}
\hline \multirow[b]{2}{*}{$\mathrm{H}(\mathrm{cm})$} & \multirow[b]{2}{*}{ Mceq (MPa) } & & & & & & ões (x1 & m) & & & \\
\hline & & Msub (MPa) & D0 & D25 & D40 & D60 & D80 & D100 & D140 & D180 & D260 \\
\hline 40 & 300 & 35 & 89,50 & 70,13 & 60,07 & 49,11 & 40,29 & 33,29 & 23,52 & 17,64 & 11,65 \\
\hline 40 & 350 & 35 & 84,23 & 67,47 & 58,41 & 48,31 & 40,01 & 33,29 & 23,71 & 17,81 & 11,69 \\
\hline 40 & 400 & 35 & 79,97 & 65,21 & 56,95 & 47,56 & 39,70 & 33,24 & 23,86 & 17,96 & 11,74 \\
\hline 40 & 450 & 35 & 76,42 & 63,25 & 55,64 & 46,85 & 39,38 & 33,17 & 23,98 & 18,09 & 11,79 \\
\hline 40 & 500 & 35 & 73,42 & 61,52 & 54,45 & 46,19 & 39,06 & 33,07 & 24,08 & 18,21 & 11,85 \\
\hline 40 & 550 & 35 & 70,84 & 59,97 & 53,37 & 45,56 & 38,75 & 32,95 & 24,16 & 18,32 & 11,90 \\
\hline 40 & 600 & 35 & 68,58 & 58,57 & 52,38 & 44,96 & 38,43 & 32,83 & 24,21 & 18,42 & 11,95 \\
\hline 40 & 650 & 35 & 66,59 & 57,31 & 51,47 & 44,40 & 38,13 & 32,70 & 24,26 & 18,51 & 12,01 \\
\hline 40 & 700 & 35 & 64,81 & 56,15 & 50,62 & 43,87 & 37,83 & 32,56 & 24,29 & 18,58 & 12,06 \\
\hline 40 & 750 & 35 & 63,22 & 55,08 & 49,84 & 43,37 & 37,54 & 32,42 & 24,31 & 18,66 & 12,11 \\
\hline 40 & 800 & 35 & 61,78 & 54,08 & 49,10 & 42,89 & 37,25 & 32,27 & 24,33 & 18,72 & 12,16 \\
\hline 40 & 850 & 35 & 60,47 & 53,16 & 48,41 & 42,43 & 36,97 & 32,13 & 24,33 & 18,78 & 12,20 \\
\hline 40 & 900 & 35 & 59,27 & 52,30 & 47,76 & 42,00 & 36,71 & 31,98 & 24,33 & 18,83 & 12,25 \\
\hline 40 & 950 & 35 & 58,17 & 51,49 & 47,14 & 41,58 & 36,45 & 31,84 & 24,32 & 18,87 & 12,30 \\
\hline 40 & 1000 & 35 & 57,16 & 50,73 & 46,56 & 41,18 & 36,19 & 31,70 & 24,31 & 18,91 & 12,34 \\
\hline 40 & 1050 & 35 & 56,22 & 50,02 & 46,01 & 40,80 & 35,95 & 31,55 & 24,30 & 18,95 & 12,38 \\
\hline 40 & 1100 & 35 & 55,35 & 49,34 & 45,49 & 40,43 & 35,71 & 31,41 & 24,28 & 18,98 & 12,42 \\
\hline 40 & 1150 & 35 & 54,54 & 48,69 & 44,99 & 40,08 & 35,48 & 31,27 & 24,25 & 19,01 & 12,46 \\
\hline 40 & 1200 & 35 & 53,78 & 48,08 & 44,51 & 39,74 & 35,25 & 31,13 & 24,23 & 19,04 & 12,50 \\
\hline 40 & 1250 & 35 & 53,06 & 47,50 & 44,06 & 39,42 & 35,03 & 31,00 & 24,20 & 19,06 & 12,54 \\
\hline 40 & 1300 & 35 & 52,39 & 46,94 & 43,62 & 39,10 & 34,82 & 30,86 & 24,17 & 19,08 & 12,57 \\
\hline 40 & 1350 & 35 & 51,76 & 46,41 & 43,21 & 38,80 & 34,61 & 30,73 & 24,14 & 19,09 & 12,61 \\
\hline 40 & 1400 & 35 & 51,17 & 45,91 & 42,81 & 38,50 & 34,40 & 30,60 & 24,11 & 19,11 & 12,64 \\
\hline 40 & 1450 & 35 & 50,61 & 45,42 & 42,42 & 38,22 & 34,21 & 30,47 & 24,07 & 19,12 & 12,67 \\
\hline 40 & 1500 & 35 & 50,07 & 44,95 & 42,05 & 37,95 & 34,01 & 30,35 & 24,04 & 19,13 & 12,70 \\
\hline 40 & 1550 & 35 & 49,57 & 44,50 & 41,69 & 37,68 & 33,83 & 30,22 & 24,00 & 19,14 & 12,73 \\
\hline 40 & 1600 & 35 & 49,08 & 44,07 & 41,35 & 37,42 & 33,64 & 30,10 & 23,96 & 19,14 & 12,76 \\
\hline 40 & 1650 & 35 & 48,62 & 43,65 & 41,01 & 37,17 & 33,46 & 29,98 & 23,92 & 19,15 & 12,79 \\
\hline 40 & 1700 & 35 & 48,19 & 43,25 & 40,69 & 36,93 & 33,29 & 29,86 & 23,88 & 19,15 & 12,81 \\
\hline 40 & 1750 & 35 & 47,77 & 42,86 & 40,38 & 36,69 & 33,12 & 29,75 & 23,84 & 19,15 & 12,84 \\
\hline 40 & 1800 & 35 & 47,37 & 42,49 & 40,08 & 36,46 & 32,95 & 29,63 & 23,80 & 19,15 & 12,86 \\
\hline 40 & 1850 & 35 & 46,98 & 42,12 & 39,78 & 36,24 & 32,79 & 29,52 & 23,76 & 19,15 & 12,88 \\
\hline 40 & 1900 & 35 & 46,61 & 41,77 & 39,50 & 36,02 & 32,63 & 29,41 & 23,72 & 19,15 & 12,91 \\
\hline 40 & 1950 & 35 & 46,26 & 41,43 & 39,22 & 35,81 & 32,47 & 29,30 & 23,68 & 19,15 & 12,93 \\
\hline 40 & 2000 & 35 & 45,92 & 41,10 & 38,96 & 35,60 & 32,32 & 29,19 & 23,64 & 19,15 & 12,95 \\
\hline 40 & 200 & 40 & 97,53 & 69,78 & 57,25 & 44,83 & 35,65 & 28,82 & 19,96 & 15,02 & 10,13 \\
\hline 40 & 250 & 40 & 88,92 & 66,24 & 55,39 & 44,17 & 35,57 & 29,00 & 20,21 & 15,17 & 10,14 \\
\hline 40 & 300 & 40 & 82,59 & 63,40 & 53,78 & 43,52 & 35,42 & 29,09 & 20,42 & 15,32 & 10,17 \\
\hline 40 & 350 & 40 & 77,67 & 61,05 & 52,37 & 42,88 & 35,23 & 29,13 & 20,60 & 15,46 & 10,20 \\
\hline 40 & 400 & 40 & 73,70 & 59,04 & 51,11 & 42,27 & 35,01 & 29,13 & 20,74 & 15,58 & 10,23 \\
\hline 40 & 450 & 40 & 70,40 & 57,29 & 49,98 & 41,70 & 34,77 & 29,09 & 20,86 & 15,70 & 10,27 \\
\hline 40 & 500 & 40 & 67,60 & 55,75 & 48,96 & 41,15 & 34,53 & 29,04 & 20,96 & 15,80 & 10,31 \\
\hline 40 & 550 & 40 & 65,18 & 54,37 & 48,02 & 40,63 & 34,29 & 28,97 & 21,04 & 15,90 & 10,35 \\
\hline 40 & 600 & 40 & 63,07 & 53,13 & 47,16 & 40,13 & 34,04 & 28,89 & 21,10 & 15,98 & 10,39 \\
\hline 40 & 650 & 40 & 61,21 & 52,00 & 46,37 & 39,66 & 33,80 & 28,79 & 21,16 & 16,06 & 10,43 \\
\hline 40 & 700 & 40 & 59,55 & 50,97 & 45,63 & 39,22 & 33,56 & 28,70 & 21,20 & 16,14 & 10,47 \\
\hline 40 & 750 & 40 & 58,06 & 50,01 & 44,94 & 38,79 & 33,33 & 28,59 & 21,23 & 16,20 & 10,51 \\
\hline 40 & 800 & 40 & 56,71 & 49,13 & 44,30 & 38,39 & 33,10 & 28,49 & 21,25 & 16,26 & 10,55 \\
\hline 40 & 850 & 40 & 55,48 & 48,30 & 43,69 & 38,00 & 32,87 & 28,38 & 21,27 & 16,32 & 10,59 \\
\hline 40 & 900 & 40 & 54,36 & 47,53 & 43,12 & 37,63 & 32,66 & 28,27 & 21,28 & 16,37 & 10,63 \\
\hline 40 & 950 & 40 & 53,33 & 46,81 & 42,58 & 37,27 & 32,44 & 28,16 & 21,29 & 16,41 & 10,66 \\
\hline 40 & 1000 & 40 & 52,37 & 46,13 & 42,07 & 36,93 & 32,23 & 28,05 & 21,29 & 16,45 & 10,70 \\
\hline 40 & 1050 & 40 & 51,49 & 45,49 & 41,58 & 36,61 & 32,03 & 27,94 & 21,29 & 16,49 & 10,73 \\
\hline 40 & 1100 & 40 & 50,67 & 44,89 & 41,12 & 36,29 & 31,83 & 27,83 & 21,28 & 16,52 & 10,77 \\
\hline 40 & 1150 & 40 & 49,91 & 44,31 & 40,68 & 35,99 & 31,64 & 27,72 & 21,27 & 16,55 & 10,80 \\
\hline 40 & 1200 & 40 & 49,19 & 43,76 & 40,26 & 35,70 & 31,45 & 27,61 & 21,26 & 16,58 & 10,83 \\
\hline 40 & 1250 & 40 & 48,52 & 43,24 & 39,86 & 35,42 & 31,27 & 27,50 & 21,24 & 16,61 & 10,87 \\
\hline 40 & 1300 & 40 & 47,89 & 42,75 & 39,47 & 35,15 & 31,09 & 27,39 & 21,23 & 16,63 & 10,90 \\
\hline 40 & 1350 & 40 & 47,30 & 42,27 & 39,10 & 34,88 & 30,92 & 27,29 & 21,21 & 16,65 & 10,92 \\
\hline 40 & 1400 & 40 & 46,74 & 41,81 & 38,75 & 34,63 & 30,75 & 27,18 & 21,19 & 16,67 & 10,95 \\
\hline 40 & 1450 & 40 & 46,21 & 41,38 & 38,41 & 34,38 & 30,58 & 27,08 & 21,17 & 16,68 & 10,98 \\
\hline 40 & 1500 & 40 & 45,70 & 40,96 & 38,08 & 34,15 & 30,42 & 26,98 & 21,14 & 16,70 & 11,01 \\
\hline 40 & 1550 & 40 & 45,23 & 40,56 & 37,76 & 33,92 & 30,26 & 26,88 & 21,12 & 16,71 & 11,03 \\
\hline 40 & 1600 & 40 & 44,77 & 40,17 & 37,45 & 33,69 & 30,10 & 26,78 & 21,09 & 16,72 & 11,06 \\
\hline 40 & 1650 & 40 & 44,34 & 39,79 & 37,16 & 33,47 & 29,95 & 26,68 & 21,07 & 16,73 & 11,08 \\
\hline 40 & 1700 & 40 & 43,93 & 39,43 & 36,87 & 33,26 & 29,80 & 26,58 & 21,04 & 16,74 & 11,11 \\
\hline 40 & 1750 & 40 & 43,53 & 39,08 & 36,60 & 33,06 & 29,66 & 26,49 & 21,01 & 16,74 & 11,13 \\
\hline 40 & 1800 & 40 & 43,16 & 38,75 & 36,33 & 32,86 & 29,52 & 26,39 & 20,98 & 16,75 & 11,15 \\
\hline 40 & 1850 & 40 & 42,80 & 38,42 & 36,07 & 32,66 & 29,38 & 26,30 & 20,95 & 16,75 & 11,17 \\
\hline 40 & 1900 & 40 & 42,45 & 38,11 & 35,81 & 32,47 & 29,24 & 26,21 & 20,92 & 16,76 & 11,19 \\
\hline 40 & 1950 & 40 & 42,12 & 37,80 & 35,57 & 32,29 & 29,11 & 26,12 & 20,89 & 16,76 & 11,21 \\
\hline 40 & 2000 & 40 & 41,80 & 37,50 & 35,33 & 32,11 & 28,98 & 26,03 & 20,86 & 16,76 & 11,23 \\
\hline 40 & 200 & 45 & 91,13 & 63,72 & 51,72 & 40,10 & 31,68 & 25,51 & 17,62 & 13,29 & 9,00 \\
\hline 40 & 250 & 45 & 82,97 & 60,53 & 50,12 & 39,59 & 31,67 & 25,70 & 17,85 & 13,41 & 9,01 \\
\hline 40 & 300 & 45 & 76,99 & 57,98 & 48,73 & 39,07 & 31,58 & 25,81 & 18,03 & 13,53 & 9,02 \\
\hline 40 & 350 & 45 & 72,36 & 55,86 & 47,51 & 38,56 & 31,45 & 25,87 & 18,19 & 13,65 & 9,04 \\
\hline 40 & 400 & 45 & 68,61 & 54,05 & 46,42 & 38,06 & 31,29 & 25,90 & 18,33 & 13,75 & 9,07 \\
\hline 40 & 450 & 45 & 65,51 & 52,48 & 45,43 & 37,58 & 31,12 & 25,89 & 18,44 & 13,85 & 9,10 \\
\hline 40 & 500 & 45 & 62,88 & 51,09 & 44,54 & 37,12 & 30,93 & 25,87 & 18,53 & 13,94 & 9,13 \\
\hline 40 & 550 & 45 & 60,61 & 49,85 & 43,71 & 36,68 & 30,74 & 25,83 & 18,61 & 14,03 & 9,16 \\
\hline 40 & 600 & 45 & 58,62 & 48,73 & 42,96 & 36,26 & 30,55 & 25,77 & 18,68 & 14,10 & 9,19 \\
\hline
\end{tabular}




\begin{tabular}{|c|c|c|c|c|c|c|c|c|c|c|c|}
\hline \multirow[b]{2}{*}{$\mathrm{H}(\mathrm{cm})$} & \multirow[b]{2}{*}{ Mceq (MPa) } & & & & & $\mathrm{De}$ & ões (x1 & & & & \\
\hline & & Msub (MPa) & D0 & D25 & D40 & D60 & D80 & D100 & D140 & D180 & D260 \\
\hline 40 & 650 & 45 & 56,87 & 47,71 & 42,26 & 35,87 & 30,36 & 25,71 & 18,74 & 14,17 & 9,22 \\
\hline 40 & 700 & 45 & 55,31 & 46,77 & 41,60 & 35,49 & 30,16 & 25,64 & 18,78 & 14,24 & 9,25 \\
\hline 40 & 750 & 45 & 53,90 & 45,91 & 40,99 & 35,12 & 29,97 & 25,57 & 18,82 & 14,30 & 9,28 \\
\hline 40 & 800 & 45 & 52,63 & 45,11 & 40,42 & 34,77 & 29,79 & 25,49 & 18,85 & 14,36 & 9,31 \\
\hline 40 & 850 & 45 & 51,47 & 44,36 & 39,88 & 34,44 & 29,60 & 25,41 & 18,87 & 14,41 & 9,35 \\
\hline 40 & 900 & 45 & 50,41 & 43,67 & 39,37 & 34,12 & 29,42 & 25,32 & 18,89 & 14,45 & 9,38 \\
\hline 40 & 950 & 45 & 49,43 & 43,02 & 38,89 & 33,82 & 29,24 & 25,24 & 18,91 & 14,50 & 9,41 \\
\hline 40 & 1000 & 45 & 48,53 & 42,40 & 38,44 & 33,52 & 29,07 & 25,15 & 18,92 & 14,54 & 9,44 \\
\hline 40 & 1050 & 45 & 47,70 & 41,82 & 38,01 & 33,24 & 28,90 & 25,06 & 18,92 & 14,57 & 9,47 \\
\hline 40 & 1100 & 45 & 46,92 & 41,27 & 37,59 & 32,96 & 28,73 & 24,98 & 18,92 & 14,61 & 9,50 \\
\hline 40 & 1150 & 45 & 46,20 & 40,75 & 37,20 & 32,70 & 28,57 & 24,89 & 18,92 & 14,64 & 9,52 \\
\hline 40 & 1200 & 45 & 45,52 & 40,26 & 36,82 & 32,45 & 28,41 & 24,80 & 18,92 & 14,67 & 9,55 \\
\hline 40 & 1250 & 45 & 44,89 & 39,78 & 36,46 & 32,20 & 28,26 & 24,71 & 18,91 & 14,69 & 9,58 \\
\hline 40 & 1300 & 45 & 44,29 & 39,33 & 36,12 & 31,96 & 28,11 & 24,63 & 18,91 & 14,72 & 9,60 \\
\hline 40 & 1350 & 45 & 43,73 & 38,90 & 35,79 & 31,73 & 27,96 & 24,54 & 18,90 & 14,74 & 9,63 \\
\hline 40 & 1400 & 45 & 43,20 & 38,49 & 35,47 & 31,51 & 27,81 & 24,46 & 18,89 & 14,76 & 9,65 \\
\hline 40 & 1450 & 45 & 42,69 & 38,09 & 35,16 & 31,29 & 27,67 & 24,37 & 18,87 & 14,78 & 9,68 \\
\hline 40 & 1500 & 45 & 42,22 & 37,71 & 34,87 & 31,09 & 27,53 & 24,29 & 18,86 & 14,79 & 9,70 \\
\hline 40 & 1550 & 45 & 41,76 & 37,35 & 34,58 & 30,88 & 27,40 & 24,20 & 18,84 & 14,81 & 9,73 \\
\hline 40 & 1600 & 45 & 41,33 & 36,99 & 34,31 & 30,68 & 27,26 & 24,12 & 18,83 & 14,82 & 9,75 \\
\hline 40 & 1650 & 45 & 40,92 & 36,65 & 34,04 & 30,49 & 27,13 & 24,04 & 18,81 & 14,83 & 9,77 \\
\hline 40 & 1700 & 45 & 40,53 & 36,33 & 33,78 & 30,31 & 27,01 & 23,96 & 18,79 & 14,84 & 9,79 \\
\hline 40 & 1750 & 45 & 40,16 & 36,01 & 33,53 & 30,12 & 26,88 & 23,88 & 18,77 & 14,85 & 9,81 \\
\hline 40 & 1800 & 45 & 39,80 & 35,70 & 33,29 & 29,95 & 26,76 & 23,80 & 18,75 & 14,86 & 9,83 \\
\hline 40 & 1850 & 45 & 39,46 & 35,41 & 33,06 & 29,78 & 26,64 & 23,72 & 18,73 & 14,87 & 9,85 \\
\hline 40 & 1900 & 45 & 39,13 & 35,12 & 32,83 & 29,61 & 26,52 & 23,65 & 18,71 & 14,88 & 9,87 \\
\hline 40 & 1950 & 45 & 38,81 & 34,84 & 32,61 & 29,44 & 26,41 & 23,57 & 18,68 & 14,88 & 9,89 \\
\hline 40 & 2000 & 45 & 38,51 & 34,57 & 32,40 & 29,28 & 26,29 & 23,50 & 18,66 & 14,89 & 9,90 \\
\hline 40 & 200 & 50 & 85,82 & 58,73 & 47,19 & 36,26 & 28,49 & 22,87 & 15,77 & 11,91 & 8,10 \\
\hline 40 & 250 & 50 & 78,03 & 55,83 & 45,80 & 35,86 & 28,52 & 23,05 & 15,96 & 12,01 & 8,10 \\
\hline 40 & 300 & 50 & 72,34 & 53,50 & 44,59 & 35,45 & 28,48 & 23,18 & 16,13 & 12,11 & 8,11 \\
\hline 40 & 350 & 50 & 67,94 & 51,58 & 43,52 & 35,02 & 28,39 & 23,25 & 16,28 & 12,21 & 8,13 \\
\hline 40 & 400 & 50 & 64,39 & 49,93 & 42,55 & 34,61 & 28,28 & 23,29 & 16,40 & 12,30 & 8,14 \\
\hline 40 & 450 & 50 & 61,45 & 48,50 & 41,68 & 34,21 & 28,15 & 23,31 & 16,50 & 12,39 & 8,16 \\
\hline 40 & 500 & 50 & 58,96 & 47,23 & 40,89 & 33,82 & 28,01 & 23,30 & 16,59 & 12,46 & 8,19 \\
\hline 40 & 550 & 50 & 56,81 & 46,10 & 40,16 & 33,45 & 27,86 & 23,28 & 16,67 & 12,54 & 8,21 \\
\hline 40 & 600 & 50 & 54,93 & 45,08 & 39,49 & 33,09 & 27,70 & 23,25 & 16,74 & 12,61 & 8,23 \\
\hline 40 & 650 & 50 & 53,27 & 44,15 & 38,86 & 32,75 & 27,55 & 23,21 & 16,80 & 12,67 & 8,26 \\
\hline 40 & 700 & 50 & 51,79 & 43,29 & 38,28 & 32,42 & 27,39 & 23,16 & 16,84 & 12,73 & 8,29 \\
\hline 40 & 750 & 50 & 50,46 & 42,51 & 37,73 & 32,11 & 27,23 & 23,11 & 16,88 & 12,79 & 8,31 \\
\hline 40 & 800 & 50 & 49,25 & 41,78 & 37,22 & 31,80 & 27,08 & 23,05 & 16,92 & 12,84 & 8,34 \\
\hline 40 & 850 & 50 & 48,15 & 41,10 & 36,74 & 31,51 & 26,93 & 22,99 & 16,95 & 12,89 & 8,36 \\
\hline 40 & 900 & 50 & 47,15 & 40,46 & 36,28 & 31,24 & 26,77 & 22,93 & 16,97 & 12,93 & 8,39 \\
\hline 40 & 950 & 50 & 46,22 & 39,86 & 35,85 & 30,97 & 26,63 & 22,86 & 16,99 & 12,97 & 8,41 \\
\hline 40 & 1000 & 50 & 45,37 & 39,30 & 35,44 & 30,71 & 26,48 & 22,79 & 17,00 & 13,01 & 8,44 \\
\hline 40 & 1050 & 50 & 44,57 & 38,77 & 35,05 & 30,46 & 26,34 & 22,72 & 17,02 & 13,04 & 8,46 \\
\hline 40 & 1100 & 50 & 43,84 & 38,27 & 34,68 & 30,22 & 26,19 & 22,65 & 17,02 & 13,08 & 8,49 \\
\hline 40 & 1150 & 50 & 43,15 & 37,79 & 34,32 & 29,99 & 26,06 & 22,58 & 17,03 & 13,11 & 8,51 \\
\hline 40 & 1200 & 50 & 42,50 & 37,34 & 33,98 & 29,76 & 25,92 & 22,51 & 17,03 & 13,14 & 8,54 \\
\hline 40 & 1250 & 50 & 41,90 & 36,91 & 33,66 & 29,55 & 25,79 & 22,44 & 17,03 & 13,16 & 8,56 \\
\hline 40 & 1300 & 50 & 41,33 & 36,49 & 33,34 & 29,34 & 25,66 & 22,37 & 17,03 & 13,19 & 8,58 \\
\hline 40 & 1350 & 50 & 40,79 & 36,10 & 33,04 & 29,13 & 25,53 & 22,30 & 17,03 & 13,21 & 8,60 \\
\hline 40 & 1400 & 50 & 40,29 & 35,72 & 32,75 & 28,94 & 25,41 & 22,23 & 17,02 & 13,23 & 8,63 \\
\hline 40 & 1450 & 50 & 39,81 & 35,36 & 32,48 & 28,75 & 25,28 & 22,16 & 17,02 & 13,25 & 8,65 \\
\hline 40 & 1500 & 50 & 39,35 & 35,01 & 32,21 & 28,56 & 25,16 & 22,09 & 17,01 & 13,27 & 8,67 \\
\hline 40 & 1550 & 50 & 38,92 & 34,68 & 31,95 & 28,38 & 25,05 & 22,02 & 17,00 & 13,28 & 8,69 \\
\hline 40 & 1600 & 50 & 38,51 & 34,35 & 31,70 & 28,20 & 24,93 & 21,95 & 16,99 & 13,30 & 8,71 \\
\hline 40 & 1650 & 50 & 38,12 & 34,04 & 31,46 & 28,03 & 24,82 & 21,88 & 16,98 & 13,31 & 8,73 \\
\hline 40 & 1700 & 50 & 37,75 & 33,74 & 31,23 & 27,87 & 24,71 & 21,81 & 16,96 & 13,32 & 8,74 \\
\hline 40 & 1750 & 50 & 37,39 & 33,45 & 31,00 & 27,70 & 24,60 & 21,75 & 16,95 & 13,33 & 8,76 \\
\hline 40 & 1800 & 50 & 37,05 & 33,17 & 30,78 & 27,55 & 24,49 & 21,68 & 16,94 & 13,34 & 8,78 \\
\hline 40 & 1850 & 50 & 36,72 & 32,90 & 30,57 & 27,39 & 24,39 & 21,61 & 16,92 & 13,35 & 8,80 \\
\hline 40 & 1900 & 50 & 36,41 & 32,64 & 30,36 & 27,24 & 24,28 & 21,55 & 16,91 & 13,36 & 8,81 \\
\hline 40 & 1950 & 50 & 36,11 & 32,38 & 30,16 & 27,10 & 24,18 & 21,48 & 16,89 & 13,37 & 8,83 \\
\hline 40 & 2000 & 50 & 35,82 & 32,13 & 29,96 & 26,95 & 24,08 & 21,42 & 16,87 & 13,38 & 8,85 \\
\hline 40 & 200 & 55 & 81,34 & 54,54 & 43,40 & 33,08 & 25,86 & 20,71 & 14,26 & 10,79 & 7,37 \\
\hline 40 & 250 & 55 & 73,85 & 51,87 & 42,19 & 32,77 & 25,92 & 20,89 & 14,44 & 10,88 & 7,36 \\
\hline 40 & 300 & 55 & 68,40 & 49,74 & 41,12 & 32,43 & 25,91 & 21,01 & 14,59 & 10,96 & 7,37 \\
\hline 40 & 350 & 55 & 64,20 & 47,97 & 40,17 & 32,08 & 25,86 & 21,10 & 14,72 & 11,05 & 7,38 \\
\hline 40 & 400 & 55 & 60,82 & 46,46 & 39,31 & 31,74 & 25,79 & 21,15 & 14,83 & 11,12 & 7,39 \\
\hline 40 & 450 & 55 & 58,02 & 45,14 & 38,54 & 31,40 & 25,69 & 21,18 & 14,93 & 11,20 & 7,41 \\
\hline 40 & 500 & 55 & 55,64 & 43,98 & 37,83 & 31,06 & 25,58 & 21,19 & 15,01 & 11,27 & 7,42 \\
\hline 40 & 550 & 55 & 53,60 & 42,94 & 37,17 & 30,75 & 25,46 & 21,18 & 15,09 & 11,33 & 7,44 \\
\hline 40 & 600 & 55 & 51,81 & 42,00 & 36,57 & 30,44 & 25,34 & 21,17 & 15,15 & 11,39 & 7,46 \\
\hline 40 & 650 & 55 & 50,23 & 41,14 & 36,00 & 30,14 & 25,21 & 21,14 & 15,21 & 11,45 & 7,48 \\
\hline 40 & 700 & 55 & 48,82 & 40,36 & 35,48 & 29,86 & 25,08 & 21,11 & 15,25 & 11,50 & 7,50 \\
\hline 40 & 750 & 55 & 47,56 & 39,63 & 34,99 & 29,58 & 24,95 & 21,07 & 15,30 & 11,56 & 7,52 \\
\hline 40 & 800 & 55 & 46,41 & 38,96 & 34,52 & 29,32 & 24,82 & 21,03 & 15,33 & 11,60 & 7,55 \\
\hline 40 & 850 & 55 & 45,36 & 38,33 & 34,09 & 29,06 & 24,69 & 20,98 & 15,36 & 11,65 & 7,57 \\
\hline 40 & 900 & 55 & 44,40 & 37,75 & 33,67 & 28,82 & 24,57 & 20,94 & 15,39 & 11,69 & 7,59 \\
\hline 40 & 950 & 55 & 43,52 & 37,20 & 33,28 & 28,58 & 24,44 & 20,88 & 15,41 & 11,73 & 7,61 \\
\hline
\end{tabular}




\begin{tabular}{|c|c|c|c|c|c|c|c|c|c|c|c|}
\hline \multirow[b]{2}{*}{$\mathrm{H}(\mathrm{cm})$} & \multirow[b]{2}{*}{ Mceq (MPa) } & & & & & $\mathrm{De}$ & ões (x1 & & & & \\
\hline & & Msub (MPa) & D0 & D25 & D40 & D60 & D80 & D100 & D140 & D180 & D260 \\
\hline 40 & 1000 & 55 & 42,70 & 36,68 & 32,91 & 28,35 & 24,32 & 20,83 & 15,43 & 11,76 & 7,63 \\
\hline 40 & 1050 & 55 & 41,95 & 36,19 & 32,55 & 28,13 & 24,19 & 20,78 & 15,45 & 11,80 & 7,65 \\
\hline 40 & 1100 & 55 & 41,24 & 35,73 & 32,22 & 27,92 & 24,07 & 20,72 & 15,46 & 11,83 & 7,67 \\
\hline 40 & 1150 & 55 & 40,59 & 35,29 & 31,89 & 27,71 & 23,95 & 20,66 & 15,47 & 11,86 & 7,69 \\
\hline 40 & 1200 & 55 & 39,97 & 34,87 & 31,58 & 27,51 & 23,84 & 20,60 & 15,47 & 11,88 & 7,71 \\
\hline 40 & 1250 & 55 & 39,39 & 34,47 & 31,29 & 27,32 & 23,72 & 20,55 & 15,48 & 11,91 & 7,73 \\
\hline 40 & 1300 & 55 & 38,85 & 34,09 & 31,00 & 27,13 & 23,61 & 20,49 & 15,48 & 11,93 & 7,75 \\
\hline 40 & 1350 & 55 & 38,34 & 33,73 & 30,73 & 26,95 & 23,50 & 20,43 & 15,48 & 11,95 & 7,77 \\
\hline 40 & 1400 & 55 & 37,85 & 33,38 & 30,47 & 26,77 & 23,39 & 20,37 & 15,48 & 11,98 & 7,79 \\
\hline 40 & 1450 & 55 & 37,39 & 33,04 & 30,21 & 26,60 & 23,28 & 20,31 & 15,48 & 11,99 & 7,81 \\
\hline 40 & 1500 & 55 & 36,96 & 32,72 & 29,97 & 26,44 & 23,18 & 20,25 & 15,48 & 12,01 & 7,83 \\
\hline 40 & 1550 & 55 & 36,54 & 32,41 & 29,73 & 26,27 & 23,08 & 20,19 & 15,47 & 12,03 & 7,84 \\
\hline 40 & 1600 & 55 & 36,15 & 32,12 & 29,50 & 26,12 & 22,97 & 20,14 & 15,47 & 12,04 & 7,86 \\
\hline 40 & 1650 & 55 & 35,78 & 31,83 & 29,28 & 25,96 & 22,88 & 20,08 & 15,46 & 12,06 & 7,88 \\
\hline 40 & 1700 & 55 & 35,42 & 31,55 & 29,07 & 25,81 & 22,78 & 20,02 & 15,45 & 12,07 & 7,90 \\
\hline 40 & 1750 & 55 & 35,08 & 31,28 & 28,86 & 25,67 & 22,68 & 19,97 & 15,45 & 12,08 & 7,91 \\
\hline 40 & 1800 & 55 & 34,75 & 31,02 & 28,66 & 25,53 & 22,59 & 19,91 & 15,44 & 12,10 & 7,93 \\
\hline 40 & 1850 & 55 & 34,44 & 30,77 & 28,46 & 25,39 & 22,50 & 19,85 & 15,43 & 12,11 & 7,94 \\
\hline 40 & 1900 & 55 & 34,14 & 30,53 & 28,27 & 25,25 & 22,41 & 19,80 & 15,42 & 12,12 & 7,96 \\
\hline 40 & 1950 & 55 & 33,85 & 30,29 & 28,09 & 25,12 & 22,32 & 19,74 & 15,40 & 12,13 & 7,97 \\
\hline 40 & 2000 & 55 & 33,57 & 30,06 & 27,91 & 24,99 & 22,23 & 19,69 & 15,39 & 12,13 & 7,99 \\
\hline 40 & 200 & 60 & 77,51 & 50,97 & 40,20 & 30,40 & 23,67 & 18,91 & 13,02 & 9,87 & 6,75 \\
\hline 40 & 250 & 60 & 70,27 & 48,49 & 39,12 & 30,16 & 23,75 & 19,09 & 13,17 & 9,94 & 6,75 \\
\hline 40 & 300 & 60 & 65,02 & 46,52 & 38,17 & 29,89 & 23,76 & 19,21 & 13,30 & 10,01 & 6,75 \\
\hline 40 & 350 & 60 & 60,98 & 44,88 & 37,32 & 29,60 & 23,74 & 19,30 & 13,42 & 10,08 & 6,76 \\
\hline 40 & 400 & 60 & 57,74 & 43,49 & 36,55 & 29,30 & 23,69 & 19,36 & 13,53 & 10,15 & 6,77 \\
\hline 40 & 450 & 60 & 55,06 & 42,27 & 35,85 & 29,01 & 23,62 & 19,40 & 13,62 & 10,21 & 6,78 \\
\hline 40 & 500 & 60 & 52,79 & 41,19 & 35,21 & 28,73 & 23,53 & 19,42 & 13,70 & 10,27 & 6,79 \\
\hline 40 & 550 & 60 & 50,84 & 40,23 & 34,62 & 28,45 & 23,44 & 19,42 & 13,77 & 10,33 & 6,81 \\
\hline 40 & 600 & 60 & 49,13 & 39,36 & 34,07 & 28,18 & 23,34 & 19,42 & 13,83 & 10,39 & 6,82 \\
\hline 40 & 650 & 60 & 47,62 & 38,57 & 33,56 & 27,92 & 23,23 & 19,41 & 13,88 & 10,44 & 6,84 \\
\hline 40 & 700 & 60 & 46,28 & 37,84 & 33,09 & 27,67 & 23,13 & 19,39 & 13,93 & 10,49 & 6,86 \\
\hline 40 & 750 & 60 & 45,06 & 37,17 & 32,64 & 27,43 & 23,02 & 19,36 & 13,97 & 10,53 & 6,87 \\
\hline 40 & 800 & 60 & 43,97 & 36,54 & 32,22 & 27,20 & 22,91 & 19,33 & 14,01 & 10,58 & 6,89 \\
\hline 40 & 850 & 60 & 42,97 & 35,96 & 31,82 & 26,97 & 22,80 & 19,29 & 14,04 & 10,62 & 6,91 \\
\hline 40 & 900 & 60 & 42,05 & 35,42 & 31,44 & 26,76 & 22,69 & 19,26 & 14,07 & 10,66 & 6,93 \\
\hline 40 & 950 & 60 & 41,20 & 34,91 & 31,09 & 26,55 & 22,59 & 19,22 & 14,09 & 10,69 & 6,94 \\
\hline 40 & 1000 & 60 & 40,42 & 34,43 & 30,74 & 26,34 & 22,48 & 19,18 & 14,11 & 10,73 & 6,96 \\
\hline 40 & 1050 & 60 & 39,70 & 33,98 & 30,42 & 26,15 & 22,37 & 19,13 & 14,13 & 10,76 & 6,98 \\
\hline 40 & 1100 & 60 & 39,03 & 33,55 & 30,11 & 25,95 & 22,27 & 19,09 & 14,15 & 10,79 & 7,00 \\
\hline 40 & 1150 & 60 & 38,40 & 33,14 & 29,81 & 25,77 & 22,17 & 19,04 & 14,16 & 10,81 & 7,02 \\
\hline 40 & 1200 & 60 & 37,81 & 32,75 & 29,53 & 25,59 & 22,07 & 18,99 & 14,17 & 10,84 & 7,03 \\
\hline 40 & 1250 & 60 & 37,25 & 32,38 & 29,26 & 25,42 & 21,97 & 18,94 & 14,18 & 10,87 & 7,05 \\
\hline 40 & 1300 & 60 & 36,73 & 32,03 & 29,00 & 25,25 & 21,87 & 18,90 & 14,18 & 10,89 & 7,07 \\
\hline 40 & 1350 & 60 & 36,24 & 31,69 & 28,75 & 25,09 & 21,77 & 18,85 & 14,19 & 10,91 & 7,08 \\
\hline 40 & 1400 & 60 & 35,77 & 31,37 & 28,50 & 24,93 & 21,68 & 18,80 & 14,19 & 10,93 & 7,10 \\
\hline 40 & 1450 & 60 & 35,33 & 31,05 & 28,27 & 24,77 & 21,58 & 18,75 & 14,19 & 10,95 & 7,12 \\
\hline 40 & 1500 & 60 & 34,92 & 30,76 & 28,05 & 24,62 & 21,49 & 18,70 & 14,19 & 10,97 & 7,13 \\
\hline 40 & 1550 & 60 & 34,52 & 30,47 & 27,83 & 24,48 & 21,40 & 18,65 & 14,19 & 10,98 & 7,15 \\
\hline 40 & 1600 & 60 & 34,14 & 30,19 & 27,62 & 24,33 & 21,31 & 18,60 & 14,19 & 11,00 & 7,16 \\
\hline 40 & 1650 & 60 & 33,78 & 29,92 & 27,41 & 24,20 & 21,22 & 18,55 & 14,19 & 11,02 & 7,18 \\
\hline 40 & 1700 & 60 & 33,44 & 29,67 & 27,22 & 24,06 & 21,14 & 18,50 & 14,18 & 11,03 & 7,19 \\
\hline 40 & 1750 & 60 & 33,11 & 29,42 & 27,03 & 23,93 & 21,05 & 18,45 & 14,18 & 11,04 & 7,21 \\
\hline 40 & 1800 & 60 & 32,79 & 29,18 & 26,84 & 23,80 & 20,97 & 18,41 & 14,17 & 11,05 & 7,22 \\
\hline 40 & 1850 & 60 & 32,49 & 28,94 & 26,66 & 23,67 & 20,89 & 18,36 & 14,17 & 11,07 & 7,24 \\
\hline 40 & 1900 & 60 & 32,21 & 28,72 & 26,49 & 23,55 & 20,81 & 18,31 & 14,16 & 11,08 & 7,25 \\
\hline 40 & 1950 & 60 & 31,93 & 28,50 & 26,32 & 23,43 & 20,73 & 18,26 & 14,15 & 11,09 & 7,26 \\
\hline 40 & 2000 & 60 & 31,66 & 28,28 & 26,15 & 23,31 & 20,65 & 18,22 & 14,14 & 11,09 & 7,28 \\
\hline 40 & 200 & 65 & 74,18 & 47,89 & 37,44 & 28,12 & 21,81 & 17,39 & 11,97 & 9,09 & 6,24 \\
\hline 40 & 250 & 65 & 67,16 & 45,58 & 36,48 & 27,93 & 21,90 & 17,56 & 12,10 & 9,15 & 6,23 \\
\hline 40 & 300 & 65 & 62,08 & 43,74 & 35,62 & 27,71 & 21,94 & 17,68 & 12,23 & 9,21 & 6,23 \\
\hline 40 & 350 & 65 & 58,19 & 42,21 & 34,86 & 27,47 & 21,93 & 17,77 & 12,33 & 9,27 & 6,24 \\
\hline 40 & 400 & 65 & 55,07 & 40,91 & 34,17 & 27,22 & 21,90 & 17,84 & 12,43 & 9,33 & 6,24 \\
\hline 40 & 450 & 65 & 52,49 & \begin{tabular}{|c|}
39,78 \\
\end{tabular} & 33,53 & 26,97 & 21,85 & 17,88 & 12,51 & 9,39 & 6,25 \\
\hline 40 & 500 & 65 & 50,31 & 38,78 & 32,95 & 26,72 & 21,78 & 17,91 & 12,59 & 9,44 & 6,26 \\
\hline 40 & 550 & 65 & 48,44 & 37,88 & 32,42 & 26,48 & 21,71 & 17,92 & 12,65 & 9,49 & 6,27 \\
\hline 40 & 600 & 65 & 46,80 & 37,07 & 31,92 & 26,24 & 21,63 & 17,93 & 12,71 & 9,54 & 6,28 \\
\hline 40 & 650 & 65 & 45,35 & 36,33 & 31,45 & 26,02 & 21,54 & 17,92 & 12,77 & 9,59 & 6,30 \\
\hline 40 & 700 & 65 & 44,06 & 35,65 & 31,02 & 25,79 & 21,45 & 17,91 & 12,81 & 9,63 & 6,31 \\
\hline 40 & 750 & 65 & 42,90 & 35,03 & 30,61 & 25,58 & 21,36 & 17,90 & 12,85 & 9,67 & 6,33 \\
\hline 40 & 800 & 65 & 41,85 & 34,45 & 30,22 & 25,37 & 21,27 & 17,88 & 12,89 & 9,71 & 6,34 \\
\hline 40 & 850 & 65 & 40,89 & 33,91 & 29,86 & 25,17 & 21,18 & 17,85 & 12,92 & 9,75 & 6,36 \\
\hline 40 & 900 & 65 & 40,01 & 33,40 & 29,51 & 24,98 & 21,09 & 17,82 & 12,95 & 9,79 & 6,37 \\
\hline 40 & 950 & 65 & 39,20 & 32,92 & 29,18 & 24,79 & 20,99 & 17,79 & 12,98 & 9,82 & 6,39 \\
\hline 40 & 1000 & 65 & 38,45 & 32,48 & 28,87 & 24,61 & 20,90 & 17,76 & 13,00 & 9,85 & 6,40 \\
\hline 40 & 1050 & 65 & 37,75 & 32,05 & 28,57 & 24,43 & 20,81 & 17,72 & 13,02 & 9,88 & 6,42 \\
\hline 40 & 1100 & 65 & 37,10 & 31,65 & 28,29 & 24,26 & 20,72 & 17,69 & 13,03 & 9,91 & 6,43 \\
\hline 40 & 1150 & 65 & 36,50 & 31,27 & 28,01 & 24,09 & 20,63 & 17,65 & 13,05 & 9,94 & 6,45 \\
\hline 40 & 1200 & 65 & 35,93 & 30,91 & 27,75 & 23,93 & 20,54 & 17,61 & 13,06 & 9,96 & 6,46 \\
\hline 40 & 1250 & 65 & 35,40 & 30,56 & 27,50 & 23,78 & 20,45 & 17,57 & 13,07 & 9,98 & 6,48 \\
\hline 40 & 1300 & 65 & 34,90 & 30,23 & 27,26 & 23,62 & 20,37 & 17,53 & 13,08 & 10,01 & 6,49 \\
\hline
\end{tabular}




\begin{tabular}{|c|c|c|c|c|c|c|c|c|c|c|c|}
\hline \multirow[b]{2}{*}{$\mathrm{H}(\mathrm{cm})$} & \multirow[b]{2}{*}{ Mceq (MPa) } & & & & & $\mathrm{De}$ & ões (x1 & & & & \\
\hline & & Msub (MPa) & D0 & D25 & D40 & D60 & D80 & D100 & D140 & D180 & D260 \\
\hline 40 & 1350 & 65 & 34,42 & 29,92 & 27,03 & 23,48 & 20,28 & 17,49 & 13,09 & 10,03 & 6,51 \\
\hline 40 & 1400 & 65 & 33,98 & 29,61 & 26,80 & 23,33 & 20,20 & 17,45 & 13,09 & 10,05 & 6,52 \\
\hline 40 & 1450 & 65 & 33,55 & 29,32 & 26,59 & 23,19 & 20,12 & 17,41 & 13,10 & 10,07 & 6,54 \\
\hline 40 & 1500 & 65 & 33,15 & 29,04 & 26,38 & 23,05 & 20,04 & 17,37 & 13,10 & 10,08 & 6,55 \\
\hline 40 & 1550 & 65 & 32,77 & 28,78 & 26,18 & 22,92 & 19,95 & 17,32 & 13,10 & 10,10 & 6,56 \\
\hline 40 & 1600 & 65 & 32,41 & 28,52 & 25,98 & 22,79 & 19,88 & 17,28 & 13,10 & 10,12 & 6,58 \\
\hline 40 & 1650 & 65 & 32,06 & 28,27 & 25,79 & 22,67 & 19,80 & 17,24 & 13,10 & 10,13 & 6,59 \\
\hline 40 & 1700 & 65 & 31,73 & 28,03 & 25,61 & 22,54 & 19,72 & 17,20 & 13,10 & 10,15 & 6,60 \\
\hline 40 & 1750 & 65 & 31,41 & 27,79 & 25,44 & 22,42 & 19,65 & 17,16 & 13,10 & 10,16 & 6,62 \\
\hline 40 & 1800 & 65 & 31,11 & 27,57 & 25,26 & 22,31 & 19,57 & 17,11 & 13,10 & 10,17 & 6,63 \\
\hline 40 & 1850 & 65 & 30,82 & 27,35 & 25,10 & 22,19 & 19,50 & 17,07 & 13,09 & 10,18 & 6,64 \\
\hline 40 & 1900 & 65 & 30,54 & 27,14 & 24,93 & 22,08 & 19,43 & 17,03 & 13,09 & 10,19 & 6,65 \\
\hline 40 & 1950 & 65 & 30,27 & 26,93 & 24,78 & 21,97 & 19,36 & 16,99 & 13,08 & 10,20 & 6,67 \\
\hline 40 & 2000 & 65 & 30,02 & 26,73 & 24,62 & 21,86 & 19,29 & 16,95 & 13,08 & 10,21 & 6,68 \\
\hline 40 & 200 & 70 & 71,26 & 45,20 & 35,05 & 26,15 & 20,21 & 16,10 & 11,07 & 8,42 & 5,79 \\
\hline 40 & 250 & 70 & 64,42 & 43,03 & 34,18 & 26,01 & 20,31 & 16,26 & 11,20 & 8,48 & 5,79 \\
\hline 40 & 300 & 70 & 59,50 & 41,30 & 33,41 & 25,82 & 20,36 & 16,38 & 11,31 & 8,53 & 5,79 \\
\hline 40 & 350 & 70 & 55,73 & 39,88 & 32,71 & 25,62 & 20,37 & 16,47 & 11,40 & 8,58 & 5,79 \\
\hline 40 & 400 & 70 & 52,72 & 38,66 & 32,08 & 25,40 & 20,35 & 16,53 & 11,49 & 8,63 & 5,79 \\
\hline 40 & 450 & 70 & 50,23 & 37,60 & 31,51 & 25,19 & 20,32 & 16,58 & 11,57 & 8,68 & 5,80 \\
\hline 40 & 500 & 70 & 48,13 & 36,66 & 30,98 & 24,97 & 20,27 & 16,61 & 11,64 & 8,73 & 5,81 \\
\hline 40 & 550 & 70 & 46,33 & 35,82 & 30,49 & 24,76 & 20,21 & 16,63 & 11,70 & 8,78 & 5,82 \\
\hline 40 & 600 & 70 & 44,75 & 35,06 & 30,03 & 24,56 & 20,15 & 16,65 & 11,76 & 8,82 & 5,83 \\
\hline 40 & 650 & 70 & 43,36 & 34,37 & 29,61 & 24,35 & 20,08 & 16,65 & 11,81 & 8,86 & 5,84 \\
\hline 40 & 700 & 70 & 42,11 & 33,74 & 29,21 & 24,16 & 20,00 & 16,64 & 11,85 & 8,90 & 5,85 \\
\hline 40 & 750 & 70 & 41,00 & 33,15 & 28,83 & 23,97 & 19,93 & 16,64 & 11,89 & 8,94 & 5,86 \\
\hline 40 & 800 & 70 & 39,98 & 32,61 & 28,48 & 23,78 & 19,85 & 16,62 & 11,93 & 8,98 & 5,87 \\
\hline 40 & 850 & 70 & 39,06 & 32,10 & 28,14 & 23,60 & 19,77 & 16,60 & 11,96 & 9,01 & 5,88 \\
\hline 40 & 900 & 70 & 38,21 & 31,62 & 27,82 & 23,43 & 19,69 & 16,58 & 11,99 & 9,05 & 5,90 \\
\hline 40 & 950 & 70 & 37,43 & 31,18 & 27,52 & 23,26 & 19,61 & 16,56 & 12,02 & 9,08 & 5,91 \\
\hline 40 & 1000 & 70 & 36,71 & 30,76 & 27,23 & 23,09 & 19,53 & 16,53 & 12,04 & 9,11 & 5,92 \\
\hline 40 & 1050 & 70 & 36,04 & 30,36 & 26,95 & 22,93 & 19,45 & 16,51 & 12,06 & 9,13 & 5,94 \\
\hline 40 & 1100 & 70 & 35,42 & 29,98 & 26,69 & 22,78 & 19,37 & 16,48 & 12,08 & 9,16 & 5,95 \\
\hline 40 & 1150 & 70 & 34,84 & 29,63 & 26,43 & 22,63 & 19,29 & 16,45 & 12,09 & 9,19 & 5,96 \\
\hline 40 & 1200 & 70 & 34,29 & 29,29 & 26,19 & 22,48 & 19,22 & 16,41 & 12,11 & 9,21 & 5,98 \\
\hline 40 & 1250 & 70 & 33,78 & 28,96 & 25,96 & 22,34 & 19,14 & 16,38 & 12,12 & 9,23 & 5,99 \\
\hline 40 & 1300 & 70 & 33,29 & 28,65 & 25,74 & 22,20 & 19,06 & 16,35 & 12,13 & 9,25 & 6,00 \\
\hline 40 & 1350 & 70 & 32,84 & 28,36 & 25,52 & 22,07 & 18,99 & 16,31 & 12,14 & 9,27 & 6,02 \\
\hline 40 & 1400 & 70 & 32,41 & 28,07 & 25,31 & 21,94 & 18,91 & 16,28 & 12,15 & 9,29 & 6,03 \\
\hline 40 & 1450 & 70 & 32,00 & 27,80 & 25,11 & 21,81 & 18,84 & 16,24 & 12,15 & 9,31 & 6,04 \\
\hline 40 & 1500 & 70 & 31,61 & 27,54 & 24,92 & 21,68 & 18,77 & 16,21 & 12,16 & 9,33 & 6,05 \\
\hline 40 & 1550 & 70 & 31,24 & 27,29 & 24,73 & 21,56 & 18,70 & 16,17 & 12,16 & 9,34 & 6,07 \\
\hline 40 & 1600 & 70 & 30,89 & 27,04 & 24,55 & 21,44 & 18,63 & 16,14 & 12,16 & 9,36 & 6,08 \\
\hline 40 & 1650 & 70 & 30,55 & 26,81 & 24,37 & 21,33 & 18,56 & 16,10 & 12,16 & 9,37 & 6,09 \\
\hline 40 & 1700 & 70 & 30,23 & 26,58 & 24,20 & 21,22 & 18,49 & 16,06 & 12,17 & 9,39 & 6,10 \\
\hline 40 & 1750 & 70 & 29,93 & 26,36 & 24,04 & 21,11 & 18,42 & 16,03 & 12,17 & 9,40 & 6,11 \\
\hline 40 & 1800 & 70 & 29,64 & 26,15 & 23,88 & 21,00 & 18,35 & 15,99 & 12,17 & 9,41 & 6,13 \\
\hline 40 & 1850 & 70 & 29,35 & 25,95 & 23,72 & 20,89 & 18,29 & 15,96 & 12,16 & 9,43 & 6,14 \\
\hline 40 & 1900 & 70 & 29,09 & 25,75 & 23,57 & 20,79 & 18,22 & 15,92 & 12,16 & 9,44 & 6,15 \\
\hline 40 & 1950 & 70 & 28,83 & 25,55 & 23,43 & 20,69 & 18,16 & 15,88 & 12,16 & 9,45 & 6,16 \\
\hline 40 & 2000 & 70 & 28,58 & 25,37 & 23,28 & 20,59 & 18,10 & 15,85 & 12,16 & 9,46 & 6,17 \\
\hline 40 & 200 & 75 & 68,69 & 42,83 & 32,95 & 24,43 & 18,83 & 14,97 & 10,30 & 7,85 & 5,41 \\
\hline 40 & 250 & 75 & 62,01 & 40,78 & 32,16 & 24,32 & 18,94 & 15,13 & 10,41 & 7,89 & 5,40 \\
\hline 40 & 300 & 75 & 57,22 & 39,15 & 31,46 & 24,17 & 18,99 & 15,24 & 10,51 & 7,94 & 5,40 \\
\hline 40 & 350 & 75 & 53,55 & 37,81 & 30,83 & 24,00 & 19,01 & 15,33 & 10,60 & 7,99 & 5,40 \\
\hline 40 & 400 & 75 & 50,63 & 36,67 & 30,25 & 23,82 & 19,01 & 15,40 & 10,68 & 8,03 & 5,40 \\
\hline 40 & 450 & 75 & 48,23 & 35,67 & 29,73 & 23,63 & 18,98 & 15,45 & 10,75 & 8,08 & 5,41 \\
\hline 40 & 500 & 75 & 46,20 & 34,79 & 29,24 & 23,44 & 18,95 & 15,49 & 10,82 & 8,12 & 5,41 \\
\hline 40 & 550 & 75 & 44,45 & 34,00 & 28,79 & 23,26 & 18,90 & 15,51 & 10,88 & 8,16 & 5,42 \\
\hline 40 & 600 & 75 & 42,93 & 33,29 & 28,37 & 23,07 & 18,85 & 15,53 & 10,93 & 8,20 & 5,43 \\
\hline 40 & 650 & 75 & 41,58 & 32,64 & 27,98 & 22,89 & 18,80 & 15,54 & 10,98 & 8,24 & 5,44 \\
\hline 40 & 700 & 75 & 40,38 & 32,04 & 27,61 & 22,72 & 18,73 & 15,54 & 11,02 & 8,27 & 5,45 \\
\hline 40 & 750 & 75 & 39,31 & 31,49 & 27,26 & 22,55 & 18,67 & 15,53 & 11,06 & 8,31 & 5,46 \\
\hline 40 & 800 & 75 & 38,33 & 30,98 & 26,93 & 22,38 & 18,60 & 15,53 & 11,10 & 8,34 & 5,47 \\
\hline 40 & 850 & 75 & 37,44 & 30,50 & 26,62 & 22,22 & 18,54 & 15,52 & 11,13 & 8,38 & 5,48 \\
\hline 40 & 900 & 75 & 36,62 & 30,05 & 26,32 & 22,06 & 18,47 & 15,50 & 11,16 & 8,41 & 5,49 \\
\hline 40 & 950 & 75 & 35,87 & 29,63 & 26,04 & 21,91 & 18,40 & 15,48 & 11,18 & 8,43 & 5,50 \\
\hline 40 & 1000 & 75 & 35,17 & 29,24 & 25,77 & 21,76 & 18,33 & 15,46 & 11,21 & 8,46 & 5,51 \\
\hline 40 & 1050 & 75 & 34,53 & 28,86 & 25,52 & 21,61 & 18,26 & 15,44 & 11,23 & 8,49 & 5,52 \\
\hline 40 & 1100 & 75 & 33,93 & 28,51 & 25,27 & 21,47 & 18,19 & 15,42 & 11,25 & 8,51 & 5,54 \\
\hline 40 & 1150 & 75 & 33,36 & 28,17 & 25,04 & 21,34 & 18,12 & 15,39 & 11,26 & 8,54 & 5,55 \\
\hline 40 & 1200 & 75 & 32,84 & 27,85 & 24,81 & 21,20 & 18,05 & 15,37 & 11,28 & 8,56 & 5,56 \\
\hline 40 & 1250 & 75 & 32,34 & 27,54 & 24,60 & 21,07 & 17,98 & 15,34 & 11,29 & 8,58 & 5,57 \\
\hline 40 & 1300 & 75 & 31,87 & 27,25 & 24,39 & 20,95 & 17,92 & 15,31 & 11,30 & 8,60 & 5,58 \\
\hline 40 & 1350 & 75 & 31,43 & 26,97 & 24,19 & 20,82 & 17,85 & 15,28 & 11,31 & 8,62 & 5,59 \\
\hline 40 & 1400 & 75 & 31,01 & 26,71 & 23,99 & 20,70 & 17,78 & 15,25 & 11,32 & 8,64 & 5,60 \\
\hline 40 & 1450 & 75 & 30,62 & 26,45 & 23,81 & 20,59 & 17,72 & 15,22 & 11,33 & 8,66 & 5,62 \\
\hline 40 & 1500 & 75 & 30,24 & 26,20 & 23,62 & 20,47 & 17,65 & 15,19 & 11,34 & 8,67 & 5,63 \\
\hline 40 & 1550 & 75 & 29,89 & 25,96 & 23,45 & 20,36 & 17,59 & 15,16 & 11,34 & 8,69 & 5,64 \\
\hline 40 & 1600 & 75 & 29,55 & 25,73 & 23,28 & 20,25 & 17,53 & 15,13 & 11,35 & 8,70 & 5,65 \\
\hline 40 & 1650 & 75 & 29,22 & 25,51 & 23,12 & 20,15 & 17,46 & 15,10 & 11,35 & 8,72 & 5,66 \\
\hline
\end{tabular}




\begin{tabular}{|c|c|c|c|c|c|c|c|c|c|c|c|}
\hline \multirow[b]{2}{*}{$\mathrm{H}(\mathrm{cm})$} & \multirow[b]{2}{*}{ Mceq (MPa) } & & & & & $\mathrm{De}$ & ões (x1 & & & & \\
\hline & & Msub (MPa) & D0 & D25 & D40 & D60 & D80 & D100 & D140 & D180 & D260 \\
\hline 40 & 1700 & 75 & 28,92 & 25,30 & 22,96 & 20,04 & 17,40 & 15,07 & 11,35 & 8,73 & 5,67 \\
\hline 40 & 1750 & 75 & 28,62 & 25,09 & 22,80 & 19,94 & 17,34 & 15,04 & 11,35 & 8,74 & 5,68 \\
\hline 40 & 1800 & 75 & 28,34 & 24,89 & 22,65 & 19,84 & 17,28 & 15,01 & 11,35 & 8,76 & 5,69 \\
\hline 40 & 1850 & 75 & 28,06 & 24,70 & 22,51 & 19,75 & 17,22 & 14,98 & 11,35 & 8,77 & 5,70 \\
\hline 40 & 1900 & 75 & 27,80 & 24,51 & 22,37 & 19,65 & 17,16 & 14,94 & 11,35 & 8,78 & 5,71 \\
\hline 40 & 1950 & 75 & 27,55 & 24,33 & 22,23 & 19,56 & 17,11 & 14,91 & 11,35 & 8,79 & 5,72 \\
\hline 40 & 2000 & 75 & 27,31 & 24,15 & 22,09 & 19,47 & 17,05 & 14,88 & 11,35 & 8,80 & 5,73 \\
\hline 40 & 200 & 80 & 66,39 & 40,73 & 31,09 & 22,92 & 17,62 & 14,00 & 9,63 & 7,35 & 5,08 \\
\hline 40 & 250 & 80 & 59,85 & 38,78 & 30,37 & 22,84 & 17,73 & 14,14 & 9,73 & 7,39 & 5,07 \\
\hline 40 & 300 & 80 & 55,17 & 37,24 & 29,73 & 22,72 & 17,79 & 14,25 & 9,82 & 7,43 & 5,06 \\
\hline 40 & 350 & 80 & 51,61 & 35,97 & 29,15 & 22,57 & 17,82 & 14,34 & 9,90 & 7,47 & 5,06 \\
\hline 40 & 400 & 80 & 48,77 & 34,89 & 28,62 & 22,42 & 17,82 & 14,41 & 9,98 & 7,51 & 5,06 \\
\hline 40 & 450 & 80 & 46,43 & 33,95 & 28,14 & 22,25 & 17,81 & 14,46 & 10,05 & 7,55 & 5,07 \\
\hline 40 & 500 & 80 & 44,46 & 33,12 & 27,69 & 22,09 & 17,79 & 14,50 & 10,11 & 7,59 & 5,07 \\
\hline 40 & 550 & 80 & 42,77 & 32,38 & 27,28 & 21,92 & 17,75 & 14,53 & 10,16 & 7,62 & 5,08 \\
\hline 40 & 600 & 80 & 41,30 & 31,70 & 26,89 & 21,76 & 17,71 & 14,55 & 10,21 & 7,66 & 5,08 \\
\hline 40 & 650 & 80 & 40,00 & 31,09 & 26,53 & 21,60 & 17,66 & 14,56 & 10,26 & 7,69 & 5,09 \\
\hline 40 & 700 & 80 & 38,84 & 30,52 & 26,18 & 21,44 & 17,61 & 14,57 & 10,30 & 7,73 & 5,10 \\
\hline 40 & 750 & 80 & 37,79 & 30,00 & 25,86 & 21,29 & 17,56 & 14,57 & 10,34 & 7,76 & 5,11 \\
\hline 40 & 800 & 80 & 36,85 & 29,52 & 25,56 & 21,14 & 17,50 & 14,56 & 10,37 & 7,79 & 5,12 \\
\hline 40 & 850 & 80 & 35,99 & 29,07 & 25,27 & 20,99 & 17,45 & 14,56 & 10,40 & 7,82 & 5,13 \\
\hline 40 & 900 & 80 & 35,20 & 28,65 & 24,99 & 20,85 & 17,39 & 14,55 & 10,43 & 7,85 & 5,13 \\
\hline 40 & 950 & 80 & 34,47 & 28,25 & 24,73 & 20,71 & 17,33 & 14,53 & 10,46 & 7,87 & 5,14 \\
\hline 40 & 1000 & 80 & 33,80 & 27,88 & 24,48 & 20,57 & 17,27 & 14,52 & 10,48 & 7,90 & 5,15 \\
\hline 40 & 1050 & 80 & 33,17 & 27,52 & 24,24 & 20,44 & 17,20 & 14,50 & 10,50 & 7,92 & 5,16 \\
\hline 40 & 1100 & 80 & 32,59 & 27,19 & 24,01 & 20,31 & 17,14 & 14,48 & 10,52 & 7,95 & 5,17 \\
\hline 40 & 1150 & 80 & 32,05 & 26,87 & 23,79 & 20,19 & 17,08 & 14,46 & 10,54 & 7,97 & 5,18 \\
\hline 40 & 1200 & 80 & 31,54 & 26,57 & 23,58 & 20,07 & 17,02 & 14,44 & 10,55 & 7,99 & 5,19 \\
\hline 40 & 1250 & 80 & 31,06 & 26,28 & 23,38 & 19,95 & 16,96 & 14,42 & 10,57 & 8,01 & 5,20 \\
\hline 40 & 1300 & 80 & 30,61 & 26,00 & 23,18 & 19,83 & 16,90 & 14,40 & 10,58 & 8,03 & 5,21 \\
\hline 40 & 1350 & 80 & 30,18 & 25,74 & 23,00 & 19,72 & 16,84 & 14,37 & 10,59 & 8,05 & 5,23 \\
\hline 40 & 1400 & 80 & 29,78 & 25,48 & 22,82 & 19,61 & 16,78 & 14,35 & 10,60 & 8,07 & 5,24 \\
\hline 40 & 1450 & 80 & 29,39 & 25,24 & 22,64 & 19,50 & 16,72 & 14,32 & 10,61 & 8,08 & 5,25 \\
\hline 40 & 1500 & 80 & 29,03 & 25,01 & 22,47 & 19,40 & 16,66 & 14,30 & 10,62 & 8,10 & 5,26 \\
\hline 40 & 1550 & 80 & 28,68 & 24,78 & 22,31 & 19,29 & 16,61 & 14,27 & 10,62 & 8,12 & 5,27 \\
\hline 40 & 1600 & 80 & 28,35 & 24,56 & 22,15 & 19,19 & 16,55 & 14,24 & 10,63 & 8,13 & 5,27 \\
\hline 40 & 1650 & 80 & 28,04 & 24,35 & 21,99 & 19,10 & 16,49 & 14,22 & 10,63 & 8,14 & 5,28 \\
\hline 40 & 1700 & 80 & 27,74 & 24,15 & 21,85 & 19,00 & 16,44 & 14,19 & 10,64 & 8,16 & 5,29 \\
\hline 40 & 1750 & 80 & 27,45 & 23,96 & 21,70 & 18,91 & 16,38 & 14,16 & 10,64 & 8,17 & 5,30 \\
\hline 40 & 1800 & 80 & 27,18 & 23,77 & 21,56 & 18,81 & 16,33 & 14,14 & 10,64 & 8,18 & 5,31 \\
\hline 40 & 1850 & 80 & 26,92 & 23,58 & 21,42 & 18,73 & 16,27 & 14,11 & 10,64 & 8,19 & 5,32 \\
\hline 40 & 1900 & 80 & 26,66 & 23,41 & 21,29 & 18,64 & 16,22 & 14,08 & 10,64 & 8,21 & 5,33 \\
\hline 40 & 1950 & 80 & 26,42 & 23,23 & 21,16 & 18,55 & 16,17 & 14,05 & 10,65 & 8,22 & 5,34 \\
\hline 40 & 2000 & 80 & 26,19 & 23,07 & 21,03 & 18,47 & 16,12 & 14,02 & 10,65 & 8,23 & 5,35 \\
\hline 40 & 200 & 85 & 64,33 & 38,85 & 29,44 & 21,58 & 16,55 & 13,14 & 9,04 & 6,90 & 4,78 \\
\hline 40 & 250 & 85 & 57,91 & 36,99 & 28,77 & 21,52 & 16,66 & 13,27 & 9,13 & 6,94 & 4,77 \\
\hline 40 & 300 & 85 & 53,33 & 35,53 & 28,19 & 21,43 & 16,73 & 13,38 & 9,21 & 6,98 & 4,77 \\
\hline 40 & 350 & 85 & 49,85 & 34,32 & 27,65 & 21,30 & 16,76 & 13,47 & 9,29 & 7,01 & 4,77 \\
\hline 40 & 400 & 85 & 47,09 & 33,30 & 27,17 & 21,17 & 16,77 & 13,53 & 9,36 & 7,05 & 4,77 \\
\hline 40 & 450 & 85 & 44,81 & 32,41 & 26,72 & 21,02 & 16,77 & 13,59 & 9,42 & 7,08 & 4,77 \\
\hline 40 & 500 & 85 & 42,90 & 31,62 & 26,31 & 20,88 & 16,76 & 13,63 & 9,48 & 7,12 & 4,77 \\
\hline 40 & 550 & 85 & 41,26 & 30,92 & 25,92 & 20,73 & 16,73 & 13,66 & 9,53 & 7,15 & 4,78 \\
\hline 40 & 600 & 85 & 39,83 & 30,28 & 25,56 & 20,59 & 16,70 & 13,68 & 9,58 & 7,19 & 4,78 \\
\hline 40 & 650 & 85 & 38,57 & 29,70 & 25,23 & 20,44 & 16,66 & 13,69 & 9,62 & 7,22 & 4,79 \\
\hline 40 & 700 & 85 & 37,44 & 29,16 & 24,91 & 20,30 & 16,62 & 13,70 & 9,66 & 7,25 & 4,79 \\
\hline 40 & 750 & 85 & 36,43 & 28,67 & 24,61 & 20,16 & 16,57 & 13,71 & 9,70 & 7,28 & 4,80 \\
\hline 40 & 800 & 85 & 35,52 & 28,21 & 24,32 & 20,03 & 16,52 & 13,71 & 9,73 & 7,31 & 4,81 \\
\hline 40 & 850 & 85 & 34,68 & 27,78 & 24,05 & 19,89 & 16,47 & 13,71 & 9,76 & 7,33 & 4,82 \\
\hline 40 & 900 & 85 & 33,92 & 27,38 & 23,80 & 19,76 & 16,42 & 13,70 & 9,79 & 7,36 & 4,82 \\
\hline 40 & 950 & 85 & 33,21 & 27,01 & 23,55 & 19,64 & 16,37 & 13,69 & 9,81 & 7,38 & 4,83 \\
\hline 40 & 1000 & 85 & 32,56 & 26,65 & 23,32 & 19,51 & 16,32 & 13,68 & 9,84 & 7,41 & 4,84 \\
\hline 40 & 1050 & 85 & 31,96 & 26,32 & 23,09 & 19,39 & 16,26 & 13,67 & 9,86 & 7,43 & 4,85 \\
\hline 40 & 1100 & 85 & 31,39 & 26,00 & 22,88 & 19,28 & 16,21 & 13,65 & 9,88 & 7,45 & 4,86 \\
\hline 40 & 1150 & 85 & 30,86 & 25,70 & 22,67 & 19,16 & 16,15 & 13,64 & 9,90 & 7,47 & 4,87 \\
\hline 40 & 1200 & 85 & 30,37 & 25,41 & 22,48 & 19,05 & 16,10 & 13,62 & 9,91 & 7,49 & 4,88 \\
\hline 40 & 1250 & 85 & 29,90 & 25,14 & 22,29 & 18,94 & 16,05 & 13,60 & 9,93 & 7,51 & 4,88 \\
\hline 40 & 1300 & 85 & 29,47 & 24,87 & 22,10 & 18,83 & 15,99 & 13,58 & 9,94 & 7,53 & 4,89 \\
\hline 40 & 1350 & 85 & 29,05 & 24,62 & 21,93 & 18,73 & 15,94 & 13,56 & 9,95 & 7,55 & 4,90 \\
\hline 40 & 1400 & 85 & 28,66 & 24,38 & 21,76 & 18,63 & 15,89 & 13,54 & 9,96 & 7,57 & 4,91 \\
\hline 40 & 1450 & 85 & 28,29 & 24,15 & 21,59 & 18,53 & 15,83 & 13,52 & 9,97 & 7,58 & 4,92 \\
\hline 40 & 1500 & 85 & 27,94 & 23,93 & 21,43 & 18,43 & 15,78 & 13,50 & 9,98 & 7,60 & 4,93 \\
\hline 40 & 1550 & 85 & 27,60 & 23,72 & 21,28 & 18,34 & 15,73 & 13,48 & 9,99 & 7,61 & 4,94 \\
\hline 40 & 1600 & 85 & 27,28 & 23,51 & 21,13 & 18,24 & 15,68 & 13,45 & 9,99 & 7,63 & 4,95 \\
\hline 40 & 1650 & 85 & 26,98 & 23,31 & 20,99 & 18,15 & 15,63 & 13,43 & 10,00 & 7,64 & 4,96 \\
\hline 40 & 1700 & 85 & 26,69 & 23,12 & 20,85 & 18,06 & 15,58 & 13,41 & 10,00 & 7,65 & 4,96 \\
\hline 40 & 1750 & 85 & 26,41 & 22,93 & 20,71 & 17,98 & 15,53 & 13,38 & 10,01 & 7,66 & 4,97 \\
\hline 40 & 1800 & 85 & 26,14 & 22,75 & 20,58 & 17,89 & 15,48 & 13,36 & 10,01 & 7,68 & 4,98 \\
\hline 40 & 1850 & 85 & 25,89 & 22,58 & 20,45 & 17,81 & 15,43 & 13,33 & 10,01 & 7,69 & 4,99 \\
\hline 40 & 1900 & 85 & 25,64 & 22,41 & 20,32 & 17,73 & 15,38 & 13,31 & 10,02 & 7,70 & 5,00 \\
\hline 40 & 1950 & 85 & 25,40 & 22,25 & 20,20 & 17,65 & 15,33 & 13,29 & 10,02 & 7,71 & 5,01 \\
\hline 40 & 2000 & 85 & 25,18 & 22,09 & 20,08 & 17,57 & 15,28 & 13,26 & 10,02 & 7,72 & 5,01 \\
\hline
\end{tabular}




\begin{tabular}{|c|c|c|c|c|c|c|c|c|c|c|c|}
\hline \multirow[b]{2}{*}{$\mathrm{H}(\mathrm{cm})$} & \multirow[b]{2}{*}{ Mceq (MPa) } & & & & & $\mathrm{De}$ & ões (x1 & & & & \\
\hline & & Msub (MPa) & D0 & D25 & D40 & D60 & D80 & D100 & D140 & D180 & D260 \\
\hline 40 & 200 & 90 & 62,46 & 37,15 & 27,95 & 20,39 & 15,60 & 12,37 & 8,52 & 6,51 & 4,52 \\
\hline 40 & 250 & 90 & 56,16 & 35,37 & 27,34 & 20,35 & 15,71 & 12,50 & 8,60 & 6,55 & 4,51 \\
\hline 40 & 300 & 90 & 51,67 & 33,98 & 26,80 & 20,27 & 15,78 & 12,61 & 8,68 & 6,58 & 4,50 \\
\hline 40 & 350 & 90 & 48,27 & 32,83 & 26,31 & 20,17 & 15,82 & 12,69 & 8,75 & 6,61 & 4,50 \\
\hline 40 & 400 & 90 & 45,57 & 31,86 & 25,86 & 20,05 & 15,84 & 12,75 & 8,81 & 6,64 & 4,50 \\
\hline 40 & 450 & 90 & 43,35 & 31,01 & 25,44 & 19,92 & 15,84 & 12,81 & 8,87 & 6,67 & 4,50 \\
\hline 40 & 500 & 90 & 41,48 & 30,27 & 25,06 & 19,80 & 15,83 & 12,85 & 8,92 & 6,71 & 4,50 \\
\hline 40 & 550 & 90 & 39,89 & 29,60 & 24,70 & 19,67 & 15,82 & 12,88 & 8,97 & 6,74 & 4,51 \\
\hline 40 & 600 & 90 & 38,50 & 28,99 & 24,37 & 19,54 & 15,79 & 12,91 & 9,02 & 6,77 & 4,51 \\
\hline 40 & 650 & 90 & 37,27 & 28,44 & 24,05 & 19,41 & 15,76 & 12,92 & 9,06 & 6,79 & 4,52 \\
\hline 40 & 700 & 90 & 36,18 & 27,93 & 23,76 & 19,28 & 15,73 & 12,94 & 9,10 & 6,82 & 4,52 \\
\hline 40 & 750 & 90 & 35,20 & 27,46 & 23,48 & 19,15 & 15,69 & 12,94 & 9,13 & 6,85 & 4,53 \\
\hline 40 & 800 & 90 & 34,31 & 27,03 & 23,21 & 19,03 & 15,65 & 12,95 & 9,16 & 6,88 & 4,53 \\
\hline 40 & 850 & 90 & 33,50 & 26,62 & 22,96 & 18,91 & 15,60 & 12,95 & 9,19 & 6,90 & 4,54 \\
\hline 40 & 900 & 90 & 32,75 & 26,24 & 22,72 & 18,79 & 15,56 & 12,95 & 9,22 & 6,92 & 4,55 \\
\hline 40 & 950 & 90 & 32,07 & 25,88 & 22,49 & 18,67 & 15,51 & 12,94 & 9,24 & 6,95 & 4,56 \\
\hline 40 & 1000 & 90 & 31,44 & 25,55 & 22,27 & 18,56 & 15,47 & 12,93 & 9,27 & 6,97 & 4,56 \\
\hline 40 & 1050 & 90 & 30,85 & 25,23 & 22,06 & 18,45 & 15,42 & 12,92 & 9,29 & 6,99 & 4,57 \\
\hline 40 & 1100 & 90 & 30,30 & 24,92 & 21,86 & 18,34 & 15,37 & 12,91 & 9,31 & 7,01 & 4,58 \\
\hline 40 & 1150 & 90 & 29,79 & 24,64 & 21,66 & 18,24 & 15,32 & 12,90 & 9,32 & 7,03 & 4,59 \\
\hline 40 & 1200 & 90 & 29,31 & 24,36 & 21,48 & 18,13 & 15,27 & 12,89 & 9,34 & 7,05 & 4,59 \\
\hline 40 & 1250 & 90 & 28,86 & 24,10 & 21,30 & 18,03 & 15,23 & 12,87 & 9,35 & 7,07 & 4,60 \\
\hline 40 & 1300 & 90 & 28,43 & 23,85 & 21,13 & 17,93 & 15,18 & 12,86 & 9,37 & 7,09 & 4,61 \\
\hline 40 & 1350 & 90 & 28,03 & 23,61 & 20,96 & 17,84 & 15,13 & 12,84 & 9,38 & 7,10 & 4,62 \\
\hline 40 & 1400 & 90 & 27,65 & 23,39 & 20,80 & 17,74 & 15,08 & 12,82 & 9,39 & 7,12 & 4,63 \\
\hline 40 & 1450 & 90 & 27,29 & 23,17 & 20,65 & 17,65 & 15,03 & 12,80 & 9,40 & 7,14 & 4,63 \\
\hline 40 & 1500 & 90 & 26,95 & 22,95 & 20,50 & 17,56 & 14,99 & 12,78 & 9,41 & 7,15 & 4,64 \\
\hline 40 & 1550 & 90 & 26,62 & 22,75 & 20,35 & 17,47 & 14,94 & 12,76 & 9,42 & 7,16 & 4,65 \\
\hline 40 & 1600 & 90 & 26,31 & 22,55 & 20,21 & 17,39 & 14,89 & 12,74 & 9,43 & 7,18 & 4,66 \\
\hline 40 & 1650 & 90 & 26,02 & 22,36 & 20,07 & 17,30 & 14,85 & 12,72 & 9,43 & 7,19 & 4,67 \\
\hline 40 & 1700 & 90 & 25,73 & 22,18 & 19,94 & 17,22 & 14,80 & 12,70 & 9,44 & 7,20 & 4,67 \\
\hline 40 & 1750 & 90 & 25,46 & 22,01 & 19,81 & 17,14 & 14,76 & 12,68 & 9,44 & 7,22 & 4,68 \\
\hline 40 & 1800 & 90 & 25,20 & 21,83 & 19,69 & 17,06 & 14,71 & 12,66 & 9,45 & 7,23 & 4,69 \\
\hline 40 & 1850 & 90 & 24,96 & 21,67 & 19,57 & 16,98 & 14,67 & 12,64 & 9,45 & 7,24 & 4,70 \\
\hline 40 & 1900 & 90 & 24,72 & 21,51 & 19,45 & 16,91 & 14,62 & 12,62 & 9,45 & 7,25 & 4,70 \\
\hline 40 & 1950 & 90 & 24,49 & 21,35 & 19,33 & 16,83 & 14,58 & 12,60 & 9,46 & 7,26 & 4,71 \\
\hline 40 & 2000 & 90 & 24,27 & 21,20 & 19,22 & 16,76 & 14,54 & 12,58 & 9,46 & 7,27 & 4,72 \\
\hline 40 & 200 & 95 & 60,77 & 35,62 & 26,61 & 19,31 & 14,74 & 11,69 & 8,05 & 6,16 & 4,28 \\
\hline 40 & 250 & 95 & 54,56 & 33,91 & 26,05 & 19,29 & 14,86 & 11,81 & 8,13 & 6,19 & 4,27 \\
\hline 40 & 300 & 95 & 50,16 & 32,58 & 25,55 & 19,23 & 14,93 & 11,91 & 8,20 & 6,22 & 4,27 \\
\hline 40 & 350 & 95 & 46,82 & 31,48 & 25,09 & 19,14 & 14,98 & 11,99 & 8,26 & 6,25 & 4,26 \\
\hline 40 & 400 & 95 & 44,18 & 30,56 & 24,67 & 19,04 & 15,00 & 12,06 & 8,32 & 6,28 & 4,26 \\
\hline 40 & 450 & 95 & 42,01 & 29,75 & 24,29 & 18,93 & 15,01 & 12,11 & 8,38 & 6,31 & 4,26 \\
\hline 40 & 500 & 95 & 40,19 & 29,04 & 23,93 & 18,82 & 15,01 & 12,15 & 8,43 & 6,34 & 4,27 \\
\hline 40 & 550 & 95 & 38,64 & 28,40 & 23,60 & 18,70 & 14,99 & 12,19 & 8,47 & 6,36 & 4,27 \\
\hline 40 & 600 & 95 & 37,28 & 27,82 & 23,28 & 18,59 & 14,98 & 12,21 & 8,52 & 6,39 & 4,27 \\
\hline 40 & 650 & 95 & 36,09 & 27,29 & 22,99 & 18,47 & 14,95 & 12,23 & 8,56 & 6,42 & 4,28 \\
\hline 40 & 700 & 95 & 35,02 & 26,81 & 22,71 & 18,35 & 14,92 & 12,25 & 8,59 & 6,44 & 4,28 \\
\hline 40 & 750 & 95 & 34,07 & 26,36 & 22,45 & 18,24 & 14,89 & 12,26 & 8,62 & 6,47 & 4,29 \\
\hline 40 & 800 & 95 & 33,21 & 25,95 & 22,20 & 18,13 & 14,86 & 12,26 & 8,66 & 6,49 & 4,29 \\
\hline 40 & 850 & 95 & 32,42 & 25,56 & 21,96 & 18,01 & 14,82 & 12,27 & 8,68 & 6,52 & 4,30 \\
\hline 40 & 900 & 95 & 31,70 & 25,20 & 21,74 & 17,91 & 14,78 & 12,27 & 8,71 & 6,54 & 4,30 \\
\hline 40 & 950 & 95 & 31,03 & 24,86 & 21,52 & 17,80 & 14,74 & 12,26 & 8,73 & 6,56 & 4,31 \\
\hline 40 & 1000 & 95 & 30,42 & 24,54 & 21,31 & 17,70 & 14,70 & 12,26 & 8,76 & 6,58 & 4,32 \\
\hline 40 & 1050 & 95 & 29,84 & 24,23 & 21,12 & 17,59 & 14,66 & 12,25 & 8,78 & 6,60 & 4,32 \\
\hline 40 & 1100 & 95 & 29,31 & 23,95 & 20,93 & 17,49 & 14,61 & 12,25 & 8,80 & 6,62 & 4,33 \\
\hline 40 & 1150 & 95 & 28,81 & 23,67 & 20,75 & 17,40 & 14,57 & 12,24 & 8,81 & 6,64 & 4,34 \\
\hline 40 & 1200 & 95 & 28,35 & 23,41 & 20,57 & 17,30 & 14,53 & 12,22 & 8,83 & 6,66 & 4,34 \\
\hline 40 & 1250 & 95 & 27,91 & 23,16 & 20,40 & 17,21 & 14,48 & 12,21 & 8,84 & 6,67 & 4,35 \\
\hline 40 & 1300 & 95 & 27,50 & 22,92 & 20,24 & 17,12 & 14,44 & 12,20 & 8,86 & 6,69 & 4,36 \\
\hline 40 & 1350 & 95 & 27,10 & 22,70 & 20,08 & 17,03 & 14,40 & 12,19 & 8,87 & 6,71 & 4,36 \\
\hline 40 & 1400 & 95 & 26,73 & 22,48 & 19,93 & 16,94 & 14,35 & 12,17 & 8,88 & 6,72 & 4,37 \\
\hline 40 & 1450 & 95 & 26,38 & 22,27 & 19,79 & 16,86 & 14,31 & 12,15 & 8,89 & 6,74 & 4,38 \\
\hline 40 & 1500 & 95 & 26,05 & 22,07 & 19,64 & 16,77 & 14,27 & 12,14 & 8,90 & 6,75 & 4,39 \\
\hline 40 & 1550 & 95 & 25,73 & 21,87 & 19,51 & 16,69 & 14,23 & 12,12 & 8,91 & 6,77 & 4,39 \\
\hline 40 & 1600 & 95 & 25,43 & 21,68 & 19,37 & 16,61 & 14,18 & 12,10 & 8,92 & 6,78 & 4,40 \\
\hline 40 & 1650 & 95 & 25,14 & 21,50 & 19,24 & 16,53 & 14,14 & 12,09 & 8,92 & 6,79 & 4,41 \\
\hline 40 & 1700 & 95 & 24,87 & 21,33 & 19,12 & 16,46 & 14,10 & 12,07 & 8,93 & 6,80 & 4,41 \\
\hline 40 & 1750 & 95 & 24,60 & 21,16 & 19,00 & 16,38 & 14,06 & 12,05 & 8,94 & 6,81 & 4,42 \\
\hline 40 & 1800 & 95 & 24,35 & 21,00 & 18,88 & 16,31 & 14,02 & 12,03 & 8,94 & 6,83 & 4,43 \\
\hline 40 & 1850 & 95 & 24,11 & 20,84 & 18,76 & 16,23 & 13,98 & 12,01 & 8,95 & 6,84 & 4,44 \\
\hline 40 & 1900 & 95 & 23,88 & 20,69 & 18,65 & 16,16 & 13,94 & 12,00 & 8,95 & 6,85 & 4,44 \\
\hline 40 & 1950 & 95 & 23,65 & 20,54 & 18,54 & 16,09 & 13,90 & 11,98 & 8,95 & 6,86 & 4,45 \\
\hline 40 & 2000 & 95 & 23,44 & 20,39 & 18,44 & 16,03 & 13,86 & 11,96 & 8,96 & 6,87 & 4,46 \\
\hline 40 & 200 & 100 & 59,23 & 34,23 & 25,40 & 18,34 & 13,98 & 11,08 & 7,63 & 5,85 & 4,07 \\
\hline 40 & 250 & 100 & 53,11 & 32,58 & 24,87 & 18,34 & 14,09 & 11,20 & 7,70 & 5,88 & 4,06 \\
\hline 40 & 300 & 100 & 48,78 & 31,30 & 24,41 & 18,29 & 14,17 & 11,29 & 7,77 & 5,90 & 4,06 \\
\hline 40 & 350 & 100 & 45,50 & 30,25 & 23,98 & 18,22 & 14,22 & 11,37 & 7,83 & 5,93 & 4,05 \\
\hline 40 & 400 & 100 & 42,91 & 29,36 & 23,59 & 18,13 & 14,24 & 11,43 & 7,88 & 5,96 & 4,05 \\
\hline 40 & 450 & 100 & 40,79 & 28,59 & 23,23 & 18,03 & 14,26 & 11,48 & 7,94 & 5,98 & 4,05 \\
\hline 40 & 500 & 100 & 39,01 & 27,91 & 22,90 & 17,93 & 14,26 & 11,53 & 7,98 & 6,01 & 4,05 \\
\hline
\end{tabular}




\begin{tabular}{|c|c|c|c|c|c|c|c|c|c|c|c|}
\hline \multirow[b]{2}{*}{$\mathrm{H}(\mathrm{cm})$} & \multirow[b]{2}{*}{ Mceq (MPa) } & & & & & $\mathrm{De}$ & ões (x1 & & & & \\
\hline & & Msub (MPa) & D0 & D25 & D40 & D60 & D80 & D100 & D140 & D180 & D260 \\
\hline 40 & 550 & 100 & 37,49 & 27,30 & 22,59 & 17,83 & 14,25 & 11,56 & 8,03 & 6,03 & 4,05 \\
\hline 40 & 600 & 100 & 36,17 & 26,75 & 22,29 & 17,72 & 14,24 & 11,59 & 8,07 & 6,06 & 4,06 \\
\hline 40 & 650 & 100 & 35,00 & 26,25 & 22,02 & 17,62 & 14,22 & 11,61 & 8,10 & 6,08 & 4,06 \\
\hline 40 & 700 & 100 & 33,97 & 25,79 & 21,76 & 17,51 & 14,20 & 11,63 & 8,14 & 6,10 & 4,06 \\
\hline 40 & 750 & 100 & 33,04 & 25,36 & 21,51 & 17,41 & 14,17 & 11,64 & 8,17 & 6,13 & 4,07 \\
\hline 40 & 800 & 100 & 32,20 & 24,97 & 21,28 & 17,30 & 14,14 & 11,65 & 8,20 & 6,15 & 4,07 \\
\hline 40 & 850 & 100 & 31,43 & 24,60 & 21,05 & 17,20 & 14,11 & 11,65 & 8,23 & 6,17 & 4,08 \\
\hline 40 & 900 & 100 & 30,73 & 24,25 & 20,84 & 17,10 & 14,07 & 11,65 & 8,25 & 6,19 & 4,08 \\
\hline 40 & 950 & 100 & 30,08 & 23,92 & 20,64 & 17,01 & 14,04 & 11,65 & 8,28 & 6,21 & 4,09 \\
\hline 40 & 1000 & 100 & 29,48 & 23,62 & 20,44 & 16,91 & 14,00 & 11,65 & 8,30 & 6,23 & 4,09 \\
\hline 40 & 1050 & 100 & 28,92 & 23,33 & 20,26 & 16,82 & 13,97 & 11,65 & 8,32 & 6,25 & 4,10 \\
\hline 40 & 1100 & 100 & 28,41 & 23,05 & 20,08 & 16,72 & 13,93 & 11,64 & 8,34 & 6,27 & 4,10 \\
\hline 40 & 1150 & 100 & 27,92 & 22,79 & 19,91 & 16,63 & 13,89 & 11,63 & 8,35 & 6,29 & 4,11 \\
\hline 40 & 1200 & 100 & 27,47 & 22,54 & 19,74 & 16,55 & 13,85 & 11,63 & 8,37 & 6,30 & 4,12 \\
\hline 40 & 1250 & 100 & 27,04 & 22,30 & 19,58 & 16,46 & 13,81 & 11,62 & 8,38 & 6,32 & 4,12 \\
\hline 40 & 1300 & 100 & 26,64 & 22,07 & 19,43 & 16,37 & 13,77 & 11,61 & 8,40 & 6,34 & 4,13 \\
\hline 40 & 1350 & 100 & 26,26 & 21,86 & 19,28 & 16,29 & 13,73 & 11,59 & 8,41 & 6,35 & 4,14 \\
\hline 40 & 1400 & 100 & 25,90 & 21,65 & 19,14 & 16,21 & 13,69 & 11,58 & 8,42 & 6,37 & 4,14 \\
\hline 40 & 1450 & 100 & 25,55 & 21,45 & 19,00 & 16,13 & 13,66 & 11,57 & 8,43 & 6,38 & 4,15 \\
\hline 40 & 1500 & 100 & 25,23 & 21,25 & 18,87 & 16,05 & 13,62 & 11,55 & 8,44 & 6,39 & 4,16 \\
\hline 40 & 1550 & 100 & 24,92 & 21,07 & 18,74 & 15,98 & 13,58 & 11,54 & 8,45 & 6,41 & 4,16 \\
\hline 40 & 1600 & 100 & 24,63 & 20,89 & 18,61 & 15,90 & 13,54 & 11,53 & 8,46 & 6,42 & 4,17 \\
\hline 40 & 1650 & 100 & 24,35 & 20,71 & 18,49 & 15,83 & 13,50 & 11,51 & 8,47 & 6,43 & 4,18 \\
\hline 40 & 1700 & 100 & 24,08 & 20,55 & 18,37 & 15,76 & 13,46 & 11,49 & 8,47 & 6,44 & 4,18 \\
\hline 40 & 1750 & 100 & 23,82 & 20,39 & 18,25 & 15,69 & 13,42 & 11,48 & 8,48 & 6,45 & 4,19 \\
\hline 40 & 1800 & 100 & 23,57 & 20,23 & 18,14 & 15,62 & 13,39 & 11,46 & 8,49 & 6,47 & 4,19 \\
\hline 40 & 1850 & 100 & 23,34 & 20,08 & 18,03 & 15,55 & 13,35 & 11,45 & 8,49 & 6,48 & 4,20 \\
\hline 40 & 1900 & 100 & 23,11 & 19,93 & 17,92 & 15,48 & 13,31 & 11,43 & 8,49 & 6,49 & 4,21 \\
\hline 40 & 1950 & 100 & 22,89 & 19,79 & 17,82 & 15,42 & 13,28 & 11,41 & 8,50 & 6,50 & 4,21 \\
\hline 40 & 2000 & 100 & 22,68 & 19,65 & 17,72 & 15,35 & 13,24 & 11,40 & 8,50 & 6,50 & 4,22 \\
\hline 40 & 200 & 105 & 57,82 & 32,95 & 24,29 & 17,46 & 13,29 & 10,53 & 7,26 & 5,57 & 3,88 \\
\hline 40 & 250 & 105 & 51,78 & 31,37 & 23,80 & 17,47 & 13,40 & 10,64 & 7,32 & 5,59 & 3,87 \\
\hline 40 & 300 & 105 & 47,51 & 30,13 & 23,37 & 17,43 & 13,48 & 10,73 & 7,38 & 5,61 & 3,86 \\
\hline 40 & 350 & 105 & 44,29 & 29,13 & 22,97 & 17,37 & 13,53 & 10,81 & 7,44 & 5,64 & 3,86 \\
\hline 40 & 400 & 105 & 41,75 & 28,27 & 22,61 & 17,30 & 13,56 & 10,87 & 7,49 & 5,66 & 3,86 \\
\hline 40 & 450 & 105 & 39,67 & 27,54 & 22,27 & 17,21 & 13,57 & 10,92 & 7,54 & 5,69 & 3,86 \\
\hline 40 & 500 & 105 & 37,93 & 26,88 & 21,96 & 17,12 & 13,58 & 10,96 & 7,58 & 5,71 & 3,86 \\
\hline 40 & 550 & 105 & 36,44 & 26,30 & 21,66 & 17,03 & 13,58 & 10,99 & 7,62 & 5,73 & 3,86 \\
\hline 40 & 600 & 105 & 35,15 & 25,77 & 21,39 & 16,94 & 13,57 & 11,02 & 7,66 & 5,76 & 3,86 \\
\hline 40 & 650 & 105 & 34,01 & 25,29 & 21,13 & 16,84 & 13,55 & 11,04 & 7,70 & 5,78 & 3,86 \\
\hline 40 & 700 & 105 & 33,00 & 24,85 & 20,89 & 16,74 & 13,54 & 11,06 & 7,73 & 5,80 & 3,87 \\
\hline 40 & 750 & 105 & 32,09 & 24,44 & 20,65 & 16,65 & 13,51 & 11,08 & 7,76 & 5,82 & 3,87 \\
\hline 40 & 800 & 105 & 31,27 & 24,06 & 20,43 & 16,56 & 13,49 & 11,09 & 7,79 & 5,84 & 3,87 \\
\hline 40 & 850 & 105 & 30,52 & 23,71 & 20,22 & 16,46 & 13,46 & 11,09 & 7,81 & 5,86 & 3,88 \\
\hline 40 & 900 & 105 & 29,83 & 23,38 & 20,02 & 16,37 & 13,43 & 11,10 & 7,84 & 5,88 & 3,88 \\
\hline 40 & 950 & 105 & 29,20 & 23,06 & 19,83 & 16,28 & 13,40 & 11,10 & 7,86 & 5,90 & 3,89 \\
\hline 40 & 1000 & 105 & 28,62 & 22,77 & 19,65 & 16,19 & 13,37 & 11,10 & 7,88 & 5,92 & 3,89 \\
\hline 40 & 1050 & 105 & 28,08 & 22,49 & 19,47 & 16,10 & 13,34 & 11,10 & 7,90 & 5,94 & 3,90 \\
\hline 40 & 1100 & 105 & 27,57 & 22,23 & 19,30 & 16,02 & 13,30 & 11,09 & 7,92 & 5,95 & 3,90 \\
\hline 40 & 1150 & 105 & 27,10 & 21,98 & 19,14 & 15,94 & 13,27 & 11,09 & 7,94 & 5,97 & 3,91 \\
\hline 40 & 1200 & 105 & 26,66 & 21,74 & 18,98 & 15,85 & 13,23 & 11,08 & 7,95 & 5,99 & 3,91 \\
\hline 40 & 1250 & 105 & 26,24 & 21,51 & 18,83 & 15,77 & 13,20 & 11,07 & 7,97 & 6,00 & 3,92 \\
\hline 40 & 1300 & 105 & 25,85 & 21,29 & 18,69 & 15,69 & 13,16 & 11,07 & 7,98 & 6,02 & 3,93 \\
\hline 40 & 1350 & 105 & 25,47 & 21,08 & 18,55 & 15,62 & 13,13 & 11,06 & 7,99 & 6,03 & 3,93 \\
\hline 40 & 1400 & 105 & 25,12 & 20,88 & 18,41 & 15,54 & 13,09 & 11,05 & 8,01 & 6,04 & 3,94 \\
\hline 40 & 1450 & 105 & 24,79 & 20,69 & 18,28 & 15,47 & 13,06 & 11,03 & 8,02 & 6,06 & 3,94 \\
\hline 40 & 1500 & 105 & 24,47 & 20,51 & 18,15 & 15,40 & 13,02 & 11,02 & 8,03 & 6,07 & 3,95 \\
\hline 40 & 1550 & 105 & 24,17 & 20,33 & 18,03 & 15,32 & 12,99 & 11,01 & 8,04 & 6,08 & 3,95 \\
\hline 40 & 1600 & 105 & 23,89 & 20,16 & 17,91 & 15,25 & 12,95 & 11,00 & 8,04 & 6,10 & 3,96 \\
\hline 40 & 1650 & 105 & 23,61 & 19,99 & 17,79 & 15,19 & 12,92 & 10,98 & 8,05 & 6,11 & 3,97 \\
\hline 40 & 1700 & 105 & 23,35 & 19,83 & 17,68 & 15,12 & 12,88 & 10,97 & 8,06 & 6,12 & 3,97 \\
\hline 40 & 1750 & 105 & 23,10 & 19,67 & 17,57 & 15,05 & 12,85 & 10,96 & 8,07 & 6,13 & 3,98 \\
\hline 40 & 1800 & 105 & 22,86 & 19,52 & 17,46 & 14,99 & 12,81 & 10,94 & 8,07 & 6,14 & 3,98 \\
\hline 40 & 1850 & 105 & 22,63 & 19,38 & 17,36 & 14,92 & 12,78 & 10,93 & 8,08 & 6,15 & 3,99 \\
\hline 40 & 1900 & 105 & 22,41 & 19,24 & 17,26 & 14,86 & 12,74 & 10,91 & 8,08 & 6,16 & 4,00 \\
\hline 40 & 1950 & 105 & 22,20 & 19,10 & 17,16 & 14,80 & 12,71 & 10,90 & 8,09 & 6,17 & 4,00 \\
\hline 40 & 2000 & 105 & 21,99 & 18,97 & 17,06 & 14,74 & 12,68 & 10,88 & 8,09 & 6,18 & 4,01 \\
\hline 40 & 200 & 110 & 56,52 & 31,78 & 23,28 & 16,66 & 12,66 & 10,03 & 6,91 & 5,31 & 3,70 \\
\hline 40 & 250 & 110 & 50,55 & 30,25 & 22,82 & 16,68 & 12,77 & 10,13 & 6,98 & 5,33 & 3,69 \\
\hline 40 & 300 & 110 & 46,34 & 29,06 & 22,41 & 16,65 & 12,85 & 10,22 & 7,03 & 5,35 & 3,69 \\
\hline 40 & 350 & 110 & 43,17 & 28,09 & 22,04 & 16,60 & 12,90 & 10,29 & 7,08 & 5,37 & 3,69 \\
\hline 40 & 400 & 110 & 40,67 & 27,27 & 21,70 & 16,54 & 12,93 & 10,35 & 7,13 & 5,40 & 3,68 \\
\hline 40 & 450 & 110 & 38,63 & 26,56 & 21,39 & 16,47 & 12,95 & 10,40 & 7,18 & 5,42 & 3,68 \\
\hline 40 & 500 & 110 & 36,93 & 25,93 & 21,09 & 16,39 & 12,96 & 10,44 & 7.22 & 5,44 & 3,68 \\
\hline 40 & 550 & 110 & 35,47 & 25,38 & 20,82 & 16,30 & 12,96 & 10,48 & 7,26 & 5,46 & 3,68 \\
\hline 40 & 600 & 110 & 34,20 & 24,87 & 20,56 & 16,22 & 12,96 & 10,51 & 7,29 & 5,48 & 3,68 \\
\hline 40 & 650 & 110 & 33,09 & 24,41 & 20,31 & 16,13 & 12,95 & 10,53 & 7,33 & 5,50 & 3,69 \\
\hline 40 & 700 & 110 & 32,10 & 23,98 & 20,08 & 16,04 & 12,93 & 10,55 & 7,36 & 5,52 & 3,69 \\
\hline 40 & 750 & 110 & 31,21 & 23,59 & 19,86 & 15,95 & 12,91 & 10,56 & 7,39 & 5,54 & 3,69 \\
\hline 40 & 800 & 110 & 30,41 & 23,23 & 19,66 & 15,87 & 12,89 & 10,57 & 7,41 & 5,56 & 3,70 \\
\hline 40 & 850 & 110 & 29,68 & 22,89 & 19,46 & 15,78 & 12,87 & 10,58 & 7,44 & 5,58 & 3,70 \\
\hline
\end{tabular}




\begin{tabular}{|c|c|c|c|c|c|c|c|c|c|c|c|}
\hline \multirow[b]{2}{*}{$\mathrm{H}(\mathrm{cm})$} & \multirow[b]{2}{*}{ Mceq (MPa) } & & & & & $\mathrm{De}$ & ões (x1 & & & & \\
\hline & & Msub (MPa) & D0 & D25 & D40 & D60 & D80 & D100 & D140 & D180 & D260 \\
\hline 40 & 900 & 110 & 29,01 & 22,57 & 19,27 & 15,70 & 12,84 & 10,59 & 7,46 & 5,60 & 3,70 \\
\hline 40 & 950 & 110 & 28,39 & 22,27 & 19,09 & 15,61 & 12,82 & 10,59 & 7,49 & 5,62 & 3,71 \\
\hline 40 & 1000 & 110 & 27,82 & 21,99 & 18,91 & 15,53 & 12,79 & 10,59 & 7,51 & 5,63 & 3,71 \\
\hline 40 & 1050 & 110 & 27,29 & 21,72 & 18,75 & 15,45 & 12,76 & 10,59 & 7,53 & 5,65 & 3,72 \\
\hline 40 & 1100 & 110 & 26,80 & 21,47 & 18,59 & 15,37 & 12,73 & 10,59 & 7,54 & 5,67 & 3,72 \\
\hline 40 & 1150 & 110 & 26,34 & 21,23 & 18,43 & 15,29 & 12,70 & 10,59 & 7,56 & 5,68 & 3,73 \\
\hline 40 & 1200 & 110 & 25,91 & 21,00 & 18,28 & 15,22 & 12,67 & 10,58 & 7,58 & 5,70 & 3,73 \\
\hline 40 & 1250 & 110 & 25,50 & 20,78 & 18,14 & 15,14 & 12,64 & 10,58 & 7,59 & 5,71 & 3,74 \\
\hline 40 & 1300 & 110 & 25,12 & 20,57 & 18,00 & 15,07 & 12,60 & 10,57 & 7,60 & 5,73 & 3,74 \\
\hline 40 & 1350 & 110 & 24,75 & 20,37 & 17,87 & 15,00 & 12,57 & 10,56 & 7,62 & 5,74 & 3,75 \\
\hline 40 & 1400 & 110 & 24,41 & 20,18 & 17,74 & 14,93 & 12,54 & 10,56 & 7,63 & 5,75 & 3,75 \\
\hline 40 & 1450 & 110 & 24,09 & 19,99 & 17,61 & 14,86 & 12,51 & 10,55 & 7,64 & 5,77 & 3,76 \\
\hline 40 & 1500 & 110 & 23,78 & 19,82 & 17,49 & 14,79 & 12,48 & 10,54 & 7,65 & 5,78 & 3,76 \\
\hline 40 & 1550 & 110 & 23,48 & 19,64 & 17,38 & 14,72 & 12,44 & 10,53 & 7,66 & 5,79 & 3,77 \\
\hline 40 & 1600 & 110 & 23,20 & 19,48 & 17,26 & 14,66 & 12,41 & 10,52 & 7,67 & 5,80 & 3,77 \\
\hline 40 & 1650 & 110 & 22,94 & 19,32 & 17,15 & 14,59 & 12,38 & 10,50 & 7,67 & 5,81 & 3,78 \\
\hline 40 & 1700 & 110 & 22,68 & 19,17 & 17,04 & 14,53 & 12,35 & 10,49 & 7,68 & 5,82 & 3,78 \\
\hline 40 & 1750 & 110 & 22,44 & 19,02 & 16,94 & 14,47 & 12,31 & 10,48 & 7,69 & 5,83 & 3,79 \\
\hline 40 & 1800 & 110 & 22,20 & 18,87 & 16,84 & 14,41 & 12,28 & 10,47 & 7,70 & 5,84 & 3,79 \\
\hline 40 & 1850 & 110 & 21,98 & 18,73 & 16,74 & 14,35 & 12,25 & 10,45 & 7,70 & 5,85 & 3,80 \\
\hline 40 & 1900 & 110 & 21,76 & 18,60 & 16,64 & 14,29 & 12,22 & 10,44 & 7,71 & 5,86 & 3,80 \\
\hline 40 & 1950 & 110 & 21,55 & 18,47 & 16,55 & 14,23 & 12,19 & 10,43 & 7,71 & 5,87 & 3,81 \\
\hline 40 & 2000 & 110 & 21,35 & 18,34 & 16,45 & 14,18 & 12,16 & 10,42 & 7,72 & 5,88 & 3,82 \\
\hline 40 & 200 & 115 & 55,32 & 30,71 & 22,35 & 15,93 & 12,08 & 9,57 & 6,60 & 5,07 & 3,55 \\
\hline 40 & 250 & 115 & 49,42 & 29,22 & 21,92 & 15,95 & 12,19 & 9,67 & 6,66 & 5,10 & 3,54 \\
\hline 40 & 300 & 115 & 45,26 & 28,07 & 21,54 & 15,94 & 12,27 & 9,76 & 6,71 & 5,12 & 3,53 \\
\hline 40 & 350 & 115 & 42,14 & 27,13 & 21,19 & 15,90 & 12,32 & 9,83 & 6,76 & 5,13 & 3,53 \\
\hline 40 & 400 & 115 & 39,68 & 26,34 & 20,87 & 15,84 & 12,36 & 9,88 & 6,81 & 5,15 & 3,52 \\
\hline 40 & 450 & 115 & 37,67 & 25,66 & 20,57 & 15,78 & 12,38 & 9,93 & 6,85 & 5,17 & 3,52 \\
\hline 40 & 500 & 115 & 36,00 & 25,06 & 20,30 & 15,71 & 12,39 & 9,97 & 6,89 & 5,19 & 3,52 \\
\hline 40 & 550 & 115 & 34,57 & 24,52 & 20,04 & 15,63 & 12,40 & 10,01 & 6,92 & 5,21 & 3,52 \\
\hline 40 & 600 & 115 & 33,33 & 24,03 & 19,79 & 15,55 & 12,40 & 10,04 & 6,96 & 5,23 & 3,52 \\
\hline 40 & 650 & 115 & 32,24 & 23,59 & 19,56 & 15,47 & 12,39 & 10,06 & 6,99 & 5,25 & 3,53 \\
\hline 40 & 700 & 115 & 31,27 & 23,18 & 19,34 & 15,40 & 12,38 & 10,08 & 7,02 & 5,27 & 3,53 \\
\hline 40 & 750 & 115 & 30,40 & 22,81 & 19,14 & 15,32 & 12,36 & 10,10 & 7,05 & 5,29 & 3,53 \\
\hline 40 & 800 & 115 & 29,61 & 22,46 & 18,94 & 15,24 & 12,35 & 10,11 & 7,07 & 5,31 & 3,53 \\
\hline 40 & 850 & 115 & 28,90 & 22,13 & 18,75 & 15,16 & 12,33 & 10,12 & 7,10 & 5,32 & 3,54 \\
\hline 40 & 900 & 115 & 28,24 & 21,83 & 18,57 & 15,08 & 12,30 & 10,12 & 7,12 & 5,34 & 3,54 \\
\hline 40 & 950 & 115 & 27,64 & 21,54 & 18,40 & 15,00 & 12,28 & 10,13 & 7,14 & 5,36 & 3,54 \\
\hline 40 & 1000 & 115 & 27,08 & 21,27 & 18,23 & 14,93 & 12,26 & 10,13 & 7,16 & 5,37 & 3,55 \\
\hline 40 & 1050 & 115 & 26,57 & 21,01 & 18,08 & 14,85 & 12,23 & 10,13 & 7,18 & 5,39 & 3,55 \\
\hline 40 & 1100 & 115 & 26,08 & 20,77 & 17,92 & 14,78 & 12,20 & 10,13 & 7,20 & 5,40 & 3,55 \\
\hline 40 & 1150 & 115 & 25,63 & 20,54 & 17,78 & 14,70 & 12,18 & 10,13 & 7,22 & 5,42 & 3,56 \\
\hline 40 & 1200 & 115 & 25,21 & 20,32 & 17,64 & 14,63 & 12,15 & 10,13 & 7,23 & 5,43 & 3,56 \\
\hline 40 & 1250 & 115 & 24,81 & 20,10 & 17,50 & 14,56 & 12,12 & 10,12 & 7,24 & 5,45 & 3,57 \\
\hline 40 & 1300 & 115 & 24,44 & 19,90 & 17,37 & 14,49 & 12,09 & 10,12 & 7,26 & 5,46 & 3,57 \\
\hline 40 & 1350 & 115 & 24,09 & 19,71 & 17,24 & 14,43 & 12,06 & 10,11 & 7,27 & 5,47 & 3,58 \\
\hline 40 & 1400 & 115 & 23,75 & 19,53 & 17,12 & 14,36 & 12,03 & 10,11 & 7,28 & 5,49 & 3,58 \\
\hline 40 & 1450 & 115 & 23,43 & 19,35 & 17,00 & 14,30 & 12,00 & 10,10 & 7,29 & 5,50 & 3,59 \\
\hline 40 & 1500 & 115 & 23,13 & 19,18 & 16,88 & 14,23 & 11,97 & 10,09 & 7,30 & 5,51 & 3,59 \\
\hline 40 & 1550 & 115 & 22,84 & 19,01 & 16,77 & 14,17 & 11,94 & 10,08 & 7,31 & 5,52 & 3,60 \\
\hline 40 & 1600 & 115 & 22,57 & 18,85 & 16,66 & 14,11 & 11,91 & 10,07 & 7,32 & 5,53 & 3,60 \\
\hline 40 & 1650 & 115 & 22,31 & 18,70 & 16,56 & 14,05 & 11,88 & 10,06 & 7,33 & 5,54 & 3,61 \\
\hline 40 & 1700 & 115 & 22,06 & 18,55 & 16,46 & 13,99 & 11,86 & 10,05 & 7,34 & 5,55 & 3,61 \\
\hline 40 & 1750 & 115 & 21,82 & 18,41 & 16,36 & 13,93 & 11,83 & 10,04 & 7,34 & 5,56 & 3,62 \\
\hline 40 & 1800 & 115 & 21,59 & 18,27 & 16,26 & 13,87 & 11,80 & 10,03 & 7,35 & 5,57 & 3,62 \\
\hline 40 & 1850 & 115 & 21,37 & 18,14 & 16,16 & 13,82 & 11,77 & 10,02 & 7,36 & 5,58 & 3,63 \\
\hline 40 & 1900 & 115 & 21,16 & 18,01 & 16,07 & 13,76 & 11,74 & 10,01 & 7,36 & 5,59 & 3,63 \\
\hline 40 & 1950 & 115 & 20,96 & 17,88 & 15,98 & 13,71 & 11,71 & 10,00 & 7,37 & 5,60 & 3,64 \\
\hline 40 & 2000 & 115 & 20,76 & 17,76 & 15,89 & 13,65 & 11,68 & 9,98 & 7,37 & 5,61 & 3,64 \\
\hline 40 & 200 & 120 & 54,21 & 29,71 & 21,49 & 15,26 & 11,56 & 9,15 & 6,32 & 4,86 & 3,40 \\
\hline 40 & 250 & 120 & 48,36 & 28,26 & 21,09 & 15,29 & 11,67 & 9,25 & 6,37 & 4,88 & 3,39 \\
\hline 40 & 300 & 120 & 44,26 & 27,15 & 20,73 & 15,28 & 11,74 & 9,33 & 6,42 & 4,90 & 3,38 \\
\hline 40 & 350 & 120 & 41,18 & 26,25 & 20,40 & 15,25 & 11,80 & 9,40 & 6,47 & 4,92 & 3,38 \\
\hline 40 & 400 & 120 & 38,75 & 25,49 & 20,10 & 15,20 & 11,83 & 9,45 & 6,51 & 4,93 & 3,38 \\
\hline 40 & 450 & 120 & 36,78 & 24,83 & 19,82 & 15,15 & 11,86 & 9,50 & 6,55 & 4,95 & 3,38 \\
\hline 40 & 500 & 120 & 35,13 & 24,25 & 19,56 & 15,08 & 11,87 & 9,54 & 6,58 & 4,97 & 3,38 \\
\hline 40 & 550 & 120 & 33,73 & 23,73 & 19,31 & 15,01 & 11,88 & 9,58 & 6,62 & 4,99 & 3,38 \\
\hline 40 & 600 & 120 & 32,51 & 23,26 & 19,08 & 14,94 & 11,88 & 9,61 & 6,65 & 5,01 & 3,38 \\
\hline 40 & 650 & 120 & 31,44 & 22,83 & 18,86 & 14,87 & 11,88 & 9,63 & 6,68 & 5,02 & 3,38 \\
\hline 40 & 700 & 120 & 30,49 & 22,44 & 18,66 & 14,80 & 11,87 & 9,65 & 6,71 & 5,04 & 3,38 \\
\hline 40 & 750 & 120 & 29,64 & 22,08 & 18,46 & 14,72 & 11,86 & 9,67 & 6,74 & 5,06 & 3,38 \\
\hline 40 & 800 & 120 & 28,87 & 21,74 & 18,28 & 14,65 & 11,84 & 9,68 & 6,76 & 5,07 & 3,38 \\
\hline 40 & 850 & 120 & 28,17 & 21,43 & 18,10 & 14,58 & 11,83 & 9,69 & 6.79 & 5,09 & 3,39 \\
\hline 40 & 900 & 120 & 27,53 & 21,13 & 17,93 & 14,51 & 11,81 & 9,70 & 6,81 & 5,11 & 3,39 \\
\hline 40 & 950 & 120 & 26,94 & 20,86 & 17,76 & 14,43 & 11,79 & 9,70 & 6,83 & 5,12 & 3,39 \\
\hline 40 & 1000 & 120 & 26,40 & 20,60 & 17,61 & 14,36 & 11,77 & 9,71 & 6,85 & 5,14 & 3,40 \\
\hline 40 & 1050 & 120 & 25,89 & 20,35 & 17,46 & 14,29 & 11,74 & 9,71 & 6,87 & 5,15 & 3,40 \\
\hline 40 & 1100 & 120 & 25,42 & 20,12 & 17,31 & 14,23 & 11,72 & 9,71 & 6,88 & 5,17 & 3,40 \\
\hline 40 & 1150 & 120 & 24,98 & 19,89 & 17,17 & 14,16 & 11,69 & 9,71 & 6,90 & 5,18 & 3,41 \\
\hline 40 & 1200 & 120 & 24,57 & 19,68 & 17,04 & 14,09 & 11,67 & 9,71 & 6,91 & 5,19 & 3,41 \\
\hline
\end{tabular}




\begin{tabular}{|c|c|c|c|c|c|c|c|c|c|c|c|}
\hline \multirow[b]{2}{*}{$\mathrm{H}(\mathrm{cm})$} & \multirow[b]{2}{*}{ Mceq (MPa) } & & & & & $\mathrm{De}$ & ões (x1 & & & & \\
\hline & & Msub (MPa) & D0 & D25 & D40 & D60 & D80 & D100 & D140 & D180 & D260 \\
\hline 40 & 1250 & 120 & 24,18 & 19,48 & 16,91 & 14,03 & 11,64 & 9,71 & 6,93 & 5,21 & 3,41 \\
\hline 40 & 1300 & 120 & 23,81 & 19,28 & 16,78 & 13,96 & 11,62 & 9,70 & 6,94 & 5,22 & 3,42 \\
\hline 40 & 1350 & 120 & 23,47 & 19,10 & 16,66 & 13,90 & 11,59 & 9,70 & 6,95 & 5,23 & 3,42 \\
\hline 40 & 1400 & 120 & 23,14 & 18,92 & 16,54 & 13,84 & 11,56 & 9,69 & 6,97 & 5,24 & 3,43 \\
\hline 40 & 1450 & 120 & 22,83 & 18,75 & 16,43 & 13,78 & 11,54 & 9,69 & 6,98 & 5,26 & 3,43 \\
\hline 40 & 1500 & 120 & 22,53 & 18,58 & 16,32 & 13,72 & 11,51 & 9,68 & 6,99 & 5,27 & 3,44 \\
\hline 40 & 1550 & 120 & 22,25 & 18,43 & 16,21 & 13,66 & 11,48 & 9,67 & 7,00 & 5,28 & 3,44 \\
\hline 40 & 1600 & 120 & 21,98 & 18,27 & 16,11 & 13,60 & 11,46 & 9,66 & 7,00 & 5,29 & 3,45 \\
\hline 40 & 1650 & 120 & 21,73 & 18,12 & 16,01 & 13,54 & 11,43 & 9,66 & 7,01 & 5,30 & 3,45 \\
\hline 40 & 1700 & 120 & 21,48 & 17,98 & 15,91 & 13,49 & 11,40 & 9,65 & 7,02 & 5,31 & 3,45 \\
\hline 40 & 1750 & 120 & 21,25 & 17,84 & 15,81 & 13,43 & 11,37 & 9,64 & 7,03 & 5,32 & 3,46 \\
\hline 40 & 1800 & 120 & 21,02 & 17,71 & 15,72 & 13,38 & 11,35 & 9,63 & 7,03 & 5,33 & 3,46 \\
\hline 40 & 1850 & 120 & 20,81 & 17,58 & 15,63 & 13,32 & 11,32 & 9,62 & 7,04 & 5,34 & 3,47 \\
\hline 40 & 1900 & 120 & 20,60 & 17,46 & 15,54 & 13,27 & 11,29 & 9,61 & 7,05 & 5,35 & 3,47 \\
\hline 40 & 1950 & 120 & 20,40 & 17,33 & 15,46 & 13,22 & 11,27 & 9,60 & 7,05 & 5,35 & 3,48 \\
\hline 40 & 2000 & 120 & 20,21 & 17,22 & 15,37 & 13,17 & 11,24 & 9,59 & 7,06 & 5,36 & 3,48 \\
\hline 40 & 200 & 125 & 53,18 & 28,79 & 20,70 & 14,63 & 11,08 & 8,77 & 6,05 & 4,66 & 3,27 \\
\hline 40 & 250 & 125 & 47,39 & 27,38 & 20,32 & 14,67 & 11,18 & 8,86 & 6,11 & 4,68 & 3,26 \\
\hline 40 & 300 & 125 & 43,33 & 26,30 & 19,98 & 14,67 & 11,26 & 8,94 & 6,15 & 4,70 & 3,25 \\
\hline 40 & 350 & 125 & 40,28 & 25,43 & 19,67 & 14,65 & 11,31 & 9,01 & 6,20 & 4,71 & 3,25 \\
\hline 40 & 400 & 125 & 37,89 & 24,69 & 19,39 & 14,61 & 11,35 & 9,06 & 6,24 & 4,73 & 3,24 \\
\hline 40 & 450 & 125 & 35,95 & 24,05 & 19,12 & 14,56 & 11,38 & 9,11 & 6,27 & 4,75 & 3,24 \\
\hline 40 & 500 & 125 & 34,33 & 23,49 & 18,87 & 14,50 & 11,39 & 9,15 & 6,31 & 4,76 & 3,24 \\
\hline 40 & 550 & 125 & 32,95 & 22,99 & 18,64 & 14,44 & 11,40 & 9,18 & 6,34 & 4,78 & 3,24 \\
\hline 40 & 600 & 125 & 31,75 & 22,54 & 18,42 & 14,38 & 11,41 & 9,21 & 6,37 & 4,80 & 3,24 \\
\hline 40 & 650 & 125 & 30,70 & 22,13 & 18,22 & 14,31 & 11,41 & 9,23 & 6,40 & 4,81 & 3,24 \\
\hline 40 & 700 & 125 & 29,77 & 21,75 & 18,02 & 14,25 & 11,40 & 9,25 & 6,43 & 4,83 & 3,24 \\
\hline 40 & 750 & 125 & 28,94 & 21,40 & 17,84 & 14,18 & 11,39 & 9,27 & 6,45 & 4,85 & 3,24 \\
\hline 40 & 800 & 125 & 28,18 & 21,08 & 17,66 & 14,11 & 11,38 & 9,28 & 6,48 & 4,86 & 3,25 \\
\hline 40 & 850 & 125 & 27,50 & 20,77 & 17,49 & 14,04 & 11,36 & 9,30 & 6,50 & 4,88 & 3,25 \\
\hline 40 & 900 & 125 & 26,87 & 20,49 & 17,33 & 13,98 & 11,35 & 9,30 & 6,52 & 4,89 & 3,25 \\
\hline 40 & 950 & 125 & 26,29 & 20,22 & 17,17 & 13,91 & 11,33 & 9,31 & 6,54 & 4,91 & 3,25 \\
\hline 40 & 1000 & 125 & 25,76 & 19,97 & 17,02 & 13,84 & 11,31 & 9,32 & 6,56 & 4,92 & 3,26 \\
\hline 40 & 1050 & 125 & 25,26 & 19,73 & 16,88 & 13,78 & 11,29 & 9,32 & 6,58 & 4,93 & 3,26 \\
\hline 40 & 1100 & 125 & 24,80 & 19,51 & 16,74 & 13,71 & 11,27 & 9,32 & 6,59 & 4,95 & 3,26 \\
\hline 40 & 1150 & 125 & 24,37 & 19,29 & 16,61 & 13,65 & 11,25 & 9,32 & 6,61 & 4,96 & 3,27 \\
\hline 40 & 1200 & 125 & 23,96 & 19,09 & 16,48 & 13,59 & 11,23 & 9,32 & 6,62 & 4,97 & 3,27 \\
\hline 40 & 1250 & 125 & 23,58 & 18,89 & 16,36 & 13,53 & 11,20 & 9,32 & 6,64 & 4,99 & 3,27 \\
\hline 40 & 1300 & 125 & 23,23 & 18,71 & 16,24 & 13,47 & 11,18 & 9,32 & 6,65 & 5,00 & 3,28 \\
\hline 40 & 1350 & 125 & 22,89 & 18,53 & 16,12 & 13,41 & 11,15 & 9,32 & 6,66 & 5,01 & 3,28 \\
\hline 40 & 1400 & 125 & 22,57 & 18,35 & 16,01 & 13,35 & 11,13 & 9,31 & 6,67 & 5,02 & 3,29 \\
\hline 40 & 1450 & 125 & 22,26 & 18,19 & 15,90 & 13,29 & 11,11 & 9,31 & 6,69 & 5,03 & 3,29 \\
\hline 40 & 1500 & 125 & 21,97 & 18,03 & 15,79 & 13,24 & 11,08 & 9,30 & 6,70 & 5,04 & 3,29 \\
\hline 40 & 1550 & 125 & 21,70 & 17,88 & 15,69 & 13,18 & 11,06 & 9,29 & 6,70 & 5,05 & 3,30 \\
\hline 40 & 1600 & 125 & 21,44 & 17,73 & 15,59 & 13,13 & 11,03 & 9,29 & 6,71 & 5,06 & 3,30 \\
\hline 40 & 1650 & 125 & 21,19 & 17,59 & 15,50 & 13,07 & 11,01 & 9,28 & 6,72 & 5,07 & 3,31 \\
\hline 40 & 1700 & 125 & 20,95 & 17,45 & 15,40 & 13,02 & 10,98 & 9,27 & 6,73 & 5,08 & 3,31 \\
\hline 40 & 1750 & 125 & 20,72 & 17,32 & 15,31 & 12,97 & 10,96 & 9,26 & 6,74 & 5,09 & 3,31 \\
\hline 40 & 1800 & 125 & 20,50 & 17,19 & 15,22 & 12,92 & 10,93 & 9,26 & 6,74 & 5,10 & 3,32 \\
\hline 40 & 1850 & 125 & 20,29 & 17,06 & 15,14 & 12,87 & 10,91 & 9,25 & 6,75 & 5,11 & 3,32 \\
\hline 40 & 1900 & 125 & 20,08 & 16,94 & 15,05 & 12,82 & 10,88 & 9,24 & 6,76 & 5,12 & 3,33 \\
\hline 40 & 1950 & 125 & 19,89 & 16,82 & 14,97 & 12,77 & 10,86 & 9,23 & 6,76 & 5,13 & 3,33 \\
\hline 40 & 2000 & 125 & 19,70 & 16,71 & 14,89 & 12,72 & 10,83 & 9,22 & 6,77 & 5,14 & 3,33 \\
\hline 40 & 200 & 130 & 52,22 & 27,93 & 19,96 & 14,06 & 10,63 & 8,42 & 5,81 & 4,48 & 3,14 \\
\hline 40 & 250 & 130 & 46,47 & 26,56 & 19,60 & 14,11 & 10,74 & 8,51 & 5,86 & 4,50 & 3,13 \\
\hline 40 & 300 & 130 & 42,46 & 25,51 & 19,28 & 14,11 & 10,81 & 8,58 & 5,91 & 4,51 & 3,13 \\
\hline 40 & 350 & 130 & 39,45 & 24,66 & 18,99 & 14,09 & 10,87 & 8,64 & 5,95 & 4,53 & 3,12 \\
\hline 40 & 400 & 130 & 37,09 & 23,95 & 18,72 & 14,06 & 10,90 & 8,70 & 5,98 & 4,54 & 3,12 \\
\hline 40 & 450 & 130 & 35,17 & 23,33 & 18,47 & 14,02 & 10,93 & 8,74 & 6,02 & 4,56 & 3,12 \\
\hline 40 & 500 & 130 & 33,58 & 22,79 & 18,24 & 13,97 & 10,95 & 8,78 & 6,05 & 4,57 & 3,12 \\
\hline 40 & 550 & 130 & 32,22 & 22,30 & 18,02 & 13,91 & 10,96 & 8,81 & 6,08 & 4,59 & 3,12 \\
\hline 40 & 600 & 130 & 31,04 & 21,87 & 17,81 & 13,85 & 10,97 & 8,84 & 6,11 & 4,61 & 3,12 \\
\hline 40 & 650 & 130 & 30,01 & 21,47 & 17,61 & 13,79 & 10,97 & 8,87 & 6,14 & 4,62 & 3,12 \\
\hline 40 & 700 & 130 & 29,10 & 21,11 & 17,43 & 13,73 & 10,96 & 8,89 & 6,17 & 4,64 & 3,12 \\
\hline 40 & 750 & 130 & 28,28 & 20,77 & 17,25 & 13,67 & 10,96 & 8,90 & 6,19 & 4,65 & 3,12 \\
\hline 40 & 800 & 130 & 27,54 & 20,46 & 17,08 & 13,61 & 10,95 & 8,92 & 6,21 & 4,67 & 3,12 \\
\hline 40 & 850 & 130 & 26,86 & 20,16 & 16,92 & 13,55 & 10,94 & 8,93 & 6,24 & 4,68 & 3,12 \\
\hline 40 & 900 & 130 & 26,25 & 19,89 & 16,77 & 13,48 & 10,92 & 8,94 & 6,26 & 4,69 & 3,13 \\
\hline 40 & 950 & 130 & 25,68 & 19,63 & 16,62 & 13,42 & 10,91 & 8,95 & 6,28 & 4,71 & 3,13 \\
\hline 40 & 1000 & 130 & 25,16 & 19,39 & 16,48 & 13,36 & 10,89 & 8,95 & 6,29 & 4,72 & 3,13 \\
\hline 40 & 1050 & 130 & 24,67 & 19,16 & 16,34 & 13,30 & 10,87 & 8,96 & 6,31 & 4,73 & 3,13 \\
\hline 40 & 1100 & 130 & 24,22 & 18,94 & 16,21 & 13,24 & 10,85 & 8,96 & 6,33 & 4,75 & 3,14 \\
\hline 40 & 1150 & 130 & 23,80 & 18,73 & 16,08 & 13,18 & 10,83 & 8,96 & 6,34 & 4,76 & 3,14 \\
\hline 40 & 1200 & 130 & 23,40 & 18,54 & 15,96 & 13,12 & 10,81 & 8.96 & 6,36 & 4.77 & 3,14 \\
\hline 40 & 1250 & 130 & 23,03 & 18,35 & 15,84 & 13,06 & 10,79 & 8,96 & 6,37 & 4,78 & 3,15 \\
\hline 40 & 1300 & 130 & 22,68 & 18,17 & 15,73 & 13,01 & 10,77 & 8,96 & 6,38 & 4,79 & 3,15 \\
\hline 40 & 1350 & 130 & 22,34 & 17,99 & 15,62 & 12,95 & 10,75 & 8,96 & 6,39 & 4,81 & 3,15 \\
\hline 40 & 1400 & 130 & 22,03 & 17,83 & 15,51 & 12,90 & 10,73 & 8,96 & 6,41 & 4,82 & 3,16 \\
\hline 40 & 1450 & 130 & 21,73 & 17,67 & 15,41 & 12,84 & 10,70 & 8,95 & 6,42 & 4,83 & 3,16 \\
\hline 40 & 1500 & 130 & 21,45 & 17,51 & 15,30 & 12,79 & 10,68 & 8,95 & 6,43 & 4,84 & 3,16 \\
\hline 40 & 1550 & 130 & 21,18 & 17,37 & 15,21 & 12,74 & 10,66 & 8,94 & 6,44 & 4,85 & 3,17 \\
\hline
\end{tabular}




\begin{tabular}{|c|c|c|c|c|c|c|c|c|c|c|c|}
\hline \multirow[b]{2}{*}{$\mathrm{H}(\mathrm{cm})$} & \multirow[b]{2}{*}{ Mceq (MPa) } & & & & & $\mathrm{De}$ & ões (x1 & & & & \\
\hline & & Msub (MPa) & D0 & D25 & D40 & D60 & D80 & D100 & D140 & D180 & D260 \\
\hline 40 & 1600 & 130 & 20,92 & 17,22 & 15,11 & 12,69 & 10,64 & 8,94 & 6,44 & 4,86 & 3,17 \\
\hline 40 & 1650 & 130 & 20,68 & 17,09 & 15,02 & 12,64 & 10,61 & 8,93 & 6,45 & 4,87 & 3,17 \\
\hline 40 & 1700 & 130 & 20,44 & 16,95 & 14,93 & 12,59 & 10,59 & 8,93 & 6,46 & 4,88 & 3,18 \\
\hline 40 & 1750 & 130 & 20,22 & 16,82 & 14,84 & 12,54 & 10,57 & 8,92 & 6,47 & 4,88 & 3,18 \\
\hline 40 & 1800 & 130 & 20,00 & 16,70 & 14,76 & 12,49 & 10,54 & 8,91 & 6,48 & 4,89 & 3,19 \\
\hline 40 & 1850 & 130 & 19,80 & 16,58 & 14,67 & 12,44 & 10,52 & 8,90 & 6,48 & 4,90 & 3,19 \\
\hline 40 & 1900 & 130 & 19,60 & 16,46 & 14,59 & 12,39 & 10,50 & 8,90 & 6,49 & 4,91 & 3,19 \\
\hline 40 & 1950 & 130 & 19,41 & 16,35 & 14,51 & 12,35 & 10,47 & 8,89 & 6,49 & 4,92 & 3,20 \\
\hline 40 & 2000 & 130 & 19,22 & 16,24 & 14,43 & 12,30 & 10,45 & 8,88 & 6,50 & 4,93 & 3,20 \\
\hline 40 & 200 & 135 & 51,32 & 27,13 & 19,28 & 13,53 & 10,22 & 8,09 & 5,59 & 4,31 & 3,03 \\
\hline 40 & 250 & 135 & 45,62 & 25,79 & 18,94 & 13,58 & 10,32 & 8,18 & 5,64 & 4,33 & 3,02 \\
\hline 40 & 300 & 135 & 41,64 & 24,77 & 18,63 & 13,59 & 10,40 & 8,25 & 5,68 & 4,34 & 3,01 \\
\hline 40 & 350 & 135 & 38,67 & 23,94 & 18,36 & 13,58 & 10,45 & 8,31 & 5,72 & 4,36 & 3,01 \\
\hline 40 & 400 & 135 & 36,34 & 23,25 & 18,10 & 13,55 & 10,49 & 8,36 & 5,75 & 4,37 & 3,00 \\
\hline 40 & 450 & 135 & 34,45 & 22,65 & 17,87 & 13,51 & 10,52 & 8,40 & 5,79 & 4,39 & 3,00 \\
\hline 40 & 500 & 135 & 32,87 & 22,13 & 17,64 & 13,47 & 10,54 & 8,44 & 5,82 & 4,40 & 3,00 \\
\hline 40 & 550 & 135 & 31,53 & 21,66 & 17,44 & 13,42 & 10,55 & 8,48 & 5,85 & 4,41 & 3,00 \\
\hline 40 & 600 & 135 & 30,38 & 21,24 & 17,24 & 13,37 & 10,56 & 8,50 & 5,87 & 4,43 & 3,00 \\
\hline 40 & 650 & 135 & 29,36 & 20,86 & 17,05 & 13,31 & 10,56 & 8,53 & 5,90 & 4,44 & 3,00 \\
\hline 40 & 700 & 135 & 28,46 & 20,50 & 16,88 & 13,25 & 10,56 & 8,55 & 5,93 & 4,46 & 3,00 \\
\hline 40 & 750 & 135 & 27,66 & 20,18 & 16,71 & 13,20 & 10,56 & 8,57 & 5,95 & 4,47 & 3,00 \\
\hline 40 & 800 & 135 & 26,93 & 19,87 & 16,55 & 13,14 & 10,55 & 8,58 & 5,97 & 4,48 & 3,00 \\
\hline 40 & 850 & 135 & 26,27 & 19,59 & 16,39 & 13,08 & 10,54 & 8,59 & 5,99 & 4,50 & 3,01 \\
\hline 40 & 900 & 135 & 25,66 & 19,33 & 16,24 & 13,02 & 10,53 & 8,60 & 6,01 & 4,51 & 3,01 \\
\hline 40 & 950 & 135 & 25,11 & 19,08 & 16,10 & 12,97 & 10,51 & 8,61 & 6,03 & 4,52 & 3,01 \\
\hline 40 & 1000 & 135 & 24,59 & 18,84 & 15,97 & 12,91 & 10,50 & 8,62 & 6,05 & 4,54 & 3,01 \\
\hline 40 & 1050 & 135 & 24,12 & 18,62 & 15,84 & 12,85 & 10,48 & 8,62 & 6,06 & 4,55 & 3,01 \\
\hline 40 & 1100 & 135 & 23,67 & 18,41 & 15,71 & 12,80 & 10,47 & 8,63 & 6,08 & 4,56 & 3,02 \\
\hline 40 & 1150 & 135 & 23,26 & 18,21 & 15,59 & 12,74 & 10,45 & 8,63 & 6,09 & 4,57 & 3,02 \\
\hline 40 & 1200 & 135 & 22,87 & 18,02 & 15,47 & 12,69 & 10,43 & 8,63 & 6,11 & 4,58 & 3,02 \\
\hline 40 & 1250 & 135 & 22,51 & 17,84 & 15,36 & 12,63 & 10,41 & 8,63 & 6,12 & 4,59 & 3,03 \\
\hline 40 & 1300 & 135 & 22,16 & 17,66 & 15,25 & 12,58 & 10,39 & 8,63 & 6,13 & 4,61 & 3,03 \\
\hline 40 & 1350 & 135 & 21,84 & 17,49 & 15,14 & 12,53 & 10,37 & 8,63 & 6,15 & 4,62 & 3,03 \\
\hline 40 & 1400 & 135 & 21,53 & 17,33 & 15,04 & 12,47 & 10,35 & 8,63 & 6,16 & 4,63 & 3,04 \\
\hline 40 & 1450 & 135 & 21,24 & 17,18 & 14,94 & 12,42 & 10,33 & 8,63 & 6,17 & 4,64 & 3,04 \\
\hline 40 & 1500 & 135 & 20,96 & 17,03 & 14,85 & 12,37 & 10,31 & 8,62 & 6,18 & 4,65 & 3,04 \\
\hline 40 & 1550 & 135 & 20,69 & 16,89 & 14,75 & 12,32 & 10,29 & 8,62 & 6,19 & 4,66 & 3,05 \\
\hline 40 & 1600 & 135 & 20,44 & 16,75 & 14,66 & 12,28 & 10,27 & 8,61 & 6,20 & 4,67 & 3,05 \\
\hline 40 & 1650 & 135 & 20,20 & 16,62 & 14,57 & 12,23 & 10,25 & 8,61 & 6,20 & 4,68 & 3,05 \\
\hline 40 & 1700 & 135 & 19,97 & 16,49 & 14,49 & 12,18 & 10,23 & 8,60 & 6,21 & 4,68 & 3,06 \\
\hline 40 & 1750 & 135 & 19,75 & 16,36 & 14,40 & 12,13 & 10,20 & 8,60 & 6,22 & 4,69 & 3,06 \\
\hline 40 & 1800 & 135 & 19,54 & 16,24 & 14,32 & 12,09 & 10,18 & 8,59 & 6,23 & 4,70 & 3,06 \\
\hline 40 & 1850 & 135 & 19,34 & 16,13 & 14,24 & 12,04 & 10,16 & 8,58 & 6,23 & 4,71 & 3,07 \\
\hline 40 & 1900 & 135 & 19,14 & 16,01 & 14,16 & 12,00 & 10,14 & 8,58 & 6,24 & 4,72 & 3,07 \\
\hline 40 & 1950 & 135 & 18,96 & 15,90 & 14,09 & 11,96 & 10,12 & 8,57 & 6,25 & 4,72 & 3,07 \\
\hline 40 & 2000 & 135 & 18,78 & 15,80 & 14,01 & 11,91 & 10,10 & 8,56 & 6,25 & 4,73 & 3,08 \\
\hline 40 & 200 & 140 & 50,48 & 26,38 & 18,64 & 13,03 & 9,84 & 7,79 & 5,38 & 4,16 & 2,92 \\
\hline 40 & 250 & 140 & 44,82 & 25,07 & 18,32 & 13,09 & 9,94 & 7,87 & 5,43 & 4,17 & 2,91 \\
\hline 40 & 300 & 140 & 40,88 & 24,08 & 18,03 & 13,10 & 10,01 & 7,94 & 5,47 & 4,18 & 2,90 \\
\hline 40 & 350 & 140 & 37,94 & 23,27 & 17,77 & 13,10 & 10,07 & 8,00 & 5,50 & 4,20 & 2,90 \\
\hline 40 & 400 & 140 & 35,63 & 22,60 & 17,52 & 13,08 & 10,11 & 8,05 & 5,54 & 4,21 & 2,90 \\
\hline 40 & 450 & 140 & 33,77 & 22,02 & 17,30 & 13,04 & 10,14 & 8,09 & 5,57 & 4,22 & 2,90 \\
\hline 40 & 500 & 140 & 32,21 & 21,51 & 17,09 & 13,00 & 10,16 & 8,13 & 5,60 & 4,24 & 2,89 \\
\hline 40 & 550 & 140 & 30,89 & 21,06 & 16,89 & 12,96 & 10,17 & 8,16 & 5,63 & 4,25 & 2,89 \\
\hline 40 & 600 & 140 & 29,75 & 20,65 & 16,70 & 12,91 & 10,18 & 8,19 & 5,65 & 4,26 & 2,89 \\
\hline 40 & 650 & 140 & 28,75 & 20,28 & 16,53 & 12,86 & 10,18 & 8,21 & 5,68 & 4,28 & 2,89 \\
\hline 40 & 700 & 140 & 27,87 & 19,94 & 16,36 & 12,81 & 10,18 & 8,23 & 5,70 & 4,29 & 2,89 \\
\hline 40 & 750 & 140 & 27,07 & 19,62 & 16,20 & 12,76 & 10,18 & 8,25 & 5,72 & 4,30 & 2,90 \\
\hline 40 & 800 & 140 & 26,36 & 19,33 & 16,04 & 12,70 & 10,18 & 8,27 & 5,75 & 4,32 & 2,90 \\
\hline 40 & 850 & 140 & 25,71 & 19,06 & 15,90 & 12,65 & 10,17 & 8,28 & 5,77 & 4,33 & 2,90 \\
\hline 40 & 900 & 140 & 25,12 & 18,80 & 15,75 & 12,59 & 10,16 & 8,29 & 5,78 & 4,34 & 2,90 \\
\hline 40 & 950 & 140 & 24,57 & 18,56 & 15,62 & 12,54 & 10,15 & 8,30 & 5,80 & 4,35 & 2,90 \\
\hline 40 & 1000 & 140 & 24,07 & 18,33 & 15,49 & 12,49 & 10,13 & 8,31 & 5,82 & 4,37 & 2,90 \\
\hline 40 & 1050 & 140 & 23,60 & 18,12 & 15,37 & 12,43 & 10,12 & 8,31 & 5,84 & 4,38 & 2,91 \\
\hline 40 & 1100 & 140 & 23,16 & 17,91 & 15,24 & 12,38 & 10,11 & 8,32 & 5,85 & 4,39 & 2,91 \\
\hline 40 & 1150 & 140 & 22,76 & 17,72 & 15,13 & 12,33 & 10,09 & 8,32 & 5,87 & 4,40 & 2,91 \\
\hline 40 & 1200 & 140 & 22,37 & 17,53 & 15,02 & 12,28 & 10,07 & 8,32 & 5,88 & 4,41 & 2,91 \\
\hline 40 & 1250 & 140 & 22,02 & 17,36 & 14,91 & 12,23 & 10,06 & 8,32 & 5,89 & 4,42 & 2,92 \\
\hline 40 & 1300 & 140 & 21,68 & 17,19 & 14,80 & 12,18 & 10,04 & 8,32 & 5,90 & 4,43 & 2,92 \\
\hline 40 & 1350 & 140 & 21,36 & 17,02 & 14,70 & 12,13 & 10,02 & 8,32 & 5,92 & 4,44 & 2,92 \\
\hline 40 & 1400 & 140 & 21,06 & 16,87 & 14,60 & 12,08 & 10,00 & 8,32 & 5,93 & 4,45 & 2,92 \\
\hline 40 & 1450 & 140 & 20,77 & 16,72 & 14,51 & 12,03 & 9,98 & 8,32 & 5,94 & 4,46 & 2,93 \\
\hline 40 & 1500 & 140 & 20,50 & 16,58 & 14,42 & 11,98 & 9,96 & 8,32 & 5,95 & 4,47 & 2,93 \\
\hline 40 & 1550 & 140 & 20,24 & 16,44 & 14,33 & 11,94 & 9,94 & 8,31 & 5,96 & 4,48 & 2,93 \\
\hline 40 & 1600 & 140 & 19,99 & 16,30 & 14,24 & 11,89 & 9,93 & 8,31 & 5,96 & 4,49 & 2,94 \\
\hline 40 & 1650 & 140 & 19,76 & 16,17 & 14,15 & 11,85 & 9,91 & 8,31 & 5,97 & 4,50 & 2,94 \\
\hline 40 & 1700 & 140 & 19,53 & 16,05 & 14,07 & 11,80 & 9,89 & 8,30 & 5,98 & 4,51 & 2,94 \\
\hline 40 & 1750 & 140 & 19,31 & 15,93 & 13,99 & 11,76 & 9,87 & 8,30 & 5,99 & 4,51 & 2,95 \\
\hline 40 & 1800 & 140 & 19,11 & 15,81 & 13,91 & 11,71 & 9,85 & 8,29 & 6,00 & 4,52 & 2,95 \\
\hline 40 & 1850 & 140 & 18,91 & 15,70 & 13,83 & 11,67 & 9,83 & 8,29 & 6,00 & 4,53 & 2,95 \\
\hline 40 & 1900 & 140 & 18,72 & 15,59 & 13,76 & 11,63 & 9,81 & 8,28 & 6,01 & 4,54 & 2,96 \\
\hline
\end{tabular}




\begin{tabular}{|c|c|c|c|c|c|c|c|c|c|c|c|}
\hline \multirow[b]{2}{*}{$\mathrm{H}(\mathrm{cm})$} & \multirow[b]{2}{*}{ Mceq (MPa) } & & & & & De & D̃es (x & & & & \\
\hline & & Msub (MPa) & D0 & D25 & D40 & D60 & D80 & D100 & D140 & D180 & D260 \\
\hline 40 & 1950 & 140 & 18,53 & 15,48 & 13,68 & 11,59 & 9,79 & 8,27 & 6,01 & 4,55 & 2,96 \\
\hline 40 & 2000 & 140 & 18,36 & 15,38 & 13,61 & 11,55 & 9,77 & 8,27 & 6,02 & 4,55 & 2,96 \\
\hline 40 & 200 & 145 & 49,69 & 25,68 & 18,04 & 12,57 & 9,48 & 7,51 & 5,19 & 4,01 & 2,82 \\
\hline 40 & 250 & 145 & 44,07 & 24,40 & 17,74 & 12,63 & 9,58 & 7,59 & 5,23 & 4,02 & 2,81 \\
\hline 40 & 300 & 145 & 40,16 & 23,43 & 17,46 & 12,65 & 9,65 & 7,65 & 5,27 & 4,04 & 2,81 \\
\hline 40 & 350 & 145 & 37,25 & 22,64 & 17,21 & 12,65 & 9,71 & 7,71 & 5,31 & 4,05 & 2,80 \\
\hline 40 & 400 & 145 & 34,97 & 21,99 & 16,98 & 12,63 & 9,75 & 7,76 & 5,34 & 4,06 & 2,80 \\
\hline 40 & 450 & 145 & 33,12 & 21,43 & 16,77 & 12,60 & 9,78 & 7,80 & 5,37 & 4,07 & 2,80 \\
\hline 40 & 500 & 145 & 31,59 & 20,93 & 16,57 & 12,57 & 9,80 & 7,84 & 5,40 & 4,09 & 2,79 \\
\hline 40 & 550 & 145 & 30,29 & 20,49 & 16,38 & 12,53 & 9,82 & 7,87 & 5,42 & 4,10 & 2,79 \\
\hline 40 & 600 & 145 & 29,16 & 20,10 & 16,20 & 12,49 & 9,83 & 7,90 & 5,45 & 4,11 & 2,79 \\
\hline 40 & 650 & 145 & 28,18 & 19,74 & 16,03 & 12,44 & 9,83 & 7,92 & 5,47 & 4,12 & 2,79 \\
\hline 40 & 700 & 145 & 27,31 & 19,41 & 15,87 & 12,39 & 9,83 & 7,94 & 5,49 & 4,14 & 2,79 \\
\hline 40 & 750 & 145 & 26,53 & 19,10 & 15,72 & 12,34 & 9,83 & 7,96 & 5,52 & 4,15 & 2,79 \\
\hline 40 & 800 & 145 & 25,82 & 18,82 & 15,57 & 12,29 & 9,83 & 7,97 & 5,54 & 4,16 & 2,80 \\
\hline 40 & 850 & 145 & 25,18 & 18,55 & 15,43 & 12,24 & 9,82 & 7,99 & 5,56 & 4,17 & 2,80 \\
\hline 40 & 900 & 145 & 24,60 & 18,30 & 15,30 & 12,19 & 9,81 & 8,00 & 5,57 & 4,18 & 2,80 \\
\hline 40 & 950 & 145 & 24,06 & 18,07 & 15,17 & 12,14 & 9,80 & 8,01 & 5,59 & 4,20 & 2,80 \\
\hline 40 & 1000 & 145 & 23,57 & 17,85 & 15,04 & 12,09 & 9,79 & 8,02 & 5,61 & 4,21 & 2,80 \\
\hline 40 & 1050 & 145 & 23,11 & 17,64 & 14,92 & 12,04 & 9,78 & 8,02 & 5,62 & 4,22 & 2,80 \\
\hline 40 & 1100 & 145 & 22,68 & 17,44 & 14,81 & 11,99 & 9,77 & 8,03 & 5,64 & 4,23 & 2,81 \\
\hline 40 & 1150 & 145 & 22,28 & 17,25 & 14,70 & 11,94 & 9,75 & 8,03 & 5,65 & 4,24 & 2,81 \\
\hline 40 & 1200 & 145 & 21,91 & 17,07 & 14,59 & 11,90 & 9,74 & 8,03 & 5,67 & 4,25 & 2,81 \\
\hline 40 & 1250 & 145 & 21,55 & 16,90 & 14,48 & 11,85 & 9,72 & 8,04 & 5,68 & 4,26 & 2,81 \\
\hline 40 & 1300 & 145 & 21,22 & 16,74 & 14,38 & 11,80 & 9,71 & 8,04 & 5,69 & 4,27 & 2,81 \\
\hline 40 & 1350 & 145 & 20,91 & 16,58 & 14,29 & 11,75 & 9,69 & 8,04 & 5,70 & 4,28 & 2,82 \\
\hline 40 & 1400 & 145 & 20,61 & 16,43 & 14,19 & 11,71 & 9,67 & 8,04 & 5,71 & 4,29 & 2,82 \\
\hline 40 & 1450 & 145 & 20,33 & 16,29 & 14,10 & 11,66 & 9,66 & 8,04 & 5,72 & 4,30 & 2,82 \\
\hline 40 & 1500 & 145 & 20,06 & 16,15 & 14,01 & 11,62 & 9,64 & 8,03 & 5,73 & 4,31 & 2,83 \\
\hline 40 & 1550 & 145 & 19,81 & 16,01 & 13,92 & 11,57 & 9,62 & 8,03 & 5,74 & 4,32 & 2,83 \\
\hline 40 & 1600 & 145 & 19,57 & 15,88 & 13,84 & 11,53 & 9,60 & 8,03 & 5,75 & 4,32 & 2,83 \\
\hline 40 & 1650 & 145 & 19,33 & 15,76 & 13,76 & 11,49 & 9,59 & 8,02 & 5,76 & 4,33 & 2,83 \\
\hline 40 & 1700 & 145 & 19,11 & 15,64 & 13,68 & 11,44 & 9,57 & 8,02 & 5,77 & 4,34 & 2,84 \\
\hline 40 & 1750 & 145 & 18,90 & 15,52 & 13,60 & 11,40 & 9,55 & 8,02 & 5,77 & 4,35 & 2,84 \\
\hline 40 & 1800 & 145 & 18,70 & 15,41 & 13,52 & 11,36 & 9,53 & 8,01 & 5,78 & 4,36 & 2,84 \\
\hline 40 & 1850 & 145 & 18,50 & 15,30 & 13,45 & 11,32 & 9,51 & 8,01 & 5,79 & 4,36 & 2,85 \\
\hline 40 & 1900 & 145 & 18,31 & 15,19 & 13,38 & 11,28 & 9,49 & 8,00 & 5,79 & 4,37 & 2,85 \\
\hline 40 & 1950 & 145 & 18,13 & 15,09 & 13,31 & 11,24 & 9,47 & 8,00 & 5,80 & 4,38 & 2,85 \\
\hline 40 & 2000 & 145 & 17,96 & 14,99 & 13,24 & 11,20 & 9,46 & 7,99 & 5,80 & 4,39 & 2,86 \\
\hline 40 & 200 & 150 & 48,95 & 25,03 & 17,48 & 12,14 & 9,15 & 7,25 & 5,01 & 3,87 & 2,73 \\
\hline 40 & 250 & 150 & 43,37 & 23,77 & 17,19 & 12,20 & 9,25 & 7,32 & 5,05 & 3,89 & 2,72 \\
\hline 40 & 300 & 150 & 39,49 & 22,82 & 16,93 & 12,23 & 9,32 & 7,39 & 5,09 & 3,90 & 2,71 \\
\hline 40 & 350 & 150 & 36,60 & 22,05 & 16,69 & 12,23 & 9,37 & 7,44 & 5,12 & 3,91 & 2,71 \\
\hline 40 & 400 & 150 & 34,34 & 21,42 & 16,47 & 12,22 & 9,41 & 7,49 & 5,15 & 3,92 & 2,71 \\
\hline 40 & 450 & 150 & 32,52 & 20,87 & 16,27 & 12,19 & 9,44 & 7,53 & 5,18 & 3,94 & 2,70 \\
\hline 40 & 500 & 150 & 31,00 & 20,39 & 16,08 & 12,16 & 9,47 & 7,56 & 5,21 & 3,95 & 2,70 \\
\hline 40 & 550 & 150 & 29,72 & 19,96 & 15,90 & 12,13 & 9,48 & 7,59 & 5,23 & 3,96 & 2,70 \\
\hline 40 & 600 & 150 & 28,61 & 19,58 & 15,73 & 12,09 & 9,50 & 7,62 & 5,26 & 3,97 & 2,70 \\
\hline 40 & 650 & 150 & 27,64 & 19,23 & 15,57 & 12,04 & 9,50 & 7,65 & 5,28 & 3,98 & 2,70 \\
\hline 40 & 700 & 150 & 26,78 & 18,91 & 15,41 & 12,00 & 9,51 & 7,67 & 5,30 & 3,99 & 2,70 \\
\hline 40 & 750 & 150 & 26,01 & 18,61 & 15,27 & 11,95 & 9,51 & 7,68 & 5,32 & 4,00 & 2,70 \\
\hline 40 & 800 & 150 & 25,32 & 18,33 & 15,13 & 11,91 & 9,50 & 7,70 & 5,34 & 4,02 & 2,70 \\
\hline 40 & 850 & 150 & 24,69 & 18,08 & 14,99 & 11,86 & 9,50 & 7,71 & 5,36 & 4,03 & 2,70 \\
\hline 40 & 900 & 150 & 24,11 & 17,83 & 14,86 & 11,82 & 9,49 & 7,73 & 5,38 & 4,04 & 2,70 \\
\hline 40 & 950 & 150 & 23,59 & 17,61 & 14,74 & 11,77 & 9,48 & 7,74 & 5,39 & 4,05 & 2,71 \\
\hline 40 & 1000 & 150 & 23,10 & 17,39 & 14,62 & 11,72 & 9,47 & 7,74 & 5,41 & 4,06 & 2,71 \\
\hline 40 & 1050 & 150 & 22,65 & 17,19 & 14,51 & 11,67 & 9,46 & 7,75 & 5,43 & 4,07 & 2,71 \\
\hline 40 & 1100 & 150 & 22,23 & 17,00 & 14,39 & 11,63 & 9,45 & 7,76 & 5,44 & 4,08 & 2,71 \\
\hline 40 & 1150 & 150 & 21,83 & 16,82 & 14,29 & 11,58 & 9,44 & 7,76 & 5,45 & 4,09 & 2,71 \\
\hline 40 & 1200 & 150 & 21,46 & 16,64 & 14,18 & 11,54 & 9,43 & 7,76 & 5,47 & 4,10 & 2,71 \\
\hline 40 & 1250 & 150 & 21,12 & 16,48 & 14,09 & 11,49 & 9,41 & 7,77 & 5,48 & 4,11 & 2,72 \\
\hline 40 & 1300 & 150 & 20,79 & 16,32 & 13,99 & 11,45 & 9,40 & 7,77 & 5,49 & 4,12 & 2,72 \\
\hline 40 & 1350 & 150 & 20,48 & 16,17 & 13,89 & 11,40 & 9,38 & 7,77 & 5,50 & 4,13 & 2,72 \\
\hline 40 & 1400 & 150 & 20,19 & 16,02 & 13,80 & 11,36 & 9,37 & 7,77 & 5,51 & 4,14 & 2,72 \\
\hline 40 & 1450 & 150 & 19,92 & 15,88 & 13,72 & 11,32 & 9,35 & 7,77 & 5,52 & 4,15 & 2,73 \\
\hline 40 & 1500 & 150 & 19,65 & 15,74 & 13,63 & 11,27 & 9,34 & 7,77 & 5,53 & 4,15 & 2,73 \\
\hline 40 & 1550 & 150 & 19,40 & 15,61 & 13,55 & 11,23 & 9,32 & 7,77 & 5,54 & 4,16 & 2,73 \\
\hline 40 & 1600 & 150 & 19,16 & 15,49 & 13,47 & 11,19 & 9,30 & 7,76 & 5,55 & 4,17 & 2,73 \\
\hline 40 & 1650 & 150 & 18,94 & 15,37 & 13,39 & 11,15 & 9,29 & 7,76 & 5,56 & 4,18 & 2,74 \\
\hline 40 & 1700 & 150 & 18,72 & 15,25 & 13,31 & 11,11 & 9,27 & 7,76 & 5,57 & 4,19 & 2,74 \\
\hline 40 & 1750 & 150 & 18,51 & 15,14 & 13,24 & 11,07 & 9,25 & 7,75 & 5,57 & 4,20 & 2,74 \\
\hline 40 & 1800 & 150 & 18,31 & 15,03 & 13,16 & 11,03 & 9,23 & 7,75 & 5,58 & 4,20 & 2,74 \\
\hline 40 & 1850 & 150 & 18,12 & 14,92 & 13,09 & 10,99 & 9,22 & 7,75 & 5,59 & 4,21 & 2,75 \\
\hline 40 & 1900 & 150 & 17,93 & 14,82 & 13,02 & 10,95 & 9,20 & 7,74 & 5,59 & 4,22 & 2,75 \\
\hline 40 & 1950 & 150 & 17,76 & 14,72 & 12,95 & 10,92 & 9,18 & 7,74 & 5,60 & 4,22 & 2,75 \\
\hline 40 & 2000 & 150 & 17,59 & 14,62 & 12,89 & 10,88 & 9,16 & 7,73 & 5,60 & 4,23 & 2,76 \\
\hline 40 & 200 & 155 & 48,26 & 24,41 & 16,96 & 11,74 & 8,84 & 7,00 & 4,85 & 3,75 & 2,64 \\
\hline 40 & 250 & 155 & 42,71 & 23,17 & 16,68 & 11,80 & 8,94 & 7,08 & 4,88 & 3,76 & 2,63 \\
\hline 40 & 300 & 155 & 38,85 & 22,24 & 16,43 & 11,83 & 9,01 & 7,14 & 4,92 & 3,77 & 2,63 \\
\hline 40 & 350 & 155 & 35,99 & 21,50 & 16,21 & 11,84 & 9,06 & 7,19 & 4,95 & 3,78 & 2,62 \\
\hline 40 & 400 & 155 & 33,75 & 20,87 & 16,00 & 11,83 & 9,10 & 7,23 & 4,98 & 3,79 & 2,62 \\
\hline
\end{tabular}




\begin{tabular}{|c|c|c|c|c|c|c|c|c|c|c|c|}
\hline \multirow[b]{2}{*}{$\mathrm{H}(\mathrm{cm})$} & \multirow[b]{2}{*}{ Mceq (MPa) } & & & & & $\mathrm{De}$ & ões (x. & & & & \\
\hline & & Msub (MPa) & D0 & D25 & D40 & D60 & D80 & D100 & D140 & D180 & D260 \\
\hline 40 & 450 & 155 & 31,95 & 20,34 & 15,80 & 11,81 & 9,13 & 7,27 & 5,00 & 3,81 & 2,62 \\
\hline 40 & 500 & 155 & 30,45 & 19,87 & 15,62 & 11,78 & 9,16 & 7,31 & 5,03 & 3,82 & 2,62 \\
\hline 40 & 550 & 155 & 29,18 & 19,46 & 15,45 & 11,75 & 9,17 & 7,34 & 5,05 & 3,83 & 2,61 \\
\hline 40 & 600 & 155 & 28,08 & 19,09 & 15,28 & 11,71 & 9,19 & 7,37 & 5,08 & 3,84 & 2,61 \\
\hline 40 & 650 & 155 & 27,12 & 18,74 & 15,13 & 11,67 & 9,19 & 7,39 & 5,10 & 3,85 & 2,61 \\
\hline 40 & 700 & 155 & 26,28 & 18,43 & 14,98 & 11,63 & 9,20 & 7,41 & 5,12 & 3,86 & 2,61 \\
\hline 40 & 750 & 155 & 25,52 & 18,14 & 14,84 & 11,59 & 9,20 & 7,43 & 5,14 & 3,87 & 2,61 \\
\hline 40 & 800 & 155 & 24,84 & 17,88 & 14,71 & 11,55 & 9,20 & 7,44 & 5,16 & 3,88 & 2,61 \\
\hline 40 & 850 & 155 & 24,22 & 17,63 & 14,58 & 11,50 & 9,19 & 7,46 & 5,18 & 3,89 & 2,62 \\
\hline 40 & 900 & 155 & 23,65 & 17,39 & 14,46 & 11,46 & 9,19 & 7,47 & 5,19 & 3,90 & 2,62 \\
\hline 40 & 950 & 155 & 23,13 & 17,17 & 14,34 & 11,42 & 9,18 & 7,48 & 5,21 & 3,91 & 2,62 \\
\hline 40 & 1000 & 155 & 22,65 & 16,97 & 14,22 & 11,37 & 9,18 & 7,49 & 5,23 & 3,92 & 2,62 \\
\hline 40 & 1050 & 155 & 22,21 & 16.77 & 14.11 & 11,33 & 9,17 & 7.50 & 5,24 & 3,93 & 2,62 \\
\hline 40 & 1100 & 155 & 21,79 & 16,58 & 14,01 & 11,28 & 9,16 & 7,50 & 5,25 & 3,94 & 2,62 \\
\hline 40 & 1150 & 155 & 21,41 & 16,41 & 13,90 & 11,24 & 9,14 & 7,51 & 5,27 & 3,95 & 2,62 \\
\hline 40 & 1200 & 155 & 21,05 & 16,24 & 13,80 & 11,20 & 9,13 & 7,51 & 5,28 & 3,96 & 2,63 \\
\hline 40 & 1250 & 155 & 20,70 & 16,07 & 13,71 & 11,16 & 9,12 & 7,51 & 5,29 & 3,97 & 2,63 \\
\hline 40 & 1300 & 155 & 20,38 & 15,92 & 13,62 & 11,11 & 9,11 & 7,52 & 5,30 & 3,98 & 2,63 \\
\hline 40 & 1350 & 155 & 20,08 & 15,77 & 13,53 & 11,07 & 9,09 & 7,52 & 5,31 & 3,99 & 2,63 \\
\hline 40 & 1400 & 155 & 19,79 & 15,63 & 13,44 & 11,03 & 9,08 & 7,52 & 5,32 & 4,00 & 2,63 \\
\hline 40 & 1450 & 155 & 19,52 & 15,49 & 13,35 & 10,99 & 9,06 & 7,52 & 5,33 & 4,00 & 2,64 \\
\hline 40 & 1500 & 155 & 19,26 & 15,36 & 13,27 & 10,95 & 9,05 & 7,52 & 5,34 & 4,01 & 2,64 \\
\hline 40 & 1550 & 155 & 19,02 & 15,24 & 13,19 & 10,91 & 9,03 & 7,52 & 5,35 & 4,02 & 2,64 \\
\hline 40 & 1600 & 155 & 18,78 & 15,11 & 13,11 & 10,87 & 9,02 & 7,52 & 5,36 & 4,03 & 2,64 \\
\hline 40 & 1650 & 155 & 18,56 & 15,00 & 13,04 & 10,83 & 9,00 & 7,51 & 5,37 & 4,04 & 2,65 \\
\hline 40 & 1700 & 155 & 18,35 & 14,88 & 12,96 & 10,79 & 8,99 & 7,51 & 5,38 & 4,04 & 2,65 \\
\hline 40 & 1750 & 155 & 18,14 & 14,77 & 12,89 & 10,76 & 8,97 & 7,51 & 5,38 & 4,05 & 2,65 \\
\hline 40 & 1800 & 155 & 17,95 & 14,66 & 12,82 & 10,72 & 8,96 & 7,50 & 5,39 & 4,06 & 2,65 \\
\hline 40 & 1850 & 155 & 17,76 & 14,56 & 12,75 & 10,68 & 8,94 & 7,50 & 5,40 & 4,07 & 2,66 \\
\hline 40 & 1900 & 155 & 17,58 & 14,46 & 12,68 & 10,65 & 8,92 & 7,50 & 5,40 & 4,07 & 2,66 \\
\hline 40 & 1950 & 155 & 17,40 & 14,36 & 12,62 & 10,61 & 8,91 & 7,49 & 5,41 & 4,08 & 2,66 \\
\hline 40 & 2000 & 155 & 17,23 & 14,27 & 12,55 & 10,57 & 8,89 & 7,49 & 5,42 & 4,09 & 2,66 \\
\hline 40 & 200 & 160 & 47,60 & 23,83 & 16,47 & 11,36 & 8,55 & 6,77 & 4,69 & 3,63 & 2,56 \\
\hline 40 & 250 & 160 & 42.08 & 22.61 & 16,20 & 11,43 & 8,64 & 6.84 & 4.73 & 3,64 & 2,55 \\
\hline 40 & 300 & 160 & 38,25 & 21,70 & 15,96 & 11,46 & 8,71 & 6,90 & 4,76 & 3,65 & 2,55 \\
\hline 40 & 350 & 160 & 35,41 & 20,97 & 15,75 & 11,47 & 8,77 & 6,95 & 4,79 & 3,66 & 2,54 \\
\hline 40 & 400 & 160 & 33,19 & 20,36 & 15,55 & 11,46 & 8,81 & 7,00 & 4,82 & 3,67 & 2,54 \\
\hline 40 & 450 & 160 & 31,41 & 19,84 & 15,36 & 11,44 & 8,84 & 7,04 & 4,84 & 3,68 & 2,54 \\
\hline 40 & 500 & 160 & 29,92 & 19,39 & 15,19 & 11,42 & 8,86 & 7,07 & 4,87 & 3,69 & 2,53 \\
\hline 40 & 550 & 160 & 28,67 & 18,98 & 15,02 & 11,39 & 8,88 & 7,10 & 4,89 & 3,70 & 2,53 \\
\hline 40 & 600 & 160 & 27,59 & 18,62 & 14,86 & 11,36 & 8,89 & 7,13 & 4,91 & 3,71 & 2,53 \\
\hline 40 & 650 & 160 & 26,64 & 18,29 & 14,72 & 11,32 & 8,90 & 7,15 & 4,93 & 3,72 & 2,53 \\
\hline 40 & 700 & 160 & 25,80 & 17,99 & 14,58 & 11,29 & 8,91 & 7,17 & 4,95 & 3,73 & 2,53 \\
\hline 40 & 750 & 160 & 25,06 & 17,71 & 14,44 & 11,25 & 8,91 & 7,19 & 4,97 & 3,74 & 2,53 \\
\hline 40 & 800 & 160 & 24,38 & 17,45 & 14,31 & 11,21 & 8,91 & 7,20 & 4,99 & 3,75 & 2,53 \\
\hline 40 & 850 & 160 & 23,77 & 17,20 & 14,19 & 11,17 & 8,91 & 7,22 & 5,01 & 3,76 & 2,53 \\
\hline 40 & 900 & 160 & 23,22 & 16,98 & 14,07 & 11,13 & 8,91 & 7,23 & 5,02 & 3,77 & 2,53 \\
\hline 40 & 950 & 160 & 22,70 & 16,76 & 13,96 & 11,08 & 8,90 & 7,24 & 5,04 & 3,78 & 2,53 \\
\hline 40 & 1000 & 160 & 22,23 & 16,56 & 13,85 & 11,04 & 8,89 & 7,25 & 5,05 & 3,79 & 2,54 \\
\hline 40 & 1050 & 160 & 21,79 & 16,37 & 13,74 & 11,00 & 8,89 & 7,26 & 5,07 & 3,80 & 2,54 \\
\hline 40 & 1100 & 160 & 21,39 & 16,19 & 13,64 & 10,96 & 8,88 & 7,26 & 5,08 & 3,81 & 2,54 \\
\hline 40 & 1150 & 160 & 21,01 & 16,02 & 13,54 & 10,92 & 8,87 & 7,27 & 5,09 & 3,82 & 2,54 \\
\hline 40 & 1200 & 160 & $\begin{array}{l}2 \pm, 01 \\
20,65\end{array}$ & $\begin{array}{l}15,85 \\
15,85\end{array}$ & זי, 13,44 & 10,88 & 8,86 & 7,27 & 5,11 & 3,83 & 2,54 \\
\hline 40 & 1250 & 160 & 20,31 & 15,69 & 13,35 & 10,84 & 8,84 & 7,28 & 5,12 & 3,84 & 2,54 \\
\hline 40 & 1300 & 160 & 20,00 & 15,54 & 13,26 & 10,80 & 8,83 & 7,28 & 5,13 & 3,85 & 2,55 \\
\hline 40 & 1350 & 160 & 19,70 & 15,40 & 13,18 & 10,76 & 8,82 & 7,28 & 5,14 & 3,86 & 2,55 \\
\hline 40 & 1400 & 160 & 19,42 & 15,26 & 13,09 & 10,72 & 8,81 & 7,28 & 5,15 & 3,86 & 2,55 \\
\hline 40 & 1450 & 160 & 19,15 & 15,13 & 13,01 & 10,68 & 8,79 & 7,28 & 5,16 & 3,87 & 2,55 \\
\hline 40 & 1500 & 160 & 18,90 & 15,00 & 12,93 & 10,64 & 8,78 & 7,28 & 5,17 & 3,88 & 2,55 \\
\hline 40 & 1550 & 160 & 18,66 & 14,88 & 12,85 & 10,61 & 8,77 & 7,28 & 5,18 & 3,89 & 2,56 \\
\hline 40 & 1600 & 160 & 18,42 & 14,76 & 12,78 & 10,57 & 8,75 & 7,28 & 5,19 & 3,90 & 2,56 \\
\hline 40 & 1650 & 160 & 18,20 & 14,65 & 12,70 & 10,53 & 8,74 & 7,28 & 5,19 & 3,90 & 2,56 \\
\hline 40 & 1700 & 160 & 17,99 & 14,53 & 12,63 & 10,50 & 8,72 & 7,28 & 5,20 & 3,91 & 2,56 \\
\hline 40 & 1750 & 160 & 17,79 & 14,43 & 12,56 & 10,46 & 8,71 & 7,28 & 5,21 & 3,92 & 2,57 \\
\hline 40 & 1800 & 160 & 17,60 & 14,32 & 12,50 & 10,42 & 8,69 & 7,27 & 5,22 & 3,92 & 2,57 \\
\hline 40 & 1850 & 160 & 17,41 & 14,22 & 12,43 & 10,39 & 8,68 & 7,27 & 5,22 & 3,93 & 2,57 \\
\hline 40 & 1900 & 160 & 17,24 & 14,12 & 12,36 & 10,35 & 8,66 & 7,27 & 5,23 & 3,94 & 2,57 \\
\hline 40 & 1950 & 160 & 17,06 & 14,03 & 12,30 & 10,32 & 8,65 & 7,26 & 5,23 & 3,94 & 2,57 \\
\hline 40 & 2000 & 160 & 16,90 & 13,94 & 12,24 & 10,29 & 8,63 & 7,26 & 5,24 & 3,95 & 2,58 \\
\hline 40 & 200 & 165 & 46,97 & 23,28 & 16,00 & 11,01 & 8,28 & 6,56 & 4,54 & 3,52 & 2,49 \\
\hline 40 & 250 & 165 & 41,48 & 22,08 & 15,75 & 11,07 & 8,37 & 6,63 & 4,58 & 3,53 & 2,48 \\
\hline 40 & 300 & 165 & 37,68 & 21,19 & 15,52 & 11,11 & 8,44 & 6,68 & 4,61 & 3,54 & 2,47 \\
\hline 40 & 350 & 165 & 34,86 & 20,47 & 15,31 & 11,12 & 8,49 & 6,73 & 4,64 & 3,55 & 2,46 \\
\hline 40 & 400 & 165 & 32,66 & 19,88 & 15,12 & 11,12 & 8,53 & 6,78 & 4,66 & 3,56 & 2,46 \\
\hline 40 & 450 & 165 & 30,89 & 19,37 & 14,94 & 11,10 & 8,56 & 6,81 & 4,69 & 3,57 & 2,46 \\
\hline 40 & 500 & 165 & 29,43 & 18,93 & 14,78 & 11,08 & 8,59 & 6,85 & 4,71 & 3,58 & 2,46 \\
\hline 40 & 550 & 165 & 28,18 & 18,54 & 14,62 & 11,06 & 8,61 & 6,88 & 4,73 & 3,59 & 2,46 \\
\hline 40 & 600 & 165 & 27,11 & 18,18 & 14,47 & 11,03 & 8,62 & 6,90 & 4,75 & 3,60 & 2,46 \\
\hline 40 & 650 & 165 & 26,18 & 17,86 & 14,33 & 10,99 & 8,63 & 6,92 & 4,77 & 3,61 & 2,46 \\
\hline 40 & 700 & 165 & 25,35 & 17,56 & 14,19 & 10,96 & 8,64 & 6,95 & 4,79 & 3,62 & 2,45 \\
\hline 40 & 750 & 165 & 24,62 & 17,29 & 14,06 & 10,92 & 8,64 & 6,96 & 4,81 & 3,63 & 2,45 \\
\hline
\end{tabular}




\begin{tabular}{|c|c|c|c|c|c|c|c|c|c|c|c|}
\hline \multirow[b]{2}{*}{$\mathrm{H}(\mathrm{cm})$} & \multirow[b]{2}{*}{ Mceq (MPa) } & & & & & $\mathrm{De}$ & ões (x & & & & \\
\hline & & Msub (MPa) & D0 & D25 & D40 & D60 & D80 & D100 & D140 & D180 & D260 \\
\hline 40 & 800 & 165 & 23,95 & 17,04 & 13,94 & 10,89 & 8,64 & 6,98 & 4,83 & 3,64 & 2,46 \\
\hline 40 & 850 & 165 & 23,35 & 16,80 & 13,82 & 10,85 & 8,64 & 6,99 & 4,85 & 3,65 & 2,46 \\
\hline 40 & 900 & 165 & 22,80 & 16,58 & 13,71 & 10,81 & 8,64 & 7,00 & 4,86 & 3,65 & 2,46 \\
\hline 40 & 950 & 165 & 22,30 & 16,37 & 13,60 & 10,77 & 8,63 & 7,02 & 4,88 & 3,66 & 2,46 \\
\hline 40 & 1000 & 165 & 21,83 & 16,18 & 13,49 & 10,73 & 8,63 & 7,02 & 4,89 & 3,67 & 2,46 \\
\hline 40 & 1050 & 165 & 21,40 & 15,99 & 13,39 & 10,69 & 8,62 & 7,03 & 4,91 & 3,68 & 2,46 \\
\hline 40 & 1100 & 165 & 21,00 & 15,81 & 13,29 & 10,66 & 8,61 & 7,04 & 4,92 & 3,69 & 2,46 \\
\hline 40 & 1150 & 165 & 20,62 & 15,65 & 13,20 & 10,62 & 8,60 & 7,05 & 4,93 & 3,70 & 2,46 \\
\hline 40 & 1200 & 165 & 20,27 & 15,49 & 13,10 & 10,58 & 8,60 & 7,05 & 4,94 & 3,71 & 2,46 \\
\hline 40 & 1250 & 165 & 19,94 & 15,33 & 13,02 & 10,54 & 8,58 & 7,05 & 4,95 & 3,72 & 2,47 \\
\hline 40 & 1300 & 165 & 19,63 & 15,19 & 12,93 & 10,50 & 8,57 & 7,06 & 4,97 & 3,72 & 2,47 \\
\hline 40 & 1350 & 165 & 19,34 & 15,05 & 12,85 & 10,47 & 8,56 & 7,06 & 4,98 & 3,73 & 2,47 \\
\hline 40 & 1400 & 165 & 19,06 & 14,91 & 12,76 & 10,43 & 8,55 & 7,06 & 4,99 & 3,74 & 2,47 \\
\hline 40 & 1450 & 165 & 18,80 & 14,78 & 12,69 & 10,39 & 8,54 & 7,06 & 4,99 & 3,75 & 2,47 \\
\hline 40 & 1500 & 165 & 18,55 & 14,66 & 12,61 & 10,35 & 8,53 & 7,06 & 5,00 & 3,76 & 2,47 \\
\hline 40 & 1550 & 165 & 18,31 & 14,54 & 12,53 & 10,32 & 8,51 & 7,06 & 5,01 & 3,76 & 2,48 \\
\hline 40 & 1600 & 165 & 18,08 & 14,42 & 12,46 & 10,28 & 8,50 & 7,06 & 5,02 & 3,77 & 2,48 \\
\hline 40 & 1650 & 165 & 17,87 & 14,31 & 12,39 & 10,25 & 8,49 & 7,06 & 5,03 & 3,78 & 2,48 \\
\hline 40 & 1700 & 165 & 17,66 & 14,20 & 12,32 & 10,21 & 8,47 & 7,06 & 5,04 & 3,78 & 2,48 \\
\hline 40 & 1750 & 165 & 17,46 & 14,10 & 12,25 & 10,18 & 8,46 & 7,06 & 5,04 & 3,79 & 2,48 \\
\hline 40 & 1800 & 165 & 17,27 & 14,00 & 12,19 & 10,15 & 8,45 & 7,06 & 5,05 & 3,80 & 2,49 \\
\hline 40 & 1850 & 165 & 17,09 & 13,90 & 12,13 & 10,11 & 8,43 & 7,05 & 5,06 & 3,80 & 2,49 \\
\hline 40 & 1900 & 165 & 16,91 & 13,81 & 12,06 & 10,08 & 8,42 & 7,05 & 5,06 & 3,81 & 2,49 \\
\hline 40 & 1950 & 165 & 16,74 & 13,71 & 12,00 & 10,05 & 8,40 & 7,05 & 5,07 & 3,82 & 2,49 \\
\hline 40 & 2000 & 165 & 16,58 & 13,62 & 11,94 & 10,01 & 8,39 & 7,04 & 5,07 & 3,82 & 2,50 \\
\hline 40 & 200 & 170 & 46,38 & 22,76 & 15,56 & 10,67 & 8,02 & 6,36 & 4,40 & 3,41 & 2,41 \\
\hline 40 & 250 & 170 & 40,92 & 21,58 & 15,32 & 10,74 & 8,11 & 6,42 & 4,44 & 3,42 & 2,40 \\
\hline 40 & 300 & 170 & 37,14 & 20,70 & 15,10 & 10,78 & 8,18 & 6,48 & 4,47 & 3,43 & 2,40 \\
\hline 40 & 350 & 170 & 34,34 & 20,00 & 14,90 & 10,79 & 8,23 & 6,53 & 4,49 & 3,44 & 2,39 \\
\hline 40 & 400 & 170 & 32,16 & 19,42 & 14,72 & 10,79 & 8,27 & 6,57 & 4,52 & 3,45 & 2,39 \\
\hline 40 & 450 & 170 & 30,41 & 18,93 & 14,55 & 10,78 & 8,30 & 6,60 & 4,54 & 3,46 & 2,39 \\
\hline 40 & 500 & 170 & 28,95 & 18,49 & 14,39 & 10,76 & 8,33 & 6,64 & 4,57 & 3,47 & 2,39 \\
\hline 40 & 550 & 170 & 27,73 & 18,11 & 14,24 & 10,74 & 8,35 & 6,67 & 4,59 & 3,48 & 2,38 \\
\hline 40 & 600 & 170 & 26,67 & 17,76 & 14,09 & 10,71 & 8,36 & 6,69 & 4,61 & 3,49 & 2,38 \\
\hline 40 & 650 & 170 & 25,74 & 17,45 & 13,96 & 10,68 & 8,37 & 6,71 & 4,63 & 3,50 & 2,38 \\
\hline 40 & 700 & 170 & 24,93 & 17,16 & 13,83 & 10,65 & 8,38 & 6,73 & 4,65 & 3,51 & 2,38 \\
\hline 40 & 750 & 170 & 24,20 & 16,90 & 13,70 & 10,62 & 8,39 & 6,75 & 4,66 & 3,52 & 2,38 \\
\hline 40 & 800 & 170 & 23,54 & 16,65 & 13,58 & 10,58 & 8,39 & 6,77 & 4,68 & 3,52 & 2,38 \\
\hline 40 & 850 & 170 & 22,95 & 16,42 & 13,47 & 10,55 & 8,39 & 6,78 & 4,70 & 3,53 & 2,38 \\
\hline 40 & 900 & 170 & 22,41 & 16,20 & 13,36 & 10,51 & 8,39 & 6,79 & 4,71 & 3,54 & 2,38 \\
\hline 40 & 950 & 170 & 21,91 & 16,00 & 13,26 & 10,48 & 8,38 & 6,80 & 4,73 & 3,55 & 2,38 \\
\hline 40 & 1000 & 170 & 21,45 & 15,81 & 13,15 & 10,44 & 8,38 & 6,81 & 4,74 & 3,56 & 2,39 \\
\hline 40 & 1050 & 170 & 21,02 & 15,63 & 13,06 & 10,40 & 8,37 & 6,82 & 4,75 & 3,57 & 2,39 \\
\hline 40 & 1100 & 170 & 20,63 & 15,46 & 12,96 & 10,37 & 8,37 & 6,83 & 4,77 & 3,58 & 2,39 \\
\hline 40 & 1150 & 170 & 20,26 & 15,29 & 12,87 & 10,33 & 8,36 & 6,83 & 4,78 & 3,58 & 2,39 \\
\hline 40 & 1200 & 170 & 19,91 & 15,14 & 12,78 & 10,29 & 8,35 & 6,84 & 4,79 & 3,59 & 2,39 \\
\hline 40 & 1250 & 170 & 19,59 & 14,99 & 12,70 & 10,26 & 8,34 & 6,84 & 4,80 & 3,60 & 2,39 \\
\hline 40 & 1300 & 170 & 19,28 & 14,85 & 12,61 & 10,22 & 8,33 & 6,85 & 4,81 & 3,61 & 2,39 \\
\hline 40 & 1350 & 170 & 18,99 & 14,71 & 12,53 & 10,19 & 8,32 & 6,85 & 4,82 & 3,62 & 2,39 \\
\hline 40 & 1400 & 170 & 18,72 & 14,58 & 12,45 & 10,15 & 8,31 & 6,85 & 4,83 & 3,62 & 2,40 \\
\hline 40 & 1450 & 170 & 18,46 & 14,46 & 12,38 & 10,12 & 8,30 & 6,85 & 4,84 & 3,63 & 2,40 \\
\hline 40 & 1500 & 170 & 18,22 & 14,33 & 12,30 & 10,08 & 8,29 & 6,85 & 4,85 & 3,64 & 2,40 \\
\hline 40 & 1550 & 170 & 17,98 & 14,22 & 12,23 & 10,05 & 8,27 & 6,86 & 4,86 & 3,65 & 2,40 \\
\hline 40 & 1600 & 170 & 17,76 & 14,11 & 12,16 & 10,01 & 8,26 & 6,86 & 4,87 & 3,65 & 2,40 \\
\hline 40 & 1650 & 170 & 17,54 & 14,00 & 12,09 & 9,98 & 8,25 & 6,85 & 4,87 & 3,66 & 2,41 \\
\hline 40 & 1700 & 170 & 17,34 & 13,89 & 12,03 & 9,95 & 8,24 & 6,85 & 4,88 & 3,67 & 2,41 \\
\hline 40 & 1750 & 170 & 17,15 & 13,79 & 11,96 & 9,91 & 8,22 & 6,85 & 4,89 & 3,67 & 2,41 \\
\hline 40 & 1800 & 170 & 16,96 & 13,69 & 11,90 & 9,88 & 8,21 & 6,85 & 4,89 & 3,68 & 2,41 \\
\hline 40 & 1850 & 170 & 16,78 & 13,60 & 11,84 & 9,85 & 8,20 & 6,85 & 4,90 & 3,69 & 2,41 \\
\hline 40 & 1900 & 170 & 16,61 & 13,50 & 11,78 & 9,82 & 8,19 & 6,85 & 4,91 & 3,69 & 2,42 \\
\hline 40 & 1950 & 170 & 16,44 & 13,41 & 11,72 & 9,79 & 8,17 & 6,84 & 4,91 & 3,70 & 2,42 \\
\hline 40 & 2000 & 170 & 16,28 & 13,33 & 11,66 & 9,76 & 8,16 & 6,84 & 4,92 & 3,70 & 2,42 \\
\hline 40 & 200 & 175 & 45,83 & 22,26 & 15,15 & 10,35 & 7,78 & 6,17 & 4,27 & 3,31 & 2,35 \\
\hline 40 & 250 & 175 & 40,39 & 21,11 & 14,91 & 10,43 & 7,87 & 6,23 & 4,31 & 3,32 & 2,34 \\
\hline 40 & 300 & 175 & 36,63 & 20,24 & 14,70 & 10,47 & 7,94 & 6,28 & 4,34 & 3,33 & 2,33 \\
\hline 40 & 350 & 175 & 33,85 & 19,56 & 14,51 & 10,48 & 7,99 & 6,33 & 4,36 & 3,34 & 2,33 \\
\hline 40 & 400 & 175 & 31,69 & 18,99 & 14,34 & 10,48 & 8,03 & 6,37 & 4,39 & 3,35 & 2,32 \\
\hline 40 & 450 & 175 & 29,95 & 18,50 & 14,17 & 10,48 & 8,06 & 6,41 & 4,41 & 3,36 & 2,32 \\
\hline 40 & 500 & 175 & 28,51 & 18,08 & 14,02 & 10,46 & 8,09 & 6,44 & 4,43 & 3,37 & 2,32 \\
\hline 40 & 550 & 175 & 27,29 & 17,70 & 13,87 & 10,44 & 8,10 & 6,47 & 4,45 & 3,38 & 2,32 \\
\hline 40 & 600 & 175 & 26,24 & 17,37 & 13,74 & 10,42 & 8,12 & 6,49 & 4,47 & 3,39 & 2,32 \\
\hline 40 & 650 & 175 & 25,33 & 17,06 & 13,61 & 10,39 & 8,13 & 6,51 & 4,49 & 3,39 & 2,31 \\
\hline 40 & 700 & 175 & 24,52 & 16,78 & 13,48 & 10,36 & 8,14 & 6,53 & 4,51 & 3,40 & 2,31 \\
\hline 40 & 750 & 175 & 23,80 & 16,52 & 13,36 & 10,33 & 8,14 & 6,55 & 4,52 & 3,41 & 2,31 \\
\hline 40 & 800 & 175 & 23,15 & 16,28 & 13,25 & 10,30 & 8,15 & 6,57 & 4,54 & 3,42 & 2,31 \\
\hline 40 & 850 & 175 & 22,57 & 16,06 & 13,14 & 10,26 & 8,15 & 6,58 & 4,55 & 3,43 & 2,32 \\
\hline 40 & 900 & 175 & 22,03 & 15,85 & 13,03 & 10,23 & 8,15 & 6,59 & 4,57 & 3,44 & 2,32 \\
\hline 40 & 950 & 175 & 21,54 & 15,65 & 12,93 & 10,20 & 8,14 & 6,60 & 4,58 & 3,44 & 2,32 \\
\hline 40 & 1000 & 175 & 21,09 & 15,46 & 12,83 & 10,16 & 8,14 & 6,61 & 4,60 & 3,45 & 2,32 \\
\hline 40 & 1050 & 175 & 20,67 & 15,29 & 12,74 & 10,13 & 8,14 & 6,62 & 4,61 & 3,46 & 2,32 \\
\hline 40 & 1100 & 175 & 20,28 & 15,12 & 12,65 & 10,09 & 8,13 & 6,63 & 4,62 & 3,47 & 2,32 \\
\hline
\end{tabular}




\begin{tabular}{|c|c|c|c|c|c|c|c|c|c|c|c|}
\hline \multirow[b]{2}{*}{$\mathrm{H}(\mathrm{cm})$} & \multirow[b]{2}{*}{ Mceq (MPa) } & & & & & $\mathrm{De}$ & ões (x. & & & & \\
\hline & & Msub (MPa) & D0 & D25 & D40 & D60 & D80 & D100 & D140 & D180 & D260 \\
\hline 40 & 1150 & 175 & 19,91 & 14,96 & 12,56 & 10,06 & 8,12 & 6,64 & 4,63 & 3,48 & 2,32 \\
\hline 40 & 1200 & 175 & 19,57 & 14,81 & 12,47 & 10,02 & 8,12 & 6,64 & 4,64 & 3,48 & 2,32 \\
\hline 40 & 1250 & 175 & 19,25 & 14,66 & 12,39 & 9,99 & 8,11 & 6,65 & 4,66 & 3,49 & 2,32 \\
\hline 40 & 1300 & 175 & 18,95 & 14,53 & 12,31 & 9,96 & 8,10 & 6,65 & 4,67 & 3,50 & 2,32 \\
\hline 40 & 1350 & 175 & 18,67 & 14,39 & 12,23 & 9,92 & 8,09 & 6,65 & 4,68 & 3,51 & 2,33 \\
\hline 40 & 1400 & 175 & 18,40 & 14,27 & 12,16 & 9,89 & 8,08 & 6,65 & 4,69 & 3,51 & 2,33 \\
\hline 40 & 1450 & 175 & 18,14 & 14,14 & 12,08 & 9,86 & 8,07 & 6,66 & 4,69 & 3,52 & 2,33 \\
\hline 40 & 1500 & 175 & 17,90 & 14,03 & 12,01 & 9,82 & 8,06 & 6,66 & 4,70 & 3,53 & 2,33 \\
\hline 40 & 1550 & 175 & 17,67 & 13,91 & 11,94 & 9,79 & 8,05 & 6,66 & 4,71 & 3,54 & 2,33 \\
\hline 40 & 1600 & 175 & 17,45 & 13,80 & 11,88 & 9,76 & 8,04 & 6,66 & 4,72 & 3,54 & 2,33 \\
\hline 40 & 1650 & 175 & 17,24 & 13,70 & 11,81 & 9,73 & 8,03 & 6,66 & 4,73 & 3,55 & 2,34 \\
\hline 40 & 1700 & 175 & 17,04 & 13,59 & 11,75 & 9,69 & 8,01 & 6,66 & 4,73 & 3,56 & 2,34 \\
\hline 40 & 1750 & 175 & 16.85 & 13,49 & 11,68 & 9.66 & 8,00 & 6.66 & 4.74 & 3,56 & 2,34 \\
\hline 40 & 1800 & 175 & 16,66 & 13,40 & 11,62 & 9,63 & 7,99 & 6,66 & 4,75 & 3,57 & 2,34 \\
\hline 40 & 1850 & 175 & 16,48 & 13,31 & 11,56 & 9,60 & 7,98 & 6,66 & 4,75 & 3,57 & 2,34 \\
\hline 40 & 1900 & 175 & 16,31 & 13,22 & 11,50 & 9,57 & 7,97 & 6,65 & 4,76 & 3,58 & 2,34 \\
\hline 40 & 1950 & 175 & 16,15 & 13,13 & 11,45 & 9,54 & 7,95 & 6,65 & 4,77 & 3,59 & 2,35 \\
\hline 40 & 2000 & 175 & 15,99 & 13,04 & 11,39 & 9,51 & 7,94 & 6,65 & 4,77 & 3,59 & 2,35 \\
\hline 40 & 200 & 180 & 45,29 & 21,80 & 14,75 & 10,06 & 7,55 & 5,99 & 4,15 & 3,22 & 2,28 \\
\hline 40 & 250 & 180 & 39,88 & 20,66 & 14,53 & 10,13 & 7,64 & 6,05 & 4,18 & 3,23 & 2,27 \\
\hline 40 & 300 & 180 & 36,14 & 19,81 & 14,33 & 10,17 & 7,71 & 6,10 & 4,21 & 3,24 & 2,27 \\
\hline 40 & 350 & 180 & 33,38 & 19,13 & 14,14 & 10,19 & 7,76 & 6,15 & 4,24 & 3,25 & 2,26 \\
\hline 40 & 400 & 180 & 31,23 & 18,58 & 13,98 & 10,19 & 7,80 & 6,19 & 4,26 & 3,26 & 2,26 \\
\hline 40 & 450 & 180 & 29,51 & 18,10 & 13,82 & 10,19 & 7,83 & 6,22 & 4,28 & 3,26 & 2,26 \\
\hline 40 & 500 & 180 & 28,08 & 17,69 & 13,67 & 10,17 & 7,85 & 6,25 & 4,30 & 3,27 & 2,25 \\
\hline 40 & 550 & 180 & 26,87 & 17,32 & 13,53 & 10,16 & 7,87 & 6,28 & 4,32 & 3,28 & 2,25 \\
\hline 40 & 600 & 180 & 25,84 & 16,99 & 13,40 & 10,13 & 7,89 & 6,30 & 4,34 & 3,29 & 2,25 \\
\hline 40 & 650 & 180 & 24,93 & 16,69 & 13,27 & 10,11 & 7,90 & 6,32 & 4,36 & 3,30 & 2,25 \\
\hline 40 & 700 & 180 & 24,13 & 16,42 & 13,15 & 10,08 & 7,91 & 6,34 & 4,37 & 3,31 & 2,25 \\
\hline 40 & 750 & 180 & 23,42 & 16,16 & 13,04 & 10,05 & 7,92 & 6,36 & 4,39 & 3,31 & 2,25 \\
\hline 40 & 800 & 180 & 22,78 & 15,93 & 12,93 & 10,02 & 7,92 & 6,38 & 4,41 & 3,32 & 2,25 \\
\hline 40 & 850 & 180 & 22,20 & 15,71 & 12,82 & 9,99 & 7,92 & 6,39 & 4,42 & 3,33 & 2,25 \\
\hline 40 & 900 & 180 & 21,67 & 15,51 & 12,72 & 9,96 & 7,92 & 6,40 & 4,43 & 3,34 & 2,25 \\
\hline 40 & 950 & 180 & 21.19 & 15,31 & 12.62 & 9,93 & 7,92 & 6,41 & 4,45 & 3,35 & 2,25 \\
\hline 40 & 1000 & 180 & 20,74 & 15,13 & 12,53 & 9,90 & 7,92 & 6,42 & 4,46 & 3,35 & 2,25 \\
\hline 40 & 1050 & 180 & 20,33 & 14,96 & 12,44 & 9,87 & 7,91 & 6,43 & 4,47 & 3,36 & 2,25 \\
\hline 40 & 1100 & 180 & 19,94 & 14,80 & 12,35 & 9,83 & 7,91 & 6,44 & 4,49 & 3,37 & 2,25 \\
\hline 40 & 1150 & 180 & 19,58 & 14,64 & 12,27 & 9,80 & 7,90 & 6,45 & 4,50 & 3,38 & 2,25 \\
\hline 40 & 1200 & 180 & 19,25 & 14,50 & 12,18 & 9,77 & 7,90 & 6,45 & 4,51 & 3,38 & 2,26 \\
\hline 40 & 1250 & 180 & 18,93 & 14,35 & 12,10 & 9,74 & 7,89 & 6,46 & 4,52 & 3,39 & 2,26 \\
\hline 40 & 1300 & 180 & 18,64 & 14,22 & 12,03 & 9,70 & 7,88 & 6,46 & 4,53 & 3,40 & 2,26 \\
\hline 40 & 1350 & 180 & 18,35 & 14,09 & 11,95 & 9,67 & 7,87 & 6,47 & 4,54 & 3,40 & 2,26 \\
\hline 40 & 1400 & 180 & 18,09 & 13,97 & 11,88 & 9,64 & 7,86 & 6,47 & 4,55 & 3,41 & 2,26 \\
\hline 40 & 1450 & 180 & 17,84 & 13,85 & 11,81 & 9,61 & 7,85 & 6,47 & 4,56 & 3,42 & 2,26 \\
\hline 40 & 1500 & 180 & 17,60 & 13,73 & 11,74 & 9,58 & 7,84 & 6,47 & 4,57 & 3,42 & 2,26 \\
\hline 40 & 1550 & 180 & 17,37 & 13,62 & 11,67 & 9,54 & 7,83 & 6,47 & 4,57 & 3,43 & 2,27 \\
\hline 40 & 1600 & 180 & 17,15 & 13,51 & 11,60 & 9,51 & 7,82 & 6,47 & 4,58 & 3,44 & 2,27 \\
\hline 40 & 1650 & 180 & 16,95 & 13,41 & 11,54 & 9,48 & 7,81 & 6,47 & 4,59 & 3,44 & 2,27 \\
\hline 40 & 1700 & 180 & 16,75 & 13,31 & 11,48 & 9,45 & 7,80 & 6,47 & 4,60 & 3,45 & 2,27 \\
\hline 40 & 1750 & 180 & 16,56 & 13,21 & 11,42 & 9,42 & 7,79 & 6,47 & 4,60 & 3,46 & 2,27 \\
\hline 40 & 1800 & 180 & 16,38 & 13,12 & 11,36 & 9,39 & 7,78 & 6,47 & 4,61 & 3,46 & 2,27 \\
\hline 40 & 1850 & 180 & 16,20 & 13,03 & 11,30 & 9,37 & 7,77 & 6,47 & 4,62 & 3,47 & 2,28 \\
\hline 40 & 1900 & 180 & 16,04 & 12,94 & 11,24 & 9,34 & 7,76 & 6,47 & 4,62 & 3,47 & 2,28 \\
\hline 40 & 1950 & 180 & 15,87 & 12,86 & 11,19 & 9,31 & 7,74 & 6,47 & 4,63 & 3,48 & 2,28 \\
\hline 40 & 2000 & 180 & 15,72 & 12,77 & 11,13 & 9,28 & 7,73 & 6,47 & 4,63 & 3,49 & 2,28 \\
\hline 40 & 200 & 185 & 44,79 & 21,35 & 14,38 & 9,77 & 7,34 & 5,82 & 4,04 & 3,13 & 2,22 \\
\hline 40 & 250 & 185 & 39,40 & 20,23 & 14,16 & 9,85 & 7,42 & 5,88 & 4,07 & 3,14 & 2,21 \\
\hline 40 & 300 & 185 & 35,68 & 19,39 & 13,97 & 9,89 & 7,49 & 5,93 & 4,09 & 3,15 & 2,21 \\
\hline 40 & 350 & 185 & 32,93 & 18,73 & 13,79 & 9,91 & 7,54 & 5,97 & 4,12 & 3,16 & 2,20 \\
\hline 40 & 400 & 185 & 30,80 & 18,18 & 13,63 & 9,92 & 7,58 & 6,01 & 4,14 & 3,17 & 2,20 \\
\hline 40 & 450 & 185 & 29,09 & 17,72 & 13,48 & 9,91 & 7,61 & 6,04 & 4,16 & 3,17 & 2,20 \\
\hline 40 & 500 & 185 & 27,67 & 17,31 & 13,34 & 9,90 & 7,64 & 6,07 & 4,18 & 3,18 & 2,19 \\
\hline 40 & 550 & 185 & 26,48 & 16,95 & 13,21 & 9,89 & 7,66 & 6,10 & 4,20 & 3,19 & 2,19 \\
\hline 40 & 600 & 185 & 25,45 & 16,63 & 13,08 & 9,87 & 7,67 & 6,13 & 4,22 & 3,20 & 2,19 \\
\hline 40 & 650 & 185 & 24,55 & 16,34 & 12,96 & 9,85 & 7,68 & 6,15 & 4,23 & 3,21 & 2,19 \\
\hline 40 & 700 & 185 & 23,76 & 16,07 & 12,84 & 9,82 & 7,69 & 6,17 & 4,25 & 3,21 & 2,19 \\
\hline 40 & 750 & 185 & 23,06 & 15,83 & 12,73 & 9,79 & 7,70 & 6,18 & 4,26 & 3,22 & 2,19 \\
\hline 40 & 800 & 185 & 22,43 & 15,60 & 12,63 & 9,77 & 7,70 & 6,20 & 4,28 & 3,23 & 2,19 \\
\hline 40 & 850 & 185 & 21,86 & 15,38 & 12,52 & 9,74 & 7,71 & 6,21 & 4,29 & 3,24 & 2,19 \\
\hline 40 & 900 & 185 & 21,33 & 15,18 & 12,43 & 9,71 & 7,71 & 6,22 & 4,31 & 3,24 & 2,19 \\
\hline 40 & 950 & 185 & 20,85 & 15,00 & 12,33 & 9,68 & 7,71 & 6,24 & 4,32 & 3,25 & 2,19 \\
\hline 40 & 1000 & 185 & 20,41 & 14,82 & 12,24 & 9,65 & 7,70 & 6,25 & 4,33 & 3,26 & 2,19 \\
\hline 40 & 1050 & 185 & 20,00 & 14,65 & 12,15 & 9,62 & 7,70 & 6,25 & 4,35 & 3,27 & 2,19 \\
\hline 40 & 1100 & 185 & 19,62 & 14,49 & 12,07 & 9,59 & 7,70 & 6,26 & 4,36 & 3,27 & 2,19 \\
\hline 40 & 1150 & 185 & 19,27 & 14,34 & 11,99 & 9,56 & 7,69 & 6,27 & 4,37 & 3,28 & 2,19 \\
\hline 40 & 1200 & 185 & 18,94 & 14,20 & 11,91 & 9,52 & 7,69 & 6,27 & 4,38 & 3,29 & 2,19 \\
\hline 40 & 1250 & 185 & 18,63 & 14,06 & 11,83 & 9,49 & 7,68 & 6,28 & 4,39 & 3,29 & 2,20 \\
\hline 40 & 1300 & 185 & 18,33 & 13,93 & 11,75 & 9,46 & 7,67 & 6,28 & 4,40 & 3,30 & 2,20 \\
\hline 40 & 1350 & 185 & 18,06 & 13,80 & 11,68 & 9,43 & 7,67 & 6,29 & 4,41 & 3,31 & 2,20 \\
\hline 40 & 1400 & 185 & 17,79 & 13,68 & 11,61 & 9,40 & 7,66 & 6,29 & 4,42 & 3,31 & 2,20 \\
\hline 40 & 1450 & 185 & 17,55 & 13,56 & 11,54 & 9,37 & 7,65 & 6,29 & 4,43 & 3,32 & 2,20 \\
\hline
\end{tabular}




\begin{tabular}{|c|c|c|c|c|c|c|c|c|c|c|c|}
\hline \multirow[b]{2}{*}{$\mathrm{H}(\mathrm{cm})$} & \multirow[b]{2}{*}{ Mceq (MPa) } & & & & & & ões (x1 & & & & \\
\hline & & Msub (MPa) & D0 & D25 & D40 & D60 & D80 & D100 & D140 & D180 & D260 \\
\hline 40 & 1500 & 185 & 17,31 & 13,45 & 11,47 & 9,34 & 7,64 & 6,30 & 4,44 & 3,33 & 2,20 \\
\hline 40 & 1550 & 185 & 17,09 & 13,34 & 11,41 & 9,31 & 7,63 & 6,30 & 4,44 & 3,33 & 2,20 \\
\hline 40 & 1600 & 185 & 16,87 & 13,24 & 11,35 & 9,28 & 7,62 & 6,30 & 4,45 & 3,34 & 2,20 \\
\hline 40 & 1650 & 185 & 16,67 & 13,14 & 11,28 & 9,25 & 7,61 & 6,30 & 4,46 & 3,35 & 2,21 \\
\hline 40 & 1700 & 185 & 16,47 & 13,04 & 11,22 & 9,23 & 7,60 & 6,30 & 4,47 & 3,35 & 2,21 \\
\hline 40 & 1750 & 185 & 16,29 & 12,95 & 11,16 & 9,20 & 7,59 & 6,30 & 4,47 & 3,36 & 2,21 \\
\hline 40 & 1800 & 185 & 16,11 & 12,85 & 11,11 & 9,17 & 7,58 & 6,30 & 4,48 & 3,36 & 2,21 \\
\hline 40 & 1850 & 185 & 15,93 & 12,77 & 11,05 & 9,14 & 7,57 & 6,30 & 4,49 & 3,37 & 2,21 \\
\hline 40 & 1900 & 185 & 15,77 & 12,68 & 11,00 & 9,11 & 7,56 & 6,30 & 4,49 & 3,37 & 2,21 \\
\hline 40 & 1950 & 185 & 15,61 & 12,60 & 10,94 & 9,09 & 7,55 & 6,30 & 4,50 & 3,38 & 2,22 \\
\hline 40 & 2000 & 185 & 15,46 & 12,51 & 10,89 & 9,06 & 7,54 & 6,29 & 4,50 & 3,39 & 2,22 \\
\hline 40 & 200 & 190 & 44,31 & 20,93 & 14,03 & 9,51 & 7,13 & 5,66 & 3,93 & 3,05 & 2,17 \\
\hline 40 & 250 & 190 & 38,94 & 19,82 & 13,82 & 9,58 & 7,22 & 5,72 & 3,96 & 3,06 & 2,16 \\
\hline 40 & 300 & 190 & 35,24 & 19,00 & 13,63 & 9,63 & 7,28 & 5,77 & 3,98 & 3,07 & 2,15 \\
\hline 40 & 350 & 190 & 32,50 & 18,35 & 13,46 & 9,65 & 7,33 & 5,81 & 4,00 & 3,07 & 2,14 \\
\hline 40 & 400 & 190 & 30,39 & 17,81 & 13,31 & 9,66 & 7,37 & 5,85 & 4,03 & 3,08 & 2,14 \\
\hline 40 & 450 & 190 & 28,69 & 17,35 & 13,16 & 9,65 & 7,40 & 5,88 & 4,05 & 3,09 & 2,14 \\
\hline 40 & 500 & 190 & 27,28 & 16,96 & 13,02 & 9,65 & 7,43 & 5,91 & 4,06 & 3,10 & 2,14 \\
\hline 40 & 550 & 190 & 26,10 & 16,61 & 12,89 & 9,63 & 7,45 & 5,93 & 4,08 & 3,10 & 2,13 \\
\hline 40 & 600 & 190 & 25,08 & 16,29 & 12,77 & 9,61 & 7,47 & 5,96 & 4,10 & 3,11 & 2,13 \\
\hline 40 & 650 & 190 & 24,19 & 16,00 & 12,66 & 9,59 & 7,48 & 5,98 & 4,12 & 3,12 & 2,13 \\
\hline 40 & 700 & 190 & 23,41 & 15,74 & 12,54 & 9,57 & 7,49 & 6,00 & 4,13 & 3,13 & 2,13 \\
\hline 40 & 750 & 190 & 22,72 & 15,50 & 12,44 & 9,55 & 7,50 & 6,01 & 4,15 & 3,13 & 2,13 \\
\hline 40 & 800 & 190 & 22,09 & 15,28 & 12,34 & 9,52 & 7,50 & 6,03 & 4,16 & 3,14 & 2,13 \\
\hline 40 & 850 & 190 & 21,52 & 15,07 & 12,24 & 9,49 & 7,50 & 6,04 & 4,18 & 3,15 & 2,13 \\
\hline 40 & 900 & 190 & 21,01 & 14,87 & 12,14 & 9,47 & 7,50 & 6,06 & 4,19 & 3,15 & 2,13 \\
\hline 40 & 950 & 190 & 20,53 & 14,69 & 12,05 & 9,44 & 7,50 & 6,07 & 4,20 & 3,16 & 2,13 \\
\hline 40 & 1000 & 190 & 20,10 & 14,52 & 11,96 & 9,41 & 7,50 & 6,08 & 4,21 & 3,17 & 2,13 \\
\hline 40 & 1050 & 190 & 19,69 & 14,35 & 11,88 & 9,38 & 7,50 & 6,09 & 4,23 & 3,18 & 2,13 \\
\hline 40 & 1100 & 190 & 19,32 & 14,20 & 11,80 & 9,35 & 7,50 & 6,09 & 4,24 & 3,18 & 2,13 \\
\hline 40 & 1150 & 190 & 18,97 & 14,05 & 11,72 & 9,32 & 7,49 & 6,10 & 4,25 & 3,19 & 2,14 \\
\hline 40 & 1200 & 190 & 18,64 & 13,91 & 11,64 & 9,29 & 7,49 & 6,11 & 4,26 & 3,20 & 2,14 \\
\hline 40 & 1250 & 190 & 18,33 & 13,78 & 11,57 & 9,26 & 7,48 & 6,11 & 4,27 & 3,20 & 2,14 \\
\hline 40 & 1300 & 190 & 18,04 & 13,65 & 11,49 & 9,23 & 7,48 & 6,12 & 4,28 & 3,21 & 2,14 \\
\hline 40 & 1350 & 190 & 17,77 & 13,52 & 11,42 & 9,21 & 7,47 & 6,12 & 4,29 & 3,22 & 2,14 \\
\hline 40 & 1400 & 190 & 17,51 & 13,41 & 11,36 & 9,18 & 7,46 & 6,12 & 4,30 & 3,22 & 2,14 \\
\hline 40 & 1450 & 190 & 17,27 & 13,29 & 11,29 & 9,15 & 7,45 & 6,13 & 4,30 & 3,23 & 2,14 \\
\hline 40 & 1500 & 190 & 17,03 & 13,18 & 11,22 & 9,12 & 7,45 & 6,13 & 4,31 & 3,23 & 2,14 \\
\hline 40 & 1550 & 190 & 16,81 & 13,08 & 11,16 & 9,09 & 7,44 & 6,13 & 4,32 & 3,24 & 2,14 \\
\hline 40 & 1600 & 190 & 16,60 & 12,97 & 11,10 & 9,06 & 7,43 & 6,13 & 4,33 & 3,25 & 2,15 \\
\hline 40 & 1650 & 190 & 16,40 & 12,88 & 11,04 & 9,03 & 7,42 & 6,13 & 4,33 & 3,25 & 2,15 \\
\hline 40 & 1700 & 190 & 16,21 & 12,78 & 10,98 & 9,01 & 7,41 & 6,13 & 4,34 & 3,26 & 2,15 \\
\hline 40 & 1750 & 190 & 16,02 & 12,69 & 10,92 & 8,98 & 7,40 & 6,13 & 4,35 & 3,26 & 2,15 \\
\hline 40 & 1800 & 190 & 15,85 & 12,60 & 10,87 & 8,95 & 7,39 & 6,13 & 4,35 & 3,27 & 2,15 \\
\hline 40 & 1850 & 190 & 15,68 & 12,51 & 10,81 & 8,93 & 7,38 & 6,13 & 4,36 & 3,27 & 2,15 \\
\hline 40 & 1900 & 190 & 15,52 & 12,43 & 10,76 & 8,90 & 7,37 & 6,13 & 4,37 & 3,28 & 2,15 \\
\hline 40 & 1950 & 190 & 15,36 & 12,35 & 10,71 & 8,87 & 7,36 & 6,13 & 4,37 & 3,29 & 2,16 \\
\hline 40 & 2000 & 190 & 15,21 & 12,27 & 10,66 & 8,85 & 7,35 & 6,13 & 4,38 & 3,29 & 2,16 \\
\hline 40 & 200 & 195 & 43,85 & 20,53 & 13,69 & 9,25 & 6,94 & 5,51 & 3,82 & 2,97 & 2,11 \\
\hline 40 & 250 & 195 & 38,50 & 19,43 & 13,49 & 9,33 & 7,02 & 5,56 & 3,85 & 2,98 & 2,10 \\
\hline 40 & 300 & 195 & 34,81 & 18,62 & 13,31 & 9,37 & 7,09 & 5,61 & 3,88 & 2,99 & 2,09 \\
\hline 40 & 350 & 195 & 32,10 & 17,98 & 13,14 & 9,40 & 7,14 & 5,65 & 3,90 & 2,99 & 2,09 \\
\hline 40 & 400 & 195 & 29,99 & 17,45 & $\begin{array}{l}0, \pm+9 \\
12,99\end{array}$ & 9,41 & 7,18 & 5,69 & 3,92 & 3,00 & 2,09 \\
\hline 40 & 450 & 195 & 28,30 & 17,01 & 12,85 & 9,41 & 7,21 & 5,72 & 3,94 & 3,01 & 2,08 \\
\hline 40 & 500 & 195 & 26,91 & 16,62 & 12,72 & 9,40 & 7,23 & 5,75 & 3,96 & 3,02 & 2,08 \\
\hline 40 & 550 & 195 & 25,74 & 16,27 & 12,60 & 9,39 & 7,25 & 5,77 & 3,97 & 3,02 & 2,08 \\
\hline 40 & 600 & 195 & 24,73 & 15,96 & 12,48 & 9,37 & 7,27 & 5,80 & 3,99 & 3,03 & 2,08 \\
\hline 40 & 650 & 195 & 23,85 & 15,68 & 12,37 & 9,36 & 7,28 & 5,82 & 4,01 & 3,04 & 2,08 \\
\hline 40 & 700 & 195 & 23,07 & 15,43 & 12,26 & 9,33 & 7,29 & 5,84 & 4,02 & 3,04 & 2,08 \\
\hline 40 & 750 & 195 & 22,39 & 15,19 & 12,16 & 9,31 & 7,30 & 5,85 & 4,03 & 3,05 & 2,08 \\
\hline 40 & 800 & 195 & 21,77 & 14,97 & 12,06 & 9,29 & 7,31 & 5,87 & 4,05 & 3,06 & 2,08 \\
\hline 40 & 850 & 195 & 21,21 & 14,77 & 11,97 & 9,26 & 7,31 & 5,88 & 4,06 & 3,06 & 2,08 \\
\hline 40 & 900 & 195 & 20,69 & 14,58 & 11,87 & 9,24 & 7,31 & 5,89 & 4,08 & 3,07 & 2,08 \\
\hline 40 & 950 & 195 & 20,23 & 14,40 & 11,79 & 9,21 & 7,31 & 5,91 & 4,09 & 3,08 & 2,08 \\
\hline 40 & 1000 & 195 & 19,80 & 14,23 & 11,70 & 9,18 & 7,31 & 5,92 & 4,10 & 3,08 & 2,08 \\
\hline 40 & 1050 & 195 & 19,40 & 14,07 & 11,62 & 9,16 & 7,31 & 5,92 & 4,11 & 3,09 & 2,08 \\
\hline 40 & 1100 & 195 & 19,03 & 13,92 & 11,54 & 9,13 & 7,31 & 5,93 & 4,12 & 3,10 & 2,08 \\
\hline 40 & 1150 & 195 & 18,68 & 13,77 & 11,46 & 9,10 & 7,30 & 5,94 & 4,13 & 3,10 & 2,08 \\
\hline 40 & 1200 & 195 & 18,36 & 13,64 & 11,39 & 9,07 & 7,30 & 5,95 & 4,14 & 3,11 & 2,08 \\
\hline 40 & 1250 & 195 & 18,05 & 13,51 & 11,32 & 9,04 & 7,29 & 5,95 & 4,15 & 3,12 & 2,08 \\
\hline 40 & 1300 & 195 & 17,77 & 13,38 & 11,25 & 9,02 & 7,29 & 5,96 & 4,16 & 3,12 & 2,08 \\
\hline 40 & 1350 & 195 & 17,50 & 13,26 & 11,18 & 8,99 & 7,28 & 5,96 & 4,17 & 3,13 & 2,08 \\
\hline 40 & 1400 & 195 & 17,24 & 13,14 & 11,11 & 8,96 & 7,28 & 5,96 & 4,18 & 3,14 & 2,08 \\
\hline 40 & 1450 & 195 & 17,00 & 13,03 & 11,05 & 8,93 & 7,27 & 5,97 & 4,19 & 3,14 & 2,09 \\
\hline 40 & 1500 & 195 & 16,77 & 12,93 & 10,98 & 8,91 & 7,26 & 5,97 & 4,20 & 3,15 & 2,09 \\
\hline 40 & 1550 & 195 & 16,55 & 12,82 & 10,92 & 8,88 & 7,25 & 5,97 & 4,20 & 3,15 & 2,09 \\
\hline 40 & 1600 & 195 & 16.34 & 12.72 & 10,86 & 8.85 & 7.24 & 5.97 & 4.21 & 3,16 & 2.09 \\
\hline 40 & 1650 & 195 & 16,15 & 12,63 & 10,81 & 8,83 & 7,24 & 5,97 & 4,22 & 3,16 & 2,09 \\
\hline 40 & 1700 & 195 & 15,96 & 12,53 & 10,75 & 8,80 & 7,23 & 5,98 & 4,22 & 3,17 & 2,09 \\
\hline 40 & 1750 & 195 & 15,77 & 12,44 & 10,69 & 8,77 & 7,22 & 5,98 & 4,23 & 3,18 & 2,09 \\
\hline 40 & 1800 & 195 & 15,60 & 12,36 & 10,64 & 8,75 & 7,21 & 5,98 & 4,24 & 3,18 & 2,09 \\
\hline
\end{tabular}




\begin{tabular}{|c|c|c|c|c|c|c|c|c|c|c|c|}
\hline \multirow[b]{2}{*}{$\mathrm{H}(\mathrm{cm})$} & \multirow[b]{2}{*}{ Mceq (MPa) } & & & & & $\mathrm{De}$ & ões (x1 & m) & & & \\
\hline & & Msub (MPa) & D0 & D25 & D40 & D60 & D80 & D100 & D140 & D180 & D260 \\
\hline 40 & 1850 & 195 & 15,43 & 12,27 & 10,59 & 8,72 & 7,20 & 5,98 & 4,24 & 3,19 & 2,10 \\
\hline 40 & 1900 & 195 & 15,27 & 12,19 & 10,54 & 8,70 & 7,19 & 5,98 & 4,25 & 3,19 & 2,10 \\
\hline 40 & 1950 & 195 & 15,12 & 12,11 & 10,48 & 8,67 & 7,18 & 5,97 & 4,26 & 3,20 & 2,10 \\
\hline 40 & 2000 & 195 & 14,97 & 12,03 & 10,44 & 8,65 & 7,17 & 5,97 & 4,26 & 3,20 & 2,10 \\
\hline 40 & 200 & 200 & 43,41 & 20,15 & 13,37 & 9,01 & 6,76 & 5,36 & 3,72 & 2,89 & 2,06 \\
\hline 40 & 250 & 200 & 38,08 & 19,06 & 13,17 & 9,09 & 6,84 & 5,42 & 3,75 & 2,90 & 2,05 \\
\hline 40 & 300 & 200 & 34,41 & 18,26 & 13,00 & 9,13 & 6,90 & 5,46 & 3,78 & 2,91 & 2,04 \\
\hline 40 & 350 & 200 & 31,71 & 17,63 & 12,84 & 9,16 & 6,95 & 5,50 & 3,80 & 2,92 & 2,04 \\
\hline 40 & 400 & 200 & 29,62 & 17,11 & 12,70 & 9,17 & 6,99 & 5,54 & 3,82 & 2,93 & 2,03 \\
\hline 40 & 450 & 200 & 27,94 & 16,67 & 12,56 & 9,17 & 7,02 & 5,57 & 3,83 & 2,93 & 2,03 \\
\hline 40 & 500 & 200 & 26,56 & 16,29 & 12,44 & 9,17 & 7,05 & 5,60 & 3,85 & 2,94 & 2,03 \\
\hline 40 & 550 & 200 & 25,39 & 15,95 & 12,32 & 9,16 & 7,07 & 5,62 & 3,87 & 2,94 & 2,03 \\
\hline 40 & 600 & 200 & 24,39 & 15,65 & 12,20 & 9,14 & 7,08 & 5,65 & 3,88 & 2,95 & 2,03 \\
\hline 40 & 650 & 200 & 23,52 & 15,38 & 12,09 & 9,13 & 7,10 & 5,67 & 3,90 & 2,96 & 2,03 \\
\hline 40 & 700 & 200 & 22,75 & 15,13 & 11,99 & 9,11 & 7,11 & 5,68 & 3,91 & 2,96 & 2,03 \\
\hline 40 & 750 & 200 & 22,07 & 14,90 & 11,89 & 9,09 & 7,12 & 5,70 & 3,93 & 2,97 & 2,03 \\
\hline 40 & 800 & 200 & 21,46 & 14,68 & 11,80 & 9,06 & 7,12 & 5,72 & 3,94 & 2,98 & 2,03 \\
\hline 40 & 850 & 200 & 20,90 & 14,48 & 11,70 & 9,04 & 7,13 & 5,73 & 3,96 & 2,98 & 2,03 \\
\hline 40 & 900 & 200 & 20,40 & 14,30 & 11,62 & 9,02 & 7,13 & 5,74 & 3,97 & 2,99 & 2,03 \\
\hline 40 & 950 & 200 & 19,93 & 14,12 & 11,53 & 8,99 & 7,13 & 5,75 & 3,98 & 3,00 & 2,03 \\
\hline 40 & 1000 & 200 & 19,51 & 13,96 & 11,45 & 8,97 & 7,13 & 5,76 & 3,99 & 3,00 & 2,03 \\
\hline 40 & 1050 & 200 & 19,11 & 13,80 & 11,37 & 8,94 & 7,13 & 5,77 & 4,00 & 3,01 & 2,03 \\
\hline 40 & 1100 & 200 & 18,75 & 13,65 & 11,29 & 8,91 & 7,13 & 5,78 & 4,01 & 3,02 & 2,03 \\
\hline 40 & 1150 & 200 & 18,40 & 13,51 & 11,22 & 8,89 & 7,12 & 5,79 & 4,02 & 3,02 & 2,03 \\
\hline 40 & 1200 & 200 & 18,08 & 13,38 & 11,15 & 8,86 & 7,12 & 5,79 & 4,03 & 3,03 & 2,03 \\
\hline 40 & 1250 & 200 & 17,78 & 13,25 & 11,08 & 8,83 & 7,11 & 5,80 & 4,04 & 3,03 & 2,03 \\
\hline 40 & 1300 & 200 & 17,50 & 13,12 & 11,01 & 8,81 & 7,11 & 5,80 & 4,05 & 3,04 & 2,03 \\
\hline 40 & 1350 & 200 & 17,24 & 13,01 & 10,94 & 8,78 & 7,10 & 5,81 & 4,06 & 3,05 & 2,03 \\
\hline 40 & 1400 & 200 & 16,98 & 12,89 & 10,88 & 8,76 & 7,10 & 5,81 & 4,07 & 3,05 & 2,03 \\
\hline 40 & 1450 & 200 & 16,75 & 12,79 & 10,82 & 8,73 & 7,09 & 5,82 & 4,08 & 3,06 & 2,03 \\
\hline 40 & 1500 & 200 & 16,52 & 12,68 & 10,76 & 8,70 & 7,08 & 5,82 & 4,08 & 3,06 & 2,03 \\
\hline 40 & 1550 & 200 & 16,30 & 12,58 & 10,70 & 8,68 & 7,08 & 5,82 & 4,09 & 3,07 & 2,03 \\
\hline 40 & 1600 & 200 & 16,10 & 12,48 & 10,64 & 8,65 & 7,07 & 5,82 & 4,10 & 3,08 & 2,04 \\
\hline 40 & 1650 & 200 & 15,90 & 12,39 & 10,58 & 8,63 & 7,06 & 5,82 & 4,11 & 3,08 & 2,04 \\
\hline 40 & 1700 & 200 & 15,71 & 12,30 & 10,53 & 8,60 & 7,05 & 5,83 & 4,11 & 3,09 & 2,04 \\
\hline 40 & 1750 & 200 & 15,53 & 12,21 & 10,47 & 8,58 & 7,05 & 5,83 & 4,12 & 3,09 & 2,04 \\
\hline 40 & 1800 & 200 & 15,36 & 12,12 & 10,42 & 8,55 & 7,04 & 5,83 & 4,13 & 3,10 & 2,04 \\
\hline 40 & 1850 & 200 & 15,20 & 12,04 & 10,37 & 8,53 & 7,03 & 5,83 & 4,13 & 3,10 & 2,04 \\
\hline 40 & 1900 & 200 & 15,04 & 11,96 & 10,32 & 8,50 & 7,02 & 5,83 & 4,14 & 3,11 & 2,04 \\
\hline 40 & 1950 & 200 & 14,89 & 11,88 & 10,27 & 8,48 & 7,01 & 5,83 & 4,14 & 3,11 & 2,05 \\
\hline 40 & 2000 & 200 & 14,74 & 11,81 & 10,22 & 8,45 & 7,00 & 5,83 & 4,15 & 3,12 & 2,05 \\
\hline 45 & 200 & 20 & 136,28 & 109,01 & 95,36 & 80,41 & 67,87 & 57,43 & 41,88 & 31,78 & 20,78 \\
\hline 45 & 250 & 20 & 124,55 & 102,50 & 90,94 & 77,84 & 66,56 & 56,93 & 42,15 & 32,20 & 21,00 \\
\hline 45 & 300 & 20 & 115,99 & 97,36 & 87,31 & 75,61 & 65,31 & 56,36 & 42,29 & 32,52 & 21,21 \\
\hline 45 & 350 & 20 & 109,40 & 93,15 & 84,24 & 73,63 & 64,14 & 55,76 & 42,32 & 32,77 & 21,41 \\
\hline 45 & 400 & 20 & 104,14 & 89,58 & 81,60 & 71,87 & 63,04 & 55,15 & 42,30 & 32,96 & 21,59 \\
\hline 45 & 450 & 20 & 99,83 & 86,51 & 79,28 & 70,28 & 62,02 & 54,56 & 42,22 & 33,10 & 21,77 \\
\hline 45 & 500 & 20 & 96,21 & 83,82 & 77,23 & 68,83 & 61,06 & 53,98 & 42,12 & 33,21 & 21,92 \\
\hline 45 & 550 & 20 & 93,12 & 81,43 & 75,39 & 67,51 & 60,16 & 53,41 & 41,99 & 33,28 & 22,07 \\
\hline 45 & 600 & 20 & 90,45 & 79,28 & 73,72 & 66,30 & 59,32 & 52,87 & 41,85 & 33,33 & 22,20 \\
\hline 45 & 650 & 20 & 88,11 & 77,34 & 72,19 & 65,18 & 58,53 & 52,35 & 41,69 & 33,36 & 22,32 \\
\hline 45 & 700 & 20 & 86,03 & 75,57 & 70,80 & 64,14 & 57,79 & 51,85 & 41,53 & 33,38 & 22,43 \\
\hline 45 & 750 & 20 & 84,18 & 73,95 & 69,51 & 63,16 & 57,08 & 51,37 & 41,35 & 33,38 & 22,53 \\
\hline 45 & 800 & 20 & 82,51 & 72,46 & 68,31 & 62,25 & 56,42 & 50,90 & 41,18 & 33,37 & 22,62 \\
\hline 45 & 850 & 20 & 80,99 & 71,07 & 67,19 & 61,40 & 55,78 & 50,45 & 41,00 & 33,35 & 22,70 \\
\hline 45 & 900 & 20 & 79,61 & 69,79 & 66,15 & 60,59 & 55,18 & 50,02 & 40,83 & 33,32 & 22,78 \\
\hline 45 & 950 & 20 & 78,34 & 68,58 & 65,17 & 59,83 & 54,60 & 49,61 & 40,65 & 33,28 & 22,85 \\
\hline 45 & 1000 & 20 & 77,16 & 67,46 & 64,25 & 59,11 & 54,05 & 49,21 & 40,47 & 33,24 & 22,91 \\
\hline 45 & 1050 & 20 & 76,08 & 66,41 & 63,37 & 58,43 & 53,53 & 48,82 & 40,29 & 33,19 & 22,97 \\
\hline 45 & 1100 & 20 & 75,06 & 65,41 & 62,55 & 57,78 & 53,03 & 48,45 & 40,12 & 33,14 & 23,02 \\
\hline 45 & 1150 & 20 & 74,12 & 64,48 & 61,76 & 57,16 & 52,54 & 48,09 & 39,95 & 33,09 & 23,07 \\
\hline 45 & 1200 & 20 & 73,23 & 63,59 & 61,02 & 56,57 & 52,08 & 47,74 & 39,77 & 33,03 & 23,11 \\
\hline 45 & 1250 & 20 & 72,40 & 62,75 & 60,31 & 56,00 & 51,64 & 47,40 & 39,61 & 32,97 & 23,15 \\
\hline 45 & 1300 & 20 & 71,61 & 61,96 & 59,63 & 55,46 & 51,21 & 47,07 & 39,44 & 32,91 & 23,18 \\
\hline 45 & 1350 & 20 & 70,86 & 61,20 & 58,98 & 54,94 & 50,79 & 46,76 & 39,27 & 32,85 & 23,22 \\
\hline 45 & 1400 & 20 & 70,16 & 60,48 & 58,35 & 54,44 & 50,40 & 46,45 & 39,11 & 32,79 & 23,24 \\
\hline 45 & 1450 & 20 & 69,48 & 59,79 & 57,76 & 53,96 & 50,01 & 46,15 & 38,95 & 32,72 & 23,27 \\
\hline 45 & 1500 & 20 & 68,84 & 59,13 & 57,18 & 53,50 & 49,64 & 45,86 & 38,79 & 32,65 & 23,29 \\
\hline 45 & 1550 & 20 & 68,23 & 58,51 & 56,63 & 53,05 & 49,28 & 45,57 & 38,64 & 32,59 & 23,31 \\
\hline 45 & 1600 & 20 & 67,64 & 57,91 & 56,10 & 52,62 & 48,93 & 45,30 & 38,48 & 32,52 & 23,33 \\
\hline 45 & 1650 & 20 & 67,08 & 57,33 & 55,58 & 52,21 & 48,59 & 45,03 & 38,33 & 32,45 & 23,35 \\
\hline 45 & 1700 & 20 & 66,54 & 56,78 & 55,09 & 51,81 & 48,26 & 44,77 & 38,18 & 32,38 & 23,36 \\
\hline 45 & 1750 & 20 & 66,02 & 56,25 & 54,61 & 51,42 & 47,94 & 44,52 & 38,04 & 32,31 & 23,37 \\
\hline 45 & 1800 & 20 & 65,52 & 55,74 & 54,15 & 51,04 & 47,63 & 44,27 & 37,89 & 32,24 & 23,38 \\
\hline 45 & 1850 & 20 & 65,04 & 55,25 & 53,70 & 50,68 & 47,33 & 44,03 & 37,75 & 32,17 & 23,39 \\
\hline 45 & 1900 & 20 & 64,57 & 54,77 & 53,27 & 50,32 & 47,04 & 43,79 & 37,61 & 32,10 & 23,40 \\
\hline 45 & 1950 & 20 & 64,12 & 54,32 & 52,85 & 49,98 & 46,76 & 43,56 & 37,47 & 32,03 & 23,40 \\
\hline 45 & 2000 & 20 & 63,69 & 53,88 & 52,44 & 49,64 & 46,48 & 43,34 & 37,34 & 31,96 & 23,41 \\
\hline 45 & 200 & 25 & 119,63 & 92,61 & 79,78 & 66,19 & 55,15 & 46,17 & 33,20 & 25,08 & 16,49 \\
\hline 45 & 250 & 25 & 109,03 & 87,21 & 76,29 & 64,32 & 54,30 & 45,94 & 33,50 & 25,42 & 16,63 \\
\hline 45 & 300 & 25 & 101,27 & 82,94 & 73,40 & 62,66 & 53,46 & 45,63 & 33,69 & 25,70 & 16,76 \\
\hline
\end{tabular}




\begin{tabular}{|c|c|c|c|c|c|c|c|c|c|c|c|}
\hline \multirow[b]{2}{*}{$\mathrm{H}(\mathrm{cm})$} & \multirow[b]{2}{*}{ Mceq (MPa) } & & & & & $\mathrm{De}$ & ões (x1 & & & & \\
\hline & & Msub (MPa) & D0 & D25 & D40 & D60 & D80 & D100 & D140 & D180 & D260 \\
\hline 45 & 350 & 25 & 95,30 & 79,43 & 70,94 & 61,17 & 52,64 & 45,27 & 33,80 & 25,92 & 16,90 \\
\hline 45 & 400 & 25 & 90,53 & 76,47 & 68,82 & 59,83 & 51,86 & 44,89 & 33,85 & 26,10 & 17,03 \\
\hline 45 & 450 & 25 & 86,61 & 73,91 & 66,95 & 58,61 & 51,13 & 44,51 & 33,86 & 26,25 & 17,16 \\
\hline 45 & 500 & 25 & 83,32 & 71,67 & 65,28 & 57,49 & 50,43 & 44,12 & 33,84 & 26,37 & 17,28 \\
\hline 45 & 550 & 25 & 80,50 & 69,67 & 63,78 & 56,47 & 49,77 & 43,74 & 33,79 & 26,46 & 17,39 \\
\hline 45 & 600 & 25 & 78,07 & 67,88 & 62,42 & 55,52 & 49,15 & 43,36 & 33,73 & 26,53 & 17,49 \\
\hline 45 & 650 & 25 & 75,94 & 66,26 & 61,18 & 54,63 & 48,56 & 43,00 & 33,66 & 26,59 & 17,59 \\
\hline 45 & 700 & 25 & 74,05 & 64,78 & 60,03 & 53,81 & 47,99 & 42,64 & 33,57 & 26,63 & 17,68 \\
\hline 45 & 750 & 25 & 72,36 & 63,42 & 58,97 & 53,04 & 47,46 & 42,30 & 33,48 & 26,67 & 17,76 \\
\hline 45 & 800 & 25 & 70,84 & 62,17 & 57,99 & 52,32 & 46,95 & 41,96 & 33,38 & 26,69 & 17,84 \\
\hline 45 & 850 & 25 & 69,47 & 61,01 & 57,07 & 51,64 & 46,46 & 41,64 & 33,27 & 26,70 & 17,91 \\
\hline 45 & 900 & 25 & 68,21 & 59,93 & 56,22 & 50,99 & 46,00 & 41,32 & 33,17 & 26,70 & 17,98 \\
\hline 45 & 950 & 25 & 67.06 & 58.91 & 55,41 & 50,38 & 45,56 & 41.02 & 33,06 & 26.70 & 18,04 \\
\hline 45 & 1000 & 25 & 66,01 & 57,96 & 54,65 & 49,80 & 45,13 & 40,72 & 32,94 & 26,69 & 18,10 \\
\hline 45 & 1050 & 25 & 65,03 & 57,07 & 53,93 & 49,25 & 44,72 & 40,43 & 32,83 & 26,68 & 18,15 \\
\hline 45 & 1100 & 25 & 64,12 & 56,23 & 53,25 & 48,73 & 44,33 & 40,16 & 32,72 & 26,66 & 18,20 \\
\hline 45 & 1150 & 25 & 63,27 & 55,44 & 52,60 & 48,23 & 43,96 & 39,88 & 32,60 & 26,64 & 18,25 \\
\hline 45 & 1200 & 25 & 62,48 & 54,68 & 51,98 & 47,75 & 43,59 & 39,62 & 32,49 & 26,62 & 18,29 \\
\hline 45 & 1250 & 25 & 61,73 & 53,97 & 51,40 & 47,29 & 43,24 & 39,37 & 32,38 & 26,59 & 18,33 \\
\hline 45 & 1300 & 25 & 61,03 & 53,29 & 50,84 & 46,85 & 42,91 & 39,12 & 32,26 & 26,56 & 18,37 \\
\hline 45 & 1350 & 25 & 60,37 & 52,64 & 50,30 & 46,43 & 42,58 & 38,88 & 32,15 & 26,53 & 18,40 \\
\hline 45 & 1400 & 25 & 59,74 & 52,03 & 49,78 & 46,02 & 42,27 & 38,64 & 32,04 & 26,50 & 18,43 \\
\hline 45 & 1450 & 25 & 59,15 & 51,44 & 49,29 & 45,63 & 41,96 & 38,41 & 31,93 & 26,46 & 18,46 \\
\hline 45 & 1500 & 25 & 58,58 & 50,87 & 48,81 & 45,25 & 41,67 & 38,19 & 31,82 & 26,43 & 18,49 \\
\hline 45 & 1550 & 25 & 58,05 & 50,33 & 48,36 & 44,89 & 41,38 & 37,97 & 31,71 & 26,39 & 18,51 \\
\hline 45 & 1600 & 25 & 57,53 & 49,82 & 47,92 & 44,54 & 41,10 & 37,76 & 31,60 & 26,35 & 18,54 \\
\hline 45 & 1650 & 25 & 57,04 & 49,32 & 47,49 & 44,20 & 40,83 & 37,56 & 31,50 & 26,31 & 18,56 \\
\hline 45 & 1700 & 25 & 56,57 & 48,84 & 47,08 & 43,87 & 40,57 & 37,35 & 31,39 & 26,27 & 18,58 \\
\hline 45 & 1750 & 25 & 56,12 & 48,38 & 46,68 & 43,55 & 40,32 & 37,16 & 31,29 & 26,23 & 18,60 \\
\hline 45 & 1800 & 25 & 55,69 & 47,94 & 46,30 & 43,24 & 40,07 & 36,97 & 31,19 & 26,19 & 18,61 \\
\hline 45 & 1850 & 25 & 55,28 & 47,51 & 45,93 & 42,95 & 39,83 & 36,78 & 31,08 & 26,14 & 18,63 \\
\hline 45 & 1900 & 25 & 54,87 & 47,10 & 45,57 & 42,66 & 39,59 & 36,59 & 30,98 & 26,10 & 18,64 \\
\hline 45 & 1950 & 25 & 54,49 & 46,71 & 45,22 & 42,37 & 39,37 & 36,42 & 30,88 & 26,06 & 18,65 \\
\hline 45 & 2000 & 25 & 54,11 & 46,32 & 44,88 & 42,10 & 39,14 & 36,24 & 30,79 & 26,01 & 18,66 \\
\hline 45 & 200 & 30 & 107,78 & 80,99 & 68,81 & 56,30 & 46,40 & 38,53 & 27,43 & 20,68 & 13,67 \\
\hline 45 & 250 & 30 & 98,00 & 76,34 & 65,95 & 54,89 & 45,84 & 38,45 & 27,72 & 20,96 & 13,76 \\
\hline 45 & 300 & 30 & 90,85 & 72,67 & 63,57 & 53,60 & 45,25 & 38,29 & 27,92 & 21,19 & 13,86 \\
\hline 45 & 350 & 30 & 85,35 & 69,66 & 61,54 & 52,44 & 44,66 & 38,07 & 28,05 & 21,38 & 13,95 \\
\hline 45 & 400 & 30 & 80,95 & 67,11 & 59,77 & 51,38 & 44,09 & 37,83 & 28,14 & 21,54 & 14,05 \\
\hline 45 & 450 & 30 & 77,33 & 64,91 & 58,20 & 50,41 & 43,54 & 37,57 & 28,19 & 21,68 & 14,14 \\
\hline 45 & 500 & 30 & 74,28 & 62,98 & 56,81 & 49,51 & 43,01 & 37,30 & 28,21 & 21,80 & 14,23 \\
\hline 45 & 550 & 30 & 71,68 & 61,26 & 55,55 & 48,68 & 42,51 & 37,04 & 28,21 & 21,89 & 14,31 \\
\hline 45 & 600 & 30 & 69,43 & 59,72 & 54,40 & 47,91 & 42,03 & 36,77 & 28,20 & 21,97 & 14,40 \\
\hline 45 & 650 & 30 & 67,45 & 58,33 & 53,35 & 47,19 & 41,57 & 36,50 & 28,17 & 22,04 & 14,47 \\
\hline 45 & 700 & 30 & 65,70 & 57,05 & 52,38 & 46,52 & 41,13 & 36,24 & 28,13 & 22,09 & 14,55 \\
\hline 45 & 750 & 30 & 64,14 & 55,88 & 51,49 & 45,89 & 40,71 & 35,98 & 28,08 & 22,14 & 14,62 \\
\hline 45 & 800 & 30 & 62,73 & 54,80 & 50,65 & 45,29 & 40,30 & 35,73 & 28,02 & 22,17 & 14,68 \\
\hline 45 & 850 & 30 & 61,46 & 53,79 & 49,87 & 44,73 & 39,92 & 35,49 & 27,96 & 22,20 & 14,74 \\
\hline 45 & 900 & 30 & 60,30 & 52,85 & 49,14 & 44,20 & 39,55 & 35,25 & 27,90 & 22,22 & 14,80 \\
\hline 45 & 950 & 30 & 59,24 & 51,98 & 48,46 & 43,70 & 39,19 & 35,02 & 27,83 & 22,24 & 14,85 \\
\hline 45 & 1000 & 30 & 58,26 & 51,16 & 47,81 & 43,21 & 38,85 & 34,79 & 27,76 & 22,25 & 14,90 \\
\hline 45 & 1050 & 30 & 57,35 & 50,38 & 47,20 & 42,76 & 38,53 & 34,57 & 27,68 & 22,25 & 14,95 \\
\hline 45 & 1100 & 30 & 56,52 & 49,65 & 46,62 & 42,32 & 38,21 & 34,35 & 27,61 & 22,25 & 15,00 \\
\hline 45 & 1150 & 30 & 55,73 & 48,96 & 46,07 & 41,90 & 37,90 & 34,14 & 27,53 & 22,25 & 15,04 \\
\hline 45 & 1200 & 30 & 55,00 & 48,30 & 45,54 & 41,50 & 37,61 & 33,93 & 27,45 & 22,24 & 15,08 \\
\hline 45 & 1250 & 30 & 54,32 & 47,68 & 45,04 & 41,12 & 37,33 & 33,73 & 27,38 & 22,24 & 15,12 \\
\hline 45 & 1300 & 30 & 53,68 & 47,09 & 44,56 & 40,75 & 37,05 & 33,54 & 27,30 & 22,22 & 15,15 \\
\hline 45 & 1350 & 30 & 53,07 & 46,52 & 44,10 & 40,40 & 36,79 & 33,35 & 27,22 & 22,21 & 15,19 \\
\hline 45 & 1400 & 30 & 52,50 & 45,98 & 43,66 & 40,05 & 36,53 & 33,16 & 27,14 & 22,20 & 15,22 \\
\hline 45 & 1450 & 30 & 51,96 & 45,47 & 43,24 & 39,73 & 36,28 & 32,98 & 27,06 & 22,18 & 15,25 \\
\hline 45 & 1500 & 30 & 51,44 & 44,97 & 42,83 & 39,41 & 36,04 & 32,81 & 26,98 & 22,16 & 15,27 \\
\hline 45 & 1550 & 30 & 50,95 & 44,50 & 42,44 & 39,10 & 35,80 & 32,63 & 26,90 & 22,14 & 15,30 \\
\hline 45 & 1600 & 30 & 50,49 & 44,05 & 42,06 & 38,81 & 35,57 & 32,46 & 26,82 & 22,12 & 15,32 \\
\hline 45 & 1650 & 30 & 50,04 & 43,61 & 41,70 & 38,52 & 35,35 & 32,30 & 26,75 & 22,10 & 15,35 \\
\hline 45 & 1700 & 30 & 49,62 & 43,19 & 41,35 & 38,24 & 35,14 & 32,14 & 26,67 & 22,07 & 15,37 \\
\hline 45 & 1750 & 30 & 49,21 & 42,78 & 41,01 & 37,97 & 34,93 & 31,98 & 26,59 & 22,05 & 15,39 \\
\hline 45 & 1800 & 30 & 48,82 & 42,39 & 40,68 & 37,71 & 34,72 & 31,83 & 26,52 & 22,02 & 15,41 \\
\hline 45 & 1850 & 30 & 48,45 & 42,02 & 40,36 & 37,46 & 34,52 & 31,67 & 26,44 & 22,00 & 15,42 \\
\hline 45 & 1900 & 30 & 48,09 & 41,65 & 40,05 & 37,21 & 34,33 & 31,53 & 26,37 & 21,97 & 15,44 \\
\hline 45 & 1950 & 30 & 47,74 & 41,30 & 39,75 & 36,97 & 34,14 & 31,38 & 26,29 & 21,94 & 15,46 \\
\hline 45 & 2000 & 30 & 47,40 & 40,96 & 39,46 & 36,74 & 33,95 & 31,24 & 26,22 & 21,91 & 15,47 \\
\hline 45 & 200 & 35 & 98,83 & 72,27 & 60,63 & 49,00 & 40,02 & 33,00 & 23,33 & 17,57 & 11,68 \\
\hline 45 & 250 & 35 & 89,68 & 68,17 & 58,23 & 47,90 & 39,64 & 33,01 & 23,59 & 17,80 & 11,74 \\
\hline 45 & 300 & 35 & 83,01 & 64,94 & 56,22 & 46,88 & 39,22 & 32,94 & 23,79 & 17,99 & 11,81 \\
\hline 45 & 350 & 35 & 77,88 & 62,29 & 54,49 & 45,95 & 38,79 & 32,82 & 23,93 & 18,16 & 11,88 \\
\hline 45 & 400 & 35 & 73,77 & 60,05 & 52,98 & 45,08 & 38,35 & 32,66 & 24,03 & 18,30 & 11,95 \\
\hline 45 & 450 & 35 & 70,38 & 58,11 & 51,64 & 44,29 & 37,93 & 32,49 & 24,10 & 18,43 & 12,02 \\
\hline 45 & 500 & 35 & 67,54 & 56,41 & 50,44 & 43,55 & 37,52 & 32,30 & 24,15 & 18,54 & 12,09 \\
\hline 45 & 550 & 35 & 65,11 & 54,90 & 49,36 & 42,87 & 37,12 & 32,11 & 24,17 & 18,63 & 12,15 \\
\hline 45 & 600 & 35 & 63,00 & 53,54 & 48,37 & 42,23 & 36,74 & 31,91 & 24,18 & 18,71 & 12,22 \\
\hline 45 & 650 & 35 & 61,15 & 52,31 & 47,47 & 41,63 & 36,37 & 31,71 & 24,18 & 18,78 & 12,28 \\
\hline
\end{tabular}




\begin{tabular}{|c|c|c|c|c|c|c|c|c|c|c|c|}
\hline \multirow[b]{2}{*}{$\mathrm{H}(\mathrm{cm})$} & \multirow[b]{2}{*}{ Mceq (MPa) } & & & & & & ões (x1 & m) & & & \\
\hline & & Msub (MPa) & D0 & D25 & D40 & D60 & D80 & D100 & D140 & D180 & D260 \\
\hline 45 & 700 & 35 & 59,51 & 51,19 & 46,63 & 41,07 & 36,02 & 31,52 & 24,17 & 18,83 & 12,34 \\
\hline 45 & 750 & 35 & 58,05 & 50,16 & 45,85 & 40,54 & 35,68 & 31,32 & 24,15 & 18,88 & 12,40 \\
\hline 45 & 800 & 35 & 56,73 & 49,20 & 45,13 & 40,04 & 35,36 & 31,13 & 24,12 & 18,92 & 12,45 \\
\hline 45 & 850 & 35 & 55,53 & 48,32 & 44,45 & 39,56 & 35,04 & 30,94 & 24,09 & 18,96 & 12,50 \\
\hline 45 & 900 & 35 & 54,45 & 47,49 & 43,82 & 39,11 & 34,74 & 30,75 & 24,05 & 18,99 & 12,55 \\
\hline 45 & 950 & 35 & 53,45 & 46,71 & 43,22 & 38,68 & 34,45 & 30,57 & 24,01 & 19,01 & 12,60 \\
\hline 45 & 1000 & 35 & 52,53 & 45,99 & 42,66 & 38,28 & 34,17 & 30,39 & 23,96 & 19,03 & 12,64 \\
\hline 45 & 1050 & 35 & 51,69 & 45,30 & 42,12 & 37,89 & 33,90 & 30,21 & 23,91 & 19,05 & 12,68 \\
\hline 45 & 1100 & 35 & 50,90 & 44,66 & 41,62 & 37,51 & 33,64 & 30,04 & 23,86 & 19,06 & 12,72 \\
\hline 45 & 1150 & 35 & 50,17 & 44,04 & 41,14 & 37,16 & 33,39 & 29,87 & 23,81 & 19,07 & 12,76 \\
\hline 45 & 1200 & 35 & 49,49 & 43,46 & 40,68 & 36,81 & 33,14 & 29,71 & 23,76 & 19,07 & 12,80 \\
\hline 45 & 1250 & 35 & 48,85 & 42,91 & 40,24 & 36,49 & 32,90 & 29,55 & 23,70 & 19,07 & 12,83 \\
\hline 45 & 1300 & 35 & 48,25 & 42,38 & 39,82 & 36,17 & 32,68 & 29,39 & 23,65 & 19,07 & 12,87 \\
\hline 45 & 1350 & 35 & 47,68 & 41,88 & 39,42 & 35,87 & 32,45 & 29,24 & 23,59 & 19,07 & 12,90 \\
\hline 45 & 1400 & 35 & 47,15 & 41,40 & 39,03 & 35,57 & 32,24 & 29,09 & 23,53 & 19,07 & 12,93 \\
\hline 45 & 1450 & 35 & 46,64 & 40,94 & 38,66 & 35,29 & 32,03 & 28,94 & 23,47 & 19,06 & 12,95 \\
\hline 45 & 1500 & 35 & 46,16 & 40,50 & 38,31 & 35,02 & 31,83 & 28,80 & 23,42 & 19,05 & 12,98 \\
\hline 45 & 1550 & 35 & 45,71 & 40,08 & 37,97 & 34,75 & 31,63 & 28,65 & 23,36 & 19,04 & 13,00 \\
\hline 45 & 1600 & 35 & 45,28 & 39,68 & 37,64 & 34,50 & 31,44 & 28,52 & 23,30 & 19,03 & 13,03 \\
\hline 45 & 1650 & 35 & 44,86 & 39,29 & 37,32 & 34,25 & 31,25 & 28,38 & 23,24 & 19,02 & 13,05 \\
\hline 45 & 1700 & 35 & 44,47 & 38,91 & 37,01 & 34,01 & 31,07 & 28,25 & 23,18 & 19,01 & 13,07 \\
\hline 45 & 1750 & 35 & 44,09 & 38,55 & 36,71 & 33,78 & 30,89 & 28,12 & 23,13 & 18,99 & 13,09 \\
\hline 45 & 1800 & 35 & 43,73 & 38,20 & 36,42 & 33,55 & 30,72 & 27,99 & 23,07 & 18,98 & 13,11 \\
\hline 45 & 1850 & 35 & 43,39 & 37,86 & 36,14 & 33,33 & 30,55 & 27,87 & 23,01 & 18,96 & 13,13 \\
\hline 45 & 1900 & 35 & 43,06 & 37,54 & 35,87 & 33,12 & 30,38 & 27,75 & 22,95 & 18,95 & 13,15 \\
\hline 45 & 1950 & 35 & 42,74 & 37,22 & 35,61 & 32,91 & 30,22 & 27,63 & 22,90 & 18,93 & 13,16 \\
\hline 45 & 2000 & 35 & 42,43 & 36,92 & 35,36 & 32,71 & 30,06 & 27,51 & 22,84 & 18,91 & 13,18 \\
\hline 45 & 200 & 40 & 91,79 & 65,45 & 54,28 & 43,39 & 35,16 & 28,83 & 20,26 & 15,27 & 10,20 \\
\hline 45 & 250 & 40 & 83,14 & 61,78 & 52,22 & 42,51 & 34,90 & 28,89 & 20,51 & 15,45 & 10,24 \\
\hline 45 & 300 & 40 & 76,85 & 58,89 & 50,48 & 41,68 & 34,60 & 28,88 & 20,69 & 15,62 & 10,29 \\
\hline 45 & 350 & 40 & 72,01 & 56,51 & 48,99 & 40,92 & 34,27 & 28,81 & 20,83 & 15,76 & 10,34 \\
\hline 45 & 400 & 40 & 68,14 & 54,50 & 47,68 & 40,20 & 33,94 & 28,71 & 20,94 & 15,89 & 10,39 \\
\hline 45 & 450 & 40 & 64,96 & 52,77 & 46,51 & 39,54 & 33,61 & 28,60 & 21,02 & 16,00 & 10,45 \\
\hline 45 & 500 & 40 & 62,28 & 51,25 & 45,47 & 38,92 & 33,28 & 28,47 & 21,08 & 16,10 & 10,50 \\
\hline 45 & 550 & 40 & 59,98 & 49,90 & 44,52 & 38,35 & 32,96 & 28,32 & 21,12 & 16,19 & 10,55 \\
\hline 45 & 600 & 40 & 58,00 & 48,68 & 43,65 & 37,80 & 32,65 & 28,18 & 21,14 & 16,26 & 10,60 \\
\hline 45 & 650 & 40 & 56,25 & 47,58 & 42,86 & 37,30 & 32,36 & 28,03 & 21,16 & 16,33 & 10,66 \\
\hline 45 & 700 & 40 & 54,70 & 46,57 & 42,12 & 36,82 & 32,07 & 27,88 & 21,16 & 16,38 & 10,70 \\
\hline 45 & 750 & 40 & 53,32 & 45,65 & 41,44 & 36,36 & 31,79 & 27,73 & 21,16 & 16,44 & 10,75 \\
\hline 45 & 800 & 40 & 52,07 & 44,79 & 40,80 & 35,93 & 31,52 & 27,58 & 21,15 & 16,48 & 10,80 \\
\hline 45 & 850 & 40 & 50,94 & 44,00 & 40,20 & 35,53 & 31,26 & 27,43 & 21,13 & 16,52 & 10,84 \\
\hline 45 & 900 & 40 & 49,91 & 43,26 & 39,64 & 35,14 & 31,01 & 27,28 & 21,11 & 16,55 & 10,88 \\
\hline 45 & 950 & 40 & 48,97 & 42,56 & 39,11 & 34,77 & 30,76 & 27,13 & 21,09 & 16,58 & 10,92 \\
\hline 45 & 1000 & 40 & 48,11 & 41,91 & 38,61 & 34,42 & 30,53 & 26,99 & 21,06 & 16,60 & 10,96 \\
\hline 45 & 1050 & 40 & 47,30 & 41,29 & 38,14 & 34,08 & 30,30 & 26,85 & 21,03 & 16,62 & 11,00 \\
\hline 45 & 1100 & 40 & 46,56 & 40,71 & 37,69 & 33,76 & 30,08 & 26,71 & 21,00 & 16,64 & 11,03 \\
\hline 45 & 1150 & 40 & 45,87 & 40,16 & 37,27 & 33,45 & 29,87 & 26,57 & 20,96 & 16,65 & 11,07 \\
\hline 45 & 1200 & 40 & 45,22 & 39,64 & 36,86 & 33,15 & 29,66 & 26,44 & 20,92 & 16,67 & 11,10 \\
\hline 45 & 1250 & 40 & 44,62 & 39,14 & 36,47 & 32,86 & 29,46 & 26,30 & 20,88 & 16,67 & 11,13 \\
\hline 45 & 1300 & 40 & 44,05 & 38,67 & 36,10 & 32,59 & 29,27 & 26,18 & 20,85 & 16,68 & 11,16 \\
\hline 45 & 1350 & 40 & 43,52 & 38,22 & 35,74 & 32,32 & 29,08 & 26,05 & 20,80 & 16,69 & 11,19 \\
\hline 45 & 1400 & 40 & 43,02 & 37,79 & 35,40 & 32,07 & 28,89 & 25,92 & 20,76 & 16,69 & 11,21 \\
\hline 45 & 1450 & 40 & 42,54 & 37,37 & 35,07 & 31,82 & 28,72 & 25,80 & 20,72 & 16,69 & 11,24 \\
\hline 45 & 1500 & 40 & 42,09 & 36,98 & 34,75 & 31,58 & 28,54 & 25,68 & 20,68 & 16,69 & 11,26 \\
\hline 45 & 1550 & 40 & 41,66 & 36,59 & 34,45 & 31,35 & 28,37 & 25,57 & 20,63 & 16,69 & 11,29 \\
\hline 45 & 1600 & 40 & 41,25 & 36,23 & 34,16 & 31,13 & 28,21 & 25,45 & 20,59 & 16,68 & 11,31 \\
\hline 45 & 1650 & 40 & 40,87 & 35,88 & 33,87 & 30,91 & 28,05 & 25,34 & 20,55 & 16,68 & 11,33 \\
\hline 45 & 1700 & 40 & 40,50 & 35,54 & 33,60 & 30,70 & 27,89 & 25,23 & 20,50 & 16,67 & 11,35 \\
\hline 45 & 1750 & 40 & 40,14 & 35,21 & 33,33 & 30,50 & 27,74 & 25,12 & 20,46 & 16,67 & 11,37 \\
\hline 45 & 1800 & 40 & 39,80 & 34,89 & 33,07 & 30,30 & 27,59 & 25,01 & 20,41 & 16,66 & 11,39 \\
\hline 45 & 1850 & 40 & 39,48 & 34,59 & 32,83 & 30,10 & 27,44 & 24,91 & 20,37 & 16,65 & 11,41 \\
\hline 45 & 1900 & 40 & 39,17 & 34,29 & 32,58 & 29,92 & 27,30 & 24,80 & 20,32 & 16,64 & 11,42 \\
\hline 45 & 1950 & 40 & 38,87 & 34,01 & 32,35 & 29,73 & 27,16 & 24,70 & 20,28 & 16,63 & 11,44 \\
\hline 45 & 2000 & 40 & 38,58 & 33,73 & 32,12 & 29,56 & 27,03 & 24,60 & 20,24 & 16,62 & 11,46 \\
\hline 45 & 200 & 45 & 86,09 & 59,96 & 49,18 & 38,92 & 31,33 & 25,57 & 17,90 & 13,49 & 9,06 \\
\hline 45 & 250 & 45 & 77,84 & 56,62 & 47,39 & 38,21 & 31,16 & 25,66 & 18,12 & 13,65 & 9,08 \\
\hline 45 & 300 & 45 & 71,85 & 53,99 & 45,87 & 37,53 & 30,94 & 25,68 & 18,29 & 13,79 & 9,12 \\
\hline 45 & 350 & 45 & 67,26 & 51,84 & 44,56 & 36,90 & 30,69 & 25,66 & 18,42 & 13,91 & 9,15 \\
\hline 45 & 400 & 45 & 63,59 & 50,02 & 43,41 & 36,30 & 30,43 & 25,60 & 18,53 & 14,02 & 9,19 \\
\hline 45 & 450 & 45 & 60,57 & 48,45 & 42,38 & 35,74 & 30,17 & 25,52 & 18,61 & 14,12 & 9,24 \\
\hline 45 & 500 & 45 & 58,03 & 47,07 & 41,46 & 35,21 & 29,90 & 25,43 & 18,68 & 14,21 & 9,28 \\
\hline 45 & 550 & 45 & 55,85 & 45,84 & 40,61 & 34,72 & 29,65 & 25,33 & 18,72 & 14,29 & 9,32 \\
\hline 45 & 600 & 45 & 53,97 & 44,74 & 39,85 & 34,25 & 29,39 & 25,22 & 18,76 & 14,36 & 9,36 \\
\hline 45 & 650 & 45 & 52,31 & 43,74 & 39,14 & 33,81 & 29,15 & 25,11 & 18,78 & 14,43 & 9,41 \\
\hline 45 & 700 & 45 & 50,84 & 42,83 & 38,48 & 33,40 & 28,91 & 24,99 & 18,80 & 14,48 & 9,45 \\
\hline 45 & 750 & 45 & 49,52 & 41,99 & 37,87 & 33,01 & 28,67 & 24,87 & 18,81 & 14,53 & 9,49 \\
\hline 45 & 800 & 45 & 48,34 & 41,21 & 37,30 & 32,63 & 28,45 & 24,75 & 18,81 & 14,57 & 9,52 \\
\hline 45 & 850 & 45 & 47,26 & 40,49 & 36,77 & 32,28 & 28,23 & 24,63 & 18,81 & 14,61 & 9,56 \\
\hline 45 & 900 & 45 & 46,29 & 39,81 & 36,27 & 31,94 & 28,02 & 24,51 & 18,80 & 14,65 & 9,60 \\
\hline 45 & 950 & 45 & 45,39 & 39,18 & 35,79 & 31,62 & 27,81 & 24,39 & 18,79 & 14,68 & 9,63 \\
\hline 45 & 1000 & 45 & 44,56 & 38,59 & 35,35 & 31,31 & 27,61 & 24,28 & 18,77 & 14,71 & 9,67 \\
\hline
\end{tabular}




\begin{tabular}{|c|c|c|c|c|c|c|c|c|c|c|c|}
\hline \multirow[b]{2}{*}{$\mathrm{H}(\mathrm{cm})$} & \multirow[b]{2}{*}{ Mceq (MPa) } & & & & & De & ões (x1 & m) & & & \\
\hline & & Msub (MPa) & D0 & D25 & D40 & D60 & D80 & D100 & D140 & D180 & D260 \\
\hline 45 & 1050 & 45 & 43,80 & 38,03 & 34,92 & 31,01 & 27,42 & 24,16 & 18,75 & 14,73 & 9,70 \\
\hline 45 & 1100 & 45 & 43,10 & 37,51 & 34,52 & 30,73 & 27,23 & 24,05 & 18,73 & 14,75 & 9,73 \\
\hline 45 & 1150 & 45 & 42,44 & 37,01 & 34,13 & 30,46 & 27,05 & 23,93 & 18,71 & 14,77 & 9,76 \\
\hline 45 & 1200 & 45 & 41,82 & 36,53 & 33,77 & 30,20 & 26,87 & 23,82 & 18,68 & 14,78 & 9,79 \\
\hline 45 & 1250 & 45 & 41,25 & 36,08 & 33,42 & 29,94 & 26,70 & 23,71 & 18,66 & 14,79 & 9,81 \\
\hline 45 & 1300 & 45 & 40,71 & 35,65 & 33,08 & 29,70 & 26,53 & 23,61 & 18,63 & 14,81 & 9,84 \\
\hline 45 & 1350 & 45 & 40,20 & 35,24 & 32,76 & 29,47 & 26,37 & 23,50 & 18,60 & 14,81 & 9,87 \\
\hline 45 & 1400 & 45 & 39,72 & 34,84 & 32,46 & 29,24 & 26,21 & 23,39 & 18,57 & 14,82 & 9,89 \\
\hline 45 & 1450 & 45 & 39,27 & 34,47 & 32,16 & 29,02 & 26,05 & 23,29 & 18,54 & 14,83 & 9,91 \\
\hline 45 & 1500 & 45 & 38,84 & 34,10 & 31,87 & 28,81 & 25,90 & 23,19 & 18,50 & 14,83 & 9,94 \\
\hline 45 & 1550 & 45 & 38,43 & 33,76 & 31,60 & 28,60 & 25,76 & 23,09 & 18,47 & 14,83 & 9,96 \\
\hline 45 & 1600 & 45 & 38,05 & 33,42 & 31,33 & 28,41 & 25,61 & 23,00 & 18,44 & 14,83 & 9,98 \\
\hline 45 & 1650 & 45 & 37,68 & 33,10 & 31,08 & 28,21 & 25,47 & 22,90 & 18,41 & 14,84 & 10,00 \\
\hline 45 & 1700 & 45 & 37,33 & 32,79 & 30,83 & 28,03 & 25,34 & 22,81 & 18,37 & 14,83 & 10,02 \\
\hline 45 & 1750 & 45 & 36,99 & 32,49 & 30,59 & 27,84 & 25,20 & 22,71 & 18,34 & 14,83 & 10,04 \\
\hline 45 & 1800 & 45 & 36,67 & 32,20 & 30,36 & 27,67 & 25,07 & 22,62 & 18,30 & 14,83 & 10,05 \\
\hline 45 & 1850 & 45 & 36,36 & 31,92 & 30,14 & 27,50 & 24,95 & 22,53 & 18,27 & 14,83 & 10,07 \\
\hline 45 & 1900 & 45 & 36,07 & 31,65 & 29,92 & 27,33 & 24,82 & 22,45 & 18,23 & 14,82 & 10,09 \\
\hline 45 & 1950 & 45 & 35,78 & 31,39 & 29,71 & 27,17 & 24,70 & 22,36 & 18,20 & 14,82 & 10,10 \\
\hline 45 & 2000 & 45 & 35,51 & 31,14 & 29,50 & 27,01 & 24,58 & 22,27 & 18,16 & 14,81 & 10,12 \\
\hline 45 & 200 & 50 & 81,37 & 55,44 & 45,01 & 35,29 & 28,23 & 22,96 & 16,01 & 12,08 & 8,15 \\
\hline 45 & 250 & 50 & 73,44 & 52,36 & 43,42 & 34,71 & 28,13 & 23,07 & 16,21 & 12,22 & 8,16 \\
\hline 45 & 300 & 50 & 67,71 & 49,95 & 42,08 & 34,14 & 27,97 & 23,11 & 16,37 & 12,33 & 8,19 \\
\hline 45 & 350 & 50 & 63,32 & 47,97 & 40,91 & 33,60 & 27,78 & 23,11 & 16,50 & 12,44 & 8,21 \\
\hline 45 & 400 & 50 & 59,82 & 46,31 & 39,89 & 33,10 & 27,57 & 23,08 & 16,60 & 12,54 & 8,25 \\
\hline 45 & 450 & 50 & 56,94 & 44,87 & 38,97 & 32,61 & 27,36 & 23,04 & 16,69 & 12,63 & 8,28 \\
\hline 45 & 500 & 50 & 54,51 & 43,60 & 38,14 & 32,16 & 27,15 & 22,97 & 16,75 & 12,71 & 8,31 \\
\hline 45 & 550 & 50 & 52,44 & 42,48 & 37,39 & 31,74 & 26,94 & 22,90 & 16,80 & 12,78 & 8,35 \\
\hline 45 & 600 & 50 & 50,64 & 41,47 & 36,70 & 31,33 & 26,73 & 22,82 & 16,84 & 12,85 & 8,38 \\
\hline 45 & 650 & 50 & 49,06 & 40,55 & 36,06 & 30,95 & 26,52 & 22,73 & 16,88 & 12,91 & 8,42 \\
\hline 45 & 700 & 50 & 47,65 & 39,72 & 35,47 & 30,59 & 26,32 & 22,64 & 16,90 & 12,96 & 8,45 \\
\hline 45 & 750 & 50 & 46,40 & 38,95 & 34,92 & 30,24 & 26,12 & 22,54 & 16,91 & 13,01 & 8,48 \\
\hline 45 & 800 & 50 & 45,27 & 38,23 & 34,41 & 29,92 & 25,93 & 22,45 & 16,92 & 13,05 & 8,52 \\
\hline 45 & 850 & 50 & 44,24 & 37,57 & 33,93 & 29,60 & 25,75 & 22,35 & 16,93 & 13,09 & 8,55 \\
\hline 45 & 900 & 50 & 43,30 & 36,95 & 33,47 & 29,31 & 25,56 & 22,25 & 16,93 & 13,12 & 8,58 \\
\hline 45 & 950 & 50 & 42,45 & 36,38 & 33,05 & 29,02 & 25,39 & 22,16 & 16,93 & 13,16 & 8,61 \\
\hline 45 & 1000 & 50 & 41,66 & 35,83 & 32,64 & 28,75 & 25,22 & 22,06 & 16,92 & 13,18 & 8,64 \\
\hline 45 & 1050 & 50 & 40,93 & 35,32 & 32,26 & 28,48 & 25,05 & 21,96 & 16,91 & 13,21 & 8,67 \\
\hline 45 & 1100 & 50 & 40,25 & 34,84 & 31,89 & 28,23 & 24,89 & 21,87 & 16,90 & 13,23 & 8,69 \\
\hline 45 & 1150 & 50 & 39,62 & 34,38 & 31,54 & 27,99 & 24,73 & 21,78 & 16,88 & 13,25 & 8,72 \\
\hline 45 & 1200 & 50 & 39,03 & 33,94 & 31,21 & 27,76 & 24,57 & 21,68 & 16,87 & 13,27 & 8,74 \\
\hline 45 & 1250 & 50 & 38,48 & 33,53 & 30,89 & 27,53 & 24,42 & 21,59 & 16,85 & 13,28 & 8,77 \\
\hline 45 & 1300 & 50 & 37,97 & 33,13 & 30,59 & 27,32 & 24,28 & 21,50 & 16,83 & 13,30 & 8,79 \\
\hline 45 & 1350 & 50 & 37,48 & 32,75 & 30,30 & 27,11 & 24,14 & 21,41 & 16,81 & 13,31 & 8,82 \\
\hline 45 & 1400 & 50 & 37,02 & 32,39 & 30,02 & 26,91 & 24,00 & 21,32 & 16,79 & 13,32 & 8,84 \\
\hline 45 & 1450 & 50 & 36,59 & 32,04 & 29,75 & 26,71 & 23,86 & 21,23 & 16,76 & 13,33 & 8,86 \\
\hline 45 & 1500 & 50 & 36,18 & 31,71 & 29,49 & 26,52 & 23,73 & 21,15 & 16,74 & 13,33 & 8,88 \\
\hline 45 & 1550 & 50 & 35,79 & 31,39 & 29,24 & 26,34 & 23,60 & 21,06 & 16,71 & 13,34 & 8,90 \\
\hline 45 & 1600 & 50 & 35,42 & 31,09 & 29,00 & 26,16 & 23,48 & 20,98 & 16,69 & 13,34 & 8,92 \\
\hline 45 & 1650 & 50 & 35,07 & 30,79 & 28,76 & 25,99 & 23,35 & 20,90 & 16,66 & 13,35 & 8,94 \\
\hline 45 & 1700 & 50 & 34,73 & 30,50 & 28,54 & 25,82 & 23,23 & 20,82 & 16,64 & 13,35 & 8,95 \\
\hline 45 & 1750 & 50 & 34,41 & 30,23 & 28,32 & 25,65 & 23,12 & 20,74 & 16,61 & 13,35 & 8,97 \\
\hline 45 & 1800 & 50 & 34,11 & 29,96 & 28,11 & 25,50 & 23,00 & 20,66 & 16,58 & 13,35 & 8,99 \\
\hline 45 & 1850 & 50 & 33,81 & 29,71 & 27,90 & 25,34 & 22,89 & 20,58 & 16,56 & 13,35 & 9,00 \\
\hline 45 & 1900 & 50 & 33,53 & 29,46 & 27,70 & 25,19 & 22,78 & 20,51 & 16,53 & 13,35 & 9,02 \\
\hline 45 & 1950 & 50 & 33,26 & 29,22 & 27,51 & 25,04 & 22,67 & 20,43 & 16,50 & 13,35 & 9,03 \\
\hline 45 & 2000 & 50 & 33,00 & 28,98 & 27,32 & 24,90 & 22,57 & 20,36 & 16,47 & 13,35 & 9,05 \\
\hline 45 & 200 & 55 & 77,37 & 51,63 & 41,51 & 32,28 & 25,68 & 20,81 & 14,48 & 10,94 & 7,40 \\
\hline 45 & 250 & 55 & 69,72 & 48,78 & 40,10 & 31,79 & 25,62 & 20,93 & 14,66 & 11,05 & 7,41 \\
\hline 45 & 300 & 55 & 64,21 & 46,55 & 38,90 & 31,32 & 25,51 & 20,99 & 14,81 & 11,16 & 7,43 \\
\hline 45 & 350 & 55 & 59,99 & 44,72 & 37,85 & 30,86 & 25,36 & 21,01 & 14,93 & 11,25 & 7,45 \\
\hline 45 & 400 & 55 & 56,63 & 43,18 & 36,93 & 30,42 & 25,20 & 21,01 & 15,03 & 11,34 & 7,48 \\
\hline 45 & 450 & 55 & 53,87 & 41,84 & 36,10 & 30,01 & 25,03 & 20,98 & 15,11 & 11,42 & 7,50 \\
\hline 45 & 500 & 55 & 51,54 & 40,68 & 35,36 & 29,61 & 24,86 & 20,94 & 15,17 & 11,49 & 7,53 \\
\hline 45 & 550 & 55 & 49,56 & 39,64 & 34,68 & 29,24 & 24,68 & 20,88 & 15,23 & 11,56 & 7,56 \\
\hline 45 & 600 & 55 & 47,83 & 38,71 & 34,05 & 28,88 & 24,51 & 20,82 & 15,27 & 11,62 & 7,59 \\
\hline 45 & 650 & 55 & 46,32 & 37,86 & 33,47 & 28,55 & 24,33 & 20,76 & 15,31 & 11,67 & 7,61 \\
\hline 45 & 700 & 55 & 44,97 & 37,09 & 32,94 & 28,23 & 24,16 & 20,68 & 15,33 & 11,72 & 7,64 \\
\hline 45 & 750 & 55 & 43,77 & 36,37 & 32,44 & 27,92 & 23,99 & 20,61 & 15,36 & 11,77 & 7,67 \\
\hline 45 & 800 & 55 & 42,68 & 35,72 & 31,97 & 27,63 & 23,83 & 20,53 & 15,37 & 11,81 & 7,70 \\
\hline 45 & 850 & 55 & 41,70 & 35,10 & 31,53 & 27,36 & 23,67 & 20,45 & 15,38 & 11,84 & 7,73 \\
\hline 45 & 900 & 55 & 40,80 & 34,53 & 31,12 & 27,09 & 23,51 & 20,37 & 15,39 & 11,88 & 7,75 \\
\hline 45 & 950 & 55 & 39,98 & 34,00 & 30,73 & 26,84 & 23,36 & 20,29 & 15,39 & 11,91 & 7,78 \\
\hline 45 & 1000 & 55 & 39,22 & 33,50 & 30,36 & 26,59 & 23,21 & 20,21 & 15,39 & 11,94 & 7,80 \\
\hline 45 & 1050 & 55 & 38,52 & 33,02 & 30,01 & 26,36 & 23,06 & 20,13 & 15,39 & 11,96 & 7,83 \\
\hline 45 & 1100 & 55 & 37,87 & 32,58 & 29,67 & 26,13 & 22,92 & 20,06 & 15,38 & 11,99 & 7,85 \\
\hline 45 & 1150 & 55 & 37,27 & 32,15 & 29,35 & 25,92 & 22,78 & 19,98 & 15,37 & 12,01 & 7,88 \\
\hline 45 & 1200 & 55 & 36,70 & 31,75 & 29,05 & 25,71 & 22,65 & 19,90 & 15,36 & 12,02 & 7,90 \\
\hline 45 & 1250 & 55 & 36,17 & 31,36 & 28,76 & 25,51 & 22,52 & 19,82 & 15,35 & 12,04 & 7,92 \\
\hline 45 & 1300 & 55 & 35,68 & 31,00 & 28,48 & 25,31 & 22,39 & 19,74 & 15,34 & 12,06 & 7,94 \\
\hline 45 & 1350 & 55 & 35,21 & 30,65 & 28,21 & 25,12 & 22,26 & 19,67 & 15,32 & 12,07 & 7,96 \\
\hline
\end{tabular}




\begin{tabular}{|c|c|c|c|c|c|c|c|c|c|c|c|}
\hline \multirow[b]{2}{*}{$\mathrm{H}(\mathrm{cm})$} & \multirow[b]{2}{*}{ Mceq (MPa) } & & & & & $\mathrm{De}$ & ões (x1 & & & & \\
\hline & & Msub (MPa) & D0 & D25 & D40 & D60 & D80 & D100 & D140 & D180 & D260 \\
\hline 45 & 1400 & 55 & 34,77 & 30,31 & 27,96 & 24,94 & 22,14 & 19,59 & 15,31 & 12,08 & 7,98 \\
\hline 45 & 1450 & 55 & 34,35 & 29,99 & 27,71 & 24,76 & 22,02 & 19,52 & 15,29 & 12,09 & 8,00 \\
\hline 45 & 1500 & 55 & 33,96 & 29,68 & 27,47 & 24,59 & 21,91 & 19,44 & 15,27 & 12,10 & 8,02 \\
\hline 45 & 1550 & 55 & 33,58 & 29,39 & 27,24 & 24,43 & 21,79 & 19,37 & 15,26 & 12,11 & 8,04 \\
\hline 45 & 1600 & 55 & 33,23 & 29,10 & 27,02 & 24,27 & 21,68 & 19,30 & 15,24 & 12,12 & 8,06 \\
\hline 45 & 1650 & 55 & 32,89 & 28,83 & 26,81 & 24,11 & 21,57 & 19,23 & 15,22 & 12,12 & 8,07 \\
\hline 45 & 1700 & 55 & 32,57 & 28,56 & 26,60 & 23,96 & 21,47 & 19,16 & 15,20 & 12,13 & 8,09 \\
\hline 45 & 1750 & 55 & 32,26 & 28,31 & 26,40 & 23,81 & 21,36 & 19,09 & 15,18 & 12,13 & 8,10 \\
\hline 45 & 1800 & 55 & 31,97 & 28,06 & 26,20 & 23,67 & 21,26 & 19,02 & 15,15 & 12,13 & 8,12 \\
\hline 45 & 1850 & 55 & 31,68 & 27,82 & 26,02 & 23,53 & 21,16 & 18,95 & 15,13 & 12,14 & 8,13 \\
\hline 45 & 1900 & 55 & 31,42 & 27,59 & 25,83 & 23,39 & 21,06 & 18,89 & 15,11 & 12,14 & 8,15 \\
\hline 45 & 1950 & 55 & 31,16 & 27,37 & 25,66 & 23,26 & 20,97 & 18,82 & 15,09 & 12,14 & 8,16 \\
\hline 45 & 2000 & 55 & 30,91 & 27,15 & 25,48 & 23,13 & 20,87 & 18,76 & 15,07 & 12,14 & 8,18 \\
\hline 45 & 200 & 60 & 73,95 & 48,39 & 38,54 & 29,73 & 23,54 & 19,03 & 13,21 & 9,99 & 6,78 \\
\hline 45 & 250 & 60 & 66,53 & 45,72 & 37,27 & 29,33 & 23,52 & 19,15 & 13,37 & 10,09 & 6,79 \\
\hline 45 & 300 & 60 & 61,20 & 43,63 & 36,18 & 28,92 & 23,44 & 19,22 & 13,51 & 10,18 & 6,80 \\
\hline 45 & 350 & 60 & 57,13 & 41,93 & 35,24 & 28,53 & 23,33 & 19,26 & 13,62 & 10,26 & 6,82 \\
\hline 45 & 400 & 60 & 53,89 & 40,50 & 34,40 & 28,15 & 23,20 & 19,26 & 13,72 & 10,34 & 6,84 \\
\hline 45 & 450 & 60 & 51,23 & 39,26 & 33,65 & 27,79 & 23,06 & 19,25 & 13,79 & 10,41 & 6,86 \\
\hline 45 & 500 & 60 & 49,00 & 38,17 & 32,98 & 27,44 & 22,92 & 19,23 & 13,86 & 10,48 & 6,88 \\
\hline 45 & 550 & 60 & 47,09 & 37,20 & 32,36 & 27,11 & 22,77 & 19,19 & 13,91 & 10,54 & 6,90 \\
\hline 45 & 600 & 60 & 45,43 & 36,34 & 31,79 & 26,80 & 22,62 & 19,14 & 13,96 & 10,59 & 6,93 \\
\hline 45 & 650 & 60 & 43,97 & 35,55 & 31,26 & 26,50 & 22,48 & 19,09 & 14,00 & 10,64 & 6,95 \\
\hline 45 & 700 & 60 & 42,68 & 34,83 & 30,77 & 26,22 & 22,33 & 19,04 & 14,03 & 10,69 & 6,98 \\
\hline 45 & 750 & 60 & 41,52 & 34,17 & 30,31 & 25,95 & 22,19 & 18,98 & 14,05 & 10,73 & 7,00 \\
\hline 45 & 800 & 60 & 40,47 & 33,55 & 29,88 & 25,69 & 22,05 & 18,91 & 14,07 & 10,77 & 7,02 \\
\hline 45 & 850 & 60 & 39,53 & 32,99 & 29,48 & 25,44 & 21,91 & 18,85 & 14,08 & 10,81 & 7,05 \\
\hline 45 & 900 & 60 & 38,66 & 32,45 & 29,10 & 25,20 & 21,77 & 18,79 & 14,10 & 10,84 & 7,07 \\
\hline 45 & 950 & 60 & 37,87 & 31,96 & 28,74 & 24,97 & 21,64 & 18,72 & 14,10 & 10,87 & 7,09 \\
\hline 45 & 1000 & 60 & 37,14 & 31,49 & 28,40 & 24,75 & 21,51 & 18,65 & 14,11 & 10,90 & 7,11 \\
\hline 45 & 1050 & 60 & 36,47 & 31,05 & 28,08 & 24,54 & 21,38 & 18,59 & 14,11 & 10,92 & 7,14 \\
\hline 45 & 1100 & 60 & 35,84 & 30,63 & 27,77 & 24,34 & 21,25 & 18,52 & 14,11 & 10,95 & 7,16 \\
\hline 45 & 1150 & 60 & 35,26 & 30,24 & 27,48 & 24,14 & 21,13 & 18,45 & 14,10 & 10,97 & 7,18 \\
\hline 45 & 1200 & 60 & 34,71 & 29,86 & 27,20 & 23,96 & 21,01 & 18,38 & 14,10 & 10,99 & 7,20 \\
\hline 45 & 1250 & 60 & 34,21 & 29,50 & 26,93 & 23,77 & 20,90 & 18,32 & 14,09 & 11,00 & 7,22 \\
\hline 45 & 1300 & 60 & 33,73 & 29,16 & 26,67 & 23,60 & 20,78 & 18,25 & 14,08 & 11,02 & 7,24 \\
\hline 45 & 1350 & 60 & 33,28 & 28,84 & 26,43 & 23,43 & 20,67 & 18,19 & 14,07 & 11,03 & 7,26 \\
\hline 45 & 1400 & 60 & 32,85 & 28,52 & 26,19 & 23,26 & 20,56 & 18,12 & 14,06 & 11,05 & 7,27 \\
\hline 45 & 1450 & 60 & 32,45 & 28,23 & 25,96 & 23,10 & 20,46 & 18,06 & 14,05 & 11,06 & 7,29 \\
\hline 45 & 1500 & 60 & 32,07 & 27,94 & 25,74 & 22,94 & 20,35 & 17,99 & 14,04 & 11,07 & 7,31 \\
\hline 45 & 1550 & 60 & 31,71 & 27,66 & 25,53 & 22,79 & 20,25 & 17,93 & 14,03 & 11,08 & 7,32 \\
\hline 45 & 1600 & 60 & 31,37 & 27,40 & 25,33 & 22,65 & 20,15 & 17,87 & 14,01 & 11,09 & 7,34 \\
\hline 45 & 1650 & 60 & 31,04 & 27,14 & 25,13 & 22,50 & 20,05 & 17,80 & 14,00 & 11,09 & 7,36 \\
\hline 45 & 1700 & 60 & 30,73 & 26,90 & 24,94 & 22,37 & 19,96 & 17,74 & 13,98 & 11,10 & 7,37 \\
\hline 45 & 1750 & 60 & 30,43 & 26,66 & 24,75 & 22,23 & 19,87 & 17,68 & 13,97 & 11,11 & 7,39 \\
\hline 45 & 1800 & 60 & 30,15 & 26,43 & 24,57 & 22,10 & 19,77 & 17,62 & 13,95 & 11,11 & 7,40 \\
\hline 45 & 1850 & 60 & 29,88 & 26,20 & 24,40 & 21,97 & 19,69 & 17,57 & 13,93 & 11,11 & 7,41 \\
\hline 45 & 1900 & 60 & 29,62 & 25,99 & 24,23 & 21,85 & 19,60 & 17,51 & 13,91 & 11,12 & 7,43 \\
\hline 45 & 1950 & 60 & 29,37 & 25,78 & 24,06 & 21,73 & 19,51 & 17,45 & 13,90 & 11,12 & 7,44 \\
\hline 45 & 2000 & 60 & 29,13 & 25,58 & 23,91 & 21,61 & 19,43 & 17,39 & 13,88 & 11,12 & 7,45 \\
\hline 45 & 200 & 65 & 70,98 & 45,58 & 35,99 & 27,56 & 21,73 & 17,51 & 12,14 & 9,20 & 6,26 \\
\hline 45 & 250 & 65 & 63,75 & 43,07 & 34,83 & 27,22 & 21,72 & 17,64 & 12,29 & 9,28 & 6,27 \\
\hline 45 & 300 & 65 & 58,58 & 41,11 & 33,84 & 26,87 & 21,67 & 17,72 & 12,42 & 9,36 & 6,27 \\
\hline 45 & 350 & 65 & 54,64 & 39,52 & 32,98 & 26,53 & 21,59 & 17,76 & 12,52 & 9,43 & 6,29 \\
\hline 45 & 400 & 65 & 51,51 & 38,17 & 32,22 & 26,20 & 21,49 & 17,78 & 12,61 & 9,50 & 6,30 \\
\hline 45 & 450 & 65 & 48,94 & 37,01 & 31,54 & 25,88 & 21,38 & 17,78 & 12,68 & 9,57 & 6,32 \\
\hline 45 & 500 & 65 & 46,78 & 35,99 & 30,92 & 25,58 & 21,26 & 17,77 & 12,75 & 9,63 & 6,34 \\
\hline 45 & 550 & 65 & 44,94 & 35,09 & 30,35 & 25,28 & 21,14 & 17,74 & 12,80 & 9,68 & 6,35 \\
\hline 45 & 600 & 65 & 43,34 & 34,28 & 29,83 & 25,01 & 21,01 & 17,71 & 12,85 & 9,73 & 6,37 \\
\hline 45 & 650 & 65 & 41,93 & 33,54 & 29,34 & 24,74 & 20,88 & 17,67 & 12,89 & 9,78 & 6,39 \\
\hline 45 & 700 & 65 & 40,68 & 32,87 & 28,89 & 24,49 & 20,76 & 17,63 & 12,92 & 9,82 & 6,42 \\
\hline 45 & 750 & 65 & 39,57 & 32,25 & 28,47 & 24,24 & 20,63 & 17,58 & 12,94 & 9,86 & 6,44 \\
\hline 45 & 800 & 65 & 38,56 & 31,67 & 28,08 & 24,01 & 20,51 & 17,53 & 12,97 & 9,90 & 6,46 \\
\hline 45 & 850 & 65 & 37,65 & 31,14 & 27,70 & 23,79 & 20,39 & 17,48 & 12,98 & 9,93 & 6,48 \\
\hline 45 & 900 & 65 & 36,81 & 30,65 & 27,35 & 23,57 & 20,27 & 17,42 & 13,00 & 9,96 & 6,50 \\
\hline 45 & 950 & 65 & 36,05 & 30,18 & 27,02 & 23,36 & 20,15 & 17,37 & 13,01 & 9,99 & 6,52 \\
\hline 45 & 1000 & 65 & 35,34 & 29,74 & 26,71 & 23,17 & 20,04 & 17,31 & 13,01 & 10,02 & 6,54 \\
\hline 45 & 1050 & 65 & 34,69 & 29,33 & 26,41 & 22,97 & 19,93 & 17,26 & 13,02 & 10,04 & 6,55 \\
\hline 45 & 1100 & 65 & 34,09 & 28,94 & 26,13 & 22,79 & 19,82 & 17,20 & 13,02 & 10,07 & 6,57 \\
\hline 45 & 1150 & 65 & 33,53 & 28,57 & 25,85 & 22,61 & 19,71 & 17,14 & 13,02 & 10,09 & 6,59 \\
\hline 45 & 1200 & 65 & 33,00 & 28,22 & 25,59 & 22,44 & 19,60 & 17,08 & 13,02 & 10,11 & 6,61 \\
\hline 45 & 1250 & 65 & 32,51 & 27,88 & 25,35 & 22,27 & 19,50 & 17,03 & 13,02 & 10,12 & 6,63 \\
\hline 45 & 1300 & 65 & 32,04 & 27,56 & 25,11 & 22,11 & 19,40 & 16,97 & 13,01 & 10,14 & 6,64 \\
\hline 45 & 1350 & 65 & 31,61 & 27,26 & 24,88 & 21,96 & 19,30 & 16,91 & 13,01 & 10,16 & 6,66 \\
\hline 45 & 1400 & 65 & 31,20 & 26,97 & 24,66 & 21,81 & 19,20 & 16,86 & 13,00 & 10,17 & 6,68 \\
\hline 45 & 1450 & 65 & 30,81 & 26,69 & 24,45 & 21,66 & 19,11 & 16,80 & 12,99 & 10,18 & 6,69 \\
\hline 45 & 1500 & 65 & 30,44 & 26,42 & 24,24 & 21,52 & 19,01 & 16,74 & 12,99 & 10,19 & 6,71 \\
\hline 45 & 1550 & 65 & 30,09 & 26,16 & 24,05 & 21,38 & 18,92 & 16,69 & 12,98 & 10,20 & 6,72 \\
\hline 45 & 1600 & 65 & 29,76 & 25,91 & 23,86 & 21,25 & 18,83 & 16,64 & 12,97 & 10,21 & 6,74 \\
\hline 45 & 1650 & 65 & 29,45 & 25,67 & 23,67 & 21,11 & 18,74 & 16,58 & 12,95 & 10,22 & 6,75 \\
\hline 45 & 1700 & 65 & 29,15 & 25,44 & 23,49 & 20,99 & 18,66 & 16,53 & 12,94 & 10,23 & 6,77 \\
\hline
\end{tabular}




\begin{tabular}{|c|c|c|c|c|c|c|c|c|c|c|c|}
\hline \multirow[b]{2}{*}{$\mathrm{H}(\mathrm{cm})$} & \multirow[b]{2}{*}{ Mceq (MPa) } & & & & & $\mathrm{De}$ & ões (x1 & & & & \\
\hline & & Msub (MPa) & D0 & D25 & D40 & D60 & D80 & D100 & D140 & D180 & D260 \\
\hline 45 & 1750 & 65 & 28,86 & 25,22 & 23,32 & 20,86 & 18,57 & 16,47 & 12,93 & 10,24 & 6,78 \\
\hline 45 & 1800 & 65 & 28,59 & 25,00 & 23,15 & 20,74 & 18,49 & 16,42 & 12,92 & 10,24 & 6,79 \\
\hline 45 & 1850 & 65 & 28,32 & 24,79 & 22,99 & 20,63 & 18,41 & 16,37 & 12,90 & 10,25 & 6,81 \\
\hline 45 & 1900 & 65 & 28,07 & 24,59 & 22,84 & 20,51 & 18,33 & 16,32 & 12,89 & 10,25 & 6,82 \\
\hline 45 & 1950 & 65 & 27,83 & 24,39 & 22,68 & 20,40 & 18,25 & 16,27 & 12,88 & 10,26 & 6,83 \\
\hline 45 & 2000 & 65 & 27,60 & 24,20 & 22,53 & 20,29 & 18,18 & 16,22 & 12,86 & 10,26 & 6,84 \\
\hline 45 & 200 & 70 & 68,38 & 43,13 & 33,77 & 25,67 & 20,16 & 16,22 & 11,23 & 8,52 & 5,82 \\
\hline 45 & 250 & 70 & 61,32 & 40,75 & 32,71 & 25,39 & 20,18 & 16,34 & 11,37 & 8,59 & 5,82 \\
\hline 45 & 300 & 70 & 56,28 & 38,91 & 31,80 & 25,09 & 20,15 & 16,43 & 11,48 & 8,66 & 5,82 \\
\hline 45 & 350 & 70 & 52,45 & 37,40 & 31,01 & 24,79 & 20,09 & 16,48 & 11,58 & 8,73 & 5,83 \\
\hline 45 & 400 & 70 & 49,42 & 36,13 & 30,32 & 24,50 & 20,01 & 16,50 & 11,66 & 8,79 & 5,84 \\
\hline 45 & 450 & 70 & 46,93 & 35,04 & 29,69 & 24,22 & 19,92 & 16,51 & 11,74 & 8,84 & 5,86 \\
\hline 45 & 500 & 70 & 44,84 & 34,09 & 29,11 & 23,95 & 19,82 & 16,51 & 11,80 & 8,90 & 5,87 \\
\hline 45 & 550 & 70 & 43,05 & 33,24 & 28,59 & 23,69 & 19,72 & 16,49 & 11,85 & 8,95 & 5,89 \\
\hline 45 & 600 & 70 & 41,50 & 32,47 & 28,11 & 23,44 & 19,61 & 16,47 & 11,89 & 9,00 & 5,90 \\
\hline 45 & 650 & 70 & 40,14 & 31,78 & 27,66 & 23,20 & 19,50 & 16,44 & 11,93 & 9,04 & 5,92 \\
\hline 45 & 700 & 70 & 38,94 & 31,14 & 27,25 & 22,97 & 19,39 & 16,41 & 11,97 & 9,08 & 5,94 \\
\hline 45 & 750 & 70 & 37,86 & 30,56 & 26,86 & 22,75 & 19,28 & 16,37 & 11,99 & 9,12 & 5,96 \\
\hline 45 & 800 & 70 & 36,88 & 30,02 & 26,49 & 22,54 & 19,18 & 16,33 & 12,02 & 9,15 & 5,97 \\
\hline 45 & 850 & 70 & 36,00 & 29,52 & 26,15 & 22,34 & 19,07 & 16,29 & 12,04 & 9,18 & 5,99 \\
\hline 45 & 900 & 70 & 35,19 & 29,06 & 25,82 & 22,14 & 18,97 & 16,24 & 12,05 & 9,21 & 6,01 \\
\hline 45 & 950 & 70 & 34,45 & 28,62 & 25,51 & 21,96 & 18,86 & 16,20 & 12,06 & 9,24 & 6,03 \\
\hline 45 & 1000 & 70 & 33,77 & 28,21 & 25,22 & 21,78 & 18,76 & 16,15 & 12,07 & 9,27 & 6,04 \\
\hline 45 & 1050 & 70 & 33,14 & 27,82 & 24,94 & 21,60 & 18,66 & 16,10 & 12,08 & 9,29 & 6,06 \\
\hline 45 & 1100 & 70 & 32,55 & 27,45 & 24,68 & 21,43 & 18,56 & 16,05 & 12,09 & 9,31 & 6,08 \\
\hline 45 & 1150 & 70 & 32,01 & 27,10 & 24,43 & 21,27 & 18,47 & 16,00 & 12,09 & 9,33 & 6,09 \\
\hline 45 & 1200 & 70 & 31,50 & 26,77 & 24,19 & 21,11 & 18,37 & 15,95 & 12,09 & 9,35 & 6,11 \\
\hline 45 & 1250 & 70 & 31,02 & 26,46 & 23,95 & 20,96 & 18,28 & 15,91 & 12,09 & 9,37 & 6,12 \\
\hline 45 & 1300 & 70 & 30,58 & 26,16 & 23,73 & 20,81 & 18,19 & 15,86 & 12,09 & 9,39 & 6,14 \\
\hline 45 & 1350 & 70 & 30,15 & 25,87 & 23,52 & 20,67 & 18,10 & 15,81 & 12,09 & 9,40 & 6,16 \\
\hline 45 & 1400 & 70 & 29,76 & 25,60 & 23,31 & 20,53 & 18,01 & 15,76 & 12,08 & 9,42 & 6,17 \\
\hline 45 & 1450 & 70 & 29,38 & 25,33 & 23,12 & 20,40 & 17,93 & 15,71 & 12,08 & 9,43 & 6,18 \\
\hline 45 & 1500 & 70 & 29,02 & 25,08 & 22,93 & 20,27 & 17,84 & 15,66 & 12,07 & 9,44 & 6,20 \\
\hline 45 & 1550 & 70 & 28,69 & 24,84 & 22,74 & 20,14 & 17,76 & 15,61 & 12,07 & 9,45 & 6,21 \\
\hline 45 & 1600 & 70 & 28,36 & 24,60 & 22,56 & 20,02 & 17,68 & 15,56 & 12,06 & 9,46 & 6,23 \\
\hline 45 & 1650 & 70 & 28,06 & 24,38 & 22,39 & 19,90 & 17,60 & 15,52 & 12,05 & 9,47 & 6,24 \\
\hline 45 & 1700 & 70 & 27,77 & 24,16 & 22,23 & 19,78 & 17,52 & 15,47 & 12,04 & 9,48 & 6,25 \\
\hline 45 & 1750 & 70 & 27,49 & 23,95 & 22,07 & 19,67 & 17,45 & 15,42 & 12,03 & 9,49 & 6,26 \\
\hline 45 & 1800 & 70 & 27,22 & 23,74 & 21,91 & 19,56 & 17,37 & 15,38 & 12,02 & 9,49 & 6,28 \\
\hline 45 & 1850 & 70 & 26,97 & 23,55 & 21,76 & 19,45 & 17,30 & 15,33 & 12,01 & 9,50 & 6,29 \\
\hline 45 & 1900 & 70 & 26,72 & 23,36 & 21,61 & 19,34 & 17,23 & 15,28 & 12,00 & 9,51 & 6,30 \\
\hline 45 & 1950 & 70 & 26,49 & 23,17 & 21,47 & 19,24 & 17,15 & 15,24 & 11,99 & 9,51 & 6,31 \\
\hline 45 & 2000 & 70 & 26,27 & 22,99 & 21,33 & 19,14 & 17,09 & 15,19 & 11,98 & 9,52 & 6,32 \\
\hline 45 & 200 & 75 & 66,08 & 40,98 & 31,81 & 24,03 & 18,80 & 15,10 & 10,44 & 7,93 & 5,43 \\
\hline 45 & 250 & 75 & 59,16 & 38,71 & 30,84 & 23,79 & 18,83 & 15,22 & 10,57 & 7,99 & 5,43 \\
\hline 45 & 300 & 75 & 54,24 & 36,96 & 30,00 & 23,53 & 18,82 & 15,30 & 10,68 & 8,06 & 5,43 \\
\hline 45 & 350 & 75 & 50,51 & 35,53 & 29,28 & 23,27 & 18,78 & 15,36 & 10,77 & 8,12 & 5,44 \\
\hline 45 & 400 & 75 & 47,56 & 34,33 & 28,63 & 23,01 & 18,72 & 15,39 & 10,85 & 8,17 & 5,45 \\
\hline 45 & 450 & 75 & 45,14 & 33,30 & 28,05 & 22,76 & 18,64 & 15,41 & 10,91 & 8,22 & 5,46 \\
\hline 45 & 500 & 75 & 43,11 & 32,40 & 27,52 & 22,52 & 18,56 & 15,41 & 10,97 & 8,27 & 5,47 \\
\hline 45 & 550 & 75 & 41,38 & 31,59 & 27,04 & 22,29 & 18,47 & 15,40 & 11,02 & 8,32 & 5,48 \\
\hline 45 & 600 & 75 & 39,88 & 30,87 & 26,59 & 22,06 & 18,38 & 15,39 & 11,07 & 8,36 & 5,50 \\
\hline 45 & 650 & 75 & 38,56 & 30,22 & 26,18 & 21,85 & 18,29 & 15,37 & 11,11 & 8,40 & 5,51 \\
\hline 45 & 700 & 75 & 37,39 & 29,62 & 25,79 & 21,64 & 18,19 & 15,34 & 11,14 & 8,44 & 5,53 \\
\hline 45 & 750 & 75 & 36,34 & 29,07 & 25,43 & 21,44 & 18,10 & 15,31 & 11,17 & 8,47 & 5,54 \\
\hline 45 & 800 & 75 & 35,40 & 28,56 & 25,09 & 21,25 & 18,01 & 15,28 & 11,19 & 8,51 & 5,56 \\
\hline 45 & 850 & 75 & 34,54 & 28,09 & 24,77 & 21,07 & 17,91 & 15,25 & 11,21 & 8,54 & 5,57 \\
\hline 45 & 900 & 75 & 33,76 & 27,65 & 24,47 & 20,89 & 17,82 & 15,21 & 11,23 & 8,57 & 5,59 \\
\hline 45 & 950 & 75 & 33,04 & 27,23 & 24,18 & 20,72 & 17,73 & 15,17 & 11,24 & 8,59 & 5,60 \\
\hline 45 & 1000 & 75 & 32,38 & 26,84 & 23,91 & 20,55 & 17,64 & 15,13 & 11,26 & 8,62 & 5,62 \\
\hline 45 & 1050 & 75 & 31,77 & 26,48 & 23,65 & 20,39 & 17,55 & 15,09 & 11,27 & 8,64 & 5,63 \\
\hline 45 & 1100 & 75 & 31,20 & 26,13 & 23,40 & 20,24 & 17,46 & 15,05 & 11,27 & 8,66 & 5,65 \\
\hline 45 & 1150 & 75 & 30,67 & 25,80 & 23,17 & 20,09 & 17,37 & 15,01 & 11,28 & 8,68 & 5,66 \\
\hline 45 & 1200 & 75 & 30,18 & 25,49 & 22,94 & 19,94 & 17,29 & 14,96 & 11,28 & 8,70 & 5,68 \\
\hline 45 & 1250 & 75 & 29,71 & 25,19 & 22,72 & 19,80 & 17,20 & 14,92 & 11,29 & 8,72 & 5,69 \\
\hline 45 & 1300 & 75 & 29,28 & 24,91 & 22,52 & 19,67 & 17,12 & 14,88 & 11,29 & 8,73 & 5,71 \\
\hline 45 & 1350 & 75 & 28,87 & 24,64 & 22,32 & 19,54 & 17,04 & 14,84 & 11,29 & 8,75 & 5,72 \\
\hline 45 & 1400 & 75 & 28,48 & 24,38 & 22,12 & 19,41 & 16,96 & 14,79 & 11,28 & 8,76 & 5,73 \\
\hline 45 & 1450 & 75 & 28,12 & 24,13 & 21,94 & 19,28 & 16,89 & 14,75 & 11,28 & 8,78 & 5,75 \\
\hline 45 & 1500 & 75 & 27,77 & 23,89 & 21,76 & 19,16 & 16,81 & 14,71 & 11,28 & 8,79 & 5,76 \\
\hline 45 & 1550 & 75 & 27,44 & 23,66 & 21,59 & 19,05 & 16,74 & 14,66 & 11,27 & 8,80 & 5,77 \\
\hline 45 & 1600 & 75 & 27,13 & 23,44 & 21,42 & 18,93 & 16,66 & 14,62 & 11,27 & 8,81 & 5,78 \\
\hline 45 & 1650 & 75 & 26,83 & 23,22 & 21,26 & 18,82 & 16,59 & 14,58 & 11,26 & 8,82 & 5,80 \\
\hline 45 & 1700 & 75 & 26,55 & 23,02 & 21,10 & 18,71 & 16,52 & 14,54 & 11,26 & 8,83 & 5,81 \\
\hline 45 & 1750 & 75 & 26,28 & 22,82 & 20,95 & 18,61 & 16,45 & 14,50 & 11,25 & 8,84 & 5,82 \\
\hline 45 & 1800 & 75 & 26,02 & 22,63 & 20,81 & 18,51 & 16,38 & 14,45 & 11,24 & 8,84 & 5,83 \\
\hline 45 & 1850 & 75 & 25,78 & 22,44 & 20,66 & 18,40 & 16,32 & 14,41 & 11,24 & 8,85 & 5,84 \\
\hline 45 & 1900 & 75 & 25,54 & 22,26 & 20,53 & 18,31 & 16,25 & 14,37 & 11,23 & 8,86 & 5,85 \\
\hline 45 & 1950 & 75 & 25,31 & 22,09 & 20,39 & 18,21 & 16,19 & 14,33 & 11,22 & 8,86 & 5,86 \\
\hline 45 & 2000 & 75 & 25,09 & 21,92 & 20,26 & 18,12 & 16,12 & 14,29 & 11,21 & 8,87 & 5,87 \\
\hline 45 & 200 & 80 & 64,02 & 39,06 & 30,08 & 22,58 & 17,61 & 14,11 & 9,76 & 7,42 & 5,09 \\
\hline
\end{tabular}




\begin{tabular}{|c|c|c|c|c|c|c|c|c|c|c|c|}
\hline \multirow[b]{2}{*}{$\mathrm{H}(\mathrm{cm})$} & \multirow[b]{2}{*}{ Mceq (MPa) } & & & & & $\mathrm{De}$ & ões (x1 & & & & \\
\hline & & Msub (MPa) & D0 & D25 & D40 & D60 & D80 & D100 & D140 & D180 & D260 \\
\hline 45 & 250 & 80 & 57,24 & 36,89 & 29,18 & 22,37 & 17,65 & 14,24 & 9,87 & 7,48 & 5,09 \\
\hline 45 & 300 & 80 & 52,42 & 35,22 & 28,41 & 22,15 & 17,65 & 14,32 & 9,97 & 7,53 & 5,09 \\
\hline 45 & 350 & 80 & 48,78 & 33,86 & 27,74 & 21,92 & 17,63 & 14,38 & 10,06 & 7,58 & 5,09 \\
\hline 45 & 400 & 80 & 45,90 & 32,73 & 27,14 & 21,69 & 17,58 & 14,42 & 10,13 & 7,63 & 5,10 \\
\hline 45 & 450 & 80 & 43,54 & 31,75 & 26,60 & 21,47 & 17,52 & 14,44 & 10,20 & 7,68 & 5,11 \\
\hline 45 & 500 & 80 & 41,57 & 30,89 & 26,11 & 21,25 & 17,45 & 14,45 & 10,25 & 7,73 & 5,12 \\
\hline 45 & 550 & 80 & 39,88 & 30,13 & 25,66 & 21,04 & 17,38 & 14,45 & 10,30 & 7,77 & 5,13 \\
\hline 45 & 600 & 80 & 38,42 & 29,44 & 25,24 & 20,84 & 17,30 & 14,44 & 10,35 & 7,81 & 5,14 \\
\hline 45 & 650 & 80 & 37,14 & 28,82 & 24,85 & 20,65 & 17,22 & 14,42 & 10,38 & 7,85 & 5,16 \\
\hline 45 & 700 & 80 & 36,01 & 28,26 & 24,49 & 20,46 & 17,13 & 14,41 & 10,42 & 7,88 & 5,17 \\
\hline 45 & 750 & 80 & 34,99 & 27,73 & 24,16 & 20,28 & 17,05 & 14,38 & 10,44 & 7,91 & 5,18 \\
\hline 45 & 800 & 80 & 34,07 & 27,25 & 23,84 & 20,10 & 16,97 & 14,36 & 10,47 & 7,94 & 5,20 \\
\hline 45 & 850 & 80 & 33,24 & 26,80 & 23,54 & 19,93 & 16,89 & 14,33 & 10,49 & 7,97 & 5,21 \\
\hline 45 & 900 & 80 & 32,48 & 26,39 & 23,26 & 19,77 & 16,80 & 14,30 & 10,51 & 8,00 & 5,22 \\
\hline 45 & 950 & 80 & 31,78 & 25,99 & 22,99 & 19,61 & 16,72 & 14,27 & 10,52 & 8,03 & 5,24 \\
\hline 45 & 1000 & 80 & 31,14 & 25,62 & 22,73 & 19,46 & 16,64 & 14,23 & 10,54 & 8,05 & 5,25 \\
\hline 45 & 1050 & 80 & 30,54 & 25,28 & 22,49 & 19,31 & 16,56 & 14,20 & 10,55 & 8,07 & 5,26 \\
\hline 45 & 1100 & 80 & 29,99 & 24,95 & 22,26 & 19,17 & 16,48 & 14,16 & 10,56 & 8,09 & 5,28 \\
\hline 45 & 1150 & 80 & 29,48 & 24,64 & 22,04 & 19,04 & 16,40 & 14,13 & 10,57 & 8,11 & 5,29 \\
\hline 45 & 1200 & 80 & 29,00 & 24,34 & 21,83 & 18,90 & 16,33 & 14,09 & 10,57 & 8,13 & 5,30 \\
\hline 45 & 1250 & 80 & 28,55 & 24,06 & 21,62 & 18,77 & 16,25 & 14,05 & 10,58 & 8,15 & 5,32 \\
\hline 45 & 1300 & 80 & 28,12 & 23,79 & 21,43 & 18,65 & 16,18 & 14,01 & 10,58 & 8,16 & 5,33 \\
\hline 45 & 1350 & 80 & 27,73 & 23,53 & 21,24 & 18,53 & 16,11 & 13,98 & 10,58 & 8,18 & 5,34 \\
\hline 45 & 1400 & 80 & 27,35 & 23,29 & 21,06 & 18,41 & 16,03 & 13,94 & 10,58 & 8,19 & 5,35 \\
\hline 45 & 1450 & 80 & 27,00 & 23,05 & 20,89 & 18,29 & 15,96 & 13,90 & 10,58 & 8,21 & 5,36 \\
\hline 45 & 1500 & 80 & 26,66 & 22,82 & 20,72 & 18,18 & 15,89 & 13,86 & 10,58 & 8,22 & 5,38 \\
\hline 45 & 1550 & 80 & 26,34 & 22,61 & 20,56 & 18,07 & 15,83 & 13,83 & 10,58 & 8,23 & 5,39 \\
\hline 45 & 1600 & 80 & 26,04 & 22,40 & 20,40 & 17,97 & 15,76 & 13,79 & 10,57 & 8,24 & 5,40 \\
\hline 45 & 1650 & 80 & 25,75 & 22,19 & 20,25 & 17,86 & 15,69 & 13,75 & 10,57 & 8,25 & 5,41 \\
\hline 45 & 1700 & 80 & 25,47 & 22,00 & 20,10 & 17,76 & 15,63 & 13,71 & 10,57 & 8,26 & 5,42 \\
\hline 45 & 1750 & 80 & 25,21 & 21,81 & 19,96 & 17,66 & 15,57 & 13,68 & 10,56 & 8,27 & 5,43 \\
\hline 45 & 1800 & 80 & 24,96 & 21,63 & 19,82 & 17,57 & 15,50 & 13,64 & 10,56 & 8,28 & 5,44 \\
\hline 45 & 1850 & 80 & 24,72 & 21,45 & 19,69 & 17,48 & 15,44 & 13,60 & 10,55 & 8,28 & 5,45 \\
\hline 45 & 1900 & 80 & 24,49 & 21,28 & 19,56 & 17,38 & 15,38 & 13,57 & 10,54 & 8,29 & 5,46 \\
\hline 45 & 1950 & 80 & 24,27 & 21,11 & 19,43 & 17,30 & 15,32 & 13,53 & 10,54 & 8,30 & 5,47 \\
\hline 45 & 2000 & 80 & 24,05 & 20,95 & 19,31 & 17,21 & 15,26 & 13,49 & 10,53 & 8,30 & 5,48 \\
\hline 45 & 200 & 85 & 62,18 & 37,34 & 28,54 & 21,29 & 16,55 & 13,25 & 9,16 & 6,97 & 4,79 \\
\hline 45 & 250 & 85 & 55,51 & 35,26 & 27,70 & 21,12 & 16,61 & 13,37 & 9,26 & 7,02 & 4,79 \\
\hline 45 & 300 & 85 & 50,79 & 33,66 & 26,98 & 20,92 & 16,62 & 13,45 & 9,35 & 7,07 & 4,79 \\
\hline 45 & 350 & 85 & 47,22 & 32,37 & 26,36 & 20,72 & 16,60 & 13,51 & 9,43 & 7,12 & 4,79 \\
\hline 45 & 400 & 85 & 44,40 & 31,28 & 25,80 & 20,52 & 16,57 & 13,55 & 9,50 & 7,16 & 4,80 \\
\hline 45 & 450 & 85 & 42,10 & 30,35 & 25,30 & 20,32 & 16,52 & 13,58 & 9,57 & 7,21 & 4,81 \\
\hline 45 & 500 & 85 & 40,18 & 29,53 & 24,84 & 20,12 & 16,46 & 13,59 & 9,62 & 7,25 & 4,81 \\
\hline 45 & 550 & 85 & 38,54 & 28,81 & 24,42 & 19,93 & 16,40 & 13,60 & 9,67 & 7,29 & 4,82 \\
\hline 45 & 600 & 85 & 37,11 & 28,16 & 24,03 & 19,75 & 16,33 & 13,59 & 9,71 & 7,32 & 4,83 \\
\hline 45 & 650 & 85 & 35,87 & 27,57 & 23,67 & 19,57 & 16,26 & 13,59 & 9,75 & 7,36 & 4,84 \\
\hline 45 & 700 & 85 & 34,76 & 27,03 & 23,33 & 19,40 & 16,19 & 13,57 & 9,78 & 7,39 & 4,86 \\
\hline 45 & 750 & 85 & 33,77 & 26,53 & 23,02 & 19,23 & 16,12 & 13,56 & 9,81 & 7,42 & 4,87 \\
\hline 45 & 800 & 85 & 32,88 & 26,07 & 22,72 & 19,07 & 16,04 & 13,54 & 9,83 & 7,45 & 4,88 \\
\hline 45 & 850 & 85 & 32,07 & 25,65 & 22,44 & 18,92 & 15,97 & 13,51 & 9,85 & 7,48 & 4,89 \\
\hline 45 & 900 & 85 & 31,33 & 25,25 & 22,17 & 18,77 & 15,90 & 13,49 & 9,87 & 7,50 & 4,90 \\
\hline 45 & 950 & 85 & 30,65 & 24,88 & 21,92 & 18,62 & 15,82 & 13,46 & $\begin{array}{c}9,89 \\
\end{array}$ & 7,53 & 4,91 \\
\hline 45 & 1000 & 85 & 30,02 & 24,53 & 21,68 & 18,49 & 15,75 & 13,43 & 9,90 & 7,55 & 4,93 \\
\hline 45 & 1050 & 85 & 29,44 & 24,20 & 21,45 & 18,35 & 15,68 & 13,40 & 9,92 & 7,57 & 4,94 \\
\hline 45 & 1100 & 85 & 28,91 & 23,88 & 21,23 & 18,22 & 15,61 & 13,37 & 9,93 & 7,59 & 4,95 \\
\hline 45 & 1150 & 85 & 28,41 & 23,59 & 21,03 & 18,09 & 15,54 & 13,34 & 9,93 & 7,61 & 4,96 \\
\hline 45 & 1200 & 85 & 27,94 & 23,31 & 20,83 & 17,97 & 15,47 & 13,31 & 9,94 & 7,63 & 4,97 \\
\hline 45 & 1250 & 85 & 27,50 & 23,04 & 20,64 & 17,85 & 15,40 & 13,28 & 9,95 & 7,64 & 4,98 \\
\hline 45 & 1300 & 85 & 27,09 & 22,78 & 20,45 & 17,73 & 15,33 & 13,24 & 9,95 & 7,66 & 5,00 \\
\hline 45 & 1350 & 85 & 26,70 & 22,54 & 20,28 & 17,62 & 15,27 & 13,21 & 9,95 & 7,67 & 5,01 \\
\hline 45 & 1400 & 85 & 26,34 & 22,30 & 20,10 & 17,51 & 15,20 & 13,18 & 9,96 & 7,69 & 5,02 \\
\hline 45 & 1450 & 85 & 25,99 & 22,08 & 19,94 & 17,40 & 15,14 & 13,14 & 9,96 & 7,70 & 5,03 \\
\hline 45 & 1500 & 85 & 25,66 & 21,86 & 19,78 & 17,30 & 15,07 & 13,11 & 9,96 & 7,71 & 5,04 \\
\hline 45 & 1550 & 85 & 25,35 & 21,66 & 19,63 & 17,20 & 15,01 & 13,08 & 9,96 & 7,72 & 5,05 \\
\hline 45 & 1600 & 85 & 25,05 & 21,46 & 19,48 & 17,10 & 14,95 & 13,04 & 9,96 & 7,74 & 5,06 \\
\hline 45 & 1650 & 85 & 24,77 & 21,26 & 19,34 & 17,00 & 14,89 & 13,01 & 9,95 & 7,75 & 5,07 \\
\hline 45 & 1700 & 85 & 24,50 & 21,08 & 19,20 & 16,91 & 14,83 & 12,98 & 9,95 & 7,76 & 5,08 \\
\hline 45 & 1750 & 85 & 24,25 & 20,90 & 19,07 & 16,82 & 14,77 & 12,94 & 9,95 & 7,76 & 5,09 \\
\hline 45 & 1800 & 85 & 24,00 & 20,73 & 18,94 & 16,73 & 14,72 & 12,91 & 9,95 & 7,77 & 5,10 \\
\hline 45 & 1850 & 85 & 23,77 & 20,56 & 18,81 & 16,64 & 14,66 & 12,88 & 9,94 & 7,78 & 5,11 \\
\hline 45 & 1900 & 85 & 23,54 & 20,40 & 18,69 & 16,56 & 14,61 & 12,84 & 9,94 & 7,79 & 5,12 \\
\hline 45 & 1950 & 85 & 23,33 & 20,24 & 18,57 & 16,47 & 14,55 & 12,81 & 9,93 & 7,79 & 5,13 \\
\hline 45 & 2000 & 85 & 23,12 & 20,08 & 18,45 & 16,39 & 14,50 & 12,78 & 9,93 & 7,80 & 5,14 \\
\hline 45 & 200 & 90 & 60,51 & 35,79 & 27,15 & 20,14 & 15,61 & 12,48 & 8,62 & 6,57 & 4,53 \\
\hline 45 & 250 & 90 & 53,94 & 33,79 & 26,36 & 19,99 & 15,68 & 12,60 & 8,72 & 6,62 & 4,52 \\
\hline 45 & 300 & 90 & 49,30 & 32,26 & 25,70 & 19,82 & 15,70 & 12,68 & 8,81 & 6,66 & 4,52 \\
\hline 45 & 350 & 90 & 45,81 & 31,02 & 25,11 & 19,64 & 15,69 & 12,74 & 8,88 & 6,71 & 4,52 \\
\hline 45 & 400 & 90 & 43,05 & 29,98 & 24,59 & 19,46 & 15,66 & 12,79 & 8,95 & 6,75 & 4,53 \\
\hline 45 & 450 & 90 & 40,80 & 29,09 & 24,12 & 19,28 & 15,63 & 12,81 & 9,01 & 6,79 & 4,53 \\
\hline 45 & 500 & 90 & 38,92 & 28,31 & 23,69 & 19,11 & 15,58 & 12,83 & 9,06 & 6,82 & 4,54 \\
\hline 45 & 550 & 90 & 37,31 & 27,62 & 23,30 & 18,93 & 15,53 & 12,84 & 9,10 & 6,86 & 4,55 \\
\hline
\end{tabular}




\begin{tabular}{|c|c|c|c|c|c|c|c|c|c|c|c|}
\hline \multirow[b]{2}{*}{$\mathrm{H}(\mathrm{cm})$} & \multirow[b]{2}{*}{ Mceq (MPa) } & & & & & $\mathrm{De}$ & ões (x1 & & & & \\
\hline & & Msub (MPa) & D0 & D25 & D40 & D60 & D80 & D100 & D140 & D180 & D260 \\
\hline 45 & 600 & 90 & 35,93 & 27,00 & 22,94 & 18,77 & 15,47 & 12,84 & 9,14 & 6,89 & 4,56 \\
\hline 45 & 650 & 90 & 34,71 & 26,43 & 22,60 & 18,60 & 15,41 & 12,84 & 9,18 & 6,93 & 4,57 \\
\hline 45 & 700 & 90 & 33,63 & 25,92 & 22,28 & 18,45 & 15,34 & 12,83 & 9,21 & 6,96 & 4,58 \\
\hline 45 & 750 & 90 & 32,67 & 25,45 & 21,98 & 18,30 & 15,28 & 12,82 & 9,24 & 6,99 & 4,59 \\
\hline 45 & 800 & 90 & 31,80 & 25,01 & 21,70 & 18,15 & 15,21 & 12,80 & 9,26 & 7,01 & 4,60 \\
\hline 45 & 850 & 90 & 31,01 & 24,60 & 21,44 & 18,01 & 15,15 & 12,78 & 9,29 & 7,04 & 4,61 \\
\hline 45 & 900 & 90 & 30,28 & 24,22 & 21,19 & 17,87 & 15,08 & 12,76 & 9,31 & 7,06 & 4,62 \\
\hline 45 & 950 & 90 & 29,62 & 23,87 & 20,95 & 17,73 & 15,02 & 12,74 & 9,32 & 7,08 & 4,63 \\
\hline 45 & 1000 & 90 & 29,01 & 23,53 & 20,73 & 17,61 & 14,95 & 12,72 & 9,34 & 7,11 & 4,64 \\
\hline 45 & 1050 & 90 & 28,45 & 23,22 & 20,51 & 17,48 & 14,89 & 12,69 & 9,35 & 7,13 & 4,65 \\
\hline 45 & 1100 & 90 & 27,93 & 22,92 & 20,31 & 17,36 & 14,82 & 12,66 & 9,36 & 7,15 & 4,66 \\
\hline 45 & 1150 & 90 & 27,44 & 22,64 & 20,11 & 17,24 & 14,76 & 12,64 & 9,37 & 7,16 & 4,67 \\
\hline 45 & 1200 & 90 & 26,98 & 22,37 & 19,92 & 17,13 & 14,70 & 12,61 & 9,38 & 7,18 & 4,68 \\
\hline 45 & 1250 & 90 & 26,56 & 22,11 & 19,74 & 17,01 & 14,63 & 12,58 & 9,39 & 7,20 & 4,69 \\
\hline 45 & 1300 & 90 & 26,15 & 21,87 & 19,57 & 16,91 & 14,57 & 12,55 & 9,39 & 7,21 & 4,70 \\
\hline 45 & 1350 & 90 & 25,78 & 21,64 & 19,40 & 16,80 & 14,51 & 12,52 & 9,40 & 7,23 & 4,71 \\
\hline 45 & 1400 & 90 & 25,42 & 21,41 & 19,24 & 16,70 & 14,45 & 12,49 & 9,40 & 7,24 & 4,72 \\
\hline 45 & 1450 & 90 & 25,08 & 21,20 & 19,09 & 16,60 & 14,40 & 12,46 & 9,40 & 7,25 & 4,73 \\
\hline 45 & 1500 & 90 & 24,76 & 20,99 & 18,94 & 16,50 & 14,34 & 12,43 & 9,40 & 7,27 & 4,74 \\
\hline 45 & 1550 & 90 & 24,46 & 20,80 & 18,79 & 16,41 & 14,28 & 12,41 & 9,41 & 7,28 & 4,75 \\
\hline 45 & 1600 & 90 & 24,17 & 20,60 & 18,65 & 16,32 & 14,22 & 12,38 & 9,41 & 7,29 & 4,76 \\
\hline 45 & 1650 & 90 & 23,89 & 20,42 & 18,52 & 16,23 & 14,17 & 12,35 & 9,40 & 7,30 & 4,77 \\
\hline 45 & 1700 & 90 & 23,63 & 20,24 & 18,38 & 16,14 & 14,11 & 12,32 & 9,40 & 7,31 & 4,78 \\
\hline 45 & 1750 & 90 & 23,38 & 20,07 & 18,26 & 16,05 & 14,06 & 12,29 & 9,40 & 7,32 & 4,79 \\
\hline 45 & 1800 & 90 & 23,14 & 19,91 & 18,13 & 15,97 & 14,01 & 12,26 & 9,40 & 7,32 & 4,80 \\
\hline 45 & 1850 & 90 & 22,91 & 19,75 & 18,01 & 15,89 & 13,96 & 12,23 & 9,40 & 7,33 & 4,81 \\
\hline 45 & 1900 & 90 & 22,69 & 19,59 & 17,90 & 15,81 & 13,91 & 12,20 & 9,39 & 7,34 & 4,82 \\
\hline 45 & 1950 & 90 & 22,48 & 19,44 & 17,78 & 15,73 & 13,86 & 12,17 & 9,39 & 7,35 & 4,82 \\
\hline 45 & 2000 & 90 & 22,28 & 19,30 & 17,67 & 15,65 & 13,81 & 12,14 & 9,39 & 7,35 & 4,83 \\
\hline 45 & 200 & 95 & 59,00 & 34,39 & 25,90 & 19,10 & 14,77 & 11,80 & 8,15 & 6,22 & 4,29 \\
\hline 45 & 250 & 95 & 52,52 & 32,46 & 25,16 & 18,98 & 14,84 & 11,91 & 8,24 & 6,26 & 4,29 \\
\hline 45 & 300 & 95 & 47,95 & 30,98 & 24,53 & 18,83 & 14,87 & 11,99 & 8,32 & 6,30 & 4,28 \\
\hline 45 & 350 & 95 & 44,52 & 29,79 & 23,99 & 18,67 & 14,87 & 12,05 & 8,39 & 6,34 & 4,29 \\
\hline 45 & 400 & 95 & 41,81 & 28,80 & 23,50 & 18,51 & 14,85 & 12,10 & 8,45 & 6,38 & 4,29 \\
\hline 45 & 450 & 95 & 39,61 & 27,94 & 23,06 & 18,35 & 14,82 & 12,13 & 8,51 & 6,41 & 4,29 \\
\hline 45 & 500 & 95 & 37,77 & 27,20 & 22,66 & 18,19 & 14,78 & 12,15 & 8,56 & 6,45 & 4,30 \\
\hline 45 & 550 & 95 & 36,20 & 26,54 & 22,29 & 18,03 & 14,74 & 12,16 & 8,60 & 6,48 & 4,31 \\
\hline 45 & 600 & 95 & 34,85 & 25,94 & 21,94 & 17,88 & 14,69 & 12,17 & 8,64 & 6,51 & 4,31 \\
\hline 45 & 650 & 95 & 33,66 & 25,40 & 21,63 & 17,73 & 14,64 & 12,17 & 8,67 & 6,54 & 4,32 \\
\hline 45 & 700 & 95 & 32,60 & 24,91 & 21,33 & 17,59 & 14,58 & 12,16 & 8,71 & 6,57 & 4,33 \\
\hline 45 & 750 & 95 & 31,66 & 24,46 & 21,05 & 17,45 & 14,52 & 12,15 & 8,73 & 6,60 & 4,34 \\
\hline 45 & 800 & 95 & 30,81 & 24,04 & 20,78 & 17,31 & 14,47 & 12,14 & 8,76 & 6,62 & 4,35 \\
\hline 45 & 850 & 95 & 30,04 & 23,65 & 20,54 & 17,18 & 14,41 & 12,13 & 8,78 & 6,65 & 4,36 \\
\hline 45 & 900 & 95 & 29,34 & 23,29 & 20,30 & 17,05 & 14,35 & 12,11 & 8,80 & 6,67 & 4,37 \\
\hline 45 & 950 & 95 & 28,69 & 22,95 & 20,08 & 16,93 & 14,29 & 12,09 & 8,82 & 6,69 & 4,38 \\
\hline 45 & 1000 & 95 & 28,10 & 22,63 & 19,86 & 16,81 & 14,23 & 12,07 & 8,83 & 6,71 & 4,38 \\
\hline 45 & 1050 & 95 & 27,55 & 22,33 & 19,66 & 16,69 & 14,17 & 12,05 & 8,85 & 6,73 & 4,39 \\
\hline 45 & 1100 & 95 & 27,03 & 22,04 & 19,46 & 16,58 & 14,11 & 12,03 & 8,86 & 6,75 & 4,40 \\
\hline 45 & 1150 & 95 & 26,56 & 21,77 & 19,28 & 16,47 & 14,06 & 12,00 & 8,87 & 6,77 & 4,41 \\
\hline 45 & 1200 & 95 & 26,11 & 21,52 & 19,10 & 16,36 & 14,00 & 11,98 & 8,88 & 6,78 & 4,42 \\
\hline 45 & 1250 & 95 & 25,70 & 21,27 & 18,93 & 16,26 & 13,94 & 11,95 & 8,88 & 6,80 & 4,43 \\
\hline 45 & 1300 & 95 & 25,30 & 21,04 & 18,77 & 16,16 & 13,89 & 11,93 & 8,89 & 6,81 & 4,44 \\
\hline 45 & 1350 & 95 & 24,93 & 20,81 & 18,61 & 16,06 & 13,83 & 11,90 & 8,90 & 6,83 & 4,45 \\
\hline 45 & 1400 & 95 & 24,59 & 20,60 & 18,45 & 15,96 & 13,78 & 11,88 & 8,90 & 6,84 & 4,46 \\
\hline 45 & 1450 & 95 & 24,26 & 20,40 & 18,31 & 15,87 & 13,72 & 11,85 & 8,90 & 6,85 & 4,47 \\
\hline 45 & 1500 & 95 & 23,94 & 20,20 & 18,17 & 15,78 & 13,67 & 11,82 & 8,91 & 6,86 & 4,48 \\
\hline 45 & 1550 & 95 & 23,65 & 20,01 & 18,03 & 15,69 & 13,62 & 11,80 & 8,91 & 6,88 & 4,49 \\
\hline 45 & 1600 & 95 & 23,37 & 19,83 & 17,90 & 15,61 & 13,57 & 11,77 & 8,91 & 6,89 & 4,50 \\
\hline 45 & 1650 & 95 & 23,10 & 19,65 & 17,77 & 15,52 & 13,51 & 11,74 & 8,91 & 6,90 & 4,51 \\
\hline 45 & 1700 & 95 & 22,84 & 19,48 & 17,64 & 15,44 & 13,46 & 11,72 & 8,91 & 6,91 & 4,51 \\
\hline 45 & 1750 & 95 & 22,60 & 19,32 & 17,52 & 15,36 & 13,42 & 11,69 & 8,91 & 6,91 & 4,52 \\
\hline 45 & 1800 & 95 & 22,36 & 19,16 & 17,40 & 15,28 & 13,37 & 11,66 & 8,91 & 6,92 & 4,53 \\
\hline 45 & 1850 & 95 & 22,14 & 19,01 & 17,29 & 15,20 & 13,32 & 11,64 & 8,91 & 6,93 & 4,54 \\
\hline 45 & 1900 & 95 & 21,93 & 18,86 & 17,18 & 15,13 & 13,27 & 11,61 & 8,90 & 6,94 & 4,55 \\
\hline 45 & 1950 & 95 & 21,72 & 18,72 & 17,07 & 15,06 & 13,22 & 11,58 & 8,90 & 6,95 & 4,55 \\
\hline 45 & 2000 & 95 & 21,52 & 18,58 & 16,97 & 14,98 & 13,18 & 11,56 & 8,90 & 6,95 & 4,56 \\
\hline 45 & 200 & 100 & 57,62 & 33,11 & 24,76 & 18,17 & 14,02 & 11,18 & 7,72 & 5,90 & 4,08 \\
\hline 45 & 250 & 100 & 51,22 & 31,24 & 24,07 & 18,06 & 14,09 & 11,29 & 7,81 & 5,94 & 4,07 \\
\hline 45 & 300 & 100 & 46,72 & 29,82 & 23,48 & 17,93 & 14,12 & 11,37 & 7,88 & 5,97 & 4,07 \\
\hline 45 & 350 & 100 & 43,34 & 28,67 & 22,96 & 17,79 & 14,13 & 11,43 & 7,95 & 6,01 & 4,07 \\
\hline 45 & 400 & 100 & 40,68 & 27,72 & 22,50 & 17,65 & 14,12 & 11,48 & 8,01 & 6,04 & 4,07 \\
\hline 45 & 450 & 100 & 38,52 & 26,90 & 22,09 & 17,50 & 14,09 & 11,51 & 8,06 & 6,08 & 4,08 \\
\hline 45 & 500 & 100 & 36,72 & 26,18 & 21,71 & 17,35 & 14,06 & 11,53 & 8,11 & 6,11 & 4,08 \\
\hline 45 & 550 & 100 & 35,18 & 25,55 & 21,36 & 17,21 & 14,02 & 11,55 & 8,15 & 6,14 & 4,09 \\
\hline 45 & 600 & 100 & 33,85 & 24,98 & 21,04 & 17,07 & 13,98 & 11,56 & 8,19 & 6,17 & 4,09 \\
\hline 45 & 650 & 100 & 32,69 & 24,46 & 20,74 & 16,94 & 13,94 & 11,56 & 8,22 & 6,20 & 4,10 \\
\hline 45 & 700 & 100 & 31,66 & 23,99 & 20,46 & 16,80 & 13,89 & 11,56 & 8,25 & 6,22 & 4,11 \\
\hline 45 & 750 & 100 & 30,74 & 23,55 & 20,19 & 16,67 & 13,84 & 11,55 & 8,28 & 6,25 & 4,12 \\
\hline 45 & 800 & 100 & 29,91 & 23,15 & 19,94 & 16,55 & 13,79 & 11,54 & 8,30 & 6,27 & 4,12 \\
\hline 45 & 850 & 100 & 29,16 & 22,78 & 19,71 & 16,43 & 13,73 & 11,53 & 8,32 & 6,29 & 4,13 \\
\hline 45 & 900 & 100 & 28,47 & 22,43 & 19,49 & 16,31 & 13,68 & 11,52 & 8,34 & 6,32 & 4,14 \\
\hline
\end{tabular}




\begin{tabular}{|c|c|c|c|c|c|c|c|c|c|c|c|}
\hline \multirow[b]{2}{*}{$\mathrm{H}(\mathrm{cm})$} & \multirow[b]{2}{*}{ Mceq (MPa) } & & & & & De & ões (x1 & m) & & & \\
\hline & & Msub (MPa) & D0 & D25 & D40 & D60 & D80 & D100 & D140 & D180 & D260 \\
\hline 45 & 950 & 100 & 27,84 & 22,11 & 19,27 & 16,19 & 13,63 & 11,50 & 8,36 & 6,34 & 4,15 \\
\hline 45 & 1000 & 100 & 27,26 & 21,80 & 19,07 & 16,08 & 13,57 & 11,49 & 8,38 & 6,36 & 4,16 \\
\hline 45 & 1050 & 100 & 26,72 & 21,51 & 18,88 & 15,97 & 13,52 & 11,47 & 8,39 & 6,37 & 4,17 \\
\hline 45 & 1100 & 100 & 26,22 & 21,24 & 18,69 & 15,87 & 13,47 & 11,45 & 8,40 & 6,39 & 4,17 \\
\hline 45 & 1150 & 100 & 25,75 & 20,98 & 18,52 & 15,77 & 13,42 & 11,43 & 8,41 & 6,41 & 4,18 \\
\hline 45 & 1200 & 100 & 25,32 & 20,73 & 18,35 & 15,67 & 13,36 & 11,41 & 8,42 & 6,42 & 4,19 \\
\hline 45 & 1250 & 100 & 24,91 & 20,50 & 18,19 & 15,57 & 13,31 & 11,39 & 8,43 & 6,44 & 4,20 \\
\hline 45 & 1300 & 100 & 24,53 & 20,28 & 18,03 & 15,47 & 13,26 & 11,36 & 8,44 & 6,45 & 4,21 \\
\hline 45 & 1350 & 100 & 24,17 & 20,06 & 17,88 & 15,38 & 13,21 & 11,34 & 8,44 & 6,47 & 4,22 \\
\hline 45 & 1400 & 100 & 23,83 & 19,86 & 17,74 & 15,29 & 13,16 & 11,32 & 8,45 & 6,48 & 4,23 \\
\hline 45 & 1450 & 100 & 23,50 & 19,66 & 17,60 & 15,21 & 13,11 & 11,29 & 8,45 & 6,49 & 4,23 \\
\hline 45 & 1500 & 100 & 23,20 & 19,47 & 17,46 & 15,12 & 13,06 & 11,27 & 8,46 & 6,50 & 4,24 \\
\hline 45 & 1550 & 100 & 22,91 & 19,29 & 17,33 & 15,04 & 13,01 & 11,25 & 8,46 & 6,52 & 4,25 \\
\hline 45 & 1600 & 100 & 22,63 & 19,12 & 17,20 & 14,96 & 12,97 & 11,22 & 8,46 & 6,53 & 4,26 \\
\hline 45 & 1650 & 100 & 22,37 & 18,95 & 17,08 & 14,88 & 12,92 & 11,20 & 8,46 & 6,54 & 4,27 \\
\hline 45 & 1700 & 100 & 22,12 & 18,79 & 16,96 & 14,80 & 12,87 & 11,18 & 8,46 & 6,55 & 4,27 \\
\hline 45 & 1750 & 100 & 21,88 & 18,63 & 16,85 & 14,73 & 12,83 & 11,15 & 8,46 & 6,55 & 4,28 \\
\hline 45 & 1800 & 100 & 21,65 & 18,48 & 16,74 & 14,65 & 12,78 & 11,13 & 8,46 & 6,56 & 4,29 \\
\hline 45 & 1850 & 100 & 21,43 & 18,33 & 16,63 & 14,58 & 12,74 & 11,10 & 8,46 & 6,57 & 4,30 \\
\hline 45 & 1900 & 100 & 21,22 & 18,19 & 16,52 & 14,51 & 12,69 & 11,08 & 8,46 & 6,58 & 4,30 \\
\hline 45 & 1950 & 100 & 21,02 & 18,05 & 16,42 & 14,44 & 12,65 & 11,05 & 8,46 & 6,59 & 4,31 \\
\hline 45 & 2000 & 100 & 20,83 & 17,92 & 16,32 & 14,37 & 12,61 & 11,03 & 8,46 & 6,59 & 4,32 \\
\hline 45 & 200 & 105 & 56,36 & 31,95 & 23,72 & 17,31 & 13,33 & 10,63 & 7,33 & 5,61 & 3,89 \\
\hline 45 & 250 & 105 & 50,03 & 30,13 & 23,07 & 17,23 & 13,40 & 10,73 & 7,42 & 5,64 & 3,88 \\
\hline 45 & 300 & 105 & 45,59 & 28,76 & 22,51 & 17,11 & 13,44 & 10,81 & 7,49 & 5,68 & 3,88 \\
\hline 45 & 350 & 105 & 42,26 & 27,65 & 22,03 & 16,99 & 13,45 & 10,87 & 7,55 & 5,71 & 3,88 \\
\hline 45 & 400 & 105 & 39,65 & 26,73 & 21,59 & 16,86 & 13,45 & 10,92 & 7,60 & 5,74 & 3,88 \\
\hline 45 & 450 & 105 & 37,52 & 25,94 & 21,20 & 16,73 & 13,43 & 10,95 & 7,65 & 5,77 & 3,88 \\
\hline 45 & 500 & 105 & 35,75 & 25,25 & 20,84 & 16,59 & 13,41 & 10,97 & 7,70 & 5,80 & 3,88 \\
\hline 45 & 550 & 105 & 34,25 & 24,64 & 20,52 & 16,46 & 13,38 & 10,99 & 7,74 & 5,83 & 3,89 \\
\hline 45 & 600 & 105 & 32,94 & 24,09 & 20,21 & 16,33 & 13,34 & 11,00 & 7,78 & 5,86 & 3,89 \\
\hline 45 & 650 & 105 & 31,80 & 23,59 & 19,93 & 16,21 & 13,30 & 11,01 & 7,81 & 5,88 & 3,90 \\
\hline 45 & 700 & 105 & 30,79 & 23,14 & 19,66 & 16,09 & 13,26 & 11,01 & 7,84 & 5,91 & 3,91 \\
\hline 45 & 750 & 105 & 29,89 & 22,72 & 19,41 & 15,97 & 13,21 & 11,00 & 7,86 & 5,93 & 3,91 \\
\hline 45 & 800 & 105 & 29,08 & 22,34 & 19,17 & 15,85 & 13,17 & 11,00 & 7,89 & 5,96 & 3,92 \\
\hline 45 & 850 & 105 & 28,34 & 21,98 & 18,95 & 15,74 & 13,12 & 10,99 & 7,91 & 5,98 & 3,93 \\
\hline 45 & 900 & 105 & 27,67 & 21,65 & 18,74 & 15,63 & 13,07 & 10,98 & 7,93 & 6,00 & 3,94 \\
\hline 45 & 950 & 105 & 27,05 & 21,33 & 18,54 & 15,52 & 13,02 & 10,97 & 7,95 & 6,02 & 3,94 \\
\hline 45 & 1000 & 105 & 26,48 & 21,04 & 18,35 & 15,42 & 12,98 & 10,95 & 7,96 & 6,04 & 3,95 \\
\hline 45 & 1050 & 105 & 25,96 & 20,76 & 18,16 & 15,32 & 12,93 & 10,94 & 7,98 & 6,05 & 3,96 \\
\hline 45 & 1100 & 105 & 25,47 & 20,50 & 17,99 & 15,22 & 12,88 & 10,92 & 7,99 & 6,07 & 3,97 \\
\hline 45 & 1150 & 105 & 25,01 & 20,25 & 17,82 & 15,12 & 12,83 & 10,91 & 8,00 & 6,09 & 3,97 \\
\hline 45 & 1200 & 105 & 24,59 & 20,02 & 17,66 & 15,03 & 12,78 & 10,89 & 8,01 & 6,10 & 3,98 \\
\hline 45 & 1250 & 105 & 24,19 & 19,79 & 17,51 & 14,94 & 12,74 & 10,87 & 8,02 & 6,12 & 3,99 \\
\hline 45 & 1300 & 105 & 23,81 & 19,58 & 17,36 & 14,85 & 12,69 & 10,85 & 8,03 & 6,13 & 4,00 \\
\hline 45 & 1350 & 105 & 23,46 & 19,37 & 17,21 & 14,76 & 12,64 & 10,83 & 8,03 & 6,14 & 4,01 \\
\hline 45 & 1400 & 105 & 23,13 & 19,17 & 17,08 & 14,68 & 12,60 & 10,81 & 8,04 & 6,16 & 4,01 \\
\hline 45 & 1450 & 105 & 22,81 & 18,99 & 16,94 & 14,60 & 12,55 & 10,79 & 8,05 & 6,17 & 4,02 \\
\hline 45 & 1500 & 105 & 22,51 & 18,80 & 16,81 & 14,52 & 12,51 & 10,77 & 8,05 & 6,18 & 4,03 \\
\hline 45 & 1550 & 105 & 22,23 & 18,63 & 16,69 & 14,44 & 12,46 & 10,75 & 8,05 & 6,19 & 4,04 \\
\hline 45 & 1600 & 105 & 21,96 & 18,46 & 16,57 & 14,36 & 12,42 & 10,72 & 8,06 & 6,20 & 4,04 \\
\hline 45 & 1650 & 105 & 21,70 & 18,30 & 16,45 & 14,29 & 12,37 & 10,70 & 8,06 & 6,21 & 4,05 \\
\hline 45 & 1700 & 105 & 21,46 & 18,14 & 16,34 & 14,22 & 12,33 & 10,68 & 8,06 & 6,22 & 4,06 \\
\hline 45 & 1750 & 105 & 21,22 & 17,99 & 16,23 & 14,15 & 12,29 & 10,66 & 8,06 & 6,23 & 4,07 \\
\hline 45 & 1800 & 105 & 21,00 & 17,85 & 16,12 & 14,08 & 12,25 & 10,64 & 8,06 & 6,24 & 4,07 \\
\hline 45 & 1850 & 105 & 20,79 & 17,71 & 16,02 & 14,01 & 12,21 & 10,61 & 8,06 & 6,24 & 4,08 \\
\hline 45 & 1900 & 105 & 20,58 & 17,57 & 15,92 & 13,94 & 12,17 & 10,59 & 8,06 & 6,25 & 4,09 \\
\hline 45 & 1950 & 105 & 20,38 & 17,44 & 15,82 & 13,88 & 12,12 & 10,57 & 8,06 & 6,26 & 4,09 \\
\hline 45 & 2000 & 105 & 20,19 & 17,31 & 15,73 & 13,81 & 12,09 & 10,55 & 8,06 & 6,27 & 4,10 \\
\hline 45 & 200 & 110 & 55,19 & 30,88 & 22,77 & 16,54 & 12,71 & 10,12 & 6,99 & 5,35 & 3,71 \\
\hline 45 & 250 & 110 & 48,93 & 29,11 & 22,15 & 16,47 & 12,78 & 10,22 & 7,06 & 5,38 & 3,71 \\
\hline 45 & 300 & 110 & 44,54 & 27,78 & 21,62 & 16,37 & 12,82 & 10,30 & 7,13 & 5,41 & 3,70 \\
\hline 45 & 350 & 110 & 41,26 & 26,71 & 21,17 & 16,26 & 12,84 & 10,36 & 7,19 & 5,44 & 3,70 \\
\hline 45 & 400 & 110 & 38,69 & 25,82 & 20,76 & 16,14 & 12,84 & 10,41 & 7,24 & 5,47 & 3,70 \\
\hline 45 & 450 & 110 & 36,60 & 25,05 & 20,39 & 16,02 & 12,83 & 10,44 & 7,29 & 5,50 & 3,70 \\
\hline 45 & 500 & 110 & 34,86 & 24,39 & 20,05 & 15,90 & 12,81 & 10,47 & 7,33 & 5,53 & 3,71 \\
\hline 45 & 550 & 110 & 33,38 & 23,80 & 19,74 & 15,78 & 12,78 & 10,48 & 7,37 & 5,55 & 3,71 \\
\hline 45 & 600 & 110 & 32,10 & 23,27 & 19,45 & 15,66 & 12,75 & 10,50 & 7,40 & 5,58 & 3,71 \\
\hline 45 & 650 & 110 & 30,98 & 22,80 & 19,18 & 15,54 & 12,72 & 10,50 & 7,44 & 5,60 & 3,72 \\
\hline 45 & 700 & 110 & 29,99 & 22,36 & 18,93 & 15,43 & 12,68 & 10,51 & 7,46 & 5,63 & 3,73 \\
\hline 45 & 750 & 110 & 29,11 & 21,96 & 18,69 & 15,32 & 12,64 & 10,51 & 7,49 & 5,65 & 3,73 \\
\hline 45 & 800 & 110 & 28,31 & 21,59 & 18,46 & $\frac{10,0}{15,21}$ & 12,60 & $\frac{10,0,50}{10,50}$ & 7,51 & 5,67 & 3,74 \\
\hline 45 & 850 & 110 & 27,59 & 21,24 & 18,25 & 15,11 & 12,56 & 10,50 & 7,53 & 5,69 & 3,74 \\
\hline 45 & 900 & 110 & 26,93 & 20,92 & 18,05 & 15,00 & 12,52 & 10,49 & 7,55 & 5,71 & 3,75 \\
\hline 45 & 950 & 110 & 26,33 & 20,62 & 17,86 & 14,90 & 12,47 & 10,48 & 7,57 & 5,73 & 3,76 \\
\hline 45 & 1000 & 110 & 25,77 & 20,34 & 17,68 & 14,81 & 12,43 & 10,47 & 7,59 & 5,75 & 3,76 \\
\hline 45 & 1050 & 110 & 25,26 & 20,07 & 17,50 & 14,71 & 12,38 & 10,46 & 7,60 & 5,76 & 3,77 \\
\hline 45 & 1100 & 110 & 24,78 & 19,82 & 17,34 & 14,62 & 12,34 & 10,44 & 7,61 & 5,78 & 3,78 \\
\hline 45 & 1150 & 110 & 24,33 & 19,58 & 17,18 & 14,53 & 12,30 & 10,43 & 7,63 & 5,79 & 3,79 \\
\hline 45 & 1200 & 110 & 23,92 & 19,35 & 17,03 & 14,44 & 12,25 & 10,41 & 7,64 & 5,81 & 3,79 \\
\hline 45 & 1250 & 110 & 23,52 & 19,14 & 16,88 & 14,36 & 12,21 & 10,39 & 7,65 & 5,82 & 3,80 \\
\hline
\end{tabular}




\begin{tabular}{|c|c|c|c|c|c|c|c|c|c|c|c|}
\hline \multirow[b]{2}{*}{$\mathrm{H}(\mathrm{cm})$} & \multirow[b]{2}{*}{ Mceq (MPa) } & & & & & $\mathrm{De}$ & ões (x1 & & & & \\
\hline & & Msub (MPa) & D0 & D25 & D40 & D60 & D80 & D100 & D140 & D180 & D260 \\
\hline 45 & 1300 & 110 & 23,16 & 18,93 & 16,74 & 14,27 & 12,17 & 10,38 & 7,65 & 5,84 & 3,81 \\
\hline 45 & 1350 & 110 & 22,81 & 18,73 & 16,60 & 14,19 & 12,12 & 10,36 & 7,66 & 5,85 & 3,81 \\
\hline 45 & 1400 & 110 & 22,49 & 18,54 & 16,47 & 14,11 & 12,08 & 10,34 & 7,67 & 5,86 & 3,82 \\
\hline 45 & 1450 & 110 & 22,18 & 18,36 & 16,34 & 14,04 & 12,04 & 10,32 & 7,67 & 5,87 & 3,83 \\
\hline 45 & 1500 & 110 & 21,88 & 18,19 & 16,22 & 13,96 & 12,00 & 10,30 & 7,68 & 5,88 & 3,84 \\
\hline 45 & 1550 & 110 & 21,61 & 18,02 & 16,10 & 13,89 & 11,96 & 10,29 & 7,68 & 5,89 & 3,84 \\
\hline 45 & 1600 & 110 & 21,34 & 17,86 & 15,99 & 13,82 & 11,91 & 10,27 & 7,69 & 5,90 & 3,85 \\
\hline 45 & 1650 & 110 & 21,09 & 17,70 & 15,87 & 13,75 & 11,87 & 10,25 & 7,69 & 5,91 & 3,86 \\
\hline 45 & 1700 & 110 & 20,85 & 17,55 & 15,77 & 13,68 & 11,83 & 10,23 & 7,69 & 5,92 & 3,86 \\
\hline 45 & 1750 & 110 & 20,62 & 17,41 & 15,66 & 13,61 & 11,80 & 10,21 & 7,69 & 5,93 & 3,87 \\
\hline 45 & 1800 & 110 & 20,40 & 17,27 & 15,56 & 13,55 & 11,76 & 10,19 & 7,69 & 5,94 & 3,88 \\
\hline 45 & 1850 & 110 & 20,19 & 17,13 & 15,46 & 13,48 & 11,72 & 10,17 & 7,69 & 5,95 & 3,88 \\
\hline 45 & 1900 & 110 & 19,99 & 17,00 & 15,36 & 13,42 & 11,68 & 10,15 & 7,70 & 5,95 & 3,89 \\
\hline 45 & 1950 & 110 & 19,80 & 16,87 & 15,27 & 13,36 & 11,64 & 10,13 & 7,70 & 5,96 & 3,90 \\
\hline 45 & 2000 & 110 & 19,61 & 16,75 & 15,18 & 13,30 & 11,61 & 10,11 & 7,69 & 5,97 & 3,90 \\
\hline 45 & 200 & 115 & 54,12 & 29,89 & 21,90 & 15,83 & 12,14 & 9,66 & 6,67 & 5,11 & 3,55 \\
\hline 45 & 250 & 115 & 47,91 & 28,17 & 21,31 & 15,77 & 12,21 & 9,76 & 6,74 & 5,14 & 3,55 \\
\hline 45 & 300 & 115 & 43,58 & 26,87 & 20,81 & 15,68 & 12,26 & 9,84 & 6,80 & 5,17 & 3,54 \\
\hline 45 & 350 & 115 & 40,34 & 25,84 & 20,37 & 15,58 & 12,28 & 9,89 & 6,86 & 5,20 & 3,54 \\
\hline 45 & 400 & 115 & 37,80 & 24,97 & 19,99 & 15,48 & 12,28 & 9,94 & 6,91 & 5,22 & 3,54 \\
\hline 45 & 450 & 115 & 35,74 & 24,24 & 19,63 & 15,37 & 12,28 & 9,98 & 6,95 & 5,25 & 3,54 \\
\hline 45 & 500 & 115 & 34,03 & 23,60 & 19,31 & 15,26 & 12,26 & 10,00 & 6,99 & 5,27 & 3,54 \\
\hline 45 & 550 & 115 & 32,58 & 23,03 & 19,02 & 15,15 & 12,24 & 10,02 & 7,03 & 5,30 & 3,55 \\
\hline 45 & 600 & 115 & 31,32 & 22,52 & 18,74 & 15,04 & 12,21 & 10,03 & 7,06 & 5,32 & 3,55 \\
\hline 45 & 650 & 115 & 30,23 & 22,06 & 18,49 & 14,93 & 12,18 & 10,04 & 7,10 & 5,35 & 3,56 \\
\hline 45 & 700 & 115 & 29,25 & 21,64 & 18,25 & 14,82 & 12,15 & 10,05 & 7,12 & 5,37 & 3,56 \\
\hline 45 & 750 & 115 & 28,39 & 21,25 & 18,02 & 14,72 & 12,12 & 10,05 & 7,15 & 5,39 & 3,57 \\
\hline 45 & 800 & 115 & 27,60 & 20,89 & 17,81 & 14,62 & 12,08 & 10,05 & 7,17 & 5,41 & 3,57 \\
\hline 45 & 850 & 115 & 26,90 & 20,56 & 17,61 & 14,52 & 12,04 & 10,05 & 7,19 & 5,43 & 3,58 \\
\hline 45 & 900 & 115 & 26,25 & 20,25 & 17,42 & 14,43 & 12,00 & 10,04 & 7,21 & 5,45 & 3,58 \\
\hline 45 & 950 & 115 & 25,66 & 19,96 & 17,23 & 14,33 & 11,96 & 10,03 & 7,23 & 5,46 & 3,59 \\
\hline 45 & 1000 & 115 & 25,11 & 19,69 & 17,06 & 14,24 & 11,92 & 10,02 & 7,24 & 5,48 & 3,60 \\
\hline 45 & 1050 & 115 & 24,61 & 19,43 & 16,89 & 14,15 & 11,88 & 10,01 & 7,26 & 5,50 & 3,60 \\
\hline 45 & 1100 & 115 & 24,14 & 19,19 & 16,74 & 14,07 & 11,84 & 10,00 & 7,27 & 5,51 & 3,61 \\
\hline 45 & 1150 & 115 & 23,70 & 18,96 & 16,58 & 13,98 & 11,80 & 9,99 & 7,28 & 5,53 & 3,61 \\
\hline 45 & 1200 & 115 & 23,29 & 18,74 & 16,44 & 13,90 & 11,76 & 9,97 & 7,29 & 5,54 & 3,62 \\
\hline 45 & 1250 & 115 & 22,91 & 18,53 & 16,30 & 13,82 & 11,72 & 9,96 & 7,30 & 5,55 & 3,63 \\
\hline 45 & 1300 & 115 & 22,55 & 18,33 & 16,16 & 13,74 & 11,68 & 9,94 & 7,31 & 5,57 & 3,63 \\
\hline 45 & 1350 & 115 & 22,21 & 18,14 & 16,03 & 13,67 & 11,64 & 9,93 & 7,32 & 5,58 & 3,64 \\
\hline 45 & 1400 & 115 & 21,89 & 17,96 & 15,91 & 13,59 & 11,61 & 9,91 & 7,33 & 5,59 & 3,65 \\
\hline 45 & 1450 & 115 & 21,59 & 17,78 & 15,79 & 13,52 & 11,57 & 9,90 & 7,33 & 5,60 & 3,65 \\
\hline 45 & 1500 & 115 & 21,30 & 17,61 & 15,67 & 13,45 & 11,53 & 9,88 & 7,34 & 5,61 & 3,66 \\
\hline 45 & 1550 & 115 & 21,03 & 17,45 & 15,55 & 13,38 & 11,49 & 9,86 & 7,34 & 5,62 & 3,67 \\
\hline 45 & 1600 & 115 & 20,77 & 17,30 & 15,44 & 13,31 & 11,45 & 9,85 & 7,35 & 5,63 & 3,67 \\
\hline 45 & 1650 & 115 & 20,52 & 17,15 & 15,34 & 13,25 & 11,41 & 9,83 & 7,35 & 5,64 & 3,68 \\
\hline 45 & 1700 & 115 & 20,29 & 17,00 & 15,23 & 13,18 & 11,38 & 9,81 & 7,35 & 5,65 & 3,69 \\
\hline 45 & 1750 & 115 & 20,06 & 16,86 & 15,13 & 13,12 & 11,34 & 9,79 & 7,36 & 5,66 & 3,69 \\
\hline 45 & 1800 & 115 & 19,85 & 16,73 & 15,04 & 13,06 & 11,30 & 9,77 & 7,36 & 5,67 & 3,70 \\
\hline 45 & 1850 & 115 & 19,64 & 16,60 & 14,94 & 12,99 & 11,27 & 9,76 & 7,36 & 5,68 & 3,70 \\
\hline 45 & 1900 & 115 & 19,44 & 16,47 & 14,85 & 12,94 & 11,23 & 9,74 & 7,36 & 5,68 & 3,71 \\
\hline 45 & 1950 & 115 & 19,25 & 16,35 & 14,76 & 12,88 & 11,20 & 9,72 & 7,36 & 5,69 & 3,72 \\
\hline 45 & 2000 & 115 & 19,07 & 16,23 & 14,67 & 12,82 & 11,16 & $\begin{array}{c}9,70 \\
\end{array}$ & 7,36 & 5,70 & 3,72 \\
\hline 45 & 200 & 120 & 53,12 & 28,98 & 21,09 & 15,17 & 11,61 & 9,24 & 6,38 & 4,89 & 3,41 \\
\hline 45 & 250 & 120 & 46,97 & 27,30 & 20,53 & 15,13 & 11,69 & 9,34 & 6,45 & 4,92 & 3,40 \\
\hline 45 & 300 & 120 & 42,68 & 26,04 & 20,05 & 15,05 & 11,74 & 9,41 & 6,51 & 4,95 & 3,39 \\
\hline 45 & 350 & 120 & 39,48 & 25,03 & 19,64 & 14,96 & 11,76 & 9,47 & 6,56 & 4,97 & 3,39 \\
\hline 45 & 400 & 120 & 36,98 & 24,19 & 19,27 & 14,87 & 11,77 & 9,51 & 6,61 & 5,00 & 3,39 \\
\hline 45 & 450 & 120 & 34,95 & 23,48 & 18,94 & 14,77 & 11,77 & 9,55 & 6,65 & 5,02 & 3,39 \\
\hline 45 & 500 & 120 & 33,26 & 22,86 & 18,63 & 14,66 & 11,76 & 9,58 & 6,69 & 5,04 & 3,40 \\
\hline 45 & 550 & 120 & 31,83 & 22,31 & 18,35 & 14,56 & 11,74 & 9,60 & 6,72 & 5,07 & 3,40 \\
\hline 45 & 600 & 120 & 30,60 & 21,82 & 18,09 & 14,46 & 11,72 & 9,61 & 6,75 & 5,09 & 3,40 \\
\hline 45 & 650 & 120 & 29,52 & 21,37 & 17,85 & 14,36 & 11,69 & 9,62 & $\begin{array}{c}6,78 \\
\end{array}$ & 5,11 & 3,40 \\
\hline 45 & 700 & 120 & 28,56 & 20,97 & 17,62 & 14,26 & 11,66 & 9,63 & 6,81 & 5,13 & 3,41 \\
\hline 45 & 750 & 120 & 27,71 & 20,59 & 17,41 & 14,17 & 11,63 & 9,63 & 6,84 & 5,15 & 3,41 \\
\hline 45 & 800 & 120 & 26,95 & 20,25 & 17,20 & 14,08 & 11,60 & 9,63 & 6,86 & 5,17 & 3,42 \\
\hline 45 & 850 & 120 & 26,25 & 19,93 & 17,01 & 13,98 & 11,57 & 9,63 & 6,88 & 5,19 & 3,42 \\
\hline 45 & 900 & 120 & 25,62 & 19,63 & 16,83 & 13,89 & 11,53 & 9,63 & 6,90 & 5,21 & 3,43 \\
\hline 45 & 950 & 120 & 25,03 & 19,35 & 16,65 & 13,81 & 11,50 & 9,62 & 6,91 & 5,22 & 3,43 \\
\hline 45 & 1000 & 120 & 24,50 & 19,09 & 16,49 & 13,72 & 11,46 & 9,61 & 6,93 & 5,24 & 3,44 \\
\hline 45 & 1050 & 120 & 24,00 & 18,84 & 16,33 & 13,64 & 11,42 & 9,60 & 6,94 & 5,25 & 3,45 \\
\hline 45 & 1100 & 120 & 23,54 & 18,60 & 16,18 & 13,56 & 11,39 & 9,59 & 6,96 & 5,27 & 3,45 \\
\hline 45 & 1150 & 120 & 23,11 & 18,38 & 16,03 & 13,48 & 11,35 & 9,58 & 6,97 & 5,28 & 3,46 \\
\hline 45 & 1200 & 120 & 22,71 & 18,17 & 15,89 & 13,40 & 11,31 & 9,57 & 6,98 & 5,30 & 3,46 \\
\hline 45 & 1250 & 120 & 22,34 & 17.97 & 15,76 & 13,33 & 11,28 & 9,56 & 6,99 & 5,31 & 3,47 \\
\hline 45 & 1300 & 120 & 21,98 & 17,77 & 15,63 & 13,25 & 11,24 & 9,55 & 7,00 & 5,32 & 3,48 \\
\hline 45 & 1350 & 120 & 21,65 & 17,59 & 15,50 & 13,18 & 11,20 & 9,53 & 7,01 & 5,33 & 3,48 \\
\hline 45 & 1400 & 120 & 21,34 & 17,41 & 15,38 & 13,11 & 11,17 & 9,52 & 7,01 & 5,35 & 3,49 \\
\hline 45 & 1450 & 120 & 21,04 & 17,25 & 15,27 & 13,04 & 11,13 & 9,50 & 7,02 & 5,36 & 3,49 \\
\hline 45 & 1500 & 120 & 20,76 & 17,08 & 15,16 & 12,97 & 11,09 & 9,49 & 7,03 & 5,37 & 3,50 \\
\hline 45 & 1550 & 120 & 20,49 & 16,93 & 15,05 & 12,91 & 11,06 & 9,47 & 7,03 & 5,38 & 3,51 \\
\hline 45 & 1600 & 120 & 20,24 & 16,78 & 14,94 & 12,84 & 11,02 & 9,46 & 7,03 & 5,39 & 3,51 \\
\hline
\end{tabular}




\begin{tabular}{|c|c|c|c|c|c|c|c|c|c|c|c|}
\hline \multirow[b]{2}{*}{$\mathrm{H}(\mathrm{cm})$} & \multirow[b]{2}{*}{ Mceq (MPa) } & & & & & Det & ões (x1 & & & & \\
\hline & & Msub (MPa) & D0 & D25 & D40 & D60 & D80 & D100 & D140 & D180 & D260 \\
\hline 45 & 1650 & 120 & 19,99 & 16,63 & 14,84 & 12,78 & 10,99 & 9,44 & 7,04 & 5,40 & 3,52 \\
\hline 45 & 1700 & 120 & 19,76 & 16,49 & 14,74 & 12,72 & 10,95 & 9,43 & 7,04 & 5,40 & 3,52 \\
\hline 45 & 1750 & 120 & 19,54 & 16,36 & 14,64 & 12,66 & 10,92 & 9,41 & 7,05 & 5,41 & 3,53 \\
\hline 45 & 1800 & 120 & 19,33 & 16,23 & 14,55 & 12,60 & 10,88 & 9,39 & 7,05 & 5,42 & 3,53 \\
\hline 45 & 1850 & 120 & 19,13 & 16,10 & 14,46 & 12,54 & 10,85 & 9,38 & 7,05 & 5,43 & 3,54 \\
\hline 45 & 1900 & 120 & 18,94 & 15,98 & 14,37 & 12,49 & 10,82 & 9,36 & 7,05 & 5,44 & 3,55 \\
\hline 45 & 1950 & 120 & 18,75 & 15,86 & 14,29 & 12,43 & 10,79 & 9,34 & 7,05 & 5,44 & 3,55 \\
\hline 45 & 2000 & 120 & 18,57 & 15,74 & 14,20 & 12,38 & 10,75 & 9,33 & 7,05 & 5,45 & 3,56 \\
\hline 45 & 200 & 125 & 52,20 & 28,13 & 20,35 & 14,57 & 11,13 & 8,85 & 6,11 & 4,69 & 3,27 \\
\hline 45 & 250 & 125 & 46,10 & 26,49 & 19,81 & 14,53 & 11,21 & 8,95 & 6,18 & 4,72 & 3,26 \\
\hline 45 & 300 & 125 & 41,85 & 25,26 & 19,36 & 14,47 & 11,26 & 9,02 & 6,23 & 4,74 & 3,26 \\
\hline 45 & 350 & 125 & 38,68 & 24,28 & 18,96 & 14,39 & 11,29 & 9,07 & 6,28 & 4,77 & 3,26 \\
\hline 45 & 400 & 125 & 36,21 & 23,47 & 18,61 & 14,30 & 11,30 & 9,12 & 6,33 & 4,79 & 3,26 \\
\hline 45 & 450 & 125 & 34,21 & 22,78 & 18,29 & 14,21 & 11,30 & 9,15 & 6,37 & 4,81 & 3,26 \\
\hline 45 & 500 & 125 & 32,55 & 22,17 & 18,00 & 14,12 & 11,29 & 9,18 & 6,41 & 4,83 & 3,26 \\
\hline 45 & 550 & 125 & 31,14 & 21,64 & 17,74 & 14,02 & 11,28 & 9,20 & 6,44 & 4,86 & 3,26 \\
\hline 45 & 600 & 125 & 29,92 & 21,17 & 17,49 & 13,93 & 11,26 & 9,22 & 6,47 & 4,88 & 3,26 \\
\hline 45 & 650 & 125 & 28,86 & 20,73 & 17,25 & 13,84 & 11,24 & 9,23 & 6,50 & 4,90 & 3,27 \\
\hline 45 & 700 & 125 & 27,92 & 20,34 & 17,04 & 13,75 & 11,21 & 9,24 & 6,52 & 4,92 & 3,27 \\
\hline 45 & 750 & 125 & 27,08 & 19,98 & 16,83 & 13,66 & 11,19 & 9,24 & 6,55 & 4,93 & 3,27 \\
\hline 45 & 800 & 125 & 26,33 & 19,65 & 16,64 & 13,57 & 11,16 & 9,25 & 6,57 & 4,95 & 3,28 \\
\hline 45 & 850 & 125 & 25,65 & 19,34 & 16,45 & 13,48 & 11,13 & 9,25 & 6,59 & 4,97 & 3,28 \\
\hline 45 & 900 & 125 & 25,02 & 19,05 & 16,28 & 13,40 & 11,09 & 9,24 & 6,61 & 4,99 & 3,29 \\
\hline 45 & 950 & 125 & 24,45 & 18,78 & 16,11 & 13,32 & 11,06 & 9,24 & 6,63 & 5,00 & 3,29 \\
\hline 45 & 1000 & 125 & 23,93 & 18,52 & 15,96 & 13,24 & 11,03 & 9,23 & 6,64 & 5,02 & 3,30 \\
\hline 45 & 1050 & 125 & 23,44 & 18,28 & 15,80 & 13,16 & 11,00 & 9,23 & 6,66 & 5,03 & 3,30 \\
\hline 45 & 1100 & 125 & 22,99 & 18,06 & 15,66 & 13,08 & 10,96 & 9,22 & 6,67 & 5,05 & 3,31 \\
\hline 45 & 1150 & 125 & 22,57 & 17,84 & 15,52 & 13,01 & 10,93 & 9,21 & 6,68 & 5,06 & 3,31 \\
\hline 45 & 1200 & 125 & 22,17 & 17,64 & 15,39 & 12,94 & 10,89 & 9,20 & 6,69 & 5,07 & 3,32 \\
\hline 45 & 1250 & 125 & 21,81 & 17,44 & 15,26 & 12,86 & 10,86 & 9,19 & 6,70 & 5,08 & 3,33 \\
\hline 45 & 1300 & 125 & 21,46 & 17,26 & 15,13 & 12,80 & 10,83 & 9,18 & 6,71 & 5,10 & 3,33 \\
\hline 45 & 1350 & 125 & 21,13 & 17,08 & 15,01 & 12,73 & 10,79 & 9,17 & 6,72 & 5,11 & 3,34 \\
\hline 45 & 1400 & 125 & 20,82 & 16,91 & 14,90 & 12,66 & 10,76 & 9,15 & 6,73 & 5,12 & 3,34 \\
\hline 45 & 1450 & 125 & 20,53 & 16,74 & 14,79 & 12,60 & 10,72 & 9,14 & 6,73 & 5,13 & 3,35 \\
\hline 45 & 1500 & 125 & 20,25 & 16,59 & 14,68 & 12,53 & 10,69 & 9,13 & 6,74 & 5,14 & 3,35 \\
\hline 45 & 1550 & 125 & 19,99 & 16,44 & 14,58 & 12,47 & 10,66 & 9,11 & 6,74 & 5,15 & 3,36 \\
\hline 45 & 1600 & 125 & 19,74 & 16,29 & 14,47 & 12,41 & 10,63 & 9,10 & 6,75 & 5,16 & 3,36 \\
\hline 45 & 1650 & 125 & 19,50 & 16,15 & 14,38 & 12,35 & 10,59 & 9,08 & 6,75 & 5,17 & 3,37 \\
\hline 45 & 1700 & 125 & 19,28 & 16,02 & 14,28 & 12,29 & 10,56 & 9,07 & 6,76 & 5,18 & 3,37 \\
\hline 45 & 1750 & 125 & 19,06 & 15,89 & 14,19 & 12,23 & 10,53 & 9,05 & 6,76 & 5,18 & 3,38 \\
\hline 45 & 1800 & 125 & 18,85 & 15,76 & 14,10 & 12,18 & 10,50 & 9,04 & 6,76 & 5,19 & 3,39 \\
\hline 45 & 1850 & 125 & 18,65 & 15,64 & 14,01 & 12,12 & 10,47 & 9,02 & 6,76 & 5,20 & 3,39 \\
\hline 45 & 1900 & 125 & 18,46 & 15,52 & 13,93 & 12,07 & 10,43 & 9,01 & 6,77 & 5,21 & 3,40 \\
\hline 45 & 1950 & 125 & 18,28 & 15,40 & 13,84 & 12,02 & 10,40 & 8,99 & 6,77 & 5,21 & 3,40 \\
\hline 45 & 2000 & 125 & 18,11 & 15,29 & 13,76 & 11,97 & 10,37 & 8,98 & 6,77 & 5,22 & 3,41 \\
\hline 45 & 200 & 130 & 51,33 & 27,34 & 19,65 & 14,01 & 10,69 & 8,50 & 5,87 & 4,51 & 3,15 \\
\hline 45 & 250 & 130 & 45,28 & 25,74 & 19,14 & 13,98 & 10,77 & 8,59 & 5,93 & 4,53 & 3,14 \\
\hline 45 & 300 & 130 & 41,07 & 24,54 & 18,71 & 13,93 & 10,82 & 8,66 & 5,98 & 4,55 & 3,13 \\
\hline 45 & 350 & 130 & 37,94 & 23,58 & 18,33 & 13,86 & 10,85 & 8,71 & 6,03 & 4,58 & 3,13 \\
\hline 45 & 400 & 130 & 35,49 & 22,79 & 17,99 & 13,78 & 10,86 & 8,76 & 6,07 & 4,60 & 3,13 \\
\hline 45 & 450 & 130 & 33,52 & 22,12 & 17,69 & 13,69 & 10,87 & 8,79 & 6,11 & 4,62 & 3,13 \\
\hline 45 & 500 & 130 & 31,88 & 21,54 & 17,42 & 13,61 & 10,86 & 8,82 & 6,15 & 4,64 & 3,13 \\
\hline 45 & 550 & 130 & 30,49 & 21,02 & 17,16 & 13,52 & 10,85 & 8,84 & 6,18 & 4,66 & 3,13 \\
\hline 45 & 600 & 130 & 29,29 & 20,56 & 16,92 & 13,44 & 10,84 & 8,86 & 6,21 & 4,68 & 3,14 \\
\hline 45 & 650 & 130 & 28,24 & 20,14 & 16,70 & 13,35 & 10,82 & 8,87 & 6,24 & 4,70 & 3,14 \\
\hline 45 & 700 & 130 & 27,32 & 19,76 & 16,49 & 13,26 & 10,80 & 8,88 & 6,26 & 4,72 & 3,14 \\
\hline 45 & 750 & 130 & 26,50 & 19,41 & 16,30 & 13,18 & 10,77 & 8,89 & 6,28 & 4,73 & 3,15 \\
\hline 45 & 800 & 130 & 25,75 & 19,09 & 16,11 & 13,10 & 10,75 & 8,89 & 6,30 & 4,75 & 3,15 \\
\hline 45 & 850 & 130 & 25,08 & 18,79 & 15,94 & 13,02 & 10,72 & 8,89 & 6,32 & 4,77 & 3,15 \\
\hline 45 & 900 & 130 & 24,47 & 18,51 & 15,77 & 12,94 & 10,69 & 8,89 & 6,34 & 4,78 & 3,16 \\
\hline 45 & 950 & 130 & 23,91 & 18,24 & 15,61 & 12,86 & 10,66 & 8,89 & 6,36 & 4,80 & 3,16 \\
\hline 45 & 1000 & 130 & 23,39 & 18,00 & 15,46 & 12,79 & 10,63 & 8,88 & 6,37 & 4,81 & 3,17 \\
\hline 45 & 1050 & 130 & 22,91 & 17,76 & 15,31 & 12,71 & 10,60 & 8,88 & 6,39 & 4,83 & 3,17 \\
\hline 45 & 1100 & 130 & 22,47 & 17,55 & 15,17 & 12,64 & 10,57 & 8,87 & 6,40 & 4,84 & 3,18 \\
\hline 45 & 1150 & 130 & 22,06 & 17,34 & 15,04 & 12,57 & 10,54 & 8,86 & 6,41 & 4,85 & 3,18 \\
\hline 45 & 1200 & 130 & 21,67 & 17,14 & 14,91 & 12,50 & 10,51 & 8,85 & 6,42 & 4,87 & 3,19 \\
\hline 45 & 1250 & 130 & 21,31 & 16,95 & 14,79 & 12,44 & 10,47 & 8,85 & 6,43 & 4,88 & 3,19 \\
\hline 45 & 1300 & 130 & 20,97 & 16,77 & 14,67 & 12,37 & 10,44 & 8,84 & 6,44 & 4,89 & 3,20 \\
\hline 45 & 1350 & 130 & 20,65 & 16,60 & 14,56 & 12,31 & 10,41 & 8,82 & 6,45 & 4,90 & 3,20 \\
\hline 45 & 1400 & 130 & 20,34 & 16,43 & 14,45 & 12,24 & 10,38 & 8,81 & 6,46 & 4,91 & 3,21 \\
\hline 45 & 1450 & 130 & 20,06 & 16,28 & 14,34 & 12,18 & 10,35 & 8,80 & 6,47 & 4,92 & 3,21 \\
\hline 45 & 1500 & 130 & 19,78 & 16,12 & 14,23 & 12,12 & 10,32 & 8,79 & 6,47 & 4,93 & 3,22 \\
\hline 45 & 1550 & 130 & 19,53 & 15,98 & 14,13 & 12,06 & 10,29 & 8,78 & 6,48 & 4,94 & 3,22 \\
\hline 45 & 1600 & 130 & 19,28 & 15,84 & 14,04 & 12,00 & 10,26 & 8,76 & 6,48 & 4,95 & 3,23 \\
\hline 45 & 1650 & 130 & 19,05 & 15,70 & 13,94 & 11,95 & 10,22 & 8,75 & 6,49 & 4,96 & 3,23 \\
\hline 45 & 1700 & 130 & 18,82 & 15,57 & 13,85 & 11,89 & 10,19 & 8,74 & 6,49 & 4,97 & 3,24 \\
\hline 45 & 1750 & 130 & 18,61 & 15,44 & 13,76 & 11,84 & 10,16 & 8,73 & 6,49 & 4,97 & 3,24 \\
\hline 45 & 1800 & 130 & 18,41 & 15,32 & 13,68 & 11,79 & 10,14 & 8,71 & 6,50 & 4,98 & 3,25 \\
\hline 45 & 1850 & 130 & 18,21 & 15,20 & 13,59 & 11,73 & 10,11 & 8,70 & 6,50 & 4,99 & 3,25 \\
\hline 45 & 1900 & 130 & 18,02 & 15,09 & 13,51 & 11,68 & 10,08 & 8,68 & 6,50 & 5,00 & 3,26 \\
\hline 45 & 1950 & 130 & 17,84 & 14,98 & 13,43 & 11,63 & 10,05 & 8,67 & 6,51 & 5,00 & 3,26 \\
\hline
\end{tabular}




\begin{tabular}{|c|c|c|c|c|c|c|c|c|c|c|c|}
\hline \multirow[b]{2}{*}{$\mathrm{H}(\mathrm{cm})$} & \multirow[b]{2}{*}{ Mceq (MPa) } & & & & & $\mathrm{De}$ & ões (x1 & & & & \\
\hline & & Msub (MPa) & D0 & D25 & D40 & D60 & D80 & D100 & D140 & D180 & D260 \\
\hline 45 & 2000 & 130 & 17,67 & 14,87 & 13,35 & 11,58 & 10,02 & 8,66 & 6,51 & 5,01 & 3,27 \\
\hline 45 & 200 & 135 & 50,53 & 26,61 & 19,01 & 13,49 & 10,28 & 8,17 & 5,64 & 4,34 & 3,03 \\
\hline 45 & 250 & 135 & 44,52 & 25,03 & 18,51 & 13,47 & 10,36 & 8,25 & 5,70 & 4,36 & 3,02 \\
\hline 45 & 300 & 135 & 40,34 & 23,86 & 18,10 & 13,42 & 10,41 & 8,32 & 5,75 & 4,38 & 3,02 \\
\hline 45 & 350 & 135 & 37,24 & 22,93 & 17,74 & 13,36 & 10,44 & 8,38 & 5,79 & 4,40 & 3,02 \\
\hline 45 & 400 & 135 & 34,82 & 22,16 & 17,42 & 13,29 & 10,46 & 8,42 & 5,83 & 4,42 & 3,02 \\
\hline 45 & 450 & 135 & 32,87 & 21,51 & 17,13 & 13,21 & 10,46 & 8,46 & 5,87 & 4,44 & 3,02 \\
\hline 45 & 500 & 135 & 31,25 & 20,94 & 16,87 & 13,14 & 10,46 & 8,48 & 5,91 & 4,46 & 3,02 \\
\hline 45 & 550 & 135 & 29,88 & 20,44 & 16,62 & 13,06 & 10,45 & 8,51 & 5,94 & 4,48 & 3,02 \\
\hline 45 & 600 & 135 & 28,70 & 19,99 & 16,39 & 12,97 & 10,44 & 8,52 & 5,97 & 4,50 & 3,02 \\
\hline 45 & 650 & 135 & 27,67 & 19,58 & 16,18 & 12,89 & 10,43 & 8,54 & 5,99 & 4,52 & 3,02 \\
\hline 45 & 700 & 135 & 26,76 & 19,21 & 15,98 & 12,82 & 10,41 & 8,55 & 6,02 & 4,53 & 3,02 \\
\hline 45 & 750 & 135 & 25,95 & 18,87 & 15,80 & 12.74 & 10,39 & 8.55 & 6.04 & 4.55 & 3,03 \\
\hline 45 & 800 & 135 & 25,22 & 18,56 & 15,62 & 12,66 & 10,36 & 8,56 & 6,06 & 4,57 & 3,03 \\
\hline 45 & 850 & 135 & 24,55 & 18,27 & 15,45 & 12,59 & 10,34 & 8,56 & 6,08 & 4,58 & 3,03 \\
\hline 45 & 900 & 135 & 23,95 & 18,00 & 15,29 & 12,51 & 10,31 & 8,56 & 6,10 & 4,60 & 3,04 \\
\hline 45 & 950 & 135 & 23,40 & 17,74 & 15,14 & 12,44 & 10,28 & 8,56 & 6,11 & 4,61 & 3,04 \\
\hline 45 & 1000 & 135 & 22,89 & 17,50 & 14,99 & 12,37 & 10,26 & 8,56 & 6,13 & 4,62 & 3,05 \\
\hline 45 & 1050 & 135 & 22,42 & 17,28 & 14,85 & 12,30 & 10,23 & 8,55 & 6,14 & 4,64 & 3,05 \\
\hline 45 & 1100 & 135 & 21,98 & 17,07 & 14,72 & 12,23 & 10,20 & 8,55 & 6,15 & 4,65 & 3,06 \\
\hline 45 & 1150 & 135 & 21,58 & 16,86 & 14,59 & 12,16 & 10,17 & 8,54 & 6,17 & 4,66 & 3,06 \\
\hline 45 & 1200 & 135 & 21,20 & 16,67 & 14,47 & 12,10 & 10,14 & 8,53 & 6,18 & 4,67 & 3,06 \\
\hline 45 & 1250 & 135 & 20,84 & 16,49 & 14,35 & 12,04 & 10,11 & 8,53 & 6,19 & 4,69 & 3,07 \\
\hline 45 & 1300 & 135 & 20,51 & 16,32 & 14,24 & 11,97 & 10,08 & 8,52 & 6,20 & 4,70 & 3,07 \\
\hline 45 & 1350 & 135 & 20,19 & 16,15 & 14,13 & 11,91 & 10,06 & 8,51 & 6,20 & 4,71 & 3,08 \\
\hline 45 & 1400 & 135 & 19,89 & 15,99 & 14,02 & 11,85 & 10,03 & 8,50 & 6,21 & 4,72 & 3,08 \\
\hline 45 & 1450 & 135 & 19,61 & 15,84 & 13,92 & 11,79 & 10,00 & 8,49 & 6,22 & 4,73 & 3,09 \\
\hline 45 & 1500 & 135 & 19,34 & 15,69 & 13,82 & 11,74 & 9,97 & 8,48 & 6,23 & 4,74 & 3,09 \\
\hline 45 & 1550 & 135 & 19,09 & 15,55 & 13,72 & 11,68 & 9,94 & 8,47 & 6,23 & 4,75 & 3,10 \\
\hline 45 & 1600 & 135 & 18,85 & 15,41 & 13,63 & 11,63 & 9,91 & 8,45 & 6,24 & 4,76 & 3,10 \\
\hline 45 & 1650 & 135 & 18,62 & 15,28 & 13,54 & 11,57 & 9,88 & 8,44 & 6,24 & 4,76 & 3,11 \\
\hline 45 & 1700 & 135 & 18,40 & 15,15 & 13,45 & 11,52 & 9,85 & 8,43 & 6,25 & 4,77 & 3,11 \\
\hline 45 & 1750 & 135 & 18,19 & 15,03 & 13,36 & 11,47 & 9,83 & 8,42 & 6,25 & 4,78 & 3,12 \\
\hline 45 & 1800 & 135 & 17,99 & 14,91 & 13,28 & 11,42 & 9,80 & 8,41 & 6,25 & 4,79 & 3,12 \\
\hline 45 & 1850 & 135 & 17,80 & 14,80 & 13,20 & 11,37 & 9,77 & 8,39 & 6,26 & 4,79 & 3,13 \\
\hline 45 & 1900 & 135 & 17,61 & 14,69 & 13,12 & 11,32 & 9,74 & 8,38 & 6,26 & 4,80 & 3,13 \\
\hline 45 & 1950 & 135 & 17,44 & 14,58 & 13,05 & 11,27 & 9,72 & 8,37 & 6,26 & 4,81 & 3,14 \\
\hline 45 & 2000 & 135 & 17,27 & 14,48 & 12,97 & 11,22 & 9,69 & 8,36 & 6,26 & 4,81 & 3,14 \\
\hline 45 & 200 & 140 & 49,77 & 25,92 & 18,41 & 13,01 & 9,89 & 7,86 & 5,43 & 4,18 & 2,93 \\
\hline 45 & 250 & 140 & 43,80 & 24,38 & 17,93 & 13,00 & 9,98 & 7,95 & 5,48 & 4,20 & 2,92 \\
\hline 45 & 300 & 140 & 39,66 & 23,23 & 17,53 & 12,96 & 10,03 & 8,01 & 5,53 & 4,22 & 2,91 \\
\hline 45 & 350 & 140 & 36,59 & 22,32 & 17,19 & 12,90 & 10,06 & 8,07 & 5,58 & 4,24 & 2,91 \\
\hline 45 & 400 & 140 & 34,19 & 21,57 & 16,88 & 12,84 & 10,08 & 8,11 & 5,61 & 4,26 & 2,91 \\
\hline 45 & 450 & 140 & 32,26 & 20,93 & 16,61 & 12,77 & 10,09 & 8,14 & 5,65 & 4,28 & 2,91 \\
\hline 45 & 500 & 140 & 30,66 & 20,38 & 16,35 & 12,69 & 10,09 & 8,17 & 5,68 & 4,29 & 2,91 \\
\hline 45 & 550 & 140 & 29,31 & 19,89 & 16,12 & 12,62 & 10,08 & 8,19 & 5,71 & 4,31 & 2,91 \\
\hline 45 & 600 & 140 & 28,14 & 19,45 & 15,90 & 12,54 & 10,07 & 8,21 & 5,74 & 4,33 & 2,91 \\
\hline 45 & 650 & 140 & 27,12 & 19,06 & 15,70 & 12,47 & 10,06 & 8,23 & 5,77 & 4,35 & 2,91 \\
\hline 45 & 700 & 140 & 26,23 & 18,70 & 15,51 & 12,40 & 10,04 & 8,24 & 5,79 & 4,36 & 2,92 \\
\hline 45 & 750 & 140 & 25,43 & 18,37 & 15,33 & 12,32 & 10,03 & 8,25 & 5,81 & 4,38 & 2,92 \\
\hline 45 & 800 & 140 & 24,71 & 18,07 & 15,16 & 12,25 & 10,01 & 8,25 & 5,83 & 4,39 & 2,92 \\
\hline 45 & 850 & 140 & 24,06 & 17,78 & 15,00 & 12,18 & 9,98 & 8,25 & 5,85 & 4,41 & 2,92 \\
\hline 45 & 900 & 140 & 23,46 & 17,52 & 14,84 & $\begin{array}{l}+L,+12,11 \\
12,\end{array}$ & 9,96 & 8,26 & 5,87 & $\begin{array}{l}, 42 \\
4,42\end{array}$ & 2,93 \\
\hline 45 & 950 & 140 & 22,92 & 17,27 & 14,70 & 12,04 & 9,94 & 8,26 & 5,88 & 4,44 & 2,93 \\
\hline 45 & 1000 & 140 & 22,42 & 17,04 & 14,56 & 11,97 & 9,91 & 8,25 & 5,90 & 4,45 & 2,94 \\
\hline 45 & 1050 & 140 & 21,96 & 16,82 & 14,42 & 11,91 & 9,88 & 8,25 & 5,91 & 4,46 & 2,94 \\
\hline 45 & 1100 & 140 & 21,53 & 16,62 & 14,30 & 11,84 & 9,86 & 8,25 & 5,92 & 4,47 & 2,94 \\
\hline 45 & 1150 & 140 & 21,13 & 16,42 & 14,17 & 11,78 & 9,83 & 8,24 & 5,94 & 4,49 & 2,95 \\
\hline 45 & 1200 & 140 & 20,75 & 16,24 & 14,05 & 11,72 & 9,80 & 8,24 & 5,95 & 4,50 & 2,95 \\
\hline 45 & 1250 & 140 & 20,40 & 16,06 & 13,94 & 11,66 & 9,78 & 8,23 & 5,96 & 4,51 & 2,96 \\
\hline 45 & 1300 & 140 & 20,07 & 15,89 & 13,83 & 11,60 & 9,75 & 8,22 & 5,97 & 4,52 & 2,96 \\
\hline 45 & 1350 & 140 & 19,76 & 15,73 & 13,72 & 11,54 & 9,72 & 8,21 & 5,97 & 4,53 & 2,96 \\
\hline 45 & 1400 & 140 & 19,47 & 15,57 & 13,62 & 11,49 & 9,70 & 8,20 & 5,98 & 4,54 & 2,97 \\
\hline 45 & 1450 & 140 & 19,19 & 15,42 & 13,52 & 11,43 & 9,67 & 8,20 & 5,99 & 4,55 & 2,97 \\
\hline 45 & 1500 & 140 & 18,93 & 15,28 & 13,43 & 11,38 & 9,64 & 8,19 & 6,00 & 4,56 & 2,98 \\
\hline 45 & 1550 & 140 & 18,68 & 15,14 & 13,34 & 11,32 & 9,62 & 8,18 & 6,00 & 4,57 & 2,98 \\
\hline 45 & 1600 & 140 & 18,44 & 15,01 & 13,25 & 11,27 & 9,59 & 8,17 & 6,01 & 4,58 & 2,99 \\
\hline 45 & 1650 & 140 & 18,22 & 14,88 & 13,16 & 11,22 & 9,56 & 8,15 & 6,01 & 4,58 & 2,99 \\
\hline 45 & 1700 & 140 & 18,00 & 14,76 & 13,07 & 11,17 & 9,54 & 8,14 & 6,02 & 4,59 & 3,00 \\
\hline 45 & 1750 & 140 & 17,79 & 14,64 & 12,99 & 11,12 & 9,51 & 8,13 & 6,02 & 4,60 & 3,00 \\
\hline 45 & 1800 & 140 & 17,60 & 14,53 & 12,91 & 11,07 & 9,48 & 8,12 & 6,03 & 4,61 & 3,00 \\
\hline 45 & 1850 & 140 & 17,41 & 14,42 & 12,83 & 11,03 & 9,46 & 8,11 & 6,03 & 4,61 & 3,01 \\
\hline 45 & 1900 & 140 & 17,23 & 14,31 & 12,76 & 10,98 & 9,43 & 8,10 & 6,03 & 4,62 & 3,01 \\
\hline 45 & 1950 & 140 & 17,05 & 14,20 & 12,68 & 10,93 & 9,41 & 8,09 & 6,03 & 4,63 & 3,02 \\
\hline 45 & 2000 & 140 & 16,89 & 14,10 & 12,61 & 10,89 & 9,38 & 8,07 & 6,04 & 4,63 & 3,02 \\
\hline 45 & 200 & 145 & 49,07 & 25,28 & 17,85 & 12,56 & 9,54 & 7,58 & 5,23 & 4,03 & 2,83 \\
\hline 45 & 250 & 145 & 43,13 & 23,76 & 17,39 & 12,55 & 9,62 & 7,66 & 5,29 & 4,05 & 2,82 \\
\hline 45 & 300 & 145 & 39,02 & 22,63 & 17,00 & 12,52 & 9,67 & 7,72 & 5,33 & 4,07 & 2,81 \\
\hline 45 & 350 & 145 & 35,97 & 21,74 & 16,67 & 12,47 & 9,71 & 7,78 & 5,37 & 4,09 & 2,81 \\
\hline 45 & 400 & 145 & 33,60 & 21,01 & 16,38 & 12,41 & 9,73 & 7,82 & 5,41 & 4,11 & 2,81 \\
\hline 45 & 450 & 145 & 31,69 & 20,39 & 16,11 & 12,35 & 9,74 & 7,85 & 5,45 & 4,12 & 2,81 \\
\hline
\end{tabular}




\begin{tabular}{|c|c|c|c|c|c|c|c|c|c|c|c|}
\hline \multirow[b]{2}{*}{$\mathrm{H}(\mathrm{cm})$} & \multirow[b]{2}{*}{ Mceq (MPa) } & & & & & $\mathrm{De}$ & ões (x. & & & & \\
\hline & & Msub (MPa) & D0 & D25 & D40 & D60 & D80 & D100 & D140 & D180 & D260 \\
\hline 45 & 500 & 145 & 30,10 & 19,85 & 15,87 & 12,28 & 9,74 & 7,88 & 5,48 & 4,14 & 2,81 \\
\hline 45 & 550 & 145 & 28,77 & 19,38 & 15,65 & 12,21 & 9,74 & 7,90 & 5,51 & 4,16 & 2,81 \\
\hline 45 & 600 & 145 & 27,62 & 18,95 & 15,44 & 12,14 & 9,73 & 7,92 & 5,53 & 4,17 & 2,81 \\
\hline 45 & 650 & 145 & 26,61 & 18,57 & 15,24 & 12,07 & 9,72 & 7,94 & 5,56 & 4,19 & 2,81 \\
\hline 45 & 700 & 145 & 25,73 & 18,22 & 15,06 & 12,00 & 9,71 & 7,95 & 5,58 & 4,20 & 2,81 \\
\hline 45 & 750 & 145 & 24,94 & 17,90 & 14,89 & 11,93 & 9,69 & 7,96 & 5,60 & 4,22 & 2,82 \\
\hline 45 & 800 & 145 & 24,23 & 17,60 & 14,72 & 11,87 & 9,67 & 7,96 & 5,62 & 4,23 & 2,82 \\
\hline 45 & 850 & 145 & 23,59 & 17,33 & 14,57 & 11,80 & 9,65 & 7,97 & 5,64 & 4,25 & 2,82 \\
\hline 45 & 900 & 145 & 23,00 & 17,07 & 14,42 & 11,73 & 9,63 & 7,97 & 5,66 & 4,26 & 2,82 \\
\hline 45 & 950 & 145 & 22,47 & 16,83 & 14,28 & 11,67 & 9,61 & 7,97 & 5,67 & 4,27 & 2,83 \\
\hline 45 & 1000 & 145 & 21,98 & 16,61 & 14,15 & 11,61 & 9,59 & 7,97 & 5,69 & 4,29 & 2,83 \\
\hline 45 & 1050 & 145 & 21,52 & 16,40 & 14,02 & 11,54 & 9,56 & 7,97 & 5,70 & 4,30 & 2,84 \\
\hline 45 & 1100 & 145 & 21,10 & 16.19 & 13,90 & 11,48 & 9,54 & 7.97 & 5,71 & 4,31 & 2,84 \\
\hline 45 & 1150 & 145 & 20,70 & 16,00 & 13,78 & 11,42 & 9,51 & 7,96 & 5,72 & 4,32 & 2,84 \\
\hline 45 & 1200 & 145 & 20,33 & 15,82 & 13,66 & 11,37 & 9,49 & 7,96 & 5,73 & 4,33 & 2,85 \\
\hline 45 & 1250 & 145 & 19,99 & 15,65 & 13,55 & 11,31 & 9,46 & 7,95 & 5,74 & 4,34 & 2,85 \\
\hline 45 & 1300 & 145 & 19,66 & 15,49 & 13,45 & 11,25 & 9,44 & 7,94 & 5,75 & 4,35 & 2,85 \\
\hline 45 & 1350 & 145 & 19,36 & 15,33 & 13,35 & 11,20 & 9,41 & 7,94 & 5,76 & 4,36 & 2,86 \\
\hline 45 & 1400 & 145 & 19,07 & 15,18 & 13,25 & 11,14 & 9,39 & 7,93 & 5,77 & 4,37 & 2,86 \\
\hline 45 & 1450 & 145 & 18,80 & 15,04 & 13,15 & 11,09 & 9,36 & 7,92 & 5,78 & 4,38 & 2,87 \\
\hline 45 & 1500 & 145 & 18,54 & 14,90 & 13,06 & 11,04 & 9,34 & 7,91 & 5,78 & 4,39 & 2,87 \\
\hline 45 & 1550 & 145 & 18,29 & 14,76 & 12,97 & 10,99 & 9,31 & 7,90 & 5,79 & 4,40 & 2,87 \\
\hline 45 & 1600 & 145 & 18,06 & 14,64 & 12,88 & 10,94 & 9,29 & 7,89 & 5,79 & 4,41 & 2,88 \\
\hline 45 & 1650 & 145 & 17,84 & 14,51 & 12,80 & 10,89 & 9,26 & 7,89 & 5,80 & 4,42 & 2,88 \\
\hline 45 & 1700 & 145 & 17,62 & 14,39 & 12,72 & 10,84 & 9,24 & 7,88 & 5,80 & 4,42 & 2,89 \\
\hline 45 & 1750 & 145 & 17,42 & 14,28 & 12,64 & 10,79 & 9,21 & 7,87 & 5,81 & 4,43 & 2,89 \\
\hline 45 & 1800 & 145 & 17,23 & 14,17 & 12,56 & 10,75 & 9,19 & 7,86 & 5,81 & 4,44 & 2,90 \\
\hline 45 & 1850 & 145 & 17,04 & 14,06 & 12,49 & 10,70 & 9,16 & 7,84 & 5,82 & 4,45 & 2,90 \\
\hline 45 & 1900 & 145 & 16,86 & 13,95 & 12,41 & 10,66 & 9,14 & 7,83 & 5,82 & 4,45 & 2,90 \\
\hline 45 & 1950 & 145 & 16,69 & 13,85 & 12,34 & 10,62 & 9,11 & 7,82 & 5,82 & 4,46 & 2,91 \\
\hline 45 & 2000 & 145 & 16,53 & 13,75 & 12,27 & 10,57 & 9,09 & 7,81 & 5,83 & 4,47 & 2,91 \\
\hline 45 & 200 & 150 & 48,40 & 24,67 & 17,32 & 12,14 & 9,21 & 7,31 & 5,05 & 3,89 & 2,73 \\
\hline 45 & 250 & 150 & 42,50 & 23,18 & 16,87 & 12,14 & 9,29 & 7,39 & 5,10 & 3,91 & 2,73 \\
\hline 45 & 300 & 150 & 38,41 & 22,08 & 16,51 & 12,11 & 9,34 & 7,45 & 5,15 & 3,93 & 2,72 \\
\hline 45 & 350 & 150 & 35,39 & 21,20 & 16,19 & 12,07 & 9,38 & 7,51 & 5,19 & 3,95 & 2,72 \\
\hline 45 & 400 & 150 & 33,04 & 20,49 & 15,91 & 12,01 & 9,40 & 7,55 & 5,22 & 3,97 & 2,71 \\
\hline 45 & 450 & 150 & 31,15 & 19,88 & 15,65 & 11,95 & 9,41 & 7,58 & 5,25 & 3,98 & 2,71 \\
\hline 45 & 500 & 150 & 29,58 & 19,36 & 15,42 & 11,89 & 9,42 & 7,61 & 5,28 & 4,00 & 2,71 \\
\hline 45 & 550 & 150 & 28,26 & 18,89 & 15,20 & 11,83 & 9,42 & 7,63 & 5,31 & 4,01 & 2,71 \\
\hline 45 & 600 & 150 & 27,12 & 18,48 & 15,00 & 11,76 & 9,41 & 7,65 & 5,34 & 4,03 & 2,72 \\
\hline 45 & 650 & 150 & 26,13 & 18,11 & 14,82 & 11,70 & 9,40 & 7,67 & 5,36 & 4,04 & 2,72 \\
\hline 45 & 700 & 150 & 25,26 & 17,77 & 14,64 & 11,63 & 9,39 & 7,68 & 5,38 & 4,06 & 2,72 \\
\hline 45 & 750 & 150 & 24,48 & 17,45 & 14,47 & 11,57 & 9,38 & 7,69 & 5,40 & 4,07 & 2,72 \\
\hline 45 & 800 & 150 & 23,78 & 17,17 & 14,32 & 11,51 & 9,36 & 7,70 & 5,42 & 4,09 & 2,72 \\
\hline 45 & 850 & 150 & 23,15 & 16,90 & 14,17 & 11,44 & 9,34 & 7,70 & 5,44 & 4,10 & 2,73 \\
\hline 45 & 900 & 150 & 22,57 & 16,65 & 14,03 & 11,38 & 9,32 & 7,70 & 5,46 & 4,11 & 2,73 \\
\hline 45 & 950 & 150 & 22,04 & 16,42 & 13,89 & 11,32 & 9,30 & 7,70 & 5,47 & 4,12 & 2,73 \\
\hline 45 & 1000 & 150 & 21,56 & 16,20 & 13,76 & 11,26 & 9,28 & 7,71 & 5,49 & 4,14 & 2,73 \\
\hline 45 & 1050 & 150 & 21,11 & 15,99 & 13,64 & 11,20 & 9,26 & 7,70 & 5,50 & 4,15 & 2,74 \\
\hline 45 & 1100 & 150 & 20,69 & 15,80 & 13,52 & 11,14 & 9,24 & 7,70 & 5,51 & 4,16 & 2,74 \\
\hline 45 & 1150 & 150 & 20,30 & 15,61 & 13,41 & 11,09 & 9,21 & 7,70 & 5,52 & 4,17 & 2,75 \\
\hline 45 & 1200 & 150 & 19,94 & 15,44 & 13,30 & 11,03 & 9,19 & 7,69 & 5,53 & 4,18 & 2,75 \\
\hline 45 & 1250 & 150 & 19,60 & $\begin{array}{l}15,27 \\
15,27\end{array}$ & 13,19 & $\begin{array}{l}1+1,0,98 \\
10,0\end{array}$ & 9,17 & 7,69 & 5,54 & 4,19 & 2,75 \\
\hline 45 & 1300 & 150 & 19,28 & 15,11 & 13,09 & 10,92 & 9,14 & 7,68 & 5,55 & 4,20 & 2,76 \\
\hline 45 & 1350 & 150 & 18,98 & 14,96 & 12,99 & 10,87 & 9,12 & 7,68 & 5,56 & 4,21 & 2,76 \\
\hline 45 & 1400 & 150 & 18,69 & 14,81 & 12,90 & 10,82 & 9,10 & 7,67 & 5,57 & 4,22 & 2,76 \\
\hline 45 & 1450 & 150 & 18,43 & 14,67 & 12,80 & 10,77 & 9,07 & 7,66 & 5,58 & 4,23 & 2,77 \\
\hline 45 & 1500 & 150 & 18,17 & 14,53 & 12,71 & 10,72 & 9,05 & 7,66 & 5,58 & 4,24 & 2,77 \\
\hline 45 & 1550 & 150 & 17,93 & 14,40 & 12,63 & 10,67 & 9,03 & 7,65 & 5,59 & 4,25 & 2,77 \\
\hline 45 & 1600 & 150 & 17,70 & 14,28 & 12,54 & 10,62 & 9,00 & 7,64 & 5,60 & 4,25 & 2,78 \\
\hline 45 & 1650 & 150 & 17,48 & 14,16 & 12,46 & 10,58 & 8,98 & 7,63 & 5,60 & 4,26 & 2,78 \\
\hline 45 & 1700 & 150 & 17,27 & 14,04 & 12,38 & 10,53 & 8,96 & 7,62 & 5,61 & 4,27 & 2,79 \\
\hline 45 & 1750 & 150 & 17,07 & 13,93 & 12,31 & 10,49 & 8,93 & 7,61 & 5,61 & 4,28 & 2,79 \\
\hline 45 & 1800 & 150 & 16,88 & 13,82 & 12,23 & 10,44 & 8,91 & 7,61 & 5,61 & 4,28 & 2,79 \\
\hline 45 & 1850 & 150 & 16,70 & 13,72 & 12,16 & 10,40 & 8,89 & 7,60 & 5,62 & 4,29 & 2,80 \\
\hline 45 & 1900 & 150 & 16,52 & 13,62 & 12,09 & 10,36 & 8,86 & 7,59 & 5,62 & 4,30 & 2,80 \\
\hline 45 & 1950 & 150 & 16,35 & 13,52 & 12,02 & 10,32 & 8,84 & 7,58 & 5,63 & 4,30 & 2,81 \\
\hline 45 & 2000 & 150 & 16,19 & 13,42 & 11,95 & 10,28 & 8,82 & 7,57 & 5,63 & 4,31 & 2,81 \\
\hline 45 & 200 & 155 & 47,77 & 24,11 & 16,82 & 11,75 & 8,90 & 7,06 & 4,88 & 3,77 & 2,65 \\
\hline 45 & 250 & 155 & 41,90 & 22,64 & 16,39 & 11,75 & 8,98 & 7,14 & 4,93 & 3,78 & 2,64 \\
\hline 45 & 300 & 155 & 37,84 & 21,55 & 16,04 & 11,73 & 9,03 & 7,20 & 4,97 & 3,80 & 2,63 \\
\hline 45 & 350 & 155 & 34,84 & 20,70 & 15,73 & 11,69 & 9,07 & 7,25 & 5,01 & 3,82 & 2,63 \\
\hline 45 & 400 & 155 & 32,51 & 19,99 & 15,46 & 11,64 & 9,09 & 7,29 & 5,04 & 3,83 & 2,63 \\
\hline 45 & 450 & 155 & 30,64 & 19,40 & 15,22 & 11,59 & 9,11 & 7,33 & 5,08 & 3,85 & 2,63 \\
\hline 45 & 500 & 155 & 29,09 & 18,89 & $\frac{10, L L}{14,99}$ & $\begin{array}{l}1+, \text { o } \\
11,53\end{array}$ & $\frac{,+1}{9,11}$ & 7,36 & 5,10 & 3,86 & 2,63 \\
\hline 45 & 550 & 155 & 27,78 & 18,44 & 14,78 & 11,47 & 9,11 & 7,38 & 5,13 & 3,88 & 2,63 \\
\hline 45 & 600 & 155 & 26,65 & 18,03 & 14,59 & 11,41 & 9,11 & 7,40 & 5,16 & 3,89 & 2,63 \\
\hline 45 & 650 & 155 & 25,68 & 17,67 & 14,41 & 11,35 & 9,10 & 7,41 & 5,18 & 3,91 & 2,63 \\
\hline 45 & 700 & 155 & 24,81 & 17,34 & 14,24 & 11,29 & 9,09 & 7,43 & 5,20 & 3,92 & 2,63 \\
\hline 45 & 750 & 155 & 24,04 & 17,03 & 14,08 & 11,23 & 9,08 & 7,44 & 5,22 & 3,93 & 2,63 \\
\hline 45 & 800 & 155 & 23,35 & 16,75 & 13,93 & 11,17 & 9,07 & 7,44 & 5,24 & 3,95 & 2,63 \\
\hline
\end{tabular}




\begin{tabular}{|c|c|c|c|c|c|c|c|c|c|c|c|}
\hline \multirow[b]{2}{*}{$\mathrm{H}(\mathrm{cm})$} & \multirow[b]{2}{*}{ Mceq (MPa) } & & & & & $\mathrm{De}$ & ões (x. & & & & \\
\hline & & Msub (MPa) & D0 & D25 & D40 & D60 & D80 & D100 & D140 & D180 & D260 \\
\hline 45 & 850 & 155 & 22,73 & 16,49 & 13,79 & 11,11 & 9,05 & 7,45 & 5,26 & 3,96 & 2,64 \\
\hline 45 & 900 & 155 & 22,16 & 16,25 & 13,65 & 11,05 & 9,03 & 7,45 & 5,27 & 3,97 & 2,64 \\
\hline 45 & 950 & 155 & 21,64 & 16,02 & 13,52 & 10,99 & 9,01 & 7,46 & 5,29 & 3,98 & 2,64 \\
\hline 45 & 1000 & 155 & 21,16 & 15,81 & 13,40 & 10,93 & 8,99 & 7,46 & 5,30 & 4,00 & 2,64 \\
\hline 45 & 1050 & 155 & 20,72 & 15,61 & 13,28 & 10,88 & 8,97 & 7,46 & 5,31 & 4,01 & 2,65 \\
\hline 45 & 1100 & 155 & 20,31 & 15,42 & 13,16 & 10,82 & 8,95 & 7,46 & 5,33 & 4,02 & 2,65 \\
\hline 45 & 1150 & 155 & 19,92 & 15,24 & 13,05 & 10,77 & 8,93 & 7,45 & 5,34 & 4,03 & 2,65 \\
\hline 45 & 1200 & 155 & 19,57 & 15,07 & 12,95 & 10,72 & 8,91 & 7,45 & 5,35 & 4,04 & 2,66 \\
\hline 45 & 1250 & 155 & 19,23 & 14,91 & 12,85 & 10,67 & 8,89 & 7,45 & 5,36 & 4,05 & 2,66 \\
\hline 45 & 1300 & 155 & 18,92 & 14,75 & 12,75 & 10,61 & 8,87 & 7,44 & 5,37 & 4,06 & 2,66 \\
\hline 45 & 1350 & 155 & 18,62 & 14,60 & 12,65 & 10,56 & 8,85 & 7,44 & 5,38 & 4,07 & 2,67 \\
\hline 45 & 1400 & 155 & 18,34 & 14,46 & 12,56 & 10,52 & 8,82 & 7,43 & 5,38 & 4,08 & 2,67 \\
\hline 45 & 1450 & 155 & 18,07 & 14.32 & 12,47 & 10,47 & 8,80 & 7,42 & 5,39 & 4.08 & 2,67 \\
\hline 45 & 1500 & 155 & 17,82 & 14,19 & 12,39 & 10,42 & 8,78 & 7,42 & 5,40 & 4,09 & 2,68 \\
\hline 45 & 1550 & 155 & 17,58 & 14,07 & 12,30 & 10,37 & 8,76 & 7,41 & 5,40 & 4,10 & 2,68 \\
\hline 45 & 1600 & 155 & 17,36 & 13,94 & 12,22 & 10,33 & 8,74 & 7,40 & 5,41 & 4,11 & 2,69 \\
\hline 45 & 1650 & 155 & 17,14 & 13,83 & 12,14 & 10,29 & 8,71 & 7,40 & 5,41 & 4,12 & 2,69 \\
\hline 45 & 1700 & 155 & 16,94 & 13,71 & 12,07 & 10,24 & 8,69 & 7,39 & 5,42 & 4,12 & 2,69 \\
\hline 45 & 1750 & 155 & 16,74 & 13,60 & 11,99 & 10,20 & 8,67 & 7,38 & 5,42 & 4,13 & 2,70 \\
\hline 45 & 1800 & 155 & 16,55 & 13,50 & 11,92 & 10,16 & 8,65 & 7,37 & 5,43 & 4,14 & 2,70 \\
\hline 45 & 1850 & 155 & 16,37 & 13,40 & 11,85 & 10,12 & 8,63 & 7,36 & 5,43 & 4,14 & 2,70 \\
\hline 45 & 1900 & 155 & 16,20 & 13,30 & 11,78 & 10,07 & 8,60 & 7,35 & 5,44 & 4,15 & 2,71 \\
\hline 45 & 1950 & 155 & 16,03 & 13,20 & 11,72 & 10,03 & 8,58 & 7,34 & 5,44 & 4,16 & 2,71 \\
\hline 45 & 2000 & 155 & 15,87 & 13,11 & 11,65 & 10,00 & 8,56 & 7,33 & 5,44 & 4,16 & 2,71 \\
\hline 45 & 200 & 160 & 47,18 & 23,57 & 16,36 & 11,38 & 8,61 & 6,83 & 4,72 & 3,65 & 2,57 \\
\hline 45 & 250 & 160 & 41,34 & 22,12 & 15,94 & 11,38 & 8,69 & 6,91 & 4,77 & 3,66 & 2,56 \\
\hline 45 & 300 & 160 & 37,30 & 21,05 & 15,60 & 11,37 & 8,74 & 6,97 & 4,81 & 3,68 & 2,55 \\
\hline 45 & 350 & 160 & 34,32 & 20,22 & 15,30 & 11,33 & 8,78 & 7,02 & 4,85 & 3,69 & 2,55 \\
\hline 45 & 400 & 160 & 32,01 & 19,53 & 15,04 & 11,29 & 8,80 & 7,06 & 4,88 & 3,71 & 2,55 \\
\hline 45 & 450 & 160 & 30,15 & 18,95 & 14,80 & 11,24 & 8,82 & 7,09 & 4,91 & 3,72 & 2,54 \\
\hline 45 & 500 & 160 & 28,62 & 18,45 & 14,59 & 11,19 & 8,83 & 7,12 & 4,94 & 3,74 & 2,54 \\
\hline 45 & 550 & 160 & 27,32 & $\begin{array}{l}18,00 \\
18,00\end{array}$ & 14,39 & $\begin{array}{l}+1,+4 \\
11,13\end{array}$ & 8,83 & $\frac{1, \pm L}{7,14}$ & 4,96 & 3,75 & 2,54 \\
\hline 45 & 600 & 160 & 26,21 & 17,61 & 14,20 & 11,07 & 8,83 & 7,16 & 4,99 & 3,77 & 2,54 \\
\hline 45 & 650 & 160 & 25,24 & 17,26 & 14,03 & 11,02 & 8,82 & 7,18 & 5,01 & 3,78 & 2,55 \\
\hline 45 & 700 & 160 & 24,39 & 16,93 & 13,87 & 10,96 & 8,81 & 7,19 & 5,03 & 3,79 & 2,55 \\
\hline 45 & 750 & 160 & 23,63 & 16,64 & 13,71 & 10,90 & 8,80 & 7,20 & 5,05 & 3,80 & 2,55 \\
\hline 45 & 800 & 160 & 22,95 & 16,36 & 13,57 & 10,85 & 8,79 & 7,21 & 5,07 & 3,82 & 2,55 \\
\hline 45 & 850 & 160 & 22,33 & 16,11 & 13,43 & 10,79 & 8,77 & 7,21 & 5,08 & 3,83 & 2,55 \\
\hline 45 & 900 & 160 & 21,77 & 15,87 & 13,30 & 10,74 & 8,76 & 7,22 & 5,10 & 3,84 & 2,56 \\
\hline 45 & 950 & 160 & 21,26 & 15,65 & 13,17 & 10,68 & 8,74 & 7,22 & 5,11 & 3,85 & 2,56 \\
\hline 45 & 1000 & 160 & 20,78 & 15,44 & 13,05 & 10,63 & 8,73 & 7,22 & 5,13 & 3,86 & 2,56 \\
\hline 45 & 1050 & 160 & 20,35 & 15,25 & 12,94 & 10,57 & 8,71 & 7,22 & 5,14 & 3,87 & 2,56 \\
\hline 45 & 1100 & 160 & 19,94 & 15,06 & 12,83 & 10,52 & 8,69 & 7,22 & 5,15 & 3,88 & 2,57 \\
\hline 45 & 1150 & 160 & 19,56 & 14,89 & 12,72 & 10,47 & 8,67 & 7,22 & 5,16 & 3,89 & 2,57 \\
\hline 45 & 1200 & 160 & 19,21 & 14,72 & 12,62 & 10,42 & 8,65 & 7,22 & 5,17 & 3,90 & 2,57 \\
\hline 45 & 1250 & 160 & 18,88 & 14,56 & 12,52 & 10,37 & 8,63 & 7,22 & 5,18 & 3,91 & 2,57 \\
\hline 45 & 1300 & 160 & 18,57 & 14,41 & 12,43 & 10,32 & 8,61 & 7,21 & 5,19 & 3,92 & 2,58 \\
\hline 45 & 1350 & 160 & 18,28 & 14,27 & 12,34 & 10,28 & 8,59 & 7,21 & 5,20 & 3,93 & 2,58 \\
\hline 45 & 1400 & 160 & 18,00 & 14,13 & 12,25 & 10,23 & 8,57 & 7,20 & 5,21 & 3,94 & 2,58 \\
\hline 45 & 1450 & 160 & 17,74 & 13,99 & 12,16 & 10,18 & 8,55 & 7,20 & 5,22 & 3,95 & 2,59 \\
\hline 45 & 1500 & 160 & 17,49 & 13,87 & 12,08 & 10,14 & 8,53 & 7,19 & 5,22 & 3,96 & 2,59 \\
\hline 45 & 1550 & 160 & 17,26 & 13,74 & 12,00 & 10,09 & 8,51 & 7,19 & 5,23 & 3,96 & 2,59 \\
\hline 45 & 1600 & 160 & 17,04 & 13,63 & $\begin{array}{l}+L, v 0 \\
11,92\end{array}$ & 10,05 & 8,48 & 7,18 & 5,23 & 3,97 & 2,60 \\
\hline 45 & 1650 & 160 & 16,82 & 13,51 & 11,84 & 10,01 & 8,46 & 7,17 & 5,24 & 3,98 & 2,60 \\
\hline 45 & 1700 & 160 & 16,62 & 13,40 & 11,77 & 9,97 & 8,44 & 7,16 & 5,25 & 3,99 & 2,60 \\
\hline 45 & 1750 & 160 & 16,42 & 13,30 & 11,70 & 9,93 & 8,42 & 7,16 & 5,25 & 3,99 & 2,61 \\
\hline 45 & 1800 & 160 & 16,24 & 13,19 & 11,63 & 9,89 & 8,40 & 7,15 & 5,25 & 4,00 & 2,61 \\
\hline 45 & 1850 & 160 & 16,06 & 13,09 & 11,56 & 9,85 & 8,38 & 7,14 & 5,26 & 4,01 & 2,61 \\
\hline 45 & 1900 & 160 & 15,89 & 13,00 & 11,49 & 9,81 & 8,36 & 7,13 & 5,26 & 4,01 & 2,62 \\
\hline 45 & 1950 & 160 & 15,73 & 12,90 & 11,43 & 9,77 & 8,34 & 7,12 & 5,27 & 4,02 & 2,62 \\
\hline 45 & 2000 & 160 & 15,57 & 12,81 & 11,37 & 9,73 & 8,32 & 7,12 & 5,27 & 4,02 & 2,62 \\
\hline 45 & 200 & 165 & 46,62 & 23,06 & 15,92 & 11,03 & 8,33 & 6,61 & 4,57 & 3,53 & 2,49 \\
\hline 45 & 250 & 165 & 40,80 & 21,63 & 15,51 & 11,04 & 8,42 & 6,69 & 4,62 & 3,55 & 2,48 \\
\hline 45 & 300 & 165 & 36,79 & 20,58 & 15,18 & 11,03 & 8,47 & 6,75 & 4,66 & 3,56 & 2,48 \\
\hline 45 & 350 & 165 & 33,83 & 19,76 & 14,90 & 11,00 & 8,51 & 6,80 & 4,69 & 3,58 & 2,47 \\
\hline 45 & 400 & 165 & 31,54 & 19,09 & 14,64 & 10,96 & 8,53 & 6,83 & 4,72 & 3,59 & 2,47 \\
\hline 45 & 450 & 165 & 29,70 & 18,52 & 14,42 & 10,91 & 8,55 & 6,87 & 4,75 & 3,61 & 2,47 \\
\hline 45 & 500 & 165 & 28,17 & 18,03 & 14,21 & 10,86 & 8,56 & 6,90 & 4,78 & 3,62 & 2,47 \\
\hline 45 & 550 & 165 & 26,89 & 17,60 & 14,02 & 10,81 & 8,56 & 6,92 & 4,80 & 3,63 & 2,47 \\
\hline 45 & 600 & 165 & 25,79 & 17,21 & 13,84 & 10,76 & 8,56 & 6,94 & 4,83 & 3,65 & 2,47 \\
\hline 45 & 650 & 165 & 24,83 & 16,86 & 13,67 & 10,71 & 8,56 & 6,95 & 4,85 & 3,66 & 2,47 \\
\hline 45 & 700 & 165 & 23,99 & 16,55 & 13,51 & 10,65 & 8,55 & 6,97 & 4,87 & 3,67 & 2,47 \\
\hline 45 & 750 & 165 & 23,24 & 16,26 & 13,37 & 10,60 & 8,54 & 6,98 & 4,89 & 3,68 & 2,47 \\
\hline 45 & 800 & 165 & 22,57 & 15,99 & 13,23 & 10,54 & 8,53 & 6,99 & 4,90 & 3,70 & 2,47 \\
\hline 45 & 850 & 165 & 21,96 & 15,75 & $\frac{10,20}{13,09}$ & 10,49 & 8,52 & 6,99 & 4,92 & 3,71 & 2,47 \\
\hline 45 & 900 & 165 & 21,40 & 15,52 & 12,97 & 10,44 & 8,50 & 7,00 & 4,94 & 3,72 & 2,48 \\
\hline 45 & 950 & 165 & 20,89 & 15,30 & 12,84 & 10,39 & 8,49 & 7,00 & 4,95 & 3,73 & 2,48 \\
\hline 45 & 1000 & 165 & 20,43 & 15,10 & 12,73 & 10,34 & 8,47 & 7,00 & 4,96 & 3,74 & 2,48 \\
\hline 45 & 1050 & 165 & 20,00 & 14,91 & 12,62 & 10,29 & 8,45 & 7,00 & 4,98 & 3,75 & 2,48 \\
\hline 45 & 1100 & 165 & 19,60 & 14,73 & 12,51 & 10,24 & 8,44 & 7,00 & 4,99 & 3,76 & 2,49 \\
\hline 45 & 1150 & 165 & 19,22 & 14,55 & 12,41 & 10,19 & 8,42 & 7,00 & 5,00 & 3,77 & 2,49 \\
\hline
\end{tabular}




\begin{tabular}{|c|c|c|c|c|c|c|c|c|c|c|c|}
\hline \multirow[b]{2}{*}{$\mathrm{H}(\mathrm{cm})$} & \multirow[b]{2}{*}{ Mceq (MPa) } & & & & & $\mathrm{De}$ & ões (x. & & & & \\
\hline & & Msub (MPa) & D0 & D25 & D40 & D60 & D80 & D100 & D140 & D180 & D260 \\
\hline 45 & 1200 & 165 & 18,88 & 14,39 & 12,31 & 10,14 & 8,40 & 7,00 & 5,01 & 3,78 & 2,49 \\
\hline 45 & 1250 & 165 & 18,55 & 14,24 & 12,21 & 10,09 & 8,38 & 7,00 & 5,02 & 3,79 & 2,49 \\
\hline 45 & 1300 & 165 & 18,24 & 14,09 & 12,12 & 10,05 & 8,36 & 7,00 & 5,03 & 3,80 & 2,50 \\
\hline 45 & 1350 & 165 & 17,96 & 13,95 & 12,03 & 10,00 & 8,34 & 6,99 & 5,04 & 3,81 & 2,50 \\
\hline 45 & 1400 & 165 & 17,68 & 13,81 & 11,95 & 9,96 & 8,32 & 6,99 & 5,04 & 3,81 & 2,50 \\
\hline 45 & 1450 & 165 & 17,43 & 13,68 & 11,87 & 9,91 & 8,31 & 6,98 & 5,05 & 3,82 & 2,51 \\
\hline 45 & 1500 & 165 & 17,18 & 13,56 & 11,79 & 9,87 & 8,29 & 6,98 & 5,06 & 3,83 & 2,51 \\
\hline 45 & 1550 & 165 & 16,95 & 13,44 & 11,71 & 9,83 & 8,27 & 6,97 & 5,06 & 3,84 & 2,51 \\
\hline 45 & 1600 & 165 & 16,73 & 13,32 & 11,63 & 9,79 & 8,25 & 6,97 & 5,07 & 3,84 & 2,52 \\
\hline 45 & 1650 & 165 & 16,52 & 13,21 & 11,56 & 9,75 & 8,23 & 6,96 & 5,08 & 3,85 & 2,52 \\
\hline 45 & 1700 & 165 & 16,32 & 13,11 & 11,49 & 9,71 & 8,21 & 6,95 & 5,08 & 3,86 & 2,52 \\
\hline 45 & 1750 & 165 & 16,13 & 13,00 & 11,42 & 9,67 & 8,19 & 6,95 & 5,09 & 3,87 & 2,53 \\
\hline 45 & 1800 & 165 & 15,94 & 12,90 & 11,35 & 9.63 & 8,17 & 6.94 & 5,09 & 3,87 & 2,53 \\
\hline 45 & 1850 & 165 & 15,77 & 12,80 & 11,28 & 9,59 & 8,15 & 6,93 & 5,09 & 3,88 & 2,53 \\
\hline 45 & 1900 & 165 & 15,60 & 12,71 & 11,22 & 9,55 & 8,13 & 6,93 & 5,10 & 3,88 & 2,54 \\
\hline 45 & 1950 & 165 & 15,44 & 12,62 & 11,16 & 9,52 & 8,11 & 6,92 & 5,10 & 3,89 & 2,54 \\
\hline 45 & 2000 & 165 & 15,28 & 12,53 & 11,10 & 9,48 & 8,09 & 6,91 & 5,11 & 3,90 & 2,54 \\
\hline 45 & 200 & 170 & 46,09 & 22,59 & 15,50 & 10,70 & 8,08 & 6,41 & 4,43 & 3,43 & 2,42 \\
\hline 45 & 250 & 170 & 40,30 & 21,17 & 15,11 & 10,72 & 8,16 & 6,48 & 4,48 & 3,44 & 2,41 \\
\hline 45 & 300 & 170 & 36,31 & 20,14 & 14,79 & 10,71 & 8,21 & 6,54 & 4,51 & 3,46 & 2,40 \\
\hline 45 & 350 & 170 & 33,37 & 19,33 & 14,51 & 10,68 & 8,25 & 6,59 & 4,55 & 3,47 & 2,40 \\
\hline 45 & 400 & 170 & 31,09 & 18,67 & 14,27 & 10,64 & 8,28 & 6,63 & 4,58 & 3,48 & 2,40 \\
\hline 45 & 450 & 170 & 29,26 & 18,11 & 14,05 & 10,60 & 8,29 & 6,66 & 4,61 & 3,50 & 2,40 \\
\hline 45 & 500 & 170 & 27,75 & 17,63 & 13,85 & 10,56 & 8,30 & 6,69 & 4,63 & 3,51 & 2,39 \\
\hline 45 & 550 & 170 & 26,48 & 17,21 & 13,66 & 10,51 & 8,31 & 6,71 & 4,66 & 3,52 & 2,39 \\
\hline 45 & 600 & 170 & 25,39 & 16,83 & 13,49 & 10,46 & 8,31 & 6,73 & 4,68 & 3,54 & 2,39 \\
\hline 45 & 650 & 170 & 24,44 & 16,49 & 13,33 & 10,41 & 8,31 & 6,74 & 4,70 & 3,55 & 2,40 \\
\hline 45 & 700 & 170 & 23,61 & 16,18 & 13,18 & 10,36 & 8,30 & 6,76 & 4,72 & 3,56 & 2,40 \\
\hline 45 & 750 & 170 & 22,87 & 15,90 & 13,03 & 10,31 & 8,29 & 6,77 & 4,74 & 3,57 & 2,40 \\
\hline 45 & 800 & 170 & 22,20 & 15,64 & 12,90 & 10,26 & 8,28 & 6,78 & 4,75 & 3,58 & 2,40 \\
\hline 45 & 850 & 170 & 21,60 & 15,40 & 12,77 & 10,21 & 8,27 & 6,78 & 4,77 & 3,59 & 2,40 \\
\hline 45 & 900 & 170 & 21,05 & 15,18 & 12,65 & 10,16 & 8,26 & 6,79 & 4,78 & 3,60 & 2,40 \\
\hline 45 & 950 & 170 & 20,55 & 14,97 & 12,53 & 10,11 & 8,25 & 6,79 & 4,80 & 3,61 & 2,40 \\
\hline 45 & 1000 & 170 & 20,09 & 14,77 & 12,42 & 10,06 & 8,23 & 6,80 & 4,81 & 3,62 & 2,41 \\
\hline 45 & 1050 & 170 & 19,66 & 14,58 & 12,31 & 10,01 & 8,22 & 6,80 & 4,82 & 3,63 & 2,41 \\
\hline 45 & 1100 & 170 & 19,27 & 14,40 & 12,21 & 9,97 & 8,20 & 6,80 & 4,83 & 3,64 & 2,41 \\
\hline 45 & 1150 & 170 & 18,90 & 14,24 & 12,11 & 9,92 & 8,18 & 6,80 & 4,84 & 3,65 & 2,41 \\
\hline 45 & 1200 & 170 & 18,56 & 14,08 & 12,01 & 9,87 & 8,17 & 6,80 & 4,85 & 3,66 & 2,42 \\
\hline 45 & 1250 & 170 & 18,24 & 13,93 & 11,92 & 9,83 & 8,15 & 6,80 & 4,86 & 3,67 & 2,42 \\
\hline 45 & 1300 & 170 & 17,93 & 13,78 & 11,83 & 9,79 & 8,13 & 6,79 & 4,87 & 3,68 & 2,42 \\
\hline 45 & 1350 & 170 & 17,65 & 13,65 & 11,75 & 9,74 & 8,11 & 6,79 & 4,88 & 3,69 & 2,42 \\
\hline 45 & 1400 & 170 & 17,38 & 13,51 & 11,67 & 9,70 & 8,10 & 6,79 & 4,89 & 3,70 & 2,43 \\
\hline 45 & 1450 & 170 & 17,13 & 13,39 & 11,59 & 9,66 & 8,08 & 6,78 & 4,90 & 3,70 & 2,43 \\
\hline 45 & 1500 & 170 & 16,88 & 13,27 & 11,51 & 9,62 & 8,06 & 6,78 & 4,90 & 3,71 & 2,43 \\
\hline 45 & 1550 & 170 & 16,66 & 13,15 & 11,43 & 9,58 & 8,04 & 6,77 & 4,91 & 3,72 & 2,44 \\
\hline 45 & 1600 & 170 & 16,44 & 13,04 & 11,36 & 9,54 & 8,02 & 6,77 & 4,92 & 3,73 & 2,44 \\
\hline 45 & 1650 & 170 & 16,23 & 12,93 & 11,29 & 9,50 & 8,00 & 6,76 & 4,92 & 3,73 & 2,44 \\
\hline 45 & 1700 & 170 & 16,03 & 12,82 & 11,22 & 9,46 & 7,99 & 6,76 & 4,93 & 3,74 & 2,45 \\
\hline 45 & 1750 & 170 & 15,84 & 12,72 & 11,15 & 9,42 & 7,97 & 6,75 & 4,93 & 3,75 & 2,45 \\
\hline 45 & 1800 & 170 & 15,66 & 12,63 & 11,09 & 9,38 & 7,95 & 6,74 & 4,94 & 3,75 & 2,45 \\
\hline 45 & 1850 & 170 & 15,49 & 12,53 & 11,02 & 9,35 & 7,93 & 6,74 & 4,94 & 3,76 & 2,45 \\
\hline 45 & 1900 & 170 & 15,32 & 12,44 & 10,96 & 9,31 & 7,91 & 6,73 & 4,94 & 3,76 & 2,46 \\
\hline 45 & 1950 & 170 & 15,16 & $\begin{array}{l}12,35 \\
12,35\end{array}$ & 10,90 & 9,28 & 7,89 & 6,72 & 4,95 & 3,77 & 2,46 \\
\hline 45 & 2000 & 170 & 15,01 & 12,26 & 10,84 & 9,24 & 7,88 & 6,72 & 4,95 & 3,77 & 2,46 \\
\hline 45 & 200 & 175 & 45,59 & 22,13 & 15,11 & 10,39 & 7,83 & 6,22 & 4,30 & 3,33 & 2,35 \\
\hline 45 & 250 & 175 & 39,82 & 20,74 & 14,73 & 10,41 & 7,92 & 6,29 & 4,34 & 3,34 & 2,34 \\
\hline 45 & 300 & 175 & 35,85 & 19,72 & 14,42 & 10,40 & 7,97 & 6,34 & 4,38 & 3,36 & 2,34 \\
\hline 45 & 350 & 175 & 32,93 & 18,92 & 14,15 & 10,38 & 8,01 & 6,39 & 4,41 & 3,37 & 2,33 \\
\hline 45 & 400 & 175 & 30,66 & 18,27 & 13,91 & 10,35 & 8,04 & 6,43 & 4,44 & 3,38 & 2,33 \\
\hline 45 & 450 & 175 & 28,85 & 17,73 & 13,70 & 10,31 & 8,05 & 6,46 & 4,47 & 3,39 & 2,33 \\
\hline 45 & 500 & 175 & 27,35 & 17,25 & 13,51 & 10,27 & 8,06 & 6,49 & 4,49 & 3,41 & 2,33 \\
\hline 45 & 550 & 175 & 26,09 & 16,84 & 13,33 & 10,22 & 8,07 & 6,51 & 4,51 & 3,42 & 2,33 \\
\hline 45 & 600 & 175 & 25,01 & 16,47 & 13,16 & 10,18 & 8,07 & 6,53 & 4,54 & 3,43 & 2,33 \\
\hline 45 & 650 & 175 & 24,07 & 16,14 & 13,01 & 10,13 & 8,07 & 6,55 & 4,56 & 3,44 & 2,33 \\
\hline 45 & 700 & 175 & 23,25 & 15,84 & 12,86 & 10,08 & 8,07 & 6,56 & 4,58 & 3,45 & 2,33 \\
\hline 45 & 750 & 175 & 22,51 & 15,56 & 12,72 & 10,04 & 8,06 & 6,57 & 4,59 & 3,46 & 2,33 \\
\hline 45 & 800 & 175 & 21,85 & 15,31 & 12,59 & 9,99 & 8,05 & 6,58 & 4,61 & 3,47 & 2,33 \\
\hline 45 & 850 & 175 & 21,26 & 15,07 & 12,47 & 9,94 & 8,04 & 6,59 & 4,62 & 3,48 & 2,33 \\
\hline 45 & 900 & 175 & 20,72 & 14,85 & 12,35 & 9,89 & 8,03 & 6,59 & 4,64 & 3,50 & 2,33 \\
\hline 45 & 950 & 175 & 20,22 & 14,65 & 12,23 & 9,85 & 8,02 & 6,60 & 4,65 & 3,51 & 2,33 \\
\hline 45 & 1000 & 175 & 19,77 & 14,45 & 12,13 & 9,80 & 8,00 & 6,60 & 4,67 & 3,51 & 2,34 \\
\hline 45 & 1050 & 175 & 19,35 & 14,27 & 12,02 & 9,76 & 7,99 & 6,60 & 4,68 & 3,52 & 2,34 \\
\hline 45 & 1100 & 175 & 18,96 & 14,10 & 11,92 & 9,71 & 7,98 & 6,60 & 4,69 & 3,53 & 2,34 \\
\hline 45 & 1150 & 175 & 18,59 & 13,94 & 11,83 & 9,67 & 7,96 & 6,60 & 4,70 & 3,54 & 2,34 \\
\hline 45 & $\frac{1+00}{1200}$ & 175 & 18,25 & $\begin{array}{l} \\
13,78\end{array}$ & $\frac{1 ., 00}{11,73}$ & 9,62 & 7,94 & 6,60 & 4,71 & 3,55 & 2,35 \\
\hline 45 & 1250 & 175 & 17,94 & 13,63 & 11,65 & 9,58 & 7,93 & 6,60 & 4,72 & 3,56 & 2,35 \\
\hline 45 & 1300 & 175 & 17,64 & 13,49 & 11,56 & 9,54 & 7,91 & 6,60 & 4,73 & 3,57 & 2,35 \\
\hline 45 & 1350 & 175 & 17,36 & 13,36 & 11,48 & 9,50 & 7,89 & 6,60 & 4,74 & 3,58 & 2,35 \\
\hline 45 & 1400 & 175 & 17,09 & 13,23 & 11,40 & 9,46 & 7,88 & 6,60 & 4,74 & 3,58 & 2,36 \\
\hline 45 & 1450 & 175 & 16,84 & 13,11 & 11,32 & 9,42 & 7,86 & 6,59 & 4,75 & 3,59 & 2,36 \\
\hline 45 & 1500 & 175 & 16,60 & 12,99 & 11,24 & 9,38 & 7,84 & 6,59 & 4,76 & 3,60 & 2,36 \\
\hline
\end{tabular}




\begin{tabular}{|c|c|c|c|c|c|c|c|c|c|c|c|}
\hline \multirow[b]{2}{*}{$\mathrm{H}(\mathrm{cm})$} & \multirow[b]{2}{*}{ Mceq (MPa) } & & & & & De & ões (x & & & & \\
\hline & & Msub (MPa) & D0 & D25 & D40 & D60 & D80 & D100 & D140 & D180 & D260 \\
\hline 45 & 1550 & 175 & 16,38 & 12,87 & 11,17 & 9,34 & 7,83 & 6,58 & 4,76 & 3,61 & 2,36 \\
\hline 45 & 1600 & 175 & 16,16 & 12,76 & 11,10 & 9,30 & 7,81 & 6,58 & 4,77 & 3,61 & 2,37 \\
\hline 45 & 1650 & 175 & 15,96 & 12,66 & 11,03 & 9,26 & 7,79 & 6,57 & 4,78 & 3,62 & 2,37 \\
\hline 45 & 1700 & 175 & 15,76 & 12,56 & 10,96 & 9,23 & 7,77 & 6,57 & 4,78 & 3,63 & 2,37 \\
\hline 45 & 1750 & 175 & 15,58 & 12,46 & 10,90 & 9,19 & 7,76 & 6,56 & 4,79 & 3,63 & 2,38 \\
\hline 45 & 1800 & 175 & 15,40 & 12,36 & 10,83 & 9,15 & 7,74 & 6,56 & 4,79 & 3,64 & 2,38 \\
\hline 45 & 1850 & 175 & 15,23 & 12,27 & 10,77 & 9,12 & 7,72 & 6,55 & 4,80 & 3,64 & 2,38 \\
\hline 45 & 1900 & 175 & 15,06 & 12,18 & 10,71 & 9,08 & 7,71 & 6,55 & 4,80 & 3,65 & 2,38 \\
\hline 45 & 1950 & 175 & 14,90 & 12,09 & 10,65 & 9,05 & 7,69 & 6,54 & 4,80 & 3,66 & 2,39 \\
\hline 45 & 2000 & 175 & 14,75 & 12,01 & 10,60 & 9,02 & 7,67 & 6,53 & 4,81 & 3,66 & 2,39 \\
\hline 45 & 200 & 180 & 45,11 & 21,70 & 14,73 & 10,10 & 7,61 & 6,04 & 4,18 & 3,23 & 2,29 \\
\hline 45 & 250 & 180 & 39,36 & 20,32 & 14,36 & 10,12 & 7,69 & 6,10 & 4,22 & 3,25 & 2,28 \\
\hline 45 & 300 & 180 & 35,41 & 19,32 & 14,06 & 10,12 & 7,74 & 6,16 & 4,25 & 3,26 & 2,27 \\
\hline 45 & 350 & 180 & 32,51 & 18,53 & 13,80 & 10,10 & 7,78 & 6,20 & 4,28 & 3,27 & 2,27 \\
\hline 45 & 400 & 180 & 30,26 & 17,90 & 13,57 & 10,07 & 7,81 & 6,24 & 4,31 & 3,29 & 2,26 \\
\hline 45 & 450 & 180 & 28,46 & 17,36 & 13,37 & 10,03 & 7,83 & 6,27 & 4,34 & 3,30 & 2,26 \\
\hline 45 & 500 & 180 & 26,97 & 16,90 & 13,18 & 10,00 & 7,84 & 6,30 & 4,36 & 3,31 & 2,26 \\
\hline 45 & 550 & 180 & 25,72 & 16,49 & 13,01 & 9,95 & 7,85 & 6,32 & 4,38 & 3,32 & 2,26 \\
\hline 45 & 600 & 180 & 24,65 & 16,13 & 12,85 & 9,91 & 7,85 & 6,34 & 4,40 & 3,33 & 2,26 \\
\hline 45 & 650 & 180 & 23,72 & 15,80 & 12,70 & 9,87 & 7,85 & 6,36 & 4,42 & 3,34 & 2,26 \\
\hline 45 & 700 & 180 & 22,90 & 15,51 & 12,56 & 9,82 & 7,84 & 6,37 & 4,44 & 3,35 & 2,26 \\
\hline 45 & 750 & 180 & 22,18 & 15,24 & 12,42 & 9,78 & 7,84 & 6,38 & 4,46 & 3,36 & 2,26 \\
\hline 45 & 800 & 180 & 21,52 & 14,99 & 12,30 & 9,73 & 7,83 & 6,39 & 4,47 & 3,37 & 2,26 \\
\hline 45 & 850 & 180 & 20,93 & 14,76 & 12,18 & 9,69 & 7,82 & 6,40 & 4,49 & 3,38 & 2,27 \\
\hline 45 & 900 & 180 & 20,40 & 14,54 & 12,06 & 9,64 & 7,81 & 6,41 & 4,50 & 3,39 & 2,27 \\
\hline 45 & 950 & 180 & 19,91 & 14,34 & 11,95 & 9,60 & 7,80 & 6,41 & 4,52 & 3,40 & 2,27 \\
\hline 45 & 1000 & 180 & 19,46 & 14,16 & 11,85 & 9,55 & 7,79 & 6,42 & 4,53 & 3,41 & 2,27 \\
\hline 45 & 1050 & 180 & 19,04 & 13,98 & 11,75 & 9,51 & 7,78 & 6,42 & 4,54 & 3,42 & 2,27 \\
\hline 45 & 1100 & 180 & 18,66 & 13,81 & 11,65 & 9,47 & 7,76 & 6,42 & 4,55 & 3,43 & 2,27 \\
\hline 45 & 1150 & 180 & 18,30 & 13,65 & 11,56 & 9,43 & 7,75 & 6,42 & 4,56 & 3,44 & 2,28 \\
\hline 45 & 1200 & 180 & 17,96 & 13,50 & 11,47 & 9,38 & 7,73 & 6,42 & 4,57 & 3,45 & 2,28 \\
\hline 45 & 1250 & 180 & 17,65 & 13,35 & 11,38 & 9,34 & 7,72 & 6,42 & 4,58 & 3,45 & 2,28 \\
\hline 45 & 1300 & 180 & 17,35 & 13,22 & 11,30 & 9,30 & 7,70 & 6,42 & 4,59 & 3,46 & 2,28 \\
\hline 45 & 1350 & 180 & 17,08 & 13,09 & 11,22 & 9,26 & 7,69 & 6,42 & 4,60 & 3,47 & 2,29 \\
\hline 45 & 1400 & 180 & 16,82 & 12,96 & 11,14 & 9,22 & 7,67 & 6,41 & 4,61 & 3,48 & 2,29 \\
\hline 45 & 1450 & 180 & 16,57 & 12,84 & 11,07 & 9,19 & 7,66 & 6,41 & 4,61 & 3,49 & 2,29 \\
\hline 45 & 1500 & 180 & 16,33 & 12,72 & 10,99 & 9,15 & 7,64 & 6,41 & 4,62 & 3,49 & 2,29 \\
\hline 45 & 1550 & 180 & 16,11 & 12,61 & 10,92 & 9,11 & 7,62 & 6,40 & 4,63 & 3,50 & 2,30 \\
\hline 45 & 1600 & 180 & 15,90 & 12,50 & 10,85 & 9,07 & 7,61 & 6,40 & 4,63 & 3,51 & 2,30 \\
\hline 45 & 1650 & 180 & 15,70 & 12,40 & 10,79 & 9,04 & 7,59 & 6,40 & 4,64 & 3,51 & 2,30 \\
\hline 45 & 1700 & 180 & 15,50 & 12,30 & 10,72 & 9,00 & 7,57 & 6,39 & 4,64 & 3,52 & 2,30 \\
\hline 45 & 1750 & 180 & 15,32 & 12,21 & 10,66 & 8,97 & 7,56 & 6,39 & 4,65 & 3,53 & 2,31 \\
\hline 45 & 1800 & 180 & 15,14 & 12,11 & 10,60 & 8,93 & 7,54 & 6,38 & 4,65 & 3,53 & 2,31 \\
\hline 45 & 1850 & 180 & 14,97 & 12,02 & 10,54 & 8,90 & 7,53 & 6,38 & 4,66 & 3,54 & 2,31 \\
\hline 45 & 1900 & 180 & 14,81 & 11,93 & 10,48 & 8,87 & 7,51 & 6,37 & 4,66 & 3,54 & 2,31 \\
\hline 45 & 1950 & 180 & 14,66 & 11,85 & 10,42 & 8,83 & 7,49 & 6,36 & 4,67 & 3,55 & 2,32 \\
\hline 45 & 2000 & 180 & 14,51 & 11,77 & 10,36 & 8,80 & 7,48 & 6,36 & 4,67 & 3,55 & 2,32 \\
\hline 45 & 200 & 185 & 44,66 & 21,29 & 14,38 & 9,82 & 7,39 & 5,86 & 4,06 & 3,14 & 2,23 \\
\hline 45 & 250 & 185 & 38,93 & 19,93 & 14,02 & 9,84 & 7,47 & 5,93 & 4,10 & 3,16 & 2,22 \\
\hline 45 & 300 & 185 & 35,00 & 18,94 & 13,73 & 9,84 & 7,52 & 5,98 & 4,13 & 3,17 & 2,21 \\
\hline 45 & 350 & 185 & 32,10 & 18,16 & 13,48 & 9,83 & 7,56 & 6,03 & 4,16 & 3,18 & 2,21 \\
\hline 45 & 400 & 185 & 29,87 & 17,54 & 13,25 & 9,80 & 7,59 & 6,07 & 4,19 & 3,19 & 2,20 \\
\hline 45 & 450 & 185 & 28,08 & 17,01 & 13,06 & 9,77 & 7,61 & 6,10 & 4,21 & 3,21 & 2,20 \\
\hline 45 & 500 & 185 & 26,61 & 16,55 & 12,87 & 9,74 & 7,62 & 6,12 & 4,24 & 3,22 & 2,20 \\
\hline 45 & 550 & 185 & 25,37 & 16,16 & 12,71 & 9,70 & 7,63 & 6,15 & 4,26 & 3,23 & 2,20 \\
\hline 45 & 600 & 185 & 24,31 & 15,80 & 12,55 & 9,66 & 7,64 & 6,16 & 4,28 & 3,24 & 2,20 \\
\hline 45 & 650 & 185 & 23,38 & 15,48 & 12,40 & 9,62 & 7,64 & 6,18 & 4,30 & 3,25 & 2,20 \\
\hline 45 & 700 & 185 & 22,57 & 15,20 & 12,27 & 9,57 & 7,63 & 6,19 & 4,31 & 3,26 & 2,20 \\
\hline 45 & 750 & 185 & 21,85 & 14,93 & 12,14 & 9,53 & 7,63 & 6,21 & 4,33 & 3,27 & 2,20 \\
\hline 45 & 800 & 185 & 21,21 & 14,69 & 12,02 & 9,49 & 7,62 & 6,22 & 4,35 & 3,28 & 2,20 \\
\hline 45 & 850 & 185 & 20,62 & 14,46 & 11,90 & 9,44 & 7,62 & 6,22 & 4,36 & 3,29 & 2,20 \\
\hline 45 & 900 & 185 & 20,10 & 14,25 & 11,79 & 9,40 & 7,61 & 6,23 & 4,37 & 3,30 & 2,21 \\
\hline 45 & 950 & 185 & 19,61 & 14,06 & 11,68 & 9,36 & 7,60 & 6,24 & 4,39 & 3,31 & 2,21 \\
\hline 45 & 1000 & 185 & 19,17 & 13,87 & 11,58 & 9,32 & 7,59 & 6,24 & 4,40 & 3,31 & 2,21 \\
\hline 45 & 1050 & 185 & 18,75 & 13,70 & 11,48 & 9,28 & 7,57 & 6,24 & 4,41 & 3,32 & 2,21 \\
\hline 45 & 1100 & 185 & 18,37 & 13,53 & 11,39 & 9,24 & 7,56 & 6,25 & 4,42 & 3,33 & 2,21 \\
\hline 45 & 1150 & 185 & 18,02 & 13,38 & 11,30 & 9,20 & 7,55 & 6,25 & 4,43 & 3,34 & 2,21 \\
\hline 45 & 1200 & 185 & 17,69 & 13,23 & 11,21 & 9,16 & 7,53 & 6,25 & 4,44 & 3,35 & 2,22 \\
\hline 45 & 1250 & 185 & 17,38 & 13,09 & 11,13 & 9,12 & 7,52 & 6,25 & 4,45 & 3,36 & 2,22 \\
\hline 45 & 1300 & 185 & 17,09 & 12,95 & 11,05 & 9,08 & 7,51 & 6,25 & 4,46 & 3,36 & 2,22 \\
\hline 45 & 1350 & 185 & 16,81 & 12,82 & 10,97 & 9,04 & 7,49 & 6,25 & 4,47 & 3,37 & 2,22 \\
\hline 45 & 1400 & 185 & 16,55 & 12,70 & 10,90 & 9,00 & 7,48 & 6,24 & 4,48 & 3,38 & 2,22 \\
\hline 45 & 1450 & 185 & 16,31 & 12,58 & 10,82 & 8,97 & 7,46 & 6,24 & 4,48 & 3,39 & 2,23 \\
\hline 45 & 1500 & 185 & 16,08 & 12,47 & 10,75 & 8,93 & 7,45 & 6,24 & 4,49 & 3,39 & 2,23 \\
\hline 45 & 1550 & 185 & 15,86 & 12,36 & 10,68 & 8,89 & 7,43 & 6,23 & 4,50 & 3,40 & 2,23 \\
\hline 45 & 1600 & 185 & 15,65 & 12,26 & 10,62 & 8,86 & 7,42 & 6,23 & 4,50 & 3,41 & 2,23 \\
\hline 45 & 1650 & 185 & 15,45 & 12,16 & 10,55 & 8,83 & 7,40 & 6,23 & 4,51 & 3,41 & 2,24 \\
\hline 45 & 1700 & 185 & 15,26 & 12,06 & 10,49 & 8,79 & 7,38 & 6,22 & 4,51 & 3,42 & 2,24 \\
\hline 45 & 1750 & 185 & 15,07 & 11,96 & 10,43 & 8,76 & 7,37 & 6,22 & 4,52 & 3,42 & 2,24 \\
\hline 45 & 1800 & 185 & 14,90 & 11,87 & 10,37 & 8,72 & 7,35 & 6,21 & 4,52 & 3,43 & 2,24 \\
\hline 45 & 1850 & 185 & 14,73 & 11,78 & 10,31 & 8,69 & 7,34 & 6,21 & 4,53 & 3,44 & 2,25 \\
\hline
\end{tabular}




\begin{tabular}{|c|c|c|c|c|c|c|c|c|c|c|c|}
\hline \multirow[b]{2}{*}{$\mathrm{H}(\mathrm{cm})$} & \multirow[b]{2}{*}{ Mceq (MPa) } & & & & & & ões (x & & & & \\
\hline & & Msub (MPa) & D0 & D25 & D40 & D60 & D80 & D100 & D140 & D180 & D260 \\
\hline 45 & 1900 & 185 & 14,57 & 11,70 & 10,25 & 8,66 & 7,32 & 6,20 & 4,53 & 3,44 & 2,25 \\
\hline 45 & 1950 & 185 & 14,42 & 11,62 & 10,20 & 8,63 & 7,31 & 6,20 & 4,54 & 3,45 & 2,25 \\
\hline 45 & 2000 & 185 & 14,27 & 11,54 & 10,14 & 8,60 & 7,29 & 6,19 & 4,54 & 3,45 & 2,25 \\
\hline 45 & 200 & 190 & 44,22 & 20,90 & 14,05 & 9,55 & 7,18 & 5,70 & 3,95 & 3,06 & 2,17 \\
\hline 45 & 250 & 190 & 38,52 & 19,55 & 13,69 & 9,58 & 7,26 & 5,77 & 3,99 & 3,07 & 2,16 \\
\hline 45 & 300 & 190 & 34,60 & 18,57 & 13,41 & 9,59 & 7,32 & 5,82 & 4,02 & 3,09 & 2,15 \\
\hline 45 & 350 & 190 & 31,72 & 17,81 & 13,16 & 9,57 & 7,36 & 5,86 & 4,05 & 3,10 & 2,15 \\
\hline 45 & 400 & 190 & 29,50 & 17,19 & 12,95 & 9,55 & 7,39 & 5,90 & 4,07 & 3,11 & 2,15 \\
\hline 45 & 450 & 190 & 27,72 & 16,68 & 12,76 & 9,52 & 7,41 & 5,93 & 4,10 & 3,12 & 2,14 \\
\hline 45 & 500 & 190 & 26,26 & 16,23 & 12,58 & 9,49 & 7,42 & 5,96 & 4,12 & 3,13 & 2,14 \\
\hline 45 & 550 & 190 & 25,03 & 15,84 & 12,42 & 9,45 & 7,43 & 5,98 & 4,14 & 3,14 & 2,14 \\
\hline 45 & 600 & 190 & 23,98 & 15,49 & 12,27 & 9,42 & 7,43 & 6,00 & 4,16 & 3,15 & 2,14 \\
\hline 45 & 650 & 190 & 23,06 & 15,18 & 12,13 & 9,38 & 7,44 & 6,01 & 4,18 & 3,16 & 2,14 \\
\hline 45 & 700 & 190 & 22,26 & 14,90 & 11,99 & 9,34 & 7,43 & 6,03 & 4,19 & 3,17 & 2,14 \\
\hline 45 & 750 & 190 & 21,55 & 14,64 & 11,87 & 9,30 & 7,43 & 6,04 & 4,21 & 3,18 & 2,14 \\
\hline 45 & 800 & 190 & 20,91 & 14,40 & 11,75 & 9,26 & 7,43 & 6,05 & 4,23 & 3,19 & 2,14 \\
\hline 45 & 850 & 190 & 20,33 & 14,18 & 11,64 & 9,21 & 7,42 & 6,06 & 4,24 & 3,20 & 2,15 \\
\hline 45 & 900 & 190 & 19,80 & 13,97 & 11,53 & 9,17 & 7,41 & 6,06 & 4,25 & 3,21 & 2,15 \\
\hline 45 & 950 & 190 & 19,33 & 13,78 & 11,43 & 9,13 & 7,40 & 6,07 & 4,27 & 3,21 & 2,15 \\
\hline 45 & 1000 & 190 & 18,88 & 13,60 & 11,33 & 9,09 & 7,39 & 6,07 & 4,28 & 3,22 & 2,15 \\
\hline 45 & 1050 & 190 & 18,48 & 13,43 & 11,23 & 9,05 & 7,38 & 6,08 & 4,29 & 3,23 & 2,15 \\
\hline 45 & 1100 & 190 & 18,10 & 13,27 & 11,14 & 9,02 & 7,37 & 6,08 & 4,30 & 3,24 & 2,15 \\
\hline 45 & 1150 & 190 & 17,75 & 13,12 & 11,06 & 8,98 & 7,36 & 6,08 & 4,31 & 3,25 & 2,15 \\
\hline 45 & 1200 & 190 & 17,42 & 12,97 & 10,97 & 8,94 & 7,34 & 6,08 & 4,32 & 3,26 & 2,16 \\
\hline 45 & 1250 & 190 & 17,12 & 12,83 & 10,89 & 8,90 & 7,33 & 6,08 & 4,33 & 3,26 & 2,16 \\
\hline 45 & 1300 & 190 & 16,83 & 12,70 & 10,81 & 8,87 & 7,32 & 6,08 & 4,34 & 3,27 & 2,16 \\
\hline 45 & 1350 & 190 & 16,56 & 12,58 & 10,74 & 8,83 & 7,30 & 6,08 & 4,34 & 3,28 & 2,16 \\
\hline 45 & 1400 & 190 & 16,30 & 12,46 & 10,66 & 8,79 & 7,29 & 6,08 & 4,35 & 3,28 & 2,16 \\
\hline 45 & 1450 & 190 & 16,06 & 12,34 & 10,59 & 8,76 & 7,28 & 6,08 & 4,36 & 3,29 & 2,17 \\
\hline 45 & 1500 & 190 & 15,83 & 12,23 & 10,52 & 8,72 & 7,26 & 6,08 & 4,37 & 3,30 & 2,17 \\
\hline 45 & 1550 & 190 & 15,61 & 12,12 & 10,46 & 8,69 & 7,25 & 6,07 & 4,37 & 3,30 & 2,17 \\
\hline 45 & 1600 & 190 & 15,41 & 12,02 & 10,39 & 8,66 & 7,23 & 6,07 & 4,38 & 3,31 & 2,17 \\
\hline 45 & 1650 & 190 & 15,21 & 11,92 & 10,33 & 8,62 & 7,22 & 6,07 & 4,38 & 3,32 & 2,18 \\
\hline 45 & 1700 & 190 & 15,02 & 11,83 & 10,27 & 8,59 & 7,20 & 6,06 & 4,39 & 3,32 & 2,18 \\
\hline 45 & 1750 & 190 & 14,84 & 11,73 & 10,21 & 8,56 & 7,19 & 6,06 & 4,39 & 3,33 & 2,18 \\
\hline 45 & 1800 & 190 & 14,67 & 11,64 & 10,15 & 8,53 & 7,17 & 6,05 & 4,40 & 3,33 & 2,18 \\
\hline 45 & 1850 & 190 & 14,50 & 11,56 & 10,09 & 8,49 & 7,16 & 6,05 & 4,40 & 3,34 & 2,19 \\
\hline 45 & 1900 & 190 & 14,35 & 11,47 & 10,04 & 8,46 & 7,14 & 6,05 & 4,41 & 3,35 & 2,19 \\
\hline 45 & 1950 & 190 & 14,19 & 11,39 & 9,98 & 8,43 & 7,13 & 6,04 & 4,41 & 3,35 & 2,19 \\
\hline 45 & 2000 & 190 & 14,05 & 11,31 & 9,93 & 8,40 & 7,12 & 6,04 & 4,42 & 3,36 & 2,19 \\
\hline 45 & 200 & 195 & 43,81 & 20,53 & 13,73 & 9,30 & 6,99 & 5,55 & 3,84 & 2,98 & 2,11 \\
\hline 45 & 250 & 195 & 38,12 & 19,20 & 13,38 & 9,34 & 7,07 & 5,61 & 3,88 & 2,99 & 2,10 \\
\hline 45 & 300 & 195 & 34,22 & 18,23 & 13,10 & 9,34 & 7,12 & 5,66 & 3,91 & 3,00 & 2,10 \\
\hline 45 & 350 & 195 & 31,36 & 17,48 & 12,87 & 9,33 & 7,16 & 5,71 & 3,94 & 3,02 & 2,09 \\
\hline 45 & 400 & 195 & 29,15 & 16,87 & 12,66 & 9,31 & 7,19 & 5,74 & 3,96 & 3,03 & 2,09 \\
\hline 45 & 450 & 195 & 27,38 & 16,36 & 12,47 & 9,28 & 7,21 & 5,77 & 3,99 & 3,04 & 2,09 \\
\hline 45 & 500 & 195 & 25,93 & 15,92 & 12,30 & 9,25 & 7,23 & 5,80 & 4,01 & 3,05 & 2,09 \\
\hline 45 & 550 & 195 & 24,71 & 15,54 & 12,14 & 9,22 & 7,24 & 5,82 & 4,03 & 3,06 & 2,09 \\
\hline 45 & 600 & 195 & 23,66 & 15,19 & 12,00 & 9,19 & 7,24 & 5,84 & 4,05 & 3,07 & 2,09 \\
\hline 45 & 650 & 195 & 22,75 & 14,89 & 11,86 & 9,15 & 7,24 & 5,85 & 4,06 & 3,07 & 2,09 \\
\hline 45 & 700 & 195 & 21,96 & 14,61 & 11,73 & 9,11 & 7,24 & 5,87 & 4,08 & 3,08 & 2,09 \\
\hline 45 & 750 & 195 & 21,25 & 14,36 & 11,61 & 9,07 & 7,24 & 5,88 & 4,10 & 3,09 & 2,09 \\
\hline 45 & 800 & 195 & 20,62 & 14,12 & 11,50 & 9,03 & 7,24 & 5,89 & 4,11 & 3,10 & 2,09 \\
\hline 45 & 850 & 195 & 20,05 & 13,91 & 11,39 & 9,00 & 7,23 & 5,90 & 4,13 & 3,11 & 2,09 \\
\hline 45 & 900 & 195 & 19,53 & 13,70 & 11,28 & 8,96 & 7,22 & 5,91 & 4,14 & 3,12 & 2,09 \\
\hline 45 & 950 & 195 & 19,05 & 13,52 & 11,18 & 8,92 & 7,22 & 5,91 & 4,15 & 3,13 & 2,09 \\
\hline 45 & 1000 & 195 & 18,62 & 13,34 & 11,09 & 8,88 & 7,21 & 5,92 & 4,16 & 3,14 & 2,09 \\
\hline 45 & 1050 & 195 & 18,21 & 13,17 & 10,99 & 8,84 & 7,20 & 5,92 & 4,17 & 3,14 & 2,10 \\
\hline 45 & 1100 & 195 & 17,84 & 13,01 & 10,91 & 8,81 & 7,19 & 5,92 & 4,18 & 3,15 & 2,10 \\
\hline 45 & 1150 & 195 & 17,49 & 12,87 & 10,82 & 8,77 & 7,18 & 5,93 & 4,19 & 3,16 & 2,10 \\
\hline 45 & 1200 & 195 & 17,17 & 12,72 & 10,74 & 8,73 & 7,16 & 5,93 & 4,20 & 3,17 & 2,10 \\
\hline 45 & 1250 & 195 & 16,87 & 12,59 & 10,66 & 8,70 & 7,15 & 5,93 & 4,21 & 3,17 & 2,10 \\
\hline 45 & 1300 & 195 & 16,58 & 12,46 & 10,59 & 8,66 & 7,14 & 5,93 & 4,22 & 3,18 & 2,10 \\
\hline 45 & 1350 & 195 & 16,31 & 12,34 & 10,51 & 8,63 & 7,13 & 5,93 & 4,23 & 3,19 & 2,11 \\
\hline 45 & 1400 & 195 & 16,06 & 12,22 & 10,44 & 8,59 & 7,11 & 5,93 & 4,24 & 3,20 & 2,11 \\
\hline 45 & 1450 & 195 & 15,82 & 12,11 & 10,37 & 8,56 & 7,10 & 5,92 & 4,24 & 3,20 & 2,11 \\
\hline 45 & 1500 & 195 & 15,59 & 12,00 & 10,31 & 8,53 & 7,09 & 5,92 & 4,25 & 3,21 & 2,11 \\
\hline 45 & 1550 & 195 & 15,38 & 11,89 & 10,24 & 8,49 & 7,07 & 5,92 & 4,26 & 3,21 & 2,11 \\
\hline 45 & 1600 & 195 & 15,17 & 11,79 & 10,18 & 8,46 & 7,06 & 5,92 & 4,26 & 3,22 & 2,12 \\
\hline 45 & 1650 & 195 & 14,98 & 11,70 & 10,12 & 8,43 & 7,05 & 5,91 & 4,27 & 3,23 & 2,12 \\
\hline 45 & 1700 & 195 & 14,79 & 11,60 & 10,06 & 8,40 & 7,03 & 5,91 & 4,27 & 3,23 & 2,12 \\
\hline 45 & 1750 & 195 & 14,62 & 11,51 & 10,00 & 8,37 & 7,02 & 5,91 & 4,28 & 3,24 & 2,12 \\
\hline 45 & 1800 & 195 & 14,45 & 11,43 & 9,94 & 8,34 & 7,00 & 5,90 & 4,28 & 3,24 & 2,12 \\
\hline 45 & 1850 & 195 & 14,28 & 11,34 & 9,89 & 8,31 & 6,99 & 5,90 & 4,29 & 3,25 & 2,13 \\
\hline 45 & 1900 & 195 & 14,13 & 11,26 & 9,83 & 8,28 & 6,98 & 5,89 & 4,29 & 3,25 & 2,13 \\
\hline 45 & 1950 & 195 & 13,98 & 11,18 & 9,78 & 8,25 & 6,96 & 5,89 & 4,30 & 3,26 & 2,13 \\
\hline 45 & 2000 & 195 & 13,83 & 11,10 & 9,73 & 8,22 & 6,95 & 5,89 & 4,30 & 3,26 & 2,13 \\
\hline 45 & 200 & 200 & 43,42 & 20,18 & 13,42 & 9,07 & 6,81 & 5,40 & 3,74 & 2,90 & 2,06 \\
\hline 45 & 250 & 200 & 37,75 & 18,86 & 13,08 & 9,10 & 6,89 & 5,46 & 3,78 & 2,92 & 2,05 \\
\hline 45 & 300 & 200 & 33,86 & 17,90 & 12,81 & 9,11 & 6,94 & 5,51 & 3,81 & 2,93 & 2,05 \\
\hline 45 & 350 & 200 & 31,01 & 17,16 & 12,58 & 9,10 & 6,98 & 5,56 & 3,84 & 2,94 & 2,04 \\
\hline
\end{tabular}




\begin{tabular}{|c|c|c|c|c|c|c|c|c|c|c|c|}
\hline & & & \multicolumn{9}{|c|}{ Deflexões $\left(\times 10^{-4} \mathrm{~cm}\right)$} \\
\hline $\mathrm{H}(\mathrm{cm})$ & Mceq (MPa) & Msub (MPa) & D0 & D25 & D40 & D60 & D80 & D100 & D140 & D180 & D260 \\
\hline 45 & 400 & 200 & 28,81 & 16,56 & 12,38 & 9,08 & 7,01 & 5,59 & 3,86 & 2,95 & 2,04 \\
\hline 45 & 450 & 200 & 27,05 & 16,05 & 12,20 & 9,06 & 7,03 & 5,62 & 3,88 & 2,96 & 2,04 \\
\hline 45 & 500 & 200 & 25,61 & 15,62 & 12,03 & 9,03 & 7,04 & 5,65 & 3,90 & 2,97 & 2,04 \\
\hline 45 & 550 & 200 & 24,40 & 15,25 & 11,88 & 9,00 & 7,05 & 5,67 & 3,92 & 2,98 & 2,04 \\
\hline 45 & 600 & 200 & 23,36 & 14,91 & 11,74 & 8,97 & 7,06 & 5,69 & 3,94 & 2,99 & 2,04 \\
\hline 45 & 650 & 200 & 22,46 & 14,61 & 11,61 & 8,93 & 7,06 & 5,70 & 3,96 & 3,00 & 2,04 \\
\hline 45 & 700 & 200 & 21,67 & 14,34 & 11,48 & 8,90 & 7,06 & 5,72 & 3,97 & 3,00 & 2,04 \\
\hline 45 & 750 & 200 & 20,97 & 14,09 & 11,36 & 8,86 & 7,06 & 5,73 & 3,99 & 3,01 & 2,04 \\
\hline 45 & 800 & 200 & 20,34 & 13,86 & 11,25 & 8,82 & 7,06 & 5,74 & 4,00 & 3,02 & 2,04 \\
\hline 45 & 850 & 200 & 19,78 & 13,65 & 11,15 & 8,79 & 7,05 & 5,75 & 4,02 & 3,03 & 2,04 \\
\hline 45 & 900 & 200 & 19,26 & 13,45 & 11,04 & 8,75 & 7,05 & 5,76 & 4,03 & 3,04 & 2,04 \\
\hline 45 & 950 & 200 & 18,79 & 13,26 & 10,95 & 8,71 & 7,04 & 5,76 & 4,04 & 3,05 & 2,04 \\
\hline 45 & 1000 & 200 & 18,36 & 13,09 & 10,86 & 8,68 & 7,03 & 5,77 & 4,05 & 3,05 & 2,04 \\
\hline 45 & 1050 & 200 & 17,96 & 12,93 & 10,77 & 8,64 & 7,02 & 5,77 & 4,06 & 3,06 & 2,04 \\
\hline 45 & 1100 & 200 & 17,59 & 12,77 & 10,68 & 8,61 & 7,01 & 5,77 & 4,07 & 3,07 & 2,04 \\
\hline 45 & 1150 & 200 & 17,25 & 12,63 & 10,60 & 8,57 & 7,00 & 5,78 & 4,08 & 3,08 & 2,04 \\
\hline 45 & 1200 & 200 & 16,93 & 12,49 & 10,52 & 8,54 & 6,99 & 5,78 & 4,09 & 3,08 & 2,05 \\
\hline 45 & 1250 & 200 & 16,63 & 12,36 & 10,44 & 8,50 & 6,98 & 5,78 & 4,10 & 3,09 & 2,05 \\
\hline 45 & 1300 & 200 & 16,35 & 12,23 & 10,37 & 8,47 & 6,97 & 5,78 & 4,11 & 3,10 & 2,05 \\
\hline 45 & 1350 & 200 & 16,08 & 12,11 & 10,30 & 8,43 & 6,96 & 5,78 & 4,12 & 3,10 & 2,05 \\
\hline 45 & 1400 & 200 & 15,83 & 11,99 & 10,23 & 8,40 & 6,94 & 5,78 & 4,12 & 3,11 & 2,05 \\
\hline 45 & 1450 & 200 & 15,59 & 11,88 & 10,16 & 8,37 & 6,93 & 5,78 & 4,13 & 3,12 & 2,06 \\
\hline 45 & 1500 & 200 & 15,37 & 11,78 & 10,10 & 8,34 & 6,92 & 5,78 & 4,14 & 3,12 & 2,06 \\
\hline 45 & 1550 & 200 & 15,16 & 11,67 & 10,03 & 8,30 & 6,91 & 5,77 & 4,14 & 3,13 & 2,06 \\
\hline 45 & 1600 & 200 & 14,95 & 11,58 & 9,97 & 8,27 & 6,89 & 5,77 & 4,15 & 3,14 & 2,06 \\
\hline 45 & 1650 & 200 & 14,76 & 11,48 & 9,91 & 8,24 & 6,88 & 5,77 & 4,16 & 3,14 & 2,06 \\
\hline 45 & 1700 & 200 & 14,58 & 11,39 & 9,85 & 8,21 & 6,87 & 5,77 & 4,16 & 3,15 & 2,07 \\
\hline 45 & 1750 & 200 & 14,40 & 11,30 & 9,80 & 8,18 & 6,85 & 5,76 & 4,17 & 3,15 & 2,07 \\
\hline 45 & 1800 & 200 & 14,23 & 11,22 & 9,74 & 8,15 & 6,84 & 5,76 & 4,17 & 3,16 & 2,07 \\
\hline 45 & 1850 & 200 & 14,07 & 11,13 & 9,69 & 8,12 & 6,83 & 5,76 & 4,18 & 3,16 & 2,07 \\
\hline 45 & 1900 & 200 & 13,92 & 11,05 & 9,64 & 8,10 & 6,81 & 5,75 & 4,18 & 3,17 & 2,07 \\
\hline 45 & 1950 & 200 & 13,77 & 10,98 & 9,59 & 8,07 & 6,80 & 5,75 & 4,18 & 3,17 & 2,08 \\
\hline 45 & 2000 & 200 & 13,63 & 10,90 & 9,54 & 8,04 & 6,79 & 5,74 & 4,19 & 3,18 & 2,08 \\
\hline 50 & 200 & 20 & 127,51 & 101,32 & 89,28 & 76,41 & 65,54 & 56,26 & 41,96 & 32,25 & 21,14 \\
\hline 50 & 250 & 20 & 116,25 & 94,89 & 84,82 & 73,64 & 63,94 & 55,48 & 42,06 & 32,60 & 21,40 \\
\hline 50 & 300 & 20 & 108,13 & 89,86 & 81,20 & 71,28 & 62,49 & 54,69 & 42,03 & 32,85 & 21,64 \\
\hline 50 & 350 & 20 & 101,94 & 85,75 & 78,17 & 69,21 & 61,16 & 53,91 & 41,92 & 33,02 & 21,85 \\
\hline 50 & 400 & 20 & 97,03 & 82,29 & 75,58 & 67,40 & 59,94 & 53,16 & 41,76 & 33,13 & 22,05 \\
\hline 50 & 450 & 20 & 93,03 & 79,33 & 73,32 & 65,77 & 58,82 & 52,44 & 41,57 & 33,20 & 22,22 \\
\hline 50 & 500 & 20 & 89,68 & 76,74 & 71,32 & 64,31 & 57,79 & 51,76 & 41,36 & 33,23 & 22,37 \\
\hline 50 & 550 & 20 & 86,84 & 74,45 & 69,53 & 62,98 & 56,84 & 51,11 & 41,13 & 33,23 & 22,50 \\
\hline 50 & 600 & 20 & 84,37 & 72,41 & 67,92 & 61,77 & 55,95 & 50,49 & 40,90 & 33,21 & 22,62 \\
\hline 50 & 650 & 20 & 82,22 & 70,56 & 66,45 & 60,65 & 55,12 & 49,90 & 40,67 & 33,18 & 22,72 \\
\hline 50 & 700 & 20 & 80,30 & 68,89 & 65,10 & 59,62 & 54,35 & 49,35 & 40,43 & 33,13 & 22,81 \\
\hline 50 & 750 & 20 & 78,59 & 67,36 & 63,86 & 58,66 & 53,62 & 48,82 & 40,19 & 33,08 & 22,89 \\
\hline 50 & 800 & 20 & 77,05 & 65,96 & 62,71 & 57,76 & 52,93 & 48,31 & 39,96 & 33,01 & 22,97 \\
\hline 50 & 850 & 20 & 75,65 & 64,66 & 61,64 & 56,92 & 52,28 & 47,82 & 39,73 & 32,94 & 23,03 \\
\hline 50 & 900 & 20 & 74,36 & 63,46 & 60,64 & 56,14 & 51,67 & 47,36 & 39,50 & 32,86 & 23,08 \\
\hline 50 & 950 & 20 & 73,18 & 62,35 & 59,70 & 55,39 & 51,08 & 46,92 & 39,28 & 32,78 & 23,13 \\
\hline 50 & 1000 & 20 & 72,09 & 61,31 & 58,81 & 54,69 & 50,53 & 46,49 & 39,06 & 32,70 & 23,17 \\
\hline 50 & 1050 & 20 & 71,07 & 60,33 & 57,98 & 54,03 & 50,00 & 46,08 & 38,84 & 32,61 & 23,21 \\
\hline 50 & 1100 & 20 & 70,12 & 59,42 & 57,19 & 53,40 & 49,49 & 45,69 & 38,63 & 32,52 & 23,24 \\
\hline 50 & 1150 & 20 & 69,23 & 58,56 & 56,44 & 52,80 & 49,01 & 45,31 & 38,42 & 32,43 & 23,26 \\
\hline 50 & 1200 & 20 & 68,40 & 57,75 & 55,73 & 52,22 & 48,54 & 44,95 & 38,21 & 32,34 & 23,29 \\
\hline 50 & 1250 & 20 & 67,60 & 56,99 & 55,05 & 51,68 & 48,10 & 44,59 & 38,01 & 32,25 & 23,30 \\
\hline 50 & 1300 & 20 & 66,86 & 56,26 & 54,40 & 51,15 & 47,67 & 44,25 & 37,82 & 32,16 & 23,32 \\
\hline 50 & 1350 & 20 & 66,14 & 55,58 & 53,79 & 50,65 & 47,26 & 43,92 & 37,63 & 32,06 & 23,33 \\
\hline 50 & 1400 & 20 & 65,47 & 54,93 & 53,19 & 50,17 & 46,86 & 43,61 & 37,44 & 31,97 & 23,34 \\
\hline 50 & 1450 & 20 & 64,82 & 54,31 & 52,63 & 49,71 & 46,48 & 43,30 & 37,26 & 31,88 & 23,35 \\
\hline 50 & 1500 & 20 & 64,20 & 53,72 & 52,08 & 49,26 & 46,11 & 43,00 & 37,08 & 31,78 & 23,35 \\
\hline 50 & 1550 & 20 & 63,61 & 53,15 & 51,56 & 48,84 & 45,76 & 42,71 & 36,90 & 31,69 & 23,35 \\
\hline 50 & 1600 & 20 & 63,04 & 52,61 & 51,05 & 48,42 & 45,42 & 42,43 & 36,73 & 31,60 & 23,35 \\
\hline 50 & 1650 & 20 & 62,49 & 52,10 & 50,57 & 48,02 & 45,08 & 42,16 & 36,56 & 31,51 & 23,35 \\
\hline 50 & 1700 & 20 & 61,97 & 51,61 & 50,10 & 47,64 & 44,76 & 41,89 & 36,39 & 31,41 & 23,34 \\
\hline 50 & 1750 & 20 & 61,46 & 51,13 & 49,65 & 47,27 & 44,45 & 41,64 & 36,23 & 31,32 & 23,34 \\
\hline 50 & 1800 & 20 & 60,97 & 50,68 & 49,21 & 46,91 & 44,15 & 41,39 & 36,07 & 31,23 & 23,33 \\
\hline 50 & 1850 & 20 & 60,49 & 50,24 & 48,79 & 46,56 & 43,85 & 41,14 & 35,91 & 31,14 & 23,32 \\
\hline 50 & 1900 & 20 & 60,03 & 49,83 & 48,38 & 46,22 & 43,57 & 40,90 & 35,76 & 31,06 & 23,31 \\
\hline 50 & 1950 & 20 & 59,59 & 49,42 & 47,99 & 45,89 & 43,29 & 40,67 & 35,61 & 30,97 & 23,30 \\
\hline 50 & 2000 & 20 & 59,15 & 49,03 & 47,60 & 45,57 & 43,02 & 40,45 & 35,46 & 30,88 & 23,29 \\
\hline 50 & 200 & 25 & 112,34 & 86,45 & 75,00 & 63,20 & 53,52 & 45,46 & 33,39 & 25,48 & 16,73 \\
\hline 50 & 250 & 25 & 102,01 & 81,05 & 71,43 & 61,13 & 52,43 & 45,01 & 33,57 & 25,80 & 16,91 \\
\hline 50 & 300 & 25 & 94,56 & 76,83 & 68,51 & 59,33 & 51,40 & 44,51 & 33,64 & 26,03 & 17,08 \\
\hline 50 & 350 & 25 & 88,88 & 73,39 & 66,05 & 57,74 & 50,44 & 44,00 & 33,64 & 26,21 & 17,24 \\
\hline 50 & 400 & 25 & 84,37 & 70,50 & 63,94 & 56,33 & 49,55 & 43,50 & 33,59 & 26,34 & 17,38 \\
\hline 50 & 450 & 25 & 80,70 & 68,01 & 62,10 & 55,07 & 48,72 & 43,00 & 33,51 & 26,44 & 17,52 \\
\hline 50 & 500 & 25 & 77,63 & 65,84 & 60,46 & 53,92 & 47,95 & 42,52 & 33,41 & 26,50 & 17,64 \\
\hline 50 & 550 & 25 & 75,02 & 63,91 & 59,00 & 52,87 & 47,23 & 42,06 & 33,29 & 26,55 & 17,75 \\
\hline 50 & 600 & 25 & 72,76 & 62,19 & 57,67 & 51,90 & 46,56 & 41,62 & 33,15 & 26,57 & 17,85 \\
\hline 50 & 650 & 25 & 70,79 & 60,63 & 56,46 & 51,01 & 45,92 & 41,19 & 33,01 & 26,58 & 17,94 \\
\hline 50 & 700 & 25 & 69,05 & 59,22 & 55,36 & 50,19 & 45,33 & 40,78 & 32,87 & 26,58 & 18,02 \\
\hline
\end{tabular}




\begin{tabular}{|c|c|c|c|c|c|c|c|c|c|c|c|}
\hline \multirow[b]{2}{*}{$\mathrm{H}(\mathrm{cm})$} & \multirow[b]{2}{*}{ Mceq (MPa) } & & & & & De & ões (x1 & m) & & & \\
\hline & & Msub (MPa) & D0 & D25 & D40 & D60 & D80 & D100 & D140 & D180 & D260 \\
\hline 50 & 750 & 25 & 67,50 & 57,92 & 54,33 & 49,42 & 44,76 & 40,39 & 32,72 & 26,57 & 18,09 \\
\hline 50 & 800 & 25 & 66,10 & 56,73 & 53,38 & 48,70 & 44,23 & 40,02 & 32,57 & 26,55 & 18,16 \\
\hline 50 & 850 & 25 & 64,83 & 55,63 & 52,50 & 48,02 & 43,72 & 39,65 & 32,42 & 26,52 & 18,22 \\
\hline 50 & 900 & 25 & 63,68 & 54,61 & 51,67 & 47,38 & 43,24 & 39,31 & 32,27 & 26,49 & 18,28 \\
\hline 50 & 950 & 25 & 62,62 & 53,66 & 50,90 & 46,78 & 42,78 & 38,97 & 32,12 & 26,45 & 18,33 \\
\hline 50 & 1000 & 25 & 61,64 & 52,77 & 50,17 & 46,21 & 42,34 & 38,65 & 31,97 & 26,41 & 18,37 \\
\hline 50 & 1050 & 25 & 60,74 & 51,93 & 49,48 & 45,67 & 41,93 & 38,34 & 31,82 & 26,37 & 18,41 \\
\hline 50 & 1100 & 25 & 59,89 & 51,15 & 48,82 & 45,16 & 41,53 & 38,04 & 31,67 & 26,32 & 18,45 \\
\hline 50 & 1150 & 25 & 59,10 & 50,41 & 48,20 & 44,67 & 41,14 & 37,74 & 31,53 & 26,27 & 18,48 \\
\hline 50 & 1200 & 25 & 58,37 & 49,71 & 47,61 & 44,20 & 40,77 & 37,46 & 31,38 & 26,21 & 18,51 \\
\hline 50 & 1250 & 25 & 57,67 & 49,05 & 47,05 & 43,75 & 40,42 & 37,19 & 31,24 & 26,16 & 18,54 \\
\hline 50 & 1300 & 25 & 57,02 & 48,42 & 46,51 & 43,33 & 40,08 & 36,93 & 31,11 & 26,10 & 18,56 \\
\hline 50 & 1350 & 25 & 56,40 & 47,82 & 46,00 & 42,92 & 39,75 & 36,68 & 30,97 & 26,05 & 18,58 \\
\hline 50 & 1400 & 25 & 55,81 & 47,26 & 45,51 & 42,52 & 39,43 & 36,43 & 30,83 & 25,99 & 18,60 \\
\hline 50 & 1450 & 25 & 55,25 & 46,72 & 45,04 & 42,14 & 39,13 & 36,19 & 30,70 & 25,93 & 18,62 \\
\hline 50 & 1500 & 25 & 54,72 & 46,20 & 44,58 & 41,78 & 38,83 & 35,96 & 30,57 & 25,87 & 18,63 \\
\hline 50 & 1550 & 25 & 54,21 & 45,71 & 44,15 & 41,43 & 38,55 & 35,73 & 30,44 & 25,81 & 18,64 \\
\hline 50 & 1600 & 25 & 53,72 & 45,24 & 43,73 & 41,09 & 38,27 & 35,51 & 30,32 & 25,75 & 18,65 \\
\hline 50 & 1650 & 25 & 53,25 & 44,79 & 43,32 & 40,76 & 38,00 & 35,30 & 30,19 & 25,69 & 18,66 \\
\hline 50 & 1700 & 25 & 52,80 & 44,36 & 42,93 & 40,44 & 37,74 & 35,09 & 30,07 & 25,63 & 18,67 \\
\hline 50 & 1750 & 25 & 52,37 & 43,94 & 42,55 & 40,14 & 37,49 & 34,89 & 29,95 & 25,58 & 18,67 \\
\hline 50 & 1800 & 25 & 51,96 & 43,54 & 42,19 & 39,84 & 37,25 & 34,69 & 29,83 & 25,52 & 18,68 \\
\hline 50 & 1850 & 25 & 51,56 & 43,16 & 41,84 & 39,55 & 37,01 & 34,50 & 29,72 & 25,46 & 18,68 \\
\hline 50 & 1900 & 25 & 51,17 & 42,79 & 41,50 & 39,27 & 36,78 & 34,31 & 29,60 & 25,40 & 18,68 \\
\hline 50 & 1950 & 25 & 50,80 & 42,43 & 41,16 & 39,00 & 36,55 & 34,12 & 29,49 & 25,34 & 18,68 \\
\hline 50 & 2000 & 25 & 50,43 & 42,09 & 40,84 & 38,74 & 36,33 & 33,94 & 29,38 & 25,28 & 18,68 \\
\hline 50 & 200 & 30 & 101,58 & 75,89 & 64,93 & 53,98 & 45,22 & 38,08 & 27,65 & 21,02 & 13,85 \\
\hline 50 & 250 & 30 & 91,95 & 71,20 & 61,96 & 52,36 & 44,45 & 37,83 & 27,86 & 21,28 & 13,97 \\
\hline 50 & 300 & 30 & 85,01 & 67,54 & 59,52 & 50,94 & 43,69 & 37,51 & 27,97 & 21,50 & 14,09 \\
\hline 50 & 350 & 30 & 79,71 & 64,56 & 57,46 & 49,68 & 42,97 & 37,17 & 28,03 & 21,67 & 14,21 \\
\hline 50 & 400 & 30 & 75,51 & 62,06 & 55,69 & 48,54 & 42,29 & 36,81 & 28,04 & 21,80 & 14,32 \\
\hline 50 & 450 & 30 & 72,09 & 59,90 & 54,13 & 47,52 & 41,66 & 36,46 & 28,02 & 21,90 & 14,43 \\
\hline 50 & 500 & 30 & 69,22 & 58,02 & 52,75 & 46,58 & 41,06 & 36,11 & 27,97 & 21,98 & 14,52 \\
\hline 50 & 550 & 30 & 66,79 & 56,36 & 51,51 & 45,72 & 40,49 & 35,77 & 27,91 & 22,04 & 14,61 \\
\hline 50 & 600 & 30 & 64,69 & 54,86 & 50,39 & 44,93 & 39,96 & 35,44 & 27,84 & 22,09 & 14,70 \\
\hline 50 & 650 & 30 & 62,85 & 53,51 & 49,36 & 44,20 & 39,46 & 35,12 & 27,76 & 22,12 & 14,77 \\
\hline 50 & 700 & 30 & 61,23 & 52,29 & 48,42 & 43,51 & 38,98 & 34,80 & 27,67 & 22,14 & 14,85 \\
\hline 50 & 750 & 30 & 59,79 & 51,16 & 47,55 & 42,87 & 38,53 & 34,50 & 27,57 & 22,15 & 14,91 \\
\hline 50 & 800 & 30 & 58,49 & 50,12 & 46,74 & 42,28 & 38,10 & 34,21 & 27,47 & 22,15 & 14,97 \\
\hline 50 & 850 & 30 & 57,32 & 49,16 & 45,98 & 41,71 & 37,69 & 33,93 & 27,37 & 22,15 & 15,03 \\
\hline 50 & 900 & 30 & 56,25 & 48,27 & 45,28 & 41,18 & 37,30 & 33,66 & 27,27 & 22,14 & 15,08 \\
\hline 50 & 950 & 30 & 55,27 & 47,44 & 44,62 & 40,68 & 36,93 & 33,40 & 27,16 & 22,13 & 15,13 \\
\hline 50 & 1000 & 30 & 54,37 & 46,66 & 43,99 & 40,20 & 36,57 & 33,14 & 27,06 & 22,11 & 15,17 \\
\hline 50 & 1050 & 30 & 53,54 & 45,93 & 43,40 & 39,75 & 36,23 & 32,90 & 26,95 & 22,09 & 15,21 \\
\hline 50 & 1100 & 30 & 52,76 & 45,24 & 42,84 & 39,31 & 35,90 & 32,66 & 26,85 & 22,07 & 15,25 \\
\hline 50 & 1150 & 30 & 52,04 & 44,59 & 42,31 & 38,90 & 35,59 & 32,43 & 26,74 & 22,04 & 15,28 \\
\hline 50 & 1200 & 30 & 51,37 & 43,97 & 41,81 & 38,51 & 35,29 & 32,21 & 26,64 & 22,01 & 15,31 \\
\hline 50 & 1250 & 30 & 50,73 & 43,39 & 41,32 & 38,13 & 35,00 & 31,99 & 26,54 & 21,98 & 15,34 \\
\hline 50 & 1300 & 30 & 50,14 & 42,84 & 40,86 & 37,77 & 34,71 & 31,78 & 26,43 & 21,94 & 15,36 \\
\hline 50 & 1350 & 30 & 49,58 & 42,31 & 40,42 & 37,42 & 34,44 & 31,57 & 26,33 & 21,91 & 15,39 \\
\hline 50 & 1400 & 30 & 49,04 & 41,81 & 40,00 & 37,09 & 34,18 & 31,38 & 26,23 & 21,87 & 15,41 \\
\hline 50 & 1450 & 30 & 48,54 & 41,33 & 39,60 & 36,77 & 33,93 & 31,18 & 26,13 & 21,84 & 15,43 \\
\hline 50 & 1500 & 30 & 48,06 & 40,87 & 39,21 & 36,46 & 33,68 & 30,99 & 26,04 & 21,80 & 15,45 \\
\hline 50 & 1550 & 30 & 47,60 & 40,43 & 38,83 & 36,16 & 33,45 & 30,81 & 25,94 & 21,76 & 15,46 \\
\hline 50 & 1600 & 30 & 47,17 & 40,02 & 38,47 & 35,88 & 33,22 & 30,63 & 25,84 & 21,72 & 15,48 \\
\hline 50 & 1650 & 30 & 46,75 & 39,61 & 38,13 & 35,60 & 32,99 & 30,46 & 25,75 & 21,68 & 15,49 \\
\hline 50 & 1700 & 30 & 46,35 & 39,23 & 37,79 & 35,33 & 32,78 & 30,29 & 25,66 & 21,64 & 15,50 \\
\hline 50 & 1750 & 30 & 45,97 & 38,86 & 37,47 & 35,07 & 32,57 & 30,12 & 25,57 & 21,60 & 15,51 \\
\hline 50 & 1800 & 30 & 45,60 & 38,50 & 37,15 & 34,82 & 32,36 & 29,96 & 25,48 & 21,56 & 15,52 \\
\hline 50 & 1850 & 30 & 45,24 & 38,16 & 36,85 & 34,57 & 32,16 & 29,81 & 25,39 & 21,52 & 15,53 \\
\hline 50 & 1900 & 30 & 44,90 & 37,83 & 36,55 & 34,33 & 31,97 & 29,65 & 25,30 & 21,48 & 15,54 \\
\hline 50 & 1950 & 30 & 44,57 & 37,51 & 36,27 & 34,10 & 31,78 & 29,50 & 25,21 & 21,44 & 15,55 \\
\hline 50 & 2000 & 30 & 44,25 & 37,20 & 35,99 & 33,88 & 31,60 & 29,36 & 25,13 & 21,40 & 15,55 \\
\hline 50 & 200 & 35 & 93,48 & 67,95 & 57,41 & 47,15 & 39,14 & 32,73 & 23,55 & 17,85 & 11,81 \\
\hline 50 & 250 & 35 & 84,39 & 63,78 & 54,87 & 45,85 & 38,57 & 32,59 & 23,76 & 18,08 & 11,90 \\
\hline 50 & 300 & 35 & 77,85 & 60,54 & 52,78 & 44,70 & 38,00 & 32,39 & 23,90 & 18,27 & 11,99 \\
\hline 50 & 350 & 35 & 72,86 & 57,90 & 51,02 & 43,66 & 37,45 & 32,15 & 23,98 & 18,43 & 12,08 \\
\hline 50 & 400 & 35 & 68,91 & 55,68 & 49,49 & 42,73 & 36,92 & 31,90 & 24,02 & 18,55 & 12,16 \\
\hline 50 & 450 & 35 & 65,68 & 53,77 & 48,15 & 41,88 & 36,41 & 31,64 & 24,03 & 18,65 & 12,25 \\
\hline 50 & 500 & 35 & 62,98 & 52,11 & 46,95 & 41,10 & 35,94 & 31,38 & 24,03 & 18,74 & 12,33 \\
\hline 50 & 550 & 35 & 60,68 & 50,63 & 45,88 & 40,38 & 35,48 & 31,12 & 24,00 & 18,80 & 12,40 \\
\hline 50 & 600 & 35 & 58,71 & 49,31 & 44,90 & 39,71 & 35,05 & 30,87 & 23,96 & 18,86 & 12,47 \\
\hline 50 & 650 & 35 & 56,98 & 48,11 & 44,01 & 39,09 & 34,64 & 30,62 & 23,92 & 18,90 & 12,54 \\
\hline 50 & 700 & 35 & 55,45 & 47.03 & 43,19 & 38,51 & 34,25 & 30,37 & 23,86 & 18,93 & 12,60 \\
\hline 50 & 750 & 35 & 54,09 & 46,03 & 42,43 & 37,97 & 33,88 & 30,14 & 23,80 & 18,96 & 12,65 \\
\hline 50 & 800 & 35 & 52,87 & 45,11 & 41,72 & 37,46 & 33,53 & 29,91 & 23,74 & 18,97 & 12,71 \\
\hline 50 & 850 & 35 & 51,76 & 44,25 & 41,07 & 36,98 & 33,19 & 29,68 & 23,67 & 18,98 & 12,76 \\
\hline 50 & 900 & 35 & 50,76 & 43,46 & 40,45 & 36,53 & 32,86 & 29,47 & 23,60 & 18,99 & 12,80 \\
\hline 50 & 950 & 35 & 49,84 & 42,72 & 39,87 & 36,10 & 32,55 & 29,26 & 23,52 & 18,99 & 12,85 \\
\hline 50 & 1000 & 35 & 48,99 & 42,03 & 39,33 & 35,69 & 32,26 & 29,05 & 23,45 & 18,99 & 12,89 \\
\hline 50 & 1050 & 35 & 48,21 & 41,37 & 38,81 & 35,30 & 31,97 & 28,85 & 23,37 & 18,98 & 12,92 \\
\hline
\end{tabular}




\begin{tabular}{|c|c|c|c|c|c|c|c|c|c|c|c|}
\hline \multirow[b]{2}{*}{$\mathrm{H}(\mathrm{cm})$} & \multirow[b]{2}{*}{ Mceq (MPa) } & & & & & De & ões (x1 & m) & & & \\
\hline & & Msub (MPa) & D0 & D25 & D40 & D60 & D80 & D100 & D140 & D180 & D260 \\
\hline 50 & 1100 & 35 & 47,49 & 40,76 & 38,32 & 34,93 & 31,70 & 28,66 & 23,30 & 18,97 & 12,96 \\
\hline 50 & 1150 & 35 & 46,82 & 40,18 & 37,86 & 34,57 & 31,43 & 28,47 & 23,22 & 18,96 & 12,99 \\
\hline 50 & 1200 & 35 & 46,19 & 39,63 & 37,41 & 34,23 & 31,18 & 28,29 & 23,14 & 18,94 & 13,02 \\
\hline 50 & 1250 & 35 & 45,60 & 39,11 & 36,99 & 33,91 & 30,93 & 28,11 & 23,06 & 18,93 & 13,05 \\
\hline 50 & 1300 & 35 & 45,04 & 38,61 & 36,59 & 33,60 & 30,70 & 27,94 & 22,99 & 18,91 & 13,08 \\
\hline 50 & 1350 & 35 & 44,52 & 38,14 & 36,20 & 33,30 & 30,47 & 27,77 & 22,91 & 18,89 & 13,10 \\
\hline 50 & 1400 & 35 & 44,03 & 37,69 & 35,83 & 33,01 & 30,25 & 27,60 & 22,83 & 18,86 & 13,12 \\
\hline 50 & 1450 & 35 & 43,56 & 37,26 & 35,48 & 32,73 & 30,03 & 27,45 & 22,76 & 18,84 & 13,14 \\
\hline 50 & 1500 & 35 & 43,12 & 36,85 & 35,14 & 32,46 & 29,82 & 27,29 & 22,68 & 18,82 & 13,16 \\
\hline 50 & 1550 & 35 & 42,70 & 36,46 & 34,81 & 32,20 & 29,62 & 27,14 & 22,61 & 18,79 & 13,18 \\
\hline 50 & 1600 & 35 & 42,30 & 36,08 & 34,49 & 31,95 & 29,43 & 26,99 & 22,53 & 18,77 & 13,20 \\
\hline 50 & 1650 & 35 & 41,91 & 35,72 & 34,19 & 31,71 & 29,24 & 26,85 & 22,46 & 18,74 & 13,21 \\
\hline 50 & 1700 & 35 & 41,55 & 35,37 & 33,89 & 31,48 & 29,05 & 26,70 & 22,39 & 18,71 & 13,23 \\
\hline 50 & 1750 & 35 & 41,19 & 35,03 & 33,61 & 31,25 & 28,87 & 26,57 & 22,32 & 18,69 & 13,24 \\
\hline 50 & 1800 & 35 & 40,86 & 34,71 & 33,33 & 31,03 & 28,70 & 26,43 & 22,25 & 18,66 & 13,25 \\
\hline 50 & 1850 & 35 & 40,53 & 34,40 & 33,07 & 30,82 & 28,53 & 26,30 & 22,18 & 18,63 & 13,26 \\
\hline 50 & 1900 & 35 & 40,22 & 34,10 & 32,81 & 30,61 & 28,36 & 26,17 & 22,11 & 18,60 & 13,27 \\
\hline 50 & 1950 & 35 & 39,92 & 33,81 & 32,56 & 30,41 & 28,20 & 26,05 & 22,04 & 18,57 & 13,28 \\
\hline 50 & 2000 & 35 & 39,63 & 33,53 & 32,31 & 30,22 & 28,04 & 25,92 & 21,97 & 18,54 & 13,29 \\
\hline 50 & 200 & 40 & 87,13 & 61,73 & 51,55 & 41,87 & 34,49 & 28,66 & 20,48 & 15,51 & 10,30 \\
\hline 50 & 250 & 40 & 78,47 & 57,97 & 49,34 & 40,81 & 34,06 & 28,60 & 20,69 & 15,70 & 10,36 \\
\hline 50 & 300 & 40 & 72,25 & 55,04 & 47,52 & 39,86 & 33,63 & 28,47 & 20,83 & 15,87 & 10,43 \\
\hline 50 & 350 & 40 & 67,51 & 52,66 & 45,98 & 38,99 & 33,19 & 28,31 & 20,92 & 16,01 & 10,50 \\
\hline 50 & 400 & 40 & 63,75 & 50,66 & 44,64 & 38,21 & 32,77 & 28,13 & 20,98 & 16,12 & 10,57 \\
\hline 50 & 450 & 40 & 60,69 & 48,94 & 43,46 & 37,49 & 32,36 & 27,94 & 21,01 & 16,22 & 10,63 \\
\hline 50 & 500 & 40 & 58,12 & 47,44 & 42,41 & 36,82 & 31,97 & 27,74 & 21,03 & 16,30 & 10,70 \\
\hline 50 & 550 & 40 & 55,95 & 46,12 & 41,46 & 36,21 & 31,60 & 27,54 & 21,03 & 16,37 & 10,76 \\
\hline 50 & 600 & 40 & 54,06 & 44,93 & 40,60 & 35,64 & 31,24 & 27,34 & 21,01 & 16,43 & 10,82 \\
\hline 50 & 650 & 40 & 52,42 & 43,85 & 39,81 & 35,11 & 30,90 & 27,15 & 20,99 & 16,47 & 10,87 \\
\hline 50 & 700 & 40 & 50,97 & 42,87 & 39,09 & 34,61 & 30,58 & 26,95 & 20,96 & 16,51 & 10,93 \\
\hline 50 & 750 & 40 & 49,68 & 41,98 & 38,41 & 34,14 & 30,27 & 26,76 & 20,92 & 16,54 & 10,98 \\
\hline 50 & 800 & 40 & 48,52 & 41,15 & 37,79 & 33,70 & 29,97 & 26,58 & 20,88 & 16,57 & 11,02 \\
\hline 50 & 850 & 40 & 47,47 & 40,38 & 37,21 & 33,28 & 29,69 & 26,40 & 20,83 & 16,58 & 11,07 \\
\hline 50 & 900 & 40 & 46,52 & 39,66 & 36,66 & 32,89 & 29,41 & 26,22 & 20,78 & 16,60 & 11,11 \\
\hline 50 & 950 & 40 & 45,64 & 39,00 & 36,14 & 32,51 & 29,15 & 26,05 & 20,73 & 16,61 & 11,15 \\
\hline 50 & 1000 & 40 & 44,84 & 38,37 & 35,66 & 32,16 & 28,90 & 25,88 & 20,68 & 16,61 & 11,18 \\
\hline 50 & 1050 & 40 & 44,10 & 37,78 & 35,20 & 31,82 & 28,65 & 25,71 & 20,62 & 16,62 & 11,22 \\
\hline 50 & 1100 & 40 & 43,42 & 37,23 & 34,77 & 31,49 & 28,42 & 25,55 & 20,57 & 16,62 & 11,25 \\
\hline 50 & 1150 & 40 & 42,78 & 36,70 & 34,35 & 31,18 & 28,19 & 25,40 & 20,51 & 16,61 & 11,28 \\
\hline 50 & 1200 & 40 & 42,19 & 36,20 & 33,96 & 30,88 & 27,98 & 25,25 & 20,45 & 16,61 & 11,31 \\
\hline 50 & 1250 & 40 & 41,63 & 35,73 & 33,58 & 30,60 & 27,77 & 25,10 & 20,39 & 16,60 & 11,34 \\
\hline 50 & 1300 & 40 & 41,11 & 35,28 & 33,22 & 30,33 & 27,56 & 24,95 & 20,33 & 16,59 & 11,36 \\
\hline 50 & 1350 & 40 & 40,62 & 34,85 & 32,88 & 30,06 & 27,36 & 24,81 & 20,27 & 16,58 & 11,38 \\
\hline 50 & 1400 & 40 & 40,15 & 34,44 & 32,55 & 29,81 & 27,17 & 24,67 & 20,21 & 16,57 & 11,41 \\
\hline 50 & 1450 & 40 & 39,71 & 34,05 & 32,23 & 29,57 & 26,99 & 24,54 & 20,16 & 16,55 & 11,43 \\
\hline 50 & 1500 & 40 & 39,30 & 33,68 & 31,93 & 29,33 & 26,81 & 24,41 & 20,10 & 16,54 & 11,45 \\
\hline 50 & 1550 & 40 & 38,90 & 33,32 & 31,64 & 29,10 & 26,63 & 24,28 & 20,04 & 16,52 & 11,47 \\
\hline 50 & 1600 & 40 & 38,53 & 32,98 & 31,35 & 28,88 & 26,47 & 24,15 & 19,98 & 16,51 & 11,48 \\
\hline 50 & 1650 & 40 & 38,17 & 32,65 & 31,08 & 28,67 & 26,30 & 24,03 & 19,92 & 16,49 & 11,50 \\
\hline 50 & 1700 & 40 & 37,82 & 32,33 & 30,82 & 28,46 & 26,14 & 23,91 & 19,86 & 16,47 & 11,51 \\
\hline 50 & 1750 & 40 & 37,50 & 32,03 & 30,56 & 28,26 & 25,98 & 23,80 & 19,81 & 16,45 & 11,53 \\
\hline 50 & 1800 & 40 & 37,18 & 31,73 & 30,32 & 28,07 & 25,83 & 23,68 & 19,75 & 16,43 & 11,54 \\
\hline 50 & 1850 & 40 & 36,88 & 31,45 & 30,08 & 27,88 & 25,68 & 23,57 & 19,69 & 16,41 & 11,55 \\
\hline 50 & 1900 & 40 & 36,59 & 31,17 & 29,85 & 27,70 & 25,54 & 23,46 & 19,64 & 16,39 & 11,57 \\
\hline 50 & 1950 & 40 & 36,31 & 30,91 & 29,62 & 27,52 & 25,40 & 23,35 & 19,58 & 16,37 & 11,58 \\
\hline 50 & 2000 & 40 & 36,05 & 30,65 & 29,41 & 27,35 & 25,26 & 23,25 & 19,53 & 16,35 & 11,59 \\
\hline 50 & 200 & 45 & 81,98 & 56,72 & 46,84 & 37,67 & 30,81 & 25,48 & 18,10 & 13,70 & 9,13 \\
\hline 50 & 250 & 45 & 73,68 & 53,27 & 44,90 & 36,79 & 30,49 & 25,46 & 18,29 & 13,86 & 9,18 \\
\hline 50 & 300 & 45 & 67,72 & 50,59 & 43,29 & 35,99 & 30,15 & 25,39 & 18,43 & 14,01 & 9,23 \\
\hline 50 & 350 & 45 & 63,19 & 48,42 & 41,92 & 35,25 & 29,80 & 25,28 & 18,53 & 14,13 & 9,28 \\
\hline 50 & 400 & 45 & 59,60 & 46,59 & 40,73 & 34,58 & 29,46 & 25,15 & 18,60 & 14,24 & 9,34 \\
\hline 50 & 450 & 45 & 56,67 & 45,03 & 39,68 & 33,96 & 29,13 & 25,01 & 18,65 & 14,33 & 9,39 \\
\hline 50 & 500 & 45 & 54,22 & 43,66 & 38,74 & 33,39 & 28,80 & 24,85 & 18,68 & 14,41 & 9,45 \\
\hline 50 & 550 & 45 & 52,14 & 42,45 & 37,90 & 32,86 & 28,49 & 24,70 & 18,69 & 14,48 & 9,50 \\
\hline 50 & 600 & 45 & 50,34 & 41,37 & 37,13 & 32,36 & 28,20 & 24,54 & 18,69 & 14,53 & 9,55 \\
\hline 50 & 650 & 45 & 48,77 & 40,39 & 36,42 & 31,90 & 27,91 & 24,38 & 18,69 & 14,58 & 9,59 \\
\hline 50 & 700 & 45 & 47,38 & 39,50 & 35,77 & 31,46 & 27,64 & 24,23 & 18,67 & 14,62 & 9,64 \\
\hline 50 & 750 & 45 & 46,15 & 38,68 & 35,17 & 31,05 & 27,37 & 24,07 & 18,65 & 14,65 & 9,68 \\
\hline 50 & 800 & 45 & 45,04 & 37,93 & 34,61 & 30,67 & 27,12 & 23,92 & 18,62 & 14,68 & 9,72 \\
\hline 50 & 850 & 45 & 44,04 & 37,23 & 34,08 & 30,30 & 26,87 & 23,77 & 18,59 & 14,71 & 9,76 \\
\hline 50 & 900 & 45 & 43,13 & 36,58 & 33,59 & 29,95 & 26,64 & 23,62 & 18,56 & 14,72 & 9,80 \\
\hline 50 & 950 & 45 & 42,29 & 35,97 & 33,13 & 29,62 & 26,41 & 23,48 & 18,52 & 14,74 & 9,83 \\
\hline 50 & 1000 & 45 & 41,53 & 35,39 & 32,69 & 29,31 & 26,20 & 23,34 & 18,48 & 14,75 & 9,87 \\
\hline 50 & 1050 & 45 & 40,82 & 34,86 & 32,28 & 29,01 & 25,99 & 23,20 & 18,44 & 14,76 & 9,90 \\
\hline 50 & 1100 & 45 & 40,17 & 34,35 & 31,89 & 28,72 & 25,78 & 23,07 & 18,40 & 14,77 & 9,93 \\
\hline 50 & 1150 & 45 & 39,56 & 33,87 & 31,51 & 28,45 & 25,59 & 22,94 & 18,36 & 14,77 & 9,95 \\
\hline 50 & 1200 & 45 & 38,99 & 33,42 & 31,16 & 28,18 & 25,40 & 22,81 & 18,31 & 14,77 & 9,98 \\
\hline 50 & 1250 & 45 & 38,46 & 32,98 & 30,82 & 27,93 & 25,22 & 22,68 & 18,27 & 14,77 & 10,01 \\
\hline 50 & 1300 & 45 & 37,97 & 32,57 & 30,50 & 27,69 & 25,04 & 22,56 & 18,22 & 14,77 & 10,03 \\
\hline 50 & 1350 & 45 & 37,50 & 32,18 & 30,19 & 27,45 & 24,87 & 22,44 & 18,18 & 14,76 & 10,05 \\
\hline 50 & 1400 & 45 & 37,06 & 31,81 & 29,89 & 27,23 & 24,70 & 22,32 & 18,13 & 14,76 & 10,07 \\
\hline
\end{tabular}




\begin{tabular}{|c|c|c|c|c|c|c|c|c|c|c|c|}
\hline \multirow[b]{2}{*}{$\mathrm{H}(\mathrm{cm})$} & \multirow[b]{2}{*}{ Mceq (MPa) } & & & & & De & ões (x1 & m) & & & \\
\hline & & Msub (MPa) & D0 & D25 & D40 & D60 & D80 & D100 & D140 & D180 & D260 \\
\hline 50 & 1450 & 45 & 36,64 & 31,45 & 29,60 & 27,01 & 24,54 & 22,21 & 18,09 & 14,75 & 10,09 \\
\hline 50 & 1500 & 45 & 36,25 & 31,11 & 29,33 & 26,80 & 24,38 & 22,10 & 18,04 & 14,74 & 10,11 \\
\hline 50 & 1550 & 45 & 35,87 & 30,78 & 29,06 & 26,60 & 24,23 & 21,99 & 17,99 & 14,73 & 10,13 \\
\hline 50 & 1600 & 45 & 35,51 & 30,46 & 28,81 & 26,40 & 24,08 & 21,88 & 17,95 & 14,72 & 10,15 \\
\hline 50 & 1650 & 45 & 35,18 & 30,16 & 28,56 & 26,21 & 23,94 & 21,77 & 17,90 & 14,71 & 10,16 \\
\hline 50 & 1700 & 45 & 34,85 & 29,87 & 28,32 & 26,03 & 23,80 & 21,67 & 17,85 & 14,70 & 10,18 \\
\hline 50 & 1750 & 45 & 34,54 & 29,59 & 28,09 & 25,85 & 23,66 & 21,57 & 17,81 & 14,69 & 10,19 \\
\hline 50 & 1800 & 45 & 34,24 & 29,31 & 27,87 & 25,67 & 23,52 & 21,47 & 17,76 & 14,67 & 10,21 \\
\hline 50 & 1850 & 45 & 33,96 & 29,05 & 27,66 & 25,50 & 23,39 & 21,37 & 17,71 & 14,66 & 10,22 \\
\hline 50 & 1900 & 45 & 33,69 & 28,80 & 27,45 & 25,34 & 23,27 & 21,28 & 17,67 & 14,64 & 10,23 \\
\hline 50 & 1950 & 45 & 33,43 & 28,56 & 27,24 & 25,18 & 23,14 & 21,19 & 17,62 & 14,63 & 10,24 \\
\hline 50 & 2000 & 45 & 33,17 & 28,32 & 27,05 & 25,03 & 23,02 & 21,09 & 17,58 & 14,61 & 10,25 \\
\hline 50 & 200 & 50 & 77,72 & 52,59 & 42,98 & 34,24 & 27,83 & 22,91 & 16,20 & 12,26 & 8,21 \\
\hline 50 & 250 & 50 & 69,70 & 49,39 & 41,24 & 33,50 & 27,59 & 22,93 & 16,38 & 12,40 & 8,24 \\
\hline 50 & 300 & 50 & 63,97 & 46,91 & 39,80 & 32,81 & 27,32 & 22,89 & 16,52 & 12,53 & 8,28 \\
\hline 50 & 350 & 50 & 59,62 & 44,90 & 38,57 & 32,18 & 27,04 & 22,82 & 16,62 & 12,64 & 8,32 \\
\hline 50 & 400 & 50 & 56,17 & 43,22 & 37,50 & 31,60 & 26,76 & 22,73 & 16,70 & 12,74 & 8,37 \\
\hline 50 & 450 & 50 & 53,35 & 41,78 & 36,56 & 31,06 & 26,48 & 22,62 & 16,75 & 12,83 & 8,41 \\
\hline 50 & 500 & 50 & 51,00 & 40,53 & 35,71 & 30,56 & 26,21 & 22,51 & 16,78 & 12,90 & 8,45 \\
\hline 50 & 550 & 50 & 49,00 & 39,41 & 34,95 & 30,10 & 25,95 & 22,38 & 16,81 & 12,96 & 8,50 \\
\hline 50 & 600 & 50 & 47,28 & 38,42 & 34,25 & 29,66 & 25,70 & 22,26 & 16,82 & 13,02 & 8,54 \\
\hline 50 & 650 & 50 & 45,77 & 37,52 & 33,62 & 29,26 & 25,46 & 22,13 & 16,82 & 13,06 & 8,58 \\
\hline 50 & 700 & 50 & 44,44 & 36,70 & 33,03 & 28,87 & 25,22 & 22,00 & 16,82 & 13,11 & 8,62 \\
\hline 50 & 750 & 50 & 43,25 & 35,94 & 32,48 & 28,51 & 24,99 & 21,88 & 16,81 & 13,14 & 8,66 \\
\hline 50 & 800 & 50 & 42,19 & 35,25 & 31,97 & 28,17 & 24,78 & 21,75 & 16,80 & 13,17 & 8,69 \\
\hline 50 & 850 & 50 & 41,22 & 34,60 & 31,50 & 27,84 & 24,56 & 21,62 & 16,78 & 13,20 & 8,72 \\
\hline 50 & 900 & 50 & 40,35 & 34,00 & 31,05 & 27,53 & 24,36 & 21,50 & 16,76 & 13,22 & 8,76 \\
\hline 50 & 950 & 50 & 39,55 & 33,44 & 30,63 & 27,24 & 24,17 & 21,38 & 16,73 & 13,24 & 8,79 \\
\hline 50 & 1000 & 50 & 38,81 & 32,92 & 30,23 & 26,96 & 23,98 & 21,26 & 16,70 & 13,25 & 8,82 \\
\hline 50 & 1050 & 50 & 38,14 & 32,42 & 29,86 & 26,69 & 23,79 & 21,15 & 16,67 & 13,26 & 8,85 \\
\hline 50 & 1100 & 50 & 37,51 & 31,96 & 29,50 & 26,43 & 23,62 & 21,03 & 16,64 & 13,27 & 8,87 \\
\hline 50 & 1150 & 50 & 36,93 & 31,51 & 29,16 & 26,19 & 23,44 & 20,92 & 16,61 & 13,28 & 8,90 \\
\hline 50 & 1200 & 50 & 36,38 & 31,09 & 28,84 & 25,95 & 23,28 & 20,81 & 16,58 & 13,29 & 8,92 \\
\hline 50 & 1250 & 50 & 35,87 & 30,70 & 28,53 & 25,72 & 23,12 & 20,70 & 16,54 & 13,29 & 8,95 \\
\hline 50 & 1300 & 50 & 35,40 & 30,32 & 28,23 & 25,51 & 22,96 & 20,60 & 16,51 & 13,29 & 8,97 \\
\hline 50 & 1350 & 50 & 34,95 & 29,96 & 27,95 & 25,30 & 22,81 & 20,49 & 16,47 & 13,29 & 8,99 \\
\hline 50 & 1400 & 50 & 34,53 & 29,61 & 27,68 & 25,09 & 22,66 & 20,39 & 16,43 & 13,29 & 9,01 \\
\hline 50 & 1450 & 50 & 34,13 & 29,28 & 27,42 & 24,90 & 22,52 & 20,29 & 16,40 & 13,29 & 9,03 \\
\hline 50 & 1500 & 50 & 33,75 & 28,96 & 27,17 & 24,71 & 22,38 & 20,20 & 16,36 & 13,29 & 9,05 \\
\hline 50 & 1550 & 50 & 33,39 & 28,66 & 26,93 & 24,52 & 22,25 & 20,10 & 16,32 & 13,28 & 9,06 \\
\hline 50 & 1600 & 50 & 33,05 & 28,37 & 26,69 & 24,35 & 22,11 & 20,01 & 16,29 & 13,28 & 9,08 \\
\hline 50 & 1650 & 50 & 32,73 & 28,09 & 26,47 & 24,18 & 21,99 & 19,92 & 16,25 & 13,27 & 9,10 \\
\hline 50 & 1700 & 50 & 32,42 & 27,82 & 26,25 & 24,01 & 21,86 & 19,83 & 16,21 & 13,26 & 9,11 \\
\hline 50 & 1750 & 50 & 32,12 & 27,56 & 26,04 & 23,85 & 21,74 & 19,74 & 16,17 & 13,25 & 9,13 \\
\hline 50 & 1800 & 50 & 31,84 & 27,30 & 25,84 & 23,69 & 21,62 & 19,65 & 16,13 & 13,25 & 9,14 \\
\hline 50 & 1850 & 50 & 31,57 & 27,06 & 25,64 & 23,54 & 21,50 & 19,57 & 16,10 & 13,24 & 9,15 \\
\hline 50 & 1900 & 50 & 31,31 & 26,83 & 25,45 & 23,39 & 21,39 & 19,48 & 16,06 & 13,23 & 9,16 \\
\hline 50 & 1950 & 50 & 31,06 & 26,60 & 25,26 & 23,25 & 21,28 & 19,40 & 16,02 & 13,22 & 9,18 \\
\hline 50 & 2000 & 50 & 30,82 & 26,38 & 25,08 & 23,11 & 21,17 & 19,32 & 15,98 & 13,21 & 9,19 \\
\hline 50 & 200 & 55 & 74,12 & 49,11 & 39,74 & 31,39 & 25,36 & 20,80 & 14,65 & 11,09 & 7,45 \\
\hline 50 & 250 & 55 & 66,35 & 46,12 & 38,17 & 30,75 & 25,18 & 20,85 & 14,83 & 11,22 & 7,48 \\
\hline 50 & 300 & 55 & 60,80 & 43,81 & 36,87 & 30,16 & 24,97 & 20,84 & 14,96 & 11,33 & 7,51 \\
\hline 50 & 350 & 55 & 56,60 & 41,94 & 35,75 & 29,62 & 24,74 & 20,79 & 15,06 & 11,43 & 7,54 \\
\hline 50 & 400 & 55 & 53,27 & 40,38 & 34,79 & 29,11 & 24,51 & 20,73 & 15,13 & 11,52 & 7,58 \\
\hline 50 & 450 & 55 & 50,56 & 39,04 & 33,93 & 28,64 & 24,28 & 20,65 & 15,19 & 11,60 & 7,61 \\
\hline 50 & 500 & 55 & 48,29 & 37,88 & 33,16 & 28,20 & 24,05 & 20,56 & 15,23 & 11,67 & 7,65 \\
\hline 50 & 550 & 55 & 46,37 & 36,84 & 32,47 & 27,79 & 23,83 & 20,46 & 15,26 & 11,73 & 7,69 \\
\hline 50 & 600 & 55 & 44,70 & 35,92 & 31,83 & 27,40 & 23,61 & 20,36 & 15,28 & 11,78 & 7,72 \\
\hline 50 & 650 & 55 & 43,25 & 35,08 & 31,25 & 27,04 & 23,40 & 20,25 & 15,29 & 11,82 & 7,76 \\
\hline 50 & 700 & 55 & 41,97 & 34,32 & 30,71 & 26,70 & 23,20 & 20,15 & 15,29 & 11,87 & 7,79 \\
\hline 50 & 750 & 55 & 40,82 & 33,62 & 30,21 & 26,37 & 23,00 & 20,04 & 15,29 & 11,90 & 7,82 \\
\hline 50 & 800 & 55 & 39,80 & 32,98 & 29,75 & 26,07 & 22,81 & 19,94 & 15,29 & 11,93 & 7,85 \\
\hline 50 & 850 & 55 & 38,87 & 32,38 & 29,31 & 25,77 & 22,63 & 19,83 & 15,28 & 11,96 & 7,88 \\
\hline 50 & 900 & 55 & 38,02 & 31,83 & 28,90 & 25,50 & 22,45 & 19,73 & 15,26 & 11,98 & 7,91 \\
\hline 50 & 950 & 55 & 37,25 & 31,31 & 28,52 & 25,23 & 22,28 & 19,63 & 15,25 & 12,00 & 7,94 \\
\hline 50 & 1000 & 55 & 36,54 & 30,82 & 28,15 & 24,98 & 22,11 & 19,53 & 15,23 & 12,02 & 7,97 \\
\hline 50 & 1050 & 55 & 35,89 & 30,36 & 27,81 & 24,74 & 21,95 & 19,43 & 15,21 & 12,04 & 7,99 \\
\hline 50 & 1100 & 55 & 35,29 & 29,93 & 27,48 & 24,51 & 21,80 & 19,33 & 15,18 & 12,05 & 8,02 \\
\hline 50 & 1150 & 55 & 34,72 & 29,51 & 27,17 & 24,29 & 21,64 & 19,23 & 15,16 & 12,06 & 8,04 \\
\hline 50 & 1200 & 55 & 34,20 & 29,13 & 26,87 & 24,07 & 21,50 & 19,14 & 15,14 & 12,07 & 8,06 \\
\hline 50 & 1250 & 55 & 33,71 & 28,76 & 26,59 & 23,87 & 21,36 & 19,05 & 15,11 & 12,07 & 8,08 \\
\hline 50 & 1300 & 55 & 33,25 & 28,40 & 26,32 & 23,67 & 21,22 & 18,95 & 15,08 & 12,08 & 8,10 \\
\hline 50 & 1350 & 55 & 32,82 & 28,07 & 26,06 & 23,48 & 21,08 & 18,86 & 15,05 & 12,08 & 8,12 \\
\hline 50 & 1400 & 55 & 32,41 & 27,75 & 25,81 & 23,29 & 20,95 & 18,78 & 15,02 & 12,08 & 8,14 \\
\hline 50 & 1450 & 55 & 32,03 & 27,44 & 25,57 & 23,12 & 20,82 & 18,69 & 14,99 & 12,08 & 8,16 \\
\hline 50 & 1500 & 55 & 31,66 & 27,14 & 25,34 & 22,95 & 20,70 & 18,61 & 14,96 & 12,08 & 8,18 \\
\hline 50 & 1550 & 55 & 31,32 & 26,86 & 25,12 & 22,78 & 20,58 & 18,52 & 14,93 & 12,08 & 8,19 \\
\hline 50 & 1600 & 55 & 30,99 & 26,59 & 24,90 & 22,62 & 20,46 & 18,44 & 14,90 & 12,08 & 8,21 \\
\hline 50 & 1650 & 55 & 30,68 & 26,33 & 24,70 & 22,46 & 20,35 & 18,36 & 14,87 & 12,08 & 8,22 \\
\hline 50 & 1700 & 55 & 30,38 & 26,08 & 24,50 & 22,31 & 20,23 & 18,28 & 14,84 & 12,07 & 8,24 \\
\hline 50 & 1750 & 55 & 30,10 & 25,84 & 24,30 & 22,16 & 20,12 & 18,20 & 14,81 & 12,07 & 8,25 \\
\hline
\end{tabular}




\begin{tabular}{|c|c|c|c|c|c|c|c|c|c|c|c|}
\hline \multirow[b]{2}{*}{$\mathrm{H}(\mathrm{cm})$} & \multirow[b]{2}{*}{ Mceq (MPa) } & & & & & $\mathrm{De}$ & ões (x1 & & & & \\
\hline & & Msub (MPa) & D0 & D25 & D40 & D60 & D80 & D100 & D140 & D180 & D260 \\
\hline 50 & 1800 & 55 & 29,83 & 25,60 & 24,12 & 22,02 & 20,02 & 18,13 & 14,78 & 12,06 & 8,27 \\
\hline 50 & 1850 & 55 & 29,57 & 25,38 & 23,94 & 21,88 & 19,91 & 18,05 & 14,75 & 12,06 & 8,28 \\
\hline 50 & 1900 & 55 & 29,32 & 25,16 & 23,76 & 21,75 & 19,81 & 17,98 & 14,72 & 12,05 & 8,29 \\
\hline 50 & 1950 & 55 & 29,08 & 24,95 & 23,59 & 21,61 & 19,71 & 17,91 & 14,69 & 12,05 & 8,30 \\
\hline 50 & 2000 & 55 & 28,85 & 24,74 & 23,42 & 21,49 & 19,62 & 17,84 & 14,65 & 12,04 & 8,31 \\
\hline 50 & 200 & 60 & 71,03 & 46,14 & 36,98 & 28,97 & 23,29 & 19,04 & 13,37 & 10,12 & 6,83 \\
\hline 50 & 250 & 60 & 63,47 & 43,32 & 35,55 & 28,43 & 23,16 & 19,10 & 13,53 & 10,24 & 6,84 \\
\hline 50 & 300 & 60 & 58,08 & 41,16 & 34,36 & 27,91 & 22,99 & 19,11 & 13,65 & 10,34 & 6,87 \\
\hline 50 & 350 & 60 & 54,01 & 39,40 & 33,35 & 27,44 & 22,81 & 19,09 & 13,75 & 10,43 & 6,89 \\
\hline 50 & 400 & 60 & 50,79 & 37,94 & 32,47 & 26,99 & 22,61 & 19,04 & 13,83 & 10,51 & 6,92 \\
\hline 50 & 450 & 60 & 48,17 & 36,69 & 31,68 & 26,57 & 22,42 & 18,98 & 13,88 & 10,58 & 6,95 \\
\hline 50 & 500 & 60 & 45,97 & 35,60 & 30,98 & 26,18 & 22,22 & 18,91 & 13,93 & 10,64 & 6,98 \\
\hline 50 & 550 & 60 & 44,11 & 34,64 & 30,34 & 25,82 & 22,03 & 18,84 & 13,96 & 10,70 & 7,01 \\
\hline 50 & 600 & 60 & 42,50 & 33,77 & 29,76 & 25,47 & 21,85 & 18,75 & 13,99 & 10,75 & 7,05 \\
\hline 50 & 650 & 60 & 41,10 & 32,99 & 29,23 & 25,15 & 21,66 & 18,67 & 14,00 & 10,79 & 7,07 \\
\hline 50 & 700 & 60 & 39,86 & 32,28 & 28,73 & 24,84 & 21,49 & 18,58 & 14,01 & 10,83 & 7,10 \\
\hline 50 & 750 & 60 & 38,75 & 31,63 & 28,27 & 24,55 & 21,31 & 18,49 & 14,02 & 10,87 & 7,13 \\
\hline 50 & 800 & 60 & 37,76 & 31,03 & 27,84 & 24,27 & 21,15 & 18,41 & 14,02 & 10,90 & 7,16 \\
\hline 50 & 850 & 60 & 36,86 & 30,47 & 27,44 & 24,01 & 20,99 & 18,32 & 14,02 & 10,93 & 7,19 \\
\hline 50 & 900 & 60 & 36,04 & 29,95 & 27,07 & 23,76 & 20,83 & 18,23 & 14,01 & 10,95 & 7,21 \\
\hline 50 & 950 & 60 & 35,30 & 29,47 & 26,71 & 23,52 & 20,68 & 18,14 & 14,00 & 10,97 & 7,24 \\
\hline 50 & 1000 & 60 & 34,61 & 29,01 & 26,38 & 23,29 & 20,53 & 18,05 & 13,99 & 10,99 & 7,26 \\
\hline 50 & 1050 & 60 & 33,98 & 28,58 & 26,06 & 23,07 & 20,39 & 17,97 & 13,97 & 11,01 & 7,28 \\
\hline 50 & 1100 & 60 & 33,39 & 28,18 & 25,75 & 22,86 & 20,25 & 17,88 & 13,96 & 11,02 & 7,31 \\
\hline 50 & 1150 & 60 & 32,85 & 27,79 & 25,47 & 22,66 & 20,11 & 17,80 & 13,94 & 11,03 & 7,33 \\
\hline 50 & 1200 & 60 & 32,34 & 27,43 & 25,19 & 22,47 & 19,98 & 17,72 & 13,92 & 11,04 & 7,35 \\
\hline 50 & 1250 & 60 & 31,87 & 27,09 & 24,93 & 22,28 & 19,85 & 17,64 & 13,90 & 11,05 & 7,37 \\
\hline 50 & 1300 & 60 & 31,43 & 26,76 & 24,68 & 22,10 & 19,73 & 17,56 & 13,88 & 11,06 & 7,39 \\
\hline 50 & 1350 & 60 & 31,01 & 26,44 & 24,44 & 21,92 & 19,61 & 17,48 & 13,86 & 11,07 & 7,41 \\
\hline 50 & 1400 & 60 & 30,62 & 26,14 & 24,21 & 21,76 & 19,49 & 17,40 & 13,83 & 11,07 & 7,42 \\
\hline 50 & 1450 & 60 & 30,25 & 25,86 & 23,99 & 21,59 & 19,38 & 17,33 & 13,81 & 11,07 & 7,44 \\
\hline 50 & 1500 & 60 & 29,89 & 25,58 & 23,77 & 21,44 & 19,26 & 17,25 & 13,79 & 11,08 & 7,46 \\
\hline 50 & 1550 & 60 & 29,56 & 25,32 & 23,57 & 21,29 & 19,16 & 17,18 & 13,76 & 11,08 & 7,47 \\
\hline 50 & 1600 & 60 & 29,25 & 25,06 & 23,37 & 21,14 & 19,05 & 17,11 & 13,74 & 11,08 & 7,49 \\
\hline 50 & 1650 & 60 & 28,95 & 24,82 & 23,18 & 20,99 & 18,95 & 17,04 & 13,71 & 11,08 & 7,50 \\
\hline 50 & 1700 & 60 & 28,66 & 24,58 & 22,99 & 20,86 & 18,85 & 16,97 & 13,69 & 11,08 & 7,51 \\
\hline 50 & 1750 & 60 & 28,39 & 24,35 & 22,81 & 20,72 & 18,75 & 16,90 & 13,66 & 11,07 & 7,53 \\
\hline 50 & 1800 & 60 & 28,12 & 24,14 & 22,64 & 20,59 & 18,65 & 16,83 & 13,63 & 11,07 & 7,54 \\
\hline 50 & 1850 & 60 & 27,87 & 23,92 & 22,47 & 20,46 & 18,56 & 16,76 & 13,61 & 11,07 & 7,55 \\
\hline 50 & 1900 & 60 & 27,64 & 23,72 & 22,31 & 20,34 & 18,46 & 16,70 & 13,58 & 11,06 & 7,56 \\
\hline 50 & 1950 & 60 & 27,41 & 23,52 & 22,15 & 20,22 & 18,37 & 16,63 & 13,56 & 11,06 & 7,57 \\
\hline 50 & 2000 & 60 & 27,18 & 23,33 & 22,00 & 20,10 & 18,29 & 16,57 & 13,53 & 11,06 & 7,58 \\
\hline 50 & 200 & 65 & 68,35 & 43,58 & 34,61 & 26,90 & 21,53 & 17,54 & 12,29 & 9,31 & 6,30 \\
\hline 50 & 250 & 65 & 60,97 & 40,90 & 33,29 & 26,43 & 21,43 & 17,61 & 12,44 & 9,41 & 6,31 \\
\hline 50 & 300 & 65 & 55,72 & 38,86 & 32,20 & 25,98 & 21,30 & 17,64 & 12,55 & 9,50 & 6,33 \\
\hline 50 & 350 & 65 & 51,76 & 37,20 & 31,27 & 25,56 & 21,14 & 17,63 & 12,65 & 9,58 & 6,35 \\
\hline 50 & 400 & 65 & 48,63 & 35,83 & 30,46 & 25,16 & 20,98 & 17,60 & 12,72 & 9,65 & 6,37 \\
\hline 50 & 450 & 65 & 46,09 & 34,65 & 29,74 & 24,79 & 20,82 & 17,56 & 12,78 & 9,72 & 6,40 \\
\hline 50 & 500 & 65 & 43,96 & 33,62 & 29,09 & 24,44 & 20,65 & 17,51 & 12,83 & 9,78 & 6,42 \\
\hline 50 & 550 & 65 & 42,16 & 32,72 & 28,50 & 24,11 & 20,49 & 17,45 & 12,86 & 9,83 & 6,45 \\
\hline 50 & 600 & 65 & 40,60 & 31,91 & 27,97 & 23,80 & 20,32 & 17,38 & 12,89 & 9,88 & 6,48 \\
\hline 50 & 650 & 65 & 39,23 & 31,17 & 27,47 & 23,51 & 20,17 & 17,31 & 12,91 & 9,92 & 6,50 \\
\hline 50 & 700 & 65 & 38,03 & 30,51 & 27,01 & 23,23 & 20,01 & 17,24 & 12,93 & 9,96 & 6,53 \\
\hline 50 & 750 & 65 & 36,96 & 29,90 & 26,59 & 22,97 & 19,86 & 17,17 & 12,94 & 9,99 & 6,55 \\
\hline 50 & 800 & 65 & 35,99 & 29,33 & 26,19 & 22,72 & 19,71 & 17,09 & 12,94 & 10,02 & 6,58 \\
\hline 50 & 850 & 65 & 35,12 & 28,81 & 25,82 & 22,48 & 19,57 & 17,02 & 12,94 & 10,05 & 6,60 \\
\hline 50 & 900 & 65 & 34,33 & 28,32 & 25,47 & 22,25 & 19,43 & 16,94 & 12,94 & 10,08 & 6,62 \\
\hline 50 & 950 & 65 & 33,61 & 27,87 & 25,14 & 22,04 & 19,29 & 16,86 & 12,93 & 10,10 & 6,65 \\
\hline 50 & 1000 & 65 & 32,95 & 27,44 & 24,83 & 21,83 & 19,16 & 16,79 & 12,93 & 10,12 & 6,67 \\
\hline 50 & 1050 & 65 & 32,33 & 27,04 & 24,54 & 21,63 & 19,03 & 16,72 & 12,92 & 10,13 & 6,69 \\
\hline 50 & 1100 & 65 & 31,76 & 26,66 & 24,25 & 21,44 & 18,91 & 16,64 & 12,91 & 10,15 & 6,71 \\
\hline 50 & 1150 & 65 & 31,24 & 26,30 & 23,99 & 21,25 & 18,79 & 16,57 & 12,89 & 10,16 & 6,73 \\
\hline 50 & 1200 & 65 & 30,75 & 25,95 & 23,73 & 21,07 & 18,67 & 16,50 & 12,88 & 10,18 & 6,75 \\
\hline 50 & 1250 & 65 & 30,29 & 25,63 & 23,49 & 20,90 & 18,55 & 16,43 & 12,86 & 10,19 & 6,77 \\
\hline 50 & 1300 & 65 & 29,86 & 25,32 & 23,25 & 20,74 & 18,44 & 16,36 & 12,85 & 10,19 & 6,78 \\
\hline 50 & 1350 & 65 & 29,45 & 25,03 & 23,03 & 20,58 & 18,33 & 16,29 & 12,83 & 10,20 & 6,80 \\
\hline 50 & 1400 & 65 & 29,07 & 24,74 & 22,82 & 20,42 & 18,23 & 16,22 & 12,81 & 10,21 & 6,82 \\
\hline 50 & 1450 & 65 & 28,71 & 24,47 & 22,61 & 20,27 & 18,12 & 16,15 & 12,79 & 10,21 & 6,83 \\
\hline 50 & 1500 & 65 & 28,37 & 24,22 & 22,41 & 20,13 & 18,02 & 16,09 & 12,78 & 10,22 & 6,85 \\
\hline 50 & 1550 & 65 & 28,05 & 23,97 & 22,22 & 19,99 & 17,93 & 16,02 & 12,76 & 10,22 & 6,86 \\
\hline 50 & 1600 & 65 & 27,74 & 23,73 & 22,03 & 19,85 & 17,83 & 15,96 & 12,74 & 10,22 & 6,88 \\
\hline 50 & 1650 & 65 & 27,45 & 23,50 & 21,86 & 19,72 & 17,74 & 15,89 & 12,71 & 10,22 & 6,89 \\
\hline 50 & 1700 & 65 & 27,17 & 23,28 & 21,68 & 19,60 & 17,64 & 15,83 & 12,69 & 10,22 & 6,90 \\
\hline 50 & 1750 & 65 & 26,91 & 23,06 & 21,52 & 19,47 & 17,55 & 15,77 & 12,67 & 10,23 & 6,91 \\
\hline 50 & 1800 & 65 & 26,66 & 22,86 & 21,35 & 19,35 & 17,47 & 15,71 & 12,65 & 10,22 & 6,93 \\
\hline 50 & 1850 & 65 & 26,42 & 22,66 & 21,20 & 19,23 & 17,38 & 15,65 & 12,63 & 10,22 & 6,94 \\
\hline 50 & 1900 & 65 & 26,18 & 22,47 & 21,05 & 19,12 & 17,30 & 15,59 & 12,61 & 10,22 & 6,95 \\
\hline 50 & 1950 & 65 & 25,96 & 22,28 & 20,90 & 19,01 & 17,22 & 15,54 & 12,58 & 10,22 & 6,96 \\
\hline 50 & 2000 & 65 & 25,75 & 22,10 & 20,75 & 18,90 & 17,14 & 15,48 & 12,56 & 10,22 & 6,97 \\
\hline 50 & 200 & 70 & 66,01 & 41,33 & 32,54 & 25,11 & 20,00 & 16,26 & 11,36 & 8,62 & 5,85 \\
\hline 50 & 250 & 70 & 58,77 & 38,78 & 31,32 & 24,70 & 19,94 & 16,34 & 11,50 & 8,71 & 5,85 \\
\hline
\end{tabular}




\begin{tabular}{|c|c|c|c|c|c|c|c|c|c|c|c|}
\hline \multirow[b]{2}{*}{$\mathrm{H}(\mathrm{cm})$} & \multirow[b]{2}{*}{ Mceq (MPa) } & & & & & $\mathrm{De}$ & ões (x1 & & & & \\
\hline & & Msub (MPa) & D0 & D25 & D40 & D60 & D80 & D100 & D140 & D180 & D260 \\
\hline 50 & 300 & 70 & 53,65 & 36,84 & 30,32 & 24,30 & 19,83 & 16,37 & 11,61 & 8,79 & 5,87 \\
\hline 50 & 350 & 70 & 49,79 & 35,28 & 29,45 & 23,93 & 19,71 & 16,38 & 11,70 & 8,86 & 5,89 \\
\hline 50 & 400 & 70 & 46,74 & 33,97 & 28,70 & 23,57 & 19,57 & 16,36 & 11,78 & 8,93 & 5,91 \\
\hline 50 & 450 & 70 & 44,26 & 32,86 & 28,04 & 23,24 & 19,43 & 16,33 & 11,83 & 8,99 & 5,93 \\
\hline 50 & 500 & 70 & 42,20 & 31,89 & 27,43 & 22,93 & 19,29 & 16,29 & 11,88 & 9,04 & 5,95 \\
\hline 50 & 550 & 70 & 40,44 & 31,03 & 26,89 & 22,63 & 19,14 & 16,25 & 11,92 & 9,09 & 5,97 \\
\hline 50 & 600 & 70 & 38,93 & 30,27 & 26,39 & 22,35 & 19,00 & 16,19 & 11,95 & 9,14 & 5,99 \\
\hline 50 & 650 & 70 & 37,60 & 29,58 & 25,93 & 22,08 & 18,86 & 16,14 & 11,97 & 9,18 & 6,02 \\
\hline 50 & 700 & 70 & 36,43 & 28,95 & 25,51 & 21,83 & 18,72 & 16,08 & 11,99 & 9,21 & 6,04 \\
\hline 50 & 750 & 70 & 35,39 & 28,37 & 25,11 & 21,59 & 18,59 & 16,01 & 12,00 & 9,25 & 6,06 \\
\hline 50 & 800 & 70 & 34,45 & 27,84 & 24,75 & 21,36 & 18,46 & 15,95 & 12,01 & 9,28 & 6,08 \\
\hline 50 & 850 & 70 & 33,61 & 27,35 & 24,40 & 21,15 & 18,33 & 15,88 & 12,02 & 9,30 & 6,10 \\
\hline 50 & 900 & 70 & 32,84 & 26,89 & 24,07 & 20,94 & 18,21 & 15,82 & 12,02 & 9,33 & 6,12 \\
\hline 50 & 950 & 70 & 32,14 & 26,46 & 23,77 & 20,74 & 18,09 & 15,75 & 12,02 & 9,35 & 6,14 \\
\hline 50 & 1000 & 70 & 31,49 & 26,05 & 23,48 & 20,55 & 17,97 & 15,69 & 12,01 & 9,37 & 6,16 \\
\hline 50 & 1050 & 70 & 30,89 & 25,67 & 23,20 & 20,36 & 17,85 & 15,63 & 12,01 & 9,39 & 6,18 \\
\hline 50 & 1100 & 70 & 30,34 & 25,32 & 22,94 & 20,19 & 17,74 & 15,56 & 12,00 & 9,40 & 6,20 \\
\hline 50 & 1150 & 70 & 29,83 & 24,98 & 22,69 & 20,02 & 17,63 & 15,50 & 11,99 & 9,42 & 6,22 \\
\hline 50 & 1200 & 70 & 29,35 & 24,65 & 22,45 & 19,86 & 17,53 & 15,43 & 11,98 & 9,43 & 6,24 \\
\hline 50 & 1250 & 70 & 28,91 & 24,35 & 22,22 & 19,70 & 17,42 & 15,37 & 11,97 & 9,44 & 6,25 \\
\hline 50 & 1300 & 70 & 28,49 & 24,06 & 22,00 & 19,55 & 17,32 & 15,31 & 11,96 & 9,45 & 6,27 \\
\hline 50 & 1350 & 70 & 28,09 & 23,78 & 21,79 & 19,40 & 17,22 & 15,25 & 11,94 & 9,46 & 6,28 \\
\hline 50 & 1400 & 70 & 27,72 & 23,51 & 21,59 & 19,26 & 17,13 & 15,19 & 11,93 & 9,47 & 6,30 \\
\hline 50 & 1450 & 70 & 27,37 & 23,26 & 21,40 & 19,12 & 17,03 & 15,13 & 11,92 & 9,47 & 6,31 \\
\hline 50 & 1500 & 70 & 27,04 & 23,01 & 21,21 & 18,99 & 16,94 & 15,07 & 11,90 & 9,48 & 6,33 \\
\hline 50 & 1550 & 70 & 26,73 & 22,78 & 21,04 & 18,86 & 16,85 & 15,01 & 11,88 & 9,48 & 6,34 \\
\hline 50 & 1600 & 70 & 26,43 & 22,55 & 20,86 & 18,73 & 16,76 & 14,95 & 11,87 & 9,49 & 6,35 \\
\hline 50 & 1650 & 70 & 26,15 & 22,34 & 20,69 & 18,61 & 16,68 & 14,90 & 11,85 & 9,49 & 6,37 \\
\hline 50 & 1700 & 70 & 25,88 & 22,13 & 20,53 & 18,49 & 16,59 & 14,84 & 11,83 & 9,49 & 6,38 \\
\hline 50 & 1750 & 70 & 25,62 & 21,93 & 20,38 & 18,37 & 16,51 & 14,79 & 11,82 & 9,49 & 6,39 \\
\hline 50 & 1800 & 70 & 25,38 & 21,73 & 20,23 & 18,26 & 16,43 & 14,73 & 11,80 & 9,49 & 6,40 \\
\hline 50 & 1850 & 70 & 25,14 & 21,54 & 20,08 & 18,15 & 16,35 & 14,68 & 11,78 & 9,49 & 6,41 \\
\hline 50 & 1900 & 70 & 24,92 & 21,36 & 19,94 & 18,05 & 16,28 & 14,63 & 11,76 & 9,49 & 6,42 \\
\hline 50 & 1950 & 70 & 24,70 & 21,18 & 19,80 & 17,94 & 16,20 & 14,58 & 11,74 & 9,49 & 6,43 \\
\hline 50 & 2000 & 70 & 24,50 & 21,01 & 19,66 & 17,84 & 16,13 & 14,53 & 11,72 & 9,49 & 6,44 \\
\hline 50 & 200 & 75 & 63,93 & 39,35 & 30,72 & 23,54 & 18,68 & 15,15 & 10,57 & 8,02 & 5,45 \\
\hline 50 & 250 & 75 & 56,83 & 36,91 & 29,59 & 23,18 & 18,63 & 15,23 & 10,70 & 8,10 & 5,46 \\
\hline 50 & 300 & 75 & 51,81 & 35,06 & 28,65 & 22,83 & 18,55 & 15,27 & 10,80 & 8,17 & 5,47 \\
\hline 50 & 350 & 75 & 48,04 & 33,57 & 27,85 & 22,49 & 18,45 & 15,29 & 10,89 & 8,24 & 5,49 \\
\hline 50 & 400 & 75 & 45,06 & 32,33 & 27,15 & 22,17 & 18,33 & 15,28 & 10,96 & 8,30 & 5,50 \\
\hline 50 & 450 & 75 & 42,65 & 31,27 & 26,53 & 21,87 & 18,21 & 15,26 & 11,01 & 8,36 & 5,52 \\
\hline 50 & 500 & 75 & 40,63 & 30,35 & 25,97 & 21,59 & 18,09 & 15,23 & 11,06 & 8,41 & 5,54 \\
\hline 50 & 550 & 75 & 38,92 & 29,54 & 25,47 & 21,32 & 17,96 & 15,20 & 11,10 & 8,45 & 5,56 \\
\hline 50 & 600 & 75 & 37,45 & 28,82 & 25,00 & 21,07 & 17,84 & 15,15 & 11,13 & 8,49 & 5,58 \\
\hline 50 & 650 & 75 & 36,16 & 28,16 & 24,57 & 20,83 & 17,72 & 15,11 & 11,16 & 8,53 & 5,60 \\
\hline 50 & 700 & 75 & 35,02 & 27,56 & 24,18 & 20,60 & 17,60 & 15,06 & 11,17 & 8,57 & 5,62 \\
\hline 50 & 750 & 75 & 34,00 & 27,02 & 23,81 & 20,38 & 17,48 & 15,00 & 11,19 & 8,60 & 5,64 \\
\hline 50 & 800 & 75 & 33,09 & 26,51 & 23,46 & 20,17 & 17,36 & 14,95 & 11,20 & 8,63 & 5,66 \\
\hline 50 & 850 & 75 & 32,27 & 26,05 & 23,14 & 19,97 & 17,25 & 14,89 & 11,21 & 8,65 & 5,67 \\
\hline 50 & 900 & 75 & 31,52 & 25,61 & 22,84 & 19,78 & 17,13 & 14,84 & 11,21 & 8,68 & 5,69 \\
\hline 50 & 950 & 75 & 30,83 & 25,20 & 22,55 & 19,59 & 17,02 & 14,78 & 11,22 & 8,70 & 5,71 \\
\hline 50 & 1000 & 75 & 30,21 & 24,82 & 22,28 & 19,42 & 16,92 & 14,72 & 11,22 & 8,72 & 5,73 \\
\hline 50 & 1050 & 75 & 29,63 & 24,46 & 22,02 & 19,25 & 16,81 & 14,67 & 11,21 & 8,74 & 5,75 \\
\hline 50 & 1100 & 75 & 29,09 & 24,12 & 21,77 & 19,09 & 16,71 & 14,61 & 11,21 & 8,75 & 5,76 \\
\hline 50 & 1150 & 75 & 28,59 & 23,80 & 21,54 & 18,93 & 16,61 & 14,56 & 11,20 & 8,77 & 5,78 \\
\hline 50 & 1200 & 75 & 28,12 & 23,50 & 21,31 & 18,78 & 16,52 & 14,50 & 11,20 & 8,78 & 5,79 \\
\hline 50 & 1250 & 75 & 27,69 & 23,21 & 21,10 & 18,63 & 16,42 & 14,44 & 11,19 & 8,79 & 5,81 \\
\hline 50 & 1300 & 75 & 27,28 & 22,93 & 20,90 & 18,49 & 16,33 & 14,39 & 11,18 & 8,80 & 5,82 \\
\hline 50 & 1350 & 75 & 26,90 & 22,67 & 20,70 & 18,36 & 16,24 & 14,33 & 11,17 & 8,81 & 5,84 \\
\hline 50 & 1400 & 75 & 26,54 & 22,42 & 20,51 & 18,22 & 16,15 & 14,28 & 11,16 & 8,82 & 5,85 \\
\hline 50 & 1450 & 75 & 26,20 & 22,18 & 20,33 & 18,10 & 16,07 & 14,23 & 11,15 & 8,83 & 5,87 \\
\hline 50 & 1500 & 75 & 25,88 & 21,95 & 20,15 & 17,97 & 15,98 & 14,17 & 11,14 & 8,83 & 5,88 \\
\hline 50 & 1550 & 75 & 25,57 & 21,72 & 19,99 & 17,85 & 15,90 & 14,12 & 11,12 & 8,84 & 5,89 \\
\hline 50 & 1600 & 75 & 25,28 & 21,51 & 19,82 & $\begin{array}{l}17,74 \\
\end{array}$ & 15,82 & 14,07 & 11,11 & 8,85 & 5,90 \\
\hline 50 & 1650 & 75 & 25,01 & 21,30 & 19,67 & 17,62 & 15,74 & 14,02 & 11,10 & 8,85 & 5,92 \\
\hline 50 & 1700 & 75 & 24,74 & 21,11 & 19,51 & 17,51 & 15,67 & 13,97 & 11,08 & 8,85 & 5,93 \\
\hline 50 & 1750 & 75 & 24,49 & 20,91 & 19,37 & 17,41 & 15,59 & 13,92 & 11,07 & 8,86 & 5,94 \\
\hline 50 & 1800 & 75 & 24,25 & 20,73 & 19,22 & 17,30 & 15,52 & 13,87 & 11,05 & 8,86 & 5,95 \\
\hline 50 & 1850 & 75 & 24,03 & 20,55 & 19,09 & 17,20 & 15,45 & 13,83 & 11,04 & 8,86 & 5,96 \\
\hline 50 & 1900 & 75 & 23,81 & 20,38 & 18,95 & 17,10 & 15,38 & 13,78 & 11,02 & 8,86 & 5,97 \\
\hline 50 & 1950 & 75 & 23,60 & 20,21 & 18,82 & 17,00 & 15,31 & 13,73 & 11,00 & 8,86 & 5,98 \\
\hline 50 & 2000 & 75 & 23,40 & 20,05 & 18,69 & 16,91 & 15,24 & 13,69 & 10,99 & 8,86 & 5,99 \\
\hline 50 & 200 & 80 & 62,07 & 37,59 & 29,11 & 22,15 & 17,51 & 14,17 & 9,87 & 7,50 & 5,11 \\
\hline 50 & 250 & 80 & 55,09 & 35,25 & 28,05 & 21,83 & 17,49 & 14,26 & 9,99 & 7,57 & 5,12 \\
\hline 50 & 300 & 80 & 50,17 & 33,47 & 27,17 & 21,52 & 17,42 & 14,31 & 10,09 & 7,64 & 5,12 \\
\hline 50 & 350 & 80 & 46,47 & 32,05 & 26,43 & 21,22 & 17,34 & 14,33 & 10,17 & 7,70 & 5,14 \\
\hline 50 & 400 & 80 & 43,56 & 30,87 & 25,77 & 20,94 & 17,24 & 14,33 & 10,24 & 7,75 & 5,15 \\
\hline 50 & 450 & 80 & 41,20 & 29,86 & 25,19 & 20,66 & 17,14 & 14,32 & 10,30 & 7,80 & 5,16 \\
\hline 50 & 500 & 80 & 39,23 & 28,98 & 24,67 & 20,41 & 17,03 & 14,30 & 10,34 & 7,85 & 5,18 \\
\hline 50 & 550 & 80 & 37,56 & 28,21 & 24,20 & 20,16 & 16,92 & 14,27 & 10,38 & 7,89 & 5,20 \\
\hline 50 & 600 & 80 & 36,12 & 27,52 & 23,76 & 19,93 & 16,81 & 14,24 & 10,41 & 7,93 & 5,21 \\
\hline
\end{tabular}




\begin{tabular}{|c|c|c|c|c|c|c|c|c|c|c|c|}
\hline \multirow[b]{2}{*}{$\mathrm{H}(\mathrm{cm})$} & \multirow[b]{2}{*}{ Mceq (MPa) } & & & & & $\mathrm{De}$ & ões (x1 & & & & \\
\hline & & Msub (MPa) & D0 & D25 & D40 & D60 & D80 & D100 & D140 & D180 & D260 \\
\hline 50 & 650 & 80 & 34,87 & 26,90 & 23,36 & 19,71 & 16,70 & 14,20 & 10,44 & 7,97 & 5,23 \\
\hline 50 & 700 & 80 & 33,76 & 26,33 & 22,99 & 19,50 & 16,60 & 14,16 & 10,46 & 8,00 & 5,25 \\
\hline 50 & 750 & 80 & 32,77 & 25,81 & 22,64 & 19,30 & 16,49 & 14,11 & 10,48 & 8,03 & 5,27 \\
\hline 50 & 800 & 80 & 31,88 & 25,33 & 22,32 & 19,10 & 16,38 & 14,07 & 10,49 & 8,06 & 5,28 \\
\hline 50 & 850 & 80 & 31,07 & 24,89 & 22,02 & 18,92 & 16,28 & 14,02 & 10,50 & 8,09 & 5,30 \\
\hline 50 & 900 & 80 & 30,34 & 24,47 & 21,73 & 18,74 & 16,18 & 13,97 & 10,51 & 8,11 & 5,32 \\
\hline 50 & 950 & 80 & 29,68 & 24,09 & 21,46 & 18,57 & 16,08 & 13,92 & 10,51 & 8,13 & 5,33 \\
\hline 50 & 1000 & 80 & 29,06 & 23,72 & 21,20 & 18,41 & 15,99 & 13,87 & 10,51 & 8,15 & 5,35 \\
\hline 50 & 1050 & 80 & 28,50 & 23,38 & 20,96 & 18,25 & 15,89 & 13,82 & 10,51 & 8,17 & 5,36 \\
\hline 50 & 1100 & 80 & 27,97 & 23,06 & 20,73 & 18,10 & 15,80 & 13,77 & 10,51 & 8,18 & 5,38 \\
\hline 50 & 1150 & 80 & 27,49 & 22,75 & 20,51 & 17,96 & 15,71 & 13,72 & 10,51 & 8,20 & 5,40 \\
\hline 50 & 1200 & 80 & 27,03 & 22,46 & 20,30 & 17,82 & 15,62 & 13,67 & 10,51 & 8,21 & 5,41 \\
\hline 50 & 1250 & 80 & 26,61 & 22,19 & 20,10 & 17,68 & 15,54 & 13,62 & 10,50 & 8,23 & 5,42 \\
\hline 50 & 1300 & 80 & 26,21 & 21,93 & 19,91 & 17,55 & 15,45 & 13,57 & 10,49 & 8,24 & 5,44 \\
\hline 50 & 1350 & 80 & 25,84 & 21,68 & 19,72 & 17,43 & 15,37 & 13,52 & 10,49 & 8,25 & 5,45 \\
\hline 50 & 1400 & 80 & 25,48 & 21,44 & 19,54 & 17,30 & 15,29 & 13,48 & 10,48 & 8,26 & 5,46 \\
\hline 50 & 1450 & 80 & 25,15 & 21,21 & 19,37 & 17,18 & 15,21 & 13,43 & 10,47 & 8,26 & 5,48 \\
\hline 50 & 1500 & 80 & 24,84 & 20,99 & 19,21 & 17,07 & 15,13 & 13,38 & 10,46 & 8,27 & 5,49 \\
\hline 50 & 1550 & 80 & 24,54 & 20,78 & 19,05 & 16,96 & 15,06 & 13,34 & 10,45 & 8,28 & 5,50 \\
\hline 50 & 1600 & 80 & 24,26 & 20,57 & 18,89 & 16,85 & 14,99 & 13,29 & 10,44 & 8,28 & 5,51 \\
\hline 50 & 1650 & 80 & 23,99 & 20,38 & 18,75 & 16,74 & 14,91 & 13,24 & 10,43 & 8,29 & 5,52 \\
\hline 50 & 1700 & 80 & 23,73 & 20,19 & 18,60 & 16,64 & 14,84 & 13,20 & 10,42 & 8,29 & 5,53 \\
\hline 50 & 1750 & 80 & 23,49 & 20,01 & 18,46 & 16,54 & 14,77 & 13,15 & 10,40 & 8,30 & 5,54 \\
\hline 50 & 1800 & 80 & 23,26 & 19,83 & 18,33 & 16,44 & 14,71 & 13,11 & 10,39 & 8,30 & 5,55 \\
\hline 50 & 1850 & 80 & 23,03 & 19,66 & 18,20 & 16,35 & 14,64 & 13,07 & 10,38 & 8,30 & 5,56 \\
\hline 50 & 1900 & 80 & 22,82 & 19,50 & 18,07 & 16,26 & 14,57 & 13,02 & 10,37 & 8,30 & 5,57 \\
\hline 50 & 1950 & 80 & 22,62 & 19,34 & 17,95 & 16,17 & 14,51 & 12,98 & 10,35 & 8,31 & 5,58 \\
\hline 50 & 2000 & 80 & 22,42 & 19,18 & 17,83 & 16,08 & 14,45 & 12,94 & 10,34 & 8,31 & 5,59 \\
\hline 50 & 200 & 85 & 60,41 & 36,01 & 27,66 & 20,92 & 16,48 & 13,31 & 9,26 & 7,04 & 4,81 \\
\hline 50 & 250 & 85 & 53,53 & 33,76 & 26,67 & 20,64 & 16,47 & 13,40 & 9,37 & 7,11 & 4,81 \\
\hline 50 & 300 & 85 & 48,69 & 32,05 & 25,85 & 20,36 & 16,42 & 13,45 & 9,47 & 7,17 & 4,82 \\
\hline 50 & 350 & 85 & 45,06 & 30,68 & 25,15 & 20,09 & 16,35 & 13,48 & 9,54 & 7,22 & 4,83 \\
\hline 50 & 400 & 85 & 42,21 & 29,55 & 24,54 & 19,83 & 16,27 & 13,49 & 9,61 & 7,27 & 4,84 \\
\hline 50 & 450 & 85 & 39,90 & 28,59 & 23,99 & 19,58 & 16,18 & 13,49 & 9,66 & 7,32 & 4,85 \\
\hline 50 & 500 & 85 & 37,98 & 27,75 & 23,50 & 19,35 & 16,09 & 13,47 & 9,71 & 7,36 & 4,87 \\
\hline 50 & 550 & 85 & 36,34 & 27,01 & 23,06 & 19,12 & 15,99 & 13,45 & 9,75 & 7,40 & 4,88 \\
\hline 50 & 600 & 85 & 34,94 & 26,35 & 22,65 & 18,91 & 15,90 & 13,42 & 9,78 & 7,44 & 4,90 \\
\hline 50 & 650 & 85 & 33,71 & 25,76 & 22,27 & 18,71 & 15,80 & 13,39 & 9,81 & 7,48 & 4,91 \\
\hline 50 & 700 & 85 & 32,62 & 25,22 & 21,92 & 18,51 & 15,70 & 13,36 & 9,83 & 7,51 & 4,93 \\
\hline 50 & 750 & 85 & 31,65 & 24,72 & 21,60 & 18,33 & 15,61 & 13,32 & 9,85 & 7,54 & 4,94 \\
\hline 50 & 800 & 85 & 30,79 & 24,26 & 21,29 & 18,15 & 15,51 & 13,28 & 9,86 & 7,56 & 4,96 \\
\hline 50 & 850 & 85 & 30,00 & 23,84 & 21,01 & 17,98 & 15,42 & 13,24 & 9,87 & 7,59 & 4,97 \\
\hline 50 & 900 & 85 & 29,29 & 23,45 & 20,74 & 17,82 & 15,33 & 13,20 & 9,88 & 7,61 & 4,99 \\
\hline 50 & 950 & 85 & 28,64 & 23,08 & 20,48 & 17,66 & 15,24 & 13,15 & 9,89 & 7,63 & 5,00 \\
\hline 50 & 1000 & 85 & 28,04 & 22,73 & 20,24 & 17,51 & 15,15 & 13,11 & 9,89 & 7,65 & 5,02 \\
\hline 50 & 1050 & 85 & 27,48 & 22,41 & 20,01 & 17,36 & 15,07 & 13,07 & 9,90 & 7,67 & 5,03 \\
\hline 50 & 1100 & 85 & 26,97 & 22,10 & 19,79 & 17,22 & 14,98 & 13,02 & 9,90 & 7,68 & 5,05 \\
\hline 50 & 1150 & 85 & 26,50 & 21,81 & 19,59 & 17,09 & 14,90 & 12,98 & 9,90 & 7,70 & 5,06 \\
\hline 50 & 1200 & 85 & 26,05 & 21,53 & 19,39 & 16,96 & 14,82 & 12,93 & 9,89 & 7,71 & 5,07 \\
\hline 50 & 1250 & 85 & 25,64 & 21,27 & 19,20 & 16,83 & 14,74 & 12,89 & 9,89 & 7,72 & 5,08 \\
\hline 50 & 1300 & 85 & 25,25 & 21,02 & 19,02 & 16,71 & 14,66 & 12,85 & 9,89 & 7,74 & 5,10 \\
\hline 50 & 1350 & 85 & 24,89 & 20,78 & 18,84 & 16,59 & 14,59 & 12,80 & 9,88 & 7,75 & 5,11 \\
\hline 50 & 1400 & 85 & 24,54 & 20,55 & 18,67 & 16,48 & 14,52 & 12,76 & 9,88 & 7,76 & 5,12 \\
\hline 50 & 1450 & 85 & 24,22 & 20,33 & 18,51 & 16,37 & 14,44 & 12,72 & 9,87 & 7,76 & 5,13 \\
\hline 50 & 1500 & 85 & 23,91 & 20,12 & 18,35 & 16,26 & 14,37 & 12,67 & 9,86 & 7,77 & 5,14 \\
\hline 50 & 1550 & 85 & 23,62 & 19,92 & 18,20 & 16,15 & 14,30 & 12,63 & 9,85 & 7,78 & 5,16 \\
\hline 50 & 1600 & 85 & 23,34 & 19,73 & 18,06 & 16,05 & 14,24 & 12,59 & 9,84 & 7,78 & 5,17 \\
\hline 50 & 1650 & 85 & 23,08 & 19,54 & 17,92 & 15,95 & 14,17 & 12,55 & 9,83 & 7,79 & 5,18 \\
\hline 50 & 1700 & 85 & 22,83 & 19,36 & 17,78 & 15,86 & 14,10 & 12,51 & 9,83 & 7,80 & 5,19 \\
\hline 50 & 1750 & 85 & 22,59 & 19,19 & 17,65 & 15,76 & 14,04 & 12,47 & 9,82 & 7,80 & 5,20 \\
\hline 50 & 1800 & 85 & 22,37 & 19,02 & 17,52 & 15,67 & 13,98 & 12,43 & 9,80 & 7,80 & 5,21 \\
\hline 50 & 1850 & 85 & 22,15 & 18,86 & 17,40 & 15,58 & 13,92 & 12,39 & 9,79 & 7,81 & 5,22 \\
\hline 50 & 1900 & 85 & 21,94 & 18,70 & 17,28 & 15,50 & 13,86 & 12,35 & 9,78 & 7,81 & 5,23 \\
\hline 50 & 1950 & 85 & 21,74 & 18,55 & 17,16 & 15,41 & 13,80 & 12,31 & 9,77 & 7,81 & 5,23 \\
\hline 50 & 2000 & 85 & 21,55 & 18,41 & 17,05 & 15,33 & 13,74 & 12,27 & 9,76 & 7,81 & 5,24 \\
\hline 50 & 200 & 90 & 58,90 & 34,59 & 26,37 & 19,82 & 15,56 & 12,55 & 8,72 & 6,63 & 4,55 \\
\hline 50 & 250 & 90 & 52,12 & 32,41 & 25,43 & 19,57 & 15,56 & 12,64 & 8,83 & 6,69 & 4,55 \\
\hline 50 & 300 & 90 & 47,35 & 30,76 & 24,66 & 19,31 & 15,53 & 12,69 & 8,91 & 6,75 & 4,55 \\
\hline 50 & 350 & 90 & 43,79 & 29,45 & 24,00 & 19,07 & 15,47 & 12,72 & 8,99 & 6,80 & 4,56 \\
\hline 50 & 400 & 90 & 40,99 & 28,36 & 23,42 & 18,83 & 15,40 & 12,74 & 9,05 & 6,85 & 4,57 \\
\hline 50 & 450 & 90 & 38,72 & 27,44 & 22,91 & 18,61 & 15,33 & 12,74 & 9,10 & 6,89 & 4,58 \\
\hline 50 & 500 & 90 & 36,84 & 26,63 & 22,45 & 18,39 & 15,25 & 12,73 & 9,15 & 6,93 & 4,59 \\
\hline 50 & 550 & 90 & 35,24 & 25,93 & 22,03 & 18,19 & 15,16 & 12,72 & 9,19 & 6,97 & 4,60 \\
\hline 50 & 600 & 90 & 33,86 & 25,30 & 21,64 & 17,99 & 15,07 & 12,69 & 9,22 & 7.01 & 4,62 \\
\hline 50 & 650 & 90 & 32,66 & 24,73 & 21,29 & 17,81 & 14,99 & 12,67 & 9,24 & 7,04 & 4,63 \\
\hline 50 & 700 & 90 & 31,60 & 24,21 & 20,96 & 17,63 & 14,90 & 12,64 & 9,27 & 7,07 & 4,64 \\
\hline 50 & 750 & 90 & 30,65 & 23,73 & 20,65 & 17,45 & 14,82 & 12,61 & 9,29 & 7,09 & 4,66 \\
\hline 50 & 800 & 90 & 29,80 & 23,30 & 20,37 & 17,29 & 14,73 & 12,57 & 9,30 & 7,12 & 4,67 \\
\hline 50 & 850 & 90 & 29,03 & 22,89 & 20,10 & 17,13 & 14,65 & 12,54 & 9,31 & 7,14 & 4,68 \\
\hline 50 & 900 & 90 & 28,34 & 22,51 & 19,84 & 16,98 & 14,56 & 12,50 & 9,32 & 7,17 & 4,70 \\
\hline 50 & 950 & 90 & 27,70 & 22,16 & 19,60 & 16,83 & 14,48 & 12,47 & 9,33 & 7,19 & 4,71 \\
\hline
\end{tabular}




\begin{tabular}{|c|c|c|c|c|c|c|c|c|c|c|c|}
\hline \multirow[b]{2}{*}{$\mathrm{H}(\mathrm{cm})$} & \multirow[b]{2}{*}{ Mceq (MPa) } & & & & & $\mathrm{De}$ & ões (x1 & & & & \\
\hline & & Msub (MPa) & D0 & D25 & D40 & D60 & D80 & D100 & D140 & D180 & D260 \\
\hline 50 & 1000 & 90 & 27,11 & 21,83 & 19,37 & 16,69 & 14,40 & 12,43 & 9,34 & 7,20 & 4,72 \\
\hline 50 & 1050 & 90 & 26,57 & 21,52 & 19,15 & 16,56 & 14,32 & 12,39 & 9,34 & 7,22 & 4,74 \\
\hline 50 & 1100 & 90 & 26,07 & 21,23 & 18,95 & 16,43 & 14,25 & 12,35 & 9,35 & 7,24 & 4,75 \\
\hline 50 & 1150 & 90 & 25,60 & 20,95 & 18,75 & 16,30 & 14,17 & 12,31 & 9,35 & 7,25 & 4,76 \\
\hline 50 & 1200 & 90 & 25,17 & 20,69 & 18,56 & 16,18 & 14,10 & 12,27 & 9,35 & 7,27 & 4,77 \\
\hline 50 & 1250 & 90 & 24,77 & 20,44 & 18,38 & 16,06 & 14,03 & 12,23 & 9,34 & 7,28 & 4,79 \\
\hline 50 & 1300 & 90 & 24,39 & 20,20 & 18,21 & 15,95 & 13,96 & 12,19 & 9,34 & 7,29 & 4,80 \\
\hline 50 & 1350 & 90 & 24,03 & 19,97 & 18,04 & 15,84 & 13,89 & 12,15 & 9,34 & 7,30 & 4,81 \\
\hline 50 & 1400 & 90 & 23,69 & 19,75 & 17,88 & 15,73 & 13,82 & 12,11 & 9,34 & 7,31 & 4,82 \\
\hline 50 & 1450 & 90 & 23,37 & 19,54 & 17,73 & 15,63 & 13,75 & 12,08 & 9,33 & 7,32 & 4,83 \\
\hline 50 & 1500 & 90 & 23,07 & 19,34 & 17,58 & 15,53 & 13,69 & 12,04 & 9,32 & 7,33 & 4,84 \\
\hline 50 & 1550 & 90 & 22,79 & 19,15 & 17,44 & 15,43 & 13,62 & 12,00 & 9,32 & 7,33 & 4,85 \\
\hline 50 & 1600 & 90 & 22,52 & 18,96 & 17,30 & 15,33 & 13,56 & 11,96 & 9,31 & 7,34 & 4,86 \\
\hline 50 & 1650 & 90 & 22,26 & 18,79 & 17,17 & 15,24 & 13,50 & 11,92 & 9,30 & 7,35 & 4,87 \\
\hline 50 & 1700 & 90 & 22,02 & 18,61 & 17,04 & 15,15 & 13,44 & 11,89 & 9,30 & 7,35 & 4,88 \\
\hline 50 & 1750 & 90 & 21,79 & 18,45 & 16,92 & 15,06 & 13,38 & 11,85 & 9,29 & 7,36 & 4,89 \\
\hline 50 & 1800 & 90 & 21,56 & 18,29 & 16,80 & 14,98 & 13,32 & 11,81 & 9,28 & 7,36 & 4,90 \\
\hline 50 & 1850 & 90 & 21,35 & 18,13 & 16,68 & 14,89 & 13,26 & 11,78 & 9,27 & 7,37 & 4,91 \\
\hline 50 & 1900 & 90 & 21,15 & 17,98 & 16,56 & 14,81 & 13,21 & 11,74 & 9,26 & 7,37 & 4,92 \\
\hline 50 & 1950 & 90 & 20,95 & 17,84 & 16,45 & 14,73 & 13,15 & 11,71 & 9,25 & 7,37 & 4,92 \\
\hline 50 & 2000 & 90 & 20,76 & 17,70 & 16,35 & 14,65 & 13,10 & 11,67 & 9,24 & 7,38 & 4,93 \\
\hline 50 & 200 & 95 & 57,53 & 33,30 & 25,20 & 18,82 & 14,74 & 11,86 & 8,23 & 6,27 & 4,31 \\
\hline 50 & 250 & 95 & 50,83 & 31,19 & 24,31 & 18,60 & 14,75 & 11,95 & 8,34 & 6,33 & 4,31 \\
\hline 50 & 300 & 95 & 46,14 & 29,59 & 23,58 & 18,37 & 14,72 & 12,01 & 8,42 & 6,38 & 4,31 \\
\hline 50 & 350 & 95 & 42,63 & 28,33 & 22,95 & 18,15 & 14,68 & 12,04 & 8,49 & 6,42 & 4,31 \\
\hline 50 & 400 & 95 & 39,88 & 27,28 & 22,41 & 17,94 & 14,62 & 12,06 & 8,55 & 6,47 & 4,32 \\
\hline 50 & 450 & 95 & 37,65 & 26,39 & 21,93 & 17,73 & 14,56 & 12,07 & 8,60 & 6,51 & 4,33 \\
\hline 50 & 500 & 95 & 35,80 & 25,62 & 21,49 & 17,53 & 14,48 & 12,07 & 8,64 & 6,55 & 4,34 \\
\hline 50 & 550 & 95 & 34,23 & 24,94 & 21,09 & 17,34 & 14,41 & 12,06 & 8,68 & 6,58 & 4,35 \\
\hline 50 & 600 & 95 & 32,88 & 24,33 & 20,73 & 17,16 & 14,33 & 12,04 & 8,71 & 6,62 & 4,36 \\
\hline 50 & 650 & 95 & 31,70 & 23,79 & 20,40 & 16,99 & 14,26 & 12,02 & 8,74 & 6,65 & 4,38 \\
\hline 50 & 700 & 95 & 30,66 & 23,29 & 20,08 & 16,82 & 14,18 & 12,00 & 8,76 & 6,67 & 4,39 \\
\hline 50 & 750 & 95 & 29,74 & 22,84 & 19,79 & 16,66 & 14,10 & 11,97 & 8,78 & 6,70 & 4,40 \\
\hline 50 & 800 & 95 & 28,90 & 22,42 & 19,52 & 16,51 & 14,02 & 11,94 & 8,80 & 6,73 & 4,41 \\
\hline 50 & 850 & 95 & 28,15 & 22,03 & 19,27 & 16,36 & 13,95 & 11,91 & 8,81 & 6,75 & 4,43 \\
\hline 50 & 900 & 95 & 27,47 & 21,67 & 19,02 & 16,22 & 13,87 & 11,88 & 8,82 & 6,77 & 4,44 \\
\hline 50 & 950 & 95 & 26,84 & 21,33 & 18,80 & 16,09 & 13,80 & 11,84 & 8,83 & 6,79 & 4,45 \\
\hline 50 & 1000 & 95 & 26,27 & 21,01 & 18,58 & 15,96 & 13,72 & 11,81 & 8,84 & 6,81 & 4,46 \\
\hline 50 & 1050 & 95 & 25,74 & 20,72 & 18,37 & 15,83 & 13,65 & 11,78 & 8,85 & 6,82 & 4,47 \\
\hline 50 & 1100 & 95 & 25,25 & 20,43 & 18,18 & 15,71 & 13,58 & 11,74 & 8,85 & 6,84 & 4,48 \\
\hline 50 & 1150 & 95 & 24,79 & 20,17 & 17,99 & 15,59 & 13,51 & 11,71 & 8,85 & 6,85 & 4,50 \\
\hline 50 & 1200 & 95 & 24,37 & 19,91 & 17,81 & 15,48 & 13,44 & 11,67 & 8,85 & 6,87 & 4,51 \\
\hline 50 & 1250 & 95 & 23,97 & 19,67 & 17,64 & 15,37 & 13,38 & 11,64 & 8,85 & 6,88 & 4,52 \\
\hline 50 & 1300 & 95 & 23,60 & 19,45 & 17,48 & 15,26 & 13,31 & 11,60 & 8,85 & 6,89 & 4,53 \\
\hline 50 & 1350 & 95 & 23,25 & 19,23 & 17,32 & 15,15 & 13,25 & 11,57 & 8,85 & 6,90 & 4,54 \\
\hline 50 & 1400 & 95 & 22,92 & 19,02 & 17,17 & 15,05 & 13,19 & 11,53 & 8,85 & 6,91 & 4,55 \\
\hline 50 & 1450 & 95 & 22,61 & 18,82 & 17,02 & 14,96 & 13,12 & 11,50 & 8,85 & 6,92 & 4,56 \\
\hline 50 & 1500 & 95 & 22,32 & 18,63 & 16,88 & 14,86 & 13,06 & 11,46 & 8,84 & 6,93 & 4,57 \\
\hline 50 & 1550 & 95 & 22,04 & 18,44 & 16,75 & 14,77 & 13,00 & 11,43 & 8,84 & 6,94 & 4,58 \\
\hline 50 & 1600 & 95 & 21,77 & 18,26 & 16,61 & 14,68 & 12,95 & 11,39 & 8,83 & 6,94 & 4,59 \\
\hline 50 & 1650 & 95 & 21,52 & 18,09 & 16,49 & 14,59 & 12,89 & 11,36 & 8,83 & 6,95 & 4,60 \\
\hline 50 & 1700 & 95 & 21,28 & 17,93 & 16,37 & 14,51 & 12,83 & 11,32 & 8,82 & 6,96 & 4,61 \\
\hline 50 & 1750 & 95 & 21,05 & 17,77 & 16,25 & 14,43 & 12,78 & 11,29 & 8,81 & 6,96 & 4,62 \\
\hline 50 & 1800 & 95 & 20,84 & 17,62 & 16,13 & 14,34 & 12,72 & 11,26 & 8,81 & 6,97 & 4,62 \\
\hline 50 & 1850 & 95 & 20,63 & 17,47 & 16,02 & 14,27 & 12,67 & 11,22 & 8,80 & 6,97 & 4,63 \\
\hline 50 & 1900 & 95 & 20,43 & 17,33 & 15,91 & 14,19 & 12,62 & 11,19 & 8,79 & 6,97 & 4,64 \\
\hline 50 & 1950 & 95 & 20,24 & 17,19 & 15,81 & 14,11 & 12,57 & 11,16 & 8,78 & 6,98 & 4,65 \\
\hline 50 & 2000 & 95 & 20,05 & 17,05 & 15,70 & 14,04 & 12,52 & 11,13 & 8,77 & 6,98 & 4,66 \\
\hline 50 & 200 & 100 & 56,29 & 32,13 & 24,13 & 17,93 & 13,99 & 11,25 & 7,80 & 5,95 & 4,09 \\
\hline 50 & 250 & 100 & 49,66 & 30,07 & 23,29 & 17,72 & 14,01 & 11,34 & 7,90 & 6,00 & 4,09 \\
\hline 50 & 300 & 100 & 45,03 & 28,53 & 22,59 & 17,52 & 14,00 & 11,40 & 7,98 & 6,04 & 4,09 \\
\hline 50 & 350 & 100 & 41,57 & 27,31 & 22,00 & 17,32 & 13,96 & 11,43 & 8,04 & 6,09 & 4,10 \\
\hline 50 & 400 & 100 & 38,86 & 26,29 & 21,49 & 17,12 & 13,91 & 11,45 & 8,10 & 6,13 & 4,10 \\
\hline 50 & 450 & 100 & 36,67 & 25,44 & 21,03 & 16,93 & 13,86 & 11,46 & 8,15 & 6,17 & 4,11 \\
\hline 50 & 500 & 100 & 34,85 & 24,69 & 20,62 & 16,75 & 13,79 & 11,47 & 8,19 & 6,20 & 4,12 \\
\hline 50 & 550 & 100 & 33,31 & 24,04 & 20,24 & 16,57 & 13,73 & 11,46 & 8,23 & 6,24 & 4,13 \\
\hline 50 & 600 & 100 & 31,98 & 23,46 & 19,90 & 16,41 & 13,66 & 11,45 & 8,26 & 6,27 & 4,14 \\
\hline 50 & 650 & 100 & 30,83 & 22,93 & 19,58 & 16,25 & 13,59 & 11,43 & 8,29 & 6,30 & 4,15 \\
\hline 50 & 700 & 100 & 29,81 & 22,45 & 19,29 & 16,09 & 13,52 & 11,41 & 8,31 & 6,32 & 4,16 \\
\hline 50 & 750 & 100 & 28,90 & 22,01 & 19,01 & 15,94 & 13,45 & 11,39 & 8,33 & 6,35 & 4,17 \\
\hline 50 & 800 & 100 & 28,08 & 21,61 & 18,75 & 15,80 & 13,38 & 11,37 & 8,35 & 6,37 & 4,18 \\
\hline 50 & 850 & 100 & 27,35 & 21,24 & 18,51 & 15,66 & 13,31 & 11,34 & 8,36 & 6,39 & 4,19 \\
\hline 50 & 900 & 100 & 26,68 & 20,89 & 18,28 & 15,53 & 13,24 & 11,31 & 8,37 & 6,41 & 4,21 \\
\hline 50 & 950 & 100 & 26,06 & 20,57 & 18,06 & 15,40 & 13,17 & 11,28 & 8,38 & 6,43 & 4,22 \\
\hline 50 & 1000 & 100 & 25,50 & 20,26 & 17,86 & 15,28 & 13,11 & 11,25 & 8,39 & 6,45 & 4,23 \\
\hline 50 & 1050 & 100 & 24,98 & 19,98 & 17,66 & 15,16 & 13,04 & 11,22 & 8,40 & 6,47 & 4,24 \\
\hline 50 & 1100 & 100 & 24,50 & 19,71 & 17,47 & 15,05 & 12,98 & 11,19 & 8,40 & 6,48 & 4,25 \\
\hline 50 & 1150 & 100 & 24,06 & 19,45 & 17,30 & 14,94 & 12,91 & 11,16 & 8,41 & 6,50 & 4,26 \\
\hline 50 & 1200 & 100 & 23,64 & 19,21 & 17,13 & 14,83 & 12,85 & 11,13 & 8,41 & 6,51 & 4,27 \\
\hline 50 & 1250 & 100 & 23,25 & 18,98 & 16,96 & 14,73 & 12,79 & 11,10 & 8,41 & 6,52 & 4,28 \\
\hline 50 & 1300 & 100 & 22,89 & 18,76 & 16,81 & 14,63 & 12,73 & 11,06 & 8,41 & 6,53 & 4,29 \\
\hline
\end{tabular}




\begin{tabular}{|c|c|c|c|c|c|c|c|c|c|c|c|}
\hline \multirow[b]{2}{*}{$\mathrm{H}(\mathrm{cm})$} & \multirow[b]{2}{*}{ Mceq (MPa) } & & & & & $\mathrm{De}$ & ões (x1 & & & & \\
\hline & & Msub (MPa) & D0 & D25 & D40 & D60 & D80 & D100 & D140 & D180 & D260 \\
\hline 50 & 1350 & 100 & 22,54 & 18,55 & 16,66 & 14,53 & 12,67 & 11,03 & 8,41 & 6,54 & 4,30 \\
\hline 50 & 1400 & 100 & 22,22 & 18,35 & 16,51 & 14,44 & 12,61 & 11,00 & 8,41 & 6,55 & 4,31 \\
\hline 50 & 1450 & 100 & 21,91 & 18,16 & 16,37 & 14,34 & 12,55 & 10,97 & 8,41 & 6,56 & 4,32 \\
\hline 50 & 1500 & 100 & 21,63 & 17,97 & 16,24 & 14,26 & 12,50 & 10,94 & 8,41 & 6,57 & 4,33 \\
\hline 50 & 1550 & 100 & 21,35 & 17,79 & 16,11 & 14,17 & 12,44 & 10,91 & 8,40 & 6,58 & 4,34 \\
\hline 50 & 1600 & 100 & 21,09 & 17,62 & 15,99 & 14,08 & 12,39 & 10,87 & 8,40 & 6,59 & 4,35 \\
\hline 50 & 1650 & 100 & 20,85 & 17,46 & 15,86 & 14,00 & 12,33 & 10,84 & 8,39 & 6,59 & 4,35 \\
\hline 50 & 1700 & 100 & 20,61 & 17,30 & 15,75 & 13,92 & 12,28 & 10,81 & 8,39 & 6,60 & 4,36 \\
\hline 50 & 1750 & 100 & 20,39 & 17,15 & 15,63 & 13,84 & 12,23 & 10,78 & 8,38 & 6,60 & 4,37 \\
\hline 50 & 1800 & 100 & 20,17 & 17,00 & 15,52 & 13,77 & 12,18 & 10,75 & 8,38 & 6,61 & 4,38 \\
\hline 50 & 1850 & 100 & 19,97 & 16,86 & 15,42 & 13,69 & 12,13 & 10,72 & 8,37 & 6,61 & 4,39 \\
\hline 50 & 1900 & 100 & 19,77 & 16,72 & 15,31 & 13,62 & 12,08 & 10,69 & 8,37 & 6,62 & 4,39 \\
\hline 50 & 1950 & 100 & 19,59 & 16,59 & 15,21 & 13,55 & 12,03 & 10,66 & 8,36 & 6,62 & 4,40 \\
\hline 50 & 2000 & 100 & 19,41 & 16,46 & 15,12 & 13,48 & 11,99 & 10,63 & 8,35 & 6,63 & 4,41 \\
\hline 50 & 200 & 105 & 55,14 & 31,06 & 23,16 & 17,11 & 13,32 & 10,69 & 7,41 & 5,66 & 3,90 \\
\hline 50 & 250 & 105 & 48,58 & 29,05 & 22,35 & 16,93 & 13,34 & 10,78 & 7,50 & 5,70 & 3,90 \\
\hline 50 & 300 & 105 & 44,00 & 27,55 & 21,69 & 16,74 & 13,34 & 10,84 & 7,58 & 5,74 & 3,90 \\
\hline 50 & 350 & 105 & 40,59 & 26,37 & 21,13 & 16,56 & 13,31 & 10,88 & 7,64 & 5,78 & 3,90 \\
\hline 50 & 400 & 105 & 37,92 & 25,39 & 20,64 & 16,38 & 13,27 & 10,90 & 7,70 & 5,82 & 3,91 \\
\hline 50 & 450 & 105 & 35,77 & 24,56 & 20,21 & 16,20 & 13,22 & 10,92 & 7,74 & 5,86 & 3,91 \\
\hline 50 & 500 & 105 & 33,98 & 23,84 & 19,82 & 16,03 & 13,17 & 10,92 & 7,78 & 5,89 & 3,92 \\
\hline 50 & 550 & 105 & 32,46 & 23,21 & 19,46 & 15,87 & 13,11 & 10,92 & 7,82 & 5,92 & 3,93 \\
\hline 50 & 600 & 105 & 31,16 & 22,65 & 19,14 & 15,72 & 13,05 & 10,91 & 7,85 & 5,95 & 3,94 \\
\hline 50 & 650 & 105 & 30,03 & 22,14 & 18,83 & 15,57 & 12,98 & 10,90 & 7,88 & 5,98 & 3,95 \\
\hline 50 & 700 & 105 & 29,02 & 21,68 & 18,55 & 15,42 & 12,92 & 10,88 & 7,90 & 6,00 & 3,96 \\
\hline 50 & 750 & 105 & 28,13 & 21,26 & 18,29 & 15,28 & 12,86 & 10,86 & 7,92 & 6,03 & 3,97 \\
\hline 50 & 800 & 105 & 27,33 & 20,87 & 18,04 & 15,15 & 12,79 & 10,84 & 7,94 & 6,05 & 3,98 \\
\hline 50 & 850 & 105 & 26,61 & 20,51 & 17,81 & 15,02 & 12,73 & 10,82 & 7,95 & 6,07 & 3,99 \\
\hline 50 & 900 & 105 & 25,95 & 20,18 & 17,59 & 14,90 & 12,67 & 10,80 & 7,97 & 6,09 & 4,00 \\
\hline 50 & 950 & 105 & 25,35 & 19,87 & 17,39 & 14,78 & 12,61 & 10,77 & 7,98 & 6,11 & 4,01 \\
\hline 50 & 1000 & 105 & 24,80 & 19,57 & 17,19 & 14,67 & 12,54 & 10,74 & 7,99 & 6,13 & 4,02 \\
\hline 50 & 1050 & 105 & 24,29 & 19,30 & 17,01 & 14,55 & 12,48 & 10,72 & 7,99 & 6,14 & 4,03 \\
\hline 50 & 1100 & 105 & 23,82 & 19,04 & 16,83 & 14,45 & 12,42 & 10,69 & 8,00 & 6,16 & 4,04 \\
\hline 50 & 1150 & 105 & 23,38 & 18,79 & 16,66 & 14,34 & 12,36 & 10,66 & 8,00 & 6,17 & 4,05 \\
\hline 50 & 1200 & 105 & 22,97 & 18,56 & 16,50 & 14,24 & 12,31 & 10,63 & 8,01 & 6,18 & 4,05 \\
\hline 50 & 1250 & 105 & 22,59 & 18,34 & 16,34 & 14,15 & 12,25 & 10,60 & 8,01 & 6,20 & 4,06 \\
\hline 50 & 1300 & 105 & 22,23 & 18,13 & 16,19 & 14,05 & 12,19 & 10,58 & 8,01 & 6,21 & 4,07 \\
\hline 50 & 1350 & 105 & 21,89 & 17,92 & 16,05 & 13,96 & 12,14 & 10,55 & 8,01 & 6,22 & 4,08 \\
\hline 50 & 1400 & 105 & 21,58 & 17,73 & 15,91 & 13,87 & 12,08 & 10,52 & 8,01 & 6,23 & 4,09 \\
\hline 50 & 1450 & 105 & 21,28 & 17,55 & 15,78 & 13,78 & 12,03 & 10,49 & 8,01 & 6,24 & 4,10 \\
\hline 50 & 1500 & 105 & 20,99 & 17,37 & 15,65 & 13,70 & 11,98 & 10,46 & 8,01 & 6,25 & 4,11 \\
\hline 50 & 1550 & 105 & 20,72 & 17,20 & 15,53 & 13,62 & 11,93 & 10,43 & 8,01 & 6,25 & 4,12 \\
\hline 50 & 1600 & 105 & 20,47 & 17,03 & 15,41 & 13,54 & 11,88 & 10,40 & 8,00 & 6,26 & 4,13 \\
\hline 50 & 1650 & 105 & 20,23 & 16,88 & 15,29 & 13,46 & 11,83 & 10,37 & 8,00 & 6,27 & 4,13 \\
\hline 50 & 1700 & 105 & 20,00 & 16,72 & 15,18 & 13,38 & 11,78 & 10,35 & 8,00 & 6,27 & 4,14 \\
\hline 50 & 1750 & 105 & 19,78 & 16,58 & 15,07 & 13,31 & 11,73 & 10,32 & 7,99 & 6,28 & 4,15 \\
\hline 50 & 1800 & 105 & 19,57 & 16,44 & 14,97 & 13,24 & 11,68 & 10,29 & 7,99 & 6,29 & 4,16 \\
\hline 50 & 1850 & 105 & 19,37 & 16,30 & 14,86 & 13,17 & 11,64 & 10,26 & 7,98 & 6,29 & 4,16 \\
\hline 50 & 1900 & 105 & 19,18 & 16,17 & 14,77 & 13,10 & 11,59 & 10,23 & 7,98 & 6,30 & 4,17 \\
\hline 50 & 1950 & 105 & 18,99 & 16,04 & 14,67 & 13,03 & 11,55 & 10,21 & 7,97 & 6,30 & 4,18 \\
\hline 50 & 2000 & 105 & 18,82 & 15,91 & 14,58 & 12,96 & 11,50 & 10,18 & 7,97 & 6,30 & 4,19 \\
\hline 50 & 200 & 110 & 54,09 & 30,07 & 22,27 & 16,36 & 12,70 & 10,18 & 7,06 & 5,39 & 3,72 \\
\hline 50 & 250 & 110 & 47,59 & 28,11 & 21,50 & 16,20 & 12,73 & 10,27 & 7,14 & 5,43 & 3,72 \\
\hline 50 & 300 & 110 & 43,06 & 26,66 & 20,87 & 16,03 & 12,73 & 10,33 & 7,21 & 5,47 & 3,72 \\
\hline 50 & 350 & 110 & 39,69 & 25,50 & 20,33 & 15,86 & 12,71 & 10,37 & 7,27 & 5,51 & 3,72 \\
\hline 50 & 400 & 110 & 37,06 & 24,56 & 19,87 & 15,69 & 12,68 & 10,40 & 7,33 & 5,55 & 3,73 \\
\hline 50 & 450 & 110 & 34,93 & 23,75 & 19,46 & 15,53 & 12,64 & 10,42 & 7,37 & 5,58 & 3,73 \\
\hline 50 & 500 & 110 & 33,17 & 23,06 & 19,08 & 15,38 & 12,59 & 10,42 & 7,41 & 5,61 & 3,74 \\
\hline 50 & 550 & 110 & 31,68 & 22,45 & 18,74 & 15,23 & 12,54 & 10,42 & 7,45 & 5,64 & 3,75 \\
\hline 50 & 600 & 110 & 30,40 & 21,90 & 18,43 & 15,08 & 12,49 & 10,42 & 7,48 & 5,67 & 3,75 \\
\hline 50 & 650 & 110 & 29,28 & 21,42 & 18,14 & 14,94 & 12,43 & 10,41 & 7,50 & 5,69 & 3,76 \\
\hline 50 & 700 & 110 & 28,30 & 20,97 & 17,88 & 14,81 & 12,37 & 10,40 & 7,53 & 5,72 & 3,77 \\
\hline 50 & 750 & 110 & 27,42 & 20,56 & 17,63 & 14,68 & 12,31 & 10,38 & 7,55 & 5,74 & 3,78 \\
\hline 50 & 800 & 110 & 26,64 & 20,19 & 17,39 & 14,55 & 12,26 & 10,36 & 7,57 & 5,76 & 3,79 \\
\hline 50 & 850 & 110 & 25,93 & 19,84 & 17,17 & 14,43 & 12,20 & 10,34 & 7,58 & 5,78 & 3,80 \\
\hline 50 & 900 & 110 & 25,28 & 19,52 & 16,96 & 14,32 & 12,14 & 10,32 & 7,59 & 5,80 & 3,81 \\
\hline 50 & 950 & 110 & 24,69 & 19,22 & 16,77 & 14,21 & 12,08 & 10,30 & 7,61 & 5,82 & 3,82 \\
\hline 50 & 1000 & 110 & 24,15 & 18,94 & 16,58 & 14,10 & 12,03 & 10,28 & 7,61 & 5,83 & 3,82 \\
\hline 50 & 1050 & 110 & 23,65 & 18,67 & 16,40 & 13,99 & 11,97 & 10,25 & 7,62 & 5,85 & 3,83 \\
\hline 50 & 1100 & 110 & 23,18 & 18,42 & 16,23 & 13,89 & 11,92 & 10,23 & 7,63 & 5,86 & 3,84 \\
\hline 50 & 1150 & 110 & 22,75 & 18,18 & 16,07 & 13,80 & 11,86 & 10,20 & 7,63 & 5,88 & 3,85 \\
\hline 50 & 1200 & 110 & 22,35 & 17,96 & 15,92 & 13,70 & 11,81 & 10,18 & 7,64 & 5,89 & 3,86 \\
\hline 50 & 1250 & 110 & 21,98 & 17,75 & 15,77 & 13,61 & 11,75 & 10,15 & 7,64 & 5,90 & 3,87 \\
\hline 50 & 1300 & 110 & 21,62 & 17,54 & 15,63 & 13,52 & 11,70 & 10,13 & 7,64 & 5,91 & 3,88 \\
\hline 50 & 1350 & 110 & 21,29 & 17,35 & 15,49 & 13,43 & 11,65 & 10,10 & 7,65 & 5,92 & 3,89 \\
\hline 50 & 1400 & 110 & 20,98 & 17,16 & 15,36 & 13,35 & 11,60 & 10,07 & 7,65 & 5,93 & 3,89 \\
\hline 50 & 1450 & 110 & 20,69 & 16,98 & 15,23 & 13,27 & 11,55 & 10,05 & 7,65 & 5,94 & 3,90 \\
\hline 50 & 1500 & 110 & 20,41 & 16,81 & 15,11 & 13,19 & 11,50 & 10,02 & 7,65 & 5,95 & 3,91 \\
\hline 50 & 1550 & 110 & 20,15 & 16,65 & 14,99 & 13,11 & 11,45 & 10,00 & 7,65 & 5,96 & 3,92 \\
\hline 50 & 1600 & 110 & 19,90 & 16,49 & 14,87 & 13,03 & 11,41 & 9,97 & 7,64 & 5,97 & 3,93 \\
\hline 50 & 1650 & 110 & 19,66 & 16,34 & 14,76 & 12,96 & 11,36 & 9,94 & 7,64 & 5,97 & 3,93 \\
\hline
\end{tabular}




\begin{tabular}{|c|c|c|c|c|c|c|c|c|c|c|c|}
\hline \multirow[b]{2}{*}{$\mathrm{H}(\mathrm{cm})$} & \multirow[b]{2}{*}{ Mceq (MPa) } & & & & & $\mathrm{De}$ & ões (x1 & & & & \\
\hline & & Msub (MPa) & D0 & D25 & D40 & D60 & D80 & D100 & D140 & D180 & D260 \\
\hline 50 & 1700 & 110 & 19,43 & 16,19 & 14,66 & 12,89 & 11,32 & 9,92 & 7,64 & 5,98 & 3,94 \\
\hline 50 & 1750 & 110 & 19,22 & 16,05 & 14,55 & 12,82 & 11,27 & 9,89 & 7,64 & 5,99 & 3,95 \\
\hline 50 & 1800 & 110 & 19,01 & 15,91 & 14,45 & 12,75 & 11,23 & 9,87 & 7,63 & 5,99 & 3,96 \\
\hline 50 & 1850 & 110 & 18,81 & 15,78 & 14,35 & 12,68 & 11,18 & 9,84 & 7,63 & 6,00 & 3,96 \\
\hline 50 & 1900 & 110 & 18,63 & 15,65 & 14,26 & 12,62 & 11,14 & 9,81 & 7,62 & 6,00 & 3,97 \\
\hline 50 & 1950 & 110 & 18,45 & 15,53 & 14,17 & 12,55 & 11,10 & 9,79 & 7,62 & 6,01 & 3,98 \\
\hline 50 & 2000 & 110 & 18,27 & 15,41 & 14,08 & 12,49 & 11,06 & 9,76 & 7,61 & 6,01 & 3,98 \\
\hline 50 & 200 & 115 & 53,12 & 29,16 & 21,45 & 15,67 & 12,14 & 9,72 & 6,73 & 5,15 & 3,56 \\
\hline 50 & 250 & 115 & 46,67 & 27,25 & 20,71 & 15,53 & 12,18 & 9,81 & 6,81 & 5,19 & 3,56 \\
\hline 50 & 300 & 115 & 42,19 & 25,83 & 20,11 & 15,37 & 12,18 & 9,87 & 6,88 & 5,22 & 3,56 \\
\hline 50 & 350 & 115 & 38,86 & 24,71 & 19,60 & 15,22 & 12,17 & 9,91 & 6,94 & 5,26 & 3,56 \\
\hline 50 & 400 & 115 & 36,26 & 23,79 & 19,15 & 15,07 & 12,14 & 9,94 & 6,99 & 5,29 & 3,56 \\
\hline 50 & 450 & 115 & 34,16 & 23,01 & 18,76 & 14,92 & 12,11 & 9,96 & 7,04 & 5,32 & 3,57 \\
\hline 50 & 500 & 115 & 32,43 & 22,33 & 18,40 & 14,77 & 12,06 & 9,97 & 7,07 & 5,35 & 3,57 \\
\hline 50 & 550 & 115 & 30,96 & 21,74 & 18,08 & 14,63 & 12,02 & 9,97 & 7,11 & 5,38 & 3,58 \\
\hline 50 & 600 & 115 & 29,70 & 21,22 & 17,78 & 14,50 & 11,97 & 9,97 & 7,14 & 5,41 & 3,59 \\
\hline 50 & 650 & 115 & 28,60 & 20,74 & 17,51 & 14,37 & 11,92 & 9,96 & 7,16 & 5,43 & 3,59 \\
\hline 50 & 700 & 115 & 27,63 & 20,31 & 17,25 & 14,24 & 11,87 & 9,95 & 7,19 & 5,45 & 3,60 \\
\hline 50 & 750 & 115 & 26,77 & 19,92 & 17,02 & 14,12 & 11,82 & 9,94 & 7,21 & 5,48 & 3,61 \\
\hline 50 & 800 & 115 & 25,99 & 19,56 & 16,79 & 14,00 & 11,76 & 9,92 & 7,23 & 5,50 & 3,62 \\
\hline 50 & 850 & 115 & 25,29 & 19,22 & 16,58 & 13,89 & 11,71 & 9,91 & 7,24 & 5,51 & 3,63 \\
\hline 50 & 900 & 115 & 24,66 & 18,91 & 16,38 & 13,78 & 11,66 & 9,89 & 7,25 & 5,53 & 3,63 \\
\hline 50 & 950 & 115 & 24,08 & 18,62 & 16,19 & 13,68 & 11,60 & 9,87 & 7,27 & 5,55 & 3,64 \\
\hline 50 & 1000 & 115 & 23,55 & 18,35 & 16,01 & 13,58 & 11,55 & 9,85 & 7,28 & 5,57 & 3,65 \\
\hline 50 & 1050 & 115 & 23,05 & 18,09 & 15,84 & 13,48 & 11,50 & 9,83 & 7,28 & 5,58 & 3,66 \\
\hline 50 & 1100 & 115 & 22,60 & 17,85 & 15,68 & 13,38 & 11,45 & 9,81 & 7,29 & 5,59 & 3,67 \\
\hline 50 & 1150 & 115 & 22,18 & 17,62 & 15,53 & 13,29 & 11,40 & 9,78 & 7,30 & 5,61 & 3,68 \\
\hline 50 & 1200 & 115 & 21,78 & 17,40 & 15,38 & 13,20 & 11,35 & 9,76 & 7,30 & 5,62 & 3,68 \\
\hline 50 & 1250 & 115 & 21,41 & 17,20 & 15,24 & 13,11 & 11,30 & 9,74 & 7,31 & 5,63 & 3,69 \\
\hline 50 & 1300 & 115 & 21,07 & 17,00 & 15,10 & 13,03 & 11,25 & 9,72 & 7,31 & 5,64 & 3,70 \\
\hline 50 & 1350 & 115 & 20,74 & 16,81 & 14,97 & 12,95 & 11,20 & 9,69 & 7,31 & 5,65 & 3,71 \\
\hline 50 & 1400 & 115 & 20,44 & 16,63 & 14,84 & 12,87 & 11,16 & 9,67 & 7,31 & 5,66 & 3,72 \\
\hline 50 & 1450 & 115 & 20,15 & 16,46 & 14,72 & 12,79 & 11,11 & 9,64 & 7,31 & 5,67 & 3,72 \\
\hline 50 & 1500 & 115 & 19,87 & 16,30 & 14,60 & 12,71 & 11,06 & 9,62 & 7,31 & 5,68 & 3,73 \\
\hline 50 & 1550 & 115 & 19,61 & 16,14 & 14,49 & 12,64 & 11,02 & 9,60 & 7,31 & 5,69 & 3,74 \\
\hline 50 & 1600 & 115 & 19,37 & 15,98 & 14,38 & 12,57 & 10,97 & 9,57 & 7,31 & 5,70 & 3,75 \\
\hline 50 & 1650 & 115 & 19,13 & 15,84 & 14,27 & 12,50 & 10,93 & 9,55 & 7,31 & 5,70 & 3,75 \\
\hline 50 & 1700 & 115 & 18,91 & 15,70 & 14,17 & 12,43 & 10,89 & 9,52 & 7,31 & 5,71 & 3,76 \\
\hline 50 & 1750 & 115 & 18,70 & 15,56 & 14,07 & 12,36 & 10,85 & 9,50 & 7,31 & 5,72 & 3,77 \\
\hline 50 & 1800 & 115 & 18,50 & 15,43 & 13,98 & 12,30 & 10,80 & 9,48 & 7,31 & 5,72 & 3,77 \\
\hline 50 & 1850 & 115 & 18,30 & 15,30 & 13,88 & 12,23 & 10,76 & 9,45 & 7,30 & 5,73 & 3,78 \\
\hline 50 & 1900 & 115 & 18,12 & 15,18 & 13,79 & 12,17 & 10,72 & 9,43 & 7,30 & 5,73 & 3,79 \\
\hline 50 & 1950 & 115 & 17,94 & 15,06 & 13,70 & 12,11 & 10,68 & 9,40 & 7,29 & 5,74 & 3,79 \\
\hline 50 & 2000 & 115 & 17,77 & 14,94 & 13,62 & 12,05 & 10,65 & 9,38 & 7,29 & 5,74 & 3,80 \\
\hline 50 & 200 & 120 & 52,22 & 28,32 & 20,69 & 15,04 & 11,62 & 9,30 & 6,44 & 4,93 & 3,42 \\
\hline 50 & 250 & 120 & 45,82 & 26,45 & 19,98 & 14,91 & 11,66 & 9,39 & 6,52 & 4,96 & 3,41 \\
\hline 50 & 300 & 120 & 41,38 & 25,06 & 19,40 & 14,77 & 11,68 & 9,45 & 6,58 & 5,00 & 3,41 \\
\hline 50 & 350 & 120 & 38,08 & 23,97 & 18,92 & 14,63 & 11,67 & 9,49 & 6,64 & 5,03 & 3,41 \\
\hline 50 & 400 & 120 & 35,52 & 23,07 & 18,49 & 14,49 & 11,65 & 9,52 & 6,69 & 5,06 & 3,41 \\
\hline 50 & 450 & 120 & 33,45 & 22,31 & 18,11 & 14,35 & 11,62 & 9,54 & 6,73 & 5,09 & 3,42 \\
\hline 50 & 500 & 120 & 31,73 & 21,66 & 17,78 & 14,21 & 11,58 & 9,55 & 6,76 & 5,12 & 3,42 \\
\hline 50 & 550 & 120 & 30,29 & 21,09 & 17,47 & 14,08 & 11,54 & 9,55 & 6,80 & 5,14 & 3,43 \\
\hline 50 & 600 & 120 & 29,04 & 20,58 & 17,18 & 13,96 & 11,50 & 9,55 & 6,83 & 5,17 & 3,43 \\
\hline 50 & 650 & 120 & 27,96 & 20,12 & 16,92 & 13,84 & 11,45 & 9,55 & 6,85 & 5,19 & 3,44 \\
\hline 50 & 700 & 120 & 27,01 & 19,70 & 16,68 & 13,72 & 11,40 & 9,54 & 6,88 & 5,21 & 3,45 \\
\hline 50 & 750 & 120 & 26,16 & 19,32 & 16,45 & 13,60 & 11,35 & 9,53 & 6,90 & 5,23 & 3,45 \\
\hline 50 & 800 & 120 & 25,40 & 18,97 & 16,23 & 13,49 & 11,31 & 9,52 & 6,91 & 5,25 & 3,46 \\
\hline 50 & 850 & 120 & 24,71 & 18,65 & 16,03 & 13,39 & 11,26 & 9,51 & 6,93 & 5,27 & 3,47 \\
\hline 50 & 900 & 120 & 24,08 & 18,35 & 15,84 & 13,29 & 11,21 & 9,49 & 6,94 & 5,29 & 3,48 \\
\hline 50 & 950 & 120 & 23,51 & 18,06 & 15,66 & 13,19 & 11,16 & 9,47 & 6,95 & 5,31 & 3,48 \\
\hline 50 & 1000 & 120 & 22,99 & 17,80 & 15,49 & 13,09 & 11,11 & 9,46 & 6,96 & 5,32 & 3,49 \\
\hline 50 & 1050 & 120 & 22,50 & 17,55 & 15,33 & 13,00 & 11,06 & 9,44 & 6,97 & 5,34 & 3,50 \\
\hline 50 & 1100 & 120 & 22,06 & 17,32 & 15,17 & 12,91 & 11,02 & 9,42 & 6,98 & 5,35 & 3,51 \\
\hline 50 & 1150 & 120 & 21,64 & 17,10 & 15,02 & 12,82 & 10,97 & 9,40 & 6,99 & 5,36 & 3,51 \\
\hline 50 & 1200 & 120 & 21,25 & 16,89 & 14,88 & 12,74 & 10,92 & 9,38 & 6,99 & 5,37 & 3,52 \\
\hline 50 & 1250 & 120 & 20,89 & 16,69 & 14,74 & 12,65 & 10,88 & 9,36 & 7,00 & 5,39 & 3,53 \\
\hline 50 & 1300 & 120 & 20,55 & 16,50 & 14,61 & 12,57 & 10,83 & 9,33 & 7,00 & 5,40 & 3,54 \\
\hline 50 & 1350 & 120 & 20,23 & 16,31 & 14,49 & 12,50 & 10,79 & 9,31 & 7,00 & 5,41 & 3,54 \\
\hline 50 & 1400 & 120 & 19,93 & 16,14 & 14,37 & 12,42 & 10,74 & 9,29 & 7,01 & 5,42 & 3,55 \\
\hline 50 & 1450 & 120 & 19,64 & 15,97 & 14,25 & 12,35 & 10,70 & 9,27 & 7,01 & 5,43 & 3,56 \\
\hline 50 & 1500 & 120 & 19,37 & 15,81 & 14,14 & 12,27 & 10,66 & 9,25 & 7,01 & 5,43 & 3,57 \\
\hline 50 & 1550 & 120 & 19,12 & 15,66 & 14,03 & 12,20 & 10,62 & 9,23 & 7,01 & 5,44 & 3,57 \\
\hline 50 & 1600 & 120 & 18,88 & 15,51 & 13,92 & 12,14 & 10,57 & 9,20 & 7,01 & 5,45 & 3,58 \\
\hline 50 & 1650 & 120 & 18,65 & 15,37 & 13,82 & 12,07 & 10,53 & 9,18 & 7,01 & 5,46 & 3,59 \\
\hline 50 & 1700 & 120 & 18,43 & 15,24 & 13,72 & 12,00 & 10,49 & 9,16 & 7,01 & 5,46 & 3,59 \\
\hline 50 & 1750 & 120 & 18,22 & 15,10 & 13,63 & 11,94 & 10,45 & 9,14 & 7,01 & 5,47 & 3,60 \\
\hline 50 & 1800 & 120 & 18,02 & 14,98 & 13,53 & 11,88 & 10,41 & 9,11 & 7,00 & 5,48 & 3,61 \\
\hline 50 & 1850 & 120 & 17,83 & 14,85 & 13,44 & 11,82 & 10,38 & 9,09 & 7,00 & 5,48 & 3,61 \\
\hline 50 & 1900 & 120 & 17,65 & 14,73 & 13,36 & 11,76 & 10,34 & 9,07 & 7,00 & 5,49 & 3,62 \\
\hline 50 & 1950 & 120 & 17,47 & 14,62 & 13,27 & 11,70 & 10,30 & 9,05 & 7,00 & 5,49 & 3,62 \\
\hline 50 & 2000 & 120 & 17,31 & 14,51 & 13,19 & 11,65 & 10,26 & 9,03 & 6,99 & 5,50 & 3,63 \\
\hline
\end{tabular}




\begin{tabular}{|c|c|c|c|c|c|c|c|c|c|c|c|}
\hline \multirow[b]{2}{*}{$\mathrm{H}(\mathrm{cm})$} & \multirow[b]{2}{*}{ Mceq (MPa) } & & & & & $\mathrm{De}$ & ões (x1 & & & & \\
\hline & & Msub (MPa) & D0 & D25 & D40 & D60 & D80 & D100 & D140 & D180 & D260 \\
\hline 50 & 200 & 125 & 51,38 & 27,54 & 19,99 & 14,46 & 11,15 & 8,91 & 6,17 & 4,72 & 3,28 \\
\hline 50 & 250 & 125 & 45,03 & 25,70 & 19,31 & 14,34 & 11,19 & 9,00 & 6,24 & 4,76 & 3,27 \\
\hline 50 & 300 & 125 & 40,63 & 24,35 & 18,75 & 14,21 & 11,21 & 9,06 & 6,30 & 4,79 & 3,27 \\
\hline 50 & 350 & 125 & 37,36 & 23,28 & 18,28 & 14,08 & 11,20 & 9,10 & 6,36 & 4,82 & 3,27 \\
\hline 50 & 400 & 125 & 34,82 & 22,41 & 17,88 & 13,95 & 11,19 & 9,13 & 6,40 & 4,85 & 3,28 \\
\hline 50 & 450 & 125 & 32,78 & 21,67 & 17,52 & 13,82 & 11,16 & 9,15 & 6,44 & 4,88 & 3,28 \\
\hline 50 & 500 & 125 & 31,09 & 21,04 & 17,19 & 13,70 & 11,13 & 9,16 & 6,48 & 4,90 & 3,28 \\
\hline 50 & 550 & 125 & 29,66 & 20,48 & 16,89 & 13,57 & 11,09 & 9,17 & 6,51 & 4,93 & 3,29 \\
\hline 50 & 600 & 125 & 28,43 & 19,98 & 16,62 & 13,46 & 11,06 & 9,17 & 6,54 & 4,95 & 3,29 \\
\hline 50 & 650 & 125 & 27,36 & 19,54 & 16,37 & 13,34 & 11,01 & 9,17 & 6,57 & 4,97 & 3,30 \\
\hline 50 & 700 & 125 & 26,42 & 19,13 & 16,14 & 13,23 & 10,97 & 9,17 & 6,59 & 4,99 & 3,31 \\
\hline 50 & 750 & 125 & 25,59 & 18,76 & 15,92 & 13,12 & 10,93 & 9,16 & 6,61 & 5,01 & 3,31 \\
\hline 50 & 800 & 125 & 24,84 & 18,42 & 15,71 & 13,02 & 10,88 & 9,15 & 6,63 & 5,03 & 3,32 \\
\hline 50 & 850 & 125 & 24,16 & 18,11 & 15,52 & 12,92 & 10,84 & 9,14 & 6,64 & 5,05 & 3,33 \\
\hline 50 & 900 & 125 & 23,55 & 17,82 & 15,34 & 12,82 & 10,79 & 9,12 & 6,66 & 5,07 & 3,33 \\
\hline 50 & 950 & 125 & 22,98 & 17,55 & 15,17 & 12,73 & 10,75 & 9,11 & 6,67 & 5,08 & 3,34 \\
\hline 50 & 1000 & 125 & 22,47 & 17,29 & 15,00 & 12,64 & 10,70 & 9,09 & 6,68 & 5,10 & 3,35 \\
\hline 50 & 1050 & 125 & 21,99 & 17,05 & 14,84 & 12,55 & 10,66 & 9,08 & 6,69 & 5,11 & 3,35 \\
\hline 50 & 1100 & 125 & 21,55 & 16,82 & 14,70 & 12,47 & 10,62 & 9,06 & 6,70 & 5,12 & 3,36 \\
\hline 50 & 1150 & 125 & 21,14 & 16,61 & 14,55 & 12,38 & 10,57 & 9,04 & 6,70 & 5,14 & 3,37 \\
\hline 50 & 1200 & 125 & 20,76 & 16,40 & 14,42 & 12,30 & 10,53 & 9,02 & 6,71 & 5,15 & 3,37 \\
\hline 50 & 1250 & 125 & 20,40 & 16,21 & 14,29 & 12,23 & 10,49 & 9,00 & 6,71 & 5,16 & 3,38 \\
\hline 50 & 1300 & 125 & 20,07 & 16,03 & 14,16 & 12,15 & 10,44 & 8,98 & 6,72 & 5,17 & 3,39 \\
\hline 50 & 1350 & 125 & 19,75 & 15,85 & 14,04 & 12,08 & 10,40 & 8,96 & 6,72 & 5,18 & 3,40 \\
\hline 50 & 1400 & 125 & 19,46 & 15,68 & 13,92 & 12,00 & 10,36 & 8,94 & 6,72 & 5,19 & 3,40 \\
\hline 50 & 1450 & 125 & 19,18 & 15,52 & 13,81 & 11,93 & 10,32 & 8,92 & 6,73 & 5,20 & 3,41 \\
\hline 50 & 1500 & 125 & 18,91 & 15,37 & 13,70 & 11,87 & 10,28 & 8,90 & 6,73 & 5,21 & 3,42 \\
\hline 50 & 1550 & 125 & 18,66 & 15,22 & 13,60 & 11,80 & 10,24 & 8,88 & 6,73 & 5,21 & 3,42 \\
\hline 50 & 1600 & 125 & 18,42 & 15,08 & 13,50 & 11,73 & 10,20 & 8,86 & 6,73 & 5,22 & 3,43 \\
\hline 50 & 1650 & 125 & 18,20 & 14,94 & 13,40 & 11,67 & 10,16 & 8,84 & 6,73 & 5,23 & 3,43 \\
\hline 50 & 1700 & 125 & 17,98 & 14,81 & 13,30 & 11,61 & 10,13 & 8,82 & 6,73 & 5,24 & 3,44 \\
\hline 50 & 1750 & 125 & 17,78 & 14,68 & 13,21 & 11,55 & 10,09 & 8,80 & 6,73 & 5,24 & 3,45 \\
\hline 50 & 1800 & 125 & 17,58 & 14,55 & 13,12 & 11,49 & 10,05 & 8,78 & 6,73 & 5,25 & 3,45 \\
\hline 50 & 1850 & 125 & 17,39 & 14,44 & 13,03 & 11,43 & 10,02 & 8,76 & 6,73 & 5,25 & 3,46 \\
\hline 50 & 1900 & 125 & 17,21 & 14,32 & 12,95 & 11,38 & 9,98 & 8,74 & 6,72 & 5,26 & 3,46 \\
\hline 50 & 1950 & 125 & 17,04 & 14,21 & 12,87 & 11,32 & 9,94 & 8,72 & 6,72 & 5,26 & 3,47 \\
\hline 50 & 2000 & 125 & 16,87 & 14,10 & 12,79 & 11,27 & 9,91 & 8,70 & 6,72 & 5,27 & 3,48 \\
\hline 50 & 200 & 130 & 50,60 & 26,82 & 19,34 & 13,92 & 10,71 & 8,55 & 5,92 & 4,54 & 3,16 \\
\hline 50 & 250 & 130 & 44,29 & 25,01 & 18,68 & 13,81 & 10,76 & 8,64 & 5,99 & 4,57 & 3,15 \\
\hline 50 & 300 & 130 & 39,93 & 23,68 & 18,14 & 13,69 & 10,78 & 8,70 & 6,05 & 4,60 & 3,15 \\
\hline 50 & 350 & 130 & 36,69 & 22,64 & 17,70 & 13,57 & 10,78 & 8,74 & 6,10 & 4,63 & 3,15 \\
\hline 50 & 400 & 130 & 34,18 & 21,79 & 17,30 & 13,45 & 10,76 & 8,77 & 6,14 & 4,66 & 3,15 \\
\hline 50 & 450 & 130 & 32,15 & 21,07 & 16,96 & 13,33 & 10,74 & 8,79 & 6,18 & 4,68 & 3,15 \\
\hline 50 & 500 & 130 & 30,48 & 20,45 & 16,65 & 13,22 & 10,71 & 8,81 & 6,22 & 4,71 & 3,15 \\
\hline 50 & 550 & 130 & 29,07 & 19,91 & 16,36 & 13,10 & 10,68 & 8,82 & 6,25 & 4,73 & 3,16 \\
\hline 50 & 600 & 130 & 27,86 & 19,43 & 16,10 & 12,99 & 10,65 & 8,82 & 6,28 & 4,75 & 3,16 \\
\hline 50 & 650 & 130 & 26,81 & 18,99 & 15,86 & 12,88 & 10,61 & 8,82 & 6,30 & 4,77 & 3,17 \\
\hline 50 & 700 & 130 & 25,88 & 18,60 & 15,64 & 12,78 & 10,57 & 8,82 & 6,32 & 4,79 & 3,17 \\
\hline 50 & 750 & 130 & 25,06 & 18,24 & 15,43 & 12,68 & 10,53 & 8,81 & 6,34 & 4,81 & 3,18 \\
\hline 50 & 800 & 130 & 24,32 & 17,91 & 15,23 & 12,58 & 10,49 & 8,80 & 6,36 & 4,83 & 3,19 \\
\hline 50 & 850 & 130 & 23,65 & 17,61 & 15,04 & 12,49 & 10,45 & 8,79 & 6,38 & 4,84 & 3,19 \\
\hline 50 & 900 & 130 & 23,04 & 17,33 & 14,87 & 12,40 & 10,41 & 8,78 & 6,39 & 4,86 & 3,20 \\
\hline 50 & 950 & 130 & 22,49 & 17,06 & 14,70 & 12,31 & 10,37 & 8,77 & 6,40 & 4,88 & 3,21 \\
\hline 50 & 1000 & 130 & 21,98 & 16,81 & 14,54 & 12,22 & 10,33 & 8,75 & 6,41 & 4,89 & 3,21 \\
\hline 50 & 1050 & 130 & 21,51 & 16,58 & 14,39 & 12,14 & 10,28 & 8,74 & 6,42 & 4,90 & 3,22 \\
\hline 50 & 1100 & 130 & 21,08 & 16,36 & 14,25 & 12,06 & 10,24 & 8,72 & 6,43 & 4,92 & 3,23 \\
\hline 50 & 1150 & 130 & 20,67 & 16,15 & 14,11 & 11,98 & 10,20 & 8,71 & 6,44 & 4,93 & 3,23 \\
\hline 50 & 1200 & 130 & 20,30 & 15,95 & 13,98 & 11,90 & 10,16 & 8,69 & 6,45 & 4,94 & 3,24 \\
\hline 50 & 1250 & 130 & 19,95 & 15,77 & 13,86 & 11,83 & 10,12 & 8,67 & 6,45 & 4,95 & 3,25 \\
\hline 50 & 1300 & 130 & 19,62 & 15,59 & 13,74 & 11,76 & 10,08 & 8,66 & 6,46 & 4,96 & 3,25 \\
\hline 50 & 1350 & 130 & 19,31 & 15,42 & 13,62 & 11,69 & 10,04 & 8,64 & 6,46 & 4,97 & 3,26 \\
\hline 50 & 1400 & 130 & 19,02 & 15,25 & 13,51 & 11,62 & 10,00 & 8,62 & 6,46 & 4,98 & 3,26 \\
\hline 50 & 1450 & 130 & 18,74 & 15,10 & 13,40 & 11,55 & 9,97 & 8,60 & 6,47 & 4,99 & 3,27 \\
\hline 50 & 1500 & 130 & 18,48 & 14,95 & 13,29 & 11,49 & 9,93 & 8,58 & 6,47 & 5,00 & 3,28 \\
\hline 50 & 1550 & 130 & 18,23 & 14,80 & 13,19 & 11,42 & 9,89 & 8,56 & 6,47 & 5,00 & 3,28 \\
\hline 50 & 1600 & 130 & 18,00 & 14,67 & 13,10 & 11,36 & 9,86 & 8,55 & 6,47 & 5,01 & 3,29 \\
\hline 50 & 1650 & 130 & 17,77 & 14,53 & 13,00 & 11,30 & 9,82 & 8,53 & 6,47 & 5,02 & 3,29 \\
\hline 50 & 1700 & 130 & 17,56 & 14,40 & 12,91 & 11,24 & 9,78 & 8,51 & 6,47 & 5,03 & 3,30 \\
\hline 50 & 1750 & 130 & 17,36 & 14,28 & 12,82 & 11,18 & 9,75 & 8,49 & 6,47 & 5,03 & 3,31 \\
\hline 50 & 1800 & 130 & 17,17 & 14,16 & 12,74 & 11,13 & 9,71 & 8,47 & 6,47 & 5,04 & 3,31 \\
\hline 50 & 1850 & 130 & 16,98 & 14,04 & 12,65 & 11,07 & 9,68 & 8,45 & 6,47 & 5,04 & 3,32 \\
\hline 50 & 1900 & 130 & 16,80 & 13,93 & 12,57 & 11,02 & 9,65 & 8,43 & 6,47 & 5,05 & 3,32 \\
\hline 50 & 1950 & 130 & 16,64 & 13,82 & 12,49 & 10,97 & 9,61 & 8,41 & 6,47 & 5,05 & 3,33 \\
\hline 50 & 2000 & 130 & 16,47 & 13,72 & 12,42 & 10,91 & 9,58 & 8,39 & 6,46 & 5,06 & 3,33 \\
\hline 50 & 200 & 135 & 49,87 & 26,14 & 18,73 & 13,42 & 10,30 & 8,22 & 5,69 & 4,36 & 3,04 \\
\hline 50 & 250 & 135 & 43,60 & 24,36 & 18,09 & 13,32 & 10,35 & 8,30 & 5,76 & 4,39 & 3,03 \\
\hline 50 & 300 & 135 & 39,27 & 23,06 & 17,58 & 13,21 & 10,37 & 8,36 & 5,81 & 4,42 & 3,03 \\
\hline 50 & 350 & 135 & 36,06 & 22,04 & 17,15 & 13,10 & 10,38 & 8,41 & 5,86 & 4,45 & 3,03 \\
\hline 50 & 400 & 135 & 33,57 & 21,21 & 16,77 & 12,99 & 10,37 & 8,44 & 5,90 & 4,48 & 3,03 \\
\hline 50 & 450 & 135 & 31,57 & 20,51 & 16,44 & 12,88 & 10,35 & 8,46 & 5,94 & 4,50 & 3,03 \\
\hline 50 & 500 & 135 & 29,92 & 19,90 & 16,14 & 12,77 & 10,33 & 8,48 & 5,98 & 4,52 & 3,04 \\
\hline
\end{tabular}




\begin{tabular}{|c|c|c|c|c|c|c|c|c|c|c|c|}
\hline \multirow[b]{2}{*}{$\mathrm{H}(\mathrm{cm})$} & \multirow[b]{2}{*}{ Mceq (MPa) } & & & & & $\mathrm{De}$ & ões (x1 & & & & \\
\hline & & Msub (MPa) & D0 & D25 & D40 & D60 & D80 & D100 & D140 & D180 & D260 \\
\hline 50 & 550 & 135 & 28,52 & 19,38 & 15,86 & 12,66 & 10,30 & 8,49 & 6,01 & 4,54 & 3,04 \\
\hline 50 & 600 & 135 & 27,33 & 18,91 & 15,61 & 12,56 & 10,27 & 8,49 & 6,03 & 4,57 & 3,04 \\
\hline 50 & 650 & 135 & 26,29 & 18,49 & 15,38 & 12,46 & 10,24 & 8,49 & 6,06 & 4,58 & 3,05 \\
\hline 50 & 700 & 135 & 25,37 & 18,10 & 15,17 & 12,36 & 10,20 & 8,49 & 6,08 & 4,60 & 3,05 \\
\hline 50 & 750 & 135 & 24,56 & 17,76 & 14,97 & 12,26 & 10,16 & 8,49 & 6,10 & 4,62 & 3,06 \\
\hline 50 & 800 & 135 & 23,83 & 17,44 & 14,78 & 12,17 & 10,13 & 8,48 & 6,12 & 4,64 & 3,07 \\
\hline 50 & 850 & 135 & 23,17 & 17,14 & 14,60 & 12,08 & 10,09 & 8,47 & 6,13 & 4,65 & 3,07 \\
\hline 50 & 900 & 135 & 22,57 & 16,86 & 14,43 & 12,00 & 10,05 & 8,46 & 6,14 & 4,67 & 3,08 \\
\hline 50 & 950 & 135 & 22,03 & 16,61 & 14,27 & 11,91 & 10,01 & 8,45 & 6,16 & 4,68 & 3,08 \\
\hline 50 & 1000 & 135 & 21,53 & 16,37 & 14,12 & 11,83 & 9,97 & 8,44 & 6,17 & 4,70 & 3,09 \\
\hline 50 & 1050 & 135 & 21,06 & 16,14 & 13,97 & 11,75 & 9,93 & 8,43 & 6,18 & 4,71 & 3,09 \\
\hline 50 & 1100 & 135 & 20,64 & 15,92 & 13,84 & 11,67 & 9,90 & 8,41 & 6,19 & 4,72 & 3,10 \\
\hline 50 & 1150 & 135 & 20,24 & 15,72 & 13,70 & 11,60 & 9,86 & 8,40 & 6,19 & 4,74 & 3,11 \\
\hline 50 & 1200 & 135 & 19,87 & 15,53 & 13,58 & 11,53 & 9,82 & 8,38 & 6,20 & 4,75 & 3,11 \\
\hline 50 & 1250 & 135 & 19,52 & 15,35 & 13,46 & 11,46 & 9,78 & 8,37 & 6,21 & 4,76 & 3,12 \\
\hline 50 & 1300 & 135 & 19,20 & 15,18 & 13,34 & 11,39 & 9,75 & 8,35 & 6,21 & 4,77 & 3,13 \\
\hline 50 & 1350 & 135 & 18,89 & 15,01 & 13,23 & 11,32 & 9,71 & 8,34 & 6,22 & 4,78 & 3,13 \\
\hline 50 & 1400 & 135 & 18,60 & 14,85 & 13,12 & 11,26 & 9,67 & 8,32 & 6,22 & 4,79 & 3,14 \\
\hline 50 & 1450 & 135 & 18,33 & 14,70 & 13,01 & 11,19 & 9,64 & 8,30 & 6,22 & 4,79 & 3,14 \\
\hline 50 & 1500 & 135 & 18,07 & 14,55 & 12,91 & 11,13 & 9,60 & 8,28 & 6,23 & 4,80 & 3,15 \\
\hline 50 & 1550 & 135 & 17,83 & 14,42 & 12,82 & 11,07 & 9,57 & 8,27 & 6,23 & 4,81 & 3,15 \\
\hline 50 & 1600 & 135 & 17,60 & 14,28 & 12,72 & 11,01 & 9,53 & 8,25 & 6,23 & 4,82 & 3,16 \\
\hline 50 & 1650 & 135 & 17,38 & 14,15 & 12,63 & 10,95 & 9,50 & 8,23 & 6,23 & 4,83 & 3,17 \\
\hline 50 & 1700 & 135 & 17,17 & 14,03 & 12,54 & 10,90 & 9,46 & 8,22 & 6,23 & 4,83 & 3,17 \\
\hline 50 & 1750 & 135 & 16,97 & 13,91 & 12,46 & 10,84 & 9,43 & 8,20 & 6,23 & 4,84 & 3,18 \\
\hline 50 & 1800 & 135 & 16,78 & 13,79 & 12,38 & 10,79 & 9,40 & 8,18 & 6,23 & 4,84 & 3,18 \\
\hline 50 & 1850 & 135 & 16,60 & 13,68 & 12,29 & 10,73 & 9,37 & 8,16 & 6,23 & 4,85 & 3,19 \\
\hline 50 & 1900 & 135 & 16,42 & 13,57 & 12,22 & 10,68 & 9,33 & 8,15 & 6,23 & 4,85 & 3,19 \\
\hline 50 & 1950 & 135 & 16,26 & 13,46 & 12,14 & 10,63 & 9,30 & 8,13 & 6,23 & 4,86 & 3,20 \\
\hline 50 & 2000 & 135 & 16,10 & 13,36 & 12,07 & 10,58 & 9,27 & 8,11 & 6,23 & 4,86 & 3,20 \\
\hline 50 & 200 & 140 & 49,18 & 25,51 & 18,17 & 12,95 & 9,92 & 7,91 & 5,47 & 4,20 & 2,93 \\
\hline 50 & 250 & 140 & 42,95 & 23,76 & 17,55 & 12,86 & 9,98 & 8,00 & 5,54 & 4,23 & 2,93 \\
\hline 50 & 300 & 140 & 38,65 & 22,48 & 17,05 & 12,76 & 10,00 & 8,05 & 5,59 & 4,26 & 2,92 \\
\hline 50 & 350 & 140 & 35,47 & 21,48 & 16,63 & 12,66 & 10,01 & 8,10 & 5,64 & 4,28 & 2,92 \\
\hline 50 & 400 & 140 & 33,00 & 20,67 & 16,27 & 12,56 & 10,00 & 8,13 & 5,68 & 4,31 & 2,92 \\
\hline 50 & 450 & 140 & 31,02 & 19,98 & 15,95 & 12,45 & 9,99 & 8,15 & 5,72 & 4,33 & 2,92 \\
\hline 50 & 500 & 140 & 29,39 & 19,39 & 15,66 & 12,35 & 9,97 & 8,17 & 5,75 & 4,35 & 2,93 \\
\hline 50 & 550 & 140 & 28,01 & 18,88 & 15,40 & 12,25 & 9,94 & 8,18 & 5,78 & 4,37 & 2,93 \\
\hline 50 & 600 & 140 & 26,83 & 18,42 & 15,16 & 12,15 & 9,92 & 8,19 & 5,81 & 4,39 & 2,93 \\
\hline 50 & 650 & 140 & 25,80 & 18,01 & 14,93 & 12,06 & 9,89 & 8,19 & 5,83 & 4,41 & 2,94 \\
\hline 50 & 700 & 140 & 24,89 & 17,64 & 14,73 & 11,96 & 9,85 & 8,19 & 5,85 & 4,43 & 2,94 \\
\hline 50 & 750 & 140 & 24,09 & 17,30 & 14,53 & 11,87 & 9,82 & 8,19 & 5,87 & 4,45 & 2,95 \\
\hline 50 & 800 & 140 & 23,37 & 16,99 & 14,35 & 11,79 & 9,79 & 8,18 & 5,89 & 4,46 & 2,95 \\
\hline 50 & 850 & 140 & 22,72 & 16,70 & 14,18 & 11,70 & 9,75 & 8,18 & 5,90 & 4,48 & 2,96 \\
\hline 50 & 900 & 140 & 22,13 & 16,43 & 14,02 & 11,62 & 9,71 & 8,17 & 5,92 & 4,49 & 2,96 \\
\hline 50 & 950 & 140 & 21,59 & 16,18 & 13,86 & 11,54 & 9,68 & 8,16 & 5,93 & 4,51 & 2,97 \\
\hline 50 & 1000 & 140 & 21,10 & 15,95 & 13,72 & 11,46 & 9,64 & 8,15 & 5,94 & 4,52 & 2,97 \\
\hline 50 & 1050 & 140 & 20,64 & 15,72 & 13,58 & 11,39 & 9,61 & 8,14 & 5,95 & 4,53 & 2,98 \\
\hline 50 & 1100 & 140 & 20,22 & 15,52 & 13,45 & 11,31 & 9,57 & 8,12 & 5,96 & 4,55 & 2,99 \\
\hline 50 & 1150 & 140 & 19,83 & 15,32 & 13,32 & 11,24 & 9,54 & 8,11 & 5,97 & 4,56 & 2,99 \\
\hline 50 & 1200 & 140 & 19,46 & 15,13 & 13,20 & 11,17 & 9,50 & 8,10 & 5,97 & 4,57 & 3,00 \\
\hline 50 & 1250 & 140 & 19,12 & 14,96 & 13,08 & 11,11 & 9,47 & 8,08 & 5,98 & 4,58 & 3,00 \\
\hline 50 & 1300 & 140 & 18,80 & 14,79 & 12,97 & 11,04 & 9,43 & 8,07 & 5,99 & 4,59 & 3,01 \\
\hline 50 & 1350 & 140 & 18,50 & 14,63 & 12,86 & 10,98 & 9,40 & 8,05 & 5,99 & 4,60 & 3,01 \\
\hline 50 & 1400 & 140 & 18,22 & 14,47 & 12,75 & 10,92 & 9,36 & 8,04 & 5,99 & 4,61 & 3,02 \\
\hline 50 & 1450 & 140 & 17,95 & 14,33 & 12,65 & 10,86 & 9,33 & 8,02 & 6,00 & 4,62 & 3,02 \\
\hline 50 & 1500 & 140 & 17,69 & 14,19 & 12,56 & 10,80 & 9,30 & 8,01 & 6,00 & 4,62 & 3,03 \\
\hline 50 & 1550 & 140 & 17,45 & 14,05 & 12,46 & 10,74 & 9,26 & 7,99 & 6,00 & 4,63 & 3,04 \\
\hline 50 & 1600 & 140 & 17,23 & 13,92 & 12,37 & 10,68 & 9,23 & 7,97 & 6,01 & 4,64 & 3,04 \\
\hline 50 & 1650 & 140 & 17,01 & 13,79 & 12,28 & 10,63 & 9,20 & 7,96 & 6,01 & 4,64 & 3,05 \\
\hline 50 & 1700 & 140 & 16,80 & 13,67 & 12,20 & 10,57 & 9,17 & 7,94 & 6,01 & 4,65 & 3,05 \\
\hline 50 & 1750 & 140 & 16,61 & 13,56 & 12,12 & 10,52 & 9,13 & 7,93 & 6,01 & 4,66 & 3,06 \\
\hline 50 & 1800 & 140 & 16,42 & 13,44 & 12,04 & 10,47 & 9,10 & 7,91 & 6,01 & 4,66 & 3,06 \\
\hline 50 & 1850 & 140 & 16,24 & 13,33 & 11,96 & 10,42 & 9,07 & 7,89 & 6,01 & 4,67 & 3,07 \\
\hline 50 & 1900 & 140 & 16,07 & 13,23 & 11,88 & 10,37 & 9,04 & 7,88 & 6,01 & 4,67 & 3,07 \\
\hline 50 & 1950 & 140 & 15,90 & 13,13 & 11,81 & 10,32 & 9,01 & 7,86 & 6,01 & 4,68 & 3,08 \\
\hline 50 & 2000 & 140 & 15,74 & 13,03 & 11,74 & 10,27 & 8,98 & 7,84 & 6,01 & 4,68 & 3,08 \\
\hline 50 & 200 & 145 & 48,54 & 24,91 & 17,64 & 12,51 & 9,57 & 7,63 & 5,28 & 4,05 & 2,83 \\
\hline 50 & 250 & 145 & 42,34 & 23,19 & 17,03 & 12,43 & 9,63 & 7,71 & 5,34 & 4,08 & 2,83 \\
\hline 50 & 300 & 145 & 38,07 & 21,93 & 16,55 & 12,34 & 9,65 & 7,77 & 5,39 & 4,11 & 2,82 \\
\hline 50 & 350 & 145 & 34,91 & 20,95 & 16,15 & 12,25 & 9,66 & 7,81 & 5,44 & 4,13 & 2,82 \\
\hline 50 & 400 & 145 & 32,47 & 20,16 & 15,80 & 12,15 & 9,66 & 7,84 & 5,48 & 4,15 & 2,82 \\
\hline 50 & 450 & 145 & 30,50 & 19,49 & 15,49 & 12,05 & 9,65 & 7,87 & 5,51 & 4,18 & 2,82 \\
\hline 50 & 500 & 145 & 28,89 & 18,91 & 15,21 & 11,96 & 9,63 & 7,88 & 5,54 & 4,20 & 2,83 \\
\hline 50 & 550 & 145 & 27,52 & 18,41 & 14,96 & 11,86 & 9,61 & 7,89 & 5,57 & 4,22 & 2,83 \\
\hline 50 & 600 & 145 & 26,35 & 17,96 & 14,73 & 11,77 & 9,59 & 7,90 & 5,60 & 4,23 & 2,83 \\
\hline 50 & 650 & 145 & 25,34 & 17,56 & 14,51 & 11,68 & 9,56 & 7,91 & 5,62 & 4,25 & 2,84 \\
\hline 50 & 700 & 145 & 24,44 & 17,20 & 14,31 & 11,59 & 9,53 & 7,91 & 5,64 & 4,27 & 2,84 \\
\hline 50 & 750 & 145 & 23,65 & 16,87 & 14,13 & 11,51 & 9,50 & 7,91 & 5,66 & 4,29 & 2,84 \\
\hline 50 & 800 & 145 & 22,94 & 16,56 & 13,95 & 11,43 & 9,47 & 7,90 & 5,68 & 4,30 & 2,85 \\
\hline 50 & 850 & 145 & 22,30 & 16,28 & 13,79 & 11,35 & 9,43 & 7,90 & 5,69 & 4,32 & 2,85 \\
\hline
\end{tabular}




\begin{tabular}{|c|c|c|c|c|c|c|c|c|c|c|c|}
\hline \multirow[b]{2}{*}{$\mathrm{H}(\mathrm{cm})$} & \multirow[b]{2}{*}{ Mceq (MPa) } & & & & & $\mathrm{De}$ & ões (x. & & & & \\
\hline & & Msub (MPa) & D0 & D25 & D40 & D60 & D80 & D100 & D140 & D180 & D260 \\
\hline 50 & 900 & 145 & 21,72 & 16,02 & 13,63 & 11,27 & 9,40 & 7,89 & 5,70 & 4,33 & 2,86 \\
\hline 50 & 950 & 145 & 21,18 & 15,78 & 13,48 & 11,19 & 9,37 & 7,88 & 5,72 & 4,34 & 2,86 \\
\hline 50 & 1000 & 145 & 20,70 & 15,55 & 13,34 & 11,12 & 9,33 & 7,87 & 5,73 & 4,36 & 2,87 \\
\hline 50 & 1050 & 145 & 20,25 & 15,34 & 13,21 & 11,05 & 9,30 & 7,86 & 5,74 & 4,37 & 2,87 \\
\hline 50 & 1100 & 145 & 19,83 & 15,13 & 13,08 & 10,98 & 9,27 & 7,85 & 5,75 & 4,38 & 2,88 \\
\hline 50 & 1150 & 145 & 19,44 & 14,94 & 12,96 & 10,91 & 9,23 & 7,84 & 5,76 & 4,39 & 2,88 \\
\hline 50 & 1200 & 145 & 19,08 & 14,76 & 12,84 & 10,84 & 9,20 & 7,83 & 5,76 & 4,40 & 2,89 \\
\hline 50 & 1250 & 145 & 18,74 & 14,59 & 12,73 & 10,78 & 9,17 & 7,82 & 5,77 & 4,41 & 2,89 \\
\hline 50 & 1300 & 145 & 18,43 & 14,42 & 12,62 & 10,72 & 9,14 & 7,80 & 5,77 & 4,42 & 2,90 \\
\hline 50 & 1350 & 145 & 18,13 & 14,27 & 12,51 & 10,66 & 9,10 & 7,79 & 5,78 & 4,43 & 2,90 \\
\hline 50 & 1400 & 145 & 17,85 & 14,12 & 12,41 & 10,60 & 9,07 & 7,77 & 5,78 & 4,44 & 2,91 \\
\hline 50 & 1450 & 145 & 17,59 & 13,97 & 12,31 & 10,54 & 9,04 & 7,76 & 5,79 & 4,45 & 2,92 \\
\hline 50 & 1500 & 145 & 17,34 & 13,84 & 12,22 & 10,48 & 9,01 & 7,75 & 5,79 & 4,46 & 2,92 \\
\hline 50 & 1550 & 145 & 17,10 & 13,71 & 12,13 & 10,43 & 8,98 & 7,73 & 5,79 & 4,46 & 2,93 \\
\hline 50 & 1600 & 145 & 16,88 & 13,58 & 12,04 & 10,37 & 8,95 & 7,72 & 5,80 & 4,47 & 2,93 \\
\hline 50 & 1650 & 145 & 16,66 & 13,46 & 11,96 & 10,32 & 8,92 & 7,70 & 5,80 & 4,48 & 2,94 \\
\hline 50 & 1700 & 145 & 16,46 & 13,34 & 11,88 & 10,27 & 8,89 & 7,69 & 5,80 & 4,48 & 2,94 \\
\hline 50 & 1750 & 145 & 16,26 & 13,22 & 11,80 & 10,22 & 8,86 & 7,67 & 5,80 & 4,49 & 2,95 \\
\hline 50 & 1800 & 145 & 16,08 & 13,12 & 11,72 & 10,17 & 8,83 & 7,66 & 5,80 & 4,50 & 2,95 \\
\hline 50 & 1850 & 145 & 15,90 & 13,01 & 11,64 & 10,12 & 8,80 & 7,64 & 5,80 & 4,50 & 2,95 \\
\hline 50 & 1900 & 145 & 15,73 & 12,91 & 11,57 & 10,07 & 8,77 & 7,63 & 5,80 & 4,51 & 2,96 \\
\hline 50 & 1950 & 145 & 15,57 & 12,81 & 11,50 & 10,03 & 8,74 & 7,61 & 5,80 & 4,51 & 2,96 \\
\hline 50 & 2000 & 145 & 15,41 & 12,71 & 11,43 & 9,98 & 8,71 & 7,60 & 5,80 & 4,52 & 2,97 \\
\hline 50 & 200 & 150 & 47,94 & 24,35 & 17,14 & 12,11 & 9,24 & 7,36 & 5,09 & 3,92 & 2,74 \\
\hline 50 & 250 & 150 & 41,77 & 22,66 & 16,55 & 12,03 & 9,30 & 7,44 & 5,15 & 3,94 & 2,73 \\
\hline 50 & 300 & 150 & 37,52 & 21,42 & 16,09 & 11,95 & 9,33 & 7,50 & 5,20 & 3,97 & 2,73 \\
\hline 50 & 350 & 150 & 34,39 & 20,46 & 15,70 & 11,86 & 9,34 & 7,54 & 5,24 & 3,99 & 2,73 \\
\hline 50 & 400 & 150 & 31,96 & 19,68 & 15,36 & 11,77 & 9,34 & 7,57 & 5,28 & 4,01 & 2,73 \\
\hline 50 & 450 & 150 & 30,02 & 19,02 & 15,06 & 11,68 & 9,33 & 7,60 & 5,32 & 4,03 & 2,73 \\
\hline 50 & 500 & 150 & 28,41 & 18,46 & 14,79 & 11,59 & 9,32 & 7,62 & 5,35 & 4,05 & 2,73 \\
\hline 50 & 550 & 150 & 27,06 & 17,97 & 14,55 & 11,50 & 9,30 & 7,63 & 5,38 & 4,07 & 2,73 \\
\hline 50 & 600 & 150 & 25,91 & 17,53 & 14,33 & 11,41 & 9,28 & 7,64 & 5,40 & 4,09 & 2,74 \\
\hline 50 & 650 & 150 & 24,90 & 17,14 & 14,12 & 11,33 & 9,25 & 7,64 & 5,42 & 4,10 & 2,74 \\
\hline 50 & 700 & 150 & 24.02 & 16.78 & 13,93 & 11.25 & 9,22 & 7.64 & 5,44 & 4.12 & 2,74 \\
\hline 50 & 750 & 150 & 23,23 & 16,46 & 13,75 & 11,17 & 9,20 & 7,64 & 5,46 & 4,13 & 2,75 \\
\hline 50 & 800 & 150 & 22,53 & 16,17 & 13,58 & 11,09 & 9,17 & 7,64 & 5,48 & 4,15 & 2,75 \\
\hline 50 & 850 & 150 & 21,90 & 15,89 & 13,42 & 11,01 & 9,14 & 7,64 & 5,49 & 4,16 & 2,76 \\
\hline 50 & 900 & 150 & 21,32 & 15,64 & 13,27 & 10,94 & 9,11 & 7,63 & 5,51 & 4,18 & 2,76 \\
\hline 50 & 950 & 150 & 20,80 & 15,40 & 13,12 & 10,87 & 9,08 & 7,62 & 5,52 & 4,19 & 2,76 \\
\hline 50 & 1000 & 150 & 20,32 & 15,18 & 12,99 & 10,80 & 9,04 & 7,62 & 5,53 & 4,20 & 2,77 \\
\hline 50 & 1050 & 150 & 19,87 & 14,97 & 12,86 & 10,73 & 9,01 & 7,61 & 5,54 & 4,21 & 2,77 \\
\hline 50 & 1100 & 150 & 19,46 & 14,77 & 12,73 & 10,66 & 8,98 & 7,60 & 5,55 & 4,23 & 2,78 \\
\hline 50 & 1150 & 150 & 19,08 & 14,58 & 12,61 & 10,60 & 8,95 & 7,59 & 5,56 & 4,24 & 2,78 \\
\hline 50 & 1200 & 150 & 18,72 & 14,41 & 12,50 & 10,53 & 8,92 & 7,58 & 5,57 & 4,25 & 2,79 \\
\hline 50 & 1250 & 150 & 18,39 & 14,24 & 12,39 & 10,47 & 8,89 & 7,57 & 5,57 & 4,26 & 2,79 \\
\hline 50 & 1300 & 150 & 18,08 & 14,08 & 12,29 & 10,41 & 8,86 & 7,55 & 5,58 & 4,27 & 2,80 \\
\hline 50 & 1350 & 150 & 17,78 & 13,93 & 12,19 & 10,35 & 8,83 & 7,54 & 5,58 & 4,28 & 2,80 \\
\hline 50 & 1400 & 150 & 17,51 & 13,78 & 12,09 & 10,30 & 8,80 & 7,53 & 5,59 & 4,28 & 2,81 \\
\hline 50 & 1450 & 150 & 17,25 & 13,64 & 11,99 & 10,24 & 8,77 & 7,52 & 5,59 & 4,29 & 2,81 \\
\hline 50 & 1500 & 150 & 17,00 & 13,51 & 11,90 & 10,19 & 8,74 & 7,50 & 5,59 & 4,30 & 2,82 \\
\hline 50 & 1550 & 150 & 16,77 & 13,38 & 11,82 & 10,14 & 8,71 & 7,49 & 5,60 & 4,31 & 2,82 \\
\hline 50 & 1600 & 150 & 16,55 & 13,26 & 11,73 & 10,08 & 8,68 & 7,47 & 5,60 & 4,31 & 2,83 \\
\hline 50 & 1650 & 150 & 16,33 & 13,14 & 11,65 & 10,03 & 8,65 & 7,46 & 5,60 & 4,32 & 2,83 \\
\hline 50 & 1700 & 150 & 16,13 & 13,02 & 11,57 & 9,98 & 8,62 & 7,45 & 5,60 & 4,33 & 2,84 \\
\hline 50 & 1750 & 150 & 15,94 & 12,91 & 11,49 & 9,94 & 8,59 & 7,43 & 5,61 & 4,33 & 2,84 \\
\hline 50 & 1800 & 150 & 15,76 & 12,81 & 11,42 & 9,89 & 8,57 & 7,42 & 5,61 & 4,34 & 2,85 \\
\hline 50 & 1850 & 150 & 15,58 & 12,70 & 11,34 & 9,84 & 8,54 & 7,40 & 5,61 & 4,34 & 2,85 \\
\hline 50 & 1900 & 150 & 15,42 & 12,60 & 11,27 & 9,80 & 8,51 & 7,39 & 5,61 & 4,35 & 2,86 \\
\hline 50 & 1950 & 150 & 15,26 & 12,51 & 11,21 & 9,75 & 8,49 & 7,38 & 5,61 & 4,35 & 2,86 \\
\hline 50 & 2000 & 150 & 15,10 & 12,41 & 11,14 & 9,71 & 8,46 & 7,36 & 5,61 & 4,36 & 2,86 \\
\hline 50 & 200 & 155 & 47,37 & 23,83 & 16,67 & 11,72 & 8,93 & 7,11 & 4,92 & 3,79 & 2,65 \\
\hline 50 & 250 & 155 & 41,23 & 22,16 & 16,10 & 11,66 & 8,99 & 7,19 & 4,98 & 3,81 & 2,65 \\
\hline 50 & 300 & 155 & 37,01 & 20,94 & 15,65 & 11,58 & 9,02 & 7,25 & 5,02 & 3,83 & 2,64 \\
\hline 50 & 350 & 155 & 33,89 & 19,99 & 15,27 & 11,50 & 9,04 & 7,29 & 5,07 & 3,85 & 2,64 \\
\hline 50 & 400 & 155 & 31,49 & 19,22 & 14,95 & 11,41 & 9,04 & 7,32 & 5,10 & 3,87 & 2,64 \\
\hline 50 & 450 & 155 & 29,56 & 18,58 & 14,66 & 11,33 & 9,03 & 7,35 & 5,14 & 3,89 & 2,64 \\
\hline 50 & 500 & 155 & 27,97 & 18,03 & 14,40 & 11,24 & 9,02 & 7,36 & 5,17 & 3,91 & 2,64 \\
\hline 50 & 550 & 155 & 26,63 & 17,55 & 14,16 & 11,16 & 9,00 & 7,38 & 5,19 & 3,93 & 2,64 \\
\hline 50 & 600 & 155 & 25,48 & 17,12 & 13,95 & 11,08 & 8,99 & 7,39 & 5,22 & 3,95 & 2,65 \\
\hline 50 & 650 & 155 & 24,49 & 16,74 & 13,75 & 11,00 & 8,96 & 7,39 & 5,24 & 3,96 & 2,65 \\
\hline 50 & 700 & 155 & 23,62 & 16,39 & 13,56 & 10,92 & 8,94 & 7,40 & 5,26 & 3,98 & 2,65 \\
\hline 50 & 750 & 155 & 22,84 & 16,08 & 13,39 & 10,84 & 8,91 & 7,40 & 5,28 & 3,99 & 2,66 \\
\hline 50 & 800 & 155 & 22,15 & 15,79 & 13,22 & 10,77 & 8,89 & 7,40 & 5,29 & 4,01 & 2,66 \\
\hline 50 & 850 & 155 & 21,52 & 15,52 & 13,07 & 10,70 & 8,86 & 7,39 & 5,31 & 4,02 & 2,66 \\
\hline 50 & 900 & 155 & 20,95 & 15,27 & 12,92 & 10,63 & 8,83 & 7,39 & 5,32 & 4,04 & 2,67 \\
\hline 50 & 950 & 155 & 20,43 & 15,04 & 12,78 & 10,56 & 8,80 & 7,38 & 5,33 & 4,05 & 2,67 \\
\hline 50 & 1000 & 155 & 19,96 & 14,82 & 12,65 & 10,49 & 8,77 & 7,38 & 5,35 & 4,06 & 2,68 \\
\hline 50 & 1050 & 155 & 1952 & 1462 & 1253 & 10.43 & 874 & 737 & 5.36 & 4.07 & 268 \\
\hline 50 & 1100 & 155 & 19,11 & 14,43 & 12,41 & 10,36 & 8,71 & 7,36 & 5,36 & 4,08 & 2,69 \\
\hline 50 & 1150 & 155 & 18,73 & 14,25 & 12,29 & 10,30 & 8,68 & 7,35 & 5,37 & 4,09 & 2,69 \\
\hline 50 & 1200 & 155 & 18,38 & 14,07 & 12,18 & 10,24 & 8,66 & 7,34 & 5,38 & 4,10 & 2,69 \\
\hline
\end{tabular}




\begin{tabular}{|c|c|c|c|c|c|c|c|c|c|c|c|}
\hline \multirow[b]{2}{*}{$\mathrm{H}(\mathrm{cm})$} & \multirow[b]{2}{*}{ Mceq (MPa) } & & & & & De & ões (x & & & & \\
\hline & & Msub (MPa) & D0 & D25 & D40 & D60 & D80 & D100 & D140 & D180 & D260 \\
\hline 50 & 1250 & 155 & 18,05 & 13,91 & 12,08 & 10,18 & 8,63 & 7,33 & 5,39 & 4,11 & 2,70 \\
\hline 50 & 1300 & 155 & 17,75 & 13,76 & 11,98 & 10,13 & 8,60 & 7,32 & 5,39 & 4,12 & 2,70 \\
\hline 50 & 1350 & 155 & 17,46 & 13,61 & 11,88 & 10,07 & 8,57 & 7,31 & 5,40 & 4,13 & 2,71 \\
\hline 50 & 1400 & 155 & 17,18 & 13,46 & 11,78 & 10,02 & 8,54 & 7,30 & 5,40 & 4,14 & 2,71 \\
\hline 50 & 1450 & 155 & 16,93 & 13,33 & 11,69 & 9,96 & 8,51 & 7,28 & 5,41 & 4,15 & 2,72 \\
\hline 50 & 1500 & 155 & 16,68 & 13,20 & 11,61 & 9,91 & 8,48 & 7,27 & 5,41 & 4,15 & 2,72 \\
\hline 50 & 1550 & 155 & 16,45 & 13,07 & 11,52 & 9,86 & 8,46 & 7,26 & 5,41 & 4,16 & 2,73 \\
\hline 50 & 1600 & 155 & 16,23 & 12,95 & 11,44 & 9,81 & 8,43 & 7,25 & 5,42 & 4,17 & 2,73 \\
\hline 50 & 1650 & 155 & 16,03 & 12,84 & 11,36 & 9,76 & 8,40 & 7,23 & 5,42 & 4,17 & 2,74 \\
\hline 50 & 1700 & 155 & 15,83 & 12,73 & 11,28 & 9,71 & 8,37 & 7,22 & 5,42 & 4,18 & 2,74 \\
\hline 50 & 1750 & 155 & 15,64 & 12,62 & 11,21 & 9,67 & 8,35 & 7,21 & 5,42 & 4,19 & 2,74 \\
\hline 50 & 1800 & 155 & 15,46 & 12,51 & 11,13 & 9,62 & 8,32 & 7,20 & 5,42 & 4,19 & 2,75 \\
\hline 50 & 1850 & 155 & 15,28 & 12,41 & 11,06 & 9,58 & 8,30 & 7,18 & 5,43 & 4,20 & 2,75 \\
\hline 50 & 1900 & 155 & 15,12 & 12,31 & 10,99 & 9,53 & 8,27 & 7,17 & 5,43 & 4,20 & 2,76 \\
\hline 50 & 1950 & 155 & 14,96 & 12,22 & 10,93 & 9,49 & 8,24 & 7,16 & 5,43 & 4,21 & 2,76 \\
\hline 50 & 2000 & 155 & 14,81 & 12,13 & 10,86 & 9,45 & 8,22 & 7,14 & 5,43 & 4,21 & 2,77 \\
\hline 50 & 200 & 160 & 46,84 & 23,34 & 16,23 & 11,36 & 8,64 & 6,88 & 4,76 & 3,66 & 2,57 \\
\hline 50 & 250 & 160 & 40,72 & 21,68 & 15,68 & 11,30 & 8,70 & 6,95 & 4,81 & 3,69 & 2,56 \\
\hline 50 & 300 & 160 & 36,52 & 20,48 & 15,24 & 11,23 & 8,74 & 7,01 & 4,86 & 3,71 & 2,56 \\
\hline 50 & 350 & 160 & 33,43 & 19,55 & 14,87 & 11,16 & 8,75 & 7,05 & 4,90 & 3,73 & 2,56 \\
\hline 50 & 400 & 160 & 31,04 & 18,80 & 14,55 & 11,08 & 8,76 & 7,09 & 4,94 & 3,75 & 2,56 \\
\hline 50 & 450 & 160 & 29,12 & 18,16 & 14,27 & 11,00 & 8,75 & 7,11 & 4,97 & 3,77 & 2,56 \\
\hline 50 & 500 & 160 & 27,54 & 17,62 & 14,02 & 10,92 & 8,74 & 7,13 & 5,00 & 3,78 & 2,56 \\
\hline 50 & 550 & 160 & 26,22 & 17,15 & 13,80 & 10,84 & 8,73 & 7,14 & 5,02 & 3,80 & 2,56 \\
\hline 50 & 600 & 160 & 25,08 & 16,74 & 13,59 & 10,76 & 8,71 & 7,15 & 5,05 & 3,82 & 2,56 \\
\hline 50 & 650 & 160 & 24,10 & 16,36 & 13,39 & 10,69 & 8,69 & 7,16 & 5,07 & 3,83 & 2,57 \\
\hline 50 & 700 & 160 & 23,24 & 16,02 & 13,21 & 10,61 & 8,67 & 7,16 & 5,09 & 3,85 & 2,57 \\
\hline 50 & 750 & 160 & 22,47 & 15,72 & 13,04 & 10,54 & 8,65 & 7,17 & 5,10 & 3,86 & 2,57 \\
\hline 50 & 800 & 160 & 21,78 & 15,43 & 12,89 & 10,47 & 8,62 & 7,17 & 5,12 & 3,88 & 2,57 \\
\hline 50 & 850 & 160 & 21,16 & 15,17 & 12,74 & 10,40 & 8,60 & 7,16 & 5,13 & 3,89 & 2,58 \\
\hline 50 & 900 & 160 & 20,60 & 14,93 & 12,60 & 10,33 & 8,57 & 7,16 & 5,15 & 3,90 & 2,58 \\
\hline 50 & 950 & 160 & 20,09 & 14,70 & 12,46 & 10,27 & 8,54 & 7,16 & 5,16 & 3,91 & 2,59 \\
\hline 50 & 1000 & 160 & 19,62 & 14,49 & 12,34 & 10,20 & 8,52 & 7,15 & 5,17 & 3,93 & 2,59 \\
\hline 50 & 1050 & 160 & 19,18 & 14,29 & 12,21 & 10,14 & 8,49 & 7,14 & 5,18 & 3,94 & 2,59 \\
\hline 50 & 1100 & 160 & 18,78 & 14,10 & 12,10 & 10,08 & 8,46 & 7,14 & 5,19 & 3,95 & 2,60 \\
\hline 50 & 1150 & 160 & 18,41 & 13,93 & 11,99 & 10,02 & 8,43 & 7,13 & 5,20 & 3,96 & 2,60 \\
\hline 50 & 1200 & 160 & 18,06 & 13,76 & 11,88 & 9,96 & 8,41 & 7,12 & 5,21 & 3,97 & 2,61 \\
\hline 50 & 1250 & 160 & 17,74 & 13,60 & 11,78 & 9,91 & 8,38 & 7,11 & 5,21 & 3,98 & 2,61 \\
\hline 50 & 1300 & 160 & 17,43 & 13,45 & 11,68 & 9,85 & 8,35 & 7,10 & 5,22 & 3,99 & 2,62 \\
\hline 50 & 1350 & 160 & 17,15 & 13,30 & 11,59 & 9,80 & 8,32 & 7,09 & 5,23 & 3,99 & 2,62 \\
\hline 50 & 1400 & 160 & 16,88 & 13,16 & 11,49 & 9,75 & 8,30 & 7,08 & 5,23 & 4,00 & 2,62 \\
\hline 50 & 1450 & 160 & 16,62 & 13,03 & 11,41 & 9,70 & 8,27 & 7,07 & 5,23 & 4,01 & 2,63 \\
\hline 50 & 1500 & 160 & 16,38 & 12,90 & 11,32 & 9,65 & 8,24 & 7,06 & 5,24 & 4,02 & 2,63 \\
\hline 50 & 1550 & 160 & 16,16 & 12,78 & 11,24 & 9,60 & 8,22 & 7,04 & 5,24 & 4,02 & 2,64 \\
\hline 50 & 1600 & 160 & 15,94 & 12,66 & 11,16 & 9,55 & 8,19 & 7,03 & 5,25 & 4,03 & 2,64 \\
\hline 50 & 1650 & 160 & 15,73 & 12,55 & 11,08 & 9,50 & 8,17 & 7,02 & 5,25 & 4,04 & 2,65 \\
\hline 50 & 1700 & 160 & 15,54 & 12,44 & 11,01 & 9,46 & 8,14 & 7,01 & 5,25 & 4,04 & 2,65 \\
\hline 50 & 1750 & 160 & 15,35 & 12,34 & 10,94 & 9,41 & 8,12 & 7,00 & 5,25 & 4,05 & 2,65 \\
\hline 50 & 1800 & 160 & 15,17 & 12,24 & 10,87 & 9,37 & 8,09 & 6,98 & 5,25 & 4,06 & 2,66 \\
\hline 50 & 1850 & 160 & 15,00 & 12,14 & 10,80 & 9,33 & 8,07 & 6,97 & 5,25 & 4,06 & 2,66 \\
\hline 50 & 1900 & 160 & 14,84 & 12,04 & 10,73 & 9,29 & 8,04 & 6,96 & 5,26 & 4,07 & 2,67 \\
\hline 50 & 1950 & 160 & 14,68 & 11,95 & 10,67 & 9,25 & 8,02 & 6,95 & 5,26 & 4,07 & 2,67 \\
\hline 50 & 2000 & 160 & 14,53 & 11,86 & 10,60 & 9,21 & 7,99 & 6,94 & 5,26 & 4,08 & 2,67 \\
\hline 50 & 200 & 165 & 46,33 & 22,87 & 15,82 & 11,02 & 8,37 & 6,66 & 4,60 & 3,55 & 2,50 \\
\hline 50 & 250 & 165 & 40,24 & 21,23 & 15,27 & 10,97 & 8,43 & 6,73 & 4,66 & 3,57 & 2,49 \\
\hline 50 & 300 & 165 & 36,06 & 20,05 & 14,85 & 10,91 & 8,47 & 6,79 & 4,70 & 3,59 & 2,48 \\
\hline 50 & 350 & 165 & 32,98 & 19,13 & 14,49 & 10,83 & 8,48 & 6,83 & 4,74 & 3,61 & 2,48 \\
\hline 50 & 400 & 165 & 30,61 & 18,39 & 14,18 & 10,76 & 8,49 & 6,86 & 4,78 & 3,63 & 2,48 \\
\hline 50 & 450 & 165 & 28,71 & 17,77 & 13,91 & 10,69 & 8,49 & 6,89 & 4,81 & 3,65 & 2,48 \\
\hline 50 & 500 & 165 & 27,14 & 17,24 & 13,67 & 10,61 & 8,48 & 6,91 & 4,84 & 3,67 & 2,48 \\
\hline 50 & 550 & 165 & 25,83 & 16,78 & 13,45 & 10,54 & 8,47 & 6,92 & 4,86 & 3,68 & 2,48 \\
\hline 50 & 600 & 165 & 24,71 & 16,37 & 13,25 & 10,46 & 8,45 & 6,93 & 4,88 & 3,70 & 2,48 \\
\hline 50 & 650 & 165 & 23,73 & 16,00 & 13,06 & 10,39 & 8,44 & 6,94 & 4,91 & 3,71 & 2,49 \\
\hline 50 & 700 & 165 & 22,87 & 15,67 & 12,89 & 10,32 & 8,42 & 6,95 & 4,92 & 3,73 & 2,49 \\
\hline 50 & 750 & 165 & 22,12 & 15,37 & 12,72 & 10,25 & 8,39 & 6,95 & 4,94 & 3,74 & 2,49 \\
\hline 50 & 800 & 165 & 21,44 & 15,10 & 12,57 & 10,18 & 8,37 & 6,95 & 4,96 & 3,75 & 2,50 \\
\hline 50 & 850 & 165 & 20,82 & 14,84 & 12,42 & 10,12 & 8,35 & 6,95 & 4,97 & 3,77 & 2,50 \\
\hline 50 & 900 & 165 & 20,27 & 14,60 & 12,29 & 10,05 & 8,32 & 6,95 & 4,99 & 3,78 & 2,50 \\
\hline 50 & 950 & 165 & 19,76 & 14,38 & 12,16 & 9,99 & 8,30 & 6,94 & 5,00 & 3,79 & 2,51 \\
\hline 50 & 1000 & 165 & 19,29 & 14,18 & 12,04 & 9,93 & 8,27 & 6,94 & 5,01 & 3,80 & 2,51 \\
\hline 50 & 1050 & 165 & 18,87 & 13,98 & 11,92 & 9,87 & 8,25 & 6,93 & 5,02 & 3,81 & 2,51 \\
\hline 50 & 1100 & 165 & 18,47 & 13,80 & 11,81 & 9,81 & 8,22 & 6,92 & 5,03 & 3,82 & 2,52 \\
\hline 50 & 1150 & 165 & 18,10 & 13,62 & 11,70 & 9,76 & 8,20 & 6,92 & 5,04 & 3,83 & 2,52 \\
\hline 50 & 1200 & 165 & 17,76 & 13,46 & 11,60 & 9,70 & 8,17 & 6,91 & 5,04 & 3,84 & 2,53 \\
\hline 50 & 1250 & 165 & 17,44 & 13,30 & 11,50 & 9,65 & 8,15 & 6,90 & 5,05 & 3,85 & 2,53 \\
\hline 50 & 1300 & 165 & 17,14 & 13,16 & 11,40 & 9,60 & 8,12 & 6,89 & 5,06 & 3,86 & 2,53 \\
\hline 50 & 1350 & 165 & 16,85 & 13,01 & 11,31 & 9,55 & 8,09 & 6,88 & 5,06 & 3,87 & 2,54 \\
\hline 50 & 1400 & 165 & 16,59 & 12,88 & 11,22 & 9,50 & 8,07 & 6,87 & 5,07 & 3,87 & 2,54 \\
\hline 50 & 1450 & 165 & 16,34 & 12,75 & 11,14 & 9,45 & 8,04 & 6,86 & 5,07 & 3,88 & 2,55 \\
\hline 50 & 1500 & 165 & 16,10 & 12,63 & 11,05 & 9,40 & 8,02 & 6,85 & 5,08 & 3,89 & 2,55 \\
\hline 50 & 1550 & 165 & 15,87 & 12,51 & 10,97 & 9,35 & 7,99 & 6,84 & 5,08 & 3,90 & 2,55 \\
\hline
\end{tabular}




\begin{tabular}{|c|c|c|c|c|c|c|c|c|c|c|c|}
\hline \multirow[b]{2}{*}{$\mathrm{H}(\mathrm{cm})$} & \multirow[b]{2}{*}{ Mceq (MPa) } & & & & & De & ões (x & & & & \\
\hline & & Msub (MPa) & D0 & D25 & D40 & D60 & D80 & D100 & D140 & D180 & D260 \\
\hline 50 & 1600 & 165 & 15,66 & 12,39 & 10,90 & 9,31 & 7,97 & 6,83 & 5,08 & 3,90 & 2,56 \\
\hline 50 & 1650 & 165 & 15,46 & 12,28 & 10,82 & 9,26 & 7,94 & 6,82 & 5,09 & 3,91 & 2,56 \\
\hline 50 & 1700 & 165 & 15,26 & 12,17 & 10,75 & 9,22 & 7,92 & 6,81 & 5,09 & 3,91 & 2,57 \\
\hline 50 & 1750 & 165 & 15,08 & 12,07 & 10,68 & 9,18 & 7,90 & 6,80 & 5,09 & 3,92 & 2,57 \\
\hline 50 & 1800 & 165 & 14,90 & 11,97 & 10,61 & 9,13 & 7,87 & 6,79 & 5,09 & 3,93 & 2,57 \\
\hline 50 & 1850 & 165 & 14,73 & 11,88 & 10,54 & 9,09 & 7,85 & 6,77 & 5,09 & 3,93 & 2,58 \\
\hline 50 & 1900 & 165 & 14,57 & 11,78 & 10,48 & 9,05 & 7,82 & 6,76 & 5,10 & 3,94 & 2,58 \\
\hline 50 & 1950 & 165 & 14,42 & 11,69 & 10,42 & 9,01 & 7,80 & 6,75 & 5,10 & 3,94 & 2,59 \\
\hline 50 & 2000 & 165 & 14,27 & 11,61 & 10,36 & 8,97 & 7,78 & 6,74 & 5,10 & 3,95 & 2,59 \\
\hline 50 & 200 & 170 & 45,85 & 22,43 & 15,42 & 10,70 & 8,12 & 6,45 & 4,46 & 3,44 & 2,42 \\
\hline 50 & 250 & 170 & 39,78 & 20,81 & 14,89 & 10,66 & 8,18 & 6,53 & 4,51 & 3,46 & 2,41 \\
\hline 50 & 300 & 170 & 35,62 & 19,64 & 14,48 & 10,60 & 8,21 & 6,58 & 4,56 & 3,48 & 2,41 \\
\hline 50 & 350 & 170 & 32,56 & 18,74 & 14,13 & 10,53 & 8,23 & 6,62 & 4,60 & 3,50 & 2,41 \\
\hline 50 & 400 & 170 & 30,20 & 18,01 & 13,83 & 10,46 & 8,24 & 6,66 & 4,63 & 3,52 & 2,41 \\
\hline 50 & 450 & 170 & 28,32 & 17,40 & 13,57 & 10,39 & 8,24 & 6,68 & 4,66 & 3,54 & 2,41 \\
\hline 50 & 500 & 170 & 26,76 & 16,88 & 13,33 & 10,32 & 8,23 & 6,70 & 4,69 & 3,55 & 2,41 \\
\hline 50 & 550 & 170 & 25,46 & 16,42 & 13,12 & 10,25 & 8,22 & 6,72 & 4,71 & 3,57 & 2,41 \\
\hline 50 & 600 & 170 & 24,35 & 16,02 & 12,92 & 10,18 & 8,21 & 6,73 & 4,73 & 3,58 & 2,41 \\
\hline 50 & 650 & 170 & 23,38 & 15,67 & 12,74 & 10,11 & 8,20 & 6,73 & 4,75 & 3,60 & 2,41 \\
\hline 50 & 700 & 170 & 22,53 & 15,34 & 12,57 & 10,04 & 8,18 & 6,74 & 4,77 & 3,61 & 2,41 \\
\hline 50 & 750 & 170 & 21,78 & 15,05 & 12,42 & 9,98 & 8,16 & 6,74 & 4,79 & 3,62 & 2,42 \\
\hline 50 & 800 & 170 & 21,11 & 14,78 & 12,27 & 9,91 & 8,14 & 6,74 & 4,80 & 3,64 & 2,42 \\
\hline 50 & 850 & 170 & 20,50 & 14,53 & 12,13 & 9,85 & 8,11 & 6,74 & 4,82 & 3,65 & 2,42 \\
\hline 50 & 900 & 170 & 19,95 & 14,29 & 12,00 & 9,79 & 8,09 & 6,74 & 4,83 & 3,66 & 2,43 \\
\hline 50 & 950 & 170 & 19,45 & 14,08 & 11,87 & 9,73 & 8,07 & 6,74 & 4,84 & 3,67 & 2,43 \\
\hline 50 & 1000 & 170 & 18,99 & 13,87 & 11,75 & 9,67 & 8,04 & 6,74 & 4,85 & 3,68 & 2,43 \\
\hline 50 & 1050 & 170 & 18,56 & 13,68 & 11,64 & 9,62 & 8,02 & 6,73 & 4,86 & 3,69 & 2,44 \\
\hline 50 & 1100 & 170 & 18,17 & 13,51 & 11,53 & 9,56 & 8,00 & 6,72 & 4,87 & 3,70 & 2,44 \\
\hline 50 & 1150 & 170 & 17,81 & 13,34 & 11,42 & 9,51 & 7,97 & 6,72 & 4,88 & 3,71 & 2,44 \\
\hline 50 & 1200 & 170 & 17,47 & 13,18 & 11,32 & 9,45 & 7,95 & 6,71 & 4,89 & 3,72 & 2,45 \\
\hline 50 & 1250 & 170 & 17,15 & 13,02 & 11,23 & 9,40 & 7,92 & 6,70 & 4,90 & 3,73 & 2,45 \\
\hline 50 & 1300 & 170 & 16,85 & 12,88 & 11,14 & 9,35 & 7,90 & 6,70 & 4,90 & 3,74 & 2,46 \\
\hline 50 & 1350 & 170 & 16,57 & 12,74 & 11,05 & 9,30 & 7,88 & 6,69 & 4,91 & 3,75 & 2,46 \\
\hline 50 & 1400 & 170 & 16,31 & 12,61 & 10,96 & 9,26 & 7,85 & 6,68 & 4,91 & 3,75 & 2,46 \\
\hline 50 & 1450 & 170 & 16,06 & 12,48 & 10,88 & 9,21 & 7,83 & 6,67 & 4,92 & 3,76 & 2,47 \\
\hline 50 & 1500 & 170 & 15,83 & 12,36 & 10,80 & 9,16 & 7,80 & 6,66 & 4,92 & 3,77 & 2,47 \\
\hline 50 & 1550 & 170 & 15,60 & 12,24 & 10,72 & 9,12 & 7,78 & 6,65 & 4,93 & 3,77 & 2,48 \\
\hline 50 & 1600 & 170 & 15,39 & 12,13 & 10,65 & 9,07 & 7,76 & 6,64 & 4,93 & 3,78 & 2,48 \\
\hline 50 & 1650 & 170 & 15,19 & 12,02 & 10,57 & 9,03 & 7,73 & 6,63 & 4,93 & 3,79 & 2,48 \\
\hline 50 & 1700 & 170 & 15,00 & 11,92 & 10,50 & 8,99 & 7,71 & 6,62 & 4,94 & 3,79 & 2,49 \\
\hline 50 & 1750 & 170 & 14,82 & 11,82 & 10,44 & 8,95 & 7,69 & 6,61 & 4,94 & 3,80 & 2,49 \\
\hline 50 & 1800 & 170 & 14,64 & 11,72 & 10,37 & 8,91 & 7,66 & 6,60 & 4,94 & 3,80 & 2,49 \\
\hline 50 & 1850 & 170 & 14,48 & 11,63 & 10,30 & 8,87 & 7,64 & 6,59 & 4,94 & 3,81 & 2,50 \\
\hline 50 & 1900 & 170 & 14,32 & 11,54 & 10,24 & 8,83 & 7,62 & 6,58 & 4,94 & 3,82 & 2,50 \\
\hline 50 & 1950 & 170 & 14,17 & 11,45 & 10,18 & 8,79 & 7,60 & 6,57 & 4,95 & 3,82 & 2,50 \\
\hline 50 & 2000 & 170 & 14,02 & 11,37 & 10,12 & 8,75 & 7,58 & 6,55 & 4,95 & 3,82 & 2,51 \\
\hline 50 & 200 & 175 & 45,39 & 22,01 & 15,05 & 10,40 & 7,87 & 6,26 & 4,33 & 3,34 & 2,35 \\
\hline 50 & 250 & 175 & 39,35 & 20,41 & 14,53 & 10,36 & 7,94 & 6,33 & 4,38 & 3,36 & 2,35 \\
\hline 50 & 300 & 175 & 35,21 & 19,25 & 14,13 & 10,30 & 7,97 & 6,39 & 4,42 & 3,38 & 2,34 \\
\hline 50 & 350 & 175 & 32,16 & 18,36 & 13,79 & 10,24 & 7,99 & 6,43 & 4,46 & 3,40 & 2,34 \\
\hline 50 & 400 & 175 & 29,82 & 17,64 & 13,50 & 10,18 & 8,00 & 6,46 & 4,49 & 3,42 & 2,34 \\
\hline 50 & 450 & 175 & 27,94 & 17,04 & 13,24 & 10,11 & 8,01 & 6,48 & 4,52 & 3,43 & 2,34 \\
\hline 50 & 500 & 175 & 26,40 & 16,53 & 13,02 & 10,04 & 8,00 & 6,50 & 4,55 & 3,45 & 2,34 \\
\hline 50 & 550 & 175 & 25,11 & 16,09 & 12,81 & 9,98 & 7,99 & 6,52 & 4,57 & 3,46 & 2,34 \\
\hline 50 & 600 & 175 & 24,00 & 15,69 & 12,62 & 9,91 & 7,98 & 6,53 & 4,59 & 3,48 & 2,34 \\
\hline 50 & 650 & 175 & 23,05 & 15,34 & 12,44 & 9,85 & 7,97 & 6,54 & 4,61 & 3,49 & 2,34 \\
\hline 50 & 700 & 175 & 22,21 & 15,03 & 12,28 & 9,78 & 7,95 & 6,55 & 4,63 & 3,50 & 2,34 \\
\hline 50 & 750 & 175 & 21,46 & 14,74 & 12,13 & 9,72 & 7,93 & 6,55 & 4,65 & 3,51 & 2,35 \\
\hline 50 & 800 & 175 & 20,79 & 14,47 & 11,98 & 9,66 & 7,91 & 6,55 & 4,66 & 3,53 & 2,35 \\
\hline 50 & 850 & 175 & 20,19 & 14,23 & 11,85 & 9,60 & 7,89 & 6,55 & 4,67 & 3,54 & 2,35 \\
\hline 50 & 900 & 175 & 19,65 & 14,00 & 11,72 & 9,54 & 7,87 & 6,55 & 4,69 & 3,55 & 2,36 \\
\hline 50 & 950 & 175 & 19,15 & 13,79 & 11,60 & 9,48 & 7,85 & 6,55 & 4,70 & 3,56 & 2,36 \\
\hline 50 & 1000 & 175 & 18,70 & 13,59 & 11,48 & 9,43 & 7,83 & 6,55 & 4,71 & 3,57 & 2,36 \\
\hline 50 & 1050 & 175 & 18,28 & 13,40 & 11,37 & 9,37 & 7,81 & 6,54 & 4,72 & 3,58 & 2,37 \\
\hline 50 & 1100 & 175 & 17,89 & 13,23 & 11,27 & 9,32 & 7,78 & 6,54 & 4,73 & 3,59 & 2,37 \\
\hline 50 & 1150 & 175 & 17,53 & 13,06 & 11,16 & 9,27 & 7,76 & 6,53 & 4,74 & 3,60 & 2,37 \\
\hline 50 & 1200 & 175 & 17,19 & 12,91 & 11,07 & 9,22 & 7,74 & 6,52 & 4,75 & 3,61 & 2,38 \\
\hline 50 & 1250 & 175 & 16,88 & 12,76 & 10,97 & 9,17 & 7,71 & 6,52 & 4,75 & 3,62 & 2,38 \\
\hline 50 & 1300 & 175 & 16,58 & 12,61 & 10,88 & 9,12 & 7,69 & 6,51 & 4,76 & 3,63 & 2,38 \\
\hline 50 & 1350 & 175 & 16,31 & 12,48 & 10,80 & 9,08 & 7,67 & 6,50 & 4,76 & 3,63 & 2,39 \\
\hline 50 & 1400 & 175 & 16,05 & 12,35 & 10,71 & 9,03 & 7,65 & 6,49 & 4,77 & 3,64 & 2,39 \\
\hline 50 & 1450 & 175 & 15,80 & 12,23 & 10,63 & 8,98 & 7,62 & 6,49 & 4,77 & 3,65 & 2,39 \\
\hline 50 & 1500 & 175 & 15,57 & 12,11 & 10,56 & 8,94 & 7,60 & 6,48 & 4,78 & 3,65 & 2,40 \\
\hline 50 & 1550 & 175 & 15,35 & 11,99 & 10,48 & 8,90 & 7,58 & 6,47 & 4,78 & 3,66 & 2,40 \\
\hline 50 & 1600 & 175 & 15,14 & 11,88 & 10,41 & 8,85 & 7,56 & 6,46 & 4,79 & 3,67 & 2,40 \\
\hline 50 & 1650 & 175 & 14,94 & 11,78 & 10,34 & 8,81 & 7,53 & 6,45 & 4,79 & 3,67 & 2,41 \\
\hline 50 & 1700 & 175 & 14,75 & 11,68 & 10,27 & 8,77 & 7,51 & 6,44 & 4,79 & 3,68 & 2,41 \\
\hline 50 & 1750 & 175 & 14,57 & 11,58 & 10,20 & 8,73 & 7,49 & 6,43 & 4,80 & 3,69 & 2,42 \\
\hline 50 & 1800 & 175 & 14,40 & 11,48 & 10,14 & 8,69 & 7,47 & 6,42 & 4,80 & 3,69 & 2,42 \\
\hline 50 & 1850 & 175 & 14,24 & 11,39 & 10,08 & 8,66 & 7,45 & 6,41 & 4,80 & 3,70 & 2,42 \\
\hline 50 & 1900 & 175 & 14,08 & 11,30 & 10,02 & 8,62 & 7,43 & 6,40 & 4,80 & 3,70 & 2,43 \\
\hline
\end{tabular}




\begin{tabular}{|c|c|c|c|c|c|c|c|c|c|c|c|}
\hline \multirow[b]{2}{*}{$\mathrm{H}(\mathrm{cm})$} & \multirow[b]{2}{*}{ Mceq (MPa) } & & & & & $\mathrm{De}$ & ões (x. & & & & \\
\hline & & Msub (MPa) & D0 & D25 & D40 & D60 & D80 & D100 & D140 & D180 & D260 \\
\hline 50 & 1950 & 175 & 13,93 & 11,22 & 9,96 & 8,58 & 7,40 & 6,39 & 4,80 & 3,71 & 2,43 \\
\hline 50 & 2000 & 175 & 13,78 & 11,14 & 9,90 & 8,55 & 7,38 & 6,38 & 4,80 & 3,71 & 2,43 \\
\hline 50 & 200 & 180 & 44,96 & 21,61 & 14,70 & 10,12 & 7,65 & 6,08 & 4,20 & 3,25 & 2,29 \\
\hline 50 & 250 & 180 & 38,93 & 20,02 & 14,19 & 10,08 & 7,71 & 6,15 & 4,25 & 3,27 & 2,28 \\
\hline 50 & 300 & 180 & 34,81 & 18,88 & 13,79 & 10,03 & 7,75 & 6,20 & 4,29 & 3,28 & 2,28 \\
\hline 50 & 350 & 180 & 31,78 & 18,00 & 13,47 & 9,97 & 7,77 & 6,24 & 4,33 & 3,30 & 2,27 \\
\hline 50 & 400 & 180 & 29,45 & 17,30 & 13,18 & 9,91 & 7,78 & 6,27 & 4,36 & 3,32 & 2,27 \\
\hline 50 & 450 & 180 & 27,59 & 16,71 & 12,94 & 9,85 & 7,78 & 6,30 & 4,39 & 3,33 & 2,27 \\
\hline 50 & 500 & 180 & 26,06 & 16,20 & 12,71 & 9,78 & 7,78 & 6,32 & 4,41 & 3,35 & 2,27 \\
\hline 50 & 550 & 180 & 24,77 & 15,77 & 12,51 & 9,72 & 7,77 & 6,33 & 4,44 & 3,36 & 2,27 \\
\hline 50 & 600 & 180 & 23,68 & 15,38 & 12,33 & 9,66 & 7,76 & 6,35 & 4,46 & 3,37 & 2,28 \\
\hline 50 & 650 & 180 & 22,73 & 15,04 & 12,16 & 9,60 & 7,75 & 6,36 & 4,48 & 3,39 & 2,28 \\
\hline 50 & 700 & 180 & 21,89 & 14,72 & 12,00 & 9,54 & 7,74 & 6,36 & 4,49 & 3,40 & 2,28 \\
\hline 50 & 750 & 180 & 21,16 & 14,44 & 11,85 & 9,48 & 7,72 & 6,37 & 4,51 & 3,41 & 2,28 \\
\hline 50 & 800 & 180 & 20,50 & 14,18 & 11,71 & 9,42 & 7,70 & 6,37 & 4,52 & 3,42 & 2,28 \\
\hline 50 & 850 & 180 & 19,90 & 13,94 & 11,58 & 9,36 & 7,68 & 6,37 & 4,54 & 3,43 & 2,29 \\
\hline 50 & 900 & 180 & 19,36 & 13,72 & 11,45 & 9,30 & 7,66 & 6,37 & 4,55 & 3,45 & 2,29 \\
\hline 50 & 950 & 180 & 18,87 & 13,51 & 11,34 & 9,25 & 7,64 & 6,37 & 4,56 & 3,46 & 2,29 \\
\hline 50 & 1000 & 180 & 18,42 & 13,32 & 11,22 & 9,20 & 7,62 & 6,37 & 4,57 & 3,47 & 2,29 \\
\hline 50 & 1050 & 180 & 18,00 & 13,13 & 11,12 & 9,15 & 7,60 & 6,36 & 4,58 & 3,48 & 2,30 \\
\hline 50 & 1100 & 180 & 17,62 & 12,96 & 11,01 & 9,09 & 7,58 & 6,36 & 4,59 & 3,49 & 2,30 \\
\hline 50 & 1150 & 180 & 17,26 & 12,80 & 10,92 & 9,04 & 7,56 & 6,35 & 4,60 & 3,49 & 2,30 \\
\hline 50 & 1200 & 180 & 16,93 & 12,65 & 10,82 & 9,00 & 7,54 & 6,35 & 4,61 & 3,50 & 2,31 \\
\hline 50 & 1250 & 180 & 16,62 & 12,50 & 10,73 & 8,95 & 7,52 & 6,34 & 4,62 & 3,51 & 2,31 \\
\hline 50 & 1300 & 180 & 16,33 & 12,36 & 10,64 & 8,90 & 7,49 & 6,33 & 4,62 & 3,52 & 2,31 \\
\hline 50 & 1350 & 180 & 16,06 & 12,23 & 10,56 & 8,86 & 7,47 & 6,33 & 4,63 & 3,53 & 2,32 \\
\hline 50 & 1400 & 180 & 15,80 & 12,10 & 10,48 & 8,81 & 7,45 & 6,32 & 4,63 & 3,53 & 2,32 \\
\hline 50 & 1450 & 180 & 15,55 & 11,98 & 10,40 & 8,77 & 7,43 & 6,31 & 4,64 & 3,54 & 2,32 \\
\hline 50 & 1500 & 180 & 15,32 & 11,87 & 10,33 & 8,73 & 7,41 & 6,30 & 4,64 & 3,55 & 2,33 \\
\hline 50 & 1550 & 180 & 15,11 & 11,76 & 10,25 & 8,69 & 7,39 & 6,30 & 4,65 & 3,55 & 2,33 \\
\hline 50 & 1600 & 180 & 14,90 & 11,65 & 10,18 & 8,64 & 7,37 & 6,29 & 4,65 & 3,56 & 2,33 \\
\hline 50 & 1650 & 180 & 14,70 & 11,55 & 10,11 & 8,61 & 7,34 & 6,28 & 4,65 & 3,57 & 2,34 \\
\hline 50 & 1700 & 180 & 14,52 & 11,45 & 10,05 & 8,57 & 7,32 & 6,27 & 4,66 & 3,57 & 2,34 \\
\hline 50 & 1750 & 180 & 14.34 & 11,35 & 9,98 & 8.53 & 7,30 & 6,26 & 4.66 & 3,58 & 2,34 \\
\hline 50 & 1800 & 180 & 14,17 & 11,26 & 9,92 & 8,49 & 7,28 & 6,25 & 4,66 & 3,58 & 2,35 \\
\hline 50 & 1850 & 180 & 14,00 & 11,17 & 9,86 & 8,45 & 7,26 & 6,24 & 4,66 & 3,59 & 2,35 \\
\hline 50 & 1900 & 180 & 13,85 & 11,08 & 9,80 & 8,42 & 7,24 & 6,23 & 4,67 & 3,59 & 2,36 \\
\hline 50 & 1950 & 180 & 13,70 & 11,00 & 9,74 & 8,38 & 7,22 & 6,22 & 4,67 & 3,60 & 2,36 \\
\hline 50 & 2000 & 180 & 13,56 & 10,92 & 9,69 & 8,35 & 7,20 & 6,21 & 4,67 & 3,60 & 2,36 \\
\hline 50 & 200 & 185 & 44,55 & 21,23 & 14,37 & 9,85 & 7,43 & 5,90 & 4,08 & 3,16 & 2,23 \\
\hline 50 & 250 & 185 & 38,54 & 19,66 & 13,87 & 9,81 & 7,50 & 5,97 & 4,13 & 3,18 & 2,22 \\
\hline 50 & 300 & 185 & 34,43 & 18,53 & 13,48 & 9,77 & 7,53 & 6,02 & 4,17 & 3,19 & 2,22 \\
\hline 50 & 350 & 185 & 31,42 & 17,66 & 13,16 & 9,71 & 7,56 & 6,07 & 4,20 & 3,21 & 2,21 \\
\hline 50 & 400 & 185 & 29,10 & 16,97 & 12,88 & 9,65 & 7,57 & 6,10 & 4,23 & 3,22 & 2,21 \\
\hline 50 & 450 & 185 & 27,25 & 16,39 & 12,64 & 9,60 & 7,57 & 6,12 & 4,26 & 3,24 & 2,21 \\
\hline 50 & 500 & 185 & 25,73 & 15,89 & 12,43 & 9,54 & 7,57 & 6,14 & 4,29 & 3,25 & 2,21 \\
\hline 50 & 550 & 185 & 24,45 & 15,46 & 12,23 & 9,48 & 7,57 & 6,16 & 4,31 & 3,27 & 2,21 \\
\hline 50 & 600 & 185 & 23,37 & 15,08 & 12,05 & 9,42 & 7,56 & 6,17 & 4,33 & 3,28 & 2,21 \\
\hline 50 & 650 & 185 & 22,42 & 14,74 & 11,89 & 9,36 & 7,55 & 6,18 & 4,35 & 3,29 & 2,21 \\
\hline 50 & 700 & 185 & 21,60 & 14,44 & 11,73 & 9,30 & 7,53 & 6,19 & 4,37 & 3,30 & 2,22 \\
\hline 50 & 750 & 185 & 20,87 & 14,16 & 11,59 & 9,24 & 7,52 & 6,19 & 4,38 & 3,32 & 2,22 \\
\hline 50 & 800 & 185 & 20,21 & 13,90 & 11,45 & 9,19 & 7,50 & 6,20 & 4,40 & 3,33 & 2,22 \\
\hline 50 & 850 & 185 & 19,62 & 13,67 & 11,32 & 9,13 & 7,48 & 6,20 & 4,41 & 3,34 & 2,22 \\
\hline 50 & 900 & 185 & 19,09 & 13,45 & 11,20 & 9,08 & 7,47 & 6,20 & 4,42 & 3,35 & 2,23 \\
\hline 50 & 950 & 185 & 18,60 & 13,25 & 11,09 & 9,03 & 7,45 & 6,20 & 4,43 & 3,36 & 2,23 \\
\hline 50 & 1000 & 185 & 18,15 & 13,06 & 10,98 & 8,98 & 7,43 & 6,20 & 4,44 & 3,37 & 2,23 \\
\hline 50 & 1050 & 185 & 17,74 & 12,88 & 10,88 & 8,93 & 7,41 & 6,19 & 4,45 & 3,38 & 2,23 \\
\hline 50 & 1100 & 185 & 17,36 & 12,71 & 10,78 & 8,88 & 7,39 & 6,19 & 4,46 & 3,39 & 2,24 \\
\hline 50 & 1150 & 185 & 17,01 & 12,55 & 10,68 & 8,83 & 7,37 & 6,18 & 4,47 & 3,39 & 2,24 \\
\hline 50 & 1200 & 185 & 16,68 & 12,40 & 10,59 & 8,78 & 7,35 & 6,18 & 4,48 & 3,40 & 2,24 \\
\hline 50 & 1250 & 185 & 16,37 & 12,26 & 10,50 & 8,74 & 7,33 & 6,17 & 4,49 & 3,41 & 2,25 \\
\hline 50 & 1300 & 185 & 16,08 & 12,12 & 10,42 & 8,69 & 7,31 & 6,17 & 4,49 & 3,42 & 2,25 \\
\hline 50 & 1350 & 185 & 15,81 & 11,99 & 10,33 & 8,65 & 7,29 & 6,16 & 4,50 & 3,43 & 2,25 \\
\hline 50 & 1400 & 185 & 15,56 & 11,87 & 10,26 & 8,61 & 7,27 & 6,15 & 4,50 & 3,43 & 2,26 \\
\hline 50 & 1450 & 185 & 15,32 & 11,75 & 10,18 & 8,57 & 7,24 & 6,15 & 4,51 & 3,44 & 2,26 \\
\hline 50 & 1500 & 185 & 15,09 & 11,64 & 10,11 & 8,52 & 7,22 & 6,14 & 4,51 & 3,45 & 2,26 \\
\hline 50 & 1550 & 185 & 14,88 & 11,53 & 10,04 & 8,48 & 7,20 & 6,13 & 4,52 & 3,45 & 2,27 \\
\hline 50 & 1600 & 185 & 14,67 & 11,42 & 9,97 & 8,45 & 7,18 & 6,12 & 4,52 & 3,46 & 2,27 \\
\hline 50 & 1650 & 185 & 14,48 & 11,32 & 9,90 & 8,41 & 7,16 & 6,12 & 4,53 & 3,46 & 2,27 \\
\hline 50 & 1700 & 185 & 14,29 & 11,23 & 9,84 & 8,37 & 7,14 & 6,11 & 4,53 & 3,47 & 2,28 \\
\hline 50 & 1750 & 185 & 14,11 & 11,13 & 9,77 & 8,33 & 7,12 & 6,10 & 4,53 & 3,48 & 2,28 \\
\hline 50 & 1800 & 185 & 13,95 & 11,04 & 9,71 & 8,30 & 7,10 & 6,09 & 4,53 & 3,48 & 2,28 \\
\hline 50 & 1850 & 185 & 13,78 & 10,95 & 9,65 & 8,26 & 7,09 & 6,08 & 4,54 & 3,49 & 2,28 \\
\hline 50 & 1900 & 185 & 13,63 & 10,87 & 9,59 & 8,23 & 7,07 & 6,07 & 4,54 & 3,49 & 2,29 \\
\hline 50 & 1950 & 185 & 13,48 & 10,79 & 9,54 & 8,19 & 7,05 & 6,06 & 4,54 & 3,50 & 2,29 \\
\hline 50 & 2000 & 185 & 13,34 & 10,71 & 9,48 & 8,16 & 7,03 & 6,06 & 4,54 & 3,50 & 2,29 \\
\hline 50 & 200 & 190 & 44.15 & 20.87 & 14.05 & 9.59 & 7.23 & 5.74 & 3.97 & 3.07 & 2.17 \\
\hline 50 & 250 & 190 & 38.17 & 1931 & 1356 & 956 & 729 & 5.81 & 4.02 & 3,09 & 216 \\
\hline 50 & 300 & 190 & 34,07 & 18,20 & 13,18 & 9,52 & 7,33 & 5,86 & 4,05 & 3,11 & 2,16 \\
\hline 50 & 350 & 190 & 31,07 & 17,34 & 12,87 & 9,47 & 7,35 & 5,90 & 4,09 & 3,12 & 2,16 \\
\hline 50 & 400 & 190 & 28,77 & 16,65 & 12,60 & 9,41 & 7,37 & 5,93 & 4,12 & 3,14 & 2,15 \\
\hline
\end{tabular}




\begin{tabular}{|c|c|c|c|c|c|c|c|c|c|c|c|}
\hline \multirow[b]{2}{*}{$\mathrm{H}(\mathrm{cm})$} & \multirow[b]{2}{*}{ Mceq (MPa) } & & & & & & ões (x. & & & & \\
\hline & & Msub (MPa) & D0 & D25 & D40 & D60 & D80 & D100 & D140 & D180 & D260 \\
\hline 50 & 450 & 190 & 26,93 & 16,08 & 12,36 & 9,36 & 7,37 & 5,96 & 4,14 & 3,15 & 2,15 \\
\hline 50 & 500 & 190 & 25,42 & 15,59 & 12,15 & 9,30 & 7,37 & 5,98 & 4,17 & 3,16 & 2,15 \\
\hline 50 & 550 & 190 & 24,15 & 15,17 & 11,96 & 9,24 & 7,37 & 5,99 & 4,19 & 3,18 & 2,15 \\
\hline 50 & 600 & 190 & 23,07 & 14,80 & 11,79 & 9,19 & 7,36 & 6,01 & 4,21 & 3,19 & 2,15 \\
\hline 50 & 650 & 190 & 22,13 & 14,46 & 11,63 & 9,13 & 7,35 & 6,01 & 4,23 & 3,20 & 2,16 \\
\hline 50 & 700 & 190 & 21,31 & 14,16 & 11,48 & 9,08 & 7,34 & 6,02 & 4,24 & 3,21 & 2,16 \\
\hline 50 & 750 & 190 & 20,59 & 13,89 & 11,34 & 9,02 & 7,33 & 6,03 & 4,26 & 3,22 & 2,16 \\
\hline 50 & 800 & 190 & 19,94 & 13,64 & 11,21 & 8,97 & 7,31 & 6,03 & 4,27 & 3,23 & 2,16 \\
\hline 50 & 850 & 190 & 19,35 & 13,41 & 11,08 & 8,92 & 7,29 & 6,03 & 4,29 & 3,24 & 2,16 \\
\hline 50 & 900 & 190 & 18,83 & 13,20 & 10,96 & 8,86 & 7,28 & 6,03 & 4,30 & 3,25 & 2,17 \\
\hline 50 & 950 & 190 & 18,34 & 13,00 & 10,85 & 8,82 & 7,26 & 6,03 & 4,31 & 3,26 & 2,17 \\
\hline 50 & 1000 & 190 & 17,90 & 12,81 & 10,75 & 8,77 & 7,24 & 6,03 & 4,32 & 3,27 & 2,17 \\
\hline 50 & 1050 & 190 & 17,49 & 12,64 & 10,64 & 8,72 & 7,22 & 6.03 & 4.33 & 3,28 & 2,17 \\
\hline 50 & 1100 & 190 & 17,12 & 12,47 & 10,55 & 8,67 & 7,20 & 6,03 & 4,34 & 3,29 & 2,18 \\
\hline 50 & 1150 & 190 & 16,77 & 12,31 & 10,45 & 8,63 & 7,19 & 6,02 & 4,35 & 3,30 & 2,18 \\
\hline 50 & 1200 & 190 & 16,44 & 12,17 & 10,37 & 8,58 & 7,17 & 6,02 & 4,36 & 3,31 & 2,18 \\
\hline 50 & 1250 & 190 & 16,14 & 12,03 & 10,28 & 8,54 & 7,15 & 6,02 & 4,36 & 3,32 & 2,19 \\
\hline 50 & 1300 & 190 & 15,85 & 11,89 & 10,20 & 8,49 & 7,13 & 6,01 & 4,37 & 3,32 & 2,19 \\
\hline 50 & 1350 & 190 & 15,58 & 11,77 & 10,12 & 8,45 & 7,11 & 6,00 & 4,38 & 3,33 & 2,19 \\
\hline 50 & 1400 & 190 & 15,33 & 11,65 & 10,04 & 8,41 & 7,09 & 6,00 & 4,38 & 3,34 & 2,19 \\
\hline 50 & 1450 & 190 & 15,09 & 11,53 & 9,97 & 8,37 & 7,07 & 5,99 & 4,39 & 3,34 & 2,20 \\
\hline 50 & 1500 & 190 & 14,87 & 11,42 & 9,90 & 8,33 & 7,05 & 5,98 & 4,39 & 3,35 & 2,20 \\
\hline 50 & 1550 & 190 & 14,65 & 11,31 & 9,83 & 8,29 & 7,03 & 5,98 & 4,40 & 3,36 & 2,20 \\
\hline 50 & 1600 & 190 & 14,45 & 11,21 & 9,76 & 8,26 & 7,01 & 5,97 & 4,40 & 3,36 & 2,21 \\
\hline 50 & 1650 & 190 & 14,26 & 11,11 & 9,70 & 8,22 & 6,99 & 5,96 & 4,40 & 3,37 & 2,21 \\
\hline 50 & 1700 & 190 & 14,08 & 11,01 & 9,63 & 8,18 & 6,97 & 5,95 & 4,41 & 3,37 & 2,21 \\
\hline 50 & 1750 & 190 & 13,90 & 10,92 & 9,57 & 8,15 & 6,95 & 5,95 & 4,41 & 3,38 & 2,22 \\
\hline 50 & 1800 & 190 & 13,73 & 10,83 & 9,51 & 8,11 & 6,94 & 5,94 & 4,41 & 3,38 & 2,22 \\
\hline 50 & 1850 & 190 & 13,57 & 10,75 & 9,45 & 8,08 & 6,92 & 5,93 & 4,41 & 3,39 & 2,22 \\
\hline 50 & 1900 & 190 & 13,42 & 10,66 & 9,40 & 8,04 & 6,90 & 5,92 & 4,42 & 3,39 & 2,22 \\
\hline 50 & 1950 & 190 & 13,28 & 10,58 & 9,34 & 8,01 & 6,88 & 5,91 & 4,42 & 3,40 & 2,23 \\
\hline 50 & 2000 & 190 & 13,14 & 10,51 & 9,29 & 7,98 & 6,86 & 5,91 & 4,42 & 3,40 & 2,23 \\
\hline 50 & 200 & 195 & 43,78 & 20,53 & 13,75 & 9,34 & 7,03 & 5,58 & 3,86 & 2,99 & 2,12 \\
\hline 50 & 250 & 195 & 37.81 & 18,98 & 13,27 & 9,32 & 7,10 & 5,65 & 3,91 & 3,01 & 2,11 \\
\hline 50 & 300 & 195 & 33,73 & 17,88 & 12,89 & 9,28 & 7,14 & 5,70 & 3,95 & 3,02 & 2,10 \\
\hline 50 & 350 & 195 & 30,74 & 17,03 & 12,59 & 9,23 & 7,16 & 5,74 & 3,98 & 3,04 & 2,10 \\
\hline 50 & 400 & 195 & 28,45 & 16,35 & 12,33 & 9,18 & 7,18 & 5,77 & 4,01 & 3,05 & 2,10 \\
\hline 50 & 450 & 195 & 26,62 & 15,79 & 12,10 & 9,13 & 7,18 & 5,80 & 4,03 & 3,07 & 2,10 \\
\hline 50 & 500 & 195 & 25,12 & 15,31 & 11,89 & 9,08 & 7,18 & 5,82 & 4,06 & 3,08 & 2,10 \\
\hline 50 & 550 & 195 & 23,86 & 14,89 & 11,71 & 9,02 & 7,18 & 5,83 & 4,08 & 3,09 & 2,10 \\
\hline 50 & 600 & 195 & 22,78 & 14,53 & 11,54 & 8,97 & 7,18 & 5,85 & 4,10 & 3,10 & 2,10 \\
\hline 50 & 650 & 195 & 21,86 & 14,20 & 11,38 & 8,91 & 7,17 & 5,86 & 4,11 & 3,11 & 2,10 \\
\hline 50 & 700 & 195 & 21,04 & 13,90 & 11,23 & 8,86 & 7,16 & 5,87 & 4,13 & 3,13 & 2,10 \\
\hline 50 & 750 & 195 & 20,32 & 13,63 & 11,10 & 8,81 & 7,14 & 5,87 & 4,15 & 3,14 & 2,10 \\
\hline 50 & 800 & 195 & 19,68 & 13,39 & 10,97 & 8,76 & 7,13 & 5,88 & 4,16 & 3,15 & 2,11 \\
\hline 50 & 850 & 195 & 19,10 & 13,16 & 10,85 & 8,71 & 7,11 & 5,88 & 4,17 & 3,16 & 2,11 \\
\hline 50 & 900 & 195 & 18,57 & 12,95 & 10,73 & 8,66 & 7,10 & 5,88 & 4,18 & 3,17 & 2,11 \\
\hline 50 & 950 & 195 & 18,10 & 12,76 & 10,63 & 8,61 & 7,08 & 5,88 & 4,20 & 3,18 & 2,11 \\
\hline 50 & 1000 & 195 & 17,66 & 12,57 & 10,52 & 8,57 & 7,07 & 5,88 & 4,21 & 3,19 & 2,11 \\
\hline 50 & 1050 & 195 & 17,25 & 12,40 & 10,42 & 8,52 & 7,05 & 5,88 & 4,22 & 3,19 & 2,12 \\
\hline 50 & 1100 & 195 & 16,88 & 12,24 & 10,33 & 8,47 & 7,03 & 5,88 & 4,22 & 3,20 & 2,12 \\
\hline 50 & 1150 & 195 & 16,53 & 12,09 & 10,24 & 8,43 & 7,01 & 5,87 & 4,23 & 3,21 & 2,12 \\
\hline 50 & 1200 & 195 & 16,21 & 11,94 & 10,15 & 8,39 & 6,99 & 5,87 & 4,24 & 3,22 & 2,12 \\
\hline 50 & 1250 & 195 & 15,91 & 11,81 & 10,07 & 8,35 & 6,98 & 5,86 & 4,25 & 3,23 & 2,13 \\
\hline 50 & 1300 & 195 & 15,63 & 11,67 & 9,99 & 8,30 & 6,96 & 5,86 & 4,25 & 3,23 & 2,13 \\
\hline 50 & 1350 & 195 & 15,36 & 11,55 & 9,91 & 8,26 & 6,94 & 5,85 & 4,26 & 3,24 & 2,13 \\
\hline 50 & 1400 & 195 & 15,11 & 11,43 & 9,84 & 8,22 & 6,92 & 5,85 & 4,27 & 3,25 & 2,14 \\
\hline 50 & 1450 & 195 & 14,88 & 11,32 & 9,77 & 8,19 & 6,90 & 5,84 & 4,27 & 3,25 & 2,14 \\
\hline 50 & 1500 & 195 & 14,65 & 11,21 & 9,70 & 8,15 & 6,88 & 5,84 & 4,28 & 3,26 & 2,14 \\
\hline 50 & 1550 & 195 & 14,44 & 11,10 & 9,63 & 8,11 & 6,87 & 5,83 & 4,28 & 3,27 & 2,14 \\
\hline 50 & 1600 & 195 & 14,24 & 11,00 & 9,56 & 8,07 & 6,85 & 5,82 & 4,28 & 3,27 & 2,15 \\
\hline 50 & 1650 & 195 & 14,05 & 10,91 & 9,50 & 8,04 & 6,83 & 5,82 & 4,29 & 3,28 & 2,15 \\
\hline 50 & 1700 & 195 & 13,87 & 10,81 & 9,44 & 8,00 & 6,81 & 5,81 & 4,29 & 3,28 & 2,15 \\
\hline 50 & 1750 & 195 & 13,70 & 10,72 & 9,38 & 7,97 & 6,79 & 5,80 & 4,29 & 3,29 & 2,16 \\
\hline 50 & 1800 & 195 & 13,53 & 10,64 & 9,32 & 7,93 & 6,77 & 5,79 & 4,30 & 3,29 & 2,16 \\
\hline 50 & 1850 & 195 & 13,37 & 10,55 & 9,27 & 7,90 & 6,76 & 5,79 & 4,30 & 3,30 & 2,16 \\
\hline 50 & 1900 & 195 & 13,22 & 10,47 & 9,21 & 7,87 & 6,74 & 5,78 & 4,30 & 3,30 & 2,16 \\
\hline 50 & 1950 & 195 & 13,08 & 10,39 & 9,16 & 7,84 & 6,72 & 5,77 & 4,30 & 3,31 & 2,17 \\
\hline 50 & 2000 & 195 & 12,94 & 10,32 & 9,11 & 7,81 & 6,70 & 5,76 & 4,31 & 3,31 & 2,17 \\
\hline 50 & 200 & 200 & 43,42 & 20,20 & 13,46 & 9,11 & 6,85 & 5,44 & 3,76 & 2,91 & 2,07 \\
\hline 50 & 250 & 200 & 37,47 & 18,67 & 12,99 & 9,09 & 6,91 & 5,50 & 3,80 & 2,93 & 2,06 \\
\hline 50 & 300 & 200 & 33,40 & 17,57 & 12,62 & 9,05 & 6,95 & 5,55 & 3,84 & 2,95 & 2,05 \\
\hline 50 & 350 & 200 & 30,43 & 16,74 & 12,32 & 9,01 & 6,98 & 5,59 & 3,87 & 2,96 & 2,05 \\
\hline 50 & 400 & 200 & 28,14 & 16,07 & 12,07 & 8,96 & 7,00 & 5,62 & 3,90 & 2,97 & 2,05 \\
\hline 50 & 450 & 200 & 26,32 & 15,51 & 11,84 & 8,91 & 7,00 & 5,65 & 3,93 & 2,99 & 2,05 \\
\hline 50 & 500 & 200 & 24,83 & 15,04 & 11,64 & 8,86 & 7,01 & 5,67 & 3,95 & 3,00 & 2,05 \\
\hline 50 & 550 & 200 & 23,58 & 14,63 & 11,46 & 8,81 & 7,00 & 5,68 & 3,97 & 3,01 & 2,05 \\
\hline 50 & 600 & 200 & 22,51 & 14,26 & 11,30 & 8,76 & 7,00 & 5,70 & 3,99 & 3,02 & 2,05 \\
\hline 50 & 650 & 200 & 21,59 & 13,94 & 11,14 & 8,71 & 6,99 & 5,71 & 4,01 & 3,03 & 2,05 \\
\hline 50 & 700 & 200 & 20,78 & 13,65 & 11,00 & 8,66 & 6,98 & 5,72 & 4,02 & 3,04 & 2,05 \\
\hline 50 & 750 & 200 & 20,07 & 13,39 & 10,87 & 8,61 & 6,97 & 5,72 & 4,04 & 3,05 & 2,05 \\
\hline
\end{tabular}




\begin{tabular}{|c|c|c|c|c|c|c|c|c|c|c|c|}
\hline \multirow[b]{2}{*}{$\mathrm{H}(\mathrm{cm})$} & \multirow[b]{2}{*}{ Mceq (MPa) } & & & & & $\mathrm{De}$ & ões (x1 & m) & & & \\
\hline & & Msub (MPa) & D0 & D25 & D40 & D60 & D80 & D100 & D140 & D180 & D260 \\
\hline 50 & 800 & 200 & 19,43 & 13,15 & 10,74 & 8,56 & 6,96 & 5,73 & 4,05 & 3,06 & 2,05 \\
\hline 50 & 850 & 200 & 18,86 & 12,92 & 10,63 & 8,51 & 6,94 & 5,73 & 4,06 & 3,07 & 2,05 \\
\hline 50 & 900 & 200 & 18,33 & 12,72 & 10,52 & 8,47 & 6,93 & 5,73 & 4,07 & 3,08 & 2,06 \\
\hline 50 & 950 & 200 & 17,86 & 12,53 & 10,41 & 8,42 & 6,91 & 5,73 & 4,09 & 3,09 & 2,06 \\
\hline 50 & 1000 & 200 & 17,43 & 12,35 & 10,31 & 8,37 & 6,90 & 5,73 & 4,10 & 3,10 & 2,06 \\
\hline 50 & 1050 & 200 & 17,03 & 12,18 & 10,21 & 8,33 & 6,88 & 5,73 & 4,11 & 3,11 & 2,06 \\
\hline 50 & 1100 & 200 & 16,66 & 12,02 & 10,12 & 8,29 & 6,86 & 5,73 & 4,11 & 3,12 & 2,06 \\
\hline 50 & 1150 & 200 & 16,31 & 11,87 & 10,03 & 8,24 & 6,85 & 5,73 & 4,12 & 3,13 & 2,07 \\
\hline 50 & 1200 & 200 & 15,99 & 11,73 & 9,95 & 8,20 & 6,83 & 5,72 & 4,13 & 3,13 & 2,07 \\
\hline 50 & 1250 & 200 & 15,69 & 11,59 & 9,87 & 8,16 & 6,81 & 5,72 & 4,14 & 3,14 & 2,07 \\
\hline 50 & 1300 & 200 & 15,41 & 11,46 & 9,79 & 8,12 & 6,80 & 5,72 & 4,14 & 3,15 & 2,08 \\
\hline 50 & 1350 & 200 & 15,15 & 11,34 & 9,72 & 8,08 & 6,78 & 5,71 & 4,15 & 3,15 & 2,08 \\
\hline 50 & 1400 & 200 & 14,90 & 11,23 & 9,64 & 8,05 & 6,76 & 5,71 & 4,16 & 3,16 & 2,08 \\
\hline 50 & 1450 & 200 & 14,67 & 11,11 & 9,57 & 8,01 & 6,74 & 5,70 & 4,16 & 3,17 & 2,08 \\
\hline 50 & 1500 & 200 & 14,45 & 11,01 & 9,50 & 7,97 & 6,73 & 5,69 & 4,17 & 3,17 & 2,09 \\
\hline 50 & 1550 & 200 & 14,24 & 10,90 & 9,44 & 7,94 & 6,71 & 5,69 & 4,17 & 3,18 & 2,09 \\
\hline 50 & 1600 & 200 & 14,04 & 10,81 & 9,38 & 7,90 & 6,69 & 5,68 & 4,17 & 3,19 & 2,09 \\
\hline 50 & 1650 & 200 & 13,85 & 10,71 & 9,31 & 7,87 & 6,67 & 5,68 & 4,18 & 3,19 & 2,09 \\
\hline 50 & 1700 & 200 & 13,67 & 10,62 & 9,25 & 7,83 & 6,66 & 5,67 & 4,18 & 3,20 & 2,10 \\
\hline 50 & 1750 & 200 & 13,50 & 10,53 & 9,20 & 7,80 & 6,64 & 5,66 & 4,18 & 3,20 & 2,10 \\
\hline 50 & 1800 & 200 & 13,34 & 10,45 & 9,14 & 7,77 & 6,62 & 5,66 & 4,19 & 3,21 & 2,10 \\
\hline 50 & 1850 & 200 & 13,18 & 10,36 & 9,08 & 7,73 & 6,60 & 5,65 & 4,19 & 3,21 & 2,11 \\
\hline 50 & 1900 & 200 & 13,03 & 10,28 & 9,03 & 7,70 & 6,59 & 5,64 & 4,19 & 3,22 & 2,11 \\
\hline 50 & 1950 & 200 & 12,89 & 10,21 & 8,98 & 7,67 & 6,57 & 5,63 & 4,19 & 3,22 & 2,11 \\
\hline 50 & 2000 & 200 & 12,75 & 10,13 & 8,93 & 7,64 & 6,55 & 5,63 & 4,20 & 3,22 & 2,11 \\
\hline 55 & 200 & 20 & 120,52 & 94,73 & 83,92 & 72,65 & 63,14 & 54,89 & 41,79 & 32,55 & 21,49 \\
\hline 55 & 250 & 20 & 109,68 & 88,38 & 79,46 & 69,75 & 61,33 & 53,87 & 41,71 & 32,82 & 21,78 \\
\hline 55 & 300 & 20 & 101,94 & 83,45 & 75,87 & 67,30 & 59,72 & 52,90 & 41,52 & 32,97 & 22,02 \\
\hline 55 & 350 & 20 & 96,07 & 79,45 & 72,90 & 65,20 & 58,28 & 51,97 & 41,27 & 33,05 & 22,24 \\
\hline 55 & 400 & 20 & 91,44 & 76,11 & 70,36 & 63,36 & 56,99 & 51,11 & 41,00 & 33,08 & 22,42 \\
\hline 55 & 450 & 20 & 87,67 & 73,25 & 68,15 & 61,73 & 55,81 & 50,30 & 40,70 & 33,06 & 22,57 \\
\hline 55 & 500 & 20 & 84,52 & 70,77 & 66,21 & 60,27 & 54,73 & 49,54 & 40,40 & 33,02 & 22,71 \\
\hline 55 & 550 & 20 & 81,84 & 68,58 & 64,48 & 58,95 & 53,74 & 48,83 & 40,09 & 32,96 & 22,82 \\
\hline 55 & 600 & 20 & 79,53 & 66,64 & 62,92 & 57,75 & 52,83 & 48,16 & 39,79 & 32,88 & 22,91 \\
\hline 55 & 650 & 20 & 77,49 & 64,90 & 61,50 & 56,65 & 51,98 & 47,53 & 39,49 & 32,78 & 22,99 \\
\hline 55 & 700 & 20 & 75,68 & 63,32 & 60,20 & 55,64 & 51,19 & 46,94 & 39,20 & 32,68 & 23,06 \\
\hline 55 & 750 & 20 & 74,06 & 61,89 & 59,00 & 54,70 & 50,45 & 46,38 & 38,91 & 32,57 & 23,11 \\
\hline 55 & 800 & 20 & 72,60 & 60,58 & 57,89 & 53,83 & 49,76 & 45,84 & 38,63 & 32,46 & 23,16 \\
\hline 55 & 850 & 20 & 71,26 & 59,38 & 56,87 & 53,01 & 49,11 & 45,34 & 38,36 & 32,35 & 23,20 \\
\hline 55 & 900 & 20 & 70,03 & 58,27 & 55,90 & 52,24 & 48,49 & 44,85 & 38,09 & 32,23 & 23,23 \\
\hline 55 & 950 & 20 & 68,90 & 57,24 & 55,00 & 51,52 & 47,91 & 44,39 & 37,83 & 32,11 & 23,25 \\
\hline 55 & 1000 & 20 & 67,85 & 56,28 & 54,16 & 50,84 & 47,35 & 43,95 & 37,58 & 31,99 & 23,27 \\
\hline 55 & 1050 & 20 & 66,86 & 55,39 & 53,36 & 50,20 & 46,83 & 43,53 & 37,33 & 31,86 & 23,28 \\
\hline 55 & 1100 & 20 & 65,94 & 54,55 & 52,60 & 49,59 & 46,33 & 43,13 & 37,09 & 31,74 & 23,29 \\
\hline 55 & 1150 & 20 & 65,07 & 53,77 & 51,89 & 49,01 & 45,85 & 42,74 & 36,86 & 31,62 & 23,29 \\
\hline 55 & 1200 & 20 & 64,26 & 53,03 & 51,21 & 48,45 & 45,39 & 42,37 & 36,63 & 31,50 & 23,29 \\
\hline 55 & 1250 & 20 & 63,48 & 52,34 & 50,56 & 47,93 & 44,95 & 42,01 & 36,41 & 31,38 & 23,29 \\
\hline 55 & 1300 & 20 & 62,74 & 51,69 & 49,95 & 47,42 & 44,53 & 41,67 & 36,19 & 31,26 & 23,28 \\
\hline 55 & 1350 & 20 & 62,04 & 51,07 & 49,36 & 46,94 & 44,13 & 41,33 & 35,98 & 31,15 & 23,27 \\
\hline 55 & 1400 & 20 & 61,37 & 50,48 & 48,80 & 46,48 & 43,74 & 41,01 & 35,78 & 31,03 & 23,26 \\
\hline 55 & 1450 & 20 & 60,73 & 49,92 & 48,26 & 46,03 & 43,37 & 40,70 & 35,58 & 30,91 & 23,25 \\
\hline 55 & 1500 & 20 & 60,11 & 49,39 & 47,75 & 45,60 & 43,01 & 40,40 & 35,38 & 30,80 & 23,23 \\
\hline 55 & 1550 & 20 & 59,52 & 48,89 & 47,25 & 45,19 & 42,66 & 40,11 & 35,19 & 30,69 & 23,22 \\
\hline 55 & 1600 & 20 & 58,95 & 48,41 & 46,78 & 44,80 & 42,32 & 39,83 & 35,01 & 30,58 & 23,20 \\
\hline 55 & 1650 & 20 & 58,40 & 47,95 & 46,32 & 44,41 & 42,00 & 39,56 & 34,83 & 30,47 & 23,18 \\
\hline 55 & 1700 & 20 & 57,87 & 47,51 & 45,88 & 44,04 & 41,69 & 39,29 & 34,65 & 30,36 & 23,16 \\
\hline 55 & 1750 & 20 & 57,36 & 47,09 & 45,46 & 43,69 & 41,38 & 39,04 & 34,48 & 30,25 & 23,14 \\
\hline 55 & 1800 & 20 & 56,86 & 46,68 & 45,05 & 43,34 & 41,09 & 38,79 & 34,31 & 30,15 & 23,12 \\
\hline 55 & 1850 & 20 & 56,38 & 46,30 & 44,65 & 43,00 & 40,80 & 38,54 & 34,14 & 30,04 & 23,09 \\
\hline 55 & 1900 & 20 & 55,92 & 45,93 & 44,27 & 42,68 & 40,53 & 38,31 & 33,98 & 29,94 & 23,07 \\
\hline 55 & 1950 & 20 & 55,46 & 45,57 & 43,90 & 42,36 & 40,26 & 38,08 & 33,82 & 29,84 & 23,04 \\
\hline 55 & 2000 & 20 & 55,02 & 45,23 & 43,54 & 42,06 & 40,00 & 37,86 & 33,66 & 29,74 & 23,02 \\
\hline 55 & 200 & 25 & 106,47 & 81,16 & 70,76 & 60,34 & 51,80 & 44,56 & 33,38 & 25,78 & 16,99 \\
\hline 55 & 250 & 25 & 96,41 & 75,78 & 67,13 & 58,12 & 50,51 & 43,91 & 33,43 & 26,04 & 17,19 \\
\hline 55 & 300 & 25 & 89,24 & 71,61 & 64,21 & 56,23 & 49,34 & 43,26 & 33,39 & 26,22 & 17,38 \\
\hline 55 & 350 & 25 & 83,81 & 68,23 & 61,78 & 54,59 & 48,27 & 42,62 & 33,28 & 26,34 & 17,54 \\
\hline 55 & 400 & 25 & 79,53 & 65,41 & 59,70 & 53,14 & 47,30 & 42,02 & 33,14 & 26,41 & 17,69 \\
\hline 55 & 450 & 25 & 76,05 & 62,99 & 57,89 & 51,85 & 46,41 & 41,44 & 32,98 & 26,45 & 17,82 \\
\hline 55 & 500 & 25 & 73,15 & 60,88 & 56,29 & 50,69 & 45,59 & 40,89 & 32,80 & 26,46 & 17,94 \\
\hline 55 & 550 & 25 & 70,69 & 59,03 & 54,86 & 49,63 & 44,83 & 40,37 & 32,61 & 26,46 & 18,04 \\
\hline 55 & 600 & 25 & 68,58 & 57,38 & 53,57 & 48,67 & 44,12 & 39,87 & 32,42 & 26,43 & 18,12 \\
\hline 55 & 650 & 25 & 66,72 & 55,89 & 52,40 & 47,78 & 43,46 & 39,40 & 32,22 & 26,40 & 18,20 \\
\hline 55 & 700 & 25 & 65,08 & 54,54 & 51,32 & 46,96 & 42,84 & 38,96 & 32,03 & 26,35 & 18,27 \\
\hline 55 & 750 & 25 & 63,62 & 53,31 & 50,33 & 46,20 & 42,26 & 38,53 & 31,83 & 26,30 & 18,33 \\
\hline 55 & 800 & 25 & 62,30 & 52,19 & 49,42 & 45,49 & 41,72 & 38,13 & 31,64 & 26,24 & 18,38 \\
\hline 55 & 850 & 25 & 61,11 & 51,15 & 48,56 & 44,83 & 41,20 & 37,74 & 31,45 & 26,18 & 18,43 \\
\hline 55 & 900 & 25 & 60,01 & 50,19 & 47,77 & 44,20 & 40,71 & 37,37 & 31,27 & 26,11 & 18,46 \\
\hline 55 & 950 & 25 & 59,01 & 49,30 & 47,02 & 43,62 & 40,25 & 37,01 & 31,08 & 26,04 & 18,50 \\
\hline 55 & 1000 & 25 & 58,08 & 48,47 & 46,32 & 43,06 & 39,81 & 36,67 & 30,90 & 25,97 & 18,53 \\
\hline 55 & 1050 & 25 & 57,21 & 47,69 & 45,65 & 42,53 & 39,39 & 36,35 & 30,73 & 25,90 & 18,55 \\
\hline 55 & 1100 & 25 & 56,41 & 46,96 & 45,02 & 42,03 & 38,99 & 36,03 & 30,56 & 25,82 & 18,57 \\
\hline
\end{tabular}




\begin{tabular}{|c|c|c|c|c|c|c|c|c|c|c|c|}
\hline \multirow[b]{2}{*}{$\mathrm{H}(\mathrm{cm})$} & \multirow[b]{2}{*}{ Mceq (MPa) } & & & & & & ões (x1 & m) & & & \\
\hline & & Msub (MPa) & D0 & D25 & D40 & D60 & D80 & D100 & D140 & D180 & D260 \\
\hline 55 & 1150 & 25 & 55,66 & 46,28 & 44,43 & 41,56 & 38,60 & 35,73 & 30,39 & 25,74 & 18,59 \\
\hline 55 & 1200 & 25 & 54,95 & 45,63 & 43,86 & 41,10 & 38,24 & 35,44 & 30,22 & 25,67 & 18,60 \\
\hline 55 & 1250 & 25 & 54,28 & 45,02 & 43,33 & 40,67 & 37,88 & 35,16 & 30,06 & 25,59 & 18,61 \\
\hline 55 & 1300 & 25 & 53,64 & 44,45 & 42,81 & 40,26 & 37,54 & 34,89 & 29,90 & 25,51 & 18,62 \\
\hline 55 & 1350 & 25 & 53,04 & 43,90 & 42,32 & 39,86 & 37,22 & 34,63 & 29,75 & 25,43 & 18,63 \\
\hline 55 & 1400 & 25 & 52,47 & 43,39 & 41,85 & 39,48 & 36,90 & 34,38 & 29,60 & 25,36 & 18,63 \\
\hline 55 & 1450 & 25 & 51,93 & 42,90 & 41,40 & 39,11 & 36,60 & 34,13 & 29,45 & 25,28 & 18,63 \\
\hline 55 & 1500 & 25 & 51,41 & 42,43 & 40,97 & 38,76 & 36,31 & 33,89 & 29,30 & 25,20 & 18,63 \\
\hline 55 & 1550 & 25 & 50,91 & 41,98 & 40,55 & 38,42 & 36,03 & 33,66 & 29,16 & 25,12 & 18,63 \\
\hline 55 & 1600 & 25 & 50,43 & 41,55 & 40,15 & 38,10 & 35,76 & 33,44 & 29,02 & 25,05 & 18,63 \\
\hline 55 & 1650 & 25 & 49,97 & 41,15 & 39,77 & 37,78 & 35,49 & 33,22 & 28,89 & 24,97 & 18,62 \\
\hline 55 & 1700 & 25 & 49,52 & 40,76 & 39,40 & 37,48 & 35,24 & 33,01 & 28,75 & 24,90 & 18,62 \\
\hline 55 & 1750 & 25 & 49,10 & 40,38 & 39,04 & 37,18 & 34,99 & 32,81 & 28,62 & 24,82 & 18,61 \\
\hline 55 & 1800 & 25 & 48,69 & 40,02 & 38,70 & 36,90 & 34,75 & 32,61 & 28,50 & 24,75 & 18,60 \\
\hline 55 & 1850 & 25 & 48,29 & 39,68 & 38,36 & 36,62 & 34,52 & 32,42 & 28,37 & 24,68 & 18,59 \\
\hline 55 & 1900 & 25 & 47,90 & 39,35 & 38,04 & 36,35 & 34,29 & 32,23 & 28,25 & 24,60 & 18,58 \\
\hline 55 & 1950 & 25 & 47,53 & 39,03 & 37,73 & 36,09 & 34,07 & 32,04 & 28,13 & 24,53 & 18,57 \\
\hline 55 & 2000 & 25 & 47,16 & 38,72 & 37,42 & 35,84 & 33,86 & 31,86 & 28,01 & 24,46 & 18,56 \\
\hline 55 & 200 & 30 & 96,56 & 71,49 & 61,46 & 51,72 & 43,93 & 37,47 & 27,72 & 21,28 & 14,03 \\
\hline 55 & 250 & 30 & 87,10 & 66,79 & 58,41 & 49,95 & 42,98 & 37,04 & 27,83 & 21,52 & 14,18 \\
\hline 55 & 300 & 30 & 80,35 & 63,15 & 55,94 & 48,43 & 42,09 & 36,59 & 27,86 & 21,70 & 14,33 \\
\hline 55 & 350 & 30 & 75,24 & 60,20 & 53,88 & 47,10 & 41,27 & 36,14 & 27,83 & 21,83 & 14,46 \\
\hline 55 & 400 & 30 & 71,22 & 57,74 & 52,12 & 45,92 & 40,51 & 35,69 & 27,77 & 21,92 & 14,58 \\
\hline 55 & 450 & 30 & 67,96 & 55,63 & 50,58 & 44,87 & 39,81 & 35,26 & 27,68 & 21,98 & 14,68 \\
\hline 55 & 500 & 30 & 65,24 & 53,80 & 49,22 & 43,91 & 39,16 & 34,85 & 27,57 & 22,02 & 14,78 \\
\hline 55 & 550 & 30 & 62,94 & 52,18 & 48,00 & 43,04 & 38,56 & 34,45 & 27,46 & 22,04 & 14,87 \\
\hline 55 & 600 & 30 & 60,96 & 50,74 & 46,91 & 42,24 & 37,99 & 34,07 & 27,33 & 22,05 & 14,95 \\
\hline 55 & 650 & 30 & 59,23 & 49,44 & 45,90 & 41,50 & 37,46 & 33,71 & 27,20 & 22,05 & 15,02 \\
\hline 55 & 700 & 30 & 57,71 & 48,26 & 44,99 & 40,82 & 36,96 & 33,36 & 27,07 & 22,03 & 15,08 \\
\hline 55 & 750 & 30 & 56,35 & 47,18 & 44,14 & 40,18 & 36,49 & 33,03 & 26,93 & 22,01 & 15,14 \\
\hline 55 & 800 & 30 & 55,13 & 46,19 & 43,36 & 39,59 & 36,04 & 32,71 & 26,80 & 21,99 & 15,19 \\
\hline 55 & 850 & 30 & 54,02 & 45,27 & 42,63 & 39,03 & 35,62 & 32,40 & 26,66 & 21,95 & 15,23 \\
\hline 55 & 900 & 30 & 53,02 & 44,43 & 41,94 & 38,50 & 35,22 & 32,11 & 26,53 & 21,92 & 15,27 \\
\hline 55 & 950 & 30 & 52,09 & 43,64 & 41,30 & 38,01 & 34,84 & 31,83 & 26,39 & 21,88 & 15,31 \\
\hline 55 & 1000 & 30 & 51,24 & 42,90 & 40,70 & 37,54 & 34,48 & 31,56 & 26,26 & 21,83 & 15,34 \\
\hline 55 & 1050 & 30 & 50,46 & 42,22 & 40,13 & 37,09 & 34,13 & 31,29 & 26,13 & 21,79 & 15,37 \\
\hline 55 & 1100 & 30 & 49,72 & 41,57 & 39,59 & 36,67 & 33,80 & 31,04 & 26,00 & 21,74 & 15,40 \\
\hline 55 & 1150 & 30 & 49,04 & 40,96 & 39,08 & 36,27 & 33,48 & 30,80 & 25,88 & 21,69 & 15,42 \\
\hline 55 & 1200 & 30 & 48,40 & 40,39 & 38,60 & 35,88 & 33,17 & 30,56 & 25,75 & 21,64 & 15,44 \\
\hline 55 & 1250 & 30 & 47,80 & 39,85 & 38,13 & 35,52 & 32,88 & 30,34 & 25,63 & 21,59 & 15,46 \\
\hline 55 & 1300 & 30 & 47,23 & 39,33 & 37,69 & 35,16 & 32,60 & 30,12 & 25,51 & 21,54 & 15,47 \\
\hline 55 & 1350 & 30 & 46,69 & 38,85 & 37,27 & 34,83 & 32,33 & 29,90 & 25,39 & 21,48 & 15,48 \\
\hline 55 & 1400 & 30 & 46,18 & 38,38 & 36,86 & 34,50 & 32,07 & 29,70 & 25,28 & 21,43 & 15,49 \\
\hline 55 & 1450 & 30 & 45,69 & 37,94 & 36,48 & 34,19 & 31,81 & 29,50 & 25,16 & 21,38 & 15,50 \\
\hline 55 & 1500 & 30 & 45,23 & 37,52 & 36,10 & 33,89 & 31,57 & 29,30 & 25,05 & 21,32 & 15,51 \\
\hline 55 & 1550 & 30 & 44,79 & 37,12 & 35,75 & 33,60 & 31,33 & 29,11 & 24,94 & 21,27 & 15,52 \\
\hline 55 & 1600 & 30 & 44,37 & 36,74 & 35,40 & 33,33 & 31,10 & 28,93 & 24,83 & 21,22 & 15,52 \\
\hline 55 & 1650 & 30 & 43,96 & 36,37 & 35,07 & 33,06 & 30,88 & 28,75 & 24,73 & 21,16 & 15,52 \\
\hline 55 & 1700 & 30 & 43,57 & 36,02 & 34,75 & 32,80 & 30,67 & 28,58 & 24,62 & 21,11 & 15,53 \\
\hline 55 & 1750 & 30 & 43,20 & 35,68 & 34,44 & 32,55 & 30,46 & 28,41 & 24,52 & 21,05 & 15,53 \\
\hline 55 & 1800 & 30 & 42,84 & 35,36 & 34,14 & 32,30 & 30,26 & 28,25 & 24,42 & 21,00 & 15,53 \\
\hline 55 & 1850 & 30 & 42,49 & 35,04 & 33,85 & 32,07 & 30,06 & 28,09 & 24,32 & 20,95 & 15,53 \\
\hline 55 & 1900 & 30 & 42,15 & 34,75 & 33,57 & 31,84 & 29,87 & 27,93 & 24,22 & 20,90 & 15,52 \\
\hline 55 & 1950 & 30 & 41,83 & 34,46 & 33,30 & 31,61 & 29,69 & 27,78 & 24,13 & 20,84 & 15,52 \\
\hline 55 & 2000 & 30 & 41,52 & 34,18 & 33,04 & 31,40 & 29,51 & 27,63 & 24,04 & 20,79 & 15,52 \\
\hline 55 & 200 & 35 & 89,12 & 64,22 & 54,50 & 45,31 & 38,15 & 32,29 & 23,66 & 18,09 & 11,95 \\
\hline 55 & 250 & 35 & 80,13 & 60,01 & 51,87 & 43,87 & 37,42 & 32,01 & 23,80 & 18,31 & 12,07 \\
\hline 55 & 300 & 35 & 73,71 & 56,76 & 49,74 & 42,62 & 36,73 & 31,70 & 23,86 & 18,47 & 12,18 \\
\hline 55 & 350 & 35 & 68,87 & 54,13 & 47,95 & 41,52 & 36,08 & 31,36 & 23,88 & 18,60 & 12,28 \\
\hline 55 & 400 & 35 & 65,05 & 51,94 & 46,42 & 40,53 & 35,47 & 31,03 & 23,86 & 18,70 & 12,38 \\
\hline 55 & 450 & 35 & 61,96 & 50,06 & 45,08 & 39,64 & 34,91 & 30,70 & 23,82 & 18,77 & 12,46 \\
\hline 55 & 500 & 35 & 59,38 & 48,43 & 43,90 & 38,83 & 34,38 & 30,38 & 23,76 & 18,82 & 12,55 \\
\hline 55 & 550 & 35 & 57,20 & 46,99 & 42,84 & 38,10 & 33,88 & 30,07 & 23,69 & 18,86 & 12,62 \\
\hline 55 & 600 & 35 & 55,33 & 45,70 & 41,88 & 37,42 & 33,42 & 29,77 & 23,61 & 18,88 & 12,69 \\
\hline 55 & 650 & 35 & 53,69 & 44,54 & 41,01 & 36,79 & 32,98 & 29,48 & 23,52 & 18,90 & 12,75 \\
\hline 55 & 700 & 35 & 52,25 & 43,49 & 40,20 & 36,21 & 32,56 & 29,21 & 23,43 & 18,90 & 12,81 \\
\hline 55 & 750 & 35 & 50,97 & 42,53 & 39,46 & 35,66 & 32,17 & 28,94 & 23,33 & 18,90 & 12,86 \\
\hline 55 & 800 & 35 & 49,82 & 41,64 & 38,78 & 35,15 & 31,80 & 28,68 & 23,23 & 18,89 & 12,91 \\
\hline 55 & 850 & 35 & 48,78 & 40,82 & 38,14 & 34,67 & 31,45 & 28,43 & 23,13 & 18,88 & 12,95 \\
\hline 55 & 900 & 35 & 47,84 & 40,07 & 37,54 & 34,22 & 31,11 & 28,19 & 23,04 & 18,86 & 12,99 \\
\hline 55 & 950 & 35 & 46,97 & 39,36 & 36,98 & 33,79 & 30,79 & 27,96 & 22,94 & 18,84 & 13,03 \\
\hline 55 & 1000 & 35 & 46,18 & 38,70 & 36,45 & 33,39 & 30,48 & 27,74 & 22,84 & 18,81 & 13,06 \\
\hline 55 & 1050 & 35 & 45,44 & 38,08 & 35,95 & 33,00 & 30,19 & 27,52 & 22,74 & 18,79 & 13,09 \\
\hline 55 & 1100 & 35 & 44,76 & 37,50 & 35,48 & 32,64 & 29,91 & 27,31 & 22,64 & 18,76 & 13,12 \\
\hline 55 & 1150 & 35 & 44,13 & 36,95 & 35,03 & 32,29 & 29,64 & 27,11 & 22,54 & 18,73 & 13,14 \\
\hline 55 & 1200 & 35 & 43,53 & 36,43 & 34,60 & 31,96 & 29,38 & 26,92 & 22,45 & 18,69 & 13,17 \\
\hline 55 & 1250 & 35 & 42,97 & 35,94 & 34,20 & 31,64 & 29,13 & 26,73 & 22,35 & 18,66 & 13,18 \\
\hline 55 & 1300 & 35 & 42,45 & 35,48 & 33,81 & 31,33 & 28,89 & 26,55 & 22,26 & 18,62 & 13,20 \\
\hline 55 & 1350 & 35 & 41,95 & 35,04 & 33,44 & 31,04 & 28,66 & 26,37 & 22,17 & 18,59 & 13,22 \\
\hline 55 & 1400 & 35 & 41,48 & 34,62 & 33,08 & 30,76 & 28,43 & 26,20 & 22,07 & 18,55 & 13,23 \\
\hline 55 & 1450 & 35 & 41,04 & 34,22 & 32,74 & 30,49 & 28,22 & 26,03 & 21,98 & 18,51 & 13,25 \\
\hline
\end{tabular}




\begin{tabular}{|c|c|c|c|c|c|c|c|c|c|c|c|}
\hline \multirow[b]{2}{*}{$\mathrm{H}(\mathrm{cm})$} & \multirow[b]{2}{*}{ Mceq (MPa) } & & & & & De & ões (x1 & m) & & & \\
\hline & & Msub (MPa) & D0 & D25 & D40 & D60 & D80 & D100 & D140 & D180 & D260 \\
\hline 55 & 1500 & 35 & 40,62 & 33,84 & 32,41 & 30,23 & 28,01 & 25,87 & 21,90 & 18,47 & 13,26 \\
\hline 55 & 1550 & 35 & 40,21 & 33,47 & 32,10 & 29,97 & 27,81 & 25,71 & 21,81 & 18,44 & 13,27 \\
\hline 55 & 1600 & 35 & 39,83 & 33,12 & 31,79 & 29,73 & 27,61 & 25,55 & 21,72 & 18,40 & 13,28 \\
\hline 55 & 1650 & 35 & 39,46 & 32,79 & 31,50 & 29,50 & 27,42 & 25,40 & 21,64 & 18,36 & 13,28 \\
\hline 55 & 1700 & 35 & 39,11 & 32,47 & 31,22 & 29,27 & 27,24 & 25,26 & 21,55 & 18,32 & 13,29 \\
\hline 55 & 1750 & 35 & 38,77 & 32,16 & 30,95 & 29,05 & 27,06 & 25,12 & 21,47 & 18,28 & 13,29 \\
\hline 55 & 1800 & 35 & 38,44 & 31,86 & 30,68 & 28,84 & 26,89 & 24,98 & 21,39 & 18,24 & 13,30 \\
\hline 55 & 1850 & 35 & 38,13 & 31,58 & 30,43 & 28,63 & 26,72 & 24,84 & 21,31 & 18,20 & 13,30 \\
\hline 55 & 1900 & 35 & 37,83 & 31,31 & 30,18 & 28,43 & 26,55 & 24,71 & 21,23 & 18,16 & 13,31 \\
\hline 55 & 1950 & 35 & 37,54 & 31,04 & 29,94 & 28,24 & 26,39 & 24,58 & 21,16 & 18,12 & 13,31 \\
\hline 55 & 2000 & 35 & 37,25 & 30,79 & 29,71 & 28,05 & 26,24 & 24,45 & 21,08 & 18,08 & 13,31 \\
\hline 55 & 200 & 40 & 83,30 & 58,52 & 49,07 & 40,36 & 33,70 & 28,36 & 20,60 & 15,71 & 10,41 \\
\hline 55 & 250 & 40 & 74,68 & 54,68 & 46,76 & 39,16 & 33,14 & 28,17 & 20,76 & 15,90 & 10,50 \\
\hline 55 & 300 & 40 & 68,54 & 51,73 & 44,88 & 38,10 & 32,59 & 27,95 & 20,84 & 16,06 & 10,58 \\
\hline 55 & 350 & 40 & 63,91 & 49,35 & 43,31 & 37,17 & 32,06 & 27,70 & 20,89 & 16,18 & 10,67 \\
\hline 55 & 400 & 40 & 60,26 & 47,36 & 41,96 & 36,33 & 31,57 & 27,44 & 20,90 & 16,28 & 10,74 \\
\hline 55 & 450 & 40 & 57,30 & 45,67 & 40,78 & 35,57 & 31,10 & 27,19 & 20,88 & 16,35 & 10,82 \\
\hline 55 & 500 & 40 & 54,84 & 44,19 & 39,73 & 34,87 & 30,66 & 26,94 & 20,85 & 16,41 & 10,89 \\
\hline 55 & 550 & 40 & 52,76 & 42,89 & 38,79 & 34,24 & 30,25 & 26,69 & 20,81 & 16,45 & 10,95 \\
\hline 55 & 600 & 40 & 50,97 & 41,73 & 37,94 & 33,65 & 29,86 & 26,45 & 20,76 & 16,49 & 11,01 \\
\hline 55 & 650 & 40 & 49,41 & 40,68 & 37,16 & 33,11 & 29,49 & 26,21 & 20,70 & 16,51 & 11,07 \\
\hline 55 & 700 & 40 & 48,03 & 39,72 & 36,45 & 32,60 & 29,14 & 25,99 & 20,64 & 16,53 & 11,12 \\
\hline 55 & 750 & 40 & 46,81 & 38,85 & 35,79 & 32,12 & 28,81 & 25,77 & 20,57 & 16,54 & 11,17 \\
\hline 55 & 800 & 40 & 45,72 & 38,05 & 35,18 & 31,68 & 28,49 & 25,56 & 20,50 & 16,54 & 11,21 \\
\hline 55 & 850 & 40 & 44,73 & 37,31 & 34,61 & 31,26 & 28,19 & 25,35 & 20,43 & 16,54 & 11,25 \\
\hline 55 & 900 & 40 & 43,84 & 36,62 & 34,08 & 30,87 & 27,90 & 25,15 & 20,35 & 16,53 & 11,29 \\
\hline 55 & 950 & 40 & 43,02 & 35,98 & 33,58 & 30,49 & 27,63 & 24,96 & 20,28 & 16,52 & 11,32 \\
\hline 55 & 1000 & 40 & 42,26 & 35,38 & 33,11 & 30,14 & 27,37 & 24,77 & 20,20 & 16,51 & 11,35 \\
\hline 55 & 1050 & 40 & 41,57 & 34,82 & 32,66 & 29,80 & 27,11 & 24,59 & 20,12 & 16,50 & 11,38 \\
\hline 55 & 1100 & 40 & 40,92 & 34,29 & 32,24 & 29,48 & 26,87 & 24,42 & 20,05 & 16,48 & 11,41 \\
\hline 55 & 1150 & 40 & 40,32 & 33,79 & 31,84 & 29,17 & 26,64 & 24,25 & 19,97 & 16,46 & 11,43 \\
\hline 55 & 1200 & 40 & 39,76 & 33,32 & 31,46 & 28,88 & 26,42 & 24,08 & 19,90 & 16,44 & 11,46 \\
\hline 55 & 1250 & 40 & 39,24 & 32,87 & 31,10 & 28,60 & 26,20 & 23,92 & 19,82 & 16,42 & 11,48 \\
\hline 55 & 1300 & 40 & 38,75 & 32,45 & 30,75 & 28,33 & 25,99 & 23,77 & 19,75 & 16,39 & 11,50 \\
\hline 55 & 1350 & 40 & 38,28 & 32,05 & 30,42 & 28,07 & 25,79 & 23,62 & 19,67 & 16,37 & 11,51 \\
\hline 55 & 1400 & 40 & 37,84 & 31,66 & 30,10 & 27,82 & 25,60 & 23,47 & 19,60 & 16,34 & 11,53 \\
\hline 55 & 1450 & 40 & 37,43 & 31,30 & 29,79 & 27,58 & 25,41 & 23,33 & 19,53 & 16,31 & 11,54 \\
\hline 55 & 1500 & 40 & 37,03 & 30,95 & 29,50 & 27,35 & 25,23 & 23,19 & 19,46 & 16,29 & 11,56 \\
\hline 55 & 1550 & 40 & 36,66 & 30,61 & 29,22 & 27,13 & 25,05 & 23,05 & 19,39 & 16,26 & 11,57 \\
\hline 55 & 1600 & 40 & 36,30 & 30,29 & 28,95 & 26,91 & 24,88 & 22,92 & 19,32 & 16,23 & 11,58 \\
\hline 55 & 1650 & 40 & 35,96 & 29,98 & 28,69 & 26,70 & 24,71 & 22,79 & 19,25 & 16,20 & 11,59 \\
\hline 55 & 1700 & 40 & 35,63 & 29,69 & 28,43 & 26,50 & 24,55 & 22,67 & 19,18 & 16,17 & 11,60 \\
\hline 55 & 1750 & 40 & 35,32 & 29,41 & 28,19 & 26,31 & 24,40 & 22,55 & 19,11 & 16,14 & 11,61 \\
\hline 55 & 1800 & 40 & 35,02 & 29,13 & 27,95 & 26,12 & 24,25 & 22,43 & 19,05 & 16,11 & 11,61 \\
\hline 55 & 1850 & 40 & 34,73 & 28,87 & 27,72 & 25,94 & 24,10 & 22,31 & 18,98 & 16,08 & 11,62 \\
\hline 55 & 1900 & 40 & 34,45 & 28,62 & 27,50 & 25,76 & 23,95 & 22,20 & 18,92 & 16,05 & 11,62 \\
\hline 55 & 1950 & 40 & 34,18 & 28,38 & 27,29 & 25,59 & 23,81 & 22,09 & 18,85 & 16,02 & 11,63 \\
\hline 55 & 2000 & 40 & 33,92 & 28,14 & 27,08 & 25,42 & 23,68 & 21,98 & 18,79 & 15,99 & 11,63 \\
\hline 55 & 200 & 45 & 78,60 & 53,92 & 44,71 & 36,40 & 30,18 & 25,26 & 18,23 & 13,87 & 9,22 \\
\hline 55 & 250 & 45 & 70,28 & 50,38 & 42,65 & 35,38 & 29,73 & 25,14 & 18,38 & 14,05 & 9,29 \\
\hline 55 & 300 & 45 & 64,37 & 47,66 & 40,97 & 34,48 & 29,29 & 24,98 & 18,48 & 14,19 & 9,36 \\
\hline 55 & 350 & 45 & 59,91 & 45,48 & 39,57 & 33,67 & 28,86 & 24,79 & 18,54 & 14,30 & 9,42 \\
\hline 55 & 400 & 45 & 56,41 & 43,66 & 38,36 & 32,95 & 28,45 & 24,60 & 18,57 & 14,39 & 9,49 \\
\hline 55 & 450 & 45 & 53,56 & 42,10 & 37,30 & 32,29 & 28,06 & 24,39 & 18,57 & 14,47 & 9,55 \\
\hline 55 & 500 & 45 & 51,20 & 40,75 & 36,36 & 31,69 & 27,69 & 24,19 & 18,56 & 14,53 & 9,61 \\
\hline 55 & 550 & 45 & 49,20 & 39,56 & 35,51 & 31,13 & 27,34 & 23,99 & 18,54 & 14,58 & 9,66 \\
\hline 55 & 600 & 45 & 47,48 & 38,49 & 34,75 & 30,62 & 27,01 & 23,80 & 18,51 & 14,61 & 9,72 \\
\hline 55 & 650 & 45 & 45,98 & 37,54 & 34,05 & 30,14 & 26,69 & 23,60 & 18,47 & 14,64 & 9,77 \\
\hline 55 & 700 & 45 & 44,67 & 36,66 & 33,41 & 29,69 & 26,39 & 23,42 & 18,43 & 14,67 & 9,81 \\
\hline 55 & 750 & 45 & 43,49 & 35,87 & 32,81 & 29,27 & 26,11 & 23,23 & 18,38 & 14,68 & 9,85 \\
\hline 55 & 800 & 45 & 42,45 & 35,13 & 32,26 & 28,88 & 25,84 & 23,06 & 18,33 & 14,69 & 9,89 \\
\hline 55 & 850 & 45 & 41,50 & 34,45 & 31,75 & 28,51 & 25,58 & 22,88 & 18,28 & 14,70 & 9,93 \\
\hline 55 & 900 & 45 & 40,64 & 33,82 & 31,27 & 28,16 & 25,33 & 22,72 & 18,22 & 14,70 & 9,96 \\
\hline 55 & 950 & 45 & 39,86 & 33,24 & 30,82 & 27,83 & 25,09 & 22,55 & 18,16 & 14,70 & 10,00 \\
\hline 55 & 1000 & 45 & 39,14 & 32,69 & 30,39 & 27,51 & 24,86 & 22,39 & 18,10 & 14,70 & 10,03 \\
\hline 55 & 1050 & 45 & 38,47 & 32,17 & 29,99 & 27,21 & 24,64 & 22,24 & 18,05 & 14,69 & 10,05 \\
\hline 55 & 1100 & 45 & 37,86 & 31,68 & 29,61 & 26,93 & 24,43 & 22,09 & 17,99 & 14,68 & 10,08 \\
\hline 55 & 1150 & 45 & 37,29 & 31,23 & 29,25 & 26,65 & 24,22 & 21,95 & 17,93 & 14,67 & 10,10 \\
\hline 55 & 1200 & 45 & 36,75 & 30,79 & 28,90 & 26,39 & 24,03 & 21,81 & 17,87 & 14,66 & 10,13 \\
\hline 55 & 1250 & 45 & 36,25 & 30,38 & 28,58 & 26,14 & 23,84 & 21,67 & 17,80 & 14,64 & 10,15 \\
\hline 55 & 1300 & 45 & 35,79 & 29,99 & 28,26 & 25,90 & 23,66 & 21,54 & 17,75 & 14,63 & 10,16 \\
\hline 55 & 1350 & 45 & 35,34 & 29,62 & 27,96 & 25,67 & 23,48 & 21,41 & 17,69 & 14,61 & 10,18 \\
\hline 55 & 1400 & 45 & 34,93 & 29,26 & 27,68 & 25,45 & 23,31 & 21,28 & 17,63 & 14,59 & 10,20 \\
\hline 55 & 1450 & 45 & 34,54 & 28,93 & 27,40 & 25,23 & 23,14 & 21,16 & 17,57 & 14,58 & 10,21 \\
\hline 55 & 1500 & 45 & 34,16 & 28,60 & 27,13 & 25,03 & 22,98 & 21,04 & 17,51 & 14,56 & 10,23 \\
\hline 55 & 1550 & 45 & 33,81 & 28,29 & 26,88 & 24,83 & 22,83 & 20,92 & 17,45 & 14,54 & 10,24 \\
\hline 55 & 1600 & 45 & 33,47 & 28,00 & 26,63 & 24,63 & 22,68 & 20,81 & 17,39 & 14,52 & 10,25 \\
\hline 55 & 1650 & 45 & 33,15 & 27,71 & 26,40 & 24,45 & 22,53 & 20,69 & 17,34 & 14,49 & 10,26 \\
\hline 55 & 1700 & 45 & 32,84 & 27,44 & 26,17 & 24,27 & 22,39 & 20,59 & 17,28 & 14,47 & 10,27 \\
\hline 55 & 1750 & 45 & 32,55 & 27,18 & 25,95 & 24,09 & 22,25 & 20,48 & 17,22 & 14,45 & 10,28 \\
\hline 55 & 1800 & 45 & 32,27 & 26,93 & 25,73 & 23,92 & 22,12 & 20,37 & 17,17 & 14,43 & 10,29 \\
\hline
\end{tabular}




\begin{tabular}{|c|c|c|c|c|c|c|c|c|c|c|c|}
\hline \multirow[b]{2}{*}{$\mathrm{H}(\mathrm{cm})$} & \multirow[b]{2}{*}{ Mceq (MPa) } & & & & & De & ões (x1 & m) & & & \\
\hline & & Msub (MPa) & D0 & D25 & D40 & D60 & D80 & D100 & D140 & D180 & D260 \\
\hline 55 & 1850 & 45 & 32,00 & 26,68 & 25,52 & 23,76 & 21,98 & 20,27 & 17,11 & 14,40 & 10,30 \\
\hline 55 & 1900 & 45 & 31,73 & 26,45 & 25,32 & 23,60 & 21,86 & 20,17 & 17,06 & 14,38 & 10,31 \\
\hline 55 & 1950 & 45 & 31,48 & 26,22 & 25,13 & 23,44 & 21,73 & 20,08 & 17,01 & 14,36 & 10,31 \\
\hline 55 & 2000 & 45 & 31,24 & 26,00 & 24,94 & 23,29 & 21,61 & 19,98 & 16,96 & 14,34 & 10,32 \\
\hline 55 & 200 & 50 & 74,71 & 50,12 & 41,12 & 33,16 & 27,32 & 22,75 & 16,33 & 12,42 & 8,28 \\
\hline 55 & 250 & 50 & 66,64 & 46,82 & 39,26 & 32,29 & 26,96 & 22,68 & 16,48 & 12,57 & 8,33 \\
\hline 55 & 300 & 50 & 60,93 & 44,29 & 37,74 & 31,51 & 26,60 & 22,57 & 16,59 & 12,70 & 8,38 \\
\hline 55 & 350 & 50 & 56,62 & 42,26 & 36,47 & 30,81 & 26,24 & 22,43 & 16,65 & 12,80 & 8,44 \\
\hline 55 & 400 & 50 & 53,23 & 40,58 & 35,38 & 30,17 & 25,90 & 22,28 & 16,69 & 12,89 & 8,49 \\
\hline 55 & 450 & 50 & 50,49 & 39,14 & 34,42 & 29,59 & 25,57 & 22,12 & 16,71 & 12,96 & 8,55 \\
\hline 55 & 500 & 50 & 48,21 & 37,89 & 33,57 & 29,06 & 25,26 & 21,96 & 16,72 & 13,02 & 8,60 \\
\hline 55 & 550 & 50 & 46,28 & 36,79 & 32,80 & 28,57 & 24,96 & 21,79 & 16,71 & 13,07 & 8,64 \\
\hline 55 & 600 & 50 & 44,62 & 35,81 & 32,11 & 28,11 & 24,67 & 21,63 & 16,69 & 13,11 & 8,69 \\
\hline 55 & 650 & 50 & 43,17 & 34,92 & 31,47 & 27,69 & 24,40 & 21,47 & 16,67 & 13,14 & 8,73 \\
\hline 55 & 700 & 50 & 41,90 & 34,12 & 30,89 & 27,29 & 24,14 & 21,31 & 16,64 & 13,17 & 8,77 \\
\hline 55 & 750 & 50 & 40,77 & 33,38 & 30,35 & 26,92 & 23,89 & 21,16 & 16,61 & 13,19 & 8,81 \\
\hline 55 & 800 & 50 & 39,76 & 32,70 & 29,85 & 26,57 & 23,65 & 21,01 & 16,57 & 13,21 & 8,85 \\
\hline 55 & 850 & 50 & 38,85 & 32,08 & 29,38 & 26,24 & 23,42 & 20,86 & 16,53 & 13,22 & 8,88 \\
\hline 55 & 900 & 50 & 38,02 & 31,49 & 28,94 & 25,92 & 23,20 & 20,72 & 16,49 & 13,23 & 8,91 \\
\hline 55 & 950 & 50 & 37,27 & 30,95 & 28,53 & 25,63 & 23,00 & 20,58 & 16,44 & 13,23 & 8,94 \\
\hline 55 & 1000 & 50 & 36,58 & 30,44 & 28,14 & 25,34 & 22,79 & 20,44 & 16,40 & 13,23 & 8,97 \\
\hline 55 & 1050 & 50 & 35,94 & 29,96 & 27,78 & 25,07 & 22,60 & 20,31 & 16,35 & 13,23 & 8,99 \\
\hline 55 & 1100 & 50 & 35,35 & 29,51 & 27,43 & 24,82 & 22,41 & 20,18 & 16,30 & 13,23 & 9,02 \\
\hline 55 & 1150 & 50 & 34,80 & 29,09 & 27,10 & 24,57 & 22,23 & 20,06 & 16,26 & 13,22 & 9,04 \\
\hline 55 & 1200 & 50 & 34,29 & 28,69 & 26,78 & 24,33 & 22,06 & 19,94 & 16,21 & 13,22 & 9,06 \\
\hline 55 & 1250 & 50 & 33,81 & 28,31 & 26,48 & 24,11 & 21,89 & 19,82 & 16,16 & 13,21 & 9,08 \\
\hline 55 & 1300 & 50 & 33,36 & 27,94 & 26,20 & 23,89 & 21,73 & 19,70 & 16,11 & 13,20 & 9,10 \\
\hline 55 & 1350 & 50 & 32,94 & 27,60 & 25,92 & 23,68 & 21,57 & 19,59 & 16,06 & 13,19 & 9,12 \\
\hline 55 & 1400 & 50 & 32,54 & 27,27 & 25,66 & 23,48 & 21,42 & 19,48 & 16,01 & 13,18 & 9,13 \\
\hline 55 & 1450 & 50 & 32,17 & 26,96 & 25,41 & 23,29 & 21,28 & 19,37 & 15,97 & 13,16 & 9,15 \\
\hline 55 & 1500 & 50 & 31,81 & 26,66 & 25,17 & 23,10 & 21,13 & 19,27 & 15,92 & 13,15 & 9,16 \\
\hline 55 & 1550 & 50 & 31,47 & 26,37 & 24,93 & 22,92 & 20,99 & 19,16 & 15,87 & 13,14 & 9,18 \\
\hline 55 & 1600 & 50 & 31,15 & 26,09 & 24,71 & 22,75 & 20,86 & 19,06 & 15,82 & 13,12 & 9,19 \\
\hline 55 & 1650 & 50 & 30,85 & 25,83 & 24,49 & 22,58 & 20,73 & 18,97 & 15,77 & 13,11 & 9,20 \\
\hline 55 & 1700 & 50 & 30,55 & 25,57 & 24,28 & 22,41 & 20,60 & 18,87 & 15,73 & 13,09 & 9,21 \\
\hline 55 & 1750 & 50 & 30,27 & 25,33 & 24,08 & 22,26 & 20,48 & 18,78 & 15,68 & 13,07 & 9,22 \\
\hline 55 & 1800 & 50 & 30,01 & 25,09 & 23,88 & 22,10 & 20,36 & 18,68 & 15,63 & 13,06 & 9,23 \\
\hline 55 & 1850 & 50 & 29,75 & 24,87 & 23,69 & 21,95 & 20,24 & 18,59 & 15,59 & 13,04 & 9,24 \\
\hline 55 & 1900 & 50 & 29,50 & 24,65 & 23,51 & 21,81 & 20,12 & 18,51 & 15,54 & 13,02 & 9,25 \\
\hline 55 & 1950 & 50 & 29,27 & 24,44 & 23,33 & 21,67 & 20,01 & 18,42 & 15,50 & 13,00 & 9,26 \\
\hline 55 & 2000 & 50 & 29,04 & 24,23 & 23,16 & 21,53 & 19,90 & 18,34 & 15,45 & 12,98 & 9,26 \\
\hline 55 & 200 & 55 & 71,42 & 46,92 & 38,11 & 30,46 & 24,95 & 20,69 & 14,78 & 11,23 & 7,51 \\
\hline 55 & 250 & 55 & 63,57 & 43,81 & 36,41 & 29,70 & 24,66 & 20,66 & 14,93 & 11,37 & 7,55 \\
\hline 55 & 300 & 55 & 58,02 & 41,45 & 35,03 & 29,02 & 24,36 & 20,58 & 15,03 & 11,48 & 7,59 \\
\hline 55 & 350 & 55 & 53,84 & 39,55 & 33,87 & 28,40 & 24,06 & 20,47 & 15,10 & 11,58 & 7,64 \\
\hline 55 & 400 & 55 & 50,56 & 37,98 & 32,87 & 27,84 & 23,77 & 20,36 & 15,15 & 11,66 & 7,68 \\
\hline 55 & 450 & 55 & 47,90 & 36,64 & 32,00 & 27,33 & 23,49 & 20,23 & 15,18 & 11,73 & 7,73 \\
\hline 55 & 500 & 55 & 45,69 & 35,47 & 31,22 & 26,86 & 23,22 & 20,09 & 15,19 & 11,79 & 7,77 \\
\hline 55 & 550 & 55 & 43,82 & 34,45 & 30,52 & 26,42 & 22,96 & 19,96 & 15,20 & 11,84 & 7,81 \\
\hline 55 & 600 & 55 & 42,22 & 33,53 & 29,88 & 26,01 & 22,71 & 19,82 & 15,19 & 11,88 & 7,85 \\
\hline 55 & 650 & 55 & 40,82 & 32,71 & 29,30 & 25,63 & 22,47 & 19,69 & 15,18 & 11,91 & 7,89 \\
\hline 55 & 700 & 55 & 39,59 & 31,96 & 28,76 & 25,28 & 22,25 & 19,56 & 15,16 & 11,94 & 7,93 \\
\hline 55 & 750 & 55 & 38,50 & 31,27 & 28,27 & 24,94 & 22,03 & 19,43 & 15,14 & 11,96 & 7,96 \\
\hline 55 & 800 & 55 & 37,52 & 30,64 & 27,81 & 24,62 & 21,82 & 19,30 & 15,11 & 11,98 & 7,99 \\
\hline 55 & 850 & 55 & 36,64 & 30,06 & 27,38 & 24,33 & 21,62 & 19,17 & 15,08 & 12,00 & 8,02 \\
\hline 55 & 900 & 55 & 35,84 & 29,52 & 26,98 & 24,04 & 21,42 & 19,05 & 15,05 & 12,01 & 8,05 \\
\hline 55 & 950 & 55 & 35,11 & 29,01 & 26,60 & 23,77 & 21,24 & 18,93 & 15,02 & 12,02 & 8,08 \\
\hline 55 & 1000 & 55 & 34,44 & 28,54 & 26,24 & 23,52 & 21,06 & 18,81 & 14,98 & 12,02 & 8,11 \\
\hline 55 & 1050 & 55 & 33,82 & 28,09 & 25,90 & 23,27 & 20,89 & 18,70 & 14,95 & 12,03 & 8,13 \\
\hline 55 & 1100 & 55 & 33,25 & 27,67 & 25,58 & 23,04 & 20,72 & 18,59 & 14,91 & 12,03 & 8,15 \\
\hline 55 & 1150 & 55 & 32,72 & 27,28 & 25,28 & 22,82 & 20,56 & 18,48 & 14,87 & 12,03 & 8,17 \\
\hline 55 & 1200 & 55 & 32,23 & 26,90 & 24,99 & 22,60 & 20,41 & 18,37 & 14,83 & 12,03 & 8,19 \\
\hline 55 & 1250 & 55 & 31,77 & 26,55 & 24,72 & 22,40 & 20,26 & 18,27 & 14,79 & 12,02 & 8,21 \\
\hline 55 & 1300 & 55 & 31,34 & 26,21 & 24,45 & 22,20 & 20,11 & 18,16 & 14,75 & 12,02 & 8,23 \\
\hline 55 & 1350 & 55 & 30,93 & 25,89 & 24,20 & 22,01 & 19,97 & 18,06 & 14,71 & 12,01 & 8,25 \\
\hline 55 & 1400 & 55 & 30,55 & 25,58 & 23,96 & 21,83 & 19,84 & 17,97 & 14,67 & 12,00 & 8,26 \\
\hline 55 & 1450 & 55 & 30,19 & 25,29 & 23,72 & 21,65 & 19,70 & 17,87 & 14,63 & 12,00 & 8,28 \\
\hline 55 & 1500 & 55 & 29,84 & 25,01 & 23,50 & 21,48 & 19,57 & 17,78 & 14,59 & 11,99 & 8,29 \\
\hline 55 & 1550 & 55 & 29,52 & 24,74 & 23,29 & 21,31 & 19,45 & 17,69 & 14,55 & 11,98 & 8,31 \\
\hline 55 & 1600 & 55 & 29,21 & 24,48 & 23,08 & 21,16 & 19,33 & 17,60 & 14,51 & 11,97 & 8,32 \\
\hline 55 & 1650 & 55 & 28,92 & 24,23 & 22,88 & 21,00 & 19,21 & 17,51 & 14,47 & 11,95 & 8,33 \\
\hline 55 & 1700 & 55 & 28,64 & 24,00 & 22,69 & 20,85 & 19,10 & 17,43 & 14,43 & 11,94 & 8,34 \\
\hline 55 & 1750 & 55 & 28,37 & 23,77 & 22,50 & 20,71 & 18,98 & 17,35 & 14,39 & 11,93 & 8,35 \\
\hline 55 & 1800 & 55 & 28,12 & 23,55 & 22,32 & 20,57 & 18,88 & 17,27 & 14,35 & 11,92 & 8,36 \\
\hline 55 & 1850 & 55 & 27,87 & 23,33 & 22,14 & 20,43 & 18,77 & 17,19 & 14,31 & 11,90 & 8,37 \\
\hline 55 & 1900 & 55 & 27,64 & 23,13 & 21,97 & 20,30 & 18,67 & 17,11 & 14,27 & 11,89 & 8,38 \\
\hline 55 & 1950 & 55 & 27,41 & 22,93 & 21,81 & 20,17 & 18,57 & 17,03 & 14,24 & 11,88 & 8,39 \\
\hline 55 & 2000 & 55 & 27,19 & 22,74 & 21,65 & 20,04 & 18,47 & 16,96 & 14,20 & 11,86 & 8,40 \\
\hline 55 & 200 & 60 & 68,61 & 44,19 & 35,54 & 28,18 & 22,95 & 18,96 & 13,49 & 10,25 & 6,88 \\
\hline 55 & 250 & 60 & 60,95 & 41,25 & 33,98 & 27,51 & 22,72 & 18,95 & 13,63 & 10,37 & 6,91 \\
\hline 55 & 300 & 60 & 55,54 & 39,01 & 32,71 & 26,90 & 22,47 & 18,90 & 13,74 & 10,47 & 6,94 \\
\hline
\end{tabular}




\begin{tabular}{|c|c|c|c|c|c|c|c|c|c|c|c|}
\hline \multirow[b]{2}{*}{$\mathrm{H}(\mathrm{cm})$} & \multirow[b]{2}{*}{ Mceq (MPa) } & & & & & $\mathrm{De}$ & ões (x1 & & & & \\
\hline & & Msub (MPa) & D0 & D25 & D40 & D60 & D80 & D100 & D140 & D180 & D260 \\
\hline 55 & 350 & 60 & 51,47 & 37,23 & 31,65 & 26,36 & 22,22 & 18,83 & 13,81 & 10,56 & 6,98 \\
\hline 55 & 400 & 60 & 48,28 & 35,75 & 30,73 & 25,86 & 21,97 & 18,73 & 13,86 & 10,64 & 7,02 \\
\hline 55 & 450 & 60 & 45,69 & 34,49 & 29,92 & 25,40 & 21,72 & 18,63 & 13,90 & 10,71 & 7,05 \\
\hline 55 & 500 & 60 & 43,55 & 33,40 & 29,20 & 24,98 & 21,49 & 18,52 & 13,92 & 10,76 & 7,09 \\
\hline 55 & 550 & 60 & 41,73 & 32,43 & 28,56 & 24,58 & 21,26 & 18,41 & 13,93 & 10,81 & 7,13 \\
\hline 55 & 600 & 60 & 40,17 & 31,58 & 27,97 & 24,22 & 21,05 & 18,30 & 13,93 & 10,85 & 7,16 \\
\hline 55 & 650 & 60 & 38,82 & 30,80 & 27,44 & 23,87 & 20,84 & 18,18 & 13,93 & 10,88 & 7,20 \\
\hline 55 & 700 & 60 & 37,62 & 30,10 & 26,94 & 23,55 & 20,64 & 18,07 & 13,92 & 10,91 & 7,23 \\
\hline 55 & 750 & 60 & 36,56 & 29,46 & 26,49 & 23,25 & 20,44 & 17,96 & 13,90 & 10,94 & 7,26 \\
\hline 55 & 800 & 60 & 35,61 & 28,87 & 26,06 & 22,96 & 20,26 & 17,85 & 13,88 & 10,96 & 7,29 \\
\hline 55 & 850 & 60 & 34,75 & 28,32 & 25,66 & 22,69 & 20,08 & 17,74 & 13,86 & 10,98 & 7,32 \\
\hline 55 & 900 & 60 & 33,98 & 27,82 & 25,29 & 22,43 & 19,91 & 17,63 & 13,84 & 10,99 & 7,34 \\
\hline 55 & 950 & 60 & 33,27 & 27,34 & 24,94 & 22,19 & 19,74 & 17,53 & 13,81 & 11,00 & 7,37 \\
\hline 55 & 1000 & 60 & 32,62 & 26,90 & 24,61 & 21,96 & 19,58 & 17,43 & 13,79 & 11,01 & 7,39 \\
\hline 55 & 1050 & 60 & 32,02 & 26,48 & 24,30 & 21,73 & 19,43 & 17,32 & 13,76 & 11,02 & 7,41 \\
\hline 55 & 1100 & 60 & 31,47 & 26,09 & 24,00 & 21,52 & 19,28 & 17,23 & 13,73 & 11,02 & 7,43 \\
\hline 55 & 1150 & 60 & 30,96 & 25,72 & 23,72 & 21,32 & 19,13 & 17,13 & 13,70 & 11,03 & 7,45 \\
\hline 55 & 1200 & 60 & 30,48 & 25,37 & 23,45 & 21,12 & 19,00 & 17,04 & 13,67 & 11,03 & 7,47 \\
\hline 55 & 1250 & 60 & 30,03 & 25,03 & 23,20 & 20,93 & 18,86 & 16,94 & 13,63 & 11,03 & 7,49 \\
\hline 55 & 1300 & 60 & 29,62 & 24,72 & 22,95 & 20,75 & 18,73 & 16,85 & 13,60 & 11,02 & 7,51 \\
\hline 55 & 1350 & 60 & 29,22 & 24,42 & 22,72 & 20,58 & 18,60 & 16,77 & 13,57 & 11,02 & 7,52 \\
\hline 55 & 1400 & 60 & 28,85 & 24,13 & 22,49 & 20,41 & 18,48 & 16,68 & 13,53 & 11,02 & 7,54 \\
\hline 55 & 1450 & 60 & 28,50 & 23,85 & 22,28 & 20,25 & 18,36 & 16,60 & 13,50 & 11,01 & 7,55 \\
\hline 55 & 1500 & 60 & 28,17 & 23,59 & 22,07 & 20,09 & 18,24 & 16,51 & 13,47 & 11,01 & 7,57 \\
\hline 55 & 1550 & 60 & 27,86 & 23,34 & 21,87 & 19,94 & 18,13 & 16,43 & 13,43 & 11,00 & 7,58 \\
\hline 55 & 1600 & 60 & 27,56 & 23,09 & 21,68 & 19,79 & 18,02 & 16,35 & 13,40 & 10,99 & 7,59 \\
\hline 55 & 1650 & 60 & 27,28 & 22,86 & 21,49 & 19,65 & 17,91 & 16,28 & 13,36 & 10,99 & 7,61 \\
\hline 55 & 1700 & 60 & 27,01 & 22,64 & 21,31 & 19,51 & 17,81 & 16,20 & 13,33 & 10,98 & 7,62 \\
\hline 55 & 1750 & 60 & 26,75 & 22,42 & 21,14 & 19,38 & 17,71 & 16,13 & 13,30 & 10,97 & 7,63 \\
\hline 55 & 1800 & 60 & 26,51 & 22,21 & 20,97 & 19,25 & 17,61 & 16,05 & 13,26 & 10,96 & 7,64 \\
\hline 55 & 1850 & 60 & 26,27 & 22,01 & 20,81 & 19,13 & 17,51 & 15,98 & 13,23 & 10,95 & 7,65 \\
\hline 55 & 1900 & 60 & 26,05 & 21,82 & 20,65 & 19,00 & 17,42 & 15,91 & 13,20 & 10,94 & 7,66 \\
\hline 55 & 1950 & 60 & 25,83 & 21,63 & 20,50 & 18,88 & 17,33 & 15,84 & 13,16 & 10,93 & 7,66 \\
\hline 55 & 2000 & 60 & 25,62 & 21,45 & 20,35 & 18,77 & 17,24 & 15,78 & 13,13 & 10,92 & 7,67 \\
\hline 55 & 200 & 65 & 66,17 & 41,82 & 33,33 & 26,21 & 21,24 & 17,49 & 12,40 & 9,42 & 6,34 \\
\hline 55 & 250 & 65 & 58,66 & 39,02 & 31,88 & 25,62 & 21,06 & 17,51 & 12,54 & 9,53 & 6,36 \\
\hline 55 & 300 & 65 & 53,38 & 36,90 & 30,71 & 25,08 & 20,85 & 17,48 & 12,64 & 9,63 & 6,39 \\
\hline 55 & 350 & 65 & 49,41 & 35,21 & 29,72 & 24,60 & 20,63 & 17,42 & 12,71 & 9,71 & 6,42 \\
\hline 55 & 400 & 65 & 46,30 & 33,81 & 28,87 & 24,15 & 20,42 & 17,35 & 12,77 & 9,78 & 6,46 \\
\hline 55 & 450 & 65 & 443,78 & 32,62 & 28,13 & 23,74 & 20,21 & 17,26 & 12,81 & 9,84 & 6,49 \\
\hline 55 & 500 & 65 & 41,69 & 31,59 & 27,46 & 23,35 & 20,00 & 17,17 & 12,83 & 9,89 & 6,52 \\
\hline 55 & 550 & 65 & 39,92 & 30,68 & 26,86 & 23,00 & 19,80 & 17,08 & 12,85 & 9,94 & 6,55 \\
\hline 55 & 600 & 65 & 38,40 & 29,87 & 26,32 & 22,67 & 19,61 & 16,99 & 12,86 & 9,98 & 6,58 \\
\hline 55 & 650 & 65 & 37,08 & 29,15 & 25,82 & 22,35 & 19,43 & 16,89 & 12,86 & 10,02 & 6,61 \\
\hline 55 & 700 & 65 & 35,92 & 28,49 & 25,36 & 22,06 & 19,25 & 16,79 & 12,86 & 10,05 & 6,64 \\
\hline 55 & 750 & 65 & 34,89 & 27,88 & 24,94 & 21,78 & 19,08 & 16,70 & 12,85 & 10,07 & 6,67 \\
\hline 55 & 800 & 65 & 33,96 & 27,33 & 24,54 & 21,52 & 18,91 & 16,60 & 12,84 & 10,09 & 6,69 \\
\hline 55 & 850 & 65 & 33,13 & 26,81 & 24,17 & 21,28 & 18,75 & 16,51 & 12,82 & 10,11 & 6,72 \\
\hline 55 & 900 & 65 & 32,38 & 26,34 & 23,83 & 21,04 & 18,60 & 16,41 & 12,80 & 10,13 & 6,74 \\
\hline 55 & 950 & 65 & 31,69 & 25,89 & 23,50 & 20,82 & 18,45 & 16,32 & 12,79 & 10,14 & 6,77 \\
\hline 55 & 1000 & 65 & 31,06 & 25,47 & 23,19 & 20,60 & 18,30 & 16,23 & 12,76 & 10,15 & 6,79 \\
\hline 55 & 1050 & 65 & 30,47 & 25,08 & 22,90 & 20,40 & 18,17 & 16,14 & 12,74 & 10,16 & 6,81 \\
\hline 55 & 1100 & 65 & 29,94 & 24,71 & 22,63 & 20,20 & 18,03 & 16,06 & 12,72 & 10,17 & 6,83 \\
\hline 55 & 1150 & 65 & 29,44 & 24,36 & 22,36 & 20,01 & 17,90 & 15,97 & 12,69 & 10,17 & 6,85 \\
\hline 55 & 1200 & 65 & 28,97 & 24,03 & 22,12 & 19,83 & 17,77 & 15,89 & 12,67 & 10,18 & 6,86 \\
\hline 55 & 1250 & 65 & 28,54 & 23,72 & 21,88 & 19,66 & 17,65 & 15,81 & 12,64 & 10,18 & 6,88 \\
\hline 55 & 1300 & 65 & 28,14 & 23,42 & 21,65 & 19,50 & 17,53 & 15,73 & 12,61 & 10,18 & 6,90 \\
\hline 55 & 1350 & 65 & 27,75 & 23,13 & 21,43 & 19,33 & 17,42 & 15,65 & 12,59 & 10,18 & 6,91 \\
\hline 55 & 1400 & 65 & 27,40 & 22,86 & 21,22 & 19,18 & 17,31 & 15,57 & 12,56 & 10,18 & 6,93 \\
\hline 55 & 1450 & 65 & 27,06 & 22,60 & 21,02 & 19,03 & 17,20 & 15,50 & 12,53 & 10,17 & 6,94 \\
\hline 55 & 1500 & 65 & 26,74 & 22,35 & 20,83 & 18,89 & 17,09 & 15,42 & 12,50 & 10,17 & 6,96 \\
\hline 55 & 1550 & 65 & 26,43 & 22,11 & 20,64 & 18,75 & 16,99 & 15,35 & 12,47 & 10,17 & 6,97 \\
\hline 55 & 1600 & 65 & 26,15 & 21,89 & 20,46 & 18,61 & 16,89 & 15,28 & 12,44 & 10,16 & 6,98 \\
\hline 55 & 1650 & 65 & 25,87 & 21,67 & 20,29 & 18,48 & 16,79 & 15,21 & 12,42 & 10,16 & 6,99 \\
\hline 55 & 1700 & 65 & 25,61 & 21,45 & 20,12 & 18,35 & 16,70 & 15,14 & 12,39 & 10,15 & 7,00 \\
\hline 55 & 1750 & 65 & 25,36 & 21,25 & 19,96 & 18,23 & 16,60 & 15,07 & 12,36 & 10,15 & 7,01 \\
\hline 55 & 1800 & 65 & 25,12 & 21,05 & 19,80 & 18,11 & 16,51 & 15,01 & 12,33 & 10,14 & 7,02 \\
\hline 55 & 1850 & 65 & 24,90 & 20,86 & 19,65 & 17,99 & 16,43 & 14,94 & 12,30 & 10,13 & 7,03 \\
\hline 55 & 1900 & 65 & 24,68 & 20,68 & 19,50 & 17,88 & 16,34 & 14,88 & 12,27 & 10,12 & 7,04 \\
\hline 55 & 1950 & 65 & 24,47 & 20,51 & 19,36 & 17,77 & 16,26 & 14,82 & 12,24 & 10,12 & 7,05 \\
\hline 55 & 2000 & 65 & 24,27 & 20,33 & 19,22 & 17,66 & 16,17 & 14,76 & 12,22 & 10,11 & 7,06 \\
\hline 55 & 200 & 70 & 64,03 & 39,76 & 31,40 & 24,51 & 19,77 & 16,23 & 11,47 & 8,71 & 5,88 \\
\hline 55 & 250 & 70 & 56,66 & 37,07 & 30,05 & 23,98 & 19,62 & 16,26 & 11,60 & 8,81 & 5,90 \\
\hline 55 & 300 & 70 & 51,48 & 35,05 & 28,96 & 23,50 & 19,44 & 16,24 & 11,70 & 8,90 & 5,92 \\
\hline 55 & 350 & 70 & 47,60 & 33,44 & 28,04 & 23,06 & 19,26 & 16,20 & 11,77 & 8,98 & 5,95 \\
\hline 55 & 400 & 70 & 44,56 & 32,11 & 27,25 & 22,66 & 19,07 & 16,15 & 11,83 & 9,04 & 5,98 \\
\hline 55 & 450 & 70 & 42,10 & 30,98 & 26,55 & 22,28 & 18,89 & 16,08 & 11,87 & 9,10 & 6,01 \\
\hline 55 & 500 & 70 & 40,06 & 30,00 & 25,93 & 21,94 & 18,71 & 16,01 & 11,90 & 9,15 & 6,03 \\
\hline 55 & 550 & 70 & 38,34 & 29,14 & 25,38 & 21,61 & 18,53 & 15,93 & 11,92 & 9,20 & 6,06 \\
\hline 55 & 600 & 70 & 36,86 & 28,38 & 24,87 & 21,31 & 18,36 & 15,85 & 11,93 & 9,24 & 6,09 \\
\hline 55 & 650 & 70 & 35,57 & 27,69 & 24,40 & 21,03 & 18,20 & 15,77 & 11,94 & 9,27 & 6,11 \\
\hline
\end{tabular}




\begin{tabular}{|c|c|c|c|c|c|c|c|c|c|c|c|}
\hline \multirow[b]{2}{*}{$\mathrm{H}(\mathrm{cm})$} & \multirow[b]{2}{*}{ Mceq (MPa) } & & & & & $\mathrm{De}$ & ões (x1 & & & & \\
\hline & & Msub (MPa) & D0 & D25 & D40 & D60 & D80 & D100 & D140 & D180 & D260 \\
\hline 55 & 700 & 70 & 34,43 & 27,07 & 23,98 & 20,76 & 18,04 & 15,68 & 11,94 & 9,30 & 6,14 \\
\hline 55 & 750 & 70 & 33,43 & 26,49 & 23,58 & 20,50 & 17,89 & 15,60 & 11,94 & 9,33 & 6,16 \\
\hline 55 & 800 & 70 & 32,53 & 25,97 & 23,21 & 20,26 & 17,74 & 15,52 & 11,93 & 9,35 & 6,19 \\
\hline 55 & 850 & 70 & 31,71 & 25,48 & 22,87 & 20,04 & 17,59 & 15,43 & 11,92 & 9,37 & 6,21 \\
\hline 55 & 900 & 70 & 30,98 & 25,03 & 22,54 & 19,82 & 17,45 & 15,35 & 11,91 & 9,38 & 6,23 \\
\hline 55 & 950 & 70 & 30,31 & 24,61 & 22,24 & 19,61 & 17,32 & 15,27 & 11,90 & 9,40 & 6,25 \\
\hline 55 & 1000 & 70 & 29,69 & 24,21 & 21,95 & 19,42 & 17,19 & 15,19 & 11,88 & 9,41 & 6,27 \\
\hline 55 & 1050 & 70 & 29,12 & 23,84 & 21,68 & 19,23 & 17,06 & 15,11 & 11,86 & 9,42 & 6,29 \\
\hline 55 & 1100 & 70 & 28,60 & 23,49 & 21,42 & 19,05 & 16,94 & 15,04 & 11,84 & 9,43 & 6,31 \\
\hline 55 & 1150 & 70 & 28,12 & 23,16 & 21,17 & 18,88 & 16,82 & 14,96 & 11,82 & 9,44 & 6,33 \\
\hline 55 & 1200 & 70 & 27,66 & 22,85 & 20,94 & 18,71 & 16,71 & 14,89 & 11,80 & 9,44 & 6,35 \\
\hline 55 & 1250 & 70 & 27,24 & 22,55 & 20,72 & 18,55 & 16,60 & 14,81 & 11,78 & 9,45 & 6,36 \\
\hline 55 & 1300 & 70 & 26,85 & 22,27 & 20,50 & 18,39 & 16,49 & 14,74 & 11,76 & 9,45 & 6,38 \\
\hline 55 & 1350 & 70 & 26,47 & 22,00 & 20,30 & 18,25 & 16,38 & 14,67 & 11,74 & 9,45 & 6,39 \\
\hline 55 & 1400 & 70 & 26,13 & 21,74 & 20,10 & 18,10 & 16,28 & 14,60 & 11,71 & 9,45 & 6,41 \\
\hline 55 & 1450 & 70 & 25,80 & 21,50 & 19,91 & 17,96 & 16,18 & 14,54 & 11,69 & 9,45 & 6,42 \\
\hline 55 & 1500 & 70 & 25,49 & 21,26 & 19,73 & 17,83 & 16,09 & 14,47 & 11,67 & 9,45 & 6,43 \\
\hline 55 & 1550 & 70 & 25,19 & 21,04 & 19,56 & 17,70 & 15,99 & 14,40 & 11,64 & 9,45 & 6,44 \\
\hline 55 & 1600 & 70 & 24,91 & 20,82 & 19,39 & 17,58 & 15,90 & 14,34 & 11,62 & 9,45 & 6,46 \\
\hline 55 & 1650 & 70 & 24,64 & 20,61 & 19,23 & 17,45 & 15,81 & 14,28 & 11,59 & 9,44 & 6,47 \\
\hline 55 & 1700 & 70 & 24,39 & 20,41 & 19,07 & 17,34 & 15,72 & 14,22 & 11,57 & 9,44 & 6,48 \\
\hline 55 & 1750 & 70 & 24,15 & 20,22 & 18,92 & 17,22 & 15,64 & 14,16 & 11,54 & 9,43 & 6,49 \\
\hline 55 & 1800 & 70 & 23,92 & 20,03 & 18,77 & 17,11 & 15,55 & 14,10 & 11,52 & 9,43 & 6,50 \\
\hline 55 & 1850 & 70 & 23,70 & 19,85 & 18,63 & 17,00 & 15,47 & 14,04 & 11,49 & 9,42 & 6,51 \\
\hline 55 & 1900 & 70 & 23,49 & 19,68 & 18,49 & 16,90 & 15,39 & 13,98 & 11,47 & 9,42 & 6,51 \\
\hline 55 & 1950 & 70 & 23,28 & 19,51 & 18,36 & 16,79 & 15,32 & 13,92 & 11,44 & 9,41 & 6,52 \\
\hline 55 & 2000 & 70 & 23,09 & 19,35 & 18,23 & 16,69 & 15,24 & 13,87 & 11,42 & 9,41 & 6,53 \\
\hline 55 & 200 & 75 & 62,13 & 37,93 & 29,70 & 23,01 & 18,48 & 15,13 & 10,67 & 8,11 & 5,49 \\
\hline 55 & 250 & 75 & 54,89 & 35,35 & 28,43 & 22,54 & 18,36 & 15,17 & 10,79 & 8,20 & 5,50 \\
\hline 55 & 300 & 75 & 49,80 & 33,41 & 27,41 & 22,11 & 18,21 & 15,17 & 10,89 & 8,28 & 5,52 \\
\hline 55 & 350 & 75 & 46,00 & 31,87 & 26,55 & 21,71 & 18,06 & 15,14 & 10,96 & 8,35 & 5,54 \\
\hline 55 & 400 & 75 & 43,02 & 30,60 & 25,81 & 21,34 & 17,89 & 15,10 & 11,01 & 8,41 & 5,56 \\
\hline 55 & 450 & 75 & 40,62 & 29,53 & 25,16 & 21,00 & 17,73 & 15,05 & 11,06 & 8,46 & 5,59 \\
\hline 55 & 500 & 75 & 38,62 & 28,60 & 24,58 & 20,69 & 17,57 & 14,99 & 11,09 & 8,51 & 5,61 \\
\hline 55 & 550 & 75 & 36,94 & 27,78 & 24,06 & 20,39 & 17,42 & 14,92 & 11,11 & 8,55 & 5,64 \\
\hline 55 & 600 & 75 & 35,49 & 27,05 & 23,59 & 20,11 & 17,27 & 14,85 & 11,13 & 8,59 & 5,66 \\
\hline 55 & 650 & 75 & 34,23 & 26,40 & 23,15 & 19,85 & 17,12 & 14,78 & 11,14 & 8,63 & 5,69 \\
\hline 55 & 700 & 75 & 33,12 & 25,80 & 22,75 & 19,61 & 16,98 & 14,71 & 11,14 & 8,65 & 5,71 \\
\hline 55 & 750 & 75 & 32,14 & 25,26 & 22,38 & 19,37 & 16,84 & 14,64 & 11,14 & 8,68 & 5,73 \\
\hline 55 & 800 & 75 & 31,26 & 24,76 & 22,03 & 19,15 & 16,70 & 14,56 & 11,14 & 8,70 & 5,75 \\
\hline 55 & 850 & 75 & 30,46 & 24,30 & 21,71 & 18,94 & 16,57 & 14,49 & 11,14 & 8,72 & 5,77 \\
\hline 55 & 900 & 75 & 29,75 & 23,87 & 21,40 & 18,74 & 16,45 & 14,42 & 11,13 & 8,74 & 5,79 \\
\hline 55 & 950 & 75 & 29,09 & 23,47 & 21,12 & 18,55 & 16,32 & 14,35 & 11,12 & 8,76 & 5,81 \\
\hline 55 & 1000 & 75 & 28,49 & 23,10 & 20,85 & 18,37 & 16,21 & 14,28 & 11,11 & 8,77 & 5,83 \\
\hline 55 & 1050 & 75 & 27,94 & 22,74 & 20,59 & 18,20 & 16,09 & 14,21 & 11,09 & 8,78 & 5,85 \\
\hline 55 & 1100 & 75 & 27,42 & 22,41 & 20,35 & 18,03 & 15,98 & 14,14 & 11,08 & 8,79 & 5,86 \\
\hline 55 & 1150 & 75 & 26,95 & 22,10 & 20,12 & 17,87 & 15,87 & 14,07 & 11,06 & 8,80 & 5,88 \\
\hline 55 & 1200 & 75 & 26,51 & 21,80 & 19,90 & 17,71 & 15,77 & 14,01 & 11,05 & 8,80 & 5,90 \\
\hline 55 & 1250 & 75 & 26,10 & 21,52 & 19,69 & 17,56 & 15,67 & 13,94 & 11,03 & 8,81 & 5,91 \\
\hline 55 & 1300 & 75 & 25,71 & 21,25 & 19,49 & 17,42 & 15,57 & 13,88 & 11,01 & 8,81 & 5,93 \\
\hline 55 & 1350 & 75 & 25,35 & 21,00 & 19,30 & 17,28 & 15,47 & 13,81 & 10,99 & 8,82 & 5,94 \\
\hline 55 & 1400 & 75 & 25,01 & 20,75 & 19,11 & 17,15 & 15,38 & 13,75 & 10,97 & 8,82 & 5,95 \\
\hline 55 & 1450 & 75 & 24,69 & 20,52 & 18,93 & 17,02 & 15,29 & 13,69 & 10,95 & 8,82 & 5,97 \\
\hline 55 & 1500 & 75 & 24,38 & 20,29 & 18,76 & 16,90 & 15,20 & 13,63 & 10,93 & 8,82 & 5,98 \\
\hline 55 & 1550 & 75 & 24,10 & 20,08 & 18,60 & 16,78 & 15,11 & 13,57 & 10,91 & 8,82 & 5,99 \\
\hline 55 & 1600 & 75 & 23,82 & 19,87 & 18,44 & 16,66 & 15,03 & 13,51 & 10,89 & 8,82 & 6,00 \\
\hline 55 & 1650 & 75 & 23,56 & 19,68 & 18,29 & 16,54 & 14,94 & 13,46 & 10,87 & 8,82 & 6,01 \\
\hline 55 & 1700 & 75 & 23,32 & 19,49 & 18,14 & 16,43 & 14,86 & 13,40 & 10,85 & 8,82 & 6,02 \\
\hline 55 & 1750 & 75 & 23,08 & 19,30 & 17,99 & 16,33 & 14,78 & 13,34 & 10,83 & 8,81 & 6,03 \\
\hline 55 & 1800 & 75 & 22,86 & 19,13 & 17,86 & 16,22 & 14,71 & 13,29 & 10,81 & 8,81 & 6,04 \\
\hline 55 & 1850 & 75 & 22,64 & 18,95 & 17,72 & 16,12 & 14,63 & 13,24 & 10,78 & 8,81 & 6,05 \\
\hline 55 & 1900 & 75 & 22,44 & 18,79 & 17,59 & 16,02 & 14,56 & 13,19 & 10,76 & 8,80 & 6,06 \\
\hline 55 & 1950 & 75 & 22,24 & 18,63 & 17,47 & 15,93 & 14,49 & 13,13 & 10,74 & 8,80 & 6,07 \\
\hline 55 & 2000 & 75 & 22,05 & 18,48 & 17,34 & 15,83 & 14,42 & 13,08 & 10,72 & 8,79 & 6,08 \\
\hline 55 & 200 & 80 & 60,44 & 36,31 & 28,19 & 21,69 & 17,35 & 14,17 & 9,96 & 7,58 & 5,14 \\
\hline 55 & 250 & 80 & 53,30 & 33,82 & 27,00 & 21,27 & 17,25 & 14,22 & 10,08 & 7,66 & 5,15 \\
\hline 55 & 300 & 80 & 48,31 & 31,95 & 26,04 & 20,87 & 17,13 & 14,22 & 10,17 & 7,73 & 5,17 \\
\hline 55 & 350 & 80 & 44,57 & 30,48 & 25,23 & 20,51 & 16,99 & 14,21 & 10,25 & 7,80 & 5,19 \\
\hline 55 & 400 & 80 & 41,65 & 29,26 & 24,53 & 20,18 & 16,85 & 14,18 & 10,30 & 7,86 & 5,21 \\
\hline 55 & 450 & 80 & 39,29 & 28,23 & 23,92 & 19,87 & 16,71 & 14,14 & 10,34 & 7,91 & 5,23 \\
\hline 55 & 500 & 80 & 37,34 & 27,34 & 23,38 & 19,58 & 16,57 & 14,09 & 10,38 & 7,95 & 5,25 \\
\hline 55 & 550 & 80 & 35,69 & 26,56 & 22,89 & 19,31 & 16,43 & 14,03 & 10,40 & 7,99 & 5,27 \\
\hline 55 & 600 & 80 & 34,27 & 25,87 & 22,44 & 19,05 & 16,29 & 13,97 & 10,42 & 8,03 & 5,29 \\
\hline 55 & 650 & 80 & 33,04 & 25,24 & 22,03 & 18,81 & 16,16 & 13,91 & 10,43 & 8,06 & 5,31 \\
\hline 55 & 700 & 80 & 31,95 & 24,67 & 21,66 & 18,58 & 16,03 & 13,85 & 10,44 & 8,09 & 5,33 \\
\hline 55 & 750 & 80 & 30,99 & 24,16 & 21,31 & 18,37 & 15,91 & 13,79 & 10,45 & 8,11 & 5,35 \\
\hline 55 & 800 & 80 & 30,13 & 23,68 & 20,98 & 18,16 & 15,78 & 13,72 & 10,45 & 8,14 & 5,37 \\
\hline 55 & 850 & 80 & 29,35 & 23,24 & 20,67 & 17,97 & 15,67 & 13,66 & 10,45 & 8,16 & 5,39 \\
\hline 55 & 900 & 80 & 28,65 & 22,83 & 20,39 & 17,78 & 15,55 & 13,59 & 10,44 & 8,18 & 5,41 \\
\hline 55 & 950 & 80 & 28,01 & 22,45 & 20,12 & 17,61 & 15,44 & 13,53 & 10,43 & 8,19 & 5,43 \\
\hline 55 & 1000 & 80 & 27,42 & 22,10 & 19,86 & 17,44 & 15,33 & 13,47 & 10,43 & 8,20 & 5,44 \\
\hline
\end{tabular}




\begin{tabular}{|c|c|c|c|c|c|c|c|c|c|c|c|}
\hline \multirow[b]{2}{*}{$\mathrm{H}(\mathrm{cm})$} & \multirow[b]{2}{*}{ Mceq (MPa) } & & & & & $\mathrm{De}$ & ões (x1 & & & & \\
\hline & & Msub (MPa) & D0 & D25 & D40 & D60 & D80 & D100 & D140 & D180 & D260 \\
\hline 55 & 1050 & 80 & 26,88 & 21,76 & 19,62 & 17,27 & 15,23 & 13,41 & 10,42 & 8,22 & 5,46 \\
\hline 55 & 1100 & 80 & 26,38 & 21,44 & 19,39 & 17,12 & 15,13 & 13,34 & 10,41 & 8,23 & 5,48 \\
\hline 55 & 1150 & 80 & 25,92 & 21,15 & 19,18 & 16,97 & 15,03 & 13,28 & 10,39 & 8,24 & 5,49 \\
\hline 55 & 1200 & 80 & 25,48 & 20,86 & 18,97 & 16,83 & 14,93 & 13,22 & 10,38 & 8,24 & 5,51 \\
\hline 55 & 1250 & 80 & 25,08 & 20,59 & 18,77 & 16,69 & 14,84 & 13,17 & 10,37 & 8,25 & 5,52 \\
\hline 55 & 1300 & 80 & 24,70 & 20,34 & 18,58 & 16,55 & 14,75 & 13,11 & 10,35 & 8,26 & 5,53 \\
\hline 55 & 1350 & 80 & 24,35 & 20,10 & 18,40 & 16,42 & 14,66 & 13,05 & 10,33 & 8,26 & 5,55 \\
\hline 55 & 1400 & 80 & 24,02 & 19,86 & 18,22 & 16,30 & 14,57 & 12,99 & 10,32 & 8,26 & 5,56 \\
\hline 55 & 1450 & 80 & 23,70 & 19,64 & 18,06 & 16,18 & 14,49 & 12,94 & 10,30 & 8,27 & 5,57 \\
\hline 55 & 1500 & 80 & 23,41 & 19,43 & 17,89 & 16,06 & 14,40 & 12,88 & 10,28 & 8,27 & 5,58 \\
\hline 55 & 1550 & 80 & 23,13 & 19,22 & 17,74 & 15,95 & 14,32 & 12,83 & 10,27 & 8,27 & 5,59 \\
\hline 55 & 1600 & 80 & 22,86 & 19,03 & 17,59 & 15,84 & 14,25 & 12,78 & 10,25 & 8,27 & 5,60 \\
\hline 55 & 1650 & 80 & 22,61 & 18,84 & 17,44 & 15,73 & 14,17 & 12,73 & 10,23 & 8,27 & 5,62 \\
\hline 55 & 1700 & 80 & 22,37 & 18,66 & 17,30 & 15,63 & 14,10 & 12,67 & 10,21 & 8,27 & 5,62 \\
\hline 55 & 1750 & 80 & 22,14 & 18,48 & 17,17 & 15,53 & 14,02 & 12,62 & 10,19 & 8,27 & 5,63 \\
\hline 55 & 1800 & 80 & 21,92 & 18,31 & 17,04 & 15,43 & 13,95 & 12,58 & 10,18 & 8,27 & 5,64 \\
\hline 55 & 1850 & 80 & 21,71 & 18,15 & 16,91 & 15,34 & 13,88 & 12,53 & 10,16 & 8,26 & 5,65 \\
\hline 55 & 1900 & 80 & 21,51 & 17,99 & 16,79 & 15,25 & 13,81 & 12,48 & 10,14 & 8,26 & 5,66 \\
\hline 55 & 1950 & 80 & 21,32 & 17,84 & 16,67 & 15,16 & 13,75 & 12,43 & 10,12 & 8,26 & 5,67 \\
\hline 55 & 2000 & 80 & 21,13 & 17,69 & 16,55 & 15,07 & 13,68 & 12,39 & 10,10 & 8,26 & 5,68 \\
\hline 55 & 200 & 85 & 58,92 & 34,85 & 26,84 & 20,51 & 16,35 & 13,32 & 9,35 & 7,11 & 4,84 \\
\hline 55 & 250 & 85 & 51,88 & 32,44 & 25,71 & 20,13 & 16,27 & 13,37 & 9,46 & 7,19 & 4,85 \\
\hline 55 & 300 & 85 & 46,96 & 30,64 & 24,80 & 19,77 & 16,16 & 13,39 & 9,55 & 7,25 & 4,86 \\
\hline 55 & 350 & 85 & 43,29 & 29,22 & 24,04 & 19,44 & 16,05 & 13,38 & 9,62 & 7,31 & 4,87 \\
\hline 55 & 400 & 85 & 40,42 & 28,05 & 23,39 & 19,14 & 15,92 & 13,36 & 9,67 & 7,37 & 4,89 \\
\hline 55 & 450 & 85 & 38,10 & 27,06 & 22,81 & 18,85 & 15,80 & 13,33 & 9,72 & 7,42 & 4,91 \\
\hline 55 & 500 & 85 & 36,18 & 26,21 & 22,30 & 18,58 & 15,67 & 13,29 & 9,75 & 7,46 & 4,93 \\
\hline 55 & 550 & 85 & 34,57 & 25,46 & 21,84 & 18,33 & 15,55 & 13,24 & 9,78 & 7,50 & 4,95 \\
\hline 55 & 600 & 85 & 33,18 & 24,80 & 21,41 & 18,10 & 15,42 & 13,19 & 9,80 & 7,53 & 4,97 \\
\hline 55 & 650 & 85 & 31,97 & 24,20 & 21,03 & 17,88 & 15,31 & 13,14 & 9,81 & 7,56 & 4,98 \\
\hline 55 & 700 & 85 & 30,90 & 23,66 & 20,67 & 17,66 & 15,19 & 13,08 & 9,82 & 7,59 & 5,00 \\
\hline 55 & 750 & 85 & 29,96 & 23,16 & 20,34 & 17,47 & 15,07 & 13,03 & 9,83 & 7,62 & 5,02 \\
\hline 55 & 800 & 85 & 29,12 & 22,71 & 20,03 & 17,28 & 14,96 & 12,97 & 9,83 & 7,64 & 5,04 \\
\hline 55 & 850 & 85 & 28,36 & 22,29 & 19,75 & 17,09 & 14,86 & 12,91 & 9,83 & 7,66 & 5,06 \\
\hline 55 & 900 & 85 & 27,67 & 21,90 & 19,47 & 16,92 & 14,75 & 12,86 & 9,83 & 7,68 & 5,07 \\
\hline 55 & 950 & 85 & 27,04 & 21,53 & 19,22 & 16,76 & 14,65 & 12,80 & 9,83 & 7,69 & 5,09 \\
\hline 55 & 1000 & 85 & 26,46 & 21,19 & 18,98 & 16,60 & 14,55 & 12,75 & 9,82 & 7,71 & 5,10 \\
\hline 55 & 1050 & 85 & 25,93 & 20,87 & 18,75 & 16,45 & 14,45 & 12,69 & 9,82 & 7,72 & 5,12 \\
\hline 55 & 1100 & 85 & 25,44 & 20,57 & 18,53 & 16,30 & 14,36 & 12,63 & 9,81 & 7,73 & 5,13 \\
\hline 55 & 1150 & 85 & 24,99 & 20,29 & 18,33 & 16,16 & 14,27 & 12,58 & 9,80 & 7,74 & 5,15 \\
\hline 55 & 1200 & 85 & 24,57 & 20,02 & 18,13 & 16,03 & 14,18 & 12,53 & 9,79 & 7,75 & 5,16 \\
\hline 55 & 1250 & 85 & 24,17 & 19,76 & 17,94 & 15,90 & 14,09 & 12,47 & 9,78 & 7,76 & 5,18 \\
\hline 55 & 1300 & 85 & 23,80 & 19,51 & 17,76 & 15,77 & 14,01 & 12,42 & 9,76 & 7,76 & 5,19 \\
\hline 55 & 1350 & 85 & 23,46 & 19,28 & 17,59 & 15,65 & 13,93 & 12,37 & 9,75 & 7,77 & 5,20 \\
\hline 55 & 1400 & 85 & 23,13 & 19,06 & 17,43 & 15,54 & 13,85 & 12,32 & 9,74 & 7,77 & 5,21 \\
\hline 55 & 1450 & 85 & 22,82 & 18,85 & 17,27 & 15,42 & 13,77 & 12,27 & 9,72 & 7,78 & 5,22 \\
\hline 55 & 1500 & 85 & 22,53 & 18,64 & 17,11 & 15,31 & 13,69 & 12,22 & 9,71 & 7,78 & 5,24 \\
\hline 55 & 1550 & 85 & 22,26 & 18,45 & 16,97 & 15,21 & 13,62 & 12,17 & 9,69 & 7,78 & 5,25 \\
\hline 55 & 1600 & 85 & 22,00 & 18,26 & 16,82 & 15,10 & 13,55 & 12,12 & 9,68 & 7,78 & 5,26 \\
\hline 55 & 1650 & 85 & 21,75 & 18,08 & 16,69 & 15,01 & 13,48 & 12,07 & 9,66 & 7,78 & 5,27 \\
\hline 55 & 1700 & 85 & 21,52 & 17,91 & 16,55 & 14,91 & 13,41 & 12,03 & 9,65 & 7,78 & 5,28 \\
\hline 55 & 1750 & 85 & 21,29 & 17,74 & 16,43 & 14,81 & 13,34 & 11,98 & 9,63 & 7,78 & 5,28 \\
\hline 55 & 1800 & 85 & 21,08 & 17,58 & 16,30 & 14,72 & 13,27 & 11,93 & 9,61 & 7,78 & 5,29 \\
\hline 55 & 1850 & 85 & 20,87 & 17,42 & 16,18 & 14,63 & 13,21 & 11,89 & 9,60 & 7,78 & 5,30 \\
\hline 55 & 1900 & 85 & 20,68 & 17,27 & 16,07 & 14,55 & 13,15 & 11,85 & 9,58 & 7,78 & 5,31 \\
\hline 55 & 1950 & 85 & 20,49 & 17,13 & 15,95 & 14,46 & 13,09 & 11,80 & 9,56 & 7,78 & 5,32 \\
\hline 55 & 2000 & 85 & 20,31 & 16,98 & 15,84 & 14,38 & 13,02 & 11,76 & 9,55 & 7,78 & 5,32 \\
\hline 55 & 200 & 90 & 57,55 & 33,54 & 25,63 & 19,46 & 15,45 & 12,56 & 8,80 & 6,70 & 4,57 \\
\hline 55 & 250 & 90 & 50,59 & 31,20 & 24,55 & 19,11 & 15,39 & 12,62 & 8,91 & 6,77 & 4,57 \\
\hline 55 & 300 & 90 & 45,74 & 29,46 & 23,69 & 18,78 & 15,30 & 12,64 & 8,99 & 6,83 & 4,58 \\
\hline 55 & 350 & 90 & 42,12 & 28,09 & 22,97 & 18,48 & 15,20 & 12,64 & 9,06 & 6,89 & 4,60 \\
\hline 55 & 400 & 90 & 39,30 & 26,96 & 22,35 & 18,20 & 15,09 & 12,63 & 9,11 & 6,94 & 4,61 \\
\hline 55 & 450 & 90 & 37,02 & 26,01 & 21,81 & 17,94 & 14,98 & 12,60 & 9,16 & 6,98 & 4,63 \\
\hline 55 & 500 & 90 & 35,14 & 25,19 & 21,32 & 17,69 & 14,87 & 12,57 & 9,19 & 7,02 & 4,64 \\
\hline 55 & 550 & 90 & 33,55 & 24,47 & 20,88 & 17,46 & 14,76 & 12,53 & 9,22 & 7,06 & 4,66 \\
\hline 55 & 600 & 90 & 32,19 & 23,83 & 20,49 & 17,24 & 14,64 & 12,49 & 9,24 & 7,09 & 4,68 \\
\hline 55 & 650 & 90 & 31,00 & 23,26 & 20,12 & 17,03 & 14,54 & 12,44 & 9,26 & 7,12 & 4,69 \\
\hline 55 & 700 & 90 & 29,96 & 22,74 & 19,78 & 16,84 & 14,43 & 12,40 & 9,27 & 7,15 & 4,71 \\
\hline 55 & 750 & 90 & 29,03 & 22,26 & 19,47 & 16,65 & 14,33 & 12,35 & 9,28 & 7,17 & 4,73 \\
\hline 55 & 800 & 90 & 28,20 & 21,83 & 19,18 & 16,47 & 14,23 & 12,30 & 9,28 & 7,20 & 4,74 \\
\hline 55 & 850 & 90 & 27,46 & 21,42 & 18,90 & 16,31 & 14,13 & 12,25 & 9,29 & 7,22 & 4,76 \\
\hline 55 & 900 & 90 & 26,78 & 21,05 & 18,65 & 16,14 & 14,03 & 12,20 & 9,29 & 7,23 & 4,78 \\
\hline 55 & 950 & 90 & 26,17 & 20,70 & 18,41 & 15,99 & 13,94 & 12,15 & 9,29 & 7,25 & 4,79 \\
\hline 55 & 1000 & 90 & 25,60 & 20,38 & 18,18 & 15,84 & 13,85 & 12,10 & 9,28 & 7,26 & 4,80 \\
\hline 55 & 1050 & 90 & 25,08 & 20,07 & 17,96 & 15,70 & 13,76 & 12,05 & 9,28 & 7,28 & 4,82 \\
\hline 55 & 1100 & 90 & 24,60 & 19,78 & 17,76 & 15,57 & 13,67 & 12,00 & 9,27 & 7,29 & 4,83 \\
\hline 55 & 1150 & 90 & 24,15 & 19,51 & 17,56 & 15,43 & 13,59 & 11,95 & 9,26 & 7,30 & 4,85 \\
\hline 55 & 1200 & 90 & 23,74 & 19,25 & 17,37 & 15,31 & 13,50 & 11,90 & 9,26 & 7,31 & 4,86 \\
\hline 55 & 1250 & 90 & 23,35 & 19,00 & 17,19 & 15,19 & 13,43 & 11,85 & 9,25 & 7,31 & 4,87 \\
\hline 55 & 1300 & 90 & 22,99 & 18,77 & 17,02 & 15,07 & 13,35 & 11,80 & 9,24 & 7,32 & 4,88 \\
\hline 55 & 1350 & 90 & 22,65 & 18,54 & 16,86 & 14,96 & 13,27 & 11,75 & 9,23 & 7,33 & 4,89 \\
\hline
\end{tabular}




\begin{tabular}{|c|c|c|c|c|c|c|c|c|c|c|c|}
\hline \multirow[b]{2}{*}{$\mathrm{H}(\mathrm{cm})$} & \multirow[b]{2}{*}{ Mceq (MPa) } & & & & & $\mathrm{De}$ & ões (x1 & & & & \\
\hline & & Msub (MPa) & D0 & D25 & D40 & D60 & D80 & D100 & D140 & D180 & D260 \\
\hline 55 & 1400 & 90 & 22,33 & 18,33 & 16,70 & 14,85 & 13,20 & 11,71 & 9,22 & 7,33 & 4,91 \\
\hline 55 & 1450 & 90 & 22,03 & 18,13 & 16,55 & 14,74 & 13,12 & 11,66 & 9,20 & 7,34 & 4,92 \\
\hline 55 & 1500 & 90 & 21,75 & 17,93 & 16,41 & 14,64 & 13,05 & 11,62 & 9,19 & 7,34 & 4,93 \\
\hline 55 & 1550 & 90 & 21,48 & 17,75 & 16,27 & 14,54 & 12,99 & 11,57 & 9,18 & 7,34 & 4,94 \\
\hline 55 & 1600 & 90 & 21,22 & 17,57 & 16,13 & 14,44 & 12,92 & 11,53 & 9,17 & 7,35 & 4,95 \\
\hline 55 & 1650 & 90 & 20,98 & 17,39 & 16,00 & 14,35 & 12,85 & 11,48 & 9,15 & 7,35 & 4,96 \\
\hline 55 & 1700 & 90 & 20,75 & 17,23 & 15,88 & 14,26 & 12,79 & 11,44 & 9,14 & 7,35 & 4,96 \\
\hline 55 & 1750 & 90 & 20,53 & 17,07 & 15,75 & 14,17 & 12,73 & 11,40 & 9,12 & 7,35 & 4,97 \\
\hline 55 & 1800 & 90 & 20,32 & 16,91 & 15,64 & 14,08 & 12,66 & 11,36 & 9,11 & 7,35 & 4,98 \\
\hline 55 & 1850 & 90 & 20,12 & 16,76 & 15,52 & 14,00 & 12,60 & 11,32 & 9,10 & 7,35 & 4,99 \\
\hline 55 & 1900 & 90 & 19,93 & 16,62 & 15,41 & 13,91 & 12,54 & 11,28 & 9,08 & 7,35 & 5,00 \\
\hline 55 & 1950 & 90 & 19,74 & 16,48 & 15,30 & 13,83 & 12,49 & 11,24 & 9,07 & 7,35 & 5,01 \\
\hline 55 & 2000 & 90 & 19,57 & 16,34 & 15,20 & 13,76 & 12,43 & 11,20 & 9,05 & 7,35 & 5,01 \\
\hline 55 & 200 & 95 & 56,31 & 32,35 & 24,53 & 18,51 & 14,64 & 11,88 & 8,31 & 6,33 & 4,33 \\
\hline 55 & 250 & 95 & 49,42 & 30,07 & 23,51 & 18,19 & 14,60 & 11,94 & 8,41 & 6,40 & 4,33 \\
\hline 55 & 300 & 95 & 44,63 & 28,38 & 22,69 & 17,89 & 14,52 & 11,97 & 8,50 & 6,45 & 4,34 \\
\hline 55 & 350 & 95 & 41,06 & 27,06 & 22,00 & 17,61 & 14,44 & 11,98 & 8,56 & 6,51 & 4,35 \\
\hline 55 & 400 & 95 & 38,28 & 25,97 & 21,41 & 17,35 & 14,34 & 11,97 & 8,61 & 6,55 & 4,36 \\
\hline 55 & 450 & 95 & 36,04 & 25,05 & 20,90 & 17,11 & 14,24 & 11,95 & 8,66 & 6,60 & 4,38 \\
\hline 55 & 500 & 95 & 34,19 & 24,26 & 20,44 & 16,88 & 14,14 & 11,93 & 8,69 & 6,63 & 4,39 \\
\hline 55 & 550 & 95 & 32,63 & 23,57 & 20,02 & 16,66 & 14,04 & 11,89 & 8,72 & 6,67 & 4,41 \\
\hline 55 & 600 & 95 & 31,29 & 22,95 & 19,64 & 16,46 & 13,94 & 11,86 & 8,74 & 6,70 & 4,42 \\
\hline 55 & 650 & 95 & 30,12 & 22,40 & 19,30 & 16,27 & 13,84 & 11,82 & 8,76 & 6,73 & 4,44 \\
\hline 55 & 700 & 95 & 29,10 & 21,90 & 18,97 & 16,09 & 13,74 & 11,78 & 8,77 & 6,75 & 4,45 \\
\hline 55 & 750 & 95 & 28,19 & 21,44 & 18,68 & 15,91 & 13,65 & 11,73 & 8,78 & 6,78 & 4,47 \\
\hline 55 & 800 & 95 & 27,37 & 21,02 & 18,40 & 15,75 & 13,56 & 11,69 & 8,79 & 6,80 & 4,48 \\
\hline 55 & 850 & 95 & 26,64 & 20,64 & 18,14 & 15,59 & 13,47 & 11,65 & 8,80 & 6,82 & 4,50 \\
\hline 55 & 900 & 95 & 25,98 & 20,28 & 17,90 & 15,44 & 13,38 & 11,60 & 8,80 & 6,84 & 4,51 \\
\hline 55 & 950 & 95 & 25,37 & 19,94 & 17,67 & 15,30 & 13,29 & 11,56 & 8,80 & 6,85 & 4,52 \\
\hline 55 & 1000 & 95 & 24,82 & 19,63 & 17,45 & 15,16 & 13,21 & 11,51 & 8,80 & 6,87 & 4,54 \\
\hline 55 & 1050 & 95 & 24,31 & 19,33 & 17,24 & 15,02 & 13,13 & 11,46 & 8,79 & 6,88 & 4,55 \\
\hline 55 & 1100 & 95 & 23,84 & 19,06 & 17,05 & 14,90 & 13,05 & 11,42 & 8,79 & 6,89 & 4,56 \\
\hline 55 & 1150 & 95 & 23,40 & 18,79 & 16,86 & 14,77 & 12,97 & 11,38 & 8,78 & 6,90 & 4,58 \\
\hline 55 & 1200 & 95 & 22,99 & 18,55 & 16,68 & 14,65 & 12,89 & 11,33 & 8,78 & 6,91 & 4,59 \\
\hline 55 & 1250 & 95 & 22,61 & 18,31 & 16,51 & 14,54 & 12,82 & 11,29 & 8,77 & 6,92 & 4,60 \\
\hline 55 & 1300 & 95 & 22,26 & 18,09 & 16,35 & 14,43 & 12,75 & 11,24 & 8,76 & 6,93 & 4,61 \\
\hline 55 & 1350 & 95 & 21,92 & 17,87 & 16,20 & 14,32 & 12,68 & 11,20 & 8,75 & 6,93 & 4,62 \\
\hline 55 & 1400 & 95 & 21,61 & 17,67 & 16,05 & 14,22 & 12,61 & 11,16 & 8,75 & 6,94 & 4,63 \\
\hline 55 & 1450 & 95 & 21,31 & 17,47 & 15,90 & 14,12 & 12,54 & 11,12 & 8,74 & 6,94 & 4,64 \\
\hline 55 & 1500 & 95 & 21,04 & 17,28 & 15,76 & 14,02 & 12,47 & 11,07 & 8,73 & 6,95 & 4,65 \\
\hline 55 & 1550 & 95 & 20,77 & 17,11 & 15,63 & 13,93 & 12,41 & 11,03 & 8,71 & 6,95 & 4,66 \\
\hline 55 & 1600 & 95 & 20,52 & 16,93 & 15,50 & 13,84 & 12,35 & 10,99 & 8,70 & 6,96 & 4,67 \\
\hline 55 & 1650 & 95 & 20,28 & 16,77 & 15,38 & 13,75 & 12,29 & 10,95 & 8,69 & 6,96 & 4,68 \\
\hline 55 & 1700 & 95 & 20,06 & 16,61 & 15,26 & 13,66 & 12,22 & 10,91 & 8,68 & 6,96 & 4,69 \\
\hline 55 & 1750 & 95 & 19,84 & 16,45 & 15,14 & 13,58 & 12,17 & 10,87 & 8,67 & 6,96 & 4,70 \\
\hline 55 & 1800 & 95 & 19,64 & 16,30 & 15,03 & 13,50 & 12,11 & 10,84 & 8,66 & 6,96 & 4,70 \\
\hline 55 & 1850 & 95 & 19,44 & 16,16 & 14,92 & 13,42 & 12,05 & 10,80 & 8,64 & 6,96 & 4,71 \\
\hline 55 & 1900 & 95 & 19,25 & 16,02 & 14,81 & 13,34 & 12,00 & 10,76 & 8,63 & 6,96 & 4,72 \\
\hline 55 & 1950 & 95 & 19,07 & 15,89 & 14,71 & 13,26 & 11,94 & 10,72 & 8,62 & 6,96 & 4,73 \\
\hline 55 & 2000 & 95 & 18,90 & 15,76 & 14,61 & 13,19 & 11,89 & 10,69 & 8,60 & 6,96 & 4,73 \\
\hline 55 & 200 & 100 & 55,17 & 31,26 & 23,53 & 17,65 & 13,92 & 11,27 & 7,87 & 6,00 & 4,11 \\
\hline 55 & 250 & 100 & 48,35 & 29,05 & 22,55 & 17,35 & 13,88 & 11,34 & 7,97 & 6,06 & 4,11 \\
\hline 55 & 300 & 100 & 43,62 & 27,40 & 21,77 & 17,08 & 13,82 & 11,37 & 8,05 & 6,11 & 4,12 \\
\hline 55 & 350 & 100 & 40,09 & 26,11 & 21,12 & 16,82 & 13,74 & 11,38 & 8,11 & 6,16 & 4,13 \\
\hline 55 & 400 & 100 & 37,35 & 25,06 & 20,56 & 16,58 & 13,66 & 11,38 & 8,16 & 6,21 & 4,14 \\
\hline 55 & 450 & 100 & 35,15 & 24,17 & 20,07 & 16,36 & 13,57 & 11,36 & 8,21 & 6,25 & 4,15 \\
\hline 55 & 500 & 100 & 33,32 & 23,41 & 19,63 & 16,14 & 13,48 & 11,34 & 8,24 & 6,28 & 4,16 \\
\hline 55 & 550 & 100 & 31,78 & 22,74 & 19,23 & 15,94 & 13,39 & 11,32 & 8,27 & 6,32 & 4,18 \\
\hline 55 & 600 & 100 & 30,46 & 22,15 & 18,87 & 15,75 & 13,30 & 11,29 & 8,29 & 6,35 & 4,19 \\
\hline 55 & 650 & 100 & 29,32 & 21,61 & 18,54 & 15,57 & 13,21 & 11,25 & 8,31 & 6,38 & 4,21 \\
\hline 55 & 700 & 100 & 28,31 & 21,13 & 18,24 & 15,40 & 13,12 & 11,22 & 8,33 & 6,40 & 4,22 \\
\hline 55 & 750 & 100 & 27,42 & 20,69 & 17,95 & 15,24 & 13,03 & 11,18 & 8,34 & 6,42 & 4,23 \\
\hline 55 & 800 & 100 & 26,62 & 20,29 & 17,69 & 15,09 & 12,95 & 11,14 & 8,35 & 6,44 & 4,25 \\
\hline 55 & 850 & 100 & 25,90 & 19,92 & 17,44 & 14,94 & 12,87 & 11,10 & 8,35 & 6,46 & 4,26 \\
\hline 55 & 900 & 100 & 25,24 & 19,57 & 17,21 & 14,80 & 12,78 & 11,06 & 8,36 & 6,48 & 4,27 \\
\hline 55 & 950 & 100 & 24,65 & 19,25 & 16,99 & 14,66 & 12,71 & 11,02 & 8,36 & 6,50 & 4,29 \\
\hline 55 & 1000 & 100 & 24,10 & 18,95 & 16,78 & 14,53 & 12,63 & 10,98 & 8,36 & 6,51 & 4,30 \\
\hline 55 & 1050 & 100 & 23,60 & 18,66 & 16,59 & 14,41 & 12,55 & 10,94 & 8,36 & 6,52 & 4,31 \\
\hline 55 & 1100 & 100 & 23,14 & 18,39 & 16,40 & 14,28 & 12,48 & 10,90 & 8,35 & 6,53 & 4,32 \\
\hline 55 & 1150 & 100 & 22,71 & 18,14 & 16,22 & 14,17 & 12,41 & 10,86 & 8,35 & 6,55 & 4,33 \\
\hline 55 & 1200 & 100 & 22,31 & 17,90 & 16,05 & 14,06 & 12,33 & 10,81 & 8,35 & 6,55 & 4,34 \\
\hline 55 & 1250 & 100 & 21,94 & 17,68 & 15,89 & 13,95 & 12,27 & 10,77 & 8,34 & 6,56 & 4,36 \\
\hline 55 & 1300 & 100 & 21,59 & 17,46 & 15,74 & 13,84 & 12,20 & 10,73 & 8,34 & 6,57 & 4,37 \\
\hline 55 & 1350 & 100 & 21,26 & 17,25 & 15,59 & 13,74 & 12,13 & 10,70 & 8,33 & 6,58 & 4,38 \\
\hline 55 & 1400 & 100 & 20,95 & 17,06 & 15,44 & 13,65 & 12,07 & 10,66 & 8,32 & 6,58 & 4,39 \\
\hline 55 & 1450 & 100 & 20,66 & 16,87 & 15,31 & 13,55 & 12,01 & 10,62 & 8,31 & 6,59 & 4,40 \\
\hline 55 & 1500 & 100 & 20,39 & 16,69 & 15,17 & 13,46 & 11,94 & 10,58 & 8,30 & 6,59 & 4,40 \\
\hline 55 & 1550 & 100 & 20,13 & 16,52 & 15,05 & 13,37 & 11,88 & 10,54 & 8,29 & 6,60 & 4,41 \\
\hline 55 & 1600 & 100 & 19,88 & 16,35 & 14,92 & 13,28 & 11,83 & 10,50 & 8,29 & 6,60 & 4,42 \\
\hline 55 & 1650 & 100 & 19,65 & 16,19 & 14,81 & 13,20 & 11,77 & 10,47 & 8,28 & 6,61 & 4,43 \\
\hline 55 & 1700 & 100 & 19,43 & 16,04 & 14,69 & 13,12 & 11,71 & 10,43 & 8,27 & 6,61 & 4,44 \\
\hline
\end{tabular}




\begin{tabular}{|c|c|c|c|c|c|c|c|c|c|c|c|}
\hline \multirow[b]{2}{*}{$\mathrm{H}(\mathrm{cm})$} & \multirow[b]{2}{*}{ Mceq (MPa) } & & & & & $\mathrm{De}$ & ões (x1 & & & & \\
\hline & & Msub (MPa) & D0 & D25 & D40 & D60 & D80 & D100 & D140 & D180 & D260 \\
\hline 55 & 1750 & 100 & 19,21 & 15,89 & 14,58 & 13,04 & 11,66 & 10,39 & 8,25 & 6,61 & 4,45 \\
\hline 55 & 1800 & 100 & 19,01 & 15,75 & 14,47 & 12,96 & 11,60 & 10,36 & 8,24 & 6,61 & 4,46 \\
\hline 55 & 1850 & 100 & 18,82 & 15,61 & 14,37 & 12,89 & 11,55 & 10,32 & 8,23 & 6,61 & 4,46 \\
\hline 55 & 1900 & 100 & 18,63 & 15,48 & 14,27 & 12,81 & 11,50 & 10,29 & 8,22 & 6,61 & 4,47 \\
\hline 55 & 1950 & 100 & 18,46 & 15,35 & 14,17 & 12,74 & 11,45 & 10,26 & 8,21 & 6,62 & 4,48 \\
\hline 55 & 2000 & 100 & 18,29 & 15,22 & 14,07 & 12,67 & 11,40 & 10,22 & 8,20 & 6,62 & 4,48 \\
\hline 55 & 200 & 105 & 54,12 & 30,27 & 22,62 & 16,86 & 13,26 & 10,72 & 7,48 & 5,70 & 3,92 \\
\hline 55 & 250 & 105 & 47,37 & 28,10 & 21,68 & 16,59 & 13,23 & 10,79 & 7,57 & 5,76 & 3,92 \\
\hline 55 & 300 & 105 & 42,68 & 26,50 & 20,93 & 16,34 & 13,18 & 10,82 & 7,65 & 5,81 & 3,92 \\
\hline 55 & 350 & 105 & 39,20 & 25,25 & 20,31 & 16,10 & 13,11 & 10,84 & 7,71 & 5,86 & 3,93 \\
\hline 55 & 400 & 105 & 36,50 & 24,23 & 19,77 & 15,88 & 13,04 & 10,84 & 7,76 & 5,90 & 3,94 \\
\hline 55 & 450 & 105 & 34,32 & 23,37 & 19,30 & 15,67 & 12,96 & 10,83 & 7,80 & 5,93 & 3,95 \\
\hline 55 & 500 & 105 & 32,52 & 22,63 & 18,89 & 15,47 & 12,88 & 10,81 & 7,83 & 5,97 & 3,96 \\
\hline 55 & 550 & 105 & 31,01 & 21,98 & 18,51 & 15,28 & 12,80 & 10,79 & 7,86 & 6,00 & 3,97 \\
\hline 55 & 600 & 105 & 29,71 & 21,41 & 18,17 & 15,10 & 12,72 & 10,76 & 7,89 & 6,03 & 3,98 \\
\hline 55 & 650 & 105 & 28,58 & 20,89 & 17,85 & 14,94 & 12,63 & 10,74 & 7,90 & 6,06 & 4,00 \\
\hline 55 & 700 & 105 & 27,59 & 20,43 & 17,56 & 14,78 & 12,55 & 10,70 & 7,92 & 6,08 & 4,01 \\
\hline 55 & 750 & 105 & 26,71 & 20,00 & 17,29 & 14,62 & 12,47 & 10,67 & 7,93 & 6,10 & 4,02 \\
\hline 55 & 800 & 105 & 25,92 & 19,61 & 17,04 & 14,48 & 12,39 & 10,64 & 7,94 & 6,12 & 4,03 \\
\hline 55 & 850 & 105 & 25,21 & 19,25 & 16,80 & 14,34 & 12,32 & 10,60 & 7,95 & 6,14 & 4,05 \\
\hline 55 & 900 & 105 & 24,57 & 18,92 & 16,58 & 14,21 & 12,24 & 10,57 & 7,95 & 6,16 & 4,06 \\
\hline 55 & 950 & 105 & 23,99 & 18,61 & 16,37 & 14,08 & 12,17 & 10,53 & 7,96 & 6,17 & 4,07 \\
\hline 55 & 1000 & 105 & 23,45 & 18,32 & 16,17 & 13,96 & 12,10 & 10,49 & 7,96 & 6,19 & 4,08 \\
\hline 55 & 1050 & 105 & 22,96 & 18,04 & 15,98 & 13,84 & 12,03 & 10,45 & 7,96 & 6,20 & 4,09 \\
\hline 55 & 1100 & 105 & 22,50 & 17,79 & 15,81 & 13,72 & 11,96 & 10,42 & 7,96 & 6,21 & 4,10 \\
\hline 55 & 1150 & 105 & 22,08 & 17,54 & 15,64 & 13,62 & 11,89 & 10,38 & 7,96 & 6,22 & 4,11 \\
\hline 55 & 1200 & 105 & 21,68 & 17,31 & 15,47 & 13,51 & 11,82 & 10,34 & 7,95 & 6,23 & 4,13 \\
\hline 55 & 1250 & 105 & 21,32 & 17,09 & 15,32 & 13,41 & 11,76 & 10,31 & 7,95 & 6,24 & 4,14 \\
\hline 55 & 1300 & 105 & 20,97 & 16,89 & 15,17 & 13,31 & 11,70 & 10,27 & 7,95 & 6,25 & 4,15 \\
\hline 55 & 1350 & 105 & 20,65 & 16,69 & 15,03 & 13,21 & 11,64 & 10,23 & 7,94 & 6,26 & 4,15 \\
\hline 55 & 1400 & 105 & 20,35 & 16,50 & 14,89 & 13,12 & 11,58 & 10,20 & 7,93 & 6,26 & 4,16 \\
\hline 55 & 1450 & 105 & 20,06 & 16,32 & 14,76 & 13,03 & 11,52 & 10,16 & 7,93 & 6,27 & 4,17 \\
\hline 55 & 1500 & 105 & 19,79 & 16,14 & 14,63 & 12,94 & 11,46 & 10,13 & 7,92 & 6,27 & 4,18 \\
\hline 55 & 1550 & 105 & 19,54 & 15,98 & 14,51 & 12,86 & 11,40 & 10,09 & 7,91 & 6,28 & 4,19 \\
\hline 55 & 1600 & 105 & 19,30 & 15,82 & 14,39 & 12,78 & 11,35 & 10,06 & 7,90 & 6,28 & 4,20 \\
\hline 55 & 1650 & 105 & 19,07 & 15,66 & 14,28 & 12,70 & 11,29 & 10,02 & 7,90 & 6,29 & 4,21 \\
\hline 55 & 1700 & 105 & 18,85 & 15,51 & 14,17 & 12,62 & 11,24 & 9,99 & 7,89 & 6,29 & 4,22 \\
\hline 55 & 1750 & 105 & 18,64 & 15,37 & 14,06 & 12,55 & 11,19 & 9,96 & 7,88 & 6,29 & 4,22 \\
\hline 55 & 1800 & 105 & 18,44 & 15,23 & 13,96 & 12,47 & 11,14 & 9,92 & 7,87 & 6,29 & 4,23 \\
\hline 55 & 1850 & 105 & 18,25 & 15,10 & 13,86 & 12,40 & 11,09 & 9,89 & 7,86 & 6,30 & 4,24 \\
\hline 55 & 1900 & 105 & 18,07 & 14,97 & 13,76 & 12,33 & 11,04 & 9,86 & 7,85 & 6,30 & 4,24 \\
\hline 55 & 1950 & 105 & 17,90 & 14,85 & 13,67 & 12,26 & 10,99 & 9,83 & 7,84 & 6,30 & 4,25 \\
\hline 55 & 2000 & 105 & 17,73 & 14,73 & 13,58 & 12,20 & 10,95 & 9,80 & 7,83 & 6,30 & 4,26 \\
\hline 55 & 200 & 110 & 53,16 & 29,36 & 21,79 & 16,15 & 12,65 & 10,22 & 7,12 & 5,43 & 3,74 \\
\hline 55 & 250 & 110 & 46,47 & 27,24 & 20,88 & 15,89 & 12,64 & 10,28 & 7,21 & 5,49 & 3,74 \\
\hline 55 & 300 & 110 & 41,83 & 25,68 & 20,16 & 15,66 & 12,60 & 10,32 & 7,28 & 5,53 & 3,74 \\
\hline 55 & 350 & 110 & 38,38 & 24,46 & 19,56 & 15,44 & 12,54 & 10,34 & 7,34 & 5,58 & 3,75 \\
\hline 55 & 400 & 110 & 35,71 & 23,46 & 19,05 & 15,23 & 12,47 & 10,35 & 7,39 & 5,61 & 3,76 \\
\hline 55 & 450 & 110 & 33,56 & 22,62 & 18,60 & 15,04 & 12,40 & 10,34 & 7,43 & 5,65 & 3,77 \\
\hline 55 & 500 & 110 & 31,79 & 21,91 & 18,20 & 14,85 & 12,33 & 10,33 & 7,46 & 5,68 & 3,78 \\
\hline 55 & 550 & 110 & 30,29 & 21,28 & 17,84 & 14,68 & 12,26 & 10,31 & 7,49 & 5,71 & 3,79 \\
\hline 55 & 600 & 110 & 29,01 & 20,72 & 17,51 & 14,51 & 12,18 & 10,29 & 7,52 & 5,74 & 3,80 \\
\hline 55 & 650 & 110 & 27,90 & 20,23 & 17,21 & 14,35 & 12,11 & 10,26 & 7,54 & 5,77 & 3,81 \\
\hline 55 & 700 & 110 & 26,92 & 19,78 & 16,94 & 14,20 & 12,03 & 10,24 & 7,55 & 5,79 & 3,82 \\
\hline 55 & 750 & 110 & 26,06 & 19,37 & 16,68 & 14,06 & 11,96 & 10,21 & 7,56 & 5,81 & 3,83 \\
\hline 55 & 800 & 110 & 25,28 & 18,99 & 16,44 & 13,92 & 11,89 & 10,18 & 7,57 & 5,83 & 3,84 \\
\hline 55 & 850 & 110 & 24,58 & 18,64 & 16,21 & 13,79 & 11,81 & 10,15 & 7,58 & 5,85 & 3,85 \\
\hline 55 & 900 & 110 & 23,95 & 18,32 & 16,00 & 13,66 & 11,74 & 10,11 & 7,59 & 5,86 & 3,86 \\
\hline 55 & 950 & 110 & 23,37 & 18,02 & 15,80 & 13,54 & 11,68 & 10,08 & 7,59 & 5,88 & 3,88 \\
\hline 55 & 1000 & 110 & 22,85 & 17,74 & 15,61 & 13,43 & 11,61 & 10,05 & 7,60 & 5,89 & 3,89 \\
\hline 55 & 1050 & 110 & 22,36 & 17,47 & 15,43 & 13,32 & 11,54 & 10,01 & 7,60 & 5,91 & 3,90 \\
\hline 55 & 1100 & 110 & 21,91 & 17,22 & 15,26 & 13,21 & 11,48 & 9,98 & 7,60 & 5,92 & 3,91 \\
\hline 55 & 1150 & 110 & 21,50 & 16,99 & 15,10 & 13,11 & 11,42 & 9,95 & 7,60 & 5,93 & 3,92 \\
\hline 55 & 1200 & 110 & 21,11 & 16,77 & 14,94 & 13,01 & 11,36 & 9,91 & 7,60 & 5,94 & 3,93 \\
\hline 55 & 1250 & 110 & 20,75 & 16,55 & 14,79 & 12,91 & 11,30 & 9,88 & 7,59 & 5,95 & 3,94 \\
\hline 55 & 1300 & 110 & 20,41 & 16,35 & 14,65 & 12,82 & 11,24 & 9,84 & 7,59 & 5,96 & 3,95 \\
\hline 55 & 1350 & 110 & 20,09 & 16,16 & 14,51 & 12,73 & 11,18 & 9,81 & 7,59 & 5,96 & 3,95 \\
\hline 55 & 1400 & 110 & 19,80 & 15,98 & 14,38 & 12,64 & 11,12 & 9,78 & 7,58 & 5,97 & 3,96 \\
\hline 55 & 1450 & 110 & 19,51 & 15,80 & 14,26 & 12,55 & 11,07 & 9,75 & 7,58 & 5,98 & 3,97 \\
\hline 55 & 1500 & 110 & 19,25 & 15,64 & 14,13 & 12,47 & 11,01 & 9,71 & 7,57 & 5,98 & 3,98 \\
\hline 55 & 1550 & 110 & 19,00 & 15,48 & 14,02 & 12,39 & 10,96 & 9,68 & 7,56 & 5,99 & 3,99 \\
\hline 55 & 1600 & 110 & 18,76 & 15,32 & 13,90 & 12,31 & 10,91 & 9,65 & 7,56 & 5,99 & 4,00 \\
\hline 55 & 1650 & 110 & 18,53 & 15,17 & 13,80 & 12,24 & 10,86 & 9,62 & 7,55 & 6,00 & 4,00 \\
\hline 55 & 1700 & 110 & 18,32 & 15,03 & 13,69 & 12,16 & 10,81 & 9,59 & 7,54 & 6,00 & 4,01 \\
\hline 55 & 1750 & 110 & 18,11 & 14,89 & 13,59 & 12,09 & 10,76 & 9,56 & 7,53 & 6,00 & 4,02 \\
\hline 55 & 1800 & 110 & 17,92 & 14,76 & 13,49 & 12,02 & 10,71 & 9,52 & 7,53 & 6,00 & 4,03 \\
\hline 55 & 1850 & 110 & 17,73 & 14,63 & 13,39 & 11,95 & 10,67 & 9,49 & 7,52 & 6,01 & 4,03 \\
\hline 55 & 1900 & 110 & 17,55 & 14,51 & 13,30 & 11,89 & 10,62 & 9,46 & 7,51 & 6,01 & 4,04 \\
\hline 55 & 1950 & 110 & 17,38 & 14,39 & 13,21 & 11,82 & 10,57 & 9,44 & 7,50 & 6,01 & 4,05 \\
\hline 55 & 2000 & 110 & 17,22 & 14,27 & 13,12 & 11,76 & 10,53 & 9,41 & 7,49 & 6,01 & 4,05 \\
\hline 55 & 200 & 115 & 52,28 & 28,52 & 21,02 & 15,49 & 12,10 & 9,76 & 6,79 & 5,19 & 3,58 \\
\hline
\end{tabular}




\begin{tabular}{|c|c|c|c|c|c|c|c|c|c|c|c|}
\hline \multirow[b]{2}{*}{$\mathrm{H}(\mathrm{cm})$} & \multirow[b]{2}{*}{ Mceq (MPa) } & & & & & De & ões (x1 & & & & \\
\hline & & Msub (MPa) & D0 & D25 & D40 & D60 & D80 & D100 & D140 & D180 & D260 \\
\hline 55 & 250 & 115 & 45,63 & 26,44 & 20,14 & 15,25 & 12,09 & 9,83 & 6,88 & 5,24 & 3,57 \\
\hline 55 & 300 & 115 & 41,03 & 24,91 & 19,45 & 15,04 & 12,06 & 9,87 & 6,95 & 5,28 & 3,58 \\
\hline 55 & 350 & 115 & 37,63 & 23,72 & 18,88 & 14,83 & 12,01 & 9,89 & 7,00 & 5,32 & 3,58 \\
\hline 55 & 400 & 115 & 34,98 & 22,75 & 18,39 & 14,64 & 11,95 & 9,90 & 7,05 & 5,36 & 3,59 \\
\hline 55 & 450 & 115 & 32,86 & 21,94 & 17,96 & 14,45 & 11,89 & 9,89 & 7,09 & 5,39 & 3,60 \\
\hline 55 & 500 & 115 & 31,11 & 21,24 & 17,57 & 14,28 & 11,82 & 9,89 & 7,13 & 5,42 & 3,61 \\
\hline 55 & 550 & 115 & 29,63 & 20,63 & 17,23 & 14,12 & 11,76 & 9,87 & 7,15 & 5,45 & 3,62 \\
\hline 55 & 600 & 115 & 28,37 & 20,09 & 16,91 & 13,96 & 11,69 & 9,85 & 7,18 & 5,48 & 3,63 \\
\hline 55 & 650 & 115 & 27,27 & 19,61 & 16,63 & 13,81 & 11,62 & 9,83 & 7,20 & 5,50 & 3,64 \\
\hline 55 & 700 & 115 & 26,31 & 19,17 & 16,36 & 13,67 & 11,55 & 9,81 & 7,21 & 5,52 & 3,65 \\
\hline 55 & 750 & 115 & 25,45 & 18,78 & 16,11 & 13,54 & 11,48 & 9,78 & 7,23 & 5,54 & 3,66 \\
\hline 55 & 800 & 115 & 24,69 & 18,41 & 15,88 & 13,41 & 11,42 & 9,76 & 7,24 & 5,56 & 3,67 \\
\hline 55 & 850 & 115 & 24,00 & 18,07 & 15,66 & 13,28 & 11,35 & 9,73 & 7,25 & 5,58 & 3,68 \\
\hline 55 & 900 & 115 & 23,38 & 17,76 & 15,46 & 13,16 & 11,29 & 9,70 & 7,25 & 5,60 & 3,69 \\
\hline 55 & 950 & 115 & 22,81 & 17,47 & 15,27 & 13,05 & 11,22 & 9,67 & 7,26 & 5,61 & 3,70 \\
\hline 55 & 1000 & 115 & 22,29 & 17,20 & 15,09 & 12,94 & 11,16 & 9,64 & 7,26 & 5,63 & 3,71 \\
\hline 55 & 1050 & 115 & 21,81 & 16,94 & 14,91 & 12,83 & 11,10 & 9,61 & 7,27 & 5,64 & 3,72 \\
\hline 55 & 1100 & 115 & 21,37 & 16,70 & 14,75 & 12,73 & 11,04 & 9,58 & 7,27 & 5,65 & 3,73 \\
\hline 55 & 1150 & 115 & 20,96 & 16,47 & 14,59 & 12,64 & 10,98 & 9,55 & 7,27 & 5,66 & 3,74 \\
\hline 55 & 1200 & 115 & 20,58 & 16,26 & 14,45 & 12,54 & 10,92 & 9,51 & 7,27 & 5,67 & 3,75 \\
\hline 55 & 1250 & 115 & 20,22 & 16,05 & 14,30 & 12,45 & 10,87 & 9,48 & 7,27 & 5,68 & 3,76 \\
\hline 55 & 1300 & 115 & 19,89 & 15,86 & 14,17 & 12,36 & 10,81 & 9,45 & 7,26 & 5,69 & 3,76 \\
\hline 55 & 1350 & 115 & 19,58 & 15,68 & 14,04 & 12,27 & 10,76 & 9,42 & 7,26 & 5,70 & 3,77 \\
\hline 55 & 1400 & 115 & 19,28 & 15,50 & 13,91 & 12,19 & 10,70 & 9,39 & 7,26 & 5,70 & 3,78 \\
\hline 55 & 1450 & 115 & 19,01 & 15,33 & 13,79 & 12,11 & 10,65 & 9,36 & 7,25 & 5,71 & 3,79 \\
\hline 55 & 1500 & 115 & 18,75 & 15,17 & 13,67 & 12,03 & 10,60 & 9,33 & 7,25 & 5,71 & 3,80 \\
\hline 55 & 1550 & 115 & 18,50 & 15,01 & 13,56 & 11,96 & 10,55 & 9,30 & 7,24 & 5,72 & 3,80 \\
\hline 55 & 1600 & 115 & 18,26 & 14,86 & 13,45 & 11,88 & 10,50 & 9,27 & 7,24 & 5,72 & 3,81 \\
\hline 55 & 1650 & 115 & 18,04 & 14,72 & 13,35 & 11,81 & 10,46 & 9,24 & 7,23 & 5,73 & 3,82 \\
\hline 55 & 1700 & 115 & 17,83 & 14,58 & 13,24 & 11,74 & 10,41 & 9,21 & 7,22 & 5,73 & 3,83 \\
\hline 55 & 1750 & 115 & 17,63 & 14,45 & 13,15 & 11,67 & 10,36 & 9,19 & 7,22 & 5,74 & 3,83 \\
\hline 55 & 1800 & 115 & 17,44 & 14,32 & 13,05 & 11,60 & 10,32 & 9,16 & 7,21 & 5,74 & 3,84 \\
\hline 55 & 1850 & 115 & 17,25 & 14,19 & 12,96 & 11,54 & 10,27 & 9,13 & 7,20 & 5,74 & 3,85 \\
\hline 55 & 1900 & 115 & 17,08 & 14,07 & 12,87 & 11,48 & 10,23 & 9,10 & 7,20 & 5,74 & 3,85 \\
\hline 55 & 1950 & 115 & 16,91 & 13,96 & 12,78 & 11,41 & 10,19 & 9,07 & 7,19 & 5,75 & 3,86 \\
\hline 55 & 2000 & 115 & 16,75 & 13,84 & 12,70 & 11,35 & 10,15 & 9,05 & 7,18 & 5,75 & 3,87 \\
\hline 55 & 200 & 120 & 51,45 & 27,74 & 20,30 & 14,88 & 11,60 & 9,34 & 6,49 & 4,96 & 3,43 \\
\hline 55 & 250 & 120 & 44,86 & 25,70 & 19,46 & 14,66 & 11,59 & 9,41 & 6,58 & 5,01 & 3,43 \\
\hline 55 & 300 & 120 & 40,29 & 24,20 & 18,79 & 14,46 & 11,57 & 9,45 & 6,64 & 5,05 & 3,43 \\
\hline 55 & 350 & 120 & 36,92 & 23,04 & 18,24 & 14,27 & 11,53 & 9,47 & 6,70 & 5,09 & 3,43 \\
\hline 55 & 400 & 120 & 34,30 & 22,09 & 17,77 & 14,09 & 11,47 & 9,48 & 6,74 & 5,12 & 3,44 \\
\hline 55 & 450 & 120 & 32,20 & 21,30 & 17,36 & 13,92 & 11,42 & 9,48 & 6,78 & 5,16 & 3,45 \\
\hline 55 & 500 & 120 & 30,47 & 20,62 & 16,99 & 13,75 & 11,36 & 9,48 & 6,82 & 5,18 & 3,45 \\
\hline 55 & 550 & 120 & 29,02 & 20,03 & 16,66 & 13,60 & 11,30 & 9,47 & 6,84 & 5,21 & 3,46 \\
\hline 55 & 600 & 120 & 27,77 & 19,51 & 16,36 & 13,45 & 11,23 & 9,45 & 6,87 & 5,24 & 3,47 \\
\hline 55 & 650 & 120 & 26,69 & 19,04 & 16,08 & 13,31 & 11,17 & 9,43 & 6,89 & 5,26 & 3,48 \\
\hline 55 & 700 & 120 & 25,73 & 18,61 & 15,82 & 13,18 & 11,11 & 9,41 & 6,90 & 5,28 & 3,49 \\
\hline 55 & 750 & 120 & 24,89 & 18,23 & 15,59 & 13,05 & 11,05 & 9,39 & 6,92 & 5,30 & 3,50 \\
\hline 55 & 800 & 120 & 24,14 & 17,87 & 15,36 & 12,93 & 10,98 & 9,37 & 6,93 & 5,32 & 3,51 \\
\hline 55 & 850 & 120 & 23,46 & 17,55 & 15,16 & 12,81 & 10,92 & 9,34 & 6,94 & 5,34 & 3,52 \\
\hline 55 & 900 & 120 & 22,85 & 17,24 & 14,96 & 12,70 & 10,86 & 9,32 & 6,95 & 5,35 & 3,53 \\
\hline 55 & 950 & 120 & 22,29 & 16,96 & 14,78 & 12,59 & 10,80 & 9,29 & 6,95 & 5,37 & 3,54 \\
\hline 55 & 1000 & 120 & 21,77 & 16,70 & 14,60 & 12,49 & 10,74 & 9,26 & 6,96 & 5,38 & 3,55 \\
\hline 55 & 1050 & 120 & 21,30 & 16,45 & 14,44 & 12,39 & 10,69 & 9,23 & 6,96 & 5,39 & 3,56 \\
\hline 55 & 1100 & 120 & 20,87 & 16,22 & 14,28 & 12,29 & 10,63 & 9,20 & 6,96 & 5,40 & 3,56 \\
\hline 55 & 1150 & 120 & 20,46 & 16,00 & 14,13 & 12,20 & 10,58 & 9,18 & 6,97 & 5,42 & 3,57 \\
\hline 55 & 1200 & 120 & 20,09 & 15,79 & 13,99 & 12,11 & 10,52 & 9,15 & 6,97 & 5,43 & 3,58 \\
\hline 55 & 1250 & 120 & 19,74 & 15,59 & 13,85 & 12,02 & 10,47 & 9,12 & 6,96 & 5,43 & 3,59 \\
\hline 55 & 1300 & 120 & 19,41 & 15,40 & 13,72 & 11,94 & 10,42 & 9,09 & 6,96 & 5,44 & 3,60 \\
\hline 55 & 1350 & 120 & 19,10 & 15,22 & 13,59 & 11,86 & 10,37 & 9,06 & 6,96 & 5,45 & 3,61 \\
\hline 55 & 1400 & 120 & 18,81 & 15,05 & 13,47 & 11,78 & 10,32 & 9,03 & 6,96 & 5,46 & 3,61 \\
\hline 55 & 1450 & 120 & 18,54 & 14,89 & 13,35 & 11,70 & 10,27 & 9,01 & 6,95 & 5,46 & 3,62 \\
\hline 55 & 1500 & 120 & 18,28 & 14,73 & 13,24 & 11,62 & 10,22 & 8,98 & 6,95 & 5,47 & 3,63 \\
\hline 55 & 1550 & 120 & 18,04 & 14,58 & 13,13 & 11,55 & 10,17 & 8,95 & 6,95 & 5,48 & 3,64 \\
\hline 55 & 1600 & 120 & 17,81 & 14,44 & 13,03 & 11,48 & 10,13 & 8,92 & 6,94 & 5,48 & 3,64 \\
\hline 55 & 1650 & 120 & 17,59 & 14,30 & 12,93 & 11,41 & 10,08 & 8,90 & 6,94 & 5,48 & 3,65 \\
\hline 55 & 1700 & 120 & 17,38 & 14,16 & 12,83 & 11,35 & 10,04 & 8,87 & 6,93 & 5,49 & 3,66 \\
\hline 55 & 1750 & 120 & 17,18 & 14,03 & 12,74 & 11,28 & 10,00 & 8,84 & 6,93 & 5,49 & 3,66 \\
\hline 55 & 1800 & 120 & 16,99 & 13,91 & 12,65 & 11,22 & 9,95 & 8,82 & 6,92 & 5,50 & 3,67 \\
\hline 55 & 1850 & 120 & 16,81 & 13,79 & 12,56 & 11,15 & 9,91 & 8,79 & 6,91 & 5,50 & 3,68 \\
\hline 55 & 1900 & 120 & 16,64 & 13,67 & 12,47 & 11,09 & 9,87 & 8,76 & 6,91 & 5,50 & 3,68 \\
\hline 55 & 1950 & 120 & 16,47 & 13,56 & 12,39 & 11,04 & 9,83 & 8,74 & 6,90 & 5,50 & 3,69 \\
\hline 55 & 2000 & 120 & 16,31 & 13,45 & 12,31 & 10,98 & 9,79 & 8,71 & 6,89 & 5,51 & 3,70 \\
\hline 55 & 200 & 125 & 50,69 & 27,02 & 19,65 & 14,32 & 11,13 & 8,95 & 6,22 & 4,76 & 3,29 \\
\hline 55 & 250 & 125 & 44,13 & 25,01 & 18,83 & 14,12 & 11,13 & 9,02 & 6,30 & 4,80 & 3,29 \\
\hline 55 & 300 & 125 & 39,61 & 23,55 & 18,18 & 13,93 & 11,11 & 9,06 & 6,36 & 4,84 & 3,29 \\
\hline 55 & 350 & 125 & 36,26 & 22,41 & 17,65 & 13,75 & 11,08 & 9,09 & 6,42 & 4,88 & 3,29 \\
\hline 55 & 400 & 125 & 33,67 & 21,48 & 17,20 & 13,58 & 11,03 & 9,10 & 6,46 & 4,91 & 3,30 \\
\hline 55 & 450 & 125 & 31,59 & 20,71 & 16,80 & 13,42 & 10,98 & 9,10 & 6,50 & 4,94 & 3,30 \\
\hline 55 & 500 & 125 & 29,88 & 20,05 & 16,45 & 13,26 & 10,93 & 9,10 & 6,53 & 4,97 & 3,31 \\
\hline 55 & 550 & 125 & 28,44 & 19,47 & 16,13 & 13,12 & 10,87 & 9,09 & 6,56 & 4,99 & 3,32 \\
\hline
\end{tabular}




\begin{tabular}{|c|c|c|c|c|c|c|c|c|c|c|c|}
\hline \multirow[b]{2}{*}{$\mathrm{H}(\mathrm{cm})$} & \multirow[b]{2}{*}{ Mceq (MPa) } & & & & & De & ões (x1 & & & & \\
\hline & & Msub (MPa) & D0 & D25 & D40 & D60 & D80 & D100 & D140 & D180 & D260 \\
\hline 55 & 600 & 125 & 27,21 & 18,96 & 15,84 & 12,98 & 10,81 & 9,08 & 6,58 & 5,02 & 3,33 \\
\hline 55 & 650 & 125 & 26,14 & 18,50 & 15,57 & 12,85 & 10,76 & 9,07 & 6,60 & 5,04 & 3,34 \\
\hline 55 & 700 & 125 & 25,20 & 18,09 & 15,33 & 12,72 & 10,70 & 9,05 & 6,62 & 5,06 & 3,34 \\
\hline 55 & 750 & 125 & 24,37 & 17,72 & 15,10 & 12,60 & 10,64 & 9,03 & 6,63 & 5,08 & 3,35 \\
\hline 55 & 800 & 125 & 23,63 & 17,37 & 14,88 & 12,49 & 10,58 & 9,01 & 6,65 & 5,10 & 3,36 \\
\hline 55 & 850 & 125 & 22,96 & 17,06 & 14,68 & 12,38 & 10,53 & 8,98 & 6,66 & 5,11 & 3,37 \\
\hline 55 & 900 & 125 & 22,35 & 16,76 & 14,50 & 12,27 & 10,47 & 8,96 & 6,66 & 5,13 & 3,38 \\
\hline 55 & 950 & 125 & 21,80 & 16,49 & 14,32 & 12,17 & 10,41 & 8,94 & 6,67 & 5,14 & 3,39 \\
\hline 55 & 1000 & 125 & 21,29 & 16,23 & 14,15 & 12,07 & 10,36 & 8,91 & 6,68 & 5,16 & 3,40 \\
\hline 55 & 1050 & 125 & 20,83 & 15,99 & 13,99 & 11,97 & 10,31 & 8,89 & 6,68 & 5,17 & 3,41 \\
\hline 55 & 1100 & 125 & 20,40 & 15,76 & 13,84 & 11,88 & 10,25 & 8,86 & 6,68 & 5,18 & 3,41 \\
\hline 55 & 1150 & 125 & 20,00 & 15,55 & 13,70 & 11,79 & 10,20 & 8,83 & 6,69 & 5,19 & 3,42 \\
\hline 55 & 1200 & 125 & 19,63 & 15,35 & 13,56 & 11,71 & 10,15 & 8,81 & 6,69 & 5,20 & 3,43 \\
\hline 55 & 1250 & 125 & 19,28 & 15,16 & 13,43 & 11,62 & 10,10 & 8,78 & 6,69 & 5,21 & 3,44 \\
\hline 55 & 1300 & 125 & 18,96 & 14,97 & 13,30 & 11,54 & 10,05 & 8,76 & 6,69 & 5,22 & 3,45 \\
\hline 55 & 1350 & 125 & 18,66 & 14,80 & 13,18 & 11,47 & 10,01 & 8,73 & 6,68 & 5,22 & 3,45 \\
\hline 55 & 1400 & 125 & 18,37 & 14,63 & 13,06 & 11,39 & 9,96 & 8,70 & 6,68 & 5,23 & 3,46 \\
\hline 55 & 1450 & 125 & 18,10 & 14,47 & 12,95 & 11,32 & 9,91 & 8,68 & 6,68 & 5,24 & 3,47 \\
\hline 55 & 1500 & 125 & 17,85 & 14,32 & 12,84 & 11,25 & 9,87 & 8,65 & 6,68 & 5,24 & 3,48 \\
\hline 55 & 1550 & 125 & 17,61 & 14,18 & 12,74 & 11,18 & 9,82 & 8,63 & 6,67 & 5,25 & 3,48 \\
\hline 55 & 1600 & 125 & 17,38 & 14,04 & 12,64 & 11,11 & 9,78 & 8,60 & 6,67 & 5,25 & 3,49 \\
\hline 55 & 1650 & 125 & 17,16 & 13,90 & 12,54 & 11,04 & 9,74 & 8,58 & 6,67 & 5,26 & 3,50 \\
\hline 55 & 1700 & 125 & 16,96 & 13,77 & 12,45 & 10,98 & 9,70 & 8,55 & 6,66 & 5,26 & 3,50 \\
\hline 55 & 1750 & 125 & 16,76 & 13,65 & 12,36 & 10,92 & 9,65 & 8,52 & 6,66 & 5,27 & 3,51 \\
\hline 55 & 1800 & 125 & 16,57 & 13,53 & 12,27 & 10,86 & 9,61 & 8,50 & 6,65 & 5,27 & 3,51 \\
\hline 55 & 1850 & 125 & 16,40 & 13,41 & 12,18 & 10,80 & 9,57 & 8,48 & 6,65 & 5,27 & 3,52 \\
\hline 55 & 1900 & 125 & 16,23 & 13,30 & 12,10 & 10,74 & 9,54 & 8,45 & 6,64 & 5,28 & 3,53 \\
\hline 55 & 1950 & 125 & 16,06 & 13,19 & 12,02 & 10,68 & 9,50 & 8,43 & 6,63 & 5,28 & 3,53 \\
\hline 55 & 2000 & 125 & 15,91 & 13,08 & 11,94 & 10,63 & 9,46 & 8,40 & 6,63 & 5,28 & 3,54 \\
\hline 55 & 200 & 130 & 49,98 & 26,35 & 19,03 & 13,80 & 10,70 & 8,59 & 5,97 & 4,57 & 3,17 \\
\hline 55 & 250 & 130 & 43,46 & 24,37 & 18,24 & 13,61 & 10,71 & 8,66 & 6,04 & 4,61 & 3,16 \\
\hline 55 & 300 & 130 & 38,97 & 22,93 & 17,62 & 13,43 & 10,69 & 8,70 & 6,10 & 4,65 & 3,16 \\
\hline 55 & 350 & 130 & 35,65 & 21,82 & 17,10 & 13,27 & 10,66 & 8,73 & 6,16 & 4,68 & 3,17 \\
\hline 55 & 400 & 130 & 33,08 & 20,91 & 16,66 & 13,11 & 10,62 & 8,75 & 6,20 & 4,71 & 3,17 \\
\hline 55 & 450 & 130 & 31,03 & 20,16 & 16,28 & 12,95 & 10,58 & 8,75 & 6,24 & 4,74 & 3,18 \\
\hline 55 & 500 & 130 & 29,33 & 19,51 & 15,94 & 12,81 & 10,53 & 8,75 & 6,27 & 4,77 & 3,18 \\
\hline 55 & 550 & 130 & 27,91 & 18,95 & 15,63 & 12,67 & 10,48 & 8,75 & 6,30 & 4,79 & 3,19 \\
\hline 55 & 600 & 130 & 26,69 & 18,45 & 15,35 & 12,54 & 10,42 & 8,74 & 6,32 & 4,81 & 3,20 \\
\hline 55 & 650 & 130 & 25,63 & 18,01 & 15,10 & 12,42 & 10,37 & 8,72 & 6,34 & 4,83 & 3,20 \\
\hline 55 & 700 & 130 & 24,70 & 17,60 & 14,86 & 12,30 & 10,32 & 8,71 & 6,36 & 4,85 & 3,21 \\
\hline 55 & 750 & 130 & 23,88 & 17,24 & 14,64 & 12,18 & 10,26 & 8,69 & 6,37 & 4,87 & 3,22 \\
\hline 55 & 800 & 130 & 23,15 & 16,90 & 14,44 & 12,07 & 10,21 & 8,67 & 6,38 & 4,89 & 3,23 \\
\hline 55 & 850 & 130 & 22,49 & 16,60 & 14,24 & 11,97 & 10,16 & 8,65 & 6,39 & 4,91 & 3,24 \\
\hline 55 & 900 & 130 & 21,89 & 16,31 & 14,06 & 11,87 & 10,10 & 8,63 & 6,40 & 4,92 & 3,24 \\
\hline 55 & 950 & 130 & 21,34 & 16,04 & 13,89 & 11,77 & 10,05 & 8,61 & 6,41 & 4,93 & 3,25 \\
\hline 55 & 1000 & 130 & 20,85 & 15,79 & 13,73 & 11,68 & 10,00 & 8,59 & 6,42 & 4,95 & 3,26 \\
\hline 55 & 1050 & 130 & 20,39 & 15,56 & 13,58 & 11,59 & 9,95 & 8,56 & 6,42 & 4,96 & 3,27 \\
\hline 55 & 1100 & 130 & 19,96 & 15,34 & 13,43 & 11,50 & 9,90 & 8,54 & 6,42 & 4,97 & 3,28 \\
\hline 55 & 1150 & 130 & 19,57 & 15,13 & 13,29 & 11,41 & 9,85 & 8,52 & 6,43 & 4,98 & 3,28 \\
\hline 55 & 1200 & 130 & 19,20 & 14,94 & 13,16 & 11,33 & 9,81 & 8,49 & 6,43 & 4,99 & 3,29 \\
\hline 55 & 1250 & 130 & 18,86 & 14,75 & 13,03 & 11,25 & 9,76 & 8,47 & 6,43 & 5,00 & 3,30 \\
\hline 55 & 1300 & 130 & 18,54 & 14,57 & 12,91 & 11,18 & 9,71 & 8,44 & 6,43 & 5,01 & 3,31 \\
\hline 55 & 1350 & 130 & 18,24 & 14,40 & 12,79 & 11,10 & 9,67 & 8,42 & 6,43 & 5,02 & 3,31 \\
\hline 55 & 1400 & 130 & 17,96 & 14,24 & 12,68 & 11,03 & 9,62 & 8,40 & 6,43 & 5,02 & 3,32 \\
\hline 55 & 1450 & 130 & 17,69 & 14,09 & 12,57 & 10,96 & 9,58 & 8,37 & 6,43 & 5,03 & 3,33 \\
\hline 55 & 1500 & 130 & 17,44 & 13,94 & 12,47 & 10,89 & 9,54 & 8,35 & 6,42 & 5,04 & 3,33 \\
\hline 55 & 1550 & 130 & 17,21 & 13,80 & 12,37 & 10,83 & 9,50 & 8,32 & 6,42 & 5,04 & 3,34 \\
\hline 55 & 1600 & 130 & 16,98 & 13,66 & 12,27 & 10,76 & 9,46 & 8,30 & 6,42 & 5,05 & 3,35 \\
\hline 55 & 1650 & 130 & 16,77 & 13,53 & 12,18 & 10,70 & 9,42 & 8,28 & 6,41 & 5,05 & 3,35 \\
\hline 55 & 1700 & 130 & 16,57 & 13,41 & 12,09 & 10,64 & 9,38 & 8,25 & 6,41 & 5,06 & 3,36 \\
\hline 55 & 1750 & 130 & 16,37 & 13,28 & 12,00 & 10,58 & 9,34 & 8,23 & 6,41 & 5,06 & 3,37 \\
\hline 55 & 1800 & 130 & 16,19 & 13,17 & 11,91 & 10,52 & 9,30 & 8,21 & 6,40 & 5,06 & 3,37 \\
\hline 55 & 1850 & 130 & 16,01 & 13,05 & 11,83 & 10,46 & 9,26 & 8,18 & 6,40 & 5,07 & 3,38 \\
\hline 55 & 1900 & 130 & 15,84 & 12,94 & 11,75 & 10,41 & 9,22 & 8,16 & 6,39 & 5,07 & 3,38 \\
\hline 55 & 1950 & 130 & 15,68 & 12,84 & 11,67 & 10,35 & 9,19 & 8,14 & 6,39 & 5,07 & 3,39 \\
\hline 55 & 2000 & 130 & 15,53 & 12,74 & 11,60 & 10,30 & 9,15 & 8,12 & 6,38 & 5,08 & 3,39 \\
\hline 55 & 200 & 135 & 49,31 & 25,72 & 18,46 & 13,31 & 10,30 & 8,26 & 5,73 & 4,39 & 3,05 \\
\hline 55 & 250 & 135 & 42,83 & 23,77 & 17,69 & 13,14 & 10,31 & 8,33 & 5,81 & 4,43 & 3,05 \\
\hline 55 & 300 & 135 & 38,37 & 22,36 & 17,09 & 12,97 & 10,30 & 8,37 & 5,87 & 4,47 & 3,05 \\
\hline 55 & 350 & 135 & 35,08 & 21,26 & 16,59 & 12,82 & 10,27 & 8,40 & 5,92 & 4,50 & 3,05 \\
\hline 55 & 400 & 135 & 32,53 & 20,38 & 16,17 & 12,67 & 10,24 & 8,42 & 5,96 & 4,53 & 3,05 \\
\hline 55 & 450 & 135 & 30,49 & 19,64 & 15,80 & 12,52 & 10,20 & 8,43 & 5,99 & 4,55 & 3,06 \\
\hline 55 & 500 & 135 & 28,82 & 19,01 & 15,47 & 12,39 & 10,16 & 8,43 & 6,03 & 4,58 & 3,06 \\
\hline 55 & 550 & 135 & 27,41 & 18,46 & 15,17 & 12,26 & 10,11 & 8,43 & 6,05 & 4,60 & 3,07 \\
\hline 55 & 600 & 135 & 26,20 & 17,97 & 14,90 & 12,13 & 10,06 & 8,42 & 6,08 & 4,62 & 3,07 \\
\hline 55 & 650 & 135 & 25,16 & 17,54 & 14,66 & 12,01 & 10,01 & 8,41 & 6,10 & 4,65 & 3,08 \\
\hline 55 & 700 & 135 & 24,24 & 17,15 & 14,43 & 11,90 & 9,96 & 8,39 & 6,11 & 4,66 & 3,09 \\
\hline 55 & 750 & 135 & 23,43 & 16,79 & 14,22 & 11,79 & 9,91 & 8,38 & 6,13 & 4,68 & 3,10 \\
\hline 55 & 800 & 135 & 22,70 & 16,47 & 14,02 & 11,69 & 9,86 & 8,36 & 6,14 & 4,70 & 3,10 \\
\hline 55 & 850 & 135 & 22,05 & 16,17 & 13,83 & 11,59 & 9,81 & 8,34 & 6,15 & 4,71 & 3,11 \\
\hline 55 & 900 & 135 & 21,46 & 15,89 & 13,66 & 11,49 & 9,76 & 8,33 & 6,16 & 4,73 & 3,12 \\
\hline
\end{tabular}




\begin{tabular}{|c|c|c|c|c|c|c|c|c|c|c|c|}
\hline \multirow[b]{2}{*}{$\mathrm{H}(\mathrm{cm})$} & \multirow[b]{2}{*}{ Mceq (MPa) } & & & & & $\mathrm{De}$ & $\operatorname{tes}(x)$ & & & & \\
\hline & & Msub (MPa) & D0 & D25 & D40 & D60 & $\mathrm{D} 80$ & D100 & D140 & D180 & D260 \\
\hline 55 & 950 & 135 & 20,92 & 15,63 & 13,49 & 11,40 & 9,71 & 8,31 & 6,17 & 4,74 & 3,13 \\
\hline 55 & 1000 & 135 & 20,43 & 15,39 & 13,34 & 11,31 & 9,67 & 8,29 & 6,17 & 4,75 & 3,13 \\
\hline 55 & 1050 & 135 & 19,97 & 15,16 & 13,19 & 11,22 & 9,62 & 8,26 & 6,18 & 4,77 & 3,14 \\
\hline 55 & 1100 & 135 & 19,55 & 14,94 & 13,05 & 11,14 & 9,57 & 8,24 & 6,18 & 4,78 & 3,15 \\
\hline 55 & 1150 & 135 & 19,16 & 14,74 & 12,91 & 11,06 & 9,53 & 8,22 & 6,19 & 4,79 & 3,16 \\
\hline 55 & 1200 & 135 & 18,80 & 14,55 & 12,79 & 10,98 & 9,48 & 8,20 & 6,19 & 4,80 & 3,16 \\
\hline 55 & 1250 & 135 & 18,47 & 14,37 & 12,66 & 10,91 & 9,44 & 8,18 & 6,19 & 4,81 & 3,17 \\
\hline 55 & 1300 & 135 & 18,15 & 14,20 & 12,55 & 10,83 & 9,40 & 8,15 & 6,19 & 4,81 & 3,18 \\
\hline 55 & 1350 & 135 & 17,85 & 14,03 & 12,43 & 10,76 & 9,35 & 8,13 & 6,19 & 4,82 & 3,18 \\
\hline 55 & 1400 & 135 & 17,58 & 13,88 & 12,32 & 10,69 & 9,31 & 8,11 & 6,19 & 4,83 & 3,19 \\
\hline 55 & 1450 & 135 & 17,31 & 13,73 & 12,22 & 10,63 & 9,27 & 8,09 & 6,19 & 4,84 & 3,20 \\
\hline 55 & 1500 & 135 & 17,07 & 13,58 & 12,12 & 10,56 & 9,23 & 8,06 & 6,19 & 4,84 & 3,20 \\
\hline 55 & 1550 & 135 & 16,83 & 13,45 & 12.02 & 10,50 & 9,19 & 8.04 & 6.19 & 4.85 & 3,21 \\
\hline 55 & 1600 & 135 & 16,61 & 13,31 & 11,93 & 10,44 & 9,15 & 8,02 & 6,18 & 4,85 & 3,22 \\
\hline 55 & 1650 & 135 & 16,40 & 13,19 & 11,84 & 10,38 & 9,11 & 8,00 & 6,18 & 4,86 & $\frac{3,22}{3,22}$ \\
\hline 55 & 1700 & 135 & 16,20 & 13,06 & 11,75 & 10,32 & 9,08 & 7,98 & 6,18 & 4,86 & 3,23 \\
\hline 55 & 1750 & 135 & 16,01 & 12,95 & 11,66 & 10,26 & 9,04 & 7,95 & 6,17 & 4,87 & 3,23 \\
\hline 55 & 1800 & 135 & 15,83 & 12,83 & 11,58 & 10,21 & 9,00 & 7,93 & 6,17 & 4,87 & 3,24 \\
\hline 55 & 1850 & 135 & 15,65 & 12,72 & 11,50 & 10,15 & 8,97 & 7,91 & 6,17 & 4,87 & 3,24 \\
\hline 55 & 1900 & 135 & 15,49 & 12,61 & 11,42 & 10,10 & 8,93 & 7,89 & 6,16 & 4,88 & 3,25 \\
\hline 55 & 1950 & 135 & 15,33 & 12,51 & 11,35 & 10,05 & 8,90 & 7,87 & 6,16 & 4,88 & 3,26 \\
\hline 55 & 2000 & 135 & 15,18 & 12,41 & 11,28 & 10,00 & 8,86 & 7,85 & 6,15 & 4,88 & 3,26 \\
\hline 55 & 200 & 140 & 48,69 & 25,14 & 17,93 & 12,86 & 9,92 & 7,95 & 5,52 & 4,23 & 2,94 \\
\hline 55 & 250 & 140 & 42,24 & 23,21 & 17,18 & 12,70 & 9,94 & 8,02 & 5,59 & 4,27 & 2,94 \\
\hline 55 & 300 & 140 & 37,81 & 21,82 & 16,59 & 12,54 & 9,94 & 8,07 & 5,65 & 4,30 & 2,94 \\
\hline 55 & 350 & 140 & 34,54 & 20,75 & 16,11 & 12,40 & 9,92 & 8,10 & 5,69 & 4,33 & 2,94 \\
\hline 55 & 400 & 140 & 32,01 & 19,88 & 15,70 & 12,25 & 9,88 & 8,12 & 5,73 & 4,36 & 2,94 \\
\hline 55 & 450 & 140 & 29,99 & 19,15 & 15,34 & 12,12 & 9,85 & 8,13 & 5,77 & 4,38 & 2,95 \\
\hline 55 & 500 & 140 & 28,33 & 18,54 & 15,02 & 11,99 & 9,81 & 8,13 & 5,80 & 4,41 & 2,95 \\
\hline 55 & 550 & 140 & 26,93 & 18,00 & 14,74 & 11,87 & 9,77 & 8,13 & 5,83 & 4,43 & 2,96 \\
\hline 55 & 600 & 140 & 25,74 & 17,53 & 14,48 & 11,75 & 9,72 & 8,12 & 5,85 & 4,45 & 2,96 \\
\hline 55 & 650 & 140 & 24,71 & $\begin{array}{l}17,10 \\
17,10\end{array}$ & 14,24 & 11,64 & 9,68 & 8,11 & 5,87 & 4,47 & 2,97 \\
\hline 55 & 700 & 140 & 23,80 & 16,72 & 14,02 & 11,53 & 9,63 & 8,10 & 5,89 & 4,49 & 2,97 \\
\hline 55 & 750 & 140 & 23,00 & 16,37 & 13,82 & 11,43 & 9,58 & 8,09 & 5,90 & 4,51 & 2,98 \\
\hline 55 & 800 & 140 & 22,28 & 16,05 & 13,62 & 11,33 & 9,54 & 8,07 & 5,91 & 4,52 & 2,99 \\
\hline 55 & 850 & 140 & 21,64 & 15,76 & 13,45 & 11,23 & 9,49 & 8,06 & 5,93 & 4,54 & 3,00 \\
\hline 55 & 900 & 140 & 21,05 & 15,49 & 13,28 & 11,14 & 9,44 & 8,04 & 5,93 & 4,55 & 3,00 \\
\hline 55 & 950 & 140 & 20,52 & 15,24 & 13,12 & 11,05 & 9,40 & 8,02 & 5,94 & 4,56 & 3,01 \\
\hline 55 & 1000 & 140 & 20,03 & 15,00 & 12,97 & 10,97 & 9,35 & 8,00 & 5,95 & 4,58 & 3,02 \\
\hline 55 & 1050 & 140 & 19,58 & 14,78 & 12,82 & 10,89 & 9,31 & 7,98 & 5,96 & 4,59 & 3,02 \\
\hline 55 & 1100 & 140 & 19,17 & 14,57 & 12,69 & 10,81 & 9,27 & 7,96 & 5,96 & 4,60 & 3,03 \\
\hline 55 & 1150 & 140 & 18,79 & 14,38 & 12,56 & 10,73 & 9,22 & 7,94 & 5,96 & 4,61 & 3,04 \\
\hline 55 & 1200 & 140 & 18,43 & 14,19 & 12,43 & 10,66 & 9,18 & 7,92 & 5,97 & 4,62 & 3,04 \\
\hline 55 & 1250 & 140 & 18,10 & 14,01 & 12,32 & 10,58 & 9,14 & 7,90 & 5,97 & 4,63 & 3,05 \\
\hline 55 & 1300 & 140 & 17,78 & 13,85 & 12,20 & 10,51 & 9,10 & 7,88 & 5,97 & 4,64 & 3,06 \\
\hline 55 & 1350 & 140 & 17,49 & 13,69 & 12,09 & 10,44 & 9,06 & 7,86 & 5,97 & 4,64 & 3,06 \\
\hline 55 & 1400 & 140 & 17,22 & 13,53 & 11,99 & 10,38 & 9,02 & 7,84 & 5,97 & 4,65 & 3,07 \\
\hline 55 & 1450 & 140 & 16,96 & 13,39 & 11,89 & 10,31 & 8,98 & 7,82 & 5,97 & 4,66 & 3,08 \\
\hline 55 & 1500 & 140 & 16,71 & 13,25 & 11,79 & 10,25 & 8,94 & 7,80 & 5,97 & 4,66 & 3,08 \\
\hline 55 & 1550 & 140 & 16,48 & 13,11 & 11,70 & 10,19 & 8,91 & 7,78 & 5,97 & 4,67 & 3,09 \\
\hline 55 & 1600 & 140 & 16,26 & 12,98 & 11,61 & 10,13 & 8,87 & 7,76 & 5,97 & 4,67 & 3,09 \\
\hline 55 & 1650 & 140 & 16,05 & 12,86 & 11,52 & 10,07 & 8,83 & 7,74 & 5,96 & 4,68 & 3,10 \\
\hline 55 & 1700 & 140 & 15,86 & 12,74 & 11,43 & 10,02 & 8,80 & 7,72 & 5,96 & 4,68 & 3,11 \\
\hline 55 & 1750 & 140 & 15,67 & 12,63 & 11,35 & 9,96 & 8,76 & 7,70 & 5,96 & 4,69 & 3,11 \\
\hline 55 & 1800 & 140 & 15,49 & 12,52 & 11,27 & 9,91 & 8,73 & 7,68 & 5,95 & 4,69 & 3,12 \\
\hline 55 & 1850 & 140 & 15,32 & 12,41 & 11,19 & 9,86 & 8,69 & 7,66 & 5,95 & 4,70 & 3,12 \\
\hline 55 & 1900 & 140 & 15,15 & 12,30 & 11,12 & 9,81 & 8,66 & 7,64 & 5,95 & 4,70 & 3,13 \\
\hline 55 & 1950 & 140 & 15,00 & 12,20 & 11,05 & 9,76 & 8,63 & 7,62 & 5,94 & 4,70 & 3,13 \\
\hline 55 & 2000 & 140 & 14,85 & 12,11 & 10,98 & 9,71 & 8,59 & 7,60 & 5,94 & 4,71 & 3,14 \\
\hline 55 & 200 & 145 & 48,10 & 24,59 & 17,43 & 12,44 & 9,58 & 7,67 & 5,32 & 4,08 & 2,84 \\
\hline 55 & 250 & 145 & 41,69 & 22,69 & 16,69 & 12,29 & 9,60 & 7,74 & 5,38 & 4,11 & 2,84 \\
\hline 55 & 300 & 145 & 37,28 & 21,32 & 16,13 & 12,14 & 9,60 & 7,78 & 5,44 & 4,14 & 2,84 \\
\hline 55 & 350 & 145 & 34,03 & 20,26 & 15,66 & 12,00 & 9,58 & 7,81 & 5,49 & 4,17 & 2,84 \\
\hline 55 & 400 & 145 & 31,53 & 19,41 & 15,26 & 11,87 & 9,55 & 7,83 & 5,53 & 4,20 & 2,84 \\
\hline 55 & 450 & 145 & 29,52 & 18,70 & 14,92 & 11,74 & 9,52 & 7,84 & 5,56 & 4,22 & 2,84 \\
\hline 55 & 500 & 145 & 27,87 & 18,09 & 14,61 & 11,62 & 9,48 & 7,85 & 5,59 & 4,25 & 2,85 \\
\hline 55 & 550 & 145 & 26,49 & 17,57 & 14,33 & 11,50 & 9,44 & 7,85 & 5,62 & 4,27 & 2,85 \\
\hline 55 & 600 & 145 & 25,31 & 17,10 & 14,08 & 11,39 & 9,40 & 7,84 & 5,64 & 4,29 & 2,86 \\
\hline 55 & 650 & 145 & 24,29 & 16,69 & 13,85 & 11,28 & 9,36 & 7,84 & 5,66 & 4,31 & 2,86 \\
\hline 55 & 700 & 145 & 23,39 & 16,32 & 13,64 & 11,18 & 9,32 & 7,83 & 5,68 & 4,33 & 2,87 \\
\hline 55 & 750 & 145 & 22,59 & 15,98 & 13,44 & 11,08 & 9,28 & 7,82 & 5,69 & 4,34 & 2,88 \\
\hline 55 & 800 & 145 & 21,89 & 15,67 & 13,25 & 10,99 & 9,23 & 7,80 & 5,70 & 4,36 & 2,88 \\
\hline 55 & 850 & 145 & 21,25 & 15,38 & 13,08 & 10,90 & 9,19 & 7,79 & 5,71 & 4,37 & 2,89 \\
\hline 55 & 900 & 145 & 20,67 & 15,12 & 12,92 & 10,81 & 9,15 & 7,77 & 5,72 & 4,39 & 2,89 \\
\hline 55 & 950 & 145 & 20,14 & $\frac{10, \pm L}{14,87}$ & 12,76 & $\frac{10,01}{10,73}$ & 9,10 & 7,76 & 5,73 & 4,40 & 2,90 \\
\hline 55 & 1000 & 145 & 19,66 & 14,64 & 12,62 & 10,65 & 9,06 & 7,74 & 5,74 & 4,41 & 2,91 \\
\hline 55 & 1050 & 145 & 19,22 & 14,42 & 12,48 & 10,57 & 9,02 & 7,72 & 5,75 & 4,42 & 2,91 \\
\hline 55 & 1100 & 145 & 18,81 & 14,22 & 12,35 & 10,49 & 8,98 & 7,70 & 5,75 & 4,43 & 2,92 \\
\hline 55 & 1150 & 145 & 18.43 & 14.03 & 1222 & 10.42 & 894 & 769 & 5.76 & 4.44 & 293 \\
\hline 55 & 1200 & 145 & 18,08 & 13,85 & 12,10 & 10,35 & 8,90 & 7,67 & 5,76 & 4,45 & 2,93 \\
\hline 55 & 1250 & 145 & 17,75 & 13,68 & 11,99 & 10,28 & 8,86 & 7,65 & 5,76 & 4,46 & 2,94 \\
\hline
\end{tabular}




\begin{tabular}{|c|c|c|c|c|c|c|c|c|c|c|c|}
\hline \multirow[b]{2}{*}{$\mathrm{H}(\mathrm{cm})$} & \multirow[b]{2}{*}{ Mceq (MPa) } & & & & & $\mathrm{De}$ & ões (x. & & & & \\
\hline & & Msub (MPa) & D0 & D25 & D40 & D60 & D80 & D100 & D140 & D180 & D260 \\
\hline 55 & 1300 & 145 & 17,44 & 13,51 & 11,88 & 10,21 & 8,82 & 7,63 & 5,76 & 4,47 & 2,95 \\
\hline 55 & 1350 & 145 & 17,15 & 13,36 & 11,77 & 10,15 & 8,78 & 7,61 & 5,76 & 4,48 & 2,95 \\
\hline 55 & 1400 & 145 & 16,88 & 13,21 & 11,67 & 10,08 & 8,75 & 7,59 & 5,76 & 4,48 & 2,96 \\
\hline 55 & 1450 & 145 & 16,62 & 13,07 & 11,57 & 10,02 & 8,71 & 7,57 & 5,76 & 4,49 & 2,96 \\
\hline 55 & 1500 & 145 & 16,38 & 12,93 & 11,48 & 9,96 & 8,67 & 7,55 & 5,76 & 4,50 & 2,97 \\
\hline 55 & 1550 & 145 & 16,15 & 12,80 & 11,39 & 9,90 & 8,64 & 7,53 & 5,76 & 4,50 & 2,98 \\
\hline 55 & 1600 & 145 & 15,94 & 12,67 & 11,30 & 9,85 & 8,60 & 7,51 & 5,76 & 4,51 & 2,98 \\
\hline 55 & 1650 & 145 & 15,73 & 12,55 & 11,22 & 9,79 & 8,57 & 7,49 & 5,76 & 4,51 & 2,99 \\
\hline 55 & 1700 & 145 & 15,54 & 12,44 & 11,13 & 9,74 & 8,53 & 7,47 & 5,76 & 4,52 & 2,99 \\
\hline 55 & 1750 & 145 & 15,35 & 12,33 & 11,06 & 9,68 & 8,50 & 7,45 & 5,76 & 4,52 & 3,00 \\
\hline 55 & 1800 & 145 & 15,17 & 12,22 & 10,98 & 9,63 & 8,47 & 7,44 & 5,75 & 4,53 & 3,00 \\
\hline 55 & 1850 & 145 & 15,00 & 12,11 & 10,90 & 9,58 & 8,44 & 7,42 & 5,75 & 4,53 & 3,01 \\
\hline 55 & 1900 & 145 & 14.84 & 12.01 & 10,83 & 9.53 & 8,40 & 7,40 & 5,75 & 4.53 & 3,01 \\
\hline 55 & 1950 & 145 & 14,68 & 11,91 & 10,76 & 9,49 & 8,37 & 7,38 & 5,74 & 4,54 & 3,02 \\
\hline 55 & 2000 & 145 & 14,54 & 11,82 & 10,69 & 9,44 & 8,34 & 7,36 & 5,74 & 4,54 & 3,02 \\
\hline 55 & 200 & 150 & 47,55 & 24,07 & 16,96 & 12,05 & 9,25 & 7,40 & 5,13 & 3,94 & 2,75 \\
\hline 55 & 250 & 150 & 41,16 & 22,19 & 16,24 & 11,90 & 9,28 & 7,47 & 5,19 & 3,97 & 2,74 \\
\hline 55 & 300 & 150 & 36,78 & 20,84 & 15,69 & 11,77 & 9,28 & 7,52 & 5,25 & 4,00 & 2,74 \\
\hline 55 & 350 & 150 & 33,55 & 19,80 & 15,23 & 11,63 & 9,26 & 7,55 & 5,29 & 4,03 & 2,74 \\
\hline 55 & 400 & 150 & 31,07 & 18,97 & 14,85 & 11,51 & 9,24 & 7,57 & 5,33 & 4,05 & 2,74 \\
\hline 55 & 450 & 150 & 29,08 & 18,27 & 14,51 & 11,39 & 9,21 & 7,58 & 5,37 & 4,08 & 2,75 \\
\hline 55 & 500 & 150 & 27,44 & 17,68 & 14,22 & 11,27 & 9,18 & 7,59 & 5,40 & 4,10 & 2,75 \\
\hline 55 & 550 & 150 & 26,07 & 17,16 & 13,95 & 11,16 & 9,14 & 7,59 & 5,42 & 4,12 & 2,75 \\
\hline 55 & 600 & 150 & 24,90 & 16,71 & 13,71 & 11,05 & 9,11 & 7,58 & 5,44 & 4,14 & 2,76 \\
\hline 55 & 650 & 150 & 23,89 & 16,30 & 13,48 & 10,95 & 9,07 & 7,58 & 5,46 & 4,16 & 2,77 \\
\hline 55 & 700 & 150 & 23,00 & 15,94 & 13,28 & 10,86 & 9,03 & 7,57 & 5,48 & 4,17 & 2,77 \\
\hline 55 & 750 & 150 & 22,21 & 15,61 & 13,09 & 10,76 & 8,99 & 7,56 & 5,49 & 4,19 & 2,78 \\
\hline 55 & 800 & 150 & 21,51 & 15,30 & 12,91 & 10,67 & 8,95 & 7,55 & 5,51 & 4,20 & 2,78 \\
\hline 55 & 850 & 150 & 20,88 & 15,02 & 12,74 & 10,59 & 8,91 & 7,54 & 5,52 & 4,22 & 2,79 \\
\hline 55 & 900 & 150 & 20,31 & 14,76 & 12,58 & 10,50 & 8,87 & 7,52 & 5,53 & 4,23 & 2,79 \\
\hline 55 & 950 & 150 & 19,79 & 14,52 & 12,43 & 10,42 & 8,83 & 7,51 & 5,54 & 4,24 & 2,80 \\
\hline 55 & 1000 & 150 & 19,31 & 14,30 & 12,29 & 10,34 & 8,79 & 7,49 & 5,54 & 4,26 & 2,81 \\
\hline 55 & 1050 & 150 & 18,87 & 14,09 & 12,16 & 10,27 & 8,75 & 7,48 & 5,55 & 4,27 & 2,81 \\
\hline 55 & 1100 & 150 & 18,47 & 13,89 & 12.03 & 10,20 & 8.71 & 7,46 & 5,56 & 4.28 & 2,82 \\
\hline 55 & 1150 & 150 & 18,09 & 13,70 & 11,91 & 10,13 & 8,67 & 7,44 & 5,56 & 4,29 & 2,82 \\
\hline 55 & 1200 & 150 & 17,74 & 13,53 & 11,79 & 10,06 & 8,63 & 7,43 & 5,56 & 4,30 & 2,83 \\
\hline 55 & 1250 & 150 & 17,42 & 13,36 & 11,68 & 9,99 & 8,60 & 7,41 & 5,57 & 4,30 & 2,84 \\
\hline 55 & 1300 & 150 & 17,11 & 13,20 & 11,58 & 9,93 & 8,56 & 7,39 & 5,57 & 4,31 & 2,84 \\
\hline 55 & 1350 & 150 & 16,83 & 13,05 & 11,47 & 9,86 & 8,52 & 7,37 & 5,57 & 4,32 & 2,85 \\
\hline 55 & 1400 & 150 & 16,56 & 12,90 & 11,37 & 9,80 & 8,49 & 7,35 & 5,57 & 4,33 & 2,85 \\
\hline 55 & 1450 & 150 & 16,31 & 12,76 & 11,28 & 9,74 & 8,45 & 7,34 & 5,57 & 4,33 & 2,86 \\
\hline 55 & 1500 & 150 & 16,07 & 12,63 & 11,19 & 9,69 & 8,42 & 7,32 & 5,57 & 4,34 & 2,87 \\
\hline 55 & 1550 & 150 & 15,84 & 12,50 & 11,10 & 9,63 & 8,38 & 7,30 & 5,57 & 4,35 & 2,87 \\
\hline 55 & 1600 & 150 & 15,63 & 12,38 & 11,02 & 9,58 & 8,35 & 7,28 & 5,57 & 4,35 & 2,88 \\
\hline 55 & 1650 & 150 & 15,43 & 12,26 & 10,93 & 9,52 & 8,32 & 7,26 & 5,57 & 4,36 & 2,88 \\
\hline 55 & 1700 & 150 & 15,23 & 12,15 & 10,85 & 9,47 & 8,29 & 7,25 & 5,57 & 4,36 & 2,89 \\
\hline 55 & 1750 & 150 & 15,05 & 12,04 & 10,78 & 9,42 & 8,25 & 7,23 & 5,57 & 4,37 & 2,89 \\
\hline 55 & 1800 & 150 & 14,87 & 11,94 & 10,70 & 9,37 & 8,22 & 7,21 & 5,56 & 4,37 & 2,90 \\
\hline 55 & 1850 & 150 & 14,71 & 11,83 & 10,63 & 9,32 & 8,19 & 7,19 & 5,56 & 4,37 & 2,90 \\
\hline 55 & 1900 & 150 & 14,54 & 11,74 & 10,56 & 9,28 & 8,16 & 7,17 & 5,56 & 4,38 & 2,91 \\
\hline 55 & 1950 & 150 & 14,39 & 11,64 & 10,49 & 9,23 & 8,13 & 7,16 & 5,56 & 4,38 & 2,91 \\
\hline 55 & 2000 & 150 & 14,24 & 11,55 & 10,42 & 9,18 & 8,10 & 7,14 & 5,55 & 4,38 & 2,92 \\
\hline 55 & 200 & 155 & $\begin{array}{l}1+4,4 \\
47,03\end{array}$ & 23,58 & $\begin{array}{l}0,+12 \\
16,52\end{array}$ & $\begin{array}{l}0,+11,68 \\
\end{array}$ & 8,95 & $\begin{array}{l}, 15 \\
7,15\end{array}$ & 4,95 & 3,81 & 2,66 \\
\hline 55 & 250 & 155 & 40,67 & 21,73 & 15,82 & 11,54 & 8,98 & 7,22 & 5,02 & 3,84 & 2,65 \\
\hline 55 & 300 & 155 & 36,31 & 20,40 & 15,28 & 11,41 & 8,98 & 7,27 & 5,07 & 3,87 & 2,65 \\
\hline 55 & 350 & 155 & 33,10 & 19,37 & 14,84 & 11,29 & 8,97 & 7,30 & 5,11 & 3,89 & 2,65 \\
\hline 55 & 400 & 155 & 30,63 & 18,55 & 14,46 & 11,17 & 8,95 & 7,32 & 5,15 & 3,92 & 2,65 \\
\hline 55 & 450 & 155 & 28,66 & 17,86 & 14,14 & 11,05 & 8,92 & 7,33 & 5,18 & 3,94 & 2,66 \\
\hline 55 & 500 & 155 & 27,04 & 17,28 & 13,85 & 10,94 & 8,89 & 7,34 & 5,21 & 3,96 & 2,66 \\
\hline 55 & 550 & 155 & 25,68 & 16,78 & 13,59 & 10,84 & 8,86 & 7,34 & 5,24 & 3,98 & 2,66 \\
\hline 55 & 600 & 155 & 24,52 & 16,33 & 13,35 & 10,74 & 8,83 & 7,34 & 5,26 & 4,00 & 2,67 \\
\hline 55 & 650 & 155 & 23,51 & 15,93 & 13,14 & 10,64 & 8,79 & 7,34 & 5,28 & 4,02 & 2,67 \\
\hline 55 & 700 & 155 & 22,63 & 15,58 & 12,94 & 10,55 & 8,75 & 7,33 & 5,30 & 4,03 & 2,68 \\
\hline 55 & 750 & 155 & 21,85 & 15,25 & 12,75 & 10,46 & 8,72 & 7,32 & 5,31 & 4,05 & 2,68 \\
\hline 55 & 800 & 155 & 21,16 & 14,96 & 12,58 & 10,37 & 8,68 & 7,31 & 5,32 & 4,06 & 2,69 \\
\hline 55 & 850 & 155 & 20,53 & 14,68 & 12,42 & 10,29 & 8,64 & 7,30 & 5,33 & 4,08 & 2,70 \\
\hline 55 & 900 & 155 & 19,97 & 14,43 & 12,26 & 10,21 & 8,60 & 7,29 & 5,34 & 4,09 & 2,70 \\
\hline 55 & 950 & 155 & 19,45 & 14,20 & 12,12 & 10,13 & 8,57 & 7,28 & 5,35 & 4,10 & 2,71 \\
\hline 55 & 1000 & 155 & 18,98 & 13,98 & 11,98 & 10,06 & 8,53 & 7,26 & 5,36 & 4,11 & 2,71 \\
\hline 55 & 1050 & 155 & 18,55 & 13,77 & 11,85 & 9,99 & 8,49 & 7,25 & 5,37 & 4,12 & 2,72 \\
\hline 55 & 1100 & 155 & 18,15 & 13,58 & 11,73 & 9,92 & 8,45 & 7,23 & 5,37 & 4,13 & 2,72 \\
\hline 55 & 1150 & 155 & 17,78 & 13,39 & 11,61 & 9,85 & 8,42 & 7,22 & 5,38 & 4,14 & 2,73 \\
\hline 55 & 1200 & 155 & 17,43 & 13,22 & 11,50 & 9,78 & 8,38 & 7,20 & 5,38 & 4,15 & 2,74 \\
\hline 55 & 1250 & 155 & 17,11 & 13,06 & 11,39 & 9,72 & 8,35 & 7,18 & 5,39 & 4,16 & 2,74 \\
\hline 55 & 1300 & 155 & 16,81 & 12,90 & 11,29 & 9,66 & 8,31 & 7,17 & 5,39 & 4,17 & 2,75 \\
\hline 55 & 1350 & 155 & 16,53 & 12,75 & 11,19 & 9,60 & 8,28 & 7,15 & 5,39 & 4,17 & 2,75 \\
\hline 55 & 1400 & 155 & 16,26 & 12,61 & 11,09 & 9,54 & 8,24 & 7,13 & 5,39 & 4,18 & 2,76 \\
\hline 55 & 1450 & 155 & 16.01 & 1248 & 1100 & 9.48 & 821 & 7.12 & 5.39 & 4.19 & 276 \\
\hline 55 & 1500 & 155 & 15,77 & 12,35 & 10,91 & 9,43 & 8,18 & 7,10 & 5,39 & 4,19 & 2,77 \\
\hline 55 & 1550 & 155 & 15,55 & 12,22 & 10,83 & 9,37 & 8,15 & 7,08 & 5,39 & 4,20 & 2,77 \\
\hline 55 & 1600 & 155 & 15,34 & 12,10 & 10,75 & 9,32 & 8,12 & 7,07 & 5,39 & 4,21 & 2,78 \\
\hline
\end{tabular}




\begin{tabular}{|c|c|c|c|c|c|c|c|c|c|c|c|}
\hline \multirow[b]{2}{*}{$\mathrm{H}(\mathrm{cm})$} & \multirow[b]{2}{*}{ Mceq (MPa) } & & & & & $\mathrm{De}$ & ões (x. & & & & \\
\hline & & Msub (MPa) & D0 & D25 & D40 & D60 & D80 & D100 & D140 & D180 & D260 \\
\hline 55 & 1650 & 155 & 15,14 & 11,99 & 10,67 & 9,27 & 8,08 & 7,05 & 5,39 & 4,21 & 2,78 \\
\hline 55 & 1700 & 155 & 14,95 & 11,88 & 10,59 & 9,22 & 8,05 & 7,03 & 5,39 & 4,22 & 2,79 \\
\hline 55 & 1750 & 155 & 14,76 & 11,77 & 10,51 & 9,17 & 8,02 & 7,01 & 5,39 & 4,22 & 2,79 \\
\hline 55 & 1800 & 155 & 14,59 & 11,67 & 10,44 & 9,12 & 7,99 & 7,00 & 5,39 & 4,22 & 2,80 \\
\hline 55 & 1850 & 155 & 14,43 & 11,57 & 10,37 & 9,08 & 7,96 & 6,98 & 5,39 & 4,23 & 2,80 \\
\hline 55 & 1900 & 155 & 14,27 & 11,47 & 10,30 & 9,03 & 7,93 & 6,96 & 5,38 & 4,23 & 2,81 \\
\hline 55 & 1950 & 155 & 14,11 & 11,38 & 10,24 & 8,99 & 7,91 & 6,95 & 5,38 & 4,24 & 2,81 \\
\hline 55 & 2000 & 155 & 13,97 & 11,29 & 10,17 & 8,95 & 7,88 & 6,93 & 5,38 & 4,24 & 2,82 \\
\hline 55 & 200 & 160 & 46,54 & 23,12 & 16,10 & 11,33 & 8,66 & 6,92 & 4,79 & 3,68 & 2,58 \\
\hline 55 & 250 & 160 & 40,21 & 21,29 & 15,42 & 11,20 & 8,69 & 6,98 & 4,85 & 3,71 & 2,57 \\
\hline 55 & 300 & 160 & 35,86 & 19,97 & 14,89 & 11,08 & 8,70 & 7,03 & 4,90 & 3,74 & 2,57 \\
\hline 55 & 350 & 160 & 32,68 & 18,96 & 14,46 & 10,96 & 8,69 & 7,06 & 4,95 & 3,77 & 2,57 \\
\hline 55 & 400 & 160 & 30,22 & 18,15 & 14,10 & 10,85 & 8,68 & 7,09 & 4,98 & 3,79 & 2,57 \\
\hline 55 & 450 & 160 & 28,26 & 17,48 & 13,78 & 10,74 & 8,65 & 7,10 & 5,01 & 3,81 & 2,57 \\
\hline 55 & 500 & 160 & 26,65 & 16,91 & 13,50 & 10,63 & 8,63 & 7,11 & 5,04 & 3,83 & 2,58 \\
\hline 55 & 550 & 160 & 25,30 & 16,41 & 13,25 & 10,53 & 8,60 & 7,11 & 5,07 & 3,85 & 2,58 \\
\hline 55 & 600 & 160 & 24,15 & 15,98 & 13,02 & 10,44 & 8,56 & 7,11 & 5,09 & 3,87 & 2,58 \\
\hline 55 & 650 & 160 & 23,16 & 15,59 & 12,81 & 10,34 & 8,53 & 7,11 & 5,11 & 3,88 & 2,59 \\
\hline 55 & 700 & 160 & 22,29 & 15,24 & 12,61 & 10,26 & 8,50 & 7,10 & 5,12 & 3,90 & 2,59 \\
\hline 55 & 750 & 160 & 21,51 & 14,92 & 12,43 & 10,17 & 8,46 & 7,10 & 5,14 & 3,91 & 2,60 \\
\hline 55 & 800 & 160 & 20,83 & 14,63 & 12,27 & 10,09 & 8,43 & 7,09 & 5,15 & 3,93 & 2,60 \\
\hline 55 & 850 & 160 & 20,21 & 14,36 & 12,11 & 10,01 & 8,39 & 7,08 & 5,16 & 3,94 & 2,61 \\
\hline 55 & 900 & 160 & 19,65 & 14,12 & 11,96 & 9,93 & 8,35 & 7,07 & 5,17 & 3,95 & 2,61 \\
\hline 55 & 950 & 160 & 19,14 & 13,89 & 11,82 & 9,86 & 8,32 & 7,06 & 5,18 & 3,96 & 2,62 \\
\hline 55 & 1000 & 160 & 18,67 & 13,67 & 11,69 & 9,79 & 8,28 & 7,04 & 5,19 & 3,98 & 2,62 \\
\hline 55 & 1050 & 160 & 18,24 & 13,47 & 11,56 & 9,72 & 8,25 & 7,03 & 5,20 & 3,99 & 2,63 \\
\hline 55 & 1100 & 160 & 17,84 & 13,28 & 11,44 & 9,65 & 8,21 & 7,02 & 5,20 & 4,00 & 2,63 \\
\hline 55 & 1150 & 160 & 17,48 & 13,10 & 11,33 & 9,59 & 8,18 & 7,00 & 5,21 & 4,01 & 2,64 \\
\hline 55 & 1200 & 160 & 17,14 & 12,93 & 11,22 & 9,53 & 8,15 & 6,99 & 5,21 & 4,01 & 2,65 \\
\hline 55 & 1250 & 160 & 16,82 & 12,77 & 11,12 & 9,46 & 8,11 & 6,97 & 5,21 & 4,02 & 2,65 \\
\hline 55 & 1300 & 160 & 16,52 & 12,62 & 11,02 & 9,41 & 8,08 & 6,96 & 5,22 & 4,03 & 2,66 \\
\hline 55 & 1350 & 160 & 16,24 & 12,48 & 10,92 & 9,35 & 8,05 & 6,94 & 5,22 & 4,04 & 2,66 \\
\hline 55 & 1400 & 160 & 15,98 & 12,34 & 10,83 & 9,29 & 8,02 & 6,92 & 5,22 & 4,04 & 2,67 \\
\hline 55 & 1450 & 160 & 15,73 & 12,21 & 10,74 & 9,24 & 7,98 & 6,91 & 5,22 & 4,05 & 2,67 \\
\hline 55 & 1500 & 160 & 15,50 & 12,08 & 10,65 & 9,18 & 7,95 & 6,89 & 5,22 & 4,06 & 2,68 \\
\hline 55 & 1550 & 160 & 15,27 & 11,96 & 10,57 & 9,13 & 7,92 & 6,88 & 5,22 & 4,06 & 2,68 \\
\hline 55 & 1600 & 160 & 15,06 & 11,84 & 10,49 & 9,08 & 7,89 & 6,86 & 5,22 & 4,07 & 2,69 \\
\hline 55 & 1650 & 160 & 14,87 & 11,73 & 10,41 & 9,03 & 7,86 & 6,85 & 5,22 & 4,07 & 2,69 \\
\hline 55 & 1700 & 160 & 14,68 & 11,62 & 10,34 & 8,98 & 7,83 & 6,83 & 5,22 & 4,08 & 2,70 \\
\hline 55 & 1750 & 160 & 14,50 & 11,52 & 10,26 & 8,94 & 7,80 & 6,81 & 5,22 & 4,08 & 2,70 \\
\hline 55 & 1800 & 160 & 14,32 & 11,42 & 10,19 & 8,89 & 7,78 & 6,80 & 5,22 & 4,09 & 2,70 \\
\hline 55 & 1850 & 160 & 14,16 & 11,32 & 10,13 & 8,85 & 7,75 & 6,78 & 5,22 & 4,09 & 2,71 \\
\hline 55 & 1900 & 160 & 14,00 & 11,23 & 10,06 & 8,80 & 7,72 & 6,77 & 5,22 & 4,10 & 2,71 \\
\hline 55 & 1950 & 160 & 13,85 & 11,14 & 9,99 & 8,76 & 7,69 & 6,75 & 5,22 & 4,10 & 2,72 \\
\hline 55 & 2000 & 160 & 13,71 & 11,05 & 9,93 & 8,72 & 7,67 & 6,73 & 5,21 & 4,10 & 2,72 \\
\hline 55 & 200 & 165 & 46,08 & 22,69 & 15,71 & 11,00 & 8,39 & 6,70 & 4,64 & 3,57 & 2,50 \\
\hline 55 & 250 & 165 & 39,76 & 20,87 & 15,04 & 10,88 & 8,43 & 6,76 & 4,70 & 3,60 & 2,49 \\
\hline 55 & 300 & 165 & 35,44 & 19,57 & 14,52 & 10,76 & 8,44 & 6,81 & 4,75 & 3,62 & 2,49 \\
\hline 55 & 350 & 165 & 32,27 & 18,58 & 14,10 & 10,65 & 8,43 & 6,84 & 4,79 & 3,65 & 2,49 \\
\hline 55 & 400 & 165 & 29,83 & 17,78 & 13,75 & 10,54 & 8,42 & 6,87 & 4,82 & 3,67 & 2,49 \\
\hline 55 & 450 & 165 & 27,88 & 17,12 & 13,44 & 10,44 & 8,40 & 6,88 & 4,85 & 3,69 & 2,49 \\
\hline 55 & 500 & 165 & 26,29 & 16,56 & 13,17 & 10,34 & 8,37 & 6,89 & 4,88 & 3,71 & 2,50 \\
\hline 55 & 550 & 165 & 24,95 & 16,07 & $\begin{array}{l}+0, \pm 1 \\
12,92\end{array}$ & 10,25 & 8,35 & 6,90 & 4,90 & 3,73 & 2,50 \\
\hline 55 & 600 & 165 & 23,81 & 15,64 & 12,70 & 10,15 & 8,32 & 6,90 & 4,93 & 3,74 & 2,50 \\
\hline 55 & 650 & 165 & 22,82 & 15,26 & 12,50 & 10,07 & 8,28 & 6,90 & 4,94 & 3,76 & 2,51 \\
\hline 55 & 700 & 165 & 21,96 & 14,92 & 12,31 & 9,98 & 8,25 & 6,89 & 4,96 & 3,77 & 2,51 \\
\hline 55 & 750 & 165 & 21,19 & 14,60 & 12,14 & 9,90 & 8,22 & 6,89 & 4,98 & 3,79 & 2,52 \\
\hline 55 & 800 & 165 & 20,51 & 14,32 & 11,97 & 9,82 & 8,19 & 6,88 & 4,99 & 3,80 & 2,52 \\
\hline 55 & 850 & 165 & 19,90 & 14,06 & 11,82 & 9,75 & 8,15 & 6,87 & 5,00 & 3,81 & 2,53 \\
\hline 55 & 900 & 165 & 19,34 & 13,82 & 11,68 & 9,67 & 8,12 & 6,86 & 5,01 & 3,83 & 2,53 \\
\hline 55 & 950 & 165 & 18,84 & 13,59 & 11,54 & 9,60 & 8,09 & 6,85 & 5,02 & 3,84 & 2,54 \\
\hline 55 & 1000 & 165 & 18,37 & 13,38 & 11,41 & 9,53 & 8,05 & 6,84 & 5,03 & 3,85 & 2,54 \\
\hline 55 & 1050 & 165 & 17,95 & 13,18 & 11,29 & 9,47 & 8,02 & 6,82 & 5,03 & 3,86 & 2,55 \\
\hline 55 & 1100 & 165 & 17,56 & 13,00 & 11,17 & 9,40 & 7,99 & 6,81 & 5,04 & 3,87 & 2,55 \\
\hline 55 & 1150 & 165 & 17,19 & 12,82 & 11,06 & 9,34 & 7,96 & 6,80 & 5,05 & 3,88 & 2,56 \\
\hline 55 & 1200 & 165 & 16,85 & 12,66 & 10,96 & 9,28 & 7,92 & 6,79 & 5,05 & 3,89 & 2,56 \\
\hline 55 & 1250 & 165 & 16,54 & 12,50 & 10,86 & 9,22 & 7,89 & 6,77 & 5,05 & 3,89 & 2,57 \\
\hline 55 & 1300 & 165 & 16,24 & 12,35 & 10,76 & 9,17 & 7,86 & 6,76 & 5,06 & 3,90 & 2,57 \\
\hline 55 & 1350 & 165 & 15,97 & 12,21 & 10,67 & 9,11 & 7,83 & 6,74 & 5,06 & 3,91 & 2,58 \\
\hline 55 & 1400 & 165 & 15,71 & 12,08 & 10,58 & 9,06 & 7,80 & 6,73 & 5,06 & 3,92 & 2,58 \\
\hline 55 & 1450 & 165 & 15,46 & 11,95 & 10,49 & 9,00 & 7,77 & 6,71 & 5,06 & 3,92 & 2,59 \\
\hline 55 & 1500 & 165 & 15,23 & 11,82 & 10,41 & 8,95 & 7,74 & 6,70 & 5,06 & 3,93 & 2,59 \\
\hline 55 & 1550 & 165 & 15,01 & 11,71 & 10,32 & 8,90 & 7,71 & 6,68 & 5,07 & 3,93 & 2,60 \\
\hline 55 & 1600 & 165 & 14,81 & 11,59 & 10,25 & 8,85 & 7,68 & 6,67 & 5,07 & 3,94 & 2,60 \\
\hline 55 & 1650 & 165 & 14,61 & 11,48 & 10,17 & 8,81 & 7,65 & 6,65 & 5,07 & 3,95 & 2,60 \\
\hline 55 & 1700 & 165 & 14,42 & 11,38 & 10,10 & 8,76 & 7,63 & 6,64 & 5,07 & 3,95 & 2,61 \\
\hline 55 & 1750 & 165 & 14,24 & 11,28 & 10,03 & 8,71 & 7,60 & 6,62 & 5,06 & 3,95 & 2,61 \\
\hline 55 & 1800 & 165 & 14,07 & 11,18 & 9,96 & 8,67 & 7,57 & 6,61 & 5,06 & 3,96 & 2,62 \\
\hline 55 & 1850 & 165 & 13,91 & 11,08 & 9,89 & 8,63 & 7,54 & 6,59 & 5,06 & 3,96 & 2,62 \\
\hline 55 & 1900 & 165 & 13,76 & 10,99 & 9,83 & 8,59 & 7,52 & 6,58 & 5,06 & 3,97 & 2,63 \\
\hline 55 & 1950 & 165 & 13,61 & 10,90 & 9,77 & 8,54 & 7,49 & 6,56 & 5,06 & 3,97 & 2,63 \\
\hline
\end{tabular}




\begin{tabular}{|c|c|c|c|c|c|c|c|c|c|c|c|}
\hline \multirow[b]{2}{*}{$\mathrm{H}(\mathrm{cm})$} & \multirow[b]{2}{*}{ Mceq (MPa) } & & & & & $\mathrm{De}$ & ões (x. & & & & \\
\hline & & Msub (MPa) & D0 & D25 & D40 & D60 & D80 & D100 & D140 & D180 & D260 \\
\hline 55 & 2000 & 165 & 13,46 & 10,82 & 9,70 & 8,50 & 7,47 & 6,55 & 5,06 & 3,97 & 2,63 \\
\hline 55 & 200 & 170 & 45,64 & 22,28 & 15,34 & 10,69 & 8,14 & 6,49 & 4,49 & 3,46 & 2,43 \\
\hline 55 & 250 & 170 & 39,35 & 20,48 & 14,68 & 10,58 & 8,18 & 6,56 & 4,55 & 3,49 & 2,42 \\
\hline 55 & 300 & 170 & 35,04 & 19,20 & 14,18 & 10,47 & 8,19 & 6,60 & 4,60 & 3,51 & 2,42 \\
\hline 55 & 350 & 170 & 31,89 & 18,21 & 13,77 & 10,36 & 8,19 & 6,64 & 4,64 & 3,53 & 2,42 \\
\hline 55 & 400 & 170 & 29,46 & 17,43 & 13,42 & 10,26 & 8,17 & 6,66 & 4,67 & 3,56 & 2,42 \\
\hline 55 & 450 & 170 & 27,53 & 16,77 & 13,12 & 10,16 & 8,16 & 6,68 & 4,70 & 3,58 & 2,42 \\
\hline 55 & 500 & 170 & 25,94 & 16,22 & 12,86 & 10,06 & 8,13 & 6,69 & 4,73 & 3,59 & 2,42 \\
\hline 55 & 550 & 170 & 24,61 & 15,74 & 12,62 & 9,97 & 8,11 & 6,69 & 4,75 & 3,61 & 2,43 \\
\hline 55 & 600 & 170 & 23,48 & 15,32 & 12,40 & 9,89 & 8,08 & 6,69 & 4,77 & 3,63 & 2,43 \\
\hline 55 & 650 & 170 & 22,50 & 14,95 & 12,20 & 9,80 & 8,05 & 6,69 & 4,79 & 3,64 & 2,43 \\
\hline 55 & 700 & 170 & 21,64 & 14,61 & 12,02 & 9,72 & 8,02 & 6,69 & 4,81 & 3,66 & 2,44 \\
\hline 55 & 750 & 170 & 20,88 & 14,31 & 11,85 & 9,64 & 7,99 & 6,69 & 4,82 & 3,67 & 2,44 \\
\hline 55 & 800 & 170 & 20,21 & 14,03 & 11,69 & 9,57 & 7,96 & 6,68 & 4,84 & 3,68 & 2,45 \\
\hline 55 & 850 & 170 & 19,60 & 13,77 & 11,55 & 9,50 & 7,93 & 6,67 & 4,85 & 3,70 & 2,45 \\
\hline 55 & 900 & 170 & 19,05 & 13,53 & 11,41 & 9,43 & 7,90 & 6,66 & 4,86 & 3,71 & 2,45 \\
\hline 55 & 950 & 170 & 18,55 & 13,31 & 11,27 & 9,36 & 7,87 & 6,65 & 4,87 & 3,72 & 2,46 \\
\hline 55 & 1000 & 170 & 18,09 & 13,11 & 11,15 & 9,29 & 7,84 & 6,64 & 4,88 & 3,73 & 2,46 \\
\hline 55 & 1050 & 170 & 17,67 & 12,91 & 11,03 & 9,23 & 7,80 & 6,63 & 4,88 & 3,74 & 2,47 \\
\hline 55 & 1100 & 170 & 17,28 & 12,73 & 10,92 & 9,17 & 7,77 & 6,62 & 4,89 & 3,75 & 2,47 \\
\hline 55 & 1150 & 170 & 16,92 & 12,56 & 10,81 & 9,11 & 7,74 & 6,61 & 4,89 & 3,76 & 2,48 \\
\hline 55 & 1200 & 170 & 16,59 & 12,40 & 10,71 & 9,05 & 7,71 & 6,59 & 4,90 & 3,77 & 2,48 \\
\hline 55 & 1250 & 170 & 16,28 & 12,25 & 10,61 & 8,99 & 7,68 & 6,58 & 4,90 & 3,77 & 2,49 \\
\hline 55 & 1300 & 170 & 15,98 & 12,10 & 10,51 & 8,94 & 7,65 & 6,57 & 4,91 & 3,78 & 2,49 \\
\hline 55 & 1350 & 170 & 15,71 & 11,96 & 10,42 & 8,88 & 7,62 & 6,56 & 4,91 & 3,79 & 2,50 \\
\hline 55 & 1400 & 170 & 15,45 & 11,83 & 10,34 & 8,83 & 7,59 & 6,54 & 4,91 & 3,80 & 2,50 \\
\hline 55 & 1450 & 170 & 15,21 & 11,70 & 10,25 & 8,78 & 7,57 & 6,53 & 4,91 & 3,80 & 2,51 \\
\hline 55 & 1500 & 170 & 14,98 & 11,58 & 10,17 & 8,73 & 7,54 & 6,51 & 4,91 & 3,81 & 2,51 \\
\hline 55 & 1550 & 170 & 14,76 & 11,47 & 10,09 & 8,68 & 7,51 & 6,50 & 4,92 & 3,81 & 2,52 \\
\hline 55 & 1600 & 170 & 14,56 & 11,35 & 10,02 & 8,64 & 7,48 & 6,49 & 4,92 & 3,82 & 2,52 \\
\hline 55 & 1650 & 170 & 14,36 & 11,25 & 9,94 & 8,59 & 7,45 & 6,47 & 4,92 & 3,82 & 2,52 \\
\hline 55 & 1700 & 170 & 14,18 & 11,14 & 9,87 & 8,55 & 7,43 & 6,46 & 4,92 & 3,83 & 2,53 \\
\hline 55 & 1750 & 170 & 14,00 & 11,05 & 9,80 & 8,50 & 7,40 & 6,44 & 4,92 & 3,83 & 2,53 \\
\hline 55 & 1800 & 170 & 13,83 & 10,95 & 9,74 & 8,46 & 7,38 & 6,43 & 4,92 & 3,84 & 2,54 \\
\hline 55 & 1850 & 170 & 13,67 & 10,86 & 9,67 & 8,42 & 7,35 & 6,42 & 4,91 & 3,84 & 2,54 \\
\hline 55 & 1900 & 170 & 13,52 & 10,77 & 9,61 & 8,38 & 7,32 & 6,40 & 4,91 & 3,85 & 2,54 \\
\hline 55 & 1950 & 170 & 13,37 & 10,68 & 9,55 & 8,34 & 7,30 & 6,39 & 4,91 & 3,85 & 2,55 \\
\hline 55 & 2000 & 170 & 13,23 & 10,60 & 9,49 & 8,30 & 7,28 & 6,37 & 4,91 & 3,85 & 2,55 \\
\hline 55 & 200 & 175 & 45,22 & 21,89 & 14,99 & 10,40 & 7,90 & 6,30 & 4,36 & 3,36 & 2,36 \\
\hline 55 & 250 & 175 & 38,95 & 20,11 & 14,34 & 10,29 & 7,94 & 6,36 & 4,41 & 3,38 & 2,35 \\
\hline 55 & 300 & 175 & 34,66 & 18,84 & 13,85 & 10,19 & 7,95 & 6,41 & 4,46 & 3,41 & 2,35 \\
\hline 55 & 350 & 175 & 31,52 & 17,87 & 13,45 & 10,08 & 7,95 & 6,44 & 4,50 & 3,43 & 2,35 \\
\hline 55 & 400 & 175 & 29,11 & 17,09 & 13,11 & 9,99 & 7,94 & 6,47 & 4,53 & 3,45 & 2,35 \\
\hline 55 & 450 & 175 & 27,19 & 16,45 & 12,82 & 9,89 & 7,93 & 6,48 & 4,56 & 3,47 & 2,35 \\
\hline 55 & 500 & 175 & 25,61 & 15,90 & 12,56 & 9,80 & 7,91 & 6,49 & 4,59 & 3,49 & 2,35 \\
\hline 55 & 550 & 175 & 24,29 & 15,43 & 12,33 & 9,72 & 7,89 & 6,50 & 4,61 & 3,50 & 2,36 \\
\hline 55 & 600 & 175 & 23,17 & 15,02 & 12,12 & 9,63 & 7,86 & 6,50 & 4,63 & 3,52 & 2,36 \\
\hline 55 & 650 & 175 & 22,20 & 14,65 & 11,93 & 9,55 & 7,83 & 6,50 & 4,65 & 3,53 & 2,36 \\
\hline 55 & 700 & 175 & 21,34 & 14,32 & 11,75 & 9,47 & 7,81 & 6,50 & 4,67 & 3,55 & 2,37 \\
\hline 55 & 750 & 175 & 20,59 & 14,02 & 11,58 & 9,40 & 7,78 & 6,50 & 4,68 & 3,56 & 2,37 \\
\hline 55 & 800 & 175 & 19,92 & 13,75 & 11,43 & 9,33 & 7,75 & 6,49 & 4,69 & 3,57 & 2,37 \\
\hline 55 & 850 & 175 & 19,32 & 13,49 & 11,28 & 9,26 & 7,72 & 6,49 & 4,70 & 3,59 & 2,38 \\
\hline 55 & 900 & 175 & 18,77 & 13,26 & $\begin{array}{l}+., 20 \\
11,15\end{array}$ & 9,19 & 7,69 & 6,48 & 4,71 & 3,60 & 2,38 \\
\hline 55 & 950 & 175 & 18,28 & 13,05 & 11,02 & 9,13 & 7,66 & 6,47 & 4,72 & 3,61 & 2,39 \\
\hline 55 & 1000 & 175 & 17,82 & 12,84 & 10,90 & 9,06 & 7,63 & 6,46 & 4,73 & 3,62 & 2,39 \\
\hline 55 & 1050 & 175 & 17,41 & 12,65 & 10,78 & 9,00 & 7,60 & 6,45 & 4,74 & 3,63 & 2,40 \\
\hline 55 & 1100 & 175 & 17,02 & 12,48 & 10,67 & 8,94 & 7,57 & 6,44 & 4,74 & 3,64 & 2,40 \\
\hline 55 & 1150 & 175 & 16,67 & 12,31 & 10,57 & 8,88 & 7,54 & 6,43 & 4,75 & 3,65 & 2,40 \\
\hline 55 & 1200 & 175 & 16,33 & 12,15 & 10,47 & 8,83 & 7,51 & 6,41 & 4,76 & 3,65 & 2,41 \\
\hline 55 & 1250 & 175 & 16,03 & 12,00 & 10,37 & 8,77 & 7,48 & 6,40 & 4,76 & 3,66 & 2,41 \\
\hline 55 & 1300 & 175 & 15,74 & 11,86 & 10,28 & 8,72 & 7,46 & 6,39 & 4,76 & 3,67 & 2,42 \\
\hline 55 & 1350 & 175 & 15,46 & 11,72 & 10,19 & 8,67 & 7,43 & 6,38 & 4,77 & 3,68 & 2,42 \\
\hline 55 & 1400 & 175 & 15,21 & 11,59 & 10,11 & 8,62 & 7,40 & 6,37 & 4,77 & 3,68 & 2,43 \\
\hline 55 & 1450 & 175 & 14,97 & 11,47 & 10,03 & 8,57 & 7,37 & 6,35 & 4,77 & 3,69 & 2,43 \\
\hline 55 & 1500 & 175 & 14,74 & 11,35 & 9,95 & 8,52 & 7,35 & 6,34 & 4,77 & 3,69 & 2,44 \\
\hline 55 & 1550 & 175 & 14,53 & 11,24 & 9,87 & 8,48 & 7,32 & 6,33 & 4,77 & 3,70 & 2,44 \\
\hline 55 & 1600 & 175 & 14,32 & 11,13 & 9,80 & 8,43 & 7,29 & 6,31 & 4,78 & 3,71 & 2,44 \\
\hline 55 & 1650 & 175 & 14,13 & 11,02 & 9,73 & 8,39 & 7,27 & 6,30 & 4,78 & 3,71 & 2,45 \\
\hline 55 & 1700 & 175 & 13,95 & 10,92 & 9,66 & 8,35 & 7,24 & 6,29 & 4,78 & 3,72 & 2,45 \\
\hline 55 & 1750 & 175 & 13,77 & 10,83 & 9,59 & 8,30 & 7,22 & 6,27 & 4,78 & 3,72 & 2,46 \\
\hline 55 & 1800 & 175 & 13,61 & 10,73 & 9,53 & 8,26 & 7,19 & 6,26 & 4,78 & 3,72 & 2,46 \\
\hline 55 & 1850 & 175 & 13,45 & 10,64 & 9,46 & 8,22 & 7,17 & 6,25 & 4,78 & 3,73 & 2,46 \\
\hline 55 & 1900 & 175 & 13,30 & 10,55 & 9,40 & 8,18 & 7,14 & 6,23 & 4,77 & 3,73 & 2,47 \\
\hline 55 & 1950 & 175 & 13,15 & 10,47 & 9,34 & 8,14 & 7,12 & 6,22 & 4,77 & 3,74 & 2,47 \\
\hline 55 & 2000 & 175 & 13,01 & 10,39 & 9,28 & 8,11 & 7,09 & 6,21 & 4,77 & 3,74 & 2,48 \\
\hline 55 & 200 & 180 & 44,83 & 21,52 & 14,66 & 10,12 & 7,68 & 6,11 & 4,23 & 3,26 & 2,30 \\
\hline 55 & 250 & 180 & 38,57 & 19,75 & 14,02 & 10,02 & 7,72 & 6,18 & 4,28 & 3,29 & 2,29 \\
\hline 55 & 300 & 180 & 3430 & 1850 & 1354 & 992 & 773 & 6.22 & 4.33 & 3.31 & 229 \\
\hline 55 & 350 & 180 & 31,18 & 17,54 & 13,14 & 9,82 & 7,73 & 6,26 & 4,37 & 3,33 & 2,28 \\
\hline 55 & 400 & 180 & 28,78 & 16,77 & 12,81 & 9,73 & 7,73 & 6,28 & 4,40 & 3,35 & 2,28 \\
\hline 55 & 450 & 180 & 26,86 & 16,14 & 12,53 & 9,64 & 7,71 & 6,30 & 4,43 & 3,37 & 2,29 \\
\hline
\end{tabular}




\begin{tabular}{|c|c|c|c|c|c|c|c|c|c|c|c|}
\hline & & & \multicolumn{9}{|c|}{ Deflexões $\left(\times 10^{-4} \mathrm{~cm}\right)$} \\
\hline $\mathrm{H}(\mathrm{cm})$ & Mceq (MPa) & Msub (MPa) & D0 & D25 & D40 & D60 & $\mathrm{D} 80$ & D100 & D140 & D180 & D260 \\
\hline 55 & 500 & 180 & 25,30 & 15,60 & 12,28 & 9,55 & 7,69 & 6,31 & 4,45 & 3,38 & 2,29 \\
\hline 55 & 550 & 180 & 23,99 & 15,14 & 12,05 & 9,47 & 7,67 & 6,32 & 4,48 & 3,40 & 2,29 \\
\hline 55 & 600 & 180 & 22,87 & 14,73 & 11,85 & 9,39 & 7,65 & 6,32 & 4,50 & 3,42 & 2,29 \\
\hline 55 & 650 & 180 & 21,90 & 14,37 & 11,66 & 9,31 & 7,63 & 6,32 & 4,51 & 3,43 & 2,30 \\
\hline 55 & 700 & 180 & 21,06 & 14,04 & 11,49 & 9,24 & 7,60 & 6,32 & 4,53 & 3,44 & 2,30 \\
\hline 55 & 750 & 180 & 20,32 & 13,75 & 11,33 & 9,17 & 7,57 & 6,32 & 4,54 & 3,46 & 2,30 \\
\hline 55 & 800 & 180 & 19,65 & 13,48 & 11,18 & 9,10 & 7,55 & 6,31 & 4,56 & 3,47 & 2,31 \\
\hline 55 & 850 & 180 & 19,05 & 13,23 & 11,04 & 9,03 & 7,52 & 6,31 & 4,57 & 3,48 & 2,31 \\
\hline 55 & 900 & 180 & 18,51 & 13,00 & 10,90 & 8,97 & 7,49 & 6,30 & 4,58 & 3,49 & 2,31 \\
\hline 55 & 950 & 180 & 18,02 & 12,79 & 10,78 & 8,91 & 7,46 & 6,29 & 4,59 & 3,50 & 2,32 \\
\hline 55 & 1000 & 180 & 17,57 & 12,59 & 10,66 & 8,84 & 7,43 & 6,28 & 4,60 & 3,51 & 2,32 \\
\hline 55 & 1050 & 180 & 17,16 & 12,41 & 10,55 & 8,79 & 7,41 & 6,28 & 4,60 & 3,52 & 2,33 \\
\hline 55 & 1100 & 180 & 16.78 & 12,23 & 10,44 & 8,73 & 7,38 & 6.27 & 4.61 & 3,53 & 2,33 \\
\hline 55 & 1150 & 180 & 16,42 & 12,07 & 10,34 & 8,67 & 7,35 & 6,26 & 4,62 & 3,54 & 2,33 \\
\hline 55 & 1200 & 180 & 16,09 & 11,92 & 10,24 & 8,62 & 7,32 & 6,24 & 4,62 & 3,55 & 2,34 \\
\hline 55 & 1250 & 180 & 15,79 & 11,77 & 10,15 & 8,57 & 7,30 & 6,23 & 4,62 & 3,55 & 2,34 \\
\hline 55 & 1300 & 180 & 15,50 & 11,63 & 10,06 & 8,52 & 7,27 & 6,22 & 4,63 & 3,56 & 2,35 \\
\hline 55 & 1350 & 180 & 15,23 & 11,50 & 9,97 & 8,47 & 7,24 & 6,21 & 4,63 & 3,57 & 2,35 \\
\hline 55 & 1400 & 180 & 14,98 & 11,37 & 9,89 & 8,42 & 7,22 & 6,20 & 4,63 & 3,57 & 2,36 \\
\hline 55 & 1450 & 180 & 14,74 & 11,25 & 9,81 & 8,37 & 7,19 & 6,19 & 4,64 & 3,58 & 2,36 \\
\hline 55 & 1500 & 180 & 14,52 & 11,13 & 9,73 & 8,33 & 7,16 & 6,17 & 4,64 & 3,59 & 2,36 \\
\hline 55 & 1550 & 180 & 14,30 & 11,02 & 9,66 & 8,28 & 7,14 & 6,16 & 4,64 & 3,59 & 2,37 \\
\hline 55 & 1600 & 180 & 14,10 & 10,91 & 9,59 & 8,24 & 7,11 & 6,15 & 4,64 & 3,60 & 2,37 \\
\hline 55 & 1650 & 180 & 13,91 & 10,81 & 9,52 & 8,19 & 7,09 & 6,14 & 4,64 & 3,60 & 2,38 \\
\hline 55 & 1700 & 180 & 13,73 & 10,71 & 9,45 & 8,15 & 7,06 & 6,12 & 4,64 & 3,61 & 2,38 \\
\hline 55 & 1750 & 180 & 13,56 & 10,62 & 9,39 & 8,11 & 7,04 & 6,11 & 4,64 & 3,61 & 2,38 \\
\hline 55 & 1800 & 180 & 13,39 & 10,53 & 9,32 & 8,07 & 7,02 & 6,10 & 4,64 & 3,62 & 2,39 \\
\hline 55 & 1850 & 180 & 13,23 & 10,44 & 9,26 & 8,03 & 6,99 & 6,09 & 4,64 & 3,62 & 2,39 \\
\hline 55 & 1900 & 180 & 13,08 & 10,35 & 9,20 & 8,00 & 6,97 & 6,07 & 4,64 & 3,62 & 2,40 \\
\hline 55 & 1950 & 180 & 12,94 & 10,27 & 9,15 & 7,96 & 6,95 & 6,06 & 4,64 & 3,63 & 2,40 \\
\hline 55 & 2000 & 180 & 12,80 & 10,19 & 9,09 & 7,92 & 6,92 & 6,05 & 4,64 & 3,63 & 2,40 \\
\hline 55 & 200 & 185 & 44,45 & 21,17 & 14,34 & 9,86 & 7,46 & 5,94 & 4,11 & 3,17 & 2,23 \\
\hline 55 & 250 & 185 & 38,21 & 19,42 & 13,72 & 9,76 & 7,50 & 6,00 & 4,16 & 3,19 & 2,23 \\
\hline 55 & 300 & 185 & 33,96 & 18,17 & 13,24 & 9,67 & 7,52 & 6,05 & 4,21 & 3,22 & 2,22 \\
\hline 55 & 350 & 185 & 30,85 & 17,22 & 12,86 & 9,58 & 7,52 & 6,08 & 4,24 & 3,24 & 2,22 \\
\hline 55 & 400 & 185 & 28,46 & 16,46 & 12,53 & 9,49 & 7,52 & 6,11 & 4,27 & 3,25 & 2,22 \\
\hline 55 & 450 & 185 & 26,55 & 15,84 & 12,25 & 9,40 & 7,51 & 6,12 & 4,30 & 3,27 & 2,22 \\
\hline 55 & 500 & 185 & 25,00 & 15,31 & 12,01 & 9,32 & 7,49 & 6,14 & 4,33 & 3,29 & 2,22 \\
\hline 55 & 550 & 185 & 23,69 & 14,86 & 11,79 & 9,24 & 7,47 & 6,14 & 4,35 & 3,30 & 2,23 \\
\hline 55 & 600 & 185 & 22,59 & 14,45 & 11,59 & 9,16 & 7,45 & 6,15 & 4,37 & 3,32 & 2,23 \\
\hline 55 & 650 & 185 & 21,63 & 14,10 & 11,41 & 9,09 & 7,43 & 6,15 & 4,39 & 3,33 & 2,23 \\
\hline 55 & 700 & 185 & 20,79 & 13,78 & 11,24 & 9,02 & 7,40 & 6,15 & 4,40 & 3,35 & 2,24 \\
\hline 55 & 750 & 185 & 20,05 & 13,49 & 11,08 & 8,95 & 7,38 & 6,15 & 4,42 & 3,36 & 2,24 \\
\hline 55 & 800 & 185 & 19,39 & 13,23 & 10,94 & 8,88 & 7,35 & 6,15 & 4,43 & 3,37 & 2,24 \\
\hline 55 & 850 & 185 & 18,80 & 12,98 & 10,80 & 8,82 & 7,33 & 6,14 & 4,44 & 3,38 & 2,25 \\
\hline 55 & 900 & 185 & 18,26 & 12,76 & 10,67 & 8,76 & 7,30 & 6,13 & 4,45 & 3,39 & 2,25 \\
\hline 55 & 950 & 185 & 17,77 & 12,55 & 10,55 & 8,70 & 7,27 & 6,13 & 4,46 & 3,40 & 2,25 \\
\hline 55 & 1000 & 185 & 17,33 & 12,36 & 10,43 & 8,64 & 7,25 & 6,12 & 4,47 & 3,41 & 2,26 \\
\hline 55 & 1050 & 185 & 16,92 & 12,17 & 10,33 & 8,58 & 7,22 & 6,11 & 4,47 & 3,42 & 2,26 \\
\hline 55 & 1100 & 185 & 16,54 & 12,00 & 10,22 & 8,53 & 7,19 & 6,10 & 4,48 & 3,43 & 2,27 \\
\hline 55 & 1150 & 185 & 16,19 & 11,84 & 10,12 & 8,47 & 7,17 & 6,09 & 4,49 & 3,44 & 2,27 \\
\hline 55 & 1200 & 185 & 15,86 & 11,69 & 10,03 & 8,42 & 7,14 & 6,08 & 4,49 & 3,45 & 2,27 \\
\hline 55 & 1250 & 185 & 15,56 & 11,55 & 9,94 & 8,37 & 7,12 & 6,07 & 4,50 & 3,45 & 2,28 \\
\hline 55 & 1300 & 185 & 15,28 & 11,41 & 9,85 & 8,32 & 7,09 & 6,06 & 4,50 & 3,46 & 2,28 \\
\hline 55 & 1350 & 185 & 15,01 & 11,28 & 9,77 & 8,27 & 7,06 & 6,05 & 4,50 & 3,47 & 2,29 \\
\hline 55 & 1400 & 185 & 14,76 & 11,15 & 9,68 & 8,23 & 7,04 & 6,04 & 4,51 & 3,47 & 2,29 \\
\hline 55 & 1450 & 185 & 14,52 & 11,04 & 9,61 & 8,18 & 7,01 & 6,03 & 4,51 & 3,48 & 2,29 \\
\hline 55 & 1500 & 185 & 14,30 & 10,92 & 9,53 & 8,14 & 6,99 & 6,02 & 4,51 & 3,49 & 2,30 \\
\hline 55 & 1550 & 185 & 14,09 & 10,81 & 9,46 & 8,09 & 6,97 & 6,01 & 4,51 & 3,49 & 2,30 \\
\hline 55 & 1600 & 185 & 13,89 & 10,71 & 9,39 & 8,05 & 6,94 & 5,99 & 4,52 & 3,50 & 2,30 \\
\hline 55 & 1650 & 185 & 13,70 & 10,61 & 9,32 & 8,01 & 6,92 & 5,98 & 4,52 & 3,50 & 2,31 \\
\hline 55 & 1700 & 185 & 13,52 & 10,51 & 9,26 & 7,97 & 6,89 & 5,97 & 4,52 & 3,51 & 2,31 \\
\hline 55 & 1750 & 185 & 13,35 & 10,42 & 9,19 & 7,93 & 6,87 & 5,96 & 4,52 & 3,51 & 2,32 \\
\hline 55 & 1800 & 185 & 13,19 & 10,33 & 9,13 & 7,89 & 6,85 & 5,95 & 4,52 & 3,51 & 2,32 \\
\hline 55 & 1850 & 185 & 13,03 & 10,24 & 9,07 & 7,85 & 6,83 & 5,93 & 4,52 & 3,52 & 2,32 \\
\hline 55 & 1900 & 185 & 12,88 & 10,16 & 9,01 & 7,82 & 6,80 & 5,92 & 4,52 & 3,52 & 2,33 \\
\hline 55 & 1950 & 185 & 12,74 & 10,08 & 8,96 & 7,78 & 6,78 & 5,91 & 4,52 & 3,53 & 2,33 \\
\hline 55 & 2000 & 185 & 12,60 & 10,00 & 8,90 & 7,75 & 6,76 & 5,90 & 4,52 & 3,53 & 2,33 \\
\hline 55 & 200 & 190 & 44,09 & 20,84 & 14,04 & 9,61 & 7,26 & 5,77 & 3,99 & 3,08 & 2,18 \\
\hline 55 & 250 & 190 & 37,87 & 19,10 & 13,42 & 9,52 & 7,30 & 5,84 & 4,05 & 3,11 & 2,17 \\
\hline 55 & 300 & 190 & 33,63 & 17,86 & 12,96 & 9,43 & 7,32 & 5,88 & 4,09 & 3,13 & 2,17 \\
\hline 55 & 350 & 190 & 30,53 & 16,92 & 12,58 & 9,34 & 7,33 & 5,92 & 4,12 & 3,15 & 2,16 \\
\hline 55 & 400 & 190 & 28,15 & 16,17 & 12,27 & 9,25 & 7,32 & 5,94 & 4,16 & 3,17 & 2,16 \\
\hline 55 & 450 & 190 & 26,26 & 15,56 & 11,99 & 9,17 & 7,31 & 5,96 & 4,18 & 3,18 & 2,16 \\
\hline 55 & 500 & 190 & 24,71 & 15,04 & $\begin{array}{l}1+1,00 \\
11,75\end{array}$ & 9,09 & 7,30 & 5,97 & 4,21 & 3,20 & 2,17 \\
\hline 55 & 550 & 190 & 23,42 & 14,59 & 11,54 & 9,02 & 7,28 & 5,98 & 4,23 & 3,21 & 2,17 \\
\hline 55 & 600 & 190 & 22,31 & 14,19 & 11,34 & 8,94 & 7,26 & 5,99 & 4,25 & 3,23 & 2,17 \\
\hline 55 & 650 & 190 & 21,36 & 13,84 & 11,17 & 8,87 & 7,24 & 5,99 & 4,26 & 3,24 & 2,17 \\
\hline 55 & 700 & 190 & 20,53 & 13,53 & 11,00 & 8,81 & 7,22 & 5,99 & 4,28 & 3,25 & 2,18 \\
\hline 55 & 750 & 190 & 19,80 & 13,24 & 10,85 & 8,74 & 7.19 & 5,99 & 4,29 & 3,26 & 2.18 \\
\hline 55 & 800 & 190 & 19,14 & 12,98 & 10,71 & 8,68 & 7,17 & 5,99 & 4,31 & 3,28 & 2,18 \\
\hline
\end{tabular}




\begin{tabular}{|c|c|c|c|c|c|c|c|c|c|c|c|}
\hline & & & \multicolumn{9}{|c|}{ Deflexões $\left(\times 10^{-4} \mathrm{~cm}\right)$} \\
\hline $\mathrm{H}(\mathrm{cm})$ & Mceq (MPa) & Msub (MPa) & D0 & D25 & D40 & D60 & D80 & D100 & D140 & D180 & D260 \\
\hline 55 & 850 & 190 & 18,55 & 12,74 & 10,57 & 8,61 & 7,15 & 5,98 & 4,32 & 3,29 & 2,18 \\
\hline 55 & 900 & 190 & 18,02 & 12,52 & 10,45 & 8,55 & 7,12 & 5,98 & 4,33 & 3,30 & 2,19 \\
\hline 55 & 950 & 190 & 17,54 & 12,32 & 10,33 & 8,50 & 7,10 & 5,97 & 4,34 & 3,31 & 2,19 \\
\hline 55 & 1000 & 190 & 17,10 & 12,13 & 10,22 & 8,44 & 7,07 & 5,96 & 4,35 & 3,32 & 2,20 \\
\hline 55 & 1050 & 190 & 16,69 & 11,95 & 10,11 & 8,39 & 7,04 & 5,95 & 4,35 & 3,33 & 2,20 \\
\hline 55 & 1100 & 190 & 16,31 & 11,78 & 10,01 & 8,33 & 7,02 & 5,95 & 4,36 & 3,33 & 2,20 \\
\hline 55 & 1150 & 190 & 15,97 & 11,62 & 9,91 & 8,28 & 6,99 & 5,94 & 4,37 & 3,34 & 2,21 \\
\hline 55 & 1200 & 190 & 15,64 & 11,48 & 9,82 & 8,23 & 6,97 & 5,93 & 4,37 & 3,35 & 2,21 \\
\hline 55 & 1250 & 190 & 15,34 & 11,33 & 9,73 & 8,18 & 6,95 & 5,92 & 4,38 & 3,36 & 2,21 \\
\hline 55 & 1300 & 190 & 15,06 & 11,20 & 9,65 & 8,13 & 6,92 & 5,91 & 4,38 & 3,36 & 2,22 \\
\hline 55 & 1350 & 190 & 14,80 & 11,07 & 9,57 & 8,09 & 6,90 & 5,90 & 4,38 & 3,37 & 2,22 \\
\hline 55 & 1400 & 190 & 14,55 & 10,95 & 9,49 & 8,04 & 6,87 & 5,89 & 4,39 & 3,38 & 2,23 \\
\hline 55 & 1450 & 190 & 14,31 & 10,83 & 9,41 & 8,00 & 6,85 & 5,88 & 4,39 & 3,38 & 2,23 \\
\hline 55 & 1500 & 190 & 14,09 & 10,72 & 9,34 & 7,96 & 6,82 & 5,87 & 4,39 & 3,39 & 2,23 \\
\hline 55 & 1550 & 190 & 13,89 & 10,61 & 9,27 & 7,91 & 6,80 & 5,86 & 4,39 & 3,39 & 2,24 \\
\hline 55 & 1600 & 190 & 13,69 & 10,51 & 9,20 & 7,87 & 6,78 & 5,85 & 4,40 & 3,40 & 2,24 \\
\hline 55 & 1650 & 190 & 13,50 & 10,41 & 9,13 & 7,83 & 6,76 & 5,83 & 4,40 & 3,40 & 2,24 \\
\hline 55 & 1700 & 190 & 13,32 & 10,32 & 9,07 & 7,80 & 6,73 & 5,82 & 4,40 & 3,41 & 2,25 \\
\hline 55 & 1750 & 190 & 13,15 & 10,23 & 9,01 & 7,76 & 6,71 & 5,81 & 4,40 & 3,41 & 2,25 \\
\hline 55 & 1800 & 190 & 12,99 & 10,14 & 8,95 & 7,72 & 6,69 & 5,80 & 4,40 & 3,42 & 2,26 \\
\hline 55 & 1850 & 190 & 12,83 & 10,05 & 8,89 & 7,68 & 6,67 & 5,79 & 4,40 & 3,42 & 2,26 \\
\hline 55 & 1900 & 190 & 12,69 & 9,97 & 8,83 & 7,65 & 6,65 & 5,78 & 4,40 & 3,43 & 2,26 \\
\hline 55 & 1950 & 190 & 12,54 & 9,89 & 8,78 & 7,61 & 6,62 & 5,77 & 4,40 & 3,43 & 2,27 \\
\hline 55 & 2000 & 190 & 12,41 & 9,81 & 8,72 & 7,58 & 6,60 & 5,76 & 4,40 & 3,43 & 2,27 \\
\hline 55 & 200 & 195 & 43,75 & 20,52 & 13,76 & 9,37 & 7,07 & 5,62 & 3,88 & 3,00 & 2,12 \\
\hline 55 & 250 & 195 & 37,55 & 18,79 & 13,15 & 9,29 & 7,11 & 5,68 & 3,94 & 3,03 & 2,11 \\
\hline 55 & 300 & 195 & 33,32 & 17,57 & 12,69 & 9,20 & 7,13 & 5,73 & 3,98 & 3,05 & 2,11 \\
\hline 55 & 350 & 195 & 30,23 & 16,64 & 12,32 & 9,12 & 7,14 & 5,76 & 4,01 & 3,06 & 2,11 \\
\hline 55 & 400 & 195 & 27,86 & 15,90 & 12,01 & 9,03 & 7,14 & 5,79 & 4,04 & 3,08 & 2,11 \\
\hline 55 & 450 & 195 & 25,98 & 15,29 & 11,74 & 8,96 & 7,13 & 5,80 & 4,07 & 3,10 & 2,11 \\
\hline 55 & 500 & 195 & 24,44 & 14,77 & 11,51 & 8,88 & 7,11 & 5,82 & 4,09 & 3,11 & 2,11 \\
\hline 55 & 550 & 195 & 23,15 & 14,33 & 11,30 & 8,81 & 7,10 & 5,83 & 4,11 & 3,13 & 2,11 \\
\hline 55 & 600 & 195 & 22,06 & 13,94 & 11,11 & 8,74 & 7,08 & 5,83 & 4,13 & 3,14 & 2,11 \\
\hline 55 & 650 & 195 & 21,11 & 13,60 & 10,94 & 8,67 & 7,06 & 5,83 & 4,15 & 3,15 & 2,12 \\
\hline 55 & 700 & 195 & 20,28 & 13,29 & 10,78 & 8,60 & 7,04 & 5,84 & 4,17 & 3,17 & 2,12 \\
\hline 55 & 750 & 195 & 19,55 & 13,01 & 10,63 & 8,54 & 7,02 & 5,84 & 4,18 & 3,18 & 2,12 \\
\hline 55 & 800 & 195 & 18,90 & 12,75 & 10,49 & 8,48 & 7,00 & 5,83 & 4,19 & 3,19 & 2,12 \\
\hline 55 & 850 & 195 & 18,32 & 12,52 & 10,36 & 8,42 & 6,97 & 5,83 & 4,20 & 3,20 & 2,13 \\
\hline 55 & 900 & 195 & 17,79 & 12,30 & 10,24 & 8,36 & 6,95 & 5,83 & 4,21 & 3,21 & 2,13 \\
\hline 55 & 950 & 195 & 17,31 & 12,10 & 10,12 & 8,31 & 6,93 & 5,82 & 4,22 & 3,22 & 2,13 \\
\hline 55 & 1000 & 195 & 16,87 & 11,91 & 10,01 & 8,25 & 6,90 & 5,81 & 4,23 & 3,23 & 2,14 \\
\hline 55 & 1050 & 195 & 16,47 & 11,74 & 9,91 & 8,20 & 6,88 & 5,81 & 4,24 & 3,24 & 2,14 \\
\hline 55 & 1100 & 195 & 16,10 & 11,57 & 9,81 & 8,15 & 6,85 & 5,80 & 4,24 & 3,24 & 2,14 \\
\hline 55 & 1150 & 195 & 15,75 & 11,42 & 9,71 & 8,10 & 6,83 & 5,79 & 4,25 & 3,25 & 2,15 \\
\hline 55 & 1200 & 195 & 15,43 & 11,27 & 9,62 & 8,05 & 6,81 & 5,78 & 4,26 & 3,26 & 2,15 \\
\hline 55 & 1250 & 195 & 15,13 & 11,13 & 9,54 & 8,00 & 6,78 & 5,77 & 4,26 & 3,27 & 2,16 \\
\hline 55 & 1300 & 195 & 14,86 & 11,00 & 9,46 & 7,96 & 6,76 & 5,76 & 4,26 & 3,27 & 2,16 \\
\hline 55 & 1350 & 195 & 14,59 & 10,87 & 9,38 & 7,91 & 6,74 & 5,75 & 4,27 & 3,28 & 2,16 \\
\hline 55 & 1400 & 195 & 14,35 & 10,75 & 9,30 & 7,87 & 6,71 & 5,74 & 4,27 & 3,29 & 2,17 \\
\hline 55 & 1450 & 195 & 14,12 & 10,64 & 9,22 & 7,83 & 6,69 & 5,73 & 4,27 & 3,29 & 2,17 \\
\hline 55 & 1500 & 195 & 13,90 & 10,53 & 9,15 & 7,78 & 6,67 & 5,72 & 4,28 & 3,30 & 2,17 \\
\hline 55 & 1550 & 195 & 13,69 & 10,42 & 9,09 & 7,74 & 6,65 & 5,71 & 4,28 & 3,30 & 2,18 \\
\hline 55 & 1600 & 195 & 13,49 & 10,32 & 9,02 & 7,70 & 6,62 & 5,70 & 4,28 & 3,31 & 2,18 \\
\hline 55 & 1650 & 195 & 13,31 & 10,23 & 8,95 & 7,67 & 6,60 & 5,69 & 4,28 & 3,31 & 2,18 \\
\hline 55 & 1700 & 195 & 13,13 & 10,13 & 8,89 & 7,63 & 6,58 & 5,68 & 4,28 & 3,32 & 2,19 \\
\hline 55 & 1750 & 195 & 12,96 & 10,04 & 8,83 & 7,59 & 6,56 & 5,67 & 4,28 & 3,32 & 2,19 \\
\hline 55 & 1800 & 195 & 12,80 & 9,96 & 8,77 & 7,56 & 6,54 & 5,66 & 4,29 & 3,33 & 2,19 \\
\hline 55 & 1850 & 195 & 12,65 & 9,87 & 8,72 & 7,52 & 6,52 & 5,65 & 4,29 & 3,33 & 2,20 \\
\hline 55 & 1900 & 195 & 12,50 & 9,79 & 8,66 & 7,49 & 6,50 & 5,64 & 4,29 & 3,33 & 2,20 \\
\hline 55 & 1950 & 195 & 12,36 & 9,72 & 8,61 & 7,45 & 6,48 & 5,63 & 4,29 & 3,34 & 2,20 \\
\hline 55 & 2000 & 195 & 12,23 & 9,64 & 8,55 & 7,42 & 6,46 & 5,62 & 4,29 & 3,34 & 2,21 \\
\hline 55 & 200 & 200 & 43,42 & 20,21 & 13,48 & 9,15 & 6,89 & 5,47 & 3,78 & 2,92 & 2,07 \\
\hline 55 & 250 & 200 & 37,23 & 18,50 & 12,88 & 9,06 & 6,93 & 5,53 & 3,83 & 2,95 & 2,06 \\
\hline 55 & 300 & 200 & 33,02 & 17,28 & 12,43 & 8,98 & 6,95 & 5,58 & 3,87 & 2,97 & 2,06 \\
\hline 55 & 350 & 200 & 29,94 & 16,36 & 12,07 & 8,90 & 6,96 & 5,61 & 3,91 & 2,98 & 2,06 \\
\hline 55 & 400 & 200 & 27,58 & 15,63 & 11,77 & 8,82 & 6,96 & 5,64 & 3,94 & 3,00 & 2,06 \\
\hline 55 & 450 & 200 & 25,71 & 15,03 & 11,51 & 8,75 & 6,95 & 5,65 & 3,96 & 3,02 & 2,06 \\
\hline 55 & 500 & 200 & 24,18 & 14,52 & 11,28 & 8,68 & 6,94 & 5,67 & 3,99 & 3,03 & 2,06 \\
\hline 55 & 550 & 200 & 22,90 & 14,08 & 11,07 & 8,61 & 6,93 & 5,68 & 4,01 & 3,04 & 2,06 \\
\hline 55 & 600 & 200 & 21,81 & 13,70 & 10,89 & 8,54 & 6,91 & 5,68 & 4,02 & 3,06 & 2,06 \\
\hline 55 & 650 & 200 & 20,87 & 13,36 & 10,72 & 8,47 & 6,89 & 5,69 & 4,04 & 3,07 & 2,06 \\
\hline 55 & 700 & 200 & 20,05 & 13,06 & 10,56 & 8,41 & 6,87 & 5,69 & 4,06 & 3,08 & 2,06 \\
\hline 55 & 750 & 200 & 19,32 & 12,78 & 10,41 & 8,35 & 6,85 & 5,69 & 4,07 & 3,09 & 2,07 \\
\hline 55 & 800 & 200 & 18,68 & 12,53 & 10,28 & 8,29 & 6,83 & 5,69 & 4,08 & 3,10 & 2,07 \\
\hline 55 & 850 & 200 & 18,10 & 12,30 & 10,15 & 8,23 & 6,81 & 5,69 & 4,09 & 3,11 & 2,07 \\
\hline 55 & 900 & 200 & 17,57 & 12,09 & 10,03 & 8,18 & 6,79 & 5,68 & 4,10 & 3,12 & 2,08 \\
\hline 55 & 950 & 200 & 17,10 & 11,89 & 9,92 & 8,12 & 6,76 & 5,68 & 4,11 & 3,13 & 2,08 \\
\hline 55 & 1000 & 200 & 16,66 & 11,70 & 9,81 & 8,07 & 6,74 & 5,67 & 4,12 & 3,14 & 2,08 \\
\hline 55 & 1050 & 200 & 16,26 & 11,53 & 9,71 & 8,02 & 6,72 & 5,66 & 4,13 & 3,15 & 2,09 \\
\hline 55 & 1100 & 200 & 15,89 & 11,37 & 9,62 & 7,97 & 6,70 & 5,66 & 4,13 & 3,16 & 2,09 \\
\hline 55 & 1150 & 200 & 15,55 & 11,22 & 9,52 & 7,92 & 6,67 & 5,65 & 4,14 & 3,17 & 2,09 \\
\hline
\end{tabular}




\begin{tabular}{|c|c|c|c|c|c|c|c|c|c|c|c|}
\hline \multirow[b]{2}{*}{$\mathrm{H}(\mathrm{cm})$} & \multirow[b]{2}{*}{ Mceq (MPa) } & & & & & De & ões (x1 & m) & & & \\
\hline & & Msub (MPa) & D0 & D25 & D40 & D60 & D80 & D100 & D140 & D180 & D260 \\
\hline 55 & 1200 & 200 & 15,23 & 11,07 & 9,44 & 7,88 & 6,65 & 5,64 & 4,15 & 3,17 & 2,10 \\
\hline 55 & 1250 & 200 & 14,94 & 10,94 & 9,35 & 7,83 & 6,63 & 5,63 & 4,15 & 3,18 & 2,10 \\
\hline 55 & 1300 & 200 & 14,66 & 10,81 & 9,27 & 7,79 & 6,60 & 5,63 & 4,16 & 3,19 & 2,10 \\
\hline 55 & 1350 & 200 & 14,40 & 10,68 & 9,19 & 7,74 & 6,58 & 5,62 & 4,16 & 3,19 & 2,11 \\
\hline 55 & 1400 & 200 & 14,15 & 10,57 & 9,12 & 7,70 & 6,56 & 5,61 & 4,16 & 3,20 & 2,11 \\
\hline 55 & 1450 & 200 & 13,93 & 10,45 & 9,05 & 7,66 & 6,54 & 5,60 & 4,17 & 3,21 & 2,11 \\
\hline 55 & 1500 & 200 & 13,71 & 10,35 & 8,98 & 7,62 & 6,52 & 5,59 & 4,17 & 3,21 & 2,12 \\
\hline 55 & 1550 & 200 & 13,50 & 10,24 & 8,91 & 7,58 & 6,50 & 5,58 & 4,17 & 3,22 & 2,12 \\
\hline 55 & 1600 & 200 & 13,31 & 10,14 & 8,84 & 7,54 & 6,47 & 5,57 & 4,17 & 3,22 & 2,12 \\
\hline 55 & 1650 & 200 & 13,12 & 10,05 & 8,78 & 7,51 & 6,45 & 5,56 & 4,17 & 3,23 & 2,13 \\
\hline 55 & 1700 & 200 & 12,95 & 9,96 & 8,72 & 7,47 & 6,43 & 5,55 & 4,18 & 3,23 & 2,13 \\
\hline 55 & 1750 & 200 & 12,78 & 9,87 & 8,66 & 7,43 & 6,41 & 5,54 & 4,18 & 3,24 & 2,13 \\
\hline 55 & 1800 & 200 & 12,62 & 9,79 & 8,60 & 7,40 & 6,39 & 5,53 & 4,18 & 3,24 & 2,14 \\
\hline 55 & 1850 & 200 & 12,47 & 9,70 & 8,55 & 7,36 & 6,37 & 5,52 & 4,18 & 3,24 & 2,14 \\
\hline 55 & 1900 & 200 & 12,32 & 9,62 & 8,50 & 7,33 & 6,35 & 5,51 & 4,18 & 3,25 & 2,14 \\
\hline 55 & 1950 & 200 & 12,19 & 9,55 & 8,44 & 7,30 & 6,33 & 5,50 & 4,18 & 3,25 & 2,15 \\
\hline 55 & 2000 & 200 & 12,05 & 9,47 & 8,39 & 7,27 & 6,31 & 5,49 & 4,18 & 3,26 & 2,15 \\
\hline 60 & 200 & 20 & 114,87 & 89,03 & 79,17 & 69,16 & 60,76 & 53,40 & 41,42 & 32,70 & 21,82 \\
\hline 60 & 250 & 20 & 104,39 & 82,77 & 74,73 & 66,17 & 58,79 & 52,19 & 41,17 & 32,86 & 22,11 \\
\hline 60 & 300 & 20 & 96,95 & 77,94 & 71,20 & 63,68 & 57,07 & 51,07 & 40,84 & 32,92 & 22,35 \\
\hline 60 & 350 & 20 & 91,33 & 74,05 & 68,28 & 61,56 & 55,56 & 50,04 & 40,47 & 32,91 & 22,54 \\
\hline 60 & 400 & 20 & 86,90 & 70,82 & 65,80 & 59,73 & 54,21 & 49,09 & 40,09 & 32,85 & 22,70 \\
\hline 60 & 450 & 20 & 83,30 & 68,07 & 63,65 & 58,11 & 53,00 & 48,21 & 39,71 & 32,76 & 22,83 \\
\hline 60 & 500 & 20 & 80,29 & 65,70 & 61,76 & 56,67 & 51,90 & 47,40 & 39,33 & 32,65 & 22,93 \\
\hline 60 & 550 & 20 & 77,72 & 63,63 & 60,08 & 55,37 & 50,89 & 46,65 & 38,96 & 32,52 & 23,01 \\
\hline 60 & 600 & 20 & 75,49 & 61,79 & 58,56 & 54,19 & 49,97 & 45,94 & 38,60 & 32,38 & 23,08 \\
\hline 60 & 650 & 20 & 73,53 & 60,15 & 57,19 & 53,11 & 49,11 & 45,28 & 38,25 & 32,24 & 23,13 \\
\hline 60 & 700 & 20 & 71,78 & 58,68 & 55,94 & 52,12 & 48,32 & 44,67 & 37,91 & 32,09 & 23,17 \\
\hline 60 & 750 & 20 & 70,21 & 57,34 & 54,78 & 51,21 & 47,58 & 44,08 & 37,58 & 31,93 & 23,19 \\
\hline 60 & 800 & 20 & 68,78 & 56,13 & 53,72 & 50,35 & 46,89 & 43,54 & 37,26 & 31,78 & 23,21 \\
\hline 60 & 850 & 20 & 67,47 & 55,01 & 52,73 & 49,56 & 46,24 & 43,02 & 36,96 & 31,63 & 23,22 \\
\hline 60 & 900 & 20 & 66,27 & 53,99 & 51,80 & 48,82 & 45,63 & 42,52 & 36,66 & 31,47 & 23,23 \\
\hline 60 & 950 & 20 & 65,15 & 53,04 & 50,94 & 48,12 & 45,06 & 42,05 & 36,38 & 31,32 & 23,23 \\
\hline 60 & 1000 & 20 & 64,11 & 52,16 & 50,13 & 47,46 & 44,51 & 41,61 & 36,10 & 31,17 & 23,22 \\
\hline 60 & 1050 & 20 & 63,14 & 51,34 & 49,37 & 46,84 & 43,99 & 41,18 & 35,83 & 31,02 & 23,21 \\
\hline 60 & 1100 & 20 & 62,22 & 50,58 & 48,65 & 46,25 & 43,50 & 40,77 & 35,57 & 30,87 & 23,19 \\
\hline 60 & 1150 & 20 & 61,36 & 49,87 & 47,97 & 45,69 & 43,03 & 40,38 & 35,32 & 30,73 & 23,18 \\
\hline 60 & 1200 & 20 & 60,54 & 49,20 & 47,32 & 45,15 & 42,58 & 40,01 & 35,08 & 30,58 & 23,15 \\
\hline 60 & 1250 & 20 & 59,76 & 48,57 & 46,71 & 44,64 & 42,15 & 39,65 & 34,84 & 30,44 & 23,13 \\
\hline 60 & 1300 & 20 & 59,02 & 47,98 & 46,13 & 44,16 & 41,74 & 39,31 & 34,61 & 30,30 & 23,11 \\
\hline 60 & 1350 & 20 & 58,31 & 47,42 & 45,57 & 43,69 & 41,35 & 38,98 & 34,39 & 30,16 & 23,08 \\
\hline 60 & 1400 & 20 & 57,64 & 46,89 & 45,04 & 43,25 & 40,97 & 38,66 & 34,17 & 30,03 & 23,05 \\
\hline 60 & 1450 & 20 & 56,99 & 46,39 & 44,54 & 42,82 & 40,61 & 38,35 & 33,96 & 29,90 & 23,02 \\
\hline 60 & 1500 & 20 & 56,36 & 45,91 & 44,05 & 42,41 & 40,26 & 38,05 & 33,76 & 29,77 & 22,99 \\
\hline 60 & 1550 & 20 & 55,76 & 45,46 & 43,59 & 42,01 & 39,92 & 37,76 & 33,56 & 29,64 & 22,95 \\
\hline 60 & 1600 & 20 & 55,18 & 45,03 & 43,14 & 41,63 & 39,59 & 37,48 & 33,36 & 29,51 & 22,92 \\
\hline 60 & 1650 & 20 & 54,62 & 44,62 & 42,71 & 41,26 & 39,28 & 37,21 & 33,17 & 29,39 & 22,89 \\
\hline 60 & 1700 & 20 & 54,08 & 44,22 & 42,30 & 40,90 & 38,98 & 36,95 & 32,99 & 29,27 & 22,85 \\
\hline 60 & 1750 & 20 & 53,55 & 43,85 & 41,91 & 40,56 & 38,68 & 36,70 & 32,81 & 29,15 & 22,81 \\
\hline 60 & 1800 & 20 & 53,04 & 43,49 & 41,52 & 40,23 & 38,40 & 36,45 & 32,63 & 29,03 & 22,78 \\
\hline 60 & 1850 & 20 & 52,55 & 43,14 & 41,16 & 39,90 & 38,12 & 36,21 & 32,46 & 28,92 & 22,74 \\
\hline 60 & 1900 & 20 & 52,07 & 42,81 & 40,80 & 39,59 & 37,85 & 35,98 & 32,30 & 28,81 & 22,70 \\
\hline 60 & 1950 & 20 & 51,60 & 42,49 & 40,46 & 39,29 & 37,59 & 35,76 & 32,13 & 28,69 & 22,67 \\
\hline 60 & 2000 & 20 & 51,14 & 42,18 & 40,13 & 39,00 & 37,34 & 35,54 & 31,97 & 28,59 & 22,63 \\
\hline 60 & 200 & 25 & 101,70 & 76,57 & 66,98 & 57,65 & 50,05 & 43,53 & 33,22 & 25,96 & 17,23 \\
\hline 60 & 250 & 25 & 91,90 & 71,22 & 63,34 & 55,33 & 48,61 & 42,72 & 33,14 & 26,16 & 17,45 \\
\hline 60 & 300 & 25 & 84,95 & 67,11 & 60,43 & 53,37 & 47,33 & 41,94 & 32,98 & 26,27 & 17,64 \\
\hline 60 & 350 & 25 & 79,72 & 63,79 & 58,02 & 51,70 & 46,19 & 41,20 & 32,78 & 26,33 & 17,81 \\
\hline 60 & 400 & 25 & 75,62 & 61,03 & 55,97 & 50,24 & 45,16 & 40,52 & 32,55 & 26,34 & 17,94 \\
\hline 60 & 450 & 25 & 72,29 & 58,69 & 54,20 & 48,94 & 44,22 & 39,87 & 32,32 & 26,32 & 18,06 \\
\hline 60 & 500 & 25 & 69,52 & 56,65 & 52,64 & 47,78 & 43,37 & 39,27 & 32,07 & 26,28 & 18,16 \\
\hline 60 & 550 & 25 & 67,17 & 54,87 & 51,24 & 46,73 & 42,59 & 38,70 & 31,83 & 26,22 & 18,24 \\
\hline 60 & 600 & 25 & 65,14 & 53,29 & 49,99 & 45,78 & 41,86 & 38,17 & 31,58 & 26,15 & 18,31 \\
\hline 60 & 650 & 25 & 63,37 & 51,87 & 48,85 & 44,90 & 41,19 & 37,67 & 31,34 & 26,08 & 18,37 \\
\hline 60 & 700 & 25 & 61,80 & 50,60 & 47,81 & 44,10 & 40,56 & 37,20 & 31,11 & 25,99 & 18,42 \\
\hline 60 & 750 & 25 & 60,39 & 49,43 & 46,85 & 43,35 & 39,97 & 36,75 & 30,88 & 25,90 & 18,46 \\
\hline 60 & 800 & 25 & 59,12 & 48,37 & 45,96 & 42,66 & 39,42 & 36,33 & 30,65 & 25,81 & 18,50 \\
\hline 60 & 850 & 25 & 57,97 & 47,40 & 45,14 & 42,01 & 38,91 & 35,93 & 30,44 & 25,72 & 18,52 \\
\hline 60 & 900 & 25 & 56,91 & 46,50 & 44,37 & 41,40 & 38,42 & 35,54 & 30,22 & 25,62 & 18,54 \\
\hline 60 & 950 & 25 & 55,93 & 45,67 & 43,65 & 40,82 & 37,95 & 35,18 & 30,01 & 25,52 & 18,56 \\
\hline 60 & 1000 & 25 & 55,03 & 44,90 & 42,97 & 40,28 & 37,51 & 34,83 & 29,81 & 25,42 & 18,57 \\
\hline 60 & 1050 & 25 & 54,18 & 44,18 & 42,33 & 39,77 & 37,10 & 34,49 & 29,62 & 25,33 & 18,58 \\
\hline 60 & 1100 & 25 & 53,39 & 43,51 & 41,73 & 39,29 & 36,70 & 34,17 & 29,42 & 25,23 & 18,58 \\
\hline 60 & 1150 & 25 & 52,65 & 42,88 & 41,16 & 38,83 & 36,32 & 33,87 & 29,24 & 25,13 & 18,58 \\
\hline 60 & 1200 & 25 & 51,95 & 42,29 & 40,62 & 38,39 & 35,96 & 33,57 & 29,06 & 25,03 & 18,58 \\
\hline 60 & 1250 & 25 & 51,29 & 41,73 & 40,10 & 37,97 & 35,61 & 33,29 & 28,88 & 24,93 & 18,58 \\
\hline 60 & 1300 & 25 & 50,66 & 41,20 & 39,61 & 37,57 & 35,27 & 33,01 & 28,71 & 24,84 & 18,57 \\
\hline 60 & 1350 & 25 & 50,07 & 40,71 & 39,15 & 37,18 & 34,95 & 32,75 & 28,54 & 24,74 & 18,56 \\
\hline 60 & 1400 & 25 & 49,50 & 40,23 & 38,70 & 36,81 & 34,65 & 32,49 & 28,38 & 24,65 & 18,55 \\
\hline 60 & 1450 & 25 & 48,95 & 39,79 & 38,27 & 36,46 & 34,35 & 32,25 & 28,22 & 24,56 & 18,54 \\
\hline 60 & 1500 & 25 & 48,43 & 39,36 & 37,86 & 36,12 & 34,06 & 32,01 & 28,06 & 24,47 & 18,52 \\
\hline
\end{tabular}




\begin{tabular}{|c|c|c|c|c|c|c|c|c|c|c|c|}
\hline \multirow[b]{2}{*}{$\mathrm{H}(\mathrm{cm})$} & \multirow[b]{2}{*}{ Mceq (MPa) } & & & & & De & ões (x1 & m) & & & \\
\hline & & Msub (MPa) & D0 & D25 & D40 & D60 & D80 & D100 & D140 & D180 & D260 \\
\hline 60 & 1550 & 25 & 47,93 & 38,96 & 37,47 & 35,79 & 33,79 & 31,78 & 27,91 & 24,37 & 18,51 \\
\hline 60 & 1600 & 25 & 47,45 & 38,57 & 37,09 & 35,48 & 33,52 & 31,55 & 27,76 & 24,29 & 18,49 \\
\hline 60 & 1650 & 25 & 46,99 & 38,20 & 36,72 & 35,17 & 33,27 & 31,34 & 27,62 & 24,20 & 18,48 \\
\hline 60 & 1700 & 25 & 46,54 & 37,85 & 36,37 & 34,88 & 33,02 & 31,13 & 27,48 & 24,11 & 18,46 \\
\hline 60 & 1750 & 25 & 46,11 & 37,51 & 36,03 & 34,60 & 32,78 & 30,92 & 27,34 & 24,02 & 18,44 \\
\hline 60 & 1800 & 25 & 45,69 & 37,19 & 35,71 & 34,32 & 32,54 & 30,73 & 27,20 & 23,94 & 18,42 \\
\hline 60 & 1850 & 25 & 45,29 & 36,88 & 35,39 & 34,05 & 32,32 & 30,53 & 27,07 & 23,86 & 18,40 \\
\hline 60 & 1900 & 25 & 44,89 & 36,58 & 35,09 & 33,80 & 32,10 & 30,35 & 26,94 & 23,77 & 18,38 \\
\hline 60 & 1950 & 25 & 44,51 & 36,30 & 34,80 & 33,55 & 31,88 & 30,16 & 26,81 & 23,69 & 18,36 \\
\hline 60 & 2000 & 25 & 44,14 & 36,02 & 34,51 & 33,30 & 31,67 & 29,99 & 26,69 & 23,61 & 18,34 \\
\hline 60 & 200 & 30 & 92,45 & 67,68 & 58,35 & 49,57 & 42,60 & 36,73 & 27,66 & 21,47 & 14,22 \\
\hline 60 & 250 & 30 & 83,16 & 62,97 & 55,26 & 47,69 & 41,50 & 36,16 & 27,68 & 21,67 & 14,39 \\
\hline 60 & 300 & 30 & 76,58 & 59,35 & 52,78 & 46,10 & 40,51 & 35,60 & 27,62 & 21,80 & 14,54 \\
\hline 60 & 350 & 30 & 71,64 & 56,44 & 50,73 & 44,73 & 39,61 & 35,05 & 27,51 & 21,88 & 14,68 \\
\hline 60 & 400 & 30 & 67,77 & 54,02 & 48,98 & 43,53 & 38,80 & 34,54 & 27,37 & 21,93 & 14,80 \\
\hline 60 & 450 & 30 & 64,63 & 51,96 & 47,47 & 42,45 & 38,05 & 34,05 & 27,22 & 21,95 & 14,90 \\
\hline 60 & 500 & 30 & 62,03 & 50,17 & 46,13 & 41,49 & 37,36 & 33,58 & 27,06 & 21,95 & 14,99 \\
\hline 60 & 550 & 30 & 59,83 & 48,61 & 44,94 & 40,62 & 36,73 & 33,14 & 26,90 & 21,93 & 15,07 \\
\hline 60 & 600 & 30 & 57,94 & 47,21 & 43,86 & 39,82 & 36,14 & 32,72 & 26,73 & 21,90 & 15,13 \\
\hline 60 & 650 & 30 & 56,28 & 45,96 & 42,89 & 39,08 & 35,59 & 32,33 & 26,56 & 21,86 & 15,19 \\
\hline 60 & 700 & 30 & 54,82 & 44,83 & 41,99 & 38,41 & 35,08 & 31,96 & 26,39 & 21,82 & 15,24 \\
\hline 60 & 750 & 30 & 53,52 & 43,80 & 41,17 & 37,78 & 34,60 & 31,60 & 26,22 & 21,76 & 15,29 \\
\hline 60 & 800 & 30 & 52,35 & 42,86 & 40,41 & 37,19 & 34,15 & 31,26 & 26,05 & 21,71 & 15,33 \\
\hline 60 & 850 & 30 & 51,29 & 42,00 & 39,70 & 36,64 & 33,72 & 30,94 & 25,89 & 21,65 & 15,36 \\
\hline 60 & 900 & 30 & 50,33 & 41,20 & 39,04 & 36,13 & 33,31 & 30,63 & 25,73 & 21,59 & 15,39 \\
\hline 60 & 950 & 30 & 49,44 & 40,45 & 38,42 & 35,64 & 32,93 & 30,33 & 25,58 & 21,52 & 15,41 \\
\hline 60 & 1000 & 30 & 48,62 & 39,76 & 37,84 & 35,18 & 32,56 & 30,05 & 25,42 & 21,46 & 15,43 \\
\hline 60 & 1050 & 30 & 47,85 & 39,12 & 37,29 & 34,75 & 32,21 & 29,78 & 25,27 & 21,39 & 15,44 \\
\hline 60 & 1100 & 30 & 47,14 & 38,52 & 36,77 & 34,34 & 31,88 & 29,52 & 25,13 & 21,32 & 15,46 \\
\hline 60 & 1150 & 30 & 46,48 & 37,95 & 36,28 & 33,94 & 31,57 & 29,27 & 24,98 & 21,25 & 15,47 \\
\hline 60 & 1200 & 30 & 45,85 & 37,42 & 35,81 & 33,57 & 31,26 & 29,02 & 24,84 & 21,19 & 15,48 \\
\hline 60 & 1250 & 30 & 45,27 & 36,92 & 35,37 & 33,21 & 30,97 & 28,79 & 24,71 & 21,12 & 15,48 \\
\hline 60 & 1300 & 30 & 44,71 & 36,44 & 34,94 & 32,87 & 30,69 & 28,57 & 24,57 & 21,05 & 15,48 \\
\hline 60 & 1350 & 30 & 44,18 & 35,99 & 34,54 & 32,54 & 30,42 & 28,35 & 24,44 & 20,98 & 15,48 \\
\hline 60 & 1400 & 30 & 43,68 & 35,56 & 34,15 & 32,23 & 30,16 & 28,14 & 24,31 & 20,91 & 15,48 \\
\hline 60 & 1450 & 30 & 43,20 & 35,16 & 33,78 & 31,93 & 29,91 & 27,94 & 24,19 & 20,85 & 15,48 \\
\hline 60 & 1500 & 30 & 42,74 & 34,77 & 33,42 & 31,64 & 29,67 & 27,74 & 24,07 & 20,78 & 15,48 \\
\hline 60 & 1550 & 30 & 42,31 & 34,41 & 33,08 & 31,36 & 29,44 & 27,55 & 23,95 & 20,71 & 15,47 \\
\hline 60 & 1600 & 30 & 41,89 & 34,06 & 32,75 & 31,09 & 29,22 & 27,36 & 23,83 & 20,65 & 15,47 \\
\hline 60 & 1650 & 30 & 41,48 & 33,72 & 32,43 & 30,83 & 29,00 & 27,18 & 23,71 & 20,58 & 15,46 \\
\hline 60 & 1700 & 30 & 41,09 & 33,40 & 32,13 & 30,58 & 28,79 & 27,01 & 23,60 & 20,52 & 15,45 \\
\hline 60 & 1750 & 30 & 40,72 & 33,10 & 31,83 & 30,34 & 28,58 & 26,84 & 23,49 & 20,45 & 15,45 \\
\hline 60 & 1800 & 30 & 40,36 & 32,80 & 31,55 & 30,10 & 28,39 & 26,67 & 23,38 & 20,39 & 15,44 \\
\hline 60 & 1850 & 30 & 40,01 & 32,52 & 31,27 & 29,87 & 28,19 & 26,51 & 23,28 & 20,33 & 15,43 \\
\hline 60 & 1900 & 30 & 39,67 & 32,25 & 31,01 & 29,65 & 28,01 & 26,36 & 23,18 & 20,26 & 15,42 \\
\hline 60 & 1950 & 30 & 39,35 & 31,99 & 30,75 & 29,44 & 27,83 & 26,20 & 23,07 & 20,20 & 15,40 \\
\hline 60 & 2000 & 30 & 39,03 & 31,74 & 30,50 & 29,23 & 27,65 & 26,06 & 22,97 & 20,14 & 15,39 \\
\hline 60 & 200 & 35 & 85,54 & 60,98 & 51,88 & 43,55 & 37,09 & 31,75 & 23,66 & 18,26 & 12,10 \\
\hline 60 & 250 & 35 & 76,65 & 56,73 & 49,19 & 42,00 & 36,23 & 31,35 & 23,72 & 18,46 & 12,24 \\
\hline 60 & 300 & 35 & 70,36 & 53,48 & 47,03 & 40,67 & 35,44 & 30,93 & 23,72 & 18,59 & 12,36 \\
\hline 60 & 350 & 35 & 65,64 & 50,87 & 45,24 & 39,52 & 34,72 & 30,51 & 23,67 & 18,69 & 12,47 \\
\hline 60 & 400 & 35 & 61,95 & 48,70 & 43,72 & 38,50 & 34,06 & 30,11 & 23,59 & 18,75 & 12,57 \\
\hline 60 & 450 & 35 & 58,96 & 46,86 & 42,39 & 37,59 & 33,45 & 29,73 & 23,50 & 18,79 & 12,65 \\
\hline 60 & 500 & 35 & 56,48 & 45,26 & 41,22 & 36,77 & 32,88 & 29,36 & 23,39 & 18,81 & 12,73 \\
\hline 60 & 550 & 35 & 54,39 & 43,86 & 40,18 & 36,02 & 32,36 & 29,01 & 23,28 & 18,81 & 12,80 \\
\hline 60 & 600 & 35 & 52,60 & 42,61 & 39,24 & 35,34 & 31,87 & 28,67 & 23,16 & 18,81 & 12,87 \\
\hline 60 & 650 & 35 & 51,04 & 41,48 & 38,38 & 34,71 & 31,41 & 28,35 & 23,03 & 18,79 & 12,92 \\
\hline 60 & 700 & 35 & 49,66 & 40,47 & 37,60 & 34,13 & 30,98 & 28,05 & 22,91 & 18,77 & 12,97 \\
\hline 60 & 750 & 35 & 48,43 & 39,54 & 36,88 & 33,59 & 30,57 & 27,76 & 22,78 & 18,74 & 13,02 \\
\hline 60 & 800 & 35 & 47,33 & 38,69 & 36,21 & 33,08 & 30,19 & 27,48 & 22,66 & 18,71 & 13,05 \\
\hline 60 & 850 & 35 & 46,34 & 37,91 & 35,59 & 32,61 & 29,83 & 27,21 & 22,54 & 18,67 & 13,09 \\
\hline 60 & 900 & 35 & 45,44 & 37,19 & 35,00 & 32,16 & 29,49 & 26,96 & 22,41 & 18,63 & 13,12 \\
\hline 60 & 950 & 35 & 44,61 & 36,52 & 34,46 & 31,74 & 29,16 & 26,71 & 22,29 & 18,59 & 13,14 \\
\hline 60 & 1000 & 35 & 43,84 & 35,89 & 33,95 & 31,34 & 28,85 & 26,48 & 22,17 & 18,55 & 13,17 \\
\hline 60 & 1050 & 35 & 43,14 & 35,31 & 33,46 & 30,97 & 28,55 & 26,25 & 22,06 & 18,50 & 13,19 \\
\hline 60 & 1100 & 35 & 42,48 & 34,76 & 33,01 & 30,61 & 28,27 & 26,04 & 21,94 & 18,46 & 13,21 \\
\hline 60 & 1150 & 35 & 41,87 & 34,25 & 32,57 & 30,27 & 28,00 & 25,83 & 21,83 & 18,41 & 13,22 \\
\hline 60 & 1200 & 35 & 41,29 & 33,76 & 32,16 & 29,94 & 27,74 & 25,62 & 21,72 & 18,36 & 13,23 \\
\hline 60 & 1250 & 35 & 40,75 & 33,31 & 31,77 & 29,63 & 27,49 & 25,43 & 21,61 & 18,31 & 13,24 \\
\hline 60 & 1300 & 35 & 40,24 & 32,87 & 31,39 & 29,33 & 27,25 & 25,24 & 21,50 & 18,26 & 13,25 \\
\hline 60 & 1350 & 35 & 39,76 & 32,46 & 31,04 & 29,05 & 27,02 & 25,05 & 21,40 & 18,21 & 13,26 \\
\hline 60 & 1400 & 35 & 39,30 & 32,07 & 30,69 & 28,77 & 26,80 & 24,88 & 21,29 & 18,16 & 13,26 \\
\hline 60 & 1450 & 35 & 38,87 & 31,70 & 30,37 & 28,51 & 26,58 & 24,71 & 21,19 & 18,11 & 13,27 \\
\hline 60 & 1500 & 35 & 38,46 & 31,35 & 30,05 & 28,26 & 26,37 & 24,54 & 21,09 & 18,06 & 13,27 \\
\hline 60 & 1550 & 35 & 38,06 & 31,01 & 29,75 & 28,01 & 26,17 & 24,38 & 21,00 & 18,01 & 13,27 \\
\hline 60 & 1600 & 35 & 37,68 & 30,69 & 29,46 & 27,78 & 25,98 & 24,22 & 20,90 & 17,96 & 13,27 \\
\hline 60 & 1650 & 35 & 37,32 & 30,38 & 29,18 & 27,55 & 25,79 & 24,07 & 20,81 & 17,91 & 13,27 \\
\hline 60 & 1700 & 35 & 36,97 & 30,09 & 28,91 & 27,33 & 25,61 & 23,92 & 20,72 & 17,86 & 13,27 \\
\hline 60 & 1750 & 35 & 36,64 & 29,81 & 28,65 & 27,12 & 25,43 & 23,78 & 20,63 & 17,81 & 13,27 \\
\hline 60 & 1800 & 35 & 36,31 & 29,54 & 28,39 & 26,91 & 25,26 & 23,64 & 20,54 & 17,76 & 13,26 \\
\hline 60 & 1850 & 35 & 36,00 & 29,28 & 28,15 & 26,71 & 25,10 & 23,50 & 20,45 & 17,71 & 13,26 \\
\hline
\end{tabular}




\begin{tabular}{|c|c|c|c|c|c|c|c|c|c|c|c|}
\hline & & & \multicolumn{9}{|c|}{ Deflexões $\left(\times 10^{-4} \mathrm{~cm}\right)$} \\
\hline $\mathrm{H}(\mathrm{cm})$ & Mceq (MPa) & Msub (MPa) & D0 & D25 & D40 & D60 & D80 & D100 & D140 & D180 & D260 \\
\hline 60 & 1900 & 35 & 35,70 & 29,03 & 27,91 & 26,52 & 24,94 & 23,36 & 20,37 & 17,66 & 13,26 \\
\hline 60 & 1950 & 35 & 35,41 & 28,79 & 27,69 & 26,33 & 24,78 & 23,23 & 20,29 & 17,62 & 13,25 \\
\hline 60 & 2000 & 35 & 35,13 & 28,55 & 27,46 & 26,15 & 24,63 & 23,11 & 20,20 & 17,57 & 13,24 \\
\hline 60 & 200 & 40 & 80,15 & 55,72 & 46,83 & 38,89 & 32,86 & 27,95 & 20,64 & 15,87 & 10,53 \\
\hline 60 & 250 & 40 & 71,57 & 51,83 & 44,44 & 37,57 & 32,17 & 27,65 & 20,73 & 16,05 & 10,64 \\
\hline 60 & 300 & 40 & 65,52 & 48,86 & 42,53 & 36,44 & 31,53 & 27,34 & 20,76 & 16,18 & 10,73 \\
\hline 60 & 350 & 40 & 60,99 & 46,49 & 40,94 & 35,45 & 30,93 & 27,02 & 20,75 & 16,28 & 10,82 \\
\hline 60 & 400 & 40 & 57,44 & 44,51 & 39,59 & 34,58 & 30,38 & 26,70 & 20,71 & 16,35 & 10,91 \\
\hline 60 & 450 & 40 & 54,57 & 42,84 & 38,41 & 33,79 & 29,87 & 26,39 & 20,65 & 16,40 & 10,98 \\
\hline 60 & 500 & 40 & 52,20 & 41,38 & 37,37 & 33,08 & 29,40 & 26,09 & 20,58 & 16,43 & 11,05 \\
\hline 60 & 550 & 40 & 50,19 & 40,11 & 36,44 & 32,43 & 28,95 & 25,81 & 20,50 & 16,45 & 11,12 \\
\hline 60 & 600 & 40 & 48,47 & 38,97 & 35,60 & 31,84 & 28,54 & 25,53 & 20,42 & 16,46 & 11,17 \\
\hline 60 & 650 & 40 & 46,98 & 37,95 & 34,84 & 31,29 & 28,15 & 25,27 & 20,33 & 16,46 & 11,23 \\
\hline 60 & 700 & 40 & 45,66 & 37,02 & 34,14 & 30,78 & 27,78 & 25,02 & 20,23 & 16,45 & 11,27 \\
\hline 60 & 750 & 40 & 44,50 & 36,18 & 33,49 & 30,31 & 27,43 & 24,78 & 20,14 & 16,44 & 11,31 \\
\hline 60 & 800 & 40 & 43,45 & 35,41 & 32,90 & 29,86 & 27,11 & 24,54 & 20,04 & 16,42 & 11,35 \\
\hline 60 & 850 & 40 & 42,51 & 34,70 & 32,34 & 29,45 & 26,79 & 24,32 & 19,95 & 16,40 & 11,38 \\
\hline 60 & 900 & 40 & 41,65 & 34,04 & 31,82 & 29,05 & 26,50 & 24,11 & 19,85 & 16,38 & 11,41 \\
\hline 60 & 950 & 40 & 40,86 & 33,42 & 31,34 & 28,68 & 26,22 & 23,90 & 19,76 & 16,35 & 11,44 \\
\hline 60 & 1000 & 40 & 40,14 & 32,85 & 30,88 & 28,33 & 25,95 & 23,70 & 19,66 & 16,32 & 11,47 \\
\hline 60 & 1050 & 40 & 39,48 & 32,32 & 30,45 & 28,00 & 25,69 & 23,51 & 19,57 & 16,29 & 11,49 \\
\hline 60 & 1100 & 40 & 38,86 & 31,81 & 30,04 & 27,68 & 25,45 & 23,32 & 19,48 & 16,26 & 11,51 \\
\hline 60 & 1150 & 40 & 38,28 & 31,34 & 29,65 & 27,38 & 25,21 & 23,14 & 19,39 & 16,23 & 11,52 \\
\hline 60 & 1200 & 40 & 37,74 & 30,90 & 29,28 & 27,09 & 24,98 & 22,97 & 19,30 & 16,19 & 11,54 \\
\hline 60 & 1250 & 40 & 37,24 & 30,48 & 28,93 & 26,82 & 24,77 & 22,80 & 19,21 & 16,15 & 11,55 \\
\hline 60 & 1300 & 40 & 36,76 & 30,08 & 28,59 & 26,56 & 24,56 & 22,64 & 19,12 & 16,12 & 11,56 \\
\hline 60 & 1350 & 40 & 36,32 & 29,70 & 28,27 & 26,30 & 24,36 & 22,49 & 19,04 & 16,08 & 11,57 \\
\hline 60 & 1400 & 40 & 35,89 & 29,34 & 27,97 & 26,06 & 24,16 & 22,33 & 18,95 & 16,04 & 11,58 \\
\hline 60 & 1450 & 40 & 35,49 & 29,00 & 27,67 & 25,83 & 23,97 & 22,19 & 18,87 & 16,00 & 11,59 \\
\hline 60 & 1500 & 40 & 35,10 & 28,67 & 27,39 & 25,60 & 23,79 & 22,04 & 18,79 & 15,97 & 11,60 \\
\hline 60 & 1550 & 40 & 34,74 & 28,36 & 27,12 & 25,39 & 23,62 & 21,90 & 18,71 & 15,93 & 11,60 \\
\hline 60 & 1600 & 40 & 34,39 & 28,06 & 26,86 & 25,18 & 23,45 & 21,77 & 18,63 & 15,89 & 11,61 \\
\hline 60 & 1650 & 40 & 34,06 & 27,78 & 26,61 & 24,98 & 23,28 & 21,64 & 18,56 & 15,85 & 11,61 \\
\hline 60 & 1700 & 40 & 33,74 & 27,51 & 26,36 & 24,78 & 23,12 & 21,51 & 18,48 & 15,81 & 11,61 \\
\hline 60 & 1750 & 40 & 33,43 & 27,24 & 26,13 & 24,59 & 22,97 & 21,38 & 18,40 & 15,77 & 11,61 \\
\hline 60 & 1800 & 40 & 33,14 & 26,99 & 25,90 & 24,41 & 22,82 & 21,26 & 18,33 & 15,74 & 11,61 \\
\hline 60 & 1850 & 40 & 32,85 & 26,75 & 25,68 & 24,23 & 22,67 & 21,14 & 18,26 & 15,70 & 11,61 \\
\hline 60 & 1900 & 40 & 32,58 & 26,52 & 25,47 & 24,06 & 22,53 & 21,03 & 18,19 & 15,66 & 11,61 \\
\hline 60 & 1950 & 40 & 32,31 & 26,30 & 25,26 & 23,89 & 22,39 & 20,91 & 18,12 & 15,62 & 11,61 \\
\hline 60 & 2000 & 40 & 32,06 & 26,08 & 25,07 & 23,73 & 22,25 & 20,80 & 18,05 & 15,58 & 11,61 \\
\hline 60 & 200 & 45 & 75,80 & 51,48 & 42,77 & 35,15 & 29,49 & 24,94 & 18,28 & 14,02 & 9,32 \\
\hline 60 & 250 & 45 & 67,49 & 47,86 & 40,62 & 34,02 & 28,93 & 24,73 & 18,39 & 14,19 & 9,40 \\
\hline 60 & 300 & 45 & 61,64 & 45,12 & 38,90 & 33,05 & 28,40 & 24,49 & 18,44 & 14,31 & 9,48 \\
\hline 60 & 350 & 45 & 57,25 & 42,93 & 37,47 & 32,19 & 27,90 & 24,24 & 18,45 & 14,41 & 9,56 \\
\hline 60 & 400 & 45 & 53,82 & 41,11 & 36,25 & 31,42 & 27,44 & 23,98 & 18,44 & 14,48 & 9,63 \\
\hline 60 & 450 & 45 & 51,05 & 39,57 & 35,19 & 30,74 & 27,01 & 23,73 & 18,41 & 14,53 & 9,70 \\
\hline 60 & 500 & 45 & 48,76 & 38,23 & 34,25 & 30,11 & 26,60 & 23,49 & 18,37 & 14,57 & 9,76 \\
\hline 60 & 550 & 45 & 46,83 & 37,06 & 33,41 & 29,54 & 26,22 & 23,25 & 18,31 & 14,60 & 9,81 \\
\hline 60 & 600 & 45 & 45,18 & 36,01 & 32,65 & 29,02 & 25,86 & 23,02 & 18,25 & 14,62 & 9,86 \\
\hline 60 & 650 & 45 & 43,74 & 35,07 & 31,97 & 28,53 & 25,53 & 22,80 & 18,18 & 14,63 & 9,91 \\
\hline 60 & 700 & 45 & 42,47 & 34,22 & 31,33 & 28,08 & 25,21 & 22,59 & 18,11 & 14,63 & 9,95 \\
\hline 60 & 750 & 45 & 41,35 & 33,45 & 30,75 & 27,66 & 24,91 & 22,39 & 18,04 & 14,63 & 9,99 \\
\hline 60 & 800 & 45 & 40,35 & 32,74 & 30,21 & 27,26 & 24,62 & 22,19 & 17,97 & 14,62 & 10,03 \\
\hline 60 & 850 & 45 & 39,44 & 32,08 & 29,71 & 26,89 & 24,35 & 22,00 & 17,89 & 14,61 & 10,06 \\
\hline 60 & 900 & 45 & 38,62 & 31,47 & 29,24 & 26,54 & 24,09 & 21,82 & 17,82 & 14,60 & 10,09 \\
\hline 60 & 950 & 45 & 37,87 & 30,91 & 28,80 & 26,21 & 23,85 & 21,64 & 17,74 & 14,58 & 10,12 \\
\hline 60 & 1000 & 45 & 37,18 & 30,38 & 28,39 & 25,90 & 23,61 & 21,47 & 17,67 & 14,56 & 10,14 \\
\hline 60 & 1050 & 45 & 36,55 & 29,89 & 28,00 & 25,60 & 23,39 & 21,30 & 17,59 & 14,54 & 10,16 \\
\hline 60 & 1100 & 45 & 35,96 & 29,42 & 27,63 & 25,32 & 23,17 & 21,14 & 17,52 & 14,52 & 10,18 \\
\hline 60 & 1150 & 45 & 35,41 & 28,99 & 27,27 & 25,05 & 22,96 & 20,99 & 17,44 & 14,50 & 10,20 \\
\hline 60 & 1200 & 45 & 34,90 & 28,57 & 26,94 & 24,79 & 22,76 & 20,84 & 17,37 & 14,47 & 10,22 \\
\hline 60 & 1250 & 45 & 34,42 & 28,18 & 26,62 & 24,55 & 22,57 & 20,70 & 17,30 & 14,45 & 10,23 \\
\hline 60 & 1300 & 45 & 33,97 & 27,81 & 26,32 & 24,31 & 22,39 & 20,56 & 17,23 & 14,42 & 10,25 \\
\hline 60 & 1350 & 45 & 33,55 & 27,46 & 26,03 & 24,08 & 22,21 & 20,42 & 17,15 & 14,39 & 10,26 \\
\hline 60 & 1400 & 45 & 33,15 & 27,13 & 25,75 & 23,87 & 22,04 & 20,29 & 17,09 & 14,36 & 10,27 \\
\hline 60 & 1450 & 45 & 32,77 & 26,81 & 25,48 & 23,66 & 21,87 & 20,16 & 17,02 & 14,33 & 10,28 \\
\hline 60 & 1500 & 45 & 32,41 & 26,51 & 25,23 & 23,45 & 21,71 & 20,03 & 16,95 & 14,30 & 10,29 \\
\hline 60 & 1550 & 45 & 32,07 & 26,22 & 24,98 & 23,26 & 21,55 & 19,91 & 16,88 & 14,28 & 10,29 \\
\hline 60 & 1600 & 45 & 31,74 & 25,94 & 24,74 & 23,07 & 21,40 & 19,79 & 16,82 & 14,25 & 10,30 \\
\hline 60 & 1650 & 45 & 31,43 & 25,68 & 24,51 & 22,89 & 21,26 & 19,68 & 16,75 & 14,22 & 10,30 \\
\hline 60 & 1700 & 45 & 31,13 & 25,42 & 24,29 & 22,71 & 21,11 & 19,57 & 16,69 & 14,19 & 10,31 \\
\hline 60 & 1750 & 45 & 30,84 & 25,18 & 24,08 & 22,54 & 20,98 & 19,46 & 16,62 & 14,15 & 10,31 \\
\hline 60 & 1800 & 45 & 30,57 & 24,95 & 23,87 & 22,38 & 20,84 & 19,35 & 16,56 & 14,12 & 10,32 \\
\hline 60 & 1850 & 45 & 30,31 & 24,72 & 23,67 & 22,22 & 20,71 & 19,24 & 16,50 & 14,09 & 10,32 \\
\hline 60 & 1900 & 45 & 30,05 & 24,50 & 23,48 & 22,07 & 20,58 & 19,14 & 16,44 & 14,06 & 10,32 \\
\hline 60 & 1950 & 45 & 29,81 & 24,29 & 23,29 & 21,91 & 20,46 & 19,04 & 16,38 & 14,03 & 10,32 \\
\hline 60 & 2000 & 45 & 29,57 & 24,09 & 23,11 & 21,77 & 20,34 & 18,95 & 16,32 & 14,00 & 10,32 \\
\hline 60 & 200 & 50 & 72,20 & 47,97 & 39,42 & 32,10 & 26,75 & 22,51 & 16,40 & 12,55 & 8,36 \\
\hline 60 & 250 & 50 & 64,12 & 44,58 & 37,47 & 31,11 & 26,29 & 22,36 & 16,51 & 12,70 & 8,43 \\
\hline 60 & 300 & 50 & 58,43 & 42,02 & 35,90 & 30,25 & 25,84 & 22,17 & 16,58 & 12,82 & 8,49 \\
\hline 60 & 350 & 50 & 54,18 & 39,97 & 34,60 & 29,50 & 25,42 & 21,97 & 16,60 & 12,91 & 8,56 \\
\hline
\end{tabular}




\begin{tabular}{|c|c|c|c|c|c|c|c|c|c|c|c|}
\hline \multirow[b]{2}{*}{$\mathrm{H}(\mathrm{cm})$} & \multirow[b]{2}{*}{ Mceq (MPa) } & & & & & $\mathrm{De}$ & ões (x1 & & & & \\
\hline & & Msub (MPa) & D0 & D25 & D40 & D60 & D80 & D100 & D140 & D180 & D260 \\
\hline 60 & 400 & 50 & 50,85 & 38,28 & 33,49 & 28,83 & 25,03 & 21,77 & 16,61 & 12,98 & 8,62 \\
\hline 60 & 450 & 50 & 48,17 & 36,85 & 32,52 & 28,22 & 24,65 & 21,56 & 16,60 & 13,04 & 8,67 \\
\hline 60 & 500 & 50 & 45,95 & 35,61 & 31,67 & 27,66 & 24,30 & 21,36 & 16,57 & 13,08 & 8,73 \\
\hline 60 & 550 & 50 & 44,08 & 34,52 & 30,91 & 27,16 & 23,98 & 21,16 & 16,53 & 13,11 & 8,78 \\
\hline 60 & 600 & 50 & 42,48 & 33,55 & 30,21 & 26,69 & 23,67 & 20,97 & 16,49 & 13,14 & 8,82 \\
\hline 60 & 650 & 50 & 41,08 & 32,68 & 29,59 & 26,25 & 23,37 & 20,78 & 16,44 & 13,15 & 8,86 \\
\hline 60 & 700 & 50 & 39,86 & 31,89 & 29,01 & 25,85 & 23,09 & 20,60 & 16,39 & 13,16 & 8,90 \\
\hline 60 & 750 & 50 & 38,78 & 31,18 & 28,48 & 25,47 & 22,83 & 20,43 & 16,33 & 13,17 & 8,94 \\
\hline 60 & 800 & 50 & 37,81 & 30,52 & 27,99 & 25,12 & 22,58 & 20,26 & 16,28 & 13,17 & 8,97 \\
\hline 60 & 850 & 50 & 36,94 & 29,91 & 27,53 & 24,78 & 22,34 & 20,09 & 16,22 & 13,17 & 9,00 \\
\hline 60 & 900 & 50 & 36,15 & 29,34 & 27,10 & 24,47 & 22,11 & 19,94 & 16,16 & 13,16 & 9,03 \\
\hline 60 & 950 & 50 & 35,42 & 28,82 & 26,70 & 24,17 & 21,89 & 19,78 & 16,10 & 13,15 & 9,06 \\
\hline 60 & 1000 & 50 & 34,76 & 28,33 & 26,32 & 23,89 & 21,68 & 19,63 & 16,04 & 13,14 & 9,08 \\
\hline 60 & 1050 & 50 & 34,15 & 27,87 & 25,96 & 23,62 & 21,48 & 19,49 & 15,97 & 13,13 & 9,10 \\
\hline 60 & 1100 & 50 & 33,59 & 27,44 & 25,62 & 23,37 & 21,29 & 19,35 & 15,91 & 13,11 & 9,12 \\
\hline 60 & 1150 & 50 & 33,06 & 27,03 & 25,30 & 23,12 & 21,11 & 19,22 & 15,85 & 13,09 & 9,14 \\
\hline 60 & 1200 & 50 & 32,57 & 26,64 & 24,99 & 22,89 & 20,93 & 19,09 & 15,79 & 13,08 & 9,16 \\
\hline 60 & 1250 & 50 & 32,11 & 26,28 & 24,70 & 22,67 & 20,76 & 18,96 & 15,73 & 13,06 & 9,17 \\
\hline 60 & 1300 & 50 & 31,69 & 25,94 & 24,43 & 22,45 & 20,59 & 18,84 & 15,67 & 13,04 & 9,19 \\
\hline 60 & 1350 & 50 & 31,28 & 25,61 & 24,16 & 22,25 & 20,43 & 18,72 & 15,61 & 13,02 & 9,20 \\
\hline 60 & 1400 & 50 & 30,90 & 25,30 & 23,90 & 22,05 & 20,28 & 18,60 & 15,55 & 13,00 & 9,21 \\
\hline 60 & 1450 & 50 & 30,54 & 25,00 & 23,66 & 21,86 & 20,13 & 18,49 & 15,50 & 12,97 & 9,22 \\
\hline 60 & 1500 & 50 & 30,20 & 24,72 & 23,43 & 21,68 & 19,99 & 18,38 & 15,44 & 12,95 & 9,23 \\
\hline 60 & 1550 & 50 & 29,87 & 24,45 & 23,20 & 21,50 & 19,85 & 18,27 & 15,38 & 12,93 & 9,24 \\
\hline 60 & 1600 & 50 & 29,56 & 24,19 & 22,98 & 21,33 & 19,71 & 18,17 & 15,33 & 12,91 & 9,25 \\
\hline 60 & 1650 & 50 & 29,27 & 23,94 & 22,77 & 21,16 & 19,58 & 18,06 & 15,27 & 12,88 & 9,26 \\
\hline 60 & 1700 & 50 & 28,98 & 23,70 & 22,57 & 21,00 & 19,45 & 17,96 & 15,22 & 12,86 & 9,26 \\
\hline 60 & 1750 & 50 & 28,71 & 23,47 & 22,37 & 20,85 & 19,33 & 17,87 & 15,16 & 12,83 & 9,27 \\
\hline 60 & 1800 & 50 & 28,45 & 23,25 & 22,19 & 20,70 & 19,21 & 17,77 & 15,11 & 12,81 & 9,27 \\
\hline 60 & 1850 & 50 & 28,20 & 23,04 & 22,00 & 20,55 & 19,09 & 17,68 & 15,06 & 12,79 & 9,28 \\
\hline 60 & 1900 & 50 & 27,97 & 22,84 & 21,82 & 20,41 & 18,98 & 17,59 & 15,01 & 12,76 & 9,28 \\
\hline 60 & 1950 & 50 & 27,73 & 22,64 & 21,65 & 20,28 & 18,87 & 17,50 & 14,96 & 12,74 & 9,28 \\
\hline 60 & 2000 & 50 & 27,51 & 22,45 & 21,49 & 20,14 & 18,76 & 17,41 & 14,91 & 12,71 & 9,29 \\
\hline 60 & 200 & 55 & 69,18 & 45,01 & 36,62 & 29,54 & 24,47 & 20,50 & 14,85 & 11,35 & 7,58 \\
\hline 60 & 250 & 55 & 61,28 & 41,81 & 34,82 & 28,67 & 24,09 & 20,39 & 14,97 & 11,49 & 7,63 \\
\hline 60 & 300 & 55 & 55,74 & 39,40 & 33,38 & 27,92 & 23,71 & 20,25 & 15,04 & 11,60 & 7,69 \\
\hline 60 & 350 & 55 & 51,59 & 37,48 & 32,18 & 27,24 & 23,35 & 20,09 & 15,08 & 11,68 & 7,74 \\
\hline 60 & 400 & 55 & 48,36 & 35,89 & 31,17 & 26,64 & 23,01 & 19,92 & 15,10 & 11,75 & 7,79 \\
\hline 60 & 450 & 55 & 45,75 & 34,55 & 30,28 & 26,10 & 22,69 & 19,75 & 15,10 & 11,81 & 7,84 \\
\hline 60 & 500 & 55 & 43,59 & 33,39 & 29,49 & 25,60 & 22,38 & 19,58 & 15,08 & 11,86 & 7,89 \\
\hline 60 & 550 & 55 & 41,77 & 32,37 & 28,79 & 25,15 & 22,10 & 19,42 & 15,06 & 11,89 & 7,93 \\
\hline 60 & 600 & 55 & 40,21 & 31,47 & 28,16 & 24,73 & 21,82 & 19,25 & 15,03 & 11,92 & 7,97 \\
\hline 60 & 650 & 55 & 38,86 & 30,66 & 27,58 & 24,34 & 21,56 & 19,09 & 15,00 & 11,94 & 8,01 \\
\hline 60 & 700 & 55 & 37,68 & 29,92 & 27,05 & 23,97 & 21,32 & 18,94 & 14,96 & 11,95 & 8,05 \\
\hline 60 & 750 & 55 & 36,63 & 29,25 & 26,56 & 23,63 & 21,08 & 18,79 & 14,92 & 11,96 & 8,08 \\
\hline 60 & 800 & 55 & 35,69 & 28,63 & 26,11 & 23,31 & 20,86 & 18,64 & 14,87 & 11,97 & 8,11 \\
\hline 60 & 850 & 55 & 34,84 & 28,06 & 25,68 & 23,01 & 20,65 & 18,50 & 14,83 & 11,97 & 8,14 \\
\hline 60 & 900 & 55 & 34,07 & 27,54 & 25,29 & 22,72 & 20,45 & 18,36 & 14,78 & 11,97 & 8,17 \\
\hline 60 & 950 & 55 & 33,38 & 27,04 & 24,92 & 22,45 & 20,25 & 18,23 & 14,73 & 11,97 & 8,19 \\
\hline 60 & 1000 & 55 & 32,74 & 26,59 & 24,57 & 22,20 & 20,06 & 18,10 & 14,68 & 11,96 & 8,21 \\
\hline 60 & 1050 & 55 & 32,15 & 26,16 & 24,24 & 21,95 & 19,89 & 17,97 & 14,63 & 11,95 & 8,24 \\
\hline 60 & 1100 & 55 & 31,60 & 25,75 & 23,93 & 21,72 & 19,71 & 17,85 & 14,58 & 11,95 & 8,25 \\
\hline 60 & 1150 & 55 & 31,09 & 25,37 & 23,63 & 21,50 & 19,55 & 17,73 & 14,53 & 11,93 & 8,27 \\
\hline 60 & 1200 & 55 & 30,62 & 25,01 & 23,35 & 21,28 & 19,39 & 17,62 & 14,48 & 11,92 & 8,29 \\
\hline 60 & 1250 & 55 & 30,18 & 24,67 & 23,08 & 21,08 & 19,23 & 17,50 & 14,43 & 11,91 & 8,31 \\
\hline 60 & 1300 & 55 & 29,77 & 24,35 & 22,82 & 20,88 & 19,09 & 17,39 & 14,38 & 11,89 & 8,32 \\
\hline 60 & 1350 & 55 & 29,38 & 24,04 & 22,58 & 20,70 & 18,94 & 17,29 & 14,33 & 11,88 & 8,33 \\
\hline 60 & 1400 & 55 & 29,01 & 23,75 & 22,34 & 20,52 & 18,80 & 17,19 & 14,28 & 11,86 & 8,34 \\
\hline 60 & 1450 & 55 & 28,67 & 23,47 & 22,12 & 20,34 & 18,67 & 17,08 & 14,23 & 11,85 & 8,36 \\
\hline 60 & 1500 & 55 & 28,34 & 23,20 & 21,90 & 20,17 & 18,54 & 16,99 & 14,18 & 11,83 & 8,37 \\
\hline 60 & 1550 & 55 & 28,03 & 22,95 & 21,69 & 20,01 & 18,41 & 16,89 & 14,13 & 11,81 & 8,38 \\
\hline 60 & 1600 & 55 & 27,73 & 22,70 & 21,49 & 19,86 & 18,29 & 16,80 & 14,08 & 11,79 & 8,38 \\
\hline 60 & 1650 & 55 & 27,45 & 22,47 & 21,30 & 19,71 & 18,17 & 16,71 & 14,04 & 11,77 & 8,39 \\
\hline 60 & 1700 & 55 & 27,18 & 22,25 & 21,11 & 19,56 & 18,05 & 16,62 & 13,99 & 11,76 & 8,40 \\
\hline 60 & 1750 & 55 & 26,92 & 22,03 & 20,93 & 19,42 & 17,94 & 16,53 & 13,94 & 11,74 & 8,41 \\
\hline 60 & 1800 & 55 & 26,68 & 21,82 & 20,75 & 19,28 & 17,83 & 16,45 & 13,90 & 11,72 & 8,41 \\
\hline 60 & 1850 & 55 & 26,44 & 21,62 & 20,58 & 19,15 & 17,73 & 16,36 & 13,85 & 11,70 & 8,42 \\
\hline 60 & 1900 & 55 & 26,21 & 21,43 & 20,42 & 19,02 & 17,62 & 16,28 & 13,81 & 11,68 & 8,42 \\
\hline 60 & 1950 & 55 & 25,99 & 21,25 & 20,26 & 18,89 & 17,52 & 16,20 & 13,76 & 11,66 & 8,43 \\
\hline 60 & 2000 & 55 & 25,78 & 21,07 & 20,11 & 18,77 & 17,42 & 16,13 & 13,72 & 11,64 & 8,43 \\
\hline 60 & 200 & 60 & 66,58 & 42,48 & 34,22 & 27,37 & 22,55 & 18,82 & 13,56 & 10,36 & 6,93 \\
\hline 60 & 250 & 60 & 58,85 & 39,44 & 32,55 & 26,60 & 22,23 & 18,74 & 13,68 & 10,48 & 6,98 \\
\hline 60 & 300 & 60 & 53,43 & 37,15 & 31,22 & 25,92 & 21,90 & 18,63 & 13,76 & 10,58 & 7,02 \\
\hline 60 & 350 & 60 & 49,39 & 35,33 & 30,12 & 25,32 & 21,60 & 18,50 & 13,81 & 10,67 & 7,07 \\
\hline 60 & 400 & 60 & 46,23 & 33,84 & 29,18 & 24,78 & 21,30 & 18,37 & 13,83 & 10,73 & 7,11 \\
\hline 60 & 450 & 60 & 43,68 & 32,58 & 28,35 & 24,29 & 21,02 & 18,22 & 13,84 & 10,79 & 7,16 \\
\hline 60 & 500 & 60 & 41,58 & 31,48 & 27,63 & 23,85 & 20,75 & 18,08 & 13,84 & 10,83 & 7,20 \\
\hline 60 & 550 & 60 & 39,81 & 30,53 & 26,98 & 23,43 & 20,50 & 17,94 & 13,83 & 10,87 & 7,24 \\
\hline 60 & 600 & 60 & 38,29 & 29,68 & 26,39 & 23,05 & 20,25 & 17,80 & 13,81 & 10,90 & 7,27 \\
\hline 60 & 650 & 60 & 36,97 & 28,91 & 25,86 & 22,70 & 20,02 & 17,66 & 13,78 & 10,92 & 7,31 \\
\hline 60 & 700 & 60 & 35,82 & 28,22 & 25,36 & 22,37 & 19,81 & 17,53 & 13,75 & 10,94 & 7,34 \\
\hline
\end{tabular}




\begin{tabular}{|c|c|c|c|c|c|c|c|c|c|c|c|}
\hline \multirow[b]{2}{*}{$\mathrm{H}(\mathrm{cm})$} & \multirow[b]{2}{*}{ Mceq (MPa) } & & & & & $\mathrm{De}$ & ões (x1 & & & & \\
\hline & & Msub (MPa) & D0 & D25 & D40 & D60 & D80 & D100 & D140 & D180 & D260 \\
\hline 60 & 750 & 60 & 34,80 & 27,59 & 24,91 & 22,06 & 19,60 & 17,40 & 13,72 & 10,95 & 7,37 \\
\hline 60 & 800 & 60 & 33,88 & 27,01 & 24,49 & 21,76 & 19,40 & 17,27 & 13,69 & 10,96 & 7,40 \\
\hline 60 & 850 & 60 & 33,06 & 26,48 & 24,10 & 21,49 & 19,21 & 17,14 & 13,65 & 10,97 & 7,42 \\
\hline 60 & 900 & 60 & 32,32 & 25,98 & 23,73 & 21,23 & 19,02 & 17,02 & 13,61 & 10,97 & 7,45 \\
\hline 60 & 950 & 60 & 31,64 & 25,52 & 23,39 & 20,98 & 18,85 & 16,90 & 13,57 & 10,97 & 7,47 \\
\hline 60 & 1000 & 60 & 31,02 & 25,09 & 23,06 & 20,74 & 18,68 & 16,79 & 13,53 & 10,97 & 7,49 \\
\hline 60 & 1050 & 60 & 30,44 & 24,68 & 22,76 & 20,52 & 18,52 & 16,68 & 13,49 & 10,97 & 7,51 \\
\hline 60 & 1100 & 60 & 29,91 & 24,30 & 22,47 & 20,31 & 18,36 & 16,57 & 13,45 & 10,96 & 7,53 \\
\hline 60 & 1150 & 60 & 29,42 & 23,94 & 22,19 & 20,10 & 18,22 & 16,47 & 13,41 & 10,96 & 7,55 \\
\hline 60 & 1200 & 60 & 28,97 & 23,61 & 21,93 & 19,91 & 18,07 & 16,36 & 13,36 & 10,95 & 7,57 \\
\hline 60 & 1250 & 60 & 28,54 & 23,29 & 21,68 & 19,72 & 17,93 & 16,26 & 13,32 & 10,94 & 7,58 \\
\hline 60 & 1300 & 60 & 28,14 & 22,98 & 21,44 & 19,54 & 17,80 & 16,17 & 13,28 & 10,93 & 7,60 \\
\hline 60 & 1350 & 60 & 27,77 & 22,69 & 21,22 & 19,37 & 17,67 & 16,07 & 13,24 & 10,92 & 7,61 \\
\hline 60 & 1400 & 60 & 27,41 & 22,42 & 21,00 & 19,20 & 17,54 & 15,98 & 13,19 & 10,91 & 7,62 \\
\hline 60 & 1450 & 60 & 27,08 & 22,15 & 20,79 & 19,04 & 17,42 & 15,89 & 13,15 & 10,90 & 7,63 \\
\hline 60 & 1500 & 60 & 26,76 & 21,90 & 20,59 & 18,89 & 17,30 & 15,80 & 13,11 & 10,88 & 7,64 \\
\hline 60 & 1550 & 60 & 26,46 & 21,66 & 20,39 & 18,74 & 17,18 & 15,71 & 13,07 & 10,87 & 7,65 \\
\hline 60 & 1600 & 60 & 26,18 & 21,43 & 20,21 & 18,60 & 17,07 & 15,63 & 13,03 & 10,85 & 7,66 \\
\hline 60 & 1650 & 60 & 25,91 & 21,21 & 20,03 & 18,46 & 16,96 & 15,55 & 12,99 & 10,84 & 7,67 \\
\hline 60 & 1700 & 60 & 25,65 & 21,00 & 19,85 & 18,32 & 16,86 & 15,47 & 12,95 & 10,82 & 7,68 \\
\hline 60 & 1750 & 60 & 25,40 & 20,79 & 19,68 & 18,19 & 16,76 & 15,39 & 12,91 & 10,81 & 7,69 \\
\hline 60 & 1800 & 60 & 25,16 & 20,60 & 19,52 & 18,06 & 16,66 & 15,31 & 12,87 & 10,79 & 7,69 \\
\hline 60 & 1850 & 60 & 24,94 & 20,41 & 19,36 & 17,94 & 16,56 & 15,24 & 12,83 & 10,78 & 7,70 \\
\hline 60 & 1900 & 60 & 24,72 & 20,23 & 19,21 & 17,82 & 16,46 & 15,17 & 12,79 & 10,76 & 7,70 \\
\hline 60 & 1950 & 60 & 24,51 & 20,05 & 19,06 & 17,70 & 16,37 & 15,09 & 12,75 & 10,75 & 7,71 \\
\hline 60 & 2000 & 60 & 24,31 & 19,88 & 18,92 & 17,59 & 16,28 & 15,02 & 12,71 & 10,73 & 7,71 \\
\hline 60 & 200 & 65 & 64,34 & 40,29 & 32,15 & 25,51 & 20,90 & 17,38 & 12,48 & 9,52 & 6,39 \\
\hline 60 & 250 & 65 & 56,75 & 37,38 & 30,60 & 24,82 & 20,63 & 17,33 & 12,59 & 9,63 & 6,42 \\
\hline 60 & 300 & 65 & 51,44 & 35,20 & 29,36 & 24,21 & 20,36 & 17,25 & 12,67 & 9,73 & 6,46 \\
\hline 60 & 350 & 65 & 47,47 & 33,47 & 28,33 & 23,67 & 20,09 & 17,14 & 12,72 & 9,81 & 6,50 \\
\hline 60 & 400 & 65 & 44,39 & 32,06 & 27,45 & 23,18 & 19,83 & 17,03 & 12,76 & 9,87 & 6,54 \\
\hline 60 & 450 & 65 & 41,90 & 30,86 & 26,69 & 22,73 & 19,58 & 16,91 & 12,77 & 9,92 & 6,58 \\
\hline 60 & 500 & 65 & 39,84 & 29,82 & 26,01 & 22,33 & 19,34 & 16,79 & 12,78 & 9,97 & 6,61 \\
\hline 60 & 550 & 65 & 38,11 & 28,92 & 25,41 & 21,95 & 19,12 & 16,67 & 12,77 & 10,01 & 6,65 \\
\hline 60 & 600 & 65 & 36,63 & 28,11 & 24,86 & 21,60 & 18,90 & 16,55 & 12,76 & 10,04 & 6,68 \\
\hline 60 & 650 & 65 & 35,35 & 27,39 & 24,36 & 21,28 & 18,70 & 16,43 & 12,75 & 10,06 & 6,71 \\
\hline 60 & 700 & 65 & 34,22 & 26,74 & 23,90 & 20,98 & 18,50 & 16,31 & 12,72 & 10,08 & 6,74 \\
\hline 60 & 750 & 65 & 33,22 & 26,14 & 23,48 & 20,69 & 18,31 & 16,20 & 12,70 & 10,10 & 6,77 \\
\hline 60 & 800 & 65 & 32,33 & 25,60 & 23,09 & 20,42 & 18,13 & 16,09 & 12,67 & 10,11 & 6,80 \\
\hline 60 & 850 & 65 & 31,53 & 25,09 & 22,72 & 20,17 & 17,96 & 15,98 & 12,64 & 10,12 & 6,82 \\
\hline 60 & 900 & 65 & 30,80 & 24,62 & 22,38 & 19,93 & 17,80 & 15,87 & 12,61 & 10,12 & 6,84 \\
\hline 60 & 950 & 65 & 30,14 & 24,19 & 22,06 & 19,70 & 17,64 & 15,76 & 12,58 & 10,13 & 6,87 \\
\hline 60 & 1000 & 65 & 29,53 & 23,78 & 21,76 & 19,49 & 17,49 & 15,66 & 12,55 & 10,13 & 6,89 \\
\hline 60 & 1050 & 65 & 28,98 & 23,40 & 21,47 & 19,28 & 17,34 & 15,56 & 12,51 & 10,13 & 6,91 \\
\hline 60 & 1100 & 65 & 28,46 & 23,04 & 21,20 & 19,08 & 17,20 & 15,47 & 12,48 & 10,13 & 6,92 \\
\hline 60 & 1150 & 65 & 27,99 & 22,70 & 20,95 & 18,90 & 17,06 & 15,37 & 12,44 & 10,12 & 6,94 \\
\hline 60 & 1200 & 65 & 27,54 & 22,38 & 20,70 & 18,72 & 16,93 & 15,28 & 12,41 & 10,12 & 6,96 \\
\hline 60 & 1250 & 65 & 27,13 & 22,08 & 20,47 & 18,54 & 16,80 & 15,19 & 12,37 & 10,11 & 6,97 \\
\hline 60 & 1300 & 65 & 26,74 & 21,79 & 20,24 & 18,38 & 16,68 & 15,10 & 12,34 & 10,11 & 6,98 \\
\hline 60 & 1350 & 65 & 26,37 & 21,52 & 20,03 & 18,22 & 16,56 & 15,02 & 12,30 & 10,10 & 7,00 \\
\hline 60 & 1400 & 65 & 26,03 & 21,26 & 19,83 & 18,06 & 16,45 & 14,94 & 12,26 & 10,09 & 7,01 \\
\hline 60 & 1450 & 65 & 25,71 & 21,01 & 19,63 & 17,92 & 16,33 & 14,85 & 12,23 & 10,08 & 7,02 \\
\hline 60 & 1500 & 65 & 25,40 & 20,77 & 19,44 & 17,77 & 16,23 & 14,77 & 12,19 & 10,07 & 7,03 \\
\hline 60 & 1550 & 65 & 25,11 & 20,54 & 19,26 & 17,63 & 16,12 & 14,70 & 12,15 & 10,06 & 7,04 \\
\hline 60 & 1600 & 65 & 24,84 & 20,32 & 19,09 & 17,50 & 16,02 & 14,62 & 12,12 & 10,05 & 7,05 \\
\hline 60 & 1650 & 65 & 24,57 & 20,11 & 18,92 & 17,37 & 15,92 & 14,55 & 12,08 & 10,04 & 7,06 \\
\hline 60 & 1700 & 65 & 24,32 & 19,91 & 18,76 & 17,25 & 15,82 & 14,48 & 12,05 & 10,03 & 7,07 \\
\hline 60 & 1750 & 65 & 24,09 & 19,72 & 18,60 & 17,12 & 15,73 & 14,40 & 12,01 & 10,01 & 7,08 \\
\hline 60 & 1800 & 65 & 23,86 & 19,53 & 18,45 & 17,01 & 15,64 & 14,34 & 11,98 & 10,00 & 7,08 \\
\hline 60 & 1850 & 65 & 23,64 & 19,35 & 18,30 & 16,89 & 15,55 & 14,27 & 11,94 & 9,99 & 7,09 \\
\hline 60 & 1900 & 65 & 23,43 & 19,18 & 18,16 & 16,78 & 15,46 & 14,20 & 11,91 & 9,98 & 7,10 \\
\hline 60 & 1950 & 65 & 23,23 & 19,01 & 18,02 & 16,67 & 15,37 & 14,14 & 11,88 & 9,96 & 7,10 \\
\hline 60 & 2000 & 65 & 23,03 & 18,85 & 17,89 & 16,57 & 15,29 & 14,07 & 11,84 & 9,95 & 7,11 \\
\hline 60 & 200 & 70 & 62,37 & 38,38 & 30,35 & 23,89 & 19,48 & 16,15 & 11,54 & 8,80 & 5,92 \\
\hline 60 & 250 & 70 & 54,90 & 35,58 & 28,88 & 23,26 & 19,25 & 16,12 & 11,66 & 8,91 & 5,95 \\
\hline 60 & 300 & 70 & 49,68 & 33,49 & 27,72 & 22,71 & 19,01 & 16,05 & 11,74 & 9,00 & 5,99 \\
\hline 60 & 350 & 70 & 45,80 & 31,84 & 26,76 & 22,22 & 18,78 & 15,97 & 11,79 & 9,07 & 6,02 \\
\hline 60 & 400 & 70 & 42,77 & 30,49 & 25,94 & 21,78 & 18,55 & 15,88 & 11,83 & 9,13 & 6,05 \\
\hline 60 & 450 & 70 & 40,34 & 29,35 & 25,23 & 21,37 & 18,33 & 15,78 & 11,85 & 9,18 & 6,09 \\
\hline 60 & 500 & 70 & 38,32 & 28,37 & 24,59 & 21,00 & 18,12 & 15,67 & 11,86 & 9,23 & 6,12 \\
\hline 60 & 550 & 70 & 36,63 & 27,51 & 24,03 & 20,66 & 17,92 & 15,57 & 11,86 & 9,26 & 6,15 \\
\hline 60 & 600 & 70 & 35,18 & 26,74 & 23,52 & 20,34 & 17,72 & 15,46 & 11,86 & 9,30 & 6,18 \\
\hline 60 & 650 & 70 & 33,92 & 26,06 & 23,05 & 20,04 & 17,54 & 15,36 & 11,85 & 9,32 & 6,21 \\
\hline 60 & 700 & 70 & 32,82 & 25,44 & 22,62 & 19,76 & 17,36 & 15,26 & 11,84 & 9,34 & 6,23 \\
\hline 60 & 750 & 70 & 31,84 & 24,87 & 22,23 & 19,50 & 17,19 & 15,16 & 11,82 & 9,36 & 6,26 \\
\hline 60 & 800 & 70 & 30,97 & 24,35 & 21,86 & 19,25 & 17,03 & 15,06 & 11,80 & 9,37 & 6,28 \\
\hline 60 & 850 & 70 & 30,19 & 23,87 & 21,52 & 19,02 & 16,87 & 14,96 & 11,77 & 9,38 & 6,31 \\
\hline 60 & 900 & 70 & 29,48 & 23,43 & 21,20 & 18,80 & 16,72 & 14,86 & 11,75 & 9,39 & 6,33 \\
\hline 60 & 950 & 70 & 28,83 & 23,02 & 20,89 & 18,59 & 16,58 & 14,77 & 11,72 & 9,40 & 6,35 \\
\hline 60 & 1000 & 70 & 28,24 & 22,63 & 20,61 & 18,38 & 16,44 & 14,68 & 11,70 & 9,40 & 6,37 \\
\hline 60 & 1050 & 70 & 27,70 & 22,27 & 20,34 & 18,19 & 16,31 & 14,59 & 11,67 & 9,41 & 6,39 \\
\hline
\end{tabular}




\begin{tabular}{|c|c|c|c|c|c|c|c|c|c|c|c|}
\hline \multirow[b]{2}{*}{$\mathrm{H}(\mathrm{cm})$} & \multirow[b]{2}{*}{ Mceq (MPa) } & & & & & De & ões (x1 & m) & & & \\
\hline & & Msub (MPa) & D0 & D25 & D40 & D60 & D80 & D100 & D140 & D180 & D260 \\
\hline 60 & 1100 & 70 & 27,20 & 21,93 & 20,09 & 18,01 & 16,18 & 14,50 & 11,64 & 9,41 & 6,40 \\
\hline 60 & 1150 & 70 & 26,73 & 21,61 & 19,85 & 17,84 & 16,05 & 14,42 & 11,61 & 9,41 & 6,42 \\
\hline 60 & 1200 & 70 & 26,30 & 21,30 & 19,62 & 17,67 & 15,93 & 14,34 & 11,58 & 9,40 & 6,43 \\
\hline 60 & 1250 & 70 & 25,90 & 21,01 & 19,40 & 17,51 & 15,82 & 14,26 & 11,55 & 9,40 & 6,45 \\
\hline 60 & 1300 & 70 & 25,52 & 20,74 & 19,19 & 17,36 & 15,70 & 14,18 & 11,52 & 9,40 & 6,46 \\
\hline 60 & 1350 & 70 & 25,16 & 20,48 & 18,99 & 17,21 & 15,59 & 14,10 & 11,49 & 9,39 & 6,47 \\
\hline 60 & 1400 & 70 & 24,83 & 20,23 & 18,80 & 17,06 & 15,49 & 14,02 & 11,45 & 9,39 & 6,49 \\
\hline 60 & 1450 & 70 & 24,51 & 20,00 & 18,61 & 16,93 & 15,39 & 13,95 & 11,42 & 9,38 & 6,50 \\
\hline 60 & 1500 & 70 & 24,22 & 19,77 & 18,44 & 16,79 & 15,29 & 13,88 & 11,39 & 9,37 & 6,51 \\
\hline 60 & 1550 & 70 & 23,94 & 19,55 & 18,27 & 16,66 & 15,19 & 13,81 & 11,36 & 9,36 & 6,52 \\
\hline 60 & 1600 & 70 & 23,67 & 19,35 & 18,10 & 16,54 & 15,10 & 13,74 & 11,33 & 9,36 & 6,53 \\
\hline 60 & 1650 & 70 & 23,41 & 19,15 & 17,95 & 16,42 & 15,00 & 13,67 & 11,30 & 9,35 & 6,54 \\
\hline 60 & 1700 & 70 & 23,17 & 18,96 & 17,79 & 16,30 & 14,91 & 13,61 & 11,27 & 9,34 & 6,54 \\
\hline 60 & 1750 & 70 & 22,94 & 18,77 & 17,65 & 16,19 & 14,83 & 13,54 & 11,24 & 9,33 & 6,55 \\
\hline 60 & 1800 & 70 & 22,72 & 18,60 & 17,50 & 16,08 & 14,74 & 13,48 & 11,21 & 9,32 & 6,56 \\
\hline 60 & 1850 & 70 & 22,51 & 18,42 & 17,36 & 15,97 & 14,66 & 13,42 & 11,18 & 9,31 & 6,57 \\
\hline 60 & 1900 & 70 & 22,30 & 18,26 & 17,23 & 15,87 & 14,58 & 13,36 & 11,15 & 9,30 & 6,57 \\
\hline 60 & 1950 & 70 & 22,11 & 18,10 & 17,10 & 15,77 & 14,50 & 13,30 & 11,12 & 9,29 & 6,58 \\
\hline 60 & 2000 & 70 & 21,92 & 17,95 & 16,97 & 15,67 & 14,42 & 13,24 & 11,09 & 9,27 & 6,58 \\
\hline 60 & 200 & 75 & 60,62 & 36,69 & 28,76 & 22,47 & 18,24 & 15,07 & 10,74 & 8,19 & 5,52 \\
\hline 60 & 250 & 75 & 53,27 & 33,98 & 27,38 & 21,90 & 18,04 & 15,05 & 10,85 & 8,28 & 5,55 \\
\hline 60 & 300 & 75 & 48,14 & 31,98 & 26,28 & 21,40 & 17,83 & 15,01 & 10,93 & 8,37 & 5,57 \\
\hline 60 & 350 & 75 & 44,32 & 30,40 & 25,38 & 20,95 & 17,63 & 14,94 & 10,99 & 8,44 & 5,60 \\
\hline 60 & 400 & 75 & 41,35 & 29,10 & 24,61 & 20,54 & 17,42 & 14,87 & 11,02 & 8,49 & 5,63 \\
\hline 60 & 450 & 75 & 38,95 & 28,01 & 23,93 & 20,17 & 17,23 & 14,78 & 11,05 & 8,54 & 5,66 \\
\hline 60 & 500 & 75 & 36,98 & 27,07 & 23,34 & 19,83 & 17,04 & 14,69 & 11,07 & 8,59 & 5,69 \\
\hline 60 & 550 & 75 & 35,32 & 26,25 & 22,81 & 19,51 & 16,86 & 14,60 & 11,07 & 8,62 & 5,72 \\
\hline 60 & 600 & 75 & 33,90 & 25,52 & 22,33 & 19,22 & 16,68 & 14,51 & 11,07 & 8,65 & 5,74 \\
\hline 60 & 650 & 75 & 32,67 & 24,87 & 21,89 & 18,94 & 16,52 & 14,42 & 11,07 & 8,68 & 5,77 \\
\hline 60 & 700 & 75 & 31,59 & 24,28 & 21,48 & 18,68 & 16,36 & 14,33 & 11,06 & 8,70 & 5,79 \\
\hline 60 & 750 & 75 & 30,63 & 23,74 & 21,11 & 18,44 & 16,20 & 14,24 & 11,05 & 8,72 & 5,82 \\
\hline 60 & 800 & 75 & 29,78 & 23,25 & 20,77 & 18,21 & 16,06 & 14,15 & 11,03 & 8,73 & 5,84 \\
\hline 60 & 850 & 75 & 29,01 & 22,79 & 20,44 & 18,00 & 15,91 & 14,06 & 11,01 & 8,75 & 5,86 \\
\hline 60 & 900 & 75 & 28,32 & 22,37 & 20,14 & 17,79 & 15,78 & 13,98 & 10,99 & 8,76 & 5,88 \\
\hline 60 & 950 & 75 & 27,68 & 21,98 & 19,86 & 17,60 & 15,65 & 13,90 & 10,97 & 8,77 & 5,90 \\
\hline 60 & 1000 & 75 & 27,11 & 21,61 & 19,59 & 17,41 & 15,52 & 13,81 & 10,95 & 8,77 & 5,92 \\
\hline 60 & 1050 & 75 & 26,57 & 21,26 & 19,34 & 17,23 & 15,40 & 13,73 & 10,93 & 8,78 & 5,94 \\
\hline 60 & 1100 & 75 & 26,08 & 20,94 & 19,10 & 17,06 & 15,28 & 13,66 & 10,90 & 8,78 & 5,95 \\
\hline 60 & 1150 & 75 & 25,63 & 20,63 & 18,87 & 16,90 & 15,16 & 13,58 & 10,88 & 8,78 & 5,97 \\
\hline 60 & 1200 & 75 & 25,21 & 20,34 & 18,66 & 16,75 & 15,05 & 13,51 & 10,85 & 8,78 & 5,98 \\
\hline 60 & 1250 & 75 & 24,81 & 20,07 & 18,45 & 16,60 & 14,95 & 13,43 & 10,83 & 8,78 & 6,00 \\
\hline 60 & 1300 & 75 & 24,44 & 19,81 & 18,25 & 16,45 & 14,84 & 13,36 & 10,80 & 8,78 & 6,01 \\
\hline 60 & 1350 & 75 & 24,10 & 19,56 & 18,07 & 16,31 & 14,74 & 13,29 & 10,77 & 8,77 & 6,02 \\
\hline 60 & 1400 & 75 & 23,77 & 19,33 & 17,89 & 16,18 & 14,64 & 13,22 & 10,74 & 8,77 & 6,03 \\
\hline 60 & 1450 & 75 & 23,46 & 19,10 & 17,71 & 16,05 & 14,55 & 13,16 & 10,72 & 8,76 & 6,04 \\
\hline 60 & 1500 & 75 & 23,17 & 18,88 & 17,55 & 15,93 & 14,46 & 13,09 & 10,69 & 8,76 & 6,05 \\
\hline 60 & 1550 & 75 & 22,90 & 18,68 & 17,38 & 15,81 & 14,37 & 13,03 & 10,66 & 8,75 & 6,06 \\
\hline 60 & 1600 & 75 & 22,64 & 18,48 & 17,23 & 15,69 & 14,28 & 12,96 & 10,64 & 8,75 & 6,07 \\
\hline 60 & 1650 & 75 & 22,39 & 18,29 & 17,08 & 15,58 & 14,20 & 12,90 & 10,61 & 8,74 & 6,08 \\
\hline 60 & 1700 & 75 & 22,15 & 18,11 & 16,94 & 15,47 & 14,11 & 12,84 & 10,58 & 8,73 & 6,09 \\
\hline 60 & 1750 & 75 & 21,93 & 17,93 & 16,80 & 15,36 & 14,03 & 12,78 & 10,55 & 8,73 & 6,10 \\
\hline 60 & 1800 & 75 & 21,71 & 17,76 & 16,66 & 15,26 & 13,95 & 12,72 & 10,53 & 8,72 & 6,10 \\
\hline 60 & 1850 & 75 & 21,51 & 17,60 & 16,53 & 15,16 & 13,88 & 12,67 & 10,50 & 8,71 & 6,11 \\
\hline 60 & 1900 & 75 & 21,31 & 17,44 & 16,41 & 15,06 & 13,80 & 12,61 & 10,47 & 8,70 & 6,12 \\
\hline 60 & 1950 & 75 & 21,12 & 17,29 & 16,28 & 14,97 & 13,73 & 12,56 & 10,45 & 8,69 & 6,12 \\
\hline 60 & 2000 & 75 & 20,94 & 17,14 & 16,16 & 14,88 & 13,66 & 12,50 & 10,42 & 8,68 & 6,13 \\
\hline 60 & 200 & 80 & 59,07 & 35,18 & 27,34 & 21,21 & 17,14 & 14,12 & 10,03 & 7,65 & 5,17 \\
\hline 60 & 250 & 80 & 51,81 & 32,56 & 26,03 & 20,69 & 16,97 & 14,12 & 10,14 & 7,74 & 5,19 \\
\hline 60 & 300 & 80 & 46,75 & 30,63 & 25,00 & 20,23 & 16,79 & 14,09 & 10,22 & 7,82 & 5,22 \\
\hline 60 & 350 & 80 & 43,00 & 29,11 & 24,15 & 19,82 & 16,61 & 14,04 & 10,28 & 7,88 & 5,24 \\
\hline 60 & 400 & 80 & 40,07 & 27,86 & 23,42 & 19,44 & 16,43 & 13,97 & 10,32 & 7,94 & 5,27 \\
\hline 60 & 450 & 80 & 37,72 & 26,82 & 22,78 & 19,10 & 16,25 & 13,90 & 10,35 & 7,98 & 5,29 \\
\hline 60 & 500 & 80 & 35,79 & 25,92 & 22,22 & 18,79 & 16,08 & 13,83 & 10,37 & 8,03 & 5,32 \\
\hline 60 & 550 & 80 & 34,16 & 25,13 & 21,72 & 18,49 & 15,92 & 13,75 & 10,38 & 8,06 & 5,34 \\
\hline 60 & 600 & 80 & 32,76 & 24,43 & 21,27 & 18,22 & 15,76 & 13,67 & 10,38 & 8,09 & 5,37 \\
\hline 60 & 650 & 80 & 31,55 & 23,81 & 20,85 & 17,97 & 15,61 & 13,59 & 10,38 & 8,12 & 5,39 \\
\hline 60 & 700 & 80 & 30,49 & 23,24 & 20,47 & 17,73 & 15,47 & 13,51 & 10,38 & 8,14 & 5,41 \\
\hline 60 & 750 & 80 & 29,56 & 22,73 & 20,12 & 17,50 & 15,33 & 13,43 & 10,37 & 8,16 & 5,43 \\
\hline 60 & 800 & 80 & 28,72 & 22,26 & 19,79 & 17,29 & 15,19 & 13,35 & 10,36 & 8,17 & 5,45 \\
\hline 60 & 850 & 80 & 27,97 & 21,82 & 19,49 & 17,09 & 15,06 & 13,27 & 10,34 & 8,19 & 5,47 \\
\hline 60 & 900 & 80 & 27,28 & 21,42 & 19,20 & 16,90 & 14,94 & 13,20 & 10,33 & 8,20 & 5,49 \\
\hline 60 & 950 & 80 & 26,66 & 21,04 & 18,94 & 16,71 & 14,81 & 13,12 & 10,31 & 8,21 & 5,51 \\
\hline 60 & 1000 & 80 & 26,10 & 20,69 & 18,68 & 16,54 & 14,70 & 13,05 & 10,29 & 8,22 & 5,53 \\
\hline 60 & 1050 & 80 & 25,58 & 20,36 & 18,45 & 16,38 & 14,59 & 12,97 & 10,27 & 8,22 & 5,54 \\
\hline 60 & 1100 & 80 & 25,10 & 20,05 & 18,22 & 16,22 & 14,48 & 12,90 & 10,25 & 8,23 & 5,56 \\
\hline 60 & 1150 & 80 & 24,65 & 19,76 & 18,00 & 16,07 & 14,37 & 12,83 & 10,23 & 8,23 & 5,57 \\
\hline 60 & 1200 & 80 & 24,24 & 19,48 & 17,80 & 15,92 & 14,27 & 12,77 & 10,21 & 8,23 & 5,59 \\
\hline 60 & 1250 & 80 & 23,85 & 19,22 & 17,60 & 15,78 & 14,17 & 12,70 & 10,19 & 8,23 & 5,60 \\
\hline 60 & 1300 & 80 & 23,49 & 18,97 & 17,42 & 15,65 & 14,07 & 12,64 & 10,16 & 8,23 & 5,61 \\
\hline 60 & 1350 & 80 & 23,15 & 18,74 & 17,24 & 15,52 & 13,98 & 12,57 & 10,14 & 8,23 & 5,62 \\
\hline 60 & 1400 & 80 & 22,83 & 18,51 & 17,07 & 15,39 & 13,89 & 12,51 & 10,12 & 8,23 & 5,64 \\
\hline
\end{tabular}




\begin{tabular}{|c|c|c|c|c|c|c|c|c|c|c|c|}
\hline \multirow[b]{2}{*}{$\mathrm{H}(\mathrm{cm})$} & \multirow[b]{2}{*}{ Mceq (MPa) } & & & & & $\mathrm{De}$ & ões (x1 & & & & \\
\hline & & Msub (MPa) & D0 & D25 & D40 & D60 & D80 & D100 & D140 & D180 & D260 \\
\hline 60 & 1450 & 80 & 22,53 & 18,30 & 16,90 & 15,27 & 13,80 & 12,45 & 10,09 & 8,22 & 5,65 \\
\hline 60 & 1500 & 80 & 22,25 & 18,09 & 16,75 & 15,15 & 13,72 & 12,39 & 10,07 & 8,22 & 5,66 \\
\hline 60 & 1550 & 80 & 21,98 & 17,89 & 16,60 & 15,04 & 13,63 & 12,33 & 10,05 & 8,22 & 5,67 \\
\hline 60 & 1600 & 80 & 21,73 & 17,70 & 16,45 & 14,93 & 13,55 & 12,27 & 10,02 & 8,21 & 5,68 \\
\hline 60 & 1650 & 80 & 21,48 & 17,52 & 16,31 & 14,83 & 13,47 & 12,22 & 10,00 & 8,21 & 5,68 \\
\hline 60 & 1700 & 80 & 21,25 & 17,35 & 16,17 & 14,72 & 13,40 & 12,16 & 9,97 & 8,20 & 5,69 \\
\hline 60 & 1750 & 80 & 21,03 & 17,18 & 16,04 & 14,62 & 13,32 & 12,11 & 9,95 & 8,20 & 5,70 \\
\hline 60 & 1800 & 80 & 20,82 & 17,02 & 15,91 & 14,53 & 13,25 & 12,05 & 9,93 & 8,19 & 5,71 \\
\hline 60 & 1850 & 80 & 20,62 & 16,86 & 15,79 & 14,43 & 13,18 & 12,00 & 9,90 & 8,18 & 5,71 \\
\hline 60 & 1900 & 80 & 20,43 & 16,71 & 15,67 & 14,34 & 13,11 & 11,95 & 9,88 & 8,18 & 5,72 \\
\hline 60 & 1950 & 80 & 20,25 & 16,57 & 15,55 & 14,25 & 13,04 & 11,90 & 9,86 & 8,17 & 5,73 \\
\hline 60 & 2000 & 80 & 20,07 & 16,43 & 15,44 & 14,17 & 12,97 & 11,85 & 9,83 & 8,16 & 5,73 \\
\hline 60 & 200 & 85 & 57,67 & 33,83 & 26,08 & 20,09 & 16,17 & 13,29 & 9,41 & 7,18 & 4,87 \\
\hline 60 & 250 & 85 & 50,50 & 31,29 & 24,83 & 19,61 & 16,02 & 13,30 & 9,52 & 7,26 & 4,88 \\
\hline 60 & 300 & 85 & 45,51 & 29,42 & 23,85 & 19,19 & 15,86 & 13,27 & 9,60 & 7,33 & 4,90 \\
\hline 60 & 350 & 85 & 41,81 & 27,95 & 23,04 & 18,81 & 15,70 & 13,23 & 9,65 & 7,39 & 4,92 \\
\hline 60 & 400 & 85 & 38,93 & 26,75 & 22,35 & 18,46 & 15,54 & 13,18 & 9,70 & 7,45 & 4,95 \\
\hline 60 & 450 & 85 & 36,62 & 25,74 & 21,75 & 18,14 & 15,38 & 13,12 & 9,73 & 7,49 & 4,97 \\
\hline 60 & 500 & 85 & 34,71 & 24,87 & 21,22 & 17,85 & 15,23 & 13,06 & 9,75 & 7,53 & 4,99 \\
\hline 60 & 550 & 85 & 33,11 & 24,12 & 20,74 & 17,58 & 15,08 & 12,99 & 9,76 & 7,57 & 5,01 \\
\hline 60 & 600 & 85 & 31,74 & 23,45 & 20,31 & 17,33 & 14,94 & 12,92 & 9,77 & 7,60 & 5,03 \\
\hline 60 & 650 & 85 & 30,55 & 22,85 & 19,92 & 17,09 & 14,80 & 12,85 & 9,77 & 7,62 & 5,06 \\
\hline 60 & 700 & 85 & 29,51 & 22,31 & 19,56 & 16,87 & 14,67 & 12,78 & 9,77 & 7,64 & 5,08 \\
\hline 60 & 750 & 85 & 28,59 & 21,82 & 19,23 & 16,66 & 14,54 & 12,70 & 9,76 & 7,66 & 5,10 \\
\hline 60 & 800 & 85 & 27,77 & 21,36 & 18,92 & 16,46 & 14,42 & 12,63 & 9,76 & 7,68 & 5,12 \\
\hline 60 & 850 & 85 & 27,03 & 20,95 & 18,63 & 16,27 & 14,30 & 12,56 & 9,75 & 7,69 & 5,13 \\
\hline 60 & 900 & 85 & 26,36 & 20,56 & 18,36 & 16,09 & 14,18 & 12,50 & 9,73 & 7,71 & 5,15 \\
\hline 60 & 950 & 85 & 25,75 & 20,20 & 18,10 & 15,92 & 14,07 & 12,43 & 9,72 & 7,72 & 5,17 \\
\hline 60 & 1000 & 85 & 25,20 & 19,87 & 17,87 & 15,76 & 13,96 & 12,36 & 9,71 & 7,72 & 5,18 \\
\hline 60 & 1050 & 85 & 24,68 & 19,55 & 17,64 & 15,61 & 13,86 & 12,30 & 9,69 & 7,73 & 5,20 \\
\hline 60 & 1100 & 85 & 24,21 & 19,25 & 17,42 & 15,46 & 13,76 & 12,23 & 9,67 & 7,74 & 5,21 \\
\hline 60 & 1150 & 85 & 23,78 & 18,97 & 17,22 & 15,32 & 13,66 & 12,17 & 9,66 & 7,74 & 5,23 \\
\hline 60 & 1200 & 85 & 23,37 & 18,71 & 17,03 & 15,18 & 13,57 & 12,11 & 9,64 & 7,74 & 5,24 \\
\hline 60 & 1250 & 85 & 22,99 & 18,46 & 16,84 & 15,05 & 13,47 & 12,05 & 9,62 & 7,75 & 5,25 \\
\hline 60 & 1300 & 85 & 22,64 & 18,22 & 16,67 & 14,92 & 13,39 & 11,99 & 9,60 & 7,75 & 5,26 \\
\hline 60 & 1350 & 85 & 22,30 & 17,99 & 16,50 & 14,80 & 13,30 & 11,93 & 9,58 & 7,75 & 5,28 \\
\hline 60 & 1400 & 85 & 21,99 & 17,78 & 16,33 & 14,68 & 13,21 & 11,87 & 9,56 & 7,75 & 5,29 \\
\hline 60 & 1450 & 85 & 21,70 & 17,57 & 16,18 & 14,57 & 13,13 & 11,81 & 9,54 & 7,74 & 5,30 \\
\hline 60 & 1500 & 85 & 21,42 & 17,37 & 16,03 & 14,46 & 13,05 & 11,76 & 9,52 & 7,74 & 5,31 \\
\hline 60 & 1550 & 85 & 21,16 & 17,19 & 15,88 & 14,35 & 12,98 & 11,71 & 9,50 & 7,74 & 5,32 \\
\hline 60 & 1600 & 85 & 20,91 & 17,00 & 15,74 & 14,25 & 12,90 & 11,65 & 9,48 & 7,74 & 5,32 \\
\hline 60 & 1650 & 85 & 20,67 & 16,83 & 15,61 & 14,15 & 12,83 & 11,60 & 9,45 & 7,73 & 5,33 \\
\hline 60 & 1700 & 85 & 20,45 & 16,66 & 15,48 & 14,05 & 12,76 & 11,55 & 9,43 & 7,73 & 5,34 \\
\hline 60 & 1750 & 85 & 20,23 & 16,50 & 15,36 & 13,96 & 12,69 & 11,50 & 9,41 & 7,72 & 5,35 \\
\hline 60 & 1800 & 85 & 20,03 & 16,35 & 15,23 & 13,87 & 12,62 & 11,45 & 9,39 & 7,72 & 5,36 \\
\hline 60 & 1850 & 85 & 19,83 & 16,20 & 15,12 & 13,78 & 12,55 & 11,40 & 9,37 & 7,71 & 5,36 \\
\hline 60 & 1900 & 85 & 19,65 & 16,05 & 15,00 & 13,69 & 12,49 & 11,36 & 9,35 & 7,71 & 5,37 \\
\hline 60 & 1950 & 85 & 19,47 & 15,91 & 14,89 & 13,61 & 12,42 & 11,31 & 9,33 & 7,70 & 5,38 \\
\hline 60 & 2000 & 85 & 19,29 & 15,78 & 14,79 & 13,53 & 12,36 & 11,26 & 9,31 & 7,70 & 5,38 \\
\hline 60 & 200 & 90 & 56,41 & 32,61 & 24,94 & 19,08 & 15,30 & 12,54 & 8,86 & 6,76 & 4,59 \\
\hline 60 & 250 & 90 & 49,32 & 30,14 & 23,75 & 18,64 & 15,17 & 12,56 & 8,97 & 6,84 & 4,61 \\
\hline 60 & 300 & 90 & 44,39 & 28,32 & 22,81 & 18,25 & 15,03 & 12,55 & 9,04 & 6,90 & 4,62 \\
\hline 60 & 350 & 90 & 40,74 & 26,90 & 22,04 & 17,90 & 14,89 & 12,51 & 9,10 & 6,96 & 4,64 \\
\hline 60 & 400 & 90 & 37,90 & 25,74 & 21,39 & 17,58 & 14,75 & 12,47 & 9,14 & 7,01 & 4,66 \\
\hline 60 & 450 & 90 & 35,62 & 24,77 & 20,82 & 17,28 & 14,60 & 12,42 & 9,17 & 7,05 & 4,68 \\
\hline 60 & 500 & 90 & 33,75 & 23,93 & 20,31 & 17,01 & 14,46 & 12,36 & 9,20 & 7,09 & 4,70 \\
\hline 60 & 550 & 90 & 32,17 & 23,20 & 19,86 & 16,76 & 14,33 & 12,31 & 9,21 & 7,13 & 4,72 \\
\hline 60 & 600 & 90 & 30,82 & 22,56 & 19,45 & 16,52 & 14,20 & 12,24 & 9,22 & 7,16 & 4,74 \\
\hline 60 & 650 & 90 & 29,65 & 21,98 & 19,08 & 16,30 & 14,07 & 12,18 & 9,23 & 7,18 & 4,76 \\
\hline 60 & 700 & 90 & 28,63 & 21,46 & 18,74 & 16,09 & 13,95 & 12,12 & 9,23 & 7,20 & 4,78 \\
\hline 60 & 750 & 90 & 27,72 & 20,99 & 18,42 & 15,90 & 13,83 & 12,05 & 9,23 & 7,22 & 4,80 \\
\hline 60 & 800 & 90 & 26,91 & 20,56 & 18,12 & 15,71 & 13,72 & 11,99 & 9,22 & 7,24 & 4,82 \\
\hline 60 & 850 & 90 & 26,18 & 20,15 & 17,85 & 15,54 & 13,61 & 11,93 & 9,21 & 7,25 & 4,83 \\
\hline 60 & 900 & 90 & 25,53 & $\begin{array}{l}19,78 \\
\end{array}$ & 17,59 & 15,37 & 13,50 & 11,87 & 9,21 & 7,27 & 4,85 \\
\hline 60 & 950 & 90 & 24,93 & 19,44 & 17,35 & 15,21 & 13,40 & 11,80 & 9,19 & 7,28 & 4,86 \\
\hline 60 & 1000 & 90 & 24,38 & 19,12 & 17,12 & 15,06 & 13,30 & 11,74 & 9,18 & 7,29 & 4,88 \\
\hline 60 & 1050 & 90 & 23,88 & 18,81 & 16,91 & 14,91 & 13,20 & 11,68 & 9,17 & 7,29 & 4,89 \\
\hline 60 & 1100 & 90 & 23,42 & 18,53 & 16,71 & 14,77 & 13,11 & 11,63 & 9,16 & 7,30 & 4,91 \\
\hline 60 & 1150 & 90 & 22,99 & 18,26 & 16,51 & 14,64 & 13,02 & 11,57 & 9,14 & 7,31 & 4,92 \\
\hline 60 & 1200 & 90 & 22,59 & 18,01 & 16,33 & 14,51 & 12,93 & 11,51 & 9,12 & 7,31 & 4,93 \\
\hline 60 & 1250 & 90 & 22,22 & 17,77 & 16,15 & 14,38 & 12,85 & 11,46 & 9,11 & 7,31 & 4,94 \\
\hline 60 & 1300 & 90 & 21,87 & 17,54 & 15,98 & 14,27 & 12,76 & 11,40 & 9,09 & 7,31 & 4,96 \\
\hline 60 & 1350 & 90 & 21,54 & 17,32 & 15,82 & 14,15 & 12,68 & 11,35 & 9,07 & 7,32 & 4,97 \\
\hline 60 & 1400 & 90 & 21,24 & 17.11 & 15,67 & 14.04 & 12,60 & 11,30 & 9.06 & 7,32 & 4,98 \\
\hline 60 & 1450 & 90 & 20,95 & 16,91 & 15,52 & 13,93 & 12,53 & 11,24 & 9,04 & 7,32 & 4,99 \\
\hline 60 & 1500 & 90 & 20,68 & 16,72 & 15,38 & 13,83 & 12,45 & 11,19 & 9,02 & 7,32 & 5,00 \\
\hline 60 & 1550 & 90 & 20,42 & 16,54 & 15,24 & 13,73 & 12,38 & 11,14 & 9,00 & 7,31 & 5,01 \\
\hline 60 & 1600 & 90 & 20,17 & 16,37 & 15,11 & 13,63 & 12,31 & 11,09 & 8,98 & 7,31 & 5,01 \\
\hline 60 & 1650 & 90 & 19,94 & 16,20 & 14,98 & 13,54 & 12,24 & 11,05 & 8,97 & 7,31 & 5,02 \\
\hline 60 & 1700 & 90 & 19,72 & 16,04 & 14,86 & 13,45 & 12,18 & 11,00 & 8,95 & 7,31 & 5,03 \\
\hline 60 & 1750 & 90 & 19,51 & 15,89 & 14,74 & 13,36 & 12,11 & 10,95 & 8,93 & 7,30 & 5,04 \\
\hline
\end{tabular}




\begin{tabular}{|c|c|c|c|c|c|c|c|c|c|c|c|}
\hline \multirow[b]{2}{*}{$\mathrm{H}(\mathrm{cm})$} & \multirow[b]{2}{*}{ Mceq (MPa) } & & & & & De & ões (x1 & m) & & & \\
\hline & & Msub (MPa) & D0 & D25 & D40 & D60 & D80 & D100 & D140 & D180 & D260 \\
\hline 60 & 1800 & 90 & 19,31 & 15,74 & 14,62 & 13,27 & 12,05 & 10,91 & 8,91 & 7,30 & 5,04 \\
\hline 60 & 1850 & 90 & 19,12 & 15,59 & 14,51 & 13,19 & 11,98 & 10,86 & 8,89 & 7,30 & 5,05 \\
\hline 60 & 1900 & 90 & 18,94 & 15,45 & 14,40 & 13,11 & 11,92 & 10,82 & 8,87 & 7,29 & 5,06 \\
\hline 60 & 1950 & 90 & 18,76 & 15,32 & 14,30 & 13,03 & 11,86 & 10,78 & 8,85 & 7,29 & 5,06 \\
\hline 60 & 2000 & 90 & 18,59 & 15,19 & 14,19 & 12,95 & 11,81 & 10,73 & 8,83 & 7,28 & 5,07 \\
\hline 60 & 200 & 95 & 55,27 & 31,51 & 23,91 & 18,17 & 14,51 & 11,87 & 8,37 & 6,39 & 4,35 \\
\hline 60 & 250 & 95 & 48,24 & 29,10 & 22,77 & 17,76 & 14,41 & 11,90 & 8,47 & 6,46 & 4,36 \\
\hline 60 & 300 & 95 & 43,37 & 27,33 & 21,87 & 17,40 & 14,28 & 11,89 & 8,55 & 6,52 & 4,37 \\
\hline 60 & 350 & 95 & 39,76 & 25,94 & 21,14 & 17,07 & 14,16 & 11,87 & 8,60 & 6,58 & 4,39 \\
\hline 60 & 400 & 95 & 36,96 & 24,82 & 20,51 & 16,78 & 14,03 & 11,83 & 8,64 & 6,62 & 4,41 \\
\hline 60 & 450 & 95 & 34,71 & 23,88 & 19,97 & 16,50 & 13,90 & 11,79 & 8,68 & 6,66 & 4,43 \\
\hline 60 & 500 & 95 & 32,86 & 23,07 & 19,49 & 16,25 & 13,77 & 11,74 & 8,70 & 6,70 & 4,44 \\
\hline 60 & 550 & 95 & 31,31 & 22,37 & 19,06 & 16,01 & 13,65 & 11,69 & 8,72 & 6,73 & 4,46 \\
\hline 60 & 600 & 95 & 29,98 & 21,75 & 18,67 & 15,79 & 13,53 & 11,64 & 8,73 & 6,76 & 4,48 \\
\hline 60 & 650 & 95 & 28,83 & 21,19 & 18,31 & 15,59 & 13,41 & 11,58 & 8,74 & 6,79 & 4,50 \\
\hline 60 & 700 & 95 & 27,82 & 20,69 & 17,99 & 15,39 & 13,30 & 11,52 & 8,74 & 6,81 & 4,51 \\
\hline 60 & 750 & 95 & 26,93 & 20,24 & 17,68 & 15,21 & 13,19 & 11,47 & 8,74 & 6,83 & 4,53 \\
\hline 60 & 800 & 95 & 26,13 & 19,82 & 17,40 & 15,03 & 13,09 & 11,41 & 8,74 & 6,85 & 4,55 \\
\hline 60 & 850 & 95 & 25,42 & 19,43 & 17,14 & 14,87 & 12,99 & 11,35 & 8,73 & 6,86 & 4,56 \\
\hline 60 & 900 & 95 & 24,77 & 19,07 & 16,90 & 14,71 & 12,89 & 11,30 & 8,73 & 6,87 & 4,58 \\
\hline 60 & 950 & 95 & 24,18 & 18,74 & 16,67 & 14,56 & 12,79 & 11,24 & 8,72 & 6,88 & 4,59 \\
\hline 60 & 1000 & 95 & 23,65 & 18,43 & 16,45 & 14,42 & 12,70 & 11,19 & 8,71 & 6,89 & 4,61 \\
\hline 60 & 1050 & 95 & 23,15 & 18,14 & 16,25 & 14,28 & 12,61 & 11,13 & 8,70 & 6,90 & 4,62 \\
\hline 60 & 1100 & 95 & 22,70 & 17,87 & 16,05 & 14,15 & 12,52 & 11,08 & 8,69 & 6,91 & 4,63 \\
\hline 60 & 1150 & 95 & 22,27 & 17,61 & 15,87 & 14,02 & 12,44 & 11,03 & 8,68 & 6,91 & 4,65 \\
\hline 60 & 1200 & 95 & 21,88 & 17,36 & 15,69 & 13,90 & 12,36 & 10,97 & 8,66 & 6,92 & 4,66 \\
\hline 60 & 1250 & 95 & 21,52 & 17,13 & 15,52 & 13,78 & 12,28 & 10,92 & 8,65 & 6,92 & 4,67 \\
\hline 60 & 1300 & 95 & 21,17 & 16,91 & 15,36 & 13,67 & 12,20 & 10,87 & 8,63 & 6,93 & 4,68 \\
\hline 60 & 1350 & 95 & 20,85 & 16,70 & 15,21 & 13,56 & 12,12 & 10,82 & 8,62 & 6,93 & 4,69 \\
\hline 60 & 1400 & 95 & 20,55 & 16,50 & 15,06 & 13,46 & 12,05 & 10,77 & 8,60 & 6,93 & 4,70 \\
\hline 60 & 1450 & 95 & 20,27 & 16,31 & 14,92 & 13,36 & 11,98 & 10,73 & 8,59 & 6,93 & 4,71 \\
\hline 60 & 1500 & 95 & 20,00 & 16,13 & 14,78 & 13,26 & 11,91 & 10,68 & 8,57 & 6,93 & 4,72 \\
\hline 60 & 1550 & 95 & 19,75 & 15,96 & 14,65 & 13,16 & 11,84 & 10,63 & 8,56 & 6,93 & 4,73 \\
\hline 60 & 1600 & 95 & 19,51 & 15,79 & 14,53 & 13,07 & 11,78 & 10,59 & 8,54 & 6,93 & 4,74 \\
\hline 60 & 1650 & 95 & 19,28 & 15,63 & 14,40 & 12,98 & 11,71 & 10,54 & 8,52 & 6,93 & 4,74 \\
\hline 60 & 1700 & 95 & 19,07 & 15,47 & 14,29 & 12,90 & 11,65 & 10,50 & 8,51 & 6,93 & 4,75 \\
\hline 60 & 1750 & 95 & 18,86 & 15,32 & 14,17 & 12,81 & 11,59 & 10,46 & 8,49 & 6,92 & 4,76 \\
\hline 60 & 1800 & 95 & 18,66 & 15,18 & 14,06 & 12,73 & 11,53 & 10,42 & 8,47 & 6,92 & 4,77 \\
\hline 60 & 1850 & 95 & 18,48 & 15,04 & 13,96 & 12,65 & 11,47 & 10,37 & 8,46 & 6,92 & 4,77 \\
\hline 60 & 1900 & 95 & 18,30 & 14,91 & 13,85 & 12,57 & 11,41 & 10,33 & 8,44 & 6,92 & 4,78 \\
\hline 60 & 1950 & 95 & 18,12 & 14,78 & 13,75 & 12,50 & 11,36 & 10,29 & 8,42 & 6,91 & 4,79 \\
\hline 60 & 2000 & 95 & 17,96 & 14,65 & 13,65 & 12,43 & 11,30 & 10,25 & 8,41 & 6,91 & 4,79 \\
\hline 60 & 200 & 100 & 54,22 & 30,50 & 22,97 & 17,35 & 13,81 & 11,27 & 7,93 & 6,05 & 4,13 \\
\hline 60 & 250 & 100 & 47,26 & 28,14 & 21,87 & 16,97 & 13,71 & 11,30 & 8,03 & 6,12 & 4,14 \\
\hline 60 & 300 & 100 & 42,43 & 26,42 & 21,02 & 16,63 & 13,61 & 11,30 & 8,10 & 6,18 & 4,15 \\
\hline 60 & 350 & 100 & 38,87 & 25,07 & 20,31 & 16,33 & 13,49 & 11,28 & 8,15 & 6,23 & 4,16 \\
\hline 60 & 400 & 100 & 36,10 & 23,98 & 19,71 & 16,05 & 13,37 & 11,26 & 8,20 & 6,27 & 4,18 \\
\hline 60 & 450 & 100 & 33,88 & 23,07 & 19,19 & 15,79 & 13,26 & 11,22 & 8,23 & 6,31 & 4,20 \\
\hline 60 & 500 & 100 & 32,06 & 22,29 & 18,73 & 15,55 & 13,14 & 11,18 & 8,26 & 6,35 & 4,21 \\
\hline 60 & 550 & 100 & 30,53 & 21,61 & 18,32 & 15,33 & 13,03 & 11,13 & 8,27 & 6,38 & 4,23 \\
\hline 60 & 600 & 100 & 29,22 & 21,01 & 17,95 & 15,13 & 12,92 & 11,09 & 8,29 & 6,41 & 4,25 \\
\hline 60 & 650 & 100 & 28,08 & 20,47 & 17,61 & 14,93 & 12,81 & 11,04 & 8,30 & 6,43 & 4,26 \\
\hline 60 & 700 & 100 & 27,09 & 19,99 & 17,30 & 14,75 & 12,71 & 10,99 & 8,30 & 6,45 & 4,28 \\
\hline 60 & 750 & 100 & 26,21 & 19,55 & 17,01 & 14,58 & 12,61 & 10,93 & 8,30 & 6,47 & 4,29 \\
\hline 60 & 800 & 100 & 25,43 & 19,14 & 16,75 & 14,41 & 12,51 & 10,88 & 8,30 & 6,49 & 4,31 \\
\hline 60 & 850 & 100 & 24,72 & 18,77 & 16,50 & 14,26 & 12,42 & 10,83 & 8,30 & 6,50 & 4,32 \\
\hline 60 & 900 & 100 & 24,08 & 18,43 & 16,26 & 14,11 & 12,33 & 10,78 & 8,30 & 6,52 & 4,34 \\
\hline 60 & 950 & 100 & 23,50 & 18,10 & 16,04 & 13,97 & 12,24 & 10,73 & 8,29 & 6,53 & 4,35 \\
\hline 60 & 1000 & 100 & 22,97 & 17,81 & 15,83 & 13,83 & 12,15 & 10,68 & 8,28 & 6,54 & 4,36 \\
\hline 60 & 1050 & 100 & 22,49 & 17,52 & 15,64 & 13,70 & 12,07 & 10,63 & 8,28 & 6,55 & 4,38 \\
\hline 60 & 1100 & 100 & 22,04 & 17,26 & 15,45 & 13,58 & 11,99 & 10,58 & 8,27 & 6,56 & 4,39 \\
\hline 60 & 1150 & 100 & 21,62 & 17,01 & 15,28 & 13,46 & 11,91 & 10,53 & 8,26 & 6,56 & 4,40 \\
\hline 60 & 1200 & 100 & 21,24 & 16,78 & 15,11 & 13,34 & 11,83 & 10,48 & 8,25 & 6,57 & 4,41 \\
\hline 60 & 1250 & 100 & 20,88 & 16,55 & 14,95 & 13,23 & 11,76 & 10,44 & 8,23 & 6,57 & 4,42 \\
\hline 60 & 1300 & 100 & 20,54 & 16,34 & 14,79 & 13,13 & 11,69 & 10,39 & 8,22 & 6,58 & 4,43 \\
\hline 60 & 1350 & 100 & 20,23 & 16,14 & 14,65 & 13,02 & 11,62 & 10,35 & 8,21 & 6,58 & 4,44 \\
\hline 60 & 1400 & 100 & 19,93 & 15,95 & 14,51 & 12,92 & 11,55 & 10,30 & 8,19 & 6,58 & 4,45 \\
\hline 60 & 1450 & 100 & 19,65 & 15,76 & 14,37 & 12,83 & 11,48 & 10,26 & 8,18 & 6,58 & 4,46 \\
\hline 60 & 1500 & 100 & 19,39 & 15,59 & 14,24 & 12,74 & 11,41 & 10,21 & 8,17 & 6,58 & 4,47 \\
\hline 60 & 1550 & 100 & 19,14 & 15,42 & 14,11 & 12,65 & 11,35 & 10,17 & 8,15 & 6,58 & 4,48 \\
\hline 60 & 1600 & 100 & 18,90 & 15,26 & 13,99 & 12,56 & 11,29 & 10,13 & 8,14 & 6,58 & 4,49 \\
\hline 60 & 1650 & 100 & 18,68 & 15,10 & 13,88 & 12,47 & 11,23 & 10,09 & 8,12 & 6,58 & 4,49 \\
\hline 60 & 1700 & 100 & 18,47 & 14,95 & 13,76 & 12,39 & 11,17 & 10,05 & 8,11 & 6,58 & 4,50 \\
\hline 60 & 1750 & 100 & 18,27 & 14,81 & 13,66 & 12,31 & 11,11 & 10,01 & 8,09 & 6,58 & 4,51 \\
\hline 60 & 1800 & 100 & 18,07 & 14,67 & 13,55 & 12,24 & 11,06 & 9,97 & 8,08 & 6,58 & 4,52 \\
\hline 60 & 1850 & 100 & 17,89 & 14,54 & 13,45 & 12,16 & 11,00 & 9,93 & 8,06 & 6,58 & 4,52 \\
\hline 60 & 1900 & 100 & 17,71 & 14,41 & 13,35 & 12,09 & 10,95 & 9,89 & 8,05 & 6,58 & 4,53 \\
\hline 60 & 1950 & 100 & 17,54 & 14,28 & 13,25 & 12,01 & 10,89 & 9,85 & 8,03 & 6,57 & 4,53 \\
\hline 60 & 2000 & 100 & 17,38 & 14,16 & 13,16 & 11,95 & 10,84 & 9,82 & 8,02 & 6,57 & 4,54 \\
\hline 60 & 200 & 105 & 53,26 & 29,58 & 22,12 & 16,60 & 13,16 & 10,72 & 7,53 & 5,75 & 3,93 \\
\hline 60 & 250 & 105 & 46,35 & 27,27 & 21,06 & 16,24 & 13,08 & 10,76 & 7,63 & 5,81 & 3,94 \\
\hline
\end{tabular}




\begin{tabular}{|c|c|c|c|c|c|c|c|c|c|c|c|}
\hline \multirow[b]{2}{*}{$\mathrm{H}(\mathrm{cm})$} & \multirow[b]{2}{*}{ Mceq (MPa) } & & & & & De & ões (x1 & & & & \\
\hline & & Msub (MPa) & D0 & D25 & D40 & D60 & D80 & D100 & D140 & D180 & D260 \\
\hline 60 & 300 & 105 & 41,58 & 25,58 & 20,23 & 15,93 & 12,99 & 10,76 & 7,70 & 5,87 & 3,95 \\
\hline 60 & 350 & 105 & 38,05 & 24,27 & 19,55 & 15,64 & 12,89 & 10,75 & 7,75 & 5,92 & 3,96 \\
\hline 60 & 400 & 105 & 35,31 & 23,21 & 18,98 & 15,38 & 12,78 & 10,73 & 7,79 & 5,96 & 3,98 \\
\hline 60 & 450 & 105 & 33,12 & 22,33 & 18,48 & 15,14 & 12,67 & 10,70 & 7,83 & 6,00 & 3,99 \\
\hline 60 & 500 & 105 & 31,32 & 21,57 & 18,04 & 14,92 & 12,57 & 10,67 & 7,85 & 6,03 & 4,00 \\
\hline 60 & 550 & 105 & 29,81 & 20,91 & 17,65 & 14,71 & 12,47 & 10,63 & 7,87 & 6,06 & 4,02 \\
\hline 60 & 600 & 105 & 28,51 & 20,33 & 17,29 & 14,52 & 12,36 & 10,58 & 7,89 & 6,09 & 4,03 \\
\hline 60 & 650 & 105 & 27,40 & 19,81 & 16,97 & 14,33 & 12,27 & 10,54 & 7,90 & 6,11 & 4,05 \\
\hline 60 & 700 & 105 & 26,42 & 19,34 & 16,67 & 14,16 & 12,17 & 10,49 & 7,90 & 6,13 & 4,06 \\
\hline 60 & 750 & 105 & 25,55 & 18,91 & 16,40 & 14,00 & 12,08 & 10,45 & 7,91 & 6,15 & 4,08 \\
\hline 60 & 800 & 105 & 24,78 & 18,52 & 16,14 & 13,84 & 11,99 & 10,40 & 7,91 & 6,17 & 4,09 \\
\hline 60 & 850 & 105 & 24,08 & 18,16 & 15,90 & 13,70 & 11,90 & 10,36 & 7,91 & 6,18 & 4,11 \\
\hline 60 & 900 & 105 & 23,45 & 17,83 & 15,68 & 13,56 & 11,81 & 10,31 & 7,91 & 6,20 & 4,12 \\
\hline 60 & 950 & 105 & 22,88 & 17,52 & 15,47 & 13,42 & 11,73 & 10,26 & 7,90 & 6,21 & 4,13 \\
\hline 60 & 1000 & 105 & 22,36 & 17,23 & 15,27 & 13,30 & 11,65 & 10,22 & 7,90 & 6,22 & 4,14 \\
\hline 60 & 1050 & 105 & 21,88 & 16,96 & 15,08 & 13,17 & 11,57 & 10,17 & 7,89 & 6,23 & 4,16 \\
\hline 60 & 1100 & 105 & 21,44 & 16,70 & 14,90 & 13,06 & 11,50 & 10,13 & 7,88 & 6,24 & 4,17 \\
\hline 60 & 1150 & 105 & 21,03 & 16,46 & 14,73 & 12,94 & 11,42 & 10,08 & 7,87 & 6,24 & 4,18 \\
\hline 60 & 1200 & 105 & 20,65 & 16,23 & 14,57 & 12,83 & 11,35 & 10,04 & 7,86 & 6,25 & 4,19 \\
\hline 60 & 1250 & 105 & 20,29 & 16,02 & 14,42 & 12,73 & 11,28 & 9,99 & 7,85 & 6,25 & 4,20 \\
\hline 60 & 1300 & 105 & 19,96 & 15,81 & 14,27 & 12,63 & 11,22 & 9,95 & 7,84 & 6,26 & 4,21 \\
\hline 60 & 1350 & 105 & 19,65 & 15,62 & 14,13 & 12,53 & 11,15 & 9,91 & 7,83 & 6,26 & 4,22 \\
\hline 60 & 1400 & 105 & 19,36 & 15,43 & 13,99 & 12,44 & 11,08 & 9,87 & 7,82 & 6,27 & 4,23 \\
\hline 60 & 1450 & 105 & 19,09 & 15,26 & 13,87 & 12,34 & 11,02 & 9,83 & 7,81 & 6,27 & 4,24 \\
\hline 60 & 1500 & 105 & 18,83 & 15,09 & 13,74 & 12,26 & 10,96 & 9,79 & 7,80 & 6,27 & 4,24 \\
\hline 60 & 1550 & 105 & 18,58 & 14,92 & 13,62 & 12,17 & 10,90 & 9,75 & 7,78 & 6,27 & 4,25 \\
\hline 60 & 1600 & 105 & 18,35 & 14,77 & 13,50 & 12,09 & 10,84 & 9,71 & 7,77 & 6,27 & 4,26 \\
\hline 60 & 1650 & 105 & 18,13 & 14,62 & 13,39 & 12,01 & 10,79 & 9,67 & 7,76 & 6,27 & 4,27 \\
\hline 60 & 1700 & 105 & 17,92 & 14,47 & 13,28 & 11,93 & 10,73 & 9,63 & 7,75 & 6,27 & 4,28 \\
\hline 60 & 1750 & 105 & 17,72 & 14,34 & 13,18 & 11,85 & 10,68 & 9,59 & 7,73 & 6,27 & 4,28 \\
\hline 60 & 1800 & 105 & 17,53 & 14,20 & 13,08 & 11,78 & 10,62 & 9,56 & 7,72 & 6,27 & 4,29 \\
\hline 60 & 1850 & 105 & 17,35 & 14,07 & 12,98 & 11,71 & 10,57 & 9,52 & 7,71 & 6,27 & 4,30 \\
\hline 60 & 1900 & 105 & 17,18 & 13,95 & 12,89 & 11,64 & 10,52 & 9,49 & 7,69 & 6,27 & 4,30 \\
\hline 60 & 1950 & 105 & 17,01 & 13,83 & 12,79 & 11,57 & 10,47 & 9,45 & 7,68 & 6,26 & 4,31 \\
\hline 60 & 2000 & 105 & 16,85 & 13,71 & 12,70 & 11,50 & 10,42 & 9,42 & 7,66 & 6,26 & 4,31 \\
\hline 60 & 200 & 110 & 52,38 & 28,73 & 21,33 & 15,91 & 12,58 & 10,22 & 7,17 & 5,48 & 3,75 \\
\hline 60 & 250 & 110 & 45,52 & 26,47 & 20,31 & 15,58 & 12,51 & 10,26 & 7,26 & 5,54 & 3,76 \\
\hline 60 & 300 & 110 & 40,79 & 24,82 & 19,51 & 15,28 & 12,42 & 10,27 & 7,33 & 5,59 & 3,77 \\
\hline 60 & 350 & 110 & 37,29 & 23,54 & 18,86 & 15,02 & 12,33 & 10,27 & 7,38 & 5,63 & 3,78 \\
\hline 60 & 400 & 110 & 34,59 & 22,50 & 18,31 & 14,77 & 12,24 & 10,25 & 7,43 & 5,68 & 3,79 \\
\hline 60 & 450 & 110 & 32,42 & 21,64 & 17,83 & 14,55 & 12,14 & 10,23 & 7,46 & 5,71 & 3,80 \\
\hline 60 & 500 & 110 & 30,64 & 20,90 & 17,41 & 14,34 & 12,04 & 10,20 & 7,48 & 5,74 & 3,82 \\
\hline 60 & 550 & 110 & 29,15 & 20,26 & 17,03 & 14,14 & 11,95 & 10,16 & 7,51 & 5,77 & 3,83 \\
\hline 60 & 600 & 110 & 27,87 & 19,70 & 16,69 & 13,96 & 11,86 & 10,13 & 7,52 & 5,80 & 3,84 \\
\hline 60 & 650 & 110 & 26,76 & 19,19 & 16,38 & 13,79 & 11,76 & 10,09 & 7,53 & 5,82 & 3,86 \\
\hline 60 & 700 & 110 & 25,80 & 18,74 & 16,09 & 13,62 & 11,68 & 10,05 & 7,54 & 5,84 & 3,87 \\
\hline 60 & 750 & 110 & 24,94 & 18,32 & 15,83 & 13,47 & 11,59 & 10,00 & 7,55 & 5,86 & 3,88 \\
\hline 60 & 800 & 110 & 24,18 & 17,95 & 15,58 & 13,32 & 11,51 & 9,96 & 7,55 & 5,88 & 3,90 \\
\hline 60 & 850 & 110 & 23,49 & 17,60 & 15,35 & 13,18 & 11,42 & 9,92 & 7,55 & 5,89 & 3,91 \\
\hline 60 & 900 & 110 & 22,87 & 17,28 & 15,14 & 13,05 & 11,34 & 9,88 & 7,55 & 5,91 & 3,92 \\
\hline 60 & 950 & 110 & 22,31 & 16,98 & 14,94 & 12,92 & 11,27 & 9,83 & 7,55 & 5,92 & 3,93 \\
\hline 60 & 1000 & 110 & 21,79 & 16,70 & 14,75 & 12,80 & 11,19 & 9,79 & 7,54 & 5,93 & 3,94 \\
\hline 60 & 1050 & 110 & 21,32 & 16,43 & 14,57 & 12,69 & 11,12 & 9,75 & 7,54 & 5,94 & 3,96 \\
\hline 60 & 1100 & 110 & 20,89 & 16,19 & 14,40 & 12,57 & 11,05 & 9,71 & 7,53 & 5,95 & 3,97 \\
\hline 60 & 1150 & 110 & 20,48 & 15,95 & 14,23 & 12,47 & 10,98 & 9,67 & 7,52 & 5,95 & 3,98 \\
\hline 60 & 1200 & 110 & 20,11 & 15,73 & 14,08 & 12,36 & 10,91 & 9,63 & 7,52 & 5,96 & 3,99 \\
\hline 60 & 1250 & 110 & 19,76 & 15,53 & 13,93 & 12,26 & 10,85 & 9,59 & 7,51 & 5,96 & 4,00 \\
\hline 60 & 1300 & 110 & 19,43 & 15,33 & 13,79 & 12,17 & 10,78 & 9,55 & 7,50 & 5,97 & 4,01 \\
\hline 60 & 1350 & 110 & 19,13 & 15,14 & 13,65 & 12,08 & 10,72 & 9,51 & 7,49 & 5,97 & 4,02 \\
\hline 60 & 1400 & 110 & 18,84 & 14,96 & 13,52 & 11,99 & 10,66 & 9,47 & 7,48 & 5,98 & 4,02 \\
\hline 60 & 1450 & 110 & 18,57 & 14,79 & 13,40 & 11,90 & 10,60 & 9,43 & 7,47 & 5,98 & 4,03 \\
\hline 60 & 1500 & 110 & 18,31 & 14,62 & 13,28 & 11,82 & 10,54 & 9,39 & 7,46 & 5,98 & 4,04 \\
\hline 60 & 1550 & 110 & 18,07 & 14,47 & 13,16 & 11,73 & 10,49 & 9,36 & 7,45 & 5,98 & 4,05 \\
\hline 60 & 1600 & 110 & 17,84 & 14,32 & 13,05 & 11,65 & 10,43 & 9,32 & 7,44 & 5,98 & 4,06 \\
\hline 60 & 1650 & 110 & 17,63 & 14,17 & 12,95 & 11,58 & 10,38 & 9,29 & 7,42 & 5,99 & 4,06 \\
\hline 60 & 1700 & 110 & 17,42 & 14,03 & 12,84 & 11,50 & 10,32 & 9,25 & 7,41 & 5,99 & 4,07 \\
\hline 60 & 1750 & 110 & 17,22 & 13,90 & 12,74 & 11,43 & 10,27 & 9,22 & 7,40 & 5,99 & 4,08 \\
\hline 60 & 1800 & 110 & 17,04 & 13,77 & 12,64 & 11,36 & 10,22 & 9,18 & 7,39 & 5,99 & 4,08 \\
\hline 60 & 1850 & 110 & 16,86 & 13,64 & 12,55 & 11,29 & 10,17 & 9,15 & 7,38 & 5,98 & 4,09 \\
\hline 60 & 1900 & 110 & 16,69 & 13,52 & 12,46 & 11,23 & 10,13 & 9,11 & 7,36 & 5,98 & 4,10 \\
\hline 60 & 1950 & 110 & 16,52 & 13,41 & 12,37 & 11,16 & 10,08 & 9,08 & 7,35 & 5,98 & 4,10 \\
\hline 60 & 2000 & 110 & 16,37 & 13,29 & 12,28 & 11,10 & 10,03 & 9,05 & 7,34 & 5,98 & 4,11 \\
\hline 60 & 200 & 115 & 51,57 & 27,95 & 20,61 & 15,28 & 12,04 & 9,77 & 6,84 & 5,23 & 3,59 \\
\hline 60 & 250 & 115 & 44,75 & 25,73 & 19,61 & 14,97 & 11,98 & 9,81 & 6,93 & 5,29 & 3,59 \\
\hline 60 & 300 & 115 & 40,06 & 24,11 & 18,84 & 14,69 & 11,90 & 9,83 & 7,00 & 5,33 & 3,60 \\
\hline 60 & 350 & 115 & 36,59 & 22,86 & 18,22 & 14,44 & 11,82 & 9,83 & 7,05 & 5,38 & 3,61 \\
\hline 60 & 400 & 115 & 33,92 & 21,85 & 17,69 & 14,21 & 11,74 & 9,81 & 7,09 & 5,42 & 3,62 \\
\hline 60 & 450 & 115 & 31,77 & 21,01 & 17,23 & 14,00 & 11,65 & 9,79 & 7,12 & 5,45 & 3,63 \\
\hline 60 & 500 & 115 & 30,01 & 20,29 & 16,82 & 13,80 & 11,56 & 9,77 & 7,15 & 5,48 & 3,64 \\
\hline 60 & 550 & 115 & 28,53 & 19,67 & 16,46 & 13,61 & 11,47 & 9,74 & 7,17 & 5,51 & 3,66 \\
\hline 60 & 600 & 115 & 27,27 & 19,12 & 16,13 & 13,44 & 11,39 & 9,70 & 7,19 & 5,53 & 3,67 \\
\hline
\end{tabular}




\begin{tabular}{|c|c|c|c|c|c|c|c|c|c|c|c|}
\hline \multirow[b]{2}{*}{$\mathrm{H}(\mathrm{cm})$} & \multirow[b]{2}{*}{ Mceq (MPa) } & & & & & De & ões (x1 & & & & \\
\hline & & Msub (MPa) & D0 & D25 & D40 & D60 & D80 & D100 & D140 & D180 & D260 \\
\hline 60 & 650 & 115 & 26,18 & 18,62 & 15,83 & 13,28 & 11,30 & 9,67 & 7,20 & 5,56 & 3,68 \\
\hline 60 & 700 & 115 & 25,22 & 18,18 & 15,56 & 13,12 & 11,22 & 9,63 & 7,21 & 5,58 & 3,69 \\
\hline 60 & 750 & 115 & 24,38 & 17,78 & 15,30 & 12,98 & 11,14 & 9,59 & 7,21 & 5,59 & 3,71 \\
\hline 60 & 800 & 115 & 23,63 & 17,41 & 15,07 & 12,84 & 11,06 & 9,56 & 7,22 & 5,61 & 3,72 \\
\hline 60 & 850 & 115 & 22,95 & 17,08 & 14,85 & 12,71 & 10,98 & 9,52 & 7,22 & 5,63 & 3,73 \\
\hline 60 & 900 & 115 & 22,34 & 16,76 & 14,64 & 12,58 & 10,91 & 9,48 & 7,22 & 5,64 & 3,74 \\
\hline 60 & 950 & 115 & 21,78 & 16,47 & 14,45 & 12,46 & 10,84 & 9,44 & 7,22 & 5,65 & 3,75 \\
\hline 60 & 1000 & 115 & 21,27 & 16,20 & 14,26 & 12,35 & 10,77 & 9,40 & 7,22 & 5,66 & 3,76 \\
\hline 60 & 1050 & 115 & 20,81 & 15,95 & 14,09 & 12,24 & 10,70 & 9,36 & 7,21 & 5,67 & 3,77 \\
\hline 60 & 1100 & 115 & 20,38 & 15,71 & 13,93 & 12,13 & 10,63 & 9,32 & 7,21 & 5,68 & 3,78 \\
\hline 60 & 1150 & 115 & 19,98 & 15,48 & 13,77 & 12,03 & 10,57 & 9,29 & 7,20 & 5,69 & 3,79 \\
\hline 60 & 1200 & 115 & 19,61 & 15,27 & 13,62 & 11,93 & 10,50 & 9,25 & 7,20 & 5,69 & 3,80 \\
\hline 60 & 1250 & 115 & 19,26 & 15,07 & 13,48 & 11,83 & 10,44 & 9,21 & 7,19 & 5,70 & 3,81 \\
\hline 60 & 1300 & 115 & 18,94 & 14,88 & 13,34 & 11,74 & 10,38 & 9,17 & 7,18 & 5,70 & 3,82 \\
\hline 60 & 1350 & 115 & 18,64 & 14,69 & 13,21 & 11,65 & 10,32 & 9,14 & 7,17 & 5,71 & 3,83 \\
\hline 60 & 1400 & 115 & 18,36 & 14,52 & 13,09 & 11,57 & 10,27 & 9,10 & 7,17 & 5,71 & 3,84 \\
\hline 60 & 1450 & 115 & 18,09 & 14,35 & 12,97 & 11,49 & 10,21 & 9,07 & 7,16 & 5,72 & 3,85 \\
\hline 60 & 1500 & 115 & 17,84 & 14,19 & 12,85 & 11,41 & 10,16 & 9,03 & 7,15 & 5,72 & 3,85 \\
\hline 60 & 1550 & 115 & 17,60 & 14,04 & 12,74 & 11,33 & 10,10 & 9,00 & 7,14 & 5,72 & 3,86 \\
\hline 60 & 1600 & 115 & 17,37 & 13,90 & 12,63 & 11,25 & 10,05 & 8,96 & 7,13 & 5,72 & 3,87 \\
\hline 60 & 1650 & 115 & 17,16 & 13,76 & 12,53 & 11,18 & 10,00 & 8,93 & 7,12 & 5,72 & 3,88 \\
\hline 60 & 1700 & 115 & 16,96 & 13,62 & 12,43 & 11,11 & 9,95 & 8,90 & 7,11 & 5,72 & 3,88 \\
\hline 60 & 1750 & 115 & 16,76 & 13,49 & 12,33 & 11,04 & 9,90 & 8,87 & 7,10 & 5,73 & 3,89 \\
\hline 60 & 1800 & 115 & 16,58 & 13,36 & 12,24 & 10,97 & 9,85 & 8,83 & 7,09 & 5,73 & 3,90 \\
\hline 60 & 1850 & 115 & 16,40 & 13,24 & 12,15 & 10,91 & 9,81 & 8,80 & 7,07 & 5,73 & 3,90 \\
\hline 60 & 1900 & 115 & 16,24 & 13,13 & 12,06 & 10,84 & 9,76 & 8,77 & 7,06 & 5,73 & 3,91 \\
\hline 60 & 1950 & 115 & 16,08 & 13,01 & 11,98 & 10,78 & 9,72 & 8,74 & 7,05 & 5,72 & 3,91 \\
\hline 60 & 2000 & 115 & 15,92 & 12,90 & 11,89 & 10,72 & 9,67 & 8,71 & 7,04 & 5,72 & 3,92 \\
\hline 60 & 200 & 120 & 50,81 & 27,23 & 19,94 & 14,70 & 11,54 & 9,35 & 6,54 & 5,00 & 3,44 \\
\hline 60 & 250 & 120 & 44,04 & 25,04 & 18,97 & 14,40 & 11,49 & 9,40 & 6,62 & 5,05 & 3,44 \\
\hline 60 & 300 & 120 & 39,38 & 23,45 & 18,23 & 14,14 & 11,43 & 9,41 & 6,69 & 5,10 & 3,45 \\
\hline 60 & 350 & 120 & 35,95 & 22,23 & 17,62 & 13,90 & 11,35 & 9,42 & 6,74 & 5,14 & 3,46 \\
\hline 60 & 400 & 120 & 33,29 & 21,24 & 17,11 & 13,69 & 11,27 & 9,41 & 6,78 & 5,18 & 3,47 \\
\hline 60 & 450 & 120 & 31,17 & 20,42 & 16,67 & 13,49 & 11,19 & 9,39 & 6,81 & 5,21 & 3,48 \\
\hline 60 & 500 & 120 & 29,43 & 19,72 & 16,28 & 13,30 & 11,11 & 9,37 & 6,84 & 5,24 & 3,49 \\
\hline 60 & 550 & 120 & 27,96 & 19,11 & 15,93 & 13,13 & 11,03 & 9,34 & 6,86 & 5,27 & 3,50 \\
\hline 60 & 600 & 120 & 26,72 & 18,57 & 15,61 & 12,96 & 10,95 & 9,32 & 6,88 & 5,29 & 3,51 \\
\hline 60 & 650 & 120 & 25,64 & 18,10 & 15,32 & 12,81 & 10,87 & 9,28 & 6,89 & 5,31 & 3,52 \\
\hline 60 & 700 & 120 & 24,69 & 17,67 & 15,06 & 12,66 & 10,80 & 9,25 & 6,90 & 5,33 & 3,53 \\
\hline 60 & 750 & 120 & 23,86 & 17,28 & 14,81 & 12,52 & 10,72 & 9,22 & 6,91 & 5,35 & 3,55 \\
\hline 60 & 800 & 120 & 23,11 & 16,92 & 14,59 & 12,39 & 10,65 & 9,18 & 6,92 & 5,37 & 3,56 \\
\hline 60 & 850 & 120 & 22,45 & 16,59 & 14,38 & 12,27 & 10,58 & 9,15 & 6,92 & 5,38 & 3,57 \\
\hline 60 & 900 & 120 & 21,84 & 16,29 & 14,18 & 12,15 & 10,51 & 9,11 & 6,92 & 5,39 & 3,58 \\
\hline 60 & 950 & 120 & 21,29 & 16,01 & 13,99 & 12,03 & 10,44 & 9,08 & 6,92 & 5,41 & 3,59 \\
\hline 60 & 1000 & 120 & 20,79 & 15,74 & 13,81 & 11,92 & 10,37 & 9,04 & 6,92 & 5,42 & 3,60 \\
\hline 60 & 1050 & 120 & 20,33 & 15,50 & 13,65 & 11,82 & 10,31 & 9,01 & 6,92 & 5,43 & 3,61 \\
\hline 60 & 1100 & 120 & 19,90 & 15,26 & 13,49 & 11,72 & 10,25 & 8,97 & 6,91 & 5,44 & 3,62 \\
\hline 60 & 1150 & 120 & 19,51 & 15,04 & 13,34 & 11,62 & 10,19 & 8,93 & 6,91 & 5,44 & 3,63 \\
\hline 60 & 1200 & 120 & 19,15 & 14,84 & 13,20 & 11,53 & 10,13 & 8,90 & 6,90 & 5,45 & 3,64 \\
\hline 60 & 1250 & 120 & 18,81 & 14,64 & 13,06 & 11,44 & 10,07 & 8,87 & 6,90 & 5,46 & 3,64 \\
\hline 60 & 1300 & 120 & 18,49 & 14,46 & 12,93 & 11,35 & 10,01 & 8,83 & 6,89 & 5,46 & 3,65 \\
\hline 60 & 1350 & 120 & 18,19 & 14,28 & 12,80 & 11,26 & 9,96 & 8,80 & 6,88 & 5,47 & 3,66 \\
\hline 60 & 1400 & 120 & 17,91 & 14,11 & 12,68 & 11,18 & 9,90 & 8,76 & 6,88 & 5,47 & 3,67 \\
\hline 60 & 1450 & 120 & 17,65 & 13,95 & 12,57 & 11,10 & 9,85 & 8,73 & 6,87 & 5,47 & 3,68 \\
\hline 60 & 1500 & 120 & 17,40 & 13,79 & 12,46 & 11,03 & 9,80 & 8,70 & 6,86 & 5,48 & 3,68 \\
\hline 60 & 1550 & 120 & 17,16 & 13,65 & 12,35 & 10,95 & 9,75 & 8,67 & 6,85 & 5,48 & 3,69 \\
\hline 60 & 1600 & 120 & 16,94 & 13,50 & 12,25 & 10,88 & 9,70 & 8,63 & 6,84 & 5,48 & 3,70 \\
\hline 60 & 1650 & 120 & 16,73 & 13,37 & 12,15 & 10,81 & 9,65 & 8,60 & 6,83 & 5,48 & 3,71 \\
\hline 60 & 1700 & 120 & 16,53 & 13,24 & 12,05 & 10,74 & 9,60 & 8,57 & 6,83 & 5,49 & 3,71 \\
\hline 60 & 1750 & 120 & 16,34 & 13,11 & 11,96 & 10,68 & 9,56 & 8,54 & 6,82 & 5,49 & 3,72 \\
\hline 60 & 1800 & 120 & 16,16 & 12,99 & 11,87 & 10,61 & 9,51 & 8,51 & 6,81 & 5,49 & 3,72 \\
\hline 60 & 1850 & 120 & 15,98 & 12,87 & 11,78 & 10,55 & 9,47 & 8,48 & 6,80 & 5,49 & 3,73 \\
\hline 60 & 1900 & 120 & 15,82 & 12,76 & 11,69 & 10,49 & 9,42 & 8,45 & 6,79 & 5,49 & 3,74 \\
\hline 60 & 1950 & 120 & 15,66 & 12,65 & 11,61 & 10,43 & 9,38 & 8,42 & 6,78 & 5,49 & 3,74 \\
\hline 60 & 2000 & 120 & 15,51 & 12,54 & 11,53 & 10,37 & 9,34 & 8,40 & 6,77 & 5,49 & 3,75 \\
\hline 60 & 200 & 125 & 50,11 & 26,56 & 19,32 & 14,16 & 11,09 & 8,97 & 6,26 & 4,79 & 3,30 \\
\hline 60 & 250 & 125 & 43,38 & 24,40 & 18,38 & 13,88 & 11,04 & 9,01 & 6,35 & 4,84 & 3,30 \\
\hline 60 & 300 & 125 & 38,75 & 22,84 & 17,66 & 13,63 & 10,99 & 9,04 & 6,41 & 4,89 & 3,31 \\
\hline 60 & 350 & 125 & 35,34 & 21,64 & 17,07 & 13,41 & 10,92 & 9,04 & 6,46 & 4,93 & 3,32 \\
\hline 60 & 400 & 125 & 32,71 & 20,67 & 16,57 & 13,20 & 10,85 & 9,04 & 6,50 & 4,96 & 3,33 \\
\hline 60 & 450 & 125 & 30,61 & 19,87 & 16,15 & 13,01 & 10,77 & 9,02 & 6,53 & 4,99 & 3,33 \\
\hline 60 & 500 & 125 & 28,88 & 19,19 & 15,77 & 12,84 & 10,70 & 9,01 & 6,56 & 5,02 & 3,34 \\
\hline 60 & 550 & 125 & 27,43 & 18,59 & 15,43 & 12,67 & 10,62 & 8,98 & 6,58 & 5,05 & 3,35 \\
\hline 60 & 600 & 125 & 26,20 & 18,07 & 15,13 & 12,52 & 10,55 & 8,96 & 6,60 & 5,07 & 3,37 \\
\hline 60 & 650 & 125 & 25,13 & 17,61 & 14,85 & 12,37 & 10,48 & 8,93 & 6,61 & 5,09 & 3,38 \\
\hline 60 & 700 & 125 & 24,20 & 17,19 & 14,60 & 12,23 & 10,41 & 8,90 & 6,62 & 5,11 & 3,39 \\
\hline 60 & 750 & 125 & 23,37 & 16,81 & 14,36 & 12,10 & 10,34 & 8,87 & 6,63 & 5,13 & 3,40 \\
\hline 60 & 800 & 125 & 22,64 & 16,46 & 14,14 & 11,98 & 10,27 & 8,84 & 6,64 & 5,14 & 3,41 \\
\hline 60 & 850 & 125 & 21,98 & 16,14 & 13,94 & 11,86 & 10,20 & 8,80 & 6,64 & 5,16 & 3,42 \\
\hline 60 & 900 & 125 & 21,38 & 15,84 & 13,75 & 11,74 & 10,14 & 8,77 & 6,64 & 5,17 & 3,43 \\
\hline 60 & 950 & 125 & 20,84 & 15,57 & 13,57 & 11,63 & 10,07 & 8,74 & 6,64 & 5,18 & 3,44 \\
\hline
\end{tabular}




\begin{tabular}{|c|c|c|c|c|c|c|c|c|c|c|c|}
\hline & & & \multicolumn{9}{|c|}{ Deflexões $\left(\times 10^{-4} \mathrm{~cm}\right)$} \\
\hline $\mathrm{H}(\mathrm{cm})$ & Mceq (MPa) & Msub (MPa) & D0 & D25 & D40 & D60 & D80 & D100 & D140 & D180 & D260 \\
\hline 60 & 1000 & 125 & 20,34 & 15,31 & 13,40 & 11,53 & 10,01 & 8,71 & 6,64 & 5,19 & 3,45 \\
\hline 60 & 1050 & 125 & 19,88 & 15,07 & 13,24 & 11,43 & 9,95 & 8,67 & 6,64 & 5,20 & 3,46 \\
\hline 60 & 1100 & 125 & 19,46 & 14,85 & 13,08 & 11,33 & 9,89 & 8,64 & 6,64 & 5,21 & 3,46 \\
\hline 60 & 1150 & 125 & 19,08 & 14,64 & 12,94 & 11,24 & 9,83 & 8,61 & 6,64 & 5,22 & 3,47 \\
\hline 60 & 1200 & 125 & 18,72 & 14,43 & 12,80 & 11,15 & 9,78 & 8,58 & 6,63 & 5,23 & 3,48 \\
\hline 60 & 1250 & 125 & 18,38 & 14,24 & 12,67 & 11,07 & 9,72 & 8,54 & 6,63 & 5,23 & 3,49 \\
\hline 60 & 1300 & 125 & 18,07 & 14,06 & 12,54 & 10,98 & 9,67 & 8,51 & 6,62 & 5,24 & 3,50 \\
\hline 60 & 1350 & 125 & 17,77 & 13,89 & 12,42 & 10,90 & 9,62 & 8,48 & 6,62 & 5,24 & 3,51 \\
\hline 60 & 1400 & 125 & 17,50 & 13,73 & 12,30 & 10,82 & 9,56 & 8,45 & 6,61 & 5,25 & 3,51 \\
\hline 60 & 1450 & 125 & 17,24 & 13,57 & 12,19 & 10,75 & 9,51 & 8,42 & 6,60 & 5,25 & 3,52 \\
\hline 60 & 1500 & 125 & 16,99 & 13,42 & 12,09 & 10,67 & 9,47 & 8,39 & 6,60 & 5,25 & 3,53 \\
\hline 60 & 1550 & 125 & 16,76 & 13,28 & 11,98 & 10,60 & 9,42 & 8,36 & 6,59 & 5,26 & 3,54 \\
\hline 60 & 1600 & 125 & 16.54 & 13,14 & 11,88 & 10,53 & 9,37 & 8.33 & 6.58 & 5,26 & 3,54 \\
\hline 60 & 1650 & 125 & 16,33 & 13,01 & 11,79 & 10,47 & 9,33 & 8,30 & 6,57 & 5,26 & 3,55 \\
\hline 60 & 1700 & 125 & 16,13 & 12,88 & 11,69 & 10,40 & 9,28 & 8,27 & 6,56 & 5,26 & 3,56 \\
\hline 60 & 1750 & 125 & 15,94 & 12,76 & 11,60 & 10,34 & 9,24 & 8,24 & 6,56 & 5,27 & 3,56 \\
\hline 60 & 1800 & 125 & 15,77 & 12,64 & 11,52 & 10,28 & 9,19 & 8,21 & 6,55 & 5,27 & 3,57 \\
\hline 60 & 1850 & 125 & 15,59 & 12,53 & 11,43 & 10,22 & 9,15 & 8,18 & 6,54 & 5,27 & 3,57 \\
\hline 60 & 1900 & 125 & 15,43 & 12,42 & 11,35 & 10,16 & 9,11 & 8,16 & 6,53 & 5,27 & 3,58 \\
\hline 60 & 1950 & 125 & 15,27 & 12,31 & 11,27 & 10,10 & 9,07 & 8,13 & 6,52 & 5,27 & 3,58 \\
\hline 60 & 2000 & 125 & 15,12 & 12,21 & 11,19 & 10,05 & 9,03 & 8,10 & 6,51 & 5,27 & 3,59 \\
\hline 60 & 200 & 130 & 49,45 & 25,93 & 18,74 & 13,66 & 10,66 & 8,61 & 6,01 & 4,60 & 3,18 \\
\hline 60 & 250 & 130 & 42,76 & 23,81 & 17,83 & 13,40 & 10,63 & 8,66 & 6,09 & 4,65 & 3,18 \\
\hline 60 & 300 & 130 & 38,16 & 22,27 & 17,12 & 13,16 & 10,58 & 8,68 & 6,15 & 4,69 & 3,18 \\
\hline 60 & 350 & 130 & 34,78 & 21,09 & 16,56 & 12,95 & 10,52 & 8,69 & 6,20 & 4,73 & 3,19 \\
\hline 60 & 400 & 130 & 32,17 & 20,15 & 16,08 & 12,76 & 10,45 & 8,69 & 6,24 & 4,76 & 3,19 \\
\hline 60 & 450 & 130 & 30,08 & 19,36 & 15,66 & 12,58 & 10,38 & 8,68 & 6,27 & 4,79 & 3,20 \\
\hline 60 & 500 & 130 & 28,37 & 18,69 & 15,30 & 12,41 & 10,32 & 8,67 & 6,30 & 4,82 & 3,21 \\
\hline 60 & 550 & 130 & 26,94 & 18,11 & 14,97 & 12,25 & 10,25 & 8,65 & 6,32 & 4,84 & 3,22 \\
\hline 60 & 600 & 130 & 25,72 & 17,60 & 14,68 & 12,10 & 10,18 & 8,62 & 6,34 & 4,86 & 3,23 \\
\hline 60 & 650 & 130 & 24,66 & 17,15 & 14,41 & 11,97 & 10,11 & 8,60 & 6,35 & 4,88 & 3,24 \\
\hline 60 & 700 & $\frac{100}{130}$ & 23,74 & $\begin{array}{l}1,+1 \\
16,74\end{array}$ & $\begin{array}{l}\perp+7,16 \\
14,16\end{array}$ & 11,83 & $\frac{10,+1}{10,04}$ & 8,57 & 6,36 & 4,90 & 3,25 \\
\hline 60 & 750 & 130 & 22,92 & 16,37 & 13,94 & 11,71 & 9,98 & 8,54 & 6,37 & 4,92 & 3,26 \\
\hline 60 & 800 & 130 & 22,19 & 16,03 & 13,73 & 11,59 & 9,91 & 8,52 & 6,38 & 4,94 & 3,27 \\
\hline 60 & 850 & 130 & 21,54 & 15,72 & 13,53 & 11,48 & 9,85 & 8,49 & 6,38 & 4,95 & 3,28 \\
\hline 60 & 900 & 130 & 20,95 & 15,43 & 13,34 & 11,37 & 9,79 & 8,46 & 6,39 & 4,96 & 3,29 \\
\hline 60 & 950 & 130 & 20,41 & 15,16 & 13,17 & 11,26 & 9,73 & 8,43 & 6,39 & 4,97 & 3,30 \\
\hline 60 & 1000 & 130 & 19,92 & 14,91 & 13,01 & 11,16 & 9,67 & 8,40 & 6,39 & 4,98 & 3,31 \\
\hline 60 & 1050 & 130 & 19,47 & 14,68 & 12,85 & 11,07 & 9,61 & 8,37 & 6,39 & 4,99 & 3,32 \\
\hline 60 & 1100 & 130 & 19,06 & 14,46 & 12,70 & 10,98 & 9,56 & 8,34 & 6,39 & 5,00 & 3,32 \\
\hline 60 & 1150 & 130 & 18,67 & 14,25 & 12,56 & 10,89 & 9,50 & 8,30 & 6,38 & 5,01 & 3,33 \\
\hline 60 & 1200 & 130 & 18,32 & 14,06 & 12,43 & 10,80 & 9,45 & 8,27 & 6,38 & 5,02 & 3,34 \\
\hline 60 & 1250 & 130 & 17,98 & 13,87 & 12,30 & 10,72 & 9,40 & 8,24 & 6,38 & 5,02 & 3,35 \\
\hline 60 & 1300 & 130 & 17,67 & 13,70 & 12,18 & 10,64 & 9,35 & 8,21 & 6,37 & 5,03 & 3,36 \\
\hline 60 & 1350 & 130 & 17,38 & 13,53 & 12,06 & 10,56 & 9,30 & 8,19 & 6,37 & 5,04 & 3,36 \\
\hline 60 & 1400 & 130 & 17,11 & 13,37 & 11,95 & 10,49 & 9,25 & 8,16 & 6,36 & 5,04 & 3,37 \\
\hline 60 & 1450 & 130 & 16,85 & 13,22 & 11,84 & 10,42 & 9,20 & 8,13 & 6,36 & 5,04 & 3,38 \\
\hline 60 & 1500 & 130 & 16,61 & 13,07 & 11,74 & 10,35 & 9,16 & 8,10 & 6,35 & 5,05 & 3,39 \\
\hline 60 & 1550 & 130 & 16,38 & 12,93 & 11,64 & 10,28 & 9,11 & 8,07 & 6,34 & 5,05 & 3,39 \\
\hline 60 & 1600 & 130 & 16,16 & 12,80 & 11,54 & 10,21 & 9,07 & 8,04 & 6,34 & 5,05 & 3,40 \\
\hline 60 & 1650 & 130 & 15,96 & 12,67 & 11,45 & 10,15 & 9,02 & 8,02 & 6,33 & 5,06 & 3,40 \\
\hline 60 & 1700 & 130 & 15,76 & 12,55 & 11,36 & 10,09 & 8,98 & 7,99 & 6,32 & 5,06 & 3,41 \\
\hline 60 & 1750 & $\frac{100}{130}$ & 15,58 & 12,43 & $\begin{array}{l}1+, \mathrm{v} \\
11,27\end{array}$ & 10,02 & 8,94 & 7,96 & 6,31 & 5,06 & 3,42 \\
\hline 60 & 1800 & 130 & 15,40 & 12,31 & 11,19 & 9,97 & 8,90 & 7,93 & 6,31 & 5,06 & 3,42 \\
\hline 60 & 1850 & 130 & 15,23 & 12,20 & 11,11 & 9,91 & 8,86 & 7,91 & 6,30 & 5,06 & 3,43 \\
\hline 60 & 1900 & 130 & 15,07 & 12,09 & 11,03 & 9,85 & 8,82 & 7,88 & 6,29 & 5,06 & 3,43 \\
\hline 60 & 1950 & 130 & 14,91 & 11,99 & 10,95 & 9,80 & 8,78 & 7,86 & 6,28 & 5,06 & 3,44 \\
\hline 60 & 2000 & 130 & 14,77 & 11,89 & 10,88 & 9,74 & 8,74 & 7,83 & 6,27 & 5,06 & 3,44 \\
\hline 60 & 200 & 135 & 48,84 & 25,35 & 18,20 & 13,20 & 10,27 & 8,28 & 5,77 & 4,42 & 3,06 \\
\hline 60 & 250 & 135 & 42,18 & 23,25 & 17,31 & 12,94 & 10,24 & 8,33 & 5,85 & 4,47 & 3,06 \\
\hline 60 & 300 & 135 & 37,61 & 21,74 & 16,63 & 12,72 & 10,20 & 8,36 & 5,91 & 4,51 & 3,06 \\
\hline 60 & 350 & 135 & 34,25 & 20,58 & 16,07 & 12,52 & 10,14 & 8,37 & 5,96 & 4,54 & 3,07 \\
\hline 60 & 400 & 135 & 31,66 & 19,65 & 15,61 & 12,34 & 10,08 & 8,37 & 6,00 & 4,57 & 3,07 \\
\hline 60 & 450 & 135 & 29,59 & 18,88 & 15,21 & 12,17 & 10,02 & 8,36 & 6,03 & 4,60 & 3,08 \\
\hline 60 & 500 & 135 & 27,90 & 18,22 & 14,86 & 12,01 & 9,96 & 8,35 & 6,05 & 4,63 & 3,09 \\
\hline 60 & 550 & 135 & 26,48 & 17,66 & 14,54 & 11,86 & 9,89 & 8,33 & 6,08 & 4,65 & 3,10 \\
\hline 60 & 600 & 135 & 25,27 & 17,16 & 14,26 & 11,72 & 9,83 & 8,31 & 6,09 & 4,67 & 3,11 \\
\hline 60 & 650 & 135 & 24,22 & 16,72 & 14,00 & 11,59 & 9,77 & 8,29 & 6,11 & 4,69 & 3,12 \\
\hline 60 & 700 & 135 & 23,30 & 16,32 & 13,76 & 11,46 & 9,70 & 8,27 & 6,12 & 4,71 & 3,13 \\
\hline 60 & 750 & 135 & 22,50 & 15,95 & 13,54 & 11,34 & 9,64 & 8,24 & 6,13 & 4,73 & 3,13 \\
\hline 60 & 800 & 135 & 21,78 & 15,62 & 13,34 & 11,23 & 9,58 & 8,22 & 6,14 & 4,74 & 3,14 \\
\hline 60 & 850 & 135 & 21,13 & 15,32 & 13,15 & 11,12 & 9,52 & 8,19 & 6,14 & 4,76 & 3,15 \\
\hline 60 & 900 & 135 & 20,55 & 15,04 & 12,97 & 11,02 & 9,47 & 8,16 & 6,15 & 4,77 & 3,16 \\
\hline 60 & 950 & 135 & 20,01 & 14,78 & 12,80 & 10,92 & 9,41 & 8,13 & 6,15 & 4,78 & 3,17 \\
\hline 60 & 1000 & 135 & $\begin{array}{ll}20,01 \\
19,53\end{array}$ & 14,54 & 12,64 & 10,82 & $\begin{array}{l}0,35 \\
9,35\end{array}$ & 8,11 & 6,15 & 4,79 & 3,18 \\
\hline 60 & 1050 & 135 & 19,08 & 14,31 & 12,49 & 10,73 & 9,30 & 8,08 & 6,15 & 4,80 & 3,19 \\
\hline 60 & 1100 & 135 & 18,67 & 14,10 & 12,35 & 10,64 & 9,25 & 8,05 & 6,15 & 4,81 & 3,19 \\
\hline 60 & 1150 & 135 & 18,29 & 13,89 & 12,21 & 10,56 & 9,20 & 8,02 & 6,15 & 4,82 & 3,20 \\
\hline 60 & 1200 & 135 & 17,94 & 13,70 & 12,08 & 10,47 & 9,15 & 7,99 & 6,15 & 4,83 & 3,21 \\
\hline 60 & 1250 & 135 & 17,61 & 13,52 & 11,96 & 10,40 & 9,10 & 7,97 & 6,14 & 4,83 & 3,22 \\
\hline 60 & 1300 & 135 & 17,31 & 13,35 & 11,84 & 10,32 & 9,05 & 7,94 & 6,14 & 4,84 & 3,22 \\
\hline
\end{tabular}




\begin{tabular}{|c|c|c|c|c|c|c|c|c|c|c|c|}
\hline \multirow[b]{2}{*}{$\mathrm{H}(\mathrm{cm})$} & \multirow[b]{2}{*}{ Mceq (MPa) } & & & & & $\mathrm{De}$ & ões (x. & & & & \\
\hline & & Msub (MPa) & D0 & D25 & D40 & D60 & D80 & D100 & D140 & D180 & D260 \\
\hline 60 & 1350 & 135 & 17,02 & 13,19 & 11,73 & 10,25 & 9,00 & 7,91 & 6,14 & 4,84 & 3,23 \\
\hline 60 & 1400 & 135 & 16,75 & 13,03 & 11,62 & 10,17 & 8,96 & 7,88 & 6,13 & 4,85 & 3,24 \\
\hline 60 & 1450 & 135 & 16,49 & 12,89 & 11,52 & 10,10 & 8,91 & 7,86 & 6,13 & 4,85 & 3,25 \\
\hline 60 & 1500 & 135 & 16,25 & 12,74 & 11,42 & 10,04 & 8,87 & 7,83 & 6,12 & 4,86 & 3,25 \\
\hline 60 & 1550 & 135 & 16,03 & 12,61 & 11,32 & 9,97 & 8,82 & 7,80 & 6,12 & 4,86 & 3,26 \\
\hline 60 & 1600 & 135 & 15,81 & 12,48 & 11,23 & 9,91 & 8,78 & 7,78 & 6,11 & 4,86 & 3,26 \\
\hline 60 & 1650 & 135 & 15,61 & 12,35 & 11,14 & 9,85 & 8,74 & 7,75 & 6,10 & 4,87 & 3,27 \\
\hline 60 & 1700 & 135 & 15,42 & 12,23 & 11,05 & 9,79 & 8,70 & 7,73 & 6,10 & 4,87 & 3,28 \\
\hline 60 & 1750 & 135 & 15,23 & 12,12 & 10,97 & 9,73 & 8,66 & 7,70 & 6,09 & 4,87 & 3,28 \\
\hline 60 & 1800 & 135 & 15,06 & 12,00 & 10,88 & 9,67 & 8,62 & 7,67 & 6,08 & 4,87 & 3,29 \\
\hline 60 & 1850 & 135 & 14,89 & 11,90 & 10,81 & 9,62 & 8,58 & 7,65 & 6,08 & 4,87 & 3,29 \\
\hline 60 & 1900 & 135 & 14,73 & 11,79 & 10,73 & 9,56 & 8,55 & 7,63 & 6,07 & 4,88 & 3,30 \\
\hline 60 & 1950 & 135 & 14.58 & 11.69 & 10,66 & 9.51 & 8,51 & 7.60 & 6.06 & 4.88 & 3,30 \\
\hline 60 & 2000 & 135 & 14,43 & 11,59 & 10,58 & 9,46 & 8,47 & 7,58 & 6,05 & 4,88 & 3,31 \\
\hline 60 & 200 & 140 & 48,27 & 24,81 & 17,70 & 12,76 & 9,91 & 7,98 & 5,55 & 4,26 & 2,95 \\
\hline 60 & 250 & 140 & 41,64 & 22,73 & 16,83 & 12,52 & 9,88 & 8,03 & 5,63 & 4,30 & 2,95 \\
\hline 60 & 300 & 140 & 37,09 & 21,24 & 16,16 & 12,31 & 9,84 & 8,06 & 5,69 & 4,34 & 2,95 \\
\hline 60 & 350 & 140 & 33,75 & 20,10 & 15,62 & 12,12 & 9,80 & 8,07 & 5,73 & 4,37 & 2,96 \\
\hline 60 & 400 & 140 & 31,18 & 19,19 & 15,17 & 11,95 & 9,74 & 8,07 & 5,77 & 4,40 & 2,96 \\
\hline 60 & 450 & 140 & 29,13 & 18,43 & 14,78 & 11,78 & 9,68 & 8,07 & 5,80 & 4,43 & 2,97 \\
\hline 60 & 500 & 140 & 27,45 & 17,79 & 14,44 & 11,63 & 9,62 & 8,06 & 5,83 & 4,45 & 2,98 \\
\hline 60 & 550 & 140 & 26,04 & 17,23 & 14,14 & 11,49 & 9,56 & 8,04 & 5,85 & 4,48 & 2,98 \\
\hline 60 & 600 & 140 & 24,84 & 16,75 & 13,86 & 11,36 & 9,51 & 8,03 & 5,87 & 4,50 & 2,99 \\
\hline 60 & 650 & 140 & 23,81 & 16,31 & 13,61 & 11,23 & 9,45 & 8,01 & 5,88 & 4,52 & 3,00 \\
\hline 60 & 700 & 140 & 22,90 & 15,92 & 13,38 & 11,11 & 9,39 & 7,98 & 5,90 & 4,54 & 3,01 \\
\hline 60 & 750 & 140 & 22,10 & 15,57 & 13,17 & 11,00 & 9,33 & 7,96 & 5,91 & 4,55 & 3,02 \\
\hline 60 & 800 & 140 & 21,39 & 15,24 & 12,97 & 10,89 & 9,27 & 7,94 & 5,91 & 4,57 & 3,03 \\
\hline 60 & 850 & 140 & 20,75 & 14,95 & 12,79 & 10,78 & 9,22 & 7,91 & 5,92 & 4,58 & 3,03 \\
\hline 60 & 900 & 140 & 20,17 & 14,67 & 12,61 & 10,69 & 9,16 & 7,89 & 5,93 & 4,59 & 3,04 \\
\hline 60 & 950 & 140 & 19,64 & 14,42 & 12,45 & 10,59 & 9,11 & 7,86 & 5,93 & 4,60 & 3,05 \\
\hline 60 & 1000 & 140 & 19,16 & 14,18 & 12,30 & 10,50 & 9,06 & 7,84 & 5,93 & 4,61 & 3,06 \\
\hline 60 & 1050 & 140 & 18,72 & 13,96 & 12,15 & 10,41 & 9,01 & 7,81 & 5,93 & 4,62 & 3,07 \\
\hline 60 & 1100 & 140 & 18,31 & 13,75 & 12,01 & 10,33 & 8,96 & 7,78 & 5,93 & 4,63 & 3,07 \\
\hline 60 & 1150 & 140 & 17,94 & 13,56 & 11,88 & 10,25 & 8,91 & 7,76 & 5,93 & 4.64 & 3,08 \\
\hline 60 & 1200 & 140 & 17,59 & 13,37 & 11,76 & 10,17 & 8,86 & 7,73 & 5,93 & 4,65 & 3,09 \\
\hline 60 & 1250 & 140 & 17,27 & 13,19 & 11,64 & 10,09 & 8,81 & 7,71 & 5,93 & 4,65 & 3,10 \\
\hline 60 & 1300 & 140 & 16,96 & 13,03 & 11,52 & 10,02 & 8,77 & 7,68 & 5,92 & 4,66 & 3,10 \\
\hline 60 & 1350 & 140 & 16,68 & 12,87 & 11,42 & 9,95 & 8,72 & 7,65 & 5,92 & 4,67 & 3,11 \\
\hline 60 & 1400 & 140 & 16,41 & 12,72 & 11,31 & 9,88 & 8,68 & 7,63 & 5,92 & 4,67 & 3,12 \\
\hline 60 & 1450 & 140 & 16,16 & 12,57 & 11,21 & 9,81 & 8,64 & 7,60 & 5,91 & 4,68 & 3,12 \\
\hline 60 & 1500 & 140 & 15,92 & 12,44 & 11,11 & 9,75 & 8,60 & 7,58 & 5,91 & 4,68 & 3,13 \\
\hline 60 & 1550 & 140 & 15,70 & 12,30 & 11,02 & 9,69 & 8,55 & 7,55 & 5,90 & 4,68 & 3,14 \\
\hline 60 & 1600 & 140 & 15,49 & 12,18 & 10,93 & 9,63 & 8,51 & 7,53 & 5,90 & 4,69 & 3,14 \\
\hline 60 & 1650 & 140 & 15,29 & 12,05 & 10,84 & 9,57 & 8,48 & 7,50 & 5,89 & 4,69 & 3,15 \\
\hline 60 & 1700 & 140 & 15,09 & 11,94 & 10,76 & 9,51 & 8,44 & 7,48 & 5,89 & 4,69 & 3,15 \\
\hline 60 & 1750 & 140 & 14,91 & 11,82 & 10,68 & 9,45 & 8,40 & 7,46 & 5,88 & 4,69 & 3,16 \\
\hline 60 & 1800 & 140 & 14,74 & 11,71 & 10,60 & 9,40 & 8,36 & 7,43 & 5,87 & 4,70 & 3,16 \\
\hline 60 & 1850 & 140 & 14,57 & 11,61 & 10,52 & 9,34 & 8,33 & 7,41 & 5,87 & 4,70 & 3,17 \\
\hline 60 & 1900 & 140 & 14,42 & 11,51 & 10,45 & 9,29 & 8,29 & 7,39 & 5,86 & 4,70 & 3,17 \\
\hline 60 & 1950 & 140 & 14,27 & 11,41 & 10,38 & 9,24 & 8,25 & 7,36 & 5,85 & 4,70 & 3,18 \\
\hline 60 & 2000 & 140 & 14,12 & 11,32 & 10,31 & 9,19 & 8,22 & 7,34 & 5,85 & 4,70 & 3,18 \\
\hline 60 & 200 & 145 & 47,73 & 24,29 & 17,23 & 12,36 & 9,56 & 7,69 & 5,35 & 4,10 & 2,85 \\
\hline 60 & 250 & 145 & 41,13 & 22,24 & 16,38 & 12,13 & 9,55 & 7,74 & 5,42 & 4,15 & 2,85 \\
\hline 60 & 300 & 145 & 36,61 & 20,78 & 15,73 & 11,93 & 9,51 & 7,77 & 5,48 & 4,18 & 2,85 \\
\hline 60 & 350 & 145 & 33,29 & 19,65 & 15,20 & 11,75 & 9,47 & 7,79 & 5,53 & 4,21 & 2,85 \\
\hline 60 & 400 & 145 & 30,73 & 18,75 & 14,76 & 11,58 & 9,42 & 7,79 & 5,56 & 4,24 & 2,86 \\
\hline 60 & 450 & 145 & 28,70 & 18,01 & 14,39 & 11,42 & 9,37 & 7,79 & 5,59 & 4,27 & 2,86 \\
\hline 60 & 500 & 145 & 27,03 & 17,38 & 14,05 & 11,28 & 9,31 & 7,78 & 5,62 & 4,29 & 2,87 \\
\hline 60 & 550 & 145 & 25,63 & 16,83 & 13,76 & 11,15 & 9,26 & 7,77 & 5,64 & 4,32 & 2,88 \\
\hline 60 & 600 & 145 & 24,44 & 16,36 & 13,49 & 11,02 & 9,20 & 7,76 & 5,66 & 4,34 & 2,89 \\
\hline 60 & 650 & 145 & 23,42 & 15,93 & 13,25 & 10,90 & 9,15 & 7,74 & 5,68 & 4,35 & 2,89 \\
\hline 60 & 700 & 145 & 22,52 & 15,55 & 13,02 & 10,78 & 9,09 & 7,72 & 5,69 & 4,37 & 2,90 \\
\hline 60 & 750 & 145 & 21,73 & 15,20 & 12,82 & 10,67 & 9,04 & 7,70 & 5,70 & 4,39 & 2,91 \\
\hline 60 & 800 & 145 & 21,02 & 14,89 & 12,63 & 10,57 & 8,98 & 7,68 & 5,71 & 4,40 & 2,92 \\
\hline 60 & 850 & 145 & 20,38 & 14,60 & 12,45 & 10,47 & 8,93 & 7,65 & 5,71 & 4,41 & 2,93 \\
\hline 60 & 900 & 145 & 19,81 & 14,33 & 12,28 & 10,38 & 8,88 & 7,63 & 5,72 & 4,43 & 2,93 \\
\hline 60 & 950 & 145 & 19,29 & 14,08 & 12,12 & 10,29 & 8,83 & 7,61 & 5,72 & 4,44 & 2,94 \\
\hline 60 & 1000 & 145 & 18,82 & 13,85 & 11,97 & 10,20 & 8,78 & 7,58 & 5,73 & 4,45 & 2,95 \\
\hline 60 & 1050 & 145 & 18,38 & 13,63 & 11,83 & 10,11 & 8,73 & 7,56 & 5,73 & 4,46 & 2,96 \\
\hline 60 & 1100 & 145 & 17,98 & 13,43 & 11,70 & 10,03 & 8,69 & 7,53 & 5,73 & 4,47 & 2,96 \\
\hline 60 & 1150 & 145 & 17,61 & 13,24 & 11,57 & 9,95 & 8,64 & 7,51 & 5,73 & 4,47 & 2,97 \\
\hline 60 & 1200 & 145 & 17,26 & 13,06 & 11,45 & 9,88 & 8,59 & 7,49 & 5,73 & 4,48 & 2,98 \\
\hline 60 & 1250 & 145 & 16,94 & 12,89 & 11,34 & 9,81 & 8,55 & 7,46 & 5,72 & 4,49 & 2,98 \\
\hline 60 & 1300 & 145 & 16,64 & 12,72 & 11,23 & 9,74 & 8,51 & 7,44 & 5,72 & 4,49 & 2,99 \\
\hline 60 & 1350 & 145 & 16,36 & 12,57 & 11,12 & 9,67 & 8,46 & 7,41 & 5,72 & 4,50 & 3,00 \\
\hline 60 & 1400 & 145 & 16,09 & 12,42 & 11,02 & 9,60 & 8,42 & 7,39 & 5,72 & 4,51 & 3,00 \\
\hline 60 & 1450 & 145 & 15,84 & 12,28 & 10,92 & 9,54 & 8,38 & 7,37 & 5,71 & 4,51 & 3,01 \\
\hline 60 & 1500 & 145 & 1561 & 1214 & 10.83 & 9.48 & 834 & 734 & 5.71 & 451 & 3.02 \\
\hline 60 & 1550 & 145 & 15,39 & 12,02 & 10,74 & 9,42 & 8,30 & 7,32 & 5,71 & 4,52 & 3,02 \\
\hline 60 & 1600 & 145 & 15,18 & 11,89 & 10,65 & 9,36 & 8,26 & 7,29 & 5,70 & 4,52 & 3,03 \\
\hline 60 & 1650 & 145 & 14,98 & 11,77 & 10,56 & 9,30 & 8,23 & 7,27 & 5,70 & 4,52 & 3,03 \\
\hline
\end{tabular}




\begin{tabular}{|c|c|c|c|c|c|c|c|c|c|c|c|}
\hline \multirow[b]{2}{*}{$\mathrm{H}(\mathrm{cm})$} & \multirow[b]{2}{*}{ Mceq (MPa) } & & & & & $\mathrm{De}$ & ões (x. & & & & \\
\hline & & Msub (MPa) & D0 & D25 & D40 & D60 & D80 & D100 & D140 & D180 & D260 \\
\hline 60 & 1700 & 145 & 14,79 & 11,66 & 10,48 & 9,25 & 8,19 & 7,25 & 5,69 & 4,53 & 3,04 \\
\hline 60 & 1750 & 145 & 14,61 & 11,55 & 10,40 & 9,19 & 8,15 & 7,23 & 5,69 & 4,53 & 3,04 \\
\hline 60 & 1800 & 145 & 14,44 & 11,44 & 10,33 & 9,14 & 8,12 & 7,20 & 5,68 & 4,53 & 3,05 \\
\hline 60 & 1850 & 145 & 14,28 & 11,34 & 10,25 & 9,09 & 8,08 & 7,18 & 5,67 & 4,53 & 3,05 \\
\hline 60 & 1900 & 145 & 14,12 & 11,24 & 10,18 & 9,04 & 8,05 & 7,16 & 5,67 & 4,54 & 3,06 \\
\hline 60 & 1950 & 145 & 13,97 & 11,14 & 10,11 & 8,99 & 8,02 & 7,14 & 5,66 & 4,54 & 3,06 \\
\hline 60 & 2000 & 145 & 13,83 & 11,05 & 10,04 & 8,94 & 7,98 & 7,12 & 5,66 & 4,54 & 3,07 \\
\hline 60 & 200 & 150 & 47,22 & 23,81 & 16,79 & 11,98 & 9,25 & 7,43 & 5,16 & 3,96 & 2,76 \\
\hline 60 & 250 & 150 & 40,65 & 21,78 & 15,95 & 11,76 & 9,23 & 7,48 & 5,23 & 4,00 & 2,75 \\
\hline 60 & 300 & 150 & 36,15 & 20,33 & 15,32 & 11,57 & 9,20 & 7,51 & 5,29 & 4,04 & 2,75 \\
\hline 60 & 350 & 150 & 32,85 & 19,23 & 14,81 & 11,39 & 9,16 & 7,53 & 5,33 & 4,07 & 2,76 \\
\hline 60 & 400 & 150 & 30,31 & 18,34 & 14,38 & 11,23 & 9,12 & 7,53 & 5,37 & 4,09 & 2,76 \\
\hline 60 & 450 & 150 & 28,29 & 17,61 & 14,01 & 11,09 & 9,07 & 7,53 & 5,40 & 4,12 & 2,77 \\
\hline 60 & 500 & 150 & 26,63 & 16,99 & 13,69 & 10,95 & 9,02 & 7,53 & 5,43 & 4,14 & 2,77 \\
\hline 60 & 550 & 150 & 25,25 & 16,46 & 13,40 & 10,82 & 8,97 & 7,52 & 5,45 & 4,16 & 2,78 \\
\hline 60 & 600 & 150 & 24,07 & 15,99 & 13,14 & 10,70 & 8,92 & 7,50 & 5,47 & 4,18 & 2,79 \\
\hline 60 & 650 & 150 & 23,05 & 15,57 & 12,91 & 10,58 & 8,86 & 7,49 & 5,48 & 4,20 & 2,79 \\
\hline 60 & 700 & 150 & 22,16 & 15,20 & 12,69 & 10,47 & 8,81 & 7,47 & 5,49 & 4,22 & 2,80 \\
\hline 60 & 750 & 150 & 21,37 & 14,86 & 12,49 & 10,37 & 8,76 & 7,45 & 5,50 & 4,23 & 2,81 \\
\hline 60 & 800 & 150 & 20,67 & 14,55 & 12,30 & 10,27 & 8,71 & 7,43 & 5,51 & 4,25 & 2,82 \\
\hline 60 & 850 & 150 & 20,04 & 14,27 & 12,13 & 10,18 & 8,66 & 7,41 & 5,52 & 4,26 & 2,82 \\
\hline 60 & 900 & 150 & 19,48 & 14,01 & 11,97 & 10,08 & 8,61 & 7,39 & 5,53 & 4,27 & 2,83 \\
\hline 60 & 950 & 150 & 18,96 & 13,76 & 11,81 & 10,00 & 8,57 & 7,37 & 5,53 & 4,28 & 2,84 \\
\hline 60 & 1000 & 150 & 18,49 & 13,54 & 11,67 & 9,91 & 8,52 & 7,35 & 5,53 & 4,29 & 2,84 \\
\hline 60 & 1050 & 150 & 18,06 & 13,32 & 11,53 & 9,83 & 8,47 & 7,32 & 5,53 & 4,30 & 2,85 \\
\hline 60 & 1100 & 150 & 17,66 & 13,13 & 11,40 & 9,76 & 8,43 & 7,30 & 5,54 & 4,31 & 2,86 \\
\hline 60 & 1150 & 150 & 17,29 & 12,94 & 11,28 & 9,68 & 8,39 & 7,28 & 5,54 & 4,32 & 2,87 \\
\hline 60 & 1200 & 150 & 16,95 & 12,76 & 11,16 & 9,61 & 8,34 & 7,26 & 5,54 & 4,33 & 2,87 \\
\hline 60 & 1250 & 150 & 16,63 & 12,59 & 11,05 & 9,54 & 8,30 & 7,23 & 5,54 & 4,33 & 2,88 \\
\hline 60 & 1300 & 150 & 16,33 & 12,43 & 10,94 & 9,47 & 8,26 & 7,21 & 5,53 & 4,34 & 2,88 \\
\hline 60 & 1350 & 150 & 16,06 & 12,28 & 10,84 & 9,41 & 8,22 & 7,19 & 5,53 & 4,35 & 2,89 \\
\hline 60 & 1400 & 150 & 15,79 & 12,14 & 10,74 & 9,34 & 8,18 & 7,16 & 5,53 & 4,35 & 2,90 \\
\hline 60 & 1450 & 150 & 15,55 & 12,00 & 10,65 & 9,28 & 8,14 & 7,14 & 5,53 & 4,36 & 2,90 \\
\hline 60 & 1500 & 150 & 15,32 & 11,87 & 10,56 & 9,22 & 8,10 & 7.12 & 5,52 & 4,36 & 2,91 \\
\hline 60 & 1550 & 150 & 15,10 & 11,74 & 10,47 & 9,16 & 8,06 & 7,10 & 5,52 & 4,36 & 2,91 \\
\hline 60 & 1600 & 150 & 14,89 & 11,62 & 10,38 & 9,11 & 8,03 & 7,08 & 5,52 & 4,37 & 2,92 \\
\hline 60 & 1650 & 150 & 14,69 & 11,51 & 10,30 & 9,05 & 7,99 & 7,05 & 5,51 & 4,37 & 2,93 \\
\hline 60 & 1700 & 150 & 14,51 & 11,40 & 10,22 & 9,00 & 7,96 & 7,03 & 5,51 & 4,37 & 2,93 \\
\hline 60 & 1750 & 150 & 14,33 & 11,29 & 10,15 & 8,95 & 7,92 & 7,01 & 5,50 & 4,38 & 2,94 \\
\hline 60 & 1800 & 150 & 14,16 & 11,18 & 10,07 & 8,90 & 7,89 & 6,99 & 5,50 & 4,38 & 2,94 \\
\hline 60 & 1850 & 150 & 14,00 & 11,08 & 10,00 & 8,85 & 7,86 & 6,97 & 5,49 & 4,38 & 2,95 \\
\hline 60 & 1900 & 150 & 13,84 & 10,99 & 9,93 & 8,80 & 7,82 & 6,95 & 5,49 & 4,38 & 2,95 \\
\hline 60 & 1950 & 150 & 13,69 & 10,89 & 9,86 & 8,75 & 7,79 & 6,93 & 5,48 & 4,38 & 2,95 \\
\hline 60 & 2000 & 150 & 13,55 & 10,80 & 9,80 & 8,71 & 7,76 & 6,91 & 5,47 & 4,39 & 2,96 \\
\hline 60 & 200 & 155 & 46,74 & 23,36 & 16,37 & 11,62 & 8,95 & 7,18 & 4,99 & 3,83 & 2,67 \\
\hline 60 & 250 & 155 & 40,19 & 21,35 & 15,55 & 11,41 & 8,94 & 7,23 & 5,05 & 3,87 & 2,66 \\
\hline 60 & 300 & 155 & 35,72 & 19,92 & 14,93 & 11,23 & 8,91 & 7,26 & 5,11 & 3,90 & 2,66 \\
\hline 60 & 350 & 155 & 32,43 & 18,83 & 14,43 & 11,06 & 8,88 & 7,28 & 5,15 & 3,93 & 2,67 \\
\hline 60 & 400 & 155 & 29,91 & 17,96 & 14,01 & 10,91 & 8,84 & 7,29 & 5,19 & 3,96 & 2,67 \\
\hline 60 & 450 & 155 & 27,90 & 17,24 & 13,66 & 10,77 & 8,79 & 7,29 & 5,22 & 3,98 & 2,68 \\
\hline 60 & 500 & 155 & 26,26 & 16,63 & 13,34 & 10,64 & 8,74 & 7,29 & 5,24 & 4,00 & 2,68 \\
\hline 60 & 550 & 155 & 24,88 & 16,10 & 13,06 & 10,52 & 8,70 & 7,28 & 5,26 & 4,02 & 2,69 \\
\hline 60 & 600 & 155 & 23,71 & $15,+64$ & 12,81 & 10,40 & 8,65 & 7,27 & 5,28 & 4,04 & 2,69 \\
\hline 60 & 650 & 155 & 22,70 & 15,23 & 12,58 & 10,29 & 8,60 & 7,25 & 5,30 & 4,06 & 2,70 \\
\hline 60 & 700 & 155 & 21,82 & 14,87 & 12,37 & 10,18 & 8,55 & 7,24 & 5,31 & 4,07 & 2,71 \\
\hline 60 & 750 & 155 & 21,04 & 14,53 & 12,18 & 10,08 & 8,50 & 7,22 & 5,32 & 4,09 & 2,71 \\
\hline 60 & 800 & 155 & 20,35 & 14,23 & 12,00 & 9,99 & 8,46 & 7,20 & 5,33 & 4,10 & 2,72 \\
\hline 60 & 850 & 155 & 19,72 & 13,95 & 11,83 & 9,90 & 8,41 & 7,18 & 5,34 & 4,12 & 2,73 \\
\hline 60 & 900 & 155 & 19,16 & 13,70 & 11,67 & 9,81 & 8,36 & 7,16 & 5,34 & 4,13 & 2,74 \\
\hline 60 & 950 & 155 & 18,65 & 13,46 & 11,52 & 9,73 & 8,32 & 7,14 & 5,35 & 4,14 & 2,74 \\
\hline 60 & 1000 & 155 & 18,18 & 13,24 & 11,38 & 9,65 & 8,27 & 7,12 & 5,35 & 4,15 & 2,75 \\
\hline 60 & 1050 & 155 & 17,76 & 13,03 & 11,25 & 9,57 & 8,23 & 7,10 & 5,35 & 4,16 & 2,76 \\
\hline 60 & 1100 & 155 & 17,36 & 12,84 & 11,12 & 9,49 & 8,19 & 7,08 & 5,36 & 4,17 & 2,76 \\
\hline 60 & 1150 & 155 & 17,00 & 12,65 & 11,00 & 9,42 & 8,15 & 7,06 & 5,36 & 4,17 & 2,77 \\
\hline 60 & 1200 & 155 & 16,66 & 12,48 & 10,89 & 9,35 & 8,11 & 7,04 & 5,36 & 4,18 & 2,77 \\
\hline 60 & 1250 & 155 & 16,34 & 12,32 & 10,78 & 9,29 & 8,06 & 7,02 & 5,36 & 4,19 & 2,78 \\
\hline 60 & 1300 & 155 & 16,05 & 12,16 & 10,68 & 9,22 & 8,03 & 7,00 & 5,36 & 4,19 & 2,79 \\
\hline 60 & 1350 & 155 & 15,77 & 12,01 & 10,58 & 9,16 & 7,99 & 6,97 & 5,36 & 4,20 & 2,79 \\
\hline 60 & 1400 & 155 & 15,51 & 11,87 & 10,48 & 9,10 & 7,95 & 6,95 & 5,35 & 4,21 & 2,80 \\
\hline 60 & 1450 & 155 & 15,27 & 11,74 & 10,39 & 9,04 & 7,91 & 6,93 & 5,35 & 4,21 & 2,80 \\
\hline 60 & 1500 & 155 & 15,04 & 11,61 & 10,30 & 8,98 & 7,88 & 6,91 & 5,35 & 4,22 & 2,81 \\
\hline 60 & 1550 & 155 & 14,82 & 11,49 & 10,22 & 8,92 & 7,84 & 6,89 & 5,34 & 4,22 & 2,82 \\
\hline 60 & 1600 & 155 & 14,62 & 11,37 & 10,13 & 8,87 & 7,81 & 6,87 & 5,34 & 4,22 & 2,82 \\
\hline 60 & 1650 & 155 & 14,42 & 11,26 & 10,05 & 8,82 & 7,77 & 6,85 & 5,34 & 4,23 & 2,83 \\
\hline 60 & 1700 & 155 & 14,24 & 11,15 & 9,98 & 8,76 & 7,74 & 6,83 & 5,33 & 4,23 & 2,83 \\
\hline 60 & 1750 & 155 & 14,06 & 11,04 & 9,90 & 8,71 & 7,70 & 6,81 & 5,33 & 4,23 & 2,84 \\
\hline 60 & 1800 & 155 & 13,89 & 10,94 & 9,83 & 8,67 & 7,67 & 6,79 & 5,33 & 4,23 & 2,84 \\
\hline 60 & 1850 & 155 & 13,73 & 10,84 & 9,76 & 8,62 & 7,64 & 6,77 & 5,32 & 4,24 & 2,84 \\
\hline 60 & 1900 & 155 & 13,58 & 10,75 & 9,69 & 8,57 & 7,61 & 6,75 & 5,32 & 4,24 & 2,85 \\
\hline 60 & 1950 & 155 & 13,43 & 10,66 & 9,63 & 8,53 & 7,58 & 6,73 & 5,31 & 4,24 & 2,85 \\
\hline 60 & 2000 & 155 & 13,29 & 10,57 & 9,56 & 8,48 & 7,55 & 6,71 & 5,31 & 4,24 & 2,86 \\
\hline
\end{tabular}




\begin{tabular}{|c|c|c|c|c|c|c|c|c|c|c|c|}
\hline \multirow[b]{2}{*}{$\mathrm{H}(\mathrm{cm})$} & \multirow[b]{2}{*}{ Mceq (MPa) } & & & & & De & ões (x & & & & \\
\hline & & Msub (MPa) & D0 & D25 & D40 & D60 & D80 & D100 & D140 & D180 & D260 \\
\hline 60 & 200 & 160 & 46,29 & 22,93 & 15,98 & 11,28 & 8,67 & 6,94 & 4,82 & 3,70 & 2,59 \\
\hline 60 & 250 & 160 & 39,77 & 20,94 & 15,17 & 11,08 & 8,66 & 7,00 & 4,89 & 3,74 & 2,58 \\
\hline 60 & 300 & 160 & 35,31 & 19,53 & 14,56 & 10,91 & 8,64 & 7,03 & 4,94 & 3,77 & 2,58 \\
\hline 60 & 350 & 160 & 32,04 & 18,45 & 14,08 & 10,75 & 8,61 & 7,05 & 4,98 & 3,80 & 2,58 \\
\hline 60 & 400 & 160 & 29,53 & 17,59 & 13,67 & 10,61 & 8,57 & 7,06 & 5,02 & 3,83 & 2,59 \\
\hline 60 & 450 & 160 & 27,54 & 16,88 & 13,32 & 10,47 & 8,53 & 7,06 & 5,05 & 3,85 & 2,59 \\
\hline 60 & 500 & 160 & 25,90 & 16,28 & 13,02 & 10,35 & 8,49 & 7,06 & 5,07 & 3,87 & 2,60 \\
\hline 60 & 550 & 160 & 24,54 & 15,77 & 12,75 & 10,23 & 8,44 & 7,05 & 5,09 & 3,89 & 2,60 \\
\hline 60 & 600 & 160 & 23,38 & 15,31 & 12,50 & 10,12 & 8,40 & 7,04 & 5,11 & 3,91 & 2,61 \\
\hline 60 & 650 & 160 & 22,37 & 14,91 & 12,28 & 10,01 & 8,35 & 7,03 & 5,13 & 3,92 & 2,61 \\
\hline 60 & 700 & 160 & 21,50 & 14,55 & 12,07 & 9,91 & 8,30 & 7,02 & 5,14 & 3,94 & 2,62 \\
\hline 60 & 750 & 160 & 20,73 & 14,23 & 11,88 & 9,81 & 8,26 & 7,00 & 5,15 & 3,95 & 2,63 \\
\hline 60 & 800 & 160 & 20,04 & 13,93 & 11,71 & 9,72 & 8,21 & 6,99 & 5,16 & 3,97 & 2,63 \\
\hline 60 & 850 & 160 & 19,42 & 13,66 & 11,54 & 9,63 & 8,17 & 6,97 & 5,17 & 3,98 & 2,64 \\
\hline 60 & 900 & 160 & 18,86 & 13,41 & 11,39 & 9,55 & 8,13 & 6,95 & 5,17 & 3,99 & 2,65 \\
\hline 60 & 950 & 160 & 18,36 & 13,17 & 11,25 & 9,47 & 8,08 & 6,93 & 5,18 & 4,00 & 2,65 \\
\hline 60 & 1000 & 160 & 17,89 & 12,96 & 11,11 & 9,39 & 8,04 & 6,91 & 5,18 & 4,01 & 2,66 \\
\hline 60 & 1050 & 160 & 17,47 & 12,75 & 10,98 & 9,32 & 8,00 & 6,89 & 5,19 & 4,02 & 2,67 \\
\hline 60 & 1100 & 160 & 17,08 & 12,56 & 10,86 & 9,25 & 7,96 & 6,87 & 5,19 & 4,03 & 2,67 \\
\hline 60 & 1150 & 160 & 16,72 & 12,39 & 10,74 & 9,18 & 7,92 & 6,85 & 5,19 & 4,04 & 2,68 \\
\hline 60 & 1200 & 160 & 16,38 & 12,22 & 10,63 & 9,11 & 7,88 & 6,83 & 5,19 & 4,05 & 2,68 \\
\hline 60 & 1250 & 160 & 16,07 & 12,06 & 10,53 & 9,05 & 7,84 & 6,81 & 5,19 & 4,05 & 2,69 \\
\hline 60 & 1300 & 160 & 15,78 & 11,90 & 10,43 & 8,98 & 7,81 & 6,79 & 5,19 & 4,06 & 2,69 \\
\hline 60 & 1350 & 160 & 15,50 & 11,76 & 10,33 & 8,92 & 7,77 & 6,77 & 5,19 & 4,06 & 2,70 \\
\hline 60 & 1400 & 160 & 15,25 & 11,62 & 10,24 & 8,86 & 7,73 & 6,75 & 5,19 & 4,07 & 2,71 \\
\hline 60 & 1450 & 160 & 15,01 & 11,49 & 10,15 & 8,81 & 7,70 & 6,73 & 5,19 & 4,07 & 2,71 \\
\hline 60 & 1500 & 160 & 14,78 & 11,36 & 10,06 & 8,75 & 7,66 & 6,71 & 5,18 & 4,08 & 2,72 \\
\hline 60 & 1550 & 160 & 14,56 & 11,24 & 9,98 & 8,70 & 7,63 & 6,69 & 5,18 & 4,08 & 2,72 \\
\hline 60 & 1600 & 160 & 14,36 & 11,13 & 9,90 & 8,64 & 7,60 & 6,67 & 5,18 & 4,09 & 2,73 \\
\hline 60 & 1650 & 160 & 14,17 & 11,02 & 9,82 & 8,59 & 7,56 & 6,66 & 5,17 & 4,09 & 2,73 \\
\hline 60 & 1700 & 160 & 13,98 & 10,91 & 9,74 & 8,54 & 7,53 & 6,64 & 5,17 & 4,09 & 2,74 \\
\hline 60 & 1750 & 160 & 13,81 & 10,81 & 9,67 & 8,50 & 7,50 & 6,62 & 5,17 & 4,10 & 2,74 \\
\hline 60 & 1800 & 160 & 13,64 & 10,71 & 9,60 & 8,45 & 7,47 & 6,60 & 5,16 & 4,10 & 2,75 \\
\hline 60 & 1850 & 160 & 13,48 & 10,61 & 9,53 & 8,40 & 7,44 & 6,58 & 5,16 & 4,10 & 2,75 \\
\hline 60 & 1900 & 160 & 13,33 & 10,52 & 9,47 & 8,36 & 7,41 & 6,56 & 5,15 & 4,10 & 2,76 \\
\hline 60 & 1950 & 160 & 13,19 & 10,43 & 9,40 & 8,31 & 7,38 & 6,54 & 5,15 & 4,11 & 2,76 \\
\hline 60 & 2000 & 160 & 13,05 & 10,35 & 9,34 & 8,27 & 7,35 & 6,52 & 5,15 & 4,11 & 2,76 \\
\hline 60 & 200 & 165 & 45,87 & 22,53 & 15,61 & 10,97 & 8,40 & 6,72 & 4,66 & 3,59 & 2,51 \\
\hline 60 & 250 & 165 & 39,36 & 20,56 & 14,82 & 10,78 & 8,40 & 6,78 & 4,73 & 3,62 & 2,50 \\
\hline 60 & 300 & 165 & 34,92 & 19,16 & 14,22 & 10,61 & 8,38 & 6,81 & 4,78 & 3,65 & 2,50 \\
\hline 60 & 350 & 165 & 31,67 & 18,09 & 13,74 & 10,46 & 8,35 & 6,83 & 4,82 & 3,68 & 2,50 \\
\hline 60 & 400 & 165 & 29,18 & 17,24 & 13,35 & 10,32 & 8,32 & 6,85 & 4,86 & 3,70 & 2,51 \\
\hline 60 & 450 & 165 & 27,19 & 16,55 & 13,01 & 10,19 & 8,28 & 6,85 & 4,89 & 3,73 & 2,51 \\
\hline 60 & 500 & 165 & 25,57 & 15,96 & 12,71 & 10,07 & 8,24 & 6,85 & 4,91 & 3,75 & 2,52 \\
\hline 60 & 550 & 165 & 24,21 & 15,45 & 12,44 & 9,95 & 8,20 & 6,84 & 4,93 & 3,77 & 2,52 \\
\hline 60 & 600 & 165 & 23,06 & 15,00 & 12,21 & 9,85 & 8,16 & 6,83 & 4,95 & 3,78 & 2,53 \\
\hline 60 & 650 & 165 & 22,06 & 14,61 & 11,99 & 9,75 & 8,11 & 6,82 & 4,97 & 3,80 & 2,53 \\
\hline 60 & 700 & 165 & 21,19 & 14,26 & 11,79 & 9,65 & 8,07 & 6,81 & 4,98 & 3,81 & 2,54 \\
\hline 60 & 750 & 165 & 20,43 & 13,94 & 11,61 & 9,56 & 8,03 & 6,80 & 4,99 & 3,83 & 2,54 \\
\hline 60 & 800 & 165 & 19,74 & 13,64 & 11,43 & 9,47 & 7,99 & 6,78 & 5,00 & 3,84 & 2,55 \\
\hline 60 & 850 & 165 & 19,13 & 13,38 & 11,28 & 9,39 & 7,94 & 6,77 & 5,01 & 3,85 & 2,56 \\
\hline 60 & 900 & 165 & 18,58 & 13,13 & 11,13 & 9,31 & 7,90 & 6,75 & 5,01 & 3,87 & 2,56 \\
\hline 60 & 950 & 165 & 18,08 & 12,90 & 10,99 & 9,23 & 7,86 & 6,73 & 5,02 & 3,88 & 2,57 \\
\hline 60 & 1000 & 165 & 17,62 & 12,69 & 10,85 & 9,15 & 7,82 & 6,71 & 5,02 & 3,89 & 2,57 \\
\hline 60 & 1050 & 165 & 17,20 & 12,49 & 10,73 & 9,08 & 7,78 & 6,70 & 5,03 & 3,89 & 2,58 \\
\hline 60 & 1100 & 165 & 16,81 & 12,31 & 10,61 & 9,01 & 7,75 & 6,68 & 5,03 & 3,90 & 2,59 \\
\hline 60 & 1150 & 165 & 16,45 & 12,13 & 10,50 & 8,95 & 7,71 & 6,66 & 5,03 & 3,91 & 2,59 \\
\hline 60 & 1200 & 165 & 16,12 & 11,96 & 10,39 & 8,88 & 7,67 & 6,64 & 5,03 & 3,92 & 2,60 \\
\hline 60 & 1250 & 165 & 15,81 & 11,81 & 10,29 & 8,82 & 7,63 & 6,62 & 5,03 & 3,92 & 2,60 \\
\hline 60 & 1300 & 165 & 15,52 & 11,66 & 10,19 & 8,76 & 7,60 & 6,60 & 5,03 & 3,93 & 2,61 \\
\hline 60 & 1350 & 165 & 15,25 & 11,52 & 10,09 & 8,70 & 7,56 & 6,58 & 5,03 & 3,94 & 2,61 \\
\hline 60 & 1400 & 165 & 14,99 & 11,38 & 10,00 & 8,64 & 7,53 & 6,57 & 5,03 & 3,94 & 2,62 \\
\hline 60 & 1450 & 165 & 14,76 & 11,25 & 9,91 & 8,59 & 7,49 & 6,55 & 5,03 & 3,95 & 2,62 \\
\hline 60 & 1500 & 165 & 14,53 & 11,13 & 9,83 & 8,53 & 7,46 & 6,53 & 5,03 & 3,95 & 2,63 \\
\hline 60 & 1550 & 165 & 14,32 & 11,01 & 9,75 & 8,48 & 7,43 & 6,51 & 5,03 & 3,96 & 2,63 \\
\hline 60 & 1600 & 165 & 14,12 & 10,90 & 9,67 & 8,43 & 7,40 & 6,49 & 5,02 & 3,96 & 2,64 \\
\hline 60 & 1650 & 165 & 13,92 & 10,79 & 9,60 & 8,38 & 7,37 & 6,47 & 5,02 & 3,96 & 2,64 \\
\hline 60 & 1700 & 165 & 13,74 & 10,69 & 9,52 & 8,33 & 7,33 & 6,45 & 5,02 & 3,97 & 2,65 \\
\hline 60 & 1750 & 165 & 13,57 & 10,59 & 9,45 & 8,29 & 7,30 & 6,44 & 5,01 & 3,97 & 2,65 \\
\hline 60 & 1800 & 165 & 13,40 & 10,49 & 9,39 & 8,24 & 7,27 & 6,42 & 5,01 & 3,97 & 2,66 \\
\hline 60 & 1850 & 165 & 13,25 & 10,40 & 9,32 & 8,20 & 7,24 & 6,40 & 5,01 & 3,98 & 2,66 \\
\hline 60 & 1900 & 165 & 13,10 & 10,31 & 9,25 & 8,15 & 7,22 & 6,38 & 5,00 & 3,98 & 2,67 \\
\hline 60 & 1950 & 165 & 12,95 & 10,22 & 9,19 & 8,11 & 7,19 & 6,36 & 5,00 & 3,98 & 2,67 \\
\hline 60 & 2000 & 165 & 12,82 & 10,13 & 9,13 & 8,07 & 7,16 & 6,35 & 5,00 & 3,98 & 2,67 \\
\hline 60 & 200 & 170 & 45,46 & 22,15 & 15,26 & 10,67 & 8,15 & 6,52 & 4,52 & 3,48 & 2,43 \\
\hline 60 & 250 & 170 & 38,98 & 20,19 & 14,48 & 10,49 & 8,16 & 6,57 & 4,58 & 3,51 & 2,43 \\
\hline 60 & 300 & 170 & 34,55 & 18,80 & 13,89 & 10,32 & 8,14 & 6,61 & 4,63 & 3,54 & 2,43 \\
\hline 60 & 350 & 170 & 31,32 & 17,75 & 13,43 & 10,18 & 8,12 & 6,63 & 4,67 & 3,57 & 2,43 \\
\hline 60 & 400 & 170 & 28,84 & 16,91 & 13,04 & 10,04 & 8,08 & 6,64 & 4,71 & 3,59 & 2,43 \\
\hline 60 & 450 & 170 & 26,86 & 16,23 & 12,71 & 9,92 & 8,05 & 6,65 & 4,74 & 3,61 & 2,44 \\
\hline 60 & 500 & 170 & 25,25 & 15,65 & 12,42 & 9,81 & 8,01 & 6,65 & 4,76 & 3,63 & 2,44 \\
\hline
\end{tabular}




\begin{tabular}{|c|c|c|c|c|c|c|c|c|c|c|c|}
\hline \multirow[b]{2}{*}{$\mathrm{H}(\mathrm{cm})$} & \multirow[b]{2}{*}{ Mceq (MPa) } & & & & & $\mathrm{De}$ & $\operatorname{ses}(x$ & & & & \\
\hline & & Msub (MPa) & D0 & D25 & D40 & D60 & D80 & D100 & D140 & D180 & D260 \\
\hline 60 & 550 & 170 & 23,90 & 15,15 & 12,16 & 9,70 & 7,97 & 6,64 & 4,78 & 3,65 & 2,45 \\
\hline 60 & 600 & 170 & 22,76 & 14,71 & 11,93 & $\begin{array}{l}9,59 \\
\end{array}$ & 7,93 & $\begin{array}{l}6,64 \\
\end{array}$ & 4,80 & 3,67 & 2,45 \\
\hline 60 & 650 & 170 & 21,77 & 14,32 & 11,71 & 9,50 & 7,89 & 6,63 & 4,81 & 3,68 & 2,46 \\
\hline 60 & 700 & 170 & 20,90 & 13,97 & 11,52 & 9,40 & 7,85 & $\begin{array}{l}6,62 \\
\end{array}$ & 4,83 & 3,70 & 2,46 \\
\hline 60 & 750 & 170 & 20,14 & 13,66 & 11,34 & 9,32 & 7,81 & 6,60 & 4,84 & 3,71 & 2,47 \\
\hline 60 & 800 & 170 & 19,47 & 13,37 & 11,17 & 9,23 & 7,77 & 6,59 & 4,85 & 3,72 & 2,47 \\
\hline 60 & 850 & 170 & 18,86 & 13,11 & 11,02 & 9,15 & 7,73 & 6,58 & 4,86 & 3,73 & 2,48 \\
\hline 60 & 900 & 170 & 18,31 & 12,87 & 10,87 & 9,07 & 7,69 & 6,56 & 4,86 & 3,75 & 2,48 \\
\hline 60 & 950 & 170 & 17,81 & 12,65 & 10,74 & 9,00 & 7,65 & 6,54 & 4,87 & 3,76 & 2,49 \\
\hline 60 & 1000 & 170 & 17,36 & 12,44 & 10,61 & 8,93 & 7,62 & 6,53 & 4,87 & 3,77 & 2,50 \\
\hline 60 & 1050 & 170 & 16,94 & 12,24 & 10,49 & 8,86 & 7,58 & 6,51 & 4,88 & 3,77 & 2,50 \\
\hline 60 & 1100 & 170 & 16,56 & 12,06 & 10,37 & 8,79 & 7,54 & 6,49 & 4,88 & 3,78 & 2,51 \\
\hline 60 & 1150 & 170 & 16,20 & 11.89 & 10,26 & 8,73 & 7.51 & 6,48 & 4.88 & 3,79 & 2,51 \\
\hline 60 & 1200 & 170 & 15,87 & 11,72 & 10,16 & 8,66 & 7,47 & 6,46 & 4,88 & 3,80 & 2,52 \\
\hline 60 & 1250 & 170 & 15,56 & 11,57 & 10,06 & 8,60 & 7,44 & 6,44 & 4,88 & 3,80 & 2,52 \\
\hline 60 & 1300 & 170 & 15,28 & 11,43 & 9,96 & 8,55 & 7,40 & 6,42 & 4,89 & 3,81 & 2,53 \\
\hline 60 & 1350 & 170 & 15,01 & 11,29 & 9,87 & 8,49 & 7,37 & 6,41 & 4,88 & 3,82 & 2,53 \\
\hline 60 & 1400 & 170 & 14,76 & 11,15 & 9,78 & 8,43 & 7,33 & 6,39 & 4,88 & 3,82 & 2,54 \\
\hline 60 & 1450 & 170 & 14,52 & 11,03 & 9,69 & 8,38 & 7,30 & 6,37 & 4,88 & 3,83 & 2,54 \\
\hline 60 & 1500 & 170 & 14,30 & 10,91 & 9,61 & 8,33 & 7,27 & 6,35 & 4,88 & 3,83 & 2,55 \\
\hline 60 & 1550 & 170 & 14,08 & 10,79 & 9,53 & 8,28 & 7,24 & 6,33 & 4,88 & 3,84 & 2,55 \\
\hline 60 & 1600 & 170 & 13,88 & 10,68 & 9,46 & 8,23 & 7,21 & 6,32 & 4,88 & 3,84 & 2,56 \\
\hline 60 & 1650 & 170 & 13,69 & 10,58 & 9,39 & 8,18 & 7,18 & 6,30 & 4,88 & 3,84 & 2,56 \\
\hline 60 & 1700 & 170 & 13,51 & 10,47 & 9,31 & 8,14 & 7,15 & 6,28 & 4,87 & 3,85 & 2,57 \\
\hline 60 & 1750 & 170 & 13,34 & 10,38 & 9,25 & 8,09 & 7,12 & 6,26 & 4,87 & 3,85 & 2,57 \\
\hline 60 & 1800 & 170 & 13,18 & 10,28 & 9,18 & 8,05 & 7,09 & 6,25 & 4,87 & 3,85 & 2,58 \\
\hline 60 & 1850 & 170 & 13,02 & 10,19 & 9,11 & 8,00 & 7,06 & 6,23 & 4,86 & 3,86 & 2,58 \\
\hline 60 & 1900 & 170 & 12,88 & 10,10 & 9,05 & 7,96 & 7,04 & 6,21 & 4,86 & 3,86 & 2,58 \\
\hline 60 & 1950 & 170 & 12,73 & 10,02 & 8,99 & 7,92 & 7,01 & 6,20 & 4,86 & 3,86 & 2,59 \\
\hline 60 & 2000 & 170 & 12,60 & 9,93 & 8,93 & 7,88 & 6,98 & 6,18 & 4,85 & 3,86 & 2,59 \\
\hline 60 & 200 & 175 & 45,08 & 21,79 & 14,93 & 10,39 & 7,92 & 6,32 & 4,38 & 3,37 & 2,37 \\
\hline 60 & 250 & 175 & 38,61 & 19,84 & 14,16 & 10,21 & 7,92 & 6,38 & 4,44 & 3,41 & 2,36 \\
\hline 60 & 300 & 175 & 34,20 & 18,47 & 13,59 & 10,05 & 7,91 & 6,42 & 4,49 & 3,43 & 2,36 \\
\hline 60 & 350 & 175 & 30,98 & 17,43 & 13,13 & 9,91 & 7,89 & 6,44 & 4,53 & 3,46 & 2,36 \\
\hline 60 & 400 & 175 & 28,51 & 16,60 & 12,75 & 9,79 & 7,86 & 6,45 & 4,57 & 3,48 & 2,36 \\
\hline 60 & 450 & 175 & 26,55 & 15,92 & 12,42 & 9,67 & 7,83 & 6,46 & 4,59 & 3,50 & 2,37 \\
\hline 60 & 500 & 175 & 24,95 & 15,35 & 12,14 & 9,56 & 7,79 & 6,46 & 4,62 & 3,52 & 2,37 \\
\hline 60 & 550 & 175 & 23,61 & 14,86 & 11,89 & 9,45 & 7,76 & 6,46 & 4,64 & 3,54 & 2,37 \\
\hline 60 & 600 & 175 & 22,47 & 14,43 & 11,66 & 9,35 & 7,72 & 6,45 & 4,66 & 3,56 & 2,38 \\
\hline 60 & 650 & 175 & 21,49 & 14,05 & 11,45 & 9,26 & 7,68 & 6,44 & 4,67 & 3,57 & 2,38 \\
\hline 60 & 700 & 175 & 20,63 & 13,70 & 11,26 & 9,17 & 7,64 & 6,43 & 4,68 & 3,59 & 2,39 \\
\hline 60 & 750 & 175 & 19,87 & 13,40 & 11,09 & 9,09 & 7,60 & 6,42 & 4,70 & 3,60 & 2,39 \\
\hline 60 & 800 & 175 & 19,20 & 13,12 & 10,93 & 9,00 & 7,57 & 6,41 & 4,71 & 3,61 & 2,40 \\
\hline 60 & 850 & 175 & 18,60 & 12,86 & 10,78 & 8,93 & 7,53 & 6,39 & 4,71 & 3,62 & 2,40 \\
\hline 60 & 900 & 175 & 18,05 & 12,62 & 10,64 & 8,85 & 7,49 & 6,38 & 4,72 & 3,63 & 2,41 \\
\hline 60 & 950 & 175 & 17,56 & 12,40 & 10,50 & 8,78 & 7,46 & 6,37 & 4,73 & 3,64 & 2,42 \\
\hline 60 & 1000 & 175 & 17,11 & 12,20 & 10,38 & 8,71 & 7,42 & 6,35 & 4,73 & 3,65 & 2,42 \\
\hline 60 & 1050 & 175 & 16,69 & 12,00 & 10,26 & 8,64 & 7,38 & 6,33 & 4,74 & 3,66 & 2,43 \\
\hline 60 & 1100 & 175 & 16,31 & 11,83 & 10,14 & 8,58 & 7,35 & 6,32 & 4,74 & 3,67 & 2,43 \\
\hline 60 & 1150 & 175 & 15,96 & 11,66 & 10,04 & 8,52 & 7,31 & 6,30 & 4,74 & 3,68 & 2,44 \\
\hline 60 & 1200 & 175 & 15,63 & 11,50 & 9,94 & 8,46 & 7,28 & 6,29 & 4,74 & 3,68 & 2,44 \\
\hline 60 & 1250 & 175 & 15,33 & 11,35 & 9,84 & 8,40 & 7,25 & 6,27 & 4,74 & 3,69 & 2,45 \\
\hline 60 & 1300 & 175 & 15,04 & 11,20 & 9,74 & 8,34 & 7,21 & 6,25 & 4,75 & 3,70 & 2,45 \\
\hline 60 & 1350 & 175 & 14,78 & 11,07 & 9,65 & 8,29 & 7,18 & 6,24 & 4,75 & 3,70 & 2,46 \\
\hline 60 & 1400 & 175 & 14,53 & 10,94 & 9,57 & 8,24 & 7,15 & 6,22 & 4,75 & 3,71 & 2,46 \\
\hline 60 & 1450 & 175 & 14,29 & 10,81 & 9,49 & 8,18 & 7,12 & 6,20 & 4,74 & 3,71 & 2,47 \\
\hline 60 & 1500 & 175 & 14,07 & 10,70 & 9,41 & 8,13 & 7,09 & 6,19 & 4,74 & 3,72 & 2,47 \\
\hline 60 & 1550 & 175 & 13,86 & 10,58 & 9,33 & 8,09 & 7,06 & 6,17 & 4,74 & 3,72 & 2,48 \\
\hline 60 & 1600 & 175 & 13,66 & 10,48 & 9,26 & 8,04 & 7,03 & 6,15 & 4,74 & 3,73 & 2,48 \\
\hline 60 & 1650 & 175 & 13,48 & 10,37 & 9,18 & 7,99 & 7,00 & 6,14 & 4,74 & 3,73 & 2,48 \\
\hline 60 & 1700 & 175 & 13,30 & 10,27 & 9,12 & 7,95 & 6,97 & 6,12 & 4,74 & 3,73 & 2,49 \\
\hline 60 & 1750 & 175 & 13,13 & 10,17 & 9,05 & 7,90 & 6,94 & 6,10 & 4,73 & 3,74 & 2,49 \\
\hline 60 & 1800 & 175 & 12,97 & 10,08 & 8,98 & 7,86 & 6,92 & 6,09 & 4,73 & 3,74 & 2,50 \\
\hline 60 & 1850 & 175 & 12,81 & 9,99 & 8,92 & 7,82 & 6,89 & 6,07 & 4,73 & 3,74 & 2,50 \\
\hline 60 & 1900 & 175 & 12,67 & 9,91 & 8,86 & 7,78 & 6,86 & 6,05 & 4,73 & 3,75 & 2,51 \\
\hline 60 & 1950 & 175 & 12,52 & 9,82 & 8,80 & 7,74 & 6,84 & 6,04 & 4,72 & 3,75 & 2,51 \\
\hline 60 & 2000 & 175 & 12,39 & 9,74 & 8,74 & 7,70 & 6,81 & 6,02 & 4,72 & 3,75 & 2,51 \\
\hline 60 & 200 & 180 & 44,71 & 21,44 & 14,61 & 10,12 & 7,70 & 6,14 & 4,25 & 3,28 & 2,30 \\
\hline 60 & 250 & 180 & 38,27 & 19,52 & 13,86 & 9,95 & 7,70 & 6,20 & 4,31 & 3,31 & 2,30 \\
\hline 60 & 300 & 180 & 33,87 & 18,15 & 13,29 & 9,80 & 7,69 & 6,23 & 4,36 & 3,33 & 2,29 \\
\hline 60 & 350 & 180 & 30,67 & 17,12 & 12,84 & 9,66 & 7,67 & 6,26 & 4,40 & 3,36 & 2,29 \\
\hline 60 & 400 & 180 & 28,21 & 16,31 & 12,47 & 9,54 & 7,65 & 6,27 & 4,43 & 3,38 & 2,30 \\
\hline 60 & 450 & 180 & 26,25 & 15,64 & 12,15 & 9,43 & 7,62 & 6,28 & 4,46 & 3,40 & 2,30 \\
\hline 60 & 500 & 180 & 24,66 & 15,07 & 11,87 & 9,32 & 7,59 & 6,28 & 4,48 & 3,42 & 2,30 \\
\hline 60 & 550 & 180 & 23,33 & 14,58 & $\frac{1+, 01}{11,63}$ & 9,22 & 7,55 & 6,28 & 4,50 & 3,44 & 2,31 \\
\hline 60 & 600 & 180 & 22,19 & 14,16 & 11,41 & 9,12 & 7,52 & 6,27 & 4,52 & 3,45 & 2,31 \\
\hline 60 & 650 & 180 & 21,22 & 13,78 & 11,21 & 9,03 & 7,48 & 6,27 & 4,54 & 3,47 & 2,32 \\
\hline 60 & 700 & 180 & 20,37 & 13,45 & 11,02 & 8,95 & 7,44 & 6,26 & 4,55 & 3,48 & 2,32 \\
\hline 60 & 750 & 180 & 1962 & 13,15 & 1085 & 8.87 & 741 & 625 & 456 & 3,49 & 233 \\
\hline 60 & 800 & 180 & 18,95 & 12,87 & 10,69 & 8,79 & 7,37 & 6,24 & 4,57 & 3,51 & 2,33 \\
\hline 60 & 850 & 180 & 18,35 & 12,62 & 10,55 & 8,71 & 7,34 & 6,22 & 4,58 & 3,52 & 2,34 \\
\hline
\end{tabular}




\begin{tabular}{|c|c|c|c|c|c|c|c|c|c|c|c|}
\hline & & & \multicolumn{9}{|c|}{ Deflexões $\left(\times 10^{-4} \mathrm{~cm}\right)$} \\
\hline $\mathrm{H}(\mathrm{cm})$ & Mceq (MPa) & Msub (MPa) & D0 & D25 & D40 & D60 & $\mathrm{D} 80$ & D100 & D140 & D180 & D260 \\
\hline 60 & 900 & 180 & 17,81 & 12,38 & 10,41 & 8,64 & 7,30 & 6,21 & 4,59 & 3,53 & 2,34 \\
\hline 60 & 950 & 180 & 17,32 & 12,17 & 10,28 & 8,57 & 7,27 & 6,20 & 4,59 & 3,54 & 2,35 \\
\hline 60 & 1000 & 180 & 16,87 & 11,97 & 10,16 & 8,51 & 7,23 & 6,18 & 4,60 & 3,55 & 2,35 \\
\hline 60 & 1050 & 180 & 16,46 & 11,78 & 10,04 & 8,44 & 7,20 & 6,17 & 4,60 & 3,56 & 2,36 \\
\hline 60 & 1100 & 180 & 16,08 & 11,60 & 9,93 & 8,38 & 7,16 & 6,15 & 4,61 & 3,56 & 2,36 \\
\hline 60 & 1150 & 180 & 15,73 & 11,44 & 9,82 & 8,32 & 7,13 & 6,14 & 4,61 & 3,57 & 2,37 \\
\hline 60 & 1200 & 180 & 15,41 & 11,28 & 9,73 & 8,26 & 7,10 & 6,12 & 4,61 & 3,58 & 2,37 \\
\hline 60 & 1250 & 180 & 15,11 & 11,13 & 9,63 & 8,21 & 7,07 & 6,11 & 4,61 & 3,58 & 2,38 \\
\hline 60 & 1300 & 180 & 14,82 & 10,99 & 9,54 & 8,15 & 7,04 & 6,09 & 4,61 & 3,59 & 2,38 \\
\hline 60 & 1350 & 180 & 14,56 & 10,86 & 9,45 & 8,10 & 7,01 & 6,07 & 4,61 & 3,60 & 2,39 \\
\hline 60 & 1400 & 180 & 14,31 & 10,73 & 9,37 & 8,05 & 6,98 & 6,06 & 4,61 & 3,60 & 2,39 \\
\hline 60 & 1450 & 180 & 14,08 & 10,61 & 9,29 & 8,00 & 6,95 & 6,04 & 4,61 & 3,61 & 2,39 \\
\hline 60 & 1500 & 180 & 13,86 & 10,49 & 9,21 & 7,95 & 6.92 & 6.03 & 4.61 & 3,61 & 2,40 \\
\hline 60 & 1550 & 180 & 13,65 & 10,38 & 9,13 & 7,90 & 6,89 & 6,01 & 4,61 & 3,62 & 2,40 \\
\hline 60 & 1600 & 180 & 13,46 & 10,28 & 9,06 & 7,86 & 6,86 & 6,00 & 4,61 & 3,62 & 2,41 \\
\hline 60 & 1650 & 180 & 13,27 & 10,18 & 8,99 & 7,81 & 6,83 & 5,98 & 4,61 & 3,62 & 2,41 \\
\hline 60 & 1700 & 180 & 13,09 & 10,08 & 8,93 & 7,77 & 6,80 & 5,96 & 4,61 & 3,63 & 2,42 \\
\hline 60 & 1750 & 180 & 12,92 & 9,98 & 8,86 & 7,73 & 6,78 & 5,95 & 4,60 & 3,63 & 2,42 \\
\hline 60 & 1800 & 180 & 12,76 & 9,89 & 8,80 & 7,68 & 6,75 & 5,93 & 4,60 & 3,63 & 2,42 \\
\hline 60 & 1850 & 180 & 12,61 & 9,80 & 8,74 & 7,64 & 6,73 & 5,92 & 4,60 & 3,64 & 2,43 \\
\hline 60 & 1900 & 180 & 12,46 & 9,72 & 8,68 & 7,60 & 6,70 & 5,90 & 4,60 & 3,64 & 2,43 \\
\hline 60 & 1950 & 180 & 12,32 & 9,64 & 8,62 & 7,57 & 6,67 & 5,89 & 4,59 & 3,64 & 2,44 \\
\hline 60 & 2000 & 180 & 12,19 & $\begin{array}{l}9,56 \\
\end{array}$ & 8,56 & 7,53 & 6,65 & 5,87 & 4,59 & 3,64 & 2,44 \\
\hline 60 & 200 & 185 & 44,37 & 21,11 & 14,31 & 9,87 & 7,49 & 5,97 & 4,13 & 3,18 & 2,24 \\
\hline 60 & 250 & 185 & 37,94 & 19,20 & 13,57 & 9,70 & 7,50 & 6,02 & 4,19 & 3,21 & 2,23 \\
\hline 60 & 300 & 185 & 33,56 & 17,85 & 13,01 & 9,56 & 7,49 & 6,06 & 4,24 & 3,24 & 2,23 \\
\hline 60 & 350 & 185 & 30,36 & 16,83 & 12,57 & 9,43 & 7,47 & 6,08 & 4,27 & 3,26 & 2,23 \\
\hline 60 & 400 & 185 & 27,91 & 16,02 & 12,21 & 9,31 & 7,45 & 6,10 & 4,31 & 3,28 & 2,23 \\
\hline 60 & 450 & 185 & 25,97 & 15,36 & 11,90 & 9,20 & 7,42 & 6,11 & 4,33 & 3,30 & 2,24 \\
\hline 60 & 500 & 185 & 24,38 & 14,80 & 11,62 & 9,10 & 7,39 & 6,11 & 4,36 & 3,32 & 2,24 \\
\hline 60 & 550 & 185 & 23,06 & 14,32 & 11,38 & 9,00 & 7,36 & 6,11 & 4,38 & 3,34 & 2,24 \\
\hline 60 & 600 & 185 & 21,93 & $\begin{array}{l}13,91 \\
13,91\end{array}$ & $\begin{array}{l}+1,+17 \\
11,17\end{array}$ & 8,91 & 7,32 & 6,10 & 4,39 & 3,35 & 2,25 \\
\hline 60 & 650 & 185 & 20,96 & 13,54 & 10,97 & 8,82 & 7,29 & 6,10 & 4,41 & 3,37 & 2,25 \\
\hline 60 & 700 & 185 & 20,12 & 13,20 & 10,79 & 8,74 & 7,26 & 6,09 & 4,42 & 3,38 & 2,26 \\
\hline 60 & 750 & 185 & 19,37 & 12,91 & 10,62 & 8,66 & 7,22 & 6,08 & 4,43 & 3,39 & 2,26 \\
\hline 60 & 800 & 185 & 18,71 & 12,63 & 10,47 & 8,58 & 7,19 & 6,07 & 4,44 & 3,41 & 2,27 \\
\hline 60 & 850 & 185 & 18,12 & 12,39 & 10,33 & 8,51 & 7,15 & 6,06 & 4,45 & 3,42 & 2,27 \\
\hline 60 & 900 & 185 & 17,58 & 12,16 & 10,19 & 8,44 & 7,12 & 6,05 & 4,46 & 3,43 & 2,27 \\
\hline 60 & 950 & 185 & 17,09 & 11,94 & 10,06 & 8,37 & 7,09 & 6,04 & 4,47 & 3,44 & 2,28 \\
\hline 60 & 1000 & 185 & 16,65 & 11,75 & 9,94 & 8,31 & 7,05 & 6,02 & 4,47 & 3,45 & 2,28 \\
\hline 60 & 1050 & 185 & 16,24 & 11,56 & 9,83 & 8,25 & 7,02 & 6,01 & 4,48 & 3,45 & 2,29 \\
\hline 60 & 1100 & 185 & 15,86 & 11,39 & 9,72 & 8,19 & 6,99 & 6,00 & 4,48 & 3,46 & 2,29 \\
\hline 60 & 1150 & 185 & 15,52 & 11,23 & 9,62 & 8,13 & 6,96 & 5,98 & 4,48 & 3,47 & 2,30 \\
\hline 60 & 1200 & 185 & 15,19 & 11,07 & 9,52 & 8,07 & 6,93 & 5,97 & 4,48 & 3,48 & 2,30 \\
\hline 60 & 1250 & 185 & 14,90 & 10,93 & 9,43 & 8,02 & 6,90 & 5,95 & 4,49 & 3,48 & 2,31 \\
\hline 60 & 1300 & 185 & 14,62 & 10,79 & 9,34 & 7,97 & 6,87 & 5,94 & 4,49 & 3,49 & 2,31 \\
\hline 60 & 1350 & 185 & 14,35 & 10,66 & 9,26 & 7,92 & 6,84 & 5,92 & 4,49 & 3,49 & 2,32 \\
\hline 60 & 1400 & 185 & 14,11 & 10,53 & 9,18 & 7,87 & 6,81 & 5,91 & 4,49 & 3,50 & 2,32 \\
\hline 60 & 1450 & 185 & 13,88 & 10,42 & 9,10 & 7,82 & 6,78 & 5,89 & 4,49 & 3,51 & 2,33 \\
\hline 60 & 1500 & 185 & 13,66 & 10,30 & 9,02 & 7,77 & 6,75 & 5,88 & 4,49 & 3,51 & 2,33 \\
\hline 60 & 1550 & 185 & 13,45 & 10,19 & 8,95 & 7,73 & 6,73 & 5,86 & 4,49 & 3,51 & 2,33 \\
\hline 60 & 1600 & 185 & 13,26 & 10,09 & 8,88 & 7,68 & 6,70 & 5,85 & 4,49 & 3,52 & 2,34 \\
\hline 60 & 1650 & 185 & 13,07 & 9,99 & 8,81 & 7,64 & 6,67 & 5,83 & 4,49 & 3,52 & 2,34 \\
\hline 60 & 1700 & 185 & 12,90 & 9,89 & 8,74 & 7,60 & 6,65 & 5,82 & 4,48 & 3,53 & 2,35 \\
\hline 60 & 1750 & 185 & 12,73 & 9,80 & 8,68 & 7,56 & 6,62 & 5,80 & 4,48 & 3,53 & 2,35 \\
\hline 60 & 1800 & 185 & 12,57 & 9,71 & 8,62 & 7,52 & 6,59 & 5,79 & 4,48 & 3,53 & 2,35 \\
\hline 60 & 1850 & 185 & 12,42 & 9,62 & 8,56 & 7,48 & 6,57 & 5,77 & 4,48 & 3,54 & 2,36 \\
\hline 60 & 1900 & 185 & 12,27 & 9,54 & 8,50 & 7,44 & 6,54 & 5,76 & 4,48 & 3,54 & 2,36 \\
\hline 60 & 1950 & 185 & 12,14 & 9,46 & 8,44 & 7,40 & 6,52 & 5,74 & 4,47 & 3,54 & 2,37 \\
\hline 60 & 2000 & 185 & 12,00 & 9,38 & 8,39 & 7,36 & 6,50 & 5,73 & 4,47 & 3,54 & 2,37 \\
\hline 60 & 200 & 190 & 44,04 & 20,80 & 14,03 & 9,62 & 7,29 & 5,80 & 4,01 & 3,10 & 2,18 \\
\hline 60 & 250 & 190 & 37,62 & 18,90 & 13,29 & 9,47 & 7,30 & 5,86 & 4,07 & 3,13 & 2,18 \\
\hline 60 & 300 & 190 & 33,26 & 17,56 & 12,75 & 9,33 & 7,29 & 5,90 & 4,12 & 3,15 & 2,17 \\
\hline 60 & 350 & 190 & 30,07 & 16,55 & 12,31 & 9,20 & 7,28 & 5,92 & 4,16 & 3,17 & 2,17 \\
\hline 60 & 400 & 190 & 27,63 & 15,75 & 11,96 & 9,09 & 7,26 & 5,93 & 4,19 & 3,19 & 2,17 \\
\hline 60 & 450 & 190 & 25,70 & 15,10 & 11,65 & 8,98 & 7,23 & 5,94 & 4,21 & 3,21 & 2,18 \\
\hline 60 & 500 & 190 & 24,12 & 14,55 & 11,38 & 8,88 & 7,20 & 5,95 & 4,24 & 3,23 & 2,18 \\
\hline 60 & 550 & 190 & 22,80 & 14,08 & 11,15 & 8,79 & 7,17 & 5,95 & 4,26 & 3,25 & 2,18 \\
\hline 60 & 600 & 190 & 21,68 & 13,66 & 10,94 & 8,70 & 7,14 & 5,95 & 4,27 & 3,26 & 2,19 \\
\hline 60 & 650 & 190 & 20,72 & 13,30 & 10,74 & 8,62 & 7,11 & 5,94 & 4,29 & 3,27 & 2,19 \\
\hline 60 & 700 & 190 & 19,88 & 12,97 & 10,57 & 8,54 & 7,08 & 5,93 & 4,30 & 3,29 & 2,19 \\
\hline 60 & 750 & 190 & 19,14 & 12,68 & 10,41 & 8,46 & 7,05 & 5,93 & 4,31 & 3,30 & 2,20 \\
\hline 60 & 800 & 190 & 18,48 & 12,41 & 10,26 & 8,39 & 7,01 & 5,92 & 4,32 & 3,31 & 2,20 \\
\hline 60 & 850 & 190 & 17,89 & 12,17 & 10,11 & 8,32 & 6,98 & 5,91 & 4,33 & 3,32 & 2,21 \\
\hline 60 & 900 & 190 & 17,36 & 11,94 & 9,98 & 8,25 & 6,95 & 5,90 & 4,34 & 3,33 & 2,21 \\
\hline 60 & 950 & 190 & 16,87 & 11,73 & 9,86 & 8,19 & 6,92 & 5,88 & 4,35 & 3,34 & 2,22 \\
\hline 60 & 1000 & 190 & 16,43 & 11,54 & 9,74 & 8,12 & 6,89 & 5,87 & 4,35 & 3,35 & 2,22 \\
\hline 60 & 1050 & 190 & 16,03 & 11,36 & 9,63 & 8,06 & 6,86 & 5,86 & 4,36 & 3,36 & 2,23 \\
\hline 60 & 1100 & 190 & 15,65 & 11,19 & 9,53 & 8,01 & 6,82 & 5,85 & 4,36 & 3,37 & 2,23 \\
\hline 60 & 1150 & 190 & 15,31 & 11,03 & 9,43 & 7,95 & 6,79 & 5,83 & 4,36 & 3,37 & 2,24 \\
\hline 60 & 1200 & 190 & 14,99 & 10,87 & 9,33 & 7,90 & 6,76 & 5,82 & 4,37 & 3,38 & 2,24 \\
\hline
\end{tabular}




\begin{tabular}{|c|c|c|c|c|c|c|c|c|c|c|c|}
\hline \multirow[b]{2}{*}{$\mathrm{H}(\mathrm{cm})$} & \multirow[b]{2}{*}{ Mceq (MPa) } & & & & & & jes ( $x 1$ & & & & \\
\hline & & Msub (MPa) & D0 & D25 & D40 & D60 & $\mathrm{D} 80$ & D100 & D140 & D180 & D260 \\
\hline 60 & 1250 & 190 & 14,69 & 10,73 & 9,24 & 7,84 & 6,74 & 5,80 & 4,37 & 3,39 & 2,24 \\
\hline 60 & 1300 & 190 & 14,42 & 10,60 & 9,16 & 7,79 & 6,71 & 5,79 & 4,37 & 3,39 & 2,25 \\
\hline 60 & 1350 & 190 & 14,15 & 10,47 & 9,07 & 7,74 & 6,68 & 5,78 & 4,37 & 3,40 & 2,25 \\
\hline 60 & 1400 & 190 & 13,91 & 10,35 & 8,99 & 7,70 & 6,65 & 5,76 & 4,37 & 3,40 & 2,26 \\
\hline 60 & 1450 & 190 & 13,68 & 10,23 & 8,92 & 7,65 & 6,62 & 5,75 & 4,37 & 3,41 & 2,26 \\
\hline 60 & 1500 & 190 & 13,46 & 10,12 & 8,84 & 7,60 & 6,60 & 5,73 & 4,37 & 3,41 & 2,27 \\
\hline 60 & 1550 & 190 & 13,26 & 10,01 & 8,77 & 7,56 & 6,57 & 5,72 & 4,37 & 3,42 & 2,27 \\
\hline 60 & 1600 & 190 & 13,07 & 9,91 & 8,70 & 7,52 & 6,54 & 5,71 & 4,37 & 3,42 & 2,27 \\
\hline 60 & 1650 & 190 & 12,88 & 9,81 & 8,64 & 7,47 & 6,52 & 5,69 & 4,37 & 3,43 & 2,28 \\
\hline 60 & 1700 & 190 & 12,71 & 9,72 & 8,57 & 7,43 & 6,49 & 5,68 & 4,37 & 3,43 & 2,28 \\
\hline 60 & 1750 & 190 & 12,54 & 9,63 & 8,51 & 7,39 & 6,47 & 5,66 & 4,37 & 3,43 & 2,29 \\
\hline 60 & 1800 & 190 & 12,39 & 9,54 & 8,45 & 7,35 & 6,44 & 5,65 & 4,36 & 3,44 & 2,29 \\
\hline 60 & 1850 & 190 & 12,24 & 9,45 & 8,39 & 7,32 & 6,42 & 5,63 & 4,36 & 3,44 & 2,29 \\
\hline 60 & 1900 & 190 & 12,09 & 9,37 & 8,33 & 7,28 & 6,40 & 5,62 & 4,36 & 3,44 & 2,30 \\
\hline 60 & 1950 & 190 & 11,95 & 9,29 & 8,28 & 7,24 & 6,37 & 5,61 & 4,36 & 3,44 & 2,30 \\
\hline 60 & 2000 & 190 & 11,82 & 9,22 & 8,23 & 7,21 & 6,35 & 5,59 & 4,36 & 3,45 & 2,30 \\
\hline 60 & 200 & 195 & 43,72 & 20,51 & 13,76 & 9,40 & 7,10 & 5,65 & 3,90 & 3,01 & 2,13 \\
\hline 60 & 250 & 195 & 37,32 & 18,62 & 13,03 & 9,24 & 7,11 & 5,70 & 3,96 & 3,04 & 2,12 \\
\hline 60 & 300 & 195 & 32,97 & 17,29 & 12,49 & 9,11 & 7,11 & 5,74 & 4,01 & 3,07 & 2,12 \\
\hline 60 & 350 & 195 & 29,79 & 16,29 & 12,07 & 8,99 & 7,10 & 5,76 & 4,04 & 3,09 & 2,12 \\
\hline 60 & 400 & 195 & 27,37 & 15,50 & 11,72 & 8,88 & 7,08 & 5,78 & 4,07 & 3,11 & 2,12 \\
\hline 60 & 450 & 195 & 25,44 & 14,85 & 11,42 & 8,77 & 7,05 & 5,79 & 4,10 & 3,13 & 2,12 \\
\hline 60 & 500 & 195 & 23,87 & 14,30 & 11,16 & 8,68 & 7,03 & 5,79 & 4,12 & 3,14 & 2,12 \\
\hline 60 & 550 & 195 & 22,56 & 13,84 & 10,92 & 8,59 & 7,00 & 5,80 & 4,14 & 3,16 & 2,13 \\
\hline 60 & 600 & 195 & 21,45 & 13,43 & 10,72 & 8,50 & 6,97 & 5,79 & 4,16 & 3,17 & 2,13 \\
\hline 60 & 650 & 195 & 20,49 & 13,07 & 10,53 & 8,42 & 6,94 & 5,79 & 4,17 & 3,19 & 2,13 \\
\hline 60 & 700 & 195 & 19,65 & 12,75 & 10,36 & 8,35 & 6,91 & 5,78 & 4,19 & 3,20 & 2,14 \\
\hline 60 & 750 & 195 & 18,92 & 12,46 & 10,20 & 8,27 & 6,88 & 5,78 & 4,20 & 3,21 & 2,14 \\
\hline 60 & 800 & 195 & 18,26 & 12,20 & 10,05 & 8,20 & 6,85 & 5,77 & 4,21 & 3,22 & 2,15 \\
\hline 60 & 850 & 195 & 17,67 & 11,96 & 9,91 & 8,13 & 6,82 & 5,76 & 4,22 & 3,23 & 2,15 \\
\hline 60 & 900 & 195 & 17,15 & 11,73 & 9,79 & 8,07 & 6,79 & 5,75 & 4,22 & 3,24 & 2,15 \\
\hline 60 & 950 & 195 & 16,66 & 11,53 & 9,66 & 8,01 & 6,75 & 5,74 & 4,23 & 3,25 & 2,16 \\
\hline 60 & 1000 & 195 & 16,23 & 11,34 & 9,55 & 7,95 & 6,73 & 5,73 & 4,24 & 3,26 & 2,16 \\
\hline 60 & 1050 & 195 & 15,82 & 11,16 & 9,44 & 7,89 & 6,70 & 5,71 & 4,24 & 3,27 & 2,17 \\
\hline 60 & 1100 & 195 & 15,45 & 10,99 & 9,34 & 7,83 & 6,67 & 5,70 & 4,25 & 3,28 & 2,17 \\
\hline 60 & 1150 & 195 & 15,11 & 10,83 & 9,24 & 7,78 & 6,64 & 5,69 & 4,25 & 3,28 & 2,18 \\
\hline 60 & 1200 & 195 & 14,80 & 10,69 & 9,15 & 7,73 & 6,61 & 5,68 & 4,25 & 3,29 & 2,18 \\
\hline 60 & 1250 & 195 & 14,50 & 10,55 & 9,06 & 7,68 & 6,58 & 5,66 & 4,25 & 3,30 & 2,18 \\
\hline 60 & 1300 & 195 & 14,22 & 10,41 & 8,98 & 7,63 & 6,55 & 5,65 & 4,26 & 3,30 & 2,19 \\
\hline 60 & 1350 & 195 & 13,97 & 10,29 & 8,90 & 7,58 & 6,53 & 5,64 & 4,26 & 3,31 & 2,19 \\
\hline 60 & 1400 & 195 & 13,72 & 10,17 & 8,82 & 7,53 & 6,50 & 5,62 & 4,26 & 3,31 & 2,20 \\
\hline 60 & 1450 & 195 & 13,50 & 10,05 & 8,74 & 7,49 & 6,47 & 5,61 & 4,26 & 3,32 & 2,20 \\
\hline 60 & 1500 & 195 & 13,28 & 9,94 & 8,67 & 7,44 & 6,45 & 5,60 & 4,26 & 3,32 & 2,20 \\
\hline 60 & 1550 & 195 & 13,08 & 9,84 & 8,60 & 7,40 & 6,42 & 5,58 & 4,26 & 3,33 & 2,21 \\
\hline 60 & 1600 & 195 & 12,89 & 9,74 & 8,53 & 7,36 & 6,40 & 5,57 & 4,26 & 3,33 & 2,21 \\
\hline 60 & 1650 & 195 & 12,70 & 9,64 & 8,47 & 7,32 & 6,37 & 5,56 & 4,26 & 3,34 & 2,22 \\
\hline 60 & 1700 & 195 & 12,53 & 9,55 & 8,41 & 7,28 & 6,35 & 5,54 & 4,26 & 3,34 & 2,22 \\
\hline 60 & 1750 & 195 & 12,37 & 9,46 & 8,35 & 7,24 & 6,32 & 5,53 & 4,26 & 3,34 & 2,22 \\
\hline 60 & 1800 & 195 & 12,21 & 9,37 & 8,29 & 7,20 & 6,30 & 5,52 & 4,25 & 3,35 & 2,23 \\
\hline 60 & 1850 & 195 & 12,06 & 9,29 & 8,23 & 7,16 & 6,28 & 5,50 & 4,25 & 3,35 & 2,23 \\
\hline 60 & 1900 & 195 & 11,92 & 9,21 & 8,17 & 7,13 & 6,25 & 5,49 & 4,25 & 3,35 & 2,23 \\
\hline 60 & 1950 & 195 & 11,78 & 9,13 & 8,12 & 7,09 & 6,23 & 5,48 & 4,25 & 3,35 & 2,24 \\
\hline 60 & 2000 & 195 & 11,65 & 9,06 & 8,07 & 7,06 & 6,21 & 5,46 & 4,25 & 3,36 & 2,24 \\
\hline 60 & 200 & 200 & 43,42 & 20,22 & 13,50 & 9,18 & 6,92 & 5,50 & 3,80 & 2,94 & 2,07 \\
\hline 60 & 250 & 200 & 37,03 & 18,35 & 12,78 & 9,03 & 6,93 & 5,56 & 3,86 & 2,96 & 2,07 \\
\hline 60 & 300 & 200 & 32,69 & 17,03 & 12,25 & 8,90 & 6,93 & 5,59 & 3,90 & 2,99 & 2,07 \\
\hline 60 & 350 & 200 & 29,53 & 16,03 & 11,83 & 8,78 & 6,92 & 5,62 & 3,94 & 3,01 & 2,06 \\
\hline 60 & 400 & 200 & 27,11 & 15,25 & 11,49 & 8,68 & 6,90 & 5,63 & 3,97 & 3,03 & 2,07 \\
\hline 60 & 450 & 200 & 25,19 & 14,61 & 11,19 & 8,58 & 6,88 & 5,64 & 3,99 & 3,04 & 2,07 \\
\hline 60 & 500 & 200 & 23,63 & 14,07 & 10,94 & 8,48 & 6,86 & 5,65 & 4,01 & 3,06 & 2,07 \\
\hline 60 & 550 & 200 & 22,32 & 13,61 & 10,71 & 8,40 & 6,83 & 5,65 & 4,03 & 3,08 & 2,07 \\
\hline 60 & 600 & 200 & 21,22 & 13,21 & 10,51 & 8,32 & 6,80 & 5,65 & 4,05 & 3,09 & 2,08 \\
\hline 60 & 650 & 200 & 20,26 & 12,85 & 10,32 & 8,24 & 6,77 & 5,65 & 4,06 & 3,10 & 2,08 \\
\hline 60 & 700 & 200 & 19,43 & 12,54 & 10,16 & 8,16 & 6,75 & 5,64 & 4,08 & 3,11 & 2,08 \\
\hline 60 & 750 & 200 & 18,70 & 12,25 & 10,00 & 8,09 & 6,72 & 5,64 & 4,09 & 3,13 & 2,09 \\
\hline 60 & 800 & 200 & 18,05 & 11,99 & 9,86 & 8,02 & 6,69 & 5,63 & 4,10 & 3,14 & 2,09 \\
\hline 60 & 850 & 200 & 17,47 & 11,75 & 9,72 & 7,96 & 6,66 & 5,62 & 4,11 & 3,15 & 2,09 \\
\hline 60 & 900 & 200 & 16,94 & 11,54 & 9,60 & 7,90 & 6,63 & 5,61 & 4,12 & 3,16 & 2,10 \\
\hline 60 & 950 & 200 & 16,47 & 11,33 & 9,48 & 7,84 & 6,60 & 5,60 & 4,12 & 3,17 & 2,10 \\
\hline 60 & 1000 & 200 & 16,03 & 11,14 & 9,37 & 7,78 & 6,57 & 5,59 & 4,13 & 3,17 & 2,11 \\
\hline 60 & 1050 & 200 & 15,63 & 10,97 & 9,26 & 7,72 & 6,54 & 5,58 & 4,13 & 3,18 & 2,11 \\
\hline 60 & 1100 & 200 & 15,26 & 10,80 & 9,16 & 7,67 & 6,52 & 5,57 & 4,14 & 3,19 & 2,11 \\
\hline 60 & 1150 & 200 & 14,92 & 10,65 & 9,07 & 7,61 & 6,49 & 5,55 & 4,14 & 3,20 & 2,12 \\
\hline 60 & 1200 & 200 & 14,61 & 10,50 & 8,98 & 7,56 & 6,46 & 5,54 & 4,14 & 3,20 & 2,12 \\
\hline 60 & 1250 & 200 & 14,31 & 10,37 & 8,89 & 7,51 & 6,43 & 5,53 & 4,15 & 3,21 & 2,13 \\
\hline 60 & 1300 & 200 & 14,04 & 10,24 & 8,81 & 7,47 & 6,41 & 5,52 & 4,15 & 3,22 & 2,13 \\
\hline 60 & 1350 & 200 & 13,78 & 10,11 & 8,73 & 7,42 & 6,38 & 5,51 & 4,15 & 3,22 & 2,13 \\
\hline 60 & 1400 & 200 & 13,54 & 9,99 & 8,65 & 7,37 & 6,36 & 5,49 & 4,15 & 3,23 & 2,14 \\
\hline 60 & 1450 & 200 & 13,32 & 9,88 & 8,58 & 7,33 & 6,33 & 5,48 & 4,15 & 3,23 & 2,14 \\
\hline 60 & 1500 & 200 & 13,10 & 9,77 & 8,51 & 7,29 & 6,31 & 5,47 & 4,15 & 3,24 & 2,15 \\
\hline 60 & 1550 & 200 & 12,90 & 9,67 & 8,44 & 7,25 & 6,28 & 5,45 & 4,15 & 3,24 & 2,15 \\
\hline
\end{tabular}




\begin{tabular}{|c|c|c|c|c|c|c|c|c|c|c|c|}
\hline & & & \multicolumn{9}{|c|}{ Deflexões $\left(\times 10^{-4} \mathrm{~cm}\right)$} \\
\hline $\mathrm{H}(\mathrm{cm})$ & Mceq (MPa) & Msub (MPa) & D0 & D25 & D40 & D60 & D80 & D100 & D140 & D180 & D260 \\
\hline 60 & 1600 & 200 & 12,71 & 9,57 & 8,37 & 7,21 & 6,26 & 5,44 & 4,15 & 3,25 & 2,15 \\
\hline 60 & 1650 & 200 & 12,53 & 9,48 & 8,31 & 7,17 & 6,23 & 5,43 & 4,15 & 3,25 & 2,16 \\
\hline 60 & 1700 & 200 & 12,36 & 9,38 & 8,25 & 7,13 & 6,21 & 5,42 & 4,15 & 3,25 & 2,16 \\
\hline 60 & 1750 & 200 & 12,20 & 9,30 & 8,19 & 7,09 & 6,19 & 5,40 & 4,15 & 3,26 & 2,16 \\
\hline 60 & 1800 & 200 & 12,04 & 9,21 & 8,13 & 7,05 & 6,16 & 5,39 & 4,15 & 3,26 & 2,17 \\
\hline 60 & 1850 & 200 & 11,89 & 9,13 & 8,08 & 7,02 & 6,14 & 5,38 & 4,15 & 3,26 & 2,17 \\
\hline 60 & 1900 & 200 & 11,75 & 9,05 & 8,02 & 6,98 & 6,12 & 5,36 & 4,15 & 3,26 & 2,18 \\
\hline 60 & 1950 & 200 & 11,62 & 8,98 & 7,97 & 6,95 & 6,10 & 5,35 & 4,14 & 3,27 & 2,18 \\
\hline 60 & 2000 & 200 & 11,49 & 8,90 & 7,92 & 6,92 & 6,08 & 5,34 & 4,14 & 3,27 & 2,18 \\
\hline 65 & 200 & 20 & 110,24 & 84,06 & 74,96 & 65,93 & 58,46 & 51,85 & 40,91 & 32,71 & 22,10 \\
\hline 65 & 250 & 20 & 100,04 & 77,89 & 70,56 & 62,89 & 56,37 & 50,49 & 40,49 & 32,76 & 22,38 \\
\hline 65 & 300 & 20 & 92,83 & 73,17 & 67,07 & 60,39 & 54,57 & 49,25 & 40,03 & 32,72 & 22,60 \\
\hline 65 & 350 & 20 & 87,39 & 69,40 & 64,20 & 58,28 & 53,01 & 48,14 & 39,56 & 32,62 & 22,76 \\
\hline 65 & 400 & 20 & 83,10 & 66,29 & 61,78 & 56,45 & 51,63 & 47,13 & 39,10 & 32,48 & 22,89 \\
\hline 65 & 450 & 20 & 79,60 & 63,66 & 59,68 & 54,86 & 50,40 & 46,20 & 38,64 & 32,32 & 22,98 \\
\hline 65 & 500 & 20 & 76,68 & 61,40 & 57,84 & 53,44 & 49,29 & 45,36 & 38,20 & 32,15 & 23,05 \\
\hline 65 & 550 & 20 & 74,17 & 59,44 & 56,21 & 52,17 & 48,28 & 44,57 & 37,78 & 31,96 & 23,10 \\
\hline 65 & 600 & 20 & 71,99 & 57,71 & 54,74 & 51,01 & 47,35 & 43,85 & 37,37 & 31,78 & 23,13 \\
\hline 65 & 650 & 20 & 70,07 & 56,17 & 53,41 & 49,96 & 46,50 & 43,17 & 36,98 & 31,59 & 23,15 \\
\hline 65 & 700 & 20 & 68,35 & 54,79 & 52,20 & 49,00 & 45,71 & 42,54 & 36,61 & 31,39 & 23,16 \\
\hline 65 & 750 & 20 & 66,79 & 53,55 & 51,09 & 48,10 & 44,98 & 41,95 & 36,25 & 31,20 & 23,16 \\
\hline 65 & 800 & 20 & 65,38 & 52,42 & 50,07 & 47,28 & 44,30 & 41,39 & 35,91 & 31,02 & 23,15 \\
\hline 65 & 850 & 20 & 64,08 & 51,39 & 49,12 & 46,51 & 43,66 & 40,87 & 35,58 & 30,83 & 23,14 \\
\hline 65 & 900 & 20 & 62,87 & 50,44 & 48,23 & 45,78 & 43,06 & 40,37 & 35,26 & 30,65 & 23,12 \\
\hline 65 & 950 & 20 & 61,75 & 49,57 & 47,41 & 45,11 & 42,49 & 39,90 & 34,95 & 30,47 & 23,09 \\
\hline 65 & 1000 & 20 & 60,71 & 48,77 & 46,64 & 44,47 & 41,96 & 39,45 & 34,66 & 30,29 & 23,06 \\
\hline 65 & 1050 & 20 & 59,73 & 48,02 & 45,91 & 43,87 & 41,45 & 39,03 & 34,38 & 30,12 & 23,03 \\
\hline 65 & 1100 & 20 & 58,80 & 47,32 & 45,23 & 43,29 & 40,97 & 38,62 & 34,10 & 29,95 & 22,99 \\
\hline 65 & 1150 & 20 & 57,93 & 46,67 & 44,58 & 42,75 & 40,51 & 38,23 & 33,84 & 29,79 & 22,95 \\
\hline 65 & 1200 & 20 & 57,10 & 46,07 & 43,97 & 42,24 & 40,07 & 37,86 & 33,58 & 29,63 & 22,91 \\
\hline 65 & 1250 & 20 & 56,30 & 45,49 & 43,39 & 41,74 & 39,65 & 37,51 & 33,34 & 29,47 & 22,87 \\
\hline 65 & 1300 & 20 & 55,55 & 44,96 & 42,84 & 41,28 & 39,25 & 37,16 & 33,10 & 29,31 & 22,83 \\
\hline 65 & 1350 & 20 & 54,83 & 44,45 & 42,32 & 40,83 & 38,87 & 36,84 & 32,87 & 29,16 & 22,78 \\
\hline 65 & 1400 & 20 & 54,13 & 43,97 & 41,82 & 40,40 & 38,50 & 36,52 & 32,64 & 29,01 & 22,74 \\
\hline 65 & 1450 & 20 & 53,47 & 43,51 & 41,35 & 39,98 & 38,15 & 36,22 & 32,43 & 28,87 & 22,69 \\
\hline 65 & 1500 & 20 & 52,83 & 43,08 & 40,89 & 39,59 & 37,81 & 35,92 & 32,22 & 28,73 & 22,65 \\
\hline 65 & 1550 & 20 & 52,21 & 42,67 & 40,46 & 39,20 & 37,48 & 35,64 & 32,01 & 28,59 & 22,60 \\
\hline 65 & 1600 & 20 & 51,62 & 42,28 & 40,04 & 38,84 & 37,17 & 35,37 & 31,81 & 28,45 & 22,55 \\
\hline 65 & 1650 & 20 & 51,04 & 41,91 & 39,65 & 38,48 & 36,86 & 35,10 & 31,62 & 28,32 & 22,50 \\
\hline 65 & 1700 & 20 & 50,48 & 41,55 & 39,26 & 38,14 & 36,57 & 34,84 & 31,43 & 28,19 & 22,45 \\
\hline 65 & 1750 & 20 & 49,94 & 41,21 & 38,90 & 37,81 & 36,28 & 34,60 & 31,25 & 28,06 & 22,41 \\
\hline 65 & 1800 & 20 & 49,42 & 40,89 & 38,54 & 37,49 & 36,01 & 34,36 & 31,07 & 27,93 & 22,36 \\
\hline 65 & 1850 & 20 & 48,91 & 40,57 & 38,20 & 37,18 & 35,74 & 34,12 & 30,89 & 27,81 & 22,31 \\
\hline 65 & 1900 & 20 & 48,42 & 40,27 & 37,87 & 36,88 & 35,48 & 33,90 & 30,72 & 27,69 & 22,26 \\
\hline 65 & 1950 & 20 & 47,94 & 39,99 & 37,56 & 36,59 & 35,23 & 33,67 & 30,56 & 27,57 & 22,21 \\
\hline 65 & 2000 & 20 & 47,47 & 39,71 & 37,25 & 36,31 & 34,99 & 33,46 & 30,40 & 27,45 & 22,16 \\
\hline 65 & 200 & 25 & 97,78 & 72,56 & 63,61 & 55,14 & 48,33 & 42,44 & 32,93 & 26,04 & 17,46 \\
\hline 65 & 250 & 25 & 88,19 & 67,25 & 59,97 & 52,75 & 46,77 & 41,48 & 32,72 & 26,17 & 17,68 \\
\hline 65 & 300 & 25 & 81,43 & 63,19 & 57,08 & 50,76 & 45,41 & 40,60 & 32,46 & 26,21 & 17,87 \\
\hline 65 & 350 & 25 & 76,36 & 59,94 & 54,70 & 49,07 & 44,21 & 39,79 & 32,18 & 26,20 & 18,01 \\
\hline 65 & 400 & 25 & 72,38 & 57,26 & 52,69 & 47,60 & 43,14 & 39,04 & 31,88 & 26,15 & 18,13 \\
\hline 65 & 450 & 25 & 69,16 & 54,98 & 50,95 & 46,31 & 42,18 & 38,34 & 31,58 & 26,08 & 18,23 \\
\hline 65 & 500 & 25 & 66,48 & 53,03 & 49,42 & 45,16 & 41,30 & 37,70 & 31,28 & 25,99 & 18,31 \\
\hline 65 & 550 & 25 & 64,20 & 51,32 & 48,06 & 44,13 & 40,51 & 37,11 & 30,99 & 25,89 & 18,37 \\
\hline 65 & 600 & 25 & 62,23 & 49,81 & 46,84 & 43,19 & 39,77 & 36,55 & 30,70 & 25,78 & 18,42 \\
\hline 65 & 650 & 25 & 60,50 & 48,47 & 45,73 & 42,33 & 39,10 & 36,03 & 30,42 & 25,66 & 18,46 \\
\hline 65 & 700 & 25 & 58,97 & 47,26 & 44,72 & 41,54 & 38,47 & 35,54 & 30,16 & 25,54 & 18,49 \\
\hline 65 & 750 & 25 & 57,59 & 46,17 & 43,79 & 40,81 & 37,88 & 35,08 & 29,90 & 25,42 & 18,51 \\
\hline 65 & 800 & 25 & 56,35 & 45,17 & 42,93 & 40,13 & 37,33 & 34,64 & 29,65 & 25,30 & 18,52 \\
\hline 65 & 850 & 25 & 55,21 & 44,26 & 42,14 & 39,50 & 36,82 & 34,23 & 29,40 & 25,18 & 18,53 \\
\hline 65 & 900 & 25 & 54,17 & 43,42 & 41,40 & 38,90 & 36,33 & 33,84 & 29,17 & 25,05 & 18,53 \\
\hline 65 & 950 & 25 & 53,20 & 42,65 & 40,70 & 38,35 & 35,87 & 33,47 & 28,94 & 24,93 & 18,53 \\
\hline 65 & 1000 & 25 & 52,30 & 41,94 & 40,05 & 37,82 & 35,44 & 33,11 & 28,72 & 24,81 & 18,52 \\
\hline 65 & 1050 & 25 & 51,46 & 41,27 & 39,44 & 37,32 & 35,03 & 32,78 & 28,51 & 24,69 & 18,51 \\
\hline 65 & 1100 & 25 & 50,67 & 40,65 & 38,86 & 36,85 & 34,64 & 32,45 & 28,31 & 24,58 & 18,50 \\
\hline 65 & 1150 & 25 & 49,93 & 40,07 & 38,32 & 36,41 & 34,26 & 32,14 & 28,11 & 24,46 & 18,48 \\
\hline 65 & 1200 & 25 & 49,23 & 39,53 & 37,80 & 35,98 & 33,91 & 31,85 & 27,91 & 24,35 & 18,47 \\
\hline 65 & 1250 & 25 & 48,57 & 39,01 & 37,31 & 35,57 & 33,57 & 31,56 & 27,73 & 24,24 & 18,45 \\
\hline 65 & 1300 & 25 & 47,94 & 38,53 & 36,84 & 35,19 & 33,24 & 31,29 & 27,54 & 24,12 & 18,43 \\
\hline 65 & 1350 & 25 & 47,33 & 38,08 & 36,40 & 34,82 & 32,93 & 31,02 & 27,37 & 24,02 & 18,40 \\
\hline 65 & 1400 & 25 & 46,76 & 37,65 & 35,97 & 34,46 & 32,62 & 30,77 & 27,20 & 23,91 & 18,38 \\
\hline 65 & 1450 & 25 & 46,21 & 37,24 & 35,57 & 34,12 & 32,34 & 30,53 & 27,03 & 23,80 & 18,36 \\
\hline 65 & 1500 & 25 & 45,68 & 36,85 & 35,18 & 33,79 & 32,06 & 30,29 & 26,87 & 23,70 & 18,33 \\
\hline 65 & 1550 & 25 & 45,17 & 36,48 & 34,80 & 33,47 & 31,79 & 30,06 & 26,71 & 23,60 & 18,30 \\
\hline 65 & 1600 & 25 & 44,68 & 36,13 & 34,45 & 33,17 & 31,53 & 29,84 & 26,55 & 23,50 & 18,28 \\
\hline 65 & 1650 & 25 & 44,21 & 35,80 & 34,10 & 32,87 & 31,28 & 29,62 & 26,40 & 23,40 & 18,25 \\
\hline 65 & 1700 & 25 & 43,75 & 35,48 & 33,78 & 32,59 & 31,04 & 29,42 & 26,26 & 23,31 & 18,22 \\
\hline 65 & 1750 & 25 & 43,31 & 35,17 & 33,46 & 32,32 & 30,80 & 29,22 & 26,12 & 23,21 & 18,19 \\
\hline 65 & 1800 & 25 & 42,88 & 34,88 & 33,15 & 32,05 & 30,58 & 29,02 & 25,98 & 23,12 & 18,16 \\
\hline 65 & 1850 & 25 & 42,47 & 34,60 & 32,86 & 31,79 & 30,36 & 28,83 & 25,84 & 23,03 & 18,13 \\
\hline 65 & 1900 & 25 & 42,06 & 34,33 & 32,57 & 31,54 & 30,14 & 28,65 & 25,71 & 22,94 & 18,10 \\
\hline
\end{tabular}




\begin{tabular}{|c|c|c|c|c|c|c|c|c|c|c|c|}
\hline \multirow[b]{2}{*}{$\mathrm{H}(\mathrm{cm})$} & \multirow[b]{2}{*}{ Mceq (MPa) } & & & & & & ões (x1 & m) & & & \\
\hline & & Msub (MPa) & D0 & D25 & D40 & D60 & D80 & D100 & D140 & D180 & D260 \\
\hline 65 & 1950 & 25 & 41,67 & 34,07 & 32,30 & 31,30 & 29,94 & 28,47 & 25,58 & 22,85 & 18,07 \\
\hline 65 & 2000 & 25 & 41,29 & 33,82 & 32,04 & 31,07 & 29,73 & 28,29 & 25,45 & 22,76 & 18,04 \\
\hline 65 & 200 & 30 & 89,07 & 64,34 & 55,57 & 47,55 & 41,26 & 35,92 & 27,50 & 21,58 & 14,41 \\
\hline 65 & 250 & 30 & 79,92 & 59,63 & 52,45 & 45,59 & 40,04 & 35,23 & 27,42 & 21,73 & 14,58 \\
\hline 65 & 300 & 30 & 73,49 & 56,04 & 49,97 & 43,95 & 38,97 & 34,57 & 27,27 & 21,81 & 14,74 \\
\hline 65 & 350 & 30 & 68,68 & 53,17 & 47,93 & 42,56 & 38,02 & 33,95 & 27,09 & 21,84 & 14,86 \\
\hline 65 & 400 & 30 & 64,92 & 50,79 & 46,21 & 41,34 & 37,16 & 33,37 & 26,89 & 21,84 & 14,97 \\
\hline 65 & 450 & 30 & 61,88 & 48,78 & 44,71 & 40,26 & 36,38 & 32,84 & 26,69 & 21,81 & 15,06 \\
\hline 65 & 500 & 30 & 59,37 & 47,05 & 43,40 & 39,30 & 35,67 & 32,33 & 26,48 & 21,77 & 15,14 \\
\hline 65 & 550 & 30 & 57,23 & 45,53 & 42,23 & 38,43 & 35,02 & 31,86 & 26,27 & 21,72 & 15,21 \\
\hline 65 & 600 & 30 & 55,40 & 44,19 & 41,18 & 37,64 & 34,42 & 31,42 & 26,06 & 21,66 & 15,26 \\
\hline 65 & 650 & 30 & 53,80 & 42,99 & 40,23 & 36,91 & 33,86 & 31,00 & 25,86 & 21,59 & 15,30 \\
\hline 65 & 700 & 30 & 52,38 & 41,91 & 39,36 & 36,24 & 33,34 & 30,61 & 25,66 & 21,51 & 15,34 \\
\hline 65 & 750 & 30 & 51,12 & 40,93 & 38,56 & 35,63 & 32,86 & 30,24 & 25,47 & 21,43 & 15,37 \\
\hline 65 & 800 & 30 & 49,98 & 40,04 & 37,82 & 35,05 & 32,40 & 29,89 & 25,28 & 21,35 & 15,39 \\
\hline 65 & 850 & 30 & 48,94 & 39,22 & 37,13 & 34,51 & 31,97 & 29,55 & 25,09 & 21,27 & 15,41 \\
\hline 65 & 900 & 30 & 48,00 & 38,47 & 36,49 & 34,01 & 31,57 & 29,23 & 24,91 & 21,18 & 15,42 \\
\hline 65 & 950 & 30 & 47,12 & 37,78 & 35,89 & 33,53 & 31,19 & 28,93 & 24,74 & 21,10 & 15,43 \\
\hline 65 & 1000 & 30 & 46,32 & 37,13 & 35,33 & 33,09 & 30,82 & 28,64 & 24,57 & 21,01 & 15,44 \\
\hline 65 & 1050 & 30 & 45,56 & 36,53 & 34,80 & 32,66 & 30,48 & 28,36 & 24,41 & 20,93 & 15,44 \\
\hline 65 & 1100 & 30 & 44,86 & 35,97 & 34,30 & 32,26 & 30,15 & 28,10 & 24,24 & 20,85 & 15,44 \\
\hline 65 & 1150 & 30 & 44,20 & 35,44 & 33,83 & 31,88 & 29,83 & 27,84 & 24,09 & 20,76 & 15,44 \\
\hline 65 & 1200 & 30 & 43,58 & 34,95 & 33,38 & 31,52 & 29,53 & 27,60 & 23,94 & 20,68 & 15,43 \\
\hline 65 & 1250 & 30 & 43,00 & 34,48 & 32,95 & 31,17 & 29,25 & 27,36 & 23,79 & 20,60 & 15,43 \\
\hline 65 & 1300 & 30 & 42,44 & 34,04 & 32,54 & 30,84 & 28,97 & 27,13 & 23,65 & 20,51 & 15,42 \\
\hline 65 & 1350 & 30 & 41,91 & 33,63 & 32,16 & 30,52 & 28,71 & 26,91 & 23,51 & 20,43 & 15,41 \\
\hline 65 & 1400 & 30 & 41,41 & 33,24 & 31,78 & 30,22 & 28,45 & 26,70 & 23,37 & 20,35 & 15,40 \\
\hline 65 & 1450 & 30 & 40,93 & 32,87 & 31,43 & 29,93 & 28,21 & 26,50 & 23,24 & 20,27 & 15,39 \\
\hline 65 & 1500 & 30 & 40,47 & 32,51 & 31,09 & 29,65 & 27,97 & 26,30 & 23,11 & 20,20 & 15,37 \\
\hline 65 & 1550 & 30 & 40,03 & 32,18 & 30,76 & 29,38 & 27,74 & 26,11 & 22,98 & 20,12 & 15,36 \\
\hline 65 & 1600 & 30 & 39,61 & 31,86 & 30,45 & 29,11 & 27,52 & 25,93 & 22,86 & 20,04 & 15,34 \\
\hline 65 & 1650 & 30 & 39,20 & 31,55 & 30,15 & 28,86 & 27,31 & 25,75 & 22,73 & 19,97 & 15,33 \\
\hline 65 & 1700 & 30 & 38,81 & 31,26 & 29,86 & 28,62 & 27,11 & 25,57 & 22,62 & 19,89 & 15,31 \\
\hline 65 & 1750 & 30 & 38,43 & 30,98 & 29,58 & 28,39 & 26,91 & 25,40 & 22,50 & 19,82 & 15,29 \\
\hline 65 & 1800 & 30 & 38,06 & 30,71 & 29,31 & 28,16 & 26,71 & 25,24 & 22,39 & 19,75 & 15,28 \\
\hline 65 & 1850 & 30 & 37,71 & 30,45 & 29,05 & 27,94 & 26,53 & 25,08 & 22,28 & 19,68 & 15,26 \\
\hline 65 & 1900 & 30 & 37,37 & 30,21 & 28,80 & 27,72 & 26,35 & 24,93 & 22,17 & 19,61 & 15,24 \\
\hline 65 & 1950 & 30 & 37,03 & 29,97 & 28,56 & 27,52 & 26,17 & 24,78 & 22,07 & 19,54 & 15,22 \\
\hline 65 & 2000 & 30 & 36,71 & 29,74 & 28,33 & 27,32 & 26,00 & 24,63 & 21,96 & 19,47 & 15,20 \\
\hline 65 & 200 & 35 & 82,58 & 58,14 & 49,54 & 41,88 & 36,02 & 31,14 & 23,57 & 18,38 & 12,25 \\
\hline 65 & 250 & 35 & 73,78 & 53,87 & 46,80 & 40,24 & 35,05 & 30,62 & 23,56 & 18,54 & 12,39 \\
\hline 65 & 300 & 35 & 67,61 & 50,62 & 44,62 & 38,86 & 34,19 & 30,11 & 23,48 & 18,64 & 12,52 \\
\hline 65 & 350 & 35 & 62,99 & 48,03 & 42,83 & 37,68 & 33,40 & 29,63 & 23,37 & 18,69 & 12,63 \\
\hline 65 & 400 & 35 & 59,40 & 45,89 & 41,32 & 36,64 & 32,70 & 29,17 & 23,24 & 18,72 & 12,73 \\
\hline 65 & 450 & 35 & 56,49 & 44,08 & 40,01 & 35,72 & 32,05 & 28,74 & 23,10 & 18,72 & 12,81 \\
\hline 65 & 500 & 35 & 54,10 & 42,52 & 38,85 & 34,89 & 31,46 & 28,34 & 22,95 & 18,71 & 12,88 \\
\hline 65 & 550 & 35 & 52,07 & 41,15 & 37,83 & 34,14 & 30,92 & 27,96 & 22,80 & 18,68 & 12,94 \\
\hline 65 & 600 & 35 & 50,33 & 39,94 & 36,90 & 33,46 & 30,41 & 27,60 & 22,65 & 18,65 & 13,00 \\
\hline 65 & 650 & 35 & 48,82 & 38,85 & 36,07 & 32,84 & 29,94 & 27,25 & 22,49 & 18,61 & 13,04 \\
\hline 65 & 700 & 35 & 47,49 & 37,88 & 35,30 & 32,26 & 29,50 & 26,93 & 22,34 & 18,56 & 13,08 \\
\hline 65 & 750 & 35 & 46,30 & 36,99 & 34,60 & 31,72 & 29,09 & 26,62 & 22,19 & 18,51 & 13,11 \\
\hline 65 & 800 & 35 & 45,23 & 36,18 & 33,94 & 31,23 & 28,70 & 26,33 & 22,04 & 18,46 & 13,14 \\
\hline 65 & 850 & 35 & 44,27 & 35,44 & 33,34 & 30,76 & 28,34 & 26,05 & 21,90 & 18,40 & 13,16 \\
\hline 65 & 900 & 35 & 43,38 & 34,75 & 32,77 & 30,32 & 27,99 & 25,79 & 21,76 & 18,34 & 13,18 \\
\hline 65 & 950 & 35 & 42,58 & 34,12 & 32,25 & 29,91 & 27,67 & 25,53 & 21,62 & 18,28 & 13,20 \\
\hline 65 & 1000 & 35 & 41,83 & 33,53 & 31,75 & 29,52 & 27,35 & 25,29 & 21,49 & 18,22 & 13,21 \\
\hline 65 & 1050 & 35 & 41,14 & 32,98 & 31,28 & 29,15 & 27,06 & 25,06 & 21,36 & 18,16 & 13,22 \\
\hline 65 & 1100 & 35 & 40,49 & 32,46 & 30,84 & 28,80 & 26,78 & 24,83 & 21,23 & 18,10 & 13,23 \\
\hline 65 & 1150 & 35 & 39,89 & 31,98 & 30,42 & 28,47 & 26,51 & 24,62 & 21,10 & 18,03 & 13,23 \\
\hline 65 & 1200 & 35 & 39,33 & 31,53 & 30,02 & 28,15 & 26,25 & 24,41 & 20,98 & 17,97 & 13,23 \\
\hline 65 & 1250 & 35 & 38,79 & 31,10 & 29,64 & 27,85 & 26,00 & 24,21 & 20,86 & 17,91 & 13,24 \\
\hline 65 & 1300 & 35 & 38,29 & 30,70 & 29,28 & 27,56 & 25,76 & 24,02 & 20,74 & 17,85 & 13,24 \\
\hline 65 & 1350 & 35 & 37,81 & 30,32 & 28,94 & 27,28 & 25,53 & 23,83 & 20,63 & 17,79 & 13,23 \\
\hline 65 & 1400 & 35 & 37,36 & 29,95 & 28,61 & 27,02 & 25,31 & 23,65 & 20,52 & 17,72 & 13,23 \\
\hline 65 & 1450 & 35 & 36,93 & 29,61 & 28,29 & 26,76 & 25,10 & 23,48 & 20,41 & 17,66 & 13,22 \\
\hline 65 & 1500 & 35 & 36,51 & 29,29 & 27,99 & 26,51 & 24,90 & 23,31 & 20,30 & 17,60 & 13,22 \\
\hline 65 & 1550 & 35 & 36,12 & 28,98 & 27,70 & 26,28 & 24,70 & 23,15 & 20,20 & 17,54 & 13,21 \\
\hline 65 & 1600 & 35 & 35,74 & 28,68 & 27,42 & 26,05 & 24,51 & 22,99 & 20,10 & 17,48 & 13,20 \\
\hline 65 & 1650 & 35 & 35,38 & 28,40 & 27,16 & 25,83 & 24,33 & 22,84 & 20,00 & 17,43 & 13,20 \\
\hline 65 & 1700 & 35 & 35,03 & 28,13 & 26,90 & 25,62 & 24,15 & 22,69 & 19,90 & 17,37 & 13,19 \\
\hline 65 & 1750 & 35 & 34,69 & 27,87 & 26,65 & 25,41 & 23,98 & 22,54 & 19,80 & 17,31 & 13,18 \\
\hline 65 & 1800 & 35 & 34,37 & 27,62 & 26,41 & 25,21 & 23,81 & 22,40 & 19,71 & 17,25 & 13,17 \\
\hline 65 & 1850 & 35 & 34,05 & 27,38 & 26,18 & 25,02 & 23,64 & 22,27 & 19,62 & 17,20 & 13,16 \\
\hline 65 & 1900 & 35 & 33,75 & 27,15 & 25,95 & 24,83 & 23,49 & 22,13 & 19,53 & 17,14 & 13,14 \\
\hline 65 & 1950 & 35 & 33,46 & 26,93 & 25,74 & 24,65 & 23,33 & 22,00 & 19,44 & 17,09 & 13,13 \\
\hline 65 & 2000 & 35 & 33,17 & 26,72 & 25,53 & 24,47 & 23,18 & 21,88 & 19,36 & 17,03 & 13,12 \\
\hline 65 & 200 & 40 & 77,53 & 53,27 & 44,82 & 37,48 & 31,98 & 27,47 & 20,60 & 15,99 & 10,65 \\
\hline 65 & 250 & 40 & 69,01 & 49,33 & 42,37 & 36,08 & 31,19 & 27,07 & 20,63 & 16,14 & 10,77 \\
\hline 65 & 300 & 40 & 63,04 & 46,36 & 40,43 & 34,89 & 30,47 & 26,68 & 20,60 & 16,25 & 10,87 \\
\hline 65 & 350 & 40 & 58,59 & 43,99 & 38,83 & 33,87 & 29,82 & 26,30 & 20,54 & 16,31 & 10,97 \\
\hline 65 & 400 & 40 & 55,12 & 42,03 & 37,48 & 32,97 & 29,23 & 25,93 & 20,45 & 16,35 & 11,05 \\
\hline
\end{tabular}




\begin{tabular}{|c|c|c|c|c|c|c|c|c|c|c|c|}
\hline & & & \multicolumn{9}{|c|}{ Deflexões $\left(\times 10^{-4} \mathrm{~cm}\right)$} \\
\hline $\mathrm{H}(\mathrm{cm})$ & Mceq (MPa) & Msub (MPa) & D0 & D25 & D40 & D60 & D80 & D100 & D140 & D180 & D260 \\
\hline 65 & 450 & 40 & 52,33 & 40,37 & 36,31 & 32,17 & 28,68 & 25,58 & 20,35 & 16,38 & 11,13 \\
\hline 65 & 500 & 40 & 50,02 & 38,95 & 35,28 & 31,45 & 28,18 & 25,24 & 20,25 & 16,38 & 11,19 \\
\hline 65 & 550 & 40 & 48,08 & 37,69 & 34,36 & 30,79 & 27,72 & 24,93 & 20,13 & 16,38 & 11,25 \\
\hline 65 & 600 & 40 & 46,41 & 36,59 & 33,54 & 30,20 & 27,29 & 24,63 & 20,02 & 16,36 & 11,30 \\
\hline 65 & 650 & 40 & 44,97 & 35,59 & 32,79 & 29,65 & 26,88 & 24,34 & 19,90 & 16,34 & 11,34 \\
\hline 65 & 700 & 40 & 43,69 & 34,70 & 32,10 & 29,14 & 26,51 & 24,07 & 19,78 & 16,31 & 11,38 \\
\hline 65 & 750 & 40 & 42,56 & 33,89 & 31,47 & 28,67 & 26,15 & 23,81 & 19,66 & 16,28 & 11,41 \\
\hline 65 & 800 & 40 & 41,55 & 33,14 & 30,89 & 28,23 & 25,82 & 23,56 & 19,55 & 16,24 & 11,44 \\
\hline 65 & 850 & 40 & 40,64 & 32,46 & 30,35 & 27,82 & 25,50 & 23,33 & 19,43 & 16,20 & 11,47 \\
\hline 65 & 900 & 40 & 39,80 & 31,83 & 29,84 & 27,43 & 25,20 & 23,10 & 19,32 & 16,16 & 11,49 \\
\hline 65 & 950 & 40 & 39,04 & 31,24 & 29,37 & 27,06 & 24,91 & 22,89 & 19,21 & 16,12 & 11,51 \\
\hline 65 & 1000 & 40 & 38,34 & 30,70 & 28,92 & 26,72 & 24,64 & 22,68 & 19,10 & 16,07 & 11,53 \\
\hline 65 & 1050 & 40 & 37,69 & 30,19 & 28,50 & 26,39 & 24,39 & 22,48 & 18,99 & 16,03 & 11,54 \\
\hline 65 & 1100 & 40 & 37,09 & 29,72 & 28,10 & 26,08 & 24,14 & 22,29 & 18,89 & 15,98 & 11,55 \\
\hline 65 & 1150 & 40 & 36,52 & 29,27 & 27,73 & 25,79 & 23,90 & 22,10 & 18,79 & 15,94 & 11,56 \\
\hline 65 & 1200 & 40 & 36,00 & 28,85 & 27,37 & 25,51 & 23,68 & 21,92 & 18,69 & 15,89 & 11,57 \\
\hline 65 & 1250 & 40 & 35,50 & 28,46 & 27,03 & 25,24 & 23,46 & 21,75 & 18,59 & 15,84 & 11,57 \\
\hline 65 & 1300 & 40 & 35,03 & 28,09 & 26,71 & 24,98 & 23,25 & 21,59 & 18,49 & 15,79 & 11,58 \\
\hline 65 & 1350 & 40 & 34,59 & 27,73 & 26,40 & 24,73 & 23,05 & 21,43 & 18,40 & 15,74 & 11,58 \\
\hline 65 & 1400 & 40 & 34,17 & 27,40 & 26,10 & 24,50 & 22,86 & 21,27 & 18,30 & 15,70 & 11,58 \\
\hline 65 & 1450 & 40 & 33,78 & 27,08 & 25,82 & 24,27 & 22,67 & 21,12 & 18,21 & 15,65 & 11,58 \\
\hline 65 & 1500 & 40 & 33,40 & 26,77 & 25,55 & 24,05 & 22,49 & 20,97 & 18,12 & 15,60 & 11,58 \\
\hline 65 & 1550 & 40 & 33,03 & 26,49 & 25,28 & 23,84 & 22,32 & 20,83 & 18,04 & 15,56 & 11,58 \\
\hline 65 & 1600 & 40 & 32,69 & 26,21 & 25,03 & 23,64 & 22,15 & 20,70 & 17,95 & 15,51 & 11,58 \\
\hline 65 & 1650 & 40 & 32,36 & 25,95 & 24,79 & 23,44 & 21,99 & 20,56 & 17,87 & 15,46 & 11,57 \\
\hline 65 & 1700 & 40 & 32,04 & 25,69 & 24,56 & 23,25 & 21,83 & 20,43 & 17,79 & 15,42 & 11,57 \\
\hline 65 & 1750 & 40 & 31,73 & 25,45 & 24,33 & 23,07 & 21,68 & 20,31 & 17,71 & 15,37 & 11,56 \\
\hline 65 & 1800 & 40 & 31,44 & 25,22 & 24,12 & 22,89 & 21,53 & 20,19 & 17,63 & 15,32 & 11,56 \\
\hline 65 & 1850 & 40 & 31,15 & 25,00 & 23,91 & 22,72 & 21,39 & 20,07 & 17,55 & 15,28 & 11,55 \\
\hline 65 & 1900 & 40 & 30,88 & 24,79 & 23,70 & 22,55 & 21,25 & 19,95 & 17,48 & 15,23 & 11,54 \\
\hline 65 & 1950 & 40 & 30,61 & 24,58 & 23,51 & 22,39 & 21,11 & 19,84 & 17,40 & 15,19 & 11,54 \\
\hline 65 & 2000 & 40 & 30,35 & 24,38 & 23,32 & 22,23 & 20,98 & 19,73 & 17,33 & 15,15 & 11,53 \\
\hline 65 & 200 & 45 & 73,46 & 49,33 & 41,02 & 33,96 & 28,77 & 24,57 & 18,28 & 14,14 & 9,42 \\
\hline 65 & 250 & 45 & 65,18 & 45,66 & 38,80 & 32,74 & 28,11 & 24,26 & 18,33 & 14,28 & 9,52 \\
\hline 65 & 300 & 45 & 59,38 & 42,90 & 37,05 & 31,70 & 27,51 & 23,95 & 18,33 & 14,38 & 9,60 \\
\hline 65 & 350 & 45 & 55,06 & 40,70 & 35,60 & 30,80 & 26,95 & 23,64 & 18,30 & 14,46 & 9,69 \\
\hline 65 & 400 & 45 & 51,70 & 38,89 & 34,38 & 30,01 & 26,45 & 23,34 & 18,25 & 14,51 & 9,76 \\
\hline 65 & 450 & 45 & 49,00 & 37,36 & 33,32 & 29,30 & 25,98 & 23,05 & 18,18 & 14,54 & 9,82 \\
\hline 65 & 500 & 45 & 46,76 & 36,04 & 32,38 & 28,67 & 25,55 & 22,77 & 18,10 & 14,56 & 9,88 \\
\hline 65 & 550 & 45 & 44,89 & 34,88 & 31,55 & 28,09 & 25,15 & 22,50 & 18,02 & 14,56 & 9,94 \\
\hline 65 & 600 & 45 & 43,28 & 33,86 & 30,80 & 27,56 & 24,77 & 22,25 & 17,93 & 14,56 & 9,98 \\
\hline 65 & 650 & 45 & 41,89 & 32,94 & 30,13 & 27,07 & 24,42 & 22,01 & 17,84 & 14,55 & 10,02 \\
\hline 65 & 700 & 45 & 40,66 & 32,12 & 29,51 & 26,62 & 24,09 & 21,78 & 17,75 & 14,53 & 10,06 \\
\hline 65 & 750 & 45 & 39,58 & 31,37 & 28,93 & 26,20 & 23,78 & 21,56 & 17,65 & 14,52 & 10,09 \\
\hline 65 & 800 & 45 & 38,61 & 30,68 & 28,41 & 25,81 & 23,49 & 21,34 & 17,56 & 14,49 & 10,12 \\
\hline 65 & 850 & 45 & 37,73 & 30,04 & 27,91 & 25,44 & 23,21 & 21,14 & 17,47 & 14,47 & 10,15 \\
\hline 65 & 900 & 45 & 36,93 & 29,46 & 27,46 & 25,09 & 22,95 & 20,95 & 17,38 & 14,44 & 10,17 \\
\hline 65 & 950 & 45 & 36,21 & 28,92 & 27,03 & 24,76 & 22,70 & 20,76 & 17,29 & 14,41 & 10,19 \\
\hline 65 & 1000 & 45 & 35,54 & 28,41 & 26,62 & 24,46 & 22,46 & 20,58 & 17,20 & 14,37 & 10,21 \\
\hline 65 & 1050 & 45 & 34,92 & 27,94 & 26,24 & 24,16 & 22,23 & 20,41 & 17,11 & 14,34 & 10,23 \\
\hline 65 & 1100 & 45 & 34,35 & 27,50 & 25,88 & 23,88 & 22,01 & 20,24 & 17,02 & 14,31 & 10,24 \\
\hline 65 & 1150 & 45 & 33,82 & 27,09 & 25,54 & 23,62 & 21,80 & 20,08 & 16,94 & 14,27 & 10,25 \\
\hline 65 & 1200 & 45 & 33,32 & 26,70 & 25,21 & 23,37 & 21,60 & 19,92 & 16,85 & 14,23 & 10,26 \\
\hline 65 & 1250 & 45 & 32,85 & 26,33 & 24,91 & 23,13 & 21,41 & 19,77 & 16,77 & 14,20 & 10,27 \\
\hline 65 & 1300 & 45 & 32,41 & 25,98 & 24,61 & 22,89 & 21,22 & 19,63 & 16,69 & 14,16 & 10,28 \\
\hline 65 & 1350 & 45 & 32,00 & 25,65 & 24,33 & 22,67 & 21,05 & 19,49 & 16,61 & 14,12 & 10,28 \\
\hline 65 & 1400 & 45 & 31,60 & 25,33 & 24,06 & 22,46 & 20,87 & 19,35 & 16,53 & 14,08 & 10,29 \\
\hline 65 & 1450 & 45 & 31,23 & 25,04 & 23,80 & 22,26 & 20,71 & 19,22 & 16,46 & 14,05 & 10,29 \\
\hline 65 & 1500 & 45 & 30,88 & 24,75 & 23,55 & 22,06 & 20,55 & 19,09 & 16,38 & 14,01 & 10,29 \\
\hline 65 & 1550 & 45 & 30,54 & 24,48 & 23,32 & 21,87 & 20,39 & 18,97 & 16,31 & 13,97 & 10,29 \\
\hline 65 & 1600 & 45 & 30,22 & 24,22 & 23,09 & 21,69 & 20,24 & 18,85 & 16,23 & 13,93 & 10,29 \\
\hline 65 & 1650 & 45 & 29,91 & 23,98 & 22,87 & 21,51 & 20,10 & 18,73 & 16,16 & 13,90 & 10,29 \\
\hline 65 & 1700 & 45 & 29,61 & 23,74 & 22,65 & 21,34 & 19,96 & 18,62 & 16,09 & 13,86 & 10,29 \\
\hline 65 & 1750 & 45 & 29,33 & 23,52 & 22,45 & 21,17 & 19,82 & 18,51 & 16,03 & 13,82 & 10,29 \\
\hline 65 & 1800 & 45 & 29,06 & 23,30 & 22,25 & 21,01 & 19,69 & 18,40 & 15,96 & 13,79 & 10,29 \\
\hline 65 & 1850 & 45 & 28,79 & 23,09 & 22,06 & 20,86 & 19,56 & 18,29 & 15,89 & 13,75 & 10,29 \\
\hline 65 & 1900 & 45 & 28,54 & 22,89 & 21,87 & 20,71 & 19,44 & 18,19 & 15,83 & 13,71 & 10,28 \\
\hline 65 & 1950 & 45 & 28,30 & 22,70 & 21,70 & 20,56 & 19,31 & 18,09 & 15,76 & 13,68 & 10,28 \\
\hline 65 & 2000 & 45 & 28,06 & 22,51 & 21,52 & 20,42 & 19,20 & 17,99 & 15,70 & 13,64 & 10,28 \\
\hline 65 & 200 & 50 & 70,11 & 46,07 & 37,89 & 31,07 & 26,14 & 22,21 & 16,41 & 12,66 & 8,45 \\
\hline 65 & 250 & 50 & 62,02 & 42,62 & 35,86 & 29,99 & 25,59 & 21,97 & 16,48 & 12,79 & 8,52 \\
\hline 65 & 300 & 50 & 56,37 & 40,02 & 34,25 & 29,07 & 25,07 & 21,72 & 16,50 & 12,89 & 8,60 \\
\hline 65 & 350 & 50 & 52,16 & 37,97 & 32,93 & 28,27 & 24,60 & 21,47 & 16,49 & 12,97 & 8,67 \\
\hline 65 & 400 & 50 & 48,89 & 36,28 & 31,81 & 27,57 & 24,16 & 21,22 & 16,46 & 13,02 & 8,73 \\
\hline 65 & 450 & 50 & 46,26 & 34,85 & 30,84 & 26,94 & 23,76 & 20,98 & 16,42 & 13,06 & 8,79 \\
\hline 65 & 500 & 50 & 44,10 & 33,62 & 29,98 & 26,37 & 23,38 & 20,74 & 16,36 & 13,08 & 8,84 \\
\hline 65 & 550 & 50 & 42,27 & 32,55 & 29,22 & 25,85 & 23,03 & 20,52 & 16,30 & 13,10 & 8,89 \\
\hline 65 & 600 & 50 & 40,72 & 31,59 & 28,54 & 25,38 & 22,70 & 20,30 & 16,23 & 13,10 & 8,93 \\
\hline 65 & 650 & 50 & 39,36 & 30,74 & 27,92 & 24,94 & 22,39 & 20,09 & 16,16 & 13,10 & 8,97 \\
\hline 65 & 700 & 50 & 38,18 & 29,97 & 27,35 & 24,53 & 22,10 & 19,89 & 16,09 & 13,10 & 9,01 \\
\hline 65 & 750 & 50 & 37,13 & 29,27 & 26,83 & 24,16 & 21,83 & 19,70 & 16,01 & 13,09 & 9,04 \\
\hline
\end{tabular}




\begin{tabular}{|c|c|c|c|c|c|c|c|c|c|c|c|}
\hline \multirow[b]{2}{*}{$\mathrm{H}(\mathrm{cm})$} & \multirow[b]{2}{*}{ Mceq (MPa) } & & & & & $\mathrm{De}$ & ões (x1 & & & & \\
\hline & & Msub (MPa) & D0 & D25 & D40 & D60 & D80 & D100 & D140 & D180 & D260 \\
\hline 65 & 800 & 50 & 36,19 & 28,63 & 26,34 & 23,80 & 21,57 & 19,52 & 15,94 & 13,07 & 9,07 \\
\hline 65 & 850 & 50 & 35,35 & 28,04 & 25,89 & 23,47 & 21,32 & 19,34 & 15,86 & 13,06 & 9,09 \\
\hline 65 & 900 & 50 & 34,58 & 27,49 & 25,47 & 23,16 & 21,09 & 19,17 & 15,79 & 13,04 & 9,12 \\
\hline 65 & 950 & 50 & 33,88 & 26,99 & 25,08 & 22,86 & 20,87 & 19,01 & 15,71 & 13,02 & 9,14 \\
\hline 65 & 1000 & 50 & 33,24 & 26,51 & 24,71 & 22,58 & 20,65 & 18,85 & 15,64 & 12,99 & 9,16 \\
\hline 65 & 1050 & 50 & 32,65 & 26,07 & 24,36 & 22,32 & 20,45 & 18,70 & 15,57 & 12,97 & 9,17 \\
\hline 65 & 1100 & 50 & 32,10 & 25,66 & 24,03 & 22,06 & 20,25 & 18,55 & 15,49 & 12,94 & 9,19 \\
\hline 65 & 1150 & 50 & 31,59 & 25,27 & 23,72 & 21,82 & 20,07 & 18,41 & 15,42 & 12,92 & 9,20 \\
\hline 65 & 1200 & 50 & 31,12 & 24,91 & 23,42 & 21,59 & 19,89 & 18,27 & 15,35 & 12,89 & 9,21 \\
\hline 65 & 1250 & 50 & 30,67 & 24,56 & 23,14 & 21,38 & 19,71 & 18,14 & 15,28 & 12,86 & 9,22 \\
\hline 65 & 1300 & 50 & 30,25 & 24,23 & 22,87 & 21,17 & 19,55 & 18,01 & 15,21 & 12,83 & 9,23 \\
\hline 65 & 1350 & 50 & 29,86 & 23,92 & 22,61 & 20,96 & 19,39 & 17,89 & 15,14 & 12,80 & 9,24 \\
\hline 65 & 1400 & 50 & 29,49 & 23,63 & 22,36 & 20,77 & 19,23 & 17,77 & 15,08 & 12,77 & 9,24 \\
\hline 65 & 1450 & 50 & 29,13 & 23,35 & 22,12 & 20,58 & 19,09 & 17,65 & 15,01 & 12,74 & 9,25 \\
\hline 65 & 1500 & 50 & 28,80 & 23,08 & 21,90 & 20,41 & 18,94 & 17,54 & 14,95 & 12,71 & 9,25 \\
\hline 65 & 1550 & 50 & 28,48 & 22,83 & 21,68 & 20,23 & 18,80 & 17,43 & 14,89 & 12,68 & 9,26 \\
\hline 65 & 1600 & 50 & 28,17 & 22,59 & 21,47 & 20,07 & 18,67 & 17,32 & 14,82 & 12,65 & 9,26 \\
\hline 65 & 1650 & 50 & 27,88 & 22,35 & 21,26 & 19,90 & 18,54 & 17,22 & 14,76 & 12,62 & 9,26 \\
\hline 65 & 1700 & 50 & 27,61 & 22,13 & 21,07 & 19,75 & 18,41 & 17,12 & 14,70 & 12,59 & 9,26 \\
\hline 65 & 1750 & 50 & 27,34 & 21,92 & 20,88 & 19,60 & 18,29 & 17,02 & 14,64 & 12,56 & 9,26 \\
\hline 65 & 1800 & 50 & 27,08 & 21,71 & 20,70 & 19,45 & 18,17 & 16,92 & 14,59 & 12,53 & 9,27 \\
\hline 65 & 1850 & 50 & 26,84 & 21,52 & 20,52 & 19,31 & 18,05 & 16,83 & 14,53 & 12,50 & 9,26 \\
\hline 65 & 1900 & 50 & 26,60 & 21,33 & 20,35 & 19,17 & 17,94 & 16,73 & 14,47 & 12,47 & 9,26 \\
\hline 65 & 1950 & 50 & 26,37 & 21,14 & 20,19 & 19,04 & 17,83 & 16,64 & 14,42 & 12,44 & 9,26 \\
\hline 65 & 2000 & 50 & 26,15 & 20,97 & 20,03 & 18,91 & 17,72 & 16,56 & 14,36 & 12,41 & 9,26 \\
\hline 65 & 200 & 55 & 67,29 & 43,33 & 35,26 & 28,65 & 23,96 & 20,26 & 14,88 & 11,45 & 7,65 \\
\hline 65 & 250 & 55 & 59,37 & 40,05 & 33,38 & 27,69 & 23,49 & 20,08 & 14,96 & 11,58 & 7,72 \\
\hline 65 & 300 & 55 & 53,84 & 37,60 & 31,89 & 26,87 & 23,04 & 19,87 & 15,00 & 11,68 & 7,78 \\
\hline 65 & 350 & 55 & 49,73 & 35,66 & 30,67 & 26,15 & 22,63 & 19,66 & 15,00 & 11,75 & 7,84 \\
\hline 65 & 400 & 55 & 46,54 & 34,07 & 29,64 & 25,52 & 22,25 & 19,45 & 14,99 & 11,80 & 7,89 \\
\hline 65 & 450 & 55 & 43,97 & 32,73 & 28,75 & 24,96 & 21,90 & 19,25 & 14,96 & 11,85 & 7,95 \\
\hline 65 & 500 & 55 & 41,86 & 31,58 & 27,96 & 24,44 & 21,57 & 19,05 & 14,92 & 11,87 & 7,99 \\
\hline 65 & 550 & 55 & 40,09 & 30,57 & 27,26 & 23,98 & 21,26 & 18,86 & 14,87 & 11,89 & 8,04 \\
\hline 65 & 600 & 55 & 38,57 & 29,67 & 26,63 & 23,55 & 20,97 & 18,67 & 14,82 & 11,91 & 8,08 \\
\hline 65 & 650 & 55 & 37,26 & 28,87 & 26,05 & 23,15 & 20,69 & 18,49 & 14,77 & 11,91 & 8,11 \\
\hline 65 & 700 & 55 & 36,10 & 28,15 & 25,53 & 22,78 & 20,43 & 18,32 & 14,71 & 11,91 & 8,15 \\
\hline 65 & 750 & 55 & 35,09 & 27,49 & 25,05 & 22,44 & 20,19 & 18,15 & 14,65 & 11,91 & 8,18 \\
\hline 65 & 800 & 55 & 34,17 & 26,89 & 24,60 & 22,11 & 19,96 & 17,99 & 14,59 & 11,90 & 8,20 \\
\hline 65 & 850 & 55 & 33,36 & 26,34 & 24,19 & 21,81 & 19,74 & 17,83 & 14,53 & 11,89 & 8,23 \\
\hline 65 & 900 & 55 & 32,61 & 25,82 & 23,80 & 21,53 & 19,53 & 17,68 & 14,46 & 11,88 & 8,25 \\
\hline 65 & 950 & 55 & 31,94 & 25,35 & 23,43 & 21,26 & 19,33 & 17,54 & 14,40 & 11,87 & 8,27 \\
\hline 65 & 1000 & 55 & 31,32 & 24,91 & 23,09 & 21,00 & 19,13 & 17,40 & 14,34 & 11,85 & 8,29 \\
\hline 65 & 1050 & 55 & 30,75 & 24,49 & 22,77 & 20,76 & 18,95 & 17,27 & 14,28 & 11,83 & 8,31 \\
\hline 65 & 1100 & 55 & 30,22 & 24,10 & 22,46 & 20,53 & 18,77 & 17,14 & 14,22 & 11,81 & 8,32 \\
\hline 65 & 1150 & 55 & 29,73 & 23,74 & 22,17 & 20,31 & 18,61 & 17,01 & 14,16 & 11,79 & 8,34 \\
\hline 65 & 1200 & 55 & 29,27 & 23,39 & 21,90 & 20,10 & 18,44 & 16,89 & 14,10 & 11,77 & 8,35 \\
\hline 65 & 1250 & 55 & 28,84 & 23,07 & 21,64 & 19,90 & 18,29 & 16,77 & 14,04 & 11,75 & 8,36 \\
\hline 65 & 1300 & 55 & 28,44 & 22,76 & 21,39 & 19,71 & 18,14 & 16,66 & 13,98 & 11,73 & 8,37 \\
\hline 65 & 1350 & 55 & 28,06 & 22,47 & 21,15 & 19,52 & 17,99 & 16,55 & 13,92 & 11,70 & 8,38 \\
\hline 65 & 1400 & 55 & 27,71 & 22,19 & 20,92 & 19,34 & 17,85 & 16,44 & 13,86 & 11,68 & 8,39 \\
\hline 65 & 1450 & 55 & 27,37 & 21,93 & 20,70 & 19,17 & 17,72 & 16,34 & 13,81 & 11,65 & 8,39 \\
\hline 65 & 1500 & 55 & 27,05 & 21,67 & 20,49 & 19,01 & 17,59 & 16,23 & 13,75 & 11,63 & 8,40 \\
\hline 65 & 1550 & 55 & 26,75 & 21,43 & 20,29 & 18,85 & 17,46 & 16,13 & 13,70 & 11,60 & 8,40 \\
\hline 65 & 1600 & 55 & 26,46 & 21,20 & 20,09 & 18,70 & 17,34 & 16,04 & 13,64 & 11,58 & 8,41 \\
\hline 65 & 1650 & 55 & 26,18 & 20,98 & 19,91 & 18,55 & 17,22 & 15,94 & 13,59 & 11,55 & 8,41 \\
\hline 65 & 1700 & 55 & 25,92 & 20,77 & 19,72 & 18,41 & 17,10 & 15,85 & 13,54 & 11,53 & 8,42 \\
\hline 65 & 1750 & 55 & 25,66 & 20,57 & 19,55 & 18,27 & 16,99 & 15,76 & 13,49 & 11,50 & 8,42 \\
\hline 65 & 1800 & 55 & 25,42 & 20,38 & 19,38 & 18,13 & 16,88 & 15,68 & 13,44 & 11,48 & 8,42 \\
\hline 65 & 1850 & 55 & 25,19 & 20,19 & 19,22 & 18,00 & 16,78 & 15,59 & 13,39 & 11,45 & 8,42 \\
\hline 65 & 1900 & 55 & 24,96 & 20,01 & 19,06 & 17,88 & 16,67 & 15,51 & 13,34 & 11,43 & 8,42 \\
\hline 65 & 1950 & 55 & 24,75 & 19,84 & 18,91 & 17,76 & 16,57 & 15,43 & 13,29 & 11,40 & 8,42 \\
\hline 65 & 2000 & 55 & 24,54 & 19,67 & 18,76 & 17,64 & 16,48 & 15,35 & 13,24 & 11,38 & 8,42 \\
\hline 65 & 200 & 60 & 64,88 & 40,98 & 33,02 & 26,59 & 22,11 & 18,62 & 13,60 & 10,45 & 6,99 \\
\hline 65 & 250 & 60 & 57,10 & 37,85 & 31,26 & 25,73 & 21,71 & 18,48 & 13,69 & 10,57 & 7,05 \\
\hline 65 & 300 & 60 & 51,69 & 35,51 & 29,88 & 24,99 & 21,32 & 18,31 & 13,73 & 10,66 & 7,10 \\
\hline 65 & 350 & 60 & 47,66 & 33,68 & 28,75 & 24,35 & 20,96 & 18,14 & 13,75 & 10,73 & 7,15 \\
\hline 65 & 400 & 60 & 44,54 & 32,17 & 27,79 & 23,77 & 20,63 & 17,96 & 13,75 & 10,79 & 7,20 \\
\hline 65 & 450 & 60 & 42,03 & 30,90 & 26,95 & 23,26 & 20,32 & 17,79 & 13,73 & 10,83 & 7,25 \\
\hline 65 & 500 & 60 & 39,96 & 29,81 & 26,22 & 22,79 & 20,02 & 17,61 & 13,71 & 10,86 & 7,29 \\
\hline 65 & 550 & 60 & 38,23 & 28,86 & 25,57 & 22,37 & 19,75 & 17,45 & 13,67 & 10,89 & 7,33 \\
\hline 65 & 600 & 60 & 36,75 & 28,02 & 24,99 & 21,98 & 19,49 & 17,28 & 13,64 & 10,90 & 7,37 \\
\hline 65 & 650 & 60 & 35,46 & 27,26 & 24,45 & 21,62 & 19,24 & 17,13 & 13,59 & 10,91 & 7,40 \\
\hline 65 & 700 & 60 & 34,34 & 26,58 & 23,97 & 21,28 & 19,01 & 16,98 & 13,55 & 10,92 & 7,43 \\
\hline 65 & 750 & 60 & 33,35 & 25,96 & 23,52 & 20,96 & 18,79 & 16,83 & 13,50 & 10,92 & 7,46 \\
\hline 65 & 800 & 60 & 32,46 & 25,40 & 23,10 & 20,67 & 18,58 & 16,69 & 13,45 & 10,92 & 7,49 \\
\hline 65 & 850 & 60 & 31,66 & 24,87 & 22,72 & 20,39 & 18,38 & 16,55 & 13,40 & 10,91 & 7,51 \\
\hline 65 & 900 & 60 & 30,94 & 24,39 & 22,36 & 20,13 & 18,19 & 16,42 & 13,34 & 10,91 & 7,53 \\
\hline 65 & 950 & 60 & 30,28 & 23,94 & 22,02 & 19,88 & 18,01 & 16,29 & 13,29 & 10,90 & 7,55 \\
\hline 65 & 1000 & 60 & 29,68 & 23,52 & 21,70 & 19,65 & 17,84 & 16,17 & 13,24 & 10,89 & 7,57 \\
\hline 65 & 1050 & 60 & 29,13 & 23,13 & 21,40 & 19,43 & 17,67 & 16,05 & 13,19 & 10,87 & 7,59 \\
\hline 65 & 1100 & 60 & 28,62 & 22,77 & 21,12 & 19,21 & 17,51 & 15,93 & 13,14 & 10,86 & 7,60 \\
\hline
\end{tabular}




\begin{tabular}{|c|c|c|c|c|c|c|c|c|c|c|c|}
\hline \multirow[b]{2}{*}{$\mathrm{H}(\mathrm{cm})$} & \multirow[b]{2}{*}{ Mceq (MPa) } & & & & & $\mathrm{De}$ & ões (x1 & & & & \\
\hline & & Msub (MPa) & D0 & D25 & D40 & D60 & D80 & D100 & D140 & D180 & D260 \\
\hline 65 & 1150 & 60 & 28,14 & 22,42 & 20,85 & 19,01 & 17,36 & 15,82 & 13,08 & 10,84 & 7,62 \\
\hline 65 & 1200 & 60 & 27,70 & 22,10 & 20,59 & 18,82 & 17,21 & 15,71 & 13,03 & 10,83 & 7,63 \\
\hline 65 & 1250 & 60 & 27,29 & 21,79 & 20,35 & 18,63 & 17,07 & 15,60 & 12,98 & 10,81 & 7,64 \\
\hline 65 & 1300 & 60 & 26,90 & 21,50 & 20,12 & 18,46 & 16,93 & 15,50 & 12,93 & 10,79 & 7,65 \\
\hline 65 & 1350 & 60 & 26,53 & 21,22 & 19,89 & 18,29 & 16,80 & 15,40 & 12,88 & 10,77 & 7,66 \\
\hline 65 & 1400 & 60 & 26,19 & 20,96 & 19,68 & 18,12 & 16,67 & 15,30 & 12,83 & 10,76 & 7,67 \\
\hline 65 & 1450 & 60 & 25,87 & 20,71 & 19,48 & 17,96 & 16,55 & 15,21 & 12,78 & 10,74 & 7,68 \\
\hline 65 & 1500 & 60 & 25,56 & 20,47 & 19,28 & 17,81 & 16,43 & 15,12 & 12,73 & 10,72 & 7,68 \\
\hline 65 & 1550 & 60 & 25,27 & 20,24 & 19,09 & 17,67 & 16,31 & 15,03 & 12,69 & 10,70 & 7,69 \\
\hline 65 & 1600 & 60 & 24,99 & 20,02 & 18,91 & 17,53 & 16,20 & 14,94 & 12,64 & 10,68 & 7,70 \\
\hline 65 & 1650 & 60 & 24,72 & 19,81 & 18,74 & 17,39 & 16,09 & 14,86 & 12,59 & 10,65 & 7,70 \\
\hline 65 & 1700 & 60 & 24,47 & 19,61 & 18,57 & 17,26 & 15,99 & 14,78 & 12,55 & 10,63 & 7,70 \\
\hline 65 & 1750 & 60 & 24,23 & 19,42 & 18,40 & 17,13 & 15,88 & 14,69 & 12,50 & 10,61 & 7,71 \\
\hline 65 & 1800 & 60 & 24,00 & 19,24 & 18,25 & 17,00 & 15,78 & 14,62 & 12,46 & 10,59 & 7,71 \\
\hline 65 & 1850 & 60 & 23,78 & 19,06 & 18,09 & 16,88 & 15,69 & 14,54 & 12,41 & 10,57 & 7,71 \\
\hline 65 & 1900 & 60 & 23,56 & 18,89 & 17,95 & 16,77 & 15,59 & 14,46 & 12,37 & 10,55 & 7,72 \\
\hline 65 & 1950 & 60 & 23,36 & 18,72 & 17,80 & 16,65 & 15,50 & 14,39 & 12,33 & 10,53 & 7,72 \\
\hline 65 & 2000 & 60 & 23,16 & 18,56 & 17,67 & 16,54 & 15,41 & 14,32 & 12,29 & 10,51 & 7,72 \\
\hline 65 & 200 & 65 & 62,79 & 38,94 & 31,08 & 24,82 & 20,53 & 17,22 & 12,52 & 9,60 & 6,44 \\
\hline 65 & 250 & 65 & 55,14 & 35,94 & 29,43 & 24,04 & 20,18 & 17,11 & 12,61 & 9,72 & 6,49 \\
\hline 65 & 300 & 65 & 49,82 & 33,71 & 28,14 & 23,37 & 19,84 & 16,98 & 12,66 & 9,80 & 6,53 \\
\hline 65 & 350 & 65 & 45,87 & 31,95 & 27,08 & 22,78 & 19,53 & 16,83 & 12,69 & 9,87 & 6,58 \\
\hline 65 & 400 & 65 & 42,80 & 30,52 & 26,18 & 22,26 & 19,23 & 16,68 & 12,69 & 9,93 & 6,62 \\
\hline 65 & 450 & 65 & 40,35 & 29,32 & 25,40 & 21,79 & 18,95 & 16,53 & 12,69 & 9,97 & 6,66 \\
\hline 65 & 500 & 65 & 38,32 & 28,28 & 24,72 & 21,37 & 18,69 & 16,38 & 12,67 & 10,01 & 6,70 \\
\hline 65 & 550 & 65 & 36,62 & 27,38 & 24,11 & 20,98 & 18,44 & 16,24 & 12,65 & 10,03 & 6,74 \\
\hline 65 & 600 & 65 & 35,17 & 26,58 & 23,56 & 20,62 & 18,21 & 16,09 & 12,62 & 10,05 & 6,77 \\
\hline 65 & 650 & 65 & 33,92 & 25,86 & 23,06 & 20,29 & 17,99 & 15,96 & 12,59 & 10,06 & 6,80 \\
\hline 65 & 700 & 65 & 32,82 & 25,22 & 22,61 & 19,98 & 17,78 & 15,82 & 12,55 & 10,07 & 6,83 \\
\hline 65 & 750 & 65 & 31,85 & 24,63 & 22,19 & 19,69 & 17,58 & 15,69 & 12,51 & 10,08 & 6,86 \\
\hline 65 & 800 & 65 & 30,98 & 24,09 & 21,80 & 19,42 & 17,39 & 15,57 & 12,47 & 10,08 & 6,88 \\
\hline 65 & 850 & 65 & 30,21 & 23,60 & 21,44 & 19,16 & 17,21 & 15,44 & 12,43 & 10,08 & 6,90 \\
\hline 65 & 900 & 65 & 29,50 & 23,14 & 21,10 & 18,92 & 17,04 & 15,33 & 12,38 & 10,08 & 6,92 \\
\hline 65 & 950 & 65 & 28,86 & 22,72 & 20,79 & 18,69 & 16,87 & 15,21 & 12,34 & 10,07 & 6,94 \\
\hline 65 & 1000 & 65 & 28,27 & 22,32 & 20,49 & 18,47 & 16,71 & 15,10 & 12,30 & 10,06 & 6,96 \\
\hline 65 & 1050 & 65 & 27,74 & 21,95 & 20,21 & 18,27 & 16,56 & 14,99 & 12,25 & 10,06 & 6,98 \\
\hline 65 & 1100 & 65 & 27,24 & 21,60 & 19,94 & 18,07 & 16,42 & 14,89 & 12,21 & 10,05 & 6,99 \\
\hline 65 & 1150 & 65 & 26,78 & 21,27 & 19,69 & 17,89 & 16,28 & 14,79 & 12,16 & 10,03 & 7,01 \\
\hline 65 & 1200 & 65 & 26,35 & 20,96 & 19,45 & 17,71 & 16,14 & 14,69 & 12,12 & 10,02 & 7,02 \\
\hline 65 & 1250 & 65 & 25,95 & 20,67 & 19,23 & 17,54 & 16,01 & 14,59 & 12,07 & 10,01 & 7,03 \\
\hline 65 & 1300 & 65 & 25,57 & 20,40 & 19,01 & 17,37 & 15,89 & 14,50 & 12,03 & 9,99 & 7,04 \\
\hline 65 & 1350 & 65 & 25,22 & 20,13 & 18,80 & 17,21 & 15,77 & 14,41 & 11,99 & 9,98 & 7,05 \\
\hline 65 & 1400 & 65 & 24,88 & 19,88 & 18,60 & 17,06 & 15,65 & 14,32 & 11,94 & 9,97 & 7,06 \\
\hline 65 & 1450 & 65 & 24,57 & 19,64 & 18,41 & 16,91 & 15,53 & 14,24 & 11,90 & 9,95 & 7,07 \\
\hline 65 & 1500 & 65 & 24,27 & 19,42 & 18,23 & 16,77 & 15,43 & 14,15 & 11,86 & 9,93 & 7,08 \\
\hline 65 & 1550 & 65 & 23,99 & 19,20 & 18,05 & 16,64 & 15,32 & 14,07 & 11,82 & 9,92 & 7,08 \\
\hline 65 & 1600 & 65 & 23,72 & 18,99 & 17,88 & 16,51 & 15,22 & 13,99 & 11,77 & 9,90 & 7,09 \\
\hline 65 & 1650 & 65 & 23,47 & 18,79 & 17,72 & 16,38 & 15,12 & 13,92 & 11,73 & 9,88 & 7,10 \\
\hline 65 & 1700 & 65 & 23,22 & 18,60 & 17,56 & 16,26 & 15,02 & 13,84 & 11,69 & 9,87 & 7,10 \\
\hline 65 & 1750 & 65 & 22,99 & 18,42 & 17,41 & 16,14 & 14,92 & 13,77 & 11,65 & 9,85 & 7,11 \\
\hline 65 & 1800 & 65 & 22,77 & 18,25 & 17,26 & 16,02 & 14,83 & 13,70 & 11,61 & 9,83 & 7,11 \\
\hline 65 & 1850 & 65 & 22,55 & 18,08 & 17,12 & 15,91 & 14,74 & 13,63 & 11,58 & 9,81 & 7,11 \\
\hline 65 & 1900 & 65 & 22,35 & 17,91 & 16,98 & 15,80 & 14,65 & 13,56 & 11,54 & 9,80 & 7,12 \\
\hline 65 & 1950 & 65 & 22,15 & 17,76 & 16,84 & 15,70 & 14,57 & 13,49 & 11,50 & 9,78 & 7,12 \\
\hline 65 & 2000 & 65 & 21,96 & 17,60 & 16,71 & 15,59 & 14,49 & 13,43 & 11,46 & 9,76 & 7,12 \\
\hline 65 & 200 & 70 & 60,96 & 37,16 & 29,38 & 23,28 & 19,16 & 16,01 & 11,59 & 8,88 & 5,97 \\
\hline 65 & 250 & 70 & 53,42 & 34,26 & 27,83 & 22,57 & 18,85 & 15,93 & 11,68 & 8,99 & 6,01 \\
\hline 65 & 300 & 70 & 48,18 & 32,12 & 26,61 & 21,96 & 18,56 & 15,82 & 11,74 & 9,07 & 6,05 \\
\hline 65 & 350 & 70 & 44,30 & 30,44 & 25,61 & 21,42 & 18,28 & 15,70 & 11,77 & 9,14 & 6,09 \\
\hline 65 & 400 & 70 & 41,29 & 29,07 & 24,77 & 20,94 & 18,01 & 15,57 & 11,79 & 9,19 & 6,13 \\
\hline 65 & 450 & 70 & 38,88 & 27,92 & 24,04 & 20,51 & 17,76 & 15,44 & 11,79 & 9,23 & 6,16 \\
\hline 65 & 500 & 70 & 36,89 & 26,93 & 23,40 & 20,12 & 17,53 & 15,31 & 11,78 & 9,27 & 6,20 \\
\hline 65 & 550 & 70 & 35,22 & 26,07 & 22,83 & 19,76 & 17,30 & 15,18 & 11,76 & 9,30 & 6,23 \\
\hline 65 & 600 & 70 & 33,80 & 25,31 & 22,31 & 19,43 & 17,09 & 15,06 & 11,74 & 9,32 & 6,26 \\
\hline 65 & 650 & 70 & 32,57 & 24,63 & 21,84 & 19,12 & 16,89 & 14,93 & 11,72 & 9,33 & 6,29 \\
\hline 65 & 700 & 70 & 31,50 & 24,02 & 21,42 & 18,84 & 16,70 & 14,82 & 11,69 & 9,35 & 6,32 \\
\hline 65 & 750 & 70 & 30,55 & 23,46 & 21,02 & 18,57 & 16,52 & 14,70 & 11,66 & 9,35 & 6,34 \\
\hline 65 & 800 & 70 & 29,70 & 22,95 & 20,66 & 18,32 & 16,35 & 14,59 & 11,62 & 9,36 & 6,36 \\
\hline 65 & 850 & 70 & 28,94 & 22,48 & 20,32 & 18,08 & 16,18 & 14,48 & 11,59 & 9,36 & 6,38 \\
\hline 65 & 900 & 70 & 28,25 & 22,04 & 20,00 & 17,86 & 16,03 & 14,37 & 11,55 & 9,36 & 6,40 \\
\hline 65 & 950 & 70 & 27,62 & 21,64 & 19,71 & 17,65 & 15,88 & 14,27 & 11,51 & 9,36 & 6,42 \\
\hline 65 & 1000 & 70 & 27,05 & 21,26 & 19,43 & 17,45 & 15,73 & 14,17 & 11,48 & 9,35 & 6,44 \\
\hline 65 & 1050 & 70 & 26,52 & 20,91 & 19,16 & 17,25 & 15,59 & 14,07 & 11,44 & 9,35 & 6,46 \\
\hline 65 & 1100 & 70 & 26,04 & 20,58 & 18,91 & 17,07 & 15,46 & 13,98 & 11,40 & 9,34 & 6,47 \\
\hline 65 & 1150 & 70 & 25,59 & 20,26 & 18,68 & 16,90 & 15,33 & 13,89 & 11,36 & 9,33 & 6,48 \\
\hline 65 & 1200 & 70 & 25,17 & 19,97 & 18,45 & 16,73 & 15,21 & 13,80 & 11,32 & 9,33 & 6,50 \\
\hline 65 & 1250 & 70 & 24,78 & 19,69 & 18,24 & 16,57 & 15,09 & 13,71 & 11,28 & 9,32 & 6,51 \\
\hline 65 & 1300 & 70 & 24,41 & 19,43 & 18,03 & 16,42 & 14,97 & 13,63 & 11,25 & 9,30 & 6,52 \\
\hline 65 & 1350 & 70 & 24,07 & 19,18 & 17,84 & 16,27 & 14,86 & 13,55 & 11,21 & 9,29 & 6,53 \\
\hline 65 & 1400 & 70 & 23,74 & 18,94 & 17,65 & 16,13 & 14,75 & 13,47 & 11,17 & 9,28 & 6,54 \\
\hline 65 & 1450 & 70 & 23,44 & 18,71 & 17,47 & 15,99 & 14,65 & 13,39 & 11,13 & 9,27 & 6,55 \\
\hline
\end{tabular}




\begin{tabular}{|c|c|c|c|c|c|c|c|c|c|c|c|}
\hline \multirow[b]{2}{*}{$\mathrm{H}(\mathrm{cm})$} & \multirow[b]{2}{*}{ Mceq (MPa) } & & & & & De & ões (x1 & m) & & & \\
\hline & & Msub (MPa) & D0 & D25 & D40 & D60 & D80 & D100 & D140 & D180 & D260 \\
\hline 65 & 1500 & 70 & 23,15 & 18,50 & 17,30 & 15,86 & 14,55 & 13,31 & 11,10 & 9,26 & 6,56 \\
\hline 65 & 1550 & 70 & 22,88 & 18,29 & 17,13 & 15,74 & 14,45 & 13,24 & 11,06 & 9,24 & 6,56 \\
\hline 65 & 1600 & 70 & 22,62 & 18,09 & 16,97 & 15,61 & 14,35 & 13,17 & 11,02 & 9,23 & 6,57 \\
\hline 65 & 1650 & 70 & 22,37 & 17,90 & 16,82 & 15,49 & 14,26 & 13,10 & 10,99 & 9,21 & 6,58 \\
\hline 65 & 1700 & 70 & 22,13 & 17,72 & 16,67 & 15,38 & 14,17 & 13,03 & 10,95 & 9,20 & 6,58 \\
\hline 65 & 1750 & 70 & 21,91 & 17,54 & 16,53 & 15,27 & 14,08 & 12,96 & 10,91 & 9,19 & 6,59 \\
\hline 65 & 1800 & 70 & 21,69 & 17,38 & 16,39 & 15,16 & 14,00 & 12,89 & 10,88 & 9,17 & 6,59 \\
\hline 65 & 1850 & 70 & 21,49 & 17,21 & 16,25 & 15,06 & 13,91 & 12,83 & 10,85 & 9,16 & 6,60 \\
\hline 65 & 1900 & 70 & 21,29 & 17,06 & 16,12 & 14,95 & 13,83 & 12,77 & 10,81 & 9,14 & 6,60 \\
\hline 65 & 1950 & 70 & 21,10 & 16,91 & 16,00 & 14,86 & 13,75 & 12,70 & 10,78 & 9,13 & 6,60 \\
\hline 65 & 2000 & 70 & 20,92 & 16,76 & 15,87 & 14,76 & 13,68 & 12,64 & 10,74 & 9,11 & 6,61 \\
\hline 65 & 200 & 75 & 59,35 & 35,59 & 27,89 & 21,93 & 17,96 & 14,96 & 10,78 & 8,26 & 5,56 \\
\hline 65 & 250 & 75 & 51,90 & 32,78 & 26,41 & 21,27 & 17,69 & 14,90 & 10,88 & 8,36 & 5,60 \\
\hline 65 & 300 & 75 & 46,74 & 30,72 & 25,26 & 20,71 & 17,43 & 14,81 & 10,94 & 8,44 & 5,63 \\
\hline 65 & 350 & 75 & 42,92 & 29,10 & 24,32 & 20,22 & 17,18 & 14,70 & 10,98 & 8,50 & 5,66 \\
\hline 65 & 400 & 75 & 39,95 & 27,79 & 23,52 & 19,78 & 16,94 & 14,59 & 10,99 & 8,55 & 5,70 \\
\hline 65 & 450 & 75 & 37,58 & 26,68 & 22,83 & 19,38 & 16,72 & 14,48 & 11,00 & 8,60 & 5,73 \\
\hline 65 & 500 & 75 & 35,63 & 25,74 & 22,23 & 19,02 & 16,50 & 14,37 & 11,00 & 8,63 & 5,76 \\
\hline 65 & 550 & 75 & 33,99 & 24,91 & 21,69 & 18,69 & 16,30 & 14,26 & 10,99 & 8,66 & 5,79 \\
\hline 65 & 600 & 75 & 32,59 & 24,19 & 21,20 & 18,38 & 16,11 & 14,15 & 10,98 & 8,68 & 5,82 \\
\hline 65 & 650 & 75 & 31,39 & 23,54 & 20,76 & 18,10 & 15,93 & 14,04 & 10,96 & 8,70 & 5,85 \\
\hline 65 & 700 & 75 & 30,33 & 22,95 & 20,36 & 17,83 & 15,75 & 13,93 & 10,93 & 8,71 & 5,87 \\
\hline 65 & 750 & 75 & 29,40 & 22,42 & 19,99 & 17,58 & 15,59 & 13,83 & 10,91 & 8,72 & 5,89 \\
\hline 65 & 800 & 75 & 28,57 & 21,93 & 19,65 & 17,35 & 15,43 & 13,73 & 10,88 & 8,73 & 5,92 \\
\hline 65 & 850 & 75 & 27,82 & 21,48 & 19,33 & 17,13 & 15,28 & 13,63 & 10,85 & 8,73 & 5,94 \\
\hline 65 & 900 & 75 & 27,14 & 21,06 & 19,03 & 16,92 & 15,14 & 13,53 & 10,82 & 8,74 & 5,96 \\
\hline 65 & 950 & 75 & 26,53 & 20,68 & 18,75 & 16,72 & 15,00 & 13,44 & 10,79 & 8,74 & 5,97 \\
\hline 65 & 1000 & 75 & 25,97 & 20,32 & 18,48 & 16,54 & 14,86 & 13,35 & 10,76 & 8,74 & 5,99 \\
\hline 65 & 1050 & 75 & 25,45 & 19,98 & 18,23 & 16,36 & 14,74 & 13,26 & 10,73 & 8,73 & 6,00 \\
\hline 65 & 1100 & 75 & 24,98 & 19,66 & 18,00 & 16,19 & 14,61 & 13,18 & 10,69 & 8,73 & 6,02 \\
\hline 65 & 1150 & 75 & 24,54 & 19,37 & 17,78 & 16,02 & 14,49 & 13,09 & 10,66 & 8,72 & 6,03 \\
\hline 65 & 1200 & 75 & 24,13 & 19,09 & 17,56 & 15,87 & 14,38 & 13,01 & 10,63 & 8,72 & 6,04 \\
\hline 65 & 1250 & 75 & 23,75 & 18,82 & 17,36 & 15,72 & 14,27 & 12,93 & 10,59 & 8,71 & 6,06 \\
\hline 65 & 1300 & 75 & 23,39 & 18,57 & 17,17 & 15,58 & 14,16 & 12,86 & 10,56 & 8,70 & 6,07 \\
\hline 65 & 1350 & 75 & 23,05 & 18,33 & 16,98 & 15,44 & 14,06 & 12,78 & 10,53 & 8,69 & 6,08 \\
\hline 65 & 1400 & 75 & 22,74 & 18,10 & 16,81 & 15,31 & 13,96 & 12,71 & 10,49 & 8,68 & 6,09 \\
\hline 65 & 1450 & 75 & 22,44 & 17,88 & 16,64 & 15,18 & 13,86 & 12,64 & 10,46 & 8,67 & 6,10 \\
\hline 65 & 1500 & 75 & 22,16 & 17,68 & 16,47 & 15,05 & 13,77 & 12,57 & 10,43 & 8,66 & 6,10 \\
\hline 65 & 1550 & 75 & 21,89 & 17,48 & 16,32 & 14,94 & 13,68 & 12,50 & 10,39 & 8,65 & 6,11 \\
\hline 65 & 1600 & 75 & 21,64 & 17,29 & 16,17 & 14,82 & 13,59 & 12,43 & 10,36 & 8,64 & 6,12 \\
\hline 65 & 1650 & 75 & 21,40 & 17,11 & 16,02 & 14,71 & 13,50 & 12,37 & 10,33 & 8,63 & 6,12 \\
\hline 65 & 1700 & 75 & 21,17 & 16,93 & 15,88 & 14,60 & 13,42 & 12,31 & 10,30 & 8,62 & 6,13 \\
\hline 65 & 1750 & 75 & 20,95 & 16,77 & 15,74 & 14,50 & 13,34 & 12,24 & 10,26 & 8,60 & 6,14 \\
\hline 65 & 1800 & 75 & 20,74 & 16,60 & 15,61 & 14,40 & 13,26 & 12,18 & 10,23 & 8,59 & 6,14 \\
\hline 65 & 1850 & 75 & 20,54 & 16,45 & 15,49 & 14,30 & 13,18 & 12,12 & 10,20 & 8,58 & 6,15 \\
\hline 65 & 1900 & 75 & 20,35 & 16,30 & 15,36 & 14,20 & 13,11 & 12,07 & 10,17 & 8,57 & 6,15 \\
\hline 65 & 1950 & 75 & 20,17 & 16,16 & 15,24 & 14,11 & 13,03 & 12,01 & 10,14 & 8,55 & 6,15 \\
\hline 65 & 2000 & 75 & 19,99 & 16,02 & 15,13 & 14,02 & 12,96 & 11,95 & 10,11 & 8,54 & 6,16 \\
\hline 65 & 200 & 80 & 57,91 & 34,19 & 26,56 & 20,73 & 16,90 & 14,04 & 10,08 & 7,72 & 5,21 \\
\hline 65 & 250 & 80 & 50,55 & 31,46 & 25,16 & 20,12 & 16,66 & 13,99 & 10,17 & 7,81 & 5,24 \\
\hline 65 & 300 & 80 & 45,45 & 29,46 & 24,06 & 19,61 & 16,43 & 13,92 & 10,24 & 7,88 & 5,27 \\
\hline 65 & 350 & 80 & 41,68 & 27,90 & 23,17 & 19,15 & 16,21 & 13,83 & 10,28 & 7,94 & 5,30 \\
\hline 65 & 400 & 80 & 38,76 & 26,64 & 22,41 & 18,74 & 15,99 & 13,73 & 10,30 & 8,00 & 5,33 \\
\hline 65 & 450 & 80 & 36,43 & 25,58 & 21,76 & 18,37 & 15,79 & 13,64 & 10,31 & 8,04 & 5,36 \\
\hline 65 & 500 & 80 & 34,50 & 24,67 & 21,19 & 18,04 & 15,60 & 13,54 & 10,31 & 8,07 & 5,38 \\
\hline 65 & 550 & 80 & 32,89 & 23,88 & 20,68 & 17,73 & 15,41 & 13,44 & 10,31 & 8,10 & 5,41 \\
\hline 65 & 600 & 80 & 31,52 & 23,18 & 20,22 & 17,45 & 15,24 & 13,34 & 10,30 & 8,12 & 5,44 \\
\hline 65 & 650 & 80 & 30,33 & 22,55 & 19,80 & 17,18 & 15,07 & 13,24 & 10,29 & 8,14 & 5,46 \\
\hline 65 & 700 & 80 & 29,29 & 21,99 & 19,42 & 16,93 & 14,91 & 13,15 & 10,27 & 8,16 & 5,48 \\
\hline 65 & 750 & 80 & 28,38 & 21,48 & 19,07 & 16,70 & 14,76 & 13,05 & 10,25 & 8,17 & 5,51 \\
\hline 65 & 800 & 80 & 27,56 & 21,01 & 18,74 & 16,48 & 14,61 & 12,96 & 10,23 & 8,18 & 5,53 \\
\hline 65 & 850 & 80 & 26,83 & 20,58 & 18,44 & 16,28 & 14,48 & 12,87 & 10,20 & 8,18 & 5,54 \\
\hline 65 & 900 & 80 & 26,16 & 20,19 & 18,15 & 16,08 & 14,34 & 12,79 & 10,18 & 8,19 & 5,56 \\
\hline 65 & 950 & 80 & 25,56 & 19,82 & 17,89 & 15,90 & 14,21 & 12,70 & 10,15 & 8,19 & 5,58 \\
\hline 65 & 1000 & 80 & 25,01 & 19,47 & 17,64 & 15,72 & 14,09 & 12,62 & 10,12 & 8,19 & 5,60 \\
\hline 65 & 1050 & 80 & 24,51 & 19,15 & 17,40 & 15,56 & 13,97 & 12,54 & 10,09 & 8,19 & 5,61 \\
\hline 65 & 1100 & 80 & 24,04 & 18,85 & 17,18 & 15,40 & 13,86 & 12,46 & 10,07 & 8,19 & 5,62 \\
\hline 65 & 1150 & 80 & 23,61 & 18,56 & 16,97 & 15,24 & 13,75 & 12,39 & 10,04 & 8,18 & 5,64 \\
\hline 65 & 1200 & 80 & 23,21 & 18,29 & 16,77 & 15,10 & 13,64 & 12,31 & 10,01 & 8,18 & 5,65 \\
\hline 65 & 1250 & 80 & 22,83 & 18,04 & 16,58 & 14,96 & 13,54 & 12,24 & 9,98 & 8,18 & 5,66 \\
\hline 65 & 1300 & 80 & 22,48 & 17,80 & 16,39 & 14,82 & 13,44 & 12,17 & 9,95 & 8,17 & 5,67 \\
\hline 65 & 1350 & 80 & 22,16 & 17,57 & 16,22 & 14,69 & 13,35 & 12,10 & 9,92 & 8,16 & 5,68 \\
\hline 65 & 1400 & 80 & 21,85 & 17,35 & 16,05 & 14,57 & 13,25 & 12,04 & 9,89 & 8,16 & 5,69 \\
\hline 65 & 1450 & 80 & 21,56 & 17,14 & 15,89 & 14,45 & 13,16 & 11,97 & 9,86 & 8,15 & 5,70 \\
\hline 65 & 1500 & 80 & 21,28 & 16,94 & 15,74 & 14,33 & 13,08 & 11,91 & 9,83 & 8,14 & 5,71 \\
\hline 65 & 1550 & 80 & 21,02 & 16,75 & 15,59 & 14,22 & 12,99 & 11,84 & 9,80 & 8,13 & 5,72 \\
\hline 65 & 1600 & 80 & 20,78 & 16,57 & 15,44 & 14,11 & 12,91 & 11,78 & 9,77 & 8,12 & 5,72 \\
\hline 65 & 1650 & 80 & 20,54 & 16,40 & 15,31 & 14,01 & 12,83 & 11,72 & 9,75 & 8,11 & 5,73 \\
\hline 65 & 1700 & 80 & 20,32 & 16,23 & 15,17 & 13,91 & 12,75 & 11,66 & 9,72 & 8,10 & 5,73 \\
\hline 65 & 1750 & 80 & 20,10 & 16,07 & 15,04 & 13,81 & 12,67 & 11,61 & 9,69 & 8,09 & 5,74 \\
\hline 65 & 1800 & 80 & 19,90 & 15,91 & 14,92 & 13,71 & 12,60 & 11,55 & 9,66 & 8,08 & 5,75 \\
\hline
\end{tabular}




\begin{tabular}{|c|c|c|c|c|c|c|c|c|c|c|c|}
\hline \multirow[b]{2}{*}{$\mathrm{H}(\mathrm{cm})$} & \multirow[b]{2}{*}{ Mceq (MPa) } & & & & & De & ões (x1 & & & & \\
\hline & & Msub (MPa) & D0 & D25 & D40 & D60 & D80 & D100 & D140 & D180 & D260 \\
\hline 65 & 1850 & 80 & 19,71 & 15,77 & 14,80 & 13,62 & 12,53 & 11,50 & 9,63 & 8,07 & 5,75 \\
\hline 65 & 1900 & 80 & 19,52 & 15,62 & 14,68 & 13,53 & 12,46 & 11,44 & 9,60 & 8,06 & 5,76 \\
\hline 65 & 1950 & 80 & 19,34 & 15,48 & 14,57 & 13,44 & 12,39 & 11,39 & 9,58 & 8,05 & 5,76 \\
\hline 65 & 2000 & 80 & 19,17 & 15,35 & 14,46 & 13,36 & 12,32 & 11,34 & 9,55 & 8,04 & 5,76 \\
\hline 65 & 200 & 85 & 56,61 & 32,93 & 25,38 & 19,66 & 15,96 & 13,22 & 9,46 & 7,24 & 4,90 \\
\hline 65 & 250 & 85 & 49,33 & 30,28 & 24,03 & 19,10 & 15,75 & 13,18 & 9,55 & 7,33 & 4,92 \\
\hline 65 & 300 & 85 & 44,30 & 28,34 & 22,98 & 18,62 & 15,54 & 13,12 & 9,62 & 7,40 & 4,95 \\
\hline 65 & 350 & 85 & 40,58 & 26,83 & 22,13 & 18,19 & 15,34 & 13,05 & 9,66 & 7,46 & 4,97 \\
\hline 65 & 400 & 85 & 37,70 & 25,60 & 21,41 & 17,81 & 15,14 & 12,97 & 9,69 & 7,50 & 5,00 \\
\hline 65 & 450 & 85 & 35,39 & 24,58 & 20,79 & 17,47 & 14,96 & 12,88 & 9,70 & 7,54 & 5,03 \\
\hline 65 & 500 & 85 & 33,50 & 23,70 & 20,25 & 17,16 & 14,78 & 12,80 & 9,71 & 7,58 & 5,05 \\
\hline 65 & 550 & 85 & 31,91 & 22,94 & 19,76 & 16,87 & 14,62 & 12,71 & 9,71 & 7,61 & 5,08 \\
\hline 65 & 600 & 85 & 30,56 & 22,27 & 19,33 & 16,61 & 14,46 & 12,62 & 9,70 & 7,63 & 5,10 \\
\hline 65 & 650 & 85 & 29,39 & 21,67 & 18,93 & 16,36 & 14,30 & 12,53 & 9,69 & 7,65 & 5,12 \\
\hline 65 & 700 & 85 & 28,37 & 21,13 & 18,57 & 16,13 & 14,16 & 12,45 & 9,68 & 7,67 & 5,14 \\
\hline 65 & 750 & 85 & 27,46 & 20,64 & 18,23 & 15,91 & 14,02 & 12,36 & 9,66 & 7,68 & 5,16 \\
\hline 65 & 800 & 85 & 26,66 & 20,19 & 17,93 & 15,71 & 13,88 & 12,28 & 9,64 & 7,69 & 5,18 \\
\hline 65 & 850 & 85 & 25,94 & 19,78 & 17,64 & 15,51 & 13,75 & 12,20 & 9,62 & 7,70 & 5,20 \\
\hline 65 & 900 & 85 & 25,29 & 19,40 & 17,37 & 15,33 & 13,63 & 12,12 & 9,60 & 7,70 & 5,22 \\
\hline 65 & 950 & 85 & 24,69 & 19,04 & 17,12 & 15,16 & 13,51 & 12,05 & 9,58 & 7,71 & 5,23 \\
\hline 65 & 1000 & 85 & 24,15 & 18,71 & 16,88 & 14,99 & 13,40 & 11,97 & 9,56 & 7,71 & 5,25 \\
\hline 65 & 1050 & 85 & 23,66 & 18,40 & 16,66 & 14,84 & 13,29 & 11,90 & 9,53 & 7,71 & 5,26 \\
\hline 65 & 1100 & 85 & 23,20 & 18,11 & 16,44 & 14,69 & 13,18 & 11,83 & 9,51 & 7,71 & 5,28 \\
\hline 65 & 1150 & 85 & 22,78 & 17,84 & 16,24 & 14,54 & 13,08 & 11,76 & 9,48 & 7,71 & 5,29 \\
\hline 65 & 1200 & 85 & 22,38 & 17,58 & 16,05 & 14,41 & 12,98 & 11,69 & 9,46 & 7,70 & 5,30 \\
\hline 65 & 1250 & 85 & 22,02 & 17,33 & 15,87 & 14,27 & 12,89 & 11,62 & 9,43 & 7,70 & 5,31 \\
\hline 65 & 1300 & 85 & 21,67 & 17,10 & 15,70 & 14,15 & 12,79 & 11,56 & 9,41 & 7,70 & 5,32 \\
\hline 65 & 1350 & 85 & 21,35 & 16,88 & 15,53 & 14,03 & 12,71 & 11,49 & 9,38 & 7,69 & 5,33 \\
\hline 65 & 1400 & 85 & 21,05 & 16,67 & 15,37 & 13,91 & 12,62 & 11,43 & 9,35 & 7,69 & 5,34 \\
\hline 65 & 1450 & 85 & 20,76 & 16,47 & 15,22 & 13,79 & 12,53 & 11,37 & 9,33 & 7,68 & 5,35 \\
\hline 65 & 1500 & 85 & 20,50 & 16,28 & 15,07 & 13,69 & 12,45 & 11,31 & 9,30 & 7,67 & 5,36 \\
\hline 65 & 1550 & 85 & 20,24 & 16,10 & 14,93 & 13,58 & 12,37 & 11,25 & 9,28 & 7,67 & 5,37 \\
\hline 65 & 1600 & 85 & 20,00 & 15,92 & 14,79 & 13,48 & 12,30 & 11,20 & 9,25 & 7,66 & 5,37 \\
\hline 65 & 1650 & 85 & 19,77 & 15,76 & 14,66 & 13,38 & 12,22 & 11,14 & 9,22 & 7,65 & 5,38 \\
\hline 65 & 1700 & 85 & 19,55 & 15,60 & 14,54 & 13,28 & 12,15 & 11,09 & 9,20 & 7,64 & 5,39 \\
\hline 65 & 1750 & 85 & 19,35 & 15,44 & 14,41 & 13,19 & 12,08 & 11,04 & 9,17 & 7,63 & 5,39 \\
\hline 65 & 1800 & 85 & 19,15 & 15,29 & 14,29 & 13,10 & 12,01 & 10,98 & 9,15 & 7,63 & 5,40 \\
\hline 65 & 1850 & 85 & 18,96 & 15,15 & 14,18 & 13,01 & 11,94 & 10,93 & 9,12 & 7,62 & 5,40 \\
\hline 65 & 1900 & 85 & 18,77 & 15,01 & 14,07 & 12,93 & 11,87 & 10,88 & 9,10 & 7,61 & 5,41 \\
\hline 65 & 1950 & 85 & 18,60 & 14,88 & 13,96 & 12,85 & 11,81 & 10,84 & 9,07 & 7,60 & 5,41 \\
\hline 65 & 2000 & 85 & 18,43 & 14,75 & 13,86 & 12,77 & 11,75 & 10,79 & 9,05 & 7,59 & 5,42 \\
\hline 65 & 200 & 90 & 55,45 & 31,79 & 24,31 & 18,70 & 15,11 & 12,48 & 8,91 & 6,82 & 4,62 \\
\hline 65 & 250 & 90 & 48,24 & 29,21 & 23,01 & 18,18 & 14,93 & 12,46 & 9,00 & 6,90 & 4,64 \\
\hline 65 & 300 & 90 & 43,25 & 27,32 & 22,01 & 17,73 & 14,74 & 12,41 & 9,07 & 6,96 & 4,66 \\
\hline 65 & 350 & 90 & 39,58 & 25,85 & 21,20 & 17,33 & 14,56 & 12,35 & 9,11 & 7,02 & 4,69 \\
\hline 65 & 400 & 90 & 36,73 & 24,67 & 20,51 & 16,98 & 14,38 & 12,28 & 9,14 & 7,07 & 4,71 \\
\hline 65 & 450 & 90 & 34,46 & 23,68 & 19,92 & 16,66 & 14,22 & 12,21 & 9,16 & 7,11 & 4,73 \\
\hline 65 & 500 & 90 & 32,59 & 22,83 & 19,40 & 16,37 & 14,05 & 12,13 & 9,17 & 7,14 & 4,76 \\
\hline 65 & 550 & 90 & 31,02 & 22,10 & 18,94 & 16,10 & 13,90 & 12,05 & 9,17 & 7,17 & 4,78 \\
\hline 65 & 600 & 90 & 29,69 & 21,45 & 18,52 & 15,85 & 13,75 & 11,97 & 9,17 & 7,19 & 4,80 \\
\hline 65 & 650 & 90 & 28,54 & 20,87 & 18,15 & 15,62 & 13,61 & 11,90 & 9,16 & 7,21 & 4,82 \\
\hline 65 & 700 & 90 & 27,53 & 20,35 & 17,80 & 15,40 & 13,48 & 11,82 & 9,15 & 7,23 & 4,84 \\
\hline 65 & 750 & 90 & 26,64 & 19,88 & 17,48 & 15,20 & 13,35 & 11,74 & 9,14 & 7,24 & 4,86 \\
\hline 65 & 800 & 90 & 25,85 & 19,44 & 17,19 & 15,00 & 13,22 & 11,67 & 9,12 & 7,25 & 4,88 \\
\hline 65 & 850 & 90 & 25,14 & 19,05 & 16,91 & 14,82 & 13,11 & 11,59 & 9,11 & 7,26 & 4,90 \\
\hline 65 & 900 & 90 & 24,50 & 18,68 & 16,66 & 14,65 & 12,99 & 11,52 & 9,09 & 7,27 & 4,91 \\
\hline 65 & 950 & 90 & 23,91 & 18,34 & 16,42 & 14,49 & 12,88 & 11,45 & 9,07 & 7,27 & 4,93 \\
\hline 65 & 1000 & 90 & 23,38 & 18,02 & 16,19 & 14,33 & 12,77 & 11,38 & 9,05 & 7,28 & 4,94 \\
\hline 65 & 1050 & 90 & 22,89 & 17,72 & 15,98 & 14,19 & 12,67 & 11,32 & 9,03 & 7,28 & 4,95 \\
\hline 65 & 1100 & 90 & 22,44 & 17,44 & 15,78 & 14,04 & 12,57 & 11,25 & 9,01 & 7,28 & 4,97 \\
\hline 65 & 1150 & 90 & 22,03 & 17,18 & 15,58 & 13,91 & 12,48 & 11,19 & 8,99 & 7,28 & 4,98 \\
\hline 65 & 1200 & 90 & 21,64 & 16,93 & 15,40 & 13,78 & 12,39 & 11,12 & 8,96 & 7,28 & 4,99 \\
\hline 65 & 1250 & 90 & 21,28 & 16,70 & 15,23 & 13,65 & 12,30 & 11,06 & 8,94 & 7,28 & 5,00 \\
\hline 65 & 1300 & 90 & 20,94 & 16,47 & 15,06 & 13,54 & 12,21 & 11,00 & 8,92 & 7,27 & 5,01 \\
\hline 65 & 1350 & 90 & 20,63 & 16,26 & 14,90 & 13,42 & 12,13 & 10,95 & 8,90 & 7,27 & 5,02 \\
\hline 65 & 1400 & 90 & 20,33 & 16,06 & 14,75 & 13,31 & 12,05 & 10,89 & 8,87 & 7,27 & 5,03 \\
\hline 65 & 1450 & 90 & 20,05 & 15,87 & 14,61 & 13,20 & 11,97 & 10,83 & 8,85 & 7,26 & 5,04 \\
\hline 65 & 1500 & 90 & 19,79 & 15,68 & 14,47 & 13,10 & 11,89 & 10,78 & 8,83 & 7,26 & 5,05 \\
\hline 65 & 1550 & 90 & 19,54 & 15,51 & 14,33 & 13,00 & 11,82 & 10,72 & 8,80 & 7,25 & 5,05 \\
\hline 65 & 1600 & 90 & 19,30 & 15,34 & 14,20 & 12,90 & 11,74 & 10,67 & 8,78 & 7,25 & 5,06 \\
\hline 65 & 1650 & 90 & 19,08 & 15,18 & 14,08 & 12,81 & 11,67 & 10,62 & 8,76 & 7,24 & 5,07 \\
\hline 65 & 1700 & 90 & 18,86 & 15,02 & 13,96 & 12,72 & 11,61 & 10,57 & 8,73 & 7,23 & 5,07 \\
\hline 65 & 1750 & 90 & 18,66 & 14,87 & 13,84 & 12,63 & 11,54 & 10,52 & 8,71 & 7,23 & 5,08 \\
\hline 65 & 1800 & 90 & 18,47 & 14,73 & 13,73 & 12,55 & 11,47 & 10,47 & 8,69 & 7,22 & 5,09 \\
\hline 65 & 1850 & 90 & 18,28 & 14,59 & 13,62 & 12,46 & 11,41 & 10,43 & 8,67 & 7,21 & 5,09 \\
\hline 65 & 1900 & 90 & 18,10 & 14,46 & 13,51 & 12,38 & 11,35 & 10,38 & 8,64 & 7,20 & 5,10 \\
\hline 65 & 1950 & 90 & 17,93 & 14,33 & 13,41 & 12,30 & 11,29 & 10,33 & 8,62 & 7,20 & 5,10 \\
\hline 65 & 2000 & 90 & 17,77 & 14,21 & 13,31 & 12,23 & 11,23 & 10,29 & 8,60 & 7,19 & 5,11 \\
\hline 65 & 200 & 95 & 54,39 & 30,77 & 23,34 & 17,84 & 14,36 & 11,83 & 8,42 & 6,44 & 4,38 \\
\hline 65 & 250 & 95 & 47,24 & 28,24 & 22,09 & 17,34 & 14,19 & 11,81 & 8,51 & 6,52 & 4,39 \\
\hline 65 & 300 & 95 & 42,31 & 26,39 & 21,13 & 16,92 & 14,02 & 11,78 & 8,57 & 6,58 & 4,41 \\
\hline
\end{tabular}




\begin{tabular}{|c|c|c|c|c|c|c|c|c|c|c|c|}
\hline \multirow[b]{2}{*}{$\mathrm{H}(\mathrm{cm})$} & \multirow[b]{2}{*}{ Mceq (MPa) } & & & & & De & ões (x1 & & & & \\
\hline & & Msub (MPa) & D0 & D25 & D40 & D60 & D80 & D100 & D140 & D180 & D260 \\
\hline 65 & 350 & 95 & 38,67 & 24,97 & 20,35 & 16,55 & 13,86 & 11,73 & 8,62 & 6,63 & 4,43 \\
\hline 65 & 400 & 95 & 35,86 & 23,82 & 19,69 & 16,22 & 13,70 & 11,66 & 8,65 & 6,68 & 4,45 \\
\hline 65 & 450 & 95 & 33,61 & 22,86 & 19,13 & 15,92 & 13,54 & 11,60 & 8,67 & 6,72 & 4,48 \\
\hline 65 & 500 & 95 & 31,76 & 22,04 & 18,63 & 15,65 & 13,39 & 11,53 & 8,68 & 6,75 & 4,50 \\
\hline 65 & 550 & 95 & 30,22 & 21,32 & 18,19 & 15,40 & 13,25 & 11,46 & 8,68 & 6,78 & 4,52 \\
\hline 65 & 600 & 95 & 28,90 & 20,70 & 17,79 & 15,16 & 13,12 & 11,39 & 8,69 & 6,80 & 4,54 \\
\hline 65 & 650 & 95 & 27,77 & 20,14 & 17,43 & 14,94 & 12,99 & 11,32 & 8,68 & 6,82 & 4,56 \\
\hline 65 & 700 & 95 & 26,77 & 19,64 & 17,10 & 14,74 & 12,86 & 11,25 & 8,68 & 6,84 & 4,57 \\
\hline 65 & 750 & 95 & 25,90 & 19,18 & 16,80 & 14,55 & 12,74 & 11,18 & 8,67 & 6,85 & 4,59 \\
\hline 65 & 800 & 95 & 25,11 & 18,76 & 16,52 & 14,37 & 12,63 & 11,11 & 8,66 & 6,86 & 4,61 \\
\hline 65 & 850 & 95 & 24,41 & 18,38 & 16,26 & 14,20 & 12,52 & 11,05 & 8,64 & 6,87 & 4,62 \\
\hline 65 & 900 & 95 & 23,78 & 18,03 & 16,01 & 14,03 & 12,41 & 10,98 & 8,63 & 6,88 & 4,64 \\
\hline 65 & 950 & 95 & 23,21 & 17,70 & 15,78 & 13,88 & 12,31 & 10,92 & 8,61 & 6,89 & 4,65 \\
\hline 65 & 1000 & 95 & 22,68 & 17,39 & 15,57 & 13,73 & 12,21 & 10,85 & 8,59 & 6,89 & 4,67 \\
\hline 65 & 1050 & 95 & 22,20 & 17,10 & 15,36 & 13,59 & 12,11 & 10,79 & 8,58 & 6,89 & 4,68 \\
\hline 65 & 1100 & 95 & 21,76 & 16,83 & 15,17 & 13,46 & 12,02 & 10,73 & 8,56 & 6,90 & 4,69 \\
\hline 65 & 1150 & 95 & 21,35 & 16,58 & 14,99 & 13,33 & 11,93 & 10,67 & 8,54 & 6,90 & 4,70 \\
\hline 65 & 1200 & 95 & 20,97 & 16,34 & 14,81 & 13,21 & 11,85 & 10,61 & 8,52 & 6,90 & 4,71 \\
\hline 65 & 1250 & 95 & 20,61 & 16,11 & 14,65 & 13,09 & 11,76 & 10,56 & 8,50 & 6,90 & 4,73 \\
\hline 65 & 1300 & 95 & 20,28 & 15,90 & 14,49 & 12,98 & 11,68 & 10,50 & 8,48 & 6,90 & 4,73 \\
\hline 65 & 1350 & 95 & 19,97 & 15,69 & 14,34 & 12,87 & 11,60 & 10,45 & 8,46 & 6,89 & 4,74 \\
\hline 65 & 1400 & 95 & 19,68 & 15,50 & 14,19 & 12,76 & 11,53 & 10,40 & 8,44 & 6,89 & 4,75 \\
\hline 65 & 1450 & 95 & 19,41 & 15,31 & 14,05 & 12,66 & 11,45 & 10,34 & 8,42 & 6,89 & 4,76 \\
\hline 65 & 1500 & 95 & 19,15 & 15,14 & 13,92 & 12,57 & 11,38 & 10,29 & 8,40 & 6,88 & 4,77 \\
\hline 65 & 1550 & 95 & 18,90 & 14,97 & 13,79 & 12,47 & 11,31 & 10,24 & 8,38 & 6,88 & 4,78 \\
\hline 65 & 1600 & 95 & 18,67 & 14,80 & 13,66 & 12,38 & 11,24 & 10,19 & 8,36 & 6,87 & 4,78 \\
\hline 65 & 1650 & 95 & 18,45 & 14,65 & 13,55 & 12,29 & 11,18 & 10,15 & 8,33 & 6,87 & 4,79 \\
\hline 65 & 1700 & 95 & 18,24 & 14,50 & 13,43 & 12,20 & 11,11 & 10,10 & 8,31 & 6,86 & 4,80 \\
\hline 65 & 1750 & 95 & 18,04 & 14,35 & 13,32 & 12,12 & 11,05 & 10,05 & 8,29 & 6,86 & 4,80 \\
\hline 65 & 1800 & 95 & 17,85 & 14,22 & 13,21 & 12,04 & 10,99 & 10,01 & 8,27 & 6,85 & 4,81 \\
\hline 65 & 1850 & 95 & 17,67 & 14,08 & 13,11 & 11,96 & 10,93 & 9,96 & 8,25 & 6,85 & 4,81 \\
\hline 65 & 1900 & 95 & 17,49 & 13,95 & 13,01 & 11,89 & 10,87 & 9,92 & 8,23 & 6,84 & 4,82 \\
\hline 65 & 1950 & 95 & 17,33 & 13,83 & 12,91 & 11,81 & 10,81 & 9,88 & 8,21 & 6,83 & 4,82 \\
\hline 65 & 2000 & 95 & 17,17 & 13,71 & 12,81 & 11,74 & 10,76 & 9,84 & 8,19 & 6,82 & 4,83 \\
\hline 65 & 200 & 100 & 53,42 & 29,83 & 22,46 & 17,05 & 13,67 & 11,23 & 7,98 & 6,10 & 4,15 \\
\hline 65 & 250 & 100 & 46,33 & 27,35 & 21,25 & 16,59 & 13,52 & 11,23 & 8,06 & 6,17 & 4,17 \\
\hline 65 & 300 & 100 & 41,44 & 25,55 & 20,33 & 16,19 & 13,37 & 11,20 & 8,13 & 6,23 & 4,18 \\
\hline 65 & 350 & 100 & 37,84 & 24,16 & 19,58 & 15,84 & 13,22 & 11,16 & 8,17 & 6,28 & 4,20 \\
\hline 65 & 400 & 100 & 35,06 & 23,04 & 18,95 & 15,53 & 13,07 & 11,11 & 8,20 & 6,33 & 4,22 \\
\hline 65 & 450 & 100 & 32,83 & 22,10 & 18,40 & 15,25 & 12,93 & 11,05 & 8,23 & 6,36 & 4,24 \\
\hline 65 & 500 & 100 & 31,01 & 21,31 & 17,93 & 14,99 & 12,79 & 10,99 & 8,24 & 6,40 & 4,26 \\
\hline 65 & 550 & 100 & 29,48 & 20,62 & 17,51 & 14,76 & 12,66 & 10,92 & 8,25 & 6,42 & 4,28 \\
\hline 65 & 600 & 100 & 28,18 & 20,01 & 17,13 & 14,54 & 12,54 & 10,86 & 8,25 & 6,45 & 4,30 \\
\hline 65 & 650 & 100 & 27,06 & 19,47 & 16,78 & 14,33 & 12,42 & 10,80 & 8,25 & 6,47 & 4,32 \\
\hline 65 & 700 & 100 & 26,08 & 18,98 & 16,46 & 14,14 & 12,30 & 10,73 & 8,25 & 6,48 & 4,33 \\
\hline 65 & 750 & 100 & 25,22 & 18,54 & 16,17 & 13,96 & 12,19 & 10,67 & 8,24 & 6,50 & 4,35 \\
\hline 65 & 800 & 100 & 24,45 & 18,14 & 15,90 & 13,79 & 12,08 & 10,61 & 8,23 & 6,51 & 4,37 \\
\hline 65 & 850 & 100 & 23,75 & 17,77 & 15,65 & 13,62 & 11,98 & 10,55 & 8,22 & 6,52 & 4,38 \\
\hline 65 & 900 & 100 & 23,13 & 17,43 & 15,42 & 13,47 & 11,88 & 10,49 & 8,21 & 6,53 & 4,39 \\
\hline 65 & 950 & 100 & 22,56 & 17,11 & 15,20 & 13,33 & 11,78 & 10,43 & 8,20 & 6,54 & 4,41 \\
\hline 65 & 1000 & 100 & 22,05 & 16,81 & 14,99 & 13,19 & 11,69 & 10,37 & 8,18 & 6,54 & 4,42 \\
\hline 65 & 1050 & 100 & 21,57 & 16,53 & 14,80 & 13,05 & 11,60 & 10,31 & 8,17 & 6,55 & 4,43 \\
\hline 65 & 1100 & 100 & 21,14 & 16,27 & 14,61 & 12,93 & 11,52 & 10,26 & 8,15 & 6,55 & 4,44 \\
\hline 65 & 1150 & 100 & 20,73 & 16,03 & 14,44 & 12,81 & 11,43 & 10,20 & 8,13 & 6,55 & 4,46 \\
\hline 65 & 1200 & 100 & 20,36 & 15,80 & 14,27 & 12,69 & 11,35 & 10,15 & 8,12 & 6,55 & 4,47 \\
\hline 65 & 1250 & 100 & 20,01 & 15,58 & 14,11 & 12,58 & 11,27 & 10,10 & 8,10 & 6,55 & 4,48 \\
\hline 65 & 1300 & 100 & 19,68 & 15,37 & 13,96 & 12,47 & 11,20 & 10,05 & 8,08 & 6,55 & 4,49 \\
\hline 65 & 1350 & 100 & 19,38 & 15,17 & 13,81 & 12,37 & 11,12 & 10,00 & 8,06 & 6,55 & 4,49 \\
\hline 65 & 1400 & 100 & 19,09 & 14,98 & 13,68 & 12,27 & 11,05 & 9,95 & 8,04 & 6,55 & 4,50 \\
\hline 65 & 1450 & 100 & 18,82 & 14,81 & 13,54 & 12,17 & 10,98 & 9,90 & 8,03 & 6,55 & 4,51 \\
\hline 65 & 1500 & 100 & 18,57 & 14,63 & 13,41 & 12,08 & 10,91 & 9,85 & 8,01 & 6,54 & 4,52 \\
\hline 65 & 1550 & 100 & 18,32 & 14,47 & 13,29 & 11,99 & 10,85 & 9,80 & 7,99 & 6,54 & 4,53 \\
\hline 65 & 1600 & 100 & 18,10 & 14,31 & 13,17 & 11,90 & 10,78 & 9,76 & 7,97 & 6,54 & 4,53 \\
\hline 65 & 1650 & 100 & 17,88 & 14,16 & 13,06 & 11,82 & 10,72 & 9,71 & 7,95 & 6,53 & 4,54 \\
\hline 65 & 1700 & 100 & 17,67 & 14,02 & 12,95 & 11,73 & 10,66 & 9,67 & 7,93 & 6,53 & 4,55 \\
\hline 65 & 1750 & 100 & 17,48 & 13,88 & 12,84 & 11,66 & 10,60 & 9,63 & 7,91 & 6,52 & 4,55 \\
\hline 65 & 1800 & 100 & 17,29 & 13,75 & 12,74 & 11,58 & 10,54 & 9,59 & 7,89 & 6,52 & 4,56 \\
\hline 65 & 1850 & 100 & 17,11 & 13,62 & 12,64 & 11,50 & 10,49 & 9,54 & 7,88 & 6,51 & 4,56 \\
\hline 65 & 1900 & 100 & 16,94 & 13,49 & 12,54 & 11,43 & 10,43 & 9,50 & 7,86 & 6,51 & 4,57 \\
\hline 65 & 1950 & 100 & 16,78 & 13,37 & 12,45 & 11,36 & 10,38 & 9,46 & 7,84 & 6,50 & 4,57 \\
\hline 65 & 2000 & 100 & 16,62 & 13,26 & 12,36 & 11,29 & 10,33 & 9,43 & 7,82 & 6,50 & 4,58 \\
\hline 65 & 200 & 105 & 52,53 & 28,97 & 21,65 & 16,33 & 13,04 & 10,69 & 7,58 & 5,80 & 3,95 \\
\hline 65 & 250 & 105 & 45,49 & 26,54 & 20,48 & 15,89 & 12,91 & 10,70 & 7,66 & 5,86 & 3,97 \\
\hline 65 & 300 & 105 & 40,64 & 24,77 & 19,59 & 15,52 & 12,77 & 10,68 & 7,73 & 5,92 & 3,98 \\
\hline 65 & 350 & 105 & 37,07 & 23,42 & 18,87 & 15,20 & 12,64 & 10,64 & 7,77 & 5,97 & 4,00 \\
\hline 65 & 400 & 105 & 34,32 & 22,32 & 18,26 & 14,90 & 12,50 & 10,60 & 7,80 & 6,01 & 4,01 \\
\hline 65 & 450 & 105 & 32,12 & 21,41 & 17,74 & 14,64 & 12,37 & 10,55 & 7,83 & 6,05 & 4,03 \\
\hline 65 & 500 & 105 & 30,32 & 20,64 & 17,28 & 14,39 & 12,25 & 10,49 & 7,84 & 6,08 & 4,05 \\
\hline 65 & 550 & 105 & 28,81 & 19,97 & 16,88 & 14,17 & 12,12 & 10,44 & 7,85 & 6,10 & 4,07 \\
\hline 65 & 600 & 105 & 27,53 & 19,38 & 16,51 & 13,96 & 12,01 & 10,38 & 7,86 & 6,13 & 4,08 \\
\hline 65 & 650 & 105 & 26,42 & 18,86 & 16,18 & 13,77 & 11,90 & 10,32 & 7,86 & 6,15 & 4,10 \\
\hline
\end{tabular}




\begin{tabular}{|c|c|c|c|c|c|c|c|c|c|c|c|}
\hline \multirow[b]{2}{*}{$\mathrm{H}(\mathrm{cm})$} & \multirow[b]{2}{*}{ Mceq (MPa) } & & & & & De & ões (x1 & & & & \\
\hline & & Msub (MPa) & D0 & D25 & D40 & D60 & D80 & D100 & D140 & D180 & D260 \\
\hline 65 & 700 & 105 & 25,45 & 18,38 & 15,88 & 13,59 & 11,79 & 10,26 & 7,86 & 6,16 & 4,12 \\
\hline 65 & 750 & 105 & 24,59 & 17,96 & 15,60 & 13,41 & 11,68 & 10,21 & 7,85 & 6,18 & 4,13 \\
\hline 65 & 800 & 105 & 23,83 & 17,57 & 15,34 & 13,25 & 11,58 & 10,15 & 7,85 & 6,19 & 4,15 \\
\hline 65 & 850 & 105 & 23,15 & 17,21 & 15,10 & 13,10 & 11,49 & 10,09 & 7,84 & 6,20 & 4,16 \\
\hline 65 & 900 & 105 & 22,54 & 16,87 & 14,87 & 12,95 & 11,40 & 10,04 & 7,83 & 6,21 & 4,17 \\
\hline 65 & 950 & 105 & 21,98 & 16,57 & 14,66 & 12,82 & 11,31 & 9,98 & 7,82 & 6,22 & 4,19 \\
\hline 65 & 1000 & 105 & 21,47 & 16,28 & 14,47 & 12,68 & 11,22 & 9,93 & 7,80 & 6,23 & 4,20 \\
\hline 65 & 1050 & 105 & 21,00 & 16,01 & 14,28 & 12,56 & 11,13 & 9,88 & 7,79 & 6,23 & 4,21 \\
\hline 65 & 1100 & 105 & 20,57 & 15,76 & 14,10 & 12,44 & 11,05 & 9,83 & 7,78 & 6,23 & 4,22 \\
\hline 65 & 1150 & 105 & 20,17 & 15,52 & 13,93 & 12,32 & 10,98 & 9,77 & 7,76 & 6,24 & 4,23 \\
\hline 65 & 1200 & 105 & 19,80 & 15,30 & 13,77 & 12,21 & 10,90 & 9,72 & 7,75 & 6,24 & 4,24 \\
\hline 65 & 1250 & 105 & 19,45 & 15,09 & 13,62 & 12,11 & 10,83 & 9,68 & 7,73 & 6,24 & 4,25 \\
\hline 65 & 1300 & 105 & 19,13 & 14,88 & 13,47 & 12,00 & 10,75 & 9,63 & 7,72 & 6,24 & 4,26 \\
\hline 65 & 1350 & 105 & 18,83 & 14,69 & 13,34 & 11,91 & 10,68 & 9,58 & 7,70 & 6,24 & 4,27 \\
\hline 65 & 1400 & 105 & 18,55 & 14,51 & 13,20 & 11,81 & 10,62 & 9,54 & 7,68 & 6,24 & 4,28 \\
\hline 65 & 1450 & 105 & 18,28 & 14,34 & 13,07 & 11,72 & 10,55 & 9,49 & 7,67 & 6,24 & 4,29 \\
\hline 65 & 1500 & 105 & 18,03 & 14,17 & 12,95 & 11,63 & 10,49 & 9,45 & 7,65 & 6,24 & 4,29 \\
\hline 65 & 1550 & 105 & 17,79 & 14,01 & 12,83 & 11,54 & 10,43 & 9,40 & 7,63 & 6,23 & 4,30 \\
\hline 65 & 1600 & 105 & 17,57 & 13,86 & 12,72 & 11,46 & 10,36 & 9,36 & 7,62 & 6,23 & 4,31 \\
\hline 65 & 1650 & 105 & 17,36 & 13,72 & 12,61 & 11,38 & 10,31 & 9,32 & 7,60 & 6,23 & 4,31 \\
\hline 65 & 1700 & 105 & 17,15 & 13,58 & 12,50 & 11,30 & 10,25 & 9,28 & 7,58 & 6,22 & 4,32 \\
\hline 65 & 1750 & 105 & 16,96 & 13,44 & 12,40 & 11,23 & 10,19 & 9,24 & 7,57 & 6,22 & 4,33 \\
\hline 65 & 1800 & 105 & 16,78 & 13,31 & 12,30 & 11,15 & 10,14 & 9,20 & 7,55 & 6,22 & 4,33 \\
\hline 65 & 1850 & 105 & 16,60 & 13,19 & 12,21 & 11,08 & 10,08 & 9,16 & 7,53 & 6,21 & 4,34 \\
\hline 65 & 1900 & 105 & 16,43 & 13,07 & 12,11 & 11,01 & 10,03 & 9,12 & 7,51 & 6,21 & 4,34 \\
\hline 65 & 1950 & 105 & 16,27 & 12,95 & 12,02 & 10,95 & 9,98 & 9,08 & 7,50 & 6,20 & 4,35 \\
\hline 65 & 2000 & 105 & 16,12 & 12,84 & 11,93 & 10,88 & 9,93 & 9,05 & 7,48 & 6,20 & 4,35 \\
\hline 65 & 200 & 110 & 51,71 & 28,18 & 20,91 & 15,67 & 12,47 & 10,20 & 7,21 & 5,52 & 3,77 \\
\hline 65 & 250 & 110 & 44,72 & 25,79 & 19,78 & 15,26 & 12,35 & 10,21 & 7,30 & 5,58 & 3,78 \\
\hline 65 & 300 & 110 & 39,91 & 24,06 & 18,91 & 14,91 & 12,23 & 10,20 & 7,36 & 5,64 & 3,80 \\
\hline 65 & 350 & 110 & 36,37 & 22,73 & 18,22 & 14,60 & 12,10 & 10,17 & 7,40 & 5,68 & 3,81 \\
\hline 65 & 400 & 110 & 33,65 & 21,66 & 17,63 & 14,32 & 11,98 & 10,13 & 7,44 & 5,72 & 3,83 \\
\hline 65 & 450 & 110 & 31,47 & 20,78 & 17,13 & 14,07 & 11,86 & 10,09 & 7,46 & 5,76 & 3,84 \\
\hline 65 & 500 & 110 & 29,68 & 20,02 & 16,69 & 13,84 & 11,74 & 10,04 & 7,48 & 5,79 & 3,86 \\
\hline 65 & 550 & 110 & 28,19 & 19,37 & 16,30 & 13,63 & 11,63 & 9,99 & 7,49 & 5,81 & 3,87 \\
\hline 65 & 600 & 110 & 26,92 & 18,80 & 15,95 & 13,43 & 11,52 & 9,94 & 7,50 & 5,84 & 3,89 \\
\hline 65 & 650 & 110 & 25,82 & 18,29 & 15,63 & 13,25 & 11,42 & 9,88 & 7,50 & 5,86 & 3,90 \\
\hline 65 & 700 & 110 & 24,87 & 17,83 & 15,34 & 13,08 & 11,32 & 9,83 & 7,50 & 5,87 & 3,92 \\
\hline 65 & 750 & 110 & 24,02 & 17,41 & 15,07 & 12,91 & 11,22 & 9,78 & 7,50 & 5,89 & 3,93 \\
\hline 65 & 800 & 110 & 23,27 & 17,03 & 14,82 & 12,76 & 11,13 & 9,73 & 7,49 & 5,90 & 3,95 \\
\hline 65 & 850 & 110 & 22,60 & 16,69 & 14,59 & 12,62 & 11,04 & 9,68 & 7,49 & 5,91 & 3,96 \\
\hline 65 & 900 & 110 & 21,99 & 16,36 & 14,37 & 12,48 & 10,95 & 9,62 & 7,48 & 5,92 & 3,97 \\
\hline 65 & 950 & 110 & 21,44 & 16,07 & 14,17 & 12,35 & 10,87 & 9,57 & 7,47 & 5,93 & 3,99 \\
\hline 65 & 1000 & 110 & 20,93 & 15,79 & 13,98 & 12,22 & 10,78 & 9,52 & 7,46 & 5,94 & 4,00 \\
\hline 65 & 1050 & 110 & 20,47 & 15,53 & 13,80 & 12,10 & 10,71 & 9,48 & 7,45 & 5,94 & 4,01 \\
\hline 65 & 1100 & 110 & 20,04 & 15,28 & 13,63 & 11,99 & 10,63 & 9,43 & 7,44 & 5,95 & 4,02 \\
\hline 65 & 1150 & 110 & 19,65 & 15,05 & 13,47 & 11,88 & 10,55 & 9,38 & 7,42 & 5,95 & 4,03 \\
\hline 65 & 1200 & 110 & 19,28 & 14,84 & 13,31 & 11,77 & 10,48 & 9,33 & 7,41 & 5,95 & 4,04 \\
\hline 65 & 1250 & 110 & 18,95 & 14,63 & 13,17 & 11,67 & 10,41 & 9,29 & 7,40 & 5,96 & 4,05 \\
\hline 65 & 1300 & 110 & 18,63 & 14,44 & 13,03 & 11,57 & 10,35 & 9,24 & 7,38 & 5,96 & 4,06 \\
\hline 65 & 1350 & 110 & 18,33 & 14,25 & 12,89 & 11,48 & 10,28 & 9,20 & 7,37 & 5,96 & 4,07 \\
\hline 65 & 1400 & 110 & 18,05 & 14,07 & 12,76 & 11,39 & 10,22 & 9,16 & 7,35 & 5,96 & 4,07 \\
\hline 65 & 1450 & 110 & 17,79 & 13,91 & 12,64 & 11,30 & 10,15 & 9,12 & 7,34 & 5,96 & 4,08 \\
\hline 65 & 1500 & 110 & 17,54 & 13,75 & 12,52 & 11,22 & 10,09 & 9,07 & 7,32 & 5,96 & 4,09 \\
\hline 65 & 1550 & 110 & 17,31 & 13,59 & 12,41 & 11,14 & 10,04 & 9,03 & 7,31 & 5,95 & 4,10 \\
\hline 65 & 1600 & 110 & 17,09 & 13,45 & 12,30 & 11,06 & 9,98 & 8,99 & 7,29 & 5,95 & 4,10 \\
\hline 65 & 1650 & 110 & 16,88 & 13,30 & 12,19 & 10,98 & 9,92 & 8,96 & 7,28 & 5,95 & 4,11 \\
\hline 65 & 1700 & 110 & 16,68 & 13,17 & 12,09 & 10,91 & 9,87 & 8,92 & 7,26 & 5,95 & 4,11 \\
\hline 65 & 1750 & 110 & 16,49 & 13,04 & 11,99 & 10,83 & 9,81 & 8,88 & 7,25 & 5,94 & 4,12 \\
\hline 65 & 1800 & 110 & 16,31 & 12,91 & 11,90 & 10,76 & 9,76 & 8,84 & 7,23 & 5,94 & 4,13 \\
\hline 65 & 1850 & 110 & 16,13 & 12,79 & 11,81 & 10,69 & 9,71 & 8,81 & 7,22 & 5,94 & 4,13 \\
\hline 65 & 1900 & 110 & 15,97 & 12,67 & 11,72 & 10,63 & 9,66 & 8,77 & 7,20 & 5,93 & 4,14 \\
\hline 65 & 1950 & 110 & 15,81 & 12,56 & 11,63 & 10,56 & 9,61 & 8,74 & 7,19 & 5,93 & 4,14 \\
\hline 65 & 2000 & 110 & 15,66 & 12,45 & 11,55 & 10,50 & 9,57 & 8,70 & 7,17 & 5,92 & 4,15 \\
\hline 65 & 200 & 115 & 50,96 & 27,45 & 20,23 & 15,07 & 11,95 & 9,76 & 6,88 & 5,27 & 3,61 \\
\hline 65 & 250 & 115 & 44,01 & 25,10 & 19,13 & 14,68 & 11,84 & 9,77 & 6,97 & 5,33 & 3,62 \\
\hline 65 & 300 & 115 & 39,23 & 23,40 & 18,29 & 14,34 & 11,73 & 9,76 & 7,03 & 5,38 & 3,63 \\
\hline 65 & 350 & 115 & 35,72 & 22,10 & 17,61 & 14,05 & 11,61 & 9,74 & 7,07 & 5,42 & 3,64 \\
\hline 65 & 400 & 115 & 33,02 & 21,05 & 17,05 & 13,79 & 11,50 & 9,70 & 7,10 & 5,46 & 3,65 \\
\hline 65 & 450 & 115 & 30,86 & 20,19 & 16,56 & 13,55 & 11,39 & 9,66 & 7,13 & 5,50 & 3,67 \\
\hline 65 & 500 & 115 & 29,10 & 19,45 & 16,14 & 13,33 & 11,28 & 9,62 & 7,15 & 5,53 & 3,68 \\
\hline 65 & 550 & 115 & 27,62 & 18,82 & 15,76 & 13,13 & 11,18 & 9,58 & 7,16 & 5,55 & 3,70 \\
\hline 65 & 600 & 115 & 26,36 & 18,26 & 15,43 & 12,95 & 11,08 & 9,53 & 7,17 & 5,57 & 3,71 \\
\hline 65 & 650 & 115 & 25,28 & 17,76 & 15,12 & 12,77 & 10,98 & 9,48 & 7,17 & 5,59 & 3,73 \\
\hline 65 & 700 & 115 & 24,33 & 17,32 & 14,84 & 12,61 & 10,88 & 9,44 & 7,18 & 5,61 & 3,74 \\
\hline 65 & 750 & 115 & 23,49 & 16,91 & 14,58 & 12,45 & 10,79 & 9,39 & 7,17 & 5,62 & 3,75 \\
\hline 65 & 800 & 115 & 22,75 & 16,54 & 14,34 & 12,31 & 10,70 & 9,34 & 7,17 & 5,64 & 3,77 \\
\hline 65 & 850 & 115 & 22,08 & 16,20 & 14,12 & 12,17 & 10,62 & 9,29 & 7,17 & 5,65 & 3,78 \\
\hline 65 & 900 & 115 & 21,48 & 15,89 & 13,91 & 12,04 & 10,54 & 9,24 & 7,16 & 5,66 & 3,79 \\
\hline 65 & 950 & 115 & 20,94 & 15,60 & 13,71 & 11,91 & 10,46 & 9,20 & 7,15 & 5,67 & 3,80 \\
\hline 65 & 1000 & 115 & 20,44 & 15,33 & 13,53 & 11,79 & 10,38 & 9,15 & 7,14 & 5,67 & 3,81 \\
\hline
\end{tabular}




\begin{tabular}{|c|c|c|c|c|c|c|c|c|c|c|c|}
\hline \multirow[b]{2}{*}{$\mathrm{H}(\mathrm{cm})$} & \multirow[b]{2}{*}{ Mceq (MPa) } & & & & & De & ões (x1 & & & & \\
\hline & & Msub (MPa) & D0 & D25 & D40 & D60 & D80 & D100 & D140 & D180 & D260 \\
\hline 65 & 1050 & 115 & 19,98 & 15,08 & 13,36 & 11,68 & 10,31 & 9,11 & 7,14 & 5,68 & 3,82 \\
\hline 65 & 1100 & 115 & 19,56 & 14,84 & 13,19 & 11,57 & 10,24 & 9,06 & 7,12 & 5,68 & 3,83 \\
\hline 65 & 1150 & 115 & 19,17 & 14,62 & 13,04 & 11,47 & 10,17 & 9,02 & 7,11 & 5,69 & 3,84 \\
\hline 65 & 1200 & 115 & 18,81 & 14,41 & 12,89 & 11,37 & 10,10 & 8,97 & 7,10 & 5,69 & 3,85 \\
\hline 65 & 1250 & 115 & 18,48 & 14,21 & 12,75 & 11,27 & 10,03 & 8,93 & 7,09 & 5,69 & 3,86 \\
\hline 65 & 1300 & 115 & 18,16 & 14,02 & 12,61 & 11,18 & 9,97 & 8,89 & 7,08 & 5,70 & 3,87 \\
\hline 65 & 1350 & 115 & 17,87 & 13,84 & 12,48 & 11,09 & 9,91 & 8,85 & 7,07 & 5,70 & 3,88 \\
\hline 65 & 1400 & 115 & 17,59 & 13,67 & 12,36 & 11,00 & 9,85 & 8,81 & 7,05 & 5,70 & 3,89 \\
\hline 65 & 1450 & 115 & 17,34 & 13,51 & 12,24 & 10,92 & 9,79 & 8,77 & 7,04 & 5,70 & 3,89 \\
\hline 65 & 1500 & 115 & 17,09 & 13,35 & 12,13 & 10,84 & 9,73 & 8,73 & 7,03 & 5,70 & 3,90 \\
\hline 65 & 1550 & 115 & 16,86 & 13,20 & 12,02 & 10,76 & 9,68 & 8,69 & 7,01 & 5,70 & 3,91 \\
\hline 65 & 1600 & 115 & 16,64 & 13,06 & 11,91 & 10,68 & 9,62 & 8,66 & 7,00 & 5,70 & 3,91 \\
\hline 65 & 1650 & 115 & 16,44 & 12,92 & 11,81 & 10,61 & 9,57 & 8,62 & 6,98 & 5,69 & 3,92 \\
\hline 65 & 1700 & 115 & 16,24 & 12,79 & 11,71 & 10,54 & 9,52 & 8,58 & 6,97 & 5,69 & 3,93 \\
\hline 65 & 1750 & 115 & 16,05 & 12,66 & 11,62 & 10,47 & 9,47 & 8,55 & 6,96 & 5,69 & 3,93 \\
\hline 65 & 1800 & 115 & 15,87 & 12,54 & 11,53 & 10,40 & 9,42 & 8,51 & 6,94 & 5,69 & 3,94 \\
\hline 65 & 1850 & 115 & 15,70 & 12,42 & 11,44 & 10,34 & 9,37 & 8,48 & 6,93 & 5,68 & 3,94 \\
\hline 65 & 1900 & 115 & 15,54 & 12,31 & 11,35 & 10,27 & 9,32 & 8,45 & 6,91 & 5,68 & 3,95 \\
\hline 65 & 1950 & 115 & 15,38 & 12,20 & 11,27 & 10,21 & 9,28 & 8,41 & 6,90 & 5,68 & 3,95 \\
\hline 65 & 2000 & 115 & 15,23 & 12,10 & 11,19 & 10,15 & 9,23 & 8,38 & 6,88 & 5,67 & 3,96 \\
\hline 65 & 200 & 120 & 50,26 & 26,78 & 19,60 & 14,51 & 11,47 & 9,34 & 6,58 & 5,04 & 3,46 \\
\hline 65 & 250 & 120 & 43,35 & 24,46 & 18,52 & 14,14 & 11,37 & 9,36 & 6,66 & 5,10 & 3,46 \\
\hline 65 & 300 & 120 & 38,61 & 22,79 & 17,71 & 13,82 & 11,27 & 9,36 & 6,72 & 5,14 & 3,47 \\
\hline 65 & 350 & 120 & 35,12 & 21,51 & 17,06 & 13,54 & 11,16 & 9,34 & 6,77 & 5,19 & 3,48 \\
\hline 65 & 400 & 120 & 32,44 & 20,49 & 16,51 & 13,30 & 11,06 & 9,31 & 6,80 & 5,22 & 3,50 \\
\hline 65 & 450 & 120 & 30,30 & 19,64 & 16,04 & 13,07 & 10,95 & 9,28 & 6,82 & 5,26 & 3,51 \\
\hline 65 & 500 & 120 & 28,55 & 18,92 & 15,63 & 12,86 & 10,85 & 9,24 & 6,84 & 5,28 & 3,52 \\
\hline 65 & 550 & 120 & 27,09 & 18,30 & 15,27 & 12,67 & 10,76 & 9,20 & 6,86 & 5,31 & 3,54 \\
\hline 65 & 600 & 120 & 25,84 & 17,76 & 14,94 & 12,49 & 10,66 & 9,16 & 6,87 & 5,33 & 3,55 \\
\hline 65 & 650 & 120 & 24,77 & 17,27 & 14,64 & 12,33 & 10,57 & 9,11 & 6,87 & 5,35 & 3,56 \\
\hline 65 & 700 & 120 & 23,83 & 16,84 & 14,37 & 12,17 & 10,48 & 9,07 & 6,88 & 5,37 & 3,58 \\
\hline 65 & 750 & 120 & 23,00 & 16,44 & 14,12 & 12,03 & 10,40 & 9,02 & 6,88 & 5,38 & 3,59 \\
\hline 65 & 800 & 120 & 22,27 & 16,09 & 13,89 & 11,89 & 10,31 & 8,98 & 6,87 & 5,39 & 3,60 \\
\hline 65 & 850 & 120 & 21,61 & 15,76 & 13,68 & 11,76 & 10,23 & 8,94 & 6,87 & 5,41 & 3,61 \\
\hline 65 & 900 & 120 & 21,01 & 15,45 & 13,48 & 11,63 & 10,16 & 8,89 & 6,87 & 5,42 & 3,62 \\
\hline 65 & 950 & 120 & 20,47 & 15,17 & 13,29 & 11,51 & 10,08 & 8,85 & 6,86 & 5,42 & 3,64 \\
\hline 65 & 1000 & 120 & 19,98 & 14,91 & 13,11 & 11,40 & 10,01 & 8,81 & 6,85 & 5,43 & 3,65 \\
\hline 65 & 1050 & 120 & 19,53 & 14,66 & 12,94 & 11,29 & 9,94 & 8,77 & 6,85 & 5,44 & 3,66 \\
\hline 65 & 1100 & 120 & 19,11 & 14,43 & 12,79 & 11,18 & 9,87 & 8,72 & 6,84 & 5,44 & 3,67 \\
\hline 65 & 1150 & 120 & 18,73 & 14,21 & 12,64 & 11,08 & 9,81 & 8,68 & 6,83 & 5,45 & 3,68 \\
\hline 65 & 1200 & 120 & 18,37 & 14,01 & 12,49 & 10,99 & 9,74 & 8,64 & 6,82 & 5,45 & 3,68 \\
\hline 65 & 1250 & 120 & 18,04 & 13,82 & 12,36 & 10,90 & 9,68 & 8,60 & 6,81 & 5,45 & 3,69 \\
\hline 65 & 1300 & 120 & 17,73 & 13,63 & 12,23 & 10,81 & 9,62 & 8,56 & 6,80 & 5,46 & 3,70 \\
\hline 65 & 1350 & 120 & 17,44 & 13,46 & 12,10 & 10,72 & 9,56 & 8,53 & 6,78 & 5,46 & 3,71 \\
\hline 65 & 1400 & 120 & 17,17 & 13,29 & 11,98 & 10,64 & 9,50 & 8,49 & 6,77 & 5,46 & 3,72 \\
\hline 65 & 1450 & 120 & 16,91 & 13,13 & 11,87 & 10,56 & 9,45 & 8,45 & 6,76 & 5,46 & 3,72 \\
\hline 65 & 1500 & 120 & 16,67 & 12,98 & 11,76 & 10,48 & 9,39 & 8,41 & 6,75 & 5,46 & 3,73 \\
\hline 65 & 1550 & 120 & 16,45 & 12,84 & 11,65 & 10,41 & 9,34 & 8,38 & 6,74 & 5,46 & 3,74 \\
\hline 65 & 1600 & 120 & 16,23 & 12,70 & 11,55 & 10,33 & 9,29 & 8,34 & 6,72 & 5,46 & 3,74 \\
\hline 65 & 1650 & 120 & 16,03 & 12,56 & 11,45 & 10,26 & 9,24 & 8,31 & 6,71 & 5,46 & 3,75 \\
\hline 65 & 1700 & 120 & 15,83 & 12,44 & 11,36 & 10,20 & 9,19 & 8,28 & 6,70 & 5,46 & 3,76 \\
\hline 65 & 1750 & 120 & 15,65 & 12,31 & 11,27 & 10,13 & 9,14 & 8,24 & 6,69 & 5,46 & 3,76 \\
\hline 65 & 1800 & 120 & 15,47 & 12,20 & 11,18 & 10,07 & 9,10 & 8,21 & 6,67 & 5,45 & 3,77 \\
\hline 65 & 1850 & 120 & 15,30 & 12,08 & 11,09 & 10,00 & 9,05 & 8,18 & 6,66 & 5,45 & 3,77 \\
\hline 65 & 1900 & 120 & 15,14 & 11,97 & 11,01 & 9,94 & 9,00 & 8,15 & 6,65 & 5,45 & 3,78 \\
\hline 65 & 1950 & 120 & 14,99 & 11,86 & 10,93 & 9,88 & 8,96 & 8,11 & 6,63 & 5,45 & 3,78 \\
\hline 65 & 2000 & 120 & 14,84 & 11,76 & 10,85 & 9,82 & 8,92 & 8,08 & 6,62 & 5,44 & 3,79 \\
\hline 65 & 200 & 125 & 49,61 & 26,15 & 19,01 & 13,99 & 11,02 & 8,96 & 6,30 & 4,83 & 3,32 \\
\hline 65 & 250 & 125 & 42,73 & 23,86 & 17,96 & 13,64 & 10,93 & 8,99 & 6,38 & 4,88 & 3,32 \\
\hline 65 & 300 & 125 & 38,02 & 22,22 & 17,17 & 13,34 & 10,84 & 8,99 & 6,44 & 4,93 & 3,33 \\
\hline 65 & 350 & 125 & 34,56 & 20,97 & 16,54 & 13,07 & 10,74 & 8,97 & 6,48 & 4,97 & 3,34 \\
\hline 65 & 400 & 125 & 31,90 & 19,96 & 16,01 & 12,84 & 10,65 & 8,95 & 6,52 & 5,00 & 3,35 \\
\hline 65 & 450 & 125 & 29,78 & 19,13 & 15,55 & 12,62 & 10,55 & 8,92 & 6,54 & 5,03 & 3,37 \\
\hline 65 & 500 & 125 & 28,04 & 18,43 & 15,16 & 12,43 & 10,46 & 8,88 & 6,56 & 5,06 & 3,38 \\
\hline 65 & 550 & 125 & 26,59 & 17,82 & 14,81 & 12,24 & 10,37 & 8,85 & 6,58 & 5,09 & 3,39 \\
\hline 65 & 600 & 125 & 25,36 & 17,29 & 14,49 & 12,08 & 10,28 & 8,81 & 6,59 & 5,11 & 3,40 \\
\hline 65 & 650 & 125 & 24,30 & 16,82 & 14,20 & 11,92 & 10,19 & 8,77 & 6,60 & 5,13 & 3,42 \\
\hline 65 & 700 & 125 & 23,37 & 16,39 & 13,94 & 11,77 & 10,11 & 8,73 & 6,60 & 5,14 & 3,43 \\
\hline 65 & 750 & 125 & 22,55 & 16,01 & 13,70 & 11,63 & 10,03 & 8,69 & 6,60 & 5,16 & 3,44 \\
\hline 65 & 800 & 125 & 21,82 & 15,66 & 13,48 & 11,50 & 9,95 & 8,65 & 6,60 & 5,17 & 3,45 \\
\hline 65 & 850 & 125 & 21,17 & 15,34 & 13,27 & 11,37 & 9,88 & 8,61 & 6,60 & 5,18 & 3,46 \\
\hline 65 & 900 & 125 & 20,58 & 15,04 & 13,08 & 11,25 & 9,80 & 8,57 & 6,60 & 5,19 & 3,47 \\
\hline 65 & 950 & 125 & 20,04 & 14,77 & 12,89 & 11,14 & 9,73 & 8,53 & 6,59 & 5,20 & 3,48 \\
\hline 65 & 1000 & 125 & 19,56 & 14,51 & 12,72 & 11,03 & 9,67 & 8,49 & 6,59 & 5,21 & 3,49 \\
\hline 65 & 1050 & 125 & 19,11 & 14,27 & 12,56 & 10,92 & 9,60 & 8,45 & 6,58 & 5,22 & 3,50 \\
\hline 65 & 1100 & 125 & 18,70 & 14,05 & 12,41 & 10,82 & 9,54 & 8,41 & 6,57 & 5,22 & 3,51 \\
\hline 65 & 1150 & 125 & 18,32 & 13,84 & 12,26 & 10,73 & 9,47 & 8,37 & 6,56 & 5,23 & 3,52 \\
\hline 65 & 1200 & 125 & 17,97 & 13,64 & 12,13 & 10,64 & 9,41 & 8,33 & 6,55 & 5,23 & 3,53 \\
\hline 65 & 1250 & 125 & 17,64 & 13,45 & 11,99 & 10,55 & 9,35 & 8,30 & 6,54 & 5,23 & 3,54 \\
\hline 65 & 1300 & 125 & 17,33 & 13,27 & 11,87 & 10,46 & 9,30 & 8,26 & 6,54 & 5,24 & 3,54 \\
\hline 65 & 1350 & 125 & 17,05 & 13,10 & 11,75 & 10,38 & 9,24 & 8,22 & 6,52 & 5,24 & 3,55 \\
\hline
\end{tabular}




\begin{tabular}{|c|c|c|c|c|c|c|c|c|c|c|c|}
\hline \multirow[b]{2}{*}{$\mathrm{H}(\mathrm{cm})$} & \multirow[b]{2}{*}{ Mceq (MPa) } & & & & & Det & ões (x1 & & & & \\
\hline & & Msub (MPa) & D0 & D25 & D40 & D60 & D80 & D100 & D140 & D180 & D260 \\
\hline 65 & 1400 & 125 & 16,78 & 12,94 & 11,63 & 10,30 & 9,19 & 8,19 & 6,51 & 5,24 & 3,56 \\
\hline 65 & 1450 & 125 & 16,52 & 12,78 & 11,52 & 10,23 & 9,13 & 8,15 & 6,50 & 5,24 & 3,57 \\
\hline 65 & 1500 & 125 & 16,29 & 12,64 & 11,42 & 10,15 & 9,08 & 8,12 & 6,49 & 5,24 & 3,57 \\
\hline 65 & 1550 & 125 & 16,06 & 12,50 & 11,31 & 10,08 & 9,03 & 8,09 & 6,48 & 5,24 & 3,58 \\
\hline 65 & 1600 & 125 & 15,85 & 12,36 & 11,22 & 10,01 & 8,98 & 8,05 & 6,47 & 5,24 & 3,59 \\
\hline 65 & 1650 & 125 & 15,65 & 12,23 & 11,12 & 9,94 & 8,93 & 8,02 & 6,46 & 5,24 & 3,59 \\
\hline 65 & 1700 & 125 & 15,45 & 12,11 & 11,03 & 9,88 & 8,89 & 7,99 & 6,45 & 5,24 & 3,60 \\
\hline 65 & 1750 & 125 & 15,27 & 11,99 & 10,94 & 9,81 & 8,84 & 7,96 & 6,44 & 5,24 & 3,60 \\
\hline 65 & 1800 & 125 & 15,10 & 11,87 & 10,85 & 9,75 & 8,80 & 7,93 & 6,42 & 5,24 & 3,61 \\
\hline 65 & 1850 & 125 & 14,93 & 11,76 & 10,77 & 9,69 & 8,75 & 7,90 & 6,41 & 5,24 & 3,61 \\
\hline 65 & 1900 & 125 & 14,77 & 11,65 & 10,69 & 9,63 & 8,71 & 7,87 & 6,40 & 5,23 & 3,62 \\
\hline 65 & 1950 & 125 & 14,62 & 11,55 & 10,61 & 9,58 & 8,67 & 7,84 & 6,39 & 5,23 & 3,62 \\
\hline 65 & 2000 & 125 & 14,48 & 11,45 & 10,54 & 9,52 & 8,63 & 7,81 & 6,38 & 5,23 & 3,63 \\
\hline 65 & 200 & 130 & 49,00 & 25,57 & 18,47 & 13,51 & 10,61 & 8,61 & 6,04 & 4,63 & 3,19 \\
\hline 65 & 250 & 130 & 42,16 & 23,31 & 17,44 & 13,17 & 10,53 & 8,64 & 6,12 & 4,68 & 3,19 \\
\hline 65 & 300 & 130 & 37,47 & 21,69 & 16,67 & 12,89 & 10,44 & 8,64 & 6,18 & 4,73 & 3,20 \\
\hline 65 & 350 & 130 & 34,04 & 20,46 & 16,05 & 12,64 & 10,35 & 8,63 & 6,22 & 4,77 & 3,21 \\
\hline 65 & 400 & 130 & 31,40 & 19,47 & 15,54 & 12,41 & 10,26 & 8,61 & 6,26 & 4,80 & 3,22 \\
\hline 65 & 450 & 130 & 29,29 & 18,66 & 15,10 & 12,21 & 10,18 & 8,59 & 6,28 & 4,83 & 3,23 \\
\hline 65 & 500 & 130 & 27,57 & 17,97 & 14,71 & 12,02 & 10,09 & 8,56 & 6,30 & 4,86 & 3,24 \\
\hline 65 & 550 & 130 & 26,13 & 17,37 & 14,37 & 11,85 & 10,00 & 8,52 & 6,32 & 4,88 & 3,26 \\
\hline 65 & 600 & 130 & 24,91 & 16,85 & 14,07 & 11,68 & 9,92 & 8,49 & 6,33 & 4,90 & 3,27 \\
\hline 65 & 650 & 130 & 23,85 & 16,39 & 13,79 & 11,53 & 9,84 & 8,45 & 6,34 & 4,92 & 3,28 \\
\hline 65 & 700 & 130 & 22,93 & 15,98 & 13,54 & 11,39 & 9,76 & 8,41 & 6,34 & 4,94 & 3,29 \\
\hline 65 & 750 & 130 & 22,12 & 15,60 & 13,30 & 11,26 & 9,69 & 8,38 & 6,35 & 4,95 & 3,30 \\
\hline 65 & 800 & 130 & 21,40 & 15,26 & 13,09 & 11,13 & 9,62 & 8,34 & 6,35 & 4,96 & 3,31 \\
\hline 65 & 850 & 130 & 20,76 & 14,95 & 12,89 & 11,01 & 9,54 & 8,30 & 6,35 & 4,98 & 3,32 \\
\hline 65 & 900 & 130 & 20,17 & 14,66 & 12,70 & 10,90 & 9,48 & 8,26 & 6,34 & 4,99 & 3,33 \\
\hline 65 & 950 & 130 & 19,64 & 14,39 & 12,52 & 10,79 & 9,41 & 8,23 & 6,34 & 4,99 & 3,34 \\
\hline 65 & 1000 & 130 & 19,16 & 14,14 & 12,36 & 10,68 & 9,34 & 8,19 & 6,34 & 5,00 & 3,35 \\
\hline 65 & 1050 & 130 & 18,72 & 13,91 & 12,20 & 10,58 & 9,28 & 8,15 & 6,33 & 5,01 & 3,36 \\
\hline 65 & 1100 & 130 & 18,31 & 13,69 & 12,06 & 10,49 & 9,22 & 8,12 & 6,32 & 5,02 & 3,37 \\
\hline 65 & 1150 & 130 & 17,94 & 13,48 & 11,91 & 10,40 & 9,16 & 8,08 & 6,32 & 5,02 & 3,38 \\
\hline 65 & 1200 & 130 & 17,59 & 13,29 & 11,78 & 10,31 & 9,10 & 8,05 & 6,31 & 5,03 & 3,39 \\
\hline 65 & 1250 & 130 & 17,26 & 13,11 & 11,65 & 10,23 & 9,05 & 8,01 & 6,30 & 5,03 & 3,39 \\
\hline 65 & 1300 & 130 & 16,96 & 12,93 & 11,53 & 10,14 & 8,99 & 7,98 & 6,29 & 5,03 & 3,40 \\
\hline 65 & 1350 & 130 & 16,68 & 12,77 & 11,42 & 10,06 & 8,94 & 7,94 & 6,28 & 5,03 & 3,41 \\
\hline 65 & 1400 & 130 & 16,41 & 12,61 & 11,30 & 9,99 & 8,89 & 7,91 & 6,27 & 5,04 & 3,41 \\
\hline 65 & 1450 & 130 & 16,16 & 12,46 & 11,20 & 9,92 & 8,84 & 7,88 & 6,27 & 5,04 & 3,42 \\
\hline 65 & 1500 & 130 & 15,93 & 12,32 & 11,10 & 9,84 & 8,79 & 7,85 & 6,26 & 5,04 & 3,43 \\
\hline 65 & 1550 & 130 & 15,70 & 12,18 & 11,00 & 9,77 & 8,74 & 7,81 & 6,25 & 5,04 & 3,43 \\
\hline 65 & 1600 & 130 & 15,49 & 12,05 & 10,90 & 9,71 & 8,69 & 7,78 & 6,23 & 5,04 & 3,44 \\
\hline 65 & 1650 & 130 & 15,29 & 11,92 & 10,81 & 9,64 & 8,65 & 7,75 & 6,22 & 5,04 & 3,45 \\
\hline 65 & 1700 & 130 & 15,10 & 11,80 & 10,72 & 9,58 & 8,60 & 7,72 & 6,21 & 5,04 & 3,45 \\
\hline 65 & 1750 & 130 & 14,92 & 11,68 & 10,63 & 9,52 & 8,56 & 7,69 & 6,20 & 5,04 & 3,46 \\
\hline 65 & 1800 & 130 & 14,75 & 11,57 & 10,55 & 9,46 & 8,52 & 7,66 & 6,19 & 5,04 & 3,46 \\
\hline 65 & 1850 & 130 & 14,59 & 11,46 & 10,47 & 9,40 & 8,48 & 7,63 & 6,18 & 5,04 & 3,47 \\
\hline 65 & 1900 & 130 & 14,43 & 11,36 & 10,39 & 9,35 & 8,44 & 7,61 & 6,17 & 5,04 & 3,47 \\
\hline 65 & 1950 & 130 & 14,28 & 11,26 & 10,32 & 9,29 & 8,40 & 7,58 & 6,16 & 5,03 & 3,48 \\
\hline 65 & 2000 & 130 & 14,14 & 11,16 & 10,25 & 9,24 & 8,36 & 7,55 & 6,15 & 5,03 & 3,48 \\
\hline 65 & 200 & 135 & 48,44 & 25,02 & 17,96 & 13,07 & 10,23 & 8,29 & 5,81 & 4,45 & 3,07 \\
\hline 65 & 250 & 135 & 41,63 & 22,79 & 16,96 & 12,74 & 10,16 & 8,32 & 5,88 & 4,50 & 3,07 \\
\hline 65 & 300 & 135 & 36,96 & 21,20 & 16,20 & 12,47 & 10,08 & 8,32 & 5,94 & 4,54 & 3,08 \\
\hline 65 & 350 & 135 & 33,55 & 19,98 & 15,60 & 12,23 & 9,99 & 8,31 & 5,98 & 4,58 & 3,09 \\
\hline 65 & 400 & 135 & 30,92 & 19,01 & 15,10 & 12,01 & 9,91 & 8,30 & 6,02 & 4,61 & 3,10 \\
\hline 65 & 450 & 135 & 28,84 & 18,21 & 14,67 & 11,82 & 9,83 & 8,28 & 6,04 & 4,64 & 3,11 \\
\hline 65 & 500 & 135 & 27,13 & 17,54 & 14,30 & 11,64 & 9,75 & 8,25 & 6,06 & 4,67 & 3,12 \\
\hline 65 & 550 & 135 & 25,70 & 16,95 & 13,97 & 11,47 & 9,67 & 8,22 & 6,08 & 4,69 & 3,13 \\
\hline 65 & 600 & 135 & 24,49 & 16,44 & 13,67 & 11,32 & 9,59 & 8,19 & 6,09 & 4,71 & 3,14 \\
\hline 65 & 650 & 135 & 23,44 & 15,99 & 13,41 & 11,18 & 9,51 & 8,16 & 6,10 & 4,73 & 3,15 \\
\hline 65 & 700 & 135 & 22,53 & 15,59 & 13,16 & 11,04 & 9,44 & 8,12 & 6,11 & 4,75 & 3,16 \\
\hline 65 & 750 & 135 & 21,73 & 15,22 & 12,93 & 10,91 & 9,37 & 8,09 & 6,11 & 4,76 & 3,17 \\
\hline 65 & 800 & 135 & 21,01 & 14,89 & 12,73 & 10,79 & 9,30 & 8,05 & 6,11 & 4,77 & 3,18 \\
\hline 65 & 850 & 135 & 20,37 & 14,58 & 12,53 & 10,68 & 9,23 & 8,02 & 6,11 & 4,78 & 3,19 \\
\hline 65 & 900 & 135 & 19,79 & 14,30 & 12,35 & 10,57 & 9,17 & 7,98 & 6,11 & 4,79 & 3,20 \\
\hline 65 & 950 & 135 & 19,27 & 14,04 & 12,18 & 10,46 & 9,11 & 7,95 & 6,11 & 4,80 & 3,21 \\
\hline 65 & 1000 & 135 & 18,79 & 13,79 & 12,02 & 10,36 & 9,04 & 7,91 & 6,10 & 4,81 & 3,22 \\
\hline 65 & 1050 & 135 & 18,35 & 13,57 & 11,87 & 10,27 & 8,98 & 7,88 & 6,10 & 4,82 & 3,23 \\
\hline 65 & 1100 & 135 & 17,95 & 13,35 & 11,72 & 10,18 & 8,93 & 7,85 & 6,10 & 4,83 & 3,24 \\
\hline 65 & 1150 & 135 & 17,58 & 13,15 & 11,59 & 10,09 & 8,87 & 7,81 & 6,09 & 4,83 & 3,24 \\
\hline 65 & 1200 & 135 & 17,23 & 12,96 & 11,46 & 10,00 & 8,82 & 7,78 & 6,08 & 4,84 & 3,25 \\
\hline 65 & 1250 & 135 & 16,91 & 12,78 & 11,34 & 9,92 & 8,76 & 7,75 & 6,08 & 4,84 & 3,26 \\
\hline 65 & 1300 & 135 & 16,61 & 12,61 & 11,22 & 9,84 & 8,71 & 7,71 & 6,07 & 4,84 & 3,27 \\
\hline 65 & 1350 & 135 & 16,33 & 12,45 & 11,11 & 9,77 & 8,66 & 7,68 & 6,06 & 4,85 & 3,27 \\
\hline 65 & 1400 & 135 & 16,07 & 12,30 & 11,00 & 9,69 & 8,61 & 7,65 & 6,05 & 4,85 & 3,28 \\
\hline 65 & 1450 & 135 & 15,82 & 12,15 & 10,89 & 9,62 & 8,56 & 7,62 & 6,04 & 4,85 & 3,29 \\
\hline 65 & 1500 & 135 & 15,59 & 12,01 & 10,79 & 9,56 & 8,52 & 7,59 & 6,03 & 4,85 & 3,29 \\
\hline 65 & 1550 & 135 & 15,37 & 11,88 & 10,70 & 9,49 & 8,47 & 7,56 & 6,02 & 4,85 & 3,30 \\
\hline 65 & 1600 & 135 & 15,16 & 11,75 & 10,61 & 9,43 & 8,43 & 7,53 & 6,02 & 4,85 & 3,31 \\
\hline 65 & 1650 & 135 & 14,96 & 11,63 & 10,52 & 9,36 & 8,38 & 7,50 & 6,01 & 4,85 & 3,31 \\
\hline 65 & 1700 & 135 & 14,78 & 11,51 & 10,43 & 9,30 & 8,34 & 7,47 & 6,00 & 4,85 & 3,32 \\
\hline
\end{tabular}




\begin{tabular}{|c|c|c|c|c|c|c|c|c|c|c|c|}
\hline \multirow[b]{2}{*}{$\mathrm{H}(\mathrm{cm})$} & \multirow[b]{2}{*}{ Mceq (MPa) } & & & & & $\mathrm{De}$ & ões (x. & & & & \\
\hline & & Msub (MPa) & D0 & D25 & D40 & D60 & D80 & D100 & D140 & D180 & D260 \\
\hline 65 & 1750 & 135 & 14,60 & 11,40 & 10,35 & 9,24 & 8,30 & 7,44 & 5,99 & 4,85 & 3,32 \\
\hline 65 & 1800 & 135 & 14,43 & 11,29 & 10,27 & 9,19 & 8,26 & 7,42 & 5,98 & 4,85 & 3,33 \\
\hline 65 & 1850 & 135 & 14,27 & 11,18 & 10,19 & 9,13 & 8,22 & 7,39 & 5,97 & 4,85 & 3,33 \\
\hline 65 & 1900 & 135 & 14,11 & 11,08 & 10,12 & 9,08 & 8,18 & 7,36 & 5,96 & 4,85 & 3,34 \\
\hline 65 & 1950 & 135 & 13,96 & 10,98 & 10,04 & 9,02 & 8,14 & 7,34 & 5,95 & 4,85 & 3,34 \\
\hline 65 & 2000 & 135 & 13,82 & 10,89 & 9,97 & 8,97 & 8,10 & 7,31 & 5,94 & 4,85 & 3,35 \\
\hline 65 & 200 & 140 & 47,91 & 24,51 & 17,48 & 12,65 & 9,87 & 7,98 & 5,59 & 4,28 & 2,96 \\
\hline 65 & 250 & 140 & 41,12 & 22,30 & 16,50 & 12,34 & 9,81 & 8,02 & 5,66 & 4,33 & 2,96 \\
\hline 65 & 300 & 140 & 36,49 & 20,73 & 15,77 & 12,08 & 9,73 & 8,02 & 5,72 & 4,37 & 2,97 \\
\hline 65 & 350 & 140 & 33,09 & 19,53 & 15,18 & 11,85 & 9,66 & 8,02 & 5,76 & 4,41 & 2,98 \\
\hline 65 & 400 & 140 & 30,48 & 18,58 & 14,69 & 11,64 & 9,58 & 8,01 & 5,79 & 4,44 & 2,99 \\
\hline 65 & 450 & 140 & 28,41 & 17,80 & 14,28 & 11,45 & 9,50 & 7,99 & 5,82 & 4,47 & 2,99 \\
\hline 65 & 500 & 140 & 26,71 & 17,13 & 13,91 & 11,28 & 9,43 & 7,96 & 5,84 & 4,49 & 3,00 \\
\hline 65 & 550 & 140 & 25,30 & 16,56 & 13,59 & 11,13 & 9,35 & 7,94 & 5,86 & 4,52 & 3,01 \\
\hline 65 & 600 & 140 & 24,09 & 16,06 & 13,31 & 10,98 & 9,28 & 7,91 & 5,87 & 4,54 & 3,02 \\
\hline 65 & 650 & 140 & 23,06 & 15,62 & 13,04 & 10,84 & 9,21 & 7,88 & 5,88 & 4,55 & 3,03 \\
\hline 65 & 700 & 140 & 22,15 & 15,22 & 12,81 & 10,71 & 9,14 & 7,85 & 5,89 & 4,57 & 3,04 \\
\hline 65 & 750 & 140 & 21,35 & 14,86 & 12,59 & 10,59 & 9,07 & 7,82 & 5,89 & 4,58 & 3,05 \\
\hline 65 & 800 & 140 & 20,65 & 14,54 & 12,38 & 10,47 & 9,01 & 7,78 & 5,89 & 4,60 & 3,06 \\
\hline 65 & 850 & 140 & 20,01 & 14,24 & 12,20 & 10,36 & 8,94 & 7,75 & 5,89 & 4,61 & 3,07 \\
\hline 65 & 900 & 140 & 19,44 & 13,96 & 12,02 & 10,26 & 8,88 & 7,72 & 5,89 & 4,62 & 3,08 \\
\hline 65 & 950 & 140 & 18,92 & 13,70 & 11,85 & 10,16 & 8,82 & 7,69 & 5,89 & 4,63 & 3,09 \\
\hline 65 & 1000 & 140 & 18,45 & 13,47 & 11,70 & 10,06 & 8,76 & 7,65 & 5,89 & 4,63 & 3,10 \\
\hline 65 & 1050 & 140 & 18,01 & 13,24 & 11,55 & 9,97 & 8,71 & 7,62 & 5,89 & 4,64 & 3,11 \\
\hline 65 & 1100 & 140 & 17,61 & 13,04 & 11,41 & 9,88 & 8,65 & 7,59 & 5,88 & 4,65 & 3,11 \\
\hline 65 & 1150 & 140 & 17,24 & 12,84 & 11,28 & 9,80 & 8,60 & 7,56 & 5,88 & 4,65 & 3,12 \\
\hline 65 & 1200 & 140 & 16,90 & 12,66 & 11,16 & 9,72 & 8,55 & 7,53 & 5,87 & 4,66 & 3,13 \\
\hline 65 & 1250 & 140 & 16,58 & 12,48 & 11,04 & 9,64 & 8,50 & 7,50 & 5,86 & 4,66 & 3,14 \\
\hline 65 & 1300 & 140 & 16,29 & 12,32 & 10,92 & 9,56 & 8,45 & 7,47 & 5,86 & 4,67 & 3,14 \\
\hline 65 & 1350 & 140 & 16,01 & 12,16 & 10,81 & 9,49 & 8,40 & 7,44 & 5,85 & 4,67 & 3,15 \\
\hline 65 & 1400 & 140 & 15,75 & 12,01 & 10,71 & 9,42 & 8,35 & 7,41 & 5,84 & 4,67 & 3,16 \\
\hline 65 & 1450 & 140 & 15,50 & 11,87 & 10,61 & 9,35 & 8,31 & 7,38 & 5,84 & 4,68 & 3,16 \\
\hline 65 & 1500 & 140 & 15,27 & 11,73 & 10,51 & 9,29 & 8,26 & 7,35 & 5,83 & 4,68 & 3,17 \\
\hline 65 & 1550 & 140 & 15,05 & 11,60 & 10,42 & 9,22 & 8,22 & 7,32 & 5,82 & 4,68 & 3,18 \\
\hline 65 & 1600 & 140 & 14,85 & 11,47 & 10,33 & 9,16 & 8,17 & 7,29 & 5,81 & 4,68 & 3,18 \\
\hline 65 & 1650 & 140 & 14,65 & 11,35 & 10,24 & 9,10 & 8,13 & 7,27 & 5,80 & 4,68 & 3,19 \\
\hline 65 & 1700 & 140 & 14,47 & 11,24 & 10,16 & 9,04 & 8,09 & 7,24 & 5,79 & 4,68 & 3,19 \\
\hline 65 & 1750 & 140 & 14,29 & 11,13 & 10,08 & 8,98 & 8,05 & 7,21 & 5,78 & 4,68 & 3,20 \\
\hline 65 & 1800 & 140 & 14,12 & 11,02 & 10,00 & 8,93 & 8,01 & 7,19 & 5,78 & 4,68 & 3,20 \\
\hline 65 & 1850 & 140 & 13,96 & 10,92 & 9,93 & 8,88 & 7,98 & 7,16 & 5,77 & 4,68 & 3,21 \\
\hline 65 & 1900 & 140 & 13,81 & 10,82 & 9,85 & 8,82 & 7,94 & 7,13 & 5,76 & 4,68 & 3,21 \\
\hline 65 & 1950 & 140 & 13,66 & 10,72 & 9,78 & 8,77 & 7,90 & 7,11 & 5,75 & 4,68 & 3,22 \\
\hline 65 & 2000 & 140 & 13,52 & 10,63 & 9,71 & 8,72 & 7,87 & 7,08 & 5,74 & 4,68 & 3,22 \\
\hline 65 & 200 & 145 & 47,41 & 24,03 & 17,04 & 12,26 & 9,54 & 7,70 & 5,38 & 4,13 & 2,86 \\
\hline 65 & 250 & 145 & 40,65 & 21,85 & 16,08 & 11,96 & 9,48 & 7,74 & 5,46 & 4,18 & 2,86 \\
\hline 65 & 300 & 145 & 36,04 & 20,30 & 15,36 & 11,71 & 9,41 & 7,75 & 5,51 & 4,22 & 2,87 \\
\hline 65 & 350 & 145 & 32,66 & 19,11 & 14,78 & 11,49 & 9,34 & 7,75 & 5,55 & 4,25 & 2,87 \\
\hline 65 & 400 & 145 & 30,07 & 18,18 & 14,31 & 11,29 & 9,27 & 7,74 & 5,59 & 4,28 & 2,88 \\
\hline 65 & 450 & 145 & 28,01 & 17,40 & 13,90 & 11,11 & 9,20 & 7,72 & 5,61 & 4,31 & 2,89 \\
\hline 65 & 500 & 145 & 26,32 & 16,75 & 13,55 & 10,95 & 9,13 & 7,70 & 5,63 & 4,33 & 2,90 \\
\hline 65 & 550 & 145 & 24,91 & 16,19 & 13,24 & 10,80 & 9,06 & 7,67 & 5,65 & 4,35 & 2,91 \\
\hline 65 & 600 & 145 & 23,72 & 15,70 & 12,96 & 10,66 & 8,99 & 7,65 & 5,66 & 4,37 & 2,92 \\
\hline 65 & 650 & 145 & 22,69 & 15,26 & 12,70 & 10,52 & 8,92 & 7,62 & 5,67 & 4,39 & 2,93 \\
\hline 65 & 700 & 145 & 21,79 & 14,88 & 12,47 & 10,40 & 8,86 & 7,59 & 5,68 & 4,40 & 2,93 \\
\hline 65 & 750 & 145 & 21,00 & 14,52 & 12,26 & 10,28 & 8,79 & 7,56 & 5,69 & 4,42 & 2,94 \\
\hline 65 & 800 & 145 & 20,30 & 14,20 & 12,06 & 10,17 & 8,73 & 7,53 & 5,69 & 4,43 & 2,95 \\
\hline 65 & 850 & 145 & 19,67 & 13,91 & 11,88 & 10,07 & 8,67 & 7,50 & 5,69 & 4,44 & 2,96 \\
\hline 65 & 900 & 145 & 19,10 & 13,64 & 11,71 & 9,96 & 8,61 & 7,47 & 5,69 & 4,45 & 2,97 \\
\hline 65 & 950 & 145 & 18,59 & 13,39 & 11,55 & 9,87 & 8,55 & 7,44 & 5,69 & 4,46 & 2,98 \\
\hline 65 & 1000 & 145 & 18,12 & 13,16 & 11,40 & 9,78 & 8,50 & 7,41 & 5,69 & 4,47 & 2,99 \\
\hline 65 & 1050 & 145 & 17,69 & 12,94 & 11,26 & 9,69 & 8,45 & 7,38 & 5,69 & 4,48 & 2,99 \\
\hline 65 & 1100 & 145 & 17,29 & 12,74 & 11,12 & 9,60 & 8,39 & 7,35 & 5,68 & 4,48 & 3,00 \\
\hline 65 & 1150 & 145 & 16,93 & 12,55 & 10,99 & 9,52 & 8,34 & 7,32 & 5,68 & 4,49 & 3,01 \\
\hline 65 & 1200 & 145 & 16,59 & 12,37 & 10,87 & 9,45 & 8,29 & 7,29 & 5,67 & 4,49 & 3,02 \\
\hline 65 & 1250 & 145 & 16,27 & 12,20 & 10,76 & 9,37 & 8,24 & 7,26 & 5,67 & 4,50 & 3,02 \\
\hline 65 & 1300 & 145 & 15,98 & 12,03 & 10,64 & 9,30 & 8,20 & 7,24 & 5,66 & 4,50 & 3,03 \\
\hline 65 & 1350 & 145 & 15,71 & 11,88 & 10,54 & 9,23 & 8,15 & 7,21 & 5,66 & 4,51 & 3,04 \\
\hline 65 & 1400 & 145 & 15,45 & 11,73 & 10,44 & 9,16 & 8,11 & 7,18 & 5,65 & 4,51 & 3,04 \\
\hline 65 & 1450 & 145 & 15,21 & 11,59 & 10,34 & 9,09 & 8,06 & 7,15 & 5,64 & 4,51 & 3,05 \\
\hline 65 & 1500 & 145 & 14,98 & 11,46 & 10,25 & 9,03 & 8,02 & 7,13 & 5,63 & 4,51 & 3,05 \\
\hline 65 & 1550 & 145 & 14,76 & 11,33 & 10,16 & 8,97 & 7,98 & 7,10 & 5,63 & 4,52 & 3,06 \\
\hline 65 & 1600 & 145 & 14,56 & 11,21 & 10,07 & 8,91 & 7,94 & 7,07 & 5,62 & 4,52 & 3,07 \\
\hline 65 & 1650 & 145 & 14,36 & 11,09 & 9,99 & 8,85 & 7,90 & 7,05 & 5,61 & 4,52 & 3,07 \\
\hline 65 & 1700 & 145 & 14,18 & 10,98 & 9,90 & 8,80 & 7,86 & 7,02 & 5,60 & 4,52 & 3,08 \\
\hline 65 & 1750 & 145 & 14,01 & 10,87 & 9,83 & 8,74 & 7,82 & 6,99 & 5,60 & 4,52 & 3,08 \\
\hline 65 & 1800 & 145 & 13,84 & 10,77 & 9,75 & 8,69 & 7,78 & 6,97 & 5,59 & 4,52 & 3,09 \\
\hline 65 & 1850 & 145 & 13,68 & 10,67 & 9,68 & 8,64 & 7,75 & 6,95 & 5,58 & 4,52 & 3,09 \\
\hline 65 & 1900 & 145 & 13,53 & 10,57 & 9,61 & 8,59 & 7,71 & 6,92 & 5,57 & 4,52 & 3,10 \\
\hline 65 & 1950 & 145 & 13,38 & 10,48 & 9,54 & 8,54 & 7,68 & 6,90 & 5,56 & 4,52 & 3,10 \\
\hline 65 & 2000 & 145 & 13,25 & 10,39 & 9,47 & 8,49 & 7,64 & 6,87 & 5,55 & 4,52 & 3,10 \\
\hline 65 & 200 & 150 & 46,94 & 23,59 & 16,62 & 11,90 & 9,23 & 7,44 & 5,19 & 3,99 & 2,77 \\
\hline
\end{tabular}




\begin{tabular}{|c|c|c|c|c|c|c|c|c|c|c|c|}
\hline \multirow[b]{2}{*}{$\mathrm{H}(\mathrm{cm})$} & \multirow[b]{2}{*}{ Mceq (MPa) } & & & & & De & ões (x & & & & \\
\hline & & Msub (MPa) & D0 & D25 & D40 & D60 & D80 & D100 & D140 & D180 & D260 \\
\hline 65 & 250 & 150 & 40,21 & 21,42 & 15,68 & 11,61 & 9,17 & 7,47 & 5,26 & 4,03 & 2,77 \\
\hline 65 & 300 & 150 & 35,61 & 19,88 & 14,97 & 11,37 & 9,11 & 7,49 & 5,32 & 4,07 & 2,77 \\
\hline 65 & 350 & 150 & 32,25 & 18,72 & 14,41 & 11,15 & 9,05 & 7,49 & 5,36 & 4,10 & 2,78 \\
\hline 65 & 400 & 150 & 29,67 & 17,79 & 13,95 & 10,97 & 8,98 & 7,48 & 5,39 & 4,13 & 2,78 \\
\hline 65 & 450 & 150 & 27,63 & 17,03 & 13,55 & 10,79 & 8,91 & 7,47 & 5,42 & 4,16 & 2,79 \\
\hline 65 & 500 & 150 & 25,95 & 16,39 & 13,21 & 10,64 & 8,84 & 7,45 & 5,44 & 4,18 & 2,80 \\
\hline 65 & 550 & 150 & 24,56 & 15,84 & 12,90 & 10,49 & 8,78 & 7,43 & 5,46 & 4,20 & 2,81 \\
\hline 65 & 600 & 150 & 23,37 & 15,36 & 12,63 & 10,36 & 8,71 & 7,40 & 5,47 & 4,22 & 2,82 \\
\hline 65 & 650 & 150 & 22,35 & 14,93 & 12,38 & 10,23 & 8,65 & 7,38 & 5,48 & 4,24 & 2,82 \\
\hline 65 & 700 & 150 & 21,46 & 14,55 & 12,16 & 10,11 & 8,59 & 7,35 & 5,49 & 4,25 & 2,83 \\
\hline 65 & 750 & 150 & 20,67 & 14,21 & 11,95 & 10,00 & 8,53 & 7,32 & 5,49 & 4,26 & 2,84 \\
\hline 65 & 800 & 150 & 19,98 & 13,89 & 11,76 & 9,89 & 8,47 & 7,30 & 5,50 & 4,28 & 2,85 \\
\hline 65 & 850 & 150 & 19,35 & 13,61 & 11,58 & 9,79 & 8,41 & 7,27 & 5,50 & 4,29 & 2,86 \\
\hline 65 & 900 & 150 & 18,79 & 13,34 & 11,42 & 9,69 & 8,36 & 7,24 & 5,50 & 4,30 & 2,87 \\
\hline 65 & 950 & 150 & 18,28 & 13,10 & 11,26 & 9,60 & 8,30 & 7,21 & 5,50 & 4,31 & 2,87 \\
\hline 65 & 1000 & 150 & 17,81 & 12,87 & 11,11 & 9,51 & 8,25 & 7,18 & 5,50 & 4,32 & 2,88 \\
\hline 65 & 1050 & 150 & 17,39 & 12,66 & 10,98 & 9,42 & 8,20 & 7,16 & 5,50 & 4,32 & 2,89 \\
\hline 65 & 1100 & 150 & 17,00 & 12,46 & 10,84 & 9,34 & 8,15 & 7,13 & 5,50 & 4,33 & 2,90 \\
\hline 65 & 1150 & 150 & 16,63 & 12,27 & 10,72 & 9,27 & 8,10 & 7,10 & 5,49 & 4,34 & 2,90 \\
\hline 65 & 1200 & 150 & 16,30 & 12,09 & 10,60 & 9,19 & 8,05 & 7,07 & 5,49 & 4,34 & 2,91 \\
\hline 65 & 1250 & 150 & 15,98 & 11,93 & 10,49 & 9,12 & 8,01 & 7,05 & 5,48 & 4,35 & 2,92 \\
\hline 65 & 1300 & 150 & 15,69 & 11,77 & 10,38 & 9,05 & 7,96 & 7,02 & 5,48 & 4,35 & 2,92 \\
\hline 65 & 1350 & 150 & 15,42 & 11,62 & 10,28 & 8,98 & 7,92 & 6,99 & 5,47 & 4,35 & 2,93 \\
\hline 65 & 1400 & 150 & 15,17 & 11,47 & 10,18 & 8,92 & 7,88 & 6,97 & 5,47 & 4,36 & 2,94 \\
\hline 65 & 1450 & 150 & 14,92 & 11,34 & 10,09 & 8,85 & 7,84 & 6,94 & 5,46 & 4,36 & 2,94 \\
\hline 65 & 1500 & 150 & 14,70 & 11,21 & 9,99 & 8,79 & 7,79 & 6,91 & 5,45 & 4,36 & 2,95 \\
\hline 65 & 1550 & 150 & 14,48 & 11,08 & 9,91 & 8,73 & 7,75 & 6,89 & 5,45 & 4,36 & 2,95 \\
\hline 65 & 1600 & 150 & 14,28 & 10,96 & 9,82 & 8,67 & 7,72 & 6,86 & 5,44 & 4,36 & 2,96 \\
\hline 65 & 1650 & 150 & 14,09 & 10,85 & 9,74 & 8,62 & 7,68 & 6,84 & 5,43 & 4,37 & 2,96 \\
\hline 65 & 1700 & 150 & 13,91 & 10,74 & 9,66 & 8,56 & 7,64 & 6,81 & 5,43 & 4,37 & 2,97 \\
\hline 65 & 1750 & 150 & 13,74 & 10,63 & 9,59 & 8,51 & 7,60 & 6,79 & 5,42 & 4,37 & 2,97 \\
\hline 65 & 1800 & 150 & 13,57 & 10,53 & 9,51 & 8,46 & 7,57 & 6,77 & 5,41 & 4,37 & 2,98 \\
\hline 65 & 1850 & 150 & 13,41 & 10,43 & 9,44 & 8,41 & 7,53 & 6,74 & 5,40 & 4,37 & 2,98 \\
\hline 65 & 1900 & 150 & 13,26 & 10,34 & 9,37 & 8,36 & 7,50 & 6,72 & 5,39 & 4,37 & 2,99 \\
\hline 65 & 1950 & 150 & 13,12 & 10,25 & 9,31 & 8,31 & 7,46 & 6,70 & 5,39 & 4,37 & 2,99 \\
\hline 65 & 2000 & 150 & 12,98 & 10,16 & 9,24 & 8,27 & 7,43 & 6,67 & 5,38 & 4,37 & 2,99 \\
\hline 65 & 200 & 155 & 46,50 & 23,16 & 16,23 & 11,55 & 8,93 & 7,19 & 5,01 & 3,85 & 2,68 \\
\hline 65 & 250 & 155 & 39,79 & 21,02 & 15,30 & 11,27 & 8,89 & 7,23 & 5,08 & 3,89 & 2,68 \\
\hline 65 & 300 & 155 & 35,21 & 19,50 & 14,61 & 11,04 & 8,83 & 7,25 & 5,14 & 3,93 & 2,68 \\
\hline 65 & 350 & 155 & 31,87 & 18,35 & 14,06 & 10,84 & 8,77 & 7,25 & 5,18 & 3,96 & 2,68 \\
\hline 65 & 400 & 155 & 29,30 & 17,43 & 13,60 & 10,66 & 8,71 & 7,24 & 5,21 & 3,99 & 2,69 \\
\hline 65 & 450 & 155 & 27,27 & 16,68 & 13,22 & 10,49 & 8,64 & 7,23 & 5,24 & 4,01 & 2,70 \\
\hline 65 & 500 & 155 & 25,60 & 16,05 & 12,88 & 10,34 & 8,58 & 7,21 & 5,26 & 4,04 & 2,71 \\
\hline 65 & 550 & 155 & 24,22 & 15,51 & 12,59 & 10,20 & 8,52 & 7,20 & 5,27 & 4,06 & 2,71 \\
\hline 65 & 600 & 155 & 23,04 & 15,04 & 12,32 & 10,07 & 8,46 & 7,17 & 5,29 & 4,08 & 2,72 \\
\hline 65 & 650 & 155 & 22,03 & 14,62 & 12,08 & 9,95 & 8,40 & 7,15 & 5,30 & 4,09 & 2,73 \\
\hline 65 & 700 & 155 & 21,14 & 14,24 & 11,86 & 9,83 & 8,34 & 7,13 & 5,31 & 4,11 & 2,74 \\
\hline 65 & 750 & 155 & 20,36 & 13,90 & 11,66 & 9,73 & 8,28 & 7,10 & 5,31 & 4,12 & 2,75 \\
\hline 65 & 800 & 155 & 19,67 & 13,60 & 11,48 & 9,62 & 8,23 & 7,08 & 5,32 & 4,13 & 2,75 \\
\hline 65 & 850 & 155 & 19,05 & 13,32 & 11,30 & 9,52 & 8,17 & 7,05 & 5,32 & 4,14 & 2,76 \\
\hline 65 & 900 & 155 & 18,49 & 13,06 & 11,14 & 9,43 & 8,12 & 7,02 & 5,32 & 4,15 & 2,77 \\
\hline 65 & 950 & 155 & 17,99 & 12,82 & 10,99 & 9,34 & 8,07 & 7,00 & 5,32 & 4,16 & 2,78 \\
\hline 65 & 1000 & 155 & 17,53 & 12,59 & 10,85 & 9,26 & 8,02 & 6,97 & 5,32 & 4,17 & 2,78 \\
\hline 65 & 1050 & 155 & 17,10 & 12,39 & 10,71 & 9,18 & 7,97 & 6,94 & 5,32 & 4,18 & 2,79 \\
\hline 65 & 1100 & 155 & 16,71 & 12,19 & 10,58 & 9,10 & 7,92 & 6,92 & 5,32 & 4,19 & 2,80 \\
\hline 65 & 1150 & 155 & 16,35 & 12,01 & 10,46 & 9,02 & 7,88 & 6,89 & 5,32 & 4,19 & 2,80 \\
\hline 65 & 1200 & 155 & 16,02 & 11,83 & 10,35 & 8,95 & 7,83 & 6,87 & 5,31 & 4,20 & 2,81 \\
\hline 65 & 1250 & 155 & 15,71 & 11,67 & 10,24 & 8,88 & 7,79 & 6,84 & 5,31 & 4,20 & 2,82 \\
\hline 65 & 1300 & 155 & 15,42 & 11,52 & 10,13 & 8,81 & 7,74 & 6,81 & 5,31 & 4,21 & 2,82 \\
\hline 65 & 1350 & 155 & 15,15 & 11,37 & 10,03 & 8,75 & 7,70 & 6,79 & 5,30 & 4,21 & 2,83 \\
\hline 65 & 1400 & 155 & 14,90 & 11,23 & 9,94 & 8,68 & 7,66 & 6,76 & 5,30 & 4,21 & 2,84 \\
\hline 65 & 1450 & 155 & 14,66 & 11,10 & 9,85 & 8,62 & 7,62 & 6,74 & 5,29 & 4,22 & 2,84 \\
\hline 65 & 1500 & 155 & 14,44 & 10,97 & 9,76 & 8,56 & 7,58 & 6,71 & 5,28 & 4,22 & 2,85 \\
\hline 65 & 1550 & 155 & 14,22 & 10,85 & 9,67 & 8,51 & 7,54 & 6,69 & 5,28 & 4,22 & 2,85 \\
\hline 65 & 1600 & 155 & 14,02 & 10,73 & 9,59 & 8,45 & 7,51 & 6,67 & 5,27 & 4,22 & 2,86 \\
\hline 65 & 1650 & 155 & 13,83 & 10,62 & 9,51 & 8,40 & 7,47 & 6,64 & 5,27 & 4,22 & 2,86 \\
\hline 65 & 1700 & 155 & 13,65 & 10,51 & 9,43 & 8,35 & 7,43 & 6,62 & 5,26 & 4,23 & 2,87 \\
\hline 65 & 1750 & 155 & 13,48 & 10,41 & 9,36 & 8,29 & 7,40 & 6,60 & 5,25 & 4,23 & 2,87 \\
\hline 65 & 1800 & 155 & 13,32 & 10,31 & 9,29 & 8,24 & 7,36 & 6,57 & 5,24 & 4,23 & 2,88 \\
\hline 65 & 1850 & 155 & 13,16 & 10,21 & 9,22 & 8,20 & 7,33 & 6,55 & 5,24 & 4,23 & 2,88 \\
\hline 65 & 1900 & 155 & 13,02 & 10,12 & 9,15 & 8,15 & 7,30 & 6,53 & 5,23 & 4,23 & 2,88 \\
\hline 65 & 1950 & 155 & 12,87 & 10,03 & 9,09 & 8,10 & 7,27 & 6,51 & 5,22 & 4,23 & 2,89 \\
\hline 65 & 2000 & 155 & 12,74 & 9,94 & 9,02 & 8,06 & 7,23 & 6,49 & 5,22 & 4,23 & 2,89 \\
\hline 65 & 200 & 160 & 46,08 & 22,76 & 15,86 & 11,23 & 8,66 & 6,96 & 4,85 & 3,72 & 2,59 \\
\hline 65 & 250 & 160 & 39,39 & 20,64 & 14,94 & 10,96 & 8,62 & 7,00 & 4,92 & 3,77 & 2,59 \\
\hline 65 & 300 & 160 & 34,83 & 19,13 & 14,26 & 10,74 & 8,57 & 7,02 & 4,97 & 3,80 & 2,59 \\
\hline 65 & 350 & 160 & 31,50 & 17,99 & 13,73 & 10,54 & 8,51 & 7,02 & 5,01 & 3,83 & 2,60 \\
\hline 65 & 400 & 160 & 28,95 & 17,09 & 13,28 & 10,37 & 8,45 & 7,02 & 5,04 & 3,86 & 2,60 \\
\hline 65 & 450 & 160 & 26,93 & 16,35 & 12,91 & 10,21 & 8,39 & 7,01 & 5,07 & 3,88 & 2,61 \\
\hline 65 & 500 & 160 & 25,28 & 15,73 & 12,58 & 10,06 & 8,33 & 6,99 & 5,09 & 3,90 & 2,62 \\
\hline 65 & 550 & 160 & 23,90 & 15,20 & 12,29 & 9,93 & 8,27 & 6,98 & 5,10 & 3,92 & 2,63 \\
\hline
\end{tabular}




\begin{tabular}{|c|c|c|c|c|c|c|c|c|c|c|c|}
\hline \multirow[b]{2}{*}{$\mathrm{H}(\mathrm{cm})$} & \multirow[b]{2}{*}{ Mceq (MPa) } & & & & & De & jes ( $x 1$ & & & & \\
\hline & & Msub (MPa) & D0 & D25 & D40 & D60 & $\mathrm{D} 80$ & D100 & D140 & D180 & D260 \\
\hline 65 & 600 & 160 & 22,73 & 14,73 & 12,03 & 9,80 & 8,21 & 6,96 & 5,12 & 3,94 & 2,63 \\
\hline 65 & 650 & 160 & 21,72 & 14,32 & 11,80 & 9,69 & 8,16 & 6,94 & 5,13 & 3,96 & 2,64 \\
\hline 65 & 700 & 160 & 20,84 & 13,95 & 11,58 & 9,57 & 8,10 & 6,91 & 5,14 & 3,97 & 2,65 \\
\hline 65 & 750 & 160 & 20,07 & 13,62 & 11,39 & 9,47 & 8,05 & 6,89 & 5,15 & 3,99 & 2,66 \\
\hline 65 & 800 & 160 & 19,38 & 13,32 & 11,21 & 9,37 & 8,00 & 6,87 & 5,15 & 4,00 & 2,66 \\
\hline 65 & 850 & 160 & 18,77 & 13,04 & 11,04 & 9,28 & 7,94 & 6,84 & 5,15 & 4,01 & 2,67 \\
\hline 65 & 900 & 160 & 18,21 & 12,79 & 10,88 & 9,19 & 7,89 & 6,82 & 5,16 & 4,02 & 2,68 \\
\hline 65 & 950 & 160 & 17,71 & 12,55 & 10,73 & 9,10 & 7,85 & 6,79 & 5,16 & 4,03 & 2,69 \\
\hline 65 & 1000 & 160 & 17,25 & 12,33 & 10,59 & 9,02 & 7,80 & 6,77 & 5,16 & 4,04 & 2,69 \\
\hline 65 & 1050 & 160 & 16,83 & 12,13 & 10,46 & 8,94 & 7,75 & 6,74 & 5,16 & 4,04 & 2,70 \\
\hline 65 & 1100 & 160 & 16,45 & 11,94 & 10,34 & 8,87 & 7,71 & 6,72 & 5,16 & 4,05 & 2,71 \\
\hline 65 & 1150 & 160 & 16,09 & 11,76 & 10,22 & 8,79 & 7,66 & 6,69 & 5,15 & 4,06 & 2,71 \\
\hline 65 & 1200 & 160 & 15,76 & 11,59 & 10,11 & 8,72 & 7,62 & 6,67 & 5,15 & 4,06 & 2,72 \\
\hline 65 & 1250 & 160 & 15,45 & 11,43 & 10,00 & 8,66 & 7,58 & 6,65 & 5,15 & 4,07 & 2,72 \\
\hline 65 & 1300 & 160 & 15,17 & 11,28 & 9,90 & 8,59 & 7,54 & 6,62 & 5,14 & 4,07 & 2,73 \\
\hline 65 & 1350 & 160 & 14,90 & 11,13 & 9,80 & 8,53 & 7,49 & 6,60 & 5,14 & 4,08 & 2,74 \\
\hline 65 & 1400 & 160 & 14,65 & 11,00 & 9,71 & 8,47 & 7,46 & 6,57 & 5,13 & 4,08 & 2,74 \\
\hline 65 & 1450 & 160 & 14,41 & 10,87 & 9,62 & 8,41 & 7,42 & 6,55 & 5,13 & 4,08 & 2,75 \\
\hline 65 & 1500 & 160 & 14,19 & 10,74 & 9,53 & 8,35 & 7,38 & 6,53 & 5,12 & 4,08 & 2,75 \\
\hline 65 & 1550 & 160 & 13,98 & 10,62 & 9,45 & 8,30 & 7,34 & 6,50 & 5,12 & 4,09 & 2,76 \\
\hline 65 & 1600 & 160 & 13,78 & 10,51 & 9,37 & 8,24 & 7,31 & 6,48 & 5,11 & 4,09 & 2,76 \\
\hline 65 & 1650 & 160 & 13,59 & 10,40 & 9,29 & 8,19 & 7,27 & 6,46 & 5,11 & 4,09 & 2,77 \\
\hline 65 & 1700 & 160 & 13,41 & 10,29 & 9,22 & 8,14 & 7,24 & 6,44 & 5,10 & 4,09 & 2,77 \\
\hline 65 & 1750 & 160 & 13,24 & 10,19 & 9,15 & 8,09 & 7,20 & 6,42 & 5,09 & 4,09 & 2,78 \\
\hline 65 & 1800 & 160 & 13,08 & 10,09 & 9,08 & 8,04 & 7,17 & 6,39 & 5,09 & 4,09 & 2,78 \\
\hline 65 & 1850 & 160 & 12,93 & 10,00 & 9,01 & 7,99 & 7,14 & 6,37 & 5,08 & 4,09 & 2,79 \\
\hline 65 & 1900 & 160 & 12,78 & 9,91 & 8,94 & 7,95 & 7,11 & 6,35 & 5,08 & 4,10 & 2,79 \\
\hline 65 & 1950 & 160 & 12,64 & 9,82 & 8,88 & 7,90 & 7,08 & 6,33 & 5,07 & 4,10 & 2,79 \\
\hline 65 & 2000 & 160 & 12,51 & 9,74 & 8,82 & 7,86 & 7,05 & 6,31 & 5,06 & 4,10 & 2,80 \\
\hline 65 & 200 & 165 & 45,68 & 22,39 & 15,51 & 10,93 & 8,40 & 6,74 & 4,69 & 3,61 & 2,51 \\
\hline 65 & 250 & 165 & 39,02 & 20,28 & 14,61 & 10,67 & 8,36 & 6,78 & 4,76 & 3,65 & 2,51 \\
\hline 65 & 300 & 165 & 34,48 & 18,79 & 13,94 & 10,45 & 8,32 & 6,80 & 4,81 & 3,68 & 2,52 \\
\hline 65 & 350 & 165 & 31,16 & 17,66 & 13,41 & 10,26 & 8,26 & 6,81 & 4,85 & 3,71 & 2,52 \\
\hline 65 & 400 & 165 & 28,62 & 16,77 & 12,98 & 10,09 & 8,21 & 6,81 & 4,88 & 3,74 & 2,52 \\
\hline 65 & 450 & 165 & 26,61 & 16,04 & 12,61 & 9,94 & 8,15 & 6,80 & 4,91 & 3,76 & 2,53 \\
\hline 65 & 500 & 165 & 24,96 & 15,43 & 12,29 & 9,80 & 8,10 & 6,79 & 4,93 & 3,78 & 2,54 \\
\hline 65 & 550 & 165 & 23,59 & 14,90 & 12,01 & 9,67 & 8,04 & 6,77 & 4,94 & 3,80 & 2,54 \\
\hline 65 & 600 & 165 & 22,43 & 14,44 & 11,75 & 9,55 & 7,99 & 6,75 & 4,96 & 3,82 & 2,55 \\
\hline 65 & 650 & 165 & 21,43 & 14,04 & 11,53 & 9,44 & 7,93 & 6,73 & 4,97 & 3,83 & 2,56 \\
\hline 65 & 700 & 165 & 20,56 & 13,68 & 11,32 & 9,33 & 7,88 & 6,71 & 4,98 & 3,85 & 2,56 \\
\hline 65 & 750 & 165 & 19,79 & 13,35 & 11,13 & 9,23 & 7,83 & 6,69 & 4,99 & 3,86 & 2,57 \\
\hline 65 & 800 & 165 & 19,11 & 13,05 & 10,95 & 9,13 & 7,78 & 6,67 & 4,99 & 3,87 & 2,58 \\
\hline 65 & 850 & 165 & 18,50 & 12,78 & 10,79 & 9,04 & 7,73 & 6,65 & 5,00 & 3,88 & 2,59 \\
\hline 65 & 900 & 165 & 17,95 & 12,53 & 10,63 & 8,96 & 7,68 & 6,62 & 5,00 & 3,89 & 2,59 \\
\hline 65 & 950 & 165 & 17,45 & 12,30 & 10,49 & 8,87 & 7,63 & 6,60 & 5,00 & 3,90 & 2,60 \\
\hline 65 & 1000 & 165 & 16,99 & 12,09 & 10,35 & 8,79 & 7,59 & 6,58 & 5,00 & 3,91 & 2,61 \\
\hline 65 & 1050 & 165 & 16,58 & 11,89 & 10,22 & 8,72 & 7,54 & 6,55 & 5,00 & 3,92 & 2,61 \\
\hline 65 & 1100 & 165 & 16,19 & 11,70 & 10,10 & 8,65 & 7,50 & 6,53 & 5,00 & 3,92 & 2,62 \\
\hline 65 & 1150 & 165 & 15,84 & 11,52 & 9,99 & 8,57 & 7,46 & 6,51 & 5,00 & 3,93 & 2,63 \\
\hline 65 & 1200 & 165 & 15,51 & 11,36 & 9,88 & 8,51 & 7,42 & 6,48 & 5,00 & 3,93 & 2,63 \\
\hline 65 & 1250 & 165 & 15,21 & 11,20 & 9,78 & 8,44 & 7,38 & 6,46 & 4,99 & 3,94 & 2,64 \\
\hline 65 & 1300 & 165 & 14,92 & 11,05 & 9,68 & 8,38 & 7,34 & 6,44 & 4,99 & 3,94 & 2,64 \\
\hline 65 & 1350 & 165 & 14,66 & 10,91 & 9,58 & 8,32 & 7,30 & 6,42 & 4,99 & 3,95 & 2,65 \\
\hline 65 & 1400 & 165 & 14,41 & 10,78 & 9,49 & 8,26 & 7,26 & 6,39 & 4,98 & 3,95 & 2,65 \\
\hline 65 & 1450 & 165 & 14,17 & 10,65 & 9,40 & 8,20 & 7,23 & 6,37 & 4,98 & 3,96 & 2,66 \\
\hline 65 & 1500 & 165 & 13,95 & 10,53 & 9,32 & 8,15 & 7,19 & 6,35 & 4,97 & 3,96 & 2,66 \\
\hline 65 & 1550 & 165 & 13,75 & 10,41 & 9,24 & 8,09 & 7,15 & 6,33 & 4,97 & 3,96 & 2,67 \\
\hline 65 & 1600 & 165 & 13,55 & 10,30 & 9,16 & 8,04 & 7,12 & 6,31 & 4,96 & 3,96 & 2,67 \\
\hline 65 & 1650 & 165 & 13,36 & 10,19 & 9,09 & 7,99 & 7,09 & 6,29 & 4,96 & 3,96 & 2,68 \\
\hline 65 & 1700 & 165 & 13,19 & 10,09 & 9,01 & 7,94 & 7,05 & 6,26 & 4,95 & 3,97 & 2,68 \\
\hline 65 & 1750 & 165 & 13,02 & 9,99 & 8,94 & 7,89 & 7,02 & 6,24 & 4,95 & 3,97 & 2,69 \\
\hline 65 & 1800 & 165 & 12,86 & 9,89 & 8,88 & 7,85 & 6,99 & 6,22 & 4,94 & 3,97 & 2,69 \\
\hline 65 & 1850 & 165 & 12,70 & 9,80 & 8,81 & 7,80 & 6,96 & 6,20 & 4,93 & 3,97 & 2,70 \\
\hline 65 & 1900 & 165 & 12,56 & 9,71 & 8,75 & 7,76 & 6,93 & 6,18 & 4,93 & 3,97 & 2,70 \\
\hline 65 & 1950 & 165 & 12,42 & 9,62 & 8,68 & 7,72 & 6,90 & 6,16 & 4,92 & 3,97 & 2,70 \\
\hline 65 & 2000 & 165 & 12,29 & 9,54 & 8,62 & 7,67 & 6,87 & 6,14 & 4,92 & 3,97 & 2,71 \\
\hline 65 & 200 & 170 & 45,31 & 22,03 & 15,18 & 10,64 & 8,16 & 6,54 & 4,54 & 3,50 & 2,44 \\
\hline 65 & 250 & 170 & 38,66 & 19,93 & 14,29 & 10,39 & 8,12 & 6,58 & 4,61 & 3,53 & 2,44 \\
\hline 65 & 300 & 170 & 34,14 & 18,46 & 13,63 & 10,18 & 8,08 & 6,60 & 4,66 & 3,57 & 2,44 \\
\hline 65 & 350 & 170 & 30,83 & 17,34 & 13,11 & 9,99 & 8,03 & 6,61 & 4,70 & 3,59 & 2,44 \\
\hline 65 & 400 & 170 & 28,31 & 16,46 & 12,69 & 9,83 & 7,98 & 6,61 & 4,73 & 3,62 & 2,45 \\
\hline 65 & 450 & 170 & 26,30 & 15,74 & 12,33 & 9,68 & 7,93 & 6,60 & 4,76 & 3,64 & 2,45 \\
\hline 65 & 500 & 170 & 24,67 & 15,14 & 12,01 & 9,55 & 7,87 & 6,59 & 4,78 & 3,66 & 2,46 \\
\hline 65 & 550 & 170 & 23,30 & 14,62 & 11,74 & 9,42 & 7,82 & 6,58 & 4,79 & 3,68 & 2,47 \\
\hline 65 & 600 & 170 & 22,15 & 14,17 & 11,49 & 9,31 & 7,77 & 6,56 & 4,81 & 3,70 & 2,47 \\
\hline 65 & 650 & 170 & 21,15 & 13,77 & 11,27 & 9,20 & 7,72 & 6,54 & 4,82 & 3,71 & 2,48 \\
\hline 65 & 700 & 170 & 20,29 & 13,41 & 11,07 & 9,10 & 7,67 & 6,52 & 4,83 & 3,73 & 2,49 \\
\hline 65 & 750 & 170 & 19,53 & 13,09 & 10,88 & 9,00 & 7,62 & 6,50 & 4,84 & 3,74 & 2,49 \\
\hline 65 & 800 & 170 & 18,85 & 12,80 & 10,71 & 8,91 & 7,57 & 6,48 & 4,84 & 3,75 & 2,50 \\
\hline 65 & 850 & 170 & 18,24 & 12,53 & 10,55 & 8,82 & 7,53 & 6,46 & 4,85 & 3,76 & 2,51 \\
\hline 65 & 900 & 170 & 17,70 & 12,29 & 10,40 & 8,74 & 7,48 & 6,44 & 4,85 & 3,77 & 2,51 \\
\hline
\end{tabular}




\begin{tabular}{|c|c|c|c|c|c|c|c|c|c|c|c|}
\hline \multirow[b]{2}{*}{$\mathrm{H}(\mathrm{cm})$} & \multirow[b]{2}{*}{ Mceq (MPa) } & & & & & $\mathrm{De}$ & $\operatorname{ses}(x$ & & & & \\
\hline & & Msub (MPa) & D0 & D25 & D40 & D60 & D80 & D100 & D140 & D180 & D260 \\
\hline 65 & 950 & 170 & 17,20 & 12,06 & 10,26 & 8,66 & 7,44 & 6,42 & 4,85 & 3,78 & 2,52 \\
\hline 65 & 1000 & 170 & 16,75 & 11,85 & 10,12 & 8,58 & 7,39 & 6,40 & 4,85 & 3,79 & 2,53 \\
\hline 65 & 1050 & 170 & 16,34 & 11,66 & 10,00 & 8,51 & 7,35 & 6,38 & 4,85 & 3,80 & 2,53 \\
\hline 65 & 1100 & 170 & 15,96 & 11,47 & 9,88 & 8,44 & 7,31 & 6,35 & 4,85 & 3,80 & 2,54 \\
\hline 65 & 1150 & 170 & 15,60 & 11,30 & 9,77 & 8,37 & 7,27 & 6,33 & 4,85 & 3,81 & 2,54 \\
\hline 65 & 1200 & 170 & 15,28 & 11,14 & 9,66 & 8,30 & 7,23 & 6,31 & 4,85 & 3,82 & 2,55 \\
\hline 65 & 1250 & 170 & 14,98 & 10,98 & 9,56 & 8,24 & 7,19 & 6,29 & 4,85 & 3,82 & 2,56 \\
\hline 65 & 1300 & 170 & 14,69 & 10,84 & 9,47 & 8,18 & 7,15 & 6,27 & 4,85 & 3,83 & 2,56 \\
\hline 65 & 1350 & 170 & 14,43 & 10,70 & 9,37 & 8,12 & 7,11 & 6,25 & 4,84 & 3,83 & 2,57 \\
\hline 65 & 1400 & 170 & 14,18 & 10,57 & 9,28 & 8,06 & 7,08 & 6,22 & 4,84 & 3,83 & 2,57 \\
\hline 65 & 1450 & 170 & 13,95 & 10,44 & 9,20 & 8,01 & 7,04 & 6,20 & 4,84 & 3,84 & 2,58 \\
\hline 65 & 1500 & 170 & 13,73 & 10,32 & 9,12 & 7,96 & 7,01 & 6,18 & 4,83 & 3,84 & 2,58 \\
\hline 65 & 1550 & 170 & 13,53 & 10,21 & 9.04 & 7,90 & 6.97 & 6.16 & 4.83 & 3,84 & 2,59 \\
\hline 65 & 1600 & 170 & 13,33 & 10,10 & 8,96 & 7,85 & 6,94 & 6,14 & 4,82 & 3,84 & 2,59 \\
\hline 65 & 1650 & 170 & 13,14 & 9,99 & 8,89 & 7,80 & 6,91 & 6,12 & 4,82 & 3,85 & 2,60 \\
\hline 65 & 1700 & 170 & 12,97 & 9,89 & 8,82 & 7,76 & 6,88 & 6,10 & 4,81 & 3,85 & 2,60 \\
\hline 65 & 1750 & 170 & 12,80 & 9,79 & 8,75 & 7,71 & 6,85 & 6,08 & 4,81 & 3,85 & 2,60 \\
\hline 65 & 1800 & 170 & 12,64 & 9,70 & 8,68 & 7,67 & 6,82 & 6,06 & 4,80 & 3,85 & 2,61 \\
\hline 65 & 1850 & 170 & 12,49 & 9,61 & 8,62 & 7,62 & 6,79 & 6,04 & 4,80 & 3,85 & 2,61 \\
\hline 65 & 1900 & 170 & 12,35 & 9,52 & 8,56 & 7,58 & 6,76 & 6,02 & 4,79 & 3,85 & 2,62 \\
\hline 65 & 1950 & 170 & 12,21 & 9,44 & 8,50 & 7,54 & 6,73 & 6,00 & 4,78 & 3,85 & 2,62 \\
\hline 65 & 2000 & 170 & 12,08 & 9,36 & 8,44 & 7,50 & 6,70 & 5,99 & 4,78 & 3,85 & 2,62 \\
\hline 65 & 200 & 175 & 44,95 & 21,69 & 14,87 & 10,37 & 7,93 & 6,35 & 4,41 & 3,39 & 2,37 \\
\hline 65 & 250 & 175 & 38,32 & 19,61 & 13,99 & 10,12 & 7,90 & 6,39 & 4,47 & 3,43 & 2,37 \\
\hline 65 & 300 & 175 & 33,81 & 18,15 & 13,34 & 9,92 & 7,86 & 6,41 & 4,52 & 3,46 & 2,37 \\
\hline 65 & 350 & 175 & 30,52 & 17,04 & 12,83 & 9,74 & 7,81 & 6,42 & 4,56 & 3,49 & 2,37 \\
\hline 65 & 400 & 175 & 28,01 & 16,17 & 12,41 & 9,58 & 7,76 & 6,42 & 4,59 & 3,51 & 2,38 \\
\hline 65 & 450 & 175 & 26,01 & 15,46 & 12,06 & 9,44 & 7,71 & 6,41 & 4,61 & 3,53 & 2,38 \\
\hline 65 & 500 & 175 & 24,39 & 14,86 & 11,75 & 9,31 & 7,66 & 6,41 & 4,64 & 3,55 & 2,39 \\
\hline 65 & 550 & 175 & 23,03 & 14,35 & 11,48 & 9,19 & 7,61 & 6,39 & 4,65 & 3,57 & 2,39 \\
\hline 65 & 600 & 175 & 21,88 & 13,91 & 11,24 & 9,08 & 7,57 & 6,38 & 4,67 & 3,59 & 2,40 \\
\hline 65 & 650 & 175 & 20,89 & 13,51 & $\begin{array}{l}+1,4+ \\
11,02\end{array}$ & 8,98 & 7,52 & 6,36 & 4,68 & 3,60 & 2,41 \\
\hline 65 & 700 & 175 & 20,03 & 13,16 & 10,83 & 8,88 & 7,47 & 6,35 & 4,69 & 3,62 & 2,41 \\
\hline 65 & 750 & 175 & 19,27 & 12,85 & 10,64 & 8,78 & 7,42 & 6,33 & 4,70 & 3,63 & 2,42 \\
\hline 65 & 800 & 175 & 18,60 & 12,56 & 10,48 & 8,69 & 7,38 & 6,31 & 4,70 & 3,64 & 2,43 \\
\hline 65 & 850 & 175 & 18,00 & 12,30 & 10,32 & 8,61 & 7,33 & 6,29 & 4,71 & 3,65 & 2,43 \\
\hline 65 & 900 & 175 & 17,46 & 12,06 & 10,17 & 8,53 & 7,29 & 6,27 & 4,71 & 3,66 & 2,44 \\
\hline 65 & 950 & 175 & 16,96 & 11,84 & 10,04 & 8,45 & 7,25 & 6,25 & 4,71 & 3,67 & 2,44 \\
\hline 65 & 1000 & 175 & 16,52 & 11,63 & 9,91 & 8,38 & 7,20 & 6,23 & 4,71 & 3,68 & 2,45 \\
\hline 65 & 1050 & 175 & 16,11 & 11,44 & 9,79 & 8,31 & 7,16 & 6,21 & 4,72 & 3,68 & 2,46 \\
\hline 65 & 1100 & 175 & 15,73 & 11,25 & 9,67 & 8,24 & 7,12 & 6,19 & 4,72 & 3,69 & 2,46 \\
\hline 65 & 1150 & 175 & 15,38 & 11,08 & 9,56 & 8,17 & 7,09 & 6,17 & 4,71 & 3,70 & 2,47 \\
\hline 65 & 1200 & 175 & 15,06 & 10,92 & 9,46 & 8,11 & 7,05 & 6,14 & 4,71 & 3,70 & 2,47 \\
\hline 65 & 1250 & 175 & 14,76 & 10,77 & 9,36 & 8,05 & 7,01 & 6,12 & 4,71 & 3,71 & 2,48 \\
\hline 65 & 1300 & 175 & 14,48 & 10,63 & 9,26 & 7,99 & 6,97 & 6,10 & 4,71 & 3,71 & 2,48 \\
\hline 65 & 1350 & 175 & 14,21 & 10,49 & 9,17 & 7,93 & 6,94 & 6,08 & 4,71 & 3,72 & 2,49 \\
\hline 65 & 1400 & 175 & 13,97 & 10,37 & 9,09 & 7,88 & 6,90 & 6,06 & 4,70 & 3,72 & 2,49 \\
\hline 65 & 1450 & 175 & 13,74 & 10,24 & 9,00 & 7,82 & 6,87 & 6,04 & 4,70 & 3,72 & 2,50 \\
\hline 65 & 1500 & 175 & 13,52 & 10,12 & 8,92 & 7,77 & 6,84 & 6,02 & 4,70 & 3,73 & 2,50 \\
\hline 65 & 1550 & 175 & 13,32 & 10,01 & 8,85 & 7,72 & 6,80 & 6,00 & 4,69 & 3,73 & 2,51 \\
\hline 65 & 1600 & 175 & 13,12 & 9,90 & 8,77 & 7,67 & 6,77 & 5,98 & 4,69 & 3,73 & 2,51 \\
\hline 65 & 1650 & 175 & 12,94 & 9,80 & 8,70 & 7,63 & 6,74 & 5,96 & 4,68 & 3,73 & 2,52 \\
\hline 65 & 1700 & 175 & $\begin{array}{l}12,76 \\
12,7\end{array}$ & 9,70 & 8,63 & 7,58 & 6,71 & 5,95 & 4,68 & 3,74 & 2,52 \\
\hline 65 & 1750 & 175 & 12,60 & 9,61 & 8,57 & 7,54 & 6,68 & 5,93 & 4,67 & 3,74 & 2,53 \\
\hline 65 & 1800 & 175 & 12,44 & 9,51 & 8,50 & 7,49 & 6,65 & 5,91 & 4,67 & 3,74 & 2,53 \\
\hline 65 & 1850 & 175 & 12,29 & 9,43 & 8,44 & 7,45 & 6,62 & 5,89 & 4,66 & 3,74 & 2,53 \\
\hline 65 & 1900 & 175 & 12,15 & 9,34 & 8,38 & 7,41 & 6,59 & 5,87 & 4,66 & 3,74 & 2,54 \\
\hline 65 & 1950 & 175 & 12,01 & 9,26 & 8,32 & 7,37 & 6,57 & 5,85 & 4,65 & 3,74 & 2,54 \\
\hline 65 & 2000 & 175 & 11,88 & 9,18 & 8,26 & 7,33 & 6,54 & 5,83 & 4,65 & 3,74 & 2,55 \\
\hline 65 & 200 & 180 & 44,62 & 21,37 & 14,57 & 10,11 & 7,71 & 6,16 & 4,27 & 3,29 & 2,31 \\
\hline 65 & 250 & 180 & 38,00 & 19,30 & 13,70 & 9,87 & 7,68 & 6,21 & 4,34 & 3,33 & 2,30 \\
\hline 65 & 300 & 180 & 33,51 & 17,85 & 13,06 & 9,67 & 7,64 & 6,23 & 4,39 & 3,36 & 2,30 \\
\hline 65 & 350 & 180 & 30,23 & 16,76 & 12,56 & 9,50 & 7,60 & 6,24 & 4,42 & 3,38 & 2,31 \\
\hline 65 & 400 & 180 & 27,72 & 15,90 & 12,15 & 9,35 & 7,56 & 6,24 & 4,46 & 3,41 & 2,31 \\
\hline 65 & 450 & 180 & 25,74 & 15,19 & 11,81 & 9,21 & 7,51 & 6,24 & 4,48 & 3,43 & 2,32 \\
\hline 65 & 500 & 180 & 24,12 & 14,60 & 11,51 & 9,09 & 7,46 & 6,23 & 4,50 & 3,45 & 2,32 \\
\hline 65 & 550 & 180 & 22,77 & 14,10 & 11,24 & 8,97 & 7,42 & 6,22 & 4,52 & 3,47 & 2,33 \\
\hline 65 & 600 & 180 & 21,63 & 13,66 & 11,01 & 8,86 & 7,37 & 6,21 & 4,53 & 3,48 & 2,33 \\
\hline 65 & 650 & 180 & 20,64 & 13,27 & 10,79 & 8,76 & 7,32 & 6,19 & 4,54 & 3,50 & 2,34 \\
\hline 65 & 700 & 180 & 19,79 & 12,93 & 10,60 & 8,67 & 7,28 & 6,18 & 4,55 & 3,51 & 2,34 \\
\hline 65 & 750 & 180 & 19,03 & 12,62 & 10,42 & 8,58 & 7,24 & 6,16 & 4,56 & 3,52 & 2,35 \\
\hline 65 & 800 & 180 & 18,37 & 12,33 & 10,26 & 8,49 & 7,19 & 6,14 & 4,57 & 3,53 & 2,36 \\
\hline 65 & 850 & 180 & 17,77 & 12,08 & 10,10 & 8,41 & 7,15 & 6,12 & 4,57 & 3,54 & 2,36 \\
\hline 65 & 900 & 180 & 17,23 & 11,84 & 9,96 & 8,33 & 7,11 & 6,10 & 4,58 & 3,55 & 2,37 \\
\hline 65 & 950 & 180 & 16,74 & 11,62 & 9,83 & 8,26 & 7,07 & 6,08 & 4,58 & 3,56 & 2,37 \\
\hline 65 & 1000 & 180 & 16,29 & 11,42 & 9,70 & 8,18 & 7,03 & 6,07 & 4,58 & 3,57 & 2,38 \\
\hline 65 & 1050 & 180 & 15,89 & 11,23 & 9,58 & 8,12 & 6,99 & 6,05 & 4,58 & 3,58 & 2,38 \\
\hline 65 & 1100 & 180 & 15,51 & 11,05 & 9,47 & 8,05 & 6,95 & 6,03 & 4,58 & 3,58 & 2,39 \\
\hline 65 & 1150 & 180 & 15,17 & 10,88 & 9,36 & 7,99 & 6,91 & 6,01 & 4,58 & 3,59 & 2,40 \\
\hline 65 & 1200 & 180 & 14,85 & 10,72 & 9,26 & 7,92 & 6,88 & 5,99 & 4,58 & 3,60 & 2,40 \\
\hline 65 & 1250 & 180 & 14,55 & 10,58 & 9,17 & 7,87 & 6,84 & 5,97 & 4,58 & 3,60 & 2,41 \\
\hline
\end{tabular}




\begin{tabular}{|c|c|c|c|c|c|c|c|c|c|c|c|}
\hline \multirow[b]{2}{*}{$\mathrm{H}(\mathrm{cm})$} & \multirow[b]{2}{*}{ Mceq (MPa) } & & & & & & jes ( $x 1$ & & & & \\
\hline & & Msub (MPa) & D0 & D25 & D40 & D60 & $\mathrm{D} 80$ & D100 & D140 & D180 & D260 \\
\hline 65 & 1300 & 180 & 14,27 & 10,43 & 9,07 & 7,81 & 6,81 & 5,95 & 4,58 & 3,61 & 2,41 \\
\hline 65 & 1350 & 180 & 14,01 & 10,30 & 8,98 & 7,75 & 6,77 & 5,93 & 4,58 & 3,61 & 2,42 \\
\hline 65 & 1400 & 180 & 13,77 & 10,17 & 8,90 & 7,70 & 6,74 & 5,91 & 4,58 & 3,61 & 2,42 \\
\hline 65 & 1450 & 180 & 13,54 & 10,05 & 8,82 & 7,65 & 6,71 & 5,89 & 4,57 & 3,62 & 2,43 \\
\hline 65 & 1500 & 180 & 13,32 & 9,94 & 8,74 & 7,60 & 6,67 & 5,87 & 4,57 & 3,62 & 2,43 \\
\hline 65 & 1550 & 180 & 13,12 & 9,83 & 8,67 & 7,55 & 6,64 & 5,85 & 4,57 & 3,62 & 2,44 \\
\hline 65 & 1600 & 180 & 12,92 & 9,72 & 8,59 & 7,50 & 6,61 & 5,83 & 4,56 & 3,63 & 2,44 \\
\hline 65 & 1650 & 180 & 12,74 & 9,62 & 8,52 & 7,46 & 6,58 & 5,82 & 4,56 & 3,63 & 2,44 \\
\hline 65 & 1700 & 180 & 12,57 & 9,52 & 8,46 & 7,41 & 6,55 & 5,80 & 4,55 & 3,63 & 2,45 \\
\hline 65 & 1750 & 180 & 12,41 & 9,43 & 8,39 & 7,37 & 6,52 & 5,78 & 4,55 & 3,63 & 2,45 \\
\hline 65 & 1800 & 180 & 12,25 & 9,34 & 8,33 & 7,33 & 6,50 & 5,76 & 4,55 & 3,63 & 2,46 \\
\hline 65 & 1850 & 180 & 12,10 & 9,25 & 8,27 & 7,28 & 6,47 & 5,74 & 4,54 & 3,64 & 2,46 \\
\hline 65 & 1900 & 180 & 11,96 & 9,17 & 8,21 & 7,24 & 6,44 & 5,73 & 4,54 & 3,64 & 2,46 \\
\hline 65 & 1950 & 180 & 11,82 & 9,09 & 8,15 & 7,21 & 6,41 & 5,71 & 4,53 & 3,64 & 2,47 \\
\hline 65 & 2000 & 180 & 11,69 & 9,01 & 8,10 & 7,17 & 6,39 & 5,69 & 4,53 & 3,64 & 2,47 \\
\hline 65 & 200 & 185 & 44,30 & 21,06 & 14,29 & 9,86 & 7,50 & 5,99 & 4,15 & 3,20 & 2,25 \\
\hline 65 & 250 & 185 & 37,70 & 19,01 & 13,43 & 9,63 & 7,48 & 6,03 & 4,21 & 3,23 & 2,24 \\
\hline 65 & 300 & 185 & 33,21 & 17,57 & 12,80 & 9,44 & 7,44 & 6,06 & 4,26 & 3,26 & 2,24 \\
\hline 65 & 350 & 185 & 29,95 & 16,49 & 12,31 & 9,28 & 7,41 & 6,07 & 4,30 & 3,29 & 2,24 \\
\hline 65 & 400 & 185 & 27,45 & 15,63 & 11,91 & 9,13 & 7,36 & 6,07 & 4,33 & 3,31 & 2,25 \\
\hline 65 & 450 & 185 & 25,47 & 14,94 & 11,56 & 9,00 & 7,32 & 6,07 & 4,35 & 3,33 & 2,25 \\
\hline 65 & 500 & 185 & 23,86 & 14,35 & 11,27 & 8,87 & 7,27 & 6,06 & 4,37 & 3,35 & 2,26 \\
\hline 65 & 550 & 185 & 22,52 & 13,86 & 11,01 & 8,76 & 7,23 & 6,06 & 4,39 & 3,37 & 2,26 \\
\hline 65 & 600 & 185 & 21,38 & 13,42 & 10,78 & 8,66 & 7,19 & 6,04 & 4,41 & 3,38 & 2,27 \\
\hline 65 & 650 & 185 & 20,41 & 13,04 & 10,57 & 8,56 & 7,14 & 6,03 & 4,42 & 3,40 & 2,27 \\
\hline 65 & 700 & 185 & 19,56 & 12,70 & 10,38 & 8,47 & 7,10 & 6,02 & 4,43 & 3,41 & 2,28 \\
\hline 65 & 750 & 185 & 18,81 & 12,39 & 10,21 & 8,38 & 7,06 & 6,00 & 4,44 & 3,42 & 2,28 \\
\hline 65 & 800 & 185 & 18,14 & 12,12 & 10,05 & 8,30 & 7,02 & 5,98 & 4,44 & 3,43 & 2,29 \\
\hline 65 & 850 & 185 & 17,55 & 11,86 & 9,90 & 8,22 & 6,98 & 5,97 & 4,45 & 3,44 & 2,30 \\
\hline 65 & 900 & 185 & 17,01 & 11,63 & 9,76 & 8,14 & 6,94 & 5,95 & 4,45 & 3,45 & 2,30 \\
\hline 65 & 950 & 185 & 16,53 & 11,41 & 9,63 & 8,07 & 6,90 & 5,93 & 4,46 & 3,46 & 2,31 \\
\hline 65 & 1000 & 185 & 16,08 & 11,21 & 9,50 & 8,00 & 6,86 & 5,91 & 4,46 & 3,47 & 2,31 \\
\hline 65 & 1050 & 185 & 15,68 & 11,03 & 9,39 & 7,93 & 6,82 & 5,89 & 4,46 & 3,48 & 2,32 \\
\hline 65 & 1100 & 185 & 15,31 & 10,85 & 9,28 & 7,87 & 6,78 & 5,87 & 4,46 & 3,48 & 2,32 \\
\hline 65 & 1150 & 185 & 14,96 & 10,69 & 9,17 & 7,81 & 6,75 & 5,86 & 4,46 & 3,49 & 2,33 \\
\hline 65 & 1200 & 185 & 14,64 & 10,53 & 9,08 & 7,75 & 6,71 & 5,84 & 4,46 & 3,50 & 2,33 \\
\hline 65 & 1250 & 185 & 14,35 & 10,39 & 8,98 & 7,69 & 6,68 & 5,82 & 4,46 & 3,50 & 2,34 \\
\hline 65 & 1300 & 185 & 14,07 & 10,25 & 8,89 & 7,64 & 6,65 & 5,80 & 4,46 & 3,51 & 2,34 \\
\hline 65 & 1350 & 185 & 13,81 & 10,12 & 8,80 & 7,58 & 6,61 & 5,78 & 4,46 & 3,51 & 2,35 \\
\hline 65 & 1400 & 185 & 13,57 & 9,99 & 8,72 & 7,53 & 6,58 & 5,76 & 4,45 & 3,51 & 2,35 \\
\hline 65 & 1450 & 185 & 13,34 & 9,87 & 8,64 & 7,48 & 6,55 & 5,75 & 4,45 & 3,52 & 2,36 \\
\hline 65 & 1500 & 185 & 13,13 & 9,76 & 8,57 & 7,43 & 6,52 & 5,73 & 4,45 & 3,52 & 2,36 \\
\hline 65 & 1550 & 185 & 12,93 & 9,65 & 8,49 & 7,39 & 6,49 & 5,71 & 4,45 & 3,52 & 2,37 \\
\hline 65 & 1600 & 185 & 12,74 & 9,55 & 8,42 & 7,34 & 6,46 & 5,69 & 4,44 & 3,53 & 2,37 \\
\hline 65 & 1650 & 185 & 12,56 & 9,45 & 8,35 & 7,29 & 6,43 & 5,67 & 4,44 & 3,53 & 2,37 \\
\hline 65 & 1700 & 185 & 12,38 & 9,35 & 8,29 & 7,25 & 6,40 & 5,66 & 4,43 & 3,53 & 2,38 \\
\hline 65 & 1750 & 185 & 12,22 & 9,26 & 8,22 & 7,21 & 6,37 & 5,64 & 4,43 & 3,53 & 2,38 \\
\hline 65 & 1800 & 185 & 12,07 & 9,17 & 8,16 & 7,17 & 6,35 & 5,62 & 4,43 & 3,53 & 2,39 \\
\hline 65 & 1850 & 185 & 11,92 & 9,09 & 8,10 & 7,13 & 6,32 & 5,61 & 4,42 & 3,54 & 2,39 \\
\hline 65 & 1900 & 185 & 11,78 & 9,01 & 8,05 & 7,09 & 6,29 & 5,59 & 4,42 & 3,54 & 2,39 \\
\hline 65 & 1950 & 185 & 11,64 & 8,93 & 7,99 & 7,05 & 6,27 & 5,57 & 4,41 & 3,54 & 2,40 \\
\hline 65 & 2000 & 185 & 11,51 & 8,85 & 7,94 & 7,01 & 6,24 & 5,56 & 4,41 & 3,54 & 2,40 \\
\hline 65 & 200 & 190 & 43,99 & 20,77 & 14,02 & 9,63 & 7,31 & 5,83 & 4,03 & 3,11 & 2,19 \\
\hline 65 & 250 & 190 & 37,41 & 18,73 & 13,17 & 9,41 & 7,29 & 5,87 & 4,10 & 3,14 & 2,18 \\
\hline 65 & 300 & 190 & 32,93 & 17,30 & 12,55 & 9,22 & 7,25 & 5,90 & 4,14 & 3,17 & 2,18 \\
\hline 65 & 350 & 190 & 29,68 & 16,23 & 12,07 & 9,06 & 7,22 & 5,91 & 4,18 & 3,20 & 2,18 \\
\hline 65 & 400 & 190 & 27,19 & 15,38 & 11,67 & 8,92 & 7,18 & 5,91 & 4,21 & 3,22 & 2,19 \\
\hline 65 & 450 & 190 & 25,22 & 14,69 & 11,33 & 8,79 & 7,14 & 5,91 & 4,23 & 3,24 & 2,19 \\
\hline 65 & 500 & 190 & 23,62 & 14,12 & 11,05 & 8,67 & 7,09 & 5,91 & 4,25 & 3,26 & 2,20 \\
\hline 65 & 550 & 190 & 22,28 & 13,63 & 10,79 & 8,56 & 7,05 & 5,90 & 4,27 & 3,27 & 2,20 \\
\hline 65 & 600 & 190 & 21,15 & 13,20 & 10,57 & 8,46 & 7,01 & 5,89 & 4,29 & 3,29 & 2,21 \\
\hline 65 & 650 & 190 & 20,18 & 12,82 & 10,36 & 8,37 & 6,97 & 5,88 & 4,30 & 3,30 & 2,21 \\
\hline 65 & 700 & 190 & 19,33 & 12,48 & 10,17 & 8,28 & 6,93 & 5,86 & 4,31 & 3,32 & 2,22 \\
\hline 65 & 750 & 190 & 18,59 & 12,18 & 10,00 & 8,19 & 6,89 & 5,85 & 4,32 & 3,33 & 2,22 \\
\hline 65 & 800 & 190 & 17,93 & 11,91 & 9,85 & 8,11 & 6,85 & 5,83 & 4,32 & 3,34 & 2,23 \\
\hline 65 & 850 & 190 & 17,34 & 11,66 & 9,70 & 8,03 & 6,81 & 5,82 & 4,33 & 3,35 & 2,23 \\
\hline 65 & 900 & 190 & 16,80 & 11,43 & 9,56 & 7,96 & 6,77 & 5,80 & 4,33 & 3,36 & 2,24 \\
\hline 65 & 950 & 190 & 16,32 & 11,22 & 9,44 & 7,89 & 6,73 & 5,78 & 4,34 & 3,37 & 2,24 \\
\hline 65 & 1000 & 190 & 15,88 & 11,02 & 9,32 & 7,82 & 6,70 & 5,77 & 4,34 & 3,37 & 2,25 \\
\hline 65 & 1050 & 190 & 15,48 & 10,83 & 9,20 & 7,76 & 6,66 & 5,75 & 4,34 & 3,38 & 2,25 \\
\hline 65 & 1100 & 190 & 15,11 & 10,66 & 9,10 & 7,70 & 6,63 & 5,73 & 4,34 & 3,39 & 2,26 \\
\hline 65 & 1150 & 190 & 14,77 & 10,50 & 8,99 & 7,64 & 6,59 & 5,71 & 4,34 & 3,39 & 2,26 \\
\hline 65 & 1200 & 190 & 14,45 & 10,35 & 8,90 & 7,58 & 6,56 & 5,70 & 4,34 & 3,40 & 2,27 \\
\hline 65 & 1250 & 190 & 14,16 & 10,21 & 8,80 & 7,53 & 6,53 & 5,68 & 4,34 & 3,41 & 2,27 \\
\hline 65 & 1300 & 190 & 13,88 & 10,07 & 8,72 & 7,47 & 6,49 & 5,66 & 4,34 & 3,41 & 2,28 \\
\hline 65 & 1350 & 190 & 13,63 & 9,94 & 8,63 & 7,42 & 6,46 & 5,64 & 4,34 & 3,41 & 2,28 \\
\hline 65 & 1400 & 190 & 13,39 & 9,82 & 8,55 & 7,37 & 6,43 & 5,63 & 4,34 & 3,42 & 2,29 \\
\hline 65 & 1450 & 190 & 13,16 & 9,70 & 8,47 & 7,32 & 6,40 & 5,61 & 4,34 & 3,42 & 2,29 \\
\hline 65 & 1500 & 190 & 12,95 & 9,59 & 8,40 & 7,27 & 6,37 & 5,59 & 4,33 & 3,43 & 2,30 \\
\hline 65 & 1550 & 190 & 12,75 & 9,48 & 8,33 & 7,23 & 6,34 & 5,57 & 4,33 & 3,43 & 2,30 \\
\hline 65 & 1600 & 190 & 12,56 & 9,38 & 8,26 & 7,18 & 6,31 & 5,56 & 4,33 & 3,43 & 2,30 \\
\hline
\end{tabular}




\begin{tabular}{|c|c|c|c|c|c|c|c|c|c|c|c|}
\hline & & & \multicolumn{9}{|c|}{ Deflexões $\left(\times 10^{-4} \mathrm{~cm}\right)$} \\
\hline $\mathrm{H}(\mathrm{cm})$ & Mceq (MPa) & Msub (MPa) & D0 & D25 & D40 & D60 & $\mathrm{D} 80$ & D100 & D140 & D180 & D260 \\
\hline 65 & 1650 & 190 & 12,38 & 9,28 & 8,19 & 7,14 & 6,29 & 5,54 & 4,32 & 3,43 & 2,31 \\
\hline 65 & 1700 & 190 & 12,21 & 9,19 & 8,13 & 7,10 & 6,26 & 5,52 & 4,32 & 3,44 & 2,31 \\
\hline 65 & 1750 & 190 & 12,05 & 9,10 & 8,07 & 7,06 & 6,23 & 5,51 & 4,32 & 3,44 & 2,32 \\
\hline 65 & 1800 & 190 & 11,89 & 9,01 & 8,01 & 7,02 & 6,20 & 5,49 & 4,31 & 3,44 & 2,32 \\
\hline 65 & 1850 & 190 & 11,74 & 8,93 & 7,95 & 6,98 & 6,18 & 5,47 & 4,31 & 3,44 & 2,32 \\
\hline 65 & 1900 & 190 & 11,60 & 8,85 & 7,89 & 6,94 & 6,15 & 5,46 & 4,31 & 3,44 & 2,33 \\
\hline 65 & 1950 & 190 & 11,47 & 8,77 & 7,84 & 6,90 & 6,13 & 5,44 & 4,30 & 3,44 & 2,33 \\
\hline 65 & 2000 & 190 & 11,34 & 8,69 & 7,78 & 6,87 & 6,10 & 5,43 & 4,30 & 3,45 & 2,33 \\
\hline 65 & 200 & 195 & 43,70 & 20,49 & 13,76 & 9,41 & 7,12 & 5,67 & 3,92 & 3,03 & 2,13 \\
\hline 65 & 250 & 195 & 37,13 & 18,46 & 12,92 & 9,19 & 7,10 & 5,72 & 3,98 & 3,06 & 2,13 \\
\hline 65 & 300 & 195 & 32,67 & 17,04 & 12,31 & 9,01 & 7,07 & 5,74 & 4,03 & 3,09 & 2,13 \\
\hline 65 & 350 & 195 & 29,42 & 15,98 & 11,83 & 8,85 & 7,04 & 5,76 & 4,07 & 3,11 & 2,13 \\
\hline 65 & 400 & 195 & 26,95 & 15,14 & 11,44 & 8,72 & 7.00 & 5.76 & 4.10 & 3,13 & 2,13 \\
\hline 65 & 450 & 195 & 24,98 & 14,46 & 11,11 & 8,59 & 6,96 & 5,76 & 4,12 & 3,15 & 2,13 \\
\hline 65 & 500 & 195 & 23,39 & 13,89 & 10,83 & 8,48 & 6,92 & 5,76 & 4,14 & 3,17 & 2,14 \\
\hline 65 & 550 & 195 & 22,06 & 13,40 & 10,58 & 8,37 & 6,88 & 5,75 & 4,16 & 3,19 & 2,14 \\
\hline 65 & 600 & 195 & 20,93 & 12,98 & 10,36 & 8,27 & 6,84 & 5,74 & 4,17 & 3,20 & 2,15 \\
\hline 65 & 650 & 195 & 19,96 & 12,61 & 10,16 & 8,18 & 6,80 & 5,73 & 4,18 & 3,21 & 2,15 \\
\hline 65 & 700 & 195 & 19,12 & 12,28 & 9,98 & 8,10 & 6,76 & 5,72 & 4,19 & 3,23 & 2,16 \\
\hline 65 & 750 & 195 & 18,38 & 11,98 & 9,81 & 8,01 & 6,73 & 5,70 & 4,20 & 3,24 & 2,16 \\
\hline 65 & 800 & 195 & 17,72 & 11,71 & 9,66 & 7,93 & 6,69 & 5,69 & 4,21 & 3,25 & 2,17 \\
\hline 65 & 850 & 195 & 17,14 & 11,46 & 9,51 & 7,86 & 6,65 & 5,67 & 4,22 & 3,26 & 2,17 \\
\hline 65 & 900 & 195 & 16,61 & 11,24 & 9,38 & 7,79 & 6,61 & 5,66 & 4,22 & 3,27 & 2,18 \\
\hline 65 & 950 & 195 & 16,13 & 11,03 & 9,25 & 7,72 & 6,58 & 5,64 & 4,22 & 3,28 & 2,18 \\
\hline 65 & 1000 & 195 & 15,69 & 10,83 & 9,14 & 7,66 & 6,54 & 5,63 & 4,23 & 3,28 & 2,19 \\
\hline 65 & 1050 & 195 & 15,29 & 10,65 & 9,03 & 7,59 & 6,51 & 5,61 & 4,23 & 3,29 & 2,19 \\
\hline 65 & 1100 & 195 & 14,92 & 10,48 & 8,92 & 7,53 & 6,48 & 5,59 & 4,23 & 3,30 & 2,20 \\
\hline 65 & 1150 & 195 & 14,58 & 10,32 & 8,82 & 7,48 & 6,44 & 5,58 & 4,23 & 3,30 & 2,20 \\
\hline 65 & 1200 & 195 & 14,27 & 10,17 & 8,73 & 7,42 & 6,41 & 5,56 & 4,23 & 3,31 & 2,21 \\
\hline 65 & 1250 & 195 & 13,98 & 10,03 & 8,64 & 7,37 & 6,38 & 5,54 & 4,23 & 3,31 & 2,21 \\
\hline 65 & 1300 & 195 & 13,70 & 9,90 & 8,55 & 7,32 & 6,35 & 5,53 & 4,23 & 3,32 & 2,22 \\
\hline 65 & 1350 & 195 & 13,45 & 9,77 & 8,47 & 7,26 & 6,32 & 5,51 & 4,23 & 3,32 & 2,22 \\
\hline 65 & 1400 & 195 & 13,21 & 9,65 & 8,39 & 7,22 & 6,29 & 5,49 & 4,23 & 3,33 & 2,23 \\
\hline 65 & 1450 & 195 & 12,99 & 9,54 & 8,31 & 7,17 & 6,26 & 5,48 & 4,23 & 3,33 & 2,23 \\
\hline 65 & 1500 & 195 & 12,77 & 9,43 & 8,24 & 7,12 & 6,23 & 5,46 & 4,22 & 3,34 & 2,23 \\
\hline 65 & 1550 & 195 & 12,57 & 9,32 & 8,17 & 7,08 & 6,20 & 5,44 & 4,22 & 3,34 & 2,24 \\
\hline 65 & 1600 & 195 & 12,39 & 9,22 & 8,10 & 7,03 & 6,17 & 5,43 & 4,22 & 3,34 & 2,24 \\
\hline 65 & 1650 & 195 & 12,21 & 9,13 & 8,04 & 6,99 & 6,15 & 5,41 & 4,22 & 3,34 & 2,25 \\
\hline 65 & 1700 & 195 & 12,04 & 9,03 & 7,97 & 6,95 & 6,12 & 5,40 & 4,21 & 3,35 & 2,25 \\
\hline 65 & 1750 & 195 & 11,88 & 8,95 & 7,91 & 6,91 & 6,09 & 5,38 & 4,21 & 3,35 & 2,25 \\
\hline 65 & 1800 & 195 & 11,72 & 8,86 & 7,85 & 6,87 & 6,07 & 5,36 & 4,21 & 3,35 & 2,26 \\
\hline 65 & 1850 & 195 & 11,58 & 8,78 & 7,80 & 6,84 & 6,04 & 5,35 & 4,20 & 3,35 & 2,26 \\
\hline 65 & 1900 & 195 & 11,44 & 8,70 & 7,74 & 6,80 & 6,02 & 5,33 & 4,20 & 3,35 & 2,26 \\
\hline 65 & 1950 & 195 & 11,31 & 8,62 & 7,69 & 6,76 & 6,00 & 5,32 & 4,20 & 3,35 & 2,27 \\
\hline 65 & 2000 & 195 & 11,18 & 8,55 & 7,64 & 6,73 & 5,97 & 5,30 & 4,19 & 3,36 & 2,27 \\
\hline 65 & 200 & 200 & 43,42 & 20,23 & 13,52 & 9,20 & 6,94 & 5,52 & 3,82 & 2,95 & 2,08 \\
\hline 65 & 250 & 200 & 36,86 & 18,21 & 12,69 & 8,98 & 6,93 & 5,57 & 3,88 & 2,98 & 2,07 \\
\hline 65 & 300 & 200 & 32,41 & 16,80 & 12,08 & 8,81 & 6,90 & 5,60 & 3,92 & 3,01 & 2,07 \\
\hline 65 & 350 & 200 & 29,18 & 15,74 & 11,61 & 8,66 & 6,87 & 5,61 & 3,96 & 3,03 & 2,07 \\
\hline 65 & 400 & 200 & 26,71 & 14,91 & 11,23 & 8,52 & 6,83 & 5,62 & 3,99 & 3,05 & 2,08 \\
\hline 65 & 450 & 200 & 24,75 & 14,24 & 10,90 & 8,40 & 6,80 & 5,62 & 4,01 & 3,07 & 2,08 \\
\hline 65 & 500 & 200 & 23,16 & 13,67 & 10,63 & 8,29 & 6,76 & 5,61 & 4,03 & 3,09 & 2,08 \\
\hline 65 & 550 & 200 & 21,84 & 13,19 & 10,38 & 8,19 & 6,72 & 5,61 & 4,05 & 3,10 & 2,09 \\
\hline 65 & 600 & 200 & 20,72 & 12,77 & 10,16 & 8,10 & 6,68 & 5,60 & 4,06 & 3,12 & 2,09 \\
\hline 65 & 650 & 200 & 19,76 & 12,41 & 9,97 & 8,01 & 6,65 & 5,59 & 4,08 & 3,13 & 2,10 \\
\hline 65 & 700 & 200 & 18,92 & 12,08 & 9,79 & 7,92 & 6,61 & 5,58 & 4,09 & 3,14 & 2,10 \\
\hline 65 & 750 & 200 & 18,18 & 11,79 & 9,62 & 7,84 & 6,57 & 5,57 & 4,09 & 3,15 & 2,11 \\
\hline 65 & 800 & 200 & 17,53 & 11,52 & 9,47 & 7,77 & 6,54 & 5,55 & 4,10 & 3,16 & 2,11 \\
\hline 65 & 850 & 200 & 16,94 & 11,28 & 9,33 & 7,69 & 6,50 & 5,54 & 4,11 & 3,17 & 2,12 \\
\hline 65 & 900 & 200 & 16,42 & 11,05 & 9,20 & 7,63 & 6,46 & 5,52 & 4,11 & 3,18 & 2,12 \\
\hline 65 & 950 & 200 & 15,94 & 10,85 & 9,08 & 7,56 & 6,43 & 5,51 & 4,12 & 3,19 & 2,13 \\
\hline 65 & 1000 & 200 & 15,51 & 10,65 & 8,96 & 7,50 & 6,40 & 5,49 & 4,12 & 3,20 & 2,13 \\
\hline 65 & 1050 & 200 & 15,11 & 10,48 & 8,86 & 7,44 & 6,36 & 5,48 & 4,12 & 3,21 & 2,14 \\
\hline 65 & 1100 & 200 & 14,74 & 10,31 & 8,75 & 7,38 & 6,33 & 5,46 & 4,12 & 3,21 & 2,14 \\
\hline 65 & 1150 & 200 & 14,40 & 10,15 & 8,66 & 7,32 & 6,30 & 5,45 & 4,13 & 3,22 & 2,14 \\
\hline 65 & 1200 & 200 & 14,09 & 10,01 & 8,56 & 7,27 & 6,27 & 5,43 & 4,13 & 3,22 & 2,15 \\
\hline 65 & 1250 & 200 & 13,80 & 9,87 & 8,47 & 7,22 & 6,24 & 5,41 & 4,13 & 3,23 & 2,15 \\
\hline 65 & 1300 & 200 & 13,53 & 9,74 & 8,39 & 7,16 & 6,21 & 5,40 & 4,13 & 3,23 & 2,16 \\
\hline 65 & 1350 & 200 & 13,28 & 9,61 & 8,31 & 7,12 & 6,18 & 5,38 & 4,12 & 3,24 & 2,16 \\
\hline 65 & 1400 & 200 & 13,04 & 9,49 & 8,23 & 7,07 & 6,15 & 5,37 & 4,12 & 3,24 & 2,17 \\
\hline 65 & 1450 & 200 & 12,82 & 9,38 & 8,16 & 7,02 & 6,12 & 5,35 & 4,12 & 3,25 & 2,17 \\
\hline 65 & 1500 & 200 & 12,61 & 9,27 & 8,09 & 6,98 & 6,09 & 5,34 & 4,12 & 3,25 & 2,17 \\
\hline 65 & 1550 & 200 & 12,41 & 9,17 & 8,02 & 6,93 & 6,07 & 5,32 & 4,12 & 3,25 & 2,18 \\
\hline 65 & 1600 & 200 & 12,22 & 9,07 & 7,95 & 6,89 & 6,04 & 5,30 & 4,12 & 3,26 & 2,18 \\
\hline 65 & 1650 & 200 & 12,05 & 8,98 & 7,89 & 6,85 & 6,02 & 5,29 & 4,11 & 3,26 & 2,19 \\
\hline 65 & 1700 & 200 & $\begin{array}{l}1<, v \\
11,88\end{array}$ & 8,88 & $\begin{array}{l}1,00 \\
7,83\end{array}$ & 6,81 & $\begin{array}{l}0,0< \\
5,99\end{array}$ & $\frac{0,27}{5,27}$ & $\begin{array}{l}4,1 \pm \\
4,11\end{array}$ & 3,26 & 2,19 \\
\hline 65 & 1750 & 200 & 11,72 & 8,80 & 7,77 & 6,77 & 5,96 & 5,26 & 4,11 & 3,26 & 2,19 \\
\hline 65 & 1800 & 200 & 11,57 & 8,71 & 7,71 & 6,74 & 5,94 & 5,24 & 4,10 & 3,26 & 2,20 \\
\hline 65 & 1850 & 200 & 11,42 & 8,63 & 7,65 & 6,70 & 5,92 & 5,23 & 4,10 & 3,27 & 2,20 \\
\hline 65 & 1900 & 200 & 11,28 & 8,55 & 7,60 & 6,66 & 5,89 & 5,21 & 4,10 & 3,27 & 2,20 \\
\hline 65 & 1950 & 200 & 11,15 & 8,48 & 7,55 & 6,63 & 5,87 & 5,20 & 4,09 & 3,27 & 2,21 \\
\hline
\end{tabular}




\begin{tabular}{|c|c|c|c|c|c|c|c|c|c|c|c|}
\hline \multirow[b]{2}{*}{$\mathrm{H}(\mathrm{cm})$} & \multirow[b]{2}{*}{ Mceq (MPa) } & & & & & De & ões (x1 & m) & & & \\
\hline & & Msub (MPa) & D0 & D25 & D40 & D60 & D80 & D100 & D140 & D180 & D260 \\
\hline 65 & 2000 & 200 & 11,02 & 8,41 & 7,50 & 6,59 & 5,85 & 5,19 & 4,09 & 3,27 & 2,21 \\
\hline 70 & 200 & 20 & 106,37 & 79,70 & 71,20 & 62,97 & 56,25 & 50,30 & 40,28 & 32,60 & 22,34 \\
\hline 70 & 250 & 20 & 96,38 & 73,64 & 66,84 & 59,90 & 54,07 & 48,81 & 39,73 & 32,55 & 22,59 \\
\hline 70 & 300 & 20 & 89,33 & 69,04 & 63,40 & 57,40 & 52,23 & 47,49 & 39,16 & 32,41 & 22,77 \\
\hline 70 & 350 & 20 & 84,01 & 65,38 & 60,58 & 55,31 & 50,64 & 46,31 & 38,60 & 32,23 & 22,90 \\
\hline 70 & 400 & 20 & 79,81 & 62,39 & 58,21 & 53,51 & 49,24 & 45,26 & 38,06 & 32,02 & 22,99 \\
\hline 70 & 450 & 20 & 76,38 & 59,88 & 56,16 & 51,93 & 48,00 & 44,30 & 37,54 & 31,80 & 23,05 \\
\hline 70 & 500 & 20 & 73,50 & 57,74 & 54,37 & 50,54 & 46,89 & 43,43 & 37,05 & 31,56 & 23,08 \\
\hline 70 & 550 & 20 & 71,02 & 55,88 & 52,79 & 49,30 & 45,88 & 42,63 & 36,59 & 31,33 & 23,09 \\
\hline 70 & 600 & 20 & 68,86 & 54,26 & 51,37 & 48,17 & 44,97 & 41,89 & 36,15 & 31,10 & 23,09 \\
\hline 70 & 650 & 20 & 66,94 & 52,81 & 50,08 & 47,14 & 44,12 & 41,20 & 35,72 & 30,87 & 23,08 \\
\hline 70 & 700 & 20 & 65,22 & 51,53 & 48,92 & 46,20 & 43,35 & 40,57 & 35,32 & 30,65 & 23,06 \\
\hline 70 & 750 & 20 & 63,67 & 50,37 & 47,85 & 45,33 & 42,63 & 39,97 & 34,94 & 30,42 & 23,03 \\
\hline 70 & 800 & 20 & 62,24 & 49,32 & 46,87 & 44,53 & 41,95 & 39,41 & 34,58 & 30,21 & 23,00 \\
\hline 70 & 850 & 20 & 60,93 & 48,37 & 45,96 & 43,78 & 41,33 & 38,89 & 34,23 & 30,00 & 22,96 \\
\hline 70 & 900 & 20 & 59,72 & 47,50 & 45,11 & 43,08 & 40,74 & 38,39 & 33,90 & 29,79 & 22,91 \\
\hline 70 & 950 & 20 & 58,58 & 46,69 & 44,33 & 42,42 & 40,18 & 37,92 & 33,58 & 29,59 & 22,86 \\
\hline 70 & 1000 & 20 & 57,52 & 45,95 & 43,59 & 41,80 & 39,66 & 37,48 & 33,27 & 29,40 & 22,81 \\
\hline 70 & 1050 & 20 & 56,52 & 45,26 & 42,91 & 41,22 & 39,16 & 37,06 & 32,98 & 29,21 & 22,76 \\
\hline 70 & 1100 & 20 & 55,58 & 44,62 & 42,26 & 40,67 & 38,69 & 36,65 & 32,70 & 29,02 & 22,71 \\
\hline 70 & 1150 & 20 & 54,69 & 44,03 & 41,65 & 40,14 & 38,25 & 36,27 & 32,43 & 28,84 & 22,65 \\
\hline 70 & 1200 & 20 & 53,84 & 43,47 & 41,08 & 39,64 & 37,82 & 35,90 & 32,16 & 28,66 & 22,59 \\
\hline 70 & 1250 & 20 & 53,03 & 42,95 & 40,53 & 39,17 & 37,41 & 35,55 & 31,91 & 28,49 & 22,53 \\
\hline 70 & 1300 & 20 & 52,26 & 42,45 & 40,02 & 38,71 & 37,03 & 35,22 & 31,67 & 28,33 & 22,47 \\
\hline 70 & 1350 & 20 & 51,52 & 41,99 & 39,53 & 38,28 & 36,65 & 34,89 & 31,43 & 28,16 & 22,42 \\
\hline 70 & 1400 & 20 & 50,81 & 41,55 & 39,06 & 37,86 & 36,30 & 34,58 & 31,20 & 28,00 & 22,36 \\
\hline 70 & 1450 & 20 & 50,13 & 41,13 & 38,62 & 37,46 & 35,95 & 34,29 & 30,98 & 27,85 & 22,30 \\
\hline 70 & 1500 & 20 & 49,47 & 40,74 & 38,19 & 37,08 & 35,62 & 34,00 & 30,77 & 27,70 & 22,24 \\
\hline 70 & 1550 & 20 & 48,84 & 40,36 & 37,79 & 36,71 & 35,31 & 33,72 & 30,56 & 27,55 & 22,18 \\
\hline 70 & 1600 & 20 & 48,23 & 40,01 & 37,40 & 36,36 & 35,00 & 33,45 & 30,36 & 27,41 & 22,12 \\
\hline 70 & 1650 & 20 & 47,64 & 39,67 & 37,03 & 36,02 & 34,71 & 33,19 & 30,16 & 27,27 & 22,06 \\
\hline 70 & 1700 & 20 & 47,06 & 39,34 & 36,68 & 35,69 & 34,42 & 32,94 & 29,97 & 27,13 & 22,00 \\
\hline 70 & 1750 & 20 & 46,51 & 39,03 & 36,34 & 35,37 & 34,14 & 32,70 & 29,79 & 26,99 & 21,94 \\
\hline 70 & 1800 & 20 & 45,97 & 38,73 & 36,01 & 35,06 & 33,88 & 32,47 & 29,61 & 26,86 & 21,88 \\
\hline 70 & 1850 & 20 & 45,45 & 38,44 & 35,70 & 34,76 & 33,62 & 32,24 & 29,43 & 26,73 & 21,82 \\
\hline 70 & 1900 & 20 & 44,95 & 38,17 & 35,40 & 34,48 & 33,37 & 32,02 & 29,26 & 26,61 & 21,76 \\
\hline 70 & 1950 & 20 & 44,45 & 37,90 & 35,11 & 34,20 & 33,12 & 31,80 & 29,10 & 26,48 & 21,71 \\
\hline 70 & 2000 & 20 & 43,98 & 37,65 & 34,83 & 33,93 & 32,89 & 31,59 & 28,94 & 26,36 & 21,65 \\
\hline 70 & 200 & 25 & 94,51 & 69,03 & 60,60 & 52,82 & 46,66 & 41,31 & 32,54 & 26,04 & 17,66 \\
\hline 70 & 250 & 25 & 85,09 & 63,76 & 56,96 & 50,37 & 45,00 & 40,24 & 32,22 & 26,08 & 17,87 \\
\hline 70 & 300 & 25 & 78,47 & 59,77 & 54,10 & 48,37 & 43,58 & 39,27 & 31,87 & 26,05 & 18,04 \\
\hline 70 & 350 & 25 & 73,52 & 56,59 & 51,75 & 46,68 & 42,35 & 38,40 & 31,51 & 25,98 & 18,16 \\
\hline 70 & 400 & 25 & 69,63 & 53,98 & 49,77 & 45,22 & 41,25 & 37,60 & 31,15 & 25,87 & 18,26 \\
\hline 70 & 450 & 25 & 66,48 & 51,79 & 48,06 & 43,94 & 40,27 & 36,87 & 30,79 & 25,75 & 18,34 \\
\hline 70 & 500 & 25 & 63,85 & 49,91 & 46,57 & 42,80 & 39,39 & 36,20 & 30,45 & 25,61 & 18,39 \\
\hline 70 & 550 & 25 & 61,61 & 48,28 & 45,24 & 41,79 & 38,59 & 35,59 & 30,12 & 25,47 & 18,43 \\
\hline 70 & 600 & 25 & 59,68 & 46,85 & 44,05 & 40,86 & 37,86 & 35,01 & 29,80 & 25,33 & 18,45 \\
\hline 70 & 650 & 25 & 57,97 & 45,57 & 42,97 & 40,02 & 37,18 & 34,48 & 29,49 & 25,18 & 18,47 \\
\hline 70 & 700 & 25 & 56,45 & 44,43 & 41,99 & 39,25 & 36,55 & 33,98 & 29,20 & 25,03 & 18,48 \\
\hline 70 & 750 & 25 & 55,09 & 43,40 & 41,09 & 38,54 & 35,97 & 33,51 & 28,92 & 24,88 & 18,48 \\
\hline 70 & 800 & 25 & 53,85 & 42,47 & 40,27 & 37,87 & 35,43 & 33,07 & 28,65 & 24,73 & 18,47 \\
\hline 70 & 850 & 25 & 52,71 & 41,62 & 39,50 & 37,26 & 34,92 & 32,65 & 28,39 & 24,59 & 18,46 \\
\hline 70 & 900 & 25 & 51,67 & 40,84 & 38,78 & 36,68 & 34,44 & 32,26 & 28,14 & 24,45 & 18,44 \\
\hline 70 & 950 & 25 & 50,70 & 40,12 & 38,12 & 36,14 & 33,99 & 31,89 & 27,90 & 24,30 & 18,42 \\
\hline 70 & 1000 & 25 & 49,79 & 39,46 & 37,49 & 35,62 & 33,56 & 31,53 & 27,66 & 24,17 & 18,40 \\
\hline 70 & 1050 & 25 & 48,95 & 38,84 & 36,91 & 35,14 & 33,16 & 31,19 & 27,44 & 24,03 & 18,37 \\
\hline 70 & 1100 & 25 & 48,15 & 38,27 & 36,36 & 34,68 & 32,77 & 30,87 & 27,22 & 23,90 & 18,34 \\
\hline 70 & 1150 & 25 & 47,40 & 37,73 & 35,83 & 34,25 & 32,41 & 30,56 & 27,02 & 23,77 & 18,31 \\
\hline 70 & 1200 & 25 & 46,69 & 37,23 & 35,34 & 33,84 & 32,06 & 30,27 & 26,81 & 23,64 & 18,28 \\
\hline 70 & 1250 & 25 & 46,02 & 36,76 & 34,88 & 33,44 & 31,73 & 29,98 & 26,62 & 23,52 & 18,25 \\
\hline 70 & 1300 & 25 & 45,38 & 36,32 & 34,43 & 33,07 & 31,41 & 29,71 & 26,43 & 23,39 & 18,22 \\
\hline 70 & 1350 & 25 & 44,76 & 35,90 & 34,01 & 32,71 & 31,10 & 29,45 & 26,25 & 23,27 & 18,18 \\
\hline 70 & 1400 & 25 & 44,18 & 35,50 & 33,61 & 32,36 & 30,81 & 29,20 & 26,07 & 23,16 & 18,15 \\
\hline 70 & 1450 & 25 & 43,61 & 35,13 & 33,23 & 32,03 & 30,53 & 28,96 & 25,90 & 23,04 & 18,11 \\
\hline 70 & 1500 & 25 & 43,07 & 34,78 & 32,86 & 31,71 & 30,26 & 28,72 & 25,73 & 22,93 & 18,07 \\
\hline 70 & 1550 & 25 & 42,55 & 34,44 & 32,51 & 31,41 & 30,00 & 28,50 & 25,57 & 22,82 & 18,04 \\
\hline 70 & 1600 & 25 & 42,05 & 34,12 & 32,17 & 31,11 & 29,74 & 28,28 & 25,41 & 22,71 & 18,00 \\
\hline 70 & 1650 & 25 & 41,57 & 33,81 & 31,85 & 30,83 & 29,50 & 28,07 & 25,26 & 22,61 & 17,96 \\
\hline 70 & 1700 & 25 & 41,10 & 33,52 & 31,54 & 30,55 & 29,27 & 27,86 & 25,11 & 22,50 & 17,92 \\
\hline 70 & 1750 & 25 & 40,65 & 33,24 & 31,25 & 30,29 & 29,04 & 27,67 & 24,96 & 22,40 & 17,88 \\
\hline 70 & 1800 & 25 & 40,21 & 32,97 & 30,96 & 30,03 & 28,82 & 27,48 & 24,82 & 22,30 & 17,85 \\
\hline 70 & 1850 & 25 & 39,78 & 32,72 & 30,69 & 29,79 & 28,60 & 27,29 & 24,68 & 22,21 & 17,81 \\
\hline 70 & 1900 & 25 & 39,37 & 32,47 & 30,42 & 29,55 & 28,40 & 27,11 & 24,55 & 22,11 & 17,77 \\
\hline 70 & 1950 & 25 & 38,97 & 32,23 & 30,17 & 29,31 & 28,20 & 26,93 & 24,42 & 22,02 & 17,73 \\
\hline 70 & 2000 & 25 & 38,58 & 32,00 & 29,92 & 29,09 & 28,00 & 26,76 & 24,29 & 21,92 & 17,69 \\
\hline 70 & 200 & 30 & 86,25 & 61,40 & 53,08 & 45,66 & 39,94 & 35,07 & 27,25 & 21,62 & 14,57 \\
\hline 70 & 250 & 30 & 77,23 & 56,70 & 49,94 & 43,64 & 38,64 & 34,27 & 27,08 & 21,71 & 14,75 \\
\hline 70 & 300 & 30 & 70,91 & 53,13 & 47,47 & 41,98 & 37,50 & 33,53 & 26,85 & 21,74 & 14,89 \\
\hline 70 & 350 & 30 & 66,20 & 50,31 & 45,44 & 40,57 & 36,50 & 32,86 & 26,61 & 21,72 & 15,01 \\
\hline 70 & 400 & 30 & 62,52 & 47,98 & 43,74 & 39,34 & 35,62 & 32,23 & 26,36 & 21,67 & 15,10 \\
\hline 70 & 450 & 30 & 59,55 & 46,02 & 42,27 & 38,27 & 34,82 & 31,66 & 26,10 & 21,61 & 15,18 \\
\hline
\end{tabular}




\begin{tabular}{|c|c|c|c|c|c|c|c|c|c|c|c|}
\hline \multirow[b]{2}{*}{$\mathrm{H}(\mathrm{cm})$} & \multirow[b]{2}{*}{ Mceq (MPa) } & & & & & De & ões (x1 & m) & & & \\
\hline & & Msub (MPa) & D0 & D25 & D40 & D60 & D80 & D100 & D140 & D180 & D260 \\
\hline 70 & 500 & 30 & 57,09 & 44,34 & 40,98 & 37,31 & 34,10 & 31,13 & 25,85 & 21,53 & 15,24 \\
\hline 70 & 550 & 30 & 55,01 & 42,88 & 39,83 & 36,45 & 33,43 & 30,63 & 25,61 & 21,44 & 15,29 \\
\hline 70 & 600 & 30 & 53,21 & 41,59 & 38,81 & 35,67 & 32,83 & 30,17 & 25,37 & 21,35 & 15,33 \\
\hline 70 & 650 & 30 & 51,64 & 40,45 & 37,88 & 34,96 & 32,27 & 29,74 & 25,14 & 21,25 & 15,35 \\
\hline 70 & 700 & 30 & 50,24 & 39,42 & 37,03 & 34,30 & 31,75 & 29,33 & 24,92 & 21,15 & 15,37 \\
\hline 70 & 750 & 30 & 49,00 & 38,49 & 36,25 & 33,69 & 31,26 & 28,95 & 24,70 & 21,04 & 15,39 \\
\hline 70 & 800 & 30 & 47,87 & 37,65 & 35,53 & 33,13 & 30,81 & 28,59 & 24,49 & 20,94 & 15,39 \\
\hline 70 & 850 & 30 & 46,85 & 36,88 & 34,87 & 32,60 & 30,38 & 28,25 & 24,29 & 20,84 & 15,40 \\
\hline 70 & 900 & 30 & 45,91 & 36,17 & 34,25 & 32,11 & 29,98 & 27,93 & 24,10 & 20,73 & 15,40 \\
\hline 70 & 950 & 30 & 45,04 & 35,52 & 33,67 & 31,65 & 29,60 & 27,62 & 23,91 & 20,63 & 15,39 \\
\hline 70 & 1000 & 30 & 44,23 & 34,91 & 33,12 & 31,21 & 29,24 & 27,32 & 23,73 & 20,53 & 15,38 \\
\hline 70 & 1050 & 30 & 43,48 & 34,35 & 32,61 & 30,80 & 28,90 & 27,04 & 23,55 & 20,43 & 15,37 \\
\hline 70 & 1100 & 30 & 42,78 & 33,83 & 32,13 & 30,41 & 28,57 & 26,78 & 23,38 & 20,33 & 15,36 \\
\hline 70 & 1150 & 30 & 42,12 & 33,34 & 31,68 & 30,04 & 28,26 & 26,52 & 23,21 & 20,23 & 15,35 \\
\hline 70 & 1200 & 30 & 41,50 & 32,88 & 31,24 & 29,69 & 27,97 & 26,28 & 23,05 & 20,14 & 15,33 \\
\hline 70 & 1250 & 30 & 40,90 & 32,45 & 30,84 & 29,35 & 27,69 & 26,04 & 22,90 & 20,04 & 15,31 \\
\hline 70 & 1300 & 30 & 40,34 & 32,05 & 30,45 & 29,03 & 27,42 & 25,81 & 22,75 & 19,95 & 15,29 \\
\hline 70 & 1350 & 30 & 39,81 & 31,66 & 30,08 & 28,72 & 27,16 & 25,59 & 22,60 & 19,86 & 15,27 \\
\hline 70 & 1400 & 30 & 39,30 & 31,30 & 29,72 & 28,42 & 26,91 & 25,38 & 22,46 & 19,77 & 15,25 \\
\hline 70 & 1450 & 30 & 38,81 & 30,96 & 29,39 & 28,14 & 26,67 & 25,18 & 22,32 & 19,68 & 15,23 \\
\hline 70 & 1500 & 30 & 38,35 & 30,63 & 29,06 & 27,87 & 26,44 & 24,99 & 22,18 & 19,60 & 15,21 \\
\hline 70 & 1550 & 30 & 37,90 & 30,32 & 28,75 & 27,61 & 26,22 & 24,80 & 22,05 & 19,51 & 15,19 \\
\hline 70 & 1600 & 30 & 37,47 & 30,03 & 28,46 & 27,35 & 26,00 & 24,61 & 21,92 & 19,43 & 15,16 \\
\hline 70 & 1650 & 30 & 37,05 & 29,75 & 28,17 & 27,11 & 25,80 & 24,44 & 21,80 & 19,35 & 15,14 \\
\hline 70 & 1700 & 30 & 36,65 & 29,48 & 27,90 & 26,88 & 25,60 & 24,26 & 21,68 & 19,27 & 15,11 \\
\hline 70 & 1750 & 30 & 36,27 & 29,23 & 27,64 & 26,65 & 25,40 & 24,10 & 21,56 & 19,19 & 15,09 \\
\hline 70 & 1800 & 30 & 35,89 & 28,98 & 27,38 & 26,43 & 25,21 & 23,94 & 21,44 & 19,11 & 15,06 \\
\hline 70 & 1850 & 30 & 35,53 & 28,74 & 27,14 & 26,21 & 25,03 & 23,78 & 21,33 & 19,03 & 15,04 \\
\hline 70 & 1900 & 30 & 35,18 & 28,52 & 26,90 & 26,01 & 24,86 & 23,63 & 21,22 & 18,96 & 15,01 \\
\hline 70 & 1950 & 30 & 34,84 & 28,30 & 26,68 & 25,81 & 24,68 & 23,48 & 21,11 & 18,88 & 14,98 \\
\hline 70 & 2000 & 30 & 34,51 & 28,09 & 26,46 & 25,61 & 24,52 & 23,33 & 21,01 & 18,81 & 14,96 \\
\hline 70 & 200 & 35 & 80,10 & 55,64 & 47,43 & 40,32 & 34,96 & 30,48 & 23,41 & 18,45 & 12,39 \\
\hline 70 & 250 & 35 & 71,39 & 51,35 & 44,65 & 38,61 & 33,90 & 29,86 & 23,32 & 18,56 & 12,54 \\
\hline 70 & 300 & 35 & 65,31 & 48,11 & 42,47 & 37,19 & 32,97 & 29,28 & 23,18 & 18,61 & 12,66 \\
\hline 70 & 350 & 35 & 60,78 & 45,54 & 40,69 & 35,98 & 32,14 & 28,74 & 23,02 & 18,63 & 12,77 \\
\hline 70 & 400 & 35 & 57,26 & 43,44 & 39,18 & 34,93 & 31,41 & 28,24 & 22,84 & 18,62 & 12,85 \\
\hline 70 & 450 & 35 & 54,42 & 41,66 & 37,88 & 34,01 & 30,74 & 27,78 & 22,65 & 18,59 & 12,93 \\
\hline 70 & 500 & 35 & 52,08 & 40,14 & 36,75 & 33,18 & 30,13 & 27,34 & 22,47 & 18,55 & 12,99 \\
\hline 70 & 550 & 35 & 50,10 & 38,81 & 35,74 & 32,44 & 29,57 & 26,94 & 22,28 & 18,49 & 13,04 \\
\hline 70 & 600 & 35 & 48,40 & 37,63 & 34,83 & 31,76 & 29,06 & 26,56 & 22,10 & 18,43 & 13,08 \\
\hline 70 & 650 & 35 & 46,91 & 36,59 & 34,01 & 31,14 & 28,58 & 26,20 & 21,92 & 18,37 & 13,11 \\
\hline 70 & 700 & 35 & 45,61 & 35,65 & 33,26 & 30,57 & 28,14 & 25,86 & 21,75 & 18,30 & 13,14 \\
\hline 70 & 750 & 35 & 44,44 & 34,80 & 32,57 & 30,05 & 27,72 & 25,54 & 21,58 & 18,22 & 13,16 \\
\hline 70 & 800 & 35 & 43,39 & 34,03 & 31,94 & 29,56 & 27,33 & 25,24 & 21,41 & 18,15 & 13,17 \\
\hline 70 & 850 & 35 & 42,44 & 33,33 & 31,35 & 29,10 & 26,97 & 24,95 & 21,25 & 18,07 & 13,18 \\
\hline 70 & 900 & 35 & 41,57 & 32,68 & 30,80 & 28,67 & 26,62 & 24,68 & 21,10 & 18,00 & 13,19 \\
\hline 70 & 950 & 35 & 40,77 & 32,08 & 30,29 & 28,27 & 26,30 & 24,42 & 20,94 & 17,92 & 13,20 \\
\hline 70 & 1000 & 35 & 40,03 & 31,52 & 29,81 & 27,89 & 25,99 & 24,17 & 20,80 & 17,85 & 13,20 \\
\hline 70 & 1050 & 35 & 39,35 & 31,00 & 29,35 & 27,53 & 25,69 & 23,94 & 20,65 & 17,77 & 13,20 \\
\hline 70 & 1100 & 35 & 38,71 & 30,52 & 28,93 & 27,18 & 25,41 & 23,71 & 20,52 & 17,70 & 13,19 \\
\hline 70 & 1150 & 35 & 38,11 & 30,07 & 28,52 & 26,86 & 25,15 & 23,49 & 20,38 & 17,62 & 13,19 \\
\hline 70 & 1200 & 35 & 37,54 & 29,65 & 28,14 & 26,55 & 24,89 & 23,28 & 20,25 & 17,55 & 13,18 \\
\hline 70 & 1250 & 35 & 37,01 & 29,25 & 27,77 & 26,26 & 24,65 & 23,08 & 20,12 & 17,48 & 13,17 \\
\hline 70 & 1300 & 35 & 36,50 & 28,87 & 27,43 & 25,97 & 24,41 & 22,89 & 20,00 & 17,40 & 13,16 \\
\hline 70 & 1350 & 35 & 36,02 & 28,52 & 27,10 & 25,70 & 24,19 & 22,70 & 19,88 & 17,33 & 13,15 \\
\hline 70 & 1400 & 35 & 35,57 & 28,18 & 26,78 & 25,45 & 23,97 & 22,52 & 19,76 & 17,26 & 13,14 \\
\hline 70 & 1450 & 35 & 35,13 & 27,87 & 26,48 & 25,20 & 23,77 & 22,35 & 19,64 & 17,19 & 13,13 \\
\hline 70 & 1500 & 35 & 34,72 & 27,57 & 26,19 & 24,96 & 23,57 & 22,18 & 19,53 & 17,12 & 13,11 \\
\hline 70 & 1550 & 35 & 34,32 & 27,28 & 25,91 & 24,73 & 23,37 & 22,02 & 19,42 & 17,06 & 13,10 \\
\hline 70 & 1600 & 35 & 33,93 & 27,01 & 25,65 & 24,51 & 23,19 & 21,86 & 19,32 & 16,99 & 13,09 \\
\hline 70 & 1650 & 35 & 33,57 & 26,74 & 25,39 & 24,29 & 23,01 & 21,71 & 19,21 & 16,93 & 13,07 \\
\hline 70 & 1700 & 35 & 33,21 & 26,50 & 25,15 & 24,09 & 22,83 & 21,56 & 19,11 & 16,86 & 13,05 \\
\hline 70 & 1750 & 35 & 32,87 & 26,26 & 24,91 & 23,89 & 22,66 & 21,42 & 19,01 & 16,80 & 13,04 \\
\hline 70 & 1800 & 35 & 32,54 & 26,03 & 24,68 & 23,69 & 22,50 & 21,28 & 18,92 & 16,73 & 13,02 \\
\hline 70 & 1850 & 35 & 32,22 & 25,81 & 24,46 & 23,51 & 22,34 & 21,14 & 18,82 & 16,67 & 13,00 \\
\hline 70 & 1900 & 35 & 31,91 & 25,60 & 24,25 & 23,33 & 22,19 & 21,01 & 18,73 & 16,61 & 12,98 \\
\hline 70 & 1950 & 35 & 31,61 & 25,40 & 24,05 & 23,15 & 22,04 & 20,88 & 18,64 & 16,55 & 12,97 \\
\hline 70 & 2000 & 35 & 31,32 & 25,21 & 23,85 & 22,98 & 21,89 & 20,76 & 18,55 & 16,49 & 12,95 \\
\hline 70 & 200 & 40 & 75,33 & 51,11 & 43,01 & 36,16 & 31,11 & 26,94 & 20,50 & 16,06 & 10,77 \\
\hline 70 & 250 & 40 & 66,87 & 47,13 & 40,51 & 34,68 & 30,23 & 26,46 & 20,46 & 16,19 & 10,89 \\
\hline 70 & 300 & 40 & 60,97 & 44,15 & 38,55 & 33,45 & 29,45 & 26,00 & 20,38 & 16,26 & 11,00 \\
\hline 70 & 350 & 40 & 56,59 & 41,79 & 36,95 & 32,40 & 28,75 & 25,56 & 20,27 & 16,29 & 11,09 \\
\hline 70 & 400 & 40 & 53,18 & 39,85 & 35,60 & 31,48 & 28,13 & 25,15 & 20,14 & 16,30 & 11,17 \\
\hline 70 & 450 & 40 & 50,45 & 38,22 & 34,44 & 30,67 & 27,56 & 24,77 & 20,00 & 16,29 & 11,24 \\
\hline 70 & 500 & 40 & 48,19 & 36,82 & 33,42 & 29,95 & 27,04 & 24,40 & 19,86 & 16,27 & 11,30 \\
\hline 70 & 550 & 40 & 46,29 & 35,60 & 32,51 & 29,30 & 26,56 & 24,06 & 19,72 & 16,24 & 11,34 \\
\hline 70 & 600 & 40 & 44,67 & 34,52 & 31,70 & 28,70 & 26,11 & 23,74 & 19,58 & 16,21 & 11,39 \\
\hline 70 & 650 & 40 & 43,25 & 33,56 & 30,96 & 28,16 & 25,70 & 23,44 & 19,44 & 16,16 & 11,42 \\
\hline 70 & 700 & 40 & 42,01 & 32,69 & 30,29 & 27,65 & 25,32 & 23,16 & 19,30 & 16,11 & 11,45 \\
\hline 70 & 750 & 40 & 40,90 & 31,91 & 29,67 & 27,19 & 24,96 & 22,89 & 19,16 & 16,06 & 11,47 \\
\hline 70 & 800 & 40 & 39,91 & 31,20 & 29,10 & 26,75 & 24,62 & 22,63 & 19,03 & 16,01 & 11,49 \\
\hline
\end{tabular}




\begin{tabular}{|c|c|c|c|c|c|c|c|c|c|c|c|}
\hline \multirow[b]{2}{*}{$\mathrm{H}(\mathrm{cm})$} & \multirow[b]{2}{*}{ Mceq (MPa) } & & & & & $\mathrm{De}$ & ões (x1 & & & & \\
\hline & & Msub (MPa) & D0 & D25 & D40 & D60 & D80 & D100 & D140 & D180 & D260 \\
\hline 70 & 850 & 40 & 39,01 & 30,54 & 28,57 & 26,35 & 24,30 & 22,38 & 18,90 & 15,95 & 11,51 \\
\hline 70 & 900 & 40 & 38,19 & 29,94 & 28,08 & 25,97 & 24,00 & 22,15 & 18,77 & 15,90 & 11,52 \\
\hline 70 & 950 & 40 & 37,44 & 29,39 & 27,62 & 25,61 & 23,72 & 21,93 & 18,65 & 15,84 & 11,53 \\
\hline 70 & 1000 & 40 & 36,75 & 28,87 & 27,19 & 25,27 & 23,44 & 21,71 & 18,53 & 15,78 & 11,54 \\
\hline 70 & 1050 & 40 & 36,11 & 28,39 & 26,78 & 24,95 & 23,19 & 21,51 & 18,41 & 15,72 & 11,54 \\
\hline 70 & 1100 & 40 & 35,51 & 27,94 & 26,39 & 24,65 & 22,94 & 21,31 & 18,29 & 15,67 & 11,55 \\
\hline 70 & 1150 & 40 & 34,95 & 27,52 & 26,03 & 24,36 & 22,71 & 21,13 & 18,18 & 15,61 & 11,55 \\
\hline 70 & 1200 & 40 & 34,43 & 27,13 & 25,68 & 24,08 & 22,48 & 20,94 & 18,07 & 15,55 & 11,55 \\
\hline 70 & 1250 & 40 & 33,94 & 26,76 & 25,36 & 23,82 & 22,27 & 20,77 & 17,97 & 15,49 & 11,55 \\
\hline 70 & 1300 & 40 & 33,47 & 26,41 & 25,04 & 23,57 & 22,06 & 20,60 & 17,86 & 15,44 & 11,54 \\
\hline 70 & 1350 & 40 & 33,03 & 26,08 & 24,74 & 23,33 & 21,86 & 20,44 & 17,76 & 15,38 & 11,54 \\
\hline 70 & 1400 & 40 & 32,61 & 25,76 & 24,46 & 23,10 & 21,67 & 20,28 & 17,66 & 15,32 & 11,53 \\
\hline 70 & 1450 & 40 & 32,21 & 25,47 & 24,19 & 22,88 & 21,49 & 20,13 & 17,57 & 15,27 & 11,52 \\
\hline 70 & 1500 & 40 & 31,83 & 25,19 & 23,92 & 22,67 & 21,31 & 19,99 & 17,47 & 15,21 & 11,52 \\
\hline 70 & 1550 & 40 & 31,47 & 24,92 & 23,67 & 22,46 & 21,14 & 19,84 & 17,38 & 15,16 & 11,51 \\
\hline 70 & 1600 & 40 & 31,12 & 24,66 & 23,43 & 22,26 & 20,98 & 19,71 & 17,29 & 15,10 & 11,50 \\
\hline 70 & 1650 & 40 & 30,79 & 24,42 & 23,20 & 22,07 & 20,82 & 19,57 & 17,20 & 15,05 & 11,49 \\
\hline 70 & 1700 & 40 & 30,47 & 24,18 & 22,98 & 21,89 & 20,66 & 19,44 & 17,12 & 15,00 & 11,48 \\
\hline 70 & 1750 & 40 & 30,16 & 23,96 & 22,76 & 21,71 & 20,51 & 19,32 & 17,03 & 14,95 & 11,47 \\
\hline 70 & 1800 & 40 & 29,86 & 23,75 & 22,56 & 21,54 & 20,37 & 19,20 & 16,95 & 14,90 & 11,46 \\
\hline 70 & 1850 & 40 & 29,57 & 23,54 & 22,36 & 21,37 & 20,23 & 19,08 & 16,87 & 14,85 & 11,44 \\
\hline 70 & 1900 & 40 & 29,29 & 23,35 & 22,16 & 21,21 & 20,09 & 18,96 & 16,79 & 14,80 & 11,43 \\
\hline 70 & 1950 & 40 & 29,02 & 23,16 & 21,98 & 21,05 & 19,96 & 18,85 & 16,71 & 14,75 & 11,42 \\
\hline 70 & 2000 & 40 & 28,76 & 22,98 & 21,80 & 20,90 & 19,83 & 18,74 & 16,64 & 14,70 & 11,41 \\
\hline 70 & 200 & 45 & 71,50 & 47,44 & 39,44 & 32,82 & 28,03 & 24,14 & 18,21 & 14,21 & 9,52 \\
\hline 70 & 250 & 45 & 63,24 & 43,72 & 37,17 & 31,53 & 27,29 & 23,76 & 18,21 & 14,33 & 9,62 \\
\hline 70 & 300 & 45 & 57,50 & 40,94 & 35,39 & 30,44 & 26,63 & 23,38 & 18,17 & 14,41 & 9,71 \\
\hline 70 & 350 & 45 & 53,23 & 38,74 & 33,93 & 29,51 & 26,03 & 23,02 & 18,09 & 14,46 & 9,80 \\
\hline 70 & 400 & 45 & 49,93 & 36,94 & 32,70 & 28,70 & 25,49 & 22,68 & 18,00 & 14,48 & 9,87 \\
\hline 70 & 450 & 45 & 47,27 & 35,42 & 31,65 & 27,99 & 25,00 & 22,36 & 17,90 & 14,49 & 9,93 \\
\hline 70 & 500 & 45 & 45,09 & 34,12 & 30,72 & 27,34 & 24,55 & 22,05 & 17,79 & 14,49 & 9,98 \\
\hline 70 & 550 & 45 & 43,25 & 32,99 & 29,90 & 26,76 & 24,13 & 21,76 & 17,68 & 14,47 & 10,03 \\
\hline 70 & 600 & 45 & 41,68 & 31,99 & 29,16 & 26,23 & 23,74 & 21,49 & 17,57 & 14,45 & 10,07 \\
\hline 70 & 650 & 45 & 40,32 & 31,09 & 28,49 & 25,74 & 23,38 & 21,23 & 17,46 & 14,42 & 10,10 \\
\hline 70 & 700 & 45 & 39,12 & 30,29 & 27,88 & 25,29 & 23,05 & 20,98 & 17,35 & 14,39 & 10,13 \\
\hline 70 & 750 & 45 & 38,06 & 29,56 & 27,32 & 24,87 & 22,73 & 20,75 & 17,24 & 14,35 & 10,16 \\
\hline 70 & 800 & 45 & 37,11 & 28,90 & 26,80 & 24,49 & 22,43 & 20,53 & 17,13 & 14,31 & 10,18 \\
\hline 70 & 850 & 45 & 36,25 & 28,29 & 26,32 & 24,12 & 22,15 & 20,32 & 17,02 & 14,27 & 10,20 \\
\hline 70 & 900 & 45 & 35,47 & 27,73 & 25,87 & 23,78 & 21,88 & 20,11 & 16,92 & 14,23 & 10,22 \\
\hline 70 & 950 & 45 & 34,76 & 27,21 & 25,45 & 23,46 & 21,63 & 19,92 & 16,81 & 14,19 & 10,23 \\
\hline 70 & 1000 & 45 & 34,10 & 26,73 & 25,06 & 23,15 & 21,39 & 19,73 & 16,71 & 14,14 & 10,24 \\
\hline 70 & 1050 & 45 & 33,50 & 26,28 & 24,69 & 22,87 & 21,16 & 19,56 & 16,61 & 14,10 & 10,25 \\
\hline 70 & 1100 & 45 & 32,93 & 25,86 & 24,33 & 22,59 & 20,95 & 19,38 & 16,52 & 14,05 & 10,26 \\
\hline 70 & 1150 & 45 & 32,41 & 25,47 & 24,00 & 22,33 & 20,74 & 19,22 & 16,42 & 14,01 & 10,26 \\
\hline 70 & 1200 & 45 & 31,91 & 25,10 & 23,69 & 22,09 & 20,54 & 19,06 & 16,33 & 13,96 & 10,26 \\
\hline 70 & 1250 & 45 & 31,45 & 24,75 & 23,39 & 21,85 & 20,35 & 18,91 & 16,24 & 13,91 & 10,26 \\
\hline 70 & 1300 & 45 & 31,02 & 24,42 & 23,10 & 21,62 & 20,16 & 18,76 & 16,15 & 13,87 & 10,27 \\
\hline 70 & 1350 & 45 & 30,60 & 24,11 & 22,83 & 21,41 & 19,98 & 18,62 & 16,06 & 13,82 & 10,26 \\
\hline 70 & 1400 & 45 & 30,21 & 23,82 & 22,57 & 21,20 & 19,81 & 18,48 & 15,98 & 13,78 & 10,26 \\
\hline 70 & 1450 & 45 & 29,84 & 23,54 & 22,32 & 21,00 & 19,65 & 18,35 & 15,90 & 13,73 & 10,26 \\
\hline 70 & 1500 & 45 & 29,49 & 23,28 & 22,08 & 20,81 & 19,49 & 18,22 & 15,82 & 13,69 & 10,26 \\
\hline 70 & 1550 & 45 & 29,15 & 23,02 & 21,85 & 20,62 & 19,34 & 18,09 & 15,74 & 13,64 & 10,25 \\
\hline 70 & 1600 & 45 & 28,83 & 22,78 & 21,63 & 20,45 & 19,19 & 17,97 & 15,66 & 13,60 & 10,25 \\
\hline 70 & 1650 & 45 & 28,52 & 22,55 & 21,42 & 20,27 & 19,05 & 17,85 & 15,59 & 13,55 & 10,24 \\
\hline 70 & 1700 & 45 & 28,22 & 22,33 & 21,22 & 20,11 & 18,91 & 17,74 & 15,51 & 13,51 & 10,24 \\
\hline 70 & 1750 & 45 & 27,94 & 22,12 & 21,02 & 19,95 & 18,78 & 17,63 & 15,44 & 13,47 & 10,23 \\
\hline 70 & 1800 & 45 & 27,66 & 21,92 & 20,83 & 19,79 & 18,65 & 17,52 & 15,37 & 13,43 & 10,22 \\
\hline 70 & 1850 & 45 & 27,40 & 21,73 & 20,65 & 19,64 & 18,52 & 17,41 & 15,30 & 13,38 & 10,21 \\
\hline 70 & 1900 & 45 & 27,14 & 21,54 & 20,47 & 19,49 & 18,40 & 17,31 & 15,23 & 13,34 & 10,21 \\
\hline 70 & 1950 & 45 & 26,90 & 21,36 & 20,30 & 19,35 & 18,28 & 17,21 & 15,16 & 13,30 & 10,20 \\
\hline 70 & 2000 & 45 & 26,66 & 21,19 & 20,13 & 19,21 & 18,16 & 17,11 & 15,10 & 13,26 & 10,19 \\
\hline 70 & 200 & 50 & 68,35 & 44,40 & 36,51 & 30,08 & 25,52 & 21,87 & 16,37 & 12,73 & 8,53 \\
\hline 70 & 250 & 50 & 60,26 & 40,89 & 34,41 & 28,93 & 24,89 & 21,56 & 16,40 & 12,85 & 8,62 \\
\hline 70 & 300 & 50 & 54,65 & 38,27 & 32,77 & 27,96 & 24,32 & 21,25 & 16,38 & 12,93 & 8,69 \\
\hline 70 & 350 & 50 & 50,48 & 36,20 & 31,43 & 27,13 & 23,80 & 20,94 & 16,33 & 12,99 & 8,77 \\
\hline 70 & 400 & 50 & 47,26 & 34,52 & 30,30 & 26,41 & 23,33 & 20,66 & 16,27 & 13,02 & 8,83 \\
\hline 70 & 450 & 50 & 44,67 & 33,10 & 29,33 & 25,77 & 22,90 & 20,38 & 16,19 & 13,04 & 8,89 \\
\hline 70 & 500 & 50 & 42,55 & 31,88 & 28,48 & 25,19 & 22,50 & 20,12 & 16,11 & 13,04 & 8,94 \\
\hline 70 & 550 & 50 & 40,76 & 30,82 & 27,73 & 24,66 & 22,13 & 19,87 & 16,03 & 13,04 & 8,98 \\
\hline 70 & 600 & 50 & 39,24 & 29,88 & 27,05 & 24,18 & 21,79 & 19,64 & 15,94 & 13,03 & 9,02 \\
\hline 70 & 650 & 50 & 37,92 & 29,05 & 26,43 & 23,75 & 21,47 & 19,41 & 15,84 & 13,01 & 9,05 \\
\hline 70 & 700 & 50 & 36,76 & 28,30 & 25,87 & 23,34 & 21,17 & 19,20 & 15,75 & 12,99 & 9,08 \\
\hline 70 & 750 & 50 & 35,73 & 27,61 & 25,36 & 22,96 & 20,89 & 19,00 & 15,66 & 12,96 & 9,11 \\
\hline 70 & 800 & 50 & 34,82 & 26,99 & 24,88 & 22,61 & 20,63 & 18,80 & 15,57 & 12,94 & 9,13 \\
\hline 70 & 850 & 50 & 33,99 & 26,42 & 24,44 & 22,28 & 20,38 & 18,61 & 15,48 & 12,91 & 9,15 \\
\hline 70 & 900 & 50 & 33,24 & 25,90 & 24,03 & 21,97 & 20,14 & 18,44 & 15,40 & 12,87 & 9,17 \\
\hline 70 & 950 & 50 & 32,55 & 25,41 & 23,65 & 21,68 & 19,91 & 18,27 & 15,31 & 12,84 & 9,18 \\
\hline 70 & 1000 & 50 & 31,93 & 24,96 & 23,28 & 21,40 & 19,70 & 18,10 & 15,22 & 12,81 & 9,20 \\
\hline 70 & 1050 & 50 & 31,35 & 24,53 & 22,94 & 21,14 & 19,49 & 17,94 & 15,14 & 12,77 & 9,21 \\
\hline 70 & 1100 & 50 & 30,81 & 24,14 & 22,62 & 20,89 & 19,30 & 17,79 & 15,06 & 12,74 & 9,21 \\
\hline 70 & 1150 & 50 & 30,31 & 23,77 & 22,31 & 20,66 & 19,11 & 17,65 & 14,98 & 12,70 & 9,22 \\
\hline
\end{tabular}




\begin{tabular}{|c|c|c|c|c|c|c|c|c|c|c|c|}
\hline \multirow[b]{2}{*}{$\mathrm{H}(\mathrm{cm})$} & \multirow[b]{2}{*}{ Mceq (MPa) } & & & & & $\mathrm{De}$ & ões (x1 & & & & \\
\hline & & Msub (MPa) & D0 & D25 & D40 & D60 & D80 & D100 & D140 & D180 & D260 \\
\hline 70 & 1200 & 50 & 29,84 & 23,42 & 22,03 & 20,43 & 18,93 & 17,51 & 14,90 & 12,66 & 9,23 \\
\hline 70 & 1250 & 50 & 29,40 & 23,10 & 21,75 & 20,22 & 18,76 & 17,37 & 14,82 & 12,63 & 9,23 \\
\hline 70 & 1300 & 50 & 28,99 & 22,79 & 21,49 & 20,01 & 18,59 & 17,24 & 14,75 & 12,59 & 9,24 \\
\hline 70 & 1350 & 50 & 28,60 & 22,49 & 21,24 & 19,81 & 18,43 & 17,11 & 14,67 & 12,55 & 9,24 \\
\hline 70 & 1400 & 50 & 28,23 & 22,22 & 21,00 & 19,62 & 18,28 & 16,99 & 14,60 & 12,51 & 9,24 \\
\hline 70 & 1450 & 50 & 27,88 & 21,95 & 20,77 & 19,44 & 18,13 & 16,87 & 14,53 & 12,48 & 9,24 \\
\hline 70 & 1500 & 50 & 27,54 & 21,70 & 20,55 & 19,27 & 17,99 & 16,76 & 14,46 & 12,44 & 9,24 \\
\hline 70 & 1550 & 50 & 27,23 & 21,46 & 20,34 & 19,10 & 17,85 & 16,64 & 14,39 & 12,40 & 9,24 \\
\hline 70 & 1600 & 50 & 26,92 & 21,24 & 20,13 & 18,94 & 17,71 & 16,53 & 14,32 & 12,37 & 9,23 \\
\hline 70 & 1650 & 50 & 26,63 & 21,02 & 19,94 & 18,78 & 17,59 & 16,43 & 14,26 & 12,33 & 9,23 \\
\hline 70 & 1700 & 50 & 26,36 & 20,81 & 19,75 & 18,63 & 17,46 & 16,33 & 14,19 & 12,29 & 9,23 \\
\hline 70 & 1750 & 50 & 26,09 & 20,61 & 19,57 & 18,48 & 17,34 & 16,23 & 14,13 & 12,26 & 9,22 \\
\hline 70 & 1800 & 50 & 25,83 & 20,42 & 19,39 & 18,34 & 17,22 & 16,13 & 14,07 & 12,22 & 9,22 \\
\hline 70 & 1850 & 50 & 25,59 & 20,24 & 19,22 & 18,20 & 17,11 & 16,03 & 14,01 & 12,19 & 9,22 \\
\hline 70 & 1900 & 50 & 25,35 & 20,06 & 19,06 & 18,07 & 16,99 & 15,94 & 13,95 & 12,15 & 9,21 \\
\hline 70 & 1950 & 50 & 25,12 & 19,89 & 18,90 & 17,94 & 16,89 & 15,85 & 13,89 & 12,12 & 9,20 \\
\hline 70 & 2000 & 50 & 24,90 & 19,73 & 18,75 & 17,81 & 16,78 & 15,77 & 13,83 & 12,08 & 9,20 \\
\hline 70 & 200 & 55 & 65,70 & 41,84 & 34,03 & 27,79 & 23,43 & 19,98 & 14,86 & 11,52 & 7,72 \\
\hline 70 & 250 & 55 & 57,76 & 38,49 & 32,08 & 26,75 & 22,88 & 19,72 & 14,90 & 11,64 & 7,80 \\
\hline 70 & 300 & 55 & 52,26 & 36,01 & 30,56 & 25,88 & 22,38 & 19,47 & 14,90 & 11,72 & 7,87 \\
\hline 70 & 350 & 55 & 48,18 & 34,06 & 29,32 & 25,13 & 21,93 & 19,21 & 14,88 & 11,78 & 7,93 \\
\hline 70 & 400 & 55 & 45,02 & 32,46 & 28,28 & 24,48 & 21,52 & 18,97 & 14,83 & 11,82 & 7,99 \\
\hline 70 & 450 & 55 & 42,50 & 31,13 & 27,38 & 23,90 & 21,13 & 18,73 & 14,78 & 11,84 & 8,04 \\
\hline 70 & 500 & 55 & 40,42 & 29,98 & 26,59 & 23,37 & 20,78 & 18,51 & 14,72 & 11,85 & 8,08 \\
\hline 70 & 550 & 55 & 38,68 & 28,98 & 25,89 & 22,90 & 20,46 & 18,29 & 14,65 & 11,86 & 8,12 \\
\hline 70 & 600 & 55 & 37,19 & 28,10 & 25,26 & 22,46 & 20,15 & 18,09 & 14,58 & 11,85 & 8,16 \\
\hline 70 & 650 & 55 & 35,91 & 27,31 & 24,70 & 22,06 & 19,87 & 17,89 & 14,50 & 11,84 & 8,19 \\
\hline 70 & 700 & 55 & 34,78 & 26,61 & 24,18 & 21,69 & 19,60 & 17,70 & 14,43 & 11,83 & 8,22 \\
\hline 70 & 750 & 55 & 33,78 & 25,96 & 23,70 & 21,35 & 19,35 & 17,52 & 14,35 & 11,82 & 8,25 \\
\hline 70 & 800 & 55 & 32,89 & 25,38 & 23,26 & 21,03 & 19,11 & 17,35 & 14,28 & 11,80 & 8,27 \\
\hline 70 & 850 & 55 & 32,09 & 24,84 & 22,85 & 20,73 & 18,88 & 17,19 & 14,20 & 11,77 & 8,29 \\
\hline 70 & 900 & 55 & 31,37 & 24,34 & 22,47 & 20,44 & 18,67 & 17,03 & 14,13 & 11,75 & 8,31 \\
\hline 70 & 950 & 55 & 30,71 & 23,89 & 22,12 & 20,18 & 18,46 & 16,88 & 14,05 & 11,73 & 8,32 \\
\hline 70 & 1000 & 55 & 30,10 & 23,46 & 21,78 & 19,92 & 18,27 & 16,73 & 13,98 & 11,70 & 8,34 \\
\hline 70 & 1050 & 55 & 29,54 & 23,06 & 21,46 & 19,68 & 18,08 & 16,59 & 13,91 & 11,67 & 8,35 \\
\hline 70 & 1100 & 55 & 29,02 & 22,69 & 21,17 & 19,46 & 17,91 & 16,46 & 13,84 & 11,64 & 8,36 \\
\hline 70 & 1150 & 55 & 28,54 & 22,34 & 20,88 & 19,24 & 17,74 & 16,33 & 13,77 & 11,61 & 8,37 \\
\hline 70 & 1200 & 55 & 28,09 & 22,01 & 20,62 & 19,03 & 17,57 & 16,20 & 13,70 & 11,58 & 8,38 \\
\hline 70 & 1250 & 55 & 27,67 & 21,70 & 20,36 & 18,84 & 17,42 & 16,08 & 13,64 & 11,55 & 8,38 \\
\hline 70 & 1300 & 55 & 27,28 & 21,41 & 20,12 & 18,65 & 17,27 & 15,96 & 13,57 & 11,52 & 8,39 \\
\hline 70 & 1350 & 55 & 26,90 & 21,13 & 19,88 & 18,47 & 17,12 & 15,85 & 13,51 & 11,49 & 8,39 \\
\hline 70 & 1400 & 55 & 26,55 & 20,87 & 19,66 & 18,29 & 16,98 & 15,74 & 13,44 & 11,46 & 8,39 \\
\hline 70 & 1450 & 55 & 26,22 & 20,62 & 19,45 & 18,13 & 16,85 & 15,63 & 13,38 & 11,43 & 8,40 \\
\hline 70 & 1500 & 55 & 25,90 & 20,38 & 19,25 & 17,96 & 16,72 & 15,53 & 13,32 & 11,40 & 8,40 \\
\hline 70 & 1550 & 55 & 25,60 & 20,15 & 19,05 & 17,81 & 16,59 & 15,43 & 13,26 & 11,37 & 8,40 \\
\hline 70 & 1600 & 55 & 25,31 & 19,94 & 18,86 & 17,66 & 16,47 & 15,33 & 13,20 & 11,34 & 8,40 \\
\hline 70 & 1650 & 55 & 25,04 & 19,73 & 18,68 & 17,52 & 16,35 & 15,23 & 13,14 & 11,31 & 8,40 \\
\hline 70 & 1700 & 55 & 24,78 & 19,53 & 18,50 & 17,38 & 16,24 & 15,14 & 13,09 & 11,28 & 8,40 \\
\hline 70 & 1750 & 55 & 24,52 & 19,34 & 18,34 & 17,24 & 16,13 & 15,05 & 13,03 & 11,25 & 8,40 \\
\hline 70 & 1800 & 55 & 24,28 & 19,16 & 18,17 & 17,11 & 16,02 & 14,96 & 12,98 & 11,22 & 8,39 \\
\hline 70 & 1850 & 55 & 24,05 & 18,99 & 18,01 & 16,98 & 15,91 & 14,88 & 12,92 & 11,19 & 8,39 \\
\hline 70 & 1900 & 55 & 23,83 & 18,82 & 17,86 & 16,86 & 15,81 & 14,79 & 12,87 & 11,16 & 8,39 \\
\hline 70 & 1950 & 55 & 23,61 & 18,66 & 17,72 & 16,74 & 15,71 & 14,71 & 12,82 & 11,13 & 8,38 \\
\hline 70 & 2000 & 55 & 23,40 & 18,50 & 17,57 & 16,63 & 15,62 & 14,63 & 12,77 & 11,10 & 8,38 \\
\hline 70 & 200 & 60 & 63,44 & 39,65 & 31,93 & 25,84 & 21,66 & 18,38 & 13,60 & 10,52 & 7,06 \\
\hline 70 & 250 & 60 & 55,63 & 36,44 & 30,09 & 24,90 & 21,18 & 18,18 & 13,65 & 10,63 & 7,12 \\
\hline 70 & 300 & 60 & 50,22 & 34,07 & 28,67 & 24,11 & 20,74 & 17,96 & 13,67 & 10,71 & 7,18 \\
\hline 70 & 350 & 60 & 46,22 & 32,22 & 27,51 & 23,43 & 20,34 & 17,75 & 13,65 & 10,77 & 7,24 \\
\hline 70 & 400 & 60 & 43,12 & 30,70 & 26,54 & 22,83 & 19,97 & 17,54 & 13,63 & 10,81 & 7,29 \\
\hline 70 & 450 & 60 & 40,65 & 29,43 & 25,70 & 22,30 & 19,63 & 17,33 & 13,59 & 10,84 & 7,33 \\
\hline 70 & 500 & 60 & 38,61 & 28,35 & 24,97 & 21,82 & 19,32 & 17,14 & 13,54 & 10,86 & 7,37 \\
\hline 70 & 550 & 60 & 36,91 & 27,40 & 24,32 & 21,39 & 19,02 & 16,95 & 13,48 & 10,86 & 7,41 \\
\hline 70 & 600 & 60 & 35,46 & 26,57 & 23,73 & 20,99 & 18,75 & 16,77 & 13,43 & 10,87 & 7,45 \\
\hline 70 & 650 & 60 & 34,20 & 25,82 & 23,20 & 20,62 & 18,49 & 16,59 & 13,37 & 10,87 & 7,48 \\
\hline 70 & 700 & 60 & 33,10 & 25,15 & 22,72 & 20,28 & 18,25 & 16,43 & 13,30 & 10,86 & 7,51 \\
\hline 70 & 750 & 60 & 32,13 & 24,55 & 22,28 & 19,97 & 18,02 & 16,27 & 13,24 & 10,85 & 7,53 \\
\hline 70 & 800 & 60 & 31,26 & 23,99 & 21,87 & 19,67 & 17,81 & 16,12 & 13,18 & 10,84 & 7,55 \\
\hline 70 & 850 & 60 & 30,48 & 23,48 & 21,49 & 19,40 & 17,60 & 15,97 & 13,12 & 10,82 & 7,57 \\
\hline 70 & 900 & 60 & 29,78 & 23,01 & 21,13 & 19,13 & 17,41 & 15,83 & 13,05 & 10,80 & 7,59 \\
\hline 70 & 950 & 60 & 29,13 & 22,58 & 20,80 & 18,89 & 17,22 & 15,69 & 12,99 & 10,78 & 7,61 \\
\hline 70 & 1000 & 60 & 28,55 & 22,17 & 20,49 & 18,66 & 17,05 & 15,56 & 12,93 & 10,76 & 7,62 \\
\hline 70 & 1050 & 60 & 28,00 & 21,79 & 20,19 & 18,44 & 16,88 & 15,44 & 12,87 & 10,74 & 7,63 \\
\hline 70 & 1100 & 60 & 27,50 & 21,44 & 19,92 & 18,23 & 16,72 & 15,32 & 12,81 & 10,72 & 7,64 \\
\hline 70 & 1150 & 60 & 27,04 & 21,11 & 19,65 & 18,03 & 16,56 & 15,20 & 12,75 & 10,70 & 7,65 \\
\hline 70 & 1200 & 60 & 26,60 & 20,80 & 19,40 & 17,84 & 16,41 & 15,09 & 12,69 & 10,67 & 7,66 \\
\hline 70 & 1250 & 60 & 26,20 & 20,50 & 19,16 & 17,65 & 16,27 & 14,98 & 12,63 & 10,65 & 7,67 \\
\hline 70 & 1300 & 60 & 25,82 & 20,22 & 18,94 & 17,48 & 16,13 & 14,87 & 12,57 & 10,62 & 7,68 \\
\hline 70 & 1350 & 60 & 25,46 & 19,96 & 18,72 & 17,31 & 16,00 & 14,77 & 12,51 & 10,60 & 7,68 \\
\hline 70 & 1400 & 60 & 25,12 & 19,71 & 18,51 & 17,15 & 15,87 & 14,67 & 12,46 & 10,57 & 7,69 \\
\hline 70 & 1450 & 60 & 24,80 & 19,47 & 18,32 & 17,00 & 15,75 & 14,57 & 12,40 & 10,55 & 7,69 \\
\hline 70 & 1500 & 60 & 24,50 & 19,25 & 18,12 & 16,85 & 15,63 & 14,48 & 12,35 & 10,52 & 7,69 \\
\hline
\end{tabular}




\begin{tabular}{|c|c|c|c|c|c|c|c|c|c|c|c|}
\hline \multirow[b]{2}{*}{$\mathrm{H}(\mathrm{cm})$} & \multirow[b]{2}{*}{ Mceq (MPa) } & & & & & $\mathrm{De}$ & ões (x1 & & & & \\
\hline & & Msub (MPa) & D0 & D25 & D40 & D60 & D80 & D100 & D140 & D180 & D260 \\
\hline 70 & 1550 & 60 & 24,21 & 19,03 & 17,94 & 16,70 & 15,51 & 14,38 & 12,30 & 10,50 & 7,70 \\
\hline 70 & 1600 & 60 & 23,94 & 18,82 & 17,77 & 16,57 & 15,40 & 14,30 & 12,25 & 10,47 & 7,70 \\
\hline 70 & 1650 & 60 & 23,67 & 18,63 & 17,60 & 16,43 & 15,29 & 14,21 & 12,20 & 10,44 & 7,70 \\
\hline 70 & 1700 & 60 & 23,42 & 18,44 & 17,43 & 16,30 & 15,19 & 14,12 & 12,15 & 10,42 & 7,70 \\
\hline 70 & 1750 & 60 & 23,18 & 18,26 & 17,27 & 16,18 & 15,09 & 14,04 & 12,10 & 10,39 & 7,70 \\
\hline 70 & 1800 & 60 & 22,95 & 18,09 & 17,12 & 16,06 & 14,99 & 13,96 & 12,05 & 10,37 & 7,70 \\
\hline 70 & 1850 & 60 & 22,73 & 17,92 & 16,98 & 15,94 & 14,89 & 13,88 & 12,00 & 10,34 & 7,70 \\
\hline 70 & 1900 & 60 & 22,52 & 17,76 & 16,83 & 15,82 & 14,80 & 13,81 & 11,95 & 10,32 & 7,70 \\
\hline 70 & 1950 & 60 & 22,31 & 17,60 & 16,69 & 15,71 & 14,71 & 13,73 & 11,91 & 10,29 & 7,69 \\
\hline 70 & 2000 & 60 & 22,12 & 17,46 & 16,56 & 15,61 & 14,62 & 13,66 & 11,86 & 10,27 & 7,69 \\
\hline 70 & 200 & 65 & 61,49 & 37,75 & 30,10 & 24,16 & 20,14 & 17,02 & 12,52 & 9,67 & 6,50 \\
\hline 70 & 250 & 65 & 53,79 & 34,66 & 28,37 & 23,30 & 19,71 & 16,86 & 12,59 & 9,78 & 6,55 \\
\hline 70 & 300 & 65 & 48,46 & 32,39 & 27,04 & 22,57 & 19,33 & 16,67 & 12,61 & 9,85 & 6,60 \\
\hline 70 & 350 & 65 & 44,53 & 30,61 & 25,95 & 21,95 & 18,97 & 16,49 & 12,61 & 9,91 & 6,65 \\
\hline 70 & 400 & 65 & 41,48 & 29,17 & 25,03 & 21,41 & 18,64 & 16,31 & 12,60 & 9,96 & 6,70 \\
\hline 70 & 450 & 65 & 39,05 & 27,96 & 24,25 & 20,92 & 18,34 & 16,13 & 12,57 & 9,99 & 6,74 \\
\hline 70 & 500 & 65 & 37,05 & 26,93 & 23,56 & 20,48 & 18,05 & 15,96 & 12,53 & 10,01 & 6,78 \\
\hline 70 & 550 & 65 & 35,38 & 26,03 & 22,95 & 20,08 & 17,79 & 15,79 & 12,49 & 10,02 & 6,81 \\
\hline 70 & 600 & 65 & 33,96 & 25,23 & 22,40 & 19,71 & 17,54 & 15,63 & 12,44 & 10,03 & 6,84 \\
\hline 70 & 650 & 65 & 32,73 & 24,52 & 21,91 & 19,37 & 17,31 & 15,48 & 12,39 & 10,03 & 6,87 \\
\hline 70 & 700 & 65 & 31,65 & 23,89 & 21,46 & 19,06 & 17,09 & 15,33 & 12,34 & 10,03 & 6,90 \\
\hline 70 & 750 & 65 & 30,70 & 23,31 & 21,04 & 18,77 & 16,88 & 15,19 & 12,29 & 10,03 & 6,92 \\
\hline 70 & 800 & 65 & 29,85 & 22,78 & 20,66 & 18,50 & 16,69 & 15,05 & 12,24 & 10,02 & 6,95 \\
\hline 70 & 850 & 65 & 29,09 & 22,30 & 20,30 & 18,24 & 16,50 & 14,92 & 12,18 & 10,01 & 6,97 \\
\hline 70 & 900 & 65 & 28,41 & 21,85 & 19,97 & 18,00 & 16,32 & 14,79 & 12,13 & 9,99 & 6,98 \\
\hline 70 & 950 & 65 & 27,78 & 21,44 & 19,66 & 17,77 & 16,15 & 14,67 & 12,08 & 9,98 & 7,00 \\
\hline 70 & 1000 & 65 & 27,21 & 21,05 & 19,36 & 17,56 & 15,99 & 14,55 & 12,02 & 9,96 & 7,01 \\
\hline 70 & 1050 & 65 & 26,68 & 20,69 & 19,09 & 17,35 & 15,84 & 14,44 & 11,97 & 9,95 & 7,03 \\
\hline 70 & 1100 & 65 & 26,19 & 20,36 & 18,83 & 17,16 & 15,69 & 14,33 & 11,92 & 9,93 & 7,04 \\
\hline 70 & 1150 & 65 & 25,74 & 20,04 & 18,58 & 16,97 & 15,55 & 14,22 & 11,86 & 9,91 & 7,05 \\
\hline 70 & 1200 & 65 & 25,32 & 19,74 & 18,35 & 16,79 & 15,41 & 14,12 & 11,81 & 9,89 & 7,06 \\
\hline 70 & 1250 & 65 & 24,93 & 19,46 & 18,12 & 16,63 & 15,28 & 14,02 & 11,76 & 9,87 & 7,07 \\
\hline 70 & 1300 & 65 & 24,56 & 19,20 & 17,91 & 16,46 & 15,15 & 13,92 & 11,71 & 9,85 & 7,07 \\
\hline 70 & 1350 & 65 & 24,21 & 18,95 & 17,71 & 16,31 & 15,03 & 13,83 & 11,66 & 9,83 & 7,08 \\
\hline 70 & 1400 & 65 & 23,88 & 18,71 & 17,51 & 16,16 & 14,91 & 13,74 & 11,61 & 9,81 & 7,09 \\
\hline 70 & 1450 & 65 & 23,58 & 18,48 & 17,33 & 16,01 & 14,80 & 13,65 & 11,56 & 9,79 & 7,09 \\
\hline 70 & 1500 & 65 & 23,28 & 18,26 & 17,15 & 15,88 & 14,69 & 13,57 & 11,52 & 9,77 & 7,09 \\
\hline 70 & 1550 & 65 & 23,01 & 18,06 & 16,98 & 15,74 & 14,58 & 13,48 & 11,47 & 9,75 & 7,10 \\
\hline 70 & 1600 & 65 & 22,74 & 17,86 & 16,81 & 15,61 & 14,48 & 13,40 & 11,42 & 9,72 & 7,10 \\
\hline 70 & 1650 & 65 & 22,49 & 17,67 & 16,65 & 15,49 & 14,38 & 13,32 & 11,38 & 9,70 & 7,10 \\
\hline 70 & 1700 & 65 & 22,25 & 17,49 & 16,50 & 15,37 & 14,28 & 13,25 & 11,33 & 9,68 & 7,10 \\
\hline 70 & 1750 & 65 & 22,02 & 17,32 & 16,35 & 15,25 & 14,19 & 13,17 & 11,29 & 9,66 & 7,11 \\
\hline 70 & 1800 & 65 & 21,80 & 17,15 & 16,21 & 15,14 & 14,10 & 13,10 & 11,25 & 9,64 & 7,11 \\
\hline 70 & 1850 & 65 & 21,59 & 16,99 & 16,07 & 15,03 & 14,01 & 13,03 & 11,20 & 9,61 & 7,11 \\
\hline 70 & 1900 & 65 & 21,38 & 16,84 & 15,94 & 14,92 & 13,92 & 12,96 & 11,16 & 9,59 & 7,11 \\
\hline 70 & 1950 & 65 & 21,19 & 16,69 & 15,81 & 14,82 & 13,84 & 12,89 & 11,12 & 9,57 & 7,11 \\
\hline 70 & 2000 & 65 & 21,00 & 16,55 & 15,68 & 14,72 & 13,75 & 12,82 & 11,08 & 9,55 & 7,11 \\
\hline 70 & 200 & 70 & 59,78 & 36,09 & 28,51 & 22,69 & 18,82 & 15,85 & 11,60 & 8,95 & 6,02 \\
\hline 70 & 250 & 70 & 52,18 & 33,10 & 26,87 & 21,90 & 18,44 & 15,71 & 11,67 & 9,05 & 6,06 \\
\hline 70 & 300 & 70 & 46,92 & 30,91 & 25,60 & 21,24 & 18,10 & 15,56 & 11,70 & 9,12 & 6,11 \\
\hline 70 & 350 & 70 & 43,05 & 29,20 & 24,58 & 20,66 & 17,78 & 15,40 & 11,71 & 9,18 & 6,15 \\
\hline 70 & 400 & 70 & 40,05 & 27,82 & 23,71 & 20,16 & 17,48 & 15,24 & 11,71 & 9,22 & 6,19 \\
\hline 70 & 450 & 70 & 37,66 & 26,66 & 22,97 & 19,71 & 17,21 & 15,08 & 11,69 & 9,26 & 6,23 \\
\hline 70 & 500 & 70 & 35,70 & 25,67 & 22,33 & 19,30 & 16,95 & 14,93 & 11,66 & 9,28 & 6,27 \\
\hline 70 & 550 & 70 & 34,05 & 24,81 & 21,75 & 18,93 & 16,71 & 14,78 & 11,63 & 9,30 & 6,30 \\
\hline 70 & 600 & 70 & 32,65 & 24,06 & 21,24 & 18,59 & 16,48 & 14,64 & 11,59 & 9,31 & 6,33 \\
\hline 70 & 650 & 70 & 31,45 & 23,38 & 20,77 & 18,28 & 16,27 & 14,50 & 11,55 & 9,31 & 6,36 \\
\hline 70 & 700 & 70 & 30,39 & 22,77 & 20,34 & 17,99 & 16,07 & 14,37 & 11,51 & 9,32 & 6,38 \\
\hline 70 & 750 & 70 & 29,46 & 22,22 & 19,95 & 17,72 & 15,88 & 14,24 & 11,46 & 9,31 & 6,41 \\
\hline 70 & 800 & 70 & 28,63 & 21,72 & 19,59 & 17,47 & 15,70 & 14,12 & 11,42 & 9,31 & 6,43 \\
\hline 70 & 850 & 70 & 27,88 & 21,26 & 19,26 & 17,23 & 15,53 & 14,00 & 11,37 & 9,30 & 6,45 \\
\hline 70 & 900 & 70 & 27,21 & 20,83 & 18,94 & 17,00 & 15,37 & 13,89 & 11,33 & 9,29 & 6,46 \\
\hline 70 & 950 & 70 & 26,60 & 20,44 & 18,65 & 16,79 & 15,21 & 13,78 & 11,28 & 9,28 & 6,48 \\
\hline 70 & 1000 & 70 & 26,04 & 20,07 & 18,37 & 16,59 & 15,06 & 13,67 & 11,23 & 9,27 & 6,49 \\
\hline 70 & 1050 & 70 & 25,52 & 19,72 & 18,11 & 16,40 & 14,92 & 13,57 & 11,19 & 9,26 & 6,51 \\
\hline 70 & 1100 & 70 & 25,05 & 19,40 & 17,87 & 16,22 & 14,79 & 13,47 & 11,14 & 9,25 & 6,52 \\
\hline 70 & 1150 & 70 & 24,61 & 19,10 & 17,64 & 16,05 & 14,65 & 13,37 & 11,10 & 9,23 & 6,53 \\
\hline 70 & 1200 & 70 & 24,20 & 18,82 & 17,42 & 15,88 & 14,53 & 13,28 & 11,05 & 9,22 & 6,54 \\
\hline 70 & 1250 & 70 & 23,82 & 18,55 & 17,21 & 15,72 & 14,41 & 13,19 & 11,01 & 9,20 & 6,55 \\
\hline 70 & 1300 & 70 & 23,46 & 18,30 & 17,01 & 15,57 & 14,29 & 13,10 & 10,96 & 9,18 & 6,55 \\
\hline 70 & 1350 & 70 & 23,12 & 18,05 & 16,81 & 15,43 & 14,18 & 13,01 & 10,92 & 9,17 & 6,56 \\
\hline 70 & 1400 & 70 & 22,80 & 17,83 & 16,63 & 15,29 & 14,07 & 12,93 & 10,87 & 9,15 & 6,57 \\
\hline 70 & 1450 & 70 & 22,50 & 17,61 & 16,46 & 15,15 & 13,96 & 12,85 & 10,83 & 9,13 & 6,57 \\
\hline 70 & 1500 & 70 & 22,22 & 17,40 & 16,29 & 15,02 & 13,86 & 12,77 & 10,79 & 9,11 & 6,58 \\
\hline 70 & 1550 & 70 & 21,95 & 17,20 & 16,13 & 14,90 & 13,76 & 12,69 & 10,75 & 9,09 & 6,58 \\
\hline 70 & 1600 & 70 & 21,70 & 17,02 & 15,97 & 14,78 & 13,67 & 12,62 & 10,71 & 9,07 & 6,59 \\
\hline 70 & 1650 & 70 & 21,45 & 16,84 & 15,82 & 14,66 & 13,57 & 12,55 & 10,67 & 9,06 & 6,59 \\
\hline 70 & 1700 & 70 & 21,22 & 16,66 & 15,68 & 14,55 & 13,48 & 12,48 & 10,63 & 9,04 & 6,59 \\
\hline 70 & 1750 & 70 & 21,00 & 16,50 & 15,54 & 14,44 & 13,40 & 12,41 & 10,59 & 9,02 & 6,59 \\
\hline 70 & 1800 & 70 & 20,79 & 16,34 & 15,40 & 14,33 & 13,31 & 12,34 & 10,55 & 9,00 & 6,60 \\
\hline 70 & 1850 & 70 & 20,58 & 16,18 & 15,27 & 14,23 & 13,23 & 12,27 & 10,51 & 8,98 & 6,60 \\
\hline
\end{tabular}




\begin{tabular}{|c|c|c|c|c|c|c|c|c|c|c|c|}
\hline \multirow[b]{2}{*}{$\mathrm{H}(\mathrm{cm})$} & \multirow[b]{2}{*}{ Mceq (MPa) } & & & & & $\mathrm{De}$ & ões (x1 & & & & \\
\hline & & Msub (MPa) & D0 & D25 & D40 & D60 & D80 & D100 & D140 & D180 & D260 \\
\hline 70 & 1900 & 70 & 20,39 & 16,04 & 15,14 & 14,13 & 13,15 & 12,21 & 10,47 & 8,96 & 6,60 \\
\hline 70 & 1950 & 70 & 20,20 & 15,90 & 15,02 & 14,04 & 13,07 & 12,15 & 10,44 & 8,94 & 6,60 \\
\hline 70 & 2000 & 70 & 20,02 & 15,76 & 14,90 & 13,94 & 12,99 & 12,09 & 10,40 & 8,92 & 6,60 \\
\hline 70 & 200 & 75 & 58,26 & 34,61 & 27,10 & 21,40 & 17,66 & 14,82 & 10,80 & 8,32 & 5,61 \\
\hline 70 & 250 & 75 & 50,75 & 31,72 & 25,54 & 20,67 & 17,32 & 14,71 & 10,88 & 8,42 & 5,65 \\
\hline 70 & 300 & 75 & 45,57 & 29,60 & 24,34 & 20,06 & 17,01 & 14,58 & 10,92 & 8,49 & 5,69 \\
\hline 70 & 350 & 75 & 41,74 & 27,96 & 23,36 & 19,53 & 16,73 & 14,44 & 10,93 & 8,54 & 5,72 \\
\hline 70 & 400 & 75 & 38,79 & 26,62 & 22,55 & 19,06 & 16,46 & 14,30 & 10,93 & 8,59 & 5,76 \\
\hline 70 & 450 & 75 & 36,43 & 25,51 & 21,84 & 18,64 & 16,21 & 14,16 & 10,92 & 8,62 & 5,80 \\
\hline 70 & 500 & 75 & 34,50 & 24,56 & 21,23 & 18,27 & 15,98 & 14,03 & 10,90 & 8,65 & 5,83 \\
\hline 70 & 550 & 75 & 32,88 & 23,74 & 20,69 & 17,92 & 15,76 & 13,90 & 10,88 & 8,67 & 5,86 \\
\hline 70 & 600 & 75 & 31,50 & 23,01 & 20,20 & 17,61 & 15,55 & 13,77 & 10,85 & 8,68 & 5,89 \\
\hline 70 & 650 & 75 & 30,32 & 22,36 & 19,76 & 17,31 & 15,36 & 13,65 & 10,81 & 8,69 & 5,91 \\
\hline 70 & 700 & 75 & 29,28 & 21,78 & 19,36 & 17,04 & 15,17 & 13,53 & 10,78 & 8,69 & 5,94 \\
\hline 70 & 750 & 75 & 28,36 & 21,25 & 18,99 & 16,79 & 15,00 & 13,41 & 10,74 & 8,69 & 5,96 \\
\hline 70 & 800 & 75 & 27,55 & 20,77 & 18,65 & 16,56 & 14,84 & 13,30 & 10,70 & 8,69 & 5,98 \\
\hline 70 & 850 & 75 & 26,82 & 20,33 & 18,33 & 16,33 & 14,68 & 13,20 & 10,66 & 8,69 & 6,00 \\
\hline 70 & 900 & 75 & 26,16 & 19,92 & 18,03 & 16,12 & 14,53 & 13,09 & 10,62 & 8,68 & 6,01 \\
\hline 70 & 950 & 75 & 25,56 & 19,54 & 17,76 & 15,93 & 14,38 & 12,99 & 10,58 & 8,68 & 6,03 \\
\hline 70 & 1000 & 75 & 25,01 & 19,19 & 17,49 & 15,74 & 14,25 & 12,89 & 10,54 & 8,67 & 6,04 \\
\hline 70 & 1050 & 75 & 24,51 & 18,86 & 17,25 & 15,56 & 14,12 & 12,80 & 10,50 & 8,66 & 6,05 \\
\hline 70 & 1100 & 75 & 24,04 & 18,56 & 17,02 & 15,39 & 13,99 & 12,71 & 10,46 & 8,65 & 6,07 \\
\hline 70 & 1150 & 75 & 23,61 & 18,27 & 16,80 & 15,23 & 13,87 & 12,62 & 10,42 & 8,64 & 6,08 \\
\hline 70 & 1200 & 75 & 23,21 & 17,99 & 16,59 & 15,07 & 13,75 & 12,53 & 10,38 & 8,62 & 6,09 \\
\hline 70 & 1250 & 75 & 22,84 & 17,74 & 16,39 & 14,92 & 13,64 & 12,45 & 10,34 & 8,61 & 6,10 \\
\hline 70 & 1300 & 75 & 22,49 & 17,49 & 16,20 & 14,78 & 13,53 & 12,37 & 10,30 & 8,60 & 6,10 \\
\hline 70 & 1350 & 75 & 22,16 & 17,26 & 16,02 & 14,65 & 13,42 & 12,29 & 10,26 & 8,58 & 6,11 \\
\hline 70 & 1400 & 75 & 21,85 & 17,04 & 15,85 & 14,52 & 13,32 & 12,21 & 10,22 & 8,57 & 6,12 \\
\hline 70 & 1450 & 75 & 21,56 & 16,84 & 15,68 & 14,39 & 13,23 & 12,14 & 10,19 & 8,55 & 6,12 \\
\hline 70 & 1500 & 75 & 21,28 & 16,64 & 15,52 & 14,27 & 13,13 & 12,07 & 10,15 & 8,54 & 6,13 \\
\hline 70 & 1550 & 75 & 21,02 & 16,45 & 15,37 & 14,15 & 13,04 & 12,00 & 10,11 & 8,52 & 6,13 \\
\hline 70 & 1600 & 75 & 20,77 & 16,27 & 15,22 & 14,04 & 12,95 & 11,93 & 10,08 & 8,51 & 6,14 \\
\hline 70 & 1650 & 75 & 20,54 & 16,09 & 15,08 & 13,93 & 12,86 & 11,86 & 10,04 & 8,49 & 6,14 \\
\hline 70 & 1700 & 75 & 20,31 & 15,93 & 14,94 & 13,82 & 12,78 & 11,80 & 10,00 & 8,47 & 6,15 \\
\hline 70 & 1750 & 75 & 20,10 & 15,77 & 14,81 & 13,72 & 12,70 & 11,73 & 9,97 & 8,46 & 6,15 \\
\hline 70 & 1800 & 75 & 19,89 & 15,62 & 14,68 & 13,62 & 12,62 & 11,67 & 9,93 & 8,44 & 6,15 \\
\hline 70 & 1850 & 75 & 19,69 & 15,47 & 14,56 & 13,52 & 12,54 & 11,61 & 9,90 & 8,43 & 6,15 \\
\hline 70 & 1900 & 75 & 19,51 & 15,33 & 14,44 & 13,43 & 12,47 & 11,55 & 9,86 & 8,41 & 6,16 \\
\hline 70 & 1950 & 75 & 19,32 & 15,19 & 14,32 & 13,34 & 12,39 & 11,49 & 9,83 & 8,39 & 6,16 \\
\hline 70 & 2000 & 75 & 19,15 & 15,06 & 14,21 & 13,25 & 12,32 & 11,44 & 9,80 & 8,38 & 6,16 \\
\hline 70 & 200 & 80 & 56,92 & 33,30 & 25,85 & 20,26 & 16,64 & 13,92 & 10,10 & 7,77 & 5,25 \\
\hline 70 & 250 & 80 & 49,48 & 30,49 & 24,36 & 19,58 & 16,34 & 13,82 & 10,18 & 7,86 & 5,28 \\
\hline 70 & 300 & 80 & 44,36 & 28,43 & 23,21 & 19,01 & 16,06 & 13,71 & 10,22 & 7,93 & 5,32 \\
\hline 70 & 350 & 80 & 40,58 & 26,84 & 22,28 & 18,51 & 15,80 & 13,59 & 10,24 & 7,99 & 5,35 \\
\hline 70 & 400 & 80 & 37,67 & 25,55 & 21,50 & 18,08 & 15,55 & 13,47 & 10,25 & 8,03 & 5,38 \\
\hline 70 & 450 & 80 & 35,34 & 24,48 & 20,84 & 17,69 & 15,33 & 13,35 & 10,24 & 8,07 & 5,42 \\
\hline 70 & 500 & 80 & 33,43 & 23,57 & 20,26 & 17,34 & 15,11 & 13,23 & 10,23 & 8,09 & 5,45 \\
\hline 70 & 550 & 80 & 31,84 & 22,77 & 19,74 & 17,02 & 14,91 & 13,11 & 10,21 & 8,11 & 5,47 \\
\hline 70 & 600 & 80 & 30,48 & 22,08 & 19,28 & 16,73 & 14,72 & 13,00 & 10,19 & 8,13 & 5,50 \\
\hline 70 & 650 & 80 & 29,31 & 21,45 & 18,86 & 16,45 & 14,55 & 12,89 & 10,16 & 8,14 & 5,52 \\
\hline 70 & 700 & 80 & 28,29 & 20,89 & 18,48 & 16,20 & 14,38 & 12,78 & 10,13 & 8,15 & 5,55 \\
\hline 70 & 750 & 80 & 27,39 & 20,39 & 18,12 & 15,96 & 14,22 & 12,68 & 10,10 & 8,15 & 5,57 \\
\hline 70 & 800 & 80 & 26,59 & 19,93 & 17,80 & 15,74 & 14,06 & 12,58 & 10,07 & 8,15 & 5,58 \\
\hline 70 & 850 & 80 & 25,87 & 19,50 & 17,50 & 15,53 & 13,92 & 12,48 & 10,04 & 8,15 & 5,60 \\
\hline 70 & 900 & 80 & 25,22 & 19,11 & 17,22 & 15,34 & 13,78 & 12,38 & 10,00 & 8,15 & 5,62 \\
\hline 70 & 950 & 80 & 24,63 & 18,75 & 16,96 & 15,15 & 13,65 & 12,29 & 9,97 & 8,14 & 5,63 \\
\hline 70 & 1000 & 80 & 24,10 & 18,41 & 16,71 & 14,98 & 13,52 & 12,20 & 9,93 & 8,14 & 5,65 \\
\hline 70 & 1050 & 80 & 23,60 & 18,09 & 16,48 & 14,81 & 13,40 & 12,12 & 9,90 & 8,13 & 5,66 \\
\hline 70 & 1100 & 80 & 23,15 & 17,80 & 16,26 & 14,65 & 13,28 & 12,03 & 9,86 & 8,12 & 5,67 \\
\hline 70 & 1150 & 80 & 22,72 & 17,52 & 16,05 & 14,50 & 13,17 & 11,95 & 9,82 & 8,11 & 5,68 \\
\hline 70 & 1200 & 80 & 22,33 & 17,26 & 15,85 & 14,35 & 13,06 & 11,87 & 9,79 & 8,10 & 5,69 \\
\hline 70 & 1250 & 80 & 21,97 & 17,01 & 15,66 & 14,21 & 12,95 & 11,80 & 9,75 & 8,09 & 5,70 \\
\hline 70 & 1300 & 80 & 21,63 & 16,78 & 15,48 & 14,08 & 12,85 & 11,72 & 9,72 & 8,08 & 5,71 \\
\hline 70 & 1350 & 80 & 21,30 & 16,56 & 15,31 & 13,95 & 12,75 & 11,65 & 9,68 & 8,07 & 5,72 \\
\hline 70 & 1400 & 80 & 21,00 & 16,35 & 15,15 & 13,83 & 12,66 & 11,58 & 9,65 & 8,06 & 5,72 \\
\hline 70 & 1450 & 80 & 20,72 & 16,15 & 14,99 & 13,71 & 12,57 & 11,51 & 9,62 & 8,04 & 5,73 \\
\hline 70 & 1500 & 80 & 20,45 & 15,95 & 14,84 & 13,59 & 12,48 & 11,44 & 9,58 & 8,03 & 5,74 \\
\hline 70 & 1550 & 80 & 20,20 & 15,77 & 14,69 & 13,48 & 12,39 & 11,38 & 9,55 & 8,02 & 5,74 \\
\hline 70 & 1600 & 80 & 19,95 & 15,60 & 14,55 & 13,38 & 12,31 & 11,31 & 9,51 & 8,00 & 5,75 \\
\hline 70 & 1650 & 80 & 19,72 & 15,43 & 14,42 & 13,27 & 12,23 & 11,25 & 9,48 & 7,99 & 5,75 \\
\hline 70 & 1700 & 80 & 19,50 & 15,27 & 14,29 & 13,17 & 12,15 & 11,19 & 9,45 & 7,98 & 5,76 \\
\hline 70 & 1750 & 80 & 19,30 & 15,12 & 14,16 & 13,08 & 12,07 & 11,13 & 9,42 & 7,96 & 5,76 \\
\hline 70 & 1800 & 80 & 19,10 & 14,97 & 14,04 & 12,98 & 12,00 & 11,07 & 9,39 & 7,95 & 5,76 \\
\hline 70 & 1850 & 80 & 18,90 & 14,83 & 13,92 & 12,89 & 11,93 & 11,02 & 9,35 & 7,93 & 5,76 \\
\hline 70 & 1900 & 80 & 18,72 & 14,69 & 13,81 & 12,80 & 11,86 & 10,96 & 9,32 & 7,92 & 5,77 \\
\hline 70 & 1950 & 80 & 18,54 & 14,56 & 13,70 & 12,72 & 11,79 & 10,91 & 9,29 & 7,91 & 5,77 \\
\hline 70 & 2000 & 80 & 18,37 & 14,43 & 13,59 & 12,64 & 11,72 & 10,86 & 9,26 & 7,89 & 5,77 \\
\hline 70 & 200 & 85 & 55,71 & 32,13 & 24,73 & 19,24 & 15,73 & 13,12 & 9,49 & 7,29 & 4,93 \\
\hline 70 & 250 & 85 & 48,35 & 29,38 & 23,30 & 18,60 & 15,46 & 13,04 & 9,56 & 7,38 & 4,96 \\
\hline 70 & 300 & 85 & 43,27 & 27,38 & 22,20 & 18,07 & 15,20 & 12,94 & 9,61 & 7,45 & 4,99 \\
\hline 70 & 350 & 85 & 39,54 & 25,84 & 21,31 & 17,61 & 14,97 & 12,84 & 9,63 & 7,50 & 5,02 \\
\hline
\end{tabular}




\begin{tabular}{|c|c|c|c|c|c|c|c|c|c|c|c|}
\hline \multirow[b]{2}{*}{$\mathrm{H}(\mathrm{cm})$} & \multirow[b]{2}{*}{ Mceq (MPa) } & & & & & $\mathrm{De}$ & ões (x1 & & & & \\
\hline & & Msub (MPa) & D0 & D25 & D40 & D60 & D80 & D100 & D140 & D180 & D260 \\
\hline 70 & 400 & 85 & 36,66 & 24,59 & 20,57 & 17,20 & 14,75 & 12,73 & 9,65 & 7,54 & 5,05 \\
\hline 70 & 450 & 85 & 34,36 & 23,55 & 19,93 & 16,84 & 14,54 & 12,63 & 9,65 & 7,58 & 5,08 \\
\hline 70 & 500 & 85 & 32,48 & 22,67 & 19,38 & 16,51 & 14,34 & 12,52 & 9,64 & 7,60 & 5,11 \\
\hline 70 & 550 & 85 & 30,91 & 21,91 & 18,89 & 16,21 & 14,16 & 12,41 & 9,62 & 7,62 & 5,13 \\
\hline 70 & 600 & 85 & 29,57 & 21,23 & 18,45 & 15,93 & 13,98 & 12,31 & 9,61 & 7,64 & 5,16 \\
\hline 70 & 650 & 85 & 28,42 & 20,63 & 18,05 & 15,68 & 13,82 & 12,21 & 9,58 & 7,65 & 5,18 \\
\hline 70 & 700 & 85 & 27,41 & 20,09 & 17,68 & 15,44 & 13,66 & 12,11 & 9,56 & 7,66 & 5,20 \\
\hline 70 & 750 & 85 & 26,52 & 19,61 & 17,35 & 15,22 & 13,51 & 12,02 & 9,53 & 7,67 & 5,22 \\
\hline 70 & 800 & 85 & 25,73 & 19,16 & 17,04 & 15,01 & 13,37 & 11,93 & 9,51 & 7,67 & 5,24 \\
\hline 70 & 850 & 85 & 25,03 & 18,75 & 16,75 & 14,82 & 13,24 & 11,84 & 9,48 & 7,67 & 5,26 \\
\hline 70 & 900 & 85 & 24,39 & 18,38 & 16,49 & 14,63 & 13,11 & 11,75 & 9,45 & 7,67 & 5,27 \\
\hline 70 & 950 & 85 & 23,81 & 18,03 & 16,24 & 14,46 & 12,98 & 11,66 & 9,42 & 7,67 & 5,29 \\
\hline 70 & 1000 & 85 & 23,28 & 17,70 & 16,00 & 14,29 & 12,86 & 11,58 & 9,39 & 7,66 & 5,30 \\
\hline 70 & 1050 & 85 & 22,79 & 17,40 & 15,78 & 14,13 & 12,75 & 11,50 & 9,36 & 7,66 & 5,31 \\
\hline 70 & 1100 & 85 & 22,35 & 17,11 & 15,57 & 13,98 & 12,64 & 11,43 & 9,32 & 7,65 & 5,32 \\
\hline 70 & 1150 & 85 & 21,93 & 16,85 & 15,37 & 13,84 & 12,54 & 11,35 & 9,29 & 7,65 & 5,33 \\
\hline 70 & 1200 & 85 & 21,55 & 16,60 & 15,18 & 13,70 & 12,43 & 11,28 & 9,26 & 7,64 & 5,34 \\
\hline 70 & 1250 & 85 & 21,19 & 16,36 & 15,00 & 13,57 & 12,34 & 11,21 & 9,23 & 7,63 & 5,35 \\
\hline 70 & 1300 & 85 & 20,85 & 16,13 & 14,83 & 13,44 & 12,24 & 11,14 & 9,20 & 7,62 & 5,36 \\
\hline 70 & 1350 & 85 & 20,54 & 15,92 & 14,67 & 13,32 & 12,15 & 11,07 & 9,17 & 7,61 & 5,37 \\
\hline 70 & 1400 & 85 & 20,24 & 15,72 & 14,51 & 13,21 & 12,06 & 11,01 & 9,14 & 7,60 & 5,38 \\
\hline 70 & 1450 & 85 & 19,97 & 15,52 & 14,36 & 13,09 & 11,98 & 10,94 & 9,10 & 7,59 & 5,38 \\
\hline 70 & 1500 & 85 & 19,70 & 15,34 & 14,22 & 12,99 & 11,89 & 10,88 & 9,07 & 7,58 & 5,39 \\
\hline 70 & 1550 & 85 & 19,45 & 15,16 & 14,08 & 12,88 & 11,81 & 10,82 & 9,04 & 7,57 & 5,40 \\
\hline 70 & 1600 & 85 & 19,22 & 15,00 & 13,95 & 12,78 & 11,74 & 10,76 & 9,01 & 7,56 & 5,40 \\
\hline 70 & 1650 & 85 & 18,99 & 14,83 & 13,82 & 12,68 & 11,66 & 10,70 & 8,98 & 7,55 & 5,40 \\
\hline 70 & 1700 & 85 & 18,78 & 14,68 & 13,70 & 12,59 & 11,59 & 10,65 & 8,96 & 7,53 & 5,41 \\
\hline 70 & 1750 & 85 & 18,58 & 14,53 & 13,58 & 12,50 & 11,51 & 10,59 & 8,93 & 7,52 & 5,41 \\
\hline 70 & 1800 & 85 & 18,38 & 14,39 & 13,46 & 12,41 & 11,44 & 10,54 & 8,90 & 7,51 & 5,42 \\
\hline 70 & 1850 & 85 & 18,19 & 14,25 & 13,35 & 12,32 & 11,38 & 10,49 & 8,87 & 7,50 & 5,42 \\
\hline 70 & 1900 & 85 & 18,02 & 14,12 & 13,24 & 12,24 & 11,31 & 10,44 & 8,84 & 7,48 & 5,42 \\
\hline 70 & 1950 & 85 & 17,84 & 14,00 & 13,14 & 12,16 & 11,25 & 10,39 & 8,81 & 7,47 & 5,42 \\
\hline 70 & 2000 & 85 & 17,68 & 13,87 & 13,04 & 12,08 & 11,18 & 10,34 & 8,79 & 7,46 & 5,43 \\
\hline 70 & 200 & 90 & 54,62 & 31,07 & 23,72 & 18,33 & 14,91 & 12,40 & 8,94 & 6,87 & 4,65 \\
\hline 70 & 250 & 90 & 47,32 & 28,38 & 22,34 & 17,73 & 14,67 & 12,34 & 9,02 & 6,95 & 4,68 \\
\hline 70 & 300 & 90 & 42,29 & 26,43 & 21,28 & 17,23 & 14,44 & 12,26 & 9,06 & 7,01 & 4,71 \\
\hline 70 & 350 & 90 & 38,60 & 24,93 & 20,43 & 16,79 & 14,22 & 12,17 & 9,09 & 7,06 & 4,73 \\
\hline 70 & 400 & 90 & 35,75 & 23,72 & 19,72 & 16,41 & 14,02 & 12,07 & 9,11 & 7,11 & 4,76 \\
\hline 70 & 450 & 90 & 33,48 & 22,71 & 19,11 & 16,07 & 13,83 & 11,98 & 9,11 & 7,14 & 4,79 \\
\hline 70 & 500 & 90 & 31,62 & 21,86 & 18,58 & 15,76 & 13,65 & 11,88 & 9,11 & 7,17 & 4,81 \\
\hline 70 & 550 & 90 & 30,07 & 21,12 & 18,11 & 15,48 & 13,48 & 11,78 & 9,10 & 7,19 & 4,84 \\
\hline 70 & 600 & 90 & 28,75 & 20,47 & 17,69 & 15,22 & 13,31 & 11,69 & 9,08 & 7,21 & 4,86 \\
\hline 70 & 650 & 90 & 27,61 & 19,89 & 17,31 & 14,98 & 13,16 & 11,60 & 9,07 & 7,22 & 4,88 \\
\hline 70 & 700 & 90 & 26,62 & 19,37 & 16,96 & 14,76 & 13,02 & 11,51 & 9,05 & 7,23 & 4,90 \\
\hline 70 & 750 & 90 & 25,74 & 18,90 & 16,65 & 14,55 & 12,88 & 11,42 & 9,03 & 7,24 & 4,92 \\
\hline 70 & 800 & 90 & 24,96 & 18,47 & 16,35 & 14,35 & 12,75 & 11,34 & 9,00 & 7,24 & 4,93 \\
\hline 70 & 850 & 90 & 24,27 & 18,08 & 16,08 & 14,17 & 12,62 & 11,26 & 8,98 & 7,24 & 4,95 \\
\hline 70 & 900 & 90 & 23,64 & 17,71 & 15,82 & 13,99 & 12,50 & 11,18 & 8,95 & 7,25 & 4,96 \\
\hline 70 & 950 & 90 & 23,07 & 17,37 & 15,58 & 13,83 & 12,39 & 11,10 & 8,92 & 7,24 & 4,98 \\
\hline 70 & 1000 & 90 & 22,54 & 17,06 & 15,36 & 13,67 & 12,27 & 11,03 & 8,90 & 7,24 & 4,99 \\
\hline 70 & 1050 & 90 & 22,07 & 16,77 & 15,15 & 13,52 & 12,17 & 10,95 & 8,87 & 7,24 & 5,00 \\
\hline 70 & 1100 & 90 & 21,63 & 16,49 & 14,95 & 13,38 & 12,07 & 10,88 & 8,84 & 7,24 & 5,01 \\
\hline 70 & 1150 & 90 & 21,22 & 16,24 & 14,76 & 13,24 & 11,97 & 10,81 & 8,81 & 7,23 & 5,03 \\
\hline 70 & 1200 & 90 & 20,84 & 15,99 & 14,58 & 13,11 & 11,87 & 10,74 & 8,79 & 7,22 & 5,03 \\
\hline 70 & 1250 & 90 & 20,49 & 15,76 & 14,41 & 12,99 & 11,78 & 10,68 & 8,76 & 7,22 & 5,04 \\
\hline 70 & 1300 & 90 & 20,16 & 15,55 & 14,24 & 12,87 & 11,69 & 10,62 & 8,73 & 7,21 & 5,05 \\
\hline 70 & 1350 & 90 & 19,85 & 15,34 & 14,09 & 12,76 & 11,61 & 10,55 & 8,70 & 7,20 & 5,06 \\
\hline 70 & 1400 & 90 & 19,56 & 15,15 & 13,94 & 12,65 & 11,52 & 10,49 & 8,67 & 7,19 & 5,07 \\
\hline 70 & 1450 & 90 & 19,29 & 14,96 & 13,80 & 12,54 & 11,44 & 10,43 & 8,65 & 7,19 & 5,07 \\
\hline 70 & 1500 & 90 & 19,03 & 14,78 & 13,66 & 12,44 & 11,37 & 10,38 & 8,62 & 7,18 & 5,08 \\
\hline 70 & 1550 & 90 & 18,79 & 14,61 & 13,53 & 12,34 & 11,29 & 10,32 & 8,59 & 7,17 & 5,09 \\
\hline 70 & 1600 & 90 & 18,56 & 14,45 & 13,40 & 12,24 & 11,22 & 10,26 & 8,56 & 7,16 & 5,09 \\
\hline 70 & 1650 & 90 & 18,34 & 14,29 & 13,28 & 12,15 & 11,14 & 10,21 & 8,54 & 7,15 & 5,10 \\
\hline 70 & 1700 & 90 & 18,13 & 14,15 & 13,16 & 12,06 & 11,08 & 10,16 & 8,51 & 7,14 & 5,10 \\
\hline 70 & 1750 & 90 & 17,93 & 14,00 & 13,05 & 11,97 & 11,01 & 10,11 & 8,48 & 7,13 & 5,10 \\
\hline 70 & 1800 & 90 & 17,74 & 13,86 & 12,94 & 11,89 & 10,94 & 10,06 & 8,46 & 7,12 & 5,11 \\
\hline 70 & 1850 & 90 & 17,55 & 13,73 & 12,83 & 11,81 & 10,88 & 10,01 & 8,43 & 7,10 & 5,11 \\
\hline 70 & 1900 & 90 & 17,38 & 13,61 & 12,73 & 11,73 & 10,82 & 9,96 & 8,41 & 7,09 & 5,11 \\
\hline 70 & 1950 & 90 & 17,21 & 13,48 & 12,63 & 11,65 & 10,76 & 9,91 & 8,38 & 7,08 & 5,12 \\
\hline 70 & 2000 & 90 & 17,05 & 13,36 & 12,53 & 11,58 & 10,70 & 9,87 & 8,36 & 7,07 & 5,12 \\
\hline 70 & 200 & 95 & 53,63 & 30,11 & 22,81 & 17,50 & 14,18 & 11,76 & 8,45 & 6,49 & 4,40 \\
\hline 70 & 250 & 95 & 46,39 & 27,47 & 21,47 & 16,93 & 13,96 & 11,71 & 8,53 & 6,56 & 4,42 \\
\hline 70 & 300 & 95 & 41,41 & 25,57 & 20,45 & 16,46 & 13,75 & 11,64 & 8,57 & 6,63 & 4,45 \\
\hline 70 & 350 & 95 & 37,74 & 24,10 & 19,64 & 16,05 & 13,55 & 11,56 & 8,61 & 6,68 & 4,47 \\
\hline 70 & 400 & 95 & 34,93 & 22,93 & 18,95 & 15,70 & 13,36 & 11,47 & 8,62 & 6,72 & 4,50 \\
\hline 70 & 450 & 95 & 32,68 & 21,95 & 18,37 & 15,37 & 13,18 & 11,39 & 8,63 & 6,75 & 4,52 \\
\hline 70 & 500 & 95 & 30,84 & 21,12 & 17,86 & 15,08 & 13,02 & 11,30 & 8,63 & 6,78 & 4,55 \\
\hline 70 & 550 & 95 & 29,31 & 20,40 & 17,41 & 14,82 & 12,86 & 11,22 & 8,62 & 6,80 & 4,57 \\
\hline 70 & 600 & 95 & 28,00 & 19,77 & 17,01 & 14,57 & 12,71 & 11,13 & 8,61 & 6,82 & 4,59 \\
\hline 70 & 650 & 95 & 26,88 & 19,21 & 16,64 & 14,35 & 12,57 & 11,05 & 8,60 & 6,83 & 4,61 \\
\hline 70 & 700 & 95 & 25,90 & 18,71 & 16,31 & 14,13 & 12,43 & 10,97 & 8,59 & 6,84 & 4,63 \\
\hline
\end{tabular}




\begin{tabular}{|c|c|c|c|c|c|c|c|c|c|c|c|}
\hline \multirow[b]{2}{*}{$\mathrm{H}(\mathrm{cm})$} & \multirow[b]{2}{*}{ Mceq (MPa) } & & & & & $\mathrm{De}$ & ões (x1 & & & & \\
\hline & & Msub (MPa) & D0 & D25 & D40 & D60 & D80 & D100 & D140 & D180 & D260 \\
\hline 70 & 750 & 95 & 25,03 & 18,25 & 16,01 & 13,94 & 12,30 & 10,89 & 8,57 & 6,85 & 4,64 \\
\hline 70 & 800 & 95 & 24,26 & 17,84 & 15,72 & 13,75 & 12,18 & 10,81 & 8,55 & 6,86 & 4,66 \\
\hline 70 & 850 & 95 & 23,58 & 17,46 & 15,46 & 13,58 & 12,06 & 10,73 & 8,53 & 6,86 & 4,68 \\
\hline 70 & 900 & 95 & 22,96 & 17,10 & 15,22 & 13,41 & 11,95 & 10,66 & 8,50 & 6,86 & 4,69 \\
\hline 70 & 950 & 95 & 22,39 & 16,78 & 14,99 & 13,26 & 11,84 & 10,59 & 8,48 & 6,86 & 4,70 \\
\hline 70 & 1000 & 95 & 21,88 & 16,48 & 14,78 & 13,11 & 11,74 & 10,52 & 8,46 & 6,86 & 4,72 \\
\hline 70 & 1050 & 95 & 21,41 & 16,19 & 14,57 & 12,97 & 11,64 & 10,45 & 8,43 & 6,86 & 4,73 \\
\hline 70 & 1100 & 95 & 20,97 & 15,93 & 14,38 & 12,83 & 11,54 & 10,39 & 8,41 & 6,86 & 4,74 \\
\hline 70 & 1150 & 95 & 20,57 & 15,68 & 14,20 & 12,70 & 11,45 & 10,32 & 8,38 & 6,86 & 4,75 \\
\hline 70 & 1200 & 95 & 20,20 & 15,44 & 14,03 & 12,58 & 11,36 & 10,26 & 8,36 & 6,85 & 4,76 \\
\hline 70 & 1250 & 95 & 19,85 & 15,22 & 13,86 & 12,46 & 11,28 & 10,20 & 8,33 & 6,85 & 4,77 \\
\hline 70 & 1300 & 95 & 19,53 & 15,01 & 13,71 & 12,35 & 11,19 & 10,14 & 8,31 & 6,84 & 4,78 \\
\hline 70 & 1350 & 95 & 19,23 & 14,81 & 13,56 & 12,24 & 11,11 & 10,08 & 8,28 & 6,83 & 4,78 \\
\hline 70 & 1400 & 95 & 18,94 & 14,63 & 13,42 & 12,14 & 11,03 & 10,03 & 8,26 & 6,83 & 4,79 \\
\hline 70 & 1450 & 95 & 18,67 & 14,44 & 13,28 & 12,03 & 10,96 & 9,97 & 8,23 & 6,82 & 4,80 \\
\hline 70 & 1500 & 95 & 18,42 & 14,27 & 13,15 & 11,94 & 10,88 & 9,92 & 8,21 & 6,81 & 4,80 \\
\hline 70 & 1550 & 95 & 18,18 & 14,11 & 13,02 & 11,84 & 10,81 & 9,86 & 8,18 & 6,80 & 4,81 \\
\hline 70 & 1600 & 95 & 17,95 & 13,95 & 12,90 & 11,75 & 10,74 & 9,81 & 8,16 & 6,80 & 4,81 \\
\hline 70 & 1650 & 95 & 17,74 & 13,80 & 12,78 & 11,66 & 10,68 & 9,76 & 8,13 & 6,79 & 4,82 \\
\hline 70 & 1700 & 95 & 17,53 & 13,66 & 12,67 & 11,58 & 10,61 & 9,71 & 8,11 & 6,78 & 4,82 \\
\hline 70 & 1750 & 95 & 17,34 & 13,52 & 12,56 & 11,50 & 10,55 & 9,67 & 8,08 & 6,77 & 4,83 \\
\hline 70 & 1800 & 95 & 17,15 & 13,39 & 12,46 & 11,42 & 10,49 & 9,62 & 8,06 & 6,76 & 4,83 \\
\hline 70 & 1850 & 95 & 16,97 & 13,26 & 12,35 & 11,34 & 10,43 & 9,57 & 8,04 & 6,75 & 4,84 \\
\hline 70 & 1900 & 95 & 16,80 & 13,14 & 12,25 & 11,26 & 10,37 & 9,53 & 8,01 & 6,74 & 4,84 \\
\hline 70 & 1950 & 95 & 16,64 & 13,02 & 12,16 & 11,19 & 10,31 & 9,48 & 7,99 & 6,73 & 4,84 \\
\hline 70 & 2000 & 95 & 16,48 & 12,90 & 12,07 & 11,12 & 10,25 & 9,44 & 7,97 & 6,72 & 4,85 \\
\hline 70 & 200 & 100 & 52,73 & 29,23 & 21,98 & 16,75 & 13,51 & 11,18 & 8,01 & 6,15 & 4,18 \\
\hline 70 & 250 & 100 & 45,53 & 26,64 & 20,68 & 16,21 & 13,31 & 11,14 & 8,08 & 6,22 & 4,20 \\
\hline 70 & 300 & 100 & 40,59 & 24,78 & 19,70 & 15,76 & 13,12 & 11,08 & 8,13 & 6,28 & 4,22 \\
\hline 70 & 350 & 100 & 36,97 & 23,35 & 18,91 & 15,38 & 12,93 & 11,01 & 8,17 & 6,33 & 4,24 \\
\hline 70 & 400 & 100 & 34,17 & 22,20 & 18,25 & 15,04 & 12,76 & 10,93 & 8,19 & 6,37 & 4,26 \\
\hline 70 & 450 & 100 & 31,95 & 21,25 & 17,69 & 14,74 & 12,60 & 10,86 & 8,20 & 6,40 & 4,29 \\
\hline 70 & 500 & 100 & 30,13 & 20,44 & 17,20 & 14,46 & 12,44 & 10,78 & 8,20 & 6,43 & 4,31 \\
\hline 70 & 550 & 100 & 28,61 & 19,75 & 16,77 & 14,21 & 12,30 & 10,70 & 8,20 & 6,45 & 4,33 \\
\hline 70 & 600 & 100 & 27,32 & 19,13 & 16,38 & 13,98 & 12,16 & 10,62 & 8,19 & 6,47 & 4,35 \\
\hline 70 & 650 & 100 & 26,21 & 18,59 & 16,03 & 13,77 & 12,03 & 10,55 & 8,18 & 6,48 & 4,37 \\
\hline 70 & 700 & 100 & 25,24 & 18,10 & 15,71 & 13,57 & 11,90 & 10,47 & 8,17 & 6,49 & 4,38 \\
\hline 70 & 750 & 100 & 24,39 & 17,66 & 15,42 & 13,38 & 11,78 & 10,40 & 8,15 & 6,50 & 4,40 \\
\hline 70 & 800 & 100 & 23,63 & 17,26 & 15,15 & 13,20 & 11,66 & 10,33 & 8,13 & 6,51 & 4,41 \\
\hline 70 & 850 & 100 & 22,95 & 16,89 & 14,90 & 13,04 & 11,55 & 10,26 & 8,12 & 6,51 & 4,43 \\
\hline 70 & 900 & 100 & 22,34 & 16,55 & 14,67 & 12,88 & 11,45 & 10,19 & 8,10 & 6,52 & 4,44 \\
\hline 70 & 950 & 100 & 21,78 & 16,23 & 14,45 & 12,73 & 11,35 & 10,12 & 8,08 & 6,52 & 4,46 \\
\hline 70 & 1000 & 100 & 21,27 & 15,94 & 14,24 & 12,59 & 11,25 & 10,06 & 8,06 & 6,52 & 4,47 \\
\hline 70 & 1050 & 100 & 20,81 & 15,67 & 14,05 & 12,46 & 11,16 & 10,00 & 8,03 & 6,52 & 4,48 \\
\hline 70 & 1100 & 100 & 20,38 & 15,41 & 13,86 & 12,33 & 11,07 & 9,94 & 8,01 & 6,52 & 4,49 \\
\hline 70 & 1150 & 100 & 19,99 & 15,17 & 13,69 & 12,21 & 10,98 & 9,88 & 7,99 & 6,52 & 4,50 \\
\hline 70 & 1200 & 100 & 19,62 & 14,94 & 13,52 & 12,09 & 10,90 & 9,82 & 7,97 & 6,51 & 4,51 \\
\hline 70 & 1250 & 100 & 19,28 & 14,73 & 13,37 & 11,98 & 10,81 & 9,76 & 7,95 & 6,51 & 4,52 \\
\hline 70 & 1300 & 100 & 18,96 & 14,52 & 13,22 & 11,87 & 10,74 & 9,71 & 7,92 & 6,51 & 4,53 \\
\hline 70 & 1350 & 100 & 18,66 & 14,33 & 13,07 & 11,77 & 10,66 & 9,65 & 7,90 & 6,50 & 4,53 \\
\hline 70 & 1400 & 100 & 18,38 & 14,15 & 12,94 & 11,67 & 10,59 & 9,60 & 7,88 & 6,49 & 4,54 \\
\hline 70 & 1450 & 100 & 18,12 & 13,97 & 12,81 & 11,57 & 10,52 & 9,55 & 7,85 & 6,49 & 4,55 \\
\hline 70 & 1500 & 100 & 17,87 & 13,81 & 12,68 & 11,48 & 10,45 & 9,50 & 7,83 & 6,48 & 4,55 \\
\hline 70 & 1550 & 100 & 17,63 & 13,65 & 12,56 & 11,39 & 10,38 & 9,45 & 7,81 & 6,48 & 4,56 \\
\hline 70 & 1600 & 100 & 17,41 & 13,50 & 12,44 & 11,30 & 10,31 & 9,40 & 7,79 & 6,47 & 4,57 \\
\hline 70 & 1650 & 100 & 17,20 & 13,35 & 12,33 & 11,22 & 10,25 & 9,35 & 7,76 & 6,46 & 4,57 \\
\hline 70 & 1700 & 100 & 16,99 & 13,21 & 12,22 & 11,14 & 10,19 & 9,31 & 7,74 & 6,45 & 4,58 \\
\hline 70 & 1750 & 100 & 16,80 & 13,08 & 12,12 & 11,06 & 10,13 & 9,26 & 7,72 & 6,45 & 4,58 \\
\hline 70 & 1800 & 100 & 16,62 & 12,95 & 12,02 & 10,98 & 10,07 & 9,22 & 7,70 & 6,44 & 4,58 \\
\hline 70 & 1850 & 100 & 16,44 & 12,82 & 11,92 & 10,91 & 10,01 & 9,18 & 7,68 & 6,43 & 4,59 \\
\hline 70 & 1900 & 100 & 16,28 & 12,70 & 11,82 & 10,84 & 9,96 & 9,13 & 7,65 & 6,42 & 4,59 \\
\hline 70 & 1950 & 100 & 16,12 & 12,59 & 11,73 & 10,77 & 9,90 & 9,09 & 7,63 & 6,41 & 4,59 \\
\hline 70 & 2000 & 100 & 15,96 & 12,48 & 11,64 & 10,70 & 9,85 & 9,05 & 7,61 & 6,40 & 4,60 \\
\hline 70 & 200 & 105 & 51,90 & 28,42 & 21,22 & 16,06 & 12,91 & 10,65 & 7,61 & 5,84 & 3,98 \\
\hline 70 & 250 & 105 & 44,75 & 25,88 & 19,96 & 15,55 & 12,72 & 10,62 & 7,68 & 5,91 & 3,99 \\
\hline 70 & 300 & 105 & 39,85 & 24,06 & 19,01 & 15,13 & 12,54 & 10,57 & 7,73 & 5,96 & 4,01 \\
\hline 70 & 350 & 105 & 36,25 & 22,66 & 18,24 & 14,76 & 12,37 & 10,51 & 7,77 & 6,01 & 4,03 \\
\hline 70 & 400 & 105 & 33,48 & 21,54 & 17,61 & 14,44 & 12,22 & 10,44 & 7,79 & 6,05 & 4,05 \\
\hline 70 & 450 & 105 & 31,28 & 20,61 & 17,07 & 14,16 & 12,06 & 10,37 & 7,80 & 6,08 & 4,07 \\
\hline 70 & 500 & 105 & 29,48 & 19,82 & 16,60 & 13,90 & 11,92 & 10,30 & 7,81 & 6,11 & 4,09 \\
\hline 70 & 550 & 105 & 27,98 & 19,14 & 16,18 & 13,66 & 11,78 & 10,23 & 7,81 & 6,13 & 4,11 \\
\hline 70 & 600 & 105 & 26,70 & 18,55 & 15,81 & 13,44 & 11,65 & 10,16 & 7,80 & 6,15 & 4,13 \\
\hline 70 & 650 & 105 & 25,60 & 18,02 & 15,47 & 13,24 & 11,53 & 10,09 & 7,80 & 6,16 & 4,15 \\
\hline 70 & 700 & 105 & 24,64 & 17,54 & 15,17 & 13,05 & 11,41 & 10,02 & 7,79 & 6,18 & 4,16 \\
\hline 70 & 750 & 105 & 23,80 & 17,12 & 14,88 & 12,87 & 11,30 & 9,95 & 7,77 & 6,19 & 4,18 \\
\hline 70 & 800 & 105 & 23,05 & 16,72 & 14,62 & 12,70 & 11,19 & 9,89 & 7,76 & 6,19 & 4,19 \\
\hline 70 & 850 & 105 & 22,37 & 16,37 & 14,38 & 12,55 & 11,09 & 9,82 & 7,74 & 6,20 & 4,21 \\
\hline 70 & 900 & 105 & 21,77 & 16,04 & 14,16 & 12,40 & 10,99 & 9,76 & 7,73 & 6,20 & 4,22 \\
\hline 70 & 950 & 105 & 21,22 & 15,73 & 13,95 & 12,26 & 10,89 & 9,70 & 7,71 & 6,21 & 4,23 \\
\hline 70 & 1000 & 105 & 20,72 & 15,45 & 13,75 & 12,12 & 10,80 & 9,64 & 7,69 & 6,21 & 4,24 \\
\hline 70 & 1050 & 105 & 20,26 & 15,18 & 13,56 & 11,99 & 10,71 & 9,58 & 7,67 & 6,21 & 4,26 \\
\hline
\end{tabular}




\begin{tabular}{|c|c|c|c|c|c|c|c|c|c|c|c|}
\hline \multirow[b]{2}{*}{$\mathrm{H}(\mathrm{cm})$} & \multirow[b]{2}{*}{ Mceq (MPa) } & & & & & $\mathrm{De}$ & ões (x1 & & & & \\
\hline & & Msub (MPa) & D0 & D25 & D40 & D60 & D80 & D100 & D140 & D180 & D260 \\
\hline 70 & 1100 & 105 & 19,84 & 14,93 & 13,39 & 11,87 & 10,63 & 9,52 & 7,65 & 6,21 & 4,27 \\
\hline 70 & 1150 & 105 & 19,45 & 14,70 & 13,22 & 11,76 & 10,55 & 9,47 & 7,63 & 6,21 & 4,28 \\
\hline 70 & 1200 & 105 & 19,09 & 14,48 & 13,06 & 11,64 & 10,47 & 9,41 & 7,61 & 6,21 & 4,28 \\
\hline 70 & 1250 & 105 & 18,75 & 14,27 & 12,91 & 11,54 & 10,39 & 9,36 & 7,59 & 6,20 & 4,29 \\
\hline 70 & 1300 & 105 & 18,43 & 14,07 & 12,77 & 11,43 & 10,32 & 9,31 & 7,57 & 6,20 & 4,30 \\
\hline 70 & 1350 & 105 & 18,14 & 13,89 & 12,63 & 11,34 & 10,25 & 9,26 & 7,55 & 6,20 & 4,31 \\
\hline 70 & 1400 & 105 & 17,86 & 13,71 & 12,50 & 11,24 & 10,18 & 9,21 & 7,53 & 6,19 & 4,32 \\
\hline 70 & 1450 & 105 & 17,60 & 13,54 & 12,37 & 11,15 & 10,11 & 9,16 & 7,51 & 6,19 & 4,32 \\
\hline 70 & 1500 & 105 & 17,36 & 13,38 & 12,25 & 11,06 & 10,04 & 9,11 & 7,49 & 6,18 & 4,33 \\
\hline 70 & 1550 & 105 & 17,13 & 13,22 & 12,13 & 10,98 & 9,98 & 9,07 & 7,47 & 6,18 & 4,33 \\
\hline 70 & 1600 & 105 & 16,91 & 13,08 & 12,02 & 10,89 & 9,92 & 9,02 & 7,45 & 6,17 & 4,34 \\
\hline 70 & 1650 & 105 & 16,70 & 12,94 & 11,91 & 10,81 & 9,86 & 8,98 & 7,43 & 6,16 & 4,35 \\
\hline 70 & 1700 & 105 & 16,50 & 12,80 & 11,81 & 10,74 & 9,80 & 8,94 & 7,41 & 6,16 & 4,35 \\
\hline 70 & 1750 & 105 & 16,31 & 12,67 & 11,71 & 10,66 & 9,74 & 8,89 & 7,39 & 6,15 & 4,35 \\
\hline 70 & 1800 & 105 & 16,13 & 12,54 & 11,61 & 10,59 & 9,69 & 8,85 & 7,37 & 6,14 & 4,36 \\
\hline 70 & 1850 & 105 & 15,96 & 12,42 & 11,52 & 10,52 & 9,63 & 8,81 & 7,35 & 6,14 & 4,36 \\
\hline 70 & 1900 & 105 & 15,80 & 12,31 & 11,43 & 10,45 & 9,58 & 8,77 & 7,33 & 6,13 & 4,37 \\
\hline 70 & 1950 & 105 & 15,64 & 12,20 & 11,34 & 10,38 & 9,53 & 8,73 & 7,31 & 6,12 & 4,37 \\
\hline 70 & 2000 & 105 & 15,49 & 12,09 & 11,25 & 10,32 & 9,48 & 8,69 & 7,29 & 6,11 & 4,37 \\
\hline 70 & 200 & 110 & 51,14 & 27,68 & 20,52 & 15,43 & 12,35 & 10,17 & 7,24 & 5,56 & 3,79 \\
\hline 70 & 250 & 110 & 44,04 & 25,18 & 19,29 & 14,95 & 12,18 & 10,14 & 7,32 & 5,63 & 3,81 \\
\hline 70 & 300 & 110 & 39,17 & 23,39 & 18,37 & 14,54 & 12,02 & 10,10 & 7,37 & 5,68 & 3,83 \\
\hline 70 & 350 & 110 & 35,59 & 22,02 & 17,63 & 14,20 & 11,86 & 10,05 & 7,41 & 5,72 & 3,84 \\
\hline 70 & 400 & 110 & 32,85 & 20,92 & 17,02 & 13,89 & 11,71 & 9,99 & 7,43 & 5,76 & 3,86 \\
\hline 70 & 450 & 110 & 30,67 & 20,01 & 16,49 & 13,62 & 11,57 & 9,93 & 7,44 & 5,79 & 3,88 \\
\hline 70 & 500 & 110 & 28,88 & 19,25 & 16,04 & 13,38 & 11,44 & 9,86 & 7,45 & 5,82 & 3,90 \\
\hline 70 & 550 & 110 & 27,39 & 18,58 & 15,64 & 13,15 & 11,31 & 9,80 & 7,45 & 5,84 & 3,92 \\
\hline 70 & 600 & 110 & 26,13 & 18,00 & 15,28 & 12,94 & 11,19 & 9,73 & 7,45 & 5,86 & 3,93 \\
\hline 70 & 650 & 110 & 25,04 & 17,49 & 14,96 & 12,75 & 11,08 & 9,67 & 7,45 & 5,88 & 3,95 \\
\hline 70 & 700 & 110 & 24,09 & 17,03 & 14,66 & 12,57 & 10,96 & 9,61 & 7,44 & 5,89 & 3,96 \\
\hline 70 & 750 & 110 & 23,25 & 16,61 & 14,39 & 12,40 & 10,86 & 9,54 & 7,43 & 5,90 & 3,98 \\
\hline 70 & 800 & 110 & 22,51 & 16,23 & 14,14 & 12,24 & 10,76 & 9,48 & 7,42 & 5,91 & 3,99 \\
\hline 70 & 850 & 110 & 21,85 & 15,88 & 13,91 & 12,09 & 10,66 & 9,42 & 7,40 & 5,91 & 4,01 \\
\hline 70 & 900 & 110 & 21,25 & 15,56 & 13,69 & 11,95 & 10,57 & 9,37 & 7,39 & 5,92 & 4,02 \\
\hline 70 & 950 & 110 & 20,71 & 15,27 & 13,49 & 11,81 & 10,48 & 9,31 & 7,37 & 5,92 & 4,03 \\
\hline 70 & 1000 & 110 & 20,21 & 14,99 & 13,29 & 11,69 & 10,39 & 9,25 & 7,36 & 5,93 & 4,04 \\
\hline 70 & 1050 & 110 & 19,76 & 14,73 & 13,12 & 11,56 & 10,31 & 9,20 & 7,34 & 5,93 & 4,05 \\
\hline 70 & 1100 & 110 & 19,34 & 14,49 & 12,95 & 11,45 & 10,23 & 9,15 & 7,32 & 5,93 & 4,06 \\
\hline 70 & 1150 & 110 & 18,95 & 14,26 & 12,79 & 11,34 & 10,15 & 9,09 & 7,31 & 5,93 & 4,07 \\
\hline 70 & 1200 & 110 & 18,60 & 14,05 & 12,63 & 11,23 & 10,08 & 9,04 & 7,29 & 5,93 & 4,08 \\
\hline 70 & 1250 & 110 & 18,26 & 13,85 & 12,49 & 11,13 & 10,00 & 8,99 & 7,27 & 5,92 & 4,09 \\
\hline 70 & 1300 & 110 & 17,95 & 13,66 & 12,35 & 11,03 & 9,93 & 8,94 & 7,25 & 5,92 & 4,10 \\
\hline 70 & 1350 & 110 & 17,66 & 13,48 & 12,22 & 10,94 & 9,86 & 8,90 & 7,23 & 5,92 & 4,10 \\
\hline 70 & 1400 & 110 & 17,39 & 13,30 & 12,09 & 10,85 & 9,80 & 8,85 & 7,21 & 5,92 & 4,11 \\
\hline 70 & 1450 & 110 & 17,13 & 13,14 & 11,97 & 10,76 & 9,73 & 8,81 & 7,19 & 5,91 & 4,12 \\
\hline 70 & 1500 & 110 & 16,89 & 12,98 & 11,85 & 10,67 & 9,67 & 8,76 & 7,18 & 5,91 & 4,12 \\
\hline 70 & 1550 & 110 & 16,66 & 12,83 & 11,74 & 10,59 & 9,61 & 8,72 & 7,16 & 5,90 & 4,13 \\
\hline 70 & 1600 & 110 & 16,45 & 12,69 & 11,63 & 10,51 & 9,55 & 8,68 & 7,14 & 5,90 & 4,13 \\
\hline 70 & 1650 & 110 & 16,24 & 12,55 & 11,53 & 10,44 & 9,50 & 8,63 & 7,12 & 5,89 & 4,14 \\
\hline 70 & 1700 & 110 & 16,05 & 12,42 & 11,43 & 10,36 & 9,44 & 8,59 & 7,10 & 5,89 & 4,15 \\
\hline 70 & 1750 & 110 & 15,86 & 12,29 & 11,33 & 10,29 & 9,39 & 8,55 & 7,08 & 5,88 & 4,15 \\
\hline 70 & 1800 & 110 & 15,68 & 12,17 & 11,24 & 10,22 & 9,33 & 8,51 & 7,06 & 5,88 & 4,15 \\
\hline 70 & 1850 & 110 & 15,52 & 12,06 & 11,15 & 10,15 & 9,28 & 8,48 & 7,05 & 5,87 & 4,16 \\
\hline 70 & 1900 & 110 & 15,35 & 11,94 & 11,06 & 10,09 & 9,23 & 8,44 & 7,03 & 5,86 & 4,16 \\
\hline 70 & 1950 & 110 & 15,20 & 11,83 & 10,97 & 10,02 & 9,18 & 8,40 & 7,01 & 5,86 & 4,17 \\
\hline 70 & 2000 & 110 & 15,05 & 11,73 & 10,89 & 9,96 & 9,13 & 8,37 & 6,99 & 5,85 & 4,17 \\
\hline 70 & 200 & 115 & 50,44 & 27,00 & 19,88 & 14,85 & 11,85 & 9,72 & 6,91 & 5,30 & 3,63 \\
\hline 70 & 250 & 115 & 43,37 & 24,54 & 18,68 & 14,39 & 11,69 & 9,71 & 6,99 & 5,37 & 3,64 \\
\hline 70 & 300 & 115 & 38,53 & 22,77 & 17,78 & 14,01 & 11,54 & 9,67 & 7,04 & 5,42 & 3,65 \\
\hline 70 & 350 & 115 & 34,99 & 21,43 & 17,06 & 13,68 & 11,39 & 9,63 & 7,08 & 5,46 & 3,67 \\
\hline 70 & 400 & 115 & 32,26 & 20,35 & 16,47 & 13,39 & 11,25 & 9,57 & 7,10 & 5,50 & 3,69 \\
\hline 70 & 450 & 115 & 30,10 & 19,47 & 15,96 & 13,13 & 11,12 & 9,52 & 7,12 & 5,53 & 3,70 \\
\hline 70 & 500 & 115 & 28,33 & 18,72 & 15,53 & 12,89 & 11,00 & 9,46 & 7,13 & 5,56 & 3,72 \\
\hline 70 & 550 & 115 & 26,85 & 18,07 & 15,14 & 12,68 & 10,88 & 9,40 & 7,13 & 5,58 & 3,74 \\
\hline 70 & 600 & 115 & 25,60 & 17,50 & 14,79 & 12,48 & 10,76 & 9,34 & 7,13 & 5,60 & 3,75 \\
\hline 70 & 650 & 115 & 24,52 & 17,00 & 14,48 & 12,30 & 10,66 & 9,28 & 7,13 & 5,61 & 3,77 \\
\hline 70 & 700 & 115 & 23,58 & 16,55 & 14,19 & 12,12 & 10,55 & 9,23 & 7,12 & 5,63 & 3,78 \\
\hline 70 & 750 & 115 & 22,75 & 16,15 & 13,93 & 11,96 & 10,45 & 9,17 & 7,11 & 5,64 & 3,80 \\
\hline 70 & 800 & 115 & 22,02 & 15,78 & 13,69 & 11,81 & 10,36 & 9,11 & 7,10 & 5,65 & 3,81 \\
\hline 70 & 850 & 115 & 21,36 & 15,44 & 13,46 & 11,67 & 10,27 & 9,06 & 7,09 & 5,65 & 3,82 \\
\hline 70 & 900 & 115 & 20,77 & 15,13 & 13,25 & 11,53 & 10,18 & 9,00 & 7,08 & 5,66 & 3,83 \\
\hline 70 & 950 & 115 & 20,23 & 14,84 & 13,06 & 11,41 & 10,09 & 8,95 & 7,07 & 5,66 & 3,85 \\
\hline 70 & 1000 & 115 & 19,74 & 14,57 & 12,87 & 11,28 & 10,01 & 8,90 & 7,05 & 5,67 & 3,86 \\
\hline 70 & 1050 & 115 & 19,29 & 14,32 & 12,70 & 11,17 & 9,93 & 8,85 & 7,04 & 5,67 & 3,87 \\
\hline 70 & 1100 & 115 & 18,88 & 14,08 & 12,54 & 11,06 & 9,86 & 8,80 & 7,02 & 5,67 & 3,88 \\
\hline 70 & 1150 & 115 & 18,50 & 13,86 & 12,38 & 10,95 & 9,78 & 8,75 & 7,01 & 5,67 & 3,89 \\
\hline 70 & 1200 & 115 & 18,15 & 13,65 & 12,24 & 10,85 & 9,71 & 8,70 & 6,99 & 5,67 & 3,89 \\
\hline 70 & 1250 & 115 & 17,82 & 13,46 & 12,10 & 10,75 & 9,64 & 8,65 & 6,97 & 5,67 & 3,90 \\
\hline 70 & 1300 & 115 & 17,51 & 13,27 & 11,96 & 10,66 & 9,58 & 8,61 & 6,96 & 5,67 & 3,91 \\
\hline 70 & 1350 & 115 & 17,22 & 13,09 & 11,83 & 10,57 & 9,51 & 8,56 & 6,94 & 5,67 & 3,92 \\
\hline 70 & 1400 & 115 & 16,95 & 12,93 & 11,71 & 10,48 & 9,45 & 8,52 & 6,92 & 5,66 & 3,92 \\
\hline
\end{tabular}




\begin{tabular}{|c|c|c|c|c|c|c|c|c|c|c|c|}
\hline \multirow[b]{2}{*}{$\mathrm{H}(\mathrm{cm})$} & \multirow[b]{2}{*}{ Mceq (MPa) } & & & & & $\mathrm{De}$ & ões (x1 & & & & \\
\hline & & Msub (MPa) & D0 & D25 & D40 & D60 & D80 & D100 & D140 & D180 & D260 \\
\hline 70 & 1450 & 115 & 16,70 & 12,77 & 11,59 & 10,40 & 9,39 & 8,48 & 6,90 & 5,66 & 3,93 \\
\hline 70 & 1500 & 115 & 16,46 & 12,61 & 11,48 & 10,32 & 9,33 & 8,44 & 6,89 & 5,66 & 3,94 \\
\hline 70 & 1550 & 115 & 16,24 & 12,47 & 11,37 & 10,24 & 9,27 & 8,40 & 6,87 & 5,65 & 3,94 \\
\hline 70 & 1600 & 115 & 16,02 & 12,33 & 11,27 & 10,16 & 9,22 & 8,36 & 6,85 & 5,65 & 3,95 \\
\hline 70 & 1650 & 115 & 15,82 & 12,20 & 11,17 & 10,09 & 9,16 & 8,32 & 6,84 & 5,64 & 3,95 \\
\hline 70 & 1700 & 115 & 15,63 & 12,07 & 11,07 & 10,02 & 9,11 & 8,28 & 6,82 & 5,64 & 3,96 \\
\hline 70 & 1750 & 115 & 15,45 & 11,95 & 10,98 & 9,95 & 9,06 & 8,24 & 6,80 & 5,63 & 3,96 \\
\hline 70 & 1800 & 115 & 15,27 & 11,83 & 10,89 & 9,88 & 9,01 & 8,20 & 6,78 & 5,63 & 3,97 \\
\hline 70 & 1850 & 115 & 15,10 & 11,71 & 10,80 & 9,82 & 8,96 & 8,17 & 6,77 & 5,62 & 3,97 \\
\hline 70 & 1900 & 115 & 14,95 & 11,60 & 10,72 & 9,75 & 8,91 & 8,13 & 6,75 & 5,62 & 3,97 \\
\hline 70 & 1950 & 115 & 14,79 & 11,50 & 10,64 & 9,69 & 8,86 & 8,10 & 6,73 & 5,61 & 3,98 \\
\hline 70 & 2000 & 115 & 14,65 & 11,40 & 10,56 & 9,63 & 8,82 & 8,06 & 6,72 & 5,61 & 3,98 \\
\hline 70 & 200 & 120 & 49,79 & 26,37 & 19,28 & 14,32 & 11,38 & 9,32 & 6,61 & 5,07 & 3,47 \\
\hline 70 & 250 & 120 & 42,76 & 23,94 & 18,11 & 13,87 & 11,23 & 9,31 & 6,68 & 5,13 & 3,48 \\
\hline 70 & 300 & 120 & 37,95 & 22,20 & 17,24 & 13,51 & 11,09 & 9,28 & 6,74 & 5,18 & 3,50 \\
\hline 70 & 350 & 120 & 34,42 & 20,88 & 16,54 & 13,20 & 10,96 & 9,24 & 6,77 & 5,22 & 3,51 \\
\hline 70 & 400 & 120 & 31,72 & 19,82 & 15,96 & 12,92 & 10,83 & 9,19 & 6,80 & 5,26 & 3,53 \\
\hline 70 & 450 & 120 & 29,57 & 18,96 & 15,47 & 12,67 & 10,71 & 9,14 & 6,81 & 5,29 & 3,54 \\
\hline 70 & 500 & 120 & 27,82 & 18,22 & 15,05 & 12,45 & 10,59 & 9,09 & 6,83 & 5,31 & 3,56 \\
\hline 70 & 550 & 120 & 26,35 & 17,59 & 14,67 & 12,24 & 10,48 & 9,04 & 6,83 & 5,34 & 3,58 \\
\hline 70 & 600 & 120 & 25,11 & 17,04 & 14,34 & 12,05 & 10,37 & 8,98 & 6,83 & 5,35 & 3,59 \\
\hline 70 & 650 & 120 & 24,04 & 16,55 & 14,03 & 11,88 & 10,27 & 8,93 & 6,83 & 5,37 & 3,60 \\
\hline 70 & 700 & 120 & 23,11 & 16,11 & 13,76 & 11,71 & 10,17 & 8,87 & 6,83 & 5,38 & 3,62 \\
\hline 70 & 750 & 120 & 22,29 & 15,71 & 13,50 & 11,56 & 10,08 & 8,82 & 6,82 & 5,40 & 3,63 \\
\hline 70 & 800 & 120 & 21,56 & 15,35 & 13,27 & 11,42 & 9,99 & 8,77 & 6,81 & 5,40 & 3,64 \\
\hline 70 & 850 & 120 & 20,91 & 15,02 & 13,05 & 11,28 & 9,90 & 8,72 & 6,80 & 5,41 & 3,65 \\
\hline 70 & 900 & 120 & 20,32 & 14,72 & 12,85 & 11,15 & 9,82 & 8,67 & 6,79 & 5,42 & 3,67 \\
\hline 70 & 950 & 120 & 19,79 & 14,44 & 12,66 & 11,03 & 9,74 & 8,62 & 6,78 & 5,42 & 3,68 \\
\hline 70 & 1000 & 120 & 19,31 & 14,17 & 12,48 & 10,91 & 9,66 & 8,57 & 6,77 & 5,43 & 3,69 \\
\hline 70 & 1050 & 120 & 18,86 & 13,93 & 12,32 & 10,80 & 9,58 & 8,52 & 6,76 & 5,43 & 3,70 \\
\hline 70 & 1100 & 120 & 18,45 & 13,70 & 12,16 & 10,69 & 9,51 & 8,47 & 6,74 & 5,43 & 3,71 \\
\hline 70 & 1150 & 120 & 18,08 & 13,49 & 12,01 & 10,59 & 9,44 & 8,43 & 6,73 & 5,43 & 3,71 \\
\hline 70 & 1200 & 120 & 17,73 & 13,28 & 11,87 & 10,49 & 9,38 & 8,38 & 6,71 & 5,43 & 3,72 \\
\hline 70 & 1250 & 120 & 17,40 & 13,09 & 11.73 & 10,40 & 9,31 & 8,34 & 6.70 & 5,43 & 3,73 \\
\hline 70 & 1300 & 120 & 17,10 & 12,91 & 11,60 & 10,31 & 9,25 & 8,30 & 6,68 & 5,43 & 3,74 \\
\hline 70 & 1350 & 120 & 16,82 & 12,74 & 11,48 & 10,22 & 9,19 & 8,26 & 6,67 & 5,43 & 3,75 \\
\hline 70 & 1400 & 120 & 16,55 & 12,58 & 11,36 & 10,14 & 9,13 & 8,21 & 6,65 & 5,43 & 3,75 \\
\hline 70 & 1450 & 120 & 16,30 & 12,42 & 11,25 & 10,06 & 9,07 & 8,17 & 6,64 & 5,43 & 3,76 \\
\hline 70 & 1500 & 120 & 16,06 & 12,27 & 11,14 & 9,98 & 9,01 & 8,13 & 6,62 & 5,42 & 3,77 \\
\hline 70 & 1550 & 120 & 15,84 & 12,13 & 11,03 & 9,91 & 8,96 & 8,10 & 6,61 & 5,42 & 3,77 \\
\hline 70 & 1600 & 120 & 15,63 & 12,00 & 10,93 & 9,84 & 8,90 & 8,06 & 6,59 & 5,42 & 3,78 \\
\hline 70 & 1650 & 120 & 15,43 & 11,87 & 10,84 & 9,77 & 8,85 & 8,02 & 6,57 & 5,41 & 3,78 \\
\hline 70 & 1700 & 120 & 15,24 & 11,74 & 10,74 & 9,70 & 8,80 & 7,99 & 6,56 & 5,41 & 3,79 \\
\hline 70 & 1750 & 120 & 15,06 & 11,62 & 10,65 & 9,63 & 8,75 & 7,95 & 6,54 & 5,41 & 3,79 \\
\hline 70 & 1800 & 120 & 14,89 & 11,51 & 10,57 & 9,57 & 8,70 & 7,91 & 6,53 & 5,40 & 3,80 \\
\hline 70 & 1850 & 120 & 14,72 & 11,40 & 10,48 & 9,50 & 8,66 & 7,88 & 6,51 & 5,40 & 3,80 \\
\hline 70 & 1900 & 120 & 14,57 & 11,29 & 10,40 & 9,44 & 8,61 & 7,85 & 6,49 & 5,39 & 3,80 \\
\hline 70 & 1950 & 120 & 14,42 & 11,19 & 10,32 & 9,39 & 8,57 & 7,81 & 6,48 & 5,39 & 3,81 \\
\hline 70 & 2000 & 120 & 14,27 & 11,09 & 10,24 & 9,33 & 8,52 & 7,78 & 6,46 & 5,38 & 3,81 \\
\hline 70 & 200 & 125 & 49,18 & 25,78 & 18,73 & 13,82 & 10,95 & 8,95 & 6,33 & 4,86 & 3,33 \\
\hline 70 & 250 & 125 & 42,18 & 23,38 & 17,58 & 13,40 & 10,81 & 8,94 & 6,40 & 4,92 & 3,34 \\
\hline 70 & 300 & 125 & 37,40 & 21,67 & 16,73 & 13,05 & 10,68 & 8,92 & 6,46 & 4,96 & 3,35 \\
\hline 70 & 350 & 125 & 33,90 & 20,37 & 16,05 & 12,75 & 10,55 & 8,88 & 6,49 & 5,00 & 3,37 \\
\hline 70 & 400 & 125 & 31,21 & 19,33 & 15,49 & 12,48 & 10,43 & 8,84 & 6,52 & 5,04 & 3,38 \\
\hline 70 & 450 & 125 & 29,08 & 18,48 & 15,02 & 12,25 & 10,32 & 8,79 & 6,54 & 5,07 & 3,40 \\
\hline 70 & 500 & 125 & 27,34 & 17,76 & 14,60 & 12,03 & 10,21 & 8,75 & 6,55 & 5,09 & 3,41 \\
\hline 70 & 550 & 125 & 25,89 & 17,14 & 14,24 & 11,84 & 10,10 & 8,70 & 6,56 & 5,11 & 3,43 \\
\hline 70 & 600 & 125 & 24,65 & 16,60 & 13,91 & 11,66 & 10,00 & 8,65 & 6,56 & 5,13 & 3,44 \\
\hline 70 & 650 & 125 & 23,59 & 16,12 & 13,62 & 11,49 & 9,91 & 8,60 & 6,56 & 5,15 & 3,45 \\
\hline 70 & 700 & 125 & 22,67 & 15,69 & 13,35 & 11,33 & 9,81 & 8,55 & 6,56 & 5,16 & 3,47 \\
\hline 70 & 750 & 125 & 21,86 & 15,31 & 13,11 & 11,19 & 9,73 & 8,50 & 6,55 & 5,17 & 3,48 \\
\hline 70 & 800 & 125 & 21,14 & 14,95 & 12,88 & 11,05 & 9,64 & 8,45 & 6,55 & 5,18 & 3,49 \\
\hline 70 & 850 & 125 & 20,49 & 14,63 & 12,67 & 10,92 & 9,56 & 8,40 & 6,54 & 5,19 & 3,50 \\
\hline 70 & 900 & 125 & 19,91 & 14,34 & 12,48 & 10,79 & 9,48 & 8,35 & 6,53 & 5,20 & 3,51 \\
\hline 70 & 950 & 125 & 19,38 & 14,06 & 12,29 & 10,68 & 9,40 & 8,31 & 6,52 & 5,20 & 3,52 \\
\hline 70 & 1000 & 125 & 18,90 & 13,81 & 12,12 & 10,56 & 9,33 & 8,26 & 6,51 & 5,21 & 3,53 \\
\hline 70 & 1050 & 125 & 18,46 & 13,57 & 11,96 & 10,46 & 9,26 & 8,22 & 6,50 & 5,21 & 3,54 \\
\hline 70 & 1100 & 125 & 18,06 & 13,35 & 11,81 & 10,36 & 9,19 & 8,17 & 6,48 & 5,21 & 3,55 \\
\hline 70 & 1150 & 125 & 17,69 & 13,14 & 11,66 & 10,26 & 9,13 & 8,13 & 6,47 & 5,22 & 3,56 \\
\hline 70 & 1200 & 125 & 17,34 & 12,94 & 11,52 & 10,16 & 9,06 & 8,09 & 6,46 & 5,22 & 3,57 \\
\hline 70 & 1250 & 125 & 17,02 & 12,75 & 11,39 & 10,07 & 9,00 & 8,05 & 6,44 & 5,22 & 3,57 \\
\hline 70 & 1300 & 125 & 16,72 & 12,58 & 11,27 & 9,99 & 8,94 & 8,01 & 6,43 & 5,22 & 3,58 \\
\hline 70 & 1350 & 125 & 16,44 & 12,41 & 11,15 & 9,91 & 8,88 & 7,97 & 6,42 & 5,22 & 3,59 \\
\hline 70 & 1400 & 125 & 16,17 & 12,25 & 11,03 & 9,83 & 8,83 & 7,93 & 6,40 & 5,21 & 3,60 \\
\hline 70 & 1450 & 125 & 15,93 & 12,10 & 10,92 & 9,75 & 8,77 & 7,89 & 6,39 & 5,21 & 3,60 \\
\hline 70 & 1500 & 125 & 15,69 & 11,95 & 10,82 & 9,67 & 8,72 & 7,85 & 6,37 & 5,21 & 3,61 \\
\hline 70 & 1550 & 125 & 15,47 & 11.82 & 10.72 & 9.60 & 8.66 & 7.82 & 6.36 & 5.21 & 3.61 \\
\hline 70 & 1600 & 125 & 15.27 & 1168 & 10.62 & 953 & 8.61 & 7.78 & 6.35 & 521 & 362 \\
\hline 70 & 1650 & 125 & 15,07 & 11,56 & 10,53 & 9,46 & 8,56 & 7,75 & 6,33 & 5,20 & 3,62 \\
\hline 70 & 1700 & 125 & 14,88 & 11,44 & 10,44 & 9,40 & 8,52 & 7,71 & 6,32 & 5,20 & 3,63 \\
\hline 70 & 1750 & 125 & 14,70 & 11,32 & 10,35 & 9,34 & 8,47 & 7,68 & 6,30 & 5,20 & 3,63 \\
\hline
\end{tabular}




\begin{tabular}{|c|c|c|c|c|c|c|c|c|c|c|c|}
\hline \multirow[b]{2}{*}{$\mathrm{H}(\mathrm{cm})$} & \multirow[b]{2}{*}{ Mceq (MPa) } & & & & & $\mathrm{De}$ & ões (x & & & & \\
\hline & & Msub (MPa) & D0 & D25 & D40 & D60 & D80 & D100 & D140 & D180 & D260 \\
\hline 70 & 1800 & 125 & 14,53 & 11,21 & 10,27 & 9,27 & 8,42 & 7,65 & 6,29 & 5,19 & 3,64 \\
\hline 70 & 1850 & 125 & 14,37 & 11,10 & 10,18 & 9,21 & 8,38 & 7,61 & 6,27 & 5,19 & 3,64 \\
\hline 70 & 1900 & 125 & 14,22 & 10,99 & 10,10 & 9,16 & 8,33 & 7,58 & 6,26 & 5,18 & 3,65 \\
\hline 70 & 1950 & 125 & 14,07 & 10,89 & 10,03 & 9,10 & 8,29 & 7,55 & 6,24 & 5,18 & 3,65 \\
\hline 70 & 2000 & 125 & 13,93 & 10,80 & 9,95 & 9,04 & 8,25 & 7,52 & 6,23 & 5,17 & 3,65 \\
\hline 70 & 200 & 130 & 48,62 & 25,24 & 18,21 & 13,36 & 10,54 & 8,60 & 6,07 & 4,66 & 3,20 \\
\hline 70 & 250 & 130 & 41,65 & 22,86 & 17,09 & 12,95 & 10,42 & 8,60 & 6,15 & 4,72 & 3,21 \\
\hline 70 & 300 & 130 & 36,89 & 21,18 & 16,26 & 12,62 & 10,30 & 8,58 & 6,20 & 4,76 & 3,22 \\
\hline 70 & 350 & 130 & 33,41 & 19,89 & 15,60 & 12,33 & 10,18 & 8,55 & 6,23 & 4,80 & 3,24 \\
\hline 70 & 400 & 130 & 30,74 & 18,87 & 15,05 & 12,08 & 10,07 & 8,51 & 6,26 & 4,84 & 3,25 \\
\hline 70 & 450 & 130 & 28,62 & 18,04 & 14,59 & 11,85 & 9,96 & 8,47 & 6,28 & 4,86 & 3,26 \\
\hline 70 & 500 & 130 & 26,89 & 17,33 & 14,19 & 11,65 & 9,86 & 8,43 & 6,29 & 4,89 & 3,28 \\
\hline 70 & 550 & 130 & 25,45 & 16,72 & 13,83 & 11,46 & 9,76 & 8,38 & 6,30 & 4,91 & 3,29 \\
\hline 70 & 600 & 130 & 24,23 & 16,19 & 13,52 & 11,29 & 9,66 & 8,34 & 6,31 & 4,93 & 3,30 \\
\hline 70 & 650 & 130 & 23,18 & 15,73 & 13,23 & 11,13 & 9,57 & 8,29 & 6,31 & 4,94 & 3,31 \\
\hline 70 & 700 & 130 & 22,26 & 15,31 & 12,97 & 10,98 & 9,48 & 8,24 & 6,31 & 4,96 & 3,33 \\
\hline 70 & 750 & 130 & 21,46 & 14,93 & 12,74 & 10,84 & 9,40 & 8,20 & 6,30 & 4,97 & 3,34 \\
\hline 70 & 800 & 130 & 20,74 & 14,58 & 12,52 & 10,70 & 9,32 & 8,15 & 6,30 & 4,98 & 3,35 \\
\hline 70 & 850 & 130 & 20,10 & 14,27 & 12,31 & 10,58 & 9,24 & 8,11 & 6,29 & 4,99 & 3,36 \\
\hline 70 & 900 & 130 & 19,53 & 13,98 & 12,12 & 10,46 & 9,17 & 8,06 & 6,28 & 4,99 & 3,37 \\
\hline 70 & 950 & 130 & 19,00 & 13,71 & 11,95 & 10,35 & 9,10 & 8,02 & 6,28 & 5,00 & 3,38 \\
\hline 70 & 1000 & 130 & 18,53 & 13,46 & 11,78 & 10,24 & 9,03 & 7,98 & 6,27 & 5,00 & 3,39 \\
\hline 70 & 1050 & 130 & 18,09 & 13,23 & 11,62 & 10,14 & 8,96 & 7,94 & 6,26 & 5,01 & 3,40 \\
\hline 70 & 1100 & 130 & 17,69 & 13,01 & 11,48 & 10,04 & 8,89 & 7,90 & 6,24 & 5,01 & 3,41 \\
\hline 70 & 1150 & 130 & 17,32 & 12,81 & 11,34 & 9,95 & 8,83 & 7,86 & 6,23 & 5,01 & 3,41 \\
\hline 70 & 1200 & 130 & 16,98 & 12,62 & 11,20 & 9,86 & 8,77 & 7,82 & 6,22 & 5,01 & 3,42 \\
\hline 70 & 1250 & 130 & 16,66 & 12,43 & 11,08 & 9,77 & 8,71 & 7,78 & 6,21 & 5,02 & 3,43 \\
\hline 70 & 1300 & 130 & 16,36 & 12,26 & 10,95 & 9,69 & 8,65 & 7,74 & 6,20 & 5,02 & 3,44 \\
\hline 70 & 1350 & 130 & 16,09 & 12,10 & 10,84 & 9,61 & 8,60 & 7,70 & 6,18 & 5,02 & 3,44 \\
\hline 70 & 1400 & 130 & 15,83 & 11,94 & 10,73 & 9,53 & 8,54 & 7,66 & 6,17 & 5,02 & 3,45 \\
\hline 70 & 1450 & 130 & 15,58 & 11,80 & 10,62 & 9,46 & 8,49 & 7,63 & 6,16 & 5,01 & 3,46 \\
\hline 70 & 1500 & 130 & 15,35 & 11,65 & 10,52 & 9,38 & 8,44 & 7,59 & 6,15 & 5,01 & 3,46 \\
\hline 70 & 1550 & 130 & 15,13 & 11,52 & 10,42 & 9,32 & 8,39 & 7,56 & 6,13 & 5,01 & 3,47 \\
\hline 70 & 1600 & 130 & 14.93 & 11,39 & 10,33 & 9,25 & 8,34 & 7.53 & 6.12 & 5,01 & 3,47 \\
\hline 70 & 1650 & 130 & 14,73 & 11,27 & 10,24 & 9,18 & 8,30 & 7,49 & 6,10 & 5,01 & 3,48 \\
\hline 70 & 1700 & 130 & 14,55 & 11,15 & 10,15 & 9,12 & 8,25 & 7,46 & 6,09 & 5,00 & 3,48 \\
\hline 70 & 1750 & 130 & 14,37 & 11,04 & 10,07 & 9,06 & 8,20 & 7,43 & 6,08 & 5,00 & 3,49 \\
\hline 70 & 1800 & 130 & 14,20 & 10,93 & 9,98 & 9,00 & 8,16 & 7,40 & 6,06 & 5,00 & 3,49 \\
\hline 70 & 1850 & 130 & 14,04 & 10,82 & 9,90 & 8,94 & 8,12 & 7,37 & 6,05 & 4,99 & 3,50 \\
\hline 70 & 1900 & 130 & 13,89 & 10,72 & 9,83 & 8,89 & 8,08 & 7,34 & 6,04 & 4,99 & 3,50 \\
\hline 70 & 1950 & 130 & 13,74 & 10,62 & 9,75 & 8,83 & 8,04 & 7,31 & 6,02 & 4,99 & 3,50 \\
\hline 70 & 2000 & 130 & 13,60 & 10,53 & 9,68 & 8,78 & 8,00 & 7,28 & 6,01 & 4,98 & 3,51 \\
\hline 70 & 200 & 135 & 48,09 & 24,73 & 17,73 & 12,94 & 10,17 & 8,28 & 5,84 & 4,48 & 3,09 \\
\hline 70 & 250 & 135 & 41,15 & 22,38 & 16,63 & 12,54 & 10,06 & 8,28 & 5,91 & 4,53 & 3,09 \\
\hline 70 & 300 & 135 & 36,41 & 20,71 & 15,82 & 12,22 & 9,94 & 8,27 & 5,96 & 4,58 & 3,10 \\
\hline 70 & 350 & 135 & 32,95 & 19,45 & 15,17 & 11,94 & 9,83 & 8,24 & 6,00 & 4,62 & 3,11 \\
\hline 70 & 400 & 135 & 30,30 & 18,45 & 14,64 & 11,70 & 9,73 & 8,21 & 6,02 & 4,65 & 3,12 \\
\hline 70 & 450 & 135 & 28,20 & 17,62 & 14,19 & 11,48 & 9,62 & 8,17 & 6,04 & 4,68 & 3,14 \\
\hline 70 & 500 & 135 & 26,48 & 16,93 & 13,80 & 11,29 & 9,53 & 8,13 & 6,06 & 4,70 & 3,15 \\
\hline 70 & 550 & 135 & 25,05 & 16,33 & 13,46 & 11,11 & 9,43 & 8,09 & 6,07 & 4,72 & 3,16 \\
\hline 70 & 600 & 135 & 23,83 & 15,81 & 13,15 & 10,94 & 9,34 & 8,05 & 6,07 & 4,74 & 3,17 \\
\hline 70 & 650 & 135 & 22,79 & 15,35 & 12,87 & 10,79 & 9,26 & 8,00 & 6,07 & 4,75 & 3,19 \\
\hline 70 & 700 & 135 & 21,88 & 14,94 & 12,62 & 10,64 & 9,18 & 7,96 & 6,07 & 4,77 & 3,20 \\
\hline 70 & 750 & 135 & 21,08 & 14,57 & 12,39 & 10,51 & 9,10 & 7,92 & 6,07 & 4,78 & 3,21 \\
\hline 70 & 800 & 135 & 20,37 & 14,24 & 12,18 & 10,38 & 9,02 & 7,88 & 6,07 & 4,79 & 3,22 \\
\hline 70 & 850 & 135 & 19,74 & 13,93 & 11,98 & 10,26 & 8,95 & 7,84 & 6,06 & 4,80 & 3,23 \\
\hline 70 & 900 & 135 & 19,17 & 13,65 & 11,80 & 10,15 & 8,88 & 7,79 & 6,06 & 4,80 & 3,24 \\
\hline 70 & 950 & 135 & 18,65 & 13,38 & 11,62 & 10,04 & 8,81 & 7,75 & 6,05 & 4,81 & 3,25 \\
\hline 70 & 1000 & 135 & 18,18 & 13,14 & 11,46 & 9,94 & 8,74 & 7,71 & 6,04 & 4,82 & 3,26 \\
\hline 70 & 1050 & 135 & 17,74 & 12,91 & 11,31 & 9,84 & 8,68 & 7,67 & 6,03 & 4,82 & 3,27 \\
\hline 70 & 1100 & 135 & 17,35 & 12,70 & 11,17 & 9,74 & 8,62 & 7,64 & 6,02 & 4,82 & 3,27 \\
\hline 70 & 1150 & 135 & 16,98 & 12,50 & 11,03 & 9,65 & 8,56 & 7,60 & 6,01 & 4,83 & 3,28 \\
\hline 70 & 1200 & 135 & 16,64 & 12,31 & 10,90 & 9,57 & 8,50 & 7,56 & 6,00 & 4,83 & 3,29 \\
\hline 70 & 1250 & 135 & 16,33 & 12,14 & 10,78 & 9,49 & 8,44 & 7,52 & 5,99 & 4,83 & 3,30 \\
\hline 70 & 1300 & 135 & 16,03 & 11,97 & 10,66 & 9,41 & 8,39 & 7,49 & 5,98 & 4,83 & 3,30 \\
\hline 70 & 1350 & 135 & 15,76 & 11,81 & 10,55 & 9,33 & 8,33 & 7,45 & 5,97 & 4,83 & 3,31 \\
\hline 70 & 1400 & 135 & 15,50 & 11,66 & 10,44 & 9,25 & 8,28 & 7,42 & 5,96 & 4,83 & 3,32 \\
\hline 70 & 1450 & 135 & 15,26 & 11,51 & 10,34 & 9,18 & 8,23 & 7,38 & 5,94 & 4,83 & 3,32 \\
\hline 70 & 1500 & 135 & 15,03 & 11,37 & 10,24 & 9,11 & 8,18 & 7,35 & 5,93 & 4,83 & 3,33 \\
\hline 70 & 1550 & 135 & 14,81 & 11,24 & 10,14 & 9,05 & 8,14 & 7,32 & 5,92 & 4,83 & 3,33 \\
\hline 70 & 1600 & 135 & 14,61 & 11,12 & 10,05 & 8,98 & 8,09 & 7,29 & 5,91 & 4,83 & 3,34 \\
\hline 70 & 1650 & 135 & 14,42 & 11,00 & 9,97 & 8,92 & 8,04 & 7,25 & 5,89 & 4,82 & 3,34 \\
\hline 70 & 1700 & 135 & 14,23 & 10,88 & 9,88 & 8,86 & 8,00 & 7,22 & 5,88 & 4,82 & 3,35 \\
\hline 70 & 1750 & 135 & 14,06 & 10,77 & 9,80 & 8,80 & 7,96 & 7,19 & 5,87 & 4,82 & 3,35 \\
\hline 70 & 1800 & 135 & 13,89 & 10,66 & 9,72 & 8,74 & 7,91 & 7,16 & 5,86 & 4,82 & 3,36 \\
\hline 70 & 1850 & 135 & 13,74 & 10,56 & 9,64 & 8,69 & 7,87 & 7,13 & 5,84 & 4,81 & 3,36 \\
\hline 70 & 1900 & 135 & 13.58 & 10,46 & 9.57 & 8.63 & 7.83 & 7.11 & 5.83 & 4.81 & 3.36 \\
\hline 70 & 1950 & 135 & 1344 & 1036 & 950 & 858 & 779 & 7.08 & 5.82 & 481 & 337 \\
\hline 70 & 2000 & 135 & 13,30 & 10,27 & 9,43 & 8,53 & 7,76 & 7,05 & 5,81 & 4,80 & 3,37 \\
\hline 70 & 200 & 140 & 47,59 & 24,25 & 17,28 & 12,54 & 9,82 & 7,98 & 5,61 & 4,31 & 2,97 \\
\hline 70 & 250 & 140 & 40,68 & 21,92 & 16,20 & 12,16 & 9,72 & 7,99 & 5,69 & 4,36 & 2,98 \\
\hline
\end{tabular}




\begin{tabular}{|c|c|c|c|c|c|c|c|c|c|c|c|}
\hline \multirow[b]{2}{*}{$\mathrm{H}(\mathrm{cm})$} & \multirow[b]{2}{*}{ Mceq (MPa) } & & & & & De & ões (x & & & & \\
\hline & & Msub (MPa) & D0 & D25 & D40 & D60 & D80 & D100 & D140 & D180 & D260 \\
\hline 70 & 300 & 140 & 35,97 & 20,28 & 15,40 & 11,84 & 9,61 & 7,98 & 5,74 & 4,41 & 2,99 \\
\hline 70 & 350 & 140 & 32,52 & 19,03 & 14,77 & 11,58 & 9,51 & 7,95 & 5,77 & 4,44 & 3,00 \\
\hline 70 & 400 & 140 & 29,89 & 18,04 & 14,25 & 11,35 & 9,41 & 7,92 & 5,80 & 4,47 & 3,01 \\
\hline 70 & 450 & 140 & 27,79 & 17,23 & 13,81 & 11,14 & 9,31 & 7,89 & 5,82 & 4,50 & 3,02 \\
\hline 70 & 500 & 140 & 26,09 & 16,55 & 13,43 & 10,95 & 9,22 & 7,85 & 5,84 & 4,52 & 3,03 \\
\hline 70 & 550 & 140 & 24,67 & 15,97 & 13,10 & 10,78 & 9,13 & 7,82 & 5,85 & 4,54 & 3,04 \\
\hline 70 & 600 & 140 & 23,46 & 15,46 & 12,80 & 10,62 & 9,05 & 7,78 & 5,85 & 4,56 & 3,06 \\
\hline 70 & 650 & 140 & 22,43 & 15,00 & 12,53 & 10,47 & 8,97 & 7,74 & 5,86 & 4,58 & 3,07 \\
\hline 70 & 700 & 140 & 21,52 & 14,60 & 12,29 & 10,33 & 8,89 & 7,70 & 5,86 & 4,59 & 3,08 \\
\hline 70 & 750 & 140 & 20,73 & 14,24 & 12,06 & 10,20 & 8,81 & 7,66 & 5,86 & 4,60 & 3,09 \\
\hline 70 & 800 & 140 & 20,03 & 13,91 & 11,86 & 10,08 & 8,74 & 7,62 & 5,85 & 4,61 & 3,10 \\
\hline 70 & 850 & 140 & 19,40 & 13,61 & 11,67 & 9,96 & 8,67 & 7,58 & 5,85 & 4,62 & 3,11 \\
\hline 70 & 900 & 140 & 18,83 & 13,33 & 11,49 & 9,85 & 8,60 & 7,54 & 5,84 & 4,63 & 3,12 \\
\hline 70 & 950 & 140 & 18,32 & 13,07 & 11,32 & 9,75 & 8,54 & 7,50 & 5,84 & 4,63 & 3,13 \\
\hline 70 & 1000 & 140 & 17,85 & 12,84 & 11,16 & 9,65 & 8,47 & 7,47 & 5,83 & 4,64 & 3,13 \\
\hline 70 & 1050 & 140 & 17,42 & 12,61 & 11,02 & 9,56 & 8,41 & 7,43 & 5,82 & 4,64 & 3,14 \\
\hline 70 & 1100 & 140 & 17,03 & 12,41 & 10,88 & 9,47 & 8,35 & 7,39 & 5,81 & 4,65 & 3,15 \\
\hline 70 & 1150 & 140 & 16,66 & 12,21 & 10,74 & 9,38 & 8,30 & 7,36 & 5,81 & 4,65 & 3,16 \\
\hline 70 & 1200 & 140 & 16,33 & 12,03 & 10,62 & 9,30 & 8,24 & 7,32 & 5,80 & 4,65 & 3,17 \\
\hline 70 & 1250 & 140 & 16,01 & 11,85 & 10,50 & 9,22 & 8,19 & 7,29 & 5,79 & 4,66 & 3,17 \\
\hline 70 & 1300 & 140 & 15,72 & 11,69 & 10,38 & 9,14 & 8,14 & 7,25 & 5,78 & 4,66 & 3,18 \\
\hline 70 & 1350 & 140 & 15,45 & 11,53 & 10,28 & 9,07 & 8,09 & 7,22 & 5,77 & 4,66 & 3,19 \\
\hline 70 & 1400 & 140 & 15,20 & 11,39 & 10,17 & 9,00 & 8,04 & 7,19 & 5,75 & 4,66 & 3,19 \\
\hline 70 & 1450 & 140 & 14,96 & 11,25 & 10,07 & 8,93 & 7,99 & 7,15 & 5,74 & 4,66 & 3,20 \\
\hline 70 & 1500 & 140 & 14,73 & 11,11 & 9,98 & 8,86 & 7,94 & 7,12 & 5,73 & 4,66 & 3,20 \\
\hline 70 & 1550 & 140 & 14,52 & 10,98 & 9,88 & 8,80 & 7,90 & 7,09 & 5,72 & 4,66 & 3,21 \\
\hline 70 & 1600 & 140 & 14,31 & 10,86 & 9,80 & 8,73 & 7,85 & 7,06 & 5,71 & 4,65 & 3,21 \\
\hline 70 & 1650 & 140 & 14,12 & 10,74 & 9,71 & 8,67 & 7,81 & 7,03 & 5,70 & 4,65 & 3,22 \\
\hline 70 & 1700 & 140 & 13,94 & 10,63 & 9,63 & 8,61 & 7,77 & 7,00 & 5,69 & 4,65 & 3,22 \\
\hline 70 & 1750 & 140 & 13,77 & 10,52 & 9,55 & 8,56 & 7,72 & 6,97 & 5,68 & 4,65 & 3,23 \\
\hline 70 & 1800 & 140 & 13,60 & 10,42 & 9,47 & 8,50 & 7,68 & 6,94 & 5,66 & 4,65 & 3,23 \\
\hline 70 & 1850 & 140 & 13,45 & 10,31 & 9,40 & 8,45 & 7,65 & 6,92 & 5,65 & 4,65 & 3,24 \\
\hline 70 & 1900 & 140 & 13,30 & 10,22 & 9,32 & 8,40 & 7,61 & 6,89 & 5,64 & 4,64 & 3,24 \\
\hline 70 & 1950 & 140 & 13,16 & 10,12 & 9,25 & 8,35 & 7,57 & 6,86 & 5,63 & 4,64 & 3,24 \\
\hline 70 & 2000 & 140 & 13,02 & 10,03 & 9,19 & 8,30 & 7,53 & 6,84 & 5,62 & 4,64 & 3,25 \\
\hline 70 & 200 & 145 & 47,13 & 23,80 & 16,86 & 12,16 & 9,50 & 7,70 & 5,41 & 4,15 & 2,87 \\
\hline 70 & 250 & 145 & 40,24 & 21,50 & 15,80 & 11,79 & 9,40 & 7,71 & 5,48 & 4,20 & 2,88 \\
\hline 70 & 300 & 145 & 35,55 & 19,87 & 15,02 & 11,49 & 9,30 & 7,70 & 5,53 & 4,25 & 2,88 \\
\hline 70 & 350 & 145 & 32,12 & 18,64 & 14,40 & 11,24 & 9,20 & 7,69 & 5,57 & 4,28 & 2,89 \\
\hline 70 & 400 & 145 & 29,50 & 17,66 & 13,89 & 11,01 & 9,11 & 7,66 & 5,59 & 4,31 & 2,90 \\
\hline 70 & 450 & 145 & 27,42 & 16,87 & 13,46 & 10,81 & 9,02 & 7,63 & 5,62 & 4,34 & 2,91 \\
\hline 70 & 500 & 145 & 25,72 & 16,20 & 13,09 & 10,63 & 8,93 & 7,60 & 5,63 & 4,36 & 2,92 \\
\hline 70 & 550 & 145 & 24,31 & 15,62 & 12,77 & 10,47 & 8,85 & 7,56 & 5,64 & 4,38 & 2,93 \\
\hline 70 & 600 & 145 & 23,11 & 15,12 & 12,48 & 10,31 & 8,77 & 7,53 & 5,65 & 4,40 & 2,95 \\
\hline 70 & 650 & 145 & 22,08 & 14,68 & 12,21 & 10,17 & 8,69 & 7,49 & 5,65 & 4,41 & 2,96 \\
\hline 70 & 700 & 145 & 21,19 & 14,28 & 11,98 & 10,04 & 8,62 & 7,45 & 5,65 & 4,43 & 2,97 \\
\hline 70 & 750 & 145 & 20,40 & 13,93 & 11,76 & 9,91 & 8,55 & 7,41 & 5,65 & 4,44 & 2,98 \\
\hline 70 & 800 & 145 & 19,70 & 13,60 & 11,56 & 9,80 & 8,48 & 7,38 & 5,65 & 4,45 & 2,99 \\
\hline 70 & 850 & 145 & 19,08 & 13,31 & 11,37 & 9,69 & 8,41 & 7,34 & 5,65 & 4,46 & 2,99 \\
\hline 70 & 900 & 145 & 18,51 & 13,04 & 11,20 & 9,58 & 8,35 & 7,30 & 5,65 & 4,46 & 3,00 \\
\hline 70 & 950 & 145 & 18,00 & 12,78 & 11,03 & 9,48 & 8,28 & 7,27 & 5,64 & 4,47 & 3,01 \\
\hline 70 & 1000 & 145 & 17,54 & 12,55 & 10,88 & 9,38 & 8,22 & 7,23 & 5,63 & 4,48 & 3,02 \\
\hline 70 & 1050 & 145 & 17,11 & 12,33 & 10,74 & 9,29 & 8,17 & 7,20 & 5,63 & 4,48 & 3,03 \\
\hline 70 & 1100 & 145 & 16,72 & 12,13 & 10,60 & 9,21 & 8,11 & 7,16 & 5,62 & 4,49 & 3,04 \\
\hline 70 & 1150 & 145 & 16,36 & 11,94 & 10,47 & 9,12 & 8,06 & 7,13 & 5,61 & 4,49 & 3,04 \\
\hline 70 & 1200 & 145 & 16,03 & 11,76 & 10,35 & 9,04 & 8,00 & 7,10 & 5,60 & 4,49 & 3,05 \\
\hline 70 & 1250 & 145 & 15,72 & 11,59 & 10,24 & 8,97 & 7,95 & 7,06 & 5,59 & 4,49 & 3,06 \\
\hline 70 & 1300 & 145 & 15,43 & 11,43 & 10,12 & 8,89 & 7,90 & 7,03 & 5,59 & 4,50 & 3,06 \\
\hline 70 & 1350 & 145 & 15,16 & 11,28 & 10,02 & 8,82 & 7,85 & 7,00 & 5,58 & 4,50 & 3,07 \\
\hline 70 & 1400 & 145 & 14,91 & 11,13 & 9,92 & 8,75 & 7,81 & 6,97 & 5,57 & 4,50 & 3,08 \\
\hline 70 & 1450 & 145 & 14,67 & 10,99 & 9,82 & 8,69 & 7,76 & 6,94 & 5,56 & 4,50 & 3,08 \\
\hline 70 & 1500 & 145 & 14,45 & 10,86 & 9,73 & 8,62 & 7,71 & 6,91 & 5,55 & 4,50 & 3,09 \\
\hline 70 & 1550 & 145 & 14,24 & 10,74 & 9,64 & 8,56 & 7,67 & 6,88 & 5,54 & 4,50 & 3,09 \\
\hline 70 & 1600 & 145 & 14,04 & 10,62 & 9,55 & 8,50 & 7,63 & 6,85 & 5,52 & 4,50 & 3,10 \\
\hline 70 & 1650 & 145 & 13,85 & 10,50 & 9,47 & 8,44 & 7,59 & 6,82 & 5,51 & 4,49 & 3,10 \\
\hline 70 & 1700 & 145 & 13,67 & 10,39 & 9,39 & 8,38 & 7,55 & 6,79 & 5,50 & 4,49 & 3,11 \\
\hline 70 & 1750 & 145 & 13,50 & 10,28 & 9,31 & 8,33 & 7,51 & 6,77 & 5,49 & 4,49 & 3,11 \\
\hline 70 & 1800 & 145 & 13,33 & 10,18 & 9,24 & 8,28 & 7,47 & 6,74 & 5,48 & 4,49 & 3,11 \\
\hline 70 & 1850 & 145 & 13,18 & 10,08 & 9,16 & 8,22 & 7,43 & 6,71 & 5,47 & 4,49 & 3,12 \\
\hline 70 & 1900 & 145 & 13,03 & 9,99 & 9,09 & 8,17 & 7,39 & 6,69 & 5,46 & 4,49 & 3,12 \\
\hline 70 & 1950 & 145 & 12,89 & 9,90 & 9,03 & 8,12 & 7,36 & 6,66 & 5,45 & 4,48 & 3,13 \\
\hline 70 & 2000 & 145 & 12,75 & 9,81 & 8,96 & 8,08 & 7,32 & 6,64 & 5,44 & 4,48 & 3,13 \\
\hline 70 & 200 & 150 & 46,69 & 23,38 & 16,47 & 11,81 & 9,20 & 7,44 & 5,22 & 4,01 & 2,78 \\
\hline 70 & 250 & 150 & 39,83 & 21,10 & 15,42 & 11,45 & 9,10 & 7,46 & 5,29 & 4,06 & 2,78 \\
\hline 70 & 300 & 150 & 35,15 & 19,49 & 14,65 & 11,16 & 9,01 & 7,45 & 5,34 & 4,10 & 2,79 \\
\hline 70 & 350 & 150 & 31,74 & 18,27 & 14,05 & 10,92 & 8,92 & 7,43 & 5,37 & 4,13 & 2,79 \\
\hline 70 & 400 & 150 & 29,13 & 17,31 & 13,55 & 10,70 & 8,83 & 7,41 & 5,40 & 4,16 & 2,80 \\
\hline 70 & 450 & 150 & 27,06 & 16,52 & 13,13 & 10,51 & 8,74 & 7,38 & 5,42 & 4,19 & 2,81 \\
\hline 70 & 500 & 150 & 25,38 & 15,86 & 12,77 & 10,34 & 8,66 & 7,35 & 5,44 & 4,21 & 2,82 \\
\hline 70 & 550 & 150 & 23,97 & 15,29 & 12,45 & 10,18 & 8,58 & 7,32 & 5,45 & 4,23 & 2,83 \\
\hline 70 & 600 & 150 & 22,78 & 14,80 & 12,17 & 10,03 & 8,51 & 7,29 & 5,46 & 4,24 & 2,84 \\
\hline
\end{tabular}




\begin{tabular}{|c|c|c|c|c|c|c|c|c|c|c|c|}
\hline \multirow[b]{2}{*}{$\mathrm{H}(\mathrm{cm})$} & \multirow[b]{2}{*}{ Mceq (MPa) } & & & & & $\mathrm{De}$ & ões (x. & & & & \\
\hline & & Msub (MPa) & D0 & D25 & D40 & D60 & D80 & D100 & D140 & D180 & D260 \\
\hline 70 & 650 & 150 & 21,76 & 14,37 & 11,91 & 9,89 & 8,43 & 7,25 & 5,46 & 4,26 & 2,85 \\
\hline 70 & 700 & 150 & 20,87 & 13,98 & 11,68 & 9,76 & 8,36 & 7,22 & 5,47 & 4,27 & 2,86 \\
\hline 70 & 750 & 150 & 20,09 & 13,63 & 11,47 & 9,64 & 8,30 & 7,19 & 5,47 & 4,28 & 2,87 \\
\hline 70 & 800 & 150 & 19,39 & 13,31 & 11,27 & 9,53 & 8,23 & 7,15 & 5,47 & 4,29 & 2,88 \\
\hline 70 & 850 & 150 & 18,77 & 13,02 & 11,09 & 9,42 & 8,17 & 7,12 & 5,46 & 4,30 & 2,89 \\
\hline 70 & 900 & 150 & 18,22 & 12,76 & 10,92 & 9,32 & 8,11 & 7,08 & 5,46 & 4,31 & 2,90 \\
\hline 70 & 950 & 150 & 17,71 & 12,51 & 10,76 & 9,22 & 8,05 & 7,05 & 5,46 & 4,32 & 2,91 \\
\hline 70 & 1000 & 150 & 17,25 & 12,28 & 10,62 & 9,13 & 7,99 & 7,01 & 5,45 & 4,32 & 2,91 \\
\hline 70 & 1050 & 150 & 16,83 & 12,07 & 10,48 & 9,04 & 7,93 & 6,98 & 5,44 & 4,33 & 2,92 \\
\hline 70 & 1100 & 150 & 16,44 & 11,87 & 10,34 & 8,96 & 7,88 & 6,95 & 5,44 & 4,33 & 2,93 \\
\hline 70 & 1150 & 150 & 16,08 & 11,68 & 10,22 & 8,88 & 7,83 & 6,92 & 5,43 & 4,34 & 2,94 \\
\hline 70 & 1200 & 150 & 15,75 & 11,51 & 10,10 & 8,80 & 7,78 & 6,89 & 5,42 & 4,34 & 2,94 \\
\hline 70 & 1250 & 150 & 15,45 & 11,34 & 9,99 & 8,73 & 7,73 & 6,85 & 5,42 & 4,34 & 2,95 \\
\hline 70 & 1300 & 150 & 15,16 & 11,18 & 9,88 & 8,66 & 7,68 & 6,82 & 5,41 & 4,34 & 2,96 \\
\hline 70 & 1350 & 150 & 14,89 & 11,03 & 9,78 & 8,59 & 7,63 & 6,79 & 5,40 & 4,35 & 2,96 \\
\hline 70 & 1400 & 150 & 14,64 & 10,89 & 9,68 & 8,52 & 7,59 & 6,76 & 5,39 & 4,35 & 2,97 \\
\hline 70 & 1450 & 150 & 14,40 & 10,76 & 9,58 & 8,46 & 7,54 & 6,74 & 5,38 & 4,35 & 2,97 \\
\hline 70 & 1500 & 150 & 14,18 & 10,63 & 9,49 & 8,40 & 7,50 & 6,71 & 5,37 & 4,35 & 2,98 \\
\hline 70 & 1550 & 150 & 13,97 & 10,50 & 9,41 & 8,34 & 7,46 & 6,68 & 5,36 & 4,35 & 2,98 \\
\hline 70 & 1600 & 150 & 13,77 & 10,39 & 9,32 & 8,28 & 7,42 & 6,65 & 5,35 & 4,35 & 2,99 \\
\hline 70 & 1650 & 150 & 13,59 & 10,27 & 9,24 & 8,22 & 7,38 & 6,62 & 5,34 & 4,35 & 2,99 \\
\hline 70 & 1700 & 150 & 13,41 & 10,17 & 9,16 & 8,17 & 7,34 & 6,60 & 5,33 & 4,34 & 3,00 \\
\hline 70 & 1750 & 150 & 13,24 & 10,06 & 9,09 & 8,11 & 7,30 & 6,57 & 5,32 & 4,34 & 3,00 \\
\hline 70 & 1800 & 150 & 13,08 & 9,96 & 9,02 & 8,06 & 7,26 & 6,55 & 5,31 & 4,34 & 3,01 \\
\hline 70 & 1850 & 150 & 12,93 & 9,86 & 8,95 & 8,01 & 7,23 & 6,52 & 5,30 & 4,34 & 3,01 \\
\hline 70 & 1900 & 150 & 12,78 & 9,77 & 8,88 & 7,96 & 7,19 & 6,50 & 5,29 & 4,34 & 3,01 \\
\hline 70 & 1950 & 150 & 12,64 & 9,68 & 8,81 & 7,92 & 7,16 & 6,47 & 5,28 & 4,34 & 3,02 \\
\hline 70 & 2000 & 150 & 12,50 & 9,60 & 8,75 & 7,87 & 7,12 & 6,45 & 5,27 & 4,33 & 3,02 \\
\hline 70 & 200 & 155 & 46,28 & 22,99 & 16,10 & 11,48 & 8,91 & 7,20 & 5,04 & 3,87 & 2,69 \\
\hline 70 & 250 & 155 & 39,44 & 20,72 & 15,07 & 11,14 & 8,82 & 7,21 & 5,11 & 3,92 & 2,69 \\
\hline 70 & 300 & 155 & 34,78 & 19,12 & 14,31 & 10,85 & 8,74 & 7,21 & 5,16 & 3,96 & 2,69 \\
\hline 70 & 350 & 155 & 31,38 & 17,92 & 13,72 & 10,62 & 8,65 & 7,20 & 5,19 & 3,99 & 2,70 \\
\hline 70 & 400 & 155 & 28,79 & 16,97 & 13,23 & 10,41 & 8,57 & 7,18 & 5,22 & 4,02 & 2,71 \\
\hline 70 & 450 & 155 & 26,73 & 16,19 & 12,82 & 10,22 & 8,49 & 7,15 & 5,24 & 4,04 & 2,72 \\
\hline 70 & 500 & 155 & 25,05 & 15,54 & 12,47 & 10,05 & 8,41 & 7,13 & 5,26 & 4,07 & 2,73 \\
\hline 70 & 550 & 155 & 23,65 & 14,99 & 12,16 & 9,90 & 8,33 & 7,10 & 5,27 & 4,08 & 2,74 \\
\hline 70 & 600 & 155 & 22,47 & 14,50 & 11,88 & 9,76 & 8,26 & 7,07 & 5,28 & 4,10 & 2,75 \\
\hline 70 & 650 & 155 & 21,46 & 14,07 & 11,63 & 9,63 & 8,19 & 7,03 & 5,28 & 4,12 & 2,76 \\
\hline 70 & 700 & 155 & 20,57 & 13,69 & 11,40 & 9,50 & 8,12 & 7,00 & 5,29 & 4,13 & 2,77 \\
\hline 70 & 750 & 155 & 19,79 & 13,35 & 11,20 & 9,39 & 8,06 & 6,97 & 5,29 & 4,14 & 2,77 \\
\hline 70 & 800 & 155 & 19,11 & 13,04 & 11,01 & 9,28 & 8,00 & 6,94 & 5,29 & 4,15 & 2,78 \\
\hline 70 & 850 & 155 & 18,49 & 12,75 & 10,83 & 9,17 & 7,94 & 6,90 & 5,29 & 4,16 & 2,79 \\
\hline 70 & 900 & 155 & 17,93 & 12,49 & 10,66 & 9,08 & 7,88 & 6,87 & 5,29 & 4,17 & 2,80 \\
\hline 70 & 950 & 155 & 17,43 & 12,25 & 10,51 & 8,98 & 7,82 & 6,84 & 5,28 & 4,17 & 2,81 \\
\hline 70 & 1000 & 155 & 16,98 & 12,03 & 10,37 & 8,89 & 7,77 & 6,81 & 5,28 & 4,18 & 2,82 \\
\hline 70 & 1050 & 155 & 16,56 & 11,82 & 10,23 & 8,81 & 7,71 & 6,78 & 5,27 & 4,19 & 2,82 \\
\hline 70 & 1100 & 155 & 16,17 & 11,62 & 10,10 & 8,73 & 7,66 & 6,75 & 5,27 & 4,19 & 2,83 \\
\hline 70 & 1150 & 155 & 15,82 & 11,44 & 9,98 & 8,65 & 7,61 & 6,72 & 5,26 & 4,19 & 2,84 \\
\hline 70 & 1200 & 155 & 15,49 & 11,27 & 9,86 & 8,58 & 7,56 & 6,69 & 5,25 & 4,20 & 2,84 \\
\hline 70 & 1250 & 155 & 15,19 & 11,10 & 9,75 & 8,50 & 7,52 & 6,66 & 5,25 & 4,20 & 2,85 \\
\hline 70 & 1300 & 155 & 14,90 & 10,95 & 9,65 & 8,44 & 7,47 & 6,63 & 5,24 & 4,20 & 2,86 \\
\hline 70 & 1350 & 155 & 14,64 & 10,80 & 9,55 & 8,37 & 7,43 & 6,60 & 5,23 & 4,20 & 2,86 \\
\hline 70 & 1400 & 155 & 14,39 & 10,66 & 9,45 & 8,31 & 7,38 & 6,57 & 5,22 & 4,21 & 2,87 \\
\hline 70 & 1450 & 155 & 14,15 & 10,53 & 9,36 & 8,24 & 7,34 & 6,54 & 5,21 & 4,21 & 2,87 \\
\hline 70 & 1500 & 155 & 13,93 & 10,40 & 9,27 & 8,18 & 7,30 & 6,52 & 5,21 & 4,21 & 2,88 \\
\hline 70 & 1550 & 155 & 13,72 & 10,28 & 9,19 & 8,12 & 7,26 & 6,49 & 5,20 & 4,21 & 2,88 \\
\hline 70 & 1600 & 155 & 13,53 & 10,17 & 9,11 & 8,07 & 7,22 & 6,46 & 5,19 & 4,21 & 2,89 \\
\hline 70 & 1650 & 155 & 13,34 & 10,06 & 9,03 & 8,01 & 7,18 & 6,44 & 5,18 & 4,21 & 2,89 \\
\hline 70 & 1700 & 155 & 13,17 & 9,95 & 8,95 & 7,96 & 7,14 & 6,41 & 5,17 & 4,21 & 2,90 \\
\hline 70 & 1750 & 155 & 13,00 & 9,85 & 8,88 & 7,91 & 7,11 & 6,39 & 5,16 & 4,20 & 2,90 \\
\hline 70 & 1800 & 155 & 12,84 & 9,75 & 8,81 & 7,86 & 7,07 & 6,36 & 5,15 & 4,20 & 2,90 \\
\hline 70 & 1850 & 155 & 12,69 & 9,66 & 8,74 & 7,81 & 7,04 & 6,34 & 5,14 & 4,20 & 2,91 \\
\hline 70 & 1900 & 155 & 12,54 & 9,57 & 8,67 & 7,76 & 7,00 & 6,32 & 5,13 & 4,20 & 2,91 \\
\hline 70 & 1950 & 155 & 12,40 & 9,48 & 8,61 & 7,72 & 6,97 & 6,29 & 5,12 & 4,20 & 2,92 \\
\hline 70 & 2000 & 155 & 12,27 & 9,40 & 8,55 & 7,67 & 6,94 & 6,27 & 5,11 & 4,20 & 2,92 \\
\hline 70 & 200 & 160 & 45,89 & 22,61 & 15,75 & 11,17 & 8,64 & 6,97 & 4,87 & 3,74 & 2,60 \\
\hline 70 & 250 & 160 & 39,07 & 20,36 & 14,73 & 10,84 & 8,56 & 6,99 & 4,94 & 3,79 & 2,60 \\
\hline 70 & 300 & 160 & 34,43 & 18,78 & 13,99 & 10,56 & 8,48 & 6,99 & 4,99 & 3,83 & 2,61 \\
\hline 70 & 350 & 160 & 31,04 & 17,59 & 13,40 & 10,33 & 8,40 & 6,98 & 5,02 & 3,86 & 2,62 \\
\hline 70 & 400 & 160 & 28,46 & 16,65 & 12,93 & 10,13 & 8,32 & 6,96 & 5,05 & 3,89 & 2,62 \\
\hline 70 & 450 & 160 & 26,41 & 15,89 & 12,52 & 9,95 & 8,24 & 6,94 & 5,07 & 3,91 & 2,63 \\
\hline 70 & 500 & 160 & 24,74 & 15,24 & 12,18 & 9,79 & 8,17 & 6,91 & 5,09 & 3,93 & 2,64 \\
\hline 70 & 550 & 160 & 23,35 & 14,69 & 11,87 & 9,64 & 8,10 & 6,89 & 5,10 & 3,95 & 2,65 \\
\hline 70 & 600 & 160 & 22,18 & 14,22 & 11,60 & 9,50 & 8,03 & 6,86 & 5,11 & 3,97 & 2,66 \\
\hline 70 & 650 & 160 & 21,17 & 13,80 & 11,36 & 9,38 & 7,96 & 6,83 & 5,12 & 3,98 & 2,67 \\
\hline 70 & 700 & 160 & 20,29 & 13,42 & 11,14 & 9,26 & 7,90 & 6,80 & 5,12 & 3,99 & 2,68 \\
\hline 70 & 750 & 160 & 19,52 & 13,08 & 10,94 & 9,15 & 7,84 & 6,77 & 5,12 & 4,01 & 2,68 \\
\hline 70 & 800 & 160 & 18,83 & 12,78 & 10,75 & 9,04 & 7,78 & 6,74 & 5,12 & 4,02 & 2,69 \\
\hline 70 & 850 & 160 & 18,22 & 12,50 & 10,58 & 8,94 & 7,72 & 6,71 & 5,12 & 4,03 & 2,70 \\
\hline 70 & 900 & 160 & 17,67 & 12,24 & 10,42 & 8,85 & 7,66 & 6,68 & 5,12 & 4,03 & 2,71 \\
\hline 70 & 950 & 160 & 17,17 & 12,00 & 10,27 & 8,76 & 7,61 & 6,65 & 5,12 & 4,04 & 2,72 \\
\hline
\end{tabular}




\begin{tabular}{|c|c|c|c|c|c|c|c|c|c|c|c|}
\hline \multirow[b]{2}{*}{$\mathrm{H}(\mathrm{cm})$} & \multirow[b]{2}{*}{ Mceq (MPa) } & & & & & $\mathrm{De}$ & ões (x. & & & & \\
\hline & & Msub (MPa) & D0 & D25 & D40 & D60 & D80 & D100 & D140 & D180 & D260 \\
\hline 70 & 1000 & 160 & 16,72 & 11,78 & 10,13 & 8,67 & 7,56 & 6,62 & 5,12 & 4,05 & 2,72 \\
\hline 70 & 1050 & 160 & 16,30 & 11,58 & 9,99 & 8,59 & 7,51 & 6,59 & 5,11 & 4,05 & 2,73 \\
\hline 70 & 1100 & 160 & 15,92 & 11,39 & 9,87 & 8,51 & 7,46 & 6,56 & 5,11 & 4,06 & 2,74 \\
\hline 70 & 1150 & 160 & 15,57 & 11,21 & 9,75 & 8,43 & 7,41 & 6,53 & 5,10 & 4,06 & 2,74 \\
\hline 70 & 1200 & 160 & 15,24 & 11,04 & 9,64 & 8,36 & 7,36 & 6,50 & 5,09 & 4,06 & 2,75 \\
\hline 70 & 1250 & 160 & 14,94 & 10,88 & 9,53 & 8,29 & 7,32 & 6,47 & 5,09 & 4,07 & 2,76 \\
\hline 70 & 1300 & 160 & 14,66 & 10,73 & 9,43 & 8,23 & 7,27 & 6,44 & 5,08 & 4,07 & 2,76 \\
\hline 70 & 1350 & 160 & 14,39 & 10,58 & 9,33 & 8,16 & 7,23 & 6,42 & 5,07 & 4,07 & 2,77 \\
\hline 70 & 1400 & 160 & 14,15 & 10,45 & 9,24 & 8,10 & 7,19 & 6,39 & 5,07 & 4,07 & 2,77 \\
\hline 70 & 1450 & 160 & 13,91 & 10,32 & 9,15 & 8,04 & 7,15 & 6,36 & 5,06 & 4,07 & 2,78 \\
\hline 70 & 1500 & 160 & 13,70 & 10,19 & 9,06 & 7,98 & 7,11 & 6,34 & 5,05 & 4,07 & 2,78 \\
\hline 70 & 1550 & 160 & 13,49 & 10,08 & 8,98 & 7,93 & 7,07 & 6,31 & 5,04 & 4,08 & 2,79 \\
\hline 70 & 1600 & 160 & 13,30 & 9,96 & 8,90 & 7,87 & 7,03 & 6,29 & 5,03 & 4,08 & 2,79 \\
\hline 70 & 1650 & 160 & 13,11 & 9,85 & 8,82 & 7,82 & 6,99 & 6,26 & 5,03 & 4,08 & 2,80 \\
\hline 70 & 1700 & 160 & 12,94 & 9,75 & 8,75 & 7,77 & 6,96 & 6,24 & 5,02 & 4,08 & 2,80 \\
\hline 70 & 1750 & 160 & 12,77 & 9,65 & 8,68 & 7,72 & 6,92 & 6,21 & 5,01 & 4,07 & 2,81 \\
\hline 70 & 1800 & 160 & 12,61 & 9,55 & 8,61 & 7,67 & 6,89 & 6,19 & 5,00 & 4,07 & 2,81 \\
\hline 70 & 1850 & 160 & 12,46 & 9,46 & 8,54 & 7,62 & 6,86 & 6,17 & 4,99 & 4,07 & 2,81 \\
\hline 70 & 1900 & 160 & 12,32 & 9,37 & 8,48 & 7,58 & 6,82 & 6,15 & 4,98 & 4,07 & 2,82 \\
\hline 70 & 1950 & 160 & 12,18 & 9,29 & 8,42 & 7,53 & 6,79 & 6,12 & 4,97 & 4,07 & 2,82 \\
\hline 70 & 2000 & 160 & 12,05 & 9,20 & 8,35 & 7,49 & 6,76 & 6,10 & 4,97 & 4,07 & 2,82 \\
\hline 70 & 200 & 165 & 45,53 & 22,26 & 15,42 & 10,88 & 8,39 & 6,76 & 4,71 & 3,63 & 2,52 \\
\hline 70 & 250 & 165 & 38,72 & 20,02 & 14,41 & 10,55 & 8,31 & 6,78 & 4,78 & 3,67 & 2,52 \\
\hline 70 & 300 & 165 & 34,09 & 18,46 & 13,68 & 10,29 & 8,24 & 6,78 & 4,83 & 3,71 & 2,53 \\
\hline 70 & 350 & 165 & 30,72 & 17,28 & 13,11 & 10,06 & 8,16 & 6,77 & 4,87 & 3,74 & 2,54 \\
\hline 70 & 400 & 165 & 28,15 & 16,35 & 12,64 & 9,87 & 8,08 & 6,75 & 4,89 & 3,76 & 2,54 \\
\hline 70 & 450 & 165 & 26,11 & 15,59 & 12,25 & 9,70 & 8,01 & 6,73 & 4,91 & 3,79 & 2,55 \\
\hline 70 & 500 & 165 & 24,45 & 14,96 & 11,91 & 9,54 & 7,94 & 6,71 & 4,93 & 3,81 & 2,56 \\
\hline 70 & 550 & 165 & 23,07 & 14,42 & 11,61 & 9,40 & 7,87 & 6,69 & 4,94 & 3,83 & 2,57 \\
\hline 70 & 600 & 165 & 21,90 & 13,95 & 11,34 & 9,26 & 7,81 & 6,66 & 4,95 & 3,84 & 2,57 \\
\hline 70 & 650 & 165 & 20,90 & 13,53 & 11,11 & 9,14 & 7,75 & 6,63 & 4,96 & 3,86 & 2,58 \\
\hline 70 & 700 & 165 & 20,02 & 13,16 & 10,89 & 9,02 & 7,69 & 6,60 & 4,97 & 3,87 & 2,59 \\
\hline 70 & 750 & 165 & 19,25 & 12,83 & 10,69 & 8,92 & 7,63 & 6,57 & 4,97 & 3,88 & 2,60 \\
\hline 70 & 800 & 165 & 18,57 & 12,53 & 10,51 & 8.81 & 7.57 & 6.55 & 4.97 & 3,89 & 2,61 \\
\hline 70 & 850 & 165 & 17,97 & 12,26 & 10,34 & 8,72 & 7,51 & 6,52 & 4,97 & 3,90 & 2,61 \\
\hline 70 & 900 & 165 & 17,42 & 12,00 & 10,19 & 8,63 & 7,46 & 6,49 & 4,97 & 3,91 & 2,62 \\
\hline 70 & 950 & 165 & 16,92 & 11,77 & 10,04 & 8,54 & 7,41 & 6,46 & 4,97 & 3,91 & 2,63 \\
\hline 70 & 1000 & 165 & 16,47 & 11,55 & 9,90 & 8,46 & 7,36 & 6,43 & 4,96 & 3,92 & 2,64 \\
\hline 70 & 1050 & 165 & 16,06 & 11,35 & 9,77 & 8,38 & 7,31 & 6,40 & 4,96 & 3,93 & 2,64 \\
\hline 70 & 1100 & 165 & 15,68 & 11,16 & 9,65 & 8,30 & 7,26 & 6,38 & 4,96 & 3,93 & 2,65 \\
\hline 70 & 1150 & 165 & 15,33 & 10,99 & 9,53 & 8,23 & 7,22 & 6,35 & 4,95 & 3,93 & 2,66 \\
\hline 70 & 1200 & 165 & 15,01 & 10,82 & 9,43 & 8,16 & 7,17 & 6,32 & 4,94 & 3,94 & 2,66 \\
\hline 70 & 1250 & 165 & 14,71 & 10,66 & 9,32 & 8,09 & 7,13 & 6,30 & 4,94 & 3,94 & 2,67 \\
\hline 70 & 1300 & 165 & 14,43 & 10,52 & 9,22 & 8,03 & 7,09 & 6,27 & 4,93 & 3,94 & 2,67 \\
\hline 70 & 1350 & 165 & 14,17 & 10,38 & 9,13 & 7,97 & 7,04 & 6,24 & 4,93 & 3,95 & 2,68 \\
\hline 70 & 1400 & 165 & 13,92 & 10,24 & 9,03 & 7,91 & 7,00 & 6,22 & 4,92 & 3,95 & 2,68 \\
\hline 70 & 1450 & 165 & 13,69 & 10,12 & 8,95 & 7,85 & 6,97 & 6,19 & 4,91 & 3,95 & 2,69 \\
\hline 70 & 1500 & 165 & 13,47 & 9,99 & 8,86 & 7,79 & 6,93 & 6,17 & 4,91 & 3,95 & 2,69 \\
\hline 70 & 1550 & 165 & 13,27 & 9,88 & 8,78 & 7,74 & 6,89 & 6,14 & 4,90 & 3,95 & 2,70 \\
\hline 70 & 1600 & 165 & 13,08 & 9,77 & 8,71 & 7,68 & 6,85 & 6,12 & 4,89 & 3,95 & 2,70 \\
\hline 70 & 1650 & 165 & 12,89 & 9,66 & 8,63 & 7,63 & 6,82 & 6,10 & 4,88 & 3,95 & 2,71 \\
\hline 70 & 1700 & 165 & 12,72 & 9,56 & 8,56 & 7,58 & 6,78 & 6,07 & 4,87 & 3,95 & 2,71 \\
\hline 70 & 1750 & 165 & $\begin{array}{l}12,5 L \\
12,55\end{array}$ & 9,46 & 8,49 & 7,53 & 6,75 & 6,05 & 4,87 & 3,95 & 2,72 \\
\hline 70 & 1800 & 165 & 12,40 & 9,37 & 8,42 & 7,49 & 6,72 & 6,03 & 4,86 & 3,95 & 2,72 \\
\hline 70 & 1850 & 165 & 12,25 & 9,28 & 8,36 & 7,44 & 6,68 & 6,01 & 4,85 & 3,95 & 2,72 \\
\hline 70 & 1900 & 165 & 12,11 & 9,19 & 8,29 & 7,40 & 6,65 & 5,98 & 4,84 & 3,95 & 2,73 \\
\hline 70 & 1950 & 165 & 11,97 & 9,10 & 8,23 & 7,35 & 6,62 & 5,96 & 4,83 & 3,95 & 2,73 \\
\hline 70 & 2000 & 165 & 11,84 & 9,02 & 8,17 & 7,31 & 6,59 & 5,94 & 4,83 & 3,95 & 2,73 \\
\hline 70 & 200 & 170 & 45,18 & 21,92 & 15,10 & 10,60 & 8,15 & 6,55 & 4,57 & 3,51 & 2,45 \\
\hline 70 & 250 & 170 & 38,39 & 19,70 & 14,11 & 10,28 & 8,08 & 6,57 & 4,63 & 3,56 & 2,45 \\
\hline 70 & 300 & 170 & 33,78 & 18,15 & 13,39 & 10,03 & 8,01 & 6,58 & 4,68 & 3,59 & 2,45 \\
\hline 70 & 350 & 170 & 30,42 & 16,98 & 12,83 & 9,81 & 7,93 & 6,57 & 4,72 & 3,62 & 2,46 \\
\hline 70 & 400 & 170 & 27,86 & 16,06 & 12,37 & 9,62 & 7,86 & 6,56 & 4,74 & 3,65 & 2,47 \\
\hline 70 & 450 & 170 & 25,83 & 15,32 & 11,98 & 9,45 & 7,80 & 6,54 & 4,77 & 3,67 & 2,47 \\
\hline 70 & 500 & 170 & 24,17 & 14,69 & 11,65 & 9,30 & 7,73 & 6,52 & 4,78 & 3,69 & 2,48 \\
\hline 70 & 550 & 170 & 22,80 & 14,16 & 11,36 & 9,16 & 7,66 & 6,50 & 4,79 & 3,71 & 2,49 \\
\hline 70 & 600 & 170 & 21,64 & 13,69 & 11,10 & 9,03 & 7,60 & 6,47 & 4,80 & 3,72 & 2,50 \\
\hline 70 & 650 & 170 & 20,64 & 13,28 & 10,87 & 8,92 & 7,54 & 6,45 & 4,81 & 3,74 & 2,50 \\
\hline 70 & 700 & 170 & 19,77 & 12,92 & 10,65 & 8,80 & 7,48 & 6,42 & 4,82 & 3,75 & 2,51 \\
\hline 70 & 750 & 170 & 19,01 & 12,59 & 10,46 & 8,70 & 7,43 & 6,39 & 4,82 & 3,76 & 2,52 \\
\hline 70 & 800 & 170 & 18,33 & 12,30 & 10,28 & 8,60 & 7,37 & 6,37 & 4,82 & 3,77 & 2,53 \\
\hline 70 & 850 & 170 & 17,72 & 12,03 & 10,12 & 8,51 & 7,32 & 6,34 & 4,82 & 3,78 & 2,53 \\
\hline 70 & 900 & 170 & 17,18 & 11,78 & 9,97 & 8,42 & 7,27 & 6,31 & 4,82 & 3,79 & 2,54 \\
\hline 70 & 950 & 170 & 16,69 & 11,55 & 9,82 & 8,34 & 7,22 & 6,29 & 4,82 & 3,80 & 2,55 \\
\hline 70 & 1000 & 170 & 16,24 & 11,34 & 9,69 & 8,26 & 7,17 & 6,26 & 4,82 & 3,80 & 2,55 \\
\hline 70 & 1050 & 170 & 15,83 & 11,14 & 9,56 & 8,18 & 7,12 & 6,23 & 4,82 & 3,81 & 2,56 \\
\hline 70 & 1100 & 170 & 15,45 & 10,95 & 9,44 & 8,11 & 7,08 & 6,21 & 4,81 & 3,81 & 2,57 \\
\hline 70 & 1150 & 170 & 15,11 & 10,78 & 9,33 & 8,04 & 7,03 & 6,18 & 4,81 & 3,82 & 2,57 \\
\hline 70 & 1200 & 170 & 14,79 & 10,62 & 9,22 & 7,97 & 6,99 & 6,16 & 4,80 & 3,82 & 2,58 \\
\hline 70 & 1250 & 170 & 14,49 & 10,46 & 9,12 & 7,90 & 6,95 & 6,13 & 4,80 & 3,82 & 2,59 \\
\hline 70 & 1300 & 170 & 14,21 & 10,32 & 9,02 & 7,84 & 6,91 & 6,10 & 4,79 & 3,83 & 2,59 \\
\hline
\end{tabular}




\begin{tabular}{|c|c|c|c|c|c|c|c|c|c|c|c|}
\hline \multirow[b]{2}{*}{$\mathrm{H}(\mathrm{cm})$} & \multirow[b]{2}{*}{ Mceq (MPa) } & & & & & $\mathrm{De}$ & ões (x. & & & & \\
\hline & & Msub (MPa) & D0 & D25 & D40 & D60 & D80 & D100 & D140 & D180 & D260 \\
\hline 70 & 1350 & 170 & 13,95 & 10,18 & 8,93 & 7,78 & 6,87 & 6,08 & 4,79 & 3,83 & 2,60 \\
\hline 70 & 1400 & 170 & 13,71 & 10,05 & 8,84 & 7,72 & 6,83 & 6,06 & 4,78 & 3,83 & 2,60 \\
\hline 70 & 1450 & 170 & 13,48 & 9,92 & 8,76 & 7,66 & 6,79 & 6,03 & 4,77 & 3,83 & 2,61 \\
\hline 70 & 1500 & 170 & 13,26 & 9,80 & 8,67 & 7,61 & 6,76 & 6,01 & 4,77 & 3,83 & 2,61 \\
\hline 70 & 1550 & 170 & 13,06 & 9,69 & 8,60 & 7,56 & 6,72 & 5,99 & 4,76 & 3,83 & 2,62 \\
\hline 70 & 1600 & 170 & 12,87 & 9,58 & 8,52 & 7,51 & 6,69 & 5,96 & 4,75 & 3,84 & 2,62 \\
\hline 70 & 1650 & 170 & 12,69 & 9,48 & 8,45 & 7,46 & 6,65 & 5,94 & 4,75 & 3,84 & 2,62 \\
\hline 70 & 1700 & 170 & 12,51 & 9,38 & 8,38 & 7,41 & 6,62 & 5,92 & 4,74 & 3,84 & 2,63 \\
\hline 70 & 1750 & 170 & 12,35 & 9,28 & 8,31 & 7,36 & 6,59 & 5,90 & 4,73 & 3,84 & 2,63 \\
\hline 70 & 1800 & 170 & 12,19 & 9,19 & 8,24 & 7,32 & 6,55 & 5,87 & 4,72 & 3,84 & 2,64 \\
\hline 70 & 1850 & 170 & 12,05 & 9,10 & 8,18 & 7,27 & 6,52 & 5,85 & 4,72 & 3,83 & 2,64 \\
\hline 70 & 1900 & 170 & 11,90 & 9,01 & 8,12 & 7,23 & 6,49 & 5,83 & 4,71 & 3,83 & 2,64 \\
\hline 70 & 1950 & 170 & 11,77 & 8,93 & 8,06 & 7,19 & 6,46 & 5,81 & 4,70 & 3,83 & 2,65 \\
\hline 70 & 2000 & 170 & 11,64 & 8,85 & 8,00 & 7,15 & 6,43 & 5,79 & 4,69 & 3,83 & 2,65 \\
\hline 70 & 200 & 175 & 44,85 & 21,60 & 14,81 & 10,34 & 7,93 & 6,36 & 4,43 & 3,41 & 2,38 \\
\hline 70 & 250 & 175 & 38,08 & 19,40 & 13,83 & 10,03 & 7,86 & 6,38 & 4,49 & 3,45 & 2,38 \\
\hline 70 & 300 & 175 & 33,48 & 17,86 & 13,11 & 9,78 & 7,79 & 6,39 & 4,54 & 3,48 & 2,38 \\
\hline 70 & 350 & 175 & 30,13 & 16,70 & 12,56 & 9,57 & 7,72 & 6,39 & 4,57 & 3,51 & 2,39 \\
\hline 70 & 400 & 175 & 27,58 & 15,79 & 12,11 & 9,39 & 7,65 & 6,37 & 4,60 & 3,54 & 2,39 \\
\hline 70 & 450 & 175 & 25,55 & 15,05 & 11,73 & 9,22 & 7,59 & 6,36 & 4,62 & 3,56 & 2,40 \\
\hline 70 & 500 & 175 & 23,91 & 14,43 & 11,40 & 9,08 & 7,53 & 6,34 & 4,64 & 3,58 & 2,41 \\
\hline 70 & 550 & 175 & 22,54 & 13,91 & 11,12 & 8,94 & 7,46 & 6,32 & 4,65 & 3,60 & 2,41 \\
\hline 70 & 600 & 175 & 21,39 & 13,45 & 10,86 & 8,82 & 7,41 & 6,30 & 4,66 & 3,61 & 2,42 \\
\hline 70 & 650 & 175 & 20,39 & 13,05 & 10,64 & 8,70 & 7,35 & 6,27 & 4,67 & 3,63 & 2,43 \\
\hline 70 & 700 & 175 & 19,53 & 12,69 & 10,43 & 8,60 & 7,29 & 6,25 & 4,68 & 3,64 & 2,44 \\
\hline 70 & 750 & 175 & 18,77 & 12,36 & 10,24 & 8,49 & 7,24 & 6,22 & 4,68 & 3,65 & 2,44 \\
\hline 70 & 800 & 175 & 18,10 & 12,07 & 10,07 & 8,40 & 7,19 & 6,20 & 4,68 & 3,66 & 2,45 \\
\hline 70 & 850 & 175 & 17,50 & 11,81 & 9,91 & 8,31 & 7,14 & 6,17 & 4,69 & 3,67 & 2,46 \\
\hline 70 & 900 & 175 & 16,96 & 11,56 & 9,76 & 8,22 & 7,09 & 6,15 & 4,69 & 3,68 & 2,46 \\
\hline 70 & 950 & 175 & 16,47 & 11,34 & 9,62 & 8,14 & 7,04 & 6,12 & 4,68 & 3,68 & 2,47 \\
\hline 70 & 1000 & 175 & 16,02 & 11,13 & 9,49 & 8,06 & 6,99 & 6,10 & 4,68 & 3,69 & 2,48 \\
\hline 70 & 1050 & 175 & 15,61 & 10,93 & 9,36 & 7,99 & 6,95 & 6,07 & 4,68 & 3,70 & 2,48 \\
\hline 70 & 1100 & 175 & 15,24 & 10,75 & 9,25 & 7,92 & 6,90 & 6,05 & 4,68 & 3,70 & 2,49 \\
\hline 70 & 1150 & 175 & 14,89 & 10,58 & 9,13 & 7,85 & 6,86 & 6,02 & 4,67 & 3,70 & 2,50 \\
\hline 70 & 1200 & 175 & 14,57 & 10,42 & 9,03 & 7,78 & 6,82 & 6,00 & 4,67 & 3,71 & 2,50 \\
\hline 70 & 1250 & 175 & 14,28 & 10,27 & 8,93 & 7,72 & 6,78 & 5,97 & 4,66 & 3,71 & 2,51 \\
\hline 70 & 1300 & 175 & 14,00 & 10,13 & 8,84 & 7,66 & 6,74 & 5,95 & 4,66 & 3,71 & 2,51 \\
\hline 70 & 1350 & 175 & 13,74 & 9,99 & 8,74 & 7,60 & 6,70 & 5,92 & 4,65 & 3,72 & 2,52 \\
\hline 70 & 1400 & 175 & 13,50 & 9,86 & 8,66 & 7,55 & 6,67 & 5,90 & 4,65 & 3,72 & 2,52 \\
\hline 70 & 1450 & 175 & 13,28 & 9,74 & 8,57 & 7,49 & 6,63 & 5,88 & 4,64 & 3,72 & 2,53 \\
\hline 70 & 1500 & 175 & 13,06 & 9,62 & 8,49 & 7,44 & 6,59 & 5,86 & 4,64 & 3,72 & 2,53 \\
\hline 70 & 1550 & 175 & 12,86 & 9,51 & 8,42 & 7,39 & 6,56 & 5,83 & 4,63 & 3,72 & 2,54 \\
\hline 70 & 1600 & 175 & 12,67 & 9,40 & 8,34 & 7,34 & 6,53 & 5,81 & 4,62 & 3,73 & 2,54 \\
\hline 70 & 1650 & 175 & 12,49 & 9,30 & 8,27 & 7,29 & 6,49 & 5,79 & 4,62 & 3,73 & 2,55 \\
\hline 70 & 1700 & 175 & 12,32 & 9,20 & 8,20 & 7,24 & 6,46 & 5,77 & 4,61 & 3,73 & 2,55 \\
\hline 70 & 1750 & 175 & 12,16 & 9,11 & 8,14 & 7,20 & 6,43 & 5,75 & 4,60 & 3,73 & 2,55 \\
\hline 70 & 1800 & 175 & 12,00 & 9,02 & 8,07 & 7,15 & 6,40 & 5,73 & 4,60 & 3,73 & 2,56 \\
\hline 70 & 1850 & 175 & 11,85 & 8,93 & 8,01 & 7,11 & 6,37 & 5,71 & 4,59 & 3,73 & 2,56 \\
\hline 70 & 1900 & 175 & 11,71 & 8,85 & 7,95 & 7,07 & 6,34 & 5,69 & 4,58 & 3,73 & 2,56 \\
\hline 70 & 1950 & 175 & 11,58 & 8,77 & 7,89 & 7,03 & 6,31 & 5,67 & 4,57 & 3,72 & 2,57 \\
\hline 70 & 2000 & 175 & 11,45 & 8,69 & 7,84 & 6,99 & 6,28 & 5,65 & 4,57 & 3,72 & 2,57 \\
\hline 70 & 200 & 180 & 44,53 & 21,30 & 14,52 & 10,09 & 7,72 & 6,18 & 4,30 & 3,31 & 2,31 \\
\hline 70 & 250 & 180 & 37,78 & 19,11 & 13,56 & 9,79 & 7,65 & 6,21 & 4,36 & 3,35 & 2,31 \\
\hline 70 & 300 & 180 & 33,19 & 17,58 & 12,85 & 9,55 & 7,59 & 6,21 & 4,41 & 3,38 & 2,32 \\
\hline 70 & 350 & 180 & 29,86 & 16,43 & 12,31 & 9,34 & 7,52 & 6,21 & 4,44 & 3,41 & 2,32 \\
\hline 70 & 400 & 180 & 27,31 & 15,53 & 11,86 & 9,16 & 7,46 & 6,20 & 4,47 & 3,43 & 2,33 \\
\hline 70 & 450 & 180 & 25,30 & 14,80 & 11,49 & 9,01 & 7,39 & 6,19 & 4,49 & 3,45 & 2,33 \\
\hline 70 & 500 & 180 & 23,66 & 14,19 & 11,17 & 8,86 & 7,33 & 6,17 & 4,51 & 3,47 & 2,34 \\
\hline 70 & 550 & 180 & 22,30 & 13,67 & 10,89 & 8,73 & 7,28 & 6,15 & 4,52 & 3,49 & 2,35 \\
\hline 70 & 600 & 180 & 21,15 & 13,22 & 10,64 & 8,61 & 7,22 & 6,13 & 4,53 & 3,51 & 2,35 \\
\hline 70 & 650 & 180 & 20,16 & 12,82 & 10,42 & 8,50 & 7,16 & 6,11 & 4,54 & 3,52 & 2,36 \\
\hline 70 & 700 & 180 & 19,30 & 12,47 & 10,22 & 8,40 & 7,11 & 6,08 & 4,55 & 3,53 & 2,37 \\
\hline 70 & 750 & 180 & 18,54 & 12,15 & 10,03 & 8,30 & 7,06 & 6,06 & 4,55 & 3,54 & 2,37 \\
\hline 70 & 800 & 180 & 17,88 & 11,86 & 9,86 & 8,21 & 7,01 & 6,04 & 4,55 & 3,55 & 2,38 \\
\hline 70 & 850 & 180 & 17,28 & 11,60 & 9,70 & 8,12 & 6,96 & 6,01 & 4,55 & 3,56 & 2,39 \\
\hline 70 & 900 & 180 & 16,74 & 11,36 & 9,56 & 8,04 & 6,91 & 5,99 & 4,56 & 3,57 & 2,39 \\
\hline 70 & 950 & 180 & 16,25 & 11,14 & 9,42 & 7,96 & 6,87 & 5,96 & 4,55 & 3,58 & 2,40 \\
\hline 70 & 1000 & 180 & 15,81 & 10,93 & 9,29 & 7,88 & 6,82 & 5,94 & 4,55 & 3,58 & 2,41 \\
\hline 70 & 1050 & 180 & 15,41 & 10,74 & 9,17 & 7,81 & 6,78 & 5,92 & 4,55 & 3,59 & 2,41 \\
\hline 70 & 1100 & 180 & 15,03 & 10,56 & 9,06 & 7,74 & 6,74 & 5,89 & 4,55 & 3,59 & 2,42 \\
\hline 70 & 1150 & 180 & 14,69 & 10,39 & 8,95 & 7,67 & 6,70 & 5,87 & 4,55 & 3,60 & 2,42 \\
\hline 70 & 1200 & 180 & 14,37 & 10,23 & 8,85 & 7,61 & 6,66 & 5,85 & 4,54 & 3,60 & 2,43 \\
\hline 70 & 1250 & 180 & 14,08 & 10,09 & 8,75 & 7,55 & 6,62 & 5,82 & 4,54 & 3,61 & 2,43 \\
\hline 70 & 1300 & 180 & 13,81 & 9,94 & 8,66 & 7,49 & 6,58 & 5,80 & 4,53 & 3,61 & 2,44 \\
\hline 70 & 1350 & 180 & 13,55 & 9,81 & 8,57 & 7,43 & 6,54 & 5,78 & 4,53 & 3,61 & 2,44 \\
\hline 70 & 1400 & 180 & 13,31 & 9,68 & 8,48 & 7,38 & 6,51 & 5,76 & 4,52 & 3,61 & 2,45 \\
\hline 70 & 1450 & 180 & 13,08 & 9,56 & 8,40 & 7,33 & 6,47 & 5,73 & 4,52 & 3,62 & 2,45 \\
\hline 70 & 1500 & 180 & 12,87 & 9,45 & 8,32 & 7,27 & 6,44 & 5,71 & 4,51 & 3,62 & 2,46 \\
\hline 70 & 1550 & 180 & 12,67 & 9,34 & 8,25 & 7,22 & 6,41 & 5,69 & 4,51 & 3,62 & 2,46 \\
\hline 70 & 1600 & 180 & 12,48 & 9,23 & 8,18 & 7,18 & 6,37 & 5,67 & 4,50 & 3,62 & 2,47 \\
\hline 70 & 1650 & 180 & 12,30 & 9,13 & 8,11 & 7,13 & 6,34 & 5,65 & 4,49 & 3,62 & 2,47 \\
\hline
\end{tabular}




\begin{tabular}{|c|c|c|c|c|c|c|c|c|c|c|c|}
\hline \multirow[b]{2}{*}{$\mathrm{H}(\mathrm{cm})$} & \multirow[b]{2}{*}{ Mceq (MPa) } & & & & & & ões (x. & & & & \\
\hline & & Msub (MPa) & D0 & D25 & D40 & D60 & D80 & D100 & D140 & D180 & D260 \\
\hline 70 & 1700 & 180 & 12,13 & 9,04 & 8,04 & 7,08 & 6,31 & 5,63 & 4,49 & 3,62 & 2,47 \\
\hline 70 & 1750 & 180 & 11,97 & 8,94 & 7,97 & 7,04 & 6,28 & 5,61 & 4,48 & 3,62 & 2,48 \\
\hline 70 & 1800 & 180 & 11,82 & 8,86 & 7,91 & 7,00 & 6,25 & 5,59 & 4,48 & 3,62 & 2,48 \\
\hline 70 & 1850 & 180 & 11,67 & 8,77 & 7,85 & 6,95 & 6,22 & 5,57 & 4,47 & 3,62 & 2,49 \\
\hline 70 & 1900 & 180 & 11,53 & 8,69 & 7,79 & 6,91 & 6,19 & 5,55 & 4,46 & 3,62 & 2,49 \\
\hline 70 & 1950 & 180 & 11,40 & 8,61 & 7,73 & 6,87 & 6,16 & 5,53 & 4,46 & 3,62 & 2,49 \\
\hline 70 & 2000 & 180 & 11,27 & 8,53 & 7,68 & 6,84 & 6,14 & 5,51 & 4,45 & 3,62 & 2,50 \\
\hline 70 & 200 & 185 & 44,24 & 21,02 & 14,26 & 9,86 & 7,51 & 6,01 & 4,17 & 3,21 & 2,25 \\
\hline 70 & 250 & 185 & 37,49 & 18,84 & 13,30 & 9,56 & 7,45 & 6,04 & 4,23 & 3,25 & 2,25 \\
\hline 70 & 300 & 185 & 32,92 & 17,32 & 12,60 & 9,32 & 7,39 & 6,04 & 4,28 & 3,28 & 2,25 \\
\hline 70 & 350 & 185 & 29,59 & 16,18 & 12,07 & 9,12 & 7,33 & 6,04 & 4,32 & 3,31 & 2,26 \\
\hline 70 & 400 & 185 & 27,06 & 15,29 & 11,63 & 8,95 & 7,27 & 6,04 & 4,34 & 3,34 & 2,26 \\
\hline 70 & 450 & 185 & 25,05 & 14,56 & 11,26 & 8,80 & 7,21 & 6,02 & 4,36 & 3,36 & 2,27 \\
\hline 70 & 500 & 185 & 23,42 & 13,96 & 10,95 & 8,66 & 7,15 & 6,01 & 4,38 & 3,38 & 2,27 \\
\hline 70 & 550 & 185 & 22,07 & 13,44 & 10,67 & 8,53 & 7,10 & 5,99 & 4,40 & 3,39 & 2,28 \\
\hline 70 & 600 & 185 & 20,92 & 13,00 & 10,43 & 8,42 & 7,04 & 5,97 & 4,41 & 3,41 & 2,29 \\
\hline 70 & 650 & 185 & 19,94 & 12,60 & 10,21 & 8,31 & 6,99 & 5,95 & 4,41 & 3,42 & 2,29 \\
\hline 70 & 700 & 185 & 19,08 & 12,25 & 10,01 & 8,21 & 6,94 & 5,93 & 4,42 & 3,43 & 2,30 \\
\hline 70 & 750 & 185 & 18,33 & 11,94 & 9,83 & 8,11 & 6,89 & 5,91 & 4,43 & 3,44 & 2,31 \\
\hline 70 & 800 & 185 & 17,66 & 11,66 & 9,66 & 8,02 & 6,84 & 5,88 & 4,43 & 3,45 & 2,31 \\
\hline 70 & 850 & 185 & 17,07 & 11,40 & 9,51 & 7,94 & 6,79 & 5,86 & 4,43 & 3,46 & 2,32 \\
\hline 70 & 900 & 185 & 16,54 & 11,16 & 9,37 & 7,86 & 6,75 & 5,84 & 4,43 & 3,47 & 2,33 \\
\hline 70 & 950 & 185 & 16,05 & 10,94 & 9,23 & 7,78 & 6,70 & 5,81 & 4,43 & 3,48 & 2,33 \\
\hline 70 & 1000 & 185 & 15,61 & 10,74 & 9,11 & 7,71 & 6,66 & 5,79 & 4,43 & 3,48 & 2,34 \\
\hline 70 & 1050 & 185 & 15,21 & 10,55 & 8,99 & 7,64 & 6,62 & 5,77 & 4,43 & 3,49 & 2,34 \\
\hline 70 & 1100 & 185 & 14,84 & 10,38 & 8,88 & 7,57 & 6,58 & 5,75 & 4,43 & 3,49 & 2,35 \\
\hline 70 & 1150 & 185 & 14,50 & 10,21 & 8,77 & 7,51 & 6,54 & 5,72 & 4,42 & 3,50 & 2,35 \\
\hline 70 & 1200 & 185 & 14,18 & 10,06 & 8,67 & 7,44 & 6,50 & 5,70 & 4,42 & 3,50 & 2,36 \\
\hline 70 & 1250 & 185 & 13,89 & 9,91 & 8,58 & 7,39 & 6,47 & 5,68 & 4,42 & 3,51 & 2,36 \\
\hline 70 & 1300 & 185 & 13,62 & 9,77 & 8,49 & 7,33 & 6,43 & 5,66 & 4,41 & 3,51 & 2,37 \\
\hline 70 & 1350 & 185 & 13,36 & 9,64 & 8,40 & 7,27 & 6,39 & 5,64 & 4,41 & 3,51 & 2,37 \\
\hline 70 & 1400 & 185 & 13,12 & 9,52 & 8,32 & 7,22 & 6,36 & 5,62 & 4,41 & 3,52 & 2,38 \\
\hline 70 & 1450 & 185 & 12,90 & 9,40 & 8,24 & 7,17 & 6,33 & 5,60 & 4,40 & 3,52 & 2,38 \\
\hline 70 & 1500 & 185 & 12,69 & 9,28 & 8,16 & 7.12 & 6.29 & 5,57 & 4,40 & 3,52 & 2,39 \\
\hline 70 & 1550 & 185 & 12,49 & 9,18 & 8,09 & 7,07 & 6,26 & 5,55 & 4,39 & 3,52 & 2,39 \\
\hline 70 & 1600 & 185 & 12,30 & 9,07 & 8,02 & 7,02 & 6,23 & 5,53 & 4,38 & 3,52 & 2,40 \\
\hline 70 & 1650 & 185 & 12,13 & 8,97 & 7,95 & 6,98 & 6,20 & 5,51 & 4,38 & 3,52 & 2,40 \\
\hline 70 & 1700 & 185 & 11,96 & 8,88 & 7,88 & 6,93 & 6,17 & 5,49 & 4,37 & 3,52 & 2,40 \\
\hline 70 & 1750 & 185 & 11,80 & 8,79 & 7,82 & 6,89 & 6,14 & 5,48 & 4,37 & 3,52 & 2,41 \\
\hline 70 & 1800 & 185 & 11,64 & 8,70 & 7,76 & 6,85 & 6,11 & 5,46 & 4,36 & 3,52 & 2,41 \\
\hline 70 & 1850 & 185 & 11,50 & 8,62 & 7,70 & 6,81 & 6,08 & 5,44 & 4,35 & 3,52 & 2,42 \\
\hline 70 & 1900 & 185 & 11,36 & 8,54 & 7,64 & 6,77 & 6,05 & 5,42 & 4,35 & 3,52 & 2,42 \\
\hline 70 & 1950 & 185 & 11,23 & 8,46 & 7,58 & 6,73 & 6,03 & 5,40 & 4,34 & 3,52 & 2,42 \\
\hline 70 & 2000 & 185 & 11,10 & 8,38 & 7,53 & 6,69 & 6,00 & 5,38 & 4,34 & 3,52 & 2,42 \\
\hline 70 & 200 & 190 & 43,95 & 20,74 & 14,00 & 9,63 & 7,32 & 5,85 & 4,05 & 3,12 & 2,19 \\
\hline 70 & 250 & 190 & 37,22 & 18,58 & 13,05 & 9,34 & 7,26 & 5,87 & 4,12 & 3,16 & 2,19 \\
\hline 70 & 300 & 190 & 32,66 & 17,07 & 12,37 & 9,11 & 7,21 & 5,89 & 4,16 & 3,19 & 2,19 \\
\hline 70 & 350 & 190 & 29,34 & 15,94 & 11,84 & 8,92 & 7,15 & 5,89 & 4,20 & 3,22 & 2,20 \\
\hline 70 & 400 & 190 & 26,82 & 15,05 & 11,41 & 8,75 & 7,09 & 5,88 & 4,22 & 3,24 & 2,20 \\
\hline 70 & 450 & 190 & 24,82 & 14,33 & 11,05 & 8,60 & 7,03 & 5,87 & 4,25 & 3,26 & 2,21 \\
\hline 70 & 500 & 190 & 23,19 & 13,74 & 10,74 & 8,47 & 6,98 & 5,85 & 4,26 & 3,28 & 2,21 \\
\hline 70 & 550 & 190 & 21,84 & 13,23 & 10,47 & 8,34 & 6,92 & 5,84 & 4,28 & 3,30 & 2,22 \\
\hline 70 & 600 & 190 & 20,70 & 12,78 & 10,23 & 8,23 & 6,87 & 5,82 & 4,29 & 3,31 & 2,22 \\
\hline 70 & 650 & 190 & 19,72 & 12,40 & 10,01 & 8,13 & 6,82 & 5,80 & 4,30 & 3,33 & 2,23 \\
\hline 70 & 700 & 190 & 18.87 & 12.05 & 9.82 & 8.03 & 6.77 & 5,78 & 4.30 & 3,34 & 2,24 \\
\hline 70 & 750 & 190 & 18,13 & 11,74 & 9,64 & 7,93 & 6,73 & 5,76 & 4,31 & 3,35 & 2,24 \\
\hline 70 & 800 & 190 & 17,46 & 11,46 & 9,48 & 7,85 & 6,68 & 5,74 & 4,31 & 3,36 & 2,25 \\
\hline 70 & 850 & 190 & 16,87 & 11,21 & 9,33 & 7,77 & 6,63 & 5,72 & 4,31 & 3,37 & 2,26 \\
\hline 70 & 900 & 190 & 16,34 & 10,97 & 9,19 & 7,69 & 6,59 & 5,69 & 4,32 & 3,37 & 2,26 \\
\hline 70 & 950 & 190 & 15,86 & 10,76 & 9,05 & 7,61 & 6,55 & 5,67 & 4,32 & 3,38 & 2,27 \\
\hline 70 & 1000 & 190 & 15,42 & 10,56 & 8,93 & 7,54 & 6,51 & 5,65 & 4,32 & 3,39 & 2,27 \\
\hline 70 & 1050 & 190 & 15,02 & 10,37 & 8,82 & 7,47 & 6,47 & 5,63 & 4,31 & 3,39 & 2,28 \\
\hline 70 & 1100 & 190 & 14,65 & 10,20 & 8,71 & 7,41 & 6,43 & 5,61 & 4,31 & 3,40 & 2,28 \\
\hline 70 & 1150 & 190 & 14,31 & 10,04 & 8,60 & 7,35 & 6,39 & 5,59 & 4,31 & 3,40 & 2,29 \\
\hline 70 & 1200 & 190 & 14,00 & 9,89 & 8,50 & 7,29 & 6,35 & 5,57 & 4,31 & 3,41 & 2,29 \\
\hline 70 & 1250 & 190 & 13,71 & 9,74 & 8,41 & 7,23 & 6,32 & 5,54 & 4,30 & 3,41 & 2,30 \\
\hline 70 & 1300 & 190 & 13,44 & 9,61 & 8,32 & 7,17 & 6,28 & 5,52 & 4,30 & 3,42 & 2,30 \\
\hline 70 & 1350 & 190 & 13,19 & 9,48 & 8,24 & 7,12 & 6,25 & 5,50 & 4,30 & 3,42 & 2,31 \\
\hline 70 & 1400 & 190 & 12,95 & 9,35 & 8,16 & 7,07 & 6,22 & 5,48 & 4,29 & 3,42 & 2,31 \\
\hline 70 & 1450 & 190 & 12,73 & 9,24 & 8,08 & 7,02 & 6,18 & 5,46 & 4,29 & 3,42 & 2,32 \\
\hline 70 & 1500 & 190 & 12,52 & 9,13 & 8,00 & 6,97 & 6,15 & 5,44 & 4,28 & 3,43 & 2,32 \\
\hline 70 & 1550 & 190 & 12,32 & 9,02 & 7,93 & 6,92 & 6,12 & 5,42 & 4,28 & 3,43 & 2,33 \\
\hline 70 & 1600 & 190 & 12,13 & 8,92 & 7,86 & 6,88 & 6,09 & 5,41 & 4,27 & 3,43 & 2,33 \\
\hline 70 & 1650 & 190 & 11,96 & 8,82 & 7,80 & 6,83 & 6,06 & 5,39 & 4,27 & 3,43 & 2,33 \\
\hline 70 & 1700 & 190 & 11,79 & 8,73 & 7,73 & 6,79 & 6,03 & 5,37 & 4,26 & 3,43 & 2,34 \\
\hline 70 & 1750 & 190 & 11,63 & 8,64 & 7,67 & 6,75 & 6,00 & 5,35 & 4,26 & 3,43 & 2,34 \\
\hline 70 & 1800 & 190 & 11,48 & 8.55 & 7.61 & 6.71 & 5.98 & 5.33 & 4.25 & 3,43 & 2.34 \\
\hline 70 & 1850 & 190 & 11,33 & 8,47 & 7,55 & 6,67 & 5,95 & 5,31 & 4,25 & 3,43 & 2,35 \\
\hline 70 & 1900 & 190 & 11,20 & 8,39 & 7,49 & 6,63 & 5,92 & 5,29 & 4,24 & 3,43 & 2,35 \\
\hline 70 & 1950 & 190 & 11,07 & 8,31 & 7,44 & 6,59 & 5,90 & 5,28 & 4,23 & 3,43 & 2,35 \\
\hline 70 & 2000 & 190 & 10,94 & 8,24 & 7,39 & 6,55 & 5,87 & 5,26 & 4,23 & 3,43 & 2,36 \\
\hline
\end{tabular}




\begin{tabular}{|c|c|c|c|c|c|c|c|c|c|c|c|}
\hline \multirow[b]{2}{*}{$\mathrm{H}(\mathrm{cm})$} & \multirow[b]{2}{*}{ Mceq (MPa) } & & & & & $\mathrm{De}$ & ões (x & & & & \\
\hline & & Msub (MPa) & D0 & D25 & D40 & D60 & D80 & D100 & D140 & D180 & D260 \\
\hline 70 & 200 & 195 & 4 & 20,48 & 13,76 & 9,42 & 7,14 & 5,69 & 3,94 & 3,04 & 2,14 \\
\hline 70 & 250 & 195 & 36,96 & 18,33 & 12,82 & 9,14 & 7,09 & 5,72 & 4,00 & 3,08 & 2,13 \\
\hline 70 & 300 & 195 & 32,41 & 16,83 & 12,14 & 8,91 & 7,03 & 5,73 & 4,05 & 3,11 & 2,14 \\
\hline 70 & 350 & 195 & 29,10 & 15,71 & 11,62 & 8,72 & 6,97 & 5,73 & 4,08 & 3,13 & 2,14 \\
\hline 70 & 400 & 195 & 26,58 & 14,83 & 11,19 & 8,56 & 6,92 & 5,73 & 4,11 & 3,16 & 2,14 \\
\hline 70 & 450 & 195 & 24,59 & 14,12 & 10,84 & 8,41 & 6,87 & 5,72 & 4,13 & 3,18 & 2,15 \\
\hline 70 & 500 & 195 & 22,98 & 13,52 & 10,53 & 8,28 & 6,81 & 5,71 & 4,15 & 3,19 & 2,15 \\
\hline 70 & 550 & 195 & 21,63 & 13,02 & 10,27 & 8,16 & 6,76 & 5,69 & 4,16 & 3,21 & 2,16 \\
\hline 70 & 600 & 195 & 20,50 & 12,58 & 10,03 & 8,05 & 6,71 & 5,67 & 4,17 & 3,22 & 2,17 \\
\hline 70 & 650 & 195 & 19,52 & 12,20 & 9,82 & 7,95 & 6,66 & 5,66 & 4,18 & 3,24 & 2,17 \\
\hline 70 & 700 & 195 & 18,67 & 11,86 & 9,63 & 7,85 & 6,62 & 5,64 & 4,19 & 3,25 & 2,18 \\
\hline 70 & 750 & 195 & 17,93 & 11,55 & 9,46 & 7,77 & 6,57 & 5,62 & 4,20 & 3,26 & 2,18 \\
\hline 70 & 800 & 195 & 17,27 & 11,28 & 9,30 & 7,68 & 6,53 & 5,60 & 4,20 & 3,27 & 2,19 \\
\hline 70 & 850 & 195 & 16,68 & 11,03 & 9,15 & 7,60 & 6,48 & 5,58 & 4,20 & 3,28 & 2,20 \\
\hline 70 & 900 & 195 & 16,15 & 10,80 & 9,01 & 7,52 & 6,44 & 5,56 & 4,20 & 3,28 & 2,20 \\
\hline 70 & 950 & 195 & 15,68 & 10,58 & 8,88 & 7,45 & 6,40 & 5,54 & 4,20 & 3,29 & 2,21 \\
\hline 70 & 1000 & 195 & 15,24 & 10,39 & 8,76 & 7,38 & 6,36 & 5,52 & 4,20 & 3,30 & 2,21 \\
\hline 70 & 1050 & 195 & 14,84 & 10,20 & 8,65 & 7,32 & 6,32 & 5,50 & 4,20 & 3,30 & 2,22 \\
\hline 70 & 1100 & 195 & 14,48 & 10,03 & 8,54 & 7,25 & 6,29 & 5,48 & 4,20 & 3,31 & 2,22 \\
\hline 70 & 1150 & 195 & 14,14 & 9,87 & 8,44 & 7,19 & 6,25 & 5,46 & 4,20 & 3,31 & 2,23 \\
\hline 70 & 1200 & 195 & 13,83 & 9,72 & 8,34 & 7,14 & 6,21 & 5,44 & 4,20 & 3,32 & 2,23 \\
\hline 70 & 1250 & 195 & 13,54 & 9,58 & 8,25 & 7,08 & 6,18 & 5,42 & 4,20 & 3,32 & 2,24 \\
\hline 70 & 1300 & 195 & 13,27 & 9,45 & 8,17 & 7,03 & 6,15 & 5,40 & 4,19 & 3,33 & 2,24 \\
\hline 70 & 1350 & 195 & 13,02 & 9,32 & 8,08 & 6,97 & 6,11 & 5,38 & 4,19 & 3,33 & 2,25 \\
\hline 70 & 1400 & 195 & 12,78 & 9,20 & 8,00 & 6,92 & 6,08 & 5,36 & 4,19 & 3,33 & 2,25 \\
\hline 70 & 1450 & 195 & 12,56 & 9,08 & 7,93 & 6,87 & 6,05 & 5,34 & 4,18 & 3,33 & 2,26 \\
\hline 70 & 1500 & 195 & 12,35 & 8,98 & 7,85 & 6,83 & 6,02 & 5,32 & 4,18 & 3,34 & 2,26 \\
\hline 70 & 1550 & 195 & 12,16 & 8,87 & 7,78 & 6,78 & 5,99 & 5,30 & 4,17 & 3,34 & 2,26 \\
\hline 70 & 1600 & 195 & 11,97 & 8,77 & 7,72 & 6,74 & 5,96 & 5,28 & 4,17 & 3,34 & 2,27 \\
\hline 70 & 1650 & 195 & 11,79 & 8,68 & 7,65 & 6,69 & 5,93 & 5,26 & 4,16 & 3,34 & 2,27 \\
\hline 70 & 1700 & 195 & 11,63 & 8,58 & 7,59 & 6,65 & 5,90 & 5,25 & 4,16 & 3,34 & 2,27 \\
\hline 70 & 1750 & 195 & 11,47 & 8,50 & 7,53 & 6,61 & 5,87 & 5,23 & 4,15 & 3,34 & 2,28 \\
\hline 70 & 1800 & 195 & 11,32 & 8,41 & 7,47 & 6,57 & 5,85 & 5,21 & 4,15 & 3,34 & 2,28 \\
\hline 70 & 1850 & 195 & 11,18 & 8,33 & 7.41 & 6.53 & 5,82 & 5,19 & 4.14 & 3,34 & 2,28 \\
\hline 70 & 1900 & 195 & 11,04 & 8,25 & 7,36 & 6,49 & 5,79 & 5,18 & 4,14 & 3,34 & 2,29 \\
\hline 70 & 1950 & 195 & 10,91 & 8,17 & 7,30 & 6,46 & 5,77 & 5,16 & 4,13 & 3,34 & 2,29 \\
\hline 70 & 2000 & 195 & 10,78 & 8,10 & 7,25 & 6,42 & 5,74 & 5,14 & 4,13 & 3,34 & 2,29 \\
\hline 70 & 200 & 200 & 43,42 & 20,23 & 13,53 & 9,22 & 6,97 & 5,55 & 3,84 & 2,96 & 2,08 \\
\hline 70 & 250 & 200 & 36,72 & 18,09 & 12,60 & 8,94 & 6,92 & 5,58 & 3,90 & 3,00 & 2,08 \\
\hline 70 & 300 & 200 & 32,17 & 16,60 & 11,93 & 8,72 & 6,86 & 5,59 & 3,94 & 3,03 & 2,08 \\
\hline 70 & 350 & 200 & 28,88 & 15,48 & 11,41 & 8,53 & 6,81 & 5,59 & 3,98 & 3,05 & 2,09 \\
\hline 70 & 400 & 200 & 26,36 & 14,61 & 10,99 & 8,37 & 6,76 & 5,59 & 4,00 & 3,07 & 2,09 \\
\hline 70 & 450 & 200 & 24,38 & 13,91 & 10,64 & 8,23 & 6,71 & 5,58 & 4,02 & 3,09 & 2,09 \\
\hline 70 & 500 & 200 & 22,77 & 13,32 & 10,34 & 8,11 & 6,65 & 5,57 & 4,04 & 3,11 & 2,10 \\
\hline 70 & 550 & 200 & 21,43 & 12,82 & 10,08 & 7,99 & 6,61 & 5,55 & 4,06 & 3,13 & 2,10 \\
\hline 70 & 600 & 200 & 20,30 & 12,39 & 9,85 & 7,88 & 6,56 & 5,54 & 4,07 & 3,14 & 2,11 \\
\hline 70 & 650 & 200 & 19,33 & 12,01 & 9,64 & 7,78 & 6,51 & 5,52 & 4,08 & 3,15 & 2,12 \\
\hline 70 & 700 & 200 & 18,48 & 11,67 & 9,45 & 7,69 & 6,47 & 5,50 & 4,08 & 3,16 & 2,12 \\
\hline 70 & 750 & 200 & 17,74 & 11,37 & 9,28 & 7,60 & 6,42 & 5,49 & 4,09 & 3,17 & 2,13 \\
\hline 70 & 800 & 200 & 17,09 & 11,10 & 9,13 & 7,52 & 6,38 & 5,47 & 4,09 & 3,18 & 2,13 \\
\hline 70 & 850 & 200 & 16,50 & 10,85 & 8,98 & 7,44 & 6,34 & 5,45 & 4,10 & 3,19 & 2,14 \\
\hline 70 & 900 & 200 & 15,98 & 10,63 & 8,85 & 7,37 & 6,30 & 5,43 & 4,10 & 3,20 & 2,14 \\
\hline 70 & 950 & 200 & 15,50 & 10,42 & 8,72 & 7,30 & 6,26 & 5,41 & 4,10 & 3,21 & 2,15 \\
\hline 70 & 1000 & 200 & 15,07 & 10,22 & 8,60 & 7,23 & 6,22 & 5,39 & 4,10 & 3,21 & 2,15 \\
\hline 70 & 1050 & 200 & 14,67 & 10,04 & 8,49 & 7,17 & 6,18 & 5,37 & 4,10 & 3,22 & 2,16 \\
\hline 70 & 1100 & 200 & 14,31 & 9,87 & 8,39 & 7,11 & 6,15 & 5,35 & 4,10 & 3,22 & 2,16 \\
\hline 70 & 1150 & 200 & 13,97 & 9,71 & 8,29 & 7,05 & 6,11 & 5,33 & 4,10 & 3,23 & 2,17 \\
\hline 70 & 1200 & 200 & 13,66 & 9,57 & 8,19 & 6,99 & 6,08 & 5,31 & 4,10 & 3,23 & 2,17 \\
\hline 70 & 1250 & 200 & 13,37 & 9,43 & 8,10 & 6,94 & 6,05 & 5,29 & 4,09 & 3,24 & 2,18 \\
\hline 70 & 1300 & 200 & 13,11 & 9,29 & 8,02 & 6,88 & 6,01 & 5,27 & 4,09 & 3,24 & 2,18 \\
\hline 70 & 1350 & 200 & 12,86 & 9,17 & 7,94 & 6,83 & 5,98 & 5,25 & 4,09 & 3,24 & 2,19 \\
\hline 70 & 1400 & 200 & 12,62 & 9,05 & 7,86 & 6,78 & 5,95 & 5,24 & 4,08 & 3,25 & 2,19 \\
\hline 70 & 1450 & 200 & 12,40 & 8,94 & 7,78 & 6,74 & 5,92 & 5,22 & 4,08 & 3,25 & 2,20 \\
\hline 70 & 1500 & 200 & 12,19 & 8,83 & 7,71 & 6,69 & 5,89 & 5,20 & 4,08 & 3,25 & 2,20 \\
\hline 70 & 1550 & 200 & 12,00 & 8,73 & 7,64 & 6,65 & 5,86 & 5,18 & 4,07 & 3,25 & 2,20 \\
\hline 70 & 1600 & 200 & 11,81 & 8,63 & 7,58 & 6,60 & 5,83 & 5,16 & 4,07 & 3,25 & 2,21 \\
\hline 70 & 1650 & 200 & 11,64 & 8,53 & 7,51 & 6,56 & 5,80 & 5,15 & 4,06 & 3,26 & 2,21 \\
\hline 70 & 1700 & 200 & 11,47 & 8,44 & 7,45 & 6,52 & 5,78 & 5,13 & 4,06 & 3,26 & 2,21 \\
\hline 70 & 1750 & 200 & 11,32 & 8,36 & 7,39 & 6,48 & 5,75 & 5,11 & 4,05 & 3,26 & 2,22 \\
\hline 70 & 1800 & 200 & 11,17 & 8,27 & 7,33 & 6,44 & 5,72 & 5,10 & 4,05 & 3,26 & 2,22 \\
\hline 70 & 1850 & 200 & 11,03 & 8,19 & 7,28 & 6,40 & 5,70 & 5,08 & 4,04 & 3,26 & 2,22 \\
\hline 70 & 1900 & 200 & 10,89 & 8,12 & 7,22 & 6,37 & 5,67 & 5,06 & 4,04 & 3,26 & 2,23 \\
\hline 70 & 1950 & 200 & 10,76 & 8,04 & 7,17 & 6,33 & 5,65 & 5,05 & 4,03 & 3,26 & 2,23 \\
\hline 70 & 2000 & 200 & 10,64 & 7,97 & 7,12 & 6,30 & 5,63 & 5,03 & 4,03 & 3,26 & 2,23 \\
\hline 75 & 200 & 20 & 103,06 & 75,87 & 67,83 & 60,25 & 54,16 & 48,77 & 39,58 & 32,40 & 22,52 \\
\hline 75 & 250 & 20 & 93,23 & 69,92 & 63,50 & 57,17 & 51,92 & 47,18 & 38,90 & 32,24 & 22,73 \\
\hline 75 & 300 & 20 & 86,29 & 65,44 & 60,12 & 54,69 & 50,04 & 45,79 & 38,24 & 32,01 & 22,87 \\
\hline 75 & 350 & 20 & 81,04 & 61,91 & 57,35 & 52,61 & 48,43 & 44,57 & 37,60 & 31,76 & 22,96 \\
\hline 75 & 400 & 20 & 76,89 & 59,04 & 55,03 & 50,84 & 47,03 & 43,48 & 37,01 & 31,48 & 23,01 \\
\hline 75 & 450 & 20 & 73,48 & 56,65 & 53,03 & 49,29 & 45,80 & 42,50 & 36,44 & 31,20 & 23,03 \\
\hline 75 & 500 & 20 & 70,61 & 54,61 & 51,29 & 47,93 & 44,69 & 41,62 & 35,91 & 30,93 & 23,03 \\
\hline
\end{tabular}




\begin{tabular}{|c|c|c|c|c|c|c|c|c|c|c|c|}
\hline \multirow[b]{2}{*}{$\mathrm{H}(\mathrm{cm})$} & \multirow[b]{2}{*}{ Mceq (MPa) } & & & & & De & ões (x1 & m) & & & \\
\hline & & Msub (MPa) & D0 & D25 & D40 & D60 & D80 & D100 & D140 & D180 & D260 \\
\hline 75 & 550 & 20 & 68,14 & 52,86 & 49,75 & 46,71 & 43,69 & 40,81 & 35,41 & 30,65 & 23,01 \\
\hline 75 & 600 & 20 & 65,97 & 51,33 & 48,38 & 45,61 & 42,79 & 40,06 & 34,94 & 30,38 & 22,98 \\
\hline 75 & 650 & 20 & 64,05 & 49,97 & 47,14 & 44,61 & 41,96 & 39,37 & 34,50 & 30,12 & 22,93 \\
\hline 75 & 700 & 20 & 62,31 & 48,77 & 46,02 & 43,69 & 41,19 & 38,74 & 34,08 & 29,87 & 22,88 \\
\hline 75 & 750 & 20 & 60,74 & 47,69 & 45,00 & 42,84 & 40,48 & 38,14 & 33,68 & 29,62 & 22,83 \\
\hline 75 & 800 & 20 & 59,30 & 46,72 & 44,06 & 42,06 & 39,83 & 37,59 & 33,30 & 29,38 & 22,77 \\
\hline 75 & 850 & 20 & 57,97 & 45,83 & 43,19 & 41,33 & 39,21 & 37,06 & 32,94 & 29,15 & 22,71 \\
\hline 75 & 900 & 20 & 56,73 & 45,02 & 42,39 & 40,65 & 38,63 & 36,57 & 32,60 & 28,92 & 22,64 \\
\hline 75 & 950 & 20 & 55,58 & 44,27 & 41,64 & 40,01 & 38,09 & 36,11 & 32,27 & 28,71 & 22,57 \\
\hline 75 & 1000 & 20 & 54,50 & 43,59 & 40,94 & 39,41 & 37,58 & 35,67 & 31,96 & 28,50 & 22,50 \\
\hline 75 & 1050 & 20 & 53,48 & 42,95 & 40,29 & 38,85 & 37,10 & 35,25 & 31,66 & 28,29 & 22,43 \\
\hline 75 & 1100 & 20 & 52,52 & 42,36 & 39,68 & 38,31 & 36,64 & 34,86 & 31,37 & 28,09 & 22,36 \\
\hline 75 & 1150 & 20 & 51,60 & 41,81 & 39,11 & 37,80 & 36,21 & 34,48 & 31,09 & 27,90 & 22,29 \\
\hline 75 & 1200 & 20 & 50,74 & 41,29 & 38,57 & 37,32 & 35,79 & 34,12 & 30,83 & 27,71 & 22,21 \\
\hline 75 & 1250 & 20 & 49,91 & 40,81 & 38,06 & 36,86 & 35,40 & 33,78 & 30,57 & 27,53 & 22,14 \\
\hline 75 & 1300 & 20 & 49,12 & 40,35 & 37,58 & 36,42 & 35,02 & 33,45 & 30,32 & 27,36 & 22,07 \\
\hline 75 & 1350 & 20 & 48,36 & 39,92 & 37,12 & 36,00 & 34,66 & 33,13 & 30,08 & 27,19 & 22,00 \\
\hline 75 & 1400 & 20 & 47,64 & 39,52 & 36,69 & 35,60 & 34,31 & 32,83 & 29,85 & 27,02 & 21,93 \\
\hline 75 & 1450 & 20 & 46,94 & 39,13 & 36,27 & 35,21 & 33,98 & 32,53 & 29,63 & 26,86 & 21,85 \\
\hline 75 & 1500 & 20 & 46,27 & 38,77 & 35,88 & 34,85 & 33,66 & 32,25 & 29,42 & 26,70 & 21,78 \\
\hline 75 & 1550 & 20 & 45,62 & 38,42 & 35,51 & 34,49 & 33,35 & 31,98 & 29,21 & 26,55 & 21,71 \\
\hline 75 & 1600 & 20 & 45,00 & 38,09 & 35,15 & 34,15 & 33,05 & 31,72 & 29,01 & 26,40 & 21,64 \\
\hline 75 & 1650 & 20 & 44,39 & 37,77 & 34,81 & 33,82 & 32,77 & 31,47 & 28,81 & 26,25 & 21,57 \\
\hline 75 & 1700 & 20 & 43,81 & 37,47 & 34,48 & 33,51 & 32,49 & 31,22 & 28,62 & 26,11 & 21,50 \\
\hline 75 & 1750 & 20 & 43,25 & 37,18 & 34,16 & 33,20 & 32,22 & 30,99 & 28,44 & 25,97 & 21,44 \\
\hline 75 & 1800 & 20 & 42,70 & 36,90 & 33,86 & 32,91 & 31,96 & 30,76 & 28,26 & 25,83 & 21,37 \\
\hline 75 & 1850 & 20 & 42,17 & 36,63 & 33,57 & 32,62 & 31,71 & 30,54 & 28,08 & 25,70 & 21,30 \\
\hline 75 & 1900 & 20 & 41,66 & 36,37 & 33,30 & 32,35 & 31,47 & 30,32 & 27,91 & 25,57 & 21,24 \\
\hline 75 & 1950 & 20 & 41,16 & 36,13 & 33,03 & 32,08 & 31,23 & 30,11 & 27,75 & 25,44 & 21,17 \\
\hline 75 & 2000 & 20 & 40,67 & 35,89 & 32,77 & 31,82 & 31,00 & 29,91 & 27,59 & 25,32 & 21,11 \\
\hline 75 & 200 & 25 & 91,74 & 65,92 & 57,90 & 50,67 & 45,06 & 40,18 & 32,08 & 25,95 & 17,82 \\
\hline 75 & 250 & 25 & 82,45 & 60,70 & 54,26 & 48,20 & 43,33 & 39,02 & 31,66 & 25,92 & 18,02 \\
\hline 75 & 300 & 25 & 75,93 & 56,77 & 51,42 & 46,19 & 41,87 & 37,98 & 31,23 & 25,82 & 18,16 \\
\hline 75 & 350 & 25 & 71,05 & 53,67 & 49,11 & 44,50 & 40,60 & 37,06 & 30,80 & 25,69 & 18,26 \\
\hline 75 & 400 & 25 & 67,22 & 51,15 & 47,16 & 43,05 & 39,50 & 36,23 & 30,38 & 25,53 & 18,33 \\
\hline 75 & 450 & 25 & 64,11 & 49,03 & 45,48 & 41,79 & 38,51 & 35,47 & 29,98 & 25,36 & 18,38 \\
\hline 75 & 500 & 25 & 61,51 & 47,23 & 44,02 & 40,67 & 37,63 & 34,78 & 29,60 & 25,19 & 18,41 \\
\hline 75 & 550 & 25 & 59,29 & 45,67 & 42,73 & 39,67 & 36,83 & 34,15 & 29,24 & 25,01 & 18,42 \\
\hline 75 & 600 & 25 & 57,36 & 44,31 & 41,57 & 38,76 & 36,10 & 33,57 & 28,90 & 24,83 & 18,42 \\
\hline 75 & 650 & 25 & 55,66 & 43,10 & 40,52 & 37,94 & 35,42 & 33,03 & 28,57 & 24,65 & 18,42 \\
\hline 75 & 700 & 25 & 54,15 & 42,03 & 39,57 & 37,18 & 34,80 & 32,52 & 28,25 & 24,48 & 18,40 \\
\hline 75 & 750 & 25 & 52,78 & 41,06 & 38,70 & 36,49 & 34,23 & 32,05 & 27,95 & 24,31 & 18,38 \\
\hline 75 & 800 & 25 & 51,53 & 40,19 & 37,90 & 35,84 & 33,69 & 31,61 & 27,67 & 24,14 & 18,35 \\
\hline 75 & 850 & 25 & 50,39 & 39,39 & 37,17 & 35,24 & 33,19 & 31,19 & 27,39 & 23,97 & 18,32 \\
\hline 75 & 900 & 25 & 49,33 & 38,66 & 36,48 & 34,68 & 32,72 & 30,80 & 27,13 & 23,81 & 18,29 \\
\hline 75 & 950 & 25 & 48,35 & 37,99 & 35,84 & 34,15 & 32,28 & 30,42 & 26,88 & 23,66 & 18,25 \\
\hline 75 & 1000 & 25 & 47,44 & 37,37 & 35,24 & 33,65 & 31,86 & 30,07 & 26,64 & 23,50 & 18,22 \\
\hline 75 & 1050 & 25 & 46,58 & 36,80 & 34,69 & 33,18 & 31,46 & 29,73 & 26,41 & 23,36 & 18,18 \\
\hline 75 & 1100 & 25 & 45,77 & 36,27 & 34,16 & 32,74 & 31,09 & 29,41 & 26,19 & 23,21 & 18,13 \\
\hline 75 & 1150 & 25 & 45,01 & 35,77 & 33,67 & 32,31 & 30,73 & 29,11 & 25,97 & 23,07 & 18,09 \\
\hline 75 & 1200 & 25 & 44,29 & 35,31 & 33,20 & 31,91 & 30,39 & 28,82 & 25,76 & 22,93 & 18,05 \\
\hline 75 & 1250 & 25 & 43,60 & 34,87 & 32,76 & 31,53 & 30,07 & 28,54 & 25,57 & 22,80 & 18,00 \\
\hline 75 & 1300 & 25 & 42,94 & 34,46 & 32,34 & 31,17 & 29,75 & 28,27 & 25,37 & 22,67 & 17,96 \\
\hline 75 & 1350 & 25 & 42,32 & 34,07 & 31,94 & 30,82 & 29,46 & 28,01 & 25,19 & 22,54 & 17,91 \\
\hline 75 & 1400 & 25 & 41,72 & 33,71 & 31,56 & 30,48 & 29,17 & 27,76 & 25,00 & 22,41 & 17,86 \\
\hline 75 & 1450 & 25 & 41,14 & 33,36 & 31,20 & 30,16 & 28,90 & 27,53 & 24,83 & 22,29 & 17,82 \\
\hline 75 & 1500 & 25 & 40,59 & 33,03 & 30,86 & 29,85 & 28,63 & 27,30 & 24,66 & 22,17 & 17,77 \\
\hline 75 & 1550 & 25 & 40,06 & 32,72 & 30,53 & 29,56 & 28,38 & 27,07 & 24,50 & 22,06 & 17,73 \\
\hline 75 & 1600 & 25 & 39,54 & 32,43 & 30,21 & 29,27 & 28,13 & 26,86 & 24,34 & 21,94 & 17,68 \\
\hline 75 & 1650 & 25 & 39,05 & 32,14 & 29,91 & 29,00 & 27,90 & 26,65 & 24,18 & 21,83 & 17,63 \\
\hline 75 & 1700 & 25 & 38,57 & 31,87 & 29,63 & 28,73 & 27,67 & 26,45 & 24,03 & 21,72 & 17,59 \\
\hline 75 & 1750 & 25 & 38,11 & 31,61 & 29,35 & 28,48 & 27,45 & 26,26 & 23,88 & 21,62 & 17,54 \\
\hline 75 & 1800 & 25 & 37,66 & 31,37 & 29,08 & 28,23 & 27,23 & 26,07 & 23,74 & 21,51 & 17,49 \\
\hline 75 & 1850 & 25 & 37,23 & 31,13 & 28,83 & 27,99 & 27,03 & 25,89 & 23,60 & 21,41 & 17,45 \\
\hline 75 & 1900 & 25 & 36,80 & 30,90 & 28,58 & 27,76 & 26,83 & 25,71 & 23,47 & 21,31 & 17,40 \\
\hline 75 & 1950 & 25 & 36,40 & 30,68 & 28,35 & 27,54 & 26,63 & 25,54 & 23,33 & 21,21 & 17,36 \\
\hline 75 & 2000 & 25 & 36,00 & 30,47 & 28,12 & 27,32 & 26,44 & 25,38 & 23,21 & 21,12 & 17,31 \\
\hline 75 & 200 & 30 & 83,86 & 58,80 & 50,84 & 43,91 & 38,67 & 34,21 & 26,94 & 21,60 & 14,72 \\
\hline 75 & 250 & 30 & 74,94 & 54,11 & 47,68 & 41,85 & 37,29 & 33,32 & 26,68 & 21,63 & 14,88 \\
\hline 75 & 300 & 30 & 68,71 & 50,58 & 45,22 & 40,17 & 36,11 & 32,51 & 26,39 & 21,60 & 15,01 \\
\hline 75 & 350 & 30 & 64,07 & 47,80 & 43,21 & 38,75 & 35,08 & 31,79 & 26,08 & 21,54 & 15,11 \\
\hline 75 & 400 & 30 & 60,45 & 45,53 & 41,53 & 37,53 & 34,17 & 31,13 & 25,78 & 21,45 & 15,19 \\
\hline 75 & 450 & 30 & 57,53 & 43,63 & 40,08 & 36,46 & 33,36 & 30,53 & 25,49 & 21,34 & 15,25 \\
\hline 75 & 500 & 30 & 55,10 & 42,00 & 38,81 & 35,51 & 32,63 & 29,97 & 25,21 & 21,23 & 15,29 \\
\hline 75 & 550 & 30 & 53,04 & 40,59 & 37,69 & 34,66 & 31,96 & 29,46 & 24,93 & 21,11 & 15,32 \\
\hline 75 & 600 & 30 & 51,26 & 39,36 & 36,68 & 33,89 & 31,36 & 28,99 & 24,67 & 20,99 & 15,34 \\
\hline 75 & 650 & 30 & 49,70 & 38,27 & 35,78 & 33,19 & 30,80 & 28,54 & 24,42 & 20,86 & 15,35 \\
\hline 75 & 700 & 30 & 48,32 & 37,29 & 34,95 & 32,55 & 30,28 & 28,13 & 24,17 & 20,74 & 15,35 \\
\hline 75 & 750 & 30 & 47,07 & 36,41 & 34,19 & 31,95 & 29,79 & 27,74 & 23,94 & 20,62 & 15,35 \\
\hline 75 & 800 & 30 & 45,95 & 35,61 & 33,50 & 31,40 & 29,34 & 27,38 & 23,72 & 20,49 & 15,34 \\
\hline 75 & 850 & 30 & 44,92 & 34,88 & 32,85 & 30,89 & 28,92 & 27,03 & 23,50 & 20,37 & 15,33 \\
\hline
\end{tabular}




\begin{tabular}{|c|c|c|c|c|c|c|c|c|c|c|c|}
\hline \multirow[b]{2}{*}{$\mathrm{H}(\mathrm{cm})$} & \multirow[b]{2}{*}{ Mceq (MPa) } & & & & & De & ões (x1 & m) & & & \\
\hline & & Msub (MPa) & D0 & D25 & D40 & D60 & D80 & D100 & D140 & D180 & D260 \\
\hline 75 & 900 & 30 & 43,98 & 34,22 & 32,25 & 30,41 & 28,52 & 26,71 & 23,29 & 20,26 & 15,32 \\
\hline 75 & 950 & 30 & 43,11 & 33,60 & 31,69 & 29,95 & 28,15 & 26,40 & 23,10 & 20,14 & 15,30 \\
\hline 75 & 1000 & 30 & 42,30 & 33,04 & 31,17 & 29,53 & 27,80 & 26,10 & 22,90 & 20,02 & 15,28 \\
\hline 75 & 1050 & 30 & 41,54 & 32,51 & 30,68 & 29,13 & 27,46 & 25,82 & 22,72 & 19,91 & 15,26 \\
\hline 75 & 1100 & 30 & 40,83 & 32,03 & 30,22 & 28,75 & 27,14 & 25,56 & 22,54 & 19,80 & 15,23 \\
\hline 75 & 1150 & 30 & 40,16 & 31,57 & 29,78 & 28,38 & 26,84 & 25,30 & 22,37 & 19,69 & 15,21 \\
\hline 75 & 1200 & 30 & 39,53 & 31,14 & 29,37 & 28,04 & 26,55 & 25,06 & 22,20 & 19,59 & 15,18 \\
\hline 75 & 1250 & 30 & 38,93 & 30,74 & 28,98 & 27,71 & 26,27 & 24,82 & 22,04 & 19,48 & 15,15 \\
\hline 75 & 1300 & 30 & 38,36 & 30,37 & 28,61 & 27,40 & 26,01 & 24,60 & 21,88 & 19,38 & 15,12 \\
\hline 75 & 1350 & 30 & 37,82 & 30,01 & 28,26 & 27,10 & 25,76 & 24,38 & 21,73 & 19,28 & 15,09 \\
\hline 75 & 1400 & 30 & 37,30 & 29,68 & 27,92 & 26,81 & 25,51 & 24,17 & 21,58 & 19,19 & 15,06 \\
\hline 75 & 1450 & 30 & 36,81 & 29,36 & 27,60 & 26,54 & 25,28 & 23,97 & 21,44 & 19,09 & 15,03 \\
\hline 75 & 1500 & 30 & 36,33 & 29,06 & 27,30 & 26,28 & 25,05 & 23,78 & 21,30 & 19,00 & 15,00 \\
\hline 75 & 1550 & 30 & 35,87 & 28,77 & 27,00 & 26,02 & 24,84 & 23,59 & 21,17 & 18,91 & 14,97 \\
\hline 75 & 1600 & 30 & 35,43 & 28,50 & 26,72 & 25,78 & 24,63 & 23,41 & 21,04 & 18,82 & 14,94 \\
\hline 75 & 1650 & 30 & 35,01 & 28,24 & 26,46 & 25,54 & 24,43 & 23,24 & 20,91 & 18,73 & 14,91 \\
\hline 75 & 1700 & 30 & 34,60 & 27,99 & 26,20 & 25,31 & 24,23 & 23,07 & 20,79 & 18,64 & 14,87 \\
\hline 75 & 1750 & 30 & 34,21 & 27,75 & 25,95 & 25,09 & 24,04 & 22,91 & 20,67 & 18,56 & 14,84 \\
\hline 75 & 1800 & 30 & 33,82 & 27,53 & 25,71 & 24,88 & 23,86 & 22,75 & 20,55 & 18,48 & 14,81 \\
\hline 75 & 1850 & 30 & 33,45 & 27,31 & 25,49 & 24,67 & 23,68 & 22,59 & 20,44 & 18,40 & 14,78 \\
\hline 75 & 1900 & 30 & 33,09 & 27,10 & 25,26 & 24,47 & 23,51 & 22,44 & 20,32 & 18,32 & 14,75 \\
\hline 75 & 1950 & 30 & 32,75 & 26,90 & 25,05 & 24,28 & 23,35 & 22,30 & 20,22 & 18,24 & 14,71 \\
\hline 75 & 2000 & 30 & 32,41 & 26,71 & 24,85 & 24,09 & 23,18 & 22,16 & 20,11 & 18,16 & 14,68 \\
\hline 75 & 200 & 35 & 78,01 & 53,42 & 45,53 & 38,86 & 33,92 & 29,79 & 23,20 & 18,46 & 12,51 \\
\hline 75 & 250 & 35 & 69,37 & 49,12 & 42,72 & 37,09 & 32,79 & 29,09 & 23,03 & 18,53 & 12,66 \\
\hline 75 & 300 & 35 & 63,36 & 45,89 & 40,54 & 35,65 & 31,81 & 28,45 & 22,83 & 18,54 & 12,78 \\
\hline 75 & 350 & 35 & 58,89 & 43,36 & 38,76 & 34,43 & 30,95 & 27,87 & 22,62 & 18,52 & 12,87 \\
\hline 75 & 400 & 35 & 55,42 & 41,28 & 37,27 & 33,37 & 30,19 & 27,33 & 22,40 & 18,47 & 12,94 \\
\hline 75 & 450 & 35 & 52,63 & 39,54 & 35,98 & 32,45 & 29,50 & 26,84 & 22,17 & 18,41 & 13,00 \\
\hline 75 & 500 & 35 & 50,32 & 38,06 & 34,86 & 31,63 & 28,88 & 26,38 & 21,96 & 18,33 & 13,05 \\
\hline 75 & 550 & 35 & 48,37 & 36,77 & 33,87 & 30,89 & 28,32 & 25,96 & 21,74 & 18,25 & 13,09 \\
\hline 75 & 600 & 35 & 46,69 & 35,64 & 32,98 & 30,22 & 27,80 & 25,56 & 21,54 & 18,17 & 13,11 \\
\hline 75 & 650 & 35 & 45,23 & 34,64 & 32,18 & 29,61 & 27,32 & 25,19 & 21,34 & 18,08 & 13,13 \\
\hline 75 & 700 & 35 & 43,94 & 33,74 & 31,44 & 29,05 & 26,88 & 24,85 & 21,15 & 17,99 & 13,15 \\
\hline 75 & 750 & 35 & 42,78 & 32,93 & 30,77 & 28,53 & 26,46 & 24,52 & 20,96 & 17,90 & 13,16 \\
\hline 75 & 800 & 35 & 41,74 & 32,19 & 30,15 & 28,05 & 26,07 & 24,21 & 20,78 & 17,81 & 13,16 \\
\hline 75 & 850 & 35 & 40,79 & 31,52 & 29,58 & 27,60 & 25,71 & 23,92 & 20,61 & 17,72 & 13,16 \\
\hline 75 & 900 & 35 & 39,93 & 30,91 & 29,05 & 27,18 & 25,37 & 23,64 & 20,44 & 17,63 & 13,16 \\
\hline 75 & 950 & 35 & 39,13 & 30,34 & 28,55 & 26,79 & 25,05 & 23,38 & 20,28 & 17,54 & 13,15 \\
\hline 75 & 1000 & 35 & 38,39 & 29,82 & 28,08 & 26,41 & 24,74 & 23,13 & 20,12 & 17,45 & 13,14 \\
\hline 75 & 1050 & 35 & 37,70 & 29,33 & 27,65 & 26,06 & 24,45 & 22,89 & 19,97 & 17,36 & 13,13 \\
\hline 75 & 1100 & 35 & 37,06 & 28,88 & 27,23 & 25,73 & 24,17 & 22,66 & 19,82 & 17,28 & 13,12 \\
\hline 75 & 1150 & 35 & 36,45 & 28,45 & 26,84 & 25,41 & 23,91 & 22,45 & 19,68 & 17,19 & 13,10 \\
\hline 75 & 1200 & 35 & 35,88 & 28,06 & 26,47 & 25,11 & 23,66 & 22,24 & 19,54 & 17,11 & 13,09 \\
\hline 75 & 1250 & 35 & 35,34 & 27,69 & 26,12 & 24,82 & 23,42 & 22,04 & 19,41 & 17,03 & 13,07 \\
\hline 75 & 1300 & 35 & 34,83 & 27,34 & 25,79 & 24,55 & 23,19 & 21,84 & 19,28 & 16,95 & 13,05 \\
\hline 75 & 1350 & 35 & 34,35 & 27,01 & 25,48 & 24,29 & 22,97 & 21,66 & 19,15 & 16,87 & 13,03 \\
\hline 75 & 1400 & 35 & 33,89 & 26,69 & 25,17 & 24,04 & 22,76 & 21,48 & 19,03 & 16,79 & 13,01 \\
\hline 75 & 1450 & 35 & 33,44 & 26,40 & 24,89 & 23,79 & 22,55 & 21,31 & 18,91 & 16,71 & 12,99 \\
\hline 75 & 1500 & 35 & 33,02 & 26,12 & 24,61 & 23,56 & 22,36 & 21,14 & 18,79 & 16,64 & 12,97 \\
\hline 75 & 1550 & 35 & 32,62 & 25,85 & 24,35 & 23,34 & 22,17 & 20,98 & 18,68 & 16,56 & 12,95 \\
\hline 75 & 1600 & 35 & 32,23 & 25,60 & 24,10 & 23,12 & 21,99 & 20,82 & 18,57 & 16,49 & 12,93 \\
\hline 75 & 1650 & 35 & 31,85 & 25,36 & 23,85 & 22,92 & 21,81 & 20,67 & 18,47 & 16,42 & 12,90 \\
\hline 75 & 1700 & 35 & 31,49 & 25,13 & 23,62 & 22,72 & 21,64 & 20,52 & 18,36 & 16,35 & 12,88 \\
\hline 75 & 1750 & 35 & 31,14 & 24,91 & 23,40 & 22,52 & 21,48 & 20,38 & 18,26 & 16,28 & 12,86 \\
\hline 75 & 1800 & 35 & 30,80 & 24,70 & 23,18 & 22,33 & 21,32 & 20,25 & 18,16 & 16,22 & 12,84 \\
\hline 75 & 1850 & 35 & 30,48 & 24,49 & 22,97 & 22,15 & 21,16 & 20,11 & 18,07 & 16,15 & 12,81 \\
\hline 75 & 1900 & 35 & 30,16 & 24,30 & 22,77 & 21,98 & 21,01 & 19,98 & 17,97 & 16,09 & 12,79 \\
\hline 75 & 1950 & 35 & 29,86 & 24,11 & 22,58 & 21,81 & 20,87 & 19,86 & 17,88 & 16,02 & 12,77 \\
\hline 75 & 2000 & 35 & 29,56 & 23,93 & 22,39 & 21,64 & 20,72 & 19,73 & 17,79 & 15,96 & 12,74 \\
\hline 75 & 200 & 40 & 73,47 & 49,19 & 41,37 & 34,92 & 30,25 & 26,39 & 20,35 & 16,10 & 10,88 \\
\hline 75 & 250 & 40 & 65,06 & 45,18 & 38,83 & 33,38 & 29,29 & 25,83 & 20,25 & 16,18 & 11,00 \\
\hline 75 & 300 & 40 & 59,21 & 42,20 & 36,86 & 32,12 & 28,46 & 25,31 & 20,11 & 16,22 & 11,10 \\
\hline 75 & 350 & 40 & 54,89 & 39,85 & 35,26 & 31,05 & 27,73 & 24,83 & 19,96 & 16,22 & 11,19 \\
\hline 75 & 400 & 40 & 51,53 & 37,94 & 33,92 & 30,12 & 27,08 & 24,38 & 19,79 & 16,20 & 11,26 \\
\hline 75 & 450 & 40 & 48,84 & 36,33 & 32,76 & 29,31 & 26,49 & 23,97 & 19,62 & 16,17 & 11,32 \\
\hline 75 & 500 & 40 & 46,62 & 34,96 & 31,75 & 28,59 & 25,96 & 23,59 & 19,45 & 16,12 & 11,37 \\
\hline 75 & 550 & 40 & 44,75 & 33,77 & 30,86 & 27,94 & 25,47 & 23,23 & 19,28 & 16,07 & 11,41 \\
\hline 75 & 600 & 40 & 43,14 & 32,72 & 30,06 & 27,34 & 25,02 & 22,89 & 19,12 & 16,01 & 11,44 \\
\hline 75 & 650 & 40 & 41,75 & 31,79 & 29,33 & 26,80 & 24,60 & 22,58 & 18,96 & 15,94 & 11,46 \\
\hline 75 & 700 & 40 & 40,52 & 30,96 & 28,67 & 26,31 & 24,22 & 22,28 & 18,80 & 15,88 & 11,48 \\
\hline 75 & 750 & 40 & 39,43 & 30,20 & 28,07 & 25,85 & 23,86 & 22,00 & 18,65 & 15,81 & 11,49 \\
\hline 75 & 800 & 40 & 38,44 & 29,52 & 27,51 & 25,42 & 23,52 & 21,74 & 18,50 & 15,74 & 11,50 \\
\hline 75 & 850 & 40 & 37,55 & 28,90 & 27,00 & 25,02 & 23,20 & 21,49 & 18,36 & 15,67 & 11,51 \\
\hline 75 & 900 & 40 & 36,74 & 28,32 & 26,52 & 24,65 & 22,90 & 21,25 & 18,22 & 15,60 & 11,51 \\
\hline 75 & 950 & 40 & 36,00 & 27,79 & 26,07 & 24,30 & 22,61 & 21,02 & 18,09 & 15,53 & 11,51 \\
\hline 75 & 1000 & 40 & 35,31 & 27,31 & 25,65 & 23,96 & 22,35 & 20,81 & 17,96 & 15,46 & 11,51 \\
\hline 75 & 1050 & 40 & 34,67 & 26,85 & 25,25 & 23,65 & 22,09 & 20,60 & 17,83 & 15,39 & 11,51 \\
\hline 75 & 1100 & 40 & 34,07 & 26,43 & 24,88 & 23,35 & 21,85 & 20,40 & 17,71 & 15,33 & 11,50 \\
\hline 75 & 1150 & 40 & 33,51 & 26,03 & 24,52 & 23,07 & 21,61 & 20,21 & 17,59 & 15,26 & 11,50 \\
\hline 75 & 1200 & 40 & 32,99 & 25,66 & 24,19 & 22,80 & 21,39 & 20,03 & 17,47 & 15,19 & 11,49 \\
\hline
\end{tabular}




\begin{tabular}{|c|c|c|c|c|c|c|c|c|c|c|c|}
\hline \multirow[b]{2}{*}{$\mathrm{H}(\mathrm{cm})$} & \multirow[b]{2}{*}{ Mceq (MPa) } & & & & & De & ões (x1 & m) & & & \\
\hline & & Msub (MPa) & D0 & D25 & D40 & D60 & D80 & D100 & D140 & D180 & D260 \\
\hline 75 & 1250 & 40 & 32,49 & 25,31 & 23,87 & 22,55 & 21,18 & 19,86 & 17,36 & 15,13 & 11,48 \\
\hline 75 & 1300 & 40 & 32,02 & 24,99 & 23,57 & 22,30 & 20,98 & 19,69 & 17,25 & 15,06 & 11,47 \\
\hline 75 & 1350 & 40 & 31,58 & 24,68 & 23,28 & 22,07 & 20,78 & 19,52 & 17,14 & 15,00 & 11,46 \\
\hline 75 & 1400 & 40 & 31,16 & 24,39 & 23,01 & 21,85 & 20,60 & 19,37 & 17,04 & 14,93 & 11,44 \\
\hline 75 & 1450 & 40 & 30,76 & 24,11 & 22,75 & 21,63 & 20,42 & 19,22 & 16,94 & 14,87 & 11,43 \\
\hline 75 & 1500 & 40 & 30,37 & 23,85 & 22,50 & 21,42 & 20,24 & 19,07 & 16,84 & 14,81 & 11,41 \\
\hline 75 & 1550 & 40 & 30,00 & 23,60 & 22,26 & 21,22 & 20,07 & 18,93 & 16,74 & 14,75 & 11,40 \\
\hline 75 & 1600 & 40 & 29,65 & 23,36 & 22,03 & 21,03 & 19,91 & 18,79 & 16,65 & 14,69 & 11,38 \\
\hline 75 & 1650 & 40 & 29,31 & 23,13 & 21,81 & 20,85 & 19,76 & 18,66 & 16,56 & 14,63 & 11,37 \\
\hline 75 & 1700 & 40 & 28,98 & 22,91 & 21,59 & 20,67 & 19,61 & 18,53 & 16,47 & 14,57 & 11,35 \\
\hline 75 & 1750 & 40 & 28,67 & 22,71 & 21,39 & 20,49 & 19,46 & 18,41 & 16,38 & 14,52 & 11,34 \\
\hline 75 & 1800 & 40 & 28,37 & 22,51 & 21,19 & 20,33 & 19,32 & 18,29 & 16,30 & 14,46 & 11,32 \\
\hline 75 & 1850 & 40 & 28,07 & 22,32 & 21,00 & 20,16 & 19,18 & 18,17 & 16,22 & 14,41 & 11,30 \\
\hline 75 & 1900 & 40 & 27,79 & 22,14 & 20,82 & 20,01 & 19,05 & 18,05 & 16,13 & 14,35 & 11,29 \\
\hline 75 & 1950 & 40 & 27,52 & 21,96 & 20,64 & 19,85 & 18,92 & 17,94 & 16,06 & 14,30 & 11,27 \\
\hline 75 & 2000 & 40 & 27,25 & 21,79 & 20,47 & 19,71 & 18,79 & 17,84 & 15,98 & 14,25 & 11,25 \\
\hline 75 & 200 & 45 & 69,84 & 45,76 & 38,02 & 31,76 & 27,31 & 23,69 & 18,11 & 14,25 & 9,61 \\
\hline 75 & 250 & 45 & 61,61 & 42,00 & 35,69 & 30,40 & 26,49 & 23,23 & 18,05 & 14,35 & 9,72 \\
\hline 75 & 300 & 45 & 55,90 & 39,20 & 33,89 & 29,27 & 25,78 & 22,80 & 17,96 & 14,40 & 9,81 \\
\hline 75 & 350 & 45 & 51,69 & 37,01 & 32,43 & 28,33 & 25,15 & 22,40 & 17,85 & 14,42 & 9,89 \\
\hline 75 & 400 & 45 & 48,42 & 35,22 & 31,20 & 27,50 & 24,58 & 22,03 & 17,72 & 14,42 & 9,95 \\
\hline 75 & 450 & 45 & 45,81 & 33,72 & 30,15 & 26,78 & 24,07 & 21,68 & 17,59 & 14,40 & 10,01 \\
\hline 75 & 500 & 45 & 43,65 & 32,44 & 29,23 & 26,13 & 23,60 & 21,35 & 17,46 & 14,37 & 10,06 \\
\hline 75 & 550 & 45 & 41,85 & 31,33 & 28,41 & 25,55 & 23,18 & 21,04 & 17,32 & 14,34 & 10,10 \\
\hline 75 & 600 & 45 & 40,30 & 30,35 & 27,68 & 25,02 & 22,78 & 20,75 & 17,19 & 14,30 & 10,13 \\
\hline 75 & 650 & 45 & 38,96 & 29,48 & 27,02 & 24,53 & 22,41 & 20,48 & 17,06 & 14,25 & 10,15 \\
\hline 75 & 700 & 45 & 37,78 & 28,70 & 26,42 & 24,09 & 22,07 & 20,22 & 16,93 & 14,20 & 10,18 \\
\hline 75 & 750 & 45 & 36,73 & 28,00 & 25,87 & 23,67 & 21,75 & 19,98 & 16,80 & 14,15 & 10,19 \\
\hline 75 & 800 & 45 & 35,79 & 27,36 & 25,37 & 23,29 & 21,45 & 19,75 & 16,68 & 14,10 & 10,21 \\
\hline 75 & 850 & 45 & 34,94 & 26,78 & 24,89 & 22,93 & 21,17 & 19,53 & 16,56 & 14,05 & 10,22 \\
\hline 75 & 900 & 45 & 34,17 & 26,24 & 24,46 & 22,59 & 20,90 & 19,32 & 16,45 & 13,99 & 10,23 \\
\hline 75 & 950 & 45 & 33,47 & 25,74 & 24,05 & 22,28 & 20,65 & 19,13 & 16,33 & 13,94 & 10,23 \\
\hline 75 & 1000 & 45 & 32,81 & 25,29 & 23,66 & 21,98 & 20,41 & 18,94 & 16,22 & 13,88 & 10,23 \\
\hline 75 & 1050 & 45 & 32,21 & 24,86 & 23,30 & 21,70 & 20,18 & 18,75 & 16,12 & 13,83 & 10,24 \\
\hline 75 & 1100 & 45 & 31,65 & 24,46 & 22,96 & 21,43 & 19,97 & 18,58 & 16,01 & 13,77 & 10,23 \\
\hline 75 & 1150 & 45 & 31,13 & 24,09 & 22,64 & 21,18 & 19,76 & 18,41 & 15,91 & 13,72 & 10,23 \\
\hline 75 & 1200 & 45 & 30,63 & 23,74 & 22,33 & 20,93 & 19,56 & 18,25 & 15,81 & 13,66 & 10,23 \\
\hline 75 & 1250 & 45 & 30,17 & 23,41 & 22,04 & 20,70 & 19,37 & 18,10 & 15,72 & 13,61 & 10,22 \\
\hline 75 & 1300 & 45 & 29,73 & 23,10 & 21,77 & 20,48 & 19,19 & 17,95 & 15,62 & 13,56 & 10,22 \\
\hline 75 & 1350 & 45 & 29,32 & 22,81 & 21,50 & 20,27 & 19,02 & 17,81 & 15,53 & 13,50 & 10,21 \\
\hline 75 & 1400 & 45 & 28,93 & 22,54 & 21,25 & 20,07 & 18,85 & 17,67 & 15,44 & 13,45 & 10,20 \\
\hline 75 & 1450 & 45 & 28,56 & 22,27 & 21,01 & 19,87 & 18,69 & 17,53 & 15,35 & 13,40 & 10,20 \\
\hline 75 & 1500 & 45 & 28,20 & 22,03 & 20,78 & 19,69 & 18,53 & 17,40 & 15,27 & 13,35 & 10,19 \\
\hline 75 & 1550 & 45 & 27,86 & 21,79 & 20,56 & 19,51 & 18,38 & 17,28 & 15,19 & 13,30 & 10,18 \\
\hline 75 & 1600 & 45 & 27,53 & 21,56 & 20,35 & 19,33 & 18,24 & 17,16 & 15,11 & 13,25 & 10,17 \\
\hline 75 & 1650 & 45 & 27,22 & 21,35 & 20,15 & 19,16 & 18,10 & 17,04 & 15,03 & 13,20 & 10,15 \\
\hline 75 & 1700 & 45 & 26,92 & 21,15 & 19,95 & 19,00 & 17,96 & 16,92 & 14,95 & 13,15 & 10,14 \\
\hline 75 & 1750 & 45 & 26,63 & 20,95 & 19,76 & 18,85 & 17,83 & 16,81 & 14,87 & 13,10 & 10,13 \\
\hline 75 & 1800 & 45 & 26,36 & 20,76 & 19,58 & 18,69 & 17,70 & 16,71 & 14,80 & 13,06 & 10,12 \\
\hline 75 & 1850 & 45 & 26,09 & 20,58 & 19,41 & 18,55 & 17,58 & 16,60 & 14,73 & 13,01 & 10,11 \\
\hline 75 & 1900 & 45 & 25,83 & 20,41 & 19,24 & 18,41 & 17,46 & 16,50 & 14,66 & 12,97 & 10,09 \\
\hline 75 & 1950 & 45 & 25,58 & 20,24 & 19,07 & 18,27 & 17,34 & 16,40 & 14,59 & 12,92 & 10,08 \\
\hline 75 & 2000 & 45 & 25,33 & 20,09 & 18,92 & 18,13 & 17,23 & 16,30 & 14,52 & 12,88 & 10,07 \\
\hline 75 & 200 & 50 & 66,85 & 42,92 & 35,25 & 29,16 & 24,90 & 21,49 & 16,30 & 12,78 & 8,61 \\
\hline 75 & 250 & 50 & 58,78 & 39,35 & 33,10 & 27,94 & 24,20 & 21,11 & 16,28 & 12,88 & 8,70 \\
\hline 75 & 300 & 50 & 53,19 & 36,71 & 31,43 & 26,93 & 23,58 & 20,75 & 16,22 & 12,94 & 8,78 \\
\hline 75 & 350 & 50 & 49,06 & 34,64 & 30,08 & 26,08 & 23,02 & 20,41 & 16,14 & 12,97 & 8,85 \\
\hline 75 & 400 & 50 & 45,87 & 32,96 & 28,95 & 25,34 & 22,53 & 20,09 & 16,04 & 12,98 & 8,91 \\
\hline 75 & 450 & 50 & 43,32 & 31,55 & 27,98 & 24,68 & 22,08 & 19,79 & 15,94 & 12,97 & 8,96 \\
\hline 75 & 500 & 50 & 41,23 & 30,35 & 27,13 & 24,10 & 21,66 & 19,51 & 15,83 & 12,96 & 9,01 \\
\hline 75 & 550 & 50 & 39,47 & 29,30 & 26,38 & 23,57 & 21,28 & 19,24 & 15,72 & 12,94 & 9,05 \\
\hline 75 & 600 & 50 & 37,97 & 28,39 & 25,71 & 23,09 & 20,93 & 18,99 & 15,61 & 12,91 & 9,08 \\
\hline 75 & 650 & 50 & 36,67 & 27,57 & 25,11 & 22,65 & 20,61 & 18,75 & 15,51 & 12,88 & 9,11 \\
\hline 75 & 700 & 50 & 35,53 & 26,84 & 24,55 & 22,25 & 20,30 & 18,53 & 15,40 & 12,84 & 9,13 \\
\hline 75 & 750 & 50 & 34,52 & 26,18 & 24,05 & 21,88 & 20,02 & 18,32 & 15,29 & 12,81 & 9,15 \\
\hline 75 & 800 & 50 & 33,61 & 25,57 & 23,58 & 21,53 & 19,75 & 18,11 & 15,19 & 12,77 & 9,17 \\
\hline 75 & 850 & 50 & 32,80 & 25,02 & 23,15 & 21,20 & 19,49 & 17,92 & 15,09 & 12,72 & 9,18 \\
\hline 75 & 900 & 50 & 32,06 & 24,52 & 22,74 & 20,89 & 19,26 & 17,74 & 14,99 & 12,68 & 9,19 \\
\hline 75 & 950 & 50 & 31,38 & 24,05 & 22,36 & 20,61 & 19,03 & 17,56 & 14,90 & 12,64 & 9,20 \\
\hline 75 & 1000 & 50 & 30,76 & 23,62 & 22,01 & 20,34 & 18,81 & 17,39 & 14,80 & 12,59 & 9,20 \\
\hline 75 & 1050 & 50 & 30,18 & 23,21 & 21,68 & 20,08 & 18,61 & 17,23 & 14,71 & 12,55 & 9,21 \\
\hline 75 & 1100 & 50 & 29,65 & 22,84 & 21,36 & 19,83 & 18,41 & 17,08 & 14,62 & 12,50 & 9,21 \\
\hline 75 & 1150 & 50 & 29,15 & 22,49 & 21,07 & 19,60 & 18,23 & 16,93 & 14,53 & 12,46 & 9,21 \\
\hline 75 & 1200 & 50 & 28,68 & 22,15 & 20,78 & 19,38 & 18,05 & 16,78 & 14,45 & 12,41 & 9,21 \\
\hline 75 & 1250 & 50 & 28,24 & 21,84 & 20,52 & 19,17 & 17,88 & 16,65 & 14,36 & 12,37 & 9,21 \\
\hline 75 & 1300 & 50 & 27,83 & 21,55 & 20,26 & 18,97 & 17,71 & 16,51 & 14,28 & 12,33 & 9,21 \\
\hline 75 & 1350 & 50 & 27,44 & 21,28 & 20,02 & 18,78 & 17,55 & 16,38 & 14,20 & 12,28 & 9,20 \\
\hline 75 & 1400 & 50 & 27,07 & 21,01 & 19,79 & 18,59 & 17,40 & 16,26 & 14,13 & 12,24 & 9,20 \\
\hline 75 & 1450 & 50 & 26,72 & 20,77 & 19,56 & 18,41 & 17,26 & 16,14 & 14,05 & 12,20 & 9,20 \\
\hline 75 & 1500 & 50 & 26,39 & 20,53 & 19,35 & 18,24 & 17,11 & 16,02 & 13,98 & 12,15 & 9,19 \\
\hline 75 & 1550 & 50 & 26,07 & 20,31 & 19,15 & 18,08 & 16,98 & 15,91 & 13,90 & 12,11 & 9,18 \\
\hline
\end{tabular}




\begin{tabular}{|c|c|c|c|c|c|c|c|c|c|c|c|}
\hline \multirow[b]{2}{*}{$\mathrm{H}(\mathrm{cm})$} & \multirow[b]{2}{*}{ Mceq (MPa) } & & & & & $\mathrm{De}$ & ões (x1 & & & & \\
\hline & & Msub (MPa) & D0 & D25 & D40 & D60 & D80 & D100 & D140 & D180 & D260 \\
\hline 75 & 1600 & 50 & 25,77 & 20,09 & 18,95 & 17,92 & 16,85 & 15,80 & 13,83 & 12,07 & 9,18 \\
\hline 75 & 1650 & 50 & 25,47 & 19,89 & 18,76 & 17,77 & 16,72 & 15,70 & 13,76 & 12,03 & 9,17 \\
\hline 75 & 1700 & 50 & 25,19 & 19,69 & 18,58 & 17,62 & 16,60 & 15,59 & 13,70 & 11,99 & 9,16 \\
\hline 75 & 1750 & 50 & 24,93 & 19,51 & 18,41 & 17,48 & 16,48 & 15,49 & 13,63 & 11,95 & 9,15 \\
\hline 75 & 1800 & 50 & 24,67 & 19,33 & 18,24 & 17,34 & 16,36 & 15,40 & 13,57 & 11,91 & 9,15 \\
\hline 75 & 1850 & 50 & 24,42 & 19,16 & 18,08 & 17,20 & 16,25 & 15,30 & 13,50 & 11,87 & 9,14 \\
\hline 75 & 1900 & 50 & 24,18 & 19,00 & 17,92 & 17,07 & 16,14 & 15,21 & 13,44 & 11,83 & 9,13 \\
\hline 75 & 1950 & 50 & 23,94 & 18,84 & 17,77 & 16,95 & 16,03 & 15,12 & 13,38 & 11,79 & 9,12 \\
\hline 75 & 2000 & 50 & 23,72 & 18,69 & 17,62 & 16,82 & 15,93 & 15,03 & 13,32 & 11,75 & 9,11 \\
\hline 75 & 200 & 55 & 64,35 & 40,52 & 32,92 & 26,98 & 22,90 & 19,66 & 14,81 & 11,57 & 7,79 \\
\hline 75 & 250 & 55 & 56,41 & 37,11 & 30,91 & 25,87 & 22,28 & 19,35 & 14,81 & 11,67 & 7,87 \\
\hline 75 & 300 & 55 & 50,92 & 34,60 & 29,36 & 24,96 & 21,73 & 19,04 & 14,78 & 11,73 & 7,94 \\
\hline 75 & 350 & 55 & 46,87 & 32,64 & 28,10 & 24,19 & 21,24 & 18,75 & 14,72 & 11,77 & 8,01 \\
\hline 75 & 400 & 55 & 43,74 & 31,05 & 27,05 & 23,51 & 20,80 & 18,48 & 14,65 & 11,79 & 8,06 \\
\hline 75 & 450 & 55 & 41,24 & 29,71 & 26,15 & 22,92 & 20,40 & 18,21 & 14,57 & 11,80 & 8,11 \\
\hline 75 & 500 & 55 & 39,19 & 28,58 & 25,36 & 22,39 & 20,03 & 17,97 & 14,48 & 11,79 & 8,15 \\
\hline 75 & 550 & 55 & 37,48 & 27,59 & 24,67 & 21,91 & 19,69 & 17,73 & 14,39 & 11,78 & 8,19 \\
\hline 75 & 600 & 55 & 36,01 & 26,72 & 24,04 & 21,47 & 19,38 & 17,51 & 14,30 & 11,76 & 8,22 \\
\hline 75 & 650 & 55 & 34,75 & 25,95 & 23,48 & 21,07 & 19,09 & 17,30 & 14,21 & 11,74 & 8,25 \\
\hline 75 & 700 & 55 & 33,64 & 25,26 & 22,97 & 20,70 & 18,81 & 17,11 & 14,12 & 11,72 & 8,27 \\
\hline 75 & 750 & 55 & 32,66 & 24,63 & 22,50 & 20,36 & 18,56 & 16,92 & 14,04 & 11,69 & 8,29 \\
\hline 75 & 800 & 55 & 31,78 & 24,06 & 22,06 & 20,04 & 18,31 & 16,74 & 13,95 & 11,66 & 8,31 \\
\hline 75 & 850 & 55 & 30,99 & 23,54 & 21,66 & 19,74 & 18,08 & 16,57 & 13,86 & 11,62 & 8,32 \\
\hline 75 & 900 & 55 & 30,28 & 23,06 & 21,29 & 19,46 & 17,87 & 16,40 & 13,78 & 11,59 & 8,34 \\
\hline 75 & 950 & 55 & 29,62 & 22,62 & 20,94 & 19,20 & 17,66 & 16,24 & 13,69 & 11,56 & 8,35 \\
\hline 75 & 1000 & 55 & 29,03 & 22,21 & 20,61 & 18,95 & 17,47 & 16,09 & 13,61 & 11,52 & 8,36 \\
\hline 75 & 1050 & 55 & 28,47 & 21,83 & 20,30 & 18,71 & 17,28 & 15,95 & 13,53 & 11,48 & 8,36 \\
\hline 75 & 1100 & 55 & 27,96 & 21,47 & 20,01 & 18,49 & 17,10 & 15,81 & 13,46 & 11,45 & 8,37 \\
\hline 75 & 1150 & 55 & 27,48 & 21,13 & 19,73 & 18,27 & 16,93 & 15,68 & 13,38 & 11,41 & 8,37 \\
\hline 75 & 1200 & 55 & 27,04 & 20,82 & 19,47 & 18,07 & 16,77 & 15,55 & 13,31 & 11,37 & 8,37 \\
\hline 75 & 1250 & 55 & 26,62 & 20,53 & 19,22 & 17,88 & 16,61 & 15,42 & 13,23 & 11,34 & 8,37 \\
\hline 75 & 1300 & 55 & 26,23 & 20,25 & 18,99 & 17,69 & 16,47 & 15,30 & 13,16 & 11,30 & 8,37 \\
\hline 75 & 1350 & 55 & 25,85 & 19,98 & 18,76 & 17,51 & 16,32 & 15,19 & 13,09 & 11,26 & 8,37 \\
\hline 75 & 1400 & 55 & 25,50 & 19,74 & 18,54 & 17,34 & 16,18 & 15,08 & 13,02 & 11,23 & 8,37 \\
\hline 75 & 1450 & 55 & 25,17 & 19,50 & 18,34 & 17,18 & 16,05 & 14,97 & 12,96 & 11,19 & 8,37 \\
\hline 75 & 1500 & 55 & 24,85 & 19,28 & 18,14 & 17,02 & 15,92 & 14,86 & 12,89 & 11,15 & 8,37 \\
\hline 75 & 1550 & 55 & 24,55 & 19,06 & 17,95 & 16,87 & 15,80 & 14,76 & 12,83 & 11,12 & 8,36 \\
\hline 75 & 1600 & 55 & 24,27 & 18,86 & 17,77 & 16,73 & 15,68 & 14,66 & 12,77 & 11,08 & 8,36 \\
\hline 75 & 1650 & 55 & 23,99 & 18,66 & 17,59 & 16,58 & 15,56 & 14,57 & 12,71 & 11,05 & 8,35 \\
\hline 75 & 1700 & 55 & 23,73 & 18,48 & 17,42 & 16,45 & 15,45 & 14,47 & 12,65 & 11,01 & 8,35 \\
\hline 75 & 1750 & 55 & 23,47 & 18,30 & 17,26 & 16,32 & 15,34 & 14,38 & 12,59 & 10,98 & 8,34 \\
\hline 75 & 1800 & 55 & 23,23 & 18,13 & 17,10 & 16,19 & 15,23 & 14,30 & 12,53 & 10,94 & 8,34 \\
\hline 75 & 1850 & 55 & 23,00 & 17,97 & 16,95 & 16,07 & 15,13 & 14,21 & 12,47 & 10,91 & 8,33 \\
\hline 75 & 1900 & 55 & 22,77 & 17,81 & 16,81 & 15,95 & 15,03 & 14,13 & 12,42 & 10,88 & 8,33 \\
\hline 75 & 1950 & 55 & 22,55 & 17,66 & 16,66 & 15,83 & 14,93 & 14,05 & 12,37 & 10,84 & 8,32 \\
\hline 75 & 2000 & 55 & 22,34 & 17,52 & 16,53 & 15,72 & 14,84 & 13,97 & 12,31 & 10,81 & 8,31 \\
\hline 75 & 200 & 60 & 62,21 & 38,47 & 30,93 & 25,12 & 21,19 & 18,12 & 13,56 & 10,57 & 7,12 \\
\hline 75 & 250 & 60 & 54,38 & 35,19 & 29,04 & 24,11 & 20,65 & 17,86 & 13,58 & 10,67 & 7,19 \\
\hline 75 & 300 & 60 & 48,98 & 32,79 & 27,58 & 23,28 & 20,16 & 17,60 & 13,56 & 10,73 & 7,25 \\
\hline 75 & 350 & 60 & 45,00 & 30,92 & 26,40 & 22,57 & 19,73 & 17,34 & 13,52 & 10,77 & 7,31 \\
\hline 75 & 400 & 60 & 41,93 & 29,40 & 25,42 & 21,96 & 19,34 & 17,10 & 13,47 & 10,80 & 7,36 \\
\hline 75 & 450 & 60 & 39,48 & 28,13 & 24,58 & 21,41 & 18,98 & 16,87 & 13,41 & 10,81 & 7,40 \\
\hline 75 & 500 & 60 & 37,47 & 27,05 & 23,84 & 20,92 & 18,64 & 16,66 & 13,34 & 10,81 & 7,44 \\
\hline 75 & 550 & 60 & 35,79 & 26,11 & 23,19 & 20,48 & 18,34 & 16,45 & 13,27 & 10,81 & 7,48 \\
\hline 75 & 600 & 60 & 34,35 & 25,29 & 22,61 & 20,08 & 18,05 & 16,26 & 13,19 & 10,80 & 7,51 \\
\hline 75 & 650 & 60 & 33,12 & 24,56 & 22,09 & 19,71 & 17,79 & 16,07 & 13,12 & 10,79 & 7,53 \\
\hline 75 & 700 & 60 & 32,03 & 23,90 & 21,61 & 19,37 & 17,54 & 15,89 & 13,04 & 10,77 & 7,56 \\
\hline 75 & 750 & 60 & 31,08 & 23,31 & 21,17 & 19,06 & 17,31 & 15,73 & 12,97 & 10,75 & 7,58 \\
\hline 75 & 800 & 60 & 30,22 & 22,76 & 20,76 & 18,76 & 17,09 & 15,56 & 12,89 & 10,72 & 7,60 \\
\hline 75 & 850 & 60 & 29,46 & 22,27 & 20,39 & 18,49 & 16,88 & 15,41 & 12,82 & 10,70 & 7,61 \\
\hline 75 & 900 & 60 & 28,76 & 21,81 & 20,04 & 18,23 & 16,68 & 15,26 & 12,75 & 10,67 & 7,62 \\
\hline 75 & 950 & 60 & 28,13 & 21,39 & 19,71 & 17,99 & 16,49 & 15,12 & 12,67 & 10,64 & 7,64 \\
\hline 75 & 1000 & 60 & 27,55 & 21,00 & 19,41 & 17,76 & 16,31 & 14,99 & 12,60 & 10,61 & 7,65 \\
\hline 75 & 1050 & 60 & 27,01 & 20,64 & 19,12 & 17,54 & 16,14 & 14,86 & 12,53 & 10,59 & 7,65 \\
\hline 75 & 1100 & 60 & 26,52 & 20,30 & 18,84 & 17,33 & 15,98 & 14,73 & 12,47 & 10,56 & 7,66 \\
\hline 75 & 1150 & 60 & 26,06 & 19,98 & 18,59 & 17,13 & 15,83 & 14,61 & 12,40 & 10,52 & 7,67 \\
\hline 75 & 1200 & 60 & 25,63 & 19,68 & 18,34 & 16,95 & 15,68 & 14,49 & 12,34 & 10,49 & 7,67 \\
\hline 75 & 1250 & 60 & 25,23 & 19,40 & 18,11 & 16,77 & 15,53 & 14,38 & 12,27 & 10,46 & 7,67 \\
\hline 75 & 1300 & 60 & 24,85 & 19,13 & 17,89 & 16,60 & 15,40 & 14,27 & 12,21 & 10,43 & 7,67 \\
\hline 75 & 1350 & 60 & 24,49 & 18,88 & 17,68 & 16,43 & 15,27 & 14,17 & 12,15 & 10,40 & 7,68 \\
\hline 75 & 1400 & 60 & 24,16 & 18,64 & 17,48 & 16,27 & 15,14 & 14,07 & 12,09 & 10,37 & 7,68 \\
\hline 75 & 1450 & 60 & 23,84 & 18,42 & 17,28 & 16,12 & 15,02 & 13,97 & 12,03 & 10,34 & 7,68 \\
\hline 75 & 1500 & 60 & 23,54 & 18,20 & 17,10 & 15,98 & 14,90 & 13,87 & 11,97 & 10,31 & 7,68 \\
\hline 75 & 1550 & 60 & 23,25 & 18,00 & 16,92 & 15,84 & 14,78 & 13,78 & 11,91 & 10,28 & 7,67 \\
\hline 75 & 1600 & 60 & 22,98 & 17,80 & 16,75 & 15,70 & 14,67 & 13,69 & 11,86 & 10,25 & 7,67 \\
\hline 75 & 1650 & 60 & 22,71 & 17,62 & 16,58 & 15,57 & 14,56 & 13,60 & 11,80 & 10,22 & 7,67 \\
\hline 75 & 1700 & 60 & 22,46 & 17,44 & 16,43 & 15,44 & 14,46 & 13,52 & 11,75 & 10,19 & 7,67 \\
\hline 75 & 1750 & 60 & 22,22 & 17,27 & 16,27 & 15,32 & 14,36 & 13,43 & 11,70 & 10,16 & 7,66 \\
\hline 75 & 1800 & 60 & 21,99 & 17,11 & 16,13 & 15,20 & 14,26 & 13,35 & 11,65 & 10,13 & 7,66 \\
\hline 75 & 1850 & 60 & 21,77 & 16,95 & 15,98 & 15,09 & 14,17 & 13,28 & 11,60 & 10,10 & 7,65 \\
\hline 75 & 1900 & 60 & 21,56 & 16,80 & 15,85 & 14,98 & 14,08 & 13,20 & 11,55 & 10,07 & 7,65 \\
\hline
\end{tabular}




\begin{tabular}{|c|c|c|c|c|c|c|c|c|c|c|c|}
\hline \multirow[b]{2}{*}{$\mathrm{H}(\mathrm{cm})$} & \multirow[b]{2}{*}{ Mceq (MPa) } & & & & & $\mathrm{De}$ & ões (x1 & & & & \\
\hline & & Msub (MPa) & D0 & D25 & D40 & D60 & D80 & D100 & D140 & D180 & D260 \\
\hline 75 & 1950 & 60 & 21,35 & 16,66 & 15,71 & 14,87 & 13,99 & 13,12 & 11,50 & 10,04 & 7,64 \\
\hline 75 & 2000 & 60 & 21,15 & 16,52 & 15,59 & 14,76 & 13,90 & 13,05 & 11,45 & 10,01 & 7,64 \\
\hline 75 & 200 & 65 & 60,37 & 36,69 & 29,21 & 23,52 & 19,73 & 16,80 & 12,50 & 9,72 & 6,55 \\
\hline 75 & 250 & 65 & 52,64 & 33,53 & 27,42 & 22,59 & 19,25 & 16,58 & 12,53 & 9,82 & 6,61 \\
\hline 75 & 300 & 65 & 47,31 & 31,22 & 26,04 & 21,83 & 18,81 & 16,35 & 12,53 & 9,88 & 6,67 \\
\hline 75 & 350 & 65 & 43,39 & 29,42 & 24,93 & 21,18 & 18,42 & 16,13 & 12,51 & 9,93 & 6,72 \\
\hline 75 & 400 & 65 & 40,37 & 27,97 & 24,00 & 20,61 & 18,07 & 15,92 & 12,47 & 9,96 & 6,76 \\
\hline 75 & 450 & 65 & 37,95 & 26,76 & 23,21 & 20,11 & 17,74 & 15,72 & 12,42 & 9,97 & 6,80 \\
\hline 75 & 500 & 65 & 35,98 & 25,73 & 22,52 & 19,66 & 17,44 & 15,53 & 12,36 & 9,98 & 6,84 \\
\hline 75 & 550 & 65 & 34,33 & 24,83 & 21,91 & 19,25 & 17,17 & 15,35 & 12,30 & 9,98 & 6,87 \\
\hline 75 & 600 & 65 & 32,92 & 24,04 & 21,36 & 18,88 & 16,91 & 15,17 & 12,24 & 9,98 & 6,90 \\
\hline 75 & 650 & 65 & 31,71 & 23,35 & 20,87 & 18,54 & 16,66 & 15,01 & 12,18 & 9,97 & 6,93 \\
\hline 75 & 700 & 65 & 30,65 & 22,72 & 20,42 & 18,22 & 16,44 & 14,85 & 12,11 & 9,96 & 6,95 \\
\hline 75 & 750 & 65 & 29,72 & 22,15 & 20,01 & 17,93 & 16,22 & 14,70 & 12,05 & 9,94 & 6,97 \\
\hline 75 & 800 & 65 & 28,88 & 21,63 & 19,63 & 17,66 & 16,02 & 14,55 & 11,99 & 9,92 & 6,99 \\
\hline 75 & 850 & 65 & 28,13 & 21,16 & 19,28 & 17,40 & 15,83 & 14,41 & 11,92 & 9,91 & 7,01 \\
\hline 75 & 900 & 65 & 27,46 & 20,73 & 18,95 & 17,16 & 15,65 & 14,28 & 11,86 & 9,88 & 7,02 \\
\hline 75 & 950 & 65 & 26,84 & 20,32 & 18,64 & 16,94 & 15,48 & 14,15 & 11,80 & 9,86 & 7,03 \\
\hline 75 & 1000 & 65 & 26,27 & 19,95 & 18,36 & 16,72 & 15,32 & 14,03 & 11,73 & 9,84 & 7,04 \\
\hline 75 & 1050 & 65 & 25,75 & 19,60 & 18,08 & 16,52 & 15,16 & 13,91 & 11,67 & 9,81 & 7,05 \\
\hline 75 & 1100 & 65 & 25,27 & 19,28 & 17,83 & 16,33 & 15,01 & 13,80 & 11,61 & 9,79 & 7,06 \\
\hline 75 & 1150 & 65 & 24,83 & 18,98 & 17,59 & 16,14 & 14,87 & 13,69 & 11,56 & 9,76 & 7,07 \\
\hline 75 & 1200 & 65 & 24,41 & 18,69 & 17,36 & 15,97 & 14,73 & 13,58 & 11,50 & 9,74 & 7,07 \\
\hline 75 & 1250 & 65 & 24,02 & 18,42 & 17,14 & 15,80 & 14,60 & 13,48 & 11,44 & 9,71 & 7,08 \\
\hline 75 & 1300 & 65 & 23,66 & 18,17 & 16,93 & 15,64 & 14,47 & 13,38 & 11,39 & 9,69 & 7,08 \\
\hline 75 & 1350 & 65 & 23,31 & 17,93 & 16,73 & 15,49 & 14,35 & 13,28 & 11,33 & 9,66 & 7,08 \\
\hline 75 & 1400 & 65 & 22,99 & 17,70 & 16,54 & 15,34 & 14,23 & 13,19 & 11,28 & 9,63 & 7,08 \\
\hline 75 & 1450 & 65 & 22,68 & 17,48 & 16,36 & 15,20 & 14,12 & 13,10 & 11,23 & 9,61 & 7,09 \\
\hline 75 & 1500 & 65 & 22,39 & 17,28 & 16,19 & 15,07 & 14,01 & 13,01 & 11,17 & 9,58 & 7,09 \\
\hline 75 & 1550 & 65 & 22,12 & 17,08 & 16,02 & 14,93 & 13,90 & 12,93 & 11,12 & 9,55 & 7,09 \\
\hline 75 & 1600 & 65 & 21,85 & 16,89 & 15,86 & 14,81 & 13,80 & 12,85 & 11,07 & 9,53 & 7,09 \\
\hline 75 & 1650 & 65 & 21,60 & 16,72 & 15,71 & 14,69 & 13,70 & 12,76 & 11,03 & 9,50 & 7,08 \\
\hline 75 & 1700 & 65 & 21,36 & 16,54 & 15,56 & 14,57 & 13,61 & 12,69 & 10,98 & 9,48 & 7,08 \\
\hline 75 & 1750 & 65 & 21,13 & 16,38 & 15,41 & 14,46 & 13,51 & 12,61 & 10,93 & 9,45 & 7,08 \\
\hline 75 & 1800 & 65 & 20,91 & 16,23 & 15,27 & 14,34 & 13,42 & 12,54 & 10,88 & 9,42 & 7,08 \\
\hline 75 & 1850 & 65 & 20,70 & 16,08 & 15,14 & 14,24 & 13,33 & 12,47 & 10,84 & 9,40 & 7,08 \\
\hline 75 & 1900 & 65 & 20,50 & 15,93 & 15,01 & 14,13 & 13,25 & 12,40 & 10,80 & 9,37 & 7,07 \\
\hline 75 & 1950 & 65 & 20,30 & 15,79 & 14,89 & 14,03 & 13,17 & 12,33 & 10,75 & 9,35 & 7,07 \\
\hline 75 & 2000 & 65 & 20,11 & 15,66 & 14,76 & 13,94 & 13,08 & 12,26 & 10,71 & 9,32 & 7,07 \\
\hline 75 & 200 & 70 & 58,76 & 35,13 & 27,71 & 22,13 & 18,46 & 15,66 & 11,59 & 9,00 & 6,07 \\
\hline 75 & 250 & 70 & 51,12 & 32,07 & 26,00 & 21,27 & 18,03 & 15,47 & 11,63 & 9,09 & 6,12 \\
\hline 75 & 300 & 70 & 45,85 & 29,84 & 24,69 & 20,56 & 17,64 & 15,27 & 11,64 & 9,15 & 6,17 \\
\hline 75 & 350 & 70 & 41,98 & 28,11 & 23,64 & 19,95 & 17,28 & 15,08 & 11,63 & 9,20 & 6,21 \\
\hline 75 & 400 & 70 & 39,00 & 26,71 & 22,76 & 19,43 & 16,96 & 14,90 & 11,60 & 9,23 & 6,26 \\
\hline 75 & 450 & 70 & 36,63 & 25,55 & 22,01 & 18,96 & 16,67 & 14,72 & 11,56 & 9,25 & 6,29 \\
\hline 75 & 500 & 70 & 34,68 & 24,56 & 21,36 & 18,55 & 16,39 & 14,55 & 11,52 & 9,26 & 6,33 \\
\hline 75 & 550 & 70 & 33,06 & 23,70 & 20,79 & 18,17 & 16,14 & 14,38 & 11,47 & 9,27 & 6,36 \\
\hline 75 & 600 & 70 & 31,68 & 22,95 & 20,27 & 17,82 & 15,90 & 14,23 & 11,42 & 9,27 & 6,39 \\
\hline 75 & 650 & 70 & 30,49 & 22,28 & 19,80 & 17,51 & 15,68 & 14,08 & 11,36 & 9,27 & 6,41 \\
\hline 75 & 700 & 70 & 29,45 & 21,68 & 19,38 & 17,21 & 15,47 & 13,93 & 11,31 & 9,26 & 6,43 \\
\hline 75 & 750 & 70 & 28,53 & 21,13 & 18,99 & 16,94 & 15,28 & 13,80 & 11,25 & 9,25 & 6,45 \\
\hline 75 & 800 & 70 & 27,71 & 20,64 & 18,63 & 16,69 & 15,09 & 13,67 & 11,20 & 9,23 & 6,47 \\
\hline 75 & 850 & 70 & 26,98 & 20,19 & 18,30 & 16,45 & 14,92 & 13,54 & 11,14 & 9,22 & 6,49 \\
\hline 75 & 900 & 70 & 26,32 & 19,77 & 17,99 & 16,22 & 14,75 & 13,42 & 11,09 & 9,20 & 6,50 \\
\hline 75 & 950 & 70 & 25,71 & 19,39 & 17,70 & 16,01 & 14,59 & 13,30 & 11,03 & 9,19 & 6,51 \\
\hline 75 & 1000 & 70 & 25,16 & 19,03 & 17,43 & 15,81 & 14,44 & 13,19 & 10,98 & 9,17 & 6,53 \\
\hline 75 & 1050 & 70 & 24,65 & 18,70 & 17,18 & 15,63 & 14,30 & 13,08 & 10,92 & 9,15 & 6,54 \\
\hline 75 & 1100 & 70 & 24,19 & 18,39 & 16,93 & 15,45 & 14,16 & 12,98 & 10,87 & 9,13 & 6,54 \\
\hline 75 & 1150 & 70 & 23,75 & 18,09 & 16,71 & 15,27 & 14,03 & 12,88 & 10,82 & 9,11 & 6,55 \\
\hline 75 & 1200 & 70 & 23,35 & 17,82 & 16,49 & 15,11 & 13,90 & 12,78 & 10,77 & 9,08 & 6,56 \\
\hline 75 & 1250 & 70 & 22,97 & 17,56 & 16,28 & 14,96 & 13,78 & 12,69 & 10,72 & 9,06 & 6,56 \\
\hline 75 & 1300 & 70 & 22,62 & 17,32 & 16,09 & 14,81 & 13,66 & 12,60 & 10,67 & 9,04 & 6,57 \\
\hline 75 & 1350 & 70 & 22,28 & 17,09 & 15,90 & 14,66 & 13,55 & 12,51 & 10,62 & 9,02 & 6,57 \\
\hline 75 & 1400 & 70 & 21,97 & 16,87 & 15,72 & 14,53 & 13,44 & 12,42 & 10,57 & 8,99 & 6,57 \\
\hline 75 & 1450 & 70 & 21,67 & 16,66 & 15,55 & 14,39 & 13,33 & 12,34 & 10,53 & 8,97 & 6,58 \\
\hline 75 & 1500 & 70 & 21,39 & 16,46 & 15,39 & 14,27 & 13,23 & 12,26 & 10,48 & 8,95 & 6,58 \\
\hline 75 & 1550 & 70 & 21,12 & 16,28 & 15,23 & 14,14 & 13,13 & 12,18 & 10,43 & 8,93 & 6,58 \\
\hline 75 & 1600 & 70 & 20,87 & 16,10 & 15,08 & 14,03 & 13,04 & 12,11 & 10,39 & 8,90 & 6,58 \\
\hline 75 & 1650 & 70 & 20,63 & 15,92 & 14,93 & 13,91 & 12,95 & 12,03 & 10,35 & 8,88 & 6,58 \\
\hline 75 & 1700 & 70 & 20,40 & 15,76 & 14,79 & 13,80 & 12,86 & 11,96 & 10,30 & 8,86 & 6,58 \\
\hline 75 & 1750 & 70 & 20,17 & 15,60 & 14,65 & 13,69 & 12,77 & 11,89 & 10,26 & 8,84 & 6,58 \\
\hline 75 & 1800 & 70 & 19,96 & 15,45 & 14,52 & 13,59 & 12,68 & 11,82 & 10,22 & 8,81 & 6,58 \\
\hline 75 & 1850 & 70 & 19,76 & 15,31 & 14,40 & 13,49 & 12,60 & 11,76 & 10,18 & 8,79 & 6,58 \\
\hline 75 & 1900 & 70 & 19,56 & 15,17 & 14,27 & 13,39 & 12,52 & 11,69 & 10,14 & 8,77 & 6,57 \\
\hline 75 & 1950 & 70 & 19,38 & 15,04 & 14,16 & 13,30 & 12,45 & 11,63 & 10,10 & 8,75 & 6,57 \\
\hline 75 & 2000 & 70 & 19,19 & 14,91 & 14,04 & 13,21 & 12,37 & 11,57 & 10,06 & 8,72 & 6,57 \\
\hline 75 & 200 & 75 & 57,34 & 33,75 & 26,38 & 20,90 & 17,35 & 14,66 & 10,80 & 8,37 & 5,65 \\
\hline 75 & 250 & 75 & 49,77 & 30,77 & 24,75 & 20,10 & 16,96 & 14,50 & 10,85 & 8,46 & 5,70 \\
\hline 75 & 300 & 75 & 44,57 & 28,61 & 23,50 & 19,44 & 16,60 & 14,33 & 10,86 & 8,52 & 5,74 \\
\hline 75 & 350 & 75 & 40,74 & 26,94 & 22,50 & 18,88 & 16,28 & 14,16 & 10,86 & 8,57 & 5,78 \\
\hline 75 & 400 & 75 & 37,80 & 25,59 & 21,66 & 18,39 & 15,99 & 13,99 & 10,84 & 8,60 & 5,82 \\
\hline
\end{tabular}




\begin{tabular}{|c|c|c|c|c|c|c|c|c|c|c|c|}
\hline \multirow[b]{2}{*}{$\mathrm{H}(\mathrm{cm})$} & \multirow[b]{2}{*}{ Mceq (MPa) } & & & & & $\mathrm{De}$ & ões (x1 & & & & \\
\hline & & Msub (MPa) & D0 & D25 & D40 & D60 & D80 & D100 & D140 & D180 & D260 \\
\hline 75 & 450 & 75 & 35,46 & 24,47 & 20,95 & 17,95 & 15,72 & 13,84 & 10,81 & 8,62 & 5,85 \\
\hline 75 & 500 & 75 & 33,54 & 23,52 & 20,33 & 17,56 & 15,47 & 13,68 & 10,78 & 8,64 & 5,89 \\
\hline 75 & 550 & 75 & 31,94 & 22,70 & 19,79 & 17,21 & 15,24 & 13,54 & 10,74 & 8,65 & 5,92 \\
\hline 75 & 600 & 75 & 30,58 & 21,97 & 19,30 & 16,89 & 15,02 & 13,39 & 10,69 & 8,65 & 5,94 \\
\hline 75 & 650 & 75 & 29,41 & 21,33 & 18,86 & 16,59 & 14,82 & 13,26 & 10,65 & 8,65 & 5,96 \\
\hline 75 & 700 & 75 & 28,39 & 20,75 & 18,46 & 16,32 & 14,62 & 13,13 & 10,60 & 8,65 & 5,99 \\
\hline 75 & 750 & 75 & 27,48 & 20,23 & 18,09 & 16,07 & 14,44 & 13,01 & 10,55 & 8,64 & 6,01 \\
\hline 75 & 800 & 75 & 26,68 & 19,76 & 17,75 & 15,83 & 14,27 & 12,89 & 10,51 & 8,63 & 6,02 \\
\hline 75 & 850 & 75 & 25,96 & 19,32 & 17,43 & 15,61 & 14,11 & 12,77 & 10,46 & 8,62 & 6,04 \\
\hline 75 & 900 & 75 & 25,31 & 18,92 & 17,14 & 15,40 & 13,96 & 12,66 & 10,41 & 8,61 & 6,05 \\
\hline 75 & 950 & 75 & 24,72 & 18,55 & 16,87 & 15,20 & 13,81 & 12,55 & 10,36 & 8,59 & 6,07 \\
\hline 75 & 1000 & 75 & 24,18 & 18,21 & 16,61 & 15,01 & 13,67 & 12,45 & 10,31 & 8,58 & 6,08 \\
\hline 75 & 1050 & 75 & 23,68 & 17,89 & 16,37 & 14,83 & 13,53 & 12,35 & 10,27 & 8,56 & 6,09 \\
\hline 75 & 1100 & 75 & 23,23 & 17,59 & 16,14 & 14,66 & 13,41 & 12,26 & 10,22 & 8,55 & 6,10 \\
\hline 75 & 1150 & 75 & 22,80 & 17,31 & 15,92 & 14,50 & 13,28 & 12,16 & 10,17 & 8,53 & 6,10 \\
\hline 75 & 1200 & 75 & 22,41 & 17,05 & 15,72 & 14,35 & 13,17 & 12,08 & 10,13 & 8,51 & 6,11 \\
\hline 75 & 1250 & 75 & 22,04 & 16,80 & 15,52 & 14,20 & 13,05 & 11,99 & 10,08 & 8,49 & 6,12 \\
\hline 75 & 1300 & 75 & 21,69 & 16,57 & 15,34 & 14,06 & 12,94 & 11,91 & 10,04 & 8,47 & 6,12 \\
\hline 75 & 1350 & 75 & 21,37 & 16,34 & 15,16 & 13,93 & 12,84 & 11,82 & 9,99 & 8,45 & 6,13 \\
\hline 75 & 1400 & 75 & 21,06 & 16,13 & 14,99 & 13,80 & 12,74 & 11,75 & 9,95 & 8,43 & 6,13 \\
\hline 75 & 1450 & 75 & 20,78 & 15,93 & 14,83 & 13,68 & 12,64 & 11,67 & 9,91 & 8,41 & 6,13 \\
\hline 75 & 1500 & 75 & 20,50 & 15,74 & 14,67 & 13,56 & 12,54 & 11,59 & 9,87 & 8,40 & 6,14 \\
\hline 75 & 1550 & 75 & 20,24 & 15,56 & 14,52 & 13,44 & 12,45 & 11,52 & 9,83 & 8,38 & 6,14 \\
\hline 75 & 1600 & 75 & 20,00 & 15,39 & 14,38 & 13,33 & 12,36 & 11,45 & 9,79 & 8,36 & 6,14 \\
\hline 75 & 1650 & 75 & 19,76 & 15,22 & 14,24 & 13,22 & 12,28 & 11,38 & 9,75 & 8,34 & 6,14 \\
\hline 75 & 1700 & 75 & 19,54 & 15,07 & 14,11 & 13,12 & 12,19 & 11,32 & 9,71 & 8,32 & 6,14 \\
\hline 75 & 1750 & 75 & 19,33 & 14,92 & 13,98 & 13,02 & 12,11 & 11,25 & 9,67 & 8,30 & 6,14 \\
\hline 75 & 1800 & 75 & 19,12 & 14,77 & 13,86 & 12,92 & 12,03 & 11,19 & 9,63 & 8,28 & 6,14 \\
\hline 75 & 1850 & 75 & 18,93 & 14,63 & 13,74 & 12,83 & 11,96 & 11,13 & 9,59 & 8,26 & 6,14 \\
\hline 75 & 1900 & 75 & 18,74 & 14,50 & 13,62 & 12,74 & 11,88 & 11,07 & 9,56 & 8,24 & 6,14 \\
\hline 75 & 1950 & 75 & 18,55 & 14,37 & 13,51 & 12,65 & 11,81 & 11,01 & 9,52 & 8,22 & 6,14 \\
\hline 75 & 2000 & 75 & 18,38 & 14,24 & 13,40 & 12,56 & 11,74 & 10,95 & 9,49 & 8,20 & 6,14 \\
\hline 75 & 200 & 80 & 56,07 & 32,52 & 25,20 & 19,81 & 16,36 & 13,78 & 10,11 & 7,82 & 5,29 \\
\hline 75 & 250 & 80 & 48,58 & 29,62 & 23,63 & 19,06 & 16,01 & 13,64 & 10,16 & 7,90 & 5,33 \\
\hline 75 & 300 & 80 & 43,43 & 27,52 & 22,44 & 18,44 & 15,68 & 13,49 & 10,18 & 7,97 & 5,37 \\
\hline 75 & 350 & 80 & 39,64 & 25,90 & 21,48 & 17,92 & 15,39 & 13,34 & 10,19 & 8,01 & 5,40 \\
\hline 75 & 400 & 80 & 36,74 & 24,59 & 20,68 & 17,46 & 15,12 & 13,20 & 10,17 & 8,05 & 5,44 \\
\hline 75 & 450 & 80 & 34,42 & 23,51 & 20,01 & 17,05 & 14,88 & 13,05 & 10,15 & 8,07 & 5,47 \\
\hline 75 & 500 & 80 & 32,53 & 22,59 & 19,42 & 16,69 & 14,65 & 12,92 & 10,12 & 8,09 & 5,50 \\
\hline 75 & 550 & 80 & 30,95 & 21,80 & 18,90 & 16,36 & 14,43 & 12,78 & 10,09 & 8,10 & 5,53 \\
\hline 75 & 600 & 80 & 29,61 & 21,10 & 18,43 & 16,06 & 14,23 & 12,66 & 10,06 & 8,11 & 5,55 \\
\hline 75 & 650 & 80 & 28,45 & 20,48 & 18,01 & 15,78 & 14,04 & 12,53 & 10,02 & 8,11 & 5,57 \\
\hline 75 & 700 & 80 & 27,44 & 19,93 & 17,63 & 15,52 & 13,87 & 12,42 & 9,98 & 8,11 & 5,59 \\
\hline 75 & 750 & 80 & 26,56 & 19,42 & 17,28 & 15,29 & 13,70 & 12,30 & 9,94 & 8,11 & 5,61 \\
\hline 75 & 800 & 80 & 25,77 & 18,97 & 16,96 & 15,06 & 13,54 & 12,19 & 9,89 & 8,10 & 5,63 \\
\hline 75 & 850 & 80 & 25,06 & 18,55 & 16,66 & 14,85 & 13,39 & 12,09 & 9,85 & 8,09 & 5,65 \\
\hline 75 & 900 & 80 & 24,42 & 18,17 & 16,38 & 14,66 & 13,25 & 11,99 & 9,81 & 8,08 & 5,66 \\
\hline 75 & 950 & 80 & 23,84 & 17,81 & 16,12 & 14,47 & 13,11 & 11,89 & 9,77 & 8,07 & 5,67 \\
\hline 75 & 1000 & 80 & 23,31 & 17,48 & 15,88 & 14,29 & 12,98 & 11,79 & 9,73 & 8,06 & 5,68 \\
\hline 75 & 1050 & 80 & 22,82 & 17,17 & 15,65 & 14,13 & 12,85 & 11,70 & 9,68 & 8,05 & 5,69 \\
\hline 75 & 1100 & 80 & 22,37 & 16,88 & 15,43 & 13,97 & 12,74 & 11,61 & 9,64 & 8,03 & 5,70 \\
\hline 75 & 1150 & 80 & 21,96 & 16,61 & 15,22 & 13,82 & 12,62 & 11,53 & 9,60 & 8,02 & 5,71 \\
\hline 75 & 1200 & 80 & 21,57 & 16,36 & 15,03 & 13,67 & 12,51 & 11,45 & 9,56 & 8,00 & 5,72 \\
\hline 75 & 1250 & 80 & 21,21 & 16,12 & 14,84 & 13,53 & 12,40 & 11,37 & 9,52 & 7,99 & 5,72 \\
\hline 75 & 1300 & 80 & 20,87 & 15,89 & 14,67 & 13,40 & 12,30 & 11,29 & 9,48 & 7,97 & 5,73 \\
\hline 75 & 1350 & 80 & 20,56 & 15,68 & 14,50 & 13,27 & 12,20 & 11,21 & 9,44 & 7,96 & 5,74 \\
\hline 75 & 1400 & 80 & 20,26 & 15,48 & 14,34 & 13,15 & 12,11 & 11,14 & 9,40 & 7,94 & 5,74 \\
\hline 75 & 1450 & 80 & 19,98 & 15,28 & 14,18 & 13,04 & 12,02 & 11,07 & 9,36 & 7,92 & 5,74 \\
\hline 75 & 1500 & 80 & 19,71 & 15,10 & 14,04 & 12,92 & 11,93 & 11,00 & 9,32 & 7,90 & 5,75 \\
\hline 75 & 1550 & 80 & 19,46 & 14,93 & 13,89 & 12,81 & 11,84 & 10,94 & 9,29 & 7,89 & 5,75 \\
\hline 75 & 1600 & 80 & 19,22 & 14,76 & 13,76 & 12,71 & 11,76 & 10,87 & 9,25 & 7,87 & 5,75 \\
\hline 75 & 1650 & 80 & 18,99 & 14,60 & 13,62 & 12,61 & 11,68 & 10,81 & 9,22 & 7,85 & 5,75 \\
\hline 75 & 1700 & 80 & 18,78 & 14,45 & 13,50 & 12,51 & 11,60 & 10,74 & 9,18 & 7,84 & 5,76 \\
\hline 75 & 1750 & 80 & 18,57 & 14,30 & 13,38 & 12,42 & 11,52 & 10,68 & 9,14 & 7,82 & 5,76 \\
\hline 75 & 1800 & 80 & 18,37 & 14,16 & 13,26 & 12,32 & 11,45 & 10,63 & 9,11 & 7,80 & 5,76 \\
\hline 75 & 1850 & 80 & 18,18 & 14,03 & 13,14 & 12,23 & 11,38 & 10,57 & 9,08 & 7,78 & 5,76 \\
\hline 75 & 1900 & 80 & 18,00 & 13,90 & 13,03 & 12,15 & 11,31 & 10,51 & 9,04 & 7,77 & 5,76 \\
\hline 75 & 1950 & 80 & 17,82 & 13,77 & 12,93 & 12,06 & 11,24 & 10,46 & 9,01 & 7,75 & 5,76 \\
\hline 75 & 2000 & 80 & 17,65 & 13,65 & 12,82 & 11,98 & 11,17 & 10,40 & 8,98 & 7,73 & 5,76 \\
\hline 75 & 200 & 85 & 54,94 & 31,42 & 24,15 & 18,84 & 15,49 & 13,00 & 9,49 & 7,34 & 4,97 \\
\hline 75 & 250 & 85 & 47,50 & 28,58 & 22,63 & 18,13 & 15,16 & 12,88 & 9,55 & 7,42 & 5,00 \\
\hline 75 & 300 & 85 & 42,40 & 26,53 & 21,48 & 17,55 & 14,87 & 12,75 & 9,58 & 7,48 & 5,04 \\
\hline 75 & 350 & 85 & 38,66 & 24,96 & 20,57 & 17,06 & 14,60 & 12,62 & 9,59 & 7,53 & 5,07 \\
\hline 75 & 400 & 85 & 35,78 & 23,69 & 19,80 & 16,63 & 14,35 & 12,48 & 9,58 & 7,56 & 5,10 \\
\hline 75 & 450 & 85 & 33,49 & 22,65 & 19,16 & 16,25 & 14,12 & 12,36 & 9,57 & 7,59 & 5,13 \\
\hline 75 & 500 & 85 & 31,62 & 21,76 & 18,59 & 15,91 & 13,91 & 12,23 & 9,54 & 7,61 & 5,16 \\
\hline 75 & 550 & 85 & 30,06 & 20,99 & 18,10 & 15,60 & 13,71 & 12,11 & 9,52 & 7,62 & 5,19 \\
\hline 75 & 600 & 85 & 28,74 & 20,31 & 17,65 & 15,31 & 13,53 & 12,00 & 9,49 & 7,63 & 5,21 \\
\hline 75 & 650 & 85 & 27,60 & 19,72 & 17,25 & 15,05 & 13,35 & 11,88 & 9,46 & 7,63 & 5,23 \\
\hline 75 & 700 & 85 & 26,60 & 19,18 & 16,89 & 14,81 & 13,19 & 11,78 & 9,42 & 7,63 & 5,25 \\
\hline 75 & 750 & 85 & 25,73 & 18,70 & 16,55 & 14,58 & 13,03 & 11,67 & 9,39 & 7,63 & 5,27 \\
\hline
\end{tabular}




\begin{tabular}{|c|c|c|c|c|c|c|c|c|c|c|c|}
\hline \multirow[b]{2}{*}{$\mathrm{H}(\mathrm{cm})$} & \multirow[b]{2}{*}{ Mceq (MPa) } & & & & & $\mathrm{De}$ & ões (x1 & & & & \\
\hline & & Msub (MPa) & D0 & D25 & D40 & D60 & D80 & D100 & D140 & D180 & D260 \\
\hline 75 & 800 & 85 & 24,95 & 18,26 & 16,25 & 14,37 & 12,88 & 11,57 & 9,35 & 7,63 & 5,28 \\
\hline 75 & 850 & 85 & 24,25 & 17,85 & 15,96 & 14,18 & 12,74 & 11,48 & 9,31 & 7,62 & 5,30 \\
\hline 75 & 900 & 85 & 23,62 & 17,48 & 15,69 & 13,99 & 12,61 & 11,38 & 9,28 & 7,62 & 5,31 \\
\hline 75 & 950 & 85 & 23,05 & 17,14 & 15,45 & 13,81 & 12,48 & 11,29 & 9,24 & 7,61 & 5,33 \\
\hline 75 & 1000 & 85 & 22,53 & 16,82 & 15,21 & 13,65 & 12,36 & 11,20 & 9,20 & 7,60 & 5,34 \\
\hline 75 & 1050 & 85 & 22,05 & 16,52 & 14,99 & 13,49 & 12,24 & 11,12 & 9,16 & 7,59 & 5,35 \\
\hline 75 & 1100 & 85 & 21,61 & 16,24 & 14,79 & 13,34 & 12,13 & 11,04 & 9,13 & 7,58 & 5,36 \\
\hline 75 & 1150 & 85 & 21,20 & 15,98 & 14,59 & 13,20 & 12,03 & 10,96 & 9,09 & 7,57 & 5,36 \\
\hline 75 & 1200 & 85 & 20,82 & 15,74 & 14,41 & 13,06 & 11,92 & 10,88 & 9,05 & 7,55 & 5,37 \\
\hline 75 & 1250 & 85 & 20,47 & 15,51 & 14,23 & 12,93 & 11,82 & 10,81 & 9,02 & 7,54 & 5,38 \\
\hline 75 & 1300 & 85 & 20,14 & 15,29 & 14,06 & 12,81 & 11,73 & 10,74 & 8,98 & 7,53 & 5,38 \\
\hline 75 & 1350 & 85 & 19,83 & 15,08 & 13,90 & 12,69 & 11,63 & 10,67 & 8,94 & 7,51 & 5,39 \\
\hline 75 & 1400 & 85 & 19,54 & 14,89 & 13,75 & 12,57 & 11,55 & 10,60 & 8,91 & 7,50 & 5,40 \\
\hline 75 & 1450 & 85 & 19,26 & 14,70 & 13,60 & 12,46 & 11,46 & 10,53 & 8,87 & 7,48 & 5,40 \\
\hline 75 & 1500 & 85 & 19,01 & 14,52 & 13,46 & 12,35 & 11,38 & 10,47 & 8,84 & 7,47 & 5,40 \\
\hline 75 & 1550 & 85 & 18,76 & 14,35 & 13,32 & 12,25 & 11,29 & 10,41 & 8,81 & 7,45 & 5,41 \\
\hline 75 & 1600 & 85 & 18,53 & 14,19 & 13,19 & 12,15 & 11,22 & 10,35 & 8,77 & 7,44 & 5,41 \\
\hline 75 & 1650 & 85 & 18,30 & 14,04 & 13,07 & 12,05 & 11,14 & 10,29 & 8,74 & 7,42 & 5,41 \\
\hline 75 & 1700 & 85 & 18,09 & 13,89 & 12,95 & 11,96 & 11,07 & 10,23 & 8,71 & 7,41 & 5,41 \\
\hline 75 & 1750 & 85 & 17,89 & 13,75 & 12,83 & 11,87 & 11,00 & 10,17 & 8,68 & 7,39 & 5,42 \\
\hline 75 & 1800 & 85 & 17,70 & 13,61 & 12,72 & 11,78 & 10,93 & 10,12 & 8,64 & 7,38 & 5,42 \\
\hline 75 & 1850 & 85 & 17,51 & 13,48 & 12,61 & 11,70 & 10,86 & 10,07 & 8,61 & 7,36 & 5,42 \\
\hline 75 & 1900 & 85 & 17,33 & 13,36 & 12,50 & 11,62 & 10,79 & 10,01 & 8,58 & 7,35 & 5,42 \\
\hline 75 & 1950 & 85 & 17,16 & 13,24 & 12,40 & 11,54 & 10,73 & 9,96 & 8,55 & 7,33 & 5,42 \\
\hline 75 & 2000 & 85 & 17,00 & 13,12 & 12,30 & 11,46 & 10,67 & 9,91 & 8,52 & 7,31 & 5,42 \\
\hline 75 & 200 & 90 & 53,91 & 30,42 & 23,19 & 17,96 & 14,70 & 12,30 & 8,95 & 6,91 & 4,68 \\
\hline 75 & 250 & 90 & 46,54 & 27,64 & 21,73 & 17,29 & 14,40 & 12,19 & 9,01 & 6,99 & 4,71 \\
\hline 75 & 300 & 90 & 41,48 & 25,64 & 20,62 & 16,75 & 14,13 & 12,08 & 9,04 & 7,05 & 4,75 \\
\hline 75 & 350 & 90 & 37,77 & 24,11 & 19,74 & 16,28 & 13,88 & 11,96 & 9,05 & 7,09 & 4,78 \\
\hline 75 & 400 & 90 & 34,92 & 22,88 & 19,01 & 15,88 & 13,65 & 11,85 & 9,05 & 7,13 & 4,81 \\
\hline 75 & 450 & 90 & 32,65 & 21,86 & 18,39 & 15,52 & 13,44 & 11,73 & 9,04 & 7,15 & 4,83 \\
\hline 75 & 500 & 90 & 30,80 & 21,00 & 17,85 & 15,20 & 13,25 & 11,62 & 9,03 & 7,17 & 4,86 \\
\hline 75 & 550 & 90 & 29,26 & 20,25 & 17,37 & 14,91 & 13,06 & 11,51 & 9,01 & 7,19 & 4,88 \\
\hline 75 & 600 & 90 & 27,95 & 19,60 & 16,95 & 14,64 & 12,89 & 11,40 & 8,98 & 7,20 & 4,91 \\
\hline 75 & 650 & 90 & 26,82 & 19,02 & 16,56 & 14,39 & 12,73 & 11,30 & 8,95 & 7,21 & 4,93 \\
\hline 75 & 700 & 90 & 25,84 & 18,50 & 16,21 & 14,16 & 12,57 & 11,20 & 8,92 & 7,21 & 4,94 \\
\hline 75 & 750 & 90 & 24,98 & 18,04 & 15,89 & 13,95 & 12,43 & 11,11 & 8,89 & 7,21 & 4,96 \\
\hline 75 & 800 & 90 & 24,21 & 17,61 & 15,60 & 13,75 & 12,29 & 11,01 & 8,86 & 7,21 & 4,98 \\
\hline 75 & 850 & 90 & 23,52 & 17,22 & 15,33 & 13,56 & 12,16 & 10,92 & 8,83 & 7,21 & 4,99 \\
\hline 75 & 900 & 90 & 22,90 & 16,86 & 15,07 & 13,39 & 12,04 & 10,84 & 8,80 & 7,20 & 5,00 \\
\hline 75 & 950 & 90 & 22,34 & 16,53 & 14,84 & 13,22 & 11,92 & 10,75 & 8,76 & 7,19 & 5,02 \\
\hline 75 & 1000 & 90 & 21,83 & 16,22 & 14,61 & 13,07 & 11,80 & 10,67 & 8,73 & 7,19 & 5,03 \\
\hline 75 & 1050 & 90 & 21,36 & 15,93 & 14,40 & 12,92 & 11,69 & 10,60 & 8,69 & 7,18 & 5,04 \\
\hline 75 & 1100 & 90 & 20,92 & 15,66 & 14,21 & 12,77 & 11,59 & 10,52 & 8,66 & 7,17 & 5,05 \\
\hline 75 & 1150 & 90 & 20,52 & 15,41 & 14,02 & 12,64 & 11,49 & 10,45 & 8,63 & 7,16 & 5,06 \\
\hline 75 & 1200 & 90 & 20,15 & 15,18 & 13,84 & 12,51 & 11,39 & 10,38 & 8,59 & 7,15 & 5,06 \\
\hline 75 & 1250 & 90 & 19,80 & 14,95 & 13,67 & 12,39 & 11,30 & 10,31 & 8,56 & 7,14 & 5,07 \\
\hline 75 & 1300 & 90 & 19,48 & 14,74 & 13,51 & 12,27 & 11,21 & 10,24 & 8,53 & 7,13 & 5,08 \\
\hline 75 & 1350 & 90 & 19,18 & 14,54 & 13,36 & 12,15 & 11,12 & 10,18 & 8,50 & 7,11 & 5,08 \\
\hline 75 & 1400 & 90 & 18,89 & 14,35 & 13,21 & 12,04 & 11,04 & 10,11 & 8,47 & 7,10 & 5,09 \\
\hline 75 & 1450 & 90 & 18,62 & 14,17 & 13,07 & 11,94 & 10,96 & 10,05 & 8,43 & 7,09 & 5,09 \\
\hline 75 & 1500 & 90 & 18,37 & 14,00 & 12,94 & 11,84 & 10,88 & $\begin{array}{c}9,99 \\
\end{array}$ & 8,40 & 7,08 & 5,10 \\
\hline 75 & 1550 & 90 & 18,13 & 13,84 & 12,81 & 11,74 & 10,80 & 9,93 & 8,37 & 7,06 & 5,10 \\
\hline 75 & 1600 & 90 & 17,90 & 13,68 & 12,68 & 11,64 & 10,73 & 9,88 & 8,34 & 7,05 & 5,10 \\
\hline 75 & 1650 & 90 & 17,68 & 13,53 & 12,56 & 11,55 & 10,65 & 9,82 & 8,31 & 7,04 & 5,11 \\
\hline 75 & 1700 & 90 & 17,47 & 13,39 & 12,45 & 11,47 & 10,59 & 9,77 & 8,28 & 7,02 & 5,11 \\
\hline 75 & 1750 & 90 & 17,28 & 13,25 & 12,34 & 11,38 & 10,52 & 9,71 & 8,25 & 7,01 & 5,11 \\
\hline 75 & 1800 & 90 & 17,09 & 13,12 & 12,23 & 11,30 & 10,45 & 9,66 & 8,22 & 7,00 & 5,11 \\
\hline 75 & 1850 & 90 & 16,91 & 12,99 & 12,12 & 11,22 & 10,39 & 9,61 & 8,19 & 6,98 & 5,11 \\
\hline 75 & 1900 & 90 & 16,73 & 12,87 & 12,02 & 11,14 & 10,33 & 9,56 & 8,17 & 6,97 & 5,12 \\
\hline 75 & 1950 & 90 & 16,57 & 12,76 & 11,93 & 11,06 & 10,27 & 9,51 & 8,14 & 6,95 & 5,12 \\
\hline 75 & 2000 & 90 & 16,41 & 12,64 & 11,83 & 10,99 & 10,21 & 9,47 & 8,11 & 6,94 & 5,12 \\
\hline 75 & 200 & 95 & 52,98 & 29,52 & 22,33 & 17,17 & 13,99 & 11,67 & 8,46 & 6,53 & 4,43 \\
\hline 75 & 250 & 95 & 45,66 & 26,79 & 20,91 & 16,54 & 13,71 & 11,58 & 8,52 & 6,60 & 4,46 \\
\hline 75 & 300 & 95 & 40,64 & 24,84 & 19,84 & 16,02 & 13,46 & 11,48 & 8,56 & 6,66 & 4,49 \\
\hline 75 & 350 & 95 & 36,96 & 23,34 & 18,99 & 15,58 & 13,24 & 11,37 & 8,57 & 6,70 & 4,51 \\
\hline 75 & 400 & 95 & 34,14 & 22,14 & 18,29 & 15,20 & 13,02 & 11,27 & 8,58 & 6,74 & 4,54 \\
\hline 75 & 450 & 95 & 31,89 & 21,15 & 17,69 & 14,86 & 12,83 & 11,16 & 8,57 & 6,77 & 4,57 \\
\hline 75 & 500 & 95 & 30,06 & 20,31 & 17,17 & 14,55 & 12,65 & 11,06 & 8,56 & 6,79 & 4,59 \\
\hline 75 & 550 & 95 & 28,54 & 19,58 & 16,71 & 14,28 & 12,47 & 10,96 & 8,54 & 6,80 & 4,61 \\
\hline 75 & 600 & 95 & 27,24 & 18,95 & 16,30 & 14,02 & 12,31 & 10,86 & 8,52 & 6,81 & 4,63 \\
\hline 75 & 650 & 95 & 26,13 & 18,39 & 15,93 & 13,79 & 12,16 & 10,77 & 8,50 & 6,82 & 4,65 \\
\hline 75 & 700 & 95 & 25,16 & 17,89 & 15,60 & 13,58 & 12,02 & 10,68 & 8,47 & 6,83 & 4,67 \\
\hline 75 & 750 & 95 & 24,30 & 17,43 & 15,29 & 13,37 & 11,88 & 10,59 & 8,45 & 6,83 & 4,69 \\
\hline 75 & 800 & 95 & 23,54 & 17,02 & 15,01 & 13,19 & 11,75 & 10,51 & 8,42 & 6,83 & 4,70 \\
\hline 75 & 850 & 95 & 22,86 & 16,64 & 14,75 & 13,01 & 11,63 & 10,42 & 8,39 & 6,83 & 4,72 \\
\hline 75 & 900 & 95 & 22,25 & 16,29 & 14,51 & 12,84 & 11,51 & 10,34 & 8,36 & 6,83 & 4,73 \\
\hline 75 & 950 & 95 & 21,70 & 15,97 & 14,28 & 12,68 & 11,40 & 10,27 & 8,33 & 6,82 & 4,74 \\
\hline 75 & 1000 & 95 & 21,19 & 15,67 & 14,07 & 12,53 & 11,30 & 10,19 & 8,30 & 6,82 & 4,75 \\
\hline 75 & 1050 & 95 & 20,73 & 15,40 & 13,87 & 12,39 & 11,19 & 10,12 & 8,27 & 6,81 & 4,76 \\
\hline 75 & 1100 & 95 & 20,30 & 15,14 & 13,68 & 12,26 & 11,09 & 10,05 & 8,24 & 6,80 & 4,77 \\
\hline
\end{tabular}




\begin{tabular}{|c|c|c|c|c|c|c|c|c|c|c|c|}
\hline \multirow[b]{2}{*}{$\mathrm{H}(\mathrm{cm})$} & \multirow[b]{2}{*}{ Mceq (MPa) } & & & & & $\mathrm{De}$ & ões (x1 & & & & \\
\hline & & Msub (MPa) & D0 & D25 & D40 & D60 & D80 & D100 & D140 & D180 & D260 \\
\hline 75 & 1150 & 95 & 19,91 & 14,89 & 13,50 & 12,13 & 11,00 & 9,98 & 8,21 & 6,79 & 4,78 \\
\hline 75 & 1200 & 95 & 19,54 & 14,66 & 13,33 & 12,01 & 10,91 & 9,92 & 8,18 & 6,79 & 4,79 \\
\hline 75 & 1250 & 95 & 19,20 & 14,45 & 13,17 & 11,89 & 10,82 & 9,85 & 8,15 & 6,78 & 4,80 \\
\hline 75 & 1300 & 95 & 18,88 & 14,24 & 13,01 & 11,78 & 10,73 & 9,79 & 8,12 & 6,77 & 4,80 \\
\hline 75 & 1350 & 95 & 18,58 & 14,05 & 12,86 & 11,67 & 10,65 & 9,73 & 8,09 & 6,76 & 4,81 \\
\hline 75 & 1400 & 95 & 18,30 & 13,86 & 12,72 & 11,56 & 10,57 & 9,67 & 8,06 & 6,75 & 4,81 \\
\hline 75 & 1450 & 95 & 18,04 & 13,69 & 12,59 & 11,46 & 10,50 & 9,61 & 8,04 & 6,73 & 4,82 \\
\hline 75 & 1500 & 95 & 17,79 & 13,52 & 12,46 & 11,37 & 10,42 & 9,56 & 8,01 & 6,72 & 4,82 \\
\hline 75 & 1550 & 95 & 17,55 & 13,37 & 12,34 & 11,27 & 10,35 & 9,50 & 7,98 & 6,71 & 4,83 \\
\hline 75 & 1600 & 95 & 17,33 & 13,21 & 12,22 & 11,18 & 10,28 & 9,45 & 7,95 & 6,70 & 4,83 \\
\hline 75 & 1650 & 95 & 17,11 & 13,07 & 12,10 & 11,10 & 10,21 & 9,40 & 7,92 & 6,69 & 4,83 \\
\hline 75 & 1700 & 95 & 16,91 & 12,93 & 11,99 & 11,01 & 10,15 & 9,34 & 7,90 & 6,68 & 4,84 \\
\hline 75 & 1750 & 95 & 16,72 & 12,80 & 11,88 & 10,93 & 10,08 & 9,30 & 7,87 & 6,66 & 4,84 \\
\hline 75 & 1800 & 95 & 16,53 & 12,67 & 11,78 & 10,85 & 10,02 & 9,25 & 7,84 & 6,65 & 4,84 \\
\hline 75 & 1850 & 95 & 16,36 & 12,55 & 11,68 & 10,78 & 9,96 & 9,20 & 7,82 & 6,64 & 4,84 \\
\hline 75 & 1900 & 95 & 16,19 & 12,43 & 11,58 & 10,70 & 9,90 & 9,15 & 7,79 & 6,63 & 4,84 \\
\hline 75 & 1950 & 95 & 16,02 & 12,32 & 11,49 & 10,63 & 9,84 & 9,11 & 7,76 & 6,62 & 4,85 \\
\hline 75 & 2000 & 95 & 15,87 & 12,21 & 11,40 & 10,56 & 9,79 & 9,06 & 7,74 & 6,60 & 4,85 \\
\hline 75 & 200 & 100 & 52,14 & 28,69 & 21,54 & 16,45 & 13,35 & 11,10 & 8,02 & 6,18 & 4,20 \\
\hline 75 & 250 & 100 & 44,86 & 26,01 & 20,16 & 15,85 & 13,09 & 11,02 & 8,09 & 6,26 & 4,23 \\
\hline 75 & 300 & 100 & 39,87 & 24,10 & 19,13 & 15,36 & 12,86 & 10,93 & 8,12 & 6,31 & 4,25 \\
\hline 75 & 350 & 100 & 36,23 & 22,63 & 18,30 & 14,94 & 12,65 & 10,84 & 8,14 & 6,36 & 4,28 \\
\hline 75 & 400 & 100 & 33,43 & 21,46 & 17,62 & 14,58 & 12,45 & 10,75 & 8,15 & 6,39 & 4,30 \\
\hline 75 & 450 & 100 & 31,20 & 20,49 & 17,05 & 14,26 & 12,27 & 10,65 & 8,15 & 6,42 & 4,33 \\
\hline 75 & 500 & 100 & 29,39 & 19,67 & 16,55 & 13,97 & 12,10 & 10,56 & 8,14 & 6,44 & 4,35 \\
\hline 75 & 550 & 100 & 27,88 & 18,97 & 16,11 & 13,71 & 11,94 & 10,47 & 8,13 & 6,46 & 4,37 \\
\hline 75 & 600 & 100 & 26,59 & 18,35 & 15,71 & 13,47 & 11,79 & 10,38 & 8,11 & 6,47 & 4,39 \\
\hline 75 & 650 & 100 & 25,49 & 17,81 & 15,36 & 13,24 & 11,65 & 10,29 & 8,09 & 6,48 & 4,41 \\
\hline 75 & 700 & 100 & 24,53 & 17,32 & 15,04 & 13,04 & 11,51 & 10,21 & 8,07 & 6,48 & 4,43 \\
\hline 75 & 750 & 100 & 23,69 & 16,88 & 14,75 & 12,85 & 11,39 & 10,12 & 8,04 & 6,49 & 4,44 \\
\hline 75 & 800 & 100 & 22,94 & 16,48 & 14,47 & 12,67 & 11,26 & 10,05 & 8,02 & 6,49 & 4,46 \\
\hline 75 & 850 & 100 & 22,26 & 16,11 & 14,22 & 12,50 & 11,15 & 9,97 & 8,00 & 6,49 & 4,47 \\
\hline 75 & 900 & 100 & 21,66 & 15,78 & 13,99 & 12,34 & 11,04 & 9,90 & 7,97 & 6,49 & 4,48 \\
\hline 75 & 950 & 100 & 21,11 & 15,46 & 13,77 & 12,19 & 10,93 & 9,82 & 7,94 & 6,48 & 4,49 \\
\hline 75 & 1000 & 100 & 20,61 & 15,17 & 13,57 & 12,05 & 10,83 & 9,75 & 7,92 & 6,48 & 4,50 \\
\hline 75 & 1050 & 100 & 20,15 & 14,90 & 13,37 & 11,91 & 10,74 & 9,69 & 7,89 & 6,48 & 4,51 \\
\hline 75 & 1100 & 100 & 19,73 & 14,65 & 13,19 & 11,79 & 10,64 & 9,62 & 7,86 & 6,47 & 4,52 \\
\hline 75 & 1150 & 100 & 19,34 & 14,42 & 13,02 & 11,66 & 10,55 & 9,56 & 7,83 & 6,46 & 4,53 \\
\hline 75 & 1200 & 100 & 18,98 & 14,19 & 12,86 & 11,55 & 10,47 & 9,50 & 7,81 & 6,46 & 4,54 \\
\hline 75 & 1250 & 100 & 18,65 & 13,98 & 12,70 & 11,43 & 10,38 & 9,44 & 7,78 & 6,45 & 4,55 \\
\hline 75 & 1300 & 100 & 18,33 & 13,78 & 12,55 & 11,33 & 10,30 & 9,38 & 7,75 & 6,44 & 4,55 \\
\hline 75 & 1350 & 100 & 18,04 & 13,60 & 12,41 & 11,22 & 10,23 & 9,32 & 7,73 & 6,43 & 4,56 \\
\hline 75 & 1400 & 100 & 17,76 & 13,42 & 12,28 & 11,12 & 10,15 & 9,26 & 7,70 & 6,42 & 4,56 \\
\hline 75 & 1450 & 100 & 17,50 & 13,25 & 12,15 & 11,03 & 10,08 & 9,21 & 7,67 & 6,41 & 4,57 \\
\hline 75 & 1500 & 100 & 17,26 & 13,09 & 12,02 & 10,94 & 10,01 & 9,16 & 7,65 & 6,40 & 4,57 \\
\hline 75 & 1550 & 100 & 17,03 & 12,93 & 11,90 & 10,85 & 9,94 & 9,11 & 7,62 & 6,39 & 4,58 \\
\hline 75 & 1600 & 100 & 16,81 & 12,79 & 11,79 & 10,76 & 9,87 & 9,06 & 7,60 & 6,38 & 4,58 \\
\hline 75 & 1650 & 100 & 16,60 & 12,65 & 11,68 & 10,68 & 9,81 & 9,01 & 7,57 & 6,37 & 4,59 \\
\hline 75 & 1700 & 100 & 16,40 & 12,51 & 11,57 & 10,60 & 9,75 & 8,96 & 7,55 & 6,36 & 4,59 \\
\hline 75 & 1750 & 100 & 16,21 & 12,38 & 11,47 & 10,52 & 9,69 & 8,91 & 7,52 & 6,35 & 4,59 \\
\hline 75 & 1800 & 100 & 16,03 & 12,26 & 11,37 & 10,45 & 9,63 & 8,87 & 7,50 & 6,34 & 4,59 \\
\hline 75 & 1850 & 100 & 15,85 & 12,14 & 11,27 & 10,37 & 9,57 & 8,82 & 7,47 & 6,33 & 4,60 \\
\hline 75 & 1900 & 100 & $\begin{array}{l}15,009 \\
15,69\end{array}$ & $\begin{array}{l}1 L, \pm+ \\
12,02\end{array}$ & $\begin{array}{l}+., L \\
11,18\end{array}$ & 10,30 & 9,51 & 8,78 & 7,45 & 6,32 & 4,60 \\
\hline 75 & 1950 & 100 & 15,53 & 11,91 & 11,09 & 10,23 & 9,46 & 8,74 & 7,42 & 6,31 & 4,60 \\
\hline 75 & 2000 & 100 & 15,38 & 11,81 & 11,01 & 10,17 & 9,41 & 8,70 & 7,40 & 6,30 & 4,60 \\
\hline 75 & 200 & 105 & 51,36 & 27,94 & 20,82 & 15,80 & 12,76 & 10,58 & 7,62 & 5,87 & 4,00 \\
\hline 75 & 250 & 105 & 44,12 & 25,30 & 19,48 & 15,22 & 12,52 & 10,52 & 7,69 & 5,94 & 4,02 \\
\hline 75 & 300 & 105 & 39,17 & 23,42 & 18,47 & 14,75 & 12,31 & 10,44 & 7,73 & 6,00 & 4,04 \\
\hline 75 & 350 & 105 & 35,55 & 21,98 & 17,68 & 14,36 & 12,11 & 10,35 & 7,75 & 6,04 & 4,07 \\
\hline 75 & 400 & 105 & 32,77 & 20,83 & 17,02 & 14,01 & 11,93 & 10,27 & 7,76 & 6,07 & 4,09 \\
\hline 75 & 450 & 105 & 30,57 & 19,89 & 16,46 & 13,70 & 11,76 & 10,18 & 7,76 & 6,10 & 4,11 \\
\hline 75 & 500 & 105 & 28,77 & 19,09 & 15,98 & 13,43 & 11,60 & 10,10 & 7,76 & 6,12 & 4,13 \\
\hline 75 & 550 & 105 & 27,27 & 18,41 & 15,55 & 13,18 & 11,45 & 10,01 & 7,75 & 6,14 & 4,15 \\
\hline 75 & 600 & 105 & 26,00 & 17,81 & 15,18 & 12,95 & 11,31 & 9,93 & 7,73 & 6,15 & 4,17 \\
\hline 75 & 650 & 105 & 24,91 & 17,28 & 14,83 & 12,74 & 11,17 & 9,85 & 7,72 & 6,16 & 4,19 \\
\hline 75 & 700 & 105 & 23,96 & 16,80 & 14,52 & 12,55 & 11,05 & 9,77 & 7,70 & 6,17 & 4,20 \\
\hline 75 & 750 & 105 & 23,12 & 16,37 & 14,24 & 12,36 & 10,93 & 9,70 & 7,68 & 6,18 & 4,22 \\
\hline 75 & 800 & 105 & 22,38 & 15,98 & 13,98 & 12,19 & 10,82 & 9,62 & 7,66 & 6,18 & 4,23 \\
\hline 75 & 850 & 105 & 21,72 & 15,63 & 13,74 & 12,03 & 10,71 & 9,55 & 7,63 & 6,18 & 4,25 \\
\hline 75 & 900 & 105 & 21,12 & 15,30 & 13,51 & 11,88 & 10,60 & 9,48 & 7,61 & 6,18 & 4,26 \\
\hline 75 & 950 & 105 & 20,58 & 15,00 & 13,30 & 11,74 & 10,50 & 9,42 & 7,59 & 6,18 & 4,27 \\
\hline 75 & 1000 & 105 & 20,08 & 14,71 & 13,11 & 11,60 & 10,41 & 9,35 & 7,56 & 6,18 & 4,28 \\
\hline 75 & 1050 & 105 & 19,63 & 14,45 & 12,92 & 11,48 & 10,32 & 9,29 & 7,54 & 6,17 & 4,29 \\
\hline 75 & 1100 & 105 & 19,21 & 14,21 & 12,75 & 11,35 & 10,23 & 9,23 & 7,51 & 6,17 & 4,30 \\
\hline 75 & 1150 & 105 & 18,83 & 13,98 & 12,58 & 11,24 & 10,14 & 9,17 & 7,49 & 6,16 & 4,31 \\
\hline 75 & 1200 & 105 & 18,47 & 13,76 & 12,42 & 11,12 & 10,06 & 9,11 & 7,47 & 6,16 & 4,31 \\
\hline 75 & 1250 & 105 & 18.14 & 13.56 & 12.27 & 11.02 & 9.98 & 9.05 & 7.44 & 6.15 & 4.32 \\
\hline 75 & 1300 & 105 & 1783 & 1336 & 1213 & 1092 & 991 & 900 & 7.42 & 6.14 & 433 \\
\hline 75 & 1350 & 105 & 17,54 & 13,18 & 11,99 & 10,82 & 9,83 & 8,95 & 7,39 & 6,14 & 4,33 \\
\hline 75 & 1400 & 105 & 17,27 & 13,01 & 11,86 & 10,72 & 9,76 & 8,89 & 7,37 & 6,13 & 4,34 \\
\hline 75 & 1450 & 105 & 17,02 & 12,84 & 11,74 & 10,63 & 9,69 & 8,84 & 7,34 & 6,12 & 4,35 \\
\hline
\end{tabular}




\begin{tabular}{|c|c|c|c|c|c|c|c|c|c|c|c|}
\hline \multirow[b]{2}{*}{$\mathrm{H}(\mathrm{cm})$} & \multirow[b]{2}{*}{ Mceq (MPa) } & & & & & $\mathrm{De}$ & ões (x1 & & & & \\
\hline & & Msub (MPa) & D0 & D25 & D40 & D60 & D80 & D100 & D140 & D180 & D260 \\
\hline 75 & 1500 & 105 & 16,77 & 12,69 & 11,62 & 10,54 & 9,63 & 8,79 & 7,32 & 6,11 & 4,35 \\
\hline 75 & 1550 & 105 & 16,55 & 12,54 & 11,51 & 10,46 & 9,56 & 8,75 & 7,30 & 6,10 & 4,35 \\
\hline 75 & 1600 & 105 & 16,33 & 12,39 & 11,40 & 10,38 & 9,50 & 8,70 & 7,27 & 6,09 & 4,36 \\
\hline 75 & 1650 & 105 & 16,12 & 12,26 & 11,29 & 10,30 & 9,44 & 8,65 & 7,25 & 6,08 & 4,36 \\
\hline 75 & 1700 & 105 & 15,93 & 12,13 & 11,19 & 10,22 & 9,38 & 8,61 & 7,23 & 6,07 & 4,37 \\
\hline 75 & 1750 & 105 & 15,74 & 12,00 & 11,09 & 10,15 & 9,32 & 8,56 & 7,20 & 6,07 & 4,37 \\
\hline 75 & 1800 & 105 & 15,56 & 11,88 & 10,99 & 10,07 & 9,27 & 8,52 & 7,18 & 6,06 & 4,37 \\
\hline 75 & 1850 & 105 & 15,39 & 11,76 & 10,90 & 10,00 & 9,21 & 8,48 & 7,16 & 6,05 & 4,37 \\
\hline 75 & 1900 & 105 & 15,23 & 11,65 & 10,81 & 9,94 & 9,16 & 8,44 & 7,13 & 6,04 & 4,38 \\
\hline 75 & 1950 & 105 & 15,08 & 11,55 & 10,73 & 9,87 & 9,11 & 8,40 & 7,11 & 6,03 & 4,38 \\
\hline 75 & 2000 & 105 & 14,93 & 11,44 & 10,64 & 9,81 & 9,06 & 8,36 & 7,09 & 6,02 & 4,38 \\
\hline 75 & 200 & 110 & 50,65 & 27,24 & 20,16 & 15,20 & 12,22 & 10,11 & 7,26 & 5,59 & 3,81 \\
\hline 75 & 250 & 110 & 43,45 & 24,65 & 18,85 & 14,64 & 12,00 & 10,06 & 7,33 & 5,66 & 3,83 \\
\hline 75 & 300 & 110 & 38,53 & 22,79 & 17,87 & 14,20 & 11,80 & 9,99 & 7,37 & 5,71 & 3,85 \\
\hline 75 & 350 & 110 & 34,93 & 21,38 & 17,10 & 13,82 & 11,62 & 9,91 & 7,39 & 5,75 & 3,88 \\
\hline 75 & 400 & 110 & 32,17 & 20,26 & 16,46 & 13,49 & 11,45 & 9,83 & 7,40 & 5,79 & 3,90 \\
\hline 75 & 450 & 110 & 29,99 & 19,34 & 15,92 & 13,20 & 11,29 & 9,75 & 7,41 & 5,81 & 3,92 \\
\hline 75 & 500 & 110 & 28,20 & 18,56 & 15,45 & 12,94 & 11,14 & 9,67 & 7,41 & 5,84 & 3,94 \\
\hline 75 & 550 & 110 & 26,72 & 17,89 & 15,04 & 12,70 & 11,00 & 9,60 & 7,40 & 5,85 & 3,95 \\
\hline 75 & 600 & 110 & 25,46 & 17,30 & 14,68 & 12,48 & 10,87 & 9,52 & 7,39 & 5,87 & 3,97 \\
\hline 75 & 650 & 110 & 24,38 & 16,78 & 14,35 & 12,28 & 10,74 & 9,45 & 7,37 & 5,88 & 3,99 \\
\hline 75 & 700 & 110 & 23,43 & 16,32 & 14,05 & 12,09 & 10,62 & 9,38 & 7,36 & 5,89 & 4,00 \\
\hline 75 & 750 & 110 & 22,60 & 15,90 & 13,78 & 11,92 & 10,51 & 9,31 & 7,34 & 5,89 & 4,02 \\
\hline 75 & 800 & 110 & 21,87 & 15,52 & 13,52 & 11,76 & 10,40 & 9,24 & 7,32 & 5,90 & 4,03 \\
\hline 75 & 850 & 110 & 21,21 & 15,18 & 13,29 & 11,60 & 10,30 & 9,17 & 7,30 & 5,90 & 4,04 \\
\hline 75 & 900 & 110 & 20,62 & 14,86 & 13,07 & 11,46 & 10,20 & 9,11 & 7,28 & 5,90 & 4,06 \\
\hline 75 & 950 & 110 & 20,09 & 14,56 & 12,87 & 11,32 & 10,11 & 9,04 & 7,26 & 5,90 & 4,07 \\
\hline 75 & 1000 & 110 & 19,60 & 14,29 & 12,68 & 11,19 & 10,02 & 8,98 & 7,24 & 5,90 & 4,08 \\
\hline 75 & 1050 & 110 & 19,15 & 14,03 & 12,50 & 11,07 & 9,93 & 8,92 & 7,22 & 5,89 & 4,09 \\
\hline 75 & 1100 & 110 & 18,74 & 13,79 & 12,33 & 10,95 & 9,85 & 8,87 & 7,20 & 5,89 & 4,09 \\
\hline 75 & 1150 & 110 & 18,36 & 13,57 & 12,17 & 10,84 & 9,77 & 8,81 & 7,17 & 5,89 & 4,10 \\
\hline 75 & 1200 & 110 & 18,01 & 13,36 & 12,02 & 10,74 & 9,69 & 8,76 & 7,15 & 5,88 & 4,11 \\
\hline 75 & 1250 & 110 & 17,68 & 13,16 & 11,88 & 10,63 & 9,62 & 8,70 & 7,13 & 5,88 & 4,12 \\
\hline 75 & 1300 & 110 & 17,37 & 12,97 & 11,74 & 10,54 & 9,54 & 8,65 & 7,11 & 5,87 & 4,12 \\
\hline 75 & 1350 & 110 & 17,09 & 12,80 & 11,61 & 10,44 & 9,47 & 8,60 & 7,08 & 5,87 & 4,13 \\
\hline 75 & 1400 & 110 & 16,82 & 12,63 & 11,48 & 10,35 & 9,41 & 8,55 & 7,06 & 5,86 & 4,14 \\
\hline 75 & 1450 & 110 & 16,57 & 12,47 & 11,36 & 10,26 & 9,34 & 8,51 & 7,04 & 5,85 & 4,14 \\
\hline 75 & 1500 & 110 & 16,33 & 12,32 & 11,25 & 10,18 & 9,28 & 8,46 & 7,02 & 5,84 & 4,15 \\
\hline 75 & 1550 & 110 & 16,10 & 12,17 & 11,14 & 10,10 & 9,22 & 8,41 & 7,00 & 5,84 & 4,15 \\
\hline 75 & 1600 & 110 & 15,89 & 12,03 & 11,03 & 10,02 & 9,16 & 8,37 & 6,97 & 5,83 & 4,15 \\
\hline 75 & 1650 & 110 & 15,69 & 11,90 & 10,93 & 9,94 & 9,10 & 8,33 & 6,95 & 5,82 & 4,16 \\
\hline 75 & 1700 & 110 & 15,50 & 11,77 & 10,83 & 9,87 & 9,04 & 8,28 & 6,93 & 5,81 & 4,16 \\
\hline 75 & 1750 & 110 & 15,31 & 11,65 & 10,74 & 9,80 & 8,99 & 8,24 & 6,91 & 5,80 & 4,17 \\
\hline 75 & 1800 & 110 & 15,14 & 11,53 & 10,64 & 9,73 & 8,93 & 8,20 & 6,89 & 5,80 & 4,17 \\
\hline 75 & 1850 & 110 & 14,97 & 11,42 & 10,56 & 9,66 & 8,88 & 8,16 & 6,87 & 5,79 & 4,17 \\
\hline 75 & 1900 & 110 & 14,81 & 11,31 & 10,47 & 9,60 & 8,83 & 8,12 & 6,85 & 5,78 & 4,17 \\
\hline 75 & 1950 & 110 & 14,66 & 11,20 & 10,39 & 9,53 & 8,78 & 8,08 & 6,83 & 5,77 & 4,18 \\
\hline 75 & 2000 & 110 & 14,51 & 11,10 & 10,31 & 9,47 & 8,73 & 8,05 & 6,81 & 5,76 & 4,18 \\
\hline 75 & 200 & 115 & 49,99 & 26,60 & 19,55 & 14,64 & 11,73 & 9,68 & 6,93 & 5,34 & 3,65 \\
\hline 75 & 250 & 115 & 42,82 & 24,04 & 18,27 & 14,11 & 11,53 & 9,63 & 7,00 & 5,40 & 3,66 \\
\hline 75 & 300 & 115 & 37,93 & 22,22 & 17,32 & 13,68 & 11,34 & 9,57 & 7,04 & 5,45 & 3,68 \\
\hline 75 & 350 & 115 & 34,36 & 20,83 & 16,56 & 13,32 & 11,17 & 9,50 & 7,07 & 5,49 & 3,70 \\
\hline 75 & 400 & 115 & 31,62 & 19,73 & 15,94 & 13,01 & 11,01 & 9,43 & 7,08 & 5,52 & 3,72 \\
\hline 75 & 450 & 115 & 29,45 & 18,82 & 15,42 & 12,73 & 10,86 & 9,36 & 7,09 & 5,55 & 3,74 \\
\hline 75 & 500 & 115 & 27,68 & 18,06 & 14,97 & 12,48 & 10,72 & 9,29 & 7,09 & 5,57 & 3,76 \\
\hline 75 & 550 & 115 & 26,20 & 17,40 & 14,57 & 12,25 & 10,58 & 9,22 & 7,08 & 5,59 & 3,77 \\
\hline 75 & 600 & 115 & 24,96 & 16,83 & 14,22 & 12,04 & 10,46 & 9,15 & 7,07 & 5,61 & 3,79 \\
\hline 75 & 650 & 115 & 23,88 & 16,33 & 13,90 & 11,85 & 10,34 & 9,08 & 7,06 & 5,62 & 3,81 \\
\hline 75 & 700 & 115 & 22,95 & 15,87 & 13,61 & 11,67 & 10,23 & 9,01 & 7,05 & 5,63 & 3,82 \\
\hline 75 & 750 & 115 & 22,13 & 15,47 & 13,34 & 11,51 & 10,12 & 8,94 & 7,03 & 5,63 & 3,83 \\
\hline 75 & 800 & 115 & 21,40 & 15,10 & 13,10 & 11,35 & 10,02 & 8,88 & 7,02 & 5,64 & 3,85 \\
\hline 75 & 850 & 115 & 20,75 & 14,76 & 12,88 & 11,21 & 9,92 & 8,82 & 7,00 & 5,64 & 3,86 \\
\hline 75 & 900 & 115 & 20,16 & 14,45 & 12,67 & 11,07 & 9,83 & 8,76 & 6,98 & 5,64 & 3,87 \\
\hline 75 & 950 & 115 & 19,63 & 14,16 & 12,47 & 10,94 & 9,74 & 8,70 & 6,96 & 5,64 & 3,88 \\
\hline 75 & 1000 & 115 & 19,15 & 13,89 & 12,29 & 10,81 & 9,66 & 8,64 & 6,94 & 5,64 & 3,89 \\
\hline 75 & 1050 & 115 & 18,71 & 13,65 & 12,11 & 10,70 & 9,57 & 8,59 & 6,92 & 5,64 & 3,90 \\
\hline 75 & 1100 & 115 & 18,30 & 13,41 & 11,95 & 10,58 & 9,50 & 8,53 & 6,90 & 5,64 & 3,91 \\
\hline 75 & 1150 & 115 & 17,92 & 13,20 & 11,80 & 10,48 & 9,42 & 8,48 & 6,88 & 5,64 & 3,92 \\
\hline 75 & 1200 & 115 & 17,58 & 12,99 & 11,65 & 10,38 & 9,35 & 8,43 & 6,86 & 5,63 & 3,92 \\
\hline 75 & 1250 & 115 & 17,25 & 12,80 & 11,51 & 10,28 & 9,27 & 8,38 & 6,84 & 5,63 & 3,93 \\
\hline 75 & 1300 & 115 & 16,95 & 12,61 & 11,38 & 10,18 & 9,21 & 8,33 & 6,82 & 5,62 & 3,94 \\
\hline 75 & 1350 & 115 & 16,67 & 12,44 & 11,25 & 10,09 & 9,14 & 8,28 & 6,80 & 5,62 & 3,94 \\
\hline 75 & 1400 & 115 & 16,40 & 12,28 & 11,13 & 10,01 & 9,08 & 8,24 & 6,78 & 5,61 & 3,95 \\
\hline 75 & 1450 & 115 & 16,15 & 12,12 & 11,02 & 9,92 & 9,01 & 8,19 & 6,76 & 5,61 & 3,95 \\
\hline 75 & 1500 & 115 & 15,92 & 11,97 & 10,90 & 9,84 & 8,95 & 8,15 & 6,74 & 5,60 & 3,96 \\
\hline 75 & 1550 & 115 & 15,70 & 11,83 & 10,80 & 9,76 & 8,89 & 8,11 & 6,72 & 5,59 & 3,96 \\
\hline 75 & 1600 & 115 & 15,49 & 11.69 & 10,70 & 9.69 & 8.84 & 8.06 & 6.70 & 5.59 & 3.97 \\
\hline 75 & 1650 & 115 & 15,29 & 11,56 & 10,60 & 9,62 & 8,78 & 8,02 & 6,68 & 5,58 & 3,97 \\
\hline 75 & 1700 & 115 & 15,10 & 11,44 & 10,50 & 9,55 & 8,73 & 7,98 & 6,66 & 5,57 & 3,98 \\
\hline 75 & 1750 & 115 & 14,92 & 11,32 & 10,41 & 9,48 & 8,68 & 7,94 & 6,64 & 5,56 & 3,98 \\
\hline 75 & 1800 & 115 & 14,75 & 11,21 & 10,32 & 9,41 & 8,63 & 7,91 & 6,62 & 5,56 & 3,98 \\
\hline
\end{tabular}




\begin{tabular}{|c|c|c|c|c|c|c|c|c|c|c|c|}
\hline \multirow[b]{2}{*}{$\mathrm{H}(\mathrm{cm})$} & \multirow[b]{2}{*}{ Mceq (MPa) } & & & & & $\mathrm{De}$ & ões (x1 & & & & \\
\hline & & Msub (MPa) & D0 & D25 & D40 & D60 & D80 & D100 & D140 & D180 & D260 \\
\hline 75 & 1850 & 115 & 14,58 & 11,10 & 10,23 & 9,35 & 8,58 & 7,87 & 6,60 & 5,55 & 3,99 \\
\hline 75 & 1900 & 115 & 14,42 & 10,99 & 10,15 & 9,28 & 8,53 & 7,83 & 6,58 & 5,54 & 3,99 \\
\hline 75 & 1950 & 115 & 14,27 & 10,89 & 10,07 & 9,22 & 8,48 & 7,80 & 6,56 & 5,53 & 3,99 \\
\hline 75 & 2000 & 115 & 14,13 & 10,79 & 9,99 & 9,16 & 8,43 & 7,76 & 6,54 & 5,52 & 3,99 \\
\hline 75 & 200 & 120 & 49,38 & 26,01 & 18,99 & 14,13 & 11,28 & 9,28 & 6,63 & 5,10 & 3,49 \\
\hline 75 & 250 & 120 & 42,25 & 23,48 & 17,73 & 13,62 & 11,09 & 9,24 & 6,70 & 5,16 & 3,51 \\
\hline 75 & 300 & 120 & 37,38 & 21,68 & 16,80 & 13,21 & 10,91 & 9,19 & 6,74 & 5,21 & 3,52 \\
\hline 75 & 350 & 120 & 33,83 & 20,32 & 16,07 & 12,86 & 10,75 & 9,13 & 6,76 & 5,25 & 3,54 \\
\hline 75 & 400 & 120 & 31,11 & 19,23 & 15,47 & 12,56 & 10,60 & 9,06 & 6,78 & 5,28 & 3,56 \\
\hline 75 & 450 & 120 & 28,95 & 18,34 & 14,96 & 12,29 & 10,46 & 8,99 & 6,79 & 5,31 & 3,58 \\
\hline 75 & 500 & 120 & 27,19 & 17,60 & 14,52 & 12,06 & 10,32 & 8,93 & 6,79 & 5,33 & 3,59 \\
\hline 75 & 550 & 120 & 25,73 & 16,96 & 14,13 & 11,84 & 10,20 & 8,86 & 6,79 & 5,35 & 3,61 \\
\hline 75 & 600 & 120 & 24,49 & 16,40 & 13,79 & 11,64 & 10,08 & 8,80 & 6,78 & 5,37 & 3,63 \\
\hline 75 & 650 & 120 & 23,43 & 15,90 & 13,48 & 11,46 & 9,97 & 8,73 & 6,77 & 5,38 & 3,64 \\
\hline 75 & 700 & 120 & 22,50 & 15,46 & 13,20 & 11,29 & 9,86 & 8,67 & 6,76 & 5,39 & 3,65 \\
\hline 75 & 750 & 120 & 21,69 & 15,06 & 12,94 & 11,13 & 9,76 & 8,61 & 6,75 & 5,39 & 3,67 \\
\hline 75 & 800 & 120 & 20,96 & 14,70 & 12,71 & 10,98 & 9,67 & 8,55 & 6,74 & 5,40 & 3,68 \\
\hline 75 & 850 & 120 & 20,32 & 14,37 & 12,49 & 10,84 & 9,58 & 8,49 & 6,72 & 5,40 & 3,69 \\
\hline 75 & 900 & 120 & 19,74 & 14,07 & 12,29 & 10,71 & 9,49 & 8,44 & 6,70 & 5,41 & 3,70 \\
\hline 75 & 950 & 120 & 19,21 & 13,79 & 12,10 & 10,58 & 9,40 & 8,38 & 6,69 & 5,41 & 3,71 \\
\hline 75 & 1000 & 120 & 18,73 & 13,53 & 11,92 & 10,46 & 9,32 & 8,33 & 6,67 & 5,41 & 3,72 \\
\hline 75 & 1050 & 120 & 18,30 & 13,28 & 11,75 & 10,35 & 9,24 & 8,28 & 6,65 & 5,41 & 3,73 \\
\hline 75 & 1100 & 120 & 17,89 & 13,06 & 11,60 & 10,24 & 9,17 & 8,23 & 6,63 & 5,41 & 3,74 \\
\hline 75 & 1150 & 120 & 17,52 & 12,85 & 11,45 & 10,14 & 9,10 & 8,18 & 6,62 & 5,40 & 3,75 \\
\hline 75 & 1200 & 120 & 17,18 & 12,65 & 11,31 & 10,04 & 9,03 & 8,13 & 6,60 & 5,40 & 3,75 \\
\hline 75 & 1250 & 120 & 16,86 & 12,46 & 11,17 & 9,95 & 8,96 & 8,08 & 6,58 & 5,40 & 3,76 \\
\hline 75 & 1300 & 120 & 16,56 & 12,28 & 11,04 & 9,86 & 8,89 & 8,04 & 6,56 & 5,39 & 3,77 \\
\hline 75 & 1350 & 120 & 16,28 & 12,11 & 10,92 & 9,77 & 8,83 & 7,99 & 6,54 & 5,39 & 3,77 \\
\hline 75 & 1400 & 120 & 16,02 & 11,95 & 10,80 & 9,69 & 8,77 & 7,95 & 6,52 & 5,38 & 3,78 \\
\hline 75 & 1450 & 120 & 15,77 & 11,80 & 10,69 & 9,61 & 8,71 & 7,90 & 6,50 & 5,38 & 3,78 \\
\hline 75 & 1500 & 120 & 15,54 & 11,65 & 10,58 & 9,53 & 8,65 & 7,86 & 6,48 & 5,37 & 3,79 \\
\hline 75 & 1550 & 120 & 15,32 & 11,51 & 10,48 & 9,45 & 8,60 & 7,82 & 6,46 & 5,37 & 3,79 \\
\hline 75 & 1600 & 120 & 15,11 & 11,38 & 10,38 & 9,38 & 8,54 & 7,78 & 6,45 & 5,36 & 3,80 \\
\hline 75 & 1650 & 120 & 14,92 & 11,26 & 10,29 & 9,31 & 8,49 & 7,74 & 6,43 & 5,36 & 3,80 \\
\hline 75 & 1700 & 120 & 14,73 & 11,13 & 10,19 & 9,24 & 8,44 & 7,71 & 6,41 & 5,35 & 3,81 \\
\hline 75 & 1750 & 120 & 14,55 & 11,02 & 10,11 & 9,18 & 8,39 & 7,67 & 6,39 & 5,34 & 3,81 \\
\hline 75 & 1800 & 120 & 14,38 & 10,91 & 10,02 & 9,11 & 8,34 & 7,63 & 6,37 & 5,34 & 3,81 \\
\hline 75 & 1850 & 120 & 14,22 & 10,80 & 9,94 & 9,05 & 8,29 & 7,60 & 6,35 & 5,33 & 3,82 \\
\hline 75 & 1900 & 120 & 14,06 & 10,70 & 9,86 & 8,99 & 8,25 & 7,56 & 6,34 & 5,32 & 3,82 \\
\hline 75 & 1950 & 120 & 13,92 & 10,60 & 9,78 & 8,93 & 8,20 & 7,53 & 6,32 & 5,31 & 3,82 \\
\hline 75 & 2000 & 120 & 13,77 & 10,50 & 9,70 & 8,88 & 8,16 & 7,49 & 6,30 & 5,31 & 3,82 \\
\hline 75 & 200 & 125 & 48,81 & 25,46 & 18,46 & 13,66 & 10,86 & 8,92 & 6,35 & 4,89 & 3,35 \\
\hline 75 & 250 & 125 & 41,71 & 22,95 & 17,23 & 13,16 & 10,68 & 8,88 & 6,42 & 4,95 & 3,36 \\
\hline 75 & 300 & 125 & 36,87 & 21,18 & 16,32 & 12,77 & 10,51 & 8,83 & 6,46 & 4,99 & 3,38 \\
\hline 75 & 350 & 125 & 33,33 & 19,84 & 15,61 & 12,43 & 10,36 & 8,78 & 6,49 & 5,03 & 3,40 \\
\hline 75 & 400 & 125 & 30,63 & 18,77 & 15,02 & 12,15 & 10,22 & 8,72 & 6,51 & 5,06 & 3,41 \\
\hline 75 & 450 & 125 & 28,49 & 17,90 & 14,53 & 11,89 & 10,09 & 8,66 & 6,52 & 5,09 & 3,43 \\
\hline 75 & 500 & 125 & 26,74 & 17,17 & 14,10 & 11,66 & 9,96 & 8,60 & 6,52 & 5,11 & 3,44 \\
\hline 75 & 550 & 125 & 25,29 & 16,54 & 13,72 & 11,45 & 9,84 & 8,54 & 6,52 & 5,13 & 3,46 \\
\hline 75 & 600 & 125 & 24,06 & 15,99 & 13,39 & 11,26 & 9,73 & 8,48 & 6,51 & 5,14 & 3,47 \\
\hline 75 & 650 & 125 & 23,00 & 15,50 & 13,09 & 11,09 & 9,63 & 8,42 & 6,51 & 5,16 & 3,49 \\
\hline 75 & 700 & 125 & 22,08 & 15,07 & 12,82 & 10,92 & 9,53 & 8,36 & 6,50 & 5,17 & 3,50 \\
\hline 75 & 750 & 125 & 21,28 & 14,68 & 12,57 & 10,77 & 9,43 & 8,30 & 6,49 & 5,17 & 3,51 \\
\hline 75 & 800 & 125 & 20,56 & 14,33 & 12,34 & 10,63 & 9,34 & 8,25 & 6,47 & 5,18 & 3,52 \\
\hline 75 & 850 & 125 & 19,92 & 14,01 & 12,13 & 10,50 & 9,25 & 8,19 & 6,46 & 5,18 & 3,54 \\
\hline 75 & 900 & 125 & 19,34 & 13,71 & 11,94 & 10,37 & 9,17 & 8,14 & 6,45 & 5,19 & 3,55 \\
\hline 75 & 950 & 125 & 18,82 & 13,44 & 11,75 & 10,25 & 9,09 & 8,09 & 6,43 & 5,19 & 3,56 \\
\hline 75 & 1000 & 125 & 18,35 & 13,18 & 11,58 & 10,13 & 9,01 & 8,04 & 6,42 & 5,19 & 3,56 \\
\hline 75 & 1050 & 125 & 17,91 & 12,95 & 11,42 & 10,03 & 8,94 & 7,99 & 6,40 & 5,19 & 3,57 \\
\hline 75 & 1100 & 125 & 17,52 & 12,73 & 11,26 & 9,92 & 8,87 & 7,94 & 6,38 & 5,19 & 3,58 \\
\hline 75 & 1150 & 125 & 17,15 & 12,52 & 11,12 & 9,82 & 8,80 & 7,89 & 6,37 & 5,19 & 3,59 \\
\hline 75 & 1200 & 125 & 16,81 & 12,32 & 10,98 & 9,73 & 8,73 & 7,85 & 6,35 & 5,19 & 3,60 \\
\hline 75 & 1250 & 125 & 16,49 & 12,14 & 10,85 & 9,64 & 8,67 & 7,80 & 6,33 & 5,18 & 3,60 \\
\hline 75 & 1300 & 125 & 16,19 & 11,97 & 10,73 & 9,55 & 8,60 & 7,76 & 6,32 & 5,18 & 3,61 \\
\hline 75 & 1350 & 125 & 15,92 & 11,80 & 10,61 & 9,47 & 8,54 & 7,72 & 6,30 & 5,18 & 3,62 \\
\hline 75 & 1400 & 125 & 15,66 & 11,64 & 10,50 & 9,39 & 8,48 & 7,68 & 6,28 & 5,17 & 3,62 \\
\hline 75 & 1450 & 125 & 15,42 & 11,50 & 10,39 & 9,31 & 8,43 & 7,64 & 6,26 & 5,17 & 3,63 \\
\hline 75 & 1500 & 125 & 15,19 & 11,35 & 10,28 & 9,24 & 8,37 & 7,60 & 6,25 & 5,16 & 3,63 \\
\hline 75 & 1550 & 125 & 14,97 & 11,22 & 10,18 & 9,17 & 8,32 & 7,56 & 6,23 & 5,16 & 3,64 \\
\hline 75 & 1600 & 125 & 14,76 & 11,09 & 10,09 & 9,10 & 8,27 & 7,52 & 6,21 & 5,15 & 3,64 \\
\hline 75 & 1650 & 125 & 14,57 & 10,97 & 10,00 & 9,03 & 8,22 & 7,48 & 6,19 & 5,15 & 3,64 \\
\hline 75 & 1700 & 125 & 14,39 & 10,85 & 9,91 & 8,96 & 8,17 & 7,45 & 6,18 & 5,14 & 3,65 \\
\hline 75 & 1750 & 125 & 14,21 & 10,73 & 9,82 & 8,90 & 8,12 & 7,41 & 6,16 & 5,14 & 3,65 \\
\hline 75 & 1800 & 125 & 14.04 & 10,63 & 9,74 & 8.84 & 8,07 & 7,38 & 6.14 & 5,13 & 3,66 \\
\hline 75 & 1850 & 125 & 13,88 & 10,52 & 9,66 & 8,78 & 8,03 & 7,34 & 6,13 & 5,13 & 3,66 \\
\hline 75 & 1900 & 125 & 13,73 & 10,42 & 9,58 & 8,72 & 7,98 & 7,31 & 6,11 & 5,12 & 3,66 \\
\hline 75 & 1950 & 125 & 13,58 & 10,32 & 9,50 & 8,67 & 7,94 & 7,28 & 6,09 & 5,11 & 3,66 \\
\hline 75 & 2000 & 125 & 13,44 & 10,23 & 9,43 & 8,61 & 7,90 & 7,25 & 6,08 & 5,11 & 3,67 \\
\hline 75 & 200 & 130 & 48,28 & 24,94 & 17,98 & 13,22 & 10,47 & 8,58 & 6,09 & 4,69 & 3,22 \\
\hline 75 & 250 & 130 & 41,21 & 22,47 & 16,77 & 12,74 & 10,30 & 8,55 & 6,16 & 4,75 & 3,23 \\
\hline 75 & 300 & 130 & 36,39 & 20,72 & 15,88 & 12,36 & 10,14 & 8,50 & 6,20 & 4,79 & 3,25 \\
\hline
\end{tabular}




\begin{tabular}{|c|c|c|c|c|c|c|c|c|c|c|c|}
\hline \multirow[b]{2}{*}{$\mathrm{H}(\mathrm{cm})$} & \multirow[b]{2}{*}{ Mceq (MPa) } & & & & & De & ões (x1 & & & & \\
\hline & & Msub (MPa) & D0 & D25 & D40 & D60 & D80 & D100 & D140 & D180 & D260 \\
\hline 75 & 350 & 130 & 32,87 & 19,39 & 15,18 & 12,04 & 10,00 & 8,45 & 6,23 & 4,83 & 3,26 \\
\hline 75 & 400 & 130 & 30,19 & 18,34 & 14,61 & 11,76 & 9,87 & 8,40 & 6,25 & 4,86 & 3,28 \\
\hline 75 & 450 & 130 & 28,05 & 17,49 & 14,12 & 11,52 & 9,74 & 8,34 & 6,26 & 4,89 & 3,29 \\
\hline 75 & 500 & 130 & 26,32 & 16,76 & 13,71 & 11,30 & 9,62 & 8,29 & 6,27 & 4,91 & 3,31 \\
\hline 75 & 550 & 130 & 24,88 & 16,15 & 13,34 & 11,10 & 9,51 & 8,23 & 6,27 & 4,93 & 3,32 \\
\hline 75 & 600 & 130 & 23,66 & 15,61 & 13,02 & 10,91 & 9,41 & 8,18 & 6,27 & 4,94 & 3,33 \\
\hline 75 & 650 & 130 & 22,61 & 15,13 & 12,73 & 10,74 & 9,31 & 8,12 & 6,26 & 4,95 & 3,35 \\
\hline 75 & 700 & 130 & 21,69 & 14,71 & 12,46 & 10,59 & 9,21 & 8,07 & 6,25 & 4,96 & 3,36 \\
\hline 75 & 750 & 130 & 20,89 & 14,33 & 12,22 & 10,44 & 9,12 & 8,01 & 6,24 & 4,97 & 3,37 \\
\hline 75 & 800 & 130 & 20,18 & 13,98 & 12,00 & 10,30 & 9,03 & 7,96 & 6,23 & 4,98 & 3,38 \\
\hline 75 & 850 & 130 & 19,55 & 13,67 & 11,80 & 10,18 & 8,95 & 7,91 & 6,22 & 4,98 & 3,39 \\
\hline 75 & 900 & 130 & 18,98 & 13,38 & 11,61 & 10,05 & 8,87 & 7,86 & 6,21 & 4,99 & 3,40 \\
\hline 75 & 950 & 130 & 18,46 & 13,11 & 11,43 & 9,94 & 8,79 & 7,81 & 6,20 & 4,99 & 3,41 \\
\hline 75 & 1000 & 130 & 17,99 & 12,86 & 11,26 & 9,83 & 8,72 & 7,76 & 6,18 & 4,99 & 3,42 \\
\hline 75 & 1050 & 130 & 17,56 & 12,63 & 11,10 & 9,72 & 8,65 & 7,72 & 6,17 & 4,99 & 3,43 \\
\hline 75 & 1100 & 130 & 17,16 & 12,42 & 10,96 & 9,62 & 8,58 & 7,67 & 6,15 & 4,99 & 3,44 \\
\hline 75 & 1150 & 130 & 16,80 & 12,21 & 10,82 & 9,53 & 8,52 & 7,63 & 6,14 & 4,99 & 3,44 \\
\hline 75 & 1200 & 130 & 16,46 & 12,02 & 10,68 & 9,44 & 8,45 & 7,59 & 6,12 & 4,99 & 3,45 \\
\hline 75 & 1250 & 130 & 16,15 & 11,84 & 10,56 & 9,35 & 8,39 & 7,54 & 6,10 & 4,99 & 3,46 \\
\hline 75 & 1300 & 130 & 15,86 & 11,67 & 10,44 & 9,27 & 8,33 & 7,50 & 6,09 & 4,98 & 3,46 \\
\hline 75 & 1350 & 130 & 15,58 & 11,51 & 10,32 & 9,19 & 8,27 & 7,46 & 6,07 & 4,98 & 3,47 \\
\hline 75 & 1400 & 130 & 15,33 & 11,36 & 10,21 & 9,11 & 8,22 & 7,42 & 6,06 & 4,98 & 3,48 \\
\hline 75 & 1450 & 130 & 15,09 & 11,21 & 10,11 & 9,04 & 8,16 & 7,39 & 6,04 & 4,98 & 3,48 \\
\hline 75 & 1500 & 130 & 14,86 & 11,08 & 10,00 & 8,97 & 8,11 & 7,35 & 6,02 & 4,97 & 3,49 \\
\hline 75 & 1550 & 130 & 14,64 & 10,94 & 9,91 & 8,90 & 8,06 & 7,31 & 6,01 & 4,97 & 3,49 \\
\hline 75 & 1600 & 130 & 14,44 & 10,82 & 9,82 & 8,83 & 8,01 & 7,28 & 5,99 & 4,96 & 3,50 \\
\hline 75 & 1650 & 130 & 14,25 & 10,70 & 9,73 & 8,76 & 7,96 & 7,24 & 5,98 & 4,96 & 3,50 \\
\hline 75 & 1700 & 130 & 14,07 & 10,58 & 9,64 & 8,70 & 7,92 & 7,21 & 5,96 & 4,95 & 3,50 \\
\hline 75 & 1750 & 130 & 13,89 & 10,47 & 9,56 & 8,64 & 7,87 & 7,17 & 5,95 & 4,95 & 3,51 \\
\hline 75 & 1800 & 130 & 13,73 & 10,36 & 9,47 & 8,58 & 7,83 & 7,14 & 5,93 & 4,94 & 3,51 \\
\hline 75 & 1850 & 130 & 13,57 & 10,26 & 9,40 & 8,52 & 7,78 & 7,11 & 5,91 & 4,94 & 3,51 \\
\hline 75 & 1900 & 130 & 13,42 & 10,16 & 9,32 & 8,47 & 7,74 & 7,08 & 5,90 & 4,93 & 3,52 \\
\hline 75 & 1950 & 130 & 13,28 & 10,07 & 9,25 & 8,41 & 7,70 & 7,04 & 5,88 & 4,93 & 3,52 \\
\hline 75 & 2000 & 130 & 13,14 & 9,98 & 9,18 & 8,36 & 7,66 & 7,01 & 5,87 & 4,92 & 3,52 \\
\hline 75 & 200 & 135 & 47,79 & 24,47 & 17,52 & 12,81 & 10,11 & 8,26 & 5,86 & 4,50 & 3,10 \\
\hline 75 & 250 & 135 & 40,74 & 22,01 & 16,34 & 12,34 & 9,95 & 8,24 & 5,92 & 4,56 & 3,11 \\
\hline 75 & 300 & 135 & 35,94 & 20,28 & 15,46 & 11,98 & 9,80 & 8,20 & 5,97 & 4,61 & 3,12 \\
\hline 75 & 350 & 135 & 32,44 & 18,97 & 14,78 & 11,67 & 9,66 & 8,15 & 6,00 & 4,64 & 3,14 \\
\hline 75 & 400 & 135 & 29,77 & 17,94 & 14,22 & 11,40 & 9,54 & 8,10 & 6,02 & 4,67 & 3,15 \\
\hline 75 & 450 & 135 & 27,65 & 17,10 & 13,75 & 11,17 & 9,42 & 8,05 & 6,03 & 4,70 & 3,16 \\
\hline 75 & 500 & 135 & 25,93 & 16,39 & 13,34 & 10,95 & 9,31 & 8,00 & 6,03 & 4,72 & 3,18 \\
\hline 75 & 550 & 135 & 24,49 & 15,78 & 12,99 & 10,76 & 9,20 & 7,95 & 6,04 & 4,74 & 3,19 \\
\hline 75 & 600 & 135 & 23,28 & 15,25 & 12,67 & 10,59 & 9,10 & 7,90 & 6,04 & 4,75 & 3,20 \\
\hline 75 & 650 & 135 & 22,24 & 14,79 & 12,39 & 10,42 & 9,01 & 7,85 & 6,03 & 4,76 & 3,22 \\
\hline 75 & 700 & 135 & 21,33 & 14,37 & 12,13 & 10,27 & 8,92 & 7,79 & 6,03 & 4,77 & 3,23 \\
\hline 75 & 750 & 135 & 20,54 & 14,00 & 11,90 & 10,13 & 8,83 & 7,74 & 6,02 & 4,78 & 3,24 \\
\hline 75 & 800 & 135 & 19,83 & 13,66 & 11,68 & 10,00 & 8,75 & 7,70 & 6,01 & 4,79 & 3,25 \\
\hline 75 & 850 & 135 & 19,20 & 13,35 & 11,48 & 9,88 & 8,67 & 7,65 & 6,00 & 4,80 & 3,26 \\
\hline 75 & 900 & 135 & 18,63 & 13,07 & 11,30 & 9,76 & 8,59 & 7,60 & 5,99 & 4,80 & 3,27 \\
\hline 75 & 950 & 135 & 18,12 & 12,80 & 11,12 & 9,65 & 8,52 & 7,56 & 5,98 & 4,80 & 3,28 \\
\hline 75 & 1000 & 135 & 17,66 & 12,56 & 10,96 & 9,54 & 8,45 & 7,51 & 5,96 & 4,80 & 3,29 \\
\hline 75 & 1050 & 135 & 17,23 & 12,34 & 10,81 & 9,44 & 8,38 & 7,47 & 5,95 & 4,81 & 3,30 \\
\hline 75 & 1100 & 135 & 16,84 & 12,12 & 10,67 & 9,35 & 8,32 & 7,42 & 5,94 & 4,81 & 3,30 \\
\hline 75 & 1150 & 135 & 16,48 & 11,93 & 10,53 & 9,25 & 8,26 & 7,38 & 5,92 & 4,81 & 3,31 \\
\hline 75 & 1200 & 135 & 16,14 & 11,74 & 10,40 & 9,17 & 8,19 & 7,34 & 5,91 & 4,81 & 3,32 \\
\hline 75 & 1250 & 135 & 15,83 & 11,56 & 10,28 & 9,08 & 8,14 & 7,30 & 5,89 & 4,80 & 3,32 \\
\hline 75 & 1300 & 135 & 15,54 & 11,40 & 10,16 & 9,00 & 8,08 & 7,26 & 5,88 & 4,80 & 3,33 \\
\hline 75 & 1350 & 135 & 15,27 & 11,24 & 10,05 & 8,93 & 8,02 & 7,23 & 5,86 & 4,80 & 3,34 \\
\hline 75 & 1400 & 135 & 15,01 & 11,09 & 9,94 & 8,85 & 7,97 & 7,19 & 5,85 & 4,80 & 3,34 \\
\hline 75 & 1450 & 135 & 14,78 & 10,95 & 9,84 & 8,78 & 7,92 & 7,15 & 5,83 & 4,79 & 3,35 \\
\hline 75 & 1500 & 135 & 14,55 & 10,81 & 9,74 & 8,71 & 7,87 & 7,12 & 5,82 & 4,79 & 3,35 \\
\hline 75 & 1550 & 135 & 14,34 & 10,68 & 9,65 & 8,64 & 7,82 & 7,08 & 5,80 & 4,79 & 3,36 \\
\hline 75 & 1600 & 135 & 14,14 & 10,56 & 9,56 & 8,58 & 7,77 & 7,05 & 5,79 & 4,78 & 3,36 \\
\hline 75 & 1650 & 135 & 13,95 & 10,44 & 9,47 & 8,52 & 7,73 & 7,01 & 5,77 & 4,78 & 3,37 \\
\hline 75 & 1700 & 135 & 13,77 & 10,33 & 9,39 & 8,46 & 7,68 & 6,98 & 5,76 & 4,78 & 3,37 \\
\hline 75 & 1750 & 135 & 13,60 & 10,22 & 9,31 & 8,40 & 7,64 & 6,95 & 5,74 & 4,77 & 3,37 \\
\hline 75 & 1800 & 135 & 13,43 & 10,12 & 9,23 & 8,34 & 7,59 & 6,92 & 5,73 & 4,77 & 3,38 \\
\hline 75 & 1850 & 135 & 13,28 & 10,02 & 9,15 & 8,28 & 7,55 & 6,89 & 5,72 & 4,76 & 3,38 \\
\hline 75 & 1900 & 135 & 13,13 & 9,92 & 9,08 & 8,23 & 7,51 & 6,86 & 5,70 & 4,76 & 3,38 \\
\hline 75 & 1950 & 135 & 12,99 & 9,83 & 9,01 & 8,18 & 7,47 & 6,83 & 5,69 & 4,75 & 3,38 \\
\hline 75 & 2000 & 135 & 12,85 & 9,74 & 8,94 & 8,13 & 7,43 & 6,80 & 5,67 & 4,75 & 3,39 \\
\hline 75 & 200 & 140 & 47,32 & 24,02 & 17,10 & 12,42 & 9,77 & 7,97 & 5,64 & 4,33 & 2,99 \\
\hline 75 & 250 & 140 & 40,30 & 21,59 & 15,93 & 11,97 & 9,62 & 7,95 & 5,70 & 4,39 & 3,00 \\
\hline 75 & 300 & 140 & 35,52 & 19,87 & 15,07 & 11,62 & 9,48 & 7,91 & 5,75 & 4,43 & 3,01 \\
\hline 75 & 350 & 140 & 32,04 & 18,58 & 14,40 & 11,32 & 9,35 & 7,87 & 5,78 & 4,47 & 3,02 \\
\hline 75 & 400 & 140 & 29,38 & 17,56 & 13,85 & 11,06 & 9,23 & 7,83 & 5,80 & 4,50 & 3,03 \\
\hline 75 & 450 & 140 & 27,27 & 16,73 & 13,39 & 10,84 & 9,12 & 7,78 & 5,81 & 4,52 & 3,05 \\
\hline 75 & 500 & 140 & 25,56 & 16,03 & 13,00 & 10,63 & 9,01 & 7,73 & 5,82 & 4,54 & 3,06 \\
\hline 75 & 550 & 140 & 24,13 & 15,44 & 12,65 & 10,45 & 8,91 & 7,69 & 5,82 & 4,56 & 3,07 \\
\hline 75 & 600 & 140 & 22,93 & 14,92 & 12,35 & 10,28 & 8,82 & 7,64 & 5,82 & 4,58 & 3,08 \\
\hline 75 & 650 & 140 & 21,89 & 14,46 & 12,07 & 10,12 & 8,73 & 7,59 & 5,82 & 4,59 & 3,10 \\
\hline
\end{tabular}




\begin{tabular}{|c|c|c|c|c|c|c|c|c|c|c|c|}
\hline \multirow[b]{2}{*}{$\mathrm{H}(\mathrm{cm})$} & \multirow[b]{2}{*}{ Mceq (MPa) } & & & & & De & ões (x & & & & \\
\hline & & Msub (MPa) & D0 & D25 & D40 & D60 & D80 & D100 & D140 & D180 & D260 \\
\hline 75 & 700 & 140 & 20,99 & 14,05 & 11,82 & 9,98 & 8,64 & 7,54 & 5,81 & 4,60 & 3,11 \\
\hline 75 & 750 & 140 & 20,20 & 13,69 & 11,59 & 9,84 & 8,56 & 7,49 & 5,81 & 4,61 & 3,12 \\
\hline 75 & 800 & 140 & 19,50 & 13,35 & 11,38 & 9,71 & 8,48 & 7,45 & 5,80 & 4,62 & 3,13 \\
\hline 75 & 850 & 140 & 18,88 & 13,05 & 11,19 & 9,59 & 8,41 & 7,40 & 5,79 & 4,62 & 3,14 \\
\hline 75 & 900 & 140 & 18,31 & 12,77 & 11,01 & 9,48 & 8,33 & 7,36 & 5,78 & 4,63 & 3,15 \\
\hline 75 & 950 & 140 & 17,80 & 12,52 & 10,84 & 9,37 & 8,26 & 7,32 & 5,77 & 4,63 & 3,16 \\
\hline 75 & 1000 & 140 & 17,34 & 12,28 & 10,68 & 9,27 & 8,20 & 7,27 & 5,76 & 4,63 & 3,16 \\
\hline 75 & 1050 & 140 & 16,92 & 12,06 & 10,53 & 9,18 & 8,13 & 7,23 & 5,75 & 4,63 & 3,17 \\
\hline 75 & 1100 & 140 & 16,53 & 11,85 & 10,39 & 9,08 & 8,07 & 7,19 & 5,73 & 4,63 & 3,18 \\
\hline 75 & 1150 & 140 & 16,17 & 11,66 & 10,26 & 9,00 & 8,01 & 7,15 & 5,72 & 4,63 & 3,19 \\
\hline 75 & 1200 & 140 & 15,84 & 11,47 & 10,13 & 8,91 & 7,95 & 7,11 & 5,71 & 4,63 & 3,19 \\
\hline 75 & 1250 & 140 & 15,53 & 11,30 & 10,02 & 8,83 & 7,90 & 7,08 & 5,69 & 4,63 & 3,20 \\
\hline 75 & 1300 & 140 & 15,24 & 11,14 & 9,90 & 8,75 & 7,84 & 7,04 & 5,68 & 4,63 & 3,21 \\
\hline 75 & 1350 & 140 & 14,97 & 10,98 & 9,79 & 8,68 & 7,79 & 7,00 & 5,67 & 4,63 & 3,21 \\
\hline 75 & 1400 & 140 & 14,72 & 10,84 & 9,69 & 8,61 & 7,74 & 6,97 & 5,65 & 4,63 & 3,22 \\
\hline 75 & 1450 & 140 & 14,49 & 10,70 & 9,59 & 8,54 & 7,69 & 6,93 & 5,64 & 4,63 & 3,22 \\
\hline 75 & 1500 & 140 & 14,26 & 10,57 & 9,50 & 8,47 & 7,64 & 6,90 & 5,63 & 4,62 & 3,23 \\
\hline 75 & 1550 & 140 & 14,05 & 10,44 & 9,40 & 8,41 & 7,59 & 6,87 & 5,61 & 4,62 & 3,23 \\
\hline 75 & 1600 & 140 & 13,86 & 10,32 & 9,32 & 8,34 & 7,55 & 6,83 & 5,60 & 4,62 & 3,24 \\
\hline 75 & 1650 & 140 & 13,67 & 10,20 & 9,23 & 8,28 & 7,50 & 6,80 & 5,58 & 4,61 & 3,24 \\
\hline 75 & 1700 & 140 & 13,49 & 10,09 & 9,15 & 8,22 & 7,46 & 6,77 & 5,57 & 4,61 & 3,24 \\
\hline 75 & 1750 & 140 & 13,32 & 9,99 & 9,07 & 8,17 & 7,42 & 6,74 & 5,56 & 4,61 & 3,25 \\
\hline 75 & 1800 & 140 & 13,16 & 9,89 & 9,00 & 8,11 & 7,38 & 6,71 & 5,54 & 4,60 & 3,25 \\
\hline 75 & 1850 & 140 & 13,00 & 9,79 & 8,92 & 8,06 & 7,34 & 6,68 & 5,53 & 4,60 & 3,25 \\
\hline 75 & 1900 & 140 & 12,86 & 9,69 & 8,85 & 8,01 & 7,30 & 6,65 & 5,52 & 4,59 & 3,26 \\
\hline 75 & 1950 & 140 & 12,72 & 9,60 & 8,78 & 7,96 & 7,26 & 6,62 & 5,50 & 4,59 & 3,26 \\
\hline 75 & 2000 & 140 & 12,58 & 9,51 & 8,72 & 7,91 & 7,22 & 6,60 & 5,49 & 4,58 & 3,26 \\
\hline 75 & 200 & 145 & 46,89 & 23,60 & 16,70 & 12,06 & 9,45 & 7,69 & 5,43 & 4,18 & 2,88 \\
\hline 75 & 250 & 145 & 39,89 & 21,18 & 15,55 & 11,63 & 9,31 & 7,68 & 5,50 & 4,23 & 2,89 \\
\hline 75 & 300 & 145 & 35,13 & 19,49 & 14,71 & 11,28 & 9,18 & 7,65 & 5,54 & 4,27 & 2,90 \\
\hline 75 & 350 & 145 & 31,66 & 18,21 & 14,05 & 11,00 & 9,06 & 7,61 & 5,57 & 4,31 & 2,91 \\
\hline 75 & 400 & 145 & 29,01 & 17,21 & 13,51 & 10,75 & 8,94 & 7,57 & 5,59 & 4,34 & 2,93 \\
\hline 75 & 450 & 145 & 26,92 & 16,39 & 13,06 & 10,53 & 8,84 & 7,53 & 5,61 & 4,36 & 2,94 \\
\hline 75 & 500 & 145 & 25,21 & 15,70 & 12,68 & 10,33 & 8,74 & 7,48 & 5,61 & 4,38 & 2,95 \\
\hline 75 & 550 & 145 & 23,79 & 15,11 & 12,34 & 10,15 & 8,64 & 7,44 & 5,62 & 4,40 & 2,96 \\
\hline 75 & 600 & 145 & 22,60 & 14,60 & 12,04 & 9,99 & 8,55 & 7,39 & 5,62 & 4,41 & 2,97 \\
\hline 75 & 650 & 145 & 21,57 & 14,15 & 11,77 & 9,84 & 8,47 & 7,35 & 5,62 & 4,43 & 2,98 \\
\hline 75 & 700 & 145 & 20,67 & 13,75 & 11,53 & 9,70 & 8,38 & 7,30 & 5,62 & 4,44 & 3,00 \\
\hline 75 & 750 & 145 & 19,89 & 13,39 & 11,30 & 9,57 & 8,31 & 7,26 & 5,61 & 4,44 & 3,01 \\
\hline 75 & 800 & 145 & 19,19 & 13,07 & 11,10 & 9,45 & 8,23 & 7,22 & 5,60 & 4,45 & 3,02 \\
\hline 75 & 850 & 145 & 18,57 & 12,77 & 10,91 & 9,33 & 8,16 & 7,17 & 5,60 & 4,46 & 3,02 \\
\hline 75 & 900 & 145 & 18,01 & 12,50 & 10,73 & 9,22 & 8,09 & 7,13 & 5,59 & 4,46 & 3,03 \\
\hline 75 & 950 & 145 & 17,51 & 12,25 & 10,57 & 9,12 & 8,02 & 7,09 & 5,58 & 4,47 & 3,04 \\
\hline 75 & 1000 & 145 & 17,05 & 12,01 & 10,42 & 9,02 & 7,96 & 7,05 & 5,57 & 4,47 & 3,05 \\
\hline 75 & 1050 & 145 & 16,63 & 11,79 & 10,27 & 8,93 & 7,90 & 7,01 & 5,56 & 4,47 & 3,06 \\
\hline 75 & 1100 & 145 & 16,24 & 11,59 & 10,14 & 8,84 & 7,84 & 6,97 & 5,55 & 4,47 & 3,06 \\
\hline 75 & 1150 & 145 & 15,89 & 11,40 & 10,01 & 8,75 & 7,78 & 6,94 & 5,53 & 4,47 & 3,07 \\
\hline 75 & 1200 & 145 & 15,56 & 11,22 & 9,89 & 8,67 & 7,72 & 6,90 & 5,52 & 4,48 & 3,08 \\
\hline 75 & 1250 & 145 & 15,25 & 11,05 & 9,77 & 8,59 & 7,67 & 6,86 & 5,51 & 4,47 & 3,08 \\
\hline 75 & 1300 & 145 & 14,97 & 10,90 & 9,66 & 8,52 & 7,62 & 6,83 & 5,50 & 4,47 & 3,09 \\
\hline 75 & 1350 & 145 & 14,70 & 10,74 & 9,55 & 8,45 & 7,57 & 6,79 & 5,48 & 4,47 & 3,10 \\
\hline 75 & 1400 & 145 & 14,45 & 10,60 & 9,45 & 8,38 & 7,52 & 6,76 & 5,47 & 4,47 & 3,10 \\
\hline 75 & 1450 & 145 & 14,22 & 10,47 & 9,36 & 8,31 & 7,47 & 6,73 & 5,46 & 4,47 & 3,11 \\
\hline 75 & 1500 & 145 & 13,99 & 10,34 & 9,26 & 8,25 & 7,42 & 6,69 & 5,45 & 4,47 & 3,11 \\
\hline 75 & 1550 & 145 & 13,79 & 10,21 & 9,17 & 8,18 & 7,38 & 6,66 & 5,43 & 4,46 & 3,12 \\
\hline 75 & 1600 & 145 & 13,59 & 10,09 & 9,09 & 8,12 & 7,34 & 6,63 & 5,42 & 4,46 & 3,12 \\
\hline 75 & 1650 & 145 & 13,40 & 9,98 & 9,01 & 8,06 & 7,29 & 6,60 & 5,41 & 4,46 & 3,12 \\
\hline 75 & 1700 & 145 & 13,23 & 9,87 & 8,93 & 8,01 & 7,25 & 6,57 & 5,39 & 4,46 & 3,13 \\
\hline 75 & 1750 & 145 & 13,06 & 9,77 & 8,85 & 7,95 & 7,21 & 6,54 & 5,38 & 4,45 & 3,13 \\
\hline 75 & 1800 & 145 & 12,90 & 9,67 & 8,78 & 7,90 & 7,17 & 6,51 & 5,37 & 4,45 & 3,13 \\
\hline 75 & 1850 & 145 & 12,75 & 9,57 & 8,71 & 7,85 & 7,13 & 6,49 & 5,36 & 4,44 & 3,14 \\
\hline 75 & 1900 & 145 & 12,60 & 9,48 & 8,64 & 7,80 & 7,09 & 6,46 & 5,34 & 4,44 & 3,14 \\
\hline 75 & 1950 & 145 & 12,46 & 9,39 & 8,57 & 7,75 & 7,06 & 6,43 & 5,33 & 4,44 & 3,14 \\
\hline 75 & 2000 & 145 & 12,33 & 9,30 & 8,50 & 7,70 & 7,02 & 6,40 & 5,32 & 4,43 & 3,15 \\
\hline 75 & 200 & 150 & 46,48 & 23,20 & 16,33 & 11,73 & 9,16 & 7,44 & 5,24 & 4,03 & 2,79 \\
\hline 75 & 250 & 150 & 39,50 & 20,81 & 15,19 & 11,30 & 9,02 & 7,43 & 5,30 & 4,08 & 2,79 \\
\hline 75 & 300 & 150 & 34,76 & 19,13 & 14,36 & 10,97 & 8,90 & 7,40 & 5,35 & 4,12 & 2,80 \\
\hline 75 & 350 & 150 & 31,30 & 17,87 & 13,72 & 10,69 & 8,78 & 7,37 & 5,38 & 4,16 & 2,81 \\
\hline 75 & 400 & 150 & 28,67 & 16,87 & 13,19 & 10,45 & 8,67 & 7,33 & 5,40 & 4,18 & 2,82 \\
\hline 75 & 450 & 150 & 26,58 & 16,06 & 12,75 & 10,24 & 8,57 & 7,29 & 5,42 & 4,21 & 2,84 \\
\hline 75 & 500 & 150 & 24,89 & 15,39 & 12,37 & 10,05 & 8,48 & 7,25 & 5,42 & 4,23 & 2,85 \\
\hline 75 & 550 & 150 & 23,48 & 14,81 & 12,04 & 9,88 & 8,39 & 7,21 & 5,43 & 4,25 & 2,86 \\
\hline 75 & 600 & 150 & 22,28 & 14,31 & 11,75 & 9,72 & 8,30 & 7,16 & 5,43 & 4,26 & 2,87 \\
\hline 75 & 650 & 150 & 21,26 & 13,86 & 11,49 & 9,57 & 8,22 & 7,12 & 5,43 & 4,27 & 2,88 \\
\hline 75 & 700 & 150 & 20,37 & 13,47 & 11,25 & 9,44 & 8,14 & 7,08 & 5,43 & 4,28 & 2,89 \\
\hline 75 & 750 & 150 & 19,59 & 13,12 & 11,03 & 9,31 & 8,07 & 7,04 & 5,43 & 4,29 & 2,90 \\
\hline 75 & 800 & 150 & 18,90 & 12,80 & 10,83 & 9,19 & 7,99 & 7,00 & 5,42 & 4,30 & 2,91 \\
\hline 75 & 850 & 150 & 18,28 & 12,50 & 10,65 & 9,08 & 7,93 & 6,96 & 5,41 & 4,31 & 2,92 \\
\hline 75 & 900 & 150 & 17,73 & 12,24 & 10,48 & 8,98 & 7,86 & 6,92 & 5,41 & 4,31 & 2,93 \\
\hline 75 & 950 & 150 & 17,23 & 11,99 & 10,32 & 8,88 & 7,80 & 6,88 & 5,40 & 4,32 & 2,94 \\
\hline 75 & 1000 & 150 & 16,77 & 11,76 & 10,17 & 8,78 & 7,73 & 6,84 & 5,39 & 4,32 & 2,94 \\
\hline
\end{tabular}




\begin{tabular}{|c|c|c|c|c|c|c|c|c|c|c|c|}
\hline \multirow[b]{2}{*}{$\mathrm{H}(\mathrm{cm})$} & \multirow[b]{2}{*}{ Mceq (MPa) } & & & & & $\mathrm{De}$ & ões (x. & & & & \\
\hline & & Msub (MPa) & D0 & D25 & D40 & D60 & D80 & D100 & D140 & D180 & D260 \\
\hline 75 & 1050 & 150 & 16,35 & 11,55 & 10,03 & 8,69 & 7,67 & 6,80 & 5,38 & 4,32 & 2,95 \\
\hline 75 & 1100 & 150 & 15,97 & 11,35 & 9,89 & 8,61 & 7,62 & 6,77 & 5,37 & 4,32 & 2,96 \\
\hline 75 & 1150 & 150 & 15,62 & 11,16 & 9,77 & 8,52 & 7,56 & 6,73 & 5,36 & 4,33 & 2,96 \\
\hline 75 & 1200 & 150 & 15,29 & 10,99 & 9,65 & 8,45 & 7,51 & 6,70 & 5,35 & 4,33 & 2,97 \\
\hline 75 & 1250 & 150 & 14,99 & 10,82 & 9,54 & 8,37 & 7,46 & 6,66 & 5,34 & 4,33 & 2,98 \\
\hline 75 & 1300 & 150 & 14,70 & 10,66 & 9,43 & 8,30 & 7,41 & 6,63 & 5,32 & 4,33 & 2,98 \\
\hline 75 & 1350 & 150 & 14,44 & 10,52 & 9,33 & 8,23 & 7,36 & 6,60 & 5,31 & 4,32 & 2,99 \\
\hline 75 & 1400 & 150 & 14,19 & 10,38 & 9,23 & 8,16 & 7,31 & 6,56 & 5,30 & 4,32 & 2,99 \\
\hline 75 & 1450 & 150 & 13,96 & 10,24 & 9,13 & 8,10 & 7,27 & 6,53 & 5,29 & 4,32 & 3,00 \\
\hline 75 & 1500 & 150 & 13,74 & 10,12 & 9,04 & 8,03 & 7,22 & 6,50 & 5,28 & 4,32 & 3,00 \\
\hline 75 & 1550 & 150 & 13,54 & 9,99 & 8,96 & 7,97 & 7,18 & 6,47 & 5,27 & 4,32 & 3,01 \\
\hline 75 & 1600 & 150 & 13,34 & 9,88 & 8,87 & 7,91 & 7,14 & 6,44 & 5,25 & 4,32 & 3,01 \\
\hline 75 & 1650 & 150 & 13,16 & 9,77 & 8,79 & 7,86 & 7,09 & 6,41 & 5,24 & 4,31 & 3,02 \\
\hline 75 & 1700 & 150 & 12,98 & 9,66 & 8,72 & 7,80 & 7,05 & 6,39 & 5,23 & 4,31 & 3,02 \\
\hline 75 & 1750 & 150 & 12,81 & 9,56 & 8,64 & 7,75 & 7,02 & 6,36 & 5,22 & 4,31 & 3,02 \\
\hline 75 & 1800 & 150 & 12,66 & 9,46 & 8,57 & 7,70 & 6,98 & 6,33 & 5,20 & 4,30 & 3,03 \\
\hline 75 & 1850 & 150 & 12,50 & 9,37 & 8,50 & 7,65 & 6,94 & 6,30 & 5,19 & 4,30 & 3,03 \\
\hline 75 & 1900 & 150 & 12,36 & 9,28 & 8,43 & 7,60 & 6,90 & 6,28 & 5,18 & 4,30 & 3,03 \\
\hline 75 & 1950 & 150 & 12,22 & 9,19 & 8,37 & 7,55 & 6,87 & 6,25 & 5,17 & 4,29 & 3,04 \\
\hline 75 & 2000 & 150 & 12,09 & 9,11 & 8,31 & 7,51 & 6,83 & 6,23 & 5,16 & 4,29 & 3,04 \\
\hline 75 & 200 & 155 & 46,10 & 22,83 & 15,97 & 11,41 & 8,88 & 7,20 & 5,06 & 3,89 & 2,70 \\
\hline 75 & 250 & 155 & 39,14 & 20,45 & 14,85 & 11,00 & 8,75 & 7,19 & 5,12 & 3,94 & 2,70 \\
\hline 75 & 300 & 155 & 34,41 & 18,79 & 14,04 & 10,67 & 8,63 & 7,17 & 5,17 & 3,98 & 2,71 \\
\hline 75 & 350 & 155 & 30,97 & 17,54 & 13,40 & 10,40 & 8,52 & 7,14 & 5,20 & 4,01 & 2,72 \\
\hline 75 & 400 & 155 & 28,34 & 16,56 & 12,89 & 10,17 & 8,42 & 7,10 & 5,22 & 4,04 & 2,73 \\
\hline 75 & 450 & 155 & 26,27 & 15,76 & 12,46 & 9,97 & 8,32 & 7,07 & 5,24 & 4,07 & 2,74 \\
\hline 75 & 500 & 155 & 24,58 & 15,09 & 12,09 & 9,78 & 8,23 & 7,03 & 5,25 & 4,09 & 2,75 \\
\hline 75 & 550 & 155 & 23,18 & 14,52 & 11,76 & 9,62 & 8,15 & 6,99 & 5,25 & 4,10 & 2,76 \\
\hline 75 & 600 & 155 & 21,99 & 14,02 & 11,48 & 9,46 & 8,06 & 6,95 & 5,26 & 4,12 & 2,77 \\
\hline 75 & 650 & 155 & 20,97 & 13,59 & 11,22 & 9,32 & 7,99 & 6,91 & 5,26 & 4,13 & 2,78 \\
\hline 75 & 700 & 155 & 20,09 & 13,20 & 10,99 & 9,19 & 7,91 & 6,87 & 5,26 & 4,14 & 2,79 \\
\hline 75 & 750 & 155 & 19,31 & 12,85 & 10,78 & 9,07 & 7,84 & 6,83 & 5,25 & 4,15 & 2,80 \\
\hline 75 & 800 & 155 & 18,63 & 12,54 & 10,58 & 8,96 & 7,77 & 6,79 & 5,25 & 4,16 & 2,81 \\
\hline 75 & 850 & 155 & 18,01 & 12,25 & 10,40 & 8,85 & 7,71 & 6,75 & 5,24 & 4,16 & 2,82 \\
\hline 75 & 900 & 155 & 17,46 & 11,99 & 10,23 & 8,75 & 7,64 & 6,72 & 5,24 & 4,17 & 2,83 \\
\hline 75 & 950 & 155 & 16,96 & 11,75 & 10,08 & 8,65 & 7,58 & 6,68 & 5,23 & 4,17 & 2,84 \\
\hline 75 & 1000 & 155 & 16,51 & 11,52 & 9,93 & 8,56 & 7,52 & 6,64 & 5,22 & 4,18 & 2,84 \\
\hline 75 & 1050 & 155 & 16,10 & 11,31 & 9,79 & 8,47 & 7,47 & 6,61 & 5,21 & 4,18 & 2,85 \\
\hline 75 & 1100 & 155 & 15,72 & 11,12 & 9,67 & 8,39 & 7,41 & 6,57 & 5,20 & 4,18 & 2,86 \\
\hline 75 & 1150 & 155 & 15,36 & 10,93 & 9,54 & 8,31 & 7,36 & 6,54 & 5,19 & 4,18 & 2,86 \\
\hline 75 & 1200 & 155 & 15,04 & 10,76 & 9,43 & 8,23 & 7,31 & 6,51 & 5,18 & 4,19 & 2,87 \\
\hline 75 & 1250 & 155 & 14,74 & 10,60 & 9,32 & 8,16 & 7,26 & 6,47 & 5,17 & 4,19 & 2,88 \\
\hline 75 & 1300 & 155 & 14,46 & 10,45 & 9,21 & 8,09 & 7,21 & 6,44 & 5,16 & 4,19 & 2,88 \\
\hline 75 & 1350 & 155 & 14,20 & 10,30 & 9,11 & 8,02 & 7,16 & 6,41 & 5,15 & 4,19 & 2,89 \\
\hline 75 & 1400 & 155 & 13,95 & 10,16 & 9,02 & 7,96 & 7,12 & 6,38 & 5,14 & 4,19 & 2,89 \\
\hline 75 & 1450 & 155 & 13,72 & 10,03 & 8,92 & 7,89 & 7,07 & 6,35 & 5,13 & 4,18 & 2,90 \\
\hline 75 & 1500 & 155 & 13,50 & 9,91 & 8,84 & 7,83 & 7,03 & 6,32 & 5,12 & 4,18 & 2,90 \\
\hline 75 & 1550 & 155 & 13,30 & 9,79 & 8,75 & 7,77 & 6,99 & 6,29 & 5,11 & 4,18 & 2,91 \\
\hline 75 & 1600 & 155 & 13,11 & 9,68 & 8,67 & 7,72 & 6,95 & 6,26 & 5,10 & 4,18 & 2,91 \\
\hline 75 & 1650 & 155 & 12,92 & 9,57 & 8,59 & 7,66 & 6,91 & 6,24 & 5,08 & 4,18 & 2,91 \\
\hline 75 & 1700 & 155 & 12,75 & 9,46 & 8,52 & 7,61 & 6,87 & 6,21 & 5,07 & 4,17 & 2,92 \\
\hline 75 & 1750 & 155 & 12,58 & 9,36 & 8,45 & 7,56 & 6,83 & 6,18 & 5,06 & 4,17 & 2,92 \\
\hline 75 & 1800 & 155 & 12,43 & 9,27 & 8,38 & 7,51 & 6,80 & 6,16 & 5,05 & 4,17 & 2,92 \\
\hline 75 & 1850 & 155 & 12,28 & 9,17 & 8,31 & 7,46 & 6,76 & 6,13 & 5,04 & 4,17 & 2,93 \\
\hline 75 & 1900 & 155 & 12,13 & 9,09 & 8,24 & 7,41 & 6,72 & 6,11 & 5,03 & 4,16 & 2,93 \\
\hline 75 & 1950 & 155 & 12,00 & 9,00 & 8,18 & 7,37 & 6,69 & 6,08 & 5,02 & 4,16 & 2,93 \\
\hline 75 & 2000 & 155 & 11,87 & 8,92 & 8,12 & 7,32 & 6,66 & 6,06 & 5,01 & 4,16 & 2,94 \\
\hline 75 & 200 & 160 & 45,73 & 22,47 & 15,64 & 11,11 & 8,62 & 6,97 & 4,89 & 3,76 & 2,61 \\
\hline 75 & 250 & 160 & 38,79 & 20,12 & 14,53 & 10,71 & 8,50 & 6,97 & 4,96 & 3,81 & 2,62 \\
\hline 75 & 300 & 160 & 34,08 & 18,47 & 13,73 & 10,39 & 8,38 & 6,95 & 5,00 & 3,85 & 2,62 \\
\hline 75 & 350 & 160 & 30,65 & 17,23 & 13,11 & 10,13 & 8,28 & 6,92 & 5,03 & 3,88 & 2,63 \\
\hline 75 & 400 & 160 & 28,04 & 16,26 & 12,60 & 9,91 & 8,18 & 6,89 & 5,05 & 3,91 & 2,64 \\
\hline 75 & 450 & 160 & 25,97 & 15,47 & 12,18 & 9,71 & 8,09 & 6,86 & 5,07 & 3,93 & 2,65 \\
\hline 75 & 500 & 160 & 24,29 & 14,81 & 11,82 & 9,53 & 8,00 & 6,82 & 5,08 & 3,95 & 2,66 \\
\hline 75 & 550 & 160 & 22,89 & 14,25 & 11,50 & 9,37 & 7,92 & 6,78 & 5,09 & 3,97 & 2,67 \\
\hline 75 & 600 & 160 & 21,71 & 13,76 & 11,22 & 9,22 & 7,84 & 6,75 & 5,09 & 3,98 & 2,68 \\
\hline 75 & 650 & 160 & 20,70 & 13,33 & 10,97 & 9,08 & 7,77 & 6,71 & 5,09 & 4,00 & 2,69 \\
\hline 75 & 700 & 160 & 19,82 & 12,95 & 10,74 & 8,96 & 7,70 & 6,67 & 5,09 & 4,01 & 2,70 \\
\hline 75 & 750 & 160 & 19,05 & 12,61 & 10,53 & 8,84 & 7,63 & 6,63 & 5,09 & 4,02 & 2,71 \\
\hline 75 & 800 & 160 & 18,37 & 12,30 & 10,34 & 8,73 & 7,56 & 6,60 & 5,09 & 4,02 & 2,72 \\
\hline 75 & 850 & 160 & 17,76 & 12,01 & 10,17 & 8,63 & 7,50 & 6,56 & 5,08 & 4,03 & 2,73 \\
\hline 75 & 900 & 160 & 17,21 & 11,76 & 10,00 & 8,53 & 7,44 & 6,53 & 5,08 & 4,04 & 2,74 \\
\hline 75 & 950 & 160 & 16,71 & 11,52 & 9,85 & 8,43 & 7,38 & 6,49 & 5,07 & 4,04 & 2,74 \\
\hline 75 & 1000 & 160 & 16,26 & 11,30 & 9,71 & 8,35 & 7,32 & 6,46 & 5,06 & 4,05 & 2,75 \\
\hline 75 & 1050 & 160 & 15,85 & 11,09 & 9,57 & 8,26 & 7,27 & 6,42 & 5,05 & 4,05 & 2,76 \\
\hline 75 & 1100 & 160 & 15,47 & 10,90 & 9,45 & 8,18 & 7,22 & 6,39 & 5,05 & 4,05 & 2,76 \\
\hline 75 & 1150 & 160 & 15,13 & 10,72 & 9,33 & 8,10 & 7,16 & 6,36 & 5,04 & 4,05 & 2,77 \\
\hline 75 & 1200 & 160 & 14,80 & 10,55 & 9,22 & 8,03 & 7,12 & 6,33 & 5,03 & 4,05 & 2,78 \\
\hline 75 & 1250 & 160 & 14,50 & 10,39 & 9,11 & 7,96 & 7,07 & 6,30 & 5,02 & 4,06 & 2,78 \\
\hline 75 & 1300 & 160 & 14,23 & 10,24 & 9,01 & 7,89 & 7,02 & 6,27 & 5,01 & 4,06 & 2,79 \\
\hline 75 & 1350 & 160 & 13,97 & 10,10 & 8,91 & 7,83 & 6,98 & 6,24 & 5,00 & 4,06 & 2,79 \\
\hline
\end{tabular}




\begin{tabular}{|c|c|c|c|c|c|c|c|c|c|c|c|}
\hline \multirow[b]{2}{*}{$\mathrm{H}(\mathrm{cm})$} & \multirow[b]{2}{*}{ Mceq (MPa) } & & & & & De & ões (x & & & & \\
\hline & & Msub (MPa) & D0 & D25 & D40 & D60 & D80 & D100 & D140 & D180 & D260 \\
\hline 75 & 1400 & 160 & 13,72 & 9,96 & 8,82 & 7,76 & 6,93 & 6,21 & 4,99 & 4,06 & 2,80 \\
\hline 75 & 1450 & 160 & 13,49 & 9,83 & 8,73 & 7,70 & 6,89 & 6,18 & 4,98 & 4,05 & 2,80 \\
\hline 75 & 1500 & 160 & 13,28 & 9,71 & 8,64 & 7,64 & 6,85 & 6,15 & 4,97 & 4,05 & 2,81 \\
\hline 75 & 1550 & 160 & 13,07 & 9,60 & 8,56 & 7,59 & 6,81 & 6,12 & 4,96 & 4,05 & 2,81 \\
\hline 75 & 1600 & 160 & 12,88 & 9,48 & 8,48 & 7,53 & 6,77 & 6,10 & 4,95 & 4,05 & 2,82 \\
\hline 75 & 1650 & 160 & 12,70 & 9,38 & 8,40 & 7,48 & 6,73 & 6,07 & 4,94 & 4,05 & 2,82 \\
\hline 75 & 1700 & 160 & 12,53 & 9,27 & 8,33 & 7,43 & 6,69 & 6,04 & 4,93 & 4,05 & 2,82 \\
\hline 75 & 1750 & 160 & 12,37 & 9,18 & 8,26 & 7,38 & 6,66 & 6,02 & 4,92 & 4,04 & 2,83 \\
\hline 75 & 1800 & 160 & 12,21 & 9,08 & 8,19 & 7,33 & 6,62 & 5,99 & 4,91 & 4,04 & 2,83 \\
\hline 75 & 1850 & 160 & 12,06 & 8,99 & 8,12 & 7,28 & 6,59 & 5,97 & 4,89 & 4,04 & 2,83 \\
\hline 75 & 1900 & 160 & 11,92 & 8,90 & 8,06 & 7,23 & 6,55 & 5,94 & 4,88 & 4,04 & 2,84 \\
\hline 75 & 1950 & 160 & 11,78 & 8,82 & 8,00 & 7,19 & 6,52 & 5,92 & 4,87 & 4,03 & 2,84 \\
\hline 75 & 2000 & 160 & 11,65 & 8,74 & 7,94 & 7,15 & 6,49 & 5,90 & 4,86 & 4,03 & 2,84 \\
\hline 75 & 200 & 165 & 45,39 & 22,14 & 15,33 & 10,83 & 8,38 & 6,76 & 4,73 & 3,64 & 2,53 \\
\hline 75 & 250 & 165 & 38,46 & 19,80 & 14,23 & 10,44 & 8,26 & 6,76 & 4,80 & 3,69 & 2,54 \\
\hline 75 & 300 & 165 & 33,76 & 18,16 & 13,44 & 10,13 & 8,15 & 6,74 & 4,84 & 3,73 & 2,54 \\
\hline 75 & 350 & 165 & 30,35 & 16,94 & 12,83 & 9,87 & 8,05 & 6,72 & 4,87 & 3,76 & 2,55 \\
\hline 75 & 400 & 165 & 27,74 & 15,98 & 12,33 & 9,66 & 7,96 & 6,69 & 4,90 & 3,79 & 2,56 \\
\hline 75 & 450 & 165 & 25,69 & 15,20 & 11,91 & 9,46 & 7,87 & 6,66 & 4,91 & 3,81 & 2,57 \\
\hline 75 & 500 & 165 & 24,01 & 14,54 & 11,56 & 9,29 & 7,79 & 6,62 & 4,92 & 3,83 & 2,58 \\
\hline 75 & 550 & 165 & 22,62 & 13,99 & 11,25 & 9,14 & 7,71 & 6,59 & 4,93 & 3,84 & 2,59 \\
\hline 75 & 600 & 165 & 21,45 & 13,51 & 10,97 & 8,99 & 7,63 & 6,55 & 4,94 & 3,86 & 2,60 \\
\hline 75 & 650 & 165 & 20,44 & 13,08 & 10,73 & 8,86 & 7,56 & 6,52 & 4,94 & 3,87 & 2,61 \\
\hline 75 & 700 & 165 & 19,57 & 12,71 & 10,51 & 8,74 & 7,49 & 6,48 & 4,94 & 3,88 & 2,62 \\
\hline 75 & 750 & 165 & 18,80 & 12,37 & 10,30 & 8,62 & 7,43 & 6,45 & 4,94 & 3,89 & 2,62 \\
\hline 75 & 800 & 165 & 18,12 & 12,07 & 10,12 & 8,52 & 7,36 & 6,42 & 4,93 & 3,90 & 2,63 \\
\hline 75 & 850 & 165 & 17,52 & 11,79 & 9,94 & 8,42 & 7,30 & 6,38 & 4,93 & 3,91 & 2,64 \\
\hline 75 & 900 & 165 & 16,97 & 11,53 & 9,79 & 8,32 & 7,24 & 6,35 & 4,93 & 3,91 & 2,65 \\
\hline 75 & 950 & 165 & 16,48 & 11,30 & 9,64 & 8,23 & 7,19 & 6,31 & 4,92 & 3,92 & 2,66 \\
\hline 75 & 1000 & 165 & 16,03 & 11,08 & 9,50 & 8,14 & 7,13 & 6,28 & 4,91 & 3,92 & 2,66 \\
\hline 75 & 1050 & 165 & 15,62 & 10,88 & 9,37 & 8,06 & 7,08 & 6,25 & 4,91 & 3,92 & 2,67 \\
\hline 75 & 1100 & 165 & 15,25 & 10,69 & 9,24 & 7,98 & 7,03 & 6,22 & 4,90 & 3,93 & 2,68 \\
\hline 75 & 1150 & 165 & 14,90 & 10,51 & 9,13 & 7,91 & 6,98 & 6,19 & 4,89 & 3,93 & 2,68 \\
\hline 75 & 1200 & 165 & 14,58 & 10,35 & 9,02 & 7,84 & 6,93 & 6,16 & 4,88 & 3,93 & 2,69 \\
\hline 75 & 1250 & 165 & 14,28 & 10,19 & 8,91 & 7,77 & 6,89 & 6,13 & 4,87 & 3,93 & 2,69 \\
\hline 75 & 1300 & 165 & 14,01 & 10,04 & 8,81 & 7,70 & 6,84 & 6,10 & 4,86 & 3,93 & 2,70 \\
\hline 75 & 1350 & 165 & 13,75 & 9,90 & 8,72 & 7,64 & 6,80 & 6,07 & 4,86 & 3,93 & 2,70 \\
\hline 75 & 1400 & 165 & 13,51 & 9,77 & 8,62 & 7,58 & 6,76 & 6,04 & 4,85 & 3,93 & 2,71 \\
\hline 75 & 1450 & 165 & 13,28 & 9,65 & 8,54 & 7,52 & 6,72 & 6,02 & 4,84 & 3,93 & 2,71 \\
\hline 75 & 1500 & 165 & 13,06 & 9,53 & 8,45 & 7,46 & 6,68 & 5,99 & 4,83 & 3,93 & 2,72 \\
\hline 75 & 1550 & 165 & 12,86 & 9,41 & 8,37 & 7,41 & 6,64 & 5,96 & 4,82 & 3,93 & 2,72 \\
\hline 75 & 1600 & 165 & 12,67 & 9,30 & 8,30 & 7,35 & 6,60 & 5,94 & 4,81 & 3,93 & 2,73 \\
\hline 75 & 1650 & 165 & 12,49 & 9,20 & 8,22 & 7,30 & 6,56 & 5,91 & 4,80 & 3,93 & 2,73 \\
\hline 75 & 1700 & 165 & 12,32 & 9,10 & 8,15 & 7,25 & 6,53 & 5,89 & 4,79 & 3,93 & 2,73 \\
\hline 75 & 1750 & 165 & 12,16 & 9,00 & 8,08 & 7,20 & 6,49 & 5,86 & 4,78 & 3,92 & 2,74 \\
\hline 75 & 1800 & 165 & 12,00 & 8,91 & 8,01 & 7,16 & 6,46 & 5,84 & 4,77 & 3,92 & 2,74 \\
\hline 75 & 1850 & 165 & 11,86 & 8,82 & 7,95 & 7,11 & 6,43 & 5,81 & 4,76 & 3,92 & 2,74 \\
\hline 75 & 1900 & 165 & 11,72 & 8,73 & 7,89 & 7,07 & 6,39 & 5,79 & 4,75 & 3,92 & 2,75 \\
\hline 75 & 1950 & 165 & 11,58 & 8,65 & 7,83 & 7,02 & 6,36 & 5,77 & 4,74 & 3,91 & 2,75 \\
\hline 75 & 2000 & 165 & 11,45 & 8,57 & 7,77 & 6,98 & 6,33 & 5,75 & 4,73 & 3,91 & 2,75 \\
\hline 75 & 200 & 170 & 45,06 & 21,83 & 15,03 & 10,57 & 8,14 & 6,56 & 4,59 & 3,53 & 2,46 \\
\hline 75 & 250 & 170 & 38,15 & 19,50 & 13,95 & 10,18 & 8,03 & 6,56 & 4,65 & 3,58 & 2,46 \\
\hline 75 & 300 & 170 & 33,47 & 17,87 & 13,17 & 9,88 & 7,93 & 6,55 & 4,69 & 3,61 & 2,47 \\
\hline 75 & 350 & 170 & 30,06 & 16,66 & 12,56 & 9,63 & 7,83 & 6,53 & 4,72 & 3,64 & 2,47 \\
\hline 75 & 400 & 170 & 27,47 & 15,71 & 12,07 & 9,42 & 7,74 & 6,50 & 4,75 & 3,67 & 2,48 \\
\hline 75 & 450 & 170 & 25,42 & 14,94 & 11,66 & 9,23 & 7,66 & 6,47 & 4,76 & 3,69 & 2,49 \\
\hline 75 & 500 & 170 & 23,75 & 14,29 & 11,32 & 9,07 & 7,58 & 6,44 & 4,78 & 3,71 & 2,50 \\
\hline 75 & 550 & 170 & 22,37 & 13,74 & 11,01 & 8,91 & 7,50 & 6,41 & 4,78 & 3,73 & 2,51 \\
\hline 75 & 600 & 170 & 21,20 & 13,27 & 10,74 & 8,78 & 7,43 & 6,37 & 4,79 & 3,74 & 2,52 \\
\hline 75 & 650 & 170 & 20,20 & 12,85 & 10,50 & 8,65 & 7,36 & 6,34 & 4,79 & 3,75 & 2,53 \\
\hline 75 & 700 & 170 & 19,33 & 12,48 & 10,28 & 8,53 & 7,30 & 6,31 & 4,79 & 3,76 & 2,54 \\
\hline 75 & 750 & 170 & 18,57 & 12,15 & 10,08 & 8,42 & 7,24 & 6,27 & 4,79 & 3,77 & 2,54 \\
\hline 75 & 800 & 170 & 17,89 & 11,85 & 9,90 & 8,31 & 7,17 & 6,24 & 4,79 & 3,78 & 2,55 \\
\hline 75 & 850 & 170 & 17,29 & 11,57 & 9,73 & 8,22 & 7,12 & 6,21 & 4,79 & 3,79 & 2,56 \\
\hline 75 & 900 & 170 & 16,75 & 11,32 & 9,58 & 8,12 & 7,06 & 6,18 & 4,78 & 3,79 & 2,57 \\
\hline 75 & 950 & 170 & 16,26 & 11,09 & 9,43 & 8,04 & 7,01 & 6,15 & 4,78 & 3,80 & 2,57 \\
\hline 75 & 1000 & 170 & 15,81 & 10,88 & 9,30 & 7,95 & 6,95 & 6,12 & 4,77 & 3,80 & 2,58 \\
\hline 75 & 1050 & 170 & 15,40 & 10,68 & 9,17 & 7,87 & 6,90 & 6,09 & 4,77 & 3,81 & 2,59 \\
\hline 75 & 1100 & 170 & 15,03 & 10,49 & 9,05 & 7,80 & 6,86 & 6,06 & 4,76 & 3,81 & 2,59 \\
\hline 75 & 1150 & 170 & 14,69 & 10,32 & 8,93 & 7,73 & 6,81 & 6,03 & 4,75 & 3,81 & 2,60 \\
\hline 75 & 1200 & 170 & 14,37 & 10,16 & 8,83 & 7,66 & 6,76 & 6,00 & 4,74 & 3,81 & 2,60 \\
\hline 75 & 1250 & 170 & 14,07 & 10,00 & 8,72 & 7,59 & 6,72 & 5,97 & 4,74 & 3,82 & 2,61 \\
\hline 75 & 1300 & 170 & 13,80 & 9,86 & 8,63 & 7,53 & 6,68 & 5,94 & 4,73 & 3,82 & 2,62 \\
\hline 75 & 1350 & 170 & 13,54 & 9,72 & 8,53 & 7,46 & 6,63 & 5,91 & 4,72 & 3,82 & 2,62 \\
\hline 75 & 1400 & 170 & 13,30 & 9,59 & 8,44 & 7,40 & 6,59 & 5,89 & 4,71 & 3,82 & 2,62 \\
\hline 75 & 1450 & 170 & 13,08 & 9,47 & 8,36 & 7,35 & 6,55 & 5,86 & 4,70 & 3,82 & 2,63 \\
\hline 75 & 1500 & 170 & 12,86 & 9,35 & 8,28 & 7,29 & 6,52 & 5,84 & 4,69 & 3,82 & 2,63 \\
\hline 75 & 1550 & 170 & 12,66 & 9,24 & 8,20 & 7,24 & 6,48 & 5,81 & 4,68 & 3,82 & 2,64 \\
\hline 75 & 1600 & 170 & 12,47 & 9,13 & 8,12 & 7,19 & 6,44 & 5,79 & 4,67 & 3,81 & 2,64 \\
\hline 75 & 1650 & 170 & 12,29 & 9,02 & 8,05 & 7,14 & 6,41 & 5,76 & 4,67 & 3,81 & 2,65 \\
\hline 75 & 1700 & 170 & 12,13 & 8,93 & 7,98 & 7,09 & 6,37 & 5,74 & 4,66 & 3,81 & 2,65 \\
\hline
\end{tabular}




\begin{tabular}{|c|c|c|c|c|c|c|c|c|c|c|c|}
\hline \multirow[b]{2}{*}{$\mathrm{H}(\mathrm{cm})$} & \multirow[b]{2}{*}{ Mceq (MPa) } & & & & & De & ões (x & & & & \\
\hline & & Msub (MPa) & D0 & D25 & D40 & D60 & D80 & D100 & D140 & D180 & D260 \\
\hline 75 & 1750 & 170 & 11,96 & 8,83 & 7,91 & 7,04 & 6,34 & 5,71 & 4,65 & 3,81 & 2,65 \\
\hline 75 & 1800 & 170 & 11,81 & 8,74 & 7,85 & 7,00 & 6,31 & 5,69 & 4,64 & 3,81 & 2,66 \\
\hline 75 & 1850 & 170 & 11,66 & 8,65 & 7,78 & 6,95 & 6,27 & 5,67 & 4,63 & 3,81 & 2,66 \\
\hline 75 & 1900 & 170 & 11,53 & 8,57 & 7,72 & 6,91 & 6,24 & 5,65 & 4,62 & 3,80 & 2,66 \\
\hline 75 & 1950 & 170 & 11,39 & 8,49 & 7,66 & 6,87 & 6,21 & 5,62 & 4,61 & 3,80 & 2,67 \\
\hline 75 & 2000 & 170 & 11,26 & 8,41 & 7,61 & 6,82 & 6,18 & 5,60 & 4,60 & 3,80 & 2,67 \\
\hline 75 & 200 & 175 & 44,76 & 21,53 & 14,75 & 10,31 & 7,92 & 6,37 & 4,45 & 3,42 & 2,39 \\
\hline 75 & 250 & 175 & 37,86 & 19,21 & 13,68 & 9,94 & 7,82 & 6,37 & 4,51 & 3,47 & 2,39 \\
\hline 75 & 300 & 175 & 33,19 & 17,60 & 12,91 & 9,64 & 7,72 & 6,36 & 4,55 & 3,50 & 2,40 \\
\hline 75 & 350 & 175 & 29,79 & 16,40 & 12,31 & 9,40 & 7,63 & 6,34 & 4,58 & 3,53 & 2,40 \\
\hline 75 & 400 & 175 & 27,21 & 15,45 & 11,83 & 9,20 & 7,54 & 6,32 & 4,61 & 3,56 & 2,41 \\
\hline 75 & 450 & 175 & 25,16 & 14,69 & 11,43 & 9,01 & 7,46 & 6,29 & 4,62 & 3,58 & 2,42 \\
\hline 75 & 500 & 175 & 23,50 & 14,05 & 11,08 & 8,85 & 7,39 & 6,26 & 4,64 & 3,60 & 2,43 \\
\hline 75 & 550 & 175 & 22,13 & 13,51 & 10,78 & 8,70 & 7,31 & 6,23 & 4,65 & 3,61 & 2,44 \\
\hline 75 & 600 & 175 & 20,96 & 13,04 & 10,52 & 8,57 & 7,24 & 6,20 & 4,65 & 3,63 & 2,44 \\
\hline 75 & 650 & 175 & 19,97 & 12,63 & 10,28 & 8,45 & 7,18 & 6,17 & 4,65 & 3,64 & 2,45 \\
\hline 75 & 700 & 175 & 19,10 & 12,26 & 10,07 & 8,33 & 7,11 & 6,14 & 4,66 & 3,65 & 2,46 \\
\hline 75 & 750 & 175 & 18,34 & 11,93 & 9,88 & 8,22 & 7,05 & 6,11 & 4,66 & 3,66 & 2,47 \\
\hline 75 & 800 & 175 & 17,67 & 11,64 & 9,70 & 8,12 & 7,00 & 6,08 & 4,65 & 3,67 & 2,48 \\
\hline 75 & 850 & 175 & 17,07 & 11,37 & 9,53 & 8,03 & 6,94 & 6,05 & 4,65 & 3,68 & 2,48 \\
\hline 75 & 900 & 175 & 16,53 & 11,12 & 9,38 & 7,94 & 6,89 & 6,02 & 4,65 & 3,68 & 2,49 \\
\hline 75 & 950 & 175 & 16,04 & 10,89 & 9,24 & 7,85 & 6,83 & 5,99 & 4,64 & 3,69 & 2,50 \\
\hline 75 & 1000 & 175 & 15,60 & 10,68 & 9,11 & 7,77 & 6,78 & 5,96 & 4,64 & 3,69 & 2,50 \\
\hline 75 & 1050 & 175 & 15,20 & 10,49 & 8,98 & 7,69 & 6,74 & 5,93 & 4,63 & 3,70 & 2,51 \\
\hline 75 & 1100 & 175 & 14,83 & 10,31 & 8,86 & 7,62 & 6,69 & 5,90 & 4,63 & 3,70 & 2,51 \\
\hline 75 & 1150 & 175 & 14,48 & 10,13 & 8,75 & 7,55 & 6,64 & 5,87 & 4,62 & 3,70 & 2,52 \\
\hline 75 & 1200 & 175 & 14,17 & 9,97 & 8,64 & 7,48 & 6,60 & 5,85 & 4,61 & 3,70 & 2,53 \\
\hline 75 & 1250 & 175 & 13,87 & 9,82 & 8,54 & 7,42 & 6,56 & 5,82 & 4,61 & 3,71 & 2,53 \\
\hline 75 & 1300 & 175 & 13,60 & 9,68 & 8,45 & 7,36 & 6,52 & 5,79 & 4,60 & 3,71 & 2,54 \\
\hline 75 & 1350 & 175 & 13,35 & 9,55 & 8,36 & 7,30 & 6,48 & 5,77 & 4,59 & 3,71 & 2,54 \\
\hline 75 & 1400 & 175 & 13,11 & 9,42 & 8,27 & 7,24 & 6,44 & 5,74 & 4,58 & 3,71 & 2,55 \\
\hline 75 & 1450 & 175 & 12,88 & 9,29 & 8,19 & 7,18 & 6,40 & 5,72 & 4,57 & 3,71 & 2,55 \\
\hline 75 & 1500 & 175 & 12,67 & 9,18 & 8,11 & 7,13 & 6,36 & 5,69 & 4,57 & 3,71 & 2,56 \\
\hline 75 & 1550 & 175 & 12,47 & 9,07 & 8,03 & 7,08 & 6,33 & 5,67 & 4,56 & 3,71 & 2,56 \\
\hline 75 & 1600 & 175 & 12,28 & 8,96 & 7,96 & 7,03 & 6,29 & 5,64 & 4,55 & 3,71 & 2,56 \\
\hline 75 & 1650 & 175 & 12,11 & 8,86 & 7,89 & 6,98 & 6,26 & 5,62 & 4,54 & 3,71 & 2,57 \\
\hline 75 & 1700 & 175 & 11,94 & 8,76 & 7,82 & 6,93 & 6,22 & 5,60 & 4,53 & 3,70 & 2,57 \\
\hline 75 & 1750 & 175 & 11,78 & 8,67 & 7,75 & 6,89 & 6,19 & 5,57 & 4,52 & 3,70 & 2,57 \\
\hline 75 & 1800 & 175 & 11,63 & 8,58 & 7,69 & 6,84 & 6,16 & 5,55 & 4,51 & 3,70 & 2,58 \\
\hline 75 & 1850 & 175 & 11,48 & 8,50 & 7,63 & 6,80 & 6,13 & 5,53 & 4,51 & 3,70 & 2,58 \\
\hline 75 & 1900 & 175 & 11,34 & 8,41 & 7,57 & 6,76 & 6,10 & 5,51 & 4,50 & 3,70 & 2,58 \\
\hline 75 & 1950 & 175 & 11,21 & 8,33 & 7,51 & 6,71 & 6,07 & 5,49 & 4,49 & 3,70 & 2,59 \\
\hline 75 & 2000 & 175 & 11,08 & 8,26 & 7,45 & 6,67 & 6,04 & 5,47 & 4,48 & 3,69 & 2,59 \\
\hline 75 & 200 & 180 & 44,46 & 21,24 & 14,48 & 10,07 & 7,72 & 6,19 & 4,31 & 3,32 & 2,32 \\
\hline 75 & 250 & 180 & 37,58 & 18,94 & 13,42 & 9,71 & 7,61 & 6,20 & 4,38 & 3,37 & 2,32 \\
\hline 75 & 300 & 180 & 32,92 & 17,34 & 12,66 & 9,42 & 7,52 & 6,19 & 4,42 & 3,40 & 2,33 \\
\hline 75 & 350 & 180 & 29,53 & 16,14 & 12,07 & 9,18 & 7,43 & 6,17 & 4,45 & 3,43 & 2,33 \\
\hline 75 & 400 & 180 & 26,96 & 15,21 & 11,60 & 8,98 & 7,35 & 6,15 & 4,47 & 3,45 & 2,34 \\
\hline 75 & 450 & 180 & 24,92 & 14,45 & 11,20 & 8,81 & 7,27 & 6,12 & 4,49 & 3,48 & 2,35 \\
\hline 75 & 500 & 180 & 23,27 & 13,82 & 10,86 & 8,65 & 7,20 & 6,10 & 4,50 & 3,49 & 2,36 \\
\hline 75 & 550 & 180 & 21,90 & 13,29 & 10,57 & 8,50 & 7,13 & 6,07 & 4,51 & 3,51 & 2,37 \\
\hline 75 & 600 & 180 & 20,74 & 12,82 & 10,31 & 8,37 & 7,06 & 6,04 & 4,52 & 3,52 & 2,37 \\
\hline 75 & 650 & 180 & 19,75 & 12,42 & 10,08 & 8,25 & 7,00 & 6,01 & 4,52 & 3,54 & 2,38 \\
\hline 75 & 700 & 180 & 18,88 & 12,05 & 9,87 & 8,14 & 6,94 & 5,98 & 4,53 & 3,55 & 2,39 \\
\hline 75 & 750 & 180 & 18,13 & 11,73 & 9,68 & 8,04 & 6,88 & 5,95 & 4,53 & 3,56 & 2,40 \\
\hline 75 & 800 & 180 & 17,46 & 11,44 & 9,50 & 7,94 & 6,83 & 5,92 & 4,53 & 3,56 & 2,40 \\
\hline 75 & 850 & 180 & 16,86 & 11,17 & 9,34 & 7,85 & 6,77 & 5,89 & 4,52 & 3,57 & 2,41 \\
\hline 75 & 900 & 180 & 16,33 & 10,93 & 9,19 & 7,76 & 6,72 & 5,87 & 4,52 & 3,58 & 2,42 \\
\hline 75 & 950 & 180 & 15,84 & 10,71 & 9,05 & 7,68 & 6,67 & 5,84 & 4,52 & 3,58 & 2,42 \\
\hline 75 & 1000 & 180 & 15,40 & 10,50 & 8,92 & 7,60 & 6,62 & 5,81 & 4,51 & 3,59 & 2,43 \\
\hline 75 & 1050 & 180 & 15,00 & 10,31 & 8,80 & 7,52 & 6,58 & 5,78 & 4,51 & 3,59 & 2,44 \\
\hline 75 & 1100 & 180 & 14,63 & 10,13 & 8,69 & 7,45 & 6,53 & 5,75 & 4,50 & 3,59 & 2,44 \\
\hline 75 & 1150 & 180 & 14,29 & 9,96 & 8,58 & 7,38 & 6,49 & 5,73 & 4,50 & 3,60 & 2,45 \\
\hline 75 & 1200 & 180 & 13,98 & 9,80 & 8,47 & 7,32 & 6,45 & 5,70 & 4,49 & 3,60 & 2,45 \\
\hline 75 & 1250 & 180 & 13,68 & 9,65 & 8,37 & 7,26 & 6,40 & 5,68 & 4,48 & 3,60 & 2,46 \\
\hline 75 & 1300 & 180 & 13,41 & 9,51 & 8,28 & 7,20 & 6,36 & 5,65 & 4,48 & 3,60 & 2,46 \\
\hline 75 & 1350 & 180 & 13,16 & 9,38 & 8,19 & 7,14 & 6,33 & 5,62 & 4,47 & 3,60 & 2,47 \\
\hline 75 & 1400 & 180 & 12,92 & 9,25 & 8,11 & 7,08 & 6,29 & 5,60 & 4,46 & 3,60 & 2,47 \\
\hline 75 & 1450 & 180 & 12,70 & 9,13 & 8,03 & 7,03 & 6,25 & 5,58 & 4,45 & 3,60 & 2,48 \\
\hline 75 & 1500 & 180 & 12,49 & 9,02 & 7,95 & 6,97 & 6,21 & 5,55 & 4,45 & 3,60 & 2,48 \\
\hline 75 & 1550 & 180 & 12,29 & 8,91 & 7,87 & 6,92 & 6,18 & 5,53 & 4,44 & 3,60 & 2,48 \\
\hline 75 & 1600 & 180 & 12,11 & 8,80 & 7,80 & 6,88 & 6,15 & 5,51 & 4,43 & 3,60 & 2,49 \\
\hline 75 & 1650 & 180 & 11,93 & 8,70 & 7,73 & 6,83 & 6,11 & 5,48 & 4,42 & 3,60 & 2,49 \\
\hline 75 & 1700 & 180 & 11,76 & 8,61 & 7,66 & 6,78 & 6,08 & 5,46 & 4,41 & 3,60 & 2,50 \\
\hline 75 & 1750 & 180 & 11,60 & 8,52 & 7,60 & 6,74 & 6,05 & 5,44 & 4,41 & 3,60 & 2,50 \\
\hline 75 & 1800 & 180 & 11,45 & 8,43 & 7,54 & 6,69 & 6,02 & 5,42 & 4,40 & 3,60 & 2,50 \\
\hline 75 & 1850 & 180 & 11,31 & 8,35 & 7,48 & 6,65 & 5,99 & 5,40 & 4,39 & 3,60 & 2,51 \\
\hline 75 & 1900 & 180 & 11,17 & 8,26 & 7,42 & 6,61 & 5,96 & 5,38 & 4,38 & 3,60 & 2,51 \\
\hline 75 & 1950 & 180 & 11,04 & 8,19 & 7,36 & 6,57 & 5,93 & 5,36 & 4,37 & 3,60 & 2,51 \\
\hline 75 & 2000 & 180 & 10,91 & 8,11 & 7,31 & 6,53 & 5,90 & 5,34 & 4,36 & 3,59 & 2,51 \\
\hline 75 & 200 & 185 & 44,18 & 20,97 & 14,23 & 9,85 & 7,52 & 6,02 & 4,19 & 3,23 & 2,26 \\
\hline
\end{tabular}




\begin{tabular}{|c|c|c|c|c|c|c|c|c|c|c|c|}
\hline \multirow[b]{2}{*}{$\mathrm{H}(\mathrm{cm})$} & \multirow[b]{2}{*}{ Mceq (MPa) } & & & & & & ões (x. & & & & \\
\hline & & Msub (MPa) & D0 & D25 & D40 & D60 & D80 & D100 & D140 & D180 & D260 \\
\hline 75 & 250 & 185 & 37,31 & 18,68 & 13,18 & 9,49 & 7,42 & 6,03 & 4,25 & 3,27 & 2,26 \\
\hline 75 & 300 & 185 & 32,66 & 17,09 & 12,42 & 9,21 & 7,33 & 6,02 & 4,29 & 3,30 & 2,26 \\
\hline 75 & 350 & 185 & 29,29 & 15,91 & 11,84 & 8,98 & 7,25 & 6,01 & 4,33 & 3,33 & 2,27 \\
\hline 75 & 400 & 185 & 26,72 & 14,98 & 11,38 & 8,78 & 7,17 & 5,99 & 4,35 & 3,36 & 2,28 \\
\hline 75 & 450 & 185 & 24,69 & 14,23 & 10,99 & 8,61 & 7,09 & 5,96 & 4,37 & 3,38 & 2,28 \\
\hline 75 & 500 & 185 & 23,04 & 13,60 & 10,65 & 8,45 & 7,02 & 5,94 & 4,38 & 3,39 & 2,29 \\
\hline 75 & 550 & 185 & 21,68 & 13,07 & 10,37 & 8,31 & 6,96 & 5,91 & 4,39 & 3,41 & 2,30 \\
\hline 75 & 600 & 185 & 20,52 & 12,62 & 10,11 & 8,19 & 6,89 & 5,89 & 4,40 & 3,42 & 2,31 \\
\hline 75 & 650 & 185 & 19,54 & 12,21 & 9,88 & 8,07 & 6,83 & 5,86 & 4,40 & 3,44 & 2,31 \\
\hline 75 & 700 & 185 & 18,68 & 11,86 & 9,68 & 7,96 & 6,78 & 5,83 & 4,40 & 3,45 & 2,32 \\
\hline 75 & 750 & 185 & 17,93 & 11,54 & 9,49 & 7,86 & 6,72 & 5,80 & 4,40 & 3,46 & 2,33 \\
\hline 75 & 800 & 185 & 17,26 & 11,25 & 9,32 & 7,77 & 6,67 & 5,78 & 4,40 & 3,46 & 2,34 \\
\hline 75 & 850 & 185 & 16,67 & 10,99 & 9,16 & 7,68 & 6,61 & 5,75 & 4,40 & 3,47 & 2,34 \\
\hline 75 & 900 & 185 & 16,13 & 10,75 & 9,01 & 7,59 & 6,56 & 5,72 & 4,40 & 3,48 & 2,35 \\
\hline 75 & 950 & 185 & 15,65 & 10,53 & 8,88 & 7,51 & 6,52 & 5,69 & 4,40 & 3,48 & 2,35 \\
\hline 75 & 1000 & 185 & 15,21 & 10,32 & 8,75 & 7,43 & 6,47 & 5,67 & 4,39 & 3,49 & 2,36 \\
\hline 75 & 1050 & 185 & 14,81 & 10,13 & 8,63 & 7,36 & 6,42 & 5,64 & 4,39 & 3,49 & 2,37 \\
\hline 75 & 1100 & 185 & 14,45 & 9,96 & 8,52 & 7,29 & 6,38 & 5,61 & 4,38 & 3,50 & 2,37 \\
\hline 75 & 1150 & 185 & 14,11 & 9,79 & 8,41 & 7,23 & 6,34 & 5,59 & 4,38 & 3,50 & 2,38 \\
\hline 75 & 1200 & 185 & 13,79 & 9,63 & 8,31 & 7,16 & 6,30 & 5,56 & 4,37 & 3,50 & 2,38 \\
\hline 75 & 1250 & 185 & 13,50 & 9,49 & 8,21 & 7,10 & 6,26 & 5,54 & 4,37 & 3,50 & 2,39 \\
\hline 75 & 1300 & 185 & 13,23 & 9,35 & 8,12 & 7,04 & 6,22 & 5,51 & 4,36 & 3,50 & 2,39 \\
\hline 75 & 1350 & 185 & 12,98 & 9,22 & 8,03 & 6,99 & 6,18 & 5,49 & 4,35 & 3,51 & 2,40 \\
\hline 75 & 1400 & 185 & 12,75 & 9,09 & 7,95 & 6,93 & 6,15 & 5,47 & 4,35 & 3,51 & 2,40 \\
\hline 75 & 1450 & 185 & 12,52 & 8,98 & 7,87 & 6,88 & 6,11 & 5,44 & 4,34 & 3,51 & 2,41 \\
\hline 75 & 1500 & 185 & 12,32 & 8,86 & 7,79 & 6,83 & 6,07 & 5,42 & 4,33 & 3,51 & 2,41 \\
\hline 75 & 1550 & 185 & 12,12 & 8,76 & 7,72 & 6,78 & 6,04 & 5,40 & 4,33 & 3,51 & 2,41 \\
\hline 75 & 1600 & 185 & 11,93 & 8,65 & 7,65 & 6,73 & 6,01 & 5,38 & 4,32 & 3,51 & 2,42 \\
\hline 75 & 1650 & 185 & 11,76 & 8,56 & 7,58 & 6,68 & 5,98 & 5,36 & 4,31 & 3,51 & 2,42 \\
\hline 75 & 1700 & 185 & 11,59 & 8,46 & 7,52 & 6,64 & 5,94 & 5,33 & 4,30 & 3,51 & 2,43 \\
\hline 75 & 1750 & 185 & 11,43 & 8,37 & 7,45 & 6,60 & 5,91 & 5,31 & 4,29 & 3,51 & 2,43 \\
\hline 75 & 1800 & 185 & 11,28 & 8,29 & 7,39 & 6,55 & 5,88 & 5,29 & 4,29 & 3,50 & 2,43 \\
\hline 75 & 1850 & 185 & 11,14 & 8,20 & 7,33 & 6,51 & 5,86 & 5,27 & 4,28 & 3,50 & 2,43 \\
\hline 75 & 1900 & 185 & 11.01 & 8,12 & 7.28 & 6.47 & 5,83 & 5,25 & 4.27 & 3,50 & 2,44 \\
\hline 75 & 1950 & 185 & 10,88 & 8,05 & 7,22 & 6,43 & 5,80 & 5,23 & 4,26 & 3,50 & 2,44 \\
\hline 75 & 2000 & 185 & 10,75 & 7,97 & 7,17 & 6,40 & 5,77 & 5,21 & 4,26 & 3,50 & 2,44 \\
\hline 75 & 200 & 190 & 43,92 & 20,72 & 13,99 & 9,63 & 7,33 & 5,86 & 4,07 & 3,14 & 2,20 \\
\hline 75 & 250 & 190 & 37,06 & 18,44 & 12,95 & 9,28 & 7,24 & 5,87 & 4,13 & 3,18 & 2,20 \\
\hline 75 & 300 & 190 & 32,42 & 16,86 & 12,20 & 9,00 & 7,15 & 5,87 & 4,18 & 3,21 & 2,20 \\
\hline 75 & 350 & 190 & 29,05 & 15,68 & 11,63 & 8,78 & 7,07 & 5,85 & 4,21 & 3,24 & 2,21 \\
\hline 75 & 400 & 190 & 26,49 & 14,76 & 11,16 & 8,59 & 6,99 & 5,83 & 4,23 & 3,26 & 2,22 \\
\hline 75 & 450 & 190 & 24,47 & 14,01 & 10,78 & 8,42 & 6,92 & 5,81 & 4,25 & 3,28 & 2,22 \\
\hline 75 & 500 & 190 & 22,83 & 13,40 & 10,45 & 8,27 & 6,86 & 5,79 & 4,26 & 3,30 & 2,23 \\
\hline 75 & 550 & 190 & 21,47 & 12,87 & 10,17 & 8,13 & 6,79 & 5,77 & 4,27 & 3,32 & 2,24 \\
\hline 75 & 600 & 190 & 20,32 & 12,42 & 9,92 & 8,01 & 6,73 & 5,74 & 4,28 & 3,33 & 2,24 \\
\hline 75 & 650 & 190 & 19,33 & 12,02 & 9,70 & 7,90 & 6,67 & 5,71 & 4,28 & 3,34 & 2,25 \\
\hline 75 & 700 & 190 & 18,48 & 11,67 & 9,49 & 7,79 & 6,62 & 5,69 & 4,29 & 3,35 & 2,26 \\
\hline 75 & 750 & 190 & 17,73 & 11,35 & 9,31 & 7,69 & 6,56 & 5,66 & 4,29 & 3,36 & 2,26 \\
\hline 75 & 800 & 190 & 17,07 & 11,07 & 9,14 & 7,60 & 6,51 & 5,63 & 4,29 & 3,37 & 2,27 \\
\hline 75 & 850 & 190 & 16,48 & 10,81 & 8,99 & 7,51 & 6,46 & 5,61 & 4,29 & 3,38 & 2,28 \\
\hline 75 & 900 & 190 & 15,95 & 10,57 & 8,84 & 7,43 & 6,41 & 5,58 & 4,29 & 3,38 & 2,28 \\
\hline 75 & 950 & 190 & 15,47 & 10,36 & 8,71 & 7,35 & 6,37 & 5,56 & 4,28 & 3,39 & 2,29 \\
\hline 75 & 1000 & 190 & 15,03 & 10,15 & 8,58 & 7,28 & 6,32 & 5,53 & 4,28 & 3,39 & 2,30 \\
\hline 75 & 1050 & 190 & 14,63 & 9,97 & 8,47 & 7,21 & 6,28 & 5,51 & 4,28 & 3,40 & 2,30 \\
\hline 75 & 1100 & 190 & 14,27 & 9,79 & 8,36 & 7,14 & 6,24 & 5,48 & 4,27 & 3,40 & 2,31 \\
\hline 75 & 1150 & 190 & 13,93 & 9,63 & 8,25 & 7,07 & 6,20 & 5,46 & 4,27 & 3,40 & 2,31 \\
\hline 75 & 1200 & 190 & 13,62 & 9,48 & 8,15 & 7,01 & 6,16 & 5,43 & 4,26 & 3,41 & 2,32 \\
\hline 75 & 1250 & 190 & 13,33 & 9,33 & 8,06 & 6,95 & 6,12 & 5,41 & 4,26 & 3,41 & 2,32 \\
\hline 75 & 1300 & 190 & 13,06 & 9,19 & 7,97 & 6,90 & 6,08 & 5,39 & 4,25 & 3,41 & 2,33 \\
\hline 75 & 1350 & 190 & 12,81 & 9,07 & 7,88 & 6,84 & 6,04 & 5,36 & 4,24 & 3,41 & 2,33 \\
\hline 75 & 1400 & 190 & 12,58 & 8,94 & 7,80 & 6,79 & 6,01 & 5,34 & 4,24 & 3,41 & 2,34 \\
\hline 75 & 1450 & 190 & 12,36 & 8,83 & 7,72 & 6,74 & 5,98 & 5,32 & 4,23 & 3,41 & 2,34 \\
\hline 75 & 1500 & 190 & 12,15 & 8,72 & 7,65 & 6,69 & 5,94 & 5,30 & 4,22 & 3,41 & 2,34 \\
\hline 75 & 1550 & 190 & 11,96 & 8,61 & 7,58 & 6,64 & 5,91 & 5,27 & 4,22 & 3,42 & 2,35 \\
\hline 75 & 1600 & 190 & 11,77 & 8,51 & 7,51 & 6,59 & 5,88 & 5,25 & 4,21 & 3,42 & 2,35 \\
\hline 75 & 1650 & 190 & 11,60 & 8,41 & 7,44 & 6,55 & 5,85 & 5,23 & 4,20 & 3,41 & 2,35 \\
\hline 75 & 1700 & 190 & 11,43 & 8,32 & 7,38 & 6,50 & 5,82 & 5,21 & 4,20 & 3,41 & 2,36 \\
\hline 75 & 1750 & 190 & 11,28 & 8,23 & 7,31 & 6,46 & 5,79 & 5,19 & 4,19 & 3,41 & 2,36 \\
\hline 75 & 1800 & 190 & 11,13 & 8,15 & 7,25 & 6,42 & 5,76 & 5,17 & 4,18 & 3,41 & 2,36 \\
\hline 75 & 1850 & 190 & 10,98 & 8,07 & 7,20 & 6,38 & 5,73 & 5,15 & 4,17 & 3,41 & 2,37 \\
\hline 75 & 1900 & 190 & 10,85 & 7,99 & 7,14 & 6,34 & 5,70 & 5,13 & 4,17 & 3,41 & 2,37 \\
\hline 75 & 1950 & 190 & 10,72 & 7,91 & 7,09 & 6,30 & 5,67 & 5,11 & 4,16 & 3,41 & 2,37 \\
\hline 75 & 2000 & 190 & 10,60 & 7,84 & 7,03 & 6,27 & 5,65 & 5,10 & 4,15 & 3,41 & 2,38 \\
\hline 75 & 200 & 195 & 43,66 & 20,47 & 13,75 & 9,43 & 7,15 & 5,71 & 3,96 & 3,05 & 2,14 \\
\hline 75 & 250 & 195 & 36,82 & 18,20 & 12,72 & 9,08 & 7,06 & 5,72 & 4,02 & 3,09 & 2,14 \\
\hline 75 & 300 & 195 & 32,19 & 16,63 & 11,99 & 8,81 & 6,98 & 5,72 & 4,06 & 3,13 & 2,15 \\
\hline 75 & 350 & 195 & 28,83 & 15,46 & 11,42 & 8,59 & 6,90 & 5,71 & 4,09 & 3,15 & 2,15 \\
\hline 75 & 400 & 195 & 26,28 & 14,55 & 10,96 & 8,40 & 6,83 & 5,69 & 4,12 & 3,17 & 2,16 \\
\hline 75 & 450 & 195 & 24,26 & 13,81 & 10,59 & 8,24 & 6,76 & 5,67 & 4,14 & 3,19 & 2,16 \\
\hline 75 & 500 & 195 & 22,62 & 13,20 & 10,26 & 8,09 & 6,70 & 5,65 & 4,15 & 3,21 & 2,17 \\
\hline 75 & 550 & 195 & 21,27 & 12,68 & 9,98 & 7,96 & 6,64 & 5,62 & 4,16 & 3,23 & 2,18 \\
\hline
\end{tabular}




\begin{tabular}{|c|c|c|c|c|c|c|c|c|c|c|c|}
\hline \multirow[b]{2}{*}{$\mathrm{H}(\mathrm{cm})$} & \multirow[b]{2}{*}{ Mceq (MPa) } & & & & & & ões (x1 & & & & \\
\hline & & Msub (MPa) & D0 & D25 & D40 & D60 & D80 & D100 & D140 & D180 & D260 \\
\hline 75 & 600 & 195 & 20,12 & 12,23 & 9,74 & 7,84 & 6,58 & 5,60 & 4,17 & 3,24 & 2,18 \\
\hline 75 & 650 & 195 & 19,14 & 11,84 & 9,52 & 7,73 & 6,52 & 5,58 & 4,17 & 3,25 & 2,19 \\
\hline 75 & 700 & 195 & 18,29 & 11,49 & 9,32 & 7,63 & 6,47 & 5,55 & 4,18 & 3,26 & 2,20 \\
\hline 75 & 750 & 195 & 17,55 & 11,18 & 9,14 & 7,53 & 6,42 & 5,53 & 4,18 & 3,27 & 2,20 \\
\hline 75 & 800 & 195 & 16,89 & 10,90 & 8,97 & 7,44 & 6,37 & 5,50 & 4,18 & 3,28 & 2,21 \\
\hline 75 & 850 & 195 & 16,30 & 10,64 & 8,82 & 7,36 & 6,32 & 5,48 & 4,18 & 3,29 & 2,22 \\
\hline 75 & 900 & 195 & 15,77 & 10,41 & 8,68 & 7,28 & 6,27 & 5,45 & 4,18 & 3,29 & 2,22 \\
\hline 75 & 950 & 195 & 15,29 & 10,19 & 8,55 & 7,20 & 6,23 & 5,43 & 4,18 & 3,30 & 2,23 \\
\hline 75 & 1000 & 195 & 14,86 & 9,99 & 8,43 & 7,13 & 6,18 & 5,40 & 4,17 & 3,30 & 2,23 \\
\hline 75 & 1050 & 195 & 14,46 & 9,81 & 8,31 & 7,06 & 6,14 & 5,38 & 4,17 & 3,31 & 2,24 \\
\hline 75 & 1100 & 195 & 14,10 & 9,64 & 8,20 & 6,99 & 6,10 & 5,35 & 4,16 & 3,31 & 2,24 \\
\hline 75 & 1150 & 195 & 13,76 & 9,47 & 8,10 & 6,93 & 6,06 & 5,33 & 4,16 & 3,32 & 2,25 \\
\hline 75 & 1200 & 195 & 13,46 & 9,32 & 8,00 & 6,87 & 6,02 & 5,31 & 4,16 & 3,32 & 2,25 \\
\hline 75 & 1250 & 195 & 13,17 & 9,18 & 7,91 & 6,81 & 5,99 & 5,28 & 4,15 & 3,32 & 2,26 \\
\hline 75 & 1300 & 195 & 12,90 & 9,05 & 7,82 & 6,76 & 5,95 & 5,26 & 4,14 & 3,32 & 2,26 \\
\hline 75 & 1350 & 195 & 12,65 & 8,92 & 7,74 & 6,70 & 5,91 & 5,24 & 4,14 & 3,32 & 2,27 \\
\hline 75 & 1400 & 195 & 12,42 & 8,80 & 7,66 & 6,65 & 5,88 & 5,22 & 4,13 & 3,33 & 2,27 \\
\hline 75 & 1450 & 195 & 12,20 & 8,68 & 7,58 & 6,60 & 5,85 & 5,20 & 4,13 & 3,33 & 2,28 \\
\hline 75 & 1500 & 195 & 11,99 & 8,58 & 7,51 & 6,55 & 5,81 & 5,18 & 4,12 & 3,33 & 2,28 \\
\hline 75 & 1550 & 195 & 11,80 & 8,47 & 7,44 & 6,51 & 5,78 & 5,16 & 4,11 & 3,33 & 2,28 \\
\hline 75 & 1600 & 195 & 11,62 & 8,37 & 7,37 & 6,46 & 5,75 & 5,14 & 4,11 & 3,33 & 2,29 \\
\hline 75 & 1650 & 195 & 11,44 & 8,28 & 7,30 & 6,42 & 5,72 & 5,12 & 4,10 & 3,33 & 2,29 \\
\hline 75 & 1700 & 195 & 11,28 & 8,19 & 7,24 & 6,37 & 5,69 & 5,10 & 4,09 & 3,33 & 2,29 \\
\hline 75 & 1750 & 195 & 11,12 & 8,10 & 7,18 & 6,33 & 5,66 & 5,08 & 4,09 & 3,33 & 2,30 \\
\hline 75 & 1800 & 195 & 10,97 & 8,01 & 7,12 & 6,29 & 5,64 & 5,06 & 4,08 & 3,33 & 2,30 \\
\hline 75 & 1850 & 195 & 10,83 & 7,93 & 7,06 & 6,25 & 5,61 & 5,04 & 4,07 & 3,33 & 2,30 \\
\hline 75 & 1900 & 195 & 10,70 & 7,86 & 7,01 & 6,22 & 5,58 & 5,02 & 4,07 & 3,32 & 2,31 \\
\hline 75 & 1950 & 195 & 10,57 & 7,78 & 6,96 & 6,18 & 5,55 & 5,00 & 4,06 & 3,32 & 2,31 \\
\hline 75 & 2000 & 195 & 10,45 & 7,71 & 6,91 & 6,14 & 5,53 & 4,98 & 4,05 & 3,32 & 2,31 \\
\hline 75 & 200 & 200 & 43,42 & 20,24 & 13,54 & 9,23 & 6,99 & 5,57 & 3,85 & 2,97 & 2,09 \\
\hline 75 & 250 & 200 & 36,59 & 17,98 & 12,51 & 8,89 & 6,90 & 5,58 & 3,91 & 3,01 & 2,09 \\
\hline 75 & 300 & 200 & 31,97 & 16,41 & 11,78 & 8,63 & 6,82 & 5,58 & 3,96 & 3,04 & 2,09 \\
\hline 75 & 350 & 200 & 28,62 & 15,25 & 11,22 & 8,41 & 6,74 & 5,57 & 3,99 & 3,07 & 2,10 \\
\hline 75 & 400 & 200 & 26,07 & 14,35 & 10,77 & 8,23 & 6,67 & 5,55 & 4,01 & 3,09 & 2,10 \\
\hline 75 & 450 & 200 & 24,06 & 13,61 & 10,40 & 8,07 & 6,61 & 5,53 & 4,03 & 3,11 & 2,11 \\
\hline 75 & 500 & 200 & 22,43 & 13,01 & 10,08 & 7,92 & 6,55 & 5,51 & 4,04 & 3,13 & 2,11 \\
\hline 75 & 550 & 200 & 21,08 & 12,49 & 9,81 & 7,80 & 6,49 & 5,49 & 4,05 & 3,14 & 2,12 \\
\hline 75 & 600 & 200 & 19,94 & 12,05 & 9,56 & 7,68 & 6,43 & 5,47 & 4,06 & 3,16 & 2,13 \\
\hline 75 & 650 & 200 & 18,96 & 11,66 & 9,35 & 7,57 & 6,38 & 5,44 & 4,07 & 3,17 & 2,13 \\
\hline 75 & 700 & 200 & 18,11 & 11,31 & 9,15 & 7,47 & 6,32 & 5,42 & 4,07 & 3,18 & 2,14 \\
\hline 75 & 750 & 200 & 17,37 & 11,01 & 8,97 & 7,38 & 6,27 & 5,40 & 4,07 & 3,19 & 2,15 \\
\hline 75 & 800 & 200 & 16,71 & 10,73 & 8,81 & 7,29 & 6,23 & 5,37 & 4,07 & 3,20 & 2,15 \\
\hline 75 & 850 & 200 & 16,13 & 10,48 & 8,66 & 7,21 & 6,18 & 5,35 & 4,07 & 3,20 & 2,16 \\
\hline 75 & 900 & 200 & 15,60 & 10,25 & 8,52 & 7,13 & 6,13 & 5,33 & 4,07 & 3,21 & 2,16 \\
\hline 75 & 950 & 200 & 15,13 & 10,03 & 8,39 & 7,05 & 6,09 & 5,30 & 4,07 & 3,21 & 2,17 \\
\hline 75 & 1000 & 200 & 14,69 & 9,84 & 8,27 & 6,98 & 6,05 & 5,28 & 4,07 & 3,22 & 2,18 \\
\hline 75 & 1050 & 200 & 14,30 & 9,66 & 8,16 & 6,92 & 6,01 & 5,26 & 4,07 & 3,22 & 2,18 \\
\hline 75 & 1100 & 200 & 13,94 & 9,49 & 8,05 & 6,85 & 5,97 & 5,23 & 4,06 & 3,23 & 2,19 \\
\hline 75 & 1150 & 200 & 13,61 & 9,33 & 7,95 & 6,79 & 5,93 & 5,21 & 4,06 & 3,23 & 2,19 \\
\hline 75 & 1200 & 200 & 13,30 & 9,18 & 7,86 & 6,73 & 5,89 & 5,19 & 4,05 & 3,23 & 2,20 \\
\hline 75 & 1250 & 200 & 13,01 & 9,04 & 7,77 & 6,68 & 5,86 & 5,17 & 4,05 & 3,24 & 2,20 \\
\hline 75 & 1300 & 200 & 12,75 & 8,90 & 7,68 & 6,62 & 5,82 & 5,15 & 4,04 & 3,24 & 2,20 \\
\hline 75 & 1350 & 200 & 12,50 & 8,78 & 7,60 & 6,57 & 5,79 & 5,12 & 4,04 & 3,24 & 2,21 \\
\hline 75 & 1400 & 200 & 12,27 & 8,66 & 7,52 & 6,52 & 5,76 & 5,10 & 4,03 & 3,24 & 2,21 \\
\hline 75 & 1450 & 200 & 12,05 & 8,55 & 7,44 & 6,47 & 5,72 & 5,08 & 4,03 & 3,24 & 2,22 \\
\hline 75 & 1500 & 200 & 11,84 & 8,44 & 7,37 & 6,42 & 5,69 & 5,06 & 4,02 & 3,24 & 2,22 \\
\hline 75 & 1550 & 200 & 11,65 & 8,34 & 7,30 & 6,38 & 5,66 & 5,04 & 4,02 & 3,24 & 2,22 \\
\hline 75 & 1600 & 200 & 11,47 & 8,24 & 7,24 & 6,33 & 5,63 & 5,02 & 4,01 & 3,24 & 2,23 \\
\hline 75 & 1650 & 200 & 11,30 & 8,15 & 7,17 & 6,29 & 5,60 & 5,00 & 4,00 & 3,24 & 2,23 \\
\hline 75 & 1700 & 200 & 11,13 & 8,06 & 7,11 & 6,25 & 5,57 & 4,98 & 4,00 & 3,24 & 2,23 \\
\hline 75 & 1750 & 200 & 10,98 & 7,97 & 7,05 & 6,21 & 5,55 & 4,97 & 3,99 & 3,24 & 2,24 \\
\hline 75 & 1800 & 200 & 10,83 & 7,89 & 6,99 & 6,17 & 5,52 & 4,95 & 3,98 & 3,24 & 2,24 \\
\hline 75 & 1850 & 200 & 10,69 & 7,81 & 6,94 & 6,13 & 5,49 & 4,93 & 3,98 & 3,24 & 2,24 \\
\hline 75 & 1900 & 200 & 10,56 & 7,73 & 6,89 & 6,10 & 5,47 & 4,91 & 3,97 & 3,24 & 2,25 \\
\hline 75 & 1950 & 200 & 10,43 & 7,66 & 6,83 & 6,06 & 5,44 & 4,89 & 3,96 & 3,24 & 2,25 \\
\hline 75 & 2000 & 200 & 10,31 & 7,59 & 6,78 & 6,02 & 5,42 & 4,88 & 3,96 & 3,24 & 2,25 \\
\hline 80 & 200 & 20 & 100,19 & 72,49 & 64,79 & 57,75 & 52,19 & 47,28 & 38,83 & 32,12 & 22,65 \\
\hline 80 & 250 & 20 & 90,46 & 66,65 & 60,50 & 54,68 & 49,90 & 45,60 & 38,04 & 31,86 & 22,82 \\
\hline 80 & 300 & 20 & 83,57 & 62,30 & 57,16 & 52,21 & 48,01 & 44,17 & 37,30 & 31,55 & 22,91 \\
\hline 80 & 350 & 20 & 78,36 & 58,90 & 54,45 & 50,16 & 46,39 & 42,91 & 36,60 & 31,23 & 22,95 \\
\hline 80 & 400 & 20 & 74,22 & 56,14 & 52,18 & 48,42 & 45,00 & 41,81 & 35,95 & 30,90 & 22,96 \\
\hline 80 & 450 & 20 & 70,82 & 53,86 & 50,23 & 46,90 & 43,77 & 40,81 & 35,35 & 30,57 & 22,94 \\
\hline 80 & 500 & 20 & 67,94 & 51,93 & 48,54 & 45,56 & 42,67 & 39,92 & 34,79 & 30,25 & 22,90 \\
\hline 80 & 550 & 20 & 65,45 & 50,27 & 47,05 & 44,37 & 41,69 & 39,11 & 34,27 & 29,94 & 22,85 \\
\hline 80 & 600 & 20 & 63,27 & 48,83 & 45,73 & 43,29 & 40,79 & 38,36 & 33,78 & 29,64 & 22,79 \\
\hline 80 & 650 & 20 & 61,32 & 47,55 & 44,54 & 42,31 & 39,98 & 37,68 & 33,31 & 29,35 & 22,72 \\
\hline 80 & 700 & 20 & 59,56 & 46,43 & 43,46 & 41,42 & 39,23 & 37,04 & 32,88 & 29,08 & 22,65 \\
\hline 80 & 750 & 20 & 57,96 & 45,41 & 42,48 & 40,60 & 38,53 & 36,45 & 32,47 & 28,81 & 22,57 \\
\hline 80 & 800 & 20 & 56,50 & 44,50 & 41,58 & 39,83 & 37,89 & 35,90 & 32,08 & 28,55 & 22,49 \\
\hline 80 & 850 & 20 & 55,14 & 43,67 & 40,76 & 39,12 & 37,29 & 35,39 & 31,71 & 28,30 & 22,40 \\
\hline 80 & 900 & 20 & 53,89 & 42,91 & 40,00 & 38,46 & 36,72 & 34,90 & 31,36 & 28,06 & 22,32 \\
\hline
\end{tabular}




\begin{tabular}{|c|c|c|c|c|c|c|c|c|c|c|c|}
\hline \multirow[b]{2}{*}{$\mathrm{H}(\mathrm{cm})$} & \multirow[b]{2}{*}{ Mceq (MPa) } & & & & & De & ões (x1 & m) & & & \\
\hline & & Msub (MPa) & D0 & D25 & D40 & D60 & D80 & D100 & D140 & D180 & D260 \\
\hline 80 & 950 & 20 & 52,71 & 42,22 & 39,29 & 37,84 & 36,20 & 34,44 & 31,03 & 27,83 & 22,23 \\
\hline 80 & 1000 & 20 & 51,61 & 41,58 & 38,63 & 37,26 & 35,70 & 34,01 & 30,71 & 27,61 & 22,14 \\
\hline 80 & 1050 & 20 & 50,57 & 40,99 & 38,02 & 36,71 & 35,23 & 33,60 & 30,41 & 27,39 & 22,06 \\
\hline 80 & 1100 & 20 & 49,58 & 40,43 & 37,45 & 36,19 & 34,78 & 33,21 & 30,11 & 27,19 & 21,97 \\
\hline 80 & 1150 & 20 & 48,65 & 39,92 & 36,91 & 35,70 & 34,36 & 32,84 & 29,84 & 26,98 & 21,88 \\
\hline 80 & 1200 & 20 & 47,77 & 39,44 & 36,40 & 35,23 & 33,95 & 32,49 & 29,57 & 26,79 & 21,80 \\
\hline 80 & 1250 & 20 & 46,92 & 38,98 & 35,93 & 34,78 & 33,57 & 32,15 & 29,31 & 26,60 & 21,71 \\
\hline 80 & 1300 & 20 & 46,12 & 38,56 & 35,48 & 34,36 & 33,20 & 31,83 & 29,06 & 26,42 & 21,63 \\
\hline 80 & 1350 & 20 & 45,35 & 38,16 & 35,05 & 33,96 & 32,85 & 31,52 & 28,82 & 26,24 & 21,55 \\
\hline 80 & 1400 & 20 & 44,61 & 37,77 & 34,65 & 33,57 & 32,51 & 31,22 & 28,59 & 26,07 & 21,46 \\
\hline 80 & 1450 & 20 & 43,90 & 37,41 & 34,26 & 33,20 & 32,19 & 30,94 & 28,37 & 25,90 & 21,38 \\
\hline 80 & 1500 & 20 & 43,22 & 37,07 & 33,90 & 32,85 & 31,88 & 30,66 & 28,16 & 25,74 & 21,30 \\
\hline 80 & 1550 & 20 & 42,56 & 36,74 & 33,55 & 32,50 & 31,58 & 30,40 & 27,95 & 25,58 & 21,22 \\
\hline 80 & 1600 & 20 & 41,93 & 36,43 & 33,22 & 32,18 & 31,29 & 30,15 & 27,75 & 25,43 & 21,14 \\
\hline 80 & 1650 & 20 & 41,32 & 36,13 & 32,90 & 31,86 & 31,01 & 29,90 & 27,55 & 25,28 & 21,07 \\
\hline 80 & 1700 & 20 & 40,73 & 35,85 & 32,60 & 31,56 & 30,74 & 29,66 & 27,37 & 25,13 & 20,99 \\
\hline 80 & 1750 & 20 & 40,16 & 35,57 & 32,31 & 31,27 & 30,48 & 29,43 & 27,18 & 24,99 & 20,91 \\
\hline 80 & 1800 & 20 & 39,61 & 35,31 & 32,03 & 30,99 & 30,23 & 29,21 & 27,01 & 24,85 & 20,84 \\
\hline 80 & 1850 & 20 & 39,08 & 35,06 & 31,76 & 30,71 & 29,99 & 28,99 & 26,83 & 24,72 & 20,77 \\
\hline 80 & 1900 & 20 & 38,56 & 34,81 & 31,51 & 30,45 & 29,75 & 28,78 & 26,66 & 24,59 & 20,70 \\
\hline 80 & 1950 & 20 & 38,06 & 34,58 & 31,26 & 30,20 & 29,52 & 28,58 & 26,50 & 24,46 & 20,62 \\
\hline 80 & 2000 & 20 & 37,57 & 34,35 & 31,02 & 29,95 & 29,30 & 28,38 & 26,34 & 24,33 & 20,55 \\
\hline 80 & 200 & 25 & 89,35 & 63,16 & 55,45 & 48,69 & 43,53 & 39,07 & 31,57 & 25,81 & 17,95 \\
\hline 80 & 250 & 25 & 80,15 & 57,99 & 51,83 & 46,20 & 41,75 & 37,82 & 31,06 & 25,70 & 18,12 \\
\hline 80 & 300 & 25 & 73,70 & 54,14 & 49,02 & 44,19 & 40,26 & 36,73 & 30,56 & 25,53 & 18,23 \\
\hline 80 & 350 & 25 & 68,86 & 51,13 & 46,73 & 42,51 & 38,98 & 35,77 & 30,07 & 25,34 & 18,30 \\
\hline 80 & 400 & 25 & 65,06 & 48,68 & 44,81 & 41,08 & 37,86 & 34,92 & 29,61 & 25,14 & 18,35 \\
\hline 80 & 450 & 25 & 61,97 & 46,64 & 43,17 & 39,83 & 36,88 & 34,15 & 29,18 & 24,93 & 18,37 \\
\hline 80 & 500 & 25 & 59,38 & 44,92 & 41,74 & 38,73 & 36,00 & 33,44 & 28,76 & 24,72 & 18,37 \\
\hline 80 & 550 & 25 & 57,16 & 43,43 & 40,48 & 37,75 & 35,20 & 32,80 & 28,38 & 24,51 & 18,36 \\
\hline 80 & 600 & 25 & 55,23 & 42,13 & 39,35 & 36,86 & 34,48 & 32,21 & 28,01 & 24,30 & 18,34 \\
\hline 80 & 650 & 25 & 53,52 & 40,99 & 38,34 & 36,05 & 33,81 & 31,67 & 27,66 & 24,10 & 18,31 \\
\hline 80 & 700 & 25 & 51,99 & 39,97 & 37,42 & 35,31 & 33,20 & 31,16 & 27,33 & 23,90 & 18,27 \\
\hline 80 & 750 & 25 & 50,61 & 39,06 & 36,58 & 34,63 & 32,64 & 30,69 & 27,02 & 23,71 & 18,23 \\
\hline 80 & 800 & 25 & 49,35 & 38,24 & 35,81 & 34,00 & 32,11 & 30,25 & 26,72 & 23,53 & 18,19 \\
\hline 80 & 850 & 25 & 48,20 & 37,49 & 35,10 & 33,41 & 31,62 & 29,83 & 26,44 & 23,35 & 18,14 \\
\hline 80 & 900 & 25 & 47,12 & 36,81 & 34,45 & 32,87 & 31,15 & 29,44 & 26,17 & 23,17 & 18,09 \\
\hline 80 & 950 & 25 & 46,13 & 36,18 & 33,84 & 32,35 & 30,72 & 29,07 & 25,91 & 23,00 & 18,04 \\
\hline 80 & 1000 & 25 & 45,20 & 35,60 & 33,27 & 31,87 & 30,31 & 28,72 & 25,66 & 22,84 & 17,99 \\
\hline 80 & 1050 & 25 & 44,33 & 35,07 & 32,74 & 31,41 & 29,92 & 28,39 & 25,43 & 22,68 & 17,94 \\
\hline 80 & 1100 & 25 & 43,50 & 34,57 & 32,24 & 30,98 & 29,56 & 28,07 & 25,20 & 22,53 & 17,88 \\
\hline 80 & 1150 & 25 & 42,72 & 34,10 & 31,77 & 30,57 & 29,21 & 27,77 & 24,98 & 22,37 & 17,83 \\
\hline 80 & 1200 & 25 & 41,99 & 33,67 & 31,33 & 30,18 & 28,88 & 27,48 & 24,77 & 22,23 & 17,77 \\
\hline 80 & 1250 & 25 & 41,28 & 33,26 & 30,91 & 29,81 & 28,56 & 27,21 & 24,57 & 22,09 & 17,71 \\
\hline 80 & 1300 & 25 & 40,62 & 32,88 & 30,51 & 29,45 & 28,25 & 26,95 & 24,37 & 21,95 & 17,66 \\
\hline 80 & 1350 & 25 & 39,98 & 32,52 & 30,14 & 29,11 & 27,96 & 26,69 & 24,18 & 21,81 & 17,60 \\
\hline 80 & 1400 & 25 & 39,37 & 32,18 & 29,78 & 28,79 & 27,69 & 26,45 & 24,00 & 21,68 & 17,55 \\
\hline 80 & 1450 & 25 & 38,78 & 31,86 & 29,44 & 28,48 & 27,42 & 26,22 & 23,83 & 21,56 & 17,49 \\
\hline 80 & 1500 & 25 & 38,21 & 31,55 & 29,12 & 28,18 & 27,16 & 25,99 & 23,65 & 21,43 & 17,44 \\
\hline 80 & 1550 & 25 & 37,67 & 31,26 & 28,82 & 27,90 & 26,91 & 25,78 & 23,49 & 21,31 & 17,38 \\
\hline 80 & 1600 & 25 & 37,15 & 30,98 & 28,52 & 27,62 & 26,68 & 25,57 & 23,33 & 21,19 & 17,33 \\
\hline 80 & 1650 & 25 & 36,65 & 30,72 & 28,24 & 27,36 & 26,45 & 25,36 & 23,17 & 21,08 & 17,28 \\
\hline 80 & 1700 & 25 & 36,16 & 30,46 & 27,97 & 27,10 & 26,22 & 25,17 & 23,02 & 20,97 & 17,22 \\
\hline 80 & 1750 & 25 & 35,69 & 30,22 & 27,72 & 26,86 & 26,01 & 24,98 & 22,88 & 20,86 & 17,17 \\
\hline 80 & 1800 & 25 & 35,23 & 29,99 & 27,47 & 26,62 & 25,80 & 24,80 & 22,73 & 20,75 & 17,12 \\
\hline 80 & 1850 & 25 & 34,79 & 29,76 & 27,23 & 26,39 & 25,60 & 24,62 & 22,59 & 20,64 & 17,07 \\
\hline 80 & 1900 & 25 & 34,36 & 29,55 & 27,00 & 26,17 & 25,40 & 24,45 & 22,46 & 20,54 & 17,02 \\
\hline 80 & 1950 & 25 & 33,95 & 29,34 & 26,79 & 25,95 & 25,21 & 24,28 & 22,33 & 20,44 & 16,97 \\
\hline 80 & 2000 & 25 & 33,55 & 29,15 & 26,57 & 25,74 & 25,03 & 24,12 & 22,20 & 20,34 & 16,91 \\
\hline 80 & 200 & 30 & 81,80 & 56,49 & 48,81 & 42,29 & 37,45 & 33,34 & 26,58 & 21,52 & 14,83 \\
\hline 80 & 250 & 30 & 72,96 & 51,81 & 45,65 & 40,20 & 36,01 & 32,37 & 26,24 & 21,50 & 14,99 \\
\hline 80 & 300 & 30 & 66,79 & 48,33 & 43,19 & 38,50 & 34,79 & 31,52 & 25,89 & 21,41 & 15,10 \\
\hline 80 & 350 & 30 & 62,20 & 45,60 & 41,20 & 37,08 & 33,74 & 30,75 & 25,53 & 21,30 & 15,18 \\
\hline 80 & 400 & 30 & 58,62 & 43,38 & 39,54 & 35,87 & 32,82 & 30,07 & 25,19 & 21,17 & 15,24 \\
\hline 80 & 450 & 30 & 55,72 & 41,53 & 38,11 & 34,81 & 32,00 & 29,44 & 24,87 & 21,04 & 15,27 \\
\hline 80 & 500 & 30 & 53,31 & 39,97 & 36,86 & 33,87 & 31,27 & 28,88 & 24,55 & 20,89 & 15,30 \\
\hline 80 & 550 & 30 & 51,26 & 38,61 & 35,77 & 33,03 & 30,60 & 28,35 & 24,25 & 20,74 & 15,31 \\
\hline 80 & 600 & 30 & 49,48 & 37,43 & 34,78 & 32,28 & 30,00 & 27,87 & 23,97 & 20,60 & 15,31 \\
\hline 80 & 650 & 30 & 47,92 & 36,39 & 33,90 & 31,59 & 29,44 & 27,42 & 23,70 & 20,45 & 15,30 \\
\hline 80 & 700 & 30 & 46,54 & 35,46 & 33,10 & 30,96 & 28,93 & 27,00 & 23,44 & 20,31 & 15,29 \\
\hline 80 & 750 & 30 & 45,29 & 34,62 & 32,36 & 30,37 & 28,45 & 26,61 & 23,19 & 20,17 & 15,27 \\
\hline 80 & 800 & 30 & 44,16 & 33,86 & 31,69 & 29,83 & 28,00 & 26,25 & 22,96 & 20,03 & 15,25 \\
\hline 80 & 850 & 30 & 43,13 & 33,18 & 31,06 & 29,33 & 27,59 & 25,90 & 22,73 & 19,89 & 15,22 \\
\hline 80 & 900 & 30 & 42,18 & 32,55 & 30,48 & 28,86 & 27,20 & 25,58 & 22,52 & 19,76 & 15,19 \\
\hline 80 & 950 & 30 & 41,30 & 31,97 & 29,95 & 28,42 & 26,83 & 25,27 & 22,31 & 19,63 & 15,16 \\
\hline 80 & 1000 & 30 & 40,48 & 31,44 & 29,44 & 28,00 & 26,48 & 24,97 & 22,11 & 19,51 & 15,13 \\
\hline 80 & 1050 & 30 & 39,71 & 30,95 & 28,97 & 27,61 & 26,15 & 24,70 & 21,92 & 19,38 & 15,10 \\
\hline 80 & 1100 & 30 & 38,99 & 30,49 & 28,53 & 27,24 & 25,84 & 24,43 & 21,74 & 19,26 & 15,06 \\
\hline 80 & 1150 & 30 & 38,31 & 30,07 & 28,12 & 26,89 & 25,54 & 24,18 & 21,56 & 19,15 & 15,03 \\
\hline 80 & 1200 & 30 & 37,67 & 29,67 & 27,72 & 26,55 & 25,26 & 23,94 & 21,39 & 19,03 & 14,99 \\
\hline 80 & 1250 & 30 & 37,06 & 29,29 & 27,35 & 26,24 & 24,99 & 23,70 & 21,22 & 18,92 & 14,95 \\
\hline
\end{tabular}




\begin{tabular}{|c|c|c|c|c|c|c|c|c|c|c|c|}
\hline \multirow[b]{2}{*}{$\mathrm{H}(\mathrm{cm})$} & \multirow[b]{2}{*}{ Mceq (MPa) } & & & & & De & ões (x1 & m) & & & \\
\hline & & Msub (MPa) & D0 & D25 & D40 & D60 & D80 & D100 & D140 & D180 & D260 \\
\hline 80 & 1300 & 30 & 36,48 & 28,94 & 27,00 & 25,93 & 24,73 & 23,48 & 21,06 & 18,81 & 14,92 \\
\hline 80 & 1350 & 30 & 35,92 & 28,61 & 26,67 & 25,64 & 24,48 & 23,27 & 20,91 & 18,71 & 14,88 \\
\hline 80 & 1400 & 30 & 35,40 & 28,30 & 26,35 & 25,36 & 24,25 & 23,06 & 20,76 & 18,60 & 14,84 \\
\hline 80 & 1450 & 30 & 34,89 & 28,00 & 26,04 & 25,09 & 24,02 & 22,87 & 20,61 & 18,50 & 14,80 \\
\hline 80 & 1500 & 30 & 34,40 & 27,72 & 25,76 & 24,84 & 23,80 & 22,67 & 20,47 & 18,41 & 14,76 \\
\hline 80 & 1550 & 30 & 33,94 & 27,45 & 25,48 & 24,59 & 23,59 & 22,49 & 20,34 & 18,31 & 14,72 \\
\hline 80 & 1600 & 30 & 33,49 & 27,20 & 25,22 & 24,35 & 23,38 & 22,31 & 20,21 & 18,22 & 14,69 \\
\hline 80 & 1650 & 30 & 33,06 & 26,96 & 24,97 & 24,13 & 23,19 & 22,14 & 20,08 & 18,12 & 14,65 \\
\hline 80 & 1700 & 30 & 32,64 & 26,72 & 24,72 & 23,90 & 23,00 & 21,98 & 19,95 & 18,03 & 14,61 \\
\hline 80 & 1750 & 30 & 32,24 & 26,50 & 24,49 & 23,69 & 22,81 & 21,82 & 19,83 & 17,95 & 14,57 \\
\hline 80 & 1800 & 30 & 31,85 & 26,29 & 24,27 & 23,49 & 22,63 & 21,66 & 19,71 & 17,86 & 14,53 \\
\hline 80 & 1850 & 30 & 31,47 & 26,09 & 24,06 & 23,29 & 22,46 & 21,51 & 19,60 & 17,78 & 14,49 \\
\hline 80 & 1900 & 30 & 31,10 & 25,89 & 23,85 & 23,09 & 22,30 & 21,36 & 19,48 & 17,69 & 14,46 \\
\hline 80 & 1950 & 30 & 30,75 & 25,71 & 23,65 & 22,91 & 22,13 & 21,22 & 19,38 & 17,61 & 14,42 \\
\hline 80 & 2000 & 30 & 30,40 & 25,52 & 23,46 & 22,73 & 21,98 & 21,08 & 19,27 & 17,53 & 14,38 \\
\hline 80 & 200 & 35 & 76,21 & 51,44 & 43,81 & 37,50 & 32,92 & 29,10 & 22,94 & 18,43 & 12,62 \\
\hline 80 & 250 & 35 & 67,63 & 47,13 & 40,98 & 35,69 & 31,72 & 28,33 & 22,70 & 18,45 & 12,76 \\
\hline 80 & 300 & 35 & 61,67 & 43,93 & 38,80 & 34,23 & 30,70 & 27,64 & 22,45 & 18,42 & 12,86 \\
\hline 80 & 350 & 35 & 57,25 & 41,42 & 37,02 & 33,00 & 29,82 & 27,01 & 22,19 & 18,36 & 12,94 \\
\hline 80 & 400 & 35 & 53,82 & 39,39 & 35,54 & 31,95 & 29,04 & 26,45 & 21,93 & 18,28 & 13,00 \\
\hline 80 & 450 & 35 & 51,05 & 37,69 & 34,27 & 31,03 & 28,35 & 25,93 & 21,68 & 18,18 & 13,05 \\
\hline 80 & 500 & 35 & 48,76 & 36,25 & 33,17 & 30,21 & 27,72 & 25,46 & 21,43 & 18,08 & 13,08 \\
\hline 80 & 550 & 35 & 46,83 & 35,00 & 32,19 & 29,48 & 27,15 & 25,02 & 21,20 & 17,98 & 13,10 \\
\hline 80 & 600 & 35 & 45,16 & 33,91 & 31,32 & 28,82 & 26,63 & 24,62 & 20,97 & 17,87 & 13,11 \\
\hline 80 & 650 & 35 & 43,70 & 32,94 & 30,53 & 28,22 & 26,16 & 24,24 & 20,75 & 17,76 & 13,12 \\
\hline 80 & 700 & 35 & 42,41 & 32,08 & 29,81 & 27,67 & 25,71 & 23,89 & 20,55 & 17,66 & 13,12 \\
\hline 80 & 750 & 35 & 41,26 & 31,31 & 29,16 & 27,16 & 25,30 & 23,56 & 20,35 & 17,55 & 13,12 \\
\hline 80 & 800 & 35 & 40,22 & 30,61 & 28,56 & 26,68 & 24,92 & 23,25 & 20,15 & 17,44 & 13,11 \\
\hline 80 & 850 & 35 & 39,27 & 29,97 & 28,00 & 26,24 & 24,56 & 22,95 & 19,97 & 17,34 & 13,10 \\
\hline 80 & 900 & 35 & 38,40 & 29,39 & 27,48 & 25,83 & 24,22 & 22,67 & 19,79 & 17,24 & 13,08 \\
\hline 80 & 950 & 35 & 37,59 & 28,85 & 27,00 & 25,45 & 23,90 & 22,41 & 19,62 & 17,13 & 13,06 \\
\hline 80 & 1000 & 35 & 36,85 & 28,36 & 26,55 & 25,08 & 23,60 & 22,16 & 19,46 & 17,04 & 13,04 \\
\hline 80 & 1050 & 35 & 36,15 & 27,90 & 26,13 & 24,74 & 23,31 & 21,92 & 19,30 & 16,94 & 13,02 \\
\hline 80 & 1100 & 35 & 35,50 & 27,47 & 25,73 & 24,41 & 23,04 & 21,69 & 19,15 & 16,84 & 13,00 \\
\hline 80 & 1150 & 35 & 34,89 & 27,08 & 25,36 & 24,10 & 22,78 & 21,48 & 19,00 & 16,75 & 12,98 \\
\hline 80 & 1200 & 35 & 34,31 & 26,71 & 25,00 & 23,81 & 22,53 & 21,27 & 18,86 & 16,66 & 12,95 \\
\hline 80 & 1250 & 35 & 33,77 & 26,36 & 24,67 & 23,53 & 22,30 & 21,07 & 18,72 & 16,57 & 12,93 \\
\hline 80 & 1300 & 35 & 33,25 & 26,03 & 24,35 & 23,26 & 22,07 & 20,88 & 18,59 & 16,48 & 12,90 \\
\hline 80 & 1350 & 35 & 32,76 & 25,72 & 24,05 & 23,01 & 21,86 & 20,69 & 18,46 & 16,40 & 12,88 \\
\hline 80 & 1400 & 35 & 32,29 & 25,43 & 23,76 & 22,76 & 21,65 & 20,52 & 18,33 & 16,31 & 12,85 \\
\hline 80 & 1450 & 35 & 31,84 & 25,15 & 23,49 & 22,53 & 21,45 & 20,35 & 18,21 & 16,23 & 12,82 \\
\hline 80 & 1500 & 35 & 31,41 & 24,89 & 23,23 & 22,30 & 21,26 & 20,18 & 18,09 & 16,15 & 12,79 \\
\hline 80 & 1550 & 35 & 30,99 & 24,64 & 22,98 & 22,08 & 21,08 & 20,02 & 17,98 & 16,07 & 12,77 \\
\hline 80 & 1600 & 35 & 30,60 & 24,41 & 22,74 & 21,87 & 20,90 & 19,87 & 17,87 & 16,00 & 12,74 \\
\hline 80 & 1650 & 35 & 30,21 & 24,18 & 22,51 & 21,67 & 20,73 & 19,72 & 17,76 & 15,92 & 12,71 \\
\hline 80 & 1700 & 35 & 29,84 & 23,97 & 22,29 & 21,48 & 20,56 & 19,57 & 17,65 & 15,85 & 12,68 \\
\hline 80 & 1750 & 35 & 29,49 & 23,76 & 22,08 & 21,29 & 20,40 & 19,44 & 17,55 & 15,78 & 12,65 \\
\hline 80 & 1800 & 35 & 29,15 & 23,56 & 21,87 & 21,11 & 20,24 & 19,30 & 17,45 & 15,71 & 12,63 \\
\hline 80 & 1850 & 35 & 28,81 & 23,37 & 21,68 & 20,93 & 20,09 & 19,17 & 17,35 & 15,64 & 12,60 \\
\hline 80 & 1900 & 35 & 28,49 & 23,19 & 21,49 & 20,76 & 19,95 & 19,04 & 17,26 & 15,57 & 12,57 \\
\hline 80 & 1950 & 35 & 28,18 & 23,02 & 21,31 & 20,60 & 19,80 & 18,92 & 17,16 & 15,50 & 12,54 \\
\hline 80 & 2000 & 35 & 27,88 & 22,85 & 21,13 & 20,44 & 19,67 & 18,80 & 17,07 & 15,44 & 12,51 \\
\hline 80 & 200 & 40 & 71,88 & 47,47 & 39,89 & 33,76 & 29,41 & 25,83 & 20,15 & 16,09 & 10,97 \\
\hline 80 & 250 & 40 & 63,50 & 43,45 & 37,32 & 32,18 & 28,39 & 25,20 & 20,00 & 16,14 & 11,09 \\
\hline 80 & 300 & 40 & 57,71 & 40,47 & 35,34 & 30,89 & 27,52 & 24,63 & 19,81 & 16,14 & 11,19 \\
\hline 80 & 350 & 40 & 53,42 & 38,14 & 33,74 & 29,81 & 26,76 & 24,11 & 19,61 & 16,11 & 11,26 \\
\hline 80 & 400 & 40 & 50,09 & 36,25 & 32,40 & 28,88 & 26,09 & 23,64 & 19,41 & 16,06 & 11,32 \\
\hline 80 & 450 & 40 & 47,43 & 34,67 & 31,25 & 28,06 & 25,49 & 23,20 & 19,22 & 16,00 & 11,37 \\
\hline 80 & 500 & 40 & 45,23 & 33,33 & 30,25 & 27,34 & 24,95 & 22,80 & 19,02 & 15,93 & 11,41 \\
\hline 80 & 550 & 40 & 43,38 & 32,17 & 29,37 & 26,69 & 24,46 & 22,43 & 18,83 & 15,86 & 11,44 \\
\hline 80 & 600 & 40 & 41,79 & 31,15 & 28,58 & 26,11 & 24,00 & 22,08 & 18,65 & 15,78 & 11,45 \\
\hline 80 & 650 & 40 & 40,40 & 30,25 & 27,87 & 25,57 & 23,58 & 21,76 & 18,47 & 15,70 & 11,47 \\
\hline 80 & 700 & 40 & 39,18 & 29,45 & 27,22 & 25,08 & 23,20 & 21,46 & 18,30 & 15,61 & 11,48 \\
\hline 80 & 750 & 40 & 38,09 & 28,73 & 26,63 & 24,63 & 22,84 & 21,17 & 18,14 & 15,53 & 11,48 \\
\hline 80 & 800 & 40 & 37,11 & 28,07 & 26,09 & 24,21 & 22,50 & 20,90 & 17,98 & 15,45 & 11,48 \\
\hline 80 & 850 & 40 & 36,22 & 27,48 & 25,58 & 23,82 & 22,18 & 20,65 & 17,82 & 15,37 & 11,48 \\
\hline 80 & 900 & 40 & 35,41 & 26,93 & 25,12 & 23,45 & 21,88 & 20,41 & 17,68 & 15,29 & 11,47 \\
\hline 80 & 950 & 40 & 34,66 & 26,43 & 24,68 & 23,11 & 21,60 & 20,18 & 17,53 & 15,21 & 11,46 \\
\hline 80 & 1000 & 40 & 33,97 & 25,96 & 24,27 & 22,78 & 21,34 & 19,96 & 17,40 & 15,13 & 11,45 \\
\hline 80 & 1050 & 40 & 33,33 & 25,54 & 23,89 & 22,47 & 21,08 & 19,75 & 17,26 & 15,05 & 11,44 \\
\hline 80 & 1100 & 40 & 32,73 & 25,14 & 23,53 & 22,18 & 20,84 & 19,55 & 17,13 & 14,97 & 11,43 \\
\hline 80 & 1150 & 40 & 32,16 & 24,76 & 23,19 & 21,91 & 20,62 & 19,36 & 17,01 & 14,90 & 11,41 \\
\hline 80 & 1200 & 40 & 31,63 & 24,41 & 22,86 & 21,65 & 20,40 & 19,18 & 16,89 & 14,82 & 11,40 \\
\hline 80 & 1250 & 40 & 31,13 & 24,09 & 22,56 & 21,40 & 20,19 & 19,01 & 16,77 & 14,75 & 11,38 \\
\hline 80 & 1300 & 40 & 30,66 & 23,78 & 22,27 & 21,16 & 19,99 & 18,84 & 16,66 & 14,68 & 11,36 \\
\hline 80 & 1350 & 40 & 30,21 & 23,49 & 21,99 & 20,93 & 19,80 & 18,68 & 16,55 & 14,61 & 11,34 \\
\hline 80 & 1400 & 40 & 29,78 & 23,21 & 21,73 & 20,71 & 19,61 & 18,52 & 16,44 & 14,54 & 11,32 \\
\hline 80 & 1450 & 40 & 29,37 & 22,95 & 21,48 & 20,50 & 19,44 & 18,37 & 16,34 & 14,47 & 11,30 \\
\hline 80 & 1500 & 40 & 28,98 & 22,71 & 21,24 & 20,30 & 19,27 & 18,23 & 16,23 & 14,40 & 11,28 \\
\hline 80 & 1550 & 40 & 28,61 & 22,47 & 21,01 & 20,10 & 19,10 & 18,09 & 16,14 & 14,34 & 11,26 \\
\hline 80 & 1600 & 40 & 28,25 & 22,25 & 20,79 & 19,92 & 18,94 & 17,95 & 16,04 & 14,27 & 11,24 \\
\hline
\end{tabular}




\begin{tabular}{|c|c|c|c|c|c|c|c|c|c|c|c|}
\hline \multirow[b]{2}{*}{$\mathrm{H}(\mathrm{cm})$} & \multirow[b]{2}{*}{ Mceq (MPa) } & & & & & De & ões (x1 & m) & & & \\
\hline & & Msub (MPa) & D0 & D25 & D40 & D60 & D80 & D100 & D140 & D180 & D260 \\
\hline 80 & 1650 & 40 & 27,90 & 22,04 & 20,58 & 19,74 & 18,79 & 17,82 & 15,95 & 14,21 & 11,22 \\
\hline 80 & 1700 & 40 & 27,57 & 21,84 & 20,38 & 19,56 & 18,64 & 17,69 & 15,86 & 14,15 & 11,20 \\
\hline 80 & 1750 & 40 & 27,25 & 21,64 & 20,19 & 19,39 & 18,50 & 17,57 & 15,77 & 14,09 & 11,18 \\
\hline 80 & 1800 & 40 & 26,94 & 21,46 & 20,00 & 19,23 & 18,36 & 17,45 & 15,68 & 14,03 & 11,16 \\
\hline 80 & 1850 & 40 & 26,64 & 21,28 & 19,82 & 19,07 & 18,23 & 17,33 & 15,60 & 13,97 & 11,14 \\
\hline 80 & 1900 & 40 & 26,35 & 21,11 & 19,65 & 18,92 & 18,10 & 17,22 & 15,51 & 13,92 & 11,12 \\
\hline 80 & 1950 & 40 & 26,07 & 20,95 & 19,48 & 18,77 & 17,97 & 17,11 & 15,43 & 13,86 & 11,09 \\
\hline 80 & 2000 & 40 & 25,80 & 20,79 & 19,32 & 18,63 & 17,85 & 17,01 & 15,35 & 13,80 & 11,07 \\
\hline 80 & 200 & 45 & 68,41 & 44,25 & 36,72 & 30,76 & 26,60 & 23,22 & 17,96 & 14,27 & 9,70 \\
\hline 80 & 250 & 45 & 60,21 & 40,46 & 34,36 & 29,34 & 25,72 & 22,70 & 17,86 & 14,33 & 9,80 \\
\hline 80 & 300 & 45 & 54,54 & 37,66 & 32,54 & 28,19 & 24,97 & 22,23 & 17,72 & 14,35 & 9,89 \\
\hline 80 & 350 & 45 & 50,35 & 35,47 & 31,07 & 27,23 & 24,31 & 21,79 & 17,57 & 14,34 & 9,96 \\
\hline 80 & 400 & 45 & 47,12 & 33,70 & 29,84 & 26,40 & 23,72 & 21,38 & 17,42 & 14,32 & 10,02 \\
\hline 80 & 450 & 45 & 44,53 & 32,22 & 28,80 & 25,67 & 23,19 & 21,01 & 17,26 & 14,28 & 10,07 \\
\hline 80 & 500 & 45 & 42,40 & 30,96 & 27,88 & 25,02 & 22,72 & 20,67 & 17,10 & 14,23 & 10,10 \\
\hline 80 & 550 & 45 & 40,61 & 29,87 & 27,08 & 24,44 & 22,28 & 20,35 & 16,95 & 14,17 & 10,13 \\
\hline 80 & 600 & 45 & 39,08 & 28,92 & 26,36 & 23,91 & 21,88 & 20,05 & 16,80 & 14,12 & 10,16 \\
\hline 80 & 650 & 45 & 37,75 & 28,08 & 25,71 & 23,43 & 21,51 & 19,76 & 16,65 & 14,06 & 10,18 \\
\hline 80 & 700 & 45 & 36,58 & 27,32 & 25,12 & 22,99 & 21,17 & 19,50 & 16,51 & 13,99 & 10,19 \\
\hline 80 & 750 & 45 & 35,54 & 26,64 & 24,58 & 22,58 & 20,85 & 19,25 & 16,37 & 13,93 & 10,20 \\
\hline 80 & 800 & 45 & 34,60 & 26,03 & 24,08 & 22,20 & 20,55 & 19,02 & 16,23 & 13,86 & 10,20 \\
\hline 80 & 850 & 45 & 33,76 & 25,47 & 23,62 & 21,85 & 20,26 & 18,79 & 16,11 & 13,80 & 10,20 \\
\hline 80 & 900 & 45 & 32,99 & 24,95 & 23,19 & 21,52 & 20,00 & 18,58 & 15,98 & 13,73 & 10,20 \\
\hline 80 & 950 & 45 & 32,28 & 24,48 & 22,79 & 21,21 & 19,75 & 18,38 & 15,86 & 13,67 & 10,20 \\
\hline 80 & 1000 & 45 & 31,63 & 24,04 & 22,42 & 20,91 & 19,51 & 18,19 & 15,74 & 13,60 & 10,20 \\
\hline 80 & 1050 & 45 & 31,03 & 23,64 & 22,06 & 20,64 & 19,28 & 18,00 & 15,63 & 13,54 & 10,19 \\
\hline 80 & 1100 & 45 & 30,46 & 23,26 & 21,73 & 20,38 & 19,07 & 17,83 & 15,52 & 13,48 & 10,18 \\
\hline 80 & 1150 & 45 & 29,94 & 22,91 & 21,42 & 20,13 & 18,86 & 17,66 & 15,41 & 13,41 & 10,18 \\
\hline 80 & 1200 & 45 & 29,44 & 22,58 & 21,12 & 19,89 & 18,67 & 17,50 & 15,31 & 13,35 & 10,17 \\
\hline 80 & 1250 & 45 & 28,98 & 22,27 & 20,84 & 19,66 & 18,48 & 17,34 & 15,20 & 13,29 & 10,15 \\
\hline 80 & 1300 & 45 & 28,54 & 21,98 & 20,58 & 19,45 & 18,30 & 17,19 & 15,11 & 13,23 & 10,14 \\
\hline 80 & 1350 & 45 & 28,12 & 21,70 & 20,32 & 19,24 & 18,13 & 17,05 & 15,01 & 13,17 & 10,13 \\
\hline 80 & 1400 & 45 & 27,72 & 21,44 & 20,08 & 19,04 & 17,97 & 16,91 & 14,92 & 13,12 & 10,12 \\
\hline 80 & 1450 & 45 & 27,34 & 21,19 & 19,85 & 18,85 & 17,81 & 16,78 & 14,83 & 13,06 & 10,10 \\
\hline 80 & 1500 & 45 & 26,98 & 20,96 & 19,63 & 18,67 & 17,65 & 16,65 & 14,74 & 13,00 & 10,09 \\
\hline 80 & 1550 & 45 & 26,64 & 20,74 & 19,42 & 18,49 & 17,51 & 16,52 & 14,65 & 12,95 & 10,07 \\
\hline 80 & 1600 & 45 & 26,31 & 20,53 & 19,22 & 18,32 & 17,36 & 16,40 & 14,57 & 12,90 & 10,06 \\
\hline 80 & 1650 & 45 & 25,99 & 20,33 & 19,02 & 18,16 & 17,23 & 16,29 & 14,49 & 12,84 & 10,04 \\
\hline 80 & 1700 & 45 & 25,69 & 20,14 & 18,83 & 18,00 & 17,09 & 16,17 & 14,41 & 12,79 & 10,03 \\
\hline 80 & 1750 & 45 & 25,39 & 19,95 & 18,65 & 17,85 & 16,96 & 16,06 & 14,33 & 12,74 & 10,01 \\
\hline 80 & 1800 & 45 & 25,11 & 19,78 & 18,48 & 17,70 & 16,84 & 15,96 & 14,26 & 12,69 & 9,99 \\
\hline 80 & 1850 & 45 & 24,84 & 19,61 & 18,32 & 17,56 & 16,72 & 15,85 & 14,18 & 12,64 & 9,98 \\
\hline 80 & 1900 & 45 & 24,57 & 19,45 & 18,15 & 17,42 & 16,60 & 15,75 & 14,11 & 12,59 & 9,96 \\
\hline 80 & 1950 & 45 & 24,32 & 19,29 & 18,00 & 17,29 & 16,49 & 15,65 & 14,04 & 12,54 & 9,94 \\
\hline 80 & 2000 & 45 & 24,07 & 19,15 & 17,85 & 17,16 & 16,38 & 15,56 & 13,97 & 12,50 & 9,93 \\
\hline 80 & 200 & 50 & 65,57 & 41,59 & 34,11 & 28,28 & 24,29 & 21,10 & 16,19 & 12,80 & 8,68 \\
\hline 80 & 250 & 50 & 57,50 & 37,98 & 31,91 & 27,01 & 23,53 & 20,66 & 16,12 & 12,87 & 8,78 \\
\hline 80 & 300 & 50 & 51,94 & 35,32 & 30,22 & 25,97 & 22,86 & 20,26 & 16,03 & 12,91 & 8,85 \\
\hline 80 & 350 & 50 & 47,84 & 33,25 & 28,86 & 25,10 & 22,28 & 19,88 & 15,91 & 12,91 & 8,92 \\
\hline 80 & 400 & 50 & 44,68 & 31,58 & 27,73 & 24,35 & 21,77 & 19,53 & 15,79 & 12,90 & 8,98 \\
\hline 80 & 450 & 50 & 42,15 & 30,18 & 26,76 & 23,69 & 21,30 & 19,21 & 15,66 & 12,88 & 9,02 \\
\hline 80 & 500 & 50 & 40,08 & 29,00 & 25,92 & 23,10 & 20,87 & 18,91 & 15,53 & 12,85 & 9,06 \\
\hline 80 & 550 & 50 & 38,34 & 27,97 & 25,17 & 22,57 & 20,49 & 18,63 & 15,40 & 12,81 & 9,09 \\
\hline 80 & 600 & 50 & 36,85 & 27,07 & 24,51 & 22,10 & 20,13 & 18,37 & 15,28 & 12,77 & 9,12 \\
\hline 80 & 650 & 50 & 35,56 & 26,27 & 23,91 & 21,66 & 19,80 & 18,12 & 15,16 & 12,72 & 9,14 \\
\hline 80 & 700 & 50 & 34,43 & 25,56 & 23,36 & 21,26 & 19,49 & 17,89 & 15,04 & 12,67 & 9,15 \\
\hline 80 & 750 & 50 & 33,43 & 24,92 & 22,87 & 20,89 & 19,20 & 17,67 & 14,92 & 12,62 & 9,16 \\
\hline 80 & 800 & 50 & 32,53 & 24,34 & 22,41 & 20,54 & 18,93 & 17,46 & 14,81 & 12,57 & 9,17 \\
\hline 80 & 850 & 50 & 31,72 & 23,81 & 21,98 & 20,22 & 18,68 & 17,26 & 14,69 & 12,52 & 9,18 \\
\hline 80 & 900 & 50 & 30,98 & 23,32 & 21,59 & 19,92 & 18,44 & 17,07 & 14,59 & 12,46 & 9,18 \\
\hline 80 & 950 & 50 & 30,31 & 22,87 & 21,22 & 19,63 & 18,21 & 16,89 & 14,48 & 12,41 & 9,18 \\
\hline 80 & 1000 & 50 & 29,69 & 22,46 & 20,87 & 19,37 & 18,00 & 16,72 & 14,38 & 12,36 & 9,18 \\
\hline 80 & 1050 & 50 & 29,11 & 22,07 & 20,55 & 19,11 & 17,79 & 16,56 & 14,28 & 12,31 & 9,18 \\
\hline 80 & 1100 & 50 & 28,58 & 21,71 & 20,24 & 18,87 & 17,60 & 16,40 & 14,19 & 12,25 & 9,18 \\
\hline 80 & 1150 & 50 & 28,08 & 21,38 & 19,95 & 18,65 & 17,42 & 16,25 & 14,09 & 12,20 & 9,17 \\
\hline 80 & 1200 & 50 & 27,61 & 21,07 & 19,68 & 18,43 & 17,24 & 16,11 & 14,00 & 12,15 & 9,17 \\
\hline 80 & 1250 & 50 & 27,18 & 20,77 & 19,42 & 18,22 & 17,07 & 15,97 & 13,92 & 12,10 & 9,16 \\
\hline 80 & 1300 & 50 & 26,76 & 20,49 & 19,17 & 18,03 & 16,91 & 15,83 & 13,83 & 12,05 & 9,15 \\
\hline 80 & 1350 & 50 & 26,37 & 20,23 & 18,93 & 17,84 & 16,75 & 15,71 & 13,75 & 12,00 & 9,15 \\
\hline 80 & 1400 & 50 & 26,00 & 19,99 & 18,71 & 17,66 & 16,60 & 15,58 & 13,67 & 11,95 & 9,14 \\
\hline 80 & 1450 & 50 & 25,64 & 19,75 & 18,50 & 17,48 & 16,46 & 15,46 & 13,59 & 11,90 & 9,13 \\
\hline 80 & 1500 & 50 & 25,31 & 19,53 & 18,29 & 17,32 & 16,32 & 15,35 & 13,51 & 11,86 & 9,12 \\
\hline 80 & 1550 & 50 & 24,98 & 19,32 & 18,09 & 17,16 & 16,18 & 15,23 & 13,43 & 11,81 & 9,11 \\
\hline 80 & 1600 & 50 & 24,68 & 19,12 & 17,91 & 17,00 & 16,05 & 15,12 & 13,36 & 11,76 & 9,09 \\
\hline 80 & 1650 & 50 & 24,38 & 18,93 & 17,73 & 16,85 & 15,93 & 15,02 & 13,29 & 11,72 & 9,08 \\
\hline 80 & 1700 & 50 & 24,10 & 18,74 & 17,55 & 16,71 & 15,81 & 14,92 & 13,22 & 11,67 & 9,07 \\
\hline 80 & 1750 & 50 & 23,83 & 18,57 & 17,38 & 16,57 & 15,69 & 14,82 & 13,15 & 11,63 & 9,06 \\
\hline 80 & 1800 & 50 & 23,56 & 18,40 & 17,22 & 16,43 & 15,58 & 14,72 & 13,08 & 11,59 & 9,05 \\
\hline 80 & 1850 & 50 & 23,31 & 18,24 & 17,07 & 16,30 & 15,47 & 14,63 & 13,02 & 11,54 & 9,03 \\
\hline 80 & 1900 & 50 & 23,06 & 18,09 & 16,92 & 16,18 & 15,36 & 14,54 & 12,96 & 11,50 & 9,02 \\
\hline 80 & 1950 & 50 & 22,83 & 17,94 & 16,77 & 16,05 & 15,26 & 14,45 & 12,89 & 11,46 & 9,01 \\
\hline
\end{tabular}




\begin{tabular}{|c|c|c|c|c|c|c|c|c|c|c|c|}
\hline \multirow[b]{2}{*}{$\mathrm{H}(\mathrm{cm})$} & \multirow[b]{2}{*}{ Mceq (MPa) } & & & & & $\mathrm{De}$ & ões (x1 & & & & \\
\hline & & Msub (MPa) & D0 & D25 & D40 & D60 & D80 & D100 & D140 & D180 & D260 \\
\hline 80 & 2000 & 50 & 22,60 & 17,80 & 16,63 & 15,93 & 15,16 & 14,36 & 12,83 & 11,42 & 8,99 \\
\hline 80 & 200 & 55 & 63,19 & 39,34 & 31,91 & 26,21 & 22,37 & 19,33 & 14,73 & 11,60 & 7,86 \\
\hline 80 & 250 & 55 & 55,24 & 35,88 & 29,84 & 25,05 & 21,69 & 18,96 & 14,69 & 11,68 & 7,94 \\
\hline 80 & 300 & 55 & 49,77 & 33,35 & 28,27 & 24,10 & 21,10 & 18,61 & 14,62 & 11,72 & 8,01 \\
\hline 80 & 350 & 55 & 45,74 & 31,38 & 27,00 & 23,31 & 20,59 & 18,29 & 14,53 & 11,74 & 8,07 \\
\hline 80 & 400 & 55 & 42,64 & 29,78 & 25,94 & 22,62 & 20,12 & 17,99 & 14,43 & 11,74 & 8,12 \\
\hline 80 & 450 & 55 & 40,16 & 28,46 & 25,04 & 22,02 & 19,71 & 17,70 & 14,33 & 11,73 & 8,17 \\
\hline 80 & 500 & 55 & 38,13 & 27,33 & 24,25 & 21,48 & 19,33 & 17,44 & 14,23 & 11,71 & 8,21 \\
\hline 80 & 550 & 55 & 36,43 & 26,36 & 23,56 & 21,00 & 18,98 & 17,19 & 14,12 & 11,68 & 8,24 \\
\hline 80 & 600 & 55 & 34,98 & 25,51 & 22,94 & 20,56 & 18,65 & 16,96 & 14,01 & 11,65 & 8,26 \\
\hline 80 & 650 & 55 & 33,73 & 24,75 & 22,39 & 20,16 & 18,36 & 16,74 & 13,91 & 11,61 & 8,28 \\
\hline 80 & 700 & 55 & 32,63 & 24,08 & 21,88 & 19,79 & 18,08 & 16,53 & 13,81 & 11,58 & 8,30 \\
\hline 80 & 750 & 55 & 31,66 & 23,47 & 21,42 & 19,45 & 17,82 & 16,34 & 13,71 & 11,54 & 8,31 \\
\hline 80 & 800 & 55 & 30,79 & 22,91 & 20,99 & 19,14 & 17,57 & 16,15 & 13,61 & 11,50 & 8,33 \\
\hline 80 & 850 & 55 & 30,01 & 22,41 & 20,59 & 18,84 & 17,34 & 15,97 & 13,52 & 11,45 & 8,33 \\
\hline 80 & 900 & 55 & 29,30 & 21,95 & 20,23 & 18,56 & 17,13 & 15,80 & 13,42 & 11,41 & 8,34 \\
\hline 80 & 950 & 55 & 28,65 & 21,52 & 19,88 & 18,30 & 16,92 & 15,64 & 13,33 & 11,37 & 8,35 \\
\hline 80 & 1000 & 55 & 28,05 & 21,12 & 19,56 & 18,06 & 16,72 & 15,49 & 13,24 & 11,32 & 8,35 \\
\hline 80 & 1050 & 55 & 27,50 & 20,76 & 19,26 & 17,83 & 16,54 & 15,34 & 13,16 & 11,28 & 8,35 \\
\hline 80 & 1100 & 55 & 26,99 & 20,42 & 18,97 & 17,61 & 16,36 & 15,20 & 13,07 & 11,24 & 8,35 \\
\hline 80 & 1150 & 55 & 26,51 & 20,10 & 18,70 & 17,40 & 16,19 & 15,07 & 12,99 & 11,19 & 8,35 \\
\hline 80 & 1200 & 55 & 26,07 & 19,80 & 18,45 & 17,20 & 16,03 & 14,94 & 12,91 & 11,15 & 8,35 \\
\hline 80 & 1250 & 55 & 25,65 & 19,52 & 18,21 & 17,01 & 15,88 & 14,81 & 12,84 & 11,11 & 8,34 \\
\hline 80 & 1300 & 55 & 25,26 & 19,25 & 17,98 & 16,83 & 15,73 & 14,69 & 12,76 & 11,06 & 8,34 \\
\hline 80 & 1350 & 55 & 24,88 & 19,00 & 17,76 & 16,65 & 15,59 & 14,57 & 12,69 & 11,02 & 8,33 \\
\hline 80 & 1400 & 55 & 24,53 & 18,77 & 17,55 & 16,49 & 15,45 & 14,46 & 12,62 & 10,98 & 8,33 \\
\hline 80 & 1450 & 55 & 24,20 & 18,54 & 17,35 & 16,33 & 15,32 & 14,35 & 12,55 & 10,94 & 8,32 \\
\hline 80 & 1500 & 55 & 23,88 & 18,33 & 17,16 & 16,17 & 15,19 & 14,25 & 12,48 & 10,90 & 8,31 \\
\hline 80 & 1550 & 55 & 23,57 & 18,13 & 16,97 & 16,02 & 15,07 & 14,14 & 12,41 & 10,86 & 8,30 \\
\hline 80 & 1600 & 55 & 23,28 & 17,94 & 16,80 & 15,88 & 14,95 & 14,05 & 12,35 & 10,82 & 8,30 \\
\hline 80 & 1650 & 55 & 23,01 & 17,75 & 16,63 & 15,74 & 14,83 & 13,95 & 12,28 & 10,78 & 8,29 \\
\hline 80 & 1700 & 55 & 22,74 & 17,58 & 16,47 & 15,61 & 14,72 & 13,86 & 12,22 & 10,74 & 8,28 \\
\hline 80 & 1750 & 55 & 22,48 & 17,41 & 16,31 & 15,48 & 14,62 & 13,77 & 12,16 & 10,70 & 8,27 \\
\hline 80 & 1800 & 55 & 22,24 & 17,25 & 16,16 & 15,36 & 14,51 & 13,68 & 12,10 & 10,66 & 8,26 \\
\hline 80 & 1850 & 55 & 22,00 & 17,10 & 16,01 & 15,24 & 14,41 & 13,59 & 12,04 & 10,63 & 8,25 \\
\hline 80 & 1900 & 55 & 21,77 & 16,95 & 15,87 & 15,12 & 14,31 & 13,51 & 11,98 & 10,59 & 8,24 \\
\hline 80 & 1950 & 55 & 21,55 & 16,81 & 15,74 & 15,01 & 14,22 & 13,43 & 11,93 & 10,55 & 8,23 \\
\hline 80 & 2000 & 55 & 21,34 & 16,68 & 15,61 & 14,90 & 14,12 & 13,35 & 11,87 & 10,52 & 8,22 \\
\hline 80 & 200 & 60 & 61,16 & 37,41 & 30,03 & 24,44 & 20,73 & 17,84 & 13,50 & 10,60 & 7,18 \\
\hline 80 & 250 & 60 & 53,32 & 34,08 & 28,08 & 23,38 & 20,13 & 17,52 & 13,48 & 10,68 & 7,25 \\
\hline 80 & 300 & 60 & 47,92 & 31,65 & 26,59 & 22,51 & 19,61 & 17,22 & 13,44 & 10,73 & 7,31 \\
\hline 80 & 350 & 60 & 43,95 & 29,76 & 25,40 & 21,78 & 19,14 & 16,94 & 13,37 & 10,75 & 7,37 \\
\hline 80 & 400 & 60 & 40,90 & 28,24 & 24,40 & 21,15 & 18,72 & 16,67 & 13,29 & 10,76 & 7,42 \\
\hline 80 & 450 & 60 & 38,47 & 26,98 & 23,56 & 20,59 & 18,35 & 16,42 & 13,21 & 10,76 & 7,46 \\
\hline 80 & 500 & 60 & 36,48 & 25,91 & 22,82 & 20,10 & 18,00 & 16,19 & 13,12 & 10,75 & 7,49 \\
\hline 80 & 550 & 60 & 34,81 & 24,98 & 22,18 & 19,65 & 17,69 & 15,97 & 13,03 & 10,73 & 7,52 \\
\hline 80 & 600 & 60 & 33,40 & 24,16 & 21,60 & 19,25 & 17,40 & 15,76 & 12,94 & 10,71 & 7,55 \\
\hline 80 & 650 & 60 & 32,17 & 23,44 & 21,08 & 18,88 & 17,12 & 15,56 & 12,85 & 10,68 & 7,57 \\
\hline 80 & 700 & 60 & 31,10 & 22,80 & 20,60 & 18,54 & 16,87 & 15,38 & 12,77 & 10,65 & 7,59 \\
\hline 80 & 750 & 60 & 30,15 & 22,22 & 20,17 & 18,23 & 16,63 & 15,20 & 12,68 & 10,62 & 7,61 \\
\hline 80 & 800 & 60 & 29,31 & 21,69 & 19,77 & 17,93 & 16,41 & 15,03 & 12,60 & 10,59 & 7,62 \\
\hline 80 & 850 & 60 & 28,55 & 21,21 & 19,40 & 17,66 & 16,20 & 14,87 & 12,51 & 10,55 & 7,63 \\
\hline 80 & 900 & 60 & 27,86 & 20,77 & 19,05 & 17,40 & 16,00 & 14,72 & 12,43 & 10,52 & 7,64 \\
\hline 80 & 950 & 60 & 27,23 & 20,36 & 18,73 & 17,16 & 15,81 & 14,58 & 12,35 & 10,48 & 7,64 \\
\hline 80 & 1000 & 60 & 26,65 & 19,98 & 18,43 & 16,94 & 15,63 & 14,44 & 12,28 & 10,45 & 7,65 \\
\hline 80 & 1050 & 60 & 26,12 & 19,63 & 18,15 & 16,72 & 15,46 & 14,30 & 12,20 & 10,41 & 7,65 \\
\hline 80 & 1100 & 60 & 25,63 & 19,31 & 17,88 & 16,52 & 15,30 & 14,18 & 12,13 & 10,37 & 7,65 \\
\hline 80 & 1150 & 60 & 25,17 & 19,00 & 17,63 & 16,32 & 15,15 & 14,05 & 12,06 & 10,34 & 7,65 \\
\hline 80 & 1200 & 60 & 24,74 & 18,71 & 17,39 & 16,14 & 15,00 & 13,94 & 11,98 & 10,30 & 7,65 \\
\hline 80 & 1250 & 60 & 24,34 & 18,45 & 17,17 & 15,96 & 14,86 & 13,82 & 11,92 & 10,26 & 7,65 \\
\hline 80 & 1300 & 60 & 23,96 & 18,19 & 16,95 & 15,79 & 14,72 & 13,71 & 11,85 & 10,23 & 7,65 \\
\hline 80 & 1350 & 60 & 23,61 & 17,95 & 16,74 & 15,63 & 14,59 & 13,60 & 11,78 & 10,19 & 7,65 \\
\hline 80 & 1400 & 60 & 23,27 & 17,73 & 16,55 & 15,48 & 14,46 & 13,50 & 11,72 & 10,15 & 7,64 \\
\hline 80 & 1450 & 60 & 22,95 & 17,51 & 16,36 & 15,33 & 14,34 & 13,40 & 11,66 & 10,12 & 7,64 \\
\hline 80 & 1500 & 60 & 22,65 & 17,31 & 16,18 & 15,19 & 14,22 & 13,31 & 11,60 & 10,08 & 7,63 \\
\hline 80 & 1550 & 60 & 22,36 & 17,12 & 16,01 & 15,05 & 14,11 & 13,21 & 11,54 & 10,05 & 7,63 \\
\hline 80 & 1600 & 60 & 22,08 & 16,93 & 15,84 & 14,92 & 14,00 & 13,12 & 11,48 & 10,01 & 7,62 \\
\hline 80 & 1650 & 60 & 21,82 & 16,76 & 15,68 & 14,79 & 13,90 & 13,04 & 11,42 & 9,98 & 7,62 \\
\hline 80 & 1700 & 60 & 21,56 & 16,59 & 15,53 & 14,67 & 13,79 & 12,95 & 11,37 & 9,95 & 7,61 \\
\hline 80 & 1750 & 60 & 21,32 & 16,43 & 15,38 & 14,55 & 13,69 & 12,87 & 11,31 & 9,91 & 7,60 \\
\hline 80 & 1800 & 60 & 21,09 & 16,28 & 15,24 & 14,43 & 13,60 & 12,79 & 11,26 & 9,88 & 7,60 \\
\hline 80 & 1850 & 60 & 20,86 & 16,13 & 15,11 & 14,32 & 13,50 & 12,71 & 11,21 & 9,85 & 7,59 \\
\hline 80 & 1900 & 60 & 20,65 & 15,99 & 14,97 & 14,21 & 13,41 & 12,63 & 11,15 & 9,82 & 7,58 \\
\hline 80 & 1950 & 60 & 20,44 & 15,85 & 14,85 & 14,10 & 13,33 & 12,56 & 11,10 & 9,78 & 7,57 \\
\hline 80 & 2000 & 60 & 20,24 & 15,72 & 14,72 & 14,00 & 13,24 & 12,49 & 11,06 & 9,75 & 7,57 \\
\hline 80 & 200 & 65 & 59,41 & 35,74 & 28,40 & 22,92 & 19,33 & 16,56 & 12,46 & 9,75 & 6,60 \\
\hline 80 & 250 & 65 & 51,66 & 32,51 & 26,55 & 21,93 & 18,79 & 16,28 & 12,46 & 9,84 & 6,67 \\
\hline 80 & 300 & 65 & 46,33 & 30,17 & 25,14 & 21,13 & 18,31 & 16,02 & 12,43 & 9,89 & 6,72 \\
\hline 80 & 350 & 65 & 42,42 & 28,36 & 24,01 & 20,45 & 17,89 & 15,77 & 12,38 & 9,92 & 6,78 \\
\hline 80 & 400 & 65 & 39,41 & 26,90 & 23,07 & 19,87 & 17,52 & 15,54 & 12,31 & 9,93 & 6,82 \\
\hline 80 & 450 & 65 & 37,01 & 25,69 & 22,27 & 19,35 & 17,17 & 15,31 & 12,25 & 9,93 & 6,86 \\
\hline
\end{tabular}




\begin{tabular}{|c|c|c|c|c|c|c|c|c|c|c|c|}
\hline \multirow[b]{2}{*}{$\mathrm{H}(\mathrm{cm})$} & \multirow[b]{2}{*}{ Mceq (MPa) } & & & & & $\mathrm{De}$ & ões (x1 & & & & \\
\hline & & Msub (MPa) & D0 & D25 & D40 & D60 & D80 & D100 & D140 & D180 & D260 \\
\hline 80 & 500 & 65 & 35,06 & 24,66 & 21,58 & 18,90 & 16,86 & 15,11 & 12,17 & 9,93 & 6,89 \\
\hline 80 & 550 & 65 & 33,42 & 23,77 & 20,97 & 18,49 & 16,57 & 14,91 & 12,10 & 9,92 & 6,92 \\
\hline 80 & 600 & 65 & 32,03 & 22,99 & 20,43 & 18,11 & 16,31 & 14,72 & 12,02 & 9,90 & 6,95 \\
\hline 80 & 650 & 65 & 30,83 & 22,31 & 19,94 & 17,77 & 16,06 & 14,55 & 11,95 & 9,88 & 6,97 \\
\hline 80 & 700 & 65 & 29,78 & 21,69 & 19,49 & 17,45 & 15,83 & 14,38 & 11,87 & 9,86 & 6,99 \\
\hline 80 & 750 & 65 & 28,85 & 21,13 & 19,08 & 17,16 & 15,61 & 14,22 & 11,80 & 9,84 & 7,00 \\
\hline 80 & 800 & 65 & 28,03 & 20,63 & 18,71 & 16,89 & 15,40 & 14,07 & 11,72 & 9,81 & 7,02 \\
\hline 80 & 850 & 65 & 27,28 & 20,17 & 18,36 & 16,64 & 15,21 & 13,92 & 11,65 & 9,78 & 7,03 \\
\hline 80 & 900 & 65 & 26,61 & 19,74 & 18,03 & 16,40 & 15,03 & 13,79 & 11,58 & 9,75 & 7,04 \\
\hline 80 & 950 & 65 & 26,00 & 19,35 & 17,73 & 16,17 & 14,85 & 13,65 & 11,51 & 9,72 & 7,05 \\
\hline 80 & 1000 & 65 & 25,44 & 18,99 & 17,45 & 15,96 & 14,69 & 13,53 & 11,44 & 9,69 & 7,05 \\
\hline 80 & 1050 & 65 & 24,92 & 18,66 & 17,18 & 15,76 & 14,53 & 13,41 & 11,38 & 9,66 & 7,06 \\
\hline 80 & 1100 & 65 & 24,45 & 18,34 & 16,93 & 15,57 & 14,38 & 13,29 & 11,31 & 9,63 & 7,06 \\
\hline 80 & 1150 & 65 & 24,00 & 18,05 & 16,70 & 15,39 & 14,24 & 13,18 & 11,25 & 9,60 & 7,06 \\
\hline 80 & 1200 & 65 & 23,59 & 17,78 & 16,47 & 15,22 & 14,10 & 13,07 & 11,18 & 9,57 & 7,06 \\
\hline 80 & 1250 & 65 & 23,20 & 17,52 & 16,26 & 15,05 & 13,97 & 12,96 & 11,12 & 9,54 & 7,06 \\
\hline 80 & 1300 & 65 & 22,84 & 17,28 & 16,05 & 14,90 & 13,84 & 12,86 & 11,06 & 9,51 & 7,06 \\
\hline 80 & 1350 & 65 & 22,49 & 17,05 & 15,86 & 14,75 & 13,72 & 12,77 & 11,00 & 9,48 & 7,06 \\
\hline 80 & 1400 & 65 & 22,17 & 16,83 & 15,68 & 14,60 & 13,61 & 12,67 & 10,95 & 9,44 & 7,06 \\
\hline 80 & 1450 & 65 & 21,86 & 16,62 & 15,50 & 14,46 & 13,49 & 12,58 & 10,89 & 9,41 & 7,06 \\
\hline 80 & 1500 & 65 & 21,57 & 16,43 & 15,33 & 14,33 & 13,39 & 12,49 & 10,84 & 9,38 & 7,06 \\
\hline 80 & 1550 & 65 & 21,30 & 16,24 & 15,17 & 14,20 & 13,28 & 12,41 & 10,78 & 9,35 & 7,05 \\
\hline 80 & 1600 & 65 & 21,03 & 16,06 & 15,01 & 14,08 & 13,18 & 12,32 & 10,73 & 9,32 & 7,05 \\
\hline 80 & 1650 & 65 & 20,78 & 15,89 & 14,86 & 13,96 & 13,08 & 12,24 & 10,68 & 9,29 & 7,05 \\
\hline 80 & 1700 & 65 & 20,54 & 15,73 & 14,72 & 13,84 & 12,99 & 12,16 & 10,63 & 9,26 & 7,04 \\
\hline 80 & 1750 & 65 & 20,31 & 15,58 & 14,58 & 13,73 & 12,89 & 12,09 & 10,58 & 9,23 & 7,04 \\
\hline 80 & 1800 & 65 & 20,08 & 15,43 & 14,44 & 13,62 & 12,80 & 12,01 & 10,53 & 9,21 & 7,03 \\
\hline 80 & 1850 & 65 & 19,87 & 15,29 & 14,32 & 13,52 & 12,72 & 11,94 & 10,48 & 9,18 & 7,02 \\
\hline 80 & 1900 & 65 & 19,66 & 15,15 & 14,19 & 13,42 & 12,63 & 11,87 & 10,44 & 9,15 & 7,02 \\
\hline 80 & 1950 & 65 & 19,47 & 15,02 & 14,07 & 13,32 & 12,55 & 11,80 & 10,39 & 9,12 & 7,01 \\
\hline 80 & 2000 & 65 & 19,27 & 14,90 & 13,95 & 13,22 & 12,47 & 11,74 & 10,35 & 9,09 & 7,01 \\
\hline 80 & 200 & 70 & 57,89 & 34,27 & 26,98 & 21,59 & 18,11 & 15,45 & 11,56 & 9,03 & 6,11 \\
\hline 80 & 250 & 70 & 50,21 & 31,14 & 25,21 & 20,67 & 17,62 & 15,21 & 11,57 & 9,11 & 6,17 \\
\hline 80 & 300 & 70 & 44,94 & 28,87 & 23,86 & 19,92 & 17,19 & 14,98 & 11,55 & 9,16 & 6,22 \\
\hline 80 & 350 & 70 & 41,07 & 27,13 & 22,79 & 19,29 & 16,80 & 14,76 & 11,52 & 9,20 & 6,27 \\
\hline 80 & 400 & 70 & 38,11 & 25,72 & 21,90 & 18,75 & 16,46 & 14,55 & 11,47 & 9,21 & 6,31 \\
\hline 80 & 450 & 70 & 35,74 & 24,55 & 21,15 & 18,27 & 16,15 & 14,35 & 11,41 & 9,22 & 6,35 \\
\hline 80 & 500 & 70 & 33,81 & 23,57 & 20,49 & 17,85 & 15,86 & 14,16 & 11,35 & 9,22 & 6,38 \\
\hline 80 & 550 & 70 & 32,20 & 22,71 & 19,91 & 17,46 & 15,60 & 13,99 & 11,29 & 9,22 & 6,41 \\
\hline 80 & 600 & 70 & 30,83 & 21,97 & 19,40 & 17,11 & 15,35 & 13,82 & 11,22 & 9,21 & 6,43 \\
\hline 80 & 650 & 70 & 29,66 & 21,30 & 18,93 & 16,79 & 15,12 & 13,66 & 11,16 & 9,19 & 6,45 \\
\hline 80 & 700 & 70 & 28,63 & 20,71 & 18,51 & 16,50 & 14,91 & 13,51 & 11,09 & 9,18 & 6,47 \\
\hline 80 & 750 & 70 & 27,72 & 20,18 & 18,13 & 16,23 & 14,71 & 13,36 & 11,03 & 9,16 & 6,49 \\
\hline 80 & 800 & 70 & 26,91 & 19,69 & 17,77 & 15,97 & 14,52 & 13,22 & 10,96 & 9,14 & 6,50 \\
\hline 80 & 850 & 70 & 26,18 & 19,25 & 17,44 & 15,74 & 14,34 & 13,09 & 10,90 & 9,11 & 6,51 \\
\hline 80 & 900 & 70 & 25,53 & 18,85 & 17,14 & 15,51 & 14,17 & 12,97 & 10,84 & 9,09 & 6,52 \\
\hline 80 & 950 & 70 & 24,93 & 18,47 & 16,85 & 15,30 & 14,01 & 12,85 & 10,78 & 9,07 & 6,53 \\
\hline 80 & 1000 & 70 & 24,38 & 18,12 & 16,58 & 15,11 & 13,86 & 12,73 & 10,72 & 9,04 & 6,54 \\
\hline 80 & 1050 & 70 & 23,88 & 17,80 & 16,33 & 14,92 & 13,72 & 12,62 & 10,66 & 9,02 & 6,55 \\
\hline 80 & 1100 & 70 & 23,41 & 17,50 & 16,10 & 14,74 & 13,58 & 12,51 & 10,60 & 8,99 & 6,55 \\
\hline 80 & 1150 & 70 & 22,98 & 17,22 & 15,87 & 14,57 & 13,44 & 12,41 & 10,54 & 8,96 & 6,55 \\
\hline 80 & 1200 & 70 & 22,58 & 16,95 & 15,66 & 14,41 & 13,32 & 12,31 & 10,49 & 8,94 & 6,56 \\
\hline 80 & 1250 & 70 & 22,20 & 16,71 & 15,46 & 14,26 & 13,19 & 12,21 & 10,43 & 8,91 & 6,56 \\
\hline 80 & 1300 & 70 & 21,85 & 16,47 & 15,27 & 14,11 & 13,08 & 12,12 & 10,38 & 8,88 & 6,56 \\
\hline 80 & 1350 & 70 & 21,52 & 16,25 & 15,08 & 13,97 & 12,96 & 12,03 & 10,32 & 8,85 & 6,56 \\
\hline 80 & 1400 & 70 & 21,21 & 16,04 & 14,91 & 13,83 & 12,86 & 11,94 & 10,27 & 8,83 & 6,56 \\
\hline 80 & 1450 & 70 & 20,91 & 15,84 & 14,74 & 13,70 & 12,75 & 11,86 & 10,22 & 8,80 & 6,56 \\
\hline 80 & 1500 & 70 & 20,63 & 15,65 & 14,58 & 13,58 & 12,65 & 11,78 & 10,17 & 8,77 & 6,56 \\
\hline 80 & 1550 & 70 & 20,36 & 15,48 & 14,43 & 13,46 & 12,55 & 11,70 & 10,12 & 8,75 & 6,56 \\
\hline 80 & 1600 & 70 & 20,11 & 15,30 & 14,28 & 13,34 & 12,46 & 11,62 & 10,08 & 8,72 & 6,55 \\
\hline 80 & 1650 & 70 & 19,87 & 15,14 & 14,14 & 13,23 & 12,37 & 11,55 & 10,03 & 8,70 & 6,55 \\
\hline 80 & 1700 & 70 & 19,63 & 14,99 & 14,00 & 13,12 & 12,28 & 11,48 & 9,98 & 8,67 & 6,55 \\
\hline 80 & 1750 & 70 & 19,41 & 14,84 & 13,87 & 13,02 & 12,19 & 11,41 & 9,94 & 8,64 & 6,54 \\
\hline 80 & 1800 & 70 & 19,20 & 14,69 & 13,74 & 12,92 & 12,11 & 11,34 & 9,90 & 8,62 & 6,54 \\
\hline 80 & 1850 & 70 & 18,99 & 14,56 & 13,62 & 12,82 & 12,03 & 11,27 & 9,85 & 8,59 & 6,54 \\
\hline 80 & 1900 & 70 & 18,80 & 14,43 & 13,50 & 12,72 & 11,95 & 11,21 & 9,81 & 8,57 & 6,53 \\
\hline 80 & 1950 & 70 & 18,61 & 14,30 & 13,39 & 12,63 & 11,87 & 11,14 & 9,77 & 8,54 & 6,53 \\
\hline 80 & 2000 & 70 & 18,42 & 14,18 & 13,28 & 12,54 & 11,80 & 11,08 & 9,73 & 8,52 & 6,52 \\
\hline 80 & 200 & 75 & 56,54 & 32,97 & 25,73 & 20,42 & 17,04 & 14,48 & 10,78 & 8,40 & 5,69 \\
\hline 80 & 250 & 75 & 48,93 & 29,93 & 24,02 & 19,56 & 16,59 & 14,27 & 10,80 & 8,48 & 5,74 \\
\hline 80 & 300 & 75 & 43,71 & 27,73 & 22,74 & 18,86 & 16,19 & 14,07 & 10,79 & 8,53 & 5,79 \\
\hline 80 & 350 & 75 & 39,89 & 26,03 & 21,71 & 18,27 & 15,85 & 13,87 & 10,77 & 8,57 & 5,83 \\
\hline 80 & 400 & 75 & 36,96 & 24,67 & 20,87 & 17,76 & 15,53 & 13,68 & 10,73 & 8,59 & 5,87 \\
\hline 80 & 450 & 75 & 34,63 & 23,55 & 20,15 & 17,31 & 15,24 & 13,50 & 10,68 & 8,60 & 5,90 \\
\hline 80 & 500 & 75 & 32,72 & 22,59 & 19,52 & 16,92 & 14,98 & 13,34 & 10,63 & 8,61 & 5,93 \\
\hline 80 & 550 & 75 & 31,13 & 21,77 & 18,97 & 16,56 & 14,74 & 13,17 & 10,58 & 8,61 & 5,96 \\
\hline 80 & 600 & 75 & 29,78 & 21,05 & 18,48 & 16,23 & 14,51 & 13,02 & 10,52 & 8,60 & 5,98 \\
\hline 80 & 650 & 75 & 28,62 & 20,41 & 18,04 & 15,93 & 14,30 & 12,88 & 10,47 & 8,59 & 6,00 \\
\hline 80 & 700 & 75 & 27,61 & 19,85 & 17,64 & 15,66 & 14,10 & 12,74 & 10,41 & 8,58 & 6,02 \\
\hline 80 & 750 & 75 & 26,72 & 19,33 & 17,28 & 15,40 & 13,92 & 12,61 & 10,35 & 8,57 & 6,04 \\
\hline 80 & 800 & 75 & 25,92 & 18,86 & 16,94 & 15,16 & 13,74 & 12,48 & 10,30 & 8,55 & 6,05 \\
\hline
\end{tabular}




\begin{tabular}{|c|c|c|c|c|c|c|c|c|c|c|c|}
\hline \multirow[b]{2}{*}{$\mathrm{H}(\mathrm{cm})$} & \multirow[b]{2}{*}{ Mceq (MPa) } & & & & & $\mathrm{De}$ & ões (x1 & & & & \\
\hline & & Msub (MPa) & D0 & D25 & D40 & D60 & D80 & D100 & D140 & D180 & D260 \\
\hline 80 & 850 & 75 & 25,21 & 18,44 & 16,63 & 14,94 & 13,58 & 12,36 & 10,24 & 8,53 & 6,07 \\
\hline 80 & 900 & 75 & 24,57 & 18,05 & 16,34 & 14,73 & 13,42 & 12,24 & 10,19 & 8,51 & 6,08 \\
\hline 80 & 950 & 75 & 23,98 & 17,69 & 16,07 & 14,53 & 13,27 & 12,13 & 10,13 & 8,49 & 6,09 \\
\hline 80 & 1000 & 75 & 23,45 & 17,35 & 15,81 & 14,35 & 13,13 & 12,03 & 10,08 & 8,47 & 6,09 \\
\hline 80 & 1050 & 75 & 22,95 & 17,04 & 15,58 & 14,17 & 12,99 & 11,92 & 10,02 & 8,45 & 6,10 \\
\hline 80 & 1100 & 75 & 22,50 & 16,75 & 15,35 & 14,00 & 12,86 & 11,83 & 9,97 & 8,43 & 6,11 \\
\hline 80 & 1150 & 75 & 22,08 & 16,48 & 15,14 & 13,85 & 12,74 & 11,73 & 9,92 & 8,40 & 6,11 \\
\hline 80 & 1200 & 75 & 21,69 & 16,23 & 14,94 & 13,69 & 12,62 & 11,64 & 9,87 & 8,38 & 6,12 \\
\hline 80 & 1250 & 75 & 21,32 & 15,99 & 14,75 & 13,55 & 12,51 & 11,55 & 9,82 & 8,36 & 6,12 \\
\hline 80 & 1300 & 75 & 20,98 & 15,76 & 14,56 & 13,41 & 12,40 & 11,46 & 9,77 & 8,33 & 6,12 \\
\hline 80 & 1350 & 75 & 20,66 & 15,55 & 14,39 & 13,28 & 12,29 & 11,38 & 9,73 & 8,31 & 6,12 \\
\hline 80 & 1400 & 75 & 20,35 & 15,35 & 14,22 & 13,15 & 12,19 & 11,30 & 9,68 & 8,29 & 6,12 \\
\hline 80 & 1450 & 75 & 20,06 & 15,15 & 14,07 & 13,03 & 12,09 & 11,22 & 9,63 & 8,26 & 6,12 \\
\hline 80 & 1500 & 75 & 19,79 & 14,97 & 13,91 & 12,91 & 12,00 & 11,15 & 9,59 & 8,24 & 6,12 \\
\hline 80 & 1550 & 75 & 19,53 & 14,80 & 13,77 & 12,80 & 11,91 & 11,07 & 9,54 & 8,22 & 6,12 \\
\hline 80 & 1600 & 75 & 19,29 & 14,63 & 13,63 & 12,69 & 11,82 & 11,00 & 9,50 & 8,19 & 6,12 \\
\hline 80 & 1650 & 75 & 19,05 & 14,48 & 13,49 & 12,58 & 11,73 & 10,93 & 9,46 & 8,17 & 6,12 \\
\hline 80 & 1700 & 75 & 18,83 & 14,33 & 13,36 & 12,48 & 11,65 & 10,87 & 9,42 & 8,15 & 6,12 \\
\hline 80 & 1750 & 75 & 18,62 & 14,18 & 13,24 & 12,38 & 11,57 & 10,80 & 9,38 & 8,12 & 6,11 \\
\hline 80 & 1800 & 75 & 18,41 & 14,04 & 13,12 & 12,29 & 11,49 & 10,74 & 9,34 & 8,10 & 6,11 \\
\hline 80 & 1850 & 75 & 18,21 & 13,91 & 13,00 & 12,19 & 11,42 & 10,68 & 9,30 & 8,08 & 6,11 \\
\hline 80 & 1900 & 75 & 18,02 & 13,79 & 12,89 & 12,11 & 11,34 & 10,62 & 9,26 & 8,06 & 6,11 \\
\hline 80 & 1950 & 75 & 17,84 & 13,66 & 12,78 & 12,02 & 11,27 & 10,56 & 9,22 & 8,03 & 6,10 \\
\hline 80 & 2000 & 75 & 17,66 & 13,55 & 12,67 & 11,93 & 11,20 & 10,50 & 9,18 & 8,01 & 6,10 \\
\hline 80 & 200 & 80 & 55,34 & 31,82 & 24,61 & 19,38 & 16,09 & 13,62 & 10,09 & 7,85 & 5,32 \\
\hline 80 & 250 & 80 & 47,80 & 28,84 & 22,97 & 18,57 & 15,68 & 13,44 & 10,12 & 7,93 & 5,37 \\
\hline 80 & 300 & 80 & 42,63 & 26,70 & 21,73 & 17,91 & 15,32 & 13,26 & 10,12 & 7,98 & 5,41 \\
\hline 80 & 350 & 80 & 38,84 & 25,05 & 20,75 & 17,36 & 14,99 & 13,08 & 10,11 & 8,02 & 5,45 \\
\hline 80 & 400 & 80 & 35,94 & 23,74 & 19,94 & 16,88 & 14,70 & 12,91 & 10,08 & 8,05 & 5,48 \\
\hline 80 & 450 & 80 & 33,63 & 22,65 & 19,25 & 16,46 & 14,44 & 12,75 & 10,04 & 8,06 & 5,52 \\
\hline 80 & 500 & 80 & 31,75 & 21,72 & 18,66 & 16,09 & 14,20 & 12,60 & 10,00 & 8,07 & 5,55 \\
\hline 80 & 550 & 80 & 30,18 & 20,93 & 18,14 & 15,75 & 13,97 & 12,45 & 9,95 & 8,07 & 5,57 \\
\hline 80 & 600 & 80 & 28,85 & 20,23 & 17,67 & 15,44 & 13,76 & 12,32 & 9,91 & 8,07 & 5,59 \\
\hline 80 & 650 & 80 & 27,71 & 19,62 & 17,25 & 15,16 & 13,57 & 12,18 & 9,86 & 8,06 & 5,61 \\
\hline 80 & 700 & 80 & 26,71 & 19,07 & 16,87 & 14,90 & 13,38 & 12,06 & 9,81 & 8,05 & 5,63 \\
\hline 80 & 750 & 80 & 25,83 & 18,57 & 16,52 & 14,66 & 13,21 & 11,93 & 9,76 & 8,04 & 5,65 \\
\hline 80 & 800 & 80 & 25,05 & 18,12 & 16,20 & 14,44 & 13,05 & 11,82 & 9,71 & 8,03 & 5,66 \\
\hline 80 & 850 & 80 & 24,35 & 17,71 & 15,90 & 14,23 & 12,89 & 11,71 & 9,66 & 8,02 & 5,67 \\
\hline 80 & 900 & 80 & 23,71 & 17,33 & 15,63 & 14,03 & 12,75 & 11,60 & 9,61 & 8,00 & 5,69 \\
\hline 80 & 950 & 80 & 23,14 & 16,99 & 15,37 & 13,85 & 12,61 & 11,50 & 9,56 & 7,98 & 5,70 \\
\hline 80 & 1000 & 80 & 22,62 & 16,66 & 15,13 & 13,67 & 12,48 & 11,40 & 9,51 & 7,97 & 5,70 \\
\hline 80 & 1050 & 80 & 22,13 & 16,36 & 14,90 & 13,50 & 12,35 & 11,31 & 9,46 & 7,95 & 5,71 \\
\hline 80 & 1100 & 80 & 21,69 & 16,08 & 14,69 & 13,35 & 12,23 & 11,21 & 9,42 & 7,93 & 5,72 \\
\hline 80 & 1150 & 80 & 21,28 & 15,82 & 14,48 & 13,20 & 12,11 & 11,13 & 9,37 & 7,91 & 5,72 \\
\hline 80 & 1200 & 80 & 20,89 & 15,58 & 14,29 & 13,05 & 12,00 & 11,04 & 9,32 & 7,89 & 5,73 \\
\hline 80 & 1250 & 80 & 20,54 & 15,34 & 14,11 & 12,92 & 11,89 & 10,96 & 9,28 & 7,87 & 5,73 \\
\hline 80 & 1300 & 80 & 20,20 & 15,13 & 13,94 & 12,79 & 11,79 & 10,88 & 9,24 & 7,85 & 5,73 \\
\hline 80 & 1350 & 80 & 19,89 & 14,92 & 13,77 & 12,66 & 11,69 & 10,80 & 9,19 & 7,83 & 5,74 \\
\hline 80 & 1400 & 80 & 19,59 & 14,72 & 13,61 & 12,54 & 11,60 & 10,73 & 9,15 & 7,81 & 5,74 \\
\hline 80 & 1450 & 80 & 19,31 & 14,54 & 13,46 & 12,43 & 11,51 & 10,66 & 9,11 & 7,79 & 5,74 \\
\hline 80 & 1500 & 80 & 19,05 & 14,36 & 13,32 & 12,31 & 11,42 & 10,59 & 9,07 & 7,77 & 5,74 \\
\hline 80 & 1550 & 80 & 18,79 & 14,20 & 13,18 & 12,21 & 11,33 & 10,52 & 9,03 & 7,74 & 5,74 \\
\hline 80 & 1600 & 80 & 18,56 & 14,04 & 13,04 & 12,10 & 11,25 & 10,45 & 8,99 & 7,72 & 5,74 \\
\hline 80 & 1650 & 80 & 18,33 & 13,88 & 12,92 & 12,00 & 11,17 & 10,39 & 8,95 & 7,70 & 5,74 \\
\hline 80 & 1700 & 80 & 18,11 & 13,74 & 12,79 & 11,91 & 11,09 & 10,32 & 8,91 & 7,68 & 5,74 \\
\hline 80 & 1750 & 80 & 17,90 & 13,60 & 12,67 & 11,81 & 11,02 & 10,26 & 8,87 & 7,66 & 5,74 \\
\hline 80 & 1800 & 80 & 17,70 & 13,47 & 12,56 & 11,72 & 10,94 & 10,20 & 8,84 & 7,64 & 5,74 \\
\hline 80 & 1850 & 80 & 17,51 & 13,34 & 12,45 & 11,64 & 10,87 & 10,15 & 8,80 & 7,62 & 5,73 \\
\hline 80 & 1900 & 80 & 17,33 & 13,21 & 12,34 & 11,55 & 10,80 & 10,09 & 8,77 & 7,60 & 5,73 \\
\hline 80 & 1950 & 80 & 17,15 & 13,10 & 12,24 & 11,47 & 10,73 & 10,03 & 8,73 & 7,58 & 5,73 \\
\hline 80 & 2000 & 80 & 16,98 & 12,98 & 12,14 & 11,39 & 10,67 & 9,98 & 8,70 & 7,56 & 5,73 \\
\hline 80 & 200 & 85 & 54,27 & 30,78 & 23,61 & 18,45 & 15,24 & 12,86 & 9,48 & 7,37 & 5,00 \\
\hline 80 & 250 & 85 & 46,78 & 27,87 & 22,02 & 17,68 & 14,86 & 12,70 & 9,52 & 7,45 & 5,04 \\
\hline 80 & 300 & 85 & 41,65 & 25,77 & 20,83 & 17,06 & 14,53 & 12,54 & 9,53 & 7,50 & 5,08 \\
\hline 80 & 350 & 85 & 37,90 & 24,17 & 19,89 & 16,54 & 14,23 & 12,38 & 9,52 & 7,54 & 5,11 \\
\hline 80 & 400 & 85 & 35,03 & 22,89 & 19,11 & 16,09 & 13,96 & 12,23 & 9,50 & 7,56 & 5,15 \\
\hline 80 & 450 & 85 & 32,75 & 21,83 & 18,45 & 15,70 & 13,72 & 12,08 & 9,47 & 7,58 & 5,18 \\
\hline 80 & 500 & 85 & 30,88 & 20,94 & 17,88 & 15,34 & 13,49 & 11,94 & 9,43 & 7,59 & 5,20 \\
\hline 80 & 550 & 85 & 29,33 & 20,17 & 17,38 & 15,03 & 13,28 & 11,81 & 9,40 & 7,60 & 5,23 \\
\hline 80 & 600 & 85 & 28,02 & 19,50 & 16,93 & 14,74 & 13,09 & 11,68 & 9,35 & 7,60 & 5,25 \\
\hline 80 & 650 & 85 & 26,89 & 18,90 & 16,53 & 14,47 & 12,91 & 11,56 & 9,31 & 7,59 & 5,27 \\
\hline 80 & 700 & 85 & 25,90 & 18,37 & 16,17 & 14,23 & 12,74 & 11,44 & 9,27 & 7,59 & 5,29 \\
\hline 80 & 750 & 85 & 25,03 & 17,89 & 15,84 & 14,00 & 12,58 & 11,33 & 9,22 & 7,58 & 5,30 \\
\hline 80 & 800 & 85 & 24,26 & 17,45 & 15,53 & 13,79 & 12,42 & 11,23 & 9,18 & 7,57 & 5,32 \\
\hline 80 & 850 & 85 & 23,57 & 17,06 & 15,25 & 13,59 & 12,28 & 11,12 & 9,14 & 7,56 & 5,33 \\
\hline 80 & 900 & 85 & 22,95 & 16,69 & 14,98 & 13,40 & 12,14 & 11,03 & 9,09 & 7,55 & 5,34 \\
\hline 80 & 950 & 85 & 22,39 & 16,36 & 14,74 & 13,23 & 12,01 & 10,93 & 9,05 & 7,53 & 5,35 \\
\hline 80 & 1000 & 85 & 21,87 & 16,04 & 14,51 & 13,06 & 11,89 & 10,84 & 9,00 & 7,52 & 5,36 \\
\hline 80 & 1050 & 85 & 21,40 & 15,75 & 14,29 & 12,90 & 11,77 & 10,75 & 8,96 & 7,50 & 5,37 \\
\hline 80 & 1100 & 85 & 20,96 & 15,48 & 14,08 & 12,75 & 11,66 & 10,67 & 8,92 & 7,48 & 5,37 \\
\hline 80 & 1150 & 85 & 20,56 & 15,23 & 13,89 & 12,61 & 11,55 & 10,59 & 8,88 & 7,47 & 5,38 \\
\hline
\end{tabular}




\begin{tabular}{|c|c|c|c|c|c|c|c|c|c|c|c|}
\hline \multirow[b]{2}{*}{$\mathrm{H}(\mathrm{cm})$} & \multirow[b]{2}{*}{ Mceq (MPa) } & & & & & $\mathrm{De}$ & ões (x1 & & & & \\
\hline & & Msub (MPa) & D0 & D25 & D40 & D60 & D80 & D100 & D140 & D180 & D260 \\
\hline 80 & 1200 & 85 & 20,18 & 14,99 & 13,71 & 12,48 & 11,44 & 10,51 & 8,84 & 7,45 & 5,38 \\
\hline 80 & 1250 & 85 & 19,83 & 14,77 & 13,53 & 12,35 & 11,34 & 10,43 & 8,80 & 7,43 & 5,39 \\
\hline 80 & 1300 & 85 & 19,50 & 14,56 & 13,37 & 12,22 & 11,25 & 10,36 & 8,76 & 7,42 & 5,39 \\
\hline 80 & 1350 & 85 & 19,20 & 14,36 & 13,21 & 12,11 & 11,15 & 10,28 & 8,72 & 7,40 & 5,40 \\
\hline 80 & 1400 & 85 & 18,91 & 14,17 & 13,06 & 11,99 & 11,07 & 10,21 & 8,68 & 7,38 & 5,40 \\
\hline 80 & 1450 & 85 & 18,63 & 13,99 & 12,92 & 11,88 & 10,98 & 10,15 & 8,64 & 7,36 & 5,40 \\
\hline 80 & 1500 & 85 & 18,37 & 13,82 & 12,78 & 11,78 & 10,90 & 10,08 & 8,60 & 7,34 & 5,40 \\
\hline 80 & 1550 & 85 & 18,13 & 13,65 & 12,64 & 11,68 & 10,81 & 10,02 & 8,57 & 7,32 & 5,40 \\
\hline 80 & 1600 & 85 & 17,90 & 13,50 & 12,52 & 11,58 & 10,74 & 9,96 & 8,53 & 7,31 & 5,40 \\
\hline 80 & 1650 & 85 & 17,68 & 13,35 & 12,39 & 11,48 & 10,66 & 9,90 & 8,49 & 7,29 & 5,40 \\
\hline 80 & 1700 & 85 & 17,46 & 13,21 & 12,28 & 11,39 & 10,59 & 9,84 & 8,46 & 7,27 & 5,40 \\
\hline 80 & 1750 & 85 & 17,26 & 13,08 & 12,16 & 11,30 & 10,52 & 9,78 & 8,43 & 7,25 & 5,40 \\
\hline 80 & 1800 & 85 & 17,07 & 12,95 & 12,05 & 11,22 & 10,45 & 9,72 & 8,39 & 7,23 & 5,40 \\
\hline 80 & 1850 & 85 & 16,88 & 12,82 & 11,95 & 11,14 & 10,38 & 9,67 & 8,36 & 7,22 & 5,40 \\
\hline 80 & 1900 & 85 & 16,71 & 12,70 & 11,84 & 11,05 & 10,31 & 9,62 & 8,33 & 7,20 & 5,40 \\
\hline 80 & 1950 & 85 & 16,54 & 12,59 & 11,75 & 10,98 & 10,25 & 9,56 & 8,29 & 7,18 & 5,40 \\
\hline 80 & 2000 & 85 & 16,37 & 12,48 & 11,65 & 10,90 & 10,19 & 9,51 & 8,26 & 7,16 & 5,39 \\
\hline 80 & 200 & 90 & 53,30 & 29,84 & 22,71 & 17,62 & 14,48 & 12,18 & 8,94 & 6,94 & 4,71 \\
\hline 80 & 250 & 90 & 45,86 & 26,98 & 21,17 & 16,88 & 14,13 & 12,04 & 8,99 & 7,01 & 4,75 \\
\hline 80 & 300 & 90 & 40,78 & 24,94 & 20,02 & 16,30 & 13,82 & 11,89 & 9,00 & 7,07 & 4,78 \\
\hline 80 & 350 & 90 & 37,06 & 23,38 & 19,11 & 15,80 & 13,55 & 11,75 & 9,00 & 7,11 & 4,82 \\
\hline 80 & 400 & 90 & 34,21 & 22,13 & 18,36 & 15,38 & 13,30 & 11,61 & 8,98 & 7,13 & 4,85 \\
\hline 80 & 450 & 90 & 31,95 & 21,10 & 17,73 & 15,00 & 13,07 & 11,48 & 8,96 & 7,15 & 4,88 \\
\hline 80 & 500 & 90 & 30,10 & 20,23 & 17,18 & 14,67 & 12,86 & 11,35 & 8,93 & 7,16 & 4,90 \\
\hline 80 & 550 & 90 & 28,57 & 19,48 & 16,70 & 14,37 & 12,66 & 11,23 & 8,90 & 7,17 & 4,92 \\
\hline 80 & 600 & 90 & 27,27 & 18,83 & 16,27 & 14,10 & 12,48 & 11,11 & 8,86 & 7,17 & 4,94 \\
\hline 80 & 650 & 90 & 26,15 & 18,25 & 15,88 & 13,85 & 12,31 & 11,00 & 8,82 & 7,17 & 4,96 \\
\hline 80 & 700 & 90 & 25,18 & 17,74 & 15,54 & 13,61 & 12,15 & 10,89 & 8,79 & 7,17 & 4,98 \\
\hline 80 & 750 & 90 & 24,32 & 17,27 & 15,22 & 13,40 & 12,00 & 10,79 & 8,75 & 7,17 & 5,00 \\
\hline 80 & 800 & 90 & 23,56 & 16,85 & 14,92 & 13,20 & 11,86 & 10,69 & 8,71 & 7,16 & 5,01 \\
\hline 80 & 850 & 90 & 22,88 & 16,46 & 14,65 & 13,01 & 11,73 & 10,60 & 8,67 & 7,15 & 5,02 \\
\hline 80 & 900 & 90 & 22,26 & 16,11 & 14,40 & 12,83 & 11,60 & 10,51 & 8,63 & 7,14 & 5,03 \\
\hline 80 & 950 & 90 & 21,71 & 15,78 & 14,16 & 12,67 & 11,47 & 10,42 & 8,59 & 7,13 & 5,04 \\
\hline 80 & 1000 & 90 & 21,20 & 15,48 & 13,94 & 12,51 & 11,36 & 10,33 & 8,55 & 7,11 & 5,05 \\
\hline 80 & 1050 & 90 & 20,73 & 15,20 & 13,73 & 12,36 & 11,25 & 10,25 & 8,51 & 7,10 & 5,06 \\
\hline 80 & 1100 & 90 & 20,30 & 14,94 & 13,54 & 12,22 & 11,14 & 10,17 & 8,47 & 7,09 & 5,07 \\
\hline 80 & 1150 & 90 & 19,91 & 14,69 & 13,35 & 12,08 & 11,04 & 10,10 & 8,44 & 7,07 & 5,07 \\
\hline 80 & 1200 & 90 & 19,54 & 14,46 & 13,18 & 11,96 & 10,94 & 10,02 & 8,40 & 7,06 & 5,08 \\
\hline 80 & 1250 & 90 & 19,20 & 14,24 & 13,01 & 11,83 & 10,85 & 9,95 & 8,36 & 7,04 & 5,08 \\
\hline 80 & 1300 & 90 & 18,87 & 14,04 & 12,85 & 11,72 & 10,76 & 9,88 & 8,32 & 7,03 & 5,09 \\
\hline 80 & 1350 & 90 & 18,57 & 13,84 & 12,70 & 11,60 & 10,67 & 9,81 & 8,29 & 7,01 & 5,09 \\
\hline 80 & 1400 & 90 & 18,29 & 13,66 & 12,56 & 11,49 & 10,58 & 9,75 & 8,25 & 7,00 & 5,09 \\
\hline 80 & 1450 & 90 & 18,02 & 13,49 & 12,42 & 11,39 & 10,50 & 9,69 & 8,22 & 6,98 & 5,10 \\
\hline 80 & 1500 & 90 & 17,77 & 13,32 & 12,29 & 11,29 & 10,42 & 9,63 & 8,18 & 6,96 & 5,10 \\
\hline 80 & 1550 & 90 & 17,53 & 13,16 & 12,16 & 11,19 & 10,35 & 9,57 & 8,15 & 6,95 & 5,10 \\
\hline 80 & 1600 & 90 & 17,30 & 13,01 & 12,04 & 11,10 & 10,27 & 9,51 & 8,12 & 6,93 & 5,10 \\
\hline 80 & 1650 & 90 & 17,09 & 12,87 & 11,92 & 11,01 & 10,20 & 9,45 & 8,08 & 6,91 & 5,10 \\
\hline 80 & 1700 & 90 & 16,88 & 12,73 & 11,81 & 10,92 & 10,13 & 9,40 & 8,05 & 6,90 & 5,10 \\
\hline 80 & 1750 & 90 & 16,68 & 12,60 & 11,70 & 10,84 & 10,06 & 9,34 & 8,02 & 6,88 & 5,10 \\
\hline 80 & 1800 & 90 & 16,49 & 12,48 & 11,59 & 10,76 & 10,00 & 9,29 & 7,99 & 6,87 & 5,10 \\
\hline 80 & 1850 & 90 & 16,31 & 12,36 & 11,49 & 10,68 & 9,94 & 9,24 & 7,96 & 6,85 & 5,10 \\
\hline 80 & 1900 & 90 & 16,14 & 12,24 & 11,39 & 10,60 & 9,87 & 9,19 & 7,93 & 6,83 & 5,10 \\
\hline 80 & 1950 & 90 & 15,97 & 12,13 & 11,30 & 10,53 & 9,81 & 9,14 & 7,90 & 6,82 & 5,10 \\
\hline 80 & 2000 & 90 & 15,81 & 12,02 & 11,21 & 10,46 & 9,75 & 9,09 & 7,87 & 6,80 & 5,10 \\
\hline 80 & 200 & 95 & 52,42 & 28,99 & 21,89 & 16,86 & 13,80 & 11,57 & 8,46 & 6,56 & 4,46 \\
\hline 80 & 250 & 95 & 45,03 & 26,18 & 20,39 & 16,16 & 13,47 & 11,44 & 8,51 & 6,63 & 4,49 \\
\hline 80 & 300 & 95 & 39,98 & 24,18 & 19,28 & 15,60 & 13,18 & 11,31 & 8,52 & 6,68 & 4,52 \\
\hline 80 & 350 & 95 & 36,29 & 22,65 & 18,40 & 15,13 & 12,93 & 11,18 & 8,53 & 6,72 & 4,55 \\
\hline 80 & 400 & 95 & 33,46 & 21,43 & 17,68 & 14,73 & 12,70 & 11,06 & 8,52 & 6,75 & 4,58 \\
\hline 80 & 450 & 95 & 31,22 & 20,43 & 17,07 & 14,38 & 12,48 & 10,93 & 8,50 & 6,77 & 4,61 \\
\hline 80 & 500 & 95 & 29,40 & 19,58 & 16,54 & 14,06 & 12,29 & 10,82 & 8,47 & 6,78 & 4,63 \\
\hline 80 & 550 & 95 & 27,88 & 18,85 & 16,08 & 13,78 & 12,10 & 10,71 & 8,45 & 6,79 & 4,65 \\
\hline 80 & 600 & 95 & 26,59 & 18,22 & 15,66 & 13,52 & 11,93 & 10,60 & 8,42 & 6,80 & 4,67 \\
\hline 80 & 650 & 95 & 25,48 & 17,66 & 15,29 & 13,28 & 11,77 & 10,49 & 8,38 & 6,80 & 4,69 \\
\hline 80 & 700 & 95 & 24,52 & 17,16 & 14,96 & 13,06 & 11,62 & 10,39 & 8,35 & 6,80 & 4,71 \\
\hline 80 & 750 & 95 & 23,67 & 16,71 & 14,65 & 12,85 & 11,48 & 10,30 & 8,32 & 6,79 & 4,72 \\
\hline 80 & 800 & 95 & 22,92 & 16,30 & 14,37 & 12,66 & 11,35 & 10,21 & 8,28 & 6,79 & 4,73 \\
\hline 80 & 850 & 95 & 22,25 & 15,92 & 14,11 & 12,48 & 11,22 & 10,12 & 8,25 & 6,78 & 4,75 \\
\hline 80 & 900 & 95 & 21,64 & 15,58 & 13,87 & 12,32 & 11,10 & 10,03 & 8,21 & 6,77 & 4,76 \\
\hline 80 & 950 & 95 & 21,09 & 15,26 & 13,64 & 12,16 & 10,99 & 9,95 & 8,17 & 6,76 & 4,77 \\
\hline 80 & 1000 & 95 & 20,59 & 14,97 & 13,43 & 12,01 & 10,88 & 9,87 & 8,14 & 6,75 & 4,78 \\
\hline 80 & 1050 & 95 & 20,13 & 14,70 & 13,23 & 11,87 & 10,77 & 9,80 & 8,10 & 6,74 & 4,79 \\
\hline 80 & 1100 & 95 & 19,71 & 14,44 & 13,04 & 11,73 & 10,67 & 9,72 & 8,07 & 6,73 & 4,79 \\
\hline 80 & 1150 & 95 & 19,32 & 14,20 & 12,86 & 11,60 & 10,58 & 9,65 & 8.03 & 6.72 & 4,80 \\
\hline 80 & 1200 & 95 & 18,96 & 13,98 & 12,70 & 11,48 & 10,48 & 9,58 & 8,00 & 6,70 & 4,80 \\
\hline 80 & 1250 & 95 & 18,62 & 13,77 & 12,54 & 11,36 & 10,39 & 9,52 & 7,97 & 6,69 & 4,81 \\
\hline 80 & 1300 & 95 & 18,30 & 13,57 & 12,38 & 11,25 & 10,31 & 9,45 & 7,93 & 6,68 & 4,81 \\
\hline 80 & 1350 & 95 & 18,01 & 13,38 & 12,24 & 11,15 & 10,23 & 9,39 & 7,90 & 6,66 & 4,82 \\
\hline 80 & 1400 & 95 & 17,73 & 13,20 & 12,10 & 11,04 & 10,15 & 9,33 & 7,87 & 6,65 & 4,82 \\
\hline 80 & 1450 & 95 & 17,47 & 13,03 & 11,97 & 10,94 & 10,07 & 9,27 & 7,84 & 6,64 & 4,82 \\
\hline 80 & 1500 & 95 & 17,22 & 12,87 & 11,84 & 10,85 & 9,99 & 9,21 & 7,80 & 6,62 & 4,83 \\
\hline
\end{tabular}




\begin{tabular}{|c|c|c|c|c|c|c|c|c|c|c|c|}
\hline \multirow[b]{2}{*}{$\mathrm{H}(\mathrm{cm})$} & \multirow[b]{2}{*}{ Mceq (MPa) } & & & & & $\mathrm{De}$ & ões (x1 & & & & \\
\hline & & Msub (MPa) & D0 & D25 & D40 & D60 & D80 & D100 & D140 & D180 & D260 \\
\hline 80 & 1550 & 95 & 16,98 & 12,72 & 11,72 & 10,76 & 9,92 & 9,16 & 7,77 & 6,61 & 4,83 \\
\hline 80 & 1600 & 95 & 16,76 & 12,57 & 11,60 & 10,67 & 9,85 & 9,10 & 7,74 & 6,59 & 4,83 \\
\hline 80 & 1650 & 95 & 16,55 & 12,43 & 11,49 & 10,58 & 9,78 & 9,05 & 7,71 & 6,58 & 4,83 \\
\hline 80 & 1700 & 95 & 16,35 & 12,30 & 11,38 & 10,50 & 9,72 & 9,00 & 7,68 & 6,56 & 4,83 \\
\hline 80 & 1750 & 95 & 16,15 & 12,17 & 11,28 & 10,42 & 9,65 & 8,95 & 7,65 & 6,55 & 4,83 \\
\hline 80 & 1800 & 95 & 15,97 & 12,05 & 11,18 & 10,34 & 9,59 & 8,90 & 7,63 & 6,53 & 4,83 \\
\hline 80 & 1850 & 95 & 15,79 & 11,93 & 11,08 & 10,27 & 9,53 & 8,85 & 7,60 & 6,52 & 4,83 \\
\hline 80 & 1900 & 95 & 15,63 & 11,82 & 10,98 & 10,19 & 9,47 & 8,80 & 7,57 & 6,50 & 4,83 \\
\hline 80 & 1950 & 95 & 15,46 & 11,71 & 10,89 & 10,12 & 9,42 & 8,76 & 7,54 & 6,49 & 4,83 \\
\hline 80 & 2000 & 95 & 15,31 & 11,61 & 10,80 & 10,05 & 9,36 & 8,71 & 7,51 & 6,48 & 4,83 \\
\hline 80 & 200 & 100 & 51,62 & 28,21 & 21,14 & 16,17 & 13,17 & 11,01 & 8,02 & 6,21 & 4,23 \\
\hline 80 & 250 & 100 & 44,27 & 25,45 & 19,69 & 15,50 & 12,87 & 10,90 & 8,07 & 6,28 & 4,26 \\
\hline 80 & 300 & 100 & 39,25 & 23,48 & 18,61 & 14,97 & 12,60 & 10,78 & 8,10 & 6,33 & 4,29 \\
\hline 80 & 350 & 100 & 35,59 & 21,99 & 17,75 & 14,53 & 12,36 & 10,66 & 8,10 & 6,37 & 4,32 \\
\hline 80 & 400 & 100 & 32,79 & 20,79 & 17,05 & 14,14 & 12,15 & 10,55 & 8,09 & 6,40 & 4,34 \\
\hline 80 & 450 & 100 & 30,56 & 19,81 & 16,46 & 13,81 & 11,95 & 10,44 & 8,08 & 6,42 & 4,37 \\
\hline 80 & 500 & 100 & 28,75 & 18,99 & 15,95 & 13,50 & 11,76 & 10,33 & 8,06 & 6,44 & 4,39 \\
\hline 80 & 550 & 100 & 27,25 & 18,28 & 15,51 & 13,23 & 11,59 & 10,23 & 8,04 & 6,45 & 4,41 \\
\hline 80 & 600 & 100 & 25,97 & 17,66 & 15,11 & 12,99 & 11,43 & 10,13 & 8,01 & 6,45 & 4,43 \\
\hline 80 & 650 & 100 & 24,87 & 17,11 & 14,75 & 12,76 & 11,28 & 10,03 & 7,98 & 6,46 & 4,44 \\
\hline 80 & 700 & 100 & 23,92 & 16,63 & 14,43 & 12,55 & 11,14 & 9,94 & 7,96 & 6,46 & 4,46 \\
\hline 80 & 750 & 100 & 23,08 & 16,19 & 14,14 & 12,35 & 11,01 & 9,85 & 7,92 & 6,46 & 4,47 \\
\hline 80 & 800 & 100 & 22,34 & 15,79 & 13,86 & 12,17 & 10,88 & 9,77 & 7,89 & 6,45 & 4,49 \\
\hline 80 & 850 & 100 & 21,67 & 15,43 & 13,61 & 12,00 & 10,76 & 9,68 & 7,86 & 6,45 & 4,50 \\
\hline 80 & 900 & 100 & 21,08 & 15,09 & 13,38 & 11,84 & 10,65 & 9,61 & 7,83 & 6,44 & 4,51 \\
\hline 80 & 950 & 100 & 20,53 & 14,78 & 13,16 & 11,69 & 10,54 & 9,53 & 7,80 & 6,43 & 4,52 \\
\hline 80 & 1000 & 100 & 20,04 & 14,50 & 12,96 & 11,55 & 10,44 & 9,46 & 7,77 & 6,42 & 4,53 \\
\hline 80 & 1050 & 100 & 19,58 & 14,23 & 12,77 & 11,41 & 10,34 & 9,38 & 7,73 & 6,42 & 4,54 \\
\hline 80 & 1100 & 100 & 19,17 & 13,99 & 12,59 & 11,29 & 10,24 & 9,31 & 7,70 & 6,41 & 4,55 \\
\hline 80 & 1150 & 100 & 18,78 & 13,75 & 12,42 & 11,16 & 10,15 & 9,25 & 7,67 & 6,39 & 4,55 \\
\hline 80 & 1200 & 100 & 18,42 & 13,54 & 12,25 & 11,05 & 10,06 & 9,18 & 7,64 & 6,38 & 4,56 \\
\hline 80 & 1250 & 100 & 18,09 & 13,33 & 12,10 & 10,94 & 9,98 & 9,12 & 7,61 & 6,37 & 4,56 \\
\hline 80 & 1300 & 100 & 17,78 & 13,14 & 11,95 & 10,83 & 9,90 & 9,06 & 7,58 & 6,36 & 4,57 \\
\hline 80 & 1350 & 100 & 17,49 & 12,95 & 11,82 & 10,73 & 9,82 & 9,00 & 7,55 & 6,35 & 4,57 \\
\hline 80 & 1400 & 100 & 17,22 & 12,78 & 11,68 & 10,63 & 9,74 & 8,94 & 7,52 & 6,34 & 4,58 \\
\hline 80 & 1450 & 100 & 16,96 & 12,62 & 11,55 & 10,53 & 9,67 & 8,89 & 7,49 & 6,32 & 4,58 \\
\hline 80 & 1500 & 100 & 16,71 & 12,46 & 11,43 & 10,44 & 9,60 & 8,83 & 7,46 & 6,31 & 4,58 \\
\hline 80 & 1550 & 100 & 16,48 & 12,31 & 11,32 & 10,35 & 9,53 & 8,78 & 7,43 & 6,30 & 4,58 \\
\hline 80 & 1600 & 100 & 16,27 & 12,17 & 11,20 & 10,27 & 9,47 & 8,73 & 7,40 & 6,28 & 4,59 \\
\hline 80 & 1650 & 100 & 16,06 & 12,03 & 11,09 & 10,19 & 9,40 & 8,68 & 7,37 & 6,27 & 4,59 \\
\hline 80 & 1700 & 100 & 15,86 & 11,90 & 10,99 & 10,11 & 9,34 & 8,63 & 7,35 & 6,26 & 4,59 \\
\hline 80 & 1750 & 100 & 15,67 & 11,78 & 10,89 & 10,03 & 9,28 & 8,58 & 7,32 & 6,25 & 4,59 \\
\hline 80 & 1800 & 100 & 15,49 & 11,66 & 10,79 & 9,96 & 9,22 & 8,54 & 7,29 & 6,23 & 4,59 \\
\hline 80 & 1850 & 100 & 15,32 & 11,55 & 10,70 & 9,89 & 9,16 & 8,49 & 7,27 & 6,22 & 4,59 \\
\hline 80 & 1900 & 100 & 15,15 & 11,44 & 10,61 & 9,82 & 9,11 & 8,45 & 7,24 & 6,21 & 4,59 \\
\hline 80 & 1950 & 100 & 15,00 & 11,33 & 10,52 & 9,75 & 9,05 & 8,40 & 7,22 & 6,19 & 4,59 \\
\hline 80 & 2000 & 100 & 14,84 & 11,23 & 10,44 & 9,68 & 9,00 & 8,36 & 7,19 & 6,18 & 4,59 \\
\hline 80 & 200 & 105 & 50,89 & 27,50 & 20,46 & 15,54 & 12,61 & 10,51 & 7,63 & 5,90 & 4,02 \\
\hline 80 & 250 & 105 & 43,58 & 24,78 & 19,04 & 14,90 & 12,32 & 10,41 & 7,68 & 5,97 & 4,05 \\
\hline 80 & 300 & 105 & 38,59 & 22,85 & 17,99 & 14,39 & 12,07 & 10,30 & 7,71 & 6,02 & 4,08 \\
\hline 80 & 350 & 105 & 34,95 & 21,38 & 17,16 & 13,97 & 11,85 & 10,19 & 7,71 & 6,06 & 4,10 \\
\hline 80 & 400 & 105 & 32,17 & 20,21 & 16,48 & 13,60 & 11,64 & 10,09 & 7,71 & 6,09 & 4,13 \\
\hline 80 & 450 & 105 & 29,96 & 19,25 & 15,91 & 13,28 & 11,46 & 9,99 & 7,70 & 6,11 & 4,15 \\
\hline 80 & 500 & 105 & 28,16 & 18,44 & 15,42 & 12,99 & 11,28 & 9,89 & 7,69 & 6,12 & 4,17 \\
\hline 80 & 550 & 105 & 26,67 & 17,75 & 14,99 & 12,74 & 11,12 & 9,79 & 7,67 & 6,14 & 4,19 \\
\hline 80 & 600 & 105 & 25,40 & 17,15 & 14,60 & 12,50 & 10,97 & 9,70 & 7,65 & 6,14 & 4,21 \\
\hline 80 & 650 & 105 & 24,32 & 16,61 & 14,26 & 12,28 & 10,83 & 9,61 & 7,62 & 6,15 & 4,22 \\
\hline 80 & 700 & 105 & 23,37 & 16,14 & 13,95 & 12,08 & 10,70 & 9,53 & 7,60 & 6,15 & 4,24 \\
\hline 80 & 750 & 105 & 22,54 & 15,71 & 13,66 & 11,90 & 10,57 & 9,44 & 7,57 & 6,15 & 4,25 \\
\hline 80 & 800 & 105 & 21,81 & 15,32 & 13,40 & 11,72 & 10,46 & 9,36 & 7,54 & 6,15 & 4,26 \\
\hline 80 & 850 & 105 & 21,15 & 14,97 & 13,16 & 11,56 & 10,34 & 9,29 & 7,51 & 6,14 & 4,28 \\
\hline 80 & 900 & 105 & 20,56 & 14,64 & 12,93 & 11,41 & 10,23 & 9,21 & 7,48 & 6,14 & 4,29 \\
\hline 80 & 950 & 105 & 20,02 & 14,34 & 12,72 & 11,27 & 10,13 & 9,14 & 7,45 & 6,13 & 4,30 \\
\hline 80 & 1000 & 105 & 19,53 & 14,07 & 12,53 & 11,13 & 10,03 & 9,07 & 7,42 & 6,13 & 4,31 \\
\hline 80 & 1050 & 105 & 19,08 & 13,81 & 12,34 & 11,00 & 9,94 & 9,00 & 7,40 & 6,12 & 4,31 \\
\hline 80 & 1100 & 105 & 18,67 & 13,57 & 12,17 & 10,88 & 9,85 & 8,94 & 7,37 & 6,11 & 4,32 \\
\hline 80 & 1150 & 105 & 18,29 & 13,34 & 12,00 & 10,76 & 9,76 & 8,88 & 7,34 & 6,10 & 4,33 \\
\hline 80 & 1200 & 105 & 17,94 & 13,13 & 11,85 & 10,65 & 9,68 & 8,82 & 7,31 & 6,09 & 4,33 \\
\hline 80 & 1250 & 105 & 17,61 & 12,93 & 11,70 & 10,54 & 9,60 & 8,76 & 7,28 & 6,08 & 4,34 \\
\hline 80 & 1300 & 105 & 17,30 & 12,74 & 11,56 & 10,44 & 9,52 & 8,70 & 7,25 & 6,07 & 4,34 \\
\hline 80 & 1350 & 105 & 17,02 & 12,56 & 11,42 & 10,34 & 9,45 & 8,64 & 7,23 & 6,06 & 4,35 \\
\hline 80 & 1400 & 105 & 16,75 & 12,39 & 11,30 & 10,25 & 9,38 & 8,59 & 7,20 & 6,05 & 4,35 \\
\hline 80 & 1450 & 105 & 16,49 & 12,23 & 11,17 & 10,16 & 9,31 & 8,54 & 7,17 & 6,04 & 4,36 \\
\hline 80 & 1500 & 105 & 16,25 & 12,08 & 11,06 & 10,07 & 9,24 & 8,49 & 7.14 & 6.03 & 4,36 \\
\hline 80 & 1550 & 105 & 16,03 & 11,94 & 10,94 & 9,99 & 9,18 & 8,44 & 7,12 & 6,02 & 4,36 \\
\hline 80 & 1600 & 105 & 15,81 & 11,80 & 10,83 & 9,91 & 9,11 & 8,39 & 7,09 & 6,00 & 4,36 \\
\hline 80 & 1650 & 105 & 15,61 & 11,67 & 10,73 & 9,83 & 9,05 & 8,34 & 7,07 & 5,99 & 4,37 \\
\hline 80 & 1700 & 105 & 15,41 & 11,54 & 10,63 & 9,75 & 8,99 & 8,30 & 7,04 & 5,98 & 4,37 \\
\hline 80 & 1750 & 105 & 15,23 & 11,42 & 10,53 & 9,68 & 8,93 & 8,25 & 7,01 & 5,97 & 4,37 \\
\hline 80 & 1800 & 105 & 15,05 & 11,30 & 10,44 & 9,61 & 8,88 & 8,21 & 6,99 & 5,96 & 4,37 \\
\hline 80 & 1850 & 105 & 14,88 & 11,19 & 10,35 & 9,54 & 8,82 & 8,16 & 6,97 & 5,95 & 4,37 \\
\hline
\end{tabular}




\begin{tabular}{|c|c|c|c|c|c|c|c|c|c|c|c|}
\hline \multirow[b]{2}{*}{$\mathrm{H}(\mathrm{cm})$} & \multirow[b]{2}{*}{ Mceq (MPa) } & & & & & $\mathrm{De}$ & ões (x1 & & & & \\
\hline & & Msub (MPa) & D0 & D25 & D40 & D60 & D80 & D100 & D140 & D180 & D260 \\
\hline 80 & 1900 & 105 & 14,72 & 11,08 & 10,26 & 9,47 & 8,77 & 8,12 & 6,94 & 5,93 & 4,37 \\
\hline 80 & 1950 & 105 & 14,57 & 10,98 & 10,18 & 9,41 & 8,72 & 8,08 & 6,92 & 5,92 & 4,37 \\
\hline 80 & 2000 & 105 & 14,42 & 10,88 & 10,09 & 9,34 & 8,67 & 8,04 & 6,89 & 5,91 & 4,37 \\
\hline 80 & 200 & 110 & 50,22 & 26,85 & 19,83 & 14,97 & 12,09 & 10,05 & 7,27 & 5,62 & 3,84 \\
\hline 80 & 250 & 110 & 42,94 & 24,16 & 18,44 & 14,35 & 11,82 & 9,96 & 7,32 & 5,69 & 3,86 \\
\hline 80 & 300 & 110 & 37,98 & 22,26 & 17,42 & 13,86 & 11,59 & 9,86 & 7,35 & 5,73 & 3,88 \\
\hline 80 & 350 & 110 & 34,36 & 20,81 & 16,61 & 13,46 & 11,38 & 9,76 & 7,36 & 5,77 & 3,91 \\
\hline 80 & 400 & 110 & 31,60 & 19,67 & 15,95 & 13,11 & 11,18 & 9,67 & 7,36 & 5,80 & 3,93 \\
\hline 80 & 450 & 110 & 29,40 & 18,73 & 15,40 & 12,80 & 11,01 & 9,57 & 7,36 & 5,82 & 3,95 \\
\hline 80 & 500 & 110 & 27,62 & 17,94 & 14,92 & 12,52 & 10,85 & 9,48 & 7,34 & 5,84 & 3,97 \\
\hline 80 & 550 & 110 & 26,14 & 17,26 & 14,50 & 12,28 & 10,69 & 9,39 & 7,33 & 5,85 & 3,99 \\
\hline 80 & 600 & 110 & 24,88 & 16,67 & 14,13 & 12,05 & 10,55 & 9,31 & 7,31 & 5,86 & 4,01 \\
\hline 80 & 650 & 110 & 23,81 & 16,15 & 13,80 & 11,84 & 10,42 & 9,22 & 7,29 & 5,87 & 4,02 \\
\hline 80 & 700 & 110 & 22,87 & 15,69 & 13,50 & 11,65 & 10,29 & 9,14 & 7,27 & 5,87 & 4,04 \\
\hline 80 & 750 & 110 & 22,05 & 15,27 & 13,22 & 11,48 & 10,17 & 9,07 & 7,24 & 5,87 & 4,05 \\
\hline 80 & 800 & 110 & 21,32 & 14,89 & 12,97 & 11,31 & 10,06 & 8,99 & 7,22 & 5,87 & 4,06 \\
\hline 80 & 850 & 110 & 20,67 & 14,55 & 12,74 & 11,16 & 9,96 & 8,92 & 7,19 & 5,87 & 4,07 \\
\hline 80 & 900 & 110 & 20,08 & 14,23 & 12,52 & 11,01 & 9,85 & 8,85 & 7,17 & 5,86 & 4,08 \\
\hline 80 & 950 & 110 & 19,55 & 13,94 & 12,32 & 10,87 & 9,76 & 8,78 & 7,14 & 5,86 & 4,09 \\
\hline 80 & 1000 & 110 & 19,07 & 13,67 & 12,13 & 10,74 & 9,66 & 8,72 & 7,11 & 5,85 & 4,10 \\
\hline 80 & 1050 & 110 & 18,62 & 13,42 & 11,95 & 10,62 & 9,57 & 8,66 & 7,09 & 5,85 & 4,11 \\
\hline 80 & 1100 & 110 & 18,22 & 13,18 & 11,78 & 10,50 & 9,49 & 8,60 & 7,06 & 5,84 & 4,12 \\
\hline 80 & 1150 & 110 & 17,84 & 12,96 & 11,62 & 10,39 & 9,41 & 8,54 & 7,03 & 5,83 & 4,12 \\
\hline 80 & 1200 & 110 & 17,49 & 12,75 & 11,47 & 10,28 & 9,33 & 8,48 & 7,01 & 5,82 & 4,13 \\
\hline 80 & 1250 & 110 & 17,17 & 12,56 & 11,33 & 10,18 & 9,25 & 8,42 & 6,98 & 5,82 & 4,14 \\
\hline 80 & 1300 & 110 & 16,87 & 12,38 & 11,19 & 10,08 & 9,18 & 8,37 & 6,96 & 5,81 & 4,14 \\
\hline 80 & 1350 & 110 & 16,58 & 12,20 & 11,06 & 9,99 & 9,11 & 8,32 & 6,93 & 5,80 & 4,15 \\
\hline 80 & 1400 & 110 & 16,32 & 12,04 & 10,94 & 9,90 & 9,04 & 8,27 & 6,90 & 5,79 & 4,15 \\
\hline 80 & 1450 & 110 & 16,07 & 11,88 & 10,82 & 9,81 & 8,97 & 8,22 & 6,88 & 5,78 & 4,15 \\
\hline 80 & 1500 & 110 & 15,83 & 11,73 & 10,71 & 9,73 & 8,91 & 8,17 & 6,85 & 5,77 & 4,16 \\
\hline 80 & 1550 & 110 & 15,61 & 11,59 & 10,60 & 9,65 & 8,85 & 8,12 & 6,83 & 5,76 & 4,16 \\
\hline 80 & 1600 & 110 & 15,40 & 11,46 & 10,49 & 9,57 & 8,79 & 8,08 & 6,81 & 5,75 & 4,16 \\
\hline 80 & 1650 & 110 & 15,20 & 11,33 & 10,39 & 9,49 & 8,73 & 8,03 & 6,78 & 5,74 & 4,17 \\
\hline 80 & 1700 & 110 & 15,00 & 11,20 & 10,30 & 9,42 & 8,67 & 7,99 & 6,76 & 5,73 & 4,17 \\
\hline 80 & 1750 & 110 & 14,82 & 11,09 & 10,20 & 9,35 & 8,62 & 7,94 & 6,73 & 5,72 & 4,17 \\
\hline 80 & 1800 & 110 & 14,65 & 10,97 & 10,11 & 9,28 & 8,56 & 7,90 & 6,71 & 5,70 & 4,17 \\
\hline 80 & 1850 & 110 & 14,48 & 10,86 & 10,03 & 9,22 & 8,51 & 7,86 & 6,69 & 5,69 & 4,17 \\
\hline 80 & 1900 & 110 & 14,32 & 10,76 & 9,94 & 9,15 & 8,46 & 7,82 & 6,67 & 5,68 & 4,17 \\
\hline 80 & 1950 & 110 & 14,17 & 10,66 & 9,86 & 9,09 & 8,41 & 7,78 & 6,64 & 5,67 & 4,17 \\
\hline 80 & 2000 & 110 & 14,03 & 10,56 & 9,78 & 9,03 & 8,36 & 7,75 & 6,62 & 5,66 & 4,17 \\
\hline 80 & 200 & 115 & 49,60 & 26,24 & 19,25 & 14,44 & 11,61 & 9,62 & 6,94 & 5,36 & 3,67 \\
\hline 80 & 250 & 115 & 42,35 & 23,59 & 17,89 & 13,84 & 11,36 & 9,54 & 7,00 & 5,43 & 3,69 \\
\hline 80 & 300 & 115 & 37,42 & 21,71 & 16,89 & 13,37 & 11,14 & 9,46 & 7,03 & 5,47 & 3,71 \\
\hline 80 & 350 & 115 & 33,82 & 20,29 & 16,11 & 12,98 & 10,94 & 9,37 & 7,04 & 5,51 & 3,73 \\
\hline 80 & 400 & 115 & 31,07 & 19,17 & 15,47 & 12,65 & 10,76 & 9,28 & 7,04 & 5,54 & 3,75 \\
\hline 80 & 450 & 115 & 28,89 & 18,25 & 14,93 & 12,35 & 10,59 & 9,19 & 7,04 & 5,56 & 3,77 \\
\hline 80 & 500 & 115 & 27,12 & 17,47 & 14,46 & 12,09 & 10,44 & 9,11 & 7,03 & 5,58 & 3,79 \\
\hline 80 & 550 & 115 & 25,65 & 16,81 & 14,06 & 11,85 & 10,30 & 9,02 & 7,02 & 5,59 & 3,81 \\
\hline 80 & 600 & 115 & 24,40 & 16,23 & 13,70 & 11,64 & 10,16 & 8,94 & 7,00 & 5,60 & 3,82 \\
\hline 80 & 650 & 115 & 23,34 & 15,72 & 13,38 & 11,44 & 10,04 & 8,87 & 6,98 & 5,61 & 3,84 \\
\hline 80 & 700 & 115 & 22,41 & 15,27 & 13,08 & 11,26 & 9,92 & 8,79 & 6,96 & 5,61 & 3,85 \\
\hline 80 & 750 & 115 & 21,59 & 14,86 & 12,82 & 11,09 & 9,81 & 8,72 & 6,94 & 5,61 & 3,87 \\
\hline 80 & 800 & 115 & 20,87 & 14,49 & 12,57 & 10,93 & 9,70 & 8,65 & 6,92 & 5,61 & 3,88 \\
\hline 80 & 850 & 115 & 20,22 & 14,16 & 12,35 & 10,78 & 9,60 & 8,58 & 6,90 & 5,61 & 3,89 \\
\hline 80 & 900 & 115 & 19,64 & 13,85 & 12,14 & 10,64 & 9,50 & 8,52 & 6,87 & 5,61 & 3,90 \\
\hline 80 & 950 & 115 & 19,12 & 13,56 & 11,94 & 10,51 & 9,41 & 8,46 & 6,85 & 5,61 & 3,91 \\
\hline 80 & 1000 & 115 & 18,64 & 13,30 & 11,76 & 10,38 & 9,32 & 8,39 & 6,83 & 5,60 & 3,92 \\
\hline 80 & 1050 & 115 & 18,20 & 13,05 & 11,58 & 10,26 & 9,24 & 8,33 & 6,80 & 5,60 & 3,92 \\
\hline 80 & 1100 & 115 & 17,80 & 12,82 & 11,42 & 10,15 & 9,15 & 8,28 & 6,78 & 5,59 & 3,93 \\
\hline 80 & 1150 & 115 & 17,42 & 12,61 & 11,27 & 10,04 & 9,08 & 8,22 & 6,75 & 5,59 & 3,94 \\
\hline 80 & 1200 & 115 & 17,08 & 12,41 & 11,12 & 9,94 & 9,00 & 8,17 & 6,73 & 5,58 & 3,95 \\
\hline 80 & 1250 & 115 & 16,76 & 12,22 & 10,98 & 9,84 & 8,93 & 8,12 & 6,70 & 5,57 & 3,95 \\
\hline 80 & 1300 & 115 & 16,46 & 12,04 & 10,85 & 9,75 & 8,86 & 8,06 & 6,68 & 5,56 & 3,96 \\
\hline 80 & 1350 & 115 & 16,18 & 11,87 & 10,73 & 9,66 & 8,79 & 8,01 & 6,66 & 5,56 & 3,96 \\
\hline 80 & 1400 & 115 & 15,92 & 11,71 & 10,61 & 9,57 & 8,73 & 7,97 & 6,63 & 5,55 & 3,97 \\
\hline 80 & 1450 & 115 & 15,67 & 11,55 & 10,49 & 9,49 & 8,66 & 7,92 & 6,61 & 5,54 & 3,97 \\
\hline 80 & 1500 & 115 & 15,44 & 11,41 & 10,38 & 9,41 & 8,60 & 7,87 & 6,59 & 5,53 & 3,97 \\
\hline 80 & 1550 & 115 & 15,22 & 11,27 & 10,28 & 9,33 & 8,54 & 7,83 & 6,56 & 5,52 & 3,98 \\
\hline 80 & 1600 & 115 & 15,01 & 11,14 & 10,18 & 9,26 & 8,49 & 7,79 & 6,54 & 5,51 & 3,98 \\
\hline 80 & 1650 & 115 & 14,81 & 11,01 & 10,08 & 9,18 & 8,43 & 7,74 & 6,52 & 5,50 & 3,98 \\
\hline 80 & 1700 & 115 & 14,63 & 10,89 & 9,99 & 9,11 & 8,38 & 7,70 & 6,50 & 5,49 & 3,98 \\
\hline 80 & 1750 & 115 & 14,45 & 10,78 & 9,90 & 9,05 & 8,32 & 7,66 & 6,48 & 5,48 & 3,99 \\
\hline 80 & 1800 & 115 & 14,28 & 10,67 & 9,81 & 8,98 & 8,27 & 7,62 & 6,45 & 5,47 & 3,99 \\
\hline 80 & 1850 & 115 & 14.11 & 10,56 & 9,73 & 8.92 & 8,22 & 7.58 & 6,43 & 5,46 & 3,99 \\
\hline 80 & 1900 & 115 & 13,96 & 10,46 & 9,64 & 8,86 & 8,17 & 7,55 & 6,41 & 5,45 & 3,99 \\
\hline 80 & 1950 & 115 & 13,81 & 10,36 & 9,56 & 8,80 & 8,13 & 7,51 & 6,39 & 5,44 & 3,99 \\
\hline 80 & 2000 & 115 & 13,66 & 10,27 & 9,49 & 8,74 & 8,08 & 7,47 & 6,37 & 5,43 & 3,99 \\
\hline 80 & 200 & 120 & 49,02 & 25,68 & 18,72 & 13,95 & 11,17 & 9,23 & 6,64 & 5,13 & 3,51 \\
\hline 80 & 250 & 120 & 41,81 & 23,06 & 17,39 & 13,37 & 10,93 & 9,16 & 6,70 & 5,19 & 3,53 \\
\hline 80 & 300 & 120 & 36,89 & 21,21 & 16,41 & 12,92 & 10,72 & 9,08 & 6,73 & 5,24 & 3,55 \\
\hline 80 & 350 & 120 & 33,32 & 19,81 & 15,64 & 12,54 & 10,54 & 9,00 & 6,74 & 5,27 & 3,57 \\
\hline
\end{tabular}




\begin{tabular}{|c|c|c|c|c|c|c|c|c|c|c|c|}
\hline \multirow[b]{2}{*}{$\mathrm{H}(\mathrm{cm})$} & \multirow[b]{2}{*}{ Mceq (MPa) } & & & & & $\mathrm{De}$ & ões (x1 & & & & \\
\hline & & Msub (MPa) & D0 & D25 & D40 & D60 & D80 & D100 & D140 & D180 & D260 \\
\hline 80 & 400 & 120 & 30,58 & 18,70 & 15,01 & 12,22 & 10,37 & 8,92 & 6,75 & 5,30 & 3,59 \\
\hline 80 & 450 & 120 & 28,42 & 17,80 & 14,49 & 11,94 & 10,21 & 8,84 & 6,75 & 5,32 & 3,61 \\
\hline 80 & 500 & 120 & 26,66 & 17,04 & 14,04 & 11,69 & 10,06 & 8,76 & 6,74 & 5,34 & 3,62 \\
\hline 80 & 550 & 120 & 25,20 & 16,39 & 13,64 & 11,46 & 9,93 & 8,68 & 6,73 & 5,35 & 3,64 \\
\hline 80 & 600 & 120 & 23,96 & 15,82 & 13,30 & 11,25 & 9,80 & 8,61 & 6,72 & 5,36 & 3,66 \\
\hline 80 & 650 & 120 & 22,90 & 15,33 & 12,98 & 11,06 & 9,68 & 8,54 & 6,70 & 5,37 & 3,67 \\
\hline 80 & 700 & 120 & 21,98 & 14,88 & 12,70 & 10,89 & 9,57 & 8,47 & 6,68 & 5,38 & 3,68 \\
\hline 80 & 750 & 120 & 21,17 & 14,48 & 12,44 & 10,73 & 9,46 & 8,40 & 6,67 & 5,38 & 3,70 \\
\hline 80 & 800 & 120 & 20,45 & 14,12 & 12,20 & 10,57 & 9,36 & 8,33 & 6,65 & 5,38 & 3,71 \\
\hline 80 & 850 & 120 & 19,81 & 13,79 & 11,98 & 10,43 & 9,27 & 8,27 & 6,63 & 5,38 & 3,72 \\
\hline 80 & 900 & 120 & 19,24 & 13,49 & 11,78 & 10,30 & 9,17 & 8,21 & 6,60 & 5,38 & 3,73 \\
\hline 80 & 950 & 120 & 18,71 & 13,21 & 11,59 & 10,17 & 9,09 & 8,15 & 6,58 & 5,38 & 3,74 \\
\hline 80 & 1000 & 120 & 18,24 & 12,95 & 11,41 & 10,05 & 9,00 & 8,09 & 6,56 & 5,37 & 3,75 \\
\hline 80 & 1050 & 120 & 17,81 & 12,71 & 11,25 & 9,94 & 8,92 & 8,04 & 6,54 & 5,37 & 3,75 \\
\hline 80 & 1100 & 120 & 17,41 & 12,49 & 11,09 & 9,83 & 8,84 & 7,98 & 6,52 & 5,37 & 3,76 \\
\hline 80 & 1150 & 120 & 17,04 & 12,28 & 10,94 & 9,72 & 8,77 & 7,93 & 6,49 & 5,36 & 3,77 \\
\hline 80 & 1200 & 120 & 16,70 & 12,08 & 10,80 & 9,63 & 8,70 & 7,88 & 6,47 & 5,35 & 3,77 \\
\hline 80 & 1250 & 120 & 16,38 & 11,90 & 10,67 & 9,53 & 8,63 & 7,83 & 6,45 & 5,35 & 3,78 \\
\hline 80 & 1300 & 120 & 16,09 & 11,72 & 10,54 & 9,44 & 8,56 & 7,78 & 6,43 & 5,34 & 3,79 \\
\hline 80 & 1350 & 120 & 15,81 & 11,56 & 10,42 & 9,35 & 8,50 & 7,73 & 6,41 & 5,33 & 3,79 \\
\hline 80 & 1400 & 120 & 15,55 & 11,40 & 10,30 & 9,27 & 8,44 & 7,69 & 6,38 & 5,33 & 3,79 \\
\hline 80 & 1450 & 120 & 15,31 & 11,25 & 10,19 & 9,19 & 8,38 & 7,64 & 6,36 & 5,32 & 3,80 \\
\hline 80 & 1500 & 120 & 15,08 & 11,11 & 10,08 & 9,11 & 8,32 & 7,60 & 6,34 & 5,31 & 3,80 \\
\hline 80 & 1550 & 120 & 14,86 & 10,97 & 9,98 & 9,04 & 8,26 & 7,56 & 6,32 & 5,30 & 3,81 \\
\hline 80 & 1600 & 120 & 14,65 & 10,85 & 9,88 & 8,97 & 8,21 & 7,52 & 6,30 & 5,29 & 3,81 \\
\hline 80 & 1650 & 120 & 14,46 & 10,72 & 9,79 & 8,90 & 8,15 & 7,48 & 6,28 & 5,29 & 3,81 \\
\hline 80 & 1700 & 120 & 14,27 & 10,60 & 9,70 & 8,83 & 8,10 & 7,44 & 6,26 & 5,28 & 3,81 \\
\hline 80 & 1750 & 120 & 14,10 & 10,49 & 9,61 & 8,77 & 8,05 & 7,40 & 6,24 & 5,27 & 3,82 \\
\hline 80 & 1800 & 120 & 13,93 & 10,38 & 9,53 & 8,70 & 8,00 & 7,36 & 6,22 & 5,26 & 3,82 \\
\hline 80 & 1850 & 120 & 13,77 & 10,28 & 9,45 & 8,64 & 7,95 & 7,32 & 6,20 & 5,25 & 3,82 \\
\hline 80 & 1900 & 120 & 13,61 & 10,18 & 9,37 & 8,58 & 7,91 & 7,29 & 6,18 & 5,24 & 3,82 \\
\hline 80 & 1950 & 120 & 13,47 & 10,08 & 9,29 & 8,52 & 7,86 & 7,25 & 6,16 & 5,23 & 3,82 \\
\hline 80 & 2000 & 120 & 13,33 & 9,99 & 9,22 & 8,47 & 7,82 & 7,22 & 6,14 & 5,22 & 3,82 \\
\hline 80 & 200 & 125 & 48,49 & 25,16 & 18,22 & 13,49 & 10,77 & 8,88 & 6,36 & 4,91 & 3,37 \\
\hline 80 & 250 & 125 & 41,30 & 22,57 & 16,91 & 12,94 & 10,54 & 8,81 & 6,42 & 4,97 & 3,38 \\
\hline 80 & 300 & 125 & 36,41 & 20,74 & 15,95 & 12,50 & 10,34 & 8,74 & 6,45 & 5,02 & 3,40 \\
\hline 80 & 350 & 125 & 32,85 & 19,36 & 15,20 & 12,14 & 10,16 & 8,66 & 6,47 & 5,05 & 3,42 \\
\hline 80 & 400 & 125 & 30,13 & 18,27 & 14,59 & 11,83 & 10,00 & 8,59 & 6,48 & 5,08 & 3,44 \\
\hline 80 & 450 & 125 & 27,98 & 17,38 & 14,08 & 11,56 & 9,85 & 8,51 & 6,48 & 5,10 & 3,46 \\
\hline 80 & 500 & 125 & 26,23 & 16,64 & 13,64 & 11,31 & 9,72 & 8,44 & 6,48 & 5,12 & 3,47 \\
\hline 80 & 550 & 125 & 24,78 & 16,00 & 13,26 & 11,10 & 9,59 & 8,37 & 6,47 & 5,13 & 3,49 \\
\hline 80 & 600 & 125 & 23,55 & 15,44 & 12,92 & 10,90 & 9,47 & 8,30 & 6,46 & 5,15 & 3,50 \\
\hline 80 & 650 & 125 & 22,49 & 14,95 & 12,61 & 10,71 & 9,35 & 8,23 & 6,44 & 5,15 & 3,52 \\
\hline 80 & 700 & 125 & 21,58 & 14,52 & 12,34 & 10,55 & 9,25 & 8,17 & 6,43 & 5,16 & 3,53 \\
\hline 80 & 750 & 125 & 20,78 & 14,13 & 12,09 & 10,39 & 9,15 & 8,10 & 6,41 & 5,16 & 3,54 \\
\hline 80 & 800 & 125 & 20,06 & 13,77 & 11,86 & 10,24 & 9,05 & 8,04 & 6,39 & 5,16 & 3,55 \\
\hline 80 & 850 & 125 & 19,43 & 13,45 & 11,64 & 10,11 & 8,96 & 7,98 & 6,37 & 5,17 & 3,56 \\
\hline 80 & 900 & 125 & 18,86 & 13,16 & 11,45 & 9,98 & 8,87 & 7,92 & 6,35 & 5,17 & 3,57 \\
\hline 80 & 950 & 125 & 18,34 & 12,88 & 11,26 & 9,85 & 8,79 & 7,87 & 6,33 & 5,16 & 3,58 \\
\hline 80 & 1000 & 125 & 17,87 & 12,63 & 11,09 & 9,74 & 8,71 & 7,81 & 6,31 & 5,16 & 3,59 \\
\hline 80 & 1050 & 125 & 17,44 & 12,40 & 10,93 & 9,63 & 8,63 & 7,76 & 6,29 & 5,16 & 3,60 \\
\hline 80 & 1100 & 125 & 17,05 & 12,18 & 10,78 & 9,52 & 8,56 & 7,71 & 6,27 & 5,15 & 3,61 \\
\hline 80 & 1150 & 125 & 16,68 & 11,97 & 10,63 & 9,43 & 8,48 & 7,66 & 6,25 & 5,15 & 3,61 \\
\hline 80 & 1200 & 125 & 16,34 & 11,78 & 10,50 & 9,33 & 8,42 & 7,61 & 6,23 & 5,15 & 3,62 \\
\hline 80 & 1250 & 125 & 16,03 & 11,60 & 10,37 & 9,24 & 8,35 & 7,56 & 6,21 & 5,14 & 3,62 \\
\hline 80 & 1300 & 125 & 15,74 & 11,43 & 10,24 & 9,15 & 8,29 & 7,52 & 6,19 & 5,13 & 3,63 \\
\hline 80 & 1350 & 125 & 15,46 & 11,27 & 10,13 & 9,07 & 8,22 & 7,47 & 6,17 & 5,13 & 3,63 \\
\hline 80 & 1400 & 125 & 15,21 & 11,11 & 10,01 & 8,99 & 8,17 & 7,43 & 6,15 & 5,12 & 3,64 \\
\hline 80 & 1450 & 125 & 14,97 & 10,97 & 9,91 & 8,91 & 8,11 & 7,39 & 6,13 & 5,11 & 3,64 \\
\hline 80 & 1500 & 125 & 14,74 & 10,83 & 9,80 & 8,84 & 8,05 & 7,35 & 6,11 & 5,11 & 3,65 \\
\hline 80 & 1550 & 125 & 14,53 & 10,70 & 9,70 & 8,77 & 8,00 & 7,31 & 6,09 & 5,10 & 3,65 \\
\hline 80 & 1600 & 125 & 14,32 & 10,57 & 9,61 & 8,70 & 7,94 & 7,27 & 6,07 & 5,09 & 3,65 \\
\hline 80 & 1650 & 125 & 14,13 & 10,45 & 9,52 & 8,63 & 7,89 & 7,23 & 6,05 & 5,08 & 3,66 \\
\hline 80 & 1700 & 125 & 13,95 & 10,34 & 9,43 & 8,57 & 7,84 & 7,19 & 6,03 & 5,08 & 3,66 \\
\hline 80 & 1750 & 125 & 13,77 & 10,23 & 9,35 & 8,50 & 7,80 & 7,15 & 6,01 & 5,07 & 3,66 \\
\hline 80 & 1800 & 125 & 13,61 & 10,12 & 9,26 & 8,44 & 7,75 & 7,12 & 6,00 & 5,06 & 3,66 \\
\hline 80 & 1850 & 125 & 13,45 & 10,02 & 9,18 & 8,38 & 7,70 & 7,08 & 5,98 & 5,05 & 3,66 \\
\hline 80 & 1900 & 125 & 13,30 & 9,92 & 9,11 & 8,33 & 7,66 & 7,05 & 5,96 & 5,04 & 3,67 \\
\hline 80 & 1950 & 125 & 13,15 & 9,83 & 9,03 & 8,27 & 7,62 & 7,02 & 5,94 & 5,04 & 3,67 \\
\hline 80 & 2000 & 125 & 13,01 & 9,74 & 8,96 & 8,22 & 7,57 & 6,98 & 5,92 & 5,03 & 3,67 \\
\hline 80 & 200 & 130 & 47,99 & 24,68 & 17,76 & 13,07 & 10,39 & 8,54 & 6,11 & 4,71 & 3,23 \\
\hline 80 & 250 & 130 & 40,83 & 22,11 & 16,47 & 12,53 & 10,17 & 8,48 & $\begin{array}{c}0,+16 \\
6,16\end{array}$ & 4,77 & 3,25 \\
\hline 80 & 300 & 130 & 35,96 & 20,30 & 15,53 & 12,11 & 9,99 & 8,42 & 6,20 & 4,81 & 3,27 \\
\hline 80 & 350 & 130 & 32,41 & 18,94 & 14,80 & 11,76 & 9,82 & 8,35 & 6,22 & 4,85 & 3,28 \\
\hline 80 & 400 & 130 & 29,71 & 17,87 & 14,20 & 11,46 & 9,66 & 8,28 & 6,23 & 4,88 & 3,30 \\
\hline 80 & 450 & 130 & 27,57 & 16,99 & 13,70 & 11,20 & 9,52 & 8,21 & 6,23 & 4,90 & 3,32 \\
\hline 80 & 500 & 130 & 25,83 & 16,26 & 13,27 & 10,97 & 9,39 & 8,14 & 6,23 & 4,92 & 3,33 \\
\hline 80 & 550 & 130 & 24,38 & 15,63 & 12,90 & 10,75 & 9,27 & 8,08 & 6,22 & 4,93 & 3,35 \\
\hline 80 & 600 & 130 & 23,16 & 15,09 & 12,57 & 10,56 & 9,16 & 8,01 & 6,21 & 4,94 & 3,36 \\
\hline 80 & 650 & 130 & 22,12 & 14,61 & 12,27 & 10,39 & 9,05 & 7,95 & 6,20 & 4,95 & 3,38 \\
\hline 80 & 700 & 130 & 21,21 & 14,18 & 12,00 & 10,23 & 8,95 & 7,89 & 6,19 & 4,96 & 3,39 \\
\hline
\end{tabular}




\begin{tabular}{|c|c|c|c|c|c|c|c|c|c|c|c|}
\hline \multirow[b]{2}{*}{$\mathrm{H}(\mathrm{cm})$} & \multirow[b]{2}{*}{ Mceq (MPa) } & & & & & Det & ões (x1 & & & & \\
\hline & & Msub (MPa) & D0 & D25 & D40 & D60 & D80 & D100 & D140 & D180 & D260 \\
\hline 80 & 750 & 130 & 20,41 & 13,80 & 11,76 & 10,07 & 8,85 & 7,83 & 6,17 & 4,96 & 3,40 \\
\hline 80 & 800 & 130 & 19,70 & 13,45 & 11,54 & 9,93 & 8,76 & 7,77 & 6,16 & 4,97 & 3,41 \\
\hline 80 & 850 & 130 & 19,07 & 13,13 & 11,33 & 9,80 & 8,67 & 7,71 & 6,14 & 4,97 & 3,42 \\
\hline 80 & 900 & 130 & 18,51 & 12,84 & 11,14 & 9,68 & 8,59 & 7,66 & 6,12 & 4,97 & 3,43 \\
\hline 80 & 950 & 130 & 17,99 & 12,58 & 10,96 & 9,56 & 8,51 & 7,60 & 6,10 & 4,97 & 3,44 \\
\hline 80 & 1000 & 130 & 17,53 & 12,33 & 10,79 & 9,45 & 8,43 & 7,55 & 6,09 & 4,96 & 3,45 \\
\hline 80 & 1050 & 130 & 17,10 & 12,10 & 10,63 & 9,34 & 8,36 & 7,50 & 6,07 & 4,96 & 3,45 \\
\hline 80 & 1100 & 130 & 16,71 & 11,89 & 10,49 & 9,24 & 8,29 & 7,45 & 6,05 & 4,96 & 3,46 \\
\hline 80 & 1150 & 130 & 16,35 & 11,69 & 10,35 & 9,15 & 8,22 & 7,41 & 6,03 & 4,96 & 3,47 \\
\hline 80 & 1200 & 130 & 16,01 & 11,50 & 10,21 & 9,06 & 8,15 & 7,36 & 6,01 & 4,95 & 3,47 \\
\hline 80 & 1250 & 130 & 15,70 & 11,32 & 10,09 & 8,97 & 8,09 & 7,32 & 5,99 & 4,95 & 3,48 \\
\hline 80 & 1300 & 130 & 15,41 & 11,15 & 9,97 & 8,88 & 8,03 & 7,27 & 5,97 & 4,94 & 3,48 \\
\hline 80 & 1350 & 130 & 15,14 & 10,99 & 9,85 & 8,80 & 7,97 & 7,23 & 5,95 & 4,94 & 3,49 \\
\hline 80 & 1400 & 130 & 14,89 & 10,84 & 9,75 & 8,73 & 7,91 & 7,19 & 5,94 & 4,93 & 3,49 \\
\hline 80 & 1450 & 130 & 14,65 & 10,70 & 9,64 & 8,65 & 7,86 & 7,15 & 5,92 & 4,92 & 3,50 \\
\hline 80 & 1500 & 130 & 14,43 & 10,57 & 9,54 & 8,58 & 7,80 & 7,11 & 5,90 & 4,92 & 3,50 \\
\hline 80 & 1550 & 130 & 14,21 & 10,44 & 9,45 & 8,51 & 7,75 & 7,07 & 5,88 & 4,91 & 3,51 \\
\hline 80 & 1600 & 130 & 14,01 & 10,31 & 9,35 & 8,44 & 7,70 & 7,03 & 5,86 & 4,91 & 3,51 \\
\hline 80 & 1650 & 130 & 13,82 & 10,20 & 9,26 & 8,38 & 7,65 & 7,00 & 5,84 & 4,90 & 3,51 \\
\hline 80 & 1700 & 130 & 13,64 & 10,08 & 9,18 & 8,32 & 7,61 & 6,96 & 5,83 & 4,89 & 3,51 \\
\hline 80 & 1750 & 130 & 13,47 & 9,98 & 9,10 & 8,26 & 7,56 & 6,93 & 5,81 & 4,88 & 3,52 \\
\hline 80 & 1800 & 130 & 13,31 & 9,87 & 9,02 & 8,20 & 7,51 & 6,89 & 5,79 & 4,88 & 3,52 \\
\hline 80 & 1850 & 130 & 13,15 & 9,77 & 8,94 & 8,14 & 7,47 & 6,86 & 5,77 & 4,87 & 3,52 \\
\hline 80 & 1900 & 130 & 13,00 & 9,68 & 8,87 & 8,09 & 7,43 & 6,83 & 5,76 & 4,86 & 3,52 \\
\hline 80 & 1950 & 130 & 12,86 & 9,58 & 8,79 & 8,03 & 7,39 & 6,79 & 5,74 & 4,85 & 3,52 \\
\hline 80 & 2000 & 130 & 12,72 & 9,50 & 8,72 & 7,98 & 7,34 & 6,76 & 5,72 & 4,85 & 3,53 \\
\hline 80 & 200 & 135 & 47,53 & 24,23 & 17,33 & 12,68 & 10,04 & 8,23 & 5,87 & 4,53 & 3,11 \\
\hline 80 & 250 & 135 & 40,39 & 21,68 & 16,06 & 12,15 & 9,83 & 8,18 & 5,93 & 4,58 & 3,13 \\
\hline 80 & 300 & 135 & 35,53 & 19,89 & 15,14 & 11,74 & 9,65 & 8,12 & 5,96 & 4,63 & 3,14 \\
\hline 80 & 350 & 135 & 32,00 & 18,55 & 14,42 & 11,41 & 9,49 & 8,06 & 5,98 & 4,66 & 3,16 \\
\hline 80 & 400 & 135 & 29,31 & 17,49 & 13,83 & 11,12 & 9,35 & 7,99 & 6,00 & 4,69 & 3,17 \\
\hline 80 & 450 & 135 & 27,18 & 16,63 & 13,35 & 10,86 & 9,22 & 7,93 & 6,00 & 4,71 & 3,19 \\
\hline 80 & 500 & 135 & 25,45 & 15,90 & 12,93 & 10,64 & 9,09 & 7,86 & 6,00 & 4,73 & 3,20 \\
\hline 80 & 550 & 135 & 24,02 & 15,29 & 12,56 & 10,44 & 8,97 & 7,80 & 5,99 & 4,74 & 3,22 \\
\hline 80 & 600 & 135 & 22,80 & 14,75 & 12,24 & 10,25 & 8,87 & 7,74 & 5,99 & 4,76 & 3,23 \\
\hline 80 & 650 & 135 & 21,76 & 14,28 & 11,95 & 10,08 & 8,76 & 7,68 & 5,98 & 4,76 & 3,24 \\
\hline 80 & 700 & 135 & 20,86 & 13,86 & 11,69 & 9,93 & 8,67 & 7,62 & 5,97 & 4,77 & 3,26 \\
\hline 80 & 750 & 135 & 20,07 & 13,49 & 11,45 & 9,78 & 8,57 & 7,57 & 5,95 & 4,78 & 3,27 \\
\hline 80 & 800 & 135 & 19,37 & 13,15 & 11,23 & 9,65 & 8,49 & 7,51 & 5,94 & 4,78 & 3,28 \\
\hline 80 & 850 & 135 & 18,74 & 12,84 & 11,03 & 9,52 & 8,40 & 7,46 & 5,92 & 4,78 & 3,29 \\
\hline 80 & 900 & 135 & 18,18 & 12,55 & 10,85 & 9,40 & 8,32 & 7,41 & 5,91 & 4,78 & 3,30 \\
\hline 80 & 950 & 135 & 17,67 & 12,29 & 10,67 & 9,28 & 8,25 & 7,36 & 5,89 & 4,78 & 3,30 \\
\hline 80 & 1000 & 135 & 17,21 & 12,05 & 10,51 & 9,18 & 8,17 & 7,31 & 5,87 & 4,78 & 3,31 \\
\hline 80 & 1050 & 135 & 16,78 & 11,82 & 10,36 & 9,08 & 8,10 & 7,26 & 5,86 & 4,78 & 3,32 \\
\hline 80 & 1100 & 135 & 16,40 & 11,61 & 10,21 & 8,98 & 8,03 & 7,22 & 5,84 & 4,78 & 3,33 \\
\hline 80 & 1150 & 135 & 16,04 & 11,42 & 10,08 & 8,89 & 7,97 & 7,17 & 5,82 & 4,78 & 3,33 \\
\hline 80 & 1200 & 135 & 15,71 & 11,23 & 9,95 & 8,80 & 7,91 & 7,13 & 5,81 & 4,77 & 3,34 \\
\hline 80 & 1250 & 135 & 15,40 & 11,06 & 9,83 & 8,71 & 7,85 & 7,09 & 5,79 & 4,77 & 3,35 \\
\hline 80 & 1300 & 135 & 15,11 & 10,89 & 9,71 & 8,63 & 7,79 & 7,04 & 5,77 & 4,76 & 3,35 \\
\hline 80 & 1350 & 135 & 14,84 & 10,74 & 9,60 & 8,56 & 7,73 & 7,00 & 5,75 & 4,76 & 3,36 \\
\hline 80 & 1400 & 135 & 14,59 & 10,59 & 9,49 & 8,48 & 7,68 & 6,96 & 5,73 & 4,75 & 3,36 \\
\hline 80 & 1450 & 135 & 14,36 & 10,45 & 9,39 & 8,41 & 7,62 & 6,93 & 5,72 & 4,75 & 3,36 \\
\hline 80 & 1500 & 135 & 14,13 & 10,32 & 9,29 & 8,34 & 7,57 & 6,89 & 5,70 & 4,74 & 3,37 \\
\hline 80 & 1550 & 135 & 13,92 & 10,19 & 9,20 & 8,27 & 7,52 & 6,85 & 5,68 & 4,74 & 3,37 \\
\hline 80 & 1600 & 135 & 13,72 & 10,07 & 9,11 & 8,21 & 7,47 & 6,82 & 5,67 & 4,73 & 3,37 \\
\hline 80 & 1650 & 135 & 13,54 & 9,96 & 9,03 & 8,15 & 7,43 & 6,78 & 5,65 & 4,72 & 3,38 \\
\hline 80 & 1700 & 135 & 13,36 & 9,85 & 8,94 & 8,09 & 7,38 & 6,75 & 5,63 & 4,72 & 3,38 \\
\hline 80 & 1750 & 135 & 13,19 & 9,74 & 8,86 & 8,03 & 7,34 & 6,71 & 5,61 & 4,71 & 3,38 \\
\hline 80 & 1800 & 135 & 13,03 & 9,64 & 8,79 & 7,97 & 7,29 & 6,68 & 5,60 & 4,71 & 3,39 \\
\hline 80 & 1850 & 135 & 12,87 & 9,54 & 8,71 & 7,92 & 7,25 & 6,65 & 5,58 & 4,70 & 3,39 \\
\hline 80 & 1900 & 135 & 12,72 & 9,45 & 8,64 & 7,86 & 7,21 & 6,62 & 5,57 & 4,69 & 3,39 \\
\hline 80 & 1950 & 135 & 12,58 & 9,36 & 8,57 & 7,81 & 7,17 & 6,59 & 5,55 & 4,69 & 3,39 \\
\hline 80 & 2000 & 135 & 12,45 & 9,27 & 8,50 & 7,76 & 7,13 & 6,56 & 5,53 & 4,68 & 3,39 \\
\hline 80 & 200 & 140 & 47,09 & 23,81 & 16,93 & 12,31 & 9,71 & 7,95 & 5,65 & 4,36 & 3,00 \\
\hline 80 & 250 & 140 & 39,97 & 21,28 & 15,68 & 11,80 & 9,51 & 7,90 & 5,71 & 4,41 & 3,01 \\
\hline 80 & 300 & 140 & 35,14 & 19,51 & 14,77 & 11,40 & 9,34 & 7,84 & 5,74 & 4,45 & 3,03 \\
\hline 80 & 350 & 140 & 31,62 & 18,18 & 14,06 & 11,07 & 9,19 & 7,78 & 5,77 & 4,49 & 3,04 \\
\hline 80 & 400 & 140 & 28,94 & 17,13 & 13,49 & 10,80 & 9,05 & 7,73 & 5,78 & 4,51 & 3,06 \\
\hline 80 & 450 & 140 & 26,82 & 16,28 & 13,01 & 10,55 & 8,93 & 7,67 & 5,78 & 4,54 & 3,07 \\
\hline 80 & 500 & 140 & 25,10 & 15,57 & 12,60 & 10,33 & 8,81 & 7,61 & 5,79 & 4,55 & 3,09 \\
\hline 80 & 550 & 140 & 23,68 & 14,96 & 12,25 & 10,14 & 8,70 & 7,55 & 5,78 & 4,57 & 3,10 \\
\hline 80 & 600 & 140 & 22,47 & 14,44 & 11,93 & 9,96 & 8,59 & 7,49 & 5,78 & 4,58 & 3,11 \\
\hline 80 & 650 & 140 & 21,43 & 13,97 & 11,65 & 9,80 & 8,50 & 7,43 & 5,77 & 4,59 & 3,12 \\
\hline 80 & 700 & 140 & 20,54 & 13,56 & 11,40 & 9,65 & 8,40 & 7,38 & 5,76 & 4,60 & 3,13 \\
\hline 80 & 750 & 140 & 19,75 & 13,19 & 11,16 & 9,51 & 8,31 & 7,33 & 5,75 & 4,60 & 3,14 \\
\hline 80 & 800 & 140 & 19,05 & 12,86 & 10,95 & 9,37 & 8,23 & 7,27 & 5,73 & 4,61 & 3,15 \\
\hline 80 & 850 & 140 & 18,43 & 12,56 & 10,76 & 9,25 & 8,15 & 7,22 & 5,72 & 4,61 & 3,16 \\
\hline 80 & 900 & 140 & 17,87 & 12,28 & 10,57 & 9,14 & 8,07 & 7,18 & 5,71 & 4,61 & 3,17 \\
\hline 80 & 950 & 140 & 17,37 & 12,02 & 10,40 & 9,03 & 8,00 & 7,13 & 5,69 & 4,61 & 3,18 \\
\hline 80 & 1000 & 140 & 16,91 & 11,78 & 10,25 & 8,92 & 7,93 & 7,08 & 5,68 & 4,61 & 3,19 \\
\hline 80 & 1050 & 140 & 16,49 & 11,56 & 10,10 & 8,82 & 7,86 & 7,04 & 5,66 & 4,61 & 3,20 \\
\hline
\end{tabular}




\begin{tabular}{|c|c|c|c|c|c|c|c|c|c|c|c|}
\hline \multirow[b]{2}{*}{$\mathrm{H}(\mathrm{cm})$} & \multirow[b]{2}{*}{ Mceq (MPa) } & & & & & De & ões (x & & & & \\
\hline & & Msub (MPa) & D0 & D25 & D40 & D60 & D80 & D100 & D140 & D180 & D260 \\
\hline 80 & 1100 & 140 & 16,10 & 11,36 & 9,96 & 8,73 & 7,80 & 6,99 & 5,64 & 4,61 & 3,20 \\
\hline 80 & 1150 & 140 & 15,75 & 11,16 & 9,82 & 8,64 & 7,74 & 6,95 & 5,63 & 4,61 & 3,21 \\
\hline 80 & 1200 & 140 & 15,42 & 10,98 & 9,70 & 8,56 & 7,68 & 6,91 & 5,61 & 4,60 & 3,22 \\
\hline 80 & 1250 & 140 & 15,11 & 10,81 & 9,58 & 8,48 & 7,62 & 6,87 & 5,60 & 4,60 & 3,22 \\
\hline 80 & 1300 & 140 & 14,83 & 10,65 & 9,47 & 8,40 & 7,56 & 6,83 & 5,58 & 4,60 & 3,23 \\
\hline 80 & 1350 & 140 & 14,56 & 10,50 & 9,36 & 8,32 & 7,51 & 6,79 & 5,56 & 4,59 & 3,23 \\
\hline 80 & 1400 & 140 & 14,31 & 10,36 & 9,26 & 8,25 & 7,46 & 6,75 & 5,55 & 4,59 & 3,24 \\
\hline 80 & 1450 & 140 & 14,08 & 10,22 & 9,16 & 8,18 & 7,40 & 6,72 & 5,53 & 4,58 & 3,24 \\
\hline 80 & 1500 & 140 & 13,86 & 10,09 & 9,06 & 8,11 & 7,36 & 6,68 & 5,51 & 4,58 & 3,24 \\
\hline 80 & 1550 & 140 & 13,65 & 9,97 & 8,97 & 8,05 & 7,31 & 6,65 & 5,50 & 4,57 & 3,25 \\
\hline 80 & 1600 & 140 & 13,45 & 9,85 & 8,89 & 7,99 & 7,26 & 6,61 & 5,48 & 4,57 & 3,25 \\
\hline 80 & 1650 & 140 & 13,27 & 9,73 & 8,80 & 7,93 & 7,22 & 6,58 & 5,47 & 4,56 & 3,25 \\
\hline 80 & 1700 & 140 & 13,09 & 9,63 & 8,72 & 7,87 & 7,17 & 6,55 & 5,45 & 4,56 & 3,26 \\
\hline 80 & 1750 & 140 & 12,92 & 9,52 & 8,64 & 7,81 & 7,13 & 6,51 & 5,43 & 4,55 & 3,26 \\
\hline 80 & 1800 & 140 & 12,76 & 9,42 & 8,57 & 7,76 & 7,09 & 6,48 & 5,42 & 4,55 & 3,26 \\
\hline 80 & 1850 & 140 & 12,61 & 9,33 & 8,50 & 7,70 & 7,05 & 6,45 & 5,40 & 4,54 & 3,26 \\
\hline 80 & 1900 & 140 & 12,46 & 9,24 & 8,43 & 7,65 & 7,01 & 6,42 & 5,39 & 4,53 & 3,27 \\
\hline 80 & 1950 & 140 & 12,32 & 9,15 & 8,36 & 7,60 & 6,97 & 6,39 & 5,37 & 4,53 & 3,27 \\
\hline 80 & 2000 & 140 & 12,19 & 9,06 & 8,29 & 7,55 & 6,93 & 6,37 & 5,36 & 4,52 & 3,27 \\
\hline 80 & 200 & 145 & 46,68 & 23,41 & 16,55 & 11,96 & 9,40 & 7,68 & 5,45 & 4,20 & 2,90 \\
\hline 80 & 250 & 145 & 39,58 & 20,90 & 15,32 & 11,47 & 9,22 & 7,63 & 5,50 & 4,25 & 2,91 \\
\hline 80 & 300 & 145 & 34,77 & 19,15 & 14,42 & 11,08 & 9,05 & 7,58 & 5,54 & 4,29 & 2,92 \\
\hline 80 & 350 & 145 & 31,27 & 17,83 & 13,73 & 10,76 & 8,91 & 7,53 & 5,56 & 4,33 & 2,93 \\
\hline 80 & 400 & 145 & 28,60 & 16,80 & 13,17 & 10,49 & 8,78 & 7,47 & 5,58 & 4,35 & 2,95 \\
\hline 80 & 450 & 145 & 26,49 & 15,96 & 12,70 & 10,26 & 8,66 & 7,42 & 5,58 & 4,37 & 2,96 \\
\hline 80 & 500 & 145 & 24,77 & 15,26 & 12,30 & 10,05 & 8,54 & 7,36 & 5,59 & 4,39 & 2,97 \\
\hline 80 & 550 & 145 & 23,35 & 14,66 & 11,95 & 9,86 & 8,44 & 7,31 & 5,58 & 4,41 & 2,99 \\
\hline 80 & 600 & 145 & 22,15 & 14,14 & 11,64 & 9,69 & 8,34 & 7,25 & 5,58 & 4,42 & 3,00 \\
\hline 80 & 650 & 145 & 21,13 & 13,69 & 11,37 & 9,53 & 8,24 & 7,20 & 5,57 & 4,43 & 3,01 \\
\hline 80 & 700 & 145 & 20,23 & 13,28 & 11,12 & 9,38 & 8,16 & 7,15 & 5,56 & 4,44 & 3,02 \\
\hline 80 & 750 & 145 & 19,45 & 12,92 & 10,89 & 9,25 & 8,07 & 7,10 & 5,55 & 4,44 & 3,03 \\
\hline 80 & 800 & 145 & 18,76 & 12,59 & 10,68 & 9,12 & 7,99 & 7,05 & 5,54 & 4,45 & 3,04 \\
\hline 80 & 850 & 145 & 18,14 & 12,29 & 10,49 & 9,00 & 7,91 & 7,00 & 5,53 & 4,45 & 3,05 \\
\hline 80 & 900 & 145 & 17,58 & 12,02 & 10,32 & 8,89 & 7,84 & 6,96 & 5,52 & 4,45 & 3,06 \\
\hline 80 & 950 & 145 & 17,08 & 11,77 & 10,15 & 8,78 & 7,77 & 6,91 & 5,50 & 4,45 & 3,07 \\
\hline 80 & 1000 & 145 & 16,63 & 11,53 & 10,00 & 8,68 & 7,70 & 6,87 & 5,49 & 4,45 & 3,07 \\
\hline 80 & 1050 & 145 & 16,21 & 11,32 & 9,85 & 8,59 & 7,64 & 6,83 & 5,48 & 4,45 & 3,08 \\
\hline 80 & 1100 & 145 & 15,83 & 11,11 & 9,71 & 8,50 & 7,58 & 6,78 & 5,46 & 4,45 & 3,09 \\
\hline 80 & 1150 & 145 & 15,47 & 10,93 & 9,59 & 8,41 & 7,52 & 6,74 & 5,45 & 4,45 & 3,09 \\
\hline 80 & 1200 & 145 & 15,15 & 10,75 & 9,46 & 8,33 & 7,46 & 6,70 & 5,43 & 4,45 & 3,10 \\
\hline 80 & 1250 & 145 & 14,84 & 10,58 & 9,35 & 8,25 & 7,40 & 6,67 & 5,42 & 4,45 & 3,11 \\
\hline 80 & 1300 & 145 & 14,56 & 10,42 & 9,24 & 8,18 & 7,35 & 6,63 & 5,40 & 4,44 & 3,11 \\
\hline 80 & 1350 & 145 & 14,30 & 10,27 & 9,13 & 8,10 & 7,30 & 6,59 & 5,39 & 4,44 & 3,12 \\
\hline 80 & 1400 & 145 & 14,05 & 10,13 & 9,03 & 8,03 & 7,25 & 6,56 & 5,37 & 4,43 & 3,12 \\
\hline 80 & 1450 & 145 & 13,82 & 10,00 & 8,94 & 7,97 & 7,20 & 6,52 & 5,36 & 4,43 & 3,12 \\
\hline 80 & 1500 & 145 & 13,60 & 9,87 & 8,84 & 7,90 & 7,15 & 6,49 & 5,34 & 4,43 & 3,13 \\
\hline 80 & 1550 & 145 & 13,39 & 9,75 & 8,76 & 7,84 & 7,10 & 6,45 & 5,33 & 4,42 & 3,13 \\
\hline 80 & 1600 & 145 & 13,20 & 9,63 & 8,67 & 7,78 & 7,06 & 6,42 & 5,31 & 4,42 & 3,13 \\
\hline 80 & 1650 & 145 & 13,02 & 9,52 & 8,59 & 7,72 & 7,02 & 6,39 & 5,30 & 4,41 & 3,14 \\
\hline 80 & 1700 & 145 & 12,84 & 9,42 & 8,51 & 7,66 & 6,97 & 6,36 & 5,28 & 4,41 & 3,14 \\
\hline 80 & 1750 & 145 & 12,67 & 9,32 & 8,44 & 7,61 & 6,93 & 6,33 & 5,27 & 4,40 & 3,14 \\
\hline 80 & 1800 & 145 & 12,52 & 9,22 & 8,36 & 7,56 & 6,89 & 6,30 & 5,25 & 4,40 & 3,15 \\
\hline 80 & 1850 & 145 & 12,36 & 9,12 & 8,29 & 7,50 & 6,85 & 6,27 & 5,24 & 4,39 & 3,15 \\
\hline 80 & 1900 & 145 & 12,22 & 9,03 & 8,22 & 7,45 & 6,82 & 6,24 & 5,22 & 4,38 & 3,15 \\
\hline 80 & 1950 & 145 & 12,08 & 8,95 & 8,16 & 7,40 & 6,78 & 6,21 & 5,21 & 4,38 & 3,15 \\
\hline 80 & 2000 & 145 & 11,95 & 8,86 & 8,09 & 7,36 & 6,74 & 6,18 & 5,19 & 4,37 & 3,15 \\
\hline 80 & 200 & 150 & 46,30 & 23,03 & 16,19 & 11,64 & 9,12 & 7,43 & 5,25 & 4,05 & 2,80 \\
\hline 80 & 250 & 150 & 39,22 & 20,55 & 14,98 & 11,16 & 8,94 & 7,39 & 5,31 & 4,10 & 2,81 \\
\hline 80 & 300 & 150 & 34,42 & 18,81 & 14,09 & 10,78 & 8,78 & 7,34 & 5,35 & 4,14 & 2,82 \\
\hline 80 & 350 & 150 & 30,93 & 17,51 & 13,41 & 10,47 & 8,64 & 7,29 & 5,37 & 4,17 & 2,83 \\
\hline 80 & 400 & 150 & 28,27 & 16,49 & 12,86 & 10,21 & 8,52 & 7,24 & 5,39 & 4,20 & 2,85 \\
\hline 80 & 450 & 150 & 26,17 & 15,66 & 12,40 & 9,98 & 8,40 & 7,19 & 5,40 & 4,22 & 2,86 \\
\hline 80 & 500 & 150 & 24,47 & 14,96 & 12,01 & 9,78 & 8,29 & 7,14 & 5,40 & 4,24 & 2,87 \\
\hline 80 & 550 & 150 & 23,05 & 14,37 & 11,67 & 9,59 & 8,19 & 7,08 & 5,40 & 4,26 & 2,88 \\
\hline 80 & 600 & 150 & 21,86 & 13,86 & 11,37 & 9,43 & 8,10 & 7,03 & 5,40 & 4,27 & 2,89 \\
\hline 80 & 650 & 150 & 20,83 & 13,41 & 11,10 & 9,28 & 8,01 & 6,98 & 5,39 & 4,28 & 2,91 \\
\hline 80 & 700 & 150 & 19,95 & 13,02 & 10,86 & 9,13 & 7,92 & 6,93 & 5,38 & 4,28 & 2,92 \\
\hline 80 & 750 & 150 & 19,17 & 12,66 & 10,64 & 9,00 & 7,84 & 6,89 & 5,37 & 4,29 & 2,93 \\
\hline 80 & 800 & 150 & 18,48 & 12,34 & 10,43 & 8,88 & 7,77 & 6,84 & 5,36 & 4,30 & 2,93 \\
\hline 80 & 850 & 150 & 17,86 & 12,04 & 10,25 & 8,77 & 7,69 & 6,80 & 5,35 & 4,30 & 2,94 \\
\hline 80 & 900 & 150 & 17,31 & 11,77 & 10,07 & 8,66 & 7,62 & 6,75 & 5,34 & 4,30 & 2,95 \\
\hline 80 & 950 & 150 & 16,81 & 11,53 & 9,91 & 8,55 & 7,55 & 6,71 & 5,33 & 4,30 & 2,96 \\
\hline 80 & 1000 & 150 & 16,36 & 11,30 & 9,76 & 8,46 & 7,49 & 6,67 & 5,32 & 4,30 & 2,97 \\
\hline 80 & 1050 & 150 & 15,95 & 11,08 & 9,62 & 8,37 & 7,43 & 6,63 & 5,30 & 4,30 & 2,97 \\
\hline 80 & 1100 & 150 & 15,57 & 10,89 & 9,49 & 8,28 & 7,37 & 6,59 & 5,29 & 4,30 & 2,98 \\
\hline 80 & 1150 & 150 & 15,22 & 10,70 & 9,36 & 8,20 & 7,31 & 6,55 & 5,28 & 4,30 & 2,99 \\
\hline 80 & 1200 & 150 & 14,89 & 10,53 & 9,24 & 8,12 & 7,26 & 6,51 & 5,26 & 4,30 & 2,99 \\
\hline 80 & 1250 & 150 & 14,59 & 10,36 & 9,13 & 8,04 & 7,20 & 6,47 & 5,25 & 4,30 & 3,00 \\
\hline 80 & 1300 & 150 & 14,31 & 10,21 & 9,02 & 7,97 & 7,15 & 6,44 & 5,23 & 4,30 & 3,00 \\
\hline 80 & 1350 & 150 & 14,05 & 10,06 & 8,92 & 7,90 & 7,10 & 6,40 & 5,22 & 4,29 & 3,01 \\
\hline 80 & 1400 & 150 & 13,81 & 9,92 & 8,82 & 7,83 & 7,05 & 6,37 & 5,21 & 4,29 & 3,01 \\
\hline
\end{tabular}




\begin{tabular}{|c|c|c|c|c|c|c|c|c|c|c|c|}
\hline \multirow[b]{2}{*}{$\mathrm{H}(\mathrm{cm})$} & \multirow[b]{2}{*}{ Mceq (MPa) } & & & & & $\mathrm{De}$ & ões (x. & & & & \\
\hline & & Msub (MPa) & D0 & D25 & D40 & D60 & D80 & D100 & D140 & D180 & D260 \\
\hline 80 & 1450 & 150 & 13,58 & 9,79 & 8,73 & 7,76 & 7,00 & 6,34 & 5,19 & 4,29 & 3,02 \\
\hline 80 & 1500 & 150 & 13,36 & 9,67 & 8,64 & 7,70 & 6,96 & 6,30 & 5,18 & 4,28 & 3,02 \\
\hline 80 & 1550 & 150 & 13,15 & 9,55 & 8,55 & 7,64 & 6,91 & 6,27 & 5,16 & 4,28 & 3,02 \\
\hline 80 & 1600 & 150 & 12,96 & 9,43 & 8,47 & 7,58 & 6,87 & 6,24 & 5,15 & 4,27 & 3,03 \\
\hline 80 & 1650 & 150 & 12,78 & 9,32 & 8,39 & 7,52 & 6,83 & 6,21 & 5,13 & 4,27 & 3,03 \\
\hline 80 & 1700 & 150 & 12,61 & 9,22 & 8,31 & 7,47 & 6,79 & 6,18 & 5,12 & 4,27 & 3,03 \\
\hline 80 & 1750 & 150 & 12,44 & 9,12 & 8,24 & 7,42 & 6,75 & 6,15 & 5,11 & 4,26 & 3,04 \\
\hline 80 & 1800 & 150 & 12,28 & 9,02 & 8,17 & 7,37 & 6,71 & 6,12 & 5,09 & 4,26 & 3,04 \\
\hline 80 & 1850 & 150 & 12,13 & 8,93 & 8,10 & 7,32 & 6,67 & 6,09 & 5,08 & 4,25 & 3,04 \\
\hline 80 & 1900 & 150 & 11,99 & 8,84 & 8,03 & 7,27 & 6,64 & 6,07 & 5,07 & 4,25 & 3,04 \\
\hline 80 & 1950 & 150 & 11,85 & 8,76 & 7,97 & 7,22 & 6,60 & 6,04 & 5,05 & 4,24 & 3,05 \\
\hline 80 & 2000 & 150 & 11,72 & 8,68 & 7,91 & 7,17 & 6,56 & 6,01 & 5,04 & 4,23 & 3,05 \\
\hline 80 & 200 & 155 & 45,94 & 22,68 & 15,86 & 11,34 & 8,85 & 7.19 & 5,08 & 3,91 & 2,71 \\
\hline 80 & 250 & 155 & 38,87 & 20,21 & 14,66 & 10,86 & 8,68 & 7,16 & 5,13 & 3,96 & 2,72 \\
\hline 80 & 300 & 155 & 34,09 & 18,49 & 13,79 & 10,50 & 8,53 & 7,11 & 5,17 & 4,00 & 2,73 \\
\hline 80 & 350 & 155 & 30,61 & 17,20 & 13,12 & 10,20 & 8,39 & 7,07 & 5,20 & 4,03 & 2,74 \\
\hline 80 & 400 & 155 & 27,96 & 16,19 & 12,58 & 9,94 & 8,27 & 7,02 & 5,21 & 4,06 & 2,75 \\
\hline 80 & 450 & 155 & 25,87 & 15,37 & 12,13 & 9,72 & 8,16 & 6,97 & 5,22 & 4,08 & 2,76 \\
\hline 80 & 500 & 155 & 24,17 & 14,68 & 11,74 & 9,52 & 8,06 & 6,92 & 5,23 & 4,10 & 2,77 \\
\hline 80 & 550 & 155 & 22,77 & 14,10 & 11,41 & 9,35 & 7,96 & 6,87 & 5,23 & 4,11 & 2,79 \\
\hline 80 & 600 & 155 & 21,58 & 13,60 & 11,11 & 9,18 & 7,87 & 6,83 & 5,22 & 4,13 & 2,80 \\
\hline 80 & 650 & 155 & 20,56 & 13,16 & 10,85 & 9,04 & 7,79 & 6,78 & 5,22 & 4,14 & 2,81 \\
\hline 80 & 700 & 155 & 19,68 & 12,76 & 10,61 & 8,90 & 7,70 & 6,73 & 5,21 & 4,14 & 2,82 \\
\hline 80 & 750 & 155 & 18,90 & 12,41 & 10,39 & 8,77 & 7,63 & 6,69 & 5,21 & 4,15 & 2,83 \\
\hline 80 & 800 & 155 & 18,22 & 12,10 & 10,20 & 8,65 & 7,55 & 6,64 & 5,20 & 4,16 & 2,84 \\
\hline 80 & 850 & 155 & 17,61 & 11,81 & 10,01 & 8,54 & 7,48 & 6,60 & 5,19 & 4,16 & 2,84 \\
\hline 80 & 900 & 155 & 17,06 & 11,54 & 9,84 & 8,44 & 7,41 & 6,56 & 5,18 & 4,16 & 2,85 \\
\hline 80 & 950 & 155 & 16,56 & 11,30 & 9,69 & 8,34 & 7,35 & 6,52 & 5,16 & 4,16 & 2,86 \\
\hline 80 & 1000 & 155 & 16,11 & 11,07 & 9,54 & 8,25 & 7,29 & 6,48 & 5,15 & 4,17 & 2,87 \\
\hline 80 & 1050 & 155 & 15,70 & 10,86 & 9,40 & 8,16 & 7,23 & 6,44 & 5,14 & 4,17 & 2,87 \\
\hline 80 & 1100 & 155 & 15,32 & 10,67 & 9,27 & 8,07 & 7,17 & 6,40 & 5,13 & 4,17 & 2,88 \\
\hline 80 & 1150 & 155 & 14,97 & 10,49 & 9,15 & 7,99 & 7,12 & 6,37 & 5,12 & 4,17 & 2,89 \\
\hline 80 & 1200 & 155 & 14,65 & 10,32 & 9,03 & 7,91 & 7,06 & 6,33 & 5,10 & 4,16 & 2,89 \\
\hline 80 & 1250 & 155 & 14.35 & 10,16 & 8,92 & 7.84 & 7.01 & 6,29 & 5,09 & 4.16 & 2,90 \\
\hline 80 & 1300 & 155 & 14,08 & 10,00 & 8,82 & 7,77 & 6,96 & 6,26 & 5,08 & 4,16 & 2,90 \\
\hline 80 & 1350 & 155 & 13,82 & 9,86 & 8,72 & 7,70 & 6,91 & 6,23 & 5,06 & 4,16 & 2,91 \\
\hline 80 & 1400 & 155 & 13,57 & 9,72 & 8,62 & 7,63 & 6,87 & 6,19 & 5,05 & 4,15 & 2,91 \\
\hline 80 & 1450 & 155 & 13,34 & 9,59 & 8,53 & 7,57 & 6,82 & 6,16 & 5,04 & 4,15 & 2,91 \\
\hline 80 & 1500 & 155 & 13,13 & 9,47 & 8,44 & 7,51 & 6,78 & 6,13 & 5,02 & 4,15 & 2,92 \\
\hline 80 & 1550 & 155 & 12,93 & 9,35 & 8,36 & 7,45 & 6,73 & 6,10 & 5,01 & 4,14 & 2,92 \\
\hline 80 & 1600 & 155 & 12,74 & 9,24 & 8,28 & 7,39 & 6,69 & 6,07 & 5,00 & 4,14 & 2,93 \\
\hline 80 & 1650 & 155 & 12,55 & 9,14 & 8,20 & 7,34 & 6,65 & 6,04 & 4,98 & 4,14 & 2,93 \\
\hline 80 & 1700 & 155 & 12,38 & 9,03 & 8,13 & 7,29 & 6,61 & 6,01 & 4,97 & 4,13 & 2,93 \\
\hline 80 & 1750 & 155 & 12,22 & 8,93 & 8,06 & 7,24 & 6,57 & 5,98 & 4,96 & 4,13 & 2,93 \\
\hline 80 & 1800 & 155 & 12,06 & 8,84 & 7,99 & 7,19 & 6,54 & 5,96 & 4,94 & 4,12 & 2,94 \\
\hline 80 & 1850 & 155 & 11,92 & 8,75 & 7,92 & 7,14 & 6,50 & 5,93 & 4,93 & 4,12 & 2,94 \\
\hline 80 & 1900 & 155 & 11,77 & 8,66 & 7,85 & 7,09 & 6,46 & 5,90 & 4,92 & 4,11 & 2,94 \\
\hline 80 & 1950 & 155 & 11,64 & 8,58 & 7,79 & 7,04 & 6,43 & 5,88 & 4,91 & 4,11 & 2,94 \\
\hline 80 & 2000 & 155 & 11,51 & 8,50 & 7,73 & 7,00 & 6,40 & 5,85 & 4,89 & 4,10 & 2,95 \\
\hline 80 & 200 & 160 & 45,59 & 22,35 & 15,54 & 11,05 & 8,59 & 6,97 & 4,91 & 3,78 & 2,62 \\
\hline 80 & 250 & 160 & 38,55 & 19,90 & 14,35 & 10,59 & 8,43 & 6,94 & 4,97 & 3,83 & 2,63 \\
\hline 80 & 300 & 160 & 33,77 & 18,19 & 13,50 & 10,23 & 8,29 & 6,90 & 5,00 & 3,87 & 2,64 \\
\hline 80 & 350 & 160 & 30,31 & $\begin{array}{l}16, \pm 01 \\
16,91\end{array}$ & 12,84 & $\begin{array}{c}10,20 \\
9,94\end{array}$ & 8,16 & 6,86 & 5,03 & 3,90 & 2,65 \\
\hline 80 & 400 & 160 & 27,67 & 15,91 & 12,30 & 9,69 & 8,04 & 6,81 & 5,05 & 3,93 & 2,66 \\
\hline 80 & 450 & 160 & 25,59 & 15,10 & 11,86 & 9,47 & 7,94 & 6,77 & 5,06 & 3,95 & 2,67 \\
\hline 80 & 500 & 160 & 23,90 & 14,42 & 11,48 & 9,28 & 7,84 & 6,72 & 5,06 & 3,97 & 2,68 \\
\hline 80 & 550 & 160 & 22,50 & 13,85 & 11,16 & 9,11 & 7,74 & 6,67 & 5,06 & 3,98 & 2,69 \\
\hline 80 & 600 & 160 & 21,31 & 13,35 & 10,87 & 8,95 & 7,66 & 6,63 & 5,06 & 3,99 & 2,71 \\
\hline 80 & 650 & 160 & 20,30 & 12,91 & 10,61 & 8,81 & 7,58 & 6,58 & 5,06 & 4,00 & 2,72 \\
\hline 80 & 700 & 160 & 19,42 & 12,53 & 10,38 & 8,68 & 7,50 & 6,54 & 5,05 & 4,01 & 2,72 \\
\hline 80 & 750 & 160 & 18,65 & 12,18 & 10,17 & 8,56 & 7,42 & 6,50 & 5,05 & 4,02 & 2,73 \\
\hline 80 & 800 & 160 & 17,97 & 11,87 & 9,97 & 8,44 & 7,35 & 6,46 & 5,04 & 4,02 & 2,74 \\
\hline 80 & 850 & 160 & 17,36 & 11,58 & 9,79 & 8,33 & 7,28 & 6,42 & 5,03 & 4,03 & 2,75 \\
\hline 80 & 900 & 160 & 16,82 & 11,32 & 9,63 & 8,23 & 7,22 & 6,38 & 5,02 & 4,03 & 2,76 \\
\hline 80 & 950 & 160 & 16,32 & 11,08 & 9,47 & 8,13 & 7,16 & 6,34 & 5,01 & 4,03 & 2,77 \\
\hline 80 & 1000 & 160 & 15,88 & 10,86 & 9,33 & 8,04 & 7,10 & 6,30 & 5,00 & 4,03 & 2,77 \\
\hline 80 & 1050 & 160 & 15,47 & 10,66 & 9,19 & 7,96 & 7,04 & 6,26 & 4,99 & 4,04 & 2,78 \\
\hline 80 & 1100 & 160 & 15,09 & 10,46 & 9,07 & 7,88 & 6,99 & 6,23 & 4,98 & 4,04 & 2,79 \\
\hline 80 & 1150 & 160 & 14,75 & 10,29 & 8,95 & 7,80 & 6,93 & 6,19 & 4,96 & 4,04 & 2,79 \\
\hline 80 & 1200 & 160 & 14,43 & 10,12 & 8,83 & 7,72 & 6,88 & 6,16 & 4,95 & 4,03 & 2,80 \\
\hline 80 & 1250 & 160 & 14,13 & 9,96 & 8,73 & 7,65 & 6,83 & 6,12 & 4,94 & 4,03 & 2,80 \\
\hline 80 & 1300 & 160 & 13,85 & 9,81 & 8,62 & 7,58 & 6,78 & 6,09 & 4,93 & 4,03 & 2,81 \\
\hline 80 & 1350 & 160 & 13,60 & 9,67 & 8,53 & 7,51 & 6,74 & 6,06 & 4,92 & 4,03 & 2,81 \\
\hline 80 & 1400 & 160 & 13,35 & 9,53 & 8,43 & 7,45 & 6,69 & 6,03 & 4,90 & 4,03 & 2,82 \\
\hline 80 & 1450 & 160 & 13,13 & 9,41 & 8,34 & 7,39 & 6,65 & 6,00 & 4,89 & 4,02 & 2,82 \\
\hline 80 & 1500 & 160 & 12,91 & 9,29 & 8,26 & 7,33 & 6,60 & 5,97 & 4,88 & 4,02 & 2,82 \\
\hline 80 & 1550 & 160 & 12,71 & 9,17 & 8,18 & 7,27 & 6,56 & 5,94 & 4,87 & 4,02 & 2,83 \\
\hline 80 & 1600 & 160 & 12,52 & 9,06 & 8,10 & 7,22 & 6,52 & 5,91 & 4,85 & 4,02 & 2,83 \\
\hline 80 & 1650 & 160 & 12,34 & 8,96 & 8,02 & 7,17 & 6,48 & 5,88 & 4,84 & 4,01 & 2,83 \\
\hline 80 & 1700 & 160 & 12,17 & 8,86 & 7,95 & 7,11 & 6,45 & 5,85 & 4,83 & 4,01 & 2,84 \\
\hline 80 & 1750 & 160 & 12,01 & 8,76 & 7,88 & 7,06 & 6,41 & 5,83 & 4,82 & 4,00 & 2,84 \\
\hline
\end{tabular}




\begin{tabular}{|c|c|c|c|c|c|c|c|c|c|c|c|}
\hline \multirow[b]{2}{*}{$\mathrm{H}(\mathrm{cm})$} & \multirow[b]{2}{*}{ Mceq (MPa) } & & & & & De & ões (x & & & & \\
\hline & & Msub (MPa) & D0 & D25 & D40 & D60 & D80 & D100 & D140 & D180 & D260 \\
\hline 80 & 1800 & 160 & 11,86 & 8,67 & 7,81 & 7,02 & 6,37 & 5,80 & 4,80 & 4,00 & 2,84 \\
\hline 80 & 1850 & 160 & 11,71 & 8,58 & 7,75 & 6,97 & 6,34 & 5,77 & 4,79 & 4,00 & 2,85 \\
\hline 80 & 1900 & 160 & 11,57 & 8,49 & 7,68 & 6,92 & 6,30 & 5,75 & 4,78 & 3,99 & 2,85 \\
\hline 80 & 1950 & 160 & 11,44 & 8,41 & 7,62 & 6,88 & 6,27 & 5,72 & 4,77 & 3,99 & 2,85 \\
\hline 80 & 2000 & 160 & 11,31 & 8,33 & 7,56 & 6,83 & 6,24 & 5,70 & 4,76 & 3,98 & 2,85 \\
\hline 80 & 200 & 165 & 45,27 & 22,04 & 15,24 & 10,78 & 8,35 & 6,76 & 4,75 & 3,66 & 2,54 \\
\hline 80 & 250 & 165 & 38,24 & 19,60 & 14,07 & 10,33 & 8,20 & 6,73 & 4,81 & 3,71 & 2,55 \\
\hline 80 & 300 & 165 & 33,48 & 17,90 & 13,22 & 9,98 & 8,06 & 6,70 & 4,85 & 3,75 & 2,56 \\
\hline 80 & 350 & 165 & 30,03 & 16,63 & 12,57 & 9,69 & 7,94 & 6,66 & 4,87 & 3,78 & 2,57 \\
\hline 80 & 400 & 165 & 27,40 & 15,64 & 12,05 & 9,45 & 7,83 & 6,62 & 4,89 & 3,80 & 2,58 \\
\hline 80 & 450 & 165 & 25,32 & 14,84 & 11,61 & 9,24 & 7,72 & 6,57 & 4,90 & 3,82 & 2,59 \\
\hline 80 & 500 & 165 & 23,64 & 14,17 & 11,24 & 9,06 & 7,63 & 6,53 & 4,91 & 3,84 & 2,60 \\
\hline 80 & 550 & 165 & 22,24 & 13,60 & 10,92 & 8,89 & 7,54 & 6,49 & 4,91 & 3,86 & 2,61 \\
\hline 80 & 600 & 165 & 21,06 & 13,11 & 10,64 & 8,74 & 7,46 & 6,44 & 4,91 & 3,87 & 2,62 \\
\hline 80 & 650 & 165 & 20,05 & 12,68 & 10,38 & 8,60 & 7,38 & 6,40 & 4,91 & 3,88 & 2,63 \\
\hline 80 & 700 & 165 & 19,18 & 12,30 & 10,16 & 8,47 & 7,30 & 6,36 & 4,90 & 3,89 & 2,64 \\
\hline 80 & 750 & 165 & 18,41 & 11,96 & 9,95 & 8,35 & 7,23 & 6,32 & 4,90 & 3,89 & 2,65 \\
\hline 80 & 800 & 165 & 17,74 & 11,65 & 9,76 & 8,24 & 7,16 & 6,28 & 4,89 & 3,90 & 2,66 \\
\hline 80 & 850 & 165 & 17,13 & 11,37 & 9,58 & 8,13 & 7,10 & 6,24 & 4,88 & 3,90 & 2,66 \\
\hline 80 & 900 & 165 & 16,59 & 11,12 & 9,42 & 8,03 & 7,03 & 6,20 & 4,87 & 3,91 & 2,67 \\
\hline 80 & 950 & 165 & 16,10 & 10,88 & 9,27 & 7,94 & 6,97 & 6,17 & 4,86 & 3,91 & 2,68 \\
\hline 80 & 1000 & 165 & 15,65 & 10,66 & 9,13 & 7,85 & 6,92 & 6,13 & 4,85 & 3,91 & 2,68 \\
\hline 80 & 1050 & 165 & 15,25 & 10,46 & 9,00 & 7,77 & 6,86 & 6,10 & 4,84 & 3,91 & 2,69 \\
\hline 80 & 1100 & 165 & 14,87 & 10,27 & 8,87 & 7,69 & 6,81 & 6,06 & 4,83 & 3,91 & 2,70 \\
\hline 80 & 1150 & 165 & 14,53 & 10,09 & 8,76 & 7,61 & 6,76 & 6,03 & 4,82 & 3,91 & 2,70 \\
\hline 80 & 1200 & 165 & 14,21 & 9,93 & 8,65 & 7,54 & 6,71 & 6,00 & 4,81 & 3,91 & 2,71 \\
\hline 80 & 1250 & 165 & 13,92 & 9,77 & 8,54 & 7,47 & 6,66 & 5,96 & 4,80 & 3,91 & 2,71 \\
\hline 80 & 1300 & 165 & 13,64 & 9,63 & 8,44 & 7,40 & 6,61 & 5,93 & 4,79 & 3,91 & 2,72 \\
\hline 80 & 1350 & 165 & 13,39 & 9,49 & 8,35 & 7,34 & 6,57 & 5,90 & 4,78 & 3,91 & 2,72 \\
\hline 80 & 1400 & 165 & 13,15 & 9,36 & 8,25 & 7,28 & 6,53 & 5,87 & 4,77 & 3,91 & 2,73 \\
\hline 80 & 1450 & 165 & 12,92 & 9,23 & 8,17 & 7,22 & 6,48 & 5,84 & 4,75 & 3,91 & 2,73 \\
\hline 80 & 1500 & 165 & 12,71 & 9,11 & 8,08 & 7,16 & 6,44 & 5,81 & 4,74 & 3,90 & 2,74 \\
\hline 80 & 1550 & 165 & 12,51 & 9,00 & 8,00 & 7,11 & 6,40 & 5,78 & 4,73 & 3,90 & 2,74 \\
\hline 80 & 1600 & 165 & 12,32 & 8,89 & 7,93 & 7,05 & 6,36 & 5,76 & 4,72 & 3,90 & 2,74 \\
\hline 80 & 1650 & 165 & 12,14 & 8,79 & 7,85 & 7,00 & 6,33 & 5,73 & 4,71 & 3,89 & 2,75 \\
\hline 80 & 1700 & 165 & 11,97 & 8,69 & 7,78 & 6,95 & 6,29 & 5,70 & 4,69 & 3,89 & 2,75 \\
\hline 80 & 1750 & 165 & 11,81 & 8,59 & 7,71 & 6,90 & 6,25 & 5,68 & 4,68 & 3,89 & 2,75 \\
\hline 80 & 1800 & 165 & 11,66 & 8,50 & 7,65 & 6,85 & 6,22 & 5,65 & 4,67 & 3,88 & 2,75 \\
\hline 80 & 1850 & 165 & 11,52 & 8,42 & 7,58 & 6,81 & 6,18 & 5,63 & 4,66 & 3,88 & 2,76 \\
\hline 80 & 1900 & 165 & 11,38 & 8,33 & 7,52 & 6,76 & 6,15 & 5,60 & 4,65 & 3,88 & 2,76 \\
\hline 80 & 1950 & 165 & 11,24 & 8,25 & 7,46 & 6,72 & 6,12 & 5,58 & 4,64 & 3,87 & 2,76 \\
\hline 80 & 2000 & 165 & 11,12 & 8,17 & 7,40 & 6,68 & 6,09 & 5,56 & 4,63 & 3,87 & 2,76 \\
\hline 80 & 200 & 170 & 44,97 & 21,74 & 14,96 & 10,53 & 8,13 & 6,56 & 4,60 & 3,55 & 2,47 \\
\hline 80 & 250 & 170 & 37,95 & 19,31 & 13,80 & 10,08 & 7,98 & 6,54 & 4,66 & 3,59 & 2,47 \\
\hline 80 & 300 & 170 & 33,20 & 17,63 & 12,96 & 9,74 & 7,84 & 6,51 & 4,70 & 3,63 & 2,48 \\
\hline 80 & 350 & 170 & 29,76 & 16,37 & 12,32 & 9,46 & 7,73 & 6,47 & 4,72 & 3,66 & 2,49 \\
\hline 80 & 400 & 170 & 27,13 & 15,39 & 11,80 & 9,23 & 7,62 & 6,43 & 4,74 & 3,69 & 2,50 \\
\hline 80 & 450 & 170 & 25,07 & 14,59 & 11,38 & 9,02 & 7,52 & 6,39 & 4,75 & 3,71 & 2,51 \\
\hline 80 & 500 & 170 & 23,39 & 13,93 & 11,01 & 8,84 & 7,43 & 6,35 & 4,76 & 3,72 & 2,52 \\
\hline 80 & 550 & 170 & 22,00 & 13,37 & 10,70 & 8,68 & 7,35 & 6,31 & 4,76 & 3,74 & 2,53 \\
\hline 80 & 600 & 170 & 20,83 & 12,89 & 10,42 & 8,53 & 7,26 & 6,27 & 4,76 & 3,75 & 2,54 \\
\hline 80 & 650 & 170 & 19,82 & 12,46 & 10,17 & 8,40 & 7,19 & 6,23 & 4,76 & 3,76 & 2,55 \\
\hline 80 & 700 & 170 & 18,95 & 12,09 & 9,95 & 8,27 & 7,12 & 6,19 & 4,76 & 3,77 & 2,56 \\
\hline 80 & 750 & 170 & 18,19 & 11,75 & 9,74 & 8,15 & 7,05 & 6,15 & 4,76 & 3,78 & 2,57 \\
\hline 80 & 800 & 170 & 17,51 & 11,45 & 9,56 & 8,05 & 6,98 & 6,11 & 4,75 & 3,78 & 2,57 \\
\hline 80 & 850 & 170 & 16,91 & 11,17 & 9,38 & 7,94 & 6,92 & 6,08 & 4,74 & 3,79 & 2,58 \\
\hline 80 & 900 & 170 & 16,37 & 10,92 & 9,23 & 7,85 & 6,86 & 6,04 & 4,73 & 3,79 & 2,59 \\
\hline 80 & 950 & 170 & 15,89 & 10,68 & 9,08 & 7,76 & 6,80 & 6,01 & 4,73 & 3,79 & 2,60 \\
\hline 80 & 1000 & 170 & 15,44 & 10,47 & 8,94 & 7,67 & 6,75 & 5,97 & 4,72 & 3,80 & 2,60 \\
\hline 80 & 1050 & 170 & 15,04 & 10,27 & 8,81 & 7,59 & 6,69 & 5,94 & 4,71 & 3,80 & 2,61 \\
\hline 80 & 1100 & 170 & 14,67 & 10,09 & 8,69 & 7,51 & 6,64 & 5,90 & 4,70 & 3,80 & 2,61 \\
\hline 80 & 1150 & 170 & 14,33 & 9,91 & 8,58 & 7,44 & 6,59 & 5,87 & 4,69 & 3,80 & 2,62 \\
\hline 80 & 1200 & 170 & 14,01 & 9,75 & 8,47 & 7,37 & 6,54 & 5,84 & 4,68 & 3,80 & 2,62 \\
\hline 80 & 1250 & 170 & 13,72 & 9,60 & 8,36 & 7,30 & 6,50 & 5,81 & 4,67 & 3,80 & 2,63 \\
\hline 80 & 1300 & 170 & 13,44 & 9,45 & 8,27 & 7,24 & 6,45 & 5,78 & 4,66 & 3,80 & 2,63 \\
\hline 80 & 1350 & 170 & 13,19 & 9,31 & 8,17 & 7,17 & 6,41 & 5,75 & 4,65 & 3,80 & 2,64 \\
\hline 80 & 1400 & 170 & 12,95 & 9,18 & 8,08 & 7,11 & 6,37 & 5,72 & 4,63 & 3,79 & 2,64 \\
\hline 80 & 1450 & 170 & 12,73 & 9,06 & 8,00 & 7,06 & 6,33 & 5,69 & 4,62 & 3,79 & 2,65 \\
\hline 80 & 1500 & 170 & 12,52 & 8,94 & 7,92 & 7,00 & 6,29 & 5,67 & 4,61 & 3,79 & 2,65 \\
\hline 80 & 1550 & 170 & 12,32 & 8,83 & 7,84 & 6,95 & 6,25 & 5,64 & 4,60 & 3,79 & 2,65 \\
\hline 80 & 1600 & 170 & 12,13 & 8,73 & 7,76 & 6,89 & 6,21 & 5,61 & 4,59 & 3,78 & 2,66 \\
\hline 80 & 1650 & 170 & 11,95 & 8,63 & 7,69 & 6,84 & 6,18 & 5,59 & 4,58 & 3,78 & 2,66 \\
\hline 80 & 1700 & 170 & 11,79 & 8,53 & 7,62 & 6,79 & 6,14 & 5,56 & 4,57 & 3,78 & 2,66 \\
\hline 80 & 1750 & 170 & 11,63 & 8,44 & 7,56 & 6,75 & 6,11 & 5,54 & 4,56 & 3,78 & 2,67 \\
\hline 80 & 1800 & 170 & 11,48 & 8,35 & 7,49 & 6,70 & 6,07 & 5,51 & 4,55 & 3,77 & 2,67 \\
\hline 80 & 1850 & 170 & 11,33 & 8,26 & 7,43 & 6,66 & 6,04 & 5,49 & 4,54 & 3,77 & 2,67 \\
\hline 80 & 1900 & 170 & 11,19 & 8,18 & 7,37 & 6,61 & 6,01 & 5,47 & 4,52 & 3,77 & 2,68 \\
\hline 80 & 1950 & 170 & 11,06 & 8,10 & 7,31 & 6,57 & 5,97 & 5,44 & 4,51 & 3,76 & 2,68 \\
\hline 80 & 2000 & 170 & 10,94 & 8,02 & 7,25 & 6,53 & 5,94 & 5,42 & 4,50 & 3,76 & 2,68 \\
\hline 80 & 200 & 175 & 44,67 & 21,46 & 14,69 & 10,28 & 7,92 & 6,38 & 4,46 & 3,44 & 2,39 \\
\hline 80 & 250 & 175 & 37,67 & 19,04 & 13,54 & 9,85 & 7,77 & 6,36 & 4,52 & 3,48 & 2,40 \\
\hline
\end{tabular}




\begin{tabular}{|c|c|c|c|c|c|c|c|c|c|c|c|}
\hline \multirow[b]{2}{*}{$\mathrm{H}(\mathrm{cm})$} & \multirow[b]{2}{*}{ Mceq (MPa) } & & & & & De & $\operatorname{ses}(x$ & & & & \\
\hline & & Msub (MPa) & D0 & D25 & D40 & D60 & D80 & D100 & D140 & D180 & D260 \\
\hline 80 & 300 & 175 & 32,93 & 17,37 & 12,71 & 9,51 & 7,64 & 6,33 & 4,56 & 3,52 & 2,41 \\
\hline 80 & 350 & 175 & 29,50 & 16,12 & 12,08 & 9,24 & 7,53 & 6,29 & 4,59 & 3,55 & 2,42 \\
\hline 80 & 400 & 175 & 26,89 & 15,15 & 11,57 & 9,01 & 7,43 & 6,26 & 4,60 & 3,57 & 2,43 \\
\hline 80 & 450 & 175 & 24,83 & 14,36 & 11,15 & 8,81 & 7,33 & 6,22 & 4,62 & 3,59 & 2,44 \\
\hline 80 & 500 & 175 & 23,15 & 13,71 & 10,79 & 8,64 & 7,24 & 6,18 & 4,62 & 3,61 & 2,45 \\
\hline 80 & 550 & 175 & 21,77 & 13,15 & 10,48 & 8,48 & 7,16 & 6,14 & 4,63 & 3,63 & 2,45 \\
\hline 80 & 600 & 175 & 20,60 & 12,67 & 10,21 & 8,33 & 7,08 & 6,10 & 4,63 & 3,64 & 2,46 \\
\hline 80 & 650 & 175 & 19,60 & 12,25 & 9,96 & 8,20 & 7,01 & 6,07 & 4,63 & 3,65 & 2,47 \\
\hline 80 & 700 & 175 & 18,73 & 11,88 & 9,75 & 8,08 & 6,94 & 6,03 & 4,63 & 3,66 & 2,48 \\
\hline 80 & 750 & 175 & 17,98 & 11,55 & 9,55 & 7,97 & 6,87 & 5,99 & 4,62 & 3,66 & 2,49 \\
\hline 80 & 800 & 175 & 17,30 & 11,25 & 9,36 & 7,86 & 6,81 & 5,96 & 4,62 & 3,67 & 2,50 \\
\hline 80 & 850 & 175 & 16,71 & 10,98 & 9,20 & 7,76 & 6,75 & 5,92 & 4,61 & 3,68 & 2,50 \\
\hline 80 & 900 & 175 & 16.17 & 10,73 & 9.04 & 7.67 & 6.69 & 5,89 & 4.60 & 3,68 & 2,51 \\
\hline 80 & 950 & 175 & 15,68 & 10,50 & 8,90 & 7,58 & 6,64 & 5,85 & 4,60 & 3,68 & 2,52 \\
\hline 80 & 1000 & 175 & 15,24 & 10,29 & 8,76 & 7,50 & 6,58 & 5,82 & 4,59 & 3,69 & $\frac{2,52}{2,52}$ \\
\hline 80 & 1050 & 175 & 14,84 & 10,09 & 8,63 & 7,42 & 6,53 & 5,79 & 4,58 & 3,69 & 2,53 \\
\hline 80 & 1100 & 175 & 14,47 & 9,91 & 8,52 & 7,35 & 6,48 & 5,76 & 4,57 & 3,69 & 2,54 \\
\hline 80 & 1150 & 175 & 14,13 & 9,74 & 8,40 & 7,27 & 6,44 & 5,73 & 4,56 & 3,69 & 2,54 \\
\hline 80 & 1200 & 175 & 13,82 & 9,58 & 8,30 & 7,20 & 6,39 & 5,70 & 4,55 & 3,69 & 2,55 \\
\hline 80 & 1250 & 175 & 13,53 & 9,43 & 8,20 & 7,14 & 6,34 & 5,67 & 4,54 & 3,69 & 2,55 \\
\hline 80 & 1300 & 175 & 13,25 & 9,28 & 8,10 & 7,08 & 6,30 & 5,64 & 4,53 & 3,69 & 2,56 \\
\hline 80 & 1350 & 175 & 13,00 & 9,15 & 8,01 & 7,01 & 6,26 & 5,61 & 4,52 & 3,69 & 2,56 \\
\hline 80 & 1400 & 175 & 12,76 & 9,02 & 7,92 & 6,96 & 6,22 & 5,58 & 4,51 & 3,69 & 2,56 \\
\hline 80 & 1450 & 175 & 12,54 & 8,90 & 7,84 & 6,90 & 6,18 & 5,55 & 4,50 & 3,69 & 2,57 \\
\hline 80 & 1500 & 175 & 12,33 & 8,79 & 7,76 & 6,85 & 6,14 & 5,53 & 4,49 & 3,68 & 2,57 \\
\hline 80 & 1550 & 175 & 12,14 & 8,68 & 7,68 & 6,79 & 6,10 & 5,50 & 4,48 & 3,68 & 2,58 \\
\hline 80 & 1600 & 175 & 11,95 & 8,57 & 7,61 & 6,74 & 6,07 & 5,48 & 4,47 & 3,68 & 2,58 \\
\hline 80 & 1650 & 175 & 11,78 & 8,47 & 7,54 & 6,69 & 6,03 & 5,45 & 4,46 & 3,68 & 2,58 \\
\hline 80 & 1700 & 175 & 11,61 & 8,38 & 7,47 & 6,65 & 6,00 & 5,43 & 4,45 & 3,67 & 2,59 \\
\hline 80 & 1750 & 175 & 11,45 & 8,28 & 7,40 & 6,60 & 5,96 & 5,40 & 4,44 & 3,67 & 2,59 \\
\hline 80 & 1800 & 175 & 11,30 & 8,20 & 7,34 & 6,56 & 5,93 & 5,38 & 4,43 & 3,67 & 2,59 \\
\hline 80 & 1850 & 175 & 11,16 & 8,11 & 7,28 & 6,51 & 5,90 & 5,36 & 4,42 & 3,67 & 2,59 \\
\hline 80 & 1900 & 175 & 11,02 & 8,03 & 7,22 & 6,47 & 5,87 & 5,33 & 4,41 & 3,66 & 2,60 \\
\hline 80 & 1950 & 175 & 10,89 & 7,95 & 7,16 & 6,43 & 5,84 & 5,31 & 4,40 & 3,66 & 2,60 \\
\hline 80 & 2000 & 175 & 10,76 & 7,88 & 7,11 & 6,39 & 5,81 & 5,29 & 4,39 & 3,66 & 2,60 \\
\hline 80 & 200 & 180 & 44,40 & 21,19 & 14,44 & 10,05 & 7,71 & 6,20 & 4,33 & 3,34 & 2,33 \\
\hline 80 & 250 & 180 & 37,41 & 18,79 & 13,30 & 9,63 & 7,57 & 6,18 & 4,39 & 3,38 & 2,33 \\
\hline 80 & 300 & 180 & 32,68 & 17,12 & 12,48 & 9,30 & 7,45 & 6,16 & 4,43 & 3,42 & 2,34 \\
\hline 80 & 350 & 180 & 29,26 & 15,89 & 11,85 & 9,03 & 7,34 & 6,12 & 4,45 & 3,45 & 2,35 \\
\hline 80 & 400 & 180 & 26,65 & 14,92 & 11,35 & 8,81 & 7,24 & 6,09 & 4,47 & 3,47 & 2,36 \\
\hline 80 & 450 & 180 & 24,60 & 14,14 & 10,94 & 8,61 & 7,15 & 6,05 & 4,48 & 3,49 & 2,37 \\
\hline 80 & 500 & 180 & 22,93 & 13,49 & 10,58 & 8,44 & 7,07 & 6,02 & 4,49 & 3,51 & 2,37 \\
\hline 80 & 550 & 180 & 21,55 & 12,94 & 10,28 & 8,29 & 6,99 & 5,98 & 4,50 & 3,52 & 2,38 \\
\hline 80 & 600 & 180 & 20,39 & 12,47 & 10,01 & 8,15 & 6,91 & 5,95 & 4,50 & 3,53 & 2,39 \\
\hline 80 & 650 & 180 & 19,39 & 12,05 & 9,77 & 8,02 & 6,84 & 5,91 & 4,50 & 3,54 & 2,40 \\
\hline 80 & 700 & 180 & 18,53 & 11,69 & 9,55 & 7,90 & 6,77 & 5,87 & 4,50 & 3,55 & 2,41 \\
\hline 80 & 750 & 180 & 17,77 & 11,36 & 9,36 & 7,79 & 6,71 & 5,84 & 4,49 & 3,56 & 2,42 \\
\hline 80 & 800 & 180 & 17,10 & 11,06 & 9,18 & 7,69 & 6,65 & 5,81 & 4,49 & 3,57 & 2,42 \\
\hline 80 & 850 & 180 & 16,51 & 10,79 & 9,02 & 7,59 & 6,59 & 5,77 & 4,48 & 3,57 & 2,43 \\
\hline 80 & 900 & 180 & 15,97 & 10,55 & 8,86 & 7,50 & 6,54 & 5,74 & 4,48 & 3,58 & 2,44 \\
\hline 80 & 950 & 180 & 15,49 & 10,32 & 8,72 & 7,42 & 6,48 & 5,71 & 4,47 & 3,58 & 2,44 \\
\hline 80 & 1000 & 180 & 15,05 & 10,11 & 8,59 & 7,34 & 6,43 & 5,68 & 4,46 & 3,58 & 2,45 \\
\hline 80 & 1050 & 180 & 14,65 & $\begin{array}{c}0,+ \pm \\
9,92\end{array}$ & 8,47 & 7,26 & 6,38 & 5,65 & 4,46 & 3,58 & 2,46 \\
\hline 80 & 1100 & 180 & 14,28 & 9,74 & 8,35 & 7,19 & 6,33 & 5,61 & 4,45 & 3,59 & 2,46 \\
\hline 80 & 1150 & 180 & 13,95 & 9,57 & 8,24 & 7,12 & 6,29 & 5,59 & 4,44 & 3,59 & 2,47 \\
\hline 80 & 1200 & 180 & 13,63 & 9,41 & 8,13 & 7,05 & 6,24 & 5,56 & 4,43 & 3,59 & 2,47 \\
\hline 80 & 1250 & 180 & 13,34 & 9,27 & 8,04 & 6,98 & 6,20 & 5,53 & 4,42 & 3,59 & 2,48 \\
\hline 80 & 1300 & 180 & 13,07 & 9,13 & 7,94 & 6,92 & 6,16 & 5,50 & 4,41 & 3,59 & 2,48 \\
\hline 80 & 1350 & 180 & 12,82 & 8,99 & 7,85 & 6,86 & 6,12 & 5,47 & 4,40 & 3,59 & 2,49 \\
\hline 80 & 1400 & 180 & 12,59 & 8,87 & 7,77 & 6,81 & 6,08 & 5,45 & 4,39 & 3,59 & 2,49 \\
\hline 80 & 1450 & 180 & 12,37 & 8,75 & 7,69 & 6,75 & 6,04 & 5,42 & 4,38 & 3,58 & 2,49 \\
\hline 80 & 1500 & 180 & 12,16 & 8,64 & 7,61 & 6,70 & 6,00 & 5,40 & 4,37 & 3,58 & 2,50 \\
\hline 80 & 1550 & 180 & 11,96 & 8,53 & 7,53 & 6,65 & 5,97 & 5,37 & 4,36 & 3,58 & 2,50 \\
\hline 80 & 1600 & 180 & 11,78 & 8,42 & 7,46 & 6,60 & 5,93 & 5,35 & 4,35 & 3,58 & 2,50 \\
\hline 80 & 1650 & 180 & 11,60 & 8,33 & 7,39 & 6,55 & 5,90 & 5,32 & 4,34 & 3,58 & 2,51 \\
\hline 80 & 1700 & 180 & 11,44 & 8,23 & 7,33 & 6,50 & 5,86 & 5,30 & 4,33 & 3,57 & 2,51 \\
\hline 80 & 1750 & 180 & 11,28 & 8,14 & 7,26 & 6,46 & 5,83 & 5,28 & 4,32 & 3,57 & 2,51 \\
\hline 80 & 1800 & 180 & 11,13 & 8,05 & 7,20 & 6,42 & 5,80 & 5,25 & 4,31 & 3,57 & 2,52 \\
\hline 80 & 1850 & 180 & 10,99 & 7,97 & 7,14 & 6,37 & 5,77 & 5,23 & 4,30 & 3,57 & 2,52 \\
\hline 80 & 1900 & 180 & 10,85 & 7,89 & 7,08 & 6,33 & 5,74 & 5,21 & 4,29 & 3,56 & 2,52 \\
\hline 80 & 1950 & 180 & 10,72 & 7,81 & 7,03 & 6,29 & 5,71 & 5,19 & 4,28 & 3,56 & 2,52 \\
\hline 80 & 2000 & 180 & 10,60 & 7,74 & 6,97 & 6,25 & 5,68 & 5,17 & 4,28 & 3,56 & 2,53 \\
\hline 80 & 200 & 185 & 44,14 & 20,93 & 14,20 & 9,84 & 7,52 & 6,03 & 4,21 & 3,24 & 2,26 \\
\hline 80 & 250 & 185 & 37,16 & 18,54 & 13,07 & 9,41 & 7,38 & 6,02 & 4,26 & 3,29 & 2,27 \\
\hline 80 & 300 & 185 & 32,44 & $\begin{array}{l}16,89 \\
16,89\end{array}$ & 12,26 & $\begin{array}{l}0,+1 \\
9,09\end{array}$ & 7,26 & 5,99 & 4,30 & 3,32 & 2,28 \\
\hline 80 & 350 & 185 & 29,02 & 15,66 & 11,64 & 8,83 & 7,16 & 5,97 & 4,33 & 3,35 & 2,28 \\
\hline 80 & 400 & 185 & 26,43 & 14,70 & 11,14 & 8,61 & 7,06 & 5,93 & 4,35 & 3,37 & 2,29 \\
\hline 80 & 450 & 185 & 24,38 & 13,93 & 10,73 & 8,42 & 6,98 & 5,90 & 4,36 & 3,39 & 2,30 \\
\hline 80 & 500 & 185 & 22,72 & 13,29 & 10,39 & 8,26 & 6,90 & 5,87 & 4,37 & 3,41 & 2,31 \\
\hline 80 & 550 & 185 & 21,34 & 12,74 & 10,09 & 8,11 & 6,82 & 5,83 & 4,38 & 3,42 & 2,32 \\
\hline 80 & 600 & 185 & 20,18 & 12,27 & 9,82 & 7,97 & 6,75 & 5,80 & 4,38 & 3,43 & 2,32 \\
\hline
\end{tabular}




\begin{tabular}{|c|c|c|c|c|c|c|c|c|c|c|c|}
\hline \multirow[b]{2}{*}{$\mathrm{H}(\mathrm{cm})$} & \multirow[b]{2}{*}{ Mceq (MPa) } & & & & & & jes ( $x 1$ & & & & \\
\hline & & Msub (MPa) & D0 & D25 & D40 & D60 & $\mathrm{D} 80$ & D100 & D140 & D180 & D260 \\
\hline 80 & 650 & 185 & 19,19 & 11,86 & 9,59 & 7,85 & 6,68 & 5,76 & 4,38 & 3,44 & 2,33 \\
\hline 80 & 700 & 185 & 18,33 & 11,50 & 9,37 & 7,73 & 6,61 & 5,73 & 4,38 & 3,45 & 2,34 \\
\hline 80 & 750 & 185 & 17,58 & 11,18 & 9,18 & 7,62 & 6,55 & 5,70 & 4,37 & 3,46 & 2,35 \\
\hline 80 & 800 & 185 & 16,91 & 10,89 & 9,01 & 7,52 & 6,49 & 5,66 & 4,37 & 3,47 & 2,36 \\
\hline 80 & 850 & 185 & 16,32 & 10,62 & 8,84 & 7,43 & 6,44 & 5,63 & 4,37 & 3,47 & 2,36 \\
\hline 80 & 900 & 185 & 15,79 & 10,38 & 8,69 & 7,34 & 6,38 & 5,60 & 4,36 & 3,48 & 2,37 \\
\hline 80 & 950 & 185 & 15,31 & 10,15 & 8,56 & 7,26 & 6,33 & 5,57 & 4,35 & 3,48 & 2,37 \\
\hline 80 & 1000 & 185 & 14,87 & 9,95 & 8,43 & 7,18 & 6,28 & 5,54 & 4,35 & 3,48 & 2,38 \\
\hline 80 & 1050 & 185 & 14,47 & 9,76 & 8,30 & 7,10 & 6,24 & 5,51 & 4,34 & 3,49 & 2,39 \\
\hline 80 & 1100 & 185 & 14,11 & 9,58 & 8,19 & 7,03 & 6,19 & 5,48 & 4,33 & 3,49 & 2,39 \\
\hline 80 & 1150 & 185 & 13,77 & 9,41 & 8,08 & 6,97 & 6,14 & 5,45 & 4,32 & 3,49 & 2,40 \\
\hline 80 & 1200 & 185 & 13,46 & 9,26 & 7,98 & 6,90 & 6,10 & 5,42 & 4,32 & 3,49 & 2,40 \\
\hline 80 & 1250 & 185 & 13,17 & 9,11 & 7,88 & 6,84 & 6,06 & 5,40 & 4,31 & 3,49 & 2,41 \\
\hline 80 & 1300 & 185 & 12,90 & 8,97 & 7,79 & 6,78 & 6,02 & 5,37 & 4,30 & 3,49 & 2,41 \\
\hline 80 & 1350 & 185 & 12,65 & 8,84 & 7,70 & 6,72 & 5,98 & 5,34 & 4,29 & 3,49 & 2,42 \\
\hline 80 & 1400 & 185 & 12,42 & 8,72 & 7,62 & 6,66 & 5,94 & 5,32 & 4,28 & 3,49 & 2,42 \\
\hline 80 & 1450 & 185 & 12,20 & 8,60 & 7,54 & 6,61 & 5,90 & 5,29 & 4,27 & 3,49 & 2,42 \\
\hline 80 & 1500 & 185 & 11,99 & 8,49 & 7,46 & 6,56 & 5,87 & 5,27 & 4,26 & 3,49 & 2,43 \\
\hline 80 & 1550 & 185 & 11,80 & 8,38 & 7,39 & 6,51 & 5,83 & 5,25 & 4,25 & 3,49 & 2,43 \\
\hline 80 & 1600 & 185 & 11,62 & 8,28 & 7,32 & 6,46 & 5,80 & 5,22 & 4,24 & 3,48 & 2,43 \\
\hline 80 & 1650 & 185 & 11,44 & 8,19 & 7,25 & 6,42 & 5,77 & 5,20 & 4,24 & 3,48 & 2,44 \\
\hline 80 & 1700 & 185 & 11,28 & 8,09 & 7,19 & 6,37 & 5,73 & 5,18 & 4,23 & 3,48 & 2,44 \\
\hline 80 & 1750 & 185 & 11,12 & 8,00 & 7,12 & 6,33 & 5,70 & 5,15 & 4,22 & 3,48 & 2,44 \\
\hline 80 & 1800 & 185 & 10,97 & 7,92 & 7,06 & 6,28 & 5,67 & 5,13 & 4,21 & 3,48 & 2,45 \\
\hline 80 & 1850 & 185 & 10,83 & 7,84 & 7,00 & 6,24 & 5,64 & 5,11 & 4,20 & 3,47 & 2,45 \\
\hline 80 & 1900 & 185 & 10,70 & 7,76 & 6,95 & 6,20 & 5,61 & 5,09 & 4,19 & 3,47 & 2,45 \\
\hline 80 & 1950 & 185 & 10,57 & 7,68 & 6,89 & 6,16 & 5,58 & 5,07 & 4,18 & 3,47 & 2,45 \\
\hline 80 & 2000 & 185 & 10,44 & 7,61 & 6,84 & 6,13 & 5,56 & 5,05 & 4,17 & 3,46 & 2,46 \\
\hline 80 & 200 & 190 & 43,89 & 20,69 & 13,97 & 9,63 & 7,34 & 5,88 & 4,09 & 3,15 & 2,20 \\
\hline 80 & 250 & 190 & 36,92 & 18,31 & 12,85 & 9,21 & 7,21 & 5,86 & 4,14 & 3,19 & 2,21 \\
\hline 80 & 300 & 190 & 32,21 & 16,67 & 12,04 & 8,90 & 7,09 & 5,84 & 4,18 & 3,23 & 2,21 \\
\hline 80 & 350 & 190 & 28,80 & 15,45 & 11,43 & 8,64 & 6,99 & 5,81 & 4,21 & 3,26 & 2,22 \\
\hline 80 & 400 & 190 & 26,21 & 14,49 & 10,94 & 8,43 & 6,90 & 5,78 & 4,23 & 3,28 & 2,23 \\
\hline 80 & 450 & 190 & 24,17 & 13,73 & 10,54 & 8,24 & 6,81 & 5,75 & 4,24 & 3,30 & 2,24 \\
\hline 80 & 500 & 190 & 22,52 & 13,09 & 10,20 & 8,08 & 6,73 & 5,72 & 4,25 & 3,31 & 2,25 \\
\hline 80 & 550 & 190 & 21,15 & 12,55 & 9,90 & 7,93 & 6,66 & 5,69 & 4,26 & 3,33 & 2,25 \\
\hline 80 & 600 & 190 & 19,99 & 12,09 & 9,64 & 7,80 & 6,59 & 5,65 & 4,26 & 3,34 & 2,26 \\
\hline 80 & 650 & 190 & 19,00 & 11,68 & 9,41 & 7,68 & 6,53 & 5,62 & 4,26 & 3,35 & 2,27 \\
\hline 80 & 700 & 190 & 18,14 & 11,32 & 9,20 & 7,57 & 6,46 & 5,59 & 4,26 & 3,36 & 2,28 \\
\hline 80 & 750 & 190 & 17,39 & 11,00 & 9,01 & 7,46 & 6,40 & 5,56 & 4,26 & 3,37 & 2,28 \\
\hline 80 & 800 & 190 & 16,73 & 10,72 & 8,84 & 7,37 & 6,35 & 5,53 & 4,26 & 3,37 & 2,29 \\
\hline 80 & 850 & 190 & 16,14 & 10,45 & 8,68 & 7,27 & 6,29 & 5,50 & 4,25 & 3,38 & 2,30 \\
\hline 80 & 900 & 190 & 15,61 & 10,21 & 8,53 & 7,19 & 6,24 & 5,47 & 4,25 & 3,38 & 2,30 \\
\hline 80 & 950 & 190 & 15,13 & 9,99 & 8,40 & 7,11 & 6,19 & 5,44 & 4,24 & 3,39 & 2,31 \\
\hline 80 & 1000 & 190 & 14,70 & 9,79 & 8,27 & 7,03 & 6,14 & 5,41 & 4,24 & 3,39 & 2,32 \\
\hline 80 & 1050 & 190 & 14,30 & 9,60 & 8,15 & 6,96 & 6,10 & 5,38 & 4,23 & 3,39 & 2,32 \\
\hline 80 & 1100 & 190 & 13,94 & 9,43 & 8,04 & 6,89 & 6,05 & 5,35 & 4,22 & 3,40 & 2,33 \\
\hline 80 & 1150 & 190 & 13,60 & 9,26 & 7,93 & 6,82 & 6,01 & 5,33 & 4,22 & 3,40 & 2,33 \\
\hline 80 & 1200 & 190 & 13,29 & 9,11 & 7,83 & 6,76 & 5,97 & 5,30 & 4,21 & 3,40 & 2,34 \\
\hline 80 & 1250 & 190 & 13,01 & 8,97 & 7,74 & 6,70 & 5,93 & 5,27 & 4,20 & 3,40 & 2,34 \\
\hline 80 & 1300 & 190 & 12,74 & 8,83 & 7,65 & 6,64 & 5,89 & 5,25 & 4,19 & 3,40 & 2,35 \\
\hline 80 & 1350 & 190 & 12,49 & 8,70 & 7,56 & 6,58 & 5,85 & 5,22 & 4,18 & 3,40 & 2,35 \\
\hline 80 & 1400 & 190 & 12,26 & 8,58 & 7,48 & 6,53 & 5,81 & 5,20 & 4,18 & 3,40 & 2,35 \\
\hline 80 & 1450 & 190 & 12,04 & 8,46 & 7,40 & 6,48 & 5,78 & 5,17 & 4,17 & 3,40 & 2,36 \\
\hline 80 & 1500 & 190 & 11,84 & 8,35 & 7,33 & 6,43 & 5,74 & 5,15 & 4,16 & 3,40 & 2,36 \\
\hline 80 & 1550 & 190 & 11,64 & 8,25 & 7,25 & 6,38 & 5,71 & 5,13 & 4,15 & 3,39 & 2,36 \\
\hline 80 & 1600 & 190 & 11,46 & 8,15 & 7,18 & 6,33 & 5,67 & 5,10 & 4,14 & 3,39 & 2,37 \\
\hline 80 & 1650 & 190 & 11,29 & 8,05 & 7,12 & 6,29 & 5,64 & 5,08 & 4,13 & 3,39 & 2,37 \\
\hline 80 & 1700 & 190 & 11,12 & 7,96 & 7,05 & 6,24 & 5,61 & 5,06 & 4,12 & 3,39 & 2,37 \\
\hline 80 & 1750 & 190 & 10,97 & 7,87 & 6,99 & 6,20 & 5,58 & 5,04 & 4,11 & 3,39 & 2,38 \\
\hline 80 & 1800 & 190 & 10,82 & 7,79 & 6,93 & 6,16 & 5,55 & 5,02 & 4,10 & 3,39 & 2,38 \\
\hline 80 & 1850 & 190 & 10,68 & 7,71 & 6,88 & 6,12 & 5,52 & 5,00 & 4,10 & 3,38 & 2,38 \\
\hline 80 & 1900 & 190 & 10,55 & 7,63 & 6,82 & 6,08 & 5,49 & 4,98 & 4,09 & 3,38 & 2,38 \\
\hline 80 & 1950 & 190 & 10,42 & 7,56 & 6,77 & 6,04 & 5,47 & 4,96 & 4,08 & 3,38 & 2,39 \\
\hline 80 & 2000 & 190 & 10,30 & 7,48 & 6,71 & 6,00 & 5,44 & 4,94 & 4,07 & 3,38 & 2,39 \\
\hline 80 & 200 & 195 & 43,65 & 20,46 & 13,75 & 9,43 & 7,17 & 5,73 & 3,98 & 3,06 & 2,15 \\
\hline 80 & 250 & 195 & 36,69 & 18,09 & 12,63 & 9,02 & 7,04 & 5,72 & 4,03 & 3,11 & 2,15 \\
\hline 80 & 300 & 195 & 31,99 & 16,45 & 11,84 & 8,71 & 6,93 & 5,69 & 4,07 & 3,14 & 2,16 \\
\hline 80 & 350 & 195 & 28,59 & 15,24 & 11,24 & 8,46 & 6,83 & 5,67 & 4,10 & 3,17 & 2,16 \\
\hline 80 & 400 & 195 & 26,01 & 14,30 & 10,75 & 8,25 & 6,74 & 5,64 & 4,12 & 3,19 & 2,17 \\
\hline 80 & 450 & 195 & 23,97 & 13,54 & 10,35 & 8,07 & 6,66 & 5,61 & 4,13 & 3,21 & 2,18 \\
\hline 80 & 500 & 195 & 22,32 & 12,90 & 10,02 & 7,91 & 6,58 & 5,58 & 4,14 & 3,23 & 2,19 \\
\hline 80 & 550 & 195 & 20,96 & 12,37 & 9,72 & 7,77 & 6,51 & 5,55 & 4,15 & 3,24 & 2,19 \\
\hline 80 & 600 & 195 & 19,80 & 11,91 & 9,47 & 7,64 & 6,44 & 5,52 & 4,15 & 3,25 & 2,20 \\
\hline 80 & 650 & 195 & 18,82 & 11,51 & 9,24 & 7,52 & 6,38 & 5,49 & 4,15 & 3,26 & 2,21 \\
\hline 80 & 700 & 195 & 17,97 & 11,16 & 9,03 & 7,41 & 6,32 & 5,46 & 4,15 & 3,27 & 2,22 \\
\hline 80 & 750 & 195 & 17,22 & 10,84 & 8,85 & 7,31 & 6,26 & 5,43 & 4,15 & 3,28 & 2,22 \\
\hline 80 & 800 & 195 & 16,56 & 10,55 & 8,68 & 7,22 & 6,21 & 5,40 & 4,15 & 3,28 & 2,23 \\
\hline 80 & 850 & 195 & 15,97 & 10,29 & 8,52 & 7,13 & 6,15 & 5,37 & 4,15 & 3,29 & 2,24 \\
\hline 80 & 900 & 195 & 15,44 & 10,06 & 8,38 & 7,04 & 6,10 & 5,34 & 4,14 & 3,30 & 2,24 \\
\hline 80 & 950 & 195 & 14,97 & 9,84 & 8,25 & 6,96 & 6,06 & 5,31 & 4,14 & 3,30 & 2,25 \\
\hline
\end{tabular}




\begin{tabular}{|c|c|c|c|c|c|c|c|c|c|c|c|}
\hline \multirow[b]{2}{*}{$\mathrm{H}(\mathrm{cm})$} & \multirow[b]{2}{*}{ Mceq (MPa) } & & & & & De & ões (x1 & m) & & & \\
\hline & & Msub (MPa) & D0 & D25 & D40 & D60 & D80 & D100 & D140 & D180 & D260 \\
\hline 80 & 1000 & 195 & 14,53 & 9,64 & 8,12 & 6,89 & 6,01 & 5,28 & 4,13 & 3,30 & 2,25 \\
\hline 80 & 1050 & 195 & 14,14 & 9,45 & 8,00 & 6,82 & 5,96 & 5,26 & 4,13 & 3,31 & 2,26 \\
\hline 80 & 1100 & 195 & 13,78 & 9,28 & 7,89 & 6,75 & 5,92 & 5,23 & 4,12 & 3,31 & 2,26 \\
\hline 80 & 1150 & 195 & 13,44 & 9,12 & 7,79 & 6,68 & 5,88 & 5,20 & 4,11 & 3,31 & 2,27 \\
\hline 80 & 1200 & 195 & 13,14 & 8,97 & 7,69 & 6,62 & 5,84 & 5,18 & 4,10 & 3,31 & 2,27 \\
\hline 80 & 1250 & 195 & 12,85 & 8,82 & 7,60 & 6,56 & 5,80 & 5,15 & 4,10 & 3,31 & 2,28 \\
\hline 80 & 1300 & 195 & 12,59 & 8,69 & 7,51 & 6,51 & 5,76 & 5,13 & 4,09 & 3,31 & 2,28 \\
\hline 80 & 1350 & 195 & 12,34 & 8,56 & 7,42 & 6,45 & 5,72 & 5,10 & 4,08 & 3,31 & 2,29 \\
\hline 80 & 1400 & 195 & 12,11 & 8,44 & 7,34 & 6,40 & 5,69 & 5,08 & 4,07 & 3,31 & 2,29 \\
\hline 80 & 1450 & 195 & 11,89 & 8,33 & 7,27 & 6,35 & 5,65 & 5,06 & 4,07 & 3,31 & 2,29 \\
\hline 80 & 1500 & 195 & 11,69 & 8,22 & 7,19 & 6,30 & 5,62 & 5,04 & 4,06 & 3,31 & 2,30 \\
\hline 80 & 1550 & 195 & 11,49 & 8,12 & 7,12 & 6,25 & 5,59 & 5,01 & 4,05 & 3,31 & 2,30 \\
\hline 80 & 1600 & 195 & 11,31 & 8,02 & 7,06 & 6,21 & 5,56 & 4,99 & 4,04 & 3,31 & 2,30 \\
\hline 80 & 1650 & 195 & 11,14 & 7,92 & 6,99 & 6,16 & 5,52 & 4,97 & 4,03 & 3,31 & 2,31 \\
\hline 80 & 1700 & 195 & 10,98 & 7,83 & 6,93 & 6,12 & 5,49 & 4,95 & 4,02 & 3,30 & 2,31 \\
\hline 80 & 1750 & 195 & 10,82 & 7,75 & 6,87 & 6,08 & 5,46 & 4,93 & 4,02 & 3,30 & 2,31 \\
\hline 80 & 1800 & 195 & 10,68 & 7,66 & 6,81 & 6,04 & 5,44 & 4,91 & 4,01 & 3,30 & 2,32 \\
\hline 80 & 1850 & 195 & 10,54 & 7,59 & 6,75 & 6,00 & 5,41 & 4,89 & 4,00 & 3,30 & 2,32 \\
\hline 80 & 1900 & 195 & 10,40 & 7,51 & 6,70 & 5,96 & 5,38 & 4,87 & 3,99 & 3,30 & 2,32 \\
\hline 80 & 1950 & 195 & 10,28 & 7,44 & 6,65 & 5,92 & 5,35 & 4,85 & 3,98 & 3,29 & 2,32 \\
\hline 80 & 2000 & 195 & 10,15 & 7,36 & 6,59 & 5,89 & 5,33 & 4,83 & 3,97 & 3,29 & 2,33 \\
\hline 80 & 200 & 200 & 43,42 & 20,24 & 13,54 & 9,24 & 7,00 & 5,58 & 3,87 & 2,98 & 2,09 \\
\hline 80 & 250 & 200 & 36,48 & 17,88 & 12,43 & 8,84 & 6,87 & 5,57 & 3,93 & 3,03 & 2,10 \\
\hline 80 & 300 & 200 & 31,79 & 16,25 & 11,65 & 8,54 & 6,77 & 5,56 & 3,96 & 3,06 & 2,10 \\
\hline 80 & 350 & 200 & 28,39 & 15,04 & 11,05 & 8,29 & 6,67 & 5,53 & 3,99 & 3,08 & 2,11 \\
\hline 80 & 400 & 200 & 25,81 & 14,11 & 10,57 & 8,09 & 6,59 & 5,51 & 4,01 & 3,11 & 2,11 \\
\hline 80 & 450 & 200 & 23,78 & 13,35 & 10,18 & 7,91 & 6,51 & 5,48 & 4,03 & 3,13 & 2,12 \\
\hline 80 & 500 & 200 & 22,14 & 12,73 & 9,84 & 7,75 & 6,43 & 5,45 & 4,04 & 3,14 & 2,13 \\
\hline 80 & 550 & 200 & 20,77 & 12,20 & 9,56 & 7,61 & 6,37 & 5,42 & 4,04 & 3,16 & 2,14 \\
\hline 80 & 600 & 200 & 19,63 & 11,74 & 9,30 & 7,49 & 6,30 & 5,39 & 4,05 & 3,17 & 2,14 \\
\hline 80 & 650 & 200 & 18,65 & 11,34 & 9,08 & 7,37 & 6,24 & 5,36 & 4,05 & 3,18 & 2,15 \\
\hline 80 & 700 & 200 & 17,80 & 10,99 & 8,88 & 7,26 & 6,18 & 5,33 & 4,05 & 3,19 & 2,16 \\
\hline 80 & 750 & 200 & 17,05 & 10,68 & 8,69 & 7,16 & 6,13 & 5,30 & 4,05 & 3,19 & 2,16 \\
\hline 80 & 800 & 200 & 16,39 & 10,40 & 8,53 & 7,07 & 6,07 & 5,27 & 4,05 & 3,20 & 2,17 \\
\hline 80 & 850 & 200 & 15,81 & 10,14 & 8,37 & 6,98 & 6,02 & 5,25 & 4,04 & 3,21 & 2,18 \\
\hline 80 & 900 & 200 & 15,28 & 9,91 & 8,23 & 6,90 & 5,97 & 5,22 & 4,04 & 3,21 & 2,18 \\
\hline 80 & 950 & 200 & 14,81 & 9,69 & 8,10 & 6,83 & 5,93 & 5,19 & 4,04 & 3,21 & 2,19 \\
\hline 80 & 1000 & 200 & 14,38 & 9,49 & 7,98 & 6,75 & 5,88 & 5,17 & 4,03 & 3,22 & 2,19 \\
\hline 80 & 1050 & 200 & 13,98 & 9,31 & 7,86 & 6,68 & 5,84 & 5,14 & 4,03 & 3,22 & 2,20 \\
\hline 80 & 1100 & 200 & 13,62 & 9,14 & 7,75 & 6,62 & 5,80 & 5,11 & 4,02 & 3,22 & 2,20 \\
\hline 80 & 1150 & 200 & 13,29 & 8,98 & 7,65 & 6,55 & 5,76 & 5,09 & 4,01 & 3,23 & 2,21 \\
\hline 80 & 1200 & 200 & 12,98 & 8,83 & 7,56 & 6,49 & 5,72 & 5,06 & 4,01 & 3,23 & 2,21 \\
\hline 80 & 1250 & 200 & 12,70 & 8,69 & 7,46 & 6,44 & 5,68 & 5,04 & 4,00 & 3,23 & 2,22 \\
\hline 80 & 1300 & 200 & 12,44 & 8,56 & 7,38 & 6,38 & 5,64 & 5,02 & 3,99 & 3,23 & 2,22 \\
\hline 80 & 1350 & 200 & 12,19 & 8,43 & 7,29 & 6,33 & 5,61 & 4,99 & 3,99 & 3,23 & 2,23 \\
\hline 80 & 1400 & 200 & 11,96 & 8,31 & 7,22 & 6,27 & 5,57 & 4,97 & 3,98 & 3,23 & 2,23 \\
\hline 80 & 1450 & 200 & 11,74 & 8,20 & 7,14 & 6,23 & 5,54 & 4,95 & 3,97 & 3,23 & 2,23 \\
\hline 80 & 1500 & 200 & 11,54 & 8,09 & 7,07 & 6,18 & 5,50 & 4,93 & 3,96 & 3,23 & 2,24 \\
\hline 80 & 1550 & 200 & 11,35 & 7,99 & 7,00 & 6,13 & 5,47 & 4,90 & 3,95 & 3,23 & 2,24 \\
\hline 80 & 1600 & 200 & 11,17 & 7,89 & 6,93 & 6,09 & 5,44 & 4,88 & 3,95 & 3,23 & 2,24 \\
\hline 80 & 1650 & 200 & 11,00 & 7,80 & 6,87 & 6,04 & 5,41 & 4,86 & 3,94 & 3,22 & 2,25 \\
\hline 80 & 1700 & 200 & 10,84 & 7,71 & 6,81 & 6,00 & 5,38 & 4,84 & 3,93 & 3,22 & 2,25 \\
\hline 80 & 1750 & 200 & 10,68 & 7,63 & 6,75 & 5,96 & 5,35 & 4,82 & 3,92 & 3,22 & 2,25 \\
\hline 80 & 1800 & 200 & 10,54 & 7,55 & 6,69 & 5,92 & 5,32 & 4,80 & 3,91 & 3,22 & 2,26 \\
\hline 80 & 1850 & 200 & 10,40 & 7,47 & 6,63 & 5,88 & 5,30 & 4,78 & 3,91 & 3,22 & 2,26 \\
\hline 80 & 1900 & 200 & 10,27 & 7,39 & 6,58 & 5,85 & 5,27 & 4,76 & 3,90 & 3,22 & 2,26 \\
\hline 80 & 1950 & 200 & 10,14 & 7,32 & 6,53 & 5,81 & 5,24 & 4,75 & 3,89 & 3,21 & 2,26 \\
\hline 80 & 2000 & 200 & 10,02 & 7,25 & 6,48 & 5,78 & 5,22 & 4,73 & 3,88 & 3,21 & 2,26 \\
\hline 85 & 200 & 20 & 97,64 & 69,51 & 62,04 & 55,46 & 50,33 & 45,83 & 38,05 & 31,78 & 22,72 \\
\hline 85 & 250 & 20 & 87,96 & 63,79 & 57,79 & 52,40 & 48,02 & 44,10 & 37,17 & 31,43 & 22,84 \\
\hline 85 & 300 & 20 & 81,10 & 59,56 & 54,50 & 49,95 & 46,11 & 42,63 & 36,36 & 31,05 & 22,89 \\
\hline 85 & 350 & 20 & 75,89 & 56,28 & 51,84 & 47,93 & 44,50 & 41,35 & 35,61 & 30,66 & 22,89 \\
\hline 85 & 400 & 20 & 71,74 & 53,64 & 49,62 & 46,21 & 43,12 & 40,23 & 34,92 & 30,28 & 22,85 \\
\hline 85 & 450 & 20 & 68,32 & 51,46 & 47,72 & 44,72 & 41,90 & 39,23 & 34,29 & 29,91 & 22,80 \\
\hline 85 & 500 & 20 & 65,42 & 49,62 & 46,08 & 43,41 & 40,82 & 38,34 & 33,70 & 29,56 & 22,73 \\
\hline 85 & 550 & 20 & 62,90 & 48,04 & 44,65 & 42,24 & 39,85 & 37,53 & 33,16 & 29,22 & 22,65 \\
\hline 85 & 600 & 20 & 60,69 & 46,68 & 43,37 & 41,18 & 38,97 & 36,79 & 32,65 & 28,90 & 22,56 \\
\hline 85 & 650 & 20 & 58,72 & 45,48 & 42,23 & 40,23 & 38,17 & 36,10 & 32,18 & 28,58 & 22,46 \\
\hline 85 & 700 & 20 & 56,93 & 44,41 & 41,20 & 39,36 & 37,43 & 35,48 & 31,73 & 28,29 & 22,36 \\
\hline 85 & 750 & 20 & 55,31 & 43,46 & 40,26 & 38,55 & 36,75 & 34,89 & 31,31 & 28,00 & 22,26 \\
\hline 85 & 800 & 20 & 53,82 & 42,60 & 39,41 & 37,81 & 36,12 & 34,35 & 30,92 & 27,73 & 22,16 \\
\hline 85 & 850 & 20 & 52,44 & 41,82 & 38,63 & 37,12 & 35,53 & 33,84 & 30,55 & 27,47 & $\frac{2 c,+06}{22,06}$ \\
\hline 85 & 900 & 20 & 51,16 & 41,11 & 37,90 & 36,48 & 34,98 & 33,36 & 30,19 & 27,22 & 21,96 \\
\hline 85 & 950 & 20 & 49,96 & 40,45 & 37,24 & 35,87 & 34,47 & 32,91 & 29,86 & 26,98 & 21,85 \\
\hline 85 & 1000 & 20 & 48,84 & 39,85 & 36,62 & 35,31 & 33,98 & 32,49 & 29,54 & 26,74 & 21,75 \\
\hline 85 & 1050 & 20 & 47,78 & 39,29 & 36,04 & 34,78 & 33,52 & 32,09 & 29,23 & 26,52 & 21,65 \\
\hline 85 & 1100 & 20 & 46,78 & 38,77 & 35,50 & 34,27 & 33,08 & 31,71 & 28,94 & 26,31 & 21,55 \\
\hline 85 & 1150 & 20 & 45,83 & 38,28 & 35,00 & 33,80 & 32,67 & 31,34 & 28,66 & 26,10 & 21,45 \\
\hline 85 & 1200 & 20 & 44,94 & 37,83 & 34,52 & 33,35 & 32,28 & 31,00 & 28,39 & 25,90 & 21,36 \\
\hline 85 & 1250 & 20 & 44,08 & 37,40 & 34,08 & 32,92 & 31,90 & 30,67 & 28,13 & 25,70 & 21,26 \\
\hline 85 & 1300 & 20 & 43,26 & 37,00 & 33,66 & 32,51 & 31,54 & 30,35 & 27,89 & 25,52 & 21,17 \\
\hline
\end{tabular}




\begin{tabular}{|c|c|c|c|c|c|c|c|c|c|c|c|}
\hline \multirow[b]{2}{*}{$\mathrm{H}(\mathrm{cm})$} & \multirow[b]{2}{*}{ Mceq (MPa) } & & & & & De & ões (x1 & m) & & & \\
\hline & & Msub (MPa) & D0 & D25 & D40 & D60 & D80 & D100 & D140 & D180 & D260 \\
\hline 85 & 1350 & 20 & 42,48 & 36,62 & 33,26 & 32,12 & 31,20 & 30,05 & 27,65 & 25,34 & 21,07 \\
\hline 85 & 1400 & 20 & 41,74 & 36,25 & 32,88 & 31,75 & 30,87 & 29,76 & 27,42 & 25,16 & 20,98 \\
\hline 85 & 1450 & 20 & 41,02 & 35,91 & 32,53 & 31,39 & 30,56 & 29,48 & 27,20 & 24,99 & 20,89 \\
\hline 85 & 1500 & 20 & 40,33 & 35,58 & 32,19 & 31,05 & 30,25 & 29,21 & 26,99 & 24,82 & 20,81 \\
\hline 85 & 1550 & 20 & 39,67 & 35,27 & 31,86 & 30,73 & 29,96 & 28,96 & 26,78 & 24,66 & 20,72 \\
\hline 85 & 1600 & 20 & 39,04 & 34,97 & 31,56 & 30,41 & 29,68 & 28,71 & 26,58 & 24,51 & 20,63 \\
\hline 85 & 1650 & 20 & 38,42 & 34,69 & 31,26 & 30,11 & 29,41 & 28,47 & 26,39 & 24,36 & 20,55 \\
\hline 85 & 1700 & 20 & 37,83 & 34,42 & 30,98 & 29,82 & 29,15 & 28,23 & 26,20 & 24,21 & 20,47 \\
\hline 85 & 1750 & 20 & 37,26 & 34,15 & 30,71 & 29,54 & 28,90 & 28,01 & 26,02 & 24,07 & 20,39 \\
\hline 85 & 1800 & 20 & 36,71 & 33,90 & 30,46 & 29,28 & 28,66 & 27,79 & 25,85 & 23,93 & 20,31 \\
\hline 85 & 1850 & 20 & 36,18 & 33,66 & 30,21 & 29,02 & 28,42 & 27,58 & 25,68 & 23,79 & 20,23 \\
\hline 85 & 1900 & 20 & 35,66 & 33,42 & 29,97 & 28,77 & 28,19 & 27,38 & 25,51 & 23,66 & 20,15 \\
\hline 85 & 1950 & 20 & 35,16 & 33,20 & 29,75 & 28,52 & 27,97 & 27,18 & 25,35 & 23,53 & 20,07 \\
\hline 85 & 2000 & 20 & 34,67 & 32,98 & 29,53 & 28,29 & 27,75 & 26,99 & 25,19 & 23,40 & 20,00 \\
\hline 85 & 200 & 25 & 87,26 & 60,70 & 53,24 & 46,87 & 42,09 & 37,98 & 31,03 & 25,61 & 18,04 \\
\hline 85 & 250 & 25 & 78,11 & 55,60 & 49,63 & 44,36 & 40,26 & 36,67 & 30,44 & 25,43 & 18,18 \\
\hline 85 & 300 & 25 & 71,70 & 51,83 & 46,84 & 42,36 & 38,75 & 35,54 & 29,87 & 25,20 & 18,26 \\
\hline 85 & 350 & 25 & 66,88 & 48,89 & 44,58 & 40,70 & 37,47 & 34,55 & 29,34 & 24,96 & 18,30 \\
\hline 85 & 400 & 25 & 63,09 & 46,52 & 42,70 & 39,28 & 36,35 & 33,68 & 28,84 & 24,71 & 18,31 \\
\hline 85 & 450 & 25 & 59,99 & 44,56 & 41,09 & 38,05 & 35,37 & 32,89 & 28,37 & 24,47 & 18,31 \\
\hline 85 & 500 & 25 & 57,40 & 42,91 & 39,69 & 36,97 & 34,49 & 32,18 & 27,94 & 24,23 & 18,28 \\
\hline 85 & 550 & 25 & 55,17 & 41,49 & 38,46 & 36,00 & 33,70 & 31,54 & 27,53 & 23,99 & 18,25 \\
\hline 85 & 600 & 25 & 53,22 & 40,25 & 37,37 & 35,13 & 32,99 & 30,95 & 27,15 & 23,76 & 18,21 \\
\hline 85 & 650 & 25 & 51,50 & 39,17 & 36,39 & 34,34 & 32,33 & 30,40 & 26,78 & 23,54 & 18,16 \\
\hline 85 & 700 & 25 & 49,95 & 38,21 & 35,50 & 33,61 & 31,73 & 29,90 & 26,44 & 23,32 & 18,10 \\
\hline 85 & 750 & 25 & 48,55 & 37,34 & 34,70 & 32,95 & 31,17 & 29,43 & 26,12 & 23,12 & 18,05 \\
\hline 85 & 800 & 25 & 47,28 & 36,56 & 33,96 & 32,33 & 30,66 & 28,99 & 25,82 & 22,92 & 17,98 \\
\hline 85 & 850 & 25 & 46,10 & 35,86 & 33,28 & 31,76 & 30,17 & 28,58 & 25,53 & 22,72 & 17,92 \\
\hline 85 & 900 & 25 & 45,01 & 35,21 & 32,65 & 31,22 & 29,72 & 28,19 & 25,25 & 22,54 & 17,86 \\
\hline 85 & 950 & 25 & 44,00 & 34,62 & 32,07 & 30,72 & 29,30 & 27,83 & 24,99 & 22,36 & 17,79 \\
\hline 85 & 1000 & 25 & 43,05 & 34,08 & 31,53 & 30,25 & 28,90 & 27,48 & 24,74 & 22,18 & 17,73 \\
\hline 85 & 1050 & 25 & 42,16 & 33,58 & 31,02 & 29,80 & 28,52 & 27,15 & 24,50 & 22,02 & 17,66 \\
\hline 85 & 1100 & 25 & 41,33 & 33,11 & 30,55 & 29,38 & 28,16 & 26,84 & 24,27 & 21,85 & 17,60 \\
\hline 85 & 1150 & 25 & 40,53 & 32,67 & 30,11 & 28,98 & 27,82 & 26,54 & 24,04 & 21,70 & 17,53 \\
\hline 85 & 1200 & 25 & 39,78 & 32,26 & 29,69 & 28,61 & 27,49 & 26,26 & 23,83 & 21,54 & 17,47 \\
\hline 85 & 1250 & 25 & 39,07 & 31,88 & 29,29 & 28,25 & 27,18 & 25,99 & 23,63 & 21,40 & 17,40 \\
\hline 85 & 1300 & 25 & 38,39 & 31,52 & 28,92 & 27,90 & 26,89 & 25,73 & 23,43 & 21,25 & 17,34 \\
\hline 85 & 1350 & 25 & 37,74 & 31,18 & 28,57 & 27,58 & 26,60 & 25,49 & 23,24 & 21,11 & 17,27 \\
\hline 85 & 1400 & 25 & 37,12 & 30,86 & 28,24 & 27,26 & 26,33 & 25,25 & 23,06 & 20,98 & 17,21 \\
\hline 85 & 1450 & 25 & 36,52 & 30,55 & 27,92 & 26,96 & 26,07 & 25,02 & 22,88 & 20,85 & 17,15 \\
\hline 85 & 1500 & 25 & 35,95 & 30,26 & 27,62 & 26,68 & 25,82 & 24,80 & 22,71 & 20,72 & 17,09 \\
\hline 85 & 1550 & 25 & 35,40 & 29,99 & 27,33 & 26,40 & 25,58 & 24,59 & 22,55 & 20,59 & 17,02 \\
\hline 85 & 1600 & 25 & 34,87 & 29,72 & 27,06 & 26,14 & 25,35 & 24,38 & 22,39 & 20,47 & 16,96 \\
\hline 85 & 1650 & 25 & 34,36 & 29,47 & 26,80 & 25,88 & 25,12 & 24,18 & 22,23 & 20,35 & 16,90 \\
\hline 85 & 1700 & 25 & 33,87 & 29,23 & 26,55 & 25,64 & 24,91 & 23,99 & 22,08 & 20,24 & 16,85 \\
\hline 85 & 1750 & 25 & 33,39 & 29,00 & 26,31 & 25,40 & 24,70 & 23,81 & 21,94 & 20,13 & 16,79 \\
\hline 85 & 1800 & 25 & 32,93 & 28,78 & 26,08 & 25,17 & 24,50 & 23,63 & 21,79 & 20,02 & 16,73 \\
\hline 85 & 1850 & 25 & 32,48 & 28,57 & 25,86 & 24,95 & 24,30 & 23,46 & 21,66 & 19,91 & 16,67 \\
\hline 85 & 1900 & 25 & 32,05 & 28,37 & 25,64 & 24,74 & 24,11 & 23,29 & 21,52 & 19,81 & 16,62 \\
\hline 85 & 1950 & 25 & 31,64 & 28,17 & 25,44 & 24,53 & 23,93 & 23,12 & 21,39 & 19,71 & 16,56 \\
\hline 85 & 2000 & 25 & 31,23 & 27,98 & 25,24 & 24,33 & 23,75 & 22,97 & 21,27 & 19,61 & 16,51 \\
\hline 85 & 200 & 30 & 80,02 & 54,42 & 46,97 & 40,79 & 36,29 & 32,48 & 26,19 & 21,40 & 14,93 \\
\hline 85 & 250 & 30 & 71,22 & 49,77 & 43,80 & 38,67 & 34,80 & 31,45 & 25,78 & 21,32 & 15,06 \\
\hline 85 & 300 & 30 & 65,09 & 46,34 & 41,36 & 36,97 & 33,55 & 30,55 & 25,37 & 21,19 & 15,15 \\
\hline 85 & 350 & 30 & 60,53 & 43,66 & 39,39 & 35,56 & 32,49 & 29,76 & 24,97 & 21,03 & 15,21 \\
\hline 85 & 400 & 30 & 56,96 & 41,50 & 37,74 & 34,35 & 31,56 & 29,05 & 24,59 & 20,87 & 15,24 \\
\hline 85 & 450 & 30 & 54,07 & 39,71 & 36,33 & 33,30 & 30,74 & 28,42 & 24,24 & 20,70 & 15,26 \\
\hline 85 & 500 & 30 & 51,66 & 38,19 & 35,11 & 32,38 & 30,01 & 27,84 & 23,90 & 20,53 & 15,26 \\
\hline 85 & 550 & 30 & 49,61 & 36,89 & 34,04 & 31,55 & 29,35 & 27,31 & 23,58 & 20,36 & 15,25 \\
\hline 85 & 600 & 30 & 47,83 & 35,76 & 33,08 & 30,81 & 28,74 & 26,82 & 23,28 & 20,19 & 15,24 \\
\hline 85 & 650 & 30 & 46,26 & 34,76 & 32,22 & 30,13 & 28,19 & 26,37 & 23,00 & 20,02 & 15,21 \\
\hline 85 & 700 & 30 & 44,87 & 33,87 & 31,43 & 29,51 & 27,68 & 25,95 & 22,73 & 19,86 & 15,18 \\
\hline 85 & 750 & 30 & 43,61 & 33,08 & 30,72 & 28,94 & 27,21 & 25,56 & 22,47 & 19,71 & 15,15 \\
\hline 85 & 800 & 30 & 42,47 & 32,36 & 30,07 & 28,41 & 26,77 & 25,19 & 22,22 & 19,55 & 15,12 \\
\hline 85 & 850 & 30 & 41,42 & 31,71 & 29,47 & 27,92 & 26,36 & 24,85 & 21,99 & 19,41 & 15,08 \\
\hline 85 & 900 & 30 & 40,46 & 31,12 & 28,91 & 27,46 & 25,98 & 24,52 & 21,77 & 19,26 & 15,04 \\
\hline 85 & 950 & 30 & 39,57 & 30,57 & 28,40 & 27,03 & 25,62 & 24,22 & 21,55 & 19,12 & 15,00 \\
\hline 85 & 1000 & 30 & 38,74 & 30,07 & 27,92 & 26,62 & 25,28 & 23,93 & 21,35 & 18,99 & 14,95 \\
\hline 85 & 1050 & 30 & 37,96 & 29,61 & 27,46 & 26,24 & 24,95 & 23,65 & 21,16 & 18,86 & 14,91 \\
\hline 85 & 1100 & 30 & 37,22 & 29,18 & 27,04 & 25,88 & 24,65 & 23,39 & 20,97 & 18,73 & 14,86 \\
\hline 85 & 1150 & 30 & 36,53 & 28,78 & 26,65 & 25,53 & 24,36 & 23,14 & 20,79 & 18,61 & 14,82 \\
\hline 85 & 1200 & 30 & 35,88 & 28,40 & 26,27 & 25,21 & 24,08 & 22,90 & 20,61 & 18,49 & 14,77 \\
\hline 85 & 1250 & 30 & 35,26 & 28,05 & 25,92 & 24,90 & 23,82 & 22,67 & 20,45 & 18,37 & 14,73 \\
\hline 85 & 1300 & 30 & 34,67 & 27,72 & 25,59 & 24,60 & 23,56 & 22,45 & 20,28 & 18,26 & 14,68 \\
\hline 85 & 1350 & 30 & 34,10 & 27,40 & 25,27 & 24,32 & 23,32 & 22,24 & 20,13 & 18,14 & 14,64 \\
\hline 85 & 1400 & 30 & 33,57 & 27,11 & 24,97 & 24,05 & 23,09 & 22,04 & 19,98 & 18,04 & 14,59 \\
\hline 85 & 1450 & 30 & 33,05 & 26,83 & 24,68 & 23,79 & 22,87 & 21,85 & 19,83 & 17,93 & 14,55 \\
\hline 85 & 1500 & 30 & 32,56 & 26,57 & 24,41 & 23,54 & 22,65 & 21,66 & 19,69 & 17,83 & 14,50 \\
\hline 85 & 1550 & 30 & 32,08 & 26,31 & 24,15 & 23,30 & 22,45 & 21,48 & 19,55 & 17,73 & 14,46 \\
\hline 85 & 1600 & 30 & 31,63 & 26,07 & 23,90 & 23,07 & 22,25 & 21,31 & 19,42 & 17,63 & 14,41 \\
\hline 85 & 1650 & 30 & 31,19 & 25,85 & 23,67 & 22,85 & 22,06 & 21,14 & 19,29 & 17,54 & 14,37 \\
\hline
\end{tabular}




\begin{tabular}{|c|c|c|c|c|c|c|c|c|c|c|c|}
\hline \multirow[b]{2}{*}{$\mathrm{H}(\mathrm{cm})$} & \multirow[b]{2}{*}{ Mceq (MPa) } & & & & & De & ões (x1 & m) & & & \\
\hline & & Msub (MPa) & D0 & D25 & D40 & D60 & D80 & D100 & D140 & D180 & D260 \\
\hline 85 & 1700 & 30 & 30,76 & 25,63 & 23,44 & 22,64 & 21,87 & 20,97 & 19,17 & 17,44 & 14,32 \\
\hline 85 & 1750 & 30 & 30,35 & 25,42 & 23,22 & 22,43 & 21,69 & 20,82 & 19,05 & 17,35 & 14,28 \\
\hline 85 & 1800 & 30 & 29,96 & 25,22 & 23,02 & 22,23 & 21,52 & 20,67 & 18,93 & 17,27 & 14,24 \\
\hline 85 & 1850 & 30 & 29,57 & 25,03 & 22,82 & 22,04 & 21,35 & 20,52 & 18,81 & 17,18 & 14,20 \\
\hline 85 & 1900 & 30 & 29,20 & 24,84 & 22,62 & 21,85 & 21,19 & 20,37 & 18,70 & 17,09 & 14,15 \\
\hline 85 & 1950 & 30 & 28,84 & 24,66 & 22,44 & 21,67 & 21,03 & 20,23 & 18,59 & 17,01 & 14,11 \\
\hline 85 & 2000 & 30 & 28,49 & 24,49 & 22,26 & 21,50 & 20,88 & 20,10 & 18,49 & 16,93 & 14,07 \\
\hline 85 & 200 & 35 & 74,65 & 49,67 & 42,24 & 36,24 & 31,96 & 28,41 & 22,64 & 18,36 & 12,71 \\
\hline 85 & 250 & 35 & 66,11 & 45,37 & 39,40 & 34,40 & 30,71 & 27,58 & 22,35 & 18,33 & 12,83 \\
\hline 85 & 300 & 35 & 60,19 & 42,19 & 37,22 & 32,92 & 29,66 & 26,84 & 22,04 & 18,26 & 12,92 \\
\hline 85 & 350 & 35 & 55,79 & 39,72 & 35,45 & 31,69 & 28,76 & 26,19 & 21,74 & 18,16 & 12,99 \\
\hline 85 & 400 & 35 & 52,38 & 37,72 & 33,98 & 30,64 & 27,97 & 25,60 & 21,45 & 18,05 & 13,03 \\
\hline 85 & 450 & 35 & 49,63 & 36,06 & 32,73 & 29,72 & 27,27 & 25,07 & 21,17 & 17,93 & 13,06 \\
\hline 85 & 500 & 35 & 47,35 & 34,66 & 31,64 & 28,92 & 26,64 & 24,59 & 20,90 & 17,80 & 13,07 \\
\hline 85 & 550 & 35 & 45,42 & 33,45 & 30,68 & 28,19 & 26,07 & 24,14 & 20,65 & 17,68 & 13,08 \\
\hline 85 & 600 & 35 & 43,75 & 32,40 & 29,82 & 27,54 & 25,55 & 23,73 & 20,41 & 17,55 & 13,08 \\
\hline 85 & 650 & 35 & 42,29 & 31,47 & 29,05 & 26,95 & 25,08 & 23,34 & 20,18 & 17,43 & 13,07 \\
\hline 85 & 700 & 35 & 41,00 & 30,65 & 28,35 & 26,41 & 24,64 & 22,99 & 19,96 & 17,30 & 13,06 \\
\hline 85 & 750 & 35 & 39,84 & 29,91 & 27,71 & 25,90 & 24,23 & 22,66 & 19,74 & 17,18 & 13,04 \\
\hline 85 & 800 & 35 & 38,79 & 29,24 & 27,13 & 25,44 & 23,85 & 22,34 & 19,54 & 17,06 & 13,02 \\
\hline 85 & 850 & 35 & 37,83 & 28,64 & 26,59 & 25,01 & 23,49 & 22,05 & 19,35 & 16,95 & 13,00 \\
\hline 85 & 900 & 35 & 36,95 & 28,08 & 26,09 & 24,61 & 23,16 & 21,77 & 19,17 & 16,84 & 12,97 \\
\hline 85 & 950 & 35 & 36,14 & 27,57 & 25,62 & 24,23 & 22,85 & 21,51 & 18,99 & 16,72 & 12,95 \\
\hline 85 & 1000 & 35 & 35,39 & 27,11 & 25,19 & 23,87 & 22,55 & 21,26 & 18,82 & 16,62 & 12,92 \\
\hline 85 & 1050 & 35 & 34,68 & 26,67 & 24,78 & 23,53 & 22,27 & 21,02 & 18,66 & 16,51 & 12,89 \\
\hline 85 & 1100 & 35 & 34,02 & 26,27 & 24,40 & 23,22 & 22,00 & 20,79 & 18,50 & 16,41 & 12,86 \\
\hline 85 & 1150 & 35 & 33,40 & 25,90 & 24,04 & 22,91 & 21,75 & 20,58 & 18,35 & 16,31 & 12,83 \\
\hline 85 & 1200 & 35 & 32,81 & 25,55 & 23,70 & 22,63 & 21,51 & 20,37 & 18,20 & 16,21 & 12,80 \\
\hline 85 & 1250 & 35 & 32,26 & 25,22 & 23,38 & 22,35 & 21,27 & 20,17 & 18,06 & 16,12 & 12,76 \\
\hline 85 & 1300 & 35 & 31,73 & 24,91 & 23,08 & 22,09 & 21,05 & 19,99 & 17,93 & 16,02 & 12,73 \\
\hline 85 & 1350 & 35 & 31,23 & 24,62 & 22,79 & 21,84 & 20,84 & 19,80 & 17,80 & 15,93 & 12,70 \\
\hline 85 & 1400 & 35 & 30,75 & 24,34 & 22,52 & 21,61 & 20,64 & 19,63 & 17,67 & 15,85 & 12,66 \\
\hline 85 & 1450 & 35 & 30,30 & 24,08 & 22,26 & 21,38 & 20,45 & 19,46 & 17,55 & 15,76 & 12,63 \\
\hline 85 & 1500 & 35 & 29,86 & 23,84 & 22,01 & 21,16 & 20,26 & 19,30 & 17,43 & 15,68 & 12,60 \\
\hline 85 & 1550 & 35 & 29,44 & 23,60 & 21,77 & 20,95 & 20,08 & 19,14 & 17,31 & 15,59 & 12,56 \\
\hline 85 & 1600 & 35 & 29,03 & 23,38 & 21,55 & 20,74 & 19,90 & 18,99 & 17,20 & 15,51 & 12,53 \\
\hline 85 & 1650 & 35 & 28,64 & 23,17 & 21,33 & 20,55 & 19,74 & 18,84 & 17,09 & 15,43 & 12,50 \\
\hline 85 & 1700 & 35 & 28,27 & 22,96 & 21,12 & 20,36 & 19,57 & 18,70 & 16,98 & 15,36 & 12,46 \\
\hline 85 & 1750 & 35 & 27,91 & 22,77 & 20,92 & 20,18 & 19,42 & 18,57 & 16,88 & 15,28 & 12,43 \\
\hline 85 & 1800 & 35 & 27,56 & 22,59 & 20,73 & 20,00 & 19,26 & 18,43 & 16,78 & 15,21 & 12,40 \\
\hline 85 & 1850 & 35 & 27,22 & 22,41 & 20,55 & 19,83 & 19,12 & 18,30 & 16,68 & 15,14 & 12,36 \\
\hline 85 & 1900 & 35 & 26,89 & 22,24 & 20,37 & 19,66 & 18,97 & 18,18 & 16,58 & 15,07 & 12,33 \\
\hline 85 & 1950 & 35 & 26,57 & 22,07 & 20,20 & 19,51 & 18,84 & 18,06 & 16,49 & 15,00 & 12,30 \\
\hline 85 & 2000 & 35 & 26,27 & 21,91 & 20,04 & 19,35 & 18,70 & 17,94 & 16,40 & 14,93 & 12,27 \\
\hline 85 & 200 & 40 & 70,50 & 45,94 & 38,54 & 32,68 & 28,60 & 25,26 & 19,93 & 16,05 & 11,05 \\
\hline 85 & 250 & 40 & 62,15 & 41,90 & 35,94 & 31,06 & 27,53 & 24,57 & 19,72 & 16,06 & 11,16 \\
\hline 85 & 300 & 40 & 56,38 & 38,93 & 33,95 & 29,75 & 26,63 & 23,96 & 19,49 & 16,03 & 11,25 \\
\hline 85 & 350 & 40 & 52,12 & 36,62 & 32,35 & 28,66 & 25,85 & 23,41 & 19,25 & 15,97 & 11,31 \\
\hline 85 & 400 & 40 & 48,82 & 34,75 & 31,02 & 27,73 & 25,17 & 22,92 & 19,02 & 15,89 & 11,36 \\
\hline 85 & 450 & 40 & 46,17 & 33,21 & 29,88 & 26,92 & 24,56 & 22,46 & 18,80 & 15,81 & 11,40 \\
\hline 85 & 500 & 40 & 43,98 & 31,89 & 28,90 & 26,20 & 24,01 & 22,05 & 18,58 & 15,71 & 11,42 \\
\hline 85 & 550 & 40 & 42,14 & 30,77 & 28,03 & 25,56 & 23,51 & 21,67 & 18,38 & 15,62 & 11,44 \\
\hline 85 & 600 & 40 & 40,55 & 29,78 & 27,25 & 24,98 & 23,06 & 21,31 & 18,18 & 15,52 & 11,44 \\
\hline 85 & 650 & 40 & 39,17 & 28,91 & 26,55 & 24,45 & 22,64 & 20,98 & 17,99 & 15,43 & 11,45 \\
\hline 85 & 700 & 40 & 37,95 & 28,14 & 25,92 & 23,96 & 22,25 & 20,68 & 17,80 & 15,33 & 11,44 \\
\hline 85 & 750 & 40 & 36,86 & 27,45 & 25,34 & 23,52 & 21,89 & 20,39 & 17,63 & 15,24 & 11,44 \\
\hline 85 & 800 & 40 & 35,87 & 26,82 & 24,81 & 23,10 & 21,56 & 20,12 & 17,46 & 15,14 & 11,43 \\
\hline 85 & 850 & 40 & 34,98 & 26,25 & 24,32 & 22,72 & 21,24 & 19,86 & 17,30 & 15,05 & 11,41 \\
\hline 85 & 900 & 40 & 34,16 & 25,73 & 23,86 & 22,36 & 20,95 & 19,62 & 17,14 & 14,96 & 11,40 \\
\hline 85 & 950 & 40 & 33,41 & 25,25 & 23,44 & 22,02 & 20,67 & 19,39 & 16,99 & 14,87 & 11,38 \\
\hline 85 & 1000 & 40 & 32,71 & 24,81 & 23,04 & 21,70 & 20,41 & 19,17 & 16,85 & 14,78 & 11,36 \\
\hline 85 & 1050 & 40 & 32,06 & 24,40 & 22,67 & 21,40 & 20,16 & 18,96 & 16,71 & 14,69 & 11,34 \\
\hline 85 & 1100 & 40 & 31,45 & 24,02 & 22,32 & 21,12 & 19,92 & 18,76 & 16,58 & 14,61 & 11,32 \\
\hline 85 & 1150 & 40 & 30,88 & 23,67 & 21,99 & 20,85 & 19,70 & 18,57 & 16,45 & 14,53 & 11,30 \\
\hline 85 & 1200 & 40 & 30,35 & 23,34 & 21,68 & 20,59 & 19,48 & 18,39 & 16,33 & 14,45 & 11,28 \\
\hline 85 & 1250 & 40 & 29,84 & 23,03 & 21,39 & 20,35 & 19,28 & 18,22 & 16,21 & 14,37 & 11,25 \\
\hline 85 & 1300 & 40 & 29,36 & 22,74 & 21,11 & 20,11 & 19,08 & 18,05 & 16,09 & 14,29 & 11,23 \\
\hline 85 & 1350 & 40 & 28,90 & 22,46 & 20,85 & 19,89 & 18,90 & 17,89 & 15,98 & 14,22 & 11,21 \\
\hline 85 & 1400 & 40 & 28,47 & 22,21 & 20,60 & 19,68 & 18,72 & 17,74 & 15,87 & 14,14 & 11,18 \\
\hline 85 & 1450 & 40 & 28,05 & 21,96 & 20,36 & 19,47 & 18,54 & 17,59 & 15,76 & 14,07 & 11,16 \\
\hline 85 & 1500 & 40 & 27,65 & 21,73 & 20,13 & 19,28 & 18,38 & 17,45 & 15,66 & 14,00 & 11,13 \\
\hline 85 & 1550 & 40 & 27,27 & 21,51 & 19,91 & 19,09 & 18,21 & 17,31 & 15,56 & 13,93 & 11,11 \\
\hline 85 & 1600 & 40 & 26,91 & 21,30 & 19,70 & 18,90 & 18,06 & 17,17 & 15,46 & 13,86 & 11,08 \\
\hline 85 & 1650 & 40 & 26,56 & 21,10 & 19,50 & 18,73 & 17,91 & 17,05 & 15,37 & 13,80 & 11,05 \\
\hline 85 & 1700 & 40 & 26,22 & 20,91 & 19,31 & 18,56 & 17,77 & 16,92 & 15,27 & 13,73 & 11,03 \\
\hline 85 & 1750 & 40 & 25,89 & 20,73 & 19,13 & 18,40 & 17,63 & 16,80 & 15,18 & 13,67 & 11,00 \\
\hline 85 & 1800 & 40 & 25,58 & 20,55 & 18,95 & 18,24 & 17,49 & 16,68 & 15,10 & 13,61 & 10,98 \\
\hline 85 & 1850 & 40 & 25,27 & 20,39 & 18,78 & 18,09 & 17,36 & 16,57 & 15,01 & 13,55 & 10,95 \\
\hline 85 & 1900 & 40 & 24,98 & 20,23 & 18,62 & 17,94 & 17,23 & 16,46 & 14,93 & 13,49 & 10,93 \\
\hline 85 & 1950 & 40 & 24,69 & 20,07 & 18,46 & 17,79 & 17,11 & 16,35 & 14,85 & 13,43 & 10,90 \\
\hline 85 & 2000 & 40 & 24,42 & 19,92 & 18,31 & 17,65 & 16,99 & 16,24 & 14,77 & 13,37 & 10,88 \\
\hline
\end{tabular}




\begin{tabular}{|c|c|c|c|c|c|c|c|c|c|c|c|}
\hline & & & \multicolumn{9}{|c|}{ Deflexões $\left(\times 10^{-4} \mathrm{~cm}\right)$} \\
\hline $\mathrm{H}(\mathrm{cm})$ & Mceq (MPa) & Msub (MPa) & D0 & D25 & D40 & D60 & D80 & D100 & D140 & D180 & D260 \\
\hline 85 & 200 & 45 & 67,18 & 42,91 & 35,54 & 29,82 & 25,91 & 22,75 & 17,79 & 14,25 & 9,77 \\
\hline 85 & 250 & 45 & 58,99 & 39,08 & 33,15 & 28,37 & 24,98 & 22,17 & 17,63 & 14,28 & 9,87 \\
\hline 85 & 300 & 45 & 53,34 & 36,28 & 31,31 & 27,19 & 24,19 & 21,65 & 17,46 & 14,27 & 9,95 \\
\hline 85 & 350 & 45 & 49,18 & 34,10 & 29,84 & 26,21 & 23,51 & 21,19 & 17,28 & 14,24 & 10,01 \\
\hline 85 & 400 & 45 & 45,97 & 32,35 & 28,62 & 25,38 & 22,91 & 20,76 & 17,09 & 14,19 & 10,06 \\
\hline 85 & 450 & 45 & 43,40 & 30,89 & 27,57 & 24,65 & 22,37 & 20,37 & 16,91 & 14,13 & 10,10 \\
\hline 85 & 500 & 45 & 41,28 & 29,66 & 26,67 & 24,00 & 21,88 & 20,01 & 16,73 & 14,06 & 10,13 \\
\hline 85 & 550 & 45 & 39,50 & 28,59 & 25,87 & 23,42 & 21,44 & 19,68 & 16,56 & 13,99 & 10,15 \\
\hline 85 & 600 & 45 & 37,97 & 27,67 & 25,16 & 22,90 & 21,04 & 19,37 & 16,40 & 13,91 & 10,16 \\
\hline 85 & 650 & 45 & 36,65 & 26,85 & 24,52 & 22,42 & 20,67 & 19,08 & 16,24 & 13,84 & 10,17 \\
\hline 85 & 700 & 45 & 35,48 & 26,12 & 23,94 & 21,99 & 20,33 & 18,81 & 16,08 & 13,76 & 10,17 \\
\hline 85 & 750 & 45 & 34,44 & 25,46 & 23,41 & 21,58 & 20,01 & 18,56 & 15,93 & 13,68 & 10,17 \\
\hline 85 & 800 & 45 & 33,51 & 24,87 & 22,92 & 21,21 & 19,71 & 18,32 & 15,79 & 13,61 & 10,17 \\
\hline 85 & 850 & 45 & 32,66 & 24,33 & 22,47 & 20,86 & 19,43 & 18,09 & 15,65 & 13,53 & 10,17 \\
\hline 85 & 900 & 45 & 31,89 & 23,84 & 22,05 & 20,54 & 19,16 & 17,88 & 15,52 & 13,46 & 10,16 \\
\hline 85 & 950 & 45 & 31,18 & 23,39 & 21,66 & 20,23 & 18,91 & 17,68 & 15,39 & 13,39 & 10,15 \\
\hline 85 & 1000 & 45 & 30,52 & 22,97 & 21,30 & 19,94 & 18,68 & 17,48 & 15,27 & 13,31 & 10,14 \\
\hline 85 & 1050 & 45 & 29,91 & 22,58 & 20,96 & 19,67 & 18,45 & 17,30 & 15,15 & 13,24 & 10,12 \\
\hline 85 & 1100 & 45 & 29,34 & 22,22 & 20,64 & 19,42 & 18,24 & 17,12 & 15,04 & 13,17 & 10,11 \\
\hline 85 & 1150 & 45 & 28,81 & 21,89 & 20,33 & 19,17 & 18,04 & 16,96 & 14,92 & 13,10 & 10,09 \\
\hline 85 & 1200 & 45 & 28,31 & 21,58 & 20,05 & 18,94 & 17,85 & 16,79 & 14,82 & 13,04 & 10,08 \\
\hline 85 & 1250 & 45 & 27,84 & 21,28 & 19,78 & 18,72 & 17,66 & 16,64 & 14,71 & 12,97 & 10,06 \\
\hline 85 & 1300 & 45 & 27,40 & 21,01 & 19,52 & 18,51 & 17,49 & 16,49 & 14,61 & 12,91 & 10,04 \\
\hline 85 & 1350 & 45 & 26,97 & 20,75 & 19,28 & 18,30 & 17,32 & 16,35 & 14,51 & 12,84 & 10,03 \\
\hline 85 & 1400 & 45 & 26,57 & 20,50 & 19,04 & 18,11 & 17,16 & 16,21 & 14,42 & 12,78 & 10,01 \\
\hline 85 & 1450 & 45 & 26,19 & 20,27 & 18,82 & 17,93 & 17,00 & 16,08 & 14,32 & 12,72 & 9,99 \\
\hline 85 & 1500 & 45 & 25,82 & 20,05 & 18,61 & 17,75 & 16,85 & 15,95 & 14,23 & 12,66 & 9,97 \\
\hline 85 & 1550 & 45 & 25,47 & 19,84 & 18,41 & 17,58 & 16,71 & 15,83 & 14,15 & 12,60 & 9,95 \\
\hline 85 & 1600 & 45 & 25,14 & 19,64 & 18,21 & 17,41 & 16,57 & 15,71 & 14,06 & 12,54 & 9,93 \\
\hline 85 & 1650 & 45 & 24,82 & 19,45 & 18,03 & 17,25 & 16,43 & 15,59 & 13,98 & 12,49 & 9,91 \\
\hline 85 & 1700 & 45 & 24,51 & 19,27 & 17,85 & 17,10 & 16,30 & 15,48 & 13,90 & 12,43 & 9,89 \\
\hline 85 & 1750 & 45 & 24,21 & 19,10 & 17,68 & 16,95 & 16,18 & 15,37 & 13,82 & 12,38 & 9,87 \\
\hline 85 & 1800 & 45 & 23,92 & 18,93 & 17,52 & 16,80 & 16,05 & 15,27 & 13,74 & 12,32 & 9,85 \\
\hline 85 & 1850 & 45 & 23,64 & 18,77 & 17,36 & 16,67 & 15,94 & 15,16 & 13,67 & 12,27 & 9,83 \\
\hline 85 & 1900 & 45 & 23,37 & 18,62 & 17,20 & 16,53 & 15,82 & 15,06 & 13,59 & 12,22 & 9,81 \\
\hline 85 & 1950 & 45 & 23,11 & 18,48 & 17,06 & 16,40 & 15,71 & 14,97 & 13,52 & 12,17 & 9,79 \\
\hline 85 & 2000 & 45 & 22,86 & 18,34 & 16,92 & 16,27 & 15,60 & 14,87 & 13,45 & 12,12 & 9,77 \\
\hline 85 & 200 & 50 & 64,46 & 40,40 & 33,07 & 27,47 & 23,70 & 20,70 & 16,05 & 12,80 & 8,75 \\
\hline 85 & 250 & 50 & 56,40 & 36,75 & 30,83 & 26,15 & 22,88 & 20,21 & 15,94 & 12,84 & 8,84 \\
\hline 85 & 300 & 50 & 50,85 & 34,08 & 29,12 & 25,08 & 22,18 & 19,76 & 15,81 & 12,85 & 8,91 \\
\hline 85 & 350 & 50 & 46,77 & 32,02 & 27,76 & 24,19 & 21,58 & 19,36 & 15,66 & 12,84 & 8,97 \\
\hline 85 & 400 & 50 & 43,63 & 30,35 & 26,62 & 23,43 & 21,04 & 18,99 & 15,52 & 12,80 & 9,02 \\
\hline 85 & 450 & 50 & 41,12 & 28,97 & 25,65 & 22,77 & 20,56 & 18,65 & 15,37 & 12,76 & 9,06 \\
\hline 85 & 500 & 50 & 39,06 & 27,80 & 24,82 & 22,18 & 20,13 & 18,33 & 15,22 & 12,71 & 9,09 \\
\hline 85 & 550 & 50 & 37,33 & 26,80 & 24,08 & 21,66 & 19,74 & 18,04 & 15,08 & 12,66 & 9,11 \\
\hline 85 & 600 & 50 & 35,85 & 25,92 & 23,42 & 21,18 & 19,38 & 17,77 & 14,94 & 12,60 & 9,13 \\
\hline 85 & 650 & 50 & 34,57 & 25,14 & 22,83 & 20,75 & 19,04 & 17,51 & 14,80 & 12,54 & 9,14 \\
\hline 85 & 700 & 50 & 33,44 & 24,45 & 22,29 & 20,35 & 18,73 & 17,28 & 14,67 & 12,48 & 9,15 \\
\hline 85 & 750 & 50 & 32,44 & 23,82 & 21,80 & 19,98 & 18,45 & 17,05 & 14,54 & 12,42 & 9,16 \\
\hline 85 & 800 & 50 & 31,54 & 23,26 & 21,35 & 19,64 & 18,18 & 16,84 & 14,42 & 12,36 & 9,16 \\
\hline 85 & 850 & 50 & 30,73 & 22,75 & 20,93 & 19,32 & 17,92 & 16,64 & 14,30 & 12,30 & 9,16 \\
\hline 85 & 900 & 50 & 30,00 & 22,28 & 20,54 & 19,03 & 17,68 & 16,45 & 14,19 & 12,23 & 9,15 \\
\hline 85 & 950 & 50 & 29,32 & 21,85 & 20,18 & 18,75 & 17,46 & 16,26 & 14,08 & 12,17 & 9,15 \\
\hline 85 & 1000 & 50 & 28,70 & 21,45 & 19,85 & 18,48 & 17,25 & 16,09 & 13,97 & 12,11 & 9,14 \\
\hline 85 & 1050 & 50 & 28,12 & 21,09 & 19,53 & 18,24 & 17,04 & 15,93 & 13,86 & 12,05 & 9,13 \\
\hline 85 & 1100 & 50 & 27,58 & 20,74 & 19,23 & 18,00 & 16,85 & 15,77 & 13,76 & 11,99 & 9,12 \\
\hline 85 & 1150 & 50 & 27,08 & 20,43 & 18,95 & 17,78 & 16,67 & 15,62 & 13,67 & 11,94 & 9,11 \\
\hline 85 & 1200 & 50 & 26,61 & 20,13 & 18,69 & 17,56 & 16,49 & 15,47 & 13,57 & 11,88 & 9,10 \\
\hline 85 & 1250 & 50 & 26,17 & 19,85 & 18,43 & 17,36 & 16,33 & 15,34 & 13,48 & 11,82 & 9,09 \\
\hline 85 & 1300 & 50 & 25,75 & 19,58 & 18,20 & 17,17 & 16,17 & 15,20 & 13,39 & 11,77 & 9,08 \\
\hline 85 & 1350 & 50 & 25,35 & 19,34 & 17,97 & 16,98 & 16,01 & 15,07 & 13,31 & 11,71 & 9,07 \\
\hline 85 & 1400 & 50 & 24,98 & 19,10 & 17,75 & 16,81 & 15,87 & 14,95 & 13,22 & 11,66 & 9,05 \\
\hline 85 & 1450 & 50 & 24,62 & 18,88 & 17,55 & 16,64 & 15,72 & 14,83 & 13,14 & 11,61 & 9,04 \\
\hline 85 & 1500 & 50 & 24,28 & 18,67 & 17,35 & 16,47 & 15,59 & 14,71 & 13,06 & 11,56 & 9,02 \\
\hline 85 & 1550 & 50 & 23,95 & 18,47 & 17,16 & 16,32 & 15,46 & 14,60 & 12,98 & 11,51 & 9,01 \\
\hline 85 & 1600 & 50 & 23,64 & 18,28 & 16,98 & 16,17 & 15,33 & 14,49 & 12,91 & 11,46 & 8,99 \\
\hline 85 & 1650 & 50 & 23,34 & 18,10 & 16,81 & 16,02 & 15,21 & 14,39 & 12,83 & 11,41 & 8,98 \\
\hline 85 & 1700 & 50 & 23,05 & 17,93 & 16,64 & 15,88 & 15,09 & 14,29 & 12,76 & 11,36 & 8,96 \\
\hline 85 & 1750 & 50 & 22,77 & 17,76 & 16,48 & 15,74 & 14,97 & 14,19 & 12,69 & 11,31 & 8,95 \\
\hline 85 & 1800 & 50 & 22,51 & 17,61 & 16,33 & 15,61 & 14,86 & 14,10 & 12,63 & 11,27 & 8,93 \\
\hline 85 & 1850 & 50 & 22,25 & 17,46 & 16,18 & 15,48 & 14,75 & 14,00 & 12,56 & 11,22 & 8,91 \\
\hline 85 & 1900 & 50 & 22,00 & 17,31 & 16,03 & 15,36 & 14,65 & 13,91 & 12,49 & 11,18 & 8,90 \\
\hline 85 & 1950 & 50 & 21,76 & 17,17 & 15,90 & 15,24 & 14,55 & 13,82 & 12,43 & 11,13 & 8,88 \\
\hline 85 & 2000 & 50 & 21,53 & 17,04 & 15,76 & 15,12 & 14,45 & 13,74 & 12,37 & 11,09 & 8,86 \\
\hline 85 & 200 & 55 & 62,19 & 38,27 & 30,99 & 25,49 & 21,85 & 18,99 & 14,62 & 11,61 & 7,92 \\
\hline 85 & 250 & 55 & 54,23 & 34,77 & 28,88 & 24,28 & 21,12 & 18,57 & 14,54 & 11,66 & 8,00 \\
\hline 85 & 300 & 55 & 48,77 & 32,22 & 27,27 & 23,31 & 20,50 & 18,18 & 14,44 & 11,68 & 8,07 \\
\hline 85 & 350 & 55 & 44,76 & 30,25 & 25,99 & 22,49 & 19,96 & 17,83 & 14,33 & 11,68 & 8,12 \\
\hline 85 & 400 & 55 & 41,67 & 28,66 & 24,93 & 21,80 & 19,48 & 17,50 & 14,20 & 11,66 & 8,17 \\
\hline 85 & 450 & 55 & 39,21 & 27,35 & 24,03 & 21,19 & 19,05 & 17,20 & 14,08 & 11,63 & 8,21 \\
\hline 85 & 500 & 55 & 37,19 & 26,23 & 23,25 & 20,65 & 18,66 & 16,93 & 13,96 & 11,60 & 8,24 \\
\hline
\end{tabular}




\begin{tabular}{|c|c|c|c|c|c|c|c|c|c|c|c|}
\hline \multirow[b]{2}{*}{$\mathrm{H}(\mathrm{cm})$} & \multirow[b]{2}{*}{ Mceq (MPa) } & & & & & De & ões (x1 & m) & & & \\
\hline & & Msub (MPa) & D0 & D25 & D40 & D60 & D80 & D100 & D140 & D180 & D260 \\
\hline 85 & 550 & 55 & 35,51 & 25,27 & 22,56 & 20,17 & 18,30 & 16,67 & 13,84 & 11,56 & 8,26 \\
\hline 85 & 600 & 55 & 34,07 & 24,44 & 21,95 & 19,73 & 17,97 & 16,42 & 13,72 & 11,51 & 8,28 \\
\hline 85 & 650 & 55 & 32,82 & 23,70 & 21,40 & 19,33 & 17,67 & 16,20 & 13,60 & 11,47 & 8,30 \\
\hline 85 & 700 & 55 & 31,73 & 23,04 & 20,89 & 18,96 & 17,39 & 15,98 & 13,49 & 11,42 & 8,31 \\
\hline 85 & 750 & 55 & 30,76 & 22,45 & 20,44 & 18,63 & 17,13 & 15,78 & 13,38 & 11,37 & 8,32 \\
\hline 85 & 800 & 55 & 29,89 & 21,91 & 20,02 & 18,31 & 16,89 & 15,59 & 13,27 & 11,32 & 8,32 \\
\hline 85 & 850 & 55 & 29,11 & 21,42 & 19,63 & 18,02 & 16,65 & 15,41 & 13,17 & 11,26 & 8,32 \\
\hline 85 & 900 & 55 & 28,40 & 20,97 & 19,27 & 17,75 & 16,44 & 15,24 & 13,07 & 11,21 & 8,32 \\
\hline 85 & 950 & 55 & 27,75 & 20,56 & 18,93 & 17,49 & 16,23 & 15,08 & 12,97 & 11,16 & 8,32 \\
\hline 85 & 1000 & 55 & 27,15 & 20,18 & 18,62 & 17,25 & 16,04 & 14,92 & 12,88 & 11,11 & 8,32 \\
\hline 85 & 1050 & 55 & 26,60 & 19,83 & 18,32 & 17,02 & 15,85 & 14,77 & 12,79 & 11,06 & 8,32 \\
\hline 85 & 1100 & 55 & 26,09 & 19,50 & 18,04 & 16,80 & 15,68 & 14,63 & 12,70 & 11,01 & 8,31 \\
\hline 85 & 1150 & 55 & 25,61 & 19,20 & 17,78 & 16,60 & 15,51 & 14,49 & 12,61 & 10,96 & 8,30 \\
\hline 85 & 1200 & 55 & 25,16 & 18,91 & 17,53 & 16,40 & 15,35 & 14,36 & 12,53 & 10,91 & 8,30 \\
\hline 85 & 1250 & 55 & 24,74 & 18,65 & 17,30 & 16,22 & 15,20 & 14,24 & 12,45 & 10,87 & 8,29 \\
\hline 85 & 1300 & 55 & 24,34 & 18,39 & 17,07 & 16,04 & 15,05 & 14,11 & 12,37 & 10,82 & 8,28 \\
\hline 85 & 1350 & 55 & 23,97 & 18,16 & 16,86 & 15,87 & 14,91 & 14,00 & 12,29 & 10,77 & 8,27 \\
\hline 85 & 1400 & 55 & 23,61 & 17,93 & 16,66 & 15,70 & 14,78 & 13,89 & 12,22 & 10,73 & 8,26 \\
\hline 85 & 1450 & 55 & 23,27 & 17,72 & 16,46 & 15,55 & 14,65 & 13,78 & 12,15 & 10,68 & 8,25 \\
\hline 85 & 1500 & 55 & 22,95 & 17,52 & 16,28 & 15,40 & 14,52 & 13,67 & 12,08 & 10,64 & 8,24 \\
\hline 85 & 1550 & 55 & 22,65 & 17,33 & 16,10 & 15,25 & 14,40 & 13,57 & 12,01 & 10,59 & 8,23 \\
\hline 85 & 1600 & 55 & 22,35 & 17,15 & 15,93 & 15,11 & 14,28 & 13,47 & 11,94 & 10,55 & 8,21 \\
\hline 85 & 1650 & 55 & 22,07 & 16,97 & 15,77 & 14,98 & 14,17 & 13,38 & 11,87 & 10,51 & 8,20 \\
\hline 85 & 1700 & 55 & 21,80 & 16,81 & 15,61 & 14,85 & 14,06 & 13,28 & 11,81 & 10,47 & 8,19 \\
\hline 85 & 1750 & 55 & 21,54 & 16,65 & 15,46 & 14,72 & 13,96 & 13,19 & 11,75 & 10,42 & 8,18 \\
\hline 85 & 1800 & 55 & 21,29 & 16,50 & 15,32 & 14,60 & 13,85 & 13,11 & 11,69 & 10,38 & 8,16 \\
\hline 85 & 1850 & 55 & 21,05 & 16,36 & 15,18 & 14,48 & 13,75 & 13,02 & 11,63 & 10,34 & 8,15 \\
\hline 85 & 1900 & 55 & 20,82 & 16,22 & 15,05 & 14,37 & 13,66 & 12,94 & 11,57 & 10,31 & 8,14 \\
\hline 85 & 1950 & 55 & 20,59 & 16,08 & 14,92 & 14,26 & 13,56 & 12,86 & 11,51 & 10,27 & 8,13 \\
\hline 85 & 2000 & 55 & 20,37 & 15,96 & 14,79 & 14,15 & 13,47 & 12,78 & 11,46 & 10,23 & 8,11 \\
\hline 85 & 200 & 60 & 60,25 & 36,46 & 29,21 & 23,81 & 20,28 & 17,55 & 13,42 & 10,61 & 7,23 \\
\hline 85 & 250 & 60 & 52,39 & 33,08 & 27,20 & 22,69 & 19,63 & 17,18 & 13,36 & 10,67 & 7,30 \\
\hline 85 & 300 & 60 & 47,00 & 30,62 & 25,69 & 21,79 & 19,07 & 16,84 & 13,29 & 10,70 & 7,37 \\
\hline 85 & 350 & 60 & 43,05 & 28,73 & 24,48 & 21,04 & 18,58 & 16,53 & 13,19 & 10,71 & 7,42 \\
\hline 85 & 400 & 60 & 40,01 & 27,21 & 23,48 & 20,39 & 18,14 & 16,24 & 13,09 & 10,70 & 7,46 \\
\hline 85 & 450 & 60 & 37,59 & 25,95 & 22,64 & 19,83 & 17,75 & 15,97 & 12,99 & 10,68 & 7,50 \\
\hline 85 & 500 & 60 & 35,61 & 24,89 & 21,90 & 19,34 & 17,40 & 15,73 & 12,89 & 10,66 & 7,53 \\
\hline 85 & 550 & 60 & 33,96 & 23,97 & 21,26 & 18,89 & 17,07 & 15,49 & 12,78 & 10,63 & 7,55 \\
\hline 85 & 600 & 60 & 32,55 & 23,17 & 20,68 & 18,49 & 16,78 & 15,28 & 12,68 & 10,59 & 7,57 \\
\hline 85 & 650 & 60 & 31,33 & 22,46 & 20,16 & 18,12 & 16,50 & 15,07 & 12,58 & 10,56 & 7,59 \\
\hline 85 & 700 & 60 & 30,26 & 21,83 & 19,69 & 17,78 & 16,24 & 14,88 & 12,48 & 10,52 & 7,60 \\
\hline 85 & 750 & 60 & 29,32 & 21,26 & 19,26 & 17,47 & 16,01 & 14,70 & 12,39 & 10,48 & 7,61 \\
\hline 85 & 800 & 60 & 28,48 & 20,75 & 18,87 & 17,18 & 15,78 & 14,53 & 12,30 & 10,43 & 7,62 \\
\hline 85 & 850 & 60 & 27,72 & 20,28 & 18,51 & 16,90 & 15,57 & 14,36 & 12,21 & 10,39 & 7,63 \\
\hline 85 & 900 & 60 & 27,03 & 19,85 & 18,17 & 16,65 & 15,37 & 14,21 & 12,12 & 10,35 & 7,63 \\
\hline 85 & 950 & 60 & 26,41 & 19,46 & 17,85 & 16,41 & 15,18 & 14,06 & 12,03 & 10,31 & 7,63 \\
\hline 85 & 1000 & 60 & 25,83 & 19,10 & 17,56 & 16,19 & 15,00 & 13,92 & 11,95 & 10,26 & 7,63 \\
\hline 85 & 1050 & 60 & 25,30 & 18,76 & 17,28 & 15,98 & 14,83 & 13,78 & 11,87 & 10,22 & 7,63 \\
\hline 85 & 1100 & 60 & 24,80 & 18,45 & 17,02 & 15,78 & 14,67 & 13,65 & 11,79 & 10,18 & 7,63 \\
\hline 85 & 1150 & 60 & 24,34 & 18,15 & 16,77 & 15,58 & 14,52 & 13,53 & 11,71 & 10,14 & 7,62 \\
\hline 85 & 1200 & 60 & 23,91 & 17,88 & 16,54 & 15,40 & 14,37 & 13,41 & 11,64 & 10,09 & 7,62 \\
\hline 85 & 1250 & 60 & 23,51 & 17,62 & 16,32 & 15,23 & 14,23 & 13,30 & 11,57 & 10,05 & 7,61 \\
\hline 85 & 1300 & 60 & 23,13 & 17,38 & 16,11 & 15,06 & 14,10 & 13,18 & 11,50 & 10,01 & 7,61 \\
\hline 85 & 1350 & 60 & 22,77 & 17,15 & 15,91 & 14,91 & 13,97 & 13,08 & 11,43 & 9,97 & 7,60 \\
\hline 85 & 1400 & 60 & 22,43 & 16,94 & 15,72 & 14,75 & 13,84 & 12,97 & 11,36 & 9,93 & 7,59 \\
\hline 85 & 1450 & 60 & 22,11 & 16,73 & 15,54 & 14,61 & 13,72 & 12,88 & 11,30 & 9,89 & 7,58 \\
\hline 85 & 1500 & 60 & 21,81 & 16,54 & 15,36 & 14,47 & 13,61 & 12,78 & 11,23 & 9,85 & 7,58 \\
\hline 85 & 1550 & 60 & 21,51 & 16,36 & 15,20 & 14,33 & 13,49 & 12,69 & 11,17 & 9,81 & 7,57 \\
\hline 85 & 1600 & 60 & 21,24 & 16,18 & 15,04 & 14,20 & 13,39 & 12,60 & 11,11 & 9,78 & 7,56 \\
\hline 85 & 1650 & 60 & 20,97 & 16,01 & 14,88 & 14,08 & 13,28 & 12,51 & 11,05 & 9,74 & 7,55 \\
\hline 85 & 1700 & 60 & 20,71 & 15,86 & 14,73 & 13,96 & 13,18 & 12,42 & 11,00 & 9,70 & 7,54 \\
\hline 85 & 1750 & 60 & 20,47 & 15,70 & 14,59 & 13,84 & 13,08 & 12,34 & 10,94 & 9,67 & 7,53 \\
\hline 85 & 1800 & 60 & 20,23 & 15,56 & 14,46 & 13,73 & 12,99 & 12,26 & 10,88 & 9,63 & 7,52 \\
\hline 85 & 1850 & 60 & 20,00 & 15,42 & 14,33 & 13,62 & 12,90 & 12,18 & 10,83 & 9,60 & 7,51 \\
\hline 85 & 1900 & 60 & 19,78 & 15,29 & 14,20 & 13,51 & 12,81 & 12,11 & 10,78 & 9,56 & 7,50 \\
\hline 85 & 1950 & 60 & 19,57 & 15,16 & 14,08 & 13,41 & 12,72 & 12,03 & 10,73 & 9,53 & 7,49 \\
\hline 85 & 2000 & 60 & 19,37 & 15,04 & 13,96 & 13,31 & 12,64 & 11,96 & 10,68 & 9,49 & 7,48 \\
\hline 85 & 200 & 65 & 58,59 & 34,88 & 27,66 & 22,35 & 18,93 & 16,31 & 12,39 & 9,77 & 6,65 \\
\hline 85 & 250 & 65 & 50,81 & 31,60 & 25,76 & 21,31 & 18,34 & 15,98 & 12,36 & 9,84 & 6,72 \\
\hline 85 & 300 & 65 & 45,48 & 29,23 & 24,32 & 20,47 & 17,83 & 15,69 & 12,30 & 9,87 & 6,77 \\
\hline 85 & 350 & 65 & 41,57 & 27,41 & 23,17 & 19,78 & 17,38 & 15,41 & 12,23 & 9,88 & 6,82 \\
\hline 85 & 400 & 65 & 38,58 & 25,95 & 22,23 & 19,18 & 16,99 & 15,15 & 12,14 & 9,88 & 6,86 \\
\hline 85 & 450 & 65 & 36,19 & 24,74 & 21,42 & 18,66 & 16,63 & 14,91 & 12,06 & 9,87 & 6,90 \\
\hline 85 & 500 & 65 & 34,24 & 23,71 & 20,73 & 18,20 & 16,31 & 14,69 & 11,97 & 9,86 & 6,93 \\
\hline 85 & 550 & 65 & 32,62 & 22,83 & 20,12 & 17,78 & 16,01 & 14,48 & 11,88 & 9,84 & 6,95 \\
\hline 85 & 600 & 65 & 31,24 & 22,07 & 19,58 & 17,41 & 15,74 & 14,29 & 11,79 & 9,81 & 6,98 \\
\hline 85 & 650 & 65 & 30,04 & 21,39 & 19,09 & 17,06 & 15,49 & 14,10 & 11,71 & 9,78 & 6,99 \\
\hline 85 & 700 & 65 & 29,00 & 20,78 & 18,65 & 16,75 & 15,25 & 13,93 & 11,62 & 9,75 & 7,01 \\
\hline 85 & 750 & 65 & 28,08 & 20,24 & 18,24 & 16,46 & 15,03 & 13,76 & 11,54 & 9,71 & 7,02 \\
\hline 85 & 800 & 65 & 27,26 & 19,74 & 17,87 & 16,19 & 14,82 & 13,61 & 11,46 & 9,68 & 7,03 \\
\hline 85 & 850 & 65 & 26,52 & 19,29 & 17,53 & 15,93 & 14,63 & 13,46 & 11,38 & 9,64 & 7,03 \\
\hline
\end{tabular}




\begin{tabular}{|c|c|c|c|c|c|c|c|c|c|c|c|}
\hline \multirow[b]{2}{*}{$\mathrm{H}(\mathrm{cm})$} & \multirow[b]{2}{*}{ Mceq (MPa) } & & & & & $\mathrm{De}$ & ões (x1 & m) & & & \\
\hline & & Msub (MPa) & D0 & D25 & D40 & D60 & D80 & D100 & D140 & D180 & D260 \\
\hline 85 & 900 & 65 & 25,85 & 18,88 & 17,21 & 15,70 & 14,45 & 13,32 & 11,30 & 9,61 & 7,04 \\
\hline 85 & 950 & 65 & 25,24 & 18,51 & 16,91 & 15,48 & 14,27 & 13,18 & 11,22 & 9,57 & 7,04 \\
\hline 85 & 1000 & 65 & 24,68 & 18,16 & 16,63 & 15,27 & 14,11 & 13,05 & 11,15 & 9,53 & 7,04 \\
\hline 85 & 1050 & 65 & 24,17 & 17,83 & 16,37 & 15,07 & 13,95 & 12,93 & 11,08 & 9,50 & 7,04 \\
\hline 85 & 1100 & 65 & 23,69 & 17,53 & 16,13 & 14,88 & 13,80 & 12,81 & 11,01 & 9,46 & 7,04 \\
\hline 85 & 1150 & 65 & 23,24 & 17,25 & 15,89 & 14,70 & 13,66 & 12,70 & 10,94 & 9,43 & 7,04 \\
\hline 85 & 1200 & 65 & 22,83 & 16,98 & 15,67 & 14,53 & 13,52 & 12,59 & 10,87 & 9,39 & 7,04 \\
\hline 85 & 1250 & 65 & 22,44 & 16,74 & 15,46 & 14,37 & 13,39 & 12,48 & 10,81 & 9,35 & 7,04 \\
\hline 85 & 1300 & 65 & 22,08 & 16,50 & 15,27 & 14,22 & 13,27 & 12,38 & 10,75 & 9,32 & 7,03 \\
\hline 85 & 1350 & 65 & 21,73 & 16,28 & 15,08 & 14,07 & 13,15 & 12,28 & 10,68 & 9,28 & 7,03 \\
\hline 85 & 1400 & 65 & 21,41 & 16,08 & 14,90 & 13,93 & 13,03 & 12,19 & 10,62 & 9,25 & 7,02 \\
\hline 85 & 1450 & 65 & 21,10 & 15,88 & 14,73 & 13,79 & 12,92 & 12,09 & 10,56 & 9,21 & 7,02 \\
\hline 85 & 1500 & 65 & 20,80 & 15,69 & 14.56 & 13,66 & 12.81 & 12.01 & 10,51 & 9,18 & 7.01 \\
\hline 85 & 1550 & 65 & 20,52 & 15,52 & 14,40 & 13,54 & 12,71 & 11,92 & 10,45 & 9,15 & 7,00 \\
\hline 85 & 1600 & 65 & 20,26 & 15,35 & 14,25 & 13,41 & 12,61 & 11,84 & 10,40 & 9,11 & 7,00 \\
\hline 85 & 1650 & 65 & 20,00 & 15,19 & 14,11 & 13,30 & 12,51 & 11,76 & 10,34 & 9,08 & 6,99 \\
\hline 85 & 1700 & 65 & 19,76 & 15,03 & 13,97 & 13,18 & 12,42 & 11,68 & 10,29 & 9,05 & 6,98 \\
\hline 85 & 1750 & 65 & 19,52 & 14,89 & 13,83 & 13,08 & 12,33 & 11,60 & 10,24 & 9,01 & 6,97 \\
\hline 85 & 1800 & 65 & 19,30 & 14,75 & 13,71 & 12,97 & 12,24 & 11,53 & 10,19 & 8,98 & 6,97 \\
\hline 85 & 1850 & 65 & 19,08 & 14,61 & 13,58 & 12,87 & 12,15 & 11,46 & 10,14 & 8,95 & 6,96 \\
\hline 85 & 1900 & 65 & 18,88 & 14,49 & 13,46 & 12,77 & 12,07 & 11,39 & 10,09 & 8,92 & 6,95 \\
\hline 85 & 1950 & 65 & 18,67 & 14,36 & 13,34 & 12,67 & 11,99 & 11,32 & 10,05 & 8,89 & 6,94 \\
\hline 85 & 2000 & 65 & 18,48 & 14,24 & 13,23 & 12,58 & 11,91 & 11,25 & 10,00 & 8,86 & 6,93 \\
\hline 85 & 200 & 70 & 57,13 & 33,50 & 26,32 & 21,08 & 17,76 & 15,23 & 11,51 & 9,05 & 6,16 \\
\hline 85 & 250 & 70 & 49,42 & 30,31 & 24,49 & 20,11 & 17,21 & 14,95 & 11,49 & 9,12 & 6,22 \\
\hline 85 & 300 & 70 & 44,15 & 28,01 & 23,11 & 19,33 & 16,75 & 14,68 & 11,45 & 9,15 & 6,27 \\
\hline 85 & 350 & 70 & 40,29 & 26,25 & 22,02 & 18,68 & 16,34 & 14,43 & 11,39 & 9,17 & 6,31 \\
\hline 85 & 400 & 70 & 37,33 & 24,84 & 21,12 & 18,12 & 15,98 & 14,20 & 11,32 & 9,18 & 6,35 \\
\hline 85 & 450 & 70 & 34,97 & 23,67 & 20,36 & 17,63 & 15,65 & 13,99 & 11,25 & 9,18 & 6,39 \\
\hline 85 & 500 & 70 & 33,05 & 22,68 & 19,70 & 17,20 & 15,36 & 13,79 & 11,17 & 9,17 & 6,42 \\
\hline 85 & 550 & 70 & 31,45 & 21,84 & 19,12 & 16,81 & 15,08 & 13,60 & 11,10 & 9,15 & 6,44 \\
\hline 85 & 600 & 70 & 30,09 & 21,10 & 18,61 & 16,46 & 14,83 & 13,42 & 11,02 & 9,13 & 6,46 \\
\hline 85 & 650 & 70 & 28,92 & 20,44 & 18,15 & 16,14 & 14,60 & 13,25 & 10,95 & 9,11 & 6,48 \\
\hline 85 & 700 & 70 & 27,90 & 19,86 & 17.73 & 15,84 & 14.38 & 13,09 & 10,87 & 9.08 & 6,49 \\
\hline 85 & 750 & 70 & 26,99 & 19,33 & 17,34 & 15,57 & 14,18 & 12,94 & 10,80 & 9,05 & 6,51 \\
\hline 85 & 800 & 70 & 26,19 & 18,86 & 16,99 & 15,32 & 13,99 & 12,80 & 10,73 & 9,02 & $\frac{6,51}{6,51}$ \\
\hline 85 & 850 & 70 & 25,47 & 18,43 & 16,67 & 15,08 & 13,81 & 12,67 & 10,65 & 8,99 & 6,52 \\
\hline 85 & 900 & 70 & 24,81 & 18,03 & 16,36 & 14,86 & 13,63 & 12,54 & 10,59 & 8,96 & 6,53 \\
\hline 85 & 950 & 70 & 24,22 & 17,67 & 16,08 & 14,65 & 13,47 & 12,41 & 10,52 & 8,93 & 6,53 \\
\hline 85 & 1000 & 70 & 23,67 & 17,33 & 15,82 & 14,46 & 13,32 & 12,29 & 10,45 & 8,90 & 6,54 \\
\hline 85 & 1050 & 70 & 23,17 & 17,02 & 15,57 & 14,27 & 13,18 & 12,18 & 10,39 & 8,87 & 6,54 \\
\hline 85 & 1100 & 70 & 22,71 & 16,73 & 15,34 & 14,10 & 13,04 & 12,07 & 10,32 & 8,84 & 6,54 \\
\hline 85 & 1150 & 70 & 22,28 & 16,46 & 15,12 & 13,93 & 12,90 & 11,96 & 10,26 & 8,81 & 6,54 \\
\hline 85 & 1200 & 70 & 21,87 & 16,20 & 14,91 & 13,77 & 12,78 & 11,86 & 10,20 & 8,78 & 6,54 \\
\hline 85 & 1250 & 70 & 21,50 & 15,96 & 14,71 & 13,62 & 12,66 & 11,77 & 10,14 & 8,74 & 6,54 \\
\hline 85 & 1300 & 70 & 21,15 & 15,74 & 14,53 & 13,47 & 12,54 & 11,67 & 10,09 & 8,71 & 6,54 \\
\hline 85 & 1350 & 70 & 20,81 & 15,53 & 14,35 & 13,34 & 12,43 & 11,58 & 10,03 & 8,68 & 6,53 \\
\hline 85 & 1400 & 70 & 20,50 & 15,32 & 14,18 & 13,20 & 12,32 & 11,49 & 9,98 & 8,65 & 6,53 \\
\hline 85 & 1450 & 70 & 20,20 & 15,14 & 14,01 & 13,07 & 12,21 & 11,41 & 9,92 & 8,62 & 6,53 \\
\hline 85 & 1500 & 70 & 19,92 & 14,96 & 13,86 & 12,95 & 12,11 & 11,33 & 9,87 & 8,59 & 6,52 \\
\hline 85 & 1550 & 70 & 19,65 & 14,78 & 13,71 & 12,83 & 12,02 & 11,25 & 9,82 & 8,56 & 6,52 \\
\hline 85 & 1600 & 70 & 19,39 & 14,62 & 13,56 & 12,72 & 11,92 & 11,17 & 9,77 & 8,53 & 6,51 \\
\hline 85 & 1650 & 70 & 19,15 & $\begin{array}{l}14,47 \\
14,4\end{array}$ & 13,43 & $\begin{array}{ll}12,61 \\
12,61\end{array}$ & 11,83 & $\begin{array}{l}+ \pm,+1 \\
11,10\end{array}$ & 9,72 & 8,50 & 6,51 \\
\hline 85 & 1700 & 70 & 18,92 & 14,32 & 13,29 & 12,50 & 11,75 & 11,02 & 9,68 & 8,47 & 6,50 \\
\hline 85 & 1750 & 70 & 18,69 & 14,18 & 13,17 & 12,40 & 11,66 & 10,95 & 9,63 & 8,45 & 6,49 \\
\hline 85 & 1800 & 70 & 18,48 & 14,04 & 13,04 & 12,30 & 11,58 & 10,89 & 9,58 & 8,42 & 6,49 \\
\hline 85 & 1850 & 70 & 18,27 & 13,91 & 12,93 & 12,21 & 11,50 & 10,82 & 9,54 & 8,39 & 6,48 \\
\hline 85 & 1900 & 70 & 18,07 & 13,79 & 12,81 & 12,11 & 11,42 & 10,75 & 9,50 & 8,36 & 6,47 \\
\hline 85 & 1950 & 70 & 17,88 & 13,67 & 12,70 & 12,02 & 11,35 & 10,69 & 9,45 & 8,34 & 6,47 \\
\hline 85 & 2000 & 70 & 17,69 & 13,55 & 12,59 & 11,94 & 11,27 & 10,63 & 9,41 & 8,31 & 6,46 \\
\hline 85 & 200 & 75 & 55,85 & 32,27 & 25,13 & 19,97 & 16,72 & 14,29 & 10,74 & 8,42 & 5,73 \\
\hline 85 & 250 & 75 & 48,20 & 29,17 & 23,36 & 19,05 & 16,23 & 14,04 & 10,73 & 8,49 & 5,78 \\
\hline 85 & 300 & 75 & 42,98 & 26,93 & 22,05 & 18,31 & 15,80 & 13,80 & 10,70 & 8,53 & 5,83 \\
\hline 85 & 350 & 75 & 39,16 & 25,22 & 21,00 & 17,70 & 15,42 & 13,58 & 10,66 & 8,56 & 5,87 \\
\hline 85 & 400 & 75 & 36,23 & 23,85 & 20,14 & 17,18 & 15,09 & 13,37 & 10,60 & 8,57 & 5,91 \\
\hline 85 & 450 & 75 & 33,90 & 22,72 & 19,42 & 16,72 & 14,79 & 13,18 & 10,54 & 8,57 & 5,94 \\
\hline 85 & 500 & 75 & 32,01 & 21,77 & 18,79 & 16,32 & 14,51 & 12,99 & 10,48 & 8,56 & 5,97 \\
\hline 85 & 550 & 75 & 30,43 & 20,95 & 18,24 & 15,95 & 14,26 & 12,82 & 10,41 & 8,55 & 5,99 \\
\hline 85 & 600 & 75 & 29,09 & 20,23 & 17,75 & 15,62 & 14,03 & 12,66 & 10,34 & 8,54 & 6,01 \\
\hline 85 & 650 & 75 & 27,93 & 19,60 & 17,31 & 15,32 & 13,81 & 12,51 & 10,28 & 8,52 & 6,03 \\
\hline 85 & 700 & 75 & 26,92 & 19,04 & 16,91 & 15,04 & 13,61 & 12,36 & 10,21 & 8,50 & 6,05 \\
\hline 85 & 750 & 75 & 26,04 & 18,53 & 16,54 & 14,79 & 13,42 & 12,22 & 10,15 & 8,48 & 6,06 \\
\hline 85 & 800 & 75 & 25,25 & 18,08 & 16,21 & 14,55 & 13,24 & 12,09 & 10,08 & 8,45 & 6,07 \\
\hline 85 & 850 & 75 & 24,54 & 17,66 & 15,90 & 14,33 & 13,08 & 11,97 & 10,02 & 8,43 & 6,08 \\
\hline 85 & 900 & 75 & 23,90 & 17,28 & 15,61 & 14,12 & $\frac{10,00}{12,92}$ & 11,85 & $\begin{array}{c}10,0< \\
9,96\end{array}$ & 8,40 & 6,09 \\
\hline 85 & 950 & 75 & 23,32 & 16,93 & 15,35 & 13,92 & 12.77 & 11,73 & 9,90 & 8,37 & 6.09 \\
\hline 85 & 1000 & 75 & 22,78 & 16,60 & 15,10 & 13,74 & 12,62 & 11,62 & 9,84 & 8,35 & 6,10 \\
\hline 85 & 1050 & 75 & 22,29 & 16,30 & 14,86 & 13,57 & 12,49 & 11,52 & 9,78 & 8,32 & 6,10 \\
\hline 85 & 1100 & 75 & 2184 & 16.02 & 14.64 & 13,40 & 1236 & $\frac{2 x}{11.42}$ & 972 & 829 & 6.10 \\
\hline 85 & 1150 & 75 & 21,42 & 15,75 & 14,43 & 13,24 & 12,24 & 11,32 & 9,67 & 8,27 & 6,10 \\
\hline 85 & 1200 & 75 & 21,03 & 15,51 & 14,23 & 13,09 & 12,12 & 11,23 & 9,61 & 8,24 & 6,10 \\
\hline
\end{tabular}




\begin{tabular}{|c|c|c|c|c|c|c|c|c|c|c|c|}
\hline \multirow[b]{2}{*}{$\mathrm{H}(\mathrm{cm})$} & \multirow[b]{2}{*}{ Mceq (MPa) } & & & & & $\mathrm{De}$ & ões (x1 & & & & \\
\hline & & Msub (MPa) & D0 & D25 & D40 & D60 & D80 & D100 & D140 & D180 & D260 \\
\hline 85 & 1250 & 75 & 20,66 & 15,28 & 14,04 & 12,95 & 12,00 & 11,14 & 9,56 & 8,21 & 6,10 \\
\hline 85 & 1300 & 75 & 20,32 & 15,06 & 13,87 & 12,81 & 11,89 & 11,05 & 9,51 & 8,18 & 6,10 \\
\hline 85 & 1350 & 75 & 20,00 & 14,85 & 13,70 & 12,68 & 11,79 & 10,96 & 9,46 & 8,16 & 6,10 \\
\hline 85 & 1400 & 75 & 19,69 & 14,66 & 13,53 & 12,56 & 11,69 & 10,88 & 9,41 & 8,13 & 6,10 \\
\hline 85 & 1450 & 75 & 19,40 & 14,48 & 13,38 & 12,44 & 11,59 & 10,80 & 9,36 & 8,10 & 6,10 \\
\hline 85 & 1500 & 75 & 19,13 & 14,30 & 13,23 & 12,32 & 11,50 & 10,73 & 9,31 & 8,08 & 6,09 \\
\hline 85 & 1550 & 75 & 18,87 & 14,14 & 13,09 & 12,21 & 11,41 & 10,65 & 9,27 & 8,05 & 6,09 \\
\hline 85 & 1600 & 75 & 18,62 & 13,98 & 12,95 & 12,10 & 11,32 & 10,58 & 9,22 & 8,02 & 6,09 \\
\hline 85 & 1650 & 75 & 18,39 & 13,83 & 12,82 & 12,00 & 11,23 & 10,51 & 9,18 & 8,00 & 6,08 \\
\hline 85 & 1700 & 75 & 18,16 & 13,69 & 12,70 & 11,90 & 11,15 & 10,45 & 9,13 & 7,97 & 6,08 \\
\hline 85 & 1750 & 75 & 17,95 & 13,55 & 12,57 & 11,80 & 11,07 & 10,38 & 9,09 & 7,95 & 6,07 \\
\hline 85 & 1800 & 75 & 17,74 & 13,42 & 12,46 & 11,71 & 11,00 & 10,32 & 9,05 & 7,92 & 6,07 \\
\hline 85 & 1850 & 75 & 17,54 & 13,29 & 12,34 & 11,62 & 10,92 & 10,25 & 9,01 & 7,89 & 6,06 \\
\hline 85 & 1900 & 75 & 17,35 & 13,17 & 12,24 & 11,53 & 10,85 & 10,19 & 8,97 & 7,87 & 6,06 \\
\hline 85 & 1950 & 75 & 17,17 & 13,06 & 12,13 & 11,45 & 10,78 & 10,13 & 8,93 & 7,85 & 6,05 \\
\hline 85 & 2000 & 75 & 16,99 & 12,95 & 12,03 & 11,36 & 10,71 & 10,08 & 8,89 & 7,82 & 6,05 \\
\hline 85 & 200 & 80 & 54,71 & 31,18 & 24,07 & 18,97 & 15,81 & 13,46 & 10,06 & 7,88 & 5,36 \\
\hline 85 & 250 & 80 & 47,12 & 28,14 & 22,36 & 18,10 & 15,35 & 13,23 & 10,07 & 7,94 & 5,41 \\
\hline 85 & 300 & 80 & 41,94 & 25,96 & 21,10 & 17,41 & 14,96 & 13,02 & 10,05 & 7,99 & 5,45 \\
\hline 85 & 350 & 80 & 38,15 & 24,30 & 20,09 & 16,83 & 14,61 & 12,82 & 10,01 & 8,01 & 5,49 \\
\hline 85 & 400 & 80 & 35,25 & 22,97 & 19,27 & 16,34 & 14,30 & 12,63 & 9,96 & 8,03 & 5,52 \\
\hline 85 & 450 & 80 & 32,95 & 21,87 & 18,57 & 15,91 & 14,02 & 12,45 & 9,91 & 8,03 & 5,55 \\
\hline 85 & 500 & 80 & 31,08 & 20,95 & 17,97 & 15,53 & 13,77 & 12,29 & 9,86 & 8,03 & 5,58 \\
\hline 85 & 550 & 80 & 29,52 & 20,16 & 17,45 & 15,19 & 13,53 & 12,13 & 9,80 & 8,02 & 5,60 \\
\hline 85 & 600 & 80 & 28,19 & 19,46 & 16,98 & 14,88 & 13,31 & 11,98 & 9,74 & 8,01 & 5,62 \\
\hline 85 & 650 & 80 & 27,05 & 18,85 & 16,56 & 14,59 & 13,11 & 11,84 & 9,69 & 8,00 & 5,64 \\
\hline 85 & 700 & 80 & 26,06 & 18,31 & 16,18 & 14,33 & 12,92 & 11,71 & 9,63 & 7,98 & 5,66 \\
\hline 85 & 750 & 80 & 25,19 & 17,82 & 15,83 & 14,09 & 12,75 & 11,58 & 9,57 & 7,97 & 5,67 \\
\hline 85 & 800 & 80 & 24,41 & 17,38 & 15,51 & 13,86 & 12,58 & 11,46 & 9,51 & 7,95 & 5,68 \\
\hline 85 & 850 & 80 & 23,71 & 16,97 & 15,22 & 13,65 & 12,43 & 11,34 & 9,46 & 7,92 & 5,69 \\
\hline 85 & 900 & 80 & 23,08 & 16,60 & 14,94 & 13,46 & 12,28 & 11,23 & 9,40 & 7,90 & 5,70 \\
\hline 85 & 950 & 80 & 22,51 & 16,26 & 14,69 & 13,27 & 12,14 & 11,13 & 9,35 & 7,88 & 5,71 \\
\hline 85 & 1000 & 80 & 21,99 & 15,95 & 14,45 & 13,10 & 12,00 & 11,02 & 9,29 & 7,86 & 5,71 \\
\hline 85 & 1050 & 80 & 21,51 & 15,66 & 14,22 & 12,93 & 11,88 & 10,93 & 9,24 & 7,83 & 5,71 \\
\hline 85 & 1100 & 80 & 21,07 & 15,38 & 14,01 & 12,78 & 11,76 & 10,83 & 9,19 & 7,81 & 5,72 \\
\hline 85 & 1150 & 80 & 20,66 & 15,13 & 13,81 & 12,63 & 11,64 & 10,74 & 9,14 & 7,79 & 5,72 \\
\hline 85 & 1200 & 80 & 20,28 & 14,89 & 13,63 & 12,49 & 11,53 & 10,66 & 9,09 & 7,76 & 5,72 \\
\hline 85 & 1250 & 80 & 19,92 & 14,67 & 13,45 & 12,35 & 11,42 & 10,57 & 9,04 & 7,74 & 5,72 \\
\hline 85 & 1300 & 80 & 19,58 & 14,46 & 13,28 & 12,22 & 11,32 & 10,49 & 8,99 & 7,71 & 5,72 \\
\hline 85 & 1350 & 80 & 19,27 & 14,26 & 13,11 & 12,10 & 11,22 & 10,41 & 8,95 & 7,69 & 5,72 \\
\hline 85 & 1400 & 80 & 18,97 & 14,07 & 12,96 & 11,98 & 11,13 & 10,34 & 8,90 & 7,67 & 5,72 \\
\hline 85 & 1450 & 80 & 18,69 & 13,89 & 12,81 & 11,87 & 11,03 & 10,26 & 8,86 & 7,64 & 5,72 \\
\hline 85 & 1500 & 80 & 18,43 & 13,72 & 12,67 & 11,76 & 10,95 & 10,19 & 8,81 & 7,62 & 5,72 \\
\hline 85 & 1550 & 80 & 18,18 & 13,56 & 12,53 & 11,65 & 10,86 & 10,12 & 8,77 & 7,59 & 5,72 \\
\hline 85 & 1600 & 80 & 17,94 & 13,41 & 12,40 & 11,55 & 10,78 & 10,06 & 8,73 & 7,57 & 5,71 \\
\hline 85 & 1650 & 80 & 17,71 & 13,26 & 12,28 & 11,45 & 10,70 & 9,99 & 8,69 & 7,55 & 5,71 \\
\hline 85 & 1700 & 80 & 17,49 & 13,12 & 12,16 & 11,36 & 10,62 & 9,93 & 8,65 & 7,52 & 5,71 \\
\hline 85 & 1750 & 80 & 17,28 & 12,99 & 12,04 & 11,27 & 10,55 & 9,87 & 8,61 & 7,50 & 5,70 \\
\hline 85 & 1800 & 80 & 17,08 & 12,86 & 11,93 & 11,18 & 10,47 & 9,81 & 8,57 & 7,48 & 5,70 \\
\hline 85 & 1850 & 80 & 16,89 & 12,74 & 11,82 & 11,09 & 10,40 & 9,75 & 8,53 & 7,46 & 5,70 \\
\hline 85 & 1900 & 80 & 16,70 & 12,63 & 11,72 & 11,01 & 10,34 & 9,69 & 8,50 & 7,43 & 5,69 \\
\hline 85 & 1950 & 80 & 16,53 & 12,51 & 11,62 & 10,93 & 10,27 & 9,64 & 8,46 & 7,41 & 5,69 \\
\hline 85 & 2000 & 80 & 16,35 & 12,40 & 11,52 & 10,85 & 10,20 & 9,58 & 8,43 & 7,39 & 5,68 \\
\hline 85 & 200 & 85 & 53,69 & 30,20 & 23,12 & 18,08 & 14,99 & 12,72 & 9,46 & 7,39 & 5,03 \\
\hline 85 & 250 & 85 & 46,15 & 27,22 & 21,47 & 17,26 & 14,57 & 12,51 & 9,48 & 7,46 & 5,08 \\
\hline 85 & 300 & 85 & 41,01 & 25,09 & 20,24 & 16,60 & 14,20 & 12,32 & 9,46 & 7,50 & 5,12 \\
\hline 85 & 350 & 85 & 37,25 & 23,47 & 19,28 & 16,06 & 13,88 & 12,14 & 9,44 & 7,53 & 5,15 \\
\hline 85 & 400 & 85 & 34,38 & 22,17 & 18,48 & 15,59 & 13,59 & 11,97 & 9,40 & 7,55 & 5,18 \\
\hline 85 & 450 & 85 & 32,10 & 21,11 & 17,81 & 15,18 & 13,33 & 11,81 & 9,36 & 7,56 & 5,21 \\
\hline 85 & 500 & 85 & 30,24 & 20,21 & 17,24 & 14,82 & 13,09 & 11,66 & 9,31 & 7,56 & 5,24 \\
\hline 85 & 550 & 85 & 28,70 & 19,44 & 16,73 & 14,50 & 12,88 & 11,51 & 9,26 & 7,56 & 5,26 \\
\hline 85 & 600 & 85 & 27,39 & 18,77 & 16,28 & 14,20 & 12,67 & 11,37 & 9,21 & 7,55 & 5,28 \\
\hline 85 & 650 & 85 & 26,27 & 18,18 & 15,88 & 13,94 & 12,49 & 11,24 & 9,16 & 7,54 & 5,30 \\
\hline 85 & 700 & 85 & 25,29 & 17,65 & 15,52 & 13,69 & 12,31 & 11,12 & 9,11 & 7,53 & 5,31 \\
\hline 85 & 750 & 85 & 24,43 & 17,18 & 15,19 & 13,46 & 12,14 & 11,00 & 9,05 & 7,51 & 5,33 \\
\hline 85 & 800 & 85 & 23,66 & 16,75 & 14,88 & 13,25 & 11,99 & 10,89 & 9,00 & 7,50 & 5,34 \\
\hline 85 & 850 & 85 & 22,97 & 16,35 & 14,60 & 13,05 & 11,84 & 10,78 & 8,95 & 7,48 & 5,35 \\
\hline 85 & 900 & 85 & 22,36 & 16,00 & 14,34 & 12,86 & 11,70 & 10,68 & 8,90 & 7,46 & 5,36 \\
\hline 85 & 950 & 85 & 21,79 & 15,67 & 14,09 & 12,69 & 11,57 & 10,58 & 8,85 & 7,44 & 5,36 \\
\hline 85 & 1000 & 85 & 21,28 & 15,36 & 13,86 & 12,52 & 11,45 & 10,49 & 8,80 & 7,42 & 5,37 \\
\hline 85 & 1050 & 85 & 20,81 & 15,08 & 13,65 & 12,37 & 11,33 & 10,40 & 8,76 & 7,40 & 5,37 \\
\hline 85 & 1100 & 85 & 20,37 & 14,81 & 13,45 & 12,22 & 11,21 & 10,31 & 8,71 & 7,38 & 5,38 \\
\hline 85 & 1150 & 85 & 19,97 & 14,57 & 13,26 & 12,08 & 11,10 & 10,23 & 8,66 & 7,36 & 5,38 \\
\hline 85 & 1200 & 85 & 19,60 & 14,34 & 13,08 & 11,94 & 11,00 & 10,15 & 8,62 & 7,34 & 5,38 \\
\hline 85 & 1250 & 85 & 19,25 & 14,12 & 12,91 & 11,82 & 10,90 & 10,07 & 8,58 & 7,32 & 5,38 \\
\hline 85 & 1300 & 85 & 18,92 & 13,91 & 12,74 & 11,69 & 10,80 & 9,99 & 8,53 & 7,29 & 5,39 \\
\hline 85 & 1350 & 85 & 18,61 & 13,72 & 12,59 & 11,58 & 10,71 & 9,92 & 8,49 & 7,27 & 5,39 \\
\hline 85 & 1400 & 85 & 18,33 & 13,54 & 12,44 & 11,46 & 10,62 & 9,85 & 8,45 & 7,25 & 5,39 \\
\hline 85 & 1450 & 85 & 18,05 & 13,37 & 12,30 & 11,36 & 10,53 & 9,78 & 8,41 & 7,23 & 5,39 \\
\hline 85 & 1500 & 85 & 17,79 & 13,20 & 12,16 & 11,25 & 10,45 & 9,71 & 8,37 & 7,21 & 5,38 \\
\hline 85 & 1550 & 85 & 17,55 & 13,05 & 12,03 & 11,15 & 10,37 & 9,65 & 8,33 & 7,19 & 5,38 \\
\hline
\end{tabular}




\begin{tabular}{|c|c|c|c|c|c|c|c|c|c|c|c|}
\hline \multirow[b]{2}{*}{$\mathrm{H}(\mathrm{cm})$} & \multirow[b]{2}{*}{ Mceq (MPa) } & & & & & De & ões (x1 & & & & \\
\hline & & Msub (MPa) & D0 & D25 & D40 & D60 & D80 & D100 & D140 & D180 & D260 \\
\hline 85 & 1600 & 85 & 17,32 & 12,90 & 11,91 & 11,06 & 10,29 & 9,59 & 8,29 & 7,17 & 5,38 \\
\hline 85 & 1650 & 85 & 17,09 & 12,76 & 11,79 & 10,96 & 10,22 & 9,53 & 8,25 & 7,15 & 5,38 \\
\hline 85 & 1700 & 85 & 16,88 & 12,62 & 11,67 & 10,87 & 10,14 & 9,47 & 8,22 & 7,13 & 5,38 \\
\hline 85 & 1750 & 85 & 16,68 & 12,49 & 11,56 & 10,79 & 10,07 & 9,41 & 8,18 & 7,10 & 5,37 \\
\hline 85 & 1800 & 85 & 16,48 & 12,37 & 11,46 & 10,70 & 10,01 & 9,35 & 8,15 & 7,08 & 5,37 \\
\hline 85 & 1850 & 85 & 16,30 & 12,25 & 11,35 & 10,62 & 9,94 & 9,30 & 8,11 & 7,06 & 5,37 \\
\hline 85 & 1900 & 85 & 16,12 & 12,14 & 11,25 & 10,54 & 9,87 & 9,24 & 8,08 & 7,04 & 5,37 \\
\hline 85 & 1950 & 85 & 15,95 & 12,03 & 11,16 & 10,46 & 9,81 & 9,19 & 8,04 & 7,02 & 5,36 \\
\hline 85 & 2000 & 85 & 15,78 & 11,92 & 11,06 & 10,39 & 9,75 & 9,14 & 8,01 & 7,00 & 5,36 \\
\hline 85 & 200 & 90 & 52,77 & 29,32 & 22,26 & 17,28 & 14,26 & 12,05 & 8,93 & 6,97 & 4,74 \\
\hline 85 & 250 & 90 & 45,28 & 26,39 & 20,66 & 16,50 & 13,86 & 11,87 & 8,95 & 7,03 & 4,78 \\
\hline 85 & 300 & 90 & 40,17 & 24,30 & 19,47 & 15,87 & 13,52 & 11,70 & 8,94 & 7,08 & 4,82 \\
\hline 85 & 350 & 90 & 36,44 & 22,72 & 18,54 & 15,35 & 13,22 & 11,53 & 8,92 & 7,11 & 4,85 \\
\hline 85 & 400 & 90 & 33,59 & 21,45 & 17,77 & 14,91 & 12,95 & 11,38 & 8,89 & 7,12 & 4,88 \\
\hline 85 & 450 & 90 & 31,33 & 20,42 & 17,13 & 14,53 & 12,71 & 11,23 & 8,86 & 7,14 & 4,91 \\
\hline 85 & 500 & 90 & 29,50 & 19,54 & 16,57 & 14,18 & 12,49 & 11,09 & 8,82 & 7,14 & 4,93 \\
\hline 85 & 550 & 90 & 27,97 & 18,79 & 16,09 & 13,88 & 12,28 & 10,95 & 8,77 & 7,14 & 4,96 \\
\hline 85 & 600 & 90 & 26,67 & 18,14 & 15,66 & 13,60 & 12,10 & 10,83 & 8,73 & 7,13 & 4,98 \\
\hline 85 & 650 & 90 & 25,56 & 17,56 & 15,27 & 13,34 & 11,92 & 10,71 & 8,68 & 7,13 & 4,99 \\
\hline 85 & 700 & 90 & 24,59 & 17,05 & 14,92 & 13,11 & 11,75 & 10,59 & 8,64 & 7,12 & 5,01 \\
\hline 85 & 750 & 90 & 23,74 & 16,59 & 14,60 & 12,89 & 11,60 & 10,48 & 8,59 & 7,11 & 5,02 \\
\hline 85 & 800 & 90 & 22,98 & 16,17 & 14,31 & 12,69 & 11,45 & 10,38 & 8,55 & 7,09 & 5,03 \\
\hline 85 & 850 & 90 & 22,31 & 15,79 & 14,04 & 12,50 & 11,32 & 10,28 & 8,50 & 7,08 & 5,04 \\
\hline 85 & 900 & 90 & 21,70 & 15,45 & 13,79 & 12,32 & 11,18 & 10,18 & 8,46 & 7,06 & 5,05 \\
\hline 85 & 950 & 90 & 21,14 & 15,13 & 13,55 & 12,16 & 11,06 & 10,09 & 8,41 & 7,05 & 5,06 \\
\hline 85 & 1000 & 90 & 20,64 & 14,83 & 13,33 & 12,00 & 10,94 & 10,01 & 8,37 & 7,03 & 5,06 \\
\hline 85 & 1050 & 90 & 20,18 & 14,55 & 13,13 & 11,85 & 10,83 & 9,92 & 8,32 & 7,01 & 5,07 \\
\hline 85 & 1100 & 90 & 19,75 & 14,30 & 12,94 & 11,71 & 10,72 & 9,84 & 8,28 & 6,99 & 5,07 \\
\hline 85 & 1150 & 90 & 19,35 & 14,06 & 12,75 & 11,58 & 10,62 & 9,76 & 8,24 & 6,97 & 5,08 \\
\hline 85 & 1200 & 90 & 18,99 & 13,83 & 12,58 & 11,45 & 10,52 & 9,68 & 8,20 & 6,96 & 5,08 \\
\hline 85 & 1250 & 90 & 18,64 & 13,62 & 12,42 & 11,33 & 10,43 & 9,61 & 8,16 & 6,94 & 5,08 \\
\hline 85 & 1300 & 90 & 18,32 & 13,42 & 12,26 & 11,21 & 10,33 & 9,54 & 8,12 & 6,92 & 5,09 \\
\hline 85 & 1350 & 90 & 18,02 & 13,24 & 12,11 & 11,10 & 10,25 & 9,47 & 8,08 & 6,90 & 5,09 \\
\hline 85 & 1400 & 90 & 17,74 & 13,06 & 11,97 & 10,99 & 10,16 & 9,41 & 8,04 & 6,88 & 5,09 \\
\hline 85 & 1450 & 90 & 17,47 & 12,89 & 11,83 & 10,89 & 10,08 & 9,34 & 8,00 & 6,86 & 5,09 \\
\hline 85 & 1500 & 90 & 17,22 & 12,73 & 11,70 & 10,79 & 10,00 & 9,28 & 7,97 & 6,84 & 5,09 \\
\hline 85 & 1550 & 90 & 16,98 & 12,58 & 11,58 & 10,70 & 9,93 & 9,22 & 7,93 & 6,82 & 5,09 \\
\hline 85 & 1600 & 90 & 16,75 & 12,43 & 11,46 & 10,61 & 9,85 & 9,16 & 7,90 & 6,80 & 5,09 \\
\hline 85 & 1650 & 90 & 16,54 & 12,30 & 11,35 & 10,52 & 9,78 & 9,10 & 7,86 & 6,79 & 5,08 \\
\hline 85 & 1700 & 90 & 16,33 & 12,17 & 11,23 & 10,43 & 9,71 & 9,05 & 7,83 & 6,77 & 5,08 \\
\hline 85 & 1750 & 90 & 16,13 & 12,04 & 11,13 & 10,35 & 9,65 & 8,99 & 7,79 & 6,75 & 5,08 \\
\hline 85 & 1800 & 90 & 15,94 & 11,92 & 11,03 & 10,27 & 9,58 & 8,94 & 7,76 & 6,73 & 5,08 \\
\hline 85 & 1850 & 90 & 15,76 & 11,80 & 10,93 & 10,19 & 9,52 & 8,89 & 7,73 & 6,71 & 5,08 \\
\hline 85 & 1900 & 90 & 15,59 & 11,69 & 10,83 & 10,12 & 9,46 & 8,84 & 7,70 & 6,69 & 5,07 \\
\hline 85 & 1950 & 90 & 15,42 & 11,59 & 10,74 & 10,04 & 9,40 & 8,79 & 7,67 & 6,67 & 5,07 \\
\hline 85 & 2000 & 90 & 15,26 & 11,48 & 10,65 & 9,97 & 9,34 & 8,74 & 7,63 & 6,66 & 5,07 \\
\hline 85 & 200 & 95 & 51,94 & 28,51 & 21,48 & 16,56 & 13,60 & 11,46 & 8,45 & 6,58 & 4,49 \\
\hline 85 & 250 & 95 & 44,49 & 25,64 & 19,92 & 15,81 & 13,23 & 11,29 & 8,47 & 6,65 & 4,52 \\
\hline 85 & 300 & 95 & 39,41 & 23,59 & 18,77 & 15,21 & 12,91 & 11,13 & 8,48 & 6,69 & 4,56 \\
\hline 85 & 350 & 95 & 35,71 & 22,03 & 17,86 & 14,72 & 12,63 & 10,98 & 8,46 & 6,72 & 4,59 \\
\hline 85 & 400 & 95 & 32,88 & 20,80 & 17,13 & 14,30 & 12,38 & 10,84 & 8,44 & 6,74 & 4,62 \\
\hline 85 & 450 & 95 & 30,64 & 19,78 & 16,50 & 13,93 & 12,15 & 10,70 & 8,41 & 6,76 & 4,64 \\
\hline 85 & 500 & 95 & 28,82 & 18,93 & 15,97 & 13,60 & 11,94 & 10,57 & 8,37 & 6,76 & 4,66 \\
\hline 85 & 550 & 95 & 27,30 & 18,20 & 15,50 & 13,31 & 11,75 & 10,45 & 8,34 & 6,76 & 4,68 \\
\hline 85 & 600 & 95 & 26,02 & 17,57 & 15,08 & 13,04 & 11,57 & 10,33 & 8,30 & 6,76 & 4,70 \\
\hline 85 & 650 & 95 & 24,92 & 17,01 & 14,71 & 12,80 & 11,40 & 10,22 & 8,26 & 6,76 & 4,72 \\
\hline 85 & 700 & 95 & 23,96 & 16,51 & 14,38 & 12,58 & 11,25 & 10,11 & 8,22 & 6,75 & 4,73 \\
\hline 85 & 750 & 95 & 23,12 & 16,06 & 14,07 & 12,37 & 11,10 & 10,01 & 8,17 & 6,74 & 4,75 \\
\hline 85 & 800 & 95 & 22,37 & 15,65 & 13,79 & 12,18 & 10,97 & 9,92 & 8,13 & 6,73 & 4,76 \\
\hline 85 & 850 & 95 & 21,70 & 15,28 & 13,53 & 12,00 & 10,84 & 9,82 & 8,09 & 6,72 & 4,77 \\
\hline 85 & 900 & 95 & 21,10 & 14,94 & 13,29 & 11,83 & 10,71 & 9,73 & 8,05 & 6,70 & 4,78 \\
\hline 85 & 950 & 95 & 20,56 & 14,63 & 13,06 & 11,67 & 10,60 & 9,65 & 8,01 & 6,69 & 4,78 \\
\hline 85 & 1000 & 95 & 20,06 & 14,34 & 12,85 & 11,53 & 10,48 & 9,57 & 7,97 & 6,68 & 4,79 \\
\hline 85 & 1050 & 95 & 19,60 & 14,08 & 12,65 & 11,38 & 10,38 & 9,49 & 7,93 & 6,66 & 4,80 \\
\hline 85 & 1100 & 95 & 19,18 & 13,83 & 12,47 & 11,25 & 10,28 & 9,41 & 7,89 & 6,65 & 4,80 \\
\hline 85 & 1150 & 95 & 18,79 & 13,59 & 12,29 & 11,12 & 10,18 & 9,34 & 7,85 & 6,63 & 4,81 \\
\hline 85 & 1200 & 95 & 18,43 & 13,38 & 12,13 & 11,00 & 10,09 & 9,27 & 7,82 & 6,61 & 4,81 \\
\hline 85 & 1250 & 95 & 18,09 & 13,17 & 11,97 & 10,88 & 10,00 & 9,20 & 7,78 & 6,60 & 4,81 \\
\hline 85 & 1300 & 95 & 17,78 & 12,98 & 11,82 & 10,77 & 9,91 & 9,13 & 7,74 & 6,58 & 4,81 \\
\hline 85 & 1350 & 95 & 17,48 & 12,79 & 11,68 & 10,67 & 9,83 & 9,07 & 7,71 & 6,56 & 4,82 \\
\hline 85 & 1400 & 95 & 17,21 & 12,62 & 11,54 & 10,57 & 9,75 & 9,00 & 7,67 & 6,54 & 4,82 \\
\hline 85 & 1450 & 95 & 16,95 & 12,46 & 11,41 & 10,47 & 9,67 & 8,94 & 7,64 & 6,53 & 4,82 \\
\hline 85 & 1500 & 95 & 16,70 & 12,30 & 11,28 & 10,37 & 9,60 & 8,89 & 7,60 & 6,51 & 4,82 \\
\hline 85 & 1550 & 95 & 16,46 & 12,16 & 11,17 & 10,28 & 9,52 & 8,83 & 7,57 & 6,49 & 4,82 \\
\hline 85 & 1600 & 95 & 16,24 & 12,01 & 11,05 & 10,20 & 9,45 & 8,77 & 7,54 & 6,48 & 4,82 \\
\hline 85 & 1650 & 95 & 16,03 & 11,88 & 10,94 & 10,11 & 9,39 & 8,72 & 7,50 & 6,46 & 4,82 \\
\hline 85 & 1700 & 95 & 15,83 & 11,75 & 10,83 & 10,03 & 9,32 & 8,67 & 7,47 & 6,44 & 4,82 \\
\hline 85 & 1750 & 95 & 15,63 & 11,63 & 10,73 & 9,95 & 9,26 & 8,62 & 7,44 & 6,43 & 4,82 \\
\hline 85 & 1800 & 95 & 15,45 & 11,51 & 10,63 & 9,87 & 9,20 & 8,57 & 7,41 & 6,41 & 4,82 \\
\hline 85 & 1850 & 95 & 15,27 & 11,40 & 10,54 & 9,80 & 9,14 & 8,52 & 7,38 & 6,39 & 4,81 \\
\hline 85 & 1900 & 95 & 15,10 & 11,29 & 10,45 & 9,73 & 9,08 & 8,47 & 7,35 & 6,38 & 4,81 \\
\hline
\end{tabular}




\begin{tabular}{|c|c|c|c|c|c|c|c|c|c|c|c|}
\hline \multirow[b]{2}{*}{$\mathrm{H}(\mathrm{cm})$} & \multirow[b]{2}{*}{ Mceq (MPa) } & & & & & De & ões (x1 & & & & \\
\hline & & Msub (MPa) & D0 & D25 & D40 & D60 & D80 & D100 & D140 & D180 & D260 \\
\hline 85 & 1950 & 95 & 14,94 & 11,19 & 10,36 & 9,66 & 9,02 & 8,42 & 7,32 & 6,36 & 4,81 \\
\hline 85 & 2000 & 95 & 14,78 & 11,09 & 10,27 & 9,59 & 8,97 & 8,38 & 7,29 & 6,34 & 4,81 \\
\hline 85 & 200 & 100 & 51,18 & 27,78 & 20,77 & 15,90 & 13,00 & 10,91 & 8,02 & 6,24 & 4,25 \\
\hline 85 & 250 & 100 & 43,77 & 24,95 & 19,25 & 15,18 & 12,65 & 10,77 & 8,05 & 6,30 & 4,29 \\
\hline 85 & 300 & 100 & 38,72 & 22,93 & 18,13 & 14,61 & 12,35 & 10,62 & 8,05 & 6,35 & 4,32 \\
\hline 85 & 350 & 100 & 35,04 & 21,41 & 17,25 & 14,14 & 12,09 & 10,48 & 8,05 & 6,38 & 4,35 \\
\hline 85 & 400 & 100 & 32,23 & 20,20 & 16,53 & 13,73 & 11,85 & 10,35 & 8,03 & 6,40 & 4,37 \\
\hline 85 & 450 & 100 & 30,01 & 19,21 & 15,93 & 13,38 & 11,64 & 10,22 & 8,00 & 6,41 & 4,40 \\
\hline 85 & 500 & 100 & 28,20 & 18,37 & 15,41 & 13,07 & 11,44 & 10,10 & 7,97 & 6,42 & 4,42 \\
\hline 85 & 550 & 100 & 26,70 & 17,66 & 14,96 & 12,79 & 11,26 & 9,99 & 7,94 & 6,43 & 4,44 \\
\hline 85 & 600 & 100 & 25,43 & 17,04 & 14,56 & 12,54 & 11,09 & 9,88 & 7,90 & 6,43 & 4,46 \\
\hline 85 & 650 & 100 & 24,34 & 16,49 & 14,20 & 12,31 & 10,94 & 9,78 & 7,87 & 6,42 & 4,47 \\
\hline 85 & 700 & 100 & 23,39 & 16,01 & 13,88 & 12,10 & 10,79 & 9,68 & 7,83 & 6,42 & 4,49 \\
\hline 85 & 750 & 100 & 22,55 & 15,57 & 13,58 & 11,90 & 10,65 & 9,58 & 7,80 & 6,41 & 4,50 \\
\hline 85 & 800 & 100 & 21,81 & 15,18 & 13,31 & 11,72 & 10,52 & 9,49 & 7,76 & 6,40 & 4,51 \\
\hline 85 & 850 & 100 & 21,15 & 14,82 & 13,06 & 11,55 & 10,40 & 9,41 & 7,72 & 6,39 & 4,52 \\
\hline 85 & 900 & 100 & 20,56 & 14,49 & 12,83 & 11,39 & 10,28 & 9,32 & 7,68 & 6,38 & 4,53 \\
\hline 85 & 950 & 100 & 20,02 & 14,18 & 12,61 & 11,23 & 10,17 & 9,24 & 7,65 & 6,37 & 4,54 \\
\hline 85 & 1000 & 100 & 19,53 & 13,90 & 12,41 & 11,09 & 10,07 & 9,17 & 7,61 & 6,36 & 4,54 \\
\hline 85 & 1050 & 100 & 19,08 & 13,64 & 12,22 & 10,96 & 9,97 & 9,09 & 7,57 & 6,34 & 4,55 \\
\hline 85 & 1100 & 100 & 18,66 & 13,40 & 12,04 & 10,83 & 9,87 & 9,02 & 7,54 & 6,33 & 4,56 \\
\hline 85 & 1150 & 100 & 18,28 & 13,17 & 11,87 & 10,71 & 9,78 & 8,95 & 7,50 & 6,32 & 4,56 \\
\hline 85 & 1200 & 100 & 17,92 & 12,96 & 11,71 & 10,59 & 9,69 & 8,88 & 7,47 & 6,30 & 4,57 \\
\hline 85 & 1250 & 100 & 17,59 & 12,76 & 11,56 & 10,48 & 9,60 & 8,82 & 7,43 & 6,29 & 4,57 \\
\hline 85 & 1300 & 100 & 17,28 & 12,57 & 11,41 & 10,37 & 9,52 & 8,76 & 7,40 & 6,27 & 4,57 \\
\hline 85 & 1350 & 100 & 16,99 & 12,39 & 11,28 & 10,27 & 9,44 & 8,70 & 7,37 & 6,26 & 4,57 \\
\hline 85 & 1400 & 100 & 16,72 & 12,22 & 11,15 & 10,17 & 9,37 & 8,64 & 7,33 & 6,24 & 4,58 \\
\hline 85 & 1450 & 100 & 16,46 & 12,06 & 11,02 & 10,08 & 9,29 & 8,58 & 7,30 & 6,22 & 4,58 \\
\hline 85 & 1500 & 100 & 16,22 & 11,91 & 10,90 & 9,99 & 9,22 & 8,53 & 7,27 & 6,21 & 4,58 \\
\hline 85 & 1550 & 100 & 15,99 & 11,77 & 10,79 & 9,90 & 9,15 & 8,47 & 7,24 & 6,19 & 4,58 \\
\hline 85 & 1600 & 100 & 15,77 & 11,63 & 10,67 & 9,82 & 9,09 & 8,42 & 7,21 & 6,18 & 4,58 \\
\hline 85 & 1650 & 100 & 15,56 & 11,50 & 10,57 & 9,74 & 9,02 & 8,37 & 7,18 & 6,16 & 4,58 \\
\hline 85 & 1700 & 100 & 15,37 & 11,38 & 10,47 & 9,66 & 8,96 & 8,32 & 7,15 & 6,15 & 4,58 \\
\hline 85 & 1750 & 100 & 15,18 & 11,26 & 10,37 & 9,59 & 8,90 & 8,27 & 7,12 & 6,13 & 4,58 \\
\hline 85 & 1800 & 100 & 15,00 & 11,14 & 10,27 & 9,51 & 8,84 & 8,22 & 7,09 & 6,12 & 4,58 \\
\hline 85 & 1850 & 100 & 14,83 & 11,03 & 10,18 & 9,44 & 8,78 & 8,18 & 7,07 & 6,10 & 4,58 \\
\hline 85 & 1900 & 100 & 14,66 & 10,93 & 10,09 & 9,37 & 8,73 & 8,13 & 7,04 & 6,09 & 4,57 \\
\hline 85 & 1950 & 100 & 14,50 & 10,82 & 10,01 & 9,31 & 8,68 & 8,09 & 7,01 & 6,07 & 4,57 \\
\hline 85 & 2000 & 100 & 14,35 & 10,73 & 9,92 & 9,24 & 8,62 & 8,05 & 6,98 & 6,06 & 4,57 \\
\hline 85 & 200 & 105 & 50,49 & 27,11 & 20,13 & 15,30 & 12,45 & 10,42 & 7,62 & 5,93 & 4,05 \\
\hline 85 & 250 & 105 & 43,11 & 24,31 & 18,64 & 14,60 & 12,12 & 10,29 & 7,66 & 5,99 & 4,08 \\
\hline 85 & 300 & 105 & 38,09 & 22,33 & 17,54 & 14,06 & 11,84 & 10,15 & 7,67 & 6,03 & 4,10 \\
\hline 85 & 350 & 105 & 34,43 & 20,83 & 16,69 & 13,60 & 11,59 & 10,03 & 7,67 & 6,07 & 4,13 \\
\hline 85 & 400 & 105 & 31,64 & 19,65 & 15,99 & 13,22 & 11,37 & 9,90 & 7,65 & 6,09 & 4,16 \\
\hline 85 & 450 & 105 & 29,43 & 18,68 & 15,41 & 12,88 & 11,17 & 9,79 & 7,63 & 6,10 & 4,18 \\
\hline 85 & 500 & 105 & 27,64 & 17,86 & 14,91 & 12,59 & 10,98 & 9,68 & 7,61 & 6,11 & 4,20 \\
\hline 85 & 550 & 105 & 26,14 & 17,16 & 14,47 & 12,32 & 10,81 & 9,57 & 7,58 & 6,12 & 4,22 \\
\hline 85 & 600 & 105 & 24,88 & 16,56 & 14,08 & 12,08 & 10,65 & 9,47 & 7,55 & 6,12 & 4,24 \\
\hline 85 & 650 & 105 & 23,80 & 16,02 & 13,73 & 11,86 & 10,51 & 9,37 & 7,52 & 6,12 & 4,25 \\
\hline 85 & 700 & 105 & 22,86 & 15,55 & 13,42 & 11,65 & 10,37 & 9,28 & 7,48 & 6,12 & 4,26 \\
\hline 85 & 750 & 105 & 22,04 & 15,12 & 13,13 & 11,47 & 10,24 & 9,19 & 7,45 & 6,11 & 4,28 \\
\hline 85 & 800 & 105 & 21,30 & 14,74 & 12,87 & 11,29 & 10,11 & 9,11 & 7,42 & 6,10 & 4,29 \\
\hline 85 & 850 & 105 & 20,65 & 14,39 & 12,63 & 11,13 & 10,00 & 9,03 & 7,38 & 6,10 & 4,30 \\
\hline 85 & 900 & 105 & 20,06 & 14,06 & 12,41 & 10,97 & 9,89 & 8,95 & 7,35 & 6,09 & 4,31 \\
\hline 85 & 950 & 105 & 19,53 & 13,77 & 12,20 & 10,83 & 9,78 & 8,87 & 7,31 & 6,08 & 4,32 \\
\hline 85 & 1000 & 105 & 19,04 & 13,49 & 12,00 & 10,69 & 9,68 & 8,80 & 7,28 & 6,07 & 4,32 \\
\hline 85 & 1050 & 105 & 18,60 & 13,24 & 11,82 & 10,56 & 9,59 & 8,73 & 7,25 & 6,05 & 4,33 \\
\hline 85 & 1100 & 105 & 18,19 & 13,00 & 11,64 & 10,44 & 9,50 & 8,66 & 7,21 & 6,04 & 4,33 \\
\hline 85 & 1150 & 105 & 17,81 & 12,78 & 11,48 & 10,32 & 9,41 & 8,60 & 7,18 & 6,03 & 4,34 \\
\hline 85 & 1200 & 105 & 17,46 & 12,57 & 11,33 & 10,21 & 9,32 & 8,53 & 7,15 & 6,02 & 4,34 \\
\hline 85 & 1250 & 105 & 17,13 & 12,38 & 11,18 & 10,11 & 9,24 & 8,47 & 7,12 & 6,00 & 4,35 \\
\hline 85 & 1300 & 105 & 16,83 & 12,19 & 11,04 & 10,00 & 9,16 & 8,41 & 7,09 & 5,99 & 4,35 \\
\hline 85 & 1350 & 105 & 16,54 & 12,02 & 10,91 & 9,91 & 9,09 & 8,36 & 7,06 & 5,98 & 4,35 \\
\hline 85 & 1400 & 105 & 16,27 & 11,86 & 10,78 & 9,81 & 9,02 & 8,30 & 7,03 & 5,96 & 4,36 \\
\hline 85 & 1450 & 105 & 16,02 & 11,70 & 10,66 & 9,72 & 8,95 & 8,25 & 7,00 & 5,95 & 4,36 \\
\hline 85 & 1500 & 105 & 15,78 & 11,55 & 10,55 & 9,64 & 8,88 & 8,20 & 6,97 & 5,93 & 4,36 \\
\hline 85 & 1550 & 105 & 15,56 & 11,41 & 10,43 & 9,56 & 8,82 & 8,14 & 6,94 & 5,92 & 4,36 \\
\hline 85 & 1600 & 105 & 15,34 & 11,28 & 10,33 & 9,48 & 8,75 & 8,09 & 6,91 & 5,91 & 4,36 \\
\hline 85 & 1650 & 105 & 15,14 & 11,15 & 10,23 & 9,40 & 8,69 & 8,05 & 6,88 & 5,89 & 4,36 \\
\hline 85 & 1700 & 105 & 14,94 & 11,03 & 10,13 & 9,32 & 8,63 & 8,00 & 6,86 & 5,88 & 4,36 \\
\hline 85 & 1750 & 105 & 14,76 & 10,91 & 10,03 & 9,25 & 8,57 & 7,95 & 6,83 & 5,86 & 4,36 \\
\hline 85 & 1800 & 105 & 14,58 & 10,80 & 9,94 & 9,18 & 8,52 & 7,91 & 6,80 & 5,85 & 4,36 \\
\hline 85 & 1850 & 105 & 14,41 & 10,69 & 9,85 & 9,11 & 8,46 & 7,87 & 6,78 & 5,84 & 4,36 \\
\hline 85 & 1900 & 105 & 14,25 & 10,59 & 9,77 & 9,05 & 8,41 & 7,82 & 6,75 & 5,82 & 4,36 \\
\hline 85 & 1950 & 105 & 14,10 & 10,49 & 9,68 & 8,98 & 8,36 & 7,78 & 6,73 & 5,81 & 4,36 \\
\hline 85 & 2000 & 105 & 13,95 & 10,40 & 9,60 & 8,92 & 8,31 & 7,74 & 6,70 & 5,80 & 4,36 \\
\hline 85 & 200 & 110 & 49,85 & 26,49 & 19,53 & 14,75 & 11,95 & 9,97 & 7,27 & 5,64 & 3,86 \\
\hline 85 & 250 & 110 & 42,50 & 23,73 & 18,07 & 14,08 & 11,64 & 9,85 & 7,31 & 5,70 & 3,88 \\
\hline 85 & 300 & 110 & 37,51 & 21,78 & 17,00 & 13,55 & 11,37 & 9,73 & 7,32 & 5,75 & 3,91 \\
\hline 85 & 350 & 110 & 33,87 & 20,30 & 16,17 & 13,12 & 11,14 & 9,61 & 7,32 & 5,78 & 3,94 \\
\hline 85 & 400 & 110 & 31,09 & 19,14 & 15,49 & 12,75 & 10,93 & 9,50 & 7,31 & 5,80 & 3,96 \\
\hline
\end{tabular}




\begin{tabular}{|c|c|c|c|c|c|c|c|c|c|c|c|}
\hline \multirow[b]{2}{*}{$\mathrm{H}(\mathrm{cm})$} & \multirow[b]{2}{*}{ Mceq (MPa) } & & & & & $\mathrm{De}$ & ões (x1 & & & & \\
\hline & & Msub (MPa) & D0 & D25 & D40 & D60 & D80 & D100 & D140 & D180 & D260 \\
\hline 85 & 450 & 110 & 28,90 & 18,18 & 14,93 & 12,42 & 10,74 & 9,39 & 7,29 & 5,82 & 3,98 \\
\hline 85 & 500 & 110 & 27,12 & 17,39 & 14,44 & 12,14 & 10,56 & 9,28 & 7,27 & 5,83 & 4,00 \\
\hline 85 & 550 & 110 & 25,64 & 16,70 & 14,01 & 11,88 & 10,40 & 9,19 & 7,25 & 5,84 & 4,02 \\
\hline 85 & 600 & 110 & 24,39 & 16,11 & 13,64 & 11,65 & 10,25 & 9,09 & 7,22 & 5,84 & 4,03 \\
\hline 85 & 650 & 110 & 23,31 & 15,59 & 13,30 & 11,44 & 10,11 & 9,00 & 7,19 & 5,84 & 4,05 \\
\hline 85 & 700 & 110 & 22,38 & 15,12 & 13,00 & 11,25 & 9,98 & 8,91 & 7,16 & 5,84 & 4,06 \\
\hline 85 & 750 & 110 & 21,56 & 14,71 & 12,72 & 11,07 & 9,86 & 8,83 & 7,13 & 5,84 & 4,07 \\
\hline 85 & 800 & 110 & 20,84 & 14,33 & 12,47 & 10,90 & 9,74 & 8,75 & 7,10 & 5,83 & 4,09 \\
\hline 85 & 850 & 110 & 20,19 & 13,99 & 12,23 & 10,74 & 9,63 & 8,68 & 7,07 & 5,82 & 4,10 \\
\hline 85 & 900 & 110 & 19,61 & 13,67 & 12,02 & 10,59 & 9,52 & 8,60 & 7,04 & 5,82 & 4,10 \\
\hline 85 & 950 & 110 & 19,08 & 13,38 & 11,81 & 10,46 & 9,42 & 8,53 & 7,01 & 5,81 & 4,11 \\
\hline 85 & 1000 & 110 & 18,60 & 13,12 & 11,62 & 10,32 & 9,33 & 8,46 & 6,98 & 5,80 & 4,12 \\
\hline 85 & 1050 & 110 & 18,16 & 12,87 & 11,45 & 10,20 & 9,24 & 8,40 & 6,95 & 5,79 & 4,13 \\
\hline 85 & 1100 & 110 & 17,75 & 12,64 & 11,28 & 10,08 & 9,15 & 8,33 & 6,92 & 5,78 & 4,13 \\
\hline 85 & 1150 & 110 & 17,38 & 12,42 & 11,12 & 9,97 & 9,07 & 8,27 & 6,89 & 5,77 & 4,14 \\
\hline 85 & 1200 & 110 & 17,03 & 12,22 & 10,97 & 9,86 & 8,99 & 8,21 & 6,86 & 5,76 & 4,14 \\
\hline 85 & 1250 & 110 & 16,71 & 12,03 & 10,83 & 9,76 & 8,91 & 8,15 & 6,83 & 5,74 & 4,15 \\
\hline 85 & 1300 & 110 & 16,41 & 11,85 & 10,70 & 9,67 & 8,84 & 8,10 & 6,80 & 5,73 & 4,15 \\
\hline 85 & 1350 & 110 & 16,13 & 11,68 & 10,57 & 9,57 & 8,76 & 8,04 & 6,77 & 5,72 & 4,15 \\
\hline 85 & 1400 & 110 & 15,86 & 11,52 & 10,45 & 9,48 & 8,70 & 7,99 & 6,74 & 5,71 & 4,15 \\
\hline 85 & 1450 & 110 & 15,61 & 11,37 & 10,33 & 9,40 & 8,63 & 7,94 & 6,72 & 5,70 & 4,16 \\
\hline 85 & 1500 & 110 & 15,38 & 11,22 & 10,22 & 9,31 & 8,57 & 7,89 & 6,69 & 5,68 & 4,16 \\
\hline 85 & 1550 & 110 & 15,16 & 11,09 & 10,11 & 9,23 & 8,50 & 7,84 & 6,66 & 5,67 & 4,16 \\
\hline 85 & 1600 & 110 & 14,95 & 10,95 & 10,01 & 9,16 & 8,44 & 7,80 & 6,64 & 5,66 & 4,16 \\
\hline 85 & 1650 & 110 & 14,75 & 10,83 & 9,91 & 9,08 & 8,38 & 7,75 & 6,61 & 5,64 & 4,16 \\
\hline 85 & 1700 & 110 & 14,56 & 10,71 & 9,81 & 9,01 & 8,33 & 7,71 & 6,58 & 5,63 & 4,16 \\
\hline 85 & 1750 & 110 & 14,37 & 10,60 & 9,72 & 8,94 & 8,27 & 7,66 & 6,56 & 5,62 & 4,16 \\
\hline 85 & 1800 & 110 & 14,20 & 10,49 & 9,63 & 8,87 & 8,22 & 7,62 & 6,53 & 5,61 & 4,16 \\
\hline 85 & 1850 & 110 & 14,03 & 10,38 & 9,55 & 8,81 & 8,17 & 7,58 & 6,51 & 5,59 & 4,16 \\
\hline 85 & 1900 & 110 & 13,88 & 10,28 & 9,47 & 8,75 & 8,12 & 7,54 & 6,49 & 5,58 & 4,16 \\
\hline 85 & 1950 & 110 & 13,72 & 10,18 & 9,39 & 8,68 & 8,07 & 7,50 & 6,46 & 5,57 & 4,16 \\
\hline 85 & 2000 & 110 & 13,58 & 10,09 & 9,31 & 8,62 & 8,02 & 7,46 & 6,44 & 5,56 & 4,16 \\
\hline 85 & 200 & 115 & 49,26 & 25,92 & 18,98 & 14,24 & 11,49 & 9,56 & 6,94 & 5,38 & 3,68 \\
\hline 85 & 250 & 115 & 41,94 & 23,19 & 17,55 & 13,59 & 11,19 & 9,45 & 6,98 & 5,45 & 3,71 \\
\hline 85 & 300 & 115 & 36,97 & 21,26 & 16,51 & 13,08 & 10,94 & 9,33 & 7,00 & 5,49 & 3,73 \\
\hline 85 & 350 & 115 & 33,35 & 19,81 & 15,69 & 12,66 & 10,72 & 9,22 & 7,00 & 5,52 & 3,76 \\
\hline 85 & 400 & 115 & 30,59 & 18,67 & 15,03 & 12,31 & 10,52 & 9,12 & 7,00 & 5,54 & 3,78 \\
\hline 85 & 450 & 115 & 28,41 & 17,73 & 14,48 & 12,00 & 10,34 & 9,02 & 6,98 & 5,56 & 3,80 \\
\hline 85 & 500 & 115 & 26,64 & 16,95 & 14,00 & 11,73 & 10,17 & 8,92 & 6,96 & 5,57 & 3,82 \\
\hline 85 & 550 & 115 & 25,17 & 16,28 & 13,59 & 11,48 & 10,02 & 8,83 & 6,94 & 5,58 & 3,84 \\
\hline 85 & 600 & 115 & 23,93 & 15,70 & 13,23 & 11,26 & 9,88 & 8,74 & 6,92 & 5,59 & 3,85 \\
\hline 85 & 650 & 115 & 22,86 & 15,19 & 12,90 & 11,06 & 9,75 & 8,66 & 6,89 & 5,59 & 3,87 \\
\hline 85 & 700 & 115 & 21,94 & 14,73 & 12,61 & 10,87 & 9,62 & 8,58 & 6,87 & 5,59 & 3,88 \\
\hline 85 & 750 & 115 & 21,12 & 14,32 & 12,34 & 10,70 & 9,50 & 8,50 & 6,84 & 5,58 & 3,89 \\
\hline 85 & 800 & 115 & 20,40 & 13,95 & 12,09 & 10,53 & 9,39 & 8,42 & 6,81 & 5,58 & 3,90 \\
\hline 85 & 850 & 115 & 19,76 & 13,62 & 11,86 & 10,38 & 9,29 & 8,35 & 6,79 & 5,58 & 3,91 \\
\hline 85 & 900 & 115 & 19,18 & 13,31 & 11,65 & 10,24 & 9,19 & 8,28 & 6,76 & 5,57 & 3,92 \\
\hline 85 & 950 & 115 & 18,66 & 13,03 & 11,46 & 10,11 & 9,09 & 8,22 & 6,73 & 5,56 & 3,93 \\
\hline 85 & 1000 & 115 & 18,19 & 12,77 & 11,28 & 9,98 & 9,00 & 8,15 & 6,70 & 5,55 & 3,93 \\
\hline 85 & 1050 & 115 & 17,75 & 12,53 & 11,10 & 9,86 & 8,92 & 8,09 & 6,67 & 5,55 & 3,94 \\
\hline 85 & 1100 & 115 & 17,35 & 12,30 & 10,94 & 9,75 & 8,83 & 8,03 & 6,64 & 5,54 & 3,95 \\
\hline 85 & 1150 & 115 & 16,98 & 12,09 & 10,79 & 9,64 & 8,75 & 7,97 & 6,62 & 5,53 & 3,95 \\
\hline 85 & 1200 & 115 & 16,64 & 11,89 & 10,65 & 9,54 & 8,68 & 7,91 & 6,59 & 5,52 & 3,96 \\
\hline 85 & 1250 & 115 & 16,32 & 11,70 & 10,51 & 9,44 & 8,60 & 7,86 & 6,56 & 5,51 & 3,96 \\
\hline 85 & 1300 & 115 & 16,02 & 11,53 & 10,38 & 9,35 & 8,53 & 7,81 & 6,54 & 5,50 & 3,96 \\
\hline 85 & 1350 & 115 & 15,74 & 11,36 & 10,25 & 9,26 & 8,46 & 7,76 & 6,51 & 5,49 & 3,97 \\
\hline 85 & 1400 & 115 & 15,48 & 11,21 & 10,14 & 9,17 & 8,40 & 7,71 & 6,48 & 5,47 & 3,97 \\
\hline 85 & 1450 & 115 & 15,24 & 11,06 & 10,02 & 9,09 & 8,33 & 7,66 & 6,46 & 5,46 & 3,97 \\
\hline 85 & 1500 & 115 & 15,01 & 10,92 & 9,91 & 9,01 & 8,27 & 7,61 & 6,43 & 5,45 & 3,98 \\
\hline 85 & 1550 & 115 & 14,79 & 10,78 & 9,81 & 8,94 & 8,21 & 7,56 & 6,41 & 5,44 & 3,98 \\
\hline 85 & 1600 & 115 & 14,58 & 10,65 & 9,71 & 8,86 & 8,16 & 7,52 & 6,38 & 5,43 & 3,98 \\
\hline 85 & 1650 & 115 & 14,38 & 10,53 & 9,62 & 8,79 & 8,10 & 7,48 & 6,36 & 5,42 & 3,98 \\
\hline 85 & 1700 & 115 & 14,20 & 10,42 & 9,52 & 8,72 & 8,05 & 7,43 & 6,33 & 5,41 & 3,98 \\
\hline 85 & 1750 & 115 & 14,02 & 10,30 & 9,43 & 8,65 & 7,99 & 7,39 & 6,31 & 5,39 & 3,98 \\
\hline 85 & 1800 & 115 & 13,85 & 10,20 & 9,35 & 8,59 & 7,94 & 7,35 & 6,29 & 5,38 & 3,98 \\
\hline 85 & 1850 & 115 & 13,68 & 10,09 & 9,27 & 8,53 & 7,89 & 7,31 & 6,26 & 5,37 & 3,98 \\
\hline 85 & 1900 & 115 & 13,53 & 10,00 & 9,19 & 8,47 & 7,84 & 7,27 & 6,24 & 5,36 & 3,98 \\
\hline 85 & 1950 & 115 & 13,38 & 9,90 & 9,11 & 8,41 & 7,80 & 7,24 & 6,22 & 5,35 & 3,98 \\
\hline 85 & 2000 & 115 & 13,23 & 9,81 & 9,03 & 8,35 & 7,75 & 7,20 & 6,20 & 5,34 & 3,98 \\
\hline 85 & 200 & 120 & 48,72 & 25,39 & 18,47 & 13,77 & 11,06 & 9,18 & 6,64 & 5,15 & 3,53 \\
\hline 85 & 250 & 120 & 41,42 & 22,69 & 17,07 & 13,14 & 10,78 & 9,07 & 6,69 & 5,21 & 3,55 \\
\hline 85 & 300 & 120 & 36,47 & 20,79 & 16,04 & 12,65 & 10,54 & 8,97 & 6,71 & 5,25 & 3,57 \\
\hline 85 & 350 & 120 & 32,87 & 19,36 & 15,25 & 12,25 & 10,33 & 8,87 & 6,71 & 5,28 & 3,59 \\
\hline 85 & 400 & 120 & 30,13 & 18,23 & 14,60 & 11,90 & 10,14 & 8,77 & 6,71 & 5,31 & 3,62 \\
\hline 85 & 450 & 120 & 27,96 & 17,31 & 14,06 & 11,61 & 9,97 & 8,68 & 6,70 & 5,32 & 3,63 \\
\hline 85 & 500 & 120 & 26,20 & 16,54 & 13,60 & 11,34 & 9,81 & 8,59 & 6,68 & 5,34 & 3,65 \\
\hline 85 & 550 & 120 & 24,74 & 15,88 & 13,20 & 11,11 & 9,67 & 8,50 & 6,66 & 5,35 & 3,67 \\
\hline 85 & 600 & 120 & 23,50 & 15,31 & 12,85 & 10,89 & 9,53 & 8,42 & 6,64 & 5,35 & 3,68 \\
\hline 85 & 650 & 120 & 22,44 & 14,81 & 12,53 & 10,70 & 9,41 & 8,34 & 6,62 & 5,35 & 3,70 \\
\hline 85 & 700 & 120 & 21,52 & 14,37 & 12,24 & 10,52 & 9,29 & 8,26 & 6,60 & 5,35 & 3,71 \\
\hline 85 & 750 & 120 & 20,72 & 13,97 & 11,98 & 10,35 & 9,18 & 8,19 & 6,57 & 5,35 & 3,72 \\
\hline
\end{tabular}




\begin{tabular}{|c|c|c|c|c|c|c|c|c|c|c|c|}
\hline \multirow[b]{2}{*}{$\mathrm{H}(\mathrm{cm})$} & \multirow[b]{2}{*}{ Mceq (MPa) } & & & & & $\mathrm{De}$ & ões (x & & & & \\
\hline & & Msub (MPa) & D0 & D25 & D40 & D60 & D80 & D100 & D140 & D180 & D260 \\
\hline 85 & 800 & 120 & 20,00 & 13,61 & 11,74 & 10,20 & 9,07 & 8,12 & 6,55 & 5,35 & 3,73 \\
\hline 85 & 850 & 120 & 19,37 & 13,28 & 11,52 & 10,05 & 8,97 & 8,05 & 6,52 & 5,35 & 3,74 \\
\hline 85 & 900 & 120 & 18,79 & 12,98 & 11,32 & 9,92 & 8,88 & 7,99 & 6,50 & 5,34 & 3,75 \\
\hline 85 & 950 & 120 & 18,28 & 12,70 & 11,13 & 9,79 & 8,79 & 7,92 & 6,47 & 5,34 & 3,76 \\
\hline 85 & 1000 & 120 & 17,81 & 12,44 & 10,95 & 9,67 & 8,70 & 7,86 & 6,44 & 5,33 & 3,76 \\
\hline 85 & 1050 & 120 & 17,37 & 12,21 & 10,78 & 9,55 & 8,62 & 7,80 & 6,42 & 5,32 & 3,77 \\
\hline 85 & 1100 & 120 & 16,98 & 11,98 & 10,63 & 9,44 & 8,54 & 7,75 & 6,39 & 5,31 & 3,78 \\
\hline 85 & 1150 & 120 & 16,61 & 11,78 & 10,48 & 9,34 & 8,46 & 7,69 & 6,37 & 5,31 & 3,78 \\
\hline 85 & 1200 & 120 & 16,27 & 11,58 & 10,34 & 9,24 & 8,39 & 7,64 & 6,34 & 5,30 & 3,79 \\
\hline 85 & 1250 & 120 & 15,96 & 11,40 & 10,21 & 9,15 & 8,32 & 7,59 & 6,32 & 5,29 & 3,79 \\
\hline 85 & 1300 & 120 & 15,66 & 11,23 & 10,08 & 9,06 & 8,25 & 7,54 & 6,29 & 5,28 & 3,80 \\
\hline 85 & 1350 & 120 & 15,39 & 11,07 & 9,96 & 8,97 & 8,19 & 7,49 & 6,27 & 5,27 & 3,80 \\
\hline 85 & 1400 & 120 & 15,13 & 10,92 & 9,85 & 8,89 & 8,12 & 7,44 & 6.24 & 5,26 & 3,80 \\
\hline 85 & 1450 & 120 & 14,89 & 10,77 & 9,74 & 8,81 & 8,06 & 7,39 & 6,22 & 5,25 & 3,80 \\
\hline 85 & 1500 & 120 & 14,66 & 10,63 & 9,63 & 8,73 & 8,00 & 7,35 & 6,19 & 5,24 & 3,81 \\
\hline 85 & 1550 & 120 & 14,44 & 10,50 & 9,53 & 8,66 & 7,95 & 7,31 & 6,17 & 5,23 & 3,81 \\
\hline 85 & 1600 & 120 & 14,24 & 10,37 & 9,43 & 8,59 & 7,89 & 7,26 & 6,15 & 5,22 & 3,81 \\
\hline 85 & 1650 & 120 & 14,05 & 10,26 & 9,34 & 8,52 & 7,84 & 7,22 & 6,13 & 5,21 & 3,81 \\
\hline 85 & 1700 & 120 & 13,86 & 10,14 & 9,25 & 8,45 & 7,78 & 7,18 & 6,10 & 5,20 & 3,81 \\
\hline 85 & 1750 & 120 & 13,68 & 10,03 & 9,17 & 8,39 & 7,73 & 7,14 & 6,08 & 5,19 & 3,81 \\
\hline 85 & 1800 & 120 & 13,52 & 9,93 & 9,08 & 8,33 & 7,69 & 7,10 & 6,06 & 5,17 & 3,81 \\
\hline 85 & 1850 & 120 & 13,36 & 9,83 & 9,00 & 8,27 & 7,64 & 7,07 & 6,04 & 5,16 & 3,82 \\
\hline 85 & 1900 & 120 & 13,20 & 9,73 & 8,93 & 8,21 & 7,59 & 7,03 & 6,02 & 5,15 & 3,82 \\
\hline 85 & 1950 & 120 & 13,06 & 9,64 & 8,85 & 8,15 & 7,55 & 6,99 & 6,00 & 5,14 & 3,82 \\
\hline 85 & 2000 & 120 & 12,91 & 9,55 & 8,78 & 8,09 & 7,50 & 6,96 & 5,98 & 5,13 & 3,82 \\
\hline 85 & 200 & 125 & 48,21 & 24,90 & 18,00 & 13,33 & 10,67 & 8,83 & 6,37 & 4,93 & 3,38 \\
\hline 85 & 250 & 125 & 40,94 & 22,22 & 16,62 & 12,72 & 10,40 & 8,73 & 6,41 & 4,99 & 3,40 \\
\hline 85 & 300 & 125 & 36,01 & 20,34 & 15,61 & 12,25 & 10,17 & 8,64 & 6,44 & 5,03 & 3,42 \\
\hline 85 & 350 & 125 & 32,43 & 18,93 & 14,83 & 11,86 & 9,97 & 8,54 & 6,44 & 5,06 & 3,45 \\
\hline 85 & 400 & 125 & 29,69 & 17,82 & 14,20 & 11,53 & 9,79 & 8,45 & 6,44 & 5,09 & 3,46 \\
\hline 85 & 450 & 125 & 27,54 & 16,92 & 13,68 & 11,24 & 9,63 & 8,36 & 6,43 & 5,11 & 3,48 \\
\hline 85 & 500 & 125 & 25,79 & 16,16 & 13,23 & 10,99 & 9,48 & 8,28 & 6,42 & 5,12 & 3,50 \\
\hline 85 & 550 & 125 & 24,33 & 15,51 & 12,84 & 10,76 & 9,34 & 8,20 & 6,41 & 5,13 & 3,51 \\
\hline 85 & 600 & 125 & 23,11 & 14,95 & 12,49 & 10,55 & 9,21 & 8,12 & 6,39 & 5,14 & 3,53 \\
\hline 85 & 650 & 125 & 22,05 & 14,46 & 12,18 & 10,37 & 9,09 & 8,05 & 6,37 & 5,14 & 3,54 \\
\hline 85 & 700 & 125 & 21,14 & 14,02 & 11,90 & 10,19 & 8,98 & 7,97 & 6,35 & 5,14 & 3,55 \\
\hline 85 & 750 & 125 & 20,34 & 13,63 & 11,65 & 10,03 & 8,87 & 7,91 & 6,32 & 5,14 & 3,57 \\
\hline 85 & 800 & 125 & 19,63 & 13,28 & 11,42 & 9,88 & 8,77 & 7,84 & 6,30 & 5,14 & 3,58 \\
\hline 85 & 850 & 125 & 19,00 & 12,96 & 11,20 & 9,74 & 8,68 & 7,77 & 6,28 & 5,14 & 3,59 \\
\hline 85 & 900 & 125 & 18,43 & 12,66 & 11,00 & 9,61 & 8,59 & 7,71 & 6,25 & 5,13 & 3,59 \\
\hline 85 & 950 & 125 & 17,92 & 12,39 & 10,82 & 9,49 & 8,50 & 7,65 & 6,23 & 5,13 & 3,60 \\
\hline 85 & 1000 & 125 & 17,45 & 12,14 & 10,65 & 9,37 & 8,42 & 7,60 & 6,21 & 5,12 & 3,61 \\
\hline 85 & 1050 & 125 & 17,02 & 11,91 & 10,49 & 9,26 & 8,34 & 7,54 & 6,18 & 5,12 & 3,62 \\
\hline 85 & 1100 & 125 & 16,63 & 11,69 & 10,33 & 9,16 & 8,26 & 7,49 & 6,16 & 5,11 & 3,62 \\
\hline 85 & 1150 & 125 & 16,27 & 11,49 & 10,19 & 9,06 & 8,19 & 7,43 & 6,13 & 5,10 & 3,63 \\
\hline 85 & 1200 & 125 & 15,93 & 11,30 & 10,06 & 8,96 & 8,12 & 7,38 & 6,11 & 5,09 & 3,63 \\
\hline 85 & 1250 & 125 & 15,62 & 11,12 & 9,93 & 8,87 & 8,05 & 7,33 & 6,09 & 5,09 & 3,64 \\
\hline 85 & 1300 & 125 & 15,33 & 10,95 & 9,80 & 8,79 & 7,99 & 7,29 & 6,06 & 5,08 & 3,64 \\
\hline 85 & 1350 & 125 & 15,06 & 10,79 & 9,69 & 8,70 & 7,93 & 7,24 & 6,04 & 5,07 & 3,64 \\
\hline 85 & 1400 & 125 & 14,80 & 10,64 & 9,58 & 8,62 & 7,87 & 7,19 & 6,02 & 5,06 & 3,65 \\
\hline 85 & 1450 & 125 & 14,57 & 10,50 & 9,47 & 8,55 & 7,81 & 7,15 & 6,00 & 5,05 & 3,65 \\
\hline 85 & 1500 & 125 & 14,34 & 10,37 & 9,37 & 8,47 & 7,75 & 7,11 & 5,97 & 5,04 & 3,65 \\
\hline 85 & 1550 & 125 & 14,13 & 10,24 & 9,27 & 8,40 & 7,70 & $\begin{array}{l}1,+1 \\
7,07\end{array}$ & 5,95 & 5,03 & 3,65 \\
\hline 85 & 1600 & 125 & 13,92 & 10,11 & 9,18 & 8,33 & 7,64 & 7,03 & 5,93 & 5,02 & 3,66 \\
\hline 85 & 1650 & 125 & 13,73 & 10,00 & 9,09 & 8,27 & 7,59 & 6,99 & 5,91 & 5,01 & 3,66 \\
\hline 85 & 1700 & 125 & 13,55 & 9,89 & 9,00 & 8,20 & 7,54 & 6,95 & 5,89 & 5,00 & 3,66 \\
\hline 85 & 1750 & 125 & 13,38 & 9,78 & 8,92 & 8,14 & 7,49 & 6,91 & 5,87 & 4,99 & 3,66 \\
\hline 85 & 1800 & 125 & 13,21 & 9,68 & 8,84 & 8,08 & 7,45 & 6,87 & 5,85 & 4,98 & 3,66 \\
\hline 85 & 1850 & 125 & 13,05 & 9,58 & 8,76 & 8,02 & 7,40 & 6,84 & 5,83 & 4,97 & 3,66 \\
\hline 85 & 1900 & 125 & 12,90 & 9,48 & 8,68 & 7,96 & 7,36 & 6,80 & 5,81 & 4,96 & 3,66 \\
\hline 85 & 1950 & 125 & 12,76 & 9,39 & 8,61 & 7,91 & 7,31 & 6,77 & 5,79 & 4,95 & 3,66 \\
\hline 85 & 2000 & 125 & 12,62 & 9,30 & 8,54 & 7,86 & 7,27 & 6,74 & 5,77 & 4,94 & 3,66 \\
\hline 85 & 200 & 130 & 47,74 & 24,44 & 17,56 & 12,93 & 10,30 & 8,50 & 6,11 & 4,73 & 3,25 \\
\hline 85 & 250 & 130 & 40,50 & 21,79 & 16,20 & 12,33 & 10,05 & 8,41 & 6,16 & 4,79 & 3,27 \\
\hline 85 & 300 & 130 & 35,58 & 19,93 & 15,21 & 11,87 & 9,83 & 8,32 & 6,18 & 4,83 & 3,29 \\
\hline 85 & 350 & 130 & 32,01 & 18,54 & 14,45 & 11,50 & 9,64 & 8,24 & 6,19 & 4,86 & 3,31 \\
\hline 85 & 400 & 130 & 29,29 & 17,44 & 13,83 & 11,18 & 9,47 & 8,15 & 6,19 & 4,89 & 3,33 \\
\hline 85 & 450 & 130 & 27,15 & 16,55 & 13,32 & 10,90 & 9,31 & 8,07 & 6,19 & 4,90 & 3,34 \\
\hline 85 & 500 & 130 & 25,40 & 15,80 & 12,88 & 10,66 & 9,17 & 7,99 & 6,18 & 4,92 & 3,36 \\
\hline 85 & 550 & 130 & 23,96 & 15,17 & 12,50 & 10,44 & 9,04 & 7,92 & 6,17 & 4,93 & 3,37 \\
\hline 85 & 600 & 130 & 22,74 & 14,62 & 12,16 & 10,24 & 8,91 & 7,84 & 6,15 & 4,94 & 3,39 \\
\hline 85 & 650 & 130 & 21,69 & 14,13 & 11,86 & 10,06 & 8,80 & 7,77 & 6,13 & 4,94 & 3,40 \\
\hline 85 & 700 & 130 & 20,79 & 13,71 & 11,59 & 9,89 & 8,69 & 7,70 & 6,11 & 4,94 & 3,41 \\
\hline 85 & 750 & 130 & 19,99 & 13,32 & 11,34 & 9,73 & 8,59 & 7,64 & 6,09 & 4,94 & 3,42 \\
\hline 85 & 800 & 130 & 19,29 & 12,97 & 11,11 & 9,59 & 8,49 & 7,58 & 6,07 & 4,94 & 3,43 \\
\hline 85 & 850 & 130 & 18,66 & 12,66 & 10,90 & 9,46 & 8,40 & 7,52 & 6,05 & 4,94 & 3,44 \\
\hline 85 & 900 & 130 & 18,10 & 12,37 & 10,71 & 9,33 & 8,32 & 7,46 & 6,03 & 4,94 & 3,45 \\
\hline 85 & 950 & 130 & 17,59 & 12,10 & 10,53 & 9,21 & 8,23 & 7,40 & 6,01 & 4,93 & 3,46 \\
\hline 85 & 1000 & 130 & 17,12 & 11,86 & 10,37 & 9,10 & 8,15 & 7,35 & 5,99 & 4,93 & 3,46 \\
\hline 85 & 1050 & 130 & 16,70 & 11,63 & 10,21 & 8,99 & 8,08 & 7,29 & 5,96 & 4,92 & 3,47 \\
\hline 85 & 1100 & 130 & 16,31 & 11,42 & 10,06 & 8,89 & 8,01 & 7,24 & 5,94 & 4,92 & 3,48 \\
\hline
\end{tabular}




\begin{tabular}{|c|c|c|c|c|c|c|c|c|c|c|c|}
\hline \multirow[b]{2}{*}{$\mathrm{H}(\mathrm{cm})$} & \multirow[b]{2}{*}{ Mceq (MPa) } & & & & & De & jes ( $x 1$ & & & & \\
\hline & & Msub (MPa) & D0 & D25 & D40 & D60 & $\mathrm{D} 80$ & D100 & D140 & D180 & D260 \\
\hline 85 & 1150 & 130 & 15,95 & 11,22 & 9,92 & 8,79 & 7,94 & 7,19 & 5,92 & 4,91 & 3,48 \\
\hline 85 & 1200 & 130 & 15,62 & 11,03 & 9,79 & 8,70 & 7,87 & 7,14 & 5,90 & 4,90 & 3,49 \\
\hline 85 & 1250 & 130 & 15,31 & 10,86 & 9,66 & 8,62 & 7,81 & 7,10 & 5,88 & 4,90 & 3,49 \\
\hline 85 & 1300 & 130 & 15,02 & 10,69 & 9,54 & 8,53 & 7,74 & 7,05 & 5,85 & 4,89 & 3,50 \\
\hline 85 & 1350 & 130 & 14,75 & 10,54 & 9,43 & 8,45 & 7,68 & 7,01 & 5,83 & 4,88 & 3,50 \\
\hline 85 & 1400 & 130 & 14,50 & 10,39 & 9,32 & 8,37 & 7,63 & 6,96 & 5,81 & 4,87 & 3,50 \\
\hline 85 & 1450 & 130 & 14,26 & 10,25 & 9,22 & 8,30 & 7,57 & 6,92 & 5,79 & 4,87 & 3,51 \\
\hline 85 & 1500 & 130 & 14,04 & 10,12 & 9,12 & 8,23 & 7,52 & 6,88 & 5,77 & 4,86 & 3,51 \\
\hline 85 & 1550 & 130 & 13,83 & 9,99 & 9,03 & 8,16 & 7,46 & 6,84 & 5,75 & 4,85 & 3,51 \\
\hline 85 & 1600 & 130 & 13,63 & 9,87 & 8,94 & 8,09 & 7,41 & 6,80 & 5,73 & 4,84 & 3,51 \\
\hline 85 & 1650 & 130 & 13,44 & 9,76 & 8,85 & 8,03 & 7,36 & 6,77 & 5,71 & 4,83 & 3,52 \\
\hline 85 & 1700 & 130 & 13,26 & 9,65 & 8,76 & 7,97 & 7,31 & 6,73 & 5,69 & 4,82 & 3,52 \\
\hline 85 & 1750 & 130 & 13,09 & 9,54 & 8,68 & 7,91 & 7,27 & 6,69 & 5,67 & 4,81 & 3,52 \\
\hline 85 & 1800 & 130 & 12,93 & 9,44 & 8,60 & 7,85 & 7,22 & 6,66 & 5,65 & 4,80 & 3,52 \\
\hline 85 & 1850 & 130 & 12,77 & 9,35 & 8,53 & 7,79 & 7,18 & 6,62 & 5,63 & 4,79 & 3,52 \\
\hline 85 & 1900 & 130 & 12,62 & 9,25 & 8,46 & 7,74 & 7,14 & 6,59 & 5,61 & 4,79 & 3,52 \\
\hline 85 & 1950 & 130 & 12,48 & 9,16 & 8,38 & 7,69 & 7,09 & 6,56 & 5,59 & 4,78 & 3,52 \\
\hline 85 & 2000 & 130 & 12,34 & 9,08 & 8,32 & 7,63 & 7,05 & 6,53 & 5,57 & 4,77 & 3,52 \\
\hline 85 & 200 & 135 & 47,30 & 24,01 & 17,15 & 12,55 & 9,96 & 8,20 & 5,88 & 4,55 & 3,13 \\
\hline 85 & 250 & 135 & 40,08 & 21,39 & 15,81 & 11,97 & 9,72 & 8,12 & 5,93 & 4,60 & 3,14 \\
\hline 85 & 300 & 135 & 35,18 & 19,54 & 14,84 & 11,52 & 9,51 & 8,04 & 5,95 & 4,64 & 3,16 \\
\hline 85 & 350 & 135 & 31,62 & 18,17 & 14,09 & 11,16 & 9,33 & 7,95 & 5,96 & 4,67 & 3,18 \\
\hline 85 & 400 & 135 & 28,92 & 17,08 & 13,48 & 10,85 & 9,16 & 7,87 & 5,97 & 4,70 & 3,20 \\
\hline 85 & 450 & 135 & 26,78 & 16,20 & 12,98 & 10,58 & 9,01 & 7,80 & 5,96 & 4,72 & 3,21 \\
\hline 85 & 500 & 135 & 25,05 & 15,47 & 12,55 & 10,34 & 8,88 & 7,72 & 5,95 & 4,73 & 3,23 \\
\hline 85 & 550 & 135 & 23,61 & 14,84 & 12,18 & 10,13 & 8,75 & 7,65 & 5,94 & 4,74 & 3,24 \\
\hline 85 & 600 & 135 & 22,39 & 14,30 & 11,85 & 9,94 & 8,64 & 7,58 & 5,93 & 4,75 & 3,26 \\
\hline 85 & 650 & 135 & 21,36 & 13,83 & 11,55 & 9,77 & 8,53 & 7,52 & 5,91 & 4,75 & 3,27 \\
\hline 85 & 700 & 135 & 20,45 & 13,41 & 11,29 & 9,60 & 8,42 & 7,45 & 5,90 & 4,76 & 3,28 \\
\hline 85 & 750 & 135 & 19,66 & 13,03 & 11,05 & 9,46 & 8,33 & 7,39 & 5,88 & 4,76 & 3,29 \\
\hline 85 & 800 & 135 & 18,97 & 12,69 & 10,83 & 9,32 & 8,23 & 7,33 & 5,86 & 4,76 & 3,30 \\
\hline 85 & 850 & 135 & 18,34 & 12,38 & 10,63 & 9,19 & 8,15 & 7,27 & 5,84 & 4,76 & 3,31 \\
\hline 85 & 900 & 135 & 17,78 & 12,09 & 10,44 & 9,06 & 8,06 & 7,22 & 5,82 & 4,76 & 3,32 \\
\hline 85 & 950 & 135 & 17,28 & 11,83 & 10,26 & 8,95 & 7,98 & 7,16 & 5,80 & 4,75 & 3,32 \\
\hline 85 & 1000 & 135 & 16,82 & 11,59 & 10,10 & 8,84 & 7,91 & 7,11 & 5,78 & 4,75 & 3,33 \\
\hline 85 & 1050 & 135 & 16,39 & 11,37 & 9,95 & 8,74 & 7,84 & 7,06 & 5,76 & 4,75 & 3,34 \\
\hline 85 & 1100 & 135 & 16,01 & 11,16 & 9,80 & 8,64 & 7,77 & 7,01 & 5,74 & 4,74 & 3,34 \\
\hline 85 & 1150 & 135 & 15,65 & 10,97 & 9,67 & 8,55 & 7,70 & 6,97 & 5,72 & 4,73 & 3,35 \\
\hline 85 & 1200 & 135 & 15,32 & 10,78 & 9,54 & 8,46 & 7,64 & 6,92 & 5,70 & 4,73 & 3,35 \\
\hline 85 & 1250 & 135 & 15,02 & 10,61 & 9,42 & 8,37 & 7,57 & 6,88 & 5,68 & 4,72 & 3,36 \\
\hline 85 & 1300 & 135 & 14,73 & 10,45 & 9,30 & 8,29 & 7,51 & 6,83 & 5,66 & 4,72 & 3,36 \\
\hline 85 & 1350 & 135 & 14,47 & 10,30 & 9,19 & 8,22 & 7,46 & 6,79 & 5,64 & 4,71 & 3,37 \\
\hline 85 & 1400 & 135 & 14,22 & 10,15 & 9,09 & 8,14 & 7,40 & 6,75 & 5,62 & 4,70 & 3,37 \\
\hline 85 & 1450 & 135 & 13,98 & 10,02 & 8,99 & 8,07 & 7,35 & 6,71 & 5,60 & 4,69 & 3,37 \\
\hline 85 & 1500 & 135 & 13,76 & 9,89 & 8,89 & 8,00 & 7,29 & 6,67 & 5,58 & 4,69 & 3,38 \\
\hline 85 & 1550 & 135 & 13,55 & 9,76 & 8,80 & 7,93 & 7,24 & 6,63 & 5,56 & 4,68 & 3,38 \\
\hline 85 & 1600 & 135 & 13,35 & 9,64 & 8,71 & 7,87 & 7,20 & 6,60 & 5,54 & 4,67 & 3,38 \\
\hline 85 & 1650 & 135 & 13,17 & 9,53 & 8,62 & 7,81 & 7,15 & 6,56 & 5,52 & 4,66 & 3,38 \\
\hline 85 & 1700 & 135 & 12,99 & 9,42 & 8,54 & 7,75 & 7,10 & 6,52 & 5,50 & 4,65 & 3,38 \\
\hline 85 & 1750 & 135 & 12,82 & 9,32 & 8,46 & 7,69 & 7,06 & 6,49 & 5,48 & 4,65 & 3,39 \\
\hline 85 & 1800 & 135 & 12,66 & 9,22 & 8,39 & 7,63 & 7,01 & 6,46 & 5,47 & 4,64 & 3,39 \\
\hline 85 & 1850 & 135 & 12,50 & 9,13 & 8,31 & 7,58 & 6,97 & 6,42 & 5,45 & 4,63 & 3,39 \\
\hline 85 & 1900 & 135 & 12,36 & 9,04 & 8,24 & 7,53 & 6,93 & 6,39 & 5,43 & 4,62 & 3,39 \\
\hline 85 & 1950 & 135 & 12,22 & 8,95 & 8,17 & 7,47 & 6,89 & 6,36 & 5,41 & 4,61 & 3,39 \\
\hline 85 & 2000 & 135 & 12,08 & 8,86 & 8,11 & 7,42 & 6,85 & 6,33 & 5,39 & 4,60 & 3,39 \\
\hline 85 & 200 & 140 & 46,89 & 23,61 & 16,77 & 12,20 & 9,65 & 7,92 & 5,66 & 4,37 & 3,01 \\
\hline 85 & 250 & 140 & 39,69 & 21,01 & 15,44 & 11,63 & 9,41 & 7,84 & 5,71 & 4,43 & 3,03 \\
\hline 85 & 300 & 140 & 34,80 & 19,18 & 14,49 & 11,20 & 9,21 & 7,77 & 5,73 & 4,47 & 3,05 \\
\hline 85 & 350 & 140 & 31,26 & 17,82 & 13,75 & 10,84 & 9,03 & 7,69 & 5,75 & 4,50 & 3,06 \\
\hline 85 & 400 & 140 & 28,56 & 16,75 & 13,16 & 10,54 & 8,88 & 7,62 & 5,75 & 4,53 & 3,08 \\
\hline 85 & 450 & 140 & 26,44 & 15,88 & 12,66 & 10,28 & 8,74 & 7,54 & 5,75 & 4,54 & 3,09 \\
\hline 85 & 500 & 140 & 24,71 & 15,16 & 12,24 & 10,05 & 8,61 & 7,47 & 5,75 & 4,56 & 3,11 \\
\hline 85 & 550 & 140 & 23,28 & 14,54 & 11,88 & 9,85 & 8,49 & 7,41 & 5,74 & 4,57 & 3,12 \\
\hline 85 & 600 & 140 & 22,07 & 14,01 & 11,56 & 9,66 & 8,37 & 7,34 & 5,72 & 4,58 & 3,13 \\
\hline 85 & 650 & 140 & 21,04 & 13,54 & 11,27 & 9,49 & 8,27 & 7,28 & 5,71 & 4,58 & 3,15 \\
\hline 85 & 700 & 140 & 20,14 & 13,12 & 11,01 & 9,34 & 8,17 & 7,22 & 5,69 & 4,59 & 3,16 \\
\hline 85 & 750 & 140 & 19,36 & 12,75 & 10,78 & 9,19 & 8,08 & 7,16 & 5,68 & 4,59 & 3,17 \\
\hline 85 & 800 & 140 & 18,66 & 12,42 & 10,56 & 9,06 & 7,99 & 7,10 & 5,66 & 4,59 & 3,18 \\
\hline 85 & 850 & 140 & 18,04 & 12,11 & 10,36 & 8,93 & 7,91 & 7,05 & 5,64 & 4,59 & 3,19 \\
\hline 85 & 900 & 140 & 17,49 & 11,83 & 10,18 & 8,82 & 7,83 & 6,99 & 5,62 & 4,59 & 3,19 \\
\hline 85 & 950 & 140 & 16,98 & 11,58 & 10,01 & 8,70 & 7,75 & 6,94 & 5,61 & 4,59 & 3,20 \\
\hline 85 & 1000 & 140 & 16,53 & 11,34 & 9,85 & 8,60 & 7,68 & 6,89 & 5,59 & 4,58 & 3,21 \\
\hline 85 & 1050 & 140 & 16,11 & 11,12 & 9,70 & 8,50 & 7,61 & 6,85 & 5,57 & 4,58 & 3,21 \\
\hline 85 & 1100 & 140 & 15,73 & 10,92 & 9,56 & 8,41 & 7,54 & 6,80 & 5,55 & 4,57 & 3,22 \\
\hline 85 & 1150 & 140 & 15,37 & 10,73 & 9,43 & 8,32 & 7,48 & 6,75 & 5,53 & 4,57 & 3,23 \\
\hline 85 & 1200 & 140 & 15,05 & 10,55 & 9,30 & 8,23 & 7,42 & 6,71 & 5,51 & 4,56 & 3,23 \\
\hline 85 & 1250 & 140 & 14,74 & 10,38 & 9,19 & 8,15 & 7,36 & 6,67 & 5,49 & 4,56 & 3,23 \\
\hline 85 & 1300 & 140 & 14,46 & 10,22 & 9,07 & 8,07 & 7,30 & 6,63 & 5,47 & 4,55 & 3,24 \\
\hline 85 & 1350 & 140 & 14,20 & 10,07 & 8,97 & 7,99 & 7,24 & 6,59 & 5,45 & 4,55 & 3,24 \\
\hline 85 & 1400 & 140 & 13,95 & 9,93 & 8,86 & 7,92 & 7,19 & 6,55 & 5,44 & 4,54 & 3,25 \\
\hline 85 & 1450 & 140 & 13,72 & 9,80 & 8,77 & 7,85 & 7,14 & 6,51 & 5,42 & 4,53 & 3,25 \\
\hline
\end{tabular}




\begin{tabular}{|c|c|c|c|c|c|c|c|c|c|c|c|}
\hline \multirow[b]{2}{*}{$\mathrm{H}(\mathrm{cm})$} & \multirow[b]{2}{*}{ Mceq (MPa) } & & & & & De & jes ( $x 1$ & & & & \\
\hline & & Msub (MPa) & D0 & D25 & D40 & D60 & $\mathrm{D} 80$ & D100 & D140 & D180 & D260 \\
\hline 85 & 1500 & 140 & 13,50 & 9,67 & 8,67 & 7,79 & 7,09 & 6,47 & 5,40 & 4,53 & 3,25 \\
\hline 85 & 1550 & 140 & 13,29 & 9,55 & 8,58 & 7,72 & 7,04 & 6,44 & 5,38 & 4,52 & 3,26 \\
\hline 85 & 1600 & 140 & 13,09 & 9,43 & 8,50 & 7,66 & 6,99 & 6,40 & 5,36 & 4,51 & 3,26 \\
\hline 85 & 1650 & 140 & 12,91 & 9,32 & 8,41 & 7,60 & 6,95 & 6,37 & 5,34 & 4,50 & 3,26 \\
\hline 85 & 1700 & 140 & 12,73 & 9,21 & 8,33 & 7,54 & 6,90 & 6,33 & 5,33 & 4,50 & 3,26 \\
\hline 85 & 1750 & 140 & 12,57 & 9,11 & 8,26 & 7,49 & 6,86 & 6,30 & 5,31 & 4,49 & 3,26 \\
\hline 85 & 1800 & 140 & 12,41 & 9,02 & 8,18 & 7,43 & 6,82 & 6,27 & 5,29 & 4,48 & 3,26 \\
\hline 85 & 1850 & 140 & 12,25 & 8,92 & 8,11 & 7,38 & 6,78 & 6,24 & 5,28 & 4,47 & 3,27 \\
\hline 85 & 1900 & 140 & 12,11 & 8,83 & 8,04 & 7,33 & 6,74 & 6,21 & 5,26 & 4,47 & 3,27 \\
\hline 85 & 1950 & 140 & 11,97 & 8,75 & 7,97 & 7,28 & 6,70 & 6,18 & 5,24 & 4,46 & 3,27 \\
\hline 85 & 2000 & 140 & 11,84 & 8,67 & 7,91 & 7,23 & 6,66 & 6,15 & 5,23 & 4,45 & 3,27 \\
\hline 85 & 200 & 145 & 46,50 & 23,24 & 16,41 & 11,87 & 9,35 & 7,65 & 5,46 & 4,22 & 2,91 \\
\hline 85 & 250 & 145 & 39,32 & 20,65 & 15,10 & 11,31 & 9,12 & 7,58 & 5,50 & 4,27 & 2,92 \\
\hline 85 & 300 & 145 & 34,45 & 18,84 & 14,16 & 10,89 & 8,93 & 7,51 & 5,53 & 4,31 & 2,94 \\
\hline 85 & 350 & 145 & 30,92 & 17,49 & 13,43 & 10,54 & 8,76 & 7,44 & 5,55 & 4,34 & 2,95 \\
\hline 85 & 400 & 145 & 28,23 & 16,43 & 12,85 & 10,25 & 8,61 & 7,37 & 5,55 & 4,36 & 2,97 \\
\hline 85 & 450 & 145 & 26,12 & 15,58 & 12,37 & 10,00 & 8,48 & 7,30 & 5,55 & 4,38 & 2,98 \\
\hline 85 & 500 & 145 & 24,40 & 14,86 & 11,95 & 9,78 & 8,35 & 7,24 & 5,55 & 4,40 & 3,00 \\
\hline 85 & 550 & 145 & 22,97 & 14,25 & 11,60 & 9,58 & 8,24 & 7,17 & 5,54 & 4,41 & 3,01 \\
\hline 85 & 600 & 145 & 21,77 & 13,73 & 11,28 & 9,40 & 8,13 & 7,11 & 5,53 & 4,42 & 3,02 \\
\hline 85 & 650 & 145 & 20,74 & 13,27 & 11,00 & 9,24 & 8,03 & 7,05 & 5,52 & 4,42 & 3,03 \\
\hline 85 & 700 & 145 & 19,85 & 12,86 & 10,75 & 9,09 & 7,93 & 7,00 & 5,51 & 4,43 & 3,04 \\
\hline 85 & 750 & 145 & 19,07 & 12,49 & 10,52 & 8,95 & 7,85 & 6,94 & 5,49 & 4,43 & 3,05 \\
\hline 85 & 800 & 145 & 18,38 & 12,16 & 10,31 & 8,82 & 7,76 & 6,89 & 5,47 & 4,43 & 3,06 \\
\hline 85 & 850 & 145 & 17,76 & 11,86 & 10,12 & 8,70 & 7,68 & 6,84 & 5,46 & 4,43 & 3,07 \\
\hline 85 & 900 & 145 & 17,21 & 11,59 & 9,94 & 8,58 & 7,60 & 6,79 & 5,44 & 4,43 & 3,08 \\
\hline 85 & 950 & 145 & 16,71 & 11,34 & 9,77 & 8,47 & 7,53 & 6,74 & 5,42 & 4,43 & 3,09 \\
\hline 85 & 1000 & 145 & 16,26 & 11,11 & 9,62 & 8,37 & 7,46 & 6,69 & 5,41 & 4,43 & 3,09 \\
\hline 85 & 1050 & 145 & 15,84 & 10,89 & 9,47 & 8,28 & 7,39 & 6,64 & 5,39 & 4,42 & 3,10 \\
\hline 85 & 1100 & 145 & 15,46 & 10,69 & 9,33 & 8,18 & 7,33 & 6,60 & 5,37 & 4,42 & 3,10 \\
\hline 85 & 1150 & 145 & 15,11 & 10,50 & 9,20 & 8,10 & 7,27 & 6,56 & 5,35 & 4,42 & 3,11 \\
\hline 85 & 1200 & 145 & 14,79 & 10,33 & 9,08 & 8,01 & 7,21 & 6,51 & 5,34 & 4,41 & 3,12 \\
\hline 85 & 1250 & 145 & 14,49 & 10,16 & 8,97 & 7,94 & 7,15 & 6,47 & 5,32 & 4,41 & 3,12 \\
\hline 85 & 1300 & 145 & 14,21 & 10,01 & 8,86 & 7,86 & 7,10 & 6,43 & 5,30 & 4,40 & 3,12 \\
\hline 85 & 1350 & 145 & 13,94 & 9,86 & 8,75 & 7,79 & 7,04 & 6,40 & 5,28 & 4,40 & 3,13 \\
\hline 85 & 1400 & 145 & 13,70 & 9,72 & 8,65 & 7,72 & 6,99 & 6,36 & 5,27 & 4,39 & 3,13 \\
\hline 85 & 1450 & 145 & 13,47 & 9,59 & 8,56 & 7,65 & 6,94 & 6,32 & 5,25 & 4,38 & 3,13 \\
\hline 85 & 1500 & 145 & 13,25 & 9,46 & 8,47 & 7,58 & 6,89 & 6,29 & 5,23 & 4,38 & 3,14 \\
\hline 85 & 1550 & 145 & 13,05 & 9,34 & 8,38 & 7,52 & 6,85 & 6,25 & 5,21 & 4,37 & 3,14 \\
\hline 85 & 1600 & 145 & 12,85 & 9,23 & 8,29 & 7,46 & 6,80 & 6,22 & 5,20 & 4,36 & 3,14 \\
\hline 85 & 1650 & 145 & 12,67 & 9,12 & 8,21 & 7,40 & 6,76 & 6,18 & 5,18 & 4,36 & 3,14 \\
\hline 85 & 1700 & 145 & 12,49 & 9,02 & 8,14 & 7,35 & 6,71 & 6,15 & 5,16 & 4,35 & 3,15 \\
\hline 85 & 1750 & 145 & 12,33 & 8,92 & 8,06 & 7,29 & 6,67 & 6,12 & 5,15 & 4,34 & 3,15 \\
\hline 85 & 1800 & 145 & 12,17 & 8,82 & 7,99 & 7,24 & 6,63 & 6,09 & 5,13 & 4,34 & 3,15 \\
\hline 85 & 1850 & 145 & 12,02 & 8,73 & 7,92 & 7,19 & 6,59 & 6,06 & 5,11 & 4,33 & 3,15 \\
\hline 85 & 1900 & 145 & 11,88 & 8,64 & 7,85 & 7,14 & 6,56 & 6,03 & 5,10 & 4,32 & 3,15 \\
\hline 85 & 1950 & 145 & 11,74 & 8,56 & 7,79 & 7,09 & 6,52 & 6,00 & 5,08 & 4,32 & 3,15 \\
\hline 85 & 2000 & 145 & 11,61 & 8,48 & 7,72 & 7,04 & 6,48 & 5,97 & 5,07 & 4,31 & 3,15 \\
\hline 85 & 200 & 150 & 46,14 & 22,89 & 16,07 & 11,56 & 9,07 & 7,41 & 5,27 & 4,07 & 2,81 \\
\hline 85 & 250 & 150 & 38,97 & 20,31 & 14,78 & 11,02 & 8,85 & 7,34 & 5,32 & 4,12 & 2,82 \\
\hline 85 & 300 & 150 & 34,12 & 18,52 & 13,85 & 10,60 & 8,67 & 7,28 & 5,34 & 4,16 & 2,84 \\
\hline 85 & 350 & 150 & 30,60 & 17,18 & 13,14 & 10,27 & 8,51 & 7,21 & 5,36 & 4,19 & 2,85 \\
\hline 85 & 400 & 150 & 27,92 & 16,14 & 12,56 & 9,98 & 8,36 & 7,14 & 5,37 & 4,21 & 2,87 \\
\hline 85 & 450 & 150 & 25,81 & 15,29 & 12,09 & 9,74 & 8,23 & 7,08 & 5,37 & 4,23 & 2,88 \\
\hline 85 & 500 & 150 & 24,10 & 14,58 & 11,68 & 9,52 & 8,11 & 7,02 & 5,37 & 4,25 & 2,89 \\
\hline 85 & 550 & 150 & 22,68 & 13,98 & 11,33 & 9,33 & 8,00 & 6,96 & 5,36 & 4,26 & 2,90 \\
\hline 85 & 600 & 150 & 21,49 & 13,47 & 11,02 & 9,16 & 7,90 & 6,90 & 5,35 & 4,27 & 2,92 \\
\hline 85 & 650 & 150 & 20,46 & 13,01 & 10,75 & 9,00 & 7,80 & 6,84 & 5,34 & 4,27 & 2,93 \\
\hline 85 & 700 & 150 & 19,58 & 12,61 & 10,50 & 8,85 & 7,71 & 6,79 & 5,33 & 4,28 & 2,94 \\
\hline 85 & 750 & 150 & 18,80 & 12,25 & 10,28 & 8,72 & 7,63 & 6,74 & 5,31 & 4,28 & 2,95 \\
\hline 85 & 800 & 150 & 18,11 & 11,92 & 10,07 & 8,59 & 7,55 & 6,69 & 5,30 & 4,28 & 2,96 \\
\hline 85 & 850 & 150 & 17,50 & 11,63 & 9,88 & 8,47 & 7,47 & 6,64 & 5,29 & 4,28 & 2,96 \\
\hline 85 & 900 & 150 & 16,95 & 11,36 & 9,71 & 8,36 & 7,39 & 6,59 & 5,27 & 4,28 & 2,97 \\
\hline 85 & 950 & 150 & 16,45 & 11,11 & 9,55 & 8,26 & 7,32 & 6,54 & 5,25 & 4,28 & 2,98 \\
\hline 85 & 1000 & 150 & 16,00 & 10,88 & 9,39 & 8,16 & 7,26 & 6,50 & 5,24 & 4,28 & 2,99 \\
\hline 85 & 1050 & 150 & 15,59 & 10,67 & 9,25 & 8,06 & 7,19 & 6,45 & 5,22 & 4,28 & 2,99 \\
\hline 85 & 1100 & 150 & 15,21 & 10,47 & 9,12 & 7,98 & 7,13 & 6,41 & 5,20 & 4,28 & 3,00 \\
\hline 85 & 1150 & 150 & 14,87 & 10,29 & 8,99 & 7,89 & 7,07 & 6,37 & 5,19 & 4,27 & 3,00 \\
\hline 85 & 1200 & 150 & 14,54 & 10,12 & 8,87 & 7,81 & 7,01 & 6,33 & 5,17 & 4,27 & 3,01 \\
\hline 85 & 1250 & 150 & 14,24 & 9,95 & 8,76 & 7,73 & 6,96 & 6,29 & 5,16 & 4,26 & 3,01 \\
\hline 85 & 1300 & 150 & 13,97 & 9,80 & 8,65 & 7,66 & 6,91 & 6,25 & 5,14 & 4,26 & 3,02 \\
\hline 85 & 1350 & 150 & 13,71 & 9,66 & 8,55 & 7,59 & 6,85 & 6,22 & 5,12 & 4,25 & 3,02 \\
\hline 85 & 1400 & 150 & 13,46 & 9,52 & 8,45 & 7,52 & 6,81 & 6,18 & 5,11 & 4,25 & 3,02 \\
\hline 85 & 1450 & 150 & 13,23 & 9,39 & 8,36 & 7,46 & 6,76 & 6,15 & 5,09 & 4,24 & 3,03 \\
\hline 85 & 1500 & 150 & 13,02 & 9,27 & 8,27 & 7,39 & 6,71 & 6,11 & 5,07 & 4,24 & 3,03 \\
\hline 85 & 1550 & 150 & 12,82 & 9,15 & 8,19 & 7,33 & 6,67 & 6,08 & 5,06 & 4,23 & 3,03 \\
\hline 85 & 1600 & 150 & 12,62 & 9,04 & 8,10 & 7,28 & 6,62 & 6,05 & 5,04 & 4,23 & 3,04 \\
\hline 85 & 1650 & 150 & 12,44 & 8,93 & 8,03 & 7,22 & 6,58 & 6,01 & 5,03 & 4,22 & 3,04 \\
\hline 85 & 1700 & 150 & 12,27 & 8,83 & 7,95 & 7,16 & 6,54 & 5,98 & 5,01 & 4,21 & 3,04 \\
\hline 85 & 1750 & 150 & 12,11 & 8,73 & 7,88 & 7,11 & 6,50 & 5,95 & 4,99 & 4,21 & 3,04 \\
\hline 85 & 1800 & 150 & 11,95 & 8,64 & 7,81 & 7,06 & 6,46 & 5,92 & 4,98 & 4,20 & 3,04 \\
\hline
\end{tabular}




\begin{tabular}{|c|c|c|c|c|c|c|c|c|c|c|c|}
\hline \multirow[b]{2}{*}{$\mathrm{H}(\mathrm{cm})$} & \multirow[b]{2}{*}{ Mceq (MPa) } & & & & & $\mathrm{De}$ & ões (x. & & & & \\
\hline & & Msub (MPa) & D0 & D25 & D40 & D60 & D80 & D100 & D140 & D180 & D260 \\
\hline 85 & 1850 & 150 & 11,80 & 8,55 & 7,74 & 7,01 & 6,42 & 5,89 & 4,96 & 4,19 & 3,04 \\
\hline 85 & 1900 & 150 & 11,66 & 8,46 & 7,67 & 6,96 & 6,38 & 5,87 & 4,95 & 4,19 & 3,05 \\
\hline 85 & 1950 & 150 & 11,52 & 8,38 & 7,61 & 6,92 & 6,35 & 5,84 & 4,93 & 4,18 & 3,05 \\
\hline 85 & 2000 & 150 & 11,39 & 8,30 & 7,55 & 6,87 & 6,31 & 5,81 & 4,92 & 4,17 & 3,05 \\
\hline 85 & 200 & 155 & 45,80 & 22,55 & 15,75 & 11,27 & 8,81 & 7,18 & 5,09 & 3,93 & 2,72 \\
\hline 85 & 250 & 155 & 38,65 & 20,00 & 14,47 & 10,74 & 8,60 & 7,12 & 5,14 & 3,98 & 2,73 \\
\hline 85 & 300 & 155 & 33,81 & 18,22 & 13,56 & 10,33 & 8,42 & 7,05 & 5,17 & 4,02 & 2,74 \\
\hline 85 & 350 & 155 & 30,30 & 16,89 & 12,85 & 10,00 & 8,26 & 6,99 & 5,18 & 4,05 & 2,76 \\
\hline 85 & 400 & 155 & 27,63 & 15,86 & 12,29 & 9,73 & 8,13 & 6,93 & 5,19 & 4,07 & 2,77 \\
\hline 85 & 450 & 155 & 25,53 & 15,02 & 11,82 & 9,49 & 8,00 & 6,87 & 5,20 & 4,09 & 2,78 \\
\hline 85 & 500 & 155 & 23,82 & 14,32 & 11,43 & 9,28 & 7,89 & 6,81 & 5,19 & 4,10 & 2,79 \\
\hline 85 & 550 & 155 & 22,41 & 13,73 & 11,08 & 9,09 & 7,78 & 6,75 & 5,19 & 4,12 & 2,81 \\
\hline 85 & 600 & 155 & 21,22 & 13,22 & 10,78 & 8.92 & 7.68 & 6.70 & 5,18 & 4.13 & 2,82 \\
\hline 85 & 650 & 155 & 20,20 & 12,77 & 10,51 & 8,77 & 7,59 & 6,65 & 5,17 & 4,13 & 2,83 \\
\hline 85 & 700 & 155 & 19,32 & 12,37 & 10,27 & 8,63 & 7,50 & 6,59 & 5,16 & 4,14 & 2,84 \\
\hline 85 & 750 & 155 & 18,55 & 12,02 & 10,05 & 8,50 & 7,42 & 6,54 & 5,15 & 4,14 & 2,85 \\
\hline 85 & 800 & 155 & 17,86 & 11,70 & 9,85 & 8,37 & 7,34 & 6,49 & 5,14 & 4,14 & 2,86 \\
\hline 85 & 850 & 155 & 17,25 & 11,41 & 9,66 & 8,26 & 7,27 & 6,45 & 5,12 & 4,15 & 2,86 \\
\hline 85 & 900 & 155 & 16,71 & 11,14 & 9,49 & 8,15 & 7,20 & 6,40 & 5,11 & 4,15 & 2,87 \\
\hline 85 & 950 & 155 & 16,21 & 10,90 & 9,33 & 8,05 & 7,13 & 6,36 & 5,09 & 4,15 & 2,88 \\
\hline 85 & 1000 & 155 & 15,76 & 10,67 & 9,18 & 7,96 & 7,06 & 6,31 & 5,08 & 4,14 & 2,88 \\
\hline 85 & 1050 & 155 & 15,35 & 10,47 & 9,05 & 7,87 & 7,00 & 6,27 & 5,06 & 4,14 & 2,89 \\
\hline 85 & 1100 & 155 & 14,98 & 10,27 & 8,92 & 7,78 & 6,94 & 6,23 & 5,05 & 4,14 & 2,90 \\
\hline 85 & 1150 & 155 & 14,63 & 10,09 & 8,79 & 7,70 & 6,89 & 6,19 & 5,03 & 4,14 & 2,90 \\
\hline 85 & 1200 & 155 & 14,31 & 9,92 & 8,68 & 7,62 & 6,83 & 6,16 & 5,02 & 4,13 & 2,91 \\
\hline 85 & 1250 & 155 & 14,02 & 9,76 & 8,57 & 7,54 & 6,78 & 6,12 & 5,00 & 4,13 & 2,91 \\
\hline 85 & 1300 & 155 & 13,74 & 9,61 & 8,46 & 7,47 & 6,73 & 6,08 & 4,99 & 4,13 & 2,92 \\
\hline 85 & 1350 & 155 & 13,48 & 9,47 & 8,36 & 7,40 & 6,68 & 6,05 & 4,97 & 4,12 & 2,92 \\
\hline 85 & 1400 & 155 & 13,24 & 9,33 & 8,27 & 7,34 & 6,63 & 6,01 & 4,96 & 4,12 & 2,92 \\
\hline 85 & 1450 & 155 & 13,01 & 9,20 & 8,18 & 7,28 & 6,58 & 5,98 & 4,94 & 4,11 & 2,93 \\
\hline 85 & 1500 & 155 & 12,80 & 9,08 & 8,09 & 7,21 & 6,54 & 5,95 & 4,92 & 4,11 & 2,93 \\
\hline 85 & 1550 & 155 & 12,60 & 8,97 & 8,01 & 7,16 & 6,49 & 5,91 & 4,91 & 4,10 & 2,93 \\
\hline 85 & 1600 & 155 & 12,41 & 8,86 & 7,93 & 7,10 & 6,45 & 5,88 & 4,89 & 4,10 & 2,93 \\
\hline 85 & 1650 & 155 & 12,23 & 8,75 & 7,85 & 7,04 & 6,41 & 5,85 & 4,88 & 4,09 & 2,94 \\
\hline 85 & 1700 & 155 & 12,06 & 8,65 & 7,77 & 6,99 & 6,37 & 5,82 & 4,86 & 4,08 & 2,94 \\
\hline 85 & 1750 & 155 & 11,89 & 8,56 & 7,70 & 6,94 & 6,33 & 5,79 & 4,85 & 4,08 & 2,94 \\
\hline 85 & 1800 & 155 & 11,74 & 8,47 & 7,63 & 6,89 & 6,29 & 5,77 & 4,84 & 4,07 & 2,94 \\
\hline 85 & 1850 & 155 & 11,59 & 8,38 & 7,57 & 6,84 & 6,26 & 5,74 & 4,82 & 4,07 & 2,94 \\
\hline 85 & 1900 & 155 & 11,45 & 8,29 & 7,50 & 6,80 & 6,22 & 5,71 & 4,81 & 4,06 & 2,95 \\
\hline 85 & 1950 & 155 & 11,32 & 8,21 & 7,44 & 6,75 & 6,19 & 5,68 & 4,79 & 4,05 & 2,95 \\
\hline 85 & 2000 & 155 & 11,19 & 8,13 & 7,38 & 6,71 & 6,15 & 5,66 & 4,78 & 4,05 & 2,95 \\
\hline 85 & 200 & 160 & 45,47 & 22,24 & 15,45 & 10,99 & 8,56 & 6,96 & 4,92 & 3,80 & 2,63 \\
\hline 85 & 250 & 160 & 38,34 & 19,70 & 14,19 & 10,47 & 8,36 & 6,90 & 4,97 & 3,85 & 2,64 \\
\hline 85 & 300 & 160 & 33,51 & 17,93 & 13,28 & 10,07 & 8,19 & 6,84 & 5,00 & 3,89 & 2,65 \\
\hline 85 & 350 & 160 & 30,01 & 16,62 & 12,59 & 9,75 & 8,04 & 6,79 & 5,02 & 3,92 & 2,67 \\
\hline 85 & 400 & 160 & 27,35 & 15,59 & 12,03 & 9,49 & 7,91 & 6,73 & 5,03 & 3,94 & 2,68 \\
\hline 85 & 450 & 160 & 25,26 & 14,76 & 11,57 & 9,25 & 7,79 & 6,67 & 5,03 & 3,96 & 2,69 \\
\hline 85 & 500 & 160 & 23,56 & 14,07 & 11,18 & 9,05 & 7,67 & 6,62 & 5,03 & 3,97 & 2,70 \\
\hline 85 & 550 & 160 & 22,15 & 13,49 & 10,84 & 8,87 & 7,57 & 6,56 & 5,03 & 3,98 & 2,71 \\
\hline 85 & 600 & 160 & 20,97 & 12,98 & 10,55 & 8,70 & 7,48 & 6,51 & 5,02 & 3,99 & 2,73 \\
\hline 85 & 650 & 160 & 19,95 & 12,54 & 10,28 & 8,55 & 7,39 & 6,46 & 5,01 & 4,00 & 2,74 \\
\hline 85 & 700 & 160 & 19,08 & 12,15 & 10,05 & 8,42 & 7,30 & 6,41 & 5,01 & 4,01 & 2,75 \\
\hline 85 & 750 & 160 & 18,31 & $\begin{array}{ll}1 L, \pm 0 \\
11,80\end{array}$ & 9,83 & 8,29 & 7,23 & $\begin{array}{l}, 31 \\
6,36\end{array}$ & 4,99 & $\begin{array}{l}4,01 \\
, 01\end{array}$ & 2,75 \\
\hline 85 & 800 & 160 & 17,63 & 11,48 & 9,63 & 8,17 & 7,15 & 6,32 & 4,98 & 4,01 & 2,76 \\
\hline 85 & 850 & 160 & 17,02 & 11,20 & 9,45 & 8,06 & 7,08 & 6,27 & 4,97 & 4,02 & 2,77 \\
\hline 85 & 900 & 160 & 16,48 & 10,94 & 9,29 & 7,96 & 7,01 & 6,23 & 4,96 & 4,02 & 2,78 \\
\hline 85 & 950 & 160 & 15,98 & 10,70 & 9,13 & 7,86 & 6,95 & 6,18 & 4,94 & 4,02 & 2,78 \\
\hline 85 & 1000 & 160 & 15,54 & 10,47 & 8,99 & 7,76 & 6,88 & 6,14 & 4,93 & 4,02 & 2,79 \\
\hline 85 & 1050 & 160 & 15,13 & 10,27 & 8,85 & 7,68 & 6,82 & 6,10 & 4,92 & 4,01 & 2,80 \\
\hline 85 & 1100 & 160 & 14,76 & 10,08 & 8,72 & 7,59 & 6,77 & 6,06 & 4,90 & 4,01 & 2,80 \\
\hline 85 & 1150 & 160 & 14,41 & 9,90 & 8,60 & 7,51 & 6,71 & 6,03 & 4,89 & 4,01 & 2,81 \\
\hline 85 & 1200 & 160 & 14,10 & 9,73 & 8,49 & 7,44 & 6,66 & 5,99 & 4,87 & 4,01 & 2,81 \\
\hline 85 & 1250 & 160 & 13,80 & 9,57 & 8,38 & 7,37 & 6,61 & 5,95 & 4,86 & 4,00 & 2,82 \\
\hline 85 & 1300 & 160 & 13,53 & 9,43 & 8,28 & 7,30 & 6,56 & 5,92 & 4,84 & 4,00 & 2,82 \\
\hline 85 & 1350 & 160 & 13,27 & 9,29 & 8,18 & 7,23 & 6,51 & 5,89 & 4,83 & 4,00 & 2,82 \\
\hline 85 & 1400 & 160 & 13,03 & 9,15 & 8,09 & 7,17 & 6,46 & 5,85 & 4,81 & 3,99 & 2,83 \\
\hline 85 & 1450 & 160 & 12,81 & 9,03 & 8,00 & 7,10 & 6,42 & 5,82 & 4,80 & 3,99 & 2,83 \\
\hline 85 & 1500 & 160 & 12,59 & 8,91 & 7,91 & 7,04 & 6,37 & 5,79 & 4,78 & 3,98 & 2,84 \\
\hline 85 & 1550 & 160 & 12,39 & 8,80 & 7,83 & 6,99 & 6,33 & 5,76 & 4,77 & 3,98 & 2,84 \\
\hline 85 & 1600 & 160 & 12,20 & 8,69 & 7,76 & 6,93 & 6,29 & 5,73 & 4,76 & 3,97 & 2,84 \\
\hline 85 & 1650 & 160 & 12,03 & 8,59 & 7,68 & 6,88 & 6,25 & 5,70 & 4,74 & 3,97 & 2,84 \\
\hline 85 & 1700 & 160 & 11,86 & 8,49 & 7,61 & 6,83 & 6,21 & 5,67 & 4,73 & 3,96 & 2,85 \\
\hline 85 & 1750 & 160 & 11,70 & 8,39 & 7,54 & 6,78 & 6,18 & 5,64 & 4,71 & 3,96 & 2,85 \\
\hline 85 & 1800 & 160 & 11,54 & 8,30 & 7,47 & 6,73 & 6,14 & 5,62 & 4,70 & 3,95 & 2,85 \\
\hline 85 & 1850 & 160 & 11,40 & 8,21 & 7,41 & 6,68 & 6,10 & 5,59 & 4,69 & 3,95 & 2,85 \\
\hline 85 & 1900 & 160 & 11,26 & 8,13 & 7,34 & 6,64 & 6,07 & 5,56 & 4,67 & 3,94 & 2,85 \\
\hline 85 & 1950 & 160 & 11,12 & 8,05 & 7,28 & 6,59 & 6,03 & 5,54 & 4,66 & 3,93 & 2,85 \\
\hline 85 & 2000 & 160 & 11,00 & 7,97 & 7,22 & 6,55 & 6,00 & 5,51 & 4,65 & 3,93 & 2,86 \\
\hline 85 & 200 & 165 & 45,17 & 21,94 & 15,17 & 10,73 & 8,33 & 6,75 & 4,76 & 3,68 & 2,55 \\
\hline 85 & 250 & 165 & 38,05 & 19,41 & 13,92 & 10,22 & 8,13 & 6,70 & 4,81 & 3,72 & 2,56 \\
\hline 85 & 300 & 165 & 33,23 & 17,66 & 13,02 & 9,83 & 7,97 & 6,65 & 4,85 & 3,76 & 2,57 \\
\hline
\end{tabular}




\begin{tabular}{|c|c|c|c|c|c|c|c|c|c|c|c|}
\hline \multirow[b]{2}{*}{$\mathrm{H}(\mathrm{cm})$} & \multirow[b]{2}{*}{ Mceq (MPa) } & & & & & $\mathrm{De}$ & $\operatorname{tes}(x)$ & & & & \\
\hline & & Msub (MPa) & D0 & D25 & D40 & D60 & $\mathrm{D} 80$ & D100 & D140 & D180 & D260 \\
\hline 85 & 350 & 165 & 29,74 & 16,36 & 12,34 & 9,52 & 7,82 & 6,59 & 4,86 & 3,79 & 2,58 \\
\hline 85 & 400 & 165 & 27,09 & 15,34 & 11,79 & 9,26 & 7,70 & $\begin{array}{l}6,54 \\
\end{array}$ & 4,88 & 3,81 & 2,60 \\
\hline 85 & 450 & 165 & 25,00 & 14,52 & 11,34 & 9,03 & 7,58 & 6,48 & 4,88 & 3,83 & 2,61 \\
\hline 85 & 500 & 165 & 23,31 & 13,84 & 10,95 & 8,83 & 7,47 & 6,43 & 4,88 & 3,85 & 2,62 \\
\hline 85 & 550 & 165 & 21,91 & 13,26 & 10,62 & 8,66 & 7,38 & 6,38 & 4,88 & 3,86 & 2,63 \\
\hline 85 & 600 & 165 & 20,73 & 12,76 & 10,33 & 8,50 & 7,28 & 6,33 & 4,87 & 3,87 & 2,64 \\
\hline 85 & 650 & 165 & 19,72 & 12,32 & 10,07 & 8,35 & 7,20 & 6,28 & 4,87 & 3,88 & 2,65 \\
\hline 85 & 700 & 165 & 18,84 & 11,94 & 9,84 & 8,22 & 7,12 & 6,24 & 4,86 & 3,88 & 2,66 \\
\hline 85 & 750 & 165 & 18,08 & 11,59 & 9,63 & 8,09 & 7,04 & 6,19 & 4,85 & 3,89 & 2,67 \\
\hline 85 & 800 & 165 & 17,40 & 11,28 & 9,43 & 7,98 & 6,97 & 6,15 & 4,84 & 3,89 & 2,67 \\
\hline 85 & 850 & 165 & 16,80 & 11,00 & 9,26 & 7,87 & 6,90 & 6,10 & 4,83 & 3,89 & 2,68 \\
\hline 85 & 900 & 165 & 16,26 & 10,74 & 9,09 & 7,77 & 6,83 & 6,06 & 4,81 & 3,89 & 2,69 \\
\hline 85 & 950 & 165 & 15,77 & 10,50 & 8.94 & 7.67 & 6.77 & 6.02 & 4.80 & 3,89 & 2,70 \\
\hline 85 & 1000 & 165 & 15,32 & 10,29 & 8,80 & 7,58 & 6,71 & 5,98 & 4,79 & 3,89 & 2,70 \\
\hline 85 & 1050 & 165 & 14,92 & 10,08 & 8,66 & 7,50 & 6,65 & 5,94 & 4,78 & 3,89 & 2,71 \\
\hline 85 & 1100 & 165 & 14,55 & 9,89 & 8,54 & 7,42 & 6,60 & 5,91 & 4,76 & 3,89 & 2,71 \\
\hline 85 & 1150 & 165 & 14,21 & 9,72 & 8,42 & 7,34 & 6,54 & 5,87 & 4,75 & 3,89 & 2,72 \\
\hline 85 & 1200 & 165 & 13,89 & 9,55 & 8,31 & 7,27 & 6,49 & 5,83 & 4,73 & 3,89 & 2,72 \\
\hline 85 & 1250 & 165 & 13,60 & 9,40 & 8,21 & 7,19 & 6,44 & 5,80 & 4,72 & 3,88 & 2,73 \\
\hline 85 & 1300 & 165 & 13,32 & 9,25 & 8,11 & 7,13 & 6,40 & 5,77 & 4,71 & 3,88 & 2,73 \\
\hline 85 & 1350 & 165 & 13,07 & 9,12 & 8,01 & 7,06 & 6,35 & 5,73 & 4,69 & 3,88 & 2,74 \\
\hline 85 & 1400 & 165 & 12,83 & 8,99 & 7,92 & 7,00 & 6,30 & 5,70 & 4,68 & 3,87 & 2,74 \\
\hline 85 & 1450 & 165 & 12,61 & 8,86 & 7,83 & 6,94 & 6,26 & 5,67 & 4,67 & 3,87 & 2,74 \\
\hline 85 & 1500 & 165 & 12,40 & 8,74 & 7,75 & 6,88 & 6,22 & 5,64 & 4,65 & 3,87 & 2,75 \\
\hline 85 & 1550 & 165 & 12,20 & 8,63 & 7,67 & 6,83 & 6,18 & 5,61 & 4,64 & 3,86 & 2,75 \\
\hline 85 & 1600 & 165 & 12,01 & 8,53 & 7,59 & 6,77 & 6,14 & 5,58 & 4,63 & 3,86 & 2,75 \\
\hline 85 & 1650 & 165 & 11,84 & 8,42 & 7,52 & 6,72 & 6,10 & 5,56 & 4,61 & 3,85 & 2,75 \\
\hline 85 & 1700 & 165 & 11,67 & 8,33 & 7,45 & 6,67 & 6,06 & 5,53 & 4,60 & 3,85 & 2,76 \\
\hline 85 & 1750 & 165 & 11,51 & 8,23 & 7,38 & 6,62 & 6,03 & 5,50 & 4,59 & 3,84 & 2,76 \\
\hline 85 & 1800 & 165 & 11,36 & 8,15 & 7,32 & 6,58 & 5,99 & 5,47 & 4,57 & 3,84 & 2,76 \\
\hline 85 & 1850 & 165 & 11,21 & 8,06 & 7,25 & 6,53 & 5,96 & 5,45 & 4,56 & 3,83 & 2,76 \\
\hline 85 & 1900 & 165 & 11,07 & 7,98 & 7,19 & 6,49 & 5,92 & 5,42 & 4,55 & 3,83 & 2,76 \\
\hline 85 & 1950 & 165 & 10,94 & 7,90 & 7,13 & 6,44 & 5,89 & 5,40 & 4,53 & 3,82 & 2,77 \\
\hline 85 & 2000 & 165 & 10,81 & 7,82 & 7,07 & 6,40 & 5,86 & 5,37 & 4,52 & 3,82 & 2,77 \\
\hline 85 & 200 & 170 & 44,88 & 21,66 & 14,90 & 10,49 & 8,11 & 6,56 & 4,61 & 3,56 & 2,47 \\
\hline 85 & 250 & 170 & 37,77 & 19,15 & 13,66 & 9,98 & 7,92 & 6,51 & 4,67 & 3,61 & 2,48 \\
\hline 85 & 300 & 170 & 32,97 & 17,40 & 12,77 & 9,60 & 7,76 & 6,46 & 4,70 & 3,65 & 2,49 \\
\hline 85 & 350 & 170 & 29,49 & 16,11 & 12,10 & 9,30 & 7,62 & 6,41 & 4,72 & 3,67 & 2,51 \\
\hline 85 & 400 & 170 & 26,84 & 15,10 & 11,56 & 9,04 & 7,50 & 6,36 & 4,73 & 3,70 & 2,52 \\
\hline 85 & 450 & 170 & 24,76 & 14,29 & 11,11 & 8,82 & 7,39 & 6,31 & 4,74 & 3,72 & 2,53 \\
\hline 85 & 500 & 170 & 23,08 & 13,61 & 10,73 & 8,63 & 7,28 & 6,26 & 4,74 & 3,73 & 2,54 \\
\hline 85 & 550 & 170 & 21,68 & 13,04 & 10,41 & 8,46 & 7,19 & 6,21 & 4,74 & 3,74 & 2,55 \\
\hline 85 & 600 & 170 & 20,50 & 12,55 & 10,12 & 8,30 & 7,10 & 6,16 & 4,73 & 3,75 & 2,56 \\
\hline 85 & 650 & 170 & 19,50 & 12,12 & 9,87 & 8,16 & 7,02 & 6,12 & 4,73 & 3,76 & 2,57 \\
\hline 85 & 700 & 170 & 18,63 & 11,73 & 9,64 & 8,03 & 6,94 & 6,07 & 4,72 & 3,77 & 2,58 \\
\hline 85 & 750 & 170 & 17,86 & 11,39 & 9,43 & 7,91 & 6,87 & 6,03 & 4,71 & 3,77 & 2,58 \\
\hline 85 & 800 & 170 & 17,19 & 11,09 & 9,24 & 7,79 & 6,80 & 5,98 & 4,70 & 3,77 & 2,59 \\
\hline 85 & 850 & 170 & 16,59 & 10,81 & 9,07 & 7,69 & 6,73 & 5,94 & 4,69 & 3,78 & 2,60 \\
\hline 85 & 900 & 170 & 16,05 & 10,55 & 8,91 & 7,59 & 6,67 & 5,90 & 4,68 & 3,78 & 2,61 \\
\hline 85 & 950 & 170 & 15,56 & 10,32 & 8,76 & 7,50 & 6,61 & 5,87 & 4,67 & 3,78 & 2,61 \\
\hline 85 & 1000 & 170 & 15,12 & 10,11 & 8,62 & 7,41 & 6,55 & 5,83 & 4,65 & 3,78 & 2,62 \\
\hline 85 & 1050 & 170 & 14,72 & 9,91 & 8,49 & 7,33 & 6,49 & 5,79 & 4,64 & 3,78 & 2,63 \\
\hline 85 & 1100 & 170 & 14,35 & 9,72 & 8,37 & 7,25 & 6,44 & 5,76 & 4,63 & 3,78 & 2,63 \\
\hline 85 & 1150 & 170 & 14,01 & 9,55 & 8,25 & 7,17 & 6,39 & 5,72 & 4,62 & 3,78 & 2,64 \\
\hline 85 & 1200 & 170 & 13,70 & 9,38 & 8,14 & 7,10 & 6,34 & 5,69 & 4,60 & 3,77 & 2,64 \\
\hline 85 & 1250 & 170 & 13,40 & 9,23 & 8,04 & 7,03 & 6,29 & 5,65 & 4,59 & 3,77 & 2,64 \\
\hline 85 & 1300 & 170 & 13,13 & 9,09 & 7,94 & 6,97 & 6,24 & 5,62 & 4,58 & 3,77 & 2,65 \\
\hline 85 & 1350 & 170 & 12,88 & 8,95 & 7,85 & 6,90 & 6,20 & 5,59 & 4,57 & 3,77 & 2,65 \\
\hline 85 & 1400 & 170 & 12,64 & 8,82 & 7,76 & 6,84 & 6,15 & 5,56 & 4,55 & 3,76 & 2,66 \\
\hline 85 & 1450 & 170 & 12,42 & 8,70 & 7,67 & 6,79 & 6,11 & 5,53 & 4,54 & 3,76 & 2,66 \\
\hline 85 & 1500 & 170 & 12,21 & 8,59 & 7,59 & 6,73 & 6,07 & 5,50 & 4,53 & 3,76 & 2,66 \\
\hline 85 & 1550 & 170 & 12,02 & 8,48 & 7,51 & 6,68 & 6,03 & 5,47 & 4,51 & 3,75 & 2,67 \\
\hline 85 & 1600 & 170 & 11,83 & 8,37 & 7,44 & 6,62 & 5,99 & 5,45 & 4,50 & 3,75 & 2,67 \\
\hline 85 & 1650 & 170 & 11,65 & 8,27 & 7,37 & 6,57 & 5,96 & 5,42 & 4,49 & 3,74 & 2,67 \\
\hline 85 & 1700 & 170 & 11,49 & 8,18 & 7,30 & 6,52 & 5,92 & 5,39 & 4,48 & 3,74 & 2,67 \\
\hline 85 & 1750 & 170 & 11,33 & 8,09 & 7,23 & 6,48 & 5,89 & 5,37 & 4,46 & 3,73 & 2,68 \\
\hline 85 & 1800 & 170 & 11,18 & 8,00 & 7,17 & 6,43 & 5,85 & 5,34 & 4,45 & 3,73 & 2,68 \\
\hline 85 & 1850 & 170 & 11,03 & 7,91 & 7,11 & 6,39 & 5,82 & 5,32 & 4,44 & 3,73 & 2,68 \\
\hline 85 & 1900 & 170 & 10,90 & 7,83 & 7,05 & 6,34 & 5,79 & 5,29 & 4,43 & 3,72 & 2,68 \\
\hline 85 & 1950 & 170 & 10,77 & 7,75 & 6,99 & 6,30 & 5,75 & 5,27 & 4,41 & 3,72 & 2,68 \\
\hline 85 & 2000 & 170 & 10,64 & 7,68 & 6,93 & 6,26 & 5,72 & 5,24 & 4,40 & 3,71 & 2,68 \\
\hline 85 & 200 & 175 & 44,60 & 21,39 & 14,64 & 10,25 & 7,90 & 6,38 & 4,48 & 3,45 & 2,40 \\
\hline 85 & 250 & 175 & 37,51 & 18,89 & 13,41 & 9,76 & 7,72 & 6,33 & 4,53 & 3,50 & 2,41 \\
\hline 85 & 300 & 175 & 32,72 & 17,16 & 12,54 & 9,39 & 7,56 & 6,29 & 4,56 & 3,54 & 2,42 \\
\hline 85 & 350 & 175 & 29,25 & 15,87 & 11,87 & 9,09 & 7,43 & 6,24 & 4,58 & 3,56 & 2,43 \\
\hline 85 & 400 & 175 & 26,61 & 14,87 & 11,34 & 8,84 & 7,31 & 6,19 & 4,59 & 3,59 & 2,44 \\
\hline 85 & 450 & 175 & 24,53 & 14,07 & 10,90 & 8,62 & 7,20 & 6,14 & 4,60 & 3,61 & 2,45 \\
\hline 85 & 500 & 175 & 22,85 & 13,40 & 10,53 & 8,43 & 7,10 & 6,09 & 4,60 & 3,62 & 2,46 \\
\hline 85 & 550 & 175 & 21,46 & 12,83 & 10,21 & 8,27 & 7,01 & 6,05 & 4,60 & 3,63 & 2,47 \\
\hline 85 & 600 & 175 & 20,29 & 12,34 & 9,92 & 8,11 & 6,93 & 6,00 & 4,60 & 3,64 & 2,48 \\
\hline 85 & 650 & 175 & 19,29 & 11,92 & 9,67 & 7,98 & 6,85 & 5,96 & 4,59 & 3,65 & 2,49 \\
\hline
\end{tabular}




\begin{tabular}{|c|c|c|c|c|c|c|c|c|c|c|c|}
\hline \multirow[b]{2}{*}{$\mathrm{H}(\mathrm{cm})$} & \multirow[b]{2}{*}{ Mceq (MPa) } & & & & & De & jes ( $x 1$ & & & & \\
\hline & & Msub (MPa) & D0 & D25 & D40 & D60 & $\mathrm{D} 80$ & D100 & D140 & D180 & D260 \\
\hline 85 & 700 & 175 & 18,42 & 11,54 & 9,45 & 7,85 & 6,77 & 5,91 & 4,59 & 3,66 & 2,50 \\
\hline 85 & 750 & 175 & 17,66 & 11,21 & 9,24 & 7,73 & 6,70 & 5,87 & 4,58 & 3,66 & 2,51 \\
\hline 85 & 800 & 175 & 16,99 & 10,90 & 9,06 & 7,62 & 6,63 & 5,83 & 4,57 & 3,67 & 2,52 \\
\hline 85 & 850 & 175 & 16,39 & 10,63 & 8,89 & 7,52 & 6,57 & 5,79 & 4,56 & 3,67 & 2,52 \\
\hline 85 & 900 & 175 & 15,85 & 10,38 & 8,73 & 7,42 & 6,51 & 5,75 & 4,55 & 3,67 & 2,53 \\
\hline 85 & 950 & 175 & 15,37 & 10,15 & 8,58 & 7,33 & 6,45 & 5,72 & 4,54 & 3,67 & 2,54 \\
\hline 85 & 1000 & 175 & 14,93 & 9,93 & 8,45 & 7,25 & 6,39 & 5,68 & 4,53 & 3,67 & 2,54 \\
\hline 85 & 1050 & 175 & 14,53 & 9,74 & 8,32 & 7,17 & 6,34 & 5,65 & 4,52 & 3,67 & 2,55 \\
\hline 85 & 1100 & 175 & 14,16 & 9,55 & 8,20 & 7,09 & 6,29 & 5,61 & 4,51 & 3,67 & 2,55 \\
\hline 85 & 1150 & 175 & 13,82 & 9,38 & 8,09 & 7,02 & 6,24 & 5,58 & 4,49 & 3,67 & 2,56 \\
\hline 85 & 1200 & 175 & 13,51 & 9,22 & 7,98 & 6,95 & 6,19 & 5,55 & 4,48 & 3,67 & 2,56 \\
\hline 85 & 1250 & 175 & 13,22 & 9,07 & 7,88 & 6,88 & 6,14 & 5,52 & 4,47 & 3,67 & 2,57 \\
\hline 85 & 1300 & 175 & 12,95 & 8,93 & 7,78 & 6,82 & 6,10 & 5,48 & 4,46 & 3,66 & 2,57 \\
\hline 85 & 1350 & 175 & 12,70 & 8,80 & 7,69 & 6,75 & 6,05 & 5,45 & 4,45 & 3,66 & 2,57 \\
\hline 85 & 1400 & 175 & 12,47 & 8,67 & 7,61 & 6,70 & 6,01 & 5,43 & 4,43 & 3,66 & 2,58 \\
\hline 85 & 1450 & 175 & 12,24 & 8,55 & 7,52 & 6,64 & 5,97 & 5,40 & 4,42 & 3,66 & 2,58 \\
\hline 85 & 1500 & 175 & 12,04 & 8,44 & 7,44 & 6,58 & 5,93 & 5,37 & 4,41 & 3,65 & 2,58 \\
\hline 85 & 1550 & 175 & 11,84 & 8,33 & 7,37 & 6,53 & 5,89 & 5,34 & 4,40 & 3,65 & 2,59 \\
\hline 85 & 1600 & 175 & 11,66 & 8,23 & 7,29 & 6,48 & 5,86 & 5,31 & 4,38 & 3,64 & 2,59 \\
\hline 85 & 1650 & 175 & 11,48 & 8,13 & 7,22 & 6,43 & 5,82 & 5,29 & 4,37 & 3,64 & 2,59 \\
\hline 85 & 1700 & 175 & 11,32 & 8,03 & 7,16 & 6,38 & 5,79 & 5,26 & 4,36 & 3,64 & 2,59 \\
\hline 85 & 1750 & 175 & 11,16 & 7,94 & 7,09 & 6,34 & 5,75 & 5,24 & 4,35 & 3,63 & 2,60 \\
\hline 85 & 1800 & 175 & 11,01 & 7,86 & 7,03 & 6,29 & 5,72 & 5,21 & 4,34 & 3,63 & 2,60 \\
\hline 85 & 1850 & 175 & 10,87 & 7,77 & 6,97 & 6,25 & 5,69 & 5,19 & 4,32 & 3,62 & 2,60 \\
\hline 85 & 1900 & 175 & 10,73 & 7,69 & 6,91 & 6,21 & 5,65 & 5,17 & 4,31 & 3,62 & 2,60 \\
\hline 85 & 1950 & 175 & 10,60 & 7,62 & 6,85 & 6,17 & 5,62 & 5,14 & 4,30 & 3,61 & 2,60 \\
\hline 85 & 2000 & 175 & 10,48 & 7,54 & 6,80 & 6,13 & 5,59 & 5,12 & 4,29 & 3,61 & 2,61 \\
\hline 85 & 200 & 180 & 44,34 & 21,14 & 14,40 & 10,03 & 7,71 & 6,21 & 4,34 & 3,35 & 2,33 \\
\hline 85 & 250 & 180 & 37,26 & 18,65 & 13,18 & 9,55 & 7,53 & 6,16 & 4,40 & 3,40 & 2,34 \\
\hline 85 & 300 & 180 & 32,48 & 16,93 & 12,32 & 9,18 & 7,38 & 6,12 & 4,43 & 3,43 & 2,35 \\
\hline 85 & 350 & 180 & 29,01 & 15,65 & 11,66 & 8,89 & 7,25 & 6,07 & 4,45 & 3,46 & 2,36 \\
\hline 85 & 400 & 180 & 26,39 & 14,66 & 11,13 & 8,64 & 7,13 & 6,03 & 4,46 & 3,48 & 2,37 \\
\hline 85 & 450 & 180 & 24,31 & 13,86 & 10,70 & 8,43 & 7,03 & 5,98 & 4,47 & 3,50 & 2,38 \\
\hline 85 & 500 & 180 & 22,64 & 13,20 & 10,33 & 8,25 & 6,93 & 5,94 & 4,47 & 3,52 & 2,39 \\
\hline 85 & 550 & 180 & 21,25 & 12,63 & 10,01 & 8,08 & 6,84 & 5,89 & 4,47 & 3,53 & 2,40 \\
\hline 85 & 600 & 180 & 20,08 & 12,15 & 9,74 & 7,94 & 6,76 & 5,85 & 4,47 & 3,54 & 2,41 \\
\hline 85 & 650 & 180 & 19,09 & 11,73 & 9,49 & 7,80 & 6,68 & 5,81 & 4,47 & 3,55 & 2,42 \\
\hline 85 & 700 & 180 & 18,22 & 11,36 & 9,27 & 7,68 & 6,61 & 5,77 & 4,46 & 3,55 & 2,43 \\
\hline 85 & 750 & 180 & 17,46 & 11,03 & 9,07 & 7,56 & 6,54 & 5,73 & 4,45 & 3,56 & 2,43 \\
\hline 85 & 800 & 180 & 16,80 & 10,73 & 8,89 & 7,46 & 6,48 & 5,69 & 4,45 & 3,56 & 2,44 \\
\hline 85 & 850 & 180 & 16,20 & 10,46 & 8,72 & 7,36 & 6,41 & 5,65 & 4,44 & 3,57 & 2,45 \\
\hline 85 & 900 & 180 & 15,67 & 10,21 & 8,56 & 7,26 & 6,36 & 5,61 & 4,43 & 3,57 & 2,46 \\
\hline 85 & 950 & 180 & 15,19 & 9,98 & 8,42 & 7,17 & 6,30 & 5,58 & 4,42 & 3,57 & 2,46 \\
\hline 85 & 1000 & 180 & 14,75 & 9,77 & 8,29 & 7,09 & 6,24 & 5,54 & 4,41 & 3,57 & 2,47 \\
\hline 85 & 1050 & 180 & 14,35 & 9,58 & 8,16 & 7,01 & 6,19 & 5,51 & 4,40 & 3,57 & 2,47 \\
\hline 85 & 1100 & 180 & 13,98 & 9,40 & 8,04 & 6,94 & 6,14 & 5,48 & 4,39 & 3,57 & 2,48 \\
\hline 85 & 1150 & 180 & 13,65 & 9,23 & 7,93 & 6,87 & 6,09 & 5,44 & 4,38 & 3,57 & 2,48 \\
\hline 85 & 1200 & 180 & 13,34 & 9,07 & 7,83 & 6,80 & 6,05 & 5,41 & 4,36 & 3,57 & 2,49 \\
\hline 85 & 1250 & 180 & 13,05 & 8,92 & 7,73 & 6,73 & 6,00 & 5,38 & 4,35 & 3,57 & 2,49 \\
\hline 85 & 1300 & 180 & 12,78 & 8,78 & 7,63 & 6,67 & 5,96 & 5,35 & 4,34 & 3,56 & 2,50 \\
\hline 85 & 1350 & 180 & 12,53 & 8,65 & 7,55 & 6,61 & 5,92 & 5,32 & 4,33 & 3,56 & 2,50 \\
\hline 85 & 1400 & 180 & 12,30 & 8,53 & 7,46 & 6,55 & 5,88 & 5,30 & 4,32 & 3,56 & 2,50 \\
\hline 85 & 1450 & 180 & 12,08 & 8,41 & 7,38 & 6,50 & 5,84 & 5,27 & 4,31 & 3,56 & 2,51 \\
\hline 85 & 1500 & 180 & 11,87 & 8,30 & 7,30 & 6,45 & 5,80 & 5,24 & 4,30 & 3,55 & 2,51 \\
\hline 85 & 1550 & 180 & 11,68 & 8,19 & 7,23 & 6,39 & 5,76 & 5,22 & 4,28 & 3,55 & 2,51 \\
\hline 85 & 1600 & 180 & 11,49 & 8,09 & 7,15 & 6,34 & 5,73 & 5,19 & 4,27 & 3,55 & 2,52 \\
\hline 85 & 1650 & 180 & 11,32 & 7,99 & 7,09 & 6,30 & 5,69 & 5,16 & 4,26 & 3,54 & 2,52 \\
\hline 85 & 1700 & 180 & 11,15 & 7,90 & 7,02 & 6,25 & 5,66 & 5,14 & 4,25 & 3,54 & 2,52 \\
\hline 85 & 1750 & 180 & 11,00 & 7,81 & 6,96 & 6,21 & 5,62 & 5,12 & 4,24 & 3,54 & 2,52 \\
\hline 85 & 1800 & 180 & 10,85 & 7,72 & 6,89 & 6,16 & 5,59 & 5,09 & 4,23 & 3,53 & 2,52 \\
\hline 85 & 1850 & 180 & 10,71 & 7,64 & 6,83 & 6,12 & 5,56 & 5,07 & 4,22 & 3,53 & 2,53 \\
\hline 85 & 1900 & 180 & 10,57 & 7,56 & 6,78 & 6,08 & 5,53 & 5,05 & 4,21 & 3,52 & 2,53 \\
\hline 85 & 1950 & 180 & 10,44 & 7,49 & 6,72 & 6,04 & 5,50 & 5,02 & 4,19 & 3,52 & 2,53 \\
\hline 85 & 2000 & 180 & 10,32 & 7,41 & 6,67 & 6,00 & 5,47 & 5,00 & 4,18 & 3,51 & 2,53 \\
\hline 85 & 200 & 185 & 44,10 & 20,90 & 14,17 & 9,82 & 7,52 & 6,04 & 4,22 & 3,25 & 2,27 \\
\hline 85 & 250 & 185 & 37,02 & 18,42 & 12,96 & 9,34 & 7,34 & 6,00 & 4,27 & 3,30 & 2,28 \\
\hline 85 & 300 & 185 & 32,25 & 16,71 & 12,10 & 8,98 & 7,20 & 5,96 & 4,31 & 3,33 & 2,29 \\
\hline 85 & 350 & 185 & 28,79 & 15,44 & 11,45 & 8,70 & 7,07 & 5,92 & 4,33 & 3,36 & 2,30 \\
\hline 85 & 400 & 185 & 26,17 & 14,45 & 10,93 & 8,46 & 6,96 & 5,87 & 4,34 & 3,38 & 2,31 \\
\hline 85 & 450 & 185 & 24,11 & 13,66 & 10,50 & 8,25 & 6,86 & 5,83 & 4,35 & 3,40 & 2,32 \\
\hline 85 & 500 & 185 & 22,44 & 13,00 & 10,14 & 8,07 & 6,77 & 5,79 & 4,35 & 3,42 & 2,32 \\
\hline 85 & 550 & 185 & 21,05 & 12,45 & 9,83 & 7,91 & 6,68 & 5,74 & 4,35 & 3,43 & 2,33 \\
\hline 85 & 600 & 185 & 19,89 & 11,97 & 9,56 & 7,77 & 6,60 & 5,70 & 4,35 & 3,44 & 2,34 \\
\hline 85 & 650 & 185 & 18,90 & 11,55 & 9,31 & 7,63 & 6,53 & 5,66 & 4,35 & 3,45 & 2,35 \\
\hline 85 & 700 & 185 & 18,03 & 11,18 & 9,10 & 7,51 & 6,46 & 5,62 & 4,34 & 3,45 & 2,36 \\
\hline 85 & 750 & 185 & 17,28 & 10,85 & 8,90 & 7,40 & 6,39 & 5,59 & 4,34 & 3,46 & 2,37 \\
\hline 85 & 800 & 185 & 16,61 & 10,56 & 8,72 & 7,30 & 6,33 & 5,55 & 4,33 & 3,46 & 2,37 \\
\hline 85 & 850 & 185 & 16,02 & 10,29 & 8,56 & 7,20 & 6,27 & 5,51 & 4,32 & 3,47 & 2,38 \\
\hline 85 & 900 & 185 & 15,49 & 10,05 & 8,40 & 7,11 & 6,21 & 5,48 & 4,31 & 3,47 & 2,39 \\
\hline 85 & 950 & 185 & 15,01 & 9,82 & 8,26 & 7,02 & 6,16 & 5,44 & 4,30 & 3,47 & 2,39 \\
\hline 85 & 1000 & 185 & 14,57 & 9,62 & 8,13 & 6,94 & 6,10 & 5,41 & 4,30 & 3,47 & 2,40 \\
\hline
\end{tabular}




\begin{tabular}{|c|c|c|c|c|c|c|c|c|c|c|c|}
\hline \multirow[b]{2}{*}{$\mathrm{H}(\mathrm{cm})$} & \multirow[b]{2}{*}{ Mceq (MPa) } & & & & & & Jes $(x$ & & & & \\
\hline & & Msub (MPa) & D0 & D25 & D40 & D60 & D80 & D100 & D140 & D180 & D260 \\
\hline 85 & 1050 & 185 & 14,18 & 9,42 & 8,01 & 6,87 & 6,05 & 5,38 & 4,29 & 3,47 & 2,40 \\
\hline 85 & 1100 & 185 & 13,81 & 9,25 & 7,89 & 6,79 & 6,01 & 5,35 & 4,27 & 3,47 & 2,41 \\
\hline 85 & 1150 & 185 & 13,48 & 9,08 & 7,78 & 6,72 & 5,96 & 5,32 & 4,26 & 3,47 & 2,41 \\
\hline 85 & 1200 & 185 & 13,17 & 8,92 & 7,68 & 6,66 & 5,91 & 5,29 & 4,25 & 3,47 & 2,42 \\
\hline 85 & 1250 & 185 & 12,88 & 8,78 & 7,58 & 6,59 & 5,87 & 5,26 & 4,24 & 3,47 & 2,42 \\
\hline 85 & 1300 & 185 & 12,62 & 8,64 & 7,49 & 6,53 & 5,83 & 5,23 & 4,23 & 3,47 & 2,43 \\
\hline 85 & 1350 & 185 & 12,37 & 8,51 & 7,40 & 6,47 & 5,79 & 5,20 & 4,22 & 3,47 & 2,43 \\
\hline 85 & 1400 & 185 & 12,13 & 8,39 & 7,32 & 6,42 & 5,75 & 5,17 & 4,21 & 3,46 & 2,43 \\
\hline 85 & 1450 & 185 & 11,92 & 8,27 & 7,24 & 6,36 & 5,71 & 5,15 & 4,20 & 3,46 & 2,44 \\
\hline 85 & 1500 & 185 & 11,71 & 8,16 & 7,16 & 6,31 & 5,67 & 5,12 & 4,19 & 3,46 & 2,44 \\
\hline 85 & 1550 & 185 & 11,52 & 8,05 & 7,09 & 6,26 & 5,64 & 5,10 & 4,18 & 3,46 & 2,44 \\
\hline 85 & 1600 & 185 & 11,34 & 7,95 & 7,02 & 6,21 & 5,60 & 5,07 & 4,17 & 3,45 & 2,45 \\
\hline 85 & 1650 & 185 & 11,16 & 7,86 & 6,95 & 6,17 & 5,57 & 5,05 & 4,16 & 3,45 & 2,45 \\
\hline 85 & 1700 & 185 & 11,00 & 7,77 & 6,89 & 6,12 & 5,54 & 5,02 & 4,15 & 3,45 & 2,45 \\
\hline 85 & 1750 & 185 & 10,84 & 7,68 & 6,83 & 6,08 & 5,50 & 5,00 & 4,13 & 3,44 & 2,45 \\
\hline 85 & 1800 & 185 & 10,70 & 7,59 & 6,77 & 6,04 & 5,47 & 4,98 & 4,12 & 3,44 & 2,45 \\
\hline 85 & 1850 & 185 & 10,56 & 7,51 & 6,71 & 6,00 & 5,44 & 4,95 & 4,11 & 3,44 & 2,46 \\
\hline 85 & 1900 & 185 & 10,42 & 7,44 & 6,65 & 5,96 & 5,41 & 4,93 & 4,10 & 3,43 & 2,46 \\
\hline 85 & 1950 & 185 & 10,29 & 7,36 & 6,60 & 5,92 & 5,38 & 4,91 & 4,09 & 3,43 & 2,46 \\
\hline 85 & 2000 & 185 & 10,17 & 7,29 & 6,54 & 5,88 & 5,35 & 4,89 & 4,08 & 3,42 & 2,46 \\
\hline 85 & 200 & 190 & 43,86 & 20,67 & 13,95 & 9,62 & 7,34 & 5,89 & 4,10 & 3,16 & 2,21 \\
\hline 85 & 250 & 190 & 36,80 & 18,20 & 12,75 & 9,15 & 7,17 & 5,85 & 4,15 & 3,21 & 2,22 \\
\hline 85 & 300 & 190 & 32,03 & 16,50 & 11,90 & 8,80 & 7,03 & 5,81 & 4,19 & 3,24 & 2,23 \\
\hline 85 & 350 & 190 & 28,59 & 15,24 & 11,25 & 8,52 & 6,91 & 5,77 & 4,21 & 3,27 & 2,23 \\
\hline 85 & 400 & 190 & 25,97 & 14,26 & 10,74 & 8,28 & 6,80 & 5,73 & 4,22 & 3,29 & 2,24 \\
\hline 85 & 450 & 190 & 23,91 & 13,47 & 10,32 & 8,08 & 6,70 & 5,69 & 4,23 & 3,31 & 2,25 \\
\hline 85 & 500 & 190 & 22,24 & 12,82 & 9,96 & 7,90 & 6,61 & 5,65 & 4,24 & 3,32 & 2,26 \\
\hline 85 & 550 & 190 & 20,87 & 12,27 & 9,65 & 7,75 & 6,53 & 5,61 & 4,24 & 3,34 & 2,27 \\
\hline 85 & 600 & 190 & 19,71 & 11,79 & 9,38 & 7,61 & 6,45 & 5,57 & 4,24 & 3,35 & 2,28 \\
\hline 85 & 650 & 190 & 18,71 & 11,38 & 9,15 & 7,48 & 6,38 & 5,53 & 4,24 & 3,35 & 2,29 \\
\hline 85 & 700 & 190 & 17,85 & 11,02 & 8,93 & 7,36 & 6,31 & 5,49 & 4,23 & 3,36 & 2,29 \\
\hline 85 & 750 & 190 & 17,10 & 10,69 & 8,74 & 7,25 & 6,25 & 5,45 & 4,23 & 3,37 & 2,30 \\
\hline 85 & 800 & 190 & 16,44 & 10,40 & 8,56 & 7,15 & 6,19 & 5,42 & 4,22 & 3,37 & 2,31 \\
\hline 85 & 850 & 190 & 15,85 & 10,13 & 8,40 & 7,05 & 6,13 & 5,38 & 4,21 & 3,38 & 2,31 \\
\hline 85 & 900 & 190 & 15,32 & 9,89 & 8,25 & 6,96 & 6,07 & 5,35 & 4,20 & 3,38 & 2,32 \\
\hline 85 & 950 & 190 & 14,84 & 9,67 & 8,11 & 6,88 & 6,02 & 5,32 & 4,20 & 3,38 & 2,33 \\
\hline 85 & 1000 & 190 & 14,41 & 9,47 & 7,98 & 6,80 & 5,97 & 5,29 & 4,19 & 3,38 & 2,33 \\
\hline 85 & 1050 & 190 & 14,01 & 9,28 & 7,86 & 6,73 & 5,92 & 5,25 & 4,18 & 3,38 & 2,34 \\
\hline 85 & 1100 & 190 & 13,65 & 9,10 & 7,75 & 6,66 & 5,87 & 5,22 & 4,17 & 3,38 & 2,34 \\
\hline 85 & 1150 & 190 & 13,32 & 8,94 & 7,64 & 6,59 & 5,83 & 5,20 & 4,16 & 3,38 & 2,35 \\
\hline 85 & 1200 & 190 & 13,01 & 8,78 & 7,54 & 6,52 & 5,79 & 5,17 & 4,15 & 3,38 & 2,35 \\
\hline 85 & 1250 & 190 & 12,72 & 8,64 & 7,45 & 6,46 & 5,74 & 5,14 & 4,14 & 3,38 & 2,36 \\
\hline 85 & 1300 & 190 & 12,46 & 8,50 & 7,36 & 6,40 & 5,70 & 5,11 & 4,13 & 3,38 & 2,36 \\
\hline 85 & 1350 & 190 & 12,21 & 8,37 & 7,27 & 6,34 & 5,66 & 5,08 & 4,12 & 3,38 & 2,36 \\
\hline 85 & 1400 & 190 & 11,98 & 8,25 & 7,19 & 6,29 & 5,62 & 5,06 & 4,11 & 3,38 & 2,37 \\
\hline 85 & 1450 & 190 & 11,76 & 8,14 & 7,11 & 6,24 & 5,59 & 5,03 & 4,10 & 3,37 & 2,37 \\
\hline 85 & 1500 & 190 & 11,56 & 8,03 & 7,03 & 6,19 & 5,55 & 5,01 & 4,09 & 3,37 & 2,37 \\
\hline 85 & 1550 & 190 & 11,37 & 7,93 & 6,96 & 6,14 & 5,52 & 4,98 & 4,08 & 3,37 & 2,38 \\
\hline 85 & 1600 & 190 & 11,19 & 7,83 & 6,89 & 6,09 & 5,48 & 4,96 & 4,07 & 3,37 & 2,38 \\
\hline 85 & 1650 & 190 & 11,01 & 7,73 & 6,83 & 6,04 & 5,45 & 4,93 & 4,06 & 3,36 & 2,38 \\
\hline 85 & 1700 & 190 & 10,85 & 7,64 & 6,76 & 6,00 & 5,42 & 4,91 & 4,05 & 3,36 & 2,38 \\
\hline 85 & 1750 & 190 & 10,70 & 7,56 & 6,70 & 5,96 & 5,39 & 4,89 & 4,04 & 3,36 & 2,39 \\
\hline 85 & 1800 & 190 & 10,55 & 7,47 & 6,64 & 5,92 & 5,36 & 4,87 & 4,03 & 3,35 & 2,39 \\
\hline 85 & 1850 & 190 & 10,41 & 7,39 & 6,59 & 5,88 & 5,33 & 4,85 & 4,02 & 3,35 & 2,39 \\
\hline 85 & 1900 & 190 & 10,28 & 7,32 & 6,53 & 5,84 & 5,30 & 4,82 & 4,01 & 3,35 & 2,39 \\
\hline 85 & 1950 & 190 & 10,15 & 7,24 & 6,48 & 5,80 & 5,27 & 4,80 & 3,99 & 3,34 & 2,39 \\
\hline 85 & 2000 & 190 & 10,03 & 7,17 & 6,43 & 5,76 & 5,24 & 4,78 & 3,99 & 3,34 & 2,40 \\
\hline 85 & 200 & 195 & 43,63 & 20,45 & 13,75 & 9,43 & 7,17 & 5,74 & 3,99 & 3,08 & 2,15 \\
\hline 85 & 250 & 195 & 36,58 & 17,99 & 12,55 & 8,97 & 7,01 & 5,71 & 4,04 & 3,12 & 2,16 \\
\hline 85 & 300 & 195 & 31,83 & 16,30 & 11,71 & 8,62 & 6,87 & 5,67 & 4,08 & 3,15 & 2,17 \\
\hline 85 & 350 & 195 & 28,39 & 15,04 & 11,07 & 8,34 & 6,75 & 5,63 & 4,10 & 3,18 & 2,18 \\
\hline 85 & 400 & 195 & 25,78 & 14,07 & 10,56 & 8,11 & 6,65 & 5,59 & 4,11 & 3,20 & 2,18 \\
\hline 85 & 450 & 195 & 23,72 & 13,29 & 10,14 & 7,91 & 6,55 & 5,55 & 4,12 & 3,22 & 2,19 \\
\hline 85 & 500 & 195 & 22,06 & 12,64 & 9,79 & 7,74 & 6,47 & 5,51 & 4,13 & 3,23 & 2,20 \\
\hline 85 & 550 & 195 & 20,69 & 12,10 & 9,49 & 7,59 & 6,39 & 5,47 & 4,13 & 3,25 & 2,21 \\
\hline 85 & 600 & 195 & 19,53 & 11,63 & 9,22 & 7,45 & 6,31 & 5,44 & 4,13 & 3,26 & 2,22 \\
\hline 85 & 650 & 195 & 18,54 & 11,22 & 8,99 & 7,33 & 6,24 & 5,40 & 4,13 & 3,27 & 2,22 \\
\hline 85 & 700 & 195 & 17,68 & 10,86 & 8,78 & 7,21 & 6,17 & 5,36 & 4,12 & 3,27 & 2,23 \\
\hline 85 & 750 & 195 & 16,94 & 10,53 & 8,59 & 7,10 & 6,11 & 5,33 & 4,12 & 3,28 & 2,24 \\
\hline 85 & 800 & 195 & 16,27 & 10,25 & 8,41 & 7,00 & 6,05 & 5,29 & 4,11 & 3,28 & 2,25 \\
\hline 85 & 850 & 195 & 15,69 & 9,98 & 8,25 & 6,91 & 6,00 & 5,26 & 4,11 & 3,29 & 2,25 \\
\hline 85 & 900 & 195 & 15,16 & 9,74 & 8,11 & 6,82 & 5,94 & 5,23 & 4,10 & 3,29 & 2,26 \\
\hline 85 & 950 & 195 & 14,68 & 9,53 & 7,97 & 6,74 & 5,89 & 5,20 & 4,09 & 3,29 & 2,26 \\
\hline 85 & 1000 & 195 & 14,25 & 9,32 & 7,84 & 6,67 & 5,84 & 5,17 & 4,08 & 3,29 & 2,27 \\
\hline 85 & 1050 & 195 & 13,86 & 9,14 & 7,72 & 6,59 & 5,79 & 5,14 & 4,08 & 3,29 & 2,27 \\
\hline 85 & 1100 & 195 & 13,50 & 8,96 & 7,61 & 6,52 & 5,75 & 5,11 & 4,07 & 3,30 & 2,28 \\
\hline 85 & 1150 & 195 & 13,16 & 8,80 & 7,51 & 6,46 & 5,71 & 5,08 & 4,06 & 3,30 & 2,28 \\
\hline 85 & 1200 & 195 & 12,86 & 8,65 & 7,41 & 6,39 & 5,66 & 5,05 & 4,05 & 3,29 & 2,29 \\
\hline 85 & 1250 & 195 & 12,57 & 8,51 & 7,31 & 6,33 & 5,62 & 5,02 & 4,04 & 3,29 & 2,29 \\
\hline 85 & 1300 & 195 & 12,31 & 8,37 & 7,23 & 6,28 & 5,58 & 5,00 & 4,03 & 3,29 & 2,30 \\
\hline 85 & 1350 & 195 & 12,06 & 8,25 & 7,14 & 6,22 & 5,54 & 4,97 & 4,02 & 3,29 & 2,30 \\
\hline
\end{tabular}




\begin{tabular}{|c|c|c|c|c|c|c|c|c|c|c|c|}
\hline & & & \multicolumn{9}{|c|}{ Deflexões $\left(\times 10^{-4} \mathrm{~cm}\right)$} \\
\hline $\mathrm{H}(\mathrm{cm})$ & Mceq (MPa) & Msub (MPa) & D0 & D25 & D40 & D60 & D80 & D100 & D140 & D180 & D260 \\
\hline 85 & 1400 & 195 & 11,83 & 8,13 & 7,06 & 6,17 & 5,51 & 4,95 & 4,01 & 3,29 & 2,30 \\
\hline 85 & 1450 & 195 & 11,62 & 8,01 & 6,98 & 6,12 & 5,47 & 4,92 & 4,00 & 3,29 & 2,31 \\
\hline 85 & 1500 & 195 & 11,41 & 7,90 & 6,91 & 6,07 & 5,44 & 4,90 & 3,99 & 3,29 & 2,31 \\
\hline 85 & 1550 & 195 & 11,22 & 7,80 & 6,84 & 6,02 & 5,40 & 4,87 & 3,98 & 3,28 & 2,31 \\
\hline 85 & 1600 & 195 & 11,04 & 7,70 & 6,77 & 5,97 & 5,37 & 4,85 & 3,97 & 3,28 & 2,32 \\
\hline 85 & 1650 & 195 & 10,87 & 7,61 & 6,71 & 5,93 & 5,34 & 4,83 & 3,96 & 3,28 & 2,32 \\
\hline 85 & 1700 & 195 & 10,71 & 7,52 & 6,64 & 5,88 & 5,31 & 4,81 & 3,95 & 3,28 & 2,32 \\
\hline 85 & 1750 & 195 & 10,56 & 7,44 & 6,58 & 5,84 & 5,28 & 4,78 & 3,94 & 3,27 & 2,32 \\
\hline 85 & 1800 & 195 & 10,41 & 7,36 & 6,53 & 5,80 & 5,25 & 4,76 & 3,93 & 3,27 & 2,33 \\
\hline 85 & 1850 & 195 & 10,27 & 7,28 & 6,47 & 5,76 & 5,22 & 4,74 & 3,92 & 3,27 & 2,33 \\
\hline 85 & 1900 & 195 & 10,14 & 7,20 & 6,42 & 5,72 & 5,19 & 4,72 & 3,91 & 3,26 & 2,33 \\
\hline 85 & 1950 & 195 & 10,01 & 7,13 & 6,36 & 5,69 & 5,16 & 4,70 & 3,90 & 3,26 & 2,33 \\
\hline 85 & 2000 & 195 & 9,89 & 7,06 & 6,31 & 5,65 & 5,14 & 4,68 & 3,89 & 3,26 & 2,33 \\
\hline 85 & 200 & 200 & 43,42 & 20,24 & 13,55 & 9,25 & 7,01 & 5,60 & 3,88 & 2,99 & 2,10 \\
\hline 85 & 250 & 200 & 36,38 & 17,79 & 12,36 & 8,79 & 6,85 & 5,57 & 3,94 & 3,04 & 2,10 \\
\hline 85 & 300 & 200 & 31,63 & 16,10 & 11,52 & 8,45 & 6,72 & 5,53 & 3,97 & 3,07 & 2,11 \\
\hline 85 & 350 & 200 & 28,19 & 14,86 & 10,89 & 8,18 & 6,60 & 5,49 & 3,99 & 3,10 & 2,12 \\
\hline 85 & 400 & 200 & 25,59 & 13,89 & 10,39 & 7,95 & 6,50 & 5,46 & 4,01 & 3,12 & 2,13 \\
\hline 85 & 450 & 200 & 23,54 & 13,11 & 9,97 & 7,76 & 6,41 & 5,42 & 4,02 & 3,14 & 2,14 \\
\hline 85 & 500 & 200 & 21,88 & 12,47 & 9,63 & 7,59 & 6,32 & 5,38 & 4,02 & 3,15 & 2,14 \\
\hline 85 & 550 & 200 & 20,51 & 11,93 & 9,33 & 7,44 & 6,25 & 5,35 & 4,03 & 3,16 & 2,15 \\
\hline 85 & 600 & 200 & 19,36 & 11,47 & 9,07 & 7,30 & 6,17 & 5,31 & 4,03 & 3,17 & 2,16 \\
\hline 85 & 650 & 200 & 18,37 & 11,06 & 8,83 & 7,18 & 6,11 & 5,28 & 4,03 & 3,18 & 2,17 \\
\hline 85 & 700 & 200 & 17,52 & 10,70 & 8,63 & 7,07 & 6,04 & 5,24 & 4,02 & 3,19 & 2,17 \\
\hline 85 & 750 & 200 & 16,77 & 10,39 & 8,44 & 6,96 & 5,98 & 5,21 & 4,02 & 3,19 & 2,18 \\
\hline 85 & 800 & 200 & 16,12 & 10,10 & 8,27 & 6,87 & 5,92 & 5,17 & 4,01 & 3,20 & 2,19 \\
\hline 85 & 850 & 200 & 15,53 & 9,84 & 8,11 & 6,78 & 5,87 & 5,14 & 4,01 & 3,20 & 2,19 \\
\hline 85 & 900 & 200 & 15,00 & 9,60 & 7,97 & 6,69 & 5,82 & 5,11 & 4,00 & 3,21 & 2,20 \\
\hline 85 & 950 & 200 & 14,53 & 9,39 & 7,83 & 6,61 & 5,77 & 5,08 & 3,99 & 3,21 & 2,20 \\
\hline 85 & 1000 & 200 & 14,10 & 9,19 & 7,71 & 6,54 & 5,72 & 5,05 & 3,99 & 3,21 & 2,21 \\
\hline 85 & 1050 & 200 & 13,71 & 9,00 & 7,59 & 6,46 & 5,67 & 5,02 & 3,98 & 3,21 & 2,21 \\
\hline 85 & 1100 & 200 & 13,35 & 8,83 & 7,48 & 6,40 & 5,63 & 5,00 & 3,97 & 3,21 & 2,22 \\
\hline 85 & 1150 & 200 & 13,02 & 8,67 & 7,38 & 6,33 & 5,59 & 4,97 & 3,96 & 3,21 & 2,22 \\
\hline 85 & 1200 & 200 & 12,71 & 8,52 & 7,28 & 6,27 & 5,55 & 4,94 & 3,95 & 3,21 & 2,23 \\
\hline 85 & 1250 & 200 & 12,43 & 8,38 & 7,19 & 6,21 & 5,51 & 4,91 & 3,94 & 3,21 & 2,23 \\
\hline 85 & 1300 & 200 & 12,17 & 8,25 & 7,10 & 6,15 & 5,47 & 4,89 & 3,93 & 3,21 & 2,24 \\
\hline 85 & 1350 & 200 & 11,92 & 8,12 & 7,02 & 6,10 & 5,43 & 4,86 & 3,93 & 3,21 & 2,24 \\
\hline 85 & 1400 & 200 & 11,69 & 8,00 & 6,94 & 6,05 & 5,39 & 4,84 & 3,92 & 3,21 & 2,24 \\
\hline 85 & 1450 & 200 & 11,48 & 7,89 & 6,86 & 6,00 & 5,36 & 4,82 & 3,91 & 3,21 & 2,25 \\
\hline 85 & 1500 & 200 & 11,28 & 7,79 & 6,79 & 5,95 & 5,33 & 4,79 & 3,90 & 3,21 & 2,25 \\
\hline 85 & 1550 & 200 & 11,09 & 7,68 & 6,72 & 5,90 & 5,29 & 4,77 & 3,89 & 3,20 & 2,25 \\
\hline 85 & 1600 & 200 & 10,91 & 7,59 & 6,66 & 5,86 & 5,26 & 4,75 & 3,88 & 3,20 & 2,26 \\
\hline 85 & 1650 & 200 & 10,74 & 7,50 & 6,59 & 5,81 & 5,23 & 4,73 & 3,87 & 3,20 & 2,26 \\
\hline 85 & 1700 & 200 & 10,58 & 7,41 & 6,53 & 5,77 & 5,20 & 4,70 & 3,86 & 3,20 & 2,26 \\
\hline 85 & 1750 & 200 & 10,42 & 7,32 & 6,47 & 5,73 & 5,17 & 4,68 & 3,85 & 3,19 & 2,26 \\
\hline 85 & 1800 & 200 & 10,28 & 7,24 & 6,41 & 5,69 & 5,14 & 4,66 & 3,84 & 3,19 & 2,27 \\
\hline 85 & 1850 & 200 & 10,14 & 7,17 & 6,36 & 5,65 & 5,11 & 4,64 & 3,83 & 3,19 & 2,27 \\
\hline 85 & 1900 & 200 & 10,01 & 7,09 & 6,31 & 5,62 & 5,09 & 4,62 & 3,82 & 3,18 & 2,27 \\
\hline 85 & 1950 & 200 & 9,88 & 7,02 & 6,25 & 5,58 & 5,06 & 4,60 & 3,81 & 3,18 & 2,27 \\
\hline 85 & 2000 & 200 & 9,76 & 6,95 & 6,20 & 5,55 & 5,03 & 4,58 & 3,80 & 3,18 & 2,27 \\
\hline 90 & 200 & 20 & 95,34 & 66,86 & 59,54 & 53,34 & 48,59 & 44,45 & 37,25 & 31,39 & 22,75 \\
\hline 90 & 250 & 20 & 85,68 & 61,27 & 55,33 & 50,30 & 46,26 & 42,67 & 36,29 & 30,96 & 22,82 \\
\hline 90 & 300 & 20 & 78,81 & 57,16 & 52,09 & 47,88 & 44,35 & 41,17 & 35,42 & 30,51 & 22,82 \\
\hline 90 & 350 & 20 & 73,58 & 53,99 & 49,48 & 45,88 & 42,75 & 39,88 & 34,63 & 30,07 & 22,77 \\
\hline 90 & 400 & 20 & 69,41 & 51,45 & 47,31 & 44,19 & 41,38 & 38,75 & 33,91 & 29,65 & 22,70 \\
\hline 90 & 450 & 20 & 65,95 & 49,37 & 45,47 & 42,72 & 40,17 & 37,75 & 33,26 & 29,25 & 22,61 \\
\hline 90 & 500 & 20 & 63,02 & 47,61 & 43,89 & 41,44 & 39,11 & 36,86 & 32,65 & 28,86 & 22,51 \\
\hline 90 & 550 & 20 & 60,47 & 46,12 & 42,50 & 40,29 & 38,15 & 36,05 & 32,09 & 28,50 & 22,40 \\
\hline 90 & 600 & 20 & 58,23 & 44,82 & 41,27 & 39,26 & 37,29 & 35,32 & 31,58 & 28,15 & 22,28 \\
\hline 90 & 650 & 20 & 56,22 & 43,68 & 40,18 & 38,33 & 36,50 & 34,65 & 31,09 & 27,82 & 22,16 \\
\hline 90 & 700 & 20 & 54,41 & 42,67 & 39,19 & 37,48 & 35,78 & 34,03 & 30,64 & 27,51 & 22,04 \\
\hline 90 & 750 & 20 & 52,76 & 41,76 & 38,30 & 36,69 & 35,12 & 33,45 & 30,22 & 27,21 & 21,93 \\
\hline 90 & 800 & 20 & 51,24 & 40,95 & 37,49 & 35,97 & 34,50 & 32,91 & 29,82 & 26,93 & 21,81 \\
\hline 90 & 850 & 20 & 49,84 & 40,21 & 36,75 & 35,30 & 33,92 & 32,41 & 29,44 & 26,66 & 21,69 \\
\hline 90 & 900 & 20 & 48,54 & 39,53 & 36,07 & 34,67 & 33,38 & 31,95 & 29,09 & 26,40 & 21,57 \\
\hline 90 & 950 & 20 & 47,33 & 38,91 & 35,44 & 34,09 & 32,88 & 31,50 & 28,75 & 26,15 & 21,45 \\
\hline 90 & 1000 & 20 & 46,19 & 38,34 & 34,85 & 33,54 & 32,40 & 31,09 & 28,43 & 25,91 & 21,34 \\
\hline 90 & 1050 & 20 & 45,12 & 37,80 & 34,31 & 33,03 & 31,96 & 30,69 & 28,13 & 25,68 & 21,23 \\
\hline 90 & 1100 & 20 & 44,11 & 37,31 & 33,80 & 32,54 & 31,53 & 30,32 & 27,83 & 25,46 & 21,12 \\
\hline 90 & 1150 & 20 & 43,15 & 36,85 & 33,33 & 32,08 & 31,13 & 29,96 & 27,56 & 25,25 & 21,01 \\
\hline 90 & 1200 & 20 & 42,24 & 36,41 & 32,89 & 31,65 & 30,74 & 29,63 & 27,29 & 25,04 & 20,90 \\
\hline 90 & 1250 & 20 & 41,38 & 36,00 & 32,47 & 31,23 & 30,38 & 29,30 & 27,03 & 24,84 & 20,80 \\
\hline 90 & 1300 & 20 & 40,56 & 35,61 & 32,08 & 30,84 & 30,03 & 29,00 & 26,79 & 24,65 & 20,69 \\
\hline 90 & 1350 & 20 & 39,77 & 35,25 & 31,70 & 30,47 & 29,70 & 28,70 & 26,55 & 24,47 & 20,59 \\
\hline 90 & 1400 & 20 & 39,02 & 34,90 & 31,35 & 30,11 & 29,38 & 28,42 & 26,33 & 24,29 & 20,50 \\
\hline 90 & 1450 & 20 & 38,31 & 34,57 & 31,02 & 29,77 & 29,07 & 28,14 & 26,11 & 24,12 & 20,40 \\
\hline 90 & 1500 & 20 & 37,62 & 34,26 & 30,71 & 29,44 & 28,77 & 27,88 & 25,90 & 23,95 & 20,30 \\
\hline 90 & 1550 & 20 & 36,96 & 33,95 & 30,40 & 29,13 & 28,49 & 27,63 & 25,69 & 23,79 & 20,21 \\
\hline 90 & 1600 & 20 & 36,32 & 33,67 & 30,12 & 28,83 & 28,22 & 27,39 & 25,50 & 23,63 & 20,12 \\
\hline 90 & 1650 & 20 & 35,71 & 33,39 & 29,85 & 28,55 & 27,96 & 27,15 & 25,31 & 23,48 & 20,03 \\
\hline 90 & 1700 & 20 & 35,12 & 33,12 & 29,58 & 28,27 & 27,70 & 26,93 & 25,12 & 23,33 & 19,94 \\
\hline
\end{tabular}




\begin{tabular}{|c|c|c|c|c|c|c|c|c|c|c|c|}
\hline \multirow[b]{2}{*}{$\mathrm{H}(\mathrm{cm})$} & \multirow[b]{2}{*}{ Mceq (MPa) } & & & & & & ões (x1 & m) & & & \\
\hline & & Msub (MPa) & D0 & D25 & D40 & D60 & D80 & D100 & D140 & D180 & D260 \\
\hline 90 & 1750 & 20 & 34,55 & 32,87 & 29,34 & 28,01 & 27,46 & 26,71 & 24,94 & 23,19 & 19,86 \\
\hline 90 & 1800 & 20 & 34,01 & 32,62 & 29,10 & 27,75 & 27,22 & 26,50 & 24,77 & 23,05 & 19,77 \\
\hline 90 & 1850 & 20 & 33,48 & 32,39 & 28,87 & 27,50 & 26,99 & 26,29 & 24,60 & 22,91 & 19,69 \\
\hline 90 & 1900 & 20 & 32,97 & 32,16 & 28,65 & 27,27 & 26,77 & 26,09 & 24,44 & 22,78 & 19,61 \\
\hline 90 & 1950 & 20 & 32,47 & 31,93 & 28,44 & 27,04 & 26,55 & 25,90 & 24,28 & 22,65 & 19,53 \\
\hline 90 & 2000 & 20 & 31,99 & 31,72 & 28,23 & 26,82 & 26,35 & 25,71 & 24,13 & 22,52 & 19,45 \\
\hline 90 & 200 & 25 & 85,39 & 58,52 & 51,23 & 45,18 & 40,72 & 36,92 & 30,47 & 25,37 & 18,10 \\
\hline 90 & 250 & 25 & 76,27 & 53,49 & 47,63 & 42,68 & 38,87 & 35,56 & 29,80 & 25,12 & 18,20 \\
\hline 90 & 300 & 25 & 69,87 & 49,79 & 44,87 & 40,68 & 37,35 & 34,40 & 29,18 & 24,84 & 18,25 \\
\hline 90 & 350 & 25 & 65,05 & 46,93 & 42,64 & 39,03 & 36,06 & 33,39 & 28,61 & 24,55 & 18,26 \\
\hline 90 & 400 & 25 & 61,25 & 44,64 & 40,79 & 37,63 & 34,95 & 32,50 & 28,08 & 24,27 & 18,24 \\
\hline 90 & 450 & 25 & 58,14 & 42,75 & 39,21 & 36,42 & 33,97 & 31,71 & 27,59 & 23,99 & 18,21 \\
\hline 90 & 500 & 25 & 55,53 & 41,16 & 37,85 & 35,35 & 33,10 & 31,00 & 27,13 & 23,72 & 18,16 \\
\hline 90 & 550 & 25 & 53,28 & 39,80 & 36,66 & 34,40 & 32,32 & 30,36 & 26,71 & 23,46 & 18,10 \\
\hline 90 & 600 & 25 & 51,31 & 38,63 & 35,60 & 33,55 & 31,62 & 29,77 & 26,31 & 23,21 & 18,04 \\
\hline 90 & 650 & 25 & 49,57 & 37,59 & 34,65 & 32,77 & 30,97 & 29,22 & 25,94 & 22,97 & 17,97 \\
\hline 90 & 700 & 25 & 48,00 & 36,67 & 33,79 & 32,06 & 30,38 & 28,72 & 25,59 & 22,74 & 17,90 \\
\hline 90 & 750 & 25 & 46,58 & 35,85 & 33,02 & 31,41 & 29,83 & 28,26 & 25,26 & 22,52 & 17,83 \\
\hline 90 & 800 & 25 & 45,28 & 35,12 & 32,31 & 30,81 & 29,32 & 27,82 & 24,95 & 22,31 & 17,75 \\
\hline 90 & 850 & 25 & 44,09 & 34,45 & 31,66 & 30,25 & 28,85 & 27,41 & 24,66 & 22,11 & 17,67 \\
\hline 90 & 900 & 25 & 42,99 & 33,83 & 31,06 & 29,72 & 28,41 & 27,03 & 24,38 & 21,91 & 17,60 \\
\hline 90 & 950 & 25 & 41,96 & 33,27 & 30,51 & 29,23 & 27,99 & 26,67 & 24,11 & 21,72 & 17,52 \\
\hline 90 & 1000 & 25 & 40,99 & 32,76 & 29,99 & 28,78 & 27,60 & 26,33 & 23,86 & 21,54 & 17,44 \\
\hline 90 & 1050 & 25 & 40,09 & 32,28 & 29,51 & 28,34 & 27,23 & 26,01 & 23,61 & 21,37 & 17,37 \\
\hline 90 & 1100 & 25 & 39,24 & 31,84 & 29,07 & 27,93 & 26,88 & 25,70 & 23,38 & 21,20 & 17,29 \\
\hline 90 & 1150 & 25 & 38,44 & 31,42 & 28,65 & 27,55 & 26,54 & 25,41 & 23,16 & 21,04 & 17,22 \\
\hline 90 & 1200 & 25 & 37,67 & 31,03 & 28,25 & 27,18 & 26,23 & 25,13 & 22,95 & 20,88 & 17,14 \\
\hline 90 & 1250 & 25 & 36,95 & 30,67 & 27,88 & 26,83 & 25,92 & 24,87 & 22,74 & 20,73 & 17,07 \\
\hline 90 & 1300 & 25 & 36,26 & 30,33 & 27,53 & 26,50 & 25,63 & 24,62 & 22,55 & 20,58 & 17,00 \\
\hline 90 & 1350 & 25 & 35,60 & 30,00 & 27,20 & 26,18 & 25,36 & 24,37 & 22,36 & 20,44 & 16,93 \\
\hline 90 & 1400 & 25 & 34,97 & 29,70 & 26,89 & 25,88 & 25,09 & 24,14 & 22,18 & 20,30 & 16,86 \\
\hline 90 & 1450 & 25 & 34,37 & 29,40 & 26,59 & 25,59 & 24,84 & 23,92 & 22,00 & 20,16 & 16,79 \\
\hline 90 & 1500 & 25 & 33,79 & 29,13 & 26,31 & 25,32 & 24,59 & 23,70 & 21,83 & 20,03 & 16,72 \\
\hline 90 & 1550 & 25 & 33,24 & 28,86 & 26,04 & 25,05 & 24,36 & 23,49 & 21,67 & 19,91 & 16,65 \\
\hline 90 & 1600 & 25 & 32,71 & 28,61 & 25,78 & 24,80 & 24,13 & 23,29 & 21,51 & 19,78 & 16,59 \\
\hline 90 & 1650 & 25 & 32,19 & 28,37 & 25,54 & 24,55 & 23,91 & 23,10 & 21,35 & 19,66 & 16,52 \\
\hline 90 & 1700 & 25 & 31,70 & 28,14 & 25,31 & 24,32 & 23,70 & 22,91 & 21,21 & 19,55 & 16,46 \\
\hline 90 & 1750 & 25 & 31,22 & 27,92 & 25,08 & 24,09 & 23,50 & 22,73 & 21,06 & 19,43 & 16,40 \\
\hline 90 & 1800 & 25 & 30,76 & 27,71 & 24,87 & 23,87 & 23,30 & 22,56 & 20,92 & 19,32 & 16,33 \\
\hline 90 & 1850 & 25 & 30,31 & 27,50 & 24,66 & 23,66 & 23,11 & 22,39 & 20,78 & 19,22 & 16,27 \\
\hline 90 & 1900 & 25 & 29,88 & 27,31 & 24,47 & 23,45 & 22,93 & 22,22 & 20,65 & 19,11 & 16,21 \\
\hline 90 & 1950 & 25 & 29,46 & 27,12 & 24,28 & 23,26 & 22,75 & 22,07 & 20,52 & 19,01 & 16,15 \\
\hline 90 & 2000 & 25 & 29,06 & 26,93 & 24,09 & 23,07 & 22,57 & 21,91 & 20,40 & 18,91 & 16,10 \\
\hline 90 & 200 & 30 & 78,43 & 52,57 & 45,29 & 39,40 & 35,18 & 31,65 & 25,77 & 21,25 & 14,99 \\
\hline 90 & 250 & 30 & 69,67 & 47,96 & 42,13 & 37,27 & 33,66 & 30,56 & 25,29 & 21,11 & 15,10 \\
\hline 90 & 300 & 30 & 63,56 & 44,57 & 39,69 & 35,56 & 32,39 & 29,63 & 24,83 & 20,93 & 15,17 \\
\hline 90 & 350 & 30 & 59,00 & 41,95 & 37,74 & 34,15 & 31,32 & 28,82 & 24,40 & 20,74 & 15,20 \\
\hline 90 & 400 & 30 & 55,43 & 39,85 & 36,11 & 32,96 & 30,39 & 28,09 & 23,99 & 20,54 & 15,22 \\
\hline 90 & 450 & 30 & 52,54 & 38,11 & 34,73 & 31,92 & 29,57 & 27,44 & 23,61 & 20,34 & 15,21 \\
\hline 90 & 500 & 30 & 50,12 & 36,64 & 33,53 & 31,01 & 28,84 & 26,86 & 23,26 & 20,14 & 15,19 \\
\hline 90 & 550 & 30 & 48,06 & 35,39 & 32,48 & 30,19 & 28,18 & 26,32 & 22,92 & 19,95 & 15,17 \\
\hline 90 & 600 & 30 & 46,27 & 34,30 & 31,54 & 29,46 & 27,58 & 25,83 & 22,61 & 19,77 & 15,13 \\
\hline 90 & 650 & 30 & 44,69 & 33,35 & 30,70 & 28,79 & 27,04 & 25,38 & 22,31 & 19,59 & 15,09 \\
\hline 90 & 700 & 30 & 43,28 & 32,50 & 29,95 & 28,19 & 26,54 & 24,96 & 22,03 & 19,41 & 15,05 \\
\hline 90 & 750 & 30 & 42,01 & 31,74 & 29,26 & 27,62 & 26,07 & 24,57 & 21,77 & 19,24 & 15,01 \\
\hline 90 & 800 & 30 & 40,86 & 31,06 & 28,63 & 27,11 & 25,64 & 24,21 & 21,52 & 19,08 & 14,96 \\
\hline 90 & 850 & 30 & 39,80 & 30,44 & 28,05 & 26,62 & 25,24 & 23,87 & 21,28 & 18,92 & 14,91 \\
\hline 90 & 900 & 30 & 38,82 & 29,88 & 27,52 & 26,17 & 24,86 & 23,55 & 21,05 & 18,77 & 14,85 \\
\hline 90 & 950 & 30 & 37,91 & 29,36 & 27,02 & 25,75 & 24,50 & 23,24 & 20,83 & 18,62 & 14,80 \\
\hline 90 & 1000 & 30 & 37,07 & 28,88 & 26,56 & 25,36 & 24,17 & 22,96 & 20,63 & 18,48 & 14,75 \\
\hline 90 & 1050 & 30 & 36,27 & 28,44 & 26,13 & 24,98 & 23,85 & 22,68 & 20,43 & 18,34 & 14,70 \\
\hline 90 & 1100 & 30 & 35,53 & 28,04 & 25,73 & 24,63 & 23,55 & 22,42 & 20,24 & 18,21 & 14,64 \\
\hline 90 & 1150 & 30 & 34,83 & 27,65 & 25,35 & 24,30 & 23,27 & 22,18 & 20,06 & 18,08 & 14,59 \\
\hline 90 & 1200 & 30 & 34,16 & 27,30 & 24,99 & 23,98 & 23,00 & 21,94 & 19,88 & 17,95 & 14,54 \\
\hline 90 & 1250 & 30 & 33,53 & 26,96 & 24,66 & 23,68 & 22,74 & 21,72 & 19,71 & 17,83 & 14,48 \\
\hline 90 & 1300 & 30 & 32,93 & 26,65 & 24,34 & 23,39 & 22,49 & 21,50 & 19,55 & 17,71 & 14,43 \\
\hline 90 & 1350 & 30 & 32,36 & 26,35 & 24,04 & 23,12 & 22,26 & 21,30 & 19,39 & 17,60 & 14,38 \\
\hline 90 & 1400 & 30 & 31,81 & 26,07 & 23,76 & 22,85 & 22,03 & 21,10 & 19,24 & 17,49 & 14,33 \\
\hline 90 & 1450 & 30 & 31,29 & 25,81 & 23,49 & 22,60 & 21,81 & 20,91 & 19,10 & 17,38 & 14,28 \\
\hline 90 & 1500 & 30 & 30,79 & 25,56 & 23,24 & 22,36 & 21,60 & 20,72 & 18,95 & 17,27 & 14,23 \\
\hline 90 & 1550 & 30 & 30,31 & 25,32 & 22,99 & 22,13 & 21,40 & 20,55 & 18,82 & 17,17 & 14,18 \\
\hline 90 & 1600 & 30 & 29,85 & 25,09 & 22,76 & 21,91 & 21,21 & 20,38 & 18,68 & 17,07 & 14,13 \\
\hline 90 & 1650 & 30 & 29,40 & 24,87 & 22,54 & 21,69 & 21,02 & 20,21 & 18,56 & 16,97 & 14,08 \\
\hline 90 & 1700 & 30 & 28,97 & 24,66 & 22,32 & 21,49 & 20,84 & 20,05 & 18,43 & 16,88 & 14,03 \\
\hline 90 & 1750 & 30 & 28,56 & 24,46 & 22,12 & 21,29 & 20,66 & 19,90 & 18,31 & 16,79 & 13,98 \\
\hline 90 & 1800 & 30 & 28,16 & 24,27 & 21,92 & 21,10 & 20,50 & 19,75 & 18,19 & 16,69 & 13,93 \\
\hline 90 & 1850 & 30 & 27,77 & 24,09 & 21,74 & 20,91 & 20,33 & 19,61 & 18,08 & 16,61 & 13,89 \\
\hline 90 & 1900 & 30 & 27,40 & 23,91 & 21,56 & 20,73 & 20,17 & 19,47 & 17,97 & 16,52 & 13,84 \\
\hline 90 & 1950 & 30 & 27,04 & 23,74 & 21,38 & 20,56 & 20,02 & 19,33 & 17,86 & 16,44 & 13,80 \\
\hline 90 & 2000 & 30 & 26,69 & 23,58 & 21,22 & 20,39 & 19,87 & 19,20 & 17,75 & 16,35 & 13,75 \\
\hline 90 & 200 & 35 & 73,28 & 48,09 & 40,82 & 35,06 & 31,04 & 27,73 & 22,32 & 18,26 & 12,77 \\
\hline
\end{tabular}




\begin{tabular}{|c|c|c|c|c|c|c|c|c|c|c|c|}
\hline \multirow[b]{2}{*}{$\mathrm{H}(\mathrm{cm})$} & \multirow[b]{2}{*}{ Mceq (MPa) } & & & & & De & ões (x1 & m) & & & \\
\hline & & Msub (MPa) & D0 & D25 & D40 & D60 & D80 & D100 & D140 & D180 & D260 \\
\hline 90 & 250 & 35 & 64,76 & 43,79 & 37,96 & 33,20 & 29,75 & 26,84 & 21,97 & 18,18 & 12,88 \\
\hline 90 & 300 & 35 & 58,86 & 40,64 & 35,78 & 31,71 & 28,68 & 26,08 & 21,62 & 18,07 & 12,96 \\
\hline 90 & 350 & 35 & 54,48 & 38,21 & 34,02 & 30,48 & 27,77 & 25,40 & 21,29 & 17,94 & 13,00 \\
\hline 90 & 400 & 35 & 51,07 & 36,25 & 32,57 & 29,44 & 26,97 & 24,79 & 20,97 & 17,80 & 13,03 \\
\hline 90 & 450 & 35 & 48,32 & 34,63 & 31,33 & 28,53 & 26,26 & 24,25 & 20,66 & 17,65 & 13,04 \\
\hline 90 & 500 & 35 & 46,04 & 33,27 & 30,25 & 27,73 & 25,64 & 23,75 & 20,38 & 17,51 & 13,04 \\
\hline 90 & 550 & 35 & 44,10 & 32,10 & 29,31 & 27,01 & 25,07 & 23,30 & 20,11 & 17,36 & 13,03 \\
\hline 90 & 600 & 35 & 42,43 & 31,09 & 28,47 & 26,37 & 24,55 & 22,89 & 19,85 & 17,22 & 13,02 \\
\hline 90 & 650 & 35 & 40,96 & 30,19 & 27,72 & 25,79 & 24,08 & 22,50 & 19,61 & 17,08 & 13,00 \\
\hline 90 & 700 & 35 & 39,66 & 29,40 & 27,04 & 25,25 & 23,64 & 22,14 & 19,38 & 16,94 & 12,97 \\
\hline 90 & 750 & 35 & 38,49 & 28,69 & 26,42 & 24,76 & 23,24 & 21,81 & 19,16 & 16,81 & 12,94 \\
\hline 90 & 800 & 35 & 37,43 & 28,06 & 25,85 & 24,30 & 22,86 & 21,50 & 18,95 & 16,68 & 12,91 \\
\hline 90 & 850 & 35 & 36,46 & 27,48 & 25,32 & 23,88 & 22,51 & 21,20 & 18,75 & 16,55 & 12,88 \\
\hline 90 & 900 & 35 & 35,57 & 26,95 & 24,84 & 23,48 & 22,19 & 20,93 & 18,56 & 16,43 & 12,84 \\
\hline 90 & 950 & 35 & 34,75 & 26,47 & 24,39 & 23,11 & 21,88 & 20,67 & 18,38 & 16,31 & 12,81 \\
\hline 90 & 1000 & 35 & 33,99 & 26,02 & 23,97 & 22,76 & 21,58 & 20,42 & 18,21 & 16,20 & 12,77 \\
\hline 90 & 1050 & 35 & 33,27 & 25,61 & 23,58 & 22,44 & 21,31 & 20,18 & 18,04 & 16,09 & 12,73 \\
\hline 90 & 1100 & 35 & 32,60 & 25,23 & 23,22 & 22,12 & 21,05 & 19,96 & 17,88 & 15,98 & 12,69 \\
\hline 90 & 1150 & 35 & 31,97 & 24,87 & 22,88 & 21,83 & 20,80 & 19,75 & 17,73 & 15,87 & 12,66 \\
\hline 90 & 1200 & 35 & 31,38 & 24,54 & 22,55 & 21,55 & 20,56 & 19,54 & 17,58 & 15,77 & 12,62 \\
\hline 90 & 1250 & 35 & 30,81 & 24,23 & 22,25 & 21,28 & 20,33 & 19,35 & 17,44 & 15,67 & 12,58 \\
\hline 90 & 1300 & 35 & 30,28 & 23,93 & 21,96 & 21,03 & 20,12 & 19,16 & 17,30 & 15,57 & 12,54 \\
\hline 90 & 1350 & 35 & 29,77 & 23,66 & 21,68 & 20,79 & 19,91 & 18,98 & 17,17 & 15,48 & 12,50 \\
\hline 90 & 1400 & 35 & 29,28 & 23,40 & 21,42 & 20,55 & 19,71 & 18,81 & 17,04 & 15,39 & 12,46 \\
\hline 90 & 1450 & 35 & 28,82 & 23,15 & 21,18 & 20,33 & 19,52 & 18,64 & 16,92 & 15,30 & 12,42 \\
\hline 90 & 1500 & 35 & 28,37 & 22,92 & 20,94 & 20,12 & 19,34 & 18,48 & 16,80 & 15,21 & 12,38 \\
\hline 90 & 1550 & 35 & 27,95 & 22,70 & 20,72 & 19,91 & 19,16 & 18,33 & 16,68 & 15,13 & 12,34 \\
\hline 90 & 1600 & 35 & 27,53 & 22,48 & 20,50 & 19,72 & 18,99 & 18,18 & 16,57 & 15,04 & 12,31 \\
\hline 90 & 1650 & 35 & 27,14 & 22,28 & 20,30 & 19,53 & 18,83 & 18,04 & 16,46 & 14,96 & 12,27 \\
\hline 90 & 1700 & 35 & 26,76 & 22,09 & 20,10 & 19,34 & 18,67 & 17,90 & 16,35 & 14,88 & 12,23 \\
\hline 90 & 1750 & 35 & 26,39 & 21,91 & 19,92 & 19,17 & 18,52 & 17,76 & 16,25 & 14,80 & 12,19 \\
\hline 90 & 1800 & 35 & 26,04 & 21,73 & 19,74 & 19,00 & 18,37 & 17,63 & 16,15 & 14,73 & 12,16 \\
\hline 90 & 1850 & 35 & 25,70 & 21,56 & 19,56 & 18,83 & 18,22 & 17,51 & 16,05 & 14,66 & 12,12 \\
\hline 90 & 1900 & 35 & 25,36 & 21,40 & 19,40 & 18,67 & 18,09 & 17,39 & 15,95 & 14,58 & 12,08 \\
\hline 90 & 1950 & 35 & 25,04 & 21,24 & 19,24 & 18,52 & 17,95 & 17,27 & 15,86 & 14,51 & 12,05 \\
\hline 90 & 2000 & 35 & 24,73 & 21,09 & 19,08 & 18,37 & 17,82 & 17,15 & 15,77 & 14,44 & 12,01 \\
\hline 90 & 200 & 40 & 69,29 & 44,55 & 37,31 & 31,68 & 27,83 & 24,70 & 19,68 & 15,99 & 11,11 \\
\hline 90 & 250 & 40 & 60,96 & 40,51 & 34,69 & 30,02 & 26,71 & 23,96 & 19,42 & 15,96 & 11,22 \\
\hline 90 & 300 & 40 & 55,21 & 37,55 & 32,70 & 28,70 & 25,78 & 23,31 & 19,15 & 15,89 & 11,29 \\
\hline 90 & 350 & 40 & 50,96 & 35,27 & 31,10 & 27,60 & 24,99 & 22,74 & 18,88 & 15,80 & 11,34 \\
\hline 90 & 400 & 40 & 47,67 & 33,43 & 29,77 & 26,67 & 24,29 & 22,22 & 18,63 & 15,70 & 11,38 \\
\hline 90 & 450 & 40 & 45,02 & 31,91 & 28,64 & 25,86 & 23,68 & 21,76 & 18,38 & 15,59 & 11,40 \\
\hline 90 & 500 & 40 & 42,84 & 30,63 & 27,67 & 25,15 & 23,13 & 21,33 & 18,15 & 15,48 & 11,41 \\
\hline 90 & 550 & 40 & 40,99 & 29,54 & 26,81 & 24,51 & 22,63 & 20,94 & 17,92 & 15,37 & 11,41 \\
\hline 90 & 600 & 40 & 39,40 & 28,58 & 26,05 & 23,94 & 22,18 & 20,58 & 17,71 & 15,26 & 11,41 \\
\hline 90 & 650 & 40 & 38,02 & 27,74 & 25,36 & 23,42 & 21,76 & 20,25 & 17,51 & 15,14 & 11,40 \\
\hline 90 & 700 & 40 & 36,79 & 27,00 & 24,74 & 22,94 & 21,38 & 19,94 & 17,32 & 15,04 & 11,39 \\
\hline 90 & 750 & 40 & 35,69 & 26,33 & 24,17 & 22,50 & 21,02 & 19,65 & 17,13 & 14,93 & 11,37 \\
\hline 90 & 800 & 40 & 34,70 & 25,73 & 23,66 & 22,09 & 20,69 & 19,38 & 16,96 & 14,82 & 11,35 \\
\hline 90 & 850 & 40 & 33,80 & 25,18 & 23,18 & 21,72 & 20,38 & 19,12 & 16,79 & 14,72 & 11,33 \\
\hline 90 & 900 & 40 & 32,98 & 24,68 & 22,74 & 21,36 & 20,09 & 18,88 & 16,63 & 14,62 & 11,30 \\
\hline 90 & 950 & 40 & 32,21 & 24,23 & 22,33 & 21,03 & 19,81 & 18,65 & 16,47 & 14,53 & 11,28 \\
\hline 90 & 1000 & 40 & 31,51 & 23,81 & 21,94 & 20,72 & 19,55 & 18,43 & 16,33 & 14,43 & 11,25 \\
\hline 90 & 1050 & 40 & 30,85 & 23,42 & 21,59 & 20,42 & 19,31 & 18,22 & 16,18 & 14,34 & 11,23 \\
\hline 90 & 1100 & 40 & 30,24 & 23,06 & 21,25 & 20,15 & 19,08 & 18,03 & 16,05 & 14,25 & 11,20 \\
\hline 90 & 1150 & 40 & 29,66 & 22,72 & 20,93 & 19,88 & 18,86 & 17,84 & 15,92 & 14,16 & 11,17 \\
\hline 90 & 1200 & 40 & 29,11 & 22,41 & 20,64 & 19,63 & 18,64 & 17,66 & 15,79 & 14,08 & 11,14 \\
\hline 90 & 1250 & 40 & 28,60 & 22,11 & 20,36 & 19,39 & 18,44 & 17,49 & 15,67 & 13,99 & 11,11 \\
\hline 90 & 1300 & 40 & 28,11 & 21,84 & 20,09 & 19,16 & 18,25 & 17,32 & 15,55 & 13,91 & 11,08 \\
\hline 90 & 1350 & 40 & 27,65 & 21,58 & 19,84 & 18,95 & 18,07 & 17,16 & 15,43 & 13,83 & 11,05 \\
\hline 90 & 1400 & 40 & 27,21 & 21,33 & 19,60 & 18,74 & 17,89 & 17,01 & 15,32 & 13,75 & 11,02 \\
\hline 90 & 1450 & 40 & 26,78 & 21,10 & 19,37 & 18,54 & 17,72 & 16,87 & 15,21 & 13,68 & 10,99 \\
\hline 90 & 1500 & 40 & 26,38 & 20,88 & 19,15 & 18,35 & 17,56 & 16,72 & 15,11 & 13,61 & 10,96 \\
\hline 90 & 1550 & 40 & 25,99 & 20,67 & 18,94 & 18,16 & 17,40 & 16,59 & 15,01 & 13,53 & 10,93 \\
\hline 90 & 1600 & 40 & 25,62 & 20,47 & 18,75 & 17,98 & 17,25 & 16,46 & 14,91 & 13,46 & 10,90 \\
\hline 90 & 1650 & 40 & 25,26 & 20,28 & 18,56 & 17,81 & 17,10 & 16,33 & 14,81 & 13,39 & 10,87 \\
\hline 90 & 1700 & 40 & 24,92 & 20,10 & 18,37 & 17,65 & 16,96 & 16,21 & 14,72 & 13,33 & 10,84 \\
\hline 90 & 1750 & 40 & 24,59 & 19,93 & 18,20 & 17,49 & 16,82 & 16,09 & 14,63 & 13,26 & 10,81 \\
\hline 90 & 1800 & 40 & 24,27 & 19,77 & 18,03 & 17,34 & 16,69 & 15,97 & 14,54 & 13,20 & 10,78 \\
\hline 90 & 1850 & 40 & 23,96 & 19,61 & 17,87 & 17,19 & 16,56 & 15,86 & 14,46 & 13,14 & 10,76 \\
\hline 90 & 1900 & 40 & 23,66 & 19,46 & 17,72 & 17,04 & 16,44 & 15,75 & 14,38 & 13,07 & 10,73 \\
\hline 90 & 1950 & 40 & 23,37 & 19,31 & 17,57 & 16,91 & 16,32 & 15,65 & 14,29 & 13,01 & 10,70 \\
\hline 90 & 2000 & 40 & 23,09 & 19,17 & 17,43 & 16,77 & 16,20 & 15,54 & 14,22 & 12,95 & 10,67 \\
\hline 90 & 200 & 45 & 66,11 & 41,69 & 34,47 & 28,95 & 25,25 & 22,28 & 17,59 & 14,21 & 9,83 \\
\hline 90 & 250 & 45 & 57,92 & 37,85 & 32,04 & 27,46 & 24,27 & 21,65 & 17,39 & 14,20 & 9,92 \\
\hline 90 & 300 & 45 & 52,29 & 35,05 & 30,20 & 26,27 & 23,45 & 21,10 & 17,18 & 14,17 & 10,00 \\
\hline 90 & 350 & 45 & 48,14 & 32,89 & 28,72 & 25,28 & 22,75 & 20,60 & 16,97 & 14,11 & 10,05 \\
\hline 90 & 400 & 45 & 44,94 & 31,15 & 27,50 & 24,44 & 22,14 & 20,16 & 16,76 & 14,03 & 10,09 \\
\hline 90 & 450 & 45 & 42,37 & 29,72 & 26,46 & 23,71 & 21,60 & 19,75 & 16,56 & 13,95 & 10,11 \\
\hline 90 & 500 & 45 & 40,26 & 28,51 & 25,56 & 23,06 & 21,11 & 19,38 & 16,36 & 13,87 & 10,13 \\
\hline 90 & 550 & 45 & 38,48 & 27,47 & 24,78 & 22,49 & 20,66 & 19,04 & 16,18 & 13,78 & 10,14 \\
\hline
\end{tabular}




\begin{tabular}{|c|c|c|c|c|c|c|c|c|c|c|c|}
\hline \multirow[b]{2}{*}{$\mathrm{H}(\mathrm{cm})$} & \multirow[b]{2}{*}{ Mceq (MPa) } & & & & & De & ões (x1 & m) & & & \\
\hline & & Msub (MPa) & D0 & D25 & D40 & D60 & D80 & D100 & D140 & D180 & D260 \\
\hline 90 & 600 & 45 & 36,96 & 26,56 & 24,07 & 21,97 & 20,26 & 18,73 & 16,00 & 13,69 & 10,14 \\
\hline 90 & 650 & 45 & 35,63 & 25,77 & 23,44 & 21,50 & 19,89 & 18,44 & 15,83 & 13,60 & 10,14 \\
\hline 90 & 700 & 45 & 34,46 & 25,06 & 22,87 & 21,07 & 19,54 & 18,16 & 15,66 & 13,52 & 10,14 \\
\hline 90 & 750 & 45 & 33,42 & 24,43 & 22,35 & 20,67 & 19,23 & 17,91 & 15,51 & 13,43 & 10,13 \\
\hline 90 & 800 & 45 & 32,48 & 23,86 & 21,88 & 20,30 & 18,93 & 17,66 & 15,36 & 13,34 & 10,12 \\
\hline 90 & 850 & 45 & 31,63 & 23,34 & 21,44 & 19,96 & 18,65 & 17,44 & 15,21 & 13,26 & 10,10 \\
\hline 90 & 900 & 45 & 30,85 & 22,87 & 21,03 & 19,64 & 18,39 & 17,22 & 15,07 & 13,18 & 10,09 \\
\hline 90 & 950 & 45 & 30,13 & 22,44 & 20,65 & 19,34 & 18,14 & 17,02 & 14,94 & 13,10 & 10,07 \\
\hline 90 & 1000 & 45 & 29,47 & 22,04 & 20,30 & 19,06 & 17,91 & 16,83 & 14,81 & 13,02 & 10,05 \\
\hline 90 & 1050 & 45 & 28,85 & 21,67 & 19,96 & 18,79 & 17,69 & 16,64 & 14,69 & 12,94 & 10,03 \\
\hline 90 & 1100 & 45 & 28,28 & 21,32 & 19,65 & 18,54 & 17,48 & 16,47 & 14,57 & 12,86 & 10,01 \\
\hline 90 & 1150 & 45 & 27,74 & 21,01 & 19,36 & 18,30 & 17,28 & 16,30 & 14,46 & 12,79 & 9,99 \\
\hline 90 & 1200 & 45 & 27,24 & 20,71 & 19,09 & 18,07 & 17,09 & 16,14 & 14,34 & 12,72 & 9,97 \\
\hline 90 & 1250 & 45 & 26,76 & 20,43 & 18,82 & 17,85 & 16,91 & 15,99 & 14,24 & 12,65 & 9,95 \\
\hline 90 & 1300 & 45 & 26,31 & 20,17 & 18,58 & 17,65 & 16,74 & 15,84 & 14,13 & 12,58 & 9,93 \\
\hline 90 & 1350 & 45 & 25,88 & 19,92 & 18,34 & 17,45 & 16,57 & 15,70 & 14,03 & 12,51 & 9,90 \\
\hline 90 & 1400 & 45 & 25,47 & 19,69 & 18,12 & 17,26 & 16,41 & 15,56 & 13,94 & 12,45 & 9,88 \\
\hline 90 & 1450 & 45 & 25,08 & 19,47 & 17,91 & 17,08 & 16,26 & 15,43 & 13,84 & 12,38 & 9,86 \\
\hline 90 & 1500 & 45 & 24,71 & 19,26 & 17,71 & 16,90 & 16,11 & 15,30 & 13,75 & 12,32 & 9,83 \\
\hline 90 & 1550 & 45 & 24,35 & 19,06 & 17,51 & 16,74 & 15,97 & 15,18 & 13,66 & 12,26 & 9,81 \\
\hline 90 & 1600 & 45 & 24,01 & 18,87 & 17,33 & 16,58 & 15,83 & 15,06 & 13,58 & 12,20 & 9,79 \\
\hline 90 & 1650 & 45 & 23,69 & 18,69 & 17,15 & 16,42 & 15,70 & 14,95 & 13,49 & 12,14 & 9,76 \\
\hline 90 & 1700 & 45 & 23,37 & 18,52 & 16,98 & 16,27 & 15,58 & 14,84 & 13,41 & 12,08 & 9,74 \\
\hline 90 & 1750 & 45 & 23,07 & 18,36 & 16,82 & 16,13 & 15,45 & 14,73 & 13,33 & 12,02 & 9,71 \\
\hline 90 & 1800 & 45 & 22,77 & 18,20 & 16,66 & 15,99 & 15,33 & 14,63 & 13,25 & 11,97 & 9,69 \\
\hline 90 & 1850 & 45 & 22,49 & 18,05 & 16,51 & 15,85 & 15,22 & 14,53 & 13,18 & 11,91 & 9,67 \\
\hline 90 & 1900 & 45 & 22,22 & 17,91 & 16,37 & 15,72 & 15,10 & 14,43 & 13,10 & 11,86 & 9,64 \\
\hline 90 & 1950 & 45 & 21,95 & 17,77 & 16,23 & 15,59 & 15,00 & 14,34 & 13,03 & 11,81 & 9,62 \\
\hline 90 & 2000 & 45 & 21,70 & 17,63 & 16,09 & 15,47 & 14,89 & 14,24 & 12,96 & 11,76 & 9,60 \\
\hline 90 & 200 & 50 & 63,50 & 39,32 & 32,12 & 26,71 & 23,13 & 20,30 & 15,90 & 12,77 & 8,80 \\
\hline 90 & 250 & 50 & 55,43 & 35,64 & 29,85 & 25,34 & 22,26 & 19,76 & 15,75 & 12,79 & 8,89 \\
\hline 90 & 300 & 50 & 49,90 & 32,97 & 28,12 & 24,26 & 21,53 & 19,28 & 15,58 & 12,77 & 8,96 \\
\hline 90 & 350 & 50 & 45,83 & 30,91 & 26,75 & 23,36 & 20,91 & 18,85 & 15,40 & 12,73 & 9,01 \\
\hline 90 & 400 & 50 & 42,69 & 29,26 & 25,61 & 22,59 & 20,36 & 18,46 & 15,23 & 12,68 & 9,05 \\
\hline 90 & 450 & 50 & 40,19 & 27,89 & 24,65 & 21,93 & 19,87 & 18,10 & 15,06 & 12,62 & 9,08 \\
\hline 90 & 500 & 50 & 38,13 & 26,74 & 23,82 & 21,34 & 19,44 & 17,78 & 14,90 & 12,56 & 9,10 \\
\hline 90 & 550 & 50 & 36,41 & 25,76 & 23,08 & 20,81 & 19,04 & 17,48 & 14,74 & 12,49 & 9,12 \\
\hline 90 & 600 & 50 & 34,93 & 24,90 & 22,43 & 20,34 & 18,67 & 17,20 & 14,59 & 12,42 & 9,12 \\
\hline 90 & 650 & 50 & 33,65 & 24,14 & 21,85 & 19,91 & 18,34 & 16,94 & 14,44 & 12,35 & 9,13 \\
\hline 90 & 700 & 50 & 32,53 & 23,47 & 21,32 & 19,52 & 18,03 & 16,69 & 14,30 & 12,28 & 9,13 \\
\hline 90 & 750 & 50 & 31,52 & 22,86 & 20,84 & 19,15 & 17,74 & 16,47 & 14,17 & 12,20 & 9,13 \\
\hline 90 & 800 & 50 & 30,63 & 22,32 & 20,39 & 18,82 & 17,47 & 16,25 & 14,04 & 12,13 & 9,12 \\
\hline 90 & 850 & 50 & 29,81 & 21,83 & 19,98 & 18,50 & 17,22 & 16,05 & 13,91 & 12,06 & 9,11 \\
\hline 90 & 900 & 50 & 29,07 & 21,38 & 19,61 & 18,21 & 16,98 & 15,86 & 13,79 & 11,99 & 9,10 \\
\hline 90 & 950 & 50 & 28,39 & 20,96 & 19,25 & 17,93 & 16,76 & 15,67 & 13,68 & 11,93 & 9,09 \\
\hline 90 & 1000 & 50 & 27,76 & 20,58 & 18,93 & 17,68 & 16,55 & 15,50 & 13,57 & 11,86 & 9,08 \\
\hline 90 & 1050 & 50 & 27,18 & 20,23 & 18,62 & 17,43 & 16,35 & 15,34 & 13,46 & 11,79 & 9,07 \\
\hline 90 & 1100 & 50 & 26,64 & 19,90 & 18,33 & 17,20 & 16,16 & 15,18 & 13,35 & 11,73 & 9,05 \\
\hline 90 & 1150 & 50 & 26,13 & 19,60 & 18,06 & 16,98 & 15,98 & 15,03 & 13,25 & 11,67 & 9,04 \\
\hline 90 & 1200 & 50 & 25,66 & 19,31 & 17,80 & 16,77 & 15,81 & 14,88 & 13,16 & 11,61 & 9,02 \\
\hline 90 & 1250 & 50 & 25,21 & 19,05 & 17,56 & 16,57 & 15,64 & 14,74 & 13,06 & 11,54 & 9,00 \\
\hline 90 & 1300 & 50 & 24,78 & 18,80 & 17,32 & 16,39 & 15,49 & 14,61 & 12,97 & 11,49 & 8,99 \\
\hline 90 & 1350 & 50 & 24,38 & 18,56 & 17,11 & 16,20 & 15,33 & 14,48 & 12,88 & 11,43 & 8,97 \\
\hline 90 & 1400 & 50 & 24,00 & 18,34 & 16,90 & 16,03 & 15,19 & 14,36 & 12,80 & 11,37 & 8,95 \\
\hline 90 & 1450 & 50 & 23,64 & 18,13 & 16,70 & 15,86 & 15,05 & 14,24 & 12,71 & 11,32 & 8,93 \\
\hline 90 & 1500 & 50 & 23,29 & 17,93 & 16,51 & 15,70 & 14,92 & 14,13 & 12,63 & 11,26 & 8,91 \\
\hline 90 & 1550 & 50 & 22,96 & 17,74 & 16,33 & 15,55 & 14,79 & 14,02 & 12,55 & 11,21 & 8,89 \\
\hline 90 & 1600 & 50 & 22,64 & 17,56 & 16,16 & 15,40 & 14,66 & 13,91 & 12,48 & 11,15 & 8,88 \\
\hline 90 & 1650 & 50 & 22,34 & 17,39 & 15,99 & 15,26 & 14,54 & 13,81 & 12,40 & 11,10 & 8,86 \\
\hline 90 & 1700 & 50 & 22,05 & 17,22 & 15,83 & 15,12 & 14,42 & 13,71 & 12,33 & 11,05 & 8,84 \\
\hline 90 & 1750 & 50 & 21,76 & 17,07 & 15,68 & 14,99 & 14,31 & 13,61 & 12,26 & 11,00 & 8,82 \\
\hline 90 & 1800 & 50 & 21,49 & 16,92 & 15,53 & 14,86 & 14,20 & 13,52 & 12,19 & 10,96 & 8,80 \\
\hline 90 & 1850 & 50 & 21,23 & 16,77 & 15,39 & 14,74 & 14,10 & 13,42 & 12,12 & 10,91 & 8,78 \\
\hline 90 & 1900 & 50 & 20,98 & 16,64 & 15,25 & 14,62 & 14,00 & 13,34 & 12,05 & 10,86 & 8,76 \\
\hline 90 & 1950 & 50 & 20,73 & 16,51 & 15,12 & 14,50 & 13,90 & 13,25 & 11,99 & 10,82 & 8,74 \\
\hline 90 & 2000 & 50 & 20,50 & 16,38 & 15,00 & 14,39 & 13,80 & 13,17 & 11,93 & 10,77 & 8,72 \\
\hline 90 & 200 & 55 & 61,32 & 37,32 & 30,14 & 24,82 & 21,35 & 18,65 & 14,49 & 11,60 & 7,97 \\
\hline 90 & 250 & 55 & 53,35 & 33,78 & 27,99 & 23,56 & 20,58 & 18,18 & 14,38 & 11,63 & 8,05 \\
\hline 90 & 300 & 55 & 47,90 & 31,21 & 26,37 & 22,56 & 19,92 & 17,76 & 14,25 & 11,62 & 8,11 \\
\hline 90 & 350 & 55 & 43,89 & 29,24 & 25,08 & 21,74 & 19,36 & 17,38 & 14,10 & 11,60 & 8,16 \\
\hline 90 & 400 & 55 & 40,82 & 27,66 & 24,02 & 21,03 & 18,87 & 17,04 & 13,96 & 11,57 & 8,20 \\
\hline 90 & 450 & 55 & 38,36 & 26,36 & 23,12 & 20,42 & 18,43 & 16,72 & 13,82 & 11,52 & 8,23 \\
\hline 90 & 500 & 55 & 36,35 & 25,26 & 22,34 & 19,88 & 18,03 & 16,43 & 13,68 & 11,47 & 8,26 \\
\hline 90 & 550 & 55 & 34,67 & 24,31 & 21,65 & 19,40 & 17,67 & 16,16 & 13,55 & 11,42 & 8,27 \\
\hline 90 & 600 & 55 & 33,23 & 23,49 & 21,04 & 18,96 & 17,34 & 15,91 & 13,42 & 11,36 & 8,29 \\
\hline 90 & 650 & 55 & 31,99 & 22,77 & 20,50 & 18,57 & 17,03 & 15,68 & 13,29 & 11,30 & 8,29 \\
\hline 90 & 700 & 55 & 30,89 & 22,12 & 20,00 & 18,20 & 16,75 & 15,46 & 13,17 & 11,24 & 8,30 \\
\hline 90 & 750 & 55 & 29,93 & 21,55 & 19,55 & 17,87 & 16,49 & 15,26 & 13,05 & 11,18 & 8,30 \\
\hline 90 & 800 & 55 & 29,06 & 21,03 & 19,14 & 17,56 & 16,25 & 15,06 & 12,94 & 11,12 & 8,30 \\
\hline 90 & 850 & 55 & 28,28 & 20,56 & 18,76 & 17,27 & 16,02 & 14,88 & 12,83 & 11,07 & 8,29 \\
\hline 90 & 900 & 55 & 27,56 & 20,12 & 18,40 & 17,00 & 15,80 & 14,71 & 12,72 & 11,01 & 8,29 \\
\hline
\end{tabular}




\begin{tabular}{|c|c|c|c|c|c|c|c|c|c|c|c|}
\hline \multirow[b]{2}{*}{$\mathrm{H}(\mathrm{cm})$} & \multirow[b]{2}{*}{ Mceq (MPa) } & & & & & $\mathrm{De}$ & ões (x1 & & & & \\
\hline & & Msub (MPa) & D0 & D25 & D40 & D60 & D80 & D100 & D140 & D180 & D260 \\
\hline 90 & 950 & 55 & 26,91 & 19,73 & 18,07 & 16,75 & 15,60 & 14,54 & 12,62 & 10,95 & 8,28 \\
\hline 90 & 1000 & 55 & 26,31 & 19,36 & 17,76 & 16,51 & 15,40 & 14,38 & 12,52 & 10,89 & 8,27 \\
\hline 90 & 1050 & 55 & 25,76 & 19,02 & 17,48 & 16,28 & 15,22 & 14,23 & 12,42 & 10,84 & 8,26 \\
\hline 90 & 1100 & 55 & 25,24 & 18,71 & 17,20 & 16,07 & 15,05 & 14,09 & 12,33 & 10,78 & 8,25 \\
\hline 90 & 1150 & 55 & 24,76 & 18,42 & 16,95 & 15,87 & 14,88 & 13,95 & 12,24 & 10,73 & 8,24 \\
\hline 90 & 1200 & 55 & 24,30 & 18,15 & 16,71 & 15,67 & 14,72 & 13,82 & 12,16 & 10,67 & 8,23 \\
\hline 90 & 1250 & 55 & 23,88 & 17,89 & 16,48 & 15,49 & 14,57 & 13,70 & 12,07 & 10,62 & 8,22 \\
\hline 90 & 1300 & 55 & 23,48 & 17,65 & 16,26 & 15,32 & 14,43 & 13,58 & 11,99 & 10,57 & 8,21 \\
\hline 90 & 1350 & 55 & 23,10 & 17,42 & 16,06 & 15,15 & 14,29 & 13,46 & 11,91 & 10,52 & 8,19 \\
\hline 90 & 1400 & 55 & 22,74 & 17,21 & 15,86 & 14,99 & 14,15 & 13,35 & 11,84 & 10,47 & 8,18 \\
\hline 90 & 1450 & 55 & 22,40 & 17,01 & 15,68 & 14,84 & 14,03 & 13,24 & 11,76 & 10,42 & 8,16 \\
\hline 90 & 1500 & 55 & 22,07 & 16,82 & 15,50 & 14,69 & 13,90 & 13,14 & 11,69 & 10,37 & 8,15 \\
\hline 90 & 1550 & 55 & 21,76 & 16,63 & 15,33 & 14,55 & 13,78 & 13,04 & 11,62 & 10,33 & 8,13 \\
\hline 90 & 1600 & 55 & 21,46 & 16,46 & 15,16 & 14,41 & 13,67 & 12,94 & 11,55 & 10,28 & 8,12 \\
\hline 90 & 1650 & 55 & 21,17 & 16,30 & 15,01 & 14,28 & 13,56 & 12,84 & 11,48 & 10,24 & 8,10 \\
\hline 90 & 1700 & 55 & 20,90 & 16,14 & 14,86 & 14,15 & 13,45 & 12,75 & 11,42 & 10,19 & 8,09 \\
\hline 90 & 1750 & 55 & 20,64 & 15,99 & 14,71 & 14,03 & 13,35 & 12,66 & 11,35 & 10,15 & 8,07 \\
\hline 90 & 1800 & 55 & 20,38 & 15,85 & 14,58 & 13,91 & 13,25 & 12,58 & 11,29 & 10,11 & 8,06 \\
\hline 90 & 1850 & 55 & 20,14 & 15,71 & 14,44 & 13,79 & 13,15 & 12,49 & 11,23 & 10,06 & 8,04 \\
\hline 90 & 1900 & 55 & 19,90 & 15,58 & 14,31 & 13,68 & 13,06 & 12,41 & 11,17 & 10,02 & 8,02 \\
\hline 90 & 1950 & 55 & 19,67 & 15,45 & 14,19 & 13,57 & 12,97 & 12,33 & 11,11 & 9,98 & 8,01 \\
\hline 90 & 2000 & 55 & 19,45 & 15,33 & 14,07 & 13,47 & 12,88 & 12,26 & 11,06 & 9,94 & 7,99 \\
\hline 90 & 200 & 60 & 59,46 & 35,60 & 28,45 & 23,21 & 19,84 & 17,25 & 13,31 & 10,61 & 7,28 \\
\hline 90 & 250 & 60 & 51,59 & 32,18 & 26,41 & 22,04 & 19,14 & 16,84 & 13,23 & 10,65 & 7,35 \\
\hline 90 & 300 & 60 & 46,20 & 29,70 & 24,87 & 21,12 & 18,55 & 16,46 & 13,12 & 10,66 & 7,41 \\
\hline 90 & 350 & 60 & 42,25 & 27,81 & 23,65 & 20,35 & 18,04 & 16,13 & 13,01 & 10,65 & 7,46 \\
\hline 90 & 400 & 60 & 39,22 & 26,29 & 22,65 & 19,70 & 17,59 & 15,82 & 12,89 & 10,62 & 7,50 \\
\hline 90 & 450 & 60 & 36,81 & 25,04 & 21,80 & 19,13 & 17,19 & 15,54 & 12,77 & 10,59 & 7,53 \\
\hline 90 & 500 & 60 & 34,83 & 23,98 & 21,06 & 18,63 & 16,83 & 15,28 & 12,65 & 10,55 & 7,55 \\
\hline 90 & 550 & 60 & 33,18 & 23,07 & 20,42 & 18,19 & 16,50 & 15,04 & 12,53 & 10,51 & 7,57 \\
\hline 90 & 600 & 60 & 31,78 & 22,29 & 19,85 & 17,78 & 16,20 & 14,82 & 12,42 & 10,46 & 7,58 \\
\hline 90 & 650 & 60 & 30,56 & 21,59 & 19,33 & 17,41 & 15,92 & 14,61 & 12,31 & 10,42 & 7,59 \\
\hline 90 & 700 & 60 & 29,50 & 20,98 & 18,87 & 17,08 & 15,66 & 14,41 & 12,20 & 10,37 & 7,60 \\
\hline 90 & 750 & 60 & 28,56 & 20,42 & 18,44 & 16,77 & 15,42 & 14,22 & 12,10 & 10,32 & 7,61 \\
\hline 90 & 800 & 60 & 27,72 & 19,92 & 18,06 & 16,48 & 15,19 & 14,05 & 12,00 & 10,27 & 7,61 \\
\hline 90 & 850 & 60 & 26,96 & 19,47 & 17,70 & 16,21 & 14,98 & 13,88 & 11,90 & 10,22 & 7,61 \\
\hline 90 & 900 & 60 & 26,27 & 19,05 & 17,36 & 15,96 & 14,78 & 13,72 & 11,81 & 10,17 & 7,61 \\
\hline 90 & 950 & 60 & 25,64 & 18,67 & 17,05 & 15,72 & 14,60 & 13,57 & 11,72 & 10,12 & 7,60 \\
\hline 90 & 1000 & 60 & 25,06 & 18,32 & 16,76 & 15,50 & 14,42 & 13,43 & 11,63 & 10,07 & 7,60 \\
\hline 90 & 1050 & 60 & 24,53 & 18,00 & 16,49 & 15,29 & 14,25 & 13,29 & 11,54 & 10,02 & 7,59 \\
\hline 90 & 1100 & 60 & 24,03 & 17,70 & 16,24 & 15,10 & 14,09 & 13,16 & 11,46 & 9,98 & 7,58 \\
\hline 90 & 1150 & 60 & 23,57 & 17,41 & 16,00 & 14,91 & 13,94 & 13,04 & 11,38 & 9,93 & 7,58 \\
\hline 90 & 1200 & 60 & 23,14 & 17,15 & 15,77 & 14,73 & 13,79 & 12,92 & 11,30 & 9,88 & 7,57 \\
\hline 90 & 1250 & 60 & 22,73 & 16,91 & 15,56 & 14,56 & 13,65 & 12,80 & 11,23 & 9,84 & 7,56 \\
\hline 90 & 1300 & 60 & 22,35 & 16,67 & 15,35 & 14,40 & 13,52 & 12,69 & 11,16 & 9,79 & 7,55 \\
\hline 90 & 1350 & 60 & 21,98 & 16,46 & 15,16 & 14,24 & 13,39 & 12,58 & 11,09 & 9,75 & 7,54 \\
\hline 90 & 1400 & 60 & 21,64 & 16,25 & 14,97 & 14,09 & 13,27 & 12,48 & 11,02 & 9,71 & 7,53 \\
\hline 90 & 1450 & 60 & 21,32 & 16,06 & 14,80 & 13,95 & 13,15 & 12,38 & 10,95 & 9,66 & 7,51 \\
\hline 90 & 1500 & 60 & 21,01 & 15,87 & 14,63 & 13,81 & 13,04 & 12,29 & 10,88 & 9,62 & 7,50 \\
\hline 90 & 1550 & 60 & 20,71 & 15,70 & 14,47 & 13,68 & 12,93 & 12,19 & 10,82 & 9,58 & 7,49 \\
\hline 90 & 1600 & 60 & 20,43 & 15,53 & 14,31 & 13,55 & 12,82 & 12,10 & 10,76 & 9,54 & 7,48 \\
\hline 90 & 1650 & 60 & 20,16 & 15,37 & 14,17 & 13,43 & 12,72 & 12,02 & 10,70 & 9,50 & 7,47 \\
\hline 90 & 1700 & 60 & 19,90 & 15,22 & 14,02 & 13,31 & 12,62 & 11,93 & 10,64 & 9,46 & 7,45 \\
\hline 90 & 1750 & 60 & 19,65 & 15,08 & 13,89 & 13,20 & 12,52 & 11,85 & 10,58 & 9,42 & 7,44 \\
\hline 90 & 1800 & 60 & 19,41 & 14,94 & 13,76 & 13,09 & 12,43 & 11,77 & 10,53 & 9,38 & 7,43 \\
\hline 90 & 1850 & 60 & 19,18 & 14,81 & 13,63 & 12,98 & 12,34 & 11,70 & 10,47 & 9,35 & 7,41 \\
\hline 90 & 1900 & 60 & 18,96 & 14,68 & 13,51 & 12,88 & 12,25 & 11,62 & 10,42 & 9,31 & 7,40 \\
\hline 90 & 1950 & 60 & 18,74 & 14,56 & 13,39 & 12,78 & 12,17 & 11,55 & 10,36 & 9,27 & 7,39 \\
\hline 90 & 2000 & 60 & 18,53 & 14,44 & 13,28 & 12,68 & 12,09 & 11,48 & 10,31 & 9,24 & 7,37 \\
\hline 90 & 200 & 65 & 57,86 & 34,11 & 26,99 & 21,82 & 18,54 & 16,05 & 12,31 & 9,77 & 6,69 \\
\hline 90 & 250 & 65 & 50,06 & 30,78 & 25,03 & 20,73 & 17,90 & 15,68 & 12,24 & 9,82 & 6,76 \\
\hline 90 & 300 & 65 & 44,73 & 28,39 & 23,57 & 19,87 & 17,36 & 15,35 & 12,16 & 9,84 & 6,82 \\
\hline 90 & 350 & 65 & 40,83 & 26,56 & 22,41 & 19,15 & 16,90 & 15,05 & 12,06 & 9,84 & 6,86 \\
\hline 90 & 400 & 65 & 37,84 & 25,09 & 21,46 & 18,54 & 16,49 & 14,78 & 11,96 & 9,82 & 6,90 \\
\hline 90 & 450 & 65 & 35,46 & 23,89 & 20,65 & 18,02 & 16,12 & 14,52 & 11,86 & 9,80 & 6,93 \\
\hline 90 & 500 & 65 & 33,52 & 22,87 & 19,96 & 17,55 & 15,79 & 14,29 & 11,76 & 9,77 & 6,95 \\
\hline 90 & 550 & 65 & 31,90 & 22,00 & 19,35 & 17,13 & 15,48 & 14,07 & 11,66 & 9,74 & 6,97 \\
\hline 90 & 600 & 65 & 30,52 & 21,24 & 18,81 & 16,76 & 15,21 & 13,87 & 11,56 & 9,70 & 6,99 \\
\hline 90 & 650 & 65 & 29,33 & 20,57 & 18,32 & 16,41 & 14,95 & 13,68 & 11,46 & 9,66 & 7,00 \\
\hline 90 & 700 & 65 & 28,29 & 19,98 & 17,88 & 16,10 & 14,71 & 13,50 & 11,37 & 9,62 & 7,01 \\
\hline 90 & 750 & 65 & 27,37 & 19,45 & 17,48 & 15,81 & 14,49 & 13,33 & 11,28 & 9,58 & 7,02 \\
\hline 90 & 800 & 65 & 26,55 & 18,96 & 17,11 & 15,54 & 14,28 & 13,17 & 11,19 & 9,54 & 7,02 \\
\hline 90 & 850 & 65 & 25,82 & 18,53 & 16,77 & 15,29 & 14,09 & 13,01 & 11,10 & 9,49 & 7,02 \\
\hline 90 & 900 & 65 & 25,15 & 18,13 & 16,46 & 15,06 & 13,90 & 12,87 & 11,02 & 9,45 & 7,02 \\
\hline 90 & 950 & 65 & 24,54 & 17,76 & 16,17 & 14,84 & 13,73 & 12,73 & 10,94 & 9,41 & 7,02 \\
\hline 90 & 1000 & 65 & 23,97 & 17,42 & 15,89 & 14,63 & 13,57 & 12,60 & 10,86 & 9,37 & 7,02 \\
\hline 90 & 1050 & 65 & 23,46 & 17,11 & 15,64 & 14,44 & 13,41 & 12,48 & 10,78 & 9,32 & 7,02 \\
\hline 90 & 1100 & 65 & 22,98 & 16,82 & 15,40 & 14,25 & 13,26 & 12,36 & 10,71 & 9,28 & 7,01 \\
\hline 90 & 1150 & 65 & 22,53 & 16,55 & 15,17 & 14,07 & 13,12 & 12,24 & 10,64 & 9,24 & 7,01 \\
\hline 90 & 1200 & 65 & 22,11 & 16,29 & 14,95 & 13,91 & 12,98 & 12,13 & 10,57 & 9,20 & 7,00 \\
\hline 90 & 1250 & 65 & 21,72 & 16,06 & 14,75 & 13,75 & 12,86 & 12,03 & 10,50 & 9,16 & 6,99 \\
\hline
\end{tabular}




\begin{tabular}{|c|c|c|c|c|c|c|c|c|c|c|c|}
\hline \multirow[b]{2}{*}{$\mathrm{H}(\mathrm{cm})$} & \multirow[b]{2}{*}{ Mceq (MPa) } & & & & & $\mathrm{De}$ & ões (x1 & & & & \\
\hline & & Msub (MPa) & D0 & D25 & D40 & D60 & D80 & D100 & D140 & D180 & D260 \\
\hline 90 & 1300 & 65 & 21,36 & 15,83 & 14,56 & 13,60 & 12,73 & 11,92 & 10,44 & 9,12 & 6,98 \\
\hline 90 & 1350 & 65 & 21,01 & 15,62 & 14,37 & 13,45 & 12,61 & 11,83 & 10,37 & 9,08 & 6,98 \\
\hline 90 & 1400 & 65 & 20,68 & 15,42 & 14,20 & 13,31 & 12,50 & 11,73 & 10,31 & 9,05 & 6,97 \\
\hline 90 & 1450 & 65 & 20,37 & 15,24 & 14,03 & 13,18 & 12,39 & 11,64 & 10,25 & 9,01 & 6,96 \\
\hline 90 & 1500 & 65 & 20,07 & 15,06 & 13,87 & 13,05 & 12,28 & 11,55 & 10,19 & 8,97 & 6,95 \\
\hline 90 & 1550 & 65 & 19,79 & 14,89 & 13,72 & 12,93 & 12,18 & 11,47 & 10,13 & 8,93 & 6,94 \\
\hline 90 & 1600 & 65 & 19,52 & 14,73 & 13,57 & 12,81 & 12,08 & 11,38 & 10,07 & 8,90 & 6,93 \\
\hline 90 & 1650 & 65 & 19,26 & 14,58 & 13,43 & 12,69 & 11,99 & 11,30 & 10,02 & 8,86 & 6,92 \\
\hline 90 & 1700 & 65 & 19,02 & 14,43 & 13,30 & 12,58 & 11,89 & 11,22 & 9,97 & 8,83 & 6,91 \\
\hline 90 & 1750 & 65 & 18,78 & 14,29 & 13,17 & 12,48 & 11,80 & 11,15 & 9,91 & 8,79 & 6,90 \\
\hline 90 & 1800 & 65 & 18,55 & 14,16 & 13,05 & 12,37 & 11,72 & 11,08 & 9,86 & 8,76 & 6,89 \\
\hline 90 & 1850 & 65 & 18,33 & 14,03 & 12,93 & 12,27 & 11,63 & 11,00 & 9,81 & 8,73 & 6,88 \\
\hline 90 & 1900 & 65 & 18,12 & 13,91 & 12,81 & 12,17 & 11,55 & 10,94 & 9,76 & 8,69 & 6,87 \\
\hline 90 & 1950 & 65 & 17,92 & 13,79 & 12,70 & 12,08 & 11,47 & 10,87 & 9,72 & 8,66 & 6,86 \\
\hline 90 & 2000 & 65 & 17,72 & 13,68 & 12,59 & 11,99 & 11,40 & 10,80 & 9,67 & 8,63 & 6,85 \\
\hline 90 & 200 & 70 & 56,47 & 32,80 & 25,71 & 20,61 & 17,41 & 15,00 & 11,44 & 9,06 & 6,20 \\
\hline 90 & 250 & 70 & 48,74 & 29,56 & 23,83 & 19,58 & 16,82 & 14,68 & 11,39 & 9,11 & 6,26 \\
\hline 90 & 300 & 70 & 43,45 & 27,24 & 22,43 & 18,77 & 16,33 & 14,38 & 11,33 & 9,13 & 6,31 \\
\hline 90 & 350 & 70 & 39,60 & 25,46 & 21,32 & 18,10 & 15,90 & 14,11 & 11,25 & 9,14 & 6,35 \\
\hline 90 & 400 & 70 & 36,64 & 24,04 & 20,41 & 17,53 & 15,52 & 13,86 & 11,16 & 9,13 & 6,39 \\
\hline 90 & 450 & 70 & 34,29 & 22,88 & 19,64 & 17,04 & 15,18 & 13,64 & 11,07 & 9,11 & 6,42 \\
\hline 90 & 500 & 70 & 32,38 & 21,90 & 18,98 & 16,60 & 14,88 & 13,42 & 10,99 & 9,09 & 6,44 \\
\hline 90 & 550 & 70 & 30,78 & 21,05 & 18,40 & 16,21 & 14,60 & 13,22 & 10,90 & 9,07 & 6,46 \\
\hline 90 & 600 & 70 & 29,43 & 20,32 & 17,89 & 15,86 & 14,34 & 13,04 & 10,81 & 9,04 & 6,48 \\
\hline 90 & 650 & 70 & 28,26 & 19,68 & 17,43 & 15,54 & 14,10 & 12,86 & 10,73 & 9,00 & 6,49 \\
\hline 90 & 700 & 70 & 27,24 & 19,10 & 17,01 & 15,24 & 13,88 & 12,70 & 10,64 & 8,97 & 6,50 \\
\hline 90 & 750 & 70 & 26,34 & 18,59 & 16,63 & 14,97 & 13,68 & 12,54 & 10,56 & 8,94 & 6,51 \\
\hline 90 & 800 & 70 & 25,54 & 18,12 & 16,28 & 14,72 & 13,48 & 12,40 & 10,48 & 8,90 & 6,51 \\
\hline 90 & 850 & 70 & 24,81 & 17,70 & 15,96 & 14,48 & 13,30 & 12,26 & 10,41 & 8,86 & 6,52 \\
\hline 90 & 900 & 70 & 24,16 & 17,32 & 15,66 & 14,26 & 13,13 & 12,12 & 10,33 & 8,83 & 6,52 \\
\hline 90 & 950 & 70 & 23,57 & 16,96 & 15,39 & 14,06 & 12,97 & 12,00 & 10,26 & 8,79 & 6,52 \\
\hline 90 & 1000 & 70 & 23,02 & 16,63 & 15,13 & 13,86 & 12,82 & 11,88 & 10,19 & 8,75 & 6,52 \\
\hline 90 & 1050 & 70 & 22,52 & 16,33 & 14,88 & 13,68 & 12,67 & 11,76 & 10,12 & 8,72 & 6,52 \\
\hline 90 & 1100 & 70 & 22,05 & 16,05 & 14,65 & 13,51 & 12,53 & 11,65 & 10,05 & 8,68 & 6,52 \\
\hline 90 & 1150 & 70 & 21,62 & 15,79 & 14,44 & 13,34 & 12,40 & 11,55 & 9,99 & 8,65 & 6,51 \\
\hline 90 & 1200 & 70 & 21,22 & 15,54 & 14,24 & 13,18 & 12,28 & 11,44 & 9,93 & 8,61 & 6,51 \\
\hline 90 & 1250 & 70 & 20,84 & 15,31 & 14,04 & 13,04 & 12,16 & 11,35 & 9,86 & 8,57 & 6,50 \\
\hline 90 & 1300 & 70 & 20,48 & 15,10 & 13,86 & 12,89 & 12,04 & 11,25 & 9,80 & 8,54 & 6,50 \\
\hline 90 & 1350 & 70 & 20,15 & 14,89 & 13,68 & 12,76 & 11,93 & 11,16 & 9,75 & 8,51 & 6,49 \\
\hline 90 & 1400 & 70 & 19,83 & 14,70 & 13,52 & 12,63 & 11,82 & 11,07 & 9,69 & 8,47 & 6,49 \\
\hline 90 & 1450 & 70 & 19,53 & 14,52 & 13,36 & 12,50 & 11,72 & 10,99 & 9,63 & 8,44 & 6,48 \\
\hline 90 & 1500 & 70 & 19,25 & 14,35 & 13,21 & 12,38 & 11,62 & 10,91 & 9,58 & 8,40 & 6,47 \\
\hline 90 & 1550 & 70 & 18,97 & 14,18 & 13,06 & 12,26 & 11,52 & 10,83 & 9,53 & 8,37 & 6,46 \\
\hline 90 & 1600 & 70 & 18,72 & 14,03 & 12,92 & 12,15 & 11,43 & 10,75 & 9,48 & 8,34 & 6,46 \\
\hline 90 & 1650 & 70 & 18,47 & 13,88 & 12,79 & 12,04 & 11,34 & 10,67 & 9,43 & 8,31 & 6,45 \\
\hline 90 & 1700 & 70 & 18,23 & 13,74 & 12,66 & 11,94 & 11,26 & 10,60 & 9,38 & 8,28 & 6,44 \\
\hline 90 & 1750 & 70 & 18,00 & 13,60 & 12,54 & 11,84 & 11,17 & 10,53 & 9,33 & 8,25 & 6,43 \\
\hline 90 & 1800 & 70 & 17,79 & 13,48 & 12,42 & 11,74 & 11,09 & 10,46 & 9,28 & 8,22 & 6,42 \\
\hline 90 & 1850 & 70 & 17,58 & 13,35 & 12,31 & 11,65 & 11,01 & 10,40 & 9,24 & 8,19 & 6,41 \\
\hline 90 & 1900 & 70 & 17,38 & 13,23 & 12,20 & 11,56 & 10,94 & 10,33 & 9,19 & 8,16 & 6,40 \\
\hline 90 & 1950 & 70 & 17,18 & 13,12 & 12,09 & 11,47 & 10,86 & 10,27 & 9,15 & 8,13 & 6,39 \\
\hline 90 & 2000 & 70 & 16,99 & 13,01 & 11,99 & 11,38 & 10,79 & 10,21 & 9,11 & 8,10 & 6,39 \\
\hline 90 & 200 & 75 & 55,25 & 31,64 & 24,58 & 19,54 & 16,42 & 14,09 & 10,68 & 8,43 & 5,77 \\
\hline 90 & 250 & 75 & 47,57 & 28,48 & 22,76 & 18,57 & 15,88 & 13,80 & 10,65 & 8,49 & 5,82 \\
\hline 90 & 300 & 75 & 42,33 & 26,21 & 21,41 & 17,80 & 15,42 & 13,53 & 10,60 & 8,52 & 5,87 \\
\hline 90 & 350 & 75 & 38,51 & 24,49 & 20,35 & 17,17 & 15,02 & 13,29 & 10,53 & 8,53 & 5,91 \\
\hline 90 & 400 & 75 & 35,58 & 23,11 & 19,48 & 16,64 & 14,67 & 13,06 & 10,46 & 8,53 & 5,94 \\
\hline 90 & 450 & 75 & 33,26 & 21,98 & 18,75 & 16,17 & 14,36 & 12,85 & 10,39 & 8,52 & 5,97 \\
\hline 90 & 500 & 75 & 31,37 & 21,03 & 18,12 & 15,76 & 14,07 & 12,66 & 10,31 & 8,50 & 6,00 \\
\hline 90 & 550 & 75 & 29,80 & 20,21 & 17,57 & 15,39 & 13,81 & 12,48 & 10,23 & 8,48 & 6,02 \\
\hline 90 & 600 & 75 & 28,46 & 19,51 & 17,08 & 15,06 & 13,57 & 12,31 & 10,16 & 8,46 & 6,03 \\
\hline 90 & 650 & 75 & 27,31 & 18,88 & 16,64 & 14,76 & 13,35 & 12,15 & 10,08 & 8,43 & 6,05 \\
\hline 90 & 700 & 75 & 26,31 & 18,33 & 16,24 & 14,48 & 13,15 & 12,00 & 10,01 & 8,40 & 6,06 \\
\hline 90 & 750 & 75 & 25,42 & 17,83 & 15,88 & 14,23 & 12,96 & 11,85 & 9,93 & 8,37 & 6,07 \\
\hline 90 & 800 & 75 & 24,64 & 17,38 & 15,55 & 13,99 & 12,78 & 11,72 & 9,86 & 8,34 & 6,07 \\
\hline 90 & 850 & 75 & 23,93 & 16,97 & 15,24 & 13,77 & 12,61 & 11,59 & 9,79 & 8,31 & 6,08 \\
\hline 90 & 900 & 75 & 23,29 & 16,60 & 14,96 & 13,56 & 12,45 & 11,47 & 9,73 & 8,28 & 6,08 \\
\hline 90 & 950 & 75 & 22,71 & 16,25 & 14,69 & 13,37 & 12,30 & 11,35 & 9,66 & 8,25 & 6,09 \\
\hline 90 & 1000 & 75 & 22,17 & 15,94 & 14,44 & 13,18 & 12,16 & 11,24 & 9,60 & 8,22 & 6,09 \\
\hline 90 & 1050 & 75 & 21,68 & 15,64 & 14,21 & 13,01 & 12,02 & 11,13 & 9,54 & 8,18 & 6,09 \\
\hline 90 & 1100 & 75 & 21,23 & 15,37 & 14,00 & 12,85 & 11,89 & 11,03 & 9,48 & 8,15 & 6,09 \\
\hline 90 & 1150 & 75 & 20,81 & 15,12 & 13,79 & 12,69 & 11,77 & 10,93 & 9,42 & 8,12 & 6,08 \\
\hline 90 & 1200 & 75 & 20,42 & 14,88 & 13,60 & 12,54 & 11,65 & 10,83 & 9,36 & 8,09 & 6,08 \\
\hline 90 & 1250 & 75 & 20,05 & 14,66 & 13,41 & 12,40 & 11,54 & 10,74 & 9,30 & 8,06 & 6,08 \\
\hline 90 & 1300 & 75 & 19,70 & 14,45 & 13,24 & 12,27 & 11,43 & 10,66 & 9,25 & 8,03 & 6,07 \\
\hline 90 & 1350 & 75 & 19,38 & 14,25 & 13,07 & 12,14 & 11,32 & 10,57 & 9,20 & 8,00 & 6,07 \\
\hline 90 & 1400 & 75 & 19,07 & 14,06 & 12,91 & 12,02 & 11,22 & 10,49 & 9,14 & 7,97 & 6,06 \\
\hline 90 & 1450 & 75 & 18,78 & 13,89 & 12,76 & 11,90 & 11,13 & 10,41 & 9,09 & 7,94 & 6,06 \\
\hline 90 & 1500 & 75 & 18,51 & 13,72 & 12,62 & 11,78 & 11,03 & 10,33 & 9,04 & 7,91 & 6,05 \\
\hline 90 & 1550 & 75 & 18,25 & 13,56 & 12,48 & 11,67 & 10,94 & 10,26 & 9,00 & 7,88 & 6,05 \\
\hline 90 & 1600 & 75 & 18,00 & 13,41 & 12,35 & 11,57 & 10,86 & 10,19 & 8,95 & 7,85 & 6,04 \\
\hline
\end{tabular}




\begin{tabular}{|c|c|c|c|c|c|c|c|c|c|c|c|}
\hline \multirow[b]{2}{*}{$\mathrm{H}(\mathrm{cm})$} & \multirow[b]{2}{*}{ Mceq (MPa) } & & & & & $\mathrm{De}$ & ões (x1 & & & & \\
\hline & & Msub (MPa) & D0 & D25 & D40 & D60 & D80 & D100 & D140 & D180 & D260 \\
\hline 90 & 1650 & 75 & 17,76 & 13,27 & 12,22 & 11,47 & 10,77 & 10,12 & 8,90 & 7,82 & 6,03 \\
\hline 90 & 1700 & 75 & 17,53 & 13,13 & 12,10 & 11,37 & 10,69 & 10,05 & 8,86 & 7,79 & 6,03 \\
\hline 90 & 1750 & 75 & 17,31 & 13,00 & 11,98 & 11,27 & 10,61 & 9,99 & 8,81 & 7,76 & 6,02 \\
\hline 90 & 1800 & 75 & 17,10 & 12,88 & 11,87 & 11,18 & 10,54 & 9,92 & 8,77 & 7,74 & 6,01 \\
\hline 90 & 1850 & 75 & 16,90 & 12,76 & 11,76 & 11,09 & 10,46 & 9,86 & 8,73 & 7,71 & 6,01 \\
\hline 90 & 1900 & 75 & 16,71 & 12,64 & 11,65 & 11,01 & 10,39 & 9,80 & 8,69 & 7,68 & 6,00 \\
\hline 90 & 1950 & 75 & 16,52 & 12,53 & 11,55 & 10,92 & 10,32 & 9,74 & 8,65 & 7,66 & 5,99 \\
\hline 90 & 2000 & 75 & 16,34 & 12,42 & 11,45 & 10,84 & 10,26 & 9,68 & 8,61 & 7,63 & 5,98 \\
\hline 90 & 200 & 80 & 54,16 & 30,61 & 23,57 & 18,59 & 15,54 & 13,28 & 10,01 & 7,89 & 5,39 \\
\hline 90 & 250 & 80 & 46,53 & 27,51 & 21,81 & 17,67 & 15,03 & 13,02 & 10,00 & 7,94 & 5,44 \\
\hline 90 & 300 & 80 & 41,33 & 25,30 & 20,51 & 16,94 & 14,61 & 12,78 & 9,96 & 7,98 & 5,49 \\
\hline 90 & 350 & 80 & 37,54 & 23,62 & 19,49 & 16,35 & 14,24 & 12,55 & 9,90 & 7,99 & 5,52 \\
\hline 90 & 400 & 80 & 34,65 & 22,28 & 18,65 & 15,84 & 13,91 & 12,35 & 9,84 & 7,99 & 5,56 \\
\hline 90 & 450 & 80 & 32,35 & 21,18 & 17,95 & 15,40 & 13,62 & 12,16 & 9,78 & 7,99 & 5,58 \\
\hline 90 & 500 & 80 & 30,48 & 20,26 & 17,34 & 15,01 & 13,36 & 11,98 & 9,71 & 7,98 & 5,61 \\
\hline 90 & 550 & 80 & 28,92 & 19,46 & 16,82 & 14,66 & 13,11 & 11,81 & 9,64 & 7,96 & 5,63 \\
\hline 90 & 600 & 80 & 27,60 & 18,78 & 16,35 & 14,35 & 12,89 & 11,66 & 9,57 & 7,94 & 5,65 \\
\hline 90 & 650 & 80 & 26,47 & 18,17 & 15,93 & 14,06 & 12,69 & 11,51 & 9,51 & 7,92 & 5,66 \\
\hline 90 & 700 & 80 & 25,48 & 17,63 & 15,55 & 13,80 & 12,49 & 11,37 & 9,44 & 7,90 & 5,67 \\
\hline 90 & 750 & 80 & 24,61 & 17,15 & 15,20 & 13,56 & 12,32 & 11,24 & 9,38 & 7,87 & 5,68 \\
\hline 90 & 800 & 80 & 23,83 & 16,72 & 14,89 & 13,34 & 12,15 & 11,11 & 9,31 & 7,85 & 5,69 \\
\hline 90 & 850 & 80 & 23,14 & 16,32 & 14,59 & 13,13 & 11,99 & 10,99 & 9,25 & 7,82 & 5,69 \\
\hline 90 & 900 & 80 & 22,51 & 15,96 & 14,32 & 12,93 & 11,84 & 10,88 & 9,19 & 7,79 & 5,70 \\
\hline 90 & 950 & 80 & 21,94 & 15,62 & 14,07 & 12,75 & 11,70 & 10,77 & 9,13 & 7,77 & 5,70 \\
\hline 90 & 1000 & 80 & 21,42 & 15,32 & 13,83 & 12,57 & 11,56 & 10,67 & 9,07 & 7,74 & 5,70 \\
\hline 90 & 1050 & 80 & 20,94 & 15,03 & 13,61 & 12,41 & 11,44 & 10,57 & 9,02 & 7,71 & 5,71 \\
\hline 90 & 1100 & 80 & 20,50 & 14,77 & 13,40 & 12,26 & 11,32 & 10,47 & 8,96 & 7,68 & 5,71 \\
\hline 90 & 1150 & 80 & 20,09 & 14,52 & 13,21 & 12,11 & 11,20 & 10,38 & 8,91 & 7,66 & 5,71 \\
\hline 90 & 1200 & 80 & 19,70 & 14,29 & 13,02 & 11,97 & 11,09 & 10,29 & 8,86 & 7,63 & 5,70 \\
\hline 90 & 1250 & 80 & 19,34 & 14,07 & 12,85 & 11,84 & 10,98 & 10,21 & 8,80 & 7,60 & 5,70 \\
\hline 90 & 1300 & 80 & 19,01 & 13,87 & 12,68 & 11,71 & 10,88 & 10,12 & 8,75 & 7,57 & 5,70 \\
\hline 90 & 1350 & 80 & 18,69 & 13,68 & 12,52 & 11,59 & 10,78 & 10,05 & 8,71 & 7,54 & 5,70 \\
\hline 90 & 1400 & 80 & 18,40 & 13,50 & 12,37 & 11,47 & 10,69 & 9,97 & 8,66 & 7,52 & 5,69 \\
\hline 90 & 1450 & 80 & 18,11 & 13,33 & 12,23 & 11,36 & 10,60 & 9,90 & 8,61 & 7,49 & 5,69 \\
\hline 90 & 1500 & 80 & 17,85 & 13,16 & 12,09 & 11,25 & 10,51 & 9,82 & 8,57 & 7,46 & 5,68 \\
\hline 90 & 1550 & 80 & 17,59 & 13,01 & 11,96 & 11,15 & 10,43 & 9,76 & 8,52 & 7,44 & 5,68 \\
\hline 90 & 1600 & 80 & 17,35 & 12,86 & 11,83 & 11,05 & 10,34 & 9,69 & 8,48 & 7,41 & 5,68 \\
\hline 90 & 1650 & 80 & 17,12 & 12,72 & 11,71 & 10,95 & 10,27 & 9,62 & 8,44 & 7,39 & 5,67 \\
\hline 90 & 1700 & 80 & 16,90 & 12,59 & 11,59 & 10,86 & 10,19 & 9,56 & 8,39 & 7,36 & 5,66 \\
\hline 90 & 1750 & 80 & 16,69 & 12,46 & 11,48 & 10,77 & 10,11 & 9,50 & 8,35 & 7,34 & 5,66 \\
\hline 90 & 1800 & 80 & 16,49 & 12,34 & 11,37 & 10,68 & 10,04 & 9,44 & 8,31 & 7,31 & 5,65 \\
\hline 90 & 1850 & 80 & 16,29 & 12,23 & 11,26 & 10,60 & 9,97 & 9,38 & 8,28 & 7,29 & 5,65 \\
\hline 90 & 1900 & 80 & 16,11 & 12,11 & 11,16 & 10,52 & 9,91 & 9,32 & 8,24 & 7,26 & 5,64 \\
\hline 90 & 1950 & 80 & 15,93 & 12,01 & 11,07 & 10,44 & 9,84 & 9,27 & 8,20 & 7,24 & 5,63 \\
\hline 90 & 2000 & 80 & 15,75 & 11,90 & 10,97 & 10,36 & 9,78 & 9,22 & 8,16 & 7,22 & 5,63 \\
\hline 90 & 200 & 85 & 53,18 & 29,68 & 22,66 & 17,74 & 14,75 & 12,56 & 9,42 & 7,41 & 5,06 \\
\hline 90 & 250 & 85 & 45,60 & 26,64 & 20,96 & 16,86 & 14,28 & 12,32 & 9,42 & 7,47 & 5,11 \\
\hline 90 & 300 & 85 & 40,44 & 24,48 & 19,70 & 16,17 & 13,88 & 12,10 & 9,39 & 7,50 & 5,15 \\
\hline 90 & 350 & 85 & 36,68 & 22,83 & 18,71 & 15,60 & 13,54 & 11,90 & 9,34 & 7,52 & 5,19 \\
\hline 90 & 400 & 85 & 33,81 & 21,53 & 17,91 & 15,12 & 13,23 & 11,71 & 9,29 & 7,52 & 5,22 \\
\hline 90 & 450 & 85 & 31,53 & 20,46 & 17,23 & 14,71 & 12,96 & 11,54 & 9,23 & 7,52 & 5,24 \\
\hline 90 & 500 & 85 & 29,68 & 19,56 & 16,65 & 14,34 & 12,71 & 11,37 & 9,18 & 7,52 & 5,27 \\
\hline 90 & 550 & 85 & 28,14 & 18,79 & 16,14 & 14,01 & 12,49 & 11,22 & 9,12 & 7,50 & 5,29 \\
\hline 90 & 600 & 85 & 26,84 & 18,12 & 15,69 & 13,71 & 12,28 & 11,07 & 9,06 & 7,49 & 5,30 \\
\hline 90 & 650 & 85 & 25,72 & 17,53 & 15,29 & 13,44 & 12,09 & 10,94 & 9,00 & 7,47 & 5,32 \\
\hline 90 & 700 & 85 & 24,74 & 17,01 & 14,93 & 13,19 & 11,91 & 10,81 & 8,94 & 7,45 & 5,33 \\
\hline 90 & 750 & 85 & 23,88 & 16,54 & 14,59 & 12,96 & 11,74 & 10,69 & 8,88 & 7,43 & 5,34 \\
\hline 90 & 800 & 85 & 23,12 & 16,12 & 14,29 & 12,75 & 11,58 & 10,57 & 8,82 & 7,41 & 5,35 \\
\hline 90 & 850 & 85 & 22,43 & 15,73 & 14,01 & 12,55 & 11,43 & 10,46 & 8,77 & 7,39 & 5,35 \\
\hline 90 & 900 & 85 & 21,81 & 15,38 & 13,75 & 12,37 & 11,29 & 10,35 & 8,71 & 7,36 & 5,36 \\
\hline 90 & 950 & 85 & 21,25 & 15,06 & 13,51 & 12,19 & 11,16 & 10,25 & 8,66 & 7,34 & 5,36 \\
\hline 90 & 1000 & 85 & 20,74 & 14,76 & 13,28 & 12,03 & 11,03 & 10,15 & 8,60 & 7,31 & 5,37 \\
\hline 90 & 1050 & 85 & 20,27 & 14,48 & 13,07 & 11,87 & 10,91 & 10,06 & 8,55 & 7,29 & 5,37 \\
\hline 90 & 1100 & 85 & 19,84 & 14,22 & 12,87 & 11,73 & 10,80 & 9,97 & 8,50 & 7,27 & 5,37 \\
\hline 90 & 1150 & 85 & 19,43 & 13,98 & 12,68 & 11,59 & 10,69 & 9,89 & 8,45 & 7,24 & 5,37 \\
\hline 90 & 1200 & 85 & 19,06 & 13,76 & 12,51 & 11,45 & 10,58 & 9,80 & 8,40 & 7,22 & 5,37 \\
\hline 90 & 1250 & 85 & 18,71 & 13,55 & 12,34 & 11,33 & 10,48 & 9,72 & 8,36 & 7,19 & 5,37 \\
\hline 90 & 1300 & 85 & 18,38 & 13,35 & 12,18 & 11,21 & 10,39 & 9,65 & 8,31 & 7,17 & 5,37 \\
\hline 90 & 1350 & 85 & 18,07 & 13,17 & 12,03 & 11,09 & 10,30 & 9,57 & 8,27 & 7,14 & 5,37 \\
\hline 90 & 1400 & 85 & 17,78 & 12,99 & 11,88 & 10,98 & 10,21 & 9,50 & 8,22 & 7,12 & 5,36 \\
\hline 90 & 1450 & 85 & 17,51 & 12,82 & 11,74 & 10,87 & 10,12 & 9,43 & 8,18 & 7,09 & 5,36 \\
\hline 90 & 1500 & 85 & 17,25 & 12,67 & 11,61 & 10,77 & 10,04 & 9,37 & 8,14 & 7,07 & 5,36 \\
\hline 90 & 1550 & 85 & 17,00 & 12,52 & 11,48 & 10,67 & 9,96 & 9,30 & 8,10 & 7,05 & 5,35 \\
\hline 90 & 1600 & 85 & 16,77 & 12,37 & 11,36 & 10,58 & 9,88 & 9,24 & 8,06 & 7,02 & 5,35 \\
\hline 90 & 1650 & 85 & 16,54 & 12,24 & 11,24 & 10,49 & 9,81 & 9,18 & 8,02 & 7,00 & 5,35 \\
\hline 90 & 1700 & 85 & 16,33 & 12,11 & 11,13 & 10,40 & 9,74 & 9,12 & 7,98 & 6,98 & 5,34 \\
\hline 90 & 1750 & 85 & 16,13 & 11,98 & 11,02 & 10,31 & 9,67 & 9,06 & 7,94 & 6,95 & 5,34 \\
\hline 90 & 1800 & 85 & 15,93 & 11,86 & 10,92 & 10,23 & 9,60 & 9,00 & 7,91 & 6,93 & 5,33 \\
\hline 90 & 1850 & 85 & 15,74 & 11,75 & 10,82 & 10,15 & 9,53 & 8,95 & 7,87 & 6,91 & 5,33 \\
\hline 90 & 1900 & 85 & 15,56 & 11,64 & 10,72 & 10,07 & 9,47 & 8,90 & 7,83 & 6,89 & 5,32 \\
\hline 90 & 1950 & 85 & 15,39 & 11,54 & 10,63 & 10,00 & 9,41 & 8,84 & 7,80 & 6,87 & 5,32 \\
\hline
\end{tabular}




\begin{tabular}{|c|c|c|c|c|c|c|c|c|c|c|c|}
\hline \multirow[b]{2}{*}{$\mathrm{H}(\mathrm{cm})$} & \multirow[b]{2}{*}{ Mceq (MPa) } & & & & & De & ões (x1 & & & & \\
\hline & & Msub (MPa) & D0 & D25 & D40 & D60 & D80 & D100 & D140 & D180 & D260 \\
\hline 90 & 2000 & 85 & 15,22 & 11,44 & 10,54 & 9,92 & 9,35 & 8,79 & 7,77 & 6,84 & 5,31 \\
\hline 90 & 200 & 90 & 52,31 & 28,84 & 21,85 & 16,97 & 14,04 & 11,92 & 8,90 & 6,98 & 4,77 \\
\hline 90 & 250 & 90 & 44,77 & 25,86 & 20,19 & 16,13 & 13,60 & 11,70 & 8,90 & 7,04 & 4,81 \\
\hline 90 & 300 & 90 & 39,64 & 23,73 & 18,97 & 15,47 & 13,23 & 11,50 & 8,88 & 7,07 & 4,85 \\
\hline 90 & 350 & 90 & 35,91 & 22,12 & 18,01 & 14,93 & 12,91 & 11,31 & 8,84 & 7,09 & 4,89 \\
\hline 90 & 400 & 90 & 33,05 & 20,85 & 17,23 & 14,48 & 12,62 & 11,14 & 8,80 & 7,10 & 4,91 \\
\hline 90 & 450 & 90 & 30,80 & 19,80 & 16,58 & 14,08 & 12,37 & 10,98 & 8,75 & 7,11 & 4,94 \\
\hline 90 & 500 & 90 & 28,96 & 18,93 & 16,02 & 13,73 & 12,14 & 10,83 & 8,70 & 7,10 & 4,96 \\
\hline 90 & 550 & 90 & 27,44 & 18,18 & 15,53 & 13,42 & 11,92 & 10,68 & 8,64 & 7,09 & 4,98 \\
\hline 90 & 600 & 90 & 26,14 & 17,52 & 15,10 & 13,13 & 11,73 & 10,55 & 8,59 & 7,08 & 5,00 \\
\hline 90 & 650 & 90 & 25,04 & 16,95 & 14,71 & 12,88 & 11,55 & 10,42 & 8,54 & 7,07 & 5,01 \\
\hline 90 & 700 & 90 & 24,07 & 16,44 & 14,36 & 12,64 & 11,38 & 10,30 & 8,48 & 7,05 & 5,02 \\
\hline 90 & 750 & 90 & 23,22 & 15,99 & 14,04 & 12,42 & 11,22 & 10,19 & 8,43 & 7,04 & 5,03 \\
\hline 90 & 800 & 90 & 22,47 & 15,57 & 13,75 & 12,22 & 11,07 & 10,08 & 8,38 & 7,02 & 5,04 \\
\hline 90 & 850 & 90 & 21,79 & 15,20 & 13,48 & 12,03 & 10,93 & 9,98 & 8,33 & 7,00 & 5,05 \\
\hline 90 & 900 & 90 & 21,19 & 14,86 & 13,23 & 11,85 & 10,80 & 9,88 & 8,28 & 6,98 & 5,06 \\
\hline 90 & 950 & 90 & 20,63 & 14,54 & 13,00 & 11,69 & 10,67 & 9,78 & 8,23 & 6,96 & 5,06 \\
\hline 90 & 1000 & 90 & 20,13 & 14,25 & 12,78 & 11,53 & 10,55 & 9,69 & 8,18 & 6,93 & 5,07 \\
\hline 90 & 1050 & 90 & 19,67 & 13,98 & 12,58 & 11,38 & 10,44 & 9,61 & 8,13 & 6,91 & 5,07 \\
\hline 90 & 1100 & 90 & 19,24 & 13,73 & 12,39 & 11,24 & 10,33 & 9,52 & 8,09 & 6,89 & 5,07 \\
\hline 90 & 1150 & 90 & 18,85 & 13,50 & 12,21 & 11,11 & 10,23 & 9,44 & 8,04 & 6,87 & 5,07 \\
\hline 90 & 1200 & 90 & 18,48 & 13,28 & 12,04 & 10,99 & 10,13 & 9,36 & 8,00 & 6,85 & 5,07 \\
\hline 90 & 1250 & 90 & 18,14 & 13,08 & 11,88 & 10,87 & 10,03 & 9,29 & 7,96 & 6,82 & 5,07 \\
\hline 90 & 1300 & 90 & 17,81 & 12,88 & 11,72 & 10,75 & 9,94 & 9,22 & 7,91 & 6,80 & 5,07 \\
\hline 90 & 1350 & 90 & 17,51 & 12,70 & 11,58 & 10,64 & 9,86 & 9,15 & 7,87 & 6,78 & 5,07 \\
\hline 90 & 1400 & 90 & 17,23 & 12,53 & 11,44 & 10,53 & 9,77 & 9,08 & 7,83 & 6,76 & 5,07 \\
\hline 90 & 1450 & 90 & 16,96 & 12,37 & 11,30 & 10,43 & 9,69 & 9,02 & 7,79 & 6,74 & 5,07 \\
\hline 90 & 1500 & 90 & 16,71 & 12,21 & 11,18 & 10,34 & 9,61 & 8,95 & 7,75 & 6,71 & 5,06 \\
\hline 90 & 1550 & 90 & 16,47 & 12,07 & 11,05 & 10,24 & 9,54 & 8,89 & 7,71 & 6,69 & 5,06 \\
\hline 90 & 1600 & 90 & 16,24 & 11,93 & 10,94 & 10,15 & 9,46 & 8,83 & 7,68 & 6,67 & 5,06 \\
\hline 90 & 1650 & 90 & 16,02 & 11,80 & 10,83 & 10,06 & 9,39 & 8,77 & 7,64 & 6,65 & 5,06 \\
\hline 90 & 1700 & 90 & 15,81 & 11,67 & 10,72 & 9,98 & 9,33 & 8,72 & 7,61 & 6,63 & 5,05 \\
\hline 90 & 1750 & 90 & 15,61 & 11,55 & 10,61 & 9,90 & 9,26 & 8,66 & 7,57 & 6,61 & 5,05 \\
\hline 90 & 1800 & 90 & 15,42 & 11,43 & 10,51 & 9,82 & 9,19 & 8,61 & 7,54 & 6,59 & 5,04 \\
\hline 90 & 1850 & 90 & 15,24 & 11,32 & 10,42 & 9,74 & 9,13 & 8,56 & 7,50 & 6,57 & 5,04 \\
\hline 90 & 1900 & 90 & 15,07 & 11,22 & 10,32 & 9,67 & 9,07 & 8,51 & 7,47 & 6,55 & 5,04 \\
\hline 90 & 1950 & 90 & 14,90 & 11,12 & 10,23 & 9,60 & 9,01 & 8,46 & 7,44 & 6,53 & 5,03 \\
\hline 90 & 2000 & 90 & 14,73 & 11,02 & 10,15 & 9,53 & 8,96 & 8,41 & 7,41 & 6,51 & 5,03 \\
\hline 90 & 200 & 95 & 51,51 & 28,08 & 21,11 & 16,28 & 13,41 & 11,34 & 8,42 & 6,60 & 4,51 \\
\hline 90 & 250 & 95 & 44,01 & 25,14 & 19,49 & 15,47 & 12,99 & 11,14 & 8,43 & 6,66 & 4,55 \\
\hline 90 & 300 & 95 & 38,91 & 23,05 & 18,30 & 14,84 & 12,64 & 10,95 & 8,42 & 6,69 & 4,59 \\
\hline 90 & 350 & 95 & 35,20 & 21,48 & 17,38 & 14,33 & 12,34 & 10,78 & 8,39 & 6,71 & 4,62 \\
\hline 90 & 400 & 95 & 32,37 & 20,23 & 16,62 & 13,89 & 12,07 & 10,62 & 8,35 & 6,73 & 4,64 \\
\hline 90 & 450 & 95 & 30,13 & 19,21 & 15,99 & 13,51 & 11,83 & 10,47 & 8,31 & 6,73 & 4,67 \\
\hline 90 & 500 & 95 & 28,31 & 18,35 & 15,45 & 13,18 & 11,61 & 10,33 & 8,26 & 6,73 & 4,69 \\
\hline 90 & 550 & 95 & 26,80 & 17,62 & 14,97 & 12,88 & 11,41 & 10,20 & 8,22 & 6,73 & 4,71 \\
\hline 90 & 600 & 95 & 25,52 & 16,98 & 14,56 & 12,61 & 11,23 & 10,07 & 8,17 & 6,72 & 4,72 \\
\hline 90 & 650 & 95 & 24,42 & 16,42 & 14,18 & 12,36 & 11,05 & 9,95 & 8,12 & 6,71 & 4,74 \\
\hline 90 & 700 & 95 & 23,47 & 15,93 & 13,85 & 12,14 & 10,89 & 9,84 & 8,07 & 6,69 & 4,75 \\
\hline 90 & 750 & 95 & 22,63 & 15,48 & 13,54 & 11,93 & 10,75 & 9,74 & 8,03 & 6,68 & 4,76 \\
\hline 90 & 800 & 95 & 21,88 & 15,08 & 13,26 & 11,74 & 10,61 & 9,63 & 7,98 & 6,66 & 4,77 \\
\hline 90 & 850 & 95 & 21,22 & 14,72 & 13,00 & 11,56 & 10,47 & 9,54 & 7,93 & 6,65 & 4,78 \\
\hline 90 & 900 & 95 & 20,62 & 14,38 & 12,76 & 11,39 & 10,35 & 9,45 & 7,89 & 6,63 & 4,78 \\
\hline 90 & 950 & 95 & 20,07 & 14,08 & 12,54 & 11,23 & 10,23 & 9,36 & 7,84 & 6,61 & 4,79 \\
\hline 90 & 1000 & 95 & 19,57 & 13,79 & 12,33 & 11,08 & 10,12 & 9,27 & 7,80 & 6,59 & 4,79 \\
\hline 90 & 1050 & 95 & 19,12 & 13,53 & 12,13 & 10,94 & 10,01 & 9,19 & 7,76 & 6,57 & 4,80 \\
\hline 90 & 1100 & 95 & 18,70 & 13,29 & 11,95 & 10,81 & 9,91 & 9,11 & 7,71 & 6,55 & 4,80 \\
\hline 90 & 1150 & 95 & 18,31 & 13,06 & 11,77 & 10,68 & 9,81 & 9,04 & 7,67 & 6,53 & 4,80 \\
\hline 90 & 1200 & 95 & 17,95 & 12,85 & 11,61 & 10,56 & 9,72 & 8,96 & 7,63 & 6,51 & 4,80 \\
\hline 90 & 1250 & 95 & 17,61 & 12,65 & 11,45 & 10,44 & 9,63 & 8,89 & 7,59 & 6,49 & 4,80 \\
\hline 90 & 1300 & 95 & 17,30 & 12,46 & 11,31 & 10,33 & 9,54 & 8,83 & 7,55 & 6,47 & 4,81 \\
\hline 90 & 1350 & 95 & 17,00 & 12,28 & 11,17 & 10,23 & 9,46 & 8,76 & 7,51 & 6,45 & 4,80 \\
\hline 90 & 1400 & 95 & 16,72 & 12,11 & 11,03 & 10,13 & 9,38 & 8,70 & 7,48 & 6,43 & 4,80 \\
\hline 90 & 1450 & 95 & 16,46 & 11,96 & 10,90 & 10,03 & 9,30 & 8,64 & 7,44 & 6,41 & 4,80 \\
\hline 90 & 1500 & 95 & 16,21 & 11,81 & 10,78 & 9,94 & 9,23 & 8,58 & 7,40 & 6,39 & 4,80 \\
\hline 90 & 1550 & 95 & 15,98 & 11,66 & 10,66 & 9,85 & 9,15 & 8,52 & 7,37 & 6,37 & 4,80 \\
\hline 90 & 1600 & 95 & 15,76 & 11,53 & 10,55 & 9,76 & 9,08 & 8,46 & 7,33 & 6,35 & 4,80 \\
\hline 90 & 1650 & 95 & 15,54 & 11,40 & 10,44 & 9,68 & 9,02 & 8,41 & 7,30 & 6,34 & 4,79 \\
\hline 90 & 1700 & 95 & 15,34 & 11,27 & 10,34 & 9,60 & 8,95 & 8,36 & 7,27 & 6,32 & 4,79 \\
\hline 90 & 1750 & 95 & 15,15 & 11,16 & 10,24 & 9,52 & 8,89 & 8,30 & 7,23 & 6,30 & 4,79 \\
\hline 90 & 1800 & 95 & 14,96 & 11,04 & 10,14 & 9,45 & 8,83 & 8,25 & 7,20 & 6,28 & 4,79 \\
\hline 90 & 1850 & 95 & 14,78 & 10,94 & 10,05 & 9,37 & 8,77 & 8,21 & 7,17 & 6,26 & 4,78 \\
\hline 90 & 1900 & 95 & 14,61 & 10,83 & 9,96 & 9,30 & 8,71 & 8,16 & 7,14 & 6,24 & 4,78 \\
\hline 90 & 1950 & 95 & 14,45 & 10,73 & 9,87 & 9,23 & 8,65 & 8,11 & 7,11 & 6,22 & 4,78 \\
\hline 90 & 2000 & 95 & 14,29 & 10,64 & 9,79 & 9,17 & 8,60 & 8,07 & 7,08 & 6,21 & 4,77 \\
\hline 90 & 200 & 100 & 50,79 & 27,39 & 20,44 & 15,65 & 12,83 & 10,81 & 8,00 & 6,25 & 4,28 \\
\hline 90 & 250 & 100 & 43,33 & 24,49 & 18,85 & 14,87 & 12,43 & 10,63 & 8,01 & 6,31 & 4,31 \\
\hline 90 & 300 & 100 & 38,25 & 22,43 & 17,70 & 14,27 & 12,10 & 10,46 & 8,00 & 6,35 & 4,35 \\
\hline 90 & 350 & 100 & 34,56 & 20,88 & 16,79 & 13,77 & 11,82 & 10,30 & 7,98 & 6,37 & 4,38 \\
\hline 90 & 400 & 100 & 31,75 & 19,66 & 16,06 & 13,35 & 11,56 & 10,15 & 7,95 & 6,39 & 4,40 \\
\hline 90 & 450 & 100 & 29,52 & 18,66 & 15,45 & 12,99 & 11,34 & 10,01 & 7,91 & 6,39 & 4,43 \\
\hline
\end{tabular}




\begin{tabular}{|c|c|c|c|c|c|c|c|c|c|c|c|}
\hline \multirow[b]{2}{*}{$\mathrm{H}(\mathrm{cm})$} & \multirow[b]{2}{*}{ Mceq (MPa) } & & & & & $\mathrm{De}$ & ões (x1 & & & & \\
\hline & & Msub (MPa) & D0 & D25 & D40 & D60 & D80 & D100 & D140 & D180 & D260 \\
\hline 90 & 500 & 100 & 27,72 & 17,82 & 14,92 & 12,67 & 11,13 & 9,88 & 7,87 & 6,40 & 4,45 \\
\hline 90 & 550 & 100 & 26,22 & 17,11 & 14,47 & 12,39 & 10,94 & 9,76 & 7,83 & 6,39 & 4,46 \\
\hline 90 & 600 & 100 & 24,95 & 16,49 & 14,06 & 12,13 & 10,77 & 9,64 & 7,79 & 6,39 & 4,48 \\
\hline 90 & 650 & 100 & 23,86 & 15,94 & 13,70 & 11,89 & 10,61 & 9,53 & 7,75 & 6,38 & 4,49 \\
\hline 90 & 700 & 100 & 22,91 & 15,46 & 13,37 & 11,68 & 10,45 & 9,42 & 7,70 & 6,37 & 4,51 \\
\hline 90 & 750 & 100 & 22,08 & 15,02 & 13,08 & 11,48 & 10,31 & 9,32 & 7,66 & 6,36 & 4,52 \\
\hline 90 & 800 & 100 & 21,35 & 14,63 & 12,81 & 11,30 & 10,18 & 9,23 & 7,62 & 6,34 & 4,53 \\
\hline 90 & 850 & 100 & 20,69 & 14,27 & 12,56 & 11,12 & 10,06 & 9,14 & 7,57 & 6,33 & 4,53 \\
\hline 90 & 900 & 100 & 20,10 & 13,95 & 12,32 & 10,96 & 9,94 & 9,05 & 7,53 & 6,31 & 4,54 \\
\hline 90 & 950 & 100 & 19,56 & 13,65 & 12,11 & 10,81 & 9,82 & 8,97 & 7,49 & 6,30 & 4,55 \\
\hline 90 & 1000 & 100 & 19,07 & 13,37 & 11,91 & 10,67 & 9,72 & 8,89 & 7,45 & 6,28 & 4,55 \\
\hline 90 & 1050 & 100 & 18,62 & 13,12 & 11,72 & 10,53 & 9,62 & 8,81 & 7,41 & 6,26 & 4,55 \\
\hline 90 & 1100 & 100 & 18,20 & 12,88 & 11,54 & 10,41 & 9,52 & 8,74 & 7,37 & 6,24 & 4,56 \\
\hline 90 & 1150 & 100 & 17,82 & 12,66 & 11,37 & 10,29 & 9,43 & 8,67 & 7,33 & 6,23 & 4,56 \\
\hline 90 & 1200 & 100 & 17,47 & 12,45 & 11,22 & 10,17 & 9,34 & 8,60 & 7,30 & 6,21 & 4,56 \\
\hline 90 & 1250 & 100 & 17,14 & 12,25 & 11,07 & 10,06 & 9,25 & 8,53 & 7,26 & 6,19 & 4,56 \\
\hline 90 & 1300 & 100 & 16,83 & 12,07 & 10,92 & 9,95 & 9,17 & 8,47 & 7,22 & 6,17 & 4,56 \\
\hline 90 & 1350 & 100 & 16,54 & 11,90 & 10,79 & 9,85 & 9,09 & 8,41 & 7,19 & 6,16 & 4,56 \\
\hline 90 & 1400 & 100 & 16,26 & 11,73 & 10,66 & 9,76 & 9,01 & 8,35 & 7,15 & 6,14 & 4,56 \\
\hline 90 & 1450 & 100 & 16,01 & 11,58 & 10,54 & 9,67 & 8,94 & 8,29 & 7,12 & 6,12 & 4,56 \\
\hline 90 & 1500 & 100 & 15,76 & 11,43 & 10,42 & 9,58 & 8,87 & 8,23 & 7,08 & 6,10 & 4,56 \\
\hline 90 & 1550 & 100 & 15,53 & 11,29 & 10,31 & 9,49 & 8,80 & 8,18 & 7,05 & 6,08 & 4,56 \\
\hline 90 & 1600 & 100 & 15,31 & 11,16 & 10,20 & 9,41 & 8,74 & 8,13 & 7,02 & 6,07 & 4,56 \\
\hline 90 & 1650 & 100 & 15,10 & 11,03 & 10,09 & 9,33 & 8,67 & 8,07 & 6,99 & 6,05 & 4,56 \\
\hline 90 & 1700 & 100 & 14,91 & 10,91 & 9,99 & 9,25 & 8,61 & 8,02 & 6,96 & 6,03 & 4,56 \\
\hline 90 & 1750 & 100 & 14,72 & 10,80 & 9,90 & 9,18 & 8,55 & 7,98 & 6,93 & 6,01 & 4,55 \\
\hline 90 & 1800 & 100 & 14,54 & 10,69 & 9,80 & 9,10 & 8,49 & 7,93 & 6,90 & 6,00 & 4,55 \\
\hline 90 & 1850 & 100 & 14,36 & 10,58 & 9,71 & 9,03 & 8,44 & 7,88 & 6,87 & 5,98 & 4,55 \\
\hline 90 & 1900 & 100 & 14,20 & 10,48 & 9,63 & 8,97 & 8,38 & 7,84 & 6,84 & 5,96 & 4,55 \\
\hline 90 & 1950 & 100 & 14,04 & 10,38 & 9,54 & 8,90 & 8,33 & 7,79 & 6,81 & 5,95 & 4,54 \\
\hline 90 & 2000 & 100 & 13,88 & 10,29 & 9,46 & 8,84 & 8,28 & 7,75 & 6,78 & 5,93 & 4,54 \\
\hline 90 & 200 & 105 & 50,13 & 26,75 & 19,82 & 15,07 & 12,30 & 10,33 & 7,61 & 5,94 & 4,07 \\
\hline 90 & 250 & 105 & 42,70 & 23,89 & 18,27 & 14,32 & 11,92 & 10,16 & 7,63 & 6,00 & 4,10 \\
\hline 90 & 300 & 105 & 37.65 & 21,87 & 17,14 & 13,74 & 11.61 & 10,00 & 7.62 & 6.04 & 4.13 \\
\hline 90 & 350 & 105 & 33,98 & 20,34 & 16,26 & 13,26 & 11,34 & 9,86 & 7,61 & 6,06 & 4,16 \\
\hline 90 & 400 & 105 & 31,18 & 19,14 & 15,55 & 12,86 & 11,10 & 9,72 & 7,58 & 6,08 & 4,18 \\
\hline 90 & 450 & 105 & 28,97 & 18,16 & 14,95 & 12,51 & 10,89 & 9,59 & 7,55 & 6,09 & 4,21 \\
\hline 90 & 500 & 105 & 27,18 & 17,34 & 14,44 & 12,21 & 10,69 & 9,47 & 7,52 & 6,09 & 4,23 \\
\hline 90 & 550 & 105 & 25,69 & 16,64 & 14,00 & 11,93 & 10,51 & 9,35 & 7,48 & 6,09 & 4,24 \\
\hline 90 & 600 & 105 & 24,43 & 16,03 & 13,61 & 11,69 & 10,35 & 9,24 & 7,44 & 6,09 & 4,26 \\
\hline 90 & 650 & 105 & 23,35 & 15,49 & 13,26 & 11,46 & 10,19 & 9,14 & 7,40 & 6,08 & 4,27 \\
\hline 90 & 700 & 105 & 22,41 & 15,02 & 12,94 & 11,26 & 10,05 & 9,04 & 7,36 & 6,07 & 4,28 \\
\hline 90 & 750 & 105 & 21,59 & 14,60 & 12,65 & 11,07 & 9,92 & 8,95 & 7,32 & 6,06 & 4,29 \\
\hline 90 & 800 & 105 & 20,86 & 14,21 & 12,39 & 10,89 & 9,79 & 8,86 & 7,28 & 6,05 & 4,30 \\
\hline 90 & 850 & 105 & 20,21 & 13,87 & 12,15 & 10,73 & 9,67 & 8,77 & 7,25 & 6,04 & 4,31 \\
\hline 90 & 900 & 105 & 19,62 & 13,55 & 11,93 & 10,57 & 9,56 & 8,69 & 7,21 & 6,02 & 4,32 \\
\hline 90 & 950 & 105 & 19,09 & 13,26 & 11,72 & 10,43 & 9,45 & 8,61 & 7,17 & 6,01 & 4,32 \\
\hline 90 & 1000 & 105 & 18,60 & 12,99 & 11,52 & 10,29 & 9,35 & 8,54 & 7,13 & 6,00 & 4,33 \\
\hline 90 & 1050 & 105 & 18,16 & 12,74 & 11,34 & 10,16 & 9,26 & 8,47 & 7,10 & 5,98 & 4,33 \\
\hline 90 & 1100 & 105 & 17,75 & 12,50 & 11,17 & 10,04 & 9,16 & 8,40 & 7,06 & 5,96 & 4,34 \\
\hline 90 & 1150 & 105 & 17,37 & 12,29 & 11,01 & 9,92 & 9,07 & 8,33 & 7,02 & 5,95 & 4,34 \\
\hline 90 & 1200 & 105 & 17,02 & 12,08 & 10,86 & 9,81 & 8,99 & 8,26 & 6,99 & 5,93 & 4,34 \\
\hline 90 & 1250 & 105 & 16,70 & 11,89 & 10,71 & 9,71 & 8,91 & 8,20 & 6,95 & 5,92 & 4,34 \\
\hline 90 & 1300 & 105 & 16,39 & 11,71 & 10,57 & 9,61 & 8,83 & 8,14 & 6,92 & 5,90 & 4,35 \\
\hline 90 & 1350 & 105 & 16,11 & 11,54 & 10,44 & 9,51 & 8,75 & 8,08 & 6,89 & 5,88 & 4,35 \\
\hline 90 & 1400 & 105 & 15,84 & 11,38 & 10,32 & 9,42 & 8,68 & 8,03 & 6,86 & 5,87 & 4,35 \\
\hline 90 & 1450 & 105 & 15,59 & 11,23 & 10,20 & 9,33 & 8,61 & 7,97 & 6,82 & 5,85 & 4,35 \\
\hline 90 & 1500 & 105 & 15,35 & 11,09 & 10,08 & 9,24 & 8,55 & 7,92 & 6,79 & 5,84 & 4,35 \\
\hline 90 & 1550 & 105 & 15,12 & 10,95 & 9,98 & 9,16 & 8,48 & 7,87 & 6,76 & 5,82 & 4,35 \\
\hline 90 & 1600 & 105 & 14,91 & 10,82 & 9,87 & 9,08 & 8,42 & 7,82 & 6,73 & 5,80 & 4,35 \\
\hline 90 & 1650 & 105 & 14,70 & 10,70 & 9,77 & 9,00 & 8,36 & 7,77 & 6,70 & 5,79 & 4,34 \\
\hline 90 & 1700 & 105 & 14,51 & 10,58 & 9,67 & 8,93 & 8,30 & 7,72 & 6,67 & 5,77 & 4,34 \\
\hline 90 & 1750 & 105 & 14,32 & 10,47 & 9,58 & 8,86 & 8,24 & 7,67 & 6,65 & 5,76 & 4,34 \\
\hline 90 & 1800 & 105 & 14,14 & 10,36 & 9,49 & 8,79 & 8,18 & 7,63 & 6,62 & 5,74 & 4,34 \\
\hline 90 & 1850 & 105 & 13,97 & 10,26 & 9,40 & 8,72 & 8,13 & 7,58 & 6,59 & 5,72 & 4,34 \\
\hline 90 & 1900 & 105 & 13,81 & 10,16 & 9,32 & 8,66 & 8,08 & 7,54 & 6,56 & 5,71 & 4,33 \\
\hline 90 & 1950 & 105 & 13,65 & 10,06 & 9,24 & 8,60 & 8,03 & 7,50 & $\begin{array}{c}6,54 \\
\end{array}$ & 5,69 & 4,33 \\
\hline 90 & 2000 & 105 & 13,50 & 9,97 & 9,16 & 8,53 & 7,98 & 7,46 & 6,51 & 5,68 & 4,33 \\
\hline 90 & 200 & 110 & 49,52 & 26,17 & 19,25 & 14,54 & 11,81 & 9,89 & 7,26 & 5,66 & 3,88 \\
\hline 90 & 250 & 110 & 42,12 & 23,34 & 17,73 & 13,81 & 11,45 & 9,73 & 7,28 & 5,72 & 3,91 \\
\hline 90 & 300 & 110 & 37,09 & 21,34 & 16,63 & 13,25 & 11,16 & 9,59 & 7,28 & 5,76 & 3,94 \\
\hline 90 & 350 & 110 & 33,44 & 19,84 & 15,77 & 12,80 & 10,90 & 9,45 & 7,27 & 5,78 & 3,96 \\
\hline 90 & 400 & 110 & 30,66 & 18,66 & 15,07 & 12,41 & 10,68 & 9,32 & 7,25 & 5,80 & 3,98 \\
\hline 90 & 450 & 110 & 28,46 & 17,69 & 14,49 & 12,08 & 10,47 & 9,20 & 7,22 & 5,81 & 4,01 \\
\hline 90 & 500 & 110 & 26,68 & 16,89 & 14,00 & 11,78 & 10,29 & 9,09 & 7,19 & 5,81 & 4,02 \\
\hline 90 & 550 & 110 & 25,20 & 16,20 & 13,57 & 11,52 & 10,12 & 8,98 & 7,16 & 5,81 & 4,04 \\
\hline 90 & 600 & 110 & 23.95 & 15.61 & 13,19 & 11.28 & 9.96 & 8.88 & 7.12 & 5.81 & 4.06 \\
\hline 90 & 650 & 110 & 22,88 & 15,08 & 12,85 & 11,07 & 9,82 & 8,78 & 7,09 & 5,81 & 4,07 \\
\hline 90 & 700 & 110 & 21,95 & 14,62 & 12,54 & 10,87 & 9,68 & 8,69 & 7,05 & 5,80 & 4,08 \\
\hline 90 & 750 & 110 & 21,13 & 14,20 & 12,26 & 10,69 & 9,55 & 8,60 & 7,02 & 5,79 & 4,09 \\
\hline 90 & 800 & 110 & 20,41 & 13,83 & 12,01 & 10,52 & 9,43 & 8,52 & 6,98 & 5,78 & 4,10 \\
\hline
\end{tabular}




\begin{tabular}{|c|c|c|c|c|c|c|c|c|c|c|c|}
\hline \multirow[b]{2}{*}{$\mathrm{H}(\mathrm{cm})$} & \multirow[b]{2}{*}{ Mceq (MPa) } & & & & & De & ões (x1 & & & & \\
\hline & & Msub (MPa) & D0 & D25 & D40 & D60 & D80 & D100 & D140 & D180 & D260 \\
\hline 90 & 850 & 110 & 19,76 & 13,49 & 11,77 & 10,36 & 9,32 & 8,44 & 6,95 & 5,77 & 4,11 \\
\hline 90 & 900 & 110 & 19,18 & 13,18 & 11,56 & 10,21 & 9,21 & 8,36 & 6,91 & 5,76 & 4,12 \\
\hline 90 & 950 & 110 & 18,65 & 12,89 & 11,36 & 10,07 & 9,11 & 8,29 & 6,87 & 5,75 & 4,12 \\
\hline 90 & 1000 & 110 & 18,18 & 12,63 & 11,17 & 9,94 & 9,01 & 8,22 & 6,84 & 5,74 & 4,13 \\
\hline 90 & 1050 & 110 & 17,74 & 12,38 & 10,99 & 9,82 & 8,92 & 8,15 & 6,81 & 5,72 & 4,13 \\
\hline 90 & 1100 & 110 & 17,33 & 12,16 & 10,83 & 9,70 & 8,83 & 8,08 & 6,77 & 5,71 & 4,14 \\
\hline 90 & 1150 & 110 & 16,96 & 11,94 & 10,67 & 9,59 & 8,75 & 8,02 & 6,74 & 5,69 & 4,14 \\
\hline 90 & 1200 & 110 & 16,62 & 11,75 & 10,52 & 9,48 & 8,67 & 7,96 & 6,71 & 5,68 & 4,14 \\
\hline 90 & 1250 & 110 & 16,29 & 11,56 & 10,38 & 9,38 & 8,59 & 7,90 & 6,68 & 5,67 & 4,15 \\
\hline 90 & 1300 & 110 & 15,99 & 11,38 & 10,25 & 9,28 & 8,52 & 7,84 & 6,64 & 5,65 & 4,15 \\
\hline 90 & 1350 & 110 & 15,71 & 11,22 & 10,12 & 9,19 & 8,45 & 7,78 & 6,61 & 5,64 & 4,15 \\
\hline 90 & 1400 & 110 & 15,45 & 11,06 & 10,00 & 9,10 & 8,38 & 7,73 & 6,58 & 5,62 & 4,15 \\
\hline 90 & 1450 & 110 & 15,20 & 10,91 & 9,89 & 9,02 & 8,31 & 7,68 & 6,55 & 5,61 & 4,15 \\
\hline 90 & 1500 & 110 & 14,96 & 10,77 & 9,78 & 8,93 & 8,25 & 7,63 & 6,52 & 5,59 & 4,15 \\
\hline 90 & 1550 & 110 & 14,74 & 10,64 & 9,67 & 8,86 & 8,18 & 7,58 & 6,50 & 5,58 & 4,15 \\
\hline 90 & 1600 & 110 & 14,53 & 10,51 & 9,57 & 8,78 & 8,12 & 7,53 & 6,47 & 5,56 & 4,15 \\
\hline 90 & 1650 & 110 & 14,33 & 10,39 & 9,47 & 8,71 & 8,06 & 7,48 & 6,44 & 5,55 & 4,15 \\
\hline 90 & 1700 & 110 & 14,14 & 10,28 & 9,38 & 8,63 & 8,01 & 7,44 & 6,41 & 5,53 & 4,15 \\
\hline 90 & 1750 & 110 & 13,96 & 10,17 & 9,29 & 8,57 & 7,95 & 7,40 & 6,39 & 5,52 & 4,15 \\
\hline 90 & 1800 & 110 & 13,78 & 10,06 & 9,20 & 8,50 & 7,90 & 7,35 & 6,36 & 5,50 & 4,14 \\
\hline 90 & 1850 & 110 & 13,62 & 9,96 & 9,12 & 8,44 & 7,85 & 7,31 & 6,33 & 5,49 & 4,14 \\
\hline 90 & 1900 & 110 & 13,46 & 9,86 & 9,04 & 8,37 & 7,80 & 7,27 & 6,31 & 5,47 & 4,14 \\
\hline 90 & 1950 & 110 & 13,30 & 9,77 & 8,96 & 8,31 & 7,75 & 7,23 & 6,28 & 5,46 & 4,14 \\
\hline 90 & 2000 & 110 & 13,16 & 9,68 & 8,88 & 8,25 & 7,70 & 7,19 & 6,26 & 5,45 & 4,14 \\
\hline 90 & 200 & 115 & 48,96 & 25,63 & 18,73 & 14,05 & 11,36 & 9,49 & 6,94 & 5,40 & 3,70 \\
\hline 90 & 250 & 115 & 41,58 & 22,83 & 17,24 & 13,35 & 11,02 & 9,34 & 6,96 & 5,46 & 3,73 \\
\hline 90 & 300 & 115 & 36,58 & 20,86 & 16,15 & 12,81 & 10,74 & 9,21 & 6,97 & 5,50 & 3,76 \\
\hline 90 & 350 & 115 & 32,94 & 19,38 & 15,31 & 12,36 & 10,50 & 9,08 & 6,96 & 5,52 & 3,78 \\
\hline 90 & 400 & 115 & 30,18 & 18,21 & 14,63 & 11,99 & 10,28 & 8,96 & 6,94 & 5,54 & 3,80 \\
\hline 90 & 450 & 115 & 27,99 & 17,27 & 14,07 & 11,67 & 10,09 & 8,85 & 6,92 & 5,55 & 3,82 \\
\hline 90 & 500 & 115 & 26,22 & 16,47 & 13,59 & 11,39 & 9,92 & 8,74 & 6,89 & 5,56 & 3,84 \\
\hline 90 & 550 & 115 & 24,75 & 15,80 & 13,17 & 11,14 & 9,75 & 8,64 & 6,86 & 5,56 & 3,86 \\
\hline 90 & 600 & 115 & 23,51 & 15,22 & 12,80 & 10,91 & 9,61 & 8,54 & 6,83 & 5,56 & 3,87 \\
\hline 90 & 650 & 115 & 22,44 & 14,70 & 12,47 & 10,70 & 9,47 & 8,45 & 6,80 & 5,56 & 3,89 \\
\hline 90 & 700 & 115 & 21,52 & 14,25 & 12,17 & 10,51 & 9,34 & 8,37 & 6,77 & 5,55 & 3,90 \\
\hline 90 & 750 & 115 & 20,71 & 13,84 & 11,90 & 10,33 & 9,22 & 8,28 & 6,73 & 5,55 & 3,91 \\
\hline 90 & 800 & 115 & 19,99 & 13,47 & 11,65 & 10,17 & 9,10 & 8,20 & 6,70 & 5,54 & 3,92 \\
\hline 90 & 850 & 115 & 19,35 & 13,14 & 11,43 & 10,02 & 8,99 & 8,13 & 6,67 & 5,53 & 3,93 \\
\hline 90 & 900 & 115 & 18,78 & 12,84 & 11,22 & 9,88 & 8,89 & 8,05 & 6,64 & 5,52 & 3,93 \\
\hline 90 & 950 & 115 & 18,26 & 12,56 & 11,02 & 9,74 & 8,80 & 7,98 & 6,60 & 5,51 & 3,94 \\
\hline 90 & 1000 & 115 & 17,78 & 12,30 & 10,84 & 9,62 & 8,70 & 7,92 & 6,57 & 5,50 & 3,94 \\
\hline 90 & 1050 & 115 & 17,35 & 12,06 & 10,67 & 9,50 & 8,61 & 7,85 & 6,54 & 5,48 & 3,95 \\
\hline 90 & 1100 & 115 & 16,95 & 11,84 & 10,51 & 9,38 & 8,53 & 7,79 & 6,51 & 5,47 & 3,95 \\
\hline 90 & 1150 & 115 & 16,58 & 11,63 & 10,36 & 9,28 & 8,45 & 7,73 & 6,48 & 5,46 & 3,96 \\
\hline 90 & 1200 & 115 & 16,24 & 11,43 & 10,21 & 9,18 & 8,37 & 7,67 & 6,45 & 5,45 & 3,96 \\
\hline 90 & 1250 & 115 & 15,92 & 11,25 & 10,08 & 9,08 & 8,30 & 7,62 & 6,42 & 5,43 & 3,96 \\
\hline 90 & 1300 & 115 & 15,62 & 11,08 & 9,95 & 8,98 & 8,23 & 7,56 & 6,39 & 5,42 & 3,96 \\
\hline 90 & 1350 & 115 & 15,35 & 10,92 & 9,82 & 8,90 & 8,16 & 7,51 & 6,36 & 5,41 & 3,97 \\
\hline 90 & 1400 & 115 & 15,09 & 10,76 & 9,71 & 8,81 & 8,09 & 7,46 & 6,33 & 5,39 & 3,97 \\
\hline 90 & 1450 & 115 & 14,84 & 10,62 & 9,60 & 8,73 & 8,03 & 7,41 & 6,30 & 5,38 & 3,97 \\
\hline 90 & 1500 & 115 & 14,61 & 10,48 & 9,49 & 8,65 & 7,97 & 7,36 & 6,28 & 5,37 & 3,97 \\
\hline 90 & 1550 & 115 & 14,39 & 10,35 & 9,39 & 8,57 & 7,91 & 7,31 & 6,25 & 5,35 & 3,97 \\
\hline 90 & 1600 & 115 & 14,18 & 10,23 & 9,29 & 8,50 & 7,85 & 7,27 & 6,22 & 5,34 & 3,97 \\
\hline 90 & 1650 & 115 & 13,98 & 10,11 & 9,19 & 8,43 & 7,79 & 7,22 & 6,20 & 5,33 & 3,97 \\
\hline 90 & 1700 & 115 & 13,80 & 10,00 & 9,10 & 8,36 & 7,74 & 7,18 & 6,17 & 5,31 & 3,97 \\
\hline 90 & 1750 & 115 & 13,62 & 9,89 & 9,02 & 8,29 & 7,69 & 7,14 & 6,15 & 5,30 & 3,97 \\
\hline 90 & 1800 & 115 & 13,45 & 9,78 & 8,93 & 8,23 & 7,64 & 7,10 & 6,12 & 5,29 & 3,97 \\
\hline 90 & 1850 & 115 & 13,28 & 9,69 & 8,85 & 8,17 & 7,59 & 7,06 & 6,10 & 5,27 & 3,97 \\
\hline 90 & 1900 & 115 & 13,13 & 9,59 & 8,77 & 8,11 & 7,54 & 7,02 & 6,08 & 5,26 & 3,96 \\
\hline 90 & 1950 & 115 & 12,98 & 9,50 & 8,70 & 8,05 & 7,49 & 6,98 & 6,05 & 5,25 & 3,96 \\
\hline 90 & 2000 & 115 & 12,83 & 9,41 & 8,62 & 7,99 & 7,45 & 6,94 & 6,03 & 5,23 & 3,96 \\
\hline 90 & 200 & 120 & 48,45 & 25,13 & 18,25 & 13,60 & 10,95 & 9,12 & 6,64 & 5,17 & 3,55 \\
\hline 90 & 250 & 120 & 41,09 & 22,35 & 16,78 & 12,92 & 10,63 & 8,98 & 6,67 & 5,22 & 3,57 \\
\hline 90 & 300 & 120 & 36,10 & 20,41 & 15,71 & 12,39 & 10,36 & 8,85 & 6,68 & 5,26 & 3,60 \\
\hline 90 & 350 & 120 & 32,49 & 18,95 & 14,89 & 11,96 & 10,13 & 8,74 & 6,67 & 5,29 & 3,62 \\
\hline 90 & 400 & 120 & 29,73 & 17,80 & 14,23 & 11,60 & 9,92 & 8,62 & 6,66 & 5,31 & 3,64 \\
\hline 90 & 450 & 120 & 27,56 & 16,87 & 13,67 & 11,29 & 9,74 & 8,52 & 6,64 & 5,32 & 3,66 \\
\hline 90 & 500 & 120 & 25,79 & 16,09 & 13,20 & 11,02 & 9,57 & 8,42 & 6,61 & 5,32 & 3,68 \\
\hline 90 & 550 & 120 & 24,33 & 15,43 & 12,80 & 10,78 & 9,42 & 8,32 & 6,59 & 5,33 & 3,69 \\
\hline 90 & 600 & 120 & 23,10 & 14,85 & 12,44 & 10,56 & 9,28 & 8,23 & 6,56 & 5,33 & 3,70 \\
\hline 90 & 650 & 120 & 22,04 & 14,35 & 12,11 & 10,36 & 9,14 & 8,15 & 6,53 & 5,33 & 3,72 \\
\hline 90 & 700 & 120 & 21,12 & 13,90 & 11,83 & 10,18 & 9,02 & 8,06 & 6,50 & 5,32 & 3,73 \\
\hline 90 & 750 & 120 & 20,32 & 13,50 & 11,56 & 10,01 & 8,90 & 7,99 & 6,47 & 5,32 & 3,74 \\
\hline 90 & 800 & 120 & 19,61 & 13,14 & 11,32 & 9,85 & 8,80 & 7,91 & 6,44 & 5,31 & 3,75 \\
\hline 90 & 850 & 120 & 18,97 & 12,82 & 11,10 & 9,70 & 8,69 & 7,84 & 6,41 & 5,30 & 3,76 \\
\hline 90 & 900 & 120 & 18,40 & 12,52 & 10,90 & 9,57 & 8,59 & 7,77 & 6,38 & 5,30 & 3,76 \\
\hline 90 & 950 & 120 & 17,89 & 12,24 & 10,71 & 9,44 & 8,50 & 7,70 & 6,35 & 5,29 & 3,77 \\
\hline 90 & 1000 & 120 & 17,42 & 11,99 & 10,53 & 9,32 & 8,41 & 7,64 & 6,32 & 5,28 & 3,78 \\
\hline 90 & 1050 & 120 & 16,99 & 11,76 & 10,37 & 9,20 & 8,33 & 7,58 & 6,29 & 5,27 & 3,78 \\
\hline 90 & 1100 & 120 & 16,59 & 11,54 & 10,21 & 9,09 & 8,25 & 7,52 & 6,27 & 5,26 & 3,79 \\
\hline 90 & 1150 & 120 & 16,23 & 11,33 & 10,06 & 8,99 & 8,17 & 7,46 & 6,24 & 5,24 & 3,79 \\
\hline
\end{tabular}




\begin{tabular}{|c|c|c|c|c|c|c|c|c|c|c|c|}
\hline \multirow[b]{2}{*}{$\mathrm{H}(\mathrm{cm})$} & \multirow[b]{2}{*}{ Mceq (MPa) } & & & & & De & ões (x1 & & & & \\
\hline & & Msub (MPa) & D0 & D25 & D40 & D60 & D80 & D100 & D140 & D180 & D260 \\
\hline 90 & 1200 & 120 & 15,89 & 11,14 & 9,92 & 8,89 & 8,10 & 7,41 & 6,21 & 5,23 & 3,79 \\
\hline 90 & 1250 & 120 & 15,58 & 10,96 & 9,79 & 8,80 & 8,03 & 7,35 & 6,18 & 5,22 & 3,80 \\
\hline 90 & 1300 & 120 & 15,28 & 10,80 & 9,67 & 8,71 & 7,96 & 7,30 & 6,15 & 5,21 & 3,80 \\
\hline 90 & 1350 & 120 & 15,01 & 10,64 & 9,55 & 8,62 & 7,89 & 7,25 & 6,13 & 5,20 & 3,80 \\
\hline 90 & 1400 & 120 & 14,75 & 10,49 & 9,43 & 8,54 & 7,83 & 7,20 & 6,10 & 5,18 & 3,80 \\
\hline 90 & 1450 & 120 & 14,51 & 10,35 & 9,33 & 8,46 & 7,77 & 7,16 & 6,07 & 5,17 & 3,80 \\
\hline 90 & 1500 & 120 & 14,28 & 10,21 & 9,22 & 8,38 & 7,71 & 7,11 & 6,05 & 5,16 & 3,80 \\
\hline 90 & 1550 & 120 & 14,06 & 10,08 & 9,12 & 8,31 & 7,65 & 7,07 & 6,02 & 5,15 & 3,80 \\
\hline 90 & 1600 & 120 & 13,86 & 9,96 & 9,03 & 8,24 & 7,60 & 7,02 & 6,00 & 5,13 & 3,80 \\
\hline 90 & 1650 & 120 & 13,66 & 9,85 & 8,94 & 8,17 & 7,54 & 6,98 & 5,97 & 5,12 & 3,80 \\
\hline 90 & 1700 & 120 & 13,48 & 9,73 & 8,85 & 8,11 & 7,49 & 6,94 & 5,95 & 5,11 & 3,80 \\
\hline 90 & 1750 & 120 & 13,30 & 9,63 & 8,76 & 8,04 & 7,44 & 6,90 & 5,93 & 5,10 & 3,80 \\
\hline 90 & 1800 & 120 & 13,13 & 9,53 & 8,68 & 7,98 & 7,39 & 6,86 & 5,90 & 5,09 & 3,80 \\
\hline 90 & 1850 & 120 & 12,97 & 9,43 & 8,60 & 7,92 & 7,34 & 6,82 & 5,88 & 5,07 & 3,80 \\
\hline 90 & 1900 & 120 & 12,82 & 9,34 & 8,53 & 7,86 & 7,30 & 6,79 & 5,86 & 5,06 & 3,80 \\
\hline 90 & 1950 & 120 & 12,67 & 9,25 & 8,45 & 7,81 & 7,25 & 6,75 & 5,84 & 5,05 & 3,80 \\
\hline 90 & 2000 & 120 & 12,53 & 9,16 & 8,38 & 7,75 & 7,21 & 6,71 & 5,81 & 5,04 & 3,80 \\
\hline 90 & 200 & 125 & 47,97 & 24,66 & 17,80 & 13,18 & 10,57 & 8,77 & 6,37 & 4,95 & 3,40 \\
\hline 90 & 250 & 125 & 40,63 & 21,91 & 16,35 & 12,52 & 10,26 & 8,65 & 6,40 & 5,00 & 3,42 \\
\hline 90 & 300 & 125 & 35,66 & 19,99 & 15,30 & 12,01 & 10,00 & 8,53 & 6,41 & 5,04 & 3,45 \\
\hline 90 & 350 & 125 & 32,06 & 18,55 & 14,50 & 11,59 & 9,78 & 8,42 & 6,41 & 5,07 & 3,47 \\
\hline 90 & 400 & 125 & 29,32 & 17,41 & 13,85 & 11,25 & 9,59 & 8,31 & 6,40 & 5,09 & 3,49 \\
\hline 90 & 450 & 125 & 27,15 & 16,49 & 13,31 & 10,95 & 9,41 & 8,21 & 6,38 & 5,10 & 3,51 \\
\hline 90 & 500 & 125 & 25,40 & 15,73 & 12,85 & 10,68 & 9,25 & 8,12 & 6,36 & 5,11 & 3,52 \\
\hline 90 & 550 & 125 & 23,95 & 15,08 & 12,45 & 10,45 & 9,10 & 8,03 & 6,34 & 5,11 & 3,54 \\
\hline 90 & 600 & 125 & 22,72 & 14,51 & 12,10 & 10,24 & 8,97 & 7,94 & 6,31 & 5,12 & 3,55 \\
\hline 90 & 650 & 125 & 21,67 & 14,02 & 11,79 & 10,04 & 8,84 & 7,86 & 6,29 & 5,12 & 3,56 \\
\hline 90 & 700 & 125 & 20,76 & 13,58 & 11,50 & 9,87 & 8,72 & 7,79 & 6,26 & 5,11 & 3,57 \\
\hline 90 & 750 & 125 & 19,96 & 13,19 & 11,25 & 9,70 & 8,61 & 7,71 & 6,23 & 5,11 & 3,58 \\
\hline 90 & 800 & 125 & 19,25 & 12,84 & 11,02 & 9,55 & 8,51 & 7,64 & 6,20 & 5,10 & 3,59 \\
\hline 90 & 850 & 125 & 18,62 & 12,51 & 10,80 & 9,41 & 8,41 & 7,57 & 6,18 & 5,10 & 3,60 \\
\hline 90 & 900 & 125 & 18,06 & 12,22 & 10,60 & 9,28 & 8,32 & 7,51 & 6,15 & 5,09 & 3,61 \\
\hline 90 & 950 & 125 & 17,54 & 11,95 & 10,42 & 9,15 & 8,23 & 7,44 & 6,12 & 5,08 & 3,61 \\
\hline 90 & 1000 & 125 & 17,08 & 11,70 & 10,25 & 9,04 & 8,14 & 7,38 & 6,09 & 5,07 & 3,62 \\
\hline 90 & 1050 & 125 & 16,65 & 11,47 & 10,08 & 8,93 & 8,06 & 7,33 & 6,07 & 5,06 & 3,63 \\
\hline 90 & 1100 & 125 & 16,26 & 11,26 & 9,93 & 8,82 & 7,99 & 7,27 & 6,04 & 5,05 & 3,63 \\
\hline 90 & 1150 & 125 & 15,90 & 11,06 & 9,79 & 8,72 & 7,91 & 7,21 & 6,01 & 5,04 & 3,63 \\
\hline 90 & 1200 & 125 & 15,56 & 10,87 & 9,65 & 8,63 & 7,84 & 7,16 & 5,99 & 5,03 & 3,64 \\
\hline 90 & 1250 & 125 & 15,25 & 10,70 & 9,53 & 8,54 & 7,77 & 7,11 & 5,96 & 5,02 & 3,64 \\
\hline 90 & 1300 & 125 & 14,96 & 10,53 & 9,41 & 8,45 & 7,71 & 7,06 & 5,93 & 5,01 & 3,64 \\
\hline 90 & 1350 & 125 & 14,69 & 10,38 & 9,29 & 8,37 & 7,65 & 7,01 & 5,91 & 5,00 & 3,65 \\
\hline 90 & 1400 & 125 & 14,44 & 10,23 & 9,18 & 8,29 & 7,58 & 6,97 & 5,88 & 4,99 & 3,65 \\
\hline 90 & 1450 & 125 & 14,20 & 10,09 & 9,07 & 8,21 & 7,53 & 6,92 & 5,86 & 4,98 & 3,65 \\
\hline 90 & 1500 & 125 & 13,97 & 9,96 & 8,97 & 8,14 & 7,47 & 6,88 & 5,84 & 4,97 & 3,65 \\
\hline 90 & 1550 & 125 & 13,76 & 9,83 & 8,88 & 8,07 & 7,41 & 6,84 & 5,81 & 4,96 & 3,65 \\
\hline 90 & 1600 & 125 & 13,56 & 9,71 & 8,78 & 8,00 & 7,36 & 6,80 & 5,79 & 4,94 & 3,65 \\
\hline 90 & 1650 & 125 & 13,37 & 9,60 & 8,70 & 7,93 & 7,31 & 6,76 & 5,77 & 4,93 & 3,65 \\
\hline 90 & 1700 & 125 & 13,18 & 9,49 & 8,61 & 7,87 & 7,26 & 6,72 & 5,74 & 4,92 & 3,65 \\
\hline 90 & 1750 & 125 & 13,01 & 9,39 & 8,53 & 7,81 & 7,21 & 6,68 & 5,72 & 4,91 & 3,65 \\
\hline 90 & 1800 & 125 & 12,84 & 9,29 & 8,45 & 7,75 & 7,16 & 6,64 & 5,70 & 4,90 & 3,65 \\
\hline 90 & 1850 & 125 & 12,69 & 9,19 & 8,37 & 7,69 & 7,12 & 6,60 & 5,68 & 4,89 & 3,65 \\
\hline 90 & 1900 & 125 & 12,53 & 9,10 & 8,30 & 7,63 & 7,07 & 6,57 & 5,66 & 4,88 & 3,65 \\
\hline 90 & 1950 & 125 & 12,39 & 9,01 & 8,23 & 7,58 & 7,03 & 6,53 & 5,64 & 4,86 & 3,65 \\
\hline 90 & 2000 & 125 & 12,25 & 8,93 & 8,16 & 7,53 & 6,99 & 6,50 & 5,62 & 4,85 & 3,65 \\
\hline 90 & 200 & 130 & 47,52 & 24,23 & 17,38 & 12,80 & 10,22 & 8,45 & 6,11 & 4,75 & 3,27 \\
\hline 90 & 250 & 130 & 40,21 & 21,50 & 15,95 & 12,14 & 9,92 & 8,34 & 6,15 & 4,80 & 3,29 \\
\hline 90 & 300 & 130 & 35,25 & 19,60 & 14,92 & 11,65 & 9,67 & 8,23 & 6,16 & 4,84 & 3,31 \\
\hline 90 & 350 & 130 & 31,66 & 18,17 & 14,13 & 11,25 & 9,46 & 8,12 & 6,16 & 4,87 & 3,33 \\
\hline 90 & 400 & 130 & 28,93 & 17,05 & 13,49 & 10,91 & 9,27 & 8,02 & 6,15 & 4,89 & 3,35 \\
\hline 90 & 450 & 130 & 26,78 & 16,15 & 12,97 & 10,62 & 9,10 & 7,93 & 6,14 & 4,90 & 3,36 \\
\hline 90 & 500 & 130 & 25,03 & 15,39 & 12,52 & 10,37 & 8,95 & 7,84 & 6,12 & 4,91 & 3,38 \\
\hline 90 & 550 & 130 & 23,59 & 14,75 & 12,13 & 10,14 & 8,81 & 7,76 & 6,10 & 4,92 & 3,39 \\
\hline 90 & 600 & 130 & 22,37 & 14,20 & 11,78 & 9,93 & 8,68 & 7,68 & 6,08 & 4,92 & 3,41 \\
\hline 90 & 650 & 130 & 21,32 & 13,71 & 11,48 & 9,75 & 8,56 & 7,60 & 6,06 & 4,92 & 3,42 \\
\hline 90 & 700 & 130 & 20,42 & 13,28 & 11,20 & 9,58 & 8,45 & 7,53 & 6,03 & 4,92 & 3,43 \\
\hline 90 & 750 & 130 & 19,62 & 12,89 & 10,96 & 9,42 & 8,34 & 7,46 & 6,01 & 4,92 & 3,44 \\
\hline 90 & 800 & 130 & 18,92 & 12,55 & 10,73 & 9,27 & 8,24 & 7,39 & 5,98 & 4,91 & 3,45 \\
\hline 90 & 850 & 130 & 18,29 & 12,23 & 10,52 & 9,14 & 8,15 & 7,32 & 5,96 & 4,91 & 3,46 \\
\hline 90 & 900 & 130 & 17,73 & 11,94 & 10,33 & 9,01 & 8,06 & 7,26 & 5,93 & 4,90 & 3,46 \\
\hline 90 & 950 & 130 & 17,22 & 11,68 & 10,15 & 8,89 & 7,97 & 7,20 & 5,90 & 4,89 & 3,47 \\
\hline 90 & 1000 & 130 & 16,76 & 11,44 & 9,98 & 8,77 & 7,89 & 7,14 & 5,88 & 4,88 & 3,48 \\
\hline 90 & 1050 & 130 & 16,34 & 11,21 & 9,82 & 8,67 & 7,82 & 7,09 & 5,85 & 4,88 & 3,48 \\
\hline 90 & 1100 & 130 & 15,95 & 11,00 & 9,67 & 8,57 & 7,74 & 7,04 & 5,83 & 4,87 & 3,49 \\
\hline 90 & 1150 & 130 & 15,59 & 10,80 & 9,53 & 8,47 & 7,67 & 6,98 & 5,80 & 4,86 & 3,49 \\
\hline 90 & 1200 & 130 & 15,26 & 10,62 & 9,40 & 8,38 & 7,60 & 6,93 & 5,78 & 4,85 & 3,49 \\
\hline 90 & 1250 & 130 & 14,95 & 10,45 & 9,28 & 8,29 & 7,54 & 6,88 & 5,75 & 4,84 & 3,50 \\
\hline 90 & 1300 & 130 & 14,67 & 10,29 & 9,16 & 8,21 & 7,48 & 6,84 & 5,73 & 4,83 & 3,50 \\
\hline 90 & 1350 & 130 & 14,40 & 10,13 & 9,05 & 8,13 & 7,41 & 6,79 & 5,71 & 4,82 & 3,50 \\
\hline 90 & 1400 & 130 & 14,15 & 9,99 & 8,94 & 8,05 & 7,36 & 6,75 & 5,68 & 4,81 & 3,51 \\
\hline 90 & 1450 & 130 & 13,91 & 9,85 & 8,84 & 7,98 & 7,30 & 6,71 & 5,66 & 4,80 & 3,51 \\
\hline 90 & 1500 & 130 & 13,69 & 9,72 & 8,74 & 7,90 & 7,25 & 6,66 & 5,64 & 4,79 & 3,51 \\
\hline
\end{tabular}




\begin{tabular}{|c|c|c|c|c|c|c|c|c|c|c|c|}
\hline \multirow[b]{2}{*}{$\mathrm{H}(\mathrm{cm})$} & \multirow[b]{2}{*}{ Mceq (MPa) } & & & & & $\mathrm{De}$ & ões (x. & & & & \\
\hline & & Msub (MPa) & D0 & D25 & D40 & D60 & D80 & D100 & D140 & D180 & D260 \\
\hline 90 & 1550 & 130 & 13,48 & 9,60 & 8,65 & 7,84 & 7,19 & 6,62 & 5,62 & 4,78 & 3,51 \\
\hline 90 & 1600 & 130 & 13,28 & 9,48 & 8,56 & 7,77 & 7,14 & 6,58 & 5,59 & 4,77 & 3,51 \\
\hline 90 & 1650 & 130 & 13,09 & 9,37 & 8,47 & 7,71 & 7,09 & 6,54 & 5,57 & 4,76 & 3,51 \\
\hline 90 & 1700 & 130 & 12,91 & 9,26 & 8,39 & 7,65 & 7,04 & 6,51 & 5,55 & 4,75 & 3,51 \\
\hline 90 & 1750 & 130 & 12,74 & 9,16 & 8,31 & 7,59 & 7,00 & 6,47 & 5,53 & 4,74 & 3,51 \\
\hline 90 & 1800 & 130 & 12,57 & 9,06 & 8,23 & 7,53 & 6,95 & 6,44 & 5,51 & 4,73 & 3,51 \\
\hline 90 & 1850 & 130 & 12,42 & 8,97 & 8,16 & 7,47 & 6,91 & 6,40 & 5,49 & 4,71 & 3,51 \\
\hline 90 & 1900 & 130 & 12,27 & 8,88 & 8,08 & 7,42 & 6,87 & 6,37 & 5,47 & 4,70 & 3,51 \\
\hline 90 & 1950 & 130 & 12,12 & 8,79 & 8,01 & 7,37 & 6,82 & 6,33 & 5,45 & 4,69 & 3,51 \\
\hline 90 & 2000 & 130 & 11,99 & 8,71 & 7,95 & 7,32 & 6,78 & 6,30 & 5,43 & 4,68 & 3,51 \\
\hline 90 & 200 & 135 & 47,10 & 23,82 & 16,99 & 12,43 & 9,89 & 8,16 & 5,88 & 4,56 & 3,14 \\
\hline 90 & 250 & 135 & 39,81 & 21,12 & 15,58 & 11,80 & 9,60 & 8,05 & 5,92 & 4,62 & 3,16 \\
\hline 90 & 300 & 135 & 34.87 & 19,23 & 14.57 & 11,31 & 9,36 & 7,94 & 5,93 & 4.65 & 3,18 \\
\hline 90 & 350 & 135 & 31,29 & 17,82 & 13,79 & 10,92 & 9,16 & 7,85 & 5,93 & 4,68 & 3,20 \\
\hline 90 & 400 & 135 & 28,57 & 16,72 & 13,16 & 10,60 & 8,98 & 7,75 & 5,93 & 4,70 & 3,22 \\
\hline 90 & 450 & 135 & 26,43 & 15,82 & 12,65 & 10,32 & 8,82 & 7,67 & 5,92 & 4,72 & 3,23 \\
\hline 90 & 500 & 135 & 24,69 & 15,08 & 12,21 & 10,07 & 8,67 & 7,58 & 5,90 & 4,73 & 3,25 \\
\hline 90 & 550 & 135 & 23,25 & 14,44 & 11,82 & 9,85 & 8,54 & 7,50 & 5,88 & 4,73 & 3,26 \\
\hline 90 & 600 & 135 & 22,04 & 13,90 & 11,49 & 9,65 & 8,42 & 7,43 & 5,86 & 4,74 & 3,28 \\
\hline 90 & 650 & 135 & 21,00 & 13,42 & 11,19 & 9,47 & 8,30 & 7,35 & 5,84 & 4,74 & 3,29 \\
\hline 90 & 700 & 135 & 20,10 & 13,00 & 10,92 & 9,31 & 8,19 & 7,28 & 5,82 & 4,74 & 3,30 \\
\hline 90 & 750 & 135 & 19,31 & 12,62 & 10,68 & 9,15 & 8,09 & 7,22 & 5,80 & 4,73 & 3,31 \\
\hline 90 & 800 & 135 & 18,61 & 12,28 & 10,46 & 9,01 & 7,99 & 7,15 & 5,77 & 4,73 & 3,32 \\
\hline 90 & 850 & 135 & 17,99 & 11,97 & 10,25 & 8,88 & 7,90 & 7,09 & 5,75 & 4,73 & 3,32 \\
\hline 90 & 900 & 135 & 17,43 & 11,68 & 10,07 & 8,76 & 7,82 & 7,03 & 5,73 & 4,72 & 3,33 \\
\hline 90 & 950 & 135 & 16,93 & 11,42 & 9,89 & 8,64 & 7,74 & 6,98 & 5,70 & 4,72 & 3,34 \\
\hline 90 & 1000 & 135 & 16,47 & 11,18 & 9,73 & 8,53 & 7,66 & 6,92 & 5,68 & 4,71 & 3,34 \\
\hline 90 & 1050 & 135 & 16,05 & 10,96 & 9,57 & 8,43 & 7,58 & 6,87 & 5,66 & 4,70 & 3,35 \\
\hline 90 & 1100 & 135 & 15,66 & 10,76 & 9,43 & 8,33 & 7,51 & 6,82 & 5,63 & 4,69 & 3,35 \\
\hline 90 & 1150 & 135 & 15,31 & 10,56 & 9,29 & 8,24 & 7,45 & 6,77 & 5,61 & 4,69 & 3,36 \\
\hline 90 & 1200 & 135 & 14,98 & 10,38 & 9,17 & 8,15 & 7,38 & 6,72 & 5,59 & 4,68 & 3,36 \\
\hline 90 & 1250 & 135 & 14,67 & 10,21 & 9,05 & 8,06 & 7,32 & 6,67 & 5,56 & 4,67 & 3,37 \\
\hline 90 & 1300 & 135 & 14,39 & 10,06 & 8,93 & 7,98 & 7,26 & 6,63 & 5,54 & 4,66 & 3,37 \\
\hline 90 & 1350 & 135 & 14.12 & 9,91 & 8,82 & 7.90 & 7.20 & 6.58 & 5,52 & 4.65 & 3,37 \\
\hline 90 & 1400 & 135 & 13,87 & 9,76 & 8,72 & 7,83 & 7,14 & 6,54 & 5,50 & 4,64 & 3,37 \\
\hline 90 & 1450 & 135 & 13,64 & 9,63 & 8,62 & 7,76 & 7,09 & 6,50 & 5,48 & 4,63 & 3,38 \\
\hline 90 & 1500 & 135 & 13,42 & 9,50 & 8,52 & 7,69 & 7,04 & 6,46 & 5,45 & 4,62 & 3,38 \\
\hline 90 & 1550 & 135 & 13,21 & 9,38 & 8,43 & 7,62 & 6,98 & 6,42 & 5,43 & 4,61 & 3,38 \\
\hline 90 & 1600 & 135 & 13,01 & 9,27 & 8,34 & 7,56 & 6,94 & 6,38 & 5,41 & 4,60 & 3,38 \\
\hline 90 & 1650 & 135 & 12,83 & 9,16 & 8,26 & 7,50 & 6,89 & 6,35 & 5,39 & 4,59 & 3,38 \\
\hline 90 & 1700 & 135 & 12,65 & 9,05 & 8,18 & 7,44 & 6,84 & 6,31 & 5,37 & 4,58 & 3,38 \\
\hline 90 & 1750 & 135 & 12,48 & 8,95 & 8,10 & 7,38 & 6,80 & 6,28 & 5,35 & 4,57 & 3,38 \\
\hline 90 & 1800 & 135 & 12,32 & 8,85 & 8,02 & 7,32 & 6,75 & 6,24 & 5,33 & 4,56 & 3,38 \\
\hline 90 & 1850 & 135 & 12,16 & 8,76 & 7,95 & 7,27 & 6,71 & 6,21 & 5,31 & 4,55 & 3,38 \\
\hline 90 & 1900 & 135 & 12,02 & 8,67 & 7,88 & 7,22 & 6,67 & 6,18 & 5,29 & 4,54 & 3,38 \\
\hline 90 & 1950 & 135 & 11,88 & 8,59 & 7,81 & 7,17 & 6,63 & 6,15 & 5,28 & 4,53 & 3,38 \\
\hline 90 & 2000 & 135 & 11,74 & 8,51 & 7,75 & 7,12 & 6,59 & 6,11 & 5,26 & 4,52 & 3,38 \\
\hline 90 & 200 & 140 & 46,71 & 23,44 & 16,62 & 12,09 & 9,58 & 7,88 & 5,66 & 4,39 & 3,03 \\
\hline 90 & 250 & 140 & 39,44 & 20,76 & 15,23 & 11,47 & 9,30 & 7,78 & 5,70 & 4,44 & 3,05 \\
\hline 90 & 300 & 140 & 34,51 & 18,89 & 14,23 & 11,00 & 9,07 & 7,68 & 5,72 & 4,48 & 3,06 \\
\hline 90 & 350 & 140 & 30,95 & 17,49 & 13,47 & 10,62 & 8,88 & 7,59 & 5,72 & 4,51 & 3,08 \\
\hline 90 & 400 & 140 & 28,24 & 16,40 & 12,85 & 10,30 & 8,71 & 7,50 & 5,72 & 4,53 & 3,10 \\
\hline 90 & 450 & 140 & 26,10 & $\begin{array}{l}15,52 \\
15,52\end{array}$ & $\begin{array}{l}+L, U 0 \\
12,35\end{array}$ & 10,03 & 8,55 & 7,42 & 5,71 & 4,54 & 3,11 \\
\hline 90 & 500 & 140 & 24,37 & 14,78 & 11,91 & 9,79 & 8,41 & 7,34 & 5,70 & 4,55 & 3,13 \\
\hline 90 & 550 & 140 & 22,94 & 14,16 & 11,54 & 9,58 & 8,28 & 7,26 & 5,68 & 4,56 & 3,14 \\
\hline 90 & 600 & 140 & 21,73 & 13,62 & 11,21 & 9,39 & 8,16 & 7,19 & 5,66 & 4,57 & 3,15 \\
\hline 90 & 650 & 140 & 20,69 & 13,15 & 10,92 & 9,21 & 8,05 & 7,12 & 5,64 & 4,57 & 3,17 \\
\hline 90 & 700 & 140 & 19,80 & 12,73 & 10,66 & 9,05 & 7,95 & 7,06 & 5,62 & 4,57 & 3,18 \\
\hline 90 & 750 & 140 & 19,01 & 12,36 & 10,42 & 8,90 & 7,85 & 6,99 & 5,60 & 4,57 & 3,18 \\
\hline 90 & 800 & 140 & 18,32 & 12,02 & 10,20 & 8,77 & 7,76 & 6,93 & 5,58 & 4,56 & 3,19 \\
\hline 90 & 850 & 140 & 17,70 & 11,72 & 10,01 & 8,64 & 7,67 & 6,87 & 5,56 & 4,56 & 3,20 \\
\hline 90 & 900 & 140 & 17,15 & 11,44 & 9,82 & 8,52 & 7,59 & 6,82 & 5,54 & 4,56 & 3,21 \\
\hline 90 & 950 & 140 & 16,65 & 11,18 & 9,65 & 8,41 & 7,51 & 6,76 & 5,51 & 4,55 & 3,21 \\
\hline 90 & 1000 & 140 & 16,19 & 10,95 & 9,49 & 8,30 & 7,44 & 6,71 & 5,49 & 4,55 & 3,22 \\
\hline 90 & 1050 & 140 & 15,77 & 10,73 & 9,34 & 8,20 & 7,37 & 6,66 & 5,47 & 4,54 & 3,23 \\
\hline 90 & 1100 & 140 & 15,39 & 10,53 & 9,20 & 8,10 & 7,30 & 6,61 & 5,45 & 4,53 & 3,23 \\
\hline 90 & 1150 & 140 & 15,04 & 10,34 & 9,07 & 8,01 & 7,23 & 6,56 & 5,43 & 4,53 & 3,24 \\
\hline 90 & 1200 & 140 & 14,71 & 10,16 & 8,94 & 7,93 & 7,17 & 6,52 & 5,41 & 4,52 & 3,24 \\
\hline 90 & 1250 & 140 & 14,41 & 9,99 & 8,83 & 7,85 & 7,11 & 6,47 & 5,38 & 4,51 & 3,24 \\
\hline 90 & 1300 & 140 & 14,13 & 9,84 & 8,71 & 7,77 & 7,05 & 6,43 & 5,36 & 4,50 & 3,25 \\
\hline 90 & 1350 & 140 & 13,87 & 9,69 & 8,61 & 7,69 & 7,00 & 6,39 & 5,34 & 4,49 & 3,25 \\
\hline 90 & 1400 & 140 & 13,62 & 9,55 & 8,51 & 7,62 & 6,94 & 6,35 & 5,32 & 4,48 & 3,25 \\
\hline 90 & 1450 & 140 & 13,39 & 9,42 & 8,41 & 7,55 & 6,89 & 6,31 & 5,30 & 4,48 & 3,25 \\
\hline 90 & 1500 & 140 & 13,17 & 9,29 & 8,32 & 7,48 & 6,84 & 6,27 & 5,28 & 4,47 & 3,25 \\
\hline 90 & 1550 & 140 & 12,96 & 9,18 & 8,23 & 7,42 & 6,79 & 6,23 & 5,26 & 4,46 & 3,26 \\
\hline 90 & 1600 & 140 & 12,77 & 9,06 & 8,14 & 7,36 & 6,74 & 6,20 & 5,24 & 4,45 & 3,26 \\
\hline 90 & 1650 & 140 & 12.58 & 8.95 & 8.06 & 7.30 & 6.70 & 6.16 & 5.22 & 4.44 & 3,26 \\
\hline 90 & 1700 & 140 & 12,41 & 8,85 & 7,98 & 7,24 & 6,65 & 6,13 & 5,20 & 4,43 & 3,26 \\
\hline 90 & 1750 & 140 & 12,24 & 8,75 & 7,90 & 7,19 & 6,61 & 6,10 & 5,18 & 4,42 & 3,26 \\
\hline 90 & 1800 & 140 & 12,08 & 8,66 & 7,83 & 7,13 & 6,57 & 6,06 & 5,17 & 4,41 & 3,26 \\
\hline 90 & 1850 & 140 & 11,93 & 8,57 & 7,76 & 7,08 & 6,53 & 6,03 & 5,15 & 4,40 & 3,26 \\
\hline
\end{tabular}




\begin{tabular}{|c|c|c|c|c|c|c|c|c|c|c|c|}
\hline \multirow[b]{2}{*}{$\mathrm{H}(\mathrm{cm})$} & \multirow[b]{2}{*}{ Mceq (MPa) } & & & & & $\mathrm{De}$ & ões (x. & & & & \\
\hline & & Msub (MPa) & D0 & D25 & D40 & D60 & D80 & D100 & D140 & D180 & D260 \\
\hline 90 & 1900 & 140 & 11,78 & 8,48 & 7,69 & 7,03 & 6,49 & 6,00 & 5,13 & 4,40 & 3,26 \\
\hline 90 & 1950 & 140 & 11,64 & 8,40 & 7,63 & 6,98 & 6,45 & 5,97 & 5,11 & 4,39 & 3,26 \\
\hline 90 & 2000 & 140 & 11,51 & 8,32 & 7,56 & 6,93 & 6,41 & 5,94 & 5,09 & 4,38 & 3,26 \\
\hline 90 & 200 & 145 & 46,34 & 23,09 & 16,28 & 11,78 & 9,29 & 7,63 & 5,46 & 4,23 & 2,92 \\
\hline 90 & 250 & 145 & 39,09 & 20,42 & 14,90 & 11,17 & 9,02 & 7,53 & 5,50 & 4,28 & 2,94 \\
\hline 90 & 300 & 145 & 34,18 & 18,56 & 13,92 & 10,71 & 8,80 & 7,44 & 5,52 & 4,32 & 2,95 \\
\hline 90 & 350 & 145 & 30,62 & 17,18 & 13,17 & 10,34 & 8,62 & 7,35 & 5,52 & 4,35 & 2,97 \\
\hline 90 & 400 & 145 & 27,92 & 16,10 & 12,56 & 10,03 & 8,45 & 7,27 & 5,52 & 4,37 & 2,99 \\
\hline 90 & 450 & 145 & 25,79 & 15,23 & 12,06 & 9,76 & 8,30 & 7,19 & 5,52 & 4,38 & 3,00 \\
\hline 90 & 500 & 145 & 24,07 & 14,50 & 11,64 & 9,53 & 8,17 & 7,11 & 5,50 & 4,39 & 3,02 \\
\hline 90 & 550 & 145 & 22,64 & 13,89 & 11,27 & 9,32 & 8,04 & 7,04 & 5,49 & 4,40 & 3,03 \\
\hline 90 & 600 & 145 & 21,44 & 13,36 & 10,95 & 9,14 & 7,93 & 6,97 & 5,47 & 4,41 & 3,04 \\
\hline 90 & 650 & 145 & 20,41 & 12,89 & 10,67 & 8,97 & 7,82 & 6,91 & 5,46 & 4,41 & 3,05 \\
\hline 90 & 700 & 145 & 19,52 & 12,48 & 10,41 & 8,81 & 7,72 & 6,84 & 5,44 & 4,41 & 3,06 \\
\hline 90 & 750 & 145 & 18,74 & 12,11 & 10,18 & 8,67 & 7,63 & 6,78 & 5,42 & 4,41 & 3,07 \\
\hline 90 & 800 & 145 & 18,05 & 11,78 & 9,97 & 8,54 & 7,54 & 6,73 & 5,40 & 4,41 & 3,08 \\
\hline 90 & 850 & 145 & 17,43 & 11,48 & 9,77 & 8,41 & 7,46 & 6,67 & 5,38 & 4,41 & 3,09 \\
\hline 90 & 900 & 145 & 16,88 & 11,21 & 9,59 & 8,30 & 7,38 & 6,62 & 5,36 & 4,40 & 3,09 \\
\hline 90 & 950 & 145 & 16,38 & 10,96 & 9,42 & 8,19 & 7,30 & 6,56 & 5,34 & 4,40 & 3,10 \\
\hline 90 & 1000 & 145 & 15,93 & 10,73 & 9,27 & 8,08 & 7,23 & 6,51 & 5,32 & 4,39 & 3,11 \\
\hline 90 & 1050 & 145 & 15,52 & 10,51 & 9,12 & 7,99 & 7,16 & 6,47 & 5,30 & 4,39 & 3,11 \\
\hline 90 & 1100 & 145 & 15,14 & 10,31 & 8,99 & 7,89 & 7,10 & 6,42 & 5,28 & 4,38 & 3,12 \\
\hline 90 & 1150 & 145 & 14,79 & 10,12 & 8,86 & 7,81 & 7,03 & 6,37 & 5,26 & 4,37 & 3,12 \\
\hline 90 & 1200 & 145 & 14,47 & 9,95 & 8,74 & 7,72 & 6,97 & 6,33 & 5,24 & 4,37 & 3,12 \\
\hline 90 & 1250 & 145 & 14,17 & 9,79 & 8,62 & 7,64 & 6,91 & 6,29 & 5,22 & 4,36 & 3,13 \\
\hline 90 & 1300 & 145 & 13,89 & 9,63 & 8,51 & 7,57 & 6,86 & 6,25 & 5,20 & 4,35 & 3,13 \\
\hline 90 & 1350 & 145 & 13,62 & 9,49 & 8,41 & 7,49 & 6,80 & 6,21 & 5,18 & 4,35 & 3,13 \\
\hline 90 & 1400 & 145 & 13,38 & 9,35 & 8,31 & 7,43 & 6,75 & 6,17 & 5,16 & 4,34 & 3,14 \\
\hline 90 & 1450 & 145 & 13,15 & 9,22 & 8,21 & 7,36 & 6,70 & 6,13 & 5,14 & 4,33 & 3,14 \\
\hline 90 & 1500 & 145 & 12,93 & 9,10 & 8,12 & 7,29 & 6,65 & 6,09 & 5,12 & 4,32 & 3,14 \\
\hline 90 & 1550 & 145 & 12,73 & 8,98 & 8,04 & 7,23 & 6,61 & 6,06 & 5,10 & 4,31 & 3,14 \\
\hline 90 & 1600 & 145 & 12,54 & 8,87 & 7,95 & 7,17 & 6,56 & 6,02 & 5,08 & 4,31 & 3,14 \\
\hline 90 & 1650 & 145 & 12,35 & 8,76 & 7,87 & 7,11 & 6,52 & 5,99 & 5,06 & 4,30 & 3,14 \\
\hline 90 & 1700 & 145 & 12,18 & 8,66 & 7.80 & 7.06 & 6,47 & 5,96 & 5,05 & 4.29 & 3,15 \\
\hline 90 & 1750 & 145 & 12,01 & 8,57 & 7,72 & 7,00 & 6,43 & 5,92 & 5,03 & 4,28 & 3,15 \\
\hline 90 & 1800 & 145 & 11,86 & 8,47 & 7,65 & 6,95 & 6,39 & 5,89 & 5,01 & 4,27 & 3,15 \\
\hline 90 & 1850 & 145 & 11,71 & 8,38 & 7,58 & 6,90 & 6,35 & 5,86 & 4,99 & 4,26 & 3,15 \\
\hline 90 & 1900 & 145 & 11,56 & 8,30 & 7,51 & 6,85 & 6,31 & 5,83 & 4,98 & 4,26 & 3,15 \\
\hline 90 & 1950 & 145 & 11,42 & 8,22 & 7,45 & 6,80 & 6,27 & 5,80 & 4,96 & 4,25 & 3,15 \\
\hline 90 & 2000 & 145 & 11,29 & 8,14 & 7,39 & 6,76 & 6,24 & 5,77 & 4,94 & 4,24 & 3,15 \\
\hline 90 & 200 & 150 & 46,00 & 22,75 & 15,96 & 11,48 & 9,02 & 7,38 & 5,27 & 4,08 & 2,82 \\
\hline 90 & 250 & 150 & 38,76 & 20,10 & 14,60 & 10,88 & 8,76 & 7,29 & 5,31 & 4,13 & 2,84 \\
\hline 90 & 300 & 150 & 33,86 & 18,26 & 13,62 & 10,43 & 8,55 & 7,21 & 5,33 & 4,17 & 2,85 \\
\hline 90 & 350 & 150 & 30,32 & 16,89 & 12,88 & 10,07 & 8,37 & 7,12 & 5,34 & 4,20 & 2,87 \\
\hline 90 & 400 & 150 & 27,62 & 15,82 & 12,29 & 9,77 & 8,21 & 7,04 & 5,34 & 4,22 & 2,88 \\
\hline 90 & 450 & 150 & 25,50 & 14,96 & 11,80 & 9,51 & 8,07 & 6,97 & 5,33 & 4,23 & 2,90 \\
\hline 90 & 500 & 150 & 23,78 & 14,24 & 11,38 & 9,28 & 7,94 & 6,90 & 5,33 & 4,24 & 2,91 \\
\hline 90 & 550 & 150 & 22,36 & 13,63 & 11,02 & 9,08 & 7,82 & 6,83 & 5,31 & 4,25 & 2,92 \\
\hline 90 & 600 & 150 & 21,17 & 13,11 & 10,71 & 8,90 & 7,71 & 6,77 & 5,30 & 4,26 & 2,93 \\
\hline 90 & 650 & 150 & 20,14 & 12,65 & 10,43 & 8,74 & 7,61 & 6,70 & 5,28 & 4,26 & 2,95 \\
\hline 90 & 700 & 150 & 19,25 & 12,24 & 10,18 & 8,59 & 7,51 & 6,64 & 5,27 & 4,26 & 2,95 \\
\hline 90 & 750 & 150 & 18,48 & 11,88 & 9,95 & 8,45 & 7,42 & 6,59 & 5,25 & 4,26 & 2,96 \\
\hline 90 & 800 & 150 & 17,79 & 11,56 & 9,74 & 8,32 & 7,34 & 6,53 & 5,23 & 4,26 & 2,97 \\
\hline 90 & 850 & 150 & 17,18 & 11,26 & 9,55 & 8,20 & 7,25 & 6,48 & 5,21 & 4,26 & 2,98 \\
\hline 90 & 900 & 150 & 16,63 & 10,99 & 9,37 & 8,09 & 7,18 & 6,43 & 5,19 & 4,26 & 2,99 \\
\hline 90 & 950 & 150 & 16,14 & 10,74 & 9,21 & 7,98 & 7,11 & 6,38 & 5,17 & 4,25 & 2,99 \\
\hline 90 & 1000 & 150 & 15,69 & 10,51 & 9,06 & 7,88 & 7,04 & 6,33 & 5,15 & 4,25 & 3,00 \\
\hline 90 & 1050 & 150 & 15,28 & 10,30 & 8,92 & 7,79 & 6,97 & 6,28 & 5,13 & 4,24 & 3,00 \\
\hline 90 & 1100 & 150 & 14,90 & 10,11 & 8,78 & 7,70 & 6,91 & 6,24 & 5,12 & 4,24 & 3,01 \\
\hline 90 & 1150 & 150 & 14,55 & 9,92 & 8,66 & 7,61 & 6,85 & 6,20 & 5,10 & 4,23 & 3,01 \\
\hline 90 & 1200 & 150 & 14,23 & 9,75 & 8,54 & 7,53 & 6,79 & 6,15 & 5,08 & 4,23 & 3,02 \\
\hline 90 & 1250 & 150 & 13,93 & 9,59 & 8,43 & 7,45 & 6,73 & 6,11 & 5,06 & 4,22 & 3,02 \\
\hline 90 & 1300 & 150 & 13,66 & 9,44 & 8,32 & 7,38 & 6,68 & 6,07 & 5,04 & 4,21 & 3,02 \\
\hline 90 & 1350 & 150 & 13,40 & 9,30 & 8,22 & 7,31 & 6,62 & 6,03 & 5,02 & 4,21 & 3,03 \\
\hline 90 & 1400 & 150 & 13,15 & 9,16 & 8,12 & 7,24 & 6,57 & 6,00 & 5,00 & 4,20 & 3,03 \\
\hline 90 & 1450 & 150 & 12,93 & 9,04 & 8,03 & 7,18 & 6,53 & 5,96 & 4,98 & 4,19 & 3,03 \\
\hline 90 & 1500 & 150 & 12,71 & 8,91 & 7,94 & 7,11 & 6,48 & 5,93 & 4,97 & 4,19 & 3,03 \\
\hline 90 & 1550 & 150 & 12,51 & 8,80 & 7,85 & 7,05 & 6,43 & 5,89 & 4,95 & 4,18 & 3,04 \\
\hline 90 & 1600 & 150 & 12,32 & 8,69 & 7,77 & 6,99 & 6,39 & 5,86 & 4,93 & 4,17 & 3,04 \\
\hline 90 & 1650 & 150 & 12,14 & 8,59 & 7,69 & 6,94 & 6,35 & 5,83 & 4,91 & 4,16 & 3,04 \\
\hline 90 & 1700 & 150 & 11,96 & 8,49 & 7,62 & 6,88 & 6,30 & 5,79 & 4,90 & 4,16 & 3,04 \\
\hline 90 & 1750 & 150 & 11,80 & 8,39 & 7,55 & 6,83 & 6,26 & 5,76 & 4,88 & 4,15 & 3,04 \\
\hline 90 & 1800 & 150 & 11,64 & 8,30 & 7,48 & 6,78 & 6,22 & 5,73 & 4,86 & 4,14 & 3,04 \\
\hline 90 & 1850 & 150 & 11,50 & 8,21 & 7,41 & 6,73 & 6,19 & 5,70 & 4,85 & 4,13 & 3,04 \\
\hline 90 & 1900 & 150 & 11,35 & 8,13 & 7,35 & 6,68 & 6,15 & 5,67 & 4,83 & 4,12 & 3,04 \\
\hline 90 & 1950 & 150 & 11,22 & 8,05 & 7,28 & 6,64 & 6,11 & 5,65 & 4,81 & 4,12 & 3,04 \\
\hline 90 & 2000 & 150 & 11.09 & 7.97 & 7.22 & 6.59 & 6.08 & 5.62 & 4.80 & 4.11 & 3.04 \\
\hline 90 & 200 & 155 & 45,67 & 22,43 & 15,65 & 11,20 & 8,77 & 7,16 & 5,09 & 3,94 & 2,73 \\
\hline 90 & 250 & 155 & 38,45 & 19,80 & 14,31 & 10,61 & 8,52 & 7,07 & 5,14 & 3,99 & 2,74 \\
\hline 90 & 300 & 155 & 33,56 & 17,97 & 13,35 & 10,17 & 8,31 & 6,99 & 5,16 & 4,03 & 2,76 \\
\hline 90 & 350 & 155 & 30,03 & 16,61 & 12,61 & 9,82 & 8,14 & 6,91 & 5,17 & 4,06 & 2,77 \\
\hline
\end{tabular}




\begin{tabular}{|c|c|c|c|c|c|c|c|c|c|c|c|}
\hline \multirow[b]{2}{*}{$\mathrm{H}(\mathrm{cm})$} & \multirow[b]{2}{*}{ Mceq (MPa) } & & & & & $\mathrm{De}$ & ões (x. & & & & \\
\hline & & Msub (MPa) & D0 & D25 & D40 & D60 & D80 & D100 & D140 & D180 & D260 \\
\hline 90 & 400 & 155 & 27,34 & 15,56 & 12,03 & 9,52 & 7,98 & 6,84 & 5,17 & 4,08 & 2,79 \\
\hline 90 & 450 & 155 & 25,23 & 14,70 & 11,55 & 9,27 & 7,85 & 6,77 & 5,16 & 4,09 & 2,80 \\
\hline 90 & 500 & 155 & 23,52 & 13,99 & 11,14 & 9,05 & 7,72 & 6,70 & 5,16 & 4,10 & 2,81 \\
\hline 90 & 550 & 155 & 22,10 & 13,39 & 10,78 & 8,86 & 7,61 & 6,63 & 5,15 & 4,11 & 2,82 \\
\hline 90 & 600 & 155 & 20,91 & 12,87 & 10,48 & 8,68 & 7,50 & 6,57 & 5,13 & 4,12 & 2,84 \\
\hline 90 & 650 & 155 & 19,89 & 12,42 & 10,20 & 8,52 & 7,40 & 6,51 & 5,12 & 4,12 & 2,85 \\
\hline 90 & 700 & 155 & 19,01 & 12,02 & 9,95 & 8,37 & 7,31 & 6,45 & 5,10 & 4,13 & 2,86 \\
\hline 90 & 750 & 155 & 18,23 & 11,66 & 9,73 & 8,24 & 7,22 & 6,40 & 5,09 & 4,13 & 2,86 \\
\hline 90 & 800 & 155 & 17,55 & 11,34 & 9,53 & 8,11 & 7,14 & 6,35 & 5,07 & 4,13 & 2,87 \\
\hline 90 & 850 & 155 & 16,94 & 11,05 & 9,34 & 8,00 & 7,06 & 6,30 & 5,05 & 4,12 & 2,88 \\
\hline 90 & 900 & 155 & 16,40 & 10,78 & 9,17 & 7,89 & 6,99 & 6,25 & 5,04 & 4,12 & 2,89 \\
\hline 90 & 950 & 155 & 15,90 & 10,54 & 9,01 & 7,78 & 6,92 & 6,20 & 5,02 & 4,12 & 2,89 \\
\hline 90 & 1000 & 155 & 15,46 & 10,32 & 8,86 & 7,69 & 6,85 & 6,15 & 5,00 & 4,12 & 2,90 \\
\hline 90 & 1050 & 155 & 15,05 & 10,11 & 8,72 & 7,60 & 6,79 & 6,11 & 4,98 & 4,11 & 2,90 \\
\hline 90 & 1100 & 155 & 14,67 & 9,91 & 8,59 & 7,51 & 6,73 & 6,07 & 4,96 & 4,11 & 2,91 \\
\hline 90 & 1150 & 155 & 14,33 & 9,73 & 8,47 & 7,43 & 6,67 & 6,03 & 4,95 & 4,10 & 2,91 \\
\hline 90 & 1200 & 155 & 14,01 & 9,57 & 8,35 & 7,35 & 6,61 & 5,99 & 4,93 & 4,10 & 2,92 \\
\hline 90 & 1250 & 155 & 13,71 & 9,41 & 8,24 & 7,27 & 6,56 & 5,95 & 4,91 & 4,09 & 2,92 \\
\hline 90 & 1300 & 155 & 13,44 & 9,26 & 8,14 & 7,20 & 6,51 & 5,91 & 4,89 & 4,08 & 2,92 \\
\hline 90 & 1350 & 155 & 13,18 & 9,12 & 8,04 & 7,13 & 6,45 & 5,87 & 4,88 & 4,08 & 2,93 \\
\hline 90 & 1400 & 155 & 12,94 & 8,99 & 7,94 & 7,07 & 6,41 & 5,84 & 4,86 & 4,07 & 2,93 \\
\hline 90 & 1450 & 155 & 12,72 & 8,86 & 7,85 & 7,00 & 6,36 & 5,80 & 4,84 & 4,06 & 2,93 \\
\hline 90 & 1500 & 155 & 12,50 & 8,74 & 7,77 & 6,94 & 6,31 & 5,77 & 4,82 & 4,06 & 2,93 \\
\hline 90 & 1550 & 155 & 12,30 & 8,63 & 7,68 & 6,88 & 6,27 & 5,73 & 4,81 & 4,05 & 2,94 \\
\hline 90 & 1600 & 155 & 12,11 & 8,52 & 7,60 & 6,83 & 6,23 & 5,70 & 4,79 & 4,04 & 2,94 \\
\hline 90 & 1650 & 155 & 11,93 & 8,42 & 7,53 & 6,77 & 6,19 & 5,67 & 4,77 & 4,04 & 2,94 \\
\hline 90 & 1700 & 155 & 11,76 & 8,32 & 7,45 & 6,72 & 6,15 & 5,64 & 4,76 & 4,03 & 2,94 \\
\hline 90 & 1750 & 155 & 11,60 & 8,22 & 7,38 & 6,67 & 6,11 & 5,61 & 4,74 & 4,02 & 2,94 \\
\hline 90 & 1800 & 155 & 11,44 & 8,13 & 7,32 & 6,62 & 6,07 & 5,58 & 4,73 & 4,01 & 2,94 \\
\hline 90 & 1850 & 155 & 11,30 & 8,05 & 7,25 & 6,57 & 6,03 & 5,55 & 4,71 & 4,01 & 2,94 \\
\hline 90 & 1900 & 155 & 11,16 & 7,97 & 7,19 & 6,52 & 6,00 & 5,53 & 4,69 & 4,00 & 2,94 \\
\hline 90 & 1950 & 155 & 11,02 & 7,89 & 7,12 & 6,48 & 5,96 & 5,50 & 4,68 & 3,99 & 2,94 \\
\hline 90 & 2000 & 155 & 10,89 & 7,81 & 7,07 & 6,44 & 5,93 & 5,47 & 4,66 & 3,99 & 2,94 \\
\hline 90 & 200 & 160 & 45,37 & 22,14 & 15,37 & 10.93 & 8,53 & 6,95 & 4.93 & 3.81 & 2,64 \\
\hline 90 & 250 & 160 & 38,15 & 19,52 & 14,03 & 10,36 & 8,28 & 6,86 & 4,97 & 3,86 & 2,65 \\
\hline 90 & 300 & 160 & 33,28 & 17,70 & 13,08 & 9,93 & 8,09 & 6,79 & 4,99 & 3,90 & 2,67 \\
\hline 90 & 350 & 160 & 29,76 & 16,35 & 12,36 & 9,58 & 7,92 & 6,71 & 5,00 & 3,92 & 2,68 \\
\hline 90 & 400 & 160 & 27,08 & 15,30 & 11,78 & 9,29 & 7,77 & 6,64 & 5,01 & 3,94 & 2,70 \\
\hline 90 & 450 & 160 & 24,97 & 14,46 & 11,31 & 9,05 & 7,64 & 6,57 & 5,00 & 3,96 & 2,71 \\
\hline 90 & 500 & 160 & 23,27 & 13,76 & 10,91 & 8,83 & 7,52 & 6,51 & 5,00 & 3,97 & 2,72 \\
\hline 90 & 550 & 160 & 21,86 & 13,16 & 10,56 & 8,64 & 7,41 & 6,45 & 4,99 & 3,98 & 2,73 \\
\hline 90 & 600 & 160 & 20,67 & 12,65 & 10,26 & 8,47 & 7,30 & 6,39 & 4,98 & 3,99 & 2,74 \\
\hline 90 & 650 & 160 & 19,65 & 12,20 & 9,99 & 8,32 & 7,21 & 6,33 & 4,96 & 3,99 & 2,75 \\
\hline 90 & 700 & 160 & 18,77 & 11,81 & 9,74 & 8,17 & 7,12 & 6,28 & 4,95 & 4,00 & 2,76 \\
\hline 90 & 750 & 160 & 18,00 & 11,46 & 9,53 & 8,04 & 7,04 & 6,22 & 4,94 & 4,00 & 2,77 \\
\hline 90 & 800 & 160 & 17,32 & 11,14 & 9,33 & 7,92 & 6,96 & 6,17 & 4,92 & 4,00 & 2,78 \\
\hline 90 & 850 & 160 & 16,72 & 10,85 & 9,14 & 7,81 & 6,88 & 6,13 & 4,90 & 4,00 & 2,79 \\
\hline 90 & 900 & 160 & 16,18 & 10,59 & 8,97 & 7,70 & 6,81 & 6,08 & 4,89 & 3,99 & 2,79 \\
\hline 90 & 950 & 160 & 15,69 & 10,35 & 8,82 & 7,60 & 6,74 & 6,03 & 4,87 & 3,99 & 2,80 \\
\hline 90 & 1000 & 160 & 15,24 & 10,13 & 8,67 & 7,51 & 6,68 & 5,99 & 4,85 & 3,99 & 2,80 \\
\hline 90 & 1050 & 160 & 14,83 & 9,92 & 8,54 & 7,42 & 6,62 & 5,95 & 4,84 & 3,99 & 2,81 \\
\hline 90 & 1100 & 160 & 14,46 & 9,73 & 8,41 & 7,33 & 6,56 & 5,91 & 4,82 & 3,98 & 2,81 \\
\hline 90 & 1150 & 160 & 14,12 & 9,55 & 8,29 & 7,25 & 6,50 & 5,87 & 4,80 & 3,98 & $\frac{L, 01}{2,82}$ \\
\hline 90 & 1200 & 160 & 13,80 & 9,39 & 8,17 & 7,17 & 6,45 & 5,83 & 4,79 & 3,97 & 2,82 \\
\hline 90 & 1250 & 160 & 13,51 & 9,23 & 8,07 & 7,10 & 6,39 & 5,79 & 4,77 & 3,97 & 2,83 \\
\hline 90 & 1300 & 160 & 13,23 & 9,09 & 7,96 & 7,03 & 6,34 & 5,75 & 4,75 & 3,96 & 2,83 \\
\hline 90 & 1350 & 160 & 12,98 & 8,95 & 7,87 & 6,97 & 6,29 & 5,72 & 4,74 & 3,96 & 2,83 \\
\hline 90 & 1400 & 160 & 12,74 & 8,82 & 7,77 & 6,90 & 6,25 & 5,68 & 4,72 & 3,95 & 2,84 \\
\hline 90 & 1450 & 160 & 12,52 & 8,69 & 7,69 & 6,84 & 6,20 & 5,65 & 4,70 & 3,94 & 2,84 \\
\hline 90 & 1500 & 160 & 12,30 & 8,58 & 7,60 & 6,78 & 6,16 & 5,62 & 4,69 & 3,94 & 2,84 \\
\hline 90 & 1550 & 160 & 12,11 & 8,46 & 7,52 & 6,72 & 6,11 & 5,59 & 4,67 & 3,93 & 2,84 \\
\hline 90 & 1600 & 160 & 11,92 & 8,36 & 7,44 & 6,67 & 6,07 & 5,56 & 4,66 & 3,92 & 2,84 \\
\hline 90 & 1650 & 160 & 11,74 & 8,26 & 7,37 & 6,61 & 6,03 & 5,53 & 4,64 & 3,92 & 2,85 \\
\hline 90 & 1700 & 160 & 11,57 & 8,16 & 7,30 & 6,56 & 5,99 & 5,50 & 4,63 & 3,91 & 2,85 \\
\hline 90 & 1750 & 160 & 11,41 & 8,07 & 7,23 & 6,51 & 5,96 & 5,47 & 4,61 & 3,90 & 2,85 \\
\hline 90 & 1800 & 160 & 11,26 & 7,98 & 7,16 & 6,47 & 5,92 & 5,44 & 4,60 & 3,90 & 2,85 \\
\hline 90 & 1850 & 160 & 11,11 & 7,89 & 7,10 & 6,42 & 5,88 & 5,41 & 4,58 & 3,89 & 2,85 \\
\hline 90 & 1900 & 160 & 10,97 & 7,81 & 7,03 & 6,37 & 5,85 & 5,39 & 4,57 & 3,88 & 2,85 \\
\hline 90 & 1950 & 160 & 10,84 & 7,73 & 6,97 & 6,33 & 5,82 & 5,36 & 4,55 & 3,88 & 2,85 \\
\hline 90 & 2000 & 160 & 10,71 & 7,66 & 6,92 & 6,29 & 5,78 & 5,33 & 4,54 & 3,87 & 2,85 \\
\hline 90 & 200 & 165 & 45,08 & 21,86 & 15,10 & 10,68 & 8,30 & 6,75 & 4,77 & 3,69 & 2,56 \\
\hline 90 & 250 & 165 & 37,88 & 19,25 & 13,77 & 10,12 & 8,07 & 6,67 & 4,82 & 3,74 & 2,57 \\
\hline 90 & 300 & 165 & 33,02 & 17,45 & 12,84 & 9,69 & 7,87 & 6,59 & 4,84 & 3,77 & 2,59 \\
\hline 90 & 350 & 165 & 29,50 & 16,11 & 12,12 & 9,36 & 7,71 & 6,52 & 4,85 & 3,80 & 2,60 \\
\hline 90 & 400 & 165 & 26,83 & 15,07 & 11,55 & 9,08 & 7,57 & 6,46 & 4,86 & 3,82 & 2,61 \\
\hline 90 & 450 & 165 & 24,73 & 14,23 & 11,08 & 8,84 & 7,44 & 6,39 & 4,85 & 3,84 & 2,62 \\
\hline 90 & 500 & 165 & 23,03 & 13,53 & 10,69 & 8,63 & 7,32 & 6,33 & 4,85 & 3,85 & 2,64 \\
\hline 90 & 550 & 165 & 21,62 & 12,94 & 10,35 & 8,44 & 7,22 & 6,27 & 4,84 & 3,86 & 2,65 \\
\hline 90 & 600 & 165 & 20,44 & 12,44 & 10,05 & 8,27 & 7,12 & 6,22 & 4,83 & 3,87 & 2,66 \\
\hline 90 & 650 & 165 & 19,43 & 12,00 & 9,78 & 8,12 & 7,03 & 6,16 & 4,82 & 3,87 & 2,67 \\
\hline 90 & 700 & 165 & 18,55 & 11,61 & 9,55 & 7,98 & 6,94 & 6,11 & 4,81 & 3,87 & 2,67 \\
\hline
\end{tabular}




\begin{tabular}{|c|c|c|c|c|c|c|c|c|c|c|c|}
\hline \multirow[b]{2}{*}{$\mathrm{H}(\mathrm{cm})$} & \multirow[b]{2}{*}{ Mceq (MPa) } & & & & & De & jes ( $x 1$ & & & & \\
\hline & & Msub (MPa) & D0 & D25 & D40 & D60 & $\mathrm{D} 80$ & D100 & D140 & D180 & D260 \\
\hline 90 & 750 & 165 & 17,78 & 11,26 & 9,33 & 7,85 & 6,86 & 6,06 & 4,79 & 3,88 & 2,68 \\
\hline 90 & 800 & 165 & 17,11 & 10,95 & 9,14 & 7,74 & 6,78 & 6,01 & 4,78 & 3,88 & 2,69 \\
\hline 90 & 850 & 165 & 16,51 & 10,66 & 8,96 & 7,63 & 6,71 & 5,96 & 4,76 & 3,88 & 2,70 \\
\hline 90 & 900 & 165 & 15,97 & 10,40 & 8,79 & 7,52 & 6,64 & 5,92 & 4,75 & 3,87 & 2,70 \\
\hline 90 & 950 & 165 & 15,48 & 10,17 & 8,64 & 7,42 & 6,58 & 5,88 & 4,73 & 3,87 & 2,71 \\
\hline 90 & 1000 & 165 & 15,03 & 9,95 & 8,49 & 7,33 & 6,51 & 5,83 & 4,72 & 3,87 & 2,72 \\
\hline 90 & 1050 & 165 & 14,63 & 9,75 & 8,36 & 7,25 & 6,45 & 5,79 & 4,70 & 3,87 & 2,72 \\
\hline 90 & 1100 & 165 & 14,26 & 9,56 & 8,24 & 7,16 & 6,40 & 5,75 & 4,69 & 3,86 & 2,73 \\
\hline 90 & 1150 & 165 & 13,92 & 9,38 & 8,12 & 7,09 & 6,34 & 5,72 & 4,67 & 3,86 & 2,73 \\
\hline 90 & 1200 & 165 & 13,61 & 9,22 & 8,01 & 7,01 & 6,29 & 5,68 & 4,65 & 3,86 & 2,73 \\
\hline 90 & 1250 & 165 & 13,31 & 9,07 & 7,90 & 6,94 & 6,24 & 5,64 & 4,64 & 3,85 & 2,74 \\
\hline 90 & 1300 & 165 & 13,04 & 8,92 & 7,80 & 6,87 & 6,19 & 5,61 & 4,62 & 3,85 & 2,74 \\
\hline 90 & 1350 & 165 & 12,79 & 8,79 & 7,71 & 6,81 & 6,14 & 5,57 & 4,61 & 3,84 & 2,74 \\
\hline 90 & 1400 & 165 & 12,55 & 8,66 & 7,61 & 6,74 & 6,10 & 5,54 & 4,59 & 3,83 & 2,75 \\
\hline 90 & 1450 & 165 & 12,33 & 8,53 & 7,53 & 6,68 & 6,05 & 5,51 & 4,58 & 3,83 & 2,75 \\
\hline 90 & 1500 & 165 & 12,12 & 8,42 & 7,45 & 6,63 & 6,01 & 5,48 & 4,56 & 3,82 & 2,75 \\
\hline 90 & 1550 & 165 & 11,92 & 8,31 & 7,37 & 6,57 & 5,97 & 5,45 & 4,55 & 3,82 & 2,75 \\
\hline 90 & 1600 & 165 & 11,73 & 8,20 & 7,29 & 6,52 & 5,93 & 5,42 & 4,53 & 3,81 & 2,76 \\
\hline 90 & 1650 & 165 & 11,56 & 8,10 & 7,22 & 6,47 & 5,89 & 5,39 & 4,52 & 3,81 & 2,76 \\
\hline 90 & 1700 & 165 & 11,39 & 8,01 & 7,15 & 6,42 & 5,85 & 5,36 & 4,50 & 3,80 & 2,76 \\
\hline 90 & 1750 & 165 & 11,23 & 7,92 & 7,08 & 6,37 & 5,82 & 5,33 & 4,49 & 3,79 & 2,76 \\
\hline 90 & 1800 & 165 & 11,08 & 7,83 & 7,01 & 6,32 & 5,78 & 5,30 & 4,47 & 3,79 & 2,76 \\
\hline 90 & 1850 & 165 & 10,93 & 7,75 & 6,95 & 6,28 & 5,74 & 5,28 & 4,46 & 3,78 & 2,76 \\
\hline 90 & 1900 & 165 & 10,79 & 7,67 & 6,89 & 6,23 & 5,71 & 5,25 & 4,44 & 3,77 & 2,76 \\
\hline 90 & 1950 & 165 & 10,66 & 7,59 & 6,83 & 6,19 & 5,68 & 5,23 & 4,43 & 3,77 & 2,76 \\
\hline 90 & 2000 & 165 & 10,54 & 7,52 & 6,78 & 6,15 & 5,65 & 5,20 & 4,42 & 3,76 & 2,77 \\
\hline 90 & 200 & 170 & 44,80 & 21,59 & 14,84 & 10,45 & 8,09 & 6,56 & 4,63 & 3,57 & 2,48 \\
\hline 90 & 250 & 170 & 37,62 & 18,99 & 13,53 & 9,89 & 7,86 & 6,48 & 4,67 & 3,62 & 2,49 \\
\hline 90 & 300 & 170 & 32,76 & 17,20 & 12,60 & 9,47 & 7,67 & 6,41 & 4,69 & 3,66 & 2,51 \\
\hline 90 & 350 & 170 & 29,25 & 15,87 & 11,89 & 9,14 & 7,51 & 6,35 & 4,71 & 3,68 & 2,52 \\
\hline 90 & 400 & 170 & 26,59 & 14,84 & 11,33 & 8,87 & 7,38 & 6,28 & 4,71 & 3,70 & 2,53 \\
\hline 90 & 450 & 170 & 24,50 & 14,01 & 10,87 & 8,63 & 7,25 & 6,22 & 4,71 & 3,72 & 2,54 \\
\hline 90 & 500 & 170 & 22,80 & 13,32 & 10,48 & 8,43 & 7,14 & 6,16 & 4,71 & 3,73 & 2,55 \\
\hline 90 & 550 & 170 & 21,40 & 12,74 & 10,14 & 8,25 & 7,04 & 6,11 & 4,70 & 3,74 & 2,57 \\
\hline 90 & 600 & 170 & 20,22 & 12,24 & 9,85 & 8,08 & 6,94 & 6,05 & 4,69 & 3,75 & 2,58 \\
\hline 90 & 650 & 170 & 19,21 & 11,80 & 9,59 & 7,94 & 6,85 & 6,00 & 4,68 & 3,75 & 2,58 \\
\hline 90 & 700 & 170 & 18,34 & 11,42 & 9,36 & 7,80 & 6,77 & 5,95 & 4,67 & 3,76 & 2,59 \\
\hline 90 & 750 & 170 & 17,58 & 11,07 & 9,15 & 7,68 & 6,69 & 5,90 & 4,66 & 3,76 & 2,60 \\
\hline 90 & 800 & 170 & 16,90 & 10,76 & 8,95 & 7,56 & 6,62 & 5,86 & 4,64 & 3,76 & 2,61 \\
\hline 90 & 850 & 170 & 16,30 & 10,48 & 8,78 & 7,45 & 6,55 & 5,81 & 4,63 & 3,76 & 2,62 \\
\hline 90 & 900 & 170 & 15,77 & 10,23 & 8,62 & 7,35 & 6,48 & 5,77 & 4,62 & 3,76 & 2,62 \\
\hline 90 & 950 & 170 & 15,28 & 9,99 & 8,46 & 7,26 & 6,42 & 5,73 & 4,60 & 3,76 & 2,63 \\
\hline 90 & 1000 & 170 & 14,84 & 9,78 & 8,32 & 7,17 & 6,36 & 5,69 & 4,59 & 3,76 & 2,63 \\
\hline 90 & 1050 & 170 & 14,44 & 9,58 & 8,19 & 7,08 & 6,30 & 5,65 & 4,57 & 3,76 & 2,64 \\
\hline 90 & 1100 & 170 & 14,07 & 9,39 & 8,07 & 7,00 & 6,24 & 5,61 & 4,56 & 3,75 & 2,64 \\
\hline 90 & 1150 & 170 & 13,73 & 9,22 & 7,96 & 6,93 & 6,19 & 5,57 & 4,54 & 3,75 & 2,65 \\
\hline 90 & 1200 & 170 & 13,42 & 9,06 & 7,85 & 6,86 & 6,14 & 5,54 & 4,53 & 3,74 & 2,65 \\
\hline 90 & 1250 & 170 & 13,13 & 8,91 & 7,74 & 6,79 & 6,09 & 5,50 & 4,51 & 3,74 & 2,65 \\
\hline 90 & 1300 & 170 & 12,86 & 8,77 & 7,64 & 6,72 & 6,04 & 5,47 & 4,50 & 3,74 & 2,66 \\
\hline 90 & 1350 & 170 & 12,61 & 8,63 & 7,55 & 6,66 & 6,00 & 5,44 & 4,48 & 3,73 & 2,66 \\
\hline 90 & 1400 & 170 & 12,37 & 8,50 & 7,46 & 6,60 & 5,95 & 5,40 & 4,47 & 3,73 & 2,66 \\
\hline 90 & 1450 & 170 & 12,15 & 8,38 & 7,38 & 6,54 & 5,91 & 5,37 & 4,45 & 3,72 & 2,67 \\
\hline 90 & 1500 & 170 & 11,94 & 8,27 & 7,30 & 6,48 & 5,87 & 5,34 & 4,44 & 3,72 & 2,67 \\
\hline 90 & 1550 & 170 & 11,74 & 8,16 & 7,22 & 6,43 & 5,83 & 5,31 & 4,42 & 3,71 & 2,67 \\
\hline 90 & 1600 & 170 & 11,56 & 8,06 & 7,14 & 6,37 & 5,79 & 5,28 & 4,41 & 3,70 & 2,67 \\
\hline 90 & 1650 & 170 & 11,38 & 7,96 & 7,07 & 6,32 & 5,75 & 5,26 & 4,40 & 3,70 & 2,68 \\
\hline 90 & 1700 & 170 & 11,22 & 7,87 & 7,00 & 6,28 & 5,72 & 5,23 & 4,38 & 3,69 & 2,68 \\
\hline 90 & 1750 & 170 & 11,06 & 7,78 & 6,94 & 6,23 & 5,68 & 5,20 & 4,37 & 3,69 & 2,68 \\
\hline 90 & 1800 & 170 & 10,91 & 7,69 & 6,88 & 6,18 & 5,65 & 5,18 & 4,36 & 3,68 & 2,68 \\
\hline 90 & 1850 & 170 & 10,76 & 7,61 & 6,81 & 6,14 & 5,61 & 5,15 & 4,34 & 3,68 & 2,68 \\
\hline 90 & 1900 & 170 & 10,63 & 7,53 & 6,75 & 6,10 & 5,58 & 5,13 & 4,33 & 3,67 & 2,68 \\
\hline 90 & 1950 & 170 & 10,50 & 7,45 & 6,70 & 6,05 & 5,55 & 5,10 & 4,31 & 3,66 & 2,68 \\
\hline 90 & 2000 & 170 & 10,37 & 7,38 & 6,64 & 6,01 & 5,52 & 5,08 & 4,30 & 3,66 & 2,68 \\
\hline 90 & 200 & 175 & 44,54 & 21,34 & 14,60 & 10,22 & 7,89 & 6,38 & 4,49 & 3,47 & 2,41 \\
\hline 90 & 250 & 175 & 37,37 & 18,75 & 13,30 & 9,67 & 7,66 & 6,31 & 4,53 & 3,51 & 2,42 \\
\hline 90 & 300 & 175 & 32,52 & 16,97 & 12,38 & 9,27 & 7,48 & 6,24 & 4,56 & 3,55 & 2,43 \\
\hline 90 & 350 & 175 & 29,02 & 15,65 & 11,68 & 8,94 & 7,33 & 6,18 & 4,57 & 3,57 & 2,45 \\
\hline 90 & 400 & 175 & 26,37 & 14,63 & 11,12 & 8,67 & 7,19 & 6,12 & 4,58 & 3,59 & 2,46 \\
\hline 90 & 450 & 175 & 24,28 & 13,80 & 10,67 & 8,44 & 7,07 & 6,06 & 4,58 & 3,61 & 2,47 \\
\hline 90 & 500 & 175 & 22,59 & 13,12 & 10,28 & 8,24 & 6,97 & 6,00 & 4,57 & 3,62 & 2,48 \\
\hline 90 & 550 & 175 & 21,19 & 12,54 & 9,95 & 8,07 & 6,87 & 5,95 & 4,57 & 3,63 & 2,49 \\
\hline 90 & 600 & 175 & 20,02 & 12,05 & 9,66 & 7,91 & 6,77 & 5,90 & 4,56 & 3,64 & 2,50 \\
\hline 90 & 650 & 175 & 19,01 & 11,62 & 9,41 & 7,76 & 6,69 & 5,85 & 4,55 & 3,65 & 2,51 \\
\hline 90 & 700 & 175 & 18,14 & 11,23 & 9,18 & 7,63 & 6,61 & 5,80 & 4,54 & 3,65 & 2,52 \\
\hline 90 & 750 & 175 & 17,38 & 10,89 & 8,97 & 7,51 & 6,53 & 5,75 & 4,53 & 3,65 & 2,52 \\
\hline 90 & 800 & 175 & 16,71 & 10,59 & 8,78 & 7,40 & 6,46 & 5,71 & 4,52 & 3,65 & 2,53 \\
\hline 90 & 850 & 175 & 16,11 & 10,31 & 8,61 & 7,29 & 6,39 & 5,67 & 4,51 & 3,65 & 2,54 \\
\hline 90 & 900 & 175 & 15,58 & 10,06 & 8,45 & 7,19 & 6,33 & 5,62 & 4,49 & 3,65 & 2,54 \\
\hline 90 & 950 & 175 & 15,09 & 9,83 & 8,30 & 7,10 & 6,27 & 5,58 & 4,48 & 3,65 & 2,55 \\
\hline 90 & 1000 & 175 & 14,66 & 9,62 & 8,16 & 7,01 & 6,21 & 5,55 & 4,46 & 3,65 & 2,55 \\
\hline 90 & 1050 & 175 & 14,26 & 9,42 & 8,04 & 6,93 & 6,15 & 5,51 & 4,45 & 3,65 & 2,56 \\
\hline
\end{tabular}




\begin{tabular}{|c|c|c|c|c|c|c|c|c|c|c|c|}
\hline \multirow[b]{2}{*}{$\mathrm{H}(\mathrm{cm})$} & \multirow[b]{2}{*}{ Mceq (MPa) } & & & & & De & ões (x & & & & \\
\hline & & Msub (MPa) & D0 & D25 & D40 & D60 & D80 & D100 & D140 & D180 & D260 \\
\hline 90 & 1100 & 175 & 13,89 & 9,24 & 7,91 & 6,85 & 6,10 & 5,47 & 4,44 & 3,65 & 2,56 \\
\hline 90 & 1150 & 175 & 13,55 & 9,07 & 7,80 & 6,78 & 6,05 & 5,44 & 4,42 & 3,64 & 2,57 \\
\hline 90 & 1200 & 175 & 13,24 & 8,91 & 7,69 & 6,71 & 6,00 & 5,40 & 4,41 & 3,64 & 2,57 \\
\hline 90 & 1250 & 175 & 12,95 & 8,76 & 7,59 & 6,64 & 5,95 & 5,37 & 4,39 & 3,64 & 2,58 \\
\hline 90 & 1300 & 175 & 12,68 & 8,62 & 7,50 & 6,58 & 5,90 & 5,34 & 4,38 & 3,63 & 2,58 \\
\hline 90 & 1350 & 175 & 12,43 & 8,48 & 7,41 & 6,51 & 5,86 & 5,30 & 4,37 & 3,63 & 2,58 \\
\hline 90 & 1400 & 175 & 12,20 & 8,36 & 7,32 & 6,45 & 5,82 & 5,27 & 4,35 & 3,62 & 2,59 \\
\hline 90 & 1450 & 175 & 11,98 & 8,24 & 7,24 & 6,40 & 5,78 & 5,24 & 4,34 & 3,62 & 2,59 \\
\hline 90 & 1500 & 175 & 11,77 & 8,13 & 7,16 & 6,34 & 5,74 & 5,22 & 4,32 & 3,61 & 2,59 \\
\hline 90 & 1550 & 175 & 11,58 & 8,02 & 7,08 & 6,29 & 5,70 & 5,19 & 4,31 & 3,61 & 2,59 \\
\hline 90 & 1600 & 175 & 11,39 & 7,92 & 7,01 & 6,24 & 5,66 & 5,16 & 4,30 & 3,60 & 2,60 \\
\hline 90 & 1650 & 175 & 11,22 & 7,82 & 6,94 & 6,19 & 5,62 & 5,13 & 4,28 & 3,60 & 2,60 \\
\hline 90 & 1700 & 175 & 11,05 & 7,73 & 6,87 & 6,14 & 5,59 & 5,11 & 4,27 & 3,59 & 2,60 \\
\hline 90 & 1750 & 175 & 10,90 & 7,64 & 6,80 & 6,10 & 5,55 & 5,08 & 4,26 & 3,59 & 2,60 \\
\hline 90 & 1800 & 175 & 10,75 & 7,56 & 6,74 & 6,05 & 5,52 & 5,05 & 4,24 & 3,58 & 2,60 \\
\hline 90 & 1850 & 175 & 10,60 & 7,47 & 6,68 & 6,01 & 5,49 & 5,03 & 4,23 & 3,58 & 2,60 \\
\hline 90 & 1900 & 175 & 10,47 & 7,40 & 6,62 & 5,97 & 5,45 & 5,01 & 4,22 & 3,57 & 2,60 \\
\hline 90 & 1950 & 175 & 10,34 & 7,32 & 6,57 & 5,93 & 5,42 & 4,98 & 4,21 & 3,57 & 2,60 \\
\hline 90 & 2000 & 175 & 10,21 & 7,25 & 6,51 & 5,89 & 5,39 & 4,96 & 4,19 & 3,56 & 2,61 \\
\hline 90 & 200 & 180 & 44,30 & 21,09 & 14,37 & 10,01 & 7,70 & 6,21 & 4,36 & 3,36 & 2,34 \\
\hline 90 & 250 & 180 & 37,13 & 18,52 & 13,08 & 9,47 & 7,48 & 6,14 & 4,40 & 3,41 & 2,35 \\
\hline 90 & 300 & 180 & 32,30 & 16,75 & 12,16 & 9,07 & 7,30 & 6,08 & 4,43 & 3,44 & 2,36 \\
\hline 90 & 350 & 180 & 28,80 & 15,44 & 11,47 & 8,75 & 7,15 & 6,02 & 4,44 & 3,47 & 2,37 \\
\hline 90 & 400 & 180 & 26,15 & 14,42 & 10,92 & 8,49 & 7,02 & 5,96 & 4,45 & 3,49 & 2,39 \\
\hline 90 & 450 & 180 & 24,07 & 13,60 & 10,47 & 8,26 & 6,91 & 5,90 & 4,45 & 3,51 & 2,40 \\
\hline 90 & 500 & 180 & 22,39 & 12,93 & 10,10 & 8,07 & 6,80 & 5,85 & 4,45 & 3,52 & 2,41 \\
\hline 90 & 550 & 180 & 20,99 & 12,36 & 9,77 & 7,89 & 6,70 & 5,80 & 4,44 & 3,53 & 2,42 \\
\hline 90 & 600 & 180 & 19,82 & 11,87 & 9,48 & 7,74 & 6,61 & 5,75 & 4,44 & 3,54 & 2,43 \\
\hline 90 & 650 & 180 & 18,82 & 11,44 & 9,23 & 7,60 & 6,53 & 5,70 & 4,43 & 3,54 & 2,43 \\
\hline 90 & 700 & 180 & 17,95 & 11,06 & 9,01 & 7,47 & 6,45 & 5,66 & 4,42 & 3,55 & 2,44 \\
\hline 90 & 750 & 180 & 17,20 & 10,73 & 8,80 & 7,35 & 6,38 & 5,61 & 4,41 & 3,55 & 2,45 \\
\hline 90 & 800 & 180 & 16,53 & 10,42 & 8,62 & 7,24 & 6,31 & 5,57 & 4,40 & 3,55 & 2,46 \\
\hline 90 & 850 & 180 & 15,93 & 10,15 & 8,45 & 7,14 & 6,25 & 5,53 & 4,39 & 3,55 & 2,46 \\
\hline 90 & 900 & 180 & 15,40 & 9,90 & 8,29 & 7,04 & 6,18 & 5,49 & 4,37 & 3,55 & 2,47 \\
\hline 90 & 950 & 180 & 14,92 & 9,67 & 8,15 & 6,95 & 6,12 & 5,45 & 4,36 & 3,55 & 2,48 \\
\hline 90 & 1000 & 180 & 14,48 & 9,46 & 8,01 & 6,86 & 6,07 & 5,41 & 4,35 & 3,55 & 2,48 \\
\hline 90 & 1050 & 180 & 14,08 & 9,27 & 7,88 & 6,78 & 6,01 & 5,38 & 4,34 & 3,55 & 2,49 \\
\hline 90 & 1100 & 180 & 13,72 & 9,09 & 7,77 & 6,71 & 5,96 & 5,34 & 4,32 & 3,55 & 2,49 \\
\hline 90 & 1150 & 180 & 13,38 & 8,92 & 7,65 & 6,64 & 5,91 & 5,31 & 4,31 & 3,54 & 2,49 \\
\hline 90 & 1200 & 180 & 13,07 & 8,76 & 7,55 & 6,57 & 5,86 & 5,27 & 4,30 & 3,54 & 2,50 \\
\hline 90 & 1250 & 180 & 12,79 & 8,61 & 7,45 & 6,50 & 5,82 & 5,24 & 4,28 & 3,54 & 2,50 \\
\hline 90 & 1300 & 180 & 12,52 & 8,48 & 7,36 & 6,44 & 5,77 & 5,21 & 4,27 & 3,53 & 2,51 \\
\hline 90 & 1350 & 180 & 12,27 & 8,35 & 7,27 & 6,38 & 5,73 & 5,18 & 4,26 & 3,53 & 2,51 \\
\hline 90 & 1400 & 180 & 12,04 & 8,22 & 7,18 & 6,32 & 5,69 & 5,15 & 4,24 & 3,53 & 2,51 \\
\hline 90 & 1450 & 180 & 11,82 & 8,10 & 7,10 & 6,26 & 5,65 & 5,12 & 4,23 & 3,52 & 2,51 \\
\hline 90 & 1500 & 180 & 11,61 & 7,99 & 7,02 & 6,21 & 5,61 & 5,09 & 4,22 & 3,52 & 2,52 \\
\hline 90 & 1550 & 180 & 11,42 & 7,89 & 6,95 & 6,16 & 5,57 & 5,07 & 4,20 & 3,51 & 2,52 \\
\hline 90 & 1600 & 180 & 11,23 & 7,79 & 6,87 & 6,11 & 5,53 & 5,04 & 4,19 & 3,51 & 2,52 \\
\hline 90 & 1650 & 180 & 11,06 & 7,69 & 6,81 & 6,06 & 5,50 & 5,01 & 4,18 & 3,50 & 2,52 \\
\hline 90 & 1700 & 180 & 10,90 & 7,60 & 6,74 & 6,02 & 5,46 & 4,99 & 4,16 & 3,50 & 2,53 \\
\hline 90 & 1750 & 180 & 10,74 & 7,51 & 6,68 & 5,97 & 5,43 & 4,96 & 4,15 & 3,49 & 2,53 \\
\hline 90 & 1800 & 180 & 10,59 & 7,43 & 6,62 & 5,93 & 5,40 & 4,94 & 4,14 & 3,49 & 2,53 \\
\hline 90 & 1850 & 180 & 10,45 & 7,35 & 6,56 & 5,89 & 5,37 & 4,91 & 4,13 & 3,48 & 2,53 \\
\hline 90 & 1900 & 180 & 10,32 & 7,27 & 6,50 & 5,84 & 5,34 & 4,89 & 4,11 & 3,48 & 2,53 \\
\hline 90 & 1950 & 180 & 10,19 & 7,20 & 6,44 & 5,80 & 5,31 & 4,87 & 4,10 & 3,47 & 2,53 \\
\hline 90 & 2000 & 180 & 10,06 & 7,13 & 6,39 & 5,77 & 5,28 & 4,85 & 4,09 & 3,47 & 2,53 \\
\hline 90 & 200 & 185 & 44,06 & 20,87 & 14,15 & 9,81 & 7,52 & 6,05 & 4,23 & 3,27 & 2,28 \\
\hline 90 & 250 & 185 & 36,91 & 18,31 & 12,87 & 9,28 & 7,30 & 5,98 & 4,28 & 3,31 & 2,29 \\
\hline 90 & 300 & 185 & 32,08 & 16,54 & 11,96 & 8,88 & 7,13 & 5,92 & 4,30 & 3,35 & 2,30 \\
\hline 90 & 350 & 185 & 28,59 & 15,24 & 11,28 & 8,57 & 6,98 & 5,87 & 4,32 & 3,37 & 2,31 \\
\hline 90 & 400 & 185 & 25,95 & 14,23 & 10,74 & 8,31 & 6,86 & 5,81 & 4,33 & 3,39 & 2,32 \\
\hline 90 & 450 & 185 & 23,87 & 13,42 & 10,29 & 8,09 & 6,75 & 5,76 & 4,33 & 3,41 & 2,33 \\
\hline 90 & 500 & 185 & 22,19 & 12,74 & 9,92 & 7,90 & 6,64 & 5,71 & 4,33 & 3,42 & 2,34 \\
\hline 90 & 550 & 185 & 20,80 & 12,18 & 9,59 & 7,73 & 6,55 & 5,66 & 4,33 & 3,43 & 2,35 \\
\hline 90 & 600 & 185 & 19,63 & 11,69 & 9,31 & 7,57 & 6,46 & 5,61 & 4,32 & 3,44 & 2,36 \\
\hline 90 & 650 & 185 & 18,64 & 11,27 & 9,07 & 7,44 & 6,38 & 5,56 & 4,31 & 3,44 & 2,37 \\
\hline 90 & 700 & 185 & 17,77 & 10,90 & 8,84 & 7,31 & 6,31 & 5,52 & 4,30 & 3,45 & 2,37 \\
\hline 90 & 750 & 185 & 17,02 & 10,56 & 8,64 & 7,20 & 6,24 & 5,48 & 4,29 & 3,45 & 2,38 \\
\hline 90 & 800 & 185 & 16,35 & 10,26 & 8,46 & 7,09 & 6,17 & 5,44 & 4,28 & 3,46 & 2,39 \\
\hline 90 & 850 & 185 & 15,76 & 9,99 & 8,29 & 6,99 & 6,11 & 5,40 & 4,27 & 3,46 & 2,39 \\
\hline 90 & 900 & 185 & 15,23 & 9,75 & 8,14 & 6,89 & 6,05 & 5,36 & 4,26 & 3,46 & 2,40 \\
\hline 90 & 950 & 185 & 14,75 & 9,52 & 8,00 & 6,81 & 5,99 & 5,32 & 4,25 & 3,46 & 2,41 \\
\hline 90 & 1000 & 185 & 14,31 & 9,32 & 7,86 & 6,72 & 5,93 & 5,29 & 4,24 & 3,46 & 2,41 \\
\hline 90 & 1050 & 185 & 13,92 & 9,12 & 7,74 & 6,64 & 5,88 & 5,25 & 4,23 & 3,45 & 2,42 \\
\hline 90 & 1100 & 185 & 13,55 & 8,95 & 7,62 & 6,57 & 5,83 & 5,22 & 4,21 & 3,45 & 2,42 \\
\hline 90 & 1150 & 185 & 13,22 & 8,78 & 7,51 & 6,50 & 5,78 & 5,18 & 4,20 & 3,45 & 2,42 \\
\hline 90 & 1200 & 185 & 12,91 & 8,62 & 7,41 & 6,43 & 5,74 & 5,15 & 4,19 & 3,45 & 2,43 \\
\hline 90 & 1250 & 185 & 12,63 & 8,48 & 7,31 & 6,37 & 5,69 & 5,12 & 4,17 & 3,44 & 2,43 \\
\hline 90 & 1300 & 185 & 12,36 & 8,34 & 7,22 & 6,31 & 5,65 & 5,09 & 4,16 & 3,44 & 2,44 \\
\hline 90 & 1350 & 185 & 12,11 & 8,21 & 7,13 & 6,25 & 5,61 & 5,06 & 4,15 & 3,44 & 2,44 \\
\hline 90 & 1400 & 185 & 11,88 & 8,09 & 7,05 & 6,19 & 5,57 & 5,03 & 4,14 & 3,43 & 2,44 \\
\hline
\end{tabular}




\begin{tabular}{|c|c|c|c|c|c|c|c|c|c|c|c|}
\hline \multirow[b]{2}{*}{$\mathrm{H}(\mathrm{cm})$} & \multirow[b]{2}{*}{ Mceq (MPa) } & & & & & & ões (x. & & & & \\
\hline & & Msub (MPa) & D0 & D25 & D40 & D60 & D80 & D100 & D140 & D180 & D260 \\
\hline 90 & 1450 & 185 & 11,66 & 7,97 & 6,97 & 6,14 & 5,53 & 5,01 & 4,12 & 3,43 & 2,44 \\
\hline 90 & 1500 & 185 & 11,46 & 7,86 & 6,89 & 6,09 & 5,49 & 4,98 & 4,11 & 3,43 & 2,45 \\
\hline 90 & 1550 & 185 & 11,27 & 7,76 & 6,82 & 6,03 & 5,45 & 4,95 & 4,10 & 3,42 & 2,45 \\
\hline 90 & 1600 & 185 & 11,08 & 7,66 & 6,75 & 5,99 & 5,42 & 4,93 & 4,09 & 3,42 & 2,45 \\
\hline 90 & 1650 & 185 & 10,91 & 7,57 & 6,68 & 5,94 & 5,38 & 4,90 & 4,08 & 3,41 & 2,45 \\
\hline 90 & 1700 & 185 & 10,75 & 7,48 & 6,62 & 5,89 & 5,35 & 4,88 & 4,06 & 3,41 & 2,46 \\
\hline 90 & 1750 & 185 & 10,59 & 7,39 & 6,55 & 5,85 & 5,32 & 4,85 & 4,05 & 3,40 & 2,46 \\
\hline 90 & 1800 & 185 & 10,45 & 7,31 & 6,49 & 5,81 & 5,28 & 4,83 & 4,04 & 3,40 & 2,46 \\
\hline 90 & 1850 & 185 & 10,31 & 7,23 & 6,44 & 5,77 & 5,25 & 4,80 & 4,03 & 3,39 & 2,46 \\
\hline 90 & 1900 & 185 & 10,17 & 7,15 & 6,38 & 5,73 & 5,22 & 4,78 & 4,02 & 3,39 & 2,46 \\
\hline 90 & 1950 & 185 & 10,04 & 7,08 & 6,33 & 5,69 & 5,19 & 4,76 & 4,00 & 3,38 & 2,46 \\
\hline 90 & 2000 & 185 & 9,92 & 7,01 & 6,27 & 5,65 & 5,16 & 4,74 & 3,99 & 3,38 & 2,46 \\
\hline 90 & 200 & 190 & 43,84 & 20,65 & 13,94 & 9,62 & 7,35 & 5,89 & 4,11 & 3,17 & 2,22 \\
\hline 90 & 250 & 190 & 36,69 & 18,10 & 12,67 & 9,09 & 7,13 & 5,83 & 4,16 & 3,22 & 2,23 \\
\hline 90 & 300 & 190 & 31,88 & 16,34 & 11,77 & 8,70 & 6,97 & 5,78 & 4,19 & 3,25 & 2,24 \\
\hline 90 & 350 & 190 & 28,40 & 15,05 & 11,09 & 8,39 & 6,83 & 5,72 & 4,20 & 3,28 & 2,25 \\
\hline 90 & 400 & 190 & 25,76 & 14,04 & 10,56 & 8,14 & 6,70 & 5,67 & 4,21 & 3,30 & 2,26 \\
\hline 90 & 450 & 190 & 23,68 & 13,24 & 10,12 & 7,92 & 6,59 & 5,62 & 4,22 & 3,32 & 2,27 \\
\hline 90 & 500 & 190 & 22,01 & 12,57 & 9,75 & 7,74 & 6,49 & 5,57 & 4,22 & 3,33 & 2,28 \\
\hline 90 & 550 & 190 & 20,62 & 12,01 & 9,43 & 7,57 & 6,40 & 5,52 & 4,21 & 3,34 & 2,28 \\
\hline 90 & 600 & 190 & 19,46 & 11,53 & 9,15 & 7,42 & 6,32 & 5,48 & 4,21 & 3,35 & 2,29 \\
\hline 90 & 650 & 190 & 18,46 & 11,11 & 8,91 & 7,29 & 6,24 & 5,43 & 4,20 & 3,35 & 2,30 \\
\hline 90 & 700 & 190 & 17,60 & 10,74 & 8,69 & 7,16 & 6,17 & 5,39 & 4,19 & 3,36 & 2,31 \\
\hline 90 & 750 & 190 & 16,85 & 10,41 & 8,49 & 7,05 & 6,10 & 5,35 & 4,19 & 3,36 & 2,32 \\
\hline 90 & 800 & 190 & 16,19 & 10,11 & 8,31 & 6,94 & 6,03 & 5,31 & 4,18 & 3,36 & 2,32 \\
\hline 90 & 850 & 190 & 15,59 & 9,85 & 8,15 & 6,85 & 5,97 & 5,27 & 4,17 & 3,37 & 2,33 \\
\hline 90 & 900 & 190 & 15,07 & 9,60 & 7,99 & 6,76 & 5,91 & 5,24 & 4,15 & 3,37 & 2,33 \\
\hline 90 & 950 & 190 & 14,59 & 9,38 & 7,85 & 6,67 & 5,86 & 5,20 & 4,14 & 3,37 & 2,34 \\
\hline 90 & 1000 & 190 & 14,16 & 9,17 & 7,72 & 6,59 & 5,80 & 5,16 & 4,13 & 3,37 & 2,34 \\
\hline 90 & 1050 & 190 & 13,76 & 8,99 & 7,60 & 6,51 & 5,75 & 5,13 & 4,12 & 3,36 & 2,35 \\
\hline 90 & 1100 & 190 & 13,40 & 8,81 & 7,49 & 6,44 & 5,70 & 5,10 & 4,11 & 3,36 & 2,35 \\
\hline 90 & 1150 & 190 & 13,07 & 8,64 & 7,38 & 6,37 & 5,66 & 5,07 & 4,10 & 3,36 & 2,36 \\
\hline 90 & 1200 & 190 & 12,76 & 8,49 & 7,28 & 6,30 & 5,61 & 5,04 & 4,09 & 3,36 & 2,36 \\
\hline 90 & 1250 & 190 & 12,47 & 8,35 & 7,18 & 6.24 & 5,57 & 5,01 & 4.07 & 3,36 & 2,37 \\
\hline 90 & 1300 & 190 & 12,21 & 8,21 & 7,09 & 6,18 & 5,53 & 4,98 & 4,06 & 3,35 & 2,37 \\
\hline 90 & 1350 & 190 & 11,96 & 8,08 & 7,01 & 6,12 & 5,49 & 4,95 & 4,05 & 3,35 & 2,37 \\
\hline 90 & 1400 & 190 & 11,73 & 7,96 & 6,92 & 6,07 & 5,45 & 4,92 & 4,04 & 3,35 & 2,38 \\
\hline 90 & 1450 & 190 & 11,52 & 7,85 & 6,84 & 6,02 & 5,41 & 4,89 & 4,03 & 3,34 & 2,38 \\
\hline 90 & 1500 & 190 & 11,31 & 7,74 & 6,77 & 5,96 & 5,37 & 4,87 & 4,01 & 3,34 & 2,38 \\
\hline 90 & 1550 & 190 & 11,12 & 7,64 & 6,70 & 5,92 & 5,34 & 4,84 & 4,00 & 3,34 & 2,38 \\
\hline 90 & 1600 & 190 & 10,94 & 7,54 & 6,63 & 5,87 & 5,30 & 4,82 & 3,99 & 3,33 & 2,39 \\
\hline 90 & 1650 & 190 & 10,77 & 7,45 & 6,56 & 5,82 & 5,27 & 4,79 & 3,98 & 3,33 & 2,39 \\
\hline 90 & 1700 & 190 & 10,61 & 7,36 & 6,50 & 5,78 & 5,24 & 4,77 & 3,97 & 3,32 & 2,39 \\
\hline 90 & 1750 & 190 & 10,45 & 7,27 & 6,44 & 5,74 & 5,20 & 4,75 & 3,96 & 3,32 & 2,39 \\
\hline 90 & 1800 & 190 & 10,31 & 7,19 & 6,38 & 5,69 & 5,17 & 4,72 & 3,94 & 3,31 & 2,39 \\
\hline 90 & 1850 & 190 & 10,17 & 7,11 & 6,32 & 5,65 & 5,14 & 4,70 & 3,93 & 3,31 & 2,39 \\
\hline 90 & 1900 & 190 & 10,04 & 7,04 & 6,27 & 5,62 & 5,11 & 4,68 & 3,92 & 3,30 & 2,40 \\
\hline 90 & 1950 & 190 & 9,91 & 6,97 & 6,21 & 5,58 & 5,09 & 4,66 & 3,91 & 3,30 & 2,40 \\
\hline 90 & 2000 & 190 & 9,79 & 6,90 & 6,16 & 5,54 & 5,06 & 4,64 & 3,90 & 3,30 & 2,40 \\
\hline 90 & 200 & 195 & 43,62 & 20,44 & 13,74 & 9,44 & 7,18 & 5,75 & 4,00 & 3,09 & 2,16 \\
\hline 90 & 250 & 195 & 36,49 & 17,90 & 12,48 & 8,91 & 6,98 & 5,69 & 4,05 & 3,13 & 2,17 \\
\hline 90 & 300 & 195 & 31,68 & 16,15 & 11,59 & 8,53 & 6,81 & 5,64 & 4,08 & 3,17 & 2,18 \\
\hline 90 & 350 & 195 & 28,21 & 14,86 & 10,91 & 8,23 & $\begin{array}{l}0,01 \\
6,67\end{array}$ & 5,58 & 4,09 & 3,19 & 2,19 \\
\hline 90 & 400 & 195 & 25,57 & 13,86 & 10,38 & 7,98 & 6,55 & 5,53 & 4,10 & 3,21 & 2,20 \\
\hline 90 & 450 & 195 & 23,50 & 13,06 & 9,95 & 7,77 & 6,45 & 5,48 & 4,11 & 3,23 & 2,21 \\
\hline 90 & 500 & 195 & 21,83 & 12,40 & 9,58 & 7,58 & 6,35 & 5,44 & 4,11 & 3,24 & 2,21 \\
\hline 90 & 550 & 195 & 20,45 & 11,85 & 9,27 & 7,42 & 6,26 & 5,39 & 4,11 & 3,25 & 2,22 \\
\hline 90 & 600 & 195 & 19,29 & 11,37 & 9,00 & 7,27 & 6,18 & 5,35 & 4,10 & 3,26 & 2,23 \\
\hline 90 & 650 & 195 & 18,30 & 10,95 & 8,75 & 7,14 & 6,11 & 5,31 & 4,10 & 3,26 & 2,24 \\
\hline 90 & 700 & 195 & 17,44 & 10,59 & 8,54 & 7,02 & 6,03 & 5,27 & 4,09 & 3,27 & 2,25 \\
\hline 90 & 750 & 195 & 16,69 & 10,26 & 8,34 & 6,91 & 5,97 & 5,23 & 4,08 & 3,27 & 2,25 \\
\hline 90 & 800 & 195 & 16,03 & 9,97 & 8,17 & 6,81 & 5,90 & 5,19 & 4,07 & 3,28 & 2,26 \\
\hline 90 & 850 & 195 & 15,44 & 9,70 & 8,01 & 6,71 & 5,85 & 5,15 & 4,06 & 3,28 & 2,27 \\
\hline 90 & 900 & 195 & 14,91 & 9,46 & 7,86 & 6,62 & 5,79 & 5,12 & 4,05 & 3,28 & 2,27 \\
\hline 90 & 950 & 195 & 14,43 & 9,24 & 7,72 & 6,54 & 5,73 & 5,08 & 4,04 & 3,28 & 2,28 \\
\hline 90 & 1000 & 195 & 14,00 & 9,04 & 7,59 & 6,46 & 5,68 & 5,05 & 4,03 & 3,28 & 2,28 \\
\hline 90 & 1050 & 195 & 13,61 & 8,85 & 7,47 & 6,38 & 5,63 & 5,02 & 4,02 & 3,28 & 2,29 \\
\hline 90 & 1100 & 195 & 13,25 & 8,68 & 7,36 & 6,31 & 5,59 & 4,99 & 4,01 & 3,28 & 2,29 \\
\hline 90 & 1150 & 195 & 12,92 & 8,52 & 7,25 & 6,25 & 5,54 & 4,96 & 4,00 & 3,28 & 2,30 \\
\hline 90 & 1200 & 195 & 12,61 & 8,36 & 7,15 & 6,18 & 5,50 & 4,93 & 3,99 & 3,27 & 2,30 \\
\hline 90 & 1250 & 195 & 12,33 & 8,22 & 7,06 & 6,12 & 5,45 & 4,90 & 3,98 & 3,27 & 2,30 \\
\hline 90 & 1300 & 195 & 12,07 & 8,09 & 6,97 & 6,06 & 5,41 & 4,87 & 3,96 & 3,27 & 2,31 \\
\hline 90 & 1350 & 195 & 11,82 & 7,96 & 6,88 & 6,01 & 5,37 & 4,84 & 3,95 & 3,27 & 2,31 \\
\hline 90 & 1400 & 195 & 11,59 & 7,84 & 6,80 & 5,95 & 5,33 & 4,81 & 3,94 & 3,26 & 2,31 \\
\hline 90 & 1450 & 195 & 11,38 & 7,73 & 6,73 & 5,90 & 5,30 & 4,79 & 3,93 & 3,26 & 2,32 \\
\hline 90 & 1500 & 195 & 11,17 & 7,62 & 6,65 & 5,85 & 5,26 & 4,76 & 3,92 & 3,26 & 2,32 \\
\hline 90 & 1550 & 195 & 10.98 & 7.52 & 6.58 & 5.80 & 5.23 & 4.74 & 3.91 & 3,25 & 2.32 \\
\hline 90 & 1600 & 195 & 10,80 & 7,43 & 6,51 & 5,76 & 5,19 & 4,71 & 3,90 & 3,25 & 2,32 \\
\hline 90 & 1650 & 195 & 10,63 & 7,33 & 6,45 & 5,71 & 5,16 & 4,69 & 3,89 & 3,25 & 2,32 \\
\hline 90 & 1700 & 195 & 10,47 & 7,24 & 6,39 & 5,67 & 5,13 & 4,67 & 3,87 & 3,24 & 2,33 \\
\hline 90 & 1750 & 195 & 10,32 & 7,16 & 6,33 & 5,63 & 5,10 & 4,64 & 3,86 & 3,24 & 2,33 \\
\hline
\end{tabular}




\begin{tabular}{|c|c|c|c|c|c|c|c|c|c|c|c|}
\hline \multirow[b]{2}{*}{$\mathrm{H}(\mathrm{cm})$} & \multirow[b]{2}{*}{ Mceq (MPa) } & \multirow[b]{2}{*}{ Msub (MPa) } & \multicolumn{9}{|c|}{ Deflexões $\left(\times 10^{-4} \mathrm{~cm}\right)$} \\
\hline & & & D0 & D25 & D40 & D60 & D80 & D100 & D140 & D180 & D260 \\
\hline 90 & 1800 & 195 & 10,17 & 7,08 & 6,27 & 5,59 & 5,07 & 4,62 & 3,85 & 3,23 & 2,33 \\
\hline 90 & 1850 & 195 & 10,04 & 7,00 & 6,21 & 5,55 & 5,04 & 4,60 & 3,84 & 3,23 & 2,33 \\
\hline 90 & 1900 & 195 & 9,90 & 6,93 & 6,16 & 5,51 & 5,01 & 4,58 & 3,83 & 3,22 & 2,33 \\
\hline 90 & 1950 & 195 & 9,78 & 6,86 & 6,11 & 5,47 & 4,98 & 4,56 & 3,82 & 3,22 & 2,33 \\
\hline 90 & 2000 & 195 & 9,66 & 6,79 & 6,06 & 5,44 & 4,96 & 4,54 & 3,81 & 3,22 & 2,33 \\
\hline 90 & 200 & 200 & 43,42 & 20,24 & 13,55 & 9,26 & 7,03 & 5,61 & 3,90 & 3,00 & 2,10 \\
\hline 90 & 250 & 200 & 36,29 & 17,71 & 12,29 & 8,75 & 6,82 & 5,56 & 3,94 & 3,05 & 2,11 \\
\hline 90 & 300 & 200 & 31,49 & 15,97 & 11,41 & 8,37 & 6,66 & 5,50 & 3,97 & 3,08 & 2,12 \\
\hline 90 & 350 & 200 & 28,02 & 14,69 & 10,74 & 8,07 & 6,53 & 5,45 & 3,99 & 3,11 & 2,13 \\
\hline 90 & 400 & 200 & 25,40 & 13,69 & 10,22 & 7,82 & 6,41 & 5,40 & 4,00 & 3,13 & 2,14 \\
\hline 90 & 450 & 200 & 23,33 & 12,90 & 9,79 & 7,62 & 6,31 & 5,36 & 4,00 & 3,14 & 2,15 \\
\hline 90 & 500 & 200 & 21,66 & 12,24 & 9,43 & 7,43 & 6,22 & 5,31 & 4,01 & 3,16 & 2,16 \\
\hline 90 & 550 & 200 & 20,29 & 11,69 & 9,12 & 7,28 & 6,13 & 5,27 & 4,00 & 3,17 & 2,17 \\
\hline 90 & 600 & 200 & 19,13 & 11,22 & 8,85 & 7,13 & 6,05 & 5,23 & 4,00 & 3,17 & 2,17 \\
\hline 90 & 650 & 200 & 18,14 & 10,81 & 8,61 & 7,00 & 5,98 & 5,19 & 4,00 & 3,18 & 2,18 \\
\hline 90 & 700 & 200 & 17,28 & 10,44 & 8,40 & 6,89 & 5,91 & 5,15 & 3,99 & 3,19 & 2,19 \\
\hline 90 & 750 & 200 & 16,53 & 10,12 & 8,20 & 6,78 & 5,84 & 5,11 & 3,98 & 3,19 & 2,19 \\
\hline 90 & 800 & 200 & 15,87 & 9,83 & 8,03 & 6,68 & 5,78 & 5,07 & 3,97 & 3,19 & 2,20 \\
\hline 90 & 850 & 200 & 15,29 & 9,57 & 7,87 & 6,58 & 5,72 & 5,04 & 3,97 & 3,20 & 2,21 \\
\hline 90 & 900 & 200 & 14,76 & 9,33 & 7,72 & 6,50 & 5,67 & 5,00 & 3,96 & 3,20 & 2,21 \\
\hline 90 & 950 & 200 & 14,29 & 9,11 & 7,59 & 6,41 & 5,62 & 4,97 & 3,95 & 3,20 & 2,22 \\
\hline 90 & 1000 & 200 & 13,86 & 8,91 & 7,46 & 6,34 & 5,57 & 4,94 & 3,94 & 3,20 & 2,22 \\
\hline 90 & 1050 & 200 & 13,47 & 8,73 & 7,34 & 6,26 & 5,52 & 4,91 & 3,93 & 3,20 & 2,23 \\
\hline 90 & 1100 & 200 & 13,11 & 8,55 & 7,23 & 6,19 & 5,47 & 4,88 & 3,92 & 3,20 & 2,23 \\
\hline 90 & 1150 & 200 & 12,78 & 8,39 & 7,13 & 6,13 & 5,43 & 4,85 & 3,91 & 3,19 & 2,24 \\
\hline 90 & 1200 & 200 & 12,47 & 8,24 & 7,03 & 6,06 & 5,38 & 4,82 & 3,89 & 3,19 & 2,24 \\
\hline 90 & 1250 & 200 & 12,19 & 8,10 & 6,94 & 6,00 & 5,34 & 4,79 & 3,88 & 3,19 & 2,24 \\
\hline 90 & 1300 & 200 & 11,93 & 7,97 & 6,85 & 5,95 & 5,30 & 4,76 & 3,87 & 3,19 & 2,25 \\
\hline 90 & 1350 & 200 & 11,69 & 7,85 & 6,77 & 5,89 & 5,26 & 4,74 & 3,86 & 3,19 & 2,25 \\
\hline 90 & 1400 & 200 & 11,46 & 7,73 & 6,69 & 5,84 & 5,23 & 4,71 & 3,85 & 3,18 & 2,25 \\
\hline 90 & 1450 & 200 & 11,24 & 7,62 & 6,61 & 5,79 & 5,19 & 4,69 & 3,84 & 3,18 & 2,26 \\
\hline 90 & 1500 & 200 & 11,04 & 7,51 & 6,54 & 5,74 & 5,16 & 4,66 & 3,83 & 3,18 & 2,26 \\
\hline 90 & 1550 & 200 & 10,85 & 7,41 & 6,47 & 5,69 & 5,12 & 4,64 & 3,82 & 3,17 & 2,26 \\
\hline 90 & 1600 & 200 & 10,67 & 7,31 & 6,40 & 5,65 & 5,09 & 4,61 & 3,81 & 3,17 & 2,26 \\
\hline 90 & 1650 & 200 & 10,50 & 7,22 & 6,34 & 5,60 & 5,06 & 4,59 & 3,80 & 3,17 & 2,26 \\
\hline 90 & 1700 & 200 & 10,34 & 7,14 & 6,28 & 5,56 & 5,03 & 4,57 & 3,79 & 3,16 & 2,27 \\
\hline 90 & 1750 & 200 & 10,19 & 7,05 & 6,22 & 5,52 & 5,00 & 4,55 & 3,78 & 3,16 & 2,27 \\
\hline 90 & 1800 & 200 & 10,05 & 6,97 & 6,16 & 5,48 & 4,97 & 4,53 & 3,77 & 3,16 & 2,27 \\
\hline 90 & 1850 & 200 & 9,91 & 6,90 & 6,11 & 5,44 & 4,94 & 4,51 & 3,76 & 3,15 & 2,27 \\
\hline 90 & 1900 & 200 & 9,78 & 6,82 & 6,05 & 5,41 & 4,91 & 4,48 & 3,75 & 3,15 & 2,27 \\
\hline 90 & 1950 & 200 & 9,65 & 6,75 & 6,00 & 5,37 & 4,89 & 4,46 & 3,74 & 3,14 & 2,27 \\
\hline 90 & 2000 & 200 & 9,53 & 6,69 & 5,95 & 5,33 & 4,86 & 4,44 & 3,73 & 3,14 & 2,28 \\
\hline
\end{tabular}


ANEXO C - Coordenadas $\left(R_{c}, D_{c}\right)$ do Ponto Inerte obtidas com o conjunto de bacias deflectométricas do Anexo $A$. 


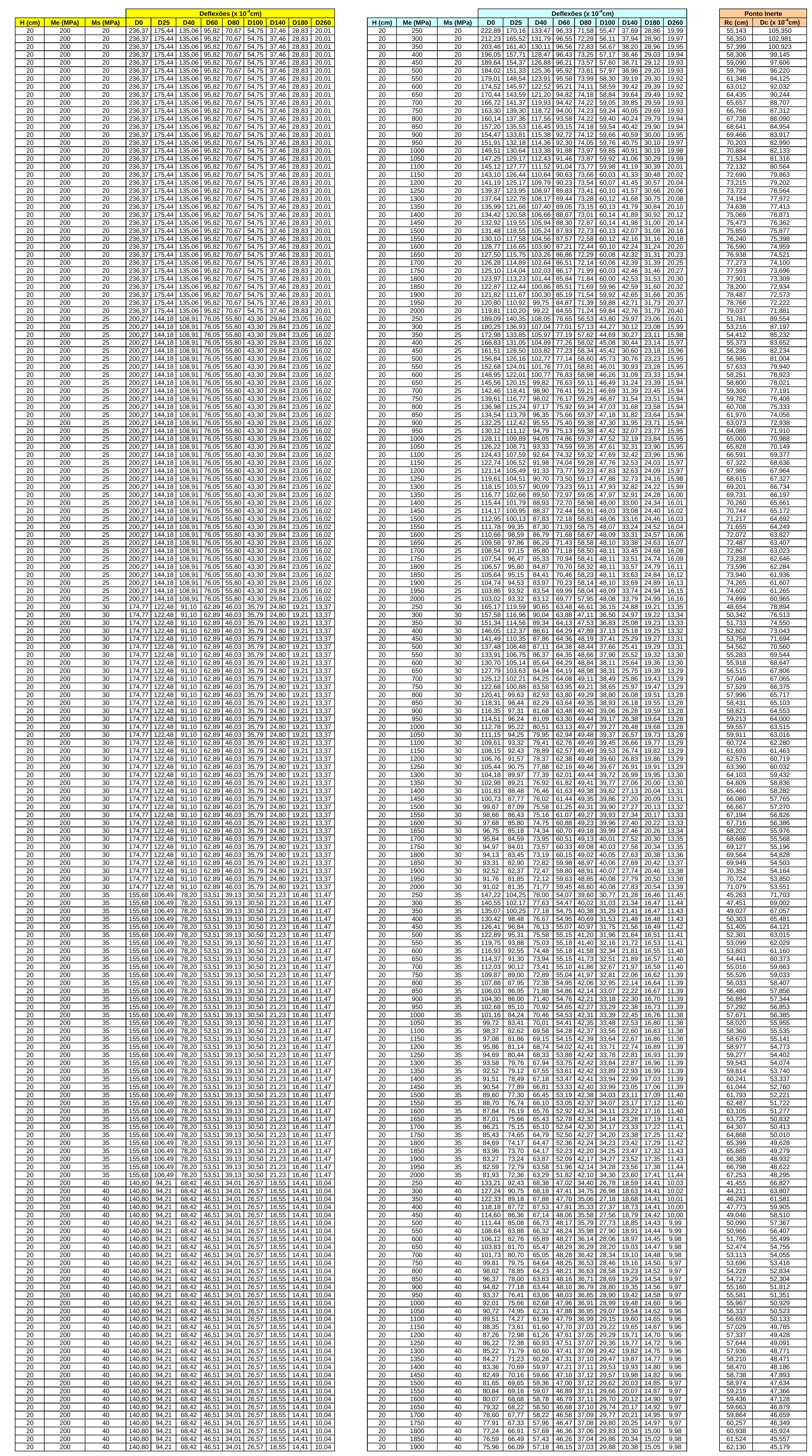




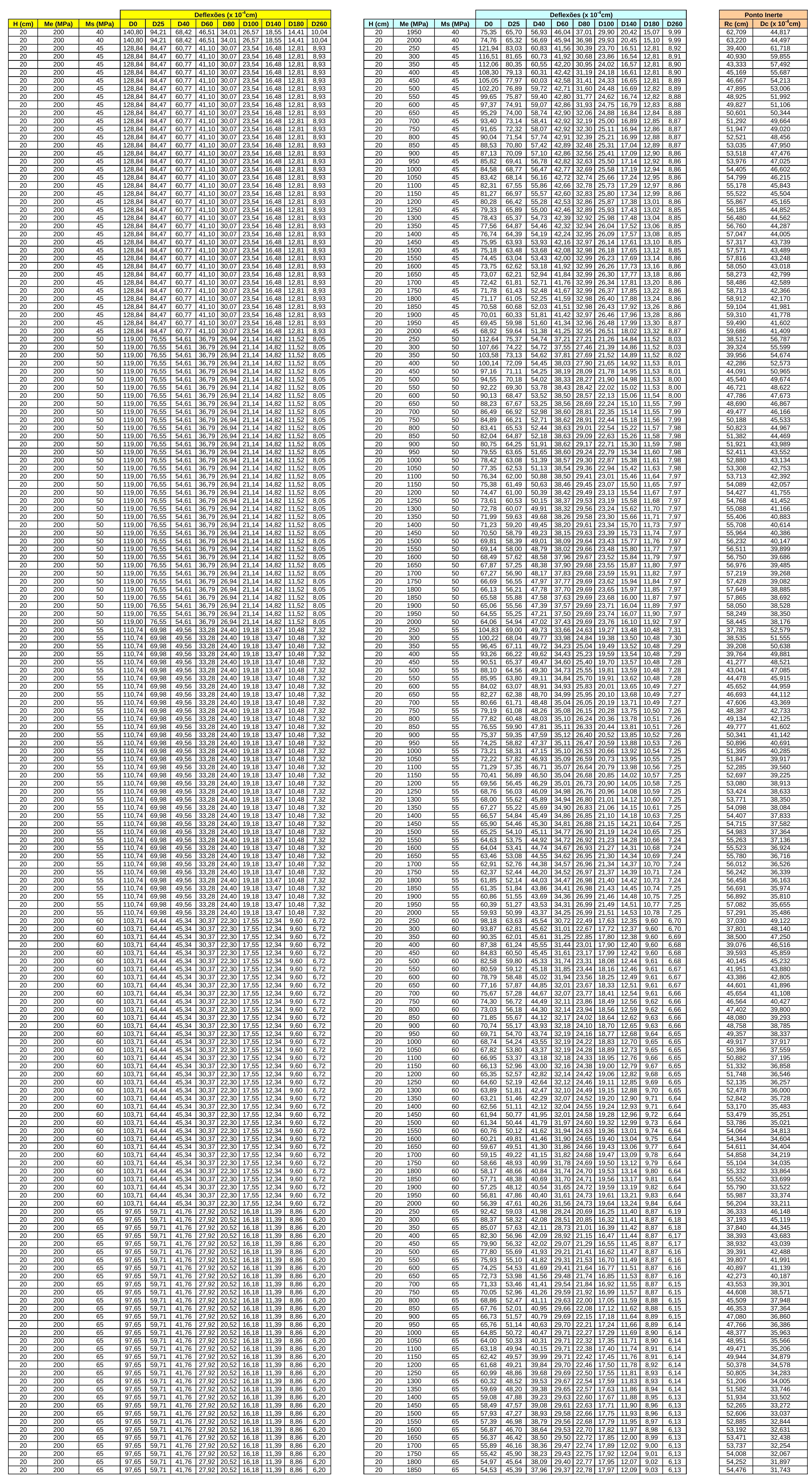




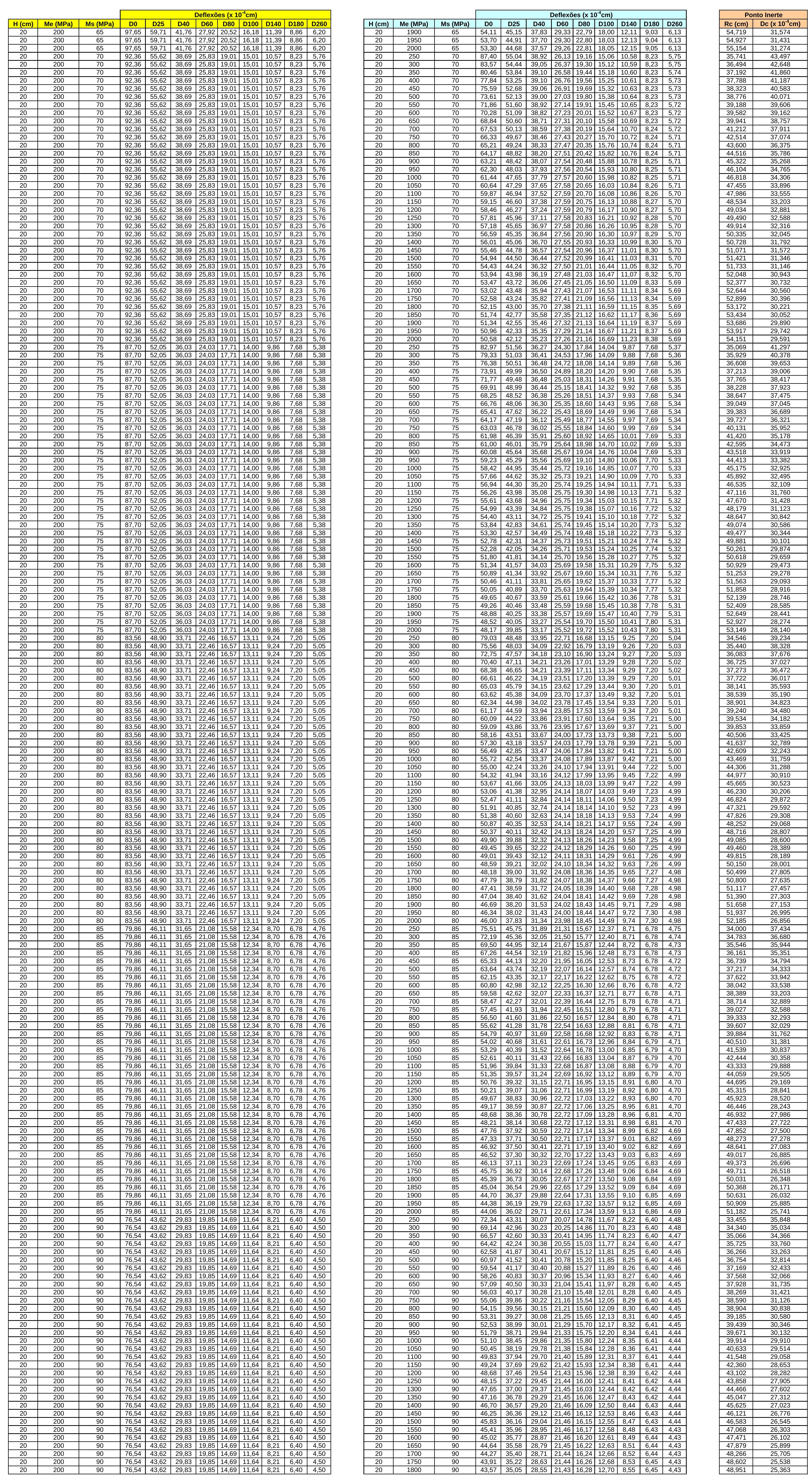




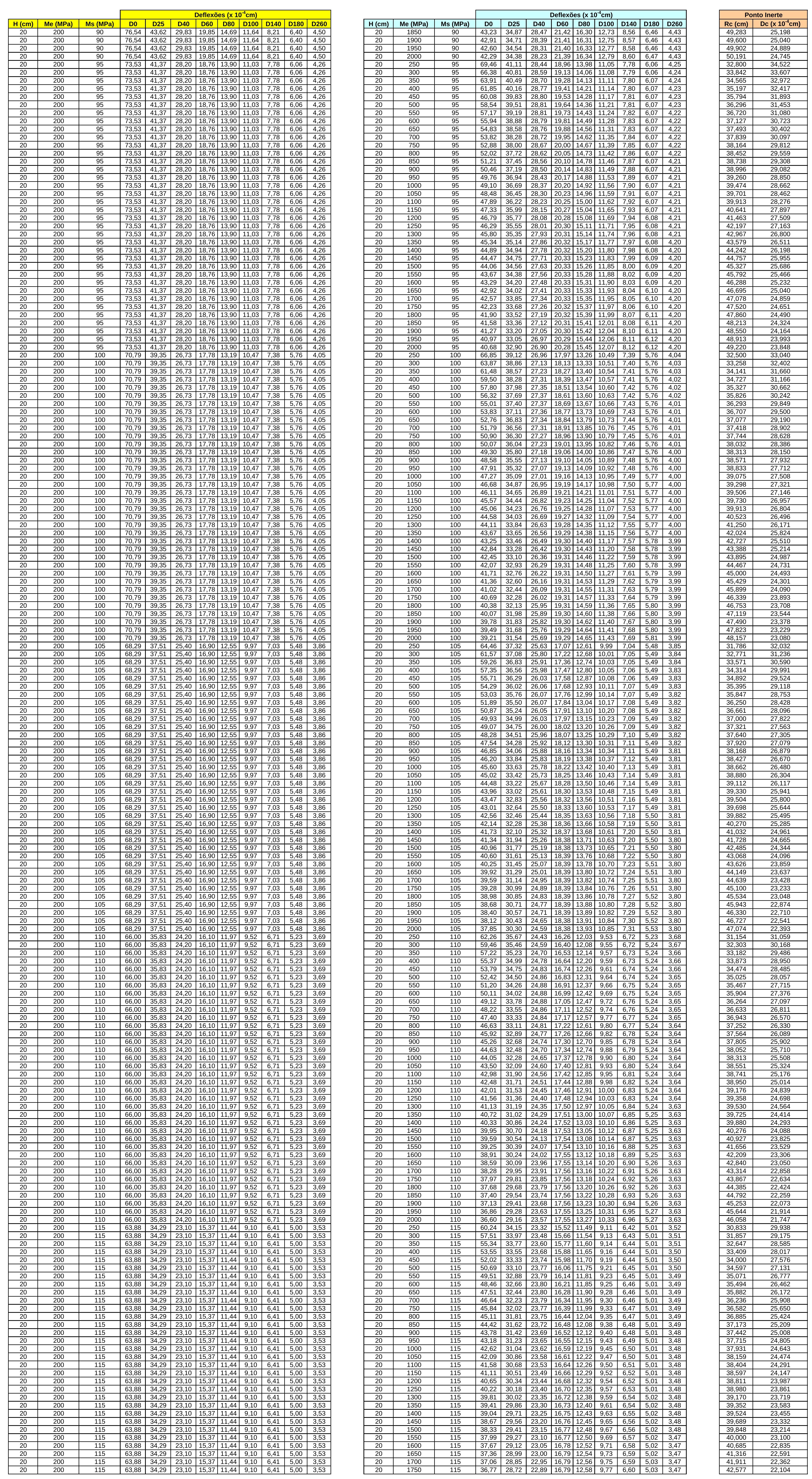




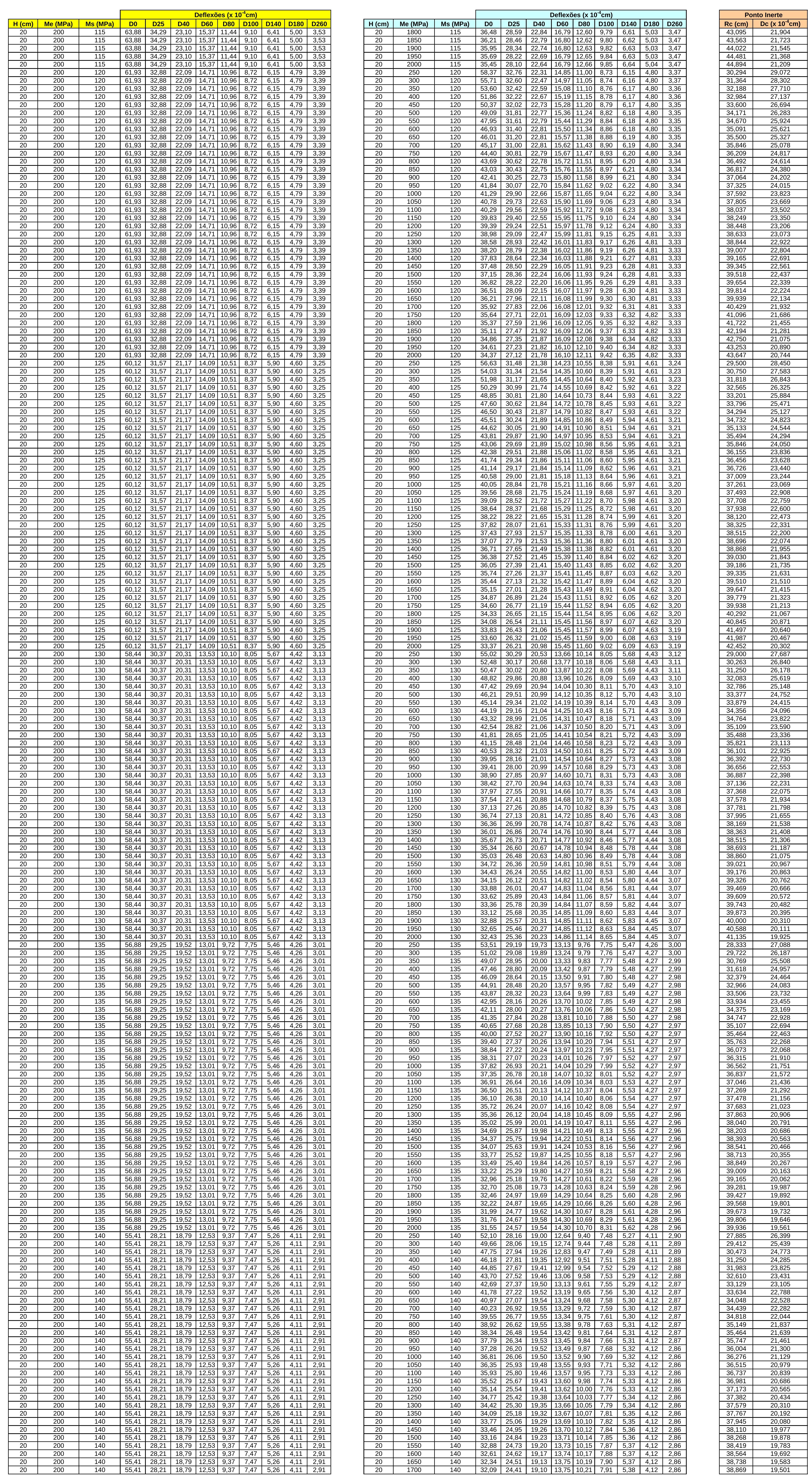




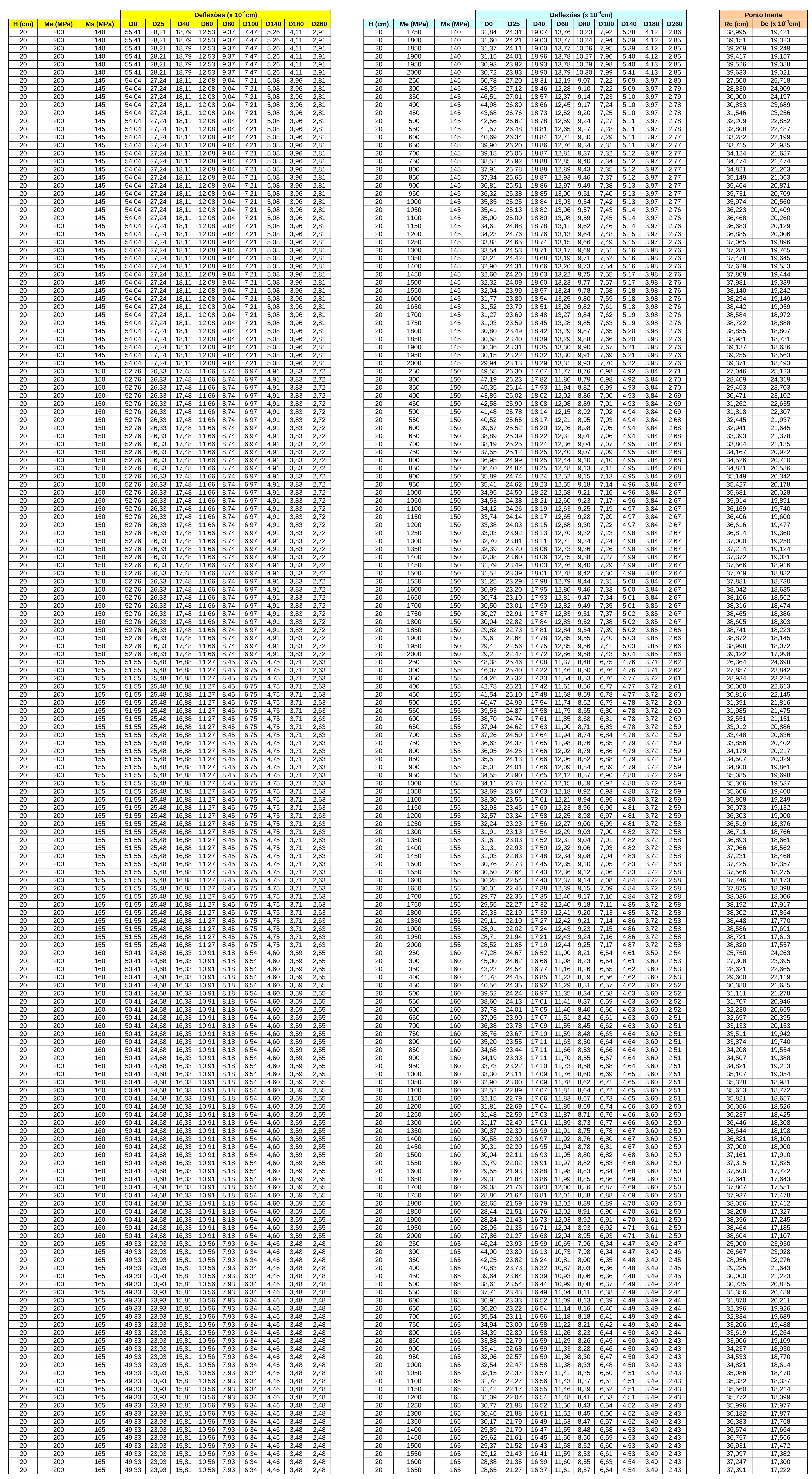




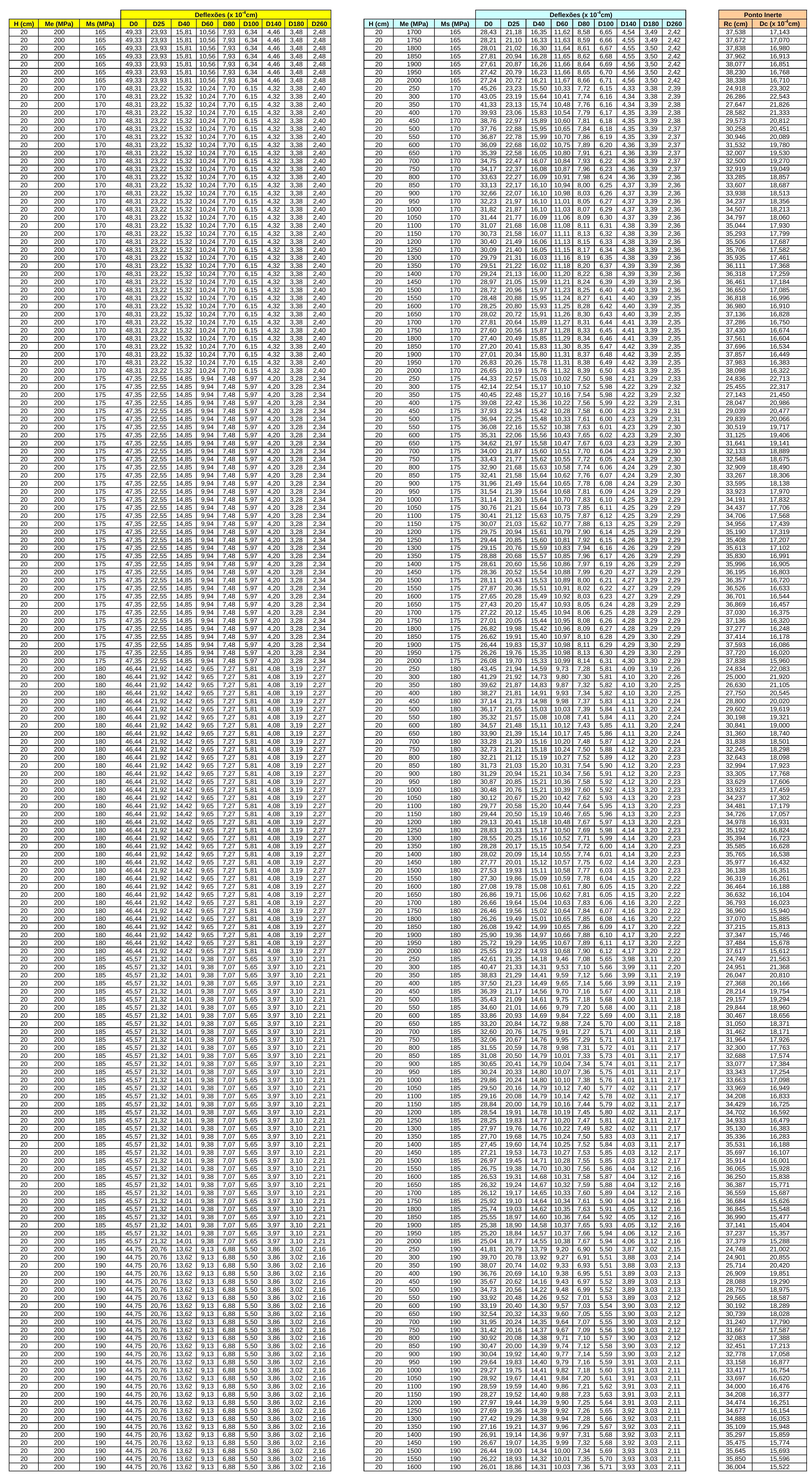




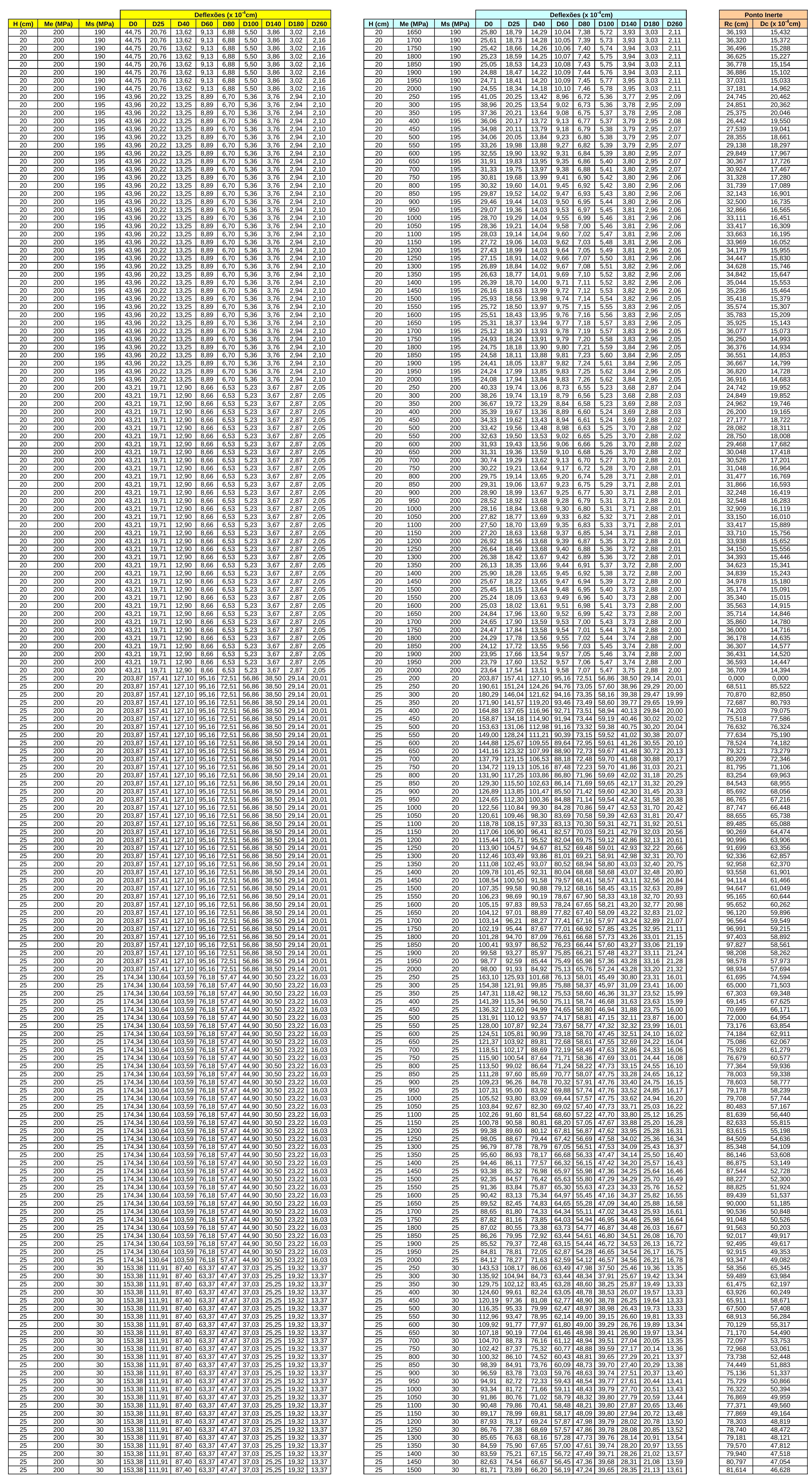




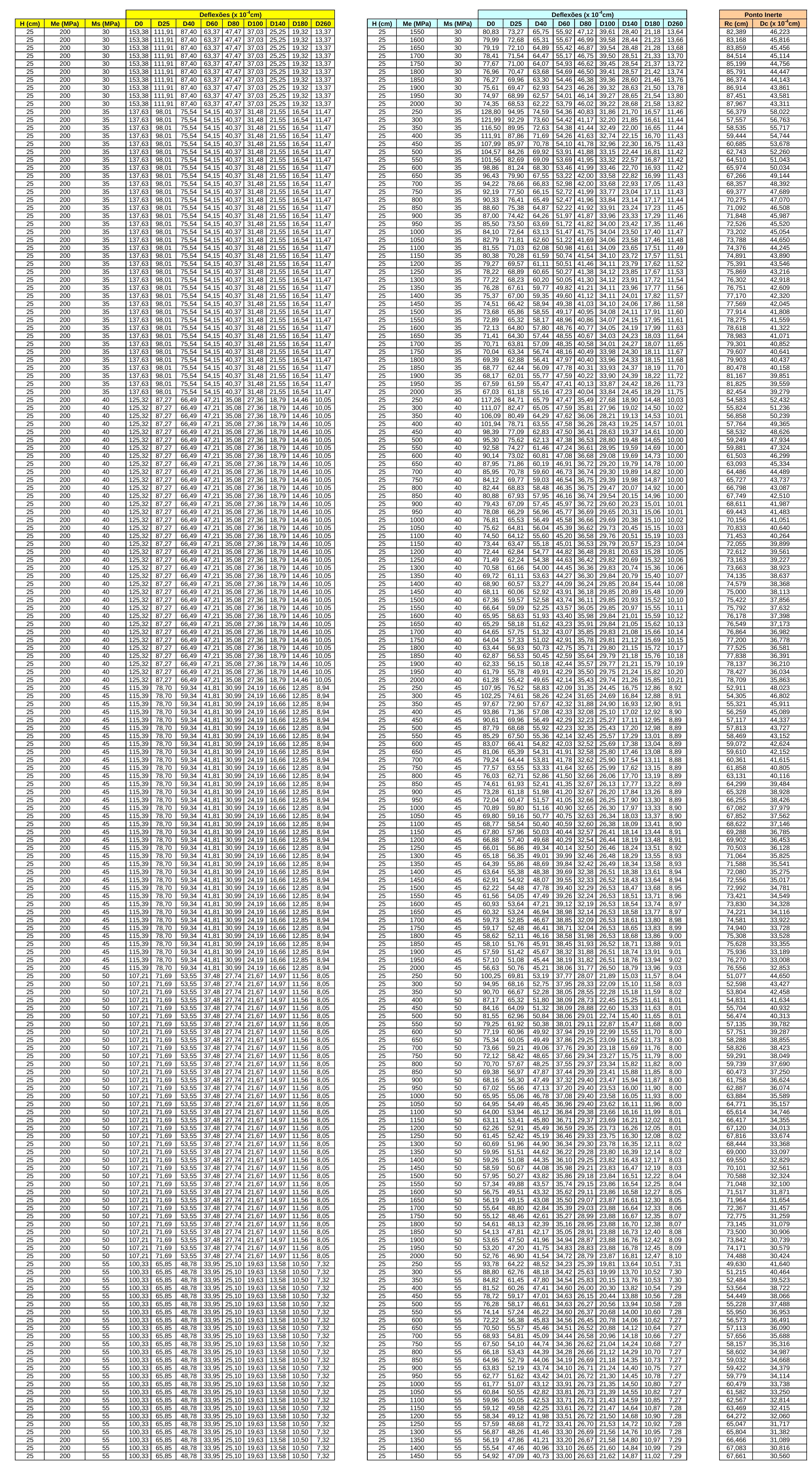




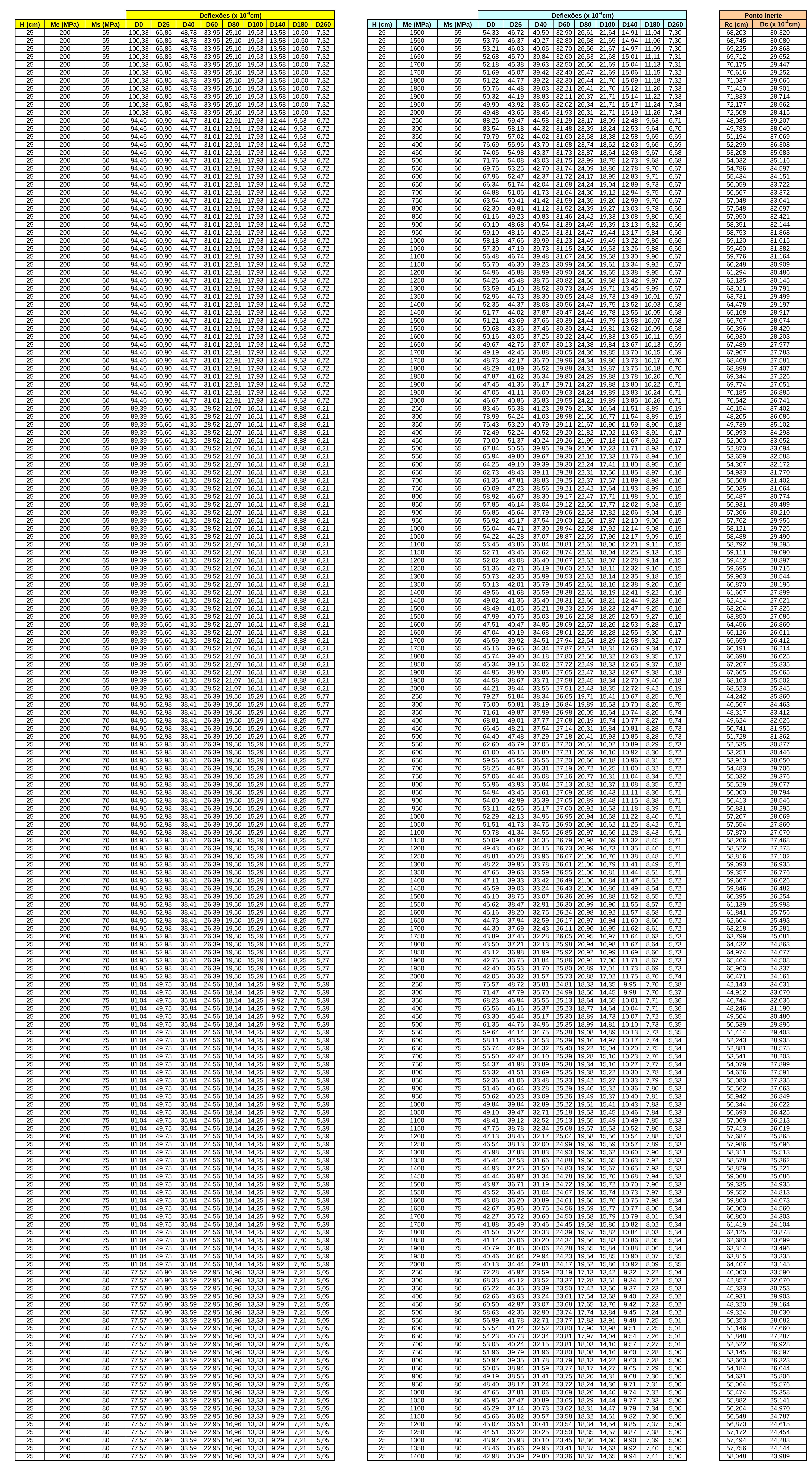




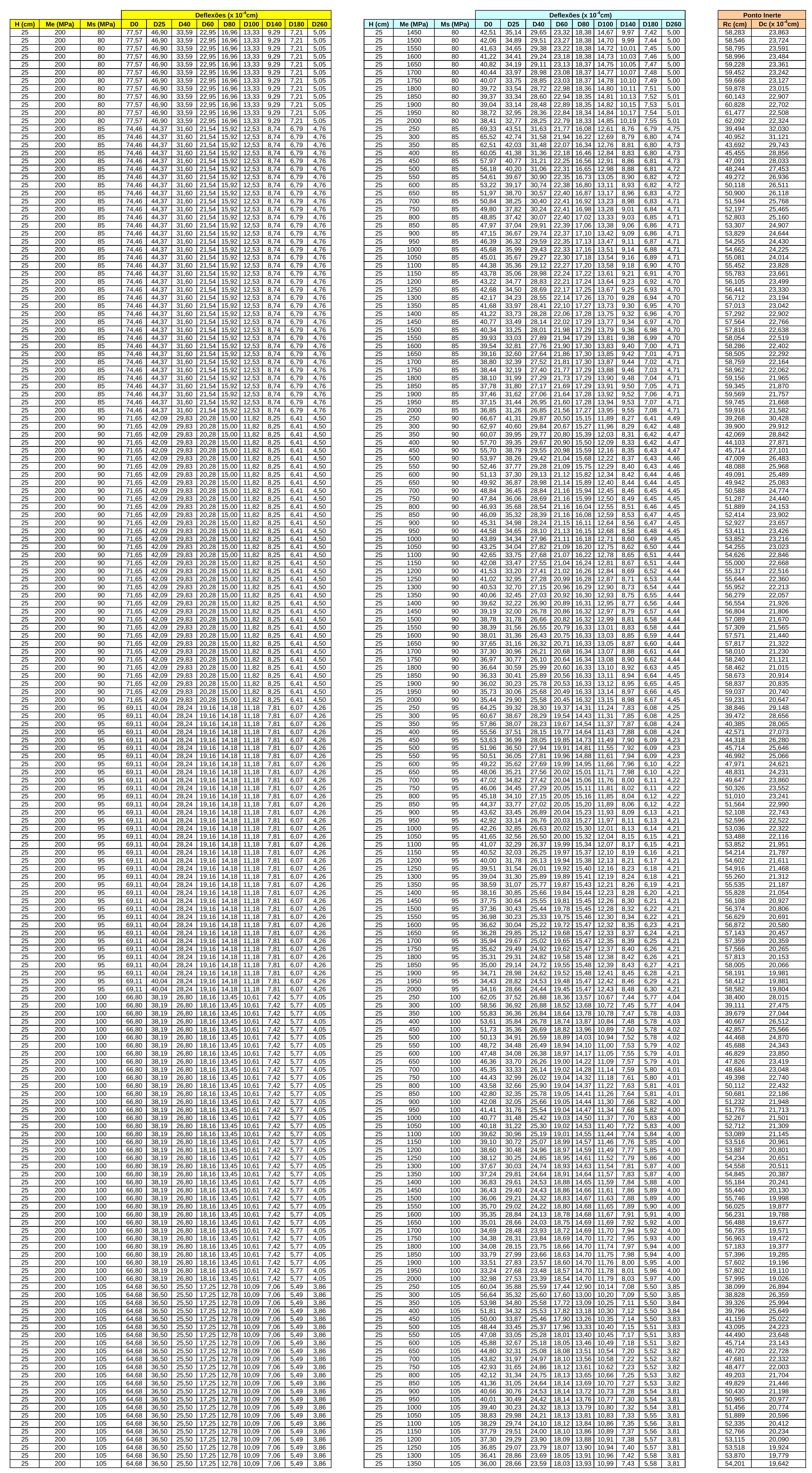




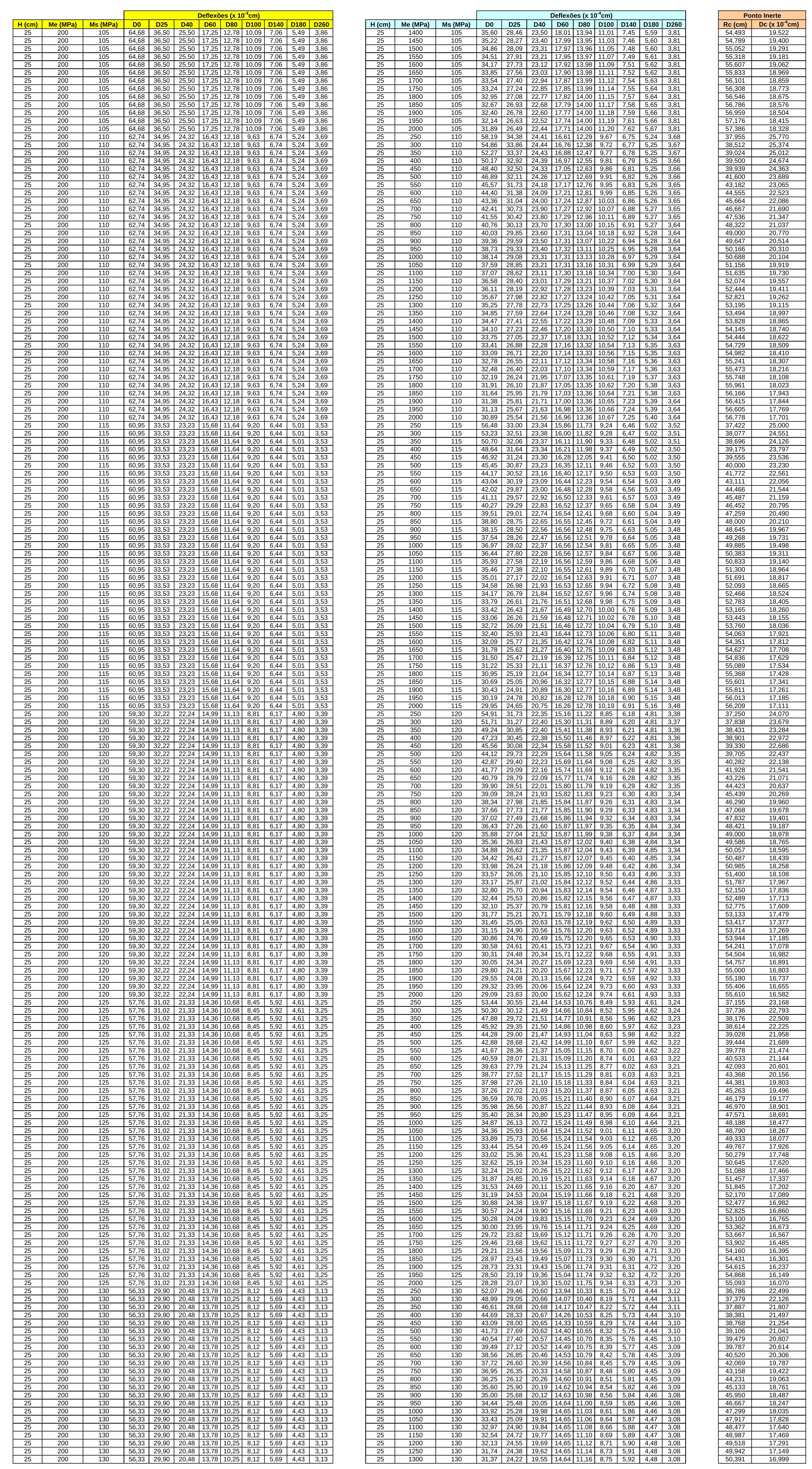




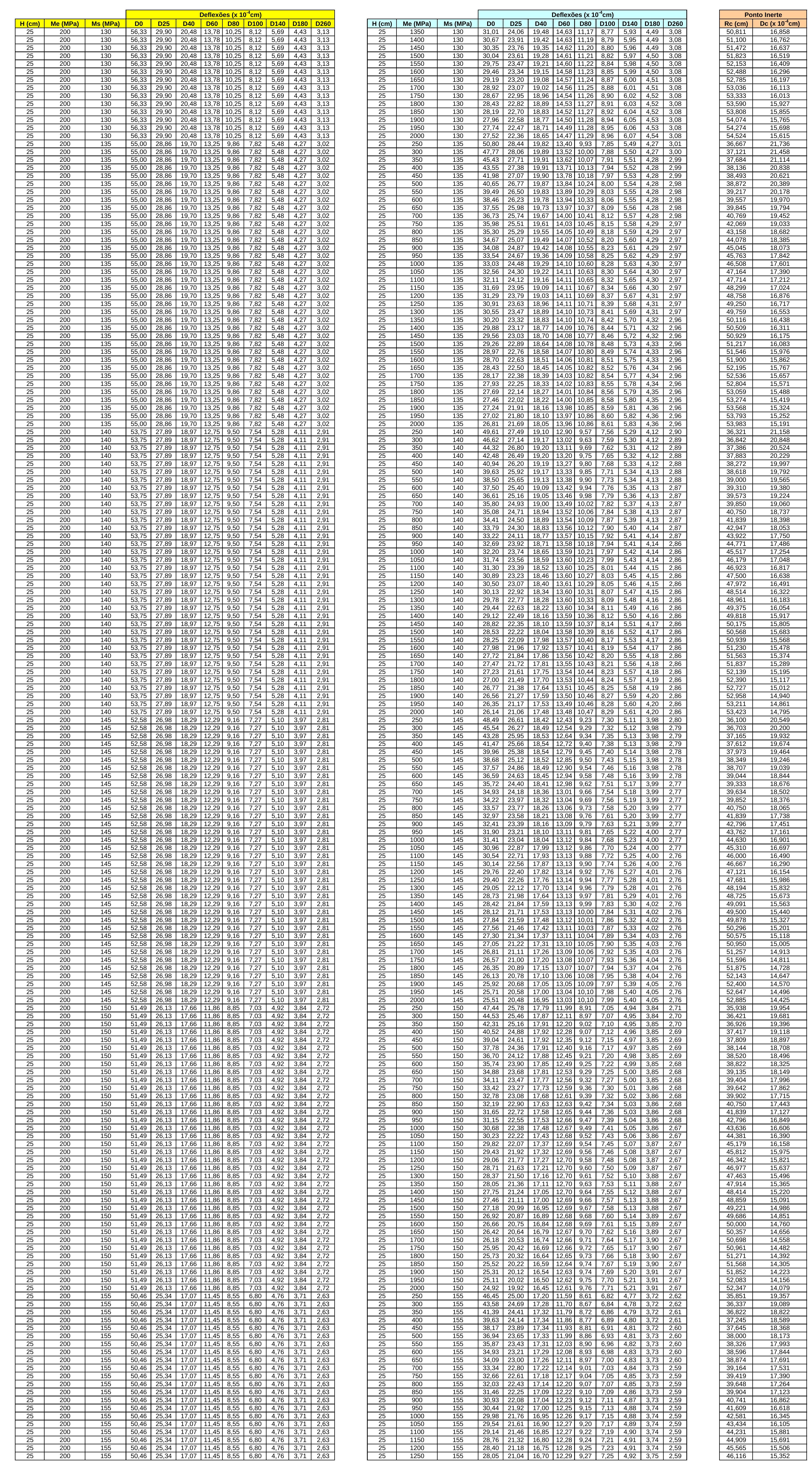




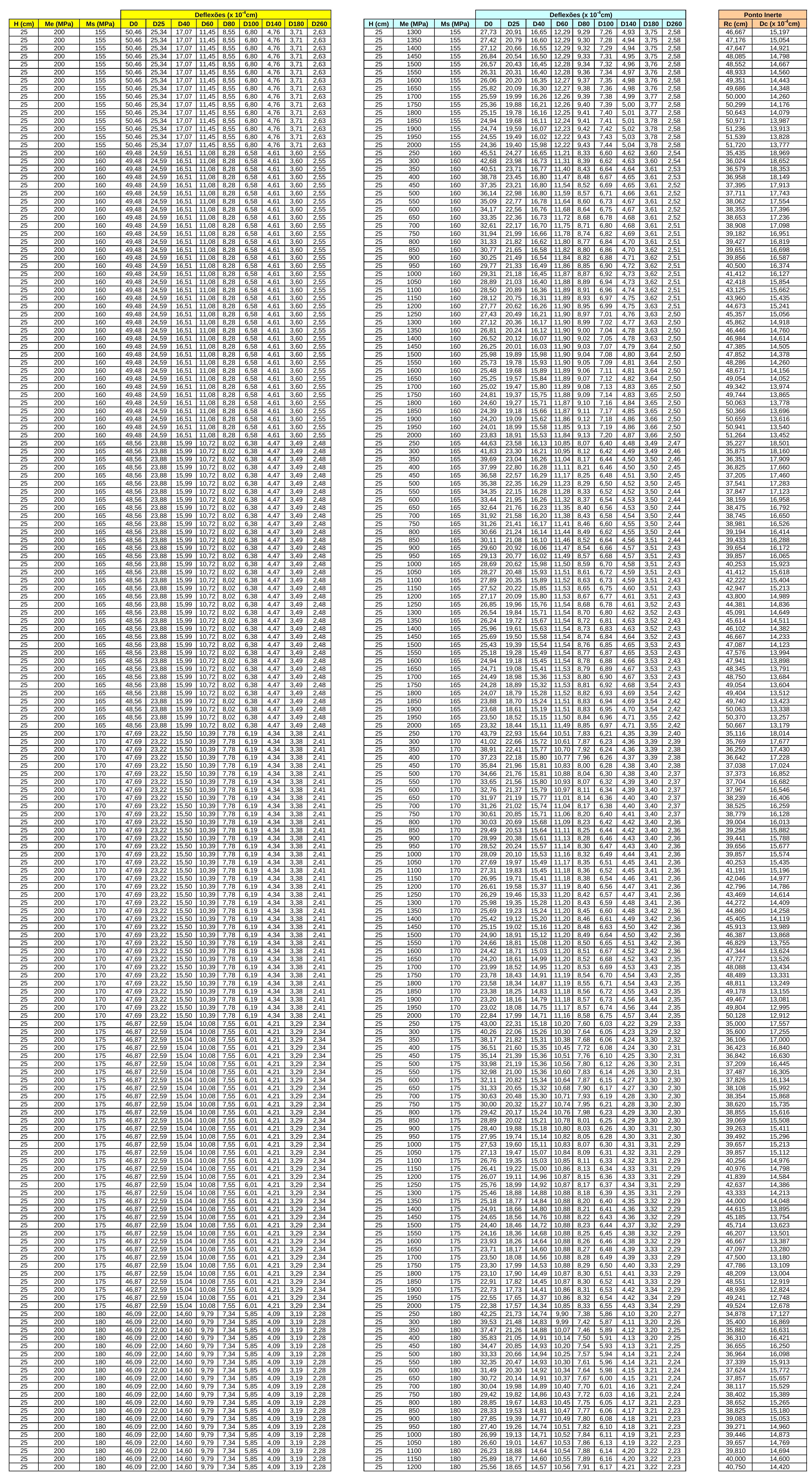




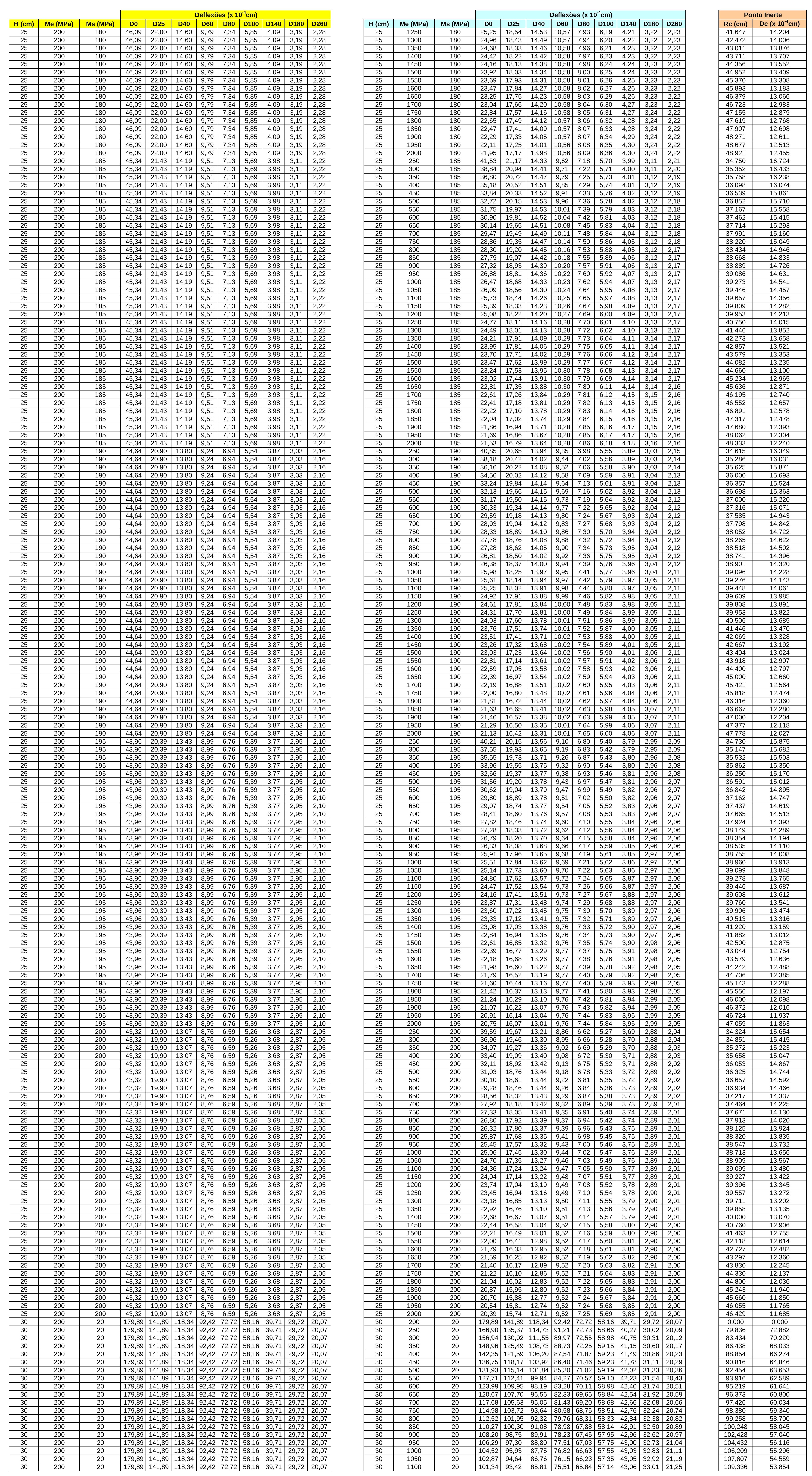




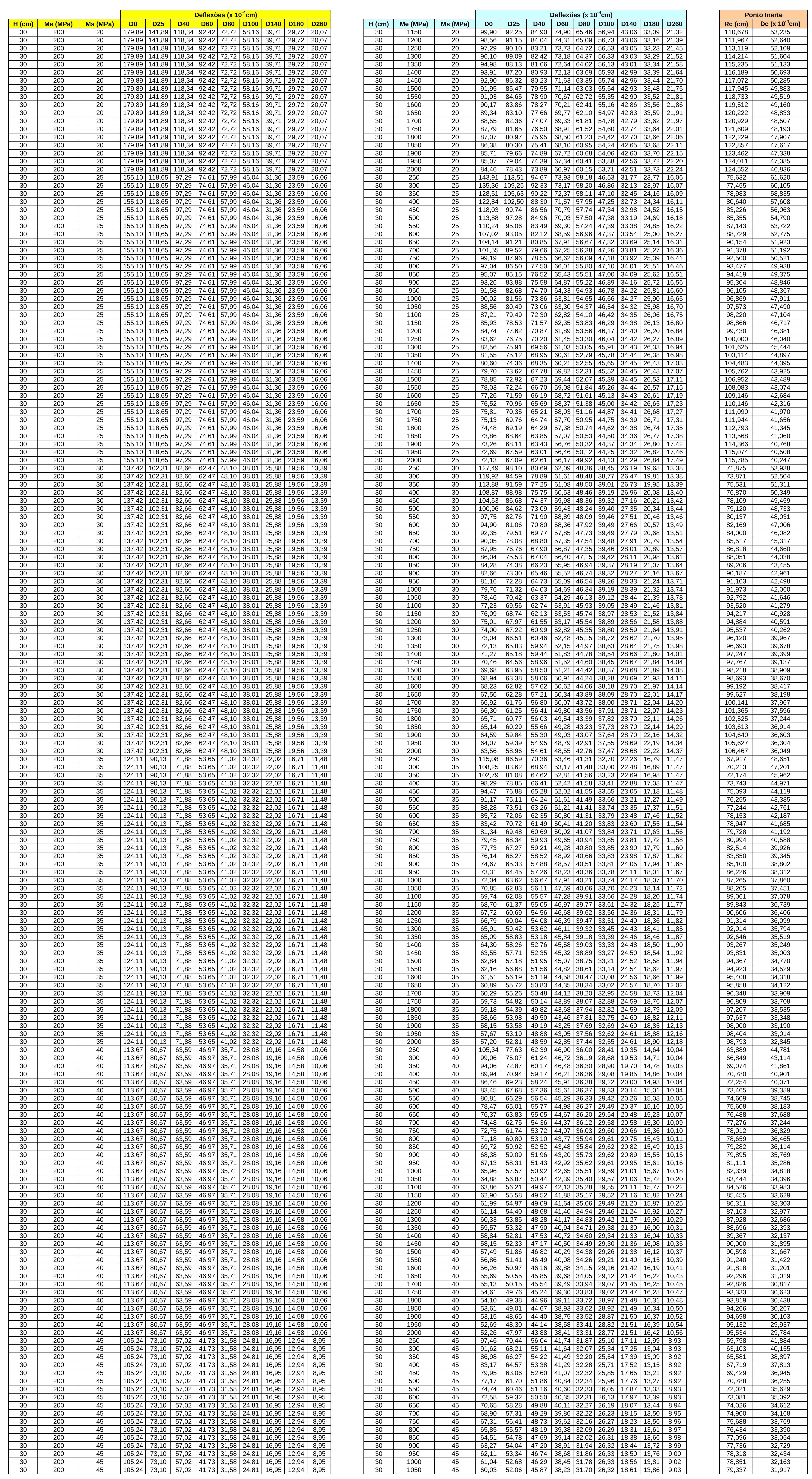




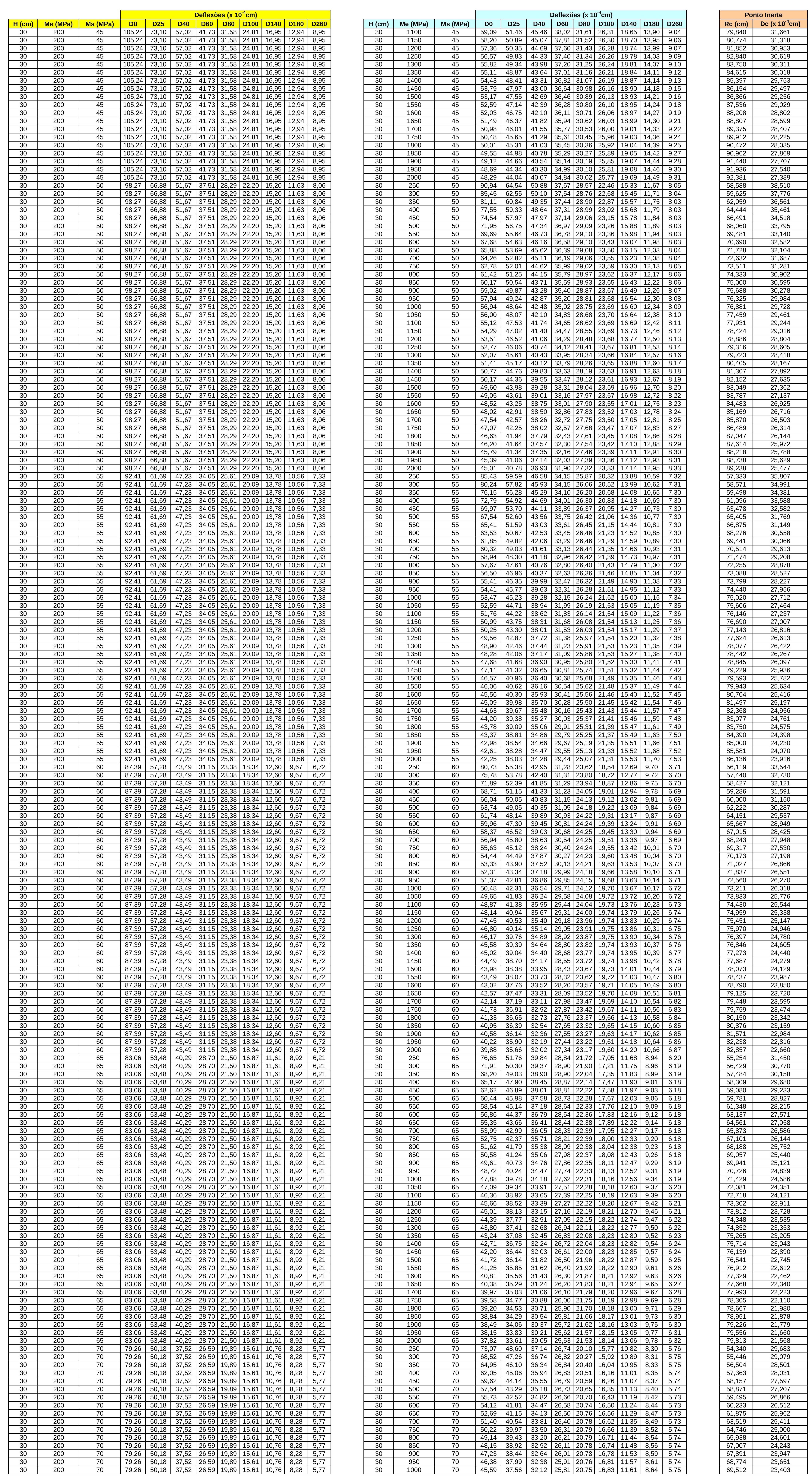




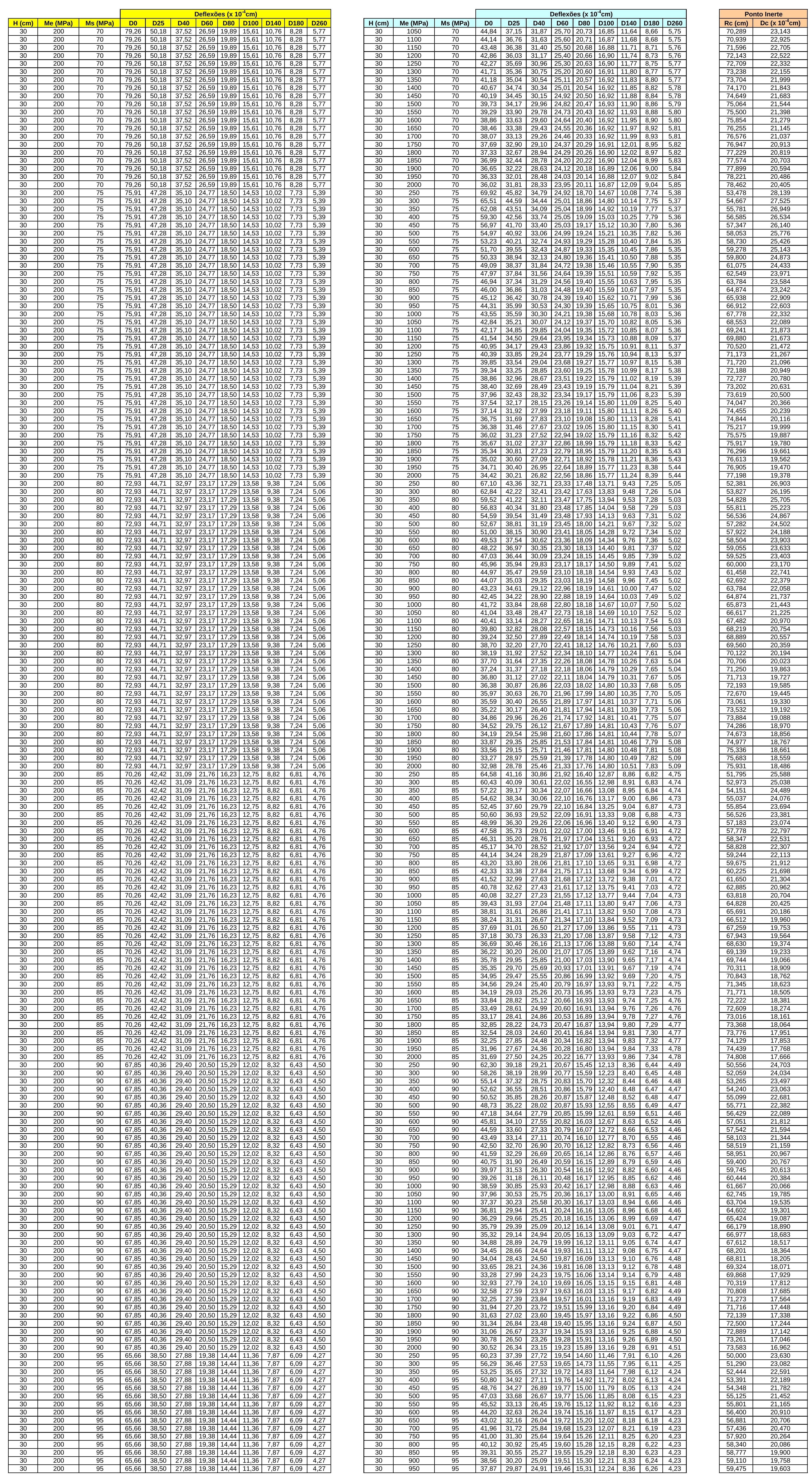




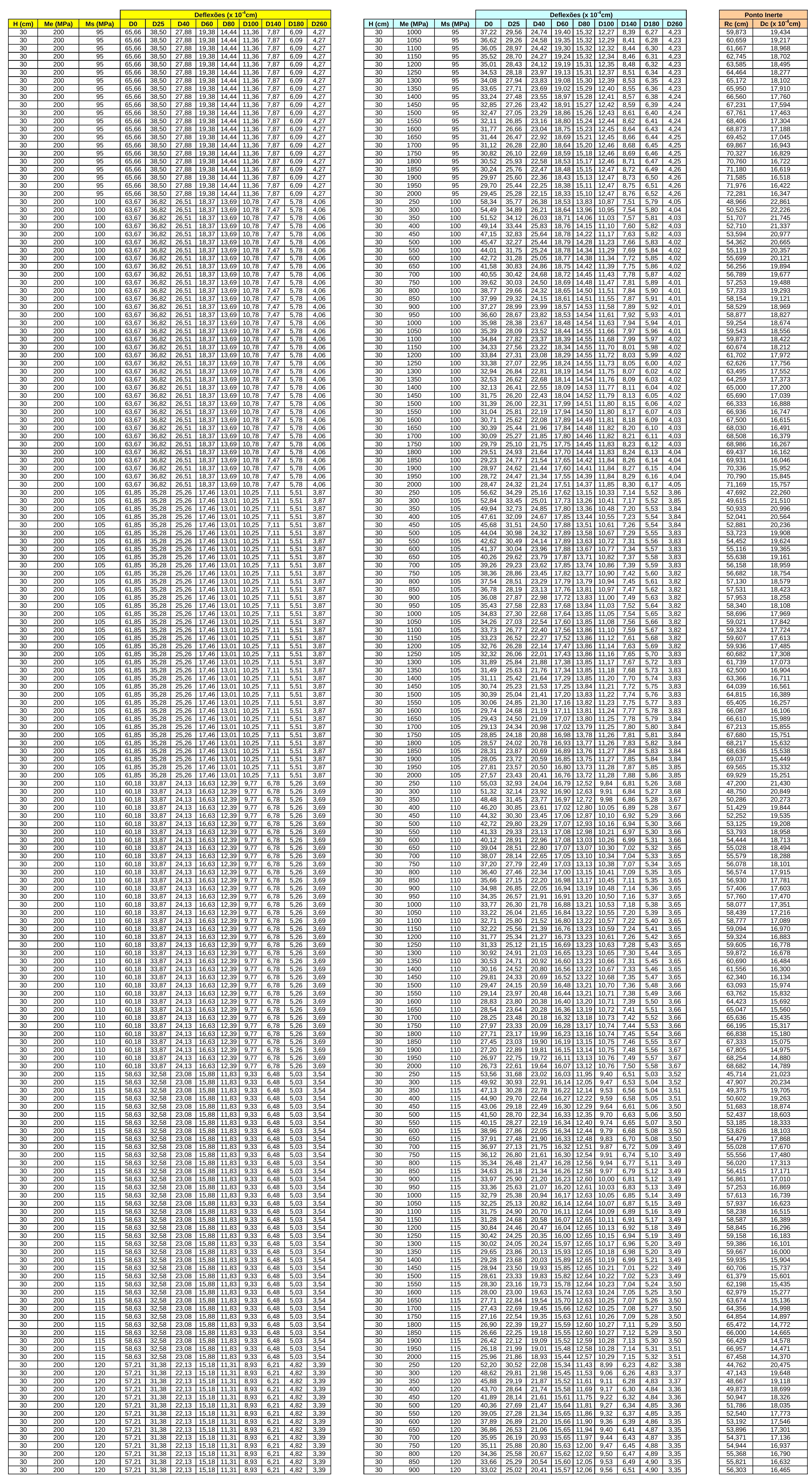




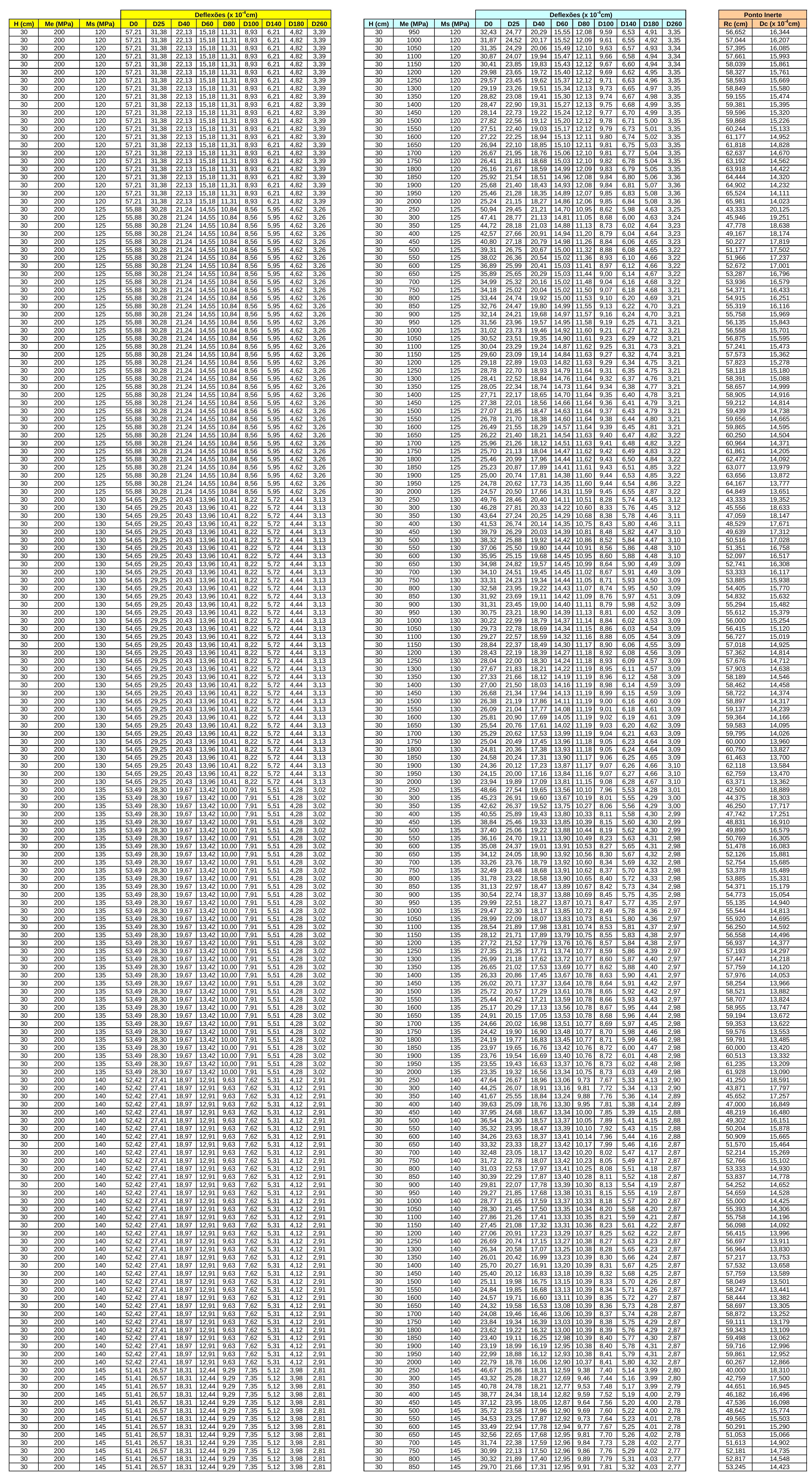




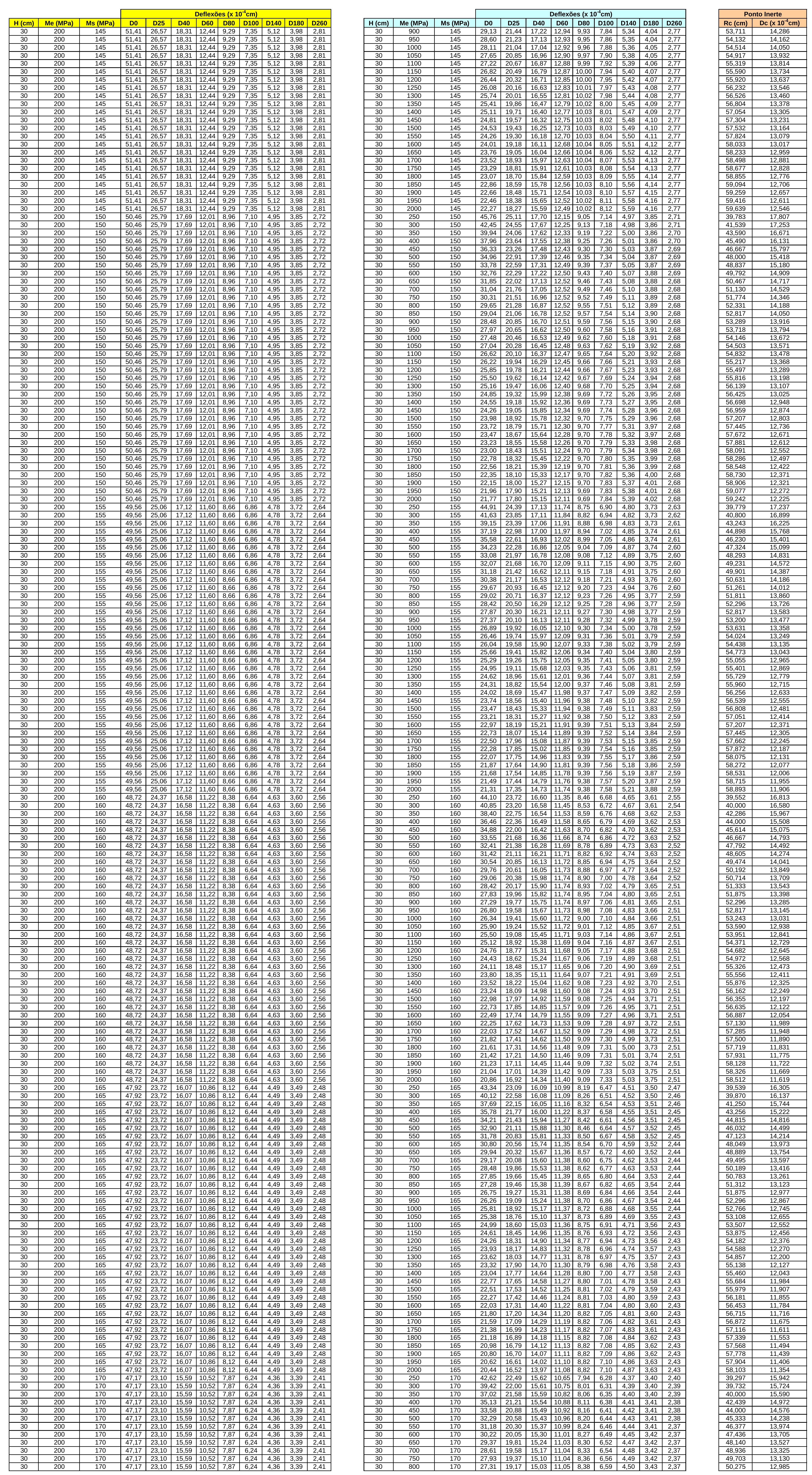




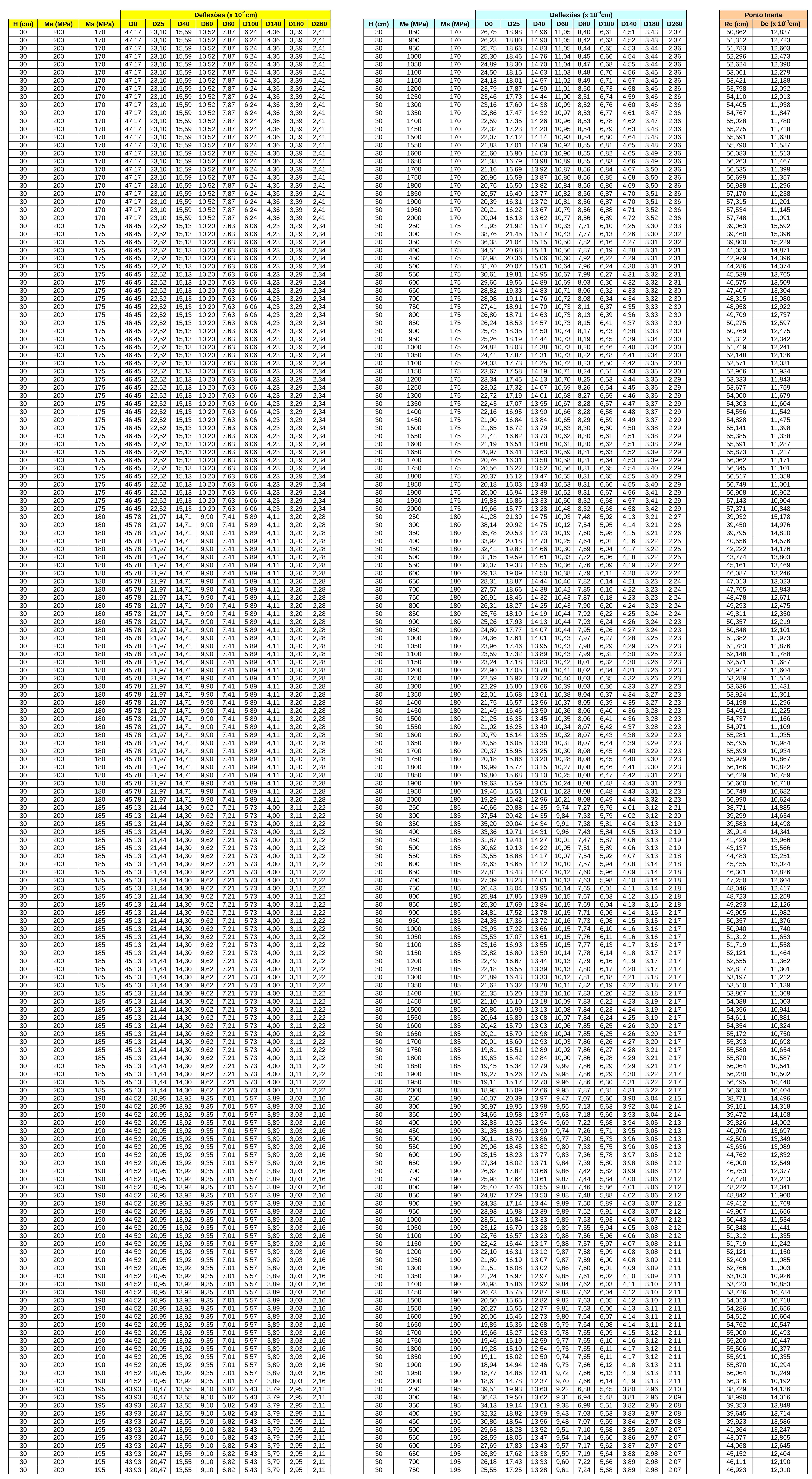




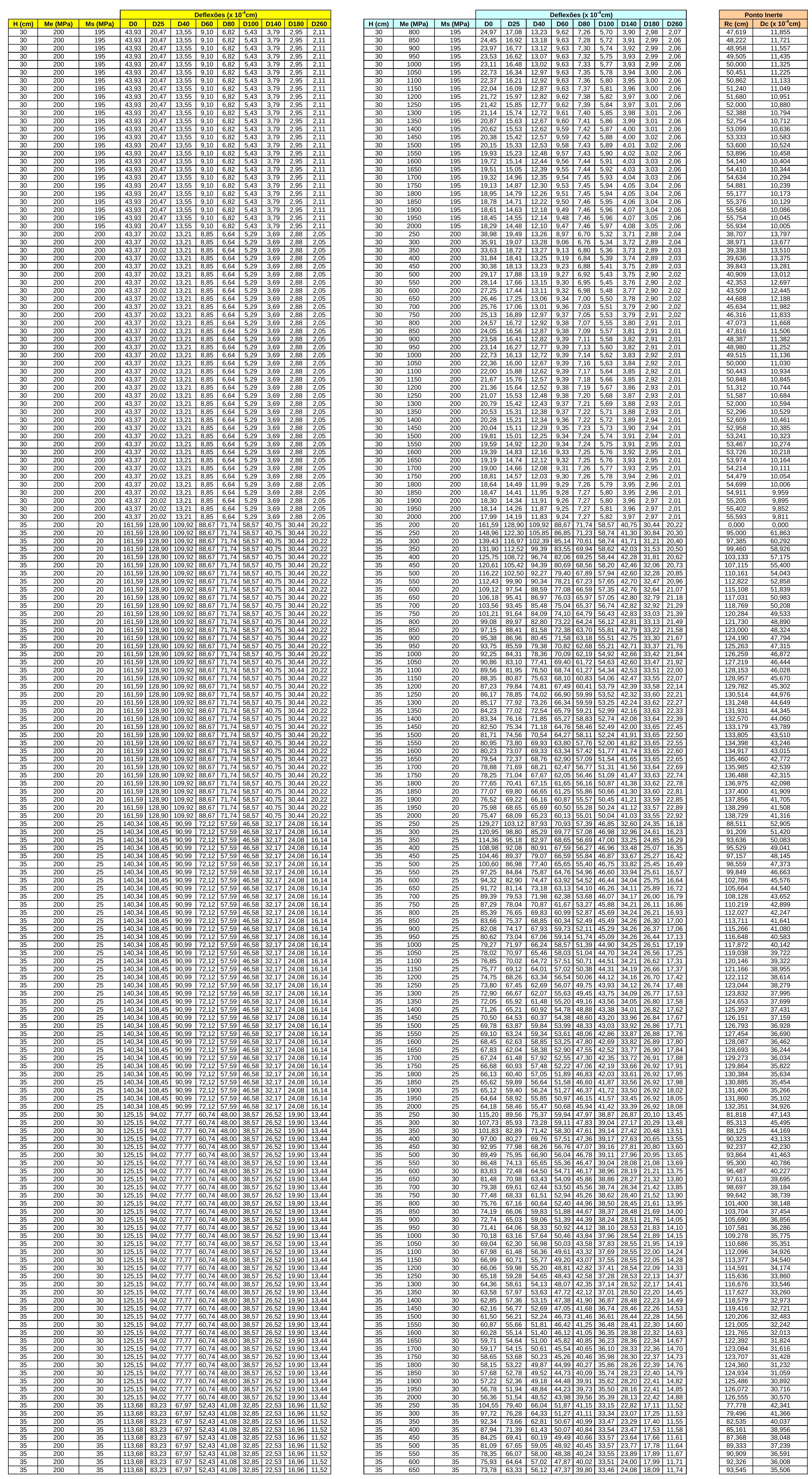




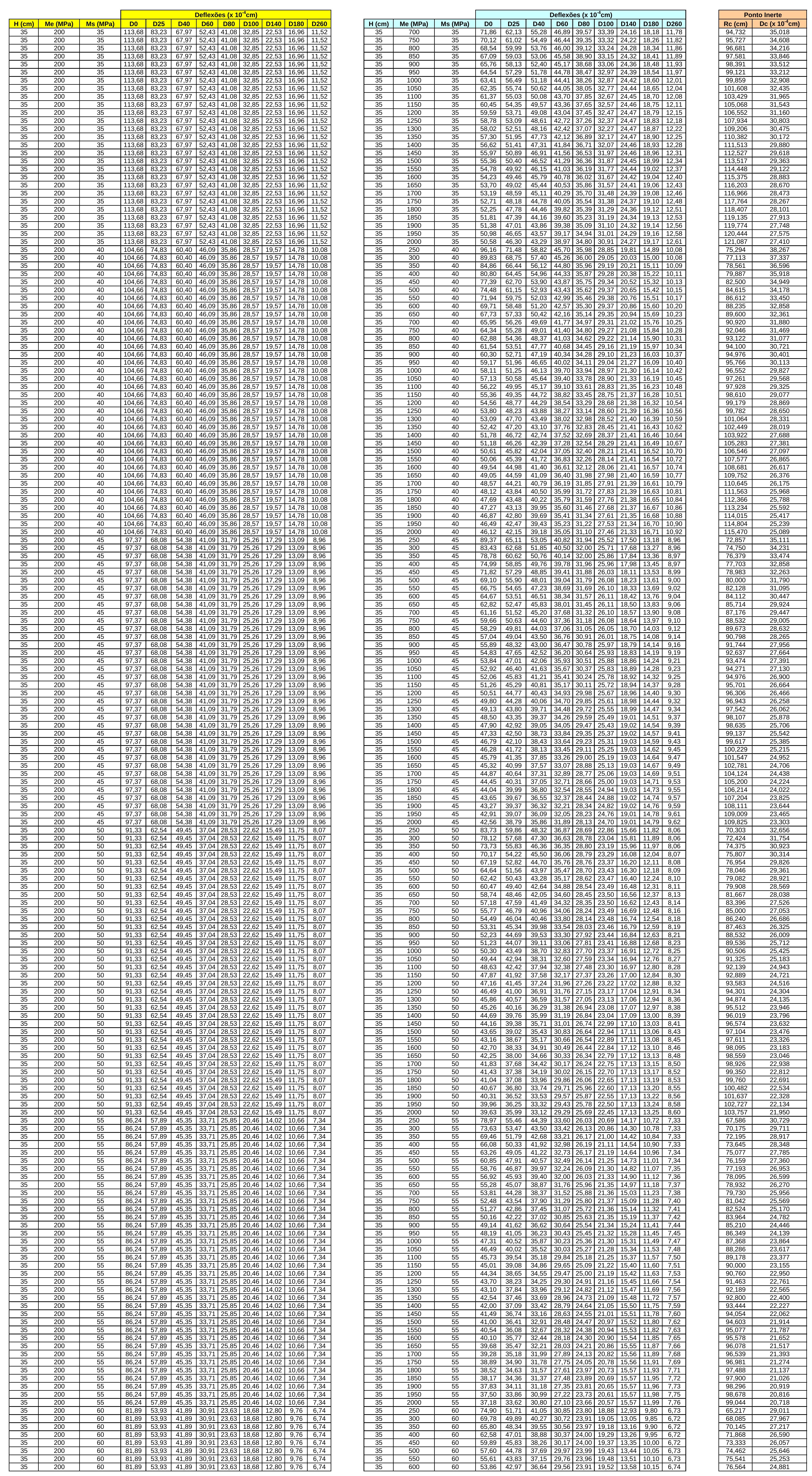




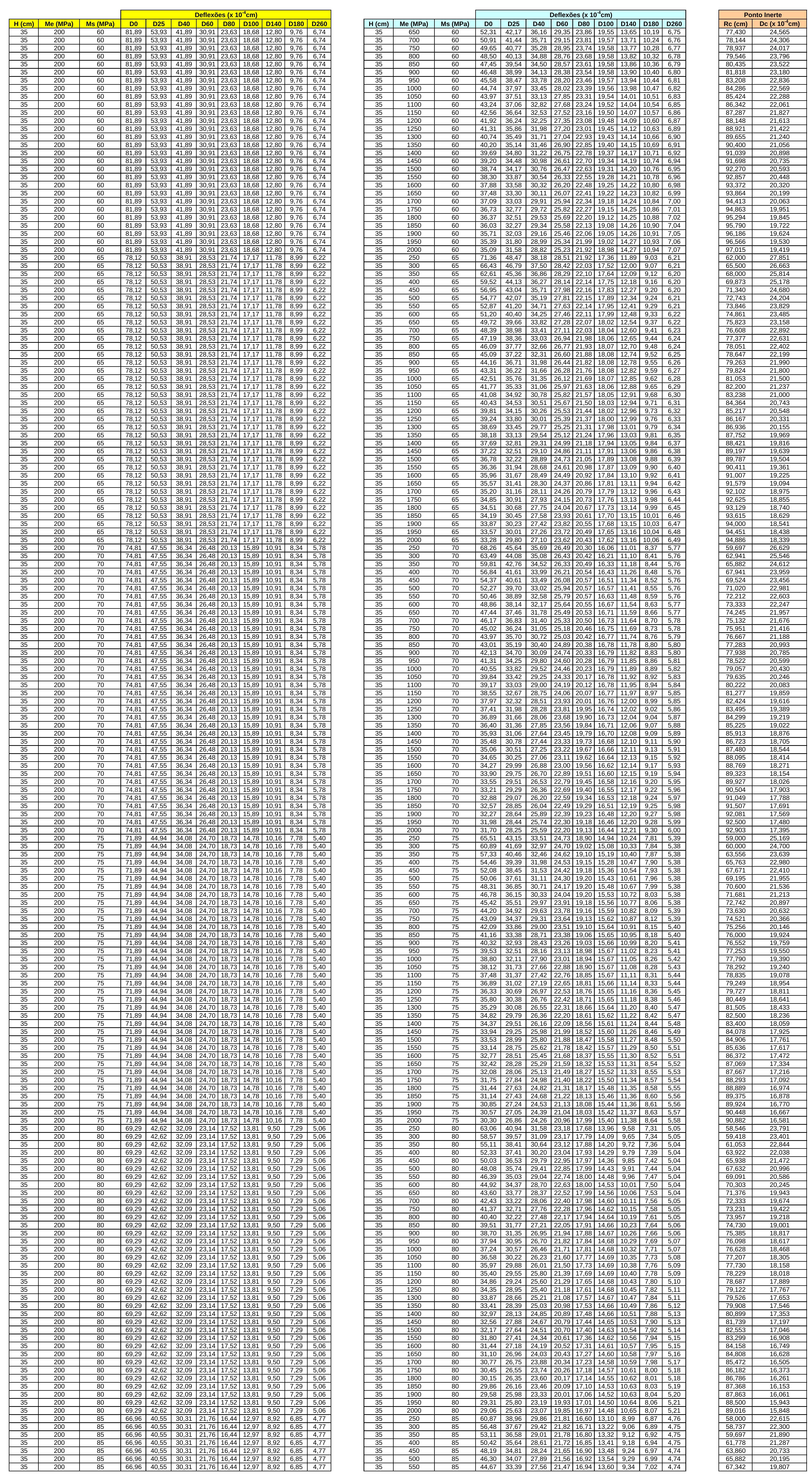




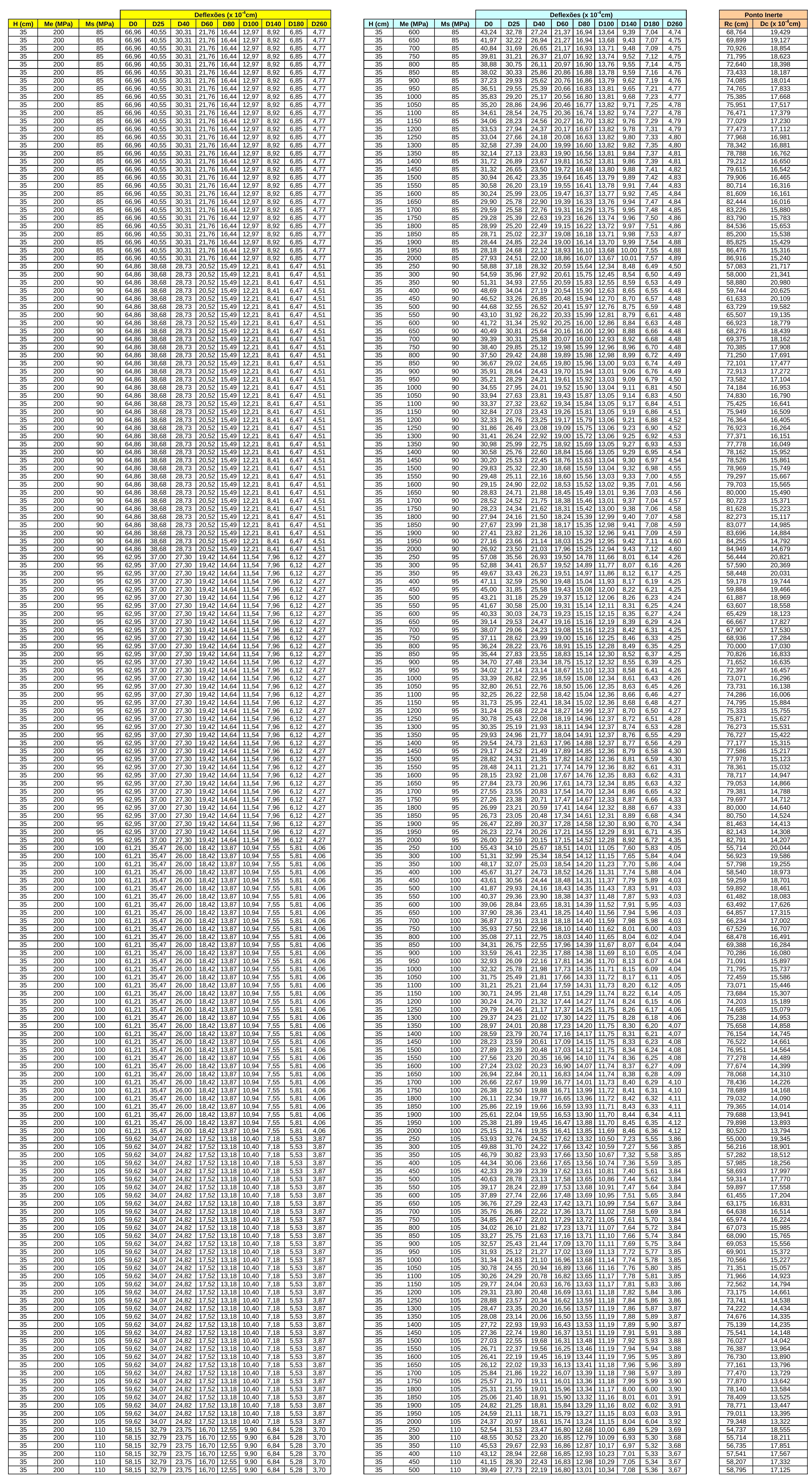




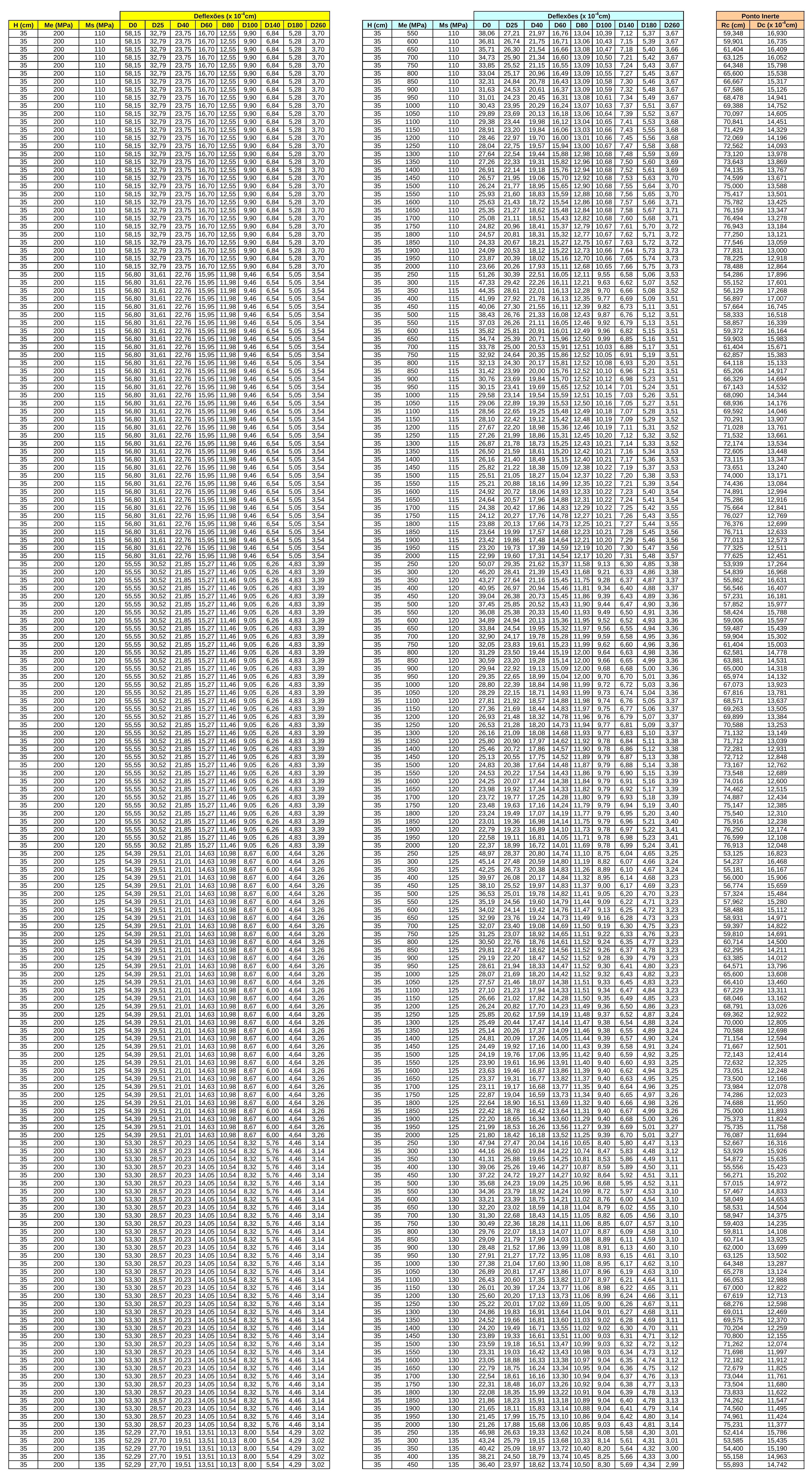



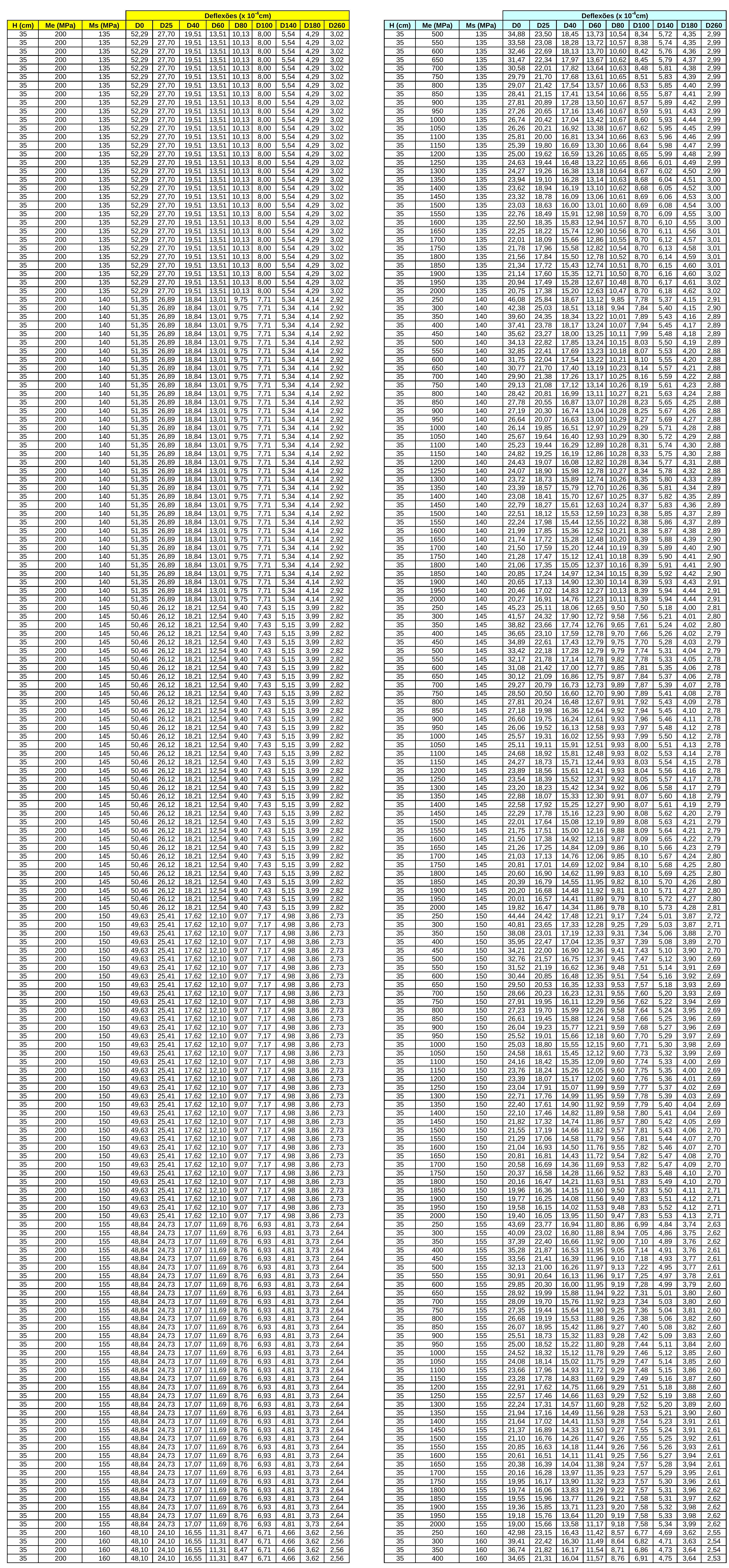

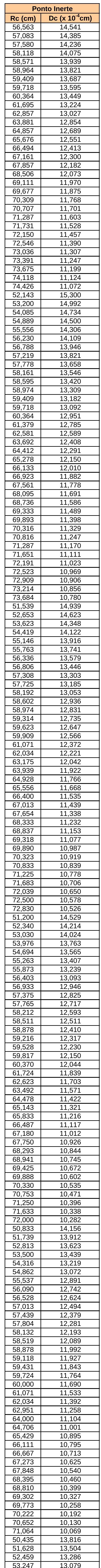




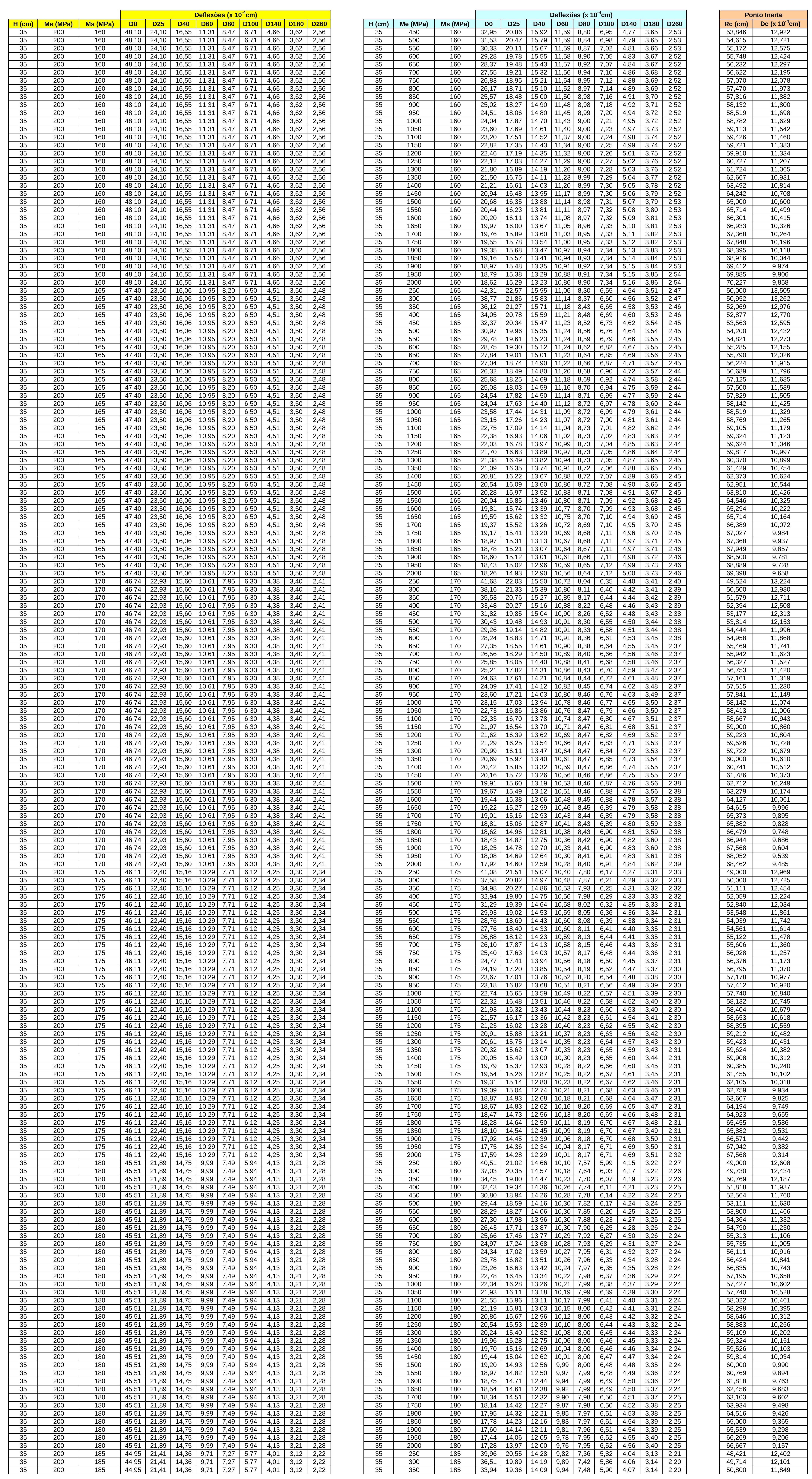




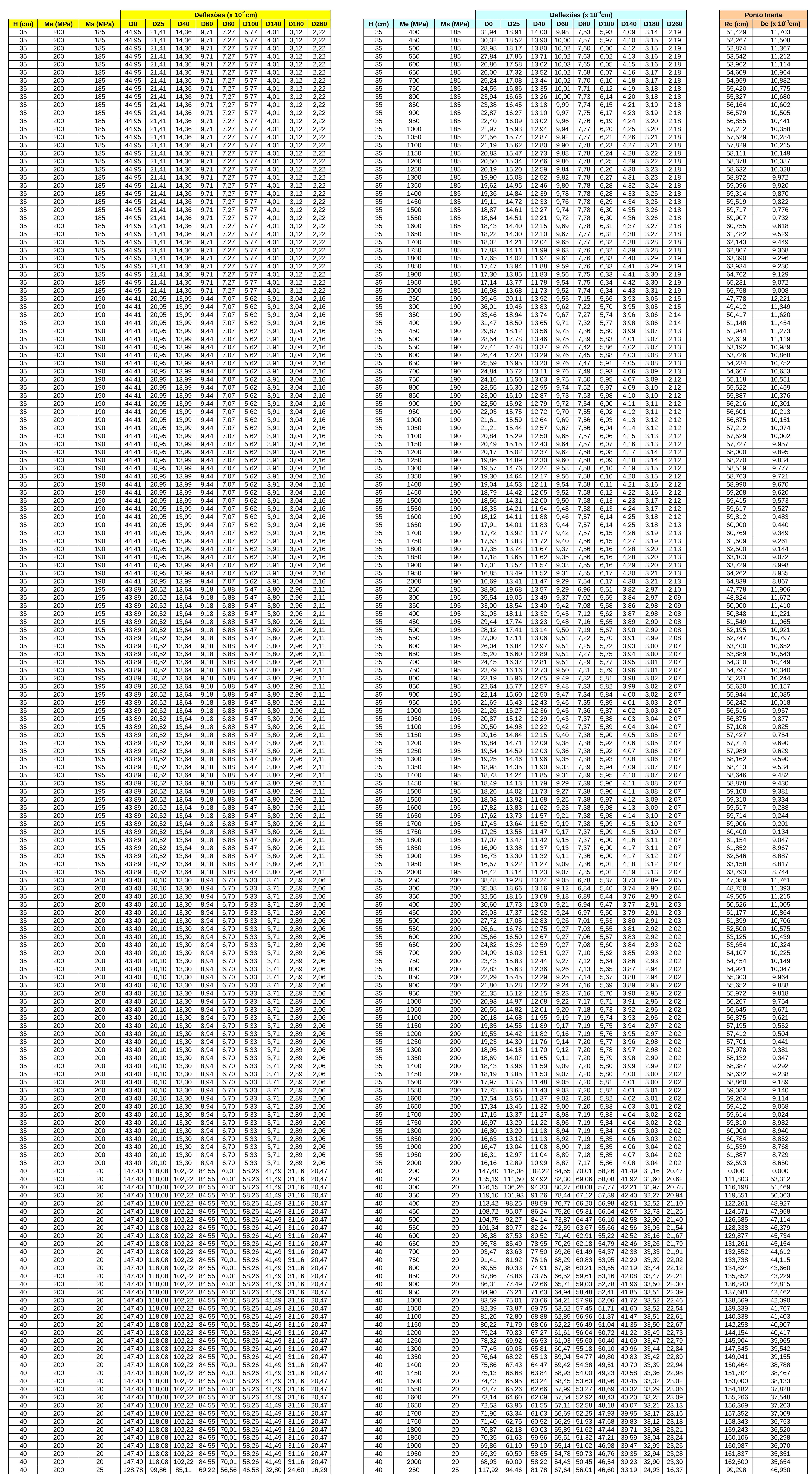




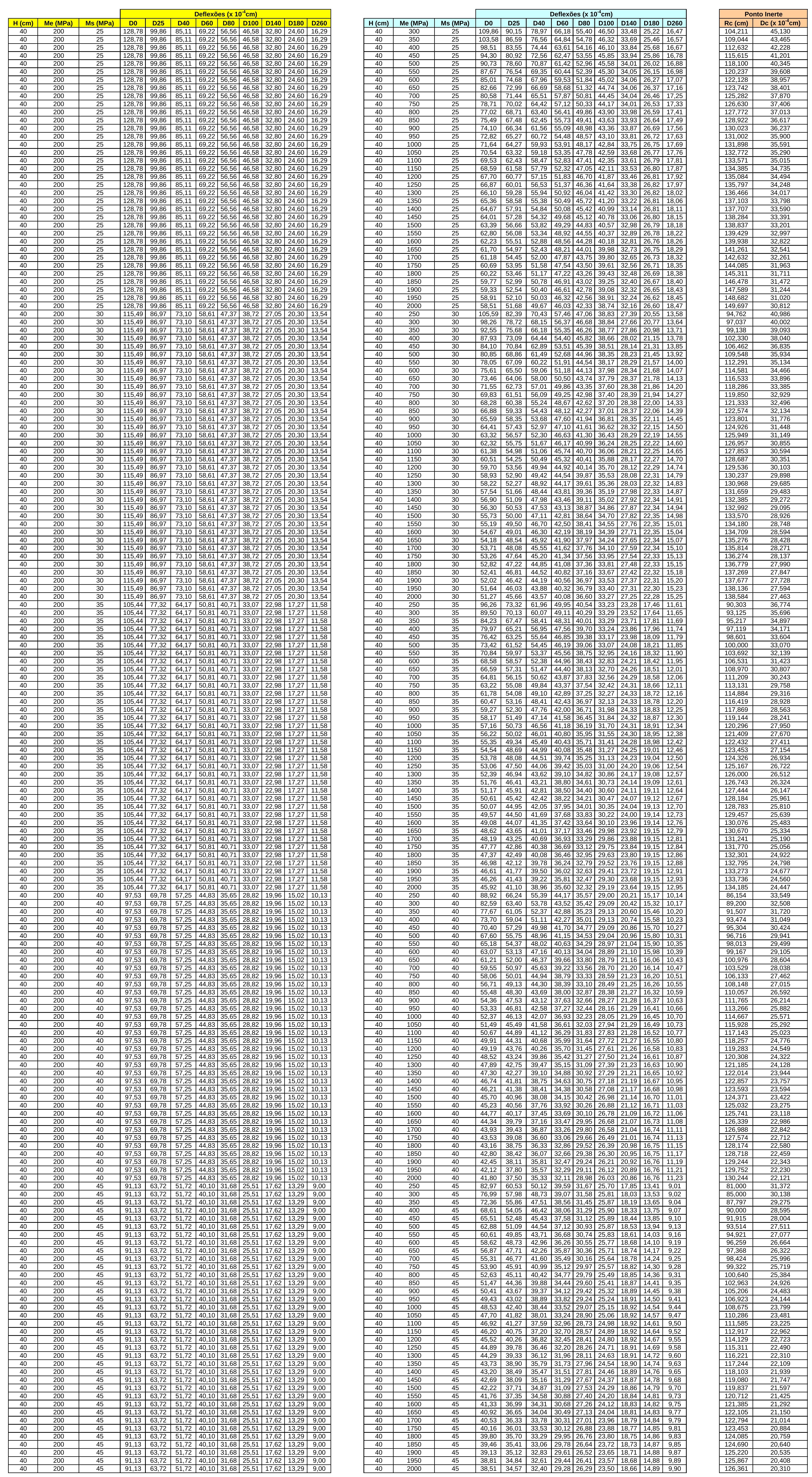




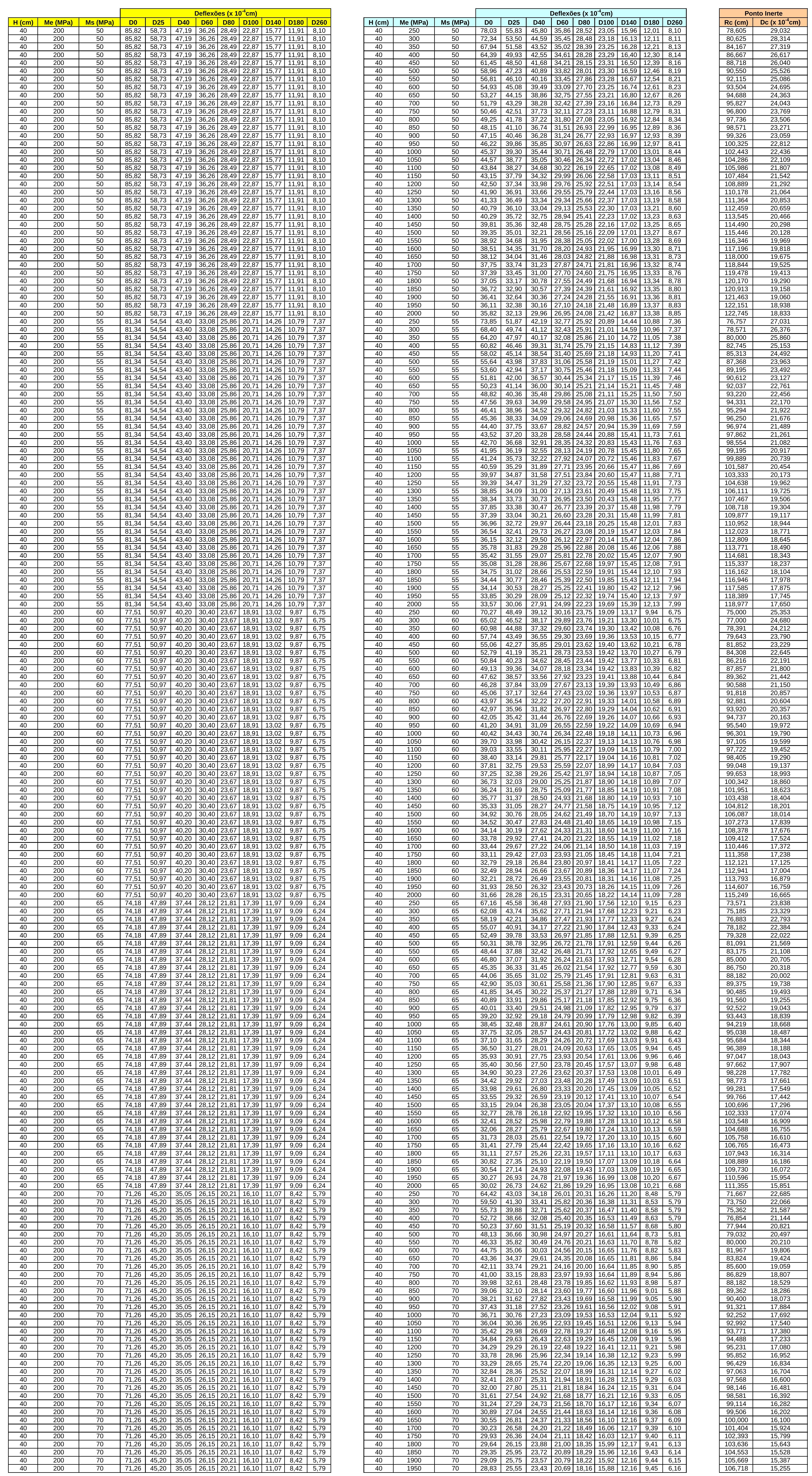




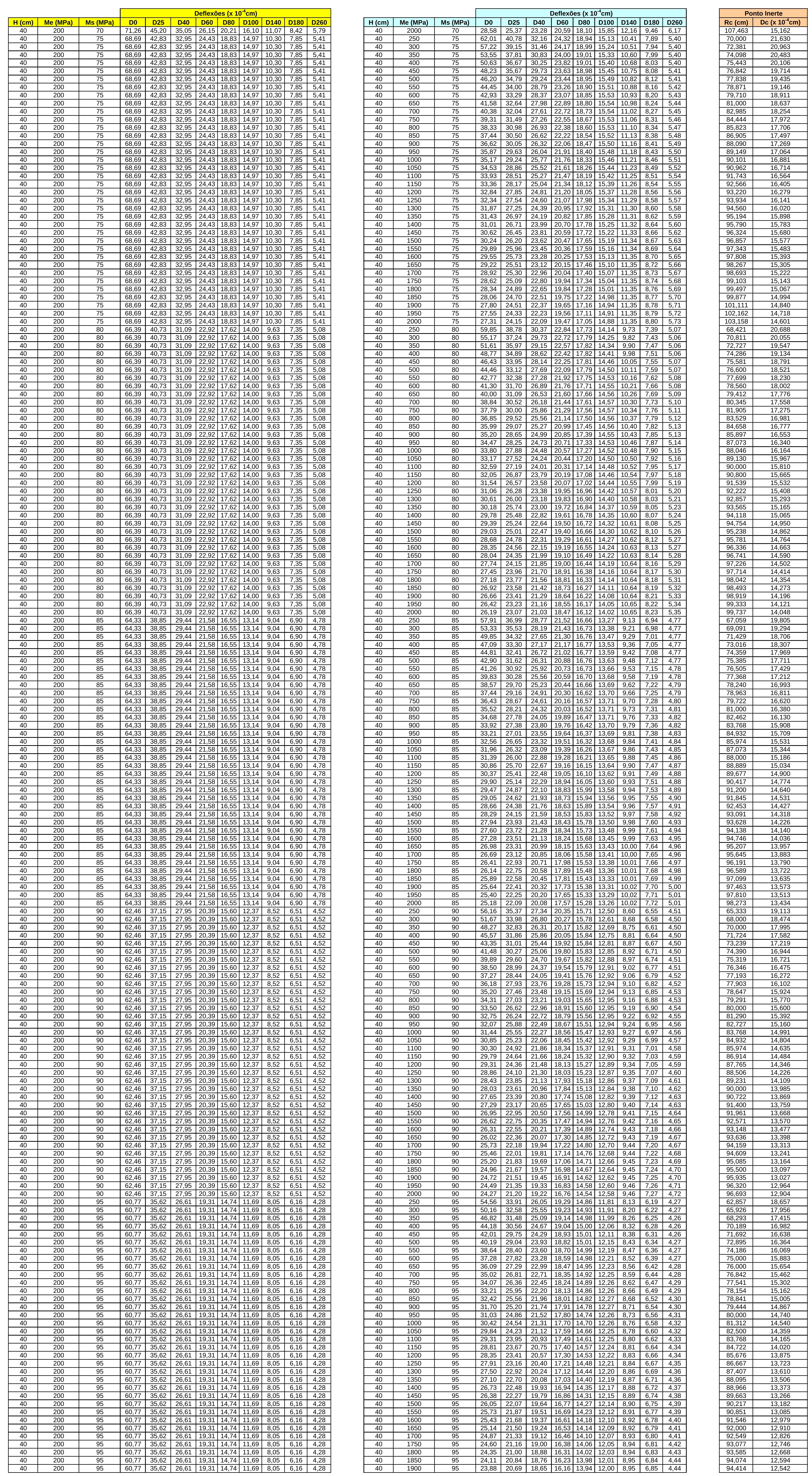




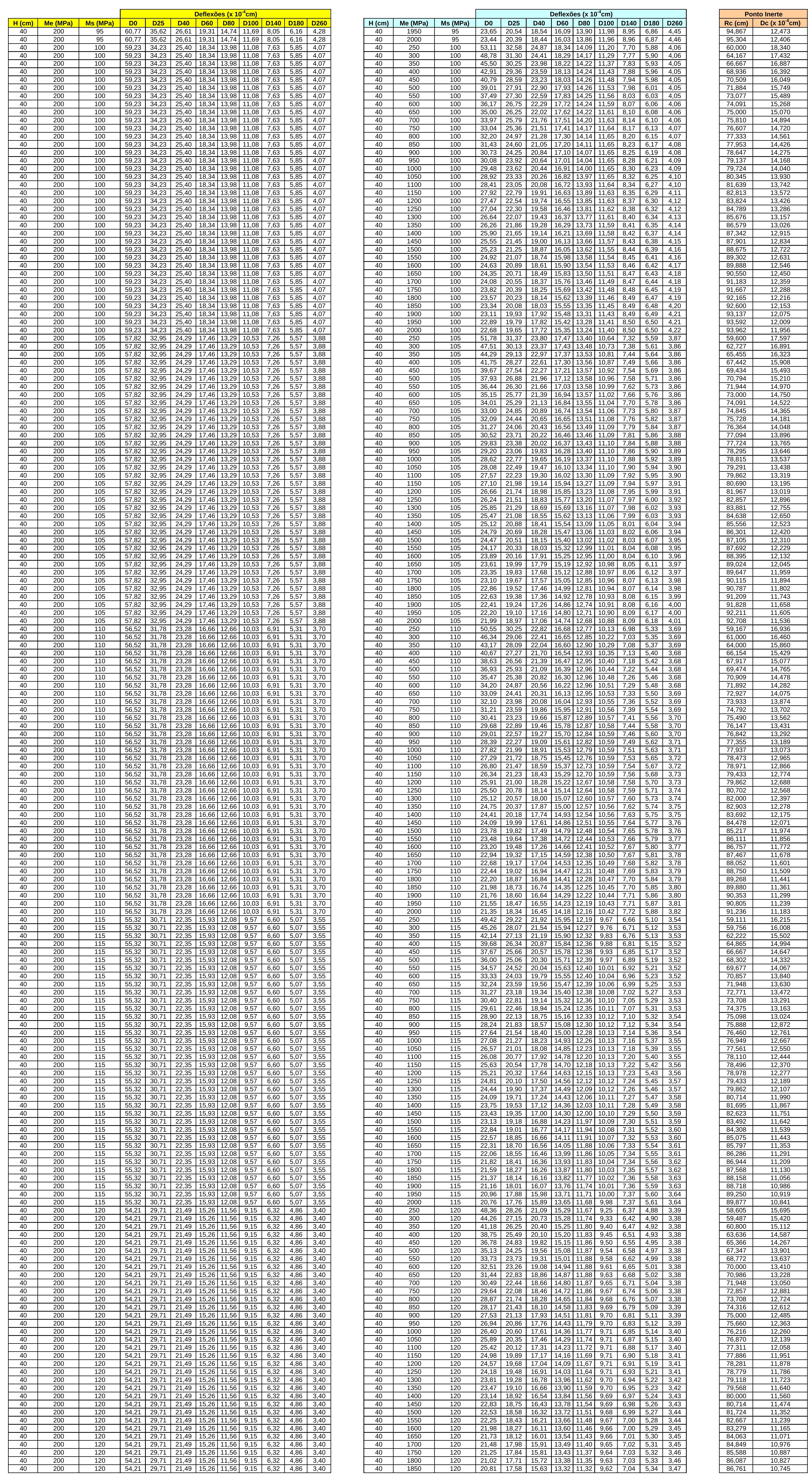




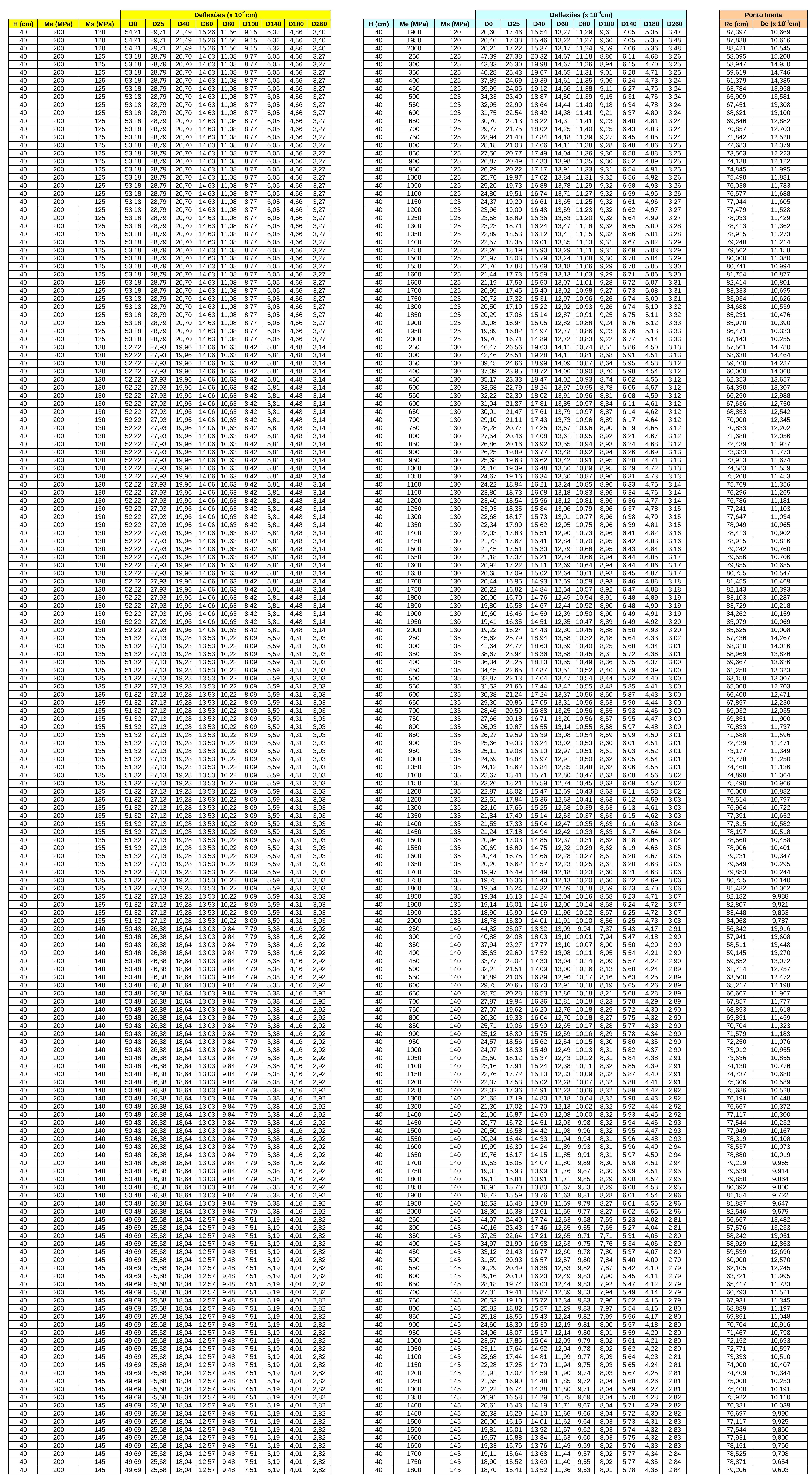




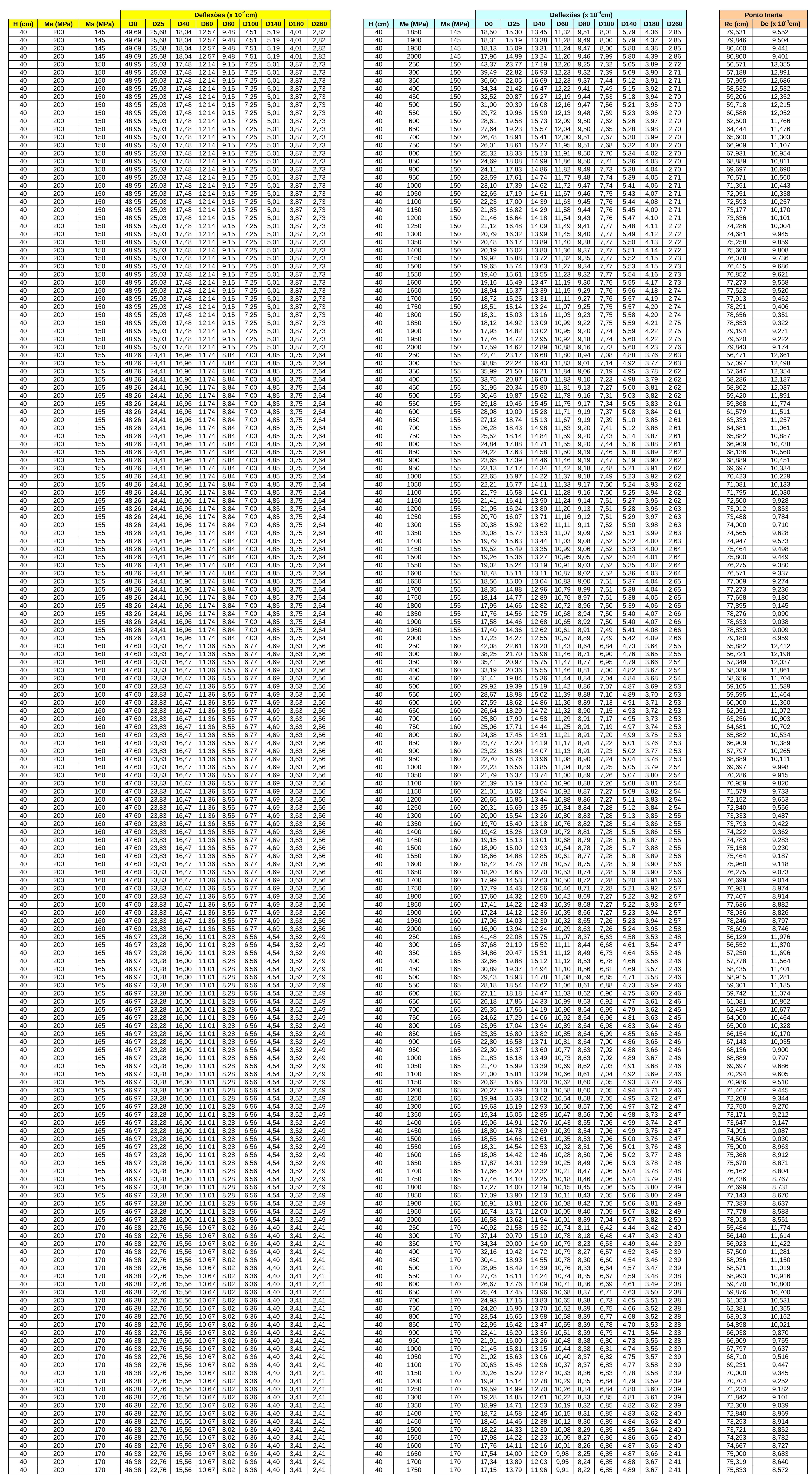




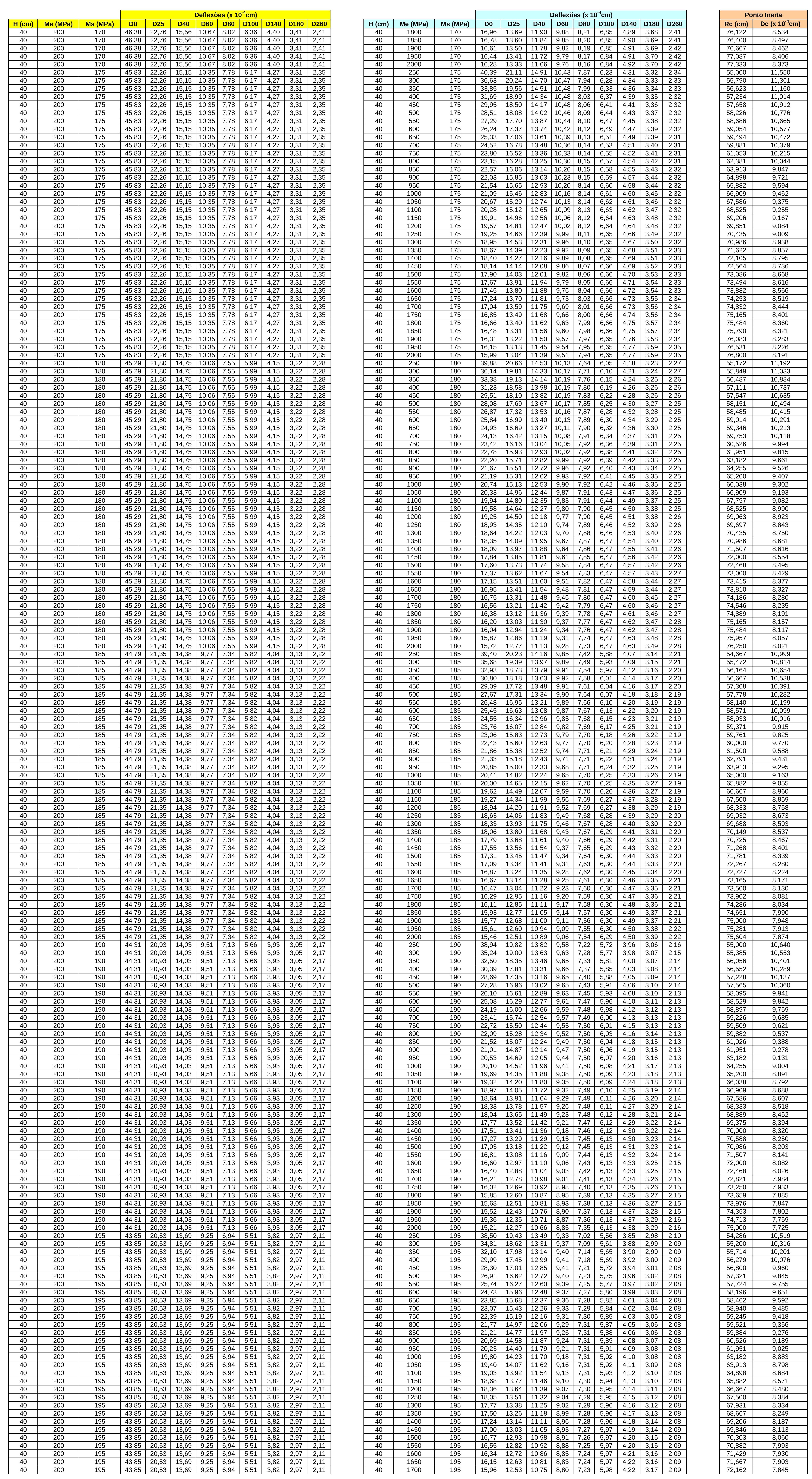




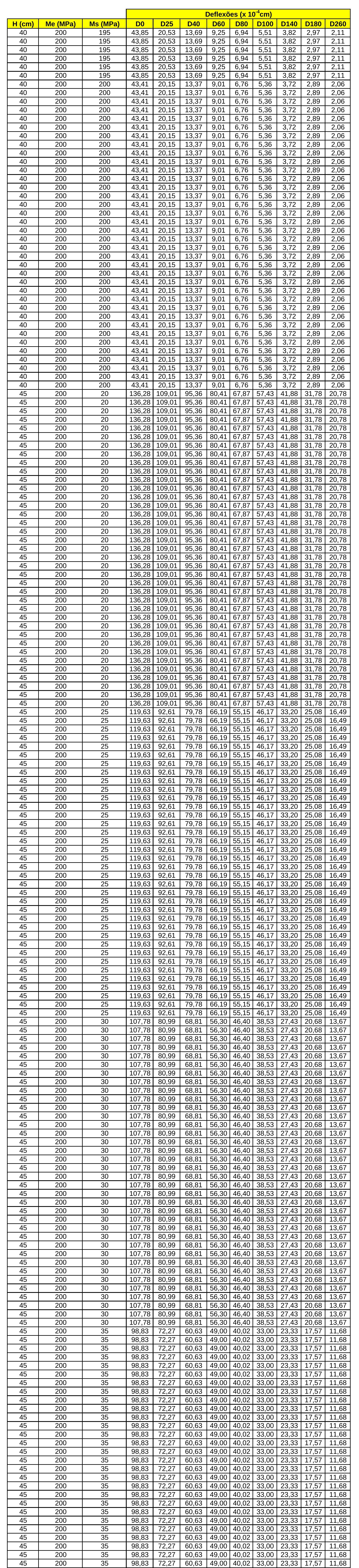

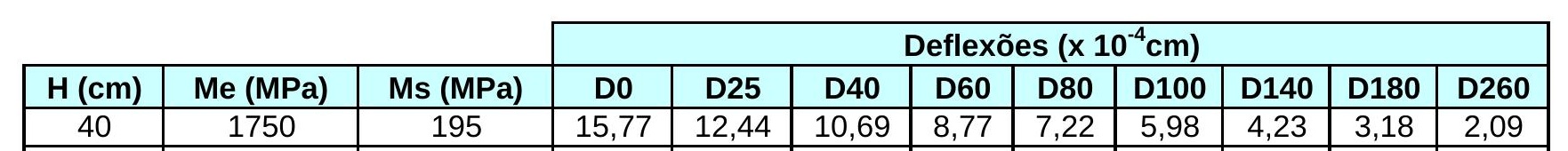

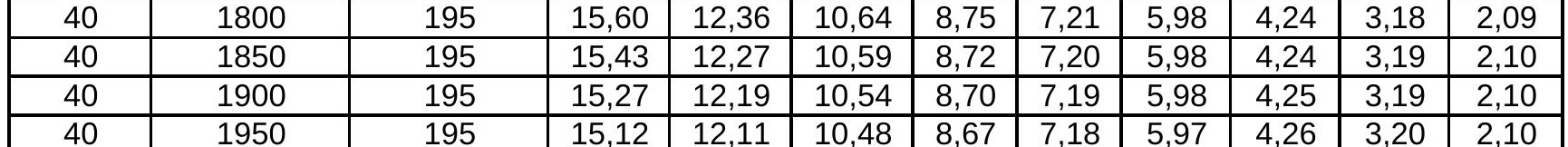

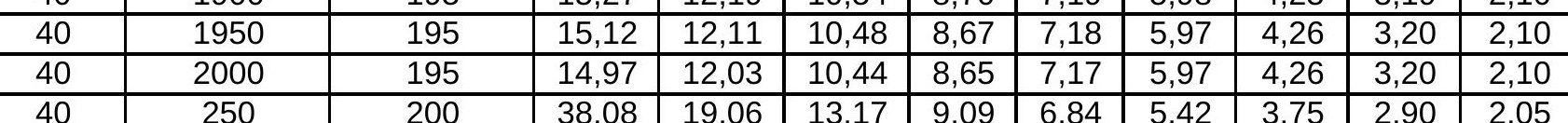

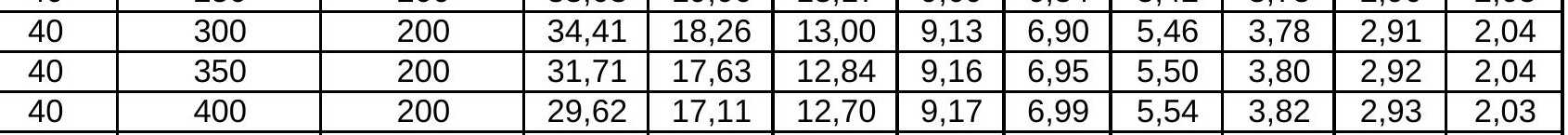

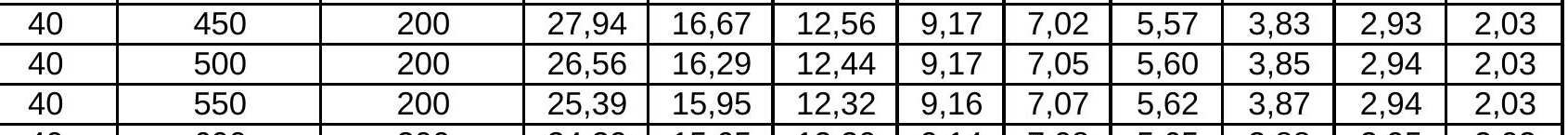

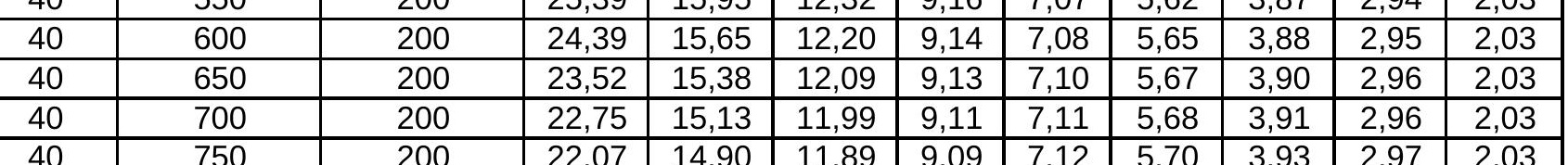

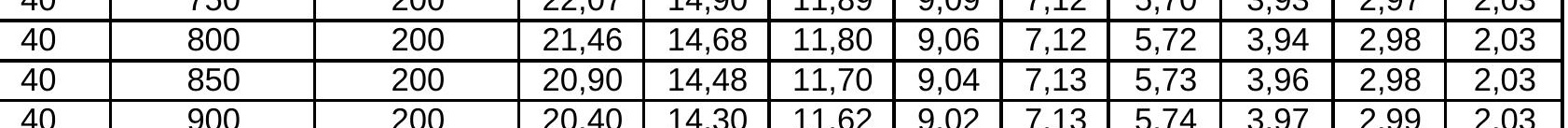

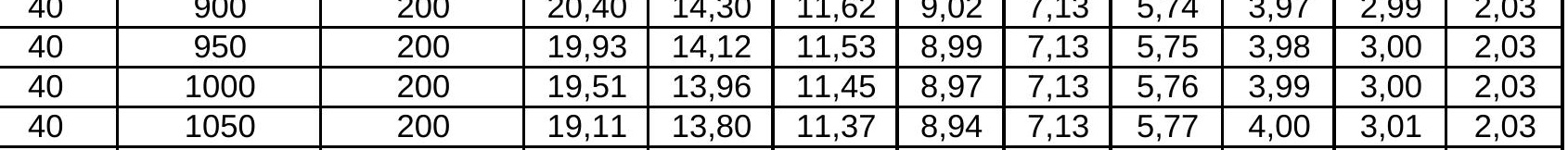

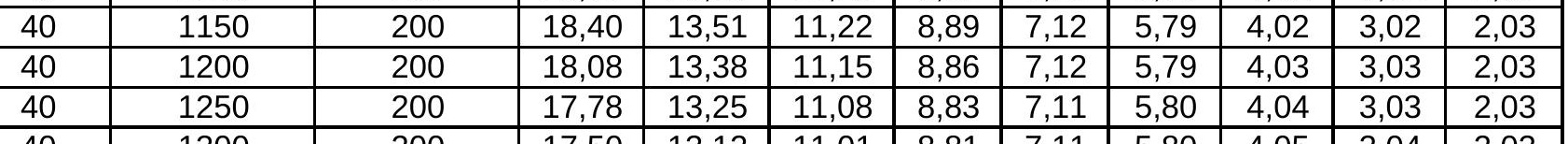

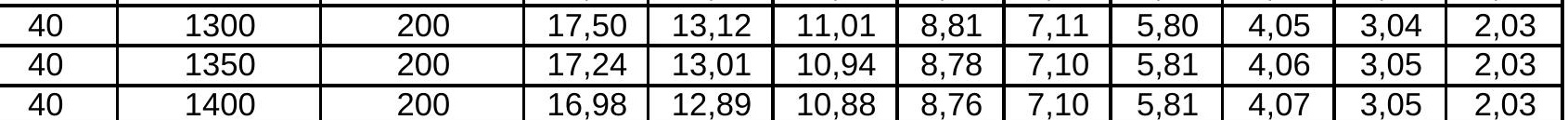

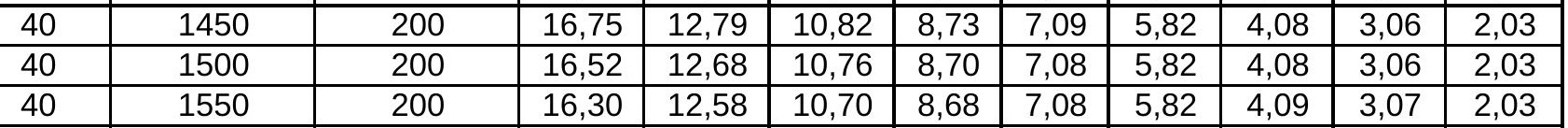

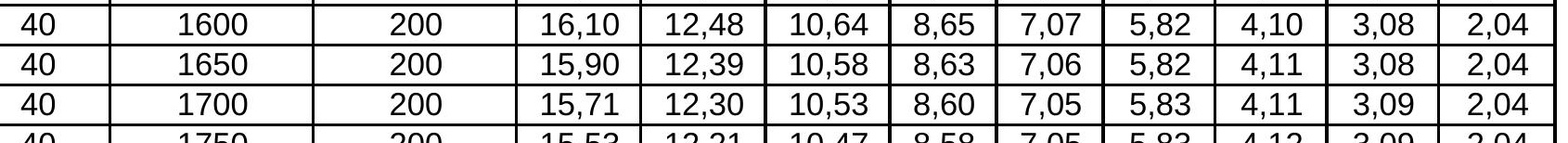

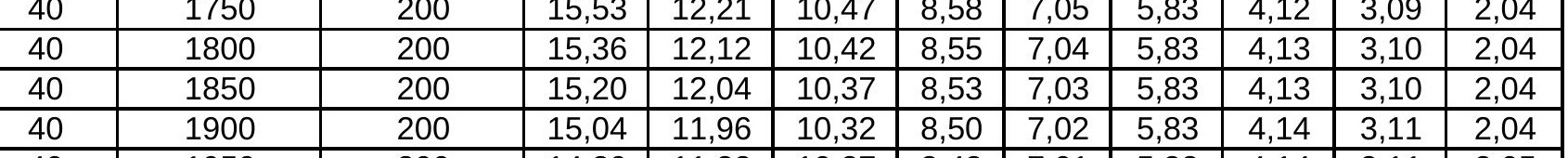

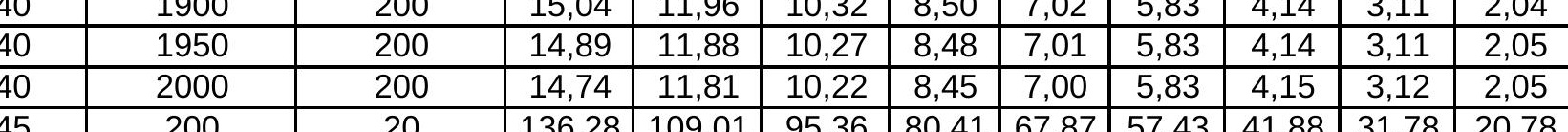

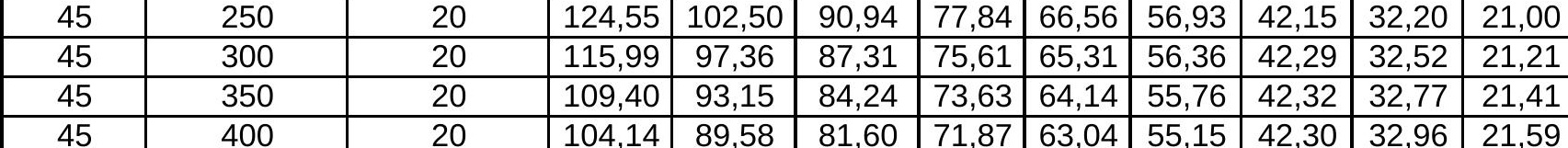

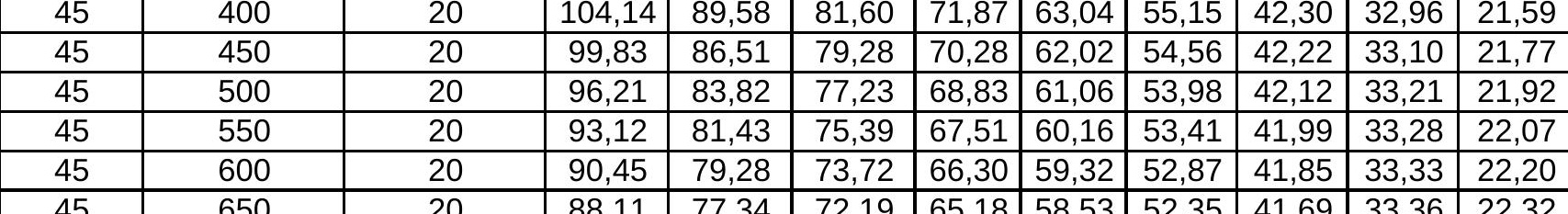

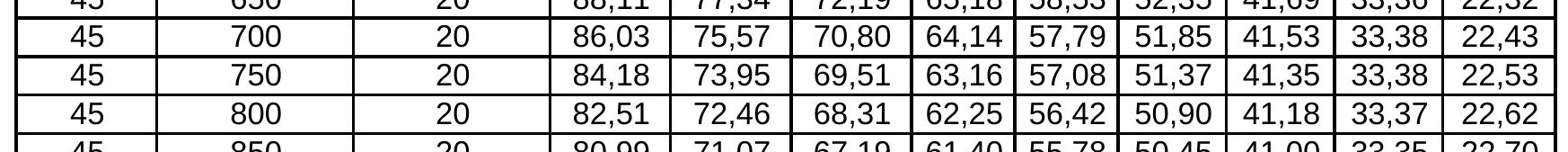

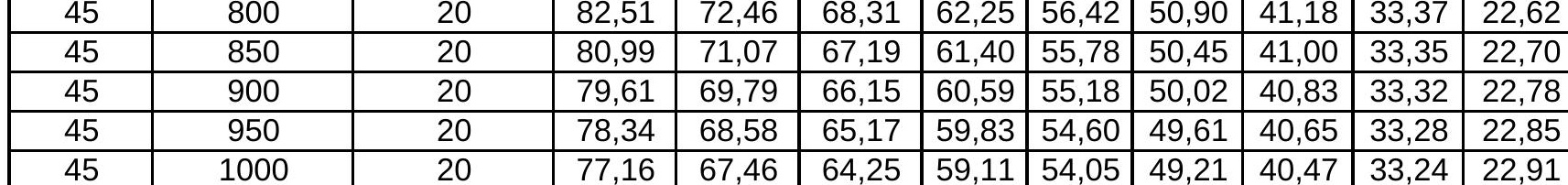

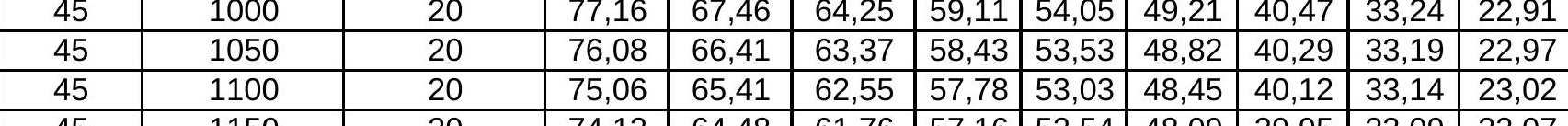

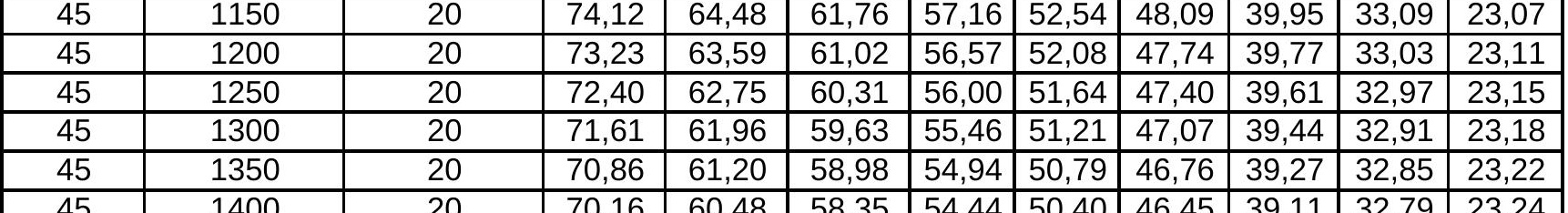

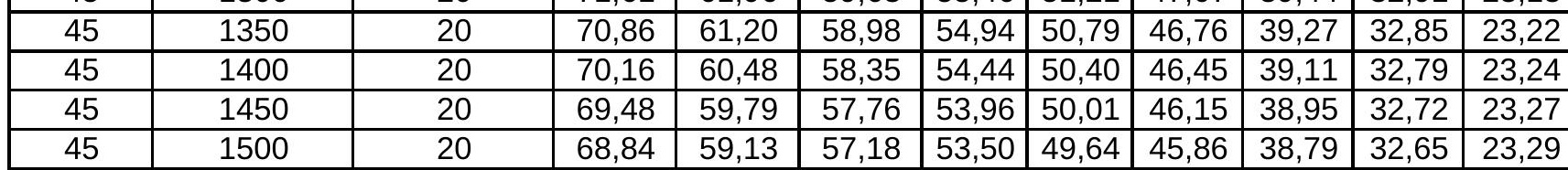

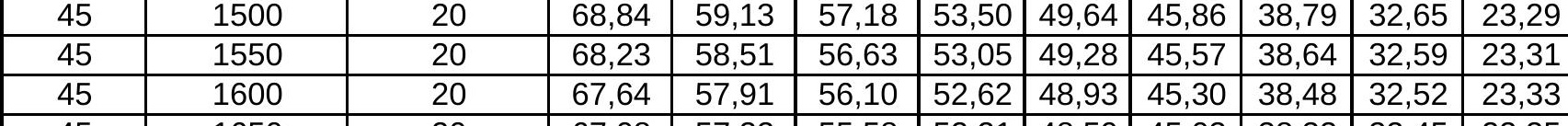

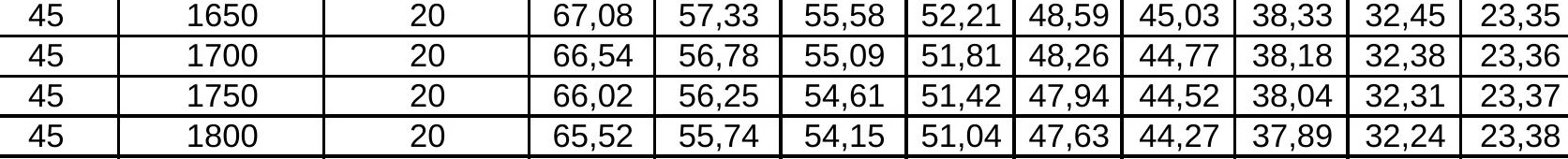
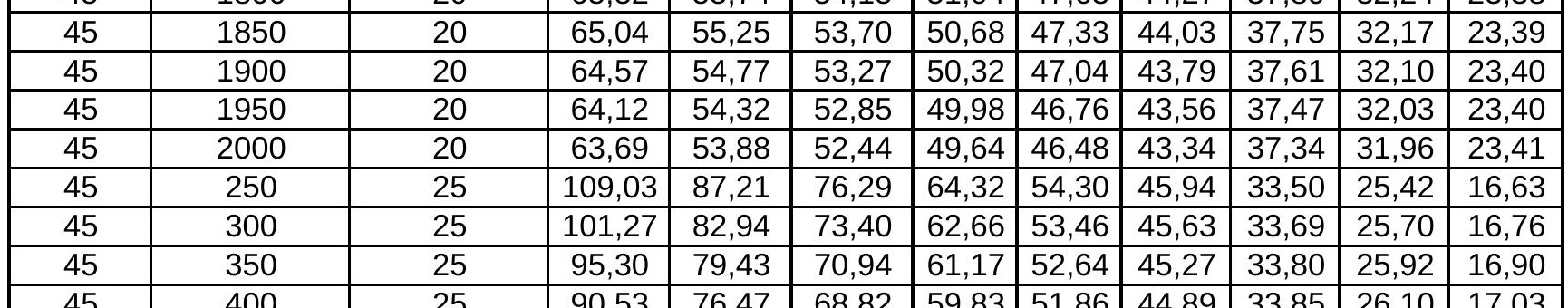

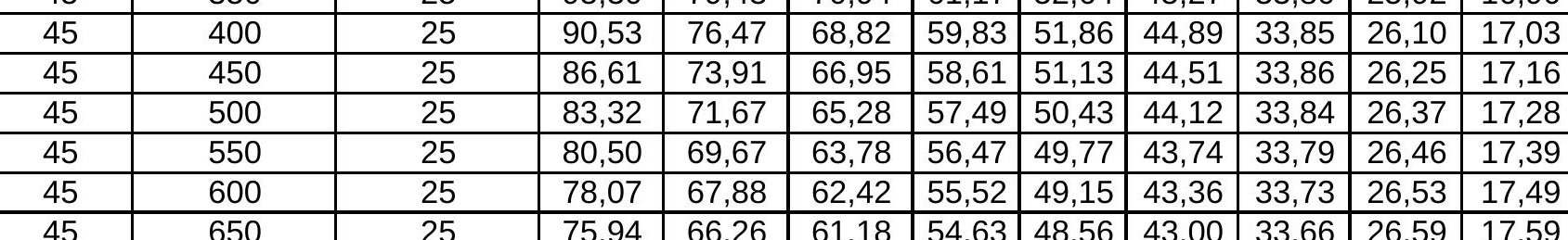
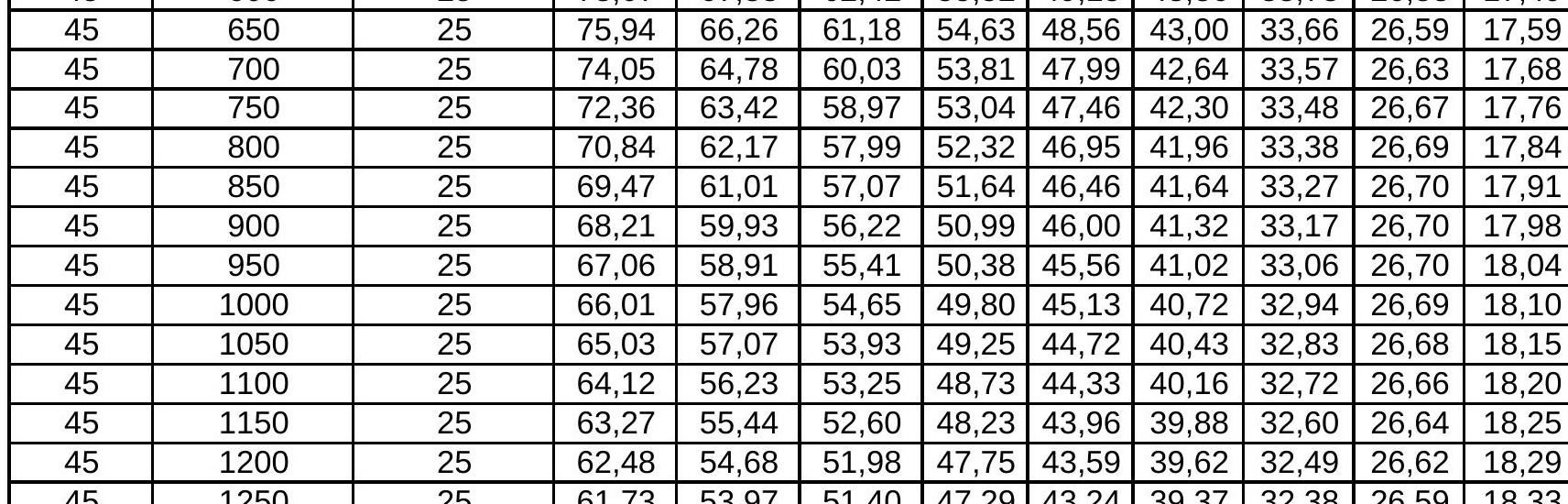

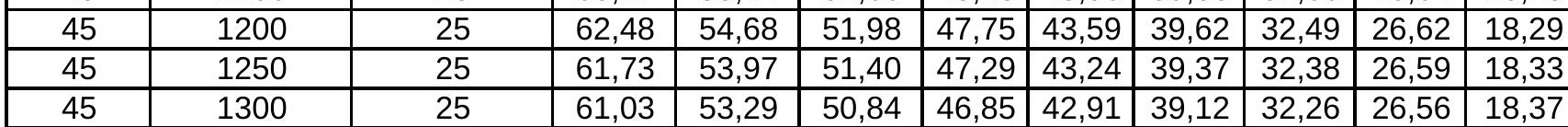
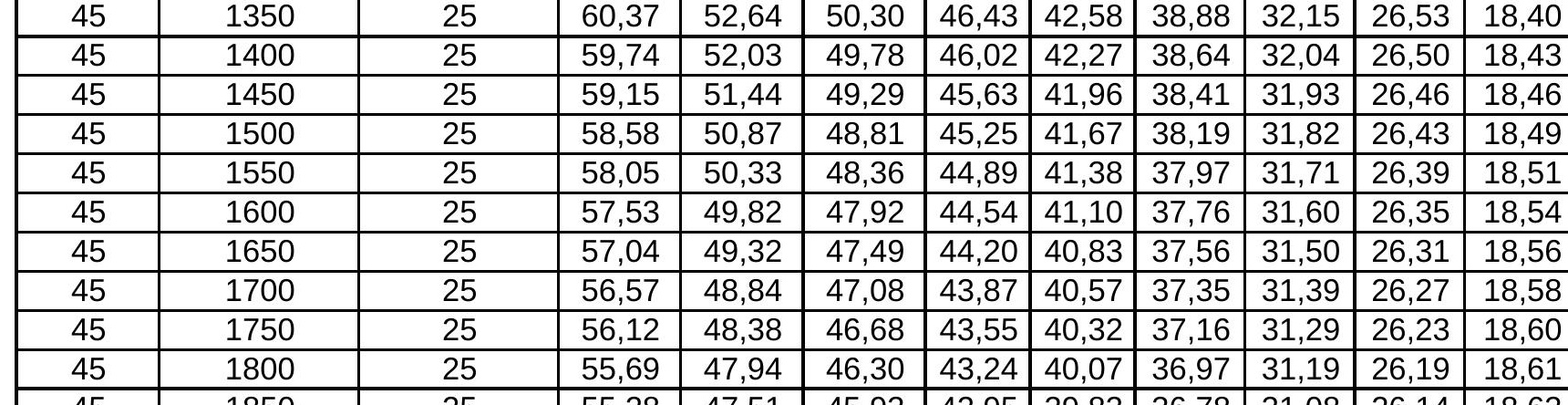

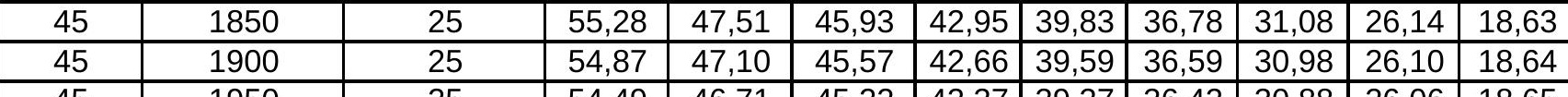
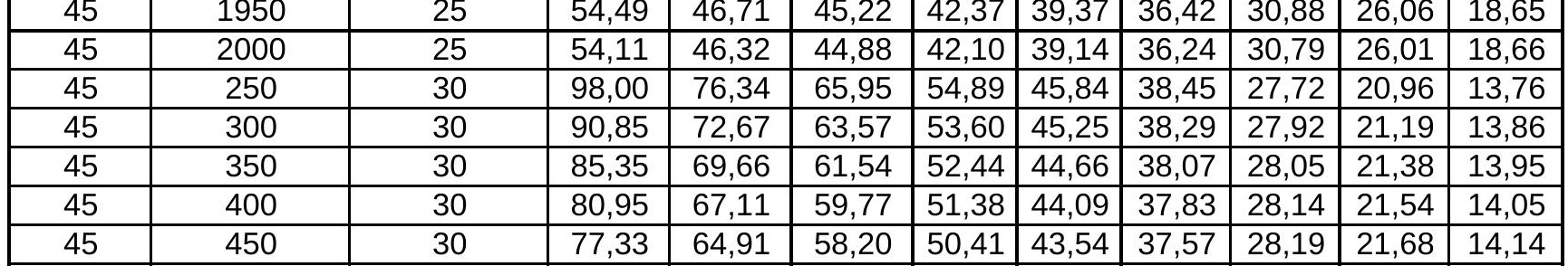

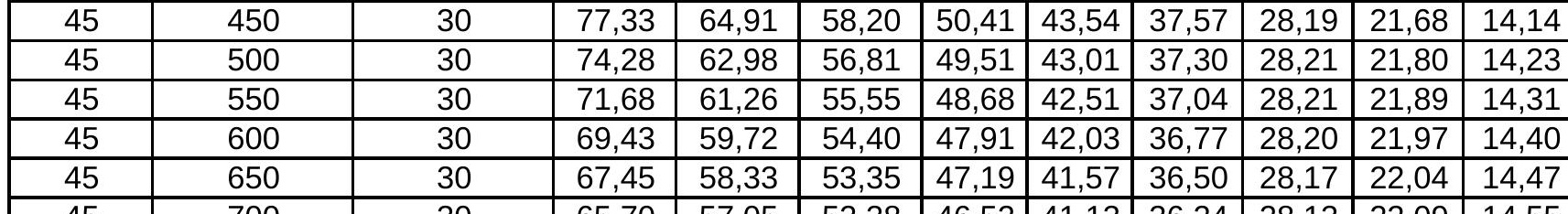
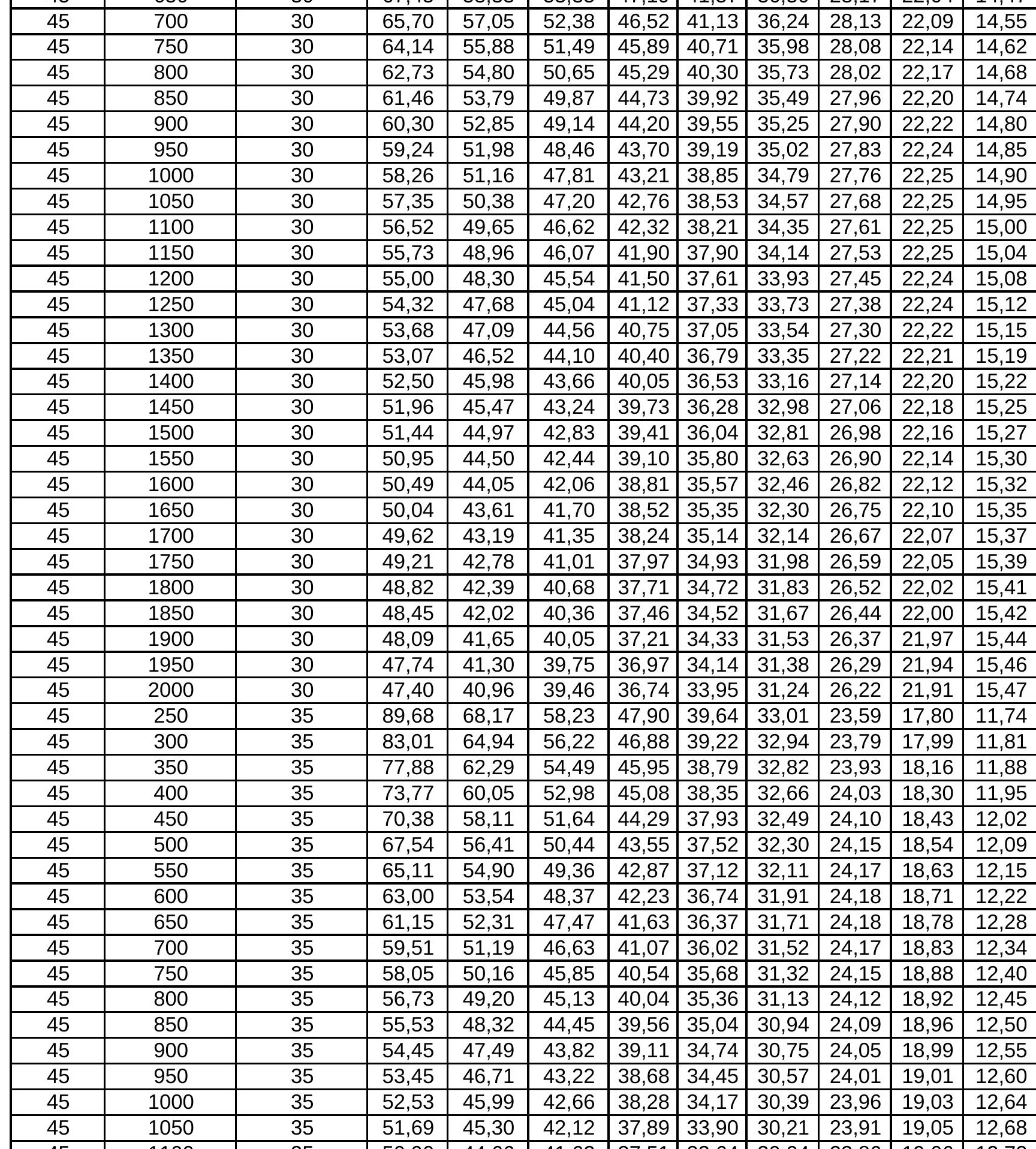

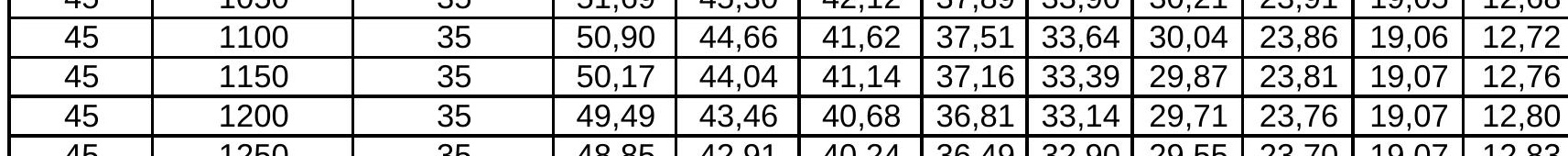

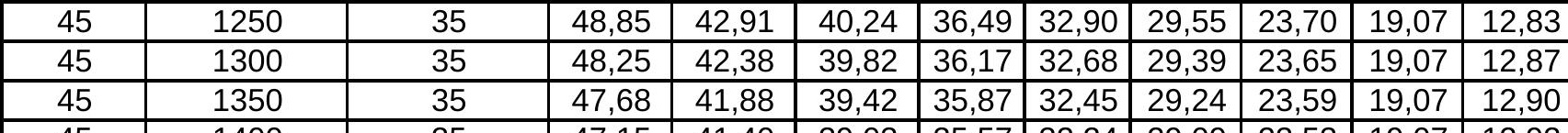

\begin{tabular}{l|l}
$77,7.750$ & 7,662 \\
\hline 74,146 & 7,610 \\
\hline
\end{tabular}

\begin{tabular}{|l|l|l|}
\hline 54,4286 & 10,256 \\
\hline 5.102 & 10.078 \\
\hline 55,588 & 9,972 \\
\hline
\end{tabular}

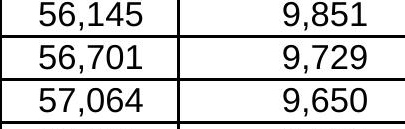

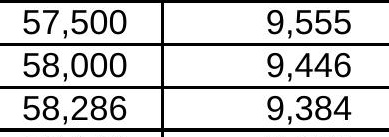

\begin{tabular}{|l|l|}
\hline 58,69 & 9.305 \\
\hline 58.974 & 9.234 \\
\hline 59383 & 9.145 \\
\hline 5 & 9.907 \\
\hline
\end{tabular}

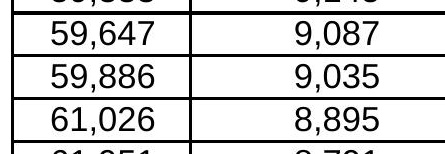

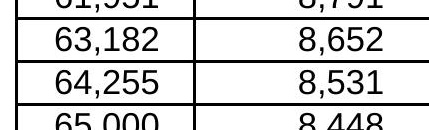

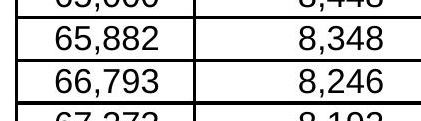

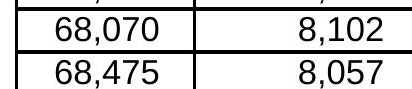

\begin{tabular}{|l|l|}
\hline $69,1,80$ & 9.97 \\
\hline 69.84 & 7,903 \\
\hline 70.154 & 7,368 \\
\hline
\end{tabular}

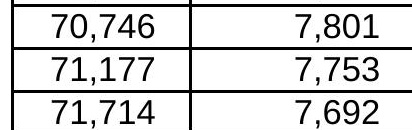

\begin{tabular}{|l|l|}
\hline 71,944 & 7.666 \\
\hline 72,42 & 7.661 \\
\hline 72,800 & 7,570 \\
\hline 73207 & 7,520 \\
\hline
\end{tabular}

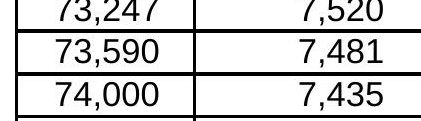

\begin{tabular}{|c|c|}
\hline 0.000 & 0.000 \\
\hline 125.974 & 47.33 \\
\hline 128.919 & 46,188 \\
\hline 19,9 & 4,129 \\
\hline
\end{tabular}

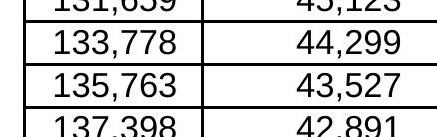

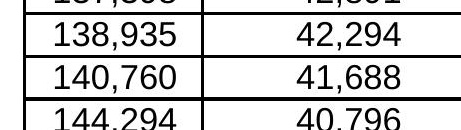

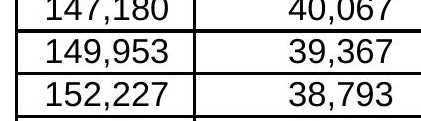

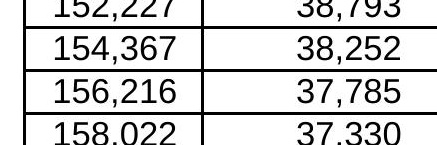

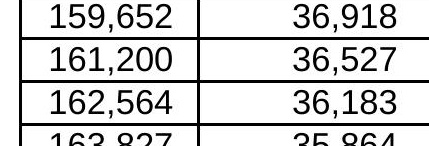

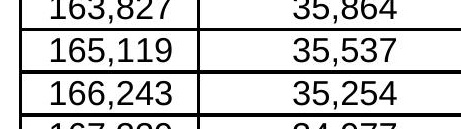

\begin{tabular}{|c|c|}
\hline 1186,370 & 34,7717 \\
\hline 179,282 & 34,49 \\
\hline 1224 & 34,233 \\
\hline
\end{tabular}

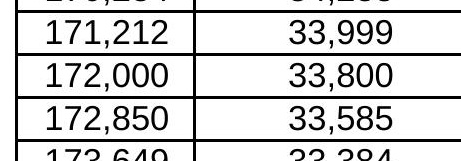

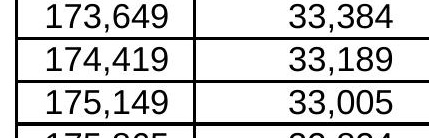

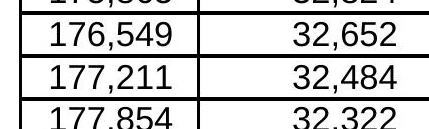

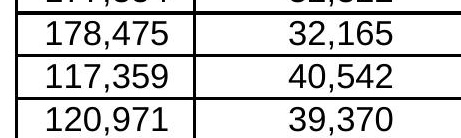

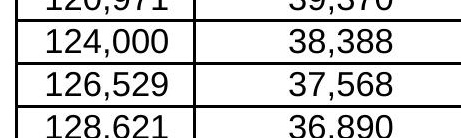

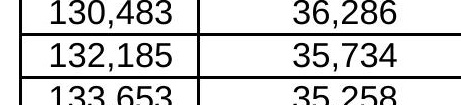

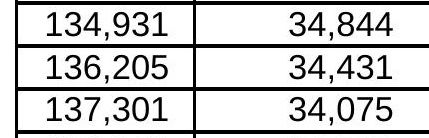

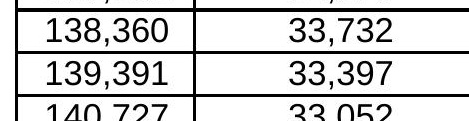

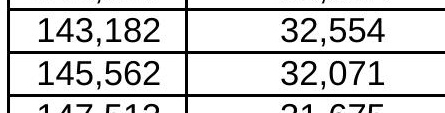

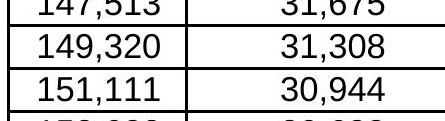

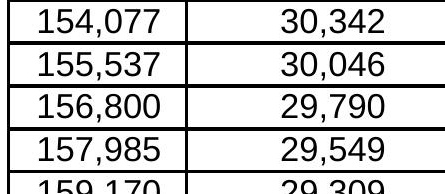

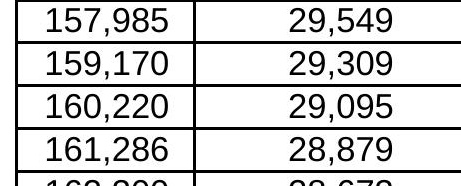

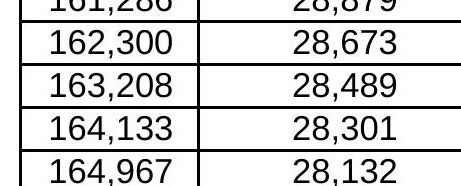

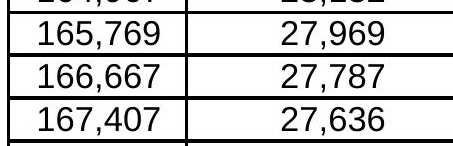

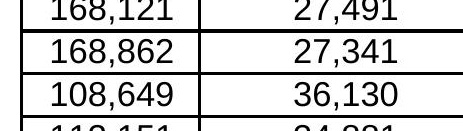

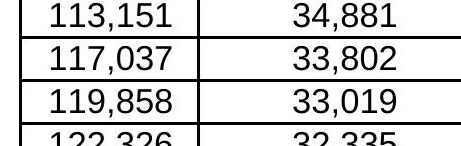

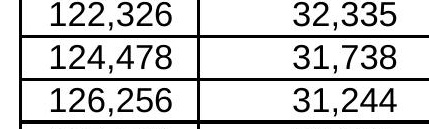

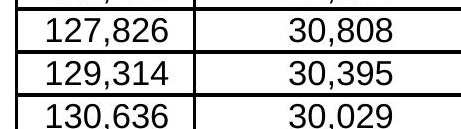

\begin{tabular}{|l|l|}
\hline 131.875 & 29,685 \\
\hline 133.038 & 29,632 \\
\hline 134.062 & 29.078 \\
\hline 13598 & 2856 \\
\hline
\end{tabular}

\begin{tabular}{|l|l|}
\hline 134,987 & 28,821 \\
\hline 135,908 & 28,566 \\
\hline 136,757 & 28,330 \\
\hline 13239 & 2789 \\
\hline
\end{tabular}

\begin{tabular}{|l|l|}
\hline 1337,625 & $28,30.09$ \\
\hline 138,349 & 27,888 \\
\hline 139309 & 27677 \\
\hline 1927 & 2728 \\
\hline
\end{tabular}

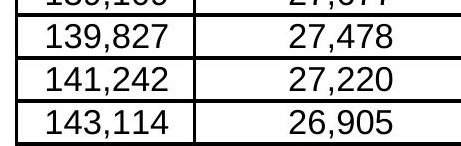

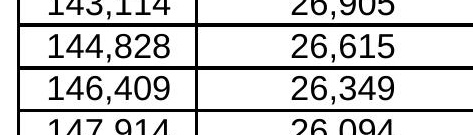

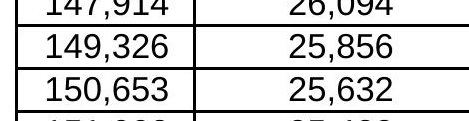

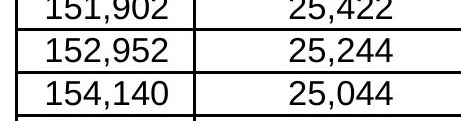

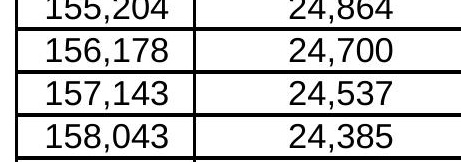

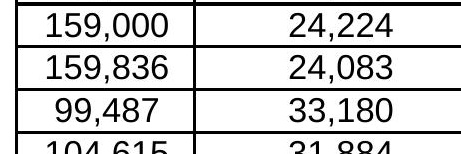

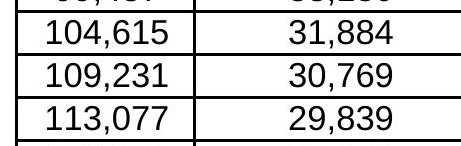

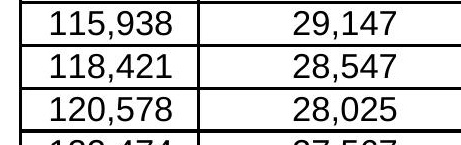

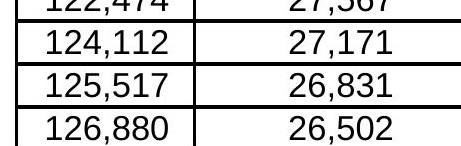

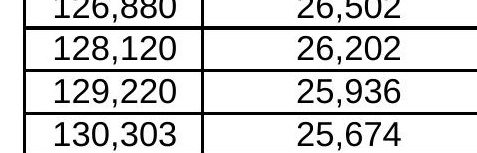

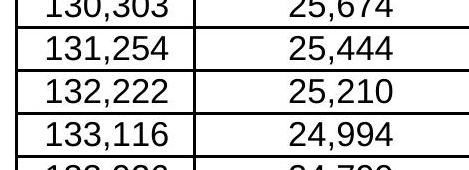

\begin{tabular}{|l|l|}
\hline 133.966 & 24799 \\
\hline 134651 & 24.616 \\
\hline 135376 & 2448 \\
\hline
\end{tabular}

\begin{tabular}{|c|c|}
\hline 136,126 & 24,267 \\
\hline 136,743 & 24,117 \\
\hline 137,413 & 23,955 \\
\hline 138054 & 2301 \\
\hline 13961 & 2362 \\
\hline
\end{tabular}

\begin{tabular}{|l|r|}
\hline 138,054 & $23,3,01$ \\
\hline 138,667 & 23,052 \\
\hline 139,161 & 23,533 \\
\hline 14025 & 23214 \\
\hline
\end{tabular} 


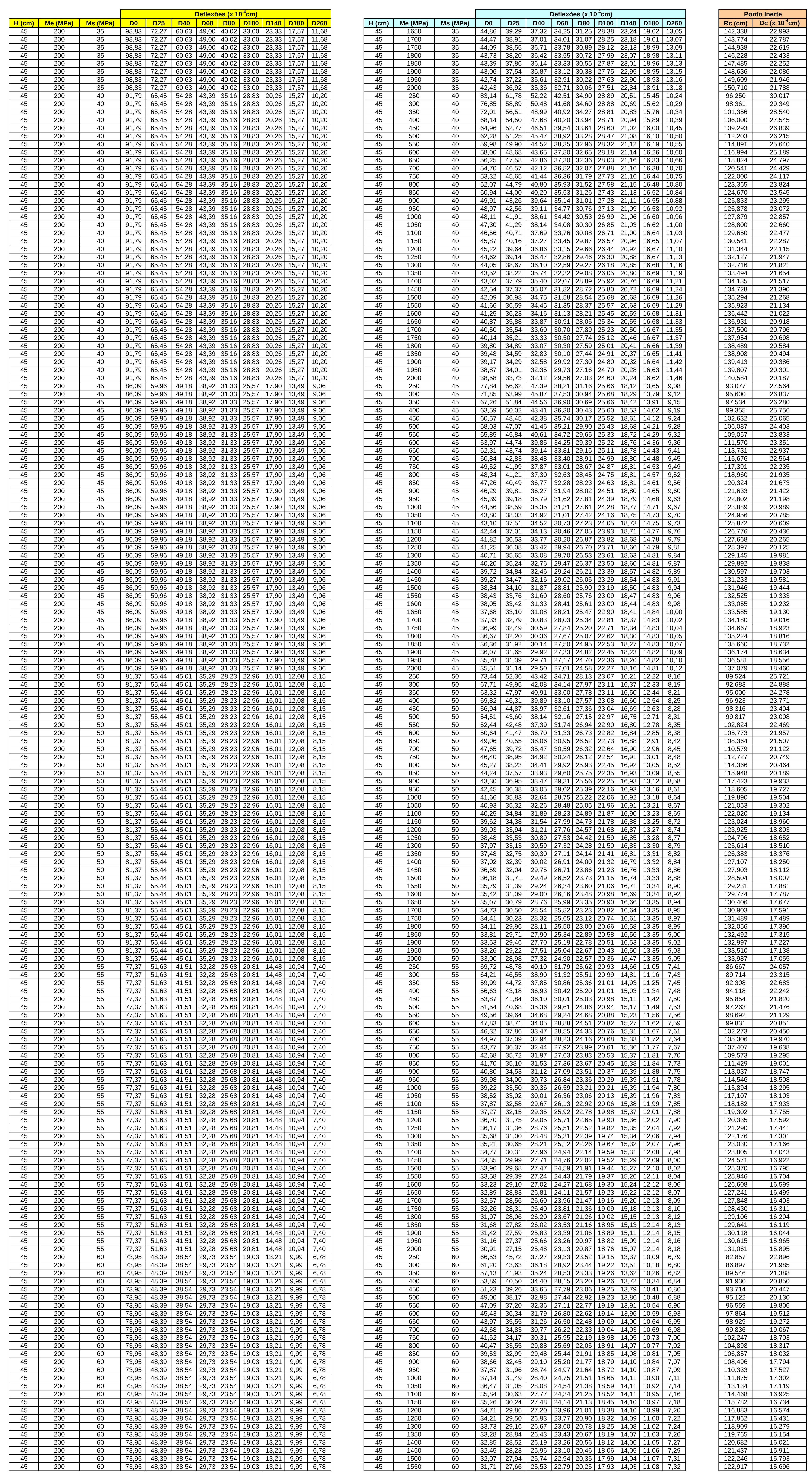




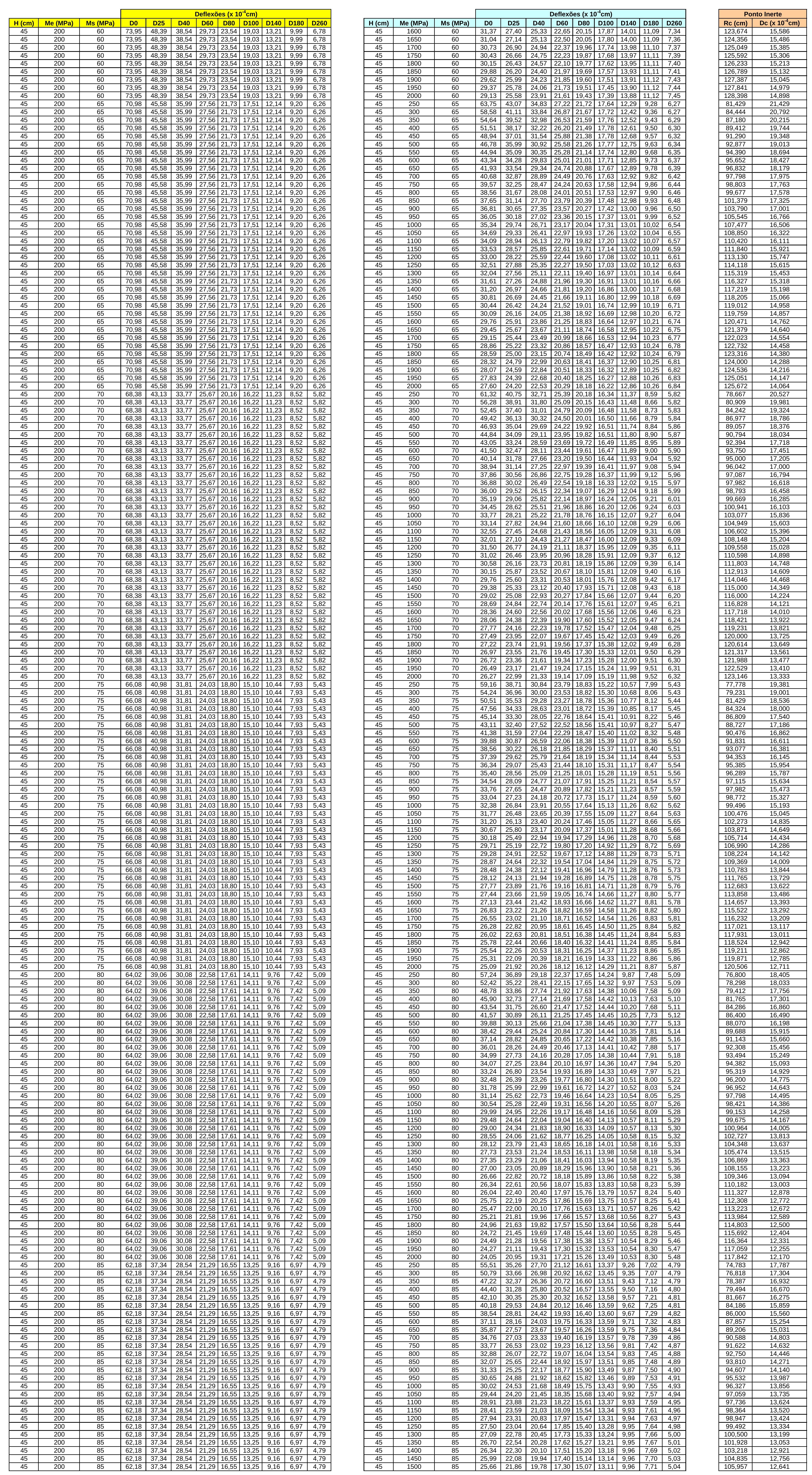




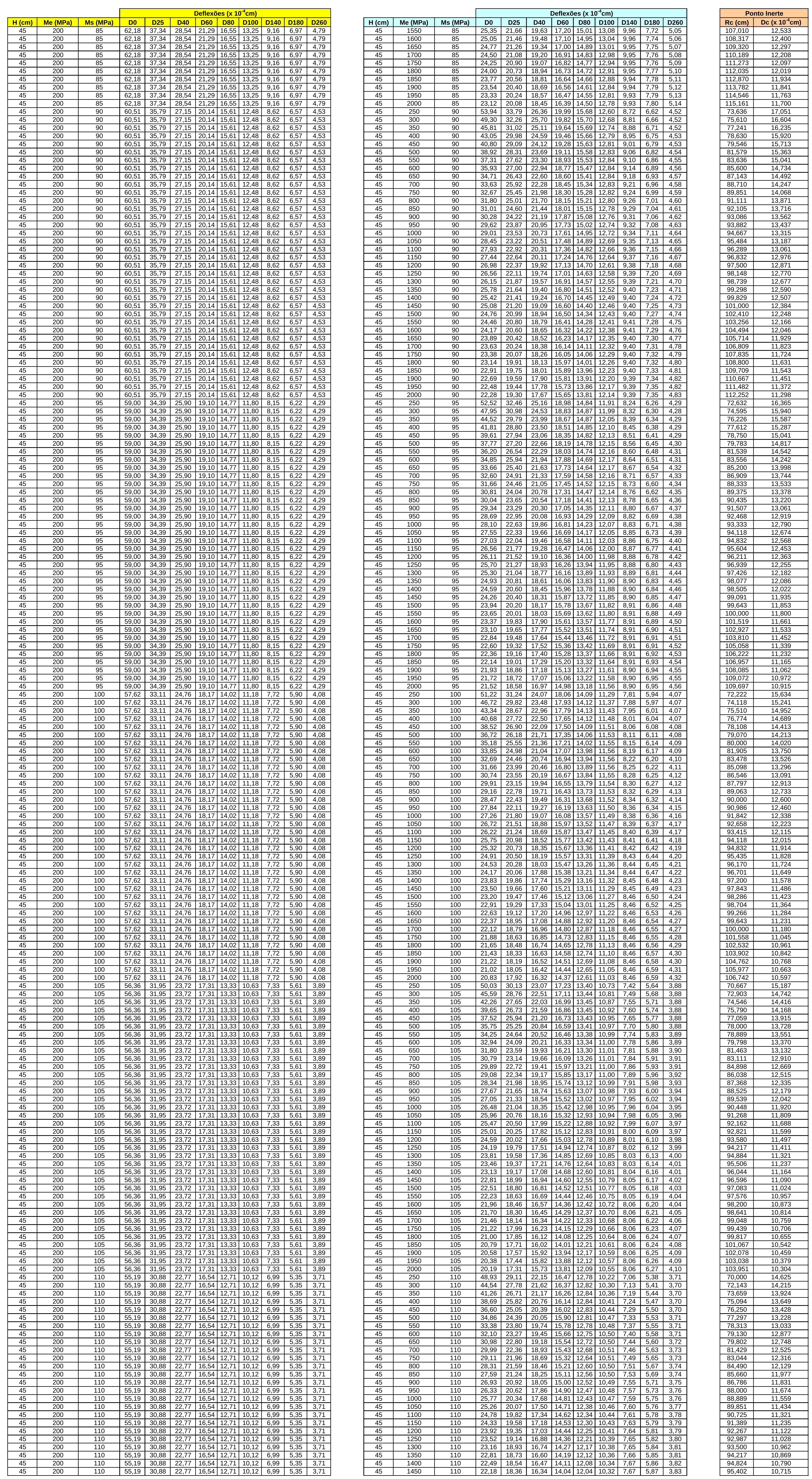




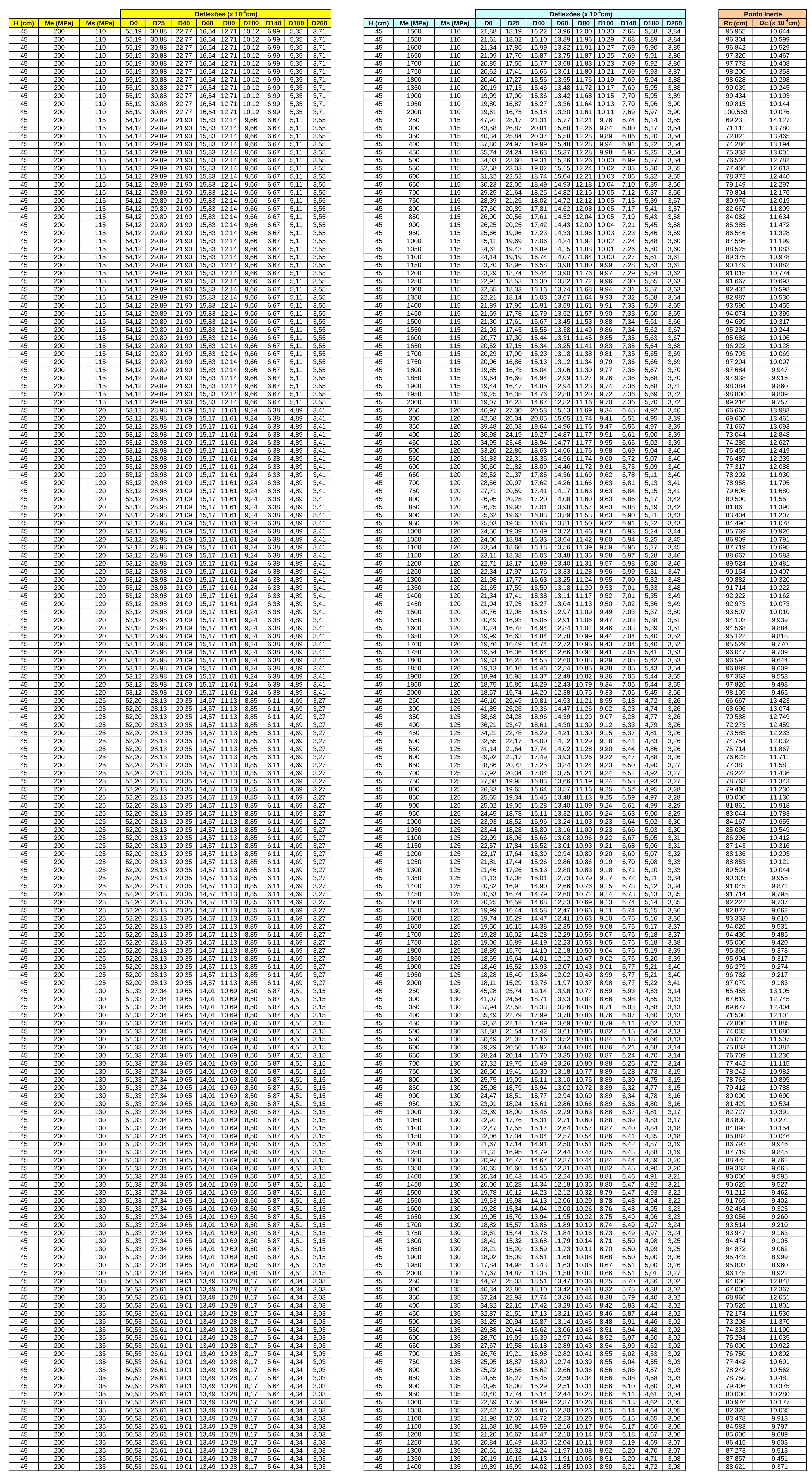




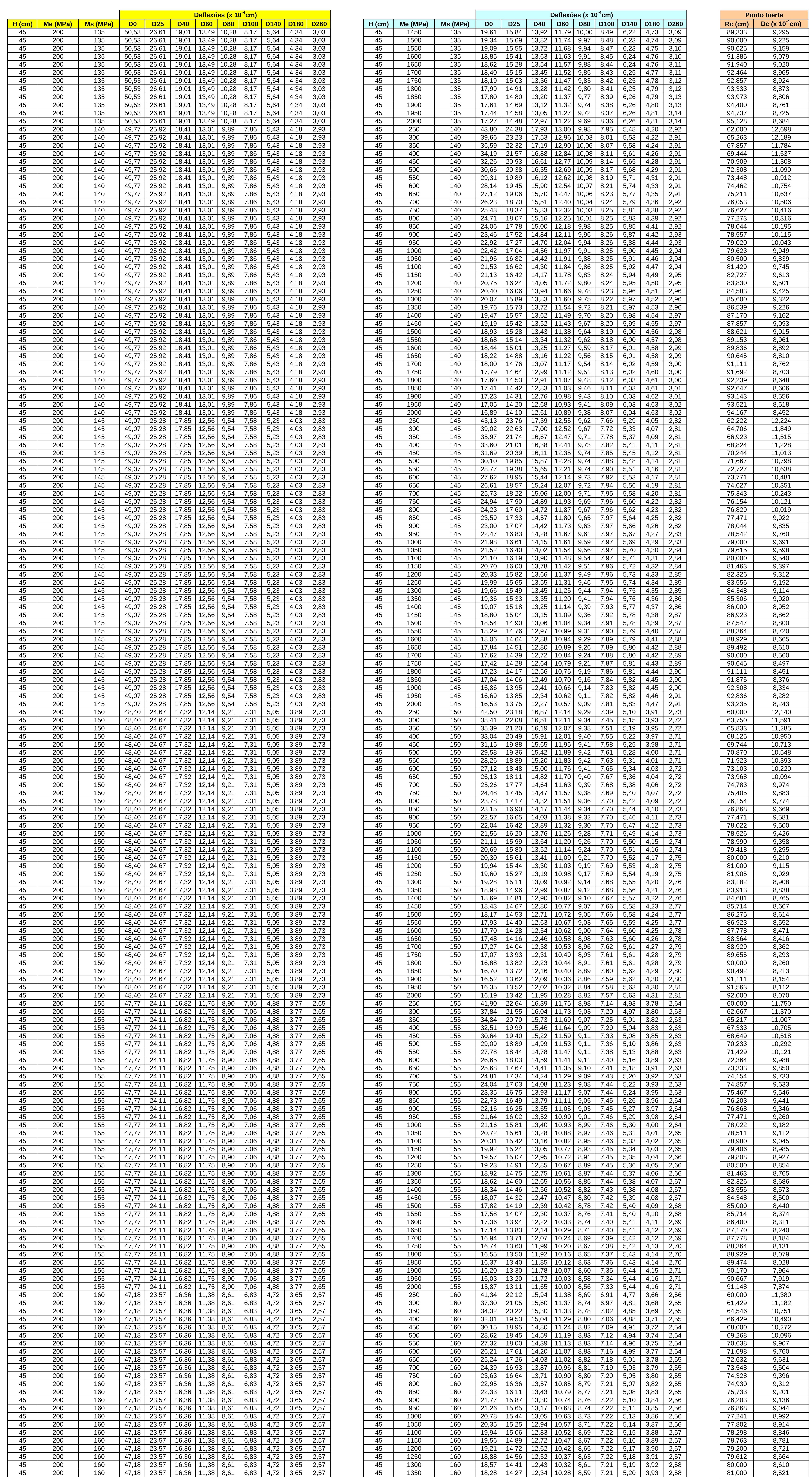




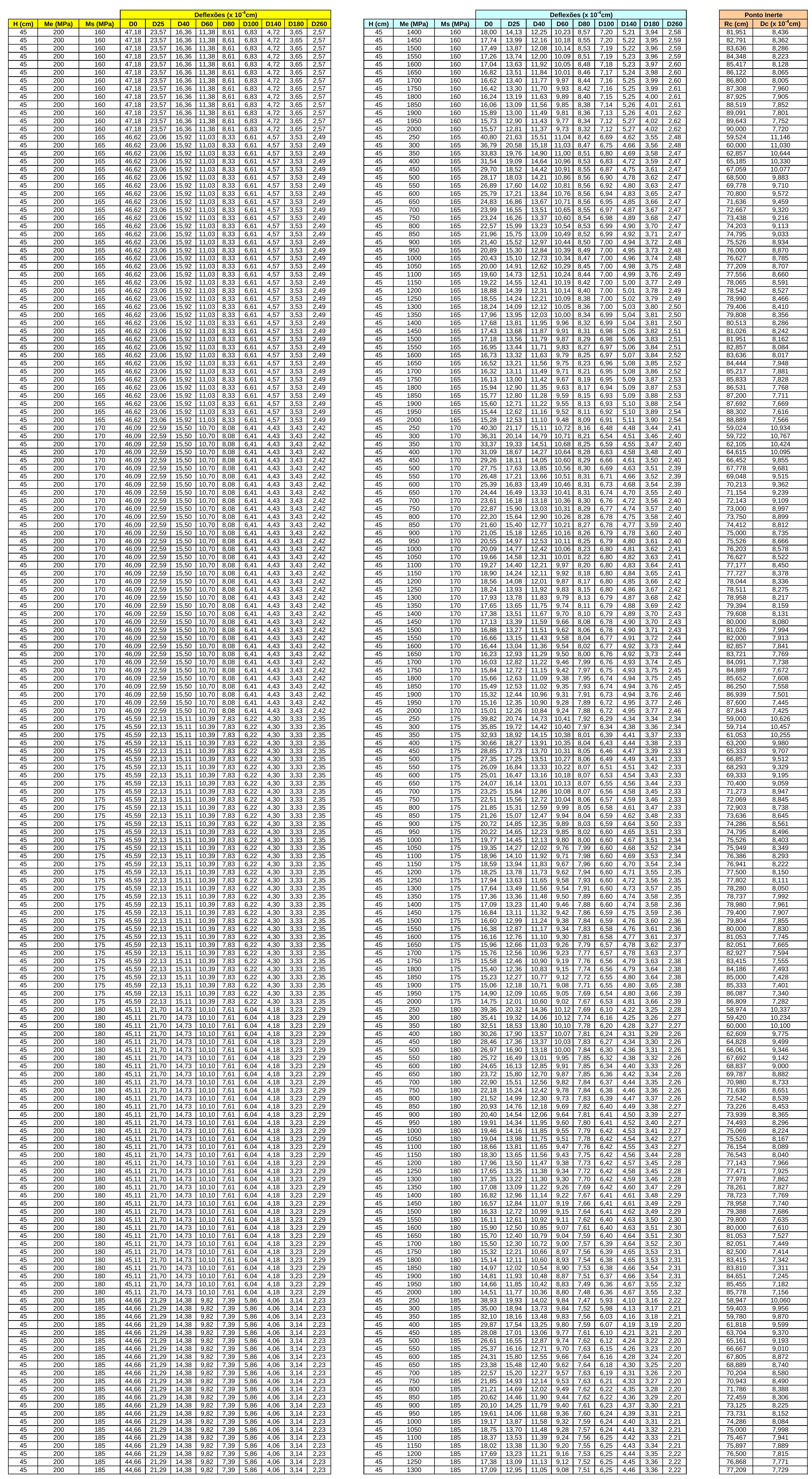




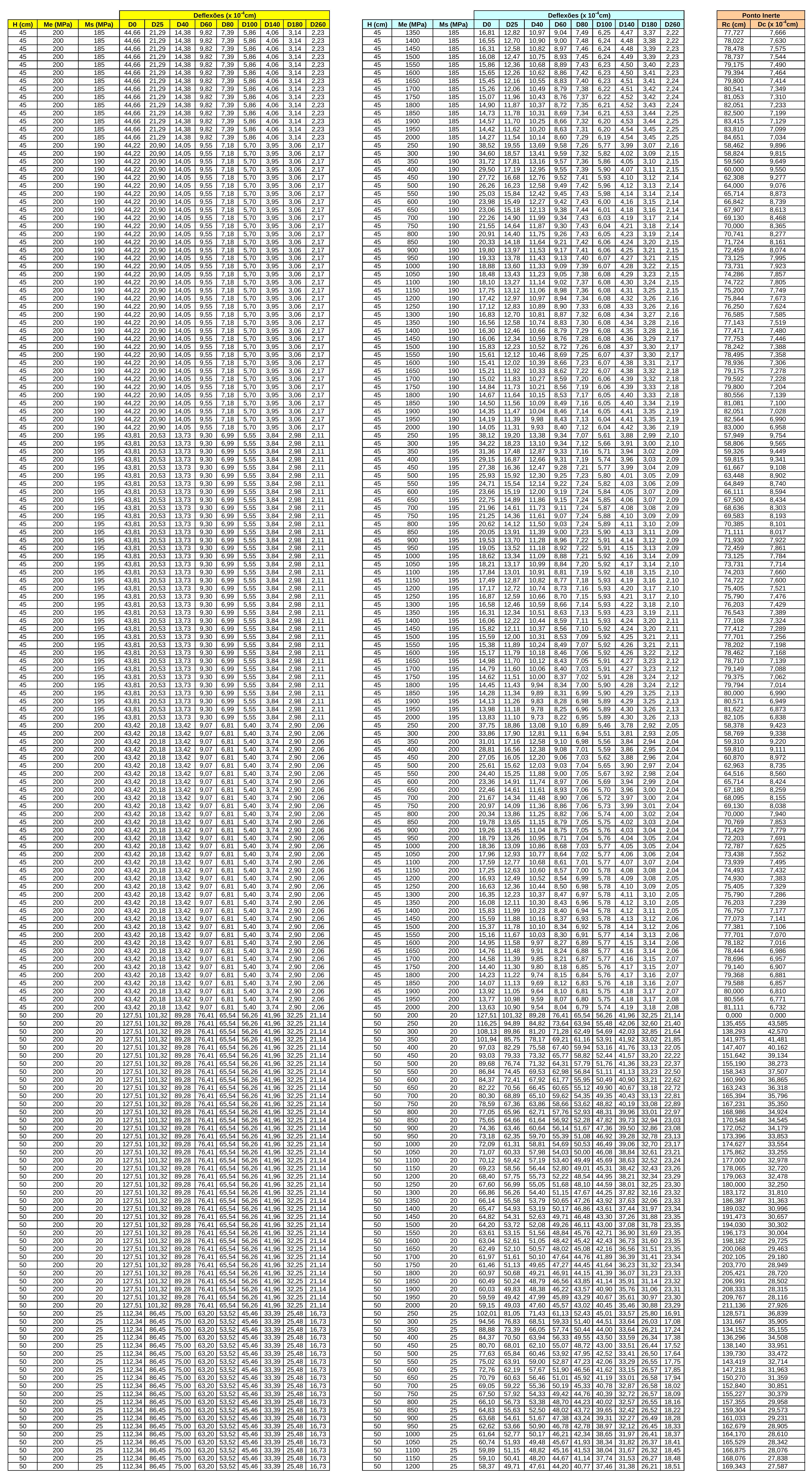




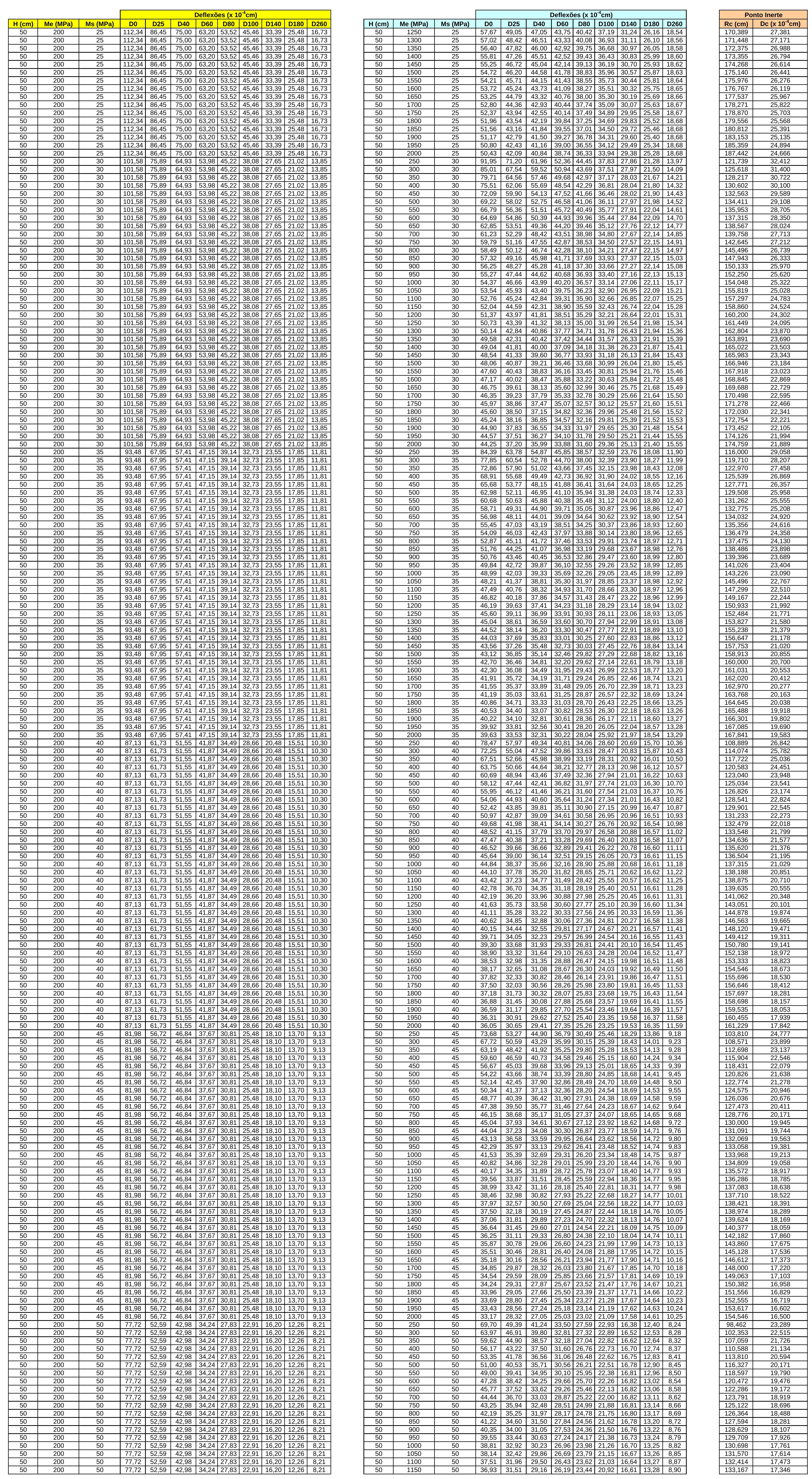




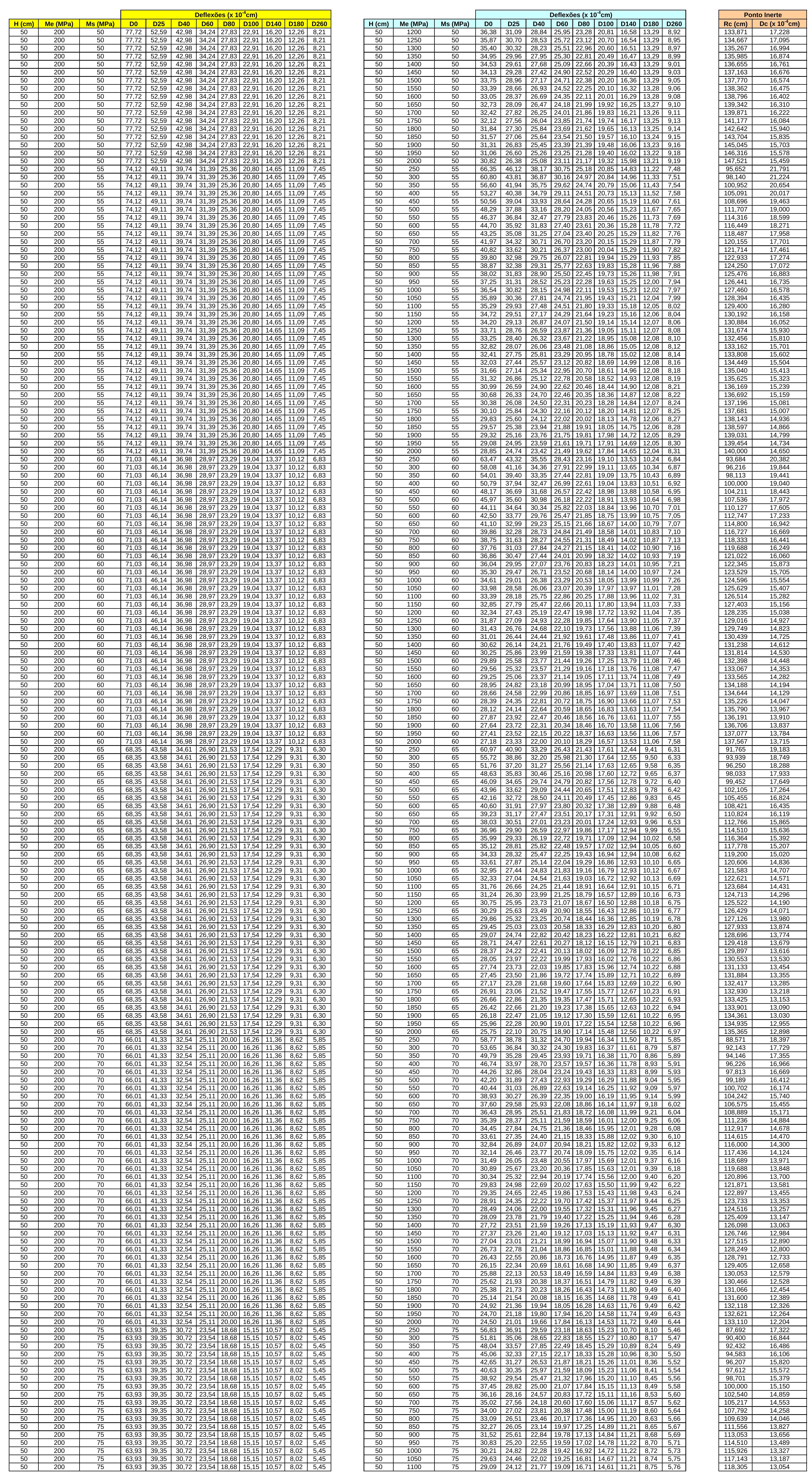




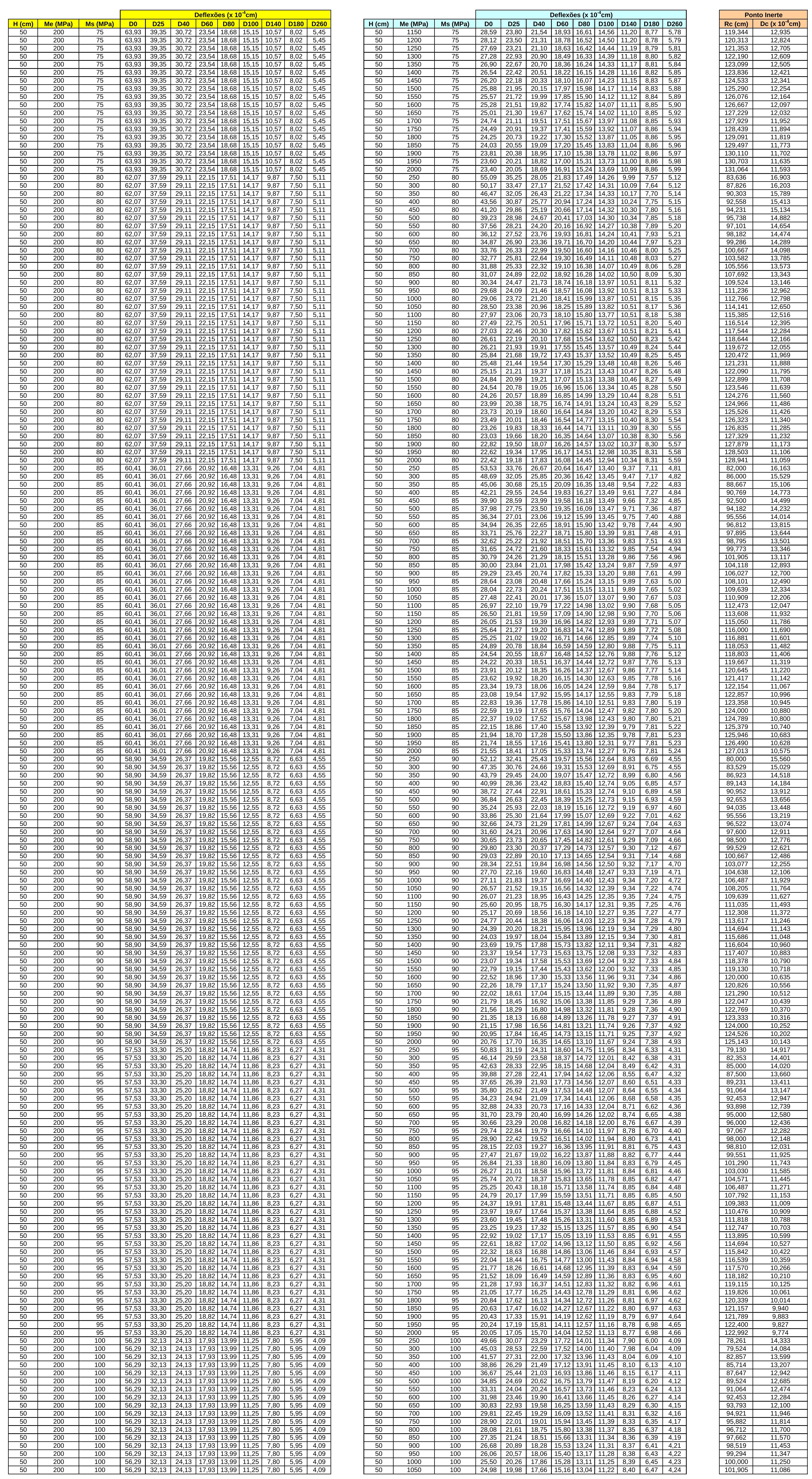




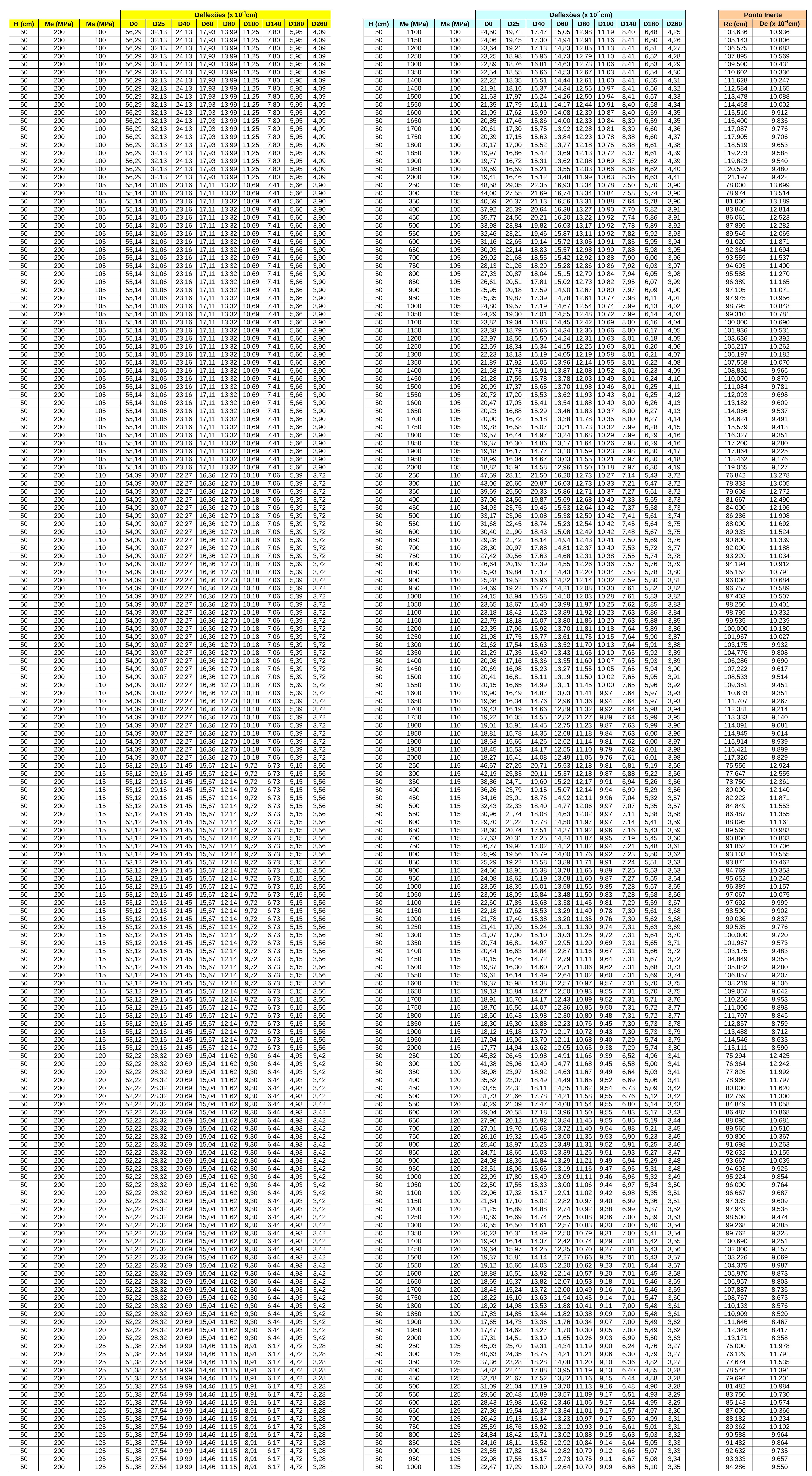




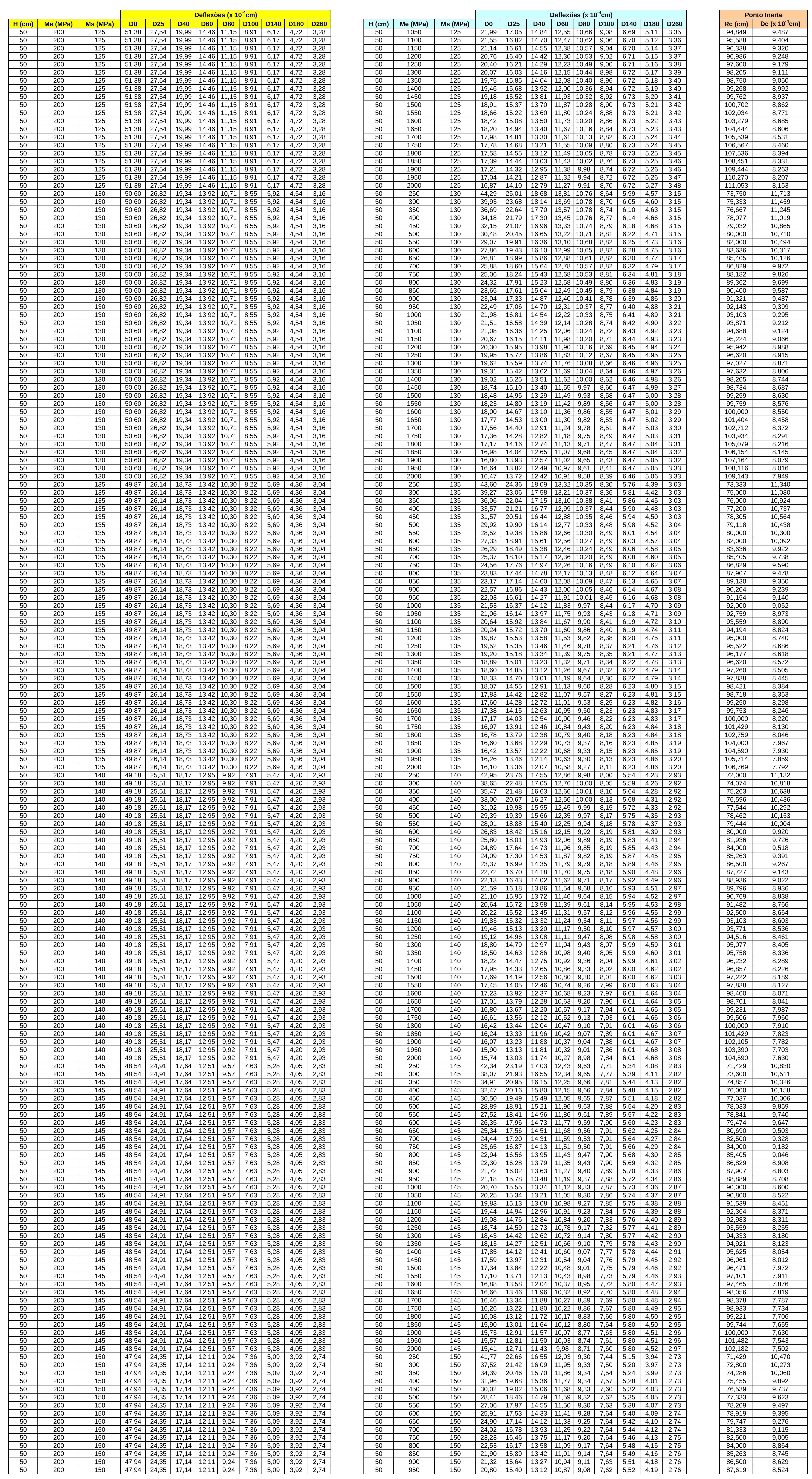




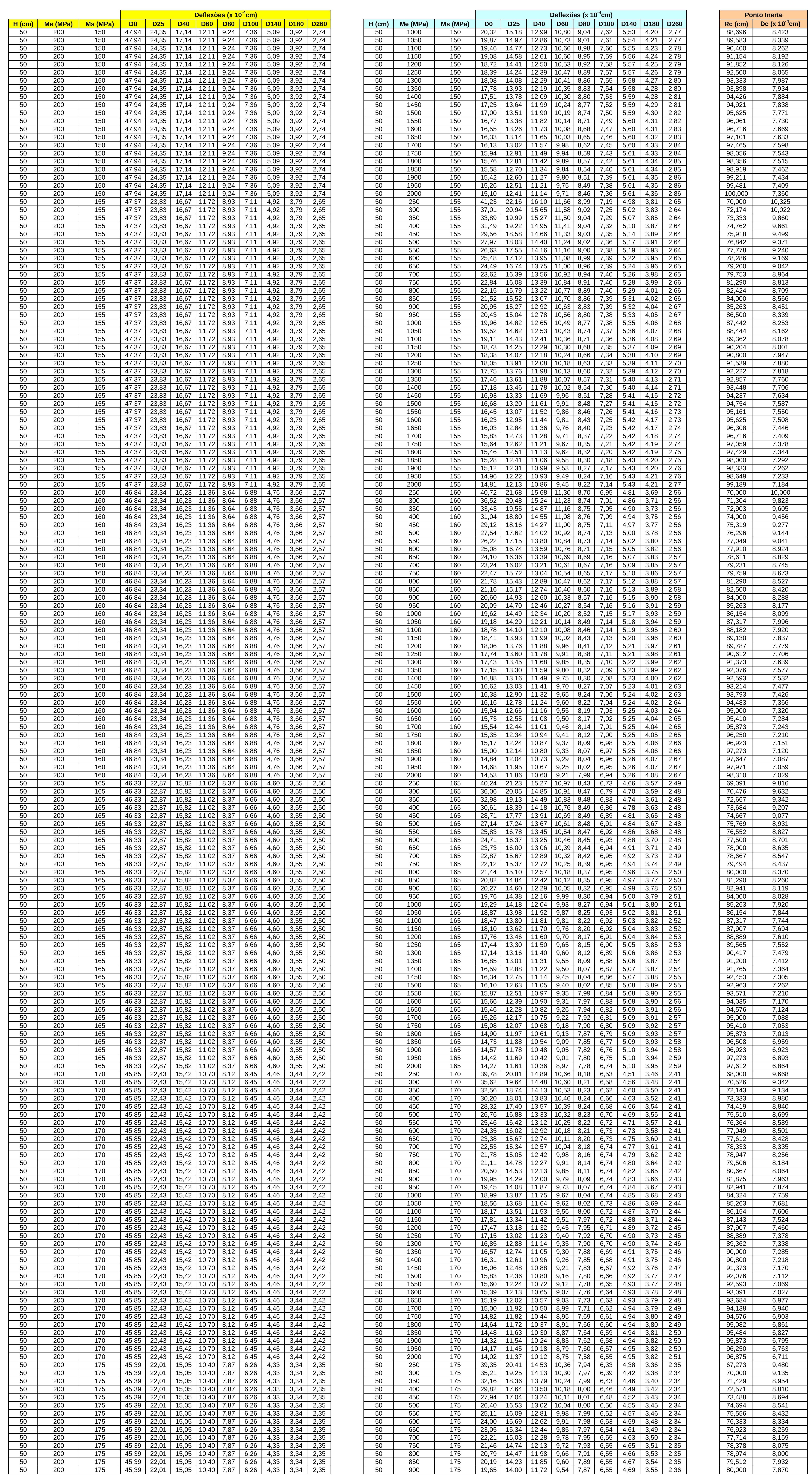




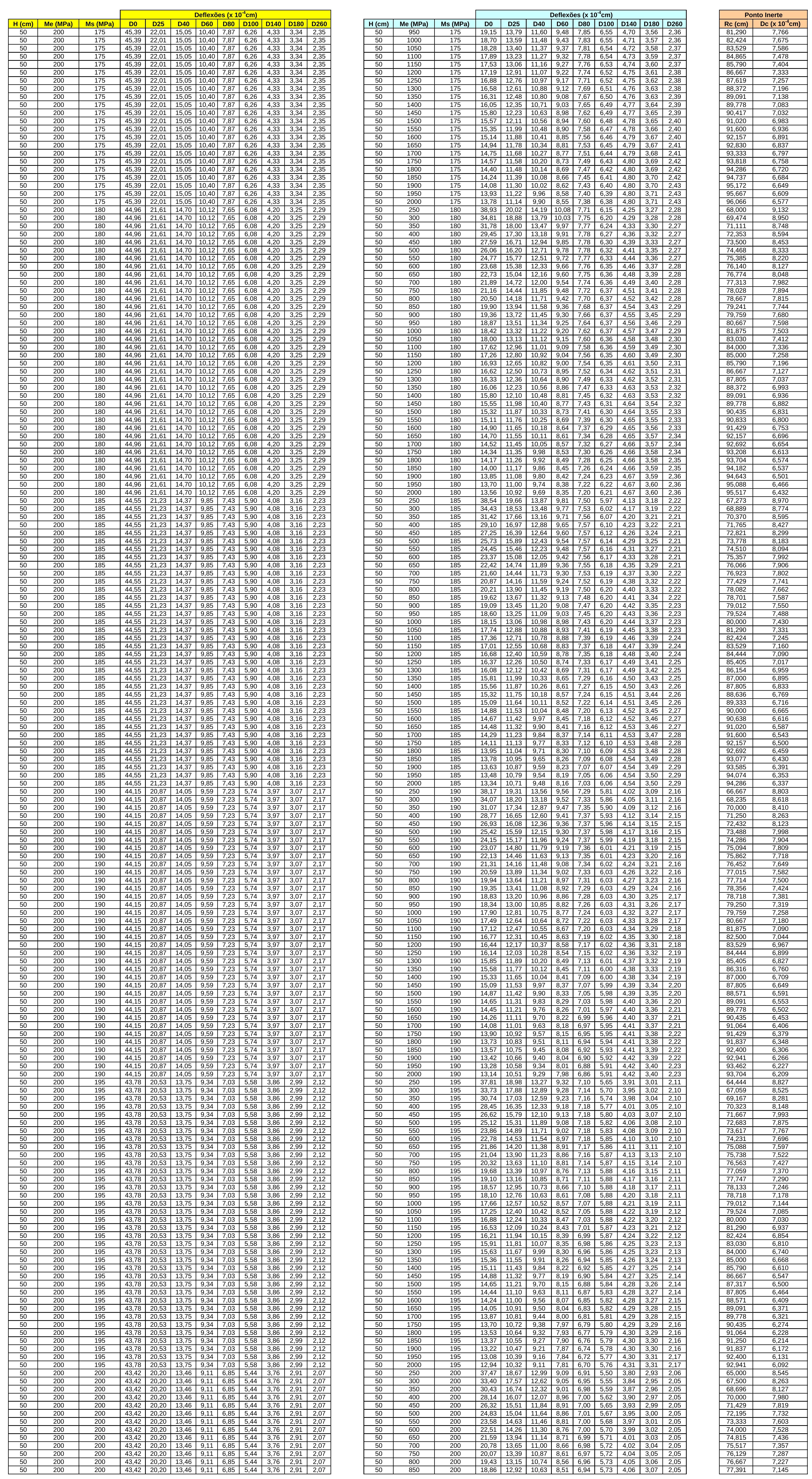




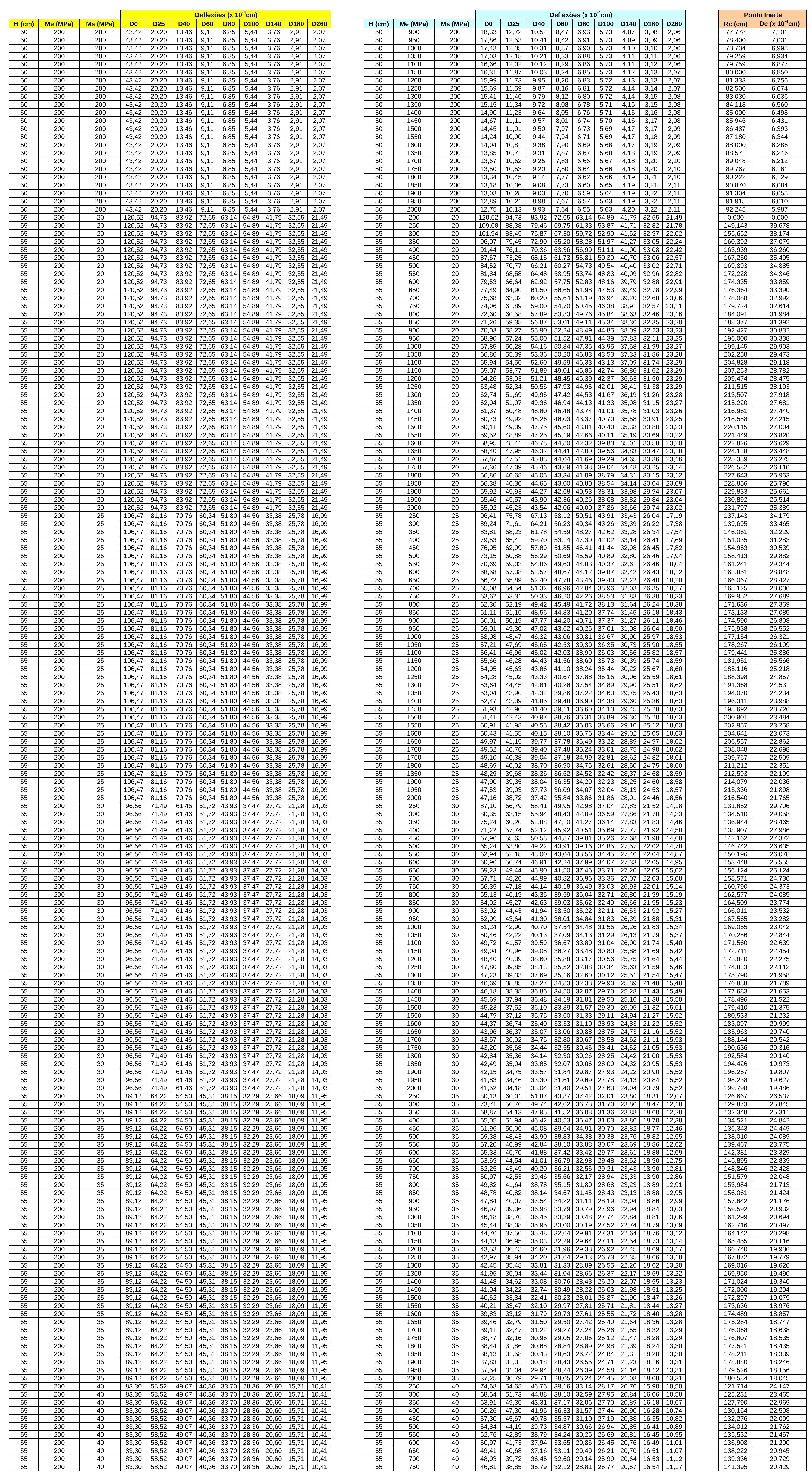




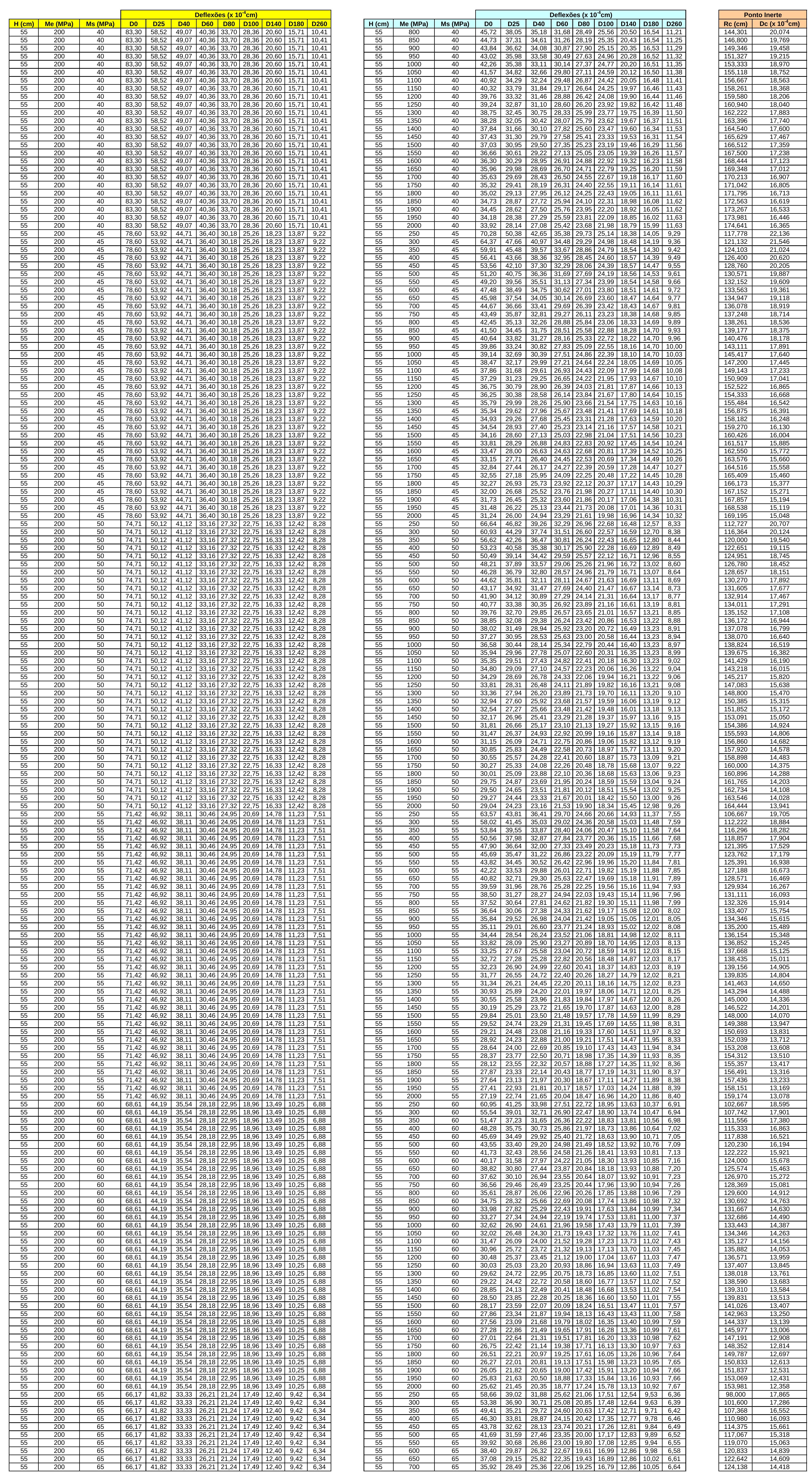




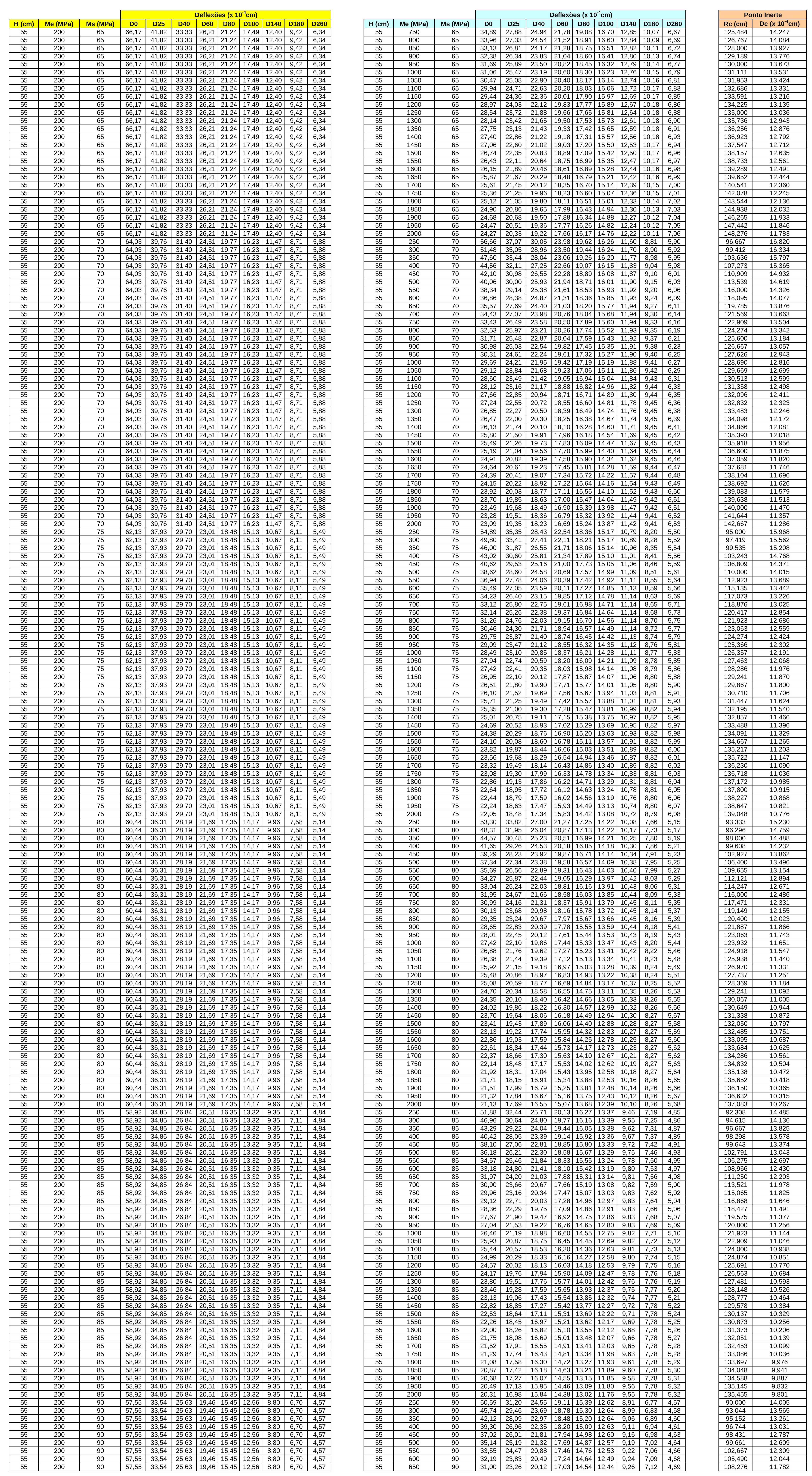




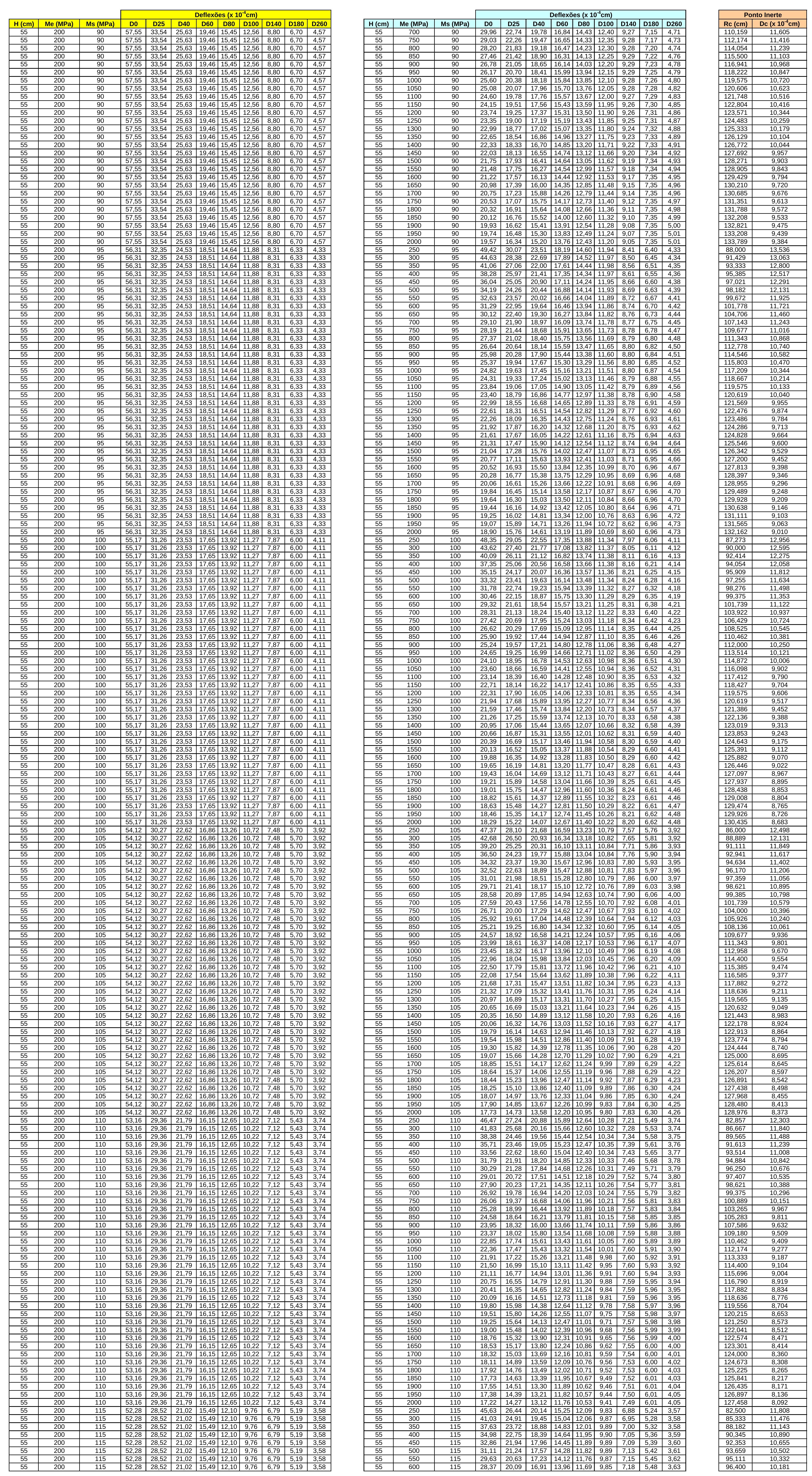




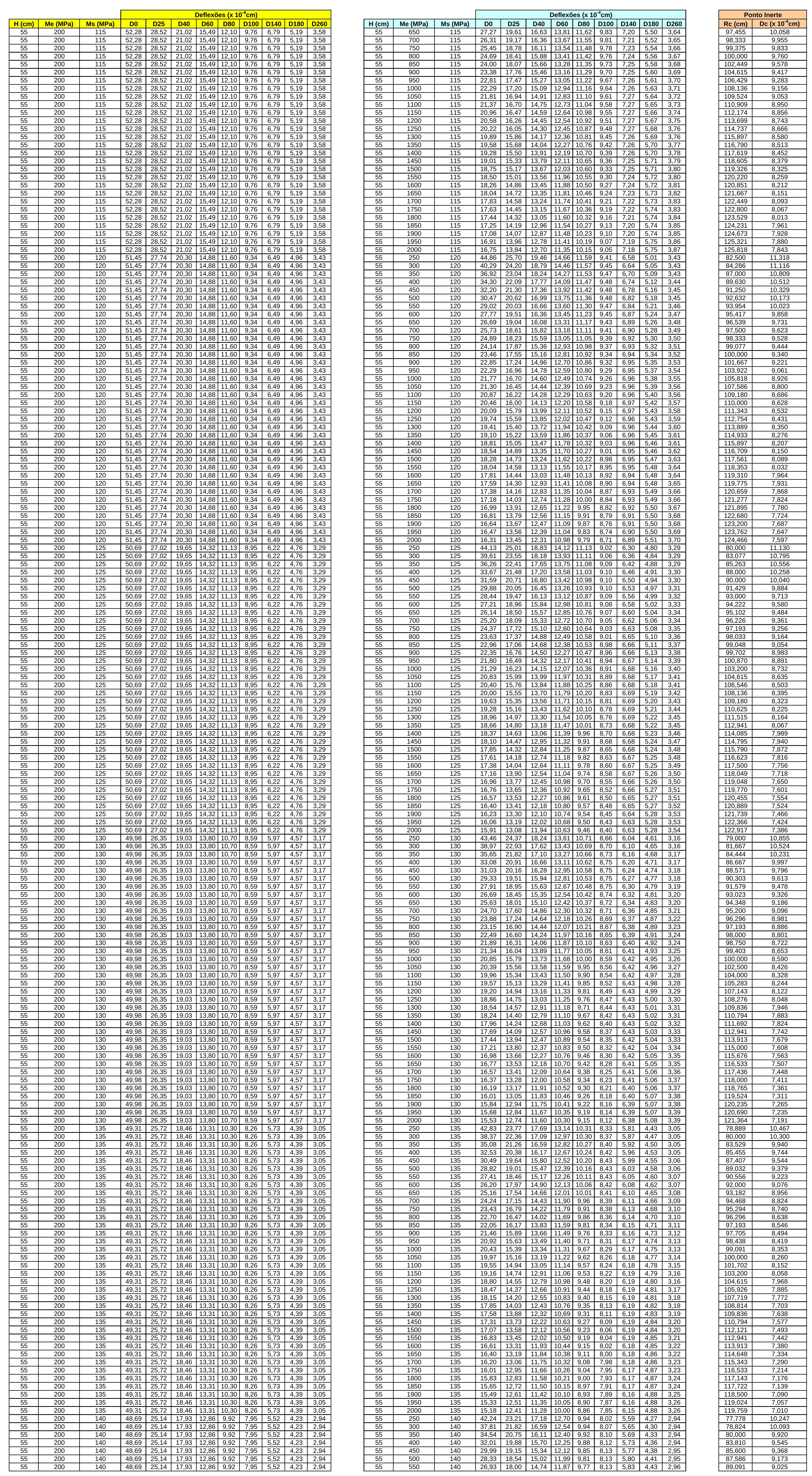




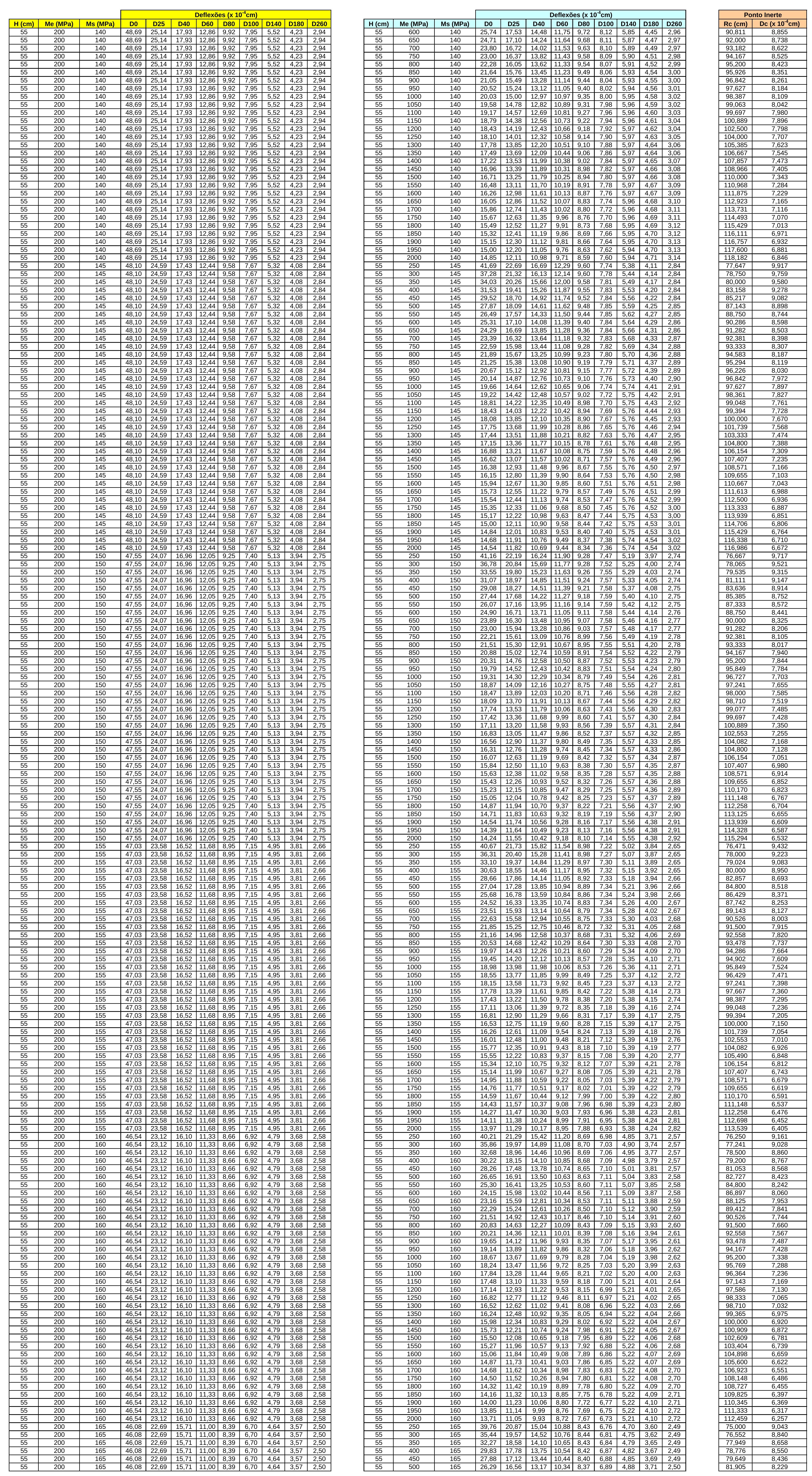




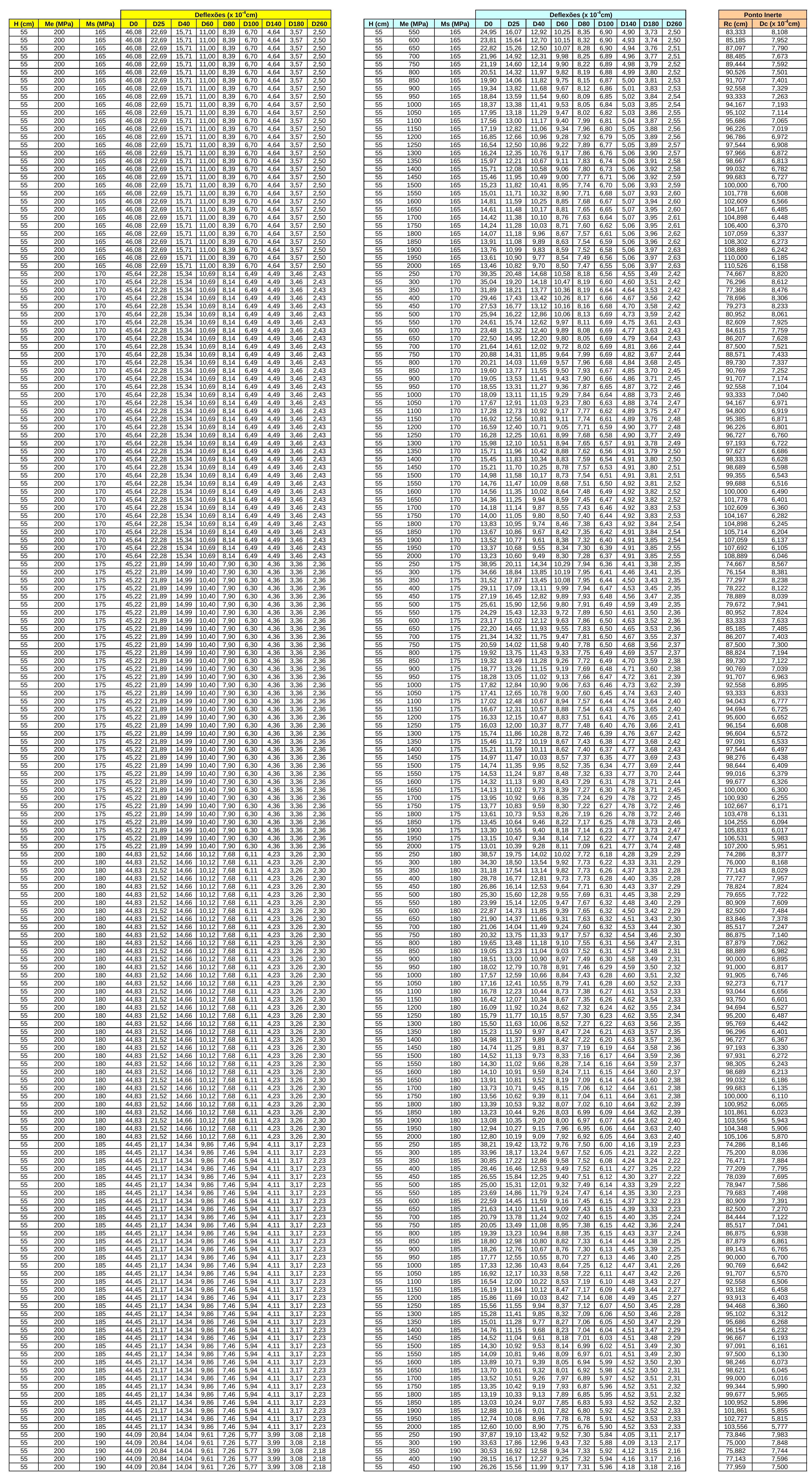




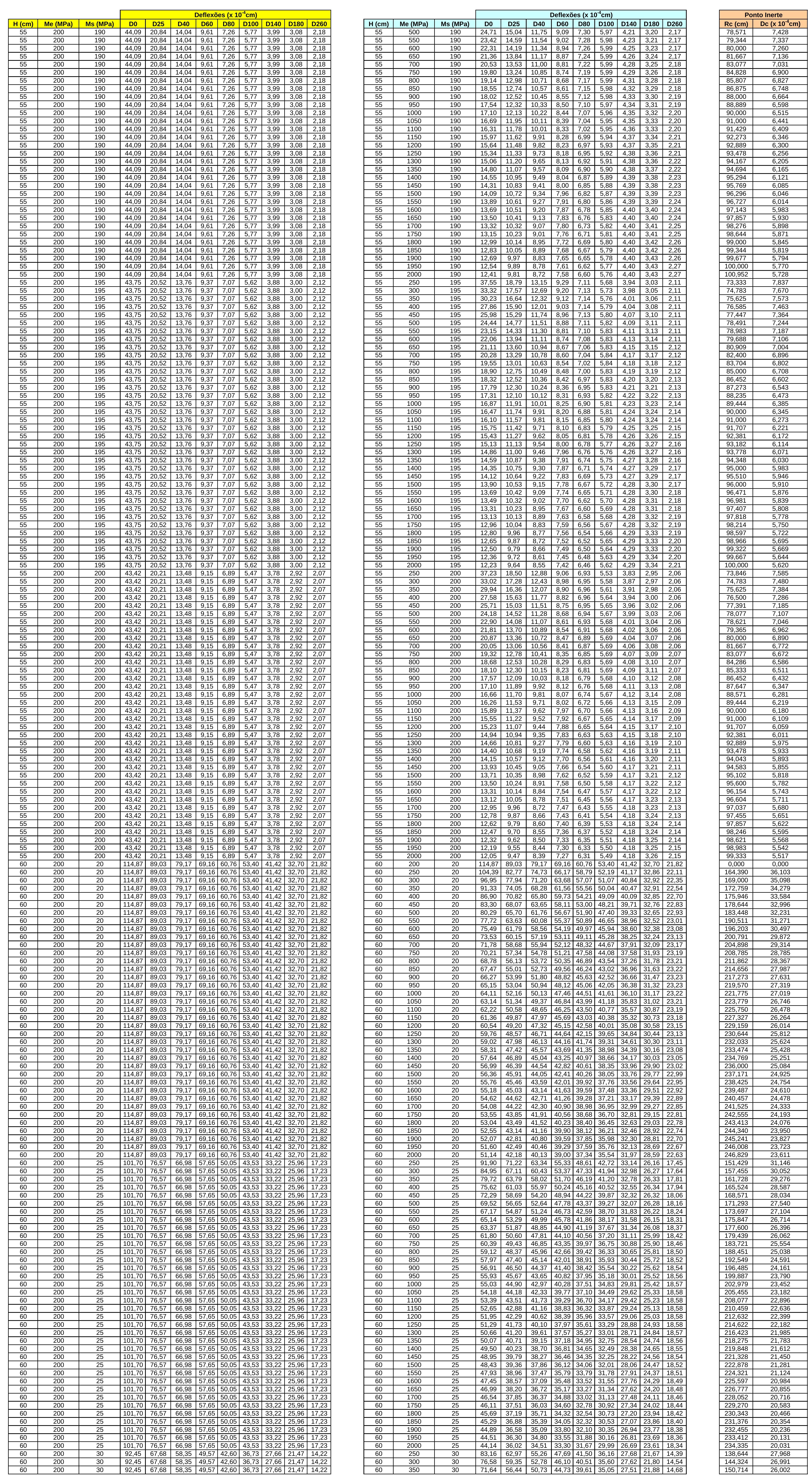




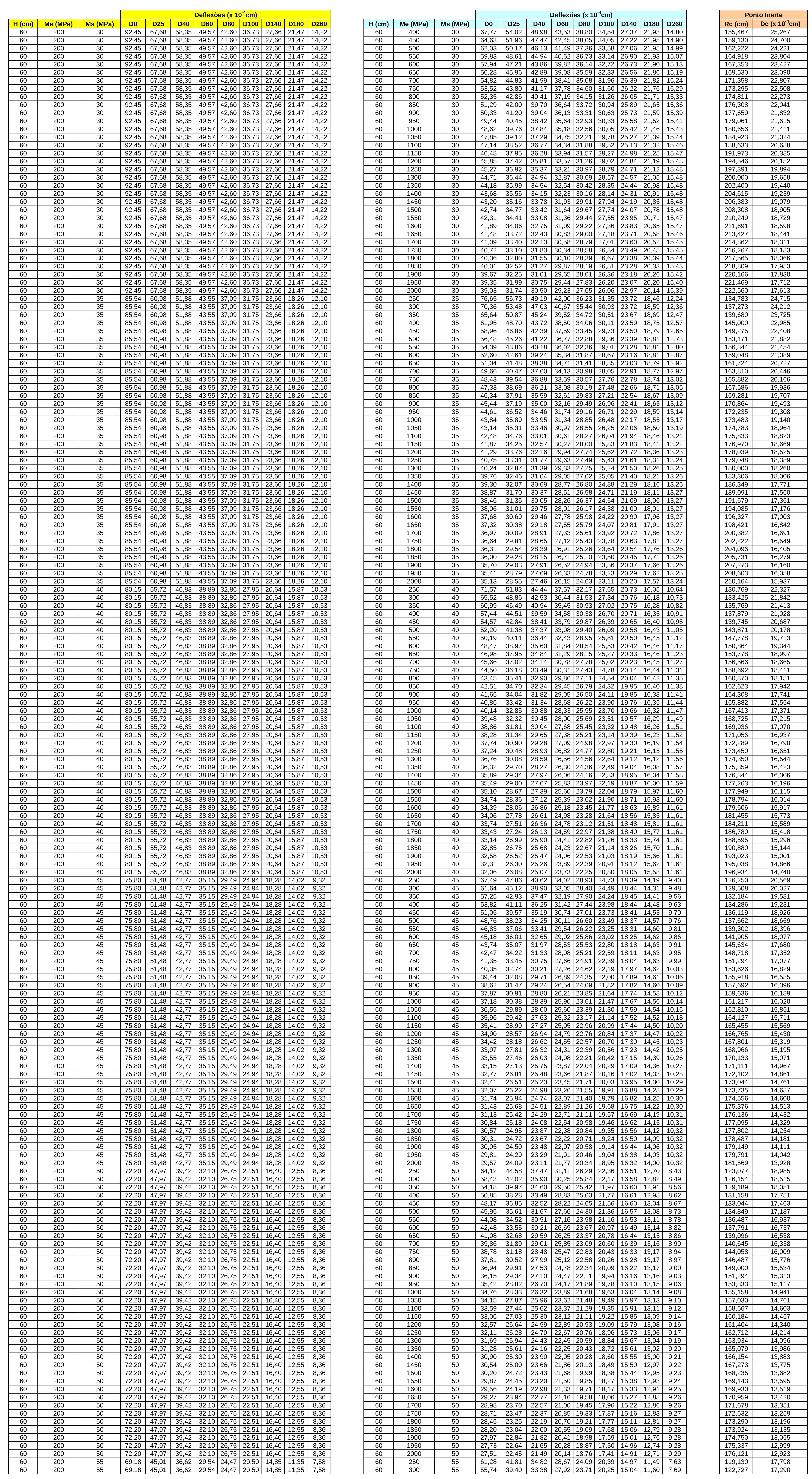




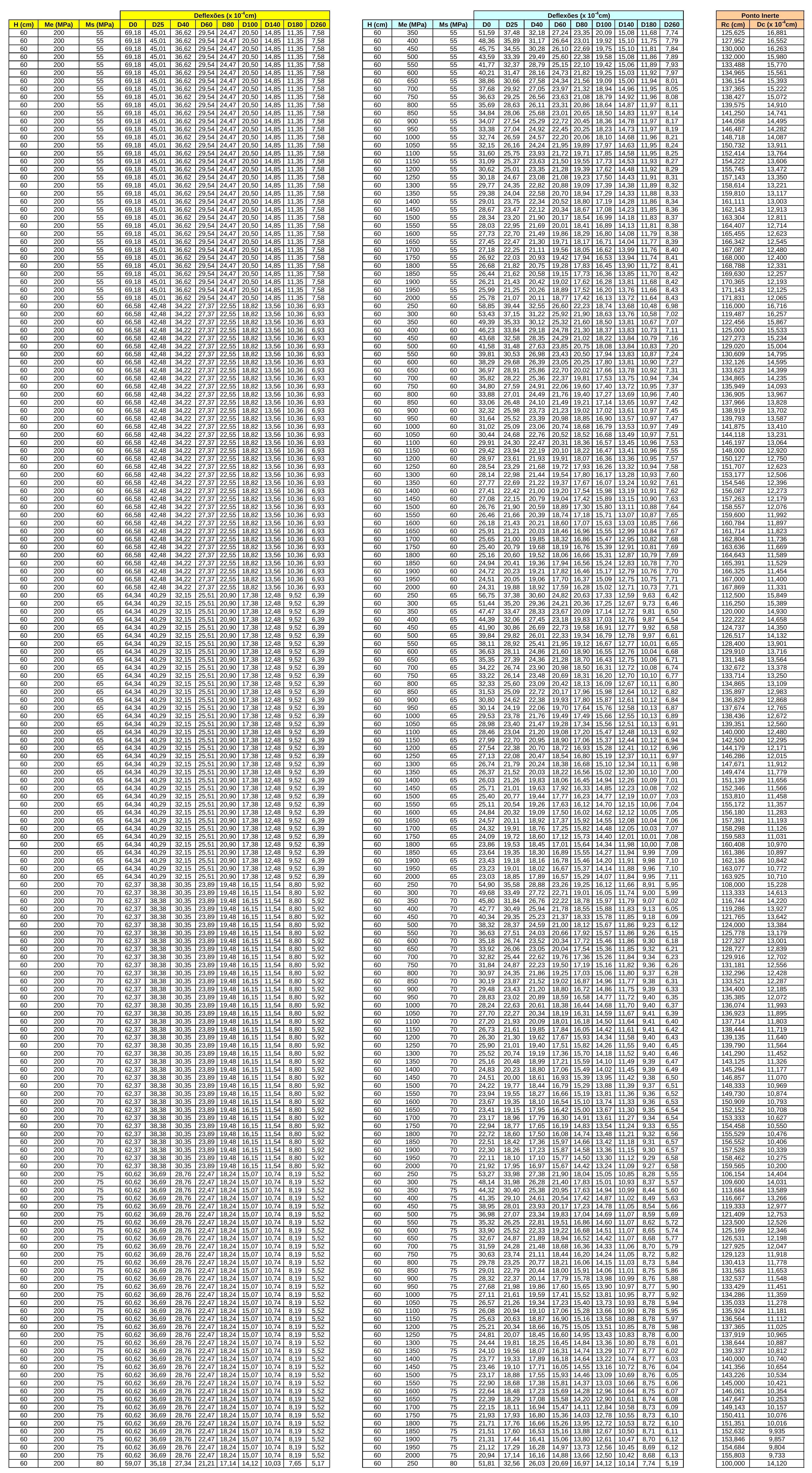




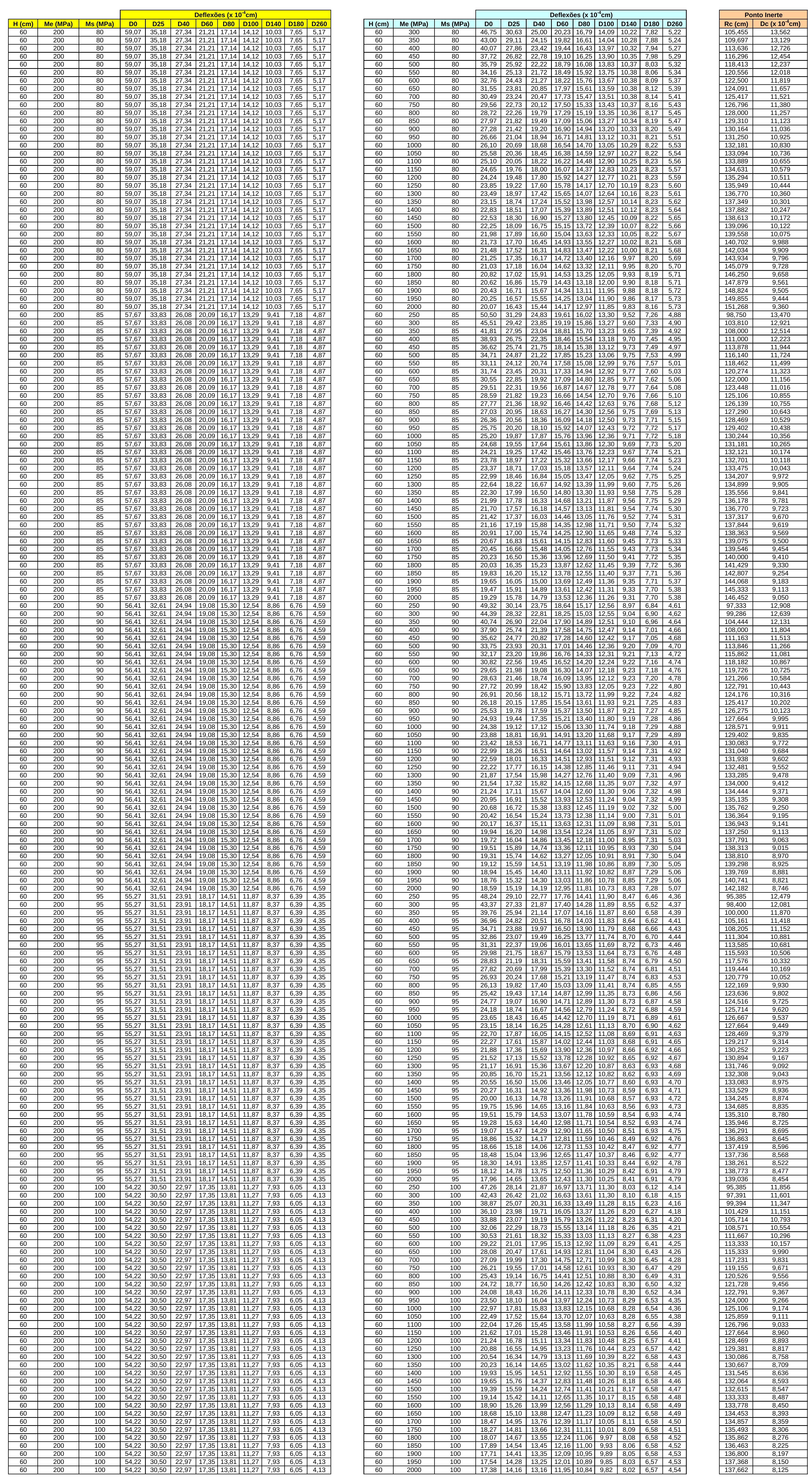




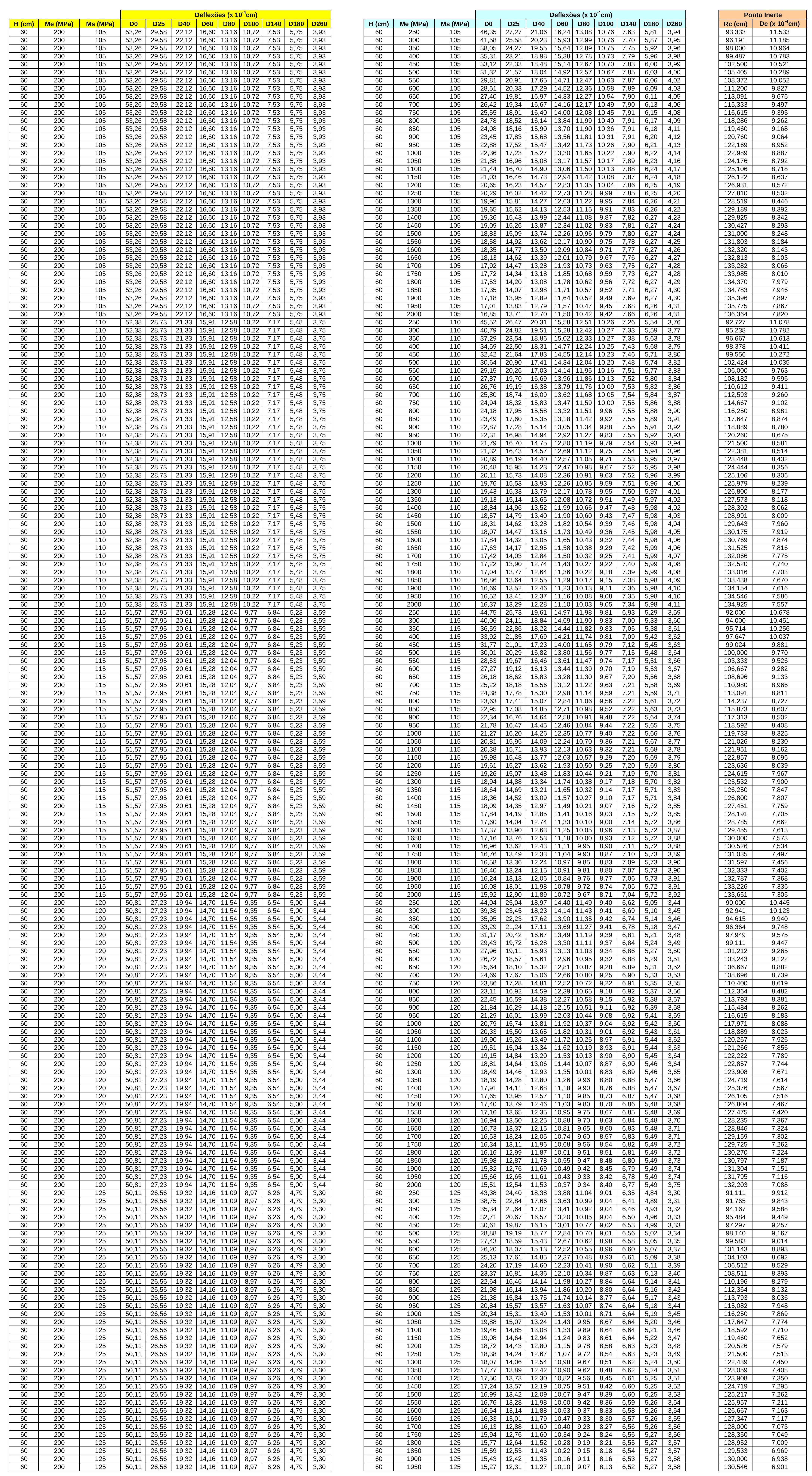




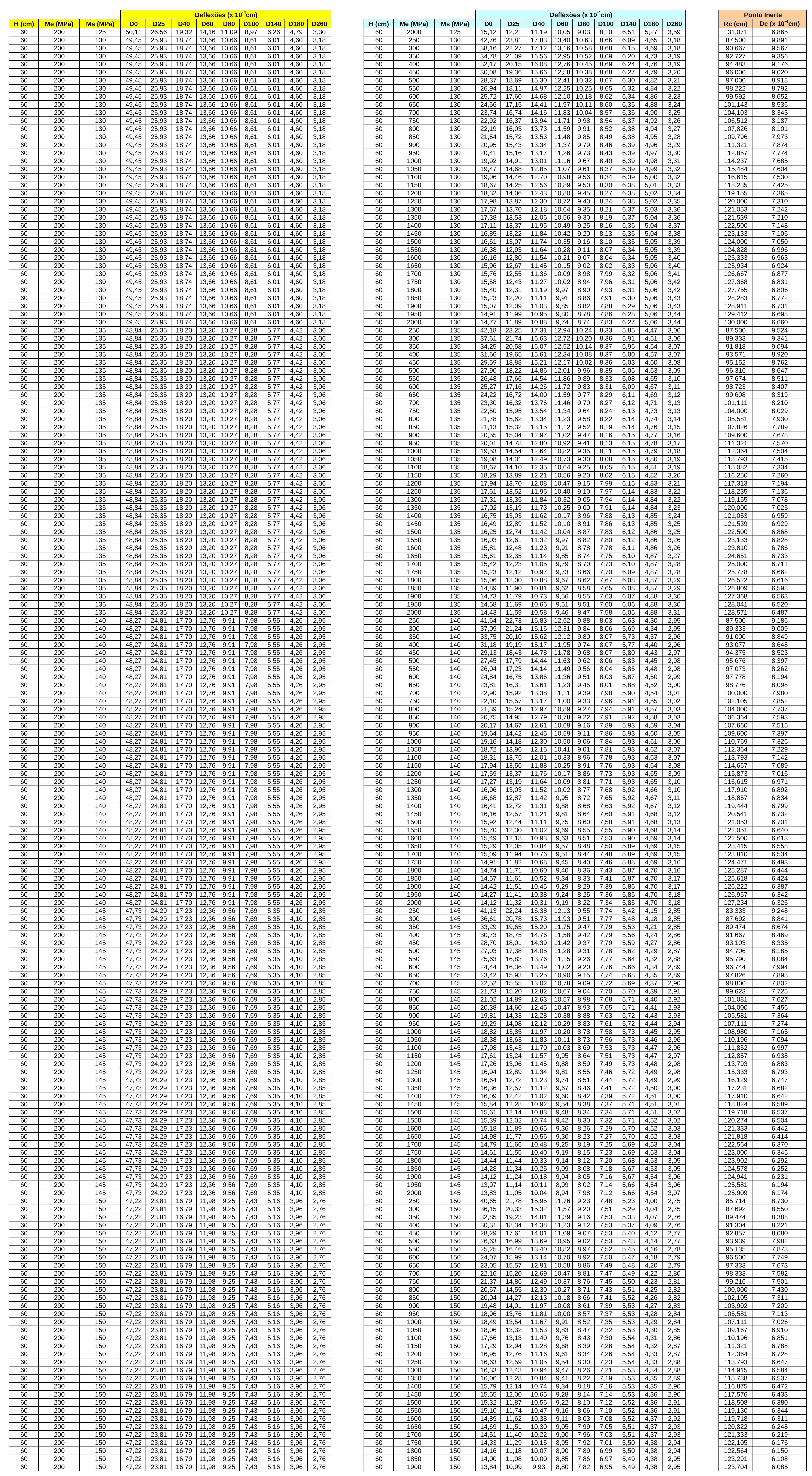




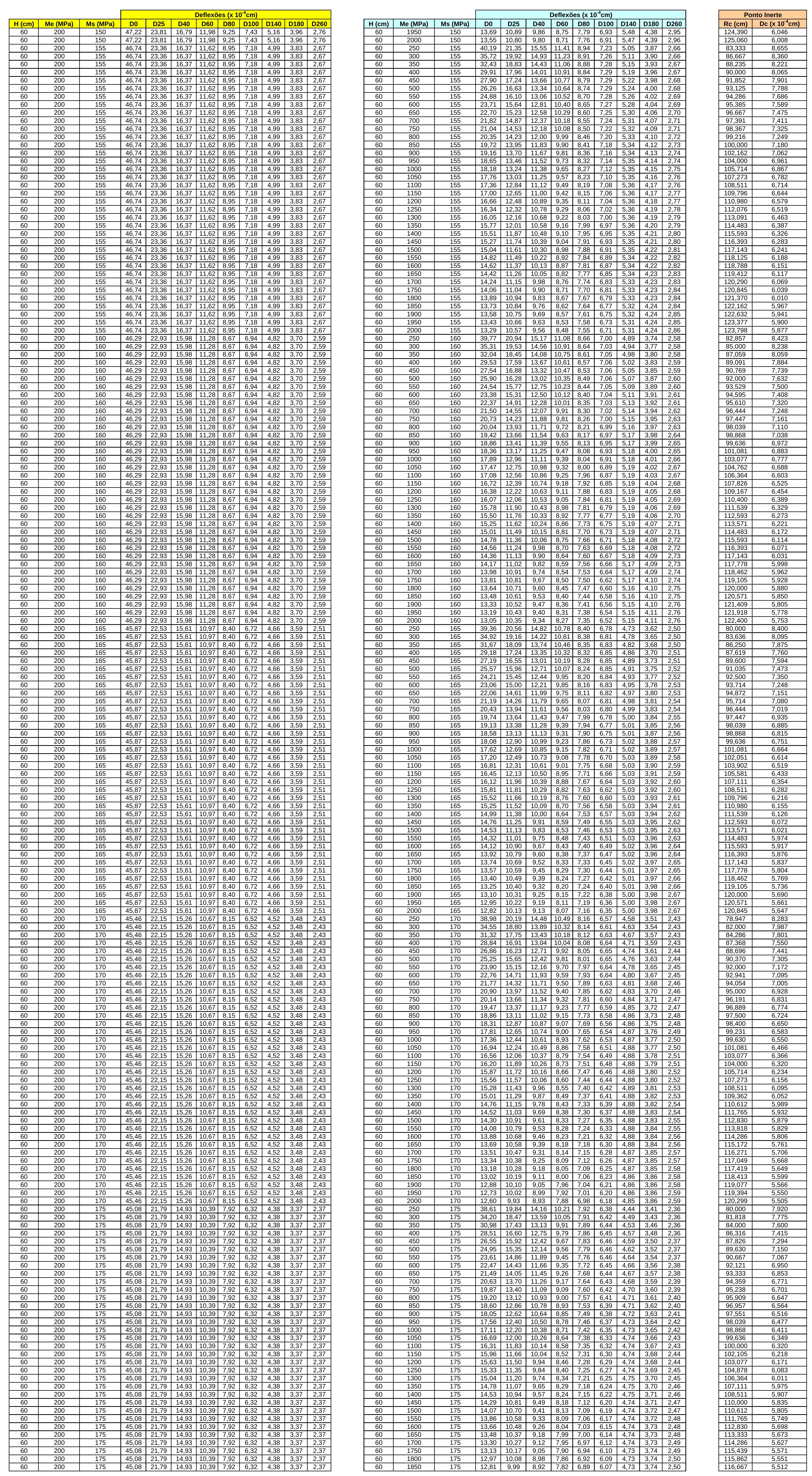




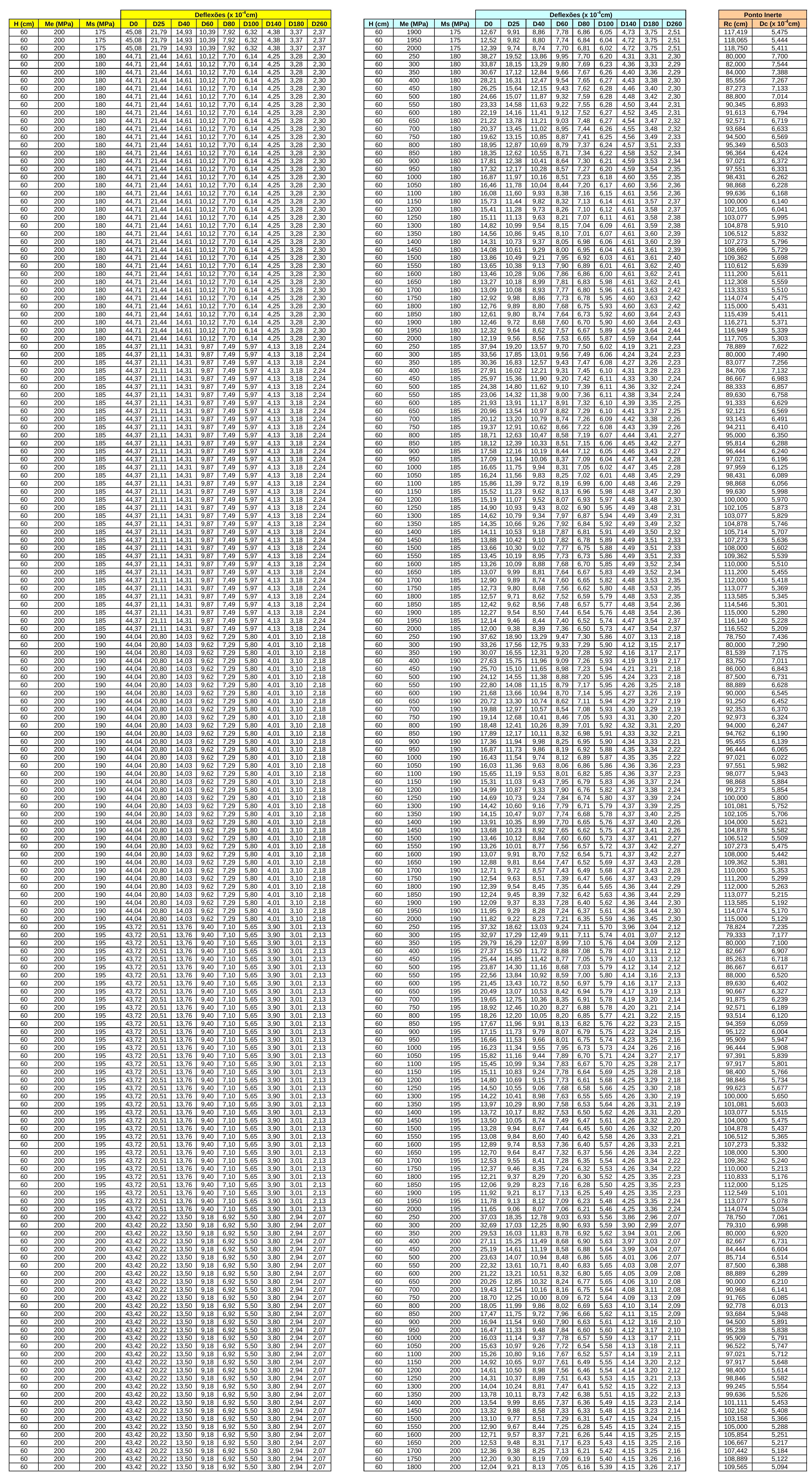




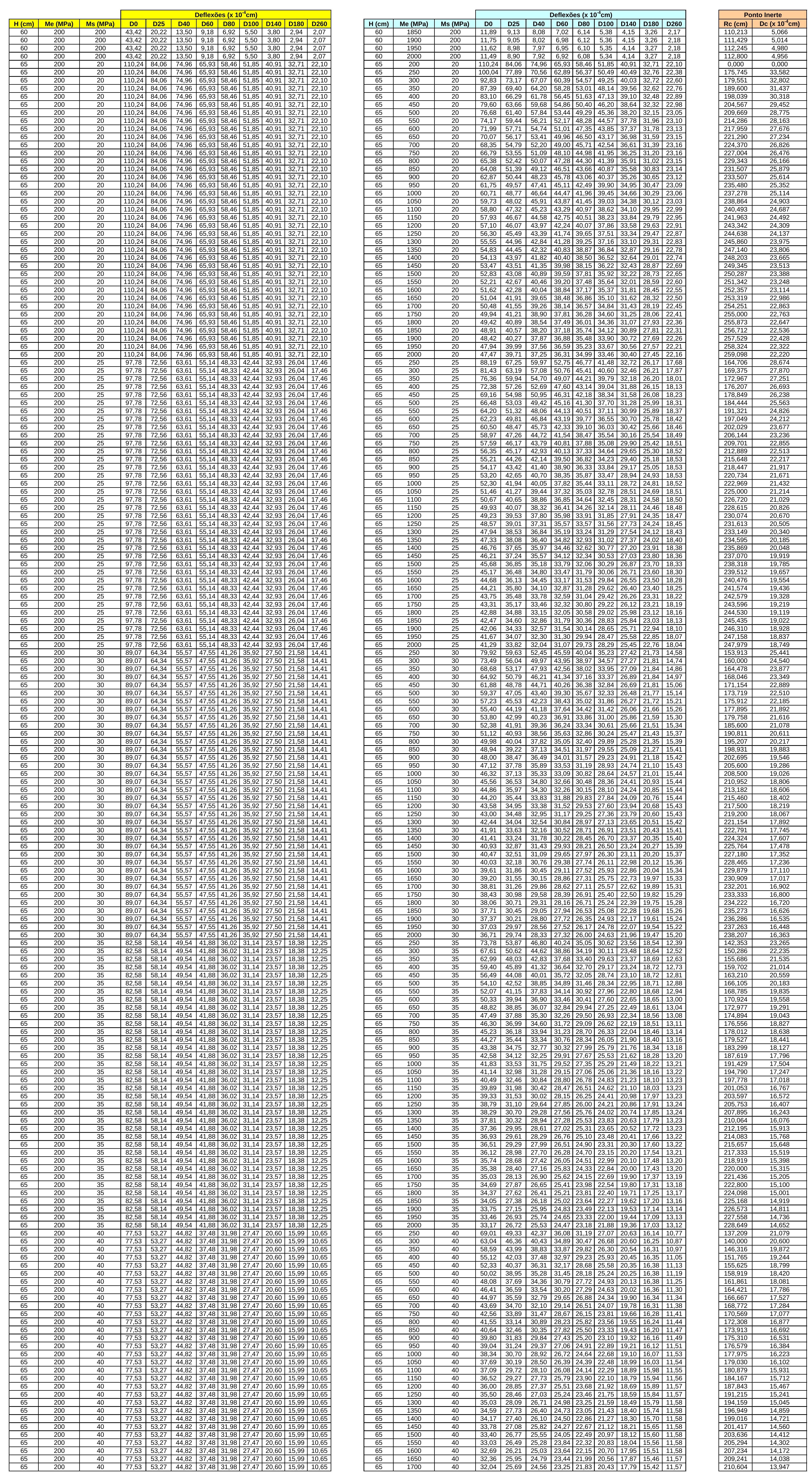




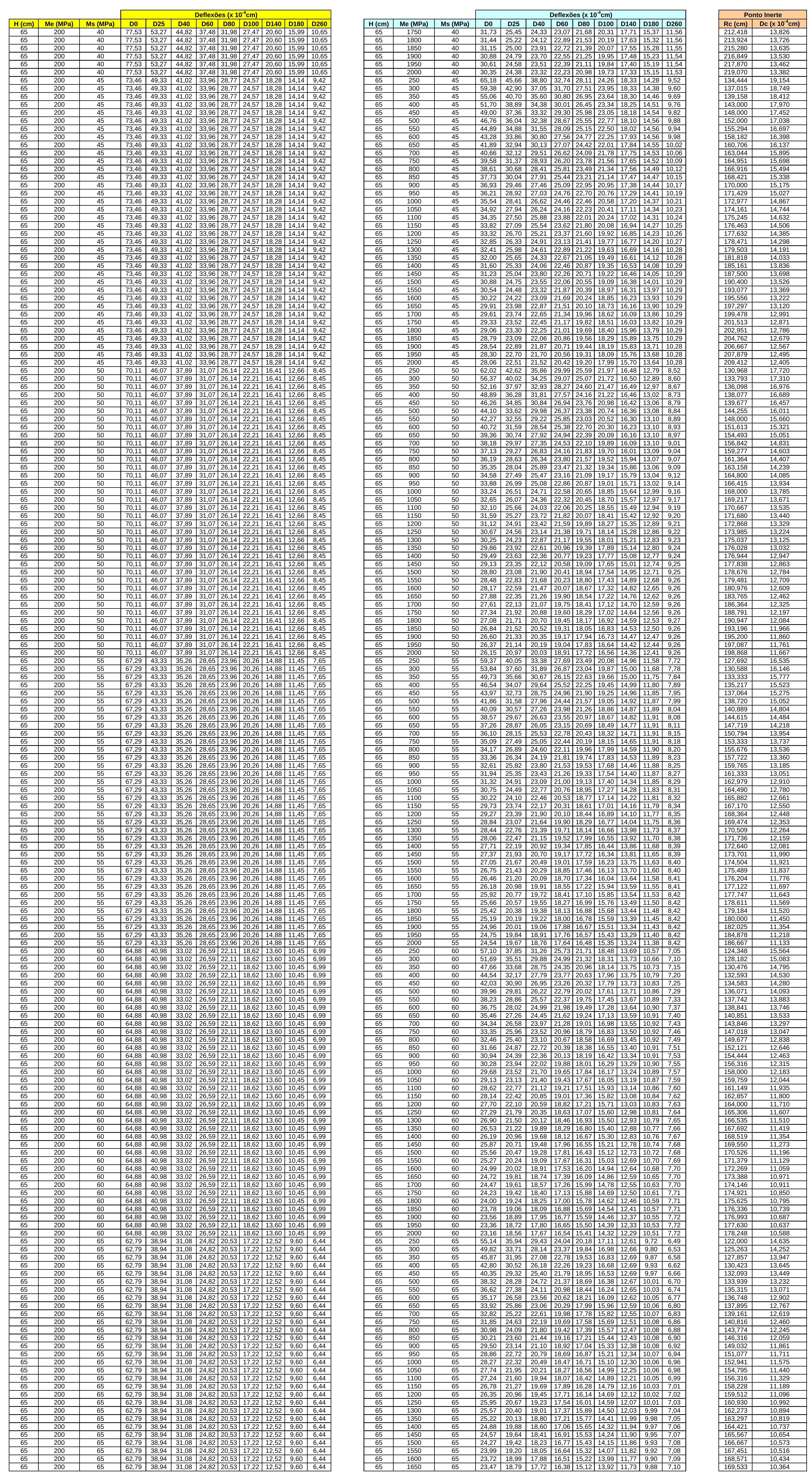




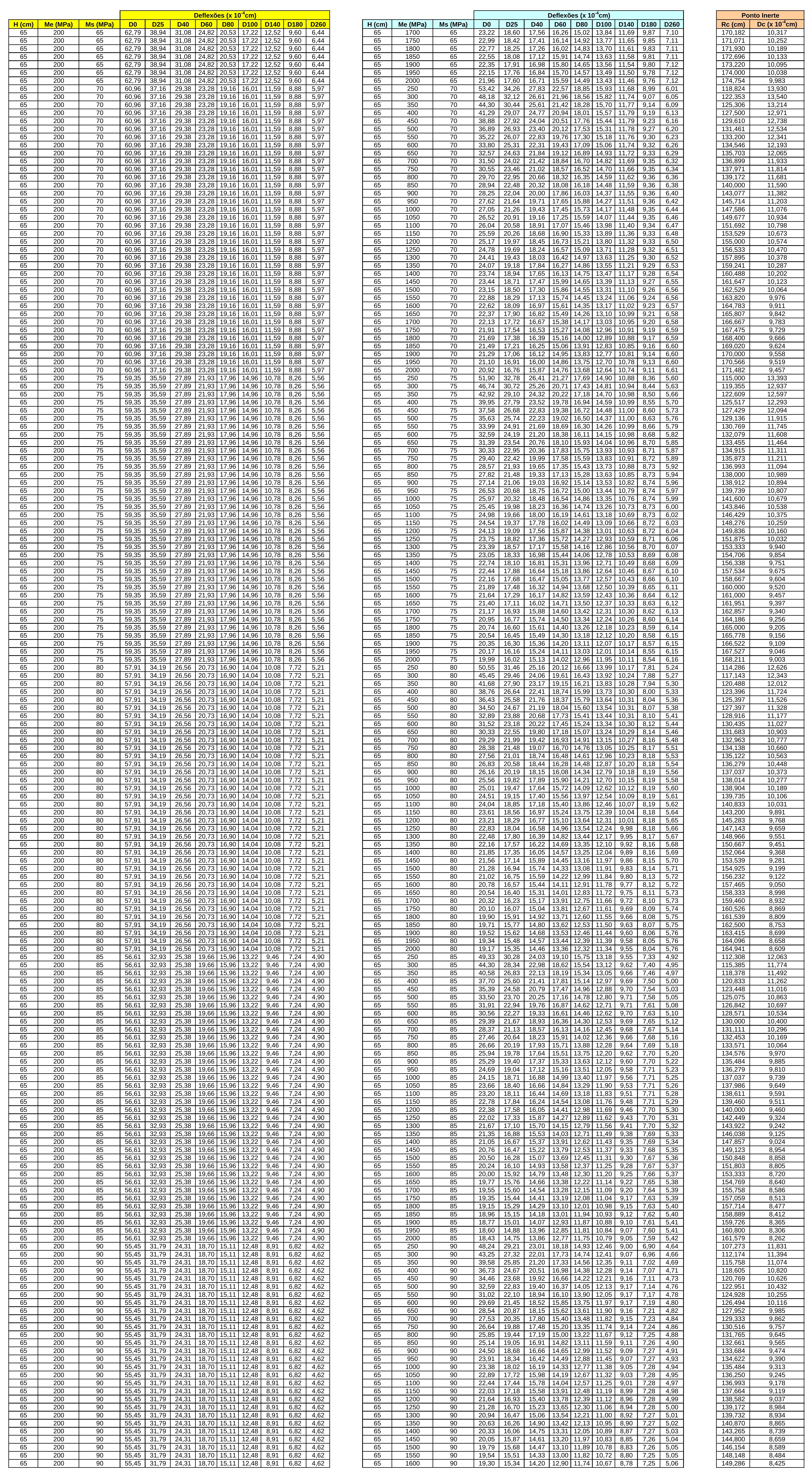




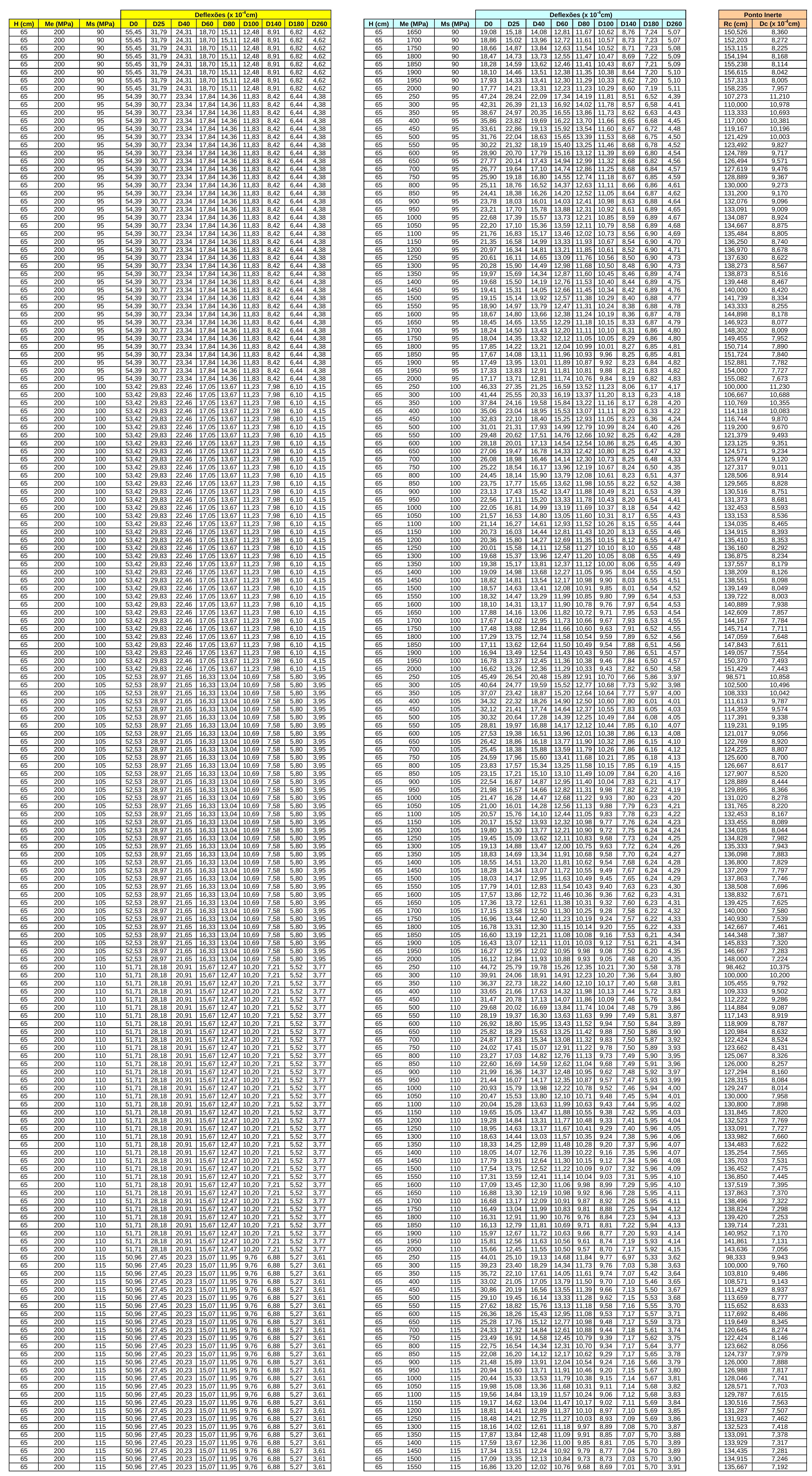




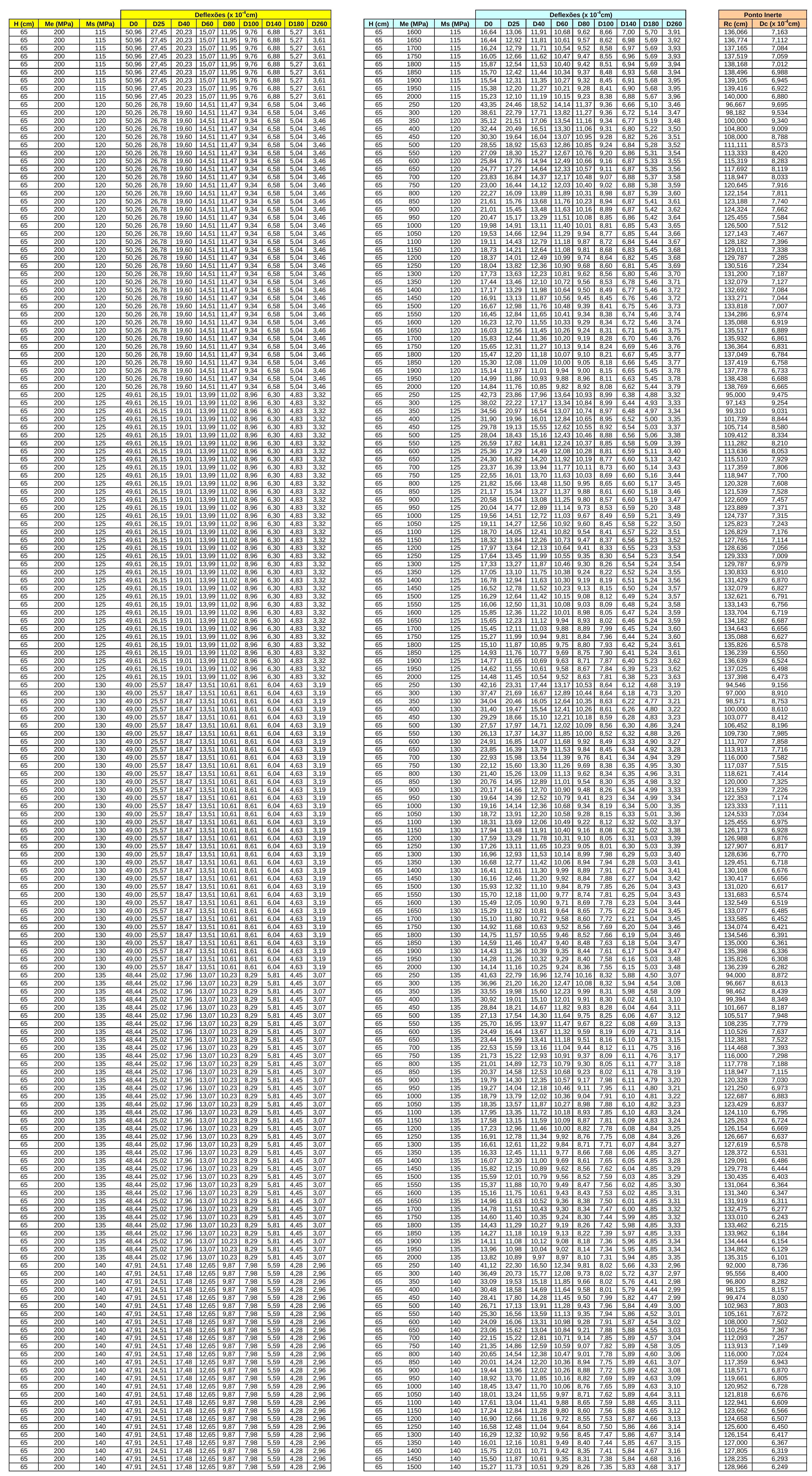




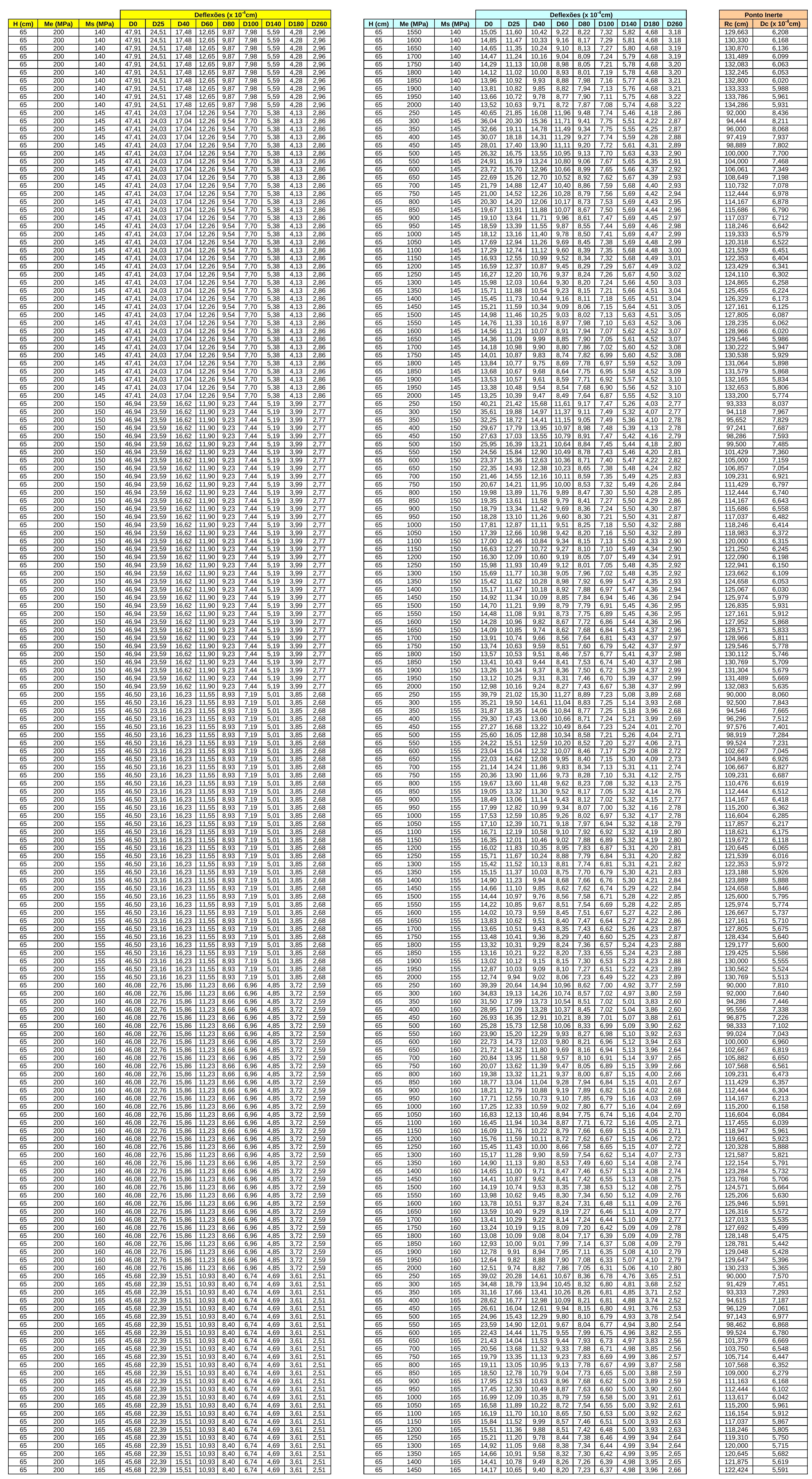




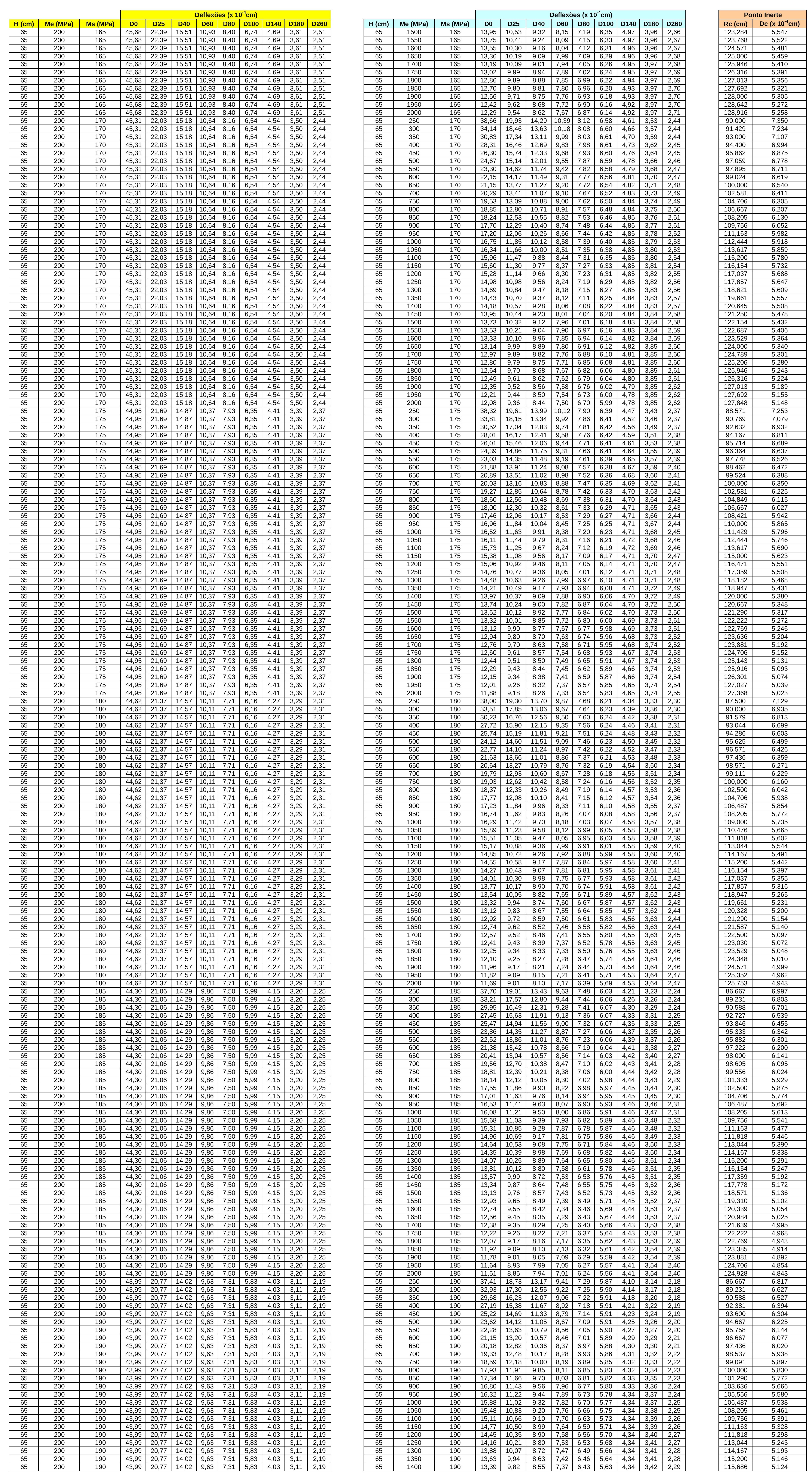




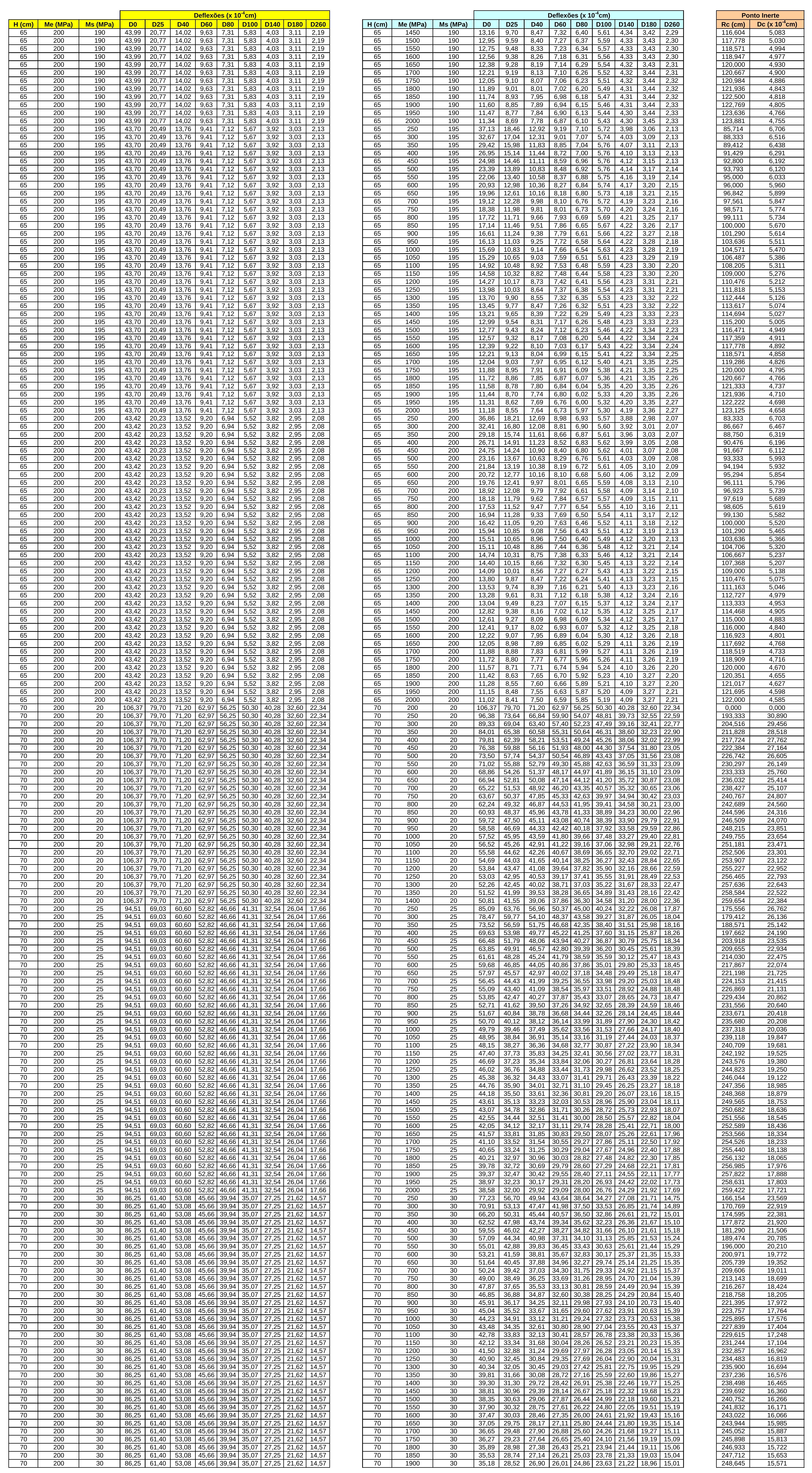




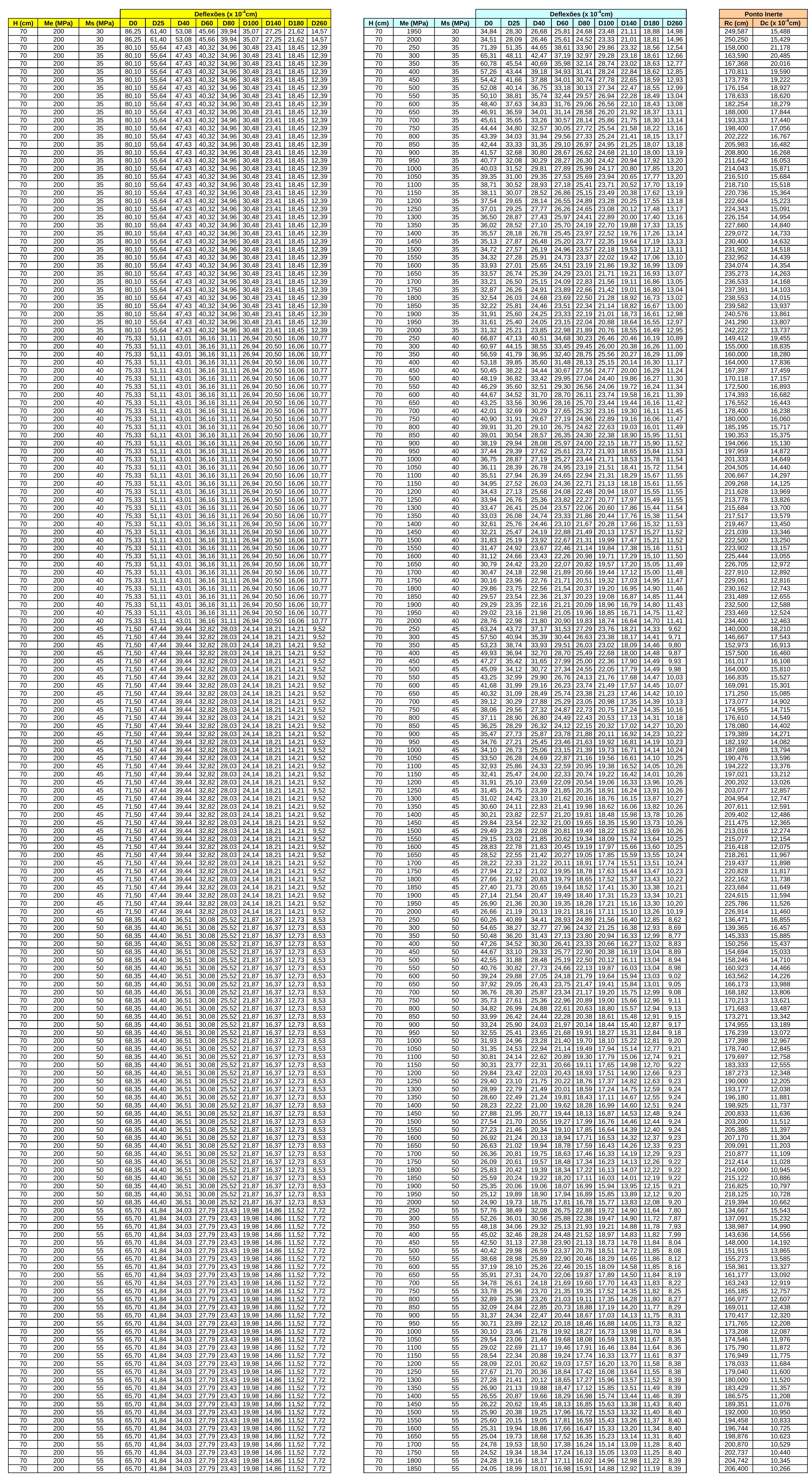




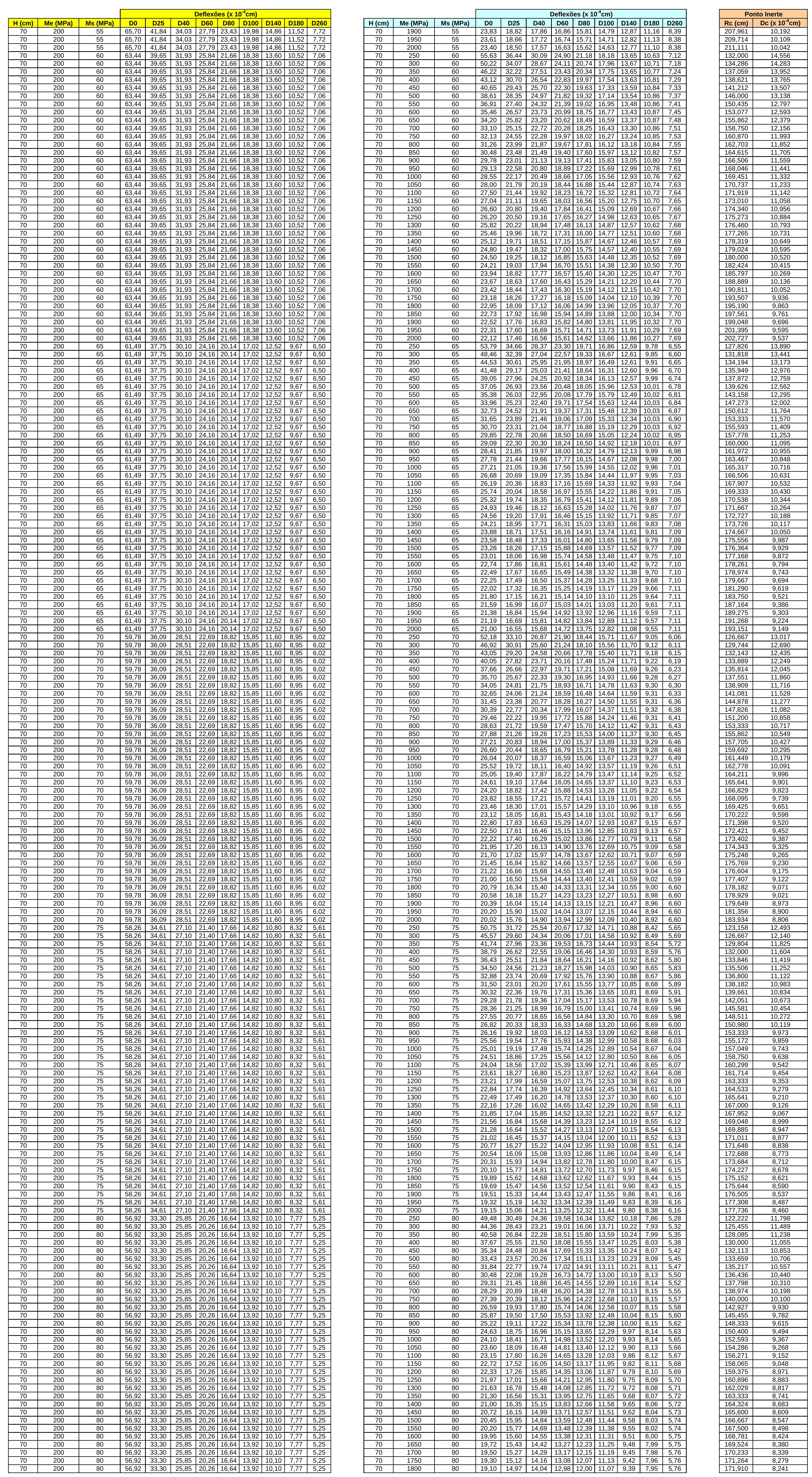




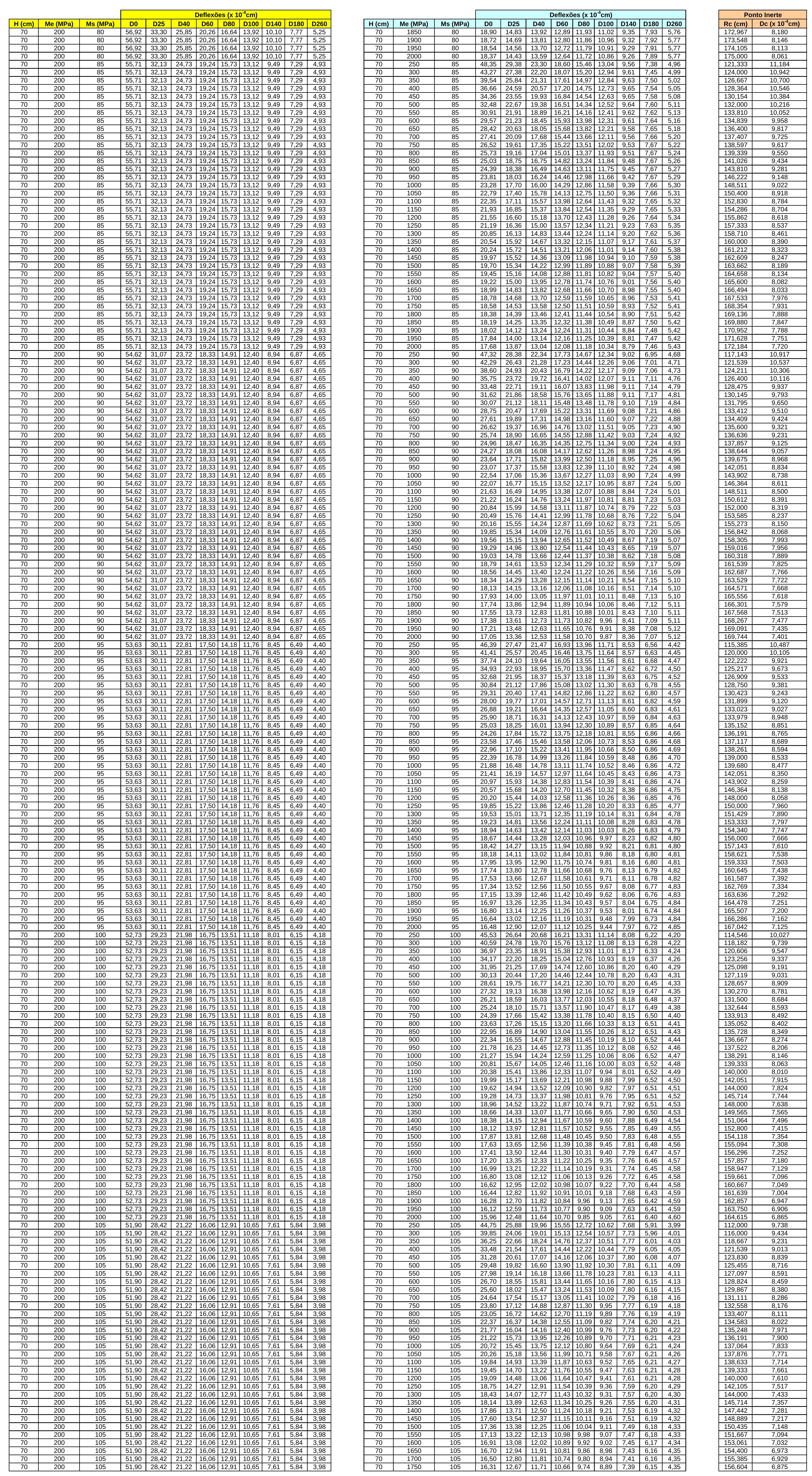




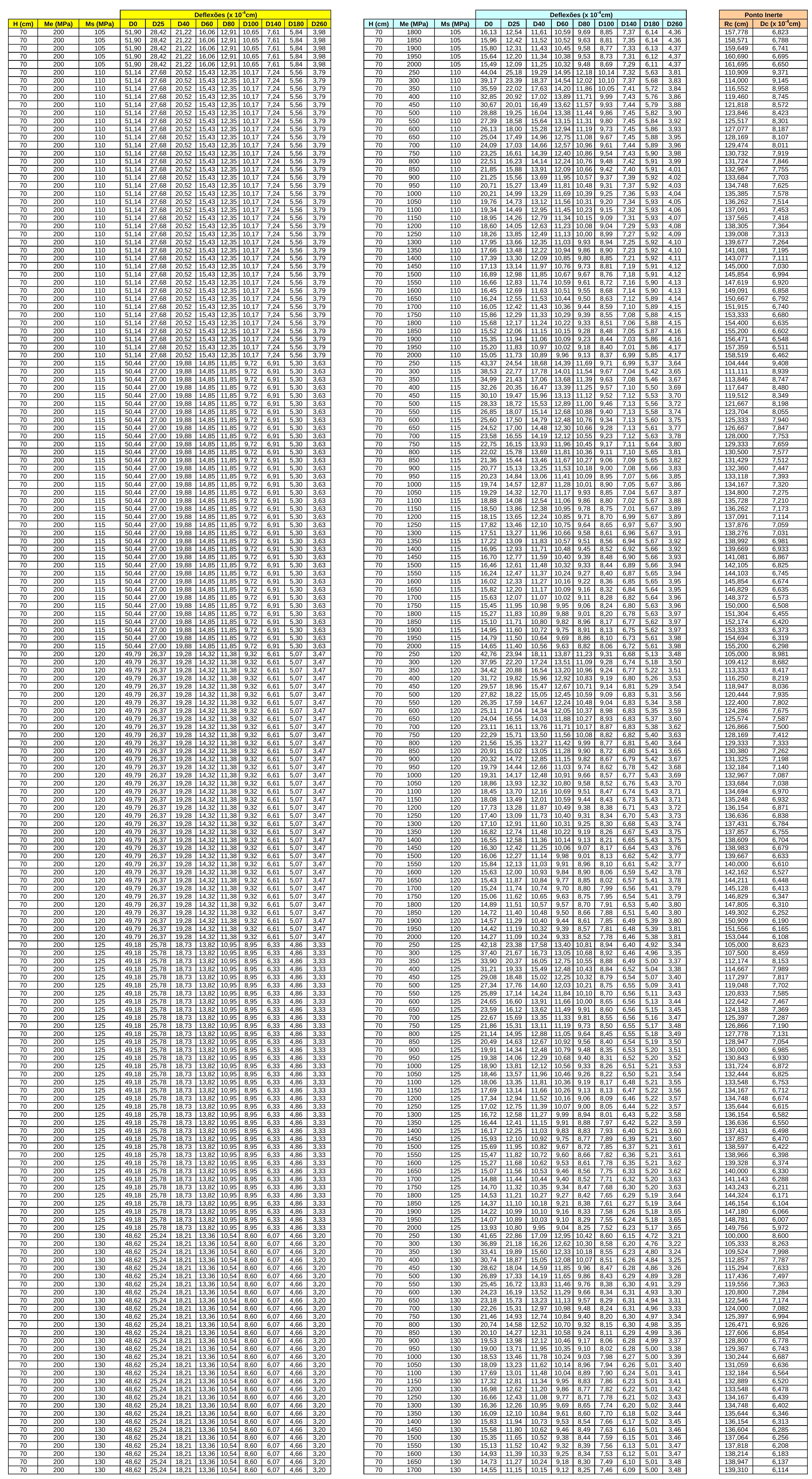




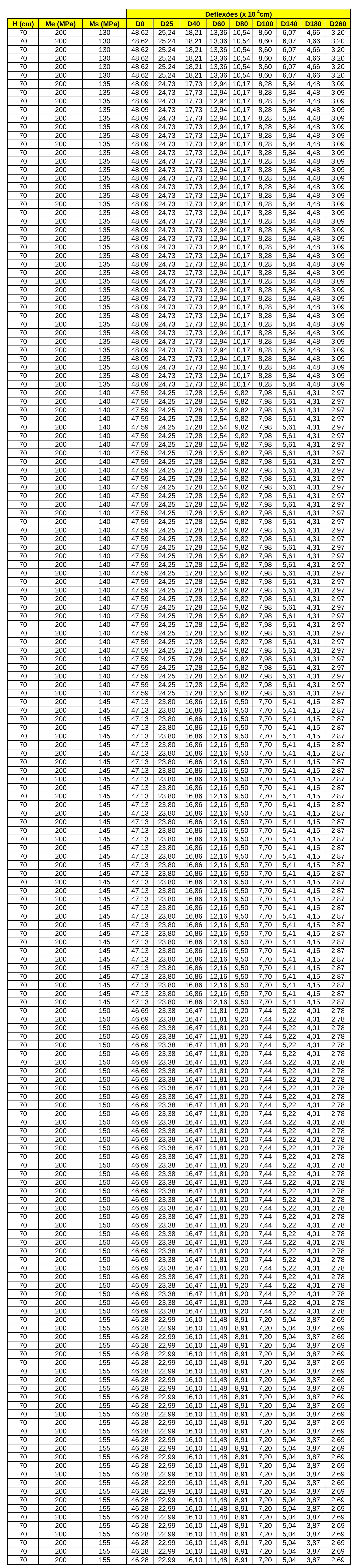

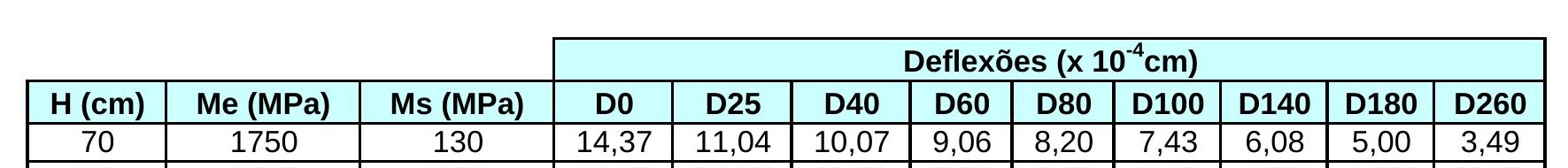

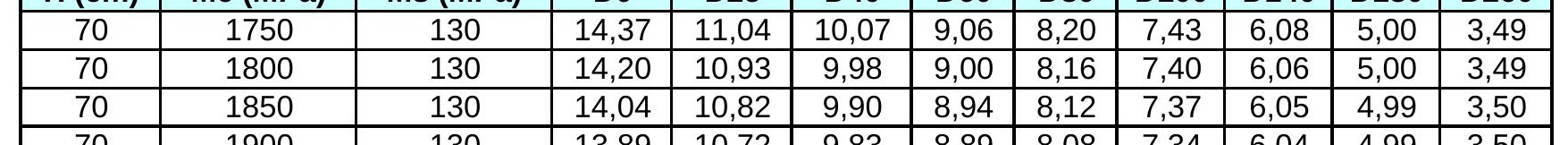

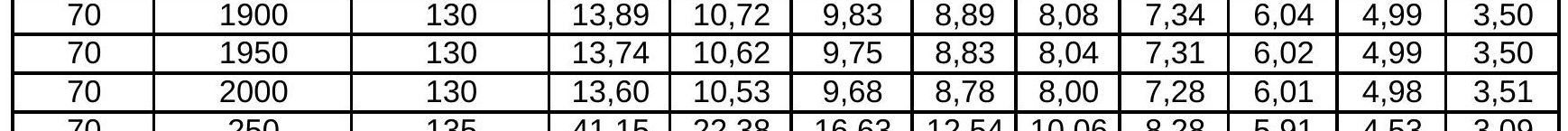

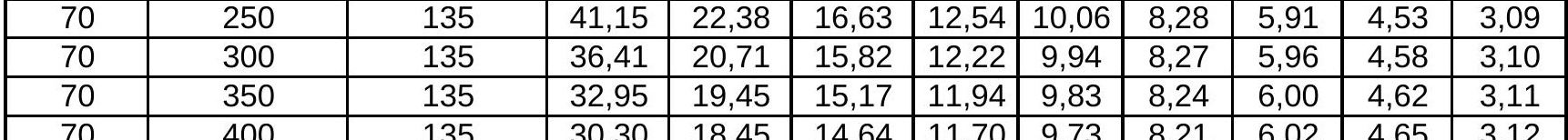

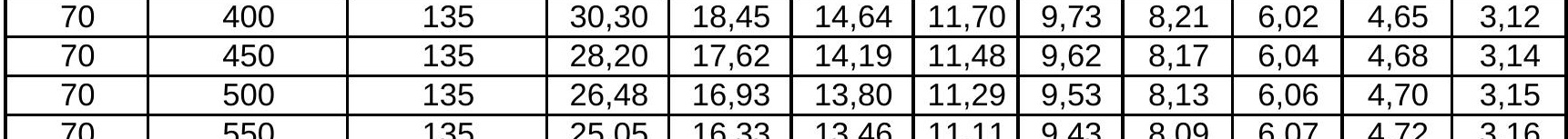

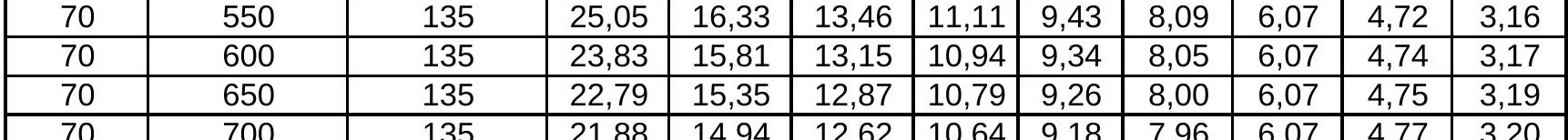

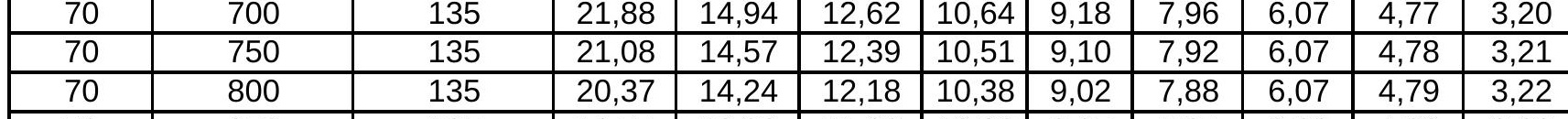

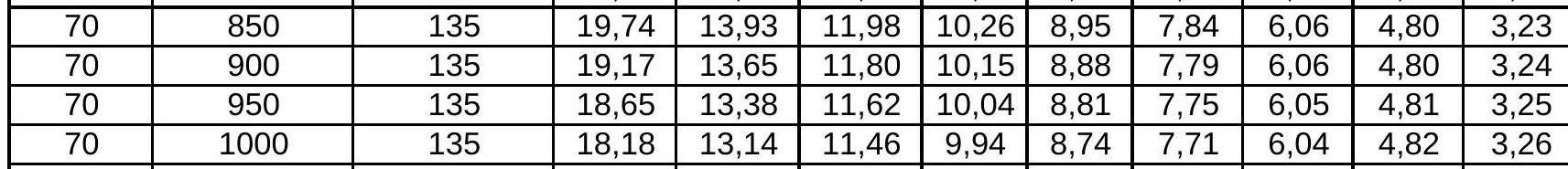

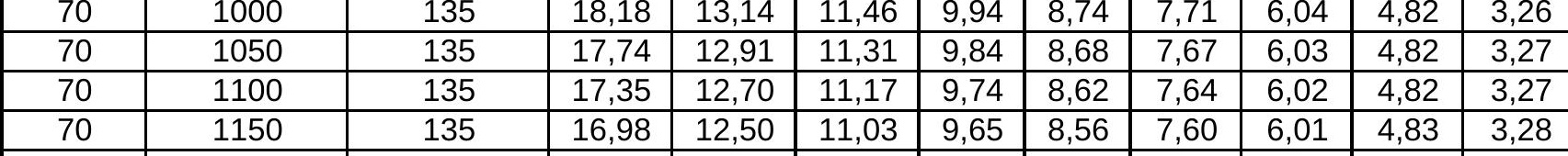

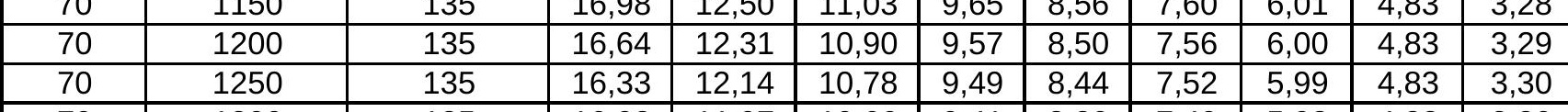

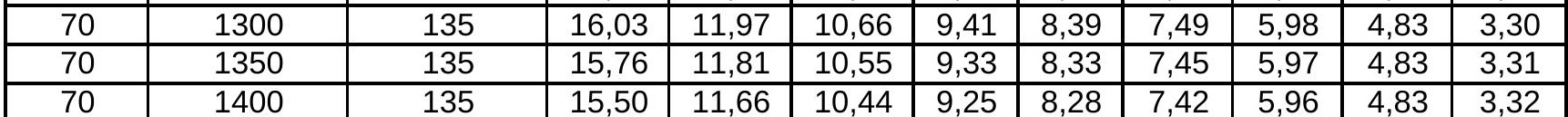

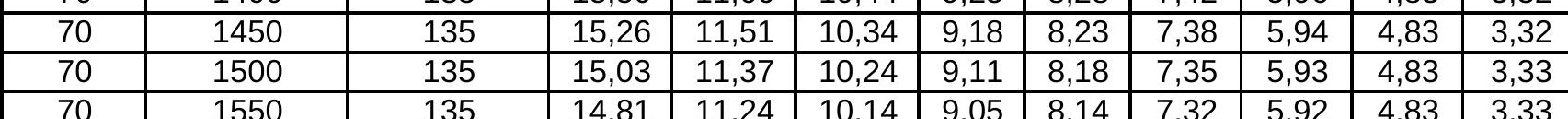

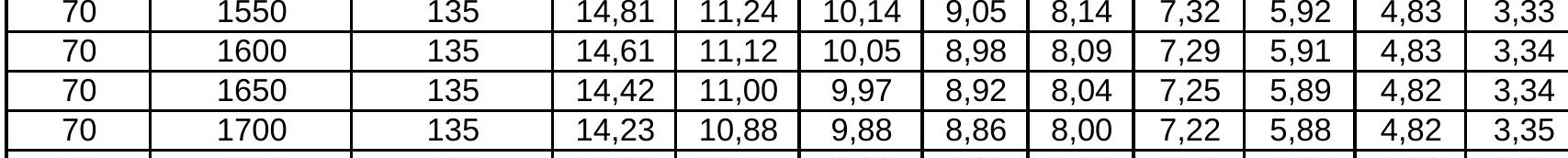

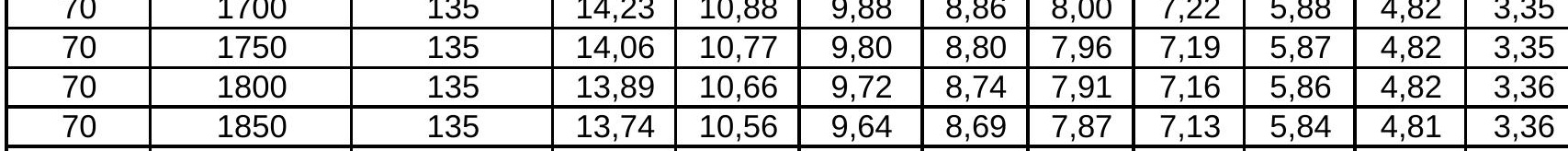

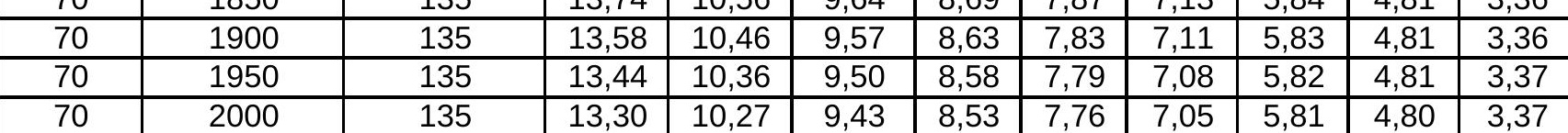

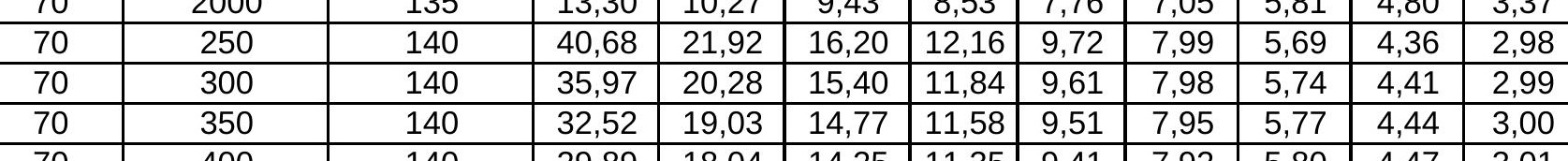

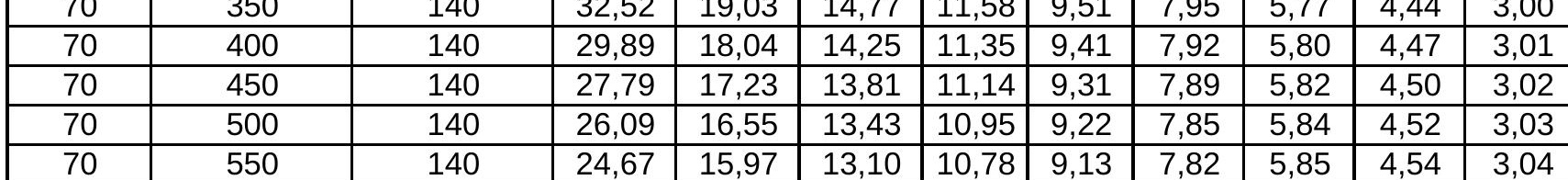

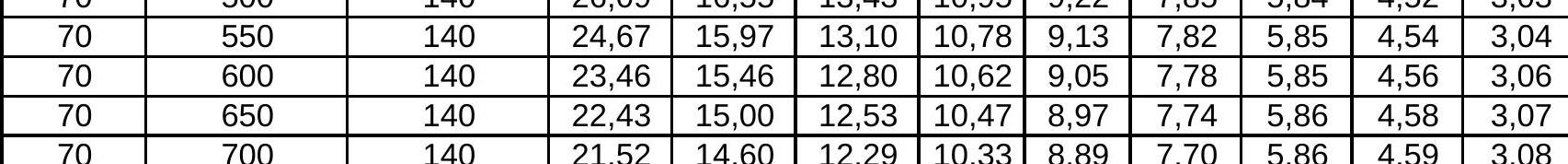

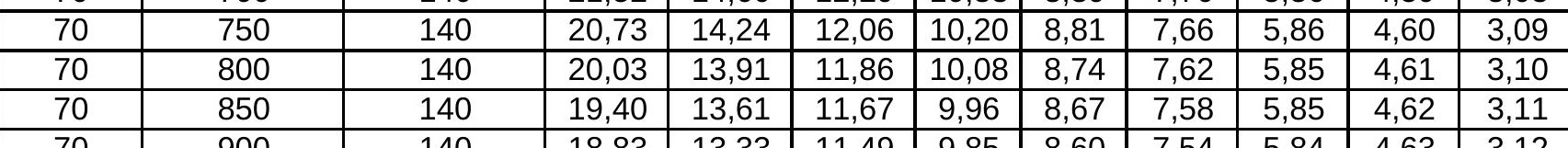

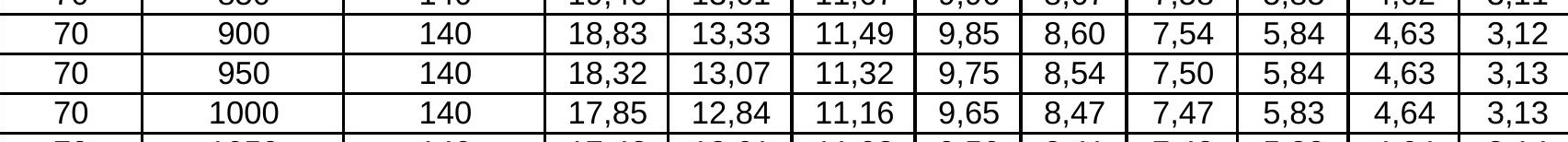

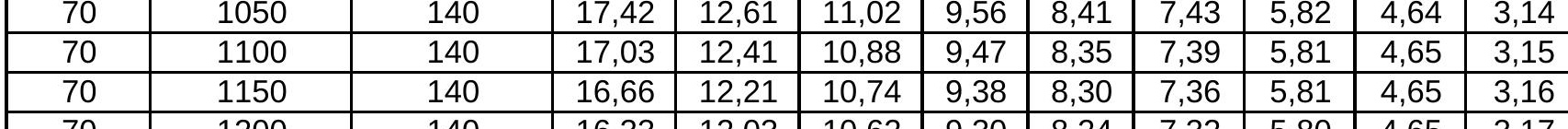

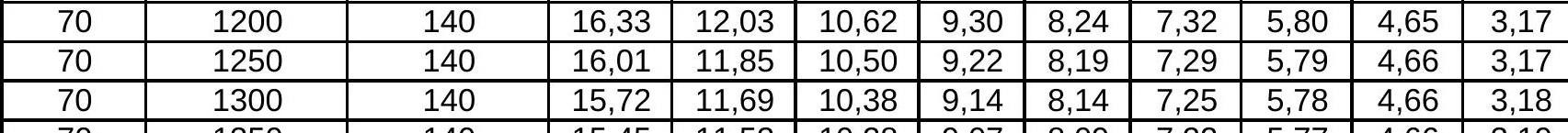

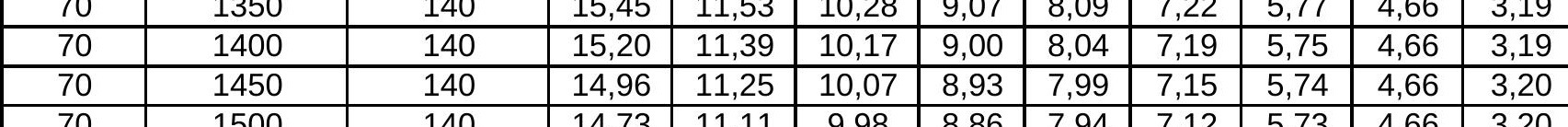

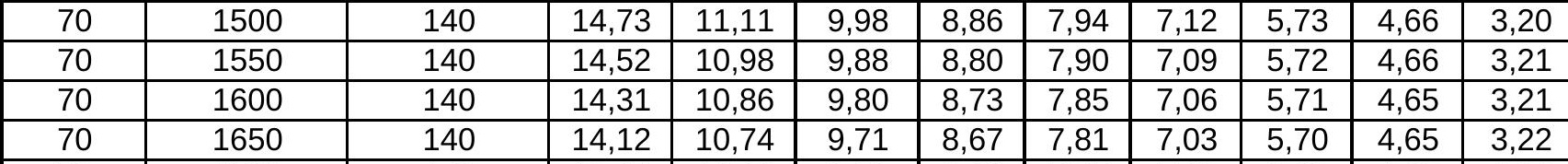

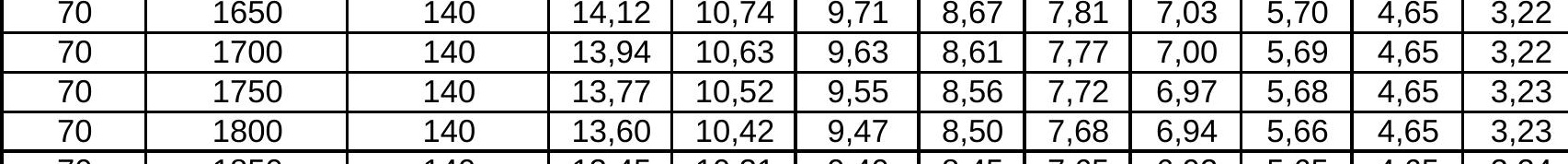

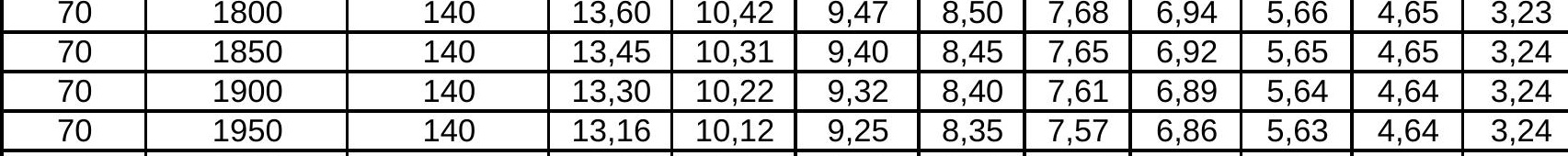

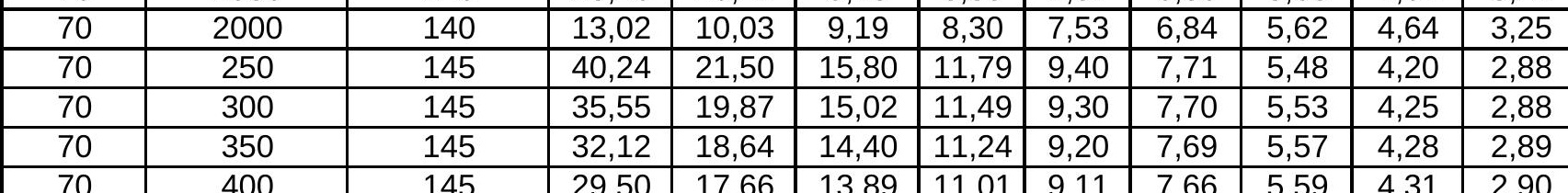

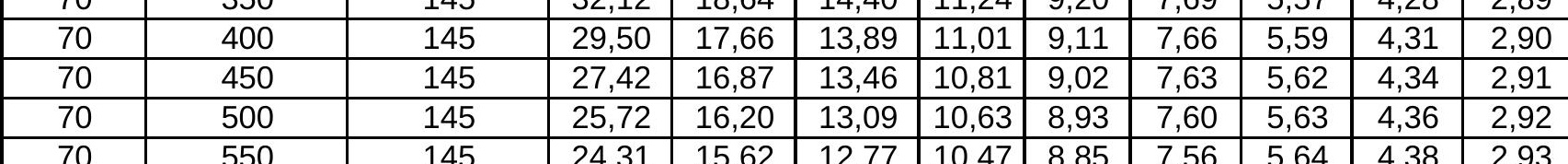

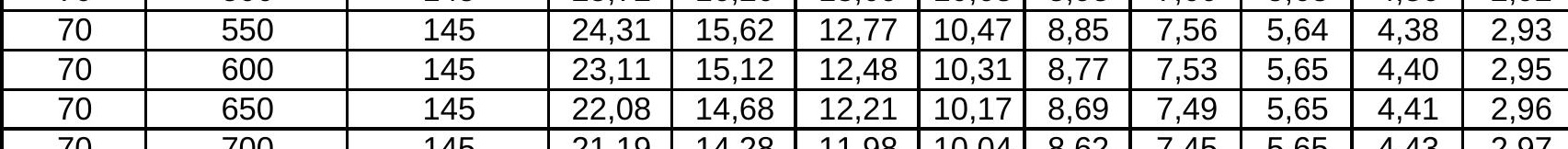

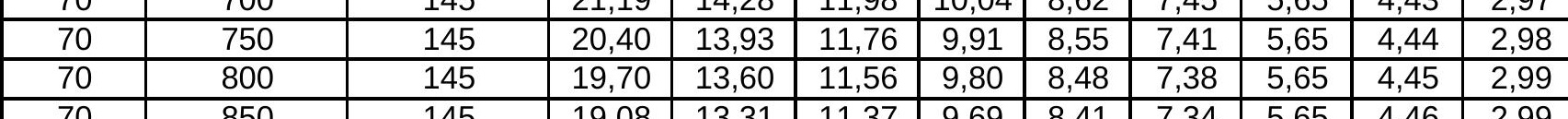

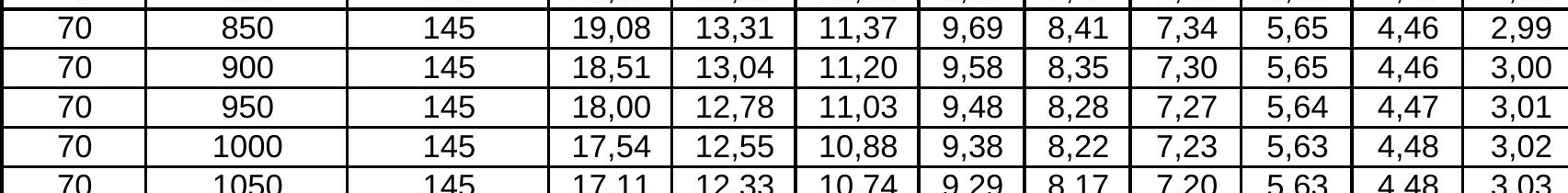

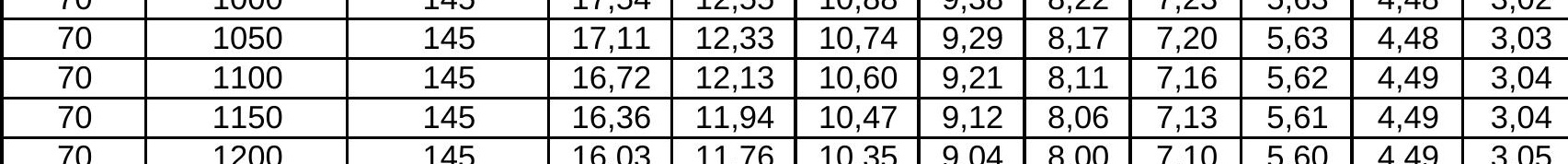

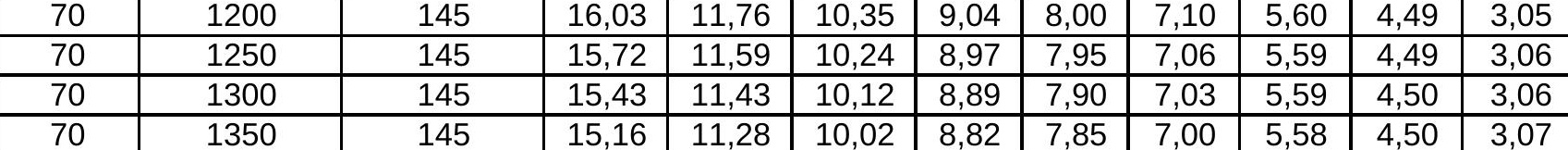

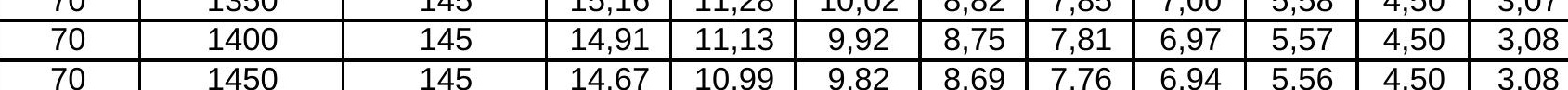

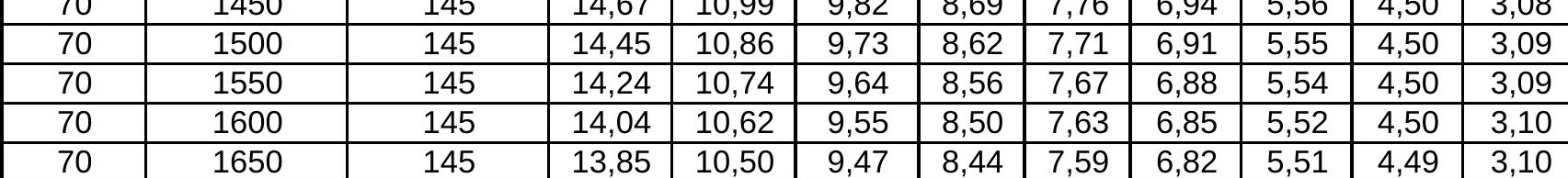

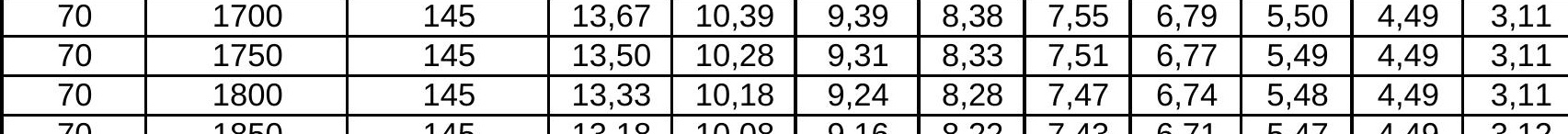

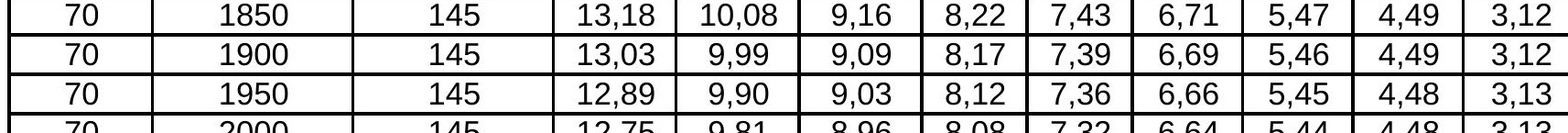

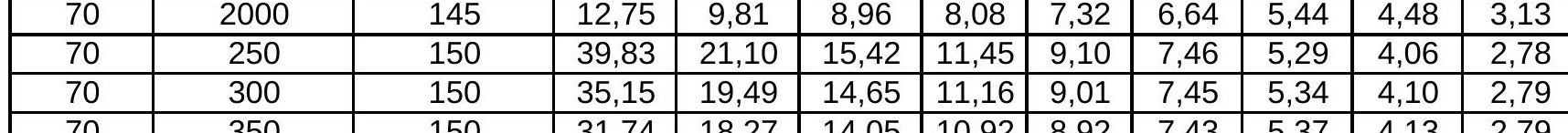

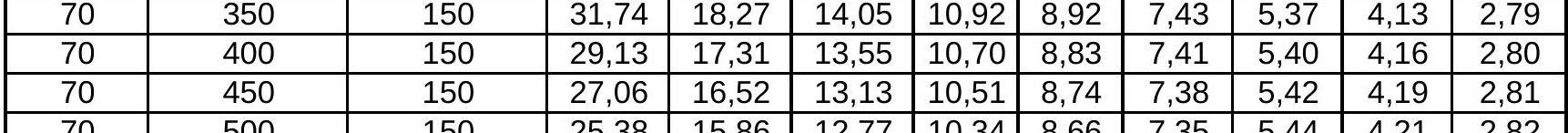

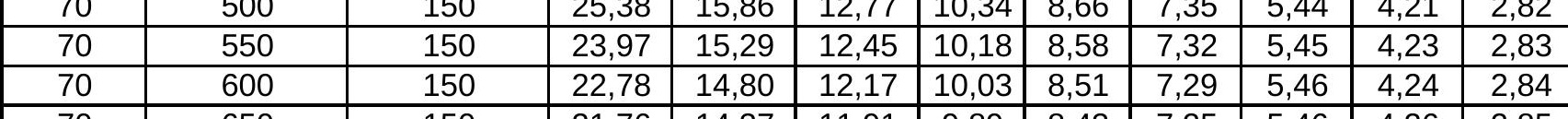

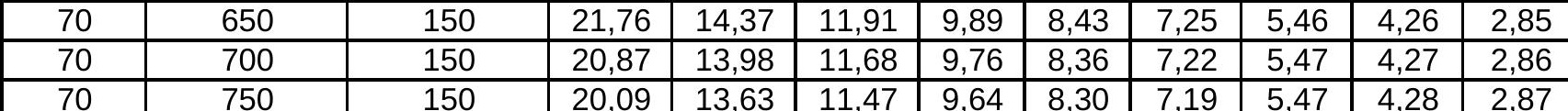

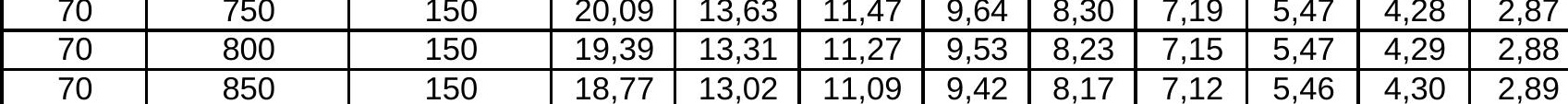

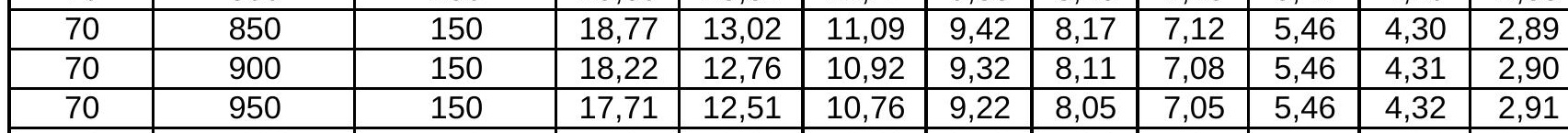

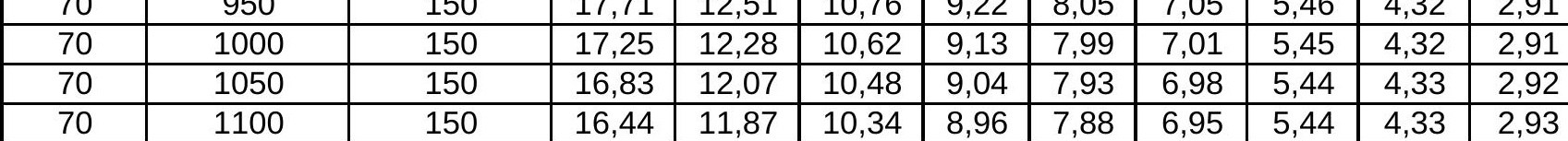

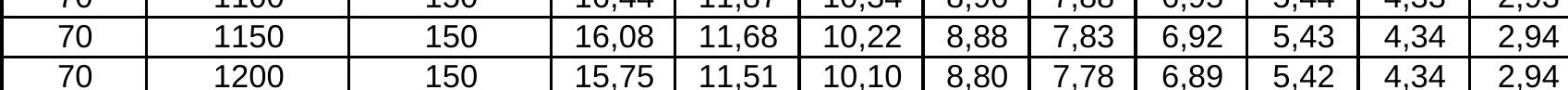

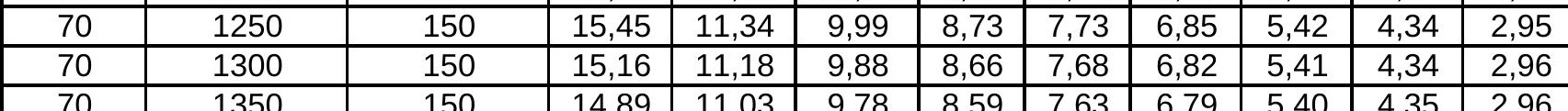

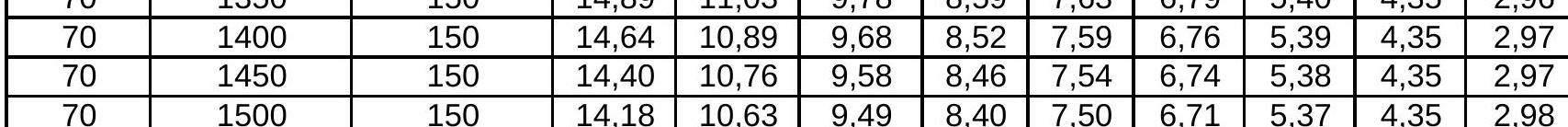

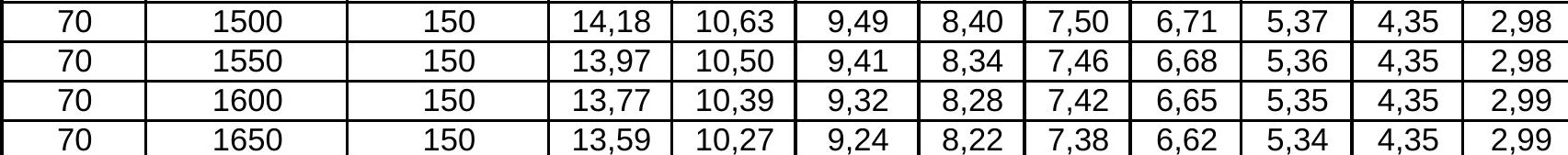

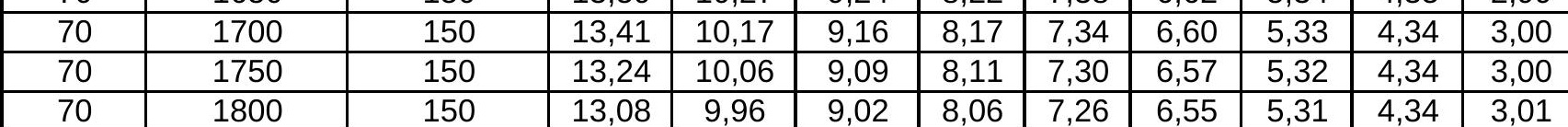

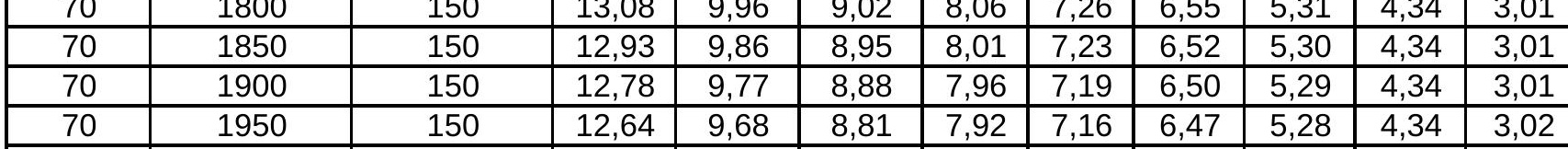

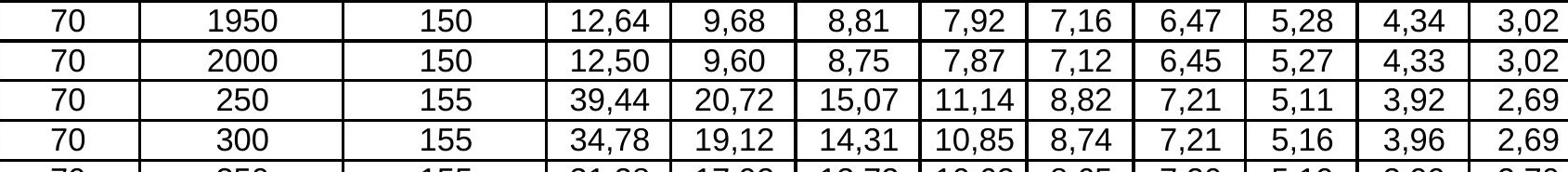

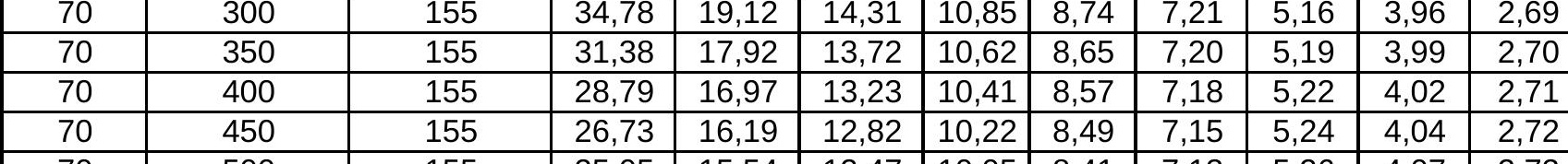

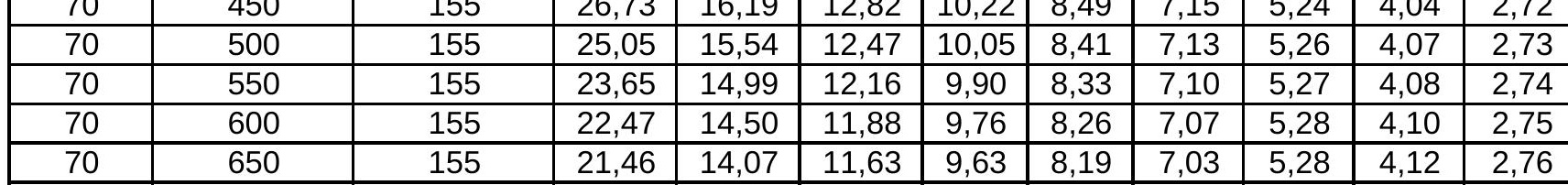

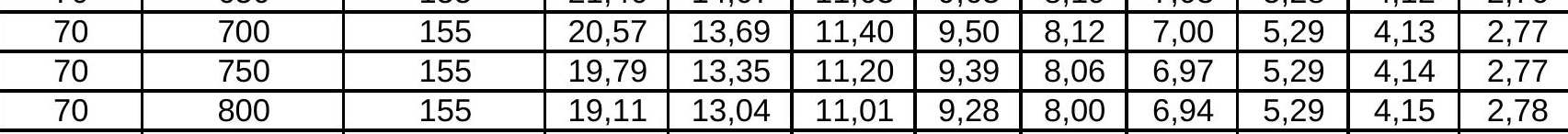

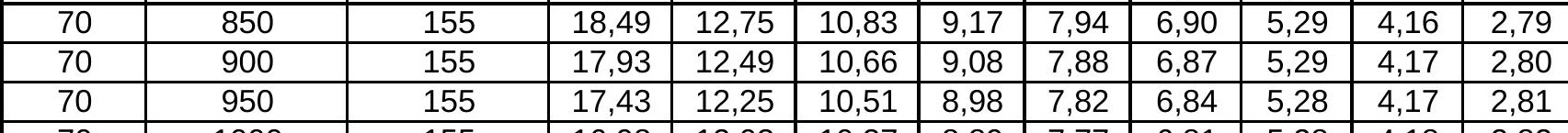

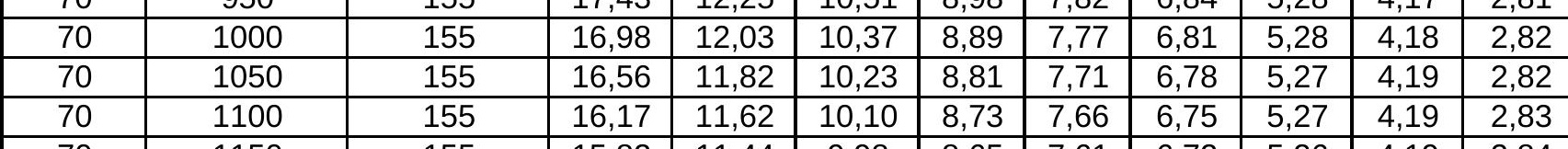

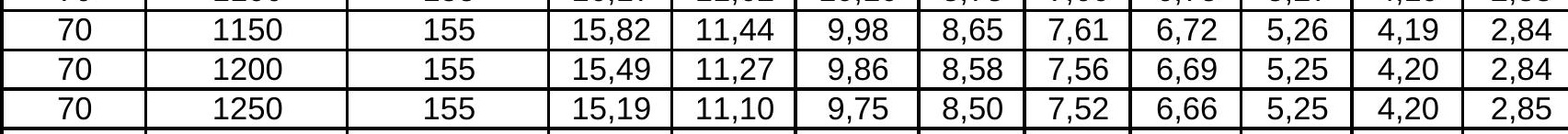

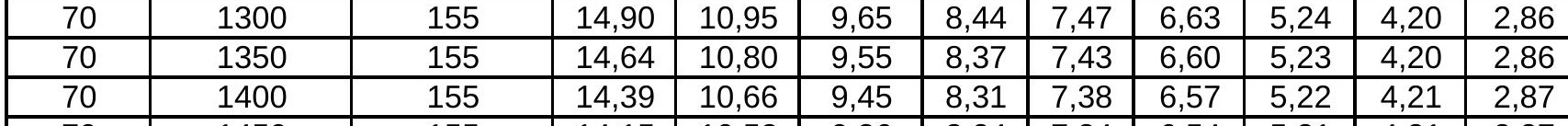

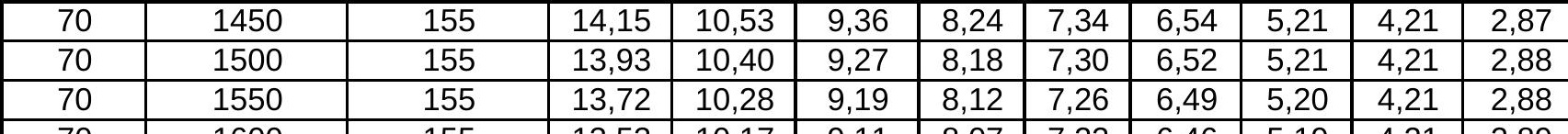

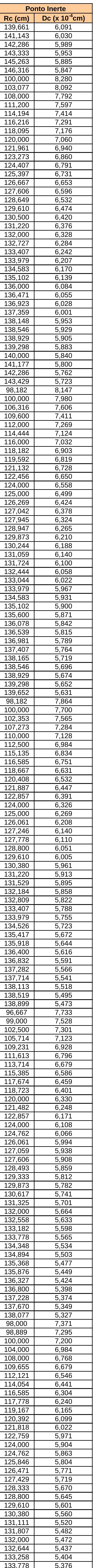




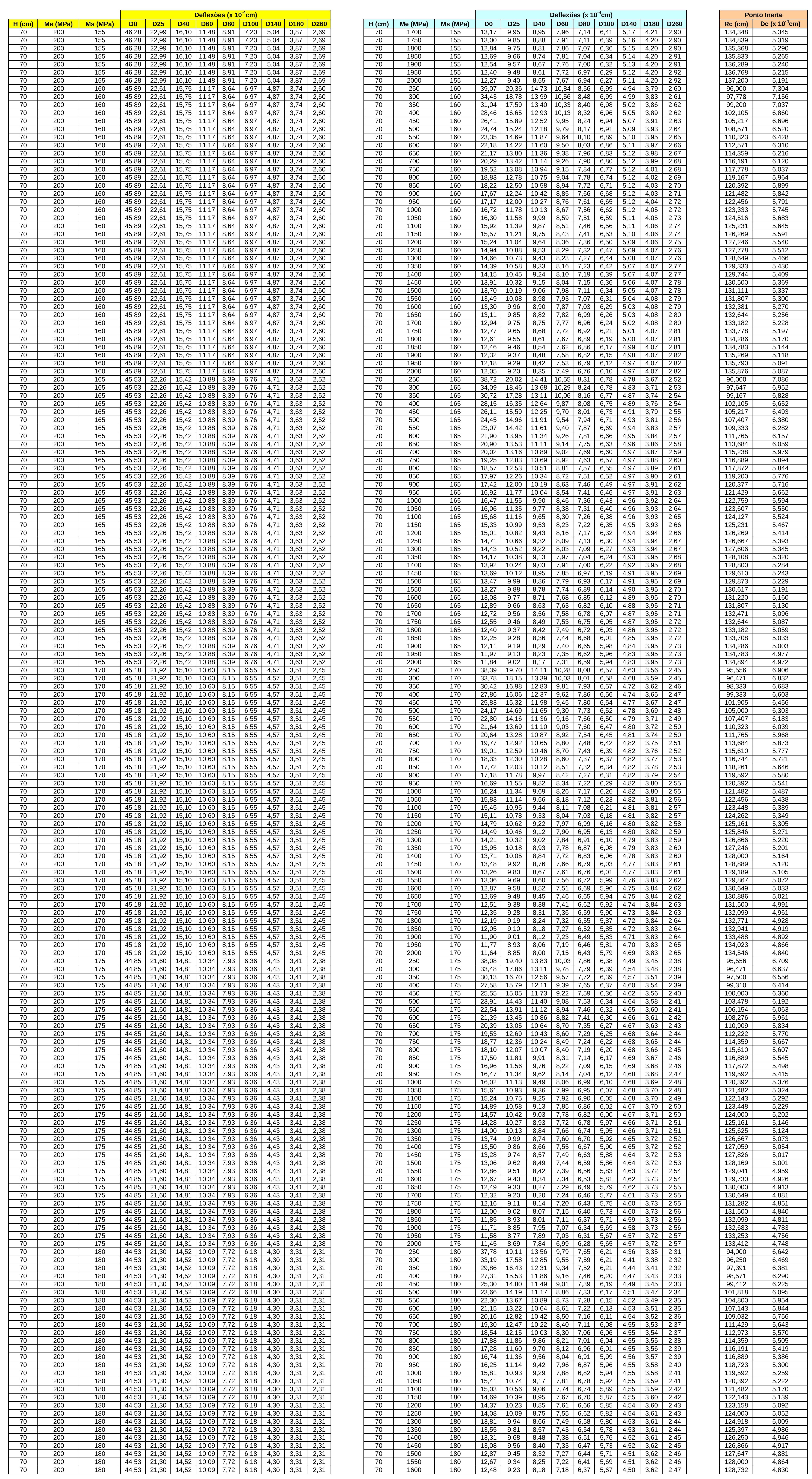



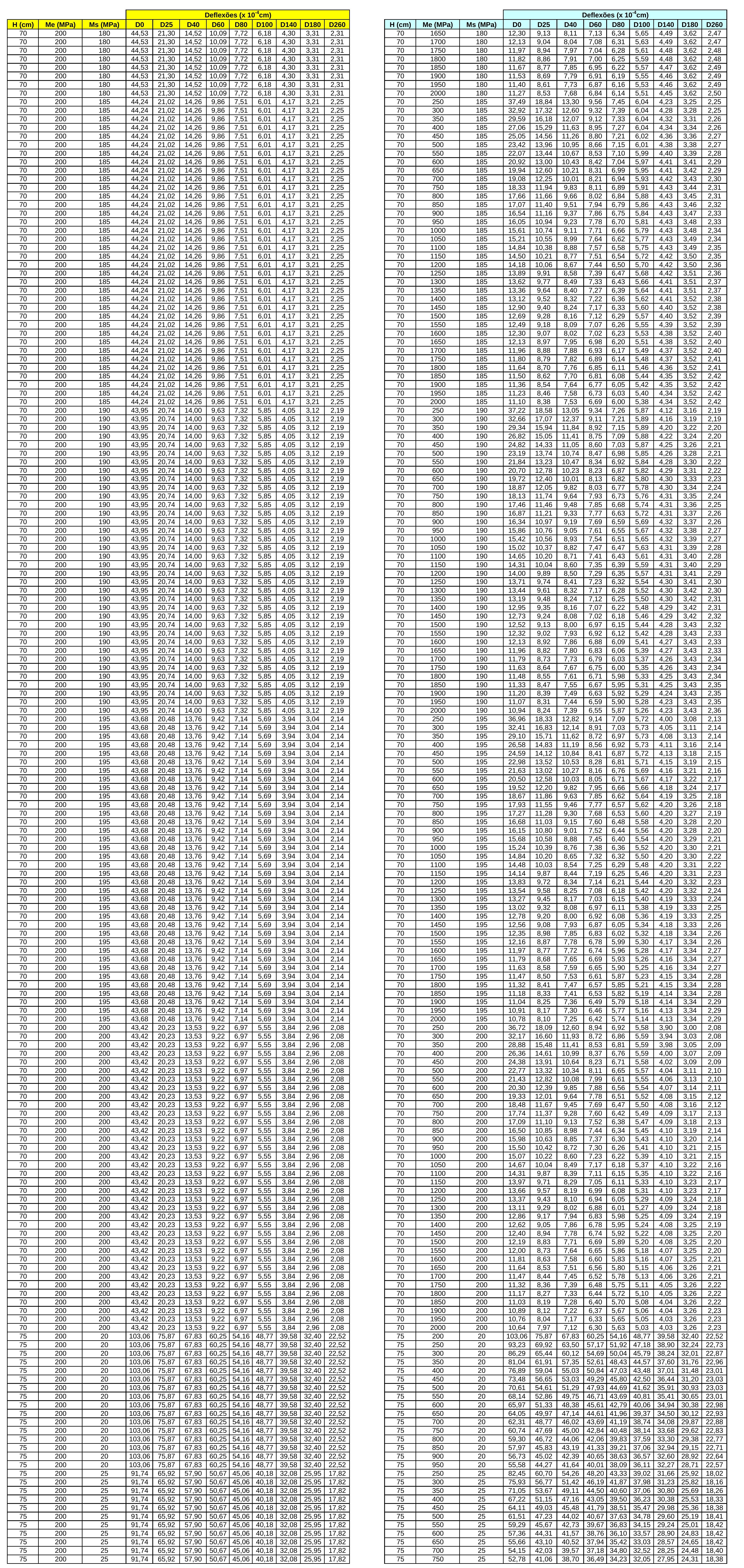

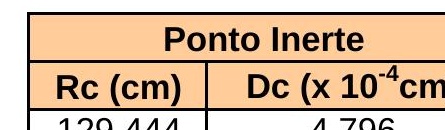

129,300478

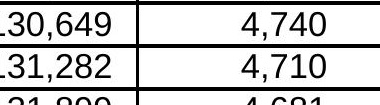

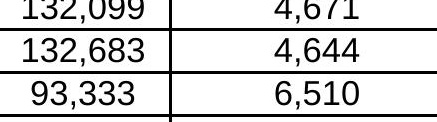

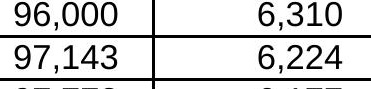

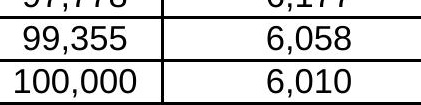

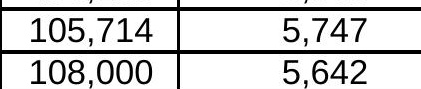

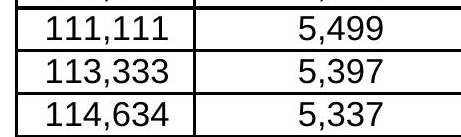

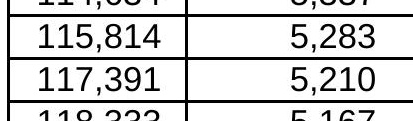

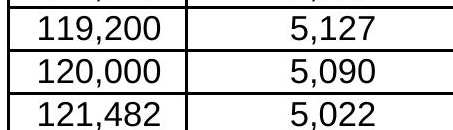

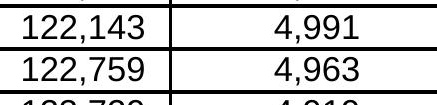

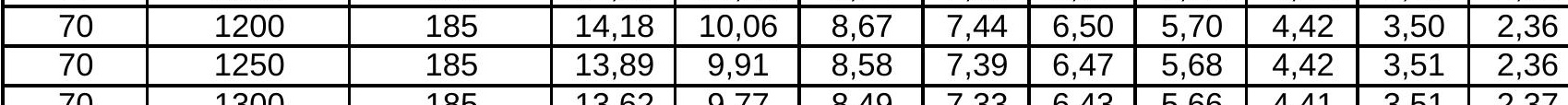

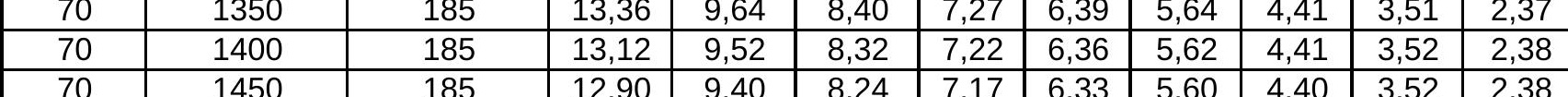

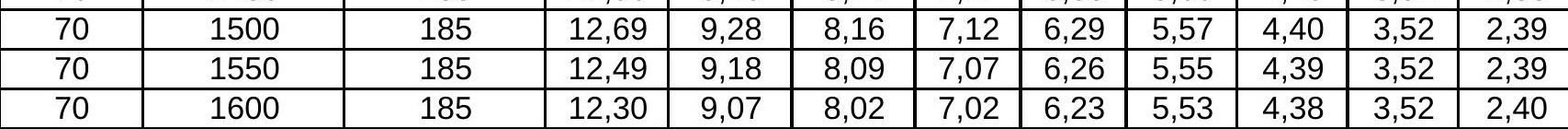

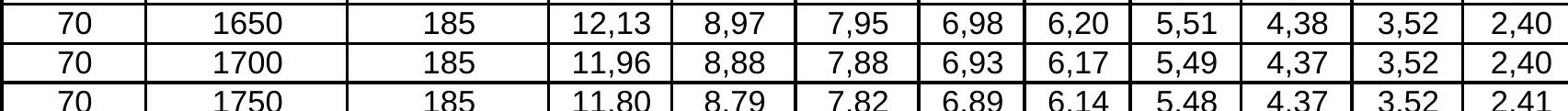

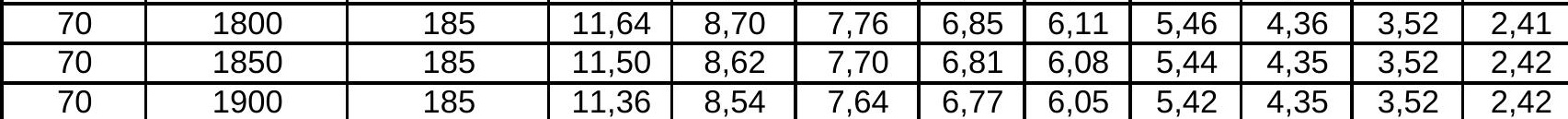

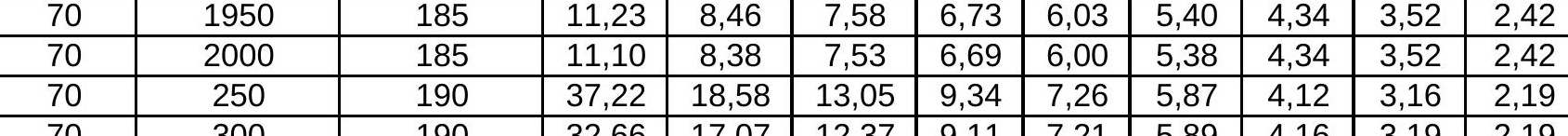

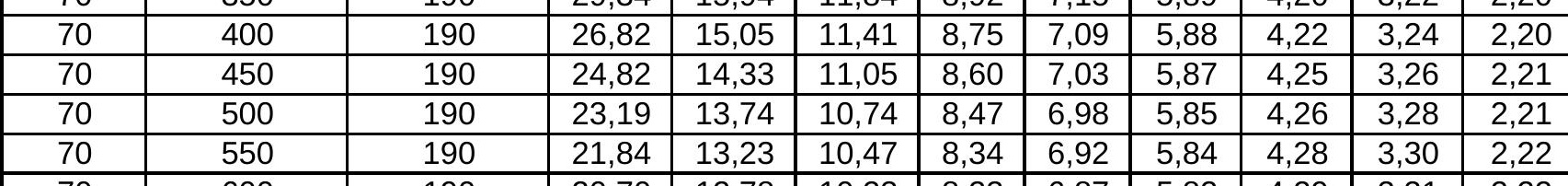

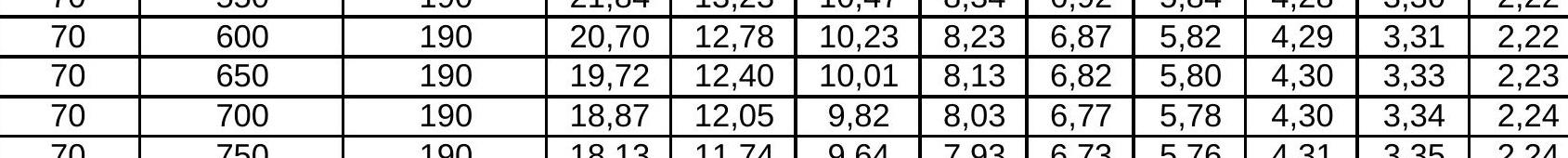

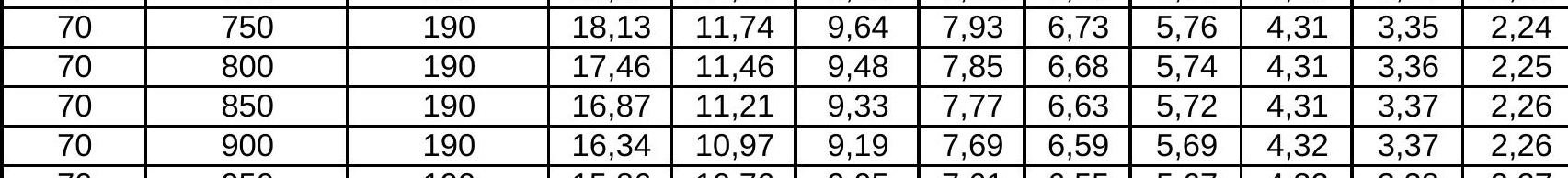

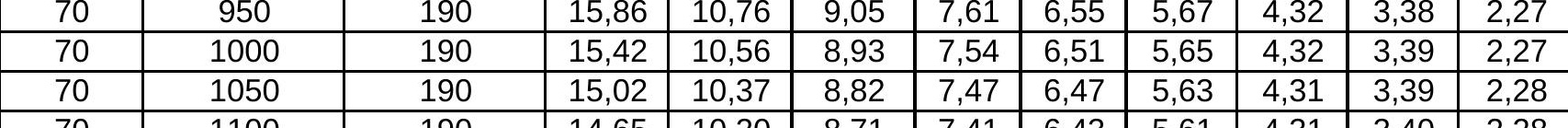

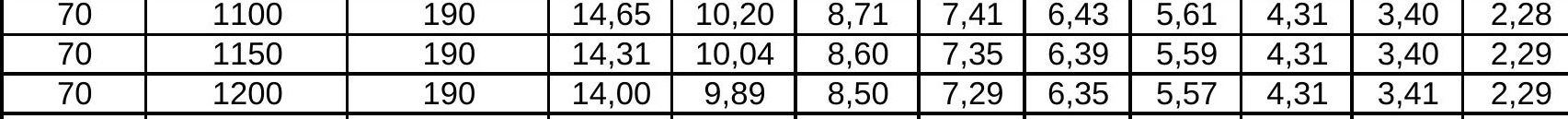

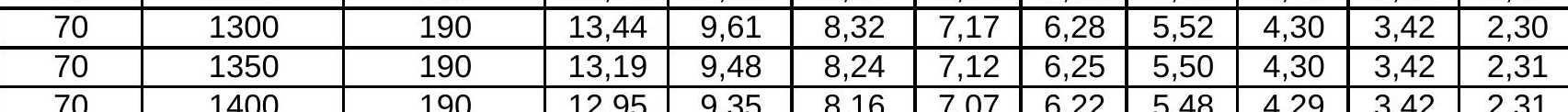

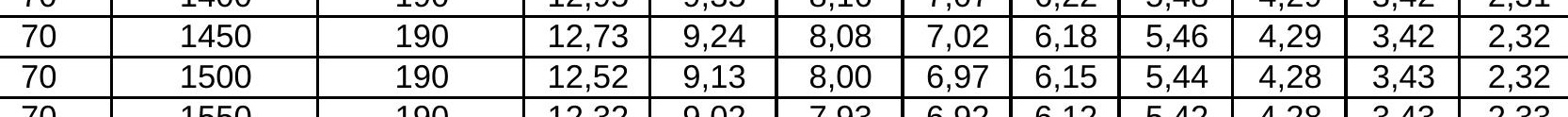

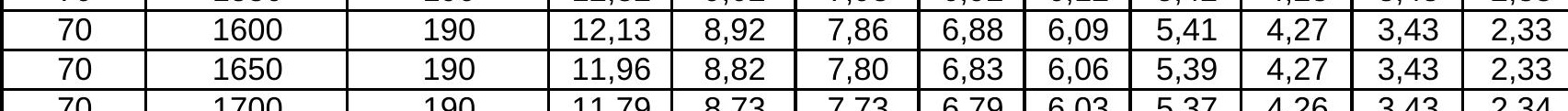

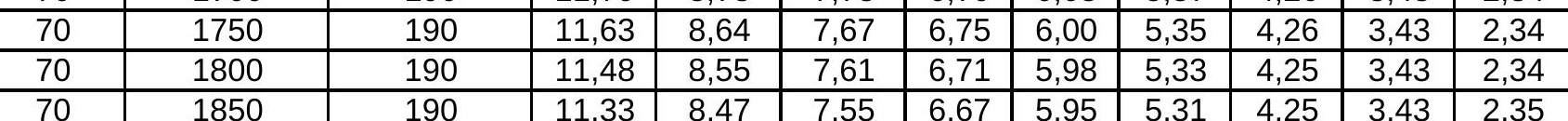
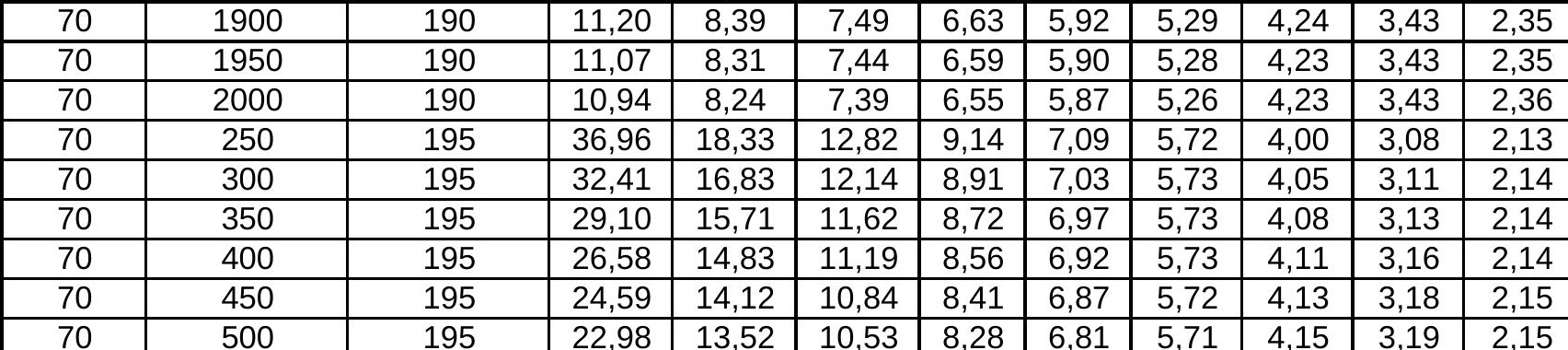

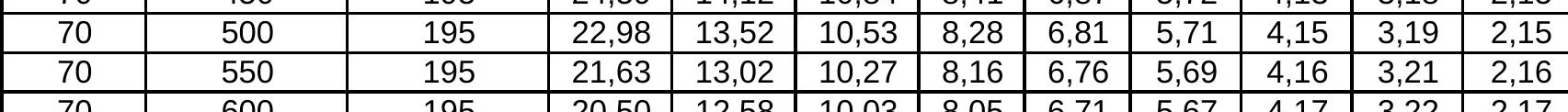

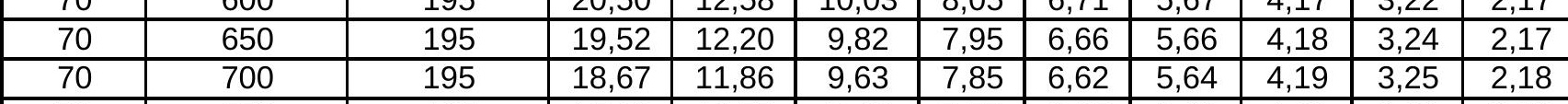
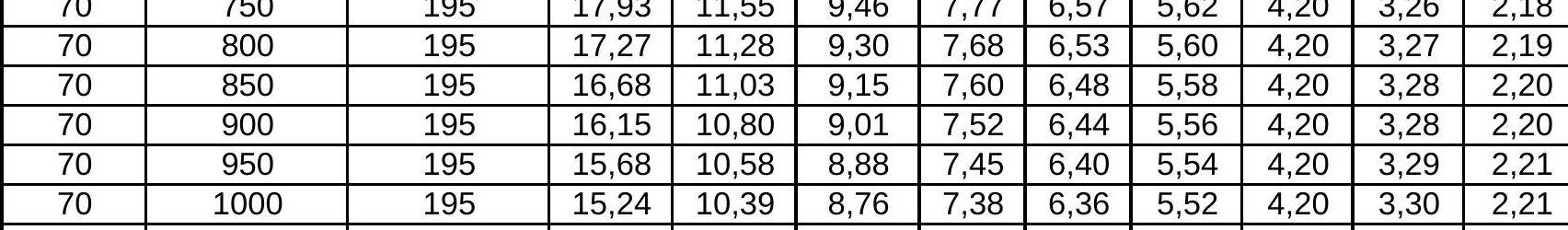

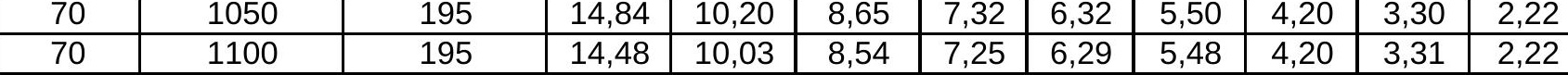

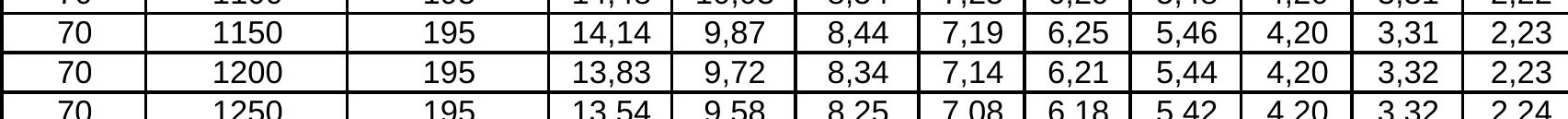

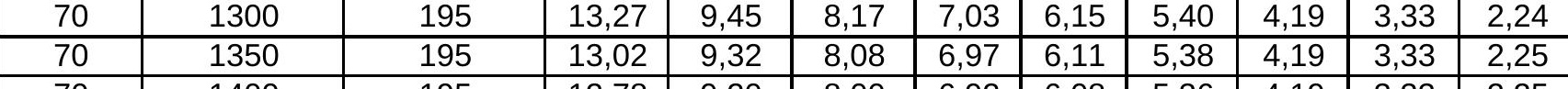

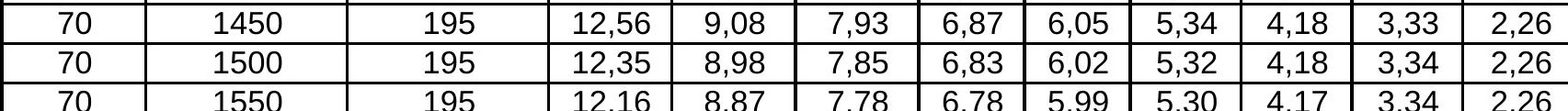

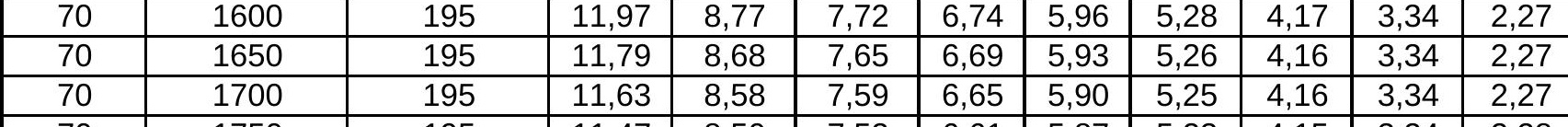

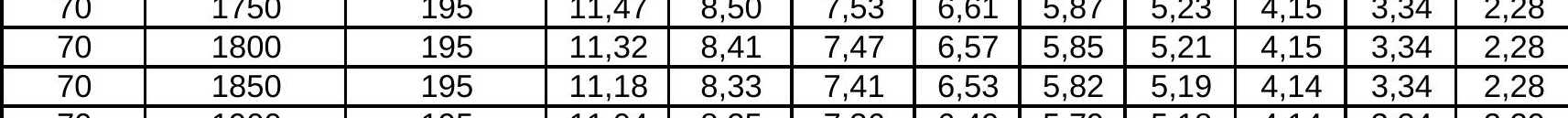

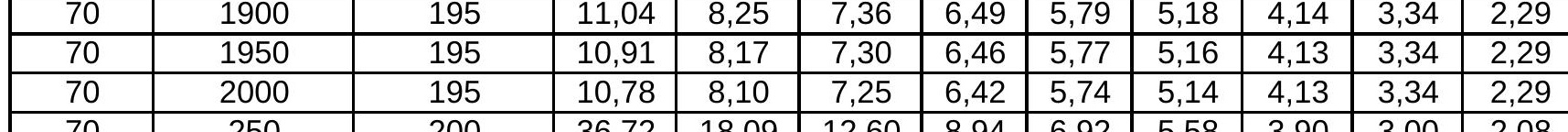

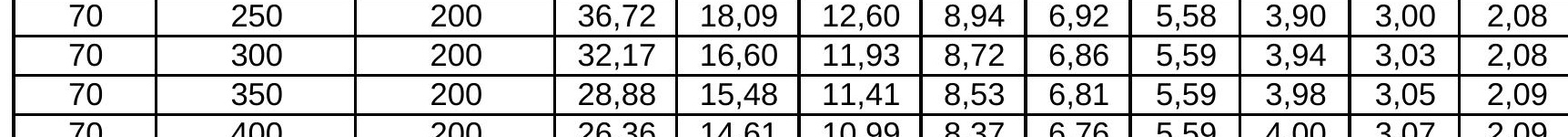

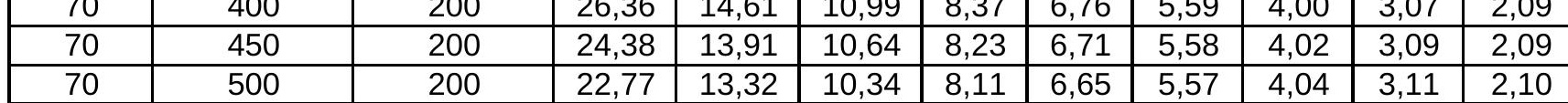

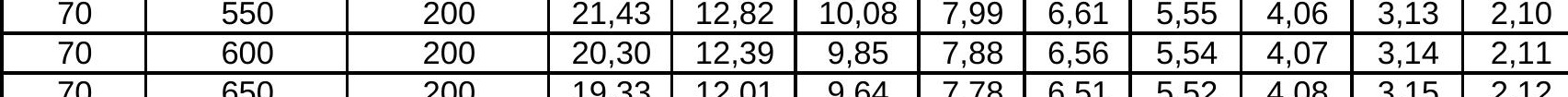

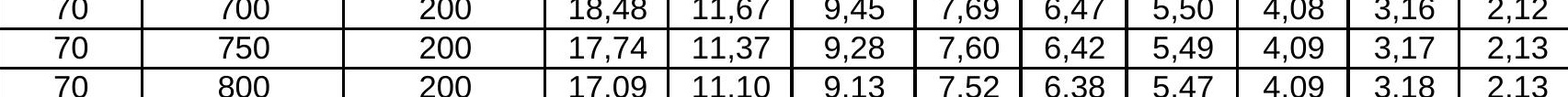

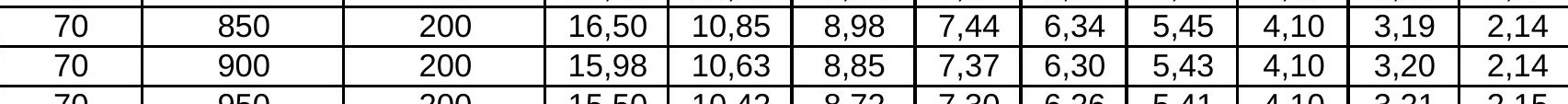

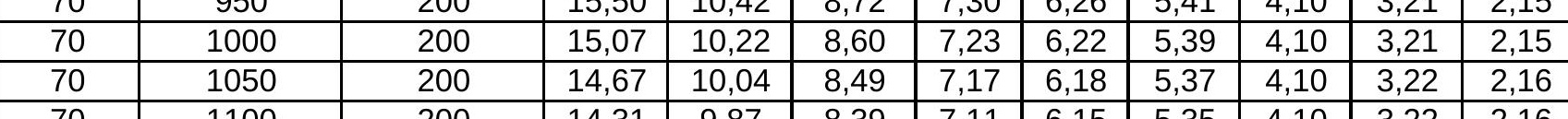

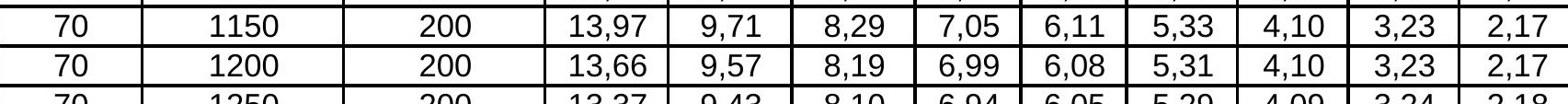

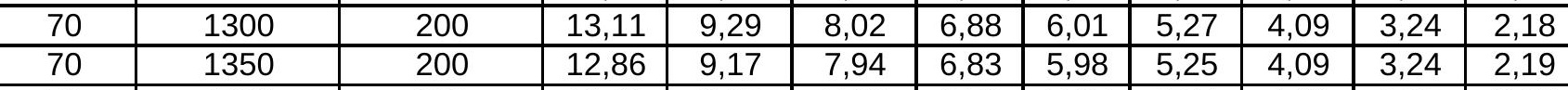

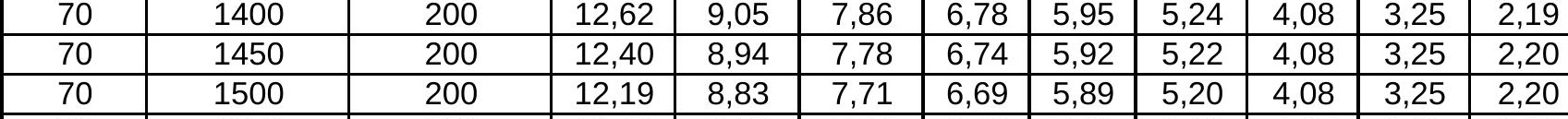

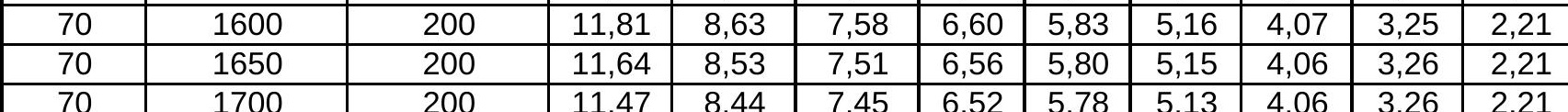

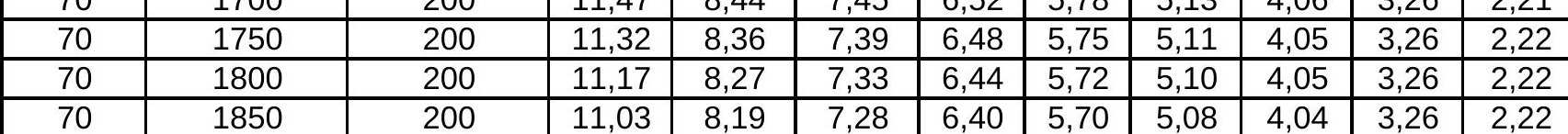

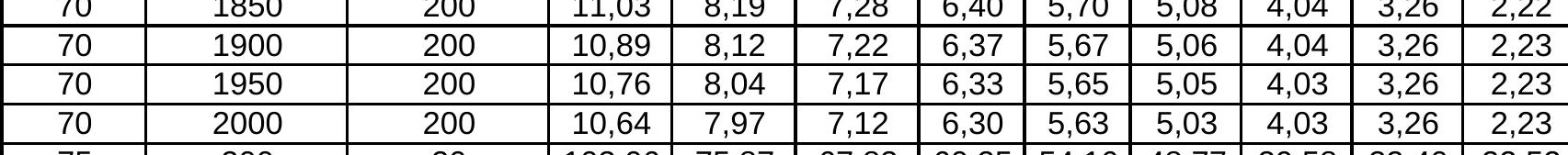

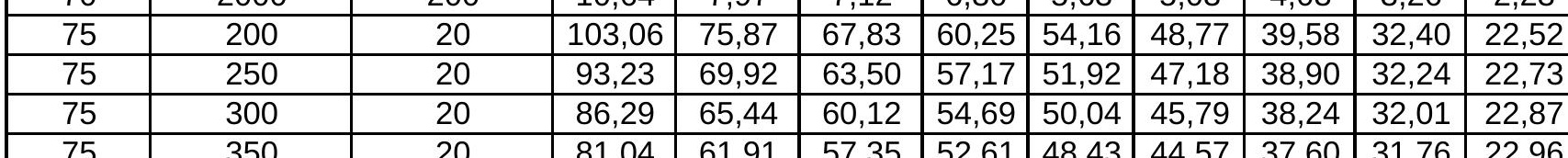

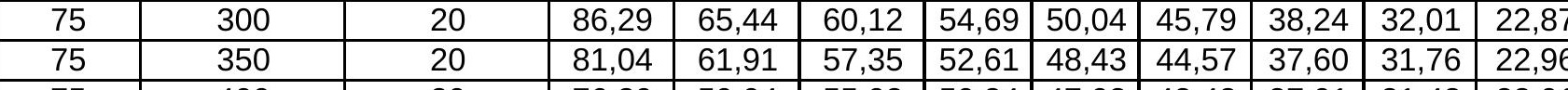

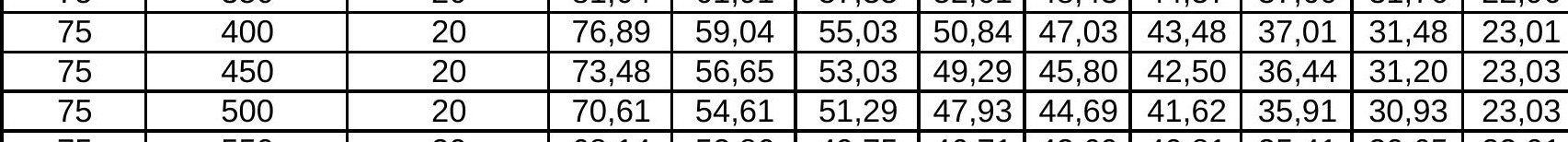

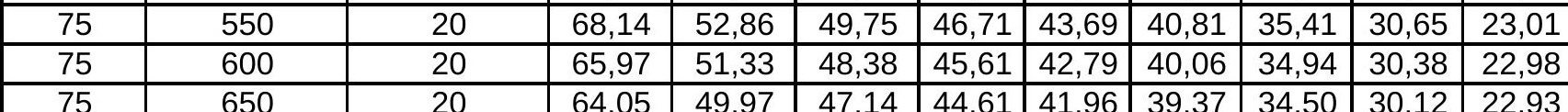

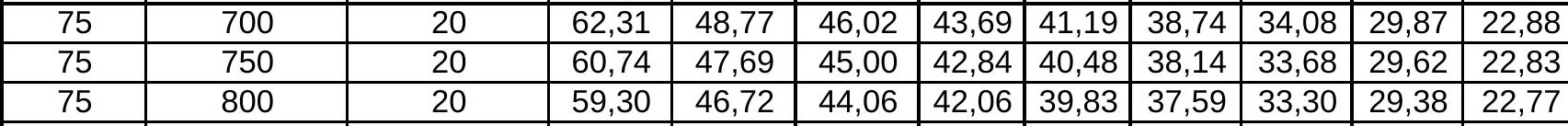

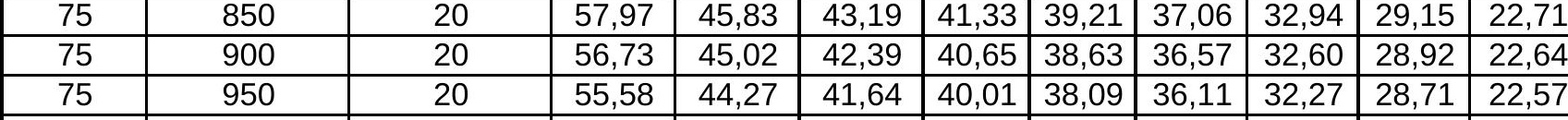

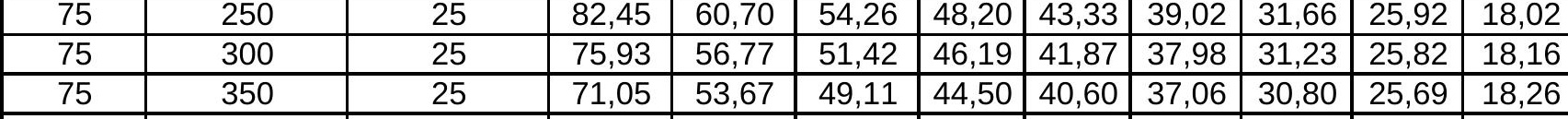

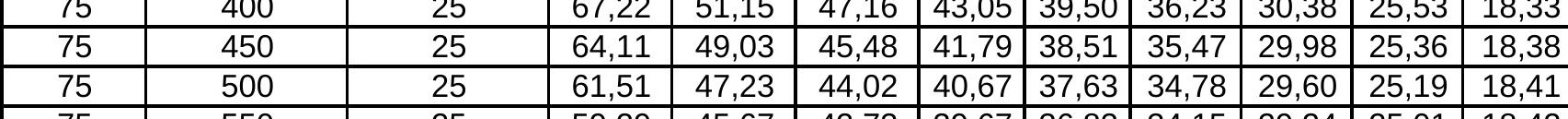

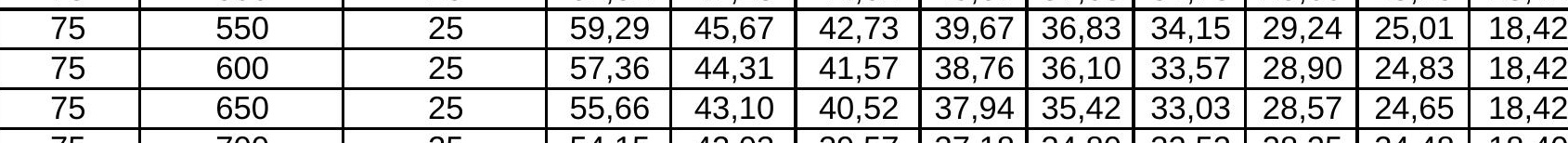

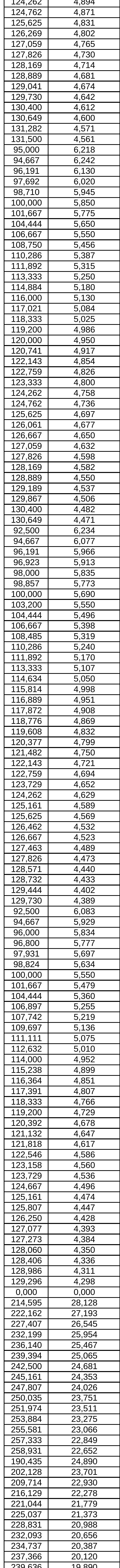




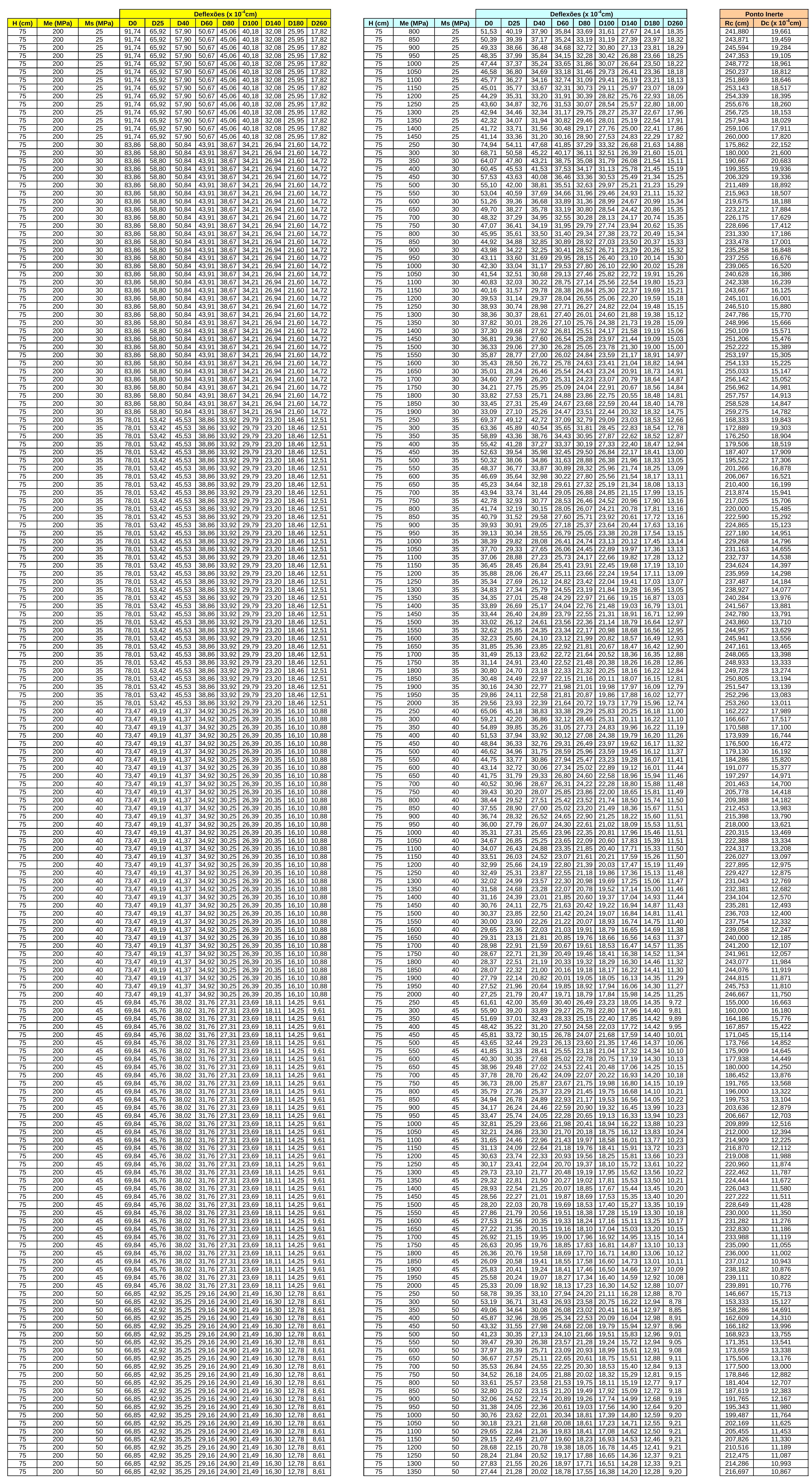




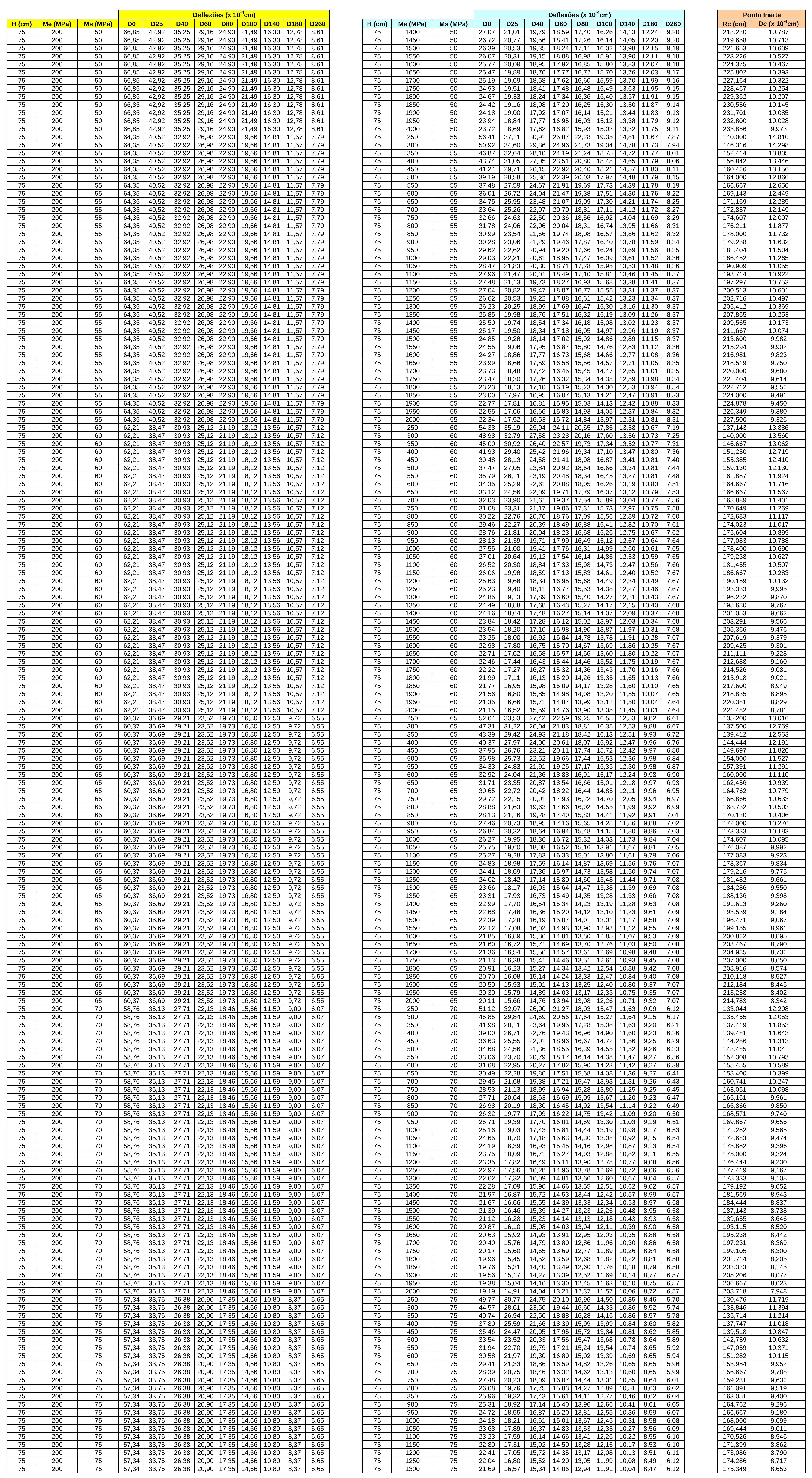




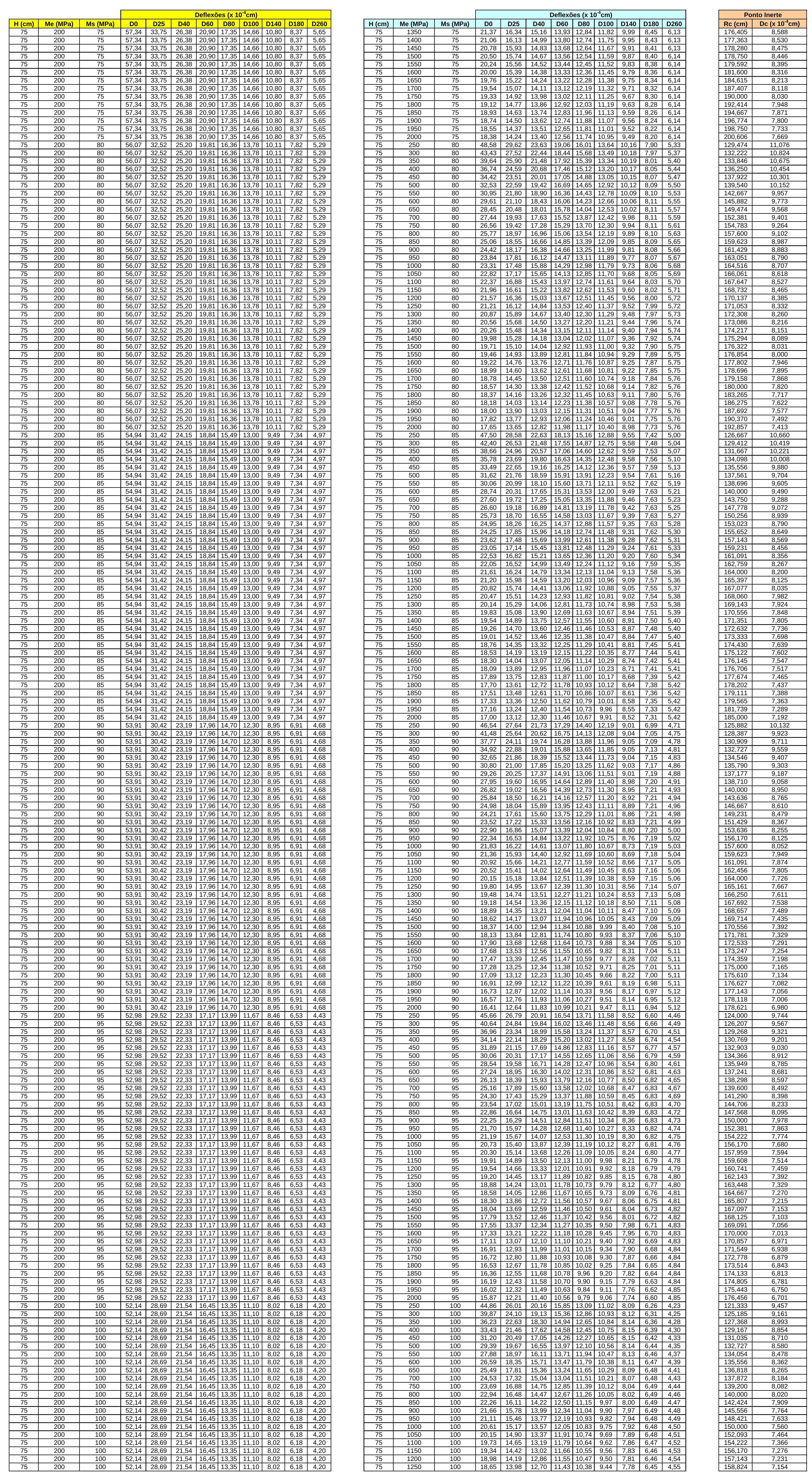




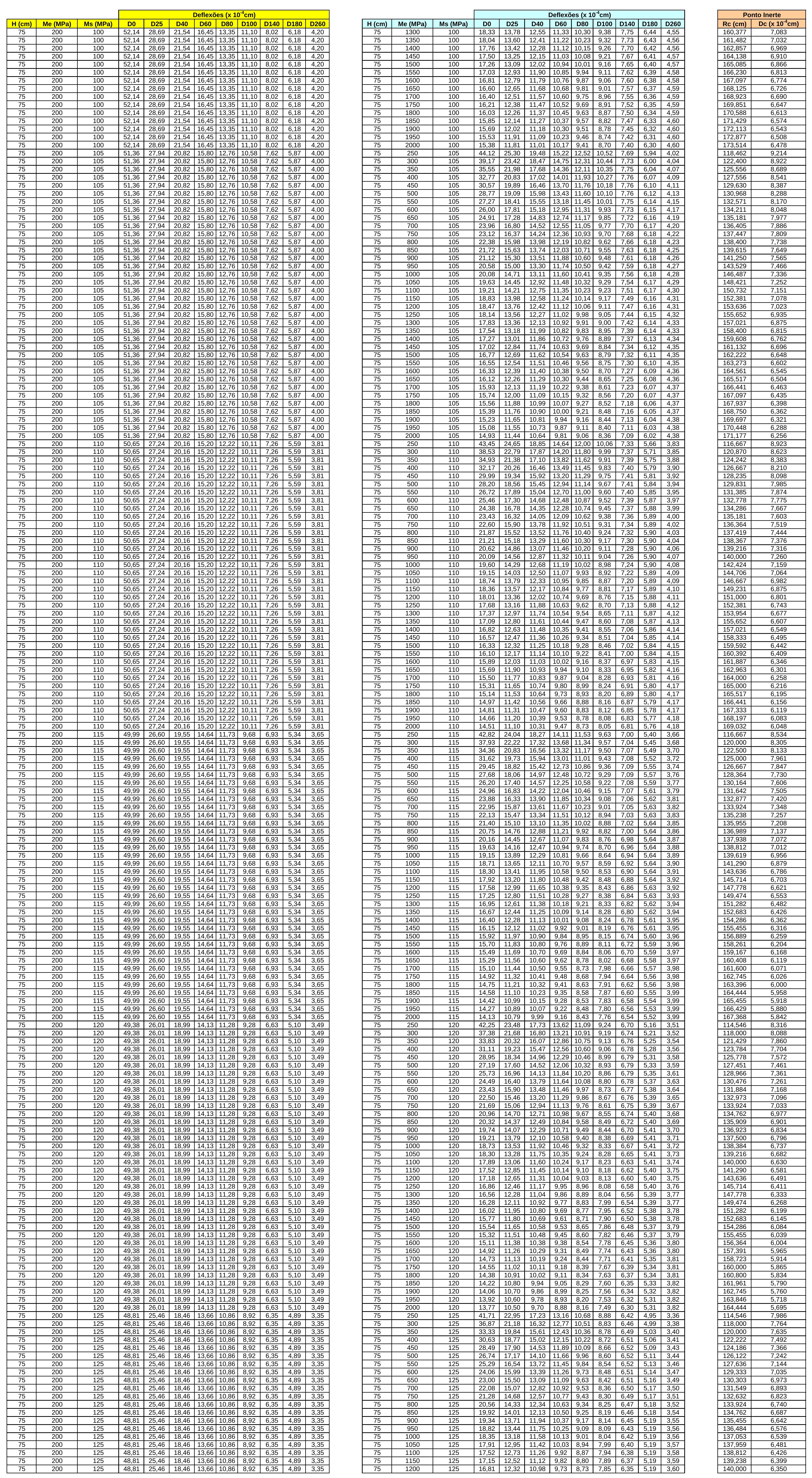




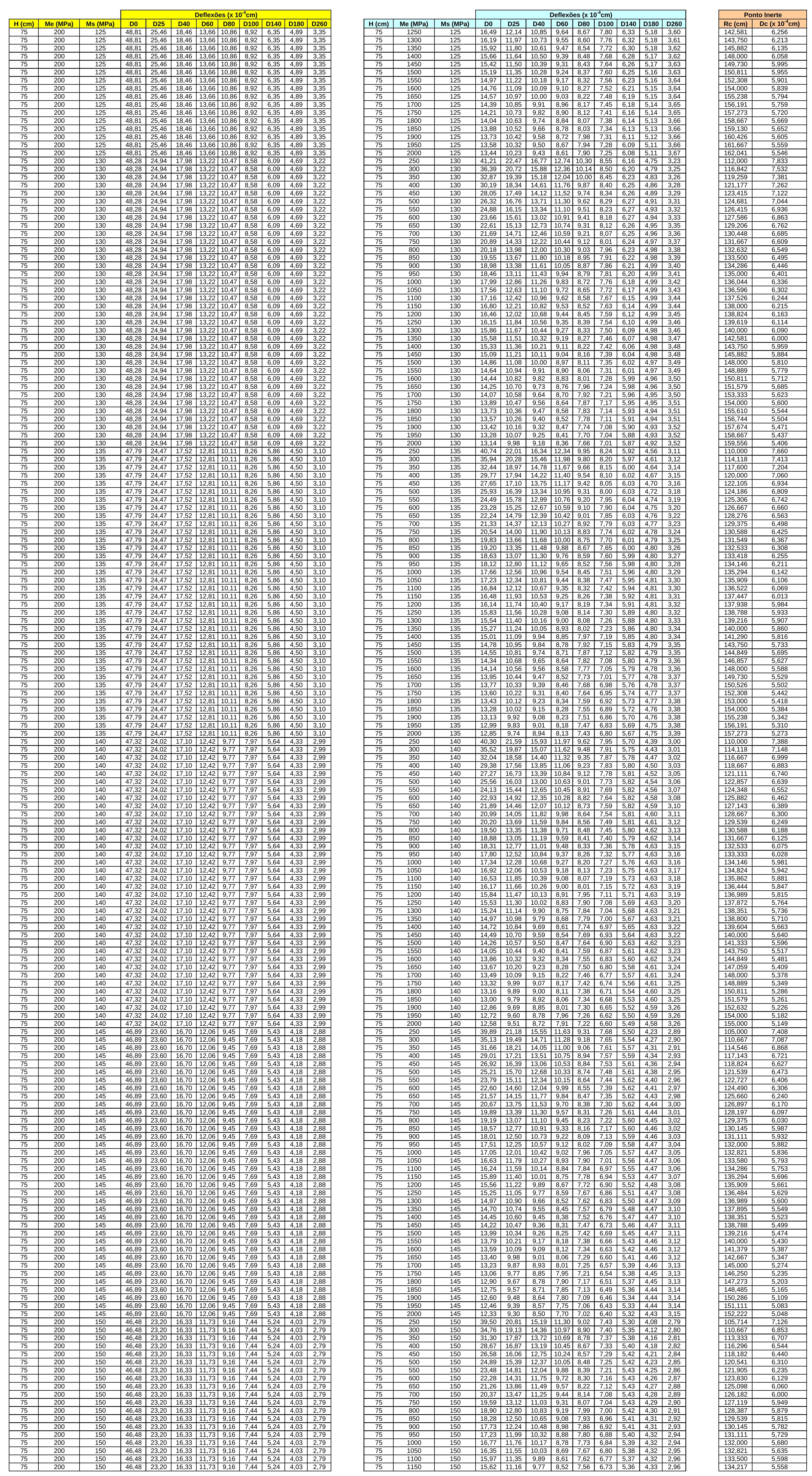




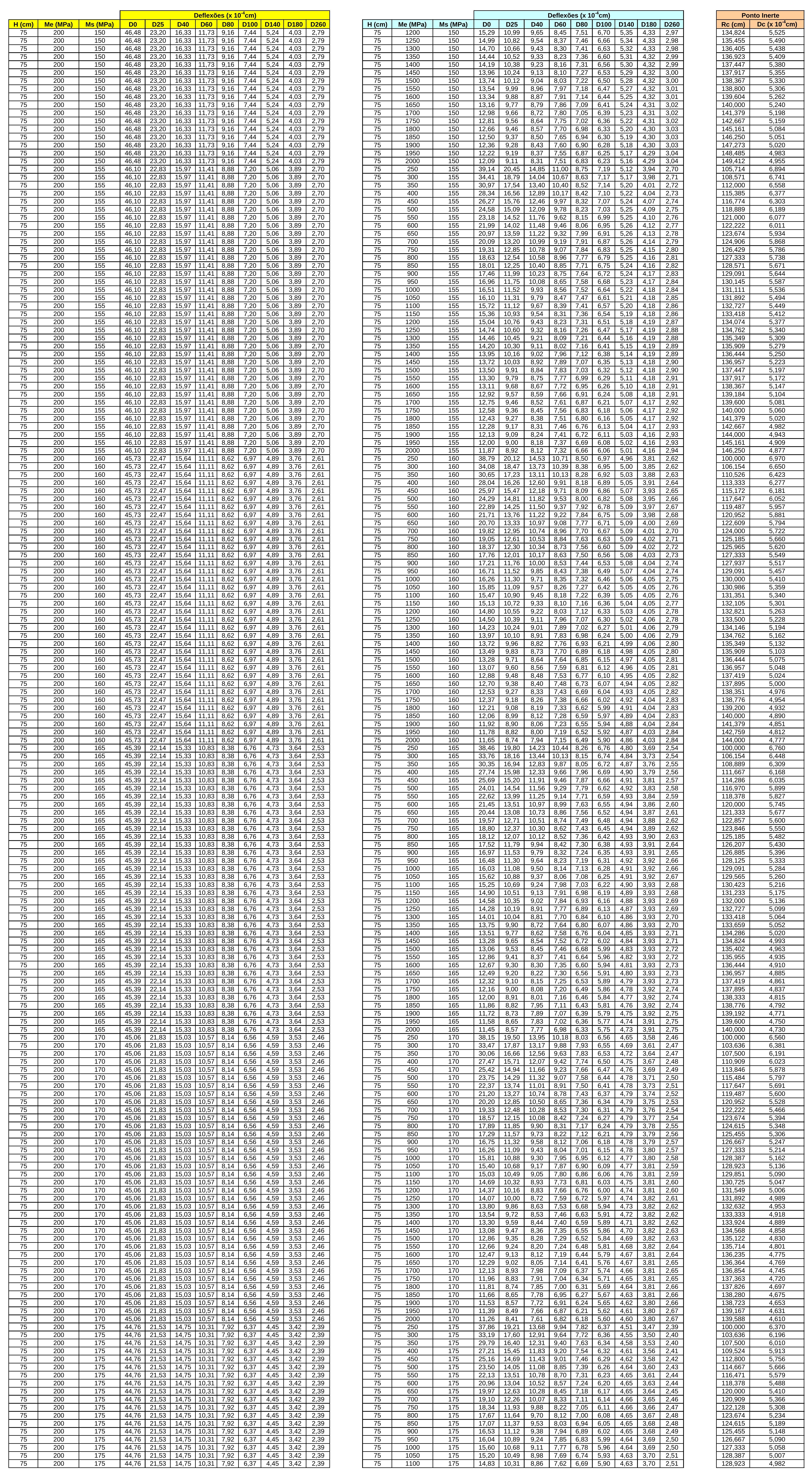




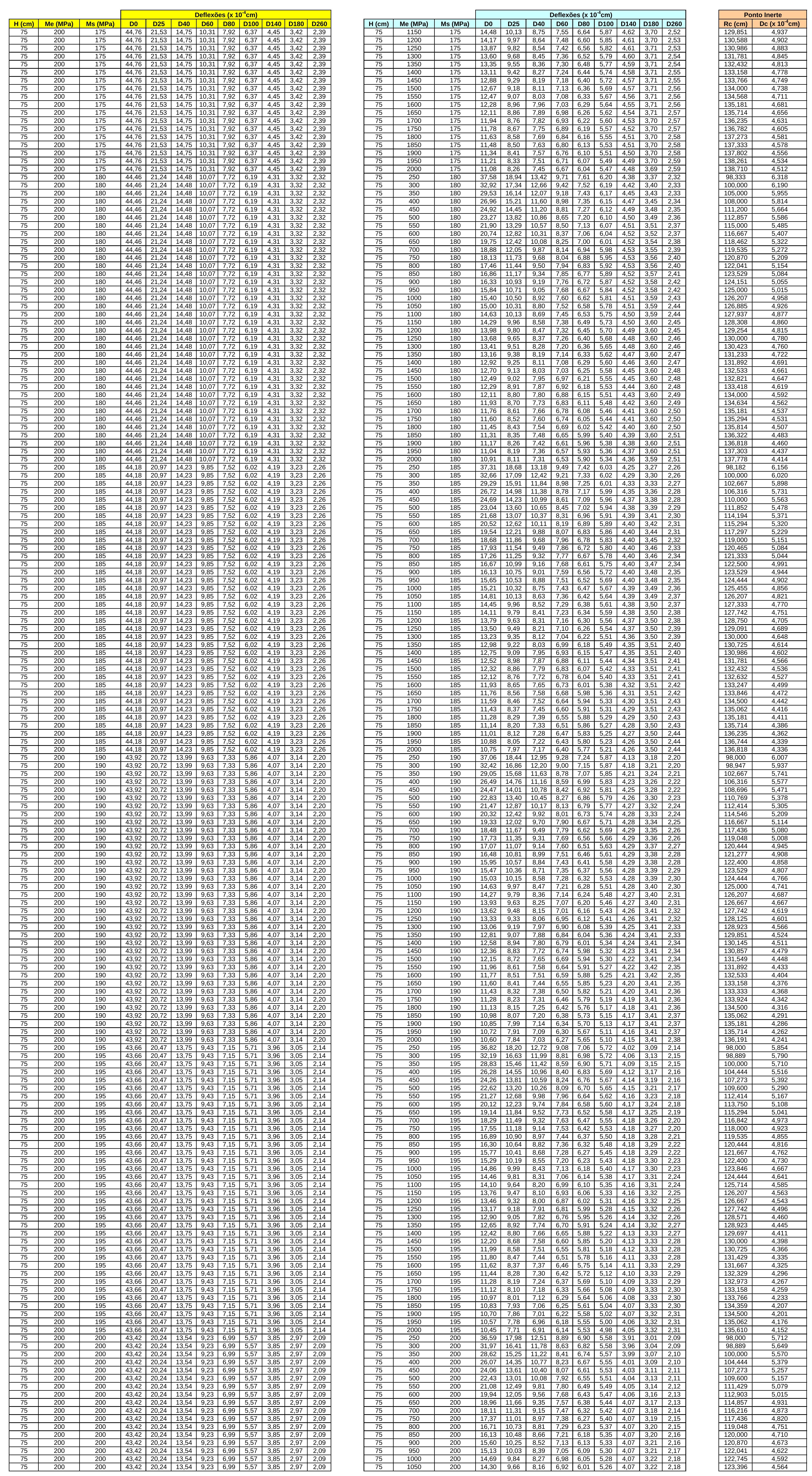




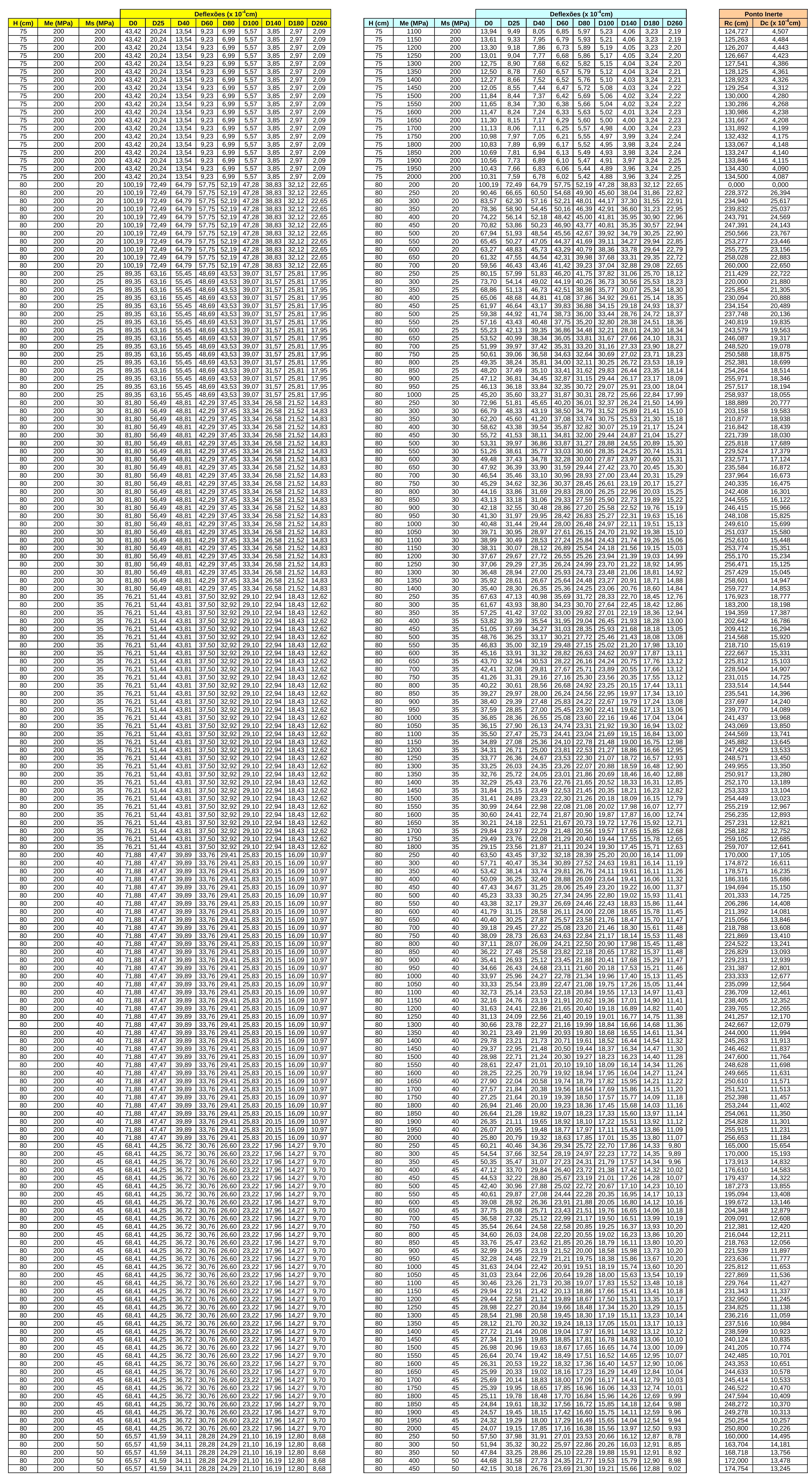




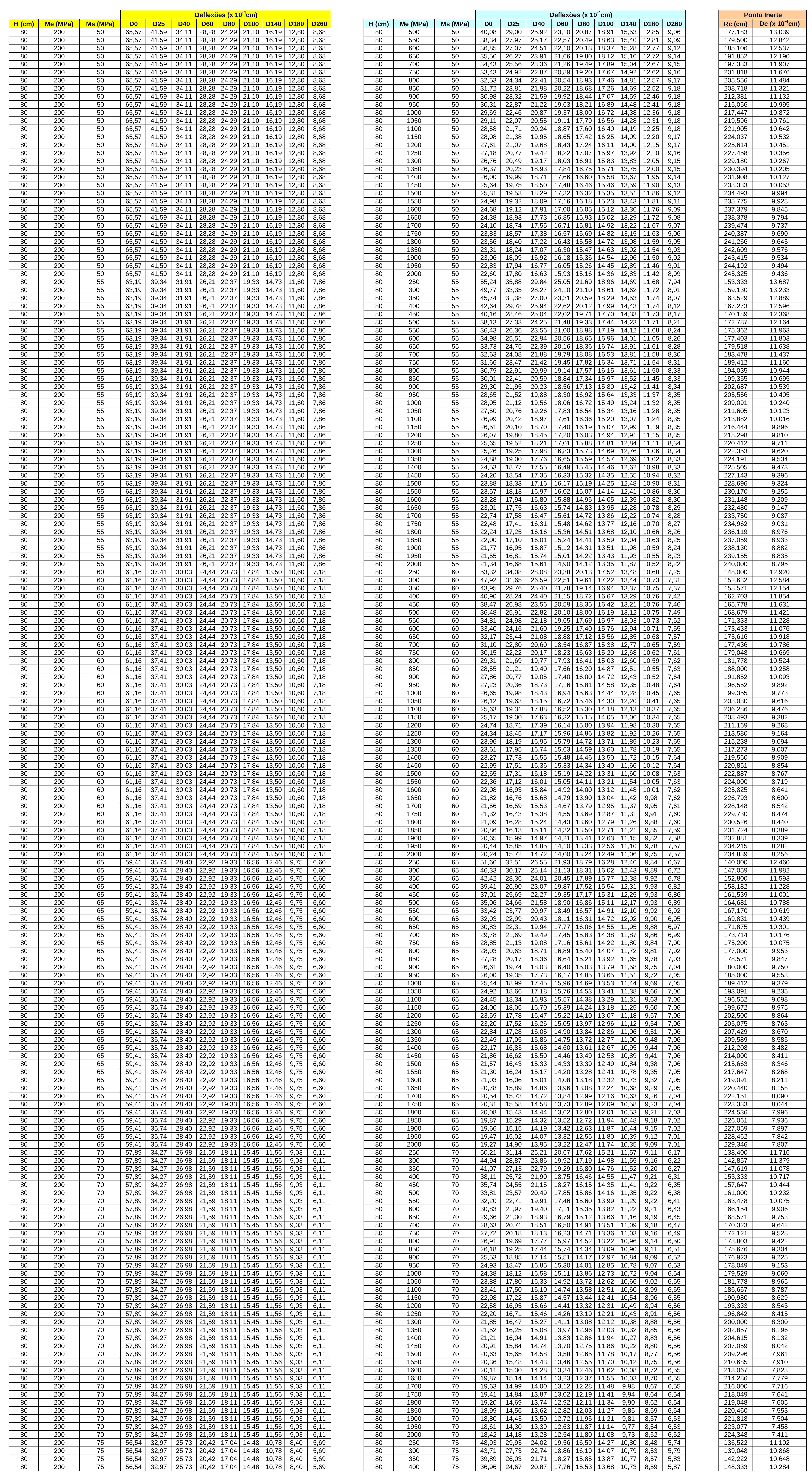




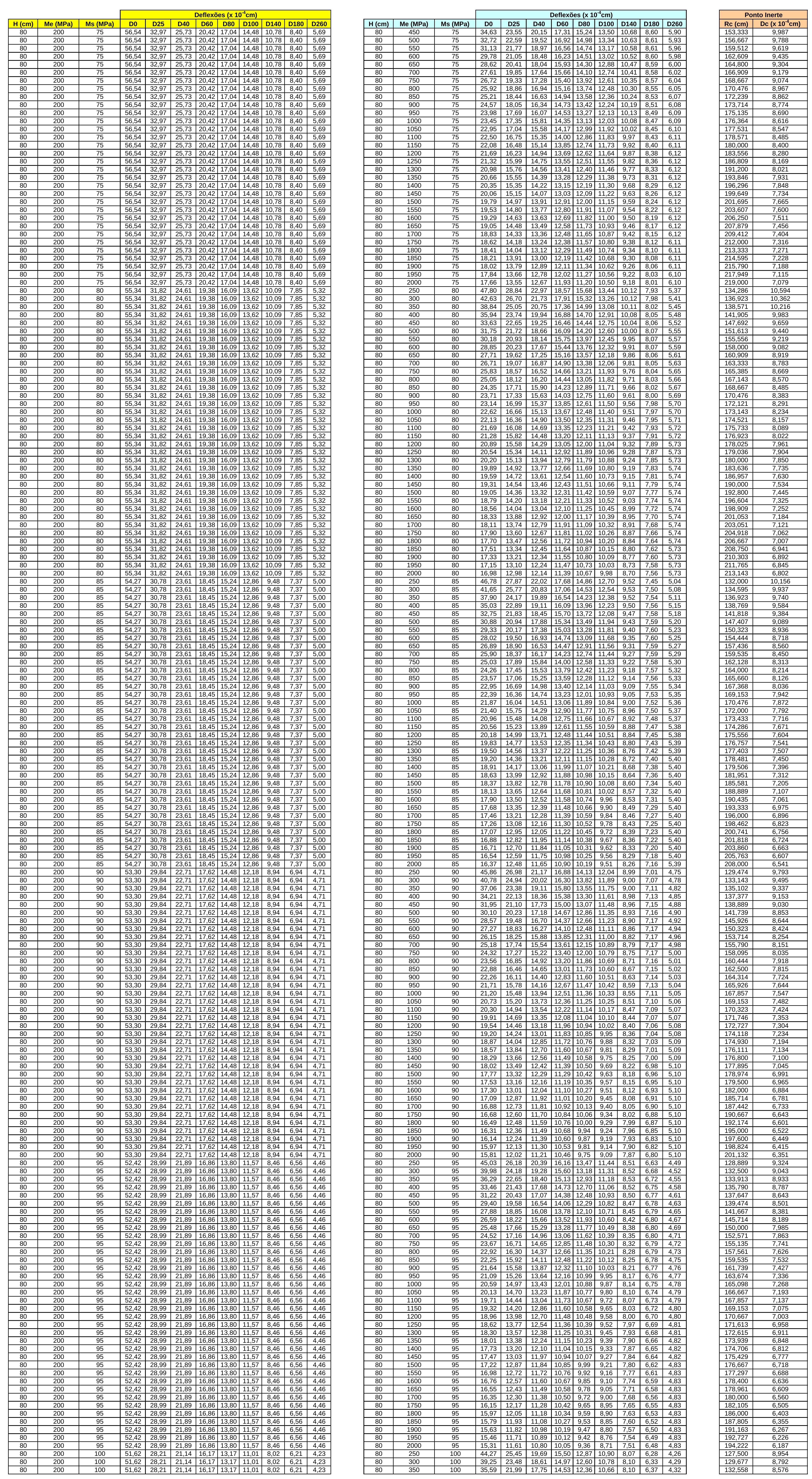




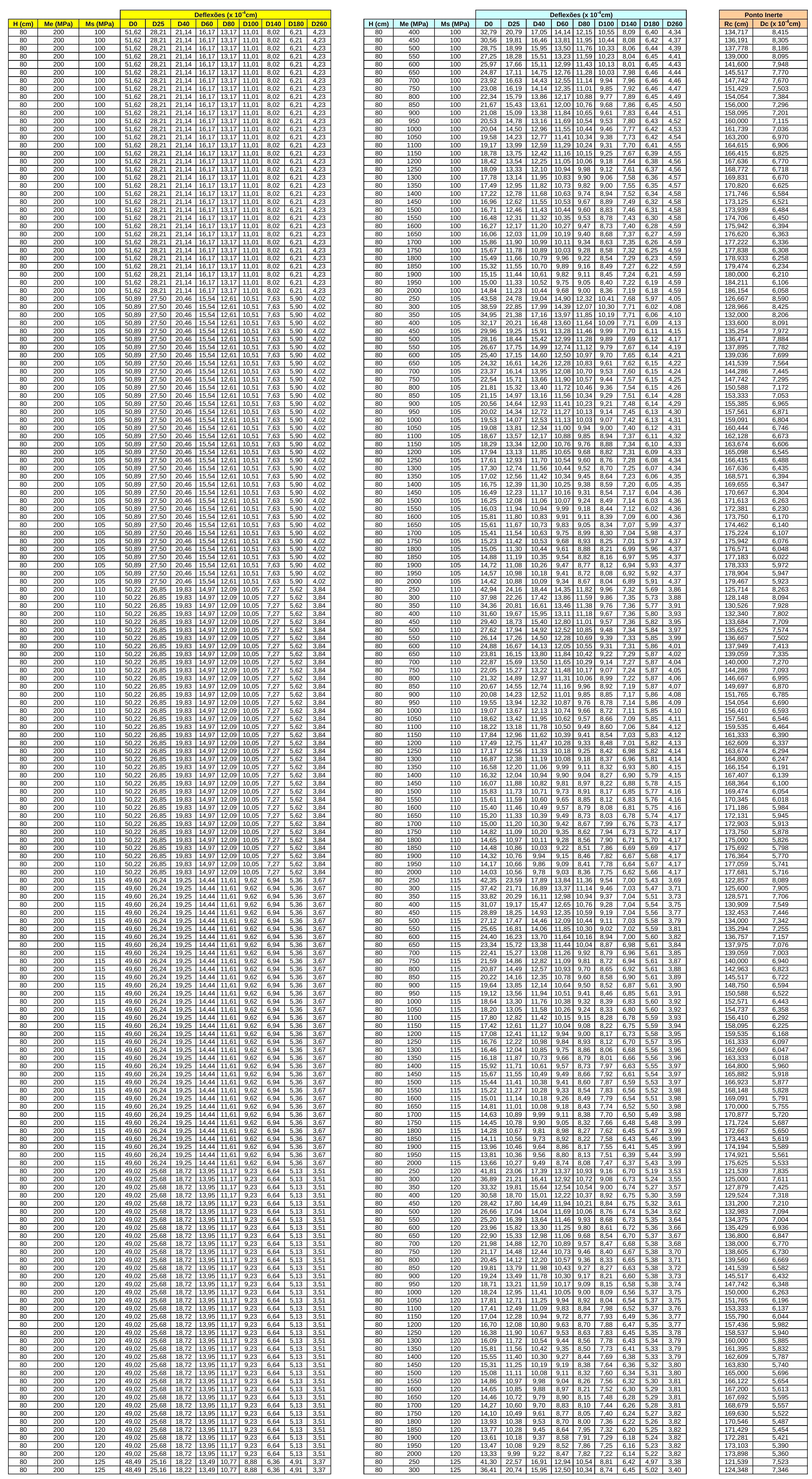




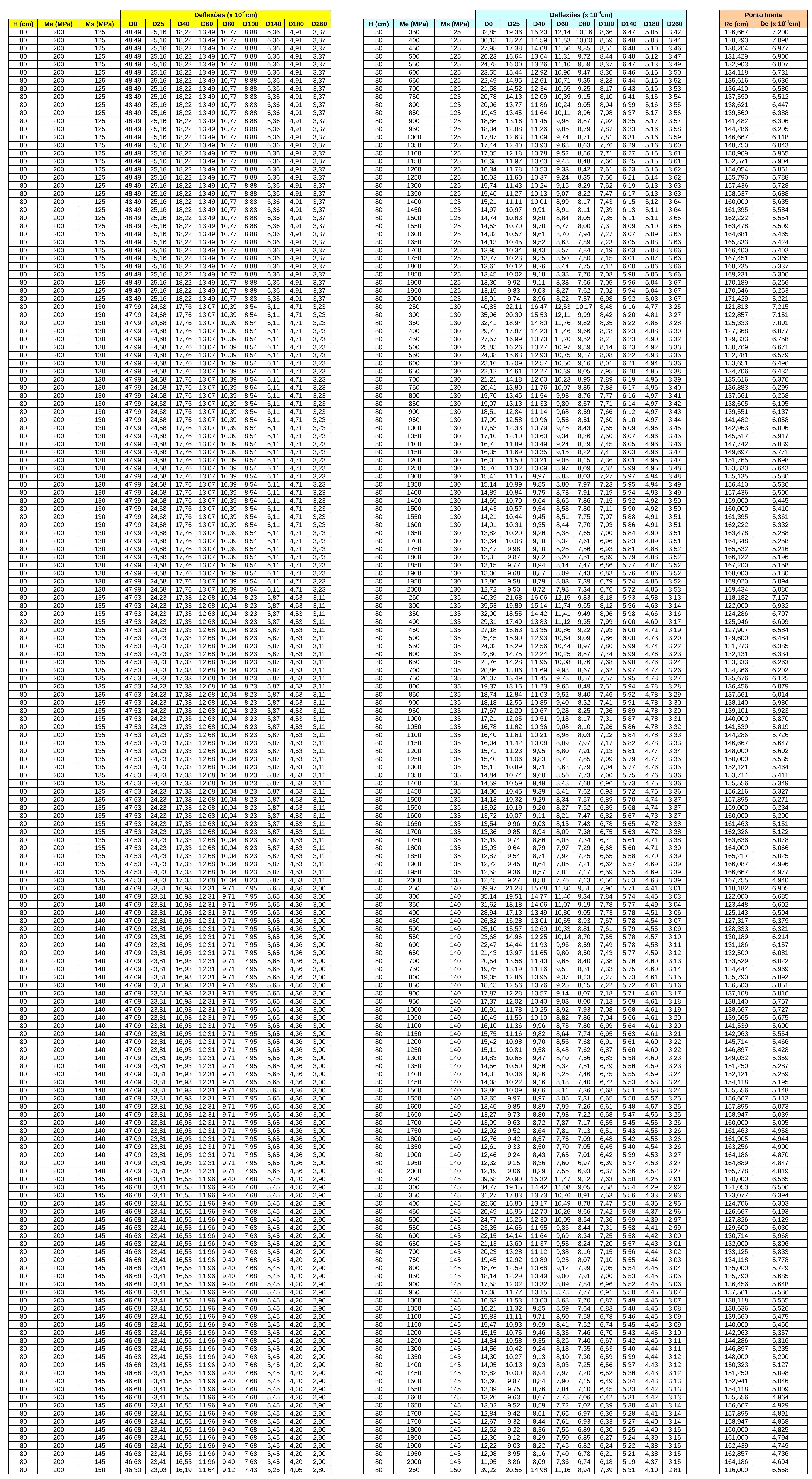




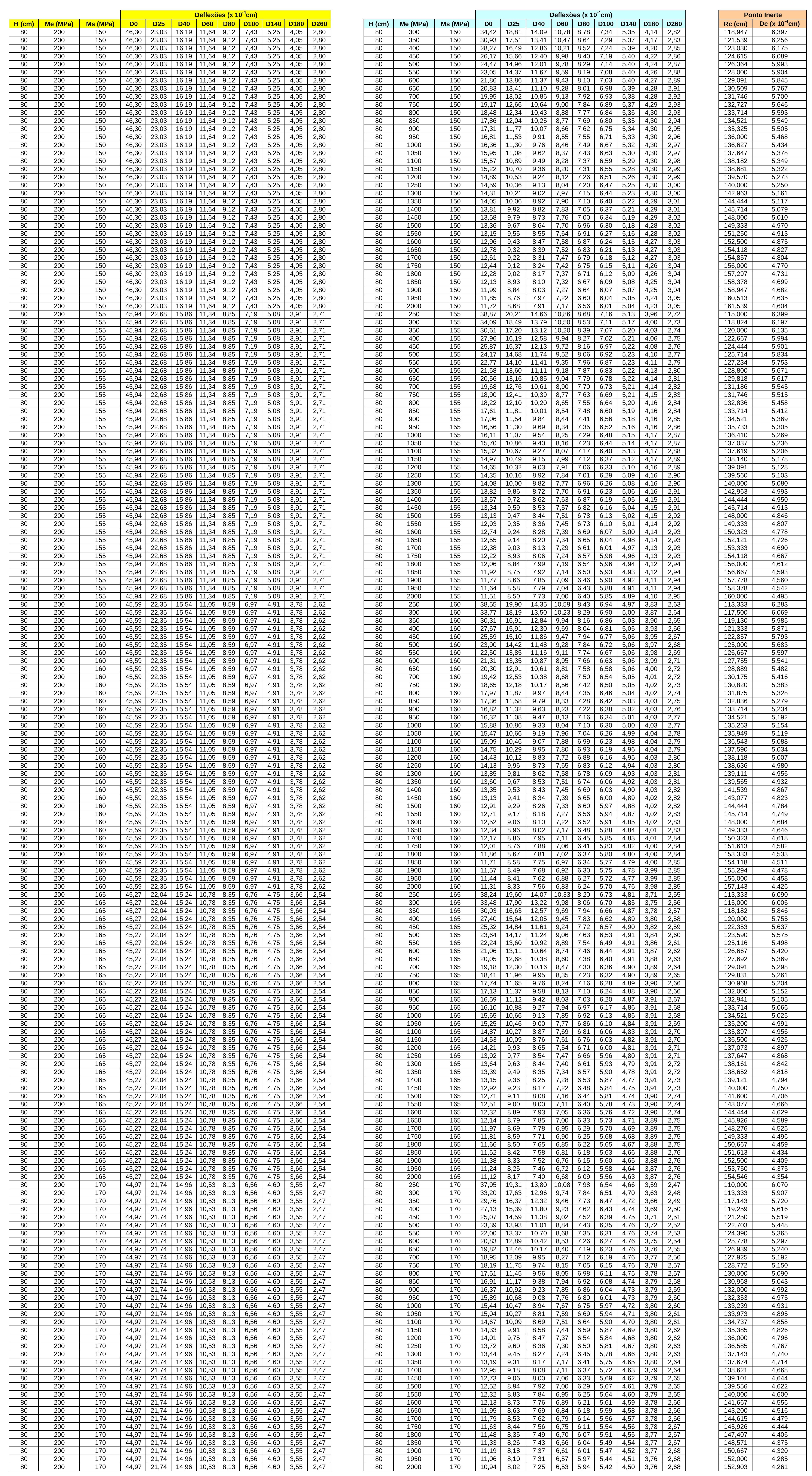




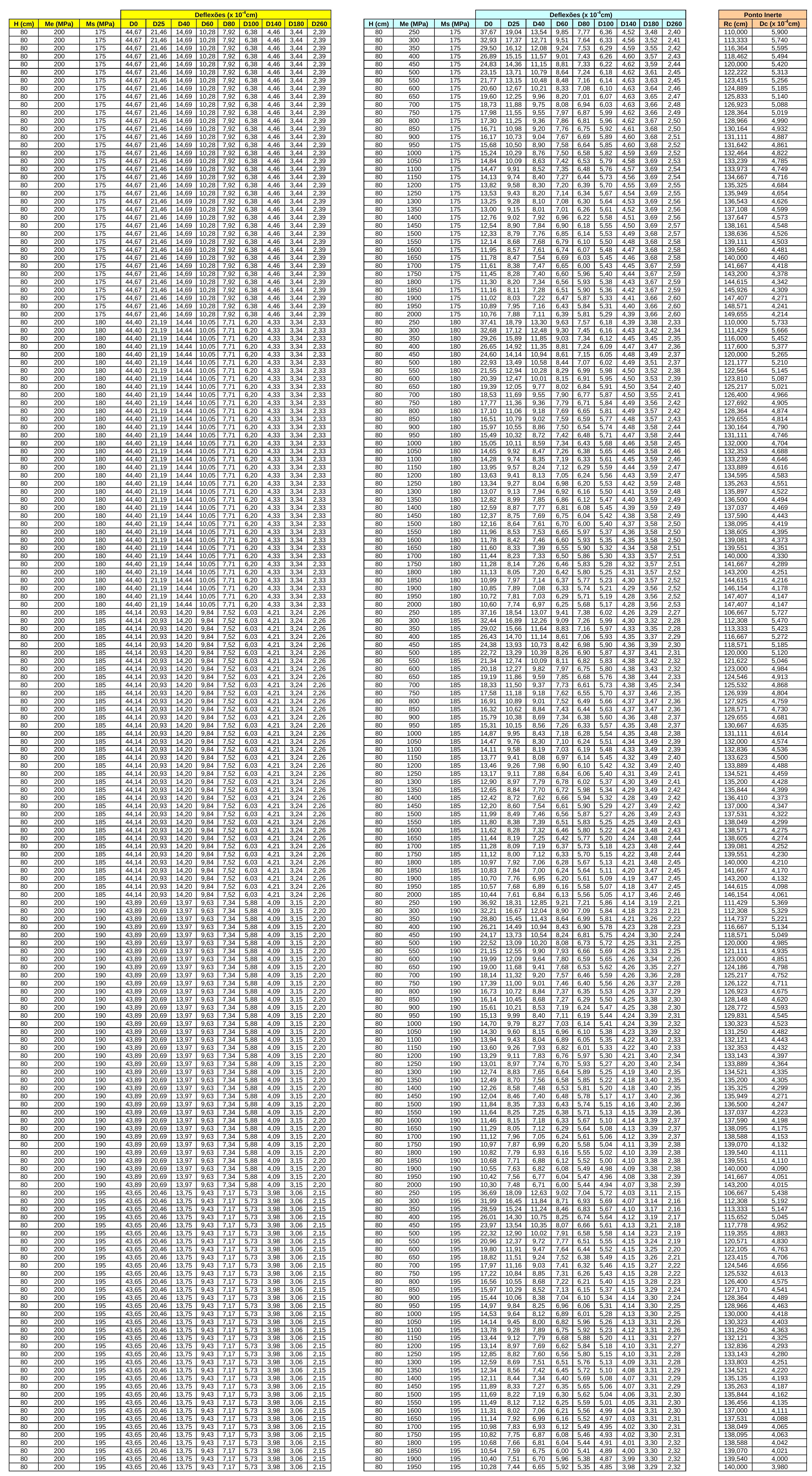




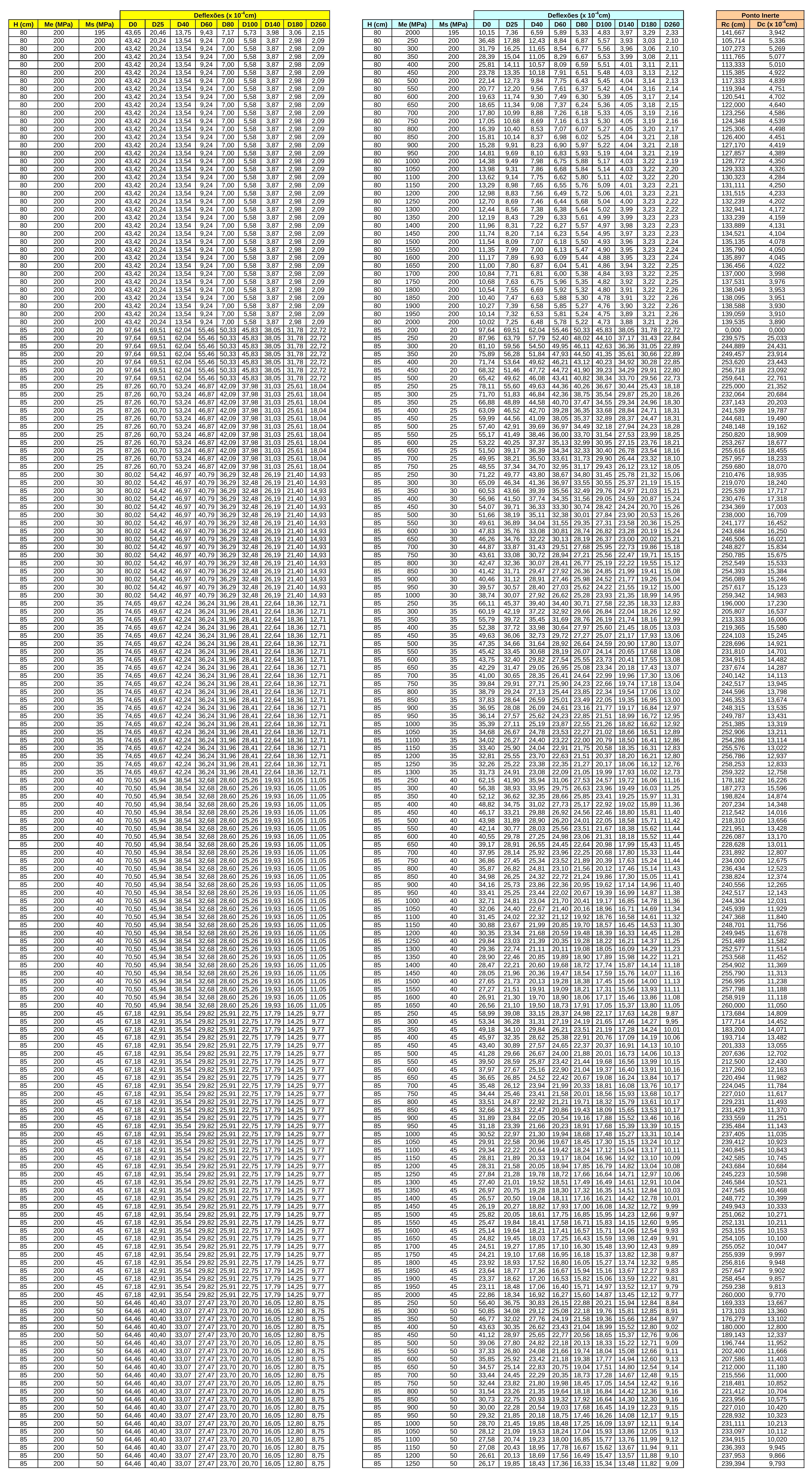




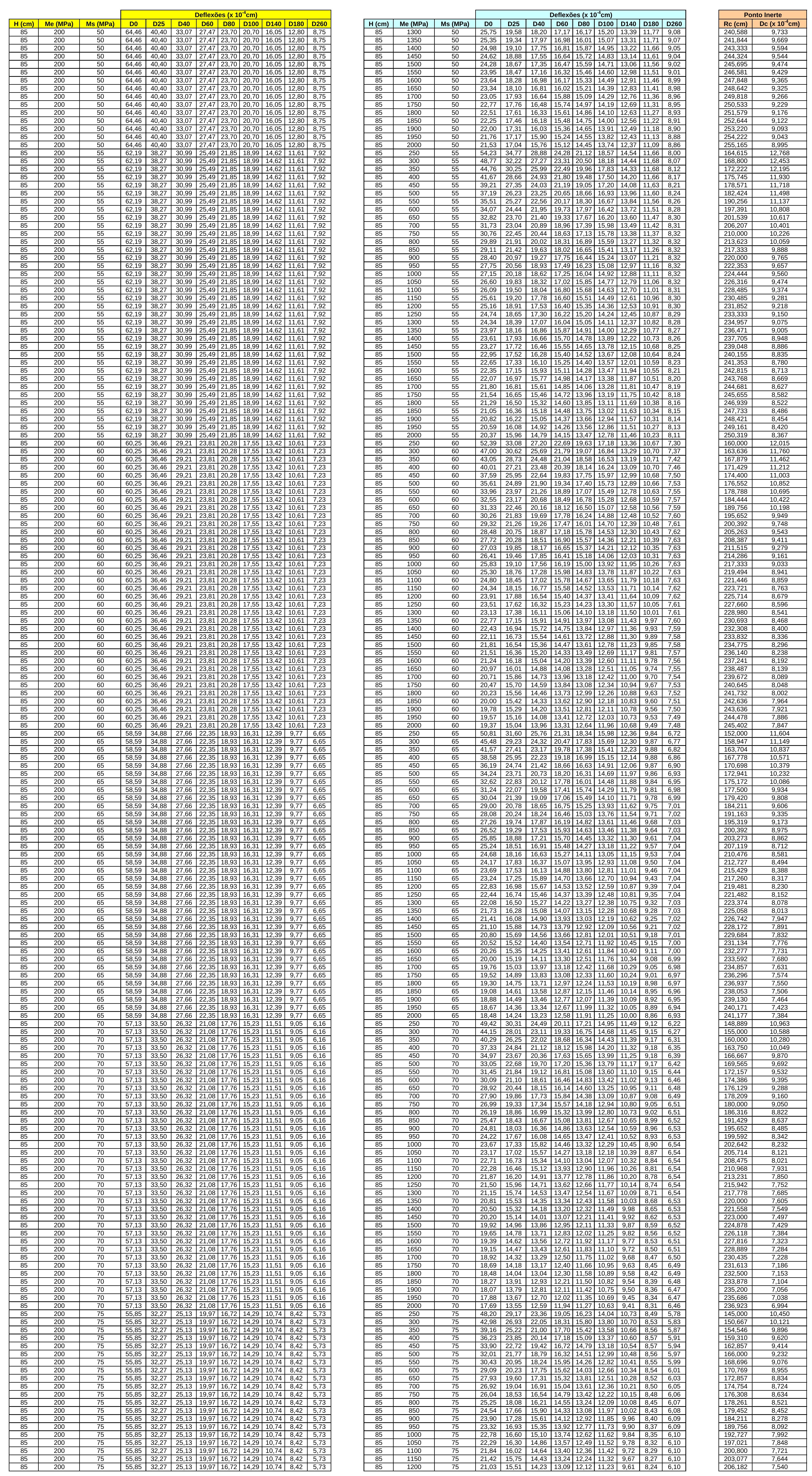




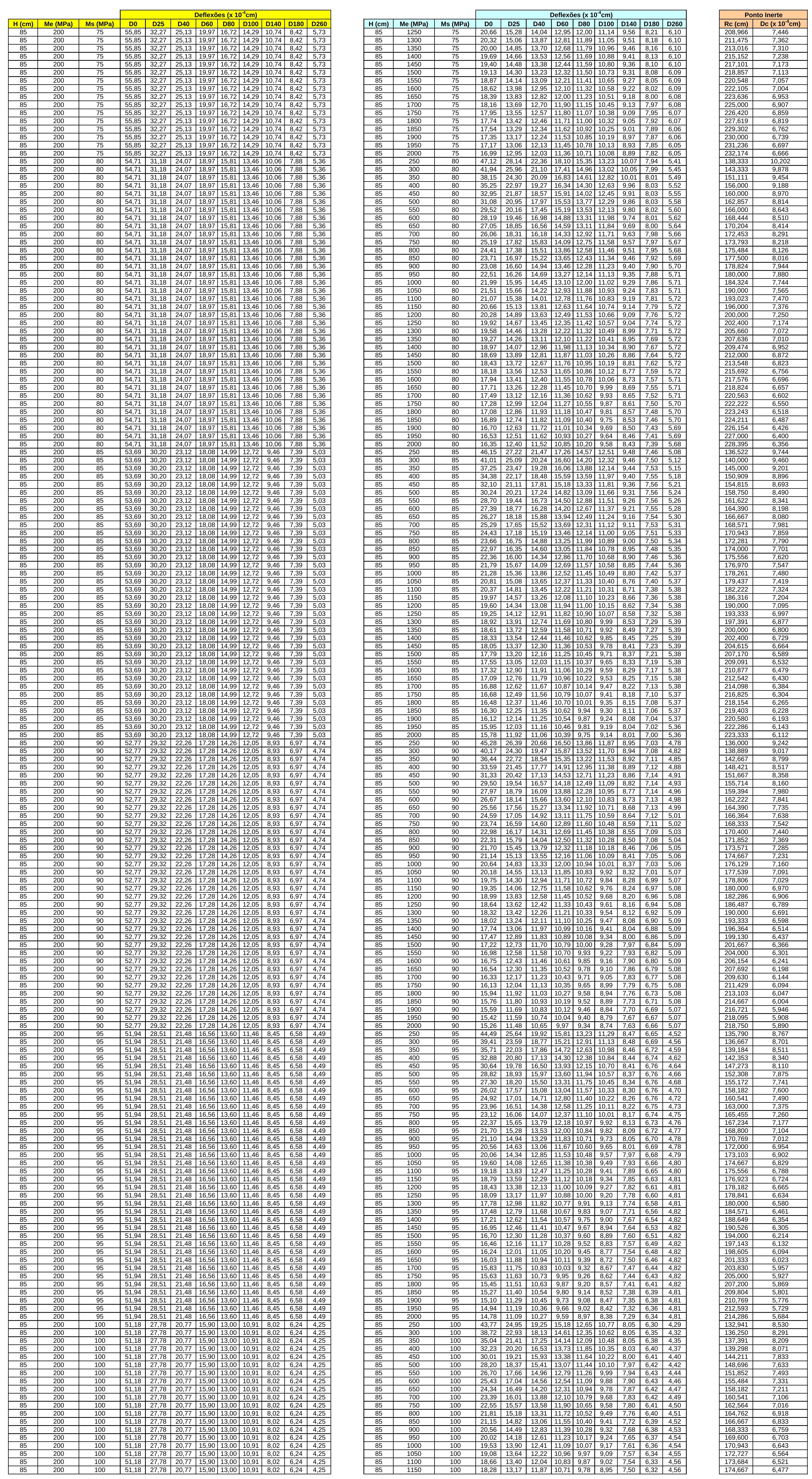




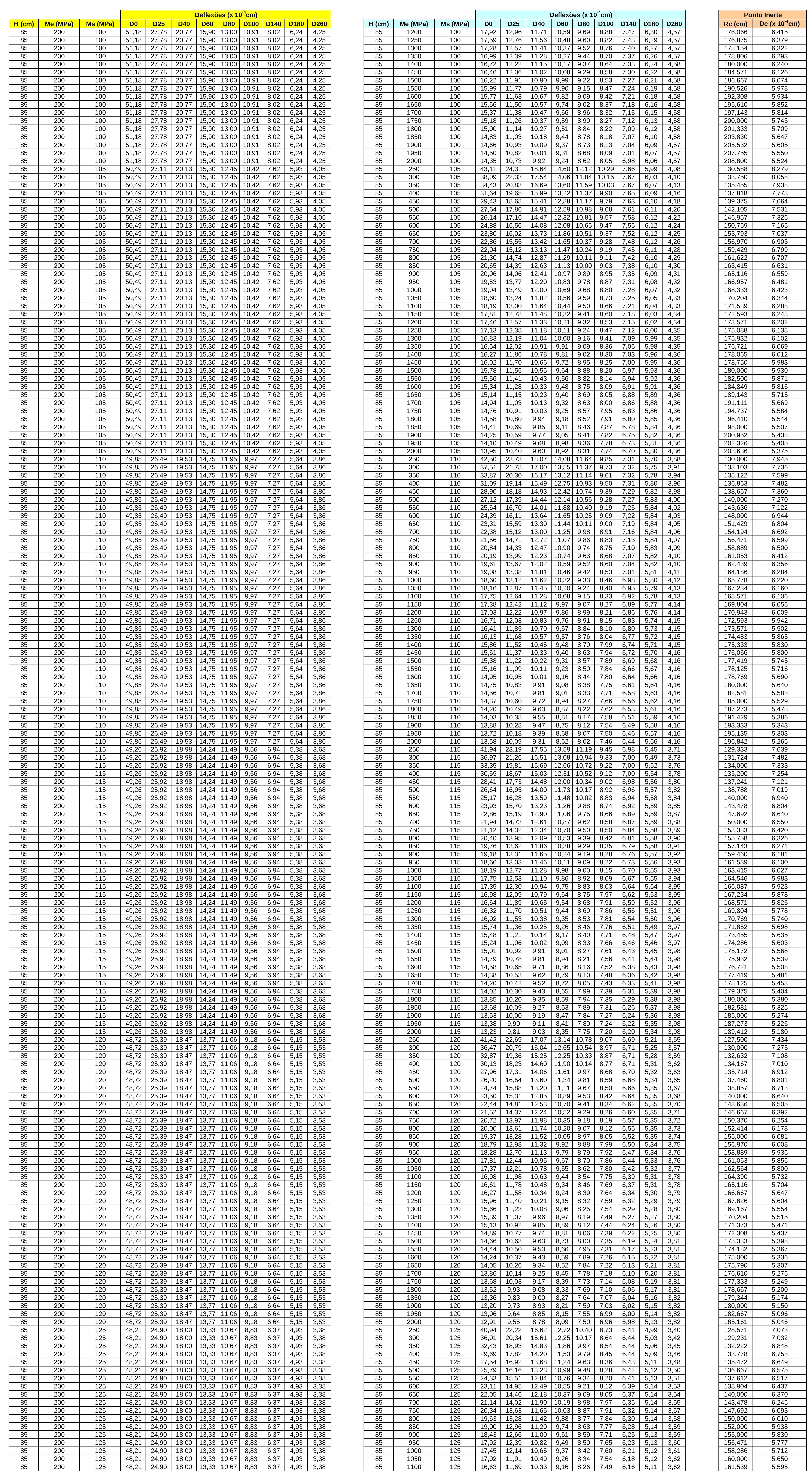




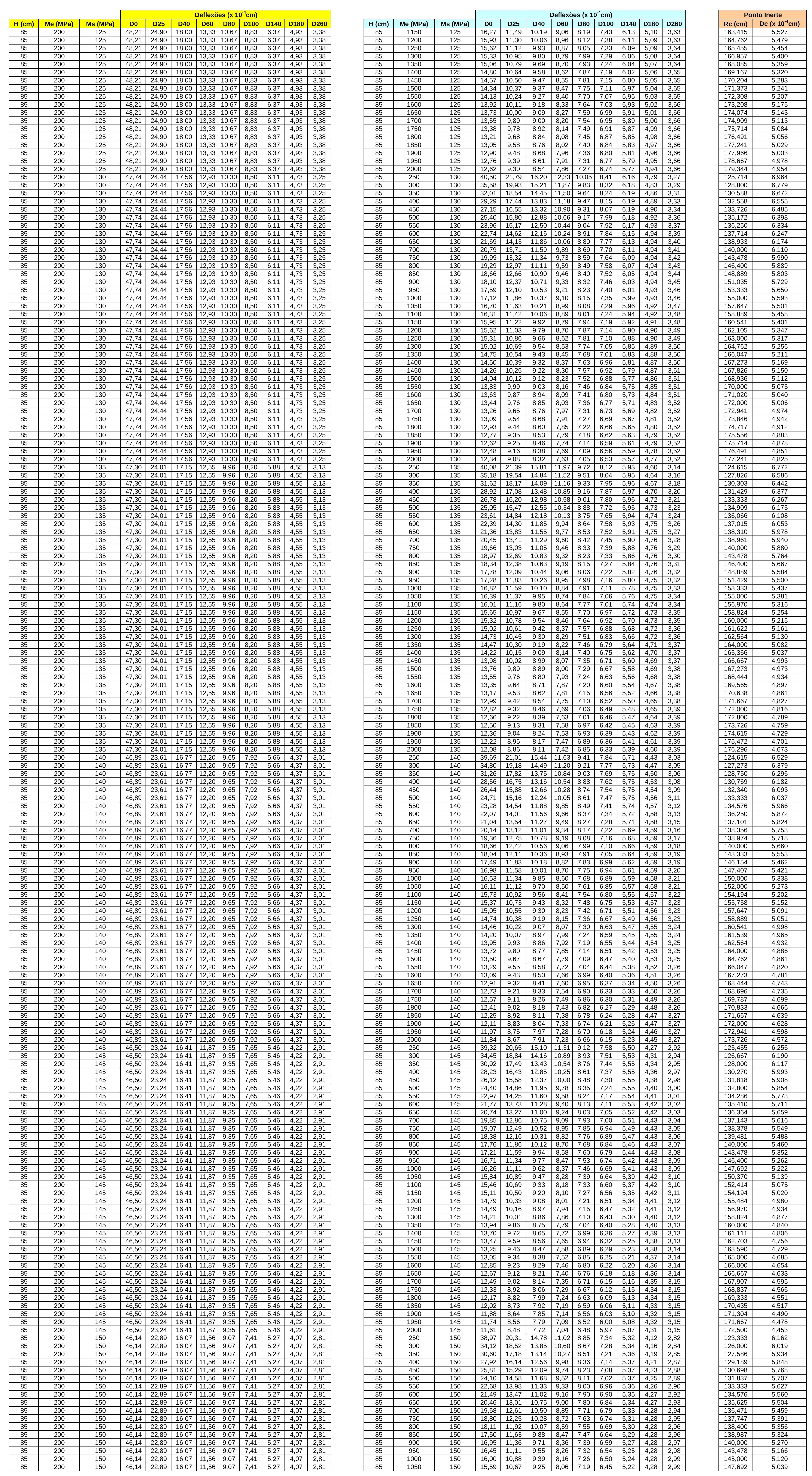




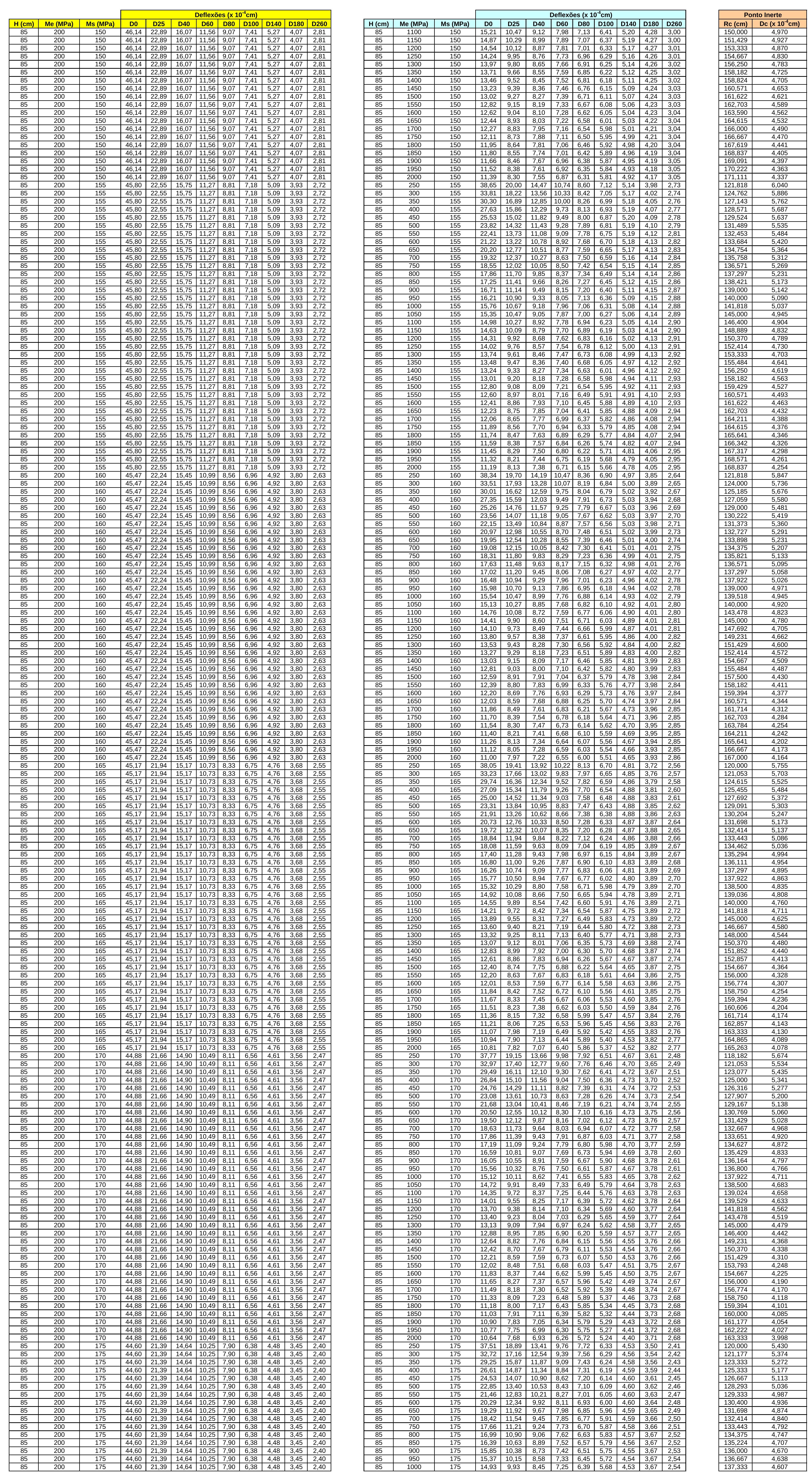




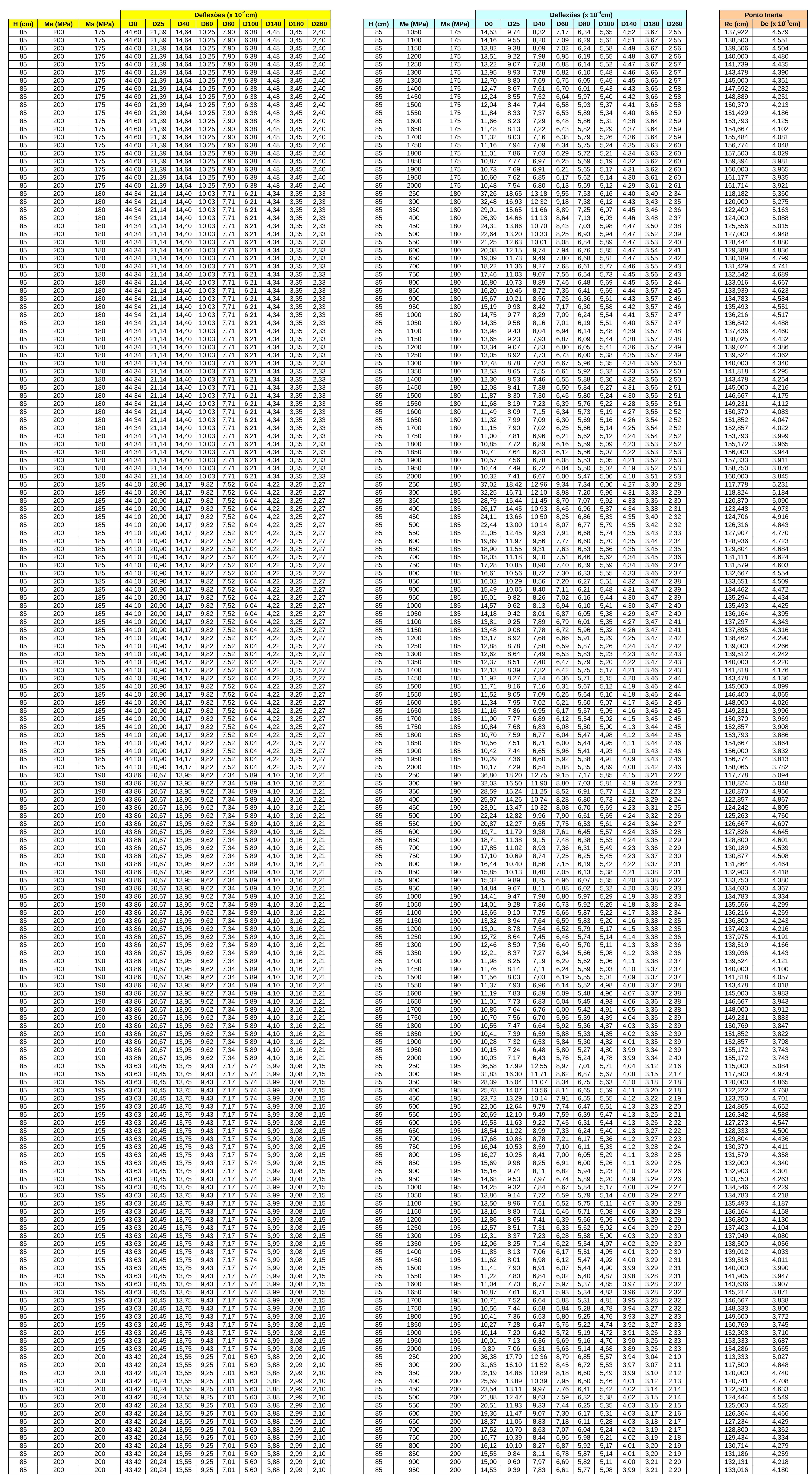




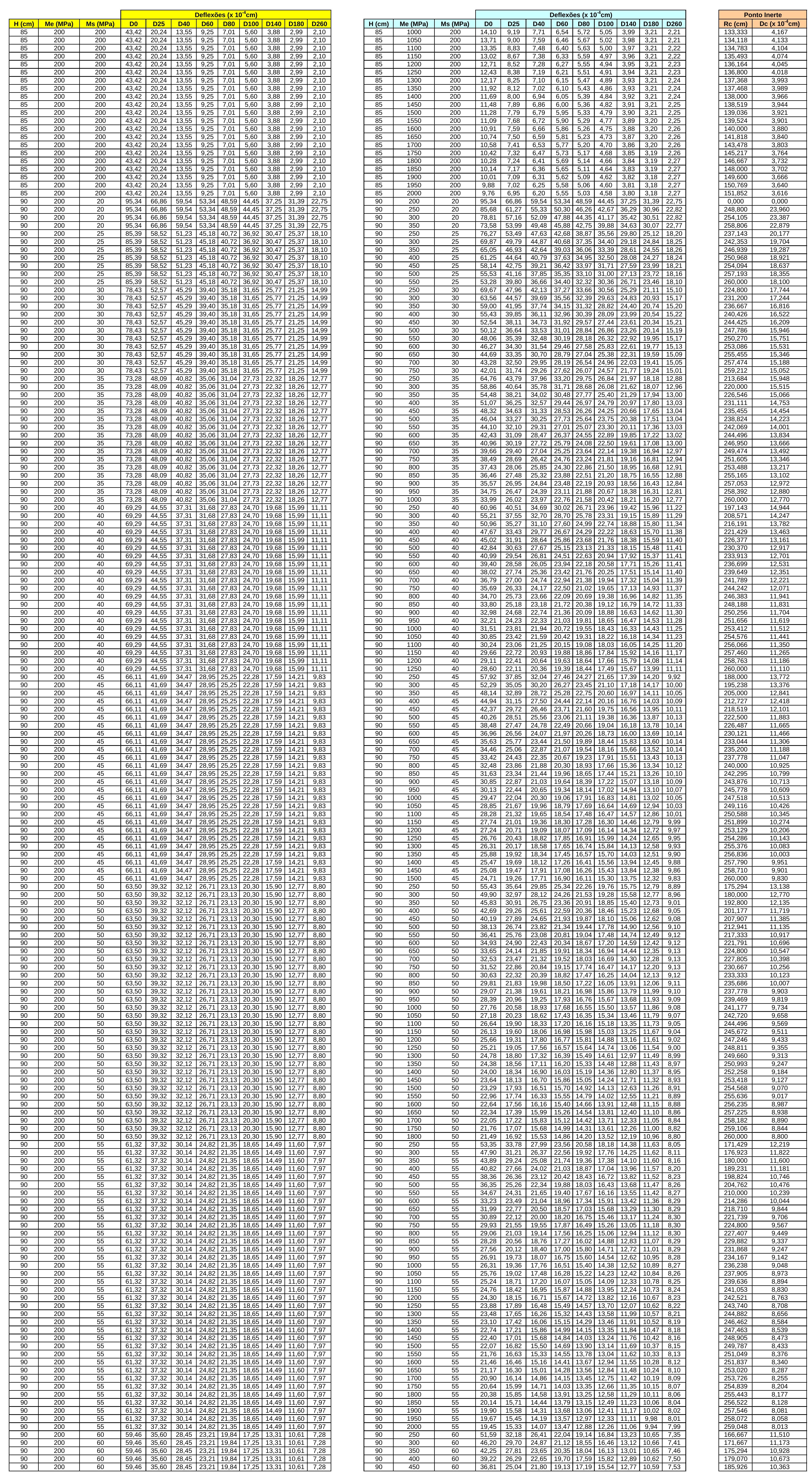




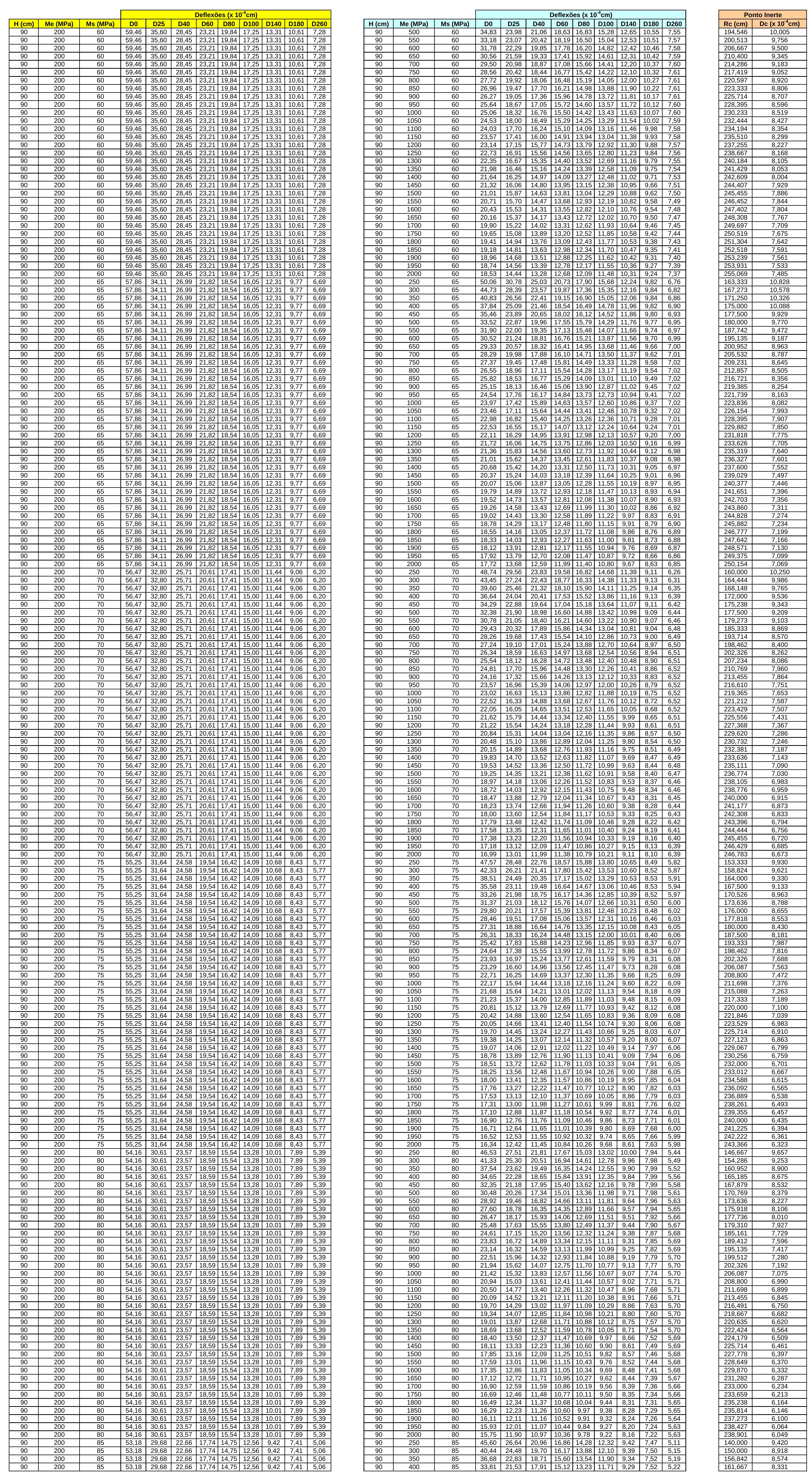




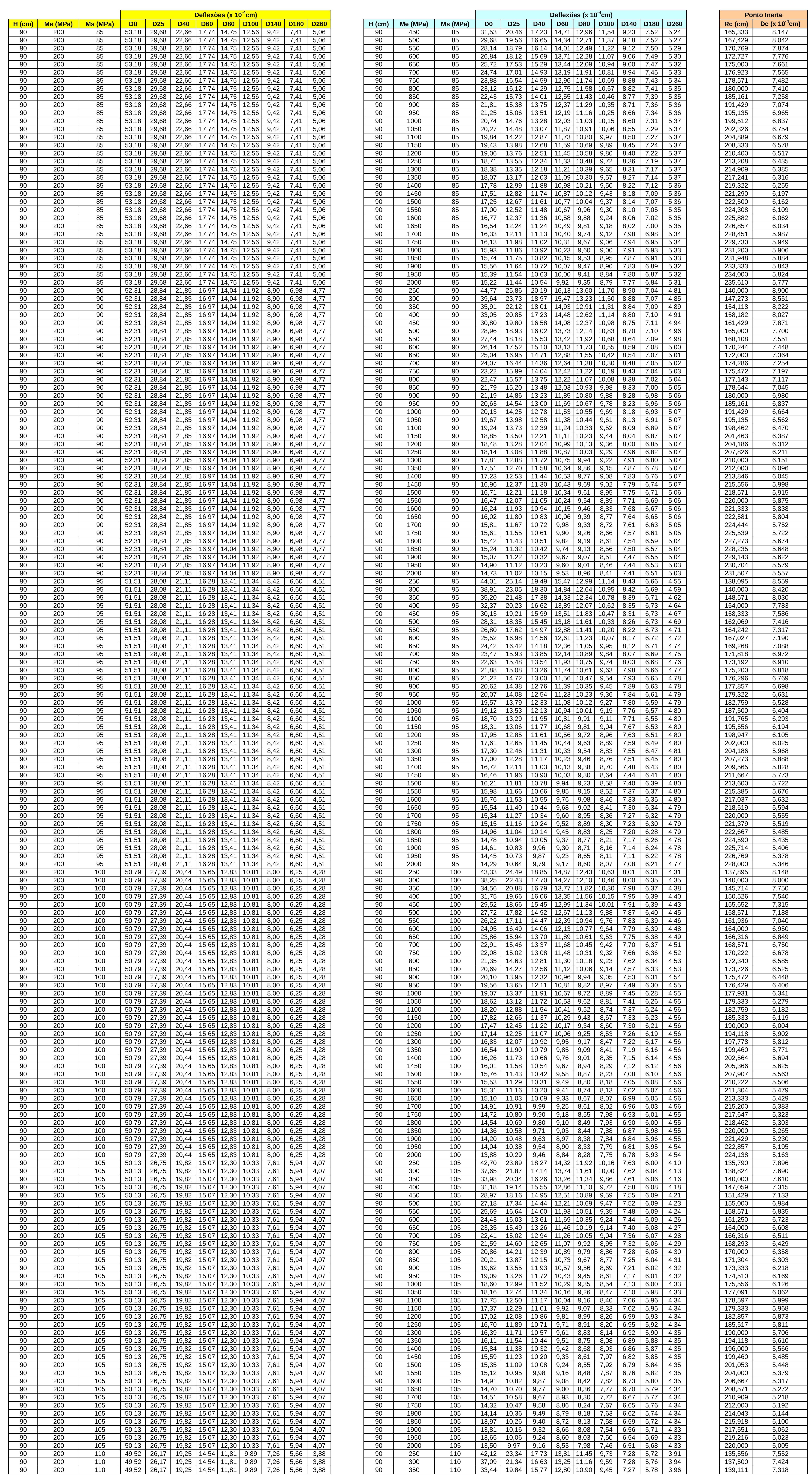




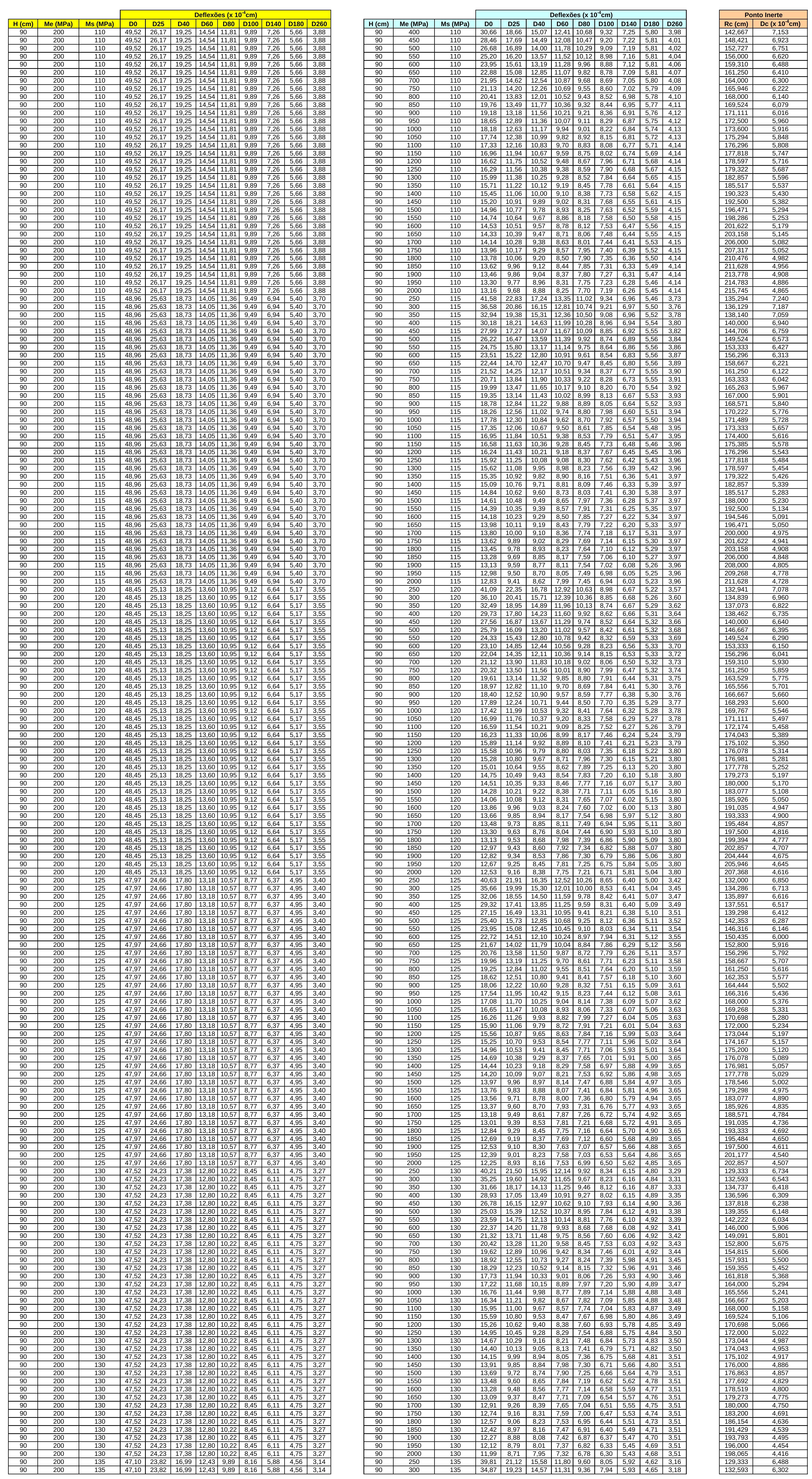




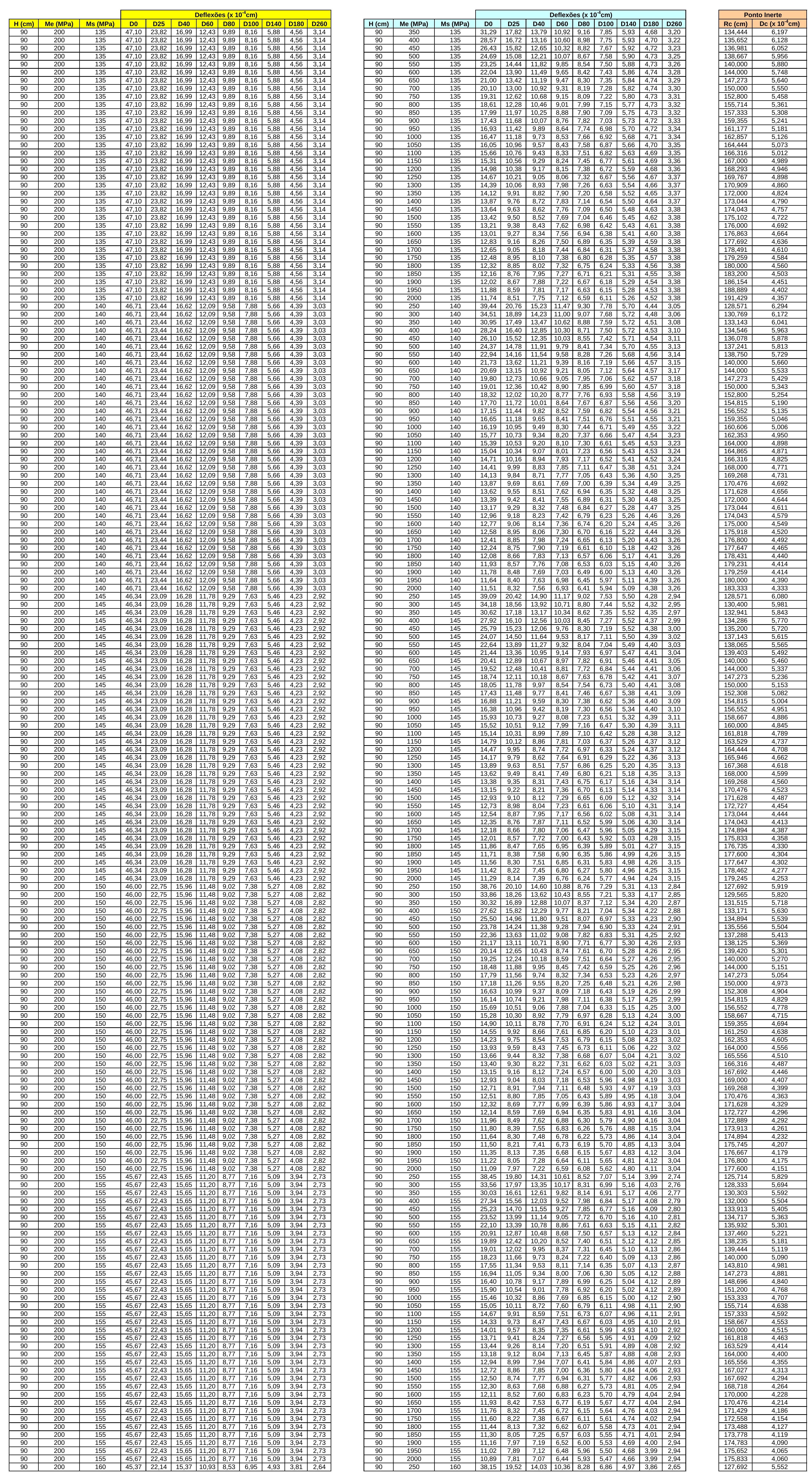




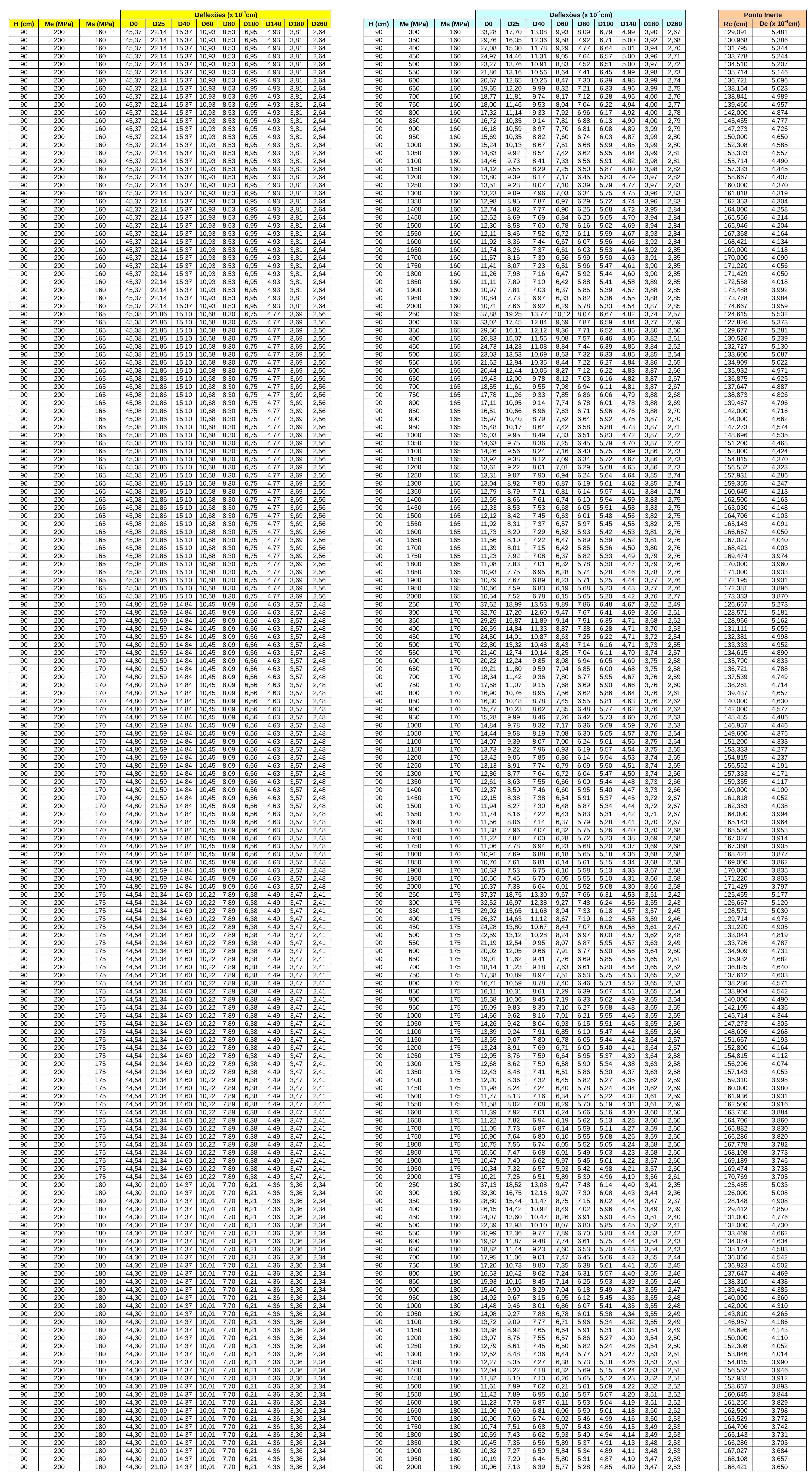



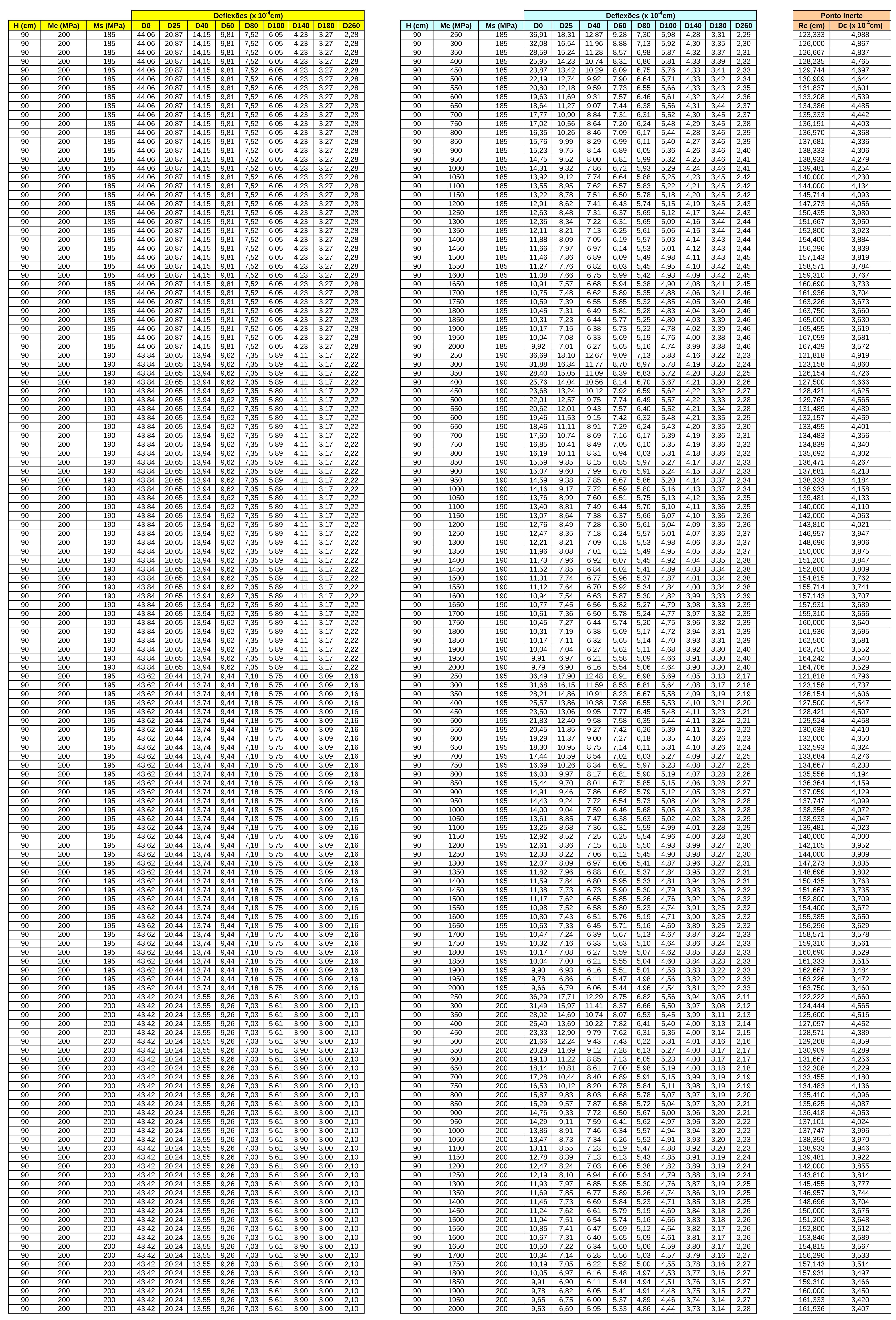
ANEXO E - Banco de dados de bacias deflectométricas aleatório. 


\begin{tabular}{|c|c|c|c|c|c|c|c|c|c|c|c|}
\hline \multirow[b]{2}{*}{ e1 (cm) } & & & & & & $\mathrm{De}$ & ões (x1 & & & & \\
\hline & Meq (MPa) & Ms (MPa) & D0 & D25 & D40 & D60 & D80 & D100 & D140 & D180 & D260 \\
\hline 45,07 & 281,20 & 123,50 & 43,52 & 25,90 & 19,71 & 14,66 & 11,38 & 9,11 & 6,29 & 4,79 & 3,30 \\
\hline 61,41 & 1230,00 & 149,40 & 16,59 & 12,49 & 10,96 & 9,47 & 8,26 & 7,21 & 5,54 & 4,35 & 2,90 \\
\hline 51,18 & 274,70 & 92,90 & 48,46 & 30,55 & 24,17 & 18,77 & 15,03 & 12,26 & 8,60 & 6,52 & 4,41 \\
\hline 31,38 & 1074,80 & 133,90 & 28,09 & 21,58 & 17,83 & 13,81 & 10,82 & 8,64 & 5,90 & 4,43 & 3,00 \\
\hline 51,13 & 1915,00 & 198,30 & 12,88 & 10,16 & 8,95 & 7,66 & 6,58 & 5,66 & 4,23 & 3,25 & 2,14 \\
\hline 31,17 & 1091,70 & 115,00 & 31,02 & 24,38 & 20,38 & 15,98 & 12,63 & 10,13 & 6,93 & 5,19 & 3,50 \\
\hline 53,13 & 1060,00 & 170,40 & 17,88 & 13,13 & 11,21 & 9,34 & 7,87 & 6,66 & 4,87 & 3,72 & 2,45 \\
\hline 85,32 & 420,70 & 43,40 & 45,59 & 32,32 & 28,78 & 25,67 & 23,27 & 21,17 & 17,55 & 14,64 & 10,46 \\
\hline 81,14 & 388,40 & 159,90 & 28,16 & 16,05 & 12,36 & 9,70 & 8,04 & 6,81 & 5,04 & 3,93 & 2,67 \\
\hline 44,62 & 1775,30 & 61,80 & 29,88 & 26,20 & 24,29 & 21,78 & 19,43 & 17,26 & 13,59 & 10,78 & 7,15 \\
\hline 49,53 & 951,70 & 166,00 & 19,77 & 14,39 & 12,16 & 9,97 & 8,27 & 6,91 & 4,96 & 3,76 & 2,49 \\
\hline 29,01 & 1678,90 & 132,70 & 25,68 & 20,79 & 17,54 & 13,86 & 10,99 & 8,83 & 6,04 & 4,50 & 3,02 \\
\hline 77,47 & 1452,70 & 186,40 & 12,30 & 8,74 & 7,66 & 6,70 & 5,97 & 5,33 & 4,28 & 3,47 & 2,40 \\
\hline 89,53 & 794,00 & 155,70 & 17,62 & 11,38 & 9,55 & 8,12 & 7,14 & 6,34 & 5,06 & 4,11 & 2,86 \\
\hline 55,06 & 1203,70 & 94,80 & 22,97 & 18,54 & 16,68 & 14,66 & 12,90 & 11,34 & 8,79 & 6,93 & 4,60 \\
\hline 80,63 & 1594,00 & 36,90 & 29,49 & 23,40 & 21,80 & 20,94 & 19,98 & 18,98 & 17,04 & 15,23 & 12,09 \\
\hline 45,60 & 306,60 & 46,60 & 69,27 & 51,91 & 44,11 & 36,13 & 29,82 & 24,79 & 17,68 & 13,34 & 8,82 \\
\hline 65,18 & 994,00 & 61,70 & 29,20 & 23,09 & 21,26 & 19,22 & 17,42 & 15,77 & 12,89 & 10,59 & 7,35 \\
\hline 38,74 & 1240,80 & 169,10 & 20,10 & 15,38 & 12,98 & 10,42 & 8,42 & 6,88 & 4,80 & 3,60 & 2,40 \\
\hline 36,44 & 861,30 & 37,10 & 62,30 & 54,67 & 49,23 & 42,44 & 36,37 & 31,11 & 22,97 & 17,45 & 11,28 \\
\hline 70,72 & 1682,50 & 83,30 & 18,99 & 14,81 & 13,82 & 12,72 & 11,72 & 10,78 & 9,09 & 7,67 & 5,52 \\
\hline 50,68 & 1110,40 & 68,60 & 30,35 & 25,33 & 23,01 & 20,32 & 17,91 & 15,76 & 12,22 & 9,61 & 6,35 \\
\hline 87,52 & 1769,40 & 162,10 & 11,41 & 8,12 & 7,29 & 6,56 & 5,99 & 5,48 & 4,60 & 3,88 & 2,81 \\
\hline 60,17 & 1196,10 & 165,90 & 16,08 & 11,91 & 10,34 & 8,83 & 7,63 & 6,61 & 5,01 & 3,90 & 2,58 \\
\hline 82,01 & 623,50 & 81,40 & 27,78 & 19,41 & 16,97 & 14,87 & 13,29 & 11,93 & 9,66 & 7,91 & 5,52 \\
\hline 64,71 & 1888,40 & 148,20 & 13,42 & 10,48 & 9,50 & 8,48 & 7,60 & 6,81 & 5,47 & 4,42 & 3,02 \\
\hline 74,66 & 1409,60 & 136,80 & 14,89 & 11,00 & 9,86 & 8,77 & 7,89 & 7,11 & 5,78 & 4,74 & 3,29 \\
\hline 66,82 & 326,70 & 36,00 & 63,18 & 47,36 & 41,96 & 36,76 & 32,53 & 28,82 & 22,70 & 18,15 & 12,27 \\
\hline 24,42 & 406,80 & 98,50 & 54,52 & 36,56 & 27,26 & 19,03 & 14,07 & 10,98 & 7,59 & 5,86 & 4,09 \\
\hline 56,26 & 1834,30 & 187,00 & 12,83 & 10,03 & 8,88 & 7,70 & 6,70 & 5,84 & 4,46 & 3,48 & 2,30 \\
\hline 61,27 & 624,90 & 95,30 & 29,06 & 21,15 & 18,22 & 15,49 & 13,33 & 11,52 & 8,70 & 6,77 & 4,49 \\
\hline 67,09 & 1035,40 & 64,20 & 27,64 & 21,69 & 19,99 & 18,11 & 16,47 & 14,95 & 12,29 & 10,14 & 7,09 \\
\hline 64,34 & 1994,60 & 161,70 & 12,51 & 9,75 & 8,82 & 7,85 & 7,03 & 6,28 & 5,02 & 4,06 & 2,76 \\
\hline 51,79 & 945,80 & 127,90 & 22,29 & 16,89 & 14,60 & 12,29 & 10,41 & 8,85 & 6,52 & 4,98 & 3,28 \\
\hline 43,64 & 1474,90 & 157,90 & 18,11 & 14,36 & 12,47 & 10,41 & 8,71 & 7,32 & 5,28 & 3,99 & 2,61 \\
\hline 48,75 & 544,80 & 115,00 & 31,47 & 22,10 & 18,33 & 14,77 & 12,08 & 9,98 & 7,09 & 5,36 & 3,57 \\
\hline 82,66 & 1096,50 & 41,50 & 31,38 & 23,96 & 22,34 & 21,06 & 19,81 & 18,60 & 16,34 & 14,31 & 10,98 \\
\hline 47,86 & 814,30 & 147,90 & 23,02 & 16,67 & 14,00 & 11,39 & 9,37 & 7,78 & 5,55 & 4,19 & 2,78 \\
\hline 43,82 & 223,20 & 172,40 & 42,96 & 21,71 & 15,15 & 10,56 & 7,99 & 6,34 & 4,38 & 3,38 & 2,38 \\
\hline 34,85 & 1102,70 & 198,80 & 20,29 & 14,77 & 12,03 & 9,25 & 7,23 & 5,77 & 3,96 & 2,98 & 2,03 \\
\hline 62,97 & 221,60 & 124,70 & 46,54 & 25,28 & 18,70 & 13,95 & 11,05 & 9,01 & 6,34 & 4,85 & 3,32 \\
\hline 64,53 & 1945,50 & 115,10 & 15,45 & 12,27 & 11,33 & 10,26 & 9,31 & 8,44 & 6,91 & 5,68 & 3,94 \\
\hline 33,28 & 1771,90 & 155,70 & 20,53 & 16,61 & 14,20 & 11,45 & 9,25 & 7,54 & 5,24 & 3,91 & 2,59 \\
\hline 60,59 & 470,90 & 193,00 & 24,79 & 14,66 & 11,36 & 8,79 & 7,10 & 5,85 & 4,16 & 3,17 & 2,15 \\
\hline 49,61 & 555,30 & 79,40 & 37,72 & 28,43 & 24,40 & 20,34 & 17,07 & 14,39 & 10,46 & 7,95 & 5,24 \\
\hline 77,37 & 841,70 & 180,70 & 16,76 & 11,01 & 9,19 & 7,72 & 6,67 & 5,82 & 4,49 & 3,56 & 2,41 \\
\hline 75,79 & 295,70 & 139,10 & 35,88 & 20,01 & 15,15 & 11,67 & 9,52 & 7,96 & 5,78 & 4,46 & 3,03 \\
\hline 41,17 & 1567,10 & 167,30 & 17,73 & 14,08 & 12,17 & 10,06 & 8,34 & 6,95 & 4,96 & 3,73 & 2,45 \\
\hline 80,33 & 1727,80 & 91,60 & 16,56 & 12,48 & 11,57 & 10,71 & 9,93 & 9,21 & 7,90 & 6,77 & 5,01 \\
\hline 45,23 & 1012,10 & 136,90 & 22,52 & 17,21 & 14,74 & 12,17 & 10,10 & 8,43 & 6,04 & 4,56 & 3,01 \\
\hline 54,52 & 1150,20 & 73,20 & 27,49 & 22,62 & 20,61 & 18,31 & 16,27 & 14,42 & 11,34 & 9,01 & 6,02 \\
\hline 86,56 & 676,70 & 28,20 & 46,62 & 35,19 & 32,60 & 30,67 & 28,83 & 27,08 & 23,81 & 20,89 & 16,08 \\
\hline 84,20 & 248,90 & 177,50 & 37,53 & 18,84 & 13,34 & 9,67 & 7,63 & 6,25 & 4,46 & 3,44 & 2,37 \\
\hline 54,20 & 1311,30 & 189,60 & 15,13 & 11,29 & 9,73 & 8,19 & 6,96 & 5,94 & 4,39 & 3,37 & 2,22 \\
\hline 34,56 & 1890,00 & 173,20 & 18,24 & 14,71 & 12,60 & 10,20 & 8,28 & 6,77 & 4,72 & 3,53 & 2,34 \\
\hline 59,79 & 1636,50 & 125,10 & 16,41 & 13,07 & 11,83 & 10,50 & 9,35 & 8,31 & 6,57 & 5,26 & 3,54 \\
\hline 66,19 & 1302,90 & 62,00 & 26,07 & 20,71 & 19,36 & 17,76 & 16,30 & 14,94 & 12,47 & 10,43 & 7,41 \\
\hline 24,47 & 1120,20 & 105,30 & 38,57 & 29,92 & 24,18 & 18,10 & 13,79 & 10,80 & 7,31 & 5,53 & 3,80 \\
\hline 20,46 & 646,30 & 96,50 & 53,57 & 37,75 & 28,24 & 19,59 & 14,36 & 11,16 & 7,72 & 5,97 & 4,16 \\
\hline 30,49 & 1977,90 & 51,90 & 43,47 & 39,29 & 35,57 & 30,72 & 26,31 & 22,46 & 16,50 & 12,47 & 8,02 \\
\hline 71,20 & 1652,30 & 116,50 & 15,55 & 11,93 & 10,92 & 9,87 & 8,97 & 8,15 & 6,72 & 5,56 & 3,90 \\
\hline 24,62 & 1704,40 & 105,00 & 33,90 & 27,64 & 23,08 & 17,92 & 13,99 & 11,10 & 7,52 & 5,62 & 3,81 \\
\hline 30,84 & 566,20 & 43,80 & 73,85 & 60,30 & 51,44 & 41,25 & 33,13 & 26,86 & 18,53 & 13,80 & 9,19 \\
\hline 89,51 & 1440,60 & 147,40 & 13,11 & 9,19 & 8,17 & 7,31 & 6,65 & 6,07 & 5,08 & 4,27 & 3,09 \\
\hline 69,67 & 1788,30 & 79,90 & 19,21 & 15,08 & 14,14 & 13,06 & 12,07 & 11,13 & 9,42 & 7,97 & 5,77 \\
\hline 32,86 & 1382,00 & 134,50 & 24,86 & 19,83 & 16,80 & 13,41 & 10,74 & 8,70 & 6,01 & 4,48 & 3,00 \\
\hline 80,93 & 1179,90 & 177,90 & 13,77 & 9,48 & 8,18 & 7,09 & 6,28 & 5,60 & 4,47 & 3,63 & 2,50 \\
\hline 83,16 & 213,30 & 53,60 & 60,69 & 38,16 & 31,25 & 25,93 & 22,33 & 19,46 & 15,03 & 11,94 & 8,14 \\
\hline 76,34 & 979,30 & 80,80 & 23,20 & 17,28 & 15,66 & 14,09 & 12,79 & 11,63 & 9,60 & 7,97 & 5,63 \\
\hline 52,55 & 1056,60 & 106,00 & 23,38 & 18,47 & 16,32 & 14,05 & 12,14 & 10,49 & 7,90 & 6,12 & 4,02 \\
\hline 74,76 & 1508,70 & 124,80 & 15,19 & 11,37 & 10,30 & 9,26 & 8,39 & 7,61 & 6,26 & 5,18 & 3,64 \\
\hline 77,18 & 654,80 & 198,40 & 18,79 & 11,54 & 9,26 & 7,52 & 6,36 & 5,45 & 4,09 & 3,20 & 2,16 \\
\hline 77,23 & 1854,80 & 78,20 & 18,12 & 13,90 & 13,02 & 12,16 & 11,34 & 10,56 & 9,13 & 7,88 & 5,88 \\
\hline 54,22 & 1634,70 & 161,50 & 14,97 & 11,81 & 10,46 & 9,05 & 7,85 & 6,82 & 5,18 & 4,03 & 2,66 \\
\hline 77,83 & 522,00 & 199,20 & 21,66 & 12,63 & 9,84 & 7,79 & 6,48 & 5,49 & 4,06 & 3,16 & 2,13 \\
\hline 37,38 & 820,70 & 81,60 & 37,76 & 30,23 & 26,00 & 21,25 & 17,40 & 14,34 & 10,09 & 7,55 & 4,98 \\
\hline 65,12 & 1899,20 & 146,90 & 13,42 & 10,47 & 9,50 & 8,49 & 7,62 & 6,84 & 5,50 & 4,46 & 3,05 \\
\hline 60,56 & 497,90 & 43,00 & 49,86 & 39,18 & 35,21 & 31,06 & 27,52 & 24,37 & 19,15 & 15,25 & 10,24 \\
\hline 64,16 & 1923,90 & 173,30 & 12,23 & 9,45 & 8,49 & 7,51 & 6,68 & 5,95 & 4,71 & 3,78 & 2,56 \\
\hline 48,64 & 318,00 & 194,30 & 32,74 & 17,69 & 12,88 & 9,32 & 7,17 & 5,73 & 3,96 & 3,03 & 2,11 \\
\hline 69,37 & 1918,10 & 45,80 & 26,90 & 21,36 & 20,32 & 19,33 & 18,22 & 17,13 & 15,05 & 13,16 & 10,03 \\
\hline 83,42 & 1235,20 & 47,30 & 27,49 & 20,95 & 19,51 & 18,39 & 17,30 & 16,25 & 14,28 & 12,52 & 9,61 \\
\hline
\end{tabular}




\begin{tabular}{|c|c|c|c|c|c|c|c|c|c|c|c|}
\hline \multirow[b]{2}{*}{ e1 (cm) } & & & & & & & ões (x1 & & & & \\
\hline & Meq (MPa) & Ms (MPa) & D0 & D25 & D40 & D60 & D80 & D100 & D140 & D180 & D260 \\
\hline 67,75 & 1603,00 & 194,20 & 12,16 & 8,98 & 7,90 & 6,89 & 6,07 & 5,37 & 4,21 & 3,36 & 2,27 \\
\hline 66,95 & 1948,60 & 34,00 & 33,35 & 26,83 & 25,54 & 24,54 & 23,30 & 22,04 & 19,58 & 17,31 & 13,43 \\
\hline 69,75 & 1298,40 & 131,20 & 16,32 & 12,23 & 10,91 & 9,64 & 8,61 & 7,69 & 6,15 & 4,97 & 3,40 \\
\hline 35,12 & 1815,30 & 29,00 & 59,23 & 54,18 & 50,88 & 46,01 & 41,28 & 36,84 & 29,16 & 23,17 & 15,32 \\
\hline 58,81 & 1369,70 & 35,90 & 39,42 & 32,35 & 30,91 & 28,87 & 26,80 & 24,80 & 21,09 & 17,88 & 12,94 \\
\hline 24,92 & 1363,80 & 27,60 & 89,42 & 80,77 & 72,29 & 61,27 & 51,45 & 43,13 & 30,79 & 22,94 & 14,79 \\
\hline 31,09 & 364,70 & 50,20 & 78,05 & 59,04 & 48,32 & 37,07 & 28,84 & 22,92 & 15,63 & 11,76 & 8,01 \\
\hline 26,14 & 1290,60 & 29,40 & 83,66 & 75,34 & 67,44 & 57,21 & 48,11 & 40,39 & 28,91 & 21,56 & 13,90 \\
\hline 87,84 & 1839,60 & 180,60 & 10,57 & 7,47 & 6,67 & 5,98 & 5,44 & 4,97 & 4,16 & 3,49 & 2,52 \\
\hline 68,47 & 1489,80 & 68,20 & 22,92 & 18,06 & 16,92 & 15,60 & 14,38 & 13,23 & 11,15 & 9,39 & 6,75 \\
\hline 45,61 & 1134,10 & 182,40 & 18,13 & 13,45 & 11,38 & 9,28 & 7,63 & 6,33 & 4,50 & 3,39 & 2,25 \\
\hline 57,02 & 1123,40 & 106,00 & 21,72 & 17,10 & 15,23 & 13,29 & 11,64 & 10,19 & 7,85 & 6,17 & 4,09 \\
\hline 30,34 & 1952,40 & 32,60 & 59,91 & 55,40 & 51,13 & 45,28 & 39,72 & 34,68 & 26,39 & 20,36 & 13,15 \\
\hline 35,44 & 1636,90 & 110,90 & 25,05 & 20,99 & 18,38 & 15,30 & 12,71 & 10,58 & 7,53 & 5,63 & 3,68 \\
\hline 30,95 & 1830,60 & 84,30 & 32,01 & 27,65 & 24,37 & 20,33 & 16,87 & 14,03 & 9,94 & 7,41 & 4,83 \\
\hline 64,49 & 1234,90 & 190,40 & 14,28 & 10,29 & 8,86 & 7,56 & 6,54 & 5,69 & 4,34 & 3,40 & 2,26 \\
\hline 54,30 & 1280,80 & 34,70 & 43,26 & 36,29 & 34,55 & 31,97 & 29,44 & 27,02 & 22,59 & 18,85 & 13,31 \\
\hline 68,01 & 1505,70 & 31,20 & 38,11 & 30,45 & 28,99 & 27,71 & 26,20 & 24,69 & 21,79 & 19,13 & 14,69 \\
\hline 83,09 & 821,80 & 153,10 & 17,81 & 11,80 & 9,98 & 8,51 & 7,47 & 6,60 & 5,22 & 4,20 & 2,89 \\
\hline 68,89 & 1084,00 & 41,20 & 35,37 & 27,92 & 26,35 & 24,52 & 22,76 & 21,09 & 18,01 & 15,34 & 11,22 \\
\hline 85,80 & 739,30 & 46,00 & 34,04 & 25,06 & 22,99 & 21,16 & 19,60 & 18,17 & 15,59 & 13,38 & 9,94 \\
\hline 40,36 & 1362,70 & 46,80 & 42,20 & 37,47 & 34,45 & 30,53 & 26,89 & 23,60 & 18,17 & 14,17 & 9,26 \\
\hline 74,17 & 580,00 & 80,30 & 30,19 & 21,47 & 18,69 & 16,23 & 14,34 & 12,71 & 10,05 & 8,08 & 5,51 \\
\hline 89,72 & 812,80 & 100,40 & 21,16 & 14,53 & 12,73 & 11,24 & 10,13 & 9,19 & 7,59 & 6,32 & 4,51 \\
\hline 41,75 & 724,70 & 112,60 & 30,44 & 22,78 & 19,17 & 15,44 & 12,55 & 10,30 & 7,23 & 5,43 & 3,61 \\
\hline 37,90 & 587,80 & 183,50 & 26,36 & 17,20 & 13,43 & 10,03 & 7,73 & 6,15 & 4,22 & 3,21 & 2,21 \\
\hline 88,62 & 1235,30 & 87,10 & 18,70 & 13,55 & 12,33 & 11,29 & 10,42 & 9,65 & 8,25 & 7,07 & 5,24 \\
\hline 74,48 & 211,60 & 195,00 & 41,81 & 19,86 & 13,48 & 9,34 & 7,13 & 5,71 & 3,97 & 3,06 & 2,14 \\
\hline 83,27 & 786,90 & 127,70 & 19,76 & 13,36 & 11,45 & 9,88 & 8,74 & 7,78 & 6,21 & 5,04 & 3,49 \\
\hline 78,22 & 1641,50 & 57,50 & 22,76 & 17,56 & 16,48 & 15,54 & 14,60 & 13,69 & 11,98 & 10,46 & 7,96 \\
\hline 42,46 & 584,70 & 196,90 & 24,35 & 15,55 & 12,17 & 9,21 & 7,19 & 5,76 & 3,97 & 3,01 & 2,06 \\
\hline 39,73 & 235,90 & 197,30 & 39,61 & 19,54 & 13,40 & 9,20 & 6,91 & 5,48 & 3,79 & 2,94 & 2,08 \\
\hline 60,25 & 680,90 & 102,30 & 27,07 & 19,80 & 17,07 & 14,50 & 12,47 & 10,76 & 8,11 & 6,29 & 4,17 \\
\hline 40,65 & 1202,10 & 168,50 & 19,81 & 15,08 & 12,77 & 10,32 & 8,40 & 6,90 & 4,84 & 3,64 & 2,41 \\
\hline 84,78 & 1406,80 & 22,50 & 39,28 & 33,29 & 30,35 & 29,32 & 28,41 & 27,31 & 25,05 & 22,88 & 18,91 \\
\hline 81,39 & 397,00 & 131,60 & 29,60 & 17,68 & 14,01 & 11,29 & 9,52 & 8,16 & 6,15 & 4,82 & 3,27 \\
\hline 80,74 & 865,40 & 27,00 & 45,37 & 35,13 & 32,87 & 31,22 & 29,50 & 27,81 & 24,60 & 21,69 & 16,81 \\
\hline 20,71 & 308,20 & 117,40 & 55,59 & 33,09 & 23,03 & 15,40 & 11,35 & 8,96 & 6,30 & 4,91 & 3,44 \\
\hline 36,88 & 1723,90 & 155,10 & 19,31 & 15,66 & 13,53 & 11,12 & 9,14 & 7,55 & 5,33 & 3,99 & 2,62 \\
\hline 73,31 & 829,60 & 45,70 & 35,37 & 27,22 & 25,27 & 23,19 & 21,34 & 19,62 & 16,53 & 13,94 & 10,05 \\
\hline 56,00 & 480,80 & 78,00 & 38,21 & 27,85 & 23,81 & 19,96 & 16,92 & 14,41 & 10,64 & 8,17 & 5,39 \\
\hline 24,49 & 937,70 & 164,80 & 29,60 & 21,00 & 16,11 & 11,49 & 8,55 & 6,66 & 4,57 & 3,51 & 2,44 \\
\hline 69,15 & 1986,70 & 63,80 & 21,47 & 16,97 & 16,09 & 15,10 & 14,10 & 13,14 & 11,34 & 9,76 & 7,25 \\
\hline 32,02 & 1996,70 & 147,10 & 21,02 & 17,32 & 14,90 & 12,08 & 9,80 & 8,01 & 5,57 & 4,15 & 2,74 \\
\hline 61,49 & 1194,30 & 28,00 & 47,40 & 38,43 & 36,82 & 34,69 & 32,44 & 30,24 & 26,09 & 22,42 & 16,58 \\
\hline 76,59 & 1069,70 & 135,60 & 16,89 & 12,05 & 10,57 & 9,25 & 8,24 & 7,36 & 5,89 & 4,78 & 3,29 \\
\hline 30,77 & 1975,10 & 172,00 & 19,60 & 15,77 & 13,34 & 10,59 & 8,44 & 6,81 & 4,68 & 3,49 & 2,34 \\
\hline 50,22 & 1023,30 & 149,90 & 20,06 & 15,04 & 12,90 & 10,75 & 9,02 & 7,61 & 5,54 & 4,21 & 2,77 \\
\hline 63,74 & 332,60 & 147,80 & 33,64 & 19,39 & 14,85 & 11,43 & 9,23 & 7,61 & 5,42 & 4,15 & 2,81 \\
\hline 48,98 & 423,60 & 91,40 & 39,92 & 27,90 & 23,10 & 18,59 & 15,19 & 12,55 & 8,91 & 6,73 & 4,49 \\
\hline 65,54 & 901,60 & 52,50 & 33,37 & 26,42 & 24,43 & 22,16 & 20,16 & 18,31 & 15,05 & 12,41 & 8,67 \\
\hline 23,43 & 1136,90 & 36,80 & 82,41 & 70,97 & 61,36 & 49,62 & 39,94 & 32,35 & 22,18 & 16,42 & 10,88 \\
\hline 50,96 & 1436,70 & 48,50 & 34,50 & 29,48 & 27,67 & 25,20 & 22,86 & 20,66 & 16,79 & 13,67 & 9,34 \\
\hline 88,85 & 245,90 & 71,00 & 49,15 & 29,71 & 23,87 & 19,55 & 16,75 & 14,57 & 11,26 & 8,97 & 6,15 \\
\hline 81,75 & 272,70 & 116,10 & 39,62 & 22,40 & 17,16 & 13,42 & 11,10 & 9,38 & 6,94 & 5,40 & 3,67 \\
\hline 86,18 & 1673,40 & 43,40 & 24,90 & 19,66 & 18,16 & 17,41 & 16,62 & 15,81 & 14,23 & 12,76 & 10,20 \\
\hline 60,47 & 1187,70 & 160,50 & 16,37 & 12,17 & 10,58 & 9,06 & 7,84 & 6,80 & 5,17 & 4,03 & 2,68 \\
\hline 24,75 & 1910,40 & 47,20 & 56,16 & 49,90 & 44,17 & 36,87 & 30,54 & 25,30 & 17,79 & 13,19 & 8,57 \\
\hline 56,03 & 1414,40 & 112,70 & 19,22 & 15,45 & 13,90 & 12,23 & 10,78 & 9,49 & 7,38 & 5,83 & 3,88 \\
\hline 47,16 & 517,80 & 194,80 & 25,10 & 15,51 & 12,07 & 9,17 & 7,22 & 5,82 & 4,04 & 3,07 & 2,09 \\
\hline 72,59 & 1520,00 & 102,10 & 17,23 & 13,18 & 12,10 & 10,98 & 10,02 & 9,14 & 7,58 & 6,31 & 4,47 \\
\hline 64,27 & 583,20 & 55,20 & 39,21 & 30,15 & 26,98 & 23,79 & 21,13 & 18,76 & 14,83 & 11,87 & 8,02 \\
\hline 22,03 & 935,20 & 28,20 & 110,84 & 95,12 & 81,78 & 65,58 & 52,39 & 42,18 & 28,74 & 21,28 & 14,17 \\
\hline 36,28 & 801,20 & 45,30 & 56,42 & 48,27 & 42,83 & 36,26 & 30,56 & 25,77 & 18,63 & 14,03 & 9,11 \\
\hline 26,34 & 539,90 & 157,90 & 34,82 & 22,70 & 16,89 & 11,83 & 8,77 & 6,86 & 4,74 & 3,66 & 2,55 \\
\hline 29,41 & 350,60 & 115,40 & 47,37 & 30,38 & 22,78 & 16,16 & 12,08 & 9,47 & 6,52 & 5,02 & 3,50 \\
\hline 62,76 & 1945,10 & 28,70 & 39,22 & 31,81 & 30,42 & 29,28 & 27,80 & 26,29 & 23,35 & 20,62 & 15,97 \\
\hline 56,34 & 1601,40 & 83,10 & 21,99 & 18,18 & 16,80 & 15,13 & 13,62 & 12,23 & 9,84 & 7,95 & 5,41 \\
\hline 74,30 & 685,40 & 31,10 & 47,89 & 36,97 & 34,60 & 32,11 & 29,79 & 27,60 & 23,60 & 20,16 & 14,81 \\
\hline 88,97 & 405,50 & 177,40 & 26,06 & 14,48 & 11,02 & 8,59 & 7,12 & 6,05 & 4,52 & 3,54 & 2,42 \\
\hline 30,00 & 504,30 & 66,90 & 59,15 & 44,87 & 36,62 & 27,95 & 21,66 & 17,17 & 11,69 & 8,80 & 6,01 \\
\hline 82,27 & 266,00 & 180,30 & 35,62 & 18,11 & 12,93 & 9,46 & 7,49 & 6,16 & 4,40 & 3,40 & 2,34 \\
\hline 78,32 & 564,10 & 86,60 & 28,91 & 20,00 & 17,25 & 14,91 & 13,16 & 11,68 & 9,26 & 7,46 & 5,12 \\
\hline 24,76 & 1371,90 & 29,70 & 85,44 & 76,72 & 68,38 & 57,61 & 48,12 & 40,15 & 28,48 & 21,17 & 13,69 \\
\hline 71,38 & 1869,60 & 130,30 & 13,83 & 10,60 & 9,71 & 8,79 & 7,99 & 7,27 & 6,00 & 4,97 & 3,50 \\
\hline 76,09 & 1293,70 & 73,40 & 21,86 & 16,64 & 15,42 & 14,16 & 13,05 & 12,03 & 10,18 & 8,62 & 6,26 \\
\hline 84,72 & 511,30 & 66,50 & 33,52 & 23,23 & 20,31 & 17,82 & 15,97 & 14,38 & 11,71 & 9,64 & 6,77 \\
\hline 77,29 & 535,90 & 190,40 & 21,66 & 12,85 & 10,11 & 8,07 & 6,74 & 5,73 & 4,26 & 3,31 & 2,24 \\
\hline 30,96 & 1306,90 & 70,60 & 40,35 & 34,30 & 29,95 & 24,70 & 20,30 & 16,74 & 11,75 & 8,75 & 5,73 \\
\hline 53,00 & 400,60 & 166,40 & 29,99 & 17,90 & 13,82 & 10,55 & 8,38 & 6,81 & 4,76 & 3,62 & 2,47 \\
\hline 36,90 & 1281,50 & 194,20 & 18,80 & 14,12 & 11,75 & 9,27 & 7,39 & 5,97 & 4,13 & 3,10 & 2,08 \\
\hline 33,59 & 863,40 & 38,20 & 65,14 & 56,84 & 50,68 & 43,03 & 36,32 & 30,65 & 22,16 & 16,65 & 10,78 \\
\hline
\end{tabular}




\begin{tabular}{|c|c|c|c|c|c|c|c|c|c|c|c|}
\hline & & & \multicolumn{9}{|c|}{ Deflexões $\left(\times 10^{-4} \mathrm{~cm}\right)$} \\
\hline e1 (cm) & Meq (MPa) & Ms (MPa) & D0 & D25 & D40 & D60 & D80 & D100 & D140 & D180 & D260 \\
\hline 22,06 & 863,60 & 109,00 & 43,36 & 31,79 & 24,53 & 17,51 & 12,98 & 10,08 & 6,89 & 5,30 & 3,67 \\
\hline 40,22 & 407,90 & 107,80 & 40,69 & 27,51 & 22,00 & 16,84 & 13,20 & 10,59 & 7,30 & 5,52 & 3,76 \\
\hline 34,52 & 1385,70 & 167,00 & 20,91 & 16,24 & 13,64 & 10,81 & 8,63 & 6,98 & 4,81 & 3,60 & 2,41 \\
\hline 56,19 & 1801,80 & 142,70 & 15,12 & 12,15 & 10,94 & 9,63 & 8,50 & 7,49 & 5,83 & 4,61 & 3,07 \\
\hline 59,55 & 1946,10 & 27,00 & 42,55 & 34,65 & 33,30 & 31,99 & 30,31 & 28,61 & 25,30 & 22,24 & 17,08 \\
\hline 82,88 & 465,30 & 87,00 & 31,44 & 20,83 & 17,61 & 15,01 & 13,16 & 11,64 & 9,19 & 7,40 & 5,08 \\
\hline 55,98 & 1503,20 & 32,20 & 42,50 & 35,17 & 33,79 & 31,68 & 29,48 & 27,34 & 23,35 & 19,85 & 14,42 \\
\hline 77,96 & 287,60 & 120,00 & 38,15 & 21,80 & 16,78 & 13,13 & 10,85 & 9,14 & 6,72 & 5,22 & 3,53 \\
\hline 20,04 & 955,40 & 144,80 & 36,26 & 25,38 & 18,87 & 13,02 & 9,53 & 7,41 & 5,14 & 3,98 & 2,77 \\
\hline 72,00 & 1355,50 & 173,80 & 13,60 & 9,83 & 8,62 & 7,51 & 6,64 & 5,89 & 4,66 & 3,74 & 2,55 \\
\hline 88,53 & 860,70 & 71,80 & 24,51 & 17,54 & 15,82 & 14,33 & 13,14 & 12,09 & 10,23 & 8,68 & 6,35 \\
\hline 80,90 & 1725,00 & 65,50 & 20,19 & 15,45 & 14,44 & 13,60 & 12,77 & 11,97 & 10,48 & 9,15 & 6,98 \\
\hline 77,66 & 638,90 & 20,20 & 62,67 & 48,65 & 45,72 & 43,31 & 40,80 & 38,35 & 33,73 & 29,56 & 22,66 \\
\hline 44,02 & 1026,00 & 31,20 & 57,08 & 50,31 & 46,90 & 42,26 & 37,87 & 33,79 & 26,80 & 21,37 & 14,24 \\
\hline 20,10 & 1257,10 & 90,00 & 47,93 & 37,12 & 29,41 & 21,45 & 16,02 & 12,43 & 8,42 & 6,42 & 4,44 \\
\hline 81,03 & 1295,50 & 79,80 & 20,12 & 15,02 & 13,83 & 12,70 & 11,72 & 10,82 & 9,21 & 7,84 & 5,74 \\
\hline 41,26 & 1765,40 & 52,00 & 35,48 & 31,60 & 29,33 & 26,27 & 23,38 & 20,73 & 16,23 & 12,82 & 8,46 \\
\hline 67,38 & 630,70 & 38,20 & 45,89 & 36,00 & 33,23 & 30,15 & 27,45 & 24,96 & 20,57 & 17,01 & 11,92 \\
\hline 43,46 & 584,20 & 112,10 & 32,74 & 23,57 & 19,56 & 15,60 & 12,60 & 10,31 & 7,22 & 5,43 & 3,63 \\
\hline 33,08 & 1948,00 & 190,70 & 17,50 & 13,95 & 11,82 & 9,44 & 7,57 & 6,14 & 4,24 & 3,17 & 2,11 \\
\hline 61,91 & 1341,80 & 35,60 & 38,63 & 31,31 & 29,91 & 28,04 & 26,13 & 24,28 & 20,82 & 17,78 & 13,03 \\
\hline 30,45 & 1247,60 & 194,40 & 21,29 & 15,78 & 12,74 & 9,63 & 7,42 & 5,87 & 4,00 & 3,02 & 2,07 \\
\hline 26,79 & 1166,70 & 161,20 & 26,69 & 19,89 & 15,85 & 11,75 & 8,92 & 7,00 & 4,75 & 3,61 & 2,49 \\
\hline 22,46 & 1955,10 & 21,10 & 104,80 & 97,36 & 88,59 & 76,73 & 65,72 & 56,04 & 40,97 & 30,80 & 19,69 \\
\hline 49,66 & 772,60 & 185,20 & 20,61 & 14,08 & 11,55 & 9,23 & 7,51 & 6,19 & 4,38 & 3,31 & 2,22 \\
\hline 56,42 & 1117,50 & 29,90 & 48,87 & 40,56 & 38,70 & 35,97 & 33,25 & 30,63 & 25,82 & 21,71 & 15,51 \\
\hline 47,35 & 268,00 & 130,90 & 42,95 & 24,77 & 18,63 & 13,79 & 10,71 & 8,58 & 5,93 & 4,53 & 3,12 \\
\hline 20,21 & 610,80 & 31,70 & 124,03 & 99,59 & 81,07 & 60,82 & 46,20 & 36,06 & 24,26 & 18,32 & 12,59 \\
\hline 61,01 & 1797,70 & 43,20 & 31,10 & 25,26 & 24,19 & 22,76 & 21,25 & 19,78 & 17,02 & 14,58 & 10,74 \\
\hline 32,87 & 699,40 & 52,10 & 58,38 & 48,14 & 41,53 & 33,84 & 27,56 & 22,59 & 15,76 & 11,75 & 7,76 \\
\hline 88,15 & 324,90 & 126,10 & 33,77 & 19,26 & 14,91 & 11,80 & 9,88 & 8,45 & 6,36 & 5,01 & 3,42 \\
\hline 88,65 & 1082,70 & 94,40 & 19,04 & 13,57 & 12,20 & 11,02 & 10,09 & 9,27 & 7,82 & 6,63 & 4,83 \\
\hline 85,49 & 535,10 & 129,80 & 24,33 & 15,31 & 12,58 & 10,48 & 9,06 & 7,93 & 6,17 & 4,93 & 3,38 \\
\hline 50,60 & 1064,80 & 48,90 & 38,22 & 32,48 & 29,99 & 26,90 & 24,05 & 21,44 & 17,00 & 13,58 & 9,10 \\
\hline 73,72 & 600,20 & 168,70 & 21,37 & 13,43 & 10,89 & 8,90 & 7,53 & 6,45 & 4,83 & 3,77 & 2,53 \\
\hline 35,59 & 349,80 & 93,50 & 49,78 & 33,62 & 26,47 & 19,78 & 15,23 & 12,07 & 8,27 & 6,28 & 4,32 \\
\hline 83,12 & 471,90 & 186,20 & 23,38 & 13,41 & 10,38 & 8,19 & 6,83 & 5,80 & 4,33 & 3,38 & 2,30 \\
\hline 43,63 & 626,70 & 176,10 & 24,73 & 16,45 & 13,17 & 10,17 & 8,04 & 6,49 & 4,50 & 3,40 & 2,31 \\
\hline 80,32 & 637,40 & 74,50 & 28,95 & 20,60 & 18,18 & 16,04 & 14,40 & 12,96 & 10,53 & 8,65 & 6,04 \\
\hline 22,66 & 308,20 & 93,40 & 63,43 & 40,24 & 28,99 & 19,75 & 14,53 & 11,39 & 7,95 & 6,17 & 4,31 \\
\hline 49,74 & 685,80 & 195,70 & 21,27 & 13,98 & 11,27 & 8,86 & 7,14 & 5,84 & 4,11 & 3,11 & 2,09 \\
\hline 56,12 & 607,70 & 74,30 & 35,09 & 26,77 & 23,40 & 20,03 & 17,26 & 14,91 & 11,23 & 8,70 & 5,74 \\
\hline 72,68 & 1128,60 & 37,90 & 35,63 & 27,86 & 26,32 & 24,75 & 23,16 & 21,63 & 18,77 & 16,24 & 12,17 \\
\hline 24,66 & 250,00 & 163,30 & 45,02 & 23,83 & 16,29 & 10,95 & 8,15 & 6,46 & 4,53 & 3,53 & 2,49 \\
\hline 62,82 & 1551,90 & 68,00 & 23,74 & 19,17 & 17,96 & 16,48 & 15,10 & 13,81 & 11,48 & 9,56 & 6,74 \\
\hline 89,49 & 1735,10 & 27,20 & 30,30 & 26,41 & 23,82 & 22,92 & 22,30 & 21,52 & 19,85 & 18,25 & 15,28 \\
\hline 52,31 & 1648,20 & 39,80 & 37,21 & 31,45 & 30,02 & 27,82 & 25,63 & 23,53 & 19,68 & 16,43 & 11,60 \\
\hline 45,46 & 1938,80 & 162,20 & 15,53 & 12,70 & 11,25 & 9,61 & 8,21 & 7,02 & 5,19 & 3,97 & 2,59 \\
\hline 37,39 & 1449,80 & 150,40 & 20,82 & 16,57 & 14,20 & 11,57 & 9,45 & 7,78 & 5,46 & 4,09 & 2,70 \\
\hline 57,27 & 254,10 & 196,40 & 36,95 & 18,51 & 12,98 & 9,19 & 7,06 & 5,65 & 3,92 & 3,01 & 2,10 \\
\hline 51,61 & 669,80 & 146,40 & 24,49 & 17,00 & 14,10 & 11,42 & 9,40 & 7,81 & 5,59 & 4,23 & 2,82 \\
\hline 57,22 & 233,50 & 59,40 & 62,47 & 41,57 & 34,08 & 27,56 & 22,80 & 19,07 & 13,76 & 10,49 & 6,99 \\
\hline 52,96 & 878,70 & 49,00 & 39,77 & 33,18 & 30,41 & 27,13 & 24,18 & 21,49 & 16,95 & 13,51 & 9,03 \\
\hline 46,48 & 980,60 & 50,30 & 40,86 & 34,96 & 31,88 & 28,15 & 24,77 & 21,74 & 16,76 & 13,12 & 8,62 \\
\hline 49,48 & 1713,50 & 195,50 & 13,89 & 10,84 & 9,46 & 8,01 & 6,81 & 5,80 & 4,28 & 3,27 & 2,14 \\
\hline 27,05 & 815,00 & 184,70 & 27,09 & 18,62 & 14,25 & 10,20 & 7,62 & 5,96 & 4,09 & 3,14 & 2,18 \\
\hline 51,19 & 299,80 & 95,80 & 45,58 & 29,11 & 23,19 & 18,11 & 14,55 & 11,90 & 8,36 & 6,34 & 4,28 \\
\hline 70,16 & 1451,20 & 119,70 & 16,30 & 12,41 & 11,24 & 10,06 & 9,07 & 8,18 & 6,65 & 5,44 & 3,77 \\
\hline 30,13 & 930,20 & 104,90 & 35,61 & 27,65 & 22,87 & 17,70 & 13,85 & 11,03 & 7,52 & 5,64 & 3,83 \\
\hline 32,75 & 781,90 & 89,20 & 39,76 & 31,02 & 25,97 & 20,45 & 16,22 & 13,06 & 8,97 & 6,71 & 4,51 \\
\hline 88,12 & 638,80 & 94,70 & 24,87 & 16,78 & 14,48 & 12,60 & 11,25 & 10,10 & 8,21 & 6,75 & 4,74 \\
\hline 44,44 & 835,90 & 177,40 & 21,40 & 15,09 & 12,43 & 9,87 & 7,95 & 6,50 & 4,55 & 3,43 & 2,30 \\
\hline 47,74 & 388,10 & 22,90 & 92,95 & 78,49 & 71,19 & 62,58 & 54,87 & 48,01 & 36,85 & 28,76 & 18,90 \\
\hline 85,89 & 1195,00 & 164,70 & 13,88 & 9,52 & 8,27 & 7,23 & 6,47 & 5,82 & 4,73 & 3,89 & 2,73 \\
\hline 83,58 & 1979,70 & 150,70 & 11,51 & 8,41 & 7,65 & 6,95 & 6,37 & 5,86 & 4,94 & 4,18 & 3,03 \\
\hline 52,04 & 1994,00 & 184,60 & 13,05 & 10,43 & 9,26 & 8,01 & 6,93 & 6,01 & 4,54 & 3,52 & 2,32 \\
\hline 42,89 & 1784,30 & 136,20 & 18,55 & 15,38 & 13,63 & 11,62 & 9,89 & 8,42 & 6,19 & 4,71 & 3,07 \\
\hline 24,81 & 945,30 & 142,00 & 32,56 & 23,73 & 18,50 & 13,39 & 10,02 & 7,81 & 5,33 & 4,08 & 2,82 \\
\hline 79,13 & 1244,50 & 140,90 & 15,17 & 10,87 & 9,62 & 8,50 & 7,63 & 6,87 & 5,58 & 4,58 & 3,20 \\
\hline 40,18 & 1945,20 & 81,40 & 26,06 & 22,88 & 20,83 & 18,25 & 15,90 & 13,81 & 10,46 & 8,07 & 5,25 \\
\hline 21,05 & 1278,10 & 86,70 & 47,43 & 37,28 & 29,97 & 22,21 & 16,76 & 13,05 & 8,81 & 6,69 & 4,61 \\
\hline 62,72 & 844,90 & 137,30 & 20,59 & 14,77 & 12,66 & 10,73 & 9,23 & 7,97 & 6,03 & 4,69 & 3,12 \\
\hline 52,07 & 1987,00 & 130,00 & 16,10 & 13,32 & 12,08 & 10,67 & 9,41 & 8,29 & 6,43 & 5,07 & 3,36 \\
\hline 47,98 & 863,60 & 194,00 & 19,37 & 13,44 & 11,08 & 8,86 & 7,20 & 5,92 & 4,18 & 3,16 & 2,11 \\
\hline 75,06 & 1932,80 & 194,60 & 10,62 & 7,81 & 6,98 & 6,20 & 5,57 & 5,02 & 4,07 & 3,33 & 2,31 \\
\hline 82,02 & 503,60 & 151,50 & 24,12 & 14,68 & 11,77 & 9,58 & 8,14 & 7,02 & 5,34 & 4,20 & 2,85 \\
\hline 85,27 & 205,30 & 59,20 & 59,48 & 36,24 & 29,17 & 23,88 & 20,40 & 17,69 & 13,58 & 10,76 & 7,34 \\
\hline 62,73 & 1175,50 & 182,00 & 15,16 & 10,96 & 9,44 & 8,03 & 6,93 & 6,00 & 4,55 & 3,55 & 2,36 \\
\hline 56,81 & 784,10 & 43,30 & 42,99 & 35,36 & 32,57 & 29,28 & 26,31 & 23,59 & 18,91 & 15,26 & 10,35 \\
\hline 42,08 & 1795,20 & 153,50 & 17,44 & 14,26 & 12,53 & 10,57 & 8,91 & 7,52 & 5,47 & 4,13 & 2,70 \\
\hline 25,80 & 989,80 & 158,30 & 29,09 & 21,10 & 16,50 & 11,99 & 9,00 & 7,03 & 4,79 & 3,66 & 2,54 \\
\hline 42,58 & 481,30 & 45,60 & 60,64 & 48,93 & 42,76 & 35,88 & 30,11 & 25,35 & 18,33 & 13,85 & 9,06 \\
\hline
\end{tabular}




\begin{tabular}{|c|c|c|c|c|c|c|c|c|c|c|c|}
\hline \multirow[b]{2}{*}{ e1 (cm) } & & & & & & $\mathrm{De}$ & ões (x1 & & & & \\
\hline & Meq (MPa) & Ms (MPa) & D0 & D25 & D40 & D60 & D80 & D100 & D140 & D180 & D260 \\
\hline 80,08 & 1750,80 & 170,90 & 11,59 & 8,40 & 7,52 & 6,71 & 6,07 & 5,51 & 4,53 & 3,76 & 2,65 \\
\hline 20,61 & 1487,30 & 27,60 & 103,03 & 91,04 & 79,73 & 65,42 & 53,26 & 43,47 & 29,98 & 22,12 & 14,52 \\
\hline 78,97 & 577,20 & 173,40 & 21,25 & 13,02 & 10,46 & 8,51 & 7,21 & 6,19 & 4,68 & 3,67 & 2,48 \\
\hline 55,45 & 1265,30 & 110,20 & 20,53 & 16,38 & 14,65 & 12,80 & 11,22 & 9,83 & 7,57 & 5,94 & 3,94 \\
\hline 42,52 & 1050,20 & 153,30 & 21,55 & 16,30 & 13,81 & 11,22 & 9,18 & 7,57 & 5,34 & 4,02 & 2,66 \\
\hline 89,57 & 1375,70 & 22,80 & 37,18 & 32,03 & 28,95 & 27,87 & 27,07 & 26,08 & 24,02 & 22,04 & 18,39 \\
\hline 44,68 & 275,40 & 58,60 & 64,66 & 45,55 & 37,54 & 29,82 & 24,05 & 19,65 & 13,77 & 10,38 & 6,95 \\
\hline 34,82 & 1564,90 & 195,30 & 18,01 & 13,92 & 11,67 & 9,24 & 7,37 & 5,96 & 4,11 & 3,08 & 2,07 \\
\hline 51,23 & 309,90 & 91,10 & 45,87 & 29,87 & 24,02 & 18,92 & 15,28 & 12,53 & 8,83 & 6,69 & 4,50 \\
\hline 61,54 & 1533,40 & 99,00 & 19,07 & 15,27 & 14,00 & 12,57 & 11,31 & 10,16 & 8,19 & 6,64 & 4,54 \\
\hline 71,90 & 409,30 & 32,70 & 58,16 & 44,12 & 40,07 & 35,98 & 32,56 & 29,47 & 24,11 & 19,84 & 13,86 \\
\hline 24,35 & 1325,40 & 31,10 & 84,95 & 75,61 & 66,96 & 55,91 & 46,31 & 38,37 & 26,97 & 19,99 & 12,99 \\
\hline 60,17 & 529,80 & 83,10 & 34,08 & 24,75 & 21,26 & 18,01 & 15,44 & 13,29 & 9,99 & 7,74 & 5,13 \\
\hline 66,32 & 231,00 & 73,50 & 54,51 & 33,88 & 27,11 & 21,73 & 18,04 & 15,18 & 11,08 & 8,52 & 5,71 \\
\hline 45,90 & 769,00 & 160,70 & 23,08 & 16,30 & 13,48 & 10,77 & 8,73 & 7,17 & 5,04 & 3,80 & 2,54 \\
\hline 20,15 & 451,80 & 156,70 & 41,05 & 24,81 & 17,29 & 11,56 & 8,50 & 6,71 & 4,72 & 3,68 & 2,58 \\
\hline 74,74 & 461,80 & 178,20 & 24,60 & 14,39 & 11,21 & 8,85 & 7,33 & 6,18 & 4,54 & 3,52 & 2,37 \\
\hline 43,35 & 543,30 & 135,80 & 30,46 & 20,79 & 16,83 & 13,12 & 10,43 & 8,45 & 5,87 & 4,43 & 2,99 \\
\hline 27,78 & 1100,60 & 136,30 & 29,81 & 22,66 & 18,35 & 13,84 & 10,62 & 8,37 & 5,68 & 4,29 & 2,94 \\
\hline 26,99 & 389,10 & 39,20 & 98,90 & 77,05 & 63,07 & 48,05 & 37,09 & 29,29 & 19,86 & 14,95 & 10,21 \\
\hline 45,85 & 593,80 & 141,90 & 27,83 & 19,12 & 15,62 & 12,33 & 9,92 & 8,09 & 5,67 & 4,28 & 2,87 \\
\hline 26,85 & 1075,60 & 194,70 & 24,01 & 17,16 & 13,37 & 9,71 & 7,30 & 5,71 & 3,90 & 2,98 & 2,06 \\
\hline 39,97 & 846,80 & 75,80 & 37,25 & 30,29 & 26,41 & 22,02 & 18,35 & 15,35 & 11,00 & 8,27 & 5,41 \\
\hline 30,75 & 1929,30 & 170,80 & 19,86 & 15,95 & 13,47 & 10,68 & 8,50 & 6,85 & 4,71 & 3,51 & 2,35 \\
\hline 40,18 & 914,80 & 109,40 & 28,84 & 22,52 & 19,26 & 15,73 & 12,90 & 10,65 & 7,52 & 5,64 & 3,73 \\
\hline 66,90 & 1731,20 & 150,60 & 13,57 & 10,42 & 9,39 & 8,35 & 7,48 & 6,69 & 5,37 & 4,34 & 2,97 \\
\hline 61,40 & 1932,60 & 75,80 & 20,77 & 16,89 & 15,90 & 14,64 & 13,44 & 12,31 & 10,28 & 8,57 & 6,07 \\
\hline 62,36 & 1248,80 & 21,90 & 54,60 & 44,15 & 42,34 & 40,45 & 38,19 & 35,94 & 31,60 & 27,63 & 21,04 \\
\hline 44,30 & 413,10 & 75,00 & 47,27 & 34,36 & 28,70 & 23,07 & 18,75 & 15,41 & 10,85 & 8,17 & 5,44 \\
\hline 52,46 & 1585,10 & 103,60 & 20,10 & 16,61 & 15,08 & 13,32 & 11,76 & 10,37 & 8,07 & 6,36 & 4,22 \\
\hline 66,15 & 453,00 & 144,60 & 27,78 & 17,26 & 13,80 & 11,06 & 9,17 & 7,72 & 5,63 & 4,33 & 2,90 \\
\hline 88,76 & 1524,70 & 113,80 & 14,68 & 10,59 & 9,61 & 8,76 & 8,08 & 7,46 & 6,36 & 5,43 & 4,01 \\
\hline 46,50 & 469,30 & 137,70 & 31,47 & 20,66 & 16,53 & 12,84 & 10,23 & 8,30 & 5,79 & 4,38 & 2,96 \\
\hline 55,16 & 822,30 & 162,80 & 20,34 & 14,31 & 12,01 & 9,89 & 8,27 & 6,96 & 5,07 & 3,86 & 2,56 \\
\hline 88,51 & 1686,30 & 139,70 & 12,56 & 8,99 & 8,12 & 7,36 & 6,75 & 6,21 & 5,26 & 4,46 & 3,27 \\
\hline 85,65 & 991,60 & 187,50 & 14,53 & 9,53 & 8,04 & 6,86 & 6,02 & 5,34 & 4,24 & 3,43 & 2,37 \\
\hline 39,68 & 338,90 & 146,20 & 37,76 & 22,72 & 17,17 & 12,56 & 9,61 & 7,63 & 5,25 & 4,01 & 2,78 \\
\hline 83,59 & 758,30 & 21,60 & 53,37 & 41,62 & 38,71 & 36,97 & 35,12 & 33,26 & 29,69 & 26,42 & 20,81 \\
\hline 87,65 & 1036,00 & 28,80 & 38,13 & 29,91 & 27,58 & 26,39 & 25,17 & 23,92 & 21,50 & 19,26 & 15,37 \\
\hline 37,19 & 972,60 & 108,00 & 29,85 & 23,52 & 20,06 & 16,24 & 13,20 & 10,82 & 7,57 & 5,66 & 3,75 \\
\hline 64,20 & 1142,90 & 60,20 & 28,35 & 22,66 & 21,05 & 19,17 & 17,47 & 15,90 & 13,11 & 10,84 & 7,59 \\
\hline 52,14 & 1745,60 & 69,60 & 25,06 & 21,25 & 19,82 & 17,95 & 16,21 & 14,59 & 11,76 & 9,53 & 6,47 \\
\hline 69,76 & 1146,40 & 131,40 & 17,28 & 12,77 & 11,29 & 9,89 & 8,77 & 7,80 & 6,18 & 4,96 & 3,37 \\
\hline 21,04 & 375,70 & 20,30 & 190,16 & 153,20 & 125,37 & 94,71 & 72,31 & 56,60 & 38,10 & 28,71 & 19,67 \\
\hline 26,46 & 706,40 & 140,90 & 34,49 & 24,20 & 18,65 & 13,41 & 10,03 & 7,83 & 5,36 & 4,11 & 2,85 \\
\hline 88,56 & 604,90 & 64,80 & 30,65 & 21,44 & 19,01 & 16,94 & 15,37 & 14,00 & 11,65 & 9,76 & 7,01 \\
\hline 69,57 & 891,50 & 74,50 & 26,45 & 20,18 & 18,26 & 16,32 & 14,69 & 13,23 & 10,72 & 8,75 & 6,05 \\
\hline 34,34 & 1337,00 & 61,70 & 40,21 & 34,99 & 31,20 & 26,52 & 22,41 & 18,94 & 13,72 & 10,32 & 6,68 \\
\hline 20,40 & 1954,50 & 39,10 & 75,18 & 65,91 & 57,39 & 46,71 & 37,76 & 30,65 & 21,02 & 15,51 & 10,23 \\
\hline 83,65 & 739,00 & 182,50 & 17,61 & 11,10 & 9,10 & 7,57 & 6,53 & 5,69 & 4,41 & 3,51 & 2,39 \\
\hline 69,61 & 1833,30 & 85,60 & 18,23 & 14,30 & 13,38 & 12,34 & 11,38 & 10,48 & 8,84 & 7,46 & 5,38 \\
\hline 32,02 & 514,70 & 84,90 & 48,28 & 35,57 & 28,82 & 21,92 & 16,98 & 13,47 & 9,19 & 6,94 & 4,74 \\
\hline 49,21 & 656,50 & 176,50 & 22,98 & 15,32 & 12,42 & 9,81 & 7,92 & 6,49 & 4,56 & 3,45 & 2,32 \\
\hline 70,94 & 1742,80 & 74,60 & 20,04 & 15,67 & 14,72 & 13,65 & 12,65 & 11,70 & 9,96 & 8,47 & 6,18 \\
\hline 39,55 & 1073,40 & 59,90 & 39,74 & 34,09 & 30,52 & 26,23 & 22,43 & 19,17 & 14,15 & 10,76 & 6,98 \\
\hline 50,18 & 800,60 & 122,90 & 25,00 & 18,60 & 15,89 & 13,19 & 11,04 & 9,29 & 6,74 & 5,12 & 3,38 \\
\hline 88,32 & 791,80 & 96,30 & 22,01 & 15,21 & 13,35 & 11,79 & 10,63 & 9,63 & 7,94 & 6,60 & 4,70 \\
\hline 65,01 & 1049,90 & 27,20 & 48,63 & 38,98 & 37,21 & 35,08 & 32,84 & 30,65 & 26,53 & 22,87 & 17,02 \\
\hline 28,91 & 633,00 & 154,10 & 32,16 & 21,94 & 16,88 & 12,19 & 9,16 & 7,18 & 4,92 & 3,77 & 2,61 \\
\hline 54,68 & 960,70 & 78,80 & 28,22 & 22,71 & 20,37 & 17,85 & 15,66 & 13,73 & 10,60 & 8,32 & 5,51 \\
\hline 62,51 & 1308,40 & 185,20 & 14,28 & 10,48 & 9,09 & 7,78 & 6,74 & 5,86 & 4,47 & 3,50 & 2,33 \\
\hline 43,41 & 215,20 & 49,20 & 80,71 & 56,13 & 45,84 & 36,01 & 28,80 & 23,39 & 16,29 & 12,28 & 8,27 \\
\hline 74,18 & 685,90 & 110,00 & 23,78 & 16,55 & 14,22 & 12,22 & 10,71 & 9,43 & 7,38 & 5,88 & 3,99 \\
\hline 54,53 & 1551,30 & 44,70 & 34,16 & 28,65 & 27,21 & 25,12 & 23,09 & 21,15 & 17,62 & 14,66 & 10,32 \\
\hline 22,17 & 319,10 & 87,70 & 66,38 & 42,79 & 30,95 & 21,10 & 15,50 & 12,14 & 8,47 & 6,58 & 4,59 \\
\hline 32,91 & 1949,10 & 183,60 & 17,99 & 14,41 & 12,24 & 9,79 & 7,86 & 6,38 & 4,41 & 3,29 & 2,20 \\
\hline 36,14 & 1550,00 & 116,90 & 24,35 & 20,17 & 17,59 & 14,58 & 12,07 & 10,03 & 7,12 & 5,33 & 3,49 \\
\hline 76,80 & 1171,50 & 25,40 & 43,40 & 34,53 & 32,38 & 31,11 & 29,64 & 28,12 & 25,17 & 22,43 & 17,69 \\
\hline 74,80 & 1138,30 & 134,60 & 16,60 & 12,02 & 10,60 & 9,31 & 8,30 & 7,42 & 5,95 & 4,82 & 3,32 \\
\hline 23,26 & 567,40 & 181,10 & 32,85 & 20,70 & 14,93 & 10,19 & 7,50 & 5,88 & 4,10 & 3,19 & 2,23 \\
\hline 81,04 & 1583,60 & 116,20 & 14,90 & 11,00 & 10,04 & 9,12 & 8,36 & 7,68 & 6,45 & 5,44 & 3,94 \\
\hline 25,43 & 870,40 & 95,60 & 43,39 & 33,17 & 26,67 & 19,90 & 15,14 & 11,87 & 8,04 & 6,10 & 4,19 \\
\hline 80,70 & 1685,50 & 104,10 & 15,48 & 11,57 & 10,65 & 9,77 & 9,02 & 8,33 & 7,08 & 6,02 & 4,41 \\
\hline 73,86 & 1347,20 & 44,30 & 29,94 & 23,36 & 22,05 & 20,78 & 19,48 & 18,23 & 15,88 & 13,78 & 10,39 \\
\hline 38,94 & 1418,70 & 193,60 & 17,51 & 13,39 & 11,31 & 9,09 & 7,35 & 6,01 & 4,20 & 3,15 & 2,10 \\
\hline 51,42 & 730,10 & 107,50 & 27,68 & 20,70 & 17,76 & 14,84 & 12,50 & 10,58 & 7,73 & 5,89 & 3,88 \\
\hline 51,63 & 648,00 & 93,10 & 31,54 & 23,67 & 20,36 & 17,05 & 14,39 & 12,20 & 8,94 & 6,82 & 4,49 \\
\hline 63,95 & 1131,20 & 21,90 & 55,40 & 44,61 & 42,71 & 40,72 & 38,41 & 36,11 & 31,69 & 27,68 & 21,03 \\
\hline 50,38 & 869,80 & 110,50 & 25,49 & 19,56 & 16,96 & 14,29 & 12,10 & 10,28 & 7,55 & 5,77 & 3,79 \\
\hline 32,74 & 938,50 & 81,20 & 39,62 & 32,08 & 27,38 & 22,04 & 17,78 & 14,47 & 10,02 & 7,47 & 4,97 \\
\hline 66,83 & 880,30 & 85,60 & 25,09 & 19,07 & 17,05 & 15,06 & 13,41 & 11,95 & 9,50 & 7,64 & 5,20 \\
\hline 30,62 & 1974,30 & 103,90 & 27,42 & 23,35 & 20,39 & 16,81 & 13,81 & 11,39 & 7,99 & 5,94 & 3,90 \\
\hline
\end{tabular}




\begin{tabular}{|c|c|c|c|c|c|c|c|c|c|c|c|}
\hline \multirow[b]{2}{*}{ e1 (cm) } & & & & & & $\mathrm{De}$ & ões (x1 & m) & & & \\
\hline & Meq (MPa) & Ms (MPa) & D0 & D25 & D40 & D60 & D80 & D100 & D140 & D180 & D260 \\
\hline 35,75 & 1309,00 & 110,30 & 27,10 & 22,13 & 19,14 & 15,71 & 12,89 & 10,64 & 7,49 & 5,60 & 3,68 \\
\hline 30,95 & 500,10 & 99,70 & 44,79 & 31,87 & 25,26 & 18,79 & 14,35 & 11,31 & 7,72 & 5,86 & 4,03 \\
\hline 74,28 & 1091,40 & 170,20 & 15,14 & 10,58 & 9,12 & 7,85 & 6,89 & 6,08 & 4,76 & 3,81 & 2,59 \\
\hline 65,19 & 261,20 & 104,90 & 44,24 & 26,08 & 20,25 & 15,80 & 12,88 & 10,70 & 7,68 & 5,88 & 3,97 \\
\hline 49,64 & 1761,70 & 59,90 & 28,48 & 24,47 & 22,92 & 20,81 & 18,82 & 16,95 & 13,69 & 11,09 & 7,53 \\
\hline 62,07 & 964,80 & 26,00 & 53,10 & 43,01 & 41,07 & 38,50 & 35,86 & 33,31 & 28,54 & 24,38 & 17,85 \\
\hline 28,40 & 892,20 & 100,70 & 38,59 & 29,79 & 24,39 & 18,63 & 14,42 & 11,42 & 7,76 & 5,84 & 3,98 \\
\hline 53,20 & 569,40 & 110,60 & 30,15 & 21,37 & 17,94 & 14,73 & 12,27 & 10,29 & 7,45 & 5,66 & 3,75 \\
\hline 20,23 & 654,60 & 168,60 & 35,37 & 22,69 & 16,19 & 10,91 & 7,99 & 6,27 & 4,40 & 3,42 & 2,39 \\
\hline 67,29 & 715,80 & 87,80 & 27,14 & 20,05 & 17,61 & 15,33 & 13,50 & 11,91 & 9,32 & 7,42 & 5,00 \\
\hline 50,14 & 1196,00 & 128,70 & 20,41 & 16,05 & 14,08 & 11,99 & 10,25 & 8,77 & 6,51 & 4,99 & 3,27 \\
\hline 49,73 & 304,60 & 58,10 & 58,79 & 42,06 & 35,26 & 28,73 & 23,71 & 19,74 & 14,12 & 10,69 & 7,09 \\
\hline 57,07 & 616,20 & 132,60 & 25,66 & 17,70 & 14,75 & 12,11 & 10,12 & 8,52 & 6,21 & 4,74 & 3,15 \\
\hline 45,28 & 1552,10 & 108,70 & 21,66 & 18,08 & 16,18 & 13,98 & 12,05 & 10,38 & 7,77 & 5,97 & 3,90 \\
\hline 42,74 & 1916,30 & 36,80 & 42,92 & 37,95 & 36,05 & 33,05 & 30,11 & 27,30 & 22,27 & 18,17 & 12,40 \\
\hline 33,19 & 1998,50 & 143,30 & 20,80 & 17,24 & 14,93 & 12,22 & 9,99 & 8,22 & 5,76 & 4,29 & 2,83 \\
\hline 21,23 & 971,10 & 34,20 & 98,76 & 83,05 & 70,22 & 55,11 & 43,26 & 34,40 & 23,23 & 17,28 & 11,65 \\
\hline 37,97 & 1071,10 & 121,60 & 26,37 & 20,73 & 17,69 & 14,35 & 11,69 & 9,60 & 6,73 & 5,04 & 3,34 \\
\hline 72,20 & 1094,80 & 26,10 & 45,94 & 36,35 & 34,43 & 32,86 & 31,07 & 29,29 & 25,88 & 22,77 & 17,55 \\
\hline 25,14 & 410,00 & 77,20 & 63,57 & 44,76 & 34,32 & 24,50 & 18,24 & 14,23 & 9,75 & 7,49 & 5,20 \\
\hline 38,15 & 1336,60 & 52,90 & 40,88 & 36,10 & 32,79 & 28,61 & 24,81 & 21,45 & 16,11 & 12,36 & 8,01 \\
\hline 46,30 & 851,00 & 167,40 & 21,46 & 15,33 & 12,75 & 10,26 & 8,36 & 6,88 & 4,86 & 3,67 & 2,44 \\
\hline 49,13 & 1609,00 & 137,40 & 17,57 & 14,26 & 12,68 & 10,94 & 9,44 & 8,15 & 6,12 & 4,72 & 3,09 \\
\hline 55,08 & 1789,70 & 66,70 & 24,71 & 20,70 & 19,44 & 17,75 & 16,17 & 14,68 & 12,04 & 9,88 & 6,83 \\
\hline 46,10 & 513,20 & 192,90 & $\begin{array}{l}2+, 1 \perp \\
25,52\end{array}$ & 15,79 & 12,28 & $\begin{array}{l}1+, 30 \\
9,30\end{array}$ & $\begin{array}{c}10, \pm 1 \\
7,30\end{array}$ & $\begin{array}{c}1+, 00 \\
5,88\end{array}$ & $\begin{array}{c}14,07 \\
4,07\end{array}$ & 3,09 & 2,11 \\
\hline 78,32 & 473,50 & 21,80 & 66,65 & 50,83 & 47,42 & 44,13 & 41,07 & 38,20 & 32,91 & 28,31 & 21,07 \\
\hline 50,00 & 866,80 & 126,90 & 23,75 & 17,82 & 15,27 & 12,72 & 10,67 & 9,00 & 6,54 & 4,98 & 3,28 \\
\hline 79,59 & 1899,20 & 131,90 & 12,93 & 9,63 & 8,82 & 8,03 & 7,37 & 6,77 & 5,69 & 4,80 & 3,47 \\
\hline 31,06 & 498,60 & $\frac{101,0}{162,10}$ & 32,84 & 21,18 & $\frac{1,06}{16,04}$ & 11,50 & 8,65 & 6,79 & 4,67 & 3,58 & 2,49 \\
\hline 48,29 & 815,00 & 104,90 & 27,67 & 21,25 & $\frac{10,0}{18,36}$ & $\frac{1+, 00}{15,36}$ & 12,92 & 10,91 & $\frac{7,91}{7,94}$ & 6,03 & 3,96 \\
\hline 26,06 & 1061,80 & 186,60 & 25,25 & 18,07 & 14,04 & 10,15 & 7,61 & 5,94 & 4,06 & 3,11 & 2,15 \\
\hline 52,70 & 765,00 & 32,90 & 54,07 & 45,66 & 42,44 & 38,34 & 34,55 & 31,03 & 24,94 & 20,15 & 13,65 \\
\hline 22,35 & 1494,10 & 89,10 & 42,58 & 34,31 & 28,20 & 21,45 & 16,47 & 12,94 & 8,72 & 6,56 & 4,48 \\
\hline 27,98 & 1547,00 & 47,00 & 54,30 & 48,18 & 42,87 & 36,13 & 30,21 & 25,26 & 17,99 & 13,41 & 8,68 \\
\hline 87,31 & 402,70 & 192,90 & 25,63 & 14,00 & 10,52 & 8,11 & 6,66 & 5,62 & 4,16 & 3,24 & 2,21 \\
\hline 64,83 & 631,80 & 107,50 & 26,52 & 18,77 & 16,03 & 13,58 & 11,70 & 10,12 & 7,67 & 5,99 & 3,99 \\
\hline 49,80 & 1473,30 & 80,80 & 24,90 & 21,02 & 19,20 & 17,03 & 15,07 & 13,30 & 10,37 & 8,18 & 5,42 \\
\hline 32,87 & 392,10 & 138,70 & 38,81 & 24,59 & 18,61 & 13,40 & 10,11 & 7,96 & 5,47 & 4,20 & 2,92 \\
\hline 64,54 & 393,80 & 107,30 & 34,39 & 22,21 & 18,10 & 14,71 & 12,30 & 10,40 & 7,63 & 5,87 & 3,92 \\
\hline 27,16 & 1632,80 & 165,70 & 23,36 & 18,20 & 14,91 & 11,37 & 8,78 & 6,94 & 4,71 & 3,54 & 2,42 \\
\hline 84,86 & 1469,00 & 167,00 & 12,46 & 8,76 & 7,75 & 6,86 & 6,19 & 5,61 & 4,61 & 3,83 & 2,71 \\
\hline 42,96 & 966,20 & 154,90 & 22,05 & 16,41 & 13,81 & 11,15 & 9,09 & 7,48 & 5,27 & 3,96 & 2,63 \\
\hline 44,09 & 815,10 & 78,90 & 34,54 & 27,77 & 24,30 & 20,47 & 17,26 & 14,58 & 10,61 & 8,04 & 5,26 \\
\hline 85,52 & 274,50 & 54,70 & 51,36 & 33,44 & 28,06 & 23,81 & 20,85 & 18,43 & 14,56 & 11,74 & 8,09 \\
\hline 24,11 & 1308,50 & 25,30 & 99,10 & 89,44 & 79,90 & 67,52 & 56,52 & 47,24 & 33,59 & 24,97 & 16,12 \\
\hline 20,42 & 609,80 & 130,00 & 43,56 & 28,96 & 21,02 & 14,30 & 10,46 & 8,18 & 5,71 & 4,43 & 3,09 \\
\hline 53,99 & 1023,30 & 155,90 & 18,89 & 13,98 & 11,99 & 10,06 & 8,51 & 7,24 & 5,33 & 4,08 & 2,69 \\
\hline 24,31 & 326,90 & 140,80 & 45,54 & 26,97 & 19,10 & 12,96 & 9,58 & 7,54 & 5,27 & 4,10 & 2,87 \\
\hline 39,55 & 1287,20 & 40,50 & 48,08 & 42,92 & 39,55 & 35,13 & 30,99 & 27,24 & 21,01 & 16,41 & 10,73 \\
\hline 47,71 & 1875,10 & 157,10 & 15,54 & 12,67 & 11,26 & 9,69 & 8,34 & 7,17 & 5,36 & 4,12 & 2,69 \\
\hline 38,30 & 310,30 & 139,00 & 40,85 & 24,36 & 18,27 & 13,24 & 10,08 & 7,98 & 5,49 & 4,21 & 2,92 \\
\hline 26,18 & 1387,70 & 119,50 & 31,58 & 24,99 & 20,60 & 15,78 & 12,22 & 9,66 & 6,55 & 4,92 & 3,35 \\
\hline 57,03 & 1426,60 & 88,20 & 21,98 & 17,95 & 16,43 & 14,69 & 13,14 & 11,72 & 9,33 & 7,49 & 5,05 \\
\hline 40,88 & 1664,00 & 193,10 & 15,96 & 12,51 & 10,75 & 8,82 & 7,27 & 6,02 & 4,27 & 3,21 & 2,12 \\
\hline 28,60 & 1555,60 & 32,60 & 67,82 & 61,94 & 56,25 & 48,74 & 41,83 & 35,78 & 26,34 & 19,91 & 12,79 \\
\hline 28,47 & 1489,00 & 104,90 & 31,72 & 25,97 & 22,02 & 17,49 & 13,91 & 11,20 & 7,67 & 5,71 & 3,83 \\
\hline 79,73 & 806,20 & 74,70 & 25,93 & 18,90 & 16,99 & 15,22 & 13,79 & 12,53 & 10,34 & 8,59 & 6,08 \\
\hline 41,68 & 1716,10 & 84,00 & 25,99 & 22,52 & 20,40 & 17,81 & 15,47 & 13,41 & 10,12 & 7,79 & 5,07 \\
\hline 40,31 & 1080,50 & 129,40 & 24,34 & 19,00 & 16,25 & 13,28 & 10,89 & 9,00 & 6,36 & 4,77 & 3,15 \\
\hline 60,34 & 338,00 & 174,20 & 31,70 & 17,68 & 13,26 & 9,98 & 7,93 & 6,46 & 4,55 & 3,47 & 2,37 \\
\hline 30,39 & 699,00 & 181,80 & 27,24 & 18,41 & 14,20 & 10,31 & 7,78 & 6,11 & 4,18 & 3,20 & 2,22 \\
\hline 78,52 & 329,60 & 166,60 & 31,31 & 17,10 & 12,80 & 9,77 & 7,95 & 6,63 & 4,81 & 3,72 & 2,53 \\
\hline 72,58 & 1409,90 & 97,10 & 18,31 & $\begin{array}{l}11, \pm 0 \\
13,98\end{array}$ & 12,82 & 11,62 & 10,59 & 9,65 & $\begin{array}{l}, 01 \\
7,99\end{array}$ & 6,64 & 4,70 \\
\hline 77,86 & 867,80 & 131,80 & 18,93 & 13,14 & $\frac{1 L, 0<}{11,34}$ & $\begin{array}{c}+1,0< \\
9,80\end{array}$ & 8,66 & 7,68 & 6,09 & 4,91 & 3,36 \\
\hline 33,72 & 462,70 & 144,80 & 35,05 & 22,85 & 17,58 & 12,84 & 9,75 & 7,69 & 5,27 & 4,03 & 2,79 \\
\hline 21,69 & 1636,50 & 23,80 & 105,56 & 95,79 & 85,61 & 72,26 & 60,37 & 50,36 & 35,66 & 26,45 & 17,06 \\
\hline 24,75 & 801,60 & 144,60 & 33,81 & 23,92 & 18,35 & 13,10 & 9,75 & 7,60 & 5,21 & 4,00 & 2,78 \\
\hline 40,65 & 386,30 & 188,20 & 30,94 & 18,00 & 13,42 & 9,74 & 7,44 & 5,90 & 4,07 & 3,11 & 2,16 \\
\hline 69,63 & 415,50 & 121,90 & 30,86 & 19,40 & 15,66 & 12,70 & 10,65 & 9,05 & 6,70 & 5,18 & 3,47 \\
\hline 36,41 & 1348,70 & 115,70 & 25,67 & 20,93 & 18,12 & 14,90 & 12,26 & 10,13 & 7,15 & 5,35 & 3,52 \\
\hline 76,79 & 1584,10 & 60,10 & 22,71 & 17,51 & 16,44 & 15,43 & 14,44 & 13,49 & 11,72 & 10,16 & 7,64 \\
\hline 81,33 & 1439,10 & 86,60 & 18,33 & 13,68 & 12,61 & 11,60 & 10,72 & 9,91 & 8,44 & 7,20 & 5,29 \\
\hline 79,01 & 1151,00 & 198,30 & 13,40 & 9,09 & 7,75 & 6,64 & 5,83 & 5,15 & 4,06 & 3,26 & 2,23 \\
\hline 53,53 & 890,80 & 120,20 & 23,28 & 17,59 & 15,23 & 12,88 & 10,96 & 9,36 & 6,94 & 5,33 & 3,51 \\
\hline 84,16 & 1033,40 & 167,20 & 15,01 & 10,13 & 8,68 & 7,49 & 6,63 & 5,91 & 4,73 & 3,85 & 2,67 \\
\hline 39,55 & 1251,70 & 191,60 & 18,35 & 13,78 & 11,55 & 9,22 & 7,43 & 6,06 & 4,22 & 3,17 & 2,12 \\
\hline 36,52 & 632,50 & 79,40 & 43,06 & 33,31 & 28,09 & 22,45 & 18,06 & 14,69 & 10,20 & 7,63 & 5,10 \\
\hline 73,29 & 1617,20 & 159,20 & 12,99 & 9,63 & 8,62 & 7,65 & 6,87 & 6,18 & 5,00 & 4,08 & 2,82 \\
\hline 46,23 & 1407,00 & 69,90 & 29,18 & 25,04 & 22,87 & 20,21 & 17,80 & 15,63 & 12,07 & 9,45 & 6,22 \\
\hline 62,48 & 244,50 & 53,00 & 62,05 & 42,22 & 35,23 & 29,16 & 24,64 & 20,98 & 15,53 & 11,97 & 7,96 \\
\hline 37,55 & 1296,40 & 138,50 & 22,80 & 18,07 & 15,47 & 12,59 & 10,27 & 8,44 & 5,92 & 4,43 & 2,93 \\
\hline 83,86 & 316,20 & 104,30 & 36,97 & 22,00 & 17,42 & 14,05 & 11,88 & 10,21 & 7,73 & 6,08 & 4,13 \\
\hline
\end{tabular}




\begin{tabular}{|c|c|c|c|c|c|c|c|c|c|c|c|}
\hline \multirow[b]{2}{*}{ e1 (cm) } & & & & & & $\mathrm{De}$ & ões (x1 & m) & & & \\
\hline & Meq (MPa) & Ms (MPa) & D0 & D25 & D40 & D60 & D80 & D100 & D140 & D180 & D260 \\
\hline 88,95 & 684,40 & 199,60 & 17,59 & 10,61 & 8,52 & 6,97 & 5,97 & 5,19 & 4,01 & 3,19 & 2,19 \\
\hline 39,82 & 771,20 & 138,90 & 26,95 & 19,66 & 16,27 & 12,84 & 10,26 & 8,32 & 5,78 & 4,34 & 2,92 \\
\hline 54,71 & 547,50 & 65,40 & 39,99 & 30,71 & 26,86 & 22,97 & 19,75 & 17,01 & 12,78 & 9,87 & 6,50 \\
\hline 39,14 & 1121,80 & 102,50 & 28,20 & 22,86 & 19,87 & 16,48 & 13,67 & 11,39 & 8,12 & 6,09 & 4,00 \\
\hline 85,12 & 308,20 & 58,20 & 46,87 & 30,81 & 26,00 & 22,17 & 19,47 & 17,24 & 13,67 & 11,04 & 7,62 \\
\hline 26,65 & 1739,60 & 145,00 & 25,43 & 20,25 & 16,78 & 12,95 & 10,08 & 7,99 & 5,42 & 4,06 & 2,76 \\
\hline 20,61 & 1656,20 & 23,00 & 112,73 & 101,84 & 90,59 & 75,94 & 63,01 & 52,25 & 36,70 & 27,14 & 17,57 \\
\hline 34,97 & 763,40 & 64,60 & 47,08 & 38,38 & 33,09 & 27,03 & 22,09 & 18,17 & 12,73 & 9,51 & 6,27 \\
\hline 58,15 & 1612,00 & 131,60 & 16,28 & 12,97 & 11,68 & 10,30 & 9,11 & 8,05 & 6,29 & 4,99 & 3,34 \\
\hline 20,50 & 463,90 & 160,00 & 39,89 & 24,21 & 16,94 & 11,34 & 8,34 & 6,58 & 4,63 & 3,60 & 2,52 \\
\hline 32,55 & 1847,90 & 76,30 & 32,67 & 28,62 & 25,52 & 21,65 & 18,25 & 15,38 & 11,09 & 8,33 & 5,39 \\
\hline 76,00 & 1634,60 & 151,50 & 13,06 & 9,65 & 8,68 & 7,75 & 7,00 & 6,33 & 5,18 & 4,27 & 2,99 \\
\hline 49,30 & 1775,00 & 163,10 & 15,23 & 12,25 & 10,84 & 9,31 & 8,01 & 6,89 & 5,16 & 3,97 & 2,60 \\
\hline 82,33 & 459,60 & 151,20 & 25,57 & 15,27 & 12,10 & 9,76 & 8,24 & 7,07 & 5,34 & 4,20 & 2,85 \\
\hline 29,74 & 979,90 & 140,30 & 29,09 & 21,79 & 17,65 & 13,36 & 10,30 & 8,14 & 5,54 & 4,18 & 2,86 \\
\hline 32,51 & 496,60 & 63,00 & 58,71 & 45,09 & 37,39 & 29,15 & 22,96 & 18,39 & 12,59 & 9,44 & 6,38 \\
\hline 85,66 & 1862,40 & 97,80 & 14,91 & 11,10 & 10,25 & 9,52 & 8,87 & 8,27 & 7,17 & 6,21 & 4,67 \\
\hline 37,63 & 1628,20 & 178,00 & 17,86 & 14,12 & 12,07 & 9,80 & 7,99 & 6,56 & 4,60 & 3,45 & 2,28 \\
\hline 88,19 & 1128,70 & 197,00 & 13,08 & 8,63 & 7,33 & 6,30 & 5,57 & 4,97 & 3,99 & 3,25 & 2,27 \\
\hline 35,84 & 904,50 & 123,00 & 28,99 & 22,14 & 18,52 & 14,65 & 11,69 & 9,45 & 6,53 & 4,89 & 3,28 \\
\hline 34,05 & 853,80 & 188,20 & 23,42 & 16,43 & 13,09 & 9,86 & 7,60 & 6,03 & 4,12 & 3,12 & 2,14 \\
\hline 56,75 & 1003,10 & 32,80 & 47,33 & 39,33 & 37,22 & 34,30 & 31,50 & 28,83 & 24,00 & 19,96 & 14,04 \\
\hline 50,21 & 1854,90 & 138,80 & 16,26 & 13,36 & 11,99 & 10,46 & 9,12 & 7,94 & 6,06 & 4,71 & 3,10 \\
\hline 38,19 & 1641,40 & 149,90 & 19,61 & 15,89 & 13,77 & 11,37 & 9,40 & 7,80 & 5,53 & 4,15 & 2,72 \\
\hline 88,34 & 1916,00 & 157,10 & 11,13 & 7,98 & 7,20 & 6,53 & 5,99 & 5,52 & 4,67 & 3,97 & 2,91 \\
\hline 36,84 & 1289,80 & 194,60 & 18,75 & 14,09 & 11,73 & 9,25 & 7,37 & 5,96 & 4,12 & 3,09 & 2,08 \\
\hline 52,05 & 1552,90 & 160,20 & 15,75 & 12,41 & 10,94 & 9,39 & 8,09 & 6,97 & 5,23 & 4,04 & 2,65 \\
\hline 82,00 & 604,00 & 32,00 & 46,83 & 35,14 & 32,54 & 30,14 & 28,00 & 26,01 & 22,38 & 19,24 & 14,32 \\
\hline 26,92 & 1972,20 & 55,30 & 46,42 & 41,27 & 36,69 & 30,86 & 25,75 & $\frac{20,01}{21,48}$ & $\begin{array}{l}\angle L, v 0 \\
15,25\end{array}$ & $\begin{array}{l}10,24 \\
11,35\end{array}$ & $\frac{14,02}{7,35}$ \\
\hline 37,32 & 853,40 & 88,10 & 35,52 & 28,29 & 24,25 & 19,76 & 16,14 & 13,28 & 9,32 & 6,98 & 4,61 \\
\hline 58,97 & 235,00 & 179,00 & 40,04 & 20,12 & 14,14 & 10,06 & 7,75 & 6,21 & 4,31 & 3,31 & 2,31 \\
\hline 78,33 & 1374,50 & 106,70 & 16,90 & 12,55 & 11,42 & 10,32 & 9,42 & 8,60 & 7,16 & 5,99 & 4,28 \\
\hline 55,82 & 1838,90 & 31,90 & 40,40 & 33,27 & 32,10 & 30,37 & 28,45 & 26,56 & 22,96 & 19,75 & 14,61 \\
\hline 81,84 & 569,30 & 111,70 & 25,27 & 16,66 & 14,01 & 11,89 & 10,39 & 9,15 & 7,18 & 5,76 & 3,94 \\
\hline 23,76 & 1813,40 & 80,50 & 41,11 & 34,46 & 29,26 & 23,15 & 18,31 & 14,65 & 9,95 & 7,39 & 4,96 \\
\hline 24,63 & 427,60 & 149,00 & 40,08 & 24,97 & 18,06 & 12,39 & 9,14 & 7,17 & 4,99 & 3,87 & 2,71 \\
\hline 88,76 & 1136,80 & 179,50 & 13,55 & 9,05 & 7,76 & 6,72 & 5,98 & 5,36 & 4,34 & 3,56 & 2,50 \\
\hline 66,01 & 376,40 & 67,90 & 42,95 & 30,00 & 25,49 & 21,52 & 18,51 & 16,00 & 12,13 & 9,47 & 6,32 \\
\hline 79,92 & 580,20 & 54,80 & 35,61 & 25,91 & 23,25 & 20,80 & 18,84 & 17,11 & 14,10 & 11,70 & 8,28 \\
\hline 65,02 & 1874,30 & 25,80 & 41,45 & 33,74 & 32,05 & 31,00 & 29,58 & 28,08 & 25,15 & 22,40 & 17,61 \\
\hline 53,57 & 378,30 & 187,60 & 29,42 & 16,75 & 12,62 & 9,45 & 7,43 & 6,01 & 4,19 & 3,19 & 2,19 \\
\hline 81,31 & 1544,70 & 188,90 & 11,62 & 8,20 & 7,21 & 6,35 & 5,69 & 5,12 & 4,15 & 3,41 & 2,38 \\
\hline 77,88 & 1197,60 & 134,40 & 15,94 & 11,48 & 10,17 & 8,99 & 8,06 & 7,25 & 5,88 & 4,81 & 3,35 \\
\hline 73,97 & 1095,50 & 186,00 & 14,52 & 10,02 & 8,57 & 7,32 & 6,40 & 5,62 & 4,37 & 3,48 & 2,35 \\
\hline 31,56 & 1126,90 & 190,80 & 21,86 & 16,02 & 12,92 & 9,78 & 7,55 & 5,98 & 4,08 & 3,08 & 2,11 \\
\hline 89,56 & 1128,40 & 184,30 & 13,40 & 8,89 & 7,60 & 6,57 & 5,83 & 5,23 & 4,23 & 3,47 & 2,43 \\
\hline 67,06 & 562,20 & 121,30 & 26,32 & 17,74 & 14,81 & 12,34 & 10,52 & 9,03 & 6,78 & 5,27 & 3,52 \\
\hline 72,12 & 417,30 & 21,90 & 72,97 & 56,50 & 52,58 & 48,31 & 44,48 & 40,91 & 34,47 & 29,06 & 20,94 \\
\hline 62,90 & 226,40 & 173,50 & 41,30 & 20,66 & 14,51 & 10,34 & 7,99 & 6,42 & 4,47 & 3,43 & 2,39 \\
\hline 80,35 & 1468,80 & 174,70 & 12,45 & 8,84 & 7,80 & 6,87 & 6,16 & 5,54 & 4,50 & 3,69 & 2,58 \\
\hline 46,92 & 419,80 & 163,80 & 30,49 & 18,67 & 14,46 & 10,94 & 8,59 & 6,92 & 4,80 & 3,64 & 2,49 \\
\hline 62,49 & 487,00 & 120,70 & 29,32 & 19,41 & 15,98 & 13,07 & 10,95 & 9,27 & 6,80 & 5,23 & 3,48 \\
\hline 37,73 & 597,90 & 36,60 & 69,71 & 59,21 & 52,51 & 44,51 & 37,58 & 31,74 & 23,03 & 17,37 & 11,28 \\
\hline 33,15 & 1025,50 & 114,50 & 30,49 & 23,88 & 20,06 & 15,87 & 12,63 & 10,19 & 7,01 & 5,24 & 3,52 \\
\hline 86,66 & 425,10 & 95,90 & 31,40 & 19,96 & 16,52 & 13,87 & 12,06 & 10,61 & 8,32 & 6,68 & 4,59 \\
\hline 57,61 & 721,70 & 48,60 & 41,00 & 33,24 & 30,28 & 26,97 & 24,05 & 21,41 & 16,96 & 13,57 & 9,14 \\
\hline 79,51 & 1664,80 & 125,50 & 14,09 & 10,44 & 9,51 & 8,62 & 7,89 & 7,22 & 6,04 & 5,07 & 3,64 \\
\hline 70,48 & 926,60 & 127,80 & 19,35 & 13,93 & 12,13 & 10,50 & 9,24 & 8,15 & 6,38 & 5,09 & 3,44 \\
\hline 32,02 & 224,60 & 52,30 & 88,68 & 61,41 & 48,26 & 35,70 & 27,23 & 21,47 & 14,67 & 11,17 & 7,70 \\
\hline 32,29 & 1242,40 & 75,70 & 37,97 & 31,99 & 27,88 & 22,98 & 18,89 & 15,59 & 10,96 & 8,17 & 5,36 \\
\hline 77,92 & 508,90 & 62,80 & 35,71 & 25,45 & 22,38 & 19,64 & 17,53 & 15,70 & 12,64 & 10,30 & 7,13 \\
\hline 72,12 & 857,20 & 52,30 & 32,47 & 24,99 & 23,08 & 21,04 & 19,26 & 17,62 & 14,70 & 12,29 & 8,75 \\
\hline 21,75 & 522,60 & 122,30 & 46,00 & 30,46 & 22,24 & 15,23 & 11,17 & 8,73 & 6,08 & 4,72 & 3,29 \\
\hline 80,59 & 1256,40 & 28,40 & 38,01 & 30,25 & 28,17 & 27,08 & 25,86 & 24,57 & 22,09 & 19,77 & 15,73 \\
\hline 35,87 & 1046,90 & 111,00 & 29,24 & 23,17 & 19,73 & 15,92 & 12,89 & 10,54 & 7,34 & 5,49 & 3,64 \\
\hline 87,11 & 755,60 & 68,70 & 26,87 & 19,17 & 17,21 & 15,49 & 14,14 & 12,95 & 10,87 & 9,16 & 6,63 \\
\hline 84,50 & 995,80 & 64,90 & 24,83 & 18,29 & 16,76 & 15,38 & 14,20 & 13,13 & 11,21 & 9,57 & 7,06 \\
\hline 69,45 & 1979,10 & 171,40 & 11,68 & 8,89 & 8,02 & 7,15 & 6,43 & 5,78 & 4,67 & 3,81 & 2,62 \\
\hline 20,78 & 1846,20 & 181,90 & 25,25 & 18,92 & 14,71 & 10,55 & 7,82 & 6,06 & 4,13 & 3,17 & 2,20 \\
\hline 53,12 & 1458,40 & 144,80 & 16,93 & 13,38 & 11,84 & 10,21 & 8,84 & 7,65 & 5,79 & 4,48 & 2,95 \\
\hline 76.29 & 1530,80 & 130,80 & 14.56 & 10,82 & 9,78 & 8.78 & 7.96 & 7,23 & 5.95 & 4.93 & 3,47 \\
\hline 73,02 & 801,50 & 149,00 & 19,12 & 13,04 & 11,05 & 9,37 & 8,13 & 7,10 & 5,47 & 4,33 & 2,92 \\
\hline 37,19 & 273,10 & 165,80 & 39,99 & 21,88 & 15,72 & 11,05 & 8,33 & 6,58 & 4,55 & 3,51 & 2,46 \\
\hline 86,98 & 1553,00 & 26,40 & 33,53 & 28,37 & 25,80 & 24,89 & 24,11 & 23,18 & 21,26 & 19,43 & 16,07 \\
\hline 21,26 & 619,50 & 179,80 & 33,45 & 21,17 & 15,12 & 10,22 & 7,50 & 5,89 & 4,12 & 3,21 & 2,24 \\
\hline 68,67 & 1217,30 & 97,20 & 20,00 & 15,36 & 13,94 & 12,48 & 11,24 & 10,13 & 8,22 & 6,71 & 4,64 \\
\hline 80,20 & 1499,20 & 102,60 & 16,45 & 12,24 & 11,21 & 10,23 & 9,40 & 8,64 & 7,28 & 6,16 & 4,46 \\
\hline 88,79 & 1358,40 & 31,10 & 32,05 & 25,88 & 23,69 & 22,78 & 21,89 & 20,91 & 18,99 & 17,19 & 13,97 \\
\hline 66,33 & 322,00 & 185,90 & 31,51 & 16,93 & 12,46 & 9,29 & 7,38 & 6,03 & 4,26 & 3,26 & 2,23 \\
\hline 81,93 & 1666,40 & 97,00 & 16,08 & 12,00 & 11,08 & 10,21 & 9,45 & 8,75 & 7,48 & 6,40 & 4,73 \\
\hline 21,77 & 1972,30 & 103,60 & 36,00 & 29,26 & 24,16 & 18,45 & 14,20 & 11,16 & 7,52 & 5,64 & 3,85 \\
\hline 37,83 & 723,80 & 143,50 & 27,90 & 20,00 & 16,32 & 12,65 & 9,98 & 8,01 & 5,52 & 4,16 & 2,82 \\
\hline
\end{tabular}




\begin{tabular}{|c|c|c|c|c|c|c|c|c|c|c|c|}
\hline \multirow[b]{2}{*}{$\mathrm{e} 1(\mathrm{~cm})$} & & & & & & $\mathrm{De}$ & $\overline{\text { ões (x1 }}$ & & & & \\
\hline & Meq (MPa) & Ms (MPa) & D0 & D25 & D40 & D60 & D80 & D100 & D140 & D180 & D260 \\
\hline 25,09 & $\begin{array}{l}797,80 \\
\end{array}$ & 147,70 & 33,10 & 23,37 & 17,93 & 12,81 & 9,54 & 7,44 & 5,10 & 3,92 & 2,72 \\
\hline 31,64 & 820,90 & 137,30 & 30,21 & 22,19 & 17,92 & 13,58 & 10,49 & 8,31 & 5,67 & 4,28 & 2,93 \\
\hline 42,20 & 1220,50 & 150,00 & 20,61 & 16,02 & 13,74 & 11,30 & 9,32 & 7,74 & 5,51 & 4,14 & 2,73 \\
\hline 39,28 & 263,60 & 53,50 & 74,10 & 52,88 & 43,25 & 33,71 & 26,71 & 21,53 & 14,88 & 11,20 & 7,57 \\
\hline 79,23 & 1680,20 & 157,40 & 12,40 & 9,05 & 8,13 & 7,27 & 6,58 & 5,98 & 4,92 & 4,08 & 2,88 \\
\hline 89,56 & 1724,70 & 195,70 & 10,40 & 7,21 & 6,36 & 5,65 & 5,12 & 4,65 & 3,86 & 3,23 & 2,32 \\
\hline 52,20 & 242,50 & 24,80 & 101,07 & 79,72 & 70,31 & 60,41 & 52,06 & 44,90 & 33,74 & 26,06 & 17,12 \\
\hline 39,07 & 1082,10 & 117,20 & 26,37 & 20,88 & 17,94 & 14,69 & 12,06 & 9,96 & 7,03 & 5,27 & 3,48 \\
\hline 70,93 & 583,10 & 164,00 & 22,24 & 14,07 & 11,41 & 9,30 & 7,84 & 6,69 & 4,98 & 3,86 & 2,59 \\
\hline 68,40 & 1433,40 & 44,80 & 30,49 & 24,17 & 22,94 & 21,53 & 20,11 & 18,74 & 16,17 & 13,91 & 10,33 \\
\hline 56,35 & 1976,20 & 93,30 & 18,92 & 15,69 & 14,57 & 13,19 & 11,92 & 10,75 & 8,70 & 7,07 & 4,84 \\
\hline 26,62 & 1723,50 & 113,40 & 30,21 & 24,72 & 20,83 & 16,38 & 12,93 & 10,34 & 7,04 & 5,25 & 3,53 \\
\hline 67,72 & 355,30 & 80,30 & 40,65 & 27,10 & 22,53 & 18,70 & 15,91 & 13,65 & 10,23 & 7,95 & 5,31 \\
\hline 55,95 & 913,90 & 154,70 & 19,68 & 14,24 & 12,12 & 10,13 & 8,56 & 7,28 & 5,36 & 4,11 & 2,71 \\
\hline 81,74 & 1292,50 & 148,10 & 14,32 & 10,16 & 8,98 & 7,94 & 7,14 & 6,45 & 5,26 & 4,34 & 3,05 \\
\hline 45,04 & 1982,50 & 62,60 & 28,38 & 24,90 & 23,22 & 20,94 & 18,79 & 16,79 & 13,34 & 10,66 & 7,13 \\
\hline 37,95 & 999,00 & 106,90 & 29,34 & 23,26 & 19,93 & 16,25 & 13,28 & 10,93 & 7,69 & 5,75 & 3,80 \\
\hline 71,64 & 1817,70 & 83,40 & 18,30 & 14,25 & 13,34 & 12,34 & 11,41 & 10,54 & 8,95 & 7,60 & 5,53 \\
\hline 25,33 & 1672,60 & 173,50 & 23,55 & 18,13 & 14,63 & 10,96 & 8,35 & 6,55 & 4,44 & 3,36 & 2,31 \\
\hline 57,86 & 1955,10 & 178,50 & 12,62 & 9,95 & 8,89 & 7,78 & 6,84 & 6,01 & 4,66 & 3,67 & 2,44 \\
\hline 67,30 & 1541,50 & 151,30 & 14,21 & 10,77 & 9,63 & 8,50 & 7,57 & 6,75 & 5,37 & 4,32 & 2,94 \\
\hline 33,25 & 1926,90 & 152,10 & 20,24 & 16,59 & 14,28 & 11,61 & 9,44 & 7,73 & 5,39 & 4,02 & 2,66 \\
\hline 57,32 & 543,60 & 55,70 & 42,72 & 33,27 & 29,48 & 25,59 & 22,33 & 19,49 & 14,94 & 11,70 & 7,75 \\
\hline 65,86 & 1257,00 & 43,70 & 33,15 & 26,48 & 25,08 & 23,36 & 21,67 & 20,06 & 17,09 & 14,53 & 10,58 \\
\hline 25,95 & 1287,80 & 159,90 & 26,57 & 20,03 & 16,01 & 11,88 & 9,02 & 7,07 & 4,80 & 3,64 & 2,51 \\
\hline 54,20 & 1347,00 & 123,60 & 18,96 & 15,09 & 13,44 & 11,68 & 10,17 & 8,86 & 6,77 & 5,28 & 3,49 \\
\hline 85,36 & 1882,10 & 193,50 & 10,21 & 7,24 & 6,45 & 5,75 & 5,22 & 4,75 & 3,94 & 3,29 & 2,35 \\
\hline 34,57 & 1898,90 & 107,40 & 24,71 & 21,08 & 18,61 & 15,62 & 13,05 & 10,93 & 7,82 & 5,86 & 3,81 \\
\hline 49,32 & 454,10 & 197,20 & 26,45 & 15,69 & 12,01 & 9,05 & 7,11 & 5,73 & 3,98 & 3,03 & 2,07 \\
\hline 84,79 & 480,00 & 195,70 & 22,67 & 12,87 & 9,91 & 7,79 & 6,48 & 5,51 & 4,11 & 3,22 & 2,19 \\
\hline 81,08 & 1847,00 & 130,40 & 13,05 & 9,66 & 8,83 & 8,05 & 7,39 & 6,79 & 5,73 & 4,84 & 3,51 \\
\hline 39,01 & 486,00 & 189,10 & 27,95 & 17,28 & 13,21 & 9,72 & 7,46 & 5,92 & 4,07 & 3,10 & 2,15 \\
\hline 21,81 & 1040,90 & 85,00 & 49,69 & 38,48 & 30,71 & 22,61 & 17,01 & 13,24 & 8,96 & 6,82 & 4,70 \\
\hline 38,06 & 1108,40 & 53,90 & 43,29 & 37,61 & 33,80 & 29,13 & 24,96 & 21,36 & 15,79 & 12,01 & 7,78 \\
\hline 61,34 & 1706,60 & 159,90 & 13,80 & 10,73 & 9,59 & 8,43 & 7,45 & 6,58 & 5,16 & 4,10 & 2,75 \\
\hline 41,12 & 364,20 & 99,50 & 44,30 & 29,72 & 23,73 & 18,18 & 14,28 & 11,47 & 7,91 & 5,98 & 4,07 \\
\hline 58,30 & 301,50 & 39,50 & 66,75 & 50,13 & 43,65 & 37,34 & 32,21 & 27,85 & 21,05 & 16,36 & 10,82 \\
\hline 67,83 & 1113,30 & 40,70 & 35,64 & 28,26 & 26,71 & 24,87 & 23,09 & 21,39 & 18,26 & 15,56 & 11,37 \\
\hline 61,11 & 1545,10 & 163,70 & 14,26 & 10,94 & 9,70 & 8,45 & 7,42 & 6,52 & 5,05 & 3,99 & 2,66 \\
\hline 82,18 & 658,40 & 108,40 & 23,58 & 15,96 & 13,66 & 11,77 & 10,39 & 9,23 & 7,35 & 5,95 & 4,10 \\
\hline 39,47 & 1267,90 & 86,90 & 29,63 & 24,88 & 22,02 & 18,67 & 15,77 & 13,34 & 9,70 & 7,33 & 4,77 \\
\hline 54,64 & 1146,00 & 27,50 & 52,34 & 43,71 & 41,82 & 38,93 & 36,02 & 33,21 & 28,03 & 23,58 & 16,85 \\
\hline 61,72 & 967,70 & 115,70 & 21,22 & 15,99 & 14,05 & 12,16 & 10,62 & 9,29 & 7,15 & 5,62 & 3,75 \\
\hline 39,60 & 249,00 & 90,00 & 56,46 & 35,54 & 27,44 & 20,38 & 15,71 & 12,49 & 8,59 & 6,54 & 4,51 \\
\hline 35,89 & 666,80 & 92,10 & 38,92 & 29,65 & 24,77 & 19,58 & 15,61 & 12,62 & 8,72 & 6,53 & 4,39 \\
\hline 71,94 & 1322,10 & 182,30 & 13,44 & 9,63 & 8,39 & 7,27 & 6,41 & 5,67 & 4,45 & 3,56 & 2,42 \\
\hline 82,70 & 1668,20 & 188,70 & 11,11 & 7,87 & 6,97 & 6,17 & 5,56 & 5,02 & 4,11 & 3,40 & 2,39 \\
\hline 22,69 & 1744,30 & 113,20 & 33,97 & 27,19 & 22,27 & 16,88 & 12,94 & 10,15 & 6,85 & 5,16 & 3,53 \\
\hline 79,38 & 1174,10 & 49,30 & 28,21 & 21,55 & 20,13 & 18,84 & 17,61 & 16,44 & 14,27 & 12,36 & 9,30 \\
\hline 74,19 & 412,30 & 82,00 & 35,86 & 24,08 & 20,27 & 17,11 & 14,81 & 12,91 & 9,94 & 7,85 & 5,30 \\
\hline 41,73 & 738,90 & 64,00 & 42,31 & 34,55 & 30,31 & 25,52 & 21,46 & 18,09 & 13,11 & 9,90 & 6,47 \\
\hline 82,75 & 766,80 & 32,20 & 42,16 & 31,98 & 29,77 & 27,93 & 26,18 & 24,51 & 21,41 & 18,66 & 14,19 \\
\hline 76,78 & 1212,60 & 21,40 & 47,49 & 38,56 & 35,94 & 34,74 & 33,32 & 31,76 & 28,70 & 25,81 & 20,71 \\
\hline 54,26 & 936,20 & 121,00 & 22,50 & 17,09 & 14,86 & 12,62 & 10,79 & 9,25 & 6,90 & 5,31 & 3,50 \\
\hline 77,93 & 1974,60 & 42,10 & 25,74 & 20,53 & 19,20 & 18,47 & 17,63 & 16,74 & 15,03 & 13,43 & 10,65 \\
\hline 77,07 & 1485,00 & 64,30 & 22,29 & 17,10 & 16,00 & 14,92 & 13,90 & 12,94 & 11,16 & 9,61 & 7,16 \\
\hline 50,74 & 706,60 & 101,00 & 29,28 & 22,02 & 18,93 & 15,83 & 13,33 & 11,27 & 8,23 & 6,27 & 4,13 \\
\hline 57,09 & 1242,80 & 121,70 & 19,22 & 15,06 & 13,38 & 11,65 & 10,18 & 8,90 & 6,84 & 5,37 & 3,56 \\
\hline 53,35 & 383,30 & 120,40 & 35,42 & 22,64 & 18,10 & 14,23 & 11,51 & 9,46 & 6,69 & 5,07 & 3,42 \\
\hline 33,81 & 1806,60 & 99,90 & 26,81 & 22,90 & 20,19 & 16,90 & 14,09 & 11,77 & 8,39 & 6,28 & 4,09 \\
\hline 50,62 & 1293,90 & 54,10 & 33,41 & 28,48 & 26,44 & 23,82 & 21,39 & 19,15 & 15,29 & 12,28 & 8,27 \\
\hline 38,89 & 1577,30 & 130,30 & 21,43 & 17,60 & 15,38 & 12,84 & 10,70 & 8,95 & 6,41 & 4,82 & 3,15 \\
\hline 68,41 & $\begin{array}{l}755,70 \\
\end{array}$ & 98,10 & 24,79 & 18,11 & 15,84 & 13,75 & 12,09 & 10,66 & 8,34 & 6,63 & 4,48 \\
\hline 62,61 & 1605,40 & 161,90 & 13,93 & 10,70 & 9,52 & 8,35 & 7,37 & 6,50 & 5,09 & 4,04 & 2,71 \\
\hline 48,68 & 439,60 & 63,00 & 48,10 & 36,28 & 31,10 & 25,85 & 21,62 & 18,18 & 13,17 & 9,99 & 6,58 \\
\hline 33,75 & 326,30 & 194,90 & 34,36 & 18,91 & 13,50 & 9,39 & 7,04 & 5,55 & 3,84 & 2,97 & 2,09 \\
\hline 33,73 & 1564,80 & 44,90 & 47,59 & 42,94 & 39,12 & 34,15 & 29,57 & 25,52 & 19,08 & 14,58 & 9,41 \\
\hline 87,41 & 608,90 & 172,90 & 20,05 & 12,20 & 9,83 & 8,06 & 6,91 & 6,01 & 4,64 & 3,69 & 2,52 \\
\hline 21,48 & 1959,80 & 107,80 & 35,41 & 28,58 & 23,45 & 17,78 & 13,61 & 10,67 & 7,19 & 5,41 & 3,70 \\
\hline 68,15 & $\begin{array}{l}767,00 \\
\end{array}$ & 131,90 & 21,29 & 14,91 & 12,73 & 10,82 & 9,36 & 8,14 & 6,23 & 4,89 & 3,28 \\
\hline 50,57 & 1000,20 & 161,90 & 19,37 & 14,27 & 12,14 & 10,05 & 8,40 & 7,06 & 5,11 & 3,88 & 2,56 \\
\hline 69,79 & 400,40 & 62,20 & 42,40 & 30,04 & 25,89 & 22,21 & 19,38 & 16,99 & 13,16 & 10,42 & 7,01 \\
\hline 74,17 & 280,20 & 93,10 & 42,87 & 25,97 & 20,63 & 16,56 & 13,86 & 11,77 & 8,73 & 6,78 & 4,56 \\
\hline 54,29 & 703,10 & 30,80 & 57,05 & 47,83 & 44,50 & 40,28 & 36,39 & 32,77 & 26,47 & 21,47 & 14,63 \\
\hline 23,92 & 567,20 & 135,40 & 39,89 & 26,74 & 19,88 & 13,84 & 10,21 & 7,97 & 5,52 & 4,26 & 2,97 \\
\hline 87,40 & 320,10 & 177,70 & 30,97 & 16,38 & 12,05 & 9,09 & 7,36 & 6,15 & 4,50 & 3,50 & 2,39 \\
\hline 69,51 & 1731,50 & 33,80 & 33,91 & 27,12 & 25,74 & 24,70 & 23,43 & 22,15 & 19,67 & 17,38 & 13,49 \\
\hline 83,95 & 349,00 & 132,60 & 31,94 & 18,44 & 14,34 & 11,37 & 9,51 & 8,11 & 6,08 & 4,76 & 3,23 \\
\hline 44,53 & 1225,80 & 64,10 & 33,27 & 28,55 & 25,92 & 22,74 & 19,87 & 17,32 & 13,21 & 10,25 & 6,70 \\
\hline 75,75 & 1577,40 & 144,50 & 13,64 & 10,10 & 9,09 & 8,12 & 7,33 & 6,63 & 5,43 & 4,47 & 3,13 \\
\hline 42,13 & 1986,10 & 34,10 & 45,26 & 40,02 & 38,14 & 35,08 & 32,05 & 29,14 & 23,90 & 19,57 & 13,43 \\
\hline 80,50 & 1157,80 & 144,60 & 15,40 & 10,87 & 9,54 & 8,38 & 7,50 & 6,73 & 5,45 & 4,46 & 3,11 \\
\hline
\end{tabular}




\begin{tabular}{|c|c|c|c|c|c|c|c|c|c|c|c|}
\hline \multirow[b]{2}{*}{ e1 (cm) } & & & & & & & ões (x1 & m) & & & \\
\hline & Meq (MPa) & Ms (MPa) & D0 & D25 & D40 & D60 & D80 & D100 & D140 & D180 & D260 \\
\hline 50,24 & 1358,60 & 73,30 & 27,13 & 22,89 & 20,94 & 18,61 & 16,50 & 14,59 & 11,41 & 9,02 & 5,99 \\
\hline 72,62 & 1440,50 & 64,10 & 23,35 & 18,14 & 17,00 & 15,76 & 14,61 & 13,52 & 11,53 & 9,82 & 7,19 \\
\hline 81,47 & 271,80 & 68,30 & 47,90 & 30,24 & 24,78 & 20,55 & 17,67 & 15,37 & 11,82 & 9,37 & 6,37 \\
\hline 35,61 & 1398,50 & 21,00 & 79,48 & 72,49 & 68,36 & 62,08 & 55,95 & 50,16 & 40,02 & 32,00 & 21,31 \\
\hline 80,35 & 1438,30 & 159,00 & 13,20 & 9,44 & 8,38 & 7,42 & 6,67 & 6,02 & 4,92 & 4,05 & 2,84 \\
\hline 24,34 & 1652,10 & 173,20 & 24,31 & 18,58 & 14,87 & 11,02 & 8,34 & 6,52 & 4,42 & 3,35 & 2,31 \\
\hline 50,76 & 1920,90 & 104,70 & 18,94 & 15,95 & 14,59 & 12,97 & 11,51 & 10,19 & 7,98 & 6,32 & 4,20 \\
\hline 25,02 & 881,70 & 138,30 & 33,70 & 24,42 & 19,00 & 13,73 & 10,28 & 8,01 & 5,47 & 4,19 & 2,90 \\
\hline 50,17 & 1106,50 & 186,60 & 17,20 & 12,58 & 10,67 & 8,79 & 7,32 & 6,13 & 4,42 & 3,36 & 2,22 \\
\hline 24,43 & 1503,80 & 90,30 & 39,34 & 32,12 & 26,84 & 20,84 & 16,27 & 12,91 & 8,74 & 6,53 & 4,42 \\
\hline 23,14 & 947,70 & 64,40 & 59,61 & 47,62 & 39,02 & 29,60 & 22,71 & 17,84 & 12,04 & 9,06 & 6,20 \\
\hline 72,26 & 485,80 & 98,10 & 30,53 & 20,55 & 17,28 & 14,54 & 12,55 & 10,90 & 8,34 & 6,56 & 4,41 \\
\hline 39,05 & 1172,20 & 139,50 & 22,99 & 17,96 & 15,32 & 12,45 & 10,16 & 8,36 & 5,88 & 4,40 & 2,92 \\
\hline 39,23 & 1224,70 & 76,50 & 32,64 & 27,68 & 24,62 & 20,97 & 17,80 & 15,11 & 11,04 & 8,36 & 5,43 \\
\hline 87,64 & 1679,50 & 54,80 & 21,47 & 16,55 & 15,30 & 14,56 & 13,81 & 13,07 & 11,66 & 10,37 & 8,17 \\
\hline 39,80 & 291,50 & 139,50 & 41,59 & 24,33 & 18,15 & 13,15 & 10,03 & 7,95 & 5,48 & 4,20 & 2,92 \\
\hline 42,67 & 1639,80 & 96,50 & 23,80 & 20,28 & 18,23 & 15,79 & 13,62 & 11,74 & 8,78 & 6,74 & 4,38 \\
\hline 20,08 & 526,90 & 157,20 & 39,47 & 24,57 & 17,31 & 11,60 & 8,52 & 6,70 & 4,71 & 3,67 & 2,56 \\
\hline 51,09 & 1938,60 & 154,30 & 14,83 & 12,08 & 10,82 & 9,42 & 8,21 & 7,14 & 5,44 & 4,23 & 2,78 \\
\hline 25,11 & 587,50 & 114,60 & 43,32 & 30,31 & 23,17 & 16,50 & 12,27 & 9,57 & 6,57 & 5,05 & 3,51 \\
\hline 80,52 & 1229,60 & 179,40 & 13,45 & 9,31 & 8,06 & 7,00 & 6,21 & 5,54 & 4,43 & 3,60 & 2,49 \\
\hline 53,41 & 1804,80 & 70,20 & 24,28 & 20,49 & 19,16 & 17,41 & 15,78 & 14,26 & 11,58 & 9,43 & 6,45 \\
\hline 88,04 & 735,30 & 87,40 & 24,00 & 16,63 & 14,63 & 12,94 & 11,68 & 10,59 & 8,74 & 7,27 & 5,18 \\
\hline 37,99 & 915,20 & 104,90 & 30,67 & 24,07 & 20,53 & 16,65 & 13,56 & 11,13 & 7,80 & 5,84 & 3,87 \\
\hline 70,72 & 318,90 & 99,40 & 39,09 & 24,19 & 19,38 & 15,63 & 13,08 & 11,10 & 8,20 & 6,34 & 4,26 \\
\hline 43,85 & 1681,50 & 93,70 & 23,56 & 20,14 & 18,20 & 15,88 & 13,80 & 11,97 & 9,05 & 6,98 & 4,55 \\
\hline 26,15 & 405,50 & 154,50 & 38,92 & 23,92 & 17,34 & 11,95 & 8,85 & 6,94 & 4,83 & 3,74 & 2,62 \\
\hline 25,54 & 1066,20 & 71,30 & 49,82 & 40,47 & 33,82 & 26,31 & 20,58 & 16,36 & 11,09 & 8,29 & 5,61 \\
\hline 72,64 & 852,80 & 163,40 & 17,76 & 12,06 & 10,19 & 8,62 & 7,46 & 6,50 & 5,00 & 3,94 & 2,66 \\
\hline 39,36 & 215,00 & 155,70 & 46,33 & 23,96 & 16,82 & 11,71 & 8,82 & 6,98 & 4,83 & 3,73 & 2,63 \\
\hline 89,26 & 1404,60 & 192,30 & 11,68 & 7,94 & 6,90 & 6,04 & 5,42 & 4,89 & 4,00 & 3,31 & 2,35 \\
\hline 36,02 & 1983,00 & 169,20 & 17,65 & 14,40 & 12,45 & 10,22 & 8,40 & 6,93 & 4,88 & 3,65 & 2,40 \\
\hline 79,91 & 1597,70 & 172,40 & 12,06 & 8,66 & 7,70 & 6,83 & 6,15 & 5,55 & 4,53 & 3,73 & 2,62 \\
\hline 52,72 & 1176,50 & 114,30 & 21,34 & 16,93 & 14,99 & 12,94 & 11,20 & 9,70 & 7,33 & 5,68 & 3,74 \\
\hline 31,41 & 1706,20 & 126,00 & 24,91 & 20,48 & 17,57 & 14,19 & 11,47 & 9,35 & 6,48 & 4,82 & 3,20 \\
\hline 34,56 & 788,90 & 110,10 & 33,45 & 25,41 & 21,10 & 16,53 & 13,09 & 10,53 & 7,24 & 5,43 & 3,66 \\
\hline 61,14 & 930,30 & 110,70 & 22,23 & 16,80 & 14,76 & 12,77 & 11,14 & 9,73 & 7,48 & 5,88 & 3,91 \\
\hline 35,31 & 916,10 & 37,20 & 62,42 & 55,01 & 49,52 & 42,64 & 36,48 & 31,15 & 22,93 & 17,39 & 11,23 \\
\hline 71,49 & 1964,40 & 163,60 & 11,87 & 8,99 & 8,14 & 7,29 & 6,58 & 5,94 & 4,84 & 3,97 & 2,76 \\
\hline 50,64 & 1753,30 & 147,10 & 15,99 & 12,96 & 11,56 & 10,03 & 8,70 & 7,54 & 5,71 & 4,43 & 2,91 \\
\hline 48,82 & 558,10 & 190,80 & 24,11 & 15,21 & 11,99 & 9,25 & 7,35 & 5,97 & 4,16 & 3,15 & 2,14 \\
\hline 58,29 & 1548,20 & 194,20 & 13,31 & 10,06 & 8,79 & 7,54 & 6,52 & 5,65 & 4,29 & 3,33 & 2,21 \\
\hline 21,54 & 1964,90 & 80,50 & 43,41 & 36,09 & 30,27 & 23,55 & 18,36 & 14,54 & 9,81 & 7,31 & 4,95 \\
\hline 67,43 & 859,70 & 173,10 & 17,72 & 12,09 & 10,17 & 8,52 & 7,30 & 6,29 & 4,75 & 3,70 & 2,47 \\
\hline 52,74 & 1998,20 & 53,90 & 28,29 & 23,92 & 22,74 & 20,99 & 19,28 & 17,64 & 14,67 & 12,18 & 8,54 \\
\hline 65,42 & 1553,00 & 85,90 & 20,03 & 15,90 & 14,74 & 13,41 & 12,22 & 11,12 & 9,17 & 7,58 & 5,31 \\
\hline 55,36 & 1799,00 & 162,70 & 14,13 & 11,23 & 10,02 & 8,74 & 7,64 & 6,68 & 5,13 & 4,02 & 2,66 \\
\hline 30,63 & 1179,30 & 161,90 & 24,40 & 18,44 & 15,06 & 11,52 & 8,94 & 7,10 & 4,83 & 3,64 & 2,48 \\
\hline 78,14 & 355,00 & 197,60 & 28,28 & 15,11 & 11,15 & 8,40 & 6,76 & 5,61 & 4,04 & 3,12 & 2,13 \\
\hline 89,74 & 1787,40 & 183,50 & 10,54 & 7,38 & 6,56 & 5,87 & 5,34 & 4,87 & 4,08 & 3,43 & 2,48 \\
\hline 22,66 & 871,50 & 45,40 & 79,49 & 65,10 & 54,20 & 41,84 & 32,46 & 25,65 & 17,31 & 12,95 & 8,80 \\
\hline 70,74 & 1799,70 & 199,20 & 11,14 & 8,24 & 7,30 & 6,42 & 5,71 & 5,09 & 4,05 & 3,27 & 2,23 \\
\hline 75,39 & 708,40 & 147,60 & 20,34 & 13,51 & 11,31 & 9,52 & 8,23 & 7,17 & 5,51 & 4,36 & 2,94 \\
\hline 61,72 & 1412,50 & 181,00 & 14,01 & 10,46 & 9,14 & 7,88 & 6,85 & 5,97 & 4,58 & 3,59 & 2,39 \\
\hline 65,29 & 257,10 & 118,70 & 42,70 & 24,32 & 18,52 & 14,21 & 11,47 & 9,47 & 6,75 & 5,17 & 3,51 \\
\hline 43,96 & 1237,90 & 49,70 & 39,40 & 34,42 & 31,65 & 28,12 & 24,87 & 21,91 & 17,00 & 13,35 & 8,78 \\
\hline 68,60 & 1557,70 & 64,00 & 23,45 & 18,51 & 17,42 & 16,14 & 14,94 & 13,80 & 11,71 & 9,93 & 7,21 \\
\hline 88,12 & 1702,30 & 97,10 & 15,32 & 11,28 & 10,36 & 9,60 & 8,93 & 8,32 & 7,21 & 6,24 & 4,70 \\
\hline 29,31 & 1545,70 & 40,10 & 57,98 & 52,31 & 47,17 & 40,50 & 34,47 & 29,27 & 21,32 & 16,04 & 10,32 \\
\hline 29,75 & 1901,10 & 101,80 & 28,83 & 24,43 & 21,23 & 17,38 & 14,19 & 11,64 & 8,11 & 6,03 & 3,97 \\
\hline 72,53 & 580,00 & 98,70 & 27,60 & 19,12 & 16,34 & 13,95 & 12,16 & 10,66 & 8,26 & 6,55 & 4,42 \\
\hline 38,32 & 1472,80 & 20,80 & 74,91 & 67,22 & 64,04 & 58,79 & 53,58 & 48,57 & 39,60 & 32,24 & 21,93 \\
\hline 53,75 & 1205,90 & 99,40 & 22,65 & 18,27 & 16,37 & 14,31 & 12,52 & 10,96 & 8,42 & 6,59 & 4,36 \\
\hline 32,40 & 1281,80 & 113,70 & 28,75 & 23,18 & 19,73 & 15,81 & 12,71 & 10,32 & 7,13 & 5,32 & 3,54 \\
\hline 61,33 & 697,50 & 180,00 & 20,24 & 13,32 & 10,91 & 8,88 & 7,40 & 6,24 & 4,55 & 3,49 & 2,33 \\
\hline 51,71 & 1432,20 & 151,60 & 16,89 & 13,28 & 11,68 & 10,00 & 8,59 & 7,39 & 5,53 & 4,26 & 2,80 \\
\hline 56,20 & 1814,30 & 112,80 & 17,36 & 14,22 & 13,00 & 11,60 & 10,36 & 9,22 & 7,31 & 5,85 & 3,94 \\
\hline 20,52 & 423,20 & 194,20 & 35,39 & 20,17 & 13,83 & 9,22 & 6,82 & 5,40 & 3,81 & 2,97 & 2,08 \\
\hline 58,62 & 1654,40 & 88,50 & 20,41 & 16,69 & 15,43 & 13,93 & 12,58 & 11,33 & 9,16 & 7,45 & 5,10 \\
\hline 28,88 & 668,30 & 129,90 & 35,39 & 25,17 & 19,76 & 14,50 & 10,98 & 8,62 & 5,88 & 4,48 & 3,10 \\
\hline 67,83 & 1382,80 & 141,60 & 15,42 & 11,61 & 10,35 & 9,12 & 8,11 & 7,22 & 5,74 & 4,61 & 3,14 \\
\hline 72,09 & 1942,60 & 60,50 & 21,82 & 17,12 & 16,20 & 15,27 & 14,32 & 13,40 & 11,66 & 10,11 & 7,61 \\
\hline 41,02 & 1185,00 & 180,80 & 19,01 & 14,27 & 12,01 & 9,66 & 7,84 & 6,42 & 4,50 & 3,38 & 2,25 \\
\hline 54,53 & 1481,30 & 166,50 & 15,32 & 11,87 & 10,42 & 8,95 & 7,72 & 6,66 & 5,02 & 3,89 & 2,56 \\
\hline 49,91 & 559,10 & 182,50 & 24,42 & 15,55 & 12,35 & 9,59 & 7,67 & 6,25 & 4,38 & 3,32 & 2,24 \\
\hline 45,42 & 998,40 & 53,40 & 39,72 & 33,97 & 30,86 & 27,11 & 23,72 & 20,71 & 15,84 & 12,32 & 8,07 \\
\hline 72,70 & 959,60 & 58,00 & 29,04 & 22,32 & 20,62 & 18,82 & 17,24 & 15,79 & 13,20 & 11,06 & 7,90 \\
\hline 87,28 & 960,00 & 193,00 & 14,54 & 9,41 & 7,88 & 6,68 & 5,86 & 5,19 & 4,11 & 3,32 & 2,30 \\
\hline 40,88 & 1410,10 & 147,30 & 20,06 & 15,98 & 13,82 & 11,44 & 9,48 & 7,90 & 5,63 & 4,24 & 2,78 \\
\hline 57,32 & 293,20 & 164,10 & 35,77 & 19,60 & 14,51 & 10,77 & 8,46 & 6,85 & 4,78 & 3,65 & 2,51 \\
\hline 88,99 & 1639,60 & 180,70 & 11,12 & 7,75 & 6,86 & 6,10 & 5,53 & 5,03 & 4,18 & 3,50 & 2,51 \\
\hline 56,41 & 1443,00 & 95,40 & 20,98 & 17,10 & 15,58 & 13,86 & 12,34 & 10,97 & 8,66 & 6,91 & 4,64 \\
\hline
\end{tabular}




\begin{tabular}{|c|c|c|c|c|c|c|c|c|c|c|c|}
\hline \multirow[b]{2}{*}{ e1 (cm) } & & & & & & & ões (x1 & m) & & & \\
\hline & Meq (MPa) & Ms (MPa) & D0 & D25 & D40 & D60 & D80 & D100 & D140 & D180 & D260 \\
\hline 31,69 & 607,60 & 115,60 & 37,51 & 26,95 & 21,53 & 16,15 & 12,41 & 9,81 & 6,69 & 5,07 & 3,48 \\
\hline 49,82 & 408,80 & 187,80 & 28,58 & 16,70 & 12,69 & 9,51 & 7,46 & 6,01 & 4,17 & 3,17 & 2,18 \\
\hline 59,84 & 1003,50 & 155,50 & 18,14 & 13,21 & 11,36 & 9,62 & 8,25 & 7,10 & 5,33 & 4,13 & 2,74 \\
\hline 33,71 & 501,00 & 54,30 & 62,86 & 49,48 & 41,74 & 33,21 & 26,56 & 21,50 & 14,84 & 11,09 & 7,42 \\
\hline 32,90 & 279,60 & 142,10 & 44,06 & 25,41 & 18,47 & 12,95 & 9,71 & 7,65 & 5,29 & 4,08 & 2,86 \\
\hline 80,72 & 1813,60 & 188,50 & 10,79 & 7,76 & 6,91 & 6,15 & 5,55 & 5,02 & 4,12 & 3,41 & 2,40 \\
\hline 58,80 & 280,30 & 181,90 & 35,39 & 18,59 & 13,44 & 9,79 & 7,63 & 6,15 & 4,29 & 3,28 & 2,27 \\
\hline 56,51 & 1795,80 & 105,90 & 18,07 & 14,83 & 13,61 & 12,18 & 10,91 & 9,74 & 7,77 & 6,24 & 4,21 \\
\hline 30,77 & 1463,10 & 113,40 & 28,58 & 23,32 & 19,88 & 15,93 & 12,79 & 10,37 & 7,15 & 5,32 & 3,55 \\
\hline 49,75 & 291,70 & 92,50 & 47,50 & 30,47 & 24,27 & 18,90 & 15,13 & 12,34 & 8,64 & 6,55 & 4,42 \\
\hline 53,36 & 843,30 & 166,30 & 20,18 & 14,26 & 11,96 & 9,81 & 8,16 & 6,85 & 4,95 & 3,77 & 2,50 \\
\hline 36,45 & 1008,20 & 161,70 & 23,25 & 17,30 & 14,31 & 11,21 & 8,88 & 7,16 & 4,93 & 3,70 & 2,50 \\
\hline 60,32 & 1347,40 & 136,20 & 16,90 & 13,07 & 11,61 & 10,14 & 8,91 & 7,83 & 6,08 & 4,80 & 3,20 \\
\hline 82,08 & 743,70 & 156,70 & 18,76 & 12,21 & 10,20 & 8,60 & 7,48 & 6,57 & 5,13 & 4,10 & 2,80 \\
\hline 27,95 & 1071,70 & 143,10 & 28,97 & 21,80 & 17,56 & 13,19 & 10,09 & 7,95 & 5,40 & 4,08 & 2,80 \\
\hline 41,59 & 682,40 & 32,90 & 66,16 & 57,41 & 52,05 & 45,46 & 39,51 & 34,26 & 25,87 & 19,94 & 12,97 \\
\hline 24,28 & 412,40 & 51,70 & 85,95 & 64,11 & 50,52 & 36,89 & 27,71 & 21,61 & 14,70 & 11,21 & 7,75 \\
\hline 27,74 & 308,80 & 133,00 & 46,26 & 27,72 & 20,05 & 13,85 & 10,28 & 8,08 & 5,61 & 4,35 & 3,04 \\
\hline 28,02 & 675,80 & 74,30 & 52,33 & 40,48 & 33,13 & 25,28 & 19,55 & 15,47 & 10,50 & 7,91 & 5,39 \\
\hline 21,02 & 1907,40 & 44,30 & 67,74 & 58,98 & 51,14 & 41,42 & 33,35 & 27,00 & 18,47 & 13,65 & 9,03 \\
\hline 85,06 & 397,00 & 118,60 & 30,40 & 18,40 & 14,75 & 12,03 & 10,25 & 8,87 & 6,79 & 5,37 & 3,66 \\
\hline 69,72 & 250,10 & 194,00 & 37,01 & 18,38 & 12,87 & 9,18 & 7,12 & 5,75 & 4,02 & 3,09 & 2,15 \\
\hline 52,15 & 480,70 & 104,30 & 34,08 & 23,67 & 19,66 & 15,95 & 13,15 & 10,95 & 7,85 & 5,95 & 3,96 \\
\hline 81,01 & 1852,10 & 33,60 & 29,13 & 23,82 & 22,01 & 21,27 & 20,46 & 19,56 & 17,76 & 16,06 & 13,01 \\
\hline 56,42 & 374,10 & 150,50 & 32,02 & 19,16 & 14,87 & 11,47 & 9,20 & 7,53 & 5,31 & 4,04 & 2,74 \\
\hline 38,69 & 539,20 & 139,70 & 31,67 & 21,52 & 17,17 & 13,07 & 10,20 & 8,15 & 5,61 & 4,24 & 2,90 \\
\hline 62,07 & 926,90 & 115,90 & 21,57 & 16,15 & 14,14 & 12,21 & 10,64 & 9,30 & 7,14 & 5,61 & 3,74 \\
\hline 27,45 & 1760,10 & 77,20 & 37,94 & 32,49 & 28,25 & 23,09 & 18,80 & 15,38 & 10,67 & 7,92 & 5,21 \\
\hline 34,33 & 685,30 & 122,00 & 33,18 & 24,21 & 19,69 & 15,11 & 11,79 & 9,40 & 6,44 & 4,85 & 3,30 \\
\hline 60,77 & 1511,20 & 146,40 & 15,37 & 11,92 & 10,63 & 9,32 & 8,21 & 7,24 & 5,64 & 4,47 & 2,99 \\
\hline 66,58 & 219,10 & 196,00 & 40,77 & 19,55 & 13,34 & 9,27 & 7,08 & 5,67 & 3,93 & 3,03 & 2,12 \\
\hline 87,76 & 1244,00 & 20,50 & 42,15 & 36,02 & 32,67 & 31,49 & 30,56 & 29,41 & 27,04 & 24,76 & 20,58 \\
\hline 40,94 & 1740,20 & 36,20 & 45,97 & 41,09 & 38,73 & 35,22 & 31,82 & 28,61 & 22,99 & 18,50 & 12,43 \\
\hline 76,35 & 213,40 & 133,70 & 45,63 & 23,75 & 17,21 & 12,73 & 10,13 & 8,32 & 5,94 & 4,57 & 3,14 \\
\hline 32,59 & 414,10 & 31,30 & 98,25 & 80,81 & 69,56 & 56,52 & 45,92 & 37,56 & 26,15 & 19,49 & 12,89 \\
\hline 82,44 & 1860,70 & 129,80 & 12,94 & 9,55 & 8,73 & 7,96 & 7,32 & 6,74 & 5,71 & 4,84 & 3,53 \\
\hline 34,79 & 253,00 & 113,50 & 51,46 & 30,72 & 22,81 & 16,28 & 12,28 & 9,68 & 6,67 & 5,13 & 3,58 \\
\hline 86,23 & 986,20 & 186,70 & 14,57 & 9,54 & 8,05 & 6,86 & 6,03 & 5,35 & 4,25 & 3,44 & 2,38 \\
\hline 50,27 & 360,70 & 168,40 & 32,10 & 18,66 & 14,15 & 10,60 & 8,31 & 6,70 & 4,65 & 3,54 & 2,43 \\
\hline 80,03 & 558,80 & 45,80 & 39,93 & 29,36 & 26,61 & 24,02 & 21,90 & 19,99 & 16,65 & 13,93 & 9,96 \\
\hline 21,82 & 1246,80 & 96,60 & 43,05 & 33,55 & 26,89 & 19,89 & 15,00 & 11,68 & 7,90 & 6,00 & 4,14 \\
\hline 83,70 & 541,00 & 95,00 & 27,70 & 18,49 & 15,73 & 13,48 & 11,87 & 10,54 & 8,37 & 6,77 & 4,67 \\
\hline 87,56 & 557,40 & 150,60 & 22,29 & 13,68 & 11,09 & 9,14 & 7,86 & 6,86 & 5,31 & 4,24 & 2,90 \\
\hline 24,06 & 1259,80 & 196,30 & 24,25 & 17,49 & 13,51 & 9,68 & 7,21 & 5,62 & 3,84 & 2,95 & 2,04 \\
\hline 73,09 & 1244,80 & 87,80 & 20,38 & 15,52 & 14,21 & 12,86 & 11,72 & 10,68 & 8,84 & 7,35 & 5,19 \\
\hline 62,74 & 1365,80 & 75,90 & 23,24 & 18,65 & 17,26 & 15,64 & 14,20 & 12,86 & 10,52 & 8,63 & 5,99 \\
\hline 77,71 & 1079,80 & 40,50 & 33,30 & 25,65 & 24,06 & 22,61 & 21,18 & 19,81 & 17,26 & 14,99 & 11,33 \\
\hline 49,20 & 1061,70 & 53,40 & 36,81 & 31,29 & 28,70 & 25,54 & 22,66 & 20,05 & 15,69 & 12,41 & 8,23 \\
\hline 76,39 & 1329,00 & 196,80 & 12,61 & 8,82 & 7,63 & 6,61 & 5,83 & 5,17 & 4,09 & 3,29 & 2,25 \\
\hline 69,03 & 1940,10 & 71,50 & 20,13 & 15,89 & 15,01 & 13,99 & 13,01 & 12,06 & 10,32 & 8,81 & 6,47 \\
\hline 39,01 & 1818,50 & 94,50 & 24,80 & 21,42 & 19,23 & 16,56 & 14,19 & 12,15 & 8,98 & 6,84 & 4,43 \\
\hline 40,62 & 1215,40 & 54,40 & 39,62 & 34,61 & 31,42 & 27,47 & 23,89 & 20,72 & 15,65 & 12,06 & 7,84 \\
\hline 63,80 & 1848,30 & 190,80 & 11,83 & 9,03 & 8,03 & 7,03 & 6,21 & 5,49 & 4,31 & 3,43 & 2,31 \\
\hline 75,52 & 996,80 & 161,40 & 16,18 & 11,20 & 9,62 & 8,26 & 7,25 & 6,39 & 5,01 & 4,01 & 2,73 \\
\hline 82,89 & 1287,10 & 155,20 & 13,94 & 9,80 & 8,63 & 7,61 & 6,83 & 6,16 & 5,02 & 4,14 & 2,91 \\
\hline 21,31 & 1631,60 & 124,20 & 33,89 & 26,35 & 21,04 & 15,49 & 11,65 & 9,06 & 6,13 & 4,66 & 3,22 \\
\hline 51,41 & 263,60 & 184,40 & 37,21 & 19,28 & 13,74 & 9,81 & 7,53 & 6,02 & 4,16 & 3,20 & 2,23 \\
\hline 37,07 & 1324,50 & 156,80 & 21,12 & 16,49 & 13,99 & 11,26 & 9,11 & 7,45 & 5,19 & 3,89 & 2,58 \\
\hline 85,10 & 628,30 & 186,30 & 19,25 & 11,67 & 9,37 & 7,64 & 6,52 & 5,64 & 4,32 & 3,42 & 2,33 \\
\hline 85,20 & 1661,90 & 96,60 & 15,81 & 11,71 & 10,77 & 9,95 & 9,24 & 8,58 & 7,38 & 6,35 & 4,74 \\
\hline 88,95 & 1789,30 & 50,40 & 21,65 & 16,98 & 15,63 & 14,95 & 14,27 & 13,56 & 12,20 & 10,95 & 8,76 \\
\hline 36,31 & 886,50 & 75,60 & 39,29 & 32,07 & 27,76 & 22,83 & 18,77 & 15,52 & 10,95 & 8,19 & 5,38 \\
\hline 50,04 & 695,40 & 69,10 & 36,79 & 29,25 & 25,79 & 22,09 & 18,95 & 16,28 & 12,15 & 9,34 & 6,12 \\
\hline 87,51 & 587,60 & 90,80 & 26,60 & 17,88 & 15,38 & 13,34 & 11,87 & 10,64 & 8,60 & 7,05 & 4,94 \\
\hline 53,35 & 1177,10 & 59,30 & 31,50 & 26,38 & 24,33 & 21,83 & 19,56 & 17,48 & 13,92 & 11,16 & 7,52 \\
\hline 77,05 & 1851,70 & 140,10 & 12,83 & 9,58 & 8,74 & 7,90 & 7,21 & 6,58 & 5,48 & 4,57 & 3,26 \\
\hline 27,50 & 978,30 & 159,50 & 27,97 & 20,38 & 16,10 & 11,85 & 8,97 & 7,03 & 4,79 & 3,65 & 2,52 \\
\hline 55,38 & 1442,00 & 93,30 & 21,51 & 17,62 & 16,06 & 14,28 & 12,70 & 11,27 & 8,88 & 7,07 & 4,74 \\
\hline 67,21 & 1309,70 & 22,90 & 49,48 & 39,81 & 37,88 & 36,41 & 34,58 & 32,70 & 29,08 & 25,71 & 19,98 \\
\hline 44,75 & 1407,40 & 134,40 & 19,98 & 16,08 & 14,11 & 11,92 & 10,08 & 8,54 & 6,24 & 4,74 & 3,10 \\
\hline 61,21 & 375,50 & 65,60 & 45,18 & 32,12 & 27,35 & 23,00 & 19,64 & 16,86 & 12,61 & 9,76 & 6,48 \\
\hline 40,48 & 273,00 & 102,30 & 50,15 & 31,27 & 24,08 & 17,89 & 13,81 & 10,99 & 7,57 & 5,76 & 3,97 \\
\hline 50,06 & 1663,20 & 29,70 & 46,97 & 39,76 & 38,29 & 35,78 & 33,19 & 30,66 & 25,96 & 21,89 & 15,67 \\
\hline 76,11 & 1748,50 & 64,10 & 21,14 & 16,35 & 15,38 & 14,45 & 13,52 & 12,64 & 10,99 & 9,53 & 7,18 \\
\hline 38,81 & 1049,10 & 114,50 & 27,18 & 21,50 & 18,44 & 15,07 & 12,35 & 10,19 & 7,19 & 5,38 & 3,56 \\
\hline 29,78 & 938,40 & 158,20 & 27,23 & 19,89 & 15,89 & 11,88 & 9,09 & 7,16 & 4,88 & 3,70 & 2,54 \\
\hline 45,72 & 1300,00 & 86,10 & 26,58 & 22,30 & 20,03 & 17,39 & 15,06 & 13,03 & 9,82 & 7,57 & 4,94 \\
\hline 56,45 & 1945,40 & 89,90 & 19,47 & 16,15 & 15,02 & 13,61 & 12,32 & 11,11 & 9,02 & 7,34 & 5,03 \\
\hline 63,92 & 1037,10 & 119,90 & 19,81 & 14,90 & 13,14 & 11,44 & 10,05 & 8,84 & 6,87 & 5,44 & 3,65 \\
\hline 46,23 & 1129,10 & 171,60 & 18,66 & 13,98 & 11,89 & 9,76 & 8,07 & 6,72 & 4,81 & 3,63 & 2,40 \\
\hline 39,08 & 1654,30 & 46,60 & 40,61 & 36,44 & 33,71 & 30,06 & 26,63 & 23,48 & 18,22 & 14,29 & 9,36 \\
\hline 25,42 & 1456,70 & 102,00 & 35,44 & 28,62 & 23,82 & 18,43 & 14,36 & 11,39 & 7,72 & 5,78 & 3,92 \\
\hline
\end{tabular}




\begin{tabular}{|c|c|c|c|c|c|c|c|c|c|c|c|}
\hline \multirow[b]{2}{*}{ e1 (cm) } & & & & & & & ões (x1 & m) & & & \\
\hline & Meq (MPa) & Ms (MPa) & D0 & D25 & D40 & D60 & D80 & D100 & D140 & D180 & D260 \\
\hline 35,67 & 481,90 & 31,90 & 86,00 & 72,28 & 63,44 & 52,97 & 44,09 & 36,80 & 26,25 & 19,66 & 12,83 \\
\hline 86,92 & 354,70 & 52,50 & 45,02 & 30,50 & 26,33 & 22,91 & 20,42 & 18,33 & 14,85 & 12,19 & 8,54 \\
\hline 62,62 & 1870,20 & 167,90 & 12,76 & 9,92 & 8,91 & 7,86 & 6,98 & 6,19 & 4,89 & 3,91 & 2,63 \\
\hline 57,71 & 914,10 & 42,70 & 40,62 & 33,50 & 31,17 & 28,29 & 25,65 & 23,20 & 18,89 & 15,43 & 10,62 \\
\hline 64,37 & 1628,80 & 128,70 & 15,54 & 12,14 & 11,00 & 9,81 & 8,79 & 7,87 & 6,30 & 5,09 & 3,48 \\
\hline 85,20 & 877,60 & 193,10 & 15,44 & 9,89 & 8,21 & 6,91 & 6,01 & 5,28 & 4,14 & 3,32 & 2,28 \\
\hline 53,51 & 517,50 & 193,20 & 24,25 & 14,86 & 11,63 & 8,99 & 7,20 & 5,88 & 4,13 & 3,14 & 2,13 \\
\hline 42,25 & 877,80 & 132,20 & 25,41 & 19,12 & 16,15 & 13,07 & 10,66 & 8,77 & 6,18 & 4,64 & 3,08 \\
\hline 43,47 & 672,50 & 139,00 & 27,28 & 19,36 & 15,96 & 12,65 & 10,17 & 8,30 & 5,80 & 4,37 & 2,93 \\
\hline 39,43 & 736,70 & 135,90 & 27,97 & 20,31 & 16,76 & 13,18 & 10,50 & 8,50 & 5,89 & 4,43 & 2,98 \\
\hline 23,87 & 1082,00 & 40,90 & 76,65 & 65,28 & 56,06 & 44,97 & 35,97 & 29,00 & 19,82 & 14,69 & 9,78 \\
\hline 22,73 & 1911,70 & 49,90 & 58,27 & 50,89 & 44,36 & 36,23 & 29,40 & 23,96 & 16,51 & 12,21 & 8,04 \\
\hline 46,86 & 996,10 & 56,70 & 37,49 & 31,81 & 28,87 & 25,37 & 22,23 & 19,43 & 14,90 & 11,61 & 7,62 \\
\hline 44,36 & 1777,50 & 23,70 & 58,70 & 50,61 & 48,90 & 45,69 & 42,34 & 39,06 & 32,96 & 27,67 & 19,66 \\
\hline 53,36 & 1625,30 & 79,40 & 23,27 & 19,51 & 18,03 & 16,20 & 14,54 & 13,01 & 10,39 & 8,35 & 5,63 \\
\hline 59,59 & 699,80 & 32,10 & 52,69 & 43,11 & 40,23 & 36,65 & 33,36 & 30,29 & 24,86 & 20,45 & 14,19 \\
\hline 74,68 & 1675,90 & 107,60 & 15,82 & 12,04 & 11,08 & 10,10 & 9,25 & 8,47 & 7,09 & 5,94 & 4,25 \\
\hline 56,77 & 1870,30 & 50,30 & 28,95 & 23,99 & 22,89 & 21,27 & 19,67 & 18,13 & 15,29 & 12,87 & 9,20 \\
\hline 88,09 & 216,50 & 71,60 & 53,40 & 31,48 & 24,88 & 20,07 & 17,02 & 14,69 & 11,21 & 8,87 & 6,06 \\
\hline 83,17 & 1871,60 & 39,60 & 25,78 & 20,77 & 19,20 & 18,49 & 17,74 & 16,91 & 15,30 & 13,79 & 11,11 \\
\hline 28,38 & 1900,70 & 50,70 & 47,60 & 42,74 & 38,34 & 32,68 & 27,61 & 23,30 & 16,80 & 12,58 & 8,11 \\
\hline 64,85 & 487,00 & 27,10 & 63,97 & 50,89 & 47,15 & 42,85 & 39,02 & 35,46 & 29,19 & 24,10 & 16,84 \\
\hline 36,21 & 609,00 & 56,80 & 54,15 & 43,67 & 37,57 & 30,67 & 25,07 & 20,63 & 14,48 & 10,83 & 7,15 \\
\hline 59,33 & 771,10 & 140,90 & 21,83 & 15,46 & 13,10 & 10,95 & 9,29 & 7,92 & 5,87 & 4,52 & 3,00 \\
\hline 79,63 & 1843,80 & 127,00 & 13,37 & 9,96 & 9,13 & 8,32 & 7,63 & 7,01 & 5,90 & 4,98 & 3,60 \\
\hline 24,72 & 1228,50 & 178,80 & 25,68 & 18,79 & 14,68 & 10,64 & 7,97 & 6,21 & 4,24 & 3,24 & 2,24 \\
\hline 63,03 & 1747,40 & 107,60 & 17,00 & 13,56 & 12,48 & 11,25 & 10,17 & 9,18 & 7,46 & 6,09 & 4,20 \\
\hline 85,29 & 1989,30 & 97,20 & 14,59 & 10,92 & 10,10 & 9,42 & 8,80 & 8,22 & 7,15 & 6,21 & 4,70 \\
\hline 65,07 & 637,30 & 52,10 & 38,74 & 30,11 & 27,23 & 24,25 & 21,71 & 19,43 & 15,56 & 12,58 & 8,59 \\
\hline 55,76 & 626,80 & 75,40 & 34,44 & 26,36 & 23,06 & 19,75 & 17,02 & 14,70 & 11,07 & 8,58 & 5,66 \\
\hline 21,74 & 1773,40 & 59,00 & 55,23 & 46,88 & 39,96 & 31,69 & 25,09 & 20,07 & 13,61 & 10,09 & 6,77 \\
\hline 67,61 & 499,30 & 42,10 & 47,67 & 36,60 & 33,08 & 29,48 & 26,46 & 23,75 & 19,13 & 15,54 & 10,67 \\
\hline 71,43 & 1910,90 & 152,30 & 12,51 & 9,51 & 8,64 & 7,75 & 7,01 & 6,34 & 5,18 & 4,26 & 2,97 \\
\hline 62,64 & 324,80 & 192,90 & 31,21 & 16,72 & 12,26 & 9,07 & 7,15 & 5,82 & 4,08 & 3,12 & 2,15 \\
\hline 47,67 & 766,90 & 120,00 & 26,57 & 19,77 & 16,81 & 13,83 & 11,47 & 9,58 & 6,88 & 5,20 & 3,44 \\
\hline 32,83 & 473,40 & 162,80 & 32,71 & 20,86 & 15,84 & 11,42 & 8,63 & 6,79 & 4,66 & 3,57 & 2,48 \\
\hline 25,94 & 1650,50 & 121,20 & 29,83 & 24,03 & 20,00 & 15,50 & 12,09 & 9,60 & 6,51 & 4,87 & 3,30 \\
\hline 80,36 & 900,50 & 21,10 & 51,96 & 41,18 & 38,40 & 36,87 & 35,15 & 33,37 & 29,93 & 26,73 & 21,19 \\
\hline 52,38 & 1962,40 & 99,20 & 19,07 & 16,02 & 14,76 & 13,22 & 11,81 & 10,53 & 8,35 & 6,68 & 4,48 \\
\hline 45,42 & 1533,80 & 108,40 & 21,74 & 18,13 & 16,22 & 14,01 & 12,08 & 10,41 & 7,79 & 5,99 & 3,90 \\
\hline 35,38 & 1391,30 & 166,30 & 20,60 & 16,03 & 13,52 & 10,77 & 8,64 & 7,01 & 4,86 & 3,63 & 2,43 \\
\hline 32,53 & 1828,20 & 91,20 & 29,22 & 25,15 & 22,20 & 18,59 & 15,49 & 12,93 & 9,21 & 6,88 & 4,48 \\
\hline 83,35 & 1075,70 & 32,20 & 36,55 & 28,37 & 26,42 & 25,17 & 23,87 & 22,57 & 20,09 & 17,82 & 13,97 \\
\hline 86,70 & 805,10 & 77,60 & 24,52 & 17,43 & 15,59 & 13,98 & 12,72 & 11,62 & 9,71 & 8,15 & 5,87 \\
\hline 28,66 & 1107,40 & 176,90 & 24,46 & 17,96 & 14,32 & 10,66 & 8,12 & 6,39 & 4,35 & 3,30 & 2,27 \\
\hline 30,32 & 1101,00 & 167,70 & 24,55 & 18,25 & 14,75 & 11,16 & 8,60 & 6,80 & 4,63 & 3,50 & 2,40 \\
\hline 66,80 & 1170,70 & 152,70 & 16,13 & 11,84 & 10,35 & 8,96 & 7,86 & 6,91 & 5,38 & 4,26 & 2,86 \\
\hline 37,05 & 1265,50 & 156,60 & 21,51 & 16,69 & 14,11 & 11,32 & 9,14 & 7,45 & 5,18 & 3,88 & 2,59 \\
\hline 89,11 & 1383,50 & 155,20 & 13,06 & 9,08 & 8,02 & 7,13 & 6,46 & 5,87 & 4,88 & 4,08 & 2,92 \\
\hline 37,25 & 1295,00 & 196,50 & 18,49 & 13,89 & 11,57 & 9,14 & 7,29 & 5,90 & 4,09 & 3,06 & 2,06 \\
\hline 54,02 & 1512,60 & 91,60 & 21,67 & 17,92 & 16,37 & 14,57 & 12,96 & 11,51 & 9,06 & 7,21 & 4,82 \\
\hline 89,44 & 735,80 & 134,10 & 19,62 & 12,81 & 10,84 & 9,28 & 8,19 & 7,30 & 5,85 & 4,77 & 3,33 \\
\hline 61,69 & 735,40 & 43,30 & 42,01 & 33,78 & 31,13 & 28,10 & 25,40 & 22,91 & 18,60 & 15,17 & 10,44 \\
\hline 37,99 & 830,10 & 44,40 & 54,43 & 46,88 & 41,91 & 35,88 & 30,57 & 26,03 & 19,09 & 14,47 & 9,38 \\
\hline 40,24 & 736,30 & 49,60 & 50,84 & 42,78 & 37,97 & 32,32 & 27,43 & 23,28 & 17,02 & 12,90 & 8,38 \\
\hline 34,90 & 653,10 & 59,10 & 52,80 & 42,67 & 36,62 & 29,75 & 24,20 & 19,84 & 13,86 & 10,35 & 6,85 \\
\hline 81,00 & 1126,00 & 176,00 & 14,19 & 9,71 & 8,36 & 7,22 & 6,39 & 5,68 & 4,53 & 3,66 & 2,53 \\
\hline 26,90 & 625,50 & 104,10 & 43,71 & 31,68 & 24,88 & 18,20 & 13,72 & 10,74 & 7,32 & 5,58 & 3,86 \\
\hline 46,49 & 1911,30 & 118,10 & 18,66 & 15,74 & 14,21 & 12,42 & 10,82 & 9,41 & 7,16 & 5,55 & 3,63 \\
\hline 66,80 & 714,80 & 130,50 & 22,39 & 15,57 & 13,22 & 11,16 & 9,61 & 8,31 & 6,31 & 4,93 & 3,29 \\
\hline 30,06 & 1720,50 & 81,10 & 34,36 & 29,53 & 25,89 & 21,44 & 17,68 & 14,61 & 10,28 & 7,65 & 5,00 \\
\hline 55,26 & 1474,30 & 151,00 & 16,09 & 12,60 & 11,15 & 9,64 & 8,37 & 7,27 & 5,53 & 4,31 & 2,84 \\
\hline 34,44 & 287,40 & 126,90 & 45,82 & 27,47 & 20,41 & 14,56 & 10,98 & 8,65 & 5,96 & 4,58 & 3,20 \\
\hline 63,92 & 1062,60 & 103,90 & 21,19 & 16,26 & 14,51 & 12,77 & 11,31 & 10,03 & 7,89 & 6,30 & 4,25 \\
\hline 20,97 & 1182,50 & 160,30 & 31,00 & 22,28 & 16,90 & 11,86 & 8,73 & 6,78 & 4,66 & 3,60 & 2,50 \\
\hline 44,27 & 1540,70 & 110,40 & 21,85 & 18,22 & 16,25 & 13,97 & 11,99 & 10,29 & 7,65 & 5,85 & 3,81 \\
\hline 82,55 & 999,50 & 58,80 & 26,54 & 19,77 & 18,23 & 16,80 & 15,55 & 14,40 & 12,32 & 10,55 & 7,80 \\
\hline 53,53 & 417,50 & 105,30 & 36,04 & 24,20 & 19,81 & 15,92 & 13,06 & 10,83 & 7,74 & 5,87 & 3,92 \\
\hline 44,09 & 1221,80 & 166,50 & 18,86 & 14,41 & 12,32 & 10,12 & 8,36 & 6,95 & 4,96 & 3,73 & 2,46 \\
\hline 46,38 & 1389,10 & 152,20 & 18,25 & 14,39 & 12,54 & 10,55 & 8,90 & 7,53 & 5,49 & 4,17 & 2,73 \\
\hline 67,87 & 1688,10 & 106,10 & 16,71 & 13,06 & 12,03 & 10,90 & 9,92 & 9,01 & 7,42 & 6,13 & 4,29 \\
\hline 38,56 & 615,80 & 186,60 & 25,41 & 16,69 & 13,10 & 9,83 & 7,61 & 6,06 & 4,17 & 3,16 & 2,17 \\
\hline 25,98 & 708,70 & 164,20 & 31,30 & 21,33 & 16,17 & 11,46 & 8,52 & 6,66 & 4,58 & 3,52 & 2,45 \\
\hline 63,68 & 458,10 & 46,00 & 48,53 & 37,15 & 33,10 & 29,06 & 25,70 & 22,74 & 17,86 & 14,23 & 9,58 \\
\hline 43,00 & 297,80 & 113,20 & 44,73 & 27,71 & 21,41 & 16,04 & 12,47 & 9,97 & 6,88 & 5,23 & 3,59 \\
\hline 26,24 & 1480,90 & 135,90 & 28,28 & 22,22 & 18,23 & 13,90 & 10,73 & 8,47 & 5,74 & 4,32 & 2,95 \\
\hline 47,59 & 840,00 & 199,60 & 19,41 & 13,32 & 10,91 & 8,67 & 7,02 & 5,75 & 4,05 & 3,06 & 2,05 \\
\hline 41,95 & 512,40 & 51,80 & 55,32 & 44,25 & 38,45 & 32,04 & 26,72 & 22,37 & 16,07 & 12,11 & 7,94 \\
\hline 41,98 & 1144,20 & 187,50 & 18,64 & 13,82 & 11,59 & 9,30 & 7,54 & 6,18 & 4,33 & 3,26 & 2,17 \\
\hline 41,75 & 1183,90 & 169,00 & 19,58 & 14,86 & 12,59 & 10,21 & 8,34 & 6,87 & 4,84 & 3,64 & 2,41 \\
\hline 86,97 & 490,30 & 27,00 & 54,61 & 40,41 & 37,20 & 34,50 & 32,12 & 29,93 & 25,92 & 22,43 & 16,89 \\
\hline 65,62 & 202,30 & 96,30 & 53,62 & 30,29 & 22,96 & 17,55 & 14,14 & 11,66 & 8,31 & 6,36 & 4,32 \\
\hline
\end{tabular}




\begin{tabular}{|c|c|c|c|c|c|c|c|c|c|c|c|}
\hline \multirow[b]{2}{*}{ e1 (cm) } & & & & & & & ões (x1 & & & & \\
\hline & Meq (MPa) & Ms (MPa) & D0 & D25 & D40 & D60 & D80 & D100 & D140 & D180 & D260 \\
\hline 23,43 & 472,40 & 53,20 & 82,81 & 62,32 & 49,19 & 35,91 & 26,94 & 20,99 & 14,26 & 10,88 & 7,52 \\
\hline 39,92 & 1690,80 & 57,00 & 34,69 & 30,85 & 28,36 & 25,13 & 22,12 & 19,40 & 14,92 & 11,62 & 7,59 \\
\hline 33,66 & 1566,00 & 115,40 & 25,80 & 21,34 & 18,48 & 15,14 & 12,39 & 10,20 & 7,15 & 5,33 & 3,51 \\
\hline 33,82 & 1566,00 & 105,50 & 27,24 & 22,77 & 19,84 & 16,38 & 13,49 & 11,16 & 7,87 & 5,87 & 3,85 \\
\hline 33,75 & 6993,90 & 145,90 & 29,81 & 21,09 & 16,86 & 12,72 & 9,82 & 7,79 & 5,32 & 4,03 & 2,76 \\
\hline 71,86 & 532,90 & 75,70 & 32,89 & 23,47 & 20,39 & 17,64 & 15,52 & 13,70 & 10,74 & 8,58 & 5,82 \\
\hline 77,89 & 1431,30 & 119,40 & 15,63 & 11,56 & 10,47 & 9,42 & 8,57 & 7,80 & 6,46 & 5,37 & 3,81 \\
\hline 77,02 & 1609,00 & 128,30 & 14,33 & 10,67 & 9,69 & 8,74 & 7,96 & 7,25 & 6,01 & 5,00 & 3,55 \\
\hline 25,77 & 711,10 & 187,40 & 28,67 & 19,05 & 14,25 & 10,00 & 7,41 & 5,79 & 4,00 & 3,09 & 2,15 \\
\hline 61,25 & 1619,70 & 95,20 & 19,17 & 15,44 & 14,23 & 12,83 & 11,59 & 10,45 & 8,47 & 6,90 & 4,74 \\
\hline 81,28 & 1976,90 & 160,80 & 11,25 & 8,25 & 7,47 & 6,75 & 6,17 & 5,64 & 4,71 & 3,95 & 2,84 \\
\hline 53,81 & 1765,80 & 54,00 & 29,02 & 24,44 & 23,14 & 21,28 & 19,49 & 17,79 & 14,72 & 12,17 & 8,49 \\
\hline 58,65 & 1849,10 & 171,00 & 13,14 & 10,32 & 9,22 & 8,07 & 7,10 & 6,25 & 4,85 & 3,83 & 2,55 \\
\hline 45,78 & 701,70 & 77,50 & 36,26 & 28,58 & 24,87 & 20,87 & 17,57 & 14,83 & 10,78 & 8,18 & 5,36 \\
\hline 72,24 & 520,20 & 105,00 & 28,51 & 19,20 & 16,14 & 13,58 & 11,72 & 10,18 & 7,79 & 6,13 & 4,12 \\
\hline 36,11 & 609,40 & 186,20 & 26,25 & 17,22 & 13,40 & 9,93 & 7,62 & 6,03 & 4,14 & 3,15 & 2,17 \\
\hline 75,00 & 789,30 & 179,00 & 17,64 & 11,54 & 9,58 & 8,00 & 6,87 & 5,96 & 4,55 & 3,58 & 2,42 \\
\hline 21,24 & 787,30 & 117,40 & 43,08 & 30,60 & 23,09 & 16,15 & 11,88 & 9,23 & 6,36 & 4,91 & 3,42 \\
\hline 40,50 & 776,00 & 190,50 & 22,22 & 15,26 & 12,30 & 9,48 & 7,47 & 6,01 & 4,15 & 3,13 & 2,13 \\
\hline 63,20 & 565,10 & 101,00 & 29,28 & 20,64 & 17,54 & 14,77 & 12,65 & 10,88 & 8,18 & 6,35 & 4,22 \\
\hline 87,34 & 822,60 & 62,40 & 27,18 & 19,66 & 17,84 & 16,25 & 14,95 & 13,78 & 11,71 & 9,97 & 7,33 \\
\hline 75,27 & 624,50 & 44,60 & 39,74 & 29,99 & 27,44 & 24,87 & 22,70 & 20,73 & 17,24 & 14,38 & 10,23 \\
\hline 53,04 & 1882,20 & 26,40 & 47,44 & 39,27 & 38,02 & 36,10 & 33,90 & 31,72 & 27,54 & 23,77 & 17,67 \\
\hline 60,63 & 401,40 & 85,50 & 38,58 & 26,46 & 22,11 & 18,27 & 15,40 & 13,08 & 9,64 & 7,41 & 4,92 \\
\hline 22,32 & 1998,30 & 65,90 & 48,23 & 41,15 & 35,25 & 28,15 & 22,42 & 18,01 & 12,25 & 9,08 & 6,06 \\
\hline 30,39 & 1514,20 & 116,80 & 27,96 & 22,80 & 19,41 & 15,52 & 12,43 & 10,06 & 6,93 & 5,16 & 3,44 \\
\hline 31,52 & 719,60 & 85,90 & 43,04 & 33,27 & 27,60 & 21,48 & 16,88 & 13,50 & 9,23 & 6,92 & 4,68 \\
\hline 23,62 & 1041,30 & 131,90 & 34,39 & 25,50 & 19,97 & 14,47 & 10,82 & 8,43 & 5,74 & 4,39 & 3,04 \\
\hline 51,77 & 640,00 & 136,20 & 25,94 & 18,10 & 15,06 & 12,22 & 10,08 & 8,39 & 6,01 & 4,56 & 3,03 \\
\hline 84,74 & 460,40 & 98,30 & 29,83 & 19,24 & 16,03 & 13,51 & 11,77 & 10,36 & 8,13 & 6,53 & 4,48 \\
\hline 20,05 & 1639,20 & 66,00 & 55,79 & 45,87 & 38,00 & 29,08 & 22,38 & 17,58 & 11,81 & 8,86 & 6,04 \\
\hline 61,23 & 1578,90 & 147,30 & 14,97 & 11,64 & 10,41 & 9,15 & 8,09 & 7,15 & 5,60 & 4,45 & 2,98 \\
\hline 58,60 & 1951,20 & 142,00 & 14,33 & 11,51 & 10,44 & 9,28 & 8,26 & 7,34 & 5,80 & 4,64 & 3,12 \\
\hline 69,77 & 1972,00 & 98,20 & 16,26 & 12,73 & 11,87 & 10,91 & 10,04 & 9,23 & 7,76 & 6,53 & 4,68 \\
\hline 72,05 & 616,90 & 164,60 & 21,37 & 13,63 & 11,12 & 9,12 & 7,73 & 6,62 & 4,96 & 3,86 & 2,59 \\
\hline 63,79 & 1686,90 & 144,20 & 14,41 & 11,21 & 10,10 & 8,95 & 7,98 & 7,12 & 5,66 & 4,55 & 3,08 \\
\hline 54,72 & 734,00 & 163,40 & 21,58 & 14,84 & 12,32 & 10,03 & 8,32 & 6,96 & 5,02 & 3,82 & 2,54 \\
\hline 46,44 & 722,10 & 43,50 & 50,20 & 42,43 & 38,36 & 33,56 & 29,28 & 25,50 & 19,42 & 15,07 & 9,87 \\
\hline 75,53 & 717,40 & 165,50 & 19,22 & 12,52 & 10,37 & 8,64 & 7,43 & 6,44 & 4,92 & 3,87 & 2,61 \\
\hline 31,02 & 1663,30 & 175,70 & 20,38 & 16,01 & 13,37 & 10,47 & 8,26 & 6,62 & 4,53 & 3,39 & 2,29 \\
\hline 51,87 & 1644,80 & 71,60 & 25,21 & 21,36 & 19,82 & 17,86 & 16,06 & 14,39 & 11,52 & 9,27 & 6,26 \\
\hline 58,71 & 1510,40 & 157,70 & 15,03 & 11,63 & 10,30 & 8,96 & 7,83 & 6,85 & 5,27 & 4,14 & 2,75 \\
\hline 36,40 & 354,40 & 183,00 & 33,63 & 19,31 & 14,15 & 10,06 & 7,59 & 5,99 & 4,13 & 3,18 & 2,22 \\
\hline 44,42 & 237,20 & 40,10 & 85,56 & 62,99 & 52,94 & 42,82 & 34,97 & 28,83 & 20,37 & 15,34 & 10,19 \\
\hline 64,66 & 1994,60 & 76,90 & 19,74 & 15,84 & 14,94 & 13,82 & 12,76 & 11,75 & 9,91 & 8,35 & 6,00 \\
\hline 20,39 & 1575,70 & 84,30 & 46,73 & 37,47 & 30,49 & 22,87 & 17,37 & 13,56 & 9,12 & 6,89 & 4,73 \\
\hline 73,77 & 297,80 & 161,30 & 34,25 & 18,52 & 13,74 & 10,37 & 8,35 & 6,90 & 4,95 & 3,81 & 2,60 \\
\hline 45,95 & 1596,00 & 85,20 & 24,68 & 21,09 & 19,17 & 16,87 & 14,79 & 12,93 & 9,92 & 7,73 & 5,07 \\
\hline 40,15 & 1341,10 & 178,40 & 18,46 & 14,18 & 12,03 & 9,75 & 7,94 & 6,52 & 4,58 & 3,44 & 2,28 \\
\hline 39,70 & 1301,40 & 135,10 & 22,25 & 17,73 & 15,30 & 12,60 & 10,40 & 8,63 & 6,12 & 4,60 & 3,02 \\
\hline 25,71 & 1981,80 & 161,70 & 23,24 & 18,47 & 15,23 & 11,67 & 9,04 & 7,14 & 4,84 & 3,63 & 2,47 \\
\hline 61,69 & 1466,30 & 149,00 & 15,30 & 11,78 & 10,47 & 9,16 & 8,07 & 7,11 & 5,54 & 4,39 & 2,94 \\
\hline 42,85 & 224,00 & 26,40 & 114,10 & 89,26 & 76,91 & 63,59 & 52,75 & 43,99 & 31,45 & 23,69 & 15,58 \\
\hline 33,14 & 521,40 & 90,60 & 45,18 & 33,05 & 26,80 & 20,45 & 15,88 & 12,63 & 8,63 & 6,51 & 4,44 \\
\hline 89,29 & 1707,50 & 39,10 & 25,38 & 20,53 & 18,77 & 18,04 & 17,35 & 16,58 & 15,07 & 13,64 & 11,10 \\
\hline 26,08 & 1703,50 & 155,50 & 24,77 & 19,46 & 15,95 & 12,16 & 9,38 & 7,40 & 5,01 & 3,77 & 2,57 \\
\hline 75,10 & 1054,60 & 142,70 & 16,71 & 11,88 & 10,37 & 9,02 & 7,99 & 7,10 & 5,64 & 4,55 & 3,11 \\
\hline 37,58 & 1796,10 & 100,00 & 24,73 & 21,21 & 18,90 & 16,11 & 13,67 & 11,60 & 8,46 & 6,40 & 4,15 \\
\hline 41,39 & 1591,20 & 189,40 & 16,31 & 12,74 & 10,93 & 8,98 & 7,40 & 6,14 & 4,36 & 3,27 & 2,16 \\
\hline 38,08 & 1565,50 & 20,70 & 74,19 & 66,51 & 63,50 & 58,41 & 53,33 & 48,44 & 39,63 & 32,36 & 22,09 \\
\hline 45,58 & 1384,40 & 31,00 & 51,01 & 44,59 & 42,29 & 38,78 & 35,35 & 32,08 & 26,24 & 21,45 & 14,70 \\
\hline 37,69 & 388,40 & 73,60 & 53,51 & 38,67 & 31,67 & 24,63 & 19,45 & 15,64 & 10,78 & 8,11 & 5,49 \\
\hline 79,62 & 234,40 & 117,20 & 44,08 & 24,10 & 18,06 & 13,81 & 11,25 & 9,40 & 6,84 & 5,30 & 3,61 \\
\hline 53,40 & 377,70 & 82,30 & 42,84 & 29,67 & 24,65 & 20,05 & 16,59 & 13,85 & 9,96 & 7,57 & 5,03 \\
\hline 36,25 & 463,10 & 27,20 & 95,24 & 81,14 & 71,83 & 60,63 & 50,97 & 42,89 & 30,93 & 23,26 & 15,11 \\
\hline 84,51 & 1301,10 & 188,00 & 12,54 & 8,59 & 7,44 & 6,48 & 5,77 & 5,17 & 4,18 & 3,42 & 2,38 \\
\hline 28,52 & 1755,30 & 140,40 & 24,68 & 19,91 & 16,74 & 13,16 & 10,40 & 8,33 & 5,68 & 4,24 & 2,86 \\
\hline 77,87 & 1373,30 & 185,60 & 12,66 & 8,92 & 7,78 & 6,79 & 6,03 & 5,38 & 4,30 & 3,49 & 2,40 \\
\hline 85,43 & 1147,60 & 194,60 & 13,17 & 8,79 & 7,50 & 6,45 & 5,70 & 5,08 & 4,06 & 3,30 & 2,29 \\
\hline 89,91 & 801,00 & 87,00 & 22,84 & 15,89 & 14,07 & 12,53 & 11,37 & 10,37 & 8,64 & 7,25 & 5,22 \\
\hline 83,45 & 283,10 & 92,20 & 41,52 & 24,79 & 19,67 & 15,88 & 13,43 & 11,55 & 8,75 & 6,88 & 4,68 \\
\hline 35,00 & 1231,90 & 184,30 & 20,35 & 15,29 & 12,65 & 9,88 & 7,81 & 6,28 & 4,32 & 3,24 & 2,19 \\
\hline 71,13 & 279,80 & 122,30 & 39,30 & 22,47 & 17,23 & 13,37 & 10,91 & 9,10 & 6,59 & 5,07 & 3,43 \\
\hline 37,70 & 1421,10 & 26,80 & 64,01 & 57,99 & 54,46 & 49,29 & 44,29 & 39,59 & 31,45 & 25,08 & 16,66 \\
\hline 62,00 & 1595,80 & 123,10 & 16,41 & 12,96 & 11,75 & 10,45 & 9,34 & 8,33 & 6,64 & 5,34 & 3,62 \\
\hline 42,64 & 1675,00 & 102,30 & 22,78 & 19,34 & 17,35 & 14,99 & 12,91 & 11,10 & 8,28 & 6,34 & 4,13 \\
\hline 37,67 & 786,10 & 33,70 & 66,74 & 58,60 & 52,96 & 45,91 & 39,56 & 34,02 & 25,32 & 19,33 & 12,51 \\
\hline 31,45 & 1426,20 & 93,90 & 32,09 & 26,74 & 23,12 & 18,84 & 15,34 & 12,57 & 8,75 & 6,52 & 4,30 \\
\hline 39,93 & 662,90 & 133,60 & 29,32 & 20,94 & 17,17 & 13,43 & 10,67 & 8,62 & 5,97 & 4,49 & 3,03 \\
\hline 40,57 & 859,70 & 166,30 & 22,96 & 16,53 & 13,62 & 10,72 & 8,56 & 6,94 & 4,82 & 3,62 & 2,44 \\
\hline 54,62 & 1839,50 & 114,60 & 17,40 & 14,34 & 13,08 & 11,64 & 10,35 & 9,19 & 7,24 & 5,76 & 3,86 \\
\hline 43,75 & 774,70 & 30,10 & 64,60 & 56,56 & 52,07 & 46,32 & 41,00 & 36,16 & 28,10 & 22,08 & 14,53 \\
\hline
\end{tabular}




\begin{tabular}{|c|c|c|c|c|c|c|c|c|c|c|c|}
\hline \multirow[b]{2}{*}{ e1 (cm) } & & & & & & & ões (x1 & m) & & & \\
\hline & Meq (MPa) & Ms (MPa) & D0 & D25 & D40 & D60 & D80 & D100 & D140 & D180 & D260 \\
\hline 54,38 & 588,50 & 70,20 & 37,37 & 28,72 & 25,12 & 21,46 & 18,45 & 15,88 & 11,91 & 9,20 & 6,06 \\
\hline 78,33 & 1349,90 & 191,40 & 12,55 & 8,78 & 7,62 & 6,63 & 5,88 & 5,23 & 4,17 & 3,38 & 2,33 \\
\hline 84,58 & 360,00 & 192,80 & 27,91 & 14,93 & 11,05 & 8,38 & 6,80 & 5,69 & 4,15 & 3,22 & 2,20 \\
\hline 46,98 & 968,20 & 139,50 & 22,22 & 16,78 & 14,35 & 11,86 & 9,86 & 8,25 & 5,93 & 4,49 & 2,96 \\
\hline 22,15 & 1655,90 & 111,30 & 35,52 & 28,21 & 22,94 & 17,23 & 13,12 & 10,26 & 6,92 & 5,23 & 3,59 \\
\hline 73,95 & 252,60 & 53,50 & 57,02 & 37,88 & 31,68 & 26,59 & 22,92 & 19,92 & 15,25 & 12,01 & 8,09 \\
\hline 39,40 & 1040,00 & 98,60 & 29,59 & 23,88 & 20,71 & 17,15 & 14,21 & 11,83 & 8,43 & 6,33 & 4,15 \\
\hline 62,33 & 925,80 & 49,50 & 35,23 & 28,36 & 26,30 & 23,87 & 21,69 & 19,66 & 16,10 & 13,23 & 9,18 \\
\hline 47,16 & 562,40 & 155,70 & 26,90 & 17,87 & 14,40 & 11,27 & 9,03 & 7,35 & 5,14 & 3,89 & 2,62 \\
\hline 34,06 & 1902,50 & 190,70 & 17,28 & 13,76 & 11,69 & 9,38 & 7,55 & 6,14 & 4,25 & 3,18 & 2,12 \\
\hline 24,48 & 508,00 & 173,00 & 34,36 & 21,51 & 15,57 & 10,68 & 7,88 & 6,18 & 4,30 & 3,34 & 2,33 \\
\hline 61,54 & 539,70 & 179,60 & 23,42 & 14,54 & 11,57 & 9,18 & 7,53 & 6,27 & 4,52 & 3,45 & 2,32 \\
\hline 20,19 & 202,30 & 139,30 & 55,38 & 28,35 & 18,92 & 12,61 & 9,43 & 7,51 & 5,29 & 4,13 & 2,92 \\
\hline 35,55 & 478,00 & 32,00 & 86,18 & 72,31 & 63,39 & 52,84 & 43,93 & 36,62 & 26,08 & 19,53 & 12,75 \\
\hline 45,73 & 1620,60 & 42,60 & 38,95 & 34,10 & 32,12 & 29,26 & 26,51 & 23,91 & 19,34 & 15,67 & 10,63 \\
\hline 80,78 & 411,10 & 51,80 & 43,13 & 30,38 & 26,66 & 23,40 & 20,93 & 18,79 & 15,21 & 12,44 & 8,67 \\
\hline 58,56 & 1643,90 & 28,10 & 44,18 & 36,05 & 34,72 & 33,02 & 31,06 & 29,11 & 25,39 & 22,02 & 16,53 \\
\hline 80,49 & 1205,70 & 82,20 & 20,47 & 15,22 & 13,94 & 12,72 & 11,69 & 10,75 & 9,08 & 7,68 & 5,57 \\
\hline 31,90 & 891,80 & 150,80 & 27,47 & 20,15 & 16,28 & 12,35 & 9,55 & 7,57 & 5,16 & 3,90 & 2,67 \\
\hline 66,97 & 669,40 & 34,30 & 48,13 & 38,05 & 35,44 & 32,43 & 29,71 & 27,17 & 22,63 & 18,87 & 13,37 \\
\hline 33,65 & 1167,60 & 176,10 & 21,88 & 16,39 & 13,48 & 10,44 & 8,19 & 6,55 & 4,49 & 3,37 & 2,29 \\
\hline 22,09 & 822,00 & 55,10 & 71,79 & 56,99 & 46,32 & 34,78 & 26,47 & 20,71 & 13,97 & 10,55 & 7,24 \\
\hline 49,91 & 959,80 & 181,30 & 18,73 & 13,42 & 11,26 & 9,19 & 7,59 & 6,32 & 4,53 & 3,43 & 2,28 \\
\hline 37,54 & 329,90 & 82,50 & 53,57 & 36,69 & 29,27 & 22,23 & 17,30 & 13,80 & 9,47 & 7,17 & 4,90 \\
\hline 66,21 & 782,90 & 173,50 & 18,77 & 12,60 & 10,50 & 8,71 & 7,41 & 6,34 & 4,74 & 3,68 & 2,45 \\
\hline 60,28 & 1977,90 & 105,40 & 16,84 & 13,68 & 12,67 & 11,47 & 10,39 & 9,38 & 7,64 & 6,24 & 4,30 \\
\hline 74,72 & 1733,90 & 111,30 & 15,30 & 11,63 & 10,71 & 9,76 & 8,94 & 8,19 & 6,86 & 5,75 & 4,11 \\
\hline 31,34 & 1884,10 & 123,90 & 24,38 & 20,31 & 17,55 & 14,30 & 11,63 & 9,52 & 6,63 & 4,94 & 3,26 \\
\hline 23,34 & 1800,50 & 164,10 & 25,34 & 19,59 & 15,72 & 11,66 & 8,82 & 6,89 & 4,66 & 3,54 & 2,44 \\
\hline 89,18 & 538,50 & 85,00 & 28,57 & 19,06 & 16,35 & 14,16 & 12,61 & 11,31 & 9,16 & 7,52 & 5,28 \\
\hline 79,40 & 1557,80 & 76,20 & 19,39 & 14,70 & 13,68 & 12,70 & 11,81 & 10,97 & 9,44 & 8,11 & 6,03 \\
\hline 27,72 & 669,40 & 155,00 & 32,10 & 22,04 & 16,91 & 12,15 & 9,09 & 7,12 & 4,88 & 3,74 & 2,60 \\
\hline 69,70 & 1429,70 & 49,60 & 28,22 & 22,24 & 21,04 & 19,69 & 18,35 & 17,06 & 14,68 & 12,59 & 9,31 \\
\hline 75,45 & 1065,10 & 154,40 & 15,97 & 11,24 & 9,74 & 8,44 & 7,45 & 6,60 & 5,22 & 4,20 & 2,87 \\
\hline 82,54 & 769,20 & 99,60 & 22,56 & 15,75 & 13,78 & 12,09 & 10,81 & 9,72 & 7,88 & 6,46 & 4,51 \\
\hline 20,10 & 895,50 & 138,50 & 38,04 & 26,56 & 19,73 & 13,61 & 9,96 & 7,75 & 5,37 & 4,16 & 2,90 \\
\hline 22,24 & 1329,10 & 197,50 & 24,90 & 17,85 & 13,61 & 9,62 & 7,11 & 5,52 & 3,79 & 2,92 & 2,03 \\
\hline 68,59 & 852,10 & 121,50 & 20,93 & 15,08 & 13,09 & 11,29 & 9,88 & 8,68 & 6,74 & 5,34 & 3,60 \\
\hline 67,19 & 305,80 & 193,90 & 32,18 & 16,86 & 12,22 & 8,99 & 7,09 & 5,77 & 4,07 & 3,12 & 2,14 \\
\hline 31,02 & 356,70 & 109,50 & 47,61 & 31,10 & 23,69 & 17,05 & 12,83 & 10,08 & 6,92 & 5,31 & 3,69 \\
\hline 68,12 & 1656,80 & 132,70 & 14,73 & 11,33 & 10,28 & 9,20 & 8,28 & 7,45 & 6,03 & 4,92 & 3,39 \\
\hline 57,83 & 579,50 & 59,00 & 40,03 & 31,15 & 27,63 & 24,02 & 20,99 & 18,35 & 14,10 & 11,06 & 7,34 \\
\hline 86,39 & 543,40 & 86,80 & 28,45 & 19,11 & 16,39 & 14,17 & 12,57 & 11,24 & 9,05 & 7,39 & 5,15 \\
\hline 36,10 & 1374,50 & 126,30 & 24,27 & 19,61 & 16,88 & 13,79 & 11,28 & 9,28 & 6,52 & 4,87 & 3,21 \\
\hline 50,83 & 1740,40 & 123,10 & 17,79 & 14,67 & 13,23 & 11,59 & 10,16 & 8,88 & 6,82 & 5,33 & 3,51 \\
\hline 87,23 & 1119,80 & 82,70 & 20,26 & 14,69 & 13,35 & 12,18 & 11,21 & 10,35 & 8,80 & 7,51 & 5,52 \\
\hline 27,57 & 934,60 & 86,00 & 43,20 & 34,14 & 28,25 & 21,79 & 16,97 & 13,47 & 9,15 & 6,86 & 4,66 \\
\hline 63,20 & 1321,80 & 154,20 & 15,56 & 11,71 & 10,32 & 8,96 & 7,86 & 6,90 & 5,35 & 4,23 & 2,83 \\
\hline 27,15 & 958,60 & 180,90 & 26,03 & 18,49 & 14,39 & 10,45 & 7,85 & 6,14 & 4,20 & 3,21 & 2,22 \\
\hline 43,35 & 1522,20 & 24,50 & 60,71 & 53,15 & 50,93 & 47,10 & 43,27 & 39,56 & 32,79 & 27,11 & 18,83 \\
\hline 39,55 & 1597,00 & 186,70 & 16,91 & 13,25 & 11,33 & 9,24 & 7,57 & 6,24 & 4,40 & 3,30 & 2,18 \\
\hline 68,61 & 329,70 & 149,20 & 33,20 & 18,90 & 14,43 & 11,13 & 9,03 & 7,50 & 5,39 & 4,13 & 2,80 \\
\hline 82,69 & 1956,80 & 169,90 & 10,88 & 7,90 & 7,13 & 6,42 & 5,85 & 5,35 & 4,46 & 3,74 & 2,68 \\
\hline 40,08 & 864,60 & 110,90 & 29,29 & 22,62 & 19,25 & 15,63 & 12,75 & 10,49 & 7,38 & 5,54 & 3,67 \\
\hline 56,77 & 778,80 & 90,30 & 28,00 & 21,49 & 18,86 & 16,23 & 14,05 & 12,18 & 9,23 & 7,18 & 4,75 \\
\hline 79,87 & 593,90 & 50,20 & 36,95 & 27,13 & 24,54 & 22,10 & 20,12 & 18,34 & 15,24 & 12,72 & 9,07 \\
\hline 71,32 & 474,30 & 149,10 & 26,13 & 16,12 & 12,90 & 10,40 & 8,71 & 7,39 & 5,46 & 4,23 & 2,84 \\
\hline 82,65 & 1292,00 & 128,30 & 15,35 & 11,02 & 9,85 & 8,79 & 7,97 & 7,24 & 5,99 & 4,98 & 3,54 \\
\hline 87,85 & 988,50 & 115,50 & 18,02 & 12,52 & 11,03 & 9,77 & 8,82 & 8,00 & 6,61 & 5,50 & 3,92 \\
\hline 69,46 & 1064,70 & 88,80 & 22,19 & 16,93 & 15,32 & 13,69 & 12,33 & 11,10 & 8,99 & 7,34 & 5,07 \\
\hline 89,55 & 683,00 & 101,50 & 23,11 & 15,53 & 13,39 & 11,65 & 10,41 & 9,36 & 7,62 & 6,28 & 4,43 \\
\hline 64,56 & 1798,80 & 52,80 & 26,24 & 21,07 & 20,07 & 18,80 & 17,52 & 16,28 & 13,97 & 11,95 & 8,78 \\
\hline 25,01 & 749,60 & 180,10 & 29,40 & 19,81 & 14,85 & 10,42 & 7,72 & 6,03 & 4,16 & 3,21 & 2,23 \\
\hline 57,99 & 1164,00 & 57,20 & 30,79 & 25,32 & 23,51 & 21,29 & 19,28 & 17,40 & 14,13 & 11,52 & 7,91 \\
\hline 89,44 & 1967,50 & 125,60 & 12,35 & 9,00 & 8,22 & 7,57 & 7,02 & 6,52 & 5,62 & 4,85 & 3,63 \\
\hline 35,66 & 701,80 & 88,80 & 39,20 & 30,26 & 25,43 & 20,21 & 16,18 & 13,11 & 9,07 & 6,79 & 4,55 \\
\hline 52,24 & 1153,10 & 163,40 & 17,74 & 13,33 & 11,49 & 9,65 & 8,16 & 6,93 & 5,10 & 3,89 & 2,56 \\
\hline 35,79 & 708,60 & 21,70 & 96,01 & 86,27 & 78,84 & 69,17 & 60,24 & 52,27 & 39,45 & 30,33 & 19,63 \\
\hline 20,69 & 1452,10 & 138,90 & 32,90 & 24,73 & 19,26 & 13,82 & 10,25 & 7,95 & 5,42 & 4,15 & 2,88 \\
\hline 76,79 & 1705,90 & 138,40 & 13,40 & 9,98 & 9,05 & 8,16 & 7,41 & 6,75 & 5,58 & 4,64 & 3,29 \\
\hline 88,18 & 1585,20 & 111,30 & 14,64 & 10,62 & 9,67 & 8,86 & 8,18 & 7,57 & 6,47 & 5,54 & 4,10 \\
\hline 22,90 & 1057,60 & 49,30 & 70,20 & 58,23 & 48,96 & 38,23 & 29,93 & 23,78 & 16,08 & 11,99 & 8,10 \\
\hline 59,18 & 1802,10 & 83,90 & 20,35 & 16,67 & 15,54 & 14,14 & 12,86 & 11,66 & 9,54 & 7,83 & 5,42 \\
\hline 47,20 & 770,70 & 151,40 & 23,48 & 16,76 & 13,97 & 11,27 & 9,21 & 7,60 & 5,39 & 4,07 & 2,71 \\
\hline 43,80 & 1429,30 & 156,60 & 18,39 & 14,53 & 12,60 & 10,51 & 8,79 & 7,38 & 5,32 & 4,02 & 2,63 \\
\hline 48,02 & 1497,50 & 164,00 & 16,57 & 13,04 & 11,39 & 9,64 & 8,17 & 6,95 & 5,11 & 3,89 & 2,55 \\
\hline 74,13 & 1525,80 & 178,40 & 12,51 & 9,08 & 8,02 & 7,05 & 6,28 & 5,61 & 4,49 & 3,64 & 2,50 \\
\hline 65,88 & 637,90 & 88,70 & 28,83 & 21,02 & 18,27 & 15,74 & 13,73 & 12,02 & 9,28 & 7,32 & 4,90 \\
\hline 34,67 & 1028,70 & 102,20 & 31,76 & 25,35 & 21,60 & 17,40 & 14,06 & 11,47 & 7,97 & 5,95 & 3,96 \\
\hline 78,53 & 1801,00 & 116,90 & 14,27 & 10,70 & 9,84 & 8,99 & 8,26 & 7,60 & 6,41 & 5,41 & 3,92 \\
\hline 54,28 & 1486,10 & 37,10 & 39,45 & 33,04 & 31,56 & 29,30 & 27,06 & 24,90 & 20,94 & 17,55 & 12,48 \\
\hline 62,30 & 531,40 & 45,70 & 46,15 & 36,06 & 32,46 & 28,71 & 25,53 & 22,68 & 17,94 & 14,36 & 9,69 \\
\hline
\end{tabular}




\begin{tabular}{|c|c|c|c|c|c|c|c|c|c|c|c|}
\hline \multirow[b]{2}{*}{ e1 (cm) } & & & & & & & ões (x1 & & & & \\
\hline & Meq (MPa) & Ms (MPa) & D0 & D25 & D40 & D60 & D80 & D100 & D140 & D180 & D260 \\
\hline 73,85 & 329,00 & 149,90 & 32,74 & 18,45 & 14,05 & 10,86 & 8,87 & 7,40 & 5,37 & 4,14 & 2,81 \\
\hline 34,85 & 648,40 & 80,70 & 43,52 & 33,65 & 28,23 & 22,36 & 17,84 & 14,43 & 9,96 & 7,45 & 5,00 \\
\hline 37,20 & 1815,30 & 186,40 & 16,79 & 13,38 & 11,47 & 9,34 & 7,63 & 6,28 & 4,40 & 3,30 & 2,18 \\
\hline 39,76 & 1363,30 & 80,40 & 30,10 & 25,68 & 22,94 & 19,66 & 16,78 & 14,31 & 10,53 & 8,00 & 5,19 \\
\hline 82,16 & 660,80 & 183,10 & 18,94 & 11,71 & 9,48 & 7,79 & 6,66 & 5,77 & 4,41 & 3,49 & 2,37 \\
\hline 76,50 & 852,40 & 48,40 & 33,05 & 25,12 & 23,27 & 21,38 & 19,72 & 18,18 & 15,39 & 13,04 & 9,48 \\
\hline 56,73 & 1357,10 & 83,20 & 23,30 & 19,06 & 17,45 & 15,60 & 13,95 & 12,45 & 9,90 & 7,94 & 5,35 \\
\hline 28,19 & 564,10 & 132,60 & 37,41 & 25,64 & 19,71 & 14,19 & 10,64 & 8,33 & 5,71 & 4,38 & 3,04 \\
\hline 40,85 & 1652,90 & 113,00 & 22,20 & 18,64 & 16,56 & 14,11 & 11,99 & 10,20 & 7,47 & 5,67 & 3,69 \\
\hline 38,52 & 1055,90 & 44,00 & 49,73 & 43,75 & 39,68 & 34,57 & 29,94 & 25,86 & 19,39 & 14,87 & 9,64 \\
\hline 70,54 & 889,00 & 60,50 & 29,66 & 22,84 & 20,95 & 18,96 & 17,25 & 15,68 & 12,93 & 10,70 & 7,52 \\
\hline 76,90 & 1486,00 & 83,10 & 19,09 & 14,51 & 13,44 & 12,37 & 11,42 & 10,54 & 8,94 & 7,59 & 5,53 \\
\hline 38,70 & 608,50 & 151,60 & 28,70 & 19,67 & 15,75 & 12,03 & 9,41 & 7,53 & 5,18 & 3,91 & 2,67 \\
\hline 72,39 & 886,60 & 133,10 & 19,18 & 13,55 & 11,72 & 10,10 & 8,86 & 7,81 & 6,11 & 4,87 & 3,30 \\
\hline 30,75 & 1311,60 & 62,60 & 43,89 & 37,76 & 33,18 & 27,58 & 22,81 & 18,92 & 13,35 & 9,95 & 6,49 \\
\hline 75,83 & 1290,80 & 187,80 & 13,13 & 9,22 & 7,99 & 6,93 & 6,11 & 5,42 & 4,29 & 3,45 & 2,36 \\
\hline 69,41 & 1256,20 & 145,60 & 15,71 & 11,60 & 10,25 & 8,97 & 7,95 & 7,06 & 5,58 & 4,48 & 3,04 \\
\hline 70,38 & 1005,40 & 69,50 & 26,03 & 20,05 & 18,37 & 16,61 & 15,09 & 13,71 & 11,29 & 9,33 & 6,55 \\
\hline 47,18 & 700,30 & 33,30 & 59,49 & 51,05 & 46,80 & 41,57 & 36,79 & 32,46 & 25,27 & 19,90 & 13,15 \\
\hline 50,55 & 1170,70 & 75,80 & 28,01 & 23,31 & 21,11 & 18,59 & 16,34 & 14,34 & 11,07 & 8,68 & 5,73 \\
\hline 72,83 & 666,20 & 163,50 & 20,41 & 13,22 & 10,89 & 9,01 & 7,68 & 6,61 & 5,00 & 3,91 & 2,62 \\
\hline 25,75 & 1969,80 & 49,60 & 51,91 & 46,30 & 41,15 & 34,57 & 28,81 & 24,00 & 17,00 & 12,63 & 8,18 \\
\hline 43,19 & 779,80 & 198,80 & 21,03 & 14,30 & 11,55 & 8,98 & 7,13 & 5,77 & 4,00 & 3,02 & 2,04 \\
\hline 84,83 & 206,70 & 174,30 & 43,49 & 21,03 & 14,49 & 10,21 & 7,91 & 6,40 & 4,50 & 3,47 & 2,41 \\
\hline 24,70 & 275,80 & 193,00 & 39,05 & 20,25 & 13,76 & 9,24 & 6,88 & 5,46 & 3,83 & 2,98 & 2,11 \\
\hline 61,70 & 305,80 & 156,20 & 35,01 & 19,53 & 14,66 & 11,07 & 8,82 & 7,21 & 5,08 & 3,88 & 2,65 \\
\hline 20,93 & 314,50 & 25,80 & 168,54 & 129,44 & 102,34 & 74,55 & 55,71 & 43,26 & 29,33 & 22,39 & 15,48 \\
\hline 31,88 & 1923,30 & 89,40 & 29,55 & 25,57 & 22,60 & 18,95 & 15,80 & 13,19 & 9,40 & 7,02 & 4,56 \\
\hline 38,09 & 1410,10 & 114,30 & 24,63 & 20,26 & 17,69 & 14,73 & 12,25 & 10,22 & 7,30 & 5,48 & 3,58 \\
\hline 62,19 & 823,10 & 149,30 & 20,10 & 14,16 & 12,02 & 10,09 & 8,62 & 7,40 & 5,54 & 4,29 & 2,85 \\
\hline 81,77 & 1618,40 & 66,90 & 20,31 & 15,45 & 14,40 & 13,51 & 12,66 & 11,85 & 10,34 & 9,01 & 6,84 \\
\hline 24,82 & 1973,60 & 188,00 & 21,48 & 16,67 & 13,49 & 10,12 & 7,72 & 6,06 & 4,10 & 3,10 & 2,13 \\
\hline 83,82 & 1095,00 & 78,70 & 21,45 & 15,73 & 14,34 & 13,08 & 12,03 & 11,08 & 9,38 & 7,96 & 5,81 \\
\hline 31,05 & 905,00 & 176,20 & 25,09 & 17,93 & 14,25 & 10,63 & 8,13 & 6,41 & 4,37 & 3,32 & 2,28 \\
\hline 59,68 & 1383,10 & 161,40 & 15,30 & 11,64 & 10,23 & 8,84 & 7,70 & 6,72 & 5,14 & 4,03 & 2,68 \\
\hline 69,59 & 932,70 & 30,10 & 45,36 & 35,80 & 33,93 & 31,84 & 29,74 & 27,72 & 23,94 & 20,62 & 15,33 \\
\hline 40,91 & 690,60 & 88,50 & 36,24 & 27,99 & 23,87 & 19,45 & 15,93 & 13,15 & 9,28 & 6,97 & 4,61 \\
\hline 61,65 & 1886,70 & 112,80 & 16,23 & 13,04 & 12,01 & 10,83 & 9,78 & 8,82 & 7,15 & 5,83 & 4,00 \\
\hline 89,72 & 1668,90 & 144,60 & 12,32 & 8,76 & 7,88 & 7,12 & 6,53 & 6,00 & 5,08 & 4,31 & 3,16 \\
\hline 32,69 & 1611,80 & 192,00 & 18,78 & 14,56 & 12,14 & 9,53 & 7,54 & 6,05 & 4,15 & 3,11 & 2,10 \\
\hline 38,41 & 1783,30 & 118,30 & 21,93 & 18,48 & 16,34 & 13,82 & 11,65 & 9,83 & 7,12 & 5,37 & 3,49 \\
\hline 21,47 & 376,70 & 76,60 & 71,20 & 48,21 & 35,51 & 24,43 & 17,93 & 13,98 & 9,71 & 7,53 & 5,24 \\
\hline 55,86 & 1108,60 & 47,60 & 36,08 & 30,05 & 28,04 & 25,48 & 23,11 & 20,89 & 17,00 & 13,88 & 9,53 \\
\hline 58,09 & 928,10 & 119,20 & 21,97 & 16,55 & 14,44 & 12,36 & 10,67 & 9,23 & 6,98 & 5,43 & 3,59 \\
\hline 64,06 & 806,70 & 172,40 & 18,75 & 12,75 & 10,65 & 8,85 & 7,51 & 6,42 & 4,78 & 3,69 & 2,46 \\
\hline 24,70 & 1206,10 & 86,50 & 43,02 & 34,51 & 28,52 & 21,88 & 16,94 & 13,38 & 9,05 & 6,79 & 4,62 \\
\hline 28,72 & 408,60 & 156,10 & 37,29 & 23,07 & 16,98 & 11,88 & 8,84 & 6,94 & 4,80 & 3,71 & 2,59 \\
\hline 23,21 & 1180,10 & 92,40 & 43,23 & 34,00 & 27,58 & 20,69 & 15,76 & 12,34 & 8,34 & 6,30 & 4,33 \\
\hline 83,60 & 1126,70 & 77,10 & 21,45 & 15,79 & 14,44 & 13,20 & 12,16 & 11,22 & 9,53 & 8,10 & 5,94 \\
\hline 80,06 & 1717,90 & 135,10 & 13,29 & 9,80 & 8,90 & 8,06 & 7,36 & 6,73 & 5,62 & 4,71 & 3,38 \\
\hline 25,58 & 1483,90 & 82,90 & 40,46 & 33,51 & 28,37 & 22,40 & 17,72 & 14,19 & 9,66 & 7,19 & 4,83 \\
\hline 34,68 & 929,30 & 143,00 & 26,66 & 19,94 & 16,44 & 12,79 & 10,08 & 8,08 & 5,55 & 4,17 & 2,82 \\
\hline 40,68 & 1280,30 & 113,70 & 24,47 & 19,92 & 17,41 & 14,56 & 12,18 & 10,22 & 7,35 & 5,54 & 3,62 \\
\hline 66,07 & 1138,20 & 54,80 & 29,65 & 23,56 & 22,01 & 20,18 & 18,51 & 16,95 & 14,14 & 11,80 & 8,38 \\
\hline 31,28 & 1349,70 & 158,40 & 23,32 & 18,06 & 14,98 & 11,66 & 9,16 & 7,32 & 5,00 & 3,75 & 2,54 \\
\hline 71,12 & 849,00 & 165,50 & 17,85 & 12,13 & 10,23 & 8,63 & 7,45 & 6,47 & 4,95 & 3,89 & 2,61 \\
\hline 54,31 & 1099,00 & 117,90 & 21,23 & 16,56 & 14,59 & 12,56 & 10,85 & 9,39 & 7,09 & 5,50 & 3,62 \\
\hline 31,76 & 612,80 & 176,60 & 28,54 & 18,92 & 14,55 & 10,57 & 7,99 & 6,29 & 4,31 & 3,30 & 2,28 \\
\hline 26,38 & 1688,00 & 100,90 & 33,14 & 27,37 & 23,18 & 18,33 & 14,53 & 11,65 & 7,94 & 5,91 & 3,97 \\
\hline 25,47 & 739,50 & 176,50 & 29,67 & 20,06 & 15,11 & 10,64 & 7,89 & 6,17 & 4,25 & 3,28 & 2,28 \\
\hline 50,63 & 1946,60 & 73,50 & 23,74 & 20,28 & 18,92 & 17,13 & 15,46 & 13,90 & 11,18 & 9,04 & 6,12 \\
\hline 22,43 & 1909,20 & 169,10 & 25,06 & 19,31 & 15,40 & 11,34 & 8,54 & 6,65 & 4,51 & 3,43 & 2,36 \\
\hline 44,37 & 570,80 & 60,90 & 46,36 & 36,76 & 31,98 & 26,79 & 22,47 & 18,92 & 13,70 & 10,36 & 6,79 \\
\hline 86,39 & 389,50 & 27,10 & 60,47 & 44,11 & 40,24 & 36,82 & 33,97 & 31,39 & 26,76 & 22,86 & 16,86 \\
\hline 79,65 & 1448,30 & 20,70 & 43,29 & 36,59 & 33,59 & 32,55 & 31,52 & 30,26 & 27,70 & 25,24 & 20,76 \\
\hline 85,08 & 270,00 & 173,40 & 35,47 & 18,21 & 13,11 & 9,67 & 7,71 & 6,37 & 4,59 & 3,55 & 2,44 \\
\hline 30,86 & 1295,30 & 186,00 & 21,46 & 16,12 & 13,13 & 10,02 & 7,77 & 6,16 & 4,20 & 3,17 & 2,16 \\
\hline 32,37 & 366,90 & 143,10 & 39,35 & 24,34 & 18,19 & 12,97 & 9,75 & 7,67 & 5,28 & 4,06 & 2,83 \\
\hline 23,18 & 1906,60 & 68,90 & 45,99 & 39,15 & 33,55 & 26,83 & 21,40 & 17,22 & 11,74 & 8,70 & 5,80 \\
\hline 31,60 & 1768,20 & 191,00 & 18,66 & 14,63 & 12,23 & 9,60 & 7,59 & 6,10 & 4,18 & 3,12 & 2,10 \\
\hline 58,03 & 885,30 & 149,80 & 19,96 & 14,38 & 12,26 & 10,29 & 8,74 & 7,46 & 5,54 & 4,26 & 2,82 \\
\hline 84,40 & 887,70 & 114,90 & 19,38 & 13,45 & 11,76 & 10,33 & 9,25 & 8,33 & 6,78 & 5,58 & 3,92 \\
\hline 64,22 & 987,50 & 175,40 & 16,69 & 11,75 & 9,99 & 8,43 & 7,23 & 6,24 & 4,71 & 3,66 & 2,44 \\
\hline 80,73 & 1655,40 & 29,10 & 33,28 & 27,32 & 25,23 & 24,40 & 23,49 & 22,46 & 20,41 & 18,47 & 15,00 \\
\hline 25,65 & 464,00 & 157,70 & 36,99 & 23,29 & 17,01 & 11,75 & 8,69 & 6,81 & 4,73 & 3,66 & 2,56 \\
\hline 61,65 & 950,10 & 58,80 & 31,56 & 25,32 & 23,26 & 20,94 & 18,88 & 17,00 & 13,75 & 11,18 & 7,67 \\
\hline 53,85 & 338,60 & 182,30 & 31,79 & 17,69 & 13,16 & 9,76 & 7,65 & 6,17 & 4,29 & 3,28 & 2,25 \\
\hline 39,23 & 1285,50 & 48,60 & 42,90 & 37,96 & 34,64 & 30,43 & 26,56 & 23,11 & 17,54 & 13,55 & 8,81 \\
\hline 76,47 & 614,10 & 98,00 & 26,32 & 18,21 & 15,65 & 13,47 & 11,84 & 10,47 & 8,24 & 6,60 & 4,50 \\
\hline 81,63 & 248,30 & 52,90 & 56,02 & 36,44 & 30,40 & 25,61 & 22,26 & 19,53 & 15,22 & 12,15 & 8,29 \\
\hline 81,98 & 609,90 & 45,10 & 38,32 & 28,21 & 25,71 & 23,38 & 21,44 & 19,69 & 16,59 & 14,01 & 10,15 \\
\hline 47,09 & 1617,70 & 30,60 & 48,19 & 41,56 & 39,81 & 36,88 & 33,95 & 31,12 & 25,94 & 21,56 & 15,10 \\
\hline
\end{tabular}




\begin{tabular}{|c|c|c|c|c|c|c|c|c|c|c|c|}
\hline \multirow[b]{2}{*}{ e1 (cm) } & & & & & & $\mathrm{De}$ & ões (x1 & m) & & & \\
\hline & Meq (MPa) & Ms (MPa) & D0 & D25 & D40 & D60 & D80 & D100 & D140 & D180 & D260 \\
\hline 88,26 & 1745,40 & 25,80 & 31,54 & 27,70 & 24,99 & 24,06 & 23,43 & 22,62 & 20,89 & 19,22 & 16,11 \\
\hline 67,90 & 580,20 & 175,30 & 22,00 & 13,79 & 11,10 & 8,96 & 7,48 & 6,33 & 4,65 & 3,59 & 2,41 \\
\hline 86,00 & 1604,00 & 137,30 & 13,15 & 9,45 & 8,53 & 7,70 & 7,04 & 6,46 & 5,43 & 4,58 & 3,32 \\
\hline 29,16 & 596,50 & 37,20 & 84,31 & 70,15 & 60,19 & 48,50 & 39,07 & 31,72 & 21,88 & 16,27 & 10,80 \\
\hline 50,52 & 833,30 & 81,40 & 30,81 & 24,53 & 21,67 & 18,60 & 15,99 & 13,77 & 10,31 & 7,94 & 5,21 \\
\hline 21,18 & 1557,60 & 153,70 & 29,52 & 22,21 & 17,34 & 12,48 & 9,28 & 7,20 & 4,90 & 3,76 & 2,60 \\
\hline 65,66 & 1052,90 & 80,70 & 24,23 & 18,88 & 17,16 & 15,34 & 13,79 & 12,39 & 9,99 & 8,12 & 5,57 \\
\hline 33,28 & 1140,30 & 47,30 & 51,85 & 45,48 & 40,64 & 34,60 & 29,27 & 24,75 & 17,94 & 13,49 & 8,72 \\
\hline 64,51 & 851,50 & 124,90 & 21,23 & 15,41 & 13,34 & 11,42 & 9,92 & 8,64 & 6,61 & 5,19 & 3,46 \\
\hline 76,10 & 1230,70 & 28,50 & 39,98 & 31,64 & 29,75 & 28,51 & 27,09 & 25,64 & 22,85 & 20,27 & 15,87 \\
\hline 36,94 & 1425,00 & 55,10 & 39,92 & 35,32 & 32,02 & 27,85 & 24,06 & 20,73 & 15,48 & 11,83 & 7,65 \\
\hline 43,78 & 1453,70 & 180,40 & 16,81 & 13,04 & 11,21 & 9,27 & 7,69 & 6,42 & 4,59 & 3,46 & 2,28 \\
\hline 71,61 & 266,70 & 179,60 & 36,00 & 18,50 & 13,27 & 9,69 & 7,63 & 6,22 & 4,39 & 3,37 & 2,32 \\
\hline 29,72 & 1063,90 & 157,20 & 26,24 & 19,57 & 15,80 & 11,93 & 9,18 & 7,25 & 4,94 & 3,73 & 2,55 \\
\hline 45,73 & 1409,70 & 118,50 & 21,21 & 17,34 & 15,36 & 13,13 & 11,23 & 9,60 & 7,11 & 5,43 & 3,55 \\
\hline 47,05 & 654,20 & 72,10 & 38,26 & 30,13 & 26,27 & 22,15 & 18,72 & 15,86 & 11,60 & 8,82 & 5,78 \\
\hline 59,25 & 1080,80 & 139,60 & 18,62 & 13,98 & 12,19 & 10,46 & 9,05 & 7,84 & 5,96 & 4,64 & 3,08 \\
\hline 37,63 & 1207,10 & 161,00 & 21,32 & 16,35 & 13,78 & 11,02 & 8,88 & 7,23 & 5,03 & 3,77 & 2,51 \\
\hline 42,20 & 896,20 & 59,10 & 40,91 & 34,48 & 30,78 & 26,43 & 22,62 & 19,36 & 14,33 & 10,93 & 7,10 \\
\hline 88,90 & 937,60 & 157,30 & 15,98 & 10,58 & 9,03 & 7,78 & 6,90 & 6,17 & 4,97 & 4,07 & 2,84 \\
\hline 47,04 & 1525,90 & 83,00 & 25,10 & 21,36 & 19,43 & 17,13 & 15,05 & 13,19 & 10,16 & 7,94 & 5,22 \\
\hline 22,28 & 673,60 & 68,80 & 64,41 & 48,70 & 38,33 & 27,87 & 20,83 & 16,20 & 11,01 & 8,41 & 5,82 \\
\hline 58,51 & 1058,70 & 169,40 & 17,11 & 12,43 & 10,65 & 8,98 & 7,67 & 6,57 & 4,90 & 3,78 & 2,50 \\
\hline 28,80 & 1438,90 & 142,30 & 25,91 & 20,39 & 16,90 & 13,09 & 10,23 & 8,15 & 5,54 & 4,16 & 2,82 \\
\hline 81,91 & 1397,50 & 138,30 & 14,27 & 10,27 & 9,18 & 8,20 & 7,43 & 6,74 & 5,57 & 4,62 & 3,28 \\
\hline 70,46 & 1518,50 & 179,60 & 12,77 & 9,38 & 8,27 & 7,24 & 6,42 & 5,70 & 4,52 & 3,63 & 2,47 \\
\hline 81,26 & 1453,30 & 144,20 & 13,75 & 9,92 & 8,87 & 7,91 & 7,16 & 6,50 & 5,36 & 4,44 & 3,15 \\
\hline 52,41 & 884,30 & 67,90 & 32,71 & 26,66 & 23,96 & 20,97 & 18,36 & 16,06 & 12,34 & 9,66 & 6,37 \\
\hline 82,45 & 203,10 & 153,00 & 45,46 & 22,56 & 15,84 & 11,38 & 8,92 & 7,27 & 5,15 & 3,98 & 2,75 \\
\hline 67,10 & 520,90 & 30,90 & 56,40 & 44,33 & 40,96 & 37,20 & 33,88 & 30,82 & 25,42 & 21,03 & 14,74 \\
\hline 42,02 & 1658,00 & 63,30 & 31,39 & 27,63 & 25,36 & 22,47 & 19,80 & 17,38 & 13,40 & 10,46 & 6,85 \\
\hline 27,76 & 579,80 & 131,80 & 37,49 & 25,83 & 19,85 & 14,28 & 10,70 & 8,37 & 5,74 & 4,40 & 3,05 \\
\hline 26,85 & 837,00 & 188,10 & 26,62 & 18,32 & 14,01 & 10,02 & 7,48 & 5,85 & 4,01 & 3,08 & 2,14 \\
\hline 63,39 & 1189,90 & 72,50 & 25,05 & 19,97 & 18,38 & 16,60 & 15,02 & 13,57 & 11,05 & 9,04 & 6,24 \\
\hline 52,46 & 269,60 & 155,50 & 39,03 & 21,34 & 15,71 & 11,52 & 8,96 & 7,20 & 5,00 & 3,82 & 2,64 \\
\hline 20,10 & 411,80 & 58,60 & 88,05 & 62,27 & 46,58 & 32,29 & 23,66 & 18,38 & 12,71 & 9,84 & 6,84 \\
\hline 61,84 & 548,40 & 150,20 & 25,01 & 16,23 & 13,21 & 10,69 & 8,89 & 7,48 & 5,45 & 4,17 & 2,79 \\
\hline 89,99 & 1456,60 & 80,40 & 18,03 & 13,26 & 12,17 & 11,30 & 10,55 & 9,85 & 8,57 & 7,45 & 5,66 \\
\hline 85,57 & 250,60 & 90,90 & 45,01 & 26,16 & 20,46 & 16,32 & 13,71 & 11,75 & 8,86 & 6,96 & 4,74 \\
\hline 27,44 & 1135,70 & 138,30 & 29,45 & 22,42 & 18,13 & 13,66 & 10,47 & 8,24 & 5,60 & 4,23 & 2,90 \\
\hline 75,62 & 229,60 & 59,50 & 57,24 & 36,43 & 29,79 & 24,57 & 20,95 & 18,06 & 13,68 & 10,72 & 7,23 \\
\hline 46,61 & 1287,30 & 50,60 & 36,92 & 32,02 & 29,61 & 26,53 & 23,66 & 21,02 & 16,56 & 13,15 & 8,74 \\
\hline 35,22 & 1741,00 & 61,10 & 36,18 & 32,24 & 29,22 & 25,38 & 21,88 & 18,82 & 13,99 & 10,67 & 6,89 \\
\hline 88,16 & 855,30 & 115,30 & 19,41 & 13,25 & 11,54 & 10,11 & 9,07 & 8,18 & 6,69 & 5,53 & 3,91 \\
\hline 35,27 & 582,60 & 42,30 & 67,65 & 56,22 & 49,01 & 40,56 & 33,51 & 27,80 & 19,67 & 14,71 & 9,64 \\
\hline 31,50 & 1404,20 & 36,80 & 59,62 & 53,99 & 49,04 & 42,58 & 36,67 & 31,47 & 23,30 & 17,70 & 11,39 \\
\hline 52,41 & 1776,80 & 48,00 & 31,91 & 27,02 & 25,68 & 23,68 & 21,74 & 19,88 & 16,51 & 13,69 & 9,58 \\
\hline 30,84 & 536,80 & 20,30 & 124,64 & 109,61 & 97,57 & 82,47 & 69,24 & 58,12 & 41,67 & 31,18 & 20,19 \\
\hline 56,99 & 1668,10 & 130,90 & 16,29 & 13,07 & 11,79 & 10,40 & 9,19 & 8,12 & 6,34 & 5,02 & 3,35 \\
\hline 70,62 & 1924,70 & 41,90 & 28,11 & 22,36 & 21,22 & 20,29 & 19,21 & 18,13 & 16,04 & 14,13 & 10,91 \\
\hline 71,19 & 203,90 & 97,40 & 52,35 & 29,30 & 22,17 & 17,01 & 13,80 & 11,45 & 8,24 & 6,34 & 4,30 \\
\hline 20,37 & 1358,00 & 180,50 & 27,87 & 19,97 & 15,07 & 10,52 & 7,73 & 6,00 & 4,13 & 3,19 & 2,22 \\
\hline 68,68 & 392,30 & 91,50 & 36,14 & 23,89 & 19,79 & 16,39 & 13,94 & 11,96 & 8,97 & 6,97 & 4,66 \\
\hline 42,54 & 1565,90 & 86,90 & 25,91 & 22,20 & 20,01 & 17,39 & 15,05 & 13,00 & 9,76 & 7,50 & 4,88 \\
\hline 46,60 & 1857,00 & 177,30 & 14,75 & 11,85 & 10,43 & 8,86 & 7,54 & 6,43 & 4,74 & 3,61 & 2,36 \\
\hline 83,15 & 633,40 & 132,70 & 21,98 & 14,28 & 11,93 & 10,07 & 8,77 & 7,71 & 6,04 & 4,84 & 3,31 \\
\hline 49,25 & 910,10 & 73,40 & 32,08 & 26,20 & 23,38 & 20,25 & 17,54 & 15,18 & 11,46 & 8,86 & 5,81 \\
\hline 38,24 & 235,80 & 100,10 & 55,33 & 33,48 & 25,27 & 18,40 & 14,03 & 11,11 & 7,64 & 5,85 & 4,06 \\
\hline 52,22 & 878,90 & 22,10 & 68,04 & 57,58 & 54,89 & 50,76 & 46,70 & 42,81 & 35,71 & 29,72 & 20,90 \\
\hline 49,58 & 1099,40 & 80,50 & 28,02 & 23,11 & 20,75 & 18,10 & 15,77 & 13,73 & 10,45 & 8,13 & 5,34 \\
\hline 67,47 & 683,90 & 49,80 & 37,90 & 29,43 & 26,85 & 24,13 & 21,80 & 19,68 & 16,01 & 13,11 & 9,07 \\
\hline 73,43 & 1911,90 & 184,30 & 11,10 & 8,25 & 7,39 & 6,57 & 5,91 & 5,32 & 4,31 & 3,52 & 2,44 \\
\hline 22,56 & 1822,30 & 97,30 & 37,47 & 30,59 & 25,40 & 19,54 & 15,13 & 11,94 & 8,05 & 6,03 & 4,10 \\
\hline 46,62 & 768,80 & 157,80 & 23,13 & 16,38 & 13,59 & 10,90 & 8,87 & 7,30 & 5,15 & 3,88 & 2,59 \\
\hline 74,96 & 750,80 & 146,50 & 19,79 & 13,31 & 11,22 & 9,49 & 8,23 & 7,19 & 5,55 & 4,40 & 2,97 \\
\hline 29,00 & 1771,20 & 24,30 & 78,53 & 73,06 & 67,68 & 60,16 & 52,97 & 46,39 & 35,48 & 27,45 & 17,74 \\
\hline 76,56 & 1423,90 & 171,20 & 13,03 & 9,36 & 8,25 & 7,25 & 6,47 & 5,79 & 4,65 & 3,78 & 2,61 \\
\hline 43,88 & 1078,10 & 36,10 & 51,02 & 44,90 & 41,64 & 37,33 & 33,29 & 29,57 & 23,26 & 18,43 & 12,22 \\
\hline 38,57 & 970,40 & 101,10 & 30,36 & 24,17 & 20,79 & 17,03 & 13,98 & 11,55 & 8,15 & 6,11 & 4,03 \\
\hline 34,09 & 387,00 & 151,10 & 36,62 & 22,66 & 17,05 & 12,26 & 9,26 & 7,30 & 5,02 & 3,85 & 2,68 \\
\hline 30,91 & 1448,30 & 188,20 & 20,48 & 15,62 & 12,83 & 9,87 & 7,70 & 6,13 & 4,18 & 3,14 & 2,13 \\
\hline 81,56 & 685,50 & 193,40 & 18,17 & 11,21 & 9,06 & 7,43 & 6,34 & 5,48 & 4,18 & 3,30 & 2,24 \\
\hline 45,16 & 1031,50 & 152,80 & 21,00 & 15,81 & 13,45 & 11,02 & 9,10 & 7,56 & 5,39 & 4,07 & 2,69 \\
\hline 54,89 & 1515,80 & 87,20 & 22,11 & 18,29 & 16,77 & 14,99 & 13,39 & 11,94 & 9,47 & 7,58 & 5,09 \\
\hline 58,04 & 366,00 & 105,00 & 37,54 & 24,29 & 19,66 & 15,74 & 12,95 & 10,79 & 7,75 & 5,91 & 3,95 \\
\hline 21,91 & 685,40 & 163,10 & 34,52 & 22,82 & 16,66 & 11,41 & 8,38 & 6,55 & 4,56 & 3,54 & 2,47 \\
\hline 65,02 & 998,70 & 82,20 & 24,63 & 19,13 & 17,29 & 15,39 & 13,77 & 12,32 & 9,86 & 7,97 & 5,44 \\
\hline 71,95 & 1742,50 & 193,10 & 11,41 & 8,40 & 7,45 & 6,56 & 5,84 & 5,22 & 4,17 & 3,37 & 2,31 \\
\hline 54,25 & 758,70 & 41,50 & 45,91 & 38,16 & 35,07 & 31,39 & 28,07 & 25,04 & 19,89 & 15,93 & 10,71 \\
\hline 75,86 & 622,40 & 72,00 & 30,52 & 22,06 & 19,50 & 17,17 & 15,34 & 13,74 & 11,06 & 9,00 & 6,22 \\
\hline 32,35 & 886,50 & 76,40 & 42,41 & 34,32 & 29,25 & 23,50 & 18,91 & 15,37 & 10,63 & 7,93 & 5,28 \\
\hline 85,50 & 826,60 & 166,30 & 16,99 & 11,04 & 9,26 & 7,85 & 6,87 & 6,07 & 4,79 & 3,86 & 2,66 \\
\hline
\end{tabular}




\begin{tabular}{|c|c|c|c|c|c|c|c|c|c|c|c|}
\hline \multirow[b]{2}{*}{ e1 (cm) } & & & & & & & ões (x1 & m) & & & \\
\hline & Meq (MPa) & Ms (MPa) & D0 & D25 & D40 & D60 & D80 & D100 & D140 & D180 & D260 \\
\hline 36,17 & 1007,10 & 60,50 & $\begin{array}{l}43,28 \\
\end{array}$ & 36,78 & 32,51 & 27,40 & 22,99 & 19,32 & 13,91 & 10,45 & 6,80 \\
\hline 63,94 & 1462,20 & 131,90 & 16,10 & 12,46 & 11,18 & 9,89 & 8,79 & 7,82 & 6,20 & 4,97 & 3,36 \\
\hline 39,88 & 1437,20 & 59,30 & 35,80 & 31,48 & 28,65 & 25,10 & 21,86 & 18,99 & 14,37 & 11,08 & 7,20 \\
\hline 60,38 & 1037,50 & 79,30 & 25,74 & 20,46 & 18,53 & 16,46 & 14,67 & 13,06 & 10,35 & 8,29 & 5,59 \\
\hline 71,24 & 1830,90 & 64,50 & 21,54 & 16,90 & 15,96 & 14,95 & 13,95 & 12,99 & 11,20 & 9,64 & 7,16 \\
\hline 63,38 & 712,20 & 29,00 & 54,00 & 43,53 & 40,96 & 37,73 & 34,70 & 31,84 & 26,66 & 22,32 & 15,88 \\
\hline 38,02 & 404,20 & 193,90 & 30,31 & 17,74 & 13,18 & 9,49 & 7,20 & 5,70 & 3,92 & 3,01 & 2,10 \\
\hline 40,02 & 936,40 & 33,90 & 59,64 & 52,84 & 48,42 & 42,74 & 37,50 & 32,79 & 25,09 & 19,48 & 12,70 \\
\hline 47,08 & 955,90 & 75,90 & 31,74 & 26,07 & 23,21 & 20,01 & 17,23 & 14,83 & 11,10 & 8,53 & 5,58 \\
\hline 61,78 & 1907,00 & 157,20 & 13,24 & 10,40 & 9,39 & 8,32 & 7,40 & 6,59 & 5,22 & 4,18 & 2,82 \\
\hline 61,32 & 1109,90 & 27,90 & 48,74 & 39,57 & 37,86 & 35,55 & 33,16 & 30,84 & 26,49 & 22,66 & 16,64 \\
\hline 74,07 & 1901,90 & 93,30 & 16,47 & 12,69 & 11,84 & 10,94 & 10,12 & 9,35 & 7,95 & 6,76 & 4,93 \\
\hline 30,49 & 1270,50 & 131,70 & 27,34 & 21,50 & 17,93 & 14,01 & 11,03 & 8,83 & 6,03 & 4,52 & 3,05 \\
\hline 72,76 & 1226,80 & 79,80 & 21,74 & 16,64 & 15,31 & 13,92 & 12,72 & 11,62 & 9,67 & 8,06 & 5,73 \\
\hline 77,24 & 1500,10 & 175,00 & 12,52 & 9,00 & 7,95 & 7,00 & 6,26 & 5,62 & 4,53 & 3,70 & 2,56 \\
\hline 42,78 & 1373,20 & 145,10 & 19,85 & 15,78 & 13,70 & 11,41 & 9,52 & 7,98 & 5,74 & 4,33 & 2,84 \\
\hline 43,69 & 1292,20 & 87,00 & 27,33 & 22,95 & 20,52 & 17,69 & 15,20 & 13,06 & 9,73 & 7,45 & 4,85 \\
\hline 73,88 & 1148,20 & 54,10 & 28,02 & 21,64 & 20,22 & 18,72 & 17,34 & 16,04 & 13,67 & 11,64 & 8,52 \\
\hline 47,31 & 959,80 & 102,20 & 26,51 & 20,97 & 18,33 & 15,51 & 13,14 & 11,16 & 8,19 & 6,24 & 4,09 \\
\hline 83,31 & 1413,80 & 149,30 & 13,54 & 9,64 & 8,58 & 7,63 & 6,90 & 6,26 & 5,16 & 4,28 & 3,04 \\
\hline 50,93 & 1903,40 & 123,80 & 17,10 & 14,21 & 12,87 & 11,34 & 9,98 & 8,76 & 6,78 & 5,32 & 3,51 \\
\hline 83,85 & 214,00 & 94,80 & 49,66 & 27,74 & 21,12 & 16,43 & 13,57 & 11,46 & 8,49 & 6,62 & 4,50 \\
\hline 52,76 & 1134,50 & 56,80 & 33,03 & 27,73 & 25,56 & 22,92 & 20,52 & 18,31 & 14,56 & 11,66 & 7,83 \\
\hline 74,60 & 1264,10 & 118,40 & 16,93 & 12,56 & 11,28 & 10,06 & 9,07 & 8,18 & 6,66 & 5,47 & 3,81 \\
\hline 45,93 & 1651,30 & 75,60 & 26,32 & 22,72 & 20,82 & 18,47 & 16,32 & 14,38 & 11,16 & 8,76 & 5,77 \\
\hline 60,66 & 1670,30 & 88,90 & 19,88 & 16,12 & 14,94 & 13,53 & 12,26 & 11,09 & 9,03 & 7,39 & 5,10 \\
\hline 34,95 & 1720,40 & 168,80 & 19,04 & 15,22 & 13,00 & 10,50 & 8,50 & 6,94 & 4,83 & 3,61 & 2,40 \\
\hline 29,45 & 1772,40 & 130,50 & 25,22 & 20,62 & 17,52 & 13,97 & 11,16 & 9,01 & 6,18 & 4,61 & 3,08 \\
\hline 21,75 & 844,10 & 51,70 & 75,44 & 60,33 & 49,22 & 37,10 & 28,30 & 22,15 & 14,93 & 11,26 & 7,72 \\
\hline 77,24 & 390,00 & 172,50 & 27,65 & 15,61 & 11,92 & 9,26 & 7,61 & 6,39 & 4,67 & 3,62 & 2,45 \\
\hline 79,81 & 1320,50 & 195,40 & 12,48 & 8,64 & 7,48 & 6,48 & 5,74 & 5,12 & 4,08 & 3,31 & 2,28 \\
\hline 36,94 & 1702,60 & 148,30 & 19,94 & 16,24 & 14,07 & 11,59 & 9,54 & 7,90 & 5,58 & 4,18 & 2,75 \\
\hline 62,09 & 638,20 & 195,50 & 20,45 & 12,93 & 10,40 & 8,32 & 6,88 & 5,75 & 4,17 & 3,19 & 2,13 \\
\hline 39,06 & 1629,90 & 173,30 & 17,70 & 14,06 & 12,09 & 9,91 & 8,14 & 6,73 & 4,76 & 3,57 & 2,35 \\
\hline 81,94 & 1972,60 & 105,60 & 14,26 & 10,70 & 9,90 & 9,17 & 8,51 & 7,91 & 6,80 & 5,84 & 4,34 \\
\hline 46,68 & 1485,80 & 113,00 & 21,08 & 17,41 & 15,54 & 13,41 & 11,56 & 9,97 & 7,47 & 5,74 & 3,75 \\
\hline 23,17 & 852,80 & 135,60 & 36,09 & 25,80 & 19,73 & 14,00 & 10,38 & 8,07 & 5,54 & 4,26 & 2,96 \\
\hline 82,55 & 696,40 & 77,40 & 26,89 & 19,09 & 16,92 & 15,00 & 13,52 & 12,23 & 10,02 & 8,28 & 5,84 \\
\hline 58,78 & 840,50 & 66,60 & 31,59 & 25,17 & 22,72 & 20,09 & 17,82 & 15,79 & 12,41 & 9,88 & 6,62 \\
\hline 41,07 & 867,90 & 25,50 & 72,58 & 64,68 & 60,01 & 53,73 & 47,81 & 42,36 & 33,15 & 26,16 & 17,25 \\
\hline 61,78 & 1039,30 & 146,60 & 18,10 & 13,32 & 11,55 & 9,89 & 8,56 & 7,43 & 5,65 & 4,41 & 2,93 \\
\hline 48,52 & 911,40 & 38,70 & 48,26 & 41,45 & 38,31 & 34,34 & 30,66 & 27,29 & 21,56 & 17,17 & 11,46 \\
\hline 44,17 & 1447,60 & 87,90 & 25,81 & 21,89 & 19,70 & 17,11 & 14,82 & 12,81 & 9,64 & 7,42 & 4,84 \\
\hline 84,40 & 901,80 & 56,00 & 28,20 & 20,83 & 19,14 & 17,60 & 16,29 & 15,08 & 12,91 & 11,06 & 8,18 \\
\hline 79,47 & 1908,50 & 117,50 & 13,80 & 10,35 & 9,54 & 8,75 & 8,06 & 7,44 & 6,30 & 5,35 & 3,90 \\
\hline 88,56 & 1005,80 & 127,00 & 17,00 & 11,69 & 10,23 & 9,01 & 8,11 & 7,34 & 6,04 & 5,01 & 3,56 \\
\hline 89,33 & 301,40 & 25,00 & 69,92 & 49,94 & 45,03 & 40,83 & 37,47 & 34,50 & 29,24 & 24,87 & 18,24 \\
\hline 38,95 & 1521,50 & 142,60 & 20,54 & 16,59 & 14,39 & 11,90 & 9,85 & 8,19 & 5,82 & 4,37 & 2,87 \\
\hline 88,99 & 1916,80 & 177,80 & 10,39 & 7,36 & 6,59 & 5,93 & 5,42 & 4,96 & 4,17 & 3,53 & 2,56 \\
\hline 47,60 & 609,70 & 173,50 & 24,37 & 16,08 & 12,93 & 10,11 & 8,09 & 6,59 & 4,61 & 3,49 & 2,35 \\
\hline 70,67 & 1366,20 & 82,70 & 20,69 & 16,02 & 14,80 & 13,48 & 12,32 & 11,26 & 9,36 & 7,80 & 5,53 \\
\hline 52,07 & 351,70 & 189,20 & 30,80 & 17,18 & 12,78 & 9,45 & 7,38 & 5,94 & 4,12 & 3,15 & 2,17 \\
\hline 23,81 & 986,40 & 25,00 & 110,51 & 97,43 & 85,65 & 70,79 & 58,09 & 47,76 & 33,26 & 24,61 & 16,08 \\
\hline 60,67 & 1785,10 & 127,10 & 15,57 & 12,43 & 11,31 & 10,09 & 9,03 & 8,06 & 6,43 & 5,18 & 3,51 \\
\hline 32,72 & 1686,70 & 144,00 & 22,25 & 18,04 & 15,41 & 12,42 & 10,02 & 8,16 & 5,66 & 4,22 & 2,80 \\
\hline 82,47 & 508,40 & 192,80 & 22,02 & 12,75 & 9,93 & 7,87 & 6,58 & 5,60 & 4,19 & 3,27 & 2,22 \\
\hline 75,92 & 849,50 & 24,30 & 50,89 & 39,78 & 37,49 & 35,62 & 33,61 & 31,63 & 27,87 & 24,47 & 18,81 \\
\hline 53,54 & 717,40 & 102,60 & 28,01 & 20,96 & 18,07 & 15,21 & 12,91 & 10,99 & 8,12 & 6,22 & 4,10 \\
\hline 84,89 & 1214,70 & 129,90 & 15,54 & 11,00 & 9,77 & 8,69 & 7,86 & 7,14 & 5,90 & 4,91 & 3,49 \\
\hline 67,35 & 1730,70 & 61,90 & 23,34 & 18,54 & 17,54 & 16,34 & 15,17 & 14,06 & 12,00 & 10,23 & 7,47 \\
\hline 52,24 & 496,90 & 60,50 & $\begin{array}{l}44,73 \\
\end{array}$ & 34,42 & 29,99 & 25,46 & 21,73 & 18,59 & 13,80 & 10,60 & 6,96 \\
\hline 20,61 & 1891,90 & 39,10 & 75,22 & 65,89 & 57,35 & 46,67 & 37,72 & 30,61 & 20,99 & 15,50 & 10,23 \\
\hline 22,26 & 1362,20 & 134,20 & 32,70 & 24,83 & 19,60 & 14,29 & 10,70 & 8,32 & 5,65 & 4,31 & 2,98 \\
\hline 67,00 & 1722,10 & 22,70 & 45,15 & 36,96 & 34,90 & 33,85 & 32,42 & 30,86 & 27,80 & 24,90 & 19,80 \\
\hline 45,77 & 1125,90 & 183,60 & 18,09 & 13,39 & 11,32 & 9,22 & 7,58 & 6,29 & 4,47 & 3,37 & 2,23 \\
\hline 34,40 & 255,50 & 135,10 & 446,66 & 26,61 & 19,34 & 13,61 & 10,22 & 8,06 & 5,57 & 4,30 & 3,01 \\
\hline 70,50 & 915,30 & 145,30 & 18,28 & 12,88 & 11,08 & 9,49 & 8,28 & 7,26 & 5,63 & 4,46 & 3,00 \\
\hline 44,48 & 432,80 & 116,20 & 36,40 & 24,43 & 19,68 & 15,30 & 12,17 & 9,86 & 6,86 & 5,18 & 3,50 \\
\hline 48,08 & 467,60 & 189,90 & 26,66 & 16,13 & 12,45 & 9,41 & 7,40 & 5,96 & 4,14 & 3,14 & 2,15 \\
\hline 56,17 & 1264,30 & 166,00 & 16,22 & 12,24 & 10,64 & 9,06 & 7,78 & 6,70 & 5,02 & 3,88 & 2,56 \\
\hline 58,83 & 1620,50 & 101,50 & 18,84 & 15,28 & 13,99 & 12,54 & 11,24 & 10,06 & 8,05 & 6,49 & 4,40 \\
\hline 89,50 & 1173,40 & 155,10 & 14,20 & 9,68 & 8,44 & 7,41 & 6,66 & 6,02 & 4,94 & 4,10 & 2,91 \\
\hline 56,29 & 1990,00 & 187,30 & 12,37 & 9,76 & 8,69 & 7,57 & 6,62 & 5,79 & 4,45 & 3,49 & 2,31 \\
\hline 39,80 & 768,00 & 195,10 & 22,20 & 15,14 & 12,14 & 9,31 & 7,30 & 5,85 & 4,04 & 3,05 & 2,08 \\
\hline 54,80 & 1858,40 & 70,30 & 23,65 & 19,83 & 18,60 & 16,97 & 15,44 & 14,00 & 11,46 & 9,39 & 6,48 \\
\hline 22,39 & 1814,30 & 35,80 & 75,22 & 67,04 & 59,23 & 49,24 & 40,58 & 33,47 & 23,38 & 17,29 & 11,25 \\
\hline 35,12 & 996,60 & 172,20 & 22,95 & 16,84 & 13,78 & 10,64 & 8,35 & 6,68 & 4,59 & 3,45 & 2,34 \\
\hline 79,86 & 860,90 & 80,80 & 24,09 & 17,53 & 15,75 & 14,09 & 12,77 & 11,59 & 9,56 & 7,93 & 5,62 \\
\hline 29,26 & 1560,10 & 37,60 & 60,43 & 54,80 & 49,57 & 42,74 & 36,54 & 31,14 & 22,80 & 17,19 & 11,05 \\
\hline 74,25 & 1960,10 & 164,00 & 11,65 & 8,73 & 7,91 & 7,10 & 6,43 & 5,82 & 4,78 & 3,94 & 2,77 \\
\hline 79,90 & 385,50 & 183,00 & 27,21 & 15,05 & 11,37 & 8,76 & 7,16 & 6,01 & 4,39 & 3,40 & 2,31 \\
\hline 43,37 & 1934,10 & 161,90 & 16,06 & 13,17 & 11,61 & 9,86 & 8,36 & 7,10 & 5,20 & 3,95 & 2,57 \\
\hline
\end{tabular}




\begin{tabular}{|c|c|c|c|c|c|c|c|c|c|c|c|}
\hline \multirow[b]{2}{*}{$\mathrm{e} 1(\mathrm{~cm})$} & & & & & & $\mathrm{De}$ & $\overline{\text { ões (x1 }}$ & & & & \\
\hline & Meq (MPa) & Ms (MPa) & D0 & D25 & D40 & D60 & D80 & D100 & D140 & D180 & D260 \\
\hline 22,35 & 1567,50 & 49,70 & 63,10 & 54,03 & 46,42 & 37,20 & 29,70 & 23,91 & 16,30 & 12,07 & 8,04 \\
\hline 52,10 & 592,90 & 169,30 & 24,16 & 15,82 & 12,77 & 10,10 & 8,19 & 6,74 & 4,77 & 3,61 & 2,43 \\
\hline 51,00 & 639,00 & 139,00 & 25,87 & 18,00 & 14,92 & 12,07 & 9,92 & 8,24 & 5,88 & 4,45 & 2,96 \\
\hline 55,54 & 1217,00 & 65,80 & 28,43 & 23,53 & 21,67 & 19,46 & 17,46 & 15,62 & 12,48 & 10,05 & 6,79 \\
\hline 75,74 & 1015,80 & 115,90 & 18,85 & 13,65 & 12,08 & 10,64 & 9,52 & 8,53 & 6,87 & 5,59 & 3,87 \\
\hline 58,23 & 903,00 & 169,00 & 18,58 & 13,13 & 11,10 & 9,24 & 7,81 & 6,64 & 4,89 & 3,76 & 2,49 \\
\hline 62,04 & 1180,40 & 58,50 & 29,06 & 23,48 & 21,86 & 19,91 & 18,14 & 16,49 & 13,56 & 11,18 & 7,80 \\
\hline 31,34 & 467,00 & 193,30 & 30,16 & 18,36 & 13,58 & 9,59 & 7,18 & 5,64 & 3,89 & 3,00 & 2,10 \\
\hline 88,95 & 1176,70 & 184,60 & 13,12 & 8,77 & 7,52 & 6,52 & 5,80 & 5,20 & 4,22 & 3,46 & 2,43 \\
\hline 42,60 & 967,40 & 58,20 & 39,85 & 33,89 & 30,43 & 26,31 & 22,67 & 19,51 & 14,57 & 11,16 & 7,26 \\
\hline 58,71 & 1295,60 & 133,30 & 17,66 & 13,69 & 12,14 & 10,56 & 9,24 & 8,09 & 6,23 & 4,90 & 3,26 \\
\hline 65,02 & 1813,60 & 129,70 & 14,73 & 11,56 & 10,55 & 9,46 & 8,52 & 7,67 & 6,20 & 5,05 & 3,47 \\
\hline 41,07 & 571,10 & 24,60 & 85,68 & 74,99 & 68,29 & 59,92 & 52,29 & 45,50 & 34,55 & 26,72 & 17,40 \\
\hline 55,88 & 889,80 & 70,30 & 30,76 & 24,75 & 22,29 & 19,61 & 17,29 & 15,23 & 11,84 & 9,35 & 6,22 \\
\hline 36,68 & 1818,30 & 154,50 & 19,05 & 15,56 & 13,49 & 11,12 & 9,16 & 7,58 & 5,36 & 4,01 & 2,64 \\
\hline 49,78 & 1263,50 & 115,00 & 21,38 & 17,20 & 15,25 & 13,12 & 11,31 & 9,75 & 7,31 & 5,63 & 3,69 \\
\hline 23,65 & 663,00 & 150,40 & 35,59 & 24,04 & 17,91 & 12,47 & 9,20 & 7,18 & 4,97 & 3,84 & 2,67 \\
\hline 56,19 & 765,80 & 55,40 & 37,52 & 30,39 & 27,53 & 24,36 & 21,58 & 19,09 & 14,96 & 11,88 & 7,93 \\
\hline 63,00 & 1688,30 & 59,20 & 25,20 & 20,36 & 19,28 & 17,88 & 16,52 & 15,23 & 12,87 & 10,85 & 7,80 \\
\hline 38,29 & 1863,20 & 127,40 & 20,65 & 17,34 & 15,30 & 12,90 & 10,85 & 9,14 & 6,60 & 4,97 & 3,24 \\
\hline 59,60 & 481,80 & 32,00 & 60,71 & 48,89 & 44,65 & 39,92 & 35,76 & 31,98 & 25,54 & 20,57 & 13,95 \\
\hline 85,95 & 895,90 & 49,80 & 29,95 & 22,20 & 20,45 & 18,95 & 17,63 & 16,40 & 14,17 & 12,24 & 9,19 \\
\hline 25,18 & 396,60 & 89,60 & 57,82 & 39,44 & 29,77 & 21,00 & 15,58 & 12,16 & 8,37 & 6,45 & 4,49 \\
\hline 34,59 & 1613,50 & 177,00 & 19,04 & 14,99 & 12,68 & 10,13 & 8,13 & 6,60 & 4,57 & 3,42 & 2,28 \\
\hline 60,48 & 693,10 & 141,90 & 22,79 & 15,76 & 13,22 & 10,96 & 9,26 & 7,87 & 5,81 & 4,47 & 2,97 \\
\hline 89,79 & 1480,80 & 156,60 & 12,53 & 8,74 & 7,76 & 6,92 & 6,29 & 5,74 & 4,79 & 4,02 & 2,90 \\
\hline 88,25 & 908,10 & 36,00 & 35,34 & 26,75 & 24,72 & 23,34 & 22,00 & 20,72 & 18,32 & 16,16 & 12,55 \\
\hline 60,02 & 575,70 & 38,60 & 50,37 & 40,48 & 36,97 & 33,06 & 29,62 & 26,50 & 21,19 & 17,08 & 11,59 \\
\hline 51,53 & 1810,30 & 39,50 & 36,76 & 31,10 & 29,79 & 27,68 & 25,57 & 23,52 & 19,76 & 16,55 & 11,73 \\
\hline 40,57 & 1632,40 & 138,30 & 19,79 & 16,21 & 14,20 & 11,92 & 9,99 & 8,39 & 6,05 & 4,56 & 2,98 \\
\hline 48,13 & 1571,50 & 140,50 & 17,74 & 14,34 & 12,70 & 10,89 & 9,35 & 8,03 & 5,99 & 4,59 & 3,01 \\
\hline 53,24 & 311,40 & 22,40 & 95,60 & 78,21 & 70,64 & 62,17 & 54,74 & 48,12 & 37,28 & 29,33 & 19,44 \\
\hline 41,78 & 1748,00 & 21,00 & 66,91 & 58,29 & 56,30 & 52,49 & 48,55 & 44,69 & 37,52 & 31,36 & 22,12 \\
\hline 32,11 & 1481,40 & 161,80 & 21,87 & 17,15 & 14,36 & 11,30 & 8,96 & 7,20 & 4,94 & 3,70 & 2,49 \\
\hline 75,58 & 691,40 & 47,50 & 36,66 & 27,70 & 25,40 & 23,08 & 21,11 & 19,30 & 16,11 & 13,48 & 9,63 \\
\hline 41,32 & 442,40 & 39,70 & 69,61 & 56,59 & 49,49 & 41,48 & 34,76 & 29,21 & 21,07 & 15,90 & 10,39 \\
\hline 66,56 & 899,90 & 188,50 & 16,71 & 11,34 & 9,50 & 7,93 & 6,76 & 5,81 & 4,36 & 3,39 & 2,26 \\
\hline 53,71 & 1975,30 & 161,70 & 13,89 & 11,21 & 10,05 & 8,78 & 7,69 & 6,73 & 5,17 & 4,05 & 2,68 \\
\hline 66,68 & 1844,90 & 124,60 & 14,78 & 11,57 & 10,60 & 9,56 & 8,65 & 7,83 & 6,39 & 5,24 & 3,64 \\
\hline 20,33 & 1977,40 & 33,30 & 83,76 & 74,40 & 65,38 & 53,87 & 44,02 & 36,03 & 24,92 & 18,39 & 12,03 \\
\hline 73,43 & 1470,80 & 143,40 & 14,34 & 10,64 & 9,53 & 8,47 & 7,61 & 6,84 & 5,54 & 4,53 & 3,14 \\
\hline 38,18 & 1470,70 & 82,00 & 29,81 & 25,57 & 22,82 & 19,50 & 16,59 & 14,10 & 10,33 & 7,82 & 5,07 \\
\hline 81,26 & 594,20 & 30,30 & 48,97 & 36,89 & 34,23 & 31,76 & 29,53 & 27,45 & 23,64 & 20,34 & 15,15 \\
\hline 49,71 & 1379,10 & 56,80 & 32,03 & 27,41 & 25,43 & 22,88 & 20,52 & 18,34 & 14,61 & 11,70 & 7,86 \\
\hline 66,26 & 1124,40 & 102,10 & 20,49 & 15,71 & 14,12 & 12,51 & 11,17 & 9,97 & 7,95 & 6,41 & 4,37 \\
\hline 59,90 & 1231,70 & 147,50 & 16,92 & 12,82 & 11,25 & 9,71 & 8,45 & 7,36 & 5,63 & 4,41 & 2,93 \\
\hline 72,52 & 1715,30 & 113,40 & 15,42 & 11,81 & 10,85 & 9,85 & 9,00 & 8,21 & 6,82 & 5,68 & 4,03 \\
\hline 51,11 & 313,90 & 165,90 & 34,88 & 19,58 & 14,60 & 10,80 & 8,42 & 6,77 & 4,70 & 3,59 & 2,47 \\
\hline 72,26 & 233,50 & 128,10 & 43,63 & 23,57 & 17,46 & 13,15 & 10,56 & 8,71 & 6,23 & 4,79 & 3,27 \\
\hline 45,49 & 1434,10 & 87,60 & 25,41 & 21,49 & 19,38 & 16,90 & 14,69 & 12,75 & 9,65 & 7,46 & 4,88 \\
\hline 45,58 & 317,00 & 174,30 & 34,74 & 19,42 & 14,34 & 10,43 & 8,02 & 6,39 & 4,41 & 3,38 & 2,34 \\
\hline 62,14 & 1141,60 & 41,20 & 36,86 & 29,90 & 28,26 & 26,14 & 24,11 & 22,17 & 18,65 & 15,67 & 11,20 \\
\hline 56,00 & 446,70 & 174,70 & 27,18 & 16,39 & 12,77 & 9,87 & 7,92 & 6,49 & 4,57 & 3,48 & 2,36 \\
\hline 89,10 & 674,00 & 119,80 & 21,67 & 14,22 & 12,06 & 10,34 & 9,14 & 8,15 & 6,54 & 5,34 & 3,73 \\
\hline 52,58 & 1434,50 & 135,10 & 17,85 & 14,22 & 12,62 & 10,91 & 9,45 & 8,20 & 6,21 & 4,81 & 3,17 \\
\hline 64,77 & 1317,40 & 25,30 & 47,52 & 38,21 & 36,55 & 34,90 & 32,96 & 31,02 & 27,30 & 23,90 & 18,24 \\
\hline 47,29 & 1385,40 & 45,70 & 38,14 & 33,13 & 30,95 & 28,00 & 25,22 & 22,62 & 18,11 & 14,57 & 9,81 \\
\hline 61,37 & 1572,30 & 106,10 & 18,14 & 14,49 & 13,25 & 11,86 & 10,65 & 9,55 & 7,67 & 6,20 & 4,23 \\
\hline 70,74 & 622,10 & 77,30 & 30,33 & 22,12 & 19,43 & 16,95 & 14,99 & 13,29 & 10,50 & 8,42 & 5,72 \\
\hline 73,17 & 1831,60 & 56,10 & 23,15 & 18,13 & 17,14 & 16,19 & 15,21 & 14,25 & 12,44 & 10,82 & 8,19 \\
\hline 36,10 & 1835,40 & 193,40 & 16,68 & 13,23 & 11,28 & 9,12 & 7,40 & 6,05 & 4,22 & 3,16 & 2,09 \\
\hline 52,71 & 202,10 & 67,80 & 65,44 & 41,21 & 32,68 & 25,49 & 20,50 & 16,78 & 11,82 & 8,96 & 6,05 \\
\hline 62,91 & 842,30 & 41,70 & 40,46 & 32,57 & 30,34 & 27,66 & 25,24 & 22,97 & 18,95 & 15,67 & 10,96 \\
\hline 74,57 & 216,30 & 32,30 & 77,83 & 54,67 & 47,28 & 40,84 & 35,95 & 31,78 & 25,01 & 20,04 & 13,64 \\
\hline 87,05 & 767,00 & 26,50 & 45,73 & 35,05 & 32,46 & 30,80 & 29,16 & 27,54 & 24,47 & 21,69 & 16,98 \\
\hline 70,14 & 269,40 & 197,60 & 34,87 & 17,56 & 12,41 & 8,94 & 6,97 & 5,65 & 3,97 & 3,05 & 2,11 \\
\hline 28,05 & 817,90 & 94,70 & 41,73 & 32,06 & 26,15 & 19,87 & 15,33 & 12,11 & 8,23 & 6,20 & 4,24 \\
\hline 71,14 & 520,30 & 194,00 & 22,35 & 13,27 & 10,39 & 8,22 & 6,80 & 5,71 & 4,18 & 3,22 & 2,17 \\
\hline 24,51 & 718,30 & 94,70 & 47,32 & 35,09 & 27,59 & 20,11 & 15,10 & 11,77 & 8,01 & 6,12 & 4,23 \\
\hline 29,32 & 1847,70 & 73,40 & 36,57 & 31,86 & 28,11 & 23,46 & 19,46 & 16,16 & 11,42 & 8,51 & 5,54 \\
\hline 81,84 & 1918,30 & 88,60 & 16,02 & 12,11 & 11,26 & 10,51 & 9,81 & 9,15 & 7,94 & 6,87 & 5,17 \\
\hline 39,76 & 1894,90 & 167,70 & 16,83 & 13,71 & 11,95 & 9,96 & 8,30 & 6,94 & 4,97 & 3,74 & 2,45 \\
\hline 46,99 & 1683,40 & 189,20 & 14,72 & 11,56 & 10,06 & 8,47 & 7,15 & 6,05 & 4,42 & 3,36 & 2,20 \\
\hline 87,53 & 1907,00 & 143,10 & 11,78 & 8,52 & 7,74 & 7,05 & 6,49 & 5,99 & 5,09 & 4,34 & 3,19 \\
\hline 45,52 & 895,30 & 58,20 & 39,18 & 32,94 & 29,61 & 25,72 & 22,29 & 19,29 & 14,54 & 11,21 & 7,32 \\
\hline 21,96 & 412,20 & 138,20 & 44,65 & 27,60 & 19,60 & 13,24 & 9,74 & 7,66 & 5,36 & 4,17 & 2,92 \\
\hline 75,92 & 767,20 & 111,00 & 22,14 & 15,56 & 13,49 & 11,69 & 10,33 & 9,16 & 7,25 & 5,84 & 3,99 \\
\hline 45,58 & 1219,90 & 176,10 & 17,92 & 13,55 & 11,56 & 9,50 & 7,87 & 6,55 & 4,69 & 3,54 & 2,33 \\
\hline 26,70 & 858,40 & 194,10 & 25,92 & 17,81 & 13,59 & 9,70 & 7,24 & 5,66 & 3,88 & 2,98 & 2,07 \\
\hline 36,68 & 1770,10 & 39,50 & 46,67 & 42,38 & 39,39 & 35,25 & 31,31 & 27,68 & 21,56 & 16,93 & 11,09 \\
\hline 60,57 & 729,60 & 185,40 & 19,58 & 12,94 & 10,62 & 8,64 & 7,20 & 6,06 & 4,42 & 3,38 & 2,26 \\
\hline 75,43 & 1718,00 & 140,90 & 13,34 & 9,97 & 9,04 & 8,13 & 7,38 & 6,70 & 5,52 & 4,58 & 3,23 \\
\hline
\end{tabular}




\begin{tabular}{|c|c|c|c|c|c|c|c|c|c|c|c|}
\hline & & & \multicolumn{9}{|c|}{ Deflexões $\left(\times 10^{-4} \mathrm{~cm}\right)$} \\
\hline e1 (cm) & Meq (MPa) & Ms (MPa) & D0 & D25 & D40 & D60 & D80 & D100 & D140 & D180 & D260 \\
\hline 71,71 & 1216,70 & 182,50 & 14,03 & 9,94 & 8,59 & 7,40 & 6,49 & 5,72 & 4,46 & 3,55 & 2,40 \\
\hline 30,96 & 1043,80 & 66,30 & 45,46 & 37,98 & 32,84 & 26,76 & 21,77 & 17,82 & 12,40 & 9,23 & 6,09 \\
\hline 87,70 & 1737,80 & 125,80 & 13,17 & 9,55 & 8,68 & 7,93 & 7,31 & 6,76 & 5,76 & 4,92 & 3,63 \\
\hline 50,49 & 1276,90 & 153,80 & 17,86 & 13,81 & 12,02 & 10,17 & 8,65 & 7,37 & 5,43 & 4,16 & 2,73 \\
\hline 73,47 & 1720,40 & 128,40 & 14,23 & 10,78 & 9,84 & 8,88 & 8,08 & 7,34 & 6,06 & 5,03 & 3,54 \\
\hline 60,29 & 545,90 & 186,40 & 23,05 & 14,26 & 11,31 & 8,93 & 7,30 & 6,06 & 4,34 & 3,31 & 2,23 \\
\hline 25,78 & 1495,80 & 94,20 & 36,75 & 30,08 & 25,29 & 19,81 & 15,58 & 12,43 & 8,44 & 6,30 & 4,25 \\
\hline 35,43 & 1495,60 & 66,60 & 35,90 & 31,39 & 28,14 & 24,10 & 20,52 & 17,45 & 12,77 & 9,65 & 6,24 \\
\hline 83,75 & 589,00 & 180,40 & 20,38 & 12,31 & 9,85 & 8,01 & 6,80 & 5,87 & 4,47 & 3,53 & 2,40 \\
\hline 84,14 & 524,40 & 105,20 & 26,93 & 17,58 & 14,75 & 12,50 & 10,93 & 9,64 & 7,59 & 6,11 & 4,19 \\
\hline 77,75 & 670,00 & 170,30 & 19,61 & 12,46 & 10,21 & 8,45 & 7,23 & 6,26 & 4,77 & 3,76 & 2,54 \\
\hline 38,61 & 244,30 & 114,70 & 50,51 & 29,73 & 22,18 & 16,03 & 12,20 & 9,65 & 6,65 & 5,09 & 3,54 \\
\hline 71,02 & 840,90 & 66,70 & 28,59 & 21,77 & 19,77 & 17,75 & 16,05 & 14,51 & 11,85 & 9,74 & 6,78 \\
\hline 56,02 & 726,10 & 29,50 & 57,02 & 47,51 & 44,47 & 40,52 & 36,85 & 33,40 & 27,31 & 22,38 & 15,44 \\
\hline 20,94 & 967,10 & 188,40 & 29,00 & 19,68 & 14,47 & 9,93 & 7,28 & 5,68 & 3,95 & 3,06 & 2,13 \\
\hline 26,80 & 787,00 & 124,20 & 36,10 & 26,37 & 20,79 & 15,25 & 11,52 & 9,01 & 6,14 & 4,68 & 3,23 \\
\hline 41,81 & 1244,40 & 194,60 & 17,65 & 13,19 & 11,10 & 8,94 & 7,26 & 5,96 & 4,19 & 3,14 & 2,09 \\
\hline 35,83 & 1944,60 & 23,20 & 67,12 & 60,74 & 57,88 & 53,12 & 48,37 & 43,82 & 35,64 & 28,95 & 19,62 \\
\hline 51,21 & 1901,10 & 129,90 & 16,55 & 13,68 & 12,36 & 10,87 & 9,55 & 8,37 & 6,45 & 5,06 & 3,34 \\
\hline 38,44 & 1611,50 & 73,60 & 30,73 & 26,84 & 24,22 & 20,98 & 18,07 & 15,53 & 11,56 & 8,83 & 5,72 \\
\hline 47,83 & 403,20 & 79,40 & 44,54 & 31,75 & 26,48 & 21,40 & 17,52 & 14,49 & 10,29 & 7,77 & 5,17 \\
\hline 52,67 & 365,40 & 89,20 & 42,11 & 28,52 & 23,42 & 18,83 & 15,44 & 12,81 & 9,14 & 6,93 & 4,62 \\
\hline 52,25 & 1532,90 & 42,80 & 36,26 & 30,75 & 29,18 & 26,86 & 24,62 & 22,48 & 18,62 & 15,40 & 10,74 \\
\hline 50,21 & 1605,50 & 176,90 & 14,99 & 11,75 & 10,29 & 8,75 & 7,47 & 6,39 & 4,73 & 3,63 & 2,38 \\
\hline 89,67 & 1749,60 & 66,70 & 18,55 & 14,08 & 12,98 & 12,28 & 11,61 & 10,96 & 9,72 & 8,61 & 6,73 \\
\hline 48,46 & 219,80 & 133,40 & 47,53 & 25,74 & 18,76 & 13,58 & 10,45 & 8,35 & 5,77 & 4,42 & 3,07 \\
\hline 45,20 & 1858,30 & 28,20 & 50,48 & 43,59 & 41,99 & 39,09 & 36,13 & 33,24 & 27,90 & 23,33 & 16,47 \\
\hline 85,33 & 677,80 & 113,20 & 22,46 & 15,03 & 12,84 & 11,06 & 9,78 & 8,72 & 6,98 & 5,67 & 3,94 \\
\hline 23,68 & 1788,50 & 25,00 & 91,47 & 84,19 & 76,19 & 65,53 & 55,77 & 47,29 & 34,30 & 25,70 & 16,47 \\
\hline 44,39 & 1977,50 & 87,20 & 23,05 & 20,01 & 18,33 & 16,22 & 14,30 & 12,56 & 9,69 & 7,59 & 4,98 \\
\hline 47,78 & 1808,00 & 69,60 & 26,21 & 22,65 & 21,01 & 18,89 & 16,92 & 15,09 & 11,97 & 9,56 & 6,39 \\
\hline 28,17 & 1501,80 & 114,00 & 30,15 & 24,44 & 20,58 & 16,21 & 12,81 & 10,27 & 7,01 & 5,23 & 3,52 \\
\hline 25,97 & 1117,80 & 163,00 & 27,36 & 20,15 & 15,89 & 11,65 & 8,78 & 6,87 & 4,67 & 3,56 & 2,46 \\
\hline 49,74 & 1990,70 & 198,50 & 12,87 & 10,24 & 9,02 & 7,72 & 6,61 & 5,67 & 4,23 & 3,25 & 2,13 \\
\hline 52,08 & 882,10 & 20,00 & 72,85 & 61,53 & 58,88 & 54,68 & 50,47 & 46,42 & 38,96 & 32,61 & 23,12 \\
\hline 57,48 & 983,80 & 87,90 & 25,48 & 20,15 & 18,02 & 15,79 & 13,88 & 12,20 & 9,45 & 7,45 & 4,96 \\
\hline 29,64 & 1714,50 & 89,70 & 32,55 & 27,64 & 24,03 & 19,70 & 16,09 & 13,20 & 9,21 & 6,84 & 4,50 \\
\hline 84,82 & 1378,40 & 20,00 & 42,15 & 36,46 & 33,10 & 31,97 & 31,07 & 29,93 & 27,56 & 25,26 & 21,04 \\
\hline 84,27 & 649,50 & 120,60 & 22,47 & 14,85 & 12,55 & 10,71 & 9,41 & 8,34 & 6,60 & 5,33 & 3,68 \\
\hline 87,88 & 1760,90 & 188,60 & 10,56 & 7,40 & 6,57 & 5,85 & 5,30 & 4,83 & 4,01 & 3,36 & 2,41 \\
\hline 30,95 & 931,50 & 63,50 & 48,65 & 40,33 & 34,71 & 28,13 & 22,78 & 18,59 & 12,89 & 9,60 & 6,35 \\
\hline 37,28 & 232,40 & 188,50 & 40,93 & 20,41 & 14,03 & 9,62 & 7,22 & 5,72 & 3,96 & 3,07 & 2,17 \\
\hline 37,13 & 665,70 & 107,90 & 34,60 & 25,70 & 21,29 & 16,72 & 13,29 & 10,73 & 7,41 & 5,56 & 3,74 \\
\hline 58,45 & 1818,00 & 165,40 & 13,52 & 10,64 & 9,51 & 8,34 & 7,34 & 6,46 & 5,02 & 3,96 & 2,64 \\
\hline 42,42 & 931,50 & 190,00 & 20,09 & 14,30 & 11,78 & 9,31 & 7,46 & 6,07 & 4,23 & 3,18 & 2,14 \\
\hline 60,64 & 366,90 & 73,70 & 43,41 & 30,12 & 25,31 & 21,03 & 17,79 & 15,15 & 11,21 & 8,63 & 5,73 \\
\hline 78,21 & 821,90 & 122,90 & 20,10 & 13,96 & 12,07 & 10,45 & 9,24 & 8,21 & 6,52 & 5,26 & 3,61 \\
\hline 76,73 & 1879,20 & 29,80 & 32,65 & 26,85 & 24,93 & 24,15 & 23,24 & 22,21 & 20,16 & 18,22 & 14,74 \\
\hline 88,76 & 394,00 & 64,70 & 38,42 & 25,53 & 21,82 & 18,84 & 16,72 & 14,96 & 12,07 & 9,89 & 6,92 \\
\hline 33,52 & 1013,40 & 47,50 & 53,57 & 46,49 & 41,31 & 34,93 & 29,37 & 24,70 & 17,78 & 13,34 & 8,65 \\
\hline 33,69 & 1902,70 & 37,80 & 50,16 & 45,98 & 42,58 & 37,91 & 33,47 & 29,41 & 22,64 & 17,63 & 11,46 \\
\hline 64,29 & 1463,10 & 36,40 & 36,09 & 29,00 & 27,71 & 26,15 & 24,48 & 22,86 & 19,80 & 17,08 & 12,71 \\
\hline 65,55 & 1899,70 & 89,70 & 18,06 & 14,39 & 13,45 & 12,34 & 11,32 & 10,36 & 8,64 & 7,21 & 5,12 \\
\hline 69,61 & 683,10 & 43,70 & 40,33 & 31,28 & 28,80 & 26,12 & 23,80 & 21,66 & 17,89 & 14,83 & 10,44 \\
\hline 24,72 & 1389,90 & 173,00 & 25,34 & 18,97 & 15,01 & 11,01 & 8,30 & 6,48 & 4,40 & 3,35 & 2,32 \\
\hline 76,60 & 1445,90 & 180,70 & 12,58 & 8,99 & 7,90 & 6,92 & 6,16 & 5,51 & 4,42 & 3,59 & 2,47 \\
\hline 37,68 & 1658,40 & 97,10 & 25,89 & 22,09 & 19,64 & 16,69 & 14,13 & 11,96 & 8,70 & 6,57 & 4,26 \\
\hline 82,78 & 1350,50 & 132,90 & 14,74 & 10,59 & 9,47 & 8,46 & 7,67 & 6,97 & 5,77 & 4,80 & 3,42 \\
\hline 68,53 & 334,90 & 75,00 & 43,11 & 28,73 & 23,90 & 19,87 & 16,94 & 14,55 & 10,94 & 8,52 & 5,69 \\
\hline 66,98 & 625,70 & 54,60 & 37,47 & 28,75 & 25,92 & 23,04 & 20,63 & 18,47 & 14,81 & 11,99 & 8,20 \\
\hline 49,07 & 342,60 & 86,30 & 45,57 & 30,83 & 25,15 & 19,97 & 16,18 & 13,29 & 9,37 & 7,08 & 4,75 \\
\hline 61,51 & 945,30 & 73,60 & 27,67 & 21,87 & 19,80 & 17,60 & 15,70 & 13,99 & 11,12 & 8,93 & 6,04 \\
\hline 39,40 & 677,40 & 178,30 & 24,78 & 16,78 & 13,39 & 10,22 & 7,99 & 6,39 & 4,40 & 3,33 & 2,27 \\
\hline 61,02 & 723,40 & 142,20 & 22,18 & 15,44 & 13,00 & 10,83 & 9,18 & 7,83 & 5,81 & 4,48 & 2,97 \\
\hline 69,75 & 1606,20 & 39,80 & 31,24 & 24,77 & 23,54 & 22,37 & 21,08 & 19,80 & 17,37 & 15,17 & 11,55 \\
\hline 32,76 & 1574,30 & 156,50 & 21,58 & 17,16 & 14,51 & 11,55 & 9,24 & 7,48 & 5,16 & 3,85 & 2,57 \\
\hline 42,86 & 1497,90 & 74,90 & 28,78 & 24,86 & 22,55 & 19,73 & 17,19 & 14,94 & 11,33 & 8,76 & 5,71 \\
\hline 51,16 & 367,20 & 39,70 & 65,50 & 51,39 & 45,11 & 38,52 & 33,00 & 28,31 & 21,10 & 16,22 & 10,64 \\
\hline 83,85 & 1270,20 & 172,70 & 13,26 & 9,17 & 7,98 & 6,98 & 6,24 & 5,60 & 4,54 & 3,72 & 2,60 \\
\hline 89,88 & 952,50 & 108,30 & 18,78 & 13,01 & 11,47 & 10,19 & 9,22 & 8,39 & 6,97 & 5,83 & 4,19 \\
\hline 28,43 & 626,60 & 117,30 & 39,04 & 27,90 & 21,92 & 16,08 & 12,16 & 9,54 & 6,51 & 4,96 & 3,43 \\
\hline 87,86 & 954,20 & 175,40 & 15,16 & 9,93 & 8,39 & 7,18 & 6,33 & 5,63 & 4,49 & 3,65 & 2,54 \\
\hline 65,46 & 1132,80 & 39,70 & 36,72 & 29,37 & 27,81 & 25,87 & 23,99 & 22,19 & 18,87 & 16,02 & 11,63 \\
\hline 76,81 & 1752,60 & 125,90 & 13,98 & 10,49 & 9,59 & 8,70 & 7,95 & 7,27 & 6,07 & 5,08 & 3,63 \\
\hline 46,76 & 1183,70 & 128,80 & 21,39 & 16,88 & 14,72 & 12,41 & 10,49 & 8,89 & 6,50 & 4,94 & 3,24 \\
\hline 27,11 & 1282,40 & 148,50 & 27,21 & 20,83 & 16,88 & 12,73 & 9,76 & 7,69 & 5,22 & 3,94 & 2,70 \\
\hline 36,17 & 1161,90 & 93,20 & 31,23 & 25,68 & 22,31 & 18,41 & 15,19 & 12,58 & 8,90 & 6,66 & 4,37 \\
\hline 72,70 & 256,20 & 59,80 & 54,25 & 35,50 & 29,40 & 24,43 & 20,90 & 18,04 & 13,67 & 10,71 & 7,19 \\
\hline 54,93 & 774,40 & 185,10 & 19,72 & 13,36 & 11,01 & 8,92 & 7,36 & 6,14 & 4,42 & 3,36 & 2,24 \\
\hline 32,32 & 1732,50 & 145,00 & 22,14 & 17,98 & 15,35 & 12,36 & 9,96 & 8,10 & 5,61 & 4,18 & 2,78 \\
\hline 22,50 & 905,60 & 89,30 & 48,79 & 37,12 & 29,36 & 21,45 & 16,09 & 12,52 & 8,50 & 6,48 & 4,48 \\
\hline 78,47 & 401,90 & 93,90 & 33,72 & 21,74 & 17,97 & 14,99 & 12,91 & 11,23 & 8,63 & 6,83 & 4,62 \\
\hline
\end{tabular}




\begin{tabular}{|c|c|c|c|c|c|c|c|c|c|c|c|}
\hline & & & \multicolumn{9}{|c|}{ Deflexões $\left(\times 10^{-4} \mathrm{~cm}\right)$} \\
\hline e1 (cm) & Meq (MPa) & Ms (MPa) & D0 & D25 & D40 & D60 & D80 & D100 & D140 & D180 & D260 \\
\hline 20,19 & 1037,20 & 73,90 & 58,09 & 45,05 & 35,75 & 26,11 & 19,52 & 15,15 & 10,25 & 7,82 & 5,41 \\
\hline 47,03 & 367,80 & 143,30 & 34,79 & 21,31 & 16,51 & 12,50 & 9,82 & 7,90 & 5,48 & 4,16 & 2,85 \\
\hline 25,40 & 1677,50 & 188,60 & 22,16 & 16,89 & 13,55 & 10,09 & 7,66 & 6,00 & 4,07 & 3,09 & 2,12 \\
\hline 57,88 & 1242,80 & 109,10 & 20,30 & 16,07 & 14,40 & 12,63 & 11,13 & 9,79 & 7,61 & 6,01 & 4,01 \\
\hline 41,62 & 1090,70 & 146,70 & 22,05 & 16,91 & 14,39 & 11,72 & 9,60 & 7,92 & 5,60 & 4,20 & 2,78 \\
\hline 36,58 & 982,50 & 171,30 & 22,62 & 16,59 & 13,63 & 10,62 & 8,38 & 6,74 & 4,64 & 3,49 & 2,36 \\
\hline 50,93 & 1648,70 & 84,20 & 22,95 & 19,38 & 17,80 & 15,89 & 14,15 & 12,56 & 9,89 & 7,86 & 5,24 \\
\hline 28,06 & 1420,40 & 124,70 & 28,98 & 23,08 & 19,22 & 14,95 & 11,71 & 9,33 & 6,35 & 4,75 & 3,21 \\
\hline 51,95 & 1711,70 & 157,50 & 15,27 & 12,22 & 10,85 & 9,38 & 8,13 & 7,04 & 5,33 & 4,13 & 2,71 \\
\hline 87,99 & 613,60 & 130,50 & 22,18 & 14,19 & 11,81 & 9,97 & 8,71 & 7,70 & 6,08 & 4,91 & 3,39 \\
\hline 76,94 & 1251,30 & 152,80 & 14,68 & 10,51 & 9,25 & 8,12 & 7,24 & 6,48 & 5,21 & 4,24 & 2,93 \\
\hline 82,90 & 582,50 & 119,50 & 24,13 & 15,75 & 13,18 & 11,15 & 9,72 & 8,56 & 6,71 & 5,38 & 3,68 \\
\hline 50,44 & 1653,70 & 135,60 & 17,23 & 14,01 & 12,51 & 10,86 & 9,43 & 8,18 & 6,20 & 4,81 & 3,16 \\
\hline 81,81 & 1380,40 & 64,30 & 22,16 & 16,75 & 15,57 & 14,52 & 13,55 & 12,64 & 10,95 & 9,48 & 7,13 \\
\hline 57,79 & 1176,90 & 28,80 & 48,61 & 40,02 & 38,32 & 35,83 & 33,29 & 30,83 & 26,26 & 22,28 & 16,14 \\
\hline 43,79 & 841,40 & 128,80 & 25,73 & 19,28 & 16,32 & 13,27 & 10,88 & 8,99 & 6,36 & 4,79 & 3,18 \\
\hline 33,36 & 1129,70 & 33,80 & 64,67 & 58,17 & 52,84 & 45,93 & 39,61 & 34,06 & 25,31 & 19,27 & 12,42 \\
\hline 53,42 & 1599,90 & 89,80 & 21,63 & 18,01 & 16,51 & 14,74 & 13,14 & 11,69 & 9,24 & 7,37 & 4,93 \\
\hline 54,54 & 737,80 & 66,10 & 34,98 & 27,89 & 24,88 & 21,67 & 18,92 & 16,52 & 12,66 & 9,89 & 6,54 \\
\hline 57,62 & 1632,10 & 50,60 & 29,84 & 24,68 & 23,43 & 21,67 & 19,96 & 18,33 & 15,36 & 12,85 & 9,11 \\
\hline 47,94 & 1023,40 & 39,50 & 46,13 & 39,84 & 36,97 & 33,25 & 29,78 & 26,58 & 21,10 & 16,86 & 11,28 \\
\hline 45,26 & 1223,70 & 44,40 & 41,73 & 36,46 & 33,77 & 30,27 & 27,00 & 23,99 & 18,88 & 14,98 & 9,95 \\
\hline 24,39 & 1942,20 & 112,80 & 31,22 & 25,57 & 21,41 & 16,67 & 13,03 & 10,35 & 7,01 & 5,23 & 3,54 \\
\hline 78,66 & 1085,70 & 53,40 & 27,88 & 21,19 & 19,72 & 18,30 & 16,99 & 15,78 & 13,55 & 11,62 & 8,61 \\
\hline 60,35 & 1269,70 & 26,50 & 48,80 & 39,68 & 38,10 & 36,02 & 33,75 & 31,52 & 27,31 & 23,54 & 17,50 \\
\hline 74,17 & 1803,40 & 191,10 & 11,14 & 8,17 & 7,28 & 6,43 & 5,76 & 5,17 & 4,17 & 3,40 & 2,35 \\
\hline 24,57 & 754,10 & 194,90 & 28,01 & 18,56 & 13,78 & 9,59 & 7,09 & 5,54 & 3,83 & 2,96 & 2,07 \\
\hline 85,10 & 1355,00 & 110,90 & 16,02 & 11,59 & 10,49 & 9,50 & 8,69 & 7,98 & 6,72 & 5,67 & 4,12 \\
\hline 69,02 & 1405,40 & 48,50 & 29,00 & 22,91 & 21,68 & 20,27 & 18,88 & 17,55 & 15,08 & 12,92 & 9,53 \\
\hline 42,83 & 495,40 & 44,20 & 60,84 & 49,47 & 43,42 & 36,62 & 30,87 & 26,08 & 18,96 & 14,36 & 9,37 \\
\hline 65,61 & 280,50 & 65,30 & 51,42 & 34,24 & 28,38 & 23,44 & 19,83 & 16,93 & 12,59 & 9,74 & 6,49 \\
\hline 81,58 & 1156,70 & 187,80 & 13,54 & 9,20 & 7,89 & 6,80 & 6,00 & 5,33 & 4,24 & 3,43 & 2,37 \\
\hline 58,56 & 326,80 & 70,00 & 47,95 & 32,98 & 27,52 & 22,66 & 19,01 & 16,07 & 11,76 & 9,01 & 5,98 \\
\hline 72,44 & 1061,30 & 165,00 & 15,75 & 11,07 & 9,54 & 8,20 & 7,19 & 6,32 & 4,93 & 3,93 & 2,66 \\
\hline 42,48 & 225,90 & 68,40 & 66,68 & 43,67 & 34,60 & 26,42 & 20,74 & 16,66 & 11,51 & 8,71 & 5,94 \\
\hline 44,74 & 335,80 & 51,50 & 63,61 & 47,63 & 40,38 & 32,95 & 27,10 & 22,46 & 15,96 & 12,02 & 7,96 \\
\hline 31,29 & 1234,00 & 173,70 & 22,63 & 17,07 & 13,96 & 10,70 & 8,32 & 6,62 & 4,51 & 3,40 & 2,31 \\
\hline 60,06 & 625,00 & 105,50 & 27,86 & 19,99 & 17,06 & 14,36 & 12,26 & 10,52 & 7,86 & 6,07 & 4,02 \\
\hline 89,71 & 825,60 & 21,80 & 48,35 & 38,31 & 35,15 & 33,68 & 32,24 & 30,71 & 27,75 & 24,99 & 20,14 \\
\hline 32,25 & 286,80 & 182,70 & 38,07 & 20,53 & 14,48 & 9,98 & 7,45 & 5,89 & 4,09 & 3,17 & 2,23 \\
\hline 37,55 & 1256,50 & 153,30 & 21,67 & 16,85 & 14,28 & 11,50 & 9,31 & 7,61 & 5,31 & 3,98 & 2,64 \\
\hline 83,89 & 1700,40 & 181,20 & 11,17 & 7,93 & 7,05 & 6,27 & 5,67 & 5,15 & 4,24 & 3,52 & 2,50 \\
\hline 79,67 & 506,10 & 139,60 & 24,97 & 15,55 & 12,61 & 10,35 & 8,83 & 7,63 & 5,81 & 4,57 & 3,10 \\
\hline 74,65 & 1879,20 & 189,10 & 10,95 & 8,07 & 7,21 & 6,40 & 5,75 & 5,17 & 4,19 & 3,43 & 2,38 \\
\hline 83,85 & 1258,10 & 157,70 & 13,93 & 9,72 & 8,53 & 7,50 & 6,73 & 6,06 & 4,94 & 4,07 & 2,86 \\
\hline 23,57 & 1852,40 & 72,10 & 44,37 & 37,61 & 32,17 & 25,67 & 20,45 & 16,44 & 11,20 & 8,31 & 5,55 \\
\hline 84,85 & 1544,30 & 92,80 & 16,73 & 12,37 & 11,38 & 10,49 & 9,72 & 9,01 & 7,74 & 6,64 & 4,94 \\
\hline 76,82 & 1438,00 & 103,90 & 16,98 & 12,74 & 11,64 & 10,56 & 9,65 & 8,82 & 7,36 & 6,16 & 4,40 \\
\hline 54,91 & 948,50 & 169,80 & 18,59 & 13,34 & 11,30 & 9,37 & 7,88 & 6,66 & 4,87 & 3,72 & 2,46 \\
\hline 38,30 & 1434,00 & 51,30 & 40,59 & 36,07 & 32,94 & 28,92 & 25,23 & 21,94 & 16,62 & 12,82 & 8,32 \\
\hline 60,33 & 1911,20 & 135,80 & 14,60 & 11,67 & 10,62 & 9,47 & 8,47 & 7,56 & 6,03 & 4,85 & 3,28 \\
\hline 84,34 & 450,00 & 193,80 & 23,80 & 13,36 & 10,21 & 7,98 & 6,60 & 5,59 & 4,15 & 3,24 & 2,20 \\
\hline 57,04 & 922,50 & 164,90 & 18,78 & 13,43 & 11,39 & 9,49 & 8,02 & 6,81 & 5,02 & 3,85 & 2,55 \\
\hline 67,04 & 218,50 & 40,40 & 72,66 & 50,38 & 42,72 & 36,04 & 31,01 & 26,82 & 20,35 & 15,90 & 10,62 \\
\hline 50,84 & 1116,70 & 175,90 & 17,56 & 12,99 & 11,08 & 9,20 & 7,70 & 6,49 & 4,71 & 3,58 & 2,36 \\
\hline 57,12 & 1065,20 & 52,70 & 33,82 & 27,91 & 25,88 & 23,40 & 21,15 & 19,06 & 15,42 & 12,53 & 8,57 \\
\hline 77,17 & 1351,10 & 33,30 & 34,69 & 27,34 & 25,68 & 24,57 & 23,32 & 22,06 & 19,63 & 17,40 & 13,60 \\
\hline 59,29 & 1486,10 & 186,90 & 13,73 & 10,35 & 9,04 & 7,77 & 6,73 & 5,85 & 4,45 & 3,47 & 2,30 \\
\hline 84,29 & 1791,50 & 106,70 & 14,55 & 10,78 & 9,92 & 9,15 & 8,47 & 7,86 & 6,74 & 5,79 & 4,29 \\
\hline 79,56 & 1384,70 & 91,50 & 18,25 & 13,63 & 12,52 & 11,44 & 10,51 & 9,67 & 8,17 & 6,91 & 5,01 \\
\hline 62,60 & 431,80 & 115,40 & 31,97 & 20,82 & 17,00 & 13,81 & 11,52 & 9,71 & 7,10 & 5,45 & 3,63 \\
\hline 34,46 & 1038,50 & 94,80 & 33,35 & 26,90 & 23,04 & 18,66 & 15,14 & 12,38 & 8,63 & 6,44 & 4,27 \\
\hline 53,73 & 1619,70 & 88,10 & 21,72 & 18,10 & 16,63 & 14,88 & 13,29 & 11,85 & 9,40 & 7,51 & 5,05 \\
\hline 27,19 & 1927,40 & 71,00 & 39,28 & 34,16 & 29,96 & 24,76 & 20,35 & 16,77 & 11,73 & 8,70 & 5,69 \\
\hline 32,56 & 1819,00 & 170,60 & 19,48 & 15,60 & 13,23 & 10,57 & 8,48 & 6,87 & 4,74 & 3,54 & 2,36 \\
\hline 75,31 & 1462,40 & 127,00 & 15,19 & 11,31 & 10,22 & 9,16 & 8,29 & 7,51 & 6,16 & 5,09 & 3,57 \\
\hline 75,52 & 723,40 & 26,10 & 51,85 & 40,18 & 37,81 & 35,52 & 33,26 & 31,08 & 27,01 & 23,42 & 17,62 \\
\hline 28,76 & 765,00 & 125,40 & 34,72 & 25,39 & 20,21 & 15,02 & 11,45 & 9,00 & 6,13 & 4,65 & 3,20 \\
\hline 64,60 & 612,40 & 97,00 & 28,39 & 20,35 & 17,49 & 14,90 & 12,88 & 11,18 & 8,51 & 6,66 & 4,44 \\
\hline 63,74 & 311,10 & 93,10 & 42,01 & 26,61 & 21,45 & 17,25 & 14,31 & 12,03 & 8,76 & 6,72 & 4,50 \\
\hline 75,17 & 576,20 & 58,80 & 35,34 & 25,95 & 23,16 & 20,55 & 18,46 & 16,61 & 13,47 & 11,02 & 7,65 \\
\hline 32,84 & 1181,10 & 181,30 & 21,70 & 16,20 & 13,25 & 10,19 & 7,96 & 6,34 & 4,34 & 3,26 & 2,22 \\
\hline 64,44 & 1576,80 & 161,10 & 13,88 & 10,58 & 9,42 & 8,26 & 7,31 & 6,47 & 5,09 & 4,06 & 2,74 \\
\hline 30,86 & 212,20 & 120,00 & 55,46 & 30,99 & 22,07 & 15,24 & 11,37 & 8,96 & 6,22 & 4,82 & 3,39 \\
\hline 85,73 & 1321,10 & 171,70 & 12,92 & 8,93 & 7,80 & 6,85 & 6,14 & 5,54 & 4,52 & 3,73 & 2,63 \\
\hline 46,49 & 1519,50 & 52,80 & 33,99 & 29,59 & 27,54 & 24,81 & 22,24 & 19,87 & 15,79 & 12,62 & 8,44 \\
\hline 24,33 & 1421,70 & 199,80 & 22,97 & 16,86 & 13,16 & 9,53 & 7,13 & 5,56 & 3,79 & 2,90 & 2,01 \\
\hline 59,25 & 447,90 & 32,20 & 62,49 & 50,11 & 45,53 & 40,51 & 36,13 & 32,18 & 25,52 & 20,44 & 13,79 \\
\hline 46,09 & 1244,70 & 172,40 & 17,87 & 13,60 & 11,64 & 9,62 & 8,00 & 6,69 & 4,80 & 3,63 & 2,39 \\
\hline 57,80 & 1634,70 & 137,60 & 15,82 & 12,58 & 11,30 & 9,94 & 8,77 & 7,73 & 6,03 & 4,77 & 3,18 \\
\hline 59,93 & 1673,10 & 185,60 & 12,97 & 9,93 & 8,76 & 7,60 & 6,64 & 5,81 & 4,47 & 3,51 & 2,34 \\
\hline 82,28 & 1096,10 & 142,50 & 15,82 & 11,05 & 9,66 & 8,47 & 7,58 & 6,80 & 5,51 & 4,52 & 3,15 \\
\hline
\end{tabular}




\begin{tabular}{|c|c|c|c|c|c|c|c|c|c|c|c|}
\hline & & & \multicolumn{9}{|c|}{ Deflexões $\left(\times 10^{-4} \mathrm{~cm}\right)$} \\
\hline e1 (cm) & Meq (MPa) & Ms (MPa) & D0 & D25 & D40 & D60 & D80 & D100 & D140 & D180 & D260 \\
\hline 25,82 & 1237,70 & 132,60 & 30,72 & 23,61 & 19,08 & 14,32 & 10,93 & 8,58 & 5,82 & 4,40 & 3,02 \\
\hline 85,94 & 1993,30 & 93,70 & 14,83 & 11,11 & 10,28 & 9,62 & 9,00 & 8,42 & 7,34 & 6,40 & 4,87 \\
\hline 37,31 & 1975,30 & 133,80 & 19,97 & 16,77 & 14,77 & 12,41 & 10,40 & 8,72 & 6,27 & 4,71 & 3,07 \\
\hline 30,36 & 874,00 & 126,20 & 32,01 & 23,99 & 19,48 & 14,81 & 11,45 & 9,06 & 6,17 & 4,66 & 3,18 \\
\hline 37,31 & 1393,90 & 26,50 & 65,31 & 59,27 & 55,58 & 50,22 & 45,04 & 40,20 & 31,83 & 25,32 & 16,78 \\
\hline 85,38 & 930,30 & 180,30 & 15,34 & 10,03 & 8,44 & 7,18 & 6,30 & 5,57 & 4,41 & 3,56 & 2,46 \\
\hline 30,05 & 1745,50 & 44,20 & 51,06 & 46,23 & 41,85 & 36,13 & 30,93 & 26,40 & 19,38 & 14,64 & 9,42 \\
\hline 35,51 & 335,40 & 170,60 & 36,03 & 20,77 & 15,22 & 10,79 & 8,13 & 6,42 & 4,43 & 3,41 & 2,38 \\
\hline 46,88 & 308,50 & 180,10 & 34,60 & 18,98 & 13,90 & 10,07 & 7,75 & 6,18 & 4,27 & 3,27 & 2,27 \\
\hline 58,24 & 604,20 & 119,60 & 27,02 & 18,89 & 15,88 & 13,16 & 11,08 & 9,40 & 6,91 & 5,30 & 3,51 \\
\hline 86,79 & 1009,00 & 199,90 & 13,94 & 9,05 & 7,60 & 6,45 & 5,66 & 5,01 & 3,97 & 3,21 & 2,22 \\
\hline 40,37 & 1343,10 & 136,40 & 21,61 & 17,28 & 14,96 & 12,38 & 10,25 & 8,54 & 6,09 & 4,57 & 3,00 \\
\hline 65,90 & 776,00 & 51,40 & 35,78 & 28,11 & 25,79 & 23,26 & 21,05 & 19,03 & 15,52 & 12,72 & 8,82 \\
\hline 26,78 & 660,90 & 87,30 & 48,60 & 36,45 & 29,16 & 21,70 & 16,50 & 12,95 & 8,79 & 6,67 & 4,59 \\
\hline 47,07 & 334,00 & 92,20 & 45,38 & 30,17 & 24,32 & 19,03 & 15,24 & 12,41 & 8,68 & 6,56 & 4,42 \\
\hline 66,89 & 219,20 & 47,30 & 67,58 & 45,56 & 38,06 & 31,69 & 27,01 & 23,19 & 17,39 & 13,52 & 9,02 \\
\hline 34,31 & 1118,90 & 31,20 & 66,98 & 60,53 & 55,32 & 48,50 & 42,18 & 36,55 & 27,51 & 21,11 & 13,63 \\
\hline 40,03 & 1892,20 & 126,30 & 19,98 & 16,82 & 14,94 & 12,71 & 10,78 & 9,15 & 6,68 & 5,06 & 3,29 \\
\hline 20,32 & 888,40 & 134,50 & 38,71 & 27,19 & 20,28 & 14,04 & 10,28 & 8,00 & 5,54 & 4,28 & 2,98 \\
\hline 72,77 & 1425,60 & 37,10 & 33,15 & 26,12 & 24,73 & 23,52 & 22,20 & 20,88 & 18,39 & 16,12 & 12,36 \\
\hline 88,73 & 1384,00 & 101,50 & 16,32 & 11,79 & 10,71 & 9,78 & 9,02 & 8,34 & 7,11 & 6,08 & 4,50 \\
\hline 74,76 & 1150,60 & 108,40 & 18,53 & 13,73 & 12,33 & 10,99 & 9,90 & 8,94 & 7,28 & 5,98 & 4,17 \\
\hline 57,42 & 861,30 & 31,60 & 50,67 & 41,98 & 39,54 & 36,29 & 33,21 & 30,30 & 25,08 & 20,76 & 14,52 \\
\hline 89,21 & 1652,00 & 195,40 & 10,65 & 7,36 & 6,48 & 5,73 & 5,18 & 4,70 & 3,89 & 3,24 & 2,32 \\
\hline 75,91 & 613,60 & 133,10 & 23,03 & 15,15 & 12,64 & 10,60 & 9,14 & 7,96 & 6,11 & 4,83 & 3,26 \\
\hline 31,08 & 1206,30 & 84,00 & 36,91 & 30,53 & 26,25 & 21,26 & 17,21 & 14,03 & 9,73 & 7,24 & 4,80 \\
\hline 37,03 & 1988,60 & 120,50 & 21,41 & 18,20 & 16,12 & 13,63 & 11,48 & 9,68 & 7,00 & 5,27 & 3,42 \\
\hline 87,02 & 338,70 & 162,20 & 30,49 & 16,66 & 12,53 & 9,65 & 7,93 & 6,69 & 4,94 & 3,86 & 2,63 \\
\hline 71,53 & 1295,80 & 116,00 & 17,27 & 13,01 & 11,72 & 10,45 & 9,40 & 8,47 & 6,86 & 5,61 & 3,88 \\
\hline 67,18 & 1634,00 & 70,70 & 21,89 & 17,36 & 16,30 & 15,05 & 13,87 & 12,77 & 10,76 & 9,07 & 6,52 \\
\hline 51,21 & 1424,70 & 74,40 & 26,10 & 22,00 & 20,19 & 18,01 & 16,03 & 14,23 & 11,20 & 8,90 & 5,94 \\
\hline 80,95 & 1968,40 & 86,50 & 16,19 & 12,30 & 11,46 & 10,71 & 10,01 & 9,35 & 8,12 & 7,03 & 5,30 \\
\hline 68,11 & 228,70 & 140,10 & 43,41 & 22,92 & 16,71 & 12,36 & 9,79 & 7,99 & 5,65 & 4,33 & 2,97 \\
\hline 68,64 & 1307,40 & 71,30 & 23,38 & 18,32 & 17,02 & 15,55 & 14,24 & 13,02 & 10,85 & 9,05 & 6,42 \\
\hline 77,50 & 1259,50 & 76,50 & 21,35 & 16,13 & 14,88 & 13,64 & 12,56 & 11,56 & 9,77 & 8,27 & 6,00 \\
\hline 70,49 & 1816,00 & 101,20 & 16,38 & 12,74 & 11,82 & 10,81 & 9,91 & 9,08 & 7,59 & 6,35 & 4,53 \\
\hline 75,92 & 1457,00 & 126,00 & 15,23 & 11,31 & 10,22 & 9,17 & 8,30 & 7,53 & 6,19 & 5,12 & 3,60 \\
\hline 58,35 & 1955,30 & 81,30 & 20,34 & 16,76 & 15,70 & 14,35 & 13,09 & 11,90 & 9,79 & 8,07 & 5,61 \\
\hline 84,29 & 730,70 & 189,80 & 17,43 & 10,86 & 8,86 & 7,33 & 6,30 & 5,49 & 4,24 & 3,37 & 2,30 \\
\hline 36,95 & 1146,90 & 132,50 & 24,81 & 19,43 & 16,51 & 13,31 & 10,78 & 8,81 & 6,15 & 4,60 & 3,06 \\
\hline 60,47 & 444,40 & 128,70 & 30,35 & 19,50 & 15,78 & 12,67 & 10,47 & 8,76 & 6,34 & 4,84 & 3,24 \\
\hline 73,68 & 1637,80 & 30,50 & 35,28 & 28,35 & 26,65 & 25,70 & 24,53 & 23,29 & 20,89 & 18,65 & 14,75 \\
\hline 41,29 & 1814,50 & 134,70 & 19,07 & 15,87 & 14,04 & 11,92 & 10,10 & 8,56 & 6,25 & 4,74 & 3,08 \\
\hline 71,93 & 1132,10 & 88,50 & 21,29 & 16,17 & 14,71 & 13,23 & 11,98 & 10,85 & 8,89 & 7,33 & 5,13 \\
\hline 59,20 & 203,40 & 137,30 & 48,09 & 24,98 & 17,93 & 12,99 & 10,10 & 8,14 & 5,67 & 4,34 & 3,01 \\
\hline 79,95 & 1920,40 & 93,70 & 15,69 & 11,88 & 11,05 & 10,27 & 9,55 & 8,88 & 7,65 & 6,58 & 4,90 \\
\hline 55,12 & 1725,10 & 191,60 & 13,16 & 10,20 & 8,97 & 7,71 & 6,67 & 5,77 & 4,36 & 3,38 & 2,23 \\
\hline 67,60 & 1193,00 & 144,10 & 16,39 & 12,12 & 10,66 & 9,29 & 8,19 & 7,24 & 5,67 & 4,52 & 3,05 \\
\hline 82,35 & 325,10 & 82,40 & 39,79 & 25,03 & 20,48 & 16,97 & 14,59 & 12,70 & 9,79 & 7,76 & 5,28 \\
\hline 30,48 & 830,60 & 102,30 & 37,32 & 28,65 & 23,58 & 18,17 & 14,17 & 11,28 & 7,69 & 5,78 & 3,92 \\
\hline 77,75 & 867,30 & 26,10 & 47,53 & 36,99 & 34,76 & 33,00 & 31,14 & 29,32 & 25,85 & 22,71 & 17,49 \\
\hline 29,58 & 1829,30 & 126,10 & 25,45 & 20,97 & 17,92 & 14,37 & 11,53 & 9,34 & 6,43 & 4,79 & 3,19 \\
\hline 58,99 & 933,30 & 57,10 & 33,14 & 26,89 & 24,67 & 22,13 & 19,88 & 17,82 & 14,29 & 11,54 & 7,84 \\
\hline 64,12 & 1756,00 & 104,60 & 17,10 & 13,61 & 12,55 & 11,36 & 10,30 & 9,33 & 7,62 & 6,25 & 4,34 \\
\hline 51,08 & 1610,30 & 120,80 & 18,50 & 15,17 & 13,63 & 11,91 & 10,41 & 9,08 & 6,95 & 5,42 & 3,57 \\
\hline 82,01 & 706,70 & 94,40 & 24,25 & 16,89 & 14,74 & 12,90 & 11,52 & 10,33 & 8,35 & 6,82 & 4,75 \\
\hline 27,34 & 1618,40 & 168,60 & 23,05 & 17,91 & 14,66 & 11,17 & 8,62 & 6,81 & 4,62 & 3,48 & 2,38 \\
\hline 69,88 & 1595,60 & 51,70 & 26,39 & 20,81 & 19,71 & 18,51 & 17,29 & 16,12 & 13,93 & 12,00 & 8,93 \\
\hline 68,23 & 1051,10 & 100,80 & 20,96 & 15,87 & 14,22 & 12,58 & 11,24 & 10,04 & 8,02 & 6,48 & 4,43 \\
\hline 63,70 & 615,80 & 120,70 & 25,63 & 17,74 & 14,95 & 12,50 & 10,66 & 9,14 & 6,84 & 5,30 & 3,52 \\
\hline 29,73 & 1468,40 & 22,70 & 85,48 & 79,25 & 73,23 & 64,93 & 57,02 & 49,83 & 37,97 & 29,31 & 18,93 \\
\hline 81,95 & 1124,90 & 92,20 & 19,62 & 14,34 & 12,99 & 11,73 & 10,72 & 9,80 & 8,20 & 6,88 & 4,95 \\
\hline 65,50 & 406,30 & 116,60 & 32,45 & 20,68 & 16,75 & 13,56 & 11,32 & 9,56 & 7,01 & 5,39 & 3,61 \\
\hline 74,60 & 721,40 & 174,00 & 18,84 & 12,19 & 10,05 & 8,34 & 7,14 & 6,17 & 4,68 & 3,68 & 2,48 \\
\hline 87,22 & 481,50 & 156,20 & 24,21 & 14,35 & 11,38 & 9,20 & 7,80 & 6,74 & 5,14 & 4,07 & 2,78 \\
\hline 47,88 & 1260,60 & 58,60 & 33,17 & 28,44 & 26,13 & 23,28 & 20,66 & 18,28 & 14,30 & 11,31 & 7,49 \\
\hline 50,13 & 1230,70 & 133,10 & 19,78 & 15,54 & 13,63 & 11,60 & 9,91 & 8,48 & 6,29 & 4,83 & 3,16 \\
\hline 61,56 & 885,30 & 49,80 & 35,93 & 28,96 & 26,76 & 24,20 & 21,92 & 19,80 & 16,12 & 13,18 & 9,09 \\
\hline 87,46 & 611,90 & 158,10 & 20,65 & 12,79 & 10,42 & 8,63 & 7,44 & 6,51 & 5,06 & 4,04 & 2,77 \\
\hline 83,94 & 1733,50 & 161,00 & 11,77 & 8,47 & 7,60 & 6,82 & 6,21 & 5,66 & 4,71 & 3,95 & 2,83 \\
\hline 74,29 & 1728,40 & 116,10 & 14,98 & 11,39 & 10,46 & 9,50 & 8,69 & 7,94 & 6,61 & 5,53 & 3,94 \\
\hline 53,50 & 662,20 & 158,60 & 23,30 & 15,82 & 13,02 & 10,51 & 8,65 & 7,19 & 5,15 & 3,91 & 2,61 \\
\hline 36,46 & 1670,70 & 69,90 & 32,69 & 28,75 & 25,93 & 22,40 & 19,23 & 16,47 & 12,19 & 9,27 & 5,99 \\
\hline 69,58 & 364,80 & 42,70 & 53,74 & 39,62 & 34,97 & 30,60 & 27,10 & 24,05 & 19,01 & 15,25 & 10,36 \\
\hline 37,12 & 639,10 & 70,10 & 45,85 & 36,20 & 30,89 & 25,03 & 20,35 & 16,68 & 11,67 & 8,73 & 5,79 \\
\hline 28,01 & 230,20 & 38,00 & 116,65 & 85,01 & 67,32 & 49,72 & 37,71 & 29,59 & 20,15 & 15,33 & 10,57 \\
\hline 53,64 & 206,30 & 170,80 & 44,69 & 22,00 & 15,22 & 10,64 & 8,10 & 6,46 & 4,47 & 3,44 & 2,41 \\
\hline 47,24 & 926,50 & 104,30 & 26,63 & 20,90 & 18,20 & 15,33 & 12,95 & 10,97 & 8,02 & 6,10 & 4,00 \\
\hline 42,14 & 947,20 & 47,80 & 45,82 & 39,58 & 35,84 & 31,27 & 27,16 & 23,54 & 17,77 & 13,69 & 8,91 \\
\hline 45,32 & 1950,00 & 94,80 & 21,64 & 18,63 & 17,01 & 15,01 & 13,20 & 11,57 & 8,91 & 6,96 & 4,57 \\
\hline 58,08 & 538,70 & 176,80 & 24,03 & 15,07 & 12,01 & 9,49 & 7,74 & 6,41 & 4,57 & 3,48 & 2,34 \\
\hline 78,69 & 502,60 & 25,60 & 58,93 & 44,70 & 41,55 & 38,47 & 35,69 & 33,10 & 28,36 & 24,28 & 17,94 \\
\hline
\end{tabular}




\begin{tabular}{|c|c|c|c|c|c|c|c|c|c|c|c|}
\hline \multirow[b]{2}{*}{ e1 (cm) } & & & & & & & ões (x1 & m) & & & \\
\hline & Meq (MPa) & Ms (MPa) & D0 & D25 & D40 & D60 & D80 & D100 & D140 & D180 & D260 \\
\hline 56,77 & 938,70 & 163,80 & 18,73 & 13,46 & 11,43 & 9,55 & 8,07 & 6,86 & 5,06 & 3,88 & 2,57 \\
\hline 65,08 & 309,60 & 190,30 & 32,21 & 17,05 & 12,43 & 9,17 & 7,24 & 5,89 & 4,14 & 3,17 & 2,18 \\
\hline 41,27 & 1147,20 & 87,50 & 29,67 & 24,61 & 21,74 & 18,42 & 15,58 & 13,20 & 9,62 & 7,28 & 4,74 \\
\hline 24,15 & 1827,60 & 197,80 & 21,60 & 16,42 & 13,08 & 9,65 & 7,29 & 5,69 & 3,86 & 2,94 & 2,02 \\
\hline 21,42 & 1966,90 & 36,00 & 76,05 & 67,71 & 59,69 & 49,44 & 40,60 & 33,38 & 23,21 & 17,15 & 11,19 \\
\hline 36,62 & 1887,90 & 23,10 & 66,83 & 60,24 & 57,48 & 52,82 & 48,17 & 43,69 & 35,64 & 29,02 & 19,74 \\
\hline 34,49 & 1582,10 & 165,10 & 20,08 & 15,91 & 13,50 & 10,83 & 8,71 & 7,09 & 4,91 & 3,67 & 2,45 \\
\hline 50,23 & 1867,50 & 158,10 & 15,00 & 12,16 & 10,84 & 9,38 & 8,13 & 7,04 & 5,32 & 4,11 & 2,70 \\
\hline 68,73 & 1845,80 & 132,70 & 14,01 & 10,84 & 9,90 & 8,92 & 8,07 & 7,30 & 5,97 & 4,91 & 3,41 \\
\hline 63,38 & 722,10 & 195,40 & 18,93 & 12,27 & 10,01 & 8,13 & 6,78 & 5,72 & 4,19 & 3,22 & 2,15 \\
\hline 49,62 & 601,30 & 34,10 & 59,93 & 50,49 & 46,03 & 40,73 & 35,97 & 31,69 & 24,61 & 19,37 & 12,81 \\
\hline 45,78 & 1171,00 & 69,60 & 31,54 & 26,72 & 24,15 & 21,11 & 18,39 & 16,00 & 12,15 & 9,42 & 6,16 \\
\hline 79,30 & 210,30 & 54,50 & 61,67 & 38,91 & 31,79 & 26,26 & 22,49 & 19,48 & 14,88 & 11,74 & 7,95 \\
\hline 32,08 & 1259,20 & 125,90 & 27,28 & 21,64 & 18,23 & 14,45 & 11,51 & 9,28 & 6,38 & 4,77 & 3,20 \\
\hline 37,95 & 1295,60 & 118,40 & 24,94 & 20,20 & 17,50 & 14,43 & 11,91 & 9,88 & 7,00 & 5,24 & 3,45 \\
\hline 69,12 & 1124,30 & 184,40 & 14,77 & 10,40 & 8,91 & 7,61 & 6,62 & 5,78 & 4,45 & 3,51 & 2,36 \\
\hline 20,04 & 900,30 & 173,80 & 32,08 & 21,60 & 15,74 & 10,72 & 7,84 & 6,12 & 4,27 & 3,31 & 2,31 \\
\hline 64,36 & 1706,40 & 52,30 & 26,92 & 21,63 & 20,57 & 19,23 & 17,89 & 16,59 & 14,19 & 12,11 & 8,85 \\
\hline 81,19 & 960,60 & 166,40 & 15,86 & 10,69 & 9,11 & 7,81 & 6,87 & 6,08 & 4,81 & 3,87 & 2,66 \\
\hline 88,24 & 1931,70 & 88,10 & 15,32 & 11,47 & 10,59 & 9,92 & 9,31 & 8,73 & 7,66 & 6,71 & 5,15 \\
\hline 23,95 & 858,40 & 84,90 & 49,29 & 37,87 & 30,35 & 22,51 & 17,04 & 13,32 & 9,02 & 6,85 & 4,72 \\
\hline 76,23 & 1620,90 & 132,60 & 14,09 & 10,50 & 9,53 & 8,57 & 7,79 & 7,08 & 5,85 & 4,85 & 3,43 \\
\hline 75,66 & 607,90 & 64,40 & 32,75 & 23,91 & 21,28 & 18,84 & 16,91 & 15,20 & 12,30 & 10,05 & 6,98 \\
\hline 77,77 & 243,90 & 90,60 & 46,78 & 27,45 & 21,46 & 17,04 & 14,20 & 12,04 & 8,93 & 6,94 & 4,70 \\
\hline 74,24 & 1517,00 & 105,50 & 16,73 & 12,69 & 11,63 & 10,55 & 9,63 & 8,79 & 7,30 & 6,09 & 4,33 \\
\hline 78,54 & 1643,50 & 56,20 & 23,01 & 17,76 & 16,67 & 15,74 & 14,80 & 13,89 & 12,18 & 10,65 & 8,13 \\
\hline 77,87 & 1676,70 & 86,30 & 17,66 & 13,42 & 12,47 & 11,54 & 10,69 & 9,90 & 8,47 & 7,23 & 5,32 \\
\hline 77,87 & 1425,20 & 101,70 & 17,14 & 12,82 & 11,72 & 10,65 & 9,75 & 8,92 & 7,47 & 6,27 & 4,50 \\
\hline 57,57 & 814,20 & 43,80 & 41,72 & 34,25 & 31,62 & 28,49 & 25,67 & 23,07 & 18,58 & 15,05 & 10,25 \\
\hline 60,29 & 809,40 & 111,90 & 23,77 & 17,61 & 15,29 & 13,07 & 11,29 & 9,78 & 7,42 & 5,78 & 3,83 \\
\hline 20,10 & 1825,70 & 197,70 & 24,33 & 17,89 & 13,69 & 9,67 & 7,12 & 5,52 & 3,78 & 2,92 & 2,02 \\
\hline 24,74 & 229,80 & 82,70 & 72,81 & 45,06 & 32,52 & 22,29 & 16,46 & 12,92 & 8,99 & 6,98 & 4,88 \\
\hline 67,43 & 1705,00 & 103,60 & 16,94 & 13,29 & 12,26 & 11,12 & 10,13 & 9,21 & 7,59 & 6,27 & 4,40 \\
\hline 32,18 & 1117,10 & 83,30 & 37,12 & 30,55 & 26,28 & 21,32 & 17,30 & 14,13 & 9,83 & 7,32 & 4,85 \\
\hline 60,31 & 634,30 & 60,80 & 36,99 & 28,77 & 25,67 & 22,49 & 19,82 & 17,46 & 13,60 & 10,77 & 7,20 \\
\hline 89,72 & 1540,70 & 193,90 & 11,06 & 7,58 & 6,63 & 5,85 & 5,27 & 4,77 & 3,93 & 3,27 & 2,33 \\
\hline 79,12 & 1881,10 & 70,20 & 18,98 & 14,58 & 13,66 & 12,85 & 12,06 & 11,29 & 9,87 & 8,60 & 6,53 \\
\hline 70,24 & 836,90 & 152,30 & 18,77 & 12,94 & 10,99 & 9,32 & 8,06 & 7,02 & 5,38 & 4,23 & 2,84 \\
\hline 65,93 & 1403,80 & 99,30 & 19,01 & 14,87 & 13,59 & 12,21 & 11,02 & 9,94 & 8,06 & 6,59 & 4,55 \\
\hline 37,60 & 965,70 & 134,00 & 26,03 & 19,84 & 16,66 & 13,29 & 10,68 & 8,68 & 6,03 & 4,52 & 3,02 \\
\hline 49,76 & 630,10 & 109,20 & 29,90 & 21,77 & 18,41 & 15,12 & 12,55 & 10,49 & 7,55 & 5,72 & 3,78 \\
\hline 55,59 & 215,00 & 44,50 & 75,83 & 52,85 & 44,19 & 36,29 & 30,28 & 25,47 & 18,51 & 14,12 & 9,36 \\
\hline 88,77 & 1427,70 & 179,90 & 11,98 & 8,23 & 7,20 & 6,35 & 5,71 & 5,17 & 4,26 & 3,53 & 2,51 \\
\hline 80,45 & 1729,40 & 127,80 & 13,64 & 10,09 & 9,20 & 8,36 & 7,65 & 7,02 & 5,89 & 4,96 & 3,58 \\
\hline 84,97 & 1455,10 & 102,60 & 16,21 & 11,86 & 10,82 & 9,89 & 9,11 & 8,40 & 7,14 & 6,08 & 4,46 \\
\hline 58,71 & 579,10 & 132,80 & 26,17 & 17,75 & 14,71 & 12,05 & 10,07 & 8,48 & 6,19 & 4,73 & 3,15 \\
\hline 29,05 & 1854,80 & 21,90 & 82,94 & 77,33 & 72,09 & 64,57 & 57,29 & 50,54 & 39,14 & 30,56 & 19,86 \\
\hline 27,72 & 1959,20 & 173,00 & 21,11 & 16,77 & 13,94 & 10,80 & 8,44 & 6,71 & 4,56 & 3,42 & 2,32 \\
\hline 80,17 & 979,70 & 131,30 & 17,61 & 12,33 & 10,76 & 9,41 & 8,38 & 7,50 & 6,03 & 4,91 & 3,41 \\
\hline 70,93 & 1915,50 & 174,50 & 11,62 & 8,75 & 7,88 & 7,01 & 6,30 & 5,66 & 4,58 & 3,73 & 2,58 \\
\hline 49,44 & 1526,50 & 191,00 & 14,81 & 11,40 & 9,89 & 8,32 & 7,03 & 5,96 & 4,37 & 3,33 & 2,19 \\
\hline 27,47 & 1242,80 & 172,50 & 24,60 & 18,37 & 14,71 & 10,97 & 8,36 & 6,56 & 4,46 & 3,38 & 2,33 \\
\hline 75,26 & 770,30 & 45,50 & 36,04 & 27,47 & 25,40 & 23,27 & 21,40 & 19,68 & 16,57 & 13,98 & 10,09 \\
\hline 83,96 & 460,20 & 160,80 & 24,91 & 14,64 & 11,51 & 9,22 & 7,76 & 6,65 & 5,02 & 3,94 & 2,68 \\
\hline 85,48 & 1858,50 & 104,30 & 14,40 & 10,68 & 9,84 & 9,11 & 8,46 & 7,87 & 6,79 & 5,86 & 4,39 \\
\hline 64,77 & 1079,20 & 113,70 & 19,89 & 15,09 & 13,41 & 11,75 & 10,39 & 9,19 & 7,21 & 5,75 & 3,88 \\
\hline 32,16 & 946,00 & 104,60 & 33,95 & 26,57 & 22,23 & 17,48 & 13,85 & 11,13 & 7,64 & 5,71 & 3,85 \\
\hline 48,02 & 1577,90 & 38,00 & 41,11 & 35,53 & 33,73 & 31,00 & 28,33 & 25,78 & 21,20 & 17,43 & 12,03 \\
\hline 53,13 & 361,80 & 152,10 & 33,01 & 19,64 & 15,14 & 11,54 & 9,16 & 7,45 & 5,21 & 3,96 & 2,70 \\
\hline 74,96 & 946,80 & 179,20 & 15,91 & 10,75 & 9,10 & 7,71 & 6,70 & 5,86 & 4,54 & 3,60 & 2,43 \\
\hline 25,70 & 1256,20 & 137,80 & 29,87 & 22,88 & 18,43 & 13,79 & 10,51 & 8,24 & 5,59 & 4,23 & 2,91 \\
\hline 40,34 & 657,40 & 40,30 & $\begin{array}{l}60,28 \\
\end{array}$ & 51,23 & 45,72 & 39,17 & 33,43 & 28,52 & 21,00 & 15,96 & 10,37 \\
\hline 35,87 & 416,00 & 170,50 & 32,60 & 19,93 & 15,00 & 10,84 & 8,22 & 6,49 & 4,46 & 3,42 & 2,38 \\
\hline 37,30 & 890,20 & 107,80 & 30,85 & 24,01 & 20,35 & 16,38 & 13,25 & 10,82 & 7,55 & 5,65 & 3,76 \\
\hline 47,05 & 1490,60 & 85,90 & 24,79 & 21,00 & 19,05 & 16,74 & 14,67 & 12,82 & 9,83 & 7,66 & 5,03 \\
\hline 24,91 & 370,20 & 131,80 & 45,42 & 28,20 & 20,40 & 14,00 & 10,34 & 8,11 & 5,65 & 4,38 & 3,06 \\
\hline 28,48 & 520,70 & 112,00 & 42,76 & 29,83 & 23,15 & 16,81 & 12,66 & 9,92 & 6,78 & 5,19 & 3,59 \\
\hline 20,73 & 1359,30 & 21,80 & 124,02 & 110,96 & 98,06 & 81,45 & 67,04 & 55,21 & 38,46 & 28,40 & 18,49 \\
\hline 67,78 & 543,50 & 25,30 & 62,53 & 49,39 & 46,23 & 42,54 & 39,16 & 35,98 & 30,22 & 25,39 & 18,19 \\
\hline 76,53 & 936,00 & 156,30 & 16,91 & 11,61 & 9,94 & 8,52 & 7,48 & 6,59 & 5,17 & 4,14 & 2,82 \\
\hline 24,90 & 539,90 & 125,10 & 41,96 & 28,45 & 21,38 & 15,02 & 11,13 & 8,68 & 5,99 & 4,62 & 3,22 \\
\hline 66,44 & 683,00 & 135,90 & 22,56 & 15,46 & 13,01 & 10,91 & 9,33 & 8,04 & 6,06 & 4,71 & 3,15 \\
\hline 86,24 & 200,50 & 143,40 & 46,49 & 23,28 & 16,47 & 11,94 & 9,42 & 7,73 & 5,52 & 4,27 & 2,94 \\
\hline 60,96 & 1559,00 & 172,80 & 13,81 & 10,54 & 9,31 & 8,09 & 7,08 & 6,21 & 4,79 & 3,78 & 2,52 \\
\hline 69,28 & 433,90 & 63,40 & 40,45 & 28,97 & 25,10 & 21,62 & 18,92 & 16,61 & 12,91 & 10,23 & 6,89 \\
\hline 27,18 & 1029,10 & 189,90 & 24,61 & 17,55 & 13,69 & 9,96 & 7,49 & 5,86 & 4,00 & 3,06 & 2,12 \\
\hline 38,15 & 379,20 & 122,20 & 40,02 & 25,92 & 20,19 & 15,05 & 11,60 & 9,22 & 6,33 & 4,81 & 3,31 \\
\hline 38,58 & 1449,30 & 125,20 & 22,82 & 18,63 & 16,22 & 13,47 & 11,19 & 9,32 & 6,65 & 4,99 & 3,27 \\
\hline 85,78 & 1856,70 & 43,00 & 24,02 & 19,22 & 17,72 & 17,03 & 16,32 & 15,56 & 14,07 & 12,67 & 10,21 \\
\hline 69,35 & 862,00 & 131,40 & 19,93 & 14,18 & 12,24 & 10,51 & 9,18 & 8,04 & 6,23 & 4,93 & 3,32 \\
\hline 89,12 & 1475,10 & 197,90 & 11,24 & 7,66 & 6,67 & 5,85 & 5,25 & 4,74 & 3,88 & 3,22 & 2,28 \\
\hline 51,98 & 746,30 & 110,00 & 26,91 & 20,10 & 17,26 & 14,44 & 12,18 & 10,32 & 7,56 & 5,77 & 3,80 \\
\hline
\end{tabular}




\begin{tabular}{|c|c|c|c|c|c|c|c|c|c|c|c|}
\hline \multirow[b]{2}{*}{ e1 (cm) } & & & & & & & ões (x1 & m) & & & \\
\hline & Meq (MPa) & Ms (MPa) & D0 & D25 & D40 & D60 & D80 & D100 & D140 & D180 & D260 \\
\hline 47,36 & $\begin{array}{l}798,70 \\
\end{array}$ & 100,10 & 29,00 & 22,39 & 19,35 & 16,18 & 13,59 & 11,45 & 8,32 & 6,31 & 4,15 \\
\hline 40,32 & 215,60 & 46,70 & 86,03 & 60,60 & 49,39 & 38,47 & 30,50 & 24,61 & 17,03 & 12,83 & 8,67 \\
\hline 30,61 & 922,50 & 179,00 & 24,86 & 17,76 & 14,09 & 10,47 & 8,00 & 6,30 & 4,30 & 3,26 & 2,25 \\
\hline 52,34 & 1196,30 & 29,20 & 50,89 & 43,01 & 41,05 & 38,02 & 35,02 & 32,14 & 26,87 & 22,41 & 15,81 \\
\hline 23,32 & 611,50 & 174,40 & 32,99 & 21,29 & 15,51 & 10,64 & 7,83 & 6,13 & 4,27 & 3,31 & 2,31 \\
\hline 20,43 & 790,20 & 50,80 & 81,53 & 64,11 & 51,44 & 38,01 & 28,60 & 22,25 & 15,02 & 11,41 & 7,87 \\
\hline 58,55 & 1374,30 & 138,10 & 16,89 & 13,14 & 11,67 & 10,16 & 8,90 & 7,80 & 6,02 & 4,73 & 3,14 \\
\hline 85,62 & 647,10 & 59,60 & 31,41 & 22,48 & 20,18 & 18,14 & 16,53 & 15,11 & 12,63 & 10,61 & 7,65 \\
\hline 26,87 & 1135,00 & 171,80 & 25,73 & 18,92 & 14,98 & 11,03 & 8,35 & 6,54 & 4,45 & 3,39 & 2,34 \\
\hline 29,39 & 970,20 & 184,90 & 24,46 & 17,48 & 13,79 & 10,18 & 7,73 & 6,07 & 4,14 & 3,15 & 2,17 \\
\hline 28,38 & 302,00 & 117,60 & 50,06 & 30,80 & 22,58 & 15,75 & 11,71 & 9,19 & 6,36 & 4,92 & 3,44 \\
\hline 64,86 & 1531,70 & 165,10 & 13,83 & 10,46 & 9,28 & 8,12 & 7,17 & 6,34 & 4,97 & 3,96 & 2,66 \\
\hline 38,94 & 1321,20 & 124,60 & 23,56 & 19,02 & 16,49 & 13,63 & 11,28 & 9,37 & 6,66 & 5,00 & 3,28 \\
\hline 37,63 & 667,40 & 102,20 & 35,45 & 26,59 & 22,16 & 17,53 & 14,01 & 11,35 & 7,86 & 5,90 & 3,96 \\
\hline 30,56 & 666,00 & 76,60 & 48,61 & 37,69 & 31,19 & 24,18 & 18,94 & 15,11 & 10,31 & 7,73 & 5,24 \\
\hline 64,26 & 268,80 & 180,10 & 36,17 & 18,73 & 13,46 & 9,80 & 7,67 & 6,21 & 4,35 & 3,34 & 2,30 \\
\hline 72,54 & 332,60 & 39,30 & 57,62 & 42,03 & 37,08 & 32,52 & 28,91 & 25,76 & 20,52 & 16,56 & 11,33 \\
\hline 62,72 & 1384,70 & 112,80 & 18,21 & 14,28 & 12,90 & 11,46 & 10,22 & 9,11 & 7,24 & 5,82 & 3,94 \\
\hline 33,47 & 969,80 & 136,80 & 27,58 & 20,88 & 17,25 & 13,41 & 10,55 & 8,45 & 5,79 & 4,35 & 2,94 \\
\hline 27,05 & 1064,70 & 26,80 & 92,15 & 82,70 & 73,98 & 62,75 & 52,77 & 44,31 & 31,74 & 23,70 & 15,29 \\
\hline 89,67 & 1433,00 & 171,20 & 12,20 & 8,41 & 7,39 & 6,54 & 5,90 & 5,36 & 4,44 & 3,70 & 2,65 \\
\hline 26,30 & 489,00 & 41,90 & 89,65 & 71,05 & 58,62 & 44,99 & 34,87 & 27,59 & 18,70 & 14,04 & 9,56 \\
\hline 26,14 & 1673,50 & 37,00 & 65,81 & 59,39 & 53,24 & 45,26 & 38,12 & 32,06 & 22,99 & 17,17 & 11,06 \\
\hline 55,18 & 439,40 & 66,70 & 43,62 & 32,22 & 27,68 & 23,28 & 19,77 & 16,86 & 12,47 & 9,58 & 6,32 \\
\hline 36,13 & 1310,00 & 54,70 & 42,06 & 36,99 & 33,34 & 28,76 & 24,65 & 21,09 & 15,58 & 11,83 & 7,65 \\
\hline 35,15 & 678,00 & 96,40 & 38,09 & 28,86 & 23,99 & 18,84 & 14,94 & 12,04 & 8,29 & 6,21 & 4,19 \\
\hline 68,71 & 1138,00 & 125,80 & 17,86 & 13,30 & 11,79 & 10,35 & 9,18 & 8,16 & 6,46 & 5,19 & 3,52 \\
\hline 35,02 & 799,00 & 57,20 & 50,02 & 41,62 & 36,28 & 30,02 & 24,79 & 20,55 & 14,54 & 10,87 & 7,12 \\
\hline 43,77 & 1052,60 & 148,20 & 21,58 & 16,40 & 13,97 & 11,44 & 9,42 & 7,81 & 5,56 & 4,18 & 2,76 \\
\hline 56,30 & 694,00 & 42,80 & 45,61 & 37,37 & 34,18 & 30,52 & 27,26 & 24,30 & 19,28 & 15,44 & 10,40 \\
\hline 57,03 & 1983,70 & 81,20 & 20,53 & 17,03 & 15,94 & 14,55 & 13,25 & 12,03 & 9,86 & 8,10 & 5,61 \\
\hline 60,03 & 343,00 & 43,70 & 58,67 & 44,04 & 38,47 & 33,07 & 28,68 & 24,92 & 18,99 & 14,83 & 9,84 \\
\hline 48,78 & 363,10 & 167,30 & 32,30 & 18,89 & 14,34 & 10,72 & 8,38 & 6,74 & 4,67 & 3,56 & 2,44 \\
\hline 31,71 & 343,10 & 177,00 & 35,93 & 20,63 & 14,90 & 10,39 & 7,76 & 6,11 & 4,23 & 3,27 & 2,29 \\
\hline 76,90 & 905,80 & 148,80 & 17,57 & 12,08 & 10,36 & 8,90 & 7,81 & 6,90 & 5,42 & 4,34 & 2,96 \\
\hline 87,04 & 801,90 & 72,70 & 25,38 & 18,11 & 16,26 & 14,64 & 13,37 & 12,24 & 10,27 & 8,66 & 6,27 \\
\hline 56,00 & 732,90 & 125,40 & 24,39 & 17,61 & 14,98 & 12,50 & 10,57 & 8,98 & 6,61 & 5,06 & 3,35 \\
\hline 82,68 & 1138,20 & 59,00 & 25,06 & 18,79 & 17,41 & 16,15 & 15,02 & 13,98 & 12,06 & 10,39 & 7,76 \\
\hline 31,60 & 1016,10 & 159,90 & 25,40 & 18,84 & 15,29 & 11,64 & 9,02 & 7,16 & 4,88 & 3,68 & 2,51 \\
\hline 40,42 & 1496,70 & 130,50 & 21,26 & 17,35 & 15,17 & 12,69 & 10,61 & 8,90 & 6,40 & 4,82 & 3,15 \\
\hline 35,47 & 678,60 & 100,30 & 36,93 & 27,83 & 23,09 & 18,10 & 14,35 & 11,56 & 7,96 & 5,97 & 4,02 \\
\hline 38,75 & 1323,80 & 166,90 & 19,75 & 15,29 & 12,98 & 10,49 & 8,52 & 6,99 & 4,89 & 3,66 & 2,43 \\
\hline 69,33 & 1027,80 & 37,90 & 37,86 & 29,85 & 28,20 & 26,29 & 24,44 & 22,68 & 19,42 & 16,59 & 12,18 \\
\hline 76,70 & 948,40 & 164,00 & 16,40 & 11,20 & 9,55 & 8,17 & 7,15 & 6,30 & 4,93 & 3,94 & 2,68 \\
\hline 46,00 & 570,10 & 181,40 & 24,97 & 16,09 & 12,75 & 9,82 & 7,77 & 6,28 & 4,37 & 3,31 & 2,25 \\
\hline 35,39 & 1826,40 & 65,90 & 33,73 & 30,00 & 27,17 & 23,57 & 20,31 & 17,45 & 12,97 & 9,88 & 6,38 \\
\hline 86,07 & 553,10 & 55,50 & 35,07 & 24,87 & 22,19 & 19,84 & 18,02 & 16,42 & 13,66 & 11,43 & 8,20 \\
\hline 87,72 & 1375,20 & 135,40 & 14,12 & 9,99 & 8,91 & 7,99 & 7,27 & 6,64 & 5,55 & 4,66 & 3,36 \\
\hline 38,45 & 932,20 & 139,60 & 25,40 & 19,13 & 16,01 & 12,74 & 10,23 & 8,32 & 5,78 & 4,34 & 2,90 \\
\hline 42,63 & 1246,30 & 35,00 & 50,76 & 45,03 & 42,01 & 37,86 & 33,92 & 30,26 & 23,97 & 19,10 & 12,70 \\
\hline 59,70 & 1938,50 & 81,80 & 20,05 & 16,42 & 15,39 & 14,08 & 12,86 & 11,72 & 9,68 & 8,00 & 5,59 \\
\hline 34,88 & 1364,70 & 69,90 & 36,38 & 31,37 & 27,87 & 23,58 & 19,86 & 16,73 & 12,07 & 9,08 & 5,89 \\
\hline 25,01 & 1670,30 & 150,50 & 26,25 & 20,53 & 16,71 & 12,62 & 9,67 & 7,60 & 5,14 & 3,88 & 2,66 \\
\hline 33,92 & 1976,50 & 161,40 & 19,03 & 15,55 & 13,39 & 10,90 & 8,88 & 7,28 & 5,09 & 3,80 & 2,51 \\
\hline 49,74 & 1993,20 & 79,70 & 22,57 & 19,33 & 17,96 & 16,19 & 14,54 & 13,01 & 10,38 & 8,34 & 5,61 \\
\hline 41,84 & 571,70 & 145,80 & 29,09 & 19,80 & 15,94 & 12,33 & 9,74 & 7,85 & 5,43 & 4,10 & 2,78 \\
\hline 31,34 & 374,80 & 96,80 & 50,30 & 34,10 & 26,45 & 19,33 & 14,64 & 11,51 & 7,88 & 6,02 & 4,16 \\
\hline 60,20 & 1897,30 & 69,40 & 22,39 & 18,32 & 17,29 & 15,94 & 14,65 & 13,43 & 11,22 & 9,37 & 6,63 \\
\hline 74,73 & 1855,60 & 73,60 & 19,17 & 14,84 & 13,95 & 13,03 & 12,15 & 11,32 & 9,77 & 8,41 & 6,26 \\
\hline 55,57 & $\begin{array}{l}797,60 \\
\end{array}$ & 155,20 & 21,07 & 14,87 & 12,50 & 10,32 & 8,64 & 7,29 & 5,32 & 4,06 & 2,69 \\
\hline 59,58 & 1583,30 & 59,60 & 26,50 & 21,74 & 20,49 & 18,84 & 17,28 & 15,81 & 13,16 & 10,95 & 7,71 \\
\hline 63,37 & 1336,80 & 89,10 & 21,12 & 16,76 & 15,34 & 13,79 & 12,43 & 11,19 & 9,05 & 7,36 & 5,06 \\
\hline 89,91 & 1768,70 & 69,50 & 18,01 & 13,63 & 12,57 & 11,87 & 11,21 & 10,57 & 9,37 & 8,29 & 6,47 \\
\hline 31,78 & 705,00 & 53,70 & 58,55 & 48,02 & 41,17 & 33,26 & 26,89 & 21,91 & 15,19 & 11,32 & 7,51 \\
\hline 39,65 & 918,30 & 192,90 & 20,74 & 14,70 & 12,00 & 9,34 & 7,40 & 5,96 & 4,12 & 3,10 & 2,10 \\
\hline 69,82 & 575,00 & 93,40 & 28,90 & 20,33 & 17,45 & 14,92 & 12,99 & 11,36 & 8,77 & 6,93 & 4,66 \\
\hline 32,22 & 1133,90 & 47,00 & 53,59 & 46,91 & 41,78 & 35,37 & 29,76 & 25,03 & 18,01 & 13,50 & 8,74 \\
\hline 40,66 & 1452,00 & 195,50 & 16,79 & 12,87 & 10,93 & 8,86 & 7,23 & 5,95 & 4,18 & 3,14 & 2,08 \\
\hline 70,31 & 679,10 & 174,10 & 19,89 & 12,84 & 10,53 & 8,66 & 7,34 & 6,28 & 4,70 & 3,65 & 2,45 \\
\hline 35,43 & 1305,20 & 38,20 & 54,11 & 48,74 & 44,59 & 39,16 & 34,13 & 29,64 & 22,39 & 17,23 & 11,15 \\
\hline 85,91 & 1026,50 & 97,70 & 19,43 & 13,85 & 12,40 & 11,13 & 10,13 & 9,25 & 7,72 & 6,48 & 4,66 \\
\hline 28,55 & 316,30 & 190,40 & 36,46 & 19,95 & 13,98 & 9,54 & 7,10 & 5,61 & 3,90 & 3,03 & 2,14 \\
\hline 83,13 & 577,40 & 181,60 & 20,63 & 12,41 & 9,90 & 8,02 & 6,80 & 5,86 & 4,45 & 3,50 & 2,38 \\
\hline 43,15 & 862,90 & 181,30 & 21,15 & 14,96 & 12,31 & 9,73 & 7,81 & 6,36 & 4,44 & 3,34 & 2,24 \\
\hline 71,80 & 1258,40 & 184,40 & 13,72 & 9,75 & 8,44 & 7,29 & 6,40 & 5,64 & 4,41 & 3,52 & 2,38 \\
\hline 43,56 & 1913,30 & 194,90 & 14,39 & 11,50 & 10,02 & 8,39 & 7,04 & 5,92 & 4,29 & 3,24 & 2,12 \\
\hline 69,06 & 1351,60 & 154,50 & 14,74 & 10,92 & 9,66 & 8,46 & 7,50 & 6,65 & 5,26 & 4,22 & 2,87 \\
\hline 58,26 & 1589,60 & 198,00 & 13,02 & 9,85 & 8,61 & 7,39 & 6,39 & 5,54 & 4,20 & 3,27 & 2,17 \\
\hline 83,73 & 639,70 & 134,30 & 21,70 & 14,07 & 11,75 & 9,92 & 8,65 & 7,61 & 5,96 & 4,78 & 3,28 \\
\hline 23,30 & 1070,00 & 123,90 & 35,98 & 26,96 & 21,20 & 15,43 & 11,55 & 8,99 & 6,12 & 4,67 & 3,23 \\
\hline 71,25 & 1078,20 & 37,30 & 37,03 & 29,05 & 27,46 & 25,74 & 24,03 & 22,39 & 19,33 & 16,65 & 12,38 \\
\hline 48,65 & 342,00 & 60,10 & 55,33 & 40,26 & 33,95 & 27,76 & 22,95 & 19,12 & 13,69 & 10,36 & 6,86 \\
\hline
\end{tabular}




\begin{tabular}{|c|c|c|c|c|c|c|c|c|c|c|c|}
\hline \multirow[b]{2}{*}{ e1 (cm) } & & & & & & & ões (x1 & m) & & & \\
\hline & Meq (MPa) & Ms (MPa) & D0 & D25 & D40 & D60 & D80 & D100 & D140 & D180 & D260 \\
\hline 22,21 & 1312,70 & 97,30 & 441,69 & 32,75 & 26,44 & 19,71 & 14,94 & 11,67 & 7,88 & 5,97 & 4,11 \\
\hline 33,27 & 743,90 & 34,10 & 74,50 & 64,76 & 57,57 & 48,69 & 40,94 & 34,43 & 24,78 & 18,59 & 12,05 \\
\hline 20,94 & 520,30 & 118,90 & $\begin{array}{l}47,88 \\
\end{array}$ & 31,60 & 22,93 & 15,62 & 11,44 & 8,95 & 6,24 & 4,85 & 3,38 \\
\hline 83,65 & 1693,70 & 32,80 & 29,79 & 24,33 & 22,40 & 21,62 & 20,80 & 19,88 & 18,07 & 16,35 & 13,28 \\
\hline 22,45 & 1455,20 & 180,00 & 25,83 & 19,05 & 14,79 & 10,61 & 7,89 & 6,13 & 4,18 & 3,21 & 2,23 \\
\hline 72,97 & 312,40 & 197,80 & 31,22 & 16,27 & 11,78 & 8,69 & 6,89 & 5,64 & 4,01 & 3,08 & 2,11 \\
\hline 33,44 & 768,10 & 71,60 & 45,43 & 36,48 & 31,07 & 24,97 & 20,12 & 16,37 & 11,35 & 8,47 & 5,63 \\
\hline 63,09 & 1944,80 & 177,90 & 12,10 & 9,37 & 8,40 & 7,41 & 6,58 & 5,84 & 4,61 & 3,68 & 2,49 \\
\hline 35,80 & 343,00 & 167,40 & 35,95 & 20,97 & 15,45 & 11,01 & 8,31 & 6,56 & 4,52 & 3,48 & 2,43 \\
\hline 73,56 & 638,80 & 29,00 & 51,64 & 39,96 & 37,41 & 34,69 & 32,16 & 29,78 & 25,41 & 21,67 & 15,88 \\
\hline 56,55 & 1036,80 & 61,00 & 31,31 & 25,70 & 23,58 & 21,11 & 18,91 & 16,89 & 13,47 & 10,82 & 7,31 \\
\hline 56,42 & 600,20 & 41,90 & 48,79 & 39,60 & 35,96 & 31,89 & 28,32 & 25,11 & 19,75 & 15,71 & 10,52 \\
\hline 85,79 & 1495,30 & 45,80 & 25,42 & 19,70 & 18,27 & 17,41 & 16,53 & 15,65 & 13,97 & 12,43 & 9,79 \\
\hline 33,30 & 321,30 & 178,50 & 36,39 & 20,46 & 14,73 & 10,28 & 7,70 & 6,07 & 4,20 & 3,25 & 2,28 \\
\hline 72,74 & 228,70 & 30,30 & 78,96 & 56,73 & 49,59 & 43,15 & 38,15 & 33,83 & 26,73 & 21,46 & 14,62 \\
\hline 30,11 & 1694,80 & 176,40 & 20,62 & 16,18 & 13,47 & 10,49 & 8,24 & 6,58 & 4,49 & 3,37 & 2,28 \\
\hline 88,76 & 494,70 & 122,70 & 25,84 & 16,07 & 13,14 & 10,93 & 9,47 & 8,30 & 6,49 & 5,21 & 3,58 \\
\hline 28,31 & 599,40 & 24,40 & 114,22 & 98,90 & 86,74 & 71,75 & 59,03 & 48,71 & 34,14 & 25,36 & 16,58 \\
\hline 34,71 & 1967,30 & 90,10 & 27,24 & 23,73 & 21,20 & 18,06 & 15,30 & 12,95 & 9,41 & 7,09 & 4,59 \\
\hline 73,38 & 1484,40 & 68,00 & 22,13 & 17,13 & 16,03 & 14,86 & 13,77 & 12,74 & 10,86 & 9,26 & 6,77 \\
\hline 42,94 & 1472,30 & 188,40 & 16,50 & 12,74 & 10,91 & 8,97 & 7,41 & 6,15 & 4,38 & 3,30 & 2,17 \\
\hline 51,21 & 431,80 & 136,40 & 31,82 & 20,38 & 16,25 & 12,71 & 10,22 & 8,36 & 5,88 & 4,45 & 3,01 \\
\hline 74,02 & 1795,20 & 167,80 & 11,98 & 8,91 & 8,00 & 7,13 & 6,42 & 5,79 & 4,71 & 3,86 & 2,69 \\
\hline 39,56 & 1642,40 & 43,70 & 42,15 & 37,83 & 35,13 & 31,47 & 27,99 & 24,79 & 19,39 & 15,28 & 10,06 \\
\hline 47,63 & 1293,30 & 131,90 & 20,10 & 15,98 & 14,02 & 11,91 & 10,13 & 8,63 & 6,36 & 4,86 & 3,18 \\
\hline 35,27 & 1275,80 & 183,00 & 20,08 & 15,20 & 12,63 & 9,92 & 7,87 & 6,34 & 4,36 & 3,27 & 2,20 \\
\hline 81,31 & 720,60 & 51,20 & 33,30 & 24,63 & 22,51 & 20,50 & 18,82 & 17,30 & 14,59 & 12,33 & 8,95 \\
\hline 50,31 & 213,60 & 124,10 & 49,47 & 27,07 & 19,88 & 14,52 & 11,24 & 9,01 & 6,24 & 4,77 & 3,30 \\
\hline 55,70 & 934,20 & 26,10 & 57,17 & 47,66 & 45,37 & 42,03 & 38,75 & 35,60 & 29,85 & 24,98 & 17,71 \\
\hline 89,48 & 752,30 & 195,90 & 16,65 & 10,25 & 8,33 & 6,90 & 5,96 & 5,21 & 4,07 & 3,26 & 2,24 \\
\hline 20,09 & 1640,60 & 164,60 & 28,67 & 21,29 & 16,40 & 11,65 & 8,59 & 6,66 & 4,55 & 3,50 & 2,43 \\
\hline 42,50 & 967,80 & 148,50 & 22,73 & 17,04 & 14,38 & 11,63 & 9,49 & 7,81 & 5,50 & 4,14 & 2,75 \\
\hline 86,65 & 1854,60 & 115,20 & 13,52 & 9,93 & 9,10 & 8,39 & 7,77 & 7,21 & 6,20 & 5,33 & 3,97 \\
\hline 42,47 & 1436,10 & 27,90 & 57,04 & 50,52 & 47,93 & 43,89 & 39,94 & 36,17 & 29,45 & 23,97 & 16,32 \\
\hline 75,44 & 1771,80 & 142,70 & 13,07 & 9,78 & 8,88 & 8,00 & 7,26 & 6,60 & 5,45 & 4,52 & 3,19 \\
\hline 34,45 & 1324,00 & 136,10 & 24,25 & 19,26 & 16,36 & 13,12 & 10,57 & 8,60 & 5,96 & 4,46 & 2,97 \\
\hline 50,39 & 284,30 & 93,50 & 47,69 & 30,30 & 24,04 & 18,68 & 14,96 & 12,19 & 8,54 & 6,48 & 4,38 \\
\hline 87,26 & 952,20 & 133,60 & 17,17 & 11,70 & 10,16 & 8,87 & 7,93 & 7,14 & 5,81 & 4,79 & 3,37 \\
\hline 45,61 & 1373,00 & 91,00 & 25,21 & 21,15 & 19,00 & 16,49 & 14,27 & 12,34 & 9,30 & 7,16 & 4,68 \\
\hline 55,55 & 692,80 & 122,80 & 25,44 & 18,26 & 15,49 & 12,88 & 10,85 & 9,19 & 6,74 & 5,16 & 3,41 \\
\hline 64,72 & 812,80 & 104,00 & 23,82 & 17,63 & 15,43 & 13,35 & 11,68 & 10,24 & 7,92 & 6,25 & 4,19 \\
\hline 82,24 & 533,00 & 181,10 & 21,81 & 12,94 & 10,21 & 8,21 & 6,91 & 5,92 & 4,46 & 3,50 & 2,37 \\
\hline 59,56 & 602,60 & 128,50 & 25,88 & 17,79 & 14,86 & 12,26 & 10,31 & 8,73 & 6,41 & 4,92 & 3,27 \\
\hline 84,96 & 1341,80 & 156,70 & 13,45 & 9,43 & 8,32 & 7,36 & 6,63 & 6,00 & 4,92 & 4,08 & 2,88 \\
\hline 34,63 & 1117,50 & 87,40 & 34,08 & 28,04 & 24,28 & 19,91 & 16,32 & 13,45 & 9,45 & 7,06 & 4,64 \\
\hline 56,07 & 1440,20 & 195,70 & 13,99 & 10,50 & 9,10 & 7,74 & 6,63 & 5,69 & 4,26 & 3,28 & 2,17 \\
\hline 71,84 & 682,00 & 84,90 & 27,45 & 19,94 & 17,52 & 15,30 & 13,55 & 12,03 & 9,53 & 7,66 & 5,22 \\
\hline 22,67 & 212,60 & 194,40 & 43,07 & 20,36 & 13,44 & 9,00 & 6,76 & 5,39 & 3,78 & 2,95 & 2,11 \\
\hline 75,34 & 1357,30 & 147,30 & 14,51 & 10,58 & 9,40 & 8,31 & 7,44 & 6,68 & 5,40 & 4,40 & 3,05 \\
\hline 72,76 & 1783,60 & 66,00 & 21,16 & 16,51 & 15,56 & 14,56 & 13,58 & 12,65 & 10,92 & 9,39 & 6,99 \\
\hline 57,20 & 226,60 & 47,10 & 70,93 & 49,24 & 41,19 & 33,92 & 28,42 & 23,99 & 17,51 & 13,39 & 8,88 \\
\hline 49,22 & 744,90 & 121,00 & 26,34 & 19,42 & 16,50 & 13,60 & 11,31 & 9,47 & 6,83 & 5,17 & 3,42 \\
\hline 65,61 & 1930,00 & 101,30 & 16,62 & 13,21 & 12,28 & 11,20 & 10,23 & 9,33 & 7,73 & 6,42 & 4,51 \\
\hline 77,72 & 1774,40 & 197,70 & 10,80 & 7,79 & 6,91 & 6,11 & 5,48 & 4,93 & 3,99 & 3,27 & 2,28 \\
\hline 57,94 & 585,50 & 174,20 & 23,10 & 14,82 & 11,95 & 9,53 & 7,82 & 6,50 & 4,66 & 3,55 & 2,38 \\
\hline 80,63 & 1456,30 & 76,70 & 19,68 & 14,82 & 13,74 & 12,72 & 11,81 & 10,96 & 9,41 & 8,07 & 5,98 \\
\hline 53,66 & 232,60 & 118,40 & 47,33 & 26,74 & 20,07 & 14,98 & 11,77 & 9,51 & 6,63 & 5,05 & 3,47 \\
\hline 63,26 & 1435,90 & 65,70 & 24,85 & 20,01 & 18,72 & 17,14 & 15,70 & 14,34 & 11,91 & 9,90 & 6,97 \\
\hline 63,87 & 1877,40 & 104,30 & 16,74 & 13,37 & 12,38 & 11,24 & 10,22 & 9,27 & 7,61 & 6,27 & 4,36 \\
\hline 65,41 & 565,60 & 77,20 & 32,94 & 24,11 & 20,99 & 18,09 & 15,79 & 13,82 & 10,66 & 8,41 & 5,63 \\
\hline 89,52 & 1467,00 & 91,80 & 16,74 & 12,21 & 11,16 & 10,29 & 9,56 & 8,89 & 7,67 & 6,62 & 4,97 \\
\hline 57,70 & 1949,90 & 190,00 & 12,21 & 9,56 & 8,50 & 7,41 & 6,49 & 5,68 & 4,38 & 3,44 & 2,29 \\
\hline 34,11 & 1476,20 & 33,20 & 58,83 & 53,69 & 49,51 & 43,87 & 38,55 & 33,73 & 25,79 & 19,98 & 12,96 \\
\hline 46,64 & 961,40 & 169,50 & 20,09 & 14,64 & 12,31 & 10,00 & 8,21 & 6,80 & 4,83 & 3,65 & 2,42 \\
\hline 49,09 & 983,50 & 180,70 & 18,70 & 13,49 & 11,33 & 9,25 & 7,63 & 6,35 & 4,55 & 3,44 & 2,28 \\
\hline 38,47 & 1011,60 & 139,60 & 24,59 & 18,76 & 15,81 & 12,67 & 10,22 & 8,34 & 5,81 & 4,36 & 2,90 \\
\hline 34,96 & 1558,60 & 160,90 & 20,34 & 16,15 & 13,74 & 11,06 & 8,93 & 7,28 & 5,06 & 3,78 & 2,51 \\
\hline 47,54 & 611,90 & 36,80 & 58,39 & 49,24 & 44,60 & 39,14 & 34,26 & 29,93 & 22,92 & 17,86 & 11,72 \\
\hline 66,41 & 720,30 & 55,20 & 35,20 & 27,35 & 24,86 & 22,25 & 20,03 & 18,01 & 14,55 & 11,85 & 8,15 \\
\hline 57,86 & 431,20 & 35,10 & 61,14 & 48,75 & 43,90 & 38,69 & 34,21 & 30,21 & 23,62 & 18,72 & 12,51 \\
\hline 34,87 & 889,20 & 185,80 & 22,96 & 16,28 & 13,08 & 9,94 & 7,71 & 6,14 & 4,20 & 3,18 & 2,17 \\
\hline 34,14 & 729,20 & 77,60 & 43,32 & 34,22 & 28,95 & 23,13 & 18,56 & 15,06 & 10,42 & 7,78 & 5,20 \\
\hline 32,49 & 678,10 & 183,00 & 26,61 & 17,90 & 13,90 & 10,20 & 7,75 & 6,11 & 4,18 & 3,19 & 2,20 \\
\hline 62,18 & 961,40 & 115,80 & 21,20 & 15,94 & 14,00 & 12,12 & 10,59 & 9,27 & 7,14 & 5,62 & 3,75 \\
\hline 80,13 & 1063,00 & 155,50 & 15,56 & 10,78 & 9,34 & 8,10 & 7,19 & 6,41 & 5,12 & 4,15 & 2,87 \\
\hline 73,56 & 774,50 & 84,80 & 25,58 & 18,75 & 16,64 & 14,68 & 13,12 & 11,74 & 9,43 & 7,66 & 5,28 \\
\hline 38,44 & 1415,20 & 60,00 & 36,73 & 32,26 & 29,23 & 25,43 & 21,99 & 18,98 & 14,20 & 10,88 & 7,05 \\
\hline 35,17 & 1241,20 & 143,00 & 23,73 & 18,56 & 15,68 & 12,52 & 10,05 & 8,16 & 5,65 & 4,23 & 2,82 \\
\hline 22,34 & 1112,50 & 39,70 & 82,03 & 69,51 & 59,26 & 47,03 & 37,27 & 29,84 & 20,25 & 15,03 & 10,07 \\
\hline 85,15 & 1175,00 & 152,30 & 14,58 & 10,10 & 8,83 & 7,75 & 6,95 & 6,26 & 5,11 & 4,21 & 2,96 \\
\hline 30,60 & 1517,50 & 43,10 & 53,61 & 48,21 & 43,49 & 37,40 & 31,90 & 27,15 & 19,84 & 14,96 & 9,63 \\
\hline 29,70 & 1226,70 & 58,90 & 48,06 & 41,18 & 36,00 & 29,70 & 24,40 & 20,12 & 14,10 & 10,48 & 6,87 \\
\hline
\end{tabular}




\begin{tabular}{|c|c|c|c|c|c|c|c|c|c|c|c|}
\hline \multirow[b]{2}{*}{ e1 (cm) } & & & & & & & ões (x1 & & & & \\
\hline & Meq (MPa) & Ms (MPa) & D0 & D25 & D40 & D60 & D80 & D100 & D140 & D180 & D260 \\
\hline 85,94 & 1673,70 & 45,10 & 24,43 & 19,20 & 17,76 & 17,00 & 16,21 & 15,40 & 13,83 & 12,38 & 9,86 \\
\hline 81,60 & 374,40 & 143,60 & 29,86 & 17,28 & 13,43 & 10,64 & 8,87 & 7,54 & 5,62 & 4,39 & 2,98 \\
\hline 86,09 & 1104,50 & 146,40 & 15,29 & 10,53 & 9,18 & 8,05 & 7,22 & 6,50 & 5,30 & 4,37 & 3,08 \\
\hline 44,46 & 260,00 & 52,40 & 70,71 & 50,37 & 41,70 & 33,24 & 26,87 & 22,00 & 15,43 & 11,62 & 7,78 \\
\hline 87,46 & 690,20 & 166,90 & 18,78 & 11,77 & 9,66 & 8,06 & 6,98 & 6,12 & 4,78 & 3,83 & 2,63 \\
\hline 40,62 & 333,10 & 81,70 & 51,70 & 35,51 & 28,62 & 22,09 & 17,41 & 14,01 & 9,68 & 7,30 & 4,96 \\
\hline 85,67 & 1371,50 & 71,80 & 20,29 & 15,10 & 13,94 & 12,96 & 12,08 & 11,26 & 9,76 & 8,45 & 6,37 \\
\hline 50,17 & 1715,90 & 160,10 & 15,44 & 12,37 & 10,95 & 9,42 & 8,12 & 6,99 & 5,25 & 4,04 & 2,65 \\
\hline 77,55 & 988,90 & 87,00 & 22,01 & 16,24 & 14,65 & 13,14 & 11,92 & 10,82 & 8,92 & 7,39 & 5,22 \\
\hline 70,23 & 353,40 & 25,90 & 71,67 & 55,04 & 50,25 & 45,28 & 41,04 & 37,19 & 30,48 & 25,11 & 17,54 \\
\hline 24,10 & 1487,60 & 159,00 & 26,81 & 20,41 & 16,27 & 12,01 & 9,07 & 7,08 & 4,80 & 3,65 & 2,52 \\
\hline 44,95 & 1900,70 & 25,40 & 54,33 & 46,69 & 45,14 & 42,23 & 39,17 & 36,19 & 30,60 & 25,75 & 18,36 \\
\hline 24,65 & 1833,30 & 118,20 & 30,51 & 24,76 & 20,61 & 15,95 & 12,42 & 9,84 & 6,66 & 4,98 & 3,38 \\
\hline 56,79 & 383,80 & 154,10 & 31,18 & 18,66 & 14,49 & 11,18 & 8,97 & 7,35 & 5,19 & 3,95 & 2,68 \\
\hline 77,25 & 622,30 & 79,40 & 28,82 & 20,50 & 17,98 & 15,73 & 14,01 & 12,52 & 10,04 & 8,15 & 5,62 \\
\hline 67,25 & 1480,40 & 133,70 & 15,50 & 11,84 & 10,65 & 9,45 & 8,45 & 7,56 & 6,05 & 4,89 & 3,34 \\
\hline 48,03 & 1281,60 & 156,60 & 18,18 & 14,08 & 12,21 & 10,25 & 8,64 & 7,30 & 5,33 & 4,05 & 2,66 \\
\hline 48,60 & 1849,10 & 183,30 & 14,11 & 11,25 & 9,90 & 8,45 & 7,22 & 6,18 & 4,58 & 3,51 & 2,30 \\
\hline 30,82 & 900,00 & 196,90 & 23,49 & 16,43 & 12,91 & 9,52 & 7,24 & 5,70 & 3,89 & 2,96 & 2,04 \\
\hline 23,29 & 420,40 & 101,90 & 53,94 & 35,91 & 26,52 & 18,35 & 13,52 & 10,56 & 7,32 & 5,67 & 3,95 \\
\hline 86,76 & 262,20 & 190,80 & 35,39 & 17,65 & 12,45 & 9,00 & 7,09 & 5,81 & 4,15 & 3,21 & 2,21 \\
\hline 66,20 & 340,10 & 196,80 & 29,82 & 16,02 & 11,79 & 8,78 & 6,97 & 5,70 & 4,02 & 3,08 & 2,11 \\
\hline 80,86 & 1348,50 & 172,10 & 13,06 & 9,18 & 8,05 & 7,06 & 6,31 & 5,66 & 4,58 & 3,75 & 2,61 \\
\hline 85,30 & 477,10 & 91,90 & 30,00 & 19,65 & 16,55 & 14,08 & 12,36 & 10,94 & 8,66 & 6,99 & $\frac{2,01}{4,82}$ \\
\hline 33,58 & 1935,00 & 195,40 & 17,09 & 13,58 & 11,51 & 9,20 & 7,38 & 5,99 & 4,14 & 3,09 & 2,06 \\
\hline 72,84 & 1855,90 & 41,20 & 28,15 & 22,34 & 21,12 & 20,22 & 19,18 & 18,12 & 16,09 & 14,22 & 11,05 \\
\hline 86,13 & 250,70 & 161,30 & 38,14 & 19,55 & 14,07 & 10,37 & 8,28 & 6,84 & 4,93 & 3,82 & 2,62 \\
\hline 29,95 & 585,30 & 189,10 & 28,50 & 18,38 & 13,85 & 9,86 & 7,39 & 5,80 & 3,99 & 3,07 & 2,13 \\
\hline 21,72 & 1610,20 & 180,70 & 25,59 & 19,01 & 14,77 & 10,59 & 7,87 & 6,11 & 4,17 & 3,20 & 2,22 \\
\hline 75,44 & 831,20 & 65,90 & 28,11 & 21,06 & 19,14 & 17,25 & 15,67 & 14,26 & 11,77 & 9,77 & 6,91 \\
\hline 45,56 & 1672,10 & 122,50 & 19,47 & 16,17 & 14,44 & 12,45 & 10,72 & 9,22 & 6,89 & 5,29 & 3,45 \\
\hline 83,71 & 1028,50 & 28,30 & 40,09 & 31,36 & 29,15 & 27,87 & 26,51 & 25,13 & 22,48 & 20,03 & 15,83 \\
\hline 36,60 & 725,70 & 147,20 & 27,93 & 19,93 & 16,17 & 12,43 & 9,74 & 7,79 & 5,35 & 4,03 & 2,74 \\
\hline 52,53 & 749,00 & 138,50 & 23,65 & 16,95 & 14,28 & 11,76 & 9,80 & 8,23 & 5,95 & 4,53 & 3,00 \\
\hline 34,55 & 1711,20 & 34,00 & 54,72 & 50,07 & 46,49 & 41,53 & 36,80 & 32,45 & 25,14 & 19,66 & 12,83 \\
\hline 27,56 & 1424,50 & 54,90 & 50,97 & 44,21 & 38,75 & 32,01 & 26,30 & 21,66 & 15,15 & 11,25 & 7,36 \\
\hline 57,30 & 862,60 & 104,20 & 24,60 & 18,74 & 16,41 & 14,09 & 12,19 & 10,56 & 8,00 & 6,22 & 4,11 \\
\hline 20,50 & 1290,90 & 29,10 & 104,30 & 90,63 & 78,39 & 63,28 & 50,79 & 41,01 & 27,98 & 20,67 & 13,71 \\
\hline 55,40 & 325,70 & 30,90 & 75,89 & 59,96 & 53,32 & 46,35 & 40,43 & 35,27 & 27,00 & 21,10 & 13,95 \\
\hline 37,36 & 531,30 & 42,00 & 67,30 & 55,50 & 48,44 & 40,26 & 33,42 & 27,84 & 19,83 & 14,87 & 9,73 \\
\hline 23,12 & 722,10 & 102,50 & 46,28 & 33,64 & 25,97 & 18,57 & 13,80 & 10,73 & 7,34 & 5,64 & 3,91 \\
\hline 52,45 & 1288,20 & 147,00 & 17,85 & 13,87 & 12,14 & 10,36 & 8,88 & 7,63 & 5,69 & 4,38 & 2,88 \\
\hline 22,77 & 291,70 & 167,70 & 42,63 & 23,25 & 15,91 & 10,66 & 7,92 & 6,27 & 4,41 & 3,43 & 2,42 \\
\hline 78,34 & 1778,30 & 101,90 & 15,56 & 11,76 & 10,88 & 10,01 & 9,24 & 8,53 & 7,25 & 6,16 & 4,51 \\
\hline 82,83 & 1013,80 & 128,00 & 17,30 & 12,11 & 10,62 & 9,33 & 8,36 & 7,52 & 6,11 & 5,02 & 3,52 \\
\hline 44,82 & 212,00 & 185,60 & 43,01 & 20,87 & 14,25 & 9,79 & 7,38 & 5,86 & 4,05 & 3,14 & 2,22 \\
\hline 82,06 & 390,30 & 94,30 & 33,80 & 21,47 & 17,66 & 14,71 & 12,68 & 11,06 & 8,55 & 6,79 & 4,62 \\
\hline 77,85 & 660,40 & 129,60 & 22,15 & 14,76 & 12,43 & 10,53 & 9,16 & 8,03 & 6,25 & 4,97 & 3,38 \\
\hline 25,94 & 824,70 & 20,90 & 122,77 & 109,56 & 97,45 & 81,96 & 68,36 & 57,00 & 40,42 & 30,06 & 19,46 \\
\hline 70,98 & 438,60 & 28,40 & 61,75 & 47,61 & 43,81 & 39,77 & 36,27 & 33,06 & 27,39 & 22,76 & 16,08 \\
\hline 72,96 & 834,00 & 109,60 & 21,70 & 15,60 & 13,64 & 11,88 & 10,51 & 9,33 & 7,38 & 5,93 & 4,04 \\
\hline 59,15 & 1118,60 & 131,40 & 18,94 & 14,41 & 12,66 & 10,93 & 9,50 & 8,28 & 6,32 & 4,95 & 3,28 \\
\hline 72,98 & 1765,10 & 189,10 & 11,40 & 8,39 & 7,46 & 6,59 & 5,89 & 5,27 & 4,23 & 3,44 & 2,37 \\
\hline 72,85 & 1773,70 & 89,50 & 17,51 & 13,54 & 12,62 & 11,63 & 10,74 & 9,90 & 8,38 & 7,09 & 5,14 \\
\hline 89,66 & 1964,20 & 106,80 & 13,51 & 9,95 & 9,14 & 8,50 & 7,93 & 7,41 & 6,45 & 5,61 & 4,26 \\
\hline 66,21 & 246,60 & 74,60 & 52,14 & 32,79 & 26,39 & 21,26 & 17,71 & 14,94 & 10,94 & 8,41 & 5,64 \\
\hline 43,74 & 479,90 & 157,80 & 29,71 & 19,06 & 14,99 & 11,42 & 8,96 & 7,20 & 4,98 & 3,77 & 2,58 \\
\hline 21,04 & 1922,80 & 22,40 & 107,14 & 98,27 & 88,40 & 75,29 & 63,42 & 53,27 & 38,07 & 28,32 & 18,18 \\
\hline 79,23 & 650,70 & 74,00 & 28,91 & 20,70 & 18,32 & 16,19 & 14,53 & 13,08 & 10,62 & 8,71 & 6,08 \\
\hline 58,91 & 752,30 & 49,10 & 39,55 & 31,97 & 29,21 & 26,12 & 23,38 & 20,90 & 16,67 & 13,41 & 9,08 \\
\hline 47,52 & 1887,10 & 89,70 & 21,96 & 18,83 & 17,27 & 15,35 & 13,60 & 12,01 & 9,36 & 7,38 & 4,88 \\
\hline 45,84 & 1657,00 & 199,20 & 14,60 & 11,36 & 9,83 & 8,20 & 6,87 & 5,78 & 4,18 & 3,16 & 2,08 \\
\hline 73,35 & 1143,00 & 38,30 & 34,98 & $\begin{array}{l}I,+, 31 \\
27,31\end{array}$ & 25,78 & 24,26 & 22,72 & 21,23 & 18,45 & 15,99 & 12,01 \\
\hline 89,57 & 1393,20 & 168,70 & 12,47 & 8,59 & 7,54 & 6,66 & 6,01 & 5,46 & 4,51 & 3,76 & 2,68 \\
\hline 64,12 & 565,60 & 79,80 & 32,70 & 23,91 & 20,75 & 17,81 & 15,49 & 13,50 & 10,35 & 8,13 & 5,42 \\
\hline 42,93 & 1860,80 & 158,00 & 16,67 & 13,64 & 12,01 & 10,17 & 8,60 & 7,29 & 5,32 & 4,03 & 2,63 \\
\hline 32,02 & 551,20 & 70,00 & 53,39 & 40,95 & 33,88 & 26,33 & 20,68 & 16,53 & 11,31 & 8,48 & 5,74 \\
\hline 47,78 & 235,00 & 131,50 & 46,09 & 25,57 & 18,86 & 13,76 & 10,63 & 8,49 & 5,87 & 4,49 & 3,11 \\
\hline 23,33 & 313,90 & 57,30 & 88,42 & 61,88 & 46,84 & 32,98 & 24,38 & 18,99 & 13,07 & 10,08 & 7,01 \\
\hline 30,83 & 1440,90 & 156,20 & 23,24 & 18,18 & 15,13 & 11,81 & 9,30 & 7,44 & 5,09 & 3,81 & 2,57 \\
\hline 49,65 & 795,20 & 140,40 & 23,48 & 17,05 & 14,39 & 11,79 & 9,78 & 8,16 & 5,86 & 4,44 & 2,94 \\
\hline 72,70 & 1699,40 & 85,70 & 18,31 & 14,17 & 13,21 & 12,17 & 11,23 & 10,35 & 8,76 & 7,41 & 5,37 \\
\hline 80,72 & 712,30 & 75,30 & 27,21 & 19,54 & 17,39 & 15,45 & 13,93 & 12,60 & 10,33 & 8,53 & 6,00 \\
\hline 83,24 & 805,60 & 184,60 & 16,66 & 10,65 & 8,81 & 7,38 & 6,39 & 5,60 & 4,35 & 3,47 & 2,37 \\
\hline 36,59 & 900,40 & 28,00 & 73,50 & 65,95 & 60,36 & 53,08 & 46,34 & 40,31 & 30,55 & 23,56 & 15,27 \\
\hline 35,92 & 1145,10 & 109,90 & 28,44 & 22,84 & 19,60 & 15,94 & 12,99 & 10,66 & 7,46 & 5,58 & 3,69 \\
\hline 63,49 & 1653,30 & 185,00 & 12,69 & 9,60 & 8,48 & 7,39 & 6,50 & 5,72 & 4,45 & 3,53 & 2,37 \\
\hline 64,20 & 1054,30 & 162,20 & 16,78 & 12,10 & 10,43 & 8,89 & 7,70 & 6,68 & 5,09 & 3,99 & 2,66 \\
\hline 24,92 & 932,20 & 75,50 & 50,81 & 40,25 & 33,01 & 25,13 & 19,35 & 15,25 & 10,31 & 7,76 & 5,30 \\
\hline 87,94 & 1479,40 & 124,70 & 14,23 & 10,19 & 9,19 & 8,32 & 7,62 & 7,00 & 5,92 & 5,02 & 3,66 \\
\hline 58,46 & 964,40 & 165,70 & 18,12 & 13,00 & 11,07 & 9,28 & 7,89 & 6,74 & 5,00 & 3,85 & 2,55 \\
\hline 27,85 & 1206,60 & 102,80 & 34,99 & 27,94 & 23,29 & 18,12 & 14,20 & 11,31 & 7,70 & 5,76 & 3,90 \\
\hline
\end{tabular}




\begin{tabular}{|c|c|c|c|c|c|c|c|c|c|c|c|}
\hline \multirow[b]{2}{*}{ e1 (cm) } & & & & & & & ões (x1 & m) & & & \\
\hline & Meq (MPa) & Ms (MPa) & D0 & D25 & D40 & D60 & D80 & D100 & D140 & D180 & D260 \\
\hline 55,92 & 710,60 & 83,70 & 30,68 & 23,54 & 20,63 & 17,70 & 15,28 & 13,21 & 9,97 & 7,73 & 5,10 \\
\hline 32,01 & 1752,40 & 94,30 & 29,38 & 25,06 & 21,98 & 18,25 & 15,09 & 12,52 & 8,84 & 6,59 & 4,31 \\
\hline 70,39 & 207,50 & 93,50 & 52,56 & 29,86 & 22,80 & 17,61 & 14,33 & 11,92 & 8,60 & 6,61 & 4,48 \\
\hline 76,32 & 1545,80 & 144,40 & 13,72 & 10,12 & 9,09 & 8,12 & 7,33 & 6,63 & 5,43 & 4,47 & 3,13 \\
\hline 20,27 & 1190,20 & 80,00 & 52,67 & 41,15 & 32,84 & 24,12 & 18,09 & 14,06 & 9,50 & 7,23 & 4,99 \\
\hline 43,08 & 1436,00 & 86,10 & 26,68 & 22,68 & 20,39 & 17,66 & 15,25 & 13,15 & 9,84 & 7,56 & 4,92 \\
\hline 62,45 & 1596,20 & 143,10 & 14,98 & 11,66 & 10,46 & 9,23 & 8,19 & 7,27 & 5,73 & 4,58 & 3,09 \\
\hline 88,57 & 1732,70 & 158,30 & 11,61 & 8,24 & 7,39 & 6,66 & 6,08 & 5,58 & 4,69 & 3,96 & 2,88 \\
\hline 44,75 & 1065,50 & 120,80 & 23,85 & 18,74 & 16,25 & 13,57 & 11,36 & 9,54 & 6,90 & 5,22 & 3,42 \\
\hline 36,20 & 1681,60 & 51,90 & 39,86 & 35,79 & 32,73 & 28,75 & 25,07 & 21,78 & 16,47 & 12,68 & 8,21 \\
\hline 61,86 & 650,10 & 137,70 & 23,69 & 16,22 & 13,56 & 11,24 & 9,50 & 8,09 & 5,99 & 4,61 & 3,07 \\
\hline 85,38 & 1978,40 & 50,10 & 21,52 & 17,01 & 15,73 & 15,09 & 14,41 & 13,71 & 12,34 & 11,06 & 8,84 \\
\hline 56,89 & 308,50 & 28,20 & 80,67 & 63,75 & 56,91 & 49,73 & 43,61 & 38,24 & 29,52 & 23,21 & 15,41 \\
\hline 27,24 & 1300,90 & 80,40 & 41,03 & 33,90 & 28,80 & 22,88 & 18,20 & 14,64 & 10,01 & 7,45 & 4,99 \\
\hline 30,40 & 962,10 & 167,70 & 25,67 & 18,67 & 14,93 & 11,18 & 8,56 & 6,76 & 4,60 & 3,49 & 2,40 \\
\hline 43,71 & 232,90 & 195,60 & 39,83 & 19,60 & 13,47 & 9,29 & 7,01 & 5,56 & 3,85 & 2,97 & 2,10 \\
\hline 71,78 & 1534,10 & 77,70 & 20,36 & 15,81 & 14,74 & 13,56 & 12,50 & 11,51 & 9,71 & 8,20 & 5,92 \\
\hline 78,68 & 1162,10 & 48,60 & 28,75 & 21,99 & 20,56 & 19,24 & 17,97 & 16,77 & 14,54 & 12,59 & 9,45 \\
\hline 88,53 & 572,20 & 35,10 & 43,67 & 31,97 & 29,28 & 27,02 & 25,09 & 23,32 & 20,12 & 17,37 & 13,02 \\
\hline 67,90 & 463,00 & 50,00 & 44,69 & 33,45 & 29,69 & 26,08 & 23,14 & 20,55 & 16,26 & 13,05 & 8,85 \\
\hline 50,26 & 1794,10 & 28,90 & 46,74 & 39,36 & 38,02 & 35,70 & 33,24 & 30,82 & 26,29 & 22,32 & 16,14 \\
\hline 26,99 & 413,20 & 125,00 & 43,99 & 28,55 & 21,27 & 14,93 & 11,09 & 8,68 & 5,99 & 4,63 & 3,23 \\
\hline 84,98 & 293,60 & 126,70 & 36,41 & 20,42 & 15,59 & 12,18 & 10,08 & 8,54 & 6,35 & 4,96 & 3,38 \\
\hline 62,64 & 1333,70 & 190,50 & 13,93 & 10,20 & 8,84 & 7,57 & 6,56 & 5,70 & 4,34 & 3,40 & 2,26 \\
\hline 40,58 & 1076,80 & 70,00 & 35,34 & 29,85 & 26,57 & 22,70 & 19,33 & 16,46 & 12,08 & 9,18 & 5,96 \\
\hline 58,63 & 1977,80 & 179,60 & 12,42 & 9,77 & 8,74 & 7,66 & 6,75 & 5,94 & 4,62 & 3,65 & 2,43 \\
\hline 72,45 & 1170,00 & 78,50 & 22,42 & 17,16 & 15,76 & 14,29 & 13,04 & 11,89 & 9,86 & 8,21 & 5,81 \\
\hline 21,45 & 1386,90 & 28,20 & 100,21 & 88,50 & 77,57 & 63,76 & 52,01 & 42,53 & 29,40 & 21,71 & 14,23 \\
\hline 37,04 & 1763,30 & 182,60 & 17,24 & 13,72 & 11,75 & 9,56 & 7,80 & 6,41 & 4,49 & 3,36 & 2,22 \\
\hline 79,36 & 1170,40 & 109,30 & 17,82 & 13,00 & 11,68 & 10,45 & 9,47 & 8,59 & 7,08 & 5,87 & 4,15 \\
\hline 81,69 & 1049,20 & 101,30 & 19,28 & 13,92 & 12,47 & 11,15 & 10,11 & 9,19 & 7,59 & 6,31 & 4,48 \\
\hline 86,38 & 438,60 & 115,20 & 28,73 & 17,78 & 14,46 & 11,96 & 10,30 & 8,98 & 6,96 & 5,55 & 3,80 \\
\hline 86,75 & 1268,50 & 81,30 & 19,42 & 14,23 & 13,03 & 11,98 & 11,09 & 10,28 & 8,82 & 7,57 & 5,63 \\
\hline 87,19 & 1213,50 & 89,60 & 18,72 & 13,57 & 12,33 & 11,25 & 10,36 & 9,56 & 8,13 & 6,94 & 5,10 \\
\hline 58,65 & 1517,40 & 45,80 & 32,37 & 26,64 & 25,33 & 23,50 & 21,70 & 19,98 & 16,83 & 14,15 & 10,11 \\
\hline 78,57 & 1170,10 & 141,00 & 15,67 & 11,18 & 9,84 & 8,66 & 7,74 & 6,95 & 5,61 & 4,58 & 3,18 \\
\hline 77,46 & 664,90 & 72,20 & 29,27 & 21,19 & 18,83 & 16,66 & 14,96 & 13,47 & 10,93 & 8,96 & 6,24 \\
\hline 57,44 & 391,60 & 66,60 & 45,23 & 32,59 & 27,77 & 23,26 & 19,73 & 16,82 & 12,45 & 9,57 & 6,33 \\
\hline 30,90 & 1061,20 & 68,60 & 44,28 & 36,92 & 31,87 & 25,93 & 21,06 & 17,22 & 11,97 & 8,91 & 5,89 \\
\hline 85,36 & 1731,70 & 147,10 & 12,27 & 8,85 & 7,98 & 7,21 & 6,59 & 6,04 & 5,08 & 4,28 & 3,10 \\
\hline 49,32 & 1455,60 & 36,00 & 43,04 & 36,96 & 35,13 & 32,33 & 29,59 & 26,98 & 22,27 & 18,37 & 12,74 \\
\hline 58,06 & 1029,40 & 78,70 & 26,52 & 21,25 & 19,21 & 17,00 & 15,08 & 13,36 & 10,50 & 8,36 & 5,60 \\
\hline 38,82 & 406,10 & 44,70 & 69,89 & 55,22 & 47,35 & 38,68 & 31,68 & 26,13 & 18,42 & 13,80 & 9,12 \\
\hline 25,28 & 470,90 & 116,30 & 45,68 & 30,66 & 22,98 & 16,13 & 11,95 & 9,34 & 6,44 & 4,97 & 3,46 \\
\hline 21,82 & 1172,40 & 73,80 & 53,16 & 42,41 & 34,55 & 26,00 & 19,82 & 15,51 & 10,45 & 7,89 & 5,41 \\
\hline 24,43 & 1377,10 & 82,10 & 43,18 & 35,28 & 29,49 & 22,92 & 17,90 & 14,20 & 9,62 & 7,18 & 4,87 \\
\hline 65,46 & 471,50 & 106,90 & 30,97 & 20,75 & 17,24 & 14,27 & 12,09 & 10,33 & 7,69 & 5,95 & 3,97 \\
\hline 38,45 & 687,40 & 112,30 & 32,69 & 24,26 & 20,16 & 15,93 & 12,73 & 10,32 & 7,15 & 5,37 & 3,60 \\
\hline 70,90 & 1856,60 & 136,10 & 13,56 & 10,39 & 9,49 & 8,55 & 7,76 & 7,04 & 5,78 & 4,77 & 3,34 \\
\hline 84,28 & 1868,50 & 160,70 & 11,36 & 8,21 & 7,41 & 6,68 & 6,10 & 5,59 & 4,68 & 3,93 & 2,84 \\
\hline 57,16 & 1183,30 & 97,10 & 22,33 & 17,83 & 16,03 & 14,11 & 12,45 & 10,98 & 8,55 & 6,76 & 4,51 \\
\hline 83,92 & 1038,90 & 48,00 & 29,14 & 21,93 & 20,35 & 19,02 & 17,78 & 16,62 & 14,46 & 12,57 & 9,52 \\
\hline 69,66 & 1022,90 & 151,60 & 17,00 & 12,13 & 10,50 & 9,04 & 7,91 & 6,94 & 5,39 & 4,28 & 2,88 \\
\hline 73,37 & 752,40 & 53,50 & 33,50 & 25,47 & 23,31 & 21,10 & 19,22 & 17,51 & 14,50 & 12,05 & 8,52 \\
\hline 30,89 & 767,80 & 177,80 & 26,51 & 18,35 & 14,34 & 10,54 & 8,00 & 6,29 & 4,30 & 3,28 & 2,26 \\
\hline 46,74 & 1381,70 & 114,20 & 21,54 & 17,62 & 15,65 & 13,44 & 11,53 & 9,90 & 7,38 & 5,66 & 3,69 \\
\hline 32,61 & 1934,20 & 96,80 & 27,49 & 23,66 & 20,88 & 17,49 & 14,58 & 12,17 & 8,67 & 6,48 & 4,22 \\
\hline 20,00 & 856,40 & 132,90 & 39,79 & 27,74 & 20,58 & 14,18 & 10,37 & 8,07 & 5,60 & 4,34 & 3,02 \\
\hline 37,02 & 1284,70 & 122,10 & 24,98 & 20,11 & 17,33 & 14,19 & 11,63 & 9,59 & 6,75 & 5,05 & 3,33 \\
\hline 53,59 & 386,00 & 149,40 & 31,99 & 19,42 & 15,14 & 11,66 & 9,31 & 7,60 & 5,33 & 4,05 & 2,75 \\
\hline 88,26 & 1983,40 & 163,90 & 10,71 & 7,68 & 6,93 & 6,28 & 5,76 & 5,30 & 4,48 & 3,81 & 2,79 \\
\hline 44,66 & 798,90 & 88,10 & 32,38 & 25,55 & 22,19 & 18,56 & 15,56 & 13,09 & 9,47 & 7,17 & 4,70 \\
\hline 88,76 & 469,30 & 187,90 & 23,13 & 13,09 & 10,09 & 7,95 & 6,64 & 5,67 & 4,27 & 3,36 & 2,29 \\
\hline 43,13 & 473,30 & 31,40 & 75,98 & 63,95 & 57,16 & 49,22 & 42,26 & 36,26 & 26,96 & 20,61 & 13,41 \\
\hline 28,85 & 1498,00 & 63,10 & 43,96 & 38,02 & 33,36 & 27,63 & 22,76 & 18,81 & 13,20 & 9,81 & 6,41 \\
\hline 56,13 & 288,00 & 33,10 & 76,61 & 58,96 & 51,78 & 44,52 & 38,50 & 33,34 & 25,24 & 19,60 & 12,94 \\
\hline 28,94 & 1859,70 & 182,90 & 20,06 & 15,80 & 13,12 & 10,18 & 7,96 & 6,34 & 4,32 & 3,24 & 2,19 \\
\hline 57,89 & 1866,00 & 50,70 & 28,48 & 23,48 & 22,41 & 20,86 & 19,31 & 17,82 & 15,08 & 12,72 & 9,14 \\
\hline 68,11 & 259,40 & 161,60 & 38,08 & 20,02 & 14,55 & 10,74 & 8,49 & 6,93 & 4,89 & 3,75 & 2,57 \\
\hline 66,48 & 1641,20 & 100,20 & 17,68 & 13,92 & 12,84 & 11,63 & 10,57 & 9,60 & 7,89 & 6,50 & 4,54 \\
\hline 38,22 & 1410,50 & 118,30 & 24,05 & 19,70 & 17,17 & 14,27 & 11,85 & 9,88 & 7,04 & 5,29 & 3,46 \\
\hline 58,21 & 202,80 & 177,40 & 44,50 & 21,52 & 14,74 & 10,25 & 7,81 & 6,23 & 4,31 & 3,32 & 2,33 \\
\hline 26,44 & 289,10 & 136,80 & 47,17 & 27,49 & 19,56 & 13,36 & 9,90 & 7,80 & 5,43 & 4,22 & 2,96 \\
\hline 21,51 & 615,60 & 185,60 & 32,58 & 20,51 & 14,64 & 9,90 & 7,27 & 5,71 & 4,00 & 3,11 & 2,17 \\
\hline 20,05 & 1513,40 & 61,50 & 60,00 & 49,29 & 40,81 & 31,20 & 24,00 & 18,84 & 12,66 & 9,50 & 6,48 \\
\hline 71,12 & 1863,80 & 95,80 & 16,70 & 12,99 & 12,10 & 11,12 & 10,24 & 9,41 & 7,92 & 6,67 & 4,80 \\
\hline 27,05 & 1654,20 & 29,70 & 74,35 & 68,27 & 62,04 & 53,77 & 46,14 & 39,44 & 28,99 & 21,89 & 14,04 \\
\hline 79,55 & 1872,60 & 166,00 & 11,44 & 8,38 & 7,55 & 6,78 & 6,16 & 5,60 & 4,64 & 3,86 & 2,74 \\
\hline 48,49 & 745,00 & 75,70 & 34,56 & 27,47 & 24,14 & 20,55 & 17,53 & 14,98 & 11,08 & 8,48 & 5,55 \\
\hline 39,80 & 749,60 & 172,80 & 24,04 & 16,73 & 13,54 & 10,47 & 8,25 & 6,64 & 4,58 & 3,45 & 2,34 \\
\hline 85,94 & 676,60 & 51,70 & 33,17 & 24,07 & 21,85 & 19,88 & 18,26 & 16,82 & 14,24 & 12,09 & 8,85 \\
\hline 89,28 & 1894,50 & 155,90 & 11,18 & 7,99 & 7,21 & 6,54 & 6,00 & 5,53 & 4,69 & 3,99 & 2,93 \\
\hline
\end{tabular}




\begin{tabular}{|c|c|c|c|c|c|c|c|c|c|c|c|}
\hline \multirow[b]{2}{*}{ e1 (cm) } & & & & & & & ões (x1 & m) & & & \\
\hline & Meq (MPa) & Ms (MPa) & D0 & D25 & D40 & D60 & D80 & D100 & D140 & D180 & D260 \\
\hline 27,56 & 405,00 & 108,90 & 48,13 & 32,07 & 24,25 & 17,22 & 12,84 & 10,05 & 6,91 & 5,32 & 3,70 \\
\hline 76,62 & 1948,90 & 84,80 & 16,99 & 13,04 & 12,21 & 11,37 & 10,59 & 9,85 & 8,49 & 7,30 & 5,43 \\
\hline 41,70 & 494,50 & 111,30 & 36,11 & 25,22 & 20,55 & 16,05 & 12,77 & 10,33 & 7,16 & 5,40 & 3,65 \\
\hline 26,82 & 1559,40 & 198,30 & 21,13 & 15,94 & 12,79 & 9,55 & 7,28 & 5,71 & 3,88 & 2,94 & 2,02 \\
\hline 21,85 & 1957,20 & 46,30 & 63,03 & 55,14 & 48,05 & 39,21 & 31,78 & 25,86 & 17,79 & 13,14 & 8,66 \\
\hline 25,35 & 1122,50 & 27,10 & 95,08 & 84,92 & 75,50 & 63,42 & 52,84 & 44,00 & 31,15 & 23,14 & 14,99 \\
\hline 89,80 & 1933,90 & 180,80 & 10,21 & 7,21 & 6,45 & 5,81 & 5,30 & 4,86 & 4,09 & 3,46 & 2,52 \\
\hline 61,47 & 999,90 & 141,30 & 18,85 & 13,87 & 12,03 & 10,29 & 8,90 & 7,72 & 5,86 & 4,58 & 3,04 \\
\hline 43,48 & 1701,90 & 106,30 & 21,80 & 18,45 & 16,56 & 14,33 & 12,36 & 10,65 & 7,97 & 6,11 & 3,98 \\
\hline 87,45 & 476,50 & 109,10 & 27,78 & 17,58 & 14,52 & 12,17 & 10,58 & 9,31 & 7,30 & 5,87 & 4,04 \\
\hline 86,22 & 1186,20 & 172,30 & 13,62 & 9,27 & 8,02 & 6,99 & 6,23 & 5,59 & 4,53 & 3,72 & 2,61 \\
\hline 84,53 & 1092,40 & 146,40 & 15,48 & 10,69 & 9,33 & 8,17 & 7,30 & 6,57 & 5,33 & 4,38 & 3,07 \\
\hline 45,10 & 633,10 & 101,60 & 32,73 & 24,31 & 20,54 & 16,73 & 13,74 & 11,37 & 8,07 & 6,08 & 4,03 \\
\hline 82,54 & 1712,90 & 58,70 & 21,35 & 16,41 & 15,31 & 14,50 & 13,68 & 12,88 & 11,37 & 10,01 & 7,74 \\
\hline 52,84 & 1788,10 & 129,30 & 16,68 & 13,66 & 12,33 & 10,84 & 9,53 & 8,37 & 6,47 & 5,08 & 3,36 \\
\hline 29,50 & 1593,80 & 29,90 & 69,38 & 63,84 & 58,45 & 51,22 & 44,46 & 38,43 & 28,76 & 21,95 & 14,11 \\
\hline 72,66 & 1004,70 & 117,10 & 19,19 & 14,01 & 12,38 & 10,87 & 9,67 & 8,62 & 6,88 & 5,55 & 3,80 \\
\hline 53,79 & 1774,40 & 130,90 & 16,43 & 13,39 & 12,08 & 10,63 & 9,36 & 8,23 & 6,38 & 5,02 & 3,33 \\
\hline 52,02 & 498,90 & 89,40 & 36,28 & 26,16 & 22,11 & 18,22 & 15,19 & 12,76 & 9,23 & 7,02 & 4,64 \\
\hline 31,73 & 1380,00 & 101,20 & 30,70 & 25,29 & 21,73 & 17,60 & 14,26 & 11,64 & 8,08 & 6,02 & 3,98 \\
\hline 24,82 & 1145,10 & 20,70 & 115,45 & 105,08 & 94,53 & 80,67 & 68,17 & 57,46 & 41,34 & 30,88 & 19,85 \\
\hline 46,51 & 1488,10 & 54,80 & 33,37 & 29,01 & 26,92 & 24,18 & 21,62 & 19,27 & 15,24 & 12,15 & 8,10 \\
\hline 52,36 & 809,20 & 132,70 & 23,36 & 17,11 & 14,57 & 12,11 & 10,16 & 8,57 & 6,25 & 4,76 & 3,14 \\
\hline 23,33 & 210,00 & 23,50 & 187,60 & 141,22 & 111,41 & 81,30 & 60,97 & 47,49 & 32,27 & 24,63 & 17,02 \\
\hline 74,56 & 1636,80 & 76,40 & 19,66 & 15,15 & 14,16 & 13,13 & 12,17 & 11,27 & 9,62 & 8,21 & 6,03 \\
\hline 57,53 & 1512,70 & 123,50 & 17,46 & 13,93 & 12,54 & 11,04 & 9,75 & 8,61 & 6,72 & 5,32 & 3,55 \\
\hline 29,97 & 768,80 & 150,60 & 30,00 & 21,37 & 16,87 & 12,48 & 9,49 & 7,47 & 5,09 & 3,87 & 2,67 \\
\hline 23,70 & 1792,70 & 149,40 & 26,83 & 21,02 & 17,04 & 12,78 & 9,74 & 7,63 & 5,16 & 3,90 & 2,68 \\
\hline 74,20 & 790,70 & 59,10 & 30,81 & 23,28 & 21,24 & 19,18 & 17,46 & 15,89 & 13,14 & 10,91 & 7,71 \\
\hline 53,32 & 340,20 & 191,40 & 31,15 & 17,13 & 12,66 & 9,33 & 7,28 & 5,86 & 4,07 & 3,11 & 2,15 \\
\hline 33,94 & 901,70 & 181,70 & 23,49 & 16,75 & 13,46 & 10,19 & 7,89 & 6,27 & 4,29 & 3,24 & 2,22 \\
\hline 24,59 & 1808,10 & 107,30 & 32,82 & 26,86 & 22,49 & 17,51 & 13,69 & 10,88 & 7,37 & 5,50 & 3,72 \\
\hline 81,05 & 1821,00 & 129,80 & 13,17 & 9,74 & 8,90 & 8,11 & 7,44 & 6,84 & 5,76 & 4,87 & 3,53 \\
\hline 26,02 & 723,30 & 37,60 & 86,05 & 71,97 & 61,40 & 48,96 & 39,03 & 31,42 & 21,48 & 15,96 & 10,66 \\
\hline 61,42 & 980,50 & 49,80 & 34,62 & 28,03 & 26,04 & 23,67 & 21,52 & 19,52 & 16,00 & 13,15 & 9,13 \\
\hline 28,06 & 479,20 & 175,10 & 32,99 & 20,59 & 15,17 & 10,60 & 7,88 & 6,18 & 4,28 & 3,30 & 2,31 \\
\hline 69,35 & 1268,20 & 148,70 & 15,47 & 11,41 & 10,07 & 8,81 & 7,80 & 6,92 & 5,47 & 4,38 & 2,97 \\
\hline 38,18 & 880,20 & 183,60 & 22,15 & 15,73 & 12,79 & 9,89 & 7,79 & 6,25 & 4,31 & 3,25 & 2,20 \\
\hline 23,71 & 1749,00 & 55,50 & 53,73 & 46,44 & 40,27 & 32,70 & 26,42 & 21,46 & 14,76 & 10,92 & 7,22 \\
\hline 64,12 & 425,00 & 89,90 & 35,75 & 24,35 & 20,38 & 16,94 & 14,38 & 12,30 & 9,17 & 7,09 & 4,72 \\
\hline 73,97 & 1469,30 & 59,90 & 23,93 & 18,55 & 17,42 & 16,25 & 15,13 & 14,06 & 12,09 & 10,38 & 7,69 \\
\hline 76,50 & 229,20 & 35,70 & 71,29 & 49,48 & 42,62 & 36,75 & 32,35 & 28,62 & 22,56 & 18,11 & 12,36 \\
\hline 80,94 & 1200,10 & 84,30 & 20,16 & 14,94 & 13,66 & 12,45 & 11,43 & 10,51 & 8,86 & 7,49 & 5,43 \\
\hline 30,63 & 1364,80 & 155,30 & 23,86 & 18,53 & 15,35 & 11,92 & 9,35 & 7,46 & 5,09 & 3,82 & 2,59 \\
\hline 82,92 & 1468,80 & 170,60 & 12,44 & 8,78 & 7,76 & 6,86 & 6,17 & 5,57 & 4,56 & 3,76 & 2,65 \\
\hline 78,66 & 478,30 & 88,30 & 31,29 & 21,02 & 17,81 & 15,17 & 13,26 & 11,67 & 9,13 & 7,30 & 4,98 \\
\hline 31,58 & 889,60 & 185,40 & 24,22 & 17,11 & 13,56 & 10,09 & 7,72 & 6,09 & 4,16 & 3,16 & 2,17 \\
\hline 53,69 & 1851,60 & 67,80 & 24,56 & 20,71 & 19,43 & 17,72 & 16,11 & 14,60 & 11,92 & 9,75 & 6,71 \\
\hline 79,98 & 1400,30 & 102,50 & 16,98 & 12,59 & 11,49 & 10,44 & 9,56 & 8,77 & 7,36 & 6,19 & 4,46 \\
\hline 76,86 & 1065,30 & 167,50 & 15,25 & 10,56 & 9,09 & 7,83 & 6,90 & 6,10 & 4,81 & 3,86 & 2,64 \\
\hline 55,29 & 1558,30 & 143,20 & 16,19 & 12,84 & 11,45 & 9,97 & 8,71 & 7,61 & 5,83 & 4,56 & 3,02 \\
\hline 48,81 & 394,60 & 147,40 & 32,70 & 20,19 & 15,75 & 12,04 & 9,52 & 7,71 & 5,36 & 4,07 & 2,77 \\
\hline 54,02 & 457,80 & 30,10 & 68,03 & 55,93 & 50,83 & 45,03 & 39,90 & 35,28 & 27,61 & 21,88 & 14,57 \\
\hline 49,66 & 495,10 & 132,10 & 30,47 & 20,34 & 16,50 & 13,06 & 10,56 & 8,66 & 6,11 & 4,62 & 3,10 \\
\hline 62,81 & 646,10 & 124,10 & 24,81 & 17,27 & 14,58 & 12,20 & 10,40 & 8,91 & 6,66 & 5,15 & 3,42 \\
\hline 54,39 & 831,30 & 26,30 & 59,85 & 50,29 & 47,56 & 43,72 & 40,03 & 36,52 & 30,22 & 24,99 & 17,44 \\
\hline 59,52 & 349,00 & 29,90 & 72,19 & 56,97 & 51,19 & 45,11 & 39,91 & 35,28 & 27,64 & 21,96 & 14,71 \\
\hline 25,68 & 577,70 & 110,10 & 44,23 & 31,17 & 23,98 & 17,18 & 12,82 & 10,01 & 6,85 & 5,26 & 3,65 \\
\hline 42,14 & 1452,90 & 147,50 & 19,41 & 15,52 & 13,49 & 11,24 & 9,38 & 7,86 & 5,65 & 4,26 & 2,79 \\
\hline 68,92 & 1925,20 & 31,10 & 34,67 & 28,02 & 26,52 & 25,60 & 24,42 & 23,17 & 20,75 & 18,48 & 14,55 \\
\hline 26,45 & 598,40 & 171,80 & 31,75 & 20,79 & 15,50 & 10,88 & 8,07 & 6,31 & 4,36 & 3,37 & 2,35 \\
\hline 85,76 & 1609,60 & 75,70 & 18,38 & 13,78 & 12,75 & 11,92 & 11,15 & 10,43 & 9,10 & 7,93 & 6,03 \\
\hline 65,29 & 1744,30 & 143,40 & 14,08 & 10,93 & 9,88 & 8,80 & 7,88 & 7,05 & 5,65 & 4,57 & 3,12 \\
\hline 39,45 & 291,00 & 31,80 & 96,87 & 76,62 & 65,84 & 53,96 & 44,35 & 36,67 & 25,93 & 19,44 & 12,82 \\
\hline 51,37 & 1746,70 & 69,30 & 25,37 & 21,59 & 20,11 & 18,20 & 16,41 & 14,74 & 11,86 & 9,58 & 6,49 \\
\hline 64,13 & 668,10 & 66,10 & 33,41 & 25,58 & 22,82 & 20,06 & 17,77 & 15,75 & 12,40 & 9,90 & 6,67 \\
\hline 58,84 & 1404,60 & 137,40 & 16,73 & 13,05 & 11,61 & 10,14 & 8,90 & 7,81 & 6,04 & 4,76 & 3,17 \\
\hline 87,93 & 638,90 & 22,50 & 53,96 & 41,29 & 38,18 & 36,22 & 34,28 & 32,38 & 28,79 & 25,53 & 20,01 \\
\hline 33,05 & 1684,00 & 148,60 & 21,65 & 17,50 & 14,94 & 12,03 & 9,70 & 7,90 & 5,48 & 4,09 & 2,72 \\
\hline 41,92 & 1913,10 & 175,70 & 15,72 & 12,74 & 11,14 & 9,34 & 7,84 & 6,59 & 4,76 & 3,60 & 2,35 \\
\hline 55,75 & 944,30 & 48,90 & 37,58 & 31,14 & 28,76 & 25,89 & 23,28 & 20,88 & 16,75 & 13,52 & 9,17 \\
\hline 58,44 & 290,70 & 149,60 & 37,10 & 20,76 & 15,57 & 11,69 & 9,26 & 7,53 & 5,28 & 4,03 & 2,76 \\
\hline 81,36 & 677,60 & 151,50 & 20,14 & 13,00 & 10,79 & 9,05 & 7,84 & 6,86 & 5,32 & 4,24 & 2,89 \\
\hline 51,62 & 976,30 & 118,50 & 22,97 & 17,70 & 15,42 & 13,08 & 11,14 & 9,52 & 7,05 & 5,41 & 3,55 \\
\hline 42,33 & 435,80 & 36,70 & 72,19 & 59,15 & 52,05 & 43,99 & 37,14 & 31,41 & 22,87 & 17,32 & 11,30 \\
\hline 80,13 & 616,90 & 83,90 & 27,77 & 19,42 & 16,93 & 14,78 & 13,15 & 11,76 & 9,45 & 7,69 & 5,33 \\
\hline 52,37 & 1657,20 & 126,10 & 17,55 & 14,32 & 12,88 & 11,28 & 9,88 & 8,64 & 6,65 & 5,20 & 3,43 \\
\hline 81,90 & 1920,50 & 145,70 & 11,99 & 8,82 & 8,02 & 7,28 & 6,67 & 6,12 & 5,15 & 4,34 & 3,14 \\
\hline 87,52 & 1210,80 & 98,30 & 17,77 & 12,78 & 11,55 & 10,48 & 9,61 & 8,84 & 7,48 & 6,35 & 4,64 \\
\hline 54,34 & 805,10 & 194,90 & 18,94 & 12,81 & 10,54 & 8,51 & 7,02 & 5,84 & 4,19 & 3,19 & 2,12 \\
\hline 53,88 & 1662,10 & 28,90 & 45,68 & 37,92 & 36,60 & 34,50 & 32,22 & 29,99 & 25,77 & 22,04 & 16,14 \\
\hline 65,66 & 1454,00 & 193,00 & 12,98 & 9,53 & 8,32 & 7,18 & 6,28 & 5,51 & 4,26 & 3,37 & 2,26 \\
\hline
\end{tabular}




\begin{tabular}{|c|c|c|c|c|c|c|c|c|c|c|c|}
\hline & & & \multicolumn{9}{|c|}{ Deflexões $\left(\times 10^{-4} \mathrm{~cm}\right)$} \\
\hline e1 (cm) & Meq (MPa) & Ms (MPa) & D0 & D25 & D40 & D60 & D80 & D100 & D140 & D180 & D260 \\
\hline 61,16 & 1323,50 & 50,60 & 30,90 & 25,17 & 23,72 & 21,85 & 20,08 & 18,40 & 15,37 & 12,84 & 9,09 \\
\hline 75,21 & 1676,70 & 132,90 & 13,96 & 10,47 & 9,51 & 8,57 & 7,79 & 7,08 & 5,85 & 4,85 & 3,42 \\
\hline 65,05 & 943,50 & 158,50 & 17,85 & 12,65 & 10,82 & 9,18 & 7,92 & 6,86 & 5,21 & 4,07 & 2,71 \\
\hline 42,66 & 1018,60 & 159,10 & 21,32 & 15,94 & 13,43 & 10,86 & 8,85 & 7,28 & 5,13 & 3,86 & 2,56 \\
\hline 71,05 & 443,50 & 25,00 & 66,31 & 51,42 & 47,69 & 43,61 & 40,00 & 36,65 & 30,65 & 25,68 & 18,33 \\
\hline 83,32 & 1188,90 & 44,20 & 29,11 & 22,23 & 20,71 & 19,56 & 18,41 & 17,31 & 15,23 & 13,37 & 10,29 \\
\hline 33,04 & 1315,90 & 30,70 & 66,06 & 60,24 & 55,28 & 48,67 & 42,49 & 36,94 & 27,94 & 21,49 & 13,88 \\
\hline 22,24 & 683,00 & 188,80 & 30,84 & 19,87 & 14,38 & 9,80 & 7,20 & 5,64 & 3,94 & 3,05 & 2,13 \\
\hline 79,42 & 1352,00 & 43,70 & 28,77 & 22,26 & 20,86 & 19,77 & 18,64 & 17,54 & 15,45 & 13,57 & 10,44 \\
\hline 27,90 & 239,60 & 141,90 & 448,81 & 26,81 & 18,77 & 12,79 & 9,51 & 7,51 & 5,23 & 4,07 & 2,86 \\
\hline 22,52 & 1604,40 & 37,70 & 75,25 & 66,21 & 57,98 & 47,65 & 38,87 & 31,80 & 22,01 & 16,26 & 10,66 \\
\hline 80,37 & 1715,30 & 128,40 & 13,66 & 10,10 & 9,20 & 8,35 & 7,65 & 7,01 & 5,88 & 4,94 & 3,56 \\
\hline 82,64 & 1675,30 & 131,10 & 13,46 & 9,85 & 8,94 & 8,11 & 7,42 & 6,81 & 5,72 & 4,82 & 3,48 \\
\hline 29,22 & 1216,30 & 110,20 & 32,19 & 25,64 & 21,45 & 16,79 & 13,22 & 10,58 & 7,22 & 5,40 & 3,64 \\
\hline 88,67 & 1717,30 & 168,20 & 11,29 & 7,97 & 7,11 & 6,37 & 5,81 & 5,31 & 4,45 & 3,74 & 2,71 \\
\hline 67,31 & 868,70 & 120,20 & 21,02 & 15,27 & 13,29 & 11,47 & 10,03 & 8,80 & 6,83 & 5,40 & 3,63 \\
\hline 32,26 & 1735,10 & 47,70 & 45,79 & 41,37 & 37,59 & 32,67 & 28,16 & 24,20 & 17,95 & 13,65 & 8,79 \\
\hline 21,35 & 330,60 & 154,50 & 44,20 & 25,22 & 17,38 & 11,62 & 8,59 & 6,80 & 4,78 & 3,73 & 2,62 \\
\hline 52,29 & 477,90 & 167,50 & 27,21 & 16,97 & 13,38 & 10,38 & 8,32 & 6,79 & 4,77 & 3,62 & 2,45 \\
\hline 67,04 & 790,00 & 28,80 & 50,60 & 40,23 & 38,03 & 35,38 & 32,82 & 30,38 & 25,88 & 22,01 & 16,03 \\
\hline 74,58 & 1051,50 & 39,50 & 35,05 & 27,19 & 25,58 & 23,97 & 22,39 & 20,88 & 18,07 & 15,60 & 11,66 \\
\hline 29,44 & 357,30 & 121,70 & 45,46 & 28,94 & 21,63 & 15,31 & 11,44 & 8,97 & 6,18 & 4,76 & 3,32 \\
\hline 73,14 & 704,00 & 36,30 & 43,42 & 33,52 & 31,21 & 28,74 & 26,51 & 24,43 & 20,66 & 17,47 & 12,66 \\
\hline 38,16 & 997,80 & 155,10 & 23,31 & 17,44 & 14,54 & 11,52 & 9,22 & 7,48 & 5,19 & 3,89 & 2,61 \\
\hline 56,49 & 270,00 & 143,40 & 39,72 & 22,10 & 16,49 & 12,30 & 9,69 & 7,85 & 5,49 & 4,19 & 2,87 \\
\hline 55,67 & 454,60 & 128,50 & 30,88 & 20,14 & 16,31 & 13,02 & 10,67 & 8,85 & 6,32 & 4,81 & 3,22 \\
\hline 76,63 & 1701,60 & 101,30 & 16,09 & 12,20 & 11,27 & 10,33 & 9,51 & 8,76 & 7,40 & 6,25 & 4,53 \\
\hline 67,89 & 1686,80 & 89,40 & 18,55 & 14,60 & 13,58 & 12,41 & 11,37 & 10,40 & 8,66 & 7,23 & 5,12 \\
\hline 70,29 & 1432,90 & 67,10 & 23,16 & 18,12 & 16,95 & 15,64 & 14,43 & 13,30 & 11,24 & 9,50 & 6,86 \\
\hline 79,08 & 425,90 & 53,80 & 41,94 & 29,69 & 26,05 & 22,85 & 20,39 & 18,27 & 14,73 & 12,01 & 8,33 \\
\hline 38,88 & 1353,70 & 102,60 & 26,35 & 21,87 & 19,21 & 16,13 & 13,52 & 11,35 & 8,17 & 6,15 & 4,01 \\
\hline 35,33 & 501,00 & 102,80 & 40,92 & 29,12 & 23,48 & 17,91 & 13,94 & 11,11 & 7,61 & 5,75 & 3,92 \\
\hline 80,90 & 340,00 & 173,70 & 30,13 & 16,36 & 12,22 & 9,32 & 7,58 & 6,34 & 4,62 & 3,58 & 2,44 \\
\hline 74,90 & 888,40 & 89,70 & 23,09 & 16,99 & 15,18 & 13,47 & 12,10 & 10,89 & 8,83 & 7,22 & 5,02 \\
\hline 20,70 & 436,70 & 31,50 & 134,32 & 104,51 & 83,30 & 61,16 & 45,88 & 35,65 & 24,11 & 18,36 & 12,68 \\
\hline 60,00 & 1504,00 & 142,90 & 15,72 & 12,25 & 10,94 & 9,58 & 8,44 & 7,44 & 5,79 & 4,58 & 3,06 \\
\hline 80,32 & 1394,00 & 193,60 & 12,16 & 8,47 & 7,37 & 6,42 & 5,71 & 5,11 & 4,10 & 3,33 & 2,31 \\
\hline 79,05 & 789,20 & 25,50 & 49,37 & 38,21 & 35,83 & 33,95 & 31,99 & 30,09 & 26,49 & 23,24 & 17,86 \\
\hline 51,59 & 267,40 & 58,70 & 61,24 & 42,48 & 35,22 & 28,51 & 23,46 & 19,50 & 13,94 & 10,57 & 7,03 \\
\hline 56,84 & 1624,20 & 176,80 & 13,89 & 10,75 & 9,48 & 8,19 & 7,12 & 6,19 & 4,72 & 3,68 & 2,43 \\
\hline 52,48 & 1657,90 & 159,50 & 15,27 & 12,14 & 10,75 & 9,28 & 8,03 & 6,95 & 5,26 & 4,07 & 2,68 \\
\hline 31,01 & 274,80 & 73,20 & 67,63 & 45,54 & 35,16 & 25,58 & 19,33 & 15,19 & 10,40 & 7,96 & 5,51 \\
\hline 52,46 & 963,70 & 89,30 & 26,86 & 21,44 & 19,04 & 16,48 & 14,29 & 12,39 & 9,39 & 7,29 & 4,79 \\
\hline 42,22 & 396,20 & 75,20 & 49,31 & 35,59 & 29,49 & 23,42 & 18,84 & 15,36 & 10,72 & 8,06 & 5,40 \\
\hline 62,80 & 1844,70 & 112,00 & 16,27 & 13,00 & 11,97 & 10,80 & 9,77 & 8,82 & 7,17 & 5,85 & 4,04 \\
\hline 36,88 & 422,40 & 173,00 & 31,84 & 19,46 & 14,70 & 10,67 & 8,12 & 6,42 & 4,41 & 3,38 & 2,34 \\
\hline 72,17 & 1017,60 & 32,30 & 41,15 & 32,27 & 30,52 & 28,76 & 26,95 & 25,20 & 21,92 & 19,00 & 14,28 \\
\hline 84,19 & 875,40 & 26,00 & 44,83 & 34,82 & 32,37 & 30,87 & 29,30 & 27,73 & 24,73 & 21,97 & 17,28 \\
\hline 77,75 & 1991,60 & 44,50 & 24,82 & 19,71 & 18,46 & 17,73 & 16,89 & 16,02 & 14,34 & 12,78 & 10,09 \\
\hline 29,15 & 1056,60 & 124,10 & 31,18 & 24,00 & 19,68 & 15,07 & 11,69 & 9,27 & 6,31 & 4,74 & 3,23 \\
\hline 67,09 & 1478,50 & 30,20 & 39,61 & 31,70 & 30,23 & 28,88 & 27,29 & 25,71 & 22,66 & 19,88 & 15,23 \\
\hline 52,17 & 1667,00 & 70,30 & 25,30 & 21,43 & 19,92 & 18,00 & 16,21 & 14,56 & 11,69 & 9,44 & 6,39 \\
\hline 58,34 & 268,10 & 31,20 & 80,04 & 61,14 & 53,72 & 46,34 & 40,25 & 35,00 & 26,69 & 20,84 & 13,81 \\
\hline 63,54 & 1908,20 & 36,60 & 33,23 & 26,79 & 25,66 & 24,46 & 23,07 & 21,68 & 19,03 & 16,61 & 12,61 \\
\hline 29,65 & 1354,20 & 71,30 & 41,01 & 34,80 & 30,26 & 24,78 & 20,24 & 16,61 & 11,58 & 8,60 & 5,66 \\
\hline 66,70 & 490,70 & 22,60 & 70,25 & 55,75 & 52,19 & 47,99 & 44,12 & 40,49 & 33,94 & 28,45 & 20,30 \\
\hline 76,87 & 568,80 & 30,50 & 51,17 & 38,95 & 36,17 & 33,35 & 30,83 & 28,49 & 24,24 & 20,63 & 15,08 \\
\hline 60,40 & 1601,10 & 102,80 & 18,52 & 14,90 & 13,64 & 12,24 & 10,99 & 9,86 & 7,92 & 6,40 & 4,36 \\
\hline 84,60 & 1799,40 & 175,00 & 11,03 & 7,88 & 7,05 & 6,31 & 5,74 & 5,23 & 4,34 & 3,63 & 2,60 \\
\hline 42,45 & 1613,70 & 192,60 & 15,80 & 12,33 & 10,61 & 8,75 & 7,24 & 6,02 & 4,30 & 3,23 & 2,13 \\
\hline 82,82 & 510,70 & 197,10 & 21,78 & 12,56 & 9,75 & 7,72 & 6,44 & 5,48 & 4,09 & 3,20 & 2,17 \\
\hline 49,17 & 336,80 & 79,90 & 47,73 & 32,70 & 26,84 & 21,43 & 17,43 & 14,35 & 10,14 & 7,67 & 5,13 \\
\hline 37,23 & 767,60 & 94,80 & 35,41 & 27,47 & 23,25 & 18,68 & 15,08 & 12,31 & 8,57 & 6,42 & 4,27 \\
\hline 50,57 & 570,30 & 54,00 & 45,83 & 36,63 & 32,42 & 27,89 & 24,03 & 20,72 & 15,55 & 11,99 & 7,86 \\
\hline 55,63 & 1123,50 & 20,40 & 64,15 & 52,93 & 51,04 & 48,17 & 45,04 & 41,97 & 36,17 & 31,02 & 22,83 \\
\hline 78,73 & 1439,40 & 23,50 & 40,90 & 33,72 & 31,19 & 30,20 & 29,09 & 27,82 & 25,30 & 22,90 & 18,59 \\
\hline 73,10 & 1570,80 & 92,80 & 17,94 & 13,78 & 12,75 & 11,65 & 10,69 & 9,81 & 8,22 & 6,90 & 4,94 \\
\hline 48,46 & 1542,20 & 168,10 & 16,04 & 12,63 & 11,04 & 9,36 & 7,95 & 6,77 & 4,98 & 3,80 & 2,49 \\
\hline 61,96 & 1858,60 & 135,30 & 14,58 & 11,57 & 10,52 & 9,39 & 8,41 & 7,53 & 6,02 & 4,86 & 3,30 \\
\hline 31,55 & 1112,10 & 72,80 & 41,20 & 34,37 & 29,73 & 24,26 & 19,77 & 16,20 & 11,30 & 8,41 & 5,55 \\
\hline 38,21 & 545,70 & 20,10 & 105,02 & 93,19 & 84,97 & 74,48 & 64,86 & 56,31 & 42,56 & 32,78 & 21,26 \\
\hline 59,26 & 1944,10 & 189,60 & 12,06 & 9,40 & 8,37 & 7,31 & 6,42 & 5,64 & 4,37 & 3,45 & 2,30 \\
\hline 25,42 & 749,40 & 138,50 & 35,02 & 24,77 & 19,06 & 13,66 & 10,19 & 7,95 & 5,44 & 4,18 & 2,90 \\
\hline 32,34 & 1268,10 & 120,90 & 27,77 & 22,18 & 18,78 & 14,96 & 11,97 & 9,68 & 6,67 & 4,98 & 3,33 \\
\hline 64,32 & 1441,50 & 151,60 & 14,96 & 11,37 & 10,10 & 8,85 & 7,81 & 6,91 & 5,42 & 4,31 & 2,90 \\
\hline 62,14 & 994,40 & 150,50 & 18,20 & 13,23 & 11,41 & 9,72 & 8,38 & 7,26 & 5,50 & 4,29 & 2,85 \\
\hline 42,38 & 911,20 & 72,20 & 35,83 & 29,58 & 26,13 & 22,18 & 18,80 & 15,95 & 11,67 & 8,85 & 5,77 \\
\hline 47,10 & 666,10 & 158,20 & 24,59 & 16,89 & 13,83 & 10,97 & 8,86 & 7,26 & 5,10 & 3,85 & 2,58 \\
\hline 89,95 & 1140,60 & 56,60 & 24,45 & 18,14 & 16,69 & 15,59 & 14,60 & 13,68 & 11,97 & 10,47 & 8,02 \\
\hline 66,68 & 1285,80 & 48,10 & 30,70 & 24,44 & 23,08 & 21,44 & 19,86 & 18,36 & 15,61 & 13,24 & 9,61 \\
\hline 64,72 & 970,30 & 98,80 & 22,55 & 17,17 & 15,29 & 13,43 & 11,89 & 10,54 & 8,29 & 6,62 & 4,47 \\
\hline 84,15 & 1683,20 & 191,20 & 10,92 & 7,69 & 6,80 & 6,03 & 5,43 & 4,92 & 4,04 & 3,35 & 2,37 \\
\hline
\end{tabular}




\begin{tabular}{|c|c|c|c|c|c|c|c|c|c|c|c|}
\hline & & & \multicolumn{9}{|c|}{ Deflexões $\left(\times 10^{-4} \mathrm{~cm}\right)$} \\
\hline e1 (cm) & Meq (MPa) & Ms (MPa) & D0 & D25 & D40 & D60 & D80 & D100 & D140 & D180 & D260 \\
\hline 62,77 & 502,90 & 42,40 & 49,11 & 38,37 & 34,59 & 30,65 & 27,30 & 24,30 & 19,28 & 15,46 & 10,46 \\
\hline 48,17 & 1246,90 & 45,80 & 38,98 & 33,67 & 31,34 & 28,26 & 25,39 & 22,72 & 18,12 & 14,53 & 9,76 \\
\hline 56,33 & 1957,90 & 138,90 & 14,84 & 12,03 & 10,91 & 9,67 & 8,58 & 7,60 & 5,97 & 4,74 & 3,17 \\
\hline 69,38 & 892,90 & 149,50 & 18,39 & 12,89 & 11,03 & 9,41 & 8,17 & 7,13 & 5,49 & 4,32 & 2,90 \\
\hline 39,42 & 698,30 & 64,10 & 44,93 & 36,40 & 31,65 & 26,27 & 21,81 & 18,18 & 12,98 & 9,75 & 6,39 \\
\hline 55,27 & 1483,30 & 142,80 & 16,56 & 13,07 & 11,61 & 10,08 & 8,79 & 7,66 & 5,85 & 4,57 & 3,02 \\
\hline 86,00 & 1998,30 & 167,20 & 10,68 & 7,70 & 6,95 & 6,29 & 5,76 & 5,28 & 4,45 & 3,76 & 2,73 \\
\hline 42,57 & 503,50 & 185,70 & 26,96 & 16,84 & 13,05 & 9,79 & 7,61 & 6,08 & 4,20 & 3,19 & 2,19 \\
\hline 42,33 & 704,60 & 118,10 & 29,73 & 21,95 & 18,38 & 14,76 & 11,96 & 9,81 & 6,88 & 5,17 & 3,45 \\
\hline 77,17 & 567,20 & 186,80 & 21,03 & 12,69 & 10,08 & 8,11 & 6,82 & 5,82 & 4,34 & 3,39 & 2,29 \\
\hline 48,58 & 230,20 & 120,60 & 48,24 & 27,24 & 20,30 & 14,95 & 11,61 & 9,30 & 6,44 & 4,91 & 3,39 \\
\hline 59,40 & 1651,00 & 190,80 & 12,92 & 9,85 & 8,66 & 7,49 & 6,52 & 5,69 & 4,35 & 3,41 & 2,26 \\
\hline 59,81 & 925,00 & 124,40 & 21,19 & 15,79 & 13,73 & 11,76 & 10,16 & 8,80 & 6,68 & 5,20 & 3,45 \\
\hline 74,25 & 1174,20 & 22,30 & 48,25 & 38,72 & 36,39 & 35,07 & 33,46 & 31,78 & 28,50 & 25,44 & 20,12 \\
\hline 31,46 & 1729,10 & 195,90 & 18,55 & 14,45 & 12,03 & 9,40 & 7,40 & 5,93 & 4,06 & 3,04 & 2,05 \\
\hline 49,74 & 1745,20 & 170,10 & 14,88 & 11,87 & 10,47 & 8,97 & 7,70 & 6,61 & 4,94 & 3,79 & 2,49 \\
\hline 60,72 & 879,40 & 59,20 & 32,65 & 26,16 & 23,90 & 21,38 & 19,18 & 17,18 & 13,76 & 11,11 & 7,56 \\
\hline 65,57 & 1650,60 & 120,10 & 15,94 & 12,47 & 11,37 & 10,19 & 9,18 & 8,27 & 6,69 & 5,45 & 3,75 \\
\hline 39,43 & 1681,40 & 78,10 & 28,59 & 24,93 & 22,54 & 19,57 & 16,91 & 14,58 & 10,90 & 8,35 & 5,41 \\
\hline 76,30 & 372,50 & 183,90 & 28,02 & 15,44 & 11,61 & 8,89 & 7,22 & 6,02 & 4,36 & 3,37 & 2,29 \\
\hline 64,23 & 1384,60 & 111,50 & 18,11 & 14,13 & 12,79 & 11,39 & 10,19 & 9,11 & 7,29 & 5,88 & 4,01 \\
\hline 34,62 & 327,20 & 78,60 & 57,47 & 39,66 & 31,43 & 23,57 & 18,15 & 14,39 & 9,85 & 7,47 & 5,13 \\
\hline 84,97 & 283,80 & 158,70 & 34,98 & 18,52 & 13,62 & 10,26 & 8,30 & 6,92 & 5,04 & 3,91 & 2,67 \\
\hline 21,09 & 1917,90 & 38,70 & 73,88 & 65,09 & 56,93 & 46,65 & 37,94 & 30,95 & 21,33 & 15,75 & 10,34 \\
\hline 58,94 & 1200,40 & 45,60 & 34,95 & 28,75 & 27,07 & 24,85 & 22,77 & 20,80 & 17,26 & 14,33 & 10,06 \\
\hline 44,41 & 1535,30 & 154,70 & 17,82 & 14,25 & 12,44 & 10,47 & 8,81 & 7,44 & 5,41 & 4,10 & 2,68 \\
\hline 84,21 & 344,00 & 93,60 & 36,39 & 22,48 & 18,23 & 15,01 & 12,87 & 11,18 & 8,60 & 6,82 & 4,65 \\
\hline 55,51 & 1071,00 & 121,00 & 20,91 & 16,15 & 14,19 & 12,20 & 10,55 & 9,13 & 6,90 & 5,35 & 3,53 \\
\hline 45,24 & 1218,90 & 129,70 & 21,48 & 17,03 & 14,84 & 12,47 & 10,50 & 8,86 & 6,44 & 4,88 & 3,20 \\
\hline 50,20 & 809,20 & 162,80 & 21,43 & 15,16 & 12,66 & 10,28 & 8,47 & 7,04 & 5,03 & 3,81 & 2,53 \\
\hline 29,81 & 1817,00 & 70,40 & 37,29 & 32,62 & 28,88 & 24,21 & 20,18 & 16,83 & 11,95 & 8,91 & 5,79 \\
\hline 56,90 & 1533,10 & 26,10 & 48,40 & 39,69 & 38,28 & 36,31 & 34,08 & 31,88 & 27,68 & 23,90 & 17,80 \\
\hline 33,76 & 866,70 & 48,10 & 55,85 & 47,69 & 42,02 & 35,17 & 29,31 & 24,47 & 17,44 & 13,05 & 8,50 \\
\hline 78,24 & 1408,00 & 24,80 & 40,32 & 32,87 & 30,53 & 29,52 & 28,36 & 27,06 & 24,51 & 22,10 & 17,82 \\
\hline 31,47 & 656,20 & 78,90 & 47,01 & 36,31 & 30,09 & 23,40 & 18,37 & 14,69 & 10,04 & 7,53 & 5,09 \\
\hline 64,76 & 958,00 & 146,60 & 18,44 & 13,29 & 11,46 & 9,78 & 8,48 & 7,37 & 5,63 & 4,41 & 2,94 \\
\hline 61,97 & 1860,50 & 181,90 & 12,29 & 9,49 & 8,47 & 7,43 & 6,56 & 5,79 & 4,53 & 3,60 & 2,41 \\
\hline 34,42 & 293,60 & 121,00 & 46,66 & 28,49 & 21,33 & 15,30 & 11,56 & 9,11 & 6,27 & 4,81 & 3,35 \\
\hline 20,04 & 385,00 & 82,00 & 69,71 & 46,17 & 33,37 & 22,63 & 16,55 & 12,95 & 9,05 & 7,03 & 4,90 \\
\hline 40,37 & 1463,30 & 103,90 & 24,70 & 20,67 & 18,29 & 15,52 & 13,14 & 11,13 & 8,11 & 6,14 & 3,99 \\
\hline 50,39 & 1120,00 & 180,20 & 17,39 & 12,83 & 10,92 & 9,04 & 7,55 & 6,34 & 4,59 & 3,49 & 2,30 \\
\hline 52,49 & 664,00 & 190,10 & 21,49 & 14,05 & 11,34 & 8,98 & 7,29 & 6,00 & 4,25 & 3,22 & 2,16 \\
\hline 32,79 & 1468,10 & 136,20 & 24,18 & 19,40 & 16,48 & 13,20 & 10,60 & 8,61 & 5,95 & 4,44 & 2,96 \\
\hline 81,10 & 381,80 & 120,40 & 31,36 & 18,94 & 15,11 & 12,24 & 10,35 & 8,89 & 6,72 & 5,28 & 3,58 \\
\hline 63,24 & 1933,20 & 83,30 & 19,20 & 15,47 & 14,52 & 13,33 & 12,24 & 11,20 & 9,34 & 7,79 & 5,51 \\
\hline 60,59 & 731,20 & 81,10 & 29,53 & 22,56 & 19,92 & 17,30 & 15,13 & 13,25 & 10,22 & 8,04 & 5,36 \\
\hline 64,17 & 1690,70 & 125,70 & 15,55 & 12,21 & 11,11 & 9,93 & 8,92 & 8,00 & 6,44 & 5,22 & 3,57 \\
\hline 89,83 & 1549,40 & 65,40 & 19,75 & 14,85 & 13,69 & 12,89 & 12,14 & 11,43 & 10,09 & 8,89 & 6,90 \\
\hline 36,05 & 308,50 & 195,70 & 34,82 & 18,80 & 13,39 & 9,35 & 7,02 & 5,55 & 3,84 & 2,97 & 2,08 \\
\hline 43,98 & 1683,10 & 183,20 & 15,63 & 12,36 & 10,73 & 8,96 & 7,50 & 6,30 & 4,55 & 3,44 & 2,25 \\
\hline 24,52 & 309,40 & 31,00 & 133,29 & 102,59 & 82,50 & 61,47 & 46,68 & 36,54 & 24,75 & 18,76 & 12,90 \\
\hline 38,31 & 1593,10 & 152,70 & 19,56 & 15,75 & 13,61 & 11,21 & 9,23 & 7,65 & 5,42 & 4,06 & 2,67 \\
\hline 73,99 & 1917,10 & 181,40 & 11,15 & 8,28 & 7,43 & 6,62 & 5,96 & 5,37 & 4,36 & 3,58 & 2,49 \\
\hline 38,23 & 965,00 & 151,80 & 23,90 & 17,85 & 14,87 & 11,78 & 9,42 & 7,64 & 5,30 & 3,97 & 2,67 \\
\hline 80,31 & 771,20 & 40,40 & 37,34 & 28,16 & 26,12 & 24,18 & 22,44 & 20,82 & 17,87 & 15,33 & 11,36 \\
\hline 57,74 & 562,80 & 181,80 & 23,20 & 14,61 & 11,66 & 9,23 & 7,53 & 6,23 & 4,45 & 3,39 & 2,28 \\
\hline 59,73 & 501,00 & 65,90 & 39,62 & 29,63 & 25,82 & 22,13 & 19,15 & 16,61 & 12,61 & 9,83 & 6,52 \\
\hline 25,81 & 1544,70 & 196,80 & 21,83 & 16,38 & 13,05 & 9,66 & 7,31 & 5,73 & 3,89 & 2,95 & 2,04 \\
\hline 42,59 & 1366,00 & 171,00 & 18,11 & 14,03 & 12,03 & 9,89 & 8,17 & 6,79 & 4,83 & 3,63 & 2,40 \\
\hline 35,10 & 765,60 & 145,20 & 28,20 & 20,36 & 16,52 & 12,66 & 9,89 & 7,89 & 5,41 & 4,08 & 2,78 \\
\hline 61,48 & 1810,30 & 21,50 & 49,47 & 40,47 & 38,59 & 37,37 & 35,66 & 33,86 & 30,31 & 26,97 & 21,17 \\
\hline 80,82 & 674,10 & 41,70 & 38,64 & 28,85 & 26,56 & 24,38 & 22,49 & 20,77 & 17,65 & 15,02 & 11,00 \\
\hline 32,23 & 640,30 & 76,30 & 47,69 & 36,94 & 30,75 & 24,05 & 18,97 & 15,22 & 10,42 & 7,81 & 5,27 \\
\hline 35,80 & 1771,70 & 130,40 & 21,79 & 18,10 & 15,79 & 13,09 & 10,83 & 9,00 & 6,38 & 4,78 & 3,13 \\
\hline 55,86 & 1238,00 & 30,40 & 47,05 & 39,09 & 37,39 & 34,85 & 32,28 & 29,80 & 25,21 & 21,27 & 15,26 \\
\hline 37,61 & 1009,40 & 117,70 & 27,71 & 21,69 & 18,46 & 14,92 & 12,11 & 9,92 & 6,94 & 5,19 & 3,45 \\
\hline 46,45 & 948,60 & 158,40 & 21,02 & 15,48 & 13,07 & 10,66 & 8,77 & 7,28 & 5,18 & 3,91 & 2,59 \\
\hline 89,25 & 549,20 & 190,30 & 20,67 & 12,04 & 9,46 & 7,59 & 6,41 & 5,53 & 4,21 & 3,33 & 2,28 \\
\hline 61,11 & 1264,80 & 133,40 & 17,47 & 13,41 & 11,89 & 10,36 & 9,10 & 8,00 & 6,20 & 4,90 & 3,27 \\
\hline 67,48 & 1980,30 & 139,30 & 13,36 & 10,40 & 9,51 & 8,56 & 7,75 & 7,00 & 5,71 & 4,68 & 3,25 \\
\hline 74,34 & 961,00 & 27,00 & 46,12 & 36,15 & 34,14 & 32,42 & 30,56 & 28,73 & 25,27 & 22,13 & 16,94 \\
\hline 73,67 & 301,20 & 159,80 & 34,08 & 18,53 & 13,79 & 10,44 & 8,42 & 6,97 & 5,00 & 3,85 & 2,62 \\
\hline 51,50 & 811,70 & 82,30 & 30,62 & 24,22 & 21,36 & 18,34 & 15,78 & 13,59 & 10,19 & 7,86 & 5,16 \\
\hline 63,26 & 1674,10 & 153,10 & 14,03 & 10,86 & 9,74 & 8,60 & 7,63 & 6,78 & 5,35 & 4,28 & 2,89 \\
\hline 42,77 & 833,80 & 59,20 & 41,61 & 34,78 & 30,95 & 26,50 & 22,64 & 19,34 & 14,28 & 10,88 & 7,08 \\
\hline 83,29 & 1962,80 & 102,00 & 14,46 & 10,83 & 10,02 & 9,30 & 8,66 & 8,06 & 6,96 & 6,00 & 4,49 \\
\hline 43,83 & 511,50 & 123,20 & 32,85 & 22,59 & 18,37 & 14,39 & 11,49 & 9,33 & 6,49 & 4,90 & 3,30 \\
\hline 69,67 & 969,10 & 34,60 & 40,93 & 32,25 & 30,49 & 28,48 & 26,52 & 24,64 & 21,16 & 18,13 & 13,37 \\
\hline 38,82 & 1468,60 & 196,50 & 17,15 & 13,16 & 11,12 & 8,95 & 7,24 & 5,92 & 4,14 & 3,10 & 2,06 \\
\hline 71,53 & 1149,20 & 108,10 & 18,95 & 14,20 & 12,75 & 11,33 & 10,17 & 9,14 & 7,39 & 6,02 & 4,16 \\
\hline 51,02 & 1657,90 & 101,10 & 20,40 & 17,03 & 15,49 & 13,69 & 12,09 & 10,65 & 8,28 & 6,52 & 4,32 \\
\hline 44,57 & 1515,80 & 91,30 & 24,61 & 20,87 & 18,81 & 16,37 & 14,20 & 12,30 & 9,28 & 7,15 & 4,67 \\
\hline
\end{tabular}




\begin{tabular}{|c|c|c|c|c|c|c|c|c|c|c|c|}
\hline & & & \multicolumn{9}{|c|}{ Deflexões $\left(\times 10^{-4} \mathrm{~cm}\right)$} \\
\hline e1 (cm) & Meq (MPa) & Ms (MPa) & D0 & D25 & D40 & D60 & D80 & D100 & D140 & D180 & D260 \\
\hline 38,51 & 1438,90 & 110,10 & 24,82 & 20,57 & 18,05 & 15,12 & 12,64 & 10,59 & 7,61 & 5,72 & 3,73 \\
\hline 38,48 & 1428,20 & 151,80 & 20,41 & 16,20 & 13,91 & 11,38 & 9,32 & 7,69 & 5,42 & 4,06 & 2,68 \\
\hline 76,63 & 1146,20 & 109,90 & 18,22 & 13,39 & 12,01 & 10,71 & 9,66 & 8,74 & 7,14 & 5,88 & 4,12 \\
\hline 20,72 & 296,40 & 130,60 & 51,91 & 29,90 & 20,59 & 13,74 & 10,16 & 8,04 & 5,66 & 4,41 & 3,10 \\
\hline 83,45 & 1421,40 & 125,00 & 14,82 & 10,72 & 9,66 & 8,70 & 7,93 & 7,25 & 6,05 & 5,07 & 3,65 \\
\hline 78,57 & 415,10 & 154,30 & 27,43 & 16,07 & 12,56 & 9,97 & 8,32 & 7,06 & 5,24 & 4,08 & 2,76 \\
\hline 63,12 & 879,30 & 55,90 & 33,09 & 26,35 & 24,20 & 21,79 & 19,67 & 17,74 & 14,38 & 11,73 & 8,07 \\
\hline 34,11 & 1159,10 & 121,80 & 27,50 & 21,76 & 18,43 & 14,73 & 11,83 & 9,60 & 6,64 & 4,96 & 3,31 \\
\hline 57,03 & 1777,50 & 185,20 & 12,98 & 10,10 & 8,94 & 7,75 & 6,75 & 5,88 & 4,50 & 3,52 & 2,33 \\
\hline 35,18 & 1003,80 & 163,40 & 23,62 & 17,51 & 14,40 & 11,18 & 8,80 & 7,06 & 4,85 & 3,64 & 2,47 \\
\hline 34,68 & 1989,80 & 110,50 & 23,79 & 20,35 & 17,98 & 15,12 & 12,66 & 10,61 & 7,61 & 5,70 & 3,71 \\
\hline 73,36 & 469,40 & 154,50 & 25,75 & 15,66 & 12,45 & 10,00 & 8,37 & 7,10 & 5,26 & 4,08 & 2,75 \\
\hline 55,13 & 1449,10 & 41,70 & 36,35 & 30,40 & 28,90 & 26,71 & 24,57 & 22,53 & 18,82 & 15,69 & 11,07 \\
\hline 65,34 & 760,70 & 140,20 & 21,13 & 14,73 & 12,49 & 10,52 & 9,03 & 7,79 & 5,88 & 4,58 & 3,05 \\
\hline 65,10 & 401,70 & 128,20 & 31,48 & 19,60 & 15,68 & 12,55 & 10,39 & 8,73 & 6,35 & 4,88 & 3,27 \\
\hline 54,24 & 307,80 & 76,90 & 48,84 & 32,82 & 26,92 & 21,68 & 17,82 & 14,82 & 10,61 & 8,06 & 5,38 \\
\hline 86,77 & 1982,10 & 156,80 & 11,06 & 7,98 & 7,23 & 6,57 & 6,03 & 5,55 & 4,69 & 3,98 & 2,91 \\
\hline 72,97 & 1126,20 & 51,40 & 29,32 & 22,73 & 21,28 & 19,71 & 18,26 & 16,89 & 14,39 & 12,25 & 8,96 \\
\hline 33,16 & 1967,50 & 57,70 & 37,85 & 34,09 & 30,98 & 26,93 & 23,23 & 19,98 & 14,85 & 11,31 & 7,29 \\
\hline 87,06 & 1986,40 & 80,30 & 16,12 & 12,19 & 11,29 & 10,64 & 10,01 & 9,42 & 8,30 & 7,30 & 5,64 \\
\hline 87,76 & 1153,90 & 126,70 & 15,92 & 11,14 & 9,86 & 8,77 & 7,94 & 7,22 & 5,99 & 5,00 & 3,58 \\
\hline 83,97 & 1380,10 & 75,80 & 19,83 & 14,77 & 13,64 & 12,63 & 11,74 & 10,91 & 9,40 & 8,10 & 6,04 \\
\hline 65,89 & 1210,10 & 57,30 & 28,22 & 22,45 & 20,99 & 19,25 & 17,67 & 16,18 & 13,51 & 11,28 & 8,01 \\
\hline 56,88 & 1361,60 & 96,40 & 21,23 & 17,19 & 15,60 & 13,84 & 12,29 & 10,90 & 8,58 & 6,83 & 4,58 \\
\hline 89,96 & 1970,40 & 196,10 & 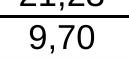 & $\begin{array}{c}\boldsymbol{L}, \pm \mathrm{J} \\
6,81\end{array}$ & $\begin{array}{c}10,00 \\
6,06\end{array}$ & $\begin{array}{c}10,0+4 \\
5,43\end{array}$ & $\begin{array}{l}1+L, L 5 \\
4,95\end{array}$ & 4,53 & 3,80 & 3,20 & 2,32 \\
\hline 66,25 & 1811,40 & 70,00 & 21,41 & 17,07 & 16,10 & 14,92 & 13,80 & 12,74 & 10,79 & 9,13 & 6,60 \\
\hline 39,91 & 861,50 & 27,80 & 70,18 & 62,54 & 57,61 & 51,16 & 45,13 & 39,67 & 30,61 & 23,91 & 15,63 \\
\hline 52,18 & 1255,10 & 138,50 & 18,73 & 14,62 & 12,83 & 10,97 & 9,41 & 8,09 & 6,05 & 4,66 & 3,06 \\
\hline 87,76 & 399,30 & 170,20 & 26,72 & 14,96 & 11,43 & 8,94 & 7,42 & 6,31 & 4,71 & 3,70 & 2,52 \\
\hline 75,15 & 1198,80 & 58,10 & 26,12 & 20,07 & 18,73 & 17,33 & 16,05 & 14,86 & 12,68 & 10,81 & 7,92 \\
\hline 68,05 & 465,80 & 126,60 & 28,60 & 18,34 & 14,94 & 12,19 & 10,26 & 8,72 & 6,46 & 5,00 & 3,34 \\
\hline 66,55 & 1661,00 & 93,20 & 18,38 & 14,51 & 13,45 & 12,24 & 11,17 & 10,17 & 8,41 & 6,97 & 4,90 \\
\hline 47,83 & 1955,80 & 95,90 & 20,69 & 17,69 & 16,21 & 14,39 & 12,74 & 11,25 & 8,76 & 6,90 & 4,56 \\
\hline 48,79 & 1231,10 & 101,30 & 23,57 & 19,23 & 17,13 & 14,80 & 12,79 & 11,04 & 8,31 & 6,41 & 4,20 \\
\hline 78,44 & 925,20 & 20,90 & 52,80 & 41,92 & 39,21 & 37,66 & 35,90 & 34,06 & 30,51 & 27,21 & 21,51 \\
\hline 62,69 & 219,90 & 188,20 & 41,20 & 20,01 & 13,77 & 9,63 & 7,37 & 5,90 & 4,09 & 3,15 & 2,20 \\
\hline 23,95 & 908,90 & 23,60 & 117,51 & 103,50 & 90,94 & 75,14 & 61,63 & 50,66 & 35,27 & 26,10 & 17,06 \\
\hline 38,75 & 1169,40 & 168,50 & 20,62 & 15,63 & 13,14 & 10,50 & 8,46 & 6,90 & 4,81 & 3,60 & 2,41 \\
\hline 22,32 & 1521,00 & 94,90 & 40,55 & 32,51 & 26,62 & 20,16 & 15,44 & 12,11 & 8,16 & 6,15 & 4,21 \\
\hline 82,62 & 496,50 & 95,50 & 29,13 & 19,22 & 16,20 & 13,78 & 12,06 & 10,64 & 8,38 & 6,73 & 4,62 \\
\hline 72,77 & 1089,70 & 93,90 & 20,81 & 15,65 & 14,14 & 12,65 & 11,42 & 10,32 & 8,41 & 6,91 & 4,82 \\
\hline 38,16 & 1039,10 & 64,20 & 39,55 & 33,57 & 29,79 & 25,28 & 21,37 & 18,08 & 13,14 & 9,92 & 6,44 \\
\hline 40,28 & 1193,50 & 77,90 & 31,96 & 26,98 & 24,00 & 20,47 & 17,40 & 14,80 & 10,84 & 8,23 & 5,34 \\
\hline 89,65 & 517,40 & 97,70 & 27,47 & 17,84 & 15,03 & 12,82 & 11,30 & 10,06 & 8,04 & 6,55 & 4,56 \\
\hline 23,96 & 1803,40 & 161,20 & 25,19 & 19,60 & 15,83 & 11,84 & 9,01 & 7,05 & 4,77 & 3,61 & 2,48 \\
\hline 77,84 & 1388,30 & 34,00 & 33,66 & 26,53 & 24,89 & 23,83 & 22,64 & 21,43 & 19,10 & 16,95 & 13,28 \\
\hline 46,25 & 1067,10 & 165,40 & 19,53 & 14,57 & 12,37 & 10,14 & 8,38 & 6,97 & 4,98 & 3,76 & 2,49 \\
\hline 49,40 & 1764,50 & 131,90 & 17,29 & 14,23 & 12,76 & 11,11 & 9,67 & 8,40 & 6,38 & 4,95 & 3,25 \\
\hline 56,24 & 1263,10 & 197,30 & 14,80 & 10,85 & 9,31 & 7,83 & 6,66 & 5,68 & 4,21 & 3,24 & 2,14 \\
\hline 56,98 & 1744,90 & 56,60 & 27,27 & 22,63 & 21,43 & 19,77 & 18,16 & 16,63 & 13,86 & 11,54 & 8,14 \\
\hline 64,65 & 231,60 & 62,50 & 58,70 & 37,99 & 30,98 & 25,21 & 21,10 & 17,85 & 13,11 & 10,09 & 6,74 \\
\hline 43,11 & 1323,50 & 72,00 & 30,74 & 26,36 & 23,82 & 20,76 & 18,02 & 15,61 & 11,77 & 9,07 & 5,91 \\
\hline 66,86 & 1536,80 & 172,40 & 13,30 & 9,94 & 8,80 & 7,70 & 6,81 & 6,03 & 4,74 & 3,79 & 2,56 \\
\hline 51,67 & 515,10 & 51,50 & 48,53 & 38,44 & 33,94 & 29,17 & 25,13 & 21,67 & 16,28 & 12,56 & 8,25 \\
\hline 54,68 & 1283,40 & 63,10 & 28,92 & 24,11 & 22,31 & 20,09 & 18,07 & 16,21 & 13,00 & 10,49 & 7,11 \\
\hline 53,42 & 1022,30 & 165,10 & 18,44 & 13,52 & 11,54 & 9,62 & 8,11 & 6,86 & 5,02 & 3,84 & 2,53 \\
\hline 84,47 & 1363,60 & 159,60 & 13,25 & 9,30 & 8,20 & 7,25 & 6,53 & 5,91 & 4,84 & 4,01 & 2,83 \\
\hline 52,64 & 803,50 & 144,00 & 22,39 & 16,14 & 13,64 & 11,26 & 9,41 & 7,91 & 5,74 & 4,37 & 2,89 \\
\hline 31,32 & 1299,10 & 77,60 & 37,69 & 31,74 & 27,59 & 22,64 & 18,53 & 15,24 & 10,66 & 7,93 & 5,22 \\
\hline 50,00 & 1123,90 & 161,70 & 18,49 & 13,91 & 11,94 & 9,96 & 8,36 & 7,06 & 5,14 & 3,91 & 2,57 \\
\hline 70,64 & 1723,10 & 107,10 & 16,14 & 12,49 & 11,52 & 10,47 & 9,56 & 8,73 & 7,24 & 6,03 & 4,27 \\
\hline 62,16 & 1777,00 & 138,70 & 14,61 & 11,52 & 10,44 & 9,28 & 8,29 & 7,40 & 5,89 & 4,73 & 3,21 \\
\hline 48,44 & 940,40 & 188,60 & 18,79 & 13,34 & 11,11 & 8,99 & 7,36 & 6,10 & 4,33 & 3,27 & 2,18 \\
\hline 75,76 & 1667,80 & 114,90 & 15,15 & 11,44 & 10,49 & 9,53 & 8,71 & 7,97 & 6,65 & 5,57 & 3,98 \\
\hline 46,25 & 1729,60 & 144,70 & 17,21 & 14,06 & 12,47 & 10,69 & 9,15 & 7,84 & 5,82 & 4,46 & 2,91 \\
\hline 29,78 & 936,00 & 137,00 & $\begin{array}{l}I, L \perp \\
29,98\end{array}$ & 22,39 & $\begin{array}{l}1 L,+10 \\
18,10\end{array}$ & $\begin{array}{l}13,69 \\
13,69\end{array}$ & 10,54 & 8,33 & 5,67 & 4,28 & 2,93 \\
\hline 62,25 & 1915,60 & 73,50 & 21,07 & 17,08 & $\frac{10,+0}{16,10}$ & 14,85 & 13,67 & 12,55 & 10,51 & 8,80 & 6,26 \\
\hline 88,53 & 1503,90 & 90,00 & 16,83 & 12,34 & 11,31 & 10,45 & 9,72 & 9,04 & 7,81 & 6,75 & 5,07 \\
\hline 80,77 & 366,90 & 29,60 & 61,07 & 44,85 & 40,68 & 36,77 & 33,57 & 30,69 & 25,63 & 21,49 & 15,41 \\
\hline 67,51 & 955,50 & 128,00 & 19,41 & 14,16 & 12,35 & 10,69 & 9,37 & 8,24 & 6,41 & 5,08 & 3,42 \\
\hline 67.35 & 1604.60 & 112,30 & 16,55 & 12,89 & 11.79 & 10,62 & 9.61 & 8.68 & 7,08 & 5,81 & 4.03 \\
\hline 53,35 & 1076,10 & 95,30 & 24,45 & 19,58 & 17,46 & 15,18 & 13,23 & 11,52 & 8,79 & 6,85 & 4,52 \\
\hline 40,62 & 1507,00 & 35,20 & 49,26 & 44,12 & 41,33 & 37,36 & 33,55 & 29,99 & 23,84 & 19,02 & 12,67 \\
\hline 24,46 & 589,20 & 168,40 & 33,48 & 21,74 & 15,98 & 11,06 & 8,16 & 6,39 & 4,43 & 3,43 & 2,39 \\
\hline 79,04 & 904,40 & 195,00 & 15,46 & 10,10 & 8,42 & 7,08 & 6,13 & 5,36 & 4,15 & 3,30 & 2,24 \\
\hline 52,73 & 328,20 & 43,00 & 64,71 & 49,20 & 42,66 & 36,07 & 30,70 & 26,21 & 19,40 & 14,88 & 9,78 \\
\hline 39,38 & 976,40 & 189,50 & 20,50 & 14,75 & 12,11 & 9,48 & 7,53 & 6,08 & 4,21 & 3,17 & 2,14 \\
\hline 57,75 & 1333,00 & 21,60 & 57,12 & 46,68 & 45,01 & 42,84 & 40,32 & 37,81 & 33,01 & 28,66 & 21,53 \\
\hline 34,18 & 1355,20 & 162,10 & 21,63 & 16,80 & 14,10 & 11,16 & 8,90 & 7,19 & 4,95 & 3,71 & 2,49 \\
\hline 42,94 & 659,00 & 190,10 & 23,34 & 15,45 & 12,31 & 9,46 & 7,46 & 6,00 & 4,15 & 3,14 & 2,14 \\
\hline 31,81 & 1165,60 & 192,20 & 21,40 & 15,76 & 12,75 & 9,69 & 7,50 & 5,94 & 4,06 & 3,06 & 2,09 \\
\hline 32,81 & 267,50 & 59,70 & 75,62 & 52,86 & 41,86 & 31,24 & 23,95 & 18,93 & 12,94 & 9,82 & 6,75 \\
\hline
\end{tabular}




\begin{tabular}{|c|c|c|c|c|c|c|c|c|c|c|c|}
\hline \multirow[b]{2}{*}{$\mathrm{e} 1(\mathrm{~cm})$} & & & & & & $\mathrm{De}$ & $\overline{\text { ões (x1 }}$ & & & & \\
\hline & Meq (MPa) & Ms (MPa) & D0 & D25 & D40 & D60 & D80 & D100 & D140 & D180 & D260 \\
\hline 52,33 & 1412,10 & 58,30 & 30,23 & 25,60 & 23,83 & 21,56 & 19,45 & 17,48 & 14,08 & 11,38 & 7,72 \\
\hline 60,83 & 759,40 & 190,70 & 18,88 & 12,51 & 10,28 & 8,38 & 6,99 & 5,89 & 4,30 & 3,30 & 2,20 \\
\hline 63,12 & 673,40 & 22,60 & 64,90 & 52,41 & 49,70 & 46,18 & 42,75 & 39,48 & 33,45 & 28,29 & 20,42 \\
\hline 43,48 & 473,10 & 198,80 & 26,69 & 16,11 & 12,30 & 9,14 & 7,08 & 5,66 & 3,90 & 2,97 & 2,05 \\
\hline 54,86 & 1283,90 & 92,40 & 22,77 & 18,54 & 16,77 & 14,81 & 13,09 & 11,55 & 9,01 & 7,12 & 4,74 \\
\hline 42,14 & 1176,50 & 86,60 & 29,13 & 24,26 & 21,51 & 18,34 & 15,59 & 13,27 & 9,74 & 7,40 & 4,82 \\
\hline 61,44 & 1958,30 & 131,30 & 14,61 & 11,68 & 10,67 & 9,56 & 8,59 & 7,71 & 6,19 & 5,01 & 3,42 \\
\hline 29,45 & 1956,70 & 117,60 & 26,15 & 21,87 & 18,84 & 15,26 & 12,34 & 10,05 & 6,96 & 5,17 & 3,42 \\
\hline 31,03 & 1048,80 & 94,60 & 35,86 & 28,75 & 24,29 & 19,26 & 15,35 & 12,37 & 8,50 & 6,34 & 4,25 \\
\hline 37,68 & 1957,30 & 120,70 & 21,23 & 18,02 & 15,97 & 13,53 & 11,41 & 9,64 & 6,99 & 5,27 & 3,42 \\
\hline 80,45 & 419,30 & 184,00 & 25,60 & 14,40 & 11,00 & 8,56 & 7,05 & 5,95 & 4,38 & 3,40 & 2,31 \\
\hline 37,78 & 1336,60 & 47,40 & 44,29 & 39,40 & 35,95 & 31,52 & 27,46 & 23,84 & 18,02 & 13,88 & 9,00 \\
\hline 53,74 & 1820,90 & 193,20 & 12,97 & 10,15 & 8,95 & 7,69 & 6,64 & 5,74 & 4,33 & 3,35 & 2,21 \\
\hline 76,37 & 1585,40 & 28,20 & 36,37 & 29,48 & 27,51 & 26,58 & 25,48 & 24,28 & 21,92 & 19,69 & 15,77 \\
\hline 37,66 & 423,70 & 53,60 & 62,74 & 48,52 & 41,05 & 32,98 & 26,65 & 21,76 & 15,17 & 11,36 & 7,56 \\
\hline 49,00 & 339,50 & 166,30 & 33,61 & 19,32 & 14,54 & 10,80 & 8,42 & 6,76 & 4,69 & 3,57 & 2,46 \\
\hline 58,46 & 1409,10 & 180,90 & 14,42 & 10,86 & 9,47 & 8,12 & 7,01 & 6,07 & 4,60 & 3,58 & 2,37 \\
\hline 45,42 & 441,40 & 78,80 & 44,08 & 32,10 & 26,91 & 21,75 & 17,77 & 14,66 & 10,36 & 7,81 & 5,19 \\
\hline 22,88 & 436,10 & 87,60 & 60,03 & 41,21 & 30,81 & 21,48 & 15,83 & 12,34 & 8,52 & 6,59 & 4,59 \\
\hline 25,50 & 1351,40 & 70,10 & 46,84 & 39,07 & 33,22 & 26,38 & 20,94 & 16,81 & 11,46 & 8,52 & 5,71 \\
\hline 62,84 & 1454,00 & 178,60 & 13,80 & 10,33 & 9,06 & 7,84 & 6,85 & 6,00 & 4,63 & 3,64 & 2,43 \\
\hline 46,87 & 1315,40 & 50,00 & 36,78 & 31,90 & 29,57 & 26,55 & 23,73 & 21,13 & 16,71 & 13,31 & 8,87 \\
\hline 59,15 & 1226,60 & 166,40 & 16,00 & 11,92 & 10,36 & 8,85 & 7,64 & 6,61 & 5,00 & 3,88 & 2,57 \\
\hline 50,28 & 1219,70 & 118,80 & 21,15 & 16,86 & 14,89 & 12,77 & 10,98 & 9,44 & 7,07 & 5,44 & 3,57 \\
\hline 58,37 & 1926,70 & 50,60 & 28,09 & 23,10 & 22,07 & 20,59 & 19,10 & 17,66 & 15,00 & 12,70 & 9,17 \\
\hline 38,77 & 1270,90 & 114,30 & 25,30 & 20,55 & 17,86 & 14,80 & 12,27 & 10,22 & 7,27 & 5,46 & 3,58 \\
\hline 82,05 & 635,50 & 164,30 & 20,22 & 12,68 & 10,35 & 8,56 & 7,35 & 6,39 & 4,91 & 3,89 & 2,65 \\
\hline 83,80 & 503,30 & 165,80 & 23,25 & 13,84 & 10,96 & 8,84 & 7,47 & 6,42 & 4,87 & 3,83 & 2,60 \\
\hline 62,58 & 890,60 & 160,00 & 18,61 & 13,12 & 11,15 & 9,38 & 8,02 & 6,89 & 5,17 & 4,01 & 2,66 \\
\hline 72,32 & 1170,70 & 31,80 & 39,45 & 31,06 & 29,42 & 27,92 & 26,30 & 24,70 & 21,68 & 18,95 & 14,45 \\
\hline 31,37 & 1189,00 & 114,40 & 30,08 & 23,94 & 20,16 & 15,95 & 12,68 & 10,21 & 7,01 & 5,24 & 3,51 \\
\hline 65,79 & 1020,80 & 20,50 & 58,80 & 47,17 & 45,06 & 43,00 & 40,60 & 38,21 & 33,62 & 29,43 & 22,46 \\
\hline 39,20 & 1781,60 & 104,00 & 23,43 & 20,01 & 17,86 & 15,28 & 13,02 & 11,09 & 8,14 & 6,18 & 4,01 \\
\hline 40,20 & 346,90 & 64,20 & 58,67 & 42,59 & 35,20 & 27,77 & 22,19 & 18,00 & 12,50 & 9,40 & 6,32 \\
\hline 53,33 & 1796,50 & 197,00 & 12,97 & 10,11 & 8,88 & 7,62 & 6,56 & 5,66 & 4,25 & 3,28 & 2,16 \\
\hline 32,81 & 1095,70 & 93,50 & 34,18 & 27,71 & 23,69 & 19,09 & 15,42 & 12,56 & 8,71 & 6,49 & 4,31 \\
\hline 58,71 & 327,90 & 101,70 & 40,32 & 25,59 & 20,53 & 16,33 & 13,39 & 11,13 & 7,98 & 6,08 & 4,08 \\
\hline 47,12 & 1464,40 & 172,50 & 16,44 & 12,82 & 11,13 & 9,34 & 7,86 & 6,64 & 4,84 & 3,68 & 2,41 \\
\hline 37,11 & 1467,60 & 159,20 & 20,10 & 15,89 & 13,57 & 11,01 & 8,95 & 7,34 & 5,14 & 3,84 & 2,55 \\
\hline 38,30 & 1782,50 & 66,50 & 31,79 & 28,18 & 25,68 & 22,50 & 19,58 & 17,00 & 12,84 & 9,88 & 6,41 \\
\hline 86,25 & 1154,20 & 41,40 & 29,90 & 22,85 & 21,19 & 20,07 & 18,96 & 17,88 & 15,84 & 13,99 & 10,89 \\
\hline 34,90 & 1938,10 & 49,10 & 40,63 & 36,88 & 33,91 & 29,95 & 26,25 & 22,91 & 17,45 & 13,49 & 8,74 \\
\hline 78,96 & 795,40 & 61,10 & 29,27 & 21,71 & 19,76 & 17,89 & 16,34 & 14,94 & 12,47 & 10,44 & 7,48 \\
\hline 52,18 & 1585,60 & 174,00 & 14,87 & 11,62 & 10,20 & 8,72 & 7,49 & 6,44 & 4,81 & 3,71 & 2,44 \\
\hline 37,47 & 836,80 & 59,40 & 45,62 & 38,11 & 33,49 & 28,06 & 23,46 & 19,65 & 14,10 & 10,59 & 6,91 \\
\hline 46,04 & 622,60 & 101,60 & 32,60 & 24,12 & 20,39 & 16,63 & 13,69 & 11,36 & 8,09 & 6,10 & 4,04 \\
\hline 70,15 & 1730,80 & 183,20 & 11,91 & 8,87 & 7,89 & 6,95 & 6,19 & 5,53 & 4,41 & 3,56 & 2,43 \\
\hline 65,88 & 315,40 & 172,00 & 32,82 & 17,90 & 13,30 & 9,98 & 7,96 & 6,52 & 4,62 & 3,54 & 2,41 \\
\hline 27,63 & 1076,20 & 30,00 & 83,58 & 74,58 & 66,55 & 56,27 & 47,20 & 39,56 & 28,27 & 21,09 & 13,63 \\
\hline 34,65 & 1367,40 & 48,50 & 46,35 & 41,25 & 37,31 & 32,30 & 27,76 & 23,80 & 17,62 & 13,39 & 8,64 \\
\hline 67,10 & 253,10 & 46,70 & 62,80 & 43,57 & 36,95 & 31,19 & 26,84 & 23,22 & 17,63 & 13,78 & 9,20 \\
\hline 44,64 & 584,40 & 141,60 & 28,42 & 19,50 & 15,87 & 12,46 & 9,98 & 8,11 & 5,66 & 4,27 & 2,88 \\
\hline 54,77 & 763,80 & 48,20 & 41,52 & 34,15 & 31,15 & 27,70 & 24,63 & 21,86 & 17,22 & 13,70 & 9,17 \\
\hline 50,32 & 566,80 & 123,10 & 29,38 & 20,46 & 16,96 & 13,70 & 11,24 & 9,31 & 6,63 & 5,02 & 3,34 \\
\hline 58,16 & 1267,10 & 118,10 & 19,18 & 15,07 & 13,45 & 11,76 & 10,33 & 9,08 & 7,03 & 5,54 & 3,69 \\
\hline 75,16 & 699,70 & 183,00 & 18,75 & 11,92 & 9,74 & 8,02 & 6,83 & 5,89 & 4,45 & 3,49 & 2,35 \\
\hline 51,75 & 252,60 & 164,20 & 39,88 & 21,10 & 15,23 & 10,99 & 8,48 & 6,79 & 4,70 & 3,60 & 2,50 \\
\hline 83,91 & 311,20 & 181,40 & 31,59 & 16,59 & 12,13 & 9,08 & 7,31 & 6,07 & 4,40 & 3,41 & 2,33 \\
\hline 56,52 & 1294,70 & 68,20 & 26,90 & 22,20 & 20,50 & 18,46 & 16,61 & 14,91 & 11,99 & 9,69 & 6,58 \\
\hline 28,98 & 835,80 & 109,40 & 36,79 & 27,87 & 22,63 & 17,16 & 13,22 & 10,45 & 7,10 & 5,36 & 3,67 \\
\hline 83,76 & 967,30 & 77,30 & 22,91 & 16,68 & 15,12 & 13,70 & 12,54 & 11,51 & 9,67 & 8,16 & 5,91 \\
\hline 83,16 & 1315,30 & 186,30 & 12,60 & 8,68 & 7,54 & 6,57 & 5,85 & 5,24 & 4,23 & 3,45 & 2,40 \\
\hline 37,38 & 590,00 & 157,90 & 28,85 & 19,48 & 15,43 & 11,64 & 9,02 & 7,18 & 4,93 & 3,74 & 2,56 \\
\hline 52,91 & 842,50 & 155,20 & 21,00 & 15,04 & 12,69 & 10,46 & 8,73 & 7,33 & 5,32 & 4,05 & 2,68 \\
\hline 28,65 & 316,40 & 105,40 & 52,65 & 33,62 & 25,08 & 17,69 & 13,19 & 10,34 & 7,13 & 5,50 & 3,83 \\
\hline 31,06 & 314,50 & 67,80 & 67,60 & 47,43 & 37,36 & 27,64 & 21,05 & 16,58 & 11,32 & 8,61 & 5,94 \\
\hline 77,68 & 900,70 & 193,00 & 15,65 & 10,27 & 8,58 & 7,21 & 6,24 & 5,44 & 4,20 & 3,33 & 2,26 \\
\hline 33,21 & 1125,20 & 178,90 & 22,13 & 16,43 & 13,42 & 10,32 & 8,06 & 6,42 & 4,39 & 3,31 & 2,25 \\
\hline 59,67 & 1522,50 & 185,00 & 13,60 & 10,29 & 9,02 & 7,77 & 6,76 & 5,88 & 4,49 & 3,51 & 2,33 \\
\hline 49,32 & 720,20 & 131,40 & 25,57 & 18,46 & 15,53 & 12,69 & 10,48 & 8,73 & 6,26 & 4,74 & 3,14 \\
\hline 33,88 & 1145,30 & 173,10 & 22,19 & 16,62 & 13,68 & 10,61 & 8,33 & 6,67 & 4,57 & 3,43 & 2,33 \\
\hline 51,88 & 1631,10 & 196,60 & 13,76 & 10,62 & 9,25 & 7,86 & 6,70 & 5,73 & 4,25 & 3,26 & 2,14 \\
\hline 55,94 & 424,60 & 161,20 & 28,97 & 17,60 & 13,76 & 10,67 & 8,58 & 7,03 & 4,96 & 3,78 & 2,55 \\
\hline 86,82 & 1000,50 & 39,60 & 32,44 & 24,58 & 22,77 & 21,48 & 20,23 & 19,03 & 16,79 & 14,78 & 11,43 \\
\hline 52,27 & 612,60 & 35,60 & 56,00 & 46,72 & 42,68 & 37,94 & 33,68 & 29,83 & 23,39 & 18,55 & 12,36 \\
\hline 72,88 & 1314,00 & 102,60 & 18,23 & 13,80 & 12,55 & 11,30 & 10,25 & 9,29 & 7,64 & 6,31 & 4,42 \\
\hline 74,74 & 1257,30 & 71,30 & 22,71 & 17,37 & 16,10 & 14,77 & 13,60 & 12,52 & 10,56 & 8,92 & 6,44 \\
\hline 24,39 & 1831,00 & 145,50 & 26,62 & 21,06 & 17,23 & 13,07 & 10,04 & 7,89 & 5,34 & 4,02 & 2,75 \\
\hline 83,83 & 555,20 & 63,20 & 33,11 & 23,36 & 20,65 & 18,29 & 16,48 & 14,91 & 12,24 & 10,13 & 7,16 \\
\hline 43,37 & 1617,00 & 56,20 & 33,48 & 29,48 & 27,26 & 24,37 & 21,66 & 19,18 & 15,00 & 11,84 & 7,82 \\
\hline 74,67 & 432,40 & 139,60 & 28,02 & 17,06 & 13,60 & 10,96 & 9,19 & 7,82 & 5,82 & 4,53 & 3,05 \\
\hline 87,55 & 1919,90 & 164,10 & 10,91 & 7,81 & 7,04 & 6,36 & 5,83 & 5,35 & 4,51 & 3,82 & 2,78 \\
\hline
\end{tabular}




\begin{tabular}{|c|c|c|c|c|c|c|c|c|c|c|c|}
\hline \multirow[b]{2}{*}{ e1 (cm) } & & & & & & & ões (x1 & m) & & & \\
\hline & Meq (MPa) & Ms (MPa) & D0 & D25 & D40 & D60 & D80 & D100 & D140 & D180 & D260 \\
\hline 85,44 & 401,80 & 188,10 & 25,94 & 14,28 & 10,78 & 8,33 & 6,85 & 5,78 & 4,27 & 3,33 & 2,27 \\
\hline 41,22 & 320,00 & 34,70 & 86,04 & 688,17 & 58,87 & 48,66 & 40,30 & 33,55 & 23,93 & 17,99 & 11,83 \\
\hline 20,57 & 1246,50 & 191,00 & 27,16 & 19,09 & 14,26 & 9,89 & 7,25 & 5,64 & 3,90 & 3,02 & 2,10 \\
\hline 87,06 & 1639,80 & 121,10 & 13,86 & 10,05 & 9,13 & 8,33 & 7,67 & 7,08 & 6,02 & 5,13 & 3,77 \\
\hline 65,55 & 643,80 & 112,20 & 25,61 & 18,02 & 15,36 & 13,00 & 11,19 & 9,68 & 7,35 & 5,74 & 3,83 \\
\hline 43,94 & 406,50 & 147,00 & 33,36 & 20,91 & 16,28 & 12,29 & 9,61 & 7,70 & 5,32 & 4,04 & 2,77 \\
\hline 42,81 & 1109,80 & 40,30 & 47,85 & 42,13 & 38,83 & 34,58 & 30,62 & 27,01 & 20,99 & 16,49 & 10,85 \\
\hline 40,18 & 1218,40 & 73,50 & 32,97 & 28,07 & 25,07 & 21,48 & 18,34 & 15,65 & 11,53 & 8,76 & 5,69 \\
\hline 86,98 & 287,20 & 159,20 & 34,55 & 18,29 & 13,46 & 10,15 & 8,23 & 6,87 & 5,02 & 3,90 & 2,67 \\
\hline 89,49 & 1645,60 & 63,80 & 19,57 & 14,84 & 13,69 & 12,94 & 12,22 & 11,52 & 10,22 & 9,04 & 7,06 \\
\hline 33,43 & 1502,80 & 124,40 & 25,07 & 20,44 & 17,55 & 14,23 & 11,55 & 9,45 & 6,58 & 4,91 & 3,25 \\
\hline 72,38 & 1122,70 & 117,90 & 18,17 & 13,44 & 11,96 & 10,57 & 9,45 & 8,46 & 6,80 & 5,52 & 3,80 \\
\hline 33,05 & 1328,10 & 143,30 & 24,11 & 18,97 & 15,97 & 12,65 & 10,09 & 8,15 & 5,61 & 4,19 & 2,81 \\
\hline 83,79 & 1035,80 & 82,00 & 21,50 & 15,66 & 14,21 & 12,88 & 11,80 & 10,83 & 9,11 & 7,69 & 5,58 \\
\hline 80,49 & 1087,10 & 41,30 & 32,11 & 24,59 & 22,99 & 21,64 & 20,31 & 19,04 & 16,66 & 14,53 & 11,07 \\
\hline 84,80 & 1740,10 & 183,40 & 10,93 & 7,75 & 6,89 & 6,14 & 5,56 & 5,05 & 4,17 & 3,47 & 2,47 \\
\hline 31,06 & 1396,00 & 119,60 & 27,85 & 22,47 & 19,05 & 15,18 & 12,13 & 9,80 & 6,75 & 5,03 & 3,36 \\
\hline 87,70 & 304,00 & 113,70 & 36,55 & 21,03 & 16,36 & 13,01 & 10,92 & 9,35 & 7,06 & 5,56 & 3,79 \\
\hline 37,06 & 278,00 & 117,00 & 47,60 & 28,89 & 21,76 & 15,77 & 12,00 & 9,48 & 6,52 & 5,00 & 3,47 \\
\hline 20,26 & 368,40 & 33,50 & 136,57 & 102,91 & 80,10 & 57,42 & 42,55 & 32,97 & 22,47 & 17,24 & 11,95 \\
\hline 89,72 & 1778,70 & 195,30 & 10,24 & 7,12 & 6,30 & 5,61 & 5,08 & 4,63 & 3,86 & 3,23 & 2,32 \\
\hline 59,87 & 917,40 & 169,30 & 18,19 & 12,84 & 10,87 & 9,09 & 7,71 & 6,58 & 4,89 & 3,77 & 2,50 \\
\hline 37,94 & 1086,00 & 61,70 & 40,07 & 34,30 & 30,57 & 26,06 & 22,12 & 18,77 & 13,71 & 10,37 & 6,72 \\
\hline 55,74 & 1627,70 & 125,00 & 17,12 & 13,82 & 12,47 & 10,99 & 9,70 & 8,55 & 6,66 & 5,26 & 3,50 \\
\hline 63,20 & 1505,60 & 167,70 & 14,00 & 10,61 & 9,37 & 8,17 & 7,18 & 6,32 & 4,92 & 3,89 & 2,61 \\
\hline 74,38 & 1806,40 & 136,40 & 13,39 & 10,10 & 9,21 & 8,32 & 7,56 & 6,88 & 5,69 & 4,73 & 3,34 \\
\hline 86,79 & 1584,30 & 165,10 & 11,96 & 8,44 & 7,50 & 6,69 & 6,07 & 5,53 & 4,59 & 3,84 & 2,75 \\
\hline 45,23 & 309,20 & 164,70 & 36,18 & 20,42 & 15,14 & 11,04 & 8,50 & 6,77 & 4,68 & 3,58 & 2,48 \\
\hline 71,46 & 885,90 & 77,70 & 25,57 & 19,29 & 17,41 & 15,54 & 14,00 & 12,61 & 10,24 & 8,37 & 5,81 \\
\hline 28,01 & 890,00 & 176,70 & 26,63 & 18,81 & 14,66 & 10,67 & 8,04 & 6,30 & 4,30 & 3,29 & 2,27 \\
\hline 40,27 & 482,40 & 68,50 & 49,28 & 37,45 & 31,64 & 25,51 & 20,71 & 16,98 & 11,90 & 8,93 & 5,94 \\
\hline 33,03 & 1176,00 & 152,10 & 24,24 & 18,59 & 15,43 & 12,05 & 9,51 & 7,62 & 5,23 & 3,92 & 2,65 \\
\hline 89,94 & 1352,10 & 192,70 & 11,88 & 8,01 & 6,94 & 6,06 & 5,42 & 4,89 & 4,00 & 3,30 & 2,34 \\
\hline 63,06 & 538,80 & 140,40 & 25,83 & 16,90 & 13,84 & 11,27 & 9,43 & 7,96 & 5,84 & 4,48 & 2,99 \\
\hline 34,46 & 412,40 & 188,20 & 31,35 & 18,63 & 13,79 & 9,82 & 7,39 & 5,83 & 4,02 & 3,09 & 2,16 \\
\hline 58,41 & 1157,10 & 179,80 & 15,90 & 11,61 & 9,98 & 8,43 & 7,20 & 6,18 & 4,62 & 3,57 & 2,36 \\
\hline 67,71 & 918,60 & 164,00 & 17,51 & 12,20 & 10,38 & 8,79 & 7,58 & 6,58 & 5,01 & 3,93 & 2,63 \\
\hline 25,95 & 1146,40 & 39,60 & 71,75 & 62,37 & 54,56 & 44,88 & 36,70 & 30,12 & 20,95 & 15,53 & 10,18 \\
\hline 63,48 & 1604,70 & 101,50 & 18,15 & 14,43 & 13,26 & 11,95 & 10,80 & 9,74 & 7,91 & 6,46 & 4,45 \\
\hline 42,15 & 1274,10 & 59,80 & 35,69 & 31,00 & 28,18 & 24,69 & 21,53 & 18,73 & 14,22 & 10,99 & 7,16 \\
\hline 68,71 & 988,30 & 38,20 & 38,43 & 30,34 & 28,62 & 26,61 & 24,68 & 22,85 & 19,48 & 16,57 & 12,09 \\
\hline 33,72 & 1532,10 & 45,00 & 47,91 & 43,16 & 39,28 & 34,24 & 29,62 & 25,53 & 19,06 & 14,54 & 9,38 \\
\hline 62,43 & 1227,70 & 175,10 & 15,16 & 11,12 & 9,64 & 8,25 & 7,14 & 6,20 & 4,73 & 3,70 & 2,46 \\
\hline 63,37 & 898,40 & 172,80 & 17,76 & 12,34 & 10,42 & 8,73 & 7,44 & 6,38 & 4,78 & 3,70 & 2,46 \\
\hline 42,93 & 1185,00 & 101,50 & 26,04 & 21,29 & 18,74 & 15,85 & 13,40 & 11,35 & 8,28 & 6,28 & 4,09 \\
\hline 70,24 & 1631,70 & 139,90 & 14,17 & 10,76 & 9,72 & 8,68 & 7,81 & 7,03 & 5,70 & 4,66 & 3,22 \\
\hline 46,61 & 1291,10 & 106,60 & 23,12 & 18,92 & 16,79 & 14,42 & 12,37 & 10,62 & 7,91 & 6,06 & 3,96 \\
\hline 65,85 & 1206,90 & 47,80 & 31,72 & 25,31 & 23,86 & 22,08 & 20,39 & 18,79 & 15,87 & 13,39 & 9,64 \\
\hline 30,22 & 1003,00 & 127,70 & 30,41 & 23,22 & 19,03 & 14,60 & 11,35 & 9,01 & 6,14 & 4,62 & 3,14 \\
\hline 51,35 & 1612,50 & 75,10 & 24,76 & 20,96 & 19,36 & 17,38 & 15,56 & 13,89 & 11,03 & 8,83 & 5,92 \\
\hline 60,66 & 701,20 & 93,20 & 27,92 & 20,80 & 18,11 & 15,54 & 13,46 & 11,69 & 8,90 & 6,95 & 4,61 \\
\hline 26,94 & 558,30 & 86,90 & 51,22 & 37,52 & 29,64 & 21,80 & 16,48 & 12,91 & 8,79 & 6,69 & 4,62 \\
\hline 74,85 & 235,00 & 167,00 & 40,12 & 20,29 & 14,41 & 10,44 & 8,20 & 6,68 & 4,72 & 3,63 & 2,50 \\
\hline 33,60 & 1480,10 & 159,20 & 21,43 & 16,89 & 14,25 & 11,33 & 9,06 & 7,34 & 5,06 & 3,78 & 2,53 \\
\hline 56,02 & 1468,60 & 102,60 & 20,03 & 16,28 & 14,78 & 13,10 & 11,62 & 10,30 & 8,08 & 6,43 & 4,30 \\
\hline 37,77 & 722,90 & 128,60 & 29,83 & 21,81 & 17,96 & 14,05 & 11,14 & 8,98 & 6,20 & 4,66 & 3,14 \\
\hline 22,89 & 1213,30 & 94,10 & 42,75 & 33,59 & 27,19 & 20,34 & 15,47 & 12,10 & 8,17 & 6,18 & 4,25 \\
\hline 63,24 & 975,10 & 53,90 & 32,50 & 26,04 & 24,11 & 21,87 & 19,87 & 18,02 & 14,77 & 12,14 & 8,44 \\
\hline 44,91 & 1118,00 & 75,60 & 30,91 & 25,91 & 23,21 & 20,08 & 17,33 & 14,94 & 11,19 & 8,60 & 5,61 \\
\hline 88,10 & 1714,30 & 32,20 & 28,45 & 23,72 & 21,61 & 20,82 & 20,13 & 19,32 & 17,67 & 16,11 & 13,27 \\
\hline 37,73 & 479,40 & 132,50 & 34,71 & 23,28 & 18,40 & 13,87 & 10,75 & 8,56 & 5,88 & 4,45 & 3,05 \\
\hline 62,10 & 931,60 & 104,60 & 22,73 & 17,26 & 15,24 & 13,25 & 11,62 & 10,20 & 7,90 & 6,24 & 4,17 \\
\hline 20,85 & 328,60 & 153,40 & 444,80 & 25,49 & 17,50 & 11,68 & 8,64 & 6,84 & 4,82 & 3,75 & 2,64 \\
\hline 43,73 & 325,40 & 40,50 & 75,07 & 58,21 & 50,05 & 41,35 & 34,30 & 28,61 & 20,47 & 15,43 & 10,16 \\
\hline 81,49 & 1136,20 & 123,80 & 16,73 & 11,95 & 10,61 & 9,41 & 8,48 & 7,67 & 6,28 & 5,19 & 3,65 \\
\hline 80,34 & 1004,00 & 51,50 & 29,04 & 21,92 & 20,35 & 18,86 & 17,52 & 16,26 & 13,98 & 12,00 & 8,91 \\
\hline 69,91 & 1362,40 & 64,90 & 24,17 & 18,93 & 17,70 & 16,31 & 15,03 & 13,84 & 11,67 & 9,84 & 7,09 \\
\hline 29,13 & 412,90 & 49,20 & 79,04 & $\begin{array}{l}60,71 \\
\end{array}$ & 49,72 & 38,03 & 29,48 & 23,36 & 15,89 & 11,96 & 8,15 \\
\hline 54,36 & 1786,20 & 160,40 & 14,45 & 11,52 & 10,28 & 8,95 & 7,81 & 6,81 & 5,22 & 4,07 & 2,69 \\
\hline 74,04 & 944,40 & 126,00 & 18,90 & 13,51 & 11,80 & 10,27 & 9,09 & 8,08 & 6,40 & 5,15 & 3,52 \\
\hline 61,91 & 990,50 & 52,50 & 33,23 & 26,81 & 24,86 & 22,56 & 20,49 & 18,57 & 15,20 & 12,48 & 8,65 \\
\hline 35,59 & 1802,90 & 66,70 & 33,45 & 29,69 & 26,88 & 23,30 & 20,06 & 17,23 & 12,80 & 9,75 & 6,30 \\
\hline 77,04 & 200,40 & 84,00 & 54,78 & 31,32 & 24,10 & 18,85 & 15,55 & 13,09 & 9,61 & 7,44 & 5,04 \\
\hline 58,16 & 1145,70 & 179,20 & 16,04 & 11,71 & 10,05 & 8,49 & 7,25 & 6,21 & 4,63 & 3,58 & 2,37 \\
\hline 72,29 & 1559,40 & 140,00 & 14,26 & 10,70 & 9,64 & 8,60 & 7,75 & 6,98 & 5,67 & 4,64 & 3,22 \\
\hline 85,35 & 364,80 & 117,60 & 32,18 & 19,17 & 15,22 & 12,31 & 10,43 & 8,99 & 6,84 & 5,40 & 3,68 \\
\hline 67,73 & 1115,60 & 161,10 & 15,98 & 11,52 & 9,99 & 8,60 & 7,51 & 6,58 & 5,10 & 4,03 & 2,71 \\
\hline 54,74 & 1343,50 & 35,80 & 41,46 & 34,69 & 33,07 & 30,64 & 28,25 & 25,96 & 21,76 & 18,20 & 12,90 \\
\hline 46,21 & 1555,30 & 84,50 & 24,95 & 21,28 & 19,34 & 17,01 & 14,91 & 13,04 & 10,00 & 7,79 & 5,11 \\
\hline 22,96 & 1486,70 & 104,50 & 37,32 & 29,66 & 24,21 & 18,28 & 13,98 & 10,96 & 7,40 & 5,58 & 3,82 \\
\hline 86,76 & 1518,90 & 183,60 & 11,59 & 8,05 & 7,07 & 6,25 & 5,63 & 5,09 & 4,19 & 3,47 & 2,46 \\
\hline 69,58 & 1380,90 & 81,20 & 21,00 & 16,35 & 15,13 & 13,78 & 12,60 & 11,50 & 9,56 & 7,96 & 5,64 \\
\hline
\end{tabular}




\begin{tabular}{|c|c|c|c|c|c|c|c|c|c|c|c|}
\hline \multirow[b]{2}{*}{ e1 (cm) } & & & & & & $\mathrm{De}$ & ões (x1 & & & & \\
\hline & Meq (MPa) & Ms (MPa) & D0 & D25 & D40 & D60 & D80 & D100 & D140 & D180 & D260 \\
\hline 29,92 & 1385,00 & 159,50 & 23,69 & 18,33 & 15,12 & 11,67 & 9,10 & 7,24 & 4,94 & 3,71 & 2,52 \\
\hline 41,22 & 1689,10 & 149,50 & 18,41 & 15,00 & 13,12 & 11,01 & 9,23 & 7,76 & 5,60 & 4,22 & 2,76 \\
\hline 80,47 & 987,70 & 34,90 & 36,98 & 28,43 & 26,60 & 25,13 & 23,64 & 22,20 & 19,50 & 17,08 & 13,09 \\
\hline 66,60 & 297,50 & 113,10 & 39,46 & 23,51 & 18,39 & 14,46 & 11,86 & 9,90 & 7,16 & 5,49 & 3,70 \\
\hline 21,72 & 1030,20 & 173,10 & 29,77 & 20,85 & 15,65 & 10,91 & 8,03 & 6,24 & 4,31 & 3,33 & 2,32 \\
\hline 23,62 & 1296,40 & 192,50 & 24,66 & 17,87 & 13,80 & 9,89 & 7,35 & 5,72 & 3,91 & 3,00 & 2,08 \\
\hline 49,80 & 1215,80 & 42,40 & 40,51 & 34,78 & 32,54 & 29,52 & 26,68 & 24,02 & 19,38 & 15,68 & 10,64 \\
\hline 75,32 & 1374,10 & 82,40 & 20,02 & 15,24 & 14,08 & 12,89 & 11,85 & 10,89 & 9,16 & 7,72 & 5,57 \\
\hline 65,67 & 556,80 & 78,80 & 32,79 & 23,85 & 20,71 & 17,81 & 15,52 & 13,56 & 10,45 & 8,23 & 5,51 \\
\hline 43,10 & 1607,60 & 30,10 & 51,81 & 45,68 & 43,47 & 39,93 & 36,45 & 33,11 & 27,12 & 22,18 & 15,20 \\
\hline 73,12 & 1118,90 & 130,60 & 17,17 & 12,52 & 11,06 & 9,71 & 8,64 & 7,71 & 6,16 & 4,98 & 3,41 \\
\hline 25,08 & 1686,00 & 85,90 & 38,52 & 32,11 & 27,26 & 21,59 & 17,11 & 13,71 & 9,34 & 6,94 & 4,66 \\
\hline 41,91 & 942,90 & 131,30 & 24,89 & 18,97 & 16,11 & 13,10 & 10,72 & 8,84 & 6,24 & 4,69 & 3,11 \\
\hline 46,84 & 576,80 & 51,60 & 49,18 & 39,84 & 35,21 & 30,09 & 25,72 & 22,00 & 16,31 & 12,47 & 8,15 \\
\hline 77,51 & 1540,00 & 190,90 & 11,80 & 8,42 & 7,40 & 6,49 & 5,79 & 5,18 & 4,17 & 3,39 & 2,34 \\
\hline 26,24 & 1997,70 & 135,90 & 25,74 & 20,94 & 17,57 & 13,73 & 10,78 & 8,60 & 5,84 & 4,36 & 2,94 \\
\hline 89,03 & 1904,70 & 91,60 & 15,00 & 11,17 & 10,29 & 9,63 & 9,02 & 8,45 & 7,40 & 6,48 & 4,96 \\
\hline 77,31 & 1877,20 & 50,80 & 23,54 & 18,44 & 17,33 & 16,52 & 15,64 & 14,76 & 13,07 & 11,54 & 8,95 \\
\hline 32,72 & 1724,20 & 76,30 & 33,33 & 29,03 & 25,81 & 21,81 & 18,33 & 15,40 & 11,07 & 8,30 & 5,38 \\
\hline 85,14 & 600,70 & 142,60 & 21,89 & 13,84 & 11,40 & 9,52 & 8,24 & 7,22 & 5,62 & 4,49 & 3,08 \\
\hline 22,31 & 631,20 & 162,10 & 35,15 & 22,99 & 16,74 & 11,46 & 8,42 & 6,59 & 4,59 & 3,56 & 2,48 \\
\hline 34,74 & 1858,30 & 40,20 & 47,32 & 43,20 & 39,98 & 35,59 & 31,42 & 27,61 & 21,27 & 16,57 & 10,79 \\
\hline 80,35 & 1164,80 & 88,70 & 19,92 & 14,71 & 13,39 & 12,14 & 11,11 & 10,17 & 8,52 & 7,16 & 5,15 \\
\hline 78,61 & 1646,10 & 28,50 & 34,65 & 28,33 & 26,28 & 25,42 & 24,43 & 23,34 & 21,16 & 19,10 & 15,44 \\
\hline 87,08 & 210,20 & 79,10 & 52,83 & 30,39 & 23,62 & 18,77 & 15,74 & 13,47 & 10,15 & 7,99 & 5,44 \\
\hline 50,15 & 412,30 & 54,70 & 52,63 & 40,11 & 34,66 & 29,09 & 24,56 & 20,81 & 15,23 & 11,61 & 7,63 \\
\hline 26,40 & 811,90 & 55,20 & 63,05 & 51,35 & 43,11 & 33,74 & 26,53 & $\begin{array}{l}20,01 \\
21,17\end{array}$ & $\begin{array}{l}14,2 \text { ( } 14,39 \\
14,3\end{array}$ & $\begin{array}{l} \pm, 01 \\
10,74\end{array}$ & 7,25 \\
\hline 70,47 & 665,20 & 142,50 & 21,91 & 14,66 & 12,25 & 10,24 & 8,78 & 7,59 & 5,75 & 4,50 & 3,02 \\
\hline 76,60 & 1777,70 & 100,20 & 15,91 & 12,10 & 11,21 & 10,31 & 9,51 & 8,77 & 7,43 & 6,30 & 4,59 \\
\hline 36,68 & 1035,80 & 26,20 & 73,26 & 66,32 & 61,29 & 54,52 & 48,12 & 42,30 & 32,61 & 25,43 & 16,58 \\
\hline 22,25 & 949,60 & 144,70 & 34,21 & 24,43 & 18,59 & 13,12 & 9,69 & 7,53 & 5,17 & 3,99 & 2,77 \\
\hline 41,56 & 455,50 & 47,10 & 61,81 & 49,29 & 42,73 & 35,49 & 29,51 & 24,65 & 17,65 & 13,29 & 8,72 \\
\hline 33,22 & 1317,50 & 135,60 & 24,97 & 19,78 & 16,72 & 13,31 & 10,65 & 8,62 & 5,95 & 4,44 & 2,97 \\
\hline 78,64 & 1042,80 & 90,20 & 20,94 & 15,41 & 13,92 & 12,51 & 11,36 & 10,34 & 8,55 & 7,11 & 5,04 \\
\hline 20,44 & 549,40 & 28,80 & 135,75 & 109,12 & 88,97 & 66,88 & 50,88 & 39,74 & 26,74 & 20,18 & 13,86 \\
\hline 64,09 & 1318,10 & 75,50 & 23,34 & 18,61 & 17,20 & 15,59 & 14,17 & 12,84 & 10,52 & 8,66 & 6,02 \\
\hline 25,99 & 888,90 & 122,40 & 35,78 & 26,58 & 21,07 & 15,52 & 11,73 & 9,18 & 6,24 & 4,75 & 3,28 \\
\hline 77,57 & 1857,60 & 52,90 & 23,00 & 17,95 & 16,87 & 16,06 & 15,18 & 14,30 & 12,65 & 11,14 & 8,61 \\
\hline 51,85 & 1641,80 & 195,30 & 13,77 & 10,65 & 9,29 & 7,89 & 6,74 & 5,76 & 4,28 & 3,29 & 2,16 \\
\hline 79,59 & 391,50 & 70,50 & 38,51 & 25,91 & 22,00 & 18,78 & 16,46 & 14,52 & 11,41 & 9,15 & 6,25 \\
\hline 67,40 & 710,40 & 159,10 & 20,45 & 13,66 & 11,37 & 9,44 & 8,03 & 6,89 & 5,16 & 4,01 & 2,68 \\
\hline 28,68 & 267,60 & 49,70 & 91,40 & 65,47 & 51,54 & 37,91 & 28,72 & 22,53 & 15,37 & 11,71 & 8,08 \\
\hline 28,58 & 1689,70 & 58,00 & 45,01 & 39,62 & 35,12 & 29,46 & 24,55 & 20,46 & 14,52 & 10,82 & 7,02 \\
\hline 82,70 & 928,80 & 95,60 & 20,96 & 14,99 & 13,36 & 11,90 & 10,77 & 9,77 & 8,06 & 6,69 & 4,75 \\
\hline 83,57 & 1889,70 & 82,10 & 16,66 & 12,60 & 11,71 & 10,97 & 10,28 & 9,62 & 8,40 & 7,32 & 5,56 \\
\hline 69,86 & 362,90 & 87,40 & 38,29 & 25,07 & 20,69 & 17,11 & 14,55 & 12,48 & 9,37 & 7,29 & 4,88 \\
\hline 69,70 & 1006,80 & 20,00 & 57,57 & 46,01 & 43,67 & 41,87 & 39,72 & 37,53 & 33,31 & 29,42 & 22,82 \\
\hline 39,53 & 581,40 & 161,20 & 27,99 & 18,74 & 14,88 & 11,31 & 8,82 & 7,05 & 4,86 & 3,68 & 2,51 \\
\hline 53,34 & 789,80 & 170,40 & 20,60 & 14,29 & 11,89 & 9,68 & 8,01 & 6,69 & 4,81 & 3,66 & 2,43 \\
\hline 39,72 & 219,50 & 131,10 & 49,57 & 27,21 & 19,68 & 13,97 & 10,58 & 8,37 & 5,78 & 4,45 & 3,11 \\
\hline 37,86 & 1302,90 & 27,80 & 63,82 & 57,78 & 53,98 & 48,60 & 43,44 & 38,64 & 30,43 & 24,10 & 15,91 \\
\hline 81,29 & 712,00 & 45,50 & 35,78 & 26,63 & 24,47 & 22,43 & 20,68 & 19,08 & 16,20 & 13,77 & 10,07 \\
\hline 69,51 & 508,60 & 130,00 & 26,69 & 17,28 & 14,17 & 11,65 & 9,86 & 8,43 & 6,30 & 4,89 & 3,27 \\
\hline 60,49 & 590,00 & 61,70 & 37,81 & 29,11 & 25,81 & 22,50 & 19,74 & 17,33 & 13,42 & 10,58 & 7,06 \\
\hline 86,94 & 698,50 & 126,00 & 20,94 & 13,80 & 11,69 & 10,01 & 8,83 & 7,85 & 6,27 & 5,09 & 3,53 \\
\hline 30,00 & 850,70 & 98,40 & 38,39 & 29,69 & 24,49 & 18,90 & 14,75 & 11,74 & 8,00 & 6,01 & 4,08 \\
\hline 34,32 & 709,50 & 173,80 & 26,31 & 18,08 & 14,29 & 10,68 & 8,21 & 6,50 & 4,45 & 3,38 & 2,32 \\
\hline 86,97 & 480,70 & 118,30 & 26,82 & 16,78 & 13,75 & 11,44 & 9,90 & 8,67 & 6,76 & 5,41 & 3,71 \\
\hline 76,27 & 1909,00 & 190,40 & 10,73 & 7,87 & 7,03 & 6,26 & 5,63 & 5,08 & 4,14 & 3,40 & 2,37 \\
\hline 44,06 & 1394,20 & 162,10 & 18,13 & 14,20 & 12,28 & 10,21 & 8,51 & 7,13 & 5,13 & 3,87 & 2,54 \\
\hline 31,53 & 1202,50 & 158,60 & 24,12 & 18,38 & 15,13 & 11,68 & 9,13 & 7,28 & 4,97 & 3,73 & 2,53 \\
\hline 86,84 & 1797,30 & 180,50 & 10,74 & 7,60 & 6,78 & 6,06 & 5,51 & 5,02 & 4,18 & 3,51 & 2,52 \\
\hline 87,40 & 702,10 & 54,90 & 31,30 & 22,58 & 20,46 & 18,60 & 17,09 & 15,74 & 13,35 & 11,35 & 8,32 \\
\hline 44,36 & 1621,30 & 79,50 & 26,27 & 22,66 & 20,64 & 18,16 & 15,91 & 13,91 & 10,65 & 8,28 & 5,42 \\
\hline 89,48 & 1372,50 & 98,80 & 16,57 & 11,96 & 10,87 & 9,94 & 9,18 & 8,49 & 7,27 & 6,23 & 4,62 \\
\hline 86,29 & 869,70 & 127,10 & 18,53 & 12,60 & 10,89 & 9,48 & 8,46 & $\frac{7,769}{7,59}$ & 6,15 & 5,04 & 3,53 \\
\hline 53,53 & 1225,80 & 177,90 & 16,26 & 12,14 & 10,45 & 8,79 & 7,45 & 6,34 & 4,68 & 3,58 & 2,36 \\
\hline 68,90 & 1640,90 & 164,10 & 13,06 & 9,83 & 8,77 & 7,75 & 6,91 & 6,17 & 4,93 & 3,98 & 2,72 \\
\hline 41,80 & 323,50 & 55,70 & 64,20 & 47,19 & 39,39 & 31,48 & 25,43 & 20,78 & 14,54 & 10,93 & 7,30 \\
\hline 87,17 & 1016,20 & 67,30 & 23,74 & 17,34 & 15,85 & 14,55 & 13,46 & 12,47 & 10,68 & 9,16 & 6,80 \\
\hline 51,39 & 1655,20 & 127,20 & 17,68 & 14,45 & 12,97 & 11,32 & 9,89 & 8,63 & 6,60 & 5,15 & 3,39 \\
\hline 68,24 & 1001,80 & 128,40 & 18,84 & 13,80 & 12,08 & 10,49 & 9,23 & 8,14 & 6,37 & 5,07 & 3,42 \\
\hline 25,61 & 529,50 & 119,90 & 42,88 & 29,30 & 22,18 & 15,70 & 11,66 & 9,11 & 6,27 & 4,82 & 3,36 \\
\hline 37,95 & 478,90 & 169,20 & 30,17 & 19,12 & 14,73 & 10,88 & 8,35 & 6,62 & 4,55 & 3,47 & 2,39 \\
\hline 37,88 & 948,10 & 87,70 & 33,86 & 27,38 & 23,69 & 19,52 & 16,09 & 13,33 & 9,43 & 7,07 & 4,65 \\
\hline 81,24 & 782,30 & 25,20 & 49,08 & 37,92 & 35,45 & 33,64 & 31,77 & 29,94 & 26,46 & 23,32 & 18,05 \\
\hline 63,12 & 1298,00 & 135,10 & 16,86 & 12,88 & 11,44 & 10,01 & 8,83 & 7,79 & 6,09 & 4,84 & 3,25 \\
\hline 46,86 & 1454,80 & 42,80 & 39,48 & 34,39 & 32,28 & 29,33 & 26,52 & 23,87 & 19,25 & 15,56 & 10,53 \\
\hline 81,63 & 1770,50 & 115,50 & 14,20 & 10,54 & 9,68 & 8,86 & 8,17 & 7,53 & 6,39 & 5,43 & 3,97 \\
\hline 78,94 & 1354,70 & 65,40 & 22,54 & 17,12 & 15,95 & 14,81 & 13,77 & 12,79 & 11,00 & 9,45 & 7,02 \\
\hline 25,70 & 1449,20 & 96,50 & 36,58 & 29,75 & 24,90 & 19,40 & 15,20 & 12,09 & 8,20 & 6,13 & 4,14 \\
\hline 64,63 & 1232,20 & 131,10 & 17,35 & 13,15 & 11,67 & 10,22 & 9,03 & 7,98 & 6,26 & 4,99 & 3,36 \\
\hline
\end{tabular}




\begin{tabular}{|c|c|c|c|c|c|c|c|c|c|c|c|}
\hline \multirow[b]{2}{*}{ e1 (cm) } & & & & & & & ões (x1 & m) & & & \\
\hline & Meq (MPa) & Ms (MPa) & D0 & D25 & D40 & D60 & D80 & D100 & D140 & D180 & D260 \\
\hline 22,36 & 1312,00 & 178,10 & 26,86 & 19,54 & 15,03 & 10,70 & 7,93 & 6,16 & 4,22 & 3,24 & 2,25 \\
\hline 36,27 & 1672,10 & 140,80 & 21,01 & 17,17 & 14,88 & 12,24 & 10,07 & 8,33 & 5,88 & 4,40 & 2,89 \\
\hline 79,08 & 558,10 & 53,00 & 37,08 & 27,04 & 24,26 & 21,68 & 19,62 & 17,80 & 14,64 & 12,12 & 8,55 \\
\hline 55,91 & 647,40 & 42,30 & 47,37 & 38,71 & 35,28 & 31,38 & 27,93 & 24,81 & 19,57 & 15,60 & 10,46 \\
\hline 88,70 & 752,00 & 99,90 & 22,17 & 15,15 & 13,20 & 11,58 & 10,40 & 9,39 & 7,70 & 6,37 & 4,52 \\
\hline 23,10 & 1820,60 & 60,40 & 51,24 & 43,94 & 37,84 & 30,45 & 24,40 & 19,70 & 13,47 & 9,97 & 6,63 \\
\hline 46,57 & 1106,50 & 83,10 & 28,56 & 23,62 & 21,09 & 18,21 & 15,71 & 13,54 & 10,15 & 7,81 & 5,10 \\
\hline 67,97 & 1843,60 & 102,40 & 16,49 & 12,95 & 12,01 & 10,96 & 10,02 & 9,15 & 7,60 & 6,32 & 4,47 \\
\hline 51,91 & 1369,40 & 168,30 & 16,21 & 12,46 & 10,85 & 9,20 & 7,84 & 6,70 & 4,96 & 3,81 & 2,50 \\
\hline 59,75 & 1169,50 & 189,50 & 15,23 & 11,01 & 9,43 & 7,96 & 6,81 & 5,85 & 4,37 & 3,38 & 2,24 \\
\hline 79,83 & 1900,70 & 124,50 & 13,34 & 9,96 & 9,15 & 8,37 & 7,70 & 7,08 & 5,99 & 5,07 & 3,68 \\
\hline 85,56 & 1729,10 & 122,30 & 13,57 & 9,91 & 9,04 & 8,26 & 7,61 & 7,02 & 5,97 & 5,09 & 3,74 \\
\hline 43,07 & 743,00 & 117,90 & 28,81 & 21,46 & 18,09 & 14,63 & 11,93 & 9,82 & 6,92 & 5,21 & 3,46 \\
\hline 67,52 & 635,10 & 63,10 & 34,21 & 25,88 & 23,11 & 20,39 & 18,16 & 16,18 & 12,87 & 10,36 & 7,05 \\
\hline 35,37 & 1993,60 & 77,30 & 29,49 & 26,08 & 23,53 & 20,33 & 17,44 & 14,93 & 11,03 & 8,38 & 5,41 \\
\hline 83,14 & 1869,50 & 180,70 & 10,73 & 7,71 & 6,90 & 6,18 & 5,61 & 5,10 & 4,23 & 3,53 & 2,52 \\
\hline 27,18 & 1829,10 & 65,00 & 42,38 & 36,97 & 32,49 & 26,92 & 22,17 & 18,30 & 12,82 & 9,52 & 6,22 \\
\hline 44,26 & 500,40 & 77,00 & 42,87 & 32,09 & 27,18 & 22,13 & 18,17 & 15,03 & 10,66 & 8,03 & 5,32 \\
\hline 54,77 & 321,20 & 55,80 & 55,84 & 40,31 & 34,23 & 28,47 & 23,96 & 20,28 & 14,85 & 11,35 & 7,50 \\
\hline 24,53 & 251,30 & 121,90 & 54,53 & 31,37 & 22,01 & 14,90 & 11,03 & 8,70 & 6,09 & 4,73 & 3,33 \\
\hline 48,61 & 1650,10 & 22,40 & 58,69 & 49,47 & 47,94 & 45,18 & 42,17 & 39,21 & 33,60 & 28,64 & 20,84 \\
\hline 50,22 & 653,00 & 135,00 & 26,17 & 18,41 & 15,33 & 12,43 & 10,22 & 8,49 & 6,06 & 4,59 & 3,05 \\
\hline 87,92 & 1526,90 & 147,10 & 12,85 & 9,10 & 8,13 & 7,30 & 6,65 & 6,08 & 5,09 & 4,28 & 3,09 \\
\hline 78,66 & 1280,00 & 181,00 & 13,23 & 9,25 & 8,03 & 6,99 & 6,20 & 5,52 & 4,41 & 3,57 & 2,46 \\
\hline 57,27 & 570,10 & 125,70 & 27,36 & 18,77 & 15,61 & 12,79 & 10,68 & 8,99 & 6,54 & 5,00 & 3,32 \\
\hline 85,63 & 1363,70 & 65,90 & 21,37 & 15,99 & 14,79 & 13,81 & 12,90 & 12,06 & 10,50 & 9,13 & 6,92 \\
\hline 28,45 & 1878,90 & 52,80 & 46,42 & 41,53 & 37,17 & 31,58 & 26,62 & 22,40 & 16,11 & 12,05 & 7,77 \\
\hline 68,73 & 1996,30 & 56,70 & 23,24 & 18,42 & 17,51 & 16,52 & 15,48 & 14,47 & 12,57 & 10,88 & 8,15 \\
\hline 60,96 & 1599,10 & 72,30 & 22,97 & 18,69 & 17,47 & 15,96 & 14,56 & 13,26 & 10,94 & 9,04 & 6,32 \\
\hline 39,89 & 1611,20 & 138,70 & 20,09 & 16,42 & 14,35 & 11,99 & 10,01 & 8,39 & 6,02 & 4,53 & 2,96 \\
\hline 78,99 & 1399,70 & 76,00 & 20,34 & 15,37 & 14,25 & 13,15 & 12,18 & 11,27 & 9,63 & 8,22 & 6,05 \\
\hline 59,93 & 1311,90 & 132,80 & 17,41 & 13,47 & 11,97 & 10,45 & 9,17 & 8,06 & 6,24 & 4,92 & 3,28 \\
\hline 21,33 & 1154,10 & 155,40 & 31,59 & 22,80 & 17,37 & 12,24 & 9,03 & 7,01 & 4,81 & 3,71 & 2,58 \\
\hline 22,74 & 837,00 & 35,30 & 95,59 & 79,97 & 67,61 & 53,15 & 41,81 & 33,32 & 22,56 & 16,78 & 11,30 \\
\hline 70,23 & 1034,80 & 194,30 & 14,96 & 10,26 & 8,69 & 7,35 & 6,35 & 5,51 & 4,22 & 3,31 & 2,22 \\
\hline 34,90 & 503,00 & 138,80 & 34,26 & 22,98 & 17,99 & 13,36 & 10,24 & 8,10 & 5,55 & 4,22 & 2,91 \\
\hline 49,93 & 1242,90 & 20,20 & 67,23 & 56,73 & 54,77 & 51,37 & 47,78 & 44,27 & 37,69 & 31,93 & 23,03 \\
\hline 84,41 & 1774,30 & 51,30 & 22,43 & 17,47 & 16,23 & 15,49 & 14,72 & 13,94 & 12,45 & 11,08 & 8,74 \\
\hline 77,20 & 1582,40 & 163,70 & 12,63 & 9,20 & 8,20 & 7,28 & 6,55 & 5,91 & 4,81 & 3,95 & 2,76 \\
\hline 64,03 & 331,80 & 188,80 & 30,89 & 16,71 & 12,33 & 9,19 & 7,29 & 5,95 & 4,19 & 3,21 & 2,20 \\
\hline 75,23 & 1232,40 & 31,90 & 37,58 & 29,54 & 27,86 & 26,57 & 25,13 & 23,70 & 20,97 & 18,48 & 14,29 \\
\hline 70,38 & 1880,30 & 187,70 & 11,30 & 8,45 & 7,55 & 6,68 & 5,97 & 5,35 & 4,29 & 3,47 & 2,38 \\
\hline 52,93 & 840,10 & 159,70 & 20,72 & 14,76 & 12,41 & 10,20 & 8,50 & 7,13 & 5,16 & 3,93 & 2,60 \\
\hline 65,63 & 496,40 & 133,20 & 27,31 & 17,65 & 14,41 & 11,74 & 9,84 & 8,34 & 6,15 & 4,74 & 3,17 \\
\hline 79,06 & 1973,90 & 113,30 & 13,95 & 10,51 & 9,72 & 8,94 & 8,26 & 7,64 & 6,50 & 5,53 & 4,05 \\
\hline 60,03 & 963,70 & 139,30 & 19,55 & 14,40 & 12,45 & 10,61 & 9,13 & 7,89 & 5,96 & 4,63 & 3,07 \\
\hline 64,75 & 208,30 & 93,40 & 53,35 & 30,63 & 23,43 & 18,03 & 14,57 & 12,03 & 8,58 & 6,57 & 4,45 \\
\hline 44,95 & 1599,10 & 179,60 & 15,93 & 12,53 & 10,88 & 9,09 & 7,62 & 6,41 & 4,64 & 3,51 & 2,30 \\
\hline 20,14 & 810,30 & 115,90 & 44,52 & 31,47 & 23,54 & 16,32 & 11,96 & 9,29 & 6,43 & 4,97 & 3,46 \\
\hline 61,31 & 1319,00 & 168,70 & 15,07 & 11,27 & 9,85 & 8,48 & 7,37 & 6,42 & 4,91 & 3,85 & 2,56 \\
\hline 55,18 & 1924,70 & 180,60 & 12,96 & 10,26 & 9,13 & 7,94 & 6,93 & 6,04 & 4,63 & 3,62 & 2,39 \\
\hline 66,23 & 1193,40 & 69,20 & 25,14 & 19,85 & 18,36 & 16,68 & 15,19 & 13,81 & 11,38 & 9,40 & 6,58 \\
\hline 64,64 & 1537,00 & 122,30 & 16,37 & 12,77 & 11,57 & 10,31 & 9,24 & 8,27 & 6,63 & 5,36 & 3,66 \\
\hline 31,36 & 402,30 & 80,90 & 55,00 & 39,11 & 31,05 & 23,14 & 17,70 & 13,96 & 9,53 & 7,24 & 4,98 \\
\hline 76,18 & 1352,90 & 134,60 & 15,17 & 11,13 & 9,95 & 8,85 & 7,97 & 7,19 & 5,85 & 4,80 & 3,35 \\
\hline 72,88 & 1645,40 & 150,30 & 13,33 & 9,97 & 8,97 & 8,00 & 7,21 & 6,49 & 5,28 & 4,32 & 3,00 \\
\hline 56,24 & 559,40 & 160,50 & 24,83 & 16,12 & 13,04 & 10,41 & 8,53 & 7,08 & 5,06 & 3,85 & 2,58 \\
\hline 26,64 & 789,10 & 77,60 & 50,04 & 39,04 & 31,95 & 24,31 & 18,75 & 14,80 & 10,03 & 7,55 & 5,16 \\
\hline 39,64 & 1271,50 & 139,50 & 22,05 & 17,43 & 14,99 & 12,29 & 10,11 & 8,36 & 5,92 & 4,44 & 2,93 \\
\hline 65,04 & 343,60 & 80,50 & 41,98 & 27,96 & 23,15 & 19,10 & 16,14 & 13,75 & 10,21 & 7,89 & 5,26 \\
\hline 64,90 & 895,60 & 50,80 & 34,32 & 27,27 & 25,24 & 22,91 & 20,85 & 18,93 & 15,56 & 12,83 & 8,96 \\
\hline 35,16 & 1667,70 & 195,30 & 17,49 & 13,65 & 11,51 & 9,18 & 7,36 & 5,98 & 4,14 & 3,09 & 2,07 \\
\hline 32,84 & 449,20 & 53,40 & 67,23 & 52,15 & 43,53 & 34,19 & 27,07 & 21,76 & 14,94 & 11,18 & 7,53 \\
\hline 61,18 & 1526,30 & 33,90 & 38,61 & 31,32 & 30,04 & 28,36 & 26,55 & 24,78 & 21,44 & 18,46 & 13,70 \\
\hline 57,39 & 519,20 & 39,90 & 52,76 & 42,35 & 38,26 & 33,81 & 29,95 & 26,49 & 20,76 & 16,48 & 11,02 \\
\hline 23,94 & 419,00 & 170,00 & 37,21 & 22,31 & 15,85 & 10,76 & 7,94 & 6,25 & 4,37 & 3,39 & 2,38 \\
\hline 36,48 & 805,10 & 121,90 & 30,14 & 22,64 & 18,81 & 14,81 & 11,78 & 9,51 & 6,56 & 4,92 & 3,31 \\
\hline 48,90 & 1566,80 & 109,10 & 20,45 & 16,97 & 15,27 & 13,34 & 11,63 & 10,13 & 7,72 & 6,00 & 3,94 \\
\hline 43,66 & 813,10 & 158,80 & 23,23 & 16,66 & 13,81 & 11,01 & 8,89 & 7,27 & 5,09 & 3,83 & 2,57 \\
\hline 66,85 & 1771,40 & 60,60 & 23,57 & 18,76 & 17,77 & 16,58 & 15,41 & 14,29 & 12,22 & 10,42 & 7,63 \\
\hline 44,06 & 343,90 & 36,30 & 77,85 & 61,85 & 53,82 & 45,06 & 37,80 & 31,80 & 23,01 & 17,41 & 11,40 \\
\hline 67,11 & 509,80 & 37,90 & 50,38 & 39,12 & 35,65 & 31,99 & 28,86 & 26,02 & 21,11 & 17,25 & 11,91 \\
\hline 62,91 & 909,10 & 102,50 & 23,09 & 17,48 & 15,44 & 13,44 & 11,80 & 10,37 & 8,05 & 6,37 & 4,26 \\
\hline 32,15 & 934,00 & 143,90 & 27,73 & 20,66 & 16,84 & 12,89 & 10,03 & 7,98 & 5,45 & 4,10 & 2,79 \\
\hline 84,86 & 1030,30 & 103,90 & 18,88 & 13,44 & 11,99 & 10,71 & 9,71 & 8,84 & 7,33 & 6,12 & 4,37 \\
\hline 87,02 & 1363,90 & 175,90 & 12,49 & 8,61 & 7,52 & 6,61 & 5,94 & 5,36 & 4,39 & 3,63 & 2,57 \\
\hline 78,71 & 210,40 & 87,70 & 52,07 & 29,72 & 22,87 & 17,91 & 14,80 & 12,49 & 9,20 & 7,14 & 4,84 \\
\hline 87,11 & 530,10 & 186,70 & 21,40 & 12,48 & 9,79 & 7,84 & 6,61 & 5,68 & 4,30 & 3,39 & 2,31 \\
\hline 49,50 & 1818,80 & 193,20 & 13,63 & 10,75 & 9,43 & 8,03 & 6,85 & 5,86 & 4,34 & 3,32 & 2,18 \\
\hline 25,67 & 842,20 & 62,00 & 58,79 & 47,27 & 39,27 & 30,34 & 23,62 & 18,73 & 12,69 & 9,50 & 6,45 \\
\hline 34,57 & 261,00 & 55,30 & 77,92 & 55,10 & 44,18 & 33,46 & 25,92 & 20,60 & 14,10 & 10,66 & 7,29 \\
\hline 22,33 & 1940,40 & 123,50 & 31,32 & 25,05 & 20,49 & 15,49 & 11,85 & 9,29 & 6,26 & 4,72 & 3,23 \\
\hline
\end{tabular}




\begin{tabular}{|c|c|c|c|c|c|c|c|c|c|c|c|}
\hline \multirow[b]{2}{*}{ e1 (cm) } & & & & & & & ões (x1 & m) & & & \\
\hline & Meq (MPa) & Ms (MPa) & D0 & D25 & D40 & D60 & D80 & D100 & D140 & D180 & D260 \\
\hline 83,28 & 1633,40 & 28,80 & 32,71 & 27,08 & 24,86 & 24,02 & 23,18 & 22,20 & 20,25 & 18,39 & 15,03 \\
\hline 83,11 & 1047,30 & 70,00 & 23,46 & 17,32 & 15,86 & 14,52 & 13,38 & 12,35 & 10,49 & 8,93 & 6,54 \\
\hline 55,38 & 1837,30 & 162,80 & 14,00 & 11,15 & 9,96 & 8,70 & 7,62 & 6,66 & 5,13 & 4,02 & 2,66 \\
\hline 24,68 & 1878,80 & 173,40 & 23,16 & 18,03 & 14,62 & 10,98 & 8,38 & 6,58 & 4,45 & 3,36 & 2,31 \\
\hline 82,37 & 591,60 & 81,70 & 28,45 & 19,72 & 17,16 & 14,98 & 13,35 & 11,96 & 9,65 & 7,88 & 5,49 \\
\hline 42,70 & 1663,40 & 155,20 & 17,68 & 14,30 & 12,51 & 10,51 & 8,84 & 7,45 & 5,40 & 4,08 & 2,67 \\
\hline 43,60 & 669,70 & 105,50 & 31,87 & 23,77 & 20,07 & 16,27 & 13,30 & 10,97 & 7,75 & 5,83 & 3,87 \\
\hline 55,70 & 922,00 & 106,80 & 23,92 & 18,40 & 16,14 & 13,86 & 11,97 & 10,35 & 7,82 & 6,06 & 4,00 \\
\hline 47,43 & 1504,60 & 171,40 & 16,24 & 12,72 & 11,07 & 9,32 & 7,87 & 6,67 & 4,87 & 3,71 & 2,43 \\
\hline 87,88 & 970,20 & 58,00 & 26,21 & 19,25 & 17,65 & 16,31 & 15,15 & 14,09 & 12,16 & 10,50 & 7,87 \\
\hline 41,36 & 1316,70 & 33,20 & 52,83 & 47,15 & 44,09 & 39,80 & 35,70 & 31,88 & 25,29 & 20,16 & 13,41 \\
\hline 68,39 & 1884,10 & 197,10 & 11,14 & 8,36 & 7,44 & 6,55 & 5,82 & 5,18 & 4,12 & 3,31 & 2,25 \\
\hline 41,41 & 865,20 & 43,40 & 51,01 & 44,13 & 39,91 & 34,75 & 30,12 & 26,05 & 19,59 & 15,06 & 9,79 \\
\hline 40,74 & 1749,00 & 178,30 & 16,46 & 13,15 & 11,39 & 9,44 & 7,83 & 6,53 & 4,66 & 3,50 & 2,30 \\
\hline 24,82 & 1070,40 & 61,00 & 56,60 & 46,57 & 39,17 & 30,66 & 24,08 & 19,19 & 13,01 & 9,70 & 6,55 \\
\hline 80,79 & 1853,10 & 97,90 & 15,42 & 11,61 & 10,76 & 9,97 & 9,25 & 8,58 & 7,37 & 6,32 & 4,69 \\
\hline 47,87 & 1082,80 & 85,70 & 27,77 & 22,79 & 20,32 & 17,56 & 15,16 & 13,09 & 9,83 & 7,58 & 4,96 \\
\hline 80,65 & 1284,70 & 127,40 & 15,61 & 11,28 & 10,09 & 9,00 & 8,14 & 7,38 & 6,08 & 5,04 & 3,56 \\
\hline 69,23 & 1866,50 & 150,40 & 12,92 & 9,90 & 8,98 & 8,04 & 7,24 & 6,53 & 5,30 & 4,33 & 3,00 \\
\hline 23,99 & 1365,00 & 187,20 & 24,55 & 18,04 & 14,08 & 10,18 & 7,61 & 5,93 & 4,04 & 3,09 & 2,14 \\
\hline 21,08 & 921,50 & 130,80 & 38,34 & 27,39 & 20,72 & 14,51 & 10,68 & 8,29 & 5,71 & 4,41 & 3,07 \\
\hline 55,07 & 1827,00 & 152,50 & 14,63 & 11,73 & 10,52 & 9,21 & 8,09 & 7,09 & 5,47 & 4,30 & 2,85 \\
\hline 89,74 & 1995,20 & 45,30 & 21,72 & 17,61 & 16,09 & 15,46 & 14,87 & 14,22 & 12,94 & 11,72 & 9,56 \\
\hline 46,99 & 325,70 & 197,40 & 32,25 & 17,50 & 12,74 & 9,20 & 7,06 & 5,63 & 3,89 & 2,98 & 2,07 \\
\hline 79,69 & 1908,60 & 32,20 & 29,95 & 24,66 & 22,79 & 22,05 & 21,24 & 20,31 & 18,47 & 16,72 & 13,58 \\
\hline 75,21 & 672,50 & 50,20 & 36,00 & 27,10 & 24,73 & 22,35 & 20,36 & 18,56 & 15,38 & 12,81 & 9,08 \\
\hline 74,08 & 556,50 & 125,60 & 25,17 & 16,52 & 13,72 & 11,45 & 9,83 & 8,52 & 6,49 & 5,10 & 3,44 \\
\hline 79,16 & 1648,40 & 75,10 & 19,16 & 14,59 & 13,61 & 12,68 & 11,81 & 11,00 & 9,50 & 8,19 & 6,12 \\
\hline 39,74 & 599,80 & 133,10 & 30,73 & 21,55 & 17,50 & 13,57 & 10,71 & 8,63 & 5,96 & 4,49 & 3,04 \\
\hline 40,34 & 1414,60 & 182,20 & 17,79 & 13,73 & 11,69 & 9,50 & 7,76 & 6,39 & 4,50 & 3,37 & 2,24 \\
\hline 61,79 & 295,60 & 132,80 & 37,95 & 21,88 & 16,74 & 12,84 & 10,32 & 8,49 & 6,02 & 4,60 & 3,12 \\
\hline 62,93 & 1915,90 & 142,10 & 13,88 & 10,95 & 9,96 & 8,89 & 7,97 & 7,14 & 5,72 & 4,62 & 3,15 \\
\hline 41,46 & 1348,10 & 35,70 & 49,78 & 44,39 & 41,42 & 37,31 & 33,40 & 29,77 & 23,54 & 18,72 & 12,42 \\
\hline 67,61 & 497,70 & 151,30 & 25,62 & 16,05 & 12,90 & 10,41 & 8,68 & 7,34 & 5,39 & 4,16 & 2,79 \\
\hline 29,73 & 1877,40 & 63,80 & 39,42 & 34,87 & 31,08 & 26,28 & 22,07 & 18,52 & 13,27 & 9,92 & 6,42 \\
\hline 42,42 & 1862,40 & 114,60 & 20,47 & 17,37 & 15,57 & 13,44 & 11,56 & 9,93 & 7,40 & 5,66 & 3,68 \\
\hline 51,74 & 920,00 & 129,20 & 22,46 & 16,92 & 14,58 & 12,24 & 10,35 & 8,78 & 6,44 & 4,92 & 3,24 \\
\hline 67,77 & 1604,10 & 120,50 & 15,83 & 12,25 & 11,16 & 10,01 & 9,04 & 8,15 & 6,62 & 5,42 & 3,75 \\
\hline 49,88 & 447,40 & 97,60 & 37,27 & 25,95 & 21,49 & 17,32 & 14,19 & 11,75 & 8,35 & 6,32 & 4,21 \\
\hline 86,35 & 523,00 & 69,80 & 32,13 & 22,09 & 19,26 & 16,88 & 15,13 & 13,63 & 11,11 & 9,16 & 6,45 \\
\hline 28,55 & 1909,20 & 41,50 & 54,02 & 49,23 & 44,62 & 38,56 & 33,02 & 28,19 & 20,68 & 15,61 & 10,02 \\
\hline 71,62 & 721,80 & 146,40 & 20,57 & 13,86 & 11,65 & 9,79 & 8,44 & 7,32 & 5,59 & 4,39 & 2,95 \\
\hline 52,71 & 1339,50 & 131,80 & 18,61 & 14,74 & 13,04 & 11,25 & 9,73 & 8,42 & 6,36 & 4,92 & 3,24 \\
\hline 26,50 & 813,00 & 79,00 & 49,17 & 38,41 & 31,43 & 23,91 & 18,43 & 14,54 & 9,86 & 7,42 & 5,07 \\
\hline 28,19 & 1082,00 & 111,50 & 34,01 & 26,55 & 21,87 & 16,80 & 13,05 & 10,35 & 7,03 & 5,28 & 3,59 \\
\hline 20,20 & 570,60 & 140,50 & 42,00 & 27,15 & 19,43 & 13,12 & 9,61 & 7,53 & 5,28 & 4,10 & 2,86 \\
\hline 82,87 & 1786,40 & 120,40 & 13,71 & 10,12 & 9,27 & 8,48 & 7,81 & 7,20 & 6,11 & 5,20 & 3,80 \\
\hline 52,03 & 1123,20 & 72,60 & 28,70 & 23,77 & 21,58 & 19,06 & 16,82 & 14,82 & 11,52 & 9,08 & 6,02 \\
\hline 32,97 & 1824,00 & 83,20 & 30,71 & 26,69 & 23,71 & 20,02 & 16,82 & 14,13 & 10,15 & 7,61 & 4,93 \\
\hline 40,40 & 715,70 & 168,80 & 24,67 & 17,08 & 13,82 & 10,69 & 8,44 & 6,79 & 4,69 & 3,54 & 2,40 \\
\hline 28,59 & 694,70 & 153,00 & 31,50 & 21,88 & 16,96 & 12,31 & 9,26 & 7,26 & 4,97 & 3,80 & 2,63 \\
\hline 28,90 & 1237,80 & 56,20 & 50,52 & 43,39 & 37,92 & 31,24 & 25,63 & 21,09 & 14,75 & 10,96 & 7,18 \\
\hline 84,32 & 549,20 & 187,20 & 21,03 & 12,41 & 9,79 & 7,87 & 6,64 & 5,70 & 4,31 & 3,39 & 2,30 \\
\hline 83,49 & 1849,90 & 153,60 & 11,75 & 8,53 & 7,72 & 6,98 & 6,38 & 5,84 & 4,89 & 4,12 & 2,97 \\
\hline 46,90 & 1475,00 & 71,40 & 28,02 & 24,03 & 22,00 & 19,51 & 17,24 & 15,18 & 11,79 & 9,26 & 6,11 \\
\hline 55,87 & 1677,40 & 56,20 & 28,09 & 23,44 & 22,14 & 20,35 & 18,64 & 17,02 & 14,10 & 11,68 & 8,17 \\
\hline 85,19 & 728,90 & 78,50 & 25,77 & 18,20 & 16,16 & 14,37 & 13,00 & 11,80 & 9,75 & 8,12 & 5,78 \\
\hline 24,53 & 1918,50 & 183,30 & 22,23 & 17,22 & 13,90 & 10,40 & 7,92 & 6,20 & 4,20 & 3,18 & 2,18 \\
\hline 30,21 & 719,70 & 155,20 & 29,95 & 20,98 & 16,45 & 12,09 & 9,18 & 7,21 & 4,93 & 3,75 & 2,59 \\
\hline 46,11 & 1747,40 & 78,00 & 25,22 & 21,78 & 20,00 & 17,77 & 15,73 & 13,88 & 10,80 & 8,50 & 5,61 \\
\hline 43,00 & 388,60 & 184,80 & 30,69 & 17,92 & 13,46 & 9,87 & 7,59 & 6,04 & 4,17 & 3,18 & 2,20 \\
\hline 65,17 & 1817,00 & 49,00 & 27,33 & 21,90 & 20,89 & 19,66 & 18,38 & 17,14 & 14,81 & 12,74 & 9,46 \\
\hline 40,86 & 1937,80 & 196,30 & 14,88 & 11,90 & 10,31 & 8,55 & 7,10 & 5,93 & 4,23 & 3,18 & 2,09 \\
\hline 34,37 & 413,50 & 56,30 & 65,08 & 49,61 & 41,25 & 32,36 & 25,63 & 20,62 & 14,18 & 10,63 & 7,16 \\
\hline 82,02 & 1386,90 & 181,20 & 12,48 & 8,72 & 7,63 & 6,68 & 5,97 & 5,36 & 4,34 & 3,55 & 2,48 \\
\hline 48,94 & 1678,40 & 174,60 & 15,05 & 11,92 & 10,46 & 8,90 & 7,59 & 6,49 & 4,80 & 3,68 & 2,41 \\
\hline 69,86 & 608,50 & 173,40 & 21,30 & 13,47 & 10,91 & 8,88 & 7,46 & 6,35 & 4,71 & 3,65 & 2,45 \\
\hline 43,09 & 302,80 & 129,00 & 41,53 & 24,98 & 19,04 & 14,11 & 10,91 & 8,71 & 6,00 & 4,58 & 3,16 \\
\hline 21,71 & 1926,00 & 72,40 & 46,73 & 39,21 & 33,14 & 26,01 & 20,42 & 16,25 & 10,98 & 8,17 & 5,51 \\
\hline 50,03 & 1600,90 & 71,40 & 26,08 & 22,23 & 20,54 & 18,43 & 16,48 & 14,69 & 11,64 & 9,30 & 6,22 \\
\hline 42,13 & 1863,60 & 112,10 & 20,86 & 17,74 & 15,91 & 13,74 & 11,82 & 10,16 & 7,56 & 5,79 & 3,76 \\
\hline 23,48 & 881,50 & 159,80 & 31,54 & 22,12 & 16,78 & 11,84 & 8,76 & 6,82 & 4,69 & 3,61 & 2,51 \\
\hline 79,38 & 1707,90 & 86,00 & 17,38 & 13,17 & 12,24 & 11,35 & 10,54 & 9,78 & 8,40 & 7,21 & 5,34 \\
\hline 82,40 & 1374,80 & 26,70 & 37,16 & 30,22 & 27,91 & 26,93 & 25,88 & 24,72 & 22,42 & 20,26 & 16,40 \\
\hline 79,76 & 1530,50 & 47,00 & 26,12 & 20,26 & 18,98 & 18,03 & 17,03 & 16,05 & 14,19 & 12,50 & 9,67 \\
\hline 86,44 & 781,70 & 106,20 & 21,32 & 14,62 & 12,72 & 11,14 & 9,97 & 8,98 & 7,32 & 6,03 & 4,24 \\
\hline 55,61 & 1189,80 & 59,40 & 30,56 & 25,37 & 23,48 & 21,16 & 19,06 & 17,12 & 13,76 & 11,13 & 7,56 \\
\hline 44,52 & 1119,50 & 128,40 & 22,62 & 17,74 & 15,37 & 12,81 & 10,71 & 8,99 & 6,48 & 4,90 & 3,22 \\
\hline 56,30 & 658,50 & 154,80 & 23,15 & 15,70 & 12,97 & 10,54 & 8,75 & 7,33 & 5,30 & 4,04 & 2,69 \\
\hline 58,12 & 1281,90 & 127,40 & 18,30 & 14,27 & 12,68 & 11,05 & 9,67 & 8,47 & 6,53 & 5,13 & 3,41 \\
\hline 50,87 & 529,00 & 151,80 & 27,26 & 17,86 & 14,40 & 11,35 & 9,17 & 7,53 & 5,31 & 4,02 & 2,70 \\
\hline 58,48 & 1255,80 & 51,20 & 32,04 & 26,39 & 24,76 & 22,64 & 20,67 & 18,82 & 15,51 & 12,80 & 8,92 \\
\hline
\end{tabular}




\begin{tabular}{|c|c|c|c|c|c|c|c|c|c|c|c|}
\hline \multirow[b]{2}{*}{ e1 (cm) } & & & & & & & ões (x1 & m) & & & \\
\hline & Meq (MPa) & Ms (MPa) & D0 & D25 & D40 & D60 & D80 & D100 & D140 & D180 & D260 \\
\hline 79,31 & 1940,00 & 51,10 & 22,71 & 17,81 & 16,68 & 15,94 & 15,12 & 14,31 & 12,73 & 11,29 & 8,84 \\
\hline 55,13 & 797,50 & 194,40 & 18,95 & 12,78 & 10,51 & 8,50 & 7,01 & 5,85 & 4,21 & 3,20 & 2,13 \\
\hline 39,23 & 1186,90 & 105,70 & 27,03 & 21,99 & 19,14 & 15,91 & 13,23 & 11,03 & 7,88 & 5,92 & 3,88 \\
\hline 86,98 & 817,00 & 134,00 & 18,66 & 12,47 & 10,66 & 9,20 & 8,16 & 7,29 & 5,86 & 4,79 & 3,34 \\
\hline 76,96 & 1227,40 & 81,00 & 20,94 & 15,78 & 14,50 & 13,22 & 12,12 & 11,12 & 9,34 & 7,85 & 5,65 \\
\hline 54,09 & 443,90 & 93,60 & 36,84 & 25,65 & 21,39 & 17,48 & 14,52 & 12,16 & 8,78 & 6,68 & 4,44 \\
\hline 85,93 & 1933,50 & 152,10 & 11,42 & 8,27 & 7,49 & 6,81 & 6,25 & 5,74 & 4,86 & 4,12 & 3,00 \\
\hline 82,82 & 1201,90 & 61,10 & 23,99 & 18,00 & 16,68 & 15,50 & 14,42 & 13,43 & 11,60 & 10,01 & 7,49 \\
\hline 87,99 & 1498,50 & 173,40 & 11,93 & 8,30 & 7,31 & 6,48 & 5,86 & 5,32 & 4,39 & 3,66 & 2,61 \\
\hline 39,66 & 1733,80 & 139,60 & 19,53 & 16,09 & 14,12 & 11,84 & 9,92 & 8,33 & 6,00 & 4,52 & 2,95 \\
\hline 34,03 & 735,20 & 99,20 & 37,04 & 28,26 & 23,48 & 18,40 & 14,55 & 11,70 & 8,04 & 6,02 & 4,06 \\
\hline 58,65 & 970,10 & 126,70 & 20,73 & 15,56 & 13,55 & 11,60 & 10,02 & 8,67 & 6,57 & 5,11 & 3,38 \\
\hline 56,78 & 993,00 & 104,20 & 23,20 & 18,04 & 15,96 & 13,82 & 12,03 & 10,47 & 8,00 & 6,25 & 4,14 \\
\hline 38,37 & 1797,50 & 161,40 & 18,04 & 14,65 & 12,72 & 10,53 & 8,71 & 7,24 & 5,15 & 3,86 & 2,53 \\
\hline 89,03 & 1169,10 & 53,40 & 25,15 & 18,80 & 17,34 & 16,26 & 15,26 & 14,32 & 12,58 & 11,03 & 8,48 \\
\hline 39,10 & 1636,10 & 130,10 & 21,08 & 17,39 & 15,25 & 12,77 & 10,68 & 8,96 & 6,44 & 4,84 & 3,16 \\
\hline 89,59 & 449,60 & 170,30 & 24,52 & 14,03 & 10,88 & 8,64 & 7,25 & 6,22 & 4,71 & 3,71 & 2,54 \\
\hline 50,36 & 562,00 & 35,30 & 59,57 & 49,70 & 45,09 & 39,75 & 34,98 & 30,73 & 23,76 & 18,65 & 12,32 \\
\hline 82,37 & 1074,40 & 149,50 & 15,61 & 10,81 & 9,40 & 8,20 & 7,31 & 6,54 & 5,28 & 4,31 & 3,00 \\
\hline 56,75 & 886,10 & 58,50 & 34,10 & 27,77 & 25,31 & 22,53 & 20,08 & 17,86 & 14,12 & 11,28 & 7,58 \\
\hline 28,58 & 1253,80 & 93,70 & 36,10 & 29,37 & 24,82 & 19,63 & 15,58 & 12,51 & 8,56 & 6,38 & 4,28 \\
\hline 27,03 & 433,20 & 90,20 & 53,97 & 37,67 & 29,04 & 20,91 & 15,66 & 12,24 & 8,38 & 6,42 & 4,46 \\
\hline 75,02 & 1483,50 & 191,70 & 12,16 & 8,70 & 7,62 & 6,66 & 5,91 & 5,26 & 4,19 & 3,38 & 2,32 \\
\hline 89,62 & 1746,20 & 156,40 & 11,58 & 8,21 & 7,37 & 6,65 & 6,08 & 5,59 & 4,71 & 3,99 & 2,92 \\
\hline 72,30 & 328,30 & 127,90 & 34,75 & 20,37 & 15,86 & 12,49 & 10,30 & 8,66 & 6,33 & 4,88 & 3,30 \\
\hline 39,03 & 540,40 & 112,80 & 35,66 & 25,32 & 20,63 & 16,03 & 12,66 & 10,19 & 7,04 & 5,30 & 3,59 \\
\hline 23,91 & 1341,70 & 26,60 & 95,61 & 86,01 & 76,65 & 64,54 & 53,85 & 44,89 & 31,79 & 23,61 & 15,26 \\
\hline 38,77 & 387,90 & 143,80 & 36,02 & 22,55 & 17,32 & 12,79 & 9,82 & 7,80 & 5,36 & 4,09 & 2,82 \\
\hline 29,79 & 1357,80 & 164,20 & 23,46 & 18,02 & 14,80 & 11,36 & 8,84 & 7,02 & 4,78 & 3,59 & 2,44 \\
\hline 31,14 & 583,40 & 155,90 & 31,72 & 21,35 & 16,49 & 12,00 & 9,07 & 7,13 & 4,88 & 3,73 & 2,59 \\
\hline 45,35 & 1201,50 & 130,20 & 21,53 & 17,02 & 14,82 & 12,44 & 10,46 & 8,83 & 6,42 & 4,86 & 3,19 \\
\hline 20,49 & 998,10 & 56,20 & 70,86 & 56,57 & 45,89 & 34,31 & 26,01 & 20,29 & 13,66 & 10,33 & 7,10 \\
\hline 57,31 & 826,70 & 49,10 & 38,75 & 31,70 & 29,09 & 26,06 & 23,37 & 20,90 & 16,70 & 13,44 & 9,10 \\
\hline 21,02 & 1786,30 & 104,70 & 37,73 & 30,13 & 24,49 & 18,37 & 13,96 & 10,90 & 7,34 & 5,55 & 3,81 \\
\hline 75,62 & 323,80 & 156,10 & 32,53 & 18,05 & 13,62 & 10,46 & 8,51 & 7,10 & 5,15 & 3,97 & 2,70 \\
\hline 36,59 & 1768,90 & 62,20 & 34,48 & 30,71 & 27,94 & 24,40 & 21,16 & 18,29 & 13,73 & 10,52 & 6,81 \\
\hline 51,49 & 858,40 & 131,70 & 23,01 & 17,08 & 14,61 & 12,18 & 10,23 & 8,64 & 6,30 & 4,80 & 3,16 \\
\hline 31,14 & 1321,80 & 166,10 & 22,82 & 17,50 & 14,43 & 11,15 & 8,72 & 6,95 & 4,75 & 3,56 & 2,42 \\
\hline 22,89 & 530,60 & 86,00 & 57,62 & 40,98 & 31,21 & 22,06 & 16,32 & 12,70 & 8,72 & 6,72 & 4,67 \\
\hline 37,42 & 1745,40 & 95,30 & 25,86 & 22,22 & 19,82 & 16,90 & 14,35 & 12,18 & 8,89 & 6,72 & 4,36 \\
\hline 22,59 & 1987,40 & 52,90 & 55,58 & 48,40 & 42,10 & 34,29 & 27,76 & 22,57 & 15,53 & 11,48 & 7,57 \\
\hline 36,91 & 1511,60 & 85,80 & 29,43 & 25,18 & 22,38 & 18,99 & 16,05 & 13,57 & 9,85 & 7,42 & 4,82 \\
\hline 83,15 & 624,00 & 97,30 & 25,39 & 17,27 & 14,86 & 12,86 & 11,40 & 10,16 & 8,14 & 6,62 & 4,58 \\
\hline 24,91 & 1500,00 & 198,90 & 22,36 & 16,60 & 13,09 & 9,58 & 7,20 & 5,62 & 3,82 & 2,92 & 2,02 \\
\hline 85,87 & 1486,70 & 137,40 & 13,63 & 9,74 & 8,74 & 7,86 & 7,16 & 6,55 & 5,47 & 4,60 & 3,32 \\
\hline 79,53 & 1944,50 & 122,80 & 13,35 & 9,99 & 9,20 & 8,42 & 7,76 & 7,15 & 6,05 & 5,13 & 3,74 \\
\hline 23,97 & 1062,60 & 107,20 & 39,23 & 30,07 & 24,06 & 17,82 & 13,48 & 10,53 & 7,13 & 5,42 & 3,73 \\
\hline 86,29 & 1357,80 & 167,50 & 12,86 & 8,93 & 7,83 & 6,91 & 6,21 & 5,62 & 4,61 & 3,81 & 2,70 \\
\hline 39,80 & 390,60 & 51,80 & 63,81 & 49,02 & 41,57 & 33,62 & 27,35 & 22,45 & 15,75 & 11,81 & 7,84 \\
\hline 48,86 & 1768,80 & 192,60 & 13,92 & 10,95 & 9,58 & 8,13 & 6,92 & 5,89 & 4,35 & 3,32 & 2,18 \\
\hline 67,70 & 457,80 & 128,60 & 28,75 & 18,32 & 14,87 & 12,09 & 10,14 & 8,61 & 6,36 & 4,91 & 3,29 \\
\hline 37,88 & 1823,90 & 55,60 & 35,80 & 32,10 & 29,50 & 26,10 & 22,92 & 20,06 & 15,35 & 11,92 & 7,76 \\
\hline 22,78 & 1837,30 & 65,00 & 49,15 & 41,81 & 35,78 & 28,55 & 22,72 & 18,25 & 12,42 & 9,21 & 6,15 \\
\hline 75,98 & 873,30 & 35,20 & 39,91 & 30,77 & 28,87 & 27,00 & 25,19 & 23,47 & 20,29 & 17,50 & 13,06 \\
\hline 69,12 & 1445,10 & 55,20 & 26,38 & 20,81 & 19,63 & 18,27 & 16,96 & 15,71 & 13,42 & 11,44 & 8,37 \\
\hline 21,52 & 705,40 & 146,50 & 37,39 & 25,23 & 18,57 & 12,76 & 9,36 & 7,31 & 5,08 & 3,94 & 2,74 \\
\hline 59,97 & 1727,80 & 23,50 & 48,30 & 39,33 & 37,75 & 36,31 & 34,45 & 32,55 & 28,84 & 25,41 & 19,58 \\
\hline 79,82 & 1551,30 & 27,30 & 35,86 & 29,35 & 27,17 & 26,27 & 25,27 & 24,14 & 21,91 & 19,80 & 16,03 \\
\hline 26,44 & 345,90 & 191,80 & 35,62 & 19,88 & 13,92 & 9,46 & 7,02 & 5,54 & 3,87 & 3,01 & 2,12 \\
\hline 36,47 & 740,60 & 116,40 & 32,03 & 23,90 & 19,80 & 15,54 & 12,33 & 9,94 & 6,86 & 5,15 & 3,47 \\
\hline 35,48 & 1553,60 & 170,10 & 19,46 & 15,34 & 13,02 & 10,46 & 8,44 & 6,87 & 4,78 & 3,57 & 2,38 \\
\hline 45,75 & 1792,40 & 27,50 & 51,44 & 44,31 & 42,69 & 39,78 & 36,78 & 33,87 & 28,47 & 23,84 & 16,87 \\
\hline 87,51 & 609,50 & 179,70 & 19,75 & 11,93 & 9,57 & 7,82 & 6,68 & 5,80 & 4,46 & 3,54 & 2,42 \\
\hline 68,91 & 311,70 & 76,70 & 44,37 & 28,99 & 23,88 & 19,69 & 16,69 & 14,29 & 10,68 & 8,29 & 5,55 \\
\hline 67,26 & 1094,40 & 120,40 & 18,81 & 14,09 & 12,48 & 10,94 & 9,69 & 8,59 & 6,78 & 5,42 & 3,67 \\
\hline 34,76 & 826,50 & 173,90 & 24,63 & 17,44 & 14,00 & 10,62 & 8,24 & 6,55 & 4,48 & 3,39 & 2,32 \\
\hline 39,07 & 357,50 & 167,80 & 34,42 & 20,26 & 15,13 & 10,95 & 8,35 & 6,61 & 4,55 & 3,49 & 2,42 \\
\hline 63,04 & 894,90 & 25,10 & 55,12 & 44,50 & 42,44 & 39,76 & 37,03 & 34,39 & 29,48 & 25,18 & 18,45 \\
\hline 70,38 & 1141,00 & 191,20 & 14,30 & 9,99 & 8,55 & 7,30 & 6,35 & 5,55 & 4,28 & 3,38 & 2,28 \\
\hline 83,58 & 1538,00 & 152,90 & 12,83 & 9,18 & 8,20 & 7,33 & 6,64 & 6,04 & 5,00 & 4,17 & 2,97 \\
\hline 62,45 & 1693,20 & 194,30 & 12,32 & 9,32 & 8,22 & 7,14 & 6,26 & 5,49 & 4,25 & 3,36 & 2,24 \\
\hline 67,41 & 1995,60 & 97,40 & 16,57 & 13,10 & 12,23 & 11,22 & 10,31 & 9,45 & 7,90 & 6,62 & 4,71 \\
\hline 23,26 & 337,20 & 85,90 & 64,91 & 42,80 & 31,46 & 21,71 & 15,98 & 12,49 & 8,67 & 6,72 & 4,69 \\
\hline 62,37 & 1460,00 & 101,90 & 18,97 & 15,07 & 13,75 & 12,31 & 11,06 & 9,92 & 7,97 & 6,45 & 4,40 \\
\hline 39,19 & 1118,00 & 194,30 & 19,16 & 14,07 & 11,66 & 9,20 & 7,35 & 5,96 & 4,13 & 3,10 & 2,08 \\
\hline 40,67 & 1193,60 & 189,20 & 18,55 & 13,84 & 11,60 & 9,29 & 7,50 & 6,13 & 4,28 & 3,22 & 2,15 \\
\hline 35,24 & 1522,20 & 158,80 & 20,57 & 16,32 & 13,89 & 11,18 & 9,04 & 7,37 & 5,13 & 3,83 & 2,55 \\
\hline 24,53 & 1827,00 & 153,80 & 25,51 & 20,07 & 16,36 & 12,37 & 9,48 & 7,45 & 5,03 & 3,80 & 2,60 \\
\hline 75,60 & 712,70 & 42,60 & 38,56 & 29,34 & 27,11 & 24,82 & 22,82 & 20,98 & 17,67 & 14,91 & 10,76 \\
\hline 75,98 & 1104,50 & 170,10 & 14,92 & 10,39 & 8,96 & 7,73 & 6,81 & 6,02 & 4,75 & 3,81 & 2,60 \\
\hline 25,41 & 1152,10 & 102,50 & 37,97 & 29,82 & 24,37 & 18,50 & 14,22 & 11,20 & 7,58 & 5,71 & 3,90 \\
\hline 34,21 & 225,50 & 156,60 & 45,86 & 24,08 & 16,86 & 11,62 & 8,70 & 6,88 & 4,77 & 3,70 & 2,61 \\
\hline
\end{tabular}




\begin{tabular}{|c|c|c|c|c|c|c|c|c|c|c|c|}
\hline & & & \multicolumn{9}{|c|}{ Deflexões $\left(\times 10^{-4} \mathrm{~cm}\right)$} \\
\hline e1 (cm) & Meq (MPa) & Ms (MPa) & D0 & D25 & D40 & D60 & D80 & D100 & D140 & D180 & D260 \\
\hline 56,06 & 1679,50 & 152,10 & 15,02 & 11,91 & 10,63 & 9,28 & 8,13 & 7,12 & 5,48 & 4,30 & 2,85 \\
\hline 79,39 & 1233,60 & 102,30 & 18,03 & 13,28 & 12,03 & 10,84 & 9,88 & 9,01 & 7,48 & 6,25 & 4,45 \\
\hline 26,24 & 578,30 & 190,00 & 30,10 & 19,14 & 14,07 & 9,78 & 7,25 & 5,68 & 3,93 & 3,04 & 2,12 \\
\hline 56,76 & 881,60 & 52,80 & 36,38 & 29,81 & 27,32 & 24,45 & 21,89 & 19,56 & 15,58 & 12,51 & 8,45 \\
\hline 22,49 & 1563,40 & 105,50 & 37,09 & 29,51 & 24,06 & 18,14 & 13,85 & 10,85 & 7,32 & 5,52 & 3,78 \\
\hline 24,06 & 1375,60 & 177,40 & 25,40 & 18,84 & 14,78 & 10,75 & 8,05 & 6,28 & 4,27 & 3,26 & 2,26 \\
\hline 38,73 & 241,80 & 71,60 & 65,44 & 43,20 & 34,00 & 25,60 & 19,85 & 15,82 & 10,87 & 8,25 & 5,66 \\
\hline 34,28 & 915,10 & 69,90 & 42,55 & 35,08 & 30,38 & 24,91 & 20,41 & 16,82 & 11,81 & 8,81 & 5,80 \\
\hline 58,50 & 642,70 & 140,70 & 24,14 & 16,54 & 13,77 & 11,32 & 9,48 & 8,00 & 5,85 & 4,48 & 2,97 \\
\hline 48,30 & 661,00 & 100,80 & 31,04 & 23,18 & 19,76 & 16,33 & 13,59 & 11,39 & 8,20 & 6,21 & 4,10 \\
\hline 79,40 & 1834,70 & 27,40 & 33,51 & 28,09 & 25,85 & 25,05 & 24,21 & 23,22 & 21,21 & 19,29 & 15,80 \\
\hline 47,01 & 545,80 & 166,60 & 26,42 & 17,17 & 13,69 & 10,61 & 8,45 & 6,86 & 4,78 & 3,62 & 2,45 \\
\hline 30,77 & 1186,60 & 34,10 & 67,69 & 60,84 & 54,89 & 47,21 & 40,28 & 34,28 & 25,06 & 18,90 & 12,17 \\
\hline 47,96 & 490,80 & 100,70 & 35,75 & 25,28 & 21,01 & 16,93 & 13,83 & 11,42 & 8,10 & 6,12 & 4,07 \\
\hline 81,49 & 1439,30 & 180,20 & 12,32 & 8,66 & 7,60 & 6,68 & 5,98 & 5,38 & 4,36 & 3,57 & 2,49 \\
\hline 32,87 & 662,40 & 93,40 & 40,85 & 30,90 & 25,46 & 19,72 & 15,47 & 12,37 & 8,46 & 6,36 & 4,31 \\
\hline 47,54 & 1389,50 & 83,70 & 25,68 & 21,65 & 19,61 & 17,21 & 15,06 & 13,16 & 10,07 & 7,85 & 5,15 \\
\hline 59,26 & 1006,30 & 124,10 & 20,49 & 15,49 & 13,56 & 11,66 & 10,12 & 8,79 & 6,70 & 5,23 & 3,47 \\
\hline 53,14 & 1992,50 & 60,70 & 26,00 & 21,97 & 20,79 & 19,09 & 17,47 & 15,92 & 13,15 & 10,86 & 7,55 \\
\hline 75,90 & 1088,70 & 190,70 & 14,26 & 9,74 & 8,30 & 7,09 & 6,19 & 5,45 & 4,25 & 3,39 & 2,30 \\
\hline 65,53 & 1106,20 & 113,60 & 19,56 & 14,84 & 13,22 & 11,61 & 10,29 & 9,13 & 7,20 & 5,75 & 3,89 \\
\hline 59,24 & 433,90 & 189,70 & 26,37 & 15,38 & 11,81 & 9,05 & 7,26 & 5,95 & 4,21 & 3,21 & 2,18 \\
\hline 37,72 & 768,10 & 188,60 & 23,20 & 15,95 & 12,75 & 9,71 & 7,57 & 6,04 & 4,15 & 3,14 & 2,14 \\
\hline 87,97 & 1073,60 & 89,10 & 19,77 & 14,18 & 12,79 & 11,59 & 10,63 & 9,77 & 8,27 & 7,01 & 5,13 \\
\hline 36,16 & 1492,40 & 92,90 & 28,56 & 24,19 & 21,34 & $\begin{array}{l}1+1,05 \\
17,93\end{array}$ & $\begin{array}{l}10,002 \\
15,02\end{array}$ & 12,60 & 9,05 & 6,79 & 4,42 \\
\hline 44,11 & 608,90 & 143,60 & 27,83 & 19,21 & 15,66 & 12,31 & 9,85 & 8,00 & 5,58 & 4,21 & 2,83 \\
\hline 45,19 & 886,20 & 151,10 & 22,58 & 16,58 & 13,95 & 11,30 & 9,25 & 7,64 & 5,41 & 4,08 & 2,71 \\
\hline 86,48 & 1859,00 & 80,70 & 16,59 & 12,49 & 11,57 & 10,86 & 10,19 & 9,56 & 8,39 & 7,35 & 5,63 \\
\hline 40,51 & 1225,40 & 102,90 & 26,54 & $\frac{1 L, 40}{21,76}$ & $\begin{array}{l}\perp, v 1 \\
19,07\end{array}$ & $\frac{10,00}{16,01}$ & $\begin{array}{l}10, \pm 0 \\
13,43\end{array}$ & $\begin{array}{l}0,11,29 \\
11,29\end{array}$ & 8,14 & 6,14 & 4,01 \\
\hline 79,20 & 1944,90 & 172,00 & 11,05 & 8,11 & 7,31 & 6,56 & 5,96 & 5,42 & 4,48 & 3,73 & 2,64 \\
\hline 38,82 & 355,00 & 114,90 & 42,37 & 27,41 & 21,37 & 15,98 & 12,34 & 9,82 & 6,75 & 5,13 & 3,53 \\
\hline 33,15 & 494,70 & 20,80 & 118,67 & 103,93 & 92,76 & 78,84 & 66,60 & 56,22 & 40,66 & 30,56 & 19,77 \\
\hline 62,96 & 1067,80 & 58,20 & 30,01 & 24,08 & 22,31 & 20,25 & 18,40 & 16,68 & 13,67 & 11,24 & 7,81 \\
\hline 20,72 & 1569,30 & 140,50 & 31,92 & 24,21 & 18,96 & 13,68 & 10,17 & 7,89 & 5,37 & 4,11 & 2,85 \\
\hline 48,25 & 1173,40 & 191,00 & 16,88 & 12,46 & 10,57 & 8,69 & 7,20 & 6,01 & 4,32 & 3,27 & 2,16 \\
\hline 79,46 & 596,10 & 74,40 & 30,08 & 21,30 & 18,71 & 16,42 & 14,67 & 13,16 & 10,62 & 8,68 & 6,03 \\
\hline 82,46 & 784,30 & 126,90 & 19,92 & 13,51 & 11,59 & 9,99 & 8,83 & 7,86 & 6,27 & 5,08 & 3,51 \\
\hline 28,13 & 659,60 & 81,20 & 49,53 & 37,74 & 30,65 & 23,19 & 17,84 & 14,08 & 9,56 & 7,22 & 4,94 \\
\hline 60,32 & 288,50 & 91,10 & 45,07 & 28,40 & 22,74 & 18,11 & 14,87 & 12,39 & 8,91 & 6,81 & 4,56 \\
\hline 77,01 & 1640,70 & 159,70 & 12,60 & 9,23 & 8,27 & 7,37 & 6,65 & 6,01 & 4,91 & 4,04 & 2,83 \\
\hline 48,70 & 1120,30 & 35,90 & 47,19 & 40,75 & 38,22 & 34,73 & 31,42 & 28,31 & 22,87 & 18,53 & 12,57 \\
\hline 39,08 & 1587,70 & 40,10 & 45,57 & 41,00 & 38,12 & 34,18 & 30,43 & 26,98 & 21,12 & 16,66 & 10,97 \\
\hline 32,20 & 1195,30 & 29,40 & 71,65 & 65,16 & 59,50 & 52,02 & 45,11 & 38,96 & 29,15 & 22,27 & 14,35 \\
\hline 60,17 & 1211,70 & 150,10 & 16,84 & 12,69 & 11,11 & 9,57 & 8,32 & 7,24 & 5,53 & 4,33 & 2,87 \\
\hline 81,39 & 321,90 & 137,60 & 33,55 & 18,96 & 14,52 & 11,35 & 9,38 & 7,92 & 5,85 & 4,56 & 3,09 \\
\hline 73,27 & 1943,20 & 85,30 & 17,38 & 13,48 & 12,63 & 11,73 & 10,89 & 10,09 & 8,62 & 7,36 & 5,41 \\
\hline 36,74 & 1628,90 & 146,90 & 20,46 & 16,59 & 14,33 & 11,76 & 9,66 & 7,97 & 5,62 & 4,21 & 2,77 \\
\hline 56,15 & 1799,50 & 40,30 & 34,38 & 28,46 & 27,31 & 25,56 & 23,76 & 22,01 & 18,75 & 15,92 & 11,53 \\
\hline 30,70 & 1796,10 & 119,90 & 25,73 & 21,36 & 18,39 & 14,90 & 12,07 & 9,84 & 6,82 & 5,08 & 3,36 \\
\hline 32,34 & 568,40 & 112,10 & 38,77 & 27,71 & 22,14 & 16,64 & 12,80 & 10,12 & 6,91 & 5,24 & 3,59 \\
\hline 72,89 & 1653,60 & 187,50 & 11,81 & 8,65 & 7,65 & 6,73 & 6,00 & 5,36 & 4,29 & 3,47 & 2,38 \\
\hline 49,79 & 1436,50 & 110,50 & 20,77 & 17,03 & 15,25 & 13,27 & 11,54 & 10,02 & 7,61 & 5,91 & 3,88 \\
\hline 62,12 & 1453,70 & 194,60 & 13,26 & 9,83 & 8,56 & 7,36 & 6,39 & 5,56 & 4,25 & 3,33 & 2,22 \\
\hline 77,04 & 1996,90 & 193,20 & 10,38 & 7,61 & 6,82 & 6,08 & 5,49 & 4,96 & 4,06 & 3,34 & 2,34 \\
\hline 55,22 & 1709,90 & 194,10 & 13,10 & 10,12 & 8,89 & 7,63 & 6,59 & 5,70 & 4,30 & 3,34 & 2,20 \\
\hline 36,26 & 676,10 & 48,00 & 57,85 & 48,26 & 42,26 & 35,21 & 29,26 & 24,40 & 17,38 & 13,03 & 8,51 \\
\hline 49,23 & 1012,80 & 88,50 & 27,50 & 22,25 & 19,76 & 17,03 & 14,68 & 12,66 & 9,50 & 7,32 & 4,80 \\
\hline 78,06 & 671,60 & 78,10 & 27,88 & 20,00 & 17,67 & 15,57 & 13,95 & 12,53 & 10,13 & 8,28 & 5,75 \\
\hline 68,79 & 1801,70 & 108,20 & 15,98 & 12,47 & 11,52 & 10,48 & 9,56 & 8,71 & 7,21 & 5,99 & 4,22 \\
\hline 59,70 & 762,10 & 67,20 & 32,47 & 25,54 & 22,91 & 20,16 & 17,81 & 15,74 & 12,31 & 9,77 & 6,54 \\
\hline 34,16 & 1832,60 & 99,20 & 26,59 & 22,78 & 20,13 & 16,91 & 14,14 & 11,84 & 8,48 & 6,35 & 4,13 \\
\hline 57,79 & 946,30 & 198,50 & 16,83 & 11,64 & 9,73 & $\begin{array}{c}10,01 \\
8,02\end{array}$ & $\begin{array}{c}, 72 \\
6,72\end{array}$ & $\begin{array}{c}+1,68 \\
5,68\end{array}$ & 4,15 & 3,18 & 2,11 \\
\hline 63,66 & 1500,20 & 52,20 & $\begin{array}{l}10,00 \\
28,32\end{array}$ & $\begin{array}{l}1+, \mathrm{U} \\
22,82\end{array}$ & 21,61 & 20,06 & 18,56 & 17,13 & 14,51 & $\frac{0,+0}{12,26}$ & 8,85 \\
\hline 82,19 & 1511,80 & 185,30 & 11,81 & 8,31 & $\begin{array}{l}2 ., 01 \\
7,30\end{array}$ & 6,43 & $\begin{array}{c}10,00 \\
5,77\end{array}$ & $\begin{array}{c}1+1,19 \\
5,19\end{array}$ & $\frac{1+, 10}{4,22}$ & $\begin{array}{c}1+L, 40 \\
3,47\end{array}$ & 2,43 \\
\hline 25,88 & 1615,80 & 104,90 & 33,22 & 27,12 & 22,77 & 17,81 & 13,99 & 11,15 & 7,57 & 5,65 & 3,82 \\
\hline 84,72 & 964,80 & 116,00 & 18,46 & 12,91 & 11,36 & 10,03 & 9,02 & 8,15 & 6,68 & 5,52 & 3,89 \\
\hline 86,69 & 882,40 & 182,70 & 15,66 & 10,10 & 8,44 & 7,14 & 6,24 & 5,51 & 4,35 & 3,51 & 2,42 \\
\hline 32,95 & 725,30 & 112,30 & 35,08 & 26,15 & 21,39 & 16,45 & 12,85 & 10,24 & 7,00 & 5,27 & 3,58 \\
\hline 54,53 & 382,10 & 151,00 & 31,88 & 19,22 & 14,95 & 11,51 & 9,20 & 7,51 & 5,28 & 4,01 & 2,72 \\
\hline 33,90 & 1833,30 & 122,80 & 23,30 & 19,50 & 17,00 & 14,05 & 11,58 & 9,58 & 6.76 & 5,05 & 3,31 \\
\hline 39,72 & 961,10 & 174,60 & 21,55 & 15,69 & 12,97 & 10,23 & 8,17 & 6,62 & 4,59 & 3,45 & 2,32 \\
\hline 38,91 & 1943,40 & 54,60 & 34,77 & 31,22 & 28,87 & 25,74 & 22,79 & 20,09 & 15,58 & 12,20 & 7,99 \\
\hline 79,59 & 888,60 & 172,70 & 16,41 & 10,90 & 9,19 & 7,79 & 6,80 & 5,97 & 4,67 & 3,73 & 2,54 \\
\hline 74,91 & 1556,70 & 106,70 & 16,37 & 12,40 & 11,37 & 10,33 & 9,44 & 8,63 & 7,19 & 6,01 & 4,28 \\
\hline 23,13 & 1572,10 & 175,30 & 25,29 & 19,02 & 14,98 & 10,91 & 8,18 & 6,37 & 4,33 & 3,30 & 2,28 \\
\hline 66,27 & 365,40 & 155,10 & 30,87 & 17,92 & 13,81 & 10,72 & 8,71 & 7,23 & 5,19 & 3,98 & 2,69 \\
\hline 21,62 & 557,10 & 124,40 & 44,78 & 29,87 & 21,87 & 14,99 & 11,00 & 8,59 & 5,98 & 4,63 & 3,23 \\
\hline 64,15 & 235,00 & 174,80 & 40,08 & 20,19 & 14,25 & 10,21 & 7,92 & 6,38 & 4,45 & 3,42 & 2,37 \\
\hline 84,15 & 368,70 & 164,50 & 28,75 & 16,02 & 12,18 & 9,47 & 7,82 & 6,60 & 4,89 & 3,81 & 2,59 \\
\hline 52,61 & 821,40 & 123,80 & 24,00 & 17,84 & 15,30 & 12,80 & 10,80 & 9,16 & 6,71 & 5,13 & 3,38 \\
\hline 73,72 & 817,50 & 105,90 & 22,20 & 15,95 & 13,96 & 12,18 & 10,79 & 9,59 & 7,61 & 6,13 & 4,19 \\
\hline 50,37 & 1879,40 & 170,90 & 14,28 & 11,47 & 10,18 & 8,77 & 7,57 & 6,54 & 4,92 & 3,80 & 2,49 \\
\hline
\end{tabular}




\begin{tabular}{|c|c|c|c|c|c|c|c|c|c|c|c|}
\hline \multirow[b]{2}{*}{ e1 (cm) } & & & & & & & ões (x1 & m) & & & \\
\hline & Meq (MPa) & Ms (MPa) & D0 & D25 & D40 & D60 & D80 & D100 & D140 & D180 & D260 \\
\hline 63,55 & 837,80 & 47,50 & 37,16 & 29,70 & 27,47 & 24,90 & 22,61 & 20,49 & 16,78 & 13,79 & 9,57 \\
\hline 79,39 & 1539,40 & 63,30 & 21,81 & 16,67 & 15,58 & 14,60 & 13,66 & 12,76 & 11,09 & 9,62 & 7,25 \\
\hline 69,89 & 1499,50 & 165,90 & 13,45 & 9,97 & 8,84 & 7,77 & 6,90 & 6,14 & 4,88 & 3,93 & 2,68 \\
\hline 32,27 & 1260,60 & 96,30 & 32,32 & 26,53 & 22,79 & 18,47 & 14,97 & 12,22 & 8,49 & 6,33 & 4,19 \\
\hline 37,41 & 588,70 & 114,40 & 34,92 & 25,12 & 20,51 & 15,89 & 12,52 & 10,05 & 6,92 & 5,21 & 3,53 \\
\hline 41,03 & 1475,30 & 74,10 & 30,08 & 26,03 & 23,52 & 20,45 & 17,70 & 15,28 & 11,47 & 8,80 & 5,72 \\
\hline 68,55 & 1456,70 & 110,50 & 17,24 & 13,29 & 12,10 & 10,86 & 9,81 & 8,86 & 7,21 & 5,90 & 4,09 \\
\hline 69,42 & 998,40 & 47,00 & 33,36 & 26,18 & 24,49 & 22,57 & 20,80 & 19,15 & 16,14 & 13,61 & 9,80 \\
\hline 22,86 & 746,10 & 20,90 & 141,72 & 123,15 & 107,00 & 87,04 & 70,40 & 57,22 & 39,34 & 29,09 & 19,20 \\
\hline 52,04 & 1721,70 & 106,40 & 19,25 & 16,00 & 14,56 & 12,89 & 11,41 & 10,07 & 7,85 & 6,20 & 4,12 \\
\hline 62,13 & 1633,80 & 174,40 & 13,32 & 10,17 & 9,02 & 7,87 & 6,92 & 6,09 & 4,73 & 3,75 & 2,51 \\
\hline 85,39 & 1533,70 & 196,60 & 11,22 & 7,77 & 6,80 & 5,98 & 5,36 & 4,84 & 3,95 & 3,26 & 2,29 \\
\hline 45,02 & 1239,60 & 140,30 & 20,44 & 16,07 & 13,94 & 11,65 & 9,77 & 8,21 & 5,94 & 4,50 & 2,95 \\
\hline 34,16 & 685,00 & 45,20 & 62,65 & 52,54 & 45,89 & 38,02 & 31,42 & 26,05 & 18,42 & 13,76 & 9,01 \\
\hline 54,50 & 1309,00 & 45,60 & 35,59 & 29,90 & 28,16 & 25,77 & 23,51 & 21,38 & 17,58 & 14,46 & 10,02 \\
\hline 45,84 & 734,70 & 178,70 & 22,29 & 15,26 & 12,44 & 9,81 & 7,88 & 6,43 & 4,50 & 3,39 & 2,28 \\
\hline 66,26 & 1603,30 & 56,30 & 25,73 & 20,52 & 19,43 & 18,09 & 16,79 & 15,55 & 13,25 & 11,27 & 8,21 \\
\hline 62,90 & 1352,50 & 115,40 & 18,13 & 14,14 & 12,74 & 11,28 & 10,05 & 8,94 & 7,09 & 5,69 & 3,85 \\
\hline 33,11 & 679,00 & 175,80 & 27,02 & 18,35 & 14,35 & 10,60 & 8,09 & 6,38 & 4,37 & 3,33 & 2,29 \\
\hline 53,37 & 925,90 & 182,10 & 18,40 & 13,01 & 10,91 & 8,95 & 7,45 & 6,25 & 4,52 & 3,44 & 2,28 \\
\hline 35,70 & 1354,20 & 187,80 & 19,18 & 14,60 & 12,18 & 9,61 & 7,66 & 6,19 & 4,27 & 3,20 & 2,15 \\
\hline 71,77 & 1148,60 & 129,70 & 17,16 & 12,62 & 11,17 & 9,82 & 8,74 & 7,79 & 6,22 & 5,02 & 3,44 \\
\hline 50,17 & 677,30 & 101,50 & 29,96 & 22,38 & 19,15 & 15,93 & 13,35 & 11,25 & 8,18 & 6,22 & 4,09 \\
\hline 32,53 & 1847,80 & 58,10 & 39,07 & 34,99 & 31,63 & 27,30 & 23,38 & 19,98 & 14,70 & 11,13 & 7,17 \\
\hline 29,45 & 590,40 & 26,50 & 105,19 & 90,64 & 79,47 & 65,79 & 54,20 & 44,77 & 31,45 & 23,39 & 15,29 \\
\hline 62,55 & 839,90 & 107,40 & 23,44 & 17,46 & 15,27 & 13,17 & 11,48 & 10,02 & 7,70 & 6,05 & 4,03 \\
\hline 32,05 & 871,40 & 83,60 & 40,51 & 32,31 & 27,30 & 21,70 & 17,32 & 13,99 & 9,63 & 7,19 & 4,81 \\
\hline 25,31 & 1237,00 & 89,70 & 40,88 & 32,87 & 27,27 & 21,02 & 16,34 & 12,94 & 8,76 & 6,56 & 4,46 \\
\hline 74,16 & 1542,10 & 163,50 & 13,02 & 9,56 & 8,51 & 7,52 & 6,74 & 6,04 & 4,87 & 3,97 & 2,74 \\
\hline 84,95 & 645,80 & 162,20 & 19,93 & 12,48 & 10,21 & 8,48 & 7,31 & 6,39 & 4,95 & 3,95 & 2,70 \\
\hline 51,57 & 1800,60 & 96,80 & 20,18 & 16,96 & 15,54 & 13,86 & 12,33 & 10,94 & 8,60 & 6,84 & 4,56 \\
\hline 49,09 & 1735,60 & 40,10 & 37,97 & 32,60 & 31,06 & 28,66 & 26,29 & 24,02 & 19,91 & 16,47 & 11,48 \\
\hline 87,47 & 881,10 & 84,50 & 22,38 & 15,87 & 14,20 & 12,74 & 11,61 & 10,61 & 8,88 & 7,47 & 5,39 \\
\hline 31,70 & 759,00 & 39,10 & 70,34 & 60,22 & 52,88 & 43,96 & 36,39 & 30,20 & 21,35 & 15,92 & 10,39 \\
\hline 58,73 & 563,90 & 164,50 & 24,08 & 15,50 & 12,52 & 10,03 & 8,25 & 6,88 & 4,95 & 3,77 & 2,53 \\
\hline 77,11 & 1609,60 & 38,50 & 29,66 & 23,42 & 21,99 & 21,06 & 20,01 & 18,94 & 16,88 & 14,98 & 11,73 \\
\hline 31,05 & 1208,60 & 109,60 & 31,00 & 24,84 & 20,98 & 16,63 & 13,25 & 10,68 & 7,34 & 5,48 & 3,67 \\
\hline 84,50 & 1645,80 & 86,30 & 17,01 & 12,70 & 11,73 & 10,90 & 10,15 & 9,45 & 8,17 & 7,06 & 5,30 \\
\hline 89,79 & 1132,80 & 181,00 & 13,47 & 8,96 & 7,67 & 6,64 & 5,91 & 5,30 & 4,29 & 3,53 & 2,48 \\
\hline 78,12 & 745,80 & 31,00 & 45,16 & 34,60 & 32,38 & 30,29 & 28,29 & 26,39 & 22,87 & 19,78 & 14,83 \\
\hline 64,57 & 914,90 & 25,90 & 52,86 & 42,44 & 40,45 & 37,96 & 35,41 & 32,95 & 28,34 & 24,29 & 17,90 \\
\hline 50,19 & 1356,60 & 22,10 & 61,42 & 51,76 & 49,98 & 46,90 & 43,65 & 40,46 & 34,48 & 29,24 & 21,12 \\
\hline 70,47 & 1109,70 & 86,80 & 21,93 & 16,75 & 15,23 & 13,67 & 12,36 & 11,18 & 9,12 & 7,49 & 5,22 \\
\hline 33,81 & 848,90 & 144,00 & 27,86 & 20,48 & 16,69 & 12,81 & 10,00 & 7,97 & 5,46 & 4,11 & 2,80 \\
\hline 64,43 & 427,10 & 89,50 & 35,65 & 24,31 & 20,36 & 16,94 & 14,40 & 12,33 & 9,20 & 7,12 & 4,74 \\
\hline 47,94 & 1607,20 & 186,40 & 14,95 & 11,67 & 10,16 & 8,55 & 7,23 & 6,13 & 4,48 & 3,41 & 2,24 \\
\hline 76,43 & 1047,00 & 37,00 & 36,02 & 27,88 & 26,22 & 24,68 & 23,14 & 21,66 & 18,88 & 16,41 & 12,41 \\
\hline 64,27 & 699,30 & 21,50 & 65,52 & 52,67 & 50,09 & 46,81 & 43,52 & 40,37 & 34,51 & 29,42 & 21,50 \\
\hline 39,86 & 1092,10 & 181,10 & 19,97 & 14,78 & 12,32 & 9,79 & 7,86 & 6,40 & 4,45 & 3,34 & 2,24 \\
\hline 29,47 & 1618,80 & 59,90 & 43,53 & 38,18 & 33,84 & 28,40 & 23,68 & 19,76 & 14,05 & 10,47 & 6,80 \\
\hline 45,97 & 1171,10 & 134,40 & 21,18 & 16,60 & 14,41 & 12,07 & 10,14 & 8,55 & 6,21 & 4,70 & 3,08 \\
\hline 89,25 & 629,70 & 131,00 & 21,71 & 13,90 & 11,59 & 9,81 & 8,59 & 7,60 & 6,03 & 4,88 & 3,38 \\
\hline 85,42 & 816,20 & 137,80 & 18,55 & 12,39 & 10,58 & 9,10 & 8,05 & 7,17 & 5,73 & 4,66 & 3,23 \\
\hline 49,36 & 1273,50 & 120,60 & 20,84 & 16,69 & 14,75 & 12,65 & 10,86 & 9,33 & 6,97 & 5,36 & 3,51 \\
\hline 82,36 & 881,60 & 39,20 & 35,52 & 26,88 & 25,00 & 23,39 & 21,86 & 20,43 & 17,77 & 15,43 & 11,67 \\
\hline 75,73 & 209,00 & 65,80 & 58,30 & 35,61 & 28,46 & 23,00 & 19,35 & 16,52 & 12,34 & 9,62 & 6,48 \\
\hline 61,11 & 1424,00 & 109,10 & 18,61 & 14,75 & 13,37 & 11,88 & 10,60 & 9,45 & 7,51 & 6,02 & 4,07 \\
\hline 45,51 & 642,40 & 43,80 & 52,99 & 44,35 & 39,75 & 34,43 & 29,75 & 25,68 & 19,29 & 14,84 & 9,69 \\
\hline 64,81 & 918,80 & 162,10 & 17,93 & 12,61 & 10,74 & 9,07 & 7,80 & 6,73 & 5,09 & 3,97 & 2,64 \\
\hline 26,13 & 878,10 & 26,60 & 101,55 & 89,36 & 78,81 & 65,53 & 54,11 & 44,75 & 31,41 & 23,30 & 15,18 \\
\hline 42,89 & 1267,80 & 156,30 & 19,60 & 15,23 & 13,08 & 10,78 & 8,92 & 7,42 & 5,29 & 3,99 & 2,62 \\
\hline 67,06 & 816,70 & 129,10 & 20,96 & 14,93 & 12,84 & 10,97 & 9,52 & 8,30 & 6,37 & 5,01 & 3,35 \\
\hline 34,09 & 1871,80 & 31,30 & 56,89 & 52,23 & 48,80 & 43,87 & 39,13 & 34,71 & 27,18 & 21,41 & 14,05 \\
\hline 86,39 & 1364,40 & 68,80 & 20,73 & 15,45 & 14,26 & 13,29 & 12,41 & 11,59 & 10,08 & 8,75 & 6,63 \\
\hline 22,18 & 340,30 & 33,70 & 130,74 & 99,15 & 78,18 & 56,91 & 42,57 & 33,10 & 22,48 & 17,17 & 11,87 \\
\hline 78,01 & 883,90 & 138,30 & 18,32 & 12,65 & 10,89 & 9,40 & 8,28 & 7,34 & 5,81 & 4,68 & 3,20 \\
\hline 75,67 & 585,10 & 174,10 & 21,28 & 13,16 & 10,59 & 8,61 & 7,28 & 6,23 & 4,67 & 3,65 & 2,46 \\
\hline 60,31 & 650,00 & 94,20 & 28,88 & 21,24 & 18,37 & 15,65 & 13,48 & 11,65 & 8,81 & 6,85 & 4,54 \\
\hline 78,66 & 1166,40 & 65,90 & 23,89 & 18,04 & 16,70 & 15,38 & 14,21 & 13,13 & 11,18 & 9,52 & 6,97 \\
\hline 24,76 & 265,60 & 104,90 & 59,10 & 35,80 & 25,63 & 17,49 & 12,92 & 10,16 & 7,08 & 5,50 & 3,85 \\
\hline 50,43 & 1917,50 & 194,60 & 13,12 & 10,40 & 9,16 & 7,84 & 6,72 & 5,78 & 4,31 & 3,31 & 2,17 \\
\hline 34,50 & 1931,00 & 196,20 & 16,74 & 13,31 & 11,32 & 9,09 & 7,33 & 5,97 & 4,14 & 3,09 & 2,06 \\
\hline 53,78 & 1224,30 & 143,10 & 18,27 & 14,11 & 12,35 & 10,55 & 9,06 & 7,80 & 5,84 & 4,51 & 2,97 \\
\hline 65,49 & 545,00 & 186,50 & 22,52 & 13,79 & 10,93 & 8,69 & 7,17 & 6,00 & 4,35 & 3,34 & 2,24 \\
\hline 62,78 & 963,10 & 194,10 & 16,27 & 11,22 & 9,43 & 7,86 & 6,68 & 5,71 & 4,25 & 3,29 & 2,18 \\
\hline 59,77 & 1934,00 & 136,40 & 14,57 & 11,68 & 10,63 & 9,47 & 8,46 & 7,55 & 6,01 & 4,83 & 3,26 \\
\hline 52,98 & 425,00 & 45,10 & 56,04 & 43,92 & 38,68 & 33,21 & 28,62 & 24,69 & 18,57 & 14,35 & 9,44 \\
\hline 47,28 & 1882,10 & 176,30 & 14,58 & 11,73 & 10,35 & 8,83 & 7,54 & 6,44 & 4,77 & 3,65 & 2,38 \\
\hline 63,95 & 1153,70 & 80,30 & 23,73 & 18,73 & 17,11 & 15,35 & 13,83 & 12,43 & 10,04 & 8,17 & 5,60 \\
\hline 71,76 & 1478,30 & 49,10 & 27,61 & 21,65 & 20,47 & 19,24 & 17,99 & 16,80 & 14,55 & 12,57 & 9,40 \\
\hline 87,93 & 652,50 & 134,00 & 21,15 & 13,62 & 11,38 & 9,64 & 8,44 & 7,46 & 5,91 & 4,78 & 3,31 \\
\hline 36,20 & 825,90 & 56,40 & 48,64 & 40,77 & 35,77 & 29,88 & 24,89 & 20,79 & 14,84 & 11,13 & 7,26 \\
\hline
\end{tabular}




\begin{tabular}{|c|c|c|c|c|c|c|c|c|c|c|c|}
\hline \multirow[b]{2}{*}{ e1 (cm) } & & & & & & & ões (x1 & m) & & & \\
\hline & Meq (MPa) & Ms (MPa) & D0 & D25 & D40 & D60 & D80 & D100 & D140 & D180 & D260 \\
\hline 42,29 & 1205,90 & 140,30 & 21,52 & 16,87 & 14,53 & 11,99 & 9,94 & 8,27 & 5,90 & 4,44 & 2,92 \\
\hline 60,34 & 298,30 & 89,90 & 444,48 & 28,33 & 22,81 & 18,25 & 15,04 & 12,56 & 9,06 & 6,92 & 4,63 \\
\hline 33,81 & 1149,80 & 35,10 & $\begin{array}{l}62,04 \\
\end{array}$ & 55,75 & 50,66 & 44,08 & 38,05 & 32,75 & 24,38 & 18,59 & 11,99 \\
\hline 83,53 & 1323,40 & 65,80 & 21,98 & 16,49 & 15,28 & 14,22 & 13,25 & 12,35 & 10,70 & 9,26 & 6,96 \\
\hline 68,11 & 1545,20 & 171,10 & 13,20 & 9,85 & 8,73 & 7,65 & 6,78 & 6,02 & 4,76 & 3,81 & 2,59 \\
\hline 27,54 & 1066,90 & 197,20 & 23,53 & 16,80 & 13,13 & 9,58 & 7,22 & 5,65 & 3,86 & 2,95 & 2,04 \\
\hline 54,38 & 954,90 & 68,10 & 30,95 & 25,26 & 22,85 & 20,17 & 17,81 & 15,71 & 12,24 & 9,67 & 6,43 \\
\hline 66,75 & 819,10 & 94,10 & 24,65 & 18,39 & 16,24 & 14,19 & 12,52 & 11,07 & 8,69 & 6,93 & 4,68 \\
\hline 41,37 & 273,00 & 82,80 & 55,68 & 36,48 & 28,83 & 21,91 & 17,13 & 13,72 & 9,47 & 7,17 & 4,90 \\
\hline 41,70 & 1026,10 & 54,50 & 41,25 & 35,51 & 32,03 & 27,83 & 24,06 & 20,77 & 15,58 & 11,96 & 7,78 \\
\hline 41,71 & 1404,20 & 151,40 & 19,51 & 15,46 & 13,37 & 11,08 & 9,20 & 7,67 & 5,48 & 4,13 & 2,71 \\
\hline 43,34 & 1564,10 & 106,60 & 22,53 & 18,90 & 16,88 & 14,52 & 12,46 & 10,68 & 7,93 & 6,06 & 3,95 \\
\hline 78,26 & 757,50 & 177,80 & 17,88 & 11,52 & 9,52 & 7,94 & 6,83 & 5,94 & 4,56 & 3,61 & 2,44 \\
\hline 87,50 & 616,60 & 54,10 & 33,50 & 23,94 & 21,54 & 19,44 & 17,78 & 16,31 & 13,73 & 11,60 & 8,43 \\
\hline 36,07 & 642,60 & 52,00 & 56,29 & 46,23 & 40,13 & 33,09 & 27,26 & 22,57 & 15,95 & 11,93 & 7,83 \\
\hline 57,64 & 1951,50 & 92,20 & 18,90 & 15,59 & 14,50 & 13,15 & 11,92 & 10,77 & 8,76 & 7,15 & 4,91 \\
\hline 71,73 & 403,40 & 52,40 & 45,46 & 32,86 & 28,76 & 25,04 & 22,13 & 19,61 & 15,48 & 12,41 & 8,44 \\
\hline 62,56 & 859,00 & 60,70 & 31,95 & 25,33 & 23,10 & 20,67 & 18,56 & 16,64 & 13,36 & 10,82 & 7,38 \\
\hline 89,81 & 724,00 & 57,20 & 29,80 & 21,34 & 19,29 & 17,55 & 16,15 & 14,90 & 12,68 & 10,82 & 7,98 \\
\hline 78,22 & 817,00 & 123,00 & 20,16 & 13,99 & 12,09 & 10,46 & 9,25 & 8,21 & 6,52 & 5,26 & 3,61 \\
\hline 35,17 & 1406,80 & 170,10 & 20,31 & 15,78 & 13,28 & 10,56 & 8,46 & 6,86 & 4,74 & 3,55 & 2,37 \\
\hline 70,76 & 1400,60 & 103,50 & 17,92 & 13,72 & 12,52 & 11,28 & 10,23 & 9,27 & 7,61 & 6,27 & 4,39 \\
\hline 45,92 & 1669,70 & 198,70 & 14,56 & 11,35 & 9,83 & 8,21 & 6,88 & 5,79 & 4,19 & 3,18 & 2,08 \\
\hline 35,51 & 1287,70 & 118,10 & 26,24 & 21,19 & 18,21 & 14,83 & 12,09 & 9,93 & 6,95 & 5,19 & 3,43 \\
\hline 77,97 & 1569,70 & 127,50 & 14,45 & 10,71 & 9,72 & 8,76 & 7,98 & 7,27 & 6,03 & 5,02 & 3,57 \\
\hline 65,52 & 1151,80 & 65,90 & 26,42 & 20,93 & 19,37 & 17,59 & 16,01 & 14,55 & 11,98 & 9,89 & 6,91 \\
\hline 27,47 & 1204,90 & 21,60 & 100,71 & 92,57 & 84,28 & 73,22 & 62,99 & 53,98 & 39,83 & 30,14 & 19,33 \\
\hline 74,61 & 1707,80 & 124,60 & 14,42 & 10,89 & 9,95 & 9,01 & 8,21 & 7,48 & 6,20 & 5,16 & 3,66 \\
\hline 41,13 & 1396,00 & 102,30 & 25,06 & 20,89 & 18,49 & 15,70 & 13,31 & 11,28 & 8,24 & 6,24 & 4,06 \\
\hline 47,87 & 1376,80 & 131,00 & 19,59 & 15,72 & 13,86 & 11,83 & 10,11 & 8,65 & 6,41 & 4,91 & 3,21 \\
\hline 48,74 & 352,20 & 159,90 & 33,53 & 19,68 & 14,97 & 11,21 & 8,77 & 7,05 & 4,89 & 3,72 & 2,56 \\
\hline 80,30 & 1933,80 & 139,30 & 12,38 & 9,18 & 8,38 & 7,62 & 6,99 & 6,42 & 5,39 & 4,55 & 3,28 \\
\hline 21,68 & 639,00 & 132,80 & 441,11 & 27,79 & 20,48 & 14,10 & 10,35 & 8,07 & 5,61 & 4,34 & 3,03 \\
\hline 46,71 & 292,30 & 129,70 & 41,28 & 24,45 & 18,62 & 13,90 & 10,83 & 8,69 & 6,01 & 4,58 & 3,15 \\
\hline 81,52 & 1083,40 & 137,90 & 16,23 & 11,39 & 9,98 & 8,76 & 7,84 & 7,04 & 5,70 & 4,67 & 3,26 \\
\hline 58,37 & 1327,20 & 28,60 & 46,71 & 38,27 & 36,76 & 34,60 & 32,30 & 30,06 & 25,85 & 22,13 & 16,25 \\
\hline 60,66 & 1596,20 & 37,90 & 35,44 & 28,83 & 27,62 & 25,97 & 24,25 & 22,57 & 19,42 & 16,63 & 12,24 \\
\hline 75,34 & 1829,00 & 55,60 & 22,87 & 17,85 & 16,83 & 15,94 & 15,00 & 14,09 & 12,36 & 10,80 & 8,25 \\
\hline 44,01 & 306,40 & 91,90 & 48,71 & 31,91 & 25,38 & 19,51 & 15,40 & 12,42 & 8,61 & 6,51 & 4,43 \\
\hline 48,82 & 1646,50 & 146,10 & 16,86 & 13,63 & 12,08 & 10,39 & 8,94 & 7,69 & 5,76 & 4,43 & 2,90 \\
\hline 21,35 & 273,60 & 26,80 & 168,09 & 126,76 & 99,20 & 71,61 & 53,29 & 41,37 & 28,15 & 21,55 & 14,93 \\
\hline 24,76 & 1199,80 & 137,80 & 31,04 & 23,50 & 18,73 & 13,84 & 10,46 & 8,18 & 5,55 & 4,22 & 2,91 \\
\hline 67,91 & 1229,70 & 125,60 & 17,35 & 13,07 & 11,65 & 10,27 & 9,13 & 8,13 & 6,46 & 5,20 & 3,54 \\
\hline 75,97 & 1802,20 & 158,10 & 12,21 & 9,06 & 8,18 & 7,33 & 6,63 & 6,01 & 4,94 & 4,08 & 2,87 \\
\hline 59,56 & 399,80 & 171,70 & 28,78 & 16,85 & 12,97 & 9,97 & 8,01 & 6,58 & 4,65 & 3,55 & 2,41 \\
\hline 61,81 & 1109,60 & 167,20 & 16,39 & 11,94 & 10,30 & 8,77 & 7,56 & 6,54 & 4,96 & 3,86 & 2,56 \\
\hline 53,45 & 1571,40 & 38,10 & 38,40 & 32,27 & 30,84 & 28,63 & 26,43 & 24,31 & 20,41 & 17,10 & 12,13 \\
\hline 67,85 & 1062,90 & 59,40 & 28,52 & 22,41 & 20,78 & 18,95 & 17,32 & 15,81 & 13,12 & 10,91 & 7,71 \\
\hline 65,44 & 1310,50 & 175,40 & 14,36 & 10,54 & 9,19 & 7,93 & 6,93 & 6,07 & 4,69 & 3,70 & 2,48 \\
\hline 85,42 & 602,60 & 102,40 & 25,06 & 16,72 & 14,26 & 12,27 & 10,84 & 9,65 & 7,72 & 6,27 & 4,35 \\
\hline 68,10 & 1882,00 & 188,10 & 11,46 & 8,64 & 7,72 & 6,81 & 6,07 & 5,41 & 4,31 & 3,47 & 2,37 \\
\hline 56,41 & 515,30 & 67,40 & 39,77 & 30,01 & 26,10 & 22,25 & 19,11 & 16,46 & 12,36 & 9,56 & 6,31 \\
\hline 88,07 & 508,30 & 173,50 & 22,50 & 13,18 & 10,37 & 8,34 & 7,05 & 6,07 & 4,62 & 3,66 & 2,50 \\
\hline 81,26 & 574,10 & 53,80 & 35,87 & 25,99 & 23,34 & 20,90 & 18,97 & 17,25 & 14,27 & 11,88 & 8,44 \\
\hline 82,96 & 1032,00 & 119,00 & 17,77 & 12,56 & 11,09 & 9,81 & 8,83 & 7,98 & 6,53 & 5,39 & 3,80 \\
\hline 77,42 & 984,20 & 54,40 & 28,92 & 21,95 & 20,34 & 18,74 & 17,31 & 15,99 & 13,59 & 11,56 & 8,45 \\
\hline 75,60 & 1867,00 & 173,20 & 11,46 & 8,47 & 7,62 & 6,80 & 6,14 & 5,55 & 4,53 & 3,73 & 2,61 \\
\hline 32,48 & 297,90 & 50,10 & 81,67 & 60,01 & 48,64 & 37,05 & 28,74 & 22,83 & 15,59 & 11,76 & 8,03 \\
\hline 49,26 & 777,10 & 137,10 & 24,14 & 17,54 & 14,79 & 12,12 & 10,03 & 8,37 & 6,00 & 4,55 & 3,01 \\
\hline 40,02 & 1313,50 & 174,50 & 18,90 & 14,51 & 12,31 & 9,97 & 8,12 & 6,67 & 4,68 & 3,51 & 2,33 \\
\hline 61,33 & 980,00 & 153,90 & 18,25 & 13,21 & 11,35 & 9,63 & 8,28 & 7,14 & 5,39 & 4,18 & 2,78 \\
\hline 64,17 & 1065,20 & 106,00 & 20,88 & $\begin{array}{l}15,98 \\
\end{array}$ & 14,25 & 12,52 & 11,09 & 9,82 & 7,73 & 6,17 & 4,16 \\
\hline 88,64 & 359,20 & 159,70 & 29,29 & 16,23 & 12,32 & 9,58 & 7,93 & 6,73 & 5,02 & 3,93 & 2,69 \\
\hline 21,22 & 1160,90 & 26,50 & 111,53 & $\begin{array}{l}97,38 \\
\end{array}$ & 84,64 & 68,79 & 55,55 & 45,07 & 30,91 & 22,82 & 15,07 \\
\hline 64,68 & 244,30 & 72,40 & 53,46 & 33,87 & 27,33 & 22,03 & 18,32 & 15,43 & 11,27 & 8,65 & 5,79 \\
\hline 62,62 & 1316,00 & 25,40 & 48,47 & 39,14 & 37,54 & 35,73 & 33,65 & 31,59 & 27,65 & 24,08 & 18,20 \\
\hline 89,16 & 1720,10 & 27,20 & 30,55 & 26,52 & 23,95 & 23,05 & 22,41 & 21,62 & 19,93 & 18,31 & 15,31 \\
\hline 31,84 & 1628,90 & 107,70 & 27,77 & 23,16 & 20,04 & 16,38 & 13,36 & 10,96 & 7,65 & 5,70 & 3,75 \\
\hline 44,32 & 1443,70 & 145,40 & 18,99 & 15,18 & 13,26 & 11,15 & 9,38 & 7,92 & 5,76 & 4,36 & 2,85 \\
\hline 65,73 & 986,60 & 31,10 & 45,09 & 36,05 & 34,25 & 32,03 & 29,81 & 27,68 & 23,72 & 20,27 & 14,87 \\
\hline 31,40 & 813,10 & 88,20 & 40,64 & 31,83 & 26,57 & 20,82 & 16,44 & 13,19 & 9,03 & 6,76 & 4,56 \\
\hline 79,18 & 1871,70 & 191,60 & 10,62 & 7,69 & 6,86 & 6,10 & 5,50 & 4,98 & 4,07 & 3,36 & 2,36 \\
\hline 39,84 & 730,00 & 85,40 & 36,82 & 28,84 & 24,69 & 20,17 & 16,53 & 13,65 & 9,63 & 7,23 & 4,77 \\
\hline 56,25 & 1456,00 & 123,40 & 17,97 & 14,35 & 12,87 & 11,28 & 9,92 & 8,71 & 6,75 & 5,32 & 3,53 \\
\hline 81,76 & 939,10 & 62,90 & 26,33 & 19,52 & 17,89 & 16,35 & 15,06 & 13,87 & 11,75 & 9,98 & 7,28 \\
\hline 36,64 & 1464,20 & 183,80 & 18,56 & 14,36 & 12,12 & 9,69 & 7,80 & 6,34 & 4,41 & 3,30 & 2,20 \\
\hline 41,33 & 1698,40 & 44,70 & 39,79 & 35,50 & 33,13 & 29,84 & 26,71 & 23,80 & 18,82 & 14,96 & 9,93 \\
\hline 69,82 & 632,60 & 59,70 & 34,77 & 26,22 & 23,52 & 20,87 & 18,69 & 16,75 & 13,47 & 10,93 & 7,51 \\
\hline 55,12 & 1813,30 & 173,60 & 13,61 & 10,75 & 9,55 & 8,30 & 7,23 & 6,30 & 4,81 & 3,76 & 2,48 \\
\hline 40,63 & 1537,40 & 79,90 & 28,46 & 24,56 & 22,14 & 19,18 & 16,54 & 14,24 & 10,64 & 8,14 & 5,29 \\
\hline 40,46 & 1045,40 & 94,20 & 29,81 & 24,22 & 21,14 & 17,65 & 14,73 & 12,34 & 8,86 & 6,67 & 4,36 \\
\hline 46,18 & 764,30 & 109,80 & 28,47 & 21,53 & 18,38 & 15,16 & 12,57 & 10,50 & 7,53 & 5,69 & 3,75 \\
\hline
\end{tabular}




\begin{tabular}{|c|c|c|c|c|c|c|c|c|c|c|c|}
\hline \multirow[b]{2}{*}{ e1 (cm) } & & & & & & & ões (x1 & m) & & & \\
\hline & Meq (MPa) & Ms (MPa) & D0 & D25 & D40 & D60 & D80 & D100 & D140 & D180 & D260 \\
\hline 21,21 & 1842,70 & 176,00 & 25,53 & 19,29 & 15,11 & 10,91 & 8,12 & 6,30 & 4,29 & 3,28 & 2,27 \\
\hline 51,86 & 806,40 & 58,70 & 37,28 & 30,59 & 27,57 & 24,18 & 21,20 & 18,57 & 14,29 & 11,19 & 7,39 \\
\hline 27,30 & 1473,50 & 146,10 & 26,21 & 20,49 & 16,83 & 12,87 & 9,96 & 7,88 & 5,35 & 4,02 & 2,74 \\
\hline 83,71 & 1552,20 & 177,70 & 11,81 & 8,33 & 7,36 & 6,52 & 5,87 & 5,31 & 4,36 & 3,60 & 2,54 \\
\hline 85,57 & 1571,80 & 71,70 & 19,19 & 14,42 & 13,35 & 12,50 & 11,71 & 10,96 & 9,57 & 8,35 & 6,36 \\
\hline 68,50 & 1401,60 & 106,70 & 17,88 & 13,79 & 12,55 & 11,26 & 10,17 & 9,18 & 7,46 & 6,11 & 4,23 \\
\hline 38,25 & 1625,00 & 63,80 & 33,76 & 29,83 & 27,11 & 23,68 & 20,55 & 17,78 & 13,37 & 10,27 & 6,66 \\
\hline 77,56 & 678,30 & 179,40 & 19,08 & 12,04 & 9,82 & 8,09 & 6,90 & 5,96 & 4,53 & 3,56 & 2,40 \\
\hline 25,39 & 1929,40 & 54,30 & 49,80 & 43,93 & 38,75 & 32,21 & 26,58 & 21,96 & 15,39 & 11,41 & 7,44 \\
\hline 65,60 & 1293,90 & 163,30 & 14,98 & 11,08 & 9,71 & 8,41 & 7,38 & 6,48 & 5,04 & 3,99 & 2,68 \\
\hline 72,19 & 752,20 & 182,30 & 18,22 & 11,85 & 9,77 & 8,09 & 6,90 & 5,94 & 4,48 & 3,50 & 2,35 \\
\hline 77,22 & 1480,80 & 119,10 & 15,48 & 11,51 & 10,45 & 9,42 & 8,57 & 7,81 & 6,47 & 5,39 & 3,82 \\
\hline 49,66 & 1983,00 & 193,90 & 13,08 & 10,43 & 9,20 & 7,88 & 6,76 & 5,81 & 4,33 & 3,33 & 2,18 \\
\hline 76,68 & 680,90 & 116,70 & 22,94 & 15,69 & 13,39 & 11,46 & 10,04 & 8,84 & 6,93 & 5,54 & 3,77 \\
\hline 49,81 & 1575,00 & 130,10 & 18,15 & 14,77 & 13,17 & 11,41 & 9,88 & 8,56 & 6,47 & 5,00 & 3,28 \\
\hline 46,53 & 1690,20 & 62,80 & 29,19 & 25,37 & 23,53 & 21,13 & 18,89 & 16,82 & 13,30 & 10,59 & 7,06 \\
\hline 21,62 & 1060,30 & 31,40 & 100,66 & 86,26 & 74,02 & 59,19 & 47,17 & 37,90 & 25,78 & 19,09 & 12,74 \\
\hline 65,26 & 1531,10 & 50,10 & 28,48 & 22,81 & 21,65 & 20,20 & 18,77 & 17,39 & 14,85 & 12,65 & 9,23 \\
\hline 63,82 & 878,80 & 147,30 & 19,34 & 13,76 & 11,77 & 9,97 & 8,58 & 7,41 & 5,61 & 4,37 & 2,91 \\
\hline 58,49 & 652,50 & 79,00 & 32,14 & 24,41 & 21,39 & 18,40 & 15,95 & 13,85 & 10,54 & 8,22 & 5,44 \\
\hline 79,10 & 1844,30 & 87,50 & 16,72 & 12,71 & 11,84 & 11,01 & 10,24 & 9,52 & 8,20 & 7,06 & 5,25 \\
\hline 64,82 & 328,10 & 121,80 & 36,34 & 21,85 & 17,15 & 13,50 & 11,06 & 9,21 & 6,64 & 5,09 & 3,43 \\
\hline 59,66 & 1806,30 & 184,60 & 12,60 & 9,75 & 8,66 & 7,55 & 6,62 & 5,81 & 4,49 & 3,54 & 2,36 \\
\hline 70,16 & 1942,40 & 164,90 & 11,98 & 9,10 & 8,23 & 7,35 & 6,62 & 5,96 & 4,83 & 3,95 & 2,73 \\
\hline 82,71 & 932,70 & 124,80 & 18,29 & 12,71 & 11,09 & 9,71 & 8,67 & 7,78 & 6,30 & 5,16 & 3,60 \\
\hline 71,93 & 1485,30 & 171,70 & 13,09 & 9,59 & 8,48 & 7,44 & 6,62 & 5,90 & 4,70 & 3,79 & 2,59 \\
\hline 30,47 & 829,80 & 82,10 & 43,21 & 34,18 & 28,60 & 22,43 & 17,71 & 14,20 & 9,71 & 7,26 & 4,89 \\
\hline 73,00 & 1964,00 & 142,20 & 12,73 & 9,68 & 8,85 & 8,00 & 7,28 & 6,62 & 5,47 & 4,54 & 3,20 \\
\hline 48,11 & 1974,60 & 29,90 & 45,69 & 38,80 & 37,49 & 35,14 & 32,66 & 30,23 & 25,68 & 21,71 & 15,60 \\
\hline 46,16 & 1344,40 & 26,80 & 56,55 & 49,12 & 46,88 & 43,25 & 39,65 & 36,20 & 29,93 & 24,71 & 17,14 \\
\hline 51,82 & 1314,80 & 156,80 & 17,18 & 13,28 & 11,58 & 9,84 & 8,40 & 7,18 & 5,33 & 4,09 & 2,69 \\
\hline 69,61 & 206,70 & 45,70 & 69,89 & 46,58 & 38,80 & 32,33 & 27,63 & 23,80 & 17,96 & 14,01 & 9,38 \\
\hline 49,26 & 1040,10 & 154,00 & 19,83 & 14,86 & 12,72 & 10,56 & 8,84 & 7,43 & 5,38 & 4,09 & 2,69 \\
\hline 87,15 & 1482,80 & 184,80 & 11,67 & 8,07 & 7,07 & 6,23 & 5,61 & 5,07 & 4,16 & 3,45 & 2,44 \\
\hline 51,78 & 1719,60 & 136,30 & 16,63 & 13,53 & 12,13 & 10,58 & 9,24 & 8,05 & 6,16 & 4,80 & 3,16 \\
\hline 37,10 & 1953,30 & 107,60 & 23,12 & 19,84 & 17,67 & 15,04 & 12,74 & 10,80 & 7,86 & 5,93 & 3,85 \\
\hline 57,50 & 1458,60 & 128,40 & 17,34 & 13,73 & 12,30 & 10,78 & 9,49 & 8,34 & 6,47 & 5,11 & 3,40 \\
\hline 50,34 & 725,40 & 22,50 & 73,05 & 62,60 & 58,96 & 53,84 & 48,95 & 44,34 & 36,17 & 29,54 & 20,25 \\
\hline 31,02 & 444,90 & 170,60 & 33,26 & 20,63 & 15,36 & 10,88 & 8,15 & 6,40 & 4,41 & 3,40 & 2,37 \\
\hline 35,15 & 1765,60 & 57,90 & 37,35 & 33,43 & 30,39 & 26,49 & 22,92 & 19,77 & 14,77 & 11,29 & 7,29 \\
\hline 66,04 & 1370,30 & 171,90 & 14,14 & 10,45 & 9,16 & 7,95 & 6,98 & 6,14 & 4,78 & 3,79 & 2,54 \\
\hline 50,92 & 1936,50 & 57,50 & 27,96 & 23,89 & 22,56 & 20,66 & 18,84 & 17,12 & 14,04 & 11,52 & 7,94 \\
\hline 37,02 & 1141,30 & 75,70 & 35,22 & 29,64 & 26,12 & 21,94 & 18,38 & 15,42 & 11,08 & 8,33 & 5,42 \\
\hline 40,85 & 476,90 & 176,90 & 28,76 & 17,97 & 13,87 & 10,33 & 7,98 & 6,36 & 4,38 & 3,33 & 2,29 \\
\hline 42,07 & 799,30 & 157,50 & 23,98 & 17,19 & 14,19 & 11,23 & 9,01 & 7,33 & 5,11 & 3,84 & 2,58 \\
\hline 45,70 & 1997,10 & 38,20 & 39,50 & 34,35 & 32,82 & 30,30 & 27,80 & 25,39 & 21,02 & 17,36 & 12,06 \\
\hline 73,21 & 1034,00 & 161,80 & 16,05 & 11,24 & 9,68 & 8,33 & 7,30 & 6,43 & 5,02 & 4,00 & 2,71 \\
\hline 59,43 & 203,60 & 171,00 & 44,84 & 21,92 & 15,14 & 10,60 & 8,11 & 6,48 & 4,49 & 3,46 & 2,42 \\
\hline 39,14 & 1067,00 & 152,50 & 22,57 & 17,13 & 14,42 & 11,56 & 9,34 & 7,62 & 5,32 & 3,99 & 2,66 \\
\hline 51,42 & 1660,00 & 45,80 & 34,07 & 29,01 & 27,51 & 25,30 & 23,16 & 21,12 & 17,45 & 14,40 & 10,01 \\
\hline 50,91 & 1228,00 & 97,60 & 23,49 & 19,14 & 17,14 & 14,92 & 12,99 & 11,30 & 8,61 & 6,69 & 4,40 \\
\hline 52,20 & 318,00 & 83,10 & 46,97 & 31,36 & 25,56 & 20,40 & 16,63 & 13,74 & 9,76 & 7,40 & 4,95 \\
\hline 46,64 & 601,10 & 76,10 & 38,66 & 29,82 & 25,73 & 21,44 & 17,95 & 15,10 & 10,92 & 8,28 & 5,44 \\
\hline 73,19 & 1814,40 & 180,20 & 11,53 & 8,55 & 7,65 & 6,78 & 6,09 & 5,47 & 4,42 & 3,61 & 2,49 \\
\hline 56,46 & 1257,60 & 171,60 & 15,93 & 11,94 & 10,35 & 8,80 & 7,54 & 6,48 & 4,85 & 3,75 & 2,47 \\
\hline 62,13 & 256,50 & 135,50 & 41,18 & 22,76 & 17,00 & 12,78 & 10,16 & 8,30 & 5,85 & 4,47 & 3,05 \\
\hline 38,87 & 1410,10 & 45,00 & 44,00 & 39,30 & 36,13 & 31,99 & 28,13 & 24,65 & 18,91 & 14,71 & 9,59 \\
\hline 86,99 & 1283,10 & 84,40 & 18,88 & 13,81 & 12,62 & 11,59 & 10,72 & 9,93 & 8,51 & 7,30 & 5,42 \\
\hline 68,04 & 239,90 & 167,00 & 39,84 & 20,36 & 14,53 & 10,54 & 8,25 & 6,69 & 4,70 & 3,61 & 2,49 \\
\hline 77,72 & 870,10 & 38,50 & 37,33 & 28,56 & 26,69 & 24,88 & 23,18 & 21,57 & 18,60 & 16,02 & 11,94 \\
\hline 42,17 & 1920,60 & 151,10 & 17,13 & 14,15 & 12,50 & 10,61 & 8,99 & 7,63 & 5,57 & 4,23 & 2,75 \\
\hline 36,30 & 819,60 & 89,00 & 36,51 & 28,84 & 24,57 & 19,83 & 16,07 & 13,14 & 9,16 & 6,85 & 4,55 \\
\hline 59,43 & 1603,00 & 50,70 & 29,44 & 24,15 & 22,93 & 21,25 & 19,62 & 18,06 & 15,20 & 12,77 & 9,12 \\
\hline 47,61 & 1874,80 & 148,70 & 16,08 & 13,20 & 11,77 & 10,16 & 8,76 & 7,56 & 5,67 & 4,37 & 2,85 \\
\hline 58,29 & 657,70 & 157,60 & 22,64 & 15,23 & 12,57 & 10,24 & 8,53 & 7,17 & 5,21 & 3,98 & 2,65 \\
\hline 70,91 & 786,10 & 198,60 & 17,24 & 11,15 & 9,16 & 7,54 & 6,40 & 5,49 & 4,12 & 3,21 & 2,15 \\
\hline 25,02 & 685,00 & 28,60 & 108,82 & 92,47 & 79,51 & 63,95 & 51,30 & 41,47 & 28,41 & 21,07 & 14,00 \\
\hline 57,50 & 1881,00 & 131,00 & 15,42 & 12,48 & 11,34 & 10,08 & 8,97 & 7,97 & 6,30 & 5,03 & 3,38 \\
\hline 68,42 & 904,80 & 32,10 & 44,45 & 35,17 & 33,27 & 31,05 & 28,87 & 26,79 & 22,95 & 19,60 & 14,39 \\
\hline 21,86 & 1515,40 & 86,70 & 43,97 & 35,45 & 29,10 & 22,09 & 16,93 & 13,28 & 8,95 & 6,73 & 4,61 \\
\hline 33,02 & 559,30 & 48,50 & 65,95 & 53,40 & 45,63 & 36,78 & 29,70 & 24,20 & 16,79 & 12,52 & 8,32 \\
\hline 31,72 & 1535,20 & 54,20 & 44,53 & 39,47 & 35,38 & 30,19 & 25,58 & 21,64 & 15,69 & 11,80 & 7,62 \\
\hline 49,84 & 1485,70 & 54,00 & 32,23 & 27,65 & 25,82 & 23,38 & 21,09 & 18,96 & 15,25 & 12,31 & 8,33 \\
\hline 63,77 & 716,40 & 88,10 & 27,79 & 20,75 & 18,20 & 15,77 & 13,81 & 12,11 & 9,37 & 7,39 & 4,95 \\
\hline 34,60 & 596,30 & 79,50 & 45,51 & 34,81 & 29,01 & 22,83 & 18,12 & 14,60 & 10,05 & 7,53 & 5,07 \\
\hline 37,19 & 1483,90 & 50,50 & 41,49 & 37,02 & 33,79 & 29,63 & 25,81 & 22,40 & 16,92 & 13,03 & 8,44 \\
\hline 80,97 & 874,70 & 119,30 & 19,48 & 13,58 & 11,84 & 10,33 & 9,21 & 8,24 & 6,63 & 5,41 & 3,75 \\
\hline 24,52 & 670,90 & 34,10 & 98,62 & 81,95 & 69,32 & 54,62 & 43,10 & 34,44 & 23,39 & 17,41 & 11,71 \\
\hline 39,96 & 1118,90 & 58,90 & 39,25 & 33,85 & 30,44 & 26,29 & 22,60 & 19,40 & 14,41 & 11,00 & 7,14 \\
\hline 50,06 & 1062,30 & 70,40 & 30,62 & 25,45 & 23,01 & 20,21 & 17,72 & 15,52 & 11,93 & 9,33 & 6,15 \\
\hline 32,07 & 1282,10 & 47,90 & 50,89 & 44,94 & 40,21 & 34,25 & 28,97 & 24,48 & 17,73 & 13,32 & 8,61 \\
\hline 32,12 & 1403,30 & 71,30 & 37,99 & 32,61 & 28,70 & 23,95 & 19,89 & 16,55 & 11,74 & 8,76 & 5,71 \\
\hline
\end{tabular}




\begin{tabular}{|c|c|c|c|c|c|c|c|c|c|c|c|}
\hline \multirow[b]{2}{*}{ e1 (cm) } & & & & & & & ões (x1 & m) & & & \\
\hline & Meq (MPa) & Ms (MPa) & D0 & D25 & D40 & D60 & D80 & D100 & D140 & D180 & D260 \\
\hline 20,74 & 258,20 & 86,10 & 73,17 & 44,83 & 31,51 & 21,14 & 15,55 & 12,24 & 8,60 & 6,69 & 4,69 \\
\hline 34,15 & 483,20 & 119,00 & 38,61 & 26,50 & 20,92 & 15,61 & 11,99 & 9,49 & 6,49 & 4,93 & 3,39 \\
\hline 23,04 & 460,70 & 177,20 & 35,59 & 21,50 & 15,23 & 10,31 & 7,60 & 5,98 & 4,19 & 3,25 & 2,28 \\
\hline 32,90 & 1641,10 & 115,90 & 25,75 & 21,37 & 18,50 & 15,14 & 12,37 & 10,17 & 7,11 & 5,30 & 3,49 \\
\hline 59,67 & 205,90 & 100,70 & 53,16 & 30,10 & 22,74 & 17,22 & 13,71 & 11,20 & 7,88 & 6,02 & 4,10 \\
\hline 53,34 & 1683,60 & 96,20 & 20,35 & 16,93 & 15,51 & 13,83 & 12,31 & 10,94 & 8,63 & 6,88 & 4,60 \\
\hline 39,45 & 709,40 & 183,40 & 23,89 & 16,24 & 12,99 & 9,93 & 7,77 & 6,22 & 4,28 & 3,24 & 2,21 \\
\hline 73,96 & 1975,80 & 149,40 & 12,26 & 9,27 & 8,45 & 7,62 & 6,93 & 6,30 & 5,21 & 4,32 & 3,05 \\
\hline 57,35 & 1404,20 & 99,20 & 20,51 & 16,58 & 15,06 & 13,37 & 11,89 & 10,56 & 8,32 & 6,64 & 4,45 \\
\hline 70,23 & 1465,20 & 52,50 & 26,85 & 21,12 & 19,95 & 18,65 & 17,37 & 16,15 & 13,88 & 11,90 & 8,79 \\
\hline 67,15 & 1794,60 & 45,60 & 28,21 & 22,49 & 21,43 & 20,28 & 19,04 & 17,83 & 15,53 & 13,47 & 10,13 \\
\hline 78,59 & 1265,80 & 140,60 & 15,10 & 10,86 & 9,63 & 8,52 & 7,65 & 6,89 & 5,60 & 4,59 & 3,20 \\
\hline 30,10 & 1439,20 & 164,10 & 22,86 & 17,72 & 14,64 & 11,32 & 8,85 & 7,05 & 4,81 & 3,61 & 2,45 \\
\hline 88,41 & 1622,90 & 117,40 & 14,05 & 10,17 & 9,25 & 8,45 & 7,79 & 7,21 & 6,15 & 5,26 & 3,89 \\
\hline 59,91 & 1594,80 & 186,20 & 13,24 & 10,07 & 8,85 & 7,65 & 6,67 & 5,82 & 4,46 & 3,49 & 2,32 \\
\hline 56,64 & 908,50 & 71,20 & 30,03 & 24,12 & 21,75 & 19,17 & 16,94 & 14,95 & 11,66 & 9,23 & 6,16 \\
\hline 39,36 & 842,40 & 108,80 & 30,29 & 23,36 & 19,83 & 16,04 & 13,05 & 10,71 & 7,51 & 5,63 & 3,74 \\
\hline 86,37 & 1281,60 & 143,80 & 14,27 & 10,00 & 8,85 & 7,85 & 7,10 & 6,44 & 5,32 & 4,43 & 3,15 \\
\hline 83,01 & 1072,60 & 20,70 & 47,50 & 38,74 & 35,71 & 34,46 & 33,15 & 31,68 & 28,77 & 26,02 & 21,11 \\
\hline 20,46 & 1129,90 & 39,70 & 87,67 & 73,27 & 61,54 & 47,88 & 37,31 & 29,53 & 19,88 & 14,82 & 10,04 \\
\hline 54,65 & 1257,10 & 63,00 & 29,15 & 24,30 & 22,45 & 20,20 & 18,15 & 16,27 & 13,03 & 10,50 & 7,10 \\
\hline 30,16 & 1748,60 & 98,80 & 29,92 & 25,25 & 21,91 & 17,91 & 14,61 & 11,98 & 8,35 & 6,21 & 4,09 \\
\hline 29,72 & 247,70 & 119,90 & 52,56 & 30,65 & 22,12 & 15,34 & 11,43 & 8,99 & 6,23 & 4,83 & 3,38 \\
\hline 38,28 & 1614,10 & 154,80 & 19,31 & 15,55 & 13,43 & 11,06 & 9,11 & 7,55 & 5,34 & 4,00 & 2,63 \\
\hline 39,50 & 1433,00 & 104,20 & 25,24 & 21,06 & 18,57 & 15,68 & 13,21 & 11,14 & 8,07 & 6,09 & 3,96 \\
\hline 63,21 & 865,10 & 89,90 & 25,30 & 19,32 & 17,17 & 15,03 & 13,26 & 11,70 & 9,15 & 7,27 & 4,88 \\
\hline 55,67 & 1449,40 & 53,20 & 30,62 & 25,58 & 24,05 & 22,01 & 20,08 & 18,26 & 15,02 & 12,36 & 8,58 \\
\hline 25,28 & 1971,80 & 47,70 & 54,15 & 48,33 & 42,95 & 36,06 & 30,02 & 24,98 & 17,67 & 13,13 & 8,50 \\
\hline 70,82 & 1859,30 & 193,20 & 11,14 & 8,29 & 7,39 & 6,52 & 5,82 & 5,21 & 4,17 & 3,37 & 2,31 \\
\hline 51,34 & 1355,50 & 116,20 & 20,24 & 16,35 & 14,57 & 12,64 & 10,97 & 9,52 & 7,22 & 5,61 & 3,68 \\
\hline 45,95 & 1804,70 & 178,20 & 15,01 & 12,02 & 10,54 & 8,92 & 7,56 & 6,42 & 4,71 & 3,58 & 2,34 \\
\hline 26,25 & 1519,00 & 148,50 & 26,38 & 20,56 & 16,79 & 12,74 & 9,80 & 7,73 & 5,23 & 3,94 & 2,70 \\
\hline 63,91 & 1309,80 & 20,70 & 54,84 & 44,35 & 42,38 & 40,74 & 38,66 & 36,54 & 32,42 & 28,60 & 22,13 \\
\hline 54,92 & 1427,70 & 157,50 & 15,99 & 12,41 & 10,92 & 9,39 & 8,12 & 7,02 & 5,31 & 4,12 & 2,71 \\
\hline 64,50 & 1796,10 & 127,00 & 15,03 & 11,83 & 10,80 & 9,69 & 8,72 & 7,85 & 6,34 & 5,16 & 3,54 \\
\hline 57,43 & 1995,40 & 158,90 & 13,44 & 10,75 & 9,69 & 8,55 & 7,56 & 6,67 & 5,22 & 4,14 & 2,76 \\
\hline 79,04 & 863,80 & 186,10 & 16,19 & 10,58 & 8,82 & 7,42 & 6,43 & 5,62 & 4,35 & 3,45 & 2,35 \\
\hline 82,59 & 1582,30 & 159,70 & 12,43 & 8,91 & 7,95 & 7,10 & 6,42 & 5,83 & 4,82 & 4,00 & 2,84 \\
\hline 71,99 & 247,30 & 188,20 & 37,55 & 18,71 & 13,14 & 9,41 & 7,32 & 5,93 & 4,16 & 3,20 & 2,22 \\
\hline 71,73 & 742,20 & 143,50 & 20,42 & 13,88 & 11,71 & 9,89 & 8,55 & 7,44 & 5,70 & 4,49 & 3,02 \\
\hline 71,88 & 745,10 & 133,50 & 21,05 & 14,48 & 12,32 & 10,47 & 9,09 & 7,94 & 6,12 & 4,83 & 3,26 \\
\hline 72,13 & 943,10 & 137,20 & 18,33 & 13,03 & 11,29 & 9,75 & 8,57 & 7,56 & 5,92 & 4,73 & 3,20 \\
\hline 32,42 & 954,60 & 194,60 & 22,57 & 16,04 & 12,78 & 9,58 & 7,36 & 5,82 & 3,98 & 3,01 & 2,07 \\
\hline 65,87 & 1691,70 & 48,90 & 27,85 & 22,26 & 21,20 & 19,91 & 18,59 & 17,31 & 14,92 & 12,81 & 9,48 \\
\hline 38,56 & 909,70 & 116,80 & 28,52 & 22,02 & 18,66 & 15,04 & 12,19 & 9,98 & 6,98 & 5,23 & 3,48 \\
\hline 30,01 & 1189,60 & 80,40 & 39,22 & 32,44 & 27,81 & 22,41 & 18,06 & 14,67 & 10,13 & 7,54 & 5,01 \\
\hline 45,19 & 994,00 & 83,60 & 30,32 & 24,80 & 21,94 & 18,73 & 15,98 & 13,65 & 10,08 & 7,69 & 5,02 \\
\hline 48,42 & 1776,00 & 32,80 & 43,83 & 37,49 & 36,00 & 33,48 & 30,93 & 28,45 & 23,88 & 19,97 & 14,13 \\
\hline 31,92 & 347,10 & 127,00 & 43,43 & 27,28 & 20,49 & 14,64 & 11,01 & 8,65 & 5,95 & 4,58 & 3,19 \\
\hline 45,26 & 1543,10 & 82,00 & 25,87 & 22,14 & 20,11 & 17,66 & 15,46 & 13,49 & 10,31 & 8,02 & 5,25 \\
\hline 39,69 & 429,10 & 106,50 & 40,30 & 27,62 & 22,19 & 17,04 & 13,37 & 10,73 & 7,39 & 5,59 & 3,80 \\
\hline 85,87 & 1833,80 & 192,70 & 10,34 & 7,30 & 6,49 & 5,79 & 5,25 & 4,77 & 3,95 & 3,30 & 2,36 \\
\hline 81,76 & 718,10 & 76,50 & 26,75 & 19,13 & 17,01 & 15,11 & 13,64 & 12,35 & 10,14 & 8,39 & 5,92 \\
\hline 70,72 & 1530,10 & 80,10 & 20,17 & 15,70 & 14,61 & 13,41 & 12,33 & 11,33 & 9,51 & 8,00 & 5,73 \\
\hline 36,13 & 1750,80 & 52,90 & 38,90 & 34,97 & 32,01 & 28,14 & 24,56 & 21,35 & 16,17 & 12,46 & 8,07 \\
\hline 65,31 & 576,40 & 154,30 & 23,58 & 15,26 & 12,46 & 10,15 & 8,51 & 7,21 & 5,31 & 4,09 & 2,73 \\
\hline 22,14 & 1632,90 & 109,30 & 36,12 & 28,69 & 23,34 & 17,53 & 13,35 & 10,45 & 7,05 & 5,32 & 3,65 \\
\hline 37,98 & 474,20 & 122,50 & 36,38 & 24,74 & 19,70 & 14,96 & 11,64 & 9,29 & 6,38 & 4,83 & 3,30 \\
\hline 86,94 & 1906,50 & 109,30 & 13,74 & 10,14 & 9,32 & 8,63 & 8,02 & 7,46 & 6,45 & 5,57 & 4,18 \\
\hline 30,55 & 1346,70 & 186,50 & 21,28 & 16,06 & 13,10 & 10,00 & 7,76 & 6,15 & 4,19 & 3,16 & 2,15 \\
\hline 73,39 & 1177,80 & 129,90 & 16,78 & 12,30 & 10,91 & 9,62 & 8,59 & 7,69 & 6,17 & 5,00 & 3,44 \\
\hline 70,75 & 200,20 & 44,00 & 71,86 & 47,80 & 39,84 & 33,24 & 28,46 & 24,57 & 18,60 & 14,55 & 9,75 \\
\hline 30,92 & 1788,90 & 53,50 & 43,56 & 39,05 & 35,19 & 30,21 & 25,74 & 21,88 & 15,97 & 12,03 & 7,75 \\
\hline 80,23 & 683,60 & 96,20 & 24,65 & 17,15 & 14,91 & 12,98 & 11,54 & 10,30 & 8,26 & 6,71 & 4,64 \\
\hline 77,67 & 1423,20 & 156,00 & 13,59 & 9,82 & 8,72 & 7,71 & 6,92 & 6,23 & 5,06 & 4,14 & 2,89 \\
\hline 86,68 & 1062,10 & 173,40 & 14,40 & 9,63 & 8,24 & 7,12 & 6,31 & 5,64 & 4,53 & 3,70 & 2,58 \\
\hline 47,17 & 1451,50 & 196,60 & 15,31 & 11,68 & 10,03 & 8,34 & 6,96 & 5,85 & 4,22 & 3,20 & 2,10 \\
\hline 44,75 & 1514,80 & 189,80 & 15,83 & 12,25 & 10,55 & 8,74 & 7,27 & 6,08 & 4,37 & 3,30 & 2,17 \\
\hline 30,86 & 1488,20 & 134,70 & 25,31 & 20,28 & 17,11 & 13,55 & 10,78 & 8,69 & 5,96 & 4,45 & 2,98 \\
\hline 69,31 & 1021,80 & 174,40 & 15,93 & 11,13 & 9,51 & 8,10 & 7,02 & 6,12 & 4,70 & 3,70 & 2,49 \\
\hline 89,03 & 1799,50 & 72,10 & 17,63 & 13,32 & 12,30 & 11,61 & 10,95 & 10,31 & 9,12 & 8,05 & 6,26 \\
\hline 38,95 & 789,10 & 185,20 & 22,84 & 15,84 & 12,77 & 9,82 & 7,71 & 6,18 & 4,26 & 3,21 & 2,19 \\
\hline 30,15 & 1948,60 & 163,50 & 20,67 & 16,68 & 14,10 & 11,18 & 8,90 & 7,17 & 4,92 & 3,67 & 2,46 \\
\hline 70,47 & 1866,20 & 134,10 & 13,69 & 10,52 & 9,61 & 8,67 & 7,87 & 7,14 & 5,86 & 4,84 & 3,39 \\
\hline 88,02 & 1999,90 & 129,20 & 12,16 & 8,88 & 8,12 & 7,47 & 6,92 & 6,42 & 5,52 & 4,74 & 3,54 \\
\hline 72,82 & 1625,90 & 168,00 & 12,62 & 9,33 & 8,32 & 7,36 & 6,59 & 5,91 & 4,76 & 3,87 & 2,67 \\
\hline 39,27 & 738,30 & 32,40 & 67,73 & 59,32 & 53,75 & 46,82 & 40,55 & 35,03 & 26,28 & 20,17 & 13,08 \\
\hline 29,41 & 504,70 & 102,80 & 44,99 & 31,78 & 24,93 & 18,31 & 13,87 & 10,89 & 7,43 & 5,67 & 3,91 \\
\hline 89,37 & 1937,90 & 155,20 & 11,08 & 7,94 & 7,17 & 6,52 & 5,99 & 5,52 & 4,69 & 4,00 & 2,94 \\
\hline 53,47 & 528,70 & 109,90 & 31,30 & 21,88 & 18,26 & 14,92 & 12,38 & 10,36 & 7,47 & 5,68 & 3,77 \\
\hline 83,04 & 800,20 & 94,80 & 22,61 & 15,92 & 14,03 & 12,39 & 11,14 & 10,05 & 8,21 & 6,77 & 4,76 \\
\hline 34,35 & 933,30 & 136,40 & 27,58 & 20,79 & 17,19 & 13,40 & 10,57 & 8,48 & 5,82 & 4,37 & 2,95 \\
\hline
\end{tabular}




\begin{tabular}{|c|c|c|c|c|c|c|c|c|c|c|c|}
\hline \multirow[b]{2}{*}{ e1 (cm) } & & & & & & & ões (x1 & m) & & & \\
\hline & Meq (MPa) & Ms (MPa) & D0 & D25 & D40 & D60 & D80 & D100 & D140 & D180 & D260 \\
\hline 56,36 & 532,20 & 82,80 & 35,15 & 25,79 & 22,12 & 18,62 & 15,83 & 13,52 & 10,03 & 7,71 & 5,09 \\
\hline 22,85 & 1852,40 & 191,50 & 22,83 & 17,31 & 13,68 & 10,00 & 7,50 & 5,84 & 3,96 & 3,02 & 2,09 \\
\hline 82,41 & 1166,90 & 181,50 & 13,64 & 9,30 & 8,01 & 6,93 & 6,14 & 5,47 & 4,37 & 3,55 & 2,46 \\
\hline 20,05 & 506,20 & 110,70 & 51,93 & 34,23 & 24,69 & 16,73 & 12,24 & 9,58 & 6,70 & 5,20 & 3,63 \\
\hline 28,83 & 1325,20 & 161,00 & 24,48 & 18,74 & 15,30 & 11,65 & 9,01 & 7,13 & 4,85 & 3,65 & 2,49 \\
\hline 49,75 & 1212,80 & 84,00 & 26,22 & 21,73 & 19,58 & 17,14 & 14,99 & 13,08 & 10,01 & 7,81 & 5,14 \\
\hline 75,36 & 834,80 & 43,40 & 35,87 & 27,47 & 25,56 & 23,57 & 21,78 & 20,12 & 17,09 & 14,52 & 10,59 \\
\hline 29,95 & 672,90 & 188,40 & 27,17 & 18,07 & 13,81 & 9,94 & 7,47 & 5,86 & 4,02 & 3,08 & 2,14 \\
\hline 49,42 & 1175,60 & 146,60 & 19,27 & 14,85 & 12,87 & 10,83 & 9,16 & 7,77 & 5,69 & 4,34 & 2,85 \\
\hline 43,18 & 1378,70 & 62,30 & 33,19 & 28,85 & 26,33 & 23,20 & 20,34 & 17,78 & 13,61 & 10,59 & 6,92 \\
\hline 73,85 & 585,50 & 87,00 & 28,96 & 20,41 & 17,66 & 15,25 & 13,42 & 11,86 & 9,32 & 7,45 & 5,07 \\
\hline 36,51 & 1106,60 & 149,70 & 23,50 & 17,97 & 15,07 & 11,97 & 9,59 & 7,77 & 5,38 & 4,03 & 2,70 \\
\hline 39,54 & 712,30 & 162,20 & 25,56 & 17,83 & 14,44 & 11,16 & 8,79 & 7,07 & 4,88 & 3,68 & 2,50 \\
\hline 39,58 & 1550,40 & 185,50 & 17,17 & 13,40 & 11,45 & 9,32 & 7,62 & 6,28 & 4,42 & 3,32 & 2,19 \\
\hline 71,73 & 1563,40 & 74,90 & 20,70 & 16,10 & 15,05 & 13,89 & 12,82 & 11,83 & 10,02 & 8,48 & 6,15 \\
\hline 60,10 & 248,60 & 83,10 & 51,13 & 31,81 & 25,30 & 20,02 & 16,38 & 13,60 & 9,75 & 7,44 & 5,00 \\
\hline 30,51 & 1002,60 & 27,30 & 83,69 & 75,48 & 68,21 & 58,79 & 50,24 & 42,83 & 31,38 & 23,69 & 15,24 \\
\hline 75,58 & 1391,50 & 166,60 & 13,43 & 9,68 & 8,53 & 7,50 & 6,68 & 5,98 & 4,79 & 3,89 & 2,68 \\
\hline 81,95 & 962,40 & 149,10 & 16,60 & 11,34 & 9,77 & 8,45 & 7,48 & 6,67 & 5,33 & 4,32 & 2,99 \\
\hline 38,45 & 892,00 & 81,70 & 35,85 & 29,05 & 25,19 & 20,82 & 17,22 & 14,31 & 10,16 & 7,62 & 5,00 \\
\hline 83,99 & 540,10 & 160,90 & 22,43 & 13,62 & 10,93 & 8,91 & 7,59 & 6,56 & 5,01 & 3,96 & 2,69 \\
\hline 67,70 & 1427,00 & 173,40 & 13,65 & 10,08 & 8,86 & 7,72 & 6,81 & 6,01 & 4,71 & 3,76 & 2,54 \\
\hline 35,46 & 1113,30 & 133,10 & 25,70 & 20,00 & 16,87 & 13,45 & 10,79 & 8,76 & 6,07 & 4,54 & 3,03 \\
\hline 56,69 & 991,70 & 65,30 & 30,53 & 24,87 & 22,67 & 20,18 & 17,98 & 15,99 & 12,65 & 10,11 & 6,79 \\
\hline 24,01 & 383,70 & 29,50 & 131,43 & 104,14 & 85,16 & 64,52 & 49,49 & 38,89 & 26,28 & 19,80 & 13,55 \\
\hline 60,71 & 1182,20 & 178,90 & 15,48 & 11,30 & 9,74 & 8,28 & 7,12 & 6,14 & 4,64 & 3,60 & 2,39 \\
\hline 44,66 & 1620,30 & 78,60 & 26,35 & 22,73 & 20,73 & 18,27 & 16,03 & 14,03 & 10,77 & 8,39 & 5,50 \\
\hline 72,31 & 1984,20 & 172,00 & 11,43 & 8,60 & 7,77 & 6,94 & 6,26 & 5,65 & 4,60 & 3,78 & 2,63 \\
\hline 81,61 & 1841,90 & 59,50 & 20,72 & 16,00 & 14,95 & 14,19 & 13,40 & 12,63 & 11,17 & 9,84 & 7,63 \\
\hline 24,64 & 1056,10 & 133,40 & 33,08 & 24,70 & 19,51 & 14,29 & 10,75 & 8,39 & 5,70 & 4,35 & 3,00 \\
\hline 31,03 & 1231,10 & 191,50 & 21,36 & 15,85 & 12,84 & 9,75 & 7,53 & 5,97 & 4,07 & 3,07 & 2,10 \\
\hline 74,99 & 817,40 & 160,20 & 18,14 & 12,19 & 10,27 & 8,68 & 7,53 & 6,58 & 5,08 & 4,02 & 2,72 \\
\hline 48,37 & 1762,80 & 45,30 & 35,05 & 30,27 & 28,68 & 26,30 & 23,99 & 21,80 & 17,87 & 14,65 & 10,09 \\
\hline 41,88 & 1904,60 & 67,00 & 28,93 & 25,56 & 23,55 & 20,95 & 18,52 & 16,32 & 12,65 & 9,92 & 6,51 \\
\hline 69,84 & 1212,70 & 172,00 & 14,64 & 10,51 & 9,13 & 7,89 & 6,92 & 6,09 & 4,75 & 3,78 & 2,55 \\
\hline 41,41 & 676,80 & 76,80 & 39,43 & 31,02 & 26,71 & 22,02 & 18,20 & 15,13 & 10,77 & 8,10 & 5,33 \\
\hline 22,40 & 565,10 & 126,60 & 43,29 & 29,05 & 21,42 & 14,78 & 10,86 & 8,48 & 5,89 & 4,56 & 3,18 \\
\hline 43,18 & 1092,30 & 39,80 & 48,16 & 42,34 & 39,06 & 34,80 & 30,84 & 27,23 & 21,20 & 16,68 & 10,98 \\
\hline 60,16 & 676,80 & 73,80 & 32,31 & 24,77 & 21,89 & 19,02 & 16,64 & 14,57 & 11,24 & 8,84 & 5,88 \\
\hline 55,56 & 1576,00 & 160,00 & 15,08 & 11,81 & 10,46 & 9,06 & 7,87 & 6,85 & 5,22 & 4,07 & 2,69 \\
\hline 82,29 & 805,90 & 134,80 & 19,11 & 12,90 & 11,03 & 9,49 & 8,37 & 7,43 & 5,91 & 4,78 & 3,29 \\
\hline 38,55 & 1131,80 & 162,20 & 21,44 & 16,27 & 13,67 & 10,92 & 8,80 & 7,17 & 4,99 & 3,74 & 2,50 \\
\hline 26,43 & 1387,10 & 186,00 & 23,11 & 17,27 & 13,77 & 10,20 & 7,74 & 6,06 & 4,12 & 3,13 & 2,16 \\
\hline 89,51 & 690,30 & 98,00 & 23,35 & 15,78 & 13,67 & 11,94 & 10,69 & 9,63 & 7,87 & 6,50 & 4,60 \\
\hline 87,70 & 1137,30 & 121,70 & 16,37 & 11,48 & 10,19 & 9,08 & 8,23 & 7,49 & 6,22 & 5,20 & 3,73 \\
\hline 36,78 & 1312,20 & 192,70 & 18,75 & 14,16 & 11,81 & 9,33 & 7,45 & 6,02 & 4,17 & 3,12 & 2,10 \\
\hline 49,24 & 1610,70 & 135,40 & 17,69 & 14,38 & 12,80 & 11,06 & 9,56 & 8,25 & 6,21 & 4,80 & 3,14 \\
\hline 45,66 & 1819,40 & 33,20 & 44,84 & 38,93 & 37,26 & 34,47 & 31,67 & 28,98 & 24,06 & 19,93 & 13,89 \\
\hline 47,92 & 249,70 & 77,20 & 56,94 & 36,84 & 29,37 & 22,80 & 18,19 & 14,78 & 10,32 & 7,81 & 5,29 \\
\hline 25,41 & 870,90 & 117,60 & 37,55 & 27,89 & 22,05 & 16,18 & 12,19 & 9,53 & 6,48 & 4,94 & 3,41 \\
\hline 41,50 & 713,60 & 97,20 & 33,52 & 25,64 & 21,79 & 17,72 & 14,50 & 11,96 & 8,44 & 6,34 & 4,20 \\
\hline 67,76 & 796,30 & 127,40 & 21,28 & 15,10 & 12,97 & 11,08 & 9,62 & 8,39 & 6,45 & 5,08 & 3,40 \\
\hline 47,91 & 1949,70 & 61,30 & 27,76 & 24,06 & 22,55 & 20,48 & 18,51 & 16,66 & 13,43 & 10,86 & 7,35 \\
\hline 75,11 & 1249,10 & 192,80 & 13,24 & 9,24 & 7,97 & 6,87 & 6,04 & 5,33 & 4,19 & 3,36 & 2,29 \\
\hline 24,70 & 290,20 & 197,40 & 37,78 & 19,76 & 13,46 & 9,04 & 6,73 & 5,34 & 3,74 & 2,92 & 2,06 \\
\hline 24,59 & 1305,20 & 199,80 & 23,40 & 16,98 & 13,19 & 9,51 & 7,11 & 5,54 & 3,78 & 2,90 & 2,01 \\
\hline 58,72 & 1375,20 & 148,50 & 16,19 & 12,48 & 11,03 & 9,57 & 8,35 & 7,29 & 5,60 & 4,39 & 2,91 \\
\hline 88,77 & 312,90 & 188,50 & 30,98 & 16,07 & 11,67 & 8,69 & 6,99 & 5,81 & 4,23 & 3,28 & 2,25 \\
\hline 57,17 & 796,70 & 64,20 & 33,51 & 26,80 & 24,13 & 21,26 & 18,78 & 16,57 & 12,93 & 10,23 & 6,83 \\
\hline 56,71 & 1936,60 & 91,50 & 19,23 & 15,92 & 14,79 & 13,40 & 12,12 & 10,93 & 8,86 & 7,21 & 4,94 \\
\hline 23,68 & 303,10 & 160,30 & 443,05 & 24,12 & 16,71 & 11,25 & 8,33 & 6,59 & 4,62 & 3,60 & 2,53 \\
\hline 86,45 & 1390,50 & 122,60 & 14,90 & 10,67 & 9,60 & 8,66 & 7,91 & 7,25 & 6,09 & 5,14 & 3,72 \\
\hline 33,22 & 923,50 & 20,10 & 98,23 & $\begin{array}{l}89,83 \\
\end{array}$ & 82,74 & 73,18 & 64,17 & 56,03 & 42,67 & 32,97 & 21,34 \\
\hline 35,88 & 1897,20 & 93,90 & 26,16 & 22,66 & 20,23 & 17,24 & 14,62 & 12,39 & 9,02 & 6,81 & 4,41 \\
\hline 35,34 & 911,20 & 62,80 & 444,62 & 37,31 & 32,63 & 27,12 & 22,48 & 18,70 & 13,28 & 9,94 & 6,50 \\
\hline 50,39 & 1056,30 & 164,20 & 18,78 & 13,94 & 11,90 & 9,87 & 8,26 & 6,95 & 5,05 & 3,84 & 2,53 \\
\hline 48,57 & 1260,80 & 51,20 & 35,87 & 30,85 & 28,58 & 25,67 & 22,98 & 20,49 & 16,25 & 12,97 & 8,68 \\
\hline 26,72 & 1947,50 & 198,60 & 19,74 & 15,34 & 12,52 & 9,51 & 7,32 & 5,77 & 3,91 & 2,95 & 2,02 \\
\hline 70,38 & 1989,90 & 52,60 & 24,04 & 19,01 & 18,05 & 17,11 & 16,10 & 15,11 & 13,23 & 11,53 & 8,75 \\
\hline 72,24 & 397,80 & 100,60 & 33,85 & 21,83 & 17,92 & 14,78 & 12,57 & 10,80 & 8,12 & 6,34 & 4,26 \\
\hline 47,41 & 1731,60 & 102,80 & 20,84 & 17,60 & 15,95 & 14,00 & 12,26 & 10,72 & 8,21 & 6,40 & 4,20 \\
\hline 20,35 & 299,50 & 144,10 & 48,41 & 27,24 & 18,59 & 12,39 & 9,17 & 7,28 & 5,13 & 4,00 & 2,81 \\
\hline 84,91 & 1012,20 & 38,80 & 33,15 & 25,22 & 23,43 & 22,11 & 20,82 & 19,58 & 17,25 & 15,16 & 11,69 \\
\hline 68,33 & 1998,90 & 171,80 & 11,71 & 8,95 & 8,08 & 7,20 & 6,47 & 5,80 & 4,68 & 3,80 & 2,61 \\
\hline 77,31 & 1443,80 & 126,10 & 15,16 & 11,20 & 10,11 & 9,07 & 8,23 & 7,47 & 6,16 & 5,10 & 3,60 \\
\hline 34,83 & 447,00 & 175,60 & 31,38 & 19,39 & 14,62 & 10,55 & 7,98 & 6,30 & 4,33 & 3,32 & 2,31 \\
\hline 70,63 & 1526,40 & 103,40 & 17,32 & 13,34 & 12,24 & 11,08 & 10,08 & 9,17 & 7,56 & 6,26 & 4,41 \\
\hline 50,27 & 1516,00 & 137,00 & 17,78 & 14,30 & 12,69 & 10,94 & 9,44 & 8,15 & 6,13 & 4,73 & 3,10 \\
\hline 38,94 & 1297,20 & 157,00 & 20,60 & 16,04 & 13,67 & 11,09 & 9,04 & 7,43 & 5,21 & 3,91 & 2,59 \\
\hline 60,23 & 1991,20 & 163,10 & 12,90 & 10,20 & 9,20 & 8,13 & 7,22 & 6,41 & 5,05 & 4,03 & 2,71 \\
\hline 89,02 & 1599,30 & 94,10 & 15,93 & 11,69 & 10,71 & 9,91 & 9,22 & 8,58 & 7,43 & 6,43 & 4,85 \\
\hline 73,88 & 1644,90 & 42,80 & 28,43 & 22,37 & 21,14 & 20,13 & 19,02 & 17,91 & 15,80 & 13,89 & 10,68 \\
\hline
\end{tabular}




\begin{tabular}{|c|c|c|c|c|c|c|c|c|c|c|c|}
\hline & & & \multicolumn{9}{|c|}{ Deflexões $\left(\times 10^{-4} \mathrm{~cm}\right)$} \\
\hline e1 (cm) & Meq (MPa) & Ms (MPa) & D0 & D25 & D40 & D60 & D80 & D100 & D140 & D180 & D260 \\
\hline 86,70 & 1962,40 & 116,30 & 13,12 & 9,67 & 8,88 & 8,20 & 7,61 & 7,08 & 6,10 & 5,26 & 3,93 \\
\hline 21,07 & 1269,80 & 95,80 & 44,18 & 34,31 & 27,36 & 20,10 & 15,09 & 11,73 & 7,94 & 6,04 & 4,17 \\
\hline 83,04 & 957,30 & 191,90 & 14,82 & 9,71 & 8,15 & 6,90 & 6,03 & 5,31 & 4,17 & 3,35 & 2,30 \\
\hline 50,55 & 1853,90 & 119,20 & 17,76 & 14,78 & 13,40 & 11,80 & 10,38 & 9,11 & 7,04 & 5,52 & 3,65 \\
\hline 78,96 & 1829,10 & 164,00 & 11,68 & 8,56 & 7,72 & 6,92 & 6,28 & 5,71 & 4,71 & 3,91 & 2,77 \\
\hline 61,68 & 953,00 & 149,90 & 18,69 & 13,52 & 11,62 & 9,86 & 8,48 & 7,32 & 5,52 & 4,30 & 2,85 \\
\hline 21,38 & 842,60 & 159,60 & 33,62 & 23,02 & 17,05 & 11,76 & 8,63 & 6,73 & 4,67 & 3,61 & 2,52 \\
\hline 79,21 & 1009,30 & 95,90 & 20,48 & 14,93 & 13,40 & 11,97 & 10,84 & 9,83 & 8,09 & 6,70 & 4,73 \\
\hline 82,30 & 1431,70 & 51,10 & 24,96 & 19,14 & 17,86 & 16,88 & 15,90 & 14,95 & 13,17 & 11,56 & 8,90 \\
\hline 86,89 & 1705,60 & 38,10 & 26,40 & 21,30 & 19,56 & 18,82 & 18,07 & 17,26 & 15,65 & 14,14 & 11,46 \\
\hline 60,08 & 1309,70 & 91,10 & 21,63 & 17,34 & 15,80 & 14,10 & 12,61 & 11,27 & 8,98 & 7,23 & 4,90 \\
\hline 46,21 & 1740,50 & 158,70 & 16,26 & 13,15 & 11,59 & 9,88 & 8,42 & 7,18 & 5,30 & 4,04 & 2,64 \\
\hline 30,06 & 1899,90 & 29,00 & 65,93 & 61,13 & 56,58 & 50,27 & 44,24 & 38,74 & 29,62 & 22,93 & 14,83 \\
\hline 35,26 & 1747,30 & 97,90 & 26,60 & 22,74 & 20,13 & 16,96 & 14,23 & 11,96 & 8,60 & 6,46 & 4,19 \\
\hline 82,04 & 1818,00 & 32,10 & 29,76 & 24,52 & 22,58 & 21,83 & 21,03 & 20,13 & 18,33 & 16,61 & 13,53 \\
\hline 28,36 & 617,10 & 170,80 & 30,59 & 20,31 & 15,39 & 10,97 & 8,20 & 6,42 & 4,41 & 3,39 & 2,36 \\
\hline 44,07 & 900,20 & 73,80 & 34,57 & 28,39 & 25,11 & 21,40 & 18,21 & 15,51 & 11,41 & 8,69 & 5,67 \\
\hline 34,67 & 987,60 & 133,00 & 27,28 & 20,84 & 17,36 & 13,65 & 10,84 & 8,73 & 6,01 & 4,50 & 3,03 \\
\hline 85,85 & 1203,20 & 195,00 & 12,80 & 8,59 & 7,36 & 6,35 & 5,63 & 5,03 & 4,04 & 3,29 & 2,29 \\
\hline 78,74 & 1916,50 & 119,30 & 13,72 & 10,31 & 9,50 & 8,70 & 8,01 & 7,38 & 6,24 & 5,29 & 3,84 \\
\hline 57,08 & 1403,40 & 83,10 & 22,92 & 18,77 & 17,22 & 15,43 & 13,83 & 12,37 & 9,87 & 7,94 & 5,37 \\
\hline 33,47 & 329,50 & 170,90 & 36,82 & 21,12 & 15,34 & 10,77 & 8,08 & 6,36 & 4,40 & 3,40 & 2,38 \\
\hline 34,73 & 457,40 & 130,80 & 36,97 & 24,60 & 19,18 & 14,19 & 10,86 & 8,58 & 5,88 & 4,48 & 3,09 \\
\hline 55,02 & 1474,60 & 174,30 & 14,89 & 11,44 & 10,02 & 8,58 & 7,39 & 6,37 & 4,79 & 3,71 & 2,44 \\
\hline 67,54 & 1745,20 & 131,20 & $\begin{array}{l}1+, 0 \mathrm{~J} \\
14,57\end{array}$ & 11,29 & 10,28 & 9,22 & 8,32 & 7,50 & 6,09 & 4,98 & $\frac{2,+7}{3,44}$ \\
\hline 25,08 & 1915,80 & 180,70 & 22,12 & 17,21 & 13,97 & 10,52 & 8,04 & 6,32 & 4,28 & 3,23 & 2,21 \\
\hline 31,75 & 709,50 & 173,70 & 27,32 & 18,73 & 14,63 & 10,76 & 8,18 & 6,44 & 4,41 & 3,36 & 2,32 \\
\hline 50,92 & 382,20 & 131,80 & 34,57 & 21,70 & 17,12 & 13,27 & 10,60 & 8,64 & 6,05 & 4,59 & 3,11 \\
\hline 55,60 & 329,80 & 61,00 & 52,26 & 37,22 & 31,44 & 26,06 & 21,90 & 18,51 & 13,54 & 10,35 & 6,85 \\
\hline 74,56 & 922,80 & 133,90 & 18,51 & 13,06 & 11,32 & 9,80 & 8,64 & 7,65 & 6,03 & 4,84 & 3,30 \\
\hline 73,65 & 606,30 & 32,30 & 49,26 & 37,91 & 35,25 & 32,41 & 29,88 & 27,52 & 23,25 & 19,65 & 14,22 \\
\hline 36,78 & 779,30 & 181,40 & 23,89 & 16,60 & 13,30 & 10,12 & 7,88 & 6,28 & 4,31 & 3,26 & 2,23 \\
\hline 20,58 & 1880,40 & 117,90 & 34,67 & 27,38 & 22,04 & 16,35 & 12,34 & 9,60 & 6,48 & 4,91 & 3,39 \\
\hline 89,93 & 880,30 & 29,50 & 39,59 & 30,46 & 28,05 & 26,68 & 25,33 & 23,99 & 21,44 & 19,11 & 15,12 \\
\hline 76,96 & 1301,60 & 172,10 & 13,56 & 9,62 & 8,41 & 7,34 & 6,52 & 5,82 & 4,65 & 3,76 & 2,59 \\
\hline 77,32 & 548,90 & 199,80 & 20,97 & 12,37 & 9,70 & 7,72 & 6,44 & 5,46 & 4,05 & 3,15 & 2,13 \\
\hline 60,74 & 810,40 & 118,90 & 22,94 & 16,83 & 14,54 & 12,38 & 10,67 & 9,23 & 6,98 & 5,43 & 3,60 \\
\hline 47,60 & 545,40 & 29,80 & 69,45 & 59,00 & 53,72 & 47,41 & 41,71 & 36,61 & 28,24 & 22,12 & 14,56 \\
\hline 42,90 & 596,60 & 178,50 & 25,30 & 16,60 & 13,18 & 10,09 & 7,94 & 6,38 & 4,41 & 3,34 & 2,28 \\
\hline 52,03 & 1670,40 & 78,30 & 23,61 & 19,94 & 18,43 & 16,56 & 14,84 & 13,26 & 10,56 & 8,47 & 5,70 \\
\hline 22,68 & 285,60 & 24,80 & 168,68 & 130,55 & 104,54 & 77,33 & 58,38 & 45,53 & 30,81 & 23,40 & 16,13 \\
\hline 78,76 & 819,40 & 170,50 & 17,34 & 11,41 & 9,55 & 8,05 & 6,99 & 6,12 & 4,74 & 3,77 & 2,56 \\
\hline 86,40 & 842,40 & 101,10 & 21,00 & 14,62 & 12,86 & 11,36 & 10,23 & 9,26 & 7,61 & 6,31 & 4,47 \\
\hline 22,74 & 231,40 & 147,90 & 50,04 & 26,49 & 17,98 & 12,03 & 8,95 & 7,11 & 4,99 & 3,89 & 2,75 \\
\hline 67,33 & 519,20 & 92,00 & 31,16 & 21,76 & 18,52 & 15,69 & 13,54 & 11,74 & 8,94 & 7,00 & 4,68 \\
\hline 32,87 & 636,50 & 52,50 & 60,10 & 48,96 & 41,95 & 33,92 & 27,46 & 22,41 & 15,56 & 11,60 & 7,69 \\
\hline 80,50 & 731,80 & 32,00 & 43,82 & 33,32 & 31,07 & 29,05 & 27,13 & 25,33 & 21,98 & 19,04 & 14,33 \\
\hline 35,04 & 776,30 & 198,50 & 23,20 & 15,81 & 12,48 & 9,33 & 7,18 & 5,69 & 3,90 & 2,96 & 2,03 \\
\hline 77,24 & 1023,30 & 116,80 & 18,56 & 13,37 & 11,83 & 10,44 & 9,35 & 8,39 & 6,78 & 5,54 & 3,85 \\
\hline 57,36 & 1582,10 & 133,90 & 16,37 & 13,02 & 11,69 & 10,27 & 9,05 & 7,97 & 6,20 & 4,90 & 3,27 \\
\hline 57,98 & 387,50 & 192,70 & 28,23 & 15,95 & 12,02 & 9,06 & 7,19 & 5,85 & 4,11 & 3,13 & 2,14 \\
\hline 83,61 & 1697,60 & 147,60 & 12,48 & 9,03 & 8,14 & 7,34 & 6,69 & 6,12 & 5,12 & 4,30 & 3,09 \\
\hline 25,93 & 980,00 & 146,40 & 30,71 & 22,53 & 17,73 & 12,97 & 9,76 & 7,63 & 5,20 & 3,96 & 2,74 \\
\hline 42,09 & 459,20 & 146,30 & 32,03 & 20,74 & 16,33 & 12,39 & 9,69 & 7,76 & 5,36 & 4,06 & 2,78 \\
\hline 61,04 & 696,40 & 153,10 & 21,85 & 14,88 & 12,39 & 10,22 & 8,61 & 7,30 & 5,38 & 4,13 & 2,75 \\
\hline 22,30 & 1372,30 & 60,40 & 57,51 & 47,76 & 40,13 & 31,29 & 24,45 & 19,40 & 13,10 & 9,77 & 6,61 \\
\hline 66,20 & 707,90 & 132,00 & 22,46 & 15,59 & 13,20 & 11,12 & 9,55 & 8,25 & 6,24 & 4,87 & 3,25 \\
\hline 72,61 & 630,50 & 134,90 & 22,88 & 15,23 & 12,72 & 10,66 & 9,17 & 7,94 & 6,06 & 4,76 & 3,20 \\
\hline 55,64 & 1139,30 & 142,10 & 18,60 & 14,16 & 12,35 & 10,55 & 9,07 & 7,82 & 5,87 & 4,54 & 2,99 \\
\hline 66,22 & 1452,30 & 146,70 & 14,96 & 11,35 & 10,12 & 8,90 & 7,91 & 7,02 & 5,56 & 4,46 & 3,02 \\
\hline 50,08 & 1449,20 & 126,40 & 19,04 & 15,38 & 13,68 & 11,81 & 10,21 & 8,83 & 6,65 & 5,14 & 3,37 \\
\hline 35,47 & 546,60 & 85,30 & 44,33 & 33,10 & 27,34 & 21,35 & 16,87 & 13,56 & 9,33 & 7,00 & 4,73 \\
\hline 55,35 & 544,10 & 159,20 & 25,45 & 16,47 & 13,29 & 10,57 & 8,63 & 7,14 & 5,09 & 3,87 & 2,59 \\
\hline 75,83 & 616,50 & 144,50 & 22,19 & 14,40 & 11,91 & 9,92 & 8,51 & 7,38 & 5,63 & 4,43 & 2,99 \\
\hline 27,31 & 1170,20 & 157,90 & 26,73 & 20,03 & 16,06 & 11,98 & 9,13 & 7,17 & 4,87 & 3,69 & 2,54 \\
\hline$\frac{L r, 01}{34,91}$ & 1796,30 & (60,90 & 36,10 & 32,23 & 29,24 & $\begin{array}{l}1+1,00 \\
25,41\end{array}$ & 21,92 & $\frac{1,1}{18,85}$ & 14,03 & 10,70 & 6,90 \\
\hline 79,22 & 1870,90 & 38,40 & 27,39 & 21,97 & 20,47 & 19,72 & 18,87 & 17,95 & 16,17 & 14,51 & 11,58 \\
\hline 39,77 & 1272,30 & 116,10 & 24,60 & 19,96 & 17,37 & 14,45 & 12,02 & 10,04 & 7,18 & 5,39 & 3,53 \\
\hline 84,55 & 1834,30 & 139,00 & 12,38 & 9,03 & 8,21 & 7,46 & 6,85 & 6,30 & 5,33 & 4,51 & 3,29 \\
\hline 20,53 & 1221,50 & 23,50 & 122,95 & 108,27 & 94,58 & 77,33 & 62,76 & 51,10 & 35,16 & 25,94 & 17,06 \\
\hline 52.67 & 1050,20 & 85,10 & 26,60 & 21,54 & 19,30 & 16,85 & 14.73 & 12.86 & 9,85 & 7.69 & 5,07 \\
\hline 38,34 & 1705,70 & 86,20 & 27,28 & 23,62 & 21,20 & 18,24 & 15,62 & 13,35 & 9,85 & 7,49 & 4,85 \\
\hline 30,28 & 661,70 & 21,40 & 113,86 & 101,31 & 90,71 & 77,22 & 65,25 & 55,06 & 39,75 & 29,81 & 19,24 \\
\hline 38,38 & 636,50 & 94,10 & 37,52 & 28,32 & 23,72 & 18,89 & 15,18 & 12,35 & 8,58 & 6,43 & 4,30 \\
\hline 83,85 & 1122,40 & 39,20 & 31,86 & 24,43 & 22,74 & 21,54 & 20,33 & 19,15 & 16,93 & 14,92 & 11,56 \\
\hline 77,92 & 1797,50 & 106,10 & 15,17 & 11,46 & 10,59 & 9,72 & 8,96 & 8,26 & 7,00 & 5,94 & 4,33 \\
\hline 89,78 & 1134,70 & 92,80 & 18,68 & 13,34 & 12,04 & 10,92 & 10,04 & 9,25 & 7,85 & 6,69 & 4,92 \\
\hline 62,07 & 761,50 & 55,60 & 35,51 & 28,15 & 25,61 & 22,86 & 20,47 & 18,32 & 14,65 & 11,82 & 8,04 \\
\hline 36,91 & 997,90 & 90,50 & 33,18 & 26,88 & 23,22 & 19,06 & 15,66 & 12,94 & 9,13 & 6,83 & 4,50 \\
\hline 69,08 & 568,60 & 64,90 & 35,08 & 25,99 & 22,98 & 20,14 & 17,85 & 15,85 & 12,53 & 10,05 & 6,83 \\
\hline 69,63 & 378,00 & 132,00 & 31,69 & 19,16 & 15,14 & 12,05 & 9,99 & 8,41 & 6,15 & 4,74 & 3,19 \\
\hline 51,71 & 1963,10 & 197,70 & 12,68 & 10,03 & 8,85 & 7,61 & 6,55 & 5,65 & 4,24 & 3,27 & 2,15 \\
\hline
\end{tabular}




\begin{tabular}{|c|c|c|c|c|c|c|c|c|c|c|c|}
\hline & & & \multicolumn{9}{|c|}{ Deflexões $\left(\times 10^{-4} \mathrm{~cm}\right)$} \\
\hline e1 (cm) & Meq (MPa) & Ms (MPa) & D0 & D25 & D40 & D60 & D80 & D100 & D140 & D180 & D260 \\
\hline 75,12 & 1918,60 & 123,80 & 13,74 & 10,44 & 9,61 & 8,75 & 8,02 & 7,35 & 6,15 & 5,16 & 3,70 \\
\hline 89,11 & 1465,20 & 53,10 & 22,90 & 17,47 & 16,12 & 15,28 & 14,46 & 13,66 & 12,15 & 10,77 & 8,45 \\
\hline 67,50 & 1828,30 & 135,30 & 14,04 & 10,89 & 9,93 & 8,91 & 8,05 & 7,26 & 5,90 & 4,83 & 3,34 \\
\hline 24,04 & 1638,50 & 32,10 & 78,62 & 70,85 & 63,23 & 53,34 & 44,59 & 37,23 & 26,42 & 19,64 & 12,68 \\
\hline 30,43 & 406,10 & 153,30 & 37,04 & 23,05 & 17,13 & 12,11 & 9,06 & 7,11 & 4,91 & 3,78 & 2,64 \\
\hline 69,75 & 738,50 & 121,80 & 22,35 & 15,69 & 13,45 & 11,48 & 9,99 & 8,73 & 6,73 & 5,31 & 3,57 \\
\hline 33,48 & 445,40 & 25,40 & 107,45 & 91,43 & 80,35 & 67,01 & 55,66 & 46,35 & 32,93 & 24,61 & 16,05 \\
\hline 26,16 & 864,80 & 96,50 & 42,37 & 32,44 & 26,20 & 19,65 & 15,01 & 11,79 & 7,99 & 6,05 & 4,15 \\
\hline 21,35 & 838,10 & 68,50 & 62,59 & 48,28 & 38,35 & 28,09 & 21,06 & 16,37 & 11,09 & 8,45 & 5,84 \\
\hline 71,51 & 870,20 & 47,00 & 34,59 & 26,82 & 24,92 & 22,86 & 21,01 & 19,29 & 16,20 & 13,62 & 9,77 \\
\hline 81,23 & 721,60 & 120,00 & 21,50 & 14,57 & 12,47 & 10,73 & 9,46 & 8,39 & 6,66 & 5,38 & 3,70 \\
\hline 67,35 & 1868,60 & 89,70 & 17,90 & 14,16 & 13,23 & 12,15 & 11,16 & 10,24 & 8,57 & 7,18 & 5,12 \\
\hline 28,05 & 332,30 & 76,40 & 64,60 & 44,46 & 34,20 & 24,64 & 18,48 & 14,47 & 9,91 & 7,60 & 5,27 \\
\hline 47,97 & 1757,50 & 103,20 & 20,50 & 17,31 & 15,71 & 13,82 & 12,13 & 10,62 & 8,16 & 6,38 & 4,19 \\
\hline 62,07 & 1503,20 & 116,60 & 17,36 & 13,70 & 12,41 & 11,04 & 9,86 & 8,80 & 7,01 & 5,64 & 3,82 \\
\hline 51,72 & 207,10 & 126,50 & 49,81 & 26,83 & 19,56 & 14,23 & 11,02 & 8,83 & 6,12 & 4,68 & 3,25 \\
\hline 34,08 & 891,50 & 108,70 & 32,54 & 25,20 & 21,11 & 16,67 & 13,27 & 10,71 & 7,37 & 5,52 & 3,71 \\
\hline 21,52 & 502,50 & 113,80 & 49,23 & 32,73 & 23,91 & 16,36 & 12,00 & 9,38 & 6,53 & 5,06 & 3,53 \\
\hline 40,21 & 1741,10 & 182,00 & 16,42 & 13,07 & 11,29 & 9,32 & 7,70 & 6,40 & 4,55 & 3,42 & 2,25 \\
\hline 72,02 & 1914,20 & 26,60 & 36,78 & 30,32 & 28,33 & 27,49 & 26,44 & 25,25 & 22,88 & 20,63 & 16,62 \\
\hline 71,36 & 568,70 & 172,10 & 22,11 & 13,76 & 11,06 & 8,95 & 7,51 & 6,39 & 4,74 & 3,67 & 2,47 \\
\hline 21,75 & 394,30 & 118,30 & 50,81 & 32,08 & 22,95 & 15,55 & 11,42 & 8,96 & 6,27 & 4,87 & 3,41 \\
\hline 38,99 & 828,10 & 165,40 & 23,89 & 17,10 & 13,99 & 10,91 & 8,64 & 6,96 & 4,81 & 3,62 & 2,45 \\
\hline 56,10 & 667,30 & 120,10 & 26,09 & 18,66 & 15,81 & 13,15 & 11,08 & 9,39 & 6,89 & 5,28 & 3,49 \\
\hline 23,97 & 944,80 & 195,80 & 26,45 & 18,20 & 13,70 & 9,62 & 7,12 & 5,55 & 3,82 & 2,95 & 2,05 \\
\hline 62,40 & 711,00 & 67,00 & 32,72 & 25,32 & 22,65 & 19,93 & 17,64 & 15,62 & 12,27 & 9,77 & 6,57 \\
\hline 69,80 & 1667,90 & 141,80 & 13,97 & 10,63 & 9,61 & 8,58 & 7,72 & 6,95 & 5,63 & 4,59 & 3,18 \\
\hline 67,86 & 480,10 & 189,60 & 23,99 & 14,13 & 11,00 & 8,62 & 7,06 & 5,89 & 4,26 & 3,27 & 2,21 \\
\hline 87,90 & 609,20 & 173,30 & 20,00 & 12,15 & 9,78 & 8,02 & 6,88 & 5,98 & 4,62 & 3,68 & 2,52 \\
\hline 22,51 & 781,80 & 177,40 & 30,91 & 20,71 & 15,27 & 10,54 & 7,75 & 6,05 & 4,20 & 3,25 & 2,27 \\
\hline 81,29 & 1765,00 & 91,10 & 16,36 & 12,31 & 11,42 & 10,59 & 9,84 & 9,14 & 7,87 & 6,77 & 5,03 \\
\hline 21,68 & 1661,10 & 167,50 & 26,84 & 20,22 & 15,84 & 11,45 & 8,53 & 6,63 & 4,51 & 3,45 & 2,39 \\
\hline 74,74 & 1951,70 & 69,40 & 19,52 & 15,16 & 14,28 & 13,42 & 12,56 & 11,74 & 10,19 & 8,83 & 6,63 \\
\hline 80,79 & 445,90 & 52,80 & 41,02 & 29,10 & 25,66 & 22,63 & 20,30 & 18,28 & 14,86 & 12,20 & 8,53 \\
\hline 63,34 & 1273,30 & 159,40 & 15,54 & 11,59 & 10,15 & 8,78 & 7,67 & 6,72 & 5,18 & 4,08 & 2,73 \\
\hline 36,65 & 537,60 & 191,20 & 27,12 & 17,17 & 13,17 & 9,66 & 7,38 & 5,84 & 4,01 & 3,06 & 2,12 \\
\hline 79,09 & 1499,50 & 149,30 & 13,46 & 9,77 & 8,74 & 7,79 & 7,03 & 6,36 & 5,22 & 4,31 & 3,03 \\
\hline 58,73 & 746,40 & 29,70 & 54,62 & 44,96 & 42,23 & 38,68 & 35,36 & 32,23 & 26,64 & 22,04 & 15,40 \\
\hline 31,32 & 730,20 & 81,30 & 44,58 & 34,79 & 28,98 & 22,65 & 17,85 & 14,30 & 9,78 & 7,33 & 4,95 \\
\hline 23,84 & 1582,30 & 194,10 & 23,01 & 17,17 & 13,50 & 9,83 & 7,37 & 5,74 & 3,91 & 2,98 & 2,06 \\
\hline 57,25 & 1847,50 & 70,50 & 23,04 & 19,10 & 17,95 & 16,44 & 15,02 & 13,67 & 11,28 & 9,31 & 6,49 \\
\hline 46,39 & 1147,10 & 180,40 & 17,99 & 13,39 & 11,36 & 9,30 & 7,68 & 6,39 & 4,56 & 3,45 & 2,28 \\
\hline 41,38 & 970,00 & 24,60 & 71,41 & 63,73 & 59,58 & 53,77 & 48,22 & 43,05 & 34,14 & 27,21 & 18,10 \\
\hline 28,87 & 856,80 & 39,90 & 71,92 & 61,62 & 53,77 & 44,21 & 36,20 & 29,76 & 20,78 & 15,44 & 10,13 \\
\hline 42,69 & 519,30 & 102,10 & 36,66 & 26,28 & 21,73 & 17,24 & 13,86 & 11,30 & 7,89 & 5,94 & 3,98 \\
\hline 65,23 & 1966,50 & 94,40 & 17,31 & 13,81 & 12,90 & 11,81 & 10,83 & 9,90 & 8,24 & 6,87 & 4,86 \\
\hline 50,99 & 417,70 & 194,20 & 27,68 & 16,09 & 12,22 & 9,17 & 7,20 & 5,81 & 4,04 & 3,08 & 2,11 \\
\hline 24,21 & 1123,00 & 37,60 & 79,37 & 68,51 & 59,41 & 48,27 & 39,03 & 31,73 & 21,84 & 16,16 & 10,68 \\
\hline 47,71 & 800,60 & 114,40 & 26,76 & 20,22 & 17,32 & 14,35 & 11,97 & 10,04 & 7,25 & 5,49 & 3,62 \\
\hline 49,51 & 516,70 & 184,10 & 25,42 & 15,86 & 12,45 & 9,58 & 7,61 & 6,18 & 4,31 & 3,27 & 2,22 \\
\hline 36,68 & 263,10 & 159,20 & 41,68 & 22,83 & 16,39 & 11,51 & 8,66 & 6,85 & 4,73 & 3,65 & 2,56 \\
\hline 70,96 & 1136,10 & 115,60 & 18,43 & 13,74 & 12,26 & 10,84 & 9,69 & 8,67 & 6,95 & 5,64 & 3,87 \\
\hline 57,46 & 1245,40 & 176,90 & 15,60 & 11,59 & 10,03 & 8,51 & 7,30 & 6,28 & 4,70 & 3,64 & 2,40 \\
\hline 25,54 & 900,00 & 138,80 & 33,00 & 24,05 & 18,82 & 13,68 & 10,27 & 8,02 & 5,47 & 4,18 & 2,89 \\
\hline 35,78 & 1458,30 & 185,00 & 18,80 & 14,51 & 12,19 & 9,70 & 7,77 & 6,30 & 4,36 & 3,26 & 2,18 \\
\hline 54,73 & 361,00 & 181,30 & 30,54 & 17,29 & 13,01 & 9,74 & 7,68 & 6,22 & 4,34 & 3,31 & 2,27 \\
\hline 73,72 & 1541,60 & 45,80 & 27,91 & 21,85 & 20,65 & 19,55 & 18,39 & 17,25 & 15,10 & 13,18 & 10,02 \\
\hline 50,69 & 989,60 & 24,80 & 61,69 & 52,62 & 50,07 & 46,18 & 42,37 & 38,72 & 32,11 & 26,60 & 18,56 \\
\hline 48,27 & 560,30 & 57,20 & 45,94 & 36,50 & 32,05 & 27,26 & 23,23 & 19,83 & 14,65 & 11,20 & 7,33 \\
\hline 70,44 & 1189,60 & 123,30 & 17,49 & 13,04 & 11,62 & 10,26 & 9,15 & 8,18 & 6,54 & 5,29 & 3,62 \\
\hline 36,00 & 929,70 & 77,90 & 38,10 & 31,15 & 26,97 & 22,17 & 18,22 & 15,06 & 10,61 & 7,94 & 5,22 \\
\hline 23,60 & 1744,80 & 35,40 & 73,28 & 65,69 & 58,38 & 48,95 & 40,69 & 33,80 & 23,83 & 17,67 & 11,45 \\
\hline 71,50 & 1964,90 & 53,80 & 23,55 & 18,57 & 17,60 & 16,69 & 15,70 & 14,73 & 12,90 & 11,25 & 8,55 \\
\hline 62,44 & 1662,80 & 78,80 & 21,14 & 17,07 & 15,93 & 14,55 & 13,29 & 12,10 & 10,00 & 8,28 & 5,80 \\
\hline 80,25 & 1595,70 & 34,00 & 31,10 & 24,89 & 23,16 & 22,30 & 21,33 & 20,29 & 18,28 & 16,39 & 13,09 \\
\hline 41,13 & 1059,60 & 168,00 & 20,75 & 15,48 & 12,99 & 10,42 & 8,44 & 6,90 & 4,83 & 3,63 & 2,42 \\
\hline 59,50 & 886,80 & 151,30 & 19,61 & 14,06 & 11,99 & 10,08 & 8,58 & 7,35 & 5,48 & 4,23 & 2,80 \\
\hline 32,92 & 1227,90 & 27,50 & 73,06 & 66,75 & 61,35 & 54,11 & 47,32 & 41,20 & 31,24 & 24,07 & 15,55 \\
\hline 78,52 & 1737,90 & 194,80 & 10,95 & 7,87 & 6,98 & 6,17 & 5,53 & 4,98 & 4,04 & 3,32 & 2,31 \\
\hline 31,26 & 555,40 & 145,30 & 33,71 & 22,79 & 17,65 & 12,88 & 9,75 & 7,66 & 5,25 & 4,01 & 2,77 \\
\hline 71,05 & 1164,50 & 122,70 & 17,64 & 13,10 & 11,66 & 10,29 & 9,18 & 8,20 & 6,56 & 5,31 & 3,64 \\
\hline 40,35 & 861,70 & 121,10 & 27,71 & 21,09 & 17,83 & 14,39 & 11,70 & 9,60 & 6,73 & 5,05 & 3,36 \\
\hline 46,52 & 292,10 & 50,60 & 66,88 & 48,93 & 41,19 & 33,50 & 27,52 & 22,80 & 16,21 & 12,23 & 8,12 \\
\hline 33,49 & 512,90 & 135,50 & 35,15 & 23,77 & 18,58 & 13,74 & 10,49 & 8,28 & 5,67 & 4,32 & 2,98 \\
\hline 54,38 & 1277,00 & 28,70 & 49,36 & 41,20 & 39,51 & 36,86 & 34,17 & 31,57 & 26,73 & 22,56 & 16,19 \\
\hline 87,47 & 402,80 & 113,90 & 30,35 & 18,48 & 14,90 & 12,22 & 10,48 & 9,12 & 7,04 & 5,60 & 3,83 \\
\hline 72,59 & 463,20 & 98,10 & 31,29 & 20,86 & 17,45 & 14,63 & 12,59 & 10,92 & 8,33 & 6,54 & 4,40 \\
\hline 72,97 & 1337,90 & 34,10 & 35,69 & 28,14 & 26,63 & 25,35 & 23,94 & 22,54 & 19,88 & 17,45 & 13,41 \\
\hline 68,56 & 1630,70 & 67,50 & 22,32 & 17,62 & 16,57 & 15,36 & 14,21 & 13,12 & 11,13 & 9,43 & 6,84 \\
\hline 69,59 & 1782,20 & 156,10 & 12,88 & 9,79 & 8,83 & 7,87 & 7,07 & 6,35 & 5,13 & 4,18 & 2,88 \\
\hline 79,45 & 1411,00 & 73,60 & 20,59 & 15,56 & 14,45 & 13,37 & 12,40 & 11,50 & 9,85 & 8,44 & 6,24 \\
\hline 80,58 & 531,60 & 199,80 & 21,23 & 12,36 & 9,64 & 7,65 & 6,38 & 5,43 & 4,04 & 3,16 & 2,14 \\
\hline
\end{tabular}




\begin{tabular}{|c|c|c|c|c|c|c|c|c|c|c|c|}
\hline \multirow[b]{2}{*}{ e1 (cm) } & & & & & & $\mathrm{De}$ & ões (x1 & & & & \\
\hline & Meq (MPa) & Ms (MPa) & D0 & D25 & D40 & D60 & D80 & D100 & D140 & D180 & D260 \\
\hline 72,23 & 1002,20 & 170,00 & 16,02 & 11,12 & 9,50 & 8,11 & 7,07 & 6,19 & 4,80 & 3,80 & 2,57 \\
\hline 47,27 & 704,00 & 67,50 & 38,43 & 30,84 & 27,15 & 23,12 & 19,71 & 16,83 & 12,44 & 9,50 & 6,21 \\
\hline 80,17 & 1814,80 & 32,80 & 30,12 & 24,60 & 22,77 & 22,01 & 21,16 & 20,21 & 18,34 & 16,56 & 13,40 \\
\hline 60,29 & 1331,20 & 182,80 & 14,50 & 10,76 & 9,35 & 7,99 & 6,91 & 5,99 & 4,54 & 3,54 & 2,35 \\
\hline 24,64 & 1961,30 & 146,30 & 25,78 & 20,58 & 16,95 & 12,95 & 10,00 & 7,89 & 5,33 & 4,01 & 2,73 \\
\hline 57,24 & 1664,20 & 57,40 & 27,35 & 22,68 & 21,42 & 19,71 & 18,07 & 16,52 & 13,72 & 11,40 & 8,00 \\
\hline 27,99 & 656,30 & 196,80 & 27,44 & 17,90 & 13,43 & 9,50 & 7,08 & 5,54 & 3,82 & 2,94 & 2,05 \\
\hline 89,81 & 1994,40 & 35,90 & 24,50 & 20,75 & 18,80 & 18,10 & 17,54 & 16,87 & 15,49 & 14,17 & 11,76 \\
\hline 49,11 & 1456,00 & 134,10 & 18,58 & 14,95 & 13,23 & 11,36 & 9,76 & 8,39 & 6,27 & 4,82 & 3,16 \\
\hline 21,19 & 1978,80 & 119,10 & 33,23 & 26,50 & 21,54 & 16,15 & 12,27 & 9,59 & 6,46 & 4,88 & 3,35 \\
\hline 29,63 & 594,70 & 151,00 & 32,92 & 22,32 & 17,18 & 12,43 & 9,35 & 7,34 & 5,03 & 3,85 & 2,67 \\
\hline 30,86 & 1138,60 & 79,90 & 39,11 & 32,30 & 27,73 & 22,41 & 18,11 & 14,75 & 10,21 & 7,60 & 5,04 \\
\hline 54,17 & 749,50 & 77,00 & 31,95 & 25,07 & 22,16 & 19,11 & 16,55 & 14,34 & 10,86 & 8,43 & 5,56 \\
\hline 66,59 & 1091,20 & 30,30 & 44,01 & 35,10 & 33,43 & 31,49 & 29,46 & 27,49 & 23,79 & 20,51 & 15,27 \\
\hline 69,52 & 1240,90 & 63,80 & 25,38 & 19,86 & 18,51 & 16,98 & 15,60 & 14,31 & 12,00 & 10,07 & 7,20 \\
\hline 70,23 & 1995,10 & 120,70 & 14,21 & 11,02 & 10,18 & 9,27 & 8,47 & 7,73 & 6,42 & 5,35 & 3,79 \\
\hline 86,71 & 1291,90 & 158,10 & 13,55 & 9,40 & 8,25 & 7,28 & 6,55 & 5,93 & 4,87 & 4,04 & 2,86 \\
\hline 34,25 & 1324,80 & 83,30 & 33,32 & 28,10 & 24,62 & 20,47 & 16,97 & 14,11 & 10,01 & 7,49 & 4,89 \\
\hline 80,48 & 1792,00 & 75,40 & 18,32 & 13,96 & 13,03 & 12,20 & 11,41 & 10,66 & 9,27 & 8,05 & 6,08 \\
\hline 47,37 & 383,00 & 29,90 & 79,74 & 65,59 & 58,50 & 50,52 & 43,59 & 37,59 & 28,20 & 21,71 & 14,20 \\
\hline 81,58 & 1569,50 & 44,20 & 26,41 & 20,61 & 19,23 & 18,36 & 17,42 & 16,47 & 14,67 & 13,01 & 10,20 \\
\hline 28,46 & 1317,70 & 150,10 & 25,94 & 20,00 & 16,37 & 12,50 & 9,68 & 7,66 & 5,20 & 3,92 & 2,67 \\
\hline 78,52 & 212,00 & 125,30 & 46,54 & 24,51 & 17,91 & 13,37 & 10,72 & 8,85 & 6,36 & 4,91 & 3,36 \\
\hline 56,81 & 1536,40 & 49,50 & 31,18 & 25,90 & 24,53 & 22,62 & 20,79 & 19,04 & 15,87 & 13,21 & 9,31 \\
\hline 68,97 & 1190,60 & 175,60 & 14,70 & 10,53 & 9,11 & 7,84 & 6,86 & 6,01 & 4,67 & 3,70 & 2,49 \\
\hline 34,85 & 568,70 & 103,70 & 39,07 & 28,40 & 23,10 & 17,74 & 13,86 & 11,07 & 7,58 & 5,72 & 3,89 \\
\hline 54,17 & 919,80 & 154,70 & 19,93 & 14,48 & 12,33 & 10,26 & 8,64 & 7,31 & 5,36 & 4,09 & 2,70 \\
\hline 74,43 & 1314,00 & 91,80 & 19,25 & 14,59 & 13,37 & 12,12 & 11,06 & 10,10 & 8,40 & 7,00 & 4,98 \\
\hline 37,10 & 1613,00 & 196,50 & 17,02 & 13,23 & 11,21 & 9,00 & 7,27 & 5,94 & 4,13 & 3,09 & 2,06 \\
\hline 88,02 & 1937,40 & 163,90 & 10,84 & 7,76 & 6,99 & 6,33 & 5,80 & 5,33 & 4,50 & 3,81 & 2,78 \\
\hline 26,92 & 1320,10 & 58,60 & 50,99 & 43,51 & 37,69 & 30,65 & 24,84 & 20,25 & 14,00 & 10,38 & 6,86 \\
\hline 63,10 & 1288,00 & 103,70 & 19,64 & 15,39 & 13,92 & 12,38 & 11,05 & 9,87 & 7,86 & 6,33 & 4,29 \\
\hline 57,67 & 1960,60 & 149,60 & 13,99 & 11,23 & 10,15 & 8,98 & 7,96 & 7,05 & 5,53 & 4,40 & 2,94 \\
\hline 70,03 & 1983,80 & 66,30 & 20,79 & 16,38 & 15,50 & 14,54 & 13,57 & 12,64 & 10,91 & 9,38 & 6,97 \\
\hline 63,07 & 1350,40 & 196,90 & 13,57 & 9,90 & 8,56 & 7,32 & 6,34 & 5,51 & 4,20 & 3,29 & 2,19 \\
\hline 44,09 & 491,90 & 121,10 & 33,67 & 23,04 & 18,70 & 14,64 & 11,68 & 9,48 & 6,60 & 4,98 & 3,36 \\
\hline 52,56 & 1203,80 & 167,40 & 17,11 & 12,89 & 11,13 & 9,37 & 7,94 & 6,76 & 4,98 & 3,81 & 2,51 \\
\hline 37,79 & 862,30 & 81,10 & 36,91 & 29,78 & 25,73 & 21,16 & 17,42 & 14,42 & 10,19 & 7,63 & 5,02 \\
\hline 53,33 & 1812,50 & 31,40 & 42,26 & 35,16 & 33,94 & 31,96 & 29,83 & 27,74 & 23,80 & 20,32 & 14,85 \\
\hline 37,71 & 398,40 & 148,30 & 35,32 & 22,10 & 16,92 & 12,43 & 9,51 & 7,53 & 5,18 & 3,95 & 2,73 \\
\hline 24,63 & 1682,50 & 86,90 & 38,80 & 32,21 & 27,24 & 21,46 & 16,93 & 13,53 & 9,19 & 6,84 & 4,60 \\
\hline 41,83 & 325,40 & 71,30 & 55,60 & 39,04 & 31,90 & 24,99 & 19,91 & 16,13 & 11,20 & 8,44 & 5,69 \\
\hline 67,02 & 1314,70 & 64,70 & 25,12 & 19,88 & 18,56 & 17,01 & 15,61 & 14,30 & 11,95 & 9,99 & 7,10 \\
\hline 47,95 & 681,00 & 61,40 & 40,82 & 32,98 & 29,18 & 25,00 & 21,44 & 18,39 & 13,69 & 10,50 & 6,87 \\
\hline 63,01 & 563,10 & 120,10 & 27,06 & 18,45 & 15,42 & 12,79 & 10,83 & 9,24 & 6,86 & 5,29 & 3,52 \\
\hline 57,21 & 704,50 & 154,90 & 22,19 & 15,22 & 12,67 & 10,38 & 8,66 & 7,29 & 5,31 & 4,05 & 2,69 \\
\hline 54,11 & 587,50 & 104,70 & 30,29 & 21,79 & 18,45 & 15,29 & 12,82 & 10,83 & 7,90 & 6,03 & 3,98 \\
\hline 39,44 & 1476,40 & 87,60 & 27,86 & 23,75 & 21,19 & 18,13 & 15,45 & 13,16 & 9,66 & 7,33 & 4,76 \\
\hline 40,97 & 1706,90 & 43,10 & 41,00 & 36,64 & 34,23 & 30,87 & 27,65 & 24,66 & 19,52 & 15,53 & 10,32 \\
\hline 48,69 & 205,40 & 112,50 & 53,02 & 29,57 & 21,89 & 16,05 & 12,43 & 9,95 & 6,88 & 5,26 & 3,64 \\
\hline 33,37 & 1032,10 & 170,60 & 23,47 & 17,32 & 14,11 & 10,83 & 8,44 & 6,73 & 4,60 & 3,47 & 2,36 \\
\hline 87,84 & 1691,30 & 91,90 & 15,87 & 11,74 & 10,80 & 10,03 & 9,35 & 8,72 & 7,57 & 6,57 & 4,96 \\
\hline 88,76 & 1012,00 & 70,60 & 22,95 & 16,64 & 15,15 & 13,88 & 12,82 & 11,87 & 10,16 & 8,72 & 6,47 \\
\hline 63,58 & 866,80 & 176,30 & 17,91 & 12,31 & 10,34 & 8,62 & 7,33 & 6,27 & 4,68 & 3,62 & 2,41 \\
\hline 53,43 & 553,80 & 180,00 & 24,13 & 15,29 & 12,18 & 9,54 & 7,71 & 6,33 & 4,47 & 3,39 & 2,28 \\
\hline 62,64 & 1271,80 & 45,30 & 33,21 & 26,87 & 25,43 & 23,54 & 21,74 & 20,02 & 16,88 & 14,21 & 10,18 \\
\hline 75,76 & 538,10 & 145,50 & 24,01 & 15,14 & 12,33 & 10,12 & 8,61 & 7,41 & 5,60 & 4,38 & 2,95 \\
\hline 57,17 & 362,20 & 20,70 & 90,72 & 74,40 & 68,42 & 61,42 & 55,14 & 49,40 & 39,55 & 31,89 & 21,62 \\
\hline 47,19 & 1311,60 & 168,40 & 17,46 & 13,43 & 11,58 & 9,66 & 8,10 & 6,82 & 4,94 & 3,75 & 2,46 \\
\hline 79,95 & 1687,30 & 130,40 & 13,67 & 10,09 & 9,18 & 8,32 & 7,60 & 6,95 & 5,81 & 4,88 & 3,50 \\
\hline 28,32 & 1046,30 & 81,30 & 42,41 & 34,31 & 28,87 & 22,72 & 17,95 & 14,38 & 9,82 & 7,33 & 4,93 \\
\hline 29,17 & 211,70 & 42,80 & 108,24 & 76,51 & 59,96 & 43,98 & 33,29 & 26,13 & 17,84 & 13,60 & 9,40 \\
\hline 26,29 & 1882,00 & 132,60 & 26,64 & 21,59 & 18,07 & 14,09 & 11,05 & 8,80 & 5,97 & 4,46 & 3,02 \\
\hline 55,90 & 1256,80 & 152,50 & 17,07 & 13,04 & 11,40 & 9,76 & 8,41 & 7,26 & 5,47 & 4,24 & 2,80 \\
\hline 47,22 & 758,20 & 127,70 & 25,95 & 19,06 & 16,10 & 13,15 & 10,85 & 9,02 & 6,44 & 4,86 & 3,22 \\
\hline 29,27 & 952,00 & 40,50 & 67,94 & 58,81 & 51,68 & 42,89 & 35,42 & 29,31 & 20,63 & 15,34 & 10,02 \\
\hline 82,83 & 283,80 & 30,20 & 67,38 & 48,01 & 42,69 & 37,96 & 34,29 & 31,08 & 25,58 & 21,20 & 15,01 \\
\hline 61,73 & 1000,50 & 177,40 & 16,78 & 11,88 & 10,10 & 8,49 & 7,26 & 6,23 & 4,66 & 3,61 & 2,40 \\
\hline 82,85 & 406,60 & 42,20 & 47,64 & 34,03 & 30,31 & 27,00 & 24,42 & 22,16 & 18,27 & 15,17 & 10,75 \\
\hline 55,48 & 571,10 & 143,50 & 26,01 & 17,41 & 14,28 & 11,52 & 9,50 & 7,92 & 5,69 & 4,33 & 2,89 \\
\hline 40,26 & 490,80 & 151,80 & 30,98 & 20,23 & 15,91 & 12,01 & 9,35 & 7,47 & 5,14 & 3,90 & 2,67 \\
\hline 26,23 & 1933,20 & 135,60 & 26,06 & 21,13 & 17,68 & 13,79 & 10,80 & 8,60 & 5,84 & 4,36 & 2,95 \\
\hline 50,40 & 620,40 & 195,80 & 22,28 & 14,30 & 11,40 & 8,89 & 7,14 & 5,83 & 4,09 & 3,10 & 2,09 \\
\hline 36,66 & 1082,20 & 59,70 & 42,09 & 36,11 & 32,12 & 27,28 & 23,07 & 19,51 & 14,16 & 10,68 & 6,93 \\
\hline 22,69 & 1144,10 & 84,90 & 47,06 & 37,10 & 30,08 & 22,55 & 17,15 & 13,42 & 9,06 & 6,85 & 4,70 \\
\hline 26,83 & 357,30 & 47,80 & 89,04 & 66,69 & 53,31 & 39,64 & 30,14 & 23,65 & 16,06 & 12,19 & 8,39 \\
\hline 20,14 & 1908,60 & 61,70 & 55,71 & 46,78 & 39,40 & 30,75 & 24,01 & 19,02 & 12,81 & 9,54 & 6,45 \\
\hline 61,64 & 523,60 & 156,70 & 25,23 & 16,05 & 12,94 & 10,38 & 8,58 & 7,18 & 5,20 & 3,98 & 2,66 \\
\hline 89,30 & 253,10 & 116,00 & 41,16 & 22,63 & 17,10 & 13,25 & 10,94 & 9,27 & 6,90 & 5,41 & 3,70 \\
\hline 80,13 & 1313,20 & 58,80 & 24,14 & 18,35 & 17,11 & 15,97 & 14,90 & 13,90 & 12,03 & 10,40 & 7,81 \\
\hline 60,58 & 394,90 & 29,50 & 68,44 & 54,46 & 49,42 & 43,96 & 39,23 & 34,97 & 27,78 & 22,30 & 15,08 \\
\hline 32,64 & 1023,00 & 157,40 & 25,11 & 18,73 & 15,30 & 11,75 & 9,17 & 7,30 & 4,99 & 3,76 & 2,56 \\
\hline
\end{tabular}




\begin{tabular}{|c|c|c|c|c|c|c|c|c|c|c|c|}
\hline \multirow[b]{2}{*}{$\mathrm{e} 1(\mathrm{~cm})$} & & & & & & $\mathrm{De}$ & $\overline{\text { ões (x1 }}$ & & & & \\
\hline & Meq (MPa) & Ms (MPa) & D0 & D25 & D40 & D60 & D80 & D100 & D140 & D180 & D260 \\
\hline 21,56 & 862,30 & 196,60 & 28,54 & 18,95 & 13,84 & 9,48 & 6,95 & 5,43 & 3,78 & 2,93 & 2,05 \\
\hline 68,76 & 1049,20 & 53,10 & 30,50 & 23,95 & 22,33 & 20,49 & 18,82 & 17,26 & 14,46 & 12,12 & 8,65 \\
\hline 71,00 & 229,30 & 196,50 & 39,31 & 19,03 & 13,09 & 9,18 & 7,06 & 5,67 & 3,95 & 3,04 & 2,12 \\
\hline 65,16 & 992,00 & 92,60 & 23,06 & 17,70 & 15,86 & 14,02 & 12,47 & 11,10 & 8,81 & 7,07 & 4,79 \\
\hline 20,52 & 721,70 & 143,30 & 38,71 & 26,08 & 19,06 & 13,02 & 9,53 & 7,44 & 5,18 & 4,02 & 2,80 \\
\hline 88,25 & 1130,80 & 41,50 & 29,65 & 22,60 & 20,89 & 19,78 & 18,70 & 17,65 & 15,66 & 13,86 & 10,84 \\
\hline 51,22 & 235,20 & 35,80 & 84,53 & 62,86 & 53,79 & 44,81 & 37,64 & 31,78 & 23,16 & 17,64 & 11,62 \\
\hline 64,62 & 391,80 & 174,70 & 28,43 & 16,35 & 12,52 & 9,64 & 7,79 & 6,43 & 4,59 & 3,51 & 2,38 \\
\hline 36,27 & 711,40 & 181,00 & 24,99 & 17,06 & 13,53 & 10,19 & 7,88 & 6,27 & 4,30 & 3,26 & 2,23 \\
\hline 84,08 & 1328,00 & 106,00 & 16,66 & 12,12 & 10,99 & 9,96 & 9,12 & 8,37 & 7,04 & 5,94 & 4,31 \\
\hline 26,66 & 1862,90 & 83,10 & 36,32 & 30,94 & 26,75 & 21,71 & 17,55 & 14,28 & 9,86 & 7,31 & 4,83 \\
\hline 46,15 & 1152,80 & 85,50 & 27,80 & 23,04 & 20,57 & 17,76 & 15,31 & 13,19 & 9,87 & 7,59 & 4,95 \\
\hline 55,38 & 1643,70 & 27,90 & 46,12 & 38,03 & 36,71 & 34,73 & 32,53 & 30,37 & 26,26 & 22,59 & 16,70 \\
\hline 48,49 & 946,70 & 194,50 & 18,42 & 13,01 & 10,82 & 8,73 & 7,15 & 5,91 & 4,20 & 3,17 & 2,11 \\
\hline 57,31 & 1869,70 & 150,60 & 14,26 & 11,40 & 10,27 & 9,05 & 7,99 & 7,06 & 5,51 & 4,36 & 2,91 \\
\hline 25,35 & 670,90 & 95,30 & 47,11 & 34,72 & 27,32 & 19,95 & 15,01 & 11,72 & 7,98 & 6,09 & 4,21 \\
\hline 26,28 & 327,60 & 127,10 & 47,52 & 29,09 & 21,07 & 14,52 & 10,75 & 8,44 & 5,87 & 4,55 & 3,18 \\
\hline 34,34 & 529,30 & 100,40 & 41,30 & 29,80 & 24,10 & 18,40 & 14,31 & 11,40 & 7,80 & 5,89 & 4,02 \\
\hline 32,24 & 796,10 & 143,50 & 29,36 & 21,31 & 17,16 & 12,98 & 10,02 & 7,94 & 5,42 & 4,10 & 2,80 \\
\hline 87,39 & 1420,20 & 47,90 & 24,96 & 19,17 & 17,74 & 16,86 & 15,97 & 15,10 & 13,44 & 11,93 & 9,37 \\
\hline 66,59 & 895,20 & 163,40 & 17,90 & 12,46 & 10,57 & 8,93 & 7,68 & 6,64 & 5,04 & 3,94 & 2,63 \\
\hline 34,75 & 1604,80 & 24,50 & 69,70 & 63,83 & 59,99 & 54,29 & 48,74 & 43,53 & 34,49 & 27,42 & 18,15 \\
\hline 75,81 & 468,40 & 83,60 & 32,88 & 22,39 & 19,05 & 16,24 & 14,18 & 12,45 & 9,70 & 7,73 & 5,24 \\
\hline 52,95 & 738,50 & 101,80 & 27,91 & 21,04 & 18,18 & 15,32 & 13,01 & 11,09 & 8,19 & 6,27 & 4,13 \\
\hline 31,75 & 1042,40 & 89,60 & 36,64 & 29,61 & 25,18 & 20,15 & 16,17 & 13,10 & 9,04 & 6,74 & 4,50 \\
\hline 63,71 & 608,80 & 155,50 & 22,98 & 15,07 & 12,37 & 10,10 & 8,47 & 7,17 & 5,27 & 4,06 & 2,71 \\
\hline 58,43 & 1370,00 & 156,40 & 15,81 & 12,11 & 10,65 & 9,20 & 8,00 & 6,97 & 5,32 & 4,16 & 2,76 \\
\hline 35,83 & 488,40 & 49,40 & 64,65 & 51,55 & 44,05 & 35,67 & 28,96 & 23,71 & 16,55 & 12,37 & 8,20 \\
\hline 66,16 & 846,30 & 178,90 & 17,74 & 12,03 & 10,06 & 8,39 & 7,15 & 6,14 & 4,60 & 3,57 & 2,38 \\
\hline 82,58 & 1440,60 & 138,60 & 14,00 & 10,08 & 9,03 & 8,08 & 7,33 & 6,67 & 5,53 & 4,60 & 3,28 \\
\hline 77,88 & 1438,50 & 29,70 & 36,04 & 28,84 & 26,95 & 25,95 & 24,79 & 23,56 & 21,18 & 18,95 & 15,06 \\
\hline 40,79 & 1280,00 & 186,70 & 18,14 & 13,72 & 11,58 & 9,34 & 7,59 & 6,22 & 4,37 & 3,28 & 2,18 \\
\hline 53,19 & 1847,20 & 127,90 & 16,51 & 13,55 & 12,27 & 10,82 & 9,55 & 8,41 & 6,53 & 5,15 & 3,41 \\
\hline 71,91 & 1938,40 & 87,00 & 17,36 & 13,52 & 12,67 & 11,73 & 10,86 & 10,04 & 8,55 & 7,27 & 5,30 \\
\hline 23,56 & 1984,70 & 112,30 & 31,95 & 26,10 & 21,76 & 16,84 & 13,10 & 10,37 & 7,01 & 5,24 & 3,56 \\
\hline 46,73 & 1989,10 & 22,70 & 56,68 & 47,85 & 46,49 & 43,95 & 41,11 & 38,30 & 32,95 & 28,17 & 20,60 \\
\hline 30,55 & 1307,70 & 121,70 & 28,49 & 22,72 & 19,11 & 15,07 & 11,95 & 9,60 & 6,58 & 4,91 & 3,30 \\
\hline 38,38 & 1347,70 & 21,20 & 75,77 & 68,21 & 64,69 & 59,13 & 53,67 & 48,45 & 39,20 & 31,71 & 21,41 \\
\hline 64,01 & 607,20 & 161,90 & 22,58 & 14,67 & 11,98 & 9,75 & 8,16 & 6,90 & 5,06 & 3,89 & 2,60 \\
\hline 66,60 & 1137,70 & 138,60 & 17,23 & 12,76 & 11,22 & 9,76 & 8,59 & 7,57 & 5,92 & 4,70 & 3,17 \\
\hline 79,99 & 927,10 & 40,10 & 34,94 & 26,61 & 24,83 & 23,22 & 21,68 & 20,24 & 17,56 & 15,20 & 11,43 \\
\hline 70,74 & 1614,90 & 23,60 & 42,99 & 35,13 & 32,99 & 31,97 & 30,65 & 29,21 & 26,36 & 23,66 & 18,90 \\
\hline 72,57 & 1370,70 & 127,30 & 15,89 & 11,88 & 10,68 & 9,51 & 8,55 & 7,70 & 6,24 & 5,10 & 3,54 \\
\hline 55,61 & 1216,10 & 196,40 & 15,19 & 11,09 & 9,48 & 7,95 & 6,73 & 5,73 & 4,23 & 3,24 & 2,14 \\
\hline 71,58 & 1840,80 & 119,40 & 14,63 & 11,25 & 10,35 & 9,40 & 8,58 & 7,83 & 6,49 & 5,40 & 3,82 \\
\hline 30,78 & 211,70 & 34,70 & 120,58 & 88,68 & 71,42 & 53,89 & 41,49 & 32,80 & 22,35 & 16,90 & 11,58 \\
\hline 30,82 & 1695,10 & 73,10 & 36,23 & 31,48 & 27,82 & 23,30 & 19,40 & 16,18 & 11,50 & 8,58 & 5,58 \\
\hline 86,40 & 915,10 & 73,90 & 23,74 & 17,13 & 15,50 & 14,06 & 12,89 & 11,85 & 10,01 & 8,48 & 6,18 \\
\hline 46,74 & 1569,20 & 77,00 & 26,17 & 22,44 & 20,52 & 18,18 & 16,04 & 14,12 & 10,94 & 8,58 & 5,66 \\
\hline 83,38 & 557,00 & 62,60 & 33,29 & 23,55 & 20,85 & 18,47 & 16,65 & 15,07 & 12,37 & 10,23 & 7,23 \\
\hline 51,54 & 1641,60 & 45,80 & 34,16 & 29,07 & 27,56 & 25,34 & 23,20 & 21,15 & 17,47 & 14,41 & 10,02 \\
\hline 71,31 & 1292,90 & 194,30 & 13,23 & 9,38 & 8,11 & 6,98 & 6,12 & 5,38 & 4,20 & 3,34 & 2,26 \\
\hline 54,06 & 1166,90 & 55,80 & 32,59 & 27,28 & 25,25 & 22,75 & 20,46 & 18,35 & 14,72 & 11,87 & 8,04 \\
\hline 74,47 & 1586,60 & 192,10 & 11,79 & 8,52 & 7,50 & 6,58 & 5,85 & 5,22 & 4,18 & 3,38 & 2,32 \\
\hline 72,90 & 1901,00 & 122,50 & 14,09 & 10,79 & 9,93 & 9,03 & 8,26 & 7,55 & 6,28 & 5,25 & 3,73 \\
\hline 50,30 & 925,90 & 52,60 & 38,50 & 32,37 & 29,53 & 26,17 & 23,15 & 20,42 & 15,91 & 12,55 & 8,31 \\
\hline 69,10 & 844,20 & 86,90 & 24,97 & 18,71 & 16,68 & 14,71 & 13,11 & 11,69 & 9,32 & 7,51 & 5,13 \\
\hline 50,30 & 1017,70 & 88,90 & 27,01 & 21,81 & 19,40 & 16,76 & 14,50 & 12,54 & 9,45 & 7,31 & 4,79 \\
\hline 87,88 & 682,20 & 29,80 & 44,63 & 33,53 & 30,98 & 29,11 & 27,34 & 25,67 & 22,57 & 19,80 & 15,24 \\
\hline 21,90 & 987,90 & 175,10 & 29,72 & 20,67 & 15,47 & 10,77 & 7,92 & 6,17 & 4,26 & 3,29 & 2,29 \\
\hline 86,66 & 1668,30 & 62,20 & 20,18 & 15,36 & 14,24 & 13,47 & 12,71 & 11,98 & 10,60 & 9,35 & 7,27 \\
\hline 37,96 & 377,80 & 150,80 & 35,77 & 21,99 & 16,71 & 12,21 & 9,33 & 7,39 & 5,08 & 3,88 & 2,69 \\
\hline 20,56 & 1310,30 & 72,20 & 54,68 & 43,77 & 35,59 & 26,69 & 20,27 & 15,82 & 10,65 & 8,05 & 5,53 \\
\hline 72,07 & 1877,10 & 56,40 & 23,10 & 18,14 & 17,18 & 16,22 & 15,23 & 14,26 & 12,43 & 10,81 & 8,16 \\
\hline 34,83 & 939,60 & 199,00 & 21,56 & 15,25 & 12,24 & 9,28 & 7,20 & 5,72 & 3,92 & 2,96 & 2,03 \\
\hline 71,39 & 692,80 & 173,70 & 19,58 & 12,67 & 10,41 & 8,59 & 7,30 & 6,27 & 4,71 & 3,67 & 2,46 \\
\hline 70,72 & 1546,60 & 125,70 & 15,37 & 11,69 & 10,61 & 9,50 & 8,58 & 7,75 & 6,31 & 5,18 & 3,60 \\
\hline 46,84 & 819,60 & 56,20 & 40,62 & 33,90 & 30,44 & 26,46 & 22,96 & 19,89 & 15,03 & 11,62 & 7,60 \\
\hline 57,46 & 210,40 & 115,10 & 50,26 & 27,71 & 20,58 & 15,32 & 12,06 & 9,77 & 6,83 & 5,22 & 3,58 \\
\hline 44,25 & 1959,20 & 148,90 & 16,59 & 13,74 & 12,21 & 10,46 & 8,95 & 7,66 & 5,67 & 4,33 & 2,82 \\
\hline 69,77 & 1787,80 & 85,30 & 18,42 & 14,43 & 13,49 & 12,43 & 11,46 & 10,54 & 8,89 & 7,49 & 5,40 \\
\hline 48,06 & 1663,30 & 175,00 & 15,26 & 12,08 & 10,58 & 8,97 & 7,63 & 6,50 & 4,79 & 3,66 & 2,39 \\
\hline 48,43 & 1538,00 & 27,20 & 52,17 & 44,54 & 42,84 & 39,91 & 36,92 & 34,01 & 28,63 & 24,01 & 17,05 \\
\hline 74,97 & 1303,20 & 185,50 & 13,20 & 9,33 & 8,10 & 7,02 & 6,20 & 5,50 & 4,35 & 3,49 & 2,39 \\
\hline 83,46 & 946,50 & 113,40 & 18,96 & 13,32 & 11,73 & 10,35 & 9,30 & 8,39 & 6,86 & 5,65 & 3,98 \\
\hline 32,10 & 1577,80 & 94,60 & 30,36 & 25,61 & 22,33 & 18,41 & 15,13 & 12,49 & 8,77 & 6,54 & 4,29 \\
\hline 21,99 & 618,20 & 175,50 & 33,59 & 21,48 & 15,47 & 10,52 & 7,73 & 6,06 & 4,23 & 3,29 & 2,30 \\
\hline 75,02 & 546,30 & 53,20 & 38,25 & 28,23 & 25,28 & 22,49 & 20,25 & 18,25 & 14,84 & 12,17 & 8,47 \\
\hline 83,87 & 355,30 & 156,60 & 29,96 & 16,75 & 12,76 & 9,94 & 8,21 & 6,94 & 5,14 & 4,01 & 2,72 \\
\hline 42,89 & 737,50 & 53,70 & 46,21 & 38,51 & 34,23 & 29,27 & 24,98 & 21,32 & 15,72 & 11,97 & 7,79 \\
\hline 85,75 & 232,20 & 31,90 & 71,61 & 49,15 & 42,75 & 37,39 & 33,44 & 30,07 & 24,44 & 20,10 & 14,11 \\
\hline 71,73 & 1681,60 & 95,60 & 17,31 & 13,39 & 12,41 & 11,35 & 10,42 & 9,55 & 8,00 & 6,71 & 4,80 \\
\hline
\end{tabular}




\begin{tabular}{|c|c|c|c|c|c|c|c|c|c|c|c|}
\hline & & & \multicolumn{9}{|c|}{ Deflexões $\left(\times 10^{-4} \mathrm{~cm}\right)$} \\
\hline e1 (cm) & Meq (MPa) & Ms (MPa) & D0 & D25 & D40 & D60 & D80 & D100 & D140 & D180 & D260 \\
\hline 83,52 & 264,10 & 171,40 & 36,22 & 18,57 & 13,35 & 9,83 & 7,83 & 6,46 & 4,64 & 3,58 & 2,46 \\
\hline 76,09 & 1883,90 & 52,50 & 23,28 & 18,22 & 17,16 & 16,33 & 15,42 & 14,53 & 12,82 & 11,27 & 8,69 \\
\hline 64,59 & 455,90 & 172,80 & 25,97 & 15,54 & 12,17 & 9,55 & 7,81 & 6,50 & 4,68 & 3,58 & 2,41 \\
\hline 22,47 & 1227,40 & 166,70 & 28,60 & 20,82 & 16,03 & 11,43 & 8,47 & 6,59 & 4,51 & 3,46 & 2,40 \\
\hline 37,48 & 1303,50 & 93,40 & 29,11 & 24,30 & 21,34 & 17,87 & 14,93 & 12,51 & 8,97 & 6,74 & 4,39 \\
\hline 39,09 & 637,20 & 60,10 & 48,73 & 39,34 & 34,12 & 28,22 & 23,36 & 19,43 & 13,82 & 10,37 & 6,81 \\
\hline 89,96 & 1151,10 & 140,80 & 15,00 & 10,30 & 9,04 & 7,98 & 7,20 & 6,54 & 5,40 & 4,50 & 3,22 \\
\hline 43,41 & 532,70 & 56,70 & 50,50 & 40,09 & 34,82 & 29,07 & 24,31 & 20,41 & 14,71 & 11,11 & 7,28 \\
\hline 43,80 & 1733,50 & 33,60 & 46,37 & 40,77 & 38,80 & 35,65 & 32,54 & 29,58 & 24,24 & 19,85 & 13,62 \\
\hline 75,16 & 1024,90 & 106,00 & 19,73 & 14,47 & 12,90 & 11,44 & 10,27 & 9,23 & 7,48 & 6,11 & 4,24 \\
\hline 37,36 & 654,60 & 90,30 & 38,70 & 29,52 & 24,79 & 19,75 & 15,86 & 12,89 & 8,95 & 6,70 & 4,48 \\
\hline 65,68 & 666,20 & 25,20 & 59,35 & 47,42 & 44,77 & 41,51 & 38,40 & 35,44 & 30,02 & 25,39 & 18,34 \\
\hline 55,53 & 720,90 & 192,50 & 20,01 & 13,22 & 10,77 & 8,65 & 7,10 & 5,91 & 4,23 & 3,22 & 2,15 \\
\hline 86,46 & 355,00 & 162,20 & 29,52 & 16,31 & 12,35 & 9,57 & 7,90 & 6,67 & 4,95 & 3,87 & 2,64 \\
\hline 47,65 & 907,20 & 125,90 & 24,02 & 18,24 & 15,65 & 13,00 & 10,86 & 9,12 & 6,59 & 4,99 & 3,29 \\
\hline 75,91 & 1140,80 & 115,80 & 17,83 & 13,06 & 11,66 & 10,36 & 9,31 & 8,39 & 6,82 & 5,59 & 3,89 \\
\hline 20,96 & 394,80 & 25,40 & 160,12 & 126,53 & 102,07 & 75,90 & 57,38 & 44,71 & 30,16 & 22,86 & 15,74 \\
\hline 40,37 & 626,40 & 151,70 & 27,78 & 19,13 & 15,44 & 11,91 & 9,39 & 7,55 & 5,21 & 3,93 & 2,67 \\
\hline 21,93 & 1039,80 & 137,50 & 34,95 & 25,43 & 19,52 & 13,86 & 10,26 & 7,97 & 5,46 & 4,20 & 2,92 \\
\hline 72,68 & 524,30 & 96,00 & 29,49 & 20,17 & 17,12 & 14,53 & 12,62 & 11,02 & 8,50 & 6,72 & 4,53 \\
\hline 49,99 & 1651,00 & 196,10 & 14,01 & 10,86 & 9,46 & 8,00 & 6,79 & 5,78 & 4,26 & 3,26 & 2,14 \\
\hline 76,95 & 1219,90 & 63,40 & 24,29 & 18,51 & 17,21 & 15,90 & 14,71 & 13,61 & 11,61 & 9,89 & 7,26 \\
\hline 74,48 & 1814,00 & 117,50 & 14,57 & 11,08 & 10,20 & 9,29 & 8,51 & 7,79 & 6,51 & 5,45 & 3,90 \\
\hline 69,51 & 601,90 & 131,00 & 24,16 & 16,16 & 13,48 & 11,24 & 9,62 & 8,29 & 6,26 & 4,89 & 3,27 \\
\hline 60,19 & 1497,00 & 39,30 & 35,48 & 28,95 & 27,67 & $\begin{array}{l}1+1, L+1 \\
25,89\end{array}$ & 24,08 & 22,32 & 19,06 & 16,22 & 11,81 \\
\hline 61,17 & 609,10 & 42,80 & 45,77 & 36,51 & 33,27 & 29,72 & 26,63 & 23,83 & 19,05 & 15,37 & 10,44 \\
\hline 26,57 & 800,10 & 186,20 & 27,33 & 18,66 & 14,20 & 10,11 & 7,53 & 5,89 & 4,04 & 3,11 & 2,16 \\
\hline 38,33 & 1786,70 & 150,70 & 18,87 & 15,45 & 13,47 & 11,19 & 9,30 & 7,75 & 5,53 & 4,15 & 2,72 \\
\hline 39,95 & 322,80 & 86,60 & 51,14 & 34,48 & 27,50 & 21,00 & 16,44 & 13,17 & 9,07 & 6,86 & 4,68 \\
\hline 85,85 & 736,90 & 154,30 & 18,72 & 12,08 & 10,08 & 8,51 & 7,44 & 6,56 & 5,17 & 4,16 & 2,86 \\
\hline 73,25 & 1825,40 & 47,40 & 25,80 & 20,32 & 19,22 & 18,29 & 17,27 & 16,26 & 14,33 & 12,58 & 9,66 \\
\hline 66,40 & 1182,20 & 175,50 & 15,00 & 10,81 & 9,35 & 8,02 & 6,98 & 6,10 & 4,69 & 3,69 & 2,47 \\
\hline 83,92 & 1317,40 & 185,00 & 12,59 & 8,66 & 7,52 & 6,56 & 5,86 & 5,25 & 4,24 & 3,47 & 2,43 \\
\hline 25,70 & 1432,00 & 132,30 & 29,53 & 23,12 & 18,88 & 14,32 & 11,01 & 8,67 & 5,87 & 4,42 & 3,03 \\
\hline 60,57 & 1672,30 & 170,80 & 13,51 & 10,43 & 9,26 & 8,09 & 7,11 & 6,25 & 4,85 & 3,83 & 2,56 \\
\hline 30,58 & 748,50 & 69,80 & 49,66 & 39,60 & 33,29 & 26,26 & 20,82 & 16,73 & 11,46 & 8,56 & 5,75 \\
\hline 57,04 & 1586,80 & 185,90 & 13,63 & 10,44 & 9,16 & 7,88 & 6,82 & 5,91 & 4,48 & 3,49 & 2,31 \\
\hline 23,23 & 432,50 & 197,40 & 33,54 & 19,47 & 13,62 & 9,18 & 6,78 & 5,35 & 3,75 & 2,92 & 2,05 \\
\hline 68,08 & 1006,60 & 163,10 & 16,70 & 11,81 & 10,14 & 8,65 & 7,52 & 6,55 & 5,04 & 3,96 & 2,66 \\
\hline 81,67 & 524,00 & 31,40 & 50,41 & 37,61 & 34,67 & 31,90 & 29,49 & 27,28 & 23,28 & 19,87 & 14,63 \\
\hline 39,15 & 1455,40 & 126,10 & 22,45 & 18,33 & 15,98 & 13,31 & 11,08 & 9,25 & 6,61 & 4,97 & 3,25 \\
\hline 69,02 & 1760,40 & 183,50 & 11,89 & 8,90 & 7,93 & 6,99 & 6,22 & 5,54 & 4,41 & 3,56 & 2,42 \\
\hline 45,54 & 857,80 & 195,70 & 19,81 & 13,75 & 11,28 & 8,93 & 7,19 & 5,88 & 4,12 & 3,11 & 2,08 \\
\hline 82,28 & 1672,50 & 148,30 & 12,62 & 9,16 & 8,25 & 7,42 & 6,76 & 6,16 & 5,13 & 4,29 & 3,07 \\
\hline 66,87 & 633,10 & 70,90 & 32,31 & 24,17 & 21,38 & 18,71 & 16,55 & 14,65 & 11,53 & 9,21 & 6,22 \\
\hline 60,59 & 1540,80 & 58,30 & 26,86 & 21,93 & 20,68 & 19,04 & 17,49 & 16,02 & 13,37 & 11,15 & 7,89 \\
\hline 59,93 & 1937,40 & 165,70 & 12,97 & 10,22 & 9,19 & 8,10 & 7,17 & 6,35 & 4,98 & 3,96 & 2,66 \\
\hline 42,03 & 1649,40 & 109,80 & 22,15 & 18,65 & 16,63 & 14,26 & 12,19 & 10,42 & 7,70 & 5,87 & 3,81 \\
\hline 26,43 & 849,30 & 95,60 & 42,61 & 32,64 & 26,39 & 19,83 & 15,16 & 11,92 & 8,08 & 6,11 & 4,19 \\
\hline 25,28 & 723,20 & 51,30 & 71,04 & 57,24 & 47,55 & 36,72 & 28,56 & 22,63 & 15,32 & 11,48 & 7,79 \\
\hline 63,89 & 1134,30 & 55,70 & 29,93 & 24,00 & 22,38 & 20,44 & 18,68 & 17,03 & 14,10 & 11,69 & 8,22 \\
\hline 49,41 & 1561,00 & 115,60 & 19,65 & 16,19 & 14,53 & 12,66 & 11,02 & 9,58 & 7,28 & 5,66 & 3,71 \\
\hline 27,24 & 1295,70 & 100,40 & 35,33 & 28,46 & 23,80 & 18,57 & 14,57 & 11,62 & 7,90 & 5,90 & 3,99 \\
\hline 71,45 & 1658,70 & 182,20 & 12,08 & 8,92 & 7,91 & 6,97 & 6,21 & 5,54 & 4,42 & 3,57 & 2,45 \\
\hline 41,33 & 1796,80 & 174,00 & 16,36 & 13,16 & 11,46 & 9,55 & 7,97 & 6,67 & 4,79 & 3,61 & 2,36 \\
\hline 47,18 & 571,60 & 38,30 & 58,80 & 49,16 & 44,23 & 38,53 & 33,50 & 29,09 & 22,06 & 17,08 & 11,18 \\
\hline 71,15 & 597,40 & 90,50 & 28,55 & 20,22 & 17,47 & 15,03 & 13,17 & 11,58 & 9,02 & 7,17 & 4,84 \\
\hline 71,84 & 619,60 & 107,10 & 25,74 & 17,83 & 15,21 & 12,97 & 11,28 & 9,87 & 7,63 & 6,04 & 4,07 \\
\hline 28,07 & 857,70 & 126,40 & 33,77 & 25,06 & 20,04 & 14,94 & 11,39 & 8,96 & 6,09 & 4,62 & 3,18 \\
\hline 32,73 & 715,40 & 88,80 & 41,17 & 31,74 & 26,39 & 20,64 & 16,30 & 13,07 & 8,96 & 6,72 & 4,53 \\
\hline 31,67 & 1022,80 & 90,00 & 36,82 & 29,66 & 25,17 & 20,10 & 16,09 & 13,02 & 8,98 & 6,70 & 4,47 \\
\hline 46,70 & 538,40 & 110,90 & 32,94 & 23,30 & 19,32 & $\begin{array}{l}20,20 \\
15,50\end{array}$ & 12,61 & 10,38 & 7,32 & 5,53 & 3,69 \\
\hline 41,51 & 817,90 & 41,90 & 53,14 & 45,89 & 44,46 & 36,07 & 31,24 & 27,00 & 20,28 & 15,59 & 10,13 \\
\hline 29,25 & 1935,10 & 103,10 & 28,80 & 24,37 & 21,13 & 17,25 & 14,04 & 11,49 & 7,98 & 5,93 & 3,91 \\
\hline 89,49 & 700,50 & 162,30 & 18,69 & 11,74 & 9,68 & 8,11 & 7,05 & 6,21 & 4,89 & 3,94 & 2,72 \\
\hline 57,02 & 1206,50 & 179,70 & 15,77 & 11,64 & 10,03 & 8,48 & 7,24 & 6,20 & 4,63 & 3,57 & 2,36 \\
\hline 64,52 & 637,80 & 56,80 & 37,02 & 28,61 & 25,72 & 22,77 & 20,29 & 18,07 & 14,36 & 11,54 & 7,83 \\
\hline 24,95 & 1500,80 & 125,50 & 30,84 & 24,33 & 19,92 & 15,13 & 11,63 & 9,16 & 6,19 & 4,66 & 3,19 \\
\hline 30,79 & 1684,60 & 139,10 & 23,79 & 19,27 & 16,36 & 13,05 & 10,43 & 8,44 & 5,80 & 4,33 & 2,89 \\
\hline 84,47 & 1252,30 & 77,20 & 20,38 & 15,06 & 13,84 & 12,73 & 11,79 & 10,92 & 9,35 & 8,01 & 5,93 \\
\hline 56.64 & 1308,70 & 30,50 & 45,73 & 37,80 & 36.24 & 33,89 & 31,48 & 29.15 & 24.81 & 21.04 & 15,22 \\
\hline 21,64 & 394,00 & 61,70 & 82,14 & 58,13 & 43,86 & 30,70 & 22,60 & 17,57 & 12,11 & 9,35 & 6,50 \\
\hline 87,98 & 294,10 & 65,40 & 45,46 & 28,87 & 23,92 & 20,11 & 17,52 & 15,44 & 12,16 & 9,79 & 6,75 \\
\hline 23,43 & 1577,40 & 115,70 & 33,64 & 26,69 & 21,80 & 16,49 & 12,62 & 9,91 & 6,69 & 5,04 & 3,45 \\
\hline 50,23 & 945,30 & 134,40 & 22,07 & 16,63 & 14,30 & 11,94 & 10,04 & 8,48 & 6,18 & 4,71 & 3,10 \\
\hline 43,97 & 1669,10 & 41,50 & 40,30 & 35,57 & 33,47 & 30,43 & 27,51 & 24,76 & 19,94 & 16,09 & 10,85 \\
\hline 83,01 & 1712,70 & 195,70 & 10,75 & 7,60 & 6,72 & 5,95 & 5,36 & 4,84 & 3,97 & 3,28 & 2,31 \\
\hline 78,66 & 728,40 & 52,30 & 33,25 & 24,79 & 22,66 & 20,59 & 18,85 & 17,27 & 14,47 & 12,16 & 8,74 \\
\hline 71,85 & 639,50 & 55,00 & 35,70 & 26,93 & 24,33 & 21,75 & 19,62 & 17,70 & 14,40 & 11,80 & 8,20 \\
\hline 70,12 & 1849,40 & 123,50 & 14,47 & 11,17 & 10,26 & 9,29 & 8,45 & 7,69 & 6,34 & 5,25 & 3,69 \\
\hline 34,75 & 1621,30 & 95,90 & 28,01 & 23,80 & 20,96 & 17,55 & 14,65 & 12,24 & 8,75 & 6,55 & 4,27 \\
\hline 73,00 & 375,30 & 21,40 & 76,71 & 59,03 & 54,70 & 50,09 & 46,02 & 42,25 & 35,48 & 29,84 & 21,43 \\
\hline
\end{tabular}




\begin{tabular}{|c|c|c|c|c|c|c|c|c|c|c|c|}
\hline \multirow[b]{2}{*}{ e1 (cm) } & & & & & & $\mathrm{De}$ & ões (x1 & & & & \\
\hline & Meq (MPa) & Ms (MPa) & D0 & D25 & D40 & D60 & D80 & D100 & D140 & D180 & D260 \\
\hline 49,58 & 1254,30 & 185,00 & 16,42 & 12,31 & 10,54 & 8,77 & 7,34 & 6,18 & 4,49 & 3,41 & 2,24 \\
\hline 29,40 & 1953,70 & 61,60 & 40,20 & 35,75 & 31,94 & 27,09 & 22,80 & 19,18 & 13,78 & 10,31 & 6,66 \\
\hline 42,75 & 910,90 & 154,30 & 22,74 & 16,75 & 14,03 & 11,27 & 9,15 & 7,51 & 5,27 & 3,96 & 2,64 \\
\hline 85,74 & 1112,60 & 97,80 & 18,71 & 13,44 & 12,10 & 10,91 & 9,96 & 9,12 & 7,65 & 6,45 & 4,66 \\
\hline 32,88 & 1496,60 & 161,70 & 21,45 & 16,87 & 14,19 & 11,23 & 8,94 & 7,22 & 4,97 & 3,71 & 2,49 \\
\hline 58,30 & 1632,20 & 156,60 & 14,63 & 11,45 & 10,20 & 8,91 & 7,82 & 6,86 & 5,31 & 4,18 & 2,78 \\
\hline 59,23 & 1024,80 & 74,30 & 27,18 & 21,79 & 19,79 & 17,60 & 15,69 & 13,96 & 11,07 & 8,86 & 5,97 \\
\hline 86,02 & 1619,20 & 29,50 & 31,37 & 26,08 & 23,83 & 23,00 & 22,22 & 21,31 & 19,47 & 17,72 & 14,55 \\
\hline 57,00 & 1124,50 & 173,40 & 16,62 & 12,20 & 10,48 & 8,83 & 7,53 & 6,44 & 4,79 & 3,69 & 2,44 \\
\hline 53,30 & 1581,80 & 187,10 & 14,12 & 10,89 & 9,52 & 8,12 & 6,96 & 5,98 & 4,47 & 3,44 & 2,26 \\
\hline 47,26 & 1495,90 & 113,00 & 20,85 & 17,21 & 15,38 & 13,30 & 11,50 & 9,93 & 7,46 & 5,75 & 3,76 \\
\hline 70,31 & 515,10 & 192,00 & 22,65 & 13,47 & 10,55 & 8,34 & 6,89 & 5,79 & 4,22 & 3,25 & 2,19 \\
\hline 60,50 & 896,50 & 55,50 & 33,79 & 27,23 & 25,00 & 22,46 & 20,22 & 18,16 & 14,63 & 11,86 & 8,10 \\
\hline 58,24 & 408,60 & 67,90 & 43,56 & 31,47 & 26,87 & 22,58 & 19,21 & 16,43 & 12,21 & 9,41 & 6,22 \\
\hline 35,40 & 349,40 & 69,30 & 59,85 & 42,87 & 34,68 & 26,54 & 20,70 & 16,51 & 11,32 & 8,54 & 5,82 \\
\hline 69,19 & 846,70 & 128,00 & 20,40 & 14,54 & 12,56 & 10,79 & 9,42 & 8,26 & 6,40 & 5,07 & 3,41 \\
\hline 23,93 & 1857,70 & 164,60 & 24,63 & 19,18 & 15,50 & 11,60 & 8,83 & 6,91 & 4,67 & 3,54 & 2,43 \\
\hline 35,72 & 1488,30 & 163,60 & 20,18 & 15,90 & 13,50 & 10,86 & 8,77 & 7,15 & 4,97 & 3,72 & 2,47 \\
\hline 80,93 & 1281,40 & 190,60 & 12,76 & 8,80 & 7,61 & 6,60 & 5,85 & 5,22 & 4,17 & 3,39 & 2,34 \\
\hline 55,95 & 633,10 & 120,70 & 26,74 & 18,92 & 15,94 & 13,19 & 11,07 & 9,36 & 6,84 & 5,23 & 3,46 \\
\hline 20,54 & 1620,30 & 97,90 & 41,40 & 32,81 & 26,48 & 19,70 & 14,88 & 11,59 & 7,82 & 5,92 & 4,08 \\
\hline 32,14 & 1317,00 & 130,80 & 26,15 & 20,77 & 17,51 & 13,89 & 11,07 & 8,93 & 6,15 & 4,59 & 3,08 \\
\hline 73,07 & 254,60 & 187,10 & 36,78 & 18,47 & 13,05 & 9,40 & 7,35 & 5,96 & 4,20 & 3,23 & 2,23 \\
\hline 34,49 & 620,00 & 29,60 & 84,61 & 73,43 & 65,40 & 55,51 & 46,85 & 39,54 & 28,61 & 21,52 & 13,94 \\
\hline 51,30 & 885,30 & 125,70 & 23,31 & 17,54 & 15,09 & 12,64 & 10,67 & 9,04 & 6,62 & 5,05 & 3,32 \\
\hline 73,87 & 672,30 & 153,10 & 20,78 & 13,62 & 11,31 & 9,43 & 8,09 & 7,00 & 5,33 & 4,19 & 2,82 \\
\hline 70,43 & 1519,50 & 79,50 & 20,36 & 15,87 & 14,77 & 13,55 & 12,46 & 11,44 & 9,60 & 8,06 & 5,78 \\
\hline 62,37 & 573,10 & 114,40 & 27,54 & 19,05 & 16,02 & 13,35 & 11,34 & 9,69 & 7,21 & 5,57 & 3,70 \\
\hline 79,52 & 703,80 & 96,20 & 24,36 & 17,06 & 14,86 & 12,96 & 11,53 & 10,30 & 8,26 & 6,72 & 4,64 \\
\hline 54,48 & 243,10 & 159,00 & 41,07 & 21,63 & 15,61 & 11,30 & 8,75 & 7,02 & 4,87 & 3,73 & 2,59 \\
\hline 53,76 & 1875,70 & 191,30 & 12,88 & 10,13 & 8,95 & 7,72 & 6,68 & 5,78 & 4,38 & 3,39 & 2,24 \\
\hline 32,76 & 333,70 & 152,30 & 39,31 & 23,35 & 17,18 & 12,13 & 9,10 & 7,17 & 4,95 & 3,81 & 2,66 \\
\hline 50,41 & 291,70 & 92,70 & 47,22 & 30,24 & 24,09 & 18,79 & 15,07 & 12,30 & 8,63 & 6,54 & 4,42 \\
\hline 72,56 & 1548,10 & 197,70 & 11,89 & 8,59 & 7,53 & 6,57 & 5,82 & 5,16 & 4,09 & 3,29 & 2,24 \\
\hline 43,79 & 661,40 & 57,20 & 45,74 & 37,32 & 32,88 & 27,89 & 23,64 & 20,06 & 14,69 & 11,15 & 7,28 \\
\hline 48,91 & 1095,20 & 91,70 & 26,19 & 21,32 & 18,97 & 16,38 & 14,14 & 12,21 & 9,18 & 7,08 & 4,64 \\
\hline 27,49 & 282,80 & 77,80 & 67,97 & 45,07 & 33,99 & 24,08 & 17,95 & 14,04 & 9,67 & 7,44 & 5,18 \\
\hline 34,67 & 1551,60 & 112,80 & 25,69 & 21,32 & 18,55 & 15,30 & 12,60 & 10,42 & 7,35 & 5,49 & 3,60 \\
\hline 33,26 & 330,30 & 144,90 & 40,44 & 24,28 & 17,98 & 12,76 & 9,59 & 7,55 & 5,21 & 4,01 & 2,80 \\
\hline 51,59 & 1165,20 & 177,20 & 17,02 & 12,65 & 10,83 & 9,03 & 7,60 & 6,42 & 4,69 & 3,57 & 2,35 \\
\hline 32,21 & 790,10 & 188,50 & 24,77 & 17,08 & 13,40 & 9,91 & 7,56 & 5,96 & 4,07 & 3,10 & 2,14 \\
\hline 24,77 & 447,60 & 154,90 & 38,39 & 23,97 & 17,37 & 11,92 & 8,80 & 6,91 & 4,81 & 3,73 & 2,61 \\
\hline 62,38 & 1607,50 & 91,80 & 19,46 & 15,63 & 14,43 & 13,06 & 11,83 & 10,70 & 8,72 & 7,14 & 4,94 \\
\hline 89,98 & 1236,80 & 196,30 & 12,37 & 8,23 & 7,05 & 6,11 & 5,44 & 4,88 & 3,96 & 3,25 & 2,29 \\
\hline 64,47 & 1086,80 & 90,40 & 22,60 & 17,57 & 15,87 & 14,11 & 12,61 & 11,27 & 9,00 & 7,25 & 4,94 \\
\hline 20,69 & 1430,80 & 147,70 & 31,57 & 23,50 & 18,18 & 12,97 & 9,60 & 7,44 & 5,08 & 3,91 & 2,71 \\
\hline 50,61 & 1936,90 & 27,30 & 47,40 & 39,64 & 38,40 & 36,28 & 33,94 & 31,63 & 27,23 & 23,32 & 17,10 \\
\hline 85,43 & 1774,90 & 85,00 & 16,53 & 12,38 & 11,46 & 10,70 & 10,00 & 9,35 & 8,14 & 7,08 & 5,37 \\
\hline 54,42 & 252,40 & 32,30 & 83,71 & 63,65 & 55,36 & 47,07 & 40,29 & 34,57 & 25,80 & 19,88 & 13,09 \\
\hline 29,36 & 1453,60 & 34,90 & 64,79 & 58,78 & 53,20 & 45,91 & 39,27 & 33,49 & 24,54 & 18,52 & 11,91 \\
\hline 48,21 & 255,40 & 180,60 & 38,51 & 19,94 & 14,17 & 10,06 & 7,68 & 6,12 & 4,23 & 3,25 & 2,27 \\
\hline 62,46 & 1019,60 & 33,90 & 43,49 & 35,22 & 33,41 & 31,03 & 28,72 & 26,50 & 22,44 & 18,95 & 13,66 \\
\hline 34,20 & 858,30 & 122,30 & 30,55 & 23,11 & 19,14 & 14,94 & 11,79 & 9,47 & 6,50 & 4,88 & 3,29 \\
\hline 44,51 & 845,10 & 106,90 & 28,30 & 21,87 & 18,81 & 15,56 & 12,94 & 10,81 & 7,75 & 5,85 & 3,85 \\
\hline 25,53 & 1942,90 & 174,70 & 22,28 & 17,49 & 14,29 & 10,85 & 8,34 & 6,57 & 4,45 & 3,35 & 2,29 \\
\hline 37,19 & 1795,20 & 117,50 & 22,51 & 18,98 & 16,74 & 14,09 & 11,82 & 9,93 & 7,15 & 5,38 & 3,50 \\
\hline 68,03 & 1000,00 & 193,70 & 15,46 & 10,60 & 8,95 & 7,53 & 6,47 & 5,60 & 4,24 & 3,32 & 2,22 \\
\hline 59,91 & 1433,20 & 27,70 & 45,82 & 37,28 & 35,84 & 33,97 & 31,89 & 29,84 & 25,93 & 22,42 & 16,75 \\
\hline 89,44 & 896,10 & 66,10 & 25,05 & 18,05 & 16,38 & 14,96 & 13,80 & 12,76 & 10,90 & 9,33 & 6,91 \\
\hline 27,09 & 1333,50 & 185,20 & 23,11 & 17,24 & 13,76 & 10,23 & 7,77 & 6,10 & 4,15 & 3,15 & 2,17 \\
\hline 29,66 & 1720,20 & 148,10 & 23,30 & 18,71 & 15,74 & 12,41 & 9,83 & 7,90 & 5,40 & 4,03 & 2,71 \\
\hline 20,29 & 1167,40 & 122,80 & 38,64 & 28,58 & 21,98 & 15,59 & 11,50 & 8,91 & 6,10 & 4,70 & 3,26 \\
\hline 69,66 & 962,20 & 96,20 & 22,16 & 16,62 & 14,85 & 13,13 & 11,72 & 10,48 & 8,38 & 6,78 & 4,64 \\
\hline 54,29 & 570,30 & 34,70 & 57,17 & 47,22 & 43,13 & 38,40 & 34,17 & 30,34 & 23,92 & 19,05 & 12,74 \\
\hline 23,49 & 343,40 & 120,10 & 50,70 & 31,38 & 22,49 & 15,31 & 11,29 & 8,86 & 6,19 & 4,80 & 3,36 \\
\hline 47,39 & 455,80 & 85,80 & 40,54 & 29,17 & 24,41 & 19,77 & 16,21 & 13,41 & 9,53 & 7,19 & 4,78 \\
\hline 37,66 & 807,70 & 89,20 & 35,76 & 28,22 & 24,11 & 19,57 & 15,95 & 13,10 & 9,18 & 6,87 & 4,55 \\
\hline 23,82 & 319,60 & 183,60 & 38,57 & 21,13 & 14,55 & 9,78 & 7,26 & 5,75 & 4,03 & 3,14 & 2,21 \\
\hline 34,41 & 1812,00 & 101,70 & 26,12 & 22,30 & 19,68 & 16,51 & 13,80 & 11,55 & 8,26 & 6,19 & 4,03 \\
\hline 65,58 & 1585,80 & 37,80 & 33,87 & 27,12 & 25,90 & 24,53 & 23,04 & 21,57 & 18,79 & 16,30 & 12,24 \\
\hline 31,11 & 1694,80 & 21,80 & 81,07 & 75,16 & 70,33 & 63,30 & 56,46 & 50,09 & 39,18 & 30,83 & 20,18 \\
\hline 20,20 & 621,40 & 161,10 & 37,10 & 23,76 & 16,94 & 11,41 & 8,36 & 6,56 & 4,60 & 3,58 & 2,50 \\
\hline 67,34 & 1247,40 & 169,80 & 14,76 & 10,75 & 9,36 & 8,09 & 7,09 & 6,22 & 4,83 & 3,83 & 2,57 \\
\hline 54,77 & 1037,00 & 159,20 & 18,44 & 13,61 & 11,67 & 9,80 & 8,31 & 7,07 & 5,22 & 4,00 & 2,64 \\
\hline 64,53 & 469,70 & 107,50 & 31,13 & 20,86 & 17,31 & 14,30 & 12,09 & 10,31 & 7,65 & 5,91 & 3,94 \\
\hline 29,06 & 1697,00 & 32,70 & 64,95 & 59,66 & 54,48 & 47,56 & 41,13 & 35,42 & 26,36 & 20,05 & 12,88 \\
\hline 42,59 & 1237,20 & 144,30 & 20,85 & 16,33 & 14,07 & 11,63 & 9,65 & 8,04 & 5,74 & 4,33 & 2,85 \\
\hline 41,88 & 1053,00 & 199,20 & 18,67 & 13,49 & 11,17 & 8,86 & 7,12 & 5,80 & 4,05 & 3,04 & 2,04 \\
\hline 45,51 & 1808,60 & 42,60 & 37,73 & 33,02 & 31,25 & 28,58 & 26,00 & 23,54 & 19,18 & 15,63 & 10,67 \\
\hline 42,52 & 220,20 & 30,20 & 106,56 & 81,40 & 69,31 & 56,57 & 46,44 & 38,41 & 27,21 & 20,46 & 13,53 \\
\hline 47,18 & 792,30 & 158,80 & 22,60 & 16,07 & 13,37 & 10,77 & 8,79 & 7,25 & 5,13 & 3,87 & 2,58 \\
\hline 65,18 & 1241,30 & 127,60 & 17,47 & 13,27 & 11,81 & 10,37 & 9,19 & 8,14 & 6,41 & 5,12 & 3,46 \\
\hline
\end{tabular}




\begin{tabular}{|c|c|c|c|c|c|c|c|c|c|c|c|}
\hline & & & \multicolumn{9}{|c|}{ Deflexões $\left(\times 10^{-4} \mathrm{~cm}\right)$} \\
\hline e1 (cm) & Meq (MPa) & Ms (MPa) & D0 & D25 & D40 & D60 & D80 & D100 & D140 & D180 & D260 \\
\hline 49,69 & 803,00 & 115,50 & 25,97 & 19,55 & 16,78 & 13,98 & 11,73 & 9,89 & 7,19 & 5,46 & 3,60 \\
\hline 36,36 & 1178,30 & 100,20 & 29,58 & 24,15 & 20,92 & 17,21 & 14,16 & 11,71 & 8,26 & 6,18 & 4,06 \\
\hline 77,71 & 1844,90 & 32,00 & 31,19 & 25,43 & 23,64 & 22,86 & 21,96 & 20,96 & 18,98 & 17,11 & 13,78 \\
\hline 53,61 & 418,70 & 48,50 & 53,77 & 41,57 & 36,40 & 31,12 & 26,73 & 23,00 & 17,23 & 13,29 & 8,75 \\
\hline 27,25 & 1129,10 & 151,00 & 27,91 & 20,94 & 16,79 & 12,53 & 9,55 & 7,50 & 5,10 & 3,86 & 2,66 \\
\hline 48,58 & 1965,00 & 73,90 & 24,21 & 20,87 & 19,41 & 17,50 & 15,72 & 14,07 & 11,22 & 9,00 & 6,04 \\
\hline 20,06 & 719,40 & 76,70 & 62,57 & 46,08 & 35,31 & 24,95 & 18,38 & 14,24 & 9,76 & 7,52 & 5,22 \\
\hline 39,45 & 1891,60 & 117,40 & 21,13 & 17,94 & 15,97 & 13,62 & 11,58 & 9,84 & 7,20 & 5,46 & 3,54 \\
\hline 35,00 & 648,00 & 33,20 & 76,36 & 65,86 & 58,52 & 49,55 & 41,75 & 35,19 & 25,41 & 19,11 & 12,39 \\
\hline 57,70 & 1018,90 & 132,90 & 19,91 & 14,99 & 13,05 & 11,16 & 9,62 & 8,31 & 6,27 & 4,86 & 3,21 \\
\hline 23,20 & 1548,30 & 186,40 & 24,26 & 18,06 & 14,15 & 10,25 & 7,66 & 5,96 & 4,06 & 3,11 & 2,15 \\
\hline 23,94 & 1393,80 & 154,10 & 28,05 & 21,23 & 16,86 & 12,39 & 9,33 & 7,28 & 4,94 & 3,76 & 2,60 \\
\hline 76,98 & 403,70 & 166,70 & 27,33 & 15,68 & 12,09 & 9,48 & 7,82 & 6,59 & 4,84 & 3,75 & 2,54 \\
\hline 51,55 & 1969,30 & 130,60 & 16,21 & 13,42 & 12,15 & 10,71 & 9,43 & 8,29 & 6,41 & 5,04 & 3,33 \\
\hline 82,01 & 1124,90 & 77,50 & 21,61 & 15,98 & 14,62 & 13,35 & 12,28 & 11,30 & 9,57 & 8,11 & 5,91 \\
\hline 51,91 & 875,50 & 76,80 & 30,72 & 24,72 & 22,02 & 19,10 & 16,58 & 14,40 & 10,93 & 8,49 & 5,58 \\
\hline 45,21 & 317,50 & 54,70 & 62,61 & 45,90 & 38,57 & 31,23 & 25,55 & 21,10 & 14,93 & 11,25 & 7,47 \\
\hline 45,15 & 538,00 & 192,50 & 25,12 & 15,76 & 12,30 & 9,34 & 7,33 & 5,89 & 4,08 & 3,10 & 2,12 \\
\hline 79,62 & 1093,50 & 108,60 & 18,43 & 13,36 & 11,94 & 10,65 & 9,62 & 8,71 & 7,15 & 5,92 & 4,17 \\
\hline 38,12 & 976,20 & 61,60 & 41,59 & 35,23 & 31,22 & 26,46 & 22,34 & 18,87 & 13,69 & 10,33 & 6,71 \\
\hline 42,71 & 1553,20 & 21,60 & 66,73 & 58,26 & 56,06 & 52,08 & 48,02 & 44,07 & 36,80 & 30,61 & 21,44 \\
\hline 28,28 & 722,50 & 22,70 & 112,47 & 99,62 & 88,58 & 74,61 & 62,37 & 52,14 & 37,13 & 27,68 & 17,93 \\
\hline 74,72 & 1826,90 & 135,50 & 13,34 & 10,07 & 9,19 & 8,31 & 7,57 & 6,89 & 5,71 & 4,75 & 3,36 \\
\hline 51,32 & 997,20 & 84,90 & 27,64 & 22,34 & 19,93 & 17,29 & 15,02 & 13,04 & 9,89 & 7,68 & 5,05 \\
\hline 77,30 & 1603,90 & 175,60 & 12,09 & 8,75 & 7,77 & 6,87 & 6,17 & 5,55 & 4,50 & 3,68 & 2,56 \\
\hline 71,16 & 1812,60 & 93,00 & 17,18 & 13,36 & 12,45 & 11,44 & 10,53 & 9,68 & 8,15 & 6,87 & 4,94 \\
\hline 60,31 & 1080,50 & 133,40 & 18,90 & 14,24 & 12,47 & 10,75 & 9,35 & 8,14 & 6,22 & 4,87 & 3,23 \\
\hline 49,48 & 1504,00 & 29,70 & 48,70 & 41,51 & 39,82 & 37,01 & 34,17 & 31,43 & 26,37 & 22,05 & 15,60 \\
\hline 27,22 & 1914,40 & 104,40 & 30,35 & 25,41 & 21,77 & $\begin{array}{l}01,01 \\
17,46\end{array}$ & 14,00 & $\frac{01,40}{11,32}$ & $\begin{array}{c}\mathrm{Lu}, \mathrm{U} \\
7,77\end{array}$ & $\begin{array}{c}L 2,00 \\
5,77\end{array}$ & $\frac{1,00}{3,84}$ \\
\hline 51,23 & 278,10 & 50,70 & 65,01 & 46,80 & 39,45 & 32,40 & 26,93 & 22,55 & 16,26 & 12,34 & 8,17 \\
\hline 41,60 & 1125,10 & 87,70 & 29,68 & 24,56 & 21,68 & 18,37 & 15,54 & 13,16 & 9,59 & 7,26 & 4,73 \\
\hline 59,14 & 1760,40 & 97,30 & 18,69 & 15,23 & 14,06 & 12,68 & 11,44 & 10,30 & 8,33 & 6,77 & 4,63 \\
\hline 25,46 & 207,60 & 156,70 & 49,32 & 25,00 & 16,91 & 11,36 & 8,48 & 6,73 & 4,72 & 3,68 & 2,60 \\
\hline 68,59 & 918,30 & 150,30 & 18,16 & 12,81 & 10,98 & 9,37 & 8,14 & 7,10 & 5,46 & 4,30 & 2,89 \\
\hline 62,12 & 1527,30 & 192,80 & 13,02 & 9,73 & 8,51 & 7,35 & 6,40 & 5,59 & 4,29 & 3,37 & 2,25 \\
\hline 41,93 & 1759,80 & 28,60 & 53,29 & 47,07 & 44,95 & 41,42 & 37,90 & 34,51 & 28,39 & 23,31 & 16,04 \\
\hline 33,89 & 1654,90 & 166,30 & 19,91 & 15,84 & 13,45 & 10,77 & 8,66 & 7,04 & 4,88 & 3,64 & 2,43 \\
\hline 26,35 & 1190,10 & 141,90 & 29,27 & 22,23 & 17,88 & 13,36 & 10,18 & 7,99 & 5,42 & 4,11 & 2,82 \\
\hline 56,04 & 1047,70 & 187,10 & 16,69 & 11,95 & 10,13 & 8,43 & 7,11 & 6,03 & 4,42 & 3,39 & 2,24 \\
\hline 68,59 & 982,00 & 91,20 & 22,78 & 17,28 & 15,51 & 13,76 & 12,31 & 11,02 & 8,84 & 7,16 & 4,90 \\
\hline 28,27 & 849,10 & 148,50 & 30,25 & 21,86 & 17,25 & 12,71 & 9,63 & 7,56 & 5,15 & 3,92 & 2,71 \\
\hline 45,50 & 1171,80 & 20,20 & 72,76 & 63,09 & 60,51 & 56,08 & 51,63 & 47,32 & 39,43 & 32,75 & 22,92 \\
\hline 60,59 & 1835,50 & 141,50 & 14,45 & 11,47 & 10,39 & 9,22 & 8,22 & 7,32 & 5,80 & 4,65 & 3,14 \\
\hline 36,28 & 1286,20 & 84,10 & 32,04 & 26,98 & 23,74 & 19,90 & 16,63 & 13,92 & 9,97 & 7,48 & 4,88 \\
\hline 41,85 & 960,70 & 28,00 & 65,06 & 57,85 & 53,78 & 48,28 & 43,08 & 38,28 & 30,11 & 23,85 & 15,78 \\
\hline 86,75 & 1237,60 & 71,40 & 21,12 & 15,59 & 14,33 & 13,26 & 12,32 & 11,46 & 9,90 & 8,54 & 6,41 \\
\hline 31,87 & 1223,10 & 93,70 & 33,56 & 27,51 & 23,59 & 19,06 & 15,41 & 12,56 & 8,71 & 6,49 & 4,30 \\
\hline 34,00 & 642,80 & 93,70 & 40,35 & 30,41 & 25,11 & 19,54 & 15,39 & 12,34 & 8,46 & 6,35 & 4,30 \\
\hline 61,81 & 248,10 & 49,60 & 63,81 & 44,18 & 37,15 & 30,94 & 26,24 & 22,40 & 16,64 & 12,84 & 8,53 \\
\hline 43,03 & 1670,00 & 49,40 & 36,32 & 32,14 & 29,94 & 26,95 & 24,11 & 21,48 & 16,99 & 13,51 & 8,98 \\
\hline 68,08 & 1004,50 & 123,00 & 19,26 & 14,20 & 12,48 & 10,87 & 9,59 & 8,47 & 6,64 & 5,30 & 3,58 \\
\hline 34,15 & 816,50 & 21,60 & 95,21 & 86,27 & 78,99 & 69,39 & 60,47 & 52,50 & 39,62 & 30,45 & 19,68 \\
\hline 77,26 & 741,20 & 52,90 & 33,10 & 24,80 & 22,69 & 20,60 & 18,84 & 17,24 & 14,41 & 12,08 & 8,65 \\
\hline 31,55 & 637,70 & 198,30 & 26,23 & 17,10 & 13,04 & 9,41 & 7,09 & 5,57 & 3,83 & 2,93 & 2,04 \\
\hline 33,21 & 1682,30 & 132,90 & 23,20 & 19,01 & 16,36 & 13,30 & 10,81 & 8,85 & 6,17 & 4,60 & 3,04 \\
\hline 36,08 & 620,70 & 191,20 & 25,65 & 16,80 & 13,06 & 9,67 & 7,41 & 5,87 & 4,03 & 3,07 & 2,11 \\
\hline 55,59 & 1586,10 & 63,80 & 26,39 & 22,03 & 20,62 & 18,79 & 17,07 & 15,47 & 12,64 & 10,35 & 7,13 \\
\hline 78,71 & 864,50 & 132,90 & 18,82 & 13,00 & 11,21 & 9,69 & 8,56 & 7,60 & 6,03 & 4,86 & 3,34 \\
\hline 83,15 & 1104,20 & 194,60 & 13,58 & 9,07 & $\begin{array}{c}+1,2,2 \\
7,71\end{array}$ & 6,61 & 5,82 & 5,16 & 4,09 & 3,31 & 2,28 \\
\hline 79,46 & 1587,70 & 54,40 & 23,61 & 18,21 & 17,06 & 16,13 & 15,18 & 14,25 & 12,52 & 10,96 & 8,39 \\
\hline 25,10 & 1866,20 & 136,50 & 27,09 & 21,73 & 17,99 & 13,83 & 10,72 & 8,48 & 5,74 & 4,30 & 2,93 \\
\hline 38,34 & 520,60 & 60,80 & 53,01 & 41,51 & 35,39 & 28,71 & 23,39 & 19,21 & 13,47 & 10,09 & 6,69 \\
\hline 73,95 & 895,60 & 193,20 & 15,95 & 10,56 & 8,82 & $\begin{array}{l}20,11 \\
7,39\end{array}$ & 6,36 & $\begin{array}{c}10,21 \\
5,52\end{array}$ & 4,22 & 3,32 & 2,24 \\
\hline 38,68 & 1342,70 & 37,50 & 50,72 & 45,57 & 42,14 & 37,54 & 33,22 & 29,27 & 22,67 & $\frac{1,06}{17,75}$ & 11,62 \\
\hline 20,12 & 1402,50 & 117,00 & 38,37 & 29,18 & 22,84 & 16,45 & 12,22 & 9,47 & 6,44 & 4,93 & 3,42 \\
\hline 42,14 & 1726,80 & 159,80 & 17,27 & 13,98 & 12,23 & 10,26 & 8,61 & 7,24 & 5,24 & 3,96 & 2,59 \\
\hline 35,35 & 1251,60 & 123,90 & 25,81 & 20,63 & 17,63 & 14,26 & 11,56 & 9,46 & 6,59 & 4,93 & 3,27 \\
\hline 21,20 & 1812,80 & 130,70 & 31,83 & 24,88 & 19,93 & 14,72 & 11,09 & 8,63 & 5,83 & 4,43 & 3,06 \\
\hline 85,69 & 1591,40 & 44,20 & 25,30 & 19,81 & 18,34 & 17,54 & 16,71 & 15,85 & 14,22 & 12,70 & 10,08 \\
\hline 83,99 & 1575,80 & 83,90 & 17,67 & 13,19 & 12,19 & 11,31 & 10,52 & 9,79 & 8,45 & 7,29 & 5,46 \\
\hline 74,92 & 1286,20 & 158,50 & 14,38 & 10,35 & 9,10 & 7,97 & 7,09 & 6,33 & 5,06 & 4,09 & 2,81 \\
\hline 75,47 & 1850,50 & 57,20 & 22,33 & 17,41 & 16,41 & 15,53 & 14,61 & 13,72 & 12,03 & 10,51 & 8,01 \\
\hline 21,55 & 729,30 & 89,50 & 53,17 & 38,96 & 29,98 & 21,32 & 15,77 & 12,25 & 8,38 & 6,45 & 4,47 \\
\hline 81,80 & 545,00 & 64,50 & 33,39 & 23,61 & 20,81 & 18,36 & 16,49 & 14,86 & 12,11 & 9,96 & 6,98 \\
\hline 89,30 & 1906,60 & 29,00 & 28,06 & 24,60 & 22,18 & 21,34 & 20,77 & 20,06 & 18,52 & 17,04 & 14,29 \\
\hline 69,96 & 1572,60 & 99,80 & 17,55 & 13,60 & 12,53 & 11,37 & 10,37 & 9,44 & 7,81 & 6,48 & 4,57 \\
\hline 83,84 & 415,60 & 125,20 & 29,04 & 17,60 & 14,10 & 11,48 & 9,77 & 8,44 & 6,44 & 5,08 & 3,46 \\
\hline 39,18 & 1585,60 & 49,00 & 39,76 & 35,54 & 32,75 & 29,08 & 25,64 & 22,53 & 17,36 & 13,55 & 8,85 \\
\hline 40,72 & 1934,70 & 199,50 & 14,78 & 11,79 & 10,20 & 8,45 & 7,00 & 5,83 & 4,16 & 3,13 & 2,05 \\
\hline 27,33 & 1230,80 & 48,90 & 58,24 & 50,33 & 43,99 & 36,19 & 29,63 & 24,34 & 16,97 & 12,59 & 8,26 \\
\hline 72,61 & 1074,60 & 180,60 & 14,97 & 10,39 & 8,89 & 7,60 & 6,63 & 5,81 & 4,51 & 3,58 & 2,42 \\
\hline 67,39 & 700,20 & 196,90 & 18,82 & 12,00 & 9,74 & 7,91 & 6,64 & 5,63 & 4,15 & 3,21 & 2,15 \\
\hline
\end{tabular}




\begin{tabular}{|c|c|c|c|c|c|c|c|c|c|c|c|}
\hline \multirow[b]{2}{*}{ e1 (cm) } & & & & & & & ões (x1 & m) & & & \\
\hline & Meq (MPa) & Ms (MPa) & D0 & D25 & D40 & D60 & D80 & D100 & D140 & D180 & D260 \\
\hline 31,66 & 1869,80 & 26,40 & $\begin{array}{l}67,92 \\
\end{array}$ & $\begin{array}{l}62,86 \\
\end{array}$ & 58,70 & 52,72 & 46,93 & 41,55 & 32,40 & 25,43 & 16,62 \\
\hline 31,91 & 1877,40 & 165,30 & 19,95 & $\begin{array}{l}16,08 \\
\end{array}$ & 13,66 & 10,92 & 8,76 & 7,10 & 4,90 & 3,65 & 2,44 \\
\hline 37,18 & 584,30 & 162,00 & 28,61 & 19,17 & 15,12 & 11,36 & 8,78 & 6,99 & 4,79 & 3,64 & 2,50 \\
\hline 72,50 & 1279,80 & 83,90 & 20,78 & 15,92 & 14,64 & 13,30 & 12,15 & 11,09 & 9,21 & 7,68 & 5,45 \\
\hline 77,52 & 305,70 & 158,90 & 33,54 & 18,23 & 13,59 & 10,34 & 8,38 & 6,97 & 5,04 & 3,89 & 2,65 \\
\hline 55,93 & 1966,90 & 108,80 & 17,27 & 14,26 & 13,12 & 11,77 & 10,56 & 9,45 & 7,55 & 6,08 & 4,11 \\
\hline 38,95 & 621,30 & 24,60 & 86,68 & 76,50 & 699,63 & 60,95 & 53,02 & 45,99 & 34,72 & 26,73 & 17,35 \\
\hline 62,12 & 237,60 & 174,80 & 39,88 & 20,18 & 14,28 & 10,23 & 7,93 & 6,38 & 4,45 & 3,41 & 2,37 \\
\hline 87,21 & 1237,50 & 156,00 & 13,91 & 9,60 & 8,41 & 7,40 & 6,66 & 6,02 & 4,94 & 4,09 & 2,90 \\
\hline 84,91 & 537,20 & 61,40 & 33,97 & 23,87 & 21,09 & 18,68 & 16,85 & 15,26 & 12,54 & 10,40 & 7,37 \\
\hline 46,45 & 909,40 & 188,60 & 19,49 & 13,77 & 11,41 & 9,14 & 7,43 & 6,11 & 4,31 & 3,25 & 2,17 \\
\hline 66,99 & 897,50 & 74,90 & 26,79 & 20,64 & 18,66 & 16,63 & 14,92 & 13,38 & 10,77 & 8,74 & 5,99 \\
\hline 76,57 & 555,50 & 150,20 & 23,18 & 14,60 & 11,88 & 9,76 & 8,31 & 7,16 & 5,42 & 4,25 & 2,86 \\
\hline 80,42 & 1854,50 & 135,50 & 12,80 & 9,47 & 8,65 & 7,86 & 7,20 & 6,61 & 5,55 & 4,68 & 3,37 \\
\hline 39,42 & 830,00 & 45,50 & 52,12 & 44,79 & 40,14 & 34,51 & 29,54 & 25,25 & 18,65 & 14,19 & 9,20 \\
\hline 28,61 & 1965,40 & 37,40 & 57,26 & 52,59 & 47,96 & 41,79 & 36,07 & 31,01 & 23,01 & 17,47 & 11,22 \\
\hline 30,22 & 882,40 & 100,00 & 37,33 & 28,97 & 23,97 & 18,56 & 14,52 & 11,57 & 7,89 & 5,92 & 4,01 \\
\hline 82,53 & 563,80 & 79,90 & 29,46 & 20,34 & 17,65 & 15,38 & 13,69 & 12,26 & 9,87 & 8,05 & 5,60 \\
\hline 77,81 & 1671,60 & 56,10 & 23,03 & 17,82 & 16,74 & 15,82 & 14,87 & 13,96 & 12,24 & 10,69 & 8,16 \\
\hline 65,13 & 1404,80 & 28,40 & 42,85 & 34,41 & 32,90 & 31,36 & 29,58 & 27,81 & 24,43 & 21,34 & 16,24 \\
\hline 58,18 & 678,80 & 198,90 & 20,03 & 12,90 & 10,41 & 8,32 & 6,84 & 5,69 & 4,09 & 3,12 & 2,09 \\
\hline 37,67 & 1041,70 & 173,60 & 21,56 & 15,95 & 13,20 & 10,38 & 8,25 & 6,67 & 4,61 & 3,46 & 2,33 \\
\hline 24,56 & 1533,60 & 174,40 & 24,58 & 18,61 & 14,82 & 10,94 & 8,26 & 6,45 & 4,38 & 3,33 & 2,30 \\
\hline 55,32 & 1281,80 & 168,60 & 16,11 & 12,18 & 10,58 & 8,99 & 7,70 & 6,62 & 4,95 & 3,81 & 2,51 \\
\hline 61,49 & 1722,30 & 185,40 & 12,65 & 9,67 & 8,56 & 7,46 & 6,55 & 5,75 & 4,46 & 3,52 & 2,35 \\
\hline 67,12 & 809,60 & 126,00 & 21,31 & 15,21 & 13,10 & 11,21 & 9,74 & 8,50 & 6,53 & 5,14 & 3,44 \\
\hline 27,86 & 669,40 & 136,90 & 34,80 & 24,45 & 18,98 & 13,77 & 10,36 & 8,11 & 5,54 & 4,24 & 2,94 \\
\hline 47,86 & 1109,20 & 187,80 & 17,56 & 12,88 & 10,88 & 8,90 & 7,36 & 6,13 & 4,38 & 3,31 & 2,19 \\
\hline 76,21 & 429,70 & 48,40 & 44,72 & 32,39 & 28,69 & 25,31 & 22,65 & 20,33 & 16,40 & 13,38 & 9,27 \\
\hline 75,04 & 695,80 & 161,60 & 19,81 & 12,90 & 10,68 & 8,90 & 7,64 & 6,61 & 5,04 & 3,97 & 2,67 \\
\hline 78,58 & 1047,40 & 133,00 & 17,05 & 12,09 & 10,60 & 9,29 & 8,29 & 7,42 & 5,97 & 4,86 & 3,37 \\
\hline 42,26 & 793,10 & 87,60 & 33,75 & 26,66 & 23,04 & 19,10 & 15,86 & 13,24 & 9,48 & 7,14 & 4,69 \\
\hline 35,02 & 1343,10 & 159,80 & 21,55 & 16,77 & 14,13 & 11,24 & 9,00 & 7,30 & 5,05 & 3,78 & 2,53 \\
\hline 30,67 & 1386,50 & 118,00 & 28,43 & 22,94 & 19,42 & 15,44 & 12,32 & 9,94 & 6,83 & 5,09 & 3,41 \\
\hline 86,27 & 1912,90 & 108,00 & 13,87 & 10,26 & 9,44 & 8,75 & 8,13 & 7,57 & 6,53 & 5,64 & 4,23 \\
\hline 35,46 & 781,50 & 112,80 & 32,54 & 24,61 & 20,45 & 16,07 & 12,75 & 10,28 & 7,08 & 5,31 & 3,58 \\
\hline 51,70 & 1378,70 & 125,60 & 19,12 & 15,32 & 13,61 & 11,77 & 10,20 & 8,83 & 6,68 & 5,18 & 3,40 \\
\hline 54,63 & 855,00 & 118,80 & 23,60 & 17,71 & 15,31 & 12,95 & 11,04 & 9,44 & 7,01 & 5,39 & 3,55 \\
\hline 69,99 & 228,20 & 184,00 & 40,14 & 19,74 & 13,72 & 9,72 & 7,52 & 6,06 & 4,23 & 3,25 & 2,26 \\
\hline 71,08 & 636,10 & 93,30 & 27,24 & 19,40 & 16,80 & 14,49 & 12,71 & 11,19 & 8,74 & 6,96 & 4,70 \\
\hline 20,92 & 1668,90 & 169,50 & 27,20 & 20,34 & 15,80 & 11,31 & 8,39 & 6,51 & 4,44 & 3,41 & 2,36 \\
\hline 71,00 & 1139,20 & 172,60 & 14,98 & 10,62 & 9,17 & 7,89 & 6,91 & 6,07 & 4,73 & 3,76 & 2,54 \\
\hline 64,30 & 429,30 & 174,30 & 26,90 & 15,84 & 12,29 & 9,56 & 7,78 & 6,45 & 4,62 & 3,54 & 2,39 \\
\hline 69,37 & 1546,90 & 23,00 & 45,15 & 36,74 & 34,65 & 33,54 & 32,09 & 30,52 & 27,46 & 24,57 & 19,50 \\
\hline 23,80 & 1985,40 & 154,50 & 25,35 & 20,03 & 16,34 & 12,34 & 9,44 & 7,41 & 5,01 & 3,78 & 2,59 \\
\hline 79,46 & 268,80 & 58,90 & 51,59 & 33,58 & 27,95 & 23,46 & 20,31 & 17,75 & 13,74 & 10,91 & 7,42 \\
\hline 65,00 & 1815,80 & 118,40 & 15,54 & 12,27 & 11,26 & 10,15 & 9,18 & 8,29 & 6,75 & 5,53 & 3,82 \\
\hline 86,40 & 1703,00 & 26,50 & 32,24 & 27,69 & 25,13 & 24,25 & 23,54 & 22,67 & 20,85 & 19,10 & 15,89 \\
\hline 73,13 & 1805,70 & 78,10 & 18,89 & 14,66 & 13,75 & 12,77 & 11,86 & 10,99 & 9,40 & 8,03 & 5,90 \\
\hline 53,65 & 1589,80 & 120,20 & 18,10 & 14,73 & 13,27 & 11,65 & 10,25 & 9,00 & 6,96 & 5,47 & 3,62 \\
\hline 71,87 & 335,30 & 111,30 & 36,13 & 21,99 & 17,49 & 14,02 & 11,70 & 9,91 & 7,31 & 5,66 & 3,80 \\
\hline 45,30 & 1735,10 & 74,90 & 26,26 & 22,77 & 20,91 & 18,58 & 16,43 & 14,49 & 11,26 & 8,85 & 5,83 \\
\hline 70,69 & 470,80 & 76,80 & 35,04 & 24,57 & 21,08 & 18,03 & 15,72 & 13,76 & 10,65 & 8,43 & 5,67 \\
\hline 55,14 & 593,70 & 171,20 & 23,51 & 15,28 & 12,34 & 9,83 & 8,03 & 6,65 & 4,74 & 3,60 & 2,41 \\
\hline 55,77 & 1040,40 & 179,50 & 17,14 & 12,37 & 10,51 & 8,77 & 7,40 & 6,28 & 4,62 & 3,54 & 2,34 \\
\hline 22,58 & 904,80 & 70,70 & 57,60 & 45,11 & 36,39 & 27,13 & 20,57 & 16,07 & 10,85 & 8,22 & 5,66 \\
\hline 87,73 & 326,60 & 115,30 & 34,67 & 20,19 & 15,82 & 12,67 & 10,68 & 9,18 & 6,97 & 5,50 & 3,75 \\
\hline 67,22 & 1849,30 & 177,40 & 12,00 & 9,12 & 8,16 & 7,22 & 6,44 & 5,74 & 4,57 & 3,69 & 2,51 \\
\hline 87,59 & 1344,20 & 84,10 & 18,47 & 13,53 & 12,39 & 11,42 & 10,59 & 9,83 & 8,46 & 7,28 & 5,43 \\
\hline 78,49 & 948,20 & 161,50 & 16,38 & 11,15 & 9,52 & 8,16 & 7,17 & 6,33 & 4,98 & 4,00 & 2,73 \\
\hline 69,08 & 407,20 & 83,20 & 36,83 & 24,95 & 20,95 & 17,57 & 15,07 & 13,02 & 9,87 & 7,71 & 5,16 \\
\hline 84,76 & 1528,50 & 197,70 & 11,24 & 7,80 & 6,82 & 5,99 & 5,37 & 4,83 & 3,94 & 3,24 & 2,28 \\
\hline 85,75 & 1685,60 & 147,70 & 12,37 & 8,89 & 8,01 & 7,22 & 6,59 & 6,04 & 5,07 & 4,27 & 3,09 \\
\hline 87,30 & 1253,00 & 84,30 & 19,06 & 13,91 & 12,70 & 11,65 & 10,77 & 9,97 & 8,53 & 7,31 & 5,42 \\
\hline 73,43 & 1130,80 & 125,00 & 17,44 & 12,78 & 11,34 & 9,99 & 8,92 & 7,98 & 6,41 & 5,20 & 3,58 \\
\hline 27,36 & 439,90 & 68,60 & 64,34 & 47,20 & 37,39 & 27,59 & 20,90 & 16,39 & 11,15 & 8,49 & 5,85 \\
\hline 40,55 & 1521,90 & 94,80 & 25,69 & 21,80 & 19,45 & 16,66 & 14,22 & 12,13 & 8,93 & 6,79 & 4,41 \\
\hline 36,05 & 1781,60 & 156,90 & 19,25 & 15,64 & 13,50 & 11,06 & 9,06 & 7,47 & 5,26 & 3,93 & 2,59 \\
\hline 86,24 & 908,50 & 191,40 & 15,13 & 9,74 & 8,12 & 6,86 & 5,99 & 5,28 & 4,16 & 3,35 & 2,31 \\
\hline 34,17 & 833,30 & 121,30 & 31,07 & 23,43 & 19,36 & 15,09 & 11,89 & 9,54 & 6,55 & 4,91 & 3,32 \\
\hline 42,85 & 360,50 & 55,20 & 60,80 & 45,60 & 38,52 & 31,21 & 25,49 & 21,01 & 14,82 & 11,14 & 7,40 \\
\hline 50,09 & 384,70 & 101,80 & 39,23 & 26,21 & 21,30 & 16,89 & 13,68 & 11,24 & 7,93 & 6,00 & 4,03 \\
\hline 61,19 & 829,20 & 187,80 & 18,08 & 12,23 & 10,16 & 8,36 & 7,03 & 5,96 & 4,38 & 3,37 & 2,24 \\
\hline 21,42 & 395,10 & 21,90 & 175,18 & 141,21 & 115,75 & 87,65 & 67,05 & 52,54 & 35,38 & 26,64 & 18,24 \\
\hline 64,06 & 1789,70 & 67,40 & 22,47 & 18,08 & 17,07 & 15,79 & 14,58 & 13,43 & 11,33 & 9,54 & 6,85 \\
\hline 32,31 & 1882,00 & 30,20 & 60,67 & 56,00 & 52,11 & 46,63 & 41,36 & 36,50 & 28,30 & 22,13 & 14,42 \\
\hline 21,01 & 1245,30 & 170,30 & 29,21 & 20,97 & 15,90 & 11,16 & 8,21 & 6,38 & 4,39 & 3,39 & 2,35 \\
\hline 23,18 & 1314,30 & 185,40 & 25,52 & 18,57 & 14,35 & 10,28 & 7,64 & 5,94 & 4,06 & 3,12 & 2,16 \\
\hline 41,70 & 328,00 & 155,50 & 36,70 & 21,48 & 16,11 & 11,76 & 9,02 & 7,17 & 4,94 & 3,78 & 2,62 \\
\hline 48,61 & 591,70 & 51,70 & 47,47 & 38,46 & 34,13 & 29,36 & 25,27 & 21,75 & 16,28 & 12,52 & 8,20 \\
\hline 55,58 & 1210,30 & 106,30 & 21,32 & 16,99 & 15,19 & 13,27 & 11,63 & 10,18 & 7,85 & 6,16 & 4,08 \\
\hline 42,29 & 1112,60 & 55,90 & 39,03 & 33,73 & 30,56 & 26,68 & 23,20 & 20,12 & 15,20 & 11,73 & 7,63 \\
\hline
\end{tabular}




\begin{tabular}{|c|c|c|c|c|c|c|c|c|c|c|c|}
\hline \multirow[b]{2}{*}{ e1 (cm) } & & & & & & & ões (x1 & m) & & & \\
\hline & Meq (MPa) & Ms (MPa) & D0 & D25 & D40 & D60 & D80 & D100 & D140 & D180 & D260 \\
\hline 30,40 & 1743,80 & 136,60 & 24,02 & 19,56 & 16,63 & 13,28 & 10,63 & 8,60 & 5,92 & 4,41 & 2,94 \\
\hline 63,59 & 404,80 & 125,20 & 31,88 & 20,05 & 16,10 & 12,90 & 10,68 & 8,96 & 6,51 & 4,99 & 3,34 \\
\hline 31,50 & 1440,00 & 183,40 & 20,62 & 15,79 & 13,03 & 10,09 & 7,90 & 6,30 & 4,30 & 3,23 & 2,19 \\
\hline 55,59 & 1754,10 & 86,10 & 20,96 & 17,41 & 16,12 & 14,55 & 13,11 & 11,78 & 9,48 & 7,68 & 5,22 \\
\hline 62,39 & 382,80 & 21,90 & 81,66 & 65,55 & 60,55 & 54,78 & 49,63 & 44,88 & 36,59 & 29,95 & 20,70 \\
\hline 36,56 & 1784,10 & 39,90 & 46,31 & 42,07 & 39,08 & 34,96 & 31,03 & 27,42 & 21,33 & 16,74 & 10,96 \\
\hline 61,86 & 1930,90 & 72,20 & 21,35 & 17,33 & 16,36 & 15,10 & 13,90 & 12,77 & 10,70 & 8,97 & 6,38 \\
\hline 52,19 & 955,50 & 157,10 & 19,79 & 14,49 & 12,34 & 10,24 & 8,59 & 7,24 & 5,27 & 4,02 & 2,65 \\
\hline 22,65 & 1122,20 & 138,10 & 33,44 & 24,73 & 19,23 & 13,84 & 10,30 & 8,01 & 5,46 & 4,19 & 2,90 \\
\hline 69,86 & 1399,30 & 178,30 & 13,39 & 9,76 & 8,55 & 7,45 & 6,57 & 5,81 & 4,57 & 3,65 & 2,47 \\
\hline 77,04 & 373,80 & 198,20 & 27,29 & 14,77 & 10,98 & 8,33 & 6,73 & 5,59 & 4,04 & 3,12 & 2,12 \\
\hline 27,19 & 1517,00 & 60,90 & 47,11 & 40,64 & 35,48 & 29,14 & 23,81 & 19,54 & 13,60 & 10,09 & 6,62 \\
\hline 54,93 & 329,40 & 127,30 & 37,25 & 22,58 & 17,61 & 13,60 & 10,90 & 8,91 & 6,27 & 4,77 & 3,23 \\
\hline 60,54 & 244,40 & 31,80 & 81,15 & 60,66 & 52,92 & 45,46 & 39,43 & 34,27 & 26,12 & 20,41 & 13,55 \\
\hline 43,60 & 1500,40 & 121,40 & 21,06 & 17,33 & 15,32 & 13,04 & 11,09 & 9,44 & 6,94 & 5,27 & 3,44 \\
\hline 57,83 & 1562,90 & 106,60 & 18,74 & 15,16 & 13,81 & 12,29 & 10,96 & 9,76 & 7,73 & 6,18 & 4,16 \\
\hline 37,49 & 1530,20 & 61,00 & 36,06 & 31,83 & 28,86 & 25,11 & 21,70 & 18,72 & 13,99 & 10,71 & 6,93 \\
\hline 63,60 & 487,90 & 31,20 & 59,23 & 47,06 & 43,21 & 38,93 & 35,17 & 31,72 & 25,75 & 21,02 & 14,48 \\
\hline 52,30 & 1282,10 & 127,90 & 19,39 & 15,34 & 13,55 & 11,67 & 10,07 & 8,70 & 6,55 & 5,07 & 3,33 \\
\hline 35,23 & 265,10 & 79,20 & 61,74 & 40,70 & 31,65 & 23,39 & 17,90 & 14,15 & 9,70 & 7,39 & 5,10 \\
\hline 52,16 & 934,60 & 179,80 & 18,64 & 13,26 & 11,14 & 9,13 & 7,58 & 6,35 & 4,58 & 3,48 & 2,30 \\
\hline 72,56 & 1605,20 & 194,60 & 11,78 & 8,56 & 7,54 & 6,60 & 5,86 & 5,21 & 4,15 & 3,34 & 2,28 \\
\hline 29,43 & 1999,00 & 124,10 & 25,06 & 20,88 & 17,95 & 14,50 & 11,70 & 9,51 & 6,57 & 4,89 & 3,24 \\
\hline 42,23 & 1438,80 & 177,30 & 17,44 & 13,55 & 11,62 & 9,55 & 7,88 & 6,55 & 4,66 & 3,50 & 2,31 \\
\hline 54,25 & 732,50 & 156,30 & 22,16 & 15,39 & 12,82 & 10,47 & 8,69 & 7,28 & 5,25 & 4,00 & 2,65 \\
\hline 68,91 & 1145,50 & 155,00 & 15,96 & 11,57 & 10,09 & 8,74 & 7,67 & 6,76 & 5,28 & 4,19 & 2,83 \\
\hline 78,79 & 238,00 & 127,90 & 42,57 & 22,92 & 17,00 & 12,87 & 10,40 & 8,65 & 6,26 & 4,83 & 3,30 \\
\hline 57,84 & 1709,60 & 159,40 & 14,26 & 11,21 & 10,00 & 8,75 & 7,68 & 6,74 & 5,21 & 4,11 & 2,73 \\
\hline 86,97 & 1750,70 & 40,00 & 25,37 & 20,40 & 18,75 & 18,03 & 17,30 & 16,51 & 14,97 & 13,51 & 10,93 \\
\hline 74,08 & 1216,50 & 187,80 & 13,66 & 9,57 & 8,25 & 7,11 & 6,24 & 5,51 & 4,32 & 3,45 & 2,34 \\
\hline 61,43 & 1508,90 & 34,80 & 37,99 & 30,80 & 29,52 & 27,83 & 26,04 & 24,28 & 20,97 & 18,03 & 13,35 \\
\hline 57,21 & 894,00 & 60,30 & 33,19 & 26,94 & 24,53 & 21,83 & 19,45 & 17,30 & 13,68 & 10,93 & 7,35 \\
\hline 84,08 & 1119,10 & 178,80 & 13,95 & 9,43 & 8,09 & 6,99 & 6,19 & 5,52 & 4,42 & 3,60 & 2,49 \\
\hline 28,96 & 442,00 & 84,10 & 54,17 & 38,67 & 30,43 & 22,39 & 16,97 & 13,32 & 9,09 & 6,92 & 4,78 \\
\hline 55,42 & 1100,30 & 67,00 & 29,25 & 24,06 & 22,01 & 19,63 & 17,51 & 15,59 & 12,34 & 9,86 & 6,62 \\
\hline 65,75 & 1176,90 & 83,40 & 22,68 & 17,76 & 16,22 & 14,57 & 13,15 & 11,85 & 9,61 & 7,84 & 5,41 \\
\hline 40,32 & 637,70 & 64,20 & 45,77 & 36,63 & 31,72 & 26,26 & 21,77 & 18,13 & 12,92 & 9,71 & 6,38 \\
\hline 26,49 & 1279,10 & 113,80 & 33,22 & 26,23 & 21,61 & 16,56 & 12,83 & 10,14 & 6,88 & 5,17 & 3,52 \\
\hline 68,08 & 387,90 & 50,10 & 48,50 & 35,48 & 31,05 & 26,95 & 23,70 & 20,89 & 16,32 & 12,98 & 8,75 \\
\hline 51,19 & 1092,90 & 146,80 & 19,49 & 14,80 & 12,79 & 10,76 & 9,10 & 7,73 & 5,68 & 4,34 & 2,85 \\
\hline 37,24 & 214,80 & 152,00 & 47,19 & 24,61 & 17,28 & 11,99 & 9,01 & 7,13 & 4,94 & 3,82 & 2,69 \\
\hline 40,44 & 911,90 & 27,10 & 69,30 & 61,85 & 57,26 & 51,14 & 45,39 & 40,11 & 31,25 & 24,57 & 16,15 \\
\hline 43,14 & 374,90 & 72,70 & 50,91 & 36,57 & 30,31 & 24,12 & 19,45 & 15,88 & 11,11 & 8,36 & 5,60 \\
\hline 72,98 & 214,80 & 31,20 & 80,21 & 56,87 & 49,31 & 42,64 & 37,52 & 33,15 & 26,03 & 20,82 & 14,14 \\
\hline 31,33 & 1106,80 & 164,90 & 24,29 & 18,16 & 14,79 & 11,29 & 8,76 & 6,95 & 4,74 & 3,57 & 2,44 \\
\hline 45,80 & 1002,00 & 29,00 & 58,90 & 51,55 & 48,34 & 43,85 & 39,57 & 35,56 & 28,57 & 23,02 & 15,51 \\
\hline 62,22 & 989,90 & 186,70 & 16,40 & 11,47 & 9,70 & 8,12 & 6,92 & 5,93 & 4,42 & 3,42 & 2,27 \\
\hline 66,17 & 1937,40 & 135,30 & 13,85 & 10,84 & 9,91 & 8,91 & 8,05 & 7,27 & 5,91 & 4,83 & 3,34 \\
\hline 43,24 & 1787,50 & 152,70 & 17,20 & 14,07 & 12,39 & 10,50 & 8,89 & 7,53 & 5,50 & 4,18 & 2,72 \\
\hline 38,11 & 559,60 & 76,10 & 45,09 & 34,49 & 29,05 & 23,26 & 18,76 & 15,29 & 10,65 & 7,98 & 5,32 \\
\hline 51,03 & 1165,20 & 59,30 & 32,53 & 27,46 & 25,24 & 22,54 & 20,08 & 17,83 & 14,06 & 11,18 & 7,46 \\
\hline 49,50 & 715,30 & 109,00 & 28,32 & 21,12 & 18,04 & 14,95 & 12,50 & 10,50 & 7,61 & 5,77 & 3,81 \\
\hline 43,55 & 751,70 & 35,00 & 59,31 & 51,42 & 46,88 & 41,27 & 36,17 & 31,61 & 24,19 & 18,81 & 12,30 \\
\hline 85,54 & 1285,20 & 35,20 & 31,61 & 24,78 & 22,94 & 21,95 & 20,92 & 19,85 & 17,81 & 15,92 & 12,64 \\
\hline 44,49 & 1931,70 & 134,80 & 17,65 & 14,76 & 13,19 & 11,37 & 9,78 & 8,41 & 6,27 & 4,81 & 3,13 \\
\hline 66,02 & 1556,40 & 61,70 & 24,55 & 19,58 & 18,45 & 17,08 & 15,78 & 14,54 & 12,29 & 10,37 & 7,47 \\
\hline 60,87 & 734,60 & 62,50 & 34,01 & 26,74 & 24,06 & 21,25 & 18,86 & 16,72 & 13,17 & 10,51 & 7,07 \\
\hline 31,75 & 419,50 & 198,70 & 30,86 & 18,14 & 13,24 & 9,28 & 6,94 & 5,46 & 3,78 & 2,92 & 2,04 \\
\hline 64,10 & 618,50 & 74,80 & 32,39 & 24,21 & 21,27 & 18,46 & 16,18 & 14,21 & 11,02 & 8,71 & 5,83 \\
\hline 48,17 & 1159,70 & 63,40 & 32,41 & 27,48 & 25,05 & 22,14 & 19,51 & 17,15 & 13,27 & 10,41 & 6,86 \\
\hline 58,27 & 1568,80 & 96,00 & 19,85 & 16,15 & 14,81 & 13,27 & 11,90 & 10,65 & 8,52 & 6,87 & 4,66 \\
\hline 50,80 & 1734,20 & 77,90 & 23,74 & 20,17 & 18,65 & 16,75 & 15,00 & 13,40 & 10,65 & 8,52 & 5,72 \\
\hline 56,32 & 1851,90 & 51,60 & 28,67 & 23,83 & 22,70 & 21,05 & 19,42 & 17,87 & 15,01 & 12,59 & 8,95 \\
\hline 46,08 & 276,10 & 191,30 & 36,10 & 18,84 & 13,42 & 9,51 & 7,25 & 5,76 & 3,98 & 3,06 & 2,14 \\
\hline 36,69 & 980,60 & 133,40 & 26,35 & 20,13 & 16,88 & 13,42 & 10,75 & 8,72 & 6,04 & 4,53 & 3,03 \\
\hline 70,06 & 219,00 & 135,60 & 45,04 & 23,67 & 17,21 & 12,73 & 10,08 & 8,25 & 5,84 & 4,48 & 3,07 \\
\hline 42,53 & 997,30 & 145,90 & 22,66 & 17,13 & 14,51 & 11,79 & 9,64 & 7,95 & 5,61 & 4,22 & 2,80 \\
\hline 83,37 & 1817,60 & 125,60 & 13,24 & 9,75 & 8,91 & 8,14 & 7,50 & 6,91 & 5,86 & 4,98 & 3,64 \\
\hline 68,12 & 1629,10 & 190,00 & 12,18 & 9,03 & 7,97 & 6,96 & 6,16 & 5,45 & 4,29 & 3,43 & 2,32 \\
\hline 28,69 & 374,20 & 102,20 & 50,63 & 33,75 & 25,66 & 18,34 & 13,73 & 10,76 & 7,39 & 5,68 & 3,94 \\
\hline 21,46 & 497,30 & 131,10 & 44,56 & 28,79 & 20,76 & 14,10 & 10,35 & 8,11 & 5,66 & 4,40 & 3,07 \\
\hline 58,03 & 1642,50 & 94,20 & 19,79 & 16,17 & 14,88 & 13,38 & 12,03 & 10,79 & 8,66 & 7,00 & 4,76 \\
\hline 66,10 & 588,90 & 130,20 & 24,98 & 16,79 & 13,99 & 11,61 & 9,87 & 8,45 & 6,31 & 4,89 & 3,27 \\
\hline 45,69 & 651,50 & 34,80 & 60,69 & 51,88 & 47,15 & 41,45 & 36,31 & 31,73 & 24,30 & 18,92 & 12,40 \\
\hline 36,26 & 625,60 & 66,00 & 48,74 & 38,66 & 32,99 & 26,69 & 21,66 & 17,73 & 12,38 & 9,25 & 6,14 \\
\hline 62,75 & 522,00 & 190,20 & 23,21 & 14,07 & 11,07 & 8,71 & 7,12 & 5,92 & 4,25 & 3,25 & 2,19 \\
\hline 32,31 & 1337,10 & 188,90 & 20,43 & 15,43 & 12,68 & 9,79 & 7,65 & 6,10 & 4,17 & 3,14 & 2,13 \\
\hline 26,16 & 699,80 & 57,30 & 64,86 & 51,64 & 42,71 & 32,86 & 25,51 & 20,20 & 13,69 & 10,27 & 6,98 \\
\hline 53,06 & 1858,00 & 197,80 & 12,78 & 10,01 & 8,81 & 7,57 & 6,52 & 5,63 & 4,23 & 3,27 & 2,15 \\
\hline 58,38 & 574,10 & 156,10 & 24,46 & 16,01 & 13,03 & 10,50 & 8,67 & 7,25 & 5,23 & 3,99 & 2,66 \\
\hline 33,05 & 753,60 & 157,50 & 27,85 & 19,72 & 15,72 & 11,81 & 9,09 & 7,20 & 4,92 & 3,73 & 2,56 \\
\hline 86,58 & 411,70 & 94,40 & 32,23 & 20,44 & 16,88 & 14,15 & 12,29 & 10,80 & 8,46 & 6,79 & 4,66 \\
\hline
\end{tabular}




\begin{tabular}{|c|c|c|c|c|c|c|c|c|c|c|c|}
\hline \multirow[b]{2}{*}{ e1 (cm) } & & & & & & & ões (x1 & m) & & & \\
\hline & Meq (MPa) & Ms (MPa) & D0 & D25 & D40 & D60 & D80 & D100 & D140 & D180 & D260 \\
\hline 57,25 & 917,90 & 29,90 & 51,58 & 42,76 & 40,50 & 37,35 & 34,33 & 31,45 & 26,23 & 21,86 & 15,42 \\
\hline 32,83 & 796,50 & 23,10 & 95,01 & $\begin{array}{l}85,61 \\
\end{array}$ & 77,75 & 67,55 & 58,22 & 50,02 & 37,13 & 28,24 & 18,20 \\
\hline 70,57 & 1122,80 & 107,10 & 19,37 & 14,55 & 13,05 & 11,58 & 10,38 & 9,30 & 7,49 & 6,09 & 4,19 \\
\hline 70,46 & 385,90 & 192,80 & 27,30 & 15,13 & 11,38 & 8,67 & 7,00 & 5,79 & 4,15 & 3,19 & 2,17 \\
\hline 45,57 & 468,90 & 59,00 & 50,43 & 38,98 & 33,59 & 27,91 & 23,29 & 19,53 & 14,07 & 10,64 & 6,99 \\
\hline 32,15 & 394,50 & 113,60 & 44,14 & 29,28 & 22,56 & 16,43 & 12,44 & 9,79 & 6,71 & 5,13 & 3,55 \\
\hline 83,65 & 1351,90 & 134,30 & 14,59 & 10,44 & 9,33 & 8,33 & 7,56 & 6,87 & 5,69 & 4,75 & 3,38 \\
\hline 41,51 & 1347,90 & 102,70 & 25,17 & 20,88 & 18,45 & 15,65 & 13,25 & 11,23 & 8,20 & 6,21 & 4,05 \\
\hline 74,90 & 1112,30 & 120,10 & 17,80 & 13,01 & 11,56 & 10,22 & 9,15 & 8,21 & 6,63 & 5,40 & 3,74 \\
\hline 81,71 & 839,40 & 50,80 & 31,23 & 23,29 & 21,45 & 19,72 & 18,23 & 16,85 & 14,37 & 12,26 & 9,02 \\
\hline 80,59 & 1626,30 & 127,20 & 14,04 & 10,34 & 9,40 & 8,51 & 7,78 & 7,12 & 5,95 & 5,00 & 3,59 \\
\hline 31,67 & 1589,00 & 172,50 & 20,67 & 16,20 & 13,54 & 10,63 & 8,41 & 6,75 & 4,63 & 3,46 & 2,33 \\
\hline 50,71 & 405,30 & 115,00 & 35,82 & 23,54 & 18,99 & 14,99 & 12,11 & 9,94 & 7,01 & 5,30 & 3,57 \\
\hline 24,28 & 1718,80 & 50,30 & 56,63 & 49,47 & 43,26 & 35,53 & 28,99 & 23,74 & 16,46 & 12,18 & 7,99 \\
\hline 27,62 & 535,30 & 164,10 & 33,34 & 21,62 & 16,15 & 11,37 & 8,46 & 6,63 & 4,57 & 3,53 & 2,46 \\
\hline 40,37 & 908,10 & 105,00 & 29,54 & 23,18 & 19,88 & 16,29 & 13,40 & 11,09 & 7,85 & 5,89 & 3,89 \\
\hline 81,89 & 1179,60 & 61,00 & 24,35 & 18,30 & 16,96 & 15,74 & 14,63 & 13,60 & 11,72 & 10,09 & 7,52 \\
\hline 20,71 & 1087,10 & 148,10 & 33,85 & 24,25 & 18,33 & 12,82 & 9,43 & 7,32 & 5,04 & 3,89 & 2,71 \\
\hline 74,69 & 1602,00 & 75,80 & 19,90 & 15,33 & 14,32 & 13,26 & 12,29 & 11,38 & 9,71 & 8,28 & 6,07 \\
\hline 82,28 & 269,00 & 119,20 & 39,63 & 22,19 & 16,90 & 13,15 & 10,84 & 9,15 & 6,75 & 5,26 & 3,57 \\
\hline 51,19 & 1114,10 & 185,50 & 17,03 & 12,47 & 10,59 & 8,76 & 7,32 & 6,15 & 4,46 & 3,39 & 2,24 \\
\hline 43,61 & 609,00 & 111,80 & 32,13 & 23,32 & 19,43 & 15,56 & 12,61 & 10,34 & 7,26 & 5,46 & 3,65 \\
\hline 54,89 & 1516,20 & 42,40 & 35,50 & 29,71 & 28,26 & 26,14 & 24,07 & 22,08 & 18,46 & 15,40 & 10,88 \\
\hline 25,78 & 1688,80 & 100,40 & 33,86 & 27,89 & 23,54 & 18,53 & 14,62 & 11,69 & 7,95 & 5,92 & 3,99 \\
\hline 72,78 & 1300,20 & 119,40 & 16,84 & 12,59 & 11,33 & 10,09 & 9,09 & 8,19 & 6,65 & 5,44 & 3,78 \\
\hline 67,62 & 1520,50 & 139,70 & 14,91 & 11,36 & 10,20 & 9,05 & 8,09 & 7,23 & 5,79 & 4,68 & 3,20 \\
\hline 23,08 & 372,80 & 77,40 & 68,24 & 46,64 & 34,84 & 24,28 & 17,89 & 13,95 & 9,64 & 7,45 & 5,19 \\
\hline 41,19 & 1739,30 & 77,50 & 27,48 & 23,99 & 21,82 & 19,12 & 16,66 & 14,48 & 10,98 & 8,48 & 5,52 \\
\hline 50,35 & 1612,00 & 41,20 & 37,49 & 32,05 & 30,45 & 28,04 & 25,69 & 23,45 & 19,39 & 16,02 & 11,14 \\
\hline 55,68 & 1441,30 & 77,50 & 24,05 & 19,90 & 18,33 & 16,47 & 14,78 & 13,24 & 10,59 & 8,53 & 5,77 \\
\hline 22,24 & 1281,20 & 85,10 & 46,14 & 36,72 & 29,90 & 22,51 & 17,16 & 13,44 & 9,06 & 6,84 & 4,69 \\
\hline 61,73 & 1847,90 & 87,30 & 19,19 & 15,54 & 14,50 & 13,23 & 12,07 & 10,99 & 9,06 & 7,48 & 5,23 \\
\hline 30,10 & 1102,50 & 183,90 & 23,19 & 16,98 & 13,61 & 10,20 & 7,82 & 6,17 & 4,20 & 3,18 & 2,19 \\
\hline 48,15 & 1842,70 & 71,20 & 25,51 & 22,01 & 20,43 & 18,38 & 16,47 & 14,70 & 11,68 & 9,34 & 6,25 \\
\hline 78,47 & 222,20 & 143,30 & 43,36 & 22,37 & 16,13 & 11,88 & 9,44 & 7,76 & 5,54 & 4,27 & 2,93 \\
\hline 62,75 & 1784,70 & 113,40 & 16,36 & 13,05 & 11,98 & 10,79 & 9,73 & 8,77 & 7,10 & 5,78 & 3,98 \\
\hline 75,87 & 1535,30 & 66,20 & 21,81 & 16,78 & 15,72 & 14,65 & 13,63 & 12,68 & 10,91 & 9,37 & 6,96 \\
\hline 78,37 & 638,30 & 66,30 & 31,04 & 22,50 & 20,06 & 17,82 & 16,05 & 14,49 & 11,82 & 9,73 & 6,81 \\
\hline 87,32 & 1485,20 & 191,90 & 11,45 & 7,88 & 6,88 & 6,05 & 5,43 & 4,91 & 4,02 & 3,33 & 2,35 \\
\hline 78,95 & 548,80 & 23,10 & 60,54 & 46,27 & 43,26 & 40,47 & 37,80 & 35,28 & 30,60 & 26,49 & 19,90 \\
\hline 47,65 & 1836,60 & 174,00 & 14,77 & 11,86 & 10,46 & 8,92 & 7,62 & 6,52 & 4,83 & 3,70 & 2,42 \\
\hline 63,38 & 1811,40 & 188,60 & 12,06 & 9,20 & 8,17 & 7,16 & 6,32 & 5,58 & 4,36 & 3,47 & 2,33 \\
\hline 20,93 & 1407,90 & 112,60 & 38,37 & 29,56 & 23,42 & 17,10 & 12,79 & 9,94 & 6,73 & 5,14 & 3,55 \\
\hline 37,75 & 1449,90 & 56,10 & 38,59 & 34,13 & 31,01 & 27,05 & 23,45 & 20,27 & 15,22 & 11,67 & 7,56 \\
\hline 62,41 & 1694,60 & 37,10 & 34,64 & 27,99 & 26,83 & 25,39 & 23,82 & 22,27 & 19,34 & 16,72 & 12,49 \\
\hline 36,25 & 392,40 & 93,60 & 47,08 & 32,55 & 25,98 & 19,67 & 15,26 & 12,15 & 8,33 & 6,30 & 4,31 \\
\hline 89,47 & 624,70 & 31,50 & 44,41 & 32,93 & 30,30 & 28,28 & 26,46 & 24,77 & 21,65 & 18,91 & 14,44 \\
\hline 72,43 & 1659,40 & 95,50 & 17,33 & 13,36 & 12,37 & 11,32 & 10,39 & 9,53 & 7,99 & 6,70 & 4,80 \\
\hline 65,47 & 241,90 & 92,00 & 48,72 & 29,09 & 22,76 & 17,87 & 14,63 & 12,19 & 8,79 & 6,74 & 4,54 \\
\hline 38,81 & 268,60 & 178,80 & 38,63 & 20,52 & 14,59 & 10,22 & 7,71 & 6,10 & 4,21 & 3,25 & 2,28 \\
\hline 72,19 & 875,70 & 43,20 & 36,18 & 28,06 & 26,19 & 24,15 & 22,29 & 20,55 & 17,39 & 14,72 & 10,66 \\
\hline 65,88 & 1104,90 & 126,30 & 18,44 & 13,80 & 12,19 & 10,64 & 9,38 & 8,29 & 6,49 & 5,17 & 3,48 \\
\hline 23,56 & 249,80 & 69,70 & 81,63 & 52,98 & 38,74 & 26,66 & 19,64 & 15,37 & 10,68 & 8,28 & 5,78 \\
\hline 33,02 & 934,00 & 168,00 & 24,73 & $\begin{array}{l}17,98 \\
\end{array}$ & 14,53 & 11,05 & 8,56 & 6,80 & 4,65 & 3,51 & 2,40 \\
\hline 62,50 & 374,90 & 119,50 & 34,16 & 21,39 & 17,11 & 13,65 & 11,25 & 9,41 & 6,80 & 5,21 & 3,49 \\
\hline 49,46 & 359,50 & 122,30 & 37,35 & 23,57 & 18,61 & 14,38 & 11,46 & 9,31 & 6,51 & 4,93 & 3,34 \\
\hline 27,48 & 298,40 & 180,30 & 38,84 & 21,19 & 14,78 & 10,04 & 7,47 & 5,90 & 4,12 & 3,20 & 2,26 \\
\hline 56,07 & 1576,50 & 95,30 & 20,37 & 16,72 & 15,31 & 13,68 & 12,22 & 10,90 & 8,65 & 6,93 & 4,67 \\
\hline 23,91 & 1190,50 & 44,10 & 70,61 & $\begin{array}{l}60,28 \\
\end{array}$ & 51,85 & 41,67 & 33,39 & 26,96 & 18,44 & 13,66 & 9,09 \\
\hline 39,53 & 1404,40 & 56,80 & 37,37 & 32,92 & 29,97 & 26,25 & 22,86 & 19,85 & 15,01 & 11,57 & 7,52 \\
\hline 32,75 & 873,30 & 69,50 & 444,95 & 36,77 & 31,57 & 25,57 & 20,73 & 16,94 & 11,77 & 8,78 & 5,81 \\
\hline 58,97 & 1525,00 & 41,30 & 34,51 & 28,32 & 27,03 & 25,21 & 23,38 & 21,62 & 18,35 & 15,53 & 11,21 \\
\hline 58,94 & 1864,70 & 145,80 & 14,33 & 11,42 & 10,32 & 9,13 & 8,11 & 7,19 & 5,66 & 4,51 & 3,03 \\
\hline 74,62 & 1513,70 & 121,10 & 15,43 & 11,59 & 10,53 & 9,47 & 8,60 & 7,81 & 6,43 & 5,33 & 3,75 \\
\hline 71,54 & 304,40 & 181,90 & 32,66 & 17,29 & 12,64 & 9,40 & 7,48 & 6,14 & 4,37 & 3,35 & 2,30 \\
\hline 28,89 & 1989,20 & 62,90 & 40,01 & 35,51 & 31,65 & 26,76 & 22,45 & 18,83 & 13,47 & 10,06 & 6,51 \\
\hline 65,53 & 1832,60 & 140,60 & 13,93 & 10,85 & 9,86 & 8,82 & 7,92 & 7,12 & 5,74 & 4,66 & 3,19 \\
\hline 57,35 & 1747,80 & 114,40 & 17,26 & 14,03 & 12,80 & 11,42 & 10,19 & 9,08 & 7,20 & 5,76 & 3,88 \\
\hline 64,77 & 896,30 & 104,90 & 22,63 & 16,95 & 14,94 & 13,00 & 11,43 & 10,06 & 7,84 & 6,22 & 4,17 \\
\hline 51,07 & 1705,40 & 112,10 & 18,93 & 15,70 & 14,22 & 12,52 & 11,02 & 9,68 & 7,48 & 5,87 & 3,88 \\
\hline 68,86 & 1137,70 & 175,90 & 15,04 & 10,69 & 9,22 & 7,90 & 6,89 & 6,03 & 4,66 & 3,68 & 2,47 \\
\hline 43,85 & 1401,00 & 85,00 & 26,81 & 22,74 & 20,46 & 17,76 & 15,36 & 13,27 & 9,96 & 7,66 & 4,99 \\
\hline 23,43 & 398,50 & 26,60 & 142,45 & 114,28 & 94,02 & 71,66 & 55,16 & 43,41 & 29,30 & 22,02 & 15,04 \\
\hline 40,23 & 618,50 & 169,10 & 26,32 & 17,67 & 14,08 & 10,74 & 8,41 & 6,74 & 4,64 & 3,51 & 2,40 \\
\hline 34,02 & 689,30 & 189,40 & 25,35 & 17,01 & 13,28 & 9,81 & 7,50 & 5,92 & 4,06 & 3,09 & 2,13 \\
\hline 43,57 & 885,20 & 67,20 & 37,12 & 30,78 & 27,32 & 23,35 & 19,93 & 17,01 & 12,55 & 9,57 & 6,23 \\
\hline 57,10 & 1898,30 & 182,40 & 12,72 & 9,99 & 8,89 & 7,74 & 6,78 & 5,93 & 4,57 & 3,58 & 2,38 \\
\hline 24,05 & 1035,70 & 50,80 & 66,51 & 55,31 & 46,74 & 36,77 & 28,97 & 23,12 & 15,69 & 11,68 & 7,86 \\
\hline 48,02 & 455,40 & 132,10 & 32,21 & 21,15 & 16,98 & 13,27 & 10,63 & 8,66 & 6,06 & 4,58 & 3,09 \\
\hline 42,09 & 929,00 & 146,90 & 23,40 & 17,46 & 14,68 & 11,83 & 9,61 & 7,89 & 5,55 & 4,17 & 2,77 \\
\hline 61,64 & 1319,60 & 79,90 & 23,02 & 18,49 & 17,01 & 15,32 & 13,83 & 12,46 & 10,09 & 8,22 & 5,64 \\
\hline 63,94 & 651,20 & 36,40 & 48,00 & 38,32 & 35,47 & 32,19 & 29,26 & 26,55 & 21,78 & 17,93 & 12,48 \\
\hline
\end{tabular}




\begin{tabular}{|c|c|c|c|c|c|c|c|c|c|c|c|}
\hline \multirow[b]{2}{*}{ e1 (cm) } & & & & & & $\mathrm{De}$ & ões (x1 & & & & \\
\hline & Meq (MPa) & Ms (MPa) & D0 & D25 & D40 & D60 & D80 & D100 & D140 & D180 & D260 \\
\hline 22,22 & 531,70 & 82,10 & 60,59 & 43,18 & 32,81 & 23,12 & 17,07 & 13,27 & 9,12 & 7,03 & 4,89 \\
\hline 52,84 & 559,80 & 137,80 & 27,34 & 18,47 & 15,16 & 12,18 & 9,99 & 8,28 & 5,91 & 4,48 & 2,99 \\
\hline 56,93 & 664,80 & 132,50 & 24,71 & 17,31 & 14,53 & 12,00 & 10,07 & 8,51 & 6,23 & 4,76 & 3,16 \\
\hline 35,31 & 488,90 & 75,50 & 50,00 & 37,40 & 30,90 & 24,12 & 19,06 & 15,31 & 10,53 & 7,91 & 5,34 \\
\hline 86,71 & 1126,60 & 190,20 & 13,37 & 8,90 & 7,59 & 6,54 & 5,79 & 5,16 & 4,14 & 3,37 & 2,35 \\
\hline 42,97 & 877,90 & 70,30 & 36,60 & 30,16 & 26,66 & 22,67 & 19,24 & 16,35 & 11,98 & 9,10 & 5,93 \\
\hline 27,95 & 343,20 & 198,50 & 34,56 & 19,12 & 13,43 & 9,16 & 6,81 & 5,37 & 3,74 & 2,91 & 2,05 \\
\hline 65,21 & 502,40 & 169,40 & 24,61 & 15,13 & 12,02 & 9,56 & 7,89 & 6,61 & 4,80 & 3,68 & 2,47 \\
\hline 50,56 & 1681,30 & 112,80 & 19,08 & 15,83 & 14,31 & 12,57 & 11,03 & 9,67 & 7,44 & 5,83 & 3,84 \\
\hline 21,16 & 1291,60 & 128,10 & 35,50 & 26,68 & 20,82 & 14,98 & 11,13 & 8,64 & 5,88 & 4,51 & 3,12 \\
\hline 41,61 & 364,10 & 122,20 & 39,46 & 25,25 & 19,74 & 14,88 & 11,59 & 9,26 & 6,39 & 4,85 & 3,32 \\
\hline 65,32 & 1849,40 & 85,80 & 18,80 & 15,00 & 14,04 & 12,88 & 11,82 & 10,82 & 9,03 & 7,54 & 5,35 \\
\hline 55,15 & 816,00 & 173,10 & 19,80 & 13,74 & 11,46 & 9,38 & 7,81 & 6,56 & 4,75 & 3,62 & 2,40 \\
\hline 36,38 & 836,70 & 114,80 & 30,87 & 23,55 & 19,72 & 15,63 & 12,50 & 10,12 & 7,00 & 5,25 & 3,52 \\
\hline 21,09 & 1063,30 & 82,80 & 51,52 & 39,87 & 31,71 & 23,25 & 17,43 & 13,55 & 9,17 & 6,99 & 4,83 \\
\hline 57,00 & 1339,50 & 81,20 & 23,70 & 19,39 & 17,77 & 15,90 & 14,23 & 12,71 & 10,13 & 8,13 & 5,49 \\
\hline 52,32 & 200,90 & 161,80 & 46,37 & 23,03 & 16,01 & 11,22 & 8,55 & 6,82 & 4,72 & 3,63 & 2,55 \\
\hline 55,63 & 1667,50 & 191,20 & 13,30 & 10,25 & 9,00 & 7,73 & 6,68 & 5,78 & 4,37 & 3,39 & 2,23 \\
\hline 60,50 & 1224,30 & 185,50 & 14,97 & 10,92 & 9,41 & 8,00 & 6,87 & 5,93 & 4,47 & 3,47 & 2,30 \\
\hline 81,84 & 1204,20 & 148,40 & 14,81 & 10,43 & 9,16 & 8,06 & 7,22 & 6,50 & 5,28 & 4,34 & 3,03 \\
\hline 54,99 & 779,60 & 128,80 & 23,56 & 17,15 & 14,63 & 12,22 & 10,32 & 8,76 & 6,44 & 4,93 & 3,26 \\
\hline 45,71 & 1034,00 & 69,50 & 33,11 & 27,74 & 24,90 & 21,59 & 18,69 & 16,15 & 12,16 & 9,37 & 6,11 \\
\hline 89,34 & 413,80 & 186,20 & 25,31 & 13,97 & 10,59 & 8,22 & 6,80 & 5,77 & 4,30 & 3,37 & 2,31 \\
\hline 83,19 & 1481,20 & 158,20 & 12,86 & 9,15 & 8,13 & 7,23 & 6,53 & 5,92 & 4,87 & 4,04 & 2,86 \\
\hline 83,62 & 1658,90 & 94,50 & 16,18 & 12,04 & 11,11 & 10,26 & 9,52 & 8,84 & 7,59 & 6,52 & 4,85 \\
\hline 54,50 & 1648,10 & 60,20 & 27,38 & 23,00 & 21,61 & 19,73 & 17,97 & 16,31 & 13,36 & 10,96 & 7,57 \\
\hline 89,09 & 1004,40 & 106,20 & 18,53 & 12,96 & 11,50 & 10,26 & 9,32 & 8,50 & 7,08 & 5,94 & 4,28 \\
\hline 84,48 & 682,10 & 170,20 & 18,95 & 11,89 & 9,74 & 8,09 & 6,98 & 6,09 & 4,72 & 3,76 & 2,57 \\
\hline 66,18 & 564,50 & 100,20 & 28,85 & 20,20 & 17,19 & 14,54 & 12,52 & 10,84 & 8,23 & 6,43 & 4,29 \\
\hline 45,69 & 1462,40 & 55,30 & 33,79 & 29,44 & 27,24 & 24,39 & 21,74 & 19,30 & 15,18 & 12,04 & 7,99 \\
\hline 79,46 & 403,70 & 99,30 & 32,76 & 20,87 & 17,15 & 14,24 & 12,23 & 10,63 & 8,15 & 6,45 & 4,37 \\
\hline 69,19 & 1430,00 & 129,70 & 15,79 & 11,97 & 10,77 & 9,58 & 8,58 & 7,70 & 6,20 & 5,03 & 3,46 \\
\hline 31,54 & 1444,70 & 52,90 & 46,43 & 41,02 & 36,68 & 31,19 & 26,34 & 22,23 & 16,06 & 12,05 & 7,79 \\
\hline 48,70 & 253,00 & 59,70 & 64,00 & 43,93 & 36,05 & 28,76 & 23,37 & 19,22 & 13,57 & 10,26 & 6,86 \\
\hline 68,03 & 676,50 & 35,70 & 46,33 & 36,44 & 33,90 & 31,00 & 28,41 & 25,99 & 21,66 & 18,08 & 12,83 \\
\hline 23,27 & 1426,30 & 81,40 & 44,63 & 36,36 & 30,23 & 23,30 & 18,07 & 14,28 & 9,64 & 7,22 & 4,91 \\
\hline 32,79 & 257,70 & 52,60 & 83,08 & 59,06 & 47,15 & 35,43 & 27,27 & 21,59 & 14,75 & 11,17 & 7,66 \\
\hline 23,06 & 737,00 & 30,30 & 109,22 & 91,79 & 77,93 & 61,59 & 48,66 & 38,90 & 26,39 & 19,61 & 13,17 \\
\hline 35,04 & 1562,00 & 74,20 & 33,25 & 28,89 & 25,78 & 21,95 & 18,58 & 15,72 & 11,42 & 8,61 & 5,57 \\
\hline 67,50 & 1884,20 & 104,10 & 16,24 & 12,78 & 11,86 & 10,81 & 9,88 & 9,02 & 7,48 & 6,22 & 4,39 \\
\hline 33,64 & 1263,70 & 106,30 & 29,39 & 23,92 & 20,53 & 16,65 & 13,52 & 11,06 & 7,70 & 5,75 & 3,80 \\
\hline 20,58 & 600,80 & 159,10 & 37,46 & 23,98 & 17,13 & 11,57 & 8,48 & 6,65 & 4,66 & 3,62 & 2,53 \\
\hline 77,61 & 333,50 & 59,80 & 45,68 & 30,93 & 26,29 & 22,43 & 19,61 & 17,26 & 13,51 & 10,79 & 7,35 \\
\hline 56,95 & 1051,60 & 174,30 & 17,14 & 12,42 & 10,60 & 8,89 & 7,54 & 6,43 & 4,76 & 3,66 & 2,42 \\
\hline 44,97 & 796,90 & 64,90 & 38,66 & 31,75 & 28,13 & 24,05 & 20,54 & 17,55 & 12,98 & 9,91 & 6,46 \\
\hline 33,64 & 301,70 & 182,40 & 36,95 & 20,26 & 14,44 & 10,03 & 7,51 & 5,93 & 4,11 & 3,18 & 2,23 \\
\hline 35,47 & 557,70 & 87,40 & 43,32 & 32,33 & 26,69 & 20,83 & 16,46 & 13,23 & 9,10 & 6,83 & 4,61 \\
\hline 64,82 & 729,80 & 160,20 & 20,38 & 13,76 & 11,47 & 9,51 & 8,07 & 6,90 & 5,14 & 3,97 & 2,65 \\
\hline 27,48 & 1361,00 & 113,10 & 31,86 & 25,48 & 21,23 & 16,50 & 12,92 & 10,29 & 6,99 & 5,23 & 3,54 \\
\hline 86,11 & 1975,40 & 87,40 & 15,48 & 11,64 & 10,78 & 10,11 & 9,48 & 8,89 & 7,78 & 6,81 & 5,21 \\
\hline 37,66 & 1642,50 & 168,00 & 18,44 & 14,71 & 12,64 & 10,32 & 8,45 & 6,96 & 4,90 & 3,67 & 2,42 \\
\hline 65,25 & 1387,30 & 167,90 & 14,31 & 10,66 & 9,37 & 8,14 & 7,15 & 6,29 & 4,90 & 3,88 & 2,61 \\
\hline 83,63 & 1516,60 & 102,00 & 16,09 & 11,86 & 10,85 & 9,93 & 9,16 & 8,45 & 7,19 & 6,12 & 4,49 \\
\hline 26,49 & 659,20 & 55,20 & 67,22 & 53,47 & 44,25 & 34,08 & 26,48 & 20,99 & 14,23 & 10,67 & 7,26 \\
\hline 41,80 & 1778,00 & 132,90 & 19,21 & 15,97 & 14,14 & 12,02 & 10,20 & 8,66 & 6,34 & 4,81 & 3,13 \\
\hline 64,91 & 1252,40 & 156,50 & 15,63 & 11,60 & 10,17 & 8,81 & 7,72 & 6,78 & 5,26 & 4,16 & 2,79 \\
\hline 42,38 & 1333,70 & 124,00 & 22,21 & 17,97 & 15,71 & 13,19 & 11,08 & 9,33 & 6,75 & 5,10 & 3,33 \\
\hline 84,74 & 310,00 & 77,80 & 41,57 & 26,05 & 21,31 & 17,70 & 15,26 & 13,32 & 10,32 & 8,23 & 5,62 \\
\hline 52,72 & 209,70 & 164,70 & 44,80 & 22,41 & 15,65 & 11,02 & 8,41 & 6,71 & 4,64 & 3,57 & 2,50 \\
\hline 36,53 & 1036,60 & 187,20 & 21,00 & 15,31 & 12,54 & 9,73 & 7,67 & 6,15 & 4,23 & 3,19 & 2,16 \\
\hline 37,51 & 797,70 & 172,50 & 24,14 & 17,02 & 13,77 & 10,58 & 8,29 & 6,64 & 4,57 & 3,44 & 2,34 \\
\hline 49,18 & 1026,20 & 99,70 & 25,52 & 20,39 & 17,98 & 15,38 & 13,18 & 11,31 & 8,42 & 6,46 & 4,23 \\
\hline 50,73 & 757,70 & 89,30 & 30,39 & 23,56 & 20,55 & 17,42 & 14,84 & 12,66 & 9,36 & 7,17 & 4,71 \\
\hline 38,00 & 1075,60 & 125,20 & 25,85 & 20,25 & 17,25 & 13,97 & 11,37 & 9,33 & 6,53 & 4,89 & 3,24 \\
\hline 65,16 & 255,30 & 180,60 & 37,40 & 19,08 & 13,59 & 9,81 & 7,65 & 6,19 & 4,33 & 3,32 & 2,30 \\
\hline 62,27 & 882,40 & 70,60 & 28,98 & 22,79 & 20,61 & 18,31 & 16,33 & 14,56 & 11,57 & 9,30 & 6,30 \\
\hline 31,05 & 203,70 & 139,90 & 51,75 & 27,25 & 18,96 & 12,96 & 9,67 & 7,65 & 5,32 & 4,13 & 2,91 \\
\hline 74,47 & 383,50 & 46,20 & 48,91 & 35,37 & 31,16 & 27,33 & 24,33 & 21,72 & 17,36 & 14,06 & 9,66 \\
\hline 89,65 & 865,50 & 109,20 & 19,67 & 13,48 & 11,79 & 10,39 & 9,36 & 8,48 & 6,99 & 5,81 & 4,14 \\
\hline 31,97 & 1733,80 & 189,80 & 18,71 & 14,66 & 12,26 & 9,64 & 7,63 & 6,13 & 4,21 & 3,15 & 2,12 \\
\hline 40,20 & 383,00 & 177,50 & 32,09 & 18,93 & 14,19 & 10,33 & 7,90 & 6,27 & 4,31 & 3,30 & 2,29 \\
\hline 34,40 & 1299,60 & 132,20 & 24,90 & 19,80 & 16,82 & 13,51 & 10,88 & 8,86 & 6,14 & 4,59 & 3,06 \\
\hline 59,89 & 1319,70 & 84,40 & 22,62 & 18,24 & 16,70 & 14,97 & 13,44 & 12,04 & 9,66 & 7,80 & 5,31 \\
\hline 85,40 & 214,40 & 184,20 & 41,77 & 20,11 & 13,81 & 9,70 & 7,49 & 6,06 & 4,26 & 3,29 & 2,28 \\
\hline 31,38 & 1236,80 & 107,60 & 30,89 & 24,90 & 21,12 & 16,85 & 13,48 & 10,90 & 7,51 & 5,60 & 3,74 \\
\hline 72,35 & 1755,40 & 132,10 & 13,99 & 10,64 & 9,70 & 8,74 & 7,94 & 7,21 & 5,93 & 4,90 & 3,44 \\
\hline 20,25 & 1964,90 & 183,90 & 25,06 & 18,81 & 14,61 & 10,45 & 7,73 & 5,99 & 4,09 & 3,14 & 2,18 \\
\hline 26,83 & 1489,00 & 69,90 & 43,67 & 37,04 & 31,96 & 25,87 & 20,88 & 16,96 & 11,69 & 8,67 & 5,74 \\
\hline 79,01 & 640,70 & 58,90 & 32,90 & 24,06 & 21,64 & 19,38 & 17,57 & 15,95 & 13,15 & 10,91 & 7,71 \\
\hline 36,24 & 1870,90 & 143,50 & 19,93 & 16,47 & 14,35 & 11,89 & 9,84 & 8,17 & 5,80 & 4,34 & 2,84 \\
\hline 79,30 & 1579,50 & 114,40 & 15,20 & 11,30 & 10,32 & 9,38 & 8,59 & 7,87 & 6,60 & 5,55 & 4,00 \\
\hline 57,88 & 1855,20 & 25,60 & 45,72 & 37,33 & 35,97 & 34,47 & 32,60 & 30,71 & 27,05 & 23,69 & 18,06 \\
\hline
\end{tabular}




\begin{tabular}{|c|c|c|c|c|c|c|c|c|c|c|c|}
\hline \multirow[b]{2}{*}{ e1 (cm) } & & & & & & $\mathrm{De}$ & ões (x1 & & & & \\
\hline & Meq (MPa) & Ms (MPa) & D0 & D25 & D40 & D60 & D80 & D100 & D140 & D180 & D260 \\
\hline 33,20 & 472,10 & 121,90 & 38,88 & 26,42 & 20,67 & 15,28 & 11,66 & 9,21 & 6,30 & 4,80 & 3,31 \\
\hline 49,22 & 986,10 & 155,70 & 20,21 & 14,98 & 12,75 & 10,54 & 8,78 & 7,36 & 5,31 & 4,03 & 2,66 \\
\hline 89,84 & 802,40 & 127,50 & 19,06 & 12,69 & 10,87 & 9,41 & 8,38 & 7,51 & 6,09 & 5,01 & 3,52 \\
\hline 25,41 & 1403,10 & 31,10 & 80,31 & 72,22 & 64,50 & 54,53 & 45,69 & 38,23 & 27,24 & 20,28 & 13,09 \\
\hline 80,77 & 1078,20 & 28,40 & 40,30 & 31,61 & 29,52 & 28,23 & 26,83 & 25,40 & 22,67 & 20,15 & 15,83 \\
\hline 52,55 & 1139,80 & 48,90 & 36,42 & 30,78 & 28,61 & 25,84 & 23,28 & 20,91 & 16,80 & 13,56 & 9,19 \\
\hline 53,15 & 1260,70 & 156,80 & 17,26 & 13,22 & 11,51 & 9,78 & 8,36 & 7,16 & 5,33 & 4,10 & 2,69 \\
\hline 43,93 & 498,00 & 163,20 & 28,64 & 18,38 & 14,47 & 11,03 & 8,67 & 6,97 & 4,82 & 3,65 & 2,49 \\
\hline 57,91 & 1811,60 & 104,20 & 17,94 & 14,66 & 13,49 & 12,12 & 10,89 & 9,77 & 7,84 & 6,33 & 4,30 \\
\hline 21,46 & 996,60 & 90,20 & 48,70 & 37,13 & 29,28 & 21,29 & 15,91 & 12,36 & 8,39 & 6,41 & 4,43 \\
\hline 48,82 & 1274,20 & 135,30 & 19,62 & 15,49 & 13,57 & 11,53 & 9,82 & 8,38 & 6,19 & 4,74 & 3,10 \\
\hline 40,53 & 1748,70 & 115,90 & 21,51 & 18,13 & 16,12 & 13,75 & 11,69 & 9,94 & 7,29 & 5,53 & 3,59 \\
\hline 34,11 & 1832,40 & 77,00 & 31,35 & 27,50 & 24,63 & 21,04 & 17,86 & 15,14 & 11,03 & 8,31 & 5,37 \\
\hline 82,75 & 808,90 & 54,30 & 30,36 & 22,43 & 20,55 & 18,80 & 17,32 & 15,97 & 13,56 & 11,53 & 8,44 \\
\hline 40,80 & 1923,30 & 108,90 & 21,48 & 18,39 & 16,50 & 14,23 & 12,22 & 10,49 & 7,79 & 5,95 & 3,86 \\
\hline 74,12 & 1992,60 & 157,70 & 11,84 & 8,91 & 8,10 & 7,29 & 6,62 & 6,01 & 4,95 & 4,10 & 2,88 \\
\hline 29,74 & 595,80 & 100,40 & 42,92 & 31,34 & 25,04 & 18,71 & 14,31 & 11,27 & 7,68 & 5,82 & 4,00 \\
\hline 84,88 & 1640,50 & 115,10 & 14,42 & 10,56 & 9,64 & 8,81 & 8,11 & 7,48 & 6,36 & 5,42 & 3,98 \\
\hline 61,07 & 1496,50 & 98,90 & 19,35 & 15,50 & 14,18 & 12,71 & 11,42 & 10,24 & 8,22 & 6,65 & 4,53 \\
\hline 82,20 & 1302,10 & 65,00 & 22,48 & 16,91 & 15,69 & 14,58 & 13,58 & 12,64 & 10,92 & 9,42 & 7,05 \\
\hline 22,15 & 700,60 & 101,50 & 48,25 & 34,70 & 26,49 & 18,74 & 13,85 & 10,76 & 7,39 & 5,69 & 3,95 \\
\hline 33,45 & 488,70 & 98,40 & 43,70 & 31,16 & 24,98 & 18,87 & 14,58 & 11,56 & 7,90 & 5,98 & 4,09 \\
\hline 41,76 & 1838,20 & 96,70 & 23,15 & 19,94 & 18,00 & 15,65 & 13,54 & 11,70 & 8,78 & 6,75 & 4,39 \\
\hline 87,96 & 1643,80 & 189,40 & 10,91 & 7,59 & 6,69 & 5,93 & 5,36 & 4,87 & 4,02 & 3,35 & 2,39 \\
\hline 46,14 & 1541,70 & 72,00 & 27,75 & 23,91 & 21,90 & 19,42 & 17,15 & 15,11 & 11,71 & 9,20 & 6,06 \\
\hline 82,20 & 368,90 & 89,30 & 35,73 & 22,68 & 18,65 & 15,53 & 13,40 & 11,68 & 9,03 & 7,18 & 4,89 \\
\hline 43,12 & 926,10 & 39,70 & 51,20 & 44,66 & 40,86 & 36,10 & 31,73 & 27,80 & 21,37 & 16,66 & 10,91 \\
\hline 25,20 & 411,50 & 36,60 & 106,88 & 83,83 & 68,41 & 51,81 & 39,77 & 31,29 & 21,17 & 15,96 & 10,92 \\
\hline 82,72 & 1177,10 & 90,90 & $\begin{array}{l}10,, 00 \\
19,29\end{array}$ & 14,12 & 12,83 & $\begin{array}{l}1,0 \perp \\
11,64\end{array}$ & 10,67 & $\begin{array}{c}1,20 \\
9,79\end{array}$ & 8,23 & $\begin{array}{l}10,90 \\
6,94\end{array}$ & $\frac{10,02}{5,03}$ \\
\hline 47,83 & 329,70 & 187,90 & 32,59 & 17,99 & 13,23 & 9,64 & 7,43 & 5,94 & 4,11 & 3,14 & 2,18 \\
\hline 60,34 & 1467,60 & 173,60 & 14,23 & 10,79 & 9,48 & 8,19 & 7,14 & 6,23 & 4,78 & 3,75 & 2,49 \\
\hline 23,91 & 1903,60 & 119,50 & 30,64 & 24,82 & 20,59 & 15,85 & 12,29 & 9,71 & 6,56 & 4,92 & 3,34 \\
\hline 31,89 & 607,40 & 199,50 & 26,52 & 17,08 & 12,97 & 9,34 & 7,04 & 5,53 & 3,80 & 2,91 & 2,03 \\
\hline 43,81 & 1151,30 & 81,60 & 29,66 & 24,78 & 22,10 & 18,99 & 16,28 & 13,96 & 10,36 & 7,92 & 5,16 \\
\hline 87,01 & 1489,30 & 190,20 & 11,49 & 7,93 & 6,94 & 6,10 & 5,48 & 4,95 & 4,06 & 3,36 & 2,37 \\
\hline 69,58 & 626,50 & 74,00 & 31,17 & 22,96 & 20,25 & 17,71 & 15,68 & 13,91 & 10,99 & 8,81 & 5,98 \\
\hline 23,24 & 1741,40 & 184,00 & 23,65 & 17,93 & 14,20 & 10,40 & 7,81 & 6,09 & 4,13 & 3,15 & 2,18 \\
\hline 29,32 & 1943,30 & 103,90 & 28,55 & 24,16 & 20,95 & 17,10 & 13,92 & 11,39 & 7,92 & 5,89 & 3,88 \\
\hline 57,48 & 1575,70 & 51,20 & 29,99 & 24,83 & 23,52 & 21,71 & 19,96 & 18,29 & 15,27 & 12,73 & 8,99 \\
\hline 83,29 & 1608,20 & 199,70 & 10,97 & 7,68 & 6,74 & 5,93 & 5,32 & 4,80 & 3,91 & 3,21 & 2,26 \\
\hline 50,96 & 1095,90 & 163,80 & 18,38 & 13,72 & 11,75 & 9,80 & 8,23 & 6,95 & 5,07 & 3,86 & 2,54 \\
\hline 77,31 & 1367,80 & 199,20 & 12,29 & 8,59 & 7,45 & 6,46 & 5,71 & 5,07 & 4,03 & 3,25 & 2,23 \\
\hline 61,33 & 1162,10 & 164,80 & 16,21 & 11,93 & 10,34 & 8,84 & 7,64 & 6,62 & 5,03 & 3,92 & 2,61 \\
\hline 43,31 & 329,80 & 145,80 & 37,39 & 22,27 & 16,89 & 12,48 & 9,64 & 7,69 & 5,30 & 4,04 & 2,79 \\
\hline 85,00 & 504,90 & 101,60 & 27,86 & 18,13 & 15,20 & 12,89 & 11,27 & 9,95 & 7,85 & 6,32 & 4,35 \\
\hline 83,41 & 358,60 & 33,40 & 56,96 & 41,00 & 36,81 & 33,02 & 30,02 & 27,37 & 22,76 & 19,03 & 13,61 \\
\hline 73,25 & 1490,60 & 83,10 & 19,56 & 15,05 & 13,96 & 12,81 & 11,78 & 10,83 & 9,11 & 7,68 & 5,53 \\
\hline 33,75 & 490,30 & 93,70 & 44,78 & 32,25 & 26,00 & 19,76 & 15,32 & 12,18 & 8,33 & 6,29 & 4,30 \\
\hline 58,42 & 726,00 & 52,00 & 38,94 & 31,33 & 28,46 & 25,29 & 22,52 & 20,03 & 15,84 & 12,66 & 8,52 \\
\hline 37,69 & 629,80 & 197,50 & 24,59 & 16,03 & 12,50 & 9,32 & 7,18 & 5,70 & 3,92 & 2,98 & 2,05 \\
\hline 86,34 & 1972,90 & 141,60 & 11,75 & 8,55 & 7,79 & 7,11 & 6,56 & 6,05 & 5,15 & 4,39 & 3,23 \\
\hline 27,96 & 1244,90 & 109,60 & 33,08 & 26,32 & 21,91 & 17,01 & 13,32 & 10,60 & 7,21 & 5,40 & 3,66 \\
\hline 49,61 & 976,10 & 132,90 & 22,05 & 16,75 & 14,44 & 12,08 & 10,16 & 8,59 & 6,26 & 4,77 & 3,13 \\
\hline 83,14 & 385,50 & 170,70 & 27,61 & 15,44 & 11,76 & 9,15 & 7,55 & 6,37 & 4,71 & 3,67 & 2,50 \\
\hline 60,90 & 653,40 & 62,00 & 35,94 & 27,94 & 24,96 & 21,90 & 19,33 & 17,06 & 13,33 & 10,57 & 7,08 \\
\hline 39,46 & 1325,90 & 140,20 & 21,69 & 17,24 & 14,85 & 12,20 & 10,05 & 8,32 & 5,89 & 4,42 & 2,91 \\
\hline 74,29 & 466,80 & 30,90 & 55,98 & 42,58 & 39,14 & 35,60 & 32,56 & 29,78 & 24,84 & 20,77 & 14,81 \\
\hline 75,03 & 1879,40 & 196,40 & 10,71 & 7,85 & 7,00 & 6,20 & 5,56 & 5,00 & 4,04 & 3,30 & 2,29 \\
\hline 85,78 & 1390,30 & 99,00 & 16,79 & 12,25 & 11,17 & 10,20 & 9,40 & 8,67 & 7,38 & 6,29 & 4,62 \\
\hline 33,61 & 1323,50 & 83,90 & 33,68 & 28,34 & 24,76 & 20,51 & 16,94 & 14,04 & 9,92 & 7,41 & 4,85 \\
\hline 52,87 & 786,30 & 145,80 & 22,43 & 16,05 & 13,53 & 11,15 & 9,30 & 7,81 & 5,66 & 4,31 & 2,85 \\
\hline 49,70 & 719,80 & 155,00 & 23,37 & 16,32 & 13,53 & $\begin{array}{l}1+1,20 \\
10,91\end{array}$ & 8,94 & 7,40 & 5,26 & 3,98 & 2,65 \\
\hline 71,93 & 1452,50 & 87,50 & 19,34 & 14,91 & 13,77 & $\begin{array}{l}12,56 \\
12,56\end{array}$ & 11,50 & 10,53 & 8,79 & 7,35 & 5,24 \\
\hline 36,68 & 1155,10 & 51,60 & 45, ד & 39,46 & 35,49 & 30,56 & 26,16 & 22,36 & 16,48 & 12,51 & 8,09 \\
\hline 31,81 & 772,20 & 196,10 & 24,51 & 16,68 & 12,99 & 9,53 & 7,24 & 5,70 & 3,90 & 2,97 & 2,06 \\
\hline 71,42 & 958,70 & 170,90 & 16,44 & 11,34 & 9,65 & 8,20 & 7,12 & 6,21 & 4,78 & 3,78 & 2,54 \\
\hline 33,51 & 924,00 & 41,70 & 60,22 & 52,44 & 46,70 & 39,58 & 33,36 & 28,11 & 20,28 & 15,23 & 9,87 \\
\hline 89,41 & 1661,00 & 137,00 & 12,73 & 9,09 & 8,20 & 7,44 & 6,83 & 6,29 & 5,33 & 4,54 & 3,33 \\
\hline 82,52 & 1581,40 & 110,90 & 15,17 & 11,19 & 10,22 & 9,33 & 8,58 & 7,90 & 6,68 & 5,66 & 4,13 \\
\hline 56,86 & 1732,50 & 121.70 & 16.77 & 13,59 & 12,34 & 10,95 & 9,73 & 8,63 & 6,80 & 5,41 & 3,63 \\
\hline 85,82 & 641,10 & 30,50 & 45,78 & 34,28 & 31,72 & 29,63 & 27,71 & 25,91 & 22,58 & 19,66 & 14,93 \\
\hline 61,51 & 860,60 & 30,00 & 50,35 & 40,94 & 38,76 & 35,87 & 33,09 & 30,45 & 25,62 & 21,53 & 15,39 \\
\hline 49,51 & 394,10 & 76,20 & 45,23 & 32,28 & 27,02 & 21,98 & 18,12 & 15,06 & 10,76 & 8,14 & 5,41 \\
\hline 60,42 & 1786,60 & 46,90 & 29,68 & 24,19 & 23,12 & 21,65 & 20,14 & 18,68 & 15,96 & 13,59 & 9,90 \\
\hline 72,06 & 596,00 & 185,20 & 20,83 & 12,86 & 10,31 & 8,32 & 6,98 & 5,93 & 4,40 & 3,41 & 2,29 \\
\hline 48,82 & 1688,10 & 119,60 & 18,80 & 15,58 & 14,01 & 12,22 & 10,64 & 9,26 & 7,04 & 5,47 & 3,59 \\
\hline 51,34 & 321,40 & 119,90 & 39,56 & 24,33 & 19,03 & 14,64 & 11,66 & 9,48 & 6,63 & 5,03 & 3,42 \\
\hline 50,49 & 801,30 & 48,60 & 42,62 & 35,64 & 32,40 & 28,63 & 25,25 & 22,22 & 17,24 & 13,56 & 8,97 \\
\hline 82,91 & 259,20 & 25,00 & 77,63 & 55,82 & 49,99 & 44,74 & 40,61 & 36,96 & 30,63 & 25,53 & 18,20 \\
\hline 41,45 & 1725,20 & 110,70 & 21,89 & 18,51 & 16,52 & 14,17 & 12,12 & 10,36 & 7,65 & 5,82 & 3,79 \\
\hline 55,12 & 652,30 & 75,60 & 33,99 & 26,19 & 22,96 & 19,69 & 16,98 & 14,66 & 11,05 & 8,56 & 5,64 \\
\hline 55,41 & 1942,20 & 77,60 & 21,67 & 18,11 & 16,95 & 15,44 & 14,04 & 12,72 & 10,39 & 8,50 & 5,86 \\
\hline
\end{tabular}




\begin{tabular}{|c|c|c|c|c|c|c|c|c|c|c|c|}
\hline & & & \multicolumn{9}{|c|}{ Deflexões $\left(\times 10^{-4} \mathrm{~cm}\right)$} \\
\hline e1 (cm) & Meq (MPa) & Ms (MPa) & D0 & D25 & D40 & D60 & D80 & D100 & D140 & D180 & D260 \\
\hline 56,36 & 1868,80 & 191,10 & 12,56 & 9,81 & 8,69 & 7,53 & 6,56 & 5,71 & 4,37 & 3,41 & 2,26 \\
\hline 70,19 & 1410,80 & 159,80 & 14,09 & 10,41 & 9,21 & 8,08 & 7,18 & 6,38 & 5,07 & 4,08 & 2,78 \\
\hline 21,80 & 1521,70 & 70,30 & 51,03 & 42,02 & 35,03 & 27,06 & 20,99 & 16,57 & 11,17 & 8,35 & 5,68 \\
\hline 25,31 & 1314,50 & 149,00 & 28,18 & 21,44 & 17,18 & 12,77 & 9,69 & 7,59 & 5,15 & 3,90 & 2,69 \\
\hline 27,63 & 1636,80 & 37,30 & 62,82 & 56,91 & 51,28 & 43,94 & 37,31 & 31,61 & 22,92 & 17,20 & 11,06 \\
\hline 38,25 & 913,30 & 184,80 & 21,72 & 15,51 & 12,65 & 9,81 & 7,74 & 6,22 & 4,29 & 3,23 & 2,19 \\
\hline 82,55 & 1052,60 & 86,30 & 20,90 & 15,24 & 13,80 & 12,48 & 11,40 & 10,44 & 8,74 & 7,35 & 5,29 \\
\hline 63,41 & 911,70 & 61,40 & 30,76 & 24,38 & 22,31 & 20,04 & 18,06 & 16,25 & 13,13 & 10,68 & 7,33 \\
\hline 64,11 & 1083,90 & 84,90 & 23,52 & 18,40 & 16,69 & 14,88 & 13,33 & 11,93 & 9,56 & 7,72 & 5,27 \\
\hline 45,74 & 1234,70 & 90,90 & 26,23 & 21,77 & 19,43 & 16,76 & 14,44 & 12,42 & 9,29 & 7,13 & 4,65 \\
\hline 85,78 & 732,30 & 23,60 & 50,37 & 38,85 & 36,04 & 34,28 & 32,49 & 30,72 & 27,34 & 24,27 & 19,04 \\
\hline 34,78 & 760,80 & 179,30 & 24,96 & 17,29 & 13,74 & 10,33 & 7,97 & 6,32 & 4,33 & 3,28 & 2,25 \\
\hline 58,13 & 1433,30 & 186,60 & 14,11 & 10,61 & 9,25 & 7,91 & 6,82 & 5,90 & 4,46 & 3,46 & 2,29 \\
\hline 74,34 & 715,20 & 61,90 & 31,31 & 23,40 & 21,14 & 18,93 & 17,12 & 15,50 & 12,69 & 10,45 & 7,32 \\
\hline 28,88 & 609,80 & 115,60 & 39,44 & 28,17 & 22,16 & 16,30 & 12,35 & 9,69 & 6,61 & 5,04 & 3,48 \\
\hline 34,83 & 1754,10 & 189,50 & 17,60 & 13,89 & 11,77 & 9,43 & 7,59 & 6,17 & 4,28 & 3,20 & 2,13 \\
\hline 48,22 & 717,10 & 122,20 & 26,95 & 19,74 & 16,68 & 13,65 & 11,29 & 9,41 & 6,74 & 5,09 & 3,37 \\
\hline 29,77 & 1504,70 & 22,40 & 85,41 & 79,26 & 73,36 & 65,18 & 57,36 & 50,22 & 38,39 & 29,71 & 19,21 \\
\hline 80,57 & 753,60 & 91,00 & 24,05 & 17,04 & 15,00 & 13,21 & 11,83 & 10,64 & 8,63 & 7,08 & 4,94 \\
\hline 36,86 & 1353,80 & 103,10 & 27,32 & 22,62 & 19,76 & 16,43 & 13,64 & 11,36 & 8,09 & 6,06 & 3,97 \\
\hline 66,89 & 656,60 & 103,00 & 26,21 & 18,70 & 16,09 & 13,75 & 11,94 & 10,41 & 7,99 & 6,28 & 4,21 \\
\hline 45,10 & 1273,30 & 89,20 & 26,47 & 22,11 & 19,77 & 17,07 & 14,71 & 12,67 & 9,48 & 7,28 & 4,74 \\
\hline 86,84 & 991,30 & 155,90 & 15,68 & 10,54 & 9,05 & 7,84 & 6,97 & 6,23 & 5,03 & 4,11 & 2,87 \\
\hline 32,85 & 667,40 & 134,40 & 32,31 & 23,02 & 18,40 & 13,85 & 10,67 & 8,45 & 5,77 & 4,37 & 3,00 \\
\hline 33,94 & 1213,10 & 113,80 & 28,36 & 22,78 & 10,43 & $\begin{array}{l}10,00 \\
15,66\end{array}$ & 12,65 & 10,31 & 7,16 & 5,34 & 3,55 \\
\hline 44,98 & 377,70 & 191,20 & 30,34 & 17,38 & 12,97 & 9,50 & 7,33 & 5,85 & 4,04 & 3,08 & 2,13 \\
\hline 40,27 & 1603,20 & 116,90 & 22,22 & 18,53 & 16,37 & 13,86 & 11,71 & 9,90 & 7,20 & 5,44 & 3,54 \\
\hline 52,08 & 1231,00 & 72,70 & 27,66 & 23,07 & 21,05 & 18,69 & 16,57 & 14,66 & 11,47 & 9,08 & 6,04 \\
\hline 73,01 & $\frac{1 L U 1,60}{811,60}$ & 94,10 & 23,77 & 17,35 & 15,33 & $\frac{10,00}{13,47}$ & $\begin{array}{l}10, v 1 \\
11,99\end{array}$ & $\frac{1+4,00}{10,70}$ & $\begin{array}{c}1+, 41 \\
8,55\end{array}$ & 6,91 & 4,74 \\
\hline 86,21 & 272,70 & 121,20 & 38,76 & 21,55 & 16,38 & 12,74 & 10,53 & 8,92 & 6,63 & 5,18 & 3,53 \\
\hline 58,68 & 1858,70 & 140,40 & 14,71 & 11,77 & 10,66 & 9,45 & 8,40 & 7,45 & 5,88 & 4,69 & 3,15 \\
\hline 67,87 & 862,60 & 44,40 & 36,98 & 29,13 & 27,13 & 24,85 & 22,78 & 20,86 & 17,41 & 14,55 & 10,34 \\
\hline 84,00 & 1908,30 & 62,00 & 19,54 & 15,06 & 14,02 & 13,32 & 12,60 & 11,89 & 10,56 & 9,34 & 7,28 \\
\hline 75,59 & 570,00 & 117,60 & 25,36 & 16,86 & 14,13 & 11,90 & 10,30 & 8,98 & 6,92 & 5,47 & 3,70 \\
\hline 21,73 & 924,20 & 59,10 & 66,84 & 53,19 & 43,24 & 32,46 & 24,70 & 19,31 & 13,02 & 9,83 & 6,75 \\
\hline 30,00 & 1613,30 & 173,80 & 21,23 & 16,58 & 13,75 & 10,67 & 8,36 & 6,67 & 4,55 & 3,41 & 2,31 \\
\hline 57,57 & 1913,20 & 150,10 & 14,12 & 11,31 & 10,20 & 9,01 & 7,97 & 7,05 & 5,52 & 4,38 & 2,93 \\
\hline 41,66 & 1255,60 & 92,30 & 27,55 & 22,95 & 20,34 & 17,31 & 14,69 & 12,48 & 9,14 & 6,93 & 4,51 \\
\hline 25,03 & 1257,20 & 159,70 & 27,40 & 20,49 & 16,23 & 11,92 & 8,99 & 7,02 & 4,77 & 3,63 & 2,51 \\
\hline 23,96 & 1425,80 & 90,30 & 40,58 & 32,85 & 27,24 & 20,97 & 16,25 & 12,84 & 8,68 & 6,50 & 4,42 \\
\hline 45,50 & 1149,60 & 91,10 & 27,04 & 22,26 & 19,78 & 16,97 & 14,54 & 12,46 & 9,26 & 7,08 & 4,62 \\
\hline 41,34 & 1764,70 & 65,10 & 30,55 & 26,97 & 24,77 & 21,94 & 19,32 & 16,95 & 13,05 & 10,18 & 6,66 \\
\hline 72,29 & 688,20 & 86,10 & 27,07 & 19,62 & 17,23 & 15,05 & 13,33 & 11,84 & 9,39 & 7,55 & 5,15 \\
\hline 47,19 & 1986,70 & 117,90 & 18,22 & 15,40 & 13,95 & 12,24 & 10,71 & 9,35 & 7,16 & 5,57 & 3,66 \\
\hline 21,30 & 1135,90 & 122,70 & 37,75 & 28,09 & 21,79 & 15,60 & 11,57 & 8,98 & 6,13 & 4,70 & 3,26 \\
\hline 33,62 & 935,80 & 173,90 & 23,93 & 17,32 & 13,99 & 10,65 & 8,26 & 6,57 & 4,49 & 3,39 & 2,32 \\
\hline 32,29 & 1312,50 & 121,30 & 27,41 & 21,97 & 18,64 & 14,88 & 11,92 & 9,66 & 6,66 & 4,97 & 3,32 \\
\hline 60,26 & 1066,90 & 159,70 & 17,31 & 12,67 & 10,93 & 9,29 & 7,99 & 6,89 & 5,19 & 4,03 & 2,67 \\
\hline 68,68 & 1055,60 & 103,60 & 20,55 & 15,50 & 13,86 & 12,26 & 10,94 & 9,77 & 7,80 & 6,30 & 4,31 \\
\hline 56,36 & 489,80 & 114,70 & 31,16 & 21,15 & 17,48 & 14,22 & 11,80 & 9,89 & 7,15 & 5,45 & 3,63 \\
\hline 84,09 & 1727,80 & 22,60 & 35,80 & 31,55 & 28,56 & 27,58 & 26,87 & 25,94 & 23,95 & 22,02 & 18,44 \\
\hline 48,01 & 925,00 & 126,80 & 23,61 & 17,96 & 15,43 & 12,84 & 10,75 & 9,04 & 6,55 & 4,97 & 3,27 \\
\hline 49,49 & 585,50 & 39,40 & 55,47 & 46,11 & 41,62 & 36,47 & 31,91 & 27,88 & 21,36 & 16,67 & 10,96 \\
\hline 82,94 & 1969,00 & 142,60 & 11,94 & 8,77 & 8,00 & 7,29 & 6,70 & 6,16 & 5,21 & 4,41 & 3,21 \\
\hline 66,86 & 778,30 & 84,90 & 26,65 & 20,00 & 17,73 & 15,55 & 13,76 & 12,20 & 9,62 & 7,69 & 5,20 \\
\hline 29,95 & 1456,70 & 56,60 & 46,25 & 40,47 & 35,84 & 30,08 & 25,08 & 20,93 & 14,88 & 11,10 & 7,21 \\
\hline 24,54 & 514,20 & 142,00 & 39,23 & 25,66 & 18,93 & 13,13 & 9,70 & 7,58 & 5,26 & 4,07 & 2,84 \\
\hline 54,48 & 1073,50 & 31,40 & 48,88 & 41,02 & 38,94 & 35,92 & 32,99 & 30,20 & 25,13 & 20,89 & 14,68 \\
\hline 60,98 & 750,20 & 178,90 & 19,55 & 13,09 & 10,81 & 8,85 & 7,42 & 6,27 & 4,59 & 3,52 & 2,34 \\
\hline 89,65 & 1222,30 & 83,30 & 19,15 & 13,88 & 12,64 & 11,60 & 10,73 & 9,95 & 8,55 & 7,35 & 5,48 \\
\hline 67,77 & 775,10 & 102,00 & 24,10 & 17,60 & 15,38 & 13,33 & 11,70 & 10,30 & 8,03 & 6,38 & 4,29 \\
\hline 61,05 & 860,60 & 150,20 & 19,75 & 14,05 & 11,96 & 10,06 & 8,59 & $\begin{array}{l}10,37 \\
7,37\end{array}$ & 5,51 & 4,26 & 2,83 \\
\hline 26,11 & 388,20 & 58,90 & 76,39 & 55,96 & 44,04 & 32,22 & 24,28 & 18,98 & 12,93 & 9,86 & 6,81 \\
\hline 74,87 & 1868,30 & 173,40 & 11,50 & 8,52 & 7,66 & $\frac{6, L L}{6,84}$ & 6,17 & 5,57 & 4,54 & 3,73 & 2,61 \\
\hline 48,21 & 1798,20 & 131,50 & 17,46 & 14,44 & 12,94 & 11,25 & 9,76 & 8,47 & 6,41 & 4,96 & 3,25 \\
\hline 33,33 & 1044,60 & 132,90 & 27,43 & 21,09 & 17,55 & 13,75 & 10,88 & 8,74 & 6,00 & 4,49 & 3,03 \\
\hline 31,86 & 1982,10 & 40,70 & 49,26 & 45,18 & 41,54 & 36,64 & 32,03 & 27,87 & 21,11 & 16,25 & 10,49 \\
\hline 72,28 & 1317,40 & 116,80 & 17,00 & 12,77 & 11,52 & 10,28 & 9,27 & 8,36 & 6,79 & 5,56 & 3,86 \\
\hline 70,18 & 1728,30 & 168,20 & 12,48 & 9,37 & 8,39 & 7,43 & 6,65 & 5,95 & 4,78 & 3,88 & 2,66 \\
\hline 89,99 & 1615,30 & 50,80 & 22,34 & 17,31 & 15,93 & 15,18 & 14,45 & 13,70 & 12,29 & 10,98 & 8,73 \\
\hline 87.73 & 416,60 & 127,30 & 28,53 & 17.10 & 13,65 & 11,11 & 9,47 & 8,21 & 6,30 & 5,00 & 3,42 \\
\hline 85,93 & 1433,10 & 183,40 & 11,99 & 8,30 & 7,26 & 6,38 & 5,73 & 5,17 & 4,22 & 3,49 & 2,46 \\
\hline 32,29 & 1538,90 & 173,80 & 20,52 & 16,02 & 13,39 & 10,52 & 8,33 & 6,70 & 4,59 & 3,44 & 2,31 \\
\hline 43,32 & 1700,00 & 68,70 & 28,88 & 25,26 & 23,19 & 20,56 & 18,14 & 15,95 & 12,33 & 9,65 & 6,33 \\
\hline 66,09 & 1321,20 & 143,50 & 15,83 & 11,91 & 10,56 & 9,25 & 8,19 & 7,25 & 5,70 & 4,55 & 3,08 \\
\hline 77,19 & 610,90 & 50,20 & 37,06 & 27,52 & 24,95 & 22,46 & 20,42 & 18,59 & 15,38 & 12,78 & 9,06 \\
\hline 22,79 & 1032,80 & 70,00 & 55,45 & 44,20 & 36,12 & 27,31 & 20,89 & 16,39 & 11,06 & 8,33 & 5,71 \\
\hline 38,28 & 1521,10 & 33,00 & 53,62 & 48,47 & 45,30 & 40,81 & 36,50 & 32,49 & 25,62 & 20,31 & 13,43 \\
\hline 31,20 & 921,30 & 61,90 & 49,34 & 41,00 & 35,35 & 28,73 & 23,33 & 19,07 & 13,25 & 9,86 & 6,52 \\
\hline 85,77 & 1329,20 & 198,60 & 12,02 & 8,16 & 7,05 & 6,12 & 5,45 & 4,88 & 3,95 & 3,23 & 2,26 \\
\hline 63,81 & 266,10 & 109,80 & 43,20 & 25,36 & 19,63 & 15,24 & 12,38 & 10,24 & 7,33 & 5,60 & 3,79 \\
\hline 57,24 & 1899,40 & 34,10 & 37,56 & 30,79 & 29,68 & 28,10 & 26,35 & 24,62 & 21,33 & 18,39 & 13,66 \\
\hline
\end{tabular}




\begin{tabular}{|c|c|c|c|c|c|c|c|c|c|c|c|}
\hline \multirow[b]{2}{*}{ e1 (cm) } & & & & & & $\mathrm{De}$ & ões (x1 & & & & \\
\hline & Meq (MPa) & Ms (MPa) & D0 & D25 & D40 & D60 & D80 & D100 & D140 & D180 & D260 \\
\hline 78,73 & 1438,80 & 58,30 & 23,65 & 18,11 & 16,95 & 15,88 & 14,85 & 13,88 & 12,05 & 10,45 & 7,87 \\
\hline 42,64 & 1697,10 & 42,90 & 40,01 & 35,52 & 33,30 & 30,16 & 27,15 & 24,32 & 19,43 & 15,57 & 10,42 \\
\hline 67,06 & 859,90 & 191,80 & 16,95 & 11,35 & 9,45 & 7,84 & 6,67 & 5,72 & 4,28 & 3,33 & 2,22 \\
\hline 20,09 & 1787,20 & 124,90 & 34,31 & 26,64 & 21,15 & 15,45 & 11,55 & 8,96 & 6,07 & 4,63 & 3,20 \\
\hline 78,46 & 318,70 & 89,40 & 39,57 & 24,62 & 19,94 & 16,34 & 13,90 & 11,98 & 9,08 & 7,13 & 4,82 \\
\hline 58,18 & 1648,10 & 99,60 & 19,07 & 15,53 & 14,25 & 12,77 & 11,46 & 10,26 & 8,21 & 6,62 & 4,49 \\
\hline 85,30 & 953,40 & 198,10 & 14,54 & 9,41 & 7,86 & 6,64 & 5,80 & 5,12 & 4,03 & 3,24 & 2,23 \\
\hline 68,93 & 1040,30 & 140,40 & 17,59 & 12,76 & 11,13 & 9,64 & 8,47 & 7,46 & 5,82 & 4,63 & 3,12 \\
\hline 67,47 & 888,90 & 158,50 & 18,13 & 12,64 & 10,75 & 9,10 & 7,85 & 6,81 & 5,19 & 4,06 & 2,72 \\
\hline 52,34 & 592,90 & 109,60 & 29,95 & 21,46 & 18,09 & 14,88 & 12,40 & 10,41 & 7,53 & 5,72 & 3,79 \\
\hline 58,10 & 1670,00 & 102,70 & 18,63 & 15,17 & 13,90 & 12,45 & 11,16 & 9,98 & 7,98 & 6,42 & 4,35 \\
\hline 56,22 & 1773,00 & 31,80 & 40,72 & 33,51 & 32,31 & 30,54 & 28,60 & 26,68 & 23,05 & 19,81 & 14,64 \\
\hline 81,45 & 1875,90 & 85,10 & 16,61 & 12,58 & 11,71 & 10,93 & 10,21 & 9,53 & 8,26 & 7,16 & 5,39 \\
\hline 56,23 & 630,60 & 50,20 & 43,03 & 34,56 & 31,11 & 27,38 & 24,15 & 21,27 & 16,55 & 13,08 & 8,70 \\
\hline 87,99 & 1834,20 & 106,60 & 14,08 & 10,36 & 9,51 & 8,80 & 8,18 & 7,62 & 6,59 & 5,70 & 4,28 \\
\hline 88,39 & 1610,70 & 57,40 & 21,15 & 16,16 & 14,93 & 14,16 & 13,40 & 12,66 & 11,25 & 9,98 & 7,82 \\
\hline 33,35 & 596,20 & 184,90 & 27,47 & 17,95 & 13,80 & 10,06 & 7,64 & 6,02 & 4,13 & 3,15 & 2,18 \\
\hline 47,94 & 1314,40 & 32,50 & 48,59 & 42,04 & 39,87 & 36,59 & 33,40 & 30,36 & 24,92 & 20,45 & 14,09 \\
\hline 59,77 & 702,10 & 178,10 & 20,46 & 13,56 & 11,12 & 9,04 & 7,52 & 6,32 & 4,60 & 3,52 & 2,34 \\
\hline 21,13 & 932,80 & 102,50 & 45,66 & 33,85 & 26,18 & 18,68 & 13,83 & 10,73 & 7,33 & 5,63 & 3,91 \\
\hline 37,50 & 1181,30 & 68,10 & 36,85 & 31,50 & 28,01 & 23,82 & 20,16 & 17,07 & 12,42 & 9,38 & 6,08 \\
\hline 29,22 & 1544,40 & 45,40 & 53,53 & 47,84 & 42,86 & 36,48 & 30,81 & 25,98 & 18,73 & 14,03 & 9,05 \\
\hline 57,91 & 475,40 & 69,40 & 40,15 & 29,67 & 25,61 & 21,72 & 18,61 & 16,00 & 11,99 & 9,27 & 6,13 \\
\hline 79,11 & 1247,00 & 110,60 & 17,22 & 12,63 & 11,39 & 10,22 & 9,28 & 8,44 & 6,98 & 5,80 & 4,11 \\
\hline 34,99 & 1611,10 & 46,10 & 44,95 & 40,56 & 37,09 & 32,56 & 28,36 & 24,61 & 18,57 & 14,28 & 9,23 \\
\hline 77,75 & 1162,40 & 20,20 & 49,46 & 40,32 & 37,48 & 36,25 & 34,81 & 33,23 & 30,09 & 27,12 & 21,85 \\
\hline 74,71 & 684,80 & 43,50 & 38,99 & 29,67 & 27,33 & 24,93 & 22,85 & 20,94 & 17,53 & 14,71 & 10,54 \\
\hline 78,85 & 608,90 & 128,20 & 23,21 & 15,24 & 12,74 & 10,73 & 9,31 & 8,14 & 6,31 & 5,02 & 3,41 \\
\hline 58,48 & 348,40 & 84,70 & 42,40 & 28,43 & 23,42 & 19,07 & 15,87 & 13,33 & 9,68 & 7,40 & 4,92 \\
\hline 53,50 & 1884,00 & 80,40 & 21,87 & 18,41 & 17,14 & 15,51 & 14,01 & 12,61 & 10,17 & 8,24 & 5,61 \\
\hline 79,65 & 824,50 & 46,00 & 33,81 & 25,47 & 23,57 & 21,74 & 20,11 & 18,61 & 15,89 & 13,56 & 9,98 \\
\hline 77,38 & 759,20 & 168,80 & 18,30 & 11,94 & 9,93 & 8,32 & 7,18 & 6,25 & 4,81 & 3,80 & 2,57 \\
\hline 60,95 & 353,80 & 74,20 & 44,00 & 30,24 & 25,30 & 20,96 & 17,69 & 15,04 & 11,11 & 8,55 & 5,68 \\
\hline 24,99 & 621,40 & 182,20 & 30,89 & 20,01 & 14,73 & 10,22 & 7,55 & 5,91 & 4,10 & 3,17 & 2,21 \\
\hline 89,75 & 310,60 & 114,60 & 35,78 & 20,57 & 16,01 & 12,75 & 10,73 & 9,22 & 6,99 & 5,52 & 3,78 \\
\hline 68,84 & 742,20 & 48,20 & 36,99 & 28,76 & 26,45 & 23,95 & 21,78 & 19,79 & 16,30 & 13,47 & 9,45 \\
\hline 39,98 & 561,20 & 25,40 & 86,10 & 75,18 & 68,13 & 59,38 & 51,47 & 44,52 & 33,46 & 25,70 & 16,68 \\
\hline 50,81 & 1842,60 & 102,90 & 19,44 & 16,34 & 14,93 & 13,26 & 11,75 & 10,39 & 8,12 & 6,43 & 4,27 \\
\hline 66,74 & 1422,40 & 198,90 & 12,82 & 9,31 & 8,10 & 6,98 & 6,10 & 5,34 & 4,13 & 3,26 & 2,19 \\
\hline 61,39 & 1543,50 & 197,80 & 12,86 & 9,61 & 8,39 & 7,23 & 6,29 & 5,48 & 4,19 & 3,28 & 2,18 \\
\hline 43,19 & 1869,00 & 33,60 & 45,71 & 40,24 & 38,36 & 35,30 & 32,27 & 29,37 & 24,13 & 19,80 & 13,61 \\
\hline 68,12 & 1484,50 & 94,00 & 18,88 & 14,74 & 13,57 & 12,30 & 11,18 & 10,16 & 8,37 & 6,91 & 4,84 \\
\hline 76,48 & 413,70 & 157,20 & 27,47 & 16,08 & 12,54 & 9,92 & 8,24 & 6,97 & 5,15 & 3,99 & 2,70 \\
\hline 67,16 & 671,40 & 32,60 & 49,54 & 39,19 & 36,60 & 33,59 & 30,84 & 28,27 & 23,64 & 19,79 & 14,09 \\
\hline 39,53 & 273,80 & 118,50 & 46,70 & 28,08 & 21,21 & 15,49 & 11,85 & 9,40 & 6,47 & 4,95 & 3,43 \\
\hline 27,59 & 321,00 & 109,40 & 51,87 & 32,86 & 24,29 & 17,00 & 12,63 & 9,90 & 6,84 & 5,29 & 3,69 \\
\hline 22,57 & 831,00 & 120,00 & 40,32 & 29,12 & 22,33 & 15,86 & 11,75 & 9,13 & 6,26 & 4,81 & 3,34 \\
\hline 64,37 & 1981,70 & 107,60 & 16,02 & 12,78 & 11,85 & 10,78 & 9,82 & 8,92 & 7,35 & 6,07 & 4,24 \\
\hline 83,98 & 274,40 & 46,10 & 55,60 & 37,33 & 31,88 & 27,43 & 24,22 & 21,55 & 17,19 & 13,94 & 9,64 \\
\hline 48,88 & 272,80 & 110,90 & 45,46 & 27,46 & 21,20 & 16,06 & 12,65 & 10,21 & 7,10 & 5,39 & 3,68 \\
\hline 36,96 & 1290,70 & 75,60 & 33,77 & 28,80 & 25,55 & 21,65 & 18,26 & 15,42 & 11,17 & 8,42 & 5,46 \\
\hline 40,37 & 1537,00 & 71,30 & 30,74 & 26,79 & 24,27 & 21,15 & 18,34 & 15,86 & 11,93 & 9,17 & 5,95 \\
\hline 58,68 & 1796,90 & 132,90 & 15,40 & 12,35 & 11,20 & 9,94 & 8,84 & 7,86 & 6,20 & 4,95 & 3,33 \\
\hline 84,70 & 203,00 & 44,60 & 66,91 & 42,95 & 35,67 & 30,00 & 26,09 & 22,93 & 17,95 & 14,39 & 9,87 \\
\hline 71,64 & 515,00 & 55,80 & 39,16 & 28,94 & 25,70 & 22,65 & 20,20 & 18,05 & 14,43 & 11,68 & 8,00 \\
\hline 40,97 & 1492,20 & 173,80 & 17,73 & 13,90 & 11,93 & 9,80 & 8,07 & 6,69 & 4,75 & 3,57 & 2,35 \\
\hline 47,66 & 556,50 & 108,80 & 32,45 & 23,17 & 19,33 & 15,63 & 12,79 & 10,58 & 7,51 & 5,67 & 3,77 \\
\hline 41,45 & 1943,10 & 193,10 & 14,87 & 11,92 & 10,36 & 8,62 & 7,19 & 6,01 & 4,31 & 3,25 & 2,13 \\
\hline 79,67 & 1612,70 & 150,30 & 12,92 & 9,42 & 8,46 & 7,57 & 6,86 & 6,23 & 5,14 & 4,27 & 3,02 \\
\hline 28,70 & 460,60 & 143,20 & 37,78 & 24,50 & 18,40 & 13,04 & 9,73 & 7,63 & 5,25 & 4,04 & 2,82 \\
\hline 24,65 & 1834,90 & 105,60 & 32,99 & 27,09 & 22,74 & 17,76 & 13,92 & 11,08 & 7,51 & 5,60 & 3,78 \\
\hline 68,25 & 969,90 & 87,00 & 23,58 & 17,97 & 16,17 & 14,37 & 12,87 & 11,53 & 9,26 & 7,51 & 5,15 \\
\hline 51,90 & 417,00 & 193,30 & 27,64 & 16,06 & 12,20 & 9,18 & 7,23 & 5,84 & 4,07 & 3,10 & 2,12 \\
\hline 51,06 & 452,10 & 87,60 & 38,78 & 27,60 & 23,14 & 18,90 & 15,64 & 13,06 & 9,38 & 7,11 & 4,72 \\
\hline 53,05 & 1795,10 & 119,00 & 17,47 & 14,40 & 13,07 & 11,55 & 10,21 & 9,00 & 7,01 & 5,54 & 3,68 \\
\hline 56,71 & 1216,60 & 72,60 & 26,42 & 21,66 & 19,86 & 17,77 & 15,91 & 14,21 & 11,33 & 9,10 & 6,14 \\
\hline 65,82 & 547,40 & 70,30 & 35,01 & 25,82 & 22,59 & 19,57 & 17,15 & 15,06 & 11,69 & 9,25 & 6,21 \\
\hline 87,30 & 993,60 & 199,90 & 14,04 & 9,08 & 7,61 & 6,45 & 5,66 & 5,01 & 3,97 & 3,21 & 2,22 \\
\hline 51,10 & 389,50 & 160,20 & 31,28 & 18,78 & 14,50 & 11,03 & 8,73 & 7,07 & 4,93 & 3,75 & 2,56 \\
\hline 28,56 & 1312,70 & 41,80 & 60,96 & 54,00 & 48,05 & 40,52 & 33,91 & 28,37 & 20,24 & 15,10 & 9,77 \\
\hline 43,54 & 1503,40 & 163,50 & 17,62 & 13,94 & 12,10 & 10,09 & 8,43 & 7,07 & 5,09 & 3,85 & 2,52 \\
\hline 49,33 & 1620,10 & 84,20 & 23,58 & 20,00 & 18,31 & 16,27 & 14,42 & 12,75 & 9,95 & 7,86 & 5,21 \\
\hline 88,56 & 1664,50 & 187,00 & 10,88 & 7,57 & 6,69 & 5,94 & 5,38 & 4,89 & 4,06 & 3,39 & 2,43 \\
\hline 70,61 & 1535,00 & 193,60 & 12,21 & 8,89 & 7,80 & 6,80 & 6,01 & 5,32 & 4,20 & 3,36 & 2,28 \\
\hline 27,64 & 304,20 & 130,90 & 47,04 & 28,19 & 20,38 & 14,08 & 10,45 & 8,21 & 5,70 & 4,42 & 3,09 \\
\hline 80,88 & 1692,80 & 158,40 & 12,21 & 8,86 & 7,95 & 7,12 & 6,46 & 5,88 & 4,86 & 4,04 & 2,87 \\
\hline 63,22 & 455,50 & 64,20 & 40,88 & 29,97 & 26,00 & 22,30 & 19,35 & 16,84 & 12,88 & 10,09 & 6,72 \\
\hline 32,75 & 1841,00 & 126,90 & 23,39 & 19,46 & 16,86 & 13,81 & 11,30 & 9,29 & 6,50 & 4,85 & 3,19 \\
\hline 45,09 & 228,30 & 186,00 & 41,03 & 20,38 & 14,10 & 9,78 & 7,40 & 5,87 & 4,06 & 3,13 & 2,21 \\
\hline 38,20 & 1224,40 & 32,20 & 58,47 & 52,69 & 48,79 & 43,54 & 38,57 & 34,02 & 26,40 & 20,69 & 13,55 \\
\hline 38,83 & 252,30 & 161,50 & 41,88 & 22,52 & 16,10 & 11,32 & 8,55 & 6,76 & 4,67 & 3,60 & 2,53 \\
\hline 66,47 & 1876,50 & 64,50 & 22,26 & 17,74 & 16,81 & 15,67 & 14,56 & 13,49 & 11,52 & 9,82 & 7,17 \\
\hline
\end{tabular}




\begin{tabular}{|c|c|c|c|c|c|c|c|c|c|c|c|}
\hline \multirow[b]{2}{*}{ e1 (cm) } & & & & & & & ões (x1 & & & & \\
\hline & Meq (MPa) & Ms (MPa) & D0 & D25 & D40 & D60 & D80 & D100 & D140 & D180 & D260 \\
\hline 88,01 & 1933,90 & 168,10 & 10,71 & 7,65 & 6,88 & 6,22 & 5,69 & 5,22 & 4,40 & 3,73 & 2,71 \\
\hline 61,76 & 1965,70 & 76,80 & 20,40 & 16,57 & 15,61 & 14,37 & 13,21 & 12,11 & 10,12 & 8,45 & 5,99 \\
\hline 81,68 & 1878,00 & 69,60 & 18,69 & 14,31 & 13,36 & 12,60 & 11,85 & 11,12 & 9,76 & 8,55 & 6,55 \\
\hline 67,08 & 1052,10 & 189,80 & 15,27 & 10,63 & 9,04 & 7,64 & 6,58 & 5,70 & 4,33 & 3,39 & 2,27 \\
\hline 25,89 & 557,90 & 138,50 & 37,99 & 25,55 & 19,23 & 13,56 & 10,07 & 7,86 & 5,42 & 4,18 & 2,91 \\
\hline 85,00 & 904,30 & 28,10 & 41,98 & 32,49 & 30,17 & 28,73 & 27,25 & 25,77 & 22,96 & 20,38 & 16,01 \\
\hline 37,41 & 1883,00 & 111,30 & 22,79 & 19,43 & 17,25 & 14,63 & 12,36 & 10,45 & 7,58 & 5,72 & 3,71 \\
\hline 67,19 & 252,60 & 162,20 & 38,80 & 20,26 & 14,66 & 10,76 & 8,48 & 6,90 & 4,86 & 3,72 & 2,56 \\
\hline 64,91 & 1979,50 & 167,10 & 12,26 & 9,50 & 8,58 & 7,62 & 6,81 & 6,09 & 4,86 & 3,92 & 2,67 \\
\hline 52,62 & 1397,60 & 171,00 & 15,80 & 12,14 & 10,58 & 8,99 & 7,68 & 6,57 & 4,89 & 3,75 & 2,47 \\
\hline 21,60 & 1263,20 & 152,50 & 31,02 & 22,80 & 17,58 & 12,52 & 9,27 & 7,20 & 4,92 & 3,78 & 2,63 \\
\hline 21,27 & 1328,00 & 139,70 & 32,96 & 24,61 & 19,13 & 13,72 & 10,18 & 7,90 & 5,39 & 4,13 & 2,87 \\
\hline 65,67 & 872,20 & 178,70 & 17,51 & 11,96 & 10,04 & 8,38 & 7,15 & 6,14 & 4,61 & 3,58 & 2,39 \\
\hline 65,01 & 522,50 & 95,20 & 31,00 & 21,67 & 18,39 & 15,50 & 13,30 & 11,48 & 8,66 & 6,75 & 4,50 \\
\hline 36,89 & 906,70 & 170,60 & 23,29 & 16,85 & 13,77 & 10,67 & 8,40 & 6,74 & 4,64 & 3,49 & 2,37 \\
\hline 61,76 & 520,20 & 87,20 & 33,15 & 23,71 & 20,26 & 17,11 & 14,67 & 12,62 & 9,49 & 7,36 & 4,89 \\
\hline 54,45 & 1849,10 & 135,00 & 15,75 & 12,82 & 11,58 & 10,21 & 9,01 & 7,94 & 6,17 & 4,87 & 3,24 \\
\hline 38,52 & 1748,80 & 93,80 & 25,53 & 21,98 & 19,68 & 16,88 & 14,41 & 12,29 & 9,05 & 6,87 & 4,45 \\
\hline 35,13 & 670,90 & 178,90 & 26,14 & 17,66 & 13,89 & 10,35 & 7,96 & 6,30 & 4,32 & 3,28 & 2,26 \\
\hline 25,35 & 454,60 & 75,20 & 62,50 & 45,00 & 34,95 & 25,23 & 18,88 & 14,73 & 10,06 & 7,70 & 5,34 \\
\hline 44,38 & 1979,00 & 105,60 & 20,40 & 17,48 & 15,85 & 13,89 & 12,12 & 10,55 & 8,02 & 6,22 & 4,06 \\
\hline 82,25 & 1277,20 & 53,20 & 25,52 & 19,38 & 18,06 & 16,94 & 15,88 & 14,86 & 12,98 & 11,30 & 8,59 \\
\hline 64,74 & 768,50 & 153,90 & 20,19 & 13,88 & 11,68 & 9,76 & 8,32 & 7,14 & 5,35 & 4,15 & 2,77 \\
\hline 73,28 & 988,20 & 113,00 & 19,63 & 14,33 & 12,68 & 11,15 & 9,94 & 8,88 & 7,10 & 5,75 & 3,95 \\
\hline 55,67 & 1789,30 & 105,80 & 18,26 & 15,04 & 13,78 & 12,32 & 11,01 & 9,82 & 7,79 & 6,24 & 4,20 \\
\hline 76,78 & 722,80 & 41,10 & 38,87 & 29,52 & 27,34 & 25,12 & 23,17 & 21,37 & 18,11 & 15,35 & 11,17 \\
\hline 77,78 & 1982,10 & 56,40 & 21,53 & 16,80 & 15,79 & 15,03 & 14,21 & 13,39 & 11,85 & 10,44 & 8,08 \\
\hline 37,24 & 1681,90 & 131,20 & 21,50 & 17,76 & 15,50 & 12,89 & 10,71 & 8,92 & 6,35 & 4,76 & 3,12 \\
\hline 62,15 & 1853,50 & 100,90 & 17,43 & 14,03 & 12,99 & 11,78 & 10,69 & 9,68 & 7,92 & 6,49 & 4,50 \\
\hline 82,25 & 358,50 & 61,20 & 42,57 & 28,66 & 24,45 & 20,99 & 18,50 & 16,41 & 13,03 & 10,52 & 7,25 \\
\hline 85,84 & 1378,20 & 46,70 & 25,98 & 19,95 & 18,51 & 17,57 & 16,63 & 15,70 & 13,94 & 12,34 & 9,64 \\
\hline 76,25 & 1521,40 & 154,00 & 13,36 & 9,78 & 8,74 & 7,76 & 6,98 & 6,29 & 5,12 & 4,20 & 2,93 \\
\hline 77,03 & 320,60 & 86,70 & 40,10 & 25,22 & 20,52 & 16,86 & 14,36 & 12,38 & 9,38 & 7,36 & 4,97 \\
\hline 76,26 & 1319,20 & 39,10 & 31,96 & 24,93 & 23,48 & 22,28 & 21,01 & 19,76 & 17,39 & 15,25 & 11,70 \\
\hline 66,93 & 326,50 & 123,20 & 36,00 & 21,48 & 16,82 & 13,24 & 10,87 & 9,08 & 6,57 & 5,04 & 3,40 \\
\hline 49,62 & 1266,90 & 97,40 & 23,61 & 19,37 & 17,35 & 15,09 & 13,11 & 11,39 & 8,64 & 6,70 & 4,40 \\
\hline 47,53 & 1116,30 & 103,60 & 24,63 & 19,84 & 17,51 & 14,96 & 12,79 & 10,94 & 8,12 & 6,21 & 4,06 \\
\hline 55,48 & 1176,10 & 144,00 & 18,23 & 13,92 & 12,16 & 10,40 & 8,95 & 7,71 & 5,80 & 4,48 & 2,96 \\
\hline 49,03 & 1734,00 & 71,60 & 25,66 & 22,02 & 20,40 & 18,33 & 16,41 & 14,64 & 11,62 & 9,28 & 6,21 \\
\hline 45,83 & 1308,70 & 177,60 & 17,25 & 13,17 & 11,29 & 9,34 & 7,76 & 6,49 & 4,66 & 3,52 & 2,32 \\
\hline 81,91 & 1765,40 & 87,80 & 16,65 & 12,54 & 11,64 & 10,82 & 10,07 & 9,37 & 8,09 & 6,98 & 5,22 \\
\hline 20,28 & 951,60 & 68,20 & 62,87 & 48,77 & 38,72 & 28,30 & 21,17 & 16,43 & 11,12 & 8,48 & 5,86 \\
\hline 75,68 & 386,10 & 197,40 & 26,78 & 14,65 & 10,96 & 8,35 & 6,76 & 5,62 & 4,06 & 3,13 & 2,13 \\
\hline 73,05 & 511,40 & 22,80 & 65,42 & 50,73 & 47,54 & 44,09 & 40,87 & 37,85 & 32,30 & 27,54 & 20,17 \\
\hline 40,43 & 353,70 & 182,80 & 32,87 & 18,81 & 13,90 & 10,03 & 7,64 & 6,06 & 4,17 & 3,20 & 2,23 \\
\hline 53,86 & 1600,10 & 129,80 & 17,21 & 13,89 & 12,46 & 10,91 & 9,56 & 8,37 & 6,44 & 5,05 & 3,34 \\
\hline 23,09 & 1964,50 & 176,20 & 23,66 & 18,30 & 14,67 & 10,87 & 8,22 & 6,41 & 4,34 & 3,29 & 2,27 \\
\hline 80,31 & 668,90 & 77,40 & 27,73 & 19,75 & 17,45 & 15,41 & 13,83 & 12,46 & 10,14 & 8,32 & 5,82 \\
\hline 63,17 & 792,20 & 190,70 & 18,19 & 12,10 & 9,99 & 8,20 & 6,89 & 5,85 & 4,31 & 3,32 & 2,21 \\
\hline 87,84 & 1480,80 & 127,20 & 14,08 & 10,07 & 9,07 & 8,20 & 7,51 & 6,89 & 5,81 & 4,92 & 3,59 \\
\hline 59,01 & 461,00 & 72,50 & 39,46 & 28,72 & 24,65 & 20,83 & 17,81 & 15,29 & 11,44 & 8,84 & 5,85 \\
\hline 30,63 & 1315,80 & 107,30 & 30,83 & 25,00 & 21,23 & 16,92 & 13,53 & 10,94 & 7,52 & 5,61 & 3,75 \\
\hline 82,10 & 1953,80 & 43,20 & 24,34 & 19,46 & 18,05 & 17,37 & 16,62 & 15,82 & 14,26 & 12,80 & 10,25 \\
\hline 72,22 & 1627,60 & 136,30 & 14,21 & 10,73 & 9,71 & 8,70 & 7,86 & 7,10 & 5,80 & 4,76 & 3,32 \\
\hline 22,66 & 483,90 & 171,30 & 36,15 & 22,20 & 15,79 & 10,69 & 7,87 & 6,19 & 4,33 & 3,37 & 2,36 \\
\hline 20,21 & 1148,20 & 121,80 & 39,16 & 28,91 & 22,20 & 15,72 & 11,59 & 8,98 & 6,15 & 4,74 & 3,29 \\
\hline 42,60 & 1112,40 & 192,70 & 18,41 & 13,51 & 11,29 & 9,05 & 7,33 & 6,01 & 4,21 & 3,17 & 2,11 \\
\hline 88,91 & 226,30 & 49,30 & 59,37 & 37,76 & 31,34 & 26,40 & 23,05 & 20,35 & 16,08 & 12,98 & 8,97 \\
\hline 35,77 & 922,00 & 148,80 & 25,60 & 19,02 & 15,68 & 12,23 & 9,66 & 7,76 & 5,34 & 4,01 & 2,71 \\
\hline 75,02 & 485,20 & 65,30 & 36,45 & 25,94 & 22,65 & 19,72 & 17,47 & 15,53 & 12,33 & 9,94 & 6,80 \\
\hline 47,59 & 1967,50 & 40,60 & 36,99 & 31,91 & 30,48 & 28,16 & 25,87 & 23,66 & 19,64 & 16,27 & 11,35 \\
\hline 86,21 & 985,90 & 114,20 & 18,27 & 12,77 & 11,27 & 9,98 & 9,00 & 8,16 & 6,72 & 5,58 & 3,96 \\
\hline 39,36 & 660,10 & 184,50 & 24,59 & 16,44 & 13,04 & 9,89 & 7,71 & 6,16 & 4,24 & 3,21 & 2,20 \\
\hline 75,16 & 301,50 & 188,90 & 32,35 & 16,86 & 12,22 & 9,04 & 7,19 & 5,90 & 4,20 & 3,23 & 2,22 \\
\hline 85,92 & 363,30 & 169,70 & 28,68 & 15,78 & 11,92 & 9,21 & 7,58 & 6,39 & 4,73 & 3,69 & 2,52 \\
\hline 35,78 & 1096,00 & 48,30 & 48,94 & 42,85 & 38,47 & 33,02 & 28,18 & 24,01 & 17,62 & 13,34 & 8,63 \\
\hline 36,27 & 1448,50 & 108,90 & 26,05 & 21,59 & 18,84 & 15,63 & 12,95 & 10,77 & 7,65 & 5,73 & 3,75 \\
\hline 89,77 & 620,40 & 71,50 & 28,66 & 19,83 & 17,47 & 15,50 & 14,02 & 12,75 & 10,58 & 8,84 & 6,34 \\
\hline 78,72 & 784,90 & 190,80 & 16,98 & 10,86 & 8,94 & 7,43 & 6,38 & 5,54 & 4,25 & 3,36 & 2,27 \\
\hline 51,62 & 1784,90 & 52,90 & 30,11 & 25,63 & 24,23 & 22,23 & 20,30 & 18,47 & 15,19 & 12,49 & 8,65 \\
\hline 82,80 & 462,20 & 114,60 & 28,19 & 17,79 & 14,59 & 12,12 & 10,44 & 9,10 & 7,03 & 5,59 & 3,81 \\
\hline 45,69 & 1402,60 & 34,60 & 47,05 & 41,17 & 38,89 & 35,52 & 32,27 & 29,18 & 23,71 & 19,28 & 13,13 \\
\hline 50,96 & 1665,80 & 37,20 & 39,53 & 33,57 & 32,10 & 29,77 & 27,44 & 25,20 & 21,08 & 17,60 & 12,42 \\
\hline 47,93 & 1763,30 & 147,30 & 16,51 & 13,46 & 11,97 & 10,31 & 8,87 & 7,64 & 5,72 & 4,40 & 2,88 \\
\hline 25,25 & 1831,80 & 142,50 & 26,33 & 20,99 & 17,31 & 13,26 & 10,26 & 8,10 & 5,48 & 4,12 & 2,81 \\
\hline 57,27 & 613,00 & 70,70 & 35,50 & 27,23 & 23,92 & 20,60 & 17,86 & 15,50 & 11,78 & 9,18 & 6,07 \\
\hline 79,63 & 744,50 & 199,10 & 17,18 & 10,76 & 8,76 & 7,22 & 6,17 & 5,34 & 4,07 & 3,21 & 2,17 \\
\hline 33,98 & 1480,20 & 51,40 & 44,08 & 39,27 & 35,48 & 30,66 & 26,30 & 22,50 & 16,61 & 12,60 & 8,13 \\
\hline 74,19 & 1425,40 & 29,10 & 38,10 & 30,41 & 28,63 & 27,52 & 26,21 & 24,85 & 22,21 & 19,76 & 15,53 \\
\hline 39,24 & 391,00 & 29,00 & 91,78 & 76,36 & 67,23 & 56,62 & 47,57 & 40,04 & 28,92 & 21,80 & 14,20 \\
\hline 71,36 & 829,10 & 131,00 & 20,13 & 14,16 & 12,18 & 10,45 & 9,14 & 8,02 & 6,23 & 4,95 & 3,34 \\
\hline 32,58 & 1938,30 & 200,00 & 17,18 & 13,58 & 11,44 & 9,08 & 7,24 & 5,84 & 4,02 & 3,00 & 2,01 \\
\hline
\end{tabular}




\begin{tabular}{|c|c|c|c|c|c|c|c|c|c|c|c|}
\hline \multirow[b]{2}{*}{ e1 (cm) } & & & & & & & ões (x1 & m) & & & \\
\hline & Meq (MPa) & Ms (MPa) & D0 & D25 & D40 & D60 & D80 & D100 & D140 & D180 & D260 \\
\hline 61,49 & 1668,50 & 37,50 & 34,89 & 28,28 & 27,11 & 25,59 & 23,96 & 22,36 & 19,35 & 16,66 & 12,37 \\
\hline 37,31 & 1432,60 & 185,30 & 18,41 & 14,18 & 11,97 & 9,58 & 7,72 & 6,29 & 4,37 & 3,28 & 2,18 \\
\hline 66,19 & 385,10 & 103,70 & 35,04 & 22,61 & 18,44 & 15,03 & 12,61 & 10,70 & 7,89 & 6,09 & 4,07 \\
\hline 66,94 & 1518,20 & 22,60 & 47,44 & 38,49 & 36,49 & 35,26 & 33,65 & 31,94 & 28,60 & 25,47 & 20,04 \\
\hline 24,27 & 1006,90 & 108,90 & 39,10 & 29,75 & 23,73 & 17,53 & 13,25 & 10,35 & 7,02 & 5,33 & 3,68 \\
\hline 23,53 & 1677,20 & 26,50 & 90,32 & 82,40 & 74,10 & 63,16 & 53,29 & 44,84 & 32,17 & 23,99 & 15,42 \\
\hline 24,78 & 1168,00 & 66,30 & 52,08 & 42,86 & 36,05 & 28,22 & 22,16 & 17,66 & 11,98 & 8,93 & 6,03 \\
\hline 24,97 & 1938,30 & 63,60 & 445,37 & 39,40 & 34,37 & 28,15 & 22,93 & 18,75 & 12,98 & 9,61 & 6,32 \\
\hline 50,65 & 1071,40 & 61,60 & 32,91 & 27,61 & 25,19 & 22,33 & 19,76 & 17,44 & 13,59 & 10,73 & 7,11 \\
\hline 39,44 & 633,20 & 34,70 & 68,30 & 58,69 & 52,60 & 45,22 & 38,71 & 33,10 & 24,44 & 18,60 & 12,06 \\
\hline 84,80 & 1283,60 & 58,30 & 23,67 & 17,81 & 16,51 & 15,45 & 14,47 & 13,53 & 11,81 & 10,29 & 7,82 \\
\hline 59,88 & 1956,50 & 94,60 & 18,17 & 14,83 & 13,80 & 12,55 & 11,41 & 10,34 & 8,46 & 6,94 & 4,81 \\
\hline 45,66 & 1573,60 & 67,10 & 29,03 & 25,16 & 23,14 & 20,59 & 18,24 & 16,11 & 12,55 & 9,88 & 6,52 \\
\hline 64,57 & 1512,20 & 156,00 & 14,38 & 10,94 & 9,73 & 8,54 & 7,55 & 6,69 & 5,26 & 4,19 & 2,83 \\
\hline 46,96 & 384,70 & 128,00 & 35,92 & 22,88 & 18,06 & 13,89 & 11,00 & 8,90 & 6,19 & 4,69 & 3,19 \\
\hline 40,45 & 390,70 & 70,50 & 52,69 & 38,42 & 31,84 & 25,20 & 20,19 & 16,41 & 11,41 & 8,57 & 5,75 \\
\hline 65,18 & 1347,20 & 188,30 & 13,69 & 9,99 & 8,68 & 7,47 & 6,51 & 5,69 & 4,38 & 3,45 & 2,31 \\
\hline 33,97 & 1009,40 & 156,30 & 24,75 & 18,48 & 15,18 & 11,76 & 9,23 & 7,38 & 5,06 & 3,80 & 2,58 \\
\hline 44,18 & 1231,50 & 77,80 & 29,58 & 24,99 & 22,44 & 19,45 & 16,81 & 14,50 & 10,88 & 8,36 & 5,45 \\
\hline 30,93 & 1077,10 & 36,80 & 66,21 & 58,74 & 52,58 & 44,77 & 37,83 & 31,94 & 23,08 & 17,32 & 11,18 \\
\hline 48,09 & 254,50 & 83,80 & 54,11 & 34,49 & 27,30 & 21,08 & 16,76 & 13,60 & 9,48 & 7,18 & 4,87 \\
\hline 24,08 & 413,30 & 175,70 & 36,45 & 21,63 & 15,31 & 10,38 & 7,67 & 6,04 & 4,22 & 3,28 & 2,30 \\
\hline 40,15 & 1179,40 & 185,70 & 18,99 & 14,18 & 11,88 & 9,49 & 7,66 & 6,25 & 4,36 & 3,27 & 2,19 \\
\hline 34,43 & 1137,90 & 24,20 & 78,74 & 71,95 & 66,58 & 59,24 & 52,29 & 45,93 & 35,36 & 27,53 & 17,91 \\
\hline 62,80 & 1979,70 & 70,10 & 21,39 & 17,30 & 16,37 & 15,17 & 14,01 & 12,91 & 10,89 & 9,18 & 6,59 \\
\hline 29,39 & 1435,20 & 85,70 & 35,86 & 30,01 & 25,85 & 20,94 & 16,93 & 13,79 & 9,54 & 7,09 & 4,70 \\
\hline 79,99 & 1063,10 & 51,10 & 28,60 & 21,67 & 20,17 & 18,75 & 17,45 & 16,23 & 14,00 & 12,05 & 8,99 \\
\hline 20,38 & 1516,10 & 198,00 & 25,28 & 18,16 & 13,73 & 9,60 & 7,05 & 5,47 & 3,77 & 2,91 & 2,02 \\
\hline 22,20 & 826,60 & 184,60 & 29,78 & 19,96 & 14,69 & 10,12 & 7,44 & 5,81 & 4,03 & 3,12 & 2,18 \\
\hline 42,06 & 588,60 & 25,30 & 81,86 & 71,55 & 65,31 & 57,50 & 50,36 & 43,97 & 33,59 & 26,08 & 17,02 \\
\hline 44,65 & 495,00 & 178,80 & 27,27 & 17,07 & 13,31 & 10,08 & 7,89 & 6,34 & 4,38 & 3,33 & 2,28 \\
\hline 26,70 & 874,50 & 42,70 & 72,66 & 61,36 & 52,77 & 42,52 & 34,20 & 27,72 & 19,05 & 14,14 & 9,39 \\
\hline 79,65 & 1223,80 & 20,00 & $\begin{array}{l}47,56 \\
\end{array}$ & 39,33 & 36,31 & 35,15 & 33,89 & 32,43 & 29,53 & 26,76 & 21,79 \\
\hline 79,68 & 1147,40 & 175,90 & 14,14 & 9,74 & 8,40 & 7,27 & 6,42 & 5,71 & 4,54 & 3,67 & 2,53 \\
\hline 79,85 & 363,10 & 21,80 & 73,54 & 55,17 & 50,89 & 46,76 & 43,16 & 39,86 & 33,88 & 28,82 & 21,10 \\
\hline 44,64 & 1888,80 & 127,60 & 18,38 & 15,42 & 13,80 & 11,93 & 10,29 & 8,86 & 6,63 & 5,09 & 3,32 \\
\hline 64,72 & 739,10 & 44,10 & 40,39 & 32,05 & 29,57 & 26,77 & 24,30 & 22,02 & 18,03 & 14,82 & 10,30 \\
\hline 60,43 & 786,60 & 190,30 & 18,58 & 12,42 & 10,25 & 8,37 & 7,00 & 5,90 & 4,31 & 3,31 & 2,20 \\
\hline 55,46 & 1903,80 & 191,80 & 12,55 & 9,84 & 8,72 & 7,55 & 6,57 & 5,71 & 4,36 & 3,40 & 2,24 \\
\hline 28,48 & 1098,00 & 179,10 & 24,41 & 17,85 & 14,20 & 10,53 & 8,01 & 6,30 & 4,29 & 3,26 & 2,24 \\
\hline 55,20 & 295,80 & 115,00 & 41,31 & 24,99 & 19,47 & 15,04 & 12,05 & 9,86 & 6,94 & 5,28 & 3,58 \\
\hline 36,01 & 261,60 & 172,50 & 40,28 & 21,49 & 15,22 & 10,59 & 7,95 & 6,28 & 4,35 & 3,36 & 2,37 \\
\hline 85,61 & 929,10 & 47,50 & 30,36 & 22,64 & 20,91 & 19,46 & 18,15 & 16,93 & 14,69 & 12,74 & 9,61 \\
\hline 76,33 & 1151,90 & 47,10 & 29,91 & 23,03 & 21,60 & 20,18 & 18,83 & 17,54 & 15,16 & 13,08 & 9,76 \\
\hline 24,06 & 1288,90 & 28,70 & 91,50 & 81,65 & 72,39 & 60,53 & 50,19 & 41,62 & 29,28 & 21,71 & 14,09 \\
\hline 45,38 & 637,60 & 76,10 & 38,33 & 29,88 & 25,84 & 21,54 & 18,02 & 15,13 & 10,93 & 8,27 & 5,43 \\
\hline 26,11 & 245,80 & 193,10 & 40,56 & 20,32 & 13,71 & 9,22 & 6,88 & 5,47 & 3,83 & 2,98 & 2,12 \\
\hline 32,27 & 1577,90 & 54,60 & 43,25 & 38,44 & 34,55 & 29,60 & 25,18 & 21,38 & 15,59 & 11,75 & 7,58 \\
\hline 62,35 & 1531,90 & 98,70 & 18,98 & 15,15 & 13,89 & 12,49 & 11,26 & 10,13 & 8,18 & 6,66 & 4,56 \\
\hline 20,96 & 1740,70 & 159,00 & 28,14 & 21,34 & 16,73 & 12,09 & 9,00 & 6,98 & 4,75 & 3,63 & 2,52 \\
\hline 36,52 & 748,90 & 48,40 & 55,16 & 46,53 & 41,00 & 34,43 & 28,82 & 24,17 & 17,35 & 13,03 & 8,48 \\
\hline 39,05 & 1922,20 & 156,20 & 17,72 & 14,58 & 12,76 & 10,67 & 8,91 & 7,46 & 5,35 & 4,03 & 2,63 \\
\hline 63,75 & 772,00 & 102,70 & 24,75 & 18,27 & 15,93 & 13,73 & 11,96 & 10,45 & 8,04 & 6,32 & 4,22 \\
\hline 24,96 & 1880,40 & 38,10 & $\begin{array}{l}64,72 \\
\end{array}$ & 58,46 & 52,33 & 44,36 & 37,26 & 31,24 & 22,31 & 16,62 & 10,71 \\
\hline 36,34 & 1796,60 & 179,70 & 17,52 & 14,00 & 11,99 & 9,75 & 7,94 & 6,51 & 4,56 & 3,41 & 2,26 \\
\hline 85,00 & 1034,70 & 168,80 & 14,89 & 10,01 & 8,57 & 7,39 & 6,55 & 5,84 & 4,68 & 3,81 & 2,64 \\
\hline 63,02 & 234,90 & 174,80 & 40,15 & 20,24 & 14,29 & 10,23 & 7,92 & 6,38 & 4,45 & 3,41 & 2,37 \\
\hline 36,24 & 539,30 & 149,30 & 31,37 & 21,03 & 16,54 & 12,37 & 9,53 & 7,56 & 5,18 & 3,94 & 2,71 \\
\hline 34,65 & 1583,10 & 181,60 & 18,84 & 14,74 & 12,43 & 9,90 & 7,93 & 6,43 & 4,44 & 3,32 & 2,22 \\
\hline 48,27 & 1273,60 & 182,80 & 16,67 & 12,57 & 10,77 & 8,94 & 7,47 & 6,27 & 4,54 & 3,44 & 2,27 \\
\hline 70,93 & 1165,80 & 138,70 & 16,53 & 12,11 & 10,68 & 9,35 & 8,29 & 7,37 & 5,84 & 4,69 & 3,20 \\
\hline 88,16 & 253,20 & 43,70 & 58,61 & 38,73 & 32,95 & 28,32 & 25,06 & 22,36 & 17,96 & 14,65 & 10,22 \\
\hline 77,53 & 1221,40 & 101,80 & 18,36 & 13,60 & 12,32 & 11,09 & 10,08 & 9,17 & 7,59 & 6,31 & 4,47 \\
\hline 75,58 & 1169,70 & 132,20 & 16,47 & 11,95 & 10,58 & 9,33 & 8,34 & 7,48 & 6,02 & 4,90 & 3,39 \\
\hline 25,94 & 278,90 & 40,00 & 110,93 & 81,89 & 64,66 & 47,44 & 35,78 & 27,98 & 19,04 & 14,51 & 10,02 \\
\hline 71,08 & 920,20 & 108,80 & 21,00 & 15,39 & 13,57 & 11,88 & 10,54 & 9,38 & 7,44 & 5,98 & 4,08 \\
\hline 89,20 & 544,30 & 95,80 & 26,93 & 17,69 & 15,02 & 12,89 & 11,40 & 10,17 & 8,17 & 6,67 & 4,66 \\
\hline 34,68 & 721,50 & 150,40 & 28,42 & 20,16 & 16,19 & 12,29 & 9,53 & 7,58 & 5,19 & 3,92 & 2,68 \\
\hline 58,00 & 866,80 & 131,90 & 21,53 & 15,80 & 13,59 & 11,49 & 9,83 & 8,43 & 6,30 & 4,86 & 3,22 \\
\hline 31,05 & 588,40 & 137,60 & 34,30 & 23,70 & 18,53 & 13,62 & 10,34 & 8,13 & 5,56 & 4,24 & 2,93 \\
\hline 26,13 & 1320,40 & 73,90 & 44,63 & 37,06 & 31,48 & 24,98 & 19,83 & 15,93 & 10,87 & 8,08 & 5,42 \\
\hline 22,77 & 728,60 & 101,60 & 46,92 & 34,10 & 26,28 & 18,75 & 13,92 & 10,82 & 7,40 & 5,69 & 3,95 \\
\hline 60,90 & 1714,90 & 33,30 & 37,78 & 30,65 & 29,44 & 27,95 & 26,27 & 24,60 & 21,43 & 18,58 & 13,93 \\
\hline 67,62 & 362,70 & 92,40 & 37,82 & 24,61 & 20,20 & 16,58 & 13,99 & 11,93 & 8,87 & 6,86 & 4,59 \\
\hline 31,23 & 629,10 & 140,50 & 32,94 & 22,97 & 18,05 & 13,33 & 10,15 & 7,99 & 5,46 & 4,16 & 2,87 \\
\hline 84,68 & 1887,40 & 196,90 & 10,14 & 7,20 & 6,40 & 5,71 & 5,17 & 4,70 & 3,89 & 3,24 & 2,31 \\
\hline 64,37 & 1738,60 & 100,30 & 17,58 & 13,99 & 12,93 & 11,72 & 10,65 & 9,66 & 7,92 & 6,51 & 4,53 \\
\hline 76,10 & 1456,00 & 97,90 & 17,56 & 13,26 & 12,17 & 11,08 & 10,15 & 9,29 & 7,78 & 6,52 & 4,67 \\
\hline 24,88 & 1381,10 & 143,00 & 28,90 & 22,20 & 17,86 & 13,32 & 10,12 & 7,93 & 5,37 & 4,07 & 2,80 \\
\hline 29,89 & 1927,80 & 154,20 & 21,70 & 17,60 & 14,90 & 11,84 & 9,44 & 7,61 & 5,22 & 3,89 & 2,60 \\
\hline 53,58 & 323,80 & 173,50 & 33,33 & 18,58 & 13,84 & 10,26 & 8,04 & 6,48 & 4,51 & 3,44 & 2,37 \\
\hline 50,79 & 720,50 & 29,90 & 60,20 & 51,30 & 47,64 & 42,96 & 38,61 & 34,59 & 27,66 & 22,24 & 14,99 \\
\hline
\end{tabular}




\begin{tabular}{|c|c|c|c|c|c|c|c|c|c|c|c|}
\hline \multirow[b]{2}{*}{ e1 (cm) } & & & & & & & ões (x1 & & & & \\
\hline & Meq (MPa) & Ms (MPa) & D0 & D25 & D40 & D60 & D80 & D100 & D140 & D180 & D260 \\
\hline 85,62 & 1214,00 & 43,20 & 28,70 & 21,95 & 20,38 & 19,30 & 18,23 & 17,19 & 15,22 & 13,44 & 10,45 \\
\hline 63,08 & 425,40 & 104,20 & 33,63 & 22,29 & 18,37 & 15,05 & 12,64 & 10,71 & 7,88 & 6,06 & 4,04 \\
\hline 26,84 & 1748,60 & 196,70 & 20,49 & 15,72 & 12,75 & 9,61 & 7,37 & 5,80 & 3,94 & 2,97 & 2,04 \\
\hline 55,08 & 247,40 & 63,60 & 59,56 & 39,72 & 32,49 & 26,14 & 21,50 & 17,89 & 12,82 & 9,75 & 6,51 \\
\hline 69,06 & 1491,00 & 173,90 & 13,23 & 9,77 & 8,63 & 7,55 & 6,68 & 5,93 & 4,68 & 3,75 & 2,54 \\
\hline 81,76 & 1694,10 & 133,00 & 13,36 & 9,80 & 8,90 & 8,06 & 7,37 & 6,76 & 5,66 & 4,77 & 3,44 \\
\hline 81,23 & 697,20 & 175,60 & 18,67 & 11,79 & 9,66 & 8,01 & 6,88 & 5,98 & 4,60 & 3,64 & 2,48 \\
\hline 30,23 & 1398,60 & 133,90 & 26,33 & 20,90 & 17,51 & 13,75 & 10,86 & 8,71 & 5,95 & 4,45 & 3,00 \\
\hline 55,81 & 791,60 & 159,90 & 20,80 & 14,56 & 12,21 & 10,05 & 8,40 & 7,08 & 5,15 & 3,93 & 2,61 \\
\hline 65,34 & 897,00 & 57,20 & 31,80 & 25,09 & 23,07 & 20,83 & 18,87 & 17,07 & 13,93 & 11,43 & 7,92 \\
\hline 72,92 & 1698,40 & 122,30 & 14,78 & 11,25 & 10,28 & 9,30 & 8,46 & 7,70 & 6,36 & 5,28 & 3,73 \\
\hline 55,43 & 961,60 & 53,60 & 35,34 & 29,22 & 26,86 & 24,07 & 21,56 & 19,27 & 15,35 & 12,33 & 8,32 \\
\hline 88,92 & 1624,60 & 106,50 & 14,78 & 10,76 & 9,82 & 9,03 & 8,36 & 7,76 & 6,67 & 5,74 & 4,29 \\
\hline 57,22 & 1713,80 & 54,10 & 28,20 & 23,37 & 22,16 & 20,47 & 18,83 & 17,27 & 14,43 & 12,05 & 8,52 \\
\hline 41,21 & 220,00 & 101,10 & 55,73 & 32,92 & 24,76 & 18,10 & 13,88 & 11,03 & 7,60 & 5,81 & 4,02 \\
\hline 81,95 & 226,20 & 184,90 & 40,07 & 19,53 & 13,53 & 9,59 & 7,44 & 6,03 & 4,25 & 3,27 & 2,27 \\
\hline 74,05 & 255,50 & 88,90 & 46,24 & 27,73 & 21,89 & 17,49 & 14,58 & 12,35 & 9,13 & 7,08 & 4,77 \\
\hline 48,49 & 862,10 & 45,80 & 44,19 & 37,52 & 34,26 & 30,35 & 26,81 & 23,62 & 18,34 & 14,43 & 9,53 \\
\hline 25,20 & 1667,80 & 51,70 & 54,39 & 47,54 & 41,66 & 34,33 & 28,12 & 23,09 & 16,07 & 11,90 & 7,80 \\
\hline 21,62 & 1487,60 & 68,00 & 52,94 & 43,58 & 36,30 & 28,00 & 21,70 & 17,13 & 11,54 & 8,63 & 5,87 \\
\hline 39,29 & 1111,20 & 47,50 & 45,77 & 40,16 & 36,44 & 31,79 & 27,57 & 23,86 & 17,94 & 13,78 & 8,94 \\
\hline 47,53 & 279,70 & 184,80 & 36,19 & 19,14 & 13,75 & 9,83 & 7,53 & 5,99 & 4,14 & 3,18 & 2,22 \\
\hline 50,22 & 1337,10 & 29,00 & 50,74 & 43,22 & 41,35 & 38,33 & 35,32 & 32,42 & 27,11 & 22,60 & 15,93 \\
\hline 48,40 & 851,10 & 118,10 & 25,38 & 19,25 & 16,54 & 13,77 & 11,53 & 9,71 & 7,04 & 5,34 & 3,51 \\
\hline 43,31 & 602,60 & 117,50 & 31,52 & 22,62 & 18,74 & 14,92 & 12,03 & 9,83 & 6,88 & 5,18 & 3,47 \\
\hline 54,90 & 1221,60 & 70,10 & 27,49 & 22,74 & 20,85 & 18,64 & 16,66 & 14,85 & 11,79 & 9,43 & 6,34 \\
\hline 57,26 & 1243,60 & 132,10 & 18,32 & 14,21 & 12,56 & 10,88 & 9,47 & 8,25 & 6,31 & 4,93 & 3,27 \\
\hline 58,04 & 214,50 & 44,80 & 74,26 & 51,41 & 43,00 & 35,45 & 29,75 & 25,15 & 18,41 & 14,09 & 9,35 \\
\hline 36,95 & 1472,40 & 48,90 & 42,71 & 38,17 & 34,86 & 30,58 & 26,64 & 23,14 & 17,48 & 13,46 & 8,72 \\
\hline 40,08 & 877,30 & 197,10 & 20,77 & 14,53 & 11,80 & 9,15 & 7,23 & 5,82 & 4,02 & 3,03 & 2,06 \\
\hline 80,37 & 488,50 & 70,90 & 33,96 & 23,53 & 20,39 & 17,72 & 15,72 & 14,02 & 11,22 & 9,11 & 6,29 \\
\hline 51,73 & 681,10 & 102,40 & 29,25 & 21,78 & 18,67 & 15,59 & 13,12 & 11,10 & 8,11 & 6,18 & 4,07 \\
\hline 87,50 & 1011,00 & 58,10 & 25,78 & 19,00 & 17,46 & 16,16 & 15,03 & 13,99 & 12,09 & 10,46 & 7,86 \\
\hline 81,26 & 395,50 & 193,00 & 26,23 & 14,39 & 10,82 & 8,31 & 6,79 & 5,69 & 4,16 & 3,23 & 2,20 \\
\hline 29,32 & 1820,90 & 142,80 & 23,62 & 19,16 & 16,20 & 12,84 & 10,20 & 8,21 & 5,62 & 4,19 & 2,81 \\
\hline 68,28 & 836,50 & 120,20 & 21,29 & 15,33 & 13,30 & 11,46 & 10,02 & 8,79 & 6,82 & 5,40 & 3,63 \\
\hline 79,34 & 883,50 & 52,80 & 30,38 & 22,83 & 21,07 & 19,36 & 17,86 & 16,49 & 14,00 & 11,90 & 8,70 \\
\hline 54,00 & 643,10 & 70,40 & 36,01 & 28,04 & 24,66 & 21,18 & 18,27 & 15,78 & 11,89 & 9,20 & 6,06 \\
\hline 43,83 & 1978,00 & 43,70 & 37,00 & 32,63 & 30,86 & 28,20 & 25,61 & 23,15 & 18,80 & 15,27 & 10,38 \\
\hline 33,12 & 1325,60 & 88,10 & 32,99 & 27,58 & 23,99 & 19,74 & 16,22 & 13,38 & 9,40 & 7,01 & 4,61 \\
\hline 73,86 & 1440,70 & 60,50 & 23,98 & 18,58 & 17,44 & 16,24 & 15,10 & 14,02 & 12,04 & 10,31 & 7,62 \\
\hline 48,50 & 1129,20 & 137,90 & 20,52 & 15,88 & 13,78 & 11,58 & 9,78 & 8,28 & 6,05 & 4,61 & 3,02 \\
\hline 53,65 & 1140,00 & 107,60 & 22,17 & 17,61 & 15,64 & 13,55 & 11,78 & 10,23 & 7,78 & 6,05 & 3,99 \\
\hline 39,61 & 1008,90 & 114,80 & 27,20 & 21,39 & 18,33 & 14,99 & 12,30 & 10,16 & 7,17 & 5,38 & 3,55 \\
\hline 60,95 & 1338,10 & 147,20 & 16,15 & 12,34 & 10,91 & 9,48 & 8,30 & 7,28 & 5,63 & 4,43 & 2,96 \\
\hline 35,63 & 1040,50 & 83,60 & 35,23 & 28,94 & 25,10 & 20,65 & 16,99 & 14,04 & 9,90 & 7,40 & 4,87 \\
\hline 39,56 & 1076,40 & 178,80 & 20,33 & 15,04 & 12,52 & 9,94 & 7,97 & 6,48 & 4,50 & 3,38 & 2,27 \\
\hline 23,05 & 1350,60 & 41,80 & 72,56 & 62,58 & 54,12 & 43,76 & 35,21 & 28,52 & 19,54 & 14,46 & 9,58 \\
\hline 27,17 & 1828,90 & 178,40 & 21,43 & 16,78 & 13,79 & 10,55 & 8,16 & 6,46 & 4,38 & 3,29 & 2,25 \\
\hline 78,95 & 1584,90 & 46,30 & 26,19 & 20,40 & 19,13 & 18,20 & 17,21 & 16,23 & 14,36 & 12,66 & 9,81 \\
\hline 71,12 & 1442,30 & 84,50 & 19,91 & 15,42 & 14,27 & 13,02 & 11,93 & 10,91 & 9,11 & 7,61 & 5,42 \\
\hline 25,60 & 639,60 & 20,10 & 138,57 & 121,24 & 106,40 & 87,88 & 72,13 & 59,34 & 41,39 & 30,67 & 20,06 \\
\hline 37,58 & 1969,90 & 152,00 & 18,36 & 15,19 & 13,28 & 11,07 & 9,22 & 7,69 & 5,49 & 4,12 & 2,69 \\
\hline 82,42 & 697,10 & 31,60 & 44,41 & 33,56 & 31,21 & 29,16 & 27,25 & 25,45 & 22,12 & 19,19 & 14,49 \\
\hline 87,26 & 1488,50 & 29,80 & 31,95 & 26,25 & 24,00 & 23,13 & 22,30 & 21,35 & 19,46 & 17,67 & 14,46 \\
\hline 31,61 & 1553,90 & 140,20 & 23,88 & 19,17 & 16,24 & 12,93 & 10,34 & 8,36 & 5,75 & 4,29 & 2,87 \\
\hline 87,62 & 1016,40 & 137,10 & 16,37 & 11,20 & 9,75 & 8,54 & 7,66 & 6,90 & 5,64 & 4,66 & 3,29 \\
\hline 76,62 & 329,20 & 84,00 & 40,02 & 25,49 & 20,88 & 17,25 & 14,75 & 12,74 & $\begin{array}{l}9,68 \\
\end{array}$ & 7,61 & 5,14 \\
\hline 22,34 & 736,70 & 63,80 & 66,19 & 51,11 & 40,81 & 30,08 & 22,65 & 17,65 & 11,95 & 9,09 & 6,27 \\
\hline 54,42 & 1589,10 & 163,20 & 15,03 & 11,79 & 10,42 & 9,00 & 7,80 & 6,76 & 5,13 & 3,98 & 2,62 \\
\hline 31,72 & 1266,80 & 133,80 & 26,36 & 20,74 & 17,38 & 13,68 & 10,84 & 8,71 & 5,97 & 4,47 & 3,01 \\
\hline 68,76 & 1212,40 & 134,00 & 16,77 & 12,48 & 11,06 & 9,71 & 8,62 & 7,66 & 6,06 & 4,87 & 3,31 \\
\hline 32,63 & 718,30 & 197,00 & 24,82 & 16,64 & 12,91 & 9,47 & 7,20 & 5,67 & 3,88 & 2,96 & 2,05 \\
\hline 87,81 & 1865,20 & 197,40 & 10,03 & 7,04 & 6,25 & 5,58 & 5,06 & 4,61 & 3,83 & 3,21 & 2,30 \\
\hline 23,34 & 318,20 & 41,70 & 110,62 & 81,47 & 63,44 & 45,74 & 34,11 & 26,54 & 18,11 & 13,87 & 9,61 \\
\hline 66,93 & 559,40 & 61,20 & 37,00 & 27,75 & 24,60 & 21,56 & 19,09 & 16,92 & 13,34 & 10,67 & 7,22 \\
\hline 61,13 & 1876,90 & 91,30 & 18,64 & 15,13 & 14,09 & 12,83 & 11,68 & 10,61 & 8,71 & 7,17 & 4,99 \\
\hline 45,89 & 612,00 & 42,90 & 54,44 & 45,41 & 40,67 & 35,21 & 30,42 & 26,26 & 19,72 & 15,18 & 9,91 \\
\hline 34,12 & 734,30 & 36,20 & 70,50 & 60,95 & 54,12 & 45,75 & 38,46 & 32,35 & 23,30 & 17,49 & 11,34 \\
\hline 87,22 & 1900,20 & 114,40 & 13,39 & 9,84 & 9,03 & 8,34 & 7,74 & 7,19 & 6,20 & 5,34 & 4,00 \\
\hline 44,11 & 1293,70 & 135,30 & 20,78 & 16,53 & 14,40 & 12,06 & 10,12 & 8,52 & 6,17 & 4,67 & 3,06 \\
\hline 75,06 & 1376,00 & 28,30 & 38,87 & 31,01 & 29,15 & 28,03 & 26,71 & 25,33 & 22,67 & 20,19 & 15,90 \\
\hline 22,06 & 1777,10 & 99,40 & 37,83 & 30,62 & 25,23 & 19,23 & 14,78 & 11,62 & 7,83 & 5,88 & 4,02 \\
\hline 78,84 & 833,60 & 83,30 & 24,19 & 17,57 & 15,71 & 13,99 & 12,63 & 11,43 & 9,36 & 7,73 & 5,43 \\
\hline 40,81 & 537,70 & 167,60 & 28,00 & 18,24 & 14,36 & 10,86 & 8,46 & 6,77 & 4,66 & 3,53 & 2,42 \\
\hline 52,97 & 1957,80 & 79,70 & 21,84 & 18,45 & 17,20 & 15,59 & 14,09 & 12,69 & 10,26 & 8,32 & 5,66 \\
\hline 73,03 & 999,50 & 138,50 & 17,63 & 12,58 & 10,95 & 9,50 & 8,38 & 7,42 & 5,85 & 4,69 & 3,19 \\
\hline 51,17 & 1818,10 & 133,40 & 16,59 & 13,63 & 12,26 & 10,73 & 9,39 & 8,21 & 6,29 & 4,92 & 3,24 \\
\hline 26,93 & 1689,30 & 133,70 & 26,92 & 21,60 & 18,00 & 13,98 & 10,94 & 8,70 & 5,91 & 4,42 & 2,99 \\
\hline 88,73 & 1699,90 & 25,00 & 32,23 & 28,41 & 25,60 & 24,64 & 24,00 & 23,18 & 21,42 & 19,72 & 16,56 \\
\hline 63,17 & 1059,50 & 74,60 & 25,82 & 20,43 & 18,64 & 16,70 & 15,01 & 13,47 & 10,84 & 8,79 & 6,01 \\
\hline 68,96 & 1007,80 & 123,50 & 19,08 & 14,02 & 12,32 & 10,74 & 9,49 & 8,39 & 6,60 & 5,27 & 3,57 \\
\hline
\end{tabular}




\begin{tabular}{|c|c|c|c|c|c|c|c|c|c|c|c|}
\hline & & & \multicolumn{9}{|c|}{ Deflexões $\left(\times 10^{-4} \mathrm{~cm}\right)$} \\
\hline e1 (cm) & Meq (MPa) & Ms (MPa) & D0 & D25 & D40 & D60 & D80 & D100 & D140 & D180 & D260 \\
\hline 29,80 & 385,90 & 68,80 & 63,80 & 46,16 & 36,72 & 27,33 & 20,85 & 16,42 & 11,19 & 8,49 & 5,84 \\
\hline 35,38 & 761,50 & 157,20 & 26,81 & 19,06 & 15,36 & 11,72 & 9,12 & 7,27 & 4,98 & 3,76 & 2,57 \\
\hline 20,44 & 990,60 & 57,20 & 70,25 & 55,90 & 45,24 & 33,73 & 25,53 & 19,90 & 13,41 & 10,15 & 6,98 \\
\hline 84,91 & 1671,90 & 120,00 & 13,97 & 10,21 & 9,31 & 8,49 & 7,82 & 7,21 & 6,12 & 5,20 & 3,81 \\
\hline 72,93 & 1181,80 & 101,20 & 19,23 & 14,46 & 13,07 & 11,70 & 10,56 & 9,55 & 7,79 & 6,41 & 4,47 \\
\hline 72,83 & 1481,90 & 50,50 & 26,84 & 20,97 & 19,81 & 18,61 & 17,41 & 16,26 & 14,10 & 12,19 & 9,13 \\
\hline 76,16 & 1873,90 & 71,10 & 19,29 & 14,90 & 14,00 & 13,13 & 12,28 & 11,46 & 9,95 & 8,61 & 6,46 \\
\hline 70,00 & 454,50 & 156,40 & 26,48 & 16,05 & 12,70 & 10,13 & 8,41 & 7,09 & 5,20 & 4,01 & 2,70 \\
\hline 41,56 & 658,70 & 135,80 & 28,53 & 20,28 & 16,66 & 13,10 & 10,47 & 8,49 & 5,90 & 4,44 & 2,99 \\
\hline 86,45 & 435,60 & 191,40 & 24,34 & 13,56 & 10,32 & 8,04 & 6,66 & 5,64 & 4,20 & 3,28 & 2,24 \\
\hline 77,00 & 435,00 & 149,30 & 27,04 & 16,17 & 12,78 & 10,24 & 8,57 & 7,30 & 5,43 & 4,23 & 2,86 \\
\hline 60,63 & 927,30 & 21,80 & 61,56 & 50,07 & 47,98 & 45,15 & 42,17 & 39,26 & 33,80 & 28,97 & 21,34 \\
\hline 57,70 & 1365,60 & 87,90 & 22,25 & 18,08 & 16,52 & 14,75 & 13,19 & 11,76 & 9,35 & 7,51 & 5,07 \\
\hline 89,17 & 575,40 & 34,60 & 43,72 & 32,01 & 29,31 & 27,09 & 25,18 & 23,44 & 20,26 & 17,53 & 13,19 \\
\hline 56,74 & 871,00 & 56,10 & 35,19 & 28,70 & 26,19 & 23,35 & 20,83 & 18,55 & 14,69 & 11,75 & 7,91 \\
\hline 63,73 & 278,30 & 97,40 & 44,06 & 26,92 & 21,29 & 16,85 & 13,83 & 11,54 & 8,32 & 6,37 & 4,28 \\
\hline 86,42 & 878,00 & 47,30 & 31,01 & 23,01 & 21,20 & 19,69 & 18,34 & 17,09 & 14,81 & 12,82 & 9,66 \\
\hline 74,49 & 482,60 & 159,90 & 24,88 & 15,07 & 11,98 & 9,62 & 8,05 & 6,85 & 5,08 & 3,95 & 2,66 \\
\hline 69,18 & 217,80 & 48,60 & 66,19 & 44,08 & 36,69 & 30,54 & 26,06 & 22,43 & 16,89 & 13,17 & 8,81 \\
\hline 40,20 & 745,70 & 90,40 & 35,07 & 27,32 & 23,35 & 19,05 & 15,61 & 12,88 & 9,09 & 6,82 & 4,51 \\
\hline 61,80 & 1182,00 & 124,10 & 18,63 & 14,28 & 12,67 & 11,06 & 9,73 & 8,56 & 6,66 & 5,27 & 3,52 \\
\hline 30,00 & 1656,10 & 74,50 & 36,86 & 31,81 & 27,96 & 23,22 & 19,19 & 15,90 & 11,21 & 8,34 & 5,44 \\
\hline 89,05 & 1305,80 & 183,80 & 12,41 & 8,41 & 7,29 & 6,37 & 5,71 & 5,14 & 4,20 & 3,47 & 2,45 \\
\hline 45,77 & 1510,30 & 38,60 & 42,53 & 37,22 & 35,10 & 32,02 & 29,04 & 26,23 & 21,26 & 17,26 & 11,73 \\
\hline 65,25 & 261,00 & 53,40 & 58,69 & 40,13 & 33,69 & 28,13 & 23,98 & 20,58 & 15,42 & 11,97 & 7,98 \\
\hline 47,44 & 762,70 & 196,10 & 20,55 & 13,87 & 11,27 & 8,89 & 7,16 & 5,85 & 4,10 & 3,10 & 2,08 \\
\hline 60,44 & 580,10 & 24,10 & 67,22 & 54,88 & 51,50 & 47,20 & 43,20 & 39,42 & 32,67 & 27,09 & 19,01 \\
\hline 47,33 & 1129,80 & 159,60 & 19,17 & 14,52 & 12,44 & 10,30 & 8,59 & 7,20 & 5,19 & 3,93 & 2,59 \\
\hline 59,72 & 1910,50 & 184,70 & 12,29 & 9,57 & 8,53 & 7,46 & 6,56 & 5,77 & 4,49 & 3,54 & 2,37 \\
\hline 28,81 & 1892,70 & 27,70 & 70,67 & 65,64 & 60,60 & 53,64 & 47,02 & 41,01 & 31,14 & 23,98 & 15,46 \\
\hline 71,62 & 682,50 & 179,80 & 19,46 & 12,46 & 10,18 & 8,36 & 7,08 & 6,07 & 4,55 & 3,54 & 2,37 \\
\hline 48,13 & 524,90 & 125,60 & 30,79 & 21,09 & 17,27 & 13,74 & 11,13 & 9,14 & 6,44 & 4,87 & 3,26 \\
\hline 34,57 & 1507,10 & 20,50 & 80,91 & 74,02 & 69,88 & 63,53 & 57,30 & 51,39 & 41,05 & 32,84 & 21,87 \\
\hline 43,94 & 1012,90 & 129,00 & 23,71 & 18,32 & 15,73 & 12,98 & 10,76 & 8,97 & 6,42 & 4,84 & 3,19 \\
\hline 74,76 & 689,80 & 148,00 & 20,69 & 13,68 & 11,43 & 9,58 & 8,26 & 7,18 & 5,51 & 4,34 & 2,93 \\
\hline 27,13 & 1620,20 & 50,70 & 52,16 & 46,00 & 40,70 & 34,02 & 28,23 & 23,45 & 16,56 & 12,31 & 8,00 \\
\hline 23,12 & 1557,90 & 36,80 & 75,45 & 66,62 & 58,55 & 48,36 & 39,64 & 32,56 & 22,64 & 16,74 & 10,95 \\
\hline 75,27 & 456,20 & 178,00 & 24,77 & 14,44 & 11,23 & 8,86 & 7,33 & 6,18 & 4,55 & 3,52 & 2,38 \\
\hline 29,45 & 1744,80 & 92,10 & 31,95 & 27,09 & 23,52 & 19,24 & 15,69 & 12,85 & 8,95 & 6,65 & 4,38 \\
\hline 41,42 & 932,20 & 127,50 & 25,62 & 19,58 & 16,64 & 13,52 & 11,05 & 9,11 & 6,43 & 4,83 & 3,20 \\
\hline 53,31 & 1544,60 & 29,00 & 46,88 & 39,12 & 37,69 & 35,37 & 32,92 & 30,54 & 26,07 & 22,16 & 16,07 \\
\hline 73,77 & 1880,50 & 101,60 & 15,74 & 12,10 & 11,24 & 10,33 & 9,52 & 8,77 & 7,40 & 6,25 & 4,52 \\
\hline 53,02 & 1719,80 & 93,60 & 20,62 & 17,22 & 15,81 & 14,12 & 12,60 & 11,21 & 8,86 & 7,07 & 4,74 \\
\hline 63,18 & 1945,00 & 137,10 & 14,06 & 11,12 & 10,15 & 9,09 & 8,17 & 7,33 & 5,90 & 4,79 & 3,27 \\
\hline 26,25 & 1868,30 & 153,10 & 24,22 & 19,29 & 15,96 & 12,29 & 9,55 & 7,56 & 5,13 & 3,84 & 2,61 \\
\hline 29,51 & 1823,40 & 93,10 & 31,22 & 26,57 & 23,12 & 18,97 & 15,50 & 12,73 & 8,88 & 6,60 & 4,34 \\
\hline 48,68 & 1632,10 & 198,80 & 14,19 & 10,98 & 9,53 & 8,02 & 6,77 & 5,74 & 4,20 & 3,20 & 2,10 \\
\hline 24,61 & 460,10 & 108,40 & 48,94 & 33,02 & 24,72 & 17,31 & 12,81 & 10,00 & 6,90 & 5,33 & 3,71 \\
\hline 64,40 & 546,50 & 121,10 & 27,17 & 18,32 & 15,26 & 12,64 & 10,71 & 9,14 & 6,79 & 5,25 & 3,50 \\
\hline 50,85 & 1004,70 & 158,10 & 19,53 & 14,45 & 12,33 & 10,23 & 8,57 & 7,22 & 5,24 & 3,99 & 2,63 \\
\hline 25,34 & 1204,40 & 37,80 & 74,26 & 64,88 & 56,86 & 46,87 & 38,39 & 31,53 & 21,95 & 16,26 & 10,65 \\
\hline 85,00 & 1262,80 & 183,80 & 12,85 & 8,78 & 7,59 & 6,61 & 5,89 & 5,28 & 4,27 & 3,49 & 2,44 \\
\hline 61,16 & 882,30 & 79,80 & 27,28 & 21,30 & 19,09 & 16,81 & 14,88 & 13,16 & 10,33 & 8,22 & 5,52 \\
\hline 21,57 & 1467,40 & 44,50 & 71,60 & 61,19 & 52,40 & 41,79 & 33,23 & 26,66 & 18,11 & 13,42 & 8,97 \\
\hline 76,40 & 371,80 & 104,30 & 34,17 & 21,36 & 17,31 & 14,17 & 12,03 & 10,34 & 7,80 & 6,11 & 4,12 \\
\hline 27,86 & 1782,70 & 154,20 & 23,44 & 18,68 & 15,56 & 12,09 & 9,47 & 7,54 & 5,13 & 3,84 & 2,60 \\
\hline 40,04 & 839,30 & 116,60 & 28,79 & 21,96 & 18,57 & 14,98 & 12,17 & 9,98 & 6,99 & 5,25 & 3,49 \\
\hline 38,21 & 358,20 & 44,00 & 74,86 & 58,17 & 49,40 & 39,89 & 32,38 & 26,52 & 18,55 & 13,89 & 9,23 \\
\hline 68,98 & 416,20 & 175,20 & 26,95 & 15,60 & 12,03 & 9,37 & 7,65 & 6,38 & 4,60 & 3,54 & 2,39 \\
\hline 85,03 & 899,40 & 154,50 & 16,73 & 11,16 & 9,51 & 8,17 & 7,21 & 6,42 & 5,12 & 4,16 & 2,88 \\
\hline 22,30 & 1210,40 & 122,60 & 36,04 & 27,28 & 21,49 & 15,64 & 11,70 & 9,10 & 6,18 & 4,72 & 3,26 \\
\hline 31,92 & 1352,40 & 91,90 & 32,79 & 27,27 & 23,57 & 19,23 & 15,66 & 12,84 & 8,95 & 6,67 & 4,40 \\
\hline 84,39 & 1030,50 & 46,10 & 29,86 & 22,50 & 20,88 & 19,55 & 18,31 & 17,13 & 14,95 & 13,03 & 9,91 \\
\hline 31,83 & 742,80 & 26,60 & 90,86 & 80,47 & 72,09 & 61,49 & $\begin{array}{l}10,01 \\
52,08\end{array}$ & $\begin{array}{l}1+.10 \\
44,06\end{array}$ & 31,94 & 24,01 & 15,50 \\
\hline 65,19 & 824,00 & 25,80 & 54,61 & 43,75 & 41,58 & 38,87 & 36,17 & 33,57 & 28,74 & 24,54 & 17,98 \\
\hline 46,56 & 625,30 & 187,90 & 23,32 & 15,22 & 12,15 & 9,42 & 7,50 & 6,08 & 4,24 & 3,20 & 2,17 \\
\hline 77,95 & 1599,50 & 123,90 & 14,57 & 10,84 & 9,86 & 8,92 & 8,13 & 7,43 & 6,18 & 5,16 & 3,68 \\
\hline 29,45 & 959,50 & 48,20 & 60,03 & 51,15 & 44,55 & 36,57 & 29,91 & 24,57 & 17,15 & 12,75 & 8,37 \\
\hline 62,37 & 1641,50 & 46,70 & 29,97 & 24,26 & 23,13 & 21,64 & 20,12 & 18,67 & 15,95 & 13,59 & 9,92 \\
\hline 42,75 & 1956,10 & 108,50 & 20,68 & 17,71 & 15,98 & 13,89 & 12,03 & 10,40 & 7,82 & 6,01 & 3,91 \\
\hline 81,07 & 698,80 & 151,30 & 19,81 & 12,87 & 10,72 & 9,02 & 7,82 & 6,85 & 5,33 & 4,25 & 2,89 \\
\hline 29,78 & 585,70 & 185,20 & 28,95 & 18,75 & 14,14 & 10,08 & 7,55 & 5,92 & 4,07 & 3,13 & 2,18 \\
\hline 20,77 & 1889,00 & 73,60 & 48,17 & 39,98 & 33,43 & 25,88 & 20,10 & 15,87 & 10,68 & 7,98 & 5,42 \\
\hline 64,38 & 1208,00 & 130,90 & 17,55 & 13,29 & 11,78 & 10,30 & 9,09 & 8,02 & 6,28 & 4,99 & 3,36 \\
\hline 24,34 & 735,30 & 57,20 & 67,41 & 53,46 & 43,79 & 33,26 & 25,56 & 20,11 & 13,59 & 10,23 & 7,00 \\
\hline 55,11 & 1114,20 & 20,00 & 65,53 & 54,17 & 52,25 & 49,28 & 46,07 & 42,91 & 36,94 & 31,65 & 23,25 \\
\hline 78,41 & 1365,20 & 57,30 & 24,45 & 18,71 & 17,50 & 16,37 & 15,29 & 14,26 & 12,35 & 10,68 & 8,01 \\
\hline 88,70 & 1354,20 & 27,40 & 34,37 & 28,32 & 25,83 & 24,87 & 23,99 & 22,99 & 20,98 & 19,08 & 15,65 \\
\hline 30,89 & 1804,10 & 127,80 & 24,52 & 20,23 & 17,36 & 14,02 & 11,33 & 9,22 & 6,39 & 4,75 & 3,15 \\
\hline 78,56 & 1638,30 & 106,00 & 15,71 & 11,79 & 10,84 & 9,90 & 9,11 & 8,37 & 7,06 & 5,97 & 4,32 \\
\hline 86,89 & 1887,30 & 168,80 & 10,87 & 7,77 & 6,98 & 6,29 & 5,75 & 5,27 & 4,42 & 3,73 & 2,70 \\
\hline 29,25 & 1132,90 & 138,60 & 28,23 & 21,62 & 17,68 & 13,50 & 10,46 & 8,29 & 5,64 & 4,24 & 2,89 \\
\hline
\end{tabular}




\begin{tabular}{|c|c|c|c|c|c|c|c|c|c|c|c|}
\hline \multirow[b]{2}{*}{ e1 (cm) } & & & & & & & ões (x1 & m) & & & \\
\hline & Meq (MPa) & Ms (MPa) & D0 & D25 & D40 & D60 & D80 & D100 & D140 & D180 & D260 \\
\hline 46,30 & 944,60 & 22,10 & 71,79 & 62,57 & 59,32 & 54,37 & 49,56 & 44,98 & 36,79 & 30,09 & 20,63 \\
\hline 78,28 & 1279,10 & 128,40 & 15,78 & 11,48 & 10,26 & 9,13 & 8,24 & 7,45 & 6,09 & 5,02 & 3,52 \\
\hline 73,18 & 1636,60 & 23,10 & 42,06 & 34,74 & 32,38 & 31,42 & 30,24 & 28,90 & 26,23 & 23,68 & 19,13 \\
\hline 50,74 & 1628,60 & 179,60 & 14,67 & 11,49 & 10,07 & 8,57 & 7,33 & 6,28 & 4,66 & 3,58 & 2,35 \\
\hline 35,95 & 564,90 & 157,00 & 29,98 & 20,08 & 15,77 & 11,77 & 9,06 & 7,18 & 4,92 & 3,74 & 2,57 \\
\hline 59,13 & 763,50 & 150,80 & 21,25 & 14,84 & 12,48 & 10,36 & 8,74 & 7,43 & 5,48 & 4,21 & 2,79 \\
\hline 23,59 & 1864,00 & 112,50 & 32,49 & 26,37 & 21,88 & 16,85 & 13,06 & 10,32 & 6,97 & 5,22 & 3,55 \\
\hline 42,89 & 878,50 & 64,70 & 38,54 & 32,08 & 28,50 & 24,35 & 20,77 & 17,71 & 13,05 & 9,94 & 6,47 \\
\hline 76,95 & 605,80 & 66,00 & 32,15 & 23,31 & 20,70 & 18,31 & 16,43 & 14,78 & 11,98 & 9,80 & 6,81 \\
\hline 39,36 & 1931,00 & 114,20 & 21,39 & 18,24 & 16,28 & 13,92 & 11,86 & 10,10 & 7,42 & 5,63 & 3,65 \\
\hline 57,56 & 780,30 & 29,10 & 55,15 & 45,66 & 42,98 & 39,41 & 36,05 & 32,88 & 27,19 & 22,49 & 15,72 \\
\hline 47,33 & 1153,00 & 31,70 & 51,90 & 45,10 & 42,52 & 38,79 & 35,21 & 31,83 & 25,85 & 21,03 & 14,33 \\
\hline 46,83 & 1012,10 & 89,70 & 28,17 & 22,85 & 20,20 & 17,27 & 14,77 & 12,64 & 9,38 & 7,17 & 4,69 \\
\hline 71,32 & 1504,00 & 137,50 & 14,73 & 11,08 & 9,96 & 8,87 & 7,97 & 7,17 & 5,80 & 4,73 & 3,27 \\
\hline 72,91 & 1014,00 & 37,50 & 37,20 & 29,00 & 27,34 & 25,59 & 23,88 & 22,24 & 19,20 & 16,53 & 12,30 \\
\hline 22,31 & 913,20 & 53,20 & 70,95 & 57,29 & 47,17 & 35,93 & 27,61 & 21,70 & 14,63 & 10,99 & 7,51 \\
\hline 86,70 & 732,80 & 104,20 & 22,23 & 15,15 & 13,13 & 11,46 & 10,24 & 9,20 & 7,47 & 6,15 & 4,32 \\
\hline 66,57 & 1024,70 & 25,70 & 50,14 & 40,02 & 38,18 & 36,12 & 33,90 & 31,73 & 27,62 & 23,94 & 17,98 \\
\hline 33,43 & 871,40 & 105,30 & 33,92 & 26,28 & 21,97 & 17,30 & 13,73 & 11,05 & 7,60 & 5,69 & 3,83 \\
\hline 53,21 & 1790,90 & 54,60 & 28,88 & 24,39 & 23,08 & 21,20 & 19,40 & 17,69 & 14,61 & 12,06 & 8,39 \\
\hline 89,82 & 1083,70 & 101,10 & 18,25 & 12,89 & 11,53 & 10,38 & 9,48 & 8,70 & 7,32 & 6,19 & 4,51 \\
\hline 35,73 & 1501,80 & 155,90 & 20,72 & 16,46 & 14,04 & 11,34 & 9,19 & 7,51 & 5,23 & 3,91 & 2,60 \\
\hline 83,79 & 353,70 & 175,70 & 29,05 & 15,82 & 11,84 & 9,07 & 7,42 & 6,22 & 4,56 & 3,55 & 2,42 \\
\hline 80,30 & 906,00 & 155,20 & 16,96 & 11,48 & 9,79 & 8,40 & 7,39 & 6,54 & 5,17 & 4,16 & 2,85 \\
\hline 28,89 & 1802,30 & 106,30 & 29,18 & 24,40 & 20,99 & 16,95 & 13,68 & 11,12 & 7,68 & 5,70 & 3,78 \\
\hline 43,54 & 1385,70 & 68,90 & 30,88 & 26,66 & 24,22 & 21,25 & 18,56 & 16,17 & 12,31 & 9,54 & 6,23 \\
\hline 87,77 & 336,20 & 54,50 & 45,43 & 30,32 & 25,95 & 22,42 & 19,90 & 17,80 & 14,35 & 11,74 & 8,20 \\
\hline 84,87 & 373,20 & 150,60 & 29,25 & 16,64 & 12,83 & 10,11 & 8,41 & 7,16 & 5,35 & 4,18 & 2,85 \\
\hline 48,57 & 278,90 & 156,80 & 38,64 & 21,39 & 15,77 & 11,52 & 8,91 & 7,13 & 4,93 & 3,77 & 2,61 \\
\hline 49,01 & 1395,80 & 51,60 & 34,28 & 29,50 & 27,49 & 24,83 & 22,34 & 20,03 & 16,03 & 12,89 & 8,68 \\
\hline 66,88 & 378,00 & 93,60 & 36,87 & 24,17 & 19,90 & 16,36 & 13,82 & 11,79 & 8,76 & 6,78 & 4,53 \\
\hline 34,92 & 1491,40 & 146,10 & 21,99 & 17,59 & 15,02 & 12,13 & 9,82 & 8,02 & 5,58 & 4,17 & 2,77 \\
\hline 88,54 & 1807,10 & 133,90 & 12,45 & 8,99 & 8,16 & 7,45 & 6,86 & 6,34 & 5,41 & 4,62 & 3,41 \\
\hline 84,60 & 976,30 & 112,70 & 18,62 & 13,09 & 11,55 & 10,23 & 9,22 & 8,34 & 6,85 & 5,67 & 4,01 \\
\hline 58,70 & 1591,10 & 196,90 & 13,00 & 9,83 & 8,60 & 7,39 & 6,40 & 5,56 & 4,22 & 3,29 & 2,18 \\
\hline 67,59 & 350,30 & 145,80 & 32,28 & 18,79 & 14,51 & 11,30 & 9,22 & 7,67 & 5,53 & 4,24 & 2,87 \\
\hline 39,36 & 715,00 & 108,60 & 32,38 & 24,33 & 20,39 & 16,29 & 13,12 & 10,69 & 7,45 & 5,59 & 3,73 \\
\hline 85,85 & 1986,60 & 67,90 & 17,94 & 13,76 & 12,77 & 12,12 & 11,47 & 10,82 & 9,61 & 8,50 & 6,64 \\
\hline 79,83 & 1427,00 & 186,10 & 12,27 & 8,64 & 7,56 & 6,61 & 5,90 & 5,28 & 4,26 & 3,47 & 2,41 \\
\hline 37,99 & 503,90 & 42,70 & 67,20 & 54,98 & 47,86 & 39,71 & 32,92 & 27,40 & 19,51 & 14,63 & 9,59 \\
\hline 46,78 & 1997,00 & 64,40 & 27,06 & 23,57 & 22,02 & 19,92 & 17,93 & 16,08 & 12,87 & 10,35 & 6,96 \\
\hline 89,69 & 726,20 & 81,20 & 24,86 & 17,26 & 15,24 & 13,55 & 12,28 & 11,18 & 9,29 & 7,78 & 5,59 \\
\hline 49,84 & 652,60 & 117,70 & 28,23 & 20,41 & 17,20 & 14,08 & 11,66 & 9,74 & 6,99 & 5,30 & 3,51 \\
\hline 84,15 & 926,60 & 86,30 & 21,97 & 15,78 & 14,16 & 12,71 & 11,57 & 10,55 & 8,79 & 7,36 & 5,28 \\
\hline 26,53 & 1858,60 & 89,00 & 34,84 & 29,45 & 25,34 & 20,42 & 16,43 & 13,31 & 9,15 & 6,79 & 4,51 \\
\hline 49,50 & 1636,70 & 23,90 & 55,46 & 46,69 & 45,19 & 42,54 & 39,67 & 36,86 & 31,55 & 26,85 & 19,51 \\
\hline 58,52 & 248,80 & 43,40 & 69,64 & 49,83 & 42,38 & 35,49 & 30,14 & 25,72 & 19,07 & 14,68 & 9,72 \\
\hline 50,60 & 1662,60 & 90,90 & 21,90 & 18,44 & 16,87 & 14,99 & 13,29 & 11,76 & 9,20 & 7,28 & 4,84 \\
\hline 39,67 & 1162,90 & 98,10 & 28,30 & 23,19 & 20,28 & 16,96 & 14,17 & 11,87 & 8,52 & 6,41 & 4,19 \\
\hline 65,55 & 957,10 & 78,50 & 25,64 & 19,88 & 17,98 & 16,02 & 14,35 & 12,85 & 10,31 & 8,34 & 5,70 \\
\hline 66,24 & 1498,50 & 107,30 & 17,64 & 13,77 & 12,58 & 11,30 & 10,20 & 9,19 & 7,46 & 6,09 & 4,21 \\
\hline 64,10 & 763,50 & 148,60 & 20,68 & 14,32 & 12,08 & 10,11 & 8,63 & 7,41 & 5,55 & 4,31 & 2,87 \\
\hline 78,67 & 1960,00 & 82,00 & 17,03 & 13,03 & 12,18 & 11,40 & 10,65 & 9,94 & 8,61 & 7,45 & 5,60 \\
\hline 41,42 & 820,00 & 72,10 & 37,96 & 30,94 & 27,10 & 22,76 & 19,10 & 16,07 & 11,61 & 8,77 & 5,73 \\
\hline 88,46 & 654,90 & 169,30 & 19,24 & 11,88 & 9,68 & 8,02 & 6,92 & 6,05 & 4,72 & 3,77 & 2,59 \\
\hline 86,48 & 1802,40 & 175,70 & 10,90 & 7,74 & 6,92 & 6,20 & 5,64 & 5,15 & 4,29 & 3,60 & 2,59 \\
\hline 47,20 & 600,50 & 30,40 & 66,61 & 56,94 & 52,03 & 46,06 & 40,64 & 35,76 & 27,70 & 21,74 & 14,33 \\
\hline 85,52 & 1152,20 & 179,20 & 13,63 & 9,21 & 7,92 & 6,86 & 6,09 & 5,45 & 4,39 & 3,58 & 2,50 \\
\hline 65,53 & 1992,60 & 153,30 & 12,79 & 9,96 & 9,05 & 8,09 & 7,27 & 6,53 & 5,26 & 4,27 & 2,93 \\
\hline 25,07 & 1645,30 & 27,90 & 83,09 & 76,03 & 68,68 & 58,95 & 50,10 & 42,45 & 30,76 & 23,05 & 14,79 \\
\hline 82,20 & 469,60 & 72,30 & 34,07 & 23,28 & 20,06 & 17,37 & 15,39 & 13,72 & 10,97 & 8,91 & 6,16 \\
\hline 80,14 & 430,60 & 193,40 & 24,76 & 13,87 & 10,55 & 8,19 & 6,73 & 5,67 & 4,16 & 3,23 & 2,19 \\
\hline 51,61 & 802,90 & 31,10 & 55,93 & 47,57 & 44,39 & 40,22 & 36,33 & 32,70 & 26,37 & 21,35 & 14,50 \\
\hline 60,08 & 1064,60 & 39,50 & 39,58 & 32,39 & 30,56 & 28,14 & 25,85 & 23,67 & 19,75 & 16,47 & 11,64 \\
\hline 34,57 & 1731,70 & 34,50 & 53,94 & 49,35 & 45,82 & 40,93 & 36,26 & 31,97 & 24,77 & 19,37 & 12,64 \\
\hline 68,84 & 1240,60 & 175,20 & 14,43 & 10,40 & 9,03 & 7,80 & 6,83 & 6,00 & 4,67 & 3,71 & 2,50 \\
\hline 37,29 & 350,80 & 175,10 & 34,38 & 19,92 & 14,70 & 10,51 & 7,96 & 6,29 & 4,33 & 3,33 & 2,32 \\
\hline 57,77 & 1648,70 & 83,10 & 21,45 & 17,64 & 16,35 & 14,79 & 13,37 & 12,05 & 9,76 & 7,94 & 5,44 \\
\hline 59,18 & 1067,00 & 81,10 & 25,40 & 20,29 & 18,37 & 16,29 & 14,49 & 12,87 & 10,16 & 8,11 & 5,46 \\
\hline 44,97 & 799,00 & 79,30 & 34,29 & 27,46 & 24,03 & 20,27 & 17,12 & 14,49 & 10,57 & 8,02 & 5,25 \\
\hline 32,95 & 1655,00 & 184,70 & 18,98 & 14,86 & 12,47 & 9,85 & 7,83 & 6,31 & 4,34 & 3,25 & 2,18 \\
\hline 81,92 & 1671,90 & 89,00 & 16,89 & 12,67 & 11,73 & 10,87 & 10,09 & 9,37 & 8,06 & 6,93 & 5,15 \\
\hline 78,95 & 312,90 & 123,50 & 35,62 & 20,58 & 15,95 & 12,58 & 10,44 & 8,84 & 6,54 & 5,09 & 3,44 \\
\hline 32,72 & 1159,50 & 182,90 & 21,77 & 16,17 & 13,20 & 10,12 & 7,89 & 6,28 & 4,29 & 3,23 & 2,20 \\
\hline 24,57 & 1791,00 & 92,60 & 36,48 & 30,27 & 25,59 & 20,15 & 15,89 & 12,69 & 8,62 & 6,41 & 4,32 \\
\hline 74,01 & 1184,10 & 65,30 & 24,64 & 18,92 & 17,56 & 16,13 & 14,85 & 13,67 & 11,53 & 9,74 & 7,04 \\
\hline 42,54 & 1111,00 & 186,80 & 18,77 & 13,85 & 11,60 & 9,32 & 7,56 & 6,20 & 4,35 & 3,27 & 2,18 \\
\hline 68,91 & 496,80 & 53,30 & 41,52 & 31,00 & 27,54 & 24,22 & 21,53 & 19,16 & 15,21 & 12,24 & 8,33 \\
\hline 86,04 & 1909,10 & 143,50 & 11,85 & 8,61 & 7,82 & 7,12 & 6,55 & 6,03 & 5,12 & 4,35 & 3,19 \\
\hline 67,04 & 1894,00 & 135,80 & 13,86 & 10,79 & 9,85 & 8,86 & 8,00 & 7,22 & 5,88 & 4,81 & 3,33 \\
\hline 88,32 & 426,30 & 149,60 & 26,57 & 15,47 & 12,13 & 9,72 & 8,21 & 7,06 & 5,36 & 4,24 & 2,89 \\
\hline 54,79 & 255,50 & 166,10 & 39,14 & 20,64 & 14,90 & 10,80 & 8,37 & 6,72 & 4,67 & 3,57 & 2,48 \\
\hline
\end{tabular}




\begin{tabular}{|c|c|c|c|c|c|c|c|c|c|c|c|}
\hline \multirow[b]{2}{*}{ e1 (cm) } & & & & & & $\mathrm{De}$ & ões (x1 & & & & \\
\hline & Meq (MPa) & Ms (MPa) & D0 & D25 & D40 & D60 & D80 & D100 & D140 & D180 & D260 \\
\hline 85,82 & 1245,70 & 137,50 & 14,84 & 10,44 & 9,25 & 8,21 & 7,42 & 6,74 & 5,56 & 4,63 & 3,30 \\
\hline 72,56 & 1739,00 & 195,40 & 11,31 & 8,29 & 7,35 & 6,46 & 5,76 & 5,14 & 4,11 & 3,33 & 2,28 \\
\hline 20,89 & 1977,70 & 96,40 & 39,08 & 31,77 & 26,17 & 19,90 & 15,26 & 11,97 & 8,06 & 6,05 & 4,14 \\
\hline 22,04 & 600,30 & 98,80 & 51,45 & 36,25 & 27,35 & 19,15 & 14,11 & 10,98 & 7,57 & 5,84 & 4,06 \\
\hline 35,12 & 1685,50 & 33,50 & 54,85 & 50,12 & 46,61 & 41,73 & 37,05 & 32,74 & 25,47 & 19,98 & 13,07 \\
\hline 49,51 & 672,20 & 73,80 & 36,18 & 28,41 & 24,86 & 21,12 & 17,99 & 15,35 & 11,35 & 8,69 & 5,69 \\
\hline 35,13 & 292,40 & 95,90 & 53,06 & 34,25 & 26,36 & 19,33 & 14,73 & 11,64 & 7,98 & 6,09 & 4,22 \\
\hline 32,97 & 1888,80 & 73,80 & 32,79 & 28,89 & 25,87 & 22,08 & 18,71 & 15,85 & 11,51 & 8,66 & 5,60 \\
\hline 26,02 & 1888,90 & 97,00 & 33,21 & 27,81 & 23,74 & 18,95 & 15,12 & 12,18 & 8,33 & 6,18 & 4,13 \\
\hline 48,16 & 983,70 & 124,80 & 23,15 & 17,82 & 15,41 & 12,91 & 10,86 & 9,17 & 6,68 & 5,07 & 3,33 \\
\hline 47,07 & 1668,00 & 173,50 & 15,52 & 12,32 & 10,78 & 9,13 & 7,74 & 6,58 & 4,83 & 3,68 & 2,41 \\
\hline 89,63 & 345,90 & 102,00 & 34,61 & 20,81 & 16,67 & 13,62 & 11,66 & 10,14 & 7,83 & 6,24 & 4,28 \\
\hline 25,66 & 647,90 & 188,60 & 29,44 & 19,16 & 14,19 & 9,89 & 7,32 & 5,73 & 3,96 & 3,06 & 2,14 \\
\hline 84,62 & 785,90 & 49,20 & 32,14 & 23,72 & 21,78 & 20,03 & 18,53 & 17,16 & 14,68 & 12,57 & 9,30 \\
\hline 81,62 & 1662,60 & 77,30 & 18,44 & 13,94 & 12,97 & 12,09 & 11,28 & 10,52 & 9,12 & 7,89 & 5,93 \\
\hline 83,96 & 1263,00 & 26,50 & 38,09 & 30,78 & 28,39 & 27,36 & 26,26 & 25,07 & 22,71 & 20,49 & 16,56 \\
\hline 86,49 & 527,60 & 189,00 & 21,41 & 12,46 & 9,75 & 7,79 & 6,56 & 5,63 & 4,25 & 3,35 & 2,28 \\
\hline 71,11 & 480,10 & 159,00 & 25,33 & 15,45 & 12,29 & 9,85 & 8,21 & 6,95 & 5,12 & 3,96 & 2,66 \\
\hline 31,12 & 1294,40 & 161,40 & 23,44 & 17,99 & 14,84 & 11,48 & 8,98 & 7,16 & 4,89 & 3,67 & 2,49 \\
\hline 78,41 & 1007,60 & 137,00 & 17,15 & 12,06 & 10,52 & 9,17 & 8,15 & 7,27 & 5,82 & 4,72 & 3,26 \\
\hline 48,95 & 1624,30 & 159,90 & 16,05 & 12,81 & 11,28 & 9,64 & 8,25 & 7,07 & 5,25 & 4,03 & 2,64 \\
\hline 49,60 & 1095,20 & 109,20 & 23,44 & 18,65 & 16,43 & 14,05 & 12,04 & 10,33 & 7,69 & 5,90 & 3,87 \\
\hline 23,13 & 280,80 & 46,40 & 106,65 & 75,73 & 57,71 & 40,83 & 30,22 & 23,52 & 16,15 & 12,44 & 8,64 \\
\hline 64,98 & 1795,30 & 135,30 & 14,42 & 11,28 & 10,26 & 9,18 & 8,25 & 7,40 & 5,96 & 4,84 & 3,32 \\
\hline 25,31 & 1825,10 & $\frac{100,00}{94,50}$ & $\begin{array}{l}+7,7 L \\
34,93\end{array}$ & $\begin{array}{l}+1+2,10 \\
29,10\end{array}$ & 24,72 & $\begin{array}{l}0,+0 \\
19,59\end{array}$ & 15,54 & 12,46 & 8,49 & 6,31 & 4,23 \\
\hline 61,00 & 438,60 & 20,80 & 81,30 & 66,06 & 61,60 & 56,15 & 51,17 & 46,51 & 38,26 & 31,54 & 21,97 \\
\hline 69,61 & 972,60 & 145,90 & 17,77 & 12,67 & 10,95 & 9,42 & 8,23 & 7,22 & 5,61 & 4,44 & 2,99 \\
\hline 23,55 & 589,30 & 48,80 & 82,30 & 64,45 & 52,20 & 39,12 & 29,79 & 23,32 & 15,76 & 11,92 & 8,19 \\
\hline$\frac{20, v 0}{32,25}$ & 892,60 & 160,40 & 26,24 & 19,06 & 15,35 & 11,61 & 8,97 & $\begin{array}{c}\text { Lu,ve } \\
7,11\end{array}$ & 4,85 & $\begin{array}{c}\perp, 6< \\
3,67\end{array}$ & 2,51 \\
\hline 54,86 & 1050,50 & 61,60 & 31,56 & 26,07 & 23,88 & 21,33 & 19,04 & 16,95 & 13,43 & 10,74 & 7,21 \\
\hline 68,28 & 1139,90 & 82,60 & 22,66 & 17,54 & 16,02 & 14,41 & 13,04 & 11,78 & 9,61 & 7,89 & 5,48 \\
\hline 83,19 & 1868,10 & 188,60 & 10,50 & 7,51 & 6,70 & 5,98 & 5,42 & 4,92 & 4,07 & 3,38 & 2,41 \\
\hline 83,97 & 380,30 & 31,80 & 56,75 & 41,15 & 37,19 & 33,61 & 30,72 & 28,14 & 23,60 & 19,87 & 14,35 \\
\hline 75,38 & 397,80 & 148,50 & 28,84 & 16,98 & 13,28 & 10,53 & 8,75 & 7,40 & 5,46 & 4,23 & 2,86 \\
\hline 87,36 & 1405,60 & 166,20 & 12,62 & 8,77 & 7,72 & 6,83 & 6,16 & 5,59 & 4,61 & 3,83 & 2,72 \\
\hline 69,42 & 1192,30 & 118,70 & 17,96 & 13,49 & 12,06 & 10,66 & 9,52 & 8,50 & 6,80 & 5,50 & 3,76 \\
\hline 46,05 & 288,10 & 114,10 & 44,36 & 27,09 & 20,92 & 15,77 & 12,34 & 9,92 & 6,87 & 5,22 & 3,57 \\
\hline 44,16 & 1455,20 & 54,10 & 35,15 & 30,79 & 28,43 & 25,38 & 22,54 & 19,94 & 15,58 & 12,29 & 8,12 \\
\hline 75,34 & 1613,30 & 164,20 & 12,63 & 9,27 & 8,28 & 7,35 & 6,60 & 5,94 & 4,82 & 3,95 & 2,74 \\
\hline 81,10 & 1862,30 & 90,20 & 16,13 & 12,18 & 11,32 & 10,54 & 9,81 & 9,13 & 7,89 & 6,80 & 5,09 \\
\hline 50,72 & 775,40 & 53,00 & 40,84 & 33,81 & 30,53 & 26,81 & 23,52 & 20,60 & 15,85 & 12,40 & 8,18 \\
\hline 85,20 & 551,10 & 113,70 & 25,24 & 16,35 & 13,67 & 11,56 & 10,10 & 8,91 & 7,02 & 5,64 & 3,88 \\
\hline 31,09 & 464,30 & 151,00 & 35,26 & 22,74 & 17,22 & 12,35 & 9,28 & 7,29 & 5,01 & 3,85 & 2,67 \\
\hline 59,70 & 597,60 & 133,10 & 25,54 & 17,39 & 14,47 & 11,90 & 9,98 & 8,44 & 6,18 & 4,74 & 3,15 \\
\hline 29,16 & 738,20 & 50,20 & 64,30 & 52,99 & 45,21 & 36,18 & 28,99 & 23,45 & 16,12 & 12,00 & 8,00 \\
\hline 44,75 & 611,60 & 199,60 & 23,21 & 14,90 & 11,75 & 8,99 & 7,08 & 5,70 & 3,95 & 2,99 & 2,04 \\
\hline 76,43 & 1774,40 & 63,50 & 21,08 & 16,31 & 15,33 & 14,43 & 13,52 & 12,65 & 11,02 & 9,57 & 7,23 \\
\hline 73,73 & 1291,40 & 46,00 & 29,72 & 23,15 & 21,82 & 20,48 & 19,15 & 17,87 & 15,49 & 13,39 & 10,02 \\
\hline 88,32 & 725,60 & 167,40 & 18,14 & 11,44 & 9,44 & 7,90 & 6,87 & 6,05 & 4,75 & 3,82 & 2,63 \\
\hline 87,93 & 1906,30 & 88,80 & 15,38 & 11,49 & 10,61 & 9,94 & 9,31 & 8,73 & 7,64 & 6,68 & 5,12 \\
\hline 70,10 & 383,20 & 158,30 & 29,36 & 17,04 & 13,17 & 10,29 & 8,43 & 7,04 & 5,10 & 3,92 & 2,65 \\
\hline 66,79 & 1377,40 & 184,80 & 13,52 & 9,88 & 8,61 & 7,45 & 6,52 & 5,73 & 4,44 & 3,52 & 2,36 \\
\hline 48,21 & 973,50 & 89,30 & 28,18 & 22,71 & 20,07 & 17,20 & 14,74 & 12,64 & 9,41 & 7,22 & 4,72 \\
\hline 35,88 & 1800,10 & 85,10 & 28,41 & 24,72 & 22,12 & 18,91 & 16,08 & 13,66 & 9,98 & 7,54 & 4,88 \\
\hline 31,51 & 289,90 & 49,70 & 84,34 & 61,66 & 49,66 & 37,53 & 28,94 & 22,91 & 15,62 & 11,81 & 8,09 \\
\hline 25,58 & 215,90 & 46,20 & 109,47 & 75,57 & 57,50 & 40,84 & 30,37 & 23,71 & 16,29 & 12,53 & 8,71 \\
\hline 53,25 & 1710,20 & 155,00 & 15,19 & 12,14 & 10,80 & 9,38 & 8,16 & 7,09 & 5,40 & 4,21 & 2,77 \\
\hline 24,58 & 1992,70 & 57,90 & 48,54 & 42,51 & 37,26 & 30,69 & 25,12 & 20,61 & 14,33 & 10,61 & 6,95 \\
\hline 50,54 & 914,40 & 140,60 & 21,79 & 16,20 & 13,84 & 11,50 & 9,64 & 8,12 & 5,90 & 4,48 & 2,96 \\
\hline 28,29 & 1899,90 & 28,60 & 70,08 & 65,02 & 59,84 & 52,74 & 46,03 & 39,98 & 30,15 & 23,11 & 14,87 \\
\hline 36,50 & 1172,30 & 25,10 & 72,81 & 66,21 & 61,62 & 55,23 & 49,13 & 43,49 & 33,94 & $\begin{array}{l}26,+1 \\
26,70\end{array}$ & 17,51 \\
\hline 78,00 & 1352,70 & 139,40 & 14,74 & 10,71 & $\begin{array}{c}9,55 \\
9,55\end{array}$ & 8,49 & 7,64 & 6,90 & 5,63 & 4,63 & 3,24 \\
\hline 64,94 & 1930,20 & 181,20 & 11,84 & $\begin{array}{c}10,01 \\
9,09\end{array}$ & 8,14 & 7,19 & 6,39 & 5,68 & 4,50 & 3,61 & 2,45 \\
\hline 32,04 & 758,10 & 116,20 & 34,36 & 25,61 & 20,88 & 15,98 & 12,43 & 9,88 & 6,74 & 5,08 & 3,46 \\
\hline 69,25 & 1304,20 & 23,00 & 48,23 & 38,79 & 36,76 & 35,39 & 33,68 & 31,91 & 28,47 & 25,26 & 19,77 \\
\hline 41,37 & 1268,40 & 179,60 & 18,47 & 14,04 & 11,89 & 9,64 & 7,86 & 6,47 & 4,55 & 3,42 & 2,27 \\
\hline 26,72 & 487,30 & 180,40 & 32,76 & 20,31 & 14,82 & 10,26 & 7,60 & 5,97 & 4,14 & 3,20 & 2,24 \\
\hline 40,33 & 342,40 & 29,10 & 94,55 & 77,40 & 67,77 & 56,80 & 47,56 & 39,93 & 28,76 & 21,67 & 14,15 \\
\hline 20,07 & 1244,60 & 129,10 & 36,88 & 27,26 & 20,94 & 14,83 & 10,93 & 8,47 & 5,80 & 4,46 & 3,10 \\
\hline 51.08 & 1230,40 & 122,20 & 20,54 & 16,31 & 14,39 & 12,36 & 10,64 & 9,16 & 6,87 & 5,29 & 3,47 \\
\hline 47,08 & 1463,20 & 83,90 & 25,32 & 21,46 & 19,47 & 17,12 & 15,00 & 13,12 & 10,06 & 7,84 & 5,15 \\
\hline 57,68 & 746,80 & 97,60 & 27,14 & 20,42 & 17,78 & 15,19 & 13,09 & 11,31 & 8,53 & 6,62 & 4,37 \\
\hline 24,42 & 640,90 & 148,90 & 35,63 & 24,08 & 18,02 & 12,61 & 9,32 & 7,28 & 5,03 & 3,88 & 2,70 \\
\hline 44,07 & 518,00 & 164,90 & 27,92 & 18,04 & 14,25 & 10,90 & 8,58 & 6,90 & 4,78 & 3,62 & 2,47 \\
\hline 75,29 & 799,40 & 30,20 & 45,66 & 35,35 & 33,24 & 31,16 & 29,12 & 27,17 & 23,54 & 20,34 & 15,24 \\
\hline 50,91 & 1607,00 & 27,60 & 49,43 & 41,60 & 40,13 & 37,63 & 34,99 & 32,42 & 27,61 & 23,40 & 16,89 \\
\hline 75,58 & 714,90 & 23,00 & 56,34 & 43,84 & 41,31 & 39,03 & 36,68 & 34,40 & 30,10 & 26,25 & 19,95 \\
\hline 62,36 & 1727,60 & 159,40 & 13,63 & 10,58 & 9,47 & 8,35 & 7,40 & 6,55 & 5,16 & 4,11 & 2,77 \\
\hline 64,98 & 1170,90 & 152,10 & 16,37 & 12,08 & 10,56 & 9,13 & 7,99 & 7,00 & 5,41 & 4,27 & 2,86 \\
\hline 24,07 & 1381,20 & 112,60 & 34,98 & 27,54 & 22,43 & 16,92 & 12,94 & 10,16 & 6,87 & 5,18 & 3,55 \\
\hline 45,42 & 868,00 & 52,60 & 42,26 & 35,78 & 32,28 & 28,15 & 24,47 & 21,24 & 16,09 & 12,44 & 8,13 \\
\hline 87,54 & 1766,00 & 47,80 & 22,74 & 17,90 & 16,50 & 15,80 & 15,09 & 14,34 & 12,91 & 11,58 & 9,26 \\
\hline
\end{tabular}




\begin{tabular}{|c|c|c|c|c|c|c|c|c|c|c|c|}
\hline \multirow[b]{2}{*}{ e1 (cm) } & & & & & & $\mathrm{De}$ & ões (x1 & & & & \\
\hline & Meq (MPa) & Ms (MPa) & D0 & D25 & D40 & D60 & D80 & D100 & D140 & D180 & D260 \\
\hline 85,52 & 228,30 & 171,40 & 40,40 & 20,03 & 14,06 & 10,11 & 7,94 & 6,48 & 4,61 & 3,56 & 2,46 \\
\hline 46,98 & 1866,70 & 58,40 & 29,48 & 25,66 & 24,02 & 21,77 & 19,64 & 17,64 & 14,16 & 11,41 & 7,70 \\
\hline 23,74 & 1809,80 & 40,60 & 65,60 & 58,39 & 51,65 & 43,05 & 35,58 & 29,43 & 20,64 & 15,29 & 9,94 \\
\hline 44,71 & 1675,00 & 34,70 & 45,10 & 39,54 & 37,57 & 34,50 & 31,48 & 28,59 & 23,42 & 19,17 & 13,16 \\
\hline 65,29 & 535,40 & 68,80 & 35,94 & 26,54 & 23,22 & 20,10 & 17,60 & 15,44 & 11,97 & 9,46 & 6,34 \\
\hline 84,85 & 1703,40 & 75,90 & 18,04 & 13,59 & 12,61 & 11,81 & 11,06 & 10,36 & 9,05 & 7,89 & 6,01 \\
\hline 28,76 & 420,20 & 103,90 & 48,08 & 32,70 & 25,10 & 18,08 & 13,57 & 10,63 & 7,29 & 5,59 & 3,88 \\
\hline 74,55 & 272,10 & 114,60 & 40,55 & 23,26 & 17,90 & 13,98 & 11,50 & 9,65 & 7,05 & 5,44 & 3,68 \\
\hline 51,35 & 1476,70 & 70,00 & 26,73 & 22,62 & 20,87 & 18,72 & 16,74 & 14,93 & 11,85 & 9,47 & 6,35 \\
\hline 76,63 & 1585,10 & 52,10 & 24,84 & 19,28 & 18,14 & 17,13 & 16,11 & 15,11 & 13,23 & 11,55 & 8,79 \\
\hline 36,99 & 801,30 & 111,00 & 31,73 & 24,18 & 20,27 & 16,12 & 12,92 & 10,48 & 7,27 & 5,44 & 3,64 \\
\hline 83,58 & 1446,30 & 112,50 & 15,57 & 11,36 & 10,32 & 9,36 & 8,58 & 7,88 & 6,63 & 5,60 & 4,06 \\
\hline 35,53 & 1496,50 & 97,70 & 28,00 & 23,56 & 20,69 & 17,28 & 14,38 & 12,00 & 8,56 & 6,41 & 4,18 \\
\hline 35,72 & 248,30 & 50,50 & 82,53 & 58,84 & 47,56 & 36,38 & 28,38 & 22,65 & 15,53 & 11,72 & 7,99 \\
\hline 64,60 & 1944,60 & 162,40 & 12,59 & 9,78 & 8,83 & 7,85 & 7,02 & 6,27 & 5,01 & 4,04 & 2,75 \\
\hline 78,87 & 1349,40 & 183,50 & 12,78 & 8,97 & 7,82 & 6,82 & 6,07 & 5,42 & 4,34 & 3,52 & 2,43 \\
\hline 30,58 & 1124,00 & 126,40 & 29,23 & 22,73 & 18,85 & 14,65 & 11,49 & 9,17 & 6,26 & 4,69 & 3,18 \\
\hline 61,70 & 420,70 & 116,20 & 32,51 & 21,06 & 17,13 & 13,85 & 11,51 & 9,67 & 7,04 & 5,39 & 3,60 \\
\hline 43,25 & 1362,30 & 68,70 & 31,28 & 26,98 & 24,49 & 21,45 & 18,70 & 16,26 & 12,35 & 9,56 & 6,24 \\
\hline 76,59 & 217,30 & 147,40 & 43,84 & 22,39 & 16,01 & 11,70 & 9,24 & 7,56 & 5,37 & 4,13 & 2,84 \\
\hline 49,45 & 1122,10 & 119,50 & 22,07 & 17,40 & 15,26 & 12,99 & 11,08 & 9,47 & 7,02 & 5,37 & 3,52 \\
\hline 75,29 & 783,60 & 44,30 & 36,38 & 27,78 & 25,75 & 23,64 & 21,78 & 20,06 & 16,95 & 14,33 & 10,38 \\
\hline 42,16 & 806,60 & 184,30 & 21,83 & 15,20 & 12,38 & 9,68 & 7,70 & 6,24 & 4,33 & 3,26 & 2,20 \\
\hline 22,82 & 1358,40 & 47,80 & 66,59 & 56,68 & 48,54 & 38,76 & 30,87 & 24,80 & 16,89 & 12,52 & 8,36 \\
\hline$\frac{L L, U L}{88,40}$ & 340,40 & 88,80 & 36,89 & 22,75 & 18,51 & 15,32 & 13,21 & 11,55 & 8,99 & $\begin{array}{c}1 L, 19 \\
7,19\end{array}$ & 4,94 \\
\hline 64,29 & 425,30 & 113,40 & 32,19 & 20,90 & 17,07 & 13,90 & 11,63 & 9,84 & 7,22 & 5,56 & 3,71 \\
\hline 74,20 & 1509,80 & 105,00 & 16,82 & 12,76 & 11,70 & 10,61 & 9,68 & 8,84 & 7,34 & 6,12 & 4,35 \\
\hline 32,69 & 302,60 & 177,00 & 37,71 & 20,88 & 14,90 & 10,34 & 7,74 & 6,10 & 4,23 & 3,27 & 2,30 \\
\hline 81,02 & 544,40 & 146,00 & 23,36 & 14,58 & 11,86 & 9,77 & 8,36 & 7,24 & 5,54 & 4,38 & 2,97 \\
\hline 64,38 & 1938,60 & 80,70 & 19,37 & 15,55 & 14,62 & 13,47 & 12,39 & 11,38 & 9,54 & 8,00 & 5,70 \\
\hline 68,04 & 981,20 & 79,50 & 24,72 & 19,01 & 17,23 & 15,40 & 13,86 & 12,46 & 10,08 & 8,21 & 5,66 \\
\hline 67,26 & 1670,80 & 56,10 & 25,21 & 20,04 & 18,99 & 17,75 & 16,51 & 15,33 & 13,14 & 11,23 & 8,24 \\
\hline 65,08 & 1879,60 & 185,30 & 11,82 & 9,02 & 8,05 & 7,09 & 6,29 & 5,59 & 4,41 & 3,53 & 2,39 \\
\hline 37,01 & 302,00 & 59,10 & 68,17 & 48,98 & 39,90 & 30,84 & 24,24 & 19,44 & 13,37 & 10,07 & 6,83 \\
\hline 84,95 & 1870,10 & 79,20 & 16,92 & 12,78 & 11,86 & 11,14 & 10,46 & 9,81 & 8,59 & 7,51 & 5,75 \\
\hline 54,70 & 499,80 & 108,10 & 32,14 & 22,24 & 18,51 & 15,11 & 12,55 & 10,51 & 7,60 & 5,78 & 3,84 \\
\hline 82,63 & 1009,40 & 117,80 & 18,08 & 12,77 & 11,27 & 9,96 & 8,96 & 8,08 & 6,61 & 5,45 & 3,83 \\
\hline 34,53 & 477,20 & 124,00 & 37,62 & 25,55 & 20,09 & 14,96 & 11,48 & 9,09 & 6,22 & 4,73 & 3,25 \\
\hline 24,15 & 694,30 & 134,90 & 37,52 & 26,13 & 19,82 & 14,00 & 10,37 & 8,08 & 5,56 & 4,28 & 2,98 \\
\hline 78,87 & 1646,60 & 28,70 & 34,41 & 28,13 & 26,08 & 25,23 & 24,25 & 23,16 & 21,01 & 18,97 & 15,33 \\
\hline 76,39 & 1892,70 & 68,00 & 19,72 & 15,26 & 14,35 & 13,49 & 12,64 & 11,83 & 10,30 & 8,95 & 6,75 \\
\hline 87,72 & 1954,60 & 123,40 & 12,63 & 9,24 & 8,46 & 7,79 & 7,22 & 6,70 & 5,76 & 4,96 & 3,70 \\
\hline 76,32 & 1819,80 & 39,10 & 28,26 & 22,49 & 21,11 & 20,28 & 19,32 & 18,33 & 16,40 & 14,61 & 11,52 \\
\hline 75,76 & 1549,00 & 37,20 & 31,18 & 24,62 & 23,17 & 22,17 & 21,04 & 19,89 & 17,68 & 15,65 & 12,20 \\
\hline 30,53 & 1109,80 & 173,30 & 23,87 & 17,68 & 14,28 & 10,80 & 8,32 & 6,58 & 4,48 & 3,39 & 2,32 \\
\hline 21,62 & 1681,80 & 159,80 & 27,73 & 21,05 & 16,56 & 12,02 & 8,97 & 6,97 & 4,73 & 3,62 & 2,50 \\
\hline 66,16 & 1589,40 & 199,70 & 12,17 & 8,99 & 7,88 & 6,84 & 6,00 & 5,28 & 4,11 & 3,26 & 2,19 \\
\hline 29,98 & 205,30 & 21,90 & 168,12 & 131,50 & 109,15 & 84,80 & 66,48 & 53,05 & 36,18 & 27,11 & 18,36 \\
\hline 20,37 & 1315,90 & 75,00 & 53,48 & 42,59 & 34,47 & 25,71 & 19,46 & 15,16 & 10,22 & 7,73 & 5,32 \\
\hline 88,62 & 1458,70 & 112,20 & 15,11 & 10,88 & 9,85 & 8,97 & 8,26 & 7,62 & 6,48 & 5,53 & 4,07 \\
\hline 79,63 & 318,20 & 166,20 & 32,05 & 17,35 & 12,92 & 9,82 & 7,97 & 6,64 & 4,82 & 3,73 & 2,54 \\
\hline 59,00 & 1322,10 & 160,90 & 15,74 & 11,93 & 10,45 & 9,00 & 7,81 & 6,78 & 5,17 & 4,03 & 2,67 \\
\hline 54,11 & 658,90 & 154,50 & 23,54 & 16,04 & 13,24 & 10,72 & 8,84 & 7,37 & 5,29 & 4,02 & 2,68 \\
\hline 74,11 & 1488,70 & 21,40 & 45,11 & 37,27 & 34,69 & 33,66 & 32,40 & 30,97 & 28,12 & 25,41 & 20,55 \\
\hline 86,52 & 944,60 & 23,70 & 44,81 & 35,54 & 32,78 & 31,45 & 30,08 & 28,63 & 25,82 & 23,20 & 18,62 \\
\hline 49,74 & 1426,40 & 62,80 & 29,62 & 25,29 & 23,37 & 20,97 & 18,75 & 16,71 & 13,24 & 10,57 & 7,07 \\
\hline 63,51 & 807,10 & 110,50 & 23,37 & 17,19 & 14,95 & 12,86 & 11,18 & 9,75 & 7,48 & 5,87 & 3,92 \\
\hline 48,28 & 1257,10 & 71,40 & 29,16 & 24,66 & 22,43 & 19,79 & 17,41 & 15,28 & 11,79 & 9,24 & 6,09 \\
\hline 67,45 & 953,70 & 87,70 & 23,78 & 18,13 & 16,28 & 14,44 & 12,90 & 11,53 & 9,22 & 7,45 & 5,09 \\
\hline 85,60 & 787,90 & 131,50 & 19,30 & 12,91 & 11,03 & 9,50 & 8,41 & 7,49 & 6,00 & 4,88 & 3,39 \\
\hline 45,52 & 228,80 & 70,30 & 63,57 & 41,33 & 32,86 & 25,34 & 20,07 & 16,22 & 11,27 & 8,53 & 5,79 \\
\hline 46,66 & 1270,20 & 187,60 & 16,77 & 12,61 & 10,76 & 8,86 & 7,35 & 6,14 & 4,40 & 3,33 & 2,20 \\
\hline 47,33 & 1678,40 & 121,00 & 19,10 & $\begin{array}{l}L, 0 \perp \\
15,85\end{array}$ & 14,20 & 12,32 & 10,68 & 9,24 & 6,98 & 5,39 & 3,52 \\
\hline 47,07 & 1819,10 & 98,50 & 21,11 & 17,97 & 16,36 & $\frac{1 L, v<}{14,42}$ & 12,68 & 11,12 & 8,56 & 6,69 & 4,40 \\
\hline 26,84 & 1836,00 & 40,90 & 58,36 & 52,80 & 47,47 & 40,53 & 34,29 & 28,94 & 20,88 & 15,63 & 10,06 \\
\hline 32,42 & 921,00 & 159,90 & 25,91 & 18,94 & 15,31 & 11,63 & 9,00 & 7,14 & 4,88 & 3,68 & 2,52 \\
\hline 50,31 & 866,30 & 94,40 & 27,92 & 21,92 & 19,21 & 16,36 & 13,97 & 11,96 & 8,88 & 6,81 & 4,46 \\
\hline 49,68 & 1338,70 & 69,20 & 28,51 & 24,16 & 22,14 & 19,69 & 17,47 & 15,46 & 12,10 & 9,57 & 6,35 \\
\hline 66,12 & 1150,40 & 121,90 & 18,41 & 13,90 & 12,34 & 10,83 & 9,59 & 8,50 & 6,70 & 5,36 & 3,62 \\
\hline 83,99 & 278,50 & 108,00 & 39,77 & 22,85 & 17,72 & 14,02 & 11,70 & 9,97 & 7,46 & 5,84 & 3,97 \\
\hline 69,61 & 1653,60 & 38,30 & 31,74 & 25,22 & 23,98 & 22,85 & 21,57 & 20,30 & 17,87 & 15,65 & 11,98 \\
\hline 54,33 & 1341,10 & 89,50 & 22,96 & 18,84 & 17,11 & 15,16 & 13,43 & 11,88 & 9,30 & 7,37 & 4,91 \\
\hline 30,50 & 741,00 & 111,10 & 36,73 & 27,38 & 22,19 & 16,83 & 12,99 & 10,28 & 7,01 & 5,29 & 3,62 \\
\hline 53,53 & 675,80 & 169,10 & 22,34 & 15,03 & 12,31 & 9,90 & 8,12 & 6,74 & 4,82 & 3,66 & 2,44 \\
\hline 61,19 & 1472,00 & 150,00 & 15,29 & 11,78 & 10,47 & 9,15 & 8,05 & 7,08 & 5,51 & 4,36 & 2,92 \\
\hline 47,56 & 1078,70 & 160,00 & 19,48 & 14,63 & 12,49 & 10,32 & 8,58 & 7,18 & 5,17 & 3,91 & 2,58 \\
\hline 84,66 & 980,00 & 50,60 & 28,81 & 21,52 & 19,89 & 18,49 & 17,23 & 16,06 & 13,90 & 12,03 & 9,04 \\
\hline 66,32 & 472,50 & 96,60 & 32,24 & 21,99 & 18,46 & 15,44 & 13,18 & 11,34 & 8,52 & 6,63 & 4,42 \\
\hline 59,99 & 1438,30 & 105,20 & 19,13 & 15,28 & 13,88 & 12,35 & 11,02 & 9,82 & 7,80 & 6,25 & 4,22 \\
\hline 23,18 & 317,40 & 137,10 & 47,52 & 27,96 & 19,64 & 13,26 & 9,79 & 7,72 & 5,41 & 4,21 & 2,95 \\
\hline 85,80 & 411,00 & 25,80 & 60,99 & 44,88 & 41,15 & 37,87 & 35,06 & 32,50 & 27,87 & 23,91 & 17,76 \\
\hline 36,77 & 787,10 & 75,30 & 40,80 & 32,82 & 28,24 & 23,08 & 18,88 & 15,56 & 10,93 & 8,18 & 5,40 \\
\hline
\end{tabular}




\begin{tabular}{|c|c|c|c|c|c|c|c|c|c|c|c|}
\hline \multirow[b]{2}{*}{ e1 (cm) } & & & & & & $\mathrm{De}$ & ões (x1 & & & & \\
\hline & Meq (MPa) & Ms (MPa) & D0 & D25 & D40 & D60 & D80 & D100 & D140 & D180 & D260 \\
\hline 81,68 & 858,50 & 67,10 & 26,44 & 19,40 & 17,63 & 15,97 & 14,61 & 13,39 & 11,23 & 9,45 & 6,81 \\
\hline 42,94 & 1891,10 & 79,30 & 25,50 & 22,29 & 20,40 & 18,04 & 15,86 & 13,91 & 10,69 & 8,34 & 5,46 \\
\hline 71,49 & 1361,50 & 85,00 & 20,25 & 15,61 & 14,40 & 13,10 & 11,97 & 10,94 & 9,09 & 7,58 & 5,38 \\
\hline 27,66 & 993,90 & 191,40 & 24,51 & 17,39 & 13,55 & 9,86 & 7,43 & 5,81 & 3,97 & 3,03 & 2,10 \\
\hline 36,72 & 1361,50 & 158,20 & 20,92 & 16,37 & 13,89 & 11,18 & 9,04 & 7,38 & 5,15 & 3,85 & 2,56 \\
\hline 24,16 & 1414,90 & 193,10 & 23,66 & 17,42 & 13,62 & 9,87 & 7,38 & 5,75 & 3,92 & 3,00 & 2,08 \\
\hline 31,64 & 1957,90 & 70,30 & 34,61 & 30,63 & 27,42 & 23,36 & 19,76 & 16,70 & 12,09 & 9,08 & 5,87 \\
\hline 50,95 & 1788,00 & 22,50 & 55,39 & 46,06 & 44,67 & 42,44 & 39,85 & 37,28 & 32,36 & 27,91 & 20,72 \\
\hline 20,43 & 1868,50 & 136,20 & 31,46 & 24,39 & 19,37 & 14,16 & 10,60 & 8,23 & 5,57 & 4,25 & 2,93 \\
\hline 38,12 & 771,40 & 165,50 & 24,88 & 17,57 & 14,25 & 10,99 & 8,64 & 6,93 & 4,77 & 3,60 & 2,44 \\
\hline 58,02 & 1849,10 & 32,90 & 38,42 & 31,42 & 30,27 & 28,71 & 26,95 & 25,21 & 21,90 & 18,93 & 14,12 \\
\hline 45,17 & 381,40 & 147,80 & 34,05 & 20,93 & 16,19 & 12,20 & 9,53 & 7,65 & 5,29 & 4,02 & 2,76 \\
\hline 71,73 & 504,40 & 55,60 & 39,60 & 29,19 & 25,90 & 22,80 & 20,32 & 18,14 & 14,49 & 11,72 & 8,03 \\
\hline 23,25 & 1299,70 & 93,50 & 41,63 & 33,07 & 27,01 & 20,42 & 15,63 & 12,26 & 8,28 & 6,24 & 4,27 \\
\hline 26,55 & 1307,40 & 121,10 & 31,56 & 24,80 & 20,38 & 15,57 & 12,04 & 9,52 & 6,45 & 4,85 & 3,31 \\
\hline 78,72 & 594,00 & 141,40 & 22,62 & 14,53 & 11,98 & 9,98 & 8,59 & 7,47 & 5,73 & 4,53 & 3,07 \\
\hline 31,54 & 440,30 & 34,20 & 93,14 & 76,18 & 65,17 & 52,49 & 42,32 & 34,42 & 23,82 & 17,74 & 11,79 \\
\hline 75,10 & 433,40 & 33,40 & 54,86 & 41,23 & 37,54 & 33,87 & 30,81 & 28,04 & 23,18 & 19,26 & 13,62 \\
\hline 28,11 & 1944,80 & 173,90 & 20,88 & 16,59 & 13,80 & 10,72 & 8,39 & 6,68 & 4,55 & 3,40 & 2,30 \\
\hline 21,40 & 1885,40 & 100,80 & 37,66 & 30,46 & 25,03 & 19,01 & 14,57 & 11,42 & 7,69 & 5,78 & 3,96 \\
\hline 55,77 & 1787,30 & 142,20 & 15,26 & 12,28 & 11,05 & 9,72 & 8,56 & 7,54 & 5,85 & 4,62 & 3,07 \\
\hline 62,87 & 918,30 & 185,60 & 17,03 & 11,74 & 9,86 & 8,22 & 6,98 & 5,97 & 4,44 & 3,43 & 2,28 \\
\hline 64,44 & 1559,20 & 194,20 & 12,62 & 9,38 & 8,23 & 7,13 & 6,24 & 5,48 & 4,24 & 3,35 & 2,25 \\
\hline 45,99 & 1899,70 & 22,30 & 58,82 & 49,91 & 48,46 & 45,68 & 42,64 & 39,63 & 33,94 & 28,90 & 20,98 \\
\hline 45,70 & 1907,20 & 155,40 & 15,98 & 13,11 & 11,63 & 9,97 & 8,53 & 7,31 & 5,42 & 4,15 & 2,71 \\
\hline 56,64 & 1988,00 & 197,90 & 11,95 & 9,36 & 8,31 & 7,22 & 6,30 & 5,50 & 4,21 & 3,30 & 2,18 \\
\hline 45,92 & 924,90 & 136,20 & 23,28 & 17,54 & 14,94 & 12,29 & 10,17 & 8,47 & 6,06 & 4,58 & 3,02 \\
\hline 49,02 & 1286,80 & 126,10 & 20,30 & 16,20 & 14,28 & 12,20 & 10,45 & 8,95 & 6,66 & 5,11 & 3,34 \\
\hline 48,94 & 657,00 & 80,20 & 35,09 & 27,15 & 23,56 & 19,83 & 16,76 & 14,21 & 10,41 & 7,93 & 5,20 \\
\hline 61,77 & 1431,80 & 38,20 & 36,14 & 29,31 & 28,00 & 26,24 & 24,44 & 22,70 & 19,45 & 16,61 & 12,16 \\
\hline 36,35 & 1023,50 & 190,90 & 20,91 & 15,16 & 12,37 & 9,57 & 7,52 & 6,02 & 4,14 & 3,12 & 2,11 \\
\hline 25,48 & 1003,50 & 193,00 & 25,41 & 17,86 & 13,70 & 9,80 & 7,30 & 5,70 & 3,90 & 3,00 & 2,08 \\
\hline 50,17 & 1811,10 & 73,00 & 24,58 & 21,02 & 19,53 & 17,61 & 15,83 & 14,17 & 11,33 & 9,10 & 6,13 \\
\hline 61,20 & 1911,60 & 89,20 & 18,79 & 15,26 & 14,24 & 12,99 & 11,85 & 10,78 & 8,88 & 7,33 & 5,12 \\
\hline 47,23 & 713,70 & 36,00 & 56,15 & 48,00 & 43,87 & 38,85 & 34,29 & 30,18 & 23,39 & 18,36 & 12,11 \\
\hline 40,67 & 1118,30 & 158,40 & 21,15 & 16,08 & 13,60 & 10,99 & 8,94 & 7,34 & 5,15 & 3,87 & 2,57 \\
\hline 39,15 & 1131,80 & 33,00 & 57,91 & 51,89 & 47,94 & 42,68 & 37,75 & 33,24 & 25,74 & 20,14 & 13,18 \\
\hline 68,32 & 1366,80 & 120,80 & 16,86 & 12,86 & 11,59 & 10,31 & 9,24 & 8,29 & 6,66 & 5,41 & 3,71 \\
\hline 88,34 & 1596,70 & 115,30 & 14,30 & 10,35 & 9,41 & 8,60 & 7,94 & 7,34 & 6,26 & 5,36 & 3,96 \\
\hline 65,30 & 1319,90 & 34,70 & 38,23 & 30,62 & 29,22 & 27,54 & 25,77 & 24,05 & 20,82 & 17,95 & 13,36 \\
\hline 49,36 & 407,70 & 157,60 & 31,05 & 18,99 & 14,76 & 11,25 & 8,90 & 7,20 & 5,01 & 3,81 & 2,59 \\
\hline 23,20 & 1338,90 & 113,00 & 36,15 & 28,18 & 22,72 & 16,94 & 12,85 & 10,05 & 6,79 & 5,15 & 3,54 \\
\hline 38,92 & 343,60 & 155,00 & 36,59 & 21,77 & 16,34 & 11,86 & 9,05 & 7,17 & 4,93 & 3,78 & 2,62 \\
\hline 62,63 & 739,50 & 166,90 & 20,12 & 13,58 & 11,28 & 9,31 & 7,85 & 6,67 & 4,93 & 3,80 & 2,53 \\
\hline 80,42 & 697,80 & 123,70 & 21,68 & 14,58 & 12,40 & 10,61 & 9,31 & 8,23 & 6,49 & 5,21 & 3,57 \\
\hline 34,85 & 1434,80 & 196,00 & 18,55 & 14,14 & 11,78 & 9,26 & 7,35 & 5,92 & 4,08 & 3,06 & 2,06 \\
\hline 47,68 & 1628,60 & 80,90 & 24,69 & 21,10 & 19,32 & 17,14 & 15,16 & 13,36 & 10,39 & 8,18 & 5,40 \\
\hline 64,61 & 1948,00 & 139,80 & 13,73 & 10,79 & 9,84 & 8,82 & 7,94 & 7,14 & 5,77 & 4,69 & 3,22 \\
\hline 49,73 & 869,70 & 73,40 & 32,49 & 26,38 & 23,49 & 20,31 & 17,57 & 15,20 & 11,46 & 8,86 & 5,81 \\
\hline 65,87 & 1443,60 & 129,20 & 16,14 & 12,41 & 11,16 & 9,89 & 8,83 & 7,88 & 6,29 & 5,07 & 3,45 \\
\hline 55,60 & 749,30 & 90,60 & 28,76 & 22,00 & 19,24 & 16,46 & 14,18 & 12,23 & 9,21 & 7,13 & 4,70 \\
\hline 29,08 & 569,30 & 159,00 & 32,59 & 21,64 & 16,46 & 11,78 & 8,83 & 6,92 & 4,75 & 3,65 & 2,54 \\
\hline 45,94 & 778,60 & 64,10 & 38,77 & 31,76 & 28,17 & 24,14 & 20,67 & 17,71 & 13,15 & 10,06 & 6,57 \\
\hline 67,74 & 1953,40 & 182,90 & 11,47 & 8,72 & 7,82 & 6,93 & 6,19 & 5,53 & 4,42 & 3,57 & 2,44 \\
\hline 25,27 & 844,20 & 105,20 & 41,11 & 30,87 & 24,54 & 18,09 & 13,67 & 10,69 & 7,26 & 5,52 & 3,81 \\
\hline 29,75 & 894,10 & 30,20 & 83,02 & 73,48 & 65,51 & 55,42 & 46,55 & 39,08 & 28,01 & 20,95 & 13,55 \\
\hline 21,64 & 436,90 & 99,10 & 56,41 & 37,52 & 27,44 & 18,80 & 13,79 & 10,77 & 7,50 & 5,82 & 4,06 \\
\hline 67,91 & 313,90 & 106,70 & 38,83 & 23,69 & 18,80 & 14,99 & 12,41 & 10,44 & 7,62 & 5,86 & 3,94 \\
\hline 79,97 & 1672,10 & 74,60 & 19,03 & 14,47 & 13,49 & 12,60 & 11,75 & 10,96 & 9,49 & 8,20 & 6,15 \\
\hline 89,91 & 1670,60 & 136,00 & 12,71 & 9,07 & 8,19 & 7,43 & 6,83 & 6,30 & 5,35 & 4,56 & 3,35 \\
\hline 54,40 & 887,00 & 124,10 & 22,72 & 17,04 & 14,72 & 12,44 & 10,59 & 9,05 & 6,71 & 5,16 & 3,40 \\
\hline 42,44 & 1954,90 & 174,30 & 15,53 & 12,63 & 11,08 & 9,33 & 7,85 & 6,63 & 4,81 & 3,64 & 2,38 \\
\hline 38,10 & 369,80 & 172,30 & 33,62 & 19,84 & 14,80 & 10,68 & 8,12 & 6,42 & 4,42 & 3,39 & 2,36 \\
\hline 29,37 & 1968,40 & 127,40 & 24,80 & 20,57 & 17,63 & 14,18 & 11,41 & 9,26 & 6,39 & 4,75 & 3,16 \\
\hline 61,93 & 987,50 & 34,20 & 43,88 & 35,62 & 33,73 & 31,24 & 28,85 & 26,57 & 22,39 & 18,84 & 13,50 \\
\hline 40,96 & 898,70 & 191,50 & 20,68 & 14,61 & 11,95 & 9,35 & 7,43 & 6,01 & 4,17 & 3,14 & 2,12 \\
\hline 48,73 & 937,50 & 105,10 & 25,87 & 20,28 & 17,70 & 14,98 & 12,72 & 10,82 & 7,96 & 6,08 & 3,98 \\
\hline 85,68 & 675,70 & 193,00 & 18,12 & 11,05 & 8,91 & 7,30 & 6,24 & 5,42 & 4,16 & 3,31 & 2,26 \\
\hline 21,98 & 1241,80 & 196,00 & 25,69 & 18,21 & 13,78 & 9,67 & 7,13 & 5,54 & 3,82 & 2,94 & 2,05 \\
\hline 53,54 & 1380,30 & 119,50 & 19,28 & 15,47 & 13,82 & 12,03 & 10,50 & 9,16 & 7,01 & 5,47 & 3,61 \\
\hline 44,68 & 310,50 & 49,00 & 67,75 & 50,49 & 42,70 & 34,76 & 28,53 & 23,61 & 16,75 & 12,62 & 8,36 \\
\hline 48,02 & 237,20 & 122,00 & 47,30 & 26,87 & 20,07 & 14,79 & 11,48 & 9,19 & 6,36 & 4,86 & 3,35 \\
\hline 79,79 & 1520,40 & 150,20 & 13,28 & 9,63 & 8,61 & 7,68 & 6,94 & 6,29 & 5,17 & 4,28 & 3,02 \\
\hline 88,42 & 1663,40 & 89,40 & 16,18 & 11,96 & 11,00 & 10,23 & 9,54 & 8,91 & 7,74 & 6,73 & 5,10 \\
\hline 41,44 & 672,60 & 65,40 & 43,51 & 35,00 & 30,46 & 25,39 & 21,19 & 17,74 & 12,74 & 9,60 & 6,29 \\
\hline 51,78 & 1656,80 & 190,00 & 13,95 & 10,84 & 9,48 & 8,07 & 6,91 & 5,92 & 4,40 & 3,38 & 2,22 \\
\hline 55,25 & 1970,50 & 175,40 & 13,04 & 10,38 & 9,27 & 8,09 & 7,08 & 6,19 & 4,76 & 3,73 & 2,47 \\
\hline 55,16 & 1137,20 & 42,40 & 38,85 & 32,53 & 30,55 & 27,91 & 25,42 & 23,08 & 18,93 & 15,54 & 10,75 \\
\hline 23,06 & 528,80 & 86,80 & 57,05 & 40,54 & 30,90 & 21,86 & 16,17 & 12,59 & 8,64 & 6,66 & 4,63 \\
\hline 68,77 & 395,30 & 88,70 & 36,45 & 24,27 & 20,18 & 16,78 & 14,31 & 12,30 & 9,25 & 7,20 & 4,82 \\
\hline 82,47 & 974,70 & 35,00 & 36,48 & 27,95 & 26,07 & 24,64 & 23,21 & 21,82 & 19,22 & 16,87 & 12,99 \\
\hline 87,11 & 1106,50 & 184,20 & 13,68 & 9,12 & 7,79 & 6,71 & 5,95 & 5,31 & 4,27 & 3,48 & 2,43 \\
\hline
\end{tabular}




\begin{tabular}{|c|c|c|c|c|c|c|c|c|c|c|c|}
\hline & & & \multicolumn{9}{|c|}{ Deflexões $\left(\times 10^{-4} \mathrm{~cm}\right)$} \\
\hline e1 (cm) & Meq (MPa) & Ms (MPa) & D0 & D25 & D40 & D60 & D80 & D100 & D140 & D180 & D260 \\
\hline 89,37 & 1395,40 & 120,10 & 14,82 & 10,55 & 9,49 & 8,58 & 7,87 & 7,23 & 6,12 & 5,19 & 3,80 \\
\hline 39,61 & 875,00 & 161,40 & 23,49 & 17,07 & 14,09 & 11,08 & 8,84 & 7,16 & 4,96 & 3,73 & 2,51 \\
\hline 54,58 & 1932,40 & 197,50 & 12,37 & 9,71 & 8,58 & 7,42 & 6,43 & 5,58 & 4,23 & 3,29 & 2,17 \\
\hline 84,85 & 901,80 & 94,10 & 21,20 & 15,04 & 13,38 & 11,93 & 10,80 & 9,82 & 8,12 & 6,77 & 4,82 \\
\hline 27,69 & 785,50 & 140,00 & 32,67 & 23,48 & 18,43 & 13,50 & 10,19 & 7,98 & 5,44 & 4,15 & 2,87 \\
\hline 52,53 & 1338,40 & 184,70 & 15,46 & 11,66 & 10,07 & 8,48 & 7,19 & 6,12 & 4,51 & 3,45 & 2,27 \\
\hline 48,38 & 1293,10 & 71,20 & 28,85 & 24,44 & 22,27 & 19,69 & 17,35 & 15,26 & 11,81 & 9,27 & 6,11 \\
\hline 80,30 & 1691,70 & 57,60 & 22,09 & 17,02 & 15,93 & 15,07 & 14,20 & 13,35 & 11,74 & 10,30 & 7,91 \\
\hline 85,92 & 1863,30 & 158,20 & 11,37 & 8,19 & 7,39 & 6,68 & 6,11 & 5,60 & 4,71 & 3,98 & 2,89 \\
\hline 36,91 & 952,10 & 159,10 & 23,83 & 17,61 & 14,53 & 11,37 & 9,01 & 7,26 & 5,01 & 3,76 & 2,54 \\
\hline 42,02 & 1812,60 & 164,20 & 16,70 & 13,56 & 11,87 & 9,97 & 8,37 & 7,05 & 5,10 & 3,85 & 2,52 \\
\hline 64,65 & 1371,60 & 75,20 & 22,94 & 18,27 & 16,94 & 15,40 & 14,03 & 12,75 & 10,50 & 8,67 & 6,06 \\
\hline 60,33 & 745,20 & 142,90 & 21,90 & 15,34 & 12,95 & 10,79 & 9,15 & 7,80 & 5,78 & 4,46 & 2,96 \\
\hline 80,33 & 1279,20 & 62,80 & 23,42 & 17,72 & 16,47 & 15,30 & 14,24 & 13,24 & 11,41 & 9,82 & 7,31 \\
\hline 57,93 & 1277,80 & 172,30 & 15,57 & 11,65 & 10,12 & 8,63 & 7,43 & 6,41 & 4,83 & 3,75 & 2,48 \\
\hline 27,72 & 1162,70 & 175,40 & 24,70 & 18,24 & 14,53 & 10,78 & 8,20 & 6,43 & 4,38 & 3,32 & 2,29 \\
\hline 76,80 & 854,00 & 118,80 & 20,18 & 14,22 & 12,38 & 10,76 & 9,54 & 8,49 & 6,75 & 5,45 & 3,74 \\
\hline 31,17 & 326,30 & 41,60 & 91,49 & 70,00 & 57,66 & 44,52 & 34,79 & 27,73 & 18,93 & 14,22 & 9,65 \\
\hline 32,53 & 1023,40 & 198,60 & 21,68 & 15,55 & 12,45 & 9,38 & 7,23 & 5,72 & 3,91 & 2,96 & 2,03 \\
\hline 59,94 & 1493,90 & 182,80 & 13,78 & 10,41 & 9,12 & 7,86 & 6,83 & 5,95 & 4,54 & 3,55 & 2,36 \\
\hline 68,19 & 1677,90 & 71,40 & 21,37 & 16,88 & 15,86 & 14,67 & 13,55 & 12,50 & 10,57 & 8,94 & 6,46 \\
\hline 63,25 & 303,60 & 69,30 & 48,58 & 32,66 & 27,12 & 22,37 & 18,87 & 16,05 & 11,87 & 9,15 & 6,09 \\
\hline 45,72 & 340,60 & 194,40 & 31,79 & 17,58 & 12,90 & 9,35 & 7,18 & 5,72 & 3,95 & 3,03 & 2,10 \\
\hline 75,22 & 800,80 & 27,40 & 48,56 & 37,72 & 35,54 & 33,47 & 31,38 & 29,36 & 25,59 & 22,23 & 16,78 \\
\hline 48,251 & 1784,80 & 104,10 & 20,02 & 16,87 & 15,34 & 13,53 & 11,91 & 10,46 & 8,08 & 6,33 & 4,18 \\
\hline 81,73 & 843,10 & 91,70 & 22,55 & 16,09 & 14,29 & 12,68 & 11,43 & 10,34 & 8,47 & 7,00 & 4,93 \\
\hline 79,08 & 1225,00 & 118,50 & 16,73 & 12,18 & 10,92 & 9,74 & 8,81 & 7,98 & 6,56 & 5,43 & 3,82 \\
\hline 65,03 & 1998,70 & 83,60 & 18,63 & 14,91 & 14,01 & 12,92 & 11,90 & 10,93 & 9,18 & 7,71 & 5,51 \\
\hline 29,31 & 1868,70 & 149,50 & 22,72 & 18,38 & 15,52 & 12,28 & 9,75 & 7,84 & 5,37 & 4,00 & 2,69 \\
\hline 66,56 & 669,70 & 137,60 & 22,66 & 15,43 & 12,95 & 10,83 & 9,25 & 7,95 & 5,98 & 4,65 & 3,11 \\
\hline 77,56 & 1839,90 & 66,80 & 19,96 & 15,40 & 14,46 & 13,61 & 12,76 & 11,94 & 10,42 & 9,06 & 6,86 \\
\hline 81,87 & 1439,10 & 95,60 & 17,26 & 12,79 & 11,73 & 10,73 & 9,88 & 9,11 & 7,73 & 6,56 & 4,79 \\
\hline 53,26 & 1618,20 & 50,20 & 31,56 & 26,66 & 25,20 & 23,14 & 21,16 & 19,28 & 15,90 & 13,12 & 9,12 \\
\hline 83,37 & 1547,40 & 150,30 & 12,92 & 9,27 & 8,30 & 7,42 & 6,74 & 6,13 & 5,08 & 4,24 & 3,02 \\
\hline 58,55 & 770,10 & 83,00 & 29,00 & 22,37 & 19,77 & 17,14 & 14,96 & 13,06 & 10,03 & 7,86 & 5,22 \\
\hline 50,73 & 870,00 & 197,10 & 18,66 & 12,88 & 10,63 & 8,56 & 7,02 & 5,81 & 4,14 & 3,13 & 2,09 \\
\hline 56,44 & 1425,00 & 158,90 & 15,68 & 12,11 & 10,66 & 9,19 & 7,96 & 6,91 & 5,25 & 4,09 & 2,70 \\
\hline 48,89 & 1731,50 & 71,70 & 25,69 & 22,05 & 20,42 & 18,34 & 16,41 & 14,64 & 11,61 & 9,27 & 6,20 \\
\hline 44,81 & 409,70 & 59,30 & 53,84 & 40,71 & 34,67 & 28,43 & 23,47 & 19,50 & 13,90 & 10,48 & 6,92 \\
\hline 61,17 & 1292,50 & 35,50 & 39,43 & 32,06 & 30,60 & 28,62 & 26,61 & 24,67 & 21,06 & 17,92 & 13,05 \\
\hline 34,83 & 700,70 & 48,80 & 58,25 & 48,61 & 42,42 & 35,13 & 29,03 & 24,08 & 17,04 & 12,74 & 8,34 \\
\hline 54,59 & 347,10 & 22,50 & 90,07 & 74,00 & 67,37 & 59,80 & 53,10 & 47,05 & 36,95 & 29,35 & 19,60 \\
\hline 50,59 & 277,60 & 67,50 & 56,48 & 38,41 & 31,49 & 25,19 & 20,54 & 16,96 & 12,03 & 9,10 & 6,08 \\
\hline 70,41 & 1482,00 & 174,00 & 13,14 & 9,66 & 8,53 & 7,47 & 6,62 & 5,88 & 4,66 & 3,74 & 2,55 \\
\hline 46,48 & 1480,90 & 49,10 & 35,97 & 31,35 & 29,24 & 26,40 & 23,72 & 21,23 & 16,93 & 13,57 & 9,10 \\
\hline 70,22 & 806,90 & 76,30 & 27,15 & 20,44 & 18,34 & 16,28 & 14,58 & 13,08 & 10,52 & 8,55 & 5,88 \\
\hline 64,94 & 365,40 & 184,60 & 29,14 & 16,23 & 12,20 & 9,25 & 7,41 & 6,08 & 4,32 & 3,30 & 2,25 \\
\hline 69,56 & 740,70 & 42,20 & 39,93 & 31,13 & 28,85 & 26,33 & 24,10 & 22,03 & 18,35 & 15,31 & 10,86 \\
\hline 36,95 & 588,10 & 194,40 & 25,76 & 16,59 & 12,84 & 9,49 & 7,28 & 5,77 & 3,96 & 3,02 & 2,08 \\
\hline 88,96 & 1433,70 & 161,00 & 12,61 & 8,77 & 7,75 & 6,88 & 6,23 & 5,67 & 4,70 & 3,93 & 2,82 \\
\hline 33,05 & 652,00 & 188,20 & 26,35 & 17,48 & 13,52 & 9,90 & 7,52 & 5,93 & 4,06 & 3,10 & 2,15 \\
\hline 57,74 & 934,10 & 69,60 & 29,76 & 23,93 & 21,66 & 19,19 & 17,03 & 15,10 & 11,88 & 9,45 & 6,34 \\
\hline 72,68 & 1795,10 & 148,20 & 12,95 & 9,77 & 8,86 & 7,94 & 7,18 & 6,50 & 5,32 & 4,38 & 3,06 \\
\hline 21,13 & 429,30 & 114,60 & 51,48 & 33,08 & 23,75 & 16,09 & 11,80 & 9,25 & 6,47 & 5,03 & 3,51 \\
\hline 81,53 & 357,90 & 35,50 & 55,80 & 40,20 & 35,95 & 32,09 & 29,05 & 26,37 & 21,75 & 18,06 & 12,79 \\
\hline 33,81 & 1009,90 & 20,50 & 92,90 & 85,09 & 78,76 & 70,07 & 61,83 & 54,30 & 41,77 & 32,50 & 21,12 \\
\hline 86,00 & 1390,90 & 22,20 & 39,20 & 33,44 & 30,40 & 29,34 & 28,46 & 27,38 & 25,15 & 23,01 & 19,09 \\
\hline 83,30 & 1470,40 & 102,80 & 16,27 & 11,97 & 10,94 & 9,99 & 9,19 & 8,47 & 7,18 & 6,10 & 4,45 \\
\hline 82,98 & 1964,20 & 98,10 & 14,82 & 11,13 & 10,31 & 9,59 & 8,94 & 8,32 & 7,20 & 6,22 & 4,67 \\
\hline 35,02 & 1527,80 & 158,60 & 20,65 & 16,39 & 13,94 & 11,21 & 9,05 & 7,38 & 5,13 & 3,83 & 2,55 \\
\hline 51,16 & 1361,30 & 67,40 & 28,27 & 23,89 & 21,99 & 19,67 & 17,55 & 15,61 & 12,34 & 9,83 & 6,57 \\
\hline 46,08 & 1077,90 & 39,00 & 46,88 & 40,84 & 37,89 & 34,03 & 30,42 & 27,10 & 21,42 & 17,06 & 11,36 \\
\hline 26,45 & 1047,80 & 190,20 & 24,82 & 17,70 & 13,75 & 9,95 & $\begin{array}{c}3,46 \\
7,46\end{array}$ & 5,83 & 3,98 & 3,05 & $\frac{1,10}{2,11}$ \\
\hline 82,55 & 1953,90 & 20,60 & 36,00 & 33,10 & 29,81 & 28,72 & 28,10 & 27,24 & 25,31 & 23,41 & 19,82 \\
\hline 83,94 & 1232,00 & 55,00 & 25,09 & 18,93 & 17,58 & 16,45 & 15,40 & 14,41 & 12,57 & 10,94 & 8,31 \\
\hline 59,66 & 1357,10 & 134,00 & 17,10 & 13,29 & 11,82 & 10,33 & 9,08 & 7,97 & 6,18 & 4,88 & 3,25 \\
\hline 69,81 & 1969,90 & 174,20 & 11,57 & 8,78 & 7,91 & 7,05 & 6,33 & 5,69 & 4,60 & 3,74 & 2,58 \\
\hline 21,38 & 1451,40 & 119,40 & 35,93 & 27,70 & 22,00 & 16,11 & 12,08 & 9,39 & 6,36 & 4,85 & 3,35 \\
\hline 45,17 & 1626,50 & 170,10 & 16,28 & 12,94 & 11,29 & 9,50 & 8,00 & 6,76 & 4,92 & 3,73 & 2,44 \\
\hline 45,47 & 546,10 & 52,40 & 50,77 & 40,82 & 35,83 & 30,34 & 25,72 & 21,83 & 16,00 & 12,17 & 7,95 \\
\hline 23,58 & 1543,40 & 37.80 & 73,01 & 64,46 & 56.70 & 46,90 & 38.50 & 31.66 & 22,06 & 16.32 & 10,66 \\
\hline 34,00 & 880,30 & 143,20 & 27,50 & 20,36 & 16,66 & 12,85 & 10,06 & 8,04 & 5,51 & 4,14 & 2,81 \\
\hline 32,45 & 723,20 & 118,60 & 34,22 & 25,25 & 20,51 & 15,65 & 12,15 & 9,66 & 6,60 & 4,97 & 3,39 \\
\hline 72,16 & 223,20 & 144,90 & 43,45 & 22,52 & 16,24 & 11,93 & 9,43 & 7,71 & 5,46 & 4,19 & 2,88 \\
\hline 39,77 & 734,60 & 124,20 & 29,39 & 21,68 & 18,04 & 14,31 & 11,47 & 9,33 & 6,48 & 4,87 & 3,26 \\
\hline 27,21 & 511,60 & 50,80 & 75,63 & 59,10 & 48,51 & 37,08 & 28,68 & 22,68 & 15,39 & 11,57 & 7,89 \\
\hline 34,72 & 1807,80 & 186,70 & 17,61 & 13,98 & 11,88 & 9,55 & 7,70 & 6,27 & 4,35 & 3,25 & 2,16 \\
\hline 25,20 & 955,60 & 142,50 & 32,08 & 23,45 & 18,35 & 13,34 & 10,00 & 7,81 & 5,32 & 4,07 & 2,81 \\
\hline 21,09 & 457,70 & 156,30 & 40,31 & 24,65 & 17,35 & 11,66 & 8,57 & 6,75 & 4,74 & 3,69 & 2,58 \\
\hline 66,38 & 1364,70 & 102,60 & 18,79 & 14,62 & 13,31 & 11,92 & 10,74 & 9,67 & 7,82 & 6,37 & 4,39 \\
\hline 70,83 & 1235,40 & 131,00 & 16,59 & 12,32 & 10,96 & 9,66 & 8,62 & 7,70 & 6,15 & 4,97 & 3,41 \\
\hline 57,16 & 914,30 & 149,80 & 19,79 & 14,37 & 12,28 & 10,31 & 8,76 & 7,47 & 5,54 & 4,26 & 2,82 \\
\hline
\end{tabular}




\begin{tabular}{|c|c|c|c|c|c|c|c|c|c|c|c|}
\hline \multirow[b]{2}{*}{ e1 (cm) } & & & & & & $\mathrm{De}$ & ões (x1 & & & & \\
\hline & Meq (MPa) & Ms (MPa) & D0 & D25 & D40 & D60 & D80 & D100 & D140 & D180 & D260 \\
\hline 34,99 & 1798,30 & 58,70 & 36,94 & 33,07 & 30,06 & 26,19 & 22,65 & 19,53 & 14,59 & 11,14 & 7,20 \\
\hline 27,82 & 201,50 & 66,80 & 83,90 & 53,52 & 39,74 & 27,89 & 20,75 & 16,26 & 11,23 & 8,67 & 6,05 \\
\hline 53,27 & 925,60 & 164,60 & 19,40 & 13,98 & 11,83 & 9,79 & 8,19 & 6,90 & 5,02 & 3,83 & 2,53 \\
\hline 72,41 & 279,50 & 143,90 & 37,17 & 20,38 & 15,25 & 11,59 & 9,35 & 7,74 & 5,56 & 4,28 & 2,91 \\
\hline 43,13 & 1879,40 & 181,00 & 15,25 & 12,28 & 10,73 & 9,01 & 7,57 & 6,38 & 4,62 & 3,50 & 2,29 \\
\hline 25,70 & 1102,00 & 189,50 & 24,89 & 17,84 & 13,85 & 10,00 & 7,48 & 5,84 & 3,99 & 3,06 & 2,12 \\
\hline 81,45 & 1923,80 & 150,00 & 11,83 & 8,69 & 7,90 & 7,15 & 6,54 & 5,99 & 5,03 & 4,23 & 3,05 \\
\hline 82,89 & 809,60 & 55,80 & 29,87 & 22,02 & 20,14 & 18,40 & 16,94 & 15,61 & 13,23 & 11,24 & 8,21 \\
\hline 89,96 & 922,10 & 117,90 & 18,33 & 12,53 & 10,95 & 9,64 & 8,68 & 7,86 & 6,48 & 5,39 & 3,84 \\
\hline 43,26 & 1146,20 & 54,50 & 38,61 & 33,45 & 30,45 & 26,76 & 23,40 & 20,42 & 15,58 & 12,09 & 7,90 \\
\hline 66,89 & 709,50 & 142,00 & 21,60 & 14,77 & 12,43 & 10,41 & 8,91 & 7,68 & 5,79 & 4,51 & 3,01 \\
\hline 65,11 & 1770,60 & 127,00 & 15,04 & 11,80 & 10,77 & 9,66 & 8,70 & 7,83 & 6,33 & 5,16 & 3,55 \\
\hline 51,51 & 616,40 & 107,30 & 29,96 & 21,74 & 18,41 & 15,19 & 12,67 & 10,64 & 7,70 & 5,85 & 3,87 \\
\hline 49,66 & 1249,50 & 192,70 & 16,08 & 11,96 & 10,21 & 8,46 & 7,07 & 5,94 & 4,30 & 3,26 & 2,15 \\
\hline 43,98 & 1446,40 & 83,20 & 26,78 & 22,83 & 20,60 & 17,94 & 15,57 & 13,49 & 10,18 & 7,85 & 5,12 \\
\hline 44,25 & 288,60 & 80,00 & 53,76 & 35,84 & 28,75 & 22,28 & 17,67 & 14,29 & 9,93 & 7,50 & 5,08 \\
\hline 61,30 & 506,90 & 120,20 & 28,94 & 19,39 & 16,03 & 13,14 & 11,02 & 9,32 & 6,83 & 5,25 & 3,49 \\
\hline 67,81 & 1520,40 & 75,20 & 21,50 & 16,96 & 15,83 & 14,52 & 13,33 & 12,22 & 10,23 & 8,56 & 6,10 \\
\hline 25,01 & 1606,30 & 71,20 & 44,58 & 37,66 & 32,26 & 25,82 & 20,63 & 16,63 & 11,37 & 8,44 & 5,62 \\
\hline 65,23 & 813,80 & 34,50 & 45,25 & 36,18 & 33,99 & 31,32 & 28,84 & 26,49 & 22,24 & 18,66 & 13,33 \\
\hline 77,89 & 745,60 & 199,00 & 17,28 & 10,87 & 8,86 & 7,29 & 6,22 & 5,37 & 4,08 & 3,21 & 2,17 \\
\hline 37,36 & 439,50 & 168,30 & 31,62 & 19,65 & 14,98 & 10,96 & 8,37 & 6,63 & 4,55 & 3,48 & 2,41 \\
\hline 28,59 & 1895,90 & 124,70 & 26,01 & 21,47 & 18,30 & 14,62 & 11,70 & 9,45 & 6,49 & 4,83 & 3,22 \\
\hline 64,93 & 1640,10 & 135,40 & 14,99 & 11,64 & 10,52 & 9,36 & 8,38 & 7,49 & 5,99 & 4,84 & 3,30 \\
\hline 75,61 & 238,90 & 146,60 & 41,03 & 21,48 & 15,62 & 11,59 & 9,24 & 7,59 & 5,42 & 4,17 & 2,86 \\
\hline 87,38 & 1005,60 & 120,10 & 17,56 & 12,19 & 10,72 & 9,48 & 8,55 & 7,75 & 6,38 & 5,30 & 3,77 \\
\hline 72,15 & 1784,10 & 129,70 & 14,06 & 10,73 & 9,80 & 8,85 & 8,04 & 7,31 & 6,03 & 4,99 & 3,51 \\
\hline 69,64 & 1944,50 & 143,50 & 13,02 & 10,01 & 9,14 & 8,22 & 7,45 & 6,74 & 5,51 & 4,53 & 3,16 \\
\hline 83,24 & 222,80 & 179,10 & 40,81 & 19,95 & 13,86 & 9,85 & 7,66 & 6,22 & 4,39 & 3,39 & 2,35 \\
\hline 21,57 & 1987,40 & 125,40 & 31,57 & 25,13 & 20,42 & 15,32 & 11,65 & 9,11 & 6,14 & 4,64 & 3,19 \\
\hline 41,55 & 1573,20 & 95,90 & 24,74 & 21,03 & 18,82 & 16,20 & 13,90 & 11,91 & 8,83 & 6,74 & 4,38 \\
\hline 79,71 & 892,10 & 60,00 & 28,01 & 20,89 & 19,16 & 17,49 & 16,07 & 14,78 & 12,46 & 10,53 & 7,63 \\
\hline 55,69 & 1903,90 & 49,60 & 29,40 & 24,48 & 23,37 & 21,71 & 20,06 & 18,48 & 15,56 & 13,07 & 9,33 \\
\hline 23,90 & 1727,60 & 44,20 & 62,61 & 55,20 & 48,53 & 40,13 & 32,93 & 27,08 & 18,87 & 13,96 & 9,12 \\
\hline 88,27 & 526,00 & 112,60 & 25,78 & 16,46 & 13,70 & 11,55 & 10,09 & 8,92 & 7,04 & 5,69 & 3,93 \\
\hline 34,80 & 1446,60 & 43,00 & 49,05 & 44,16 & 40,30 & 35,27 & 30,63 & 26,51 & 19,92 & 15,27 & 9,87 \\
\hline 26,57 & 1765,60 & 88,40 & 35,53 & 29,91 & 25,66 & 20,62 & 16,54 & 13,38 & 9,18 & 6,82 & 4,53 \\
\hline 29,52 & 701,70 & 128,20 & 34,70 & 24,99 & 19,80 & 14,68 & 11,17 & 8,79 & 5,99 & 4,55 & 3,14 \\
\hline 20,78 & 1156,60 & 187,00 & 27,96 & 19,53 & 14,56 & 10,09 & 7,40 & 5,75 & 3,98 & 3,08 & 2,15 \\
\hline 87,09 & 1638,30 & 133,50 & 13,14 & 9,46 & 8,55 & 7,75 & 7,11 & 6,54 & 5,53 & 4,69 & 3,42 \\
\hline 26,34 & 1267,90 & 32,30 & 78,48 & 70,14 & 62,49 & 52,69 & 44,06 & 36,81 & 26,18 & 19,49 & 12,61 \\
\hline 29,91 & 656,50 & 57,50 & 60,01 & 48,13 & 40,51 & 31,96 & 25,33 & 20,35 & 13,93 & 10,40 & 6,99 \\
\hline 23,74 & 1266,60 & 161,80 & 28,01 & 20,76 & 16,26 & 11,79 & 8,82 & 6,87 & 4,68 & 3,58 & 2,48 \\
\hline 31,66 & 607,40 & 84,20 & 46,11 & 34,89 & 28,62 & 22,03 & 17,18 & 13,69 & 9,34 & 7,03 & 4,78 \\
\hline 63,75 & 1859,40 & 194,20 & 11,69 & 8,91 & 7,92 & 6,93 & 6,12 & 5,41 & 4,23 & 3,37 & 2,26 \\
\hline 84,23 & 1003,70 & 28,80 & 39,91 & 31,11 & 28,90 & 27,60 & 26,23 & 24,84 & 22,19 & 19,76 & 15,58 \\
\hline 73,04 & 984,20 & 63,40 & 27,19 & 20,81 & 19,16 & 17,43 & 15,94 & 14,57 & 12,13 & 10,13 & 7,21 \\
\hline 47,64 & 552,30 & 186,10 & 24,74 & 15,69 & 12,38 & 9,53 & 7,56 & 6,12 & 4,26 & 3,23 & 2,19 \\
\hline 23,62 & 1801,00 & 62,50 & 49,27 & 42,23 & 36,40 & 29,32 & 23,54 & 19,03 & 13,02 & 9,64 & 6,40 \\
\hline 53,94 & 1139,50 & 186,20 & 16,37 & 11,96 & 10,20 & 8,51 & 7,17 & 6,08 & 4,45 & 3,40 & 2,25 \\
\hline 45,28 & 1742,00 & 149,20 & 17,08 & 13,94 & 12,32 & 10,51 & 8,96 & 7,64 & 5,64 & 4,30 & 2,81 \\
\hline 40,45 & 1970,70 & 106,20 & 21,77 & 18,73 & 16,84 & 14,55 & 12,51 & 10,75 & 7,99 & 6,11 & 3,96 \\
\hline 61,13 & 208,20 & 82,60 & 56,65 & 33,74 & 26,25 & 20,42 & 16,54 & 13,66 & 9,73 & 7,43 & 5,02 \\
\hline 59,12 & 1261,50 & 90,30 & 22,27 & 17,87 & 16,24 & 14,45 & 12,89 & 11,48 & 9,10 & 7,29 & 4,92 \\
\hline 45,93 & 1566,40 & 161,80 & 16,85 & 13,40 & 11,72 & 9,89 & 8,36 & 7,08 & 5,17 & 3,93 & 2,57 \\
\hline 62,64 & 613,60 & 114,00 & 26,56 & 18,61 & 15,76 & 13,22 & 11,28 & 9,68 & 7,24 & 5,61 & 3,73 \\
\hline 26,87 & 1153,20 & 113,90 & 33,94 & 26,50 & 21,71 & 16,55 & 12,78 & 10,09 & 6,84 & 5,15 & 3,52 \\
\hline 51,98 & 657,00 & 95,80 & 30,74 & 23,00 & 19,77 & 16,55 & 13,97 & 11,84 & 8,68 & 6,63 & 4,36 \\
\hline 30,62 & 1191,00 & 46,80 & 55,08 & 48,24 & 42,82 & 36,05 & 30,15 & 25,23 & 18,02 & 13,46 & 8,73 \\
\hline 78,43 & 315,40 & 57,30 & 47,86 & 32,26 & 27,38 & 23,35 & 20,42 & 17,98 & 14,08 & 11,26 & 7,68 \\
\hline 80,99 & 1772,40 & 52,60 & 22,78 & 17,70 & 16,54 & 15,75 & 14,91 & 14,08 & 12,49 & 11,04 & 8,60 \\
\hline 25,09 & 1107,90 & 182,50 & 25,87 & 18,61 & 14,43 & 10,40 & 7,77 & 6,06 & 4,14 & 3,17 & 2,20 \\
\hline 54,98 & 1682,90 & 94,20 & 20,25 & 16,77 & 15,40 & 13,79 & 12,34 & 11,01 & 8,76 & 7,02 & 4,73 \\
\hline 50,49 & 1439,60 & 190,30 & 15,04 & 11,47 & 9,91 & 8,33 & 7,04 & 5,97 & 4,38 & 3,34 & 2,20 \\
\hline 77,76 & 1781,30 & 38,20 & 28,46 & 22,69 & 21,22 & 20,41 & 19,47 & 18,49 & 16,59 & 14,81 & 11,73 \\
\hline 64,81 & 665,40 & 50,70 & 38,72 & 30,28 & 27,52 & 24,59 & 22,08 & 19,81 & 15,94 & 12,92 & 8,85 \\
\hline 70,40 & 475,10 & 54,20 & 41,61 & 30,69 & 27,15 & 23,81 & 21,15 & 18,81 & 14,94 & 12,02 & 8,19 \\
\hline 24,59 & 456,40 & 110,90 & 48,31 & 32,41 & 24,19 & 16,91 & 12,50 & 9,76 & 6,74 & 5,21 & 3,63 \\
\hline 89,87 & 1890,10 & 172,20 & 10,59 & 7,49 & 6,72 & 6,05 & 5,54 & 5,08 & 4,28 & 3,63 & 2,65 \\
\hline 25,23 & 493,00 & 85,90 & 55,73 & 39,77 & 30,72 & 22,07 & 16,48 & 12,85 & 8,79 & 6,74 & 4,68 \\
\hline 22,87 & 928,10 & 197,50 & 27,06 & 18,39 & 13,68 & 9,50 & 7,00 & 5,46 & 3,78 & 2,92 & 2,04 \\
\hline 73,10 & 835,20 & 40,40 & 38,10 & 29,48 & 27,53 & 25,43 & 23,51 & 21,71 & 18,44 & 15,65 & 11,39 \\
\hline 27,84 & 1286,20 & 128,30 & 29,50 & 23,10 & 19,03 & 14,62 & 11,35 & 9,00 & 6,11 & 4,59 & 3,12 \\
\hline 37,70 & 1277,30 & 21,10 & 78,17 & 70,70 & 66,79 & 60,80 & 54,95 & 49,41 & 39,66 & 31,88 & 21,36 \\
\hline 74,24 & 1545,50 & 178,60 & 12,41 & 9,02 & 7,98 & 7,01 & 6,26 & 5,59 & 4,48 & 3,64 & 2,50 \\
\hline 49,45 & 1199,60 & 117,10 & 21,70 & 17,32 & 15,27 & 13,07 & 11,21 & 9,62 & 7,17 & 5,51 & 3,61 \\
\hline 89,71 & 465,50 & 40,20 & 44,23 & 31,45 & 28,28 & 25,58 & 23,44 & 21,56 & 18,24 & 15,48 & 11,34 \\
\hline 64,03 & 416,50 & 74,10 & 39,60 & 27,87 & 23,71 & 20,00 & 17,15 & 14,79 & 11,15 & 8,67 & 5,77 \\
\hline 77,10 & 1986,90 & 155,20 & 11,74 & 8,75 & 7,96 & 7,19 & 6,55 & 5,97 & 4,96 & 4,13 & 2,94 \\
\hline 26,87 & 1324,60 & 170,50 & 24,64 & 18,56 & 14,89 & 11,11 & 8,46 & 6,64 & 4,51 & 3,42 & 2,35 \\
\hline 77,74 & 532,70 & 112,80 & 26,58 & 17,49 & 14,61 & 12,29 & 10,65 & 9,30 & 7,18 & 5,70 & 3,86 \\
\hline 87,18 & 928,70 & 77,10 & 22,94 & 16,48 & 14,88 & 13,48 & 12,35 & 11,35 & 9,58 & 8,12 & 5,92 \\
\hline
\end{tabular}




\begin{tabular}{|c|c|c|c|c|c|c|c|c|c|c|c|}
\hline & & & \multicolumn{9}{|c|}{ Deflexões $\left(\times 10^{-4} \mathrm{~cm}\right)$} \\
\hline e1 (cm) & Meq (MPa) & Ms (MPa) & D0 & D25 & D40 & D60 & D80 & D100 & D140 & D180 & D260 \\
\hline 86,97 & 1711,90 & 43,70 & 24,37 & 19,30 & 17,79 & 17,06 & 16,31 & 15,53 & 14,00 & 12,58 & 10,09 \\
\hline 54,57 & 1591,60 & 149,60 & 15,76 & 12,50 & 11,11 & 9,65 & 8,41 & 7,32 & 5,59 & 4,36 & 2,88 \\
\hline 65,48 & 470,80 & 56,40 & 42,33 & 31,54 & 27,75 & 24,14 & 21,22 & 18,69 & 14,57 & 11,56 & 7,77 \\
\hline 61,28 & 865,20 & 139,50 & 20,40 & 14,71 & 12,61 & 10,68 & 9,16 & 7,89 & 5,94 & 4,61 & 3,06 \\
\hline 63,27 & 251,80 & 53,10 & 60,72 & 41,46 & 34,70 & 28,82 & 24,43 & 20,86 & 15,51 & 11,98 & 7,97 \\
\hline 58,39 & 694,60 & 64,60 & 34,98 & 27,47 & 24,53 & 21,47 & 18,87 & 16,58 & 12,86 & 10,14 & 6,76 \\
\hline 81,58 & 1732,70 & 50,10 & 23,55 & 18,33 & 17,12 & 16,32 & 15,47 & 14,62 & 13,00 & 11,52 & 9,01 \\
\hline 71,38 & 265,00 & 171,90 & 36,64 & 19,01 & 13,72 & 10,07 & 7,96 & 6,50 & 4,60 & 3,53 & 2,43 \\
\hline 78,58 & 636,40 & 34,20 & 45,11 & 34,15 & 31,67 & 29,24 & 27,07 & 25,06 & 21,39 & 18,26 & 13,43 \\
\hline 58,52 & 1360,00 & 20,60 & 58,12 & 477,39 & 45,65 & 43,63 & 41,18 & 38,73 & 34,01 & 29,69 & 22,52 \\
\hline 42,69 & 1797,10 & 190,20 & 15,18 & 12,06 & 10,47 & 8,72 & 7,27 & 6,09 & 4,38 & 3,30 & 2,16 \\
\hline 70,85 & 220,70 & 63,80 & 58,14 & 36,56 & 29,56 & 24,03 & 20,22 & 17,22 & 12,79 & 9,92 & 6,66 \\
\hline 80,62 & 711,50 & 133,40 & 20,72 & 13,81 & 11,68 & 9,94 & 8,70 & 7,67 & 6,02 & 4,83 & 3,30 \\
\hline 67,47 & 301,30 & 49,00 & 55,89 & 39,57 & 33,95 & 28,95 & 25,11 & 21,88 & 16,77 & 13,19 & 8,83 \\
\hline 56,37 & 1329,40 & 109,10 & 20,03 & 16,04 & 14,41 & 12,66 & 11,16 & 9,82 & 7,63 & 6,02 & 4,00 \\
\hline 38,27 & 1174,50 & 194,00 & 19,05 & 14,11 & 11,71 & 9,24 & 7,37 & 5,97 & 4,13 & 3,10 & 2,09 \\
\hline 27,86 & 1326,90 & 27,00 & 82,89 & 75,70 & 68,63 & 59,30 & 50,76 & 43,31 & 31,74 & 23,94 & 15,37 \\
\hline 70,82 & 1375,70 & 44,20 & 30,53 & 24,01 & 22,74 & 21,38 & 20,00 & 18,67 & 16,17 & 13,97 & 10,44 \\
\hline 58,97 & 1922,30 & 97,60 & 18,08 & 14,79 & 13,72 & 12,43 & 11,25 & 10,16 & 8,26 & 6,74 & 4,64 \\
\hline 31,69 & 1452,10 & 175,00 & 21,12 & 16,31 & 13,53 & 10,53 & 8,28 & 6,63 & 4,53 & 3,40 & 2,30 \\
\hline 81,49 & 1741,30 & 102,60 & 15,32 & 11,45 & 10,56 & 9,72 & 8,99 & 8,32 & 7,10 & 6,07 & 4,47 \\
\hline 77,12 & 1776,00 & 130,10 & 13,62 & 10,19 & 9,31 & 8,44 & 7,71 & 7,05 & 5,87 & 4,92 & 3,51 \\
\hline 29,69 & 878,80 & 129,20 & 31,90 & 23,80 & 19,23 & 14,52 & 11,17 & 8,82 & 6,01 & 4,54 & 3,11 \\
\hline 38,28 & 876,60 & 47,50 & 50,84 & 43,73 & 39,10 & 33,49 & 28,55 & 24,32 & 17,85 & 13,54 & 8,77 \\
\hline 23,55 & 829,50 & 43,90 & 80,16 & 65,95 & 55,24 & 42,98 & 33,56 & 26,63 & 18,01 & 13,45 & 9,10 \\
\hline 38,86 & 1981,70 & 153,60 & 17,75 & 14,69 & 12,89 & 10,81 & 9,04 & 7,58 & 5,45 & 4,10 & 2,68 \\
\hline 49,59 & 333,50 & 107,60 & 41,25 & 26,36 & 20,94 & 16,27 & 13,01 & 10,60 & 7,42 & 5,62 & 3,80 \\
\hline 58,19 & 1780,50 & 83,00 & 20,77 & 17,09 & 15,92 & 14,46 & 13,12 & 11,88 & 9,69 & 7,93 & 5,47 \\
\hline 55,96 & 561,00 & 69,90 & 37,68 & 28,67 & 25,02 & 21,39 & 18,41 & 15,87 & 11,94 & 9,24 & 6,10 \\
\hline 22,17 & 1131,10 & 61,20 & 60,60 & 49,25 & 40,72 & 31,16 & 24,02 & 18,91 & 12,74 & 9,56 & 6,52 \\
\hline 62,50 & 472,00 & 105,80 & 31,66 & 21,40 & 17,80 & 14,69 & 12,39 & 10,53 & 7,78 & 5,99 & 3,99 \\
\hline 22,75 & 1463,70 & 57,10 & 57,68 & 48,61 & 41,32 & 32,69 & 25,85 & 20,67 & 14,02 & 10,41 & 6,99 \\
\hline 30,69 & 1651,20 & 43,80 & 51,39 & 46,44 & 42,05 & 36,33 & 31,12 & 26,59 & 19,55 & 14,78 & 9,51 \\
\hline 82,73 & 1777,00 & 41,30 & 25,85 & 20,56 & 19,08 & 18,34 & 17,52 & 16,67 & 15,01 & 13,46 & 10,75 \\
\hline 54,20 & 585,10 & 28,60 & 63,99 & 53,48 & 49,46 & 44,52 & 40,02 & 35,87 & 28,73 & 23,15 & 15,66 \\
\hline 88,33 & 1666,30 & 135,00 & 12,88 & 9,24 & 8,35 & 7,58 & 6,96 & 6,41 & 5,43 & 4,61 & 3,38 \\
\hline 78,35 & 1956,70 & 119,20 & 13,64 & 10,27 & 9,48 & 8,69 & 8,00 & 7,38 & 6,24 & 5,29 & 3,85 \\
\hline 59,58 & 946,50 & 54,60 & 33,72 & 27,38 & 25,22 & 22,72 & 20,48 & 18,42 & 14,87 & 12,07 & 8,25 \\
\hline 84,72 & 307,60 & 105,10 & 37,48 & 22,10 & 17,42 & 13,99 & 11,80 & 10,14 & 7,67 & 6,03 & 4,10 \\
\hline 68,00 & 496,50 & 57,80 & 40,03 & 29,69 & 26,21 & 22,90 & 20,25 & 17,93 & 14,11 & 11,28 & 7,63 \\
\hline 65,51 & 338,90 & 102,90 & 38,01 & 23,92 & 19,24 & 15,49 & 12,88 & 10,85 & 7,93 & 6,09 & 4,08 \\
\hline 68,38 & 272,00 & 119,20 & 40,73 & 23,37 & 17,92 & 13,87 & 11,29 & 9,38 & 6,75 & 5,18 & 3,51 \\
\hline 38,63 & 1746,30 & 90,70 & 26,03 & 22,48 & 20,17 & 17,34 & 14,84 & 12,68 & 9,36 & 7,12 & 4,61 \\
\hline 84,68 & 1050,30 & 115,40 & 17,75 & 12,53 & 11,11 & 9,86 & 8,91 & 8,08 & 6,66 & 5,53 & 3,93 \\
\hline 33,78 & 1120,70 & 195,50 & 20,74 & 15,18 & 12,34 & 9,45 & 7,36 & 5,87 & 4,01 & 3,03 & 2,06 \\
\hline 85,10 & 400,30 & 129,00 & 29,35 & 17,50 & 13,89 & 11,24 & 9,52 & 8,21 & 6,24 & 4,93 & 3,35 \\
\hline 34,94 & 1454,60 & 39,80 & 51,40 & 46,48 & 42,60 & 37,48 & 32,72 & 28,45 & 21,54 & 16,59 & 10,74 \\
\hline 52,55 & 467,10 & 142,20 & 29,65 & 19,12 & 15,33 & 12,07 & 9,76 & 8,02 & 5,66 & 4,29 & 2,89 \\
\hline 72,61 & 528,30 & 186,10 & 22,37 & 13,41 & 10,58 & 8,43 & 7,01 & 5,93 & 4,36 & 3,37 & 2,27 \\
\hline 44,97 & 1125,30 & 196,10 & 17,61 & 12,89 & 10,82 & 8,75 & 7,14 & 5,89 & 4,16 & 3,14 & 2,09 \\
\hline 45,06 & 1581,00 & 104,00 & 22,17 & 18,63 & 16,72 & 14,49 & 12,53 & 10,82 & 8,13 & 6,26 & 4,08 \\
\hline 32,52 & 1633,70 & 198,40 & 18,36 & 14,19 & 11,81 & 9,24 & 7,29 & 5,85 & 4,01 & 3,01 & 2,03 \\
\hline 40,52 & 920,60 & 57,20 & 42,57 & 36,13 & 32,24 & 27,62 & 23,57 & 20,11 & 14,81 & 11,26 & 7,31 \\
\hline 78,09 & 1808,40 & 83,20 & 17,50 & 13,35 & 12,46 & 11,60 & 10,79 & 10,03 & 8,64 & 7,43 & 5,53 \\
\hline 82,96 & 1276,10 & 148,40 & 14,31 & 10,10 & 8,92 & 7,88 & 7,09 & 6,40 & 5,24 & 4,32 & 3,04 \\
\hline 47,18 & 397,90 & 180,60 & 29,93 & 17,61 & 13,38 & 9,97 & 7,77 & 6,24 & 4,32 & 3,29 & 2,26 \\
\hline 68,20 & 1642,50 & 174,10 & 12,70 & 9,52 & 8,46 & 7,44 & 6,61 & 5,88 & 4,67 & 3,75 & 2,55 \\
\hline 53,30 & 1189,80 & 85,90 & 24,96 & 20,41 & 18,43 & 16,22 & 14,28 & 12,55 & 9,73 & 7,65 & 5,07 \\
\hline 83,81 & 1903,70 & 119,10 & 13,35 & 9,87 & 9,07 & 8,34 & 7,71 & 7,13 & 6,09 & 5,21 & 3,85 \\
\hline 52,31 & 1695,80 & 128,00 & 17,25 & 14,09 & 12,67 & 11,10 & 9,73 & 8,52 & 6,55 & 5,13 & 3,38 \\
\hline 88,67 & 1863,80 & 47,70 & 22,00 & 17,48 & 16,05 & 15,40 & 14,74 & 14,04 & 12,69 & 11,43 & 9,21 \\
\hline 69,49 & 356,50 & 72,90 & 41,97 & 28,39 & 23,84 & 20,00 & 17,17 & 14,84 & 11,26 & 8,81 & 5,90 \\
\hline 42,16 & 427,10 & 100,80 & 40,51 & 28,01 & 22,75 & 17,73 & 14,09 & 11,39 & 7,90 & 5,96 & 4,03 \\
\hline 80,54 & 868,50 & 69,70 & 25,92 & 19,06 & 17,29 & 15,63 & 14,27 & 13,05 & 10,90 & 9,13 & 6,55 \\
\hline 81,24 & 1025,60 & 25,00 & 44,22 & 34,95 & 32,56 & 31,23 & 29,77 & 28,25 & 25,32 & 22,61 & 17,91 \\
\hline 41,68 & 980,60 & 21,00 & 78,93 & 70,32 & 66,30 & 60,34 & 54,56 & 49,10 & 39,51 & 31,86 & 21,45 \\
\hline 28,12 & 1667,50 & 65,00 & 42,49 & 36,91 & 32,42 & 26,87 & 22,14 & 18,29 & 12,83 & 9,53 & 6,23 \\
\hline 83,82 & 1169,20 & 195,60 & 13,09 & 8,80 & 7,52 & 6,47 & 5,72 & 5,08 & 4,06 & 3,29 & 2,28 \\
\hline 45,16 & 1255,70 & 50,10 & 38,30 & 33,35 & 30,75 & 27,42 & 24,34 & 21,53 & 16,82 & 13,27 & 8,77 \\
\hline 26,36 & 254,80 & 50,10 & 96,76 & 68,04 & 52,46 & 37,72 & 28,21 & 22,03 & 15,08 & 11,57 & 8,02 \\
\hline 53,15 & 638,30 & 55,40 & 41,79 & 33,56 & 29,95 & 26,07 & 22,72 & 19,80 & 15,12 & 11,79 & 7,77 \\
\hline 22,19 & 232,60 & 32,20 & 150,13 & 108,77 & 83,40 & 59,20 & 43,81 & 34,04 & 23,33 & 17,95 & 12,46 \\
\hline 43,89 & 1670,60 & 136,30 & 18,73 & 15,40 & 13,62 & 11,60 & 9,87 & 8,40 & 6,18 & 4,70 & 3,07 \\
\hline 69,33 & 1489,00 & 173,60 & 13,22 & 9,76 & 8,62 & 7,54 & 6,68 & 5,93 & 4,68 & 3,75 & 2,55 \\
\hline 81,01 & 1817,50 & 73,40 & 18,43 & 14,06 & 13,12 & 12,32 & 11,54 & 10,81 & 9,43 & 8,21 & 6,23 \\
\hline 88,91 & 228,50 & 125,30 & 43,44 & 22,99 & 16,93 & 12,79 & 10,39 & 8,70 & 6,37 & 4,97 & 3,40 \\
\hline 53,35 & 1251,70 & 105,50 & 21,63 & 17,42 & 15,58 & 13,59 & 11,87 & 10,36 & 7,94 & 6,20 & 4,09 \\
\hline 27,23 & 408,00 & 53,60 & 78,24 & 58,85 & 47,25 & 35,31 & 26,93 & 21,16 & 14,37 & 10,89 & 7,48 \\
\hline 39,31 & 1082,00 & 144,00 & 23,18 & 17,80 & 15,07 & 12,16 & 9,87 & 8,09 & 5,66 & 4,24 & 2,82 \\
\hline 45,95 & 1698,60 & 32,50 & 46,27 & 40,18 & 38,40 & 35,47 & 32,56 & 29,76 & 24,66 & 20,39 & 14,18 \\
\hline 68,34 & 1425,70 & 101,60 & 18,29 & 14,17 & 12,96 & 11,67 & 10,56 & 9,56 & 7,81 & 6,41 & 4,46 \\
\hline 71,46 & 1961,40 & 177,40 & 11,35 & 8,54 & 7,69 & 6,85 & 6,16 & 5,54 & 4,49 & 3,67 & 2,54 \\
\hline
\end{tabular}




\begin{tabular}{|c|c|c|c|c|c|c|c|c|c|c|c|}
\hline & & & \multicolumn{9}{|c|}{ Deflexões $\left(\times 10^{-4} \mathrm{~cm}\right)$} \\
\hline e1 (cm) & Meq (MPa) & Ms (MPa) & D0 & D25 & D40 & D60 & D80 & D100 & D140 & D180 & D260 \\
\hline 45,33 & 1167,90 & 166,60 & 18,91 & 14,33 & 12,23 & 10,06 & 8,32 & 6,93 & 4,96 & 3,74 & 2,47 \\
\hline 34,23 & 1161,00 & 85,70 & 34,34 & 28,43 & 24,67 & 20,28 & 16,65 & 13,73 & 9,66 & 7,21 & 4,74 \\
\hline 86,93 & 487,10 & 171,70 & 23,29 & 13,59 & 10,65 & 8,53 & 7,19 & 6,18 & 4,68 & 3,69 & 2,52 \\
\hline 70,75 & 1489,60 & 120,20 & 16,02 & 12,19 & 11,06 & 9,92 & 8,96 & 8,09 & 6,60 & 5,41 & 3,76 \\
\hline 89,53 & 1658,30 & 91,20 & 15,91 & 11,72 & 10,76 & 9,99 & 9,32 & 8,70 & 7,57 & 6,58 & 4,99 \\
\hline 28,68 & 483,40 & 112,70 & 43,49 & 29,90 & 23,07 & 16,68 & 12,54 & 9,82 & 6,73 & 5,15 & 3,57 \\
\hline 79,01 & 767,80 & 87,20 & 24,56 & 17,60 & 15,58 & 13,76 & 12,35 & 11,12 & 9,03 & 7,40 & 5,16 \\
\hline 52,27 & 1907,40 & 199,40 & 12,69 & 9,98 & 8,79 & 7,54 & 6,50 & 5,60 & 4,20 & 3,24 & 2,13 \\
\hline 80,60 & 553,40 & 146,90 & 23,10 & 14,46 & 11,78 & 9,71 & 8,31 & 7,20 & 5,51 & 4,35 & 2,95 \\
\hline 56,96 & 550,10 & 186,60 & 23,35 & 14,56 & 11,55 & 9,08 & 7,37 & 6,08 & 4,32 & 3,29 & 2,21 \\
\hline 23,31 & 802,40 & 171,40 & 30,92 & 21,07 & 15,73 & 10,96 & 8,09 & 6,31 & 4,36 & 3,37 & 2,35 \\
\hline 33,28 & 1570,40 & 144,60 & 22,48 & 18,08 & 15,40 & 12,38 & 9,97 & 8,11 & 5,62 & 4,19 & 2,79 \\
\hline 33,23 & 1217,40 & 56,00 & 45,44 & 39,48 & 35,08 & 29,65 & 24,93 & 20,95 & 15,07 & 11,30 & 7,33 \\
\hline 72,94 & 752,80 & 97,00 & 24,29 & 17,51 & 15,34 & 13,37 & 11,84 & 10,52 & 8,33 & 6,70 & 4,57 \\
\hline 70,11 & 1173,90 & 43,00 & 33,08 & 26,02 & 24,57 & 22,94 & 21,35 & 19,83 & 17,02 & 14,57 & 10,74 \\
\hline 81,89 & 532,90 & 94,40 & 28,22 & 18,90 & 16,07 & 13,76 & 12,09 & 10,70 & 8,47 & 6,82 & 4,69 \\
\hline 35,86 & 1916,10 & 50,70 & 39,05 & 35,34 & 32,52 & 28,76 & 25,25 & 22,07 & 16,86 & 13,07 & 8,48 \\
\hline 58,53 & 1990,70 & 112,60 & 16,39 & 13,37 & 12,32 & 11,09 & 9,99 & 8,97 & 7,23 & 5,85 & 3,99 \\
\hline 47,01 & 539,50 & 66,80 & 43,43 & 33,60 & 29,06 & 24,29 & 20,39 & 17,18 & 12,47 & 9,46 & 6,21 \\
\hline 41,62 & 1689,50 & 149,10 & 18,32 & 14,92 & 13,07 & 10,98 & 9,22 & 7,77 & 5,62 & 4,24 & 2,77 \\
\hline 80,75 & 210,00 & 93,70 & 50,81 & 28,47 & 21,68 & 16,84 & 13,87 & 11,68 & 8,59 & 6,67 & 4,53 \\
\hline 30,29 & 1134,20 & 164,10 & 24,67 & 18,49 & 15,01 & 11,40 & 8,81 & 6,97 & 4,75 & 3,58 & 2,45 \\
\hline 32,13 & 1815,70 & 103,10 & 27,30 & 23,17 & 20,26 & 16,77 & 13,83 & 11,45 & 8,07 & 6,02 & 3,94 \\
\hline 48,86 & 1509,30 & 79,10 & 25,34 & 21,51 & 19,67 & 17,45 & 15,44 & 13,63 & 10,61 & 8,36 & 5,53 \\
\hline 31,14 & 1956,20 & 172,60 & 19,46 & 15,65 & 13,24 & 10,53 & 8,41 & 6,79 & 4,67 & 3,48 & 2,33 \\
\hline 48,59 & 1692,60 & 135,70 & 17,47 & 14,30 & 12,75 & 11,03 & 9,54 & 8,24 & 6,21 & 4,79 & 3,14 \\
\hline 33,01 & 263,60 & 181,60 & 39,58 & 20,83 & 14,56 & 10,01 & 7,49 & 5,92 & 4,11 & 3,18 & 2,25 \\
\hline 33,47 & 1130,50 & 143,20 & 25,34 & 19,50 & 16,25 & 12,74 & 10,09 & 8,11 & 5,57 & 4,17 & 2,81 \\
\hline 40,49 & 1255,20 & 86,70 & 29,24 & 24,54 & 21,76 & 18,51 & 15,70 & 13,32 & 9,74 & 7,38 & 4,80 \\
\hline 87,28 & 1400,10 & 190,10 & 11,86 & 8,11 & 7,06 & 6,18 & 5,54 & 4,99 & 4,07 & 3,36 & 2,37 \\
\hline 51,40 & 695,40 & 143,40 & 24,34 & 17,11 & 14,26 & 11,60 & 9,58 & 7,98 & 5,72 & 4,34 & 2,88 \\
\hline 35,47 & 686,70 & 145,80 & 29,18 & 20,64 & 16,60 & 12,64 & 9,82 & 7,83 & 5,36 & 4,05 & 2,77 \\
\hline 24,77 & 1566,90 & 89,30 & 38,73 & 31,86 & 26,79 & 20,96 & 16,46 & 13,11 & 8,89 & 6,63 & 4,47 \\
\hline 72,50 & 1561,10 & 38,80 & 31,25 & 24,68 & 23,37 & 22,27 & 21,04 & 19,81 & 17,48 & 15,35 & 11,80 \\
\hline 65,78 & 1780,60 & 44,60 & 29,13 & 23,30 & 22,24 & 21,02 & 19,72 & 18,44 & 16,02 & 13,87 & 10,38 \\
\hline 73,45 & 396,70 & 69,20 & 39,71 & 27,33 & 23,30 & 19,87 & 17,32 & 15,18 & 11,78 & 9,34 & 6,32 \\
\hline 81,48 & 392,20 & 24,20 & 66,21 & 49,34 & 45,42 & 41,71 & 38,51 & 35,58 & 30,29 & 25,80 & 18,94 \\
\hline 64,32 & 1202,80 & 122,30 & 18,26 & 13,93 & 12,40 & 10,89 & 9,64 & 8,53 & 6,71 & 5,35 & 3,61 \\
\hline 55,01 & 1820,40 & 69,00 & 24,06 & 20,15 & 18,91 & 17,26 & 15,71 & 14,25 & 11,66 & 9,56 & 6,60 \\
\hline 42,48 & 1563,80 & 162,30 & 17,71 & 14,11 & 12,25 & 10,21 & 8,52 & 7,14 & 5,13 & 3,87 & 2,54 \\
\hline 40,69 & 1396,40 & 128,30 & 21,97 & 17,81 & 15,53 & 12,96 & 10,82 & 9,06 & 6,51 & 4,90 & 3,21 \\
\hline 54,90 & 376,50 & 146,40 & 32,51 & 19,68 & 15,33 & 11,83 & 9,48 & 7,75 & 5,45 & 4,15 & 2,81 \\
\hline 62,00 & 1955,80 & 113,00 & 15,94 & 12,81 & 11,82 & 10,68 & 9,67 & 8,74 & 7,11 & 5,81 & 4,01 \\
\hline 64,61 & 460,60 & 68,10 & 39,06 & 28,31 & 24,47 & 20,95 & 18,18 & 15,83 & 12,11 & 9,50 & 6,34 \\
\hline 63,78 & 1680,40 & 147,80 & 14,24 & 11,04 & 9,93 & 8,79 & 7,83 & 6,97 & 5,53 & 4,44 & 3,01 \\
\hline 31,46 & 376,60 & 69,00 & 62,25 & 45,00 & 36,03 & 27,07 & 20,80 & 16,44 & 11,22 & 8,49 & 5,83 \\
\hline 82,57 & 1773,00 & 28,40 & 32,00 & 26,85 & 24,60 & 23,80 & 23,01 & 22,08 & 20,20 & 18,39 & 15,12 \\
\hline 21,26 & 1335,70 & 116,90 & 37,48 & 28,64 & 22,60 & 16,45 & 12,29 & 9,54 & 6,48 & 4,95 & 3,42 \\
\hline 77,01 & 1097,80 & 103,50 & 19,16 & 14,08 & 12,64 & 11,29 & 10,20 & 9,23 & 7,56 & 6,24 & 4,38 \\
\hline 63,59 & 200,90 & 109,40 & 51,84 & 28,37 & 21,09 & 15,81 & 12,57 & 10,27 & 7,25 & 5,54 & 3,79 \\
\hline 43,53 & 1841,90 & 120,50 & 19,56 & 16,48 & 14,76 & 12,73 & 10,96 & 9,42 & 7,02 & 5,38 & 3,50 \\
\hline 29,47 & 1029,30 & 38,60 & 67,87 & 59,47 & 52,67 & 44,16 & 36,80 & 30,68 & 21,79 & 16,24 & 10,55 \\
\hline 61,79 & 897,30 & 47,60 & 36,70 & 29,62 & 27,47 & 24,92 & 22,63 & 20,51 & 16,77 & 13,77 & 9,54 \\
\hline 40,94 & 1283,30 & 65,90 & 34,16 & 29,50 & 26,62 & 23,11 & 19,97 & 17,22 & 12,89 & 9,89 & 6,42 \\
\hline 46,69 & 1108,70 & 186,40 & 17,87 & 13,14 & 11,09 & 9,05 & 7,45 & 6,18 & 4,41 & 3,33 & 2,20 \\
\hline 21,84 & 1559,10 & 70,60 & 50,46 & 41,65 & 34,79 & 26,92 & 20,92 & 16,54 & 11,15 & 8,33 & 5,65 \\
\hline 53,83 & 1067,30 & 124,60 & 20,96 & 16,18 & 14,16 & 12,10 & 10,40 & 8,95 & 6,71 & 5,18 & 3,41 \\
\hline 67,79 & 1809,10 & 79,00 & 19,56 & 15,47 & 14,52 & 13,41 & 12,37 & 11,39 & 9,61 & 8,10 & 5,83 \\
\hline 43,64 & 1184,00 & 130,70 & 22,15 & 17,48 & 15,16 & 12,63 & 10,55 & 8,84 & 6,37 & 4,81 & 3,15 \\
\hline 47,54 & 1791,80 & 170,70 & 15,11 & 12,13 & 10,68 & 9,11 & 7,78 & 6,65 & 4,92 & 3,76 & 2,46 \\
\hline 68,83 & 1159,40 & 96,70 & 20,46 & 15,65 & 14,16 & 12,65 & 11,38 & 10,23 & 8,28 & 6,75 & 4,65 \\
\hline 61,12 & 522,80 & 143,80 & 26,29 & 17,06 & 13,88 & 11,22 & 9,32 & 7,82 & 5,68 & 4,35 & 2,91 \\
\hline 81,97 & 1439,00 & 179,60 & 12,31 & 8,65 & 7,59 & 6,67 & 5,98 & 5,38 & 4,37 & 3,58 & 2,51 \\
\hline 80,30 & 248,60 & 120,90 & 41,84 & 23,00 & 17,30 & 13,29 & 10,85 & 9,09 & 6,64 & 5,15 & 3,50 \\
\hline 55,98 & 357,90 & 196,80 & 29,62 & 16,34 & 12,12 & 9,00 & 7,06 & 5,71 & 3,98 & 3,04 & 2,09 \\
\hline 71,24 & 245,40 & 165,40 & 39,14 & 20,11 & 14,42 & 10,53 & 8,29 & 6,76 & 4,77 & 3,66 & 2,52 \\
\hline 35,23 & 1476,70 & 36,80 & 53,52 & 48,59 & 44,75 & 39,62 & 34,80 & 30,43 & 23,26 & 18,03 & 11,70 \\
\hline 85,89 & 313,90 & 48,50 & 50,12 & 33,86 & 29,14 & 25,25 & 22,44 & 20,08 & 16,19 & 13,23 & 9,23 \\
\hline 33,24 & 1624,40 & 27,00 & 67,18 & 61,83 & 57,63 & 51,68 & 45,94 & 40,64 & 31,64 & 24,82 & 16,23 \\
\hline 61,44 & 1945,70 & 115,90 & 15,80 & 12,71 & 11,70 & 10,55 & 9,53 & 8,59 & 6,96 & 5,67 & 3,89 \\
\hline 87,39 & 845,50 & 153,90 & 17,21 & 11,30 & 9,57 & 8,19 & 7,22 & 6,42 & 5,13 & 4,17 & 2,89 \\
\hline 48,05 & 897,70 & 64,10 & 35,56 & 29,49 & 26,47 & 23,03 & 20,01 & 17,36 & 13,15 & 10,19 & 6,67 \\
\hline 82,55 & 1031,80 & 107,80 & 18,73 & 13,39 & 11,92 & 10,61 & 9,59 & 8,70 & 7,16 & 5,94 & 4,21 \\
\hline 67,00 & 1758,90 & 93,90 & 17,85 & 14,09 & 13,10 & 11,96 & 10,94 & 9,99 & 8,30 & 6,90 & 4,88 \\
\hline 22,52 & 299,80 & 138,30 & 48,47 & 27,96 & 19,45 & 13,06 & 9,66 & 7,63 & 5,35 & 4,17 & 2,93 \\
\hline 38,34 & 1824,50 & 37,30 & 46,54 & 42,07 & 39,43 & 35,62 & 31,96 & 28,53 & 22,61 & 17,99 & 11,94 \\
\hline 71,80 & 891,90 & 154,80 & 17,86 & 12,36 & 10,54 & 8,98 & 7,81 & 6,83 & 5,28 & 4,18 & 2,81 \\
\hline 41,33 & 1504,90 & 151,50 & 19,08 & 15,28 & 13,26 & 11,03 & 9,18 & 7,67 & 5,49 & 4,14 & 2,71 \\
\hline 38,33 & 1555,70 & 184,30 & 17,58 & 13,74 & 11,70 & 9,48 & 7,71 & 6,33 & 4,44 & 3,32 & 2,20 \\
\hline 73,52 & 612,80 & 137,60 & 22,97 & 15,11 & 12,56 & 10,48 & 9,00 & 7,79 & 5,93 & 4,66 & 3,14 \\
\hline 42,01 & 875,70 & 72,60 & 36,47 & 29,94 & 26,35 & 22,27 & 18,80 & 15,90 & 11,57 & 8,75 & 5,71 \\
\hline 74,84 & 1969,60 & 176,20 & 11,13 & 8,28 & 7,46 & 6,67 & 6,03 & 5,45 & 4,46 & 3,67 & 2,57 \\
\hline
\end{tabular}




\begin{tabular}{|c|c|c|c|c|c|c|c|c|c|c|c|}
\hline & & & \multicolumn{9}{|c|}{ Deflexões $\left(\times 10^{-4} \mathrm{~cm}\right)$} \\
\hline e1 (cm) & Meq (MPa) & Ms (MPa) & D0 & D25 & D40 & D60 & D80 & D100 & D140 & D180 & D260 \\
\hline 46,92 & 539,80 & 46,20 & 53,87 & 43,87 & 38,88 & 33,33 & 28,57 & 24,50 & 18,22 & 13,96 & 9,12 \\
\hline 61,74 & 1544,90 & 180,90 & 13,44 & 10,16 & 8,94 & 7,75 & 6,77 & 5,93 & 4,57 & 3,60 & 2,40 \\
\hline 73,13 & 1607,00 & 148,30 & 13,55 & 10,12 & 9,10 & 8,11 & 7,30 & 6,58 & 5,34 & 4,38 & 3,04 \\
\hline 59,39 & 1915,80 & 27,10 & 42,71 & 34,78 & 33,44 & 32,09 & 30,38 & 28,65 & 25,30 & 22,21 & 17,02 \\
\hline 21,55 & 405,60 & 123,20 & 49,15 & 30,91 & 22,05 & 14,91 & 10,95 & 8,60 & 6,02 & 4,68 & 3,27 \\
\hline 55,30 & 541,10 & 199,90 & 23,08 & 14,13 & 11,09 & 8,61 & 6,93 & 5,68 & 4,01 & 3,05 & 2,06 \\
\hline 57,31 & 1031,20 & 48,50 & 35,99 & 29,73 & 27,64 & 25,06 & 22,70 & 20,51 & 16,67 & 13,59 & 9,33 \\
\hline 29,81 & 1657,80 & 170,60 & 21,39 & 16,80 & 13,96 & 10,86 & 8,53 & 6,81 & 4,64 & 3,48 & 2,35 \\
\hline 55,22 & 1998,40 & 181,70 & 12,70 & 10,09 & 9,00 & 7,84 & 6,85 & 5,99 & 4,60 & 3,60 & 2,38 \\
\hline 59,69 & 210,70 & 67,80 & 61,44 & 38,60 & 30,84 & 24,48 & 20,06 & 16,68 & 11,97 & 9,13 & 6,13 \\
\hline 77,32 & 440,60 & 43,00 & 46,77 & 34,23 & 30,66 & 27,32 & 24,65 & 22,29 & 18,22 & 15,01 & 10,52 \\
\hline 55,20 & 1138,10 & 62,40 & 30,24 & 25,04 & 23,04 & 20,66 & 18,51 & 16,54 & 13,19 & 10,59 & 7,15 \\
\hline 80,06 & 642,30 & 183,60 & 19,39 & 11,97 & 9,67 & 7,91 & 6,73 & 5,81 & 4,41 & 3,47 & 2,35 \\
\hline 74,44 & 266,70 & 132,30 & 39,24 & 21,65 & 16,28 & 12,45 & 10,10 & 8,40 & 6,07 & 4,67 & 3,18 \\
\hline 25,74 & 295,60 & 23,40 & 159,19 & 127,01 & 105,01 & 80,72 & 62,61 & 49,54 & 33,55 & 25,17 & 17,13 \\
\hline 38,04 & 401,70 & 166,70 & 32,93 & 20,04 & 15,16 & 11,05 & 8,43 & 6,67 & 4,59 & 3,51 & 2,43 \\
\hline 63,18 & 1977,10 & 101,00 & 16,84 & 13,53 & 12,58 & 11,46 & 10,45 & 9,50 & 7,83 & 6,46 & 4,51 \\
\hline 80,10 & 860,20 & 199,00 & 15,72 & 10,11 & 8,37 & 6,99 & 6,03 & 5,26 & 4,06 & 3,22 & 2,19 \\
\hline 78,16 & 1132,00 & 62,30 & 25,08 & 18,99 & 17,60 & 16,23 & 15,01 & 13,87 & 11,82 & 10,06 & 7,38 \\
\hline 87,10 & 228,00 & 117,60 & 44,37 & 23,86 & 17,74 & 13,52 & 11,04 & 9,26 & 6,81 & 5,30 & 3,62 \\
\hline 27,36 & 1179,30 & 79,40 & 42,57 & 34,87 & 29,47 & 23,28 & 18,44 & 14,79 & 10,09 & 7,52 & 5,05 \\
\hline 47,98 & 975,10 & 27,30 & 60,06 & 52,03 & 49,06 & 44,79 & 40,68 & 36,80 & 29,94 & 24,38 & 16,65 \\
\hline 41,78 & 1753,60 & 71,20 & 28,63 & 25,12 & 22,98 & 20,28 & 17,79 & 15,56 & 11,92 & 9,27 & 6,05 \\
\hline 64,62 & 604,70 & 32,20 & 53,00 & 42,26 & 39,25 & 35,73 & 32,58 & 29,65 & 24,46 & 20,23 & 14,17 \\
\hline 65,92 & 955,10 & 26,50 & 50,64 & 40,48 & 38,57 & 36,30 & 33,93 & 31,64 & 27,34 & 23,54 & $\begin{array}{l}\frac{1+,+1}{17,48} \\
\end{array}$ \\
\hline 35,54 & 1833,10 & 36,90 & 49,52 & 45,19 & 42,06 & 37,68 & 33,50 & 29,63 & 23,09 & 18,13 & $\begin{array}{l}1+, 40 \\
11,88\end{array}$ \\
\hline 30,78 & 1754,80 & 120,80 & 25,76 & 21,32 & 18,32 & 14,82 & 11,98 & 9,76 & 6,76 & 5,03 & 3,34 \\
\hline 49,43 & 1242,90 & 167,50 & 17,45 & 13,28 & 11,45 & 9,58 & 8,06 & 6,81 & 4,97 & 3,78 & 2,49 \\
\hline 75,54 & 1558,40 & 65,50 & 21,87 & 16,86 & 15,81 & 14,74 & 13,73 & 12,77 & 11,00 & 9,46 & 7,03 \\
\hline 54,71 & 1783,60 & 86,50 & 20,98 & 17,50 & $\frac{10,0 \pm}{16,20}$ & $\frac{14,60}{14,60}$ & 13,14 & 11,80 & $\frac{1+, 00}{9,47}$ & 7,65 & 5,19 \\
\hline 30,29 & 1040,70 & 29,50 & 78,84 & 70,85 & 63,84 & 54,81 & 46,67 & 39,65 & 28,90 & 21,77 & 14,01 \\
\hline 74,06 & 688,00 & 97,20 & 25,23 & 17,89 & 15,55 & 13,48 & 11,90 & 10,54 & 8,32 & 6,68 & 4,55 \\
\hline 37,53 & 1718,80 & 35,40 & 49,87 & 45,21 & 42,27 & 38,08 & 34,05 & 30,30 & 23,88 & 18,92 & 12,49 \\
\hline 46,19 & 762,40 & 172,20 & 22,26 & 15,47 & 12,71 & 10,10 & 8,16 & 6,68 & 4,69 & 3,54 & 2,37 \\
\hline 69,05 & 1672,90 & 143,90 & 13,91 & 10,61 & 9,58 & 8,54 & 7,67 & 6,89 & 5,57 & 4,53 & 3,12 \\
\hline 63,80 & 397,40 & 149,50 & 29,97 & 18,00 & 14,10 & 11,07 & 9,04 & 7,52 & 5,40 & 4,13 & 2,79 \\
\hline 69,22 & 420,20 & 167,20 & 27,21 & 15,96 & 12,40 & 9,72 & 7,98 & 6,67 & 4,83 & 3,72 & 2,51 \\
\hline 31,03 & 1043,10 & 106,10 & 33,32 & 26,30 & 22,03 & 17,30 & 13,69 & 10,99 & 7,52 & 5,63 & 3,79 \\
\hline 85,18 & 1720,80 & 157,80 & 11,87 & 8,51 & 7,64 & 6,87 & 6,26 & 5,72 & 4,78 & 4,01 & 2,89 \\
\hline 32,40 & 1554,20 & 126,00 & 25,14 & 20,50 & 17,55 & 14,17 & 11,45 & 9,33 & 6,47 & 4,82 & 3,20 \\
\hline 67,59 & 388,80 & 21,10 & 79,42 & 62,52 & 58,05 & 52,99 & 48,47 & 44,27 & 36,78 & 30,61 & 21,64 \\
\hline 89,90 & 1638,00 & 67,00 & 19,01 & 14,34 & 13,21 & 12,46 & 11,75 & 11,07 & 9,79 & 8,65 & 6,73 \\
\hline 37,25 & 409,40 & 76,50 & 51,54 & 37,35 & 30,58 & 23,76 & 18,74 & 15,06 & 10,37 & 7,81 & 5,28 \\
\hline 73,68 & 884,90 & 133,10 & 19,06 & 13,41 & 11,59 & 10,00 & 8,79 & 7,76 & 6,09 & 4,87 & 3,31 \\
\hline 64,04 & 1663,70 & 123,90 & 15,80 & 12,41 & 11,29 & 10,09 & 9,06 & 8,13 & 6,53 & 5,29 & 3,62 \\
\hline 69,66 & 887,10 & 23,10 & 54,85 & 43,45 & 41,30 & 39,16 & 36,83 & 34,55 & 30,22 & 26,33 & 19,95 \\
\hline 52,80 & 1883,60 & 103,50 & 18,75 & 15,67 & 14,37 & 12,82 & 11,43 & 10,16 & 8,02 & 6,39 & 4,28 \\
\hline 69,43 & 1593,60 & 48,50 & 27,65 & 21,86 & 20,74 & 19,52 & 18,26 & 17,05 & 14,78 & 12,76 & 9,53 \\
\hline 47,07 & 1890,40 & 98,10 & 20,86 & 17,81 & 16,25 & 14,36 & 12,65 & 11,11 & 8,59 & 6,73 & 4,43 \\
\hline 77,45 & 938,80 & 142,90 & 17,52 & 12,17 & 10,50 & 9,08 & 8,01 & 7,10 & 5,62 & 4,53 & 3,10 \\
\hline 24,46 & 1657,30 & 184,60 & 23,14 & 17,56 & 14,00 & 10,34 & 7,81 & 6,10 & 4,14 & 3,15 & 2,17 \\
\hline 62,25 & 293,20 & 88,10 & 44,85 & 28,48 & 22,94 & 18,41 & 15,23 & 12,77 & 9,25 & 7,08 & 4,74 \\
\hline 72,60 & 1290,00 & 171,20 & 13,99 & 10,06 & 8,79 & 7,64 & 6,76 & 5,99 & 4,73 & 3,80 & 2,58 \\
\hline 26,91 & 1877,80 & 62,10 & 43,69 & 38,30 & 33,75 & 28,06 & 23,17 & 19,16 & 13,46 & 9,99 & 6,51 \\
\hline 57,90 & 670,50 & 77,60 & 32,22 & 24,66 & 21,67 & 18,68 & 16,22 & 14,09 & 10,73 & 8,37 & 5,54 \\
\hline 34,83 & 345,70 & 173,90 & 35,33 & 20,44 & 14,96 & 10,59 & 7,97 & 6,28 & 4,34 & 3,34 & 2,34 \\
\hline 38,24 & 620,60 & 32,80 & 73,04 & 62,99 & 56,39 & 48,37 & 41,28 & 35,21 & 25,89 & 19,65 & 12,73 \\
\hline 23,02 & 599,50 & 161,50 & 35,25 & 22,96 & 16,76 & 11,51 & 8,47 & 6,63 & 4,61 & 3,57 & 2,49 \\
\hline 23,84 & 402,20 & 156,10 & 40,03 & 24,24 & 17,27 & 11,73 & 8,66 & 6,81 & 4,76 & 3,70 & 2,59 \\
\hline 33,78 & 1704,90 & 143,40 & 21,71 & 17,68 & 15,18 & 12,33 & 10,01 & 8,20 & 5,71 & 4,26 & 2,82 \\
\hline 78,24 & 1455,20 & 135,10 & 14,47 & 10,60 & 9,53 & 8,52 & 7,72 & 7,00 & 5,75 & 4,76 & 3,36 \\
\hline 80,13 & 1801,40 & 174,10 & 11,32 & 8,21 & 7,36 & 6,57 & 5,95 & 5,40 & 4,44 & 3,68 & 2,60 \\
\hline 43,56 & 1269,50 & 193,00 & 17,17 & 12,88 & 10,90 & 8,87 & 7,26 & 6,00 & 4,25 & 3,19 & 2,12 \\
\hline 46,34 & 1156,90 & 185,70 & 17,64 & 13,09 & 11,08 & 9,06 & 7,47 & 6,21 & 4,43 & 3,34 & 2,21 \\
\hline 47,05 & 1233,70 & 114,40 & 22,44 & 18,09 & 15,96 & 13,61 & 11,62 & $\frac{0, L \perp}{9,93}$ & $\frac{7,7,35}{7,35}$ & 5,62 & 3,67 \\
\hline 61,49 & 624,70 & 78,10 & 32,16 & 24,12 & 21,11 & $\frac{10,01}{18,21}$ & 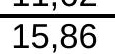 & 13,84 & 10,61 & 8,32 & 5,54 \\
\hline 27,35 & 952,60 & 160,20 & 28,22 & 20,45 & $\frac{L \perp, \pm \perp}{16,10}$ & $\frac{10,2+}{11,81}$ & $\begin{array}{l}10,00 \\
8,92\end{array}$ & $\begin{array}{c}10,0 \\
6,98\end{array}$ & $\frac{10,01}{4,76}$ & 3,63 & 2,51 \\
\hline 22,23 & 795,60 & 141,80 & 36,44 & 25,39 & 19,06 & 13,31 & 9,80 & 7,63 & 5,27 & 4,07 & 2,83 \\
\hline 76,33 & 1366,50 & 179,70 & 13,00 & 9,24 & 8,08 & 7,05 & 6,26 & 5,58 & 4,46 & 3,61 & 2,48 \\
\hline 55,33 & 385,30 & 188,10 & 28,87 & 16,46 & 12,43 & 9,36 & 7,40 & 6,00 & 4,19 & 3,20 & 2,19 \\
\hline 82.87 & 1994,40 & 198,10 & 9,93 & 7.12 & 6.37 & 5,69 & 5,15 & 4,68 & 3,87 & 3,22 & 2,29 \\
\hline 46,41 & 1199,60 & 171,60 & 18,13 & 13,72 & 11,72 & 9,68 & 8,04 & 6,71 & 4,82 & 3,64 & 2,40 \\
\hline 52,37 & 485,10 & 61,90 & 44,61 & 34,08 & 29,60 & 25,06 & 21,34 & 18,22 & 13,50 & 10,35 & 6,80 \\
\hline 24,34 & 776,50 & 67,10 & 59,23 & 46,39 & 37,69 & 28,37 & 21,68 & 17,01 & 11,50 & 8,69 & 5,96 \\
\hline 44,89 & 473,20 & 145,20 & 30,93 & 20,13 & 15,99 & 12,31 & 9,73 & 7,86 & 5,45 & 4,12 & 2,80 \\
\hline 62,30 & 1357,60 & 105,30 & 19,18 & 15,12 & 13,70 & 12,19 & 10,89 & 9,72 & 7,75 & 6,24 & 4,23 \\
\hline 87,21 & 1796,70 & 124,20 & 13,10 & 9,54 & 8,70 & 7,97 & 7,36 & 6,80 & 5,81 & 4,97 & 3,68 \\
\hline 60,63 & 988,80 & 69,90 & 28,23 & 22,55 & 20,53 & 18,32 & 16,40 & 14,65 & 11,69 & 9,41 & 6,38 \\
\hline 56,65 & 1401,60 & 72,20 & 25,15 & 20,77 & 19,20 & 17,32 & 15,60 & 14,02 & 11,29 & 9,15 & 6,23 \\
\hline 59,93 & 1459,30 & 187,70 & 13,74 & 10,30 & 8,99 & 7,72 & 6,69 & 5,81 & 4,43 & 3,45 & 2,29 \\
\hline 29,02 & 1033,60 & 73,40 & 44,80 & 36,72 & 31,22 & 24,87 & 19,86 & 16,02 & 10,99 & 8,19 & 5,47 \\
\hline 36,14 & 1278,50 & 108,40 & 27,43 & 22,39 & 19,38 & 15,93 & 13,09 & 10,82 & 7,63 & 5,70 & 3,75 \\
\hline
\end{tabular}




\begin{tabular}{|c|c|c|c|c|c|c|c|c|c|c|c|}
\hline \multirow[b]{2}{*}{ e1 (cm) } & & & & & & & ões (x1 & m) & & & \\
\hline & Meq (MPa) & Ms (MPa) & D0 & D25 & D40 & D60 & D80 & D100 & D140 & D180 & D260 \\
\hline 38,11 & 441,40 & 90,30 & 444,74 & 31,88 & 25,96 & 20,11 & 15,84 & 12,73 & 8,77 & 6,61 & 4,48 \\
\hline 59,10 & 925,90 & 40,80 & 441,06 & 33,70 & 31,50 & 28,73 & 26,17 & 23,78 & 19,54 & 16,08 & 11,17 \\
\hline 52,59 & 557,80 & 132,50 & 27,97 & 19,05 & 15,69 & 12,64 & 10,38 & 8,62 & 6,16 & 4,67 & 3,11 \\
\hline 52,65 & 618,20 & 28,80 & 63,64 & 53,62 & 49,62 & 44,66 & 40,10 & 35,89 & 28,67 & 23,05 & 15,55 \\
\hline 79,38 & 1534,70 & 162,80 & 12,70 & 9,16 & 8,15 & 7,23 & 6,51 & 5,88 & 4,80 & 3,96 & 2,77 \\
\hline 53,77 & 517,50 & 141,60 & 27,91 & 18,40 & 14,94 & 11,92 & 9,73 & 8,05 & 5,73 & 4,35 & 2,91 \\
\hline 75,74 & 267,50 & 35,90 & 65,92 & 46,83 & 40,88 & 35,62 & 31,59 & 28,11 & 22,37 & 18,06 & 12,38 \\
\hline 51,58 & 1064,50 & 141,70 & 20,02 & 15,22 & 13,17 & 11,09 & 9,40 & 7,99 & 5,88 & 4,50 & 2,96 \\
\hline 67,96 & 721,20 & 109,80 & 24,04 & 17,18 & 14,83 & 12,72 & 11,08 & 9,69 & 7,48 & 5,90 & 3,96 \\
\hline 45,35 & 1670,60 & 177,20 & 15,68 & 12,44 & 10,84 & 9,11 & 7,68 & 6,48 & 4,72 & 3,58 & 2,34 \\
\hline 61,65 & 1633,40 & 129,70 & 15,81 & 12,47 & 11,28 & 10,01 & 8,93 & 7,95 & 6,31 & 5,06 & 3,42 \\
\hline 37,56 & 957,70 & 157,20 & 23,71 & 17,58 & 14,56 & 11,45 & 9,11 & 7,36 & 5,09 & 3,82 & 2,57 \\
\hline 63,80 & 287,80 & 104,60 & 41,95 & 25,40 & 19,99 & 15,75 & 12,90 & 10,74 & 7,74 & 5,92 & 3,98 \\
\hline 49,92 & 862,40 & 46,30 & 43,06 & 36,37 & 33,27 & 29,55 & 26,19 & 23,14 & 18,07 & 14,28 & 9,47 \\
\hline 49,25 & 1607,90 & 136,50 & 17,62 & 14,30 & 12,73 & 10,99 & 9,49 & 8,19 & 6,16 & 4,76 & 3,12 \\
\hline 63,90 & 1595,20 & 127,00 & 15,86 & 12,41 & 11,24 & 10,00 & 8,95 & 8,01 & 6,40 & 5,17 & 3,52 \\
\hline 87,52 & 1505,70 & 46,50 & 24,74 & 19,17 & 17,72 & 16,89 & 16,06 & 15,21 & 13,61 & 12,13 & 9,60 \\
\hline 64,01 & 398,10 & 122,80 & 32,37 & 20,36 & 16,35 & 13,12 & 10,87 & 9,12 & 6,63 & 5,09 & 3,41 \\
\hline 57,54 & 1793,30 & 120,50 & 16,52 & 13,40 & 12,21 & 10,87 & 9,70 & 8,63 & 6,84 & 5,47 & 3,68 \\
\hline 22,55 & 772,80 & 196,80 & 28,75 & 18,86 & 13,78 & 9,45 & 6,95 & 5,43 & 3,78 & 2,93 & 2,05 \\
\hline 64,35 & 677,50 & 198,50 & 19,41 & 12,34 & 9,97 & 8,04 & 6,69 & 5,63 & 4,11 & 3,16 & 2,11 \\
\hline 68,94 & 272,50 & 167,40 & 36,35 & 19,16 & 13,96 & 10,32 & 8,18 & 6,68 & 4,73 & 3,63 & 2,49 \\
\hline 57,22 & 1429,40 & 62,70 & 27,18 & 22,50 & 21,00 & 19,10 & 17,35 & 15,71 & 12,83 & 10,50 & 7,24 \\
\hline 49,37 & 1598,50 & 190,00 & 14,57 & 11,31 & 9,84 & 8,31 & 7,04 & 5,99 & 4,40 & 3,36 & 2,20 \\
\hline 74,12 & 547,30 & 38,30 & 46,25 & 35,10 & 32,15 & 29,15 & 26,59 & 24,26 & 20,15 & 16,79 & 11,92 \\
\hline 43,99 & 985,00 & 174,10 & 20,20 & 14,76 & 12,35 & 9,93 & 8,08 & 6,64 & 4,67 & 3,52 & 2,34 \\
\hline 81,56 & 998,80 & 142,20 & 16,67 & 11,54 & 10,01 & 8,72 & 7,75 & 6,93 & 5,57 & 4,53 & 3,14 \\
\hline 57,47 & 1642,20 & 113,60 & 17,75 & 14,37 & 13,07 & 11,62 & 10,34 & 9,19 & 7,27 & 5,80 & 3,90 \\
\hline 49,17 & 1860,90 & 93,40 & 21,03 & 17,88 & 16,39 & 14,59 & 12,95 & 11,45 & 8,96 & 7,09 & 4,70 \\
\hline 52,54 & 1275,90 & 130,90 & 19,12 & 15,06 & 13,29 & 11,43 & 9,85 & 8,51 & 6,40 & 4,95 & 3,25 \\
\hline 77,44 & 1010,90 & 123,00 & 18,16 & 12,99 & 11,43 & 10,04 & 8,96 & 8,03 & 6,46 & 5,26 & 3,64 \\
\hline 21,29 & 1748,00 & 24,30 & 103,47 & 93,92 & 83,90 & 70,77 & 59,08 & 49,24 & 34,84 & 25,82 & 16,66 \\
\hline 52,75 & 1862,10 & 98,60 & 19,44 & 16,28 & 14,96 & 13,37 & 11,94 & 10,63 & 8,41 & 6,72 & 4,50 \\
\hline 60,69 & 1053,20 & 125,60 & 19,69 & 14,89 & 13,08 & 11,31 & 9,85 & 8,60 & 6,60 & 5,18 & 3,45 \\
\hline 78,63 & 253,00 & 50,90 & 57,02 & 37,76 & 31,72 & 26,82 & 23,32 & 20,44 & 15,89 & 12,66 & 8,60 \\
\hline 64,25 & 1121,50 & 146,00 & 17,17 & 12,70 & 11,09 & 9,58 & 8,37 & 7,32 & 5,65 & 4,45 & 2,98 \\
\hline 35,09 & 1259,30 & 46,80 & 48,34 & 42,88 & 38,75 & 33,52 & 28,79 & 24,67 & 18,25 & 13,87 & 8,96 \\
\hline 74,17 & 394,20 & 36,80 & 54,57 & 40,55 & 36,44 & 32,49 & 29,27 & 26,40 & 21,49 & 17,63 & 12,28 \\
\hline 80,34 & 1940,80 & 29,00 & 31,26 & 26,30 & 24,15 & 23,39 & 22,63 & 21,72 & 19,86 & 18,09 & 14,85 \\
\hline 59,70 & 1276,30 & 61,90 & 27,86 & 22,75 & 21,17 & 19,24 & 17,47 & 15,83 & 12,95 & 10,62 & 7,35 \\
\hline 58,49 & 1399,00 & 46,50 & 32,94 & 27,15 & 25,71 & 23,74 & 21,85 & 20,04 & 16,76 & 14,00 & 9,92 \\
\hline 65,36 & 229,80 & 93,80 & 49,94 & 29,31 & 22,72 & 17,69 & 14,41 & 11,96 & 8,59 & 6,58 & 4,44 \\
\hline 26,28 & 1110,50 & 62,30 & 52,78 & 43,86 & 37,29 & 29,62 & 23,54 & 18,92 & 12,92 & 9,60 & 6,43 \\
\hline 43,43 & 1305,20 & 26,70 & 59,54 & 52,53 & 49,82 & 45,63 & 41,53 & 37,62 & 30,66 & 24,98 & 17,03 \\
\hline 80,19 & 1573,60 & 125,50 & 14,38 & 10,59 & 9,62 & 8,69 & 7,94 & 7,26 & 6,06 & 5,08 & 3,64 \\
\hline 81,07 & 1304,70 & 84,70 & 19,39 & 14,43 & 13,25 & 12,13 & 11,18 & 10,30 & 8,74 & 7,42 & 5,41 \\
\hline 84,57 & 391,60 & 174,00 & 27,08 & 15,09 & 11,48 & 8,93 & 7,38 & 6,24 & 4,62 & 3,60 & 2,45 \\
\hline 75,51 & 981,10 & 35,50 & 38,16 & 29,57 & 27,82 & 26,14 & 24,47 & 22,87 & 19,87 & 17,22 & 12,95 \\
\hline 80,43 & 791,80 & 65,10 & 28,06 & 20,60 & 18,67 & 16,85 & 15,36 & 14,03 & 11,69 & 9,79 & 7,00 \\
\hline 54,48 & 1224,60 & 158,00 & 17,18 & 13,05 & 11,34 & 9,64 & 8,25 & 7,08 & 5,28 & 4,07 & 2,68 \\
\hline 44,87 & 1989,10 & 183,20 & 14,41 & 11,66 & 10,25 & 8,69 & 7,37 & 6,25 & 4,58 & 3,48 & 2,28 \\
\hline 47,57 & 882,30 & 128,00 & 24,12 & 18,18 & 15,55 & 12,87 & 10,72 & 8,98 & 6,47 & 4,90 & 3,23 \\
\hline 77,70 & 1983,90 & 22,20 & 37,06 & 32,50 & 29,64 & 28,75 & 27,98 & 26,99 & 24,87 & 22,82 & 19,01 \\
\hline 50,25 & 1277,40 & 38,80 & 42,04 & 36,04 & 33,97 & 31,04 & 28,24 & 25,59 & 20,89 & 17,07 & 11,72 \\
\hline 67,40 & 1616,60 & 172,60 & 12,93 & 9,71 & 8,62 & 7,57 & 6,72 & 5,97 & 4,72 & 3,78 & 2,57 \\
\hline 84,78 & 824,80 & 72,40 & 25,39 & 18,29 & 16,47 & 14,85 & 13,55 & 12,40 & 10,38 & 8,73 & 6,30 \\
\hline 50,37 & 753,30 & 149,80 & 23,12 & 16,39 & 13,70 & 11,14 & 9,19 & 7,65 & 5,47 & 4,15 & 2,75 \\
\hline 59,45 & 1799,50 & 56,70 & 26,29 & 21,56 & 20,48 & 18,98 & 17,53 & 16,13 & 13,58 & 11,41 & 8,15 \\
\hline 58,61 & 1926,80 & 22,50 & $\begin{array}{l}48,81 \\
\end{array}$ & 39,92 & 38,30 & 36,98 & 35,17 & 33,30 & 29,65 & 26,22 & 20,36 \\
\hline 59,69 & 1441,10 & 38,70 & 36,51 & 29,86 & 28,52 & 26,64 & 24,74 & 22,90 & 19,50 & 16,55 & 12,00 \\
\hline 50,98 & 1279,80 & 84,60 & 25,16 & 20,87 & 18,89 & 16,63 & 14,62 & 12,83 & 9,91 & 7,77 & 5,13 \\
\hline 83,27 & 756,20 & 149,50 & 18,86 & 12,37 & 10,39 & 8,82 & 7,71 & 6,80 & 5,35 & 4,30 & 2,95 \\
\hline 26,45 & 333,60 & 157,50 & 40,94 & 23,88 & 16,99 & 11,61 & 8,61 & 6,78 & 4,72 & 3,67 & 2,57 \\
\hline 84,26 & 1769,00 & 123,50 & 13,46 & 9,87 & 9,02 & 8,24 & 7,59 & 7,00 & 5,94 & 5,06 & 3,71 \\
\hline 43,71 & 1447,40 & 123,10 & 21,15 & 17,30 & 15,25 & 12,95 & 10,98 & 9,33 & 6,83 & 5,19 & 3,39 \\
\hline 21,39 & 346,40 & 96,00 & 61,74 & 39,48 & 28,33 & 19,20 & 14,09 & 11,05 & 7,73 & 6,00 & 4,19 \\
\hline 70,76 & 700,30 & 124,30 & 22,63 & 15,65 & 13,32 & 11,32 & 9,82 & 8,56 & 6,59 & 5,19 & 3,49 \\
\hline 79,01 & 844,50 & 156,10 & 17,69 & 11,87 & 10,06 & 8,57 & 7,49 & 6,60 & 5,16 & 4,13 & 2,82 \\
\hline 57,68 & 546,10 & 35,90 & 54,88 & 44,55 & 40,65 & 36,25 & 32,36 & 28,84 & 22,90 & 18,35 & 12,37 \\
\hline 80,27 & 1692,30 & 59,00 & 21,79 & 16,77 & 15,69 & 14,83 & 13,96 & 13,11 & 11,52 & 10,10 & 7,74 \\
\hline 53,31 & 1266,20 & 187,10 & 15,63 & 11,64 & 10,00 & 8,40 & 7,11 & 6,04 & 4,45 & 3,40 & 2,24 \\
\hline 88,98 & 1237,10 & 95,30 & 17,76 & 12,78 & 11,57 & 10,54 & 9,70 & 8,95 & 7,62 & 6,50 & 4,79 \\
\hline 55,15 & 824,80 & 85,00 & 28,68 & 22,45 & 19,85 & 17,16 & 14,89 & 12,93 & 9,83 & 7,65 & 5,05 \\
\hline 23,12 & 727,00 & 75,70 & 57,42 & 43,57 & 34,51 & 25,28 & 18,99 & 14,79 & 10,04 & 7,65 & 5,29 \\
\hline 27,24 & 760,60 & 122,20 & 36,54 & 26,67 & 21,05 & 15,48 & 11,71 & 9,17 & 6,25 & 4,76 & 3,28 \\
\hline 23,68 & 1200,30 & 191,10 & 25,30 & 18,14 & 13,94 & 9,94 & 7,38 & 5,75 & 3,94 & 3,03 & 2,10 \\
\hline 74,27 & 1658,90 & 167,50 & 12,42 & 9,16 & 8,18 & 7,26 & 6,51 & 5,86 & 4,74 & 3,87 & 2,69 \\
\hline 69,74 & 1013,70 & 58,00 & 29,05 & 22,63 & 20,97 & 19,13 & 17,51 & 16,01 & 13,33 & 11,13 & 7,90 \\
\hline 63,73 & 279,40 & 129,60 & 39,41 & 22,47 & 17,11 & 13,10 & 10,54 & 8,68 & 6,17 & 4,72 & 3,20 \\
\hline 50,14 & 1941,30 & 164,80 & 14,43 & 11,69 & 10,42 & 9,01 & 7,80 & 6,76 & 5,10 & 3,95 & 2,59 \\
\hline 78,27 & 1462,50 & 137,60 & 14,29 & 10,46 & 9,39 & 8,40 & 7,60 & 6,88 & 5,66 & 4,68 & 3,30 \\
\hline 83,10 & 1234,20 & 167,40 & 13,71 & 9,50 & 8,28 & 7,24 & 6,46 & 5,80 & 4,69 & 3,84 & 2,68 \\
\hline
\end{tabular}




\begin{tabular}{|c|c|c|c|c|c|c|c|c|c|c|c|}
\hline \multirow[b]{2}{*}{ e1 (cm) } & & & & & & & ões (x1 & & & & \\
\hline & Meq (MPa) & Ms (MPa) & D0 & D25 & D40 & D60 & D80 & D100 & D140 & D180 & D260 \\
\hline 43,98 & 1658,80 & 147,20 & 17,91 & 14,57 & 12,82 & 10,86 & 9,20 & 7,80 & 5,71 & 4,33 & 2,83 \\
\hline 31,86 & 1175,40 & 198,10 & 20,90 & 15,34 & 12,39 & 9,40 & 7,27 & 5,76 & 3,93 & 2,97 & 2,03 \\
\hline 76,97 & 1025,60 & 102,20 & 19,90 & 14,56 & 13,02 & 11,58 & 10,44 & 9,42 & 7,69 & 6,32 & 4,42 \\
\hline 30,29 & 818,70 & 182,50 & 25,74 & 17,92 & 14,01 & 10,28 & 7,80 & 6,13 & 4,19 & 3,19 & 2,21 \\
\hline 71,95 & 324,50 & 83,60 & 41,24 & 26,51 & 21,72 & 17,87 & 15,18 & 13,02 & 9,78 & 7,62 & 5,12 \\
\hline 84,69 & 1128,10 & 28,10 & 38,35 & 30,36 & 28,10 & 26,96 & 25,75 & 24,49 & 22,03 & 19,76 & 15,78 \\
\hline 78,62 & 755,40 & 191,60 & 17,35 & 11,01 & 9,02 & 7,46 & 6,40 & 5,54 & 4,23 & 3,34 & 2,26 \\
\hline 31,30 & 1410,50 & 104,40 & 30,18 & 24,80 & 21,26 & 17,16 & 13,86 & 11,28 & 7,81 & 5,82 & 3,86 \\
\hline 63,98 & 839,70 & 54,20 & 34,11 & 27,05 & 24,83 & 22,36 & 20,21 & 18,23 & 14,81 & 12,09 & 8,34 \\
\hline 81,47 & 844,20 & 34,60 & 39,20 & 29,84 & 27,84 & 26,13 & 24,48 & 22,91 & 19,99 & 17,41 & 13,21 \\
\hline 58,71 & 1940,30 & 143,10 & 14,28 & 11,45 & 10,39 & 9,22 & 8,20 & 7,29 & 5,76 & 4,60 & 3,09 \\
\hline 32,59 & 724,70 & 193,00 & 25,07 & 16,91 & 13,16 & 9,67 & 7,35 & 5,80 & 3,97 & 3,03 & 2,09 \\
\hline 81,06 & 1079,50 & 109,60 & 18,31 & 13,18 & 11,77 & 10,48 & 9,48 & 8,59 & 7,06 & 5,85 & 4,13 \\
\hline 46,32 & 1656,00 & 179,10 & 15,44 & 12,20 & 10,64 & 8,96 & 7,56 & 6,40 & 4,67 & 3,55 & 2,32 \\
\hline 45,08 & 670,50 & 122,40 & 28,76 & 20,87 & 17,45 & 14,05 & 11,45 & 9,43 & 6,65 & 5,01 & 3,34 \\
\hline 47,60 & 1125,00 & 42,10 & 42,99 & 37,20 & 34,56 & 31,10 & 27,87 & 24,88 & 19,77 & 15,80 & 10,57 \\
\hline 61,84 & 1488,60 & 113,40 & 17,75 & 14,04 & 12,73 & 11,33 & 10,13 & 9,04 & 7,20 & 5,79 & 3,93 \\
\hline 43,11 & 256,80 & 119,80 & 46,86 & 27,51 & 20,72 & 15,22 & 11,72 & 9,34 & 6,44 & 4,92 & 3,40 \\
\hline 61,19 & 550,60 & 177,50 & 23,31 & 14,59 & 11,65 & 9,27 & 7,62 & 6,35 & 4,57 & 3,49 & 2,34 \\
\hline 50,56 & 488,30 & 183,40 & 26,07 & 16,03 & 12,52 & 9,60 & 7,63 & 6,19 & 4,33 & 3,28 & 2,23 \\
\hline 81,89 & 279,30 & 51,20 & 53,02 & 35,33 & 29,93 & 25,55 & 22,41 & 19,81 & 15,62 & 12,57 & 8,62 \\
\hline 53,74 & 1763,50 & 71,10 & 24,17 & 20,35 & 19,00 & 17,25 & 15,62 & 14,10 & 11,44 & 9,30 & 6,36 \\
\hline 23,50 & 927,50 & 101,90 & 42,85 & 32,38 & 25,62 & 18,76 & 14,09 & 10,98 & 7,46 & 5,69 & 3,93 \\
\hline 40,77 & 1175,00 & 144,20 & 21,89 & 17,03 & 14,56 & 11,90 & 9,76 & 8,07 & 5,70 & 4,28 & 2,83 \\
\hline 22,31 & 1342,70 & 66,00 & 54,39 & 44,69 & 37,26 & 28,79 & 22,35 & 17,66 & 11,91 & 8,91 & 6,05 \\
\hline 59,40 & 792,10 & 83,80 & 28,26 & 21,80 & 19,30 & 16,78 & 14,68 & 12,85 & 9,91 & 7,79 & 5,18 \\
\hline 41,28 & 1250,90 & 123,60 & 23,24 & 18,65 & 16,21 & 13,49 & 11,24 & 9,40 & 6,74 & 5,08 & 3,33 \\
\hline 59,53 & 1422,80 & 149,70 & 15,76 & 12,16 & 10,77 & 9,37 & 8,20 & 7,19 & 5,54 & 4,36 & 2,90 \\
\hline 85,45 & 589,60 & 82,50 & 27,99 & 19,18 & 16,66 & 14,54 & 12,99 & 11,67 & 9,47 & 7,77 & 5,45 \\
\hline 39,59 & 1730,50 & 68,70 & 30,65 & 27,03 & 24,63 & 21,60 & 18,83 & 16,37 & 12,40 & 9,57 & 6,22 \\
\hline 73,65 & 1759,00 & 174,60 & 11,86 & 8,78 & 7,85 & 6,97 & 6,26 & 5,63 & 4,55 & 3,72 & 2,58 \\
\hline 21,57 & 852,80 & 95,20 & 48,70 & 36,17 & 28,06 & 20,10 & 14,91 & 11,58 & 7,90 & 6,06 & 4,20 \\
\hline 55,16 & 1294,30 & 60,40 & 29,49 & 24,59 & 22,82 & 20,63 & 18,62 & 16,75 & 13,51 & 10,95 & 7,46 \\
\hline 45,25 & 1685,00 & 80,20 & 25,41 & 21,92 & 20,02 & 17,70 & 15,57 & 13,67 & 10,53 & 8,24 & 5,41 \\
\hline 41,28 & 1621,70 & 68,70 & 30,39 & 26,62 & 24,27 & 21,33 & 18,65 & 16,25 & 12,37 & 9,58 & 6,24 \\
\hline 53,44 & 443,10 & 195,30 & 26,38 & 15,50 & 11,87 & 9,01 & 7,14 & 5,79 & 4,05 & 3,08 & 2,10 \\
\hline 49,15 & 1058,20 & 190,50 & 17,56 & 12,71 & 10,70 & 8,75 & 7,23 & 6,02 & 4,32 & 3,27 & 2,16 \\
\hline 26,54 & 729,10 & 120,30 & 38,01 & 27,54 & 21,59 & 15,75 & 11,85 & 9,27 & 6,32 & 4,83 & 3,34 \\
\hline 51,24 & 525,40 & 169,90 & 25,86 & 16,47 & 13,10 & 10,22 & 8,21 & 6,71 & 4,71 & 3,57 & 2,41 \\
\hline 78,35 & 297,60 & 196,10 & 32,20 & 16,53 & 11,88 & 8,72 & 6,91 & 5,67 & 4,04 & 3,12 & 2,14 \\
\hline 61,61 & 1548,00 & 32,80 & 39,08 & 31,65 & 30,37 & 28,74 & 26,96 & 25,21 & 21,89 & 18,92 & 14,12 \\
\hline 48,55 & 1886,70 & 35,30 & 40,79 & 34,88 & 33,48 & 31,13 & 28,75 & 26,44 & 22,18 & 18,55 & 13,11 \\
\hline 86,69 & 1072,50 & 129,20 & 16,44 & 11,43 & 10,05 & 8,87 & 7,99 & 7,24 & 5,95 & 4,93 & 3,50 \\
\hline 88,84 & 375,30 & 181,50 & 27,37 & 14,89 & 11,17 & 8,59 & 7,06 & 5,96 & 4,41 & 3,45 & 2,36 \\
\hline 54,03 & 1589,70 & 189,70 & 13,88 & 10,67 & 9,33 & 7,96 & 6,84 & 5,88 & 4,40 & 3,40 & 2,24 \\
\hline 81,80 & 1732,80 & 92,10 & 16,32 & 12,25 & 11,34 & 10,50 & 9,76 & 9,06 & 7,79 & 6,69 & 4,98 \\
\hline 45,06 & 733,90 & 52,60 & 45,31 & 37,74 & 33,71 & 29,06 & 25,01 & 21,51 & 16,06 & 12,32 & 8,03 \\
\hline 63,75 & 379,10 & 133,60 & 32,25 & 19,68 & 15,55 & 12,29 & 10,09 & 8,41 & 6,07 & 4,64 & 3,12 \\
\hline 41,48 & 1203,10 & 36,00 & 51,39 & 45,72 & 42,42 & 37,99 & 33,82 & 29,98 & 23,49 & 18,55 & 12,24 \\
\hline 56,33 & 732,80 & 78,80 & 31,15 & 24,17 & 21,33 & 18,43 & 16,00 & 13,90 & 10,58 & 8,25 & 5,45 \\
\hline 71,74 & 1853,80 & 115,00 & 14,91 & 11,48 & 10,59 & 9,65 & 8,82 & 8,06 & 6,71 & 5,60 & 3,98 \\
\hline 52,00 & 1549,80 & 104,20 & 20,31 & 16,78 & 15,19 & 13,39 & 11,79 & 10,37 & 8,03 & 6,32 & 4,18 \\
\hline 27,41 & 1237,00 & 158,60 & 26,13 & 19,74 & 15,90 & 11,92 & 9,11 & 7,17 & 4,87 & 3,68 & 2,53 \\
\hline 50,07 & 1559,30 & 189,20 & 14,64 & 11,32 & 9,84 & 8,31 & 7,05 & 6,00 & 4,42 & 3,37 & 2,21 \\
\hline 59,35 & 1249,50 & 33,00 & 42,66 & 34,94 & 33,38 & 31,18 & 28,96 & 26,81 & 22,82 & 19,37 & 14,04 \\
\hline 35,54 & 831,30 & 168,70 & 24,76 & 17,66 & 14,27 & 10,91 & 8,50 & 6,78 & 4,65 & 3,51 & 2,39 \\
\hline 42,80 & 1857,30 & 149,20 & 17,31 & 14,26 & 12,60 & 10,70 & 9,07 & 7,71 & 5,64 & 4,28 & 2,79 \\
\hline 68,63 & 268,80 & 180,40 & 35,91 & 18,51 & 13,29 & 9,70 & 7,62 & 6,20 & 4,36 & 3,35 & 2,31 \\
\hline 31,53 & 1859,20 & 55,90 & 41,05 & 36,83 & 33,25 & 28,63 & 24,46 & 20,85 & 15,28 & 11,54 & 7,43 \\
\hline 82,64 & 816,80 & 127,60 & 19,43 & 13,23 & 11,39 & 9,85 & 8,72 & 7,77 & 6,22 & 5,05 & 3,49 \\
\hline 44,62 & 1925,80 & 144,10 & 16,94 & 14,05 & 12,51 & 10,74 & 9,21 & 7,89 & 5,86 & 4,48 & 2,92 \\
\hline 35,12 & 1357,70 & 21,70 & 79,13 & 72,38 & 67,97 & 61,46 & 55,14 & 49,20 & 38,94 & 30,94 & 20,46 \\
\hline 39,46 & 1029,70 & 79,60 & 33,85 & 28,03 & 24,63 & 20,70 & 17,37 & 14,60 & 10,53 & 7,94 & 5,18 \\
\hline 88,32 & 1000,00 & 119,00 & 17,61 & 12,19 & 10,73 & 9,49 & 8,56 & $\begin{array}{c}1+7,00 \\
7,77\end{array}$ & 6,41 & 5,34 & 3,80 \\
\hline 55,72 & 1069,50 & 109,00 & 22,13 & 17,32 & 15,33 & 13,28 & 11,55 & 10,04 & 7,66 & 5,97 & 3,95 \\
\hline 20,13 & 229,90 & 197,50 & 41,72 & 19,99 & 13,18 & 8,82 & 6,63 & 5,30 & 3,72 & 2,91 & 2,07 \\
\hline 84,26 & 449,60 & 39,30 & 46,79 & 33,78 & 30,44 & 27,43 & 25,03 & 22,90 & 19,15 & 16,10 & 11,60 \\
\hline 89,96 & 200,20 & 196,40 & 43,53 & 20,37 & 13,68 & 9,38 & 7,13 & 5,71 & 3,97 & 3,06 & 2,14 \\
\hline 38,66 & 712,30 & 71,50 & 42,26 & 33,82 & 29,17 & 23,97 & 19,73 & 16,33 & 11,56 & 8,66 & 5,70 \\
\hline 30,92 & 1740,00 & 120,50 & 25,78 & 21,33 & 18,33 & 14,83 & 12,00 & 9,78 & 6,78 & 5,05 & 3,34 \\
\hline 43,47 & 1555,30 & 85,20 & 25,90 & 22,19 & 20,06 & 17,49 & 15,19 & 13,17 & 9,95 & 7,68 & 5,00 \\
\hline 51,78 & 1195,20 & 90,80 & 24,54 & 20,05 & 18,02 & 15,76 & 13,79 & 12,05 & 9,24 & 7,22 & 4,76 \\
\hline 50,42 & 1869,50 & 55,60 & 29,09 & 24,91 & 23,51 & 21,51 & 19,59 & 17,78 & 14,55 & 11,91 & 8,19 \\
\hline 68,62 & 716,50 & 64,50 & 31,76 & 24,15 & 21,73 & 19,32 & 17,31 & 15,52 & 12,47 & 10,12 & 6,94 \\
\hline 38,98 & 291,60 & 170,80 & 37,79 & 20,87 & 15,12 & 10,73 & 8,12 & 6,42 & 4,43 & 3,41 & 2,39 \\
\hline 51,10 & 1931,90 & 115,90 & 17,67 & 14,76 & 13,44 & 11,90 & 10,52 & 9,28 & 7,22 & 5,69 & 3,77 \\
\hline 25,40 & 1509,70 & 32,10 & 76,75 & 69,23 & 61,96 & 52,52 & 44,11 & 37,00 & 26,43 & 19,70 & 12,70 \\
\hline 84,99 & 1967,50 & 53,70 & 20,81 & 16,31 & 15,12 & 14,47 & 13,78 & 13,08 & 11,72 & 10,47 & 8,31 \\
\hline 70,10 & 1011,20 & 174,20 & 15,95 & 11,11 & 9,48 & 8,07 & 7,01 & 6,11 & 4,70 & 3,71 & 2,49 \\
\hline 21,81 & 843,90 & 152,60 & 34,35 & 23,79 & 17,76 & 12,34 & 9,07 & 7,06 & 4,89 & 3,78 & 2,63 \\
\hline 58,68 & 1377,90 & 134,40 & 17,11 & 13,36 & 11,89 & 10,38 & 9,11 & 7,99 & 6,18 & 4,87 & 3,24 \\
\hline 87,21 & 1031,40 & 165,00 & 14,93 & 10,00 & 8,57 & 7,41 & 6,58 & 5,89 & 4,75 & 3,88 & 2,71 \\
\hline
\end{tabular}




\begin{tabular}{|c|c|c|c|c|c|c|c|c|c|c|c|}
\hline \multirow[b]{2}{*}{$\mathrm{e} 1(\mathrm{~cm})$} & & & & & & $\mathrm{De}$ & $\overline{\text { ões (x1 }}$ & & & & \\
\hline & Meq (MPa) & Ms (MPa) & D0 & D25 & D40 & D60 & D80 & D100 & D140 & D180 & D260 \\
\hline 42,12 & 505,50 & 134,30 & 32,07 & 21,63 & 17,36 & 13,39 & 10,57 & 8,51 & 5,89 & 4,45 & 3,02 \\
\hline 52,64 & 1267,00 & 149,80 & 17,76 & 13,72 & 11,98 & 10,20 & 8,73 & 7,49 & 5,58 & 4,29 & 2,82 \\
\hline 85,00 & 543,70 & 116,20 & 25,23 & 16,26 & 13,54 & 11,41 & 9,95 & 8,76 & 6,87 & 5,52 & 3,79 \\
\hline 69,81 & 448,80 & 73,00 & 37,00 & 26,03 & 22,34 & 19,10 & 16,62 & 14,54 & 11,22 & 8,87 & 5,96 \\
\hline 74,67 & 1965,60 & 102,60 & 15,28 & 11,73 & 10,91 & 10,05 & 9,28 & 8,57 & 7,27 & 6,16 & 4,48 \\
\hline 26,45 & 1796,30 & 79,50 & 38,10 & 32,44 & 28,04 & 22,72 & 18,35 & 14,92 & 10,29 & 7,63 & 5,05 \\
\hline 54,61 & 823,20 & 171,10 & 19,92 & 13,90 & 11,61 & 9,51 & 7,91 & 6,64 & 4,81 & 3,66 & 2,43 \\
\hline 56,64 & 1077,70 & 125,80 & 20,19 & 15,48 & 13,58 & 11,68 & 10,10 & 8,75 & 6,63 & 5,15 & 3,40 \\
\hline 66,76 & 1424,00 & 115,30 & 17,21 & 13,30 & 12,05 & 10,75 & 9,66 & 8,67 & 6,99 & 5,67 & 3,90 \\
\hline 43,55 & 1141,40 & 146,80 & 21,04 & 16,23 & 13,92 & 11,46 & 9,48 & 7,89 & 5,63 & 4,24 & 2,80 \\
\hline 79,34 & 632,30 & 157,40 & 20,83 & 13,24 & 10,87 & 9,01 & 7,74 & 6,72 & 5,15 & 4,07 & 2,76 \\
\hline 29,55 & 264,60 & 121,40 & 50,91 & 30,11 & 21,84 & 15,18 & 11,31 & 8,89 & 6,16 & 4,77 & 3,34 \\
\hline 51,80 & 339,80 & 157,70 & 33,92 & 19,71 & 14,98 & 11,26 & 8,86 & 7,16 & 4,99 & 3,80 & 2,60 \\
\hline 80,23 & 200,80 & 165,10 & 45,11 & 21,98 & 15,21 & 10,77 & 8,35 & 6,76 & 4,75 & 3,66 & 2,54 \\
\hline 61,17 & 1753,60 & 99,40 & 18,12 & 14,63 & 13,50 & 12,20 & 11,04 & 9,96 & 8,10 & 6,61 & 4,55 \\
\hline 76,58 & 1100,90 & 35,00 & 36,56 & 28,41 & 26,74 & 25,30 & 23,81 & 22,35 & 19,61 & 17,15 & 13,09 \\
\hline 20,30 & 1309,30 & 115,90 & 39,12 & 29,59 & 23,09 & 16,60 & 12,31 & 9,54 & 6,50 & 4,98 & 3,45 \\
\hline 64,59 & 954,00 & 77,20 & 26,14 & 20,36 & 18,43 & 16,41 & 14,69 & 13,14 & 10,52 & 8,50 & 5,79 \\
\hline 65,56 & 563,70 & 179,10 & 22,43 & 13,97 & 11,18 & 8,95 & 7,42 & 6,24 & 4,55 & 3,49 & 2,34 \\
\hline 74,61 & 942,30 & 62,90 & 27,53 & 20,90 & 19,20 & 17,46 & 15,97 & 14,61 & 12,19 & 10,19 & 7,27 \\
\hline 64,82 & 817,10 & 178,50 & 18,24 & 12,33 & 10,28 & 8,53 & 7,24 & 6,19 & 4,61 & 3,57 & 2,38 \\
\hline 39,22 & 1249,40 & 76,10 & 32,51 & 27,65 & 24,62 & 21,01 & 17,86 & 15,18 & 11,11 & 8,42 & 5,46 \\
\hline 27,68 & 1651,80 & 106,60 & 30,99 & 25,54 & 21,69 & 17,24 & 13,72 & 11,04 & 7,55 & 5,62 & 3,76 \\
\hline 75,14 & 1369,90 & 116,20 & 16,45 & 12,27 & 11,10 & 9,96 & 9,03 & 8,18 & 6,72 & 5,55 & 3,90 \\
\hline 22,11 & 1676,50 & 105,80 & 36,74 & 29,37 & 23,99 & 18,11 & 13,83 & 10,84 & 7,30 & 5,51 & 3,77 \\
\hline 64,48 & 1481,30 & 56,00 & 26,97 & 21,65 & 20,44 & 18,92 & 17,48 & 16,10 & 13,59 & 11,46 & 8,24 \\
\hline 60,49 & 1939,60 & 97,20 & 17,81 & 14,48 & 13,46 & 12,23 & 11,11 & 10,06 & 8,23 & 6,75 & 4,67 \\
\hline 30,63 & 1652,40 & 47,40 & 48,82 & 43,87 & 39,56 & 34,00 & 28,99 & 24,66 & 18,01 & 13,57 & 8,74 \\
\hline 36,08 & 1428,80 & 156,20 & 20,94 & 16,52 & 14,06 & 11,33 & 9,17 & 7,49 & 5,21 & 3,90 & 2,59 \\
\hline 47,73 & 450,70 & 170,10 & 28,69 & 17,69 & 13,77 & 10,48 & 8,26 & 6,67 & 4,63 & 3,52 & 2,40 \\
\hline 65,64 & 1702,40 & 107,10 & 16,85 & 13,29 & 12,23 & 11,05 & 10,02 & 9,07 & 7,42 & 6,09 & 4,23 \\
\hline 27,35 & 1055,70 & 95,30 & 38,95 & 30,82 & 25,50 & 19,67 & 15,31 & 12,15 & 8,25 & 6,19 & 4,20 \\
\hline 50,55 & 388,20 & 78,30 & 44,47 & 31,43 & 26,24 & 21,33 & 17,59 & 14,63 & 10,47 & 7,93 & 5,27 \\
\hline 55,74 & 425,00 & 197,60 & 26,65 & 15,38 & 11,70 & 8,86 & 7,03 & 5,72 & 4,01 & 3,05 & 2,08 \\
\hline 31,68 & 1173,50 & 125,60 & 28,24 & 22,18 & 18,56 & 14,59 & 11,55 & 9,28 & 6,36 & 4,76 & 3,20 \\
\hline 42,91 & 575,20 & 28,00 & 76,23 & 65,96 & 59,93 & 52,54 & 45,84 & 39,90 & 30,33 & 23,48 & 15,32 \\
\hline 37,97 & 705,90 & 59,30 & 48,23 & 39,50 & 34,40 & 28,55 & 23,68 & 19,72 & 14,04 & 10,53 & 6,90 \\
\hline 77,75 & 336,40 & 36,50 & 57,76 & 41,77 & 37,11 & 32,85 & 29,51 & 26,57 & 21,58 & 17,69 & 12,33 \\
\hline 37,70 & 1944,50 & 129,30 & 20,37 & 17,15 & 15,14 & 12,76 & 10,72 & 9,02 & 6,50 & 4,90 & 3,19 \\
\hline 69,48 & 1370,30 & 113,70 & 17,28 & 13,19 & 11,94 & 10,68 & 9,62 & 8,66 & 7,02 & 5,73 & 3,96 \\
\hline 70,57 & 371,50 & 84,00 & 38,30 & 25,36 & 21,07 & 17,54 & 14,99 & 12,91 & 9,75 & 7,62 & 5,11 \\
\hline 40,97 & 652,80 & 54,50 & 49,60 & 40,70 & 35,73 & 30,06 & 25,27 & 21,28 & 15,39 & 11,62 & 7,58 \\
\hline 48,65 & 1822,20 & 66,40 & 26,65 & 22,98 & 21,41 & 19,34 & 17,40 & 15,59 & 12,47 & 10,02 & 6,75 \\
\hline 20,60 & 657,10 & 51,20 & 84,75 & 65,30 & 51,67 & 37,65 & 28,13 & 21,83 & 14,80 & 11,29 & 7,81 \\
\hline 43,63 & 1950,60 & 58,20 & 30,62 & 27,03 & 25,20 & 22,71 & 20,34 & 18,15 & 14,39 & 11,47 & 7,64 \\
\hline 34,83 & 1529,00 & 47,80 & 44,86 & 40,27 & 36,66 & 32,00 & 27,72 & 23,94 & 17,92 & 13,70 & 8,85 \\
\hline 29,48 & 1286,60 & 176,00 & 22,96 & 17,31 & 14,05 & 10,65 & 8,22 & 6,50 & 4,42 & 3,34 & 2,28 \\
\hline 68,20 & 258,90 & 180,50 & 36,90 & 18,85 & 13,45 & 9,75 & 7,63 & 6,19 & 4,35 & 3,34 & 2,30 \\
\hline 66,15 & 1792,90 & 159,50 & 13,01 & 10,00 & 9,00 & 7,98 & 7,13 & 6,37 & 5,09 & 4,10 & 2,80 \\
\hline 29,89 & 942,60 & 187,40 & 24,26 & 17,23 & 13,58 & 10,03 & 7,62 & 5,99 & 4,09 & 3,11 & 2,15 \\
\hline 21,62 & 1182,20 & 184,70 & 27,44 & 19,42 & 14,65 & 10,26 & 7,55 & 5,87 & 4,05 & 3,12 & 2,17 \\
\hline 61,36 & 419,50 & 98,80 & 35,07 & 23,52 & 19,46 & 15,96 & 13,39 & 11,33 & 8,31 & 6,38 & 4,25 \\
\hline 52,63 & 304,20 & 154,00 & 36,41 & 20,64 & 15,49 & 11,55 & 9,06 & 7,31 & 5,09 & 3,88 & 2,66 \\
\hline 78,71 & 1289,10 & 145,80 & 14,68 & 10,54 & 9,33 & 8,24 & 7,40 & 6,66 & 5,40 & 4,43 & 3,09 \\
\hline 87,82 & 964,60 & 54,20 & 27,32 & 20,15 & 18,52 & 17,17 & 15,99 & 14,90 & 12,90 & 11,17 & 8,42 \\
\hline 78,94 & 969,40 & 194,10 & 14,89 & 9,86 & 8,29 & 7,01 & 6,10 & 5,35 & 4,16 & 3,32 & 2,26 \\
\hline 44,34 & 347,90 & 119,60 & 39,87 & 25,28 & 19,81 & 15,05 & 11,81 & 9,49 & 6,57 & 4,98 & 3,40 \\
\hline 60,31 & 1887,30 & 183,50 & 12,33 & 9,58 & 8,54 & 7,48 & 6,58 & 5,79 & 4,51 & 3,57 & 2,38 \\
\hline 83,58 & 970,90 & 57,40 & 27,06 & 20,10 & 18,51 & 17,07 & 15,81 & 14,65 & 12,56 & 10,77 & 7,98 \\
\hline 27,93 & 1977,50 & 87,30 & 33,16 & 28,44 & 24,78 & 20,32 & 16,59 & 13,60 & 9,47 & 7,03 & 4,62 \\
\hline 24,45 & 376,00 & 180,80 & 36,69 & 21,14 & 14,84 & 10,04 & 7,43 & 5,86 & 4,10 & 3,19 & 2,24 \\
\hline 56,44 & 1666,90 & 37,30 & 37,03 & 30,61 & 29,37 & 27,51 & 25,58 & 23,71 & 20,22 & 17,18 & 12,46 \\
\hline 87,66 & 1034,00 & 116,00 & 17,59 & 12,28 & 10,85 & 9,64 & 8,72 & 7,92 & 6,56 & 5,47 & 3,91 \\
\hline 34,68 & 1911,00 & 26,40 & 62,99 & 57,61 & 54,37 & 49,42 & 44,56 & 39,96 & 31,90 & 25,51 & 16,99 \\
\hline 50,08 & 1431,40 & 78,70 & 25,52 & 21,52 & 19,66 & 17,45 & 15,45 & 13,65 & 10,65 & 8,41 & 5,57 \\
\hline 47,22 & 1367,60 & 31,10 & 49,95 & 43,30 & 41,17 & 37,86 & 34,62 & 31,52 & 25,94 & 21,33 & 14,73 \\
\hline 81,02 & 1758,10 & 183,70 & 11,08 & 7,95 & 7,08 & 6,30 & 5,69 & 5,15 & 4,23 & 3,49 & 2,46 \\
\hline 71,92 & 1330,40 & 72,40 & 22,45 & 17,37 & 16,14 & 14,80 & 13,61 & 12,50 & 10,50 & 8,83 & 6,34 \\
\hline 56,39 & 1320,30 & 123,50 & 18,69 & 14,76 & 13,15 & 11,46 & 10,03 & 8,77 & 6,75 & 5,29 & 3,51 \\
\hline 74,30 & 1947,90 & 45,10 & 25,74 & 20,37 & 19,22 & 18,39 & 17,45 & 16,49 & 14,65 & 12,95 & 10,08 \\
\hline 77,23 & 1667,90 & 42,40 & 27,53 & 21,65 & 20,34 & 19,44 & 18,43 & 17,42 & 15,48 & 13,70 & 10,68 \\
\hline 83,87 & 789,50 & 131,50 & 19,42 & 13,06 & 11,16 & 9,61 & 8,49 & 7,55 & 6,03 & 4,89 & 3,38 \\
\hline 49,98 & 755,20 & 192,00 & 20,41 & 13,76 & 11,23 & 8,93 & 7,25 & 5,96 & 4,21 & 3,19 & 2,14 \\
\hline 36,07 & 1586,70 & 154,60 & 20,28 & 16,25 & 13,94 & 11,33 & 9,23 & 7,58 & 5,30 & 3,96 & 2,62 \\
\hline 70,60 & 1522,70 & 36,00 & 33,71 & 26,73 & 25,38 & 24,18 & 22,84 & 21,50 & 18,95 & 16,62 & 12,74 \\
\hline 75,97 & 1137,90 & 167,20 & 14,81 & 10,39 & 9,00 & 7,79 & 6,87 & 6,09 & 4,82 & 3,88 & 2,65 \\
\hline 61,55 & 253,20 & 142,90 & 40,83 & 22,20 & 16,41 & 12,22 & 9,66 & 7,86 & 5,52 & 4,22 & 2,89 \\
\hline 48,43 & 1942,50 & 20,30 & 60,32 & 50,33 & 48,94 & 46,60 & 43,83 & 41,06 & 35,72 & 30,87 & 22,98 \\
\hline 23,95 & 454,10 & 54,30 & 81,37 & 60,96 & 48,09 & 35,13 & 26,37 & 20,56 & 13,98 & 10,66 & 7,37 \\
\hline 68,89 & 512,90 & 174,70 & 23,65 & 14,40 & 11,42 & 9,11 & 7,56 & 6,36 & 4,65 & 3,59 & 2,41 \\
\hline 50,06 & 1820,70 & 42,90 & 35,27 & 30,14 & 28,73 & 26,53 & 24,37 & 22,30 & 18,52 & 15,36 & 10,74 \\
\hline 72,33 & 932,70 & 166,10 & 16,82 & 11,57 & 9,85 & 8,38 & 7,28 & 6,36 & 4,91 & 3,89 & 2,62 \\
\hline
\end{tabular}




\begin{tabular}{|c|c|c|c|c|c|c|c|c|c|c|c|}
\hline & & & \multicolumn{9}{|c|}{ Deflexões $\left(\times 10^{-4} \mathrm{~cm}\right)$} \\
\hline e1 (cm) & Meq (MPa) & Ms (MPa) & D0 & D25 & D40 & D60 & D80 & D100 & D140 & D180 & D260 \\
\hline 68,13 & 1839,90 & 59,80 & 23,21 & 18,40 & 17,45 & 16,35 & 15,24 & 14,18 & 12,20 & 10,47 & 7,73 \\
\hline 64,18 & 1617,70 & 22,60 & 488,03 & 39,04 & 37,18 & 35,91 & 34,22 & 32,45 & 28,99 & 25,75 & 20,15 \\
\hline 45,14 & 627,90 & 37,00 & 59,64 & 50,63 & 45,72 & 39,90 & 34,71 & 30,14 & 22,84 & 17,67 & 11,54 \\
\hline 47,03 & 1526,20 & 73,40 & 27,15 & 23,29 & 21,34 & 18,93 & 16,74 & 14,76 & 11,47 & 9,02 & 5,95 \\
\hline 49,27 & 562,50 & 101,20 & 33,01 & 23,89 & 20,12 & 16,46 & 13,61 & 11,34 & 8,13 & 6,15 & 4,08 \\
\hline 37,43 & 552,60 & 150,10 & 30,52 & 20,54 & 16,25 & 12,25 & 9,49 & 7,55 & 5,18 & 3,93 & 2,69 \\
\hline 36,95 & 1289,10 & 88,20 & 30,64 & 25,70 & 22,60 & 18,94 & 15,83 & 13,26 & 9,51 & 7,14 & 4,65 \\
\hline 28,91 & 950,80 & 138,40 & 30,16 & 22,48 & 18,10 & 13,59 & 10,42 & 8,21 & 5,59 & 4,23 & 2,90 \\
\hline 84,03 & 202,20 & 198,90 & 43,09 & 20,16 & 13,53 & 9,27 & 7,04 & 5,62 & 3,91 & 3,01 & 2,11 \\
\hline 33,84 & 1256,00 & 180,60 & 20,89 & 15,78 & 13,04 & 10,15 & 7,99 & 6,40 & 4,39 & 3,30 & 2,23 \\
\hline 79,67 & 1489,60 & 82,10 & 18,85 & 14,20 & 13,15 & 12,14 & 11,24 & 10,40 & 8,89 & 7,59 & 5,59 \\
\hline 63,52 & 1147,40 & 166,40 & 15,96 & 11,64 & 10,07 & 8,62 & 7,48 & 6,50 & 4,97 & 3,89 & 2,59 \\
\hline 85,97 & 1844,80 & 120,40 & 13,27 & 9,73 & 8,91 & 8,18 & 7,56 & 7,00 & 5,99 & 5,13 & 3,80 \\
\hline 63,65 & 1783,30 & 190,70 & 12,04 & 9,15 & 8,12 & 7,10 & 6,26 & 5,52 & 4,31 & 3,43 & 2,30 \\
\hline 77,11 & 1815,80 & 43,70 & 26,19 & 20,67 & 19,41 & 18,59 & 17,66 & 16,71 & 14,89 & 13,21 & 10,34 \\
\hline 37,31 & 640,10 & 125,40 & 32,01 & 22,99 & 18,75 & 14,51 & 11,42 & 9,17 & 6,31 & 4,75 & 3,22 \\
\hline 66,02 & 305,70 & 151,80 & 34,93 & 19,51 & 14,70 & 11,18 & 8,98 & 7,39 & 5,26 & 4,03 & 2,74 \\
\hline 60,62 & 691,90 & 113,30 & 25,44 & 18,32 & 15,69 & 13,25 & 11,34 & 9,75 & 7,32 & 5,67 & 3,76 \\
\hline 80,23 & 512,40 & 93,90 & 29,12 & 19,50 & 16,53 & 14,10 & 12,35 & 10,89 & 8,56 & 6,87 & 4,70 \\
\hline 66,71 & 767,10 & 140,10 & 20,87 & 14,52 & 12,32 & 10,40 & 8,95 & 7,75 & 5,88 & 4,59 & 3,07 \\
\hline 47,82 & 783,10 & 21,40 & 76,05 & 65,92 & 62,21 & 56,82 & 51,64 & 46,74 & 38,05 & 31,01 & 21,19 \\
\hline 32,56 & 677,20 & 195,30 & 25,55 & 16,95 & 13,08 & 9,55 & 7,24 & 5,70 & 3,91 & 2,99 & 2,07 \\
\hline 76,28 & 762,80 & 73,70 & 27,32 & 20,09 & 18,01 & 16,04 & 14,47 & 13,07 & 10,66 & 8,77 & 6,13 \\
\hline 81,45 & 992,40 & 40,10 & 33,63 & 25,63 & 23,91 & 22,45 & 21,05 & 19,71 & 17,21 & 15,00 & 11,40 \\
\hline 35,92 & 1760,50 & 132,10 & 21,61 & 17,91 & 15,61 & 12,93 & 10,70 & 8,88 & 6,30 & 4,71 & 3,09 \\
\hline 88,42 & 479,60 & 30,30 & 51,24 & 37,44 & 34,25 & 31,55 & 29,25 & 27,17 & 23,39 & 20,15 & 15,07 \\
\hline 74,32 & 1510,50 & 54,10 & 25,19 & 19,58 & 18,45 & 17,32 & 16,20 & 15,13 & 13,12 & 11,35 & 8,51 \\
\hline 74,62 & 537,10 & 81,00 & 31,21 & 21,89 & 18,92 & 16,33 & 14,37 & 12,70 & 9,99 & 8,00 & 5,44 \\
\hline 64,36 & 1856,00 & 122,50 & 15,18 & 12,00 & 11,00 & 9,90 & 8,95 & 8,07 & 6,55 & 5,35 & 3,69 \\
\hline 26,75 & 1239,40 & 143,60 & 28,39 & 21,69 & 17,53 & 13,18 & 10,09 & 7,93 & 5,38 & 4,07 & 2,79 \\
\hline 85,24 & 494,70 & 126,80 & 25,80 & 16,08 & 13,13 & 10,88 & 9,37 & 8,18 & 6,33 & 5,04 & 3,45 \\
\hline 57,83 & 1188,50 & 134,90 & 18,38 & 14,11 & 12,42 & 10,72 & 9,31 & 8,10 & 6,17 & 4,82 & 3,19 \\
\hline 83,16 & 1262,40 & 129,80 & 15,39 & 10,99 & 9,80 & 8,73 & 7,90 & 7,18 & 5,92 & 4,92 & 3,50 \\
\hline 21,30 & 1620,50 & 49,00 & 65,68 & 56,03 & 47,88 & 38,09 & 30,22 & 24,20 & 16,42 & 12,17 & 8,14 \\
\hline 88,37 & 1503,00 & 92,00 & 16,65 & 12,20 & 11,17 & 10,31 & 9,57 & 8,90 & 7,67 & 6,62 & 4,96 \\
\hline 77,04 & 794,90 & 96,90 & 23,11 & 16,54 & 14,56 & 12,78 & 11,41 & 10,21 & 8,21 & 6,68 & 4,62 \\
\hline 67,63 & 904,90 & 79,70 & 25,64 & 19,61 & 17,67 & 15,71 & 14,07 & 12,61 & 10,12 & 8,20 & 5,62 \\
\hline 65,08 & 584,20 & 130,30 & 25,23 & 16,97 & 14,12 & 11,70 & 9,92 & 8,48 & 6,31 & 4,88 & 3,25 \\
\hline 78,92 & 307,20 & 26,10 & 71,72 & 52,81 & 47,77 & 42,98 & 39,09 & 35,60 & 29,51 & 24,58 & 17,47 \\
\hline 29,52 & 1911,30 & 23,90 & 76,39 & 71,12 & 66,26 & 59,31 & 52,59 & 46,38 & 35,89 & 28,01 & 18,20 \\
\hline 75,01 & 357,30 & 24,80 & 70,70 & 53,49 & 49,02 & 44,49 & 40,64 & 37,13 & 30,92 & 25,82 & 18,39 \\
\hline 46,19 & 428,00 & 145,60 & 32,12 & 20,37 & 16,03 & 12,27 & 9,68 & 7,82 & 5,43 & 4,11 & 2,80 \\
\hline 28,40 & 1515,60 & 22,60 & 88,06 & 81,73 & 75,27 & 66,41 & 58,03 & 50,45 & 38,11 & 29,24 & 18,82 \\
\hline 24,84 & 958,90 & 38,40 & 80,44 & 68,55 & 59,03 & 47,55 & 38,19 & 30,90 & 21,19 & 15,70 & 10,43 \\
\hline 23,04 & 1820,40 & 191,70 & 22,81 & 17,27 & 13,66 & 9,99 & 7,49 & 5,84 & 3,96 & 3,02 & 2,09 \\
\hline 32,51 & 558,90 & 21,50 & 113,22 & 99,81 & 89,31 & 76,10 & 64,41 & 54,46 & 39,47 & 29,68 & 19,18 \\
\hline 67,39 & 537,20 & 196,80 & 22,09 & 13,26 & 10,42 & 8,23 & 6,78 & 5,67 & 4,12 & 3,16 & 2,13 \\
\hline 78,73 & 1523,20 & 20,10 & 43,54 & 37,17 & 34,07 & 33,04 & 32,04 & 30,80 & 28,25 & 25,79 & 21,28 \\
\hline 57,95 & 1581,00 & 56,80 & 27,82 & 22,99 & 21,69 & 19,94 & 18,28 & 16,70 & 13,87 & 11,52 & 8,09 \\
\hline 24,96 & 1397,30 & 42,60 & 66,11 & 57,78 & 50,61 & 41,68 & 34,10 & 27,98 & 19,46 & 14,41 & 9,44 \\
\hline 86,02 & 1720,20 & 68,60 & 18,91 & 14,33 & 13,29 & 12,53 & 11,79 & 11,08 & 9,76 & 8,58 & 6,62 \\
\hline 67,74 & 387,40 & 153,20 & 29,73 & 17,52 & 13,63 & 10,68 & 8,75 & 7,30 & 5,28 & 4,05 & 2,73 \\
\hline 80,50 & 717,50 & 36,70 & 40,71 & 30,72 & 28,52 & 26,45 & 24,57 & 22,82 & 19,62 & 16,86 & 12,52 \\
\hline 31,89 & 1369,70 & 127,10 & 26,43 & 21,16 & 17,91 & 14,26 & 11,39 & 9,21 & 6,34 & 4,73 & 3,17 \\
\hline 70,62 & 1983,20 & 103,70 & 15,58 & 12,14 & 11,30 & 10,37 & 9,53 & 8,75 & 7,35 & 6,18 & 4,43 \\
\hline 84,38 & 457,80 & 78,10 & 33,07 & 22,12 & 18,87 & 16,22 & 14,32 & 12,73 & 10,15 & 8,23 & 5,70 \\
\hline 79,35 & 898,80 & 117,50 & 19,51 & 13,74 & 12,02 & 10,52 & 9,38 & 8,39 & 6,75 & 5,50 & 3,81 \\
\hline 27,93 & 851,10 & 111,10 & 37,06 & 27,98 & 22,58 & 16,98 & 13,01 & 10,25 & 6,96 & 5,26 & 3,61 \\
\hline 52,60 & 1814,90 & 194,60 & 13,10 & 10,26 & 9,02 & 7,74 & 6,66 & 5,74 & 4,30 & 3,32 & 2,18 \\
\hline 49,28 & 722,40 & 147,80 & 24,00 & 16,95 & 14,11 & 11,42 & 9,37 & 7,76 & 5,53 & 4,18 & 2,78 \\
\hline 61,27 & 1957,60 & 187,60 & 11,89 & 9,22 & 8,23 & 7,22 & 6,38 & 5,63 & 4,40 & 3,49 & 2,34 \\
\hline 70,07 & 1041,00 & 43,90 & 34,13 & 26,78 & 25,17 & 23,34 & 21,61 & 19,98 & 17,00 & 14,44 & 10,51 \\
\hline 47,15 & 1985,70 & 79,40 & 23,47 & 20,30 & 18,78 & 16,82 & 15,01 & 13,35 & 10,53 & 8,37 & 5,57 \\
\hline 50,00 & 1188,40 & 113,90 & 22,00 & 17,58 & 15,53 & 13,33 & 11,46 & 9,86 & 7,38 & 5,68 & 3,72 \\
\hline 58,27 & 326,00 & 64,20 & 50,17 & 35,11 & 29,53 & 24,48 & 20,62 & 17,49 & 12,86 & 9,86 & 6,54 \\
\hline 65,28 & 983,60 & 189,90 & 16,00 & 11,06 & 9,34 & 7,83 & 6,70 & 5,77 & 4,34 & 3,38 & 2,25 \\
\hline 84,60 & 740,10 & 73,80 & 26,47 & 18,87 & 16,85 & 15,06 & 13,66 & 12,44 & 10,32 & 8,61 & 6,15 \\
\hline 39,79 & 1708,20 & 44,20 & 41,10 & 36,88 & 34,32 & 30,80 & 27,45 & 24,37 & 19,12 & 15,11 & 9,97 \\
\hline 62,42 & 1117,90 & 50,30 & 32,52 & 26,29 & 24,61 & 22,53 & 20,61 & 18,82 & 15,60 & 12,95 & 9,11 \\
\hline 59,25 & 1320,10 & 152,50 & 16,18 & 12,34 & 10,86 & 9,38 & 8,17 & 7,12 & 5,45 & 4,27 & 2,83 \\
\hline 88,64 & 206,10 & 89,50 & 51,40 & 28,61 & 21,80 & 17,01 & 14,11 & 11,99 & 8,96 & 7,02 & 4,80 \\
\hline 74,27 & 1844,80 & 81,20 & 18,14 & 14,02 & 13,13 & 12,20 & 11,33 & 10,51 & 9,01 & 7,70 & 5,68 \\
\hline 54,85 & 661,40 & 121,90 & 26,29 & 18,76 & 15,85 & 13,12 & 11,01 & 9,29 & 6,78 & 5,18 & 3,43 \\
\hline 30,84 & 983,80 & 139,90 & 28,45 & 21,40 & 17,45 & 13,32 & 10,33 & 8,20 & 5,59 & 4,21 & 2,87 \\
\hline 48,10 & 600,20 & 126,60 & 28,77 & 20,22 & 16,77 & 13,48 & 11,00 & 9,08 & 6,43 & 4,86 & 3,24 \\
\hline 37,45 & 502,80 & 99,10 & 40,52 & 29,08 & 23,71 & 18,36 & 14,45 & 11,60 & 7,99 & 6,02 & 4,08 \\
\hline 59,37 & 1269,10 & 144,90 & 16,92 & 12,92 & 11,38 & 9,84 & 8,58 & 7,48 & 5,74 & 4,49 & 2,98 \\
\hline 82,40 & 1779,90 & 125,90 & 13,42 & 9,89 & 9,04 & 8,24 & 7,58 & 6,97 & 5,89 & 4,99 & 3,64 \\
\hline 33,76 & 1738,00 & 156,20 & 20,42 & 16,48 & 14,09 & 11,38 & 9,21 & 7,51 & 5,22 & 3,90 & 2,59 \\
\hline 80,75 & 242,30 & 63,50 & 53,00 & 33,25 & 27,12 & 22,39 & 19,19 & 16,64 & 12,74 & 10,07 & 6,83 \\
\hline 34,48 & 1878,60 & 114,20 & 23,89 & 20,23 & 17,78 & 14,84 & 12,34 & 10,29 & 7,33 & 5,48 & 3,58 \\
\hline 38,63 & 1941,70 & 34,70 & 47,75 & 43,06 & 40,63 & 36,96 & 33,38 & 30,00 & 24,06 & 19,34 & 12,96 \\
\hline
\end{tabular}




\begin{tabular}{|c|c|c|c|c|c|c|c|c|c|c|c|}
\hline \multirow[b]{2}{*}{$\mathrm{e} 1(\mathrm{~cm})$} & & & & & & $\mathrm{De}$ & $\overline{\text { ões (x1 }}$ & & & & \\
\hline & Meq (MPa) & Ms (MPa) & D0 & D25 & D40 & D60 & D80 & D100 & D140 & D180 & D260 \\
\hline 75,26 & $\begin{array}{l}791,70 \\
\end{array}$ & 25,10 & 51,49 & 40,11 & 37,82 & 35,74 & 33,60 & 31,51 & 27,58 & 24,05 & 18,28 \\
\hline 69,17 & 1395,40 & 113,90 & 17,17 & 13,14 & 11,91 & 10,65 & 9,60 & 8,64 & 7,01 & 5,73 & 3,96 \\
\hline 78,95 & 1175,20 & 90,70 & 19,76 & 14,65 & 13,33 & 12,06 & 11,01 & 10,07 & 8,40 & 7,04 & 5,04 \\
\hline 58,93 & 1976,20 & 85,10 & 19,57 & 16,08 & 15,04 & 13,73 & 12,52 & 11,38 & 9,36 & 7,71 & 5,36 \\
\hline 22,12 & 299,00 & 51,70 & 99,45 & 69,57 & 52,30 & 36,55 & 26,91 & 20,94 & 14,45 & 11,16 & 7,77 \\
\hline 41,32 & 360,70 & 101,70 & 43,88 & 29,23 & 23,28 & 17,80 & 13,97 & 11,21 & 7,74 & 5,85 & 3,99 \\
\hline 30,03 & 1861,40 & 136,50 & 23,73 & 19,45 & 16,58 & 13,28 & 10,65 & 8,62 & 5,93 & 4,42 & 2,95 \\
\hline 36,73 & 626,00 & 71,60 & 45,92 & 36,02 & 30,61 & 24,67 & 19,97 & 16,31 & 11,37 & 8,51 & 5,66 \\
\hline 42,85 & 1638,80 & 173,40 & 16,61 & 13,20 & 11,45 & 9,54 & 7,97 & 6,68 & 4,80 & 3,62 & 2,38 \\
\hline 28,83 & 1671,30 & 35,70 & 61,88 & 56,49 & 51,30 & 44,45 & 38,16 & 32,65 & 24,04 & 18,18 & 11,68 \\
\hline 22,08 & 1662,40 & 60,90 & 54,36 & 45,85 & 38,94 & 30,75 & 24,26 & 19,37 & 13,12 & 9,75 & 6,55 \\
\hline 53,32 & 277,50 & 141,10 & 39,75 & 22,48 & 16,87 & 12,59 & 9,88 & 7,98 & 5,56 & 4,24 & 2,91 \\
\hline 28,42 & 1846,40 & 129,70 & 25,66 & 21,01 & 17,81 & 14,14 & 11,25 & 9,06 & 6,20 & 4,62 & 3,09 \\
\hline 38,65 & 788,40 & 176,10 & 23,61 & 16,54 & 13,38 & 10,32 & 8,11 & 6,51 & 4,48 & 3,38 & 2,30 \\
\hline 85,31 & 1233,80 & 79,20 & 20,11 & 14,79 & 13,56 & 12,46 & 11,52 & 10,66 & 9,12 & 7,81 & 5,78 \\
\hline 78,89 & 1611,70 & 193,20 & 11,39 & 8,12 & 7,15 & 6,29 & 5,63 & 5,06 & 4,09 & 3,34 & 2,32 \\
\hline 85,79 & 1522,40 & 43,90 & 25,84 & 20,15 & 18,67 & 17,83 & 16,96 & 16,08 & 14,39 & 12,84 & 10,17 \\
\hline 86,28 & 1960,90 & 164,60 & 10,85 & 7,81 & 7,05 & 6,38 & 5,84 & 5,36 & 4,51 & 3,82 & 2,77 \\
\hline 69,66 & 1594,50 & 145,90 & 14,04 & 10,62 & 9,55 & 8,49 & 7,61 & 6,83 & 5,50 & 4,47 & 3,07 \\
\hline 62,72 & 1472,30 & 50,30 & 29,48 & 23,85 & 22,60 & 20,97 & 19,39 & 17,89 & 15,12 & 12,77 & 9,19 \\
\hline 42,90 & 1558,80 & 148,30 & 18,59 & 14,99 & 13,11 & 11,01 & 9,25 & 7,79 & 5,64 & 4,27 & 2,79 \\
\hline 89,03 & 1003,70 & 36,40 & 33,42 & 25,49 & 23,53 & 22,30 & 21,11 & 19,93 & 17,72 & 15,71 & 12,32 \\
\hline 48,18 & 1952,40 & 172,50 & 14,37 & 11,64 & 10,31 & 8,86 & 7,61 & 6,54 & 4,88 & 3,75 & 2,45 \\
\hline 33,49 & 1237,50 & 28,30 & 70,39 & 64,23 & 59,08 & 52,16 & 45,68 & 39,83 & 30,27 & 23,36 & 15,11 \\
\hline 63,15 & 679,00 & 123,30 & 24,19 & 17,00 & 14,43 & 12,13 & 10,38 & 8,92 & 6,70 & 5,20 & 3,46 \\
\hline 64,35 & 358,40 & 107,00 & 36,40 & 23,05 & 18,58 & 14,96 & 12,43 & 10,46 & 7,63 & 5,86 & 3,92 \\
\hline 38,10 & 1686,30 & 106,60 & 24,05 & 20,37 & 18,05 & 15,29 & 12,90 & 10,90 & 7,91 & 5,97 & 3,88 \\
\hline 67,24 & 1982,60 & 84,40 & 18,22 & 14,45 & 13,58 & 12,54 & 11,57 & 10,66 & 9,00 & 7,59 & 5,46 \\
\hline 42,33 & 1333,40 & 66,00 & 32,84 & 28,41 & 25,76 & 22,52 & 19,59 & 17,01 & 12,87 & 9,93 & 6,47 \\
\hline 59,65 & 1350,40 & 166,60 & 15,21 & 11,48 & 10,05 & 8,66 & 7,52 & 6,54 & 4,99 & 3,90 & 2,58 \\
\hline 44,34 & 1420,70 & 163,90 & 17,81 & 13,96 & 12,08 & 10,06 & 8,40 & 7,05 & 5,08 & 3,84 & 2,52 \\
\hline 52,41 & 1693,70 & 176,00 & 14,32 & 11,27 & 9,93 & 8,53 & 7,35 & 6,34 & 4,76 & 3,68 & 2,42 \\
\hline 88,65 & 522,50 & 197,30 & 21,16 & 12,13 & 9,42 & 7,48 & 6,28 & 5,38 & 4,07 & 3,20 & 2,19 \\
\hline 72,52 & 252,50 & 41,40 & 64,52 & 44,97 & 38,57 & 33,03 & 28,85 & 25,32 & 19,68 & 15,63 & 10,56 \\
\hline 85,21 & 1096,90 & 112,00 & 17,59 & 12,49 & 11,13 & 9,94 & 9,01 & 8,20 & 6,80 & 5,68 & 4,05 \\
\hline 75,40 & 1055,10 & 137,50 & 16,99 & 12,13 & 10,62 & 9,27 & 8,23 & 7,33 & 5,84 & 4,72 & 3,24 \\
\hline 79,18 & 215,90 & 99,20 & 49,15 & 27,42 & 20,81 & 16,10 & 13,20 & 11,08 & 8,11 & 6,29 & 4,27 \\
\hline 78,51 & 1557,30 & 53,00 & 24,38 & 18,83 & 17,67 & 16,69 & 15,70 & 14,74 & 12,93 & 11,30 & 8,63 \\
\hline 81,85 & 853,20 & 172,80 & 16,63 & 10,91 & 9,15 & 7,74 & 6,75 & 5,94 & 4,65 & 3,72 & 2,54 \\
\hline 35,11 & 1422,10 & 101,50 & 28,10 & 23,40 & 20,40 & 16,89 & 13,96 & 11,58 & 8,20 & 6,13 & 4,01 \\
\hline 58,43 & 1820,90 & 186,90 & 12,61 & 9,79 & 8,68 & 7,55 & 6,60 & 5,78 & 4,45 & 3,49 & 2,32 \\
\hline 54,72 & 672,90 & 174,50 & 21,87 & 14,56 & 11,90 & 9,56 & 7,85 & 6,52 & 4,67 & 3,55 & 2,37 \\
\hline 42,64 & 398,50 & 179,00 & 30,84 & 18,30 & 13,84 & 10,19 & 7,85 & 6,25 & 4,31 & 3,29 & 2,27 \\
\hline 47,97 & 1341,90 & 187,20 & 16,13 & 12,23 & 10,50 & 8,72 & 7,29 & 6,13 & 4,43 & 3,36 & 2,21 \\
\hline 64,71 & 1745,70 & 33,80 & 35,64 & 28,66 & 27,41 & 26,16 & 24,70 & 23,24 & 20,44 & 17,88 & 13,63 \\
\hline 89,37 & 1017,30 & 176,40 & 14,50 & 9,54 & 8,11 & 6,97 & 6,17 & 5,51 & 4,43 & 3,63 & 2,53 \\
\hline 22,20 & 231,40 & 99,80 & 66,13 & 38,69 & 26,99 & 18,13 & 13,39 & 10,57 & 7,42 & 5,77 & 4,05 \\
\hline 67,60 & 1796,90 & 152,40 & 13,20 & 10,13 & 9,15 & 8,15 & 7,31 & 6,56 & 5,28 & 4,29 & 2,94 \\
\hline 53,68 & 810,20 & 177,90 & 19,85 & 13,72 & 11,39 & 9,27 & 7,67 & 6,40 & 4,61 & 3,50 & 2,33 \\
\hline 52,25 & 1775,80 & 175,70 & 14,07 & 11,15 & 9,85 & 8,49 & 7,33 & 6,33 & 4,77 & 3,69 & 2,43 \\
\hline 62,75 & 508,50 & 48,70 & 45,24 & 34,92 & 31,20 & 27,44 & 24,29 & 21,50 & 16,90 & 13,46 & 9,06 \\
\hline 84,16 & 1061,30 & 190,70 & 13,95 & 9,27 & 7,86 & 6,73 & 5,92 & 5,25 & 4,17 & 3,37 & 2,33 \\
\hline 48,09 & 240,30 & 106,90 & 49,77 & 29,40 & 22,41 & 16,79 & 13,13 & 10,55 & 7,31 & 5,57 & 3,82 \\
\hline 38,78 & 670,10 & 106,60 & 33,90 & 25,27 & 21,07 & 16,72 & 13,40 & 10,88 & 7,55 & 5,67 & 3,80 \\
\hline 21,85 & 1476,70 & 122,10 & 34,66 & 26,81 & 21,38 & 15,74 & 11,83 & 9,21 & 6,24 & 4,74 & 3,27 \\
\hline 66,63 & 1203,80 & 161,20 & 15,50 & 11,33 & 9,89 & 8,54 & 7,48 & 6,57 & 5,10 & 4,03 & 2,71 \\
\hline 81,56 & 773,70 & 118,70 & 20,77 & 14,23 & 12,27 & 10,62 & 9,41 & 8,38 & 6,69 & 5,43 & 3,75 \\
\hline 54,72 & 1128,50 & 177,50 & 16,74 & 12,30 & 10,53 & 8,82 & 7,47 & 6,35 & 4,68 & 3,59 & 2,37 \\
\hline 64,52 & 1653,30 & 72,50 & 21,95 & 17,59 & 16,50 & 15,17 & 13,93 & 12,77 & 10,68 & 8,93 & 6,34 \\
\hline 53,28 & 687,50 & 38,80 & 50,22 & 41,82 & 38,32 & 34,18 & 30,46 & 27,07 & 21,37 & 17,03 & 11,40 \\
\hline 63,52 & 834,40 & 185,30 & 17,87 & 12,07 & 10,05 & 8,31 & 7,03 & 5,99 & 4,44 & 3,43 & 2,28 \\
\hline 35,85 & 1912,80 & 149,30 & 19,43 & 16,02 & 13,93 & 11,50 & 9,49 & 7,86 & 5,56 & 4,16 & 2,73 \\
\hline 64,01 & 1597,90 & 102,90 & 17,94 & 14,22 & 13,06 & 11,76 & 10,63 & 9,59 & 7,79 & 6,36 & 4,39 \\
\hline 77,46 & 342,50 & 91,50 & 37,65 & 23,71 & 19,32 & 15,90 & 13,56 & 11,70 & 8,88 & 6,97 & 4,71 \\
\hline 33,03 & 1671,70 & 167,80 & 20,08 & 15,95 & 13,49 & 10,76 & 8,61 & 6,97 & 4,81 & 3,59 & 2,40 \\
\hline 89,36 & 678,90 & 163,80 & 18,99 & 11,85 & 9,72 & 8,11 & 7,04 & 6,19 & 4,85 & 3,90 & 2,69 \\
\hline 27,67 & 1609,70 & 182,10 & 21,73 & 16,72 & 13,63 & 10,35 & 7,97 & 6,29 & 4,27 & 3,22 & 2,20 \\
\hline 48,90 & 815,70 & 47,60 & 43,77 & 36,88 & 33,52 & 29,57 & 26,02 & 22,85 & 17,65 & 13,84 & 9,12 \\
\hline 74,01 & 1550,60 & 112,40 & 16,00 & 12,12 & 11,08 & 10,03 & 9,13 & 8,32 & 6,89 & 5,73 & 4,06 \\
\hline 20,52 & 507,50 & 85,20 & 62,43 & 43,23 & 32,04 & 22,09 & 16,18 & 12,59 & 8,74 & 6,77 & 4,71 \\
\hline 25,02 & 1626,80 & 160,20 & 25,32 & 19,59 & 15,84 & 11,88 & 9,06 & 7,11 & 4,81 & 3,64 & 2,50 \\
\hline 40,64 & 313,30 & 160,30 & 37,24 & 21,37 & 15,82 & 11,43 & 8,72 & 6,91 & 4,76 & 3,65 & 2,54 \\
\hline 61,37 & 395,00 & 26,90 & 71,81 & 57,35 & 52,37 & 46,88 & 42,08 & 37,71 & 30,25 & 24,46 & 16,66 \\
\hline 22,74 & 398,50 & 123,20 & 48,30 & 30,54 & 21,98 & 14,97 & 11,01 & 8,64 & 6,03 & 4,68 & 3,27 \\
\hline 59,49 & 1934,10 & 32,60 & 37,52 & 30,53 & 29,38 & 28,00 & 26,38 & 24,77 & 21,67 & 18,86 & 14,23 \\
\hline 68,84 & 1826,80 & 88,30 & 18,01 & 14,16 & 13,23 & 12,16 & 11,19 & 10,28 & 8,64 & 7,26 & 5,21 \\
\hline 40,19 & 1031,70 & 187,70 & 19,93 & 14,51 & 12,01 & 9,49 & 7,59 & 6,16 & 4,28 & 3,22 & 2,16 \\
\hline 32,19 & 1404,90 & 135,50 & 24,96 & 19,90 & 16,82 & 13,38 & 10,69 & 8,64 & 5,95 & 4,44 & 2,97 \\
\hline 43,17 & 955,70 & 156,10 & 22,00 & 16,31 & 13,72 & 11,07 & 9,02 & 7,42 & 5,22 & 3,93 & 2,61 \\
\hline 74,46 & 1654,30 & 182,60 & 11,86 & 8,66 & 7,68 & $\begin{array}{ll}6,78 \\
\end{array}$ & 6,06 & 5,43 & 4,37 & 3,55 & 2,45 \\
\hline 58,83 & 544,40 & 193,90 & 22,88 & 14,05 & 11,08 & 8,69 & 7,06 & 5,84 & 4,16 & 3,17 & 2,13 \\
\hline 72,06 & 1387,50 & 152,10 & 14,40 & 10,61 & 9,42 & 8,30 & 7,40 & 6,61 & 5,29 & 4,28 & 2,93 \\
\hline
\end{tabular}




\begin{tabular}{|c|c|c|c|c|c|c|c|c|c|c|c|}
\hline & & & \multicolumn{9}{|c|}{ Deflexões $\left(\times 10^{-4} \mathrm{~cm}\right)$} \\
\hline e1 (cm) & Meq (MPa) & Ms (MPa) & D0 & D25 & D40 & D60 & D80 & D100 & D140 & D180 & D260 \\
\hline 34,69 & 1113,00 & 194,60 & 20,54 & 15,04 & 12,27 & 9,45 & 7,39 & 5,91 & 4,05 & 3,05 & 2,07 \\
\hline 29,16 & 1654,70 & 62,80 & 42,26 & 36,94 & 32,65 & 27,30 & 22,69 & 18,87 & 13,36 & 9,95 & 6,47 \\
\hline 86,48 & 1034,80 & 69,60 & 23,20 & 16,96 & 15,50 & 14,21 & 13,13 & 12,14 & 10,38 & 8,88 & 6,57 \\
\hline 67,14 & 631,10 & 110,70 & 25,79 & 18,05 & 15,38 & 13,03 & 11,25 & 9,76 & 7,44 & 5,82 & 3,89 \\
\hline 66,13 & 1969,30 & 112,00 & 15,43 & 12,20 & 11,30 & 10,27 & 9,36 & 8,51 & 7,02 & 5,81 & 4,07 \\
\hline 73,56 & 418,20 & 124,40 & 30,01 & 18,65 & 15,02 & 12,20 & 10,28 & 8,78 & 6,55 & 5,09 & 3,43 \\
\hline 32,57 & 1015,10 & 150,90 & 25,91 & 19,43 & 15,92 & 12,26 & 9,57 & 7,63 & 5,22 & 3,92 & 2,67 \\
\hline 89,03 & 769,10 & 179,20 & 17,01 & 10,69 & 8,81 & 7,37 & 6,41 & 5,64 & 4,43 & 3,57 & 2,46 \\
\hline 78,81 & 1006,60 & 58,40 & 27,20 & 20,51 & 18,96 & 17,43 & 16,10 & 14,86 & 12,63 & 10,74 & 7,86 \\
\hline 33,61 & 493,00 & 34,70 & 84,47 & 70,23 & 60,97 & 50,11 & 41,12 & 33,91 & 23,82 & 17,77 & 11,68 \\
\hline 28,62 & 1471,20 & 43,10 & 57,38 & 51,19 & 45,76 & 38,82 & 32,67 & 27,46 & 19,71 & 14,74 & 9,52 \\
\hline 55,18 & 1072,00 & 74,70 & 27,71 & 22,60 & 20,49 & 18,14 & 16,07 & 14,21 & 11,12 & 8,82 & 5,88 \\
\hline 29,97 & 571,90 & 174,90 & 30,20 & 19,71 & 14,93 & 10,68 & 8,01 & 6,28 & 4,32 & 3,32 & 2,31 \\
\hline 59,13 & 1476,90 & 27,30 & 46,31 & 37,75 & 36,33 & 34,47 & 32,37 & 30,29 & 26,34 & 22,79 & 17,03 \\
\hline 31,90 & 743,90 & 78,10 & 44,89 & 35,36 & 29,67 & 23,39 & 18,56 & 14,93 & 10,25 & 7,66 & 5,15 \\
\hline 54,71 & 1444,90 & 109,50 & 19,66 & 15,94 & 14,37 & 12,65 & 11,15 & 9,81 & 7,62 & 6,01 & 3,99 \\
\hline 46,47 & 695,30 & 196,10 & 21,68 & 14,36 & 11,54 & 9,00 & 7,18 & 5,84 & 4,07 & 3,08 & 2,08 \\
\hline 30,50 & 1263,10 & 167,20 & 23,40 & 17,78 & 14,55 & 11,15 & 8,66 & 6,88 & 4,69 & 3,53 & 2,40 \\
\hline 30,26 & 1971,30 & 106,80 & 27,20 & 23,06 & 20,07 & 16,47 & 13,48 & 11,08 & 7,74 & 5,76 & 3,78 \\
\hline 35,33 & 574,70 & 145,30 & 31,44 & 21,48 & 16,99 & 12,74 & 9,82 & 7,79 & 5,33 & 4,05 & 2,78 \\
\hline 46,96 & 1098,30 & 129,50 & 21,95 & 17,11 & 14,85 & 12,45 & 10,48 & 8,85 & 6,44 & 4,89 & 3,21 \\
\hline 38,13 & 1215,10 & 189,20 & 19,12 & 14,31 & 11,93 & 9,45 & 7,56 & 6,13 & 4,25 & 3,19 & 2,14 \\
\hline 28,96 & 581,90 & 94,60 & 45,73 & 33,51 & 26,73 & 19,91 & 15,19 & 11,95 & 8,14 & 6,17 & 4,25 \\
\hline 44,58 & 401,50 & 46,70 & 62,51 & 48,95 & 42,35 & 35,27 & 29,47 & 24,72 & 17,82 & 13,47 & 8,84 \\
\hline 81,27 & 818,40 & 84,90 & 23,85 & 17,13 & 15,26 & 13,58 & 12,27 & 11,11 & 9,13 & 7,55 & 5,33 \\
\hline 70,64 & 601,00 & 121,40 & 24,87 & 16,82 & 14,14 & 11,88 & 10,23 & 8,86 & 6,75 & 5,29 & 3,55 \\
\hline 39,77 & 1909,20 & 157,90 & 17,41 & 14,30 & 12,53 & 10,49 & 8,78 & 7,37 & 5,30 & 3,99 & 2,61 \\
\hline 51,81 & 731,70 & 127,00 & 25,20 & 18,29 & 15,49 & 12,79 & 10,68 & 8,98 & 6,50 & 4,95 & 3,27 \\
\hline 69,08 & 879,00 & 27,30 & 49,59 & 39,22 & 37,21 & 34,97 & 32,69 & 30,49 & 26,36 & 22,72 & 16,92 \\
\hline 83,13 & 1306,60 & 109,90 & 16,55 & 12,03 & 10,87 & 9,81 & 8,96 & 8,20 & 6,86 & 5,77 & 4,15 \\
\hline 34,71 & 1002,50 & 110,80 & 30,44 & 23,93 & 20,24 & 16,18 & 12,99 & 10,55 & 7,30 & 5,46 & 3,64 \\
\hline 63,04 & 969,70 & 179,00 & 16,82 & 11,79 & 9,99 & 8,39 & 7,17 & 6,16 & 4,62 & 3,58 & 2,38 \\
\hline 74,17 & 927,00 & 73,90 & 25,33 & 19,06 & 17,31 & 15,58 & 14,14 & 12,83 & 10,56 & 8,74 & 6,15 \\
\hline 77,21 & 1825,20 & 54,00 & 22,94 & 17,87 & 16,81 & 15,97 & 15,07 & 14,18 & 12,51 & 10,99 & 8,46 \\
\hline 70,72 & 671,70 & 86,60 & 27,58 & 20,02 & 17,53 & 15,26 & 13,47 & 11,92 & 9,39 & 7,51 & 5,10 \\
\hline 35,10 & 444,30 & 99,20 & 43,98 & 30,80 & 24,62 & 18,63 & 14,43 & 11,47 & 7,85 & 5,94 & 4,07 \\
\hline 66,84 & 310,80 & 162,20 & 33,71 & 18,57 & 13,89 & 10,50 & 8,41 & 6,91 & 4,91 & 3,76 & 2,56 \\
\hline 84,05 & 1055,10 & 20,50 & 47,54 & 38,85 & 35,74 & 34,48 & 33,19 & 31,74 & 28,85 & 26,12 & 21,24 \\
\hline 62,21 & 896,00 & 176,20 & 17,76 & 12,33 & 10,38 & 8,66 & 7,36 & 6,29 & 4,68 & 3,62 & 2,40 \\
\hline 54,37 & 1051,30 & 123,30 & 21,10 & 16,26 & 14,24 & 12,18 & 10,47 & 9,02 & 6,77 & 5,23 & 3,45 \\
\hline 31,13 & 1452,60 & 73,90 & 37,60 & 32,18 & 28,21 & 23,40 & 19,32 & 16,00 & 11,28 & 8,40 & 5,49 \\
\hline 84,79 & 1965,60 & 152,90 & 11,37 & 8,27 & 7,51 & 6,82 & 6,25 & 5,75 & 4,85 & 4,11 & 2,99 \\
\hline 52,54 & 1503,50 & 133,20 & 17,66 & 14,17 & 12,62 & 10,95 & 9,52 & 8,28 & 6,30 & 4,90 & 3,22 \\
\hline 61,40 & 1490,30 & 111,80 & 17,95 & 14,24 & 12,92 & 11,51 & 10,28 & 9,18 & 7,31 & 5,88 & 3,98 \\
\hline 32,72 & 1235,40 & 52,30 & 47,90 & 41,89 & 37,33 & 31,64 & 26,66 & 22,46 & 16,19 & 12,15 & 7,87 \\
\hline 31,06 & 369,30 & 79,40 & 57,65 & 40,47 & 31,88 & 23,59 & 17,97 & 14,15 & 9,66 & 7,35 & 5,07 \\
\hline 81,34 & 1344,10 & 152,90 & 13,85 & 9,85 & 8,71 & 7,71 & 6,93 & 6,26 & 5,11 & 4,21 & 2,95 \\
\hline 74,20 & 1813,30 & 84,90 & 17,77 & 13,71 & 12,82 & 11,87 & 11,00 & 10,18 & 8,69 & 7,41 & 5,43 \\
\hline 63,58 & 1606,30 & 68,80 & 23,13 & 18,62 & 17,48 & 16,06 & 14,75 & 13,51 & 11,28 & 9,42 & 6,68 \\
\hline 37,48 & 1210,60 & 122,50 & 25,27 & 20,18 & 17,34 & 14,16 & 11,59 & 9,55 & 6,71 & 5,03 & 3,32 \\
\hline 44,92 & 1134,40 & 81,00 & 29,44 & 24,54 & 21,91 & 18,89 & 16,25 & 13,97 & 10,43 & 7,99 & 5,21 \\
\hline 30,80 & 1161,90 & 29,40 & 75,23 & 68,22 & 61,93 & 53,69 & 46,16 & 39,55 & 29,22 & 22,15 & 14,25 \\
\hline 53,12 & 1789,50 & 185,60 & 13,46 & 10,58 & 9,33 & 8,03 & 6,93 & 5,99 & 4,51 & 3,49 & 2,30 \\
\hline 73,62 & 1001,80 & 29,70 & 43,07 & 33,74 & 31,89 & 30,18 & 28,39 & 26,63 & 23,32 & 20,35 & 15,47 \\
\hline 85,73 & 926,10 & 170,70 & 15,72 & 10,35 & 8,76 & 7,48 & 6,58 & 5,84 & 4,64 & 3,76 & 2,60 \\
\hline 71,26 & 1564,00 & 29,70 & 37,48 & 30,02 & 28,39 & 27,30 & 25,98 & 24,61 & 21,96 & 19,49 & 15,26 \\
\hline 23,60 & 750,80 & 143,40 & 35,57 & 24,75 & 18,71 & 13,16 & 9,73 & 7,58 & 5,22 & 4,03 & 2,80 \\
\hline 76,30 & 1447,00 & 130,00 & 14,98 & 11,08 & 9,99 & 8,94 & 8,09 & 7,33 & 6,01 & 4,96 & 3,49 \\
\hline 38,43 & 738,50 & 189,10 & 23,35 & 15,91 & 12,70 & 9,67 & 7,54 & 6,02 & 4,14 & 3,13 & 2,14 \\
\hline 56,86 & 1665,80 & 158,50 & 14,61 & 11,49 & 10,23 & 8,92 & 7,80 & 6,83 & 5,26 & 4,12 & 2,74 \\
\hline 47,18 & 481,90 & 78,00 & 41,73 & 30,88 & 26,16 & 21,44 & 17,72 & 14,76 & 10,55 & 7,97 & 5,27 \\
\hline 69,95 & 1089,00 & 104,20 & 20,01 & 15,06 & 13,50 & 11,97 & 10,72 & 9,60 & 7,71 & 6,26 & 4,30 \\
\hline 52,45 & 572,10 & 189,20 & 23,32 & 14,74 & 11,71 & 9,14 & 7,35 & 6,02 & 4,24 & 3,21 & 2,17 \\
\hline 21,01 & 786,00 & 197,30 & 29,51 & 19,16 & 13,81 & 9,37 & 6,87 & 5,38 & 3,76 & 2,92 & 2,04 \\
\hline 76,91 & 1046,00 & 34,30 & 37,63 & 29,19 & 27,46 & 25,95 & 24,40 & 22,90 & 20,06 & 17,53 & 13,36 \\
\hline 24,87 & 942,40 & 154,20 & 30,71 & 22,09 & 17,11 & 12,31 & 9,19 & 7,16 & 4,90 & 3,75 & 2,60 \\
\hline 52,00 & 1643,60 & 22,30 & 56,43 & 46,84 & 45,38 & 43,08 & 40,43 & 37,80 & 32,78 & 28,26 & 20,96 \\
\hline 25,69 & 1253,60 & 132,40 & 30,74 & 23,65 & 19,12 & 14,34 & 10,95 & 8,60 & 5,82 & 4,41 & 3,02 \\
\hline 23,23 & 959,00 & 95,70 & 44,75 & 34,17 & 27,19 & 20,01 & 15,07 & 11,75 & 7,96 & 6,06 & 4,18 \\
\hline 88,08 & 1934,60 & 66,90 & 17,96 & 13,76 & 12,72 & 12,08 & 11,44 & 10,81 & 9,62 & 8,54 & 6,70 \\
\hline 81,33 & 317,60 & 137,00 & 33,91 & 19,13 & 14,64 & 11,42 & 9,43 & 7,97 & 5,88 & 4,58 & 3,11 \\
\hline 27,75 & 1672,50 & 169,30 & 22,52 & 17,59 & 14,47 & 11,09 & 8,60 & 6,81 & 4,62 & 3,48 & 2,37 \\
\hline 42,08 & 669,10 & 154,10 & 26,23 & 18,23 & 14,84 & 11,58 & 9,21 & 7,46 & 5,17 & 3,90 & 2,63 \\
\hline 33,68 & 622,60 & 188,70 & 26,57 & 17,45 & 13,47 & 9,86 & 7,49 & 5,91 & 4,05 & 3,09 & 2,14 \\
\hline 40,17 & 1006,80 & 135,00 & 24,46 & 18,76 & 15,92 & 12,88 & 10,49 & 8,62 & 6,05 & 4,54 & 3,01 \\
\hline 84,83 & 954,60 & 57,40 & 27,04 & 20,00 & 18,39 & 16,95 & 15,71 & 14,57 & 12,50 & 10,73 & 7,97 \\
\hline 82,32 & 1603,00 & 58,30 & 22,04 & 16,88 & 15,75 & 14,87 & 14,00 & 13,16 & 11,58 & 10,16 & 7,81 \\
\hline 77,95 & 1675,10 & 108,90 & 15,38 & 11,56 & 10,63 & 9,71 & 8,92 & 8,20 & 6,90 & 5,82 & 4,21 \\
\hline 54,72 & 1826,70 & 112,40 & 17,64 & 14,54 & 13,28 & 11,82 & 10,53 & 9,35 & 7,38 & 5,88 & 3,94 \\
\hline 27,67 & 1288,00 & 119,10 & 31,15 & 24,60 & 20,36 & 15,72 & 12,24 & 9,72 & 6,60 & 4,95 & 3,36 \\
\hline 23,40 & 1763,90 & 109,90 & 33,77 & 27,28 & 22,56 & 17,28 & 13,35 & 10,53 & 7,11 & 5,33 & 3,63 \\
\hline 32,67 & 973,00 & 51,20 & 52,87 & 45,28 & 39,86 & 33,28 & 27,67 & 23,04 & 16,37 & 12,23 & 7,97 \\
\hline
\end{tabular}




\begin{tabular}{|c|c|c|c|c|c|c|c|c|c|c|c|}
\hline \multirow[b]{2}{*}{ e1 (cm) } & & & & & & $\mathrm{De}$ & ões (x1 & & & & \\
\hline & Meq (MPa) & Ms (MPa) & D0 & D25 & D40 & D60 & D80 & D100 & D140 & D180 & D260 \\
\hline 61,05 & 1340,00 & 157,20 & 15,56 & 11,79 & 10,37 & 8,98 & 7,84 & 6,85 & 5,27 & 4,14 & 2,76 \\
\hline 65,18 & 1430,30 & 103,60 & 18,50 & 14,50 & 13,22 & 11,85 & 10,67 & 9,60 & 7,76 & 6,32 & 4,34 \\
\hline 80,12 & 1966,00 & 21,60 & 36,37 & 32,52 & 29,48 & 28,51 & 27,82 & 26,89 & 24,88 & 22,91 & 19,23 \\
\hline 80,65 & 479,40 & 157,20 & 24,66 & 14,79 & 11,74 & 9,46 & 7,98 & 6,84 & 5,15 & 4,03 & 2,73 \\
\hline 60,11 & 255,30 & 93,70 & 47,88 & 29,12 & 22,88 & 17,93 & 14,57 & 12,05 & 8,60 & 6,56 & 4,42 \\
\hline 24,88 & 1834,30 & 168,20 & 23,70 & 18,49 & 15,02 & 11,31 & 8,65 & 6,79 & 4,60 & 3,47 & 2,38 \\
\hline 87,59 & 1126,90 & 86,10 & 19,73 & 14,25 & 12,93 & 11,77 & 10,83 & 9,98 & 8,48 & 7,22 & 5,31 \\
\hline 23,82 & 1848,30 & 124,30 & 30,15 & 24,22 & 19,98 & 15,28 & 11,79 & 9,29 & 6,28 & 4,71 & 3,21 \\
\hline 77,86 & 1619,60 & 28,70 & 35,06 & 28,53 & 26,53 & 25,64 & 24,62 & 23,48 & 21,25 & 19,14 & 15,41 \\
\hline 61,08 & 489,40 & 178,90 & 24,91 & 15,14 & 11,91 & 9,34 & 7,61 & 6,31 & 4,51 & 3,44 & 2,32 \\
\hline 35,16 & 856,80 & 33,90 & 68,04 & 60,07 & 54,12 & 46,64 & 39,93 & 34,12 & 25,13 & 19,06 & 12,31 \\
\hline 44,07 & 765,80 & 81,90 & 34,68 & 27,50 & 23,91 & 20,00 & 16,76 & 14,09 & 10,19 & 7,70 & 5,05 \\
\hline 30,32 & 811,70 & 32,20 & 80,93 & 70,75 & 62,68 & 52,64 & 43,92 & 36,68 & 26,11 & 19,49 & 12,65 \\
\hline 45,85 & 1497,10 & 174,00 & 16,48 & 12,89 & 11,18 & 9,35 & 7,85 & 6,61 & 4,79 & 3,63 & 2,38 \\
\hline 76,94 & 396,60 & 166,20 & 27,70 & 15,84 & 12,19 & 9,53 & 7,86 & 6,62 & 4,86 & 3,76 & 2,55 \\
\hline 85,71 & 628,40 & 71,40 & 29,02 & 20,36 & 17,99 & 15,95 & 14,40 & 13,05 & 10,76 & 8,93 & 6,34 \\
\hline 85,16 & 1792,70 & 137,10 & 12,56 & 9,14 & 8,30 & 7,54 & 6,93 & 6,37 & 5,39 & 4,57 & 3,33 \\
\hline 38,42 & 1388,90 & 55,80 & 38,77 & 34,20 & 31,06 & 27,11 & 23,51 & 20,34 & 15,29 & 11,73 & 7,61 \\
\hline 55,68 & 484,50 & 90,40 & 35,40 & 25,17 & 21,25 & 17,60 & 14,79 & 12,50 & 9,14 & 6,99 & 4,62 \\
\hline 52,12 & 1399,30 & 136,60 & 18,02 & 14,30 & 12,65 & 10,90 & 9,42 & 8,14 & 6,14 & 4,75 & 3,12 \\
\hline 44,60 & 1147,40 & 96,20 & 26,54 & 21,72 & 19,20 & 16,37 & 13,94 & 11,88 & 8,75 & 6,66 & 4,35 \\
\hline 50,39 & 1048,50 & 38,00 & 45,46 & 38,91 & 36,37 & 32,98 & 29,79 & 26,81 & 21,62 & 17,50 & 11,87 \\
\hline 60,24 & 1718,30 & 177,20 & 13,12 & 10,12 & 8,98 & 7,83 & 6,87 & 6,04 & 4,68 & 3,69 & 2,46 \\
\hline 40,71 & 751,10 & 165,60 & 24,34 & 17,08 & 13,91 & 10,84 & 8,60 & 6,94 & 4,81 & 3,62 & 2,45 \\
\hline 38,69 & 1733,80 & 139,80 & 19,86 & 16,36 & 14,31 & 11,95 & 9,97 & 8,34 & 5,98 & 4,49 & 2,93 \\
\hline 43,04 & 1972,70 & 101,30 & 21,43 & 18,47 & 16,74 & 14,63 & 12,74 & 11,06 & 8,38 & 6,47 & 4,22 \\
\hline 35,55 & 623,00 & 26,70 & 88,17 & 77,36 & 69,51 & 59,72 & 50,99 & 43,47 & 31,92 & 24,17 & 15,63 \\
\hline 82,22 & 856,50 & 71,70 & 25,42 & 18,53 & 16,76 & 15,13 & 13,81 & 12,62 & 10,55 & 8,85 & 6,36 \\
\hline 57,48 & 268,90 & 80,00 & 50,42 & 32,40 & 26,11 & $\frac{10, \pm 0}{20,82}$ & $\begin{array}{l}10,01 \\
17,06\end{array}$ & $\frac{1 L, 0<}{14,18}$ & $\frac{10,00}{10,15}$ & 7,73 & 5,18 \\
\hline 59,92 & 1070,70 & 138,20 & 18,69 & 14,01 & 12,22 & 10,50 & 9,10 & 7,90 & 6,01 & 4,69 & 3,11 \\
\hline 83,39 & 786,90 & 62,40 & 28,32 & 20,65 & 18,73 & 16,97 & 15,54 & 14,26 & 11,98 & 10,11 & 7,32 \\
\hline 81,00 & 1957,80 & 30,90 & 29,81 & 24,92 & 22,90 & 22,17 & 21,42 & 20,54 & 18,76 & 17,06 & 13,98 \\
\hline 53,24 & 1224,60 & 172,70 & 16,58 & 12,45 & 10,74 & 9,04 & 7,67 & 6,54 & 4,82 & 3,70 & 2,43 \\
\hline 51,47 & 252,10 & 94,10 & 50,37 & 30,97 & 24,22 & 18,63 & 14,84 & 12,07 & 8,45 & 6,41 & 4,35 \\
\hline 31,62 & 876,20 & 52,60 & 55,23 & 46,52 & 40,47 & 33,25 & 27,25 & 22,44 & 15,72 & 11,70 & 7,69 \\
\hline 81,61 & 1904,80 & 81,80 & 16,88 & 12,82 & 11,95 & 11,19 & 10,47 & 9,78 & 8,52 & 7,40 & 5,60 \\
\hline 62,84 & 1966,30 & 125,80 & 14,79 & 11,78 & 10,82 & 9,73 & 8,78 & 7,91 & 6,41 & 5,22 & 3,59 \\
\hline 49,78 & 854,40 & 72,20 & 33,03 & 26,81 & 23,88 & 20,65 & 17,87 & 15,46 & 11,66 & 9,01 & 5,91 \\
\hline 53,81 & 623,40 & 161,00 & 23,81 & 15,89 & 12,99 & 10,42 & 8,54 & 7,08 & 5,06 & 3,84 & 2,56 \\
\hline 25,74 & 950,50 & 184,70 & 26,48 & 18,60 & 14,29 & 10,23 & 7,63 & 5,96 & 4,08 & 3,13 & 2,18 \\
\hline 52,58 & 920,70 & 82,30 & 28,68 & 22,98 & 20,47 & 17,75 & 15,43 & 13,41 & 10,19 & 7,92 & 5,22 \\
\hline 68,67 & 1968,70 & 24,60 & 39,89 & 32,95 & 30,91 & 30,04 & 28,87 & 27,56 & 24,96 & 22,48 & 18,05 \\
\hline 21,74 & 1852,00 & 35,50 & 77,19 & 68,64 & 60,48 & 50,08 & 41,12 & 33,80 & 23,51 & 17,37 & 11,34 \\
\hline 20,74 & 1270,70 & 97,00 & 44,26 & 34,23 & 27,17 & 19,87 & 14,87 & 11,55 & 7,82 & 5,96 & 4,12 \\
\hline 47,96 & 935,50 & 85,80 & 29,43 & 23,73 & 20,97 & 17,95 & 15,38 & 13,18 & 9,80 & 7,52 & 4,92 \\
\hline 29,05 & 1534,50 & 33,00 & 66,69 & 60,87 & 55,31 & 47,97 & 41,22 & 35,30 & 26,03 & 19,70 & 12,65 \\
\hline 52,08 & 1475,50 & 198,20 & 14,30 & 10,84 & 9,38 & 7,90 & 6,70 & 5,71 & 4,21 & 3,22 & 2,12 \\
\hline 22,79 & 288,80 & 159,50 & 44,26 & 24,41 & 16,76 & 11,24 & 8,33 & 6,60 & 4,64 & 3,61 & 2,54 \\
\hline 85,54 & 1342,10 & 166,20 & 13,03 & 9,06 & 7,95 & 7,01 & 6,30 & 5,69 & 4,66 & 3,85 & 2,72 \\
\hline 89,69 & 1846,90 & 93,80 & 14,93 & 11,06 & 10,17 & 9,49 & 8,88 & 8,31 & 7,26 & 6,34 & 4,85 \\
\hline 56,76 & 1833,80 & 21,90 & 51,87 & 42,46 & 40,90 & 39,35 & 37,32 & 35,24 & 31,20 & 27,44 & 21,08 \\
\hline 65,57 & 1495,70 & 74,20 & 22,23 & 17,70 & 16,50 & 15,10 & 13,82 & 12,63 & 10,50 & 8,74 & 6,18 \\
\hline 72,40 & 1970,60 & 167,00 & 11,64 & 8,78 & 7,94 & 7,11 & 6,42 & 5,80 & 4,73 & 3,89 & 2,71 \\
\hline 36,52 & 640,00 & 119,60 & 33,31 & 24,13 & 19,71 & 15,25 & 11,99 & 9,61 & 6,61 & 4,98 & 3,37 \\
\hline 83,45 & 1564,20 & 33,60 & 30,52 & 24,56 & 22,70 & 21,86 & 20,96 & 19,99 & 18,08 & 16,29 & 13,12 \\
\hline 31,73 & 625,70 & 190,70 & 27,01 & 17,69 & 13,53 & 9,79 & 7,39 & 5,81 & 3,98 & 3,05 & 2,12 \\
\hline 67,90 & 254,20 & 69,50 & 52,33 & 33,53 & 27,30 & 22,26 & 18,71 & 15,91 & 11,77 & 9,10 & 6,09 \\
\hline 61,83 & 1987,90 & 170,20 & 12,42 & 9,73 & 8,75 & 7,74 & 6,88 & 6,11 & 4,82 & 3,86 & 2,60 \\
\hline 68,78 & 1572,00 & 49,20 & 27,66 & 21,89 & 20,77 & 19,51 & 18,23 & 16,99 & 14,67 & 12,63 & 9,39 \\
\hline 39,91 & 1617,70 & 151,70 & 18,98 & 15,34 & 13,34 & 11,08 & 9,20 & 7,68 & 5,49 & 4,12 & 2,70 \\
\hline 72,46 & 222,50 & 89,00 & 50,77 & 29,57 & 22,94 & 18,01 & 14,83 & 12,45 & 9,08 & 7,01 & 4,73 \\
\hline 68,50 & 401,00 & 73,20 & 39,50 & 27,35 & 23,21 & $\begin{array}{l}19,64 \\
19,64\end{array}$ & 16,95 & 14,71 & 11,22 & 8,79 & 5,89 \\
\hline 38,24 & 202,60 & 174,70 & 45,61 & 22,27 & $\begin{array}{l}20,2 . \\
15,17\end{array}$ & 10,36 & $\begin{array}{l}10,00 \\
7,77\end{array}$ & $\begin{array}{c}1+1,1 \\
6,16\end{array}$ & $\begin{array}{c}1+, 2 L \\
4,27\end{array}$ & 3,32 & 2,35 \\
\hline 36,19 & 1222,20 & 55,60 & 42,61 & 37,22 & 33,40 & 28,66 & 24,46 & 20,84 & 15,30 & 11,59 & 7,50 \\
\hline 21,68 & 421,90 & 101,50 & 55,90 & 36,81 & 26,79 & 18,31 & 13,44 & 10,51 & 7,32 & 5,68 & 3,96 \\
\hline 49,93 & 718,30 & 169,60 & 22,29 & 15,27 & 12,55 & 10,05 & 8,19 & 6,76 & 4,79 & 3,62 & 2,42 \\
\hline 85,83 & 873,80 & 72,60 & 24,54 & 17,70 & 15,99 & 14,47 & 13,25 & 12,16 & 10,24 & 8,65 & 6,29 \\
\hline 48,46 & 725,00 & 70,40 & 36,47 & 29,17 & 25,70 & 21,95 & 18,77 & 16,07 & 11,93 & 9,14 & 5,98 \\
\hline 43,47 & 1054,50 & 174,50 & 19,71 & 14,58 & 12,25 & 9,89 & 8,06 & 6,63 & 4,67 & 3,52 & 2,34 \\
\hline 53,02 & 1314.60 & 76.80 & 25,80 & 21,46 & 19,62 & 17,46 & 15,53 & 13,77 & 10,83 & 8,61 & 5,75 \\
\hline 64,02 & 864,00 & 128,20 & 20,88 & 15,15 & 13,09 & 11,20 & 9,71 & 8,44 & 6,45 & 5,05 & 3,37 \\
\hline 82,71 & 1751,10 & 150,60 & 12,22 & 8,88 & 8,02 & 7,22 & 6,59 & 6,02 & 5,03 & 4,22 & 3,03 \\
\hline 30,47 & 680,10 & 130,20 & 34,11 & 24,42 & 19,38 & 14,41 & 11,00 & 8,66 & 5,91 & 4,49 & 3,09 \\
\hline 29,17 & 908,90 & 30,50 & 83,45 & 73,75 & 65,62 & 55,34 & 46,34 & 38,80 & 27,70 & 20,68 & 13,39 \\
\hline 65,35 & 1003,00 & 184,50 & 16,04 & 11,19 & 9,49 & 7,99 & 6,86 & 5,92 & 4,47 & 3,48 & 2,32 \\
\hline 22,51 & 820,30 & 193,60 & 28,63 & 19,05 & 14,00 & 9,64 & 7,09 & 5,53 & 3,84 & 2,98 & 2,08 \\
\hline 64,10 & 1428,80 & 173,30 & 14,00 & 10,46 & 9,19 & 7,97 & 6,99 & 6,13 & 4,75 & 3,76 & 2,52 \\
\hline 82,43 & 1135,10 & 145,00 & 15,40 & 10,77 & 9,43 & 8,28 & 7,41 & 6,67 & 5,41 & 4,44 & 3,10 \\
\hline 81,16 & 703,30 & 60,90 & 30,58 & 22,31 & 20,14 & 18,13 & 16,50 & 15,05 & 12,52 & 10,47 & 7,48 \\
\hline 43,40 & 499,10 & 63,00 & 48,73 & 37,71 & 32,36 & 26,67 & 22,08 & 18,38 & 13,12 & 9,89 & 6,51 \\
\hline 53,09 & 259,20 & 69,40 & 56,60 & 37,54 & 30,54 & 24,37 & 19,90 & 16,45 & 11,70 & 8,88 & 5,94 \\
\hline 54,00 & 1831,90 & 164,40 & 14,15 & 11,30 & 10,07 & 8,76 & 7,64 & 6,66 & 5,09 & 3,97 & 2,62 \\
\hline
\end{tabular}




\begin{tabular}{|c|c|c|c|c|c|c|c|c|c|c|c|}
\hline \multirow[b]{2}{*}{ e1 (cm) } & & & & & & & ões (x1 & & & & \\
\hline & Meq (MPa) & Ms (MPa) & D0 & D25 & D40 & D60 & D80 & D100 & D140 & D180 & D260 \\
\hline 83,99 & 1388,70 & 164,80 & 12,95 & 9,09 & 8,01 & 7,08 & 6,37 & 5,75 & 4,71 & 3,89 & 2,74 \\
\hline 76,94 & 362,60 & 27,10 & 66,04 & 49,41 & 45,07 & 40,80 & 37,24 & 34,00 & 28,30 & 23,65 & 16,86 \\
\hline 39,44 & 1109,30 & 188,50 & 19,50 & 14,37 & 11,94 & 9,45 & 7,57 & 6,14 & 4,27 & 3,20 & 2,15 \\
\hline 20,35 & 1014,20 & 32,10 & 105,67 & 89,08 & 75,29 & 59,02 & 46,26 & 36,74 & 24,77 & 18,42 & 12,43 \\
\hline 63,52 & 1330,30 & 157,70 & 15,28 & 11,47 & 10,10 & 8,77 & 7,68 & 6,75 & 5,23 & 4,13 & 2,77 \\
\hline 58,48 & 961,60 & 118,40 & 21,61 & 16,37 & 14,32 & 12,31 & 10,66 & 9,25 & 7,03 & 5,48 & 3,63 \\
\hline 47,34 & 1311,10 & 110,90 & 22,21 & 18,10 & 16,06 & 13,80 & 11,85 & 10,18 & 7,59 & 5,83 & 3,81 \\
\hline 56,60 & 1135,30 & 62,60 & 29,78 & 24,53 & 22,59 & 20,30 & 18,23 & 16,34 & 13,09 & 10,56 & 7,16 \\
\hline 60,73 & 1645,90 & 182,20 & 13,11 & 10,01 & 8,84 & 7,68 & 6,72 & 5,89 & 4,55 & 3,58 & 2,38 \\
\hline 71,48 & 484,00 & 98,10 & 30,71 & 20,70 & 17,40 & 14,63 & 12,60 & 10,93 & 8,34 & 6,55 & 4,40 \\
\hline 60,84 & 213,60 & 78,00 & 57,16 & 34,76 & 27,34 & 21,45 & 17,47 & 14,47 & 10,35 & 7,90 & 5,32 \\
\hline 34,22 & 236,40 & 41,70 & 96,87 & 70,76 & 57,57 & 44,16 & 34,46 & 27,48 & 18,82 & 14,18 & 9,65 \\
\hline 84,25 & 1667,20 & 37,40 & 27,67 & 22,17 & 20,48 & 19,71 & 18,88 & 17,99 & 16,26 & 14,63 & 11,77 \\
\hline 41,44 & 481,10 & 194,90 & 27,12 & 16,56 & 12,66 & 9,37 & 7,23 & 5,76 & 3,97 & 3,02 & 2,09 \\
\hline 31,05 & 878,50 & 47,60 & 59,78 & 50,82 & 44,38 & 36,61 & 30,10 & 24,84 & 17,44 & 12,98 & 8,51 \\
\hline 25,09 & 1827,80 & 142,90 & 26,42 & 21,03 & 17,32 & 13,24 & 10,23 & 8,07 & 5,46 & 4,10 & 2,80 \\
\hline 86,07 & 373,90 & 56,80 & 42,37 & 28,68 & 24,71 & 21,45 & 19,08 & 17,09 & 13,80 & 11,29 & 7,89 \\
\hline 34,80 & 909,20 & 110,30 & 31,57 & 24,50 & 20,59 & 16,34 & 13,05 & 10,56 & 7,30 & 5,46 & 3,66 \\
\hline 40,62 & 838,30 & 115,40 & 28,72 & 21,94 & 18,59 & 15,05 & 12,26 & 10,07 & 7,08 & 5,31 & 3,53 \\
\hline 61,53 & 495,40 & 134,10 & 27,87 & 18,14 & 14,79 & 11,98 & 9,96 & 8,38 & 6,10 & 4,67 & 3,12 \\
\hline 87,79 & 1540,60 & 70,90 & 19,18 & 14,35 & 13,26 & 12,42 & 11,65 & 10,92 & 9,57 & 8,37 & 6,41 \\
\hline 78,38 & 1716,20 & 46,30 & 25,52 & 19,98 & 18,75 & 17,89 & 16,95 & 16,01 & 14,21 & 12,57 & 9,78 \\
\hline 75,84 & 606,70 & 70,50 & 31,24 & 22,57 & 19,95 & 17,56 & 15,68 & 14,05 & 11,30 & 9,19 & 6,35 \\
\hline 84,98 & 989,90 & 132,30 & 17,07 & 11,78 & 10,28 & 9,00 & 8,06 & $\begin{array}{c}1+, 00 \\
7,25\end{array}$ & $\begin{array}{c}1+, 00 \\
5,90\end{array}$ & 4,85 & 3,40 \\
\hline 66,10 & 1964,70 & 177,60 & 11,77 & 9,03 & 8,12 & 7,19 & 6,42 & 5,73 & 4,57 & 3,69 & 2,51 \\
\hline 44,51 & 505,90 & 87,20 & 39,64 & 29,08 & 24,41 & 19,72 & 16,09 & 13,26 & 9,36 & 7,05 & 4,69 \\
\hline 87,48 & 1144,30 & 23,90 & 40,56 & 33,11 & 30,31 & 29,19 & 28,11 & 26,89 & 24,48 & 22,20 & 18,11 \\
\hline 35,26 & 883,00 & 96,50 & 34,42 & 27,13 & 23,01 & 18,46 & 14,88 & 12,11 & 8,41 & 6,29 & 4,19 \\
\hline 64,60 & 201,30 & 63,20 & 63,38 & 39,65 & 31,78 & 25,46 & 21,09 & 17,71 & 12,89 & 9,89 & 6,63 \\
\hline 35,94 & 491,40 & 89,70 & 44,41 & 32,29 & 26,37 & 20,38 & 16,00 & 12,82 & 8,80 & 6,63 & 4,50 \\
\hline 22,29 & 607,50 & 22,40 & 147,22 & 124,34 & 105,73 & 83,66 & 66,13 & 52,85 & 35,83 & 26,61 & 17,86 \\
\hline 60,07 & 259,10 & 168,40 & 38,16 & 20,01 & 14,46 & 10,54 & 8,23 & 6,65 & 4,64 & 3,55 & 2,45 \\
\hline 22,07 & 1053,90 & 21,40 & 128,86 & 114,35 & 100,67 & 83,28 & 68,32 & 56,14 & 39,03 & 28,85 & 18,83 \\
\hline 55,43 & 537,80 & 197,00 & 23,29 & 14,29 & 11,22 & 8,72 & 7,02 & 5,76 & 4,07 & 3,09 & 2,09 \\
\hline 67,76 & 1542,60 & 98,20 & 18,16 & 14,20 & 13,06 & 11,83 & 10,75 & 9,76 & 8,03 & 6,63 & 4,63 \\
\hline 51,85 & 972,30 & 176,90 & 18,50 & 13,31 & 11,23 & 9,24 & 7,69 & 6,45 & 4,66 & 3,54 & 2,34 \\
\hline 28,70 & 1886,10 & 73,00 & 37,11 & 32,34 & 28,49 & 23,72 & 19,63 & 16,27 & 11,47 & 8,53 & 5,56 \\
\hline 63,44 & 1122,50 & 36,00 & 40,08 & 32,32 & 30,70 & 28,61 & 26,54 & 24,55 & 20,89 & 17,73 & 12,87 \\
\hline 67,94 & 1513,20 & 55,50 & 26,14 & 20,71 & 19,57 & 18,23 & 16,92 & 15,68 & 13,38 & 11,40 & 8,33 \\
\hline 48,06 & 981,30 & 22,90 & 67,62 & 58,38 & 55,52 & 51,09 & 46,75 & 42,61 & 35,13 & 28,94 & 20,04 \\
\hline 73,74 & 897,60 & 20,40 & 56,76 & 44,98 & 42,46 & 40,65 & 38,56 & 36,44 & 32,37 & 28,62 & 22,26 \\
\hline 37,82 & 359,70 & 78,40 & 53,07 & 37,36 & 30,22 & 23,25 & 18,23 & 14,61 & 10,05 & 7,58 & 5,15 \\
\hline 42,87 & 1326,40 & 25,70 & 61,41 & 54,27 & 51,54 & 47,25 & 43,03 & 39,01 & 31,83 & 25,96 & 17,72 \\
\hline 79,30 & 811,50 & 118,10 & 20,52 & 14,26 & 12,35 & 10,72 & 9,50 & 8,47 & 6,75 & 5,47 & 3,77 \\
\hline 66,01 & 1976,40 & 174,10 & 11,88 & 9,14 & 8,23 & 7,30 & 6,53 & 5,83 & 4,66 & 3,76 & 2,56 \\
\hline 55,90 & 1139,50 & 158,10 & 17,52 & 13,11 & 11,35 & 9,62 & 8,23 & 7,06 & 5,27 & 4,06 & 2,68 \\
\hline 21,91 & 1020,90 & 23,50 & 122,66 & 107,60 & 93,94 & 76,84 & 62,42 & 50,88 & 35,07 & 25,91 & 17,04 \\
\hline 27,79 & 1351,70 & 91,50 & 36,57 & 29,99 & 25,40 & 20,13 & 15,98 & 12,84 & 8,78 & 6,54 & 4,38 \\
\hline 32,57 & 1652,10 & 188,50 & 18,88 & 14,72 & 12,31 & 9,69 & 7,68 & 6,17 & 4,24 & 3,17 & 2,13 \\
\hline 20,06 & 1783,50 & 181,00 & 26,17 & 19,40 & 14,93 & 10,59 & 7,81 & 6,05 & 4,14 & 3,19 & 2,21 \\
\hline 77,48 & 1862,40 & 89,40 & 16,63 & 12,69 & 11,83 & 10,98 & 10,19 & 9,46 & 8,12 & 6,96 & 5,14 \\
\hline 66,73 & 905,90 & 83,20 & 25,19 & 19,26 & 17,29 & 15,32 & 13,68 & 12,21 & 9,75 & 7,86 & 5,36 \\
\hline 66,16 & 1403,20 & 104,30 & 18,43 & 14,36 & 13,08 & 11,72 & 10,56 & 9,51 & 7,69 & 6,27 & 4,32 \\
\hline 79,57 & 1842,90 & 156,40 & 11,91 & 8,75 & 7,91 & 7,12 & 6,48 & 5,91 & 4,90 & 4,09 & 2,91 \\
\hline 65,04 & 1632,20 & 44,60 & 30,16 & 24,18 & 23,06 & 21,68 & 20,26 & 18,88 & 16,29 & 14,01 & 10,37 \\
\hline 62,04 & 378,70 & 141,60 & 31,76 & 19,16 & 15,03 & 11,78 & 9,60 & 7,96 & 5,70 & 4,35 & 2,93 \\
\hline 49,41 & 1103,40 & 86,60 & 26,84 & 21,98 & 19,65 & 17,06 & 14,80 & 12,83 & 9,72 & 7,53 & 4,93 \\
\hline 61,53 & 1267,40 & 143,10 & 16,73 & 12,72 & 11,22 & 9,75 & 8,53 & 7,48 & 5,78 & 4,56 & 3,04 \\
\hline 30,83 & 1072,90 & 34,10 & 69,91 & 62,37 & $\begin{array}{l}1 . \pm, L L \\
56,01\end{array}$ & 47,88 & 40,62 & 34,40 & 24,97 & 18,77 & 12,11 \\
\hline 73,74 & 1682,20 & 167,30 & 12,38 & 9,16 & 8,19 & 7,27 & 6,53 & 5,87 & 4,75 & 3,88 & 2,69 \\
\hline 20,89 & 1709,90 & 37,10 & 79,52 & 69,54 & 60,48 & 49,17 & 39,72 & 32,23 & 22,10 & 16,32 & 10,77 \\
\hline 66,89 & 1245,30 & 173,90 & 14,64 & 10,63 & 9,24 & 7,97 & 6,96 & 6,10 & 4,72 & $\begin{array}{c}0,73 \\
3,73\end{array}$ & 2,51 \\
\hline 87,51 & 396,20 & 72,00 & $\begin{array}{l}1+, 0+ \\
36,73\end{array}$ & 24,13 & 20,43 & 17,48 & 15,42 & 13,71 & 10,96 & 8,91 & 6,19 \\
\hline 27,45 & 1958,60 & 119,40 & 27,33 & 22,63 & 19,27 & 15,35 & 12,24 & 9,86 & 6,75 & 5,02 & 3,36 \\
\hline 84,37 & 1351,70 & 166,40 & 13,05 & 9,11 & 8,00 & 7,05 & 6,33 & 5,71 & 4,67 & 3,85 & 2,71 \\
\hline 47,81 & 1423,20 & 162,50 & 17,07 & 13,36 & 11,63 & 9,80 & 8,29 & 7,03 & 5,15 & 3,92 & 2,57 \\
\hline 77,83 & 1345,50 & 195,00 & 12,49 & 8,72 & 7,56 & 6,56 & 5,81 & 5,17 & 4,11 & 3,32 & 2,28 \\
\hline 33,04 & 650,80 & 86,10 & 43,16 & 32,98 & 27,33 & 21,30 & 16,79 & 13,45 & 9,22 & 6,92 & 4,67 \\
\hline 31,05 & 318,40 & 172,20 & 37,87 & 21,44 & 15,36 & 10,65 & 7,94 & 6,26 & 4,34 & 3,36 & 2,36 \\
\hline 51,56 & 1167,60 & 72,80 & 28,38 & 23,61 & 21,46 & 18,97 & 16,76 & 14,77 & 11,49 & 9,05 & 6,00 \\
\hline 87,80 & 1220,60 & 27,00 & 36,69 & 29,70 & 27,22 & 26,19 & 25,17 & 24,06 & 21,85 & 19,77 & 16,07 \\
\hline 68,64 & 287,20 & 127,50 & 38,37 & 21,95 & 16,80 & 12,99 & 10,56 & 8,77 & 6,31 & 4,84 & 3,28 \\
\hline 81,77 & 1108,00 & 154,00 & 15,19 & 10,53 & 9,16 & 7,99 & 7,12 & 6,37 & 5,13 & 4,18 & 2,91 \\
\hline 23,83 & 1357,00 & 42,30 & 69,83 & 60,50 & 52,56 & 42,79 & 34,65 & 28,19 & 19,42 & 14,37 & 9,48 \\
\hline 36,67 & 1949,00 & 184,80 & 16,60 & 13,37 & 11,50 & 9,40 & 7,70 & 6,34 & 4,46 & 3,33 & 2,20 \\
\hline 49,66 & 1605,20 & 33,70 & 43,55 & 37,17 & 35,57 & 32,99 & 30,40 & 27,91 & 23,33 & 19,45 & 13,70 \\
\hline 48,48 & 209,70 & 64,90 & 67,49 & 43,63 & 34,80 & 27,06 & 21,62 & 17,59 & 12,30 & 9,31 & 6,30 \\
\hline 39,65 & 306,10 & 163,90 & 37,48 & 21,25 & 15,61 & 11,19 & 8,50 & 6,73 & 4,64 & 3,56 & 2,48 \\
\hline 62,11 & 955,00 & 25,80 & 53,48 & 43,32 & 41,36 & 38,76 & 36,10 & 33,53 & 28,73 & 24,53 & 17,97 \\
\hline 77,53 & 1157,50 & 54,20 & 27,17 & 20,75 & 19,36 & 17,99 & 16,72 & 15,54 & 13,35 & 11,46 & 8,49 \\
\hline 57,84 & 827,20 & 32,60 & 50,06 & 41,38 & 38,86 & 35,56 & 32,47 & 29,57 & 24,38 & 20,13 & 14,02 \\
\hline 84,89 & 803,20 & 180,00 & 16,76 & 10,72 & 8,88 & 7,45 & 6,48 & 5,69 & 4,45 & 3,56 & 2,44 \\
\hline
\end{tabular}




\begin{tabular}{|c|c|c|c|c|c|c|c|c|c|c|c|}
\hline \multirow[b]{2}{*}{ e1 (cm) } & & & & & & $\mathrm{De}$ & ões (x1 & & & & \\
\hline & Meq (MPa) & Ms (MPa) & D0 & D25 & D40 & D60 & D80 & D100 & D140 & D180 & D260 \\
\hline 59,53 & 1847,50 & 119,20 & 16,13 & 13,01 & 11,91 & 10,66 & 9,56 & 8,56 & 6,85 & 5,52 & 3,75 \\
\hline 72,64 & 1034,20 & 159,90 & 16,19 & 11,38 & 9,81 & 8,44 & 7,40 & 6,51 & 5,09 & 4,05 & 2,74 \\
\hline 59,35 & 1361,40 & 84,90 & 22,39 & 18,12 & 16,61 & 14,90 & 13,38 & 11,99 & 9,61 & 7,76 & 5,28 \\
\hline 80,25 & 1422,30 & 196,40 & 11,95 & 8,34 & 7,26 & 6,33 & 5,63 & 5,03 & 4,04 & 3,29 & 2,28 \\
\hline 41,86 & 1240,90 & 130,70 & 22,34 & 17,77 & 15,39 & 12,78 & 10,63 & 8,88 & 6,36 & 4,79 & 3,14 \\
\hline 31,29 & 1649,10 & 199,60 & 18,70 & 14,42 & 11,93 & 9,26 & 7,26 & 5,80 & 3,96 & 2,97 & 2,01 \\
\hline 45,61 & 473,00 & 76,40 & 43,37 & 32,15 & 27,18 & 22,16 & 18,22 & 15,11 & 10,74 & 8,10 & 5,37 \\
\hline 62,61 & 1197,30 & 154,50 & 16,36 & 12,17 & 10,63 & 9,17 & 7,99 & 6,97 & 5,35 & 4,21 & 2,80 \\
\hline 60,22 & 300,30 & 120,30 & 39,28 & 23,38 & 18,17 & 14,09 & 11,39 & 9,39 & 6,67 & 5,09 & 3,44 \\
\hline 40,77 & 459,50 & 68,30 & 49,97 & 37,68 & 31,76 & 25,57 & 20,74 & 17,00 & 11,92 & 8,95 & 5,95 \\
\hline 39,89 & 580,60 & 54,80 & 52,68 & 42,53 & 36,95 & 30,68 & 25,48 & 21,25 & 15,17 & 11,40 & 7,48 \\
\hline 66,44 & 1931,70 & 142,40 & 13,43 & 10,46 & 9,53 & 8,55 & 7,71 & 6,94 & 5,63 & 4,59 & 3,17 \\
\hline 80,84 & 1959,70 & 149,10 & 11,81 & 8,71 & 7,93 & 7,19 & 6,58 & 6,03 & 5,06 & 4,25 & 3,06 \\
\hline 74,43 & 254,60 & 134,80 & 40,29 & 21,89 & 16,30 & 12,35 & 9,96 & 8,25 & 5,94 & 4,57 & 3,11 \\
\hline 88,25 & 329,40 & 66,50 & 42,14 & 27,18 & 22,75 & 19,29 & 16,91 & 14,98 & 11,89 & 9,63 & 6,66 \\
\hline 20,42 & 1626,60 & 25,40 & 106,82 & 95,50 & 84,33 & 69,95 & 57,49 & 47,29 & 32,89 & 24,28 & 15,82 \\
\hline 36,47 & 1204,50 & 74,20 & 35,37 & 29,99 & 26,50 & 22,32 & 18,73 & 15,74 & 11,33 & 8,52 & 5,54 \\
\hline 39,23 & 1483,90 & 95,00 & 26,54 & 22,45 & 19,94 & 16,96 & 14,37 & 12,19 & 8,89 & 6,73 & 4,37 \\
\hline 82,74 & 963,40 & 128,60 & 17,73 & 12,32 & 10,75 & 9,41 & 8,41 & 7,55 & 6,11 & 5,00 & 3,49 \\
\hline 64,15 & 557,50 & 112,20 & 27,88 & 19,17 & 16,12 & 13,46 & 11,46 & 9,83 & 7,35 & 5,69 & 3,79 \\
\hline 84,60 & 1746,30 & 20,80 & 36,79 & 33,25 & 29,97 & 28,87 & 28,21 & 27,30 & 25,31 & 23,37 & 19,71 \\
\hline 34,52 & 1485,60 & 73,00 & 34,60 & 29,95 & 26,63 & 22,56 & 19,01 & 16,02 & 11,57 & 8,70 & 5,64 \\
\hline 53,06 & 1972,50 & 180,00 & 13,15 & 10,50 & 9,34 & 8,10 & 7,04 & 6,12 & 4,65 & 3,62 & 2,38 \\
\hline 82,41 & 782,00 & 125,30 & 20,07 & 13,63 & 11,70 & 10,10 & 8,93 & 7,95 & 6,34 & 5,14 & 3,55 \\
\hline 85,28 & 745,20 & 184,70 & 17,34 & 10,88 & 8,91 & 7,41 & 6,40 & 5,59 & 4,34 & 3,47 & 2,37 \\
\hline 39,68 & 321,20 & 195,10 & 33,61 & 18,36 & 13,25 & 9,39 & 7,10 & 5,62 & 3,88 & 2,99 & 2,09 \\
\hline 65,10 & 331,80 & 171,80 & 31,81 & 17,60 & 13,18 & 9,96 & 7,97 & 6,54 & 4,64 & 3,55 & 2,42 \\
\hline 67,75 & 1782,30 & 88,90 & 18,26 & 14,40 & 13,44 & 12,32 & 11,31 & 10,37 & 8,67 & 7,25 & 5,17 \\
\hline 21,15 & 811,20 & 179,00 & 31,36 & 20,87 & 15,22 & 10,40 & 7,62 & 5,96 & 4,15 & 3,22 & 2,25 \\
\hline 53,24 & 1137,10 & 125,90 & 20,39 & 15,88 & 13,94 & 11,95 & 10,28 & 8,85 & 6,65 & 5,13 & 3,37 \\
\hline 43,58 & 1861,50 & 99,50 & 21,94 & 18,82 & 17,04 & 14,89 & 12,95 & 11,25 & 8,52 & 6,58 & 4,29 \\
\hline 28,76 & 213,40 & 57,50 & 89,45 & 59,79 & 45,53 & 32,60 & 24,42 & 19,13 & 13,13 & 10,09 & 7,01 \\
\hline 25,33 & 413,00 & 76,10 & 63,84 & 45,16 & 34,75 & 24,89 & 18,56 & 14,48 & 9,91 & 7,61 & 5,28 \\
\hline 73,93 & 566,90 & 152,10 & 23,02 & 14,61 & 11,90 & 9,77 & 8,30 & 7,12 & 5,36 & 4,19 & 2,82 \\
\hline 40,60 & 1374,70 & 97,00 & 26,29 & 22,01 & 19,50 & 16,57 & 14,04 & 11,91 & 8,70 & 6,59 & 4,28 \\
\hline 34,89 & 1815,70 & 93,10 & 27,33 & 23,56 & 20,93 & 17,72 & 14,92 & 12,57 & 9,07 & 6,82 & 4,42 \\
\hline 89,01 & 1588,80 & 63,30 & 20,02 & 15,14 & 13,98 & 13,19 & 12,44 & 11,72 & 10,37 & 9,16 & 7,12 \\
\hline 74,43 & 839,60 & 54,70 & 31,37 & 23,86 & 21,95 & 19,99 & 18,29 & 16,74 & 13,98 & 11,71 & 8,36 \\
\hline 35,15 & 1206,20 & 197,90 & 19,57 & 14,49 & 11,91 & 9,24 & 7,27 & 5,83 & 4,00 & 3,01 & 2,04 \\
\hline 70,22 & 1474,30 & 89,50 & 19,19 & 14,89 & 13,75 & 12,51 & 11,43 & 10,43 & 8,67 & 7,21 & 5,11 \\
\hline 20,45 & 1481,90 & 191,60 & 26,01 & 18,72 & 14,18 & 9,93 & 7,29 & 5,66 & 3,90 & 3,01 & 2,09 \\
\hline 68,19 & 1055,70 & 80,90 & 23,71 & 18,29 & 16,64 & 14,93 & 13,47 & 12,15 & 9,87 & 8,07 & 5,58 \\
\hline 49,34 & 741,90 & 68,40 & 36,33 & 29,20 & 25,85 & 22,20 & 19,09 & 16,42 & 12,28 & 9,45 & 6,19 \\
\hline 72,75 & 1633,40 & 175,70 & 12,30 & 9,06 & 8,06 & 7,11 & 6,35 & 5,68 & 4,56 & 3,70 & 2,55 \\
\hline 30,57 & 1980,70 & 64,90 & 37,37 & 33,24 & 29,77 & 25,36 & 21,44 & 18,11 & 13,09 & 9,82 & 6,34 \\
\hline 77,50 & 747,10 & 132,60 & 20,50 & 13,91 & 11,83 & 10,11 & 8,84 & 7,79 & 6,09 & 4,87 & 3,32 \\
\hline 85,26 & 1114,10 & 188,20 & 13,60 & 9,09 & 7,75 & 6,67 & 5,90 & 5,25 & 4,20 & 3,41 & 2,37 \\
\hline 72,95 & 1878,50 & 189,40 & 11,06 & 8,20 & 7,32 & 6,49 & 5,82 & 5,22 & 4,21 & 3,43 & 2,37 \\
\hline 89,05 & 481,40 & 141,00 & 24,97 & 15,05 & 12,07 & 9,87 & 8,45 & 7,35 & 5,67 & 4,52 & 3,10 \\
\hline 58,59 & 1776,80 & 85,70 & 20,29 & 16,65 & 15,48 & 14,05 & 12,74 & 11,53 & 9,39 & 7,68 & 5,29 \\
\hline 71,43 & 1615,90 & 84,90 & 18,95 & 14,71 & 13,69 & 12,57 & 11,57 & 10,63 & 8,94 & 7,53 & 5,41 \\
\hline 52,67 & 662,00 & 162,40 & 23,18 & 15,68 & 12,87 & 10,34 & 8,48 & 7,03 & 5,02 & 3,80 & 2,54 \\
\hline 67,99 & 1615,80 & 98,20 & 17,80 & 13,93 & 12,86 & 11,67 & 10,63 & 9,68 & 7,99 & 6,61 & 4,64 \\
\hline 79,69 & 1982,60 & 126,40 & 13,00 & 9,72 & 8,94 & 8,19 & 7,54 & 6,95 & 5,88 & 4,98 & 3,63 \\
\hline 58,77 & 1506,20 & 25,80 & 48,02 & 39,15 & 37,71 & 35,87 & 33,74 & 31,63 & 27,60 & 23,95 & 17,99 \\
\hline 54,36 & 1306,90 & 30,90 & 46,56 & 38,92 & 37,25 & 34,68 & 32,09 & 29,59 & 24,97 & 21,01 & 15,02 \\
\hline 67,17 & 598,70 & 24,60 & 61,70 & 48,96 & 46,08 & 42,63 & 39,38 & 36,31 & 30,71 & 25,94 & 18,72 \\
\hline 36,29 & 369,90 & 152,40 & 36,43 & 22,23 & 16,75 & 12,12 & 9,20 & 7,27 & 5,00 & 3,83 & 2,66 \\
\hline 83,51 & 1404,10 & 114,40 & 15,63 & 11,37 & 10,30 & 9,32 & 8,52 & 7,81 & 6,56 & 5,52 & 3,99 \\
\hline 30,33 & 1753,10 & 163,40 & 21,33 & 17,00 & 14,27 & 11,24 & 8,90 & 7,14 & 4,89 & 3,65 & 2,46 \\
\hline 80,16 & 1372,40 & 51,30 & 25,75 & 19,74 & 18,47 & 17,39 & 16,33 & 15,31 & 13,40 & 11,69 & 8,91 \\
\hline 54,91 & 529,80 & 178,20 & 24,61 & 15,43 & 12,25 & 9,60 & 7,76 & 6,38 & 4,52 & 3,43 & 2,31 \\
\hline 76,78 & 983,00 & 33,30 & 39,28 & 30,44 & 28,62 & 27,01 & 25,37 & 23,78 & 20,79 & 18,13 & 13,77 \\
\hline 36,01 & 390,10 & 42,40 & 77,06 & 60,84 & 51,76 & 41,72 & 33,75 & 27,57 & 19,20 & 14,35 & 9,54 \\
\hline 33,31 & 1287,80 & 41,20 & 54,38 & 48,70 & 44,09 & 38,16 & 32,79 & 28,09 & 20,76 & 15,76 & 10,16 \\
\hline 70,88 & 456,90 & 92,40 & 32,66 & 22,06 & 18,54 & 15,59 & 13,42 & 11,63 & 8,86 & 6,95 & 4,67 \\
\hline 69,94 & 1336,50 & 199,60 & 12,94 & 9,22 & 7,97 & 6,86 & 6,00 & 5,27 & 4,10 & 3,25 & 2,19 \\
\hline 78,10 & 1282,40 & 44,20 & 29,46 & 22,76 & 21,36 & 20,16 & 18,95 & 17,77 & 15,57 & 13,59 & 10,36 \\
\hline 51,75 & 1374,50 & 125,60 & 19,14 & 15,33 & 13,62 & 11,78 & 10,20 & 8,83 & 6,68 & 5,18 & 3,40 \\
\hline 66,39 & 1359,90 & 116,90 & 17,46 & 13,44 & 12,13 & 10,78 & 9,65 & 8,64 & 6,92 & 5,60 & 3,83 \\
\hline 67,34 & 914,10 & 197,00 & 16,17 & 10,89 & 9,10 & 7,58 & 6,46 & 5,55 & 4,17 & 3,24 & 2,17 \\
\hline 69,81 & 614,10 & 176,60 & 21,03 & 13,27 & 10,74 & 8,73 & 7,34 & 6,24 & 4,62 & 3,58 & 2,40 \\
\hline 89,17 & 1870,10 & 131,70 & 12,32 & 8,92 & 8,11 & 7,43 & 6,86 & 6,35 & 5,44 & 4,67 & 3,47 \\
\hline 62,29 & 692,10 & 61,40 & 34,81 & 27,12 & 24,35 & 21,50 & 19,09 & 16,94 & 13,36 & 10,68 & 7,20 \\
\hline 72,35 & 541,90 & 108,60 & 27,45 & 18,50 & 15,56 & 13,11 & 11,31 & 9,83 & 7,53 & 5,93 & 3,99 \\
\hline 50,78 & 924,10 & 118,00 & 23,82 & 18,25 & 15,82 & 13,34 & 11,31 & 9,61 & 7,07 & 5,41 & 3,55 \\
\hline 69,11 & 1643,10 & 193,90 & 11,92 & 8,80 & 7,76 & 6,78 & 6,00 & 5,32 & 4,20 & 3,36 & 2,28 \\
\hline 33,74 & 1579,10 & 171,80 & 19,89 & 15,65 & 13,20 & 10,50 & 8,40 & 6,80 & 4,69 & 3,51 & 2,35 \\
\hline 68,28 & 515,00 & 68,30 & 36,00 & 26,23 & 22,91 & 19,85 & 17,43 & 15,35 & 11,98 & 9,52 & 6,42 \\
\hline 64,72 & 1043,30 & 56,80 & 30,29 & 24,12 & 22,38 & 20,35 & 18,54 & 16,87 & 13,90 & 11,48 & 8,03 \\
\hline 80,34 & 580,90 & 109,50 & 25,36 & 16,90 & 14,28 & 12,15 & 10,63 & 9,37 & 7,35 & 5,89 & 4,02 \\
\hline 20,47 & 1809,00 & 33,60 & 85,22 & 75,22 & 65,80 & 53,92 & 43,83 & 35,74 & 24,62 & 18,16 & 11,93 \\
\hline
\end{tabular}




\begin{tabular}{|c|c|c|c|c|c|c|c|c|c|c|c|}
\hline & & & \multicolumn{9}{|c|}{ Deflexões $\left(\times 10^{-4} \mathrm{~cm}\right)$} \\
\hline e1 (cm) & Meq (MPa) & Ms (MPa) & D0 & D25 & D40 & D60 & D80 & D100 & D140 & D180 & D260 \\
\hline 40,99 & 1298,30 & 127,80 & 22,55 & 18,11 & 15,73 & 13,08 & 10,89 & 9,10 & 6,51 & 4,90 & 3,21 \\
\hline 44,93 & 578,80 & 56,00 & 48,07 & 38,63 & 33,86 & 28,61 & 24,19 & 20,50 & 14,97 & 11,37 & 7,43 \\
\hline 65,25 & 710,50 & 110,80 & 24,55 & 17,61 & 15,16 & 12,94 & 11,21 & 9,74 & 7,44 & 5,83 & 3,89 \\
\hline 31,96 & 566,30 & 197,20 & 27,42 & 17,42 & 13,16 & 9,44 & 7,10 & 5,58 & 3,84 & 2,95 & 2,05 \\
\hline 43,24 & 1188,70 & 27,80 & 59,78 & 52,91 & 49,86 & 45,39 & 41,06 & 36,98 & 29,81 & 24,07 & 16,25 \\
\hline 55,97 & 625,40 & 121,90 & 26,77 & 18,87 & 15,87 & 13,11 & 10,99 & 9,28 & 6,77 & 5,18 & 3,43 \\
\hline 77,22 & 923,70 & 151,90 & 17,19 & 11,81 & 10,12 & 8,70 & 7,64 & 6,75 & 5,31 & 4,26 & 2,90 \\
\hline 53,74 & 1779,60 & 138,90 & 15,85 & 12,85 & 11,55 & 10,13 & 8,89 & 7,80 & 6,02 & 4,72 & 3,13 \\
\hline 44,07 & 438,10 & 163,60 & 30,44 & 18,92 & 14,68 & 11,05 & 8,63 & 6,92 & 4,78 & 3,63 & 2,49 \\
\hline 52,35 & 1084,70 & 133,20 & 20,37 & 15,65 & 13,63 & 11,57 & 9,88 & 8,45 & 6,27 & 4,81 & 3,16 \\
\hline 22,11 & 1064,70 & 32,00 & 97,30 & 83,58 & 71,91 & 57,73 & 46,17 & 37,20 & 25,36 & 18,77 & 12,49 \\
\hline 24,51 & 1384,10 & 163,90 & 26,50 & 19,95 & 15,83 & 11,64 & 8,77 & 6,85 & 4,65 & 3,54 & 2,44 \\
\hline 76,67 & 778,10 & 60,70 & 30,08 & 22,46 & 20,44 & 18,45 & 16,80 & 15,32 & 12,70 & 10,58 & 7,51 \\
\hline 51,89 & 1153,40 & 67,80 & 29,70 & 24,79 & 22,62 & 20,08 & 17,80 & 15,74 & 12,32 & 9,75 & 6,48 \\
\hline 29,88 & 367,10 & 66,30 & 66,36 & 47,92 & 38,09 & 28,33 & 21,61 & 17,02 & 11,60 & 8,81 & 6,06 \\
\hline 55,60 & 1268,20 & 196,80 & 14,88 & 10,94 & 9,38 & 7,88 & 6,69 & 5,71 & 4,22 & 3,24 & 2,14 \\
\hline 84,29 & 919,60 & 115,70 & 18,98 & 13,22 & 11,60 & 10,20 & 9,15 & 8,25 & 6,73 & 5,54 & 3,90 \\
\hline 39,14 & 1160,90 & 36,40 & 53,82 & 48,09 & 44,28 & 39,28 & 34,61 & 30,38 & 23,38 & 18,23 & 11,90 \\
\hline 57,33 & 1137,60 & 46,60 & 35,66 & 29,53 & 27,66 & 25,25 & 23,00 & 20,89 & 17,15 & 14,10 & 9,77 \\
\hline 58,33 & 1809,20 & 24,70 & 46,96 & 38,31 & 36,88 & 35,38 & 33,49 & 31,58 & 27,87 & 24,44 & 18,69 \\
\hline 27,40 & 1184,30 & 196,40 & 22,89 & 16,63 & 13,11 & 9,63 & 7,28 & 5,70 & 3,89 & 2,96 & 2,04 \\
\hline 24,96 & 1035,40 & 88,50 & 43,98 & 34,62 & 28,29 & 21,44 & 16,47 & 12,96 & 8,76 & 6,60 & 4,52 \\
\hline 72,86 & 554,70 & 153,20 & 23,36 & 14,77 & 12,00 & 9,82 & 8,31 & 7,11 & 5,33 & 4,15 & 2,79 \\
\hline 36,28 & 1024,50 & 171,20 & 22,37 & 16,53 & 13,61 & 10,62 & 8,39 & 6,75 & 4,64 & 3,49 & 2,36 \\
\hline 37,47 & 882,10 & 139,70 & 26,35 & 19,65 & 16,33 & 12,87 & 10,26 & 8,30 & 5,74 & 4,31 & 2,89 \\
\hline 38,26 & 1459,80 & 70,10 & 32,98 & 28,69 & 25,81 & 22,27 & 19,12 & 16,38 & 12,13 & 9,24 & 5,98 \\
\hline 52,33 & 631,50 & 43,40 & 49,02 & 40,37 & 36,53 & 32,17 & 28,33 & 24,91 & 19,29 & 15,17 & 10,04 \\
\hline 29,23 & 932,30 & 86,30 & 41,39 & 32,89 & 27,47 & 21,46 & 16,89 & 13,50 & 9,21 & 6,89 & 4,65 \\
\hline 33,19 & 407,90 & 141,70 & 37,58 & 23,92 & 18,16 & 13,12 & 9,91 & 7,81 & 5,36 & 4,11 & 2,85 \\
\hline 61,76 & 918,20 & 35,40 & 44,01 & 35,74 & 33,68 & 31,04 & 28,54 & 26,17 & 21,89 & 18,30 & 12,98 \\
\hline 48,38 & 648,10 & 63,00 & 40,83 & 32,65 & 28,77 & 24,56 & 21,00 & 17,97 & 13,33 & 10,21 & 6,68 \\
\hline 41,03 & 515,60 & 136,50 & 31,87 & 21,53 & 17,25 & 13,25 & 10,42 & 8,37 & 5,78 & 4,37 & 2,97 \\
\hline 35,43 & 1021,80 & 161,50 & 23,54 & 17,54 & 14,47 & 11,29 & 8,91 & 7,16 & 4,92 & 3,70 & 2,50 \\
\hline 31,87 & 867,90 & 67,90 & 46,66 & 38,16 & 32,67 & 26,36 & 21,28 & 17,33 & 12,01 & 8,95 & 5,94 \\
\hline 83,53 & 1707,50 & 40,70 & 26,31 & 20,90 & 19,37 & 18,60 & 17,78 & 16,91 & 15,22 & 13,65 & 10,91 \\
\hline 43,23 & 1594,90 & 111,00 & 21,85 & 18,30 & 16,31 & 14,01 & 12,00 & 10,27 & 7,62 & 5,82 & 3,79 \\
\hline 59,53 & 489,80 & 48,30 & 47,50 & 36,93 & 32,87 & 28,71 & 25,22 & 22,16 & 17,18 & 13,56 & 9,04 \\
\hline 70,79 & 1271,30 & 59,70 & 25,96 & 20,27 & 18,97 & 17,50 & 16,16 & 14,90 & 12,61 & 10,66 & 7,72 \\
\hline 38,94 & 1068,10 & 155,80 & 22,35 & 16,91 & 14,20 & 11,35 & 9,15 & 7,46 & 5,20 & 3,90 & 2,60 \\
\hline 23,54 & 1907,20 & 40,60 & 64,98 & 58,00 & 51,39 & 42,92 & 35,54 & 29,44 & 20,68 & 15,32 & 9,95 \\
\hline 37,54 & 563,30 & 30,00 & 81,19 & 69,93 & 62,47 & 53,39 & 45,41 & 38,61 & 28,25 & 21,38 & 13,86 \\
\hline 89,83 & 1372,10 & 21,80 & 37,90 & 32,99 & 29,76 & 28,62 & 27,84 & 26,86 & 24,78 & 22,78 & 19,07 \\
\hline 66,10 & 1531,20 & 177,90 & 13,17 & 9,83 & 8,67 & 7,57 & 6,67 & 5,89 & 4,61 & 3,67 & 2,47 \\
\hline 88,85 & 947,30 & 183,30 & 14,89 & 9,65 & 8,11 & 6,91 & 6,08 & 5,40 & 4,30 & 3,49 & 2,43 \\
\hline 43,27 & 622,20 & 24,90 & 79,49 & 69,58 & 63,90 & 56,68 & 50,02 & 43,99 & 34,02 & 26,64 & 17,48 \\
\hline 87,95 & 422,10 & 45,30 & 44,01 & 30,84 & 27,35 & 24,37 & 22,10 & 20,12 & 16,72 & 13,99 & 10,03 \\
\hline 52,87 & 1976,40 & 80,40 & 21,66 & 18,30 & 17,06 & 15,46 & 13,97 & 12,58 & 10,16 & 8,24 & 5,61 \\
\hline 43,44 & 1190,80 & 131,80 & 22,05 & 17,41 & 15,08 & 12,55 & 10,47 & 8,78 & 6,31 & 4,76 & 3,13 \\
\hline 30,52 & 422,60 & 89,60 & 51,32 & 36,08 & 28,38 & 20,94 & 15,92 & 12,53 & 8,55 & 6,51 & 4,49 \\
\hline 86,74 & 1409,20 & 73,10 & 19,71 & 14,65 & 13,52 & 12,58 & 11,73 & 10,95 & 9,51 & 8,26 & 6,25 \\
\hline 23,53 & 1953,60 & 166,60 & 24,34 & 18,99 & 15,35 & 11,47 & 8,72 & 6,82 & 4,61 & 3,49 & 2,40 \\
\hline 26,28 & 899,30 & 135,60 & 32,99 & 24,22 & 19,09 & 14,00 & 10,56 & 8,26 & 5,62 & 4,29 & 2,96 \\
\hline 61,76 & 1400,30 & 23,00 & 51,39 & 41,63 & 39,94 & 38,23 & 36,15 & 34,05 & 30,01 & 26,30 & 20,10 \\
\hline 74,90 & 280,30 & 102,00 & 41,36 & 24,52 & 19,25 & 15,30 & 12,73 & 10,77 & 7,95 & 6,16 & 4,16 \\
\hline 40,31 & 772,30 & 107,20 & 31,17 & 23,77 & 20,12 & 16,25 & 13,21 & 10,85 & 7,61 & 5,71 & 3,79 \\
\hline 57,54 & 1274,30 & 144,30 & 17,21 & 13,23 & 11,64 & 10,04 & 8,72 & 7,58 & 5,77 & 4,50 & 2,98 \\
\hline 30,97 & 568,00 & 121,70 & 37,62 & 26,43 & 20,81 & 15,39 & 11,72 & 9,23 & 6,30 & 4,80 & 3,31 \\
\hline 64,91 & 1490,90 & 193,20 & 12,88 & 9,51 & 8,32 & 7,19 & 6,29 & 5,51 & 4,26 & 3,37 & 2,25 \\
\hline 71,64 & 1552,80 & 36,40 & 32,91 & 26,07 & 24,71 & 23,59 & 22,30 & 21,02 & 18,57 & 16,33 & 12,58 \\
\hline 71,45 & 1846,90 & 23,60 & 40,43 & 33,62 & 31,34 & 30,46 & 29,35 & 28,07 & 25,51 & 23,07 & 18,67 \\
\hline 52,96 & 1963,70 & 145,10 & 14,97 & 12,23 & 11,03 & 9,68 & 8,51 & 7,47 & 5,77 & 4,53 & 3,00 \\
\hline 20,43 & 1209,40 & 38,60 & 87,71 & 73,93 & 62,49 & 48,99 & 38,40 & 30,50 & 20,57 & 15,30 & 10,32 \\
\hline$\frac{20,70}{77,41}$ & 1413,50 & 83,00 & 19,43 & 14,70 & 13,59 & 12,48 & 11,50 & 10,60 & 8,98 & $\begin{array}{c}10,60 \\
7,61\end{array}$ & $\frac{10,06}{5,53}$ \\
\hline 57,28 & 1140,80 & 111,10 & 20,96 & 16,43 & 14,61 & 12,72 & 11,13 & $\begin{array}{c}10,00 \\
9,74\end{array}$ & 7,49 & 5,88 & 3,90 \\
\hline 52,61 & 793,60 & 113,50 & 25,55 & 19,16 & $\frac{1+7,0 \pm}{16,50}$ & 13,86 & $\begin{array}{l}1+x_{1} \\
11,73\end{array}$ & 9,97 & 7,33 & 5,61 & 3,69 \\
\hline 60,70 & 850,80 & 61,40 & 32,40 & 25,84 & 23,50 & 20,95 & 18,73 & 16,72 & 13,33 & 10,72 & 7,26 \\
\hline 80,19 & 965,70 & 29,50 & 41,42 & 32,14 & 30,09 & 28,60 & 27,03 & 25,49 & 22,55 & 19,89 & 15,42 \\
\hline 40,79 & 1084,70 & 54,30 & 41,19 & 35,66 & 32,21 & 27,99 & 24,20 & 20,89 & 15,65 & 12,01 & 7,80 \\
\hline 70,14 & 939,70 & 65,70 & 27,70 & 21,34 & 19,54 & 17,65 & 16,03 & 14,55 & 11,96 & 9,88 & 6,92 \\
\hline 72,89 & 357,80 & 159,90 & 30,36 & 17,22 & 13,15 & 10,19 & 8,32 & 6.95 & 5,04 & 3,88 & 2,63 \\
\hline 68,22 & 1130,80 & 47,10 & 32,14 & 25,40 & 23,89 & 22,12 & 20,45 & 18,87 & 15,99 & 13,54 & 9,80 \\
\hline 51,47 & 1418,00 & 68,60 & 27,43 & 23,18 & 21,37 & 19,15 & 17,11 & 15,25 & 12,09 & 9,66 & 6,47 \\
\hline 21,86 & 1191,20 & 185,80 & 27,09 & 19,22 & 14,54 & 10,20 & 7,52 & 5,84 & 4,02 & 3,11 & 2,16 \\
\hline 32,19 & 657,70 & 152,60 & 30,28 & 20,99 & 16,52 & 12,24 & 9,34 & 7,37 & 5,04 & 3,83 & 2,64 \\
\hline 46,88 & 275,60 & 178,30 & 37,11 & 19,76 & 14,24 & 10,20 & 7,80 & 6,21 & 4,29 & 3,29 & 2,30 \\
\hline 76,13 & 1331,00 & 187,70 & 12,90 & 9,09 & 7,91 & 6,87 & 6,07 & 5,40 & 4,28 & 3,45 & 2,36 \\
\hline 58,74 & 1604,80 & 101,50 & 18,94 & 15,35 & 14,05 & 12,58 & 11,28 & 10,09 & 8,06 & 6,50 & 4,40 \\
\hline 56,21 & 1502,40 & 22,10 & 55,22 & 45,27 & 43,72 & 41,68 & 39,25 & 36,84 & 32,20 & 27,97 & 21,04 \\
\hline 63,29 & 1967,80 & 159,60 & 12,78 & 10,01 & 9,05 & 8,04 & 7,18 & 6,41 & 5,11 & 4,11 & 2,79 \\
\hline 65,12 & 341,20 & 153,60 & 32,48 & 18,62 & 14,23 & 10,95 & 8,85 & 7,31 & 5,22 & 3,99 & 2,71 \\
\hline 38,54 & 992,30 & 194,50 & 20,29 & 14,57 & 11,93 & 9,29 & 7,35 & 5,92 & 4,09 & 3,08 & 2,08 \\
\hline 42,61 & 1145,40 & 98,70 & 26,98 & 22,04 & 19,38 & 16,37 & 13,82 & 11,69 & 8,51 & 6,44 & 4,20 \\
\hline
\end{tabular}




\begin{tabular}{|c|c|c|c|c|c|c|c|c|c|c|c|}
\hline \multirow[b]{2}{*}{ e1 (cm) } & & & & & & & ões (x1 & & & & \\
\hline & Meq (MPa) & Ms (MPa) & D0 & D25 & D40 & D60 & D80 & D100 & D140 & D180 & D260 \\
\hline 41,17 & 1415,50 & 133,00 & 21,21 & 17,14 & 14,94 & 12,47 & 10,42 & 8,73 & 6,28 & 4,73 & 3,09 \\
\hline 63,59 & 869,00 & 164,80 & 18,46 & 12,86 & 10,87 & 9,11 & 7,78 & 6,68 & 5,01 & 3,88 & 2,58 \\
\hline 42,88 & 380,40 & 50,40 & 62,64 & 48,11 & 41,10 & 33,68 & 27,75 & 23,01 & 16,35 & 12,30 & 8,12 \\
\hline 44,58 & 1411,80 & 160,60 & 18,01 & 14,15 & 12,26 & 10,23 & 8,56 & 7,18 & 5,19 & 3,92 & 2,57 \\
\hline 58,95 & 1895,10 & 38,00 & 34,16 & 27,89 & 26,82 & 25,35 & 23,74 & 22,16 & 19,17 & 16,50 & 12,23 \\
\hline 68,20 & 1426,10 & 21,50 & 49,38 & 40,08 & 37,91 & 36,66 & 35,01 & 33,27 & 29,85 & 26,63 & 21,03 \\
\hline 58,19 & 1522,20 & 155,90 & 15,14 & 11,76 & 10,43 & 9,07 & 7,93 & 6,93 & 5,34 & 4,19 & 2,78 \\
\hline 61,36 & 1723,40 & 97,90 & 18,38 & 14,82 & 13,68 & 12,37 & 11,19 & 10,10 & 8,21 & 6,71 & 4,62 \\
\hline 81,01 & 1617,50 & 193,80 & 11,23 & 7,95 & 7,00 & 6,17 & 5,53 & 4,98 & 4,05 & 3,32 & 2,32 \\
\hline 22,96 & 938,90 & 154,30 & 32,17 & 22,84 & 17,38 & 12,28 & 9,09 & 7,07 & 4,86 & 3,74 & 2,60 \\
\hline 40,88 & 891,50 & 91,30 & 32,12 & 25,65 & 22,22 & 18,41 & 15,28 & 12,74 & 9,10 & 6,84 & 4,49 \\
\hline 43,21 & 796,80 & 59,40 & 41,96 & 34,87 & 30,97 & 26,47 & 22,59 & 19,28 & 14,22 & 10,83 & 7,05 \\
\hline 60,08 & 997,70 & 66,20 & 29,20 & 23,47 & 21,45 & 19,19 & 17,21 & 15,40 & 12,32 & 9,94 & 6,75 \\
\hline 63,47 & 1944,40 & 64,80 & 22,54 & 18,17 & 17,24 & 16,03 & 14,85 & 13,73 & 11,65 & 9,87 & 7,14 \\
\hline 77,11 & 947,00 & 63,40 & 26,89 & 20,24 & 18,58 & 16,93 & 15,52 & 14,23 & 11,94 & 10,04 & 7,22 \\
\hline 69,86 & 410,70 & 63,10 & 41,53 & 29,47 & 25,42 & 21,83 & 19,06 & 16,72 & 12,96 & 10,27 & 6,91 \\
\hline 20,52 & 953,20 & 96,60 & 48,29 & 35,97 & 27,82 & 19,84 & 14,67 & 11,37 & 7,77 & 5,97 & 4,14 \\
\hline 36,25 & 1302,70 & 126,70 & 24,64 & 19,77 & 16,96 & 13,81 & 11,26 & 9,25 & 6,48 & 4,84 & 3,20 \\
\hline 80,91 & 666,40 & 176,20 & 19,19 & 12,02 & 9,79 & 8,08 & 6,92 & 6,00 & 4,59 & 3,63 & 2,46 \\
\hline 33,75 & 683,90 & 162,70 & 28,01 & 19,36 & 15,30 & 11,42 & 8,77 & 6,94 & 4,75 & 3,60 & 2,48 \\
\hline 53,67 & 1920,00 & 121,10 & 16,72 & 13,80 & 12,57 & 11,16 & 9,90 & 8,76 & 6,87 & 5,45 & 3,63 \\
\hline 23,82 & 1433,10 & 190,20 & 24,03 & 17,73 & 13,85 & 10,02 & 7,49 & 5,83 & 3,98 & 3,04 & 2,11 \\
\hline 35,02 & 585,00 & 185,80 & 27,06 & 17,59 & 13,58 & 9,98 & 7,61 & 6,01 & 4,12 & 3,15 & 2,18 \\
\hline 44,71 & 1379,80 & 97,20 & 24,49 & 20,45 & 18,27 & 15,75 & 13,55 & 11,65 & 8,70 & 6,67 & 4,35 \\
\hline 47,19 & 1899,40 & 165,50 & 15,09 & 12,26 & 10,86 & 9,31 & 7,97 & 6,84 & 5,09 & 3,90 & 2,55 \\
\hline 64,06 & 1706,80 & 100,40 & 17,75 & 14,13 & 13,05 & 11,81 & 10,72 & 9,71 & 7,94 & 6,52 & 4,52 \\
\hline 49,73 & 617,20 & 150,00 & 25,61 & 17,44 & 14,29 & 11,41 & 9,28 & 7,64 & 5,41 & 4,09 & 2,74 \\
\hline 33,95 & 1484,80 & 49,00 & 45,50 & 40,68 & 36,85 & 31,93 & 27,47 & 23,56 & 17,45 & 13,27 & 8,56 \\
\hline 55,27 & 328,40 & 90,20 & 43,43 & 28,53 & 23,17 & 18,54 & $\begin{array}{l}21,4 i \\
15,19\end{array}$ & 12,61 & $\begin{array}{c}1+, 4 \\
9,01\end{array}$ & $\begin{array}{c}0, L 1 \\
6,85\end{array}$ & 4,58 \\
\hline 45,56 & 1444,00 & 190,90 & 15,92 & 12,21 & 10,49 & 8,68 & 7,22 & 6,04 & 4,34 & 3,28 & 2,16 \\
\hline 69,10 & 365,00 & 112,50 & 34,52 & 21,49 & 17,25 & 13,91 & 11,62 & 9,84 & 7,25 & 5,60 & 3,75 \\
\hline 43,62 & 1760,80 & 61,90 & 30,38 & 26,72 & 24,71 & 22,08 & 19,63 & 17,39 & 13,61 & 10,74 & 7,10 \\
\hline 79,64 & 1462,70 & 77,80 & 19,62 & 14,81 & 13,74 & 12,70 & 11,77 & 10,91 & 9,34 & 8,00 & 5,91 \\
\hline 82,96 & 623,60 & 109,00 & 24,15 & 16,17 & 13,76 & 11,80 & 10,39 & 9,21 & 7,31 & 5,91 & 4,07 \\
\hline 61,03 & 696,90 & 87,60 & 28,85 & 21,64 & 18,93 & 16,32 & 14,19 & 12,36 & 9,46 & 7,41 & 4,93 \\
\hline 76,63 & 1270,00 & 91,60 & 19,27 & 14,46 & 13,22 & 11,99 & 10,95 & 10,01 & 8,35 & 6,98 & 4,99 \\
\hline 86,17 & 870,40 & 72,00 & 24,67 & 17,78 & 16,07 & 14,55 & 13,32 & 12,24 & 10,31 & 8,72 & 6,35 \\
\hline 32,04 & 1833,60 & 185,20 & 18,62 & 14,75 & 12,42 & 9,83 & 7,82 & 6,31 & 4,34 & 3,24 & 2,17 \\
\hline 62,13 & 1620,30 & 191,20 & 12,72 & 9,59 & 8,44 & 7,32 & 6,40 & 5,60 & 4,33 & 3,41 & 2,27 \\
\hline 65,81 & 283,50 & 93,90 & 43,80 & 27,00 & 21,50 & 17,15 & 14,19 & 11,91 & 8,66 & 6,65 & 4,46 \\
\hline 73,12 & 682,50 & 136,10 & 21,75 & 14,64 & 12,32 & 10,39 & 8,98 & 7,81 & 6,00 & 4,73 & 3,18 \\
\hline 43,89 & 1586,10 & 82,00 & 26,16 & 22,50 & 20,41 & 17,89 & 15,61 & 13,59 & 10,33 & 8,01 & 5,23 \\
\hline 87,87 & 248,50 & 46,80 & 57,59 & 37,59 & 31,70 & 27,05 & 23,81 & 21,15 & 16,86 & 13,69 & 9,50 \\
\hline 51,17 & 1961,30 & 36,20 & 38,35 & 32,32 & 31,11 & 29,10 & 27,01 & 24,98 & 21,19 & 17,90 & 12,85 \\
\hline 79,46 & 909,50 & 138,30 & 17,92 & 12,37 & 10,68 & 9,24 & 8,17 & 7,26 & 5,78 & 4,67 & 3,21 \\
\hline 45,64 & 1274,30 & 141,90 & 19,90 & 15,67 & 13,62 & 11,42 & 9,60 & 8,10 & 5,88 & 4,46 & 2,92 \\
\hline 72,70 & 1320,80 & 58,50 & 25,53 & 19,83 & 18,59 & 17,24 & 15,98 & 14,80 & 12,63 & 10,76 & 7,88 \\
\hline 61,00 & 337,70 & 75,10 & 44,83 & 30,45 & 25,34 & 20,88 & 17,56 & 14,89 & 10,96 & 8,42 & 5,60 \\
\hline 77,09 & 217,20 & 108,40 & 47,83 & 26,25 & 19,70 & 15,06 & 12,24 & 10,21 & 7,40 & 5,72 & 3,89 \\
\hline 38,21 & 1893,70 & 31,30 & 52,15 & 47,05 & 44,50 & 40,57 & 36,72 & 33,07 & 26,62 & 21,45 & 14,41 \\
\hline 76,85 & 1677,70 & 190,00 & 11,38 & 8,22 & 7,28 & 6,42 & 5,75 & 5,16 & 4,17 & 3,41 & 2,36 \\
\hline 27,65 & 1704,20 & 172,30 & 22,17 & 17,32 & 14,23 & 10,90 & 8,45 & 6,69 & 4,54 & 3,41 & 2,33 \\
\hline 82,18 & 1245,00 & 55,80 & 25,07 & 18,97 & 17,65 & 16,50 & 15,42 & 14,41 & 12,52 & 10,87 & 8,21 \\
\hline 84,11 & 1236,00 & 84,30 & 19,53 & 14,36 & 13,13 & 12,01 & 11,07 & 10,22 & 8,69 & 7,40 & 5,43 \\
\hline 87,94 & 275,20 & 184,10 & 34,36 & 17,44 & 12,46 & 9,14 & 7,27 & 5,99 & 4,31 & 3,34 & 2,30 \\
\hline 57,62 & 225,20 & 188,20 & 40,66 & 19,92 & 13,77 & 9,64 & 7,36 & 5,88 & 4,07 & 3,14 & 2,20 \\
\hline 36,49 & 1665,40 & 118,80 & 23,32 & 19,45 & 17,04 & 14,21 & 11,82 & 9,86 & 7,04 & 5,27 & 3,45 \\
\hline 36,82 & 1198,40 & 192,90 & 19,40 & 14,42 & 11,94 & 9,37 & 7,44 & 6,00 & 4,14 & 3,11 & 2,09 \\
\hline 22,78 & 1591,90 & 169,10 & 26,11 & 19,71 & 15,54 & 11,32 & 8,48 & 6,60 & 4,48 & 3,42 & 2,37 \\
\hline 24,43 & 245,30 & 45,80 & 108,63 & 76,30 & 58,20 & 41,33 & 30,68 & 23,91 & 16,42 & 12,63 & 8,78 \\
\hline 42,09 & 1996,50 & 88,70 & 23,60 & 20,58 & 18,76 & 16,49 & 14,41 & 12,57 & 9,58 & 7,42 & 4,84 \\
\hline 76,81 & 1115,90 & 55,00 & 27,44 & 20,96 & 19,53 & 18,08 & 16,77 & 15,54 & 13,29 & 11,35 & 8,36 \\
\hline 56,90 & 1978,20 & 98,20 & 18,20 & 15,04 & 13,94 & $\begin{array}{l}10,00 \\
12,59\end{array}$ & 11,37 & 10,24 & 8,28 & $\begin{array}{c}+ \pm, 60 \\
6,72\end{array}$ & 4,59 \\
\hline 43,62 & 705,80 & 87,10 & 34,83 & 27,04 & 23,26 & 19,22 & 15,94 & 13,30 & 9,52 & 7,17 & 4,72 \\
\hline 87,77 & 1306,40 & 160,70 & 13,30 & 9,19 & 8,07 & 7,12 & 6,41 & 5,80 & 4,77 & 3,96 & 2,81 \\
\hline 32,04 & 1517,00 & 102,30 & 29,29 & 24,38 & 21,10 & 17,23 & 14,06 & 11,53 & 8,05 & 6,00 & 3,95 \\
\hline 55,09 & 579,30 & 75,50 & 35,90 & 27,19 & 23,63 & 20,10 & 17,21 & 14,78 & 11,05 & 8,52 & 5,61 \\
\hline 81,58 & 1738,00 & 141,00 & 12,80 & 9,37 & 8,49 & 7,68 & 7,01 & 6,42 & 5,36 & 4,50 & 3,24 \\
\hline 60,19 & 428,40 & 137,00 & 30,21 & 18,98 & 15,18 & 12,06 & 9,90 & 8,24 & 5,92 & 4,52 & 3,03 \\
\hline 58,83 & 526,70 & 37,00 & 54,10 & 43,53 & 39,59 & 35,25 & 31,45 & 28,01 & 22,22 & 17,80 & 12,00 \\
\hline 85,35 & 806,90 & 114,80 & 20,30 & 13,88 & 12,04 & 10,50 & 9,37 & 8,41 & 6,81 & 5,59 & 3,91 \\
\hline 39,49 & 1603,10 & 53,60 & 37,09 & 33,02 & 30,34 & 26,85 & 23,61 & 20,69 & 15,87 & 12,35 & 8,06 \\
\hline 87,47 & 1396,20 & 166,30 & 12,66 & 8,79 & 7,73 & 6,84 & 6,17 & 5,59 & 4,60 & 3,83 & 2,72 \\
\hline 53,84 & 534,00 & 48,00 & 48,56 & 38,77 & 34,55 & 30,04 & 26,18 & 22,81 & 17,43 & 13,59 & 8,97 \\
\hline 54,37 & 308,50 & 26,00 & 86,87 & 69,77 & 62,48 & 54,61 & 47,83 & 41,85 & 32,20 & 25,23 & 16,69 \\
\hline 54,39 & 1077,60 & 88,50 & 25,23 & 20,31 & 18,22 & 15,95 & 13,99 & 12,25 & 9,45 & 7,41 & 4,91 \\
\hline 22,90 & 950,00 & 70,40 & 56,40 & 44,55 & 36,20 & 27,19 & 20,72 & 16,23 & 10,96 & 8,28 & 5,68 \\
\hline 31,68 & 1384,40 & 115,50 & 28,16 & 22,84 & 19,46 & 15,60 & 12,53 & 10,17 & 7,02 & 5,23 & 3,49 \\
\hline 51,14 & 791,40 & 128,30 & 24,32 & 17,89 & 15,23 & 12,62 & 10,56 & 8,89 & 6,45 & 4,91 & 3,24 \\
\hline 79,81 & 1295,40 & 29,90 & 36,70 & 29,12 & 27,17 & 26,10 & 24,89 & 23,63 & 21,19 & 18,92 & 14,99 \\
\hline 53,90 & 314,30 & 197,40 & 32,29 & 17,21 & 12,50 & 9,09 & 7,05 & 5,66 & 3,93 & 3,01 & 2,08 \\
\hline 20,31 & 1130,50 & 45,60 & 79,98 & 65,91 & 54,74 & 42,02 & 32,42 & 25,50 & 17,14 & 12,84 & 8,75 \\
\hline
\end{tabular}




\begin{tabular}{|c|c|c|c|c|c|c|c|c|c|c|c|}
\hline \multirow[b]{2}{*}{ e1 (cm) } & & & & & & & ões (x1 & m) & & & \\
\hline & Meq (MPa) & Ms (MPa) & D0 & D25 & D40 & D60 & D80 & D100 & D140 & D180 & D260 \\
\hline 51,29 & 1147,10 & 75,50 & 28,04 & 23,24 & 21,06 & 18,55 & 16,33 & 14,35 & 11,10 & 8,72 & 5,76 \\
\hline 66,87 & 419,10 & 45,40 & 49,68 & 37,31 & 33,10 & 29,03 & 25,72 & 22,80 & 17,99 & 14,39 & 9,74 \\
\hline 29,74 & 222,00 & 194,80 & 41,81 & 20,25 & 13,60 & 9,16 & 6,86 & 5,44 & 3,80 & 2,96 & 2,10 \\
\hline 26,12 & 1599,10 & 129,40 & 28,64 & 22,83 & 18,89 & 14,54 & 11,29 & 8,95 & 6,06 & 4,55 & 3,09 \\
\hline 54,71 & 1469,60 & 96,50 & 21,07 & 17,28 & 15,72 & 13,95 & 12,38 & 10,97 & 8,61 & 6,84 & 4,56 \\
\hline 37,81 & 1618,60 & 109,10 & 24,21 & 20,35 & 17,95 & 15,12 & 12,70 & 10,68 & 7,70 & 5,80 & 3,77 \\
\hline 58,19 & 1078,30 & 98,60 & 22,79 & 17,94 & 16,03 & 14,04 & 12,35 & 10,85 & 8,42 & 6,64 & 4,43 \\
\hline 73,01 & 1604,60 & 87,50 & 18,45 & 14,22 & 13,21 & 12,12 & 11,16 & 10,26 & 8,64 & 7,29 & 5,25 \\
\hline 71,26 & 1542,90 & 185,30 & 12,41 & 9,07 & 7,99 & 6,99 & 6,20 & 5,51 & 4,37 & 3,51 & 2,39 \\
\hline 55,31 & 507,60 & 109,40 & 31,55 & 21,83 & 18,18 & 14,86 & 12,37 & 10,38 & 7,51 & 5,73 & 3,80 \\
\hline 69,09 & 214,60 & 92,90 & 51,74 & 29,75 & 22,85 & 17,72 & 14,45 & 12,02 & 8,67 & 6,66 & 4,50 \\
\hline 47,89 & 636,10 & 135,20 & 27,09 & 19,02 & 15,75 & 12,65 & 10,31 & 8,50 & 6,02 & 4,54 & 3,03 \\
\hline 30,03 & 1671,10 & 171,60 & 21,14 & 16,62 & 13,84 & 10,79 & 8,48 & 6,77 & 4,62 & 3,46 & 2,34 \\
\hline 66,54 & 1141,90 & 90,40 & 21,77 & 16,86 & 15,30 & 13,67 & 12,28 & 11,04 & 8,90 & 7,23 & 4,97 \\
\hline 35,86 & 1140,50 & 70,70 & 37,70 & 31,92 & 28,14 & 23,62 & 19,76 & 16,56 & 11,87 & 8,91 & 5,80 \\
\hline 53,09 & 812,00 & 68,70 & 33,37 & 26,88 & 24,03 & 20,94 & 18,28 & 15,94 & 12,20 & 9,52 & 6,28 \\
\hline 51,00 & 1059,10 & 112,20 & 23,02 & 18,12 & 15,92 & 13,61 & 11,67 & 10,02 & 7,47 & 5,74 & 3,77 \\
\hline 47,67 & 383,20 & 184,60 & 30,18 & 17,46 & 13,16 & 9,76 & 7,59 & 6,09 & 4,21 & 3,21 & 2,21 \\
\hline 74,26 & 239,80 & 71,00 & 52,30 & 32,49 & 26,17 & 21,28 & 17,95 & 15,35 & 11,48 & 8,94 & 6,02 \\
\hline 52,19 & 1138,70 & 107,70 & 22,53 & 17,95 & 15,92 & 13,75 & 11,90 & 10,30 & 7,78 & 6,03 & 3,96 \\
\hline 31,98 & 580,60 & 77,20 & 49,23 & 37,50 & 30,91 & 23,92 & 18,74 & 14,96 & 10,22 & 7,68 & 5,21 \\
\hline 31,04 & 1589,60 & 105,50 & 28,94 & 24,06 & 20,75 & 16,86 & 13,69 & 11,19 & 7,77 & 5,78 & 3,82 \\
\hline 80,47 & 840,40 & 174,20 & 16,82 & 11,02 & 9,23 & 7,79 & 6,77 & 5,94 & 4,63 & 3,69 & 2,52 \\
\hline 63,60 & 1903,00 & 41,00 & 30,83 & 24,83 & 23,78 & 22,56 & 21,20 & 19,86 & 17,32 & 15,03 & 11,30 \\
\hline 36,10 & 1085,80 & 193,60 & 20,34 & 14,86 & 12,16 & 9,43 & 7,42 & 5,95 & 4,09 & 3,08 & 2,08 \\
\hline 61,49 & 1351,10 & 47,50 & 31,89 & 25,93 & 24,54 & 22,70 & 20,94 & 19,26 & 16,19 & 13,60 & 9,71 \\
\hline 43,43 & 1173,20 & 116,70 & 23,85 & 19,11 & 16,68 & 13,99 & 11,74 & 9,89 & 7,16 & 5,42 & 3,54 \\
\hline 59,01 & 712,50 & 114,70 & 25,24 & 18,30 & 15,68 & 13,22 & 11,29 & 9,68 & 7,23 & 5,59 & 3,70 \\
\hline 32,96 & 1220,20 & 133,40 & 26,08 & 20,48 & 17,21 & 13,62 & 10,84 & 8,75 & 6,02 & 4,50 & 3,02 \\
\hline 69,66 & 369,90 & 98,60 & 36,04 & 23,12 & 18,88 & 15,46 & 13,05 & 11,14 & 8,30 & 6,44 & 4,31 \\
\hline 38,88 & 1389,40 & 119,90 & 23,69 & 19,35 & 16,86 & 14,03 & 11,66 & 9,73 & 6,95 & 5,22 & 3,42 \\
\hline 36,38 & 1740,60 & 98,80 & 25,85 & 22,10 & 19,61 & 16,61 & 14,00 & 11,81 & 8,54 & 6,43 & 4,17 \\
\hline 21,25 & 1070,10 & 120,40 & 38,95 & 28,81 & 22,27 & 15,88 & 11,76 & 9,13 & 6,24 & 4,79 & 3,32 \\
\hline 39,92 & 967,20 & 86,50 & 32,67 & 26,57 & 23,16 & 19,31 & 16,09 & 13,45 & 9,64 & 7,25 & 4,75 \\
\hline 79,34 & 1569,70 & 65,10 & 21,27 & 16,26 & 15,19 & 14,23 & 13,30 & 12,42 & 10,79 & 9,35 & 7,05 \\
\hline 37,44 & 393,20 & 163,40 & 33,78 & 20,56 & 15,53 & 11,29 & 8,60 & 6,80 & 4,68 & 3,58 & 2,48 \\
\hline 38,52 & 1312,90 & 187,00 & 18,56 & 14,09 & 11,85 & 9,47 & 7,63 & 6,22 & 4,33 & 3,24 & 2,17 \\
\hline 41,49 & 1268,60 & 141,80 & 21,20 & 16,72 & 14,42 & 11,90 & 9,85 & 8,20 & 5,84 & 4,39 & 2,89 \\
\hline 87,08 & 259,80 & 128,20 & 39,41 & 21,39 & 16,01 & 12,28 & 10,06 & 8,47 & 6,25 & 4,87 & 3,33 \\
\hline 70,60 & 540,40 & 63,90 & 35,86 & 26,32 & 23,21 & 20,31 & 18,01 & 16,00 & 12,68 & 10,19 & 6,93 \\
\hline 49,34 & 725,90 & 54,00 & 42,18 & 34,74 & 31,16 & 27,13 & 23,61 & 20,52 & 15,59 & 12,10 & 7,94 \\
\hline 38,69 & 1290,50 & 44,50 & 45,85 & 40,81 & 37,37 & 32,92 & 28,82 & 25,14 & 19,15 & 14,83 & 9,64 \\
\hline 53,07 & 1762,60 & 150,50 & 15,29 & 12,31 & 10,99 & 9,58 & 8,35 & 7,28 & 5,57 & 4,34 & 2,86 \\
\hline 87,60 & 1251,60 & 132,40 & 14,97 & 10,52 & 9,34 & 8,33 & 7,55 & 6,88 & 5,72 & 4,78 & 3,43 \\
\hline 69,43 & 1535,60 & 184,50 & 12,61 & 9,27 & 8,17 & 7,13 & 6,31 & 5,59 & 4,41 & 3,53 & 2,39 \\
\hline 38,45 & 981,50 & 124,30 & 26,70 & 20,65 & 17,51 & 14,12 & 11,45 & 9,38 & 6,56 & 4,91 & 3,26 \\
\hline 68,62 & 894,30 & 103,30 & 22,22 & 16,46 & 14,54 & 12,72 & 11,26 & 9,98 & 7,88 & 6,31 & 4,28 \\
\hline 62,96 & 696,90 & 117,20 & 24,49 & 17,46 & 14,92 & 12,62 & 10,84 & 9,35 & 7,05 & 5,48 & 3,65 \\
\hline 63,05 & 432,00 & 81,10 & 37,44 & 26,16 & 22,13 & 18,56 & 15,84 & 13,59 & 10,18 & 7,89 & 5,24 \\
\hline 36,03 & 639,80 & 111,80 & 34,99 & 25,65 & 21,03 & 16,32 & 12,85 & 10,31 & 7,09 & 5,33 & 3,61 \\
\hline 24,23 & 656,40 & 178,20 & 31,29 & 20,50 & 15,11 & 10,46 & 7,72 & 6,04 & 4,19 & 3,24 & 2,26 \\
\hline 22,76 & 1454,60 & 37,60 & 76,98 & 67,29 & 58,70 & 47,99 & 38,98 & 31,79 & 21,93 & 16,21 & 10,66 \\
\hline 53,79 & 1694,30 & 62,00 & 26,81 & 22,59 & 21,21 & 19,34 & 17,59 & 15,94 & 13,02 & 10,66 & 7,33 \\
\hline 45,21 & 1022,80 & 104,70 & 26,20 & 20,88 & 18,25 & 15,37 & 12,97 & 10,97 & 7,99 & 6,06 & 3,97 \\
\hline 55,16 & 434,00 & 111,80 & 33,91 & 22,60 & 18,48 & 14,87 & 12,23 & 10,18 & 7,30 & 5,55 & 3,70 \\
\hline 54,58 & 1904,60 & 166,60 & 13,73 & 10,97 & 9,80 & 8,55 & 7,48 & 6,54 & 5,02 & 3,93 & 2,60 \\
\hline 85,65 & 1025,00 & 154,50 & 15,53 & 10,54 & 9,09 & 7,89 & 7,02 & 6,29 & 5,08 & 4,15 & 2,90 \\
\hline 71,37 & 1403,00 & 192,90 & 12,73 & 9,14 & 7,96 & 6,90 & 6,08 & 5,37 & 4,22 & 3,37 & 2,28 \\
\hline 47,04 & 1821,80 & 181,00 & 14,60 & 11,66 & 10,24 & 8,69 & 7,39 & 6,29 & 4,64 & 3,54 & 2,31 \\
\hline 66,60 & 297,50 & 69,80 & 48,05 & 31,88 & 26,40 & 21,81 & 18,48 & 15,80 & 11,77 & 9,12 & 6,09 \\
\hline 77,77 & 1887,90 & 130,70 & 13,18 & 9,87 & 9,05 & 8,23 & 7,54 & 6,91 & 5,79 & 4,87 & 3,50 \\
\hline 63,98 & 1578,20 & 57,00 & 26,20 & 21,08 & 19,94 & 18,49 & 17,09 & 15,76 & 13,33 & 11,25 & 8,10 \\
\hline 85,10 & 1653,20 & 74,90 & 18,38 & 13,82 & 12,81 & 11,99 & 11,23 & 10,51 & 9,18 & 8,00 & 6,09 \\
\hline 46,47 & 1521,80 & 192,40 & 15,32 & 11,82 & 10,20 & 8,50 & 7,11 & 5,98 & 4,32 & 3,27 & 2,15 \\
\hline 80,79 & 236,20 & 21,00 & 89,95 & 65,58 & 59,10 & 53,09 & 48,27 & 43,97 & 36,48 & 30,42 & 21,67 \\
\hline 79,61 & 1084,90 & 50,40 & 28,68 & 21,79 & 20,30 & 18,91 & 17,61 & 16,40 & 14,15 & 12,20 & 9,11 \\
\hline 22,33 & 1917,00 & 175,50 & 24,45 & 18,75 & 14,90 & 10,93 & 8,21 & 6,39 & 4,33 & 3,30 & 2,28 \\
\hline 55,12 & 1068,00 & 98,30 & 23,63 & 18,75 & 16,70 & 14,54 & 12,70 & 11,08 & 8,49 & 6,64 & 4,39 \\
\hline 24,36 & 920,30 & 124,30 & 36,47 & 26,93 & 21,10 & 15,33 & 11,49 & 8,96 & 6,10 & 4,66 & 3,23 \\
\hline 50,28 & 1106,50 & 147,20 & 19,55 & 14,89 & 12,87 & 10,80 & 9,12 & 7,73 & 5,66 & 4,32 & 2,84 \\
\hline 66,07 & 510,90 & 177,70 & 23,82 & 14,51 & 11,48 & 9,11 & 7,52 & 6,30 & 4,57 & 3,51 & 2,36 \\
\hline 40,53 & 1061,10 & 108,80 & 27,13 & 21,66 & 18,74 & 15,51 & 12,85 & 10,70 & 7,63 & 5,74 & 3,77 \\
\hline 65,31 & 1176,20 & 135,70 & 17,31 & 12,97 & 11,44 & 9,98 & 8,78 & 7,75 & 6,05 & 4,81 & 3,23 \\
\hline 84,23 & 513,40 & 167,30 & 22,84 & 13,61 & 10,80 & 8,72 & 7,38 & 6,35 & 4,82 & 3,79 & 2,58 \\
\hline 68,03 & 1742,80 & 129,50 & 14,64 & 11,33 & 10,32 & 9,27 & 8,38 & 7,56 & 6,15 & 5,04 & 3,49 \\
\hline 30,96 & 1642,30 & 105,20 & 28,73 & 23,98 & 20,72 & 16,87 & 13,72 & 11,22 & 7,81 & 5,81 & 3,84 \\
\hline 73,45 & 1064,50 & 182,60 & 14,91 & 10,29 & 8,78 & 7,50 & 6,54 & 5,74 & 4,46 & 3,54 & 2,39 \\
\hline 52,59 & 513,00 & 187,50 & 24,83 & 15,32 & 12,02 & 9,29 & 7,43 & 6,06 & 4,26 & 3,23 & 2,19 \\
\hline 58,04 & 1312,40 & 150,50 & 16,52 & 12,65 & 11,13 & 9,60 & 8,34 & 7,25 & 5,53 & 4,32 & 2,86 \\
\hline 68,43 & 1794,50 & 52,40 & 25,44 & 20,17 & 19,17 & 18,05 & 16,90 & 15,78 & 13,67 & 11,81 & 8,81 \\
\hline 56,21 & 1084,00 & 103,90 & 22,50 & 17,72 & 15,76 & 13,71 & 11,98 & 10,46 & 8,03 & 6,29 & 4,16 \\
\hline 66,49 & 1349,00 & 61,50 & 25,81 & 20,50 & 19,21 & 17,67 & 16,25 & 14,91 & 12,50 & 10,48 & 7,48 \\
\hline
\end{tabular}




\begin{tabular}{|c|c|c|c|c|c|c|c|c|c|c|c|}
\hline \multirow[b]{2}{*}{ e1 (cm) } & & & & & & $\mathrm{De}$ & ões (x1 & m) & & & \\
\hline & Meq (MPa) & Ms (MPa) & D0 & D25 & D40 & D60 & D80 & D100 & D140 & D180 & D260 \\
\hline 66,70 & 1219,30 & 20,60 & 54,53 & 43,94 & 41,82 & 40,22 & 38,21 & 36,15 & 32,16 & 28,45 & 22,12 \\
\hline 50,33 & 493,80 & 95,00 & 35,90 & 25,61 & 21,47 & 17,51 & 14,47 & 12,06 & 8,64 & 6,55 & 4,34 \\
\hline 51,24 & 427,00 & 92,90 & 38,62 & 26,85 & 22,27 & 18,02 & 14,82 & 12,31 & 8,80 & 6,67 & 4,44 \\
\hline 60,75 & 1590,70 & 118,60 & 16,99 & 13,51 & 12,26 & 10,91 & 9,74 & 8,69 & 6,91 & 5,55 & 3,75 \\
\hline 22,56 & 1175,40 & 151,40 & 30,96 & 22,73 & 17,60 & 12,60 & 9,36 & 7,28 & 4,97 & 3,82 & 2,65 \\
\hline 55,19 & 1223,00 & 24,60 & 55,10 & 45,68 & 43,95 & 41,26 & 38,43 & 35,67 & 30,50 & 25,97 & 18,90 \\
\hline 76,83 & 1370,20 & 64,20 & 23,05 & 17,64 & 16,47 & 15,29 & 14,21 & 13,19 & 11,31 & 9,70 & 7,17 \\
\hline 79,41 & 577,80 & 102,70 & 26,26 & 17,71 & 15,06 & 12,87 & 11,29 & 9,96 & 7,83 & 6,28 & 4,29 \\
\hline 54,86 & 1496,10 & 106,30 & 19,70 & 16,06 & 14,54 & 12,85 & 11,36 & 10,03 & 7,83 & 6,20 & 4,13 \\
\hline 21,62 & 1290,00 & 152,00 & 30,91 & 22,80 & 17,62 & 12,58 & 9,32 & 7,23 & 4,94 & 3,80 & 2,63 \\
\hline 54,79 & 1912,70 & 120,90 & 16,55 & 13,61 & 12,42 & 11,04 & 9,82 & 8,71 & 6,86 & 5,46 & 3,65 \\
\hline 42,87 & 1618,10 & 55,70 & 33,96 & 29,95 & 27,69 & 24,72 & 21,95 & 19,42 & 15,16 & 11,95 & 7,88 \\
\hline 29,52 & 1279,70 & 91,40 & 35,59 & 29,21 & 24,88 & 19,89 & 15,93 & 12,88 & 8,85 & 6,59 & 4,40 \\
\hline 68,84 & 1301,00 & 64,50 & 24,89 & 19,55 & 18,24 & 16,76 & 15,40 & 14,14 & 11,86 & 9,96 & 7,12 \\
\hline 65,62 & 327,00 & 147,70 & 33,80 & 19,34 & 14,78 & 11,37 & 9,20 & 7,60 & 5,43 & 4,16 & 2,82 \\
\hline 43,83 & 688,70 & 156,70 & 25,16 & 17,51 & 14,31 & 11,27 & 9,03 & 7,34 & 5,12 & 3,86 & 2,60 \\
\hline 37,78 & 1078,40 & 112,80 & 27,64 & 21,98 & 18,86 & 15,38 & 12,58 & 10,36 & 7,29 & 5,45 & 3,60 \\
\hline 38,78 & 308,40 & 71,80 & 58,84 & 40,89 & 32,97 & 25,34 & 19,89 & 15,95 & 10,98 & 8,29 & 5,64 \\
\hline 86,38 & 1011,80 & 75,20 & 22,46 & 16,31 & 14,83 & 13,52 & 12,44 & 11,47 & 9,74 & 8,29 & 6,08 \\
\hline 75,59 & 303,40 & 169,80 & 33,18 & 17,76 & 13,11 & 9,86 & 7,92 & 6,55 & 4,70 & 3,62 & 2,47 \\
\hline 24,30 & 596,80 & 61,10 & 68,48 & 52,49 & 42,06 & 31,22 & 23,65 & 18,49 & 12,53 & 9,51 & 6,55 \\
\hline 39,80 & 1240,70 & 107,10 & 26,09 & 21,31 & 18,62 & 15,55 & 12,98 & 10,87 & 7,80 & 5,87 & 3,84 \\
\hline 50,69 & 1775,40 & 121,50 & 17,83 & 14,76 & 13,33 & 11,70 & 10,26 & 8,99 & 6,91 & 5,41 & 3,57 \\
\hline 63,38 & 772,40 & 34,90 & 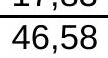 & 37,49 & 35,10 & 32,17 & 29,48 & 26,94 & 22,40 & $\frac{1,+1}{18,64}$ & 13,16 \\
\hline 32,02 & 1821,50 & 109,50 & 26,31 & 22,18 & 19,33 & 15,92 & 13,08 & 10,79 & 7,57 & 5,64 & 3,70 \\
\hline 33,31 & 1866,00 & 76,20 & 32,00 & 28,11 & 25,14 & 21,43 & 18,15 & 15,36 & 11,15 & 8,39 & 5,42 \\
\hline 59,05 & 1845,60 & 43,80 & 31,19 & 25,53 & 24,46 & 22,95 & 21,38 & 19,86 & 17,00 & 14,51 & 10,60 \\
\hline 69,39 & 729,90 & 145,20 & 20,76 & 14,12 & 11,89 & 9,99 & 8,59 & 7,44 & 5,65 & 4,42 & 2,96 \\
\hline 63,84 & 896,70 & 159,90 & 18,39 & 12,95 & 11,01 & 9,28 & 7,96 & 6,86 & 5,16 & 4,02 & 2,67 \\
\hline 67,49 & 1265,50 & 96,20 & 19,98 & 15,47 & 14,07 & 12,62 & 11,38 & 10,25 & 8,32 & 6,79 & 4,69 \\
\hline 45,38 & 1751,20 & 38,50 & 40,97 & 35,84 & 34,01 & 31,19 & 28,44 & 25,82 & 21,13 & 17,28 & 11,85 \\
\hline 64,19 & 830,60 & 177,70 & 18,18 & 12,36 & 10,33 & 8,58 & 7,28 & 6,22 & 4,63 & 3,58 & 2,39 \\
\hline 89,97 & 225,20 & 61,70 & 54,52 & 33,20 & 26,83 & 22,10 & 19,01 & 16,60 & 12,91 & 10,33 & 7,10 \\
\hline 82,84 & 1185,00 & 42,70 & 29,85 & 22,85 & 21,31 & 20,14 & 18,97 & 17,84 & 15,72 & 13,81 & 10,64 \\
\hline 87,77 & 844,90 & 65,70 & 26,05 & 18,78 & 17,02 & 15,48 & 14,23 & 13,12 & 11,13 & 9,48 & 6,96 \\
\hline 23,75 & 1442,20 & 31,20 & 84,45 & 75,41 & 66,84 & 55,87 & 46,30 & 38,38 & 26,98 & 20,00 & 12,98 \\
\hline 85,99 & 767,60 & 158,70 & 18,05 & 11,67 & 9,75 & 8,25 & 7,21 & 6,36 & 5,02 & 4,04 & 2,78 \\
\hline 42,75 & 1673,20 & 81,90 & 26,17 & 22,64 & 20,56 & 18,01 & 15,70 & 13,65 & 10,36 & 8,02 & 5,23 \\
\hline 32,54 & 1944,50 & 120,00 & 23,92 & 20,14 & 17,55 & 14,48 & 11,91 & 9,83 & 6,91 & 5,16 & 3,38 \\
\hline 30,25 & 465,10 & 49,60 & 73,72 & 57,70 & 47,96 & 37,33 & 29,31 & 23,41 & 15,98 & 11,97 & 8,10 \\
\hline 68,07 & 1904,50 & 20,20 & 46,00 & 38,69 & 36,08 & 35,15 & 33,94 & 32,51 & 29,61 & 26,83 & 21,80 \\
\hline 63,92 & 1934,40 & 181,40 & 11,91 & 9,18 & 8,22 & 7,25 & 6,43 & 5,71 & 4,51 & 3,61 & 2,44 \\
\hline 29,30 & 1490,80 & 120,20 & 28,33 & 22,90 & 19,33 & 15,28 & 12,13 & 9,75 & 6,67 & 4,98 & 3,34 \\
\hline 48,80 & 271,20 & 90,00 & 50,33 & 31,98 & 25,31 & 19,57 & 15,59 & 12,66 & 8,84 & 6,70 & 4,54 \\
\hline 68,08 & 1153,90 & 63,80 & 26,38 & 20,71 & 19,22 & 17,54 & 16,04 & 14,65 & 12,18 & 10,14 & 7,17 \\
\hline 57,57 & 557,60 & 136,80 & 26,55 & 17,80 & 14,65 & 11,90 & 9,87 & 8,27 & 5,99 & 4,57 & 3,04 \\
\hline 63,07 & 1988,30 & 36,70 & 32,93 & 26,57 & 25,47 & 24,31 & 22,94 & 21,57 & 18,95 & 16,56 & 12,59 \\
\hline 58,93 & 979,30 & 150,90 & 18,79 & 13,73 & 11,80 & 9,99 & 8,55 & 7,35 & 5,50 & 4,26 & 2,82 \\
\hline 21,21 & 414,60 & 179,20 & 37,37 & 21,71 & 15,02 & 10,05 & 7,42 & 5,87 & 4,13 & 3,21 & 2,26 \\
\hline 80,54 & 1896,20 & 118,80 & 13,66 & 10,20 & 9,39 & 8,61 & 7,94 & 7,32 & 6,22 & 5,28 & 3,86 \\
\hline 29,97 & 1275,60 & 115,10 & 30,22 & 24,15 & 20,29 & 15,98 & 12,65 & 10,15 & 6,94 & 5,19 & 3,49 \\
\hline 39,72 & 1880,20 & 161,80 & 17,27 & 14,11 & 12,33 & 10,30 & 8,59 & 7,19 & 5,16 & 3,88 & 2,54 \\
\hline 22,48 & 1971,70 & 145,50 & 27,60 & 21,74 & 17,60 & 13,17 & 10,01 & 7,82 & 5,28 & 3,99 & 2,75 \\
\hline 44,90 & 1500,00 & 137,90 & 19,13 & 15,47 & 13,61 & 11,54 & 9,78 & 8,31 & 6,09 & 4,63 & 3,02 \\
\hline 88,47 & 1492,30 & 37,50 & 27,80 & 22,12 & 20,32 & 19,50 & 18,68 & 17,80 & 16,09 & 14,50 & 11,69 \\
\hline 33,74 & 234,10 & 168,60 & 43,45 & 22,54 & 15,69 & 10,77 & 8,06 & 6,38 & 4,43 & 3,43 & 2,42 \\
\hline 50,42 & 521,70 & 190,20 & 24,76 & 15,34 & 12,02 & 9,25 & 7,36 & 5,98 & 4,18 & 3,17 & 2,15 \\
\hline 70,48 & 1886,20 & 29,50 & 35,44 & 28,77 & 27,10 & 26,22 & 25,08 & 23,85 & 21,45 & 19,19 & 15,23 \\
\hline 82,46 & 590,80 & 36,20 & 43,87 & 32,62 & 30,01 & 27,59 & 25,50 & 23,59 & 20,13 & 17,19 & 12,66 \\
\hline 20,90 & 794,50 & 170,90 & 32,83 & 21,90 & 15,96 & 10,90 & 7,98 & 6,24 & 4,35 & 3,37 & 2,35 \\
\hline 39,34 & 1513,60 & 152,50 & 19,61 & 15,69 & 13,56 & 11,17 & 9,22 & 7,65 & 5,43 & 4,07 & 2,68 \\
\hline 75,90 & 887,30 & 135,30 & 18,67 & 13,02 & 11,24 & $\begin{array}{c}+1,+1 \\
9,70\end{array}$ & 8,55 & 7,56 & 5,96 & 4,79 & 3,26 \\
\hline 75,66 & 1864,50 & 57,30 & 22,23 & $\begin{array}{l}10,0< \\
17,33\end{array}$ & $\begin{array}{l}1+1, L+ \\
16,33\end{array}$ & 15,46 & 14,55 & 13,67 & 11,99 & 10,48 & 8,00 \\
\hline 81,15 & 1284,70 & 155,00 & 14,08 & $\begin{array}{l}1,90 \\
9,95\end{array}$ & $\begin{array}{c}10,00 \\
8,76\end{array}$ & $\begin{array}{c}10,70 \\
7,72\end{array}$ & $\begin{array}{l}, 9,92 \\
6,92\end{array}$ & $\frac{10,01}{6,23}$ & 5,06 & $\begin{array}{c}10,10 \\
4,15\end{array}$ & 2,90 \\
\hline 23,30 & 1553,50 & 92,90 & 39,59 & 32,11 & 26,60 & 20,43 & 15,81 & 12,47 & 8,42 & 6,31 & 4,30 \\
\hline 89,21 & 1138,10 & 124,20 & 16,09 & 11,22 & 9,93 & 8,84 & 8,02 & 7,30 & 6,07 & 5,09 & 3,66 \\
\hline 85,50 & 1430,80 & 40,50 & 27,88 & 21,77 & 20,18 & 19,28 & 18,35 & 17,40 & 15,59 & 13,91 & 11,02 \\
\hline 59,40 & 782,50 & 42,50 & 42,42 & 34,55 & 31,94 & 28,85 & 26,07 & 23,50 & 19,04 & 15,50 & 10,63 \\
\hline 51,33 & 1055,70 & 115,70 & 22,57 & 17,67 & 15,49 & 13,22 & 11,33 & 9,71 & 7,24 & 5,56 & 3,65 \\
\hline 67,48 & 1174,80 & 105,60 & 19,55 & 14.93 & 13,43 & 11,93 & 10,67 & 9,55 & 7,65 & 6.19 & 4,23 \\
\hline 37,58 & 1071,40 & 48,90 & 47,10 & 41,14 & 37,05 & 31,99 & 27,46 & 23,52 & 17,42 & 13,26 & 8,58 \\
\hline 44,60 & 860,30 & 116,00 & 26,77 & 20,48 & 17,53 & 14,44 & 11,96 & 9,97 & 7,13 & 5,38 & 3,54 \\
\hline 41,02 & 1469,00 & 185,30 & 17,16 & 13,29 & 11,35 & 9,26 & 7,60 & 6,28 & 4,44 & 3,33 & 2,20 \\
\hline 22,41 & 842,70 & 96,30 & 47,31 & 35,27 & 27,54 & 19,88 & 14,81 & 11,51 & 7,84 & 6,01 & 4,16 \\
\hline 57,85 & 569,80 & 148,30 & 25,23 & 16,69 & 13,65 & 11,03 & 9,12 & 7,63 & 5,51 & 4,20 & 2,80 \\
\hline 79,12 & 1631,10 & 116,20 & 14,88 & 11,08 & 10,13 & 9,21 & 8,44 & 7,74 & 6,49 & 5,46 & 3,94 \\
\hline 85,36 & 1754,10 & 69,70 & 18,66 & 14,16 & 13,14 & 12,38 & 11,65 & 10,95 & 9,63 & 8,46 & 6,51 \\
\hline 82,93 & 911,90 & 56,70 & 28,10 & 20,84 & 19,16 & 17,61 & 16,27 & 15,05 & 12,84 & 10,96 & 8,08 \\
\hline 25,93 & 516,20 & 141,20 & 38,39 & 25,33 & 18,91 & 13,25 & 9,83 & 7,68 & 5,31 & 4,10 & 2,85 \\
\hline 58,15 & 1703,60 & 192,70 & 12,81 & 9,83 & 8,65 & 7,47 & 6,50 & 5,66 & 4,32 & 3,37 & 2,24 \\
\hline 68,93 & 1410,00 & 53,30 & 27,26 & 21,51 & 20,30 & 18,90 & 17,55 & 16,26 & 13,89 & 11,84 & 8,66 \\
\hline 76,95 & 732,10 & 140,70 & 20,24 & 13,57 & 11,46 & 9,72 & 8,46 & 7,41 & 5,76 & 4,58 & 3,11 \\
\hline
\end{tabular}




\begin{tabular}{|c|c|c|c|c|c|c|c|c|c|c|c|}
\hline \multirow[b]{2}{*}{ e1 (cm) } & & & & & & & ões (x1 & m) & & & \\
\hline & Meq (MPa) & Ms (MPa) & D0 & D25 & D40 & D60 & D80 & D100 & D140 & D180 & D260 \\
\hline 41,27 & 1555,60 & 97,50 & 24,71 & 20,95 & 18,71 & 16,06 & 13,74 & 11,75 & 8,68 & 6,61 & 4,30 \\
\hline 40,54 & 314,90 & 164,60 & 36,70 & 20,93 & 15,45 & 11,14 & 8,48 & 6,73 & 4,64 & 3,55 & 2,47 \\
\hline 20,39 & 763,90 & 117,60 & 44,39 & 31,12 & 23,20 & 16,05 & 11,76 & 9,15 & 6,33 & 4,90 & 3,41 \\
\hline 28,35 & 1605,90 & 69,50 & 40,87 & 35,19 & 30,76 & 25,34 & 20,77 & 17,09 & 11,94 & 8,87 & 5,81 \\
\hline 60,81 & 1009,60 & 143,30 & 18,72 & 13,80 & 11,96 & 10,21 & 8,82 & 7,64 & 5,79 & 4,51 & 2,99 \\
\hline 67,45 & 811,00 & 110,00 & 22,72 & 16,55 & 14,42 & 12,46 & 10,92 & 9,59 & 7,45 & 5,91 & 3,97 \\
\hline 76,36 & 1253,30 & 128,70 & 16,09 & 11,76 & 10,49 & 9,31 & 8,37 & 7,55 & 6,13 & 5,03 & 3,50 \\
\hline 41,27 & 415,30 & 178,70 & 30,50 & 18,34 & 13,91 & 10,23 & 7,87 & 6,26 & 4,31 & 3,29 & 2,27 \\
\hline 45,14 & 1297,70 & 94,00 & 25,42 & 21,15 & 18,88 & 16,27 & 14,00 & 12,04 & 8,98 & 6,89 & 4,49 \\
\hline 69,68 & 1232,80 & 145,00 & 15,86 & 11,68 & 10,30 & 9,01 & 7,98 & 7,09 & 5,60 & 4,49 & 3,05 \\
\hline 60,18 & 1737,60 & 196,30 & 12,34 & 9,42 & 8,30 & 7,20 & 6,29 & 5,49 & 4,23 & 3,32 & 2,21 \\
\hline 58,74 & 1753,80 & 108,80 & 17,53 & 14,23 & 13,04 & 11,69 & 10,48 & 9,39 & 7,51 & 6,06 & 4,11 \\
\hline 43,87 & 391,70 & 163,00 & 32,31 & 19,54 & 14,95 & 11,13 & 8,64 & 6,91 & 4,77 & 3,63 & 2,50 \\
\hline 58,03 & 659,10 & 164,90 & 22,19 & 14,79 & 12,15 & 9,86 & 8,18 & 6,86 & 4,97 & 3,79 & 2,53 \\
\hline 32,43 & 929,50 & 143,20 & 27,73 & 20,67 & 16,87 & 12,94 & 10,08 & 8,02 & 5,48 & 4,13 & 2,81 \\
\hline 28,33 & 1644,00 & 157,30 & 23,46 & 18,50 & 15,34 & 11,87 & 9,26 & 7,37 & 5,01 & 3,76 & 2,55 \\
\hline 62,65 & 350,60 & 114,60 & 36,13 & 22,48 & 17,93 & 14,27 & 11,75 & 9,82 & 7,09 & 5,42 & 3,64 \\
\hline 24,55 & 1512,70 & 68,50 & 47,36 & 39,82 & 33,96 & 27,02 & 21,48 & 17,25 & 11,76 & 8,73 & 5,84 \\
\hline 83,45 & 904,90 & 109,20 & 19,77 & 13,87 & 12,21 & 10,77 & 9,67 & 8,73 & 7,13 & 5,88 & 4,13 \\
\hline 86,86 & 1436,70 & 97,80 & 16,56 & 12,08 & 11,03 & 10,11 & 9,34 & 8,64 & 7,38 & 6,32 & 4,68 \\
\hline 23,07 & 690,00 & 79,10 & 56,58 & 42,38 & 33,29 & 24,18 & 18,09 & 14,08 & 9,58 & 7,32 & 5,06 \\
\hline 45,21 & 201,80 & 47,70 & 82,89 & 57,13 & 46,65 & 36,79 & 29,54 & 24,08 & 16,84 & 12,70 & 8,54 \\
\hline 31,30 & 1386,80 & 21,20 & 87,42 & 80,91 & 75,21 & 67,19 & 59,48 & 52,38 & 40,46 & 31,55 & 20,51 \\
\hline 52,79 & 1287,90 & 93,50 & 23,11 & 18,92 & 17,07 & 15,00 & 13,19 & 11,57 & 8,94 & 7,02 & 4,65 \\
\hline 51,68 & 1316,20 & 173,80 & 16,25 & 12,36 & 10,70 & 9,02 & 7,65 & 6,51 & 4,80 & 3,67 & 2,41 \\
\hline 55,99 & 444,10 & 25,30 & 75,13 & 61,92 & 56,89 & 50,98 & 45,68 & 40,83 & 32,56 & 26,16 & 17,67 \\
\hline 42,05 & 1597,90 & 122,20 & 20,99 & 17,41 & 15,40 & 13,09 & 11,10 & 9,43 & 6,90 & 5,23 & 3,41 \\
\hline 35,25 & 1505,50 & 177,20 & 19,27 & 15,03 & 12,68 & 10,11 & 8,11 & 6,58 & 4,56 & 3,41 & 2,28 \\
\hline 31,93 & 401,80 & 176,70 & 33,60 & 20,15 & 14,84 & 10,46 & 7,84 & 6,17 & 4,26 & 3,28 & 2,29 \\
\hline 83,04 & 809,70 & 187,70 & 16,51 & 10,54 & 8,71 & 7,28 & 6,30 & 5,51 & 4,28 & 3,42 & 2,33 \\
\hline 40,73 & 1436,70 & 159,20 & 19,05 & 15,05 & 12,96 & 10,67 & 8,81 & 7,31 & 5,20 & 3,90 & 2,57 \\
\hline 79,00 & 1292,80 & 168,90 & 13,59 & 9,59 & 8,39 & 7,34 & 6,54 & 5,85 & 4,70 & 3,83 & 2,65 \\
\hline 77,53 & 827,20 & 107,80 & 21,43 & 15,19 & 13,29 & 11,62 & 10,34 & 9,23 & 7,40 & 6,00 & 4,14 \\
\hline 32,23 & 1884,80 & 110,70 & 25,67 & 21,71 & 18,96 & 15,66 & 12,90 & 10,66 & 7,50 & 5,59 & 3,66 \\
\hline 89,42 & 505,50 & 114,10 & 26,17 & 16,52 & 13,65 & 11,46 & 9,99 & 8,81 & 6,95 & 5,61 & 3,87 \\
\hline 28,55 & 1283,10 & 179,10 & 23,17 & 17,36 & 13,99 & 10,51 & 8,06 & 6,35 & 4,32 & 3,27 & 2,24 \\
\hline 65,74 & 706,30 & 176,60 & 19,77 & 12,97 & 10,67 & 8,75 & 7,38 & 6,27 & 4,64 & 3,59 & 2,39 \\
\hline 60,47 & 651,90 & 132,90 & 24,29 & 16,81 & 14,10 & 11,70 & 9,88 & 8,41 & 6,21 & 4,78 & 3,17 \\
\hline 38,58 & 1167,70 & 88,50 & 30,72 & 25,49 & 22,38 & 18,76 & 15,70 & 13,17 & 9,47 & 7,12 & 4,65 \\
\hline 75,57 & 469,40 & 143,90 & 26,24 & 16,13 & 12,94 & 10,48 & 8,84 & 7,55 & 5,65 & 4,41 & 2,97 \\
\hline 75,75 & 1631,60 & 114,90 & 15,29 & 11,53 & 10,56 & 9,58 & 8,75 & 8,00 & 6,67 & 5,57 & 3,98 \\
\hline 29,80 & 816,40 & 33,70 & 79,64 & 69,26 & 61,11 & 51,01 & 42,34 & 35,19 & 24,90 & 18,55 & 12,08 \\
\hline 39,23 & 1273,70 & 27,90 & 62,48 & 56,27 & 52,70 & 47,59 & 42,68 & 38,09 & 30,18 & 24,03 & 15,95 \\
\hline 38,70 & 641,90 & 157,80 & 27,42 & 18,84 & 15,11 & 11,56 & 9,04 & 7,24 & 4,98 & 3,76 & 2,56 \\
\hline 38,34 & 1696,20 & 134,10 & 20,69 & 17,08 & 14,94 & 12,48 & 10,41 & 8,70 & 6,23 & 4,68 & 3,06 \\
\hline 36,18 & 699,10 & 122,40 & 31,90 & 23,37 & 19,17 & 14,89 & 11,73 & 9,41 & 6,47 & 4,87 & 3,30 \\
\hline 51,59 & 555,00 & 95,90 & 33,38 & 24,26 & 20,55 & 16,97 & 14,16 & 11,90 & 8,62 & 6,55 & 4,33 \\
\hline 58,50 & 1808,00 & 92,50 & 19,22 & 15,75 & 14,60 & 13,21 & 11,95 & 10,78 & 8,74 & 7,12 & 4,89 \\
\hline 52,88 & 906,50 & 192,50 & 18,16 & 12,66 & 10,54 & 8,58 & 7,10 & 5,93 & 4,26 & 3,24 & 2,15 \\
\hline 82,57 & 291,60 & 147,30 & 35,14 & 19,09 & 14,27 & 10,90 & 8,89 & 7,45 & 5,44 & 4,22 & 2,88 \\
\hline 28,61 & 1411,00 & 147,30 & 25,59 & 19,98 & 16,48 & 12,69 & 9,88 & 7,84 & 5,33 & 4,00 & 2,72 \\
\hline 71,51 & 1621,70 & 63,60 & 22,65 & 17,71 & 16,68 & 15,55 & 14,46 & 13,42 & 11,50 & 9,84 & 7,25 \\
\hline 84,56 & 1947,40 & 21,40 & 34,34 & 31,70 & 28,49 & 27,39 & 26,81 & 26,01 & 24,18 & 22,38 & 18,99 \\
\hline 75,68 & 1554,50 & 66,50 & 21,68 & 16,70 & 15,64 & 14,58 & 13,57 & 12,62 & 10,86 & 9,33 & 6,93 \\
\hline 72,58 & 1621,10 & 150,50 & 13,44 & 10,05 & 9,03 & 8,04 & 7,23 & 6,51 & 5,28 & 4,32 & 2,99 \\
\hline 33,73 & 1162,40 & 153,70 & 23,86 & 18,25 & 15,17 & 11,88 & 9,40 & 7,55 & 5,18 & 3,89 & 2,62 \\
\hline 44,22 & 1941,80 & 88,20 & 23,09 & 20,02 & 18,30 & 16,17 & 14,22 & 12,47 & 9,59 & 7,49 & 4,91 \\
\hline 39,27 & 806,60 & 185,60 & 22,51 & 15,67 & 12,67 & 9,77 & 7,69 & 6,17 & 4,26 & 3,21 & 2,18 \\
\hline 40,67 & 1727,10 & 144,10 & 18,85 & 15,47 & 13,57 & 11,40 & 9,57 & 8,05 & 5,82 & 4,39 & 2,86 \\
\hline 21,50 & 772,30 & 90,00 & 52,22 & 38,53 & 29,77 & 21,24 & 15,73 & 12,21 & 8,35 & 6,41 & 4,45 \\
\hline 86,48 & 1817,90 & 80,80 & 16,74 & 12,58 & 11,65 & 10,92 & 10,24 & 9,60 & 8,41 & 7,36 & 5,63 \\
\hline 52,57 & 534,40 & 97,20 & 33,42 & 24,02 & 20,28 & 16,71 & 13,95 & 11,72 & 8,49 & 6,46 & 4,27 \\
\hline 50,48 & 248,60 & 68,70 & 59,27 & 39,20 & 31,72 & 25,07 & 20,28 & 16,65 & 11,74 & 8,89 & 5,97 \\
\hline 65,68 & 1449,60 & 39,00 & 34,13 & 27,31 & 26,04 & 24,53 & 22,95 & 21,41 & 18,52 & 15,96 & 11,87 \\
\hline 68,89 & 772,30 & 23,20 & 57,88 & 45,82 & 43,51 & 40,95 & 38,32 & 35,77 & 30,98 & 26,74 & 19,96 \\
\hline 87,23 & 774,20 & 142,50 & 18,71 & 12,28 & 10,38 & 8,87 & 7,82 & 6,95 & 5,54 & 4,50 & 3,12 \\
\hline 29,57 & 382,70 & 140,20 & 40,46 & 25,32 & 18,80 & 13,25 & 9,89 & 7,76 & 5,36 & 4,13 & 2,88 \\
\hline 38,09 & 463,30 & 132,00 & 35,15 & 23,41 & 18,47 & 13,91 & 10,78 & 8,58 & 5,90 & 4,47 & 3,07 \\
\hline 42,23 & 1825,10 & 176,60 & 15,88 & 12,78 & 11,15 & 9,33 & 7,81 & 6,56 & 4,73 & 3,57 & 2,34 \\
\hline 30,52 & 803,70 & 38,00 & 72,44 & 62,32 & 54,73 & 45,45 & 37,56 & 31,12 & 21,94 & 16,34 & 10,67 \\
\hline 22,52 & 1778,60 & 132,30 & 30,40 & 23,93 & 19,37 & 14,49 & 11,01 & 8,60 & 5,81 & 4,40 & 3,02 \\
\hline 75,62 & 1274,60 & 107,80 & 17,66 & 13,16 & 11,91 & 10,69 & 9,69 & 8,79 & 7,23 & 5,98 & 4,21 \\
\hline 63,76 & 1278,00 & 104,30 & 19,54 & 15,26 & 13,80 & 12,26 & 10,96 & 9,79 & 7,81 & 6,29 & 4,28 \\
\hline 60,56 & 1432,30 & 165,10 & 14,76 & 11,22 & 9,88 & 8,56 & 7,47 & 6,53 & 5,02 & 3,94 & 2,63 \\
\hline 32,40 & 502,40 & 51,90 & 66,47 & 52,54 & 44,23 & 35,03 & 27,90 & 22,51 & 15,48 & 11,57 & 7,76 \\
\hline 79,43 & 369,30 & 23,70 & 69,59 & 52,08 & 47,89 & 43,82 & 40,32 & 37,13 & 31,39 & 26,58 & 19,32 \\
\hline 55,46 & 276,10 & 147,10 & 38,92 & 21,67 & 16,15 & 12,03 & 9,45 & 7,65 & 5,34 & 4,07 & 2,80 \\
\hline 59,58 & 1816,40 & 105,30 & 17,52 & 14,22 & 13,09 & 11,79 & 10,63 & 9,56 & 7,71 & 6,26 & 4,28 \\
\hline 65,04 & 213,50 & 104,00 & 50,50 & 28,38 & 21,45 & 16,34 & 13,13 & 10,80 & 7,68 & 5,88 & 4,00 \\
\hline 39,65 & 521,30 & 85,90 & 42,12 & 31,22 & 26,02 & 20,67 & 16,59 & 13,49 & 9,39 & 7,05 & 4,72 \\
\hline 36,54 & 1822,30 & 120,30 & 22,35 & 18,81 & 16,55 & 13,88 & 11,61 & 9,72 & 6,97 & 5,23 & 3,41 \\
\hline 89,80 & 951,90 & 128,00 & 17,34 & 11,79 & 10,26 & 9,00 & 8,08 & 7,30 & 5,99 & 4,97 & 3,53 \\
\hline
\end{tabular}




\begin{tabular}{|c|c|c|c|c|c|c|c|c|c|c|c|}
\hline \multirow[b]{2}{*}{ e1 (cm) } & & & & & & & ões (x1 & m) & & & \\
\hline & Meq (MPa) & Ms (MPa) & D0 & D25 & D40 & D60 & D80 & D100 & D140 & D180 & D260 \\
\hline 50,37 & 1172,30 & 30,00 & 51,48 & 44,00 & 41,81 & 38,50 & 35,28 & 32,19 & 26,62 & 21,99 & 15,30 \\
\hline 88,16 & 1772,10 & 160,60 & 11,42 & 8,12 & 7,29 & 6,57 & 6,00 & 5,50 & 4,63 & 3,91 & 2,84 \\
\hline 29,38 & 991,00 & 110,10 & 34,34 & 26,66 & 21,98 & 16,94 & 13,20 & 10,50 & 7,15 & 5,37 & 3,65 \\
\hline 78,98 & 1644,50 & 103,20 & 15,89 & 11,92 & 10,98 & 10,05 & 9,26 & 8,53 & 7,21 & 6,11 & 4,44 \\
\hline 31,65 & 701,50 & 31,70 & 83,09 & 72,06 & 63,74 & 53,47 & 44,61 & 37,26 & 26,55 & 19,84 & 12,89 \\
\hline 76,75 & 1224,10 & 76,60 & 21,70 & 16,41 & 15,13 & 13,83 & 12,71 & 11,68 & 9,84 & 8,29 & 5,99 \\
\hline 80,46 & 1018,40 & 188,20 & 14,58 & 9,75 & 8,25 & 7,04 & 6,16 & 5,43 & 4,27 & 3,42 & 2,34 \\
\hline 62,03 & 1575,40 & 82,00 & 21,11 & 17,03 & 15,81 & 14,36 & 13,06 & 11,84 & 9,71 & 7,98 & 5,55 \\
\hline 23,25 & 1199,70 & 133,20 & 33,12 & 24,95 & 19,68 & 14,36 & 10,77 & 8,39 & 5,70 & 4,35 & 3,01 \\
\hline 21,16 & 1087,10 & 50,50 & 72,86 & 59,66 & 49,44 & 37,88 & 29,21 & 22,98 & 15,47 & 11,59 & 7,90 \\
\hline 48,63 & 1125,00 & 171,40 & 18,18 & 13,57 & 11,58 & 9,58 & 7,98 & 6,69 & 4,83 & 3,66 & 2,41 \\
\hline 22,82 & 1195,50 & 184,50 & 26,54 & 19,00 & 14,52 & 10,30 & 7,62 & 5,93 & 4,07 & 3,13 & 2,17 \\
\hline 45,10 & 1079,50 & 128,40 & 22,78 & 17,77 & 15,36 & 12,80 & 10,70 & 8,98 & 6,48 & 4,90 & 3,22 \\
\hline 71,48 & 353,00 & 192,80 & 28,95 & 15,67 & 11,62 & 8,76 & 7,02 & 5,79 & 4,14 & 3,18 & 2,17 \\
\hline 25,80 & 959,50 & 30,20 & 91,57 & 80,18 & 70,44 & 58,26 & 47,87 & 39,43 & 27,54 & 20,41 & 13,34 \\
\hline 50,38 & 1573,80 & 189,00 & 14,54 & 11,25 & 9,79 & 8,28 & 7,04 & 6,00 & 4,42 & 3,38 & 2,22 \\
\hline 78,74 & 1501,70 & 140,40 & 13,93 & 10,18 & 9,15 & 8,18 & 7,41 & 6,72 & 5,53 & 4,58 & 3,23 \\
\hline 61,98 & 1691,70 & 55,70 & 26,48 & 21,49 & 20,39 & 18,93 & 17,51 & 16,16 & 13,67 & 11,54 & 8,30 \\
\hline 67,98 & 1834,70 & 45,40 & 27,85 & 22,17 & 21,11 & 20,02 & 18,83 & 17,66 & 15,43 & 13,43 & 10,15 \\
\hline 22,28 & 396,00 & 199,00 & 34,66 & 19,54 & 13,48 & 9,03 & 6,69 & 5,29 & 3,72 & 2,90 & 2,04 \\
\hline 31,26 & 970,70 & 194,50 & 22,88 & 16,28 & 12,92 & 9,63 & 7,36 & 5,81 & 3,96 & 3,01 & 2,07 \\
\hline 77,96 & 785,70 & 81,90 & 25,23 & 18,31 & 16,32 & 14,49 & 13,04 & 11,77 & 9,59 & 7,88 & 5,51 \\
\hline 37,26 & 394,10 & 89,70 & 47,57 & 33,21 & 26,71 & 20,41 & 15,94 & 12,74 & 8,75 & 6,61 & 4,50 \\
\hline 47,44 & 805,60 & 57,70 & 39,88 & 33,10 & 29,68 & 25,77 & 22,34 & 19,35 & 14,62 & 11,29 & 7,39 \\
\hline 24,20 & 513,50 & 181,60 & 33,26 & 20,61 & 14,84 & 10,14 & 7,48 & 5,87 & 4,09 & 3,18 & 2,22 \\
\hline 56,16 & 619,70 & 179,80 & 22,32 & 14,45 & 11,68 & 9,31 & 7,62 & 6,32 & 4,52 & 3,43 & 2,30 \\
\hline 60,37 & 1272,50 & 173,50 & 15,22 & 11,30 & 9,82 & 8,41 & 7,27 & 6,30 & 4,78 & 3,73 & 2,47 \\
\hline 32,91 & 1581,00 & 61,60 & 39,32 & 34,65 & 31,03 & 26,48 & 22,44 & 19,00 & 13,80 & 10,38 & 6,71 \\
\hline 60,22 & 636,90 & 143,80 & 23,73 & 16,10 & 13,37 & 10,99 & 9,22 & 7,80 & 5,72 & 4,39 & 2,92 \\
\hline 24,99 & 1181,90 & 156,90 & 28,29 & 21,01 & 16,58 & 12,13 & 9,13 & 7,13 & 4,85 & 3,70 & 2,55 \\
\hline 60,97 & 1671,30 & 53,10 & 27,72 & 22,58 & 21,45 & 19,92 & 18,43 & 17,00 & 14,37 & 12,12 & 8,71 \\
\hline 27,52 & 1958,10 & 68,50 & 39,61 & 34,65 & 30,53 & 25,39 & 20,98 & 17,37 & 12,21 & 9,07 & 5,91 \\
\hline 71,91 & 841,80 & 27,70 & 48,70 & 38,17 & 36,10 & 33,95 & 31,76 & 29,66 & 25,73 & 22,24 & 16,66 \\
\hline 73,88 & 1077,00 & 152,00 & 16,14 & 11,45 & 9,95 & 8,63 & 7,61 & 6,74 & 5,32 & 4,27 & 2,91 \\
\hline 65,02 & 1455,40 & 81,60 & 21,26 & 16,90 & 15,65 & 14,22 & 12,94 & 11,76 & 9,68 & 7,99 & 5,59 \\
\hline 87,49 & 1638,30 & 77,10 & 17,84 & 13,33 & 12,31 & 11,52 & 10,79 & 10,11 & 8,84 & 7,72 & 5,90 \\
\hline 52,88 & 731,90 & 85,10 & 30,94 & 23,94 & 20,95 & 17,87 & 15,32 & 13,16 & 9,82 & 7,57 & 4,97 \\
\hline 57,55 & 1916,20 & 24,30 & 47,13 & 38,52 & 37,09 & 35,64 & 33,78 & 31,88 & 28,19 & 24,77 & 19,00 \\
\hline 86,34 & 982,10 & 94,50 & 20,15 & 14,34 & 12,82 & 11,50 & 10,47 & 9,56 & 7,98 & 6,69 & 4,82 \\
\hline 63,80 & 872,40 & 104,30 & 23,15 & 17,35 & 15,25 & 13,24 & 11,61 & 10,19 & 7,90 & 6,25 & 4,18 \\
\hline 60,57 & 1992,60 & 72,20 & 21,39 & 17,47 & 16,50 & 15,22 & 14,01 & 12,85 & 10,75 & 8,99 & 6,38 \\
\hline 22,44 & 1579,00 & 51,90 & 60,92 & 52,04 & 44,63 & 35,70 & 28,46 & 22,89 & 15,59 & 11,55 & 7,70 \\
\hline 82,03 & 1250,50 & 21,50 & 43,90 & 36,32 & 33,41 & 32,30 & 31,16 & 29,83 & 27,19 & 24,67 & 20,14 \\
\hline 84,29 & 559,50 & 169,10 & 21,53 & 13,03 & 10,43 & 8,49 & 7,23 & 6,25 & 4,77 & 3,77 & 2,56 \\
\hline 41,12 & 1517,60 & 113,00 & 22,82 & 18,99 & 16,79 & 14,24 & 12,06 & 10,22 & 7,45 & 5,65 & 3,68 \\
\hline 70,85 & 1761,50 & 68,00 & 21,20 & 16,62 & 15,66 & 14,60 & 13,57 & 12,60 & 10,79 & 9,23 & 6,79 \\
\hline 36,06 & 944,60 & 137,90 & 26,47 & 19,99 & 16,64 & 13,10 & 10,42 & 8,41 & 5,81 & 4,35 & 2,93 \\
\hline 64,72 & 1323,00 & 150,90 & 15,55 & 11,68 & 10,32 & 8,99 & 7,92 & 6,98 & 5,45 & 4,32 & 2,90 \\
\hline 31,34 & 1859,30 & 80,30 & 32,53 & 28,31 & 25,07 & 21,06 & 17,58 & 14,70 & 10,48 & 7,83 & 5,09 \\
\hline 68,54 & 629,90 & 159,90 & 21,71 & 14,11 & 11,58 & 9,52 & 8,05 & 6,87 & 5,12 & 3,97 & 2,66 \\
\hline 76,53 & 735,30 & 178,00 & 18,31 & 11,79 & 9,71 & 8,06 & 6,92 & 5,99 & 4,57 & 3,60 & 2,43 \\
\hline 31,01 & 1038,70 & 190,80 & 22,72 & 16,40 & 13,10 & 9,81 & 7,52 & 5,94 & 4,05 & 3,07 & 2,11 \\
\hline 41,26 & 1898,70 & 122,60 & 19,88 & 16,80 & 14,98 & 12,84 & 10,96 & 9,36 & 6,90 & 5,25 & 3,41 \\
\hline 35,85 & 447,00 & 151,60 & 33,79 & 21,64 & 16,64 & 12,21 & 9,32 & 7,37 & 5,06 & 3,86 & 2,67 \\
\hline 64,75 & 1136,00 & 179,00 & 15,33 & 10,99 & 9,45 & 8,06 & 6,97 & 6,05 & 4,61 & 3,61 & 2,41 \\
\hline 50,61 & 991,70 & 89,90 & 27,02 & 21,71 & 19,27 & 16,62 & 14,36 & 12,41 & 9,34 & 7,22 & 4,74 \\
\hline 58,97 & 856,40 & 193,30 & 17,80 & 12,11 & 10,05 & 8,24 & 6,90 & 5,82 & 4,25 & 3,26 & 2,16 \\
\hline 36,11 & 1215,20 & 185,50 & 19,99 & 14,99 & 12,43 & 9,76 & 7,75 & 6,24 & 4,30 & 3,23 & 2,18 \\
\hline 24,29 & 1054,50 & 108,50 & 38,65 & 29,61 & 23,71 & 17,59 & 13,32 & 10,42 & 7,06 & 5,36 & 3,69 \\
\hline 65,44 & 1885,90 & 176,50 & 12,09 & 9,26 & 8,30 & 7,34 & 6,53 & 5,81 & 4,62 & 3,71 & 2,52 \\
\hline 73,22 & 1088,60 & 39,00 & 35,25 & 27,48 & 25,92 & 24,30 & 22,71 & 21,18 & 18,33 & 15,82 & 11,81 \\
\hline 86,16 & 1380,20 & 45,40 & 26,32 & 20,26 & 18,79 & 17,86 & 16,92 & 15,99 & 14,23 & 12,62 & 9,90 \\
\hline 31,66 & 813,40 & 43,40 & 64,20 & 54,76 & 47,98 & 39,78 & 32,85 & 27,21 & 19,19 & 14,30 & 9,35 \\
\hline 35,17 & 1509,90 & 171,10 & 19,71 & 15,46 & 13,07 & 10,45 & 8,40 & 6,83 & 4,73 & 3,54 & 2,36 \\
\hline 73,58 & 1452,40 & 160,60 & 13,57 & 9,94 & 8,81 & 7,77 & 6,94 & 6,21 & 4,98 & 4,05 & 2,79 \\
\hline 86,57 & 1733,90 & 66,60 & 19,09 & 14,50 & 13,44 & 12,70 & 11,97 & 11,27 & 9,95 & 8,77 & 6,80 \\
\hline 64,93 & 1685,80 & 92,60 & 18,61 & 14,80 & 13,72 & 12,48 & 11,37 & 10,34 & 8,52 & 7,04 & 4,93 \\
\hline 70,88 & 949,10 & 54,70 & 30,61 & 23,73 & 21,98 & 20,07 & 18,39 & 16,83 & 14,05 & 11,75 & 8,37 \\
\hline 42,17 & 215,70 & 40,60 & 91,08 & 65,85 & 54,60 & 43,38 & 34,91 & 28,47 & 19,87 & 14,95 & 10,01 \\
\hline 60,50 & 742,90 & 37,50 & 46,26 & 37,61 & 34,93 & 31,72 & 28,80 & 26,09 & 21,33 & 17,49 & 12,10 \\
\hline 69,27 & 219,10 & 83,30 & 53,05 & 31,45 & 24,59 & 19,38 & 15,95 & 13,37 & 9,72 & 7,48 & 5,04 \\
\hline 61,16 & 1264,50 & 121,20 & 18,42 & 14,29 & 12,76 & 11,19 & 9,88 & 8,72 & 6,81 & 5,40 & 3,62 \\
\hline 80,76 & 1030,40 & 118,60 & 18,01 & 12,81 & 11,33 & 10,01 & 8,99 & 8,10 & 6,60 & 5,43 & 3,80 \\
\hline 76,24 & 1652,70 & 92,90 & 17,18 & 13,08 & 12,12 & 11,14 & 10,28 & 9,47 & 8,02 & 6,80 & 4,94 \\
\hline 83,02 & 405,80 & 29,20 & 58,05 & 42,66 & 38,93 & 35,47 & 32,59 & 29,99 & 25,35 & 21,48 & 15,65 \\
\hline 78,65 & 993,90 & 188,00 & 14,90 & 9,97 & 8,43 & 7,16 & 6,25 & 5,50 & 4,29 & 3,43 & 2,34 \\
\hline 58,29 & 1809,60 & 21,10 & 52,25 & 42,74 & 41,03 & 39,59 & 37,65 & 35,63 & 31,70 & 28,02 & 21,72 \\
\hline 47,75 & 648,10 & 149,10 & 25,54 & 17,65 & 14,50 & 11,56 & 9,38 & 7,70 & 5,43 & 4,10 & 2,74 \\
\hline 82,93 & 1983,50 & 126,30 & 12,75 & 9,44 & 8,67 & 7,96 & 7,35 & 6,79 & 5,78 & 4,93 & 3,63 \\
\hline 36,34 & 352,60 & 164,30 & 35,71 & 21,09 & 15,66 & 11,22 & 8,49 & 6,70 & 4,62 & 3,55 & 2,47 \\
\hline 49,71 & 486,80 & 118,40 & 32,46 & 22,10 & 18,11 & 14,45 & 11,75 & 9,68 & 6,85 & 5,18 & 3,47 \\
\hline 53,52 & 398,00 & 135,10 & 32,90 & 20,64 & 16,35 & 12,76 & 10,28 & 8,42 & 5,94 & 4,51 & 3,04 \\
\hline
\end{tabular}




\begin{tabular}{|c|c|c|c|c|c|c|c|c|c|c|c|}
\hline \multirow[b]{2}{*}{$\mathrm{e} 1(\mathrm{~cm})$} & & & & & & $\mathrm{De}$ & $\overline{\text { ões (x1 }}$ & & & & \\
\hline & Meq (MPa) & Ms (MPa) & D0 & D25 & D40 & D60 & D80 & D100 & D140 & D180 & D260 \\
\hline 80,31 & 1070,10 & 63,00 & 25,12 & 18,84 & 17,39 & 15,99 & 14,78 & 13,66 & 11,64 & 9,92 & 7,28 \\
\hline 36,85 & 585,60 & 175,90 & 27,36 & 18,01 & 14,08 & 10,49 & 8,07 & 6,40 & 4,39 & 3,34 & 2,30 \\
\hline 67,19 & 1874,10 & 121,30 & 14,86 & 11,63 & 10,69 & 9,67 & 8,77 & 7,95 & 6,52 & 5,37 & 3,74 \\
\hline 82,73 & 1915,10 & 101,80 & 14,68 & 10,99 & 10,17 & 9,43 & 8,76 & 8,14 & 7,02 & 6,04 & 4,50 \\
\hline 62,39 & 405,70 & 62,20 & 44,25 & 32,08 & 27,63 & 23,52 & 20,29 & 17,56 & 13,31 & 10,37 & 6,90 \\
\hline 25,01 & 344,50 & 199,20 & 35,26 & 19,37 & 13,41 & 9,05 & 6,72 & 5,31 & 3,72 & 2,89 & 2,04 \\
\hline 28,88 & 705,20 & 175,20 & 28,50 & 19,37 & 14,87 & 10,72 & 8,05 & 6,31 & 4,32 & 3,31 & 2,30 \\
\hline 76,36 & 402,60 & 88,80 & 34,78 & 22,79 & 18,97 & 15,89 & 13,70 & 11,92 & 9,15 & 7,23 & 4,89 \\
\hline 20,74 & 1455,30 & 121,60 & 36,18 & 27,68 & 21,81 & 15,83 & 11,80 & 9,16 & 6,22 & 4,75 & 3,29 \\
\hline 36,67 & 1064,40 & 42,70 & 52,53 & 46,36 & 41,92 & 36,34 & 31,30 & 26,89 & 19,99 & 15,24 & 9,86 \\
\hline 29,70 & 258,40 & 114,50 & 53,18 & 31,75 & 23,13 & 16,13 & 12,02 & 9,45 & 6,54 & 5,06 & 3,54 \\
\hline 25,70 & 1898,00 & 77,80 & 38,89 & 33,23 & 28,73 & 23,28 & 18,79 & 15,27 & 10,51 & 7,79 & 5,16 \\
\hline 24,60 & 745,70 & 180,50 & 29,64 & 19,90 & 14,86 & 10,39 & 7,68 & 6,00 & 4,14 & 3,20 & 2,23 \\
\hline 56,32 & 1104,30 & 30,20 & 48,68 & 40,44 & 38,55 & 35,78 & 33,04 & 30,41 & 25,58 & 21,47 & 15,30 \\
\hline 84,11 & 356,20 & 46,30 & 48,29 & 33,54 & 29,33 & 25,74 & 23,05 & 20,75 & 16,87 & 13,87 & 9,73 \\
\hline 53,20 & 273,40 & 64,30 & 57,05 & 38,90 & 32,07 & 25,90 & 21,32 & 17,73 & 12,69 & 9,64 & 6,42 \\
\hline 72,33 & 1338,90 & 182,50 & 13,32 & 9,55 & 8,32 & 7,23 & 6,37 & 5,64 & 4,44 & 3,56 & 2,42 \\
\hline 78,63 & 399,00 & 168,50 & 27,34 & 15,57 & 11,96 & 9,35 & 7,72 & 6,51 & 4,79 & 3,72 & 2,52 \\
\hline 68,60 & 1188,20 & 183,80 & 14,42 & 10,26 & 8,85 & 7,58 & 6,61 & 5,78 & 4,46 & 3,53 & 2,37 \\
\hline 82,16 & 1178,50 & 94,50 & 18,93 & 13,85 & 12,56 & 11,37 & 10,39 & 9,52 & 7,97 & 6,71 & 4,83 \\
\hline 71,98 & 1808,70 & 168,20 & 12,08 & 9,05 & 8,13 & 7,24 & 6,50 & 5,85 & 4,74 & 3,87 & 2,67 \\
\hline 75,64 & 1780,10 & 91,50 & 16,91 & 12,95 & 12,05 & 11,12 & 10,29 & 9,51 & 8,09 & 6,88 & 5,03 \\
\hline 24,73 & 1820,60 & 47,10 & 57,15 & 50,59 & 44,66 & 37,15 & 30,67 & 25,34 & 17,76 & 13,16 & 8,57 \\
\hline 76,30 & 390,60 & 160,30 & 28,36 & 16,31 & 12,59 & 9,87 & 8,15 & 6,86 & 5,04 & 3,90 & 2,64 \\
\hline 61,20 & 1476,20 & 63,60 & 25,62 & 20,83 & 19,53 & 17,88 & 16,36 & 14,93 & 12,37 & 10,26 & 7,20 \\
\hline 82,12 & 1598,70 & 48,20 & 24,79 & 19,23 & 17,95 & 17,09 & 16,19 & 15,29 & 13,58 & 12,02 & 9,38 \\
\hline 37,01 & 985,50 & 166,90 & 22,80 & 16,81 & 13,87 & 10,85 & 8,59 & 6,92 & 4,77 & 3,59 & 2,42 \\
\hline 57,28 & 357,40 & 58,20 & 50,74 & 36,86 & 31,52 & 26,48 & 22,51 & 19,22 & 14,26 & 10,97 & 7,25 \\
\hline 51,52 & 1283,00 & 46,70 & 36,50 & 31,08 & 29,09 & 26,43 & 23,93 & 21,59 & 17,48 & 14,20 & 9,68 \\
\hline 26,21 & 720,30 & 57,60 & 63,98 & 51,10 & 42,35 & 32,66 & 25,40 & 20,13 & 13,65 & 10,23 & 6,95 \\
\hline 75,67 & 791,30 & 157,70 & 18,54 & 12,40 & 10,43 & 8,81 & 7,64 & 6,67 & 5,16 & 4,08 & 2,76 \\
\hline 28,75 & 1345,10 & 120,70 & 29,64 & 23,60 & 19,71 & 15,38 & 12,08 & 9,65 & 6,58 & 4,92 & 3,32 \\
\hline 35,47 & 1688,00 & 158,80 & 19,72 & 15,87 & 13,61 & 11,06 & 9,01 & 7,39 & 5,16 & 3,86 & 2,55 \\
\hline 32,43 & 1331,20 & 199,10 & 19,73 & 14,78 & 12,09 & 9,30 & 7,25 & 5,78 & 3,95 & 2,97 & 2,02 \\
\hline 73,44 & 1781,60 & 131,80 & 13,82 & 10,48 & 9,56 & 8,64 & 7,86 & 7,15 & 5,90 & 4,90 & 3,45 \\
\hline 20,97 & 520,60 & 72,20 & 69,26 & 49,61 & 37,56 & 26,32 & 19,36 & 15,04 & 10,35 & 7,99 & 5,55 \\
\hline 69,76 & 1013,10 & 122,50 & 19,01 & 13,95 & 12,28 & 10,72 & 9,49 & 8,41 & 6,64 & 5,32 & 3,61 \\
\hline 70,84 & 1335,80 & 41,30 & 32,21 & 25,35 & 24,02 & 22,63 & 21,19 & 19,81 & 17,20 & 14,88 & 11,16 \\
\hline 55,51 & 1928,50 & 172,50 & 13,25 & 10,54 & 9,41 & 8,21 & 7,19 & 6,29 & 4,84 & 3,79 & 2,51 \\
\hline 78,70 & 1856,60 & 24,80 & 35,51 & 30,25 & 27,74 & 26,90 & 26,08 & 25,06 & 22,97 & 20,96 & 17,28 \\
\hline 37,12 & 419,90 & 42,00 & 73,93 & 59,13 & 50,79 & 41,44 & 33,88 & 27,89 & 19,60 & 14,66 & 9,68 \\
\hline 87,66 & 1891,00 & 110,60 & 13,64 & 10,04 & 9,21 & 8,52 & 7,92 & 7,37 & 6,37 & 5,50 & 4,13 \\
\hline 75,84 & 1944,30 & 38,40 & 27,99 & 22,43 & 21,03 & 20,26 & 19,34 & 18,37 & 16,49 & 14,74 & 11,68 \\
\hline 74,43 & 869,30 & 185,80 & 16,46 & 10,91 & 9,11 & 7,64 & 6,59 & 5,73 & 4,39 & 3,46 & 2,33 \\
\hline 61,92 & 1135,80 & 145,50 & 17,40 & 12,99 & 11,35 & 9,78 & 8,51 & 7,43 & 5,69 & 4,47 & 2,97 \\
\hline 51,20 & 893,50 & 87,30 & 28,51 & 22,67 & 20,03 & 17,22 & 14,84 & 12,80 & 9,61 & 7,41 & 4,87 \\
\hline 52,37 & 692,30 & 185,90 & 21,27 & 14,11 & 11,47 & 9,14 & 7,44 & 6,14 & 4,36 & 3,31 & 2,21 \\
\hline 59,28 & 865,10 & 132,90 & 21,24 & 15,51 & 13,34 & 11,30 & 9,68 & 8,33 & 6,25 & 4,84 & 3,20 \\
\hline 82,90 & 1786,50 & 75,90 & 17,94 & 13,59 & 12,65 & 11,86 & 11,12 & 10,41 & 9,08 & 7,91 & 6,02 \\
\hline 61,75 & 545,20 & 186,10 & 22,92 & 14,14 & 11,22 & 8,88 & 7,28 & 6,06 & 4,35 & 3,33 & 2,24 \\
\hline 72,18 & 722,00 & 55,20 & 33,73 & 25,64 & 23,35 & 21,03 & 19,07 & 17,30 & 14,21 & 11,73 & 8,22 \\
\hline 49,54 & 623,20 & 94,70 & 32,54 & 24,27 & 20,74 & 17,20 & 14,38 & 12,09 & 8,75 & 6,65 & 4,38 \\
\hline 78,73 & 1284,00 & 51,40 & 26,69 & 20,45 & 19,14 & 17,95 & 16,79 & 15,69 & 13,64 & 11,83 & 8,92 \\
\hline 82,09 & 1257,20 & 122,50 & 15,98 & 11,51 & 10,30 & 9,21 & 8,35 & 7,59 & 6,27 & 5,22 & 3,71 \\
\hline 27,30 & 1779,00 & 87,00 & 35,07 & 29,70 & 25,63 & 20,75 & 16,76 & 13,63 & 9,40 & 6,98 & 4,62 \\
\hline 53,80 & 1189,40 & 26,80 & 53,23 & 44,56 & 42,70 & 39,80 & 36,85 & 34,01 & 28,74 & 24,20 & 17,32 \\
\hline 68,89 & 1739,10 & 151,80 & 13,29 & 10,12 & 9,13 & 8,13 & 7,30 & 6,56 & 5,29 & 4,30 & 2,96 \\
\hline 63,55 & 597,90 & 24,30 & 64,24 & 51,75 & 48,70 & 44,87 & 41,28 & 37,88 & 31,74 & 26,58 & 18,92 \\
\hline 40,96 & 1222,30 & 82,80 & 30,12 & 25,32 & 22,51 & 19,20 & 16,34 & 13,90 & 10,20 & 7,74 & 5,03 \\
\hline 37,45 & 860,00 & 146,60 & 25,85 & 19,04 & 15,72 & 12,31 & 9,77 & 7,88 & 5,44 & 4,09 & 2,76 \\
\hline 63,06 & 1877,70 & 115,60 & 15,82 & 12,62 & 11,61 & 10,47 & 9,47 & 8,55 & 6,94 & 5,67 & 3,91 \\
\hline 56,63 & 779,50 & 87,80 & 28,46 & 21,94 & 19,30 & 16,63 & 14,41 & 12,51 & 9,50 & 7,39 & 4,89 \\
\hline 70,10 & 272,00 & 25,20 & 81,55 & 61,54 & 55,29 & 49,14 & 44,07 & 39,54 & 31,85 & 25,90 & 17,82 \\
\hline 30,04 & 998,00 & 120,40 & 31,79 & 24,45 & 20,11 & 15,47 & 12,05 & 9,58 & 6,53 & 4,90 & 3,33 \\
\hline 61,87 & 1814,00 & 107,00 & 16,99 & 13,65 & 12,58 & 11,35 & 10,26 & 9,26 & 7,52 & 6,14 & 4,22 \\
\hline 59,60 & 562,20 & 63,50 & 38,34 & 29,30 & 25,83 & 22,37 & 19,51 & 17,03 & 13,08 & 10,25 & 6,81 \\
\hline 34,40 & 214,80 & 125,30 & 52,67 & 29,19 & 20,94 & 14,63 & 10,97 & 8,66 & 5,99 & 4,63 & 3,25 \\
\hline 81,80 & 1323,40 & 25,00 & 39,46 & 32,16 & 29,70 & 28,68 & 27,57 & 26,34 & 23,90 & 21,60 & 17,49 \\
\hline 35,31 & 1875,20 & 197,90 & 16,56 & 13,11 & 11,15 & 8,97 & 7,25 & 5,91 & 4,11 & 3,07 & 2,04 \\
\hline 47,50 & 1774,50 & 150,20 & 16,37 & 13,34 & 11,84 & 10,18 & 8,74 & 7,51 & 5,61 & 4,31 & 2,81 \\
\hline 74,15 & 1817,30 & 39,00 & 28,98 & 23,05 & 21,72 & 20,85 & 19,82 & 18,76 & 16,73 & 14,85 & 11,62 \\
\hline 35,49 & 549,50 & 189,00 & 27,37 & 17,47 & 13,40 & 9,80 & 7,47 & 5,90 & 4,05 & 3,09 & 2,14 \\
\hline 51,58 & 1897,10 & 95,30 & 20,00 & 16,87 & 15,52 & 13,88 & 12,39 & 11,03 & 8,72 & 6,96 & 4,65 \\
\hline 22,25 & 1531,90 & 141,70 & 30,44 & 23,30 & 18,48 & 13,54 & 10,16 & 7,91 & 5,36 & 4,09 & 2,82 \\
\hline 63,04 & 235,40 & 152,40 & 41,83 & 21,89 & 15,83 & 11,57 & 9,07 & 7,35 & 5,15 & 3,94 & 2,72 \\
\hline 61,92 & 460,30 & 113,20 & 31,23 & 20,74 & 17,08 & 13,97 & 11,70 & 9,89 & 7,25 & 5,57 & 3,71 \\
\hline 69,35 & 686,40 & 24,50 & 57,87 & 45,65 & 43,15 & 40,30 & 37,51 & 34,84 & 29,89 & 25,58 & 18,84 \\
\hline 52,76 & 221,60 & 155,10 & 44,13 & 22,83 & 16,27 & 11,65 & 8,96 & 7,16 & 4,96 & 3,81 & 2,65 \\
\hline 42,10 & 581,90 & 166,60 & 26,76 & 17,75 & 14,14 & 10,83 & 8,52 & 6,84 & 4,73 & 3,58 & 2,44 \\
\hline 71,79 & 1657,00 & 121,40 & 15,11 & 11,53 & 10,53 & 9,50 & 8,63 & 7,84 & 6,45 & 5,33 & 3,75 \\
\hline 56,18 & 1066,20 & 193,10 & 16,26 & 11,62 & 9,84 & 8,18 & 6,89 & 5,84 & 4,29 & 3,28 & 2,17 \\
\hline 82,04 & 1817,60 & 111,90 & 14,26 & 10,61 & 9,77 & 8,97 & 8,29 & 7,66 & 6,53 & 5,57 & 4,10 \\
\hline
\end{tabular}




\begin{tabular}{|c|c|c|c|c|c|c|c|c|c|c|c|}
\hline \multirow[b]{2}{*}{ e1 (cm) } & & & & & & & ões (x1 & & & & \\
\hline & Meq (MPa) & Ms (MPa) & D0 & D25 & D40 & D60 & D80 & D100 & D140 & D180 & D260 \\
\hline 41,86 & 1009,10 & 166,40 & 21,09 & 15,62 & 13,09 & 10,50 & 8,51 & 6,97 & 4,88 & 3,67 & 2,45 \\
\hline 62,89 & 1963,10 & 117,90 & 15,39 & 12,30 & 11,33 & 10,23 & 9,26 & 8,36 & 6,80 & 5,56 & 3,84 \\
\hline 48,99 & 1539,70 & 142,60 & 17,54 & 14,10 & 12,47 & 10,70 & 9,19 & 7,90 & 5,90 & 4,53 & 2,97 \\
\hline 70,97 & 632,20 & 137,50 & 22,85 & 15,22 & 12,70 & 10,61 & 9,09 & 7,86 & 5,96 & 4,66 & 3,13 \\
\hline 74,50 & 533,20 & 111,90 & 27,05 & 17,97 & 15,04 & 12,64 & 10,91 & 9,49 & 7,28 & 5,74 & 3,87 \\
\hline 51,22 & 871,50 & 133,20 & 22,78 & 16,93 & 14,49 & 12,06 & 10,13 & 8,55 & 6,23 & 4,75 & 3,13 \\
\hline 55,72 & 723,50 & 192,00 & 19,98 & 13,21 & 10,77 & 8,66 & 7,12 & 5,92 & 4,25 & 3,23 & 2,16 \\
\hline 42,41 & 1484,10 & 55,10 & 35,49 & 31,24 & 28,74 & 25,53 & 22,55 & 19,85 & 15,37 & 12,04 & 7,90 \\
\hline 28,46 & 917,20 & 83,10 & 43,48 & 34,54 & 28,77 & 22,38 & 17,55 & 13,99 & 9,52 & 7,13 & 4,82 \\
\hline 32,80 & 630,10 & 103,40 & 39,02 & 28,80 & 23,43 & 17,92 & 13,94 & 11,09 & 7,58 & 5,71 & 3,89 \\
\hline 31,63 & 1678,80 & 143,90 & 22,84 & 18,46 & 15,69 & 12,55 & 10,06 & 8,15 & 5,62 & 4,19 & 2,80 \\
\hline 20,07 & 1817,60 & 64,80 & 54,75 & 45,54 & 38,07 & 29,44 & 22,83 & 18,01 & 12,11 & 9,05 & 6,15 \\
\hline 80,00 & 1446,10 & 165,40 & 12,92 & 9,23 & 8,16 & 7,21 & 6,47 & 5,83 & 4,74 & 3,90 & 2,72 \\
\hline 39,31 & 1136,60 & 48,00 & 45,09 & 39,61 & 35,96 & 31,40 & 27,26 & 23,60 & 17,76 & 13,65 & 8,86 \\
\hline 59,46 & 275,30 & 151,40 & 38,11 & 20,92 & 15,53 & 11,58 & 9,14 & 7,43 & 5,21 & 3,98 & 2,73 \\
\hline 77,95 & 1056,90 & 110,40 & 18,74 & 13,60 & 12,11 & 10,75 & 9,68 & 8,73 & 7,11 & 5,85 & 4,09 \\
\hline 78,56 & 493,30 & 79,00 & 32,38 & 22,25 & 19,11 & 16,46 & 14,50 & 12,85 & 10,16 & 8,18 & 5,60 \\
\hline 78,75 & 1575,40 & 91,10 & 17,43 & 13,14 & 12,15 & 11,18 & 10,32 & 9,53 & 8,10 & 6,89 & 5,04 \\
\hline 85,33 & 1836,50 & 63,40 & 19,37 & 14,85 & 13,80 & 13,08 & 12,37 & 11,67 & 10,34 & 9,14 & 7,12 \\
\hline 51,22 & 1609,60 & 176,70 & 14,81 & 11,59 & 10,16 & 8,67 & 7,42 & 6,37 & 4,74 & 3,64 & 2,39 \\
\hline 55,37 & 526,70 & 70,60 & 38,79 & 29,23 & 25,36 & 21,53 & 18,43 & 15,81 & 11,81 & 9,10 & 6,00 \\
\hline 63,81 & 1853,50 & 104,90 & 16,76 & 13,38 & 12,38 & 11,23 & 10,20 & 9,25 & 7,58 & 6,23 & 4,33 \\
\hline 59,97 & 1640,90 & 26,30 & 45,49 & 36,97 & 35,56 & 33,98 & 32,08 & 30,18 & 26,51 & 23,16 & 17,59 \\
\hline 24,04 & 517,40 & 146,70 & 38,63 & 25,06 & 18,37 & 12,68 & 9,35 & 7,31 & 5,08 & 3,93 & 2,75 \\
\hline 25,37 & 1852,00 & 102,90 & 32,75 & 27,11 & 22,93 & 18,08 & 14,28 & 11,42 & 7,77 & 5,78 & 3,89 \\
\hline 50,04 & 1855,60 & 97,40 & 20,27 & 17,14 & 15,70 & 13,96 & 12,39 & 10,97 & 8,58 & 6,79 & 4,51 \\
\hline 50,66 & 762,30 & 66,40 & 35,96 & 29,03 & 25,83 & 22,35 & 19,35 & 16,75 & 12,65 & 9,79 & 6,43 \\
\hline 33,72 & 1154,50 & 110,80 & 29,50 & 23,61 & 20,09 & 16,14 & 13,01 & 10,58 & 7,33 & 5,47 & 3,64 \\
\hline 86,13 & 1846,80 & 189,80 & 10,37 & 7,34 & 6,53 & 5,83 & 5,29 & 4,82 & 4,00 & 3,34 & 2,39 \\
\hline 21,11 & 546,20 & 88,20 & 58,74 & 41,17 & 30,81 & 21,41 & 15,72 & 12,23 & 8,45 & 6,54 & 4,55 \\
\hline 32,35 & 702,90 & 170,60 & 27,48 & 18,89 & 14,81 & 10,95 & 8,35 & 6,58 & 4,50 & 3,43 & 2,36 \\
\hline 42,56 & 744,90 & 138,90 & 26,38 & 19,11 & 15,87 & 12,64 & 10,19 & 8,32 & 5,82 & 4,38 & 2,93 \\
\hline 73,45 & 1821,50 & 102,80 & 15,86 & 12,19 & 11,30 & 10,36 & 9,53 & 8,76 & 7,37 & 6,21 & 4,47 \\
\hline 62,86 & 785,30 & 69,50 & 30,58 & 23,78 & 21,37 & 18,88 & 16,78 & 14,91 & 11,79 & 9,43 & 6,37 \\
\hline 72,90 & 1009,70 & 166,20 & 16,07 & 11,18 & 9,58 & 8,21 & 7,17 & 6,30 & 4,90 & 3,89 & 2,63 \\
\hline 73,16 & 489,50 & 150,40 & 25,36 & 15,66 & 12,56 & 10,17 & 8,54 & 7,28 & 5,41 & 4,21 & 2,83 \\
\hline 52,19 & 816,90 & 26,40 & 61,61 & 52,33 & 49,32 & 45,11 & 41,10 & 37,31 & 30,56 & 25,06 & 17,28 \\
\hline 82,65 & 1392,20 & 172,70 & 12,72 & 8,92 & 7,84 & 6,89 & 6,18 & 5,57 & 4,53 & 3,72 & 2,61 \\
\hline 34,30 & 912,40 & 71,70 & 41,88 & 34,42 & 29,75 & 24,35 & 19,92 & 16,39 & 11,49 & 8,58 & 5,65 \\
\hline 67,55 & 674,60 & 144,50 & 21,95 & 14,79 & 12,36 & 10,31 & 8,80 & 7,56 & 5,69 & 4,43 & 2,96 \\
\hline 56,26 & 805,00 & 52,90 & 37,81 & 30,85 & 28,11 & 25,01 & 22,27 & 19,79 & 15,62 & 12,47 & 8,36 \\
\hline 32,77 & 1990,20 & 170,90 & 18,76 & 15,20 & 12,99 & 10,46 & 8,44 & 6,87 & 4,76 & 3,55 & 2,36 \\
\hline 73,60 & 1796,00 & 183,90 & 11,43 & 8,44 & 7,53 & 6,67 & 5,98 & 5,37 & 4,33 & 3,53 & 2,44 \\
\hline 45,82 & 1741,20 & 124,40 & 18,92 & 15,75 & 14,09 & 12,18 & 10,51 & 9,06 & 6,79 & 5,22 & 3,41 \\
\hline 80,44 & 635,60 & 90,00 & 26,40 & 18,35 & 15,93 & 13,87 & 12,32 & 11,01 & 8,82 & 7,17 & 4,96 \\
\hline 67,59 & 288,70 & 126,70 & 38,44 & 22,08 & 16,93 & 13,10 & 10,65 & 8,83 & 6,35 & 4,87 & 3,29 \\
\hline 59,00 & 1877,00 & 117,00 & 16,29 & 13,20 & 12,10 & 10,84 & 9,73 & 8,72 & 6,98 & 5,63 & 3,82 \\
\hline 68,38 & 1946,10 & 136,40 & 13,53 & 10,49 & 9,60 & 8,65 & 7,84 & 7,10 & 5,81 & 4,77 & 3,32 \\
\hline 38,03 & 1249,80 & 140,40 & 22,72 & 17,89 & 15,28 & 12,42 & 10,12 & 8,32 & 5,84 & 4,37 & 2,89 \\
\hline 66,90 & 1308,40 & 136,10 & 16,26 & 12,26 & 10,91 & 9,60 & 8,52 & 7,57 & 5,99 & 4,80 & 3,25 \\
\hline 36,81 & 1632,20 & 77,00 & 30,75 & 26,78 & 24,03 & 20,63 & 17,61 & 15,02 & 11,04 & 8,37 & 5,42 \\
\hline 24,64 & 275,00 & 51,50 & 96,23 & 67,63 & 51,67 & 36,75 & 27,30 & 21,28 & 14,61 & 11,23 & 7,80 \\
\hline 85,30 & 331,60 & 84,50 & 38,55 & 24,05 & 19,65 & 16,29 & 14,04 & 12,25 & 9,49 & 7,57 & 5,17 \\
\hline 47,32 & 282,90 & 22,60 & 106,62 & 87,50 & 77,93 & 67,20 & 57,90 & 49,88 & 37,35 & 28,73 & 18,78 \\
\hline 81,10 & 946,30 & 166,20 & 16,00 & 10,76 & 9,16 & 7,84 & 6,89 & 6,10 & 4,82 & 3,88 & 2,66 \\
\hline 72,04 & 1822,40 & 121,00 & 14,53 & 11,14 & 10,24 & 9,29 & 8,48 & 7,73 & 6,41 & 5,33 & 3,77 \\
\hline 35,26 & 213,50 & 86,40 & 64,32 & 39,45 & 29,68 & 21,41 & 16,22 & 12,79 & 8,80 & 6,75 & 4,69 \\
\hline 86,18 & 1061,90 & 38,10 & 32,51 & 24,84 & 23,04 & 21,82 & 20,61 & 19,43 & 17,21 & 15,21 & 11,84 \\
\hline 22,94 & 1697,80 & 53,10 & 57,50 & 49,50 & 42,74 & 34,49 & 27,71 & 22,41 & 15,34 & 11,35 & 7,53 \\
\hline 28,16 & 684,80 & 175,70 & 29,08 & 19,60 & 14,94 & 10,69 & 8,00 & 6,26 & 4,30 & 3,30 & 2,29 \\
\hline 53,18 & 1962,60 & 141,60 & 15,16 & 12,40 & 11,20 & 9,85 & 8,67 & 7,62 & 5,90 & 4,64 & 3,08 \\
\hline 68,85 & 1153,50 & 83,70 & 22,29 & 17,22 & 15,72 & 14,16 & 12,81 & 11,59 & 9,47 & 7,78 & 5,41 \\
\hline 77,15 & 1483,00 & 175,90 & 12,56 & $\begin{array}{c}+, L \\
9,01\end{array}$ & $\begin{array}{c}10,12 \\
7,95\end{array}$ & $\begin{array}{c}1+,+1 \\
6,99\end{array}$ & $\begin{array}{c} \pm L, 0 \perp \\
6,25\end{array}$ & $\begin{array}{c}1+, 60 \\
5,60\end{array}$ & 4,52 & 3,68 & 2,55 \\
\hline 67,89 & 1113,10 & 177,50 & 15,24 & 10,81 & 9,29 & 7,94 & 6,90 & 6,02 & 4,63 & 3,65 & 2,44 \\
\hline 51,38 & 1712,20 & 92,40 & 21,23 & 17,85 & 16,35 & 14,57 & 12,95 & 11,49 & 9,03 & 7,17 & 4,77 \\
\hline 71,51 & 1068,10 & 193,10 & 14,65 & 10,08 & 8,56 & 7,27 & 6,31 & 5,50 & 4,23 & 3,34 & 2,25 \\
\hline 73,86 & 693,40 & 99,30 & 24,89 & 17,63 & 15,31 & 13,26 & 11,69 & 10,34 & 8,15 & 6,53 & 4,45 \\
\hline 63,28 & 1044,20 & 181,20 & 16,07 & 11,38 & 9,70 & 8,19 & 7,02 & 6,05 & 4,56 & 3,55 & 2,36 \\
\hline 61,28 & 1363,50 & 147,30 & 15,97 & 12,21 & 10,81 & 9,42 & 8,26 & 7,25 & 5,62 & 4,43 & 2,96 \\
\hline 60,28 & 1771,80 & 100,20 & 18.12 & 14.68 & 13,55 & 12,23 & 11,04 & 9,96 & 8.07 & 6,57 & 4,51 \\
\hline 51,41 & 993,10 & 67,90 & 31,61 & 26,11 & 23,61 & 20,76 & 18,24 & 16,01 & 12,35 & 9,69 & 6,40 \\
\hline 76,37 & 987,00 & 81,70 & 22,97 & 17,10 & 15,49 & 13,94 & 12,66 & 11,50 & 9,49 & 7,88 & 5,57 \\
\hline 47,22 & 954,50 & 137,10 & 22,51 & 17,00 & 14,54 & 12,03 & 10,02 & 8,39 & 6,04 & 4,57 & 3,01 \\
\hline 85,70 & 431,00 & 170,60 & 25,43 & 14,51 & 11,21 & 8,85 & 7,39 & 6,29 & 4,72 & 3,70 & 2,52 \\
\hline 77,30 & 1791,20 & 193,30 & 10,91 & 7,91 & 7,03 & 6,22 & 5,59 & 5,03 & 4,08 & 3,34 & 2,33 \\
\hline 76,02 & 1380,60 & 182,90 & 12,84 & 9,13 & 7,98 & 6,96 & 6,18 & 5,50 & 4,38 & 3,54 & 2,43 \\
\hline 76,12 & 1346,90 & 34,70 & 34,18 & 26,86 & 25,29 & 24,14 & 22,86 & 21,58 & 19,12 & 16,88 & 13,10 \\
\hline 76,70 & 1236,90 & 103,20 & 18,22 & 13,54 & 12,26 & 11,03 & 10,01 & 9,10 & 7,51 & 6,24 & 4,41 \\
\hline 70,68 & 433,50 & 115,40 & 30,62 & 19,61 & 16,00 & 13,12 & 11,09 & 9,48 & 7,08 & 5,50 & 3,69 \\
\hline 66,58 & 1510,30 & 104,70 & 17,78 & 13,90 & 12,72 & 11,45 & 10,35 & 9,35 & 7,61 & 6,24 & 4,32 \\
\hline 56,30 & 1364,60 & 93,40 & 21,75 & 17,69 & 16,08 & 14,27 & 12,68 & 11,25 & 8,86 & 7,05 & 4,73 \\
\hline 71,64 & 1552,50 & 196,30 & 11,98 & 8,69 & 7,63 & 6,65 & 5,89 & 5,22 & 4,13 & 3,31 & 2,26 \\
\hline
\end{tabular}




\begin{tabular}{|c|c|c|c|c|c|c|c|c|c|c|c|}
\hline \multirow[b]{2}{*}{ e1 (cm) } & & & & & & & ões (x1 & m) & & & \\
\hline & Meq (MPa) & Ms (MPa) & D0 & D25 & D40 & D60 & D80 & D100 & D140 & D180 & D260 \\
\hline 67,77 & 910,70 & 144,60 & 18,68 & 13,27 & 11,41 & 9,75 & 8,47 & 7,39 & 5,68 & 4,48 & 3,00 \\
\hline 23,44 & 1933,90 & 100,50 & 34,94 & 28,78 & 24,11 & 18,77 & 14,66 & 11,63 & 7,87 & 5,87 & 3,97 \\
\hline 55,91 & 930,40 & 118,10 & 22,50 & 17,08 & 14,88 & 12,70 & 10,92 & 9,41 & 7,06 & 5,46 & 3,60 \\
\hline 46,79 & 1233,60 & 126,90 & 21,19 & 16,85 & 14,76 & 12,49 & 10,59 & 9,00 & 6,60 & 5,03 & 3,29 \\
\hline 21,95 & 1358,30 & 52,80 & 64,18 & 53,79 & 45,45 & 35,67 & 28,01 & 22,28 & 15,07 & 11,21 & 7,56 \\
\hline 30,93 & 236,50 & 171,20 & 43,35 & 22,43 & 15,50 & 10,56 & 7,89 & 6,24 & 4,34 & 3,37 & 2,38 \\
\hline 28,67 & 321,10 & 62,40 & 73,96 & 52,57 & 41,22 & 30,21 & 22,85 & 17,92 & 12,23 & 9,33 & 6,44 \\
\hline 44,37 & 259,20 & 34,60 & 89,70 & 68,76 & 58,88 & 48,51 & 40,17 & 33,46 & 23,92 & 18,03 & 11,89 \\
\hline 77,90 & 1474,00 & 27,60 & 37,27 & 30,13 & 28,07 & 27,10 & 25,97 & 24,75 & 22,34 & 20,08 & 16,09 \\
\hline 82,41 & 1321,60 & 77,50 & 20,13 & 15,01 & 13,84 & 12,75 & 11,81 & 10,94 & 9,36 & 8,01 & 5,92 \\
\hline 45,33 & 1754,70 & 23,20 & 58,85 & 50,44 & 48,80 & 45,70 & 42,44 & 39,24 & 33,26 & 28,04 & 20,06 \\
\hline 74,73 & 1361,60 & 192,00 & 12,71 & 9,00 & 7,82 & 6,79 & 5,99 & 5,32 & 4,20 & 3,38 & 2,31 \\
\hline 45,48 & 1582,80 & 194,10 & 15,18 & 11,78 & 10,17 & 8,47 & 7,07 & 5,94 & 4,28 & 3,24 & 2,13 \\
\hline 29,85 & 1939,80 & 178,80 & 19,65 & 15,66 & 13,13 & 10,31 & 8,14 & 6,53 & 4,46 & 3,33 & 2,25 \\
\hline 42,59 & 460,80 & 87,20 & 42,27 & 30,52 & 25,32 & 20,14 & 16,23 & 13,25 & 9,26 & 6,97 & 4,66 \\
\hline 87,35 & 1734,10 & 82,40 & 16,78 & 12,53 & 11,57 & 10,82 & 10,13 & 9,49 & 8,29 & 7,24 & 5,52 \\
\hline 49,35 & 895,30 & 150,30 & 21,50 & 15,76 & 13,35 & 10,98 & 9,12 & 7,63 & 5,49 & 4,16 & 2,75 \\
\hline 54,93 & 1111,40 & 102,00 & 22,79 & 18,10 & 16,12 & 14,03 & 12,25 & 10,69 & 8,19 & 6,40 & 4,23 \\
\hline 46,02 & 1201,40 & 94,60 & 25,78 & 21,23 & 18,88 & 16,23 & 13,94 & 11,97 & 8,92 & 6,84 & 4,46 \\
\hline 28,69 & 202,70 & 57,20 & 91,51 & 60,59 & 45,92 & 32,76 & 24,50 & 19,19 & 13,19 & 10,14 & 7,05 \\
\hline 85,84 & 624,60 & 195,70 & 18,96 & 11,35 & 9,04 & 7,33 & 6,23 & 5,38 & 4,11 & 3,25 & 2,21 \\
\hline 59,55 & 1382,80 & 110,00 & 19,02 & 15,11 & 13,64 & 12,07 & 10,72 & 9,51 & 7,50 & 5,98 & 4,02 \\
\hline 85,38 & 326,20 & 187,80 & 30,18 & 15,87 & 11,62 & 8,71 & 7,03 & 5,85 & 4,25 & 3,30 & 2,26 \\
\hline 25,08 & 946,50 & 196,70 & 25,74 & 17,81 & 13,53 & 9,59 & 7,12 & 5,56 & 3,82 & 2,94 & 2,04 \\
\hline 33,88 & 1350,40 & 173,60 & 20,85 & 16,02 & 13,36 & 10,49 & 8,32 & 6,69 & 4,60 & 3,45 & 2,32 \\
\hline 89,05 & 764,80 & 97,00 & 22,27 & 15,28 & 13,36 & 11,77 & 10,60 & 9,59 & 7,89 & 6,56 & 4,66 \\
\hline 26,64 & 1699,80 & 104,90 & 31,96 & 26,33 & 22,29 & 17,62 & 13,96 & 11,20 & 7,63 & 5,69 & 3,82 \\
\hline 66,55 & 295,20 & 155,80 & 35,39 & 19,45 & 14,52 & 10,96 & 8,77 & 7,20 & 5,11 & 3,92 & 2,67 \\
\hline 41,39 & 1103,90 & 196,10 & 18,58 & 13,58 & 11,30 & 8,99 & 7,24 & 5,90 & 4,12 & 3,09 & 2,07 \\
\hline 84,40 & 675,70 & 168,70 & 19,13 & 12,01 & 9,83 & 8,17 & 7,04 & 6,15 & 4,76 & 3,79 & 2,59 \\
\hline 68,61 & 635,40 & 197,70 & 19,80 & 12,31 & 9,87 & 7,95 & 6,63 & 5,61 & 4,12 & 3,18 & 2,13 \\
\hline 32,81 & 208,50 & 107,70 & 58,61 & 33,65 & 24,40 & 17,09 & 12,80 & 10,08 & 6,97 & 5,39 & 3,77 \\
\hline 27,34 & 1248,70 & 145,80 & 27,64 & 21,15 & 17,15 & 12,95 & 9,94 & 7,83 & 5,32 & 4,01 & 2,75 \\
\hline 50,42 & 1981,00 & 50,50 & 30,53 & 26,09 & 24,79 & 22,84 & 20,93 & 19,10 & 15,81 & 13,06 & 9,09 \\
\hline 41,03 & 703,20 & 29,20 & 71,32 & 62,58 & 57,09 & 50,19 & 43,88 & 38,24 & 29,12 & 22,55 & 14,69 \\
\hline 75,46 & 1302,20 & 20,30 & 48,39 & 39,74 & 36,99 & 35,84 & 34,47 & 32,92 & 29,85 & 26,94 & 21,74 \\
\hline 86,68 & 250,30 & 87,50 & 45,49 & 26,60 & 20,88 & 16,74 & 14,12 & 12,13 & 9,19 & 7,25 & 4,94 \\
\hline 81,45 & 890,00 & 182,10 & 15,90 & 10,42 & 8,73 & 7,38 & 6,43 & 5,65 & 4,42 & 3,53 & 2,41 \\
\hline 83,58 & 1908,40 & 137,80 & 12,29 & 9,02 & 8,23 & 7,50 & 6,89 & 6,34 & 5,37 & 4,55 & 3,32 \\
\hline 61,92 & 1786,10 & 33,80 & 36,47 & 29,51 & 28,32 & 26,95 & 25,38 & 23,82 & 20,83 & 18,13 & 13,69 \\
\hline 62,00 & 1983,30 & 40,50 & 31,20 & 25,23 & 24,21 & 22,97 & 21,58 & 20,21 & 17,61 & 15,27 & 11,45 \\
\hline 37,12 & 1468,80 & 42,20 & 46,97 & 42,28 & 38,89 & 34,41 & 30,23 & 26,45 & 20,25 & 15,71 & 10,22 \\
\hline 56,28 & 1604,80 & 198,60 & 13,18 & 10,03 & 8,76 & 7,49 & 6,46 & 5,57 & 4,20 & 3,25 & 2,15 \\
\hline 45,16 & 546,10 & 92,90 & 36,69 & 26,96 & 22,68 & 18,38 & 15,05 & 12,43 & 8,80 & 6,63 & 4,40 \\
\hline 33,23 & 1359,00 & 134,00 & 24,88 & 19,82 & 16,80 & 13,43 & 10,77 & 8,74 & 6,04 & 4,51 & 3,01 \\
\hline 58,27 & 398,80 & 133,70 & 32,14 & 20,05 & 15,93 & 12,57 & 10,24 & 8,47 & 6,05 & 4,61 & 3,10 \\
\hline 59,03 & 1074,00 & 143,40 & 18,44 & 13,78 & 11,99 & 10,25 & 8,85 & 7,66 & 5,80 & 4,51 & 2,99 \\
\hline 55,07 & 310,20 & 80,00 & 47,44 & 31,61 & 25,85 & 20,79 & 17,10 & 14,23 & 10,19 & 7,75 & 5,17 \\
\hline 61,65 & 1616,10 & 33,00 & 38,44 & 31,12 & 29,87 & 28,32 & 26,60 & 24,90 & 21,68 & 18,77 & 14,06 \\
\hline 60,82 & 1618,50 & 112,20 & 17,42 & 13,92 & 12,70 & 11,34 & 10,16 & 9,09 & 7,27 & 5,86 & 3,98 \\
\hline 64,87 & 1719,50 & 42,10 & 30,90 & 24,79 & 23,68 & 22,38 & 20,98 & 19,61 & 17,03 & 14,72 & 11,01 \\
\hline 32,60 & 1915,70 & 95,50 & 27,85 & 23,98 & 21,17 & 17,74 & 14,79 & 12,34 & 8,80 & 6,58 & 4,28 \\
\hline 72,31 & 1689,50 & 45,50 & 27,49 & 21,65 & 20,51 & 19,47 & 18,34 & 17,24 & 15,13 & 13,23 & 10,10 \\
\hline 81,30 & 1550,90 & 98,60 & 16,48 & 12,27 & 11,28 & 10,34 & 9,53 & 8,80 & 7,47 & 6,35 & 4,65 \\
\hline 65,19 & 226,60 & 79,80 & 53,63 & 32,63 & 25,78 & 20,42 & 16,80 & 14,04 & 10,16 & 7,79 & 5,24 \\
\hline 86,02 & 1280,20 & 68,20 & 21,46 & 15,95 & 14,71 & 13,66 & 12,72 & 11,86 & 10,27 & 8,89 & 6,70 \\
\hline 39,55 & 465,10 & 47,90 & 62,76 & 50,06 & 43,21 & 35,59 & 29,36 & 24,36 & 17,28 & 12,97 & 8,53 \\
\hline 29,88 & 517,10 & 153,40 & 34,11 & 22,40 & 17,02 & 12,19 & 9,15 & 7,18 & 4,93 & 3,78 & 2,63 \\
\hline 67,16 & 1846,10 & 123,90 & 14,77 & 11,54 & 10,58 & 9,55 & 8,66 & 7,84 & 6,41 & 5,26 & 3,66 \\
\hline 46,17 & 1587,20 & 163,00 & 16,63 & 13,24 & 11,58 & 9,79 & 8,28 & 7,02 & 5,14 & 3,91 & 2,56 \\
\hline 77,83 & 1199,00 & 143,90 & 15,39 & 11,00 & 9,70 & 8,53 & 7,62 & 6,84 & 5,51 & 4,50 & 3,12 \\
\hline 72,92 & 1532,40 & 74,10 & 20,80 & 16,10 & 15,04 & 13,89 & 12,84 & 11,85 & 10,06 & 8,54 & 6,21 \\
\hline 64,77 & 691,40 & 53,70 & 36,87 & 28,79 & 26,13 & 23,32 & 20,92 & 18,76 & 15,07 & 12,20 & 8,34 \\
\hline 29,35 & 778,50 & 107,10 & 37,91 & 28,54 & 23,14 & 17,52 & 13,50 & 10,67 & 7,26 & 5,48 & 3,75 \\
\hline 38,84 & 1277,90 & 29,60 & 60,41 & 54,47 & 50,83 & 45,73 & 40,86 & 36,33 & 28,60 & 22,65 & 14,96 \\
\hline 60,53 & 837,10 & 133,80 & 21,30 & 15,40 & 13,21 & 11,18 & 9,58 & 8,25 & 6,19 & 4,80 & 3,18 \\
\hline 31,50 & 1910,90 & 128,00 & 23,66 & 19,69 & 17,00 & 13,85 & 11,26 & 9,22 & 6,42 & 4,78 & 3,16 \\
\hline 42,63 & 454,00 & 78,60 & 45,13 & 33,12 & 27,69 & 22,20 & 17,98 & 14,73 & 10,33 & 7,77 & 5,18 \\
\hline 64,33 & 1903,60 & 26,60 & 40,70 & 33,08 & 31,49 & 30,42 & 28,99 & 27,49 & 24,57 & 21,82 & 17,09 \\
\hline 65,22 & 531,30 & 113,30 & 28,30 & 19,19 & 16,05 & 13,35 & 11,35 & 9,72 & 7,26 & 5,63 & 3,75 \\
\hline 20,41 & 466,80 & 136,40 & 44,94 & 28,18 & 19,95 & 13,41 & 9,84 & 7,74 & 5,43 & 4,22 & 2,95 \\
\hline 77,30 & 235,60 & 80,30 & 49,99 & 29,93 & 23,67 & 18,98 & 15,91 & 13,55 & 10,10 & 7,87 & 5,31 \\
\hline 25,21 & 718,50 & 43,10 & 80,48 & 66,02 & 55,48 & 43,41 & 34,09 & 27,17 & 18,43 & 13,75 & 9,28 \\
\hline 43,39 & 776,40 & 39,40 & 54,54 & 47,01 & 42,66 & 37,36 & 32,58 & 28,34 & 21,53 & 16,66 & 10,87 \\
\hline 50,86 & 1600,70 & 183,30 & 14,60 & 11,37 & 9,93 & 8,44 & 7,20 & 6,16 & 4,57 & 3,50 & 2,30 \\
\hline 68,51 & 1030,80 & 161,60 & 16,53 & 11,74 & 10,11 & 8,65 & 7,53 & 6,59 & 5,08 & 4,01 & 2,69 \\
\hline 44,34 & 804,70 & 198,20 & 20,52 & 14,04 & 11,40 & 8,93 & 7,13 & 5,79 & 4,04 & 3,05 & 2,05 \\
\hline 69,87 & 1547,60 & 56,90 & 25,09 & 19,75 & 18,65 & 17,40 & 16,19 & 15,03 & 12,89 & 11,03 & 8,12 \\
\hline 52,30 & 1014,50 & 22,20 & 64,90 & 54,69 & 52,42 & 48,78 & 45,11 & 41,55 & 35,00 & 29,38 & 20,92 \\
\hline 38,44 & 1130,80 & 182,70 & 20,00 & 14,87 & 12,37 & 9,79 & 7,82 & 6,34 & 4,40 & 3,30 & 2,22 \\
\hline 31,23 & 958,60 & 136,40 & 28,96 & 21,80 & 17,81 & 13,64 & 10,60 & 8,42 & 5,74 & 4,32 & 2,95 \\
\hline 88,52 & 1479,00 & 194,70 & 11,33 & 7,75 & 6,76 & 5,94 & 5,33 & 4,82 & 3,95 & 3,27 & 2,32 \\
\hline
\end{tabular}




\begin{tabular}{|c|c|c|c|c|c|c|c|c|c|c|c|}
\hline & & & \multicolumn{9}{|c|}{ Deflexões $\left(\times 10^{-4} \mathrm{~cm}\right)$} \\
\hline e1 (cm) & Meq (MPa) & Ms (MPa) & D0 & D25 & D40 & D60 & D80 & D100 & D140 & D180 & D260 \\
\hline 32,15 & 1857,00 & 64,70 & 36,72 & 32,61 & 29,29 & 25,08 & 21,31 & 18,08 & 13,16 & 9,92 & 6,40 \\
\hline 39,88 & 1197,10 & 118,60 & 24,82 & 19,91 & 17,24 & 14,27 & 11,81 & 9,83 & 7,00 & 5,26 & 3,45 \\
\hline 33,09 & 1990,70 & 195,50 & 17,08 & 13,61 & 11,54 & 9,21 & 7,39 & 5,99 & 4,14 & 3,09 & 2,06 \\
\hline 37,06 & 1607,00 & 189,10 & 17,47 & 13,65 & 11,59 & 9,33 & 7,56 & 6,17 & 4,31 & 3,22 & 2,14 \\
\hline 69,70 & 1846,70 & 183,80 & 11,57 & 8,69 & 7,76 & 6,86 & 6,13 & 5,48 & 4,39 & 3,55 & 2,43 \\
\hline 82,13 & 871,00 & 128,00 & 18,79 & 12,92 & 11,18 & 9,72 & 8,63 & 7,71 & 6,19 & 5,04 & 3,49 \\
\hline 50,32 & 1057,10 & 134,50 & 20,97 & 16,08 & 13,94 & 11,74 & 9,94 & 8,45 & 6,21 & 4,74 & 3,11 \\
\hline 58,72 & 671,30 & 58,40 & 37,48 & 29,61 & 26,56 & 23,36 & 20,62 & 18,19 & 14,19 & 11,24 & 7,51 \\
\hline 41,07 & 756,30 & 199,60 & 21,76 & 14,71 & 11,78 & 9,06 & 7,12 & 5,72 & 3,95 & 2,99 & 2,03 \\
\hline 68,96 & 1538,50 & 185,40 & 12,61 & 9,28 & 8,17 & 7,13 & 6,30 & 5,58 & 4,39 & 3,51 & 2,38 \\
\hline 44,10 & 1963,70 & 92,50 & 22,36 & 19,35 & 17,65 & 15,56 & 13,65 & 11,94 & 9,16 & 7,14 & 4,67 \\
\hline 56,51 & 1262,10 & 43,40 & 36,44 & 30,32 & 28,63 & 26,31 & 24,10 & 22,01 & 18,24 & 15,12 & 10,58 \\
\hline 54,35 & 346,50 & 161,30 & 32,86 & 19,00 & 14,45 & 10,91 & 8,63 & 7,00 & 4,90 & 3,73 & 2,55 \\
\hline 36,42 & 1043,90 & 88,40 & 33,43 & 27,30 & 23,66 & 19,47 & 16,03 & 13,26 & 9,36 & 7,00 & 4,60 \\
\hline 84,97 & 1609,30 & 28,20 & 32,64 & 27,23 & 24,90 & 24,04 & 23,24 & 22,29 & 20,37 & 18,55 & 15,24 \\
\hline 67,05 & 1595,60 & 124,90 & 15,62 & 12,09 & 10,98 & 9,82 & 8,84 & 7,95 & 6,43 & 5,23 & 3,60 \\
\hline 40,42 & 1973,60 & 62,10 & 30,85 & 27,48 & 25,38 & 22,60 & 20,00 & 17,63 & 13,67 & 10,71 & 7,03 \\
\hline 46,69 & 1880,10 & 93,50 & 21,68 & 18,58 & 16,98 & 15,03 & 13,25 & 11,65 & 9,02 & 7,07 & 4,66 \\
\hline 82,78 & 1840,60 & 120,10 & 13,56 & 10,04 & 9,21 & 8,44 & 7,78 & 7,18 & 6,11 & 5,20 & 3,82 \\
\hline 29,18 & 919,90 & 150,00 & 28,74 & 21,07 & 16,82 & 12,55 & 9,58 & 7,54 & 5,14 & 3,90 & 2,68 \\
\hline 70,91 & 1551,80 & 196,30 & 12,04 & 8,75 & 7,68 & 6,69 & 5,91 & 5,24 & 4,13 & 3,31 & 2,25 \\
\hline 63,96 & 696,50 & 125,80 & 23,52 & 16,51 & 14,02 & 11,81 & 10,12 & 8,72 & 6,56 & 5,10 & 3,40 \\
\hline 88,48 & 259,70 & 169,60 & 36,61 & 18,67 & 13,39 & 9,85 & 7,86 & 6,49 & 4,69 & 3,63 & 2,50 \\
\hline 38,43 & 1864,50 & 134,20 & 19,93 & 16,64 & 14,65 & 12,32 & 10,33 & 8,68 & 6,26 & 4,71 & 3,07 \\
\hline 84,62 & 1576,70 & 89,10 & 17,00 & 12,63 & 11,64 & 10,77 & 10,00 & 9,29 & 8,00 & 6,89 & 5,14 \\
\hline 67,06 & 1509,80 & 36,50 & 34,70 & 27,68 & 26,39 & 25,03 & 23,53 & 22,06 & 19,27 & 16,75 & 12,65 \\
\hline 58,11 & 1577,90 & 63,70 & 25,75 & 21,25 & 19,94 & 18,23 & 16,64 & 15,15 & 12,48 & 10,30 & 7,17 \\
\hline 89,50 & 1787,00 & 64,80 & 18,71 & 14,28 & 13,17 & 12,48 & 11,82 & 11,16 & 9,93 & 8,81 & 6,92 \\
\hline 23,86 & 1175,50 & 43,90 & 71,20 & 60,71 & 52,17 & 41,89 & 33,53 & 27,05 & 18,49 & 13,70 & 9,12 \\
\hline 59,55 & 910,70 & 141,50 & 20,01 & 14,58 & 12,53 & 10,61 & 9,09 & 7,82 & 5,86 & 4,54 & 3,01 \\
\hline 55,09 & 530,50 & 195,90 & 23,57 & 14,44 & 11,33 & 8,79 & 7,07 & 5,79 & 4,09 & 3,11 & 2,10 \\
\hline 70,62 & 420,00 & 112,00 & 31,60 & 20,23 & 16,51 & 13,53 & 11,44 & 9,78 & 7,30 & 5,67 & 3,80 \\
\hline 29,10 & 1814,70 & 151,90 & 22,81 & 18,34 & 15,42 & 12,13 & 9,59 & 7,69 & 5,26 & 3,92 & 2,64 \\
\hline 86,04 & 1239,30 & 157,30 & 13,91 & 9,63 & 8,43 & 7,42 & 6,66 & 6,01 & 4,92 & 4,06 & 2,87 \\
\hline 47,04 & 832,00 & 120,20 & 25,79 & 19,47 & 16,64 & 13,75 & 11,44 & 9,57 & 6,88 & 5,21 & 3,43 \\
\hline 82,31 & 1930,10 & 129,70 & 12,75 & 9,43 & 8,64 & 7,90 & 7,28 & 6,71 & 5,69 & 4,83 & 3,53 \\
\hline 85,45 & 1824,00 & 102,00 & 14,70 & 10,91 & 10,05 & 9,31 & 8,65 & 8,05 & 6,94 & 5,99 & 4,49 \\
\hline 32,23 & 884,30 & 108,90 & 33,80 & 26,06 & 21,63 & 16,87 & 13,29 & 10,64 & 7,29 & 5,46 & 3,69 \\
\hline 23,23 & 1822,40 & 185,80 & 23,19 & 17,66 & 14,03 & 10,30 & 7,75 & 6,04 & 4,10 & 3,12 & 2,15 \\
\hline 82,16 & 1782,10 & 157,70 & 11,86 & 8,61 & 7,76 & 6,98 & 6,36 & 5,80 & 4,83 & 4,04 & 2,89 \\
\hline 77,41 & 1439,00 & 27,80 & 37,65 & 30,30 & 28,29 & 27,29 & 26,11 & 24,85 & 22,38 & 20,07 & 16,02 \\
\hline 81,69 & 406,50 & 153,30 & 27,64 & 16,05 & 12,51 & 9,92 & 8,29 & 7,05 & 5,27 & 4,11 & 2,79 \\
\hline 48,33 & 1989,60 & 176,60 & 14,04 & 11,36 & 10,06 & 8,64 & 7,42 & 6,38 & 4,76 & 3,66 & 2,39 \\
\hline 56,96 & 603,00 & 27,20 & 63,46 & 52,55 & 48,96 & 44,46 & 40,32 & 36,46 & 29,68 & 24,24 & 16,67 \\
\hline 49,01 & 1465,60 & 117,20 & 20,09 & 16,43 & 14,67 & 12,70 & 11,00 & 9,52 & 7,18 & 5,55 & 3,64 \\
\hline 51,83 & 305,10 & 64,70 & 54,48 & 38,04 & 31,65 & 25,70 & 21,21 & 17,66 & 12,66 & 9,60 & 6,38 \\
\hline 24,98 & 1168,20 & 118,60 & 34,55 & 26,62 & 21,46 & 16,04 & 12,22 & 9,57 & 6,48 & 4,91 & 3,37 \\
\hline 86,22 & 1508,70 & 181,50 & 11,72 & 8,16 & 7,18 & 6,34 & 5,71 & 5,17 & 4,24 & 3,52 & 2,49 \\
\hline 37,56 & 1236,80 & 123,60 & 24,89 & 19,91 & 17,13 & 14,00 & 11,47 & 9,46 & 6,66 & 4,99 & 3,29 \\
\hline 20,96 & 563,40 & 175,50 & 35,12 & 21,86 & 15,48 & 10,42 & 7,65 & 6,02 & 4,22 & 3,28 & 2,30 \\
\hline 76,29 & 234,20 & 26,10 & 82,48 & 59,79 & 53,01 & 46,80 & 41,91 & 37,63 & 30,40 & 24,81 & 17,20 \\
\hline 73,65 & 1672,50 & 198,40 & 11,35 & 8,25 & 7,27 & 6,38 & 5,68 & 5,07 & 4,05 & 3,27 & 2,25 \\
\hline 54,31 & 928,60 & 184,30 & 18,11 & 12,76 & 10,70 & 8,79 & 7,34 & 6,16 & 4,47 & 3,41 & 2,26 \\
\hline 53,87 & 1567,80 & 168,20 & 14,95 & 11,68 & 10,29 & 8,84 & 7,63 & 6,60 & 4,97 & 3,85 & 2,54 \\
\hline 48,34 & 963,60 & 182,50 & 18,93 & 13,59 & 11,38 & 9,24 & 7,60 & 6,30 & 4,49 & 3,39 & 2,25 \\
\hline 23,56 & 700,40 & 137,70 & 37,38 & 25,88 & 19,50 & 13,70 & 10,12 & 7,89 & 5,44 & 4,19 & 2,92 \\
\hline 26,48 & 1283,90 & 125,30 & 31,05 & 24,23 & 19,82 & 15,07 & 11,61 & 9,16 & 6,21 & 4,68 & 3,19 \\
\hline 39,78 & 863,40 & 171,60 & 22,74 & 16,29 & 13,37 & 10,46 & 8,31 & 6,72 & 4,65 & 3,50 & 2,36 \\
\hline 68,71 & 240,20 & 46,40 & 64,16 & 43,95 & 37,11 & 31,25 & 26,89 & 23,28 & 17,69 & 13,85 & 9,27 \\
\hline 47,38 & 1092,20 & 101,70 & 25,17 & 20,27 & 17,89 & 15,27 & 13,04 & 11,16 & 8,26 & 6,32 & 4,13 \\
\hline 35,64 & 1583,90 & 64,90 & 35,59 & 31,34 & 28,23 & 24,32 & 20,83 & 17,80 & 13,12 & 9,96 & 6,43 \\
\hline 67,96 & 1681,60 & 107,00 & 16,63 & 12,99 & 11,96 & 10,83 & 9,85 & 8,94 & 7,36 & 6,07 & 4,25 \\
\hline 49,63 & 1335,80 & 184,80 & 15,96 & 12,10 & 10,41 & 8,70 & 7,31 & 6,18 & 4,50 & 3,42 & 2,25 \\
\hline 85,37 & 1646,50 & 29,10 & 31,60 & 26,35 & 24,09 & 23,25 & 22,47 & 21,56 & 19,71 & 17,94 & 14,75 \\
\hline 61,10 & 439,40 & 178,60 & 26,60 & 15,75 & 12,21 & 9,47 & 7,66 & 6,32 & 4,50 & 3,43 & 2,32 \\
\hline 55,44 & 299,10 & 48,50 & 61,75 & 45,08 & 38,51 & 32,25 & 27,30 & 23,22 & 17,12 & 13,13 & 8,67 \\
\hline 60,34 & 498,90 & 94,00 & 32,99 & 23,18 & 19,60 & 16,36 & 13,88 & 11,85 & 8,80 & 6,78 & 4,50 \\
\hline 75,92 & 805,00 & 156,90 & 18,38 & 12,33 & 10,40 & 8,80 & 7,65 & 6,69 & 5,18 & 4,11 & 2,78 \\
\hline 84,01 & 363,90 & 100,10 & 34,28 & 21,14 & 17,12 & 14,08 & 12,06 & 10,47 & 8,04 & 6,38 & 4,34 \\
\hline 44,15 & 1395,90 & 130,40 & 20,59 & 16,63 & 14,59 & 12,32 & 10,41 & 8,82 & 6,43 & 4,88 & 3,19 \\
\hline 45,42 & 1985,00 & 98,40 & 20,97 & 18,03 & 16,45 & 14,51 & 12,75 & 11,17 & 8,59 & 6,71 & 4,40 \\
\hline 77,26 & 835,60 & 156,20 & 17,93 & 12,07 & 10,21 & 8,68 & 7,57 & 6,65 & 5,18 & 4,13 & 2,81 \\
\hline 85,70 & 950,40 & 40,30 & 33,08 & 24,97 & 23,15 & 21,76 & 20,43 & 19,16 & 16,81 & 14,72 & 11,29 \\
\hline 60,60 & 573,40 & 157,70 & 24,04 & 15,62 & 12,71 & 10,27 & 8,51 & 7,14 & 5,18 & 3,96 & 2,65 \\
\hline 53,54 & 1428,00 & 37,60 & 39,88 & 33,56 & 31,97 & 29,58 & 27,23 & 24,97 & 20,86 & 17,39 & 12,27 \\
\hline 54,46 & 747,20 & 143,90 & 22,82 & 16,17 & 13,60 & 11,21 & 9,37 & 7,88 & 5,73 & 4,37 & 2,89 \\
\hline 20,89 & 619,00 & 86,60 & 58,00 & 41,46 & 31,33 & 21,93 & 16,12 & 12,52 & 8,63 & 6,66 & 4,63 \\
\hline 88,56 & 1489,60 & 156,20 & 12,58 & 8,82 & 7,83 & 6,99 & 6,35 & 5,79 & 4,82 & 4,04 & 2,91 \\
\hline 49,48 & 1015,60 & 44,20 & 42,07 & 35,97 & 33,26 & 29,84 & 26,67 & 23,77 & 18,83 & 15,03 & 10,05 \\
\hline 24,10 & 1869,10 & 105,90 & 33,32 & 27,31 & 22,86 & 17,78 & 13,89 & 11,03 & 7,46 & 5,57 & 3,77 \\
\hline 52,42 & 935,10 & 122,40 & 22,80 & 17,35 & 15,04 & 12,71 & 10,81 & 9,22 & 6,82 & 5,22 & 3,43 \\
\hline 79,85 & 394,40 & 35,30 & 53,99 & 39,46 & 35,56 & 31,92 & 28,98 & 26,37 & 21,82 & 18,16 & 12,89 \\
\hline
\end{tabular}




\begin{tabular}{|c|c|c|c|c|c|c|c|c|c|c|c|}
\hline \multirow[b]{2}{*}{$\mathrm{e} 1(\mathrm{~cm})$} & & & & & & $\mathrm{De}$ & $\overline{\text { ões }(x 1}$ & & & & \\
\hline & Meq (MPa) & Ms (MPa) & D0 & D25 & D40 & D60 & D80 & D100 & D140 & D180 & D260 \\
\hline 76,72 & 1529,90 & 69,40 & 21,06 & 16,14 & 15,09 & 14,03 & 13,05 & 12,12 & 10,42 & 8,94 & 6,63 \\
\hline 85,68 & 1668,60 & 91,80 & 16,20 & 12,02 & 11,08 & 10,27 & 9,56 & 8,89 & 7,69 & 6,64 & 4,98 \\
\hline 41,18 & 1955,60 & 58,50 & 31,77 & 28,29 & 26,23 & 23,48 & 20,88 & 18,49 & 14,46 & 11,40 & 7,52 \\
\hline 37,93 & 645,60 & 123,70 & 31,87 & 22,99 & 18,82 & 14,64 & 11,57 & 9,31 & 6,42 & 4,83 & 3,27 \\
\hline 35,55 & 1170,70 & 59,30 & 42,10 & 36,38 & 32,41 & 27,54 & 23,28 & 19,68 & 14,28 & 10,76 & 6,97 \\
\hline 59,78 & 1885,40 & 82,70 & 20,09 & 16,44 & 15,38 & 14,04 & 12,81 & 11,66 & 9,60 & 7,92 & 5,52 \\
\hline 87,63 & 1692,10 & 149,30 & 12,16 & 8,68 & 7,81 & 7,04 & 6,44 & 5,91 & 4,97 & 4,20 & 3,05 \\
\hline 55,87 & 1167,20 & 92,60 & 23,39 & 18,81 & 16,94 & 14,90 & 13,13 & 11,56 & 8,99 & 7,09 & 4,72 \\
\hline 86,34 & 650,00 & 154,90 & 20,12 & 12,68 & 10,43 & 8,70 & 7,54 & 6,61 & 5,16 & 4,13 & 2,83 \\
\hline 61,13 & 558,80 & 116,30 & 27,93 & 19,22 & 16,10 & 13,35 & 11,28 & 9,60 & 7,09 & 5,46 & 3,63 \\
\hline 50,76 & 401,40 & 171,00 & 29,95 & 17,82 & 13,70 & 10,37 & 8,19 & 6,62 & 4,61 & 3,51 & 2,39 \\
\hline 89,77 & 1982,00 & 54,40 & 19,69 & 15,52 & 14,25 & 13,64 & 13,04 & 12,41 & 11,19 & 10,06 & 8,09 \\
\hline 25,75 & 1765,70 & 32,20 & 71,91 & 65,67 & 59,31 & 50,91 & 43,27 & 36,67 & 26,59 & 19,94 & 12,80 \\
\hline 60,17 & 982,00 & 60,20 & 31,11 & 25,12 & 23,07 & 20,73 & 18,66 & 16,76 & 13,49 & 10,93 & 7,46 \\
\hline 38,59 & 494,40 & 171,40 & 29,36 & 18,68 & 14,45 & 10,72 & 8,25 & 6,56 & 4,51 & 3,43 & 2,36 \\
\hline 72,50 & 404,50 & 164,60 & 27,76 & 16,10 & 12,46 & 9,76 & 8,03 & 6,73 & 4,91 & 3,79 & 2,56 \\
\hline 55,82 & 489,10 & 29,60 & 65,73 & 54,00 & 49,43 & 44,13 & 39,41 & 35,12 & 27,85 & 22,29 & 15,00 \\
\hline 57,18 & 1261,10 & 92,20 & 22,42 & 18,08 & 16,38 & 14,51 & 12,88 & 11,41 & 8,97 & 7,14 & 4,78 \\
\hline 72,26 & 1776,40 & 128,20 & 14,17 & 10,81 & 9,88 & 8,93 & 8,12 & 7,38 & 6,09 & 5,04 & 3,55 \\
\hline 85,93 & 1386,40 & 182,40 & 12,23 & 8,43 & 7,36 & 6,46 & 5,79 & 5,22 & 4,26 & 3,51 & 2,47 \\
\hline 63,16 & 1562,40 & 66,50 & 23,96 & 19,32 & 18,14 & 16,67 & 15,30 & 14,01 & 11,69 & 9,76 & 6,91 \\
\hline 60,10 & 1747,10 & 137,50 & 15,07 & 11,96 & 10,81 & 9,58 & 8,52 & 7,57 & 5,98 & 4,78 & 3,22 \\
\hline 45,97 & 1682,90 & 187,20 & 15,01 & 11,82 & 10,28 & 8,63 & 7,27 & 6,13 & 4,46 & 3,39 & 2,22 \\
\hline 44,12 & 576,20 & 55,10 & 49,18 & 39,60 & 34,69 & 29,25 & 24,68 & 20,87 & 15,20 & 11,52 & 7,53 \\
\hline 49,81 & 270,00 & 91,40 & 49,74 & 31,41 & 24,83 & 19,21 & 15,33 & 12,47 & 8,72 & 6,61 & 4,48 \\
\hline 80,52 & 793,60 & 170,10 & 17,56 & 11,44 & 9,54 & 8,03 & 6,97 & 6,10 & 4,74 & 3,78 & 2,57 \\
\hline 44,41 & 1064,80 & 55,40 & 38,49 & 33,05 & 30,01 & 26,33 & 23,00 & 20,05 & 15,28 & 11,86 & 7,75 \\
\hline 75,65 & 1309,30 & 23,50 & 44,15 & 35,70 & 33,38 & 32,24 & 30,87 & 29,39 & 26,50 & 23,77 & 18,98 \\
\hline 81,16 & 1568,10 & 145,90 & 13,20 & 9,57 & 8,60 & 7,71 & 6,99 & 6,36 & 5,27 & 4,38 & 3,12 \\
\hline 22,84 & 1252,80 & 182,10 & 26,43 & 19,10 & 14,68 & 10,45 & 7,75 & 6,02 & 4,13 & 3,17 & 2,20 \\
\hline 53,00 & 541,10 & 63,80 & 41,46 & 32,01 & 27,98 & 23,85 & 20,44 & 17,54 & 13,09 & 10,08 & 6,63 \\
\hline 72,34 & 803,50 & 74,10 & 27,25 & 20,41 & 18,35 & 16,34 & 14,70 & 13,23 & 10,73 & 8,77 & 6,08 \\
\hline 48,56 & 505,80 & 25,50 & 77,88 & 66,33 & 60,76 & 53,99 & 47,82 & 42,24 & 32,95 & 26,00 & 17,21 \\
\hline 24,66 & 902,80 & 126,20 & 36,00 & 26,50 & 20,76 & 15,08 & 11,31 & 8,82 & 6,01 & 4,59 & 3,18 \\
\hline 82,89 & 1636,50 & 195,70 & 11,01 & 7,75 & 6,82 & 6,02 & 5,41 & 4,88 & 3,98 & 3,28 & 2,30 \\
\hline 36,96 & 967,40 & 143,50 & 25,20 & 19,00 & 15,84 & 12,52 & 9,99 & 8,09 & 5,59 & 4,19 & 2,82 \\
\hline 55,63 & 820,30 & 191,50 & 18,74 & 12,74 & 10,53 & 8,56 & 7,09 & 5,93 & 4,28 & 3,26 & 2,17 \\
\hline 47,66 & 1606,90 & 29,80 & 48,87 & 41,97 & 40,27 & 37,39 & 34,48 & 31,67 & 26,49 & 22,09 & 15,56 \\
\hline 56,22 & 1527,50 & 183,40 & 14,08 & 10,77 & 9,42 & 8,08 & 6,97 & 6,03 & 4,55 & 3,53 & 2,33 \\
\hline 64,31 & 1297,40 & 82,50 & 22,22 & 17,61 & 16,18 & 14,59 & 13,20 & 11,92 & 9,70 & 7,94 & 5,49 \\
\hline 79,87 & 604,70 & 41,40 & 40,88 & 30,45 & 27,90 & 25,44 & 23,36 & 21,47 & 18,10 & 15,29 & 11,07 \\
\hline 74,68 & 1680,80 & 102,50 & 16,27 & 12,41 & 11,46 & 10,47 & 9,61 & 8,82 & 7,41 & 6,23 & 4,48 \\
\hline 43,53 & 1813,70 & 46,80 & 36,41 & 32,20 & 30,22 & 27,40 & 24,70 & 22,17 & 17,76 & 14,28 & 9,59 \\
\hline 68,82 & 984,20 & 72,60 & 25,88 & 19,97 & 18,22 & 16,38 & 14,82 & 13,40 & 10,93 & 8,97 & 6,24 \\
\hline 21,46 & 633,50 & 178,90 & 33,25 & 21,20 & 15,20 & 10,30 & 7,56 & 5,93 & 4,15 & 3,22 & 2,25 \\
\hline 29,71 & 926,80 & 105,60 & 35,82 & 27,74 & 22,87 & 17,63 & 13,75 & 10,94 & 7,45 & 5,59 & 3,80 \\
\hline 59,91 & 1079,20 & 34,10 & 43,52 & 35,63 & 33,84 & 31,38 & 28,99 & 26,70 & 22,50 & 18,93 & 13,55 \\
\hline 22,68 & 1224,10 & 130,50 & 33,96 & 25,61 & 20,16 & 14,67 & 10,98 & 8,54 & 5,81 & 4,43 & 3,07 \\
\hline 46,26 & 502,10 & 120,10 & 32,77 & 22,50 & 18,38 & 14,54 & 11,71 & 9,57 & 6,70 & 5,06 & 3,40 \\
\hline 36,16 & 1100,00 & 141,60 & 24,54 & 18,90 & 15,89 & 12,65 & 10,14 & 8,23 & 5,70 & 4,27 & 2,85 \\
\hline 75,14 & 1412,50 & 151,00 & 14,07 & 10,28 & 9,15 & 8,09 & 7,25 & 6,51 & 5,26 & 4,29 & 2,97 \\
\hline 81,70 & 1778,80 & 73,00 & 18,56 & 14,12 & 13,17 & 12,36 & 11,58 & 10,84 & 9,47 & 8,25 & 6,26 \\
\hline 22,97 & 1287,60 & 92,00 & 42,60 & 33,80 & 27,56 & 20,78 & 15,88 & 12,45 & 8,40 & 6,34 & 4,34 \\
\hline 39,24 & 732,30 & 24,00 & 82,67 & 73,71 & 67,74 & 59,97 & 52,74 & 46,21 & 35,46 & 27,59 & 17,99 \\
\hline 20,99 & 1721,90 & 47,80 & 66,38 & 56,90 & 48,78 & 38,94 & 30,97 & 24,85 & 16,87 & 12,49 & 8,34 \\
\hline 86,48 & 745,80 & 138,40 & 19,41 & 12,75 & 10,77 & 9,20 & 8,09 & 7,19 & 5,72 & 4,64 & 3,21 \\
\hline 86,10 & 1576,70 & 177,20 & 11,61 & 8,14 & 7,20 & 6,39 & 5,77 & 5,24 & 4,32 & 3,59 & 2,56 \\
\hline 52,24 & 1460,70 & 154,40 & 16,47 & 12,94 & 11,39 & 9,76 & 8,40 & 7,23 & 5,43 & 4,19 & 2,75 \\
\hline 45,11 & 869,10 & 67,80 & 36,33 & 29,98 & 26,65 & 22,86 & 19,58 & 16,77 & 12,45 & 9,52 & 6,21 \\
\hline 62,78 & 1305,50 & 80,40 & 22,80 & 18,22 & 16,76 & 15,11 & 13,65 & 12,32 & 10,00 & 8,16 & 5,62 \\
\hline 40,84 & 1549,30 & 46,90 & 39,99 & 35,63 & 32,99 & 29,47 & 26,17 & 23,13 & 18,04 & 14,19 & 9,34 \\
\hline 78,69 & 1623,60 & 98,40 & 16,46 & 12,39 & 11,43 & 10,48 & 9,66 & 8,91 & 7,55 & 6,40 & 4,67 \\
\hline 35,74 & 1612,90 & 129,70 & 22,66 & 18,62 & 16,15 & 13,30 & 10,94 & 9,05 & 6,39 & 4,77 & 3,14 \\
\hline 33,96 & 358,30 & 24,30 & 118,03 & 98,62 & 85,93 & 70,95 & 58,46 & 48,37 & 34,11 & 25,47 & 16,70 \\
\hline 84,67 & 296,10 & 198,30 & 32,02 & 16,29 & 11,65 & 8,53 & 6,78 & 5,58 & 4,00 & 3,09 & 2,13 \\
\hline 41,51 & 755,60 & 25,90 & 74,68 & 66,13 & 60,97 & 54,24 & 47,97 & 42,26 & 32,76 & 25,68 & 16,85 \\
\hline 65,49 & 366,90 & 35,90 & 60,60 & 46,24 & 41,31 & 36,41 & 32,34 & 28,74 & 22,75 & 18,23 & 12,35 \\
\hline 44,51 & 366,10 & 108,50 & 40,84 & 26,81 & 21,37 & 16,48 & 13,04 & 10,53 & 7,30 & 5,52 & 3,75 \\
\hline 60,00 & 1834,00 & 107,30 & 17,18 & 13,91 & 12,81 & 11,54 & 10,40 & 9,36 & 7,56 & 6,14 & 4,20 \\
\hline 71,41 & 1613,50 & 55,60 & 24,75 & 19,41 & 18,35 & 17,20 & 16,06 & 14,97 & 12,94 & 11,14 & 8,30 \\
\hline 24,48 & 701,50 & 144,40 & 35,40 & 24,46 & 18,51 & 13,06 & 9,68 & 7,55 & 5,19 & 4,00 & 2,78 \\
\hline 68,48 & 335,20 & 167,40 & 31,59 & 17,56 & 13,21 & 10,06 & 8,10 & 6,69 & 4,78 & 3,66 & 2,49 \\
\hline 76,97 & 1433,00 & 186,70 & 12,41 & 8,81 & 7,71 & 6,74 & 5,99 & 5,35 & 4,28 & 3,47 & 2,39 \\
\hline 54,56 & 1063,30 & 175,70 & 17,34 & 12,63 & 10,77 & 8,99 & 7,58 & 6,43 & 4,72 & 3,61 & 2,38 \\
\hline 56,73 & 1370,10 & 167,80 & 15,46 & 11,77 & 10,29 & 8,82 & 7,61 & 6,58 & 4,97 & 3,86 & 2,55 \\
\hline 43,50 & 738,80 & 151,00 & 24,98 & 17,76 & 14,66 & 11,63 & 9,36 & 7,64 & 5,34 & 4,02 & 2,70 \\
\hline 49,43 & 1426,30 & 189,90 & 15,31 & 11,67 & 10,07 & 8,44 & 7,11 & 6,01 & 4,38 & 3,34 & 2,19 \\
\hline 24,98 & 461,10 & 78,60 & 60,82 & 43,49 & 33,59 & 24,12 & 17,99 & 14,03 & 9,60 & 7,36 & 5,11 \\
\hline 36,81 & 878,50 & 125,20 & 28,52 & 21,64 & 18,09 & 14,33 & 11,46 & 9,28 & 6,42 & 4,82 & 3,23 \\
\hline 81,95 & 1700,80 & 176,80 & 11,43 & 8,18 & 7,29 & 6,49 & 5,86 & 5,32 & 4,37 & 3,62 & 2,56 \\
\hline 71,73 & 1009,20 & 72,40 & 25,13 & 19,21 & 17,57 & 15,87 & 14,43 & 13,11 & 10,80 & 8,94 & 6,29 \\
\hline 85,26 & 749,30 & 134,40 & 19,69 & 13,04 & 11,07 & 9,47 & 8,35 & 7,41 & 5,90 & 4,78 & 3,31 \\
\hline
\end{tabular}




\begin{tabular}{|c|c|c|c|c|c|c|c|c|c|c|c|}
\hline \multirow[b]{2}{*}{ e1 (cm) } & & & & & & $\mathrm{De}$ & ões (x1 & & & & \\
\hline & Meq (MPa) & Ms (MPa) & D0 & D25 & D40 & D60 & D80 & D100 & D140 & D180 & D260 \\
\hline 72,04 & 253,20 & 177,20 & 37,51 & 19,08 & 13,59 & 9,87 & 7,74 & 6,30 & 4,44 & 3,41 & 2,35 \\
\hline 67,28 & 645,00 & 49,40 & 39,05 & 30,24 & 27,50 & 24,63 & 22,20 & 19,99 & 16,19 & 13,21 & 9,11 \\
\hline 82,98 & 1128,10 & 157,10 & 14,82 & 10,24 & 8,90 & 7,77 & 6,93 & 6,21 & 5,01 & 4,10 & 2,85 \\
\hline 28,04 & 728,80 & 117,30 & 37,45 & 27,40 & 21,75 & 16,10 & 12,23 & 9,60 & 6,53 & 4,97 & 3,42 \\
\hline 43,01 & 580,80 & 144,70 & 28,64 & 19,57 & 15,84 & 12,33 & 9,80 & 7,93 & 5,50 & 4,15 & 2,81 \\
\hline 21,81 & 1974,30 & 63,40 & 50,71 & 43,20 & 36,93 & 29,40 & 23,34 & 18,71 & 12,70 & 9,42 & 6,30 \\
\hline 45,02 & 1031,00 & 139,70 & 22,15 & 16,92 & 14,49 & 11,95 & 9,91 & 8,27 & 5,92 & 4,47 & 2,94 \\
\hline 75,59 & 713,90 & 176,60 & 18,76 & 12,05 & 9,91 & 8,21 & 7,02 & 6,07 & 4,61 & 3,62 & 2,44 \\
\hline 64,25 & 1449,30 & 175,20 & 13,81 & 10,32 & 9,07 & 7,87 & 6,90 & 6,06 & 4,70 & 3,72 & 2,49 \\
\hline 20,88 & 1690,00 & 75,90 & 48,48 & 39,74 & 32,92 & 25,21 & 19,43 & 15,28 & 10,28 & 7,70 & 5,25 \\
\hline 85,32 & 948,50 & 128,10 & 17,70 & 12,19 & 10,62 & 9,30 & 8,32 & 7,48 & 6,09 & 5,00 & 3,51 \\
\hline 72,76 & 492,60 & 124,00 & 27,32 & 17,61 & 14,46 & 11,93 & 10,16 & 8,74 & 6,59 & 5,14 & 3,46 \\
\hline 66,54 & 1431,80 & 51,20 & 28,42 & 22,64 & 21,42 & 19,93 & 18,49 & 17,12 & 14,58 & 12,40 & 9,03 \\
\hline 87,96 & 1669,70 & 151,10 & 12,14 & 8,64 & 7,76 & 6,99 & 6,39 & 5,85 & 4,92 & 4,16 & 3,02 \\
\hline 79,87 & 357,70 & 183,90 & 28,63 & 15,55 & 11,60 & 8,84 & 7,18 & 5,99 & 4,36 & 3,37 & 2,30 \\
\hline 78,51 & 271,30 & 80,90 & 45,40 & 27,89 & 22,42 & 18,25 & 15,46 & 13,28 & 10,03 & 7,86 & 5,31 \\
\hline 48,30 & 893,80 & 43,00 & 45,49 & 38,87 & 35,68 & 31,76 & 28,17 & 24,92 & 19,48 & 15,39 & 10,20 \\
\hline 47,16 & 327,70 & 187,60 & 32,81 & 18,10 & 13,30 & 9,67 & 7,45 & 5,94 & 4,11 & 3,14 & 2,18 \\
\hline 40,85 & 438,60 & 149,10 & 32,75 & 20,90 & 16,29 & 12,23 & 9,49 & 7,58 & 5,22 & 3,96 & 2,72 \\
\hline 49,12 & 1132,50 & 173,60 & 17,90 & 13,34 & 11,39 & 9,43 & 7,87 & 6,60 & 4,77 & 3,62 & 2,39 \\
\hline 40,30 & 960,00 & 27,70 & 67,37 & 60,21 & 55,81 & 49,90 & 44,33 & 39,21 & 30,60 & 24,09 & 15,84 \\
\hline 22,91 & 1600,80 & 124,60 & 32,29 & 25,36 & 20,53 & 15,36 & 11,68 & 9,13 & 6,17 & 4,67 & 3,21 \\
\hline 64,66 & 1263,60 & 176,10 & 14,67 & 10,73 & 9,32 & 8,02 & 6,98 & 6,09 & 4,69 & 3,69 & 2,46 \\
\hline 40,50 & 1302,40 & 113,60 & 24,39 & 19,90 & 17,40 & 14,57 & 12,19 & 10,22 & 7,36 & 5,54 & 3,62 \\
\hline 32,85 & 801,30 & 135,20 & 30,10 & 22,12 & 17,96 & 13,71 & 10,65 & 8,47 & 5,79 & 4,36 & 2,98 \\
\hline 20,51 & 1244,00 & 92,10 & 46,58 & 36,07 & 28,64 & 20,93 & 15,66 & 12,16 & 8,23 & 6,28 & 4,34 \\
\hline 23,65 & 916,60 & 110,20 & 40,50 & 30,26 & 23,80 & 17,33 & 12,98 & 10,11 & 6,88 & 5,25 & 3,63 \\
\hline 88,07 & 1471,00 & 59,40 & 21,61 & 16,34 & 15,10 & 14,24 & 13,42 & 12,63 & 11,15 & 9,82 & 7,61 \\
\hline 43,73 & 1245,90 & 40,00 & 45,60 & 40,19 & 37,34 & 33,54 & 29,96 & 26,65 & 21,02 & 16,69 & 11,08 \\
\hline 26,18 & 1058,70 & 98,10 & 39,34 & 30,86 & 25,29 & 19,26 & 14,85 & 11,72 & 7,94 & 5,98 & 4,08 \\
\hline 33,81 & 237,90 & 54,80 & 82,13 & 57,12 & 45,30 & 33,93 & 26,09 & 20,66 & 14,13 & 10,72 & 7,36 \\
\hline 86,92 & 1000,80 & 101,40 & 19,20 & 13,57 & 12,10 & 10,81 & 9,82 & 8,96 & 7,46 & 6,25 & 4,49 \\
\hline 58,07 & 1675,50 & 179,00 & 13,45 & 10,40 & 9,19 & 7,97 & 6,95 & 6,07 & 4,65 & 3,64 & 2,42 \\
\hline 22,94 & 1729,80 & 103,60 & 35,94 & 29,07 & 24,01 & 18,37 & 14,17 & 11,16 & 7,53 & 5,65 & 3,85 \\
\hline 49,93 & 1561,10 & 126,40 & 18,50 & 15,08 & 13,47 & 11,68 & 10,14 & 8,79 & 6,65 & 5,15 & 3,38 \\
\hline 61,99 & 1233,50 & 118,10 & 18,76 & 14,52 & 12,96 & 11,39 & 10,07 & 8,90 & 6,97 & 5,55 & 3,72 \\
\hline 30,54 & 1280,10 & 44,20 & 55,93 & 49,52 & 44,24 & 37,55 & 31,65 & 26,65 & 19,19 & 14,38 & 9,29 \\
\hline 42,69 & 904,50 & 156,70 & 22,62 & 16,60 & 13,87 & 11,12 & 9,01 & 7,38 & 5,18 & 3,90 & 2,60 \\
\hline 56,10 & 684,60 & 101,80 & 28,06 & 20,76 & 17,87 & 15,08 & 12,85 & 11,00 & 8,17 & 6,29 & 4,15 \\
\hline 29,32 & 729,00 & 165,90 & 28,99 & 20,06 & 15,57 & 11,33 & 8,55 & 6,70 & 4,59 & 3,51 & 2,43 \\
\hline 36,29 & 1806,30 & 188,30 & 17,00 & 13,51 & 11,54 & 9,34 & 7,59 & 6,22 & 4,34 & 3,25 & 2,15 \\
\hline 28,34 & 1935,40 & 187,90 & 19,73 & 15,53 & 12,86 & 9,94 & 7,76 & 6,17 & 4,19 & 3,14 & 2,13 \\
\hline 82,61 & 1307,90 & 173,00 & 13,13 & 9,14 & 7,98 & 6,99 & 6,25 & 5,61 & 4,54 & 3,72 & 2,60 \\
\hline 44,95 & 718,10 & 131,00 & 26,91 & 19,53 & 16,33 & 13,15 & 10,71 & 8,82 & 6,22 & 4,68 & 3,12 \\
\hline 33,66 & 216,40 & 79,90 & 67,97 & 42,64 & 32,23 & 23,23 & 17,55 & 13,82 & 9,50 & 7,29 & 5,06 \\
\hline 84,62 & 1763,50 & 115,70 & 13,95 & 10,27 & 9,41 & 8,63 & 7,97 & 7,37 & 6,28 & 5,37 & 3,96 \\
\hline 54,13 & 932,90 & 184,00 & 18,12 & 12,78 & 10,73 & 8,82 & 7,35 & 6,18 & 4,48 & 3,41 & 2,26 \\
\hline 80,18 & 460,40 & 51,60 & 40,97 & 29,30 & 25,95 & 22,96 & 20,64 & 18,61 & 15,17 & 12,48 & 8,74 \\
\hline 45,42 & 1327,20 & 64,70 & 31,69 & 27,28 & 24,90 & 21,98 & 19,33 & 16,95 & 13,06 & 10,20 & 6,70 \\
\hline 61,10 & 1648,60 & 128,20 & 15,93 & 12,61 & 11,42 & 10,14 & 9,04 & 8,05 & 6,39 & 5,12 & 3,46 \\
\hline 45,21 & 1399,10 & 133,40 & 19,98 & 16,08 & 14,12 & 11,95 & 10,12 & 8,59 & 6,29 & 4,78 & 3,13 \\
\hline 41,95 & 941,30 & 177,60 & 20,90 & 15,10 & 12,51 & 9,93 & 7,98 & 6,51 & 4,54 & 3,41 & 2,29 \\
\hline 20,55 & 1931,10 & 164,50 & 27,05 & 20,60 & 16,17 & 11,69 & 8,70 & 6,75 & 4,59 & 3,51 & 2,43 \\
\hline 70,37 & 1085,30 & 53,30 & 29,65 & 23,16 & 21,62 & 19,90 & 18,34 & 16,87 & 14,22 & 11,98 & 8,63 \\
\hline 46,16 & 303,70 & 50,50 & 66,04 & 48,68 & 41,10 & 33,49 & 27,54 & 22,84 & 16,25 & 12,26 & 8,12 \\
\hline 22,06 & 458,00 & 118,60 & 48,40 & 31,53 & 22,89 & 15,64 & 11,48 & 8,99 & 6,26 & 4,86 & 3,39 \\
\hline 79,01 & 1770,00 & 191,40 & 10,92 & 7,87 & 6,99 & 6,20 & 5,57 & 5,03 & 4,10 & 3,37 & 2,36 \\
\hline 62,20 & 271,90 & 169,10 & 36,75 & 19,46 & 14,16 & 10,41 & 8,18 & 6,63 & 4,64 & 3,55 & 2,45 \\
\hline 42,04 & 345,10 & 68,00 & 55,53 & 39,81 & 32,86 & 26,00 & 20,86 & 16,97 & 11,82 & 8,90 & 5,97 \\
\hline 43,83 & 882,70 & 98,50 & 29,44 & 23,21 & 20,11 & 16,75 & 13,99 & 11,74 & 8,45 & 6,38 & 4,19 \\
\hline 69,10 & 1393,70 & 78,70 & 21,39 & 16,71 & 15,49 & 14,14 & 12,94 & 11,82 & 9,84 & 8,20 & 5,81 \\
\hline 72,00 & 887,50 & 153,20 & 17,97 & 12,44 & 10,62 & 9,05 & 7,88 & 6,89 & 5,33 & 4,22 & 2,84 \\
\hline 45,49 & 503,60 & 162,50 & 28,18 & 18,12 & 14,33 & 10,99 & 8,69 & 7,01 & 4,87 & 3,68 & 2,51 \\
\hline 64,74 & 1075,00 & 33,60 & 42,03 & 33,73 & 32,06 & 29,96 & 27,86 & 25,84 & 22,10 & 18,85 & 13,78 \\
\hline 44,87 & 321,00 & 52,20 & 64,27 & 47,62 & 40,19 & 32,66 & 26,78 & 22,14 & 15,70 & 11,83 & 7,84 \\
\hline 43,89 & 592,30 & 148,50 & 27,74 & 18,91 & 15,32 & 11,96 & 9,53 & 7,73 & 5,37 & 4,06 & 2,74 \\
\hline 78,08 & 1690,40 & 47,60 & 25,32 & 19,77 & 18,57 & 17,68 & 16,73 & 15,78 & 13,97 & 12,32 & 9,55 \\
\hline 31,73 & 620,60 & 49,10 & 64,99 & 53,06 & 45,37 & 36,54 & 29,46 & 23,96 & 16,58 & 12,35 & 8,21 \\
\hline 23,25 & 784,80 & 175,90 & 30,58 & 20,65 & 15,34 & 10,66 & 7,86 & 6,13 & 4,24 & 3,28 & 2,29 \\
\hline 38,04 & 1846,40 & 44,20 & 41,45 & 37,45 & 34,81 & 31,19 & 27,74 & 24,57 & 19,19 & 15,11 & 9,93 \\
\hline 62,95 & 689,30 & 23,60 & 62,68 & 50,66 & 48,00 & 44,55 & 41,20 & 38,01 & 32,16 & 27,15 & 19,55 \\
\hline 27,10 & 874,70 & 44,80 & 69,49 & 58,51 & 50,28 & 40,50 & 32,57 & 26,39 & 18,15 & 13,47 & 8,95 \\
\hline 26,79 & 827,10 & 98,00 & 41,84 & 31,87 & 25,73 & 19,31 & 14,76 & 11,61 & 7,87 & 5,96 & 4,09 \\
\hline 59,38 & 447,00 & 183,00 & 26,25 & 15,56 & 12,06 & 9,32 & 7,51 & 6,18 & 4,38 & 3,34 & 2,26 \\
\hline 59,83 & 515,20 & 25,90 & 67,30 & 54,87 & 50,95 & 46,23 & 41,94 & 37,95 & 30,96 & 25,35 & 17,50 \\
\hline 68,56 & 1452,50 & 125,90 & 16,02 & 12,22 & 11,03 & 9,83 & 8,82 & 7,92 & 6,38 & 5,19 & 3,57 \\
\hline 28,65 & 860,30 & 122,00 & 34,11 & 25,51 & 20,54 & 15,43 & 11,83 & 9,32 & 6,34 & 4,79 & 3,29 \\
\hline 39,78 & 1052,90 & 37,80 & 53,58 & 47,51 & 43,53 & 38,41 & 33,69 & 29,44 & 22,51 & 17,47 & 11,38 \\
\hline 56,08 & 921,80 & 158,90 & 19,31 & 13,92 & 11,84 & 9,88 & 8,34 & 7,09 & 5,22 & 4,00 & 2,64 \\
\hline 81,62 & 314,00 & 117,40 & 35,90 & 20,89 & 16,30 & 12,95 & 10,82 & 9,21 & 6,88 & 5,38 & 3,65 \\
\hline 53,97 & 1480,70 & 69,10 & 26,12 & 21,88 & 20,28 & 18,29 & 16,47 & 14,78 & 11,87 & 9,58 & 6,50 \\
\hline 20,76 & 495,30 & 91,90 & 59,00 & 40,30 & 29,69 & 20,40 & 14,94 & 11,65 & 8,09 & 6,27 & 4,37 \\
\hline
\end{tabular}




\begin{tabular}{|c|c|c|c|c|c|c|c|c|c|c|c|}
\hline \multirow[b]{2}{*}{ e1 (cm) } & & & & & & $\mathrm{De}$ & ões (x1 & & & & \\
\hline & Meq (MPa) & Ms (MPa) & D0 & D25 & D40 & D60 & D80 & D100 & D140 & D180 & D260 \\
\hline 32,01 & 1459,10 & 173,60 & 21,05 & 16,30 & 13,55 & 10,59 & 8,34 & 6,69 & 4,58 & 3,43 & 2,32 \\
\hline 78,45 & 1505,70 & 31,80 & 33,77 & 26,98 & 25,19 & 24,25 & 23,16 & 22,01 & 19,78 & 17,70 & 14,07 \\
\hline 53,26 & 1958,80 & 175,70 & 13,35 & 10,67 & 9,51 & 8,26 & 7,19 & 6,26 & 4,77 & 3,71 & 2,45 \\
\hline 56,10 & 1099,00 & 90,60 & 24,23 & 19,40 & 17,43 & 15,30 & 13,47 & 11,84 & 9,19 & 7,24 & 4,81 \\
\hline 25,19 & 1141,70 & 128,00 & 32,80 & 24,98 & 20,01 & 14,87 & 11,29 & 8,84 & 5,99 & 4,55 & 3,13 \\
\hline 62,23 & 762,40 & 128,60 & 22,48 & 16,04 & 13,70 & 11,58 & 9,93 & 8,55 & 6,43 & 5,00 & 3,32 \\
\hline 78,42 & 651,30 & 26,30 & 52,46 & 40,21 & 37,64 & 35,27 & 32,97 & 30,80 & 26,74 & 23,17 & 17,44 \\
\hline 34,87 & 1321,20 & 54,00 & 43,50 & 38,30 & 34,42 & 29,57 & 25,23 & 21,50 & 15,77 & 11,93 & 7,71 \\
\hline 28,40 & 323,90 & 175,60 & 37,95 & 21,41 & 15,17 & 10,39 & 7,73 & 6,09 & 4,24 & 3,29 & 2,31 \\
\hline 57,41 & 1783,20 & 131,80 & 15,72 & 12,66 & 11,46 & 10,15 & 9,01 & 7,98 & 6,28 & 4,99 & 3,35 \\
\hline 80,05 & 1445,20 & 72,00 & 20,59 & 15,57 & 14,47 & 13,43 & 12,49 & 11,60 & 9,98 & 8,58 & 6,38 \\
\hline 20,38 & 763,20 & 99,00 & 50,47 & 36,29 & 27,45 & 19,20 & 14,10 & 10,94 & 7,54 & 5,82 & 4,05 \\
\hline 32,97 & 204,70 & 152,60 & 48,94 & 25,10 & 17,35 & 11,87 & 8,88 & 7,02 & 4,88 & 3,79 & 2,68 \\
\hline 59,97 & 484,50 & 162,20 & 26,23 & 16,31 & 12,97 & 10,26 & 8,39 & 6,97 & 4,99 & 3,81 & 2,56 \\
\hline 81,76 & 1521,50 & 52,50 & 24,08 & 18,51 & 17,29 & 16,36 & 15,42 & 14,51 & 12,79 & 11,24 & 8,66 \\
\hline 84,22 & 924,10 & 193,60 & 15,01 & 9,72 & 8,12 & 6,86 & 5,98 & 5,26 & 4,13 & 3,32 & 2,28 \\
\hline 40,85 & 1475,40 & 32,60 & 52,09 & 46,60 & 43,79 & 39,71 & 35,77 & 32,08 & 25,64 & 20,55 & 13,75 \\
\hline 79,95 & 810,50 & 22,20 & 52,85 & 41,33 & 38,67 & 36,92 & 35,01 & 33,10 & 29,44 & 26,09 & 20,39 \\
\hline 63,17 & 1972,40 & 178,00 & 12,01 & 9,31 & 8,36 & 7,38 & 6,56 & 5,82 & 4,60 & 3,68 & 2,49 \\
\hline 33,44 & 361,10 & 96,50 & 49,61 & 33,48 & 26,14 & 19,30 & 14,73 & 11,62 & 7,96 & 6,06 & 4,18 \\
\hline 38,35 & 1068,90 & 172,70 & 21,19 & 15,76 & 13,10 & 10,36 & 8,28 & 6,71 & 4,65 & 3,49 & 2,34 \\
\hline 46,60 & 1456,10 & 198,40 & 15,32 & 11,68 & 10,02 & 8,31 & 6,92 & 5,80 & 4,18 & 3,16 & 2,08 \\
\hline 71,36 & 1644,10 & 77,60 & 19,92 & 15,52 & 14,51 & 13,40 & 12,38 & 11,42 & 9,67 & 8,19 & 5,93 \\
\hline 75,71 & 531,30 & 20,90 & 66,73 & 51,54 & 48,40 & 45,29 & 42,28 & 39,42 & 34,10 & 29,43 & 22,00 \\
\hline 65,06 & 579,60 & 147,50 & 24,00 & 15,71 & 12,90 & 10,56 & 8,87 & 7,53 & 5,56 & 4,29 & 2,86 \\
\hline 51,13 & 723,80 & 83,20 & 32,12 & 24,99 & 21,84 & 18,57 & 15,85 & 13,56 & 10,06 & 7,72 & 5,07 \\
\hline 87,53 & 496,60 & 161,40 & 23,45 & 13,89 & 11,00 & 8,89 & 7,55 & 6,52 & 4,97 & 3,94 & 2,69 \\
\hline 87,23 & 326,80 & 85,20 & 38,57 & 23,86 & 19,42 & 16,07 & 13,85 & 12,10 & 9,40 & 7,50 & 5,14 \\
\hline 86,29 & 1781,40 & 35,70 & 27,01 & 22,13 & 20,28 & 19,54 & 18,83 & 18,02 & 16,41 & 14,88 & 12,14 \\
\hline 71,10 & 475,60 & 141,90 & 26,61 & 16,61 & 13,38 & 10,85 & 9,11 & 7,75 & 5,75 & 4,45 & 2,99 \\
\hline 42,64 & 390,90 & 58,60 & 56,94 & 42,86 & 36,25 & 29,40 & 24,02 & 19,80 & 13,97 & 10,50 & 6,97 \\
\hline 25,25 & 784,50 & 86,40 & 48,25 & 36,84 & 29,58 & 22,02 & 16,73 & 13,11 & 8,88 & 6,74 & 4,63 \\
\hline 38,38 & 248,20 & 82,20 & 60,10 & 38,67 & 30,04 & 22,36 & 17,23 & 13,69 & 9,41 & 7,16 & 4,93 \\
\hline 52,86 & 1344,80 & 37,90 & 40,71 & 34,42 & 32,67 & 30,10 & 27,60 & 25,22 & 20,92 & 17,33 & 12,11 \\
\hline 48,01 & 476,80 & 98,40 & 36,66 & 25,89 & 21,50 & 17,32 & 14,15 & 11,68 & 8,28 & 6,25 & 4,17 \\
\hline 82,32 & 421,30 & 154,40 & 26,89 & 15,69 & 12,27 & 9,77 & 8,18 & 6,98 & 5,23 & 4,09 & 2,78 \\
\hline 59,80 & 1996,10 & 27,10 & 41,95 & 34,17 & 32,80 & 31,55 & 29,93 & 28,27 & 25,04 & 22,05 & 16,99 \\
\hline 23,09 & 548,60 & 89,40 & 55,23 & 39,30 & 29,97 & 21,22 & 15,71 & 12,22 & 8,39 & 6,46 & 4,49 \\
\hline 37,17 & 1742,30 & 62,90 & 34,00 & 30,22 & 27,51 & 24,04 & 20,87 & 18,06 & 13,58 & 10,42 & 6,75 \\
\hline 29,40 & 1406,50 & 54,90 & 48,45 & 42,29 & 37,36 & 31,22 & 25,94 & 21,57 & 15,28 & 11,38 & 7,40 \\
\hline 34,47 & 1603,30 & 155,60 & 20,76 & 16,62 & 14,17 & 11,42 & 9,23 & 7,53 & 5,24 & 3,91 & 2,60 \\
\hline 85,60 & 1380,40 & 179,30 & 12,38 & 8,56 & 7,48 & 6,57 & 5,89 & 5,31 & 4,33 & 3,57 & 2,51 \\
\hline 69,05 & 1983,00 & 37,90 & 30,20 & 24,18 & 22,97 & 22,04 & 20,92 & 19,78 & 17,57 & 15,52 & 12,05 \\
\hline 74,86 & 718,60 & 162,60 & 19,40 & 12,70 & 10,55 & 8,81 & 7,57 & 6,56 & 5,01 & 3,94 & 2,66 \\
\hline 64,99 & 1323,60 & 95,30 & 20,10 & 15,77 & 14,38 & 12,90 & 11,62 & 10,45 & 8,45 & 6,87 & 4,72 \\
\hline 47,99 & 1750,60 & 68,00 & 26,81 & 23,14 & 21,47 & 19,31 & 17,29 & 15,42 & 12,24 & 9,78 & 6,54 \\
\hline 80,04 & 1262,40 & 143,30 & 14,86 & 10,61 & 9,39 & 8,30 & 7,46 & 6,72 & 5,47 & 4,49 & 3,14 \\
\hline 51,86 & 333,00 & 153,00 & 34,75 & 20,24 & 15,40 & 11,60 & 9,13 & 7,38 & 5,14 & 3,91 & 2,68 \\
\hline 65,69 & 1263,50 & 128,50 & 17,20 & 13,06 & 11,63 & 10,23 & 9,07 & 8,05 & 6,36 & 5,09 & 3,44 \\
\hline 65,52 & 549,00 & 54,00 & 40,39 & 30,80 & 27,51 & 24,24 & 21,53 & 19,13 & 15,13 & 12,13 & 8,21 \\
\hline 49,80 & 1160,90 & 96,60 & 24,51 & 19,93 & 17,76 & 15,38 & 13,32 & 11,53 & 8,70 & 6,73 & 4,41 \\
\hline 46,16 & 1390,10 & 63,20 & 31,30 & 27,00 & 24,77 & 22,00 & 19,45 & 17,15 & 13,33 & 10,48 & 6,91 \\
\hline 85,92 & 874,40 & 22,90 & 47,50 & 37,44 & 34,60 & 33,16 & 31,65 & 30,08 & 27,05 & 24,24 & 19,35 \\
\hline 56,70 & 595,30 & 178,50 & 22,81 & 14,65 & 11,79 & 9,38 & 7,67 & 6,36 & 4,54 & 3,46 & 2,32 \\
\hline 60,76 & 1406,20 & 160,60 & 15,09 & 11,48 & 10,11 & 8,77 & 7,66 & 6,70 & 5,16 & 4,06 & 2,70 \\
\hline 79,17 & 1762,00 & 45,20 & 25,46 & 20,01 & 18,74 & 17,92 & 17,02 & 16,11 & 14,36 & 12,74 & 9,99 \\
\hline 23,74 & 680,60 & 43,90 & 84,58 & 68,24 & 56,43 & 43,27 & 33,45 & 26,39 & 17,82 & 13,37 & 9,11 \\
\hline 79,12 & 618,40 & 121,10 & 23,54 & 15,64 & 13,17 & 11,17 & 9,73 & 8,55 & 6,67 & 5,32 & 3,62 \\
\hline 37,92 & 987,80 & 170,90 & 22,15 & 16,28 & 13,44 & 10,54 & 8,38 & 6,76 & 4,67 & 3,51 & 2,37 \\
\hline 31,51 & 695,80 & 147,80 & 30,62 & 21,56 & 17,04 & 12,66 & 9,67 & 7,62 & 5,21 & 3,96 & 2,72 \\
\hline 56,95 & 720,40 & 163,50 & 21,41 & 14,61 & 12,12 & 9,90 & 8,24 & 6,92 & 5,02 & 3,83 & 2,55 \\
\hline 25,16 & 789,60 & 42,20 & 79,34 & 65,85 & 55,75 & 44,02 & 34,79 & 27,85 & 18,94 & 14,09 & 9,47 \\
\hline 50,95 & 212,90 & 198,50 & 41,72 & 19,83 & 13,40 & 9,18 & 6,93 & 5,51 & 3,81 & 2,94 & 2,08 \\
\hline 79,85 & 819,10 & 62,30 & 28,42 & 21,02 & 19,14 & 17,35 & 15,86 & 14,52 & 12,15 & 10,20 & 7,33 \\
\hline 45,94 & 1267,90 & 115,10 & 22,46 & 18,18 & 16,03 & 13,65 & 11,62 & 9,91 & 7,31 & 5,57 & 3,64 \\
\hline 44,69 & 1538,70 & 79,60 & 26,63 & 22,86 & 20,78 & 18,25 & 15,96 & 13,93 & 10,64 & 8,27 & 5,41 \\
\hline 88,32 & 625,50 & 75,50 & 27,96 & 19,33 & 16,98 & 15,01 & 13,53 & 12,27 & 10,12 & 8,41 & 5,99 \\
\hline 81,29 & 1357,20 & 103,90 & 16,95 & 12,48 & 11,35 & 10,29 & 9,42 & 8,64 & 7,25 & 6,10 & 4,40 \\
\hline 36,90 & 658,00 & 103,80 & 35,72 & 26,65 & 22,10 & 17,38 & 13,82 & 11,15 & 7,70 & 5,78 & 3,89 \\
\hline 72,09 & 477,00 & 192,10 & 23,65 & 13,77 & 10,67 & 8,37 & 6,88 & 5,77 & 4,21 & 3,24 & 2,19 \\
\hline 43,90 & 1260,90 & 118,90 & 22,75 & 18,35 & 16,08 & 13,56 & 11,44 & 9,68 & 7,05 & 5,34 & 3,49 \\
\hline 38,88 & 1246,50 & 39,70 & 49,84 & 44,53 & 40,94 & 36,26 & 31,89 & 27,94 & 21,45 & 16,69 & 10,88 \\
\hline 22,89 & 225,30 & 111,90 & 60,98 & 34,60 & 23,98 & 16,11 & 11,92 & 9,43 & 6,62 & 5,15 & 3,62 \\
\hline 55,34 & 1286,30 & 75,50 & 25,61 & 21,12 & 19,36 & 17,30 & 15,45 & 13,78 & 10,93 & 8,75 & 5,89 \\
\hline 32,94 & 378,40 & 68,10 & 61,12 & 44,43 & 35,89 & 27,27 & 21,13 & 16,78 & 11,46 & 8,66 & 5,91 \\
\hline 72,71 & 1122,50 & 193,80 & 14,15 & 9,78 & 8,34 & 7,12 & 6,20 & 5,43 & 4,21 & 3,34 & 2,25 \\
\hline 64,10 & 1090,40 & 191,50 & 15,21 & 10,73 & 9,13 & 7,71 & 6,62 & 5,71 & 4,31 & 3,36 & 2,23 \\
\hline 72,64 & 617,70 & 60,10 & 34,35 & 25,57 & 22,90 & 20,33 & 18,25 & 16,40 & 13,25 & 10,81 & 7,47 \\
\hline 53,43 & 1819,70 & 38,90 & 36,25 & 30,36 & 29,14 & 27,20 & 25,22 & 23,30 & 19,73 & 16,65 & 11,94 \\
\hline 81,95 & 879,70 & 188,90 & 15,74 & 10,21 & 8,51 & 7,17 & 6,23 & 5,46 & 4,26 & 3,40 & 2,32 \\
\hline 40,04 & 1258,30 & 31,70 & 56,61 & 50,77 & 47,33 & 42,57 & 38,03 & 33,82 & 26,63 & 21,10 & 13,96 \\
\hline 88,43 & 204,10 & 131,50 & 46,72 & 23,90 & 17,17 & 12,66 & 10,12 & 8,37 & 6,05 & 4,69 & 3,22 \\
\hline
\end{tabular}




\begin{tabular}{|c|c|c|c|c|c|c|c|c|c|c|c|}
\hline \multirow[b]{2}{*}{ e1 (cm) } & & & & & & & ões (x1 & m) & & & \\
\hline & Meq (MPa) & Ms (MPa) & D0 & D25 & D40 & D60 & D80 & D100 & D140 & D180 & D260 \\
\hline 22,43 & 1833,60 & 39,00 & 70,62 & 62,58 & 55,08 & 45,55 & 37,37 & 30,71 & 21,36 & 15,79 & 10,31 \\
\hline 50,59 & 1279,80 & 66,70 & 29,30 & 24,75 & 22,69 & 20,22 & 17,97 & 15,93 & 12,51 & 9,92 & 6,60 \\
\hline 89,76 & 1466,90 & 183,50 & 11,65 & 7,99 & 6,99 & 6,17 & 5,56 & 5,04 & 4,15 & 3,46 & 2,47 \\
\hline 26,62 & 873,80 & 74,00 & 50,11 & 39,83 & 32,96 & 25,39 & 19,73 & 15,64 & 10,61 & 7,96 & 5,41 \\
\hline 77,10 & 1519,40 & 179,90 & 12,27 & 8,81 & 7,77 & 6,84 & 6,11 & 5,48 & 4,41 & 3,60 & 2,49 \\
\hline 36,28 & 1705,30 & 158,50 & 19,35 & 15,61 & 13,44 & 10,98 & 8,98 & 7,39 & 5,19 & 3,88 & 2,56 \\
\hline 28,63 & 1084,40 & 57,60 & 52,36 & 44,21 & 38,22 & 31,06 & 25,19 & 20,54 & 14,23 & 10,57 & 6,98 \\
\hline 88,16 & $\begin{array}{l}795,00 \\
\end{array}$ & 146,90 & 18,13 & 11,86 & 10,02 & 8,57 & 7,55 & 6,71 & 5,36 & 4,36 & 3,03 \\
\hline 37,45 & 1806,10 & 175,30 & 17,39 & 13,97 & 12,04 & 9,86 & 8,09 & 6,67 & 4,70 & 3,52 & 2,32 \\
\hline 43,57 & 887,80 & 55,10 & 41,89 & 35,48 & 31,86 & 27,58 & 23,81 & 20,52 & 15,37 & 11,80 & 7,68 \\
\hline 67,50 & 1855,20 & 40,00 & 30,33 & 24,22 & 23,09 & 22,02 & 20,78 & 19,55 & 17,20 & 15,06 & 11,50 \\
\hline 44,93 & 1562,60 & 103,00 & 22,45 & 18,87 & 16,93 & 14,67 & 12,67 & 10,94 & 8,21 & 6,32 & 4,12 \\
\hline 26,61 & 1208,30 & 179,80 & 24,59 & 18,11 & 14,33 & 10,54 & 7,97 & 6,24 & 4,25 & 3,23 & 2,23 \\
\hline 31,76 & 1441,20 & 110,60 & 28,52 & 23,37 & 20,02 & 16,17 & 13,06 & 10,64 & 7,37 & 5,49 & 3,64 \\
\hline 45,33 & 1214,20 & 190,80 & 17,22 & 12,83 & 10,87 & 8,87 & 7,30 & 6,05 & 4,31 & 3,25 & 2,15 \\
\hline 23,64 & 1143,50 & 176,30 & 27,19 & 19,59 & 15,09 & 10,78 & 8,01 & 6,24 & 4,27 & 3,28 & 2,27 \\
\hline 39,46 & 1766,10 & 169,00 & 17,31 & 13,95 & 12,09 & 10,01 & 8,29 & 6,90 & 4,91 & 3,69 & 2,42 \\
\hline 26,94 & 1266,30 & 55,70 & 53,50 & 45,70 & 39,62 & 32,25 & 26,16 & 21,33 & 14,76 & 10,94 & 7,22 \\
\hline 54,05 & 1544,90 & 126,10 & 17,72 & 14,29 & 12,82 & 11,22 & 9,83 & 8,61 & 6,63 & 5,20 & 3,44 \\
\hline 37,08 & 1336,30 & 49,90 & 43,46 & 38,55 & 35,02 & 30,54 & 26,45 & 22,85 & 17,12 & 13,12 & 8,49 \\
\hline 50,11 & 1164,90 & 51,40 & 36,05 & 30,73 & 28,42 & 25,51 & 22,83 & 20,36 & 16,16 & 12,91 & 8,65 \\
\hline 28,03 & 686,00 & 76,70 & 50,98 & 39,35 & 32,17 & 24,52 & 18,95 & 14,98 & 10,17 & 7,66 & 5,23 \\
\hline 23,63 & 669,10 & 126,00 & 40,29 & 28,11 & 21,28 & 14,99 & 11,09 & 8,64 & 5,95 & 4,58 & 3,19 \\
\hline 44,06 & 636,30 & 133,30 & 28,43 & 20,11 & 16,58 & 13,15 & 10,60 & 8,65 & 6,05 & 4,56 & 3,06 \\
\hline 63,48 & 502,70 & 69,60 & 37,32 & 27,41 & 23,82 & 20,46 & 17,79 & 15,50 & 11,88 & 9,32 & 6,21 \\
\hline 27,43 & 1383,00 & 29,30 & 78,50 & 71,41 & 64,51 & 55,46 & 47,24 & 40,12 & 29,20 & 21,95 & 14,10 \\
\hline 61,36 & 320,70 & 49,20 & 56,37 & 40,97 & 35,27 & 29,98 & 25,80 & 22,28 & 16,83 & 13,09 & 8,69 \\
\hline 84,45 & 839,80 & 193,70 & 15,87 & 10,11 & 8,35 & 6,99 & 6,06 & 5,31 & 4,14 & 3,31 & 2,27 \\
\hline 69,55 & 504,50 & 100,90 & 29,94 & 20,34 & 17,11 & 14,38 & 12,37 & 10,70 & 8,13 & 6,37 & 4,27 \\
\hline 86,36 & 303,70 & 123,10 & 35,77 & 20,28 & 15,62 & 12,29 & 10,24 & 8,72 & 6,53 & 5,12 & 3,49 \\
\hline 81,32 & 1325,50 & 155,70 & 13,82 & 9,80 & 8,64 & 7,63 & 6,85 & 6,17 & 5,03 & 4,13 & 2,90 \\
\hline 82,74 & 529,40 & 163,70 & 22,66 & 13,70 & 10,94 & 8,89 & 7,54 & 6,50 & 4,93 & 3,89 & 2,64 \\
\hline 58,91 & 1007,90 & 93,40 & 24,03 & 18,85 & 16,84 & 14,75 & 12,99 & 11,43 & 8,88 & 7,02 & 4,68 \\
\hline 89,44 & 487,90 & 22,80 & 59,31 & 44,23 & 40,75 & 38,18 & 35,82 & 33,60 & 29,49 & 25,84 & 19,86 \\
\hline 68,59 & 572,00 & 115,50 & 26,43 & 17,96 & 15,10 & 12,67 & 10,87 & 9,39 & 7,11 & 5,56 & 3,72 \\
\hline 51,70 & 639,20 & 162,40 & 23,79 & 16,00 & 13,07 & 10,45 & 8,52 & 7,04 & 5,00 & 3,79 & 2,53 \\
\hline 27,39 & 227,10 & 35,00 & 125,52 & 92,26 & 73,17 & 54,06 & 40,98 & 32,13 & 21,87 & 16,63 & 11,47 \\
\hline 40,70 & 1718,30 & 113,70 & 21,85 & 18,42 & 16,38 & 13,99 & 11,90 & 10,13 & 7,43 & 5,64 & 3,67 \\
\hline 25,27 & 1068,40 & 116,50 & 35,66 & 27,26 & 21,91 & 16,33 & 12,41 & 9,72 & 6,59 & 5,00 & 3,44 \\
\hline 26,72 & 973,80 & 52,40 & 61,09 & 51,09 & 43,67 & 34,93 & 27,92 & 22,53 & 15,44 & 11,47 & 7,65 \\
\hline 35,52 & 1503,50 & 199,60 & 17,81 & 13,65 & 11,42 & 9,04 & 7,21 & 5,83 & 4,02 & 3,01 & 2,02 \\
\hline 42,72 & 482,00 & 68,80 & 47,46 & 36,02 & 30,59 & 24,91 & 20,42 & 16,87 & 11,93 & 8,97 & 5,94 \\
\hline 61,21 & 1220,70 & 21,00 & 57,34 & 46,47 & 44,64 & 42,61 & 40,20 & 37,79 & 33,17 & 28,96 & 21,98 \\
\hline 49,56 & 500,00 & 82,10 & 38,88 & 28,61 & 24,29 & 20,02 & 16,66 & 13,96 & 10,06 & 7,63 & 5,04 \\
\hline 58,46 & 1372,20 & 108,70 & 19,40 & 15,48 & 13,97 & 12,34 & 10,94 & 9,69 & 7,60 & 6,05 & 4,05 \\
\hline 50,11 & 421,50 & 67,00 & 46,64 & 34,48 & 29,37 & 24,31 & 20,31 & 17,06 & 12,35 & 9,38 & 6,19 \\
\hline 57,15 & 1038,70 & 88,60 & 24,87 & 19,78 & 17,75 & 15,58 & 13,72 & 12,07 & 9,38 & 7,40 & 4,93 \\
\hline 38,19 & 208,90 & 65,00 & 74,10 & 48,39 & 37,83 & 28,29 & 21,84 & 17,37 & 11,93 & 9,07 & 6,23 \\
\hline 76,40 & 261,90 & 60,90 & 52,29 & 33,93 & 28,08 & 23,40 & 20,12 & 17,46 & 13,35 & 10,53 & 7,11 \\
\hline 47,75 & 1071,00 & 55,30 & 36,59 & 31,19 & 28,50 & 25,24 & 22,28 & 19,61 & 15,21 & 11,95 & 7,88 \\
\hline 82,32 & 914,70 & 30,70 & 40,56 & 31,22 & 29,14 & 27,62 & 26,07 & 24,56 & 21,70 & 19,12 & 14,80 \\
\hline 75,02 & 1597,50 & 47,10 & 26,77 & 20,92 & 19,74 & 18,71 & 17,62 & 16,56 & 14,54 & 12,73 & 9,73 \\
\hline 58,38 & 1797,30 & 102,70 & 18,07 & 14,75 & 13,58 & 12,21 & 10,99 & 9,87 & 7,94 & 6,42 & 4,37 \\
\hline 22,10 & 1114,20 & 181,20 & 27,92 & 19,72 & 14,90 & 10,45 & 7,70 & 5,99 & 4,13 & 3,18 & 2,21 \\
\hline 60,15 & 1491,60 & 93,70 & 20,18 & 16,28 & 14,92 & 13,39 & 12,04 & 10,80 & 8,68 & 7,02 & 4,79 \\
\hline 47,10 & 948,40 & 197,00 & 18,54 & 13,09 & 10,85 & 8,71 & 7,09 & 5,84 & 4,13 & 3,11 & 2,08 \\
\hline 64,42 & 1379,00 & 104,50 & 18,81 & 14,74 & 13,39 & 11,97 & 10,74 & 9,64 & 7,75 & 6,28 & 4,29 \\
\hline 61,84 & 1062,70 & 36,60 & 40,94 & 33,24 & 31,48 & 29,17 & 26,93 & 24,80 & 20,91 & 17,60 & 12,61 \\
\hline 54,43 & 467,40 & 101,70 & 34,35 & 23,75 & 19,75 & 16,11 & 13,37 & 11,19 & 8,07 & 6,14 & 4,08 \\
\hline 34,07 & 238,70 & 97,70 & 57,82 & 35,36 & 26,46 & 18,96 & 14,31 & 11,27 & 7,76 & 5,96 & 4,15 \\
\hline 30,45 & 1336,60 & 47,50 & 52,67 & 46,52 & 41,48 & 35,12 & 29,53 & 24,82 & 17,82 & 13,34 & 8,63 \\
\hline 27,58 & 1097,40 & 31,70 & 80,13 & 71,28 & 63,47 & 53,52 & 44,78 & 37,45 & 26,68 & 19,88 & 12,87 \\
\hline 38,18 & 984,10 & 33,20 & $\begin{array}{l}61,61 \\
\end{array}$ & 54,94 & 50,30 & 44,29 & 38,74 & 33,77 & 25,69 & 19,86 & 12,90 \\
\hline 23,74 & 1870,10 & 149,00 & 26,51 & 20,88 & 16,99 & 12,80 & 9,78 & 7,67 & 5,18 & 3,91 & 2,68 \\
\hline 60,76 & 1110,40 & 63,60 & 28,55 & 23,08 & 21,29 & 19,21 & 17,36 & 15,66 & 12,69 & 10,34 & 7,10 \\
\hline 53,41 & 1184,00 & 101,20 & 22,66 & 18,22 & 16,28 & 14,19 & 12,38 & 10,81 & 8,27 & 6,46 & 4,26 \\
\hline 46,27 & 1279,80 & 179,40 & 17,22 & 13,08 & 11,19 & 9,25 & 7,69 & 6,42 & 4,61 & 3,49 & 2,30 \\
\hline 29,95 & 1645,10 & 22,10 & 83,41 & 77,54 & 72,13 & 64,46 & 57,07 & 50,26 & 38,80 & 30,23 & 19,63 \\
\hline 24,31 & 852,10 & 136,70 & 34,90 & 25,10 & 19,38 & 13,89 & 10,35 & 8,06 & 5,52 & 4,23 & 2,94 \\
\hline 66,72 & 423,70 & 29,00 & 63,77 & 49,85 & 45,65 & 41,13 & 37,21 & 33,64 & 27,43 & 22,48 & 15,59 \\
\hline 74,33 & 1055,50 & 34,70 & 38,04 & 29,65 & 27,97 & 26,37 & 24,73 & 23,15 & 20,18 & 17,54 & 13,25 \\
\hline 44,00 & 1768,00 & 140,10 & 17,99 & 14,84 & 13,15 & 11,22 & 9,57 & 8,16 & 6,02 & 4,59 & 2,99 \\
\hline 85,91 & 1868,00 & 152,30 & 11,60 & 8,38 & 7,58 & 6,86 & 6,29 & 5,78 & 4,87 & 4,12 & 3,00 \\
\hline 32,86 & 639,40 & 65,60 & 51,93 & 41,12 & 34,71 & 27,58 & 22,03 & 17,81 & 12,27 & 9,17 & 6,14 \\
\hline 20,33 & 1107,10 & 44,00 & 82,44 & 68,04 & 56,58 & 43,50 & 33,59 & 26,44 & 17,78 & 13,31 & 9,06 \\
\hline 82,55 & 1984,20 & 127,00 & 12,73 & 9,44 & 8,67 & 7,95 & 7,34 & 6,78 & 5,77 & 4,91 & 3,61 \\
\hline 38,21 & 664,50 & 115,20 & 32,74 & 24,05 & 19,87 & 15,61 & 12,42 & 10,03 & 6,94 & 5,21 & 3,51 \\
\hline 50,72 & 1552,00 & 196,00 & 14,27 & 10,95 & 9,50 & 8,02 & 6,80 & 5,78 & 4,26 & 3,25 & 2,14 \\
\hline 67,48 & 1059,70 & 174,70 & 15,79 & 11,16 & 9,56 & 8,14 & 7,06 & 6,15 & 4,71 & 3,70 & 2,48 \\
\hline 81,15 & 814,80 & 122,70 & 19,94 & 13,71 & 11,84 & 10,26 & 9,10 & 8,11 & 6,48 & 5,26 & 3,63 \\
\hline 88,87 & 1791,10 & 25,40 & 31,08 & 27,66 & 24,89 & 23,93 & 23,34 & 22,56 & 20,88 & 19,25 & 16,21 \\
\hline 32,60 & 1904,10 & 45,70 & 45,31 & 41,27 & 37,78 & 33,14 & 28,83 & 24,98 & 18,79 & 14,40 & 9,29 \\
\hline
\end{tabular}




\begin{tabular}{|c|c|c|c|c|c|c|c|c|c|c|c|}
\hline & & & \multicolumn{9}{|c|}{ Deflexões $\left(\times 10^{-4} \mathrm{~cm}\right)$} \\
\hline e1 (cm) & Meq (MPa) & Ms (MPa) & D0 & D25 & D40 & D60 & D80 & D100 & D140 & D180 & D260 \\
\hline 48,66 & 926,10 & 168,60 & 20,04 & 14,49 & 12,18 & 9,93 & 8,19 & 6,81 & 4,87 & 3,68 & 2,44 \\
\hline 82,49 & 1687,50 & 134,40 & 13,25 & 9,68 & 8,79 & 7,96 & 7,28 & 6,67 & 5,59 & 4,71 & 3,40 \\
\hline 80,88 & 1325,40 & 178,30 & 12,95 & 9,05 & 7,89 & 6,90 & 6,15 & 5,51 & 4,43 & 3,62 & 2,51 \\
\hline 71,02 & 925,00 & 65,00 & 27,88 & 21,40 & 19,59 & 17,71 & 16,10 & 14,63 & 12,05 & 9,97 & 7,00 \\
\hline 63,75 & 408,20 & 150,20 & 29,44 & 17,77 & 13,97 & 10,99 & 8,99 & 7,48 & 5,38 & 4,12 & 2,77 \\
\hline 50,00 & 278,90 & 190,60 & 35,59 & 18,59 & 13,30 & 9,51 & 7,29 & 5,82 & 4,03 & 3,09 & 2,15 \\
\hline 33,62 & 1907,70 & 163,40 & 19,25 & 15,63 & 13,40 & 10,85 & 8,80 & 7,19 & 5,01 & 3,73 & 2,47 \\
\hline 47,27 & 369,90 & 66,20 & 51,43 & 37,37 & 31,40 & 25,53 & 20,99 & 17,40 & 12,39 & 9,36 & 6,21 \\
\hline 48,93 & 310,50 & 101,30 & 44,29 & 28,26 & 22,41 & 17,36 & 13,85 & 11,26 & 7,87 & 5,96 & 4,04 \\
\hline 64,71 & 342,50 & 116,50 & 36,05 & 22,13 & 17,56 & 13,95 & 11,50 & 9,62 & 6,97 & 5,34 & 3,59 \\
\hline 20,08 & 1247,90 & 118,10 & 39,34 & 29,44 & 22,79 & 16,25 & 12,01 & 9,30 & 6,35 & 4,88 & 3,39 \\
\hline 32,07 & 753,70 & 93,70 & 39,54 & 30,43 & 25,23 & 19,64 & 15,45 & 12,36 & 8,46 & 6,34 & 4,29 \\
\hline 78,22 & 1081,80 & 89,80 & 20,69 & 15,30 & 13,86 & 12,48 & 11,35 & 10,34 & 8,57 & 7,13 & 5,07 \\
\hline 56,49 & 622,10 & 93,60 & 30,58 & 22,56 & 19,41 & 16,38 & 13,96 & 11,95 & 8,88 & 6,84 & 4,52 \\
\hline 57,23 & 1582,10 & 125,10 & 17,05 & 13,66 & 12,32 & 10,86 & 9,60 & 8,48 & 6,63 & 5,25 & 3,51 \\
\hline 35,99 & 835,80 & 93,20 & 35,42 & 27,86 & 23,66 & 19,03 & 15,37 & 12,54 & 8,72 & 6,52 & 4,34 \\
\hline 60,01 & 1012,80 & 30,90 & 47,49 & 38,84 & 36,94 & 34,33 & 31,75 & 29,29 & 24,75 & 20,87 & 14,99 \\
\hline 34,68 & 1886,30 & 176,00 & 18,02 & 14,50 & 12,41 & 10,04 & 8,15 & 6,66 & 4,64 & 3,47 & 2,30 \\
\hline 34,78 & 1365,90 & 123,20 & 25,38 & 20,51 & 17,60 & 14,30 & 11,63 & 9,53 & 6,65 & 4,97 & 3,29 \\
\hline 23,43 & 629,10 & 195,20 & 30,14 & 19,13 & 13,84 & 9,47 & 6,97 & 5,47 & 3,81 & 2,96 & 2,07 \\
\hline 88,38 & 1288,60 & 44,50 & 26,93 & 20,64 & 19,07 & 18,11 & 17,16 & 16,22 & 14,45 & 12,83 & 10,08 \\
\hline 85,38 & 448,10 & 60,30 & 37,53 & 25,85 & 22,53 & 19,73 & 17,66 & 15,89 & 12,93 & 10,63 & 7,47 \\
\hline 63,72 & 938,50 & 33,90 & 44,17 & 35,58 & 33,65 & 31,19 & 28,82 & 26,57 & 22,45 & 18,94 & 13,63 \\
\hline 71,34 & 1994,10 & 198,60 & 10,60 & 7,91 & 7,07 & 6,26 & 5,60 & 5,02 & 4,04 & 3,28 & 2,26 \\
\hline 52,77 & 834,50 & 58,60 & 36,42 & 29,90 & 27,04 & 23,81 & 20,96 & 18,43 & 14,28 & 11,23 & 7,44 \\
\hline 63,18 & 1681,20 & 69,00 & 22,80 & 18,39 & 17,30 & 15,92 & 14,64 & 13,42 & 11,23 & 9,39 & 6,67 \\
\hline 40,14 & 1308,50 & 130,90 & 22,47 & 18,00 & 15,59 & 12,90 & 10,69 & 8,90 & 6,34 & 4,76 & 3,13 \\
\hline 34,53 & 1294,90 & 108,70 & 28,17 & 22,97 & 19,79 & 16,14 & 13,16 & 10,81 & 7,56 & 5,65 & 3,73 \\
\hline 36,77 & 770,80 & 98,30 & 34,84 & 26,89 & 22,67 & 18,12 & 14,58 & 11,86 & 8,24 & 6,17 & 4,12 \\
\hline 55,14 & 1713,00 & 101,40 & 19,17 & 15,81 & 14,48 & 12,93 & 11,54 & 10,28 & 8,15 & 6,51 & 4,38 \\
\hline 88,84 & 1567,40 & 182,10 & 11,34 & 7,86 & 6,93 & 6,14 & 5,55 & 5,04 & 4,17 & 3,48 & 2,49 \\
\hline 63,51 & 1922,20 & 183,70 & 11,90 & 9,16 & 8,19 & 7,21 & 6,39 & 5,67 & 4,46 & 3,56 & 2,40 \\
\hline 21,80 & 1813,30 & 199,40 & 23,00 & 17,15 & 13,36 & 9,60 & 7,14 & 5,54 & 3,78 & 2,90 & 2,01 \\
\hline 52,15 & 916,20 & 165,80 & 19,63 & 14,13 & 11,93 & 9,82 & 8,19 & 6,88 & 4,98 & 3,78 & 2,50 \\
\hline 87,27 & 1073,60 & 150,80 & 15,22 & 10,37 & 9,00 & 7,86 & 7,03 & 6,33 & 5,15 & 4,24 & 2,98 \\
\hline 23,93 & 1231,80 & 66,40 & 52,63 & 43,33 & 36,35 & 28,34 & 22,18 & 17,63 & 11,93 & 8,90 & 6,02 \\
\hline 30,25 & 1022,60 & 173,60 & 24,64 & 18,00 & 14,41 & 10,80 & 8,28 & 6,53 & 4,45 & 3,37 & 2,31 \\
\hline 43,71 & 301,90 & 91,70 & 49,23 & 32,16 & 25,53 & 19,58 & 15,43 & 12,43 & 8,60 & 6,51 & 4,43 \\
\hline 47,23 & 851,10 & 68,60 & 35,27 & 28,92 & 25,74 & 22,17 & 19,09 & 16,43 & 12,29 & 9,45 & 6,17 \\
\hline 61,66 & 204,90 & 110,90 & 51,18 & 28,13 & 20,93 & 15,68 & 12,43 & 10,14 & 7,13 & 5,45 & 3,73 \\
\hline 82,60 & 367,30 & 154,70 & 29,46 & 16,67 & 12,79 & 10,01 & 8,29 & 7,02 & 5,21 & 4,06 & 2,76 \\
\hline 56,67 & 1205,50 & 142,70 & 17,91 & 13,70 & 12,01 & 10,32 & 8,92 & 7,72 & 5,84 & 4,54 & 3,00 \\
\hline 37,97 & 1495,50 & 66,90 & 33,90 & 29,66 & 26,76 & 23,17 & 19,94 & 17,13 & 12,73 & 9,71 & 6,29 \\
\hline 88,07 & 1279,50 & 188,90 & 12,44 & 8,40 & 7,26 & 6,32 & 5,64 & 5,07 & 4,11 & 3,38 & 2,38 \\
\hline 58,57 & 1613,30 & 50,60 & 29,67 & 24,43 & 23,20 & 21,48 & 19,81 & 18,21 & 15,29 & 12,82 & 9,12 \\
\hline 76,11 & 1749,30 & 198,60 & 10,95 & 7,93 & 7,02 & 6,19 & 5,53 & 4,96 & 4,00 & 3,26 & 2,26 \\
\hline 52,95 & 1514,80 & 123,00 & 18,36 & 14,86 & 13,31 & 11,63 & 10,17 & 8,88 & 6,81 & 5,32 & 3,51 \\
\hline 77,36 & 1118,70 & 53,60 & 27,75 & 21,19 & 19,75 & 18,33 & 17,02 & 15,80 & 13,55 & 11,61 & 8,59 \\
\hline 39,63 & 1253,60 & 38,40 & 50,20 & 44,85 & 41,39 & 36,82 & 32,54 & 28,64 & 22,16 & 17,33 & 11,35 \\
\hline 51,00 & 1554,30 & 44,40 & 35,72 & 30,49 & 28,86 & 26,48 & 24,19 & 22,01 & 18,11 & 14,89 & 10,30 \\
\hline 88,07 & 1019,40 & 127,60 & 16,88 & 11,63 & 10,19 & 8,98 & 8,08 & 7,31 & 6,01 & 4,99 & 3,54 \\
\hline 28,17 & 308,90 & 194,70 & 36,41 & 19,64 & 13,67 & 9,30 & 6,92 & 5,47 & 3,81 & 2,96 & 2,09 \\
\hline 88,54 & 573,60 & 25,70 & 52,06 & 39,00 & 36,00 & 33,79 & 31,73 & 29,78 & 26,17 & 22,95 & 17,66 \\
\hline 58,60 & 557,50 & 89,20 & 32,46 & 23,58 & 20,21 & 17,04 & 14,55 & 12,47 & 9,30 & 7,18 & 4,75 \\
\hline 88,09 & 1234,80 & 157,00 & 13,83 & 9,51 & 8,32 & 7,33 & 6,59 & 5,96 & 4,89 & 4,06 & 2,88 \\
\hline 27,66 & 355,90 & 149,10 & 40,89 & 24,67 & 17,89 & 12,37 & 9,18 & 7,21 & 5,01 & 3,88 & 2,71 \\
\hline 39,56 & 540,00 & 193,40 & 26,18 & 16,52 & 12,76 & 9,48 & 7,31 & 5,82 & 4,00 & 3,04 & 2,10 \\
\hline 41,21 & 937,10 & 63,60 & 39,08 & 32,85 & 29,21 & 24,95 & 21,24 & 18,08 & 13,28 & 10,09 & 6,56 \\
\hline 69,84 & 1338,90 & 118,30 & 17,03 & 12,92 & 11,64 & 10,37 & 9,32 & 8,37 & 6,76 & 5,51 & 3,80 \\
\hline 59,75 & 609,60 & 75,10 & 33,70 & 25,44 & 22,28 & 19,19 & 16,66 & 14,49 & 11,06 & 8,64 & 5,74 \\
\hline 35,97 & 612,30 & 124,00 & 33,44 & 23,86 & 19,31 & 14,80 & 11,56 & 9,23 & 6,34 & 4,78 & 3,25 \\
\hline 27,53 & 897,40 & 60,80 & 55,41 & 45,38 & 38,37 & 30,34 & 24,04 & 19,30 & 13,17 & 9,82 & 6,59 \\
\hline 85,03 & 460,80 & 48,20 & 41,41 & 29,35 & 26,11 & 23,27 & 21,08 & 19,16 & 15,86 & 13,21 & 9,42 \\
\hline 53,48 & 1958,60 & 35,10 & 38,14 & 31,75 & 30,62 & 28,80 & 26,86 & 24,96 & 21,38 & 18,23 & 13,29 \\
\hline 42,48 & 482,80 & 97,30 & 38,98 & 27,81 & 22,94 & 18,14 & 14,56 & 11,85 & 8,26 & $\frac{10,2 u}{6,22}$ & 4,18 \\
\hline 70,19 & 1174,60 & 73,40 & 23,67 & 18,34 & 16,91 & 15,37 & 14,02 & 12,78 & 10,59 & 8,80 & 6,22 \\
\hline 22,70 & 1013,60 & 68,90 & 56,52 & 45,01 & 36,75 & 27,74 & 21,21 & 16,63 & 11,22 & 8,46 & 5,80 \\
\hline 65,03 & 1966,70 & 54,80 & 24,74 & 19,83 & 18,90 & 17,76 & 16,59 & 15,45 & 13,32 & 11,44 & 8,46 \\
\hline 78,45 & 1783,80 & 55,20 & 22,57 & 17,52 & 16,45 & 15,61 & 14,72 & 13,86 & 12,22 & 10,73 & 8,26 \\
\hline 42,55 & 1403,70 & 58,00 & 34,92 & 30,56 & 27,98 & 24,72 & 21,73 & 19,04 & 14,63 & 11,40 & 7,46 \\
\hline 42,45 & 714,30 & 147,50 & 26,01 & 18,47 & 15,20 & 12,00 & 9,61 & 7,82 & 5,45 & 4,10 & 2,76 \\
\hline 46,20 & 932,40 & 40,50 & 48,04 & 41,54 & 38,20 & 34,01 & 30,15 & 26,64 & 20,78 & 16,39 & 10,83 \\
\hline 62,19 & 747,50 & 116,80 & 23,82 & 17,22 & 14,81 & 12,58 & 10,84 & 9,37 & 7,09 & 5,52 & 3,67 \\
\hline 88,30 & 1954,50 & 29,40 & 27,88 & 24,37 & 22,01 & 21,19 & 20,62 & 19,90 & 18,37 & 16,89 & 14,14 \\
\hline 82,64 & 1334,50 & 79,00 & 19,79 & 14,74 & 13,58 & 12,51 & 11,58 & 10,73 & 9,18 & 7,85 & 5,80 \\
\hline 46,39 & 1387,30 & 197,10 & 15,75 & 11,93 & 10,20 & 8,42 & 7,00 & 5,85 & 4,20 & 3,17 & 2,09 \\
\hline 59,97 & 730,20 & 39,10 & 45,63 & 37,10 & 34,34 & 31,07 & 28,12 & 25,39 & 20,63 & 16,84 & 11,58 \\
\hline 83,42 & 1798,90 & 63,60 & 19,80 & 15,17 & 14,13 & 13,37 & 12,61 & 11,87 & 10,48 & 9,22 & 7,13 \\
\hline 54,96 & 1841,20 & 176,30 & 13,42 & 10,61 & 9,43 & 8,18 & 7,13 & 6,21 & 4,74 & 3,70 & 2,44 \\
\hline 77,97 & 1588,10 & 49,00 & 25,49 & 19,80 & 18,61 & 17,65 & 16,64 & 15,66 & 13,79 & 12,11 & 9,31 \\
\hline 28,39 & 298,10 & 73,90 & 68,06 & 46,20 & 35,38 & 25,41 & 19,05 & 14,91 & 10,23 & 7,85 & 5,45 \\
\hline 88,32 & 405,90 & 166,30 & 26,58 & 14,99 & 11,51 & 9,05 & 7,54 & 6,43 & 4,83 & 3,79 & 2,59 \\
\hline
\end{tabular}




\begin{tabular}{|c|c|c|c|c|c|c|c|c|c|c|c|}
\hline \multirow[b]{2}{*}{ e1 (cm) } & & & & & & $\mathrm{De}$ & ões (x1 & & & & \\
\hline & Meq (MPa) & Ms (MPa) & D0 & D25 & D40 & D60 & D80 & D100 & D140 & D180 & D260 \\
\hline 32,41 & 930,60 & 127,20 & 29,92 & 22,72 & 18,73 & 14,50 & 11,37 & 9,08 & 6,21 & 4,66 & 3,16 \\
\hline 21,05 & 1826,00 & 156,10 & 28,07 & 21,47 & 16,94 & 12,32 & 9,20 & 7,14 & 4,85 & 3,70 & 2,56 \\
\hline 28,90 & 1542,00 & 152,30 & 24,15 & 19,01 & 15,77 & 12,23 & 9,56 & 7,62 & 5,18 & 3,89 & 2,63 \\
\hline 54,47 & 1591,00 & 82,00 & 22,69 & 18,90 & 17,43 & 15,66 & 14,05 & 12,57 & 10,04 & 8,08 & 5,45 \\
\hline 71,53 & 750,50 & 57,00 & 32,72 & 24,94 & 22,72 & 20,46 & 18,54 & 16,81 & 13,79 & 11,37 & 7,96 \\
\hline 33,87 & 327,70 & 186,20 & 35,12 & 19,62 & 14,11 & 9,85 & 7,39 & 5,83 & 4,03 & 3,11 & 2,19 \\
\hline 40,15 & 1763,50 & 181,00 & 16,41 & 13,10 & 11,32 & 9,35 & 7,74 & 6,43 & 4,58 & 3,44 & 2,26 \\
\hline 87,77 & 1018,00 & 58,90 & 25,46 & 18,74 & 17,21 & 15,93 & 14,81 & 13,79 & 11,92 & 10,31 & 7,75 \\
\hline 63,11 & 641,70 & 23,20 & 64,88 & 52,40 & 49,55 & 45,88 & 42,36 & 39,02 & 32,91 & 27,71 & 19,88 \\
\hline 48,40 & 1216,00 & 177,80 & 17,25 & 12,97 & 11,10 & 9,20 & 7,69 & 6,45 & 4,66 & 3,53 & 2,33 \\
\hline 89,82 & 1213,00 & 82,90 & 19,24 & 13,94 & 12,69 & 11,64 & 10,77 & 9,99 & 8,58 & 7,38 & 5,50 \\
\hline 76,69 & 737,20 & 97,30 & 24,00 & 17,03 & 14,89 & 13,00 & 11,55 & 10,30 & 8,22 & 6,66 & 4,58 \\
\hline 70,63 & 970,30 & 110,80 & 20,33 & 14,98 & 13,25 & 11,63 & 10,33 & 9,19 & 7,30 & 5,88 & 4,01 \\
\hline 36,04 & 1282,60 & 51,40 & 44,22 & 39,02 & 35,23 & 30,45 & 26,16 & 22,42 & 16,60 & 12,62 & 8,16 \\
\hline 70,22 & 1739,20 & 35,70 & 32,44 & 25,88 & 24,55 & 23,53 & 22,31 & 21,07 & 18,69 & 16,50 & 12,78 \\
\hline 47,69 & 329,80 & 21,70 & 102,17 & 85,46 & 77,02 & 67,26 & 58,62 & 51,01 & 38,82 & 30,13 & 19,75 \\
\hline 68,89 & 1432,90 & 152,40 & 14,47 & 10,81 & 9,61 & 8,46 & 7,52 & 6,70 & 5,32 & 4,28 & 2,92 \\
\hline 21,92 & 706,40 & 77,40 & 58,99 & 44,05 & 34,36 & 24,74 & 18,41 & 14,30 & 9,74 & 7,47 & 5,17 \\
\hline 49,00 & 1560,80 & 118,60 & 19,45 & 16,00 & 14,33 & 12,45 & 10,81 & 9,38 & 7,10 & 5,50 & 3,61 \\
\hline 40,51 & 1204,20 & 85,80 & 29,87 & 24,98 & 22,11 & 18,77 & 15,89 & 13,47 & 9,82 & 7,43 & 4,84 \\
\hline 84,81 & 221,80 & 53,40 & 59,02 & 37,26 & 30,63 & 25,54 & 22,08 & 19,32 & 15,02 & 11,99 & 8,20 \\
\hline 60,78 & 288,50 & 67,50 & 51,34 & 34,53 & 28,58 & 23,44 & 19,64 & 16,61 & 12,17 & 9,34 & 6,22 \\
\hline 70,16 & 399,20 & 21,30 & 76,69 & 59,79 & 55,60 & 50,94 & 46,77 & 42,90 & 35,93 & 30,13 & 21,53 \\
\hline 82,06 & 291,60 & 62,20 & 47,60 & 30,92 & 25,79 & 21,72 & 18,89 & 16,57 & 12,93 & 10,33 & 7,06 \\
\hline 27,72 & 1819,60 & 182,60 & 20,83 & 16,29 & 13,40 & 10,28 & 7,97 & 6,31 & 4,29 & 3,22 & 2,19 \\
\hline 61,86 & 1531,20 & 138,90 & 15,60 & 12,14 & 10,89 & 9,59 & 8,50 & 7,53 & 5,92 & 4,72 & 3,18 \\
\hline 66,93 & 1734,10 & 30,00 & 37,69 & 30,34 & 28,88 & 27,76 & 26,36 & 24,93 & 22,16 & 19,59 & 15,22 \\
\hline 49,80 & 683,70 & 104,00 & 29,56 & 22,04 & 18,83 & 15,63 & 13,08 & 11,00 & 7,97 & 6,06 & 3,99 \\
\hline 86,40 & 1701,30 & 20,70 & 36,44 & 33,18 & 29,83 & 28,68 & 28,03 & 27,16 & 25,21 & 23,30 & 19,72 \\
\hline 67,36 & 1385,50 & 53,20 & 27,83 & 22,09 & 20,84 & 19,35 & 17,93 & 16,57 & 14,08 & 11,95 & 8,68 \\
\hline 52,87 & 904,70 & 154,90 & 20,32 & 14,76 & 12,52 & 10,38 & 8,70 & 7,34 & 5,34 & 4,07 & 2,69 \\
\hline 62,98 & 732,20 & 161,70 & 20,49 & 13,87 & 11,56 & 9,56 & 8,08 & 6,88 & 5,09 & 3,93 & 2,61 \\
\hline 61,80 & 1337,80 & 192,20 & 13,93 & 10,22 & 8,85 & 7,56 & 6,54 & 5,67 & 4,31 & 3,36 & 2,24 \\
\hline 20,16 & 350,50 & 49,10 & 104,50 & 74,13 & 55,56 & 38,58 & 28,28 & 21,97 & 15,18 & 11,74 & 8,17 \\
\hline 61,57 & 591,50 & 53,70 & 40,44 & 31,51 & 28,24 & 24,88 & 22,03 & 19,50 & 15,32 & 12,20 & 8,20 \\
\hline 28,92 & 1471,70 & 121,20 & 28,56 & 23,00 & 19,34 & 15,22 & 12,03 & 9,64 & 6,59 & 4,92 & 3,31 \\
\hline 72,19 & 1083,20 & 28,90 & 43,15 & 34,00 & 32,21 & 30,59 & 28,82 & 27,08 & 23,78 & 20,80 & 15,87 \\
\hline 36,48 & 800,80 & 92,30 & 35,89 & 28,11 & 23,85 & 19,19 & 15,50 & 12,65 & 8,81 & 6,59 & 4,39 \\
\hline 31,72 & 1614,20 & 47,60 & 47,69 & 42,86 & 38,75 & 33,44 & 28,64 & 24,45 & 17,98 & 13,60 & 8,76 \\
\hline 68,97 & 756,30 & 58,70 & 32,65 & 25,09 & 22,81 & 20,46 & 18,47 & 16,67 & 13,55 & 11,10 & 7,69 \\
\hline 76,93 & 964,40 & 144,50 & 17,23 & 12,01 & 10,38 & 8,98 & 7,93 & 7,03 & 5,57 & 4,48 & 3,07 \\
\hline 26,22 & 1057,80 & 27,30 & 93,70 & 83,61 & 74,41 & 62,63 & 52,29 & 43,63 & 30,98 & 23,05 & 14,92 \\
\hline 45,42 & 1181,60 & 184,10 & 17,76 & 13,26 & 11,24 & 9,18 & 7,56 & 6,28 & 4,47 & 3,37 & 2,23 \\
\hline 82,03 & 417,90 & 177,20 & 25,88 & 14,63 & 11,22 & 8,78 & 7,26 & 6,14 & 4,55 & 3,54 & 2,41 \\
\hline 48,46 & 1150,30 & 120,20 & 22,03 & 17,44 & 15,30 & 13,00 & 11,07 & 9,44 & 6,97 & 5,33 & 3,49 \\
\hline 44,30 & 1876,70 & 123,30 & 18,92 & 15,92 & 14,27 & 12,34 & 10,64 & 9,17 & 6,86 & 5,27 & 3,43 \\
\hline 88,34 & 307,00 & 88,90 & 39,38 & 23,82 & 19,13 & 15,66 & 13,41 & 11,66 & 9,00 & 7,17 & 4,91 \\
\hline 65,99 & 1866,80 & 77,80 & 19,83 & 15,81 & 14,87 & 13,73 & 12,66 & 11,65 & 9,81 & 8,26 & 5,93 \\
\hline 47,92 & 1863,40 & 169,30 & 14,86 & 12,00 & 10,61 & 9,09 & 7,79 & 6,68 & 4,97 & 3,81 & 2,49 \\
\hline 48,91 & 1028,50 & 167,60 & 19,11 & 14,09 & 11,96 & 9,85 & 8,19 & 6,85 & 4,93 & 3,73 & 2,47 \\
\hline 35,35 & 395,80 & 56,50 & 64,81 & 49,09 & 40,81 & 32,07 & 25,46 & 20,52 & 14,13 & 10,60 & 7,14 \\
\hline 55,76 & 1851,70 & 63,60 & 25,04 & 20,91 & 19,73 & 18,11 & 16,57 & 15,11 & 12,49 & 10,33 & 7,20 \\
\hline 55,24 & 1228,00 & 59,10 & 30,46 & 25,36 & 23,50 & 21,21 & 19,12 & 17,19 & 13,84 & 11,20 & 7,62 \\
\hline 67,34 & 384,40 & 161,40 & 29,35 & 17,05 & 13,16 & 10,23 & 8,34 & 6,93 & 4,99 & 3,83 & 2,59 \\
\hline 82,64 & 1102,00 & 81,90 & 21,06 & 15,46 & 14,09 & 12,81 & 11,75 & 10,80 & 9,10 & 7,69 & 5,58 \\
\hline 44,54 & 1948,90 & 92,70 & 22,22 & 19,20 & 17,52 & 15,45 & 13,57 & 11,88 & 9,12 & 7,12 & 4,66 \\
\hline 81,84 & 1356,10 & 68,10 & 21,57 & 16,24 & 15,07 & 14,00 & 13,03 & 12,12 & 10,46 & 9,02 & 6,74 \\
\hline 56,49 & 1608,80 & 91,10 & 20,69 & 17,02 & 15,65 & 14,04 & 12,60 & 11,27 & 9,01 & 7,25 & 4,91 \\
\hline 81,59 & 833,00 & 194,70 & 16,08 & 10,29 & 8,50 & 7,10 & 6,13 & 5,35 & 4,14 & 3,29 & 2,24 \\
\hline 79,29 & 710,80 & 121,80 & 21,72 & 14,74 & 12,58 & 10,78 & 9,47 & 8,37 & 6,60 & 5,30 & 3,63 \\
\hline 89,49 & 1366,70 & 151,70 & 13,27 & 9,23 & 8,16 & 7,25 & 6,57 & 5,99 & 4,98 & 4,17 & 2,99 \\
\hline 40,63 & 1683,50 & 92,50 & 25,09 & 21,55 & 19,36 & 16,72 & 14,38 & 12,34 & 9,18 & 7,01 & 4,55 \\
\hline 82,59 & 1193,50 & 135,10 & 15,53 & 11,01 & 9,74 & 8,62 & 7,77 & 7,02 & 5,75 & 4,75 & 3,34 \\
\hline 76,01 & 1108,80 & 127,70 & 17,16 & 12,41 & 10,97 & 9,66 & 8,64 & 7,74 & 6,23 & 5,08 & 3,51 \\
\hline 74,73 & 1070,40 & 123,10 & 17,92 & 13,01 & 11,51 & 10,13 & 9,04 & 8,09 & 6,49 & 5,27 & 3,63 \\
\hline 28,61 & 1422,50 & 169,60 & 23,22 & 17,80 & 14,53 & 11,07 & 8,55 & 6,77 & 4,60 & 3,46 & 2,37 \\
\hline 37,58 & 1128,90 & 146,00 & 23,25 & 17,92 & 15,13 & 12,13 & 9,79 & 7,98 & 5,56 & 4,16 & 2,77 \\
\hline 77,94 & 1612,30 & 66,90 & 20,93 & 16,04 & 15,02 & 14,04 & 13,11 & 12,23 & 10,60 & 9,16 & 6,87 \\
\hline 41,67 & 337,30 & 32,80 & 86,41 & 69,49 & 60,50 & 50,49 & 42,17 & 35,34 & 25,41 & 19,15 & 12,54 \\
\hline 32,69 & 1062,70 & 94,50 & 34,40 & 27,75 & 23,64 & 18,98 & 15,28 & 12,41 & 8,59 & 6,41 & 4,27 \\
\hline 64,75 & 1506,00 & 152,10 & 14,59 & 11,12 & 9,91 & 8,71 & 7,71 & 6,84 & 5,39 & 4,30 & 2,90 \\
\hline 59,15 & 1748,90 & 56,60 & 26,63 & 21,88 & 20,75 & 19,20 & 17,70 & 16,27 & 13,66 & 11,45 & 8,15 \\
\hline 65,08 & 866,30 & 162,30 & 18,45 & 12,83 & 10,86 & 9,13 & 7,82 & 6,74 & 5,08 & 3,95 & 2,63 \\
\hline 63,16 & 1522,50 & 33,80 & 37,88 & 30,54 & 29,25 & 27,69 & 25,99 & 24,31 & 21,14 & 18,29 & 13,69 \\
\hline 79,94 & 706,00 & 185,70 & 18,21 & 11,44 & 9,33 & 7,70 & 6,59 & 5,71 & 4,36 & 3,44 & 2,33 \\
\hline 81,57 & 1389,20 & 128,40 & 14,92 & 10,81 & 9,72 & 8,71 & 7,91 & 7,20 & 5,97 & 4,98 & 3,54 \\
\hline 50,95 & 905,80 & 64,10 & 34,12 & 28,13 & 25,37 & 22,24 & 19,48 & 17,05 & 13,09 & 10,24 & 6,75 \\
\hline 88,20 & 917,90 & 194,50 & 14,84 & 9,49 & 7,91 & 6,68 & 5,84 & 5,16 & 4,08 & 3,29 & 2,28 \\
\hline 78,91 & 1639,30 & 63,90 & 21,23 & 16,28 & 15,24 & 14,31 & 13,41 & 12,54 & 10,92 & 9,49 & 7,18 \\
\hline 67,07 & 1693,40 & 139,80 & 14,28 & 11,00 & 9,95 & 8,88 & 7,97 & 7,15 & 5,76 & 4,68 & 3,21 \\
\hline 85,90 & 254,00 & 62,70 & 50,85 & 31,87 & 26,12 & 21,72 & 18,77 & 16,42 & 12,77 & 10,20 & 6,99 \\
\hline 36,23 & 862,70 & 34,80 & 65,13 & 57,44 & 51,87 & 44,85 & 38,54 & 33,05 & 24,48 & 18,63 & 12,04 \\
\hline
\end{tabular}




\begin{tabular}{|c|c|c|c|c|c|c|c|c|c|c|c|}
\hline \multirow[b]{2}{*}{$\mathrm{e} 1(\mathrm{~cm})$} & & & & & & $\mathrm{De}$ & $\overline{\text { ões (x1 }}$ & & & & \\
\hline & Meq (MPa) & Ms (MPa) & D0 & D25 & D40 & D60 & D80 & D100 & D140 & D180 & D260 \\
\hline 57,76 & 720,50 & 89,80 & 28,83 & 21,84 & 19,09 & 16,37 & 14,15 & 12,25 & 9,27 & 7,21 & 4,77 \\
\hline 65,97 & 976,80 & 24,10 & 53,55 & 42,83 & 40,88 & 38,68 & 36,30 & 33,97 & 29,56 & 25,61 & 19,22 \\
\hline 70,37 & 253,40 & 44,30 & 63,13 & 43,81 & 37,35 & 31,77 & 27,56 & 24,04 & 18,49 & 14,58 & 9,80 \\
\hline 36,25 & 981,90 & 194,10 & 21,07 & 15,11 & 12,26 & 9,43 & 7,39 & 5,91 & 4,06 & 3,06 & 2,08 \\
\hline 67,67 & 662,90 & 107,70 & 25,39 & 17,97 & 15,42 & 13,16 & 11,42 & 9,95 & 7,63 & 6,00 & 4,02 \\
\hline 53,03 & 1408,80 & 186,60 & 14,94 & 11,33 & 9,82 & 8,31 & 7,07 & 6,04 & 4,47 & 3,43 & 2,26 \\
\hline 73,51 & 650,70 & 188,60 & 19,49 & 12,18 & 9,84 & 8,01 & 6,76 & 5,78 & 4,32 & 3,36 & 2,26 \\
\hline 55,24 & 548,60 & 39,90 & 52,74 & 42,84 & 38,75 & 34,22 & 30,25 & 26,70 & 20,84 & 16,49 & 10,98 \\
\hline 49,55 & 732,70 & 72,70 & 35,15 & 27,98 & 24,65 & 21,08 & 18,07 & 15,50 & 11,54 & 8,86 & 5,80 \\
\hline 24,97 & 1336,50 & 174,60 & 25,31 & 18,84 & 14,88 & 10,90 & 8,21 & 6,41 & 4,36 & 3,32 & 2,30 \\
\hline 40,85 & 1858,20 & 145,20 & 18,18 & 15,04 & 13,25 & 11,19 & 9,44 & 7,97 & 5,79 & 4,37 & 2,85 \\
\hline 89,51 & 1128,90 & 85,10 & 19,64 & 14,13 & 12,81 & 11,68 & 10,77 & 9,95 & 8,49 & 7,26 & 5,37 \\
\hline 56,22 & 319,40 & 106,60 & 40,65 & 25,47 & 20,24 & 15,92 & 12,91 & 10,65 & 7,56 & 5,75 & 3,87 \\
\hline 57,46 & 1461,60 & 121,10 & 17,92 & 14,29 & 12,84 & 11,30 & 9,97 & 8,80 & 6,86 & 5,42 & 3,62 \\
\hline 24,51 & 265,40 & 37,30 & 122,45 & 89,97 & 70,36 & 51,04 & 38,22 & 29,80 & 20,31 & 15,53 & 10,75 \\
\hline 43,41 & 1206,90 & 104,20 & 25,26 & 20,62 & 18,16 & 15,38 & 13,02 & 11,04 & 8,07 & 6,12 & 3,99 \\
\hline 42,13 & 1502,50 & 187,50 & 16,60 & 12,88 & 11,03 & 9,05 & 7,46 & 6,19 & 4,40 & 3,31 & 2,18 \\
\hline 26,10 & 631,20 & 157,90 & 33,27 & 22,36 & 16,85 & 11,89 & 8,83 & 6,90 & 4,76 & 3,66 & 2,55 \\
\hline 45,71 & 794,70 & 126,70 & 25,98 & 19,30 & 16,34 & 13,34 & 10,98 & 9,11 & 6,49 & 4,89 & 3,24 \\
\hline 55,39 & 222,00 & 192,30 & 40,86 & 19,83 & 13,61 & 9,46 & 7,19 & 5,73 & 3,97 & 3,06 & 2,15 \\
\hline 33,99 & 868,00 & 57,40 & 49,55 & 41,53 & 36,25 & 29,99 & 24,76 & 20,51 & 14,49 & 10,82 & 7,09 \\
\hline 37,67 & 1370,50 & 109,90 & 25,71 & 21,17 & 18,48 & 15,37 & 12,76 & 10,64 & 7,58 & 5,69 & 3,72 \\
\hline 88,17 & 372,80 & 85,10 & 35,46 & 22,41 & 18,51 & 15,52 & 13,51 & 11,89 & 9,35 & 7,52 & 5,18 \\
\hline 54,53 & 497,10 & 46,00 & 50,93 & 40,46 & 36,01 & 31,30 & 27,29 & 23,78 & 18,18 & 14,19 & 9,37 \\
\hline 20,29 & 1467,80 & 102,10 & 41,64 & 32,41 & 25,80 & 18,90 & 14,16 & 10,99 & 7,44 & 5,66 & 3,91 \\
\hline 64,98 & 1477,90 & 119,50 & 16,82 & 13,09 & 11,85 & 10,55 & 9,45 & 8,46 & 6,78 & 5,48 & 3,74 \\
\hline 63,21 & 1411,50 & 198,50 & 13,21 & 9,68 & 8,41 & 7,21 & 6,26 & 5,45 & 4,17 & 3,26 & 2,17 \\
\hline 49,41 & 1970,60 & 52,80 & 30,05 & 25,83 & 24,47 & 22,44 & 20,49 & 18,62 & 15,29 & 12,55 & 8,66 \\
\hline 30,74 & 1710,50 & 28,00 & 68,58 & 63,43 & 58,67 & 52,10 & 45,85 & 40,14 & 30,69 & 23,76 & 15,37 \\
\hline 84,60 & 745,90 & 37,50 & 38,46 & 28,77 & 26,62 & 24,78 & 23,11 & 21,55 & 18,69 & 16,19 & 12,20 \\
\hline 42,64 & 836,50 & 56,70 & 42,74 & 35,90 & 32,02 & 27,48 & 23,53 & 20,13 & 14,90 & 11,37 & 7,40 \\
\hline 89,80 & 1536,60 & 26,90 & 32,24 & 27,46 & 24,86 & 23,93 & 23,21 & 22,34 & 20,53 & 18,80 & 15,63 \\
\hline 20,40 & 1813,90 & 30,80 & 90,64 & 80,51 & 70,76 & 58,33 & 47,67 & 39,03 & 27,00 & 19,93 & 13,04 \\
\hline 40,39 & 513,40 & 172,40 & 28,29 & 18,11 & 14,13 & 10,60 & 8,22 & 6,55 & 4,51 & 3,43 & 2,35 \\
\hline 27,98 & 514,20 & 22,10 & 129,78 & 111,65 & 97,47 & 80,12 & 65,56 & 53,85 & 37,54 & 27,87 & 18,29 \\
\hline 55,87 & 532,30 & 103,50 & 31,52 & 22,23 & 18,70 & 15,45 & 12,95 & 10,93 & 7,98 & 6,10 & 4,04 \\
\hline 35,30 & 509,00 & 135,30 & 34,45 & 23,29 & 18,33 & 13,68 & 10,52 & 8,34 & 5,71 & 4,34 & 2,98 \\
\hline 75,16 & 1867,80 & 194,50 & 10,79 & 7,91 & 7,05 & 6,24 & 5,60 & 5,04 & 4,08 & 3,33 & 2,31 \\
\hline 71,85 & 1437,90 & 197,80 & 12,38 & 8,88 & 7,73 & 6,70 & 5,91 & 5,22 & 4,11 & 3,28 & 2,23 \\
\hline 22,55 & 1465,90 & 148,40 & 29,54 & 22,40 & 17,69 & 12,91 & 9,67 & 7,53 & 5,11 & 3,90 & 2,70 \\
\hline 50,89 & 371,80 & 150,40 & 33,06 & 19,94 & 15,43 & 11,75 & 9,31 & 7,54 & 5,26 & 3,99 & 2,72 \\
\hline 73,47 & 1841,70 & 35,70 & 30,68 & 24,57 & 23,14 & 22,27 & 21,23 & 20,14 & 18,02 & 16,05 & 12,64 \\
\hline 49,35 & 547,00 & 88,70 & 35,86 & 26,45 & 22,47 & 18,54 & 15,43 & 12,92 & 9,32 & 7,06 & 4,66 \\
\hline 57,20 & 1428,50 & 38,30 & 37,83 & 31,28 & 29,86 & 27,78 & 25,71 & 23,71 & 20,03 & 16,88 & 12,10 \\
\hline 50,78 & 1810,40 & 165,00 & 14,72 & 11,82 & 10,49 & 9,05 & 7,82 & 6,76 & 5,09 & 3,93 & 2,58 \\
\hline 88,85 & 1374,50 & 127,50 & 14,50 & 10,27 & 9,20 & 8,28 & 7,56 & 6,93 & 5,83 & 4,92 & 3,57 \\
\hline 27,40 & 646,50 & 45,20 & 75,55 & 61,62 & 51,96 & 40,93 & 32,35 & 25,91 & 17,67 & 13,17 & 8,86 \\
\hline 41,03 & 1137,90 & 144,50 & 22,07 & 17,07 & 14,57 & 11,89 & 9,75 & 8,05 & 5,69 & 4,27 & 2,82 \\
\hline 25,08 & 1371,60 & 197,30 & 22,99 & 16,89 & 13,24 & 9,64 & 7,24 & 5,65 & 3,85 & 2,94 & 2,03 \\
\hline 45,15 & 445,30 & 126,60 & 34,11 & 22,59 & 18,10 & 14,04 & 11,15 & 9,03 & 6,28 & 4,75 & 3,22 \\
\hline 45,06 & 340,30 & 72,30 & 52,17 & 36,75 & 30,31 & 24,11 & 19,47 & 15,93 & 11,18 & 8,42 & 5,64 \\
\hline 68,74 & 756,30 & 132,70 & 21,31 & 14,85 & 12,65 & 10,74 & 9,29 & 8,08 & 6,19 & 4,86 & 3,26 \\
\hline 27,90 & 1884,50 & 106,60 & 29,50 & 24,68 & 21,17 & 17,03 & 13,68 & 11,09 & 7,63 & 5,67 & 3,77 \\
\hline 56,18 & 995,00 & 49,30 & 36,51 & 30,25 & 28,02 & 25,29 & 22,81 & 20,52 & 16,54 & 13,40 & 9,13 \\
\hline 81,48 & 1537,00 & 136,80 & 13,76 & 10,01 & 9,02 & 8,10 & 7,37 & 6,72 & 5,58 & 4,66 & 3,33 \\
\hline 30,53 & 486,50 & 186,40 & 30,60 & $\begin{array}{l}18,98 \\
\end{array}$ & 14,10 & 9,96 & 7,45 & 5,85 & 4,04 & 3,11 & 2,17 \\
\hline 43,90 & 846,30 & 63,50 & 38,91 & 32,30 & 28,71 & 24,59 & 21,02 & 17,97 & 13,30 & 10,15 & 6,61 \\
\hline 77,70 & 1918,40 & 47,00 & 24,40 & 19,24 & 18,05 & 17,28 & 16,42 & 15,54 & 13,85 & 12,29 & 9,62 \\
\hline 82,19 & 1233,30 & 26,70 & 39,02 & 31,27 & 28,99 & 27,91 & 26,73 & 25,45 & 22,97 & 20,65 & 16,56 \\
\hline 53,88 & 1897,70 & 171,70 & 13,61 & 10,86 & 9,68 & 8,41 & 7,33 & 6,38 & 4,88 & 3,80 & 2,51 \\
\hline 27,15 & 642,40 & 100,60 & 44,12 & 32,31 & 25,55 & 18,81 & 14,24 & 11,15 & 7,59 & 5,78 & 3,99 \\
\hline 75,22 & 1619,40 & 41,60 & 28,74 & 22,60 & 21,31 & 20,33 & 19,24 & 18,15 & 16,06 & 14,16 & 10,95 \\
\hline 77,31 & 976,50 & 160,80 & 16,24 & 11,15 & 9,56 & 8,21 & 7,21 & 6,37 & 5,01 & 4,02 & 2,74 \\
\hline 55,78 & 1159,20 & 187,10 & 15,92 & 11,62 & 9,94 & 8,33 & 7,06 & 6,01 & 4,44 & 3,40 & 2,25 \\
\hline 27,56 & 1382,30 & 115,20 & 31,24 & 24,99 & 20,83 & 16,20 & 12,68 & 10,10 & 6,87 & 5,14 & 3,48 \\
\hline 39,16 & 1777,90 & 199,20 & 15,69 & 12,37 & 10,60 & 8,66 & 7,10 & 5,86 & 4,13 & 3,10 & 2,04 \\
\hline 26,94 & 1349,90 & 120,40 & 31,04 & 24,55 & 20,28 & 15,60 & 12,12 & 9,60 & 6,51 & 4,89 & 3,33 \\
\hline 26,03 & 375,30 & 92,70 & 56,53 & 38,08 & 28,70 & 20,26 & 15,05 & 11,76 & 8,10 & 6,24 & 4,34 \\
\hline 75,07 & 1692,30 & 73,50 & 19,82 & 15,28 & 14,32 & 13,33 & 12,39 & 11,51 & 9,89 & 8,48 & 6,27 \\
\hline 33,04 & 775,00 & 84,80 & 40,97 & 32,18 & 27,05 & 21,41 & 17,06 & 13,77 & 9,48 & 7,08 & 4,75 \\
\hline 82,33 & 779,50 & 39,90 & 36,95 & 27,75 & 25,72 & 23,87 & 22,21 & 20,66 & 17,82 & 15,36 & 11,48 \\
\hline 69,13 & 1717,00 & 189,60 & 11,81 & 8,79 & 7,79 & 6,84 & 6,07 & 5,40 & 4,28 & 3,44 & 2,34 \\
\hline 55,35 & 1109,80 & 193,10 & 16,06 & 11,58 & 9,83 & 8,19 & 6,90 & 5,85 & 4,29 & 3,28 & 2,17 \\
\hline 80,02 & 1045,10 & 58,00 & 26,70 & 20,09 & 18,60 & 17,16 & 15,89 & 14,71 & 12,57 & 10,74 & 7,92 \\
\hline 38,47 & 892,50 & 120,90 & 28,17 & 21,56 & 18,19 & 14,60 & 11,79 & 9,63 & 6,71 & 5,03 & 3,35 \\
\hline 72,79 & 1566,50 & 41,90 & 29,62 & 23,31 & 22,07 & 20,97 & 19,77 & 18,58 & 16,34 & 14,30 & 10,94 \\
\hline 86,57 & 382,70 & 35,40 & 52,76 & 37,64 & 33,76 & 30,36 & 27,69 & 25,33 & 21,20 & 17,84 & 12,88 \\
\hline 43,34 & 1745,80 & 69,90 & 28,28 & 24,75 & 22,73 & 20,17 & 17,80 & 15,66 & 12,11 & 9,49 & 6,23 \\
\hline 76,13 & 1429,70 & 184,00 & 12,57 & 8,96 & 7,85 & 6,87 & 6,10 & 5,45 & 4,35 & 3,52 & 2,42 \\
\hline 74,03 & 1012,20 & 47,40 & 31,85 & 24,59 & 22,98 & 21,29 & 19,72 & 18,25 & 15,56 & 13,26 & 9,71 \\
\hline 55,67 & 337,50 & 74,10 & 46,91 & 32,30 & 26,86 & 21,95 & 18,26 & 15,32 & 11,09 & 8,46 & 5,62 \\
\hline 42,42 & 490,10 & 189,70 & 27,05 & 16,69 & 12,85 & 9,59 & 7,44 & 5,94 & 4,09 & 3,11 & 2,14 \\
\hline
\end{tabular}




\begin{tabular}{|c|c|c|c|c|c|c|c|c|c|c|c|}
\hline \multirow[b]{2}{*}{ e1 (cm) } & & & & & & $\mathrm{De}$ & ões (x1 & & & & \\
\hline & Meq (MPa) & Ms (MPa) & D0 & D25 & D40 & D60 & D80 & D100 & D140 & D180 & D260 \\
\hline 72,28 & 809,50 & 76,70 & 26,65 & 19,91 & 17,87 & 15,89 & 14,27 & 12,83 & 10,38 & 8,47 & 5,86 \\
\hline 66,49 & 1435,30 & 175,80 & 13,62 & 10,09 & 8,86 & 7,71 & 6,78 & 5,97 & 4,66 & 3,71 & 2,49 \\
\hline 37,53 & 477,90 & 94,50 & 42,51 & 30,49 & 24,86 & 19,25 & 15,16 & 12,17 & 8,38 & 6,31 & 4,28 \\
\hline 78,76 & 1877,20 & 20,90 & 38,67 & 34,17 & 31,09 & 30,11 & 29,35 & 28,33 & 26,15 & 24,03 & 20,08 \\
\hline 23,49 & 1470,20 & 195,60 & 23,60 & 17,36 & 13,52 & 9,75 & 7,27 & 5,66 & 3,86 & 2,96 & 2,05 \\
\hline 62,55 & 464,80 & 31,80 & 60,18 & 47,83 & 43,70 & 39,17 & 35,22 & 31,62 & 25,45 & 20,64 & 14,11 \\
\hline 74,53 & 1038,80 & 60,50 & 27,09 & 20,71 & 19,17 & 17,56 & 16,15 & 14,84 & 12,49 & 10,53 & 7,59 \\
\hline 32,94 & 1048,00 & 39,10 & 61,01 & 53,98 & 48,45 & 41,46 & 35,24 & 29,91 & 21,79 & 16,43 & 10,60 \\
\hline 63,41 & 802,70 & 162,70 & 19,39 & 13,34 & 11,21 & 9,34 & 7,94 & 6,80 & 5,07 & 3,92 & 2,61 \\
\hline 32,95 & 563,00 & 136,00 & 34,11 & 23,48 & 18,47 & 13,71 & 10,48 & 8,28 & 5,66 & 4,30 & 2,96 \\
\hline 85,37 & 393,70 & 193,10 & 26,13 & 14,23 & 10,67 & 8,19 & 6,71 & 5,64 & 4,15 & 3,23 & 2,21 \\
\hline 38,83 & 229,90 & 99,00 & 56,07 & 33,78 & 25,49 & 18,58 & 14,19 & 11,24 & 7,74 & 5,92 & 4,10 \\
\hline 33,98 & 543,70 & 72,40 & 50,53 & 38,62 & 32,11 & 25,17 & 19,92 & 16,02 & 11,00 & 8,25 & 5,56 \\
\hline 55,34 & 772,40 & 123,50 & 24,10 & 17,64 & 15,09 & 12,64 & 10,71 & 9,11 & 6,72 & 5,15 & 3,40 \\
\hline 42,83 & 1265,30 & 78,00 & 29,88 & 25,34 & 22,73 & 19,64 & 16,91 & 14,55 & 10,86 & 8,32 & 5,41 \\
\hline 77,06 & 1518,70 & 82,40 & 18,99 & 14,44 & 13,40 & 12,35 & 11,41 & 10,54 & 8,97 & 7,63 & 5,58 \\
\hline 74,64 & 1129,50 & 39,30 & 34,21 & 26,60 & 25,06 & 23,57 & 22,07 & 20,63 & 17,94 & 15,55 & 11,70 \\
\hline 47,94 & 1182,60 & 75,90 & 28,85 & 24,17 & 21,82 & 19,10 & 16,68 & 14,55 & 11,10 & 8,64 & 5,67 \\
\hline 76,96 & 1861,60 & 195,70 & 10,66 & 7,76 & 6,91 & 6,12 & 5,50 & 4,96 & 4,03 & 3,30 & 2,30 \\
\hline 59,69 & 361,50 & 69,30 & 45,36 & 31,81 & 26,84 & 22,35 & 18,92 & 16,12 & 11,92 & 9,17 & 6,08 \\
\hline 60,60 & 1547,10 & 127,10 & 16,52 & 13,04 & 11,76 & 10,40 & 9,24 & 8,20 & 6,47 & 5,17 & 3,48 \\
\hline 26,07 & 751,50 & 179,90 & 28,81 & 19,53 & 14,77 & 10,45 & 7,77 & 6,07 & 4,18 & 3,22 & 2,24 \\
\hline 76,68 & 1648,20 & 135,60 & 13,77 & 10,25 & 9,29 & 8,36 & 7,60 & 6,91 & 5,71 & 4,74 & 3,35 \\
\hline 37,94 & 1308,10 & 123,70 & 24,19 & 19,50 & 16,85 & 13,87 & 11,42 & 9,45 & 6,69 & 5,01 & 3,29 \\
\hline 89,34 & 1767,40 & 28,60 & 29,37 & 25,41 & 22,95 & 22,10 & 21,48 & 20,70 & 19,08 & 17,51 & 14,63 \\
\hline 83,82 & 968,50 & 199,80 & 14,43 & 9,39 & 7,85 & 6,64 & 5,79 & 5,10 & 4,01 & 3,22 & 2,21 \\
\hline 75,52 & 966,40 & 80,80 & 23,45 & 17,50 & 15,84 & 14,23 & 12,91 & 11,72 & 9,64 & 7,98 & 5,62 \\
\hline 43,71 & 1419,40 & 63,60 & 32,12 & 27,91 & 25,51 & 22,52 & 19,78 & 17,33 & 13,31 & 10,38 & 6,80 \\
\hline 61,08 & 929,70 & 63,60 & 30,51 & 24,39 & 22,26 & 19,91 & 17,86 & 16,00 & 12,82 & 10,35 & 7,04 \\
\hline 29,55 & 1703,50 & 117,70 & 27,31 & 22,50 & 19,21 & 15,40 & 12,36 & 10,01 & 6,89 & 5,13 & 3,42 \\
\hline 60,41 & 325,00 & 166,30 & 33,04 & 18,46 & 13,86 & 10,44 & 8,30 & 6,77 & 4,76 & 3,64 & 2,48 \\
\hline 76,46 & 1017,10 & 104,60 & 19,79 & 14,46 & 12,90 & 11,45 & 10,29 & 9,28 & 7,54 & 6,18 & 4,31 \\
\hline 37,72 & 1459,00 & 45,80 & 44,00 & 39,41 & 36,16 & 31,91 & 27,97 & 24,42 & 18,63 & 14,43 & 9,38 \\
\hline 62,62 & 604,20 & 172,30 & 22,21 & 14,26 & 11,56 & 9,33 & 7,75 & 6,51 & 4,74 & 3,63 & 2,43 \\
\hline 62,37 & 448,50 & 121,50 & 30,63 & 19,90 & 16,22 & 13,15 & 10,95 & 9,23 & 6,73 & 5,16 & 3,45 \\
\hline 59,72 & 626,80 & 197,90 & 20,81 & 13,13 & 10,51 & 8,36 & 6,86 & 5,71 & 4,10 & 3,13 & 2,10 \\
\hline 88,68 & 695,40 & 143,50 & 19,76 & 12,69 & 10,59 & 8,97 & 7,85 & 6,95 & 5,51 & 4,46 & 3,09 \\
\hline 41,13 & 1477,30 & 120,00 & 22,22 & 18,29 & 16,09 & 13,57 & 11,43 & 9,64 & 6,99 & 5,29 & 3,45 \\
\hline 68,15 & 668,70 & 77,50 & 29,76 & 22,08 & 19,49 & 17,04 & 15,07 & 13,35 & 10,52 & 8,41 & 5,70 \\
\hline 63,52 & 1810,40 & 162,60 & 13,08 & 10,14 & 9,10 & 8,04 & 7,15 & 6,36 & 5,03 & 4,03 & 2,73 \\
\hline 52,35 & 1315,50 & 75,40 & 26,30 & 21,95 & 20,07 & 17,86 & 15,87 & 14,07 & 11,05 & 8,77 & 5,85 \\
\hline 26,29 & 1859,30 & 189,90 & 20,88 & 16,19 & 13,18 & 9,97 & 7,65 & 6,02 & 4,08 & 3,08 & 2,11 \\
\hline 68,32 & 1524,00 & 55,40 & 26,01 & 20,58 & 19,46 & 18,13 & 16,85 & 15,62 & 13,36 & 11,39 & 8,34 \\
\hline 80,28 & 1505,50 & 133,10 & 14,19 & 10,37 & 9,35 & 8,40 & 7,63 & 6,95 & 5,76 & 4,80 & 3,42 \\
\hline 72,24 & 278,70 & 50,20 & 56,02 & 38,47 & 32,70 & 27,79 & 24,13 & 21,08 & 16,26 & 12,85 & 8,66 \\
\hline 88,20 & 800,90 & 101,00 & 21,40 & 14,73 & 12,89 & 11,36 & 10,22 & 9,25 & 7,60 & 6,31 & 4,48 \\
\hline 56,99 & 968,60 & 96,20 & 24,49 & 19,17 & 17,02 & 14,79 & 12,92 & 11,29 & 8,66 & 6,79 & 4,50 \\
\hline 79,88 & 1465,30 & 150,00 & 13,51 & 9,76 & 8,71 & 7,75 & 6,99 & 6,33 & 5,19 & 4,29 & 3,02 \\
\hline 81,37 & 1742,60 & 35,30 & 28,95 & 23,36 & 21,65 & 20,87 & 20,02 & 19,08 & 17,25 & 15,53 & 12,50 \\
\hline 68,25 & 658,20 & 187,20 & 19,85 & 12,60 & 10,21 & 8,29 & 6,96 & 5,91 & 4,36 & 3,37 & 2,26 \\
\hline 35,07 & 1475,60 & 155,40 & 21,17 & 16,77 & 14,25 & 11,46 & 9,24 & 7,53 & 5,23 & 3,91 & 2,60 \\
\hline 54,52 & 663,50 & 194,40 & 20,97 & 13,60 & 10,96 & 8,70 & 7,09 & 5,86 & 4,17 & 3,16 & 2,12 \\
\hline 27,20 & 1484,50 & 27,50 & 80,74 & 74,04 & 67,24 & 58,21 & 49,91 & 42,63 & 31,30 & 23,62 & 15,15 \\
\hline 60,08 & 1684,20 & 59,60 & 25,82 & 21,13 & 19,98 & 18,44 & 16,97 & 15,57 & 13,03 & 10,90 & 7,73 \\
\hline 62,87 & 1371,30 & 160,70 & 15,00 & 11,30 & 9,95 & 8,64 & 7,57 & 6,64 & 5,14 & 4,06 & 2,71 \\
\hline 38,67 & 1798,60 & 64,80 & 31,98 & 28,40 & 25,95 & 22,81 & 19,92 & 17,34 & 13,16 & 10,16 & 6,60 \\
\hline 81,91 & 1476,40 & 55,80 & 23,47 & 17,94 & 16,74 & 15,78 & 14,83 & 13,92 & 12,21 & 10,68 & 8,18 \\
\hline 33,25 & 1661,70 & 124,10 & 24,33 & 20,07 & 17,34 & 14,16 & 11,55 & 9,49 & 6,63 & 4,94 & 3,26 \\
\hline 87,47 & 1040,90 & 82,90 & 20,89 & 15,05 & 13,62 & 12,37 & 11,36 & 10,45 & 8,85 & 7,52 & 5,51 \\
\hline 41,34 & 505,40 & 26,80 & 84,38 & 72,66 & 65,51 & 56,84 & 49,09 & 42,33 & 31,69 & 24,30 & 15,79 \\
\hline 45,51 & 1444,00 & 143,90 & 18,78 & 15,02 & 13,15 & 11,11 & 9,40 & 7,97 & 5,82 & 4,42 & 2,89 \\
\hline 64,41 & 919,40 & 197,90 & 16,36 & 11,10 & 9,27 & 7,70 & 6,53 & 5,58 & 4,16 & 3,22 & 2,14 \\
\hline 87,24 & 1556,10 & 194,50 & 11,10 & 7,67 & 6,72 & 5,92 & 5,33 & 4,82 & 3,96 & 3,28 & 2,32 \\
\hline 51,94 & 1212,20 & 78,40 & 26,62 & 22,06 & 20,02 & 17,68 & 15,60 & 13,74 & 10,67 & 8,41 & 5,57 \\
\hline 69,70 & 1779,10 & 155,10 & 12,93 & 9,82 & 8,86 & 7,90 & 7,10 & 6,38 & 5,16 & 4,20 & 2,90 \\
\hline 47,03 & 1814,30 & 57,40 & 30,08 & 26,17 & 24,49 & 22,19 & 20,00 & 17,96 & 14,42 & 11,61 & 7,83 \\
\hline 26,20 & 903,10 & 39,80 & 76,65 & 65,22 & 56,29 & 45,55 & 36,74 & 29,83 & 20,54 & 15,23 & 10,09 \\
\hline 30,19 & 1855,80 & 20,50 & 84,33 & 78,36 & 73,57 & 66,42 & 59,44 & 52,88 & 41,57 & 32,83 & 21,54 \\
\hline 21,08 & 1094,40 & 153,10 & 32,62 & 23,36 & 17,69 & 12,40 & 9,13 & 7,09 & 4,88 & 3,77 & 2,62 \\
\hline 80,31 & 1817,80 & 81,20 & 17,44 & 13,25 & 12,35 & 11,53 & 10,76 & 10,04 & 8,70 & 7,52 & 5,65 \\
\hline 61,14 & 1668,60 & 31,70 & 39,27 & 31,83 & 30,57 & 29,06 & 27,33 & 25,62 & 22,36 & 19,42 & 14,60 \\
\hline 83,17 & 745,20 & 156,80 & 18,65 & 12,11 & 10,11 & 8,53 & 7,43 & 6,53 & 5,11 & 4,10 & 2,80 \\
\hline 88,62 & 1455,10 & 159,60 & 12,58 & 8,78 & 7,77 & 6,92 & 6,27 & 5,70 & 4,74 & 3,96 & 2,84 \\
\hline 58,42 & 1906,10 & 46,80 & 29,74 & 24,42 & 23,38 & 21,88 & 20,35 & 18,86 & 16,09 & 13,67 & 9,93 \\
\hline 37,21 & 1630,20 & 82,20 & 29,24 & 25,31 & 22,66 & 19,41 & 16,53 & 14,08 & 10,32 & 7,82 & 5,06 \\
\hline 28,22 & 1113,00 & 162,20 & 26,13 & 19,43 & 15,57 & 11,63 & 8,88 & 6,98 & 4,75 & 3,60 & 2,47 \\
\hline 82,88 & 1579,00 & 24,50 & 36,43 & 30,79 & 28,15 & 27,23 & 26,37 & 25,33 & 23,20 & 21,17 & 17,45 \\
\hline 64,41 & 979,80 & 66,50 & 28,26 & 22,30 & 20,41 & 18,35 & 16,55 & 14,92 & 12,09 & 9,85 & 6,78 \\
\hline 42,16 & 1907,10 & 23,00 & 60,83 & 52,88 & 51,10 & 47,68 & 44,13 & 40,66 & 34,19 & 28,62 & 20,23 \\
\hline 57,87 & 509,30 & 137,90 & 27,72 & 18,17 & 14,80 & 11,92 & 9,84 & 8,21 & 5,92 & 4,51 & 3,01 \\
\hline 81,79 & 349,60 & 185,50 & 28,94 & 15,57 & 11,55 & 8,77 & 7,11 & 5,93 & 4,32 & 3,34 & 2,28 \\
\hline 54,65 & 1778,40 & 182,90 & 13,39 & 10,49 & 9,28 & 8,01 & 6,95 & 6,02 & 4,57 & 3,55 & 2,34 \\
\hline
\end{tabular}




\begin{tabular}{|c|c|c|c|c|c|c|c|c|c|c|c|}
\hline \multirow[b]{2}{*}{ e1 (cm) } & & & & & & & ões (x1 & m) & & & \\
\hline & Meq (MPa) & Ms (MPa) & DO & D25 & D40 & D60 & D80 & D100 & D140 & D180 & D260 \\
\hline 23,19 & 244,40 & 38,20 & 127,38 & 91,29 & 69,93 & 49,70 & 36,84 & 28,67 & 19,65 & 15,12 & 10,50 \\
\hline 86,82 & 1464,40 & 181,60 & 11,87 & 8,22 & 7,21 & 6,35 & 5,72 & 5,17 & 4,24 & 3,51 & 2,49 \\
\hline 25,36 & 882,30 & 67,00 & 55,43 & 44,34 & 36,67 & 28,18 & 21,85 & 17,28 & 11,70 & 8,77 & 5,97 \\
\hline 34,68 & 621,10 & 77,50 & 445,51 & 35,17 & 29,47 & 23,32 & 18,59 & 15,02 & 10,36 & 7,76 & 5,20 \\
\hline 35,41 & 640,70 & 144,10 & 30,22 & 21,14 & 16,91 & 12,81 & 9,93 & 7,90 & 5,41 & 4,09 & 2,80 \\
\hline 51,68 & 1792,10 & 105,80 & 19,10 & 15,95 & 14,54 & 12,90 & 11,43 & 10,10 & 7,89 & 6,24 & 4,15 \\
\hline 55,88 & 567,50 & 98,70 & 31,27 & 22,51 & 19,13 & 15,94 & 13,45 & 11,42 & 8,39 & 6,43 & 4,25 \\
\hline 75,55 & 920,50 & 138,20 & 18,16 & 12,71 & 10,99 & 9,49 & 8,37 & 7,41 & 5,84 & 4,69 & 3,20 \\
\hline 21,62 & 1348,70 & 58,10 & 60,89 & 50,41 & 42,17 & 32,70 & 25,43 & 20,11 & 13,56 & 10,12 & 6,87 \\
\hline 27,89 & 985,80 & 146,90 & 29,27 & 21,67 & 17,29 & 12,86 & 9,79 & 7,69 & 5,23 & 3,97 & 2,73 \\
\hline 57,50 & 279,80 & 96,70 & 45,39 & 28,14 & 22,28 & 17,49 & 14,20 & 11,72 & 8,34 & 6,35 & 4,27 \\
\hline 22,37 & 1492,00 & 25,40 & 101,28 & 91,29 & 81,28 & 68,28 & 56,81 & 47,22 & 33,31 & 24,69 & 15,97 \\
\hline 82,18 & 1716,20 & 178,80 & 11,30 & 8,08 & 7,20 & 6,41 & 5,79 & 5,25 & 4,32 & 3,58 & 2,53 \\
\hline 62,85 & 400,90 & 114,60 & 33,40 & 21,42 & 17,35 & 14,01 & 11,64 & 9,79 & 7,13 & 5,47 & 3,65 \\
\hline 20,39 & 328,90 & 100,50 & 61,72 & 38,37 & 27,06 & 18,16 & 13,33 & 10,49 & 7,37 & 5,73 & 4,01 \\
\hline 56,78 & 1624,10 & 59,00 & 27,21 & 22,61 & 21,30 & 19,53 & 17,86 & 16,28 & 13,46 & 11,12 & 7,76 \\
\hline 46,26 & 1813,90 & 48,00 & 34,34 & 29,99 & 28,26 & 25,77 & 23,37 & 21,10 & 17,10 & 13,88 & 9,43 \\
\hline 77,13 & 1167,60 & 20,40 & 49,40 & 40,18 & 37,41 & 36,18 & 34,72 & 33,11 & 29,95 & 26,96 & 21,67 \\
\hline 21,07 & 996,80 & 78,20 & 54,69 & 42,29 & 33,61 & 24,61 & 18,45 & 14,34 & 9,71 & 7,40 & 5,11 \\
\hline 20,91 & 970,00 & 122,60 & 39,85 & 28,92 & 22,05 & 15,54 & 11,45 & 8,88 & 6,10 & 4,70 & 3,27 \\
\hline 80,38 & 1987,70 & 113,90 & 13,74 & 10,32 & 9,54 & 8,79 & 8,13 & 7,52 & 6,42 & 5,48 & 4,03 \\
\hline 22,13 & 366,50 & 87,80 & 63,94 & 42,29 & 30,93 & 21,22 & 15,58 & 12,18 & 8,47 & 6,57 & 4,58 \\
\hline 50,33 & 1537,40 & 87,70 & 23,13 & 19,44 & 17,73 & 15,72 & 13,90 & 12,26 & 9,55 & 7,53 & 4,99 \\
\hline 83,32 & 1381,30 & 40,90 & 28,68 & 22,28 & 20,74 & 19,78 & 18,76 & 17,75 & 15,80 & 14,03 & 11,00 \\
\hline 58,29 & 1141,40 & 49,10 & 34,10 & 28,09 & 26,27 & 23,96 & 21,82 & 19,82 & 16,26 & 13,38 & 9,28 \\
\hline 78,65 & 1557,00 & 194,80 & 11,55 & 8,20 & 7,20 & 6,32 & 5,64 & 5,05 & 4,07 & 3,32 & 2,30 \\
\hline 33,39 & 268,80 & 148,80 & 43,56 & 24,52 & 17,66 & 12,34 & 9,24 & 7,29 & 5,04 & 3,90 & 2,73 \\
\hline 51,30 & 230,00 & 30,80 & 92,58 & 70,31 & 60,77 & 51,12 & 43,28 & 36,76 & 27,02 & 20,64 & 13,57 \\
\hline 62,49 & 499,80 & 62,70 & 39,80 & 29,74 & 26,04 & 22,49 & 19,62 & 17,15 & 13,19 & 10,37 & 6,92 \\
\hline 89,97 & 1820,10 & 119,70 & 13,09 & 9,50 & 8,66 & 7,97 & 7,39 & 6,86 & 5,91 & 5,09 & 3,81 \\
\hline 46,26 & 390,60 & 167,60 & 31,46 & 18,81 & 14,38 & 10,76 & 8,39 & 6,73 & 4,66 & 3,54 & 2,43 \\
\hline 69,14 & 1209,50 & 162,30 & 15,16 & 11,00 & 9,60 & 8,32 & 7,31 & 6,44 & 5,03 & 4,01 & 2,71 \\
\hline 36,51 & 491,40 & 160,20 & 31,22 & 20,18 & 15,62 & 11,54 & 8,84 & 7,00 & 4,80 & 3,66 & 2,53 \\
\hline 24,81 & 1857,00 & 73,20 & 42,04 & 35,88 & 30,92 & 24,93 & 20,04 & 16,23 & 11,13 & 8,25 & 5,47 \\
\hline 86,18 & 1639,70 & 109,60 & 14,72 & 10,77 & 9,85 & 9,03 & 8,34 & 7,72 & 6,60 & 5,65 & 4,18 \\
\hline 50,90 & 597,80 & 36,70 & 56,45 & 47,12 & 42,83 & 37,85 & 33,40 & 29,41 & 22,84 & 17,98 & 11,90 \\
\hline 65,77 & 468,90 & 78,50 & 35,81 & 25,35 & 21,69 & 18,42 & 15,91 & 13,80 & 10,50 & 8,22 & 5,49 \\
\hline 63,31 & 1715,80 & 191,10 & 12,27 & 9,29 & 8,22 & 7,16 & 6,30 & 5,54 & 4,31 & 3,42 & 2,29 \\
\hline 53,18 & 1115,40 & 101,80 & 23,22 & 18,54 & 16,50 & 14,31 & 12,44 & 10,82 & 8,23 & 6,40 & 4,22 \\
\hline 49,72 & 1230,90 & 174,70 & 17,07 & 12,87 & 11,06 & 9,23 & 7,75 & 6,54 & 4,76 & 3,62 & 2,38 \\
\hline 45,58 & 1056,90 & 21,90 & 70,56 & 61,56 & 58,59 & 53,90 & 49,28 & 44,86 & 36,90 & 30,31 & 20,90 \\
\hline 55,58 & 893,90 & 103,50 & 24,69 & 19,01 & 16,67 & 14,31 & 12,35 & 10,68 & 8,06 & 6,25 & 4,12 \\
\hline 58,80 & 1672,20 & 95,30 & 19,36 & 15,78 & 14,54 & 13,08 & 11,78 & 10,59 & 8,53 & 6,91 & 4,72 \\
\hline 74,04 & 1892,10 & 173,80 & 11,48 & 8,54 & 7,68 & 6,86 & 6,18 & 5,58 & 4,54 & 3,73 & 2,60 \\
\hline 67,70 & 1525,80 & 65,60 & 23,43 & 18,54 & 17,42 & 16,09 & 14,85 & 13,68 & 11,55 & 9,75 & 7,02 \\
\hline 27,08 & 1448,20 & 139,30 & 27,38 & 21,47 & 17,65 & 13,51 & 10,46 & 8,28 & 5,61 & 4,22 & 2,88 \\
\hline 72,55 & 928,70 & 92,00 & 22,65 & 16,83 & 15,06 & 13,36 & 11,98 & 10,75 & 8,68 & 7,07 & 4,88 \\
\hline 34,69 & 315,40 & 124,70 & 44,37 & 27,37 & 20,61 & 14,85 & 11,24 & 8,86 & 6,09 & 4,67 & 3,25 \\
\hline 36,48 & 295,70 & 173,70 & 37,69 & 20,83 & 15,01 & 10,56 & 7,95 & 6,28 & 4,34 & 3,35 & 2,35 \\
\hline 27,76 & 452,10 & 173,20 & 34,05 & 21,00 & 15,37 & 10,69 & 7,94 & 6,23 & 4,32 & 3,34 & 2,33 \\
\hline 47,40 & 1009,90 & 126,50 & 22,93 & 17,71 & 15,31 & 12,80 & 10,75 & 9,07 & 6,59 & 5,00 & 3,28 \\
\hline 61,66 & 720,30 & 37,00 & 46,69 & 37,75 & 35,06 & 31,86 & 28,96 & 26,27 & 21,53 & 17,69 & 12,28 \\
\hline 64,65 & 761,50 & 28,90 & 52,27 & 41,94 & 39,59 & 36,65 & 33,86 & 31,20 & 26,34 & 22,22 & 15,98 \\
\hline 38,11 & 1539,30 & 116,80 & 23,49 & 19,48 & 17,08 & 14,29 & 11,93 & 9,99 & 7,16 & 5,38 & 3,51 \\
\hline 89,95 & 1819,30 & 56,20 & 20,05 & 15,57 & 14,32 & 13,66 & 13,01 & 12,35 & 11,08 & 9,91 & 7,89 \\
\hline 64,47 & 1664,60 & 187,60 & 12,46 & 9,39 & 8,29 & 7,23 & 6,37 & 5,61 & 4,38 & 3,48 & 2,34 \\
\hline 88,38 & 443,90 & 93,40 & 30,75 & 19,69 & 16,41 & 13,87 & 12,13 & 10,72 & 8,48 & 6,86 & 4,74 \\
\hline 33,60 & 1471,20 & 71,60 & 35,96 & 31,10 & 27,59 & 23,28 & 19,54 & 16,41 & 11,79 & 8,84 & 5,73 \\
\hline 25,51 & 1261,30 & 127,90 & 31,58 & 24,40 & 19,76 & 14,85 & 11,35 & 8,91 & 6,03 & 4,56 & 3,13 \\
\hline 27,11 & 1422,70 & 132,50 & 28,47 & 22,42 & 18,48 & 14,19 & 11,01 & 8,72 & 5,91 & 4,44 & 3,02 \\
\hline 39,52 & 768,30 & 58,00 & 446,00 & 38,20 & 33,63 & 28,32 & 23,80 & 20,04 & 14,48 & 10,92 & 7,11 \\
\hline 48,54 & 986,10 & 190,60 & 18,25 & 13,05 & 10,91 & 8,85 & 7,27 & 6,03 & 4,29 & 3,25 & 2,16 \\
\hline 74,46 & 1932,00 & 123,30 & 13,80 & 10,51 & 9,68 & 8,82 & 8,08 & 7,40 & 6,19 & 5,19 & 3,71 \\
\hline 87,62 & 1030,80 & 185,80 & 14,16 & 9,31 & 7,89 & 6,76 & 5,96 & 5,31 & 4,24 & 3,45 & 2,40 \\
\hline 82,04 & 1316,80 & 47,10 & 27,18 & 20,84 & 19,45 & 18,39 & 17,31 & 16,28 & 14,33 & 12,57 & 9,67 \\
\hline 61,56 & 1144,00 & 58,80 & 29,44 & 23,81 & 22,11 & 20,09 & 18,26 & 16,56 & 13,57 & 11,15 & 7,74 \\
\hline 70,46 & 1716,70 & 197,50 & 11,46 & 8,45 & 7,47 & 6,55 & 5,81 & 5,17 & 4,10 & 3,30 & 2,25 \\
\hline 20,83 & 1941,90 & 180,40 & 25,03 & 18,91 & 14,78 & 10,65 & 7,92 & 6,14 & 4,18 & 3,20 & 2,22 \\
\hline 82,49 & 776,00 & 47,50 & 33,43 & 24,85 & 22,87 & 21,03 & 19,44 & 17,98 & 15,35 & 13,11 & 9,66 \\
\hline 43,41 & 795,60 & 116,90 & 28,00 & 21,14 & 17,93 & 14,61 & 11,99 & 9,91 & 7,02 & 5,28 & 3,50 \\
\hline 55,96 & 1462,10 & 155,70 & 15,76 & 12,26 & 10,82 & 9,35 & 8,11 & 7,05 & 5,36 & 4,17 & 2,76 \\
\hline 46,55 & 1149,20 & 23,20 & 65,19 & 56,52 & 53,95 & 49,79 & 45,67 & 41,70 & 34,51 & 28,51 & 19,80 \\
\hline 34,92 & 1285,30 & 159,30 & 21,99 & 17,01 & 14,28 & 11,32 & 9,04 & 7,31 & 5,05 & 3,78 & 2,53 \\
\hline 59,54 & 900,40 & 182,50 & 17,75 & 12,32 & 10,34 & 8,57 & 7,23 & 6,14 & 4,52 & 3,47 & 2,30 \\
\hline 75,75 & 969,60 & 101,80 & 20,62 & 15,07 & 13,42 & 11,89 & 10,68 & 9,60 & 7,78 & 6,36 & 4,42 \\
\hline 27,64 & 1376,40 & 165,70 & 24,38 & 18,60 & 15,08 & 11,39 & 8,74 & 6,89 & 4,68 & 3,53 & 2,42 \\
\hline 60,87 & 1520,10 & 116,50 & 17,47 & 13,86 & 12,56 & 11,16 & 9,95 & 8,87 & 7,04 & 5,65 & 3,82 \\
\hline 76,18 & 998,40 & 189,10 & 14,99 & 10,10 & 8,54 & 7,25 & 6,31 & 5,53 & 4,29 & 3,41 & 2,31 \\
\hline 78,89 & 205,10 & 149,20 & 45,52 & 22,82 & 16,13 & 11,65 & 9,15 & 7,46 & 5,29 & 4,07 & 2,81 \\
\hline 40,89 & 525,90 & 179,50 & 27,25 & 17,38 & 13,54 & 10,16 & 7,89 & 6,30 & 4,34 & 3,29 & 2,26 \\
\hline 34,05 & 690,20 & 161,30 & 27,95 & 19,39 & 15,37 & 11,51 & 8,86 & 7,02 & 4,80 & 3,64 & 2,50 \\
\hline 49,56 & 1917,30 & 45,40 & 33,57 & 28,77 & 27,40 & 25,27 & 23,18 & 21,18 & 17,56 & 14,53 & 10,13 \\
\hline
\end{tabular}




\begin{tabular}{|c|c|c|c|c|c|c|c|c|c|c|c|}
\hline \multirow[b]{2}{*}{ e1 (cm) } & & & & & & & ões (x1 & m) & & & \\
\hline & Meq (MPa) & Ms (MPa) & D0 & D25 & D40 & D60 & D80 & D100 & D140 & D180 & D260 \\
\hline 25,24 & 1981,20 & 106,00 & 31,54 & 26,18 & 22,18 & 17,52 & 13,86 & 11,10 & 7,55 & 5,62 & 3,77 \\
\hline 73,46 & 1376,30 & 113,10 & 16,85 & 12,68 & 11,49 & 10,32 & 9,34 & 8,46 & 6,94 & 5,72 & 4,01 \\
\hline 64,68 & 1347,60 & 129,10 & 16,79 & 12,88 & 11,52 & 10,15 & 9,02 & 8,01 & 6,33 & 5,07 & 3,43 \\
\hline 67,15 & 1950,30 & 77,90 & 19,31 & 15,33 & 14,45 & 13,39 & 12,38 & 11,43 & 9,68 & 8,19 & 5,92 \\
\hline 72,16 & 372,60 & 68,30 & 41,60 & 28,50 & 24,18 & 20,52 & 17,80 & 15,54 & 11,97 & 9,45 & 6,36 \\
\hline 87,44 & 1487,50 & 24,30 & 35,51 & 30,35 & 27,53 & 26,55 & 25,76 & 24,79 & 22,79 & 20,86 & 17,33 \\
\hline 28,68 & 496,80 & 100,20 & 46,63 & 32,93 & 25,74 & 18,81 & 14,21 & 11,14 & 7,61 & 5,81 & 4,02 \\
\hline 54,83 & 1701,00 & 176,10 & 13,92 & 10,90 & 9,63 & 8,31 & 7,21 & 6,25 & 4,75 & 3,69 & 2,43 \\
\hline 78,72 & 309,90 & 69,30 & 44,49 & 28,90 & 24,01 & 20,11 & 17,37 & 15,15 & 11,69 & 9,26 & 6,28 \\
\hline 79,79 & 1317,60 & 196,70 & 12,46 & 8,61 & 7,45 & 6,45 & 5,72 & 5,09 & 4,06 & 3,28 & 2,26 \\
\hline 82,94 & 268,20 & 29,10 & 70,57 & 50,18 & 44,54 & 39,56 & 35,71 & 32,35 & 26,59 & 22,03 & 15,58 \\
\hline 60,84 & 1329,40 & 131,60 & 17,25 & 13,35 & 11,89 & 10,40 & 9,16 & 8,07 & 6,28 & 4,97 & 3,32 \\
\hline 66,51 & 347,90 & 145,90 & 32,54 & 18,94 & 14,62 & 11,36 & 9,25 & 7,68 & 5,52 & 4,23 & 2,86 \\
\hline 89,12 & 839,10 & 59,00 & 27,51 & 19,92 & 18,12 & 16,60 & 15,33 & 14,20 & 12,16 & 10,43 & 7,75 \\
\hline 85,70 & 435,20 & 85,10 & 32,62 & 21,29 & 17,90 & 15,21 & 13,34 & 11,80 & 9,34 & 7,54 & 5,20 \\
\hline 50,41 & 1357,20 & 138,50 & 18,48 & 14,63 & 12,88 & 11,02 & 9,46 & 8,12 & 6,06 & 4,66 & 3,05 \\
\hline 70,16 & 1014,70 & 36,10 & 39,00 & 30,68 & 29,00 & 27,11 & 25,26 & 23,49 & 20,20 & 17,32 & 12,80 \\
\hline 53,09 & 597,80 & 172,10 & 23,70 & 15,46 & 12,48 & 9,89 & 8,04 & 6,63 & 4,70 & 3,56 & 2,39 \\
\hline 73,46 & 1721,10 & 138,90 & 13,61 & 10,26 & 9,31 & 8,37 & 7,58 & 6,88 & 5,64 & 4,66 & 3,27 \\
\hline 75,03 & 1181,90 & 144,30 & 15,71 & 11,32 & 9,96 & 8,73 & 7,77 & 6,94 & 5,55 & 4,50 & 3,09 \\
\hline 80,53 & 1345,00 & 68,70 & 21,72 & 16,39 & 15,22 & 14,11 & 13,11 & 12,18 & 10,47 & 9,00 & 6,69 \\
\hline 75,26 & 421,30 & 101,00 & 32,25 & 20,86 & 17,21 & 14,30 & 12,25 & 10,60 & 8,06 & 6,34 & 4,27 \\
\hline 48,33 & 1188,00 & 80,70 & 27,60 & 22,99 & 20,71 & 18,08 & 15,76 & 13,72 & 10,45 & 8,12 & 5,32 \\
\hline 63,38 & 1184,80 & 172,60 & 15,43 & 11,25 & 9,74 & 8,33 & 7,22 & 6,28 & 4,79 & 3,75 & 2,50 \\
\hline 26,08 & 1576,60 & 36,40 & 68,02 & 61,18 & 54,71 & 46,35 & 38,93 & 32,65 & 23,33 & 17,39 & 11,22 \\
\hline 29,60 & 1674,70 & 55,00 & 45,37 & 40,23 & 35,89 & 30,40 & 25,56 & 21,47 & 15,40 & 11,52 & 7,45 \\
\hline 53,31 & 1136,10 & 163,10 & 17,69 & 13,24 & 11,40 & 9,59 & 8,13 & 6,92 & 5,10 & 3,91 & 2,57 \\
\hline 87,33 & 971,00 & 187,90 & 14,60 & 9,51 & 8,00 & 6,80 & 5,98 & 5,30 & 4,21 & 3,41 & 2,36 \\
\hline 43,59 & 770,50 & 46,20 & 49,29 & 41,87 & 37,67 & 32,69 & 28,26 & 24,41 & 18,32 & 14,09 & 9,18 \\
\hline 87,32 & 330,30 & 95,10 & 36,79 & 22,32 & 17,95 & 14,71 & 12,59 & 10,94 & 8,43 & 6,70 & 4,58 \\
\hline 76,00 & 1806,30 & 127,30 & 13,78 & 10,38 & 9,51 & 8,63 & 7,88 & 7,21 & 6,01 & 5,03 & 3,59 \\
\hline 72,75 & 551,40 & 48,50 & 40,66 & 30,52 & 27,53 & 24,60 & 22,19 & 20,03 & 16,31 & 13,38 & 9,31 \\
\hline 33,95 & 339,00 & 169,20 & 36,43 & 21,12 & 15,44 & 10,89 & 8,18 & 6,45 & 4,45 & 3,43 & 2,40 \\
\hline 84,96 & 531,00 & 31,30 & 49,18 & 36,41 & 33,50 & 30,92 & 28,68 & 26,62 & 22,88 & 19,67 & 14,64 \\
\hline 77,76 & 309,10 & 189,90 & 31,61 & 16,51 & 12,00 & 8,90 & 7,10 & 5,85 & 4,19 & 3,23 & 2,21 \\
\hline 68,57 & 1802,80 & 111,60 & 15,70 & 12,25 & 11,29 & 10,25 & 9,34 & 8,50 & 7,02 & 5,81 & 4,08 \\
\hline 34,42 & 1763,10 & 186,20 & 17,91 & 14,17 & 12,01 & 9,61 & 7,73 & 6,28 & 4,35 & 3,25 & 2,17 \\
\hline 84,57 & 1445,60 & 61,80 & 21,83 & 16,50 & 15,32 & 14,38 & 13,48 & 12,64 & 11,06 & 9,66 & 7,38 \\
\hline 69,56 & 928,80 & 71,00 & 26,72 & 20,51 & 18,67 & 16,77 & 15,16 & 13,70 & 11,17 & 9,17 & 6,37 \\
\hline 63,29 & 1237,30 & 105,70 & 19,73 & 15,37 & 13,85 & 12,27 & 10,94 & 9,74 & 7,73 & 6,20 & 4,20 \\
\hline 77,76 & 1022,80 & 191,50 & 14,61 & 9,82 & 8,31 & 7,06 & 6,16 & 5,41 & 4,22 & 3,37 & 2,29 \\
\hline 42,79 & 1537,40 & 133,10 & 19,98 & 16,31 & 14,34 & 12,12 & 10,24 & 8,66 & 6,31 & 4,78 & 3,12 \\
\hline 64,23 & 685,90 & 23,00 & 63,17 & 50,79 & 48,17 & 44,83 & 41,56 & 38,44 & 32,68 & 27,72 & 20,11 \\
\hline 29,41 & 1335,60 & 124,60 & 28,61 & 22,73 & 18,99 & 14,85 & 11,69 & 9,35 & 6,38 & 4,77 & 3,22 \\
\hline 57,11 & 1563,90 & 108,30 & 18,69 & 15,15 & 13,77 & 12,23 & 10,88 & 9,67 & 7,63 & 6,08 & 4,08 \\
\hline 83,21 & 253,20 & 80,90 & 46,78 & 28,05 & 22,32 & 18,06 & 15,29 & 13,16 & 9,98 & 7,86 & 5,34 \\
\hline 53,94 & 901,60 & 22,20 & 65,80 & 55,18 & 52,71 & 48,94 & 45,19 & 41,58 & 34,94 & 29,28 & 20,80 \\
\hline 20,31 & 1369,20 & 49,00 & 71,82 & 59,84 & 50,12 & 38,86 & 30,21 & 23,86 & 16,06 & 11,98 & 8,13 \\
\hline 58,47 & 1233,30 & 115,30 & 19,62 & 15,39 & 13,74 & 12,02 & 10,56 & 9,28 & 7,20 & 5,68 & 3,78 \\
\hline 75,89 & 238,20 & 144,40 & 41,28 & 21,67 & 15,79 & 11,74 & 9,37 & 7,71 & 5,51 & 4,24 & 2,90 \\
\hline 89,67 & 872,10 & 198,10 & 15,12 & 9,53 & 7,87 & 6,60 & 5,75 & 5,07 & 4,00 & 3,23 & 2,23 \\
\hline 63,38 & 463,20 & 65,50 & 40,08 & 29,35 & 25,46 & 21,84 & 18,95 & 16,50 & 12,62 & 9,89 & 6,59 \\
\hline 56,95 & 1924,70 & 105,00 & 17,61 & 14,49 & 13,36 & 12,02 & 10,81 & 9,69 & 7,78 & 6,29 & 4,27 \\
\hline 88,65 & 841,00 & 81,90 & 23,13 & 16,32 & 14,57 & 13,07 & 11,91 & 10,89 & 9,12 & 7,68 & 5,56 \\
\hline 62,97 & 822,80 & 30,00 & 50,44 & 40,76 & 38,53 & 35,66 & 32,91 & 30,30 & 25,53 & 21,49 & 15,40 \\
\hline 30,44 & 1333,70 & 184,60 & 21,54 & 16,25 & 13,25 & 10,11 & 7,84 & 6,21 & 4,23 & 3,19 & 2,18 \\
\hline 31,05 & 1474,80 & 173,00 & 21,44 & 16,60 & 13,75 & 10,68 & 8,38 & 6,69 & 4,57 & 3,43 & 2,32 \\
\hline 35,73 & 1048,80 & 105,80 & 30,20 & 24,09 & 20,58 & 16,66 & 13,52 & 11,06 & 7,72 & 5,77 & 3,83 \\
\hline 71,78 & 1832,90 & 122,00 & 14,45 & 11,09 & 10,19 & 9,25 & 8,43 & 7,68 & 6,37 & 5,29 & 3,74 \\
\hline 69,77 & 1656,10 & 63,80 & 22,77 & 17,91 & 16,89 & 15,72 & 14,60 & 13,54 & 11,57 & 9,87 & 7,23 \\
\hline 75,81 & 1804,40 & 68,30 & 20,13 & 15,56 & 14,63 & 13,72 & 12,82 & 11,97 & 10,38 & 8,98 & 6,74 \\
\hline 67,17 & 1514,80 & 28,70 & 40,54 & 32,51 & 30,98 & 29,68 & 28,12 & 26,54 & 23,49 & 20,69 & 15,96 \\
\hline 84,48 & 1659,90 & 45,10 & 24,85 & 19,48 & 18,07 & 17,29 & 16,47 & 15,62 & 14,00 & 12,50 & 9,91 \\
\hline 28,54 & 1631,80 & 125,10 & 27,29 & 22,13 & 18,66 & 14,73 & 11,66 & 9,36 & 6,40 & 4,77 & 3,20 \\
\hline 29,67 & 1313,50 & 38,90 & 61,85 & 55,32 & 49,63 & 42,34 & 35,83 & 30,28 & 21,90 & 16,43 & 10,59 \\
\hline 47,45 & 1381,70 & 184,10 & 16,17 & 12,37 & 10,64 & 8,86 & 7,42 & 6,24 & 4,51 & 3,42 & 2,25 \\
\hline 46,09 & 723,60 & 37,70 & 55,21 & 47,24 & 43,02 & 37,92 & 33,30 & 29,17 & 22,43 & 17,51 & 11,49 \\
\hline 36,96 & 698,80 & 187,30 & 24,46 & 16,51 & 13,06 & 9,83 & 7,61 & 6,05 & 4,15 & 3,15 & 2,16 \\
\hline 24,49 & 1724,70 & 144,50 & 27,15 & 21,36 & 17,42 & 13,17 & 10,09 & 7,93 & 5,36 & 4,04 & 2,77 \\
\hline 67,16 & 1752,60 & 46,90 & 27,94 & 22,26 & 21,20 & 20,02 & 18,76 & 17,54 & 15,24 & 13,18 & 9,87 \\
\hline 70,13 & 1552,80 & 125,20 & 15,43 & 11,78 & 10,69 & 9,57 & 8,64 & 7,80 & 6,35 & 5,20 & 3,61 \\
\hline 56,78 & 1619,80 & 43,60 & 33,40 & 27,68 & 26,41 & 24,54 & 22,70 & 20,92 & 17,64 & 14,84 & 10,61 \\
\hline 67,15 & 212,40 & 92,20 & 52,52 & 30,28 & 23,25 & 18,01 & 14,64 & 12,15 & 8,72 & 6,69 & 4,53 \\
\hline 53,08 & 1604,00 & 88,40 & 21,92 & 18,29 & 16,78 & 14,98 & 13,36 & 11,88 & 9,39 & 7,49 & 5,01 \\
\hline 72,93 & 1405,20 & 84,00 & 19,94 & 15,31 & 14,16 & 12,93 & 11,86 & 10,87 & 9,10 & 7,63 & 5,46 \\
\hline 72,58 & 1492,20 & 36,30 & 33,14 & 26,19 & 24,79 & 23,65 & 22,36 & 21,07 & 18,61 & 16,37 & 12,61 \\
\hline 54,03 & 519,40 & 65,70 & 41,12 & 31,35 & 27,28 & 23,20 & 19,85 & 17,02 & 12,70 & 9,78 & 6,44 \\
\hline 67,20 & 1075,20 & 101,60 & 20,81 & 15,84 & 14,20 & 12,56 & 11,21 & 10,00 & 7,98 & 6,43 & 4,39 \\
\hline 58,01 & 1694,30 & 193,70 & 12,82 & 9,83 & 8,64 & 7,46 & 6,48 & 5,64 & 4,30 & 3,35 & 2,22 \\
\hline 83,67 & 1482,30 & 55,70 & 23,12 & 17,64 & 16,42 & 15,50 & 14,59 & 13,71 & 12,07 & 10,60 & 8,16 \\
\hline 84,91 & 1987,20 & 156,50 & 11,17 & 8,11 & 7,35 & 6,67 & 6,12 & 5,62 & 4,74 & 4,01 & 2,92 \\
\hline 67,20 & 1818,30 & 64,90 & 22,26 & 17,69 & 16,74 & 15,59 & 14,48 & 13,41 & 11,45 & 9,75 & 7,12 \\
\hline
\end{tabular}




\begin{tabular}{|c|c|c|c|c|c|c|c|c|c|c|c|}
\hline \multirow[b]{2}{*}{ e1 (cm) } & & & & & & & ões (x1 & & & & \\
\hline & Meq (MPa) & Ms (MPa) & D0 & D25 & D40 & D60 & D80 & D100 & D140 & D180 & D260 \\
\hline 86,64 & 1359,50 & 65,70 & 21,30 & 15,91 & 14,70 & 13,73 & 12,84 & 12,01 & 10,47 & 9,12 & 6,94 \\
\hline 31,19 & 1146,20 & 48,70 & 53,53 & 46,62 & 41,30 & 34,70 & 28,98 & 24,22 & 17,27 & 12,91 & 8,38 \\
\hline 89,18 & 1229,30 & 169,60 & 13,30 & 9,03 & 7,84 & 6,87 & 6,15 & 5,55 & 4,54 & 3,76 & 2,66 \\
\hline 34,24 & 1713,60 & 188,10 & 18,05 & 14,20 & 11,99 & 9,56 & 7,66 & 6,21 & 4,29 & 3,21 & 2,15 \\
\hline 89,03 & 1540,90 & 182,30 & 11,43 & 7,90 & 6,95 & 6,15 & 5,56 & 5,04 & 4,17 & 3,48 & 2,48 \\
\hline 56,25 & 1553,80 & 68,40 & 25,21 & 20,95 & 19,53 & 17,74 & 16,08 & 14,54 & 11,83 & 9,65 & 6,63 \\
\hline 69,29 & 760,20 & 74,30 & 28,48 & 21,44 & 19,19 & 16,98 & 15,17 & 13,57 & 10,86 & 8,79 & 6,02 \\
\hline 58,50 & 1990,60 & 55,30 & 26,11 & 21,48 & 20,49 & 19,07 & 17,66 & 16,30 & 13,80 & 11,65 & 8,37 \\
\hline 62,08 & 856,80 & 118,40 & 22,14 & 16,33 & 14,19 & 12,16 & 10,55 & 9,17 & 6,99 & 5,47 & 3,64 \\
\hline 75,30 & 275,50 & 190,70 & 34,45 & 17,53 & 12,50 & 9,10 & 7,17 & 5,85 & 4,14 & 3,19 & 2,19 \\
\hline 73,81 & 1787,60 & 50,30 & 24,89 & 19,53 & 18,46 & 17,51 & 16,50 & 15,51 & 13,62 & 11,92 & 9,11 \\
\hline 32,77 & 501,50 & 32,10 & 90,13 & 75,62 & 65,84 & 54,23 & 44,56 & 36,78 & 25,85 & 19,27 & 12,65 \\
\hline 25,92 & 447,20 & 97,00 & 51,98 & 35,85 & 27,32 & 19,44 & 14,47 & 11,30 & 7,76 & 5,97 & 4,15 \\
\hline 44,27 & 315,60 & 129,60 & 40,25 & 24,41 & 18,72 & 13,98 & 10,87 & 8,69 & 6,00 & 4,57 & 3,14 \\
\hline 22,95 & 1864,90 & 154,20 & 26,53 & 20,70 & 16,68 & 12,42 & 9,42 & 7,36 & 4,97 & 3,77 & 2,59 \\
\hline 55,95 & 1643,40 & 77,20 & 22,92 & 19,04 & 17,68 & 16,00 & 14,45 & 13,02 & 10,53 & 8,55 & 5,84 \\
\hline 28,76 & 414,20 & 129,20 & 41,89 & 27,15 & 20,39 & 14,45 & 10,79 & 8,46 & 5,82 & 4,48 & 3,12 \\
\hline 51,31 & 1629,70 & 105,50 & 19,93 & 16,55 & 15,00 & 13,23 & 11,66 & 10,25 & 7,94 & 6,24 & 4,13 \\
\hline 81,59 & 203,00 & 153,80 & 45,44 & 22,54 & 15,81 & 11,35 & 8,88 & 7,24 & 5,12 & 3,95 & 2,73 \\
\hline 53,39 & 734,00 & 127,00 & 24,78 & 17,95 & 15,23 & 12,63 & 10,59 & 8,94 & 6,51 & 4,97 & 3,28 \\
\hline 38,01 & 1869,40 & 33,10 & 50,50 & 45,66 & 43,03 & 39,09 & 35,25 & 31,63 & 25,30 & 20,28 & 13,55 \\
\hline 50,18 & 302,30 & 154,30 & 36,89 & 20,94 & 15,68 & 11,63 & 9,07 & 7,29 & 5,05 & 3,85 & 2,65 \\
\hline 79,02 & 531,10 & 105,50 & 27,26 & 18,08 & 15,20 & 12,87 & 11,20 & 9,83 & 7,66 & 6,11 & 4,16 \\
\hline 66,57 & 960,80 & 43,00 & 36,63 & 29,10 & 27,28 & 25,12 & 23,12 & 21,24 & 17,83 & 14,97 & 10,70 \\
\hline 51,62 & 1942,40 & 69,30 & 24,40 & 20,77 & 19,47 & 17,70 & 16,05 & 14,49 & 11,76 & 9,57 & 6,53 \\
\hline 28,71 & 1162,00 & 106,30 & 33,90 & 26,93 & 22,45 & 17,49 & 13,72 & 10,95 & 7,46 & 5,58 & 3,77 \\
\hline 36,53 & 452,10 & 180,00 & 30,30 & 18,65 & 14,12 & 10,26 & 7,80 & 6,17 & 4,24 & 3,25 & 2,25 \\
\hline 52,96 & 1147,50 & 51,20 & 35,10 & 29,57 & 27,44 & 24,76 & 22,29 & 20,00 & 16,05 & 12,95 & 8,76 \\
\hline 49,51 & 1166,50 & 163,80 & 18,16 & 13,73 & 11,80 & 9,84 & 8,27 & 6,97 & 5,07 & 3,86 & 2,54 \\
\hline 41,37 & 1609,40 & 88,60 & 25,87 & 22,21 & 19,98 & 17,30 & 14,92 & 12,84 & 9,59 & 7,34 & 4,77 \\
\hline 78,16 & 1784,60 & 97,50 & 15,98 & 12,10 & 11,22 & 10,35 & 9,57 & 8,85 & 7,54 & 6,43 & 4,71 \\
\hline 46,55 & 1842,40 & 93,20 & 21,93 & 18,78 & 17,14 & 15,15 & 13,35 & 11,72 & 9,05 & 7,09 & 4,66 \\
\hline 83,19 & 203,30 & 156,70 & 45,16 & 22,29 & 15,58 & 11,15 & 8,72 & 7,10 & 5,03 & 3,88 & 2,68 \\
\hline 78,32 & 1861,10 & 64,00 & 20,28 & 15,66 & 14,70 & 13,88 & 13,05 & 12,24 & 10,73 & 9,37 & 7,15 \\
\hline 38,37 & 539,40 & 112,00 & 36,15 & 25,69 & 20,91 & 16,19 & 12,76 & 10,26 & 7,07 & 5,33 & 3,61 \\
\hline 82,02 & 245,90 & 186,30 & 37,51 & 18,59 & 13,04 & 9,36 & 7,33 & 5,97 & 4,23 & 3,26 & 2,26 \\
\hline 76,13 & 1966,70 & 39,00 & 27,50 & 22,04 & 20,65 & 19,89 & 18,99 & 18,05 & 16,20 & 14,48 & 11,49 \\
\hline 74,26 & 1710,00 & 173,20 & 12,02 & 8,86 & 7,92 & 7,02 & 6,30 & 5,67 & 4,59 & 3,75 & 2,60 \\
\hline 26,40 & 1634,60 & 96,40 & 34,52 & 28,55 & 24,21 & 19,17 & 15,20 & 12,20 & 8,32 & 6,19 & 4,15 \\
\hline 88,12 & 1461,50 & 56,70 & 22,25 & 16,87 & 15,60 & 14,73 & 13,90 & 13,10 & 11,59 & 10,23 & 7,96 \\
\hline 40,55 & 1655,30 & 65,50 & 31,55 & 27,79 & 25,39 & 22,35 & 19,55 & 17,06 & 13,00 & 10,07 & 6,56 \\
\hline 39,42 & 1159,20 & 96,30 & 28,78 & 23,62 & 20,67 & 17,28 & 14,43 & 12,09 & 8,68 & 6,53 & 4,27 \\
\hline 66,54 & 702,30 & 159,40 & 20,66 & 13,80 & 11,47 & 9,50 & 8,07 & 6,90 & 5,16 & 4,00 & 2,67 \\
\hline 62,28 & 482,00 & 52,80 & 44,44 & 33,83 & 29,92 & 26,07 & 22,90 & 20,13 & 15,63 & 12,36 & 8,27 \\
\hline 54,88 & 549,20 & 113,70 & 29,85 & 20,83 & 17,41 & 14,28 & 11,89 & 9,99 & 7,24 & 5,52 & 3,66 \\
\hline 52,07 & 1234,20 & 92,70 & 23,84 & 19,49 & 17,53 & 15,35 & 13,45 & 11,77 & 9,04 & 7,07 & 4,67 \\
\hline 77,01 & 1018,00 & 116,40 & 18,66 & 13,45 & 11,90 & 10,50 & 9,40 & 8,44 & 6,81 & 5,56 & 3,86 \\
\hline 78,73 & 637,30 & 138,20 & 21,91 & 14,31 & 11,93 & 10,02 & 8,67 & 7,57 & 5,86 & 4,65 & 3,16 \\
\hline 43,04 & 1696,50 & 187,10 & 15,61 & 12,33 & 10,67 & 8,87 & 7,39 & 6,19 & 4,45 & 3,35 & 2,20 \\
\hline 85,94 & 1982,00 & 23,90 & 31,61 & 28,74 & 25,86 & 24,87 & 24,31 & 23,55 & 21,85 & 20,20 & 17,08 \\
\hline 75,83 & 1156,30 & 63,40 & 25,01 & 19,08 & 17,71 & 16,30 & 15,04 & 13,87 & 11,76 & 9,97 & 7,25 \\
\hline 45,25 & 1705,60 & 73,50 & 26,76 & 23,21 & 21,31 & 18,93 & 16,75 & 14,76 & 11,47 & 9,01 & 5,94 \\
\hline 65,49 & 1414,60 & 47,20 & 30,39 & 24,31 & 23,06 & 21,50 & 19,97 & 18,51 & 15,79 & 13,44 & 9,81 \\
\hline 73,37 & 1758,90 & 121,40 & 14,58 & 11,10 & 10,18 & 9,23 & 8,42 & 7,68 & 6,37 & 5,30 & 3,76 \\
\hline 35,28 & 1717,00 & 96,30 & 27,04 & 23,12 & 20,46 & 17,25 & 14,47 & 12,16 & 8,74 & 6,56 & 4,27 \\
\hline 72,93 & 1636,60 & 171,30 & 12,45 & 9,19 & 8,18 & 7,24 & 6,47 & 5,80 & 4,67 & 3,79 & 2,62 \\
\hline 48,68 & 573,90 & 54,90 & 46,35 & 37,13 & 32,76 & 28,02 & 24,00 & 20,57 & 15,30 & 11,74 & 7,68 \\
\hline 38,11 & 502,20 & 115,70 & 36,66 & 25,53 & 20,56 & 15,77 & 12,35 & 9,89 & 6,80 & 5,13 & 3,50 \\
\hline 73,74 & 1270,90 & 65,90 & 23,88 & 18,39 & 17,12 & 15,77 & 14,55 & 13,42 & 11,36 & 9,62 & 6,98 \\
\hline 89,22 & 328,80 & 126,00 & 33,43 & 19,09 & 14,79 & 11,72 & 9,83 & 8,42 & 6,36 & 5,02 & 3,43 \\
\hline 68,57 & 969,10 & 69,30 & 26,81 & 20,76 & 18,97 & 17,08 & 15,47 & 14,00 & 11,44 & 9,40 & 6,54 \\
\hline 49,80 & 496,60 & 141,50 & 29,37 & 19,31 & 15,56 & 12,25 & 9,87 & 8,08 & 5,68 & 4,30 & 2,89 \\
\hline 64,47 & 1635,50 & 26,90 & 42,56 & 34,36 & 32,83 & 31,53 & 29,91 & 28,25 & 25,05 & 22,09 & 17,07 \\
\hline 49,91 & 1990,20 & 65,80 & 25,61 & 21,99 & 20,63 & 18,77 & 17,01 & 15,35 & 12,44 & 10,10 & 6,88 \\
\hline 85,21 & 746,30 & 56,80 & 30,26 & 22,01 & 20,00 & 18,19 & 16,71 & 15,38 & 13,01 & 11,03 & 8,06 \\
\hline 71,78 & 1444,20 & 35,70 & 34,16 & 27,01 & 25,60 & 24,38 & 23,02 & 21,67 & 19,10 & 16,75 & 12,85 \\
\hline 55,53 & 1741,20 & 48,90 & 30,62 & 25,55 & 24,31 & 22,51 & 20,74 & 19,05 & 15,96 & 13,34 & 9,45 \\
\hline 34,13 & 1998,20 & 101,60 & 25,41 & 21,90 & 19,42 & 16,38 & 13,75 & 11,55 & 8,30 & 6,23 & 4,04 \\
\hline 24,31 & 716,10 & 98,90 & 46,18 & 33,97 & 26,56 & 19,25 & 14,41 & 11,23 & 7,66 & 5,85 & 4,05 \\
\hline 50,30 & 1322,40 & 150,20 & 17,87 & 13,94 & 12,18 & 10,35 & 8,82 & 7,53 & 5,57 & 4,27 & 2,80 \\
\hline 27,61 & 1714,80 & 39,50 & 59,57 & 53,92 & 48,56 & 41,58 & 35,28 & 29,86 & 21,63 & 16,23 & 10,44 \\
\hline 38,52 & 271,70 & 62,30 & 67,60 & 47,11 & 38,02 & 29,22 & 22,93 & 18,38 & 12,65 & 9,55 & 6,49 \\
\hline 59,66 & 698,80 & 90,90 & 28,58 & 21,41 & 18,67 & 16,01 & 13,86 & 12,03 & 9,14 & 7,12 & 4,72 \\
\hline 74,54 & 1035,40 & 135,40 & 17,37 & 12,42 & 10,87 & 9,48 & 8,41 & 7,48 & 5,94 & 4,79 & 3,28 \\
\hline 69,32 & 292,10 & 74,10 & 46,67 & 30,28 & 24,86 & 20,44 & 17,31 & 14,80 & 11,05 & 8,58 & 5,75 \\
\hline 61,12 & 668,80 & 143,10 & 23,03 & 15,76 & 13,16 & 10,89 & 9,18 & 7,80 & 5,76 & 4,43 & 2,94 \\
\hline 24,59 & 482,10 & 171,80 & 35,03 & 21,72 & 15,67 & 10,73 & 7,92 & 6,22 & 4,33 & 3,36 & 2,35 \\
\hline 59,51 & 1916,90 & 98,10 & 17,95 & 14,65 & 13,59 & 12,31 & 11,15 & 10,08 & 8,21 & 6,71 & 4,62 \\
\hline 88,60 & 1109,70 & 41,30 & 29,90 & 22,76 & 21,02 & 19,90 & 18,81 & 17,75 & 15,75 & 13,94 & 10,89 \\
\hline 49,22 & 1100,50 & 22,80 & 64,45 & 55,12 & 52,75 & 48,90 & 45,05 & 41,34 & 34,53 & 28,77 & 20,23 \\
\hline 69,82 & 623,70 & 160,30 & 21,68 & 14,01 & 11,48 & 9,44 & 7,99 & 6,83 & 5,10 & 3,96 & 2,66 \\
\hline 20,93 & 1231,60 & 170,40 & 29,36 & 21,03 & 15,91 & 11,15 & 8,20 & 6,37 & 4,38 & 3,38 & 2,35 \\
\hline
\end{tabular}




\begin{tabular}{|c|c|c|c|c|c|c|c|c|c|c|c|}
\hline \multirow[b]{2}{*}{ e1 (cm) } & & & & & & & ões (x1 & m) & & & \\
\hline & Meq (MPa) & Ms (MPa) & D0 & D25 & D40 & D60 & D80 & D100 & D140 & D180 & D260 \\
\hline 23,68 & 1232,20 & 25,70 & 101,58 & 90,91 & 80,71 & 67,60 & 56,12 & 46,58 & 32,81 & 24,33 & 15,77 \\
\hline 45,99 & 1913,00 & 171,30 & 15,00 & 12,16 & 10,73 & 9,15 & 7,80 & 6,65 & 4,91 & 3,75 & 2,45 \\
\hline 27,20 & 1206,30 & 152,30 & 27,20 & 20,57 & 16,57 & 12,42 & 9,49 & 7,46 & 5,06 & 3,83 & 2,63 \\
\hline 56,97 & 1300,20 & 36,60 & 40,32 & 33,41 & 31,83 & 29,54 & 27,28 & 25,11 & 21,13 & 17,74 & 12,65 \\
\hline 20,04 & 1057,70 & 190,30 & 28,80 & 19,62 & 14,38 & 9,83 & 7,19 & 5,61 & 3,90 & 3,03 & 2,11 \\
\hline 78,25 & 1527,60 & 83,60 & 18,63 & 14,11 & 13,08 & 12,06 & 11,16 & 10,32 & 8,79 & 7,49 & 5,50 \\
\hline 64,21 & 720,00 & 58,00 & 34,80 & 27,16 & 24,58 & 21,88 & 19,58 & 17,50 & 14,00 & 11,30 & 7,70 \\
\hline 73,80 & 718,00 & 50,90 & 35,06 & 26,61 & 24,36 & 22,06 & 20,11 & 18,33 & 15,20 & 12,65 & 8,96 \\
\hline 60,07 & 724,90 & 81,30 & 29,73 & 22,71 & 20,03 & 17,37 & 15,17 & 13,26 & 10,20 & 8,01 & 5,33 \\
\hline 33,72 & 1942,20 & 193,30 & 17,13 & 13,64 & 11,58 & 9,28 & 7,46 & 6,06 & 4,19 & 3,13 & 2,09 \\
\hline 24,40 & 1309,90 & 138,10 & 30,48 & 23,29 & 18,63 & 13,81 & 10,46 & 8,17 & 5,54 & 4,21 & 2,90 \\
\hline 28,00 & 265,20 & 40,90 & 106,05 & 78,12 & 62,21 & 46,18 & 35,13 & 27,59 & 18,77 & 14,26 & 9,82 \\
\hline 62,23 & 1528,60 & 113,20 & 17,51 & 13,86 & 12,60 & 11,24 & 10,06 & 9,00 & 7,19 & 5,80 & 3,95 \\
\hline 36,61 & 1220,10 & 194,60 & 19,22 & 14,31 & 11,85 & 9,29 & 7,38 & 5,95 & 4,10 & 3,08 & 2,07 \\
\hline 25,61 & 1379,90 & 178,70 & 24,27 & 18,16 & 14,43 & 10,64 & 8,04 & 6,29 & 4,27 & 3,25 & 2,24 \\
\hline 42,52 & 1562,00 & 43,50 & 40,82 & 36,23 & 33,81 & 30,47 & 27,30 & 24,36 & 19,30 & 15,37 & 10,23 \\
\hline 20,18 & 310,30 & 161,90 & 44,13 & 24,31 & 16,49 & 10,98 & 8,15 & 6,47 & 4,56 & 3,56 & 2,50 \\
\hline 84,19 & 537,40 & 29,40 & 50,98 & 37,98 & 35,07 & 32,49 & 30,19 & 28,08 & 24,21 & 20,86 & 15,59 \\
\hline 40,15 & 834,10 & 128,80 & 27,16 & 20,35 & 17,07 & 13,67 & 11,03 & 9,01 & 6,29 & 4,72 & 3,15 \\
\hline 64,07 & 664,40 & 179,90 & 20,49 & 13,26 & 10,81 & 8,79 & 7,34 & 6,20 & 4,55 & 3,50 & 2,34 \\
\hline 67,65 & 1031,50 & 72,70 & 25,58 & 19,89 & 18,19 & 16,38 & 14,82 & 13,40 & 10,93 & 8,97 & 6,23 \\
\hline 46,12 & 1863,40 & 105,10 & 20,37 & 17,32 & 15,71 & 13,78 & 12,06 & 10,52 & 8,04 & 6,25 & 4,10 \\
\hline 60,53 & 475,90 & 55,10 & 44,32 & 33,67 & 29,63 & 25,66 & 22,39 & 19,57 & 15,04 & 11,81 & 7,86 \\
\hline 82,33 & 1814,70 & 133,50 & 12,89 & 9,48 & 8,64 & 7,86 & 7,21 & 6,63 & 5,59 & 4,72 & 3,43 \\
\hline 64,25 & 1597,00 & 140,30 & 14,93 & 11,57 & 10,41 & 9,22 & 8,21 & 7,32 & 5,82 & 4,67 & 3,17 \\
\hline 42,98 & 847,90 & 159,80 & 22,92 & 16,56 & 13,75 & 10,96 & 8,85 & 7,23 & 5,06 & 3,81 & 2,55 \\
\hline 41,13 & 363,90 & 31,00 & 87,66 & 71,75 & 62,93 & 52,91 & 44,44 & 37,41 & 27,05 & 20,42 & 13,33 \\
\hline 55,87 & 1494,20 & 74,80 & 24,24 & 20,10 & 18,60 & 16,77 & 15,11 & 13,58 & 10,93 & 8,84 & 6,01 \\
\hline 80,61 & 1177,30 & 55,70 & 25,97 & 19,67 & 18,30 & 17,04 & 15,87 & 14,78 & 12,77 & 11,02 & 8,24 \\
\hline 49,21 & 1849,70 & 195,10 & 13,50 & 10,66 & 9,35 & 7,96 & 6,79 & 5,80 & 4,30 & 3,29 & 2,15 \\
\hline 86,06 & 1187,60 & 80,40 & 20,19 & 14,77 & 13,50 & 12,37 & 11,42 & 10,56 & 9,02 & 7,71 & 5,69 \\
\hline 32,68 & 1640,50 & 156,90 & 21,27 & 17,00 & 14,41 & 11,50 & 9,22 & 7,47 & 5,15 & 3,85 & 2,57 \\
\hline 29,43 & 783,90 & 73,10 & 48,72 & 38,70 & 32,34 & 25,29 & 19,91 & 15,93 & 10,87 & 8,13 & 5,49 \\
\hline 55,01 & 1306,70 & 65,30 & 28,00 & 23,30 & 21,54 & 19,40 & 17,45 & 15,65 & 12,55 & 10,13 & 6,87 \\
\hline 35,94 & 342,40 & 157,40 & 37,16 & 22,04 & 16,37 & 11,72 & 8,86 & 7,00 & 4,82 & 3,70 & 2,58 \\
\hline 72,42 & 1799,50 & 64,60 & 21,45 & 16,76 & 15,81 & 14,81 & 13,83 & 12,89 & 11,13 & 9,59 & 7,14 \\
\hline 39,94 & 1241,10 & 41,00 & 47,90 & 42,64 & 39,24 & 34,80 & 30,67 & 26,93 & 20,74 & 16,18 & 10,57 \\
\hline 35,98 & 1012,80 & 42,70 & 54,28 & 47,70 & 42,95 & 37,01 & 31,69 & 27,09 & 19,97 & 15,16 & 9,80 \\
\hline 87,08 & 1418,50 & 43,50 & 26,48 & 20,53 & 18,99 & 18,11 & 17,21 & 16,30 & 14,58 & 12,99 & 10,27 \\
\hline 66,65 & 585,20 & 145,60 & 23,80 & 15,60 & 12,83 & 10,55 & 8,90 & 7,59 & 5,63 & 4,36 & 2,91 \\
\hline 29,79 & 237,10 & 50,80 & 91,98 & 64,45 & 50,43 & 36,99 & 28,02 & 22,01 & 15,03 & 11,47 & 7,92 \\
\hline 56,15 & 915,10 & 171,60 & 18,62 & 13,22 & 11,15 & 9,25 & 7,77 & 6,58 & 4,82 & 3,68 & 2,44 \\
\hline 42,83 & 364,80 & 115,80 & 40,14 & 25,99 & 20,50 & 15,60 & 12,23 & 9,82 & 6,79 & 5,14 & 3,51 \\
\hline 48,44 & 1168,00 & 89,10 & 26,13 & 21,51 & 19,24 & 16,69 & 14,46 & 12,53 & 9,46 & 7,32 & 4,79 \\
\hline 66,30 & 1881,10 & 155,10 & 12,94 & 10,00 & 9,04 & 8,06 & 7,23 & 6,48 & 5,21 & 4,22 & 2,89 \\
\hline 51,95 & 777,90 & 119,00 & 25,32 & 18,79 & 16,09 & 13,42 & 11,30 & 9,55 & 6,98 & 5,32 & 3,51 \\
\hline 81,23 & 857,60 & 117,70 & 19,79 & 13,78 & 12,00 & 10,47 & 9,33 & 8,35 & 6,72 & 5,48 & 3,80 \\
\hline 77,47 & 664,70 & 35,30 & 43,81 & 33,30 & 30,92 & 28,54 & 26,41 & 24,42 & 20,82 & 17,74 & 13,01 \\
\hline 68,82 & 723,50 & 62,60 & 32,12 & 24,50 & 22,11 & 19,70 & 17,69 & 15,89 & 12,82 & 10,43 & 7,18 \\
\hline 58,66 & 1080,40 & 186,00 & 16,13 & 11,57 & 9,85 & 8,26 & 7,02 & 6,00 & 4,46 & 3,43 & 2,27 \\
\hline 35,23 & 469,00 & 155,80 & 32,81 & 21,12 & 16,24 & 11,90 & 9,07 & 7,16 & 4,92 & 3,75 & 2,60 \\
\hline 25,51 & 1360,60 & 68,70 & 47,38 & 39,63 & 33,76 & 26,86 & 21,37 & 17,18 & 11,72 & 8,71 & 5,83 \\
\hline 26,99 & 1883,80 & 130,10 & 26,46 & 21,57 & 18,16 & 14,27 & 11,25 & 9,00 & 6,13 & 4,57 & 3,08 \\
\hline 56,65 & 843,80 & 143,00 & 21,17 & 15,29 & 13,03 & 10,90 & 9,23 & 7,85 & 5,80 & 4,45 & 2,94 \\
\hline 62,82 & 701,60 & 45,10 & 41,34 & 32,94 & 30,23 & 27,19 & 24,53 & 22,10 & 17,89 & 14,56 & 10,00 \\
\hline 54,97 & 1274,30 & 99,90 & 21,78 & 17,58 & 15,83 & 13,91 & 12,24 & 10,76 & 8,34 & 6,57 & 4,36 \\
\hline 80,47 & 838,30 & 111,50 & 20,63 & 14,45 & 12,62 & 11,04 & 9,84 & 8,81 & 7,10 & 5,79 & 4,02 \\
\hline 20,25 & 1045,00 & 123,80 & 39,60 & 28,80 & 21,92 & 15,41 & 11,33 & 8,79 & 6,04 & 4,66 & 3,24 \\
\hline 83,51 & 1403,20 & 23,10 & 39,41 & 33,05 & 30,24 & 29,24 & 28,28 & 27,14 & 24,82 & 22,61 & 18,59 \\
\hline 76,28 & 1861,50 & 115,60 & 14,38 & 10,89 & 10,04 & 9,18 & 8,44 & 7,75 & 6,52 & 5,50 & 3,97 \\
\hline 49,11 & 1653,20 & 152,40 & 16,35 & 13,15 & 11,64 & 9,99 & 8,59 & 7,38 & 5,52 & 4,24 & 2,78 \\
\hline 69,44 & 703,70 & 148,70 & 20,95 & 14,09 & 11,79 & 9,86 & 8,45 & 7,29 & 5,52 & 4,31 & 2,89 \\
\hline 73,55 & 1336,50 & 178,70 & 13,38 & 9,58 & 8,36 & 7,28 & 6,44 & 5,71 & 4,52 & 3,63 & 2,48 \\
\hline 50,12 & 680,70 & 172,80 & 22,64 & 15,26 & 12,46 & 9,91 & 8,05 & 6,63 & 4,69 & 3,55 & 2,37 \\
\hline 64,22 & 1384,30 & 69,70 & 24,06 & 19,25 & 17,93 & 16,36 & 14,94 & 13,62 & 11,27 & 9,34 & 6,56 \\
\hline 44,57 & 1992,00 & 65,00 & 27,81 & 24,43 & 22,72 & 20,43 & 18,28 & 16,29 & 12,88 & 10,26 & 6,83 \\
\hline 25,67 & 1403,30 & 28,70 & 84,09 & 76,17 & 68,39 & 58,25 & 49,14 & 41,38 & 29,73 & 22,20 & 14,29 \\
\hline 42,15 & 812,70 & 173,20 & 22,53 & 15,91 & 13,04 & 10,26 & 8,19 & 6,65 & 4,62 & 3,48 & 2,34 \\
\hline 84,14 & 1951,90 & 162,60 & 11,07 & 8,02 & 7,25 & 6,56 & 6,00 & 5,49 & 4,61 & 3,88 & 2,81 \\
\hline 70,54 & 595,50 & 72,20 & 32,13 & 23,52 & 20,70 & 18,09 & 16,01 & 14,21 & 11,23 & 9,01 & 6,13 \\
\hline 21,10 & 1222,80 & 113,60 & 39,41 & 29,85 & 23,41 & 16,92 & 12,59 & 9,77 & 6,65 & 5,09 & 3,52 \\
\hline 70,20 & 714,10 & 114,70 & 23,34 & 16,43 & 14,12 & 12,08 & 10,53 & 9,22 & 7,13 & 5,64 & 3,80 \\
\hline 81,79 & 1074,60 & 55,10 & 26,88 & 20,21 & 18,74 & 17,39 & 16,17 & 15,04 & 12,96 & 11,16 & 8,32 \\
\hline 43,14 & 1174,40 & 114,20 & 24,26 & 19,50 & 17,03 & 14,30 & 12,01 & 10,11 & 7,32 & 5,54 & 3,62 \\
\hline 30,75 & 673,90 & 145,30 & 31,71 & 22,24 & 17,48 & 12,91 & 9,82 & 7,72 & 5,28 & 4,02 & 2,77 \\
\hline 44,58 & 1324,00 & 98,90 & 24,68 & 20,48 & 18,23 & 15,65 & 13,42 & 11,50 & 8,54 & 6,53 & 4,26 \\
\hline 22,18 & 1297,30 & 27,70 & 100,67 & 89,04 & 78,23 & 64,53 & 52,82 & 43,32 & 30,06 & 22,21 & 14,53 \\
\hline 32,29 & 596,80 & 97,10 & 41,79 & 30,87 & 25,07 & 19,13 & 14,84 & 11,79 & 8,05 & 6,07 & 4,14 \\
\hline 58,32 & 1079,10 & 194,50 & 15,83 & 11,27 & 9,55 & 7,98 & 6,76 & 5,76 & 4,26 & 3,27 & 2,17 \\
\hline 82,92 & 888,70 & 88,10 & 22,31 & 16,00 & 14,30 & 12,78 & 11,58 & 10,53 & 8,71 & 7,25 & 5,16 \\
\hline 69,06 & 862,10 & 31,70 & 45,30 & 35,75 & 33,77 & 31,49 & 29,26 & 27,15 & 23,23 & 19,84 & 14,55 \\
\hline 61,20 & 759,90 & 47,40 & 39,44 & 31,69 & 29,09 & 26,16 & 23,57 & 21,19 & 17,10 & 13,89 & 9,50 \\
\hline
\end{tabular}




\begin{tabular}{|c|c|c|c|c|c|c|c|c|c|c|c|}
\hline \multirow[b]{2}{*}{ e1 (cm) } & & & & & & & ões (x1 & m) & & & \\
\hline & Meq (MPa) & Ms (MPa) & D0 & D25 & D40 & D60 & D80 & D100 & D140 & D180 & D260 \\
\hline 79,77 & 1953,80 & 52,50 & 22,19 & $\begin{array}{l}17,38 \\
\end{array}$ & 16,26 & 15,53 & 14,74 & 13,94 & 12,40 & 11,00 & 8,60 \\
\hline 83,52 & 413,40 & 59,00 & 39,89 & 27,43 & 23,79 & 20,73 & 18,47 & 16,54 & 13,35 & 10,91 & 7,60 \\
\hline 73,71 & 214,60 & 185,70 & 441,84 & 20,19 & 13,86 & 9,71 & 7,47 & 6,00 & 4,19 & 3,22 & 2,25 \\
\hline 55,60 & 1888,80 & 76,50 & 22,05 & 18,41 & 17,22 & 15,68 & 14,25 & 12,91 & 10,54 & 8,63 & 5,94 \\
\hline 58,45 & 1023,80 & 160,50 & 17,88 & 13,04 & 11,20 & 9,46 & 8,08 & 6,93 & 5,17 & 4,00 & 2,64 \\
\hline 87,07 & 1823,20 & 152,60 & 11,64 & 8,36 & 7,55 & 6,83 & 6,26 & 5,75 & 4,85 & 4,11 & 2,99 \\
\hline 78,26 & 968,70 & 187,80 & 15,15 & 10,11 & 8,52 & 7,23 & 6,30 & 5,53 & 4,30 & 3,43 & 2,33 \\
\hline 86,93 & 603,60 & 39,90 & 40,03 & 29,27 & 26,75 & 24,56 & 22,71 & 21,03 & 18,01 & 15,44 & 11,45 \\
\hline 30,52 & 1559,10 & 106,50 & 29,32 & 24,27 & 20,84 & 16,83 & 13,60 & 11,07 & 7,66 & 5,70 & 3,78 \\
\hline 58,80 & 1476,60 & 162,00 & 14,94 & 11,49 & 10,14 & 8,79 & 7,67 & 6,69 & 5,13 & 4,02 & 2,67 \\
\hline 75,03 & 1307,70 & 108,70 & 17,44 & 13,04 & 11,81 & 10,61 & 9,62 & 8,73 & 7,18 & 5,94 & 4,18 \\
\hline 64,34 & 754,90 & 187,00 & 18,72 & 12,34 & 10,16 & 8,33 & 7,01 & 5,95 & 4,39 & 3,38 & 2,26 \\
\hline 20,87 & 1768,80 & 24,30 & 105,08 & 95,18 & 84,86 & 71,37 & 59,40 & 49,38 & 34,81 & 25,77 & 16,65 \\
\hline 71,12 & 1774,70 & 123,40 & 14,62 & 11,22 & 10,28 & 9,30 & 8,46 & 7,69 & 6,34 & 5,25 & 3,69 \\
\hline 25,97 & 1653,80 & 56,60 & 49,98 & 43,49 & 38,06 & 31,33 & 25,64 & 21,05 & 14,66 & 10,86 & 7,12 \\
\hline 87,80 & 223,60 & 43,70 & 63,02 & 40,90 & 34,36 & 29,22 & 25,67 & 22,76 & 18,09 & 14,66 & 10,15 \\
\hline 78,16 & 475,50 & 79,30 & 33,04 & 22,59 & 19,33 & 16,60 & 14,58 & 12,89 & 10,15 & 8,15 & 5,57 \\
\hline 71,49 & 1766,40 & 191,60 & 11,42 & 8,44 & 7,49 & 6,60 & 5,89 & 5,26 & 4,20 & 3,40 & 2,33 \\
\hline 29,88 & 1733,20 & 169,00 & 21,17 & 16,75 & 13,98 & 10,93 & 8,61 & 6,89 & 4,70 & 3,52 & 2,38 \\
\hline 34,22 & 1480,00 & 85,70 & 31,48 & 26,79 & 23,58 & 19,72 & 16,43 & 13,72 & 9,78 & 7,32 & 4,77 \\
\hline 42,81 & 849,70 & 71,40 & 36,79 & 30,15 & 26,56 & 22,49 & 19,02 & 16,12 & 11,76 & 8,92 & 5,82 \\
\hline 23,30 & 783,60 & 75,60 & 55,96 & 42,94 & 34,28 & 25,31 & 19,09 & 14,90 & 10,09 & 7,67 & 5,29 \\
\hline 34,94 & 1642,10 & 85,00 & 30,01 & 25,85 & 22,96 & 19,42 & 16,35 & 13,77 & 9,94 & 7,47 & 4,84 \\
\hline 35,00 & 1291,40 & 26,60 & 70,06 & 64,00 & 59,41 & 53,07 & 47,02 & 41,46 & 32,13 & 25,14 & 16,41 \\
\hline 27,93 & 352,70 & 146,60 & 41,34 & 25,00 & 18,17 & 12,59 & 9,35 & 7,35 & 5,10 & 3,94 & 2,76 \\
\hline 79,54 & 1237,20 & 190,00 & 13,11 & 9,03 & 7,79 & 6,73 & 5,95 & 5,29 & 4,21 & 3,40 & 2,34 \\
\hline 67,98 & 1488,60 & 192,30 & 12,65 & 9,26 & 8,10 & 7,03 & 6,18 & 5,45 & 4,25 & 3,38 & 2,28 \\
\hline 56,31 & 1276,90 & 141,70 & 17,58 & 13,59 & 11,96 & 10,31 & 8,94 & 7,76 & 5,89 & 4,58 & 3,03 \\
\hline 24,14 & 812,30 & 79,00 & 52,41 & 40,40 & 32,47 & 24,16 & 18,33 & 14,34 & 9,71 & 7,36 & 5,06 \\
\hline 55,14 & 478,50 & 146,90 & 28,35 & 18,16 & 14,57 & 11,53 & 9,38 & 7,74 & 5,51 & 4,18 & 2,81 \\
\hline 23,16 & 1999,00 & 177,30 & 23,39 & 18,12 & 14,55 & 10,80 & 8,17 & 6,38 & 4,32 & 3,28 & 2,26 \\
\hline 23,55 & 465,10 & 46,00 & 91,98 & 70,47 & 56,27 & 41,57 & 31,38 & 24,50 & 16,60 & 12,61 & 8,70 \\
\hline 28,61 & 1041,50 & 51,20 & 57,48 & 488,93 & 42,50 & 34,74 & 28,30 & 23,17 & 16,11 & 11,96 & 7,88 \\
\hline 23,65 & 1227,70 & 26,30 & 100,13 & 89,41 & 79,25 & 66,22 & 54,86 & 45,46 & 31,95 & 23,68 & 15,37 \\
\hline 61,01 & 587,40 & 70,40 & 35,11 & 26,51 & 23,28 & 20,12 & 17,55 & 15,32 & 11,77 & 9,24 & 6,15 \\
\hline 62,66 & 1758,20 & 92,20 & 18,72 & 15,06 & 13,98 & 12,71 & 11,56 & 10,49 & 8,62 & 7,09 & 4,94 \\
\hline 42,55 & 1373,90 & 180,20 & 17,53 & 13,49 & 11,52 & 9,44 & 7,77 & 6,44 & 4,57 & 3,44 & 2,27 \\
\hline 88,01 & 720,10 & 177,80 & 17,82 & 11,11 & 9,10 & 7,57 & 6,55 & 5,75 & 4,49 & 3,60 & 2,47 \\
\hline 34,41 & 1399,10 & 113,80 & 26,67 & 21,83 & 18,84 & 15,39 & 12,57 & 10,33 & 7,24 & 5,40 & 3,56 \\
\hline 48,44 & 1654,20 & 24,30 & 55,38 & 46,89 & 45,35 & 42,58 & 39,63 & 36,74 & 31,31 & 26,54 & 19,16 \\
\hline 88,05 & 1553,50 & 62,10 & 20,58 & 15,57 & 14,39 & 13,58 & 12,80 & 12,05 & 10,64 & 9,38 & 7,27 \\
\hline 49,84 & 290,80 & 133,60 & 40,18 & 23,47 & 17,84 & 13,37 & 10,48 & 8,44 & 5,86 & 4,46 & 3,06 \\
\hline 66,54 & 1724,00 & 177,20 & 12,45 & 9,42 & 8,39 & 7,38 & 6,55 & 5,82 & 4,60 & 3,69 & 2,50 \\
\hline 24,29 & 1842,30 & 42,70 & 61,81 & 55,06 & 48,78 & 40,75 & 33,76 & 27,98 & 19,68 & 14,59 & 9,47 \\
\hline 81,42 & 1242,50 & 115,20 & 16,66 & 12,08 & 10,85 & 9,73 & 8,83 & 8,04 & 6,66 & 5,55 & 3,95 \\
\hline 58,22 & 804,80 & 71,30 & 31,08 & 24,54 & 21,98 & 19,29 & 16,99 & 14,96 & 11,63 & 9,19 & 6,13 \\
\hline 51,02 & 1048,40 & 196,80 & 17,01 & 12,18 & 10,24 & 8,39 & 6,96 & 5,81 & 4,18 & 3,17 & 2,10 \\
\hline 54,26 & 1663,80 & 71,00 & 24,55 & 20,60 & 19,19 & 17,39 & 15,73 & 14,18 & 11,48 & 9,32 & 6,36 \\
\hline 59,25 & 997,60 & 95,90 & 23,71 & 18,50 & 16,49 & 14,42 & 12,68 & 11,15 & 8,65 & 6,83 & 4,55 \\
\hline 87,90 & 558,80 & 130,60 & 23,47 & 14,78 & 12,18 & 10,19 & 8,85 & 7,78 & 6,10 & 4,90 & 3,37 \\
\hline 36,32 & 360,70 & 21,70 & 120,18 & 102,13 & 90,30 & 76,12 & 63,92 & 53,74 & 38,70 & 29,09 & 18,92 \\
\hline 71,02 & 1953,70 & 35,40 & 30,99 & 24,89 & 23,52 & 22,66 & 21,58 & 20,47 & 18,29 & 16,27 & 12,78 \\
\hline 48,37 & 1017,90 & 47,70 & 40,62 & 34,76 & 31,95 & 28,48 & 25,31 & 22,42 & 17,57 & 13,91 & 9,23 \\
\hline 60,26 & 1677,20 & 57,80 & 26,35 & 21,55 & 20,40 & 18,85 & 17,37 & 15,96 & 13,39 & 11,22 & 7,98 \\
\hline 24,72 & 1200,70 & 90,30 & 41,77 & 33,33 & 27,45 & 20,98 & 16,20 & 12,78 & 8,64 & 6,49 & 4,43 \\
\hline 74,56 & 1062,20 & 130,70 & 17,45 & 12,58 & 11,07 & 9,69 & 8,62 & 7,69 & 6,14 & 4,97 & 3,41 \\
\hline 66,61 & 1193,80 & 69,10 & 25,10 & 19,79 & 18,31 & 16,64 & 15,16 & 13,79 & 11,38 & 9,42 & 6,60 \\
\hline 44,89 & 821,00 & 56,50 & 41,64 & 34,85 & 31,19 & 26,94 & 23,23 & 20,00 & 14,97 & 11,49 & 7,49 \\
\hline 35,65 & 520,50 & 190,90 & 27,80 & 17,47 & 13,31 & 9,70 & 7,38 & 5,83 & 4,00 & 3,06 & 2,12 \\
\hline 39,13 & 451,20 & 192,70 & 28,63 & $\begin{array}{l}17,28 \\
\end{array}$ & 13,06 & 9,54 & 7,29 & 5,78 & 3,98 & 3,04 & 2,11 \\
\hline 82,79 & 1280,20 & 66,90 & 22,16 & 16,61 & 15,37 & 14,26 & 13,26 & 12,34 & 10,64 & 9,17 & 6,85 \\
\hline 54,76 & 1850,90 & 132,00 & 15,90 & 12,96 & 11,73 & 10,36 & 9,16 & 8,08 & 6,31 & 4,99 & 3,32 \\
\hline 64,55 & 1738,70 & 196,20 & 11,92 & 8,97 & 7,93 & 6,92 & 6,09 & 5,37 & 4,19 & 3,33 & 2,24 \\
\hline 29,06 & 758,60 & 45,20 & 68,54 & 57,28 & 49,27 & 39,82 & 32,14 & 26,14 & 18,05 & 13,42 & 8,90 \\
\hline 42,33 & 746,00 & 85,80 & 35,00 & 27,48 & 23,69 & 19,58 & 16,23 & 13,53 & 9,66 & 7,27 & 4,78 \\
\hline 61,55 & 1630,00 & 146,60 & 14,76 & 11,52 & 10,33 & 9,10 & 8,06 & 7,14 & 5,62 & 4,47 & 3,01 \\
\hline 34,63 & 1932,90 & 130,00 & 21,69 & 18,17 & 15,87 & 13,16 & 10,89 & 9,04 & 6,40 & 4,79 & 3,13 \\
\hline 79,23 & 1896,80 & 135,90 & 12,74 & 9,48 & 8,67 & 7,88 & 7,22 & 6,62 & 5,55 & 4,67 & 3,37 \\
\hline 50,28 & 377,40 & 79,00 & 44,98 & 31,57 & 26,26 & 21,27 & 17,48 & 14,51 & 10,36 & 7,84 & 5,22 \\
\hline 80,80 & 676,40 & 181,40 & 18,81 & 11,75 & 9,56 & 7,87 & 6,73 & 5,83 & 4,46 & 3,52 & 2,39 \\
\hline 25,20 & 1638,20 & 101,50 & 34,52 & 28,22 & 23,66 & 18,46 & 14,47 & 11,51 & 7,81 & 5,83 & 3,94 \\
\hline 57,34 & 1560,00 & 119,20 & 17,63 & 14,16 & 12,80 & 11,31 & 10,02 & 8,87 & 6,95 & 5,52 & 3,69 \\
\hline 89,38 & 1078,20 & 88,40 & 19,67 & 14,06 & 12,68 & 11,51 & 10,57 & 9,73 & 8,26 & 7,03 & 5,16 \\
\hline 82,14 & 1291,80 & 155,60 & 13,95 & 9,83 & 8,66 & 7,63 & 6,85 & 6,17 & 5,02 & 4,13 & 2,90 \\
\hline 87,88 & 446,80 & 117,10 & 28,10 & 17,34 & 14,10 & 11,66 & 10,05 & 8,78 & 6,83 & 5,45 & 3,74 \\
\hline 68,53 & 772,80 & 140,20 & 20,56 & 14,25 & 12,10 & 10,24 & 8,84 & 7,68 & 5,86 & 4,60 & 3,08 \\
\hline 33,70 & 417,90 & 24,90 & 110,80 & 93,89 & 82,38 & 68,57 & 56,88 & 47,31 & 33,57 & 25,08 & 16,38 \\
\hline 41,25 & 1582,40 & 37,40 & 46,03 & 41,11 & 38,55 & 34,89 & 31,37 & 28,08 & 22,38 & 17,90 & 11,95 \\
\hline 40,67 & 605,00 & 92,50 & 37,39 & 28,06 & 23,59 & 18,94 & 15,34 & 12,55 & 8,79 & 6,60 & 4,40 \\
\hline 24,62 & 445,10 & 168,50 & 36,37 & 22,24 & 15,97 & 10,91 & 8,06 & 6,33 & 4,41 & 3,42 & 2,40 \\
\hline 28,62 & 603,50 & 169,20 & 30,89 & 20,47 & 15,52 & 11,07 & 8,28 & 6,48 & 4,46 & 3,43 & 2,38 \\
\hline 40,44 & 399,40 & 34,00 & 80,79 & 66,11 & 57,90 & 48,53 & 40,65 & 34,14 & 24,60 & 18,54 & 12,11 \\
\hline
\end{tabular}




\begin{tabular}{|c|c|c|c|c|c|c|c|c|c|c|c|}
\hline \multirow[b]{2}{*}{ e1 (cm) } & & & & & & & ões (x1 & & & & \\
\hline & Meq (MPa) & Ms (MPa) & D0 & D25 & D40 & D60 & D80 & D100 & D140 & D180 & D260 \\
\hline 68,34 & 1545,70 & 164,10 & 13,48 & 10,09 & 8,97 & 7,89 & 7,01 & 6,24 & 4,95 & 3,98 & 2,71 \\
\hline 70,70 & 1219,30 & 57,70 & 26,95 & 21,04 & 19,68 & 18,16 & 16,76 & 15,44 & 13,06 & 11,04 & 7,98 \\
\hline 22,15 & 1286,60 & 122,80 & 35,55 & 27,08 & 21,41 & 15,63 & 11,70 & 9,10 & 6,18 & 4,71 & 3,26 \\
\hline 33,17 & 1377,40 & 84,40 & 33,41 & 28,19 & 24,65 & 20,41 & 16,85 & 13,96 & 9,86 & 7,36 & 4,82 \\
\hline 72,80 & 1026,90 & 107,30 & 19,87 & 14,68 & 13,08 & 11,56 & 10,35 & 9,27 & 7,46 & 6,06 & 4,18 \\
\hline 22,27 & 1961,30 & 51,80 & 57,36 & 49,88 & 43,31 & 35,19 & 28,42 & 23,07 & 15,84 & 11,70 & 7,73 \\
\hline 72,63 & 1967,30 & 187,30 & 10,92 & 8,14 & 7,30 & 6,49 & 5,84 & 5,25 & 4,25 & 3,47 & 2,40 \\
\hline 54,80 & 1444,10 & 161,60 & 15,70 & 12,17 & 10,69 & 9,19 & 7,93 & 6,85 & 5,17 & 4,01 & 2,64 \\
\hline 39,10 & 212,00 & 120,20 & 52,79 & 29,45 & 21,44 & 15,26 & 11,56 & 9,15 & 6,31 & 4,85 & 3,39 \\
\hline 78,39 & 1986,60 & 85,10 & 16,60 & 12,69 & 11,87 & 11,08 & 10,34 & 9,64 & 8,34 & 7,21 & 5,40 \\
\hline 79,89 & 1306,00 & 112,60 & 16,63 & 12,19 & 11,01 & 9,90 & 9,01 & 8,21 & 6,81 & 5,68 & 4,04 \\
\hline 85,08 & 504,20 & 176,30 & 22,66 & 13,29 & 10,44 & 8,37 & 7,05 & 6,04 & 4,57 & 3,59 & 2,44 \\
\hline 38,47 & 1153,80 & 135,30 & 23,80 & 18,63 & 15,88 & 12,89 & 10,50 & 8,63 & 6,05 & 4,53 & 3,00 \\
\hline 72,90 & 569,70 & 26,00 & 58,03 & 45,01 & 42,14 & 39,03 & 36,16 & 33,45 & 28,50 & 24,26 & 17,73 \\
\hline 51,25 & 872,40 & 158,30 & 20,76 & 14,96 & 12,61 & 10,37 & 8,62 & 7,22 & 5,21 & 3,95 & 2,62 \\
\hline 87,51 & 1366,00 & 152,10 & 13,37 & 9,35 & 8,27 & 7,35 & 6,65 & 6,04 & 5,00 & 4,17 & 2,98 \\
\hline 85,34 & 1381,20 & 58,80 & 22,76 & 17,18 & 15,94 & 14,97 & 14,05 & 13,18 & 11,55 & 10,10 & 7,74 \\
\hline 21,04 & 819,90 & 141,00 & 37,43 & 25,95 & 19,31 & 13,36 & 9,80 & 7,63 & 5,28 & 4,09 & 2,85 \\
\hline 60,57 & 1514,10 & 130,60 & 16,41 & 12,90 & 11,59 & 10,23 & 9,06 & 8,03 & 6,31 & 5,02 & 3,37 \\
\hline 46,52 & 797,10 & 78,40 & 33,80 & 27,06 & 23,76 & 20,15 & 17,12 & 14,56 & 10,71 & 8,16 & 5,33 \\
\hline 35,91 & 1276,50 & 173,00 & 20,56 & 15,71 & 13,15 & 10,41 & 8,31 & 6,72 & 4,65 & 3,48 & 2,33 \\
\hline 40,52 & 1619,30 & 45,80 & 40,33 & 36,03 & 33,45 & 29,96 & 26,66 & 23,62 & 18,48 & 14,58 & 9,61 \\
\hline 52,44 & 1454,30 & 170,20 & 15,59 & 12,07 & 10,55 & 8,98 & 7,69 & 6,59 & 4,91 & 3,78 & 2,48 \\
\hline 63,78 & 1253,70 & 37,20 & 37,62 & 30,30 & 28,85 & 26,98 & 25,10 & 23,30 & 19,94 & 17,01 & 12,44 \\
\hline 57,72 & 1465,70 & 30,50 & 43,66 & 35,84 & 34,45 & 32,44 & 30,29 & 28,20 & 24,25 & $\begin{array}{l}1+, 01 \\
20,76\end{array}$ & 15,25 \\
\hline 63,13 & 922,80 & 116,10 & 21,41 & 15,96 & 13,98 & 12,08 & 10,55 & 9,23 & 7,11 & 5,60 & 3,74 \\
\hline 73,24 & 693,70 & 196,20 & 18,48 & 11,61 & 9,41 & 7,68 & 6,49 & 5,55 & 4,16 & 3,24 & 2,18 \\
\hline 82,47 & 1392,10 & 63,60 & 22,13 & 16,71 & 15,54 & 14,51 & 13,56 & 12,66 & 11,00 & 9,54 & 7,20 \\
\hline 61,83 & 504,80 & 75,70 & $\frac{2 L, \pm v}{36,11}$ & $\frac{10,1 \pm}{26,31}$ & $\frac{10,04}{22,70}$ & $\begin{array}{l}+, 19,34 \\
19,34\end{array}$ & $\begin{array}{l}10, v 0 \\
16,68\end{array}$ & $\frac{1 L, v 0}{14,44}$ & $\begin{array}{l}1+, 00 \\
10,94\end{array}$ & 8,52 & 5,66 \\
\hline 81,08 & 460,50 & 163,70 & 24,93 & 14,68 & 11,53 & 9,21 & 7,72 & 6,59 & 4,94 & 3,86 & 2,62 \\
\hline 38,31 & 1018,90 & 183,90 & 20,82 & 15,18 & 12,51 & 9,80 & 7,78 & 6,28 & 4,34 & 3,26 & 2,20 \\
\hline 62,79 & 1592,10 & 143,60 & 14,93 & 11,59 & 10,40 & 9,18 & 8,15 & 7,24 & 5,71 & 4,56 & 3,08 \\
\hline 51,62 & 219,30 & 83,30 & 57,41 & 35,13 & 27,41 & 21,06 & 16,76 & 13,63 & 9,54 & 7,24 & 4,92 \\
\hline 68,00 & 1576,90 & 38,30 & 32,82 & 26,12 & 24,88 & 23,62 & 22,23 & 20,85 & 18,25 & 15,90 & 12,04 \\
\hline 44,09 & 1019,70 & 29,90 & 58,84 & 51,87 & 48,45 & 43,74 & 39,27 & 35,10 & 27,93 & 22,33 & 14,92 \\
\hline 24,30 & 924,00 & 167,50 & 29,53 & 20,82 & 15,91 & 11,30 & 8,39 & 6,54 & 4,49 & 3,45 & 2,40 \\
\hline 61,41 & 1776,70 & 186,70 & 12,43 & 9,53 & 8,46 & 7,38 & 6,49 & 5,70 & 4,43 & 3,50 & 2,34 \\
\hline 53,64 & 1708,40 & 170,30 & 14,34 & 11,31 & 10,01 & 8,64 & 7,49 & 6,49 & 4,91 & 3,81 & 2,51 \\
\hline 30,00 & 1498,90 & 108,20 & 29,80 & 24,46 & 20,88 & 16,73 & 13,43 & 10,88 & 7,49 & 5,58 & 3,72 \\
\hline 83,29 & 457,80 & 25,30 & 59,85 & 44,66 & 41,25 & 38,17 & 35,44 & 32,92 & 28,32 & 24,36 & 18,14 \\
\hline 23,86 & 796,40 & 100,70 & 44,74 & 33,24 & 26,08 & 18,95 & 14,20 & 11,06 & 7,53 & 5,75 & 3,98 \\
\hline 59,81 & 472,50 & 22,10 & 76,90 & 62,83 & 58,58 & 53,34 & 48,53 & 44,05 & 36,12 & 29,70 & 20,60 \\
\hline 56,07 & 1856,10 & 48,50 & 29,97 & 24,91 & 23,78 & 22,11 & 20,44 & 18,83 & 15,88 & 13,35 & 9,54 \\
\hline 42,63 & 1928,20 & 71,10 & 27,34 & 24,07 & 22,16 & 19,71 & 17,43 & 15,35 & 11,91 & 9,34 & 6,13 \\
\hline 51,75 & 1346,30 & 95,20 & 22,74 & 18,71 & 16,89 & 14,83 & 13,02 & 11,42 & 8,80 & 6,90 & 4,56 \\
\hline 49,69 & 457,00 & 193,30 & 26,54 & 15,85 & 12,18 & 9,21 & 7,25 & 5,85 & 4,07 & 3,09 & 2,12 \\
\hline 66,65 & 368,40 & 103,70 & 35,88 & 22,90 & 18,59 & 15,09 & 12,64 & 10,71 & 7,88 & 6,08 & 4,07 \\
\hline 23,28 & 1620,20 & 183,80 & 24,13 & 18,13 & 14,28 & 10,40 & 7,80 & 6,07 & 4,13 & 3,15 & 2,18 \\
\hline 51,24 & 1693,00 & 49,40 & 32,21 & 27,47 & 25,98 & 23,82 & 21,75 & 19,79 & 16,27 & 13,37 & 9,25 \\
\hline 68,37 & 797,10 & 163,60 & 18,85 & 12,78 & 10,73 & 8,99 & 7,70 & 6,64 & 5,02 & 3,92 & 2,62 \\
\hline 63,06 & 1056,50 & 170,10 & 16,50 & 11,85 & 10,16 & 8,63 & 7,43 & 6,42 & 4,86 & 3,79 & 2,52 \\
\hline 70,31 & 1258,50 & 180,60 & 13,98 & 10,01 & 8,69 & 7,50 & 6,58 & 5,79 & 4,52 & 3,60 & 2,43 \\
\hline 67,61 & 226,80 & 29,80 & 82,55 & 60,36 & 52,75 & 45,71 & 40,13 & 35,32 & 27,53 & 21,85 & 14,71 \\
\hline 65,17 & 419,70 & 131,20 & 30,38 & 19,00 & 15,23 & 12,22 & 10,14 & 8,52 & 6,21 & 4,77 & 3,20 \\
\hline 24,46 & 1918,90 & 97,50 & 34,58 & 28,73 & 24,30 & 19,14 & 15,09 & 12,06 & 8,19 & 6,09 & 4,10 \\
\hline 66,63 & 371,80 & 156,40 & 30,40 & 17,68 & 13,64 & 10,60 & 8,63 & 7,17 & 5,15 & 3,95 & 2,67 \\
\hline 59,67 & 1811,70 & 43,80 & 31,17 & 25,45 & 24,38 & 22,88 & 21,32 & 19,80 & 16,97 & 14,48 & 10,59 \\
\hline 20,52 & 1641,20 & 85,70 & 45,42 & 36,55 & 29,83 & 22,45 & 17,10 & 13,36 & 8,99 & 6,78 & 4,65 \\
\hline 39,57 & 681,80 & 127,90 & 29,87 & 21,63 & 17,82 & 14,00 & 11,16 & 9,03 & 6,25 & 4,70 & 3,17 \\
\hline 67,40 & 1461,50 & 137,30 & 15,34 & 11,67 & 10,47 & 9,27 & 8,28 & 7,39 & 5,90 & 4,76 & 3,25 \\
\hline 48,08 & 1882,70 & 120,50 & 18,12 & 15,19 & 13,72 & 12,01 & 10,50 & 9,16 & 7,00 & 5,45 & 3,57 \\
\hline 29,33 & 685,90 & 69,00 & 53,07 & 41,74 & 34,67 & 26,93 & 21,09 & 16,82 & 11,46 & 8,59 & 5,81 \\
\hline 89,61 & 570,70 & 114,70 & 24,26 & 15,60 & 13,06 & 11,08 & 9,73 & 8,63 & $\begin{array}{c}1+,+7 \\
6,87\end{array}$ & 5,58 & 3,87 \\
\hline 70,01 & 1930,50 & 59,70 & 22,45 & 17,71 & 16,79 & $\begin{array}{l}1 ., 0 \\
15,80\end{array}$ & 14,79 & 13,81 & 11,97 & 10,34 & 7,73 \\
\hline 74,37 & 1071,10 & 172,00 & 15,21 & 10,58 & 9,09 & 7,81 & 6,84 & 6,03 & 4,72 & 3,76 & 2,56 \\
\hline 81,47 & 815,70 & 59,10 & 29,05 & 21,44 & 19,57 & 17,81 & 16,34 & 15,01 & 12,64 & 10,68 & 7,74 \\
\hline 76,11 & 1982,70 & 163,60 & 11,47 & 8,55 & 7,75 & 6,97 & 6,33 & 5,75 & 4,75 & 3,94 & 2,78 \\
\hline 43,11 & 529,90 & 129,90 & 31,64 & 21,69 & 17,58 & 13,71 & 10,91 & 8,83 & 6,14 & 4,63 & 3,13 \\
\hline 69,41 & 217,90 & 151,30 & 43,81 & 22,38 & 15,97 & 11,60 & 9,09 & 7,38 & 5,19 & 3,99 & 2,75 \\
\hline 71,56 & 988,60 & 199,10 & 15,07 & 10,17 & 8,55 & 7,19 & 6,20 & 5,38 & 4,11 & 3,23 & 2,17 \\
\hline 78,14 & 476,10 & 155,60 & 25,05 & 15,11 & 12,01 & 9,68 & 8,14 & 6,96 & 5,21 & 4,07 & 2,75 \\
\hline 76,66 & 1250,80 & 43,70 & 30,31 & 23,46 & 22,06 & 20,78 & 19,50 & 18,26 & 15,93 & 13,87 & 10,50 \\
\hline 42,89 & 1688,20 & 114,60 & 21,08 & 17,70 & 15,79 & 13,57 & 11,62 & 9,95 & 7,38 & 5,63 & 3,67 \\
\hline 31,37 & 1142,90 & 57,00 & 48,13 & 41,30 & 36,29 & 30,18 & 24,99 & 20,74 & 14,66 & 10,93 & 7,13 \\
\hline 54,26 & 564,10 & 186,90 & 23,36 & 14,72 & 11,70 & 9,17 & 7,41 & 6,09 & 4,30 & 3,27 & 2,20 \\
\hline 82,20 & 880,50 & 96,10 & 21,50 & 15,31 & 13,59 & 12,06 & 10,88 & 9,84 & 8,07 & 6,67 & 4,71 \\
\hline 26,10 & 1582,30 & 77,30 & 40,91 & 34,44 & 29,52 & 23,67 & 18,95 & 15,31 & 10,49 & 7,79 & 5,19 \\
\hline 69,32 & 675,60 & 122,90 & 23,38 & 16,16 & 13,73 & 11,63 & 10,05 & 8,73 & 6,68 & 5,25 & 3,52 \\
\hline 54,38 & 1987,00 & 24,30 & 48,57 & 39,93 & 38,62 & 36,97 & 34,92 & 32,86 & 28,86 & 25,19 & 19,09 \\
\hline 28,96 & 825,10 & 120,20 & 34,70 & 25,87 & 20,82 & 15,65 & 12,00 & 9,46 & 6,43 & 4,87 & 3,34 \\
\hline 33,40 & 812,60 & 182,00 & 24,61 & 17,20 & 13,65 & 10,22 & 7,86 & 6,22 & 4,25 & 3,22 & 2,22 \\
\hline 63,45 & 354,20 & 46,10 & 54,68 & 40,53 & 35,40 & 30,54 & 26,63 & 23,28 & 17,92 & 14,09 & 9,41 \\
\hline
\end{tabular}




\begin{tabular}{|c|c|c|c|c|c|c|c|c|c|c|c|}
\hline \multirow[b]{2}{*}{ e1 (cm) } & & & & & & & ões (x1 & m) & & & \\
\hline & Meq (MPa) & Ms (MPa) & D0 & D25 & D40 & D60 & D80 & D100 & D140 & D180 & D260 \\
\hline 31,42 & 1108,50 & 62,40 & 445,80 & 38,82 & 33,88 & 27,94 & 22,96 & 18,95 & 13,30 & 9,91 & 6,50 \\
\hline 58,15 & 1386,10 & 131,90 & 17,34 & 13,59 & 12,11 & 10,58 & 9,29 & 8,15 & 6,30 & 4,96 & 3,30 \\
\hline 73,51 & 752,10 & 147,90 & 19,83 & 13,37 & 11,26 & 9,51 & 8,23 & 7,17 & 5,52 & 4,36 & 2,94 \\
\hline 82,24 & 1358,10 & 125,10 & 15,23 & 11,01 & 9,90 & 8,88 & 8,07 & 7,35 & 6,10 & 5,10 & 3,64 \\
\hline 78,96 & 1559,50 & 189,70 & 11,68 & 8,31 & 7,31 & 6,43 & 5,75 & 5,16 & 4,17 & 3,40 & 2,37 \\
\hline 61,39 & 234,70 & 23,90 & 95,83 & 73,81 & 65,62 & 57,38 & 50,51 & 44,48 & 34,63 & 27,41 & 18,34 \\
\hline 28,04 & 612,20 & 177,40 & 30,07 & 19,76 & 14,88 & 10,55 & 7,87 & 6,16 & 4,24 & 3,27 & 2,27 \\
\hline 63,14 & 1066,90 & 84,40 & 23,95 & 18,80 & 17,02 & 15,15 & 13,54 & 12,10 & 9,65 & 7,78 & 5,28 \\
\hline 31,62 & 1451,40 & 61,20 & 42,04 & 36,69 & 32,57 & 27,45 & 23,00 & 19,27 & 13,79 & 10,32 & 6,69 \\
\hline 30,43 & 1813,10 & 152,50 & 22,03 & 17,79 & 15,05 & 11,96 & 9,53 & 7,69 & 5,28 & 3,94 & 2,64 \\
\hline 82,39 & 1257,70 & 161,60 & 13,86 & 9,69 & 8,48 & 7,44 & 6,66 & 5,99 & 4,85 & 3,98 & 2,78 \\
\hline 56,59 & 530,90 & 165,00 & 25,19 & 16,04 & 12,86 & 10,19 & 8,31 & 6,88 & 4,91 & 3,73 & 2,51 \\
\hline 60,07 & 1729,70 & 98,50 & 18,51 & 15,01 & 13,84 & 12,48 & 11,27 & 10,15 & 8,22 & 6,68 & 4,58 \\
\hline 79,02 & 426,80 & 77,40 & 35,30 & 23,76 & 20,17 & 17,21 & 15,06 & 13,27 & 10,41 & 8,33 & 5,69 \\
\hline 74,83 & 374,60 & 91,70 & 36,03 & 23,24 & 19,13 & 15,86 & 13,56 & 11,71 & 8,89 & 6,98 & 4,70 \\
\hline 44,47 & 924,00 & 183,90 & 20,04 & 14,31 & 11,86 & 9,47 & 7,66 & 6,27 & 4,40 & 3,32 & 2,22 \\
\hline 22,66 & 1250,80 & 122,10 & 35,44 & 27,03 & 21,43 & 15,70 & 11,79 & 9,18 & 6,23 & 4,75 & 3,28 \\
\hline 28,85 & 658,60 & 167,00 & 30,12 & 20,38 & 15,62 & 11,24 & 8,43 & 6,61 & 4,53 & 3,47 & 2,41 \\
\hline 81,08 & 695,90 & 33,10 & 43,63 & 32,99 & 30,68 & 28,57 & 26,62 & 24,80 & 21,44 & 18,51 & 13,86 \\
\hline 47,72 & 291,80 & 176,30 & 35,95 & 19,51 & 14,22 & 10,28 & 7,91 & 6,31 & 4,36 & 3,34 & 2,32 \\
\hline 76,12 & 1324,30 & 45,50 & 29,06 & 22,53 & 21,20 & 19,98 & 18,74 & 17,55 & 15,32 & 13,33 & 10,09 \\
\hline 63,13 & 444,30 & 46,30 & 49,26 & 37,62 & 33,42 & 29,25 & 25,80 & 22,77 & 17,80 & 14,14 & 9,49 \\
\hline 36,44 & 1497,30 & 26,80 & 64,61 & 58,83 & 55,18 & 49,86 & 44,72 & 39,90 & 31,58 & 25,09 & 16,61 \\
\hline 71,66 & 1947,60 & 79,70 & 18,36 & 14,33 & 13,48 & 12,54 & 11,64 & 10,80 & 9,24 & 7,89 & 5,79 \\
\hline 25,44 & 826,20 & 45,60 & 73,55 & 60,94 & 51,58 & 40,72 & 32,20 & 25,77 & 17,54 & 13,05 & 8,77 \\
\hline 84,31 & 951,10 & 82,40 & 22,22 & 16,05 & 14,47 & 13,05 & 11,91 & 10,90 & 9,13 & 7,67 & 5,53 \\
\hline 81,84 & 432,90 & 39,60 & 48,04 & 34,82 & 31,31 & 28,09 & 25,53 & 23,26 & 19,30 & 16,10 & 11,48 \\
\hline 45,59 & 1624,90 & 36,80 & 43,10 & 37,68 & 35,73 & 32,74 & 29,83 & 27,06 & 22,12 & 18,07 & 12,37 \\
\hline 36,95 & 401,60 & 96,40 & 45,41 & 31,37 & 25,07 & 19,05 & 14,81 & 11,81 & 8,11 & 6,13 & 4,19 \\
\hline 31,94 & 1086,60 & 49,20 & 53,12 & 46,09 & 40,80 & 34,28 & 28,64 & 23,95 & 17,10 & 12,78 & 8,30 \\
\hline 47,65 & 1019,80 & 175,60 & 18,97 & 13,87 & 11,70 & 9,55 & 7,88 & 6,55 & 4,68 & 3,54 & 2,34 \\
\hline 42,58 & 1707,90 & 96,30 & 23,52 & 20,12 & 18,13 & 15,74 & 13,61 & 11,75 & 8,81 & 6,77 & 4,40 \\
\hline 82,82 & 1872,90 & 107,10 & 14,38 & 10,72 & 9,89 & 9,13 & 8,46 & 7,85 & 6,73 & 5,77 & 4,28 \\
\hline 76,63 & 895,20 & 37,10 & 38,09 & 29,30 & 27,46 & 25,65 & 23,92 & 22,29 & 19,26 & 16,61 & 12,40 \\
\hline 24,21 & 1865,90 & 25,70 & 86,78 & 80,12 & 72,74 & 62,86 & 53,75 & 45,78 & 33,43 & 25,13 & 16,09 \\
\hline 25,99 & 1574,00 & 116,80 & 31,01 & 24,96 & 20,77 & 16,08 & 12,54 & 9,96 & 6,75 & 5,05 & 3,43 \\
\hline 55,37 & 695,50 & 134,10 & 24,32 & 17,19 & 14,47 & 11,94 & 10,01 & 8,44 & 6,15 & 4,70 & 3,11 \\
\hline 73,41 & 490,10 & 169,00 & 24,23 & 14,58 & 11,53 & 9,22 & 7,68 & 6,51 & 4,81 & 3,72 & 2,51 \\
\hline 35,81 & 533,50 & 107,30 & 38,64 & 27,61 & 22,35 & 17,12 & 13,37 & 10,67 & 7,32 & 5,52 & 3,76 \\
\hline 66,35 & 224,90 & 92,70 & 50,68 & 29,62 & 22,92 & 17,85 & 14,55 & 12,09 & 8,69 & 6,66 & 4,50 \\
\hline 29,29 & 751,70 & 51,30 & 62,81 & 51,77 & 44,19 & 35,39 & 28,37 & 22,96 & 15,79 & 11,75 & 7,83 \\
\hline 69,60 & 1035,70 & 104,20 & 20,53 & 15,39 & 13,74 & 12,15 & 10,84 & 9,69 & 7,74 & 6,26 & 4,28 \\
\hline 44,37 & 932,00 & 34,60 & 54,70 & 47,89 & 44,24 & 39,51 & 35,11 & 31,08 & 24,32 & 19,20 & 12,69 \\
\hline 73,33 & 567,20 & 24,80 & 59,72 & 46,30 & 43,41 & 40,32 & 37,42 & 34,69 & 29,67 & 25,34 & 18,62 \\
\hline 32,64 & 1778,60 & 196,90 & 17,86 & 13,99 & 11,73 & 9,26 & 7,35 & 5,92 & 4,07 & 3,04 & 2,04 \\
\hline 71,96 & 1569,10 & 109,60 & 16,39 & 12,54 & 11,48 & 10,39 & 9,46 & 8,61 & 7,11 & 5,90 & 4,16 \\
\hline 80,48 & 480,60 & 63,50 & 36,09 & 25,30 & 22,11 & 19,34 & 17,25 & 15,45 & 12,45 & 10,16 & 7,05 \\
\hline 66,41 & 378,90 & 90,30 & 37,51 & 24,82 & 20,52 & 16,92 & 14,32 & 12,23 & 9,10 & 7,04 & 4,70 \\
\hline 71,97 & 521,80 & 88,40 & 30,83 & 21,41 & 18,31 & 15,63 & 13,62 & 11,93 & 9,23 & 7,32 & 4,93 \\
\hline 50,85 & 1986,90 & 115,90 & 17,54 & 14,69 & 13,39 & 11,87 & 10,50 & 9,27 & 7,22 & 5,70 & 3,78 \\
\hline 30,68 & 1834,60 & 106,30 & 27,66 & 23,32 & 20,25 & 16,59 & 13,55 & 11,12 & 7,76 & 5,78 & 3,80 \\
\hline 38,45 & 984,90 & 167,60 & 22,26 & 16,40 & 13,59 & 10,70 & 8,53 & 6,90 & 4,78 & 3,59 & 2,41 \\
\hline 42,24 & 429,50 & 76,30 & 47,24 & 34,52 & 28,77 & 22,98 & 18,56 & 15,17 & 10,61 & 7,98 & 5,33 \\
\hline 27,42 & 1839,00 & 171,70 & 21,82 & 17,20 & 14,20 & 10,93 & 8,49 & 6,73 & 4,57 & 3,43 & 2,33 \\
\hline 87,21 & 781,30 & 104,40 & 21,42 & 14,69 & 12,80 & 11,22 & 10,06 & 9,07 & 7,41 & 6,12 & 4,32 \\
\hline 63,21 & 1644,10 & 77,40 & 21,34 & 17,18 & 16,05 & 14,67 & 13,42 & 12,24 & 10,15 & 8,42 & 5,92 \\
\hline 69,53 & 385,20 & 111,50 & 33,48 & 21,11 & 17,07 & 13,86 & 11,64 & 9,89 & 7,32 & 5,67 & 3,80 \\
\hline 74,62 & 1693,10 & 165,80 & 12,34 & 9,12 & 8,16 & 7,26 & 6,53 & 5,88 & 4,78 & 3,91 & 2,72 \\
\hline 21,30 & 1129,90 & 153,20 & 32,13 & 23,16 & 17,63 & 12,42 & 9,15 & 7,11 & 4,88 & 3,76 & 2,62 \\
\hline 41,61 & 1174,40 & 173,30 & 19,40 & 14,65 & 12,37 & 10,01 & 8,15 & 6,70 & 4,71 & 3,54 & 2,35 \\
\hline 39,39 & 1199,60 & 138,70 & 22,73 & 17,84 & 15,26 & 12,45 & 10,20 & 8,41 & 5,93 & 4,44 & 2,94 \\
\hline 86,56 & 512,30 & 112,60 & 26,34 & 16,82 & 13,96 & 11,75 & 10,23 & 9,01 & 7,08 & 5,69 & 3,92 \\
\hline 73,51 & 788,60 & 40,60 & 38,75 & 29,88 & 27,82 & 25,63 & 23,65 & 21,81 & 18,46 & 15,63 & 11,34 \\
\hline 67,28 & 1867,00 & 42,00 & 29,36 & 23,44 & 22,35 & 21,27 & 20,05 & 18,83 & 16,52 & 14,43 & 10,97 \\
\hline 72,39 & 995,50 & 180,20 & 15,64 & 10,73 & 9,12 & 7,75 & 6,73 & 5,88 & 4,53 & 3,58 & 2,41 \\
\hline 48,09 & 893,40 & 50,80 & 41,11 & 34,78 & 31,63 & 27,88 & 24,52 & 21,51 & 16,59 & 12,98 & 8,55 \\
\hline 74,80 & 431,50 & 57,10 & 41,37 & 29,53 & 25,81 & 22,50 & 19,94 & 17,73 & 14,09 & 11,36 & 7,78 \\
\hline 75,50 & 1580,10 & 35,70 & 31,83 & 25,23 & 23,74 & 22,76 & 21,63 & 20,48 & 18,25 & 16,20 & 12,68 \\
\hline 45,49 & 228,30 & 115,40 & 50,11 & 28,69 & 21,43 & 15,73 & 12,14 & 9,69 & 6,69 & 5,11 & 3,54 \\
\hline 26,67 & 537,30 & 159,30 & 34,48 & 22,45 & 16,72 & 11,72 & 8,70 & 6,81 & 4,70 & 3,63 & 2,53 \\
\hline 35,83 & 1018,90 & 140,40 & 25,54 & 19,46 & 16,26 & 12,85 & 10,24 & 8,28 & 5,72 & 4,28 & 2,88 \\
\hline 37,33 & 1427,80 & 194,40 & 17,89 & 13,67 & 11,49 & 9,16 & 7,36 & 5,99 & 4,16 & 3,11 & 2,08 \\
\hline 37,02 & 1673,90 & 84,40 & 28,60 & 24,76 & 22,15 & 18,96 & 16,14 & 13,73 & 10,05 & 7,61 & 4,93 \\
\hline 41,57 & 1859,20 & 170,40 & 16,29 & 13,20 & 11,54 & 9,67 & 8,10 & 6,80 & 4,91 & 3,70 & 2,42 \\
\hline 71,80 & 1008,20 & 26,20 & 47,37 & 37,39 & 35,44 & 33,68 & 31,75 & 29,85 & 26,23 & 22,96 & 17,54 \\
\hline 41,30 & 342,60 & 21,50 & 112,04 & 94,96 & 84,83 & 72,83 & 62,30 & 53,27 & 39,37 & 29,99 & 19,49 \\
\hline 37,15 & 1487,00 & 31,60 & 56,88 & 51,62 & 48,14 & 43,25 & 38,58 & 34,24 & 26,85 & 21,19 & 13,95 \\
\hline 45,01 & 411,70 & 52,40 & 57,48 & 44,36 & 38,16 & 31,62 & 26,31 & 22,01 & 15,81 & 11,94 & 7,86 \\
\hline 83,06 & 1974,00 & 142,90 & 11,90 & 8,74 & 7,97 & 7,26 & 6,67 & 6,14 & 5,19 & 4,40 & 3,20 \\
\hline 57,94 & 1436,50 & 71,60 & 24,73 & 20,33 & 18,86 & 17,07 & 15,44 & 13,93 & 11,30 & 9,20 & 6,31 \\
\hline 80,58 & 340,50 & 47,80 & 49,43 & 34,37 & 29,87 & 26,02 & 23,14 & 20,67 & 16,58 & 13,49 & 9,34 \\
\hline 36,79 & 1919,90 & 173,60 & 17,32 & 14,03 & 12,12 & 9,95 & 8,17 & 6,75 & 4,76 & 3,56 & 2,34 \\
\hline
\end{tabular}




\begin{tabular}{|c|c|c|c|c|c|c|c|c|c|c|c|}
\hline & & & \multicolumn{9}{|c|}{ Deflexões $\left(\times 10^{-4} \mathrm{~cm}\right)$} \\
\hline e1 (cm) & Meq (MPa) & Ms (MPa) & D0 & D25 & D40 & D60 & D80 & D100 & D140 & D180 & D260 \\
\hline 45,46 & 1444,00 & 49,40 & 36,67 & 32,06 & 29,80 & 26,80 & 23,98 & 21,37 & 16,92 & 13,48 & 8,98 \\
\hline 79,54 & 848,60 & 74,60 & 25,36 & 18,58 & 16,76 & 15,06 & 13,68 & 12,45 & 10,31 & 8,58 & 6,09 \\
\hline 76,24 & 1983,30 & 37,70 & 27,95 & 22,49 & 21,04 & 20,30 & 19,41 & 18,46 & 16,61 & 14,88 & 11,85 \\
\hline 20,33 & 1613,20 & 169,00 & 28,02 & 20,74 & 15,97 & 11,33 & 8,36 & 6,48 & 4,44 & 3,41 & 2,37 \\
\hline 84,63 & 1624,50 & 165,60 & 11,92 & 8,48 & 7,56 & 6,75 & 6,12 & 5,57 & 4,61 & 3,84 & 2,74 \\
\hline 23,87 & 1691,90 & 123,70 & 31,01 & 24,69 & 20,24 & 15,38 & 11,82 & 9,29 & 6,28 & 4,72 & 3,23 \\
\hline 84,73 & 428,80 & 108,00 & 30,00 & 18,79 & 15,37 & 12,75 & 11,00 & 9,60 & 7,44 & 5,92 & 4,05 \\
\hline 88,25 & 204,20 & 107,40 & 49,18 & 26,29 & 19,49 & 14,81 & 12,07 & 10,13 & 7,44 & 5,80 & 3,97 \\
\hline 89,57 & 1975,50 & 165,70 & 10,60 & 7,56 & 6,81 & 6,17 & 5,66 & 5,21 & 4,42 & 3,75 & 2,75 \\
\hline 85,60 & 345,50 & 185,00 & 29,04 & 15,51 & 11,48 & 8,70 & 7,07 & 5,91 & 4,32 & 3,36 & 2,30 \\
\hline 71,63 & 1003,50 & 135,60 & 17,92 & 12,89 & 11,24 & 9,76 & 8,61 & 7,61 & 5,99 & 4,79 & 3,25 \\
\hline 82,73 & 301,60 & 182,30 & 32,33 & 16,86 & 12,26 & 9,13 & 7,32 & 6,06 & 4,37 & 3,38 & 2,32 \\
\hline 64,99 & 1728,10 & 96,80 & 17,93 & 14,25 & 13,20 & 11,99 & 10,92 & 9,92 & 8,16 & 6,74 & 4,71 \\
\hline 69,44 & 267,50 & 89,30 & 45,60 & 27,85 & 22,14 & 17,71 & 14,72 & 12,42 & 9,11 & 7,02 & 4,72 \\
\hline 56,43 & 1623,20 & 111,20 & 18,26 & 14,84 & 13,49 & 11,98 & 10,65 & 9,45 & 7,44 & 5,93 & 3,97 \\
\hline 76,64 & 409,10 & 155,20 & 27,79 & 16,26 & 12,69 & 10,05 & 8,35 & 7,06 & 5,22 & 4,05 & 2,74 \\
\hline 28,26 & 1803,80 & 100,60 & 30,79 & 25,83 & 22,22 & 17,94 & 14,47 & 11,75 & 8,11 & 6,02 & 3,99 \\
\hline 22,90 & 1875,30 & 182,20 & 23,54 & 18,00 & 14,31 & 10,51 & 7,91 & 6,16 & 4,18 & 3,18 & 2,20 \\
\hline 57,70 & 1104,30 & 191,80 & 15,83 & 11,36 & 9,66 & 8,08 & 6,85 & 5,84 & 4,32 & 3,32 & 2,20 \\
\hline 70,80 & 795,90 & 96,10 & 24,05 & 17,60 & 15,50 & 13,55 & 12,00 & 10,66 & 8,43 & 6,77 & 4,61 \\
\hline 26,31 & 1572,70 & 126,50 & 29,10 & 23,24 & 19,27 & 14,86 & 11,56 & 9,17 & 6,22 & 4,66 & 3,17 \\
\hline 29,78 & 464,20 & 52,00 & 72,26 & 56,10 & 46,34 & 35,80 & 27,95 & 22,25 & 15,16 & 11,38 & 7,72 \\
\hline 51,60 & 1596,80 & 37,60 & 39,48 & 33,47 & 31,96 & 29,61 & 27,28 & 25,03 & 20,92 & 17,45 & 12,30 \\
\hline 23,73 & 1507,90 & 39,10 & 71,51 & 62,91 & 55,21 & 45,53 & 37,29 & 30,61 & 21,27 & 15,74 & 10,30 \\
\hline 86,44 & 796,90 & 188,60 & 16,45 & 10,37 & 8,54 & 7,13 & 6,18 & 5,42 & 4,24 & 3,39 & 2,33 \\
\hline 33,04 & 975,70 & 102,20 & 33,47 & 26,44 & 22,30 & 17,72 & 14,15 & 11,44 & 7,88 & 5,89 & 3,94 \\
\hline 77,01 & 373,70 & 189,40 & 27,68 & 15,14 & 11,34 & $\begin{array}{c}1+, 1 L \\
8,65\end{array}$ & $\begin{array}{c}1+1, \pm 0 \\
7,02\end{array}$ & $\begin{array}{c}1 \pm,+4 \\
5,85\end{array}$ & 4,23 & 3,27 & 2,22 \\
\hline 71,67 & 684,70 & 145,40 & 21,24 & 14,19 & 11,87 & 9,94 & 8,54 & 7,39 & 5,63 & 4,41 & 2,96 \\
\hline$\frac{1,01}{20,93}$ & 1617,20 & $\frac{140,40}{75,10}$ & 49,24 & 40,35 & 33,36 & 25,49 & 19,61 & 15,41 & 10,37 & $\frac{7,4 \pm}{7,78}$ & 5,31 \\
\hline 28,23 & $\frac{10+1,20}{774,80}$ & 110,30 & 38,12 & 28,45 & 22,84 & 17,10 & $\frac{10,0 \pm}{13,07}$ & $\frac{10,+1}{10,28}$ & $\frac{10,01}{6,99}$ & 5,30 & 3,64 \\
\hline 62,36 & 919,20 & 192,80 & 16,78 & 11,50 & 9,62 & 7,99 & 6,76 & 5,77 & 4,28 & 3,30 & 2,19 \\
\hline 20,95 & 1516,40 & 28,40 & 98,95 & 87,61 & 76,87 & 63,26 & 51,63 & 42,24 & 29,21 & 21,56 & 14,12 \\
\hline 46,61 & 662,30 & 197,80 & 22,08 & 14,43 & 11,53 & 8,94 & 7,12 & 5,78 & 4,02 & 3,04 & 2,06 \\
\hline 59,18 & 477,70 & 184,90 & 25,15 & 15,12 & 11,81 & 9,18 & 7,43 & 6,12 & 4,35 & 3,31 & 2,24 \\
\hline 26,69 & 1380,00 & 48,30 & 57,63 & 50,22 & 44,07 & 36,42 & 29,92 & 24,64 & 17,22 & 12,77 & 8,35 \\
\hline 80,35 & 1027,40 & 131,10 & 17,19 & 12,10 & 10,61 & 9,30 & 8,31 & 7,46 & 6,02 & 4,92 & 3,42 \\
\hline 34,60 & 1720,10 & 124,40 & 23,28 & 19,34 & 16,82 & 13,87 & 11,43 & 9,45 & 6,67 & 4,98 & 3,27 \\
\hline 73,17 & 1582,70 & 46,20 & 27,66 & 21,69 & 20,52 & 19,43 & 18,27 & 17,15 & 15,01 & 13,10 & 9,95 \\
\hline 37,66 & 829,40 & 176,50 & 23,40 & 16,55 & 13,41 & 10,33 & 8,11 & 6,50 & 4,47 & 3,37 & 2,29 \\
\hline 30,02 & 1952,10 & 54,00 & 43,11 & 38,79 & 34,97 & 30,02 & 25,56 & 21,72 & 15,83 & 11,92 & 7,67 \\
\hline 43,88 & 1116.20 & 172.20 & 19,28 & 14.43 & 12,21 & 9.93 & 8.14 & 6.72 & 4.76 & 3.58 & 2,38 \\
\hline 84,28 & 715,90 & 194,30 & 17,50 & 10,81 & 8,77 & 7,22 & 6,19 & 5,38 & 4,14 & 3,29 & 2,24 \\
\hline 36,14 & 1426,70 & 197,00 & 18,11 & 13,80 & 11,54 & 9,13 & 7,29 & 5,90 & 4,08 & 3,06 & 2,05 \\
\hline 41,13 & 1193,10 & 47,00 & 43,45 & 38,24 & 34,99 & 30,86 & 27,07 & 23,66 & 18,10 & 14,06 & 9,18 \\
\hline 29,57 & 216,70 & 61,40 & 84,21 & 55,83 & 42,52 & 30,50 & 22,88 & 17,94 & 12,32 & 9,46 & 6,57 \\
\hline 52,17 & 1899,90 & 48,40 & 31,19 & 26,41 & 25,16 & 23,25 & 21,38 & 19,58 & 16,32 & 13,57 & 9,53 \\
\hline 76,15 & 1183,30 & 138,40 & 15,94 & 11,50 & 10,16 & 8,94 & 7,98 & 7,15 & 5,75 & 4,68 & 3,24 \\
\hline 67,84 & 353,40 & 164,90 & 30,72 & 17,38 & 13,21 & 10,14 & 8,21 & 6,79 & 4,86 & 3,73 & 2,53 \\
\hline 25,93 & 658,00 & 45,90 & 77,48 & 62,76 & 52,44 & 40,79 & 31,91 & 25,38 & 17,22 & 12,87 & 8,71 \\
\hline 27,65 & 1180,60 & 59,70 & 51,12 & 43,21 & 37,28 & 30,19 & 24,39 & 19,84 & 13,69 & 10,16 & 6,73 \\
\hline 35,76 & 1255,70 & 146,80 & 22,98 & 17,95 & 15,18 & 12,15 & 9,77 & 7,95 & 5,52 & 4,13 & 2,75 \\
\hline 38,45 & 573,20 & 150,20 & 29,68 & 20,13 & 16,03 & 12,18 & 9,49 & 7,58 & 5,21 & 3,94 & 2,69 \\
\hline 50,55 & 784,90 & 45,90 & 44,48 & 37,29 & 33,98 & 30,08 & 26,59 & 23,44 & 18,24 & 14,38 & 9,52 \\
\hline 22,38 & 268,90 & 23,00 & 182,95 & 141,56 & 113,19 & 83,57 & 63,00 & 49,10 & 33,23 & 25,25 & 17,41 \\
\hline 61,01 & 1273,10 & 52,60 & 30,56 & 24,89 & 23,37 & 21,44 & 19,65 & 17,95 & 14,91 & 12,39 & 8,72 \\
\hline 40,59 & 1904,00 & 186,70 & 15,51 & 12,46 & 10,82 & 8,99 & 7,47 & 6,23 & 4,46 & 3,35 & 2,20 \\
\hline 65,35 & 217,00 & 41,90 & 72,50 & 50,11 & 42,31 & 35,50 & 30,38 & 26,15 & 19,68 & 15,31 & 10,20 \\
\hline 35,51 & 1318,00 & 149,50 & 22,42 & 17,58 & 14,89 & 11,93 & 9,60 & 7,81 & 5,42 & 4,05 & 2,70 \\
\hline 74,46 & 920,80 & 184,70 & 15,98 & 10,71 & 9,00 & 7,60 & 6,57 & 5,73 & 4,41 & 3,49 & 2,35 \\
\hline 43,81 & 1946,90 & 89,70 & 22,98 & 19,93 & 18,19 & 16,04 & 14,08 & 12,32 & 9,45 & 7,36 & 4,82 \\
\hline 20,19 & 869,80 & 48,40 & 82,83 & 66,00 & 53,42 & 39,83 & 30,13 & 23,48 & 15,81 & 11,97 & 8,24 \\
\hline 46,74 & 1779,60 & 150,00 & 16,53 & 13,49 & 11,97 & 10,26 & 8,80 & 7,55 & 5,62 & 4,30 & 2,81 \\
\hline 63,56 & 488,10 & 183,30 & 24,45 & $\begin{array}{l}14,7 u \\
14,69\end{array}$ & 11,51 & $\begin{array}{l}10,204 \\
9,04\end{array}$ & 7,38 & 6,14 & 4,41 & 3,37 & 2,27 \\
\hline 32,74 & 1926,70 & 35,30 & 53,57 & 49,28 & 45,66 & 40,67 & 35,90 & 31,54 & 24,28 & 18,89 & 12,27 \\
\hline 27,40 & 624,00 & 184,30 & 29,42 & 19,21 & 14,38 & 10,14 & 7,54 & 5,91 & 4,07 & 3,14 & 2,19 \\
\hline 75,39 & 1317,50 & 60,90 & 24,44 & 18,79 & 17,56 & 16,30 & 15,13 & 14,03 & 12,01 & 10,27 & 7,56 \\
\hline 34,23 & 1119,60 & 78,90 & 36,68 & 30,53 & 26,57 & 21,91 & 18,04 & 14,91 & 10,51 & 7,85 & 5,15 \\
\hline 34,83 & 1765,10 & 155,80 & 19,89 & 16,12 & 13,86 & 11,28 & 9,19 & 7,54 & 5,27 & 3,93 & 2,60 \\
\hline 40,56 & 465,90 & 198,50 & 27,46 & 16,56 & 12,56 & 9,23 & 7,09 & 5,63 & 3,88 & 2,96 & 2,05 \\
\hline 88,30 & 1265,70 & 72,40 & 20,54 & 15,12 & 13,88 & 12,86 & 11,97 & 11,15 & 9,65 & 8,36 & 6,30 \\
\hline 84.12 & 898,30 & 82.00 & 22.91 & 16,49 & 14,82 & 13,32 & 12.13 & 11.07 & 9,23 & 7.74 & 5,56 \\
\hline 85,80 & 1699,70 & 139,90 & 12,69 & 9,16 & 8,28 & 7,50 & 6,87 & 6,30 & 5,31 & 4,49 & 3,26 \\
\hline 63,47 & 1302,60 & 107,30 & 19,11 & 14,93 & 13,49 & 11,98 & 10,69 & 9,54 & 7,60 & 6,11 & 4,15 \\
\hline 57,79 & 716,10 & 129,10 & 23,95 & 17,06 & 14,47 & 12,07 & 10,21 & 8,69 & 6,41 & 4,92 & 3,26 \\
\hline 71,25 & 215,60 & 125,00 & 46,55 & 24,83 & 18,25 & 13,63 & 10,88 & 8,94 & 6,36 & 4,88 & 3,34 \\
\hline 56,53 & 470,60 & 102,10 & 33,61 & 23,16 & 19,29 & 15,81 & 13,19 & 11,09 & 8,06 & 6,15 & 4,08 \\
\hline 88,94 & 485,90 & 126,70 & 25,81 & 15,90 & 12,93 & 10,70 & 9,24 & 8,08 & 6,29 & 5,04 & 3,46 \\
\hline 74,53 & 1811,60 & 190,80 & 11,10 & 8,14 & 7,25 & 6,42 & 5,75 & 5,16 & 4,17 & 3,40 & 2,35 \\
\hline 52,75 & 1855,70 & 169,70 & 14,01 & 11,19 & 9,95 & 8,63 & 7,49 & 6,50 & 4,94 & 3,84 & 2,53 \\
\hline 88,27 & 1934,00 & 178,20 & 10,37 & 7,36 & 6,60 & 5,94 & 5,42 & 4,97 & 4,18 & 3,52 & 2,56 \\
\hline 51,84 & 749,20 & 180,30 & 20,82 & 14,16 & 11,64 & 9,35 & 7,66 & 6,34 & 4,52 & 3,42 & 2,28 \\
\hline 69,01 & 1573,80 & 158,80 & 13,54 & 10,17 & 9,08 & 8,02 & 7,15 & 6,38 & 5,09 & 4,11 & 2,81 \\
\hline
\end{tabular}




\begin{tabular}{|c|c|c|c|c|c|c|c|c|c|c|c|}
\hline & & & \multicolumn{9}{|c|}{ Deflexões $\left(\times 10^{-4} \mathrm{~cm}\right)$} \\
\hline e1 (cm) & Meq (MPa) & Ms (MPa) & D0 & D25 & D40 & D60 & D80 & D100 & D140 & D180 & D260 \\
\hline 51,37 & 1630,20 & 182,70 & 14,42 & 11,26 & 9,86 & 8,40 & 7,19 & 6,16 & 4,58 & 3,52 & 2,31 \\
\hline 30,05 & 764,60 & 167,80 & 27,96 & 19,51 & 15,26 & 11,19 & 8,48 & 6,66 & 4,55 & 3,47 & 2,40 \\
\hline 63,45 & 695,90 & 35,40 & 47,91 & 38,45 & 35,78 & 32,61 & 29,74 & 27,06 & 22,32 & 18,45 & 12,91 \\
\hline 50,96 & 419,60 & 163,70 & 29,75 & 18,10 & 14,07 & 10,76 & 8,54 & 6,93 & 4,84 & 3,67 & 2,50 \\
\hline 49,69 & 1050,20 & 98,10 & 25,36 & 20,34 & 18,00 & 15,46 & 13,30 & 11,45 & 8,57 & 6,59 & 4,32 \\
\hline 79,87 & 1557,90 & 80,10 & 18,75 & 14,17 & 13,16 & 12,19 & 11,32 & 10,50 & 9,01 & 7,73 & 5,73 \\
\hline 78,45 & 684,10 & 171,10 & 19,28 & 12,27 & 10,07 & 8,34 & 7,15 & 6,20 & 4,74 & 3,74 & 2,53 \\
\hline 65,51 & 1286,60 & 58,20 & 27,42 & 21,87 & 20,49 & 18,83 & 17,30 & 15,86 & 13,27 & 11,10 & 7,90 \\
\hline 60,65 & 1737,80 & 94,20 & 18,89 & 15,31 & 14,16 & 12,82 & 11,61 & 10,49 & 8,53 & 6,97 & 4,80 \\
\hline 48,69 & 1003,90 & 71,10 & 31,69 & 26,27 & 23,61 & 20,59 & 17,93 & 15,59 & 11,86 & 9,20 & 6,04 \\
\hline 29,56 & 965,70 & 29,40 & 82,89 & 73,95 & 66,23 & 56,36 & 47,59 & 40,14 & 28,94 & 21,69 & 13,99 \\
\hline 28,50 & 1844,60 & 103,10 & 29,87 & 25,08 & 21,60 & 17,47 & 14,11 & 11,47 & 7,92 & 5,89 & 3,90 \\
\hline 25,94 & 1262,60 & 191,10 & 23,62 & 17,30 & 13,60 & 9,93 & 7,48 & 5,84 & 3,98 & 3,04 & 2,10 \\
\hline 56,10 & 490,60 & 117,60 & 30,82 & 20,82 & 17,16 & 13,92 & 11,53 & 9,65 & 6,96 & 5,30 & 3,53 \\
\hline 72,61 & 317,40 & 34,60 & 62,95 & 46,32 & 41,13 & 36,26 & 32,37 & 28,95 & 23,20 & 18,81 & 12,92 \\
\hline 85,23 & 1137,60 & 68,30 & 22,66 & 16,74 & 15,39 & 14,19 & 13,16 & 12,21 & 10,48 & 9,01 & 6,70 \\
\hline 54,19 & 804,00 & 141,60 & 22,26 & 16,04 & 13,60 & 11,28 & 9,47 & 8,00 & 5,84 & 4,46 & 2,95 \\
\hline 67,22 & 787,90 & 180,20 & 18,28 & 12,17 & 10,11 & 8,38 & 7,11 & 6,09 & 4,56 & 3,54 & 2,36 \\
\hline 66,25 & 529,70 & 30,90 & 56,43 & 44,55 & 41,19 & 37,40 & 34,05 & 30,96 & 25,50 & 21,07 & 14,75 \\
\hline 53,78 & 302,00 & 115,20 & 41,11 & 25,05 & 19,56 & 15,09 & 12,07 & 9,86 & 6,93 & 5,26 & 3,57 \\
\hline 84,49 & 685,20 & 109,10 & 22,78 & 15,39 & 13,21 & 11,42 & 10,12 & 9,03 & 7,24 & 5,89 & 4,09 \\
\hline 39,04 & 1114,50 & 199,00 & 18,95 & 13,85 & 11,44 & 9,01 & 7,18 & 5,81 & 4,02 & 3,02 & 2,03 \\
\hline 64,54 & 699,50 & 137,40 & 22,42 & 15,48 & 13,04 & 10,92 & 9,32 & 8,00 & 6,00 & 4,66 & 3,10 \\
\hline 62,97 & 1850,30 & 191,50 & 11,88 & 9,09 & 8,07 & 7,07 & 6,23 & 5,50 & 4,30 & 3,42 & 2,29 \\
\hline 75,29 & 1822,40 & $\begin{array}{l}187,00 \\
187,00\end{array}$ & $\begin{array}{l}1+1,00 \\
11,14\end{array}$ & 8,17 & 7,29 & 6,47 & 5,81 & 5,23 & 4,24 & 3,47 & 2,41 \\
\hline 28,23 & 1451,30 & 98,80 & 33,51 & 27,51 & 23,35 & 18,56 & 14,77 & 11,89 & 8,14 & 6,06 & 4,06 \\
\hline 31,59 & 1262,20 & 132,90 & 26,59 & 20,92 & 17,53 & 13,78 & 10,92 & 8,77 & 6,01 & 4,50 & 3,03 \\
\hline 87,94 & 1865,20 & 62,10 & 19,07 & 14,67 & 13,56 & 12,89 & 12,23 & 11,57 & 10,31 & 9,17 & 7,22 \\
\hline 20,99 & 1596,40 & 143,60 & 31,00 & 23,56 & 18,50 & 13,39 & 9,97 & 7,74 & 5,26 & 4,02 & 2,78 \\
\hline 36,51 & 1067,50 & 57,40 & 43,52 & 37,43 & 33,33 & 28,34 & 23,98 & 20,29 & 14,75 & 11,12 & 7,21 \\
\hline 57,14 & 339,90 & 113,50 & 38,00 & 23,77 & 18,89 & 14,88 & 12,10 & 9,99 & 7,11 & 5,41 & 3,64 \\
\hline 67,67 & 501,80 & 80,20 & 33,80 & 23,99 & 20,62 & 17,61 & 15,29 & 13,34 & 10,25 & 8,06 & 5,40 \\
\hline 55,15 & 903,70 & 85,80 & 27,43 & 21,68 & 19,28 & 16,75 & 14,60 & 12,73 & 9,74 & 7,60 & 5,03 \\
\hline 69,57 & 374,50 & 168,40 & 29,22 & 16,63 & 12,71 & 9,81 & 7,98 & 6,63 & 4,78 & 3,67 & 2,49 \\
\hline 75,88 & 1127,70 & 110,60 & 18,37 & 13,51 & 12,09 & 10,76 & 9,69 & 8,75 & 7,12 & 5,85 & 4,08 \\
\hline 27,42 & 574,40 & 143,40 & 35,76 & 24,17 & 18,38 & 13,10 & 9,78 & 7,65 & 5,26 & 4,04 & 2,81 \\
\hline 42,88 & 244,70 & 191,10 & 39,09 & 19,70 & 13,70 & 9,53 & 7,20 & 5,71 & 3,95 & 3,05 & 2,15 \\
\hline 22,74 & 1087,50 & 134,50 & 34,30 & 25,36 & 19,73 & 14,20 & 10,58 & 8,22 & 5,61 & 4,30 & 2,98 \\
\hline 24,69 & 1908,40 & 31,80 & 73,40 & 67,13 & 60,57 & 51,90 & 44,03 & 37,24 & 26,92 & 20,15 & 12,93 \\
\hline 23,94 & 1705,80 & 82,40 & 41,00 & 34,13 & 28,85 & 22,70 & 17,89 & 14,28 & 9,69 & 7,21 & 4,85 \\
\hline 89,96 & 1447,30 & 56,20 & 22,14 & 16,78 & 15,47 & 14,62 & 13,81 & 13,03 & 11,56 & 10,23 & 8,00 \\
\hline 29,38 & 944,40 & 179,90 & 25,15 & 17,97 & 14,18 & 10,46 & 7,95 & 6,24 & 4,26 & 3,24 & 2,24 \\
\hline 31,39 & 266,40 & 192,80 & 38,41 & 19,88 & 13,75 & 9,38 & 7,01 & 5,54 & 3,86 & 3,00 & 2,12 \\
\hline 27,56 & 1824,70 & 115,00 & 28,60 & 23,61 & 20,07 & 15,96 & 12,71 & 10,23 & 7,00 & 5,21 & 3,49 \\
\hline 38,85 & 613,40 & 115,80 & 33,40 & 24,16 & 19,86 & 15,54 & 12,34 & 9,96 & 6,89 & 5,18 & 3,49 \\
\hline 65,67 & 332,80 & 25,90 & 76,02 & 59,17 & 53,72 & 48,00 & 43,12 & 38,71 & 31,18 & 25,31 & 17,36 \\
\hline 31,55 & 1687,80 & 112,50 & 26,84 & 22,35 & 19,31 & 15,74 & 12,81 & 10,49 & 7,31 & 5,44 & 3,59 \\
\hline 63,81 & 1435,80 & 112,80 & 17,77 & 13,92 & 12,61 & 11,24 & 10,06 & 9,00 & 7,20 & 5,81 & 3,96 \\
\hline 45,04 & 1553,80 & 166,90 & 16,81 & 13,31 & 11,59 & 9,73 & 8,18 & 6,90 & 5,01 & 3,79 & 2,48 \\
\hline 67,50 & 985,40 & 182,60 & 16,06 & 11,12 & 9,43 & 7,96 & 6,85 & 5,93 & 4,51 & 3,52 & 2,36 \\
\hline 84,12 & 961,80 & 152,80 & 16,27 & 11,00 & 9,45 & 8,17 & 7,24 & 6,46 & 5,17 & 4,21 & 2,92 \\
\hline 43,83 & 248,20 & 42,90 & 81,40 & 59,72 & 50,06 & 40,32 & 32,82 & 26,99 & 19,01 & 14,31 & 9,52 \\
\hline 53,83 & 304,40 & 33,30 & 76,15 & 59,31 & 52,15 & 44,77 & 38,60 & 33,32 & 25,09 & 19,41 & 12,77 \\
\hline 77,09 & 1152,20 & 29,90 & 39,40 & 30,94 & 29,08 & 27,77 & 26,31 & 24,85 & 22,05 & 19,50 & 15,16 \\
\hline 64,33 & 1133,10 & 88,40 & 22,52 & 17,62 & 15,98 & 14,25 & 12,77 & 11,44 & 9,17 & 7,42 & 5,07 \\
\hline 83,88 & 1032,50 & 58,60 & 26,00 & 19,34 & 17,84 & 16,49 & 15,30 & 14,20 & 12,21 & 10,50 & 7,81 \\
\hline 45,28 & 763,20 & 93,80 & 31,53 & 24,47 & 21,11 & 17,55 & 14,65 & 12,29 & 8,86 & 6,70 & 4,40 \\
\hline 48,18 & 779,40 & 104,50 & 28,32 & 21,61 & 18,61 & 15,52 & 13,02 & 10,97 & 7,96 & 6,04 & 3,97 \\
\hline 88,36 & 1132,40 & 43,80 & 28,73 & 21,79 & 20,14 & 19,03 & 17,96 & 16,93 & 14,99 & 13,24 & 10,30 \\
\hline 78,03 & 1748,00 & 168,50 & 11,82 & 8,64 & 7,74 & 6,91 & 6,24 & 5,65 & 4,63 & 3,82 & 2,69 \\
\hline 61,93 & 525,50 & 102,30 & 30,48 & 21,21 & 17,88 & 14,92 & 12,68 & 10,84 & 8,07 & 6,23 & 4,14 \\
\hline 46,66 & 524,60 & 170,50 & 26,71 & $\begin{array}{l}2 L 1, L \perp \\
17,11\end{array}$ & 13,54 & 10,42 & 8,26 & 6,68 & 4,65 & 3,52 & 2,39 \\
\hline 82,84 & 843,70 & 38,70 & 36,34 & $\begin{array}{l}+1, \pm \pm \\
27,43\end{array}$ & 25,48 & $\frac{10,+L}{23,81}$ & 22,25 & 20,78 & 18,06 & 15,67 & 11,84 \\
\hline 74,87 & 330,00 & 86,30 & 39,80 & 25,33 & 20,70 & $\begin{array}{l}c u, 01 \\
17,04\end{array}$ & 14,51 & 12,49 & 9,44 & $\begin{array}{c}10,01 \\
7,39\end{array}$ & $\begin{array}{c}, 1,97 \\
4,97\end{array}$ \\
\hline 52,59 & 1876,90 & 199,90 & 12,72 & 9,97 & 8,78 & 7,53 & 6,48 & 5,58 & 4,19 & 3,23 & 2,13 \\
\hline 20,40 & 1566,30 & 185,50 & 26,29 & 19,15 & 14,60 & 10,28 & 7,57 & 5,87 & 4,03 & 3,11 & 2,16 \\
\hline 25,47 & 1745,50 & 64,30 & 45,81 & 39,48 & 34,31 & 27,97 & 22,70 & 18,51 & 12,79 & 9,47 & 6,25 \\
\hline 53,95 & 1328,70 & 167,10 & 16,14 & 12,32 & 10,73 & 9,12 & 7,81 & 6,70 & 5,00 & 3,85 & 2,53 \\
\hline 22,76 & 1044,10 & 131,60 & 35,22 & 25,98 & 20,19 & 14,51 & 10,80 & 8,40 & 5,73 & 4,39 & 3,05 \\
\hline 71,70 & 1601,60 & 142,00 & 14,03 & 10,57 & 9,53 & 8,50 & 7,65 & 6,90 & 5,60 & 4,58 & 3,17 \\
\hline 68,53 & 1764,50 & 90,20 & 18,05 & 14,19 & 13,22 & 12,12 & 11,12 & 10,20 & 8,53 & 7,14 & 5,09 \\
\hline 39,44 & 1315,90 & 105,50 & 25,91 & 21,36 & 18,73 & 15,70 & 13,14 & 11,03 & 7,93 & 5,97 & 3,90 \\
\hline 67,44 & 335,50 & 28,40 & 70,76 & 54,34 & 49,08 & 43,72 & 39,23 & 35,19 & 28,31 & 22,98 & 15,76 \\
\hline 29,74 & 1324,10 & 20,80 & 93,69 & 86,82 & 80,17 & 71,02 & 62,32 & 54,42 & 41,41 & 31,94 & 20,62 \\
\hline 72,63 & 1336,10 & 152,40 & 14,59 & 10,68 & 9,45 & 8,31 & 7,40 & 6,61 & 5,28 & 4,27 & 2,93 \\
\hline 34,34 & 817,30 & 48,50 & 55,96 & 47,50 & 41,77 & 34,90 & 29,05 & 24,24 & 17,27 & 12,92 & 8,42 \\
\hline 39,13 & 514,50 & 135,20 & 32,76 & 22,20 & 17,71 & 13,49 & 10,54 & 8,43 & 5,80 & 4,39 & 3,00 \\
\hline 57,24 & 1936,90 & 164,80 & 13,34 & 10,62 & 9,52 & 8,36 & 7,37 & 6,49 & 5,04 & 3,98 & 2,65 \\
\hline 75,71 & 1365,20 & 100,10 & 17,86 & 13,44 & 12,27 & 11,11 & 10,13 & 9,25 & 7,68 & 6,41 & 4,56 \\
\hline 73,33 & 832,20 & 125,10 & 20,31 & 14,31 & 12,37 & 10,67 & 9,38 & 8,27 & 6,49 & 5,18 & 3,52 \\
\hline 65,10 & 1263,80 & 49,40 & 30,77 & 24,64 & 23,23 & 21,49 & 19,84 & 18,28 & 15,42 & 13,00 & 9,34 \\
\hline 28,56 & 1834,20 & 92,50 & 32,12 & 27,26 & 23,64 & 19,28 & 15,67 & 12,81 & 8,89 & 6,60 & 4,35 \\
\hline
\end{tabular}




\begin{tabular}{|c|c|c|c|c|c|c|c|c|c|c|c|}
\hline \multirow[b]{2}{*}{ e1 (cm) } & & & & & & $\mathrm{De}$ & ões (x1 & m) & & & \\
\hline & Meq (MPa) & Ms (MPa) & D0 & D25 & D40 & D60 & D80 & D100 & D140 & D180 & D260 \\
\hline 44,40 & 702,80 & 53,10 & 46,29 & 38,36 & 34,12 & 29,26 & 25,05 & 21,44 & 15,89 & 12,14 & 7,91 \\
\hline 85,94 & 637,00 & 179,10 & 19,32 & 11,81 & 9,53 & 7,83 & 6,70 & 5,83 & 4,49 & 3,56 & 2,43 \\
\hline 26,51 & 1484,50 & 149,90 & 26,21 & 20,37 & 16,62 & 12,61 & 9,70 & 7,65 & 5,18 & 3,91 & 2,67 \\
\hline 47,55 & 1354,00 & 110,50 & 21,91 & 17,93 & 15,95 & 13,74 & 11,83 & 10,19 & 7,63 & 5,87 & 3,83 \\
\hline 72,98 & 965,10 & 80,50 & 23,89 & 17,99 & 16,29 & 14,61 & 13,21 & 11,95 & 9,78 & 8,05 & 5,62 \\
\hline 40,94 & 242,20 & 152,80 & 43,56 & 23,49 & 16,89 & 11,96 & 9,07 & 7,18 & 4,96 & 3,82 & 2,67 \\
\hline 78,68 & 1478,10 & 96,20 & 17,34 & 13,00 & 11,95 & 10,92 & 10,04 & 9,23 & 7,79 & 6,58 & 4,76 \\
\hline 24,28 & 489,80 & 180,20 & 33,89 & 20,83 & 14,95 & 10,21 & 7,53 & 5,92 & 4,13 & 3,20 & 2,24 \\
\hline 53,38 & 1499,90 & 56,60 & 29,81 & 25,16 & 23,56 & 21,44 & 19,46 & 17,60 & 14,32 & 11,68 & 8,01 \\
\hline 76,25 & 917,70 & 73,40 & 25,21 & 18,82 & 17,09 & 15,40 & 14,01 & 12,75 & 10,54 & 8,76 & 6,20 \\
\hline 85,87 & 1430,90 & 42,80 & 26,89 & 20,89 & 19,36 & 18,47 & 17,55 & 16,62 & 14,85 & 13,23 & 10,44 \\
\hline 34,29 & 975,60 & 87,60 & 36,01 & 29,10 & 24,93 & 20,20 & 16,39 & 13,41 & 9,34 & 6,97 & 4,62 \\
\hline 70,40 & 310,70 & 98,50 & 39,90 & 24,62 & 19,69 & 15,85 & 13,24 & 11,21 & 8,27 & 6,39 & 4,29 \\
\hline 87,61 & 690,80 & 40,70 & 37,17 & 27,34 & 25,09 & 23,20 & 21,55 & 20,05 & 17,31 & 14,95 & 11,22 \\
\hline 79,98 & 1681,50 & 113,20 & 14,83 & 11,05 & 10,13 & 9,25 & 8,50 & 7,82 & 6,60 & 5,58 & 4,05 \\
\hline 51,92 & 1717,80 & 119,80 & 17,94 & 14,77 & 13,34 & 11,73 & 10,31 & 9,05 & 6,99 & 5,49 & 3,63 \\
\hline 40,46 & 404,80 & 33,20 & 81,59 & 67,10 & 58,90 & 49,51 & 41,57 & 34,98 & 25,27 & 19,06 & 12,44 \\
\hline 21,62 & 218,90 & 51,80 & 109,18 & 72,07 & 52,50 & 35,89 & 26,33 & 20,59 & 14,34 & 11,13 & 7,76 \\
\hline 50,20 & 1750,20 & 198,90 & 13,51 & 10,54 & 9,21 & 7,82 & 6,66 & 5,69 & 4,21 & 3,22 & 2,11 \\
\hline 22,66 & 674,60 & 65,50 & 65,91 & 50,30 & 39,90 & 29,24 & 21,96 & 17,10 & 11,60 & 8,84 & 6,10 \\
\hline 69,94 & 1800,90 & 90,90 & 17,63 & 13,78 & 12,85 & 11,81 & 10,86 & 9,98 & 8,39 & 7,05 & 5,06 \\
\hline 37,62 & 264,40 & 123,30 & 47,16 & 27,83 & 20,73 & 14,93 & 11,34 & 8,96 & 6,17 & 4,73 & 3,30 \\
\hline 79,81 & 1301,30 & 25,20 & 40,49 & 32,74 & 30,40 & 29,34 & 28,13 & 26,82 & 24,25 & 21,82 & 17,54 \\
\hline 70,57 & 381,80 & 170,60 & 28,63 & 16,30 & 12,46 & 9,63 & 7,85 & 6,53 & 4,72 & 3,63 & 2,46 \\
\hline 69,84 & 1123,00 & 101,80 & 20,01 & 15,15 & 13,63 & 12,12 & 10,88 & 9,77 & 7,87 & 6,40 & 4,41 \\
\hline 50,94 & 1310,70 & 197,50 & 15,31 & 11,41 & 9,77 & 8,14 & 6,84 & 5,77 & 4,20 & 3,20 & 2,11 \\
\hline 59,72 & 1920,60 & 102,00 & 17,47 & 14,22 & 13,17 & 11,91 & 10,78 & 9,73 & 7,91 & 6,45 & 4,43 \\
\hline 72,49 & 1846,30 & 41,60 & 28,14 & 22,32 & 21,12 & 20,21 & 19,15 & 18,08 & 16,03 & 14,15 & 10,97 \\
\hline 64,46 & 1474,90 & 79,00 & 21,69 & 17,31 & 16,07 & 14,62 & 13,33 & 12,12 & 9,99 & 8,26 & 5,78 \\
\hline 37,06 & 1939,00 & 31,10 & 53,19 & 48,23 & 45,54 & 41,43 & 37,41 & 33,61 & 26,93 & 21,61 & 14,45 \\
\hline 32,52 & 1115,60 & 72,70 & 40,26 & 33,69 & 29,27 & 24,04 & 19,70 & 16,23 & 11,38 & 8,48 & 5,57 \\
\hline 83,29 & 677,00 & 132,60 & 21,15 & 13,89 & 11,69 & 9,92 & 8,68 & 7,66 & 6,03 & 4,85 & 3,33 \\
\hline 38,21 & 700,10 & 197,50 & 23,37 & 15,59 & 12,32 & 9,29 & 7,21 & 5,74 & 3,94 & 2,99 & 2,05 \\
\hline 87,70 & 604,90 & 75,60 & 28,50 & 19,66 & 17,23 & 15,18 & 13,66 & 12,36 & 10,16 & 8,42 & 5,97 \\
\hline 57,71 & 1572,80 & 110,10 & 18,35 & 14,83 & 13,48 & 11,98 & 10,67 & 9,48 & 7,49 & 5,98 & 4,02 \\
\hline 23,06 & 826,20 & 171,10 & 30,87 & 21,11 & 15,76 & 10,99 & 8,10 & 6,31 & 4,36 & 3,37 & 2,35 \\
\hline 25,99 & 1559,30 & 145,60 & 26,71 & 20,91 & 17,10 & 13,00 & 10,01 & 7,89 & 5,34 & 4,02 & 2,75 \\
\hline 34,60 & 1970,20 & 193,40 & 16,73 & 13,37 & 11,40 & 9,19 & 7,43 & 6,06 & 4,21 & 3,14 & 2,09 \\
\hline 40,09 & 851,60 & 57,00 & 44,23 & 37,24 & 33,06 & 28,13 & 23,86 & 20,25 & 14,80 & 11,21 & 7,29 \\
\hline 36,72 & 697,30 & 155,60 & 27,40 & 19,20 & 15,45 & 11,79 & 9,20 & 7,34 & 5,04 & 3,81 & 2,60 \\
\hline 62,27 & 1035,00 & 128,10 & 19,39 & 14,53 & 12,73 & 11,00 & 9,60 & 8,39 & 6,46 & 5,08 & 3,39 \\
\hline 28,22 & 703,70 & 121,70 & 36,82 & 26,65 & 21,05 & 15,51 & 11,76 & 9,22 & 6,29 & 4,78 & 3,30 \\
\hline 32,15 & 1330,40 & 87,30 & 33,91 & 28,33 & 24,56 & 20,12 & 16,45 & 13,52 & 9,46 & 7,04 & 4,64 \\
\hline 25,87 & 504,70 & 45,30 & 85,03 & 66,86 & 54,79 & 41,73 & 32,16 & 25,37 & 17,18 & 12,93 & 8,83 \\
\hline 48,38 & 540,60 & 98,30 & 34,46 & 24,93 & 20,95 & 17,07 & 14,07 & 11,69 & 8,35 & 6,31 & 4,19 \\
\hline 75,53 & 970,50 & 138,50 & 17,65 & 12,44 & 10,81 & 9,37 & 8,28 & 7,35 & 5,82 & 4,68 & 3,20 \\
\hline 81,34 & 1906,40 & 43,50 & 24,70 & 19,65 & 18,28 & 17,57 & 16,78 & 15,95 & 14,34 & 12,85 & 10,23 \\
\hline 65,60 & 1072,70 & 34,20 & 41,20 & 32,96 & 31,30 & 29,25 & 27,21 & 25,25 & 21,61 & 18,45 & 13,52 \\
\hline 25,64 & 240,60 & 21,70 & 178,72 & 140,24 & 114,69 & 87,11 & 67,02 & 52,80 & 35,74 & 26,92 & 18,40 \\
\hline 48,67 & 1939,80 & 137,50 & 16,40 & 13,59 & 12,21 & 10,65 & 9,27 & 8,06 & 6,13 & 4,76 & 3,12 \\
\hline 33,69 & 1927,80 & 66,60 & 34,21 & 30,48 & 27,52 & 23,75 & 20,35 & 17,40 & 12,82 & 9,72 & 6,27 \\
\hline 71,29 & 1993,70 & 29,70 & 34,18 & 27,91 & 26,20 & 25,38 & 24,34 & 23,19 & 20,93 & 18,79 & 15,01 \\
\hline 76,85 & 470,50 & 165,40 & 24,79 & 14,75 & 11,62 & 9,29 & 7,76 & 6,60 & 4,90 & 3,81 & 2,57 \\
\hline 41,34 & 1725,00 & 160,70 & 17,44 & 14,11 & 12,31 & 10,29 & 8,61 & 7,22 & 5,20 & 3,92 & 2,56 \\
\hline 75,70 & 1138,90 & 119,40 & 17,57 & 12,85 & 11,44 & 10,14 & 9,10 & 8,19 & 6,63 & 5,42 & 3,77 \\
\hline 52,20 & 1180,50 & 197,00 & 15,88 & 11,60 & 9,87 & 8,18 & 6,85 & 5,78 & 4,20 & 3,20 & 2,11 \\
\hline 39,73 & 1287,10 & 24,50 & 67,62 & 60,71 & 57,28 & 52,13 & 47,12 & 42,38 & 34,05 & 27,40 & 18,40 \\
\hline 54,28 & 1428,00 & 97,20 & 21,32 & 17,46 & 15,85 & 14,02 & 12,41 & 10,96 & 8,57 & 6,78 & 4,52 \\
\hline 77,35 & 495,10 & 191,70 & 22,76 & 13,24 & 10,30 & 8,14 & 6,75 & 5,71 & 4,22 & 3,28 & 2,22 \\
\hline 76,89 & 538,30 & 98,00 & 28,21 & 19,09 & 16,21 & 13,81 & 12,05 & 10,59 & 8,26 & 6,59 & 4,48 \\
\hline 69,74 & 1695,40 & 149,90 & 13,45 & 10,21 & 9,20 & 8,19 & 7,36 & 6,61 & 5,34 & 4,35 & 3,00 \\
\hline 28,45 & 1478,50 & 144,20 & 25,68 & 20,21 & 16,74 & 12,95 & 10,11 & 8,04 & 5,47 & 4,10 & 2,78 \\
\hline 34,50 & 1570,80 & 99,60 & 27,80 & 23,44 & 20,54 & 17,10 & 14,19 & 11,81 & 8,38 & 6,27 & 4,10 \\
\hline 60,20 & 1418,10 & 33,40 & 40,37 & 32,89 & 31,52 & 29,64 & 27,66 & 25,74 & 22,13 & 18,94 & 13,92 \\
\hline 49,78 & 1822,30 & 92,20 & 21,20 & 17,99 & 16,50 & 14,70 & 13,06 & 11,57 & 9,07 & 7,19 & 4,78 \\
\hline 61,57 & 969,60 & 36,50 & 42,45 & 34,50 & 32,55 & 30,02 & 27,62 & 25,35 & 21,23 & 17,76 & 12,62 \\
\hline 85,05 & 290,90 & 197,10 & 32,49 & 16,48 & 11,76 & 8,60 & 6,83 & 5,62 & 4,03 & 3,11 & 2,14 \\
\hline 88,34 & 1282,30 & 130,10 & 14,88 & 10,47 & 9,32 & 8,34 & 7,58 & 6,92 & 5,78 & 4,85 & 3,50 \\
\hline 58,45 & 533,50 & 123,20 & 28,37 & 19,22 & 15,92 & 13,02 & 10,87 & 9,15 & 6,67 & 5,10 & 3,39 \\
\hline 38,30 & 464,90 & 24,90 & 96,48 & 83,08 & 74,34 & 63,71 & 54,35 & 46,32 & 34,04 & 25,82 & 16,74 \\
\hline 57,06 & 655,90 & 150,20 & 23,40 & 15,93 & 13,20 & 10,77 & 8,97 & 7,53 & 5,46 & 4,17 & 2,77 \\
\hline 76,55 & 385,90 & 44,70 & 48,99 & 35,33 & 31,22 & 27,50 & 24,59 & 22,04 & 17,77 & 14,48 & 10,02 \\
\hline 54,08 & 243,50 & 166,30 & 40,41 & 21,02 & 15,06 & 10,83 & 8,36 & 6,70 & 4,64 & 3,56 & 2,47 \\
\hline 38,73 & 451,50 & 147,60 & 33,16 & 21,39 & 16,66 & 12,44 & 9,60 & 7,64 & 5,25 & 3,99 & 2,74 \\
\hline 60,52 & 1091,70 & 98,40 & 22,21 & 17,38 & 15,58 & 13,71 & 12,12 & 10,71 & 8,39 & 6,67 & 4,47 \\
\hline 49,51 & 623,10 & 94,90 & 32,51 & 24,24 & 20,70 & 17,17 & 14,35 & 12,06 & 8,73 & 6,63 & 4,37 \\
\hline 26,48 & 1873,80 & 198,50 & 20,11 & 15,53 & 12,62 & 9,53 & 7,32 & 5,76 & 3,90 & 2,95 & 2,02 \\
\hline 41,46 & 1212,50 & 98,20 & 26,97 & 22,22 & 19,56 & 16,52 & 13,94 & 11,77 & 8,56 & 6,47 & 4,22 \\
\hline 67,45 & 1143,00 & 197,90 & 14,30 & 10,02 & 8,55 & 7,25 & 6,27 & 5,45 & 4,16 & 3,26 & 2,18 \\
\hline 65,22 & 627,70 & 156,00 & 22,37 & 14,71 & 12,11 & 9,93 & 8,37 & 7,11 & 5,26 & 4,06 & 2,71 \\
\hline 36,09 & 251,30 & 157,50 & 42,99 & $\begin{array}{l}17,1 . \\
23,30\end{array}$ & $\begin{array}{l}L, \pm 1 \\
16,63\end{array}$ & 11,62 & 8,73 & 6,90 & 4,77 & 3,69 & 2,59 \\
\hline 54,28 & 736,60 & 20,50 & 73,79 & 61,94 & 58,90 & 54,44 & 50,07 & 45,90 & 38,30 & 31,90 & 22,48 \\
\hline
\end{tabular}




\begin{tabular}{|c|c|c|c|c|c|c|c|c|c|c|c|}
\hline & & & \multicolumn{9}{|c|}{ Deflexões $\left(\times 10^{-4} \mathrm{~cm}\right)$} \\
\hline e1 (cm) & Meq (MPa) & Ms (MPa) & D0 & D25 & D40 & D60 & D80 & D100 & D140 & D180 & D260 \\
\hline 86,15 & 1148,30 & 80,40 & 20,48 & 14,94 & 13,63 & 12,46 & 11,49 & 10,62 & 9,05 & 7,72 & 5,69 \\
\hline 72,45 & 871,20 & 51,70 & 32,39 & 24,93 & 23,05 & 21,06 & 19,30 & 17,68 & 14,79 & 12,39 & 8,86 \\
\hline 86,10 & 1681,00 & 47,90 & 23,51 & 18,36 & 16,99 & 16,24 & 15,46 & 14,66 & 13,14 & 11,73 & 9,31 \\
\hline 34,10 & 1793,00 & 83,90 & 29,90 & 25,98 & 23,14 & 19,62 & 16,55 & 13,96 & 10,09 & 7,58 & 4,91 \\
\hline 39,15 & 1384,10 & 130,60 & 22,40 & 18,08 & 15,68 & 12,97 & 10,74 & 8,93 & 6,36 & 4,77 & 3,13 \\
\hline 54,64 & 540,60 & 67,70 & 39,49 & 30,11 & 26,25 & 22,36 & 19,18 & 16,48 & 12,33 & 9,51 & 6,26 \\
\hline 48,98 & 518,70 & 34,30 & 63,66 & 53,07 & 47,91 & 41,96 & 36,70 & 32,05 & 24,53 & 19,11 & 12,56 \\
\hline 53,64 & 1661,50 & 48,40 & 31,95 & 26,92 & 25,53 & 23,52 & 21,58 & 19,72 & 16,37 & 13,57 & 9,50 \\
\hline 51,20 & 350,70 & 111,30 & 39,11 & 25,02 & 19,95 & 15,59 & 12,54 & 10,25 & 7,21 & 5,46 & 3,69 \\
\hline 79,83 & 383,30 & 125,80 & 30,91 & 18,56 & 14,73 & 11,87 & 10,01 & 8,57 & 6,44 & 5,04 & 3,41 \\
\hline 75,61 & 818,30 & 51,30 & 32,68 & 24,81 & 22,87 & 20,88 & 19,17 & 17,59 & 14,77 & 12,43 & 8,94 \\
\hline 85,75 & 837,80 & 103,50 & 20,88 & 14,51 & 12,74 & 11,22 & 10,09 & 9,12 & 7,47 & 6,17 & 4,36 \\
\hline 30,86 & 1880,20 & 184,20 & 19,02 & 15,08 & 12,65 & 9,96 & 7,89 & 6,33 & 4,34 & 3,24 & 2,18 \\
\hline 76,45 & 1906,20 & 94,10 & 16,10 & 12,31 & 11,47 & 10,62 & 9,84 & 9,12 & 7,79 & 6,65 & 4,89 \\
\hline 75,75 & 1167,30 & 154,50 & 15,21 & 10,83 & 9,46 & 8,25 & 7,32 & 6,52 & 5,19 & 4,20 & 2,88 \\
\hline 68,19 & 1432,70 & 49,80 & 28,49 & 22,57 & 21,36 & 19,95 & 18,56 & 17,23 & 14,77 & 12,62 & 9,27 \\
\hline 56,06 & 1931,90 & 118,80 & 16,44 & 13,49 & 12,33 & 11,01 & 9,83 & 8,76 & 6,94 & 5,56 & 3,74 \\
\hline 55,27 & 334,70 & 44,90 & 61,05 & 46,00 & 39,90 & 33,88 & 28,98 & 24,86 & 18,55 & 14,30 & 9,43 \\
\hline 66,20 & 717,40 & 145,80 & 21,30 & 14,55 & 12,22 & 10,22 & 8,73 & 7,51 & 5,64 & 4,39 & 2,93 \\
\hline 84,98 & 1369,50 & 168,30 & 12,85 & 8,96 & 7,87 & 6,93 & 6,23 & 5,63 & 4,60 & 3,80 & 2,68 \\
\hline 28,19 & 1829,30 & 127,10 & 26,26 & 21,51 & 18,23 & 14,46 & 11,50 & 9,25 & 6,33 & 4,71 & 3,16 \\
\hline 26,67 & 994,80 & 108,10 & 37,05 & 28,54 & 23,18 & 17,50 & 13,43 & 10,57 & 7,17 & 5,41 & 3,71 \\
\hline 54,58 & 1219,60 & 71,40 & 27,29 & 22,57 & 20,67 & 18,45 & 16,46 & 14,65 & 11,59 & 9,26 & 6,21 \\
\hline 21,86 & 1951,60 & 62,70 & 51,18 & 43,62 & 37,30 & 29,71 & 23,60 & 18,92 & 12,85 & 9,53 & 6,37 \\
\hline 39,64 & 1339,20 & 107,40 & 25,37 & 20,91 & 18,35 & 15,39 & 12,90 & 10,83 & $\begin{array}{c}1 L, 00 \\
7,80\end{array}$ & 5,88 & 3,84 \\
\hline 20,44 & 1269,90 & 73,70 & 54,58 & 43,40 & 35,11 & 26,17 & 19,80 & 15,43 & 10,40 & 7,87 & 5,42 \\
\hline 65,05 & 1869,60 & 75,70 & 20,34 & 16,28 & 15,33 & 14,16 & 13,05 & 12,01 & 10,11 & 8,50 & 6,09 \\
\hline 72,38 & 1889,30 & 53,50 & 23,77 & 18,69 & 17,70 & 16,76 & 15,77 & 14,80 & 12,96 & 11,30 & 8,59 \\
\hline 65,05 & 1641,50 & 25,80 & 43,37 & 35,07 & 33,43 & 32,19 & 30,59 & 28,95 & $\frac{1\llcorner,, 0}{25,76}$ & $\frac{1 \pm, v 0}{22,79}$ & $\frac{0,00}{17,72}$ \\
\hline 76,03 & 202,10 & 92,20 & 52,99 & 29,76 & 22,64 & 17,51 & 14,33 & 11,99 & 8,74 & 6,75 & 4,58 \\
\hline 57,82 & 1485,20 & 107,30 & 19,06 & 15,35 & 13,93 & 12,36 & 10,99 & 9,76 & 7,70 & 6,14 & 4,12 \\
\hline 51,85 & 1527,20 & 137,20 & 17,38 & 13,94 & 12,40 & 10,74 & 9,31 & 8,07 & 6,12 & 4,74 & 3,12 \\
\hline 79,22 & 1056,20 & 41,10 & 32,90 & 25,22 & 23,61 & 22,17 & 20,77 & 19,44 & 16,94 & 14,73 & 11,15 \\
\hline 78,77 & 1417,00 & 157,30 & 13,48 & 9,69 & 8,60 & 7,60 & 6,83 & 6,15 & 5,00 & 4,10 & 2,86 \\
\hline 44,03 & 748,80 & 63,90 & 40,57 & 33,16 & 29,25 & 24,85 & 21,10 & 17,93 & 13,15 & 10,00 & 6,52 \\
\hline 85,61 & 1337,80 & 38,50 & 29,49 & 23,00 & 21,31 & 20,36 & 19,36 & 18,36 & 16,43 & 14,65 & 11,60 \\
\hline 28,68 & 1116,10 & 196,80 & 22,70 & 16,41 & 12,97 & 9,58 & 7,27 & 5,71 & 3,89 & 2,96 & 2,04 \\
\hline 49,20 & 957,10 & 87,60 & 28,33 & 22,80 & 20,19 & 17,34 & 14,91 & 12,83 & 9,60 & 7,38 & 4,83 \\
\hline 75,34 & 1568,70 & 164,20 & 12,80 & 9,37 & 8,35 & 7,39 & 6,63 & 5,96 & 4,83 & 3,95 & 2,74 \\
\hline 45,10 & 1071,90 & 52,20 & 39,44 & 33,97 & 30,99 & 27,34 & 24,02 & 21,05 & 16,18 & 12,63 & 8,28 \\
\hline 80,89 & 608,60 & 130,90 & 22,82 & 14,85 & 12,38 & 10,41 & 9,04 & 7,92 & 6,16 & 4,91 & 3,34 \\
\hline 44,59 & 829,90 & 193,80 & 20,43 & 14,12 & 11,54 & 9,09 & 7,29 & 5,93 & 4,14 & 3,12 & 2,10 \\
\hline 42,99 & 1719,50 & 111,30 & 21,28 & 17,96 & 16,07 & 13,85 & 11,90 & 10,22 & 7,61 & 5,82 & 3,79 \\
\hline 64,99 & 771,40 & 58,00 & 33,63 & 26,31 & 23,93 & 21,41 & 19,24 & 17,28 & 13,92 & 11,31 & 7,75 \\
\hline 82,90 & 1877,30 & 125,90 & 13,08 & 9,66 & 8,85 & 8,09 & 7,46 & 6,88 & 5,84 & 4,97 & 3,64 \\
\hline 88,71 & 410,20 & 78,00 & 34,64 & 22,53 & 18,97 & 16,18 & 14,24 & 12,65 & 10,10 & 8,21 & 5,70 \\
\hline 85,63 & 1960,70 & 74,20 & 17,16 & 13,06 & 12,12 & 11,45 & 10,79 & 10,16 & 8,97 & 7,89 & 6,11 \\
\hline 76,99 & 689,30 & 32,00 & 46,04 & 35,23 & 32,89 & 30,57 & 28,41 & 26,38 & 22,65 & 19,43 & 14,39 \\
\hline 56,69 & 1527,10 & 155,20 & 15,37 & 12,01 & 10,64 & 9,23 & 8,05 & 7,02 & 5,37 & 4,20 & 2,78 \\
\hline 88,12 & 481,40 & 140,00 & 25,09 & 15,17 & 12,19 & 9,97 & 8,53 & 7,42 & 5,72 & 4,55 & 3,12 \\
\hline 21,28 & 1578,60 & 63,70 & 55,13 & 45,80 & 38,37 & 29,79 & 23,19 & 18,35 & 12,37 & 9,23 & 6,26 \\
\hline 47,17 & 1685,00 & 92,40 & 22,58 & 19,20 & 17,47 & 15,39 & 13,53 & 11,86 & 9,13 & 7,13 & 4,69 \\
\hline 51,95 & 1795,70 & 23,30 & 53,34 & 44,23 & 42,87 & 40,76 & 38,30 & 35,86 & 31,17 & 26,93 & 20,05 \\
\hline 86,09 & 528,90 & 165,20 & 22,40 & 13,41 & 10,68 & 8,67 & 7,37 & 6,37 & 4,87 & 3,85 & 2,63 \\
\hline 72,15 & 1840,80 & 131,30 & 13,78 & 10,52 & 9,62 & 8,70 & 7,91 & 7,20 & 5,94 & 4,92 & 3,47 \\
\hline 32,70 & 1322,00 & 60,30 & 42,63 & 37,02 & 32,85 & 27,71 & 23,24 & 19,49 & 13,98 & 10,47 & 6,79 \\
\hline 24,86 & 1435,80 & 153,90 & 27,15 & 20,76 & 16,65 & 12,38 & 9,39 & 7,35 & 4,98 & 3,78 & 2,60 \\
\hline 42,75 & 315,00 & 24,10 & 105,31 & 87,29 & 77,33 & 65,89 & 56,04 & 47,70 & 35,03 & 26,63 & 17,34 \\
\hline 49,13 & 1719,60 & 63,60 & 27,78 & 23,90 & 22,27 & 20,12 & 18,11 & 16,24 & 13,00 & 10,46 & 7,05 \\
\hline 23,98 & 1401,90 & 61,80 & 53,04 & 44,56 & 37,91 & 30,07 & 23,84 & 19,10 & 12,99 & 9,65 & 6,47 \\
\hline 40,64 & 1953,30 & 107,50 & 21,59 & 18,54 & 16,66 & 14,38 & 12,36 & 10,62 & 7,89 & 6,03 & 3,91 \\
\hline 36,46 & 1762,60 & 37,10 & 49,00 & 44,57 & 41,50 & 37,22 & 33,13 & 29,34 & 22,93 & 18,05 & 11,84 \\
\hline 38,00 & 1872,30 & 50,50 & 37,77 & 34,02 & 31,46 & 28,02 & 24,77 & 21,81 & 16,87 & 13,19 & $\begin{array}{c}+, \text { T } \\
8,63\end{array}$ \\
\hline 26,25 & 360,60 & 152,50 & 40,79 & 24,45 & 17,56 & $\frac{c u, v L}{12,05}$ & 8,92 & $\begin{array}{c}c 1,01 \\
7,02\end{array}$ & 4,88 & $\begin{array}{c}10, \pm 0 \\
3,79\end{array}$ & 2,65 \\
\hline 65,55 & 1965,50 & 167,50 & 12,22 & 9,44 & 8,52 & 7,57 & 6,77 & 6,06 & 4,84 & 3,91 & 2,67 \\
\hline 53,04 & 264,80 & 33,50 & 81,55 & 62,32 & 54,20 & 45,99 & 39,25 & 33,59 & 24,96 & 19,17 & 12,61 \\
\hline 32,35 & 340,00 & 111,00 & 47,29 & 30,52 & 23,24 & 16,79 & 12,67 & 9,97 & 6,84 & 5,25 & 3,64 \\
\hline 37,27 & 1336,70 & 69,90 & 34,81 & 30,03 & 26,83 & 22,94 & 19,51 & 16,58 & 12,13 & 9,18 & 5,95 \\
\hline 27,80 & 1107,10 & 123,40 & 31,82 & 24,55 & 20,04 & 15,25 & 11,77 & 9,30 & 6,31 & 4,76 & 3,25 \\
\hline 52,25 & 857,80 & 44,90 & 42.76 & 35,89 & 32,99 & 29,49 & 26,31 & 23,41 & 18,51 & 14.76 & 9,88 \\
\hline 79,12 & 1226,60 & 61,40 & 24,33 & 18,45 & 17,16 & 15,91 & 14,77 & 13,71 & 11,77 & 10,10 & 7,48 \\
\hline 38,11 & 1826,90 & 66,50 & 31,63 & 28,08 & 25,61 & 22,45 & 19,55 & 16,98 & 12,83 & 9,88 & 6,41 \\
\hline 31,75 & 737,00 & 188,80 & 25,56 & 17,37 & 13,51 & 9,90 & 7,52 & 5,92 & 4,05 & 3,09 & 2,14 \\
\hline 57,98 & 877,90 & 143,40 & 20,50 & 14,87 & 12,71 & 10,69 & 9,10 & 7,78 & 5,79 & 4,46 & 2,95 \\
\hline 84,47 & 1171,40 & 190,40 & 13,20 & 8,89 & 7,62 & 6,57 & 5,82 & 5,19 & 4,15 & 3,38 & 2,34 \\
\hline 47,87 & 1856,60 & 93,20 & 21,46 & 18,32 & 16,77 & 14,88 & 13,16 & 11,60 & 9,02 & 7,10 & 4,69 \\
\hline 55,55 & 917,10 & 20,10 & 69,02 & 57,26 & 54,97 & 51,45 & 47,82 & 44,30 & 37,72 & 32,00 & 23,15 \\
\hline 36,19 & 1351,80 & 66,90 & 36,49 & 31,62 & 28,26 & 24,12 & 20,48 & 17,38 & 12,68 & 9,58 & 6,20 \\
\hline 77,35 & 805,40 & 131,50 & 19,77 & 13,59 & 11,66 & 10,02 & 8,81 & 7,78 & 6,13 & 4,92 & 3,36 \\
\hline 59,85 & 1949,80 & 177,50 & 12,44 & 9,75 & 8,72 & 7,66 & 6,76 & 5,97 & 4,66 & 3,69 & 2,47 \\
\hline 31,13 & 1247,20 & 168,40 & 23,09 & 17,51 & 14,36 & 11,03 & 8,60 & 6,84 & 4,66 & 3,51 & 2,39 \\
\hline 88,00 & 482,30 & 129,90 & 25,76 & 15,81 & 12,82 & 10,57 & 9,10 & 7,94 & 6,16 & 4,92 & 3,37 \\
\hline
\end{tabular}




\begin{tabular}{|c|c|c|c|c|c|c|c|c|c|c|c|}
\hline \multirow[b]{2}{*}{ e1 (cm) } & & & & & & & ões (x1 & m) & & & \\
\hline & Meq (MPa) & Ms (MPa) & D0 & D25 & D40 & D60 & D80 & D100 & D140 & D180 & D260 \\
\hline 72,06 & 459,00 & 186,90 & 24,49 & 14,22 & 11,00 & 8,62 & 7,08 & 5,94 & 4,32 & 3,33 & 2,25 \\
\hline 88,80 & 968,00 & 197,20 & 14,27 & 9,17 & 7,67 & 6,50 & 5,70 & 5,05 & 4,01 & 3,25 & 2,25 \\
\hline 21,77 & 705,50 & 78,40 & 58,72 & 43,71 & 34,00 & 24,41 & 18,14 & 14,09 & 9,61 & 7,37 & 5,11 \\
\hline 26,70 & 1142,90 & 128,90 & 31,40 & 24,08 & 19,50 & 14,68 & 11,25 & 8,85 & 6,00 & 4,53 & 3,11 \\
\hline 22,65 & 1346,10 & 194,30 & 24,85 & 17,95 & 13,78 & 9,79 & 7,26 & 5,64 & 3,87 & 2,97 & 2,06 \\
\hline 40,04 & 825,60 & 162,40 & 23,84 & 17,11 & 14,06 & 11,03 & 8,78 & 7,10 & 4,92 & 3,70 & 2,50 \\
\hline 84,51 & 1699,20 & 58,00 & 21,23 & 16,30 & 15,16 & 14,38 & 13,59 & 12,81 & 11,35 & 10,03 & 7,80 \\
\hline 47,00 & 1635,80 & 136,00 & 18,07 & 14,77 & 13,11 & 11,27 & 9,68 & 8,31 & 6,20 & 4,75 & 3,11 \\
\hline 72,07 & 1498,20 & 44,10 & 29,34 & 23,06 & 21,84 & 20,64 & 19,39 & 18,17 & 15,86 & 13,80 & 10,44 \\
\hline 42,91 & 1205,10 & 29,70 & 57,10 & 50,64 & 47,56 & 43,15 & 38,92 & 34,94 & 28,00 & 22,50 & 15,11 \\
\hline 57,45 & 244,10 & 49,90 & 66,23 & 46,11 & 38,64 & 31,88 & 26,75 & 22,60 & 16,54 & 12,65 & 8,39 \\
\hline 72,38 & 1595,00 & 149,70 & 13,59 & 10,16 & 9,12 & 8,12 & 7,30 & 6,56 & 5,32 & 4,34 & 3,01 \\
\hline 48,51 & 852,30 & 182,60 & 20,01 & 14,02 & 11,61 & 9,33 & 7,62 & 6,29 & 4,46 & 3,37 & 2,25 \\
\hline 78,12 & 1580,70 & 109,70 & 15,68 & 11,73 & 10,75 & 9,78 & 8,96 & 8,22 & 6,89 & 5,80 & 4,17 \\
\hline 26,00 & 1982,60 & 190,20 & 20,61 & 16,09 & 13,13 & 9,96 & 7,65 & 6,03 & 4,08 & 3,08 & 2,11 \\
\hline 22,34 & 997,40 & 95,50 & 45,50 & 34,70 & 27,48 & 20,09 & 15,07 & 11,73 & 7,95 & 6,07 & 4,19 \\
\hline 29,20 & 1613,30 & 177,30 & 21,33 & 16,57 & 13,66 & 10,52 & 8,20 & 6,51 & 4,43 & 3,33 & 2,26 \\
\hline 86,03 & 1583,70 & 61,40 & 20,88 & 15,85 & 14,71 & 13,88 & 13,08 & 12,30 & 10,85 & 9,55 & 7,38 \\
\hline 45,51 & 1612,30 & 173,10 & 16,10 & 12,74 & 11,10 & 9,33 & 7,86 & 6,64 & 4,83 & 3,66 & 2,40 \\
\hline 32,27 & 268,70 & 97,20 & 56,27 & 35,45 & 26,70 & 19,13 & 14,40 & 11,32 & 7,79 & 5,98 & 4,16 \\
\hline 42,12 & 1563,30 & 38,10 & 44,98 & 40,02 & 37,55 & 34,02 & 30,63 & 27,45 & 21,93 & 17,58 & 11,76 \\
\hline 39,60 & 591,30 & 80,30 & 41,69 & 31,91 & 27,00 & 21,77 & 17,67 & 14,48 & 10,14 & 7,61 & 5,06 \\
\hline 40,62 & 1154,70 & 122,40 & 24,39 & 19,38 & 16,74 & 13,82 & 11,44 & 9,51 & 6,77 & 5,09 & 3,34 \\
\hline 81,25 & 1418,90 & 80,90 & 19,20 & 14,38 & 13,29 & 12,25 & 11,35 & 10,51 & 8,99 & 7,69 & 5,67 \\
\hline 39,63 & 1789,60 & 77,00 & 28,10 & 24,64 & 22,37 & 19,53 & 16,95 & 14,68 & 11,06 & 8,50 & 5,52 \\
\hline 57,57 & 1811,00 & 179,70 & 13,03 & 10,18 & 9,04 & 7,87 & 6,88 & 6,02 & 4,63 & 3,64 & 2,41 \\
\hline 73,19 & 1165,00 & 185,60 & 14,12 & 9,87 & 8,49 & 7,29 & 6,38 & 5,61 & 4,38 & 3,49 & 2,36 \\
\hline 23,97 & 1071,20 & 51,40 & 65,53 & 54,59 & 46,19 & 36,38 & 28,68 & 22,90 & 15,54 & 11,56 & 7,78 \\
\hline 76,59 & 876,30 & 174,20 & 16,69 & 11,14 & 9,37 & 7,92 & 6,88 & 6,02 & 4,66 & 3,70 & 2,51 \\
\hline 88,62 & 1881,60 & 185,10 & 10,28 & 7,25 & 6,47 & 5,80 & 5,28 & 4,83 & 4,04 & 3,40 & 2,46 \\
\hline 59,50 & 1744,20 & 21,80 & 50,90 & 41,55 & 39,85 & 38,42 & 36,52 & 34,55 & 30,72 & 27,14 & 21,03 \\
\hline 47,82 & 1019,60 & 45,50 & 42,16 & 36,22 & 33,35 & 29,77 & 26,47 & 23,47 & 18,41 & 14,58 & 9,68 \\
\hline 23,65 & 1720,10 & 157,10 & 26,25 & 20,33 & 16,35 & 12,17 & 9,23 & 7,22 & 4,88 & 3,70 & 2,55 \\
\hline 23,10 & 1263,50 & 189,80 & 25,42 & 18,32 & 14,07 & 10,02 & 7,43 & 5,78 & 3,96 & 3,04 & 2,11 \\
\hline 20,41 & 1455,70 & 52,60 & 66,89 & 55,74 & 46,70 & 36,23 & 28,17 & 22,26 & 14,98 & 11,18 & 7,58 \\
\hline 69,78 & 1133,20 & 184,80 & 14,64 & 10,29 & 8,83 & 7,55 & 6,57 & 5,74 & 4,43 & 3,50 & 2,35 \\
\hline 42,32 & 1803,90 & 134,60 & 18,79 & 15,62 & 13,85 & 11,80 & 10,03 & 8,54 & 6,27 & 4,76 & 3,10 \\
\hline 72,95 & 291,90 & 153,00 & 35,35 & 19,29 & 14,39 & 10,91 & 8,80 & 7,28 & 5,23 & 4,02 & 2,74 \\
\hline 20,56 & 1256,80 & 45,30 & 77,12 & 64,36 & 54,01 & 41,98 & 32,69 & 25,86 & 17,42 & 12,99 & 8,80 \\
\hline 51,93 & 1871,90 & 185,40 & 13,39 & 10,61 & 9,38 & 8,07 & 6,96 & 6,01 & 4,52 & 3,49 & 2,30 \\
\hline 42,51 & 1116,00 & 92,00 & 28,48 & 23,40 & 20,62 & 17,47 & 14,78 & 12,52 & 9,13 & 6,92 & 4,51 \\
\hline 73,18 & 627,20 & 82,90 & 28,75 & 20,63 & 18,03 & 15,70 & 13,89 & 12,33 & 9,75 & 7,84 & 5,34 \\
\hline 38,79 & 844,80 & 193,00 & 21,71 & 15,14 & 12,23 & 9,42 & 7,40 & 5,93 & 4,09 & 3,08 & 2,10 \\
\hline 25,71 & 1437,10 & 133,90 & 29,24 & 22,86 & 18,66 & 14,15 & 10,87 & 8,56 & 5,80 & 4,37 & 2,99 \\
\hline 31,50 & 1446,80 & 177,60 & 21,02 & 16,19 & 13,40 & 10,40 & 8,16 & 6,52 & 4,46 & 3,34 & 2,26 \\
\hline 56,51 & 298,30 & 95,30 & 44,30 & 28,04 & 22,41 & 17,71 & 14,42 & 11,92 & 8,48 & 6,45 & 4,34 \\
\hline 69,16 & 1849,20 & 152,70 & 12,87 & 9,84 & 8,91 & 7,97 & 7,17 & 6,46 & 5,23 & 4,27 & 2,95 \\
\hline 29,64 & 1850,00 & 34,60 & 59,66 & 54,92 & 50,31 & 44,12 & 38,34 & 33,16 & 24,85 & 18,99 & 12,21 \\
\hline 58,89 & 1053,20 & 68,80 & 28,24 & 22,83 & 20,86 & 18,65 & 16,69 & 14,92 & 11,90 & 9,57 & 6,48 \\
\hline 77,95 & 1265,00 & 198,10 & 12,80 & 8,84 & 7,61 & 6,56 & 5,79 & 5,13 & 4,06 & 3,26 & 2,23 \\
\hline 74,79 & 1037,80 & 117,50 & 18,62 & 13,54 & 11,99 & 10,56 & 9,44 & 8,45 & 6,79 & 5,52 & 3,81 \\
\hline 53,32 & 332,60 & 194,50 & 31,39 & 17,08 & 12,55 & 9,20 & 7,16 & 5,76 & 4,00 & 3,06 & 2,11 \\
\hline 47,74 & 1897,00 & 169,80 & 14,76 & 11,94 & 10,57 & 9,05 & 7,76 & 6,66 & 4,95 & 3,80 & 2,48 \\
\hline 49,77 & 1527,70 & 129,20 & 18,46 & 14,98 & 13,34 & 11,54 & 9,98 & 8,63 & 6,51 & 5,03 & 3,30 \\
\hline 24,08 & 736,40 & 97,70 & 46,48 & 34,34 & 26,89 & 19,51 & 14,61 & 11,38 & 7,75 & 5,93 & 4,10 \\
\hline 23,05 & 1428,00 & 126,00 & 32,97 & 25,54 & 20,49 & 15,20 & 11,49 & 8,97 & 6,07 & 4,61 & 3,17 \\
\hline 45,76 & 680,20 & 173,10 & 23,53 & 15,95 & 12,95 & 10,16 & 8,14 & 6,63 & 4,63 & 3,50 & 2,36 \\
\hline 41,73 & 1425,60 & 45,70 & 41,19 & 36,54 & 33,81 & 30,20 & 26,81 & 23,71 & 18,50 & 14,56 & 9,59 \\
\hline 72,01 & 1990,70 & 46,40 & 25,67 & 20,34 & 19,26 & 18,39 & 17,40 & 16,41 & 14,51 & 12,78 & 9,86 \\
\hline 87,21 & 1080,10 & 192,90 & 13,59 & 8,96 & 7,60 & 6,51 & 5,75 & 5,11 & 4,09 & 3,32 & 2,31 \\
\hline 58,23 & 964,10 & 197,00 & 16,67 & 11,58 & 9,71 & 8,02 & 6,74 & 5,71 & 4,19 & 3,21 & 2,13 \\
\hline 24,60 & 1673,40 & 107,70 & 33,53 & 27,21 & 22,65 & 17,52 & 13,63 & 10,80 & 7,31 & 5,47 & 3,71 \\
\hline 73,96 & 968,10 & 141,70 & 17,63 & 12,44 & 10,78 & 9,32 & 8,21 & 7,26 & 5,71 & 4,58 & 3,11 \\
\hline 22,76 & 261,40 & 101,40 & 62,60 & 37,68 & 26,62 & 17,98 & 13,26 & 10,44 & 7,31 & 5,69 & 3,98 \\
\hline 50,36 & 851,00 & 154,90 & 21,44 & 15,46 & 13,02 & 10,67 & 8,85 & 7,39 & 5,32 & 4,03 & 2,67 \\
\hline 55,87 & 1294,80 & 55,40 & 30,94 & 25,77 & 24,05 & 21,86 & 19,83 & 17,93 & 14,60 & 11,92 & 8,19 \\
\hline 22,02 & 1960,10 & 22,70 & 101,19 & 93,40 & 84,51 & 72,61 & 61,69 & 52,23 & 37,77 & 28,24 & 18,08 \\
\hline 58,34 & 1425,60 & 195,00 & 13,80 & 10,29 & 8,93 & 7,62 & 6,56 & 5,66 & 4,26 & 3,31 & 2,19 \\
\hline 21,86 & 1125,40 & 191,40 & 26,91 & 18,84 & 14,14 & 9,87 & 7,26 & 5,65 & 3,90 & 3,01 & 2,10 \\
\hline 79,01 & 523,40 & 138,50 & 24,59 & 15,46 & 12,60 & 10,39 & 8,88 & 7,68 & 5,85 & 4,61 & 3,12 \\
\hline 84,82 & 1793,20 & 24,80 & 33,23 & 29,05 & 26,32 & 25,41 & 24,73 & 23,86 & 22,00 & 20,21 & 16,89 \\
\hline 47,58 & 515,40 & 155,50 & 28,01 & 18,24 & 14,57 & 11,33 & 9,04 & 7,35 & 5,13 & 3,88 & 2,63 \\
\hline 28,67 & 511,90 & 155,10 & 34,59 & 22,56 & 16,98 & 12,05 & 9,00 & 7,05 & 4,85 & 3,74 & 2,60 \\
\hline 54,67 & 230,70 & 64,40 & 61,64 & 40,39 & 32,74 & 26,12 & 21,36 & 17,69 & 12,61 & 9,58 & 6,41 \\
\hline 77,63 & 1878,80 & 159,30 & 11,82 & 8,74 & 7,91 & 7,11 & 6,46 & 5,87 & 4,85 & 4,03 & 2,86 \\
\hline 56,32 & 1106,70 & 33,90 & 44,98 & 37,43 & 35,51 & 32,79 & 30,16 & 27,65 & 23,08 & 19,25 & 13,58 \\
\hline 36,79 & 1253,00 & 129,80 & 24,37 & 19,39 & 16,60 & 13,48 & 10,98 & 9,01 & 6,31 & 4,72 & 3,13 \\
\hline 50,17 & 1215,40 & 49,50 & 36,38 & 31,10 & 28,88 & 26,03 & 23,38 & 20,93 & 16,72 & 13,42 & 9,03 \\
\hline 76,18 & 1739,20 & 198,80 & 10,97 & 7,93 & 7,02 & 6,19 & 5,53 & 4,96 & 4,00 & 3,26 & 2,26 \\
\hline 27,92 & 247,40 & 96,30 & 61,45 & 37,77 & 27,62 & 19,21 & 14,27 & 11,20 & 7,76 & 6,00 & 4,20 \\
\hline 45,93 & 1855,70 & 60,70 & 29,20 & 25,51 & 23,79 & 21,46 & 19,27 & 17,23 & 13,72 & 10,98 & 7,35 \\
\hline 40,13 & 1839,80 & 181,60 & 16,11 & 12,93 & 11,21 & 9,28 & 7,70 & 6,41 & 4,57 & 3,44 & 2,26 \\
\hline
\end{tabular}




\begin{tabular}{|c|c|c|c|c|c|c|c|c|c|c|c|}
\hline \multirow[b]{2}{*}{ e1 (cm) } & & & & & & & ões (x1 & m) & & & \\
\hline & Meq (MPa) & Ms (MPa) & D0 & D25 & D40 & D60 & D80 & D100 & D140 & D180 & D260 \\
\hline 38,50 & 1439,20 & 77,80 & 30,88 & 26,57 & 23,78 & 20,39 & 17,40 & 14,83 & 10,91 & 8,28 & 5,36 \\
\hline 34,92 & 1800,00 & 106,00 & 25,21 & 21,44 & 18,90 & 15,85 & 13,24 & 11,07 & 7,92 & 5,94 & 3,87 \\
\hline 33,94 & 1152,60 & 196,00 & 20,44 & 15,02 & 12,25 & 9,41 & 7,35 & 5,86 & 4,01 & 3,02 & 2,06 \\
\hline 20,51 & 1899,30 & 187,00 & 24,77 & 18,52 & 14,36 & 10,26 & 7,59 & 5,89 & 4,02 & 3,09 & 2,14 \\
\hline 35,02 & 1089,10 & 20,60 & 88,04 & 80,53 & 75,04 & 67,31 & 59,90 & 53,03 & 41,39 & 32,54 & 21,32 \\
\hline 68,53 & 1170,30 & 199,10 & 13,99 & 9,80 & 8,38 & 7,13 & 6,18 & 5,38 & 4,12 & 3,24 & 2,17 \\
\hline 34,39 & 1953,40 & 78,10 & 30,18 & 26,60 & 23,90 & 20,51 & 17,49 & 14,88 & 10,90 & 8,24 & 5,32 \\
\hline 54,11 & 740,20 & 153,90 & 22,24 & 15,53 & 12,97 & 10,61 & 8,82 & 7,39 & 5,34 & 4,07 & 2,70 \\
\hline 44,15 & 810,40 & 96,90 & 30,65 & 23,90 & 20,62 & 17,11 & 14,25 & 11,93 & 8,57 & 6,47 & 4,25 \\
\hline 62,76 & 256,50 & 172,80 & 37,92 & 19,64 & 14,10 & 10,25 & 8,00 & 6,47 & 4,53 & 3,47 & 2,40 \\
\hline 33,50 & 1494,90 & 144,10 & 22,82 & 18,25 & 15,51 & 12,44 & 10,01 & 8,13 & 5,63 & 4,20 & 2,80 \\
\hline 57,59 & 1369,40 & 55,00 & 29,94 & 24,77 & 23,24 & 21,24 & 19,37 & 17,62 & 14,50 & 11,94 & 8,30 \\
\hline 29,74 & 1009,00 & 42,80 & 63,33 & 54,91 & 48,36 & 40,27 & 33,35 & 27,67 & 19,54 & 14,55 & 9,48 \\
\hline 78,95 & 838,90 & 33,90 & 40,53 & 31,03 & 29,03 & 27,21 & 25,45 & 23,78 & 20,67 & 17,93 & 13,51 \\
\hline 52,59 & 779,60 & 73,60 & 32,81 & 26,12 & 23,18 & 20,04 & 17,36 & 15,05 & 11,40 & 8,84 & 5,81 \\
\hline 76,58 & 1386,10 & 42,70 & 29,61 & 23,05 & 21,70 & 20,56 & 19,36 & 18,20 & 15,99 & 14,00 & 10,72 \\
\hline 46,01 & 942,80 & 46,50 & 43,89 & 37,70 & 34,42 & 30,43 & 26,79 & 23,52 & 18,15 & 14,21 & 9,34 \\
\hline 57,97 & 1438,50 & 141,60 & 16,42 & 12,82 & 11,40 & 9,94 & 8,70 & 7,62 & 5,87 & 4,62 & 3,07 \\
\hline 24,79 & 1095,20 & 84,20 & 45,00 & 35,83 & 29,48 & 22,51 & 17,36 & 13,69 & 9,26 & 6,96 & 4,75 \\
\hline 69,94 & 388,50 & 104,90 & 34,09 & 21,79 & 17,76 & 14,53 & 12,26 & 10,47 & 7,79 & 6,05 & 4,05 \\
\hline 81,86 & 610,80 & 87,50 & 27,14 & 18,75 & 16,26 & 14,15 & 12,58 & 11,25 & 9,04 & 7,36 & 5,11 \\
\hline 52,85 & 1652,40 & 45,70 & 33,58 & 28,38 & 26,96 & 24,86 & 22,82 & 20,86 & 17,32 & 14,37 & 10,06 \\
\hline 42,27 & 1169,40 & 89,50 & 28,57 & 23,68 & 20,96 & 17,83 & 15,13 & 12,86 & 9,42 & 7,15 & 4,66 \\
\hline 35,03 & 850,40 & 161,20 & 25,43 & 18,36 & 14,89 & 11,41 & 8,91 & 7,11 & 4,87 & 3,67 & 2,50 \\
\hline 59,56 & 1528,20 & 178,00 & 13,88 & 10,56 & 9,29 & 8,03 & 6,99 & 6,09 & 4,67 & 3,65 & 2,43 \\
\hline 79,33 & 710,00 & 43,50 & 37,22 & 27,93 & 25,75 & 23,61 & 21,77 & 20,07 & 17,02 & 14,45 & 10,54 \\
\hline 47,19 & 1990,40 & 185,50 & 13,84 & 11,15 & 9,83 & 8,39 & 7,16 & 6,12 & 4,53 & 3,46 & 2,26 \\
\hline 86,57 & 1734,60 & 178,60 & 11,01 & 7,78 & 6,92 & 6,18 & 5,61 & 5,11 & 4,25 & 3,55 & 2,54 \\
\hline 72,45 & 237,90 & 125,00 & 43,40 & 23,68 & 17,66 & 13,39 & 10,79 & 8,92 & 6,40 & 4,92 & 3,35 \\
\hline 84,30 & 407,60 & 144,40 & 27,97 & 16,38 & 12,85 & 10,28 & 8,65 & 7,41 & 5,58 & 4,39 & 2,98 \\
\hline 77,40 & 770,00 & 153,80 & 18,89 & 12,56 & 10,56 & 8,93 & 7,76 & 6,79 & 5,27 & 4,19 & 2,84 \\
\hline 89,57 & 1635,80 & 180,70 & 11,11 & 7,72 & 6,83 & 6,08 & 5,51 & 5,02 & 4,17 & 3,50 & 2,51 \\
\hline 81,77 & 752,80 & 84,90 & 24,78 & 17,62 & 15,59 & 13,80 & 12,42 & 11,22 & 9,17 & 7,57 & 5,32 \\
\hline 49,40 & 1479,50 & 126,80 & 19,00 & 15,41 & 13,70 & 11,83 & 10,21 & 8,82 & 6,63 & 5,12 & 3,35 \\
\hline 58,46 & 1777,70 & 110,70 & 17,30 & 14,05 & 12,87 & 11,53 & 10,34 & 9,25 & 7,39 & 5,95 & 4,04 \\
\hline 21,46 & 862,40 & 65,10 & 64,18 & 50,02 & 40,03 & 29,55 & 22,25 & 17,32 & 11,71 & 8,90 & 6,14 \\
\hline 22,34 & 624,10 & 111,70 & 46,21 & 32,20 & 24,19 & 16,90 & 12,45 & 9,69 & 6,69 & 5,17 & 3,59 \\
\hline 76,06 & 620,50 & 84,20 & 28,22 & 20,00 & 17,45 & 15,19 & 13,47 & 11,98 & 9,54 & 7,70 & 5,28 \\
\hline 46,08 & 749,50 & 184,50 & 21,66 & 14,78 & 12,04 & 9,49 & 7,63 & 6,22 & 4,35 & 3,29 & 2,21 \\
\hline 64,79 & 321,10 & 112,90 & 37,94 & 23,11 & 18,27 & 14,46 & 11,89 & 9,94 & 7,18 & 5,50 & 3,70 \\
\hline 59,42 & 1739,20 & 199,30 & 12,32 & 9,40 & 8,27 & 7,16 & 6,24 & 5,44 & 4,17 & 3,26 & 2,17 \\
\hline 71,85 & 1679,70 & 157,60 & 12,95 & 9,70 & 8,71 & 7,75 & 6,96 & 6,26 & 5,06 & 4,13 & 2,85 \\
\hline 78,67 & 1761,90 & 55,70 & 22,50 & 17,44 & 16,37 & 15,52 & 14,63 & 13,76 & 12,12 & 10,64 & 8,18 \\
\hline 38,83 & 1406,80 & 100,50 & 26,33 & 22,00 & 19,40 & 16,35 & 13,74 & 11,57 & 8,36 & 6,30 & 4,10 \\
\hline 48,88 & 1259,30 & 159,10 & 17,97 & 13,83 & 11,97 & 10,05 & 8,48 & 7,17 & 5,24 & 3,99 & 2,62 \\
\hline 59,19 & 1803,80 & 103,00 & 17,87 & 14,54 & 13,39 & 12,06 & 10,87 & 9,78 & 7,89 & 6,40 & 4,37 \\
\hline 72,48 & 496,00 & 45,10 & 44,48 & 33,33 & 30,00 & 26,75 & 24,08 & 21,70 & 17,62 & 14,42 & 10,01 \\
\hline 33,44 & 1179,10 & 193,00 & 20,65 & 15,26 & 12,45 & 9,57 & 7,47 & 5,95 & 4,07 & 3,07 & 2,09 \\
\hline 77,37 & 895,00 & 143,20 & 17,96 & 12,39 & 10,64 & 9,16 & 8,06 & 7,13 & 5,62 & 4,52 & 3,09 \\
\hline 49,73 & 1176,60 & 31,60 & 49,98 & 42,91 & 40,64 & 37,30 & 34,07 & 30,99 & 25,47 & 20,93 & 14,46 \\
\hline 41,74 & 1851,90 & 152,60 & 17,39 & 14,29 & 12,58 & 10,62 & 8,96 & 7,57 & 5,50 & 4,16 & 2,71 \\
\hline 66,21 & 1384,40 & 63,00 & 25,22 & 20,06 & 18,79 & 17,28 & 15,89 & 14,58 & 12,21 & 10,23 & 7,30 \\
\hline 59,82 & 1680,10 & 106,90 & 17,84 & 14,40 & 13,19 & 11,82 & 10,61 & 9,51 & 7,63 & 6,16 & 4,19 \\
\hline 52,35 & 1276,70 & 52,30 & 33,57 & 28,43 & 26,48 & 23,96 & 21,62 & 19,44 & 15,66 & 12,67 & 8,60 \\
\hline 59,31 & 564,40 & 97,40 & 30,69 & 21,96 & 18,71 & 15,70 & 13,36 & 11,43 & 8,51 & 6,56 & 4,34 \\
\hline 86,10 & 922,60 & 79,60 & 22,75 & 16,34 & 14,73 & 13,30 & 12,16 & 11,15 & 9,37 & 7,90 & 5,73 \\
\hline 65,04 & 1434,80 & 139,70 & 15,59 & 11,92 & 10,65 & 9,38 & 8,33 & 7,40 & 5,85 & 4,69 & 3,17 \\
\hline 51,95 & 1563,80 & 146,50 & 16,54 & 13,20 & 11,71 & 10,12 & 8,75 & 7,58 & 5,73 & 4,43 & 2,91 \\
\hline 24,17 & 1773,30 & 45,40 & 60,32 & 53,26 & 46,90 & 38,86 & 31,96 & 26,33 & 18,38 & 13,61 & 8,88 \\
\hline 86,56 & 749,90 & 137,20 & 19,42 & 12,78 & 10,81 & 9,25 & 8,14 & 7,24 & 5,77 & 4,68 & 3,24 \\
\hline 82,90 & 1592,40 & 33,30 & 30,59 & 24,66 & 22,80 & 21,97 & 21,07 & 20,10 & 18,18 & 16,39 & 13,20 \\
\hline 24,44 & 1794,30 & 29,60 & 79,34 & 72,52 & 65,39 & 55,97 & 47,43 & 40,07 & 28,92 & 21,62 & 13,88 \\
\hline 89,05 & 213,40 & 75,00 & 52,97 & 30,80 & 24,14 & 19,34 & 16,33 & 14,06 & 10,69 & 8,46 & 5,78 \\
\hline 39,26 & 790,70 & 150,50 & 25,65 & 18,52 & 15,23 & 11,94 & 9,49 & 7,67 & 5,30 & 3,99 & 2,69 \\
\hline 42,36 & 999,30 & 125,10 & 24,83 & 19,25 & 16,49 & 13,55 & 11,17 & 9,28 & 6,60 & 4,96 & 3,27 \\
\hline 49,42 & 1998,70 & 78,00 & 22,97 & 19,72 & 18,33 & 16,53 & 14,85 & 13,29 & 10,62 & 8,52 & 5,73 \\
\hline 72,63 & 284,40 & 88,30 & 43,55 & 26,86 & 21,53 & 17,39 & 14,60 & 12,42 & 9,22 & 7,15 & 4,81 \\
\hline 48,03 & 1265,90 & 170,60 & 17,42 & 13,28 & 11,43 & 9,53 & 7,98 & 6,72 & 4,87 & 3,70 & 2,43 \\
\hline 39,85 & 1048,60 & 160,00 & 21,85 & 16,41 & 13,77 & 11,01 & 8,89 & 7,26 & 5,06 & 3,80 & 2,54 \\
\hline 58,05 & 1543,50 & 41,70 & 34,50 & 28,42 & 27,13 & 25,26 & 23,40 & 21,61 & 18,30 & 15,45 & 11,11 \\
\hline 49,33 & 833,30 & 31,20 & 56,66 & 48,69 & 45,35 & 40,97 & 36,86 & 33,05 & 26,46 & 21,29 & 14,35 \\
\hline 86,07 & 1316,60 & 152,10 & 13,72 & 9,59 & 8,47 & 7,50 & 6,76 & 6,13 & 5,05 & 4,19 & 2,98 \\
\hline 59,23 & 1597,40 & 112,40 & 17,76 & 14,26 & 12,98 & 11,56 & 10,32 & 9,20 & 7,31 & 5,86 & 3,96 \\
\hline 49,23 & 1605,40 & 45,50 & 35,55 & 30,61 & 28,90 & 26,44 & 24,07 & 21,82 & 17,83 & 14,58 & 10,01 \\
\hline 22,26 & 1416,60 & 129,00 & 33,29 & 25,53 & 20,28 & 14,88 & 11,17 & 8,70 & 5,90 & 4,49 & 3,10 \\
\hline 84,66 & 1866,30 & 32,70 & 28,24 & 23,52 & 21,52 & 20,79 & 20,08 & 19,26 & 17,60 & 16,01 & 13,14 \\
\hline 50,12 & 590,50 & 146,50 & 26,40 & 17,89 & 14,63 & 11,67 & 9,49 & 7,82 & 5,53 & 4,19 & 2,80 \\
\hline 34,20 & 928,40 & 45,50 & 55,91 & 48,38 & 42,98 & 36,36 & 30,60 & 25,76 & 18,57 & 13,94 & 9,04 \\
\hline 88,88 & 696,40 & 172,00 & 18,38 & 11,43 & 9,36 & 7,79 & 6,75 & 5,92 & 4,63 & 3,72 & 2,56 \\
\hline 58,05 & 1269,60 & 82,10 & 23,77 & 19,29 & 17,63 & 15,74 & 14,08 & 12,57 & 10,00 & 8,03 & 5,42 \\
\hline 37,89 & 861,10 & 190,40 & 21,96 & 15,42 & 12,46 & 9,58 & 7,51 & 6,01 & 4,14 & 3,12 & 2,12 \\
\hline 79,17 & 265,60 & 131,70 & 39,03 & 21,39 & 16,05 & 12,29 & 10,01 & 8,37 & 6,09 & 4,71 & 3,21 \\
\hline
\end{tabular}




\begin{tabular}{|c|c|c|c|c|c|c|c|c|c|c|c|}
\hline \multirow[b]{2}{*}{ e1 (cm) } & & & & & & & ões (x1 & m) & & & \\
\hline & Meq (MPa) & Ms (MPa) & D0 & D25 & D40 & D60 & D80 & D100 & D140 & D180 & D260 \\
\hline 61,79 & 1743,20 & 84,30 & 20,04 & 16,22 & 15,11 & 13,78 & 12,56 & 11,42 & 9,41 & 7,76 & 5,41 \\
\hline 82,24 & 933,80 & 154,10 & 16,60 & 11,23 & 9,61 & 8,28 & 7,31 & 6,49 & 5,17 & 4,18 & 2,88 \\
\hline 83,47 & 1579,90 & 150,10 & 12,79 & 9,19 & 8,24 & 7,39 & 6,71 & 6,11 & 5,08 & 4,24 & 3,03 \\
\hline 23,16 & 909,00 & 71,20 & 56,20 & 44,19 & 35,83 & 26,87 & 20,46 & 16,01 & 10,82 & 8,18 & 5,61 \\
\hline 81,98 & 238,30 & 32,20 & 71,52 & 49,76 & 43,39 & 37,93 & 33,84 & 30,33 & 24,49 & 20,01 & 13,93 \\
\hline 68,23 & 1268,90 & 72,40 & 23,51 & 18,43 & 17,07 & 15,56 & 14,21 & 12,97 & 10,76 & 8,94 & 6,32 \\
\hline 80,42 & 872,50 & 65,30 & 26,84 & 19,84 & 18,08 & 16,41 & 15,02 & 13,77 & 11,55 & 9,72 & 7,00 \\
\hline 20,59 & 750,70 & 121,70 & 443,22 & 30,11 & 22,40 & 15,48 & 11,35 & 8,83 & 6,12 & 4,74 & 3,30 \\
\hline 34,08 & 312,80 & 21,00 & 135,81 & 113,64 & 99,13 & 81,97 & 67,63 & 56,01 & 39,55 & 29,54 & 19,35 \\
\hline 77,29 & 1792,40 & 85,60 & 17,36 & 13,26 & 12,36 & 11,47 & 10,65 & 9,89 & 8,48 & 7,27 & 5,37 \\
\hline 46,03 & 949,10 & 53,60 & 40,02 & 34,04 & 30,86 & 27,07 & 23,67 & 20,65 & 15,77 & 12,26 & 8,03 \\
\hline 85,84 & 1276,20 & 21,40 & 41,70 & 35,19 & 32,07 & 30,96 & 29,98 & 28,81 & 26,40 & 24,11 & 19,91 \\
\hline 73,68 & 485,40 & 123,30 & 27,52 & 17,67 & 14,49 & 11,96 & 10,18 & 8,77 & 6,62 & 5,18 & 3,48 \\
\hline 40,30 & 525,40 & 109,90 & 36,05 & 25,57 & 20,91 & 16,33 & 12,97 & 10,48 & 7,25 & 5,46 & 3,69 \\
\hline 49,03 & 519,50 & 162,60 & 26,99 & 17,38 & 13,85 & 10,78 & 8,62 & 7,02 & 4,91 & 3,72 & 2,51 \\
\hline 35,95 & 1317,50 & 43,40 & 49,03 & 43,87 & 39,97 & 34,94 & 30,33 & 26,24 & 19,71 & 15,12 & 9,78 \\
\hline 54,86 & 1310,70 & 122,90 & 19,11 & 15,14 & 13,47 & 11,71 & 10,21 & 8,90 & 6,80 & 5,31 & 3,51 \\
\hline 21,04 & 1517,80 & 160,80 & 28,89 & 21,51 & 16,67 & 11,92 & 8,83 & 6,85 & 4,68 & 3,59 & 2,49 \\
\hline 62,27 & 1931,30 & 115,10 & 15,80 & 12,66 & 11,67 & 10,53 & 9,52 & 8,60 & 6,98 & 5,70 & 3,93 \\
\hline 42,19 & 1705,70 & 147,40 & 18,21 & 14,87 & 13,06 & 11,01 & 9,28 & 7,84 & 5,69 & 4,31 & 2,81 \\
\hline 40,24 & 677,80 & 114,50 & 31,66 & 23,36 & 19,46 & 15,47 & 12,43 & 10,12 & 7,05 & 5,29 & 3,54 \\
\hline 75,92 & 788,80 & 96,50 & 23,40 & 16,80 & 14,79 & 12,97 & 11,56 & 10,33 & 8,28 & 6,72 & 4,63 \\
\hline 27,22 & 1771,00 & 158,90 & 23,40 & 18,52 & 15,32 & 11,81 & 9,19 & 7,29 & 4,95 & 3,71 & 2,52 \\
\hline 44,47 & 604,60 & 88,80 & 36,33 & 27,41 & 23,30 & 19,06 & 15,70 & 13,02 & 9,26 & 6,98 & 4,62 \\
\hline 25,32 & 1670,50 & 160,20 & 24,92 & 19,38 & 15,74 & 11,86 & 9,08 & 7,13 & 4,83 & 3,65 & 2,50 \\
\hline 31,36 & 1499,20 & 84,30 & 33,93 & 28,76 & 25,09 & 20,68 & 17,00 & 14,02 & 9,84 & 7,33 & 4,81 \\
\hline 53,20 & 469,40 & 93,80 & 36,07 & 25,43 & 21,30 & 17,45 & 14,50 & 12,15 & 8,78 & 6,67 & 4,42 \\
\hline 51,36 & 1986,90 & 186,80 & 13,09 & 10,45 & 9,26 & 7,99 & 6,90 & 5,96 & 4,49 & 3,47 & 2,28 \\
\hline 88,71 & 663,90 & 91,20 & 24,73 & 16,82 & 14,62 & 12,79 & 11,47 & 10,34 & 8,46 & 6,99 & 4,94 \\
\hline 63,30 & 476,20 & 60,10 & 41,40 & 30,84 & 27,00 & 23,34 & 20,38 & 17,83 & 13,75 & 10,83 & 7,23 \\
\hline 71,37 & 501,40 & 133,50 & 26,40 & 16,87 & 13,77 & 11,29 & 9,56 & 8,18 & 6,12 & 4,76 & 3,20 \\
\hline 60,60 & 646,80 & 131,60 & 24,48 & 16,94 & 14,22 & 11,80 & 9,97 & 8,48 & 6,27 & 4,83 & 3,20 \\
\hline 46,01 & 264,60 & 174,70 & 38,43 & 20,36 & 14,61 & 10,42 & 7,96 & 6,33 & 4,37 & 3,36 & 2,34 \\
\hline 20,93 & 1382,00 & 28,40 & 102,07 & 89,70 & 78,29 & 63,96 & 51,88 & 42,23 & 29,05 & 21,44 & 14,11 \\
\hline 46,75 & 1649,90 & 141,90 & 17,62 & 14,34 & 12,70 & 10,88 & 9,32 & 7,99 & 5,93 & 4,54 & 2,97 \\
\hline 55,02 & 1917,20 & 65,90 & 24,38 & 20,43 & 19,26 & 17,66 & 16,13 & 14,69 & 12,11 & 9,99 & 6,95 \\
\hline 87,34 & 1825,20 & 121,80 & 13,15 & 9,59 & 8,76 & 8,04 & 7,44 & 6,89 & 5,90 & 5,06 & 3,75 \\
\hline 84,73 & 1603,20 & 197,60 & 10,97 & 7,65 & 6,72 & 5,92 & 5,32 & 4,80 & 3,93 & 3,24 & 2,28 \\
\hline 85,51 & 415,60 & 184,90 & 25,46 & 14,17 & 10,77 & 8,38 & 6,92 & 5,86 & 4,35 & 3,39 & 2,31 \\
\hline 44,07 & 1679,10 & 78,70 & 26,24 & 22,72 & 20,73 & 18,27 & 16,03 & 14,03 & 10,76 & 8,38 & 5,49 \\
\hline 24,27 & 711,50 & 46,20 & 79,14 & 64,02 & 53,12 & 40,92 & 31,75 & 25,11 & 16,98 & 12,72 & 8,65 \\
\hline 39,53 & 386,50 & 67,40 & 55,04 & 40,38 & 33,48 & 26,46 & 21,16 & 17,17 & 11,92 & 8,95 & 6,01 \\
\hline 68,28 & 652,50 & 79,20 & 29,74 & 21,92 & 19,28 & 16,81 & 14,83 & 13,12 & 10,30 & 8,22 & 5,56 \\
\hline 54,52 & 579,60 & 122,80 & 28,05 & 19,49 & 16,25 & 13,29 & 11,05 & 9,26 & 6,69 & 5,10 & 3,38 \\
\hline 71,06 & 1023,10 & 50,60 & 31,17 & 24,27 & 22,66 & 20,86 & 19,23 & 17,70 & 14,94 & 12,61 & 9,09 \\
\hline 20,62 & 200,80 & 37,70 & 144,67 & 98,47 & 72,37 & 49,63 & 36,34 & 28,33 & 19,71 & 15,28 & 10,65 \\
\hline 40,84 & 1272,70 & 36,70 & 50,29 & 44,87 & 41,64 & 37,29 & 33,18 & 29,40 & 23,01 & 18,16 & 11,97 \\
\hline 69,07 & 1119,00 & 156,40 & 16,06 & 11,58 & 10,07 & 8,70 & 7,63 & 6,71 & 5,23 & 4,15 & 2,80 \\
\hline 37,84 & 1305,30 & 36,60 & 52,89 & 47,59 & 43,91 & 39,00 & 34,40 & 30,21 & 23,27 & 18,14 & 11,84 \\
\hline 63,82 & 1637,10 & 66,40 & 23,45 & 18,87 & 17,76 & 16,37 & 15,07 & 13,84 & 11,60 & 9,73 & 6,93 \\
\hline 53,89 & 576,60 & 41,60 & 51,21 & 41,80 & 37,78 & 33,29 & 29,35 & 25,84 & 20,07 & 15,82 & 10,50 \\
\hline 61,35 & 469,80 & 35,90 & 56,38 & 44,66 & 40,49 & 36,01 & 32,15 & 28,67 & 22,80 & 18,31 & 12,40 \\
\hline 85,78 & 550,60 & 42,90 & 40,36 & 29,26 & 26,54 & 24,11 & 22,13 & 20,36 & 17,22 & 14,60 & 10,66 \\
\hline 61,17 & 1100,50 & 138,10 & 18,27 & 13,70 & 11,99 & 10,33 & 8,99 & 7,84 & 6,00 & 4,70 & 3,13 \\
\hline 87,27 & 1575,80 & 78,80 & 17,93 & 13,35 & 12,32 & 11,49 & 10,73 & 10,03 & 8,74 & 7,61 & 5,78 \\
\hline 38,60 & 1535,60 & 187,00 & 17,44 & 13,57 & 11,54 & 9,34 & 7,60 & 6,24 & 4,37 & 3,27 & 2,17 \\
\hline 82,38 & 1019,40 & 161,70 & 15,47 & 10,52 & 9,04 & 7,81 & 6,91 & 6,15 & 4,91 & 3,98 & 2,75 \\
\hline 64,17 & 705,00 & 172,00 & 20,20 & 13,37 & 11,02 & 9,05 & 7,61 & 6,47 & 4,77 & 3,68 & 2,45 \\
\hline 39,33 & 1564,90 & 195,00 & 16,67 & 12,93 & 11,00 & 8,92 & 7,27 & 5,97 & 4,20 & 3,14 & 2,08 \\
\hline 21,18 & 1176,30 & 177,80 & 28,59 & 20,26 & 15,26 & 10,66 & 7,83 & 6,09 & 4,20 & 3,24 & 2,26 \\
\hline 72,30 & 1227,40 & 47,00 & 30,23 & 23,59 & 22,22 & 20,75 & 19,33 & 17,97 & 15,46 & 13,27 & 9,82 \\
\hline 41,69 & 461,40 & 47,00 & $\begin{array}{l}61,43 \\
\end{array}$ & 49,09 & 42,61 & 35,44 & 29,52 & 24,69 & 17,70 & 13,33 & 8,74 \\
\hline 35,64 & 1253,80 & 42,10 & 51,23 & $\begin{array}{l}45,78 \\
\end{array}$ & 41,63 & 36,31 & 31,45 & 27,15 & 20,32 & 15,55 & 10,05 \\
\hline 76,28 & 1322,80 & 39,80 & 31,54 & 24,59 & 23,15 & 21,96 & 20,69 & 19,45 & 17,10 & 14,99 & 11,48 \\
\hline 59,13 & 1420,00 & 181,30 & 14,27 & 10,73 & 9,37 & 8,04 & 6,96 & 6,04 & 4,59 & 3,57 & 2,37 \\
\hline 28,93 & 747,20 & 116,00 & 36,75 & 27,12 & 21,72 & 16,23 & 12,41 & 9,77 & 6,65 & 5,04 & 3,46 \\
\hline 47,28 & 1442,60 & 21,90 & 63,00 & 53,77 & 51,91 & 48,55 & 45,05 & 41,62 & 35,23 & 29,69 & 21,22 \\
\hline 85,05 & 1152,60 & 167,30 & 14,09 & 9,63 & 8,33 & 7,25 & 6,46 & 5,80 & 4,68 & 3,84 & 2,68 \\
\hline 51,15 & 1168,90 & 136,60 & 19,70 & 15,29 & 13,34 & 11,33 & 9,67 & 8,26 & 6,13 & 4,70 & 3,08 \\
\hline 75,33 & 1711,80 & 141,30 & 13,35 & 9,98 & 9,04 & 8,13 & 7,37 & 6,70 & 5,51 & 4,56 & 3,21 \\
\hline 31,27 & 1179,60 & 34,10 & 66,87 & 60,13 & 54,33 & 46,84 & 40,05 & 34,16 & 25,06 & 18,94 & 12,19 \\
\hline 21,65 & 846,90 & 132,40 & 38,25 & 27,07 & 20,43 & 14,30 & 10,53 & 8,19 & 5,64 & 4,36 & 3,03 \\
\hline 51,99 & 1057,90 & 87,90 & 26,21 & 21,21 & 18,96 & 16,50 & 14,38 & 12,52 & 9,54 & 7,43 & 4,89 \\
\hline 39,65 & 458,60 & 70,50 & 49,91 & 37,44 & 31,38 & 25,07 & 20,20 & 16,48 & 11,49 & 8,62 & 5,76 \\
\hline 45,17 & 446,10 & 124,30 & 34,40 & 22,89 & 18,38 & 14,28 & 11,36 & 9,21 & 6,41 & 4,84 & 3,28 \\
\hline 82,96 & 522,20 & 136,40 & 24,44 & 15,26 & 12,44 & 10,28 & 8,83 & 7,68 & 5,91 & 4,69 & 3,19 \\
\hline 58,37 & 1378,40 & 83,50 & 22,72 & 18,49 & 16,96 & 15,21 & 13,65 & 12,23 & 9,79 & 7,90 & 5,36 \\
\hline 86,88 & 344,40 & 72,10 & 39,92 & 25,68 & 21,43 & 18,11 & 15,83 & 13,98 & 11,03 & 8,89 & 6,13 \\
\hline 74,29 & 1966,80 & 94,30 & 16,13 & 12,43 & 11,61 & 10,74 & 9,94 & 9,20 & 7,84 & 6,67 & 4,88 \\
\hline 33,94 & 1817,00 & 130,40 & 22,48 & 18,66 & 16,20 & 13,32 & 10,94 & 9,02 & 6,34 & 4,74 & 3,11 \\
\hline 88,79 & 228,80 & 79,20 & 49,69 & 28,99 & 22,77 & 18,28 & 15,45 & 13,30 & 10,13 & 8,01 & 5,47 \\
\hline 53,00 & 1542,70 & 96,90 & 21,03 & 17,40 & 15,84 & 14,05 & 12,44 & 11,00 & 8,60 & 6,81 & 4,53 \\
\hline
\end{tabular}




\begin{tabular}{|c|c|c|c|c|c|c|c|c|c|c|c|}
\hline & & & \multicolumn{9}{|c|}{ Deflexões $\left(\times 10^{-4} \mathrm{~cm}\right)$} \\
\hline e1 (cm) & Meq (MPa) & Ms (MPa) & D0 & D25 & D40 & D60 & D80 & D100 & D140 & D180 & D260 \\
\hline 83,68 & 1503,90 & 62,90 & 21,40 & 16,21 & 15,08 & 14,16 & 13,28 & 12,44 & 10,89 & 9,51 & 7,25 \\
\hline 78,53 & 1209,30 & 160,40 & 14,45 & 10,19 & 8,90 & 7,78 & 6,92 & 6,19 & 4,96 & 4,03 & 2,78 \\
\hline 64,79 & 1423,50 & 117,40 & 17,29 & 13,44 & 12,15 & 10,81 & 9,67 & 8,65 & 6,91 & 5,58 & 3,80 \\
\hline 61,99 & 1360,30 & 21,30 & 54,39 & 44,07 & 42,25 & 40,53 & 38,38 & 36,21 & 32,01 & 28,13 & 21,60 \\
\hline 25,99 & 1837,80 & 184,90 & 21,52 & 16,69 & 13,57 & 10,25 & 7,86 & 6,18 & 4,19 & 3,16 & 2,17 \\
\hline 71,34 & 868,20 & 148,50 & 18,51 & 12,86 & 10,98 & 9,36 & 8,15 & 7,12 & 5,50 & 4,35 & 2,93 \\
\hline 62,78 & 1005,00 & 131,10 & 19,35 & 14,36 & 12,54 & 10,81 & 9,41 & 8,21 & 6,31 & 4,95 & 3,30 \\
\hline 49,97 & 870,70 & 197,40 & 18,76 & 12,96 & 10,70 & 8,60 & 7,03 & 5,81 & 4,12 & 3,12 & 2,08 \\
\hline 40,55 & 1435,80 & 178,80 & 17,82 & 13,83 & 11,81 & 9,63 & 7,89 & 6,51 & 4,59 & 3,45 & 2,28 \\
\hline 78,76 & 1298,70 & 58,30 & 24,62 & 18,77 & 17,52 & 16,33 & 15,22 & 14,17 & 12,24 & 10,56 & 7,88 \\
\hline 45,17 & 1814,80 & 43,20 & 37,53 & 32,91 & 31,11 & 28,42 & 25,82 & 23,36 & 18,98 & 15,43 & 10,51 \\
\hline 31,72 & 1814,50 & 189,00 & 18,57 & 14,64 & 12,28 & 9,67 & 7,67 & 6,17 & 4,23 & 3,16 & 2,13 \\
\hline 76,86 & 1758,30 & 43,20 & 26,79 & 21,11 & 19,84 & 18,98 & 18,02 & 17,04 & 15,16 & 13,43 & 10,49 \\
\hline 65,48 & 325,20 & 34,80 & 65,05 & 49,14 & 43,61 & 38,21 & 33,79 & 29,90 & 23,50 & 18,75 & 12,65 \\
\hline 36,94 & 862,10 & 40,90 & 57,83 & 50,34 & 45,17 & 38,79 & 33,13 & 28,26 & 20,77 & 15,75 & 10,20 \\
\hline 38,89 & 1319,00 & 128,20 & 23,19 & 18,64 & 16,12 & 13,30 & 10,98 & 9,11 & 6,46 & 4,85 & 3,19 \\
\hline 69,58 & 1281,90 & 69,00 & 23,87 & 18,65 & 17,34 & 15,87 & 14,56 & 13,33 & 11,15 & 9,33 & 6,65 \\
\hline 47,19 & 724,40 & 140,70 & 25,14 & 17,98 & 15,00 & 12,11 & 9,90 & 8,18 & 5,80 & 4,38 & 2,91 \\
\hline 21,66 & 1341,70 & 81,70 & 47,81 & 38,23 & 31,18 & 23,48 & 17,91 & 14,01 & 9,44 & 7,12 & 4,89 \\
\hline 88,43 & $\begin{array}{l}783,50 \\
\end{array}$ & 137,00 & 18,82 & 12,40 & 10,54 & 9,05 & 8,00 & 7,14 & 5,73 & 4,67 & 3,26 \\
\hline 36,05 & 1709,40 & 153,50 & 19,82 & 16,06 & 13,84 & 11,32 & 9,27 & 7,64 & 5,37 & 4,01 & 2,64 \\
\hline 68,06 & 1044,50 & 183,40 & 15,49 & 10,81 & 9,21 & 7,81 & 6,75 & 5,87 & 4,48 & 3,52 & 2,35 \\
\hline 20,53 & 548,20 & 146,40 & 40,82 & 26,08 & 18,61 & 12,55 & 9,20 & 7,22 & 5,06 & 3,94 & 2,75 \\
\hline 82,40 & 937,20 & 148,40 & 16,84 & 11,46 & 9,85 & 8,51 & 7,53 & 6,70 & 5,35 & 4,34 & 3,00 \\
\hline 41,03 & 1228,10 & 144,90 & 21,36 & 16,71 & 14,34 & 11,76 & 9,69 & 8,03 & 5,69 & 4,28 & 2,82 \\
\hline 33,65 & 952,30 & 121,60 & 29,82 & 22,93 & 19,10 & 14,99 & 11,87 & 9,55 & 6,56 & 4,92 & 3,31 \\
\hline 45,20 & 877,00 & 183,30 & 20,39 & 14,41 & 11,91 & 9,49 & 7,68 & 6,29 & 4,41 & 3,33 & 2,23 \\
\hline 46,01 & 410,30 & 113,80 & 37,20 & 24,75 & 19,91 & 15,52 & 12,39 & 10,06 & 7,01 & 5,30 & 3,58 \\
\hline 33,58 & 983,70 & 28,30 & 75,81 & 68,37 & 62,26 & 54,30 & 46,98 & 40,51 & 30,25 & 23,09 & 14,89 \\
\hline 48,42 & 1583,50 & 141,10 & 17,57 & 14,21 & 12,59 & 10,81 & 9,29 & 7,98 & 5,96 & 4,58 & 3,00 \\
\hline 48,89 & 440,20 & 105,40 & 36,44 & 24,93 & 20,44 & 16,29 & 13,23 & 10,88 & 7,69 & 5,81 & 3,89 \\
\hline 40,19 & 1268,90 & 112,10 & 24,98 & 20,35 & 17,77 & 14,84 & 12,39 & 10,38 & 7,45 & 5,61 & 3,67 \\
\hline 36,94 & 1025,30 & 148,60 & 24,13 & 18,26 & 15,25 & 12,08 & 9,65 & 7,82 & 5,41 & 4,06 & 2,72 \\
\hline 24,27 & 1059,70 & 76,20 & 49,51 & 39,60 & 32,61 & 24,91 & 19,22 & 15,15 & 10,24 & 7,69 & 5,25 \\
\hline 23,44 & 930,10 & 170,40 & 29,69 & 20,78 & 15,74 & 11,09 & 8,20 & 6,39 & 4,40 & 3,39 & 2,36 \\
\hline 48,53 & 1888,40 & 86,40 & 22,19 & 19,00 & 17,49 & 15,62 & 13,90 & 12,33 & 9,69 & 7,68 & 5,11 \\
\hline 73,54 & 526,90 & 130,60 & 25,62 & 16,53 & 13,60 & 11,24 & 9,59 & 8,26 & 6,25 & 4,89 & 3,29 \\
\hline 52,82 & 1835,50 & 115,90 & 17,65 & 14,62 & 13,30 & 11,78 & 10,43 & 9,22 & 7,20 & 5,69 & 3,79 \\
\hline 79,65 & 1287,20 & 98,30 & 18,07 & 13,38 & 12,18 & 11,03 & 10,09 & 9,23 & 7,72 & 6,48 & 4,65 \\
\hline 44,53 & 1790,80 & 180,20 & 15,27 & 12,21 & 10,66 & 8,97 & 7,56 & 6,38 & 4,64 & 3,52 & 2,30 \\
\hline 82,36 & 1112,80 & 94,90 & 19,37 & 14,09 & 12,73 & 11,48 & 10,47 & 9,57 & 7,99 & 6,70 & 4,81 \\
\hline 38,02 & 1951,50 & 123,80 & 20,78 & 17,59 & 15,58 & 13,19 & 11,13 & 9,40 & 6,81 & 5,14 & 3,34 \\
\hline 30,21 & 1451,70 & 56,60 & 45,93 & 40,20 & 35,64 & 29,94 & 25,00 & 20,88 & 14,87 & 11,10 & 7,20 \\
\hline 51,22 & 1957,20 & 86,30 & 21,18 & 17,98 & 16,65 & 14,99 & 13,45 & 12,02 & 9,59 & 7,69 & 5,18 \\
\hline 51,53 & 1206,30 & 135,20 & 19,45 & 15,17 & 13,29 & 11,33 & 9,70 & 8,31 & 6,19 & 4,76 & 3,12 \\
\hline 70,26 & 764,50 & 142,80 & 20,30 & 13,93 & 11,80 & 9,98 & 8,63 & 7,50 & 5,74 & 4,51 & 3,03 \\
\hline 54,39 & 1964,90 & 171,00 & 13,37 & 10,70 & 9,56 & 8,34 & 7,29 & 6,37 & 4,89 & 3,83 & 2,53 \\
\hline 24,02 & 581,80 & 50,60 & 79,42 & 62,02 & 50,23 & 37,67 & 28,71 & 22,50 & 15,21 & 11,50 & 7,90 \\
\hline 41,99 & 1373,60 & 121,30 & 22,39 & 18,23 & 15,99 & 13,45 & 11,31 & 9,53 & 6,91 & 5,22 & 3,41 \\
\hline 32,95 & 1581,60 & 25,60 & 70,71 & 65,15 & 60,74 & 54,46 & 48,42 & 42,83 & 33,35 & 26,16 & 17,10 \\
\hline 63,49 & 992,00 & 54,60 & 31,95 & 25,57 & 23,68 & 21,50 & 19,54 & 17,73 & 14,54 & 11,97 & 8,32 \\
\hline 29,87 & 509,00 & 165,30 & 32,70 & 21,06 & 15,85 & 11,28 & 8,45 & 6,63 & 4,56 & 3,51 & 2,44 \\
\hline 63,17 & 896,30 & 169,60 & 17,97 & 12,53 & 10,60 & 8,88 & 7,58 & 6,50 & 4,87 & 3,77 & 2,51 \\
\hline 66,85 & 262,30 & 101,10 & 44,47 & 26,40 & 20,61 & 16,19 & 13,27 & 11,07 & 8,00 & 6,14 & 4,14 \\
\hline 64,79 & 202,10 & 29,30 & 89,78 & 65,24 & 56,51 & 48,46 & 42,11 & 36,71 & 28,15 & 22,11 & 14,77 \\
\hline 78,10 & 334,30 & 94,60 & 37,64 & 23,39 & 18,92 & 15,49 & 13,16 & 11,33 & 8,58 & 6,73 & 4,55 \\
\hline 24,02 & 926,60 & 99,00 & 43,14 & 32,83 & 26,16 & 19,29 & 14,56 & 11,37 & 7,71 & 5,86 & 4,04 \\
\hline 45,11 & 1792,70 & 169,60 & 15,68 & 12,64 & 11,10 & 9,40 & 7,96 & 6,76 & 4,95 & 3,76 & 2,46 \\
\hline 23,15 & 1835,80 & 175,60 & 24,14 & 18,53 & 14,78 & 10,90 & 8,22 & 6,41 & 4,34 & 3,30 & 2,28 \\
\hline 70,61 & 1986,90 & 114,70 & 14,64 & 11,36 & 10,52 & 9,61 & 8,80 & 8,05 & 6,71 & 5,61 & 3,99 \\
\hline 26,18 & 809,20 & 42,80 & 75,65 & 63,21 & 53,92 & 43,00 & 34,28 & 27,60 & 18,87 & 14,02 & 9,37 \\
\hline 53,20 & 430,60 & 56,50 & 49,05 & 37,26 & 32,32 & 27,36 & 23,31 & 19,92 & 14,77 & 11,34 & 7,46 \\
\hline 46,31 & 541,00 & 168,50 & 26,53 & 17,18 & 13,65 & 10,54 & 8,36 & 6,77 & 4,71 & 3,56 & 2,42 \\
\hline 75,84 & 1369,20 & 127,50 & 15,57 & 11,50 & 10,34 & 9,23 & 8,33 & 7,53 & 6,16 & 5,07 & 3,55 \\
\hline 33,92 & 559,50 & 196,50 & 27,00 & 17,14 & 13,04 & 9,45 & 7,16 & 5,64 & 3,87 & 2,97 & 2,06 \\
\hline 74,66 & 1849,20 & 120,30 & 14,23 & 10,82 & 9,96 & 9,07 & 8,30 & 7,60 & 6,35 & 5,32 & 3,80 \\
\hline 29,00 & 1749,90 & 191,40 & 19,82 & 15,40 & 12,68 & 9,76 & 7,59 & 6,03 & 4,10 & 3,08 & 2,10 \\
\hline 38,41 & 1183,80 & 38,80 & 52,00 & 46,43 & 42,59 & 37,59 & 32,96 & 28,80 & 21,99 & 17,05 & 11,09 \\
\hline 61,33 & 1408,70 & 32,10 & 41,05 & 33,30 & 31,92 & 30,11 & 28,17 & 26,28 & 22,70 & 19,53 & 14,47 \\
\hline 58,87 & 290,70 & 175,40 & 34,98 & 18,75 & 13,71 & 10,09 & 7,91 & 6,40 & 4,47 & 3,42 & 2,35 \\
\hline 43,67 & 1319,90 & 157,30 & 18,99 & 14,82 & 12,78 & 10,59 & 8,81 & 7,36 & 5,28 & 3,98 & 2,62 \\
\hline 79,23 & 820,20 & 74,70 & 25,79 & 18,86 & 16,98 & 15,21 & 13,80 & 12,53 & 10,34 & 8,59 & 6,08 \\
\hline 70,78 & 1234,60 & 168,50 & 14,57 & 10,49 & 9,14 & 7,93 & 6,98 & 6,16 & 4,83 & 3,86 & 2,61 \\
\hline 62,20 & 1894,20 & 21,10 & 48,82 & 40,13 & 38,11 & 37,00 & 35,41 & 33,70 & 30,31 & 27,09 & 21,45 \\
\hline 40,69 & 1291,20 & 174,70 & 18,82 & 14,42 & 12,24 & 9,92 & 8,09 & 6,66 & 4,68 & 3,52 & 2,33 \\
\hline 71,04 & 1547,60 & 41,40 & 30,47 & 24,06 & 22,82 & 21,65 & 20,37 & 19,12 & 16,75 & 14,61 & 11,10 \\
\hline 40,66 & 1386,00 & 50,20 & 39,83 & 35,25 & 32,35 & 28,62 & 25,16 & 22,05 & 16,93 & 13,19 & 8,61 \\
\hline 23,01 & 1335,90 & 96,70 & 40,64 & 32,21 & 26,24 & 19,78 & 15,10 & 11,84 & 7,99 & 6,03 & 4,13 \\
\hline 82,36 & 247,60 & 32,20 & 70,01 & 48,89 & 42,77 & 37,50 & 33,53 & 30,12 & 24,41 & 20,00 & 13,97 \\
\hline 60,29 & 358,00 & 111,00 & 36,61 & 23,17 & 18,59 & 14,83 & 12,20 & 10,17 & 7,32 & 5,59 & 3,75 \\
\hline 37,82 & 1067,30 & 31,30 & 62,86 & 56,47 & 51,99 & 46,07 & 40,54 & 35,53 & 27,27 & 21,21 & 13,82 \\
\hline 54,62 & 1383,10 & 92,00 & 22,23 & 18,23 & 16,57 & 14,68 & 13,02 & 11,52 & 9,03 & 7,17 & 4,78 \\
\hline
\end{tabular}




\begin{tabular}{|c|c|c|c|c|c|c|c|c|c|c|c|}
\hline & & & \multicolumn{9}{|c|}{ Deflexões $\left(\times 10^{-4} \mathrm{~cm}\right)$} \\
\hline e1 (cm) & Meq (MPa) & Ms (MPa) & D0 & D25 & D40 & D60 & D80 & D100 & D140 & D180 & D260 \\
\hline 87,93 & 872,70 & 162,70 & 16,47 & 10,77 & 9,09 & 7,76 & 6,84 & 6,08 & 4,85 & 3,94 & 2,74 \\
\hline 86,45 & 1089,30 & 140,50 & 15,68 & 10,82 & 9,46 & 8,31 & 7,46 & 6,73 & 5,51 & 4,55 & 3,21 \\
\hline 88,89 & 492,60 & 147,90 & 24,20 & 14,52 & 11,61 & 9,47 & 8,09 & 7,02 & 5,41 & 4,30 & 2,95 \\
\hline 46,25 & 691,10 & 25,30 & 72,40 & 63,01 & 58,45 & 52,49 & 46,92 & 41,79 & 33,04 & 26,30 & 17,52 \\
\hline 65,05 & 1864,50 & 30,70 & 36,99 & 29,85 & 28,49 & 27,38 & 25,98 & 24,56 & 21,80 & 19,24 & 14,90 \\
\hline 77,49 & 1172,60 & 184,30 & 13,81 & 9,55 & 8,22 & 7,08 & 6,24 & 5,53 & 4,37 & 3,51 & 2,40 \\
\hline 43,22 & 1828,20 & 71,00 & 27,58 & 24,18 & 22,24 & 19,75 & 17,45 & 15,37 & 11,91 & 9,34 & 6,13 \\
\hline 31,85 & 1928,00 & 35,30 & 54,74 & 50,42 & 46,59 & 41,33 & 36,35 & 31,81 & 24,32 & 18,82 & 12,19 \\
\hline 63,05 & 216,10 & 82,10 & 55,08 & 33,04 & 25,86 & 20,26 & 16,52 & 13,71 & 9,83 & 7,52 & 5,07 \\
\hline 82,97 & 329,10 & 89,20 & 38,24 & 23,71 & 19,25 & 15,85 & 13,58 & 11,79 & 9,05 & 7,16 & 4,87 \\
\hline 32,32 & 1426,60 & 90,60 & 32,16 & 26,97 & 23,45 & 19,27 & 15,80 & 13,02 & 9,13 & 6,80 & 4,47 \\
\hline 26,77 & 1868,90 & 198,30 & 19,99 & 15,46 & 12,58 & 9,53 & 7,32 & 5,77 & 3,91 & 2,95 & 2,02 \\
\hline 40,39 & 265,60 & 75,40 & 59,93 & 39,89 & 31,68 & 24,12 & 18,85 & 15,09 & 10,40 & 7,87 & 5,38 \\
\hline 72,95 & 501,80 & 20,00 & 71,60 & 55,71 & 52,40 & 48,87 & 45,48 & 42,26 & 36,31 & 31,14 & 23,02 \\
\hline 60,92 & 642,20 & 137,10 & 24,05 & 16,47 & 13,76 & 11,38 & 9,60 & 8,15 & 6,01 & 4,62 & 3,07 \\
\hline 33,95 & 827,40 & 172,20 & 25,09 & 17,79 & 14,25 & 10,77 & 8,32 & 6,61 & 4,52 & 3,42 & 2,34 \\
\hline 51,82 & 1167,00 & 102,50 & 23,05 & 18,54 & 16,51 & 14,32 & 12,43 & 10,79 & 8,19 & 6,35 & 4,18 \\
\hline 51,66 & 816,20 & 32,80 & 53,60 & 45,54 & 42,42 & 38,37 & 34,60 & 31,09 & 25,01 & 20,20 & 13,69 \\
\hline 88,20 & 1458,20 & 25,30 & 34,84 & 29,53 & 26,81 & 25,84 & 25,04 & 24,08 & 22,10 & 20,21 & 16,75 \\
\hline 40,63 & 755,30 & 112,50 & 30,42 & 22,93 & 19,32 & 15,54 & 12,60 & 10,32 & 7,23 & 5,43 & 3,61 \\
\hline 28,89 & 408,40 & 126,90 & 42,52 & 27,59 & 20,75 & 14,72 & 11,00 & 8,62 & 5,94 & 4,57 & 3,18 \\
\hline 53,79 & 446,80 & 58,70 & 46,95 & 35,60 & 30,90 & 26,19 & 22,35 & 19,12 & 14,21 & 10,92 & 7,19 \\
\hline 54,00 & 1248,10 & 154,20 & 17,35 & 13,27 & 11,57 & 9,86 & 8,45 & 7,25 & 5,42 & 4,17 & 2,75 \\
\hline 82,84 & 868,60 & 119,10 & 19,40 & $\begin{array}{l}10,61 \\
13,44\end{array}$ & 11,70 & $\begin{array}{c}0,00 \\
10,22\end{array}$ & 9,12 & 8,17 & $\frac{0,7 L}{6,60}$ & 5,40 & 3,76 \\
\hline 37,48 & 1660,90 & 169,40 & 18,33 & 14,62 & 12,55 & 10,25 & 8,38 & 6,90 & 4,85 & 3,63 & 2,40 \\
\hline 38,93 & 1548,00 & 62,30 & 34,38 & 30,31 & 27,56 & 24,10 & 20,94 & 18,14 & 13,68 & 10,52 & 6,82 \\
\hline 85,45 & 1270,70 & 46,70 & 26,97 & 20,58 & 19,11 & 18,07 & 17,05 & 16,06 & 14,19 & 12,51 & 9,70 \\
\hline 61,50 & 1898,80 & 155,10 & 13,40 & 10,55 & 9,52 & 8,44 & 7,51 & 6,68 & 5,29 & 4,23 & 2,86 \\
\hline 58,77 & 483,50 & 130,90 & 29,04 & 19,01 & 15,48 & 12,49 & 10,33 & 8,64 & 6,24 & 4,76 & 3,18 \\
\hline 63,78 & 1808,90 & 61,90 & 23,73 & 19,12 & 18,12 & 16,83 & 15,59 & 14,40 & 12,21 & 10,33 & 7,47 \\
\hline 74,44 & 1560,20 & 157,10 & 13,21 & 9,73 & 8,70 & 7,72 & 6,93 & 6,24 & 5,05 & 4,13 & 2,86 \\
\hline 26,89 & 886,20 & 144,10 & 31,35 & 22,80 & 17,94 & 13,14 & 9,92 & 7,76 & 5,29 & 4,03 & 2,79 \\
\hline 62,99 & 1503,00 & 81,00 & 21,48 & 17,24 & 15,98 & 14,51 & 13,20 & 11,97 & 9,82 & 8,08 & 5,62 \\
\hline 63,11 & 1912,60 & 32,10 & 36,48 & 29,48 & 28,24 & 27,05 & 25,61 & 24,14 & 21,32 & 18,72 & 14,36 \\
\hline 24,82 & 1459,20 & 187,40 & 23,55 & 17,56 & 13,87 & 10,16 & 7,65 & 5,97 & 4,06 & 3,10 & 2,14 \\
\hline 21,33 & 273,20 & 46,00 & 113,17 & 78,94 & 59,00 & 40,98 & 30,10 & 23,42 & 16,20 & 12,53 & 8,72 \\
\hline 36,56 & 312,70 & 101,90 & 49,04 & 31,69 & 24,53 & 18,13 & 13,89 & 11,00 & 7,55 & 5,75 & 3,97 \\
\hline 81,11 & 313,90 & 124,00 & 35,32 & 20,32 & 15,74 & 12,42 & 10,33 & 8,76 & 6,51 & 5,08 & 3,44 \\
\hline 60,58 & 1313,80 & 106,50 & 19,61 & 15,49 & 13,98 & 12,38 & 11,01 & 9,78 & 7,72 & 6,17 & 4,15 \\
\hline 81,80 & 1772,80 & 82,50 & 17,27 & 13,05 & 12,14 & 11,32 & 10,56 & 9,85 & 8,54 & 7,39 & 5,56 \\
\hline 30,31 & 583,10 & 153,80 & 32,40 & 21,83 & 16,81 & 12,18 & 9,18 & 7,21 & 4,94 & 3,78 & 2,62 \\
\hline 55,96 & 676,80 & 55,20 & 39,63 & 31,78 & 28,56 & 25,09 & 22,09 & 19,42 & 15,07 & 11,88 & 7,90 \\
\hline 24,04 & 1611,20 & 31,30 & 80,39 & 72,49 & 64,72 & 54,63 & 45,69 & 38,16 & 27,10 & 20,14 & 13,01 \\
\hline 29,52 & 418,50 & 143,20 & 38,67 & 24,59 & 18,38 & 13,01 & 9,72 & 7,63 & 5,26 & 4,05 & 2,82 \\
\hline 66,84 & 442,50 & 51,10 & 45,46 & 33,88 & 29,90 & 26,12 & 23,05 & 20,38 & 16,00 & 12,76 & 8,61 \\
\hline 82,98 & 1934,10 & 95,20 & 15,18 & 11,41 & 10,58 & 9,85 & 9,18 & 8,56 & 7,41 & 6,41 & 4,81 \\
\hline 34,68 & 678,90 & 133,00 & 31,38 & 22,51 & 18,18 & 13,87 & 10,79 & 8,59 & 5,88 & 4,44 & 3,03 \\
\hline 54,16 & 1552,60 & 199,60 & 13,62 & 10,36 & 9,00 & 7,65 & 6,54 & 5,61 & 4,18 & 3,22 & 2,12 \\
\hline 56,89 & 244,00 & 36,00 & 78,45 & 58,01 & 50,00 & 42,29 & 36,12 & 30,96 & 23,09 & 17,81 & 11,76 \\
\hline 33,33 & 592,80 & 190,00 & 27,09 & 17,57 & 13,46 & 9,79 & 7,42 & 5,85 & 4,01 & 3,07 & 2,13 \\
\hline 21,34 & 1006,00 & 107,60 & 42,89 & 31,97 & 24,84 & 17,80 & 13,21 & 10,25 & 6,99 & 5,37 & 3,72 \\
\hline 40,14 & 920,60 & 60,90 & 41,20 & 34,73 & 30,85 & 26,28 & 22,31 & 18,95 & 13,86 & 10,51 & 6,83 \\
\hline 62,94 & 1675,40 & 42,60 & 31,49 & 25,42 & 24,30 & 22,86 & 21,36 & 19,90 & 17,15 & 14,73 & 10,88 \\
\hline 62,37 & 829,50 & 130,70 & 21,35 & 15,41 & 13,24 & 11,25 & 9,68 & 8,37 & 6,33 & 4,93 & 3,28 \\
\hline 75,19 & 926,50 & 154,50 & 17,20 & 11,86 & 10,16 & 8,70 & 7,62 & 6,71 & 5,25 & 4,18 & 2,84 \\
\hline 84,74 & 996,40 & 154,50 & 15,84 & 10,73 & 9,23 & 8,00 & 7,10 & 6,34 & 5,10 & 4,16 & 2,89 \\
\hline 82,37 & 884,00 & 56,20 & 28,73 & 21,32 & 19,59 & 17,97 & 16,58 & 15,32 & 13,04 & 11,11 & 8,16 \\
\hline 22,98 & 1710,30 & 92,20 & 39,10 & 31,98 & 26,63 & 20,57 & 15,97 & 12,62 & 8,52 & 6,38 & 4,33 \\
\hline 33,55 & 1468,40 & 65,70 & 38,08 & 33,19 & 29,57 & 25,09 & 21,16 & 17,84 & 12,88 & 9,68 & 6,27 \\
\hline 45,35 & 1896,70 & 60,30 & 29,38 & 25,74 & 24,00 & 21,65 & 19,44 & 17,37 & 13,83 & 11,06 & 7,40 \\
\hline 36,28 & 1423,60 & 63,30 & 37,03 & 32,40 & 29,12 & 25,03 & 21,40 & 18,26 & 13,43 & 10,19 & 6,59 \\
\hline 62,49 & 1724,70 & 90,10 & 19,17 & 15,43 & 14,33 & 13,02 & 11,85 & 10,75 & 8,83 & 7,27 & 5,05 \\
\hline 31,20 & 734,00 & 176,00 & $\begin{array}{l}v, \pm r \\
26,99\end{array}$ & $\begin{array}{l}10,70 \\
18,56\end{array}$ & 14,49 & $\begin{array}{l}10,0< \\
10,64\end{array}$ & $\begin{array}{c}1+1,00 \\
8,08\end{array}$ & 6,35 & 4,34 & 3,31 & 2,29 \\
\hline 37,17 & 1451,50 & 97,40 & 27,42 & 23,04 & 20,30 & 17,05 & 14,29 & 11,99 & 8,62 & 6,48 & 4,22 \\
\hline 46,45 & 1629,70 & 65,10 & 28,92 & 25,08 & 23,17 & 20,73 & 18,47 & 16,39 & 12,89 & 10,22 & 6,78 \\
\hline 78,10 & 1452,10 & 156,70 & 13,40 & 9,68 & 8,61 & 7,62 & 6,85 & 6,17 & 5,02 & 4,12 & 2,88 \\
\hline 27,92 & 1021,00 & 168,70 & 26,33 & 19,18 & 15,18 & 11,20 & 8,49 & 6,66 & 4,54 & 3,45 & 2,38 \\
\hline 56,76 & 1101,50 & 197,00 & 15,76 & 11,27 & 9,56 & 7,96 & 6,72 & 5,71 & 4,20 & 3,22 & 2,13 \\
\hline 26,53 & 902,40 & 31,20 & 89,35 & 77,89 & 68,34 & 56,46 & 46,37 & 38,18 & 26,67 & 19,78 & 12,94 \\
\hline 78,91 & 1123,50 & 63,40 & 24,78 & 18,70 & 17,30 & 15,94 & 14,73 & 13,62 & 11,60 & 9,88 & 7,25 \\
\hline 36.97 & 1706.90 & 167.60 & 18,44 & 14.78 & 12,70 & 10,37 & 8,48 & 6.99 & 4,91 & 3,67 & 2,42 \\
\hline 82,57 & 1378,50 & 172,70 & 12,79 & 8,96 & 7,86 & 6,91 & 6,20 & 5,58 & 4,53 & 3,72 & 2,61 \\
\hline 42,24 & 643,60 & 195,20 & 23,43 & 15,34 & 12,14 & 9,26 & 7,26 & 5,83 & 4,03 & 3,05 & 2,08 \\
\hline 41,76 & 1683,30 & 49,70 & 36,83 & 32,74 & 30,42 & 27,28 & 24,32 & 21,59 & 16,95 & 13,41 & 8,87 \\
\hline 41,12 & 898,70 & 155,70 & 23,24 & 17,07 & 14,22 & 11,32 & 9,12 & 7,43 & 5,19 & 3,90 & 2,61 \\
\hline 80,45 & 1711,30 & 138,10 & 13,12 & 9,64 & 8,75 & 7,90 & 7,21 & 6,59 & 5,50 & 4,61 & 3,30 \\
\hline 68,48 & 258,40 & 101,70 & 44,53 & 26,23 & 20,41 & 16,01 & 13,14 & 10,98 & 7,95 & 6,11 & 4,12 \\
\hline 22,36 & 243,00 & 92,20 & 68,84 & 41,54 & 29,31 & 19,77 & 14,57 & 11,47 & 8,04 & 6,25 & 4,38 \\
\hline 30,99 & 1062,90 & 41,00 & 61,85 & 54,32 & 48,33 & 40,83 & 34,27 & 28,76 & 20,61 & 15,42 & 9,99 \\
\hline 55,49 & 397,20 & 73,20 & 43,53 & 31,04 & 26,23 & 21,74 & 18,27 & 15,45 & 11,30 & 8,64 & 5,71 \\
\hline 84,93 & 1550,70 & 37,70 & 28,24 & 22,43 & 20,74 & 19,91 & 19,04 & 18,12 & 16,33 & 14,66 & 11,74 \\
\hline 30,92 & 1119,80 & 95,20 & 35,02 & 28,27 & 23,97 & 19,09 & 15,25 & 12,32 & 8,47 & 6,32 & 4,23 \\
\hline
\end{tabular}




\begin{tabular}{|c|c|c|c|c|c|c|c|c|c|c|c|}
\hline \multirow[b]{2}{*}{ e1 (cm) } & & & & & & $\mathrm{De}$ & ões (x1 & & & & \\
\hline & Meq (MPa) & Ms (MPa) & D0 & D25 & D40 & D60 & D80 & D100 & D140 & D180 & D260 \\
\hline 39,31 & 1619,50 & 90,90 & 26,38 & 22,62 & 20,24 & 17,36 & 14,83 & 12,66 & 9,33 & 7,09 & 4,60 \\
\hline 69,97 & 976,90 & 111,20 & 20,32 & 15,01 & 13,28 & 11,64 & 10,33 & 9,19 & 7,29 & 5,86 & 3,99 \\
\hline 50,32 & 1819,50 & 124,80 & 17,45 & 14,45 & 13,04 & 11,44 & 10,02 & 8,77 & 6,73 & 5,26 & 3,47 \\
\hline 42,35 & 1325,50 & 92,00 & 26,73 & 22,40 & 19,94 & 17,07 & 14,58 & 12,45 & 9,19 & 7,00 & 4,55 \\
\hline 65,98 & 1761,90 & 171,10 & 12,63 & 9,62 & 8,60 & 7,59 & 6,75 & 6,01 & 4,76 & 3,82 & 2,59 \\
\hline 54,52 & 1370,70 & 187,90 & 14,85 & 11,17 & 9,67 & 8,18 & 6,98 & 5,97 & 4,44 & 3,41 & 2,25 \\
\hline 34,98 & 535,50 & 112,10 & 38,02 & 26,95 & 21,67 & 16,47 & 12,78 & 10,17 & 6,97 & 5,27 & 3,60 \\
\hline 22,36 & 733,40 & 104,60 & 46,36 & 33,48 & 25,65 & 18,20 & 13,47 & 10,47 & 7,18 & 5,52 & 3,83 \\
\hline 50,12 & 1313,10 & 38,30 & 42,16 & 36,15 & 34,14 & 31,24 & 28,46 & 25,83 & 21,14 & 17,31 & 11,91 \\
\hline 63,18 & 1882,20 & 186,60 & 11,94 & 9,17 & 8,17 & 7,18 & 6,35 & 5,61 & 4,40 & 3,51 & 2,36 \\
\hline 88,16 & 402,60 & 54,70 & 41,10 & 28,05 & 24,40 & 21,37 & 19,16 & 17,28 & 14,13 & 11,67 & 8,25 \\
\hline 31,68 & 1104,70 & 143,80 & 26,39 & 20,16 & 16,62 & 12,86 & 10,07 & 8,03 & 5,49 & 4,12 & 2,79 \\
\hline 38,11 & 219,60 & 189,30 & 42,09 & 20,56 & 14,00 & 9,56 & 7,18 & 5,69 & 3,94 & 3,06 & 2,17 \\
\hline 41,46 & 463,10 & 140,10 & 32,84 & 21,53 & 17,02 & 12,95 & 10,13 & 8,11 & 5,60 & 4,24 & 2,90 \\
\hline 79,83 & 1428,00 & 189,80 & 12,15 & 8,53 & 7,45 & 6,51 & 5,80 & 5,19 & 4,18 & 3,40 & 2,36 \\
\hline 59,13 & 495,00 & 172,90 & 25,33 & 15,62 & 12,35 & 9,71 & 7,91 & 6,54 & 4,67 & 3,56 & 2,40 \\
\hline 60,48 & 497,30 & 44,30 & 49,10 & 38,47 & 34,50 & 30,37 & 26,87 & 23,76 & 18,62 & 14,80 & 9,93 \\
\hline 57,16 & 582,40 & 159,50 & 24,22 & 15,86 & 12,90 & 10,36 & 8,53 & 7,11 & 5,11 & 3,89 & 2,60 \\
\hline 34,45 & 222,50 & 112,70 & 54,85 & 31,67 & 23,14 & 16,34 & 12,28 & 9,68 & 6,69 & 5,15 & 3,60 \\
\hline 29,21 & 1326,30 & 40,40 & 60,89 & 54,26 & 48,52 & 41,20 & 34,71 & 29,22 & 21,01 & 15,72 & 10,15 \\
\hline 31,71 & 1697,30 & 108,00 & 27,40 & 22,94 & 19,89 & 16,29 & 13,31 & 10,93 & 7,64 & 5,69 & 3,74 \\
\hline 83,64 & 1936,60 & 34,20 & 27,44 & 22,74 & 20,87 & 20,16 & 19,46 & 18,64 & 17,01 & 15,45 & 12,64 \\
\hline 64,73 & 1288,50 & 175,00 & 14,57 & 10,69 & 9,31 & 8,02 & 7,00 & 6,12 & 4,71 & 3,71 & 2,48 \\
\hline 57,28 & 1305,20 & 84,30 & 23,32 & 18,98 & 17,33 & 15,46 & 13,81 & 12,31 & 9,77 & 7,82 & 5,27 \\
\hline 45,34 & 1347,20 & 38,60 & 44,36 & 38,91 & 36,47 & 33,06 & 29,81 & 26,76 & 21,47 & 17,27 & 11,62 \\
\hline 37,89 & 506,50 & 152,40 & 31,24 & 20,55 & 16,11 & 12,06 & 9,32 & 7,41 & 5,09 & 3,86 & 2,66 \\
\hline 48,82 & 838,30 & 91,90 & 29,29 & 23,02 & 20,13 & 17,07 & 14,51 & 12,36 & 9,12 & 6,96 & 4,56 \\
\hline 70,85 & 1488,60 & 121,20 & 15,93 & 12,12 & 10,99 & 9,85 & 8,89 & 8,03 & 6,54 & 5,36 & 3,73 \\
\hline 55,47 & 1355,70 & 85,50 & 23,21 & 19,05 & 17,39 & 15,48 & 13,79 & 12,26 & 9,68 & 7,72 & 5,18 \\
\hline 73,68 & 732,90 & 160,10 & 19,41 & 12,83 & 10,70 & 8,95 & 7,70 & 6,68 & 5,10 & 4,01 & 2,70 \\
\hline 36,74 & 1224,30 & 179,70 & 20,12 & 15,19 & 12,67 & 10,01 & 7,99 & 6,46 & 4,47 & 3,35 & 2,25 \\
\hline 38,98 & 1273,90 & 177,80 & 19,23 & 14,65 & 12,35 & 9,91 & 8,01 & 6,54 & 4,57 & 3,42 & 2,28 \\
\hline 46,01 & 689,30 & 180,10 & 22,84 & 15,40 & 12,47 & 9,77 & 7,82 & 6,37 & 4,45 & 3,36 & 2,26 \\
\hline 58,17 & 648,90 & 52,80 & 40,52 & 32,27 & 29,07 & 25,64 & 22,68 & 20,04 & 15,69 & 12,45 & 8,32 \\
\hline 25,95 & 1661,00 & 152,00 & 25,45 & 19,97 & 16,36 & 12,45 & 9,59 & 7,56 & 5,12 & 3,86 & 2,63 \\
\hline 79,80 & 1705,70 & 189,20 & 11,14 & 7,98 & 7,08 & 6,27 & 5,63 & 5,08 & 4,14 & 3,40 & 2,38 \\
\hline 36,27 & 1710,60 & 157,00 & 19,45 & 15,72 & 13,55 & 11,08 & 9,07 & 7,47 & 5,25 & 3,92 & 2,59 \\
\hline 61,89 & 221,90 & 135,20 & 45,36 & 24,16 & 17,64 & 13,00 & 10,22 & 8,29 & 5,81 & 4,45 & 3,06 \\
\hline 36,66 & 1921,40 & 199,80 & 15,90 & 12,64 & 10,81 & 8,77 & 7,14 & 5,86 & 4,10 & 3,07 & 2,03 \\
\hline 65,71 & 1873,90 & 70,60 & 21,14 & 16,89 & 15,95 & 14,79 & 13,68 & 12,63 & 10,70 & 9,05 & 6,54 \\
\hline 36,32 & 1892,40 & 173,10 & 17,60 & 14,23 & 12,27 & 10,03 & 8,22 & 6,77 & 4,76 & 3,56 & 2,35 \\
\hline 30,05 & 1124,70 & 189,40 & 22,62 & 16,53 & 13,23 & 9,91 & 7,59 & 5,99 & 4,08 & 3,09 & 2,12 \\
\hline 57,60 & 1832,60 & 67,30 & 23,73 & 19,65 & 18,51 & 16,99 & 15,55 & 14,19 & 11,75 & 9,73 & 6,81 \\
\hline 38,76 & 1527,60 & 119,90 & 22,90 & 18,92 & 16,58 & 13,88 & 11,60 & 9,72 & 6,98 & 5,25 & 3,43 \\
\hline 86,15 & 1701,10 & 198,00 & 10,57 & 7,38 & 6,51 & 5,76 & 5,20 & 4,71 & 3,88 & 3,22 & 2,29 \\
\hline 51,19 & 1122,00 & 45,10 & 39,22 & 33,39 & 31,08 & 28,08 & 25,30 & 22,71 & 18,23 & 14,71 & 9,95 \\
\hline 64,03 & 1867,00 & 81,00 & 19,65 & 15,78 & 14,81 & 13,61 & 12,50 & 11,45 & 9,57 & 7,99 & 5,67 \\
\hline 41,64 & 1476,30 & 164,60 & 18,21 & 14,36 & 12,39 & 10,24 & 8,48 & 7,06 & 5,04 & 3,79 & 2,49 \\
\hline 48,06 & 1019,70 & 78,20 & 29,98 & 24,68 & 22,06 & 19,11 & 16,53 & 14,30 & 10,78 & 8,32 & 5,45 \\
\hline 44,28 & 1820,70 & 158,80 & 16,41 & 13,37 & 11,79 & 10,01 & 8,49 & 7,22 & 5,29 & 4,02 & 2,63 \\
\hline 62,73 & 954,70 & 148,00 & 18,65 & 13,48 & 11,61 & 9,88 & 8,52 & 7,37 & 5,59 & 4,36 & 2,90 \\
\hline 30,70 & 224,70 & 91,00 & 63,94 & 39,12 & 28,91 & 20,37 & 15,23 & 11,97 & 8,26 & 6,37 & 4,45 \\
\hline 63,50 & 1048,20 & 55,90 & 30,84 & 24,70 & 22,92 & 20,84 & 18,97 & 17,23 & 14,17 & 11,68 & 8,14 \\
\hline 44,11 & 1329,50 & 110,30 & 23,23 & 19,05 & 16,84 & 14,34 & 12,20 & 10,38 & 7,63 & 5,81 & 3,79 \\
\hline 70,71 & 719,30 & 38,90 & 42,03 & 32,68 & 30,37 & 27,82 & 25,55 & 23,44 & 19,64 & 16,48 & 11,79 \\
\hline 44,56 & 617,50 & 187,60 & 23,89 & 15,60 & 12,40 & 9,54 & 7,54 & 6,08 & 4,22 & 3,19 & 2,17 \\
\hline 65,17 & 715,80 & 108,40 & 24,74 & 17,84 & 15,39 & 13,16 & 11,42 & 9,94 & 7,61 & 5,97 & 3,99 \\
\hline 60,18 & 1938,30 & 33,70 & 36,33 & 29,52 & 28,39 & 27,04 & 25,48 & 23,92 & 20,93 & 18,21 & 13,75 \\
\hline 40,37 & 714,20 & 99,30 & 33,65 & 25,66 & 21,72 & 17,55 & 14,27 & 11,71 & 8,22 & 6,17 & 4,10 \\
\hline 33,20 & 296,90 & 88,50 & 56,62 & 37,32 & 28,79 & 21,05 & 15,98 & 12,60 & 8,63 & 6,59 & 4,56 \\
\hline 89,83 & 559,30 & 50,40 & 35,99 & 25,49 & 22,86 & 20,62 & 18,87 & 17,32 & 14,62 & 12,38 & 9,04 \\
\hline 34,55 & 1232,20 & 123,00 & 26,49 & 21,12 & 17,98 & 14,47 & 11,68 & 9,52 & 6,61 & 4,94 & 3,28 \\
\hline 39,43 & 739,00 & 142,90 & 27,13 & 19,54 & 16,05 & 12,57 & 9,99 & 8,07 & 5,59 & 4,20 & 2,83 \\
\hline 49,27 & 315,30 & 127,70 & 39,31 & 23,76 & 18,35 & 13,93 & 10,98 & 8,87 & 6,17 & 4,69 & 3,20 \\
\hline 40,01 & 1860,10 & 61,80 & 31,81 & 28,30 & 26,04 & 23,10 & 20,35 & 17,87 & 13,76 & 10,74 & 7,02 \\
\hline 68,23 & 450,80 & 45,00 & 47,79 & 36,04 & 32,18 & 28,41 & 25,32 & 22,58 & 17,99 & 14,50 & 9,89 \\
\hline 33,57 & 342,80 & 144,70 & 39,74 & 24,10 & 17,95 & 12,80 & 9,63 & 7,59 & 5,23 & 4,02 & 2,80 \\
\hline 29,75 & 215,10 & 28,00 & 141,20 & 107,33 & 87,60 & 66,84 & 51,77 & 41,02 & 27,92 & 21,03 & 14,35 \\
\hline 42,84 & 1029,60 & 61,90 & 37,30 & 31,71 & 28,48 & 24,65 & 21,26 & 18,31 & 13,69 & 10,50 & 6,83 \\
\hline 89,77 & 920,00 & 192,80 & 14,79 & 9,44 & 7,87 & 6,65 & 5,83 & 5,16 & 4,09 & 3,32 & 2,30 \\
\hline 65,79 & 1019,40 & 148,20 & 17,66 & 12,79 & 11,08 & 9,51 & 8,28 & 7,23 & 5,56 & 4,38 & 2,93 \\
\hline 71,80 & 1582,20 & 107,50 & 16,54 & 12,68 & 11,63 & 10,54 & 9,60 & 8,75 & 7,24 & 6,01 & 4,24 \\
\hline 46,10 & 975,00 & 197,10 & 18,49 & 13,14 & 10,91 & 8,74 & 7,11 & 5,84 & 4,12 & 3,11 & 2,07 \\
\hline 82,46 & 780,90 & 21,80 & 52,88 & 41,28 & 38,47 & 36,74 & 34,89 & 33,03 & 29,46 & 26,19 & 20,59 \\
\hline 64,51 & 1703,80 & 116,20 & 16,19 & 12,77 & 11,68 & 10,50 & 9,47 & 8,53 & 6,91 & 5,64 & 3,88 \\
\hline 58,03 & 1954,60 & 71,60 & 22,20 & 18,34 & 17,29 & 15,88 & 14,55 & 13,29 & 11,02 & 9,14 & 6,41 \\
\hline 68,65 & 1559,80 & 195,40 & 12,21 & 8,95 & 7,86 & 6,84 & 6,03 & 5,32 & 4,18 & 3,33 & 2,25 \\
\hline 22,84 & 843,50 & 120,90 & 39,65 & 28,72 & 22,09 & 15,75 & 11,68 & 9,08 & 6,22 & 4,78 & 3,32 \\
\hline 88,85 & 667,50 & 162,40 & 19,29 & 12,03 & 9,86 & 8,22 & 7,13 & 6,26 & 4,90 & 3,94 & 2,71 \\
\hline 60,04 & 1275,10 & 75,50 & 24,51 & 19,84 & 18,25 & 16,43 & 14,80 & 13,31 & 10,74 & 8,72 & 5,96 \\
\hline 41,38 & 260,80 & 163,50 & 40,50 & 21,88 & 15,75 & 11,18 & 8,48 & 6,72 & 4,64 & 3,57 & 2,50 \\
\hline 79,66 & 1778,40 & 30,10 & 32,11 & 26,42 & 24,43 & 23,63 & 22,76 & 21,77 & 19,79 & 17,91 & 14,54 \\
\hline
\end{tabular}




\begin{tabular}{|c|c|c|c|c|c|c|c|c|c|c|c|}
\hline \multirow[b]{2}{*}{ e1 (cm) } & & & & & & & ões (x1 & m) & & & \\
\hline & Meq (MPa) & Ms (MPa) & D0 & D25 & D40 & D60 & D80 & D100 & D140 & D180 & D260 \\
\hline 29,50 & 733,80 & 44,80 & $\begin{array}{l}68,86 \\
\end{array}$ & 57,49 & 49,48 & 40,04 & 32,36 & 26,34 & 18,22 & 13,55 & 8,98 \\
\hline 42,20 & 1913,10 & 171,30 & 15,89 & 12,92 & 11,32 & 9,52 & 8,01 & 6,75 & 4,89 & 3,70 & 2,41 \\
\hline 60,00 & 786,90 & 79,60 & 29,01 & 22,45 & 19,95 & 17,41 & 15,29 & 13,43 & 10,41 & 8,21 & 5,48 \\
\hline 86,44 & 1845,70 & 69,60 & 18,14 & 13,80 & 12,80 & 12,10 & 11,41 & 10,75 & 9,50 & 8,37 & 6,50 \\
\hline 81,36 & 619,90 & 87,60 & 26,98 & 18,70 & 16,24 & 14,15 & 12,58 & 11,25 & 9,04 & 7,36 & 5,10 \\
\hline 40,40 & 698,40 & 90,50 & 35,87 & 27,66 & 23,54 & 19,12 & 15,62 & 12,86 & 9,05 & 6,79 & 4,50 \\
\hline 46,16 & 1189,60 & 199,90 & 16,76 & 12,33 & 10,40 & 8,47 & 6,96 & 5,77 & 4,10 & 3,10 & 2,05 \\
\hline 56,09 & 1759,90 & 25,00 & 448,35 & 39,64 & 38,28 & 36,53 & 34,44 & 32,34 & 28,31 & 24,64 & 18,58 \\
\hline 23,31 & 1408,80 & 127,50 & 32,57 & 25,19 & 20,22 & 15,01 & 11,36 & 8,87 & 6,00 & 4,55 & 3,14 \\
\hline 39,68 & 660,50 & 36,50 & 64,85 & 55,68 & 49,90 & 42,93 & 36,76 & 31,45 & 23,24 & 17,70 & 11,48 \\
\hline 87,44 & 1988,60 & 21,00 & 32,74 & 31,25 & 27,92 & 26,70 & 26,19 & 25,48 & 23,80 & 22,12 & 18,94 \\
\hline 85,62 & 1772,90 & 113,90 & 13,96 & 10,26 & 9,40 & 8,64 & 7,99 & 7,40 & 6,33 & 5,43 & 4,02 \\
\hline 53,09 & 647,40 & 85,40 & 32,55 & 24,71 & 21,42 & 18,12 & 15,43 & 13,18 & 9,76 & 7,49 & 4,93 \\
\hline 56,44 & 1837,30 & 67,50 & 23,95 & 19,93 & 18,76 & 17,18 & 15,70 & 14,29 & 11,79 & 9,73 & 6,77 \\
\hline 35,32 & 631,50 & 148,90 & 29,84 & 20,68 & 16,47 & 12,42 & 9,60 & 7,63 & 5,22 & 3,96 & 2,71 \\
\hline 47,15 & 367,70 & 160,40 & 32,98 & 19,61 & 14,98 & 11,21 & 8,76 & 7,03 & 4,87 & 3,71 & 2,54 \\
\hline 39,87 & 595,30 & 80,60 & 41,34 & 31,66 & 26,81 & 21,66 & 17,61 & 14,44 & 10,13 & 7,60 & 5,05 \\
\hline 31,34 & 1874,60 & 79,40 & 32,68 & 28,49 & 25,26 & 21,24 & 17,76 & 14,86 & 10,61 & 7,93 & 5,15 \\
\hline 63,44 & 1321,80 & 94,50 & 20,47 & 16,17 & 14,74 & 13,20 & 11,86 & 10,65 & 8,57 & 6,95 & 4,75 \\
\hline 34,25 & 1989,70 & 144,60 & 20,23 & 16,78 & 14,57 & 11,99 & 9,86 & 8,14 & 5,73 & 4,28 & 2,81 \\
\hline 44,03 & 278,20 & 170,50 & 37,98 & 20,61 & 14,94 & 10,70 & 8,16 & 6,49 & 4,48 & 3,44 & 2,40 \\
\hline 45,26 & 657,10 & 155,90 & 25,40 & 17,49 & 14,28 & 11,26 & 9,04 & 7,37 & 5,16 & 3,89 & 2,61 \\
\hline 29,62 & 1869,40 & 62,60 & 40,10 & 35,50 & 31,65 & 26,77 & 22,48 & 18,87 & 13,52 & 10,11 & 6,54 \\
\hline 32,45 & 1088,10 & 107,50 & 31,55 & 25,09 & 21,20 & 16,85 & 13,46 & 10,88 & 7,49 & 5,60 & 3,75 \\
\hline 37,13 & 435,20 & 93,40 & 44,68 & 31,55 & 25,50 & 19,57 & 15,32 & 12,25 & 8,42 & 6,35 & 4,32 \\
\hline 42,09 & 993,80 & 102,60 & 28,12 & 22,43 & 19,47 & 16,20 & 13,51 & 11,30 & 8,11 & 6,12 & 4,01 \\
\hline 34,83 & 216,50 & 139,40 & 49,51 & 26,62 & 18,86 & 13,10 & 9,82 & 7,76 & 5,37 & 4,16 & 2,92 \\
\hline 42,29 & 231,10 & 199,40 & 39,79 & 19,41 & 13,26 & 9,11 & 6,86 & 5,44 & 3,76 & 2,91 & 2,06 \\
\hline 43,80 & 1641,90 & 87,50 & 24,84 & 21,31 & 19,31 & 16,88 & 14,70 & 12,78 & 9,69 & 7,50 & 4,89 \\
\hline 70,79 & 465,40 & 149,10 & 26,49 & 16,29 & 13,01 & 10,46 & 8,74 & 7,40 & 5,46 & 4,22 & 2,84 \\
\hline 89,89 & 574,20 & 114,60 & 24,17 & 15,55 & 13,02 & 11,06 & 9,72 & 8,62 & 6,87 & 5,58 & 3,88 \\
\hline 31,90 & 493,40 & 44,80 & 74,37 & 59,70 & 50,61 & 40,36 & 32,30 & 26,13 & 18,01 & 13,44 & 8,98 \\
\hline 74,75 & 1030,60 & 32,70 & 39,74 & 30,99 & 29,23 & 27,62 & 25,94 & 24,32 & 21,26 & 18,53 & 14,06 \\
\hline 38,66 & 498,30 & 102,60 & 39,18 & 27,89 & 22,74 & 17,65 & 13,93 & 11,21 & 7,73 & 5,82 & 3,94 \\
\hline 43,54 & 668,60 & 168,10 & 24,62 & 16,78 & 13,58 & 10,59 & 8,42 & 6,82 & 4,74 & 3,58 & 2,42 \\
\hline 38,14 & 1799,80 & 75,50 & 29,25 & 25,72 & 23,29 & 20,25 & 17,51 & 15,09 & 11,29 & 8,64 & 5,59 \\
\hline 84,92 & 627,60 & 151,10 & 20,85 & 13,16 & 10,82 & 9,02 & 7,80 & 6,83 & 5,31 & 4,24 & 2,90 \\
\hline 50,86 & 722,60 & 41,80 & 48,46 & 40,62 & 37,05 & 32,85 & 29,07 & 25,66 & 20,01 & 15,80 & 10,48 \\
\hline 72,30 & 1495,70 & 177,40 & 12,80 & 9,34 & 8,24 & 7,22 & 6,42 & 5,71 & 4,55 & 3,67 & 2,51 \\
\hline 27,22 & 571,90 & 140,70 & 36,39 & 24,65 & 18,74 & 13,35 & 9,97 & 7,79 & 5,35 & 4,12 & 2,86 \\
\hline 56,46 & 1409,20 & 123,60 & 18,17 & 14,44 & 12,92 & 11,31 & 9,93 & 8,72 & 6,74 & 5,30 & 3,52 \\
\hline 67,19 & 713,80 & 143,70 & 21,38 & 14,59 & 12,27 & 10,28 & 8,80 & 7,59 & 5,72 & 4,46 & 2,98 \\
\hline 37,44 & 1202,70 & 84,00 & 32,09 & 26,86 & 23,62 & 19,81 & 16,58 & 13,90 & 9,98 & 7,50 & 4,89 \\
\hline 70,82 & 1312,30 & 135,90 & 15,82 & 11,78 & 10,50 & 9,27 & 8,28 & 7,40 & 5,92 & 4,79 & 3,29 \\
\hline 45,20 & 785,70 & 159,70 & 23,11 & 16,42 & 13,60 & 10,87 & 8,80 & 7,22 & 5,07 & 3,82 & 2,56 \\
\hline 57,00 & 1188,50 & 134,50 & 18,56 & 14,28 & 12,56 & 10,83 & 9,39 & 8,15 & 6,20 & 4,83 & 3,19 \\
\hline 23,13 & 1839,70 & 21,80 & 101,57 & 94,15 & 85,60 & 74,08 & 63,41 & 54,04 & 39,49 & 29,69 & 18,99 \\
\hline 69,05 & 1535,30 & 62,20 & 23,93 & 18,86 & 17,75 & 16,47 & 15,26 & 14,11 & 12,00 & 10,19 & 7,42 \\
\hline 72,46 & 462,70 & 66,60 & 37,49 & 26,66 & 23,13 & 20,00 & 17,60 & 15,54 & 12,19 & 9,74 & 6,61 \\
\hline 48,64 & 1823,70 & 106,40 & 19,66 & 16,58 & 15,07 & 13,28 & 11,68 & 10,25 & 7,91 & 6,20 & 4,08 \\
\hline 67,05 & 597,40 & 56,00 & 37,66 & 28,70 & 25,74 & 22,78 & 20,33 & 18,15 & 14,47 & 11,67 & 7,96 \\
\hline 60,42 & 1488,20 & 94,50 & 20,05 & 16,14 & 14,80 & 13,28 & 11,94 & 10,71 & 8,61 & 6,97 & 4,75 \\
\hline 24,75 & 482,60 & 122,90 & 44,07 & 29,32 & 21,83 & 15,23 & 11,26 & 8,80 & 6,08 & 4,70 & 3,28 \\
\hline 72,79 & 1352,60 & 87,20 & 19,81 & 15,17 & 13,97 & 12,70 & 11,61 & 10,61 & 8,83 & 7,37 & 5,24 \\
\hline 57,26 & 1262,40 & 188,70 & 15,01 & 11,07 & 9,53 & 8,06 & 6,89 & 5,90 & 4,41 & 3,40 & 2,25 \\
\hline 68,65 & 683,60 & 48,20 & 38,30 & 29,66 & 27,13 & 24,46 & 22,16 & 20,07 & 16,42 & 13,50 & 9,41 \\
\hline 71,04 & 277,50 & 166,20 & 35,83 & 18,97 & 13,87 & 10,31 & 8,20 & 6,72 & 4,78 & 3,67 & 2,51 \\
\hline 23,69 & 1130,60 & 73,80 & 50,55 & 40,71 & 33,62 & 25,74 & 19,87 & 15,67 & 10,58 & 7,94 & 5,41 \\
\hline 72,90 & 1423,60 & 181,50 & 12,91 & 9,32 & 8,17 & 7,13 & 6,32 & 5,61 & 4,45 & 3,58 & 2,44 \\
\hline 26,97 & 1545,40 & 25,10 & 85,35 & 78,79 & 71,90 & 62,65 & 54,04 & 46,42 & 34,37 & 26,06 & 16,71 \\
\hline 81,13 & 1867,70 & 159,20 & 11,62 & 8,49 & 7,67 & 6,91 & 6,30 & 5,75 & 4,79 & 4,00 & 2,86 \\
\hline 57,77 & 1521,50 & 180,40 & 14,03 & 10,70 & 9,39 & 8,08 & 7,00 & 6,07 & 4,62 & 3,60 & 2,38 \\
\hline 53,47 & 998,30 & 25,50 & 58,31 & 49,05 & 46,78 & 43,33 & 39,93 & 36,66 & 30,68 & 25,62 & 18,11 \\
\hline 44,03 & 873,80 & 78,90 & 33,63 & 27,29 & 23,99 & 20,30 & 17,18 & 14,56 & 10,64 & 8,08 & 5,27 \\
\hline 66,21 & 442,80 & 109,90 & 31,56 & 20,72 & 17,05 & 14,01 & 11,82 & 10,07 & 7,46 & 5,77 & 3,85 \\
\hline 68,38 & 1912,90 & 115,40 & 15,06 & 11,77 & 10,87 & 9,87 & 9,00 & 8,20 & 6,78 & 5,62 & 3,95 \\
\hline 70,80 & 1886,50 & 26,60 & 37,64 & 30,88 & 28,96 & 28,09 & 26,96 & 25,71 & 23,25 & 20,91 & 16,75 \\
\hline 80,96 & 392,20 & 85,10 & 35,28 & 22,91 & 19,08 & 16,04 & 13,92 & 12,19 & 9,47 & 7,55 & 5,14 \\
\hline 35,30 & 1492,20 & 198,70 & 17,98 & 13,77 & 11,51 & 9,09 & 7,24 & 5,85 & 4,04 & 3,02 & 2,03 \\
\hline 72,63 & 740,60 & 56,60 & 32,81 & 24,90 & 22,68 & 20,44 & 18,54 & 16,83 & 13,84 & 11,44 & 8,03 \\
\hline 39,49 & 711,50 & 179,00 & 24,18 & 16,53 & 13,25 & 10,15 & 7,96 & 6,38 & 4,39 & 3,32 & 2,26 \\
\hline 51,20 & 1105,10 & 92,60 & 25,20 & 20,41 & 18,22 & 15,82 & 13,75 & 11,94 & 9,07 & 7,04 & 4,63 \\
\hline 38,31 & 1672,70 & 93,90 & 26,03 & 22,32 & 19,92 & 17,02 & 14,48 & 12,32 & 9,02 & 6,83 & 4,43 \\
\hline 86,96 & 390,40 & 86,10 & 34,47 & 21,98 & 18,23 & 15,33 & 13,36 & 11,77 & 9,25 & 7,44 & 5,12 \\
\hline 73,09 & 662,00 & 174,70 & 19,91 & 12,70 & 10,37 & 8,52 & 7,24 & 6,21 & 4,67 & 3,64 & 2,45 \\
\hline 61,25 & 1522,20 & 31,30 & 40,73 & 33,01 & 31,69 & 30,02 & 28,17 & 26,36 & 22,91 & 19,81 & 14,80 \\
\hline 42,28 & 643,20 & 198,80 & 23,20 & 15,12 & 11,95 & 9,10 & 7,13 & 5,72 & 3,95 & 2,99 & 2,04 \\
\hline 70,01 & 1809,50 & 177,70 & 11,87 & 8,91 & 7,97 & 7,06 & 6,31 & 5,65 & 4,53 & 3,67 & 2,52 \\
\hline 63,79 & 735,10 & 192,00 & 18,84 & 12,30 & 10,07 & 8,21 & 6,87 & 5,81 & 4,27 & 3,28 & 2,19 \\
\hline 77,65 & 1100,80 & 144,60 & 16,03 & 11,35 & 9,92 & 8,67 & 7,71 & 6,89 & 5,52 & 4,48 & 3,09 \\
\hline 67,02 & 449,00 & 190,90 & 25,04 & 14,52 & 11,18 & 8,68 & 7,06 & 5,87 & 4,22 & 3,23 & 2,19 \\
\hline 52,43 & 742,50 & 106,30 & 27,34 & 20,51 & 17,66 & 14,82 & 12,54 & 10,65 & 7,83 & 5,98 & 3,94 \\
\hline
\end{tabular}




\begin{tabular}{|c|c|c|c|c|c|c|c|c|c|c|c|}
\hline \multirow[b]{2}{*}{ e1 (cm) } & & & & & & & ões (x1 & m) & & & \\
\hline & Meq (MPa) & Ms (MPa) & DO & D25 & D40 & D60 & D80 & D100 & D140 & D180 & D260 \\
\hline 41,73 & 1688,90 & 47,80 & 37,80 & 33,64 & 31,31 & 28,14 & 25,13 & 22,35 & 17,61 & 13,96 & 9,25 \\
\hline 32,40 & 1937,00 & 115,20 & 24,67 & 20,85 & 18,20 & 15,04 & 12,39 & 10,24 & 7,21 & 5,38 & 3,52 \\
\hline 40,62 & 954,50 & 175,20 & 21,30 & 15,48 & 12,82 & 10,14 & 8,12 & 6,60 & 4,59 & 3,45 & 2,32 \\
\hline 31,43 & 567,90 & 22,20 & 113,50 & 99,68 & 88,78 & 75,13 & 63,16 & 53,09 & 38,14 & 28,57 & 18,49 \\
\hline 81,72 & 1122,00 & 174,70 & 14,22 & 9,72 & 8,36 & 7,23 & 6,40 & 5,70 & 4,55 & 3,69 & 2,55 \\
\hline 88,61 & 1422,20 & 87,90 & 17,47 & 12,78 & 11,70 & 10,79 & 10,02 & 9,31 & 8,03 & 6,93 & 5,19 \\
\hline 62,46 & 1630,00 & 86,10 & 20,14 & 16,21 & 15,05 & 13,67 & 12,43 & 11,27 & 9,24 & 7,60 & 5,29 \\
\hline 81,42 & 1944,70 & 164,60 & 11,18 & 8,17 & 7,38 & 6,66 & 6,07 & 5,54 & 4,62 & 3,87 & 2,77 \\
\hline 77,10 & 1174,50 & 117,30 & 17,34 & 12,68 & 11,33 & 10,08 & 9,09 & 8,20 & 6,69 & 5,50 & 3,85 \\
\hline 21,38 & 213,80 & 185,90 & 44,35 & 21,26 & 14,05 & 9,40 & 7,06 & 5,63 & 3,96 & 3,09 & 2,20 \\
\hline 48,51 & 1872,00 & 108,60 & 19,25 & 16,24 & 14,76 & 13,02 & 11,45 & 10,04 & 7,75 & 6,07 & 4,00 \\
\hline 56,19 & 1125,30 & 75,00 & 26,84 & 21,88 & 19,92 & 17,71 & 15,76 & 13,99 & 11,03 & 8,80 & 5,90 \\
\hline 45,80 & 1846,00 & 132,20 & 17,83 & 14,84 & 13,27 & 11,47 & 9,89 & 8,53 & 6,39 & 4,91 & 3,21 \\
\hline 27,59 & 1953,60 & 49,00 & 49,39 & 44,43 & 39,84 & 33,91 & 28,62 & 24,11 & 17,35 & 12,98 & 8,36 \\
\hline 70,79 & 666,60 & 56,70 & 34,71 & 26,32 & 23,79 & 21,26 & 19,16 & 17,27 & 14,02 & 11,47 & 7,95 \\
\hline 83,32 & 1244,00 & 36,80 & 31,86 & 24,76 & 23,05 & 21,97 & 20,85 & 19,72 & 17,56 & 15,59 & 12,23 \\
\hline 52,66 & 1436,20 & 173,40 & 15,48 & 11,92 & 10,40 & 8,84 & 7,56 & 6,48 & 4,82 & 3,70 & 2,44 \\
\hline 89,39 & 442,20 & 72,00 & 34,28 & 22,77 & 19,47 & 16,82 & 14,95 & 13,39 & 10,83 & 8,88 & 6,23 \\
\hline 84,85 & 210,70 & 186,80 & 42,22 & 20,19 & 13,79 & 9,64 & 7,42 & 5,98 & 4,19 & 3,23 & 2,25 \\
\hline 28,11 & 1139,40 & 157,70 & 26,50 & 19,85 & 15,96 & 11,96 & 9,15 & 7,20 & 4,89 & 3,71 & 2,54 \\
\hline 40,38 & 983,90 & 157,60 & 22,45 & 16,72 & 13,99 & 11,18 & 9,02 & 7,36 & 5,14 & 3,86 & 2,58 \\
\hline 30,77 & 1885,00 & 119,90 & 25,26 & 21,09 & 18,21 & 14,82 & 12,04 & 9,85 & 6,85 & 5,09 & 3,36 \\
\hline 25,23 & 1134,40 & 30,70 & 87,53 & 77,41 & 68,36 & 56,92 & 47,03 & 38,90 & 27,31 & 20,25 & 13,18 \\
\hline 33,10 & 1188,40 & 49,10 & 50,13 & 43,98 & 39,29 & 33,43 & 28,26 & 23,88 & 17,29 & 13,00 & 8,41 \\
\hline 36,74 & 1959,20 & 114,90 & 22,32 & 19,03 & 16,88 & 14,28 & 12,04 & 10,15 & 7,34 & 5,53 & 3,59 \\
\hline 57,34 & 1484,20 & 162,30 & 15,09 & 11,66 & 10,28 & 8,89 & 7,73 & 6,73 & 5,13 & 4,01 & 2,65 \\
\hline 31,43 & 1956,20 & 83,90 & 30,98 & 26,98 & 23,91 & 20,11 & 16,81 & 14,06 & 10,04 & 7,50 & 4,87 \\
\hline 84,04 & 1241,70 & 133,70 & 15,21 & 10,78 & 9,57 & 8,51 & 7,69 & 6,98 & 5,75 & 4,78 & 3,39 \\
\hline 53,66 & 1722,60 & 40,30 & 35,82 & 30,04 & 28,75 & 26,74 & 24,73 & 22,78 & 19,19 & 16,12 & 11,49 \\
\hline 72,62 & 576,80 & 132,90 & 24,23 & 15,90 & 13,18 & 10,97 & 9,39 & 8,11 & 6,15 & 4,82 & 3,24 \\
\hline 65,15 & 442,20 & 41,50 & 51,59 & 39,58 & 35,46 & 31,32 & 27,86 & 24,79 & 19,66 & 15,78 & 10,69 \\
\hline 87,41 & 456,50 & 143,90 & 25,78 & 15,37 & 12,22 & 9,91 & 8,43 & 7,29 & 5,58 & 4,42 & 3,02 \\
\hline 70,02 & 1802,30 & 47,40 & 26,72 & 21,15 & 20,09 & 19,05 & 17,92 & 16,81 & 14,70 & 12,81 & 9,71 \\
\hline 40,29 & 1276,80 & 156,50 & 20,32 & 15,80 & 13,50 & 11,01 & 9,01 & 7,44 & 5,25 & 3,94 & 2,60 \\
\hline 70,87 & 941,90 & 198,10 & 15,57 & 10,44 & 8,74 & 7,32 & 6,29 & 5,44 & 4,14 & 3,24 & 2,17 \\
\hline 78,51 & 1262,70 & 67,40 & 22,85 & 17,31 & 16,06 & 14,83 & 13,74 & 12,72 & 10,86 & 9,27 & 6,82 \\
\hline 31,51 & 1271,60 & 135,80 & 26,20 & 20,57 & 17,20 & 13,51 & 10,69 & 8,58 & 5,88 & 4,40 & 2,96 \\
\hline 81,40 & 1285,20 & 147,00 & 14,44 & 10,26 & 9,07 & 8,02 & 7,21 & 6,51 & 5,31 & 4,37 & 3,07 \\
\hline 47,90 & 859,90 & 76,40 & 32,65 & 26,43 & 23,41 & 20,08 & 17,23 & 14,79 & 11,02 & 8,46 & 5,53 \\
\hline 48,98 & 1170,90 & 167,70 & 18,00 & 13,57 & 11,64 & 9,68 & 8,11 & 6,82 & 4,95 & 3,76 & 2,47 \\
\hline 61,60 & 1766,90 & 141,70 & 14,54 & 11,46 & 10,36 & 9,19 & 8,19 & 7,29 & 5,78 & 4,64 & 3,13 \\
\hline 71,21 & 1325,30 & 94,30 & 19,29 & 14,79 & 13,53 & 12,22 & 11,10 & 10,09 & 8,31 & 6,87 & 4,82 \\
\hline 24,07 & 871,90 & 91,10 & 46,52 & 35,52 & 28,36 & 20,97 & 15,85 & 12,38 & 8,39 & 6,38 & 4,40 \\
\hline 75,87 & 774,00 & 80,60 & 25,94 & 18,96 & 16,90 & 14,98 & 13,46 & 12,11 & 9,82 & 8,04 & 5,59 \\
\hline 80,87 & 1591,20 & 175,70 & 11,90 & 8,51 & 7,54 & 6,68 & 6,02 & 5,43 & 4,44 & 3,66 & 2,57 \\
\hline 46,68 & 1901,50 & 139,00 & 16,88 & 14,00 & 12,52 & 10,83 & 9,36 & 8,08 & 6,07 & 4,68 & 3,06 \\
\hline 89,79 & 467,90 & 111,40 & 27,66 & 17,29 & 14,20 & 11,86 & 10,31 & 9,07 & 7,13 & 5,74 & 3,96 \\
\hline 42,10 & 1093,60 & 143,40 & 22,17 & 17,06 & 14,56 & 11,90 & 9,78 & 8,10 & 5,74 & 4,31 & 2,85 \\
\hline 75,71 & 1646,50 & 173,30 & 12,13 & 8,86 & 7,89 & 6,99 & 6,28 & 5,64 & 4,57 & 3,74 & 2,60 \\
\hline 65,14 & 1267,70 & 143,30 & 16,25 & 12,21 & 10,79 & 9,42 & 8,30 & 7,33 & 5,73 & 4,55 & 3,06 \\
\hline 25,09 & 453,40 & 98,80 & 51,97 & 35,67 & 26,99 & 19,07 & 14,15 & 11,04 & 7,60 & 5,85 & 4,07 \\
\hline 65,08 & 791,60 & 185,20 & 18,23 & 12,14 & 10,06 & 8,30 & 7,01 & 5,98 & 4,44 & 3,43 & 2,29 \\
\hline 41,69 & 1099,50 & 41,90 & 47,67 & 41,98 & 38,51 & 34,09 & 30,00 & 26,32 & 20,25 & 15,79 & 10,33 \\
\hline 52,61 & 1450,10 & 158,20 & 16,23 & 12,68 & 11,14 & 9,54 & 8,20 & 7,06 & 5,29 & 4,08 & 2,68 \\
\hline 24,11 & 1685,20 & 170,60 & 24,58 & 18,85 & 15,09 & 11,19 & 8,47 & 6,62 & 4,49 & 3,41 & 2,35 \\
\hline 60,64 & 805,80 & 99,30 & 25,30 & 19,05 & 16,69 & 14,39 & 12,52 & 10,91 & 8,35 & 6,54 & 4,35 \\
\hline 44,71 & 774,30 & 78,90 & 34,96 & 27,90 & 24,36 & 20,50 & 17,26 & 14,58 & 10,61 & 8,04 & 5,26 \\
\hline 33,85 & 1311,20 & 58,90 & 42,23 & 36,82 & 32,83 & 27,88 & 23,55 & 19,88 & 14,38 & 10,81 & 7,00 \\
\hline 46,04 & 1479,30 & 198,50 & 15,32 & 11,72 & 10,06 & 8,33 & 6,94 & 5,81 & 4,18 & 3,16 & 2,08 \\
\hline 72,54 & 1957,10 & 104,00 & 15,41 & 11,91 & 11,08 & 10,18 & 9,37 & 8,62 & 7,27 & 6,13 & 4,42 \\
\hline 33,89 & 765,20 & 97,50 & 36,99 & 28,46 & 23,74 & 18,66 & 14,80 & 11,91 & 8,19 & 6,14 & 4,13 \\
\hline 73,23 & 1950,30 & 39,00 & 28,48 & 22,75 & 21,45 & 20,62 & 19,63 & 18,60 & 16,62 & 14,77 & 11,59 \\
\hline 25,66 & 514,10 & 78,60 & 57,98 & 42,33 & 33,18 & 24,17 & 18,16 & 14,18 & 9,66 & 7,38 & 5,11 \\
\hline 82,09 & 399,80 & 172,80 & 26,88 & 15,14 & 11,57 & 9,03 & 7,46 & 6,30 & 4,66 & 3,63 & 2,46 \\
\hline 58,57 & 1136,70 & 143,30 & 18,03 & 13,61 & 11,89 & 10,20 & 8,83 & 7,65 & 5,80 & 4,52 & 2,99 \\
\hline 48,22 & 1371,60 & 144,20 & 18,47 & 14,62 & 12,81 & 10,87 & 9,25 & 7,88 & 5,81 & 4,44 & 2,91 \\
\hline 81,41 & 1619,80 & 156,90 & 12,49 & 9,02 & 8,08 & 7,22 & 6,54 & 5,94 & 4,91 & 4,08 & 2,89 \\
\hline 23,61 & 485,20 & 72,70 & $\begin{array}{l}65,46 \\
\end{array}$ & 47,36 & 36,55 & 26,16 & 19,46 & 15,14 & 10,36 & 7,95 & 5,52 \\
\hline 72,23 & 1491,10 & 199,90 & 12,07 & 8,67 & 7,57 & 6,58 & 5,81 & 5,14 & 4,06 & 3,25 & 2,21 \\
\hline 81,98 & 307,20 & 28,10 & 67,61 & 48,97 & 44,03 & 39,51 & 35,91 & 32,72 & 27,15 & 22,66 & 16,16 \\
\hline 31,11 & 1775,50 & 196,80 & 18,46 & 14,41 & 11,99 & 9,36 & 7,37 & 5,90 & 4,04 & 3,02 & 2,04 \\
\hline 88,87 & 629,20 & 24,50 & 51,30 & 38,88 & 35,90 & 33,93 & 32,02 & 30,18 & 26,73 & 23,62 & 18,41 \\
\hline 85,80 & 1783,40 & 148,10 & 12,03 & 8,68 & 7,84 & 7,10 & 6,50 & 5,96 & 5,02 & 4,24 & 3,08 \\
\hline 71,98 & 1685,60 & 162,70 & 12,70 & 9,48 & 8,50 & 7,54 & 6,77 & 6,08 & 4,91 & 4,00 & 2,76 \\
\hline 67,29 & 489,20 & 126,10 & 27,95 & 18,15 & 14,88 & 12,19 & 10,28 & 8,76 & 6,50 & 5,02 & 3,36 \\
\hline 33,58 & 267,60 & 145,60 & 44,12 & 24,96 & 18,03 & 12,62 & 9,46 & 7,46 & 5,16 & 3,98 & 2,79 \\
\hline 47,48 & 763,90 & 42,90 & 48,82 & 41,40 & 37,63 & 33,15 & 29,11 & 25,51 & 19,63 & 15,34 & 10,09 \\
\hline 21,60 & 524,60 & 131,30 & 43,75 & 28,58 & 20,72 & 14,12 & 10,36 & 8,11 & 5,66 & 4,39 & 3,07 \\
\hline 23,33 & 684,90 & 187,40 & 30,33 & 19,74 & 14,43 & 9,92 & 7,31 & 5,72 & 3,97 & 3,08 & 2,15 \\
\hline 51,79 & 400,40 & 98,00 & 38,65 & 26,19 & 21,49 & 17,23 & 14,09 & 11,66 & 8,30 & 6,29 & 4,20 \\
\hline 55,24 & 1796,30 & 67,50 & 24,45 & 20,46 & 19,21 & 17,54 & 15,98 & 14,51 & 11,89 & 9,76 & 6,75 \\
\hline 40,40 & 472,80 & 194,30 & 27,61 & 16,81 & 12,81 & 9,43 & 7,25 & 5,76 & 3,97 & 3,03 & 2,09 \\
\hline
\end{tabular}




\begin{tabular}{|c|c|c|c|c|c|c|c|c|c|c|c|}
\hline \multirow[b]{2}{*}{ e1 (cm) } & & & & & & $\mathrm{De}$ & ões (x1 & & & & \\
\hline & Meq (MPa) & Ms (MPa) & D0 & D25 & D40 & D60 & D80 & D100 & D140 & D180 & D260 \\
\hline 53,09 & 1861,40 & 42,50 & 33,97 & 28,55 & 27,34 & 25,43 & 23,51 & 21,66 & 18,24 & 15,31 & 10,91 \\
\hline 61,67 & 1929,80 & 107,60 & 16,56 & 13,35 & 12,34 & 11,17 & 10,12 & 9,15 & 7,45 & 6,10 & 4,21 \\
\hline 64,09 & 1233,20 & 183,40 & 14,60 & 10,59 & 9,15 & 7,82 & 6,78 & 5,90 & 4,50 & 3,53 & 2,35 \\
\hline 39,95 & 303,30 & 168,80 & 37,07 & 20,78 & 15,19 & 10,86 & 8,25 & 6,53 & 4,50 & 3,46 & 2,41 \\
\hline 49,32 & 1149,50 & 155,80 & 18,83 & 14,32 & 12,34 & 10,32 & 8,68 & 7,33 & 5,34 & 4,06 & 2,67 \\
\hline 22,89 & 1564,50 & 190,60 & 24,00 & 17,80 & 13,89 & 10,03 & 7,48 & 5,81 & 3,96 & 3,03 & 2,10 \\
\hline 53,47 & 1111,90 & 132,30 & 19,98 & 15,40 & 13,45 & 11,47 & 9,84 & 8,45 & 6,32 & 4,87 & 3,20 \\
\hline 84,07 & 1812,40 & 127,20 & 13,11 & 9,62 & 8,79 & 8,02 & 7,39 & 6,81 & 5,78 & 4,91 & 3,60 \\
\hline 65,36 & 1728,50 & 93,40 & 18,27 & 14,52 & 13,47 & 12,27 & 11,19 & 10,19 & 8,42 & 6,97 & 4,89 \\
\hline 79,80 & 1242,60 & 186,00 & 13,19 & 9,12 & 7,88 & 6,83 & 6,05 & 5,38 & 4,29 & 3,47 & 2,39 \\
\hline 48,07 & 1627,20 & 179,00 & 15,20 & 11,95 & 10,44 & 8,83 & 7,49 & 6,37 & 4,68 & 3,57 & 2,34 \\
\hline 30,53 & 412,60 & 80,60 & 55,45 & 39,57 & 31,35 & 23,29 & 17,77 & 13,99 & 9,55 & 7,25 & 4,99 \\
\hline 20,35 & 842,30 & 111,10 & 45,23 & 32,43 & 24,49 & 17,10 & 12,56 & 9,75 & 6,72 & 5,19 & 3,61 \\
\hline 74,17 & 1699,20 & 36,40 & 31,01 & 24,66 & 23,24 & 22,31 & 21,21 & 20,08 & 17,91 & 15,89 & 12,44 \\
\hline 58,63 & 1578,20 & 45,60 & 32,07 & 26,38 & 25,12 & 23,35 & 21,60 & 19,92 & 16,82 & 14,17 & 10,16 \\
\hline 72,75 & 1950,80 & 125,70 & 13,75 & 10,53 & 9,70 & 8,82 & 8,06 & 7,37 & 6,13 & 5,12 & 3,64 \\
\hline 27,86 & 1809,40 & 70,50 & 39,46 & 34,23 & 30,03 & 24,84 & 20,43 & 16,85 & 11,80 & 8,76 & 5,73 \\
\hline 71,07 & 766,40 & 89,20 & 25,42 & 18,67 & 16,49 & 14,45 & 12,83 & 11,42 & 9,07 & 7,30 & 4,98 \\
\hline 59,04 & 923,40 & 103,50 & 23,56 & 18,06 & 15,92 & 13,78 & 12,01 & 10,48 & 8,03 & 6,29 & 4,18 \\
\hline 74,87 & 1800,60 & 29,70 & 34,10 & 27,78 & 25,95 & 25,11 & 24,09 & 22,97 & 20,76 & 18,67 & 14,97 \\
\hline 49,05 & 554,90 & 124,60 & 29,84 & 20,68 & 17,07 & 13,69 & 11,16 & 9,21 & 6,53 & 4,93 & 3,29 \\
\hline 28,65 & 467,80 & 151,30 & 36,28 & 23,32 & 17,44 & 12,33 & 9,19 & 7,21 & 4,97 & 3,83 & 2,67 \\
\hline 57,93 & 1176,40 & 76,20 & 25,65 & 20,82 & 19,02 & 16,98 & 15,18 & 13,55 & 10,78 & 8,65 & 5,84 \\
\hline 24,68 & 1295,50 & 132,60 & 31,24 & 24,01 & 19,30 & 14,38 & 10,92 & 8,55 & 5,79 & 4,39 & 3,02 \\
\hline 87,03 & 1545,40 & 137,20 & 13,31 & 9,52 & 8,56 & 7,72 & 7,05 & 6,46 & 5,43 & 4,58 & 3,32 \\
\hline 39,45 & 990,70 & 159,90 & 22,50 & 16,74 & 13,96 & 11,10 & 8,91 & 7,25 & 5,04 & 3,79 & 2,54 \\
\hline 74,19 & 321,70 & 56,30 & 48,68 & 33,41 & 28,48 & 24,29 & 21,18 & 18,58 & 14,44 & 11,47 & 7,76 \\
\hline 54,69 & 1493,10 & 37,30 & 39,03 & 32,62 & 31,17 & 28,96 & 26,76 & 24,64 & 20,74 & 17,41 & 12,40 \\
\hline 55,11 & 1917,40 & 125,90 & 16,08 & 13,17 & 11,99 & 10,64 & 9,45 & 8,38 & 6,59 & 5,24 & 3,50 \\
\hline 83,78 & 1786,00 & 118,10 & 13,79 & 10,17 & 9,31 & 8,53 & 7,87 & 7,27 & 6,19 & 5,28 & 3,88 \\
\hline 70,59 & 917,30 & 160,50 & 17,41 & 12,07 & 10,29 & 8,75 & 7,60 & 6,63 & 5,10 & 4,02 & 2,70 \\
\hline 48,82 & 1351,50 & 179,50 & 16,29 & 12,44 & 10,73 & 8,97 & 7,54 & 6,37 & 4,64 & 3,53 & 2,32 \\
\hline 74,99 & 1978,20 & 194,80 & 10,51 & 7,75 & 6,93 & 6,16 & 5,55 & 5,00 & 4,06 & 3,33 & 2,31 \\
\hline 85,95 & 1279,60 & 126,10 & 15,31 & 10,88 & 9,72 & 8,70 & 7,91 & 7,21 & 6,00 & 5,03 & 3,61 \\
\hline 76,02 & 1171,00 & 125,30 & 16,88 & 12,30 & 10,94 & 9,68 & 8,69 & 7,81 & 6,32 & 5,17 & 3,59 \\
\hline 44,19 & 1004,40 & 98,30 & 27,82 & 22,33 & 19,53 & 16,45 & 13,86 & 11,71 & 8,52 & 6,46 & 4,22 \\
\hline 47,46 & 866,40 & 192,10 & 19,53 & 13,61 & 11,22 & 8,96 & 7,28 & 5,98 & 4,22 & 3,19 & 2,13 \\
\hline 89,53 & 1670,10 & 42,80 & 24,33 & 19,35 & 17,75 & 17,02 & 16,30 & 15,54 & 14,06 & 12,67 & 10,23 \\
\hline 74,28 & 1159,30 & 183,10 & 14,17 & 9,88 & 8,50 & 7,31 & 6,42 & 5,66 & 4,43 & 3,54 & 2,40 \\
\hline 53,91 & 1431,80 & 107,60 & 20,12 & 16,36 & 14,75 & 12,97 & 11,41 & 10,03 & 7,76 & 6,11 & 4,05 \\
\hline 53,63 & 1755,50 & 78,30 & 22,76 & 19,13 & 17,77 & 16,05 & 14,47 & 13,00 & 10,46 & 8,46 & 5,74 \\
\hline 75,87 & 1916,80 & 92,30 & 16,32 & 12,51 & 11,68 & 10,82 & 10,03 & 9,29 & 7,94 & 6,78 & 4,99 \\
\hline 79,86 & 1237,10 & 152,80 & 14,54 & 10,30 & 9,05 & 7,96 & 7,12 & 6,39 & 5,17 & 4,22 & 2,94 \\
\hline 40,01 & 1209,60 & 145,90 & 21,75 & 16,96 & 14,49 & 11,82 & 9,68 & 7,99 & 5,63 & 4,22 & 2,79 \\
\hline 79,85 & 1704,80 & 117,40 & 14,45 & 10,76 & 9,85 & 8,98 & 8,25 & 7,58 & 6,38 & 5,39 & 3,90 \\
\hline 29,32 & 1808,30 & 49,20 & 47,97 & 43,14 & 38,81 & 33,22 & 28,20 & 23,89 & 17,33 & 13,02 & 8,38 \\
\hline 41,04 & 230,30 & 145,30 & 45,79 & 24,70 & 17,76 & 12,58 & 9,54 & 7,56 & 5,22 & 4,02 & 2,81 \\
\hline 46,89 & 1330,50 & 28,80 & 53,45 & 46,35 & 44,14 & 40,65 & 37,22 & 33,93 & 27,99 & 23,05 & 15,96 \\
\hline 56,43 & 1007,40 & 85,40 & 25,92 & 20,68 & 18,55 & 16,27 & 14,31 & 12,58 & 9,75 & 7,68 & 5,11 \\
\hline 85,20 & 588,80 & 48,70 & 36,64 & 26,49 & 23,95 & 21,67 & 19,83 & 18,20 & 15,31 & 12,93 & 9,38 \\
\hline 50,36 & 988,90 & 156,80 & 19,85 & 14,68 & 12,51 & 10,37 & 8,67 & 7,29 & 5,28 & 4,01 & 2,65 \\
\hline 63,47 & 976,10 & 63,80 & 29,25 & 23,22 & 21,29 & 19,16 & 17,29 & 15,57 & 12,62 & 10,28 & 7,07 \\
\hline 74,08 & 1569,40 & 65,80 & 21,99 & 17,03 & 15,98 & 14,89 & 13,84 & 12,86 & 11,04 & 9,47 & 7,00 \\
\hline 26,88 & 1334,70 & 53,60 & 54,01 & 46,52 & 40,54 & 33,21 & 27,08 & 22,17 & 15,40 & 11,42 & 7,51 \\
\hline 80,74 & 966,10 & 146,80 & 16,78 & 11,54 & 9,96 & 8,62 & 7,63 & 6,80 & 5,43 & 4,40 & 3,03 \\
\hline 33,76 & 670,50 & 48,70 & 60,71 & 50,31 & 43,62 & 35,80 & 29,35 & 24,18 & 16,98 & 12,66 & 8,33 \\
\hline 23,66 & 597,10 & 194,10 & 30,60 & 19,26 & 13,91 & 9,51 & 7,01 & 5,50 & 3,83 & 2,97 & 2,08 \\
\hline 72,17 & 1044,80 & 40,50 & 35,28 & 27,53 & 25,93 & 24,20 & 22,53 & 20,94 & 17,99 & 15,43 & 11,40 \\
\hline 59,01 & 1183,00 & 131,60 & 18,47 & 14,17 & 12,50 & 10,82 & 9,44 & 8,23 & 6,32 & 4,95 & 3,29 \\
\hline 29,84 & 1653,50 & 104,90 & 29,55 & 24,60 & 21,16 & 17,11 & 13,83 & 11,26 & 7,79 & 5,79 & 3,84 \\
\hline 40,23 & 833,70 & 26,20 & 73,35 & 65,38 & 60,35 & 53,72 & 47,51 & 41,85 & 32,42 & 25,39 & 16,64 \\
\hline 35,18 & 1646,20 & 26,30 & 65,18 & 59,61 & 55,98 & 50,63 & 45,43 & 40,55 & 32,11 & 25,52 & 16,88 \\
\hline 63,13 & 1972,80 & 20,20 & 48,70 & 40,38 & 38,13 & 37,11 & 35,65 & 34,02 & 30,76 & 27,65 & 22,12 \\
\hline 22,01 & 1779,10 & 56,60 & 56,17 & 47,96 & 41,08 & 32,80 & 26,10 & 20,96 & 14,25 & 10,56 & 7,05 \\
\hline 71,62 & 473,30 & 51,50 & 42,51 & 31,39 & 27,88 & 24,56 & 21,90 & 19,56 & 15,63 & 12,64 & 8,67 \\
\hline 48,75 & 628,30 & 192,40 & 22,60 & 14,64 & 11,69 & 9,11 & 7,29 & 5,94 & 4,15 & 3,14 & 2,13 \\
\hline 27,10 & 844,10 & 195,00 & 25,79 & 17,67 & 13,50 & 9,65 & 7,21 & 5,64 & 3,87 & 2,97 & 2,06 \\
\hline 38,59 & 1011,00 & 183,10 & 20,85 & 15,20 & 12,53 & 9,82 & 7,81 & 6,31 & 4,36 & 3,28 & 2,21 \\
\hline 70,59 & 1118,90 & 67,60 & 25,30 & 19,60 & 18,11 & 16,49 & 15,08 & 13,77 & 11,45 & 9,55 & 6,77 \\
\hline 52,51 & 1532,40 & 196,60 & 14,05 & 10,73 & 9,31 & 7,88 & 6,71 & 5,73 & 4,25 & 3,26 & 2,14 \\
\hline 81,39 & 380,70 & 176,20 & 27,68 & 15,37 & 11,64 & 9,00 & 7,39 & 6,21 & 4,56 & 3,54 & 2,41 \\
\hline 66,18 & 391,10 & 82,60 & 38,40 & 26,04 & 21,79 & 18,16 & 15,48 & 13,29 & 9,96 & 7,74 & 5,16 \\
\hline 46,42 & 1643,60 & 197,90 & 14,59 & 11,35 & 9,82 & 8,21 & 6,89 & 5,80 & 4,21 & 3,19 & 2,09 \\
\hline 51,25 & 1166,00 & 147,60 & 18,86 & 14,46 & 12,55 & 10,60 & 9,00 & 7,67 & 5,66 & 4,33 & 2,84 \\
\hline 81,87 & 675,10 & 178,60 & 18,88 & 11,79 & 9,60 & 7,92 & 6,79 & 5,89 & 4,52 & 3,58 & 2,43 \\
\hline 77,66 & 1797,90 & 34,70 & 30,08 & 24,22 & 22,60 & 21,80 & 20,87 & 19,86 & 17,90 & 16,06 & 12,83 \\
\hline 37,76 & 1771,40 & 161,30 & 18,34 & 14,86 & 12,87 & 10,61 & 8,75 & 7,25 & 5,13 & 3,85 & 2,53 \\
\hline 22,82 & 1145,10 & 195,00 & 25,80 & 18,19 & 13,79 & 9,71 & 7,17 & 5,58 & 3,84 & 2,96 & 2,06 \\
\hline 84,71 & 268,70 & 134,70 & 38,08 & 20,67 & 15,45 & 11,83 & 9,66 & 8,11 & 5,95 & 4,63 & 3,16 \\
\hline 56,01 & 355,90 & 37,20 & 65,37 & 50,96 & 45,04 & 38,96 & 33,86 & 29,44 & 22,43 & 17,48 & 11,56 \\
\hline 75,67 & 1678,50 & 86,00 & 17,96 & 13,75 & 12,80 & 11,82 & 10,93 & 10,10 & 8,60 & 7,31 & 5,35 \\
\hline 78,08 & 1131,00 & 108,40 & 18,32 & 13,39 & 12,01 & 10,72 & 9,69 & 8,77 & 7,19 & 5,94 & 4,18 \\
\hline
\end{tabular}




\begin{tabular}{|c|c|c|c|c|c|c|c|c|c|c|c|}
\hline \multirow[b]{2}{*}{ e1 (cm) } & & & & & & $\mathrm{De}$ & ões (x1 & & & & \\
\hline & Meq (MPa) & Ms (MPa) & D0 & D25 & D40 & D60 & D80 & D100 & D140 & D180 & D260 \\
\hline 441,90 & 960,10 & 157,30 & 22,24 & 16,49 & 13,83 & 11,10 & 9,00 & 7,37 & 5,17 & 3,88 & 2,59 \\
\hline 22,04 & 1317,50 & 79,70 & 48,30 & 38,76 & 31,74 & 24,03 & 18,39 & 14,42 & 9,71 & 7,32 & 5,01 \\
\hline 61,34 & 1916,80 & 91,20 & 18,48 & 14,99 & 13,98 & 12,74 & 11,62 & 10,56 & 8,69 & 7,17 & 5,00 \\
\hline 47,68 & 673,90 & 169,80 & 23,45 & 15,89 & 12,94 & 10,23 & 8,26 & 6,76 & 4,75 & 3,58 & 2,41 \\
\hline 32,06 & 595,80 & 148,00 & 32,09 & 21,95 & 17,15 & 12,63 & 9,61 & 7,57 & 5,18 & 3,95 & 2,72 \\
\hline 64,80 & 1891,90 & 70,60 & 21,24 & 17,03 & 16,09 & 14,91 & 13,78 & 12,71 & 10,75 & 9,08 & 6,54 \\
\hline 77,89 & 504,00 & 86,70 & 30,77 & 20,96 & 17,89 & 15,31 & 13,43 & 11,85 & 9,31 & 7,45 & 5,08 \\
\hline 27,42 & 1337,60 & 114,80 & 31,75 & 25,29 & 21,01 & 16,28 & 12,72 & 10,11 & 6,87 & 5,14 & 3,49 \\
\hline 20,30 & 1863,80 & 98,40 & 40,01 & 32,09 & 26,11 & 19,59 & 14,87 & 11,61 & 7,81 & 5,90 & 4,05 \\
\hline 68,68 & 1756,10 & 89,60 & 18,14 & 14,24 & 13,27 & 12,17 & 11,17 & 10,24 & 8,57 & 7,18 & 5,12 \\
\hline 87,44 & 1146,00 & 167,60 & 13,99 & 9,48 & 8,19 & 7,13 & 6,37 & 5,72 & 4,64 & 3,82 & 2,68 \\
\hline 63,39 & 1796,80 & 103,10 & 17,21 & 13,76 & 12,72 & 11,52 & 10,45 & 9,46 & 7,74 & 6,35 & 4,40 \\
\hline 26,90 & 752,10 & 145,50 & 32,78 & 23,17 & 17,96 & 12,99 & 9,74 & 7,62 & 5,21 & 3,99 & 2,76 \\
\hline 26,29 & 1061,80 & 178,50 & 25,91 & 18,69 & 14,60 & 10,62 & 7,98 & 6,23 & 4,25 & 3,25 & 2,25 \\
\hline 76,23 & 304,20 & 191,50 & 31,97 & 16,63 & 12,04 & 8,90 & 7,08 & 5,82 & 4,15 & 3,19 & 2,19 \\
\hline 53,62 & 762,70 & 97,10 & 28,03 & 21,37 & 18,59 & 15,78 & 13,49 & 11,55 & 8,60 & 6,61 & 4,35 \\
\hline 44,98 & 801,50 & 131,20 & 25,61 & 18,96 & 15,99 & 13,00 & 10,65 & 8,81 & 6,25 & 4,71 & 3,12 \\
\hline 23,03 & 640,10 & 94,40 & 50,92 & 36,78 & 28,27 & 20,15 & 14,95 & 11,62 & 7,96 & 6,12 & 4,25 \\
\hline 64,76 & 1332,20 & 170,00 & 14,55 & 10,77 & 9,43 & 8,16 & 7,14 & 6,26 & 4,85 & 3,83 & 2,56 \\
\hline 32,73 & 636,60 & 128,00 & 33,96 & 24,20 & 19,34 & 14,54 & 11,20 & 8,86 & 6,05 & 4,59 & 3,15 \\
\hline 27,31 & 1473,50 & 145,20 & 26,32 & 20,59 & 16,92 & 12,95 & 10,03 & 7,94 & 5,39 & 4,05 & 2,76 \\
\hline 75,27 & 358,40 & 52,90 & 47,08 & 33,06 & 28,62 & 24,76 & 21,83 & 19,33 & 15,25 & 12,24 & 8,35 \\
\hline 41,92 & 1923,70 & 80,80 & 25,47 & 22,30 & 20,37 & 17,95 & 15,73 & 13,75 & 10,51 & 8,16 & 5,33 \\
\hline 78,91 & 1281,60 & 24,30 & 42,02 & 33,98 & 31,60 & 30,51 & 29,25 & 27,88 & 25,19 & 22,66 & 18,19 \\
\hline 27,02 & 1893,80 & 169,60 & 22,02 & 17,42 & 14,39 & 11,07 & 8,60 & 6,82 & 4,63 & 3,47 & 2,36 \\
\hline 53,60 & 1618,30 & 84,50 & 22,33 & 18,66 & 17,18 & 15,39 & 13,78 & 12,30 & 9,78 & 7,83 & 5,27 \\
\hline 85,13 & 1973,70 & 130,20 & 12,39 & 9,10 & 8,33 & 7,64 & 7,06 & 6,53 & 5,57 & 4,76 & 3,51 \\
\hline 39,66 & 331,10 & 50,90 & 69,12 & 51,85 & 43,46 & 34,72 & 27,98 & 22,82 & 15,91 & 11,94 & 7,98 \\
\hline 38,27 & 1898,90 & 198,30 & 15,58 & 12,40 & 10,65 & 8,71 & 7,14 & 5,89 & 4,15 & 3,11 & 2,05 \\
\hline 34,20 & 1921,50 & 157,00 & 19,45 & 15,90 & 13,71 & 11,18 & 9,12 & 7,49 & 5,24 & 3,91 & 2,58 \\
\hline 60,47 & 1395,40 & 52,30 & 29,89 & 24,42 & 23,03 & 21,21 & 19,49 & 17,85 & 14,90 & 12,43 & 8,80 \\
\hline 53,52 & 1201,70 & 192,90 & 15,73 & 11,54 & 9,85 & 8,22 & 6,93 & 5,87 & 4,30 & 3,29 & 2,17 \\
\hline 35,75 & 376,60 & 190,00 & 32,18 & 18,60 & 13,65 & 9,69 & 7,31 & 5,77 & 3,98 & 3,06 & 2,14 \\
\hline 35,92 & 1794,90 & 138,80 & 20,80 & 17,17 & 14,94 & 12,35 & 10,19 & 8,45 & 5,98 & 4,48 & 2,93 \\
\hline 57,73 & 1126,90 & 110,00 & 21,10 & 16,51 & 14,68 & 12,80 & 11,21 & 9,81 & 7,56 & 5,94 & 3,95 \\
\hline 70,72 & 1119,80 & 180,90 & 14,80 & 10,39 & 8,93 & 7,64 & 6,66 & 5,84 & 4,52 & 3,58 & 2,41 \\
\hline 48,07 & 280,80 & 32,70 & 85,30 & 66,55 & 57,90 & 48,78 & 41,23 & 34,96 & 25,59 & 19,48 & 12,77 \\
\hline 86,43 & 558,40 & 161,30 & 21,79 & 13,24 & 10,65 & 8,72 & 7,46 & 6,47 & 4,98 & 3,95 & 2,70 \\
\hline 63,04 & 1693,50 & 134,70 & 15,06 & 11,82 & 10,70 & 9,51 & 8,50 & 7,59 & 6,05 & 4,87 & 3,31 \\
\hline 80,68 & 283,40 & 113,30 & 39,00 & 22,40 & 17,32 & 13,65 & 11,33 & 9,61 & 7,13 & 5,55 & 3,76 \\
\hline 24,78 & 1121,00 & 101,80 & 39,15 & 30,56 & 24,82 & 18,69 & 14,29 & 11,22 & 7,59 & 5,73 & 3,93 \\
\hline 25,59 & 1509,20 & 87,50 & 38,75 & 31,97 & 27,00 & 21,26 & 16,77 & 13,41 & 9,12 & 6,79 & 4,57 \\
\hline 82,83 & 607,80 & 95,80 & 25,97 & 17,66 & 15,18 & 13,12 & 11,61 & 10,35 & 8,28 & 6,72 & 4,65 \\
\hline 35,98 & 510,60 & 52,90 & 60,75 & 48,29 & 41,22 & 33,35 & 27,06 & 22,14 & 15,45 & 11,55 & 7,66 \\
\hline 54,14 & 338,30 & 148,50 & 34,51 & 20,27 & 15,54 & 11,81 & 9,38 & 7,62 & 5,33 & 4,06 & 2,77 \\
\hline 28,77 & 1779,90 & 170,80 & 21,40 & 16,90 & 14,04 & 10,90 & 8,53 & 6,80 & 4,63 & 3,47 & 2,35 \\
\hline 81,41 & 1554,20 & 125,10 & 14,38 & 10,54 & 9,56 & 8,65 & 7,90 & 7,23 & 6,05 & 5,08 & 3,65 \\
\hline 30,22 & 1189,40 & 172,40 & 23,54 & 17,63 & 14,30 & 10,85 & 8,38 & 6,63 & 4,52 & 3,41 & 2,33 \\
\hline 83,90 & 512,70 & 162,70 & 23,11 & 13,86 & 11,03 & 8,93 & 7,57 & 6,52 & 4,96 & 3,91 & 2,66 \\
\hline 27,18 & 1300,90 & 178,40 & 23,84 & 17,82 & 14,25 & 10,61 & 8,07 & 6,34 & 4,31 & 3,27 & 2,25 \\
\hline 74,23 & 1740,30 & 183,20 & 11,58 & 8,50 & 7,57 & 6,70 & 6,00 & 5,39 & 4,35 & 3,54 & 2,45 \\
\hline 38,67 & 1104,40 & 99,40 & 29,15 & 23,68 & 20,57 & 17,04 & 14,12 & 11,75 & 8,36 & 6,28 & 4,12 \\
\hline 45,97 & 552,80 & 78,40 & 39,75 & 30,13 & 25,75 & 21,23 & 17,62 & 14,71 & 10,54 & 7,97 & 5,25 \\
\hline 51,07 & 1802,90 & 129,50 & 16,97 & 13,97 & 12,58 & 11,02 & 9,65 & 8,44 & 6,48 & 5,07 & 3,34 \\
\hline 66,22 & 892,20 & 166,30 & 17,82 & 12,37 & 10,48 & 8,83 & 7,58 & 6,55 & 4,95 & 3,86 & 2,58 \\
\hline 34,33 & 870,50 & 59,50 & 48,01 & 40,12 & 34,99 & 28,94 & 23,88 & 19,78 & 13,98 & 10,44 & 6,84 \\
\hline 54,71 & 1965,60 & 65,70 & 24,31 & 20,40 & 19,25 & 17,66 & 16,14 & 14,71 & 12,14 & 10,02 & 6,97 \\
\hline 75,60 & 1166,10 & 108,60 & 18,30 & 13,53 & 12,16 & 10,86 & 9,80 & 8,86 & 7,24 & 5,95 & 4,16 \\
\hline 55,43 & 878,50 & 116,60 & 23,36 & 17,63 & 15,31 & 13,01 & 11,14 & 9,57 & 7,15 & 5,51 & 3,63 \\
\hline 30,79 & 1996,90 & 40,00 & 51,20 & 47,01 & 43,12 & 37,90 & 33,00 & 28,62 & 21,53 & 16,50 & 10,63 \\
\hline 40,94 & 806,80 & 177,10 & 22,65 & 15,91 & 12,97 & 10,12 & 8,04 & 6,49 & 4,50 & 3,39 & 2,29 \\
\hline 69,69 & 360,50 & 150,50 & 31,14 & 18,04 & 13,93 & 10,86 & 8,88 & 7,41 & 5,36 & 4,12 & 2,79 \\
\hline 53,26 & 519,90 & 60,10 & 43,52 & 33,68 & 29,49 & 25,19 & 21,62 & 18,59 & 13,91 & 10,72 & 7,05 \\
\hline 85,70 & 300,90 & 168,20 & 32,96 & 17,44 & 12,82 & 9,66 & 7,82 & 6,52 & 4,75 & 3,69 & 2,52 \\
\hline 83,83 & 1262,70 & 40,90 & 29,61 & 22,84 & 21,26 & 20,20 & 19,11 & 18,04 & 16,01 & 14,16 & 11,04 \\
\hline 84,77 & 981,90 & 72,90 & 23,36 & 17,04 & 15,51 & 14,12 & 12,98 & 11,95 & 10,12 & 8,59 & 6,27 \\
\hline 47,62 & 1764,00 & 102,30 & 20,70 & 17,50 & 15,89 & 13,98 & 12,26 & 10,73 & 8,24 & 6,44 & 4,23 \\
\hline 70,52 & 1929,90 & 182,90 & 11,31 & 8,51 & 7,63 & 6,77 & 6,07 & 5,45 & 4,38 & 3,56 & 2,45 \\
\hline 58,55 & 697,60 & 76,90 & 31,61 & 24,31 & 21,44 & 18,57 & 16,18 & 14,12 & 10,81 & 8,47 & 5,62 \\
\hline 84,62 & 858,00 & 165,00 & 16,73 & 10,98 & 9,25 & 7,87 & 6,90 & 6,11 & 4,83 & 3,89 & 2,68 \\
\hline 35,93 & 1765,10 & 177,60 & 17,91 & 14,29 & 12,22 & 9,90 & 8,05 & 6,59 & 4,61 & 3,44 & 2,28 \\
\hline 73,05 & 1685,30 & 164,70 & 12,53 & 9,31 & 8,34 & 7,40 & 6,65 & 5,98 & 4,83 & 3,95 & 2,73 \\
\hline 43,86 & 1362,30 & 180,30 & 17,26 & 13,25 & 11,35 & 9,34 & 7,72 & 6,42 & 4,58 & 3,45 & 2,28 \\
\hline 38,18 & 1927,40 & 159,60 & 17,75 & 14,56 & 12,70 & 10,56 & 8,78 & 7,32 & 5,22 & 3,92 & 2,56 \\
\hline 72,25 & 1208,50 & 26,70 & 43,65 & 34,67 & 32,81 & 31,40 & 29,77 & 28,12 & 24,95 & 22,03 & 17,09 \\
\hline 56,64 & 1794,20 & 104,60 & 18,18 & 14,93 & 13,70 & 12,28 & 11,00 & 9,84 & 7,85 & 6,31 & 4,27 \\
\hline 77,09 & 1694,20 & 20,70 & 41,81 & 35,91 & 32,93 & 31,96 & 31,02 & 29,84 & 27,39 & 25,02 & 20,68 \\
\hline 51,63 & 277,00 & 199,60 & 35,02 & 17,98 & 12,75 & 9,07 & 6,96 & 5,55 & 3,84 & 2,95 & 2,06 \\
\hline 86,46 & 619,10 & 171,20 & 19,96 & 12,23 & 9,89 & 8,13 & 6,98 & 6,07 & 4,69 & 3,73 & 2,55 \\
\hline 73,28 & 451,60 & 29,90 & 58,18 & 44,42 & 40,82 & 37,09 & 33,88 & 30,95 & 25,75 & 21,48 & 15,27 \\
\hline 85,51 & 1777,30 & 46,20 & 23,56 & 18,58 & 17,18 & 16,47 & 15,72 & 14,94 & 13,43 & 12,03 & 9,60 \\
\hline 43,23 & 1071,90 & 28,60 & 60,51 & 53,58 & 50,18 & 45,40 & 40,83 & 36,57 & 29,18 & 23,37 & 15,64 \\
\hline
\end{tabular}




\begin{tabular}{|c|c|c|c|c|c|c|c|c|c|c|c|}
\hline \multirow[b]{2}{*}{ e1 (cm) } & & & & & & & ões (x1 & m) & & & \\
\hline & Meq (MPa) & Ms (MPa) & D0 & D25 & D40 & D60 & D80 & D100 & D140 & D180 & D260 \\
\hline 84,69 & 716,10 & 126,30 & 20,80 & 13,84 & 11,76 & 10,08 & 8,88 & 7,89 & 6,28 & 5,09 & 3,52 \\
\hline 52,55 & 887,70 & 168,20 & 19,71 & 14,05 & 11,82 & 9,71 & 8,08 & 6,78 & 4,90 & 3,73 & 2,47 \\
\hline 20,80 & 615,80 & 21,70 & 158,27 & 132,62 & 111,70 & 87,23 & 68,18 & 54,06 & 36,45 & 27,14 & 18,35 \\
\hline 64,76 & 519,50 & 120,40 & 27,95 & 18,67 & 15,48 & 12,77 & 10,80 & 9,20 & 6,83 & 5,27 & 3,52 \\
\hline 25,73 & 1419,10 & 140,80 & 28,33 & 21,98 & 17,86 & 13,47 & 10,32 & 8,11 & 5,50 & 4,15 & 2,84 \\
\hline 49,59 & 823,20 & 100,50 & 27,79 & 21,48 & 18,66 & 15,73 & 13,33 & 11,32 & 8,31 & 6,34 & 4,16 \\
\hline 63,37 & 1583,50 & 106,40 & 17,74 & 14,07 & 12,88 & 11,57 & 10,42 & 9,38 & 7,58 & 6,17 & 4,23 \\
\hline 21,03 & 1892,50 & 105,40 & 36,94 & 29,66 & 24,21 & 18,24 & 13,90 & 10,87 & 7,32 & 5,52 & 3,79 \\
\hline 67,84 & 1299,90 & 43,70 & 32,20 & 25,54 & 24,21 & 22,63 & 21,07 & 19,57 & 16,80 & 14,37 & 10,58 \\
\hline 79,08 & 605,10 & 175,90 & 20,51 & 12,65 & 10,20 & 8,33 & 7,07 & 6,09 & 4,61 & 3,62 & 2,45 \\
\hline 53,27 & 841,60 & 96,30 & 27,05 & 20,96 & 18,37 & 15,70 & 13,49 & 11,60 & 8,69 & 6,70 & 4,41 \\
\hline 53,94 & 455,10 & 96,30 & 35,91 & 25,00 & 20,84 & 17,02 & 14,12 & 11,82 & 8,53 & 6,49 & 4,31 \\
\hline 37,36 & 1164,70 & 105,50 & 28,21 & 22,86 & 19,78 & 16,28 & 13,40 & 11,09 & 7,84 & 5,87 & 3,86 \\
\hline 80,96 & 1053,30 & 143,70 & 16,18 & 11,28 & 9,83 & 8,58 & 7,64 & 6,84 & 5,51 & 4,49 & 3,12 \\
\hline 49,52 & 793,10 & 121,60 & 25,45 & 18,96 & 16,18 & 13,41 & 11,21 & 9,42 & 6,82 & 5,17 & 3,41 \\
\hline 87,64 & 477,30 & 150,20 & 24,65 & 14,70 & 11,69 & 9,48 & 8,07 & 6,98 & 5,34 & 4,24 & 2,89 \\
\hline 86,15 & 1110,50 & 180,40 & 13,83 & 9,28 & 7,94 & 6,86 & 6,08 & 5,43 & 4,36 & 3,56 & 2,48 \\
\hline 73,34 & 407,20 & 147,80 & 28,64 & 17,04 & 13,38 & 10,63 & 8,83 & 7,46 & 5,49 & 4,25 & 2,86 \\
\hline 22,40 & 1893,00 & 184,00 & 23,67 & 18,02 & 14,26 & 10,42 & 7,81 & 6,08 & 4,13 & 3,15 & 2,17 \\
\hline 53,11 & 849,20 & 89,90 & 28,05 & 21,98 & 19,36 & 16,64 & 14,34 & 12,38 & 9,32 & 7,20 & 4,74 \\
\hline 20,69 & 1026,90 & 199,00 & 27,59 & 18,70 & 13,72 & 9,40 & 6,88 & 5,37 & 3,73 & 2,90 & 2,02 \\
\hline 65,22 & 741,40 & 82,80 & 27,96 & 21,03 & 18,60 & 16,25 & 14,34 & 12,66 & 9,91 & 7,89 & 5,31 \\
\hline 76,13 & 1189,90 & 25,80 & 43,01 & 34,20 & 32,11 & 30,85 & 29,37 & 27,84 & 24,89 & 22,16 & 17,44 \\
\hline 53,43 & 222,30 & 184,00 & 41,47 & 20,42 & 14,13 & 9,87 & 7,52 & 6,00 & 4,15 & 3,19 & 2,24 \\
\hline 53,22 & 1116,00 & 141,80 & 19,26 & 14,70 & 12,78 & 10,84 & 9,26 & 7,92 & 5,89 & 4,53 & 2,98 \\
\hline 29,33 & 713,40 & 145,70 & 31,81 & 22,45 & 17,60 & 12,91 & 9,78 & 7,67 & 5,24 & 4,00 & 2,76 \\
\hline 66,86 & 1485,70 & 185,10 & 13,01 & 9,61 & 8,43 & 7,32 & 6,44 & 5,67 & 4,43 & 3,52 & 2,37 \\
\hline 89,32 & 1528,30 & 105,10 & 15,27 & 11,07 & 10,08 & 9,24 & 8,55 & 7,92 & 6,79 & 5,84 & 4,35 \\
\hline 56,40 & 991,80 & 167,20 & 18,09 & 13,09 & 11,15 & 9,33 & 7,90 & 6,72 & 4,96 & 3,80 & 2,51 \\
\hline 88,08 & 1939,60 & 80,20 & 16,17 & 12,20 & 11,27 & 10,62 & 10,00 & 9,40 & 8,29 & 7,30 & 5,64 \\
\hline 62,40 & 1895,20 & 45,40 & 29,14 & 23,56 & 22,55 & 21,26 & 19,88 & 18,54 & 16,02 & 13,78 & 10,21 \\
\hline 34,60 & 1530,60 & 21,60 & 77,52 & 70,96 & 66,89 & 60,72 & 54,68 & 48,97 & 39,00 & 31,14 & 20,69 \\
\hline 85,43 & 1862,40 & 109,10 & 14,02 & 10,37 & 9,54 & 8,81 & 8,18 & 7,59 & 6,53 & 5,62 & 4,19 \\
\hline 31,77 & 926,00 & 128,70 & 30,13 & 22,79 & 18,70 & 14,40 & 11,24 & 8,95 & 6,11 & 4,60 & 3,12 \\
\hline 47,35 & 1472,80 & 160,20 & 17,06 & 13,45 & 11,75 & 9,92 & 8,40 & 7,13 & 5,23 & 3,98 & 2,61 \\
\hline 67,36 & 833,60 & 159,40 & 18,72 & 12,90 & 10,90 & 9,17 & 7,88 & 6,81 & 5,16 & 4,03 & 2,69 \\
\hline 47,99 & 1720,20 & 180,70 & 14,78 & 11,70 & 10,25 & 8,69 & 7,39 & 6,29 & 4,64 & 3,54 & 2,32 \\
\hline 33,49 & 1289,20 & 139,20 & 24,60 & 19,37 & 16,33 & 12,98 & 10,37 & 8,39 & 5,79 & 4,32 & 2,89 \\
\hline 63,11 & 985,60 & 163,50 & 17,42 & 12,44 & 10,65 & 9,02 & 7,75 & 6,69 & 5,06 & 3,94 & 2,62 \\
\hline 88,84 & 1501,90 & 106,00 & 15,35 & 11,12 & 10,12 & 9,26 & 8,55 & 7,92 & 6,77 & 5,81 & 4,31 \\
\hline 89,45 & 1642,60 & 161,00 & 11,76 & 8,27 & 7,38 & 6,62 & 6,03 & 5,52 & 4,63 & 3,90 & 2,83 \\
\hline 58,37 & 364,80 & 119,60 & 35,45 & 22,22 & 17,71 & 14,00 & 11,43 & 9,47 & 6,77 & 5,16 & 3,46 \\
\hline 23,36 & 393,20 & 157,20 & 40,39 & 24,23 & 17,15 & 11,61 & 8,57 & 6,75 & 4,72 & 3,67 & 2,57 \\
\hline 73,81 & 1142,30 & 157,80 & 15,38 & 10,95 & 9,54 & 8,28 & 7,32 & 6,49 & 5,12 & 4,11 & 2,80 \\
\hline 70,53 & 1921,30 & 93,70 & 16,81 & 13,13 & 12,26 & 11,29 & 10,41 & 9,58 & 8,08 & 6,82 & 4,91 \\
\hline 84,47 & 1890,80 & 80,60 & 16,73 & 12,64 & 11,74 & 11,02 & 10,34 & 9,69 & 8,48 & 7,41 & 5,66 \\
\hline 67,15 & 638,10 & 124,00 & 24,31 & 16,70 & 14,09 & 11,85 & 10,16 & 8,77 & 6,63 & 5,18 & 3,46 \\
\hline 88,44 & 1149,10 & 97,00 & 18,26 & 13,06 & 11,77 & 10,65 & 9,76 & 8,98 & 7,59 & 6,44 & 4,71 \\
\hline 36,11 & 1713,50 & 144,10 & 20,58 & 16,82 & 14,56 & 11,97 & 9,85 & 8,14 & 5,74 & 4,29 & 2,82 \\
\hline 31,74 & 847,20 & 159,80 & 27,03 & 19,45 & 15,56 & 11,69 & 8,98 & 7,10 & 4,84 & 3,67 & 2,52 \\
\hline 59,14 & 967,30 & 143,00 & 19,39 & 14,26 & 12,30 & 10,45 & 8,97 & 7,73 & 5,81 & 4,50 & 2,98 \\
\hline 28,14 & 1996,60 & 148,80 & 22,98 & 18,67 & 15,74 & 12,41 & 9,82 & 7,87 & 5,37 & 4,01 & 2,69 \\
\hline 36,12 & 1590,40 & 93,40 & 27,84 & 23,71 & 20,99 & 17,71 & 14,88 & 12,51 & 9,02 & 6,78 & 4,41 \\
\hline 42,32 & 522,10 & 38,00 & 65,96 & 55,00 & $\begin{array}{l}48,82 \\
\end{array}$ & 41,67 & 35,49 & 30,23 & 22,23 & 16,90 & 11,00 \\
\hline 24,79 & 439,20 & 92,30 & 55,38 & 38,19 & 28,92 & 20,43 & 15,15 & 11,82 & 8,13 & 6,27 & 4,36 \\
\hline 62,59 & 475,50 & 72,50 & 37,81 & 27,43 & 23,64 & 20,14 & 17,38 & 15,05 & 11,42 & 8,91 & 5,92 \\
\hline 68,50 & 546,40 & 106,40 & 28,14 & 19,26 & 16,25 & 13,68 & 11,76 & 10,17 & 7,72 & 6,04 & 4,04 \\
\hline 72,71 & 208,80 & 175,00 & 43,37 & 21,09 & 14,56 & 10,26 & 7,91 & 6,37 & 4,45 & 3,42 & 2,38 \\
\hline 29,33 & 362,50 & 184,40 & 34,96 & 20,10 & 14,40 & 9,94 & 7,40 & 5,83 & 4,05 & 3,13 & 2,20 \\
\hline 85,06 & 479,30 & 83,50 & 31,20 & 20,77 & 17,67 & 15,16 & 13,38 & 11,89 & 9,48 & 7,69 & 5,33 \\
\hline 60,93 & 1349,50 & 82,10 & 22,59 & 18,19 & 16,72 & 15,05 & 13,56 & 12,20 & 9,85 & 8,01 & 5,48 \\
\hline 42,98 & 207,10 & 171,10 & 445,13 & 22,33 & 15,39 & 10,63 & 8,02 & 6,36 & 4,40 & 3,40 & 2,40 \\
\hline 24,90 & 613,50 & 53,40 & 73,40 & 57,62 & 46,99 & 35,55 & 27,26 & 21,44 & 14,50 & 10,93 & 7,49 \\
\hline 87,01 & 1900,60 & 32,40 & 27,34 & 23,12 & 21,03 & 20,28 & 19,65 & 18,89 & 17,32 & 15,83 & 13,10 \\
\hline 87,24 & 443,10 & 175,70 & 24,64 & 14,02 & 10,82 & 8,54 & 7,14 & 6,09 & 4,57 & 3,59 & 2,45 \\
\hline 51,46 & 1947,20 & 187,40 & 13,16 & 10,48 & 9,27 & 7,98 & 6,89 & 5,95 & 4,48 & 3,46 & 2,27 \\
\hline 38,21 & 383,60 & 71,20 & 54,43 & 39,49 & 32,45 & 25,35 & 20,09 & 16,19 & 11,18 & 8,41 & 5,68 \\
\hline 67,68 & 1411,80 & 26,30 & $\begin{array}{l}43,78 \\
\end{array}$ & 35,12 & 33,42 & 32,07 & 30,41 & 28,73 & 25,48 & 22,49 & 17,41 \\
\hline 49,84 & 503,90 & 173,80 & 26,41 & 16,60 & 13,09 & 10,11 & 8,06 & 6,55 & 4,58 & 3,47 & 2,35 \\
\hline 44,13 & 315,70 & 46,80 & 69,50 & 52,36 & 44,46 & 36,29 & 29,84 & 24,72 & 17,55 & 13,22 & 8,75 \\
\hline 61,74 & 1277,60 & 108,60 & 19,42 & 15,22 & 13,71 & 12,12 & 10,78 & 9,57 & 7,56 & 6,05 & 4,08 \\
\hline 58,00 & 442,80 & 85,20 & 37,43 & 26,33 & 22,19 & 18,42 & 15,53 & 13,18 & 9,69 & 7,44 & 4,93 \\
\hline 88,05 & 1838,40 & 189,70 & 10,30 & 7,24 & 6,44 & 5,76 & 5,23 & 4,77 & 3,97 & 3,33 & 2,40 \\
\hline 65,59 & 482,90 & 72,00 & 36,85 & 26,60 & 22,99 & 19,70 & 17,11 & 14,92 & 11,45 & 9,00 & 6,01 \\
\hline 31,79 & 595,10 & 45,30 & 69,42 & 56,95 & 48,84 & 39,46 & 31,90 & 26,00 & 18,03 & 13,43 & 8,91 \\
\hline 60,13 & 671,70 & 104,10 & 27,05 & 19,69 & 16,93 & 14,35 & 12,31 & 10,60 & 7,97 & 6,18 & 4,09 \\
\hline 46,20 & 1530,50 & 80,90 & 25,79 & 22,04 & 20,06 & 17,67 & 15,51 & 13,58 & 10,43 & 8,14 & 5,34 \\
\hline 74,44 & 621,30 & 33,60 & 47,41 & 36,37 & 33,79 & 31,07 & 28,65 & 26,40 & 22,33 & 18,89 & 13,69 \\
\hline 80,05 & 665,20 & 105,70 & 23,94 & 16,40 & 14,09 & 12,16 & 10,73 & 9,53 & 7,57 & 6,11 & 4,20 \\
\hline 68,61 & 374,50 & 85,20 & 38,28 & 25,43 & 21,12 & 17,54 & 14,93 & 12,83 & 9,63 & 7,49 & 5,01 \\
\hline 54,65 & 1117,80 & 137,10 & 19,32 & 14,78 & 12,90 & 11,01 & 9,45 & 8,13 & 6,09 & 4,70 & 3,10 \\
\hline 38,74 & 1559,60 & 78,90 & 29,57 & 25,60 & 23,00 & 19,82 & 16,99 & 14,55 & 10,76 & 8,20 & 5,31 \\
\hline
\end{tabular}




\begin{tabular}{|c|c|c|c|c|c|c|c|c|c|c|c|}
\hline \multirow[b]{2}{*}{ e1 (cm) } & & & & & & & ões (x1 & m) & & & \\
\hline & Meq (MPa) & Ms (MPa) & D0 & D25 & D40 & D60 & D80 & D100 & D140 & D180 & D260 \\
\hline 32,97 & 753,90 & 167,70 & 26,81 & 18,76 & 14,87 & 11,11 & 8,52 & 6,74 & 4,61 & 3,50 & 2,40 \\
\hline 21,95 & 360,30 & 29,80 & 141,47 & 109,49 & 87,40 & 64,38 & 48,45 & 37,73 & 25,53 & 19,42 & 13,40 \\
\hline 22,82 & 841,50 & 90,10 & 449,07 & 37,03 & 29,18 & 21,26 & 15,92 & 12,39 & 8,42 & 6,43 & 4,44 \\
\hline 52,36 & 1172,00 & 182,20 & 16,59 & 12,27 & 10,49 & 8,75 & 7,37 & 6,23 & 4,55 & 3,47 & 2,29 \\
\hline 26,77 & 950,10 & 153,00 & 29,52 & 21,49 & 16,91 & 12,38 & 9,34 & 7,31 & 4,98 & 3,80 & 2,62 \\
\hline 85,05 & 455,10 & 111,10 & 28,59 & 17,99 & 14,77 & 12,29 & 10,62 & 9,29 & 7,22 & 5,76 & 3,94 \\
\hline 89,66 & 1440,50 & 120,00 & 14,58 & 10,40 & 9,37 & 8,50 & 7,80 & 7,18 & 6,09 & 5,18 & 3,80 \\
\hline 41,50 & 412,40 & 115,10 & 38,51 & 25,71 & 20,50 & 15,70 & 12,34 & 9,91 & 6,84 & 5,17 & 3,52 \\
\hline 43,43 & 365,40 & 75,20 & 50,34 & 35,75 & 29,48 & 23,37 & 18,80 & 15,33 & 10,71 & 8,07 & 5,41 \\
\hline 58,28 & 743,60 & 172,70 & 20,32 & 13,76 & 11,39 & 9,31 & 7,77 & 6,54 & 4,76 & 3,64 & 2,42 \\
\hline 24,82 & 402,40 & 160,80 & 38,67 & 23,37 & 16,72 & 11,41 & 8,43 & 6,63 & 4,62 & 3,59 & 2,51 \\
\hline 51,80 & 406,50 & 37,50 & 64,31 & 51,43 & 45,66 & 39,46 & 34,16 & 29,58 & 22,36 & 17,32 & 11,38 \\
\hline 63,85 & 1355,60 & 165,20 & 14,75 & 11,02 & 9,68 & 8,39 & 7,35 & 6,45 & 4,99 & 3,94 & 2,64 \\
\hline 89,88 & 1348,60 & 190,00 & 11,98 & 8,10 & 7,01 & 6,13 & 5,49 & 4,95 & 4,05 & 3,35 & 2,37 \\
\hline 81,24 & 413,30 & 122,70 & 29,60 & 18,10 & 14,54 & 11,85 & 10,07 & 8,68 & 6,59 & 5,19 & 3,52 \\
\hline 63,59 & 566,10 & 118,40 & 27,06 & 18,50 & 15,49 & 12,88 & 10,93 & 9,35 & 6,96 & 5,38 & 3,58 \\
\hline 22,12 & 1480,60 & 86,40 & 43,95 & 35,43 & 29,11 & 22,12 & 16,97 & 13,33 & 8,98 & 6,75 & 4,62 \\
\hline 87,29 & 1301,40 & 171,20 & 12,95 & 8,89 & 7,76 & 6,81 & 6,11 & 5,52 & 4,51 & 3,73 & 2,63 \\
\hline 85,57 & 1770,90 & 119,20 & 13,62 & 9,98 & 9,13 & 8,36 & 7,72 & 7,14 & 6,09 & 5,20 & 3,84 \\
\hline 37,27 & 1197,40 & 169,80 & 20,83 & 15,82 & 13,25 & 10,53 & 8,44 & 6,85 & 4,75 & 3,56 & 2,38 \\
\hline 84,59 & 1072,30 & 111,00 & 17,92 & 12,73 & 11,34 & 10,11 & 9,16 & 8,32 & 6,89 & 5,74 & 4,09 \\
\hline 30,79 & 1620,30 & 113,70 & 27,54 & 22,74 & 19,52 & 15,77 & 12,73 & 10,37 & 7,18 & 5,34 & 3,54 \\
\hline 68,44 & 1870,00 & 84,00 & 18,49 & 14,58 & 13,67 & 12,61 & 11,63 & 10,71 & 9,04 & 7,62 & 5,49 \\
\hline 43,11 & 1730,50 & 139,60 & 18,43 & 15,18 & 13,41 & 11,40 & 9,68 & 8,23 & 6,03 & 4,58 & 2,99 \\
\hline 25,12 & 1482,40 & 35,70 & 72,64 & 64,81 & 57,56 & 48,27 & 40,15 & 33,39 & 23,59 & 17,52 & 11,35 \\
\hline 79,82 & 337,30 & 192,80 & 29,47 & 15,62 & 11,47 & 8,61 & 6,93 & 5,74 & 4,14 & 3,20 & 2,19 \\
\hline 39,18 & 960,10 & 183,60 & 21,09 & 15,22 & 12,51 & 9,79 & 7,78 & 6,28 & 4,35 & 3,27 & 2,21 \\
\hline 71,31 & 590,30 & 106,30 & 26,58 & 18,31 & 15,56 & 13,21 & 11,46 & 10,00 & 7,69 & 6,07 & 4,08 \\
\hline 37,19 & 1826,90 & 38,70 & 46,34 & 42,05 & 39,22 & 35,25 & 31,45 & 27,92 & 21,90 & 17,29 & 11,39 \\
\hline 87,67 & 1338,60 & 102,30 & 16,60 & 11,99 & 10,87 & 9,90 & 9,11 & 8,40 & 7,13 & 6,08 & 4,47 \\
\hline 54,70 & 1954,60 & 170,50 & 13,38 & 10,69 & 9,56 & 8,34 & 7,30 & 6,38 & 4,90 & 3,84 & 2,54 \\
\hline 32,56 & 605,50 & 196,20 & 26,60 & 17,20 & 13,12 & 9,49 & 7,17 & 5,64 & 3,87 & 2,97 & 2,06 \\
\hline 37,12 & 294,60 & 186,90 & 36,29 & 19,59 & 13,98 & 9,79 & 7,37 & 5,82 & 4,03 & 3,11 & 2,18 \\
\hline 23,38 & 1849,80 & 160,20 & 25,54 & 19,88 & 16,02 & 11,94 & 9,06 & 7,08 & 4,79 & 3,63 & 2,50 \\
\hline 45,82 & 955,40 & 50,30 & 41,65 & 35,63 & 32,41 & 28,52 & 25,02 & 21,88 & 16,79 & 13,08 & 8,58 \\
\hline 65,18 & 1516,70 & 123,10 & 16,33 & 12,69 & 11,49 & 10,23 & 9,17 & 8,21 & 6,58 & 5,32 & 3,64 \\
\hline 71,34 & 1032,40 & 155,00 & 16,57 & 11,75 & 10,16 & 8,75 & 7,67 & 6,75 & 5,26 & 4,19 & 2,83 \\
\hline 77,62 & 232,80 & 159,20 & 40,80 & 20,78 & 14,84 & 10,83 & 8,55 & 7,00 & 4,97 & 3,83 & 2,63 \\
\hline 31,62 & 1948,50 & 119,20 & 24,55 & 20,64 & 17,94 & 14,72 & 12,05 & 9,91 & 6,94 & 5,17 & 3,40 \\
\hline 75,41 & 871,30 & 180,60 & 16,57 & 11,01 & 9,23 & 7,77 & 6,72 & 5,85 & 4,51 & 3,56 & 2,41 \\
\hline 75,42 & 1415,50 & 54,80 & 25,36 & 19,62 & 18,43 & 17,26 & 16,12 & 15,03 & 13,00 & 11,23 & 8,39 \\
\hline 63,56 & 278,10 & 118,90 & 40,83 & 23,77 & 18,31 & 14,16 & 11,46 & 9,47 & 6,75 & 5,16 & 3,50 \\
\hline 61,04 & 406,60 & 83,20 & 38,72 & 26,74 & 22,43 & 18,62 & 15,75 & 13,41 & 9,92 & 7,64 & 5,07 \\
\hline 27,02 & 1801,10 & 50,40 & 50,74 & 45,14 & 40,15 & 33,80 & 28,23 & 23,57 & 16,75 & 12,47 & 8,07 \\
\hline 73,24 & 1254,70 & 66,20 & 24,02 & 18,52 & 17,23 & 15,85 & 14,61 & 13,45 & 11,36 & 9,60 & 6,94 \\
\hline 55,65 & 1435,40 & 114,10 & 19,04 & 15,32 & 13,79 & 12,12 & 10,68 & 9,40 & 7,30 & 5,75 & 3,83 \\
\hline 47,15 & 942,70 & 39,60 & 47,84 & 41,31 & 38,11 & 34,06 & 30,33 & 26,91 & 21,14 & 16,76 & 11,13 \\
\hline 66,55 & 1765,90 & 109,10 & 16,30 & 12,82 & 11,82 & 10,70 & 9,72 & 8,82 & 7,24 & 5,97 & 4,17 \\
\hline 39,69 & 250,00 & 60,40 & 70,27 & 48,44 & 39,02 & 30,03 & 23,61 & 18,95 & 13,07 & 9,87 & 6,71 \\
\hline 47,82 & 1473,30 & 79,20 & 25,91 & 22,03 & 20,08 & 17,75 & 15,64 & 13,75 & 10,63 & 8,34 & 5,49 \\
\hline 79,55 & 1865,90 & 57,80 & 21,37 & 16,57 & 15,53 & 14,75 & 13,92 & 13,12 & 11,58 & 10,20 & 7,88 \\
\hline 65,80 & 314,80 & 33,40 & 67,42 & 50,93 & 45,24 & 39,68 & 35,13 & 31,12 & 24,50 & 19,57 & 13,22 \\
\hline 26,92 & 1839,90 & 129,40 & 26,80 & 21,80 & 18,32 & 14,37 & 11,31 & 9,04 & 6,15 & 4,59 & 3,09 \\
\hline 26,41 & 221,30 & 155,90 & 448,03 & 24,95 & 17,05 & 11,50 & 8,56 & 6,79 & 4,75 & 3,70 & 2,62 \\
\hline 74,36 & 974,00 & 110,70 & 19,85 & 14,46 & 12,79 & 11,27 & 10,06 & 9,00 & 7,22 & 5,86 & 4,04 \\
\hline 70,41 & 1430,00 & 121,20 & 16,26 & 12,35 & 11,17 & 9,98 & 8,99 & 8,10 & 6,57 & 5,37 & 3,72 \\
\hline 63,70 & 1713,30 & 192,10 & 12,21 & 9,23 & 8,16 & 7,11 & 6,25 & 5,51 & 4,29 & 3,40 & 2,28 \\
\hline 77,12 & 646,40 & 121,60 & 23,13 & 15,56 & 13,16 & 11,18 & 9,75 & 8,55 & 6,66 & 5,30 & 3,60 \\
\hline 52,90 & 1852,20 & 129,00 & 16,46 & 13,52 & 12,23 & 10,78 & 9,50 & 8,35 & 6,48 & 5,10 & 3,38 \\
\hline 59,85 & 454,40 & 27,10 & $\begin{array}{l}68,62 \\
\end{array}$ & 55,56 & 51,10 & 45,96 & 41,39 & 37,20 & 29,98 & 24,31 & 16,60 \\
\hline 37,04 & 1340,70 & 37,40 & 52,58 & 477,39 & 43,64 & 38,67 & 34,01 & 29,80 & 22,85 & 17,75 & 11,55 \\
\hline 89,65 & 1611,00 & 94,60 & 15,78 & 11,56 & 10,59 & 9,80 & 9,12 & 8,50 & 7,36 & 6,38 & 4,82 \\
\hline 44,24 & 608,50 & 113,80 & 31,58 & 22,83 & 19,02 & 15,24 & 12,37 & 10,15 & 7,13 & 5,37 & 3,58 \\
\hline 69,20 & 1467,70 & 99,60 & 18,18 & 14,08 & 12,91 & 11,67 & 10,60 & 9,62 & 7,90 & 6,52 & 4,57 \\
\hline 49,74 & 1488,60 & 21,30 & 61,67 & 51,81 & 50,17 & 47,29 & 44,15 & 41,06 & 35,21 & 30,04 & 21,89 \\
\hline 45,24 & 1281,90 & 29,50 & 54,31 & 47,58 & 45,05 & 41,22 & 37,51 & 33,97 & 27,69 & 22,57 & 15,41 \\
\hline 70,42 & 1012,60 & 123,40 & 18,87 & 13,81 & 12,15 & 10,61 & 9,39 & 8,33 & 6,58 & 5,28 & 3,59 \\
\hline 38,83 & 1651,60 & 74,40 & 30,02 & 26,25 & 23,73 & 20,60 & 17,78 & 15,32 & 11,44 & 8,75 & 5,67 \\
\hline 42,19 & 317,20 & 96,30 & 47,53 & 31,11 & 24,63 & 18,78 & 14,72 & 11,82 & 8,16 & 6,18 & 4,22 \\
\hline 29,50 & 1515,10 & 180,10 & 21,41 & 16,47 & 13,52 & 10,37 & 8,06 & 6,40 & 4,35 & 3,27 & 2,23 \\
\hline 82,47 & 1135,60 & 117,40 & 17,12 & 12,25 & 10,91 & 9,72 & 8,79 & 7,97 & 6,57 & 5,45 & 3,86 \\
\hline 76,89 & 424,40 & 124,30 & 29,39 & 18,19 & 14,66 & 11,95 & 10,12 & 8,68 & 6,54 & 5,12 & 3,45 \\
\hline 39,24 & 620,60 & 158,10 & 27,61 & 18,83 & 15,07 & 11,52 & 9,02 & 7,22 & 4,97 & 3,76 & 2,56 \\
\hline 21,89 & 1915,90 & 153,40 & 27,31 & 21,21 & 16,97 & 12,53 & 9,44 & 7,35 & 4,97 & 3,78 & 2,61 \\
\hline 50,99 & 1351,30 & 103,40 & 21,81 & 17,85 & 16,01 & 13,98 & 12,20 & 10,63 & 8,12 & 6,33 & 4,16 \\
\hline 38,99 & 1749,20 & 73,60 & 29,55 & 25,97 & 23,57 & 20,56 & 17,82 & 15,42 & 11,59 & 8,90 & 5,77 \\
\hline 47,02 & 1633,50 & 154,70 & 16,75 & 13,47 & 11,86 & 10,10 & 8,61 & 7,35 & 5,43 & 4,15 & 2,71 \\
\hline 67,13 & 1829,20 & 177,70 & 12,05 & 9,15 & 8,19 & 7,23 & 6,44 & 5,74 & 4,57 & 3,68 & 2,50 \\
\hline 41,56 & 1557,70 & 63,20 & 32,38 & 28,43 & 25,99 & 22,92 & 20,10 & 17,57 & 13,44 & 10,45 & 6,82 \\
\hline 81,58 & 1522,60 & 98,10 & 16,63 & 12,36 & 11,35 & 10,40 & 9,59 & 8,85 & 7,51 & 6,39 & 4,67 \\
\hline 79,59 & 1540,20 & 182,60 & 11,94 & 8,50 & 7,50 & 6,61 & 5,92 & 5,32 & 4,31 & 3,53 & 2,46 \\
\hline 45,27 & 342,40 & 106,30 & 42,35 & 27,48 & 21,82 & 16,79 & 13,29 & 10,73 & 7,45 & 5,64 & 3,83 \\
\hline
\end{tabular}




\begin{tabular}{|c|c|c|c|c|c|c|c|c|c|c|c|}
\hline & & & \multicolumn{9}{|c|}{ Deflexões $\left(\times 10^{-4} \mathrm{~cm}\right)$} \\
\hline e1 (cm) & Meq (MPa) & Ms (MPa) & D0 & D25 & D40 & D60 & D80 & D100 & D140 & D180 & D260 \\
\hline 84,49 & 1780,40 & 151,00 & 12,00 & 8,68 & 7,84 & 7,08 & 6,47 & 5,92 & 4,97 & 4,18 & 3,02 \\
\hline 52,82 & 1599,00 & 52,70 & 30,82 & 26,10 & 24,59 & 22,50 & 20,51 & 18,63 & 15,28 & 12,54 & 8,66 \\
\hline 20,83 & 785,00 & 80,30 & 57,70 & 43,06 & 33,39 & 23,88 & 17,69 & 13,72 & 9,36 & 7,19 & 4,99 \\
\hline 20,64 & 1994,20 & 146,00 & 29,16 & 22,64 & 18,01 & 13,20 & 9,89 & 7,68 & 5,20 & 3,96 & 2,74 \\
\hline 69,07 & 434,70 & 200,00 & 25,01 & 14,17 & 10,79 & 8,30 & 6,74 & 5,59 & 4,02 & 3,08 & 2,09 \\
\hline 68,30 & 948,80 & 21,30 & 57,33 & 45,69 & 43,51 & 41,45 & 39,12 & 36,80 & 32,36 & 28,33 & 21,63 \\
\hline 31,00 & 232,90 & 22,00 & 156,74 & 124,91 & 105,14 & 83,08 & 65,98 & 53,10 & 36,42 & 27,20 & 18,26 \\
\hline 36,76 & 686,30 & 149,00 & 28,28 & 19,93 & 16,07 & 12,30 & 9,60 & 7,67 & 5,27 & 3,98 & 2,71 \\
\hline 35,89 & 391,10 & 151,50 & 35,78 & 22,18 & 16,81 & 12,21 & 9,27 & 7,32 & 5,03 & 3,85 & 2,67 \\
\hline 84,39 & 237,90 & 87,00 & 47,40 & 27,57 & 21,54 & 17,17 & 14,40 & 12,31 & 9,26 & 7,27 & 4,94 \\
\hline 88,53 & 559,80 & 127,40 & 23,62 & 14,93 & 12,33 & 10,34 & 9,00 & 7,93 & 6,24 & 5,02 & 3,47 \\
\hline 36,00 & 1218,40 & 107,30 & 28,18 & 22,89 & 19,76 & 16,18 & 13,26 & 10,93 & 7,69 & 5,75 & 3,79 \\
\hline 62,70 & 886,70 & 135,40 & 20,24 & 14,67 & 12,65 & 10,77 & 9,30 & 8,06 & 6,11 & 4,77 & 3,17 \\
\hline 69,73 & 1443,90 & 55,40 & 26,20 & 20,62 & 19,45 & 18,11 & 16,82 & 15,59 & 13,33 & 11,38 & 8,34 \\
\hline 70,45 & 1541,50 & 154,90 & 13,72 & 10,26 & 9,16 & 8,10 & 7,24 & 6,48 & 5,19 & 4,21 & 2,89 \\
\hline 30,68 & 1612,70 & 116,10 & 27,28 & 22,45 & 19,23 & 15,49 & 12,48 & 10,15 & 7,01 & 5,22 & 3,47 \\
\hline 24,96 & 289,60 & 158,00 & 43,57 & 24,32 & 16,93 & 11,44 & 8,48 & 6,70 & 4,69 & 3,65 & 2,57 \\
\hline 76,28 & 1604,40 & 155,70 & 12,96 & 9,52 & 8,53 & 7,60 & 6,85 & 6,19 & 5,05 & 4,15 & 2,90 \\
\hline 63,35 & 771,70 & 69,90 & 30,60 & 23,70 & 21,27 & 18,78 & 16,69 & 14,83 & 11,72 & 9,38 & 6,34 \\
\hline 72,63 & 1848,10 & 53,60 & 23,88 & 18,75 & 17,75 & 16,80 & 15,79 & 14,81 & 12,96 & 11,30 & 8,57 \\
\hline 65,35 & 1065,90 & 184,10 & 15,56 & 10,97 & 9,36 & 7,92 & 6,82 & 5,90 & 4,48 & 3,50 & 2,33 \\
\hline 30,16 & 413,40 & 107,80 & 46,15 & 31,16 & 24,00 & 17,39 & 13,10 & 10,29 & 7,05 & 5,39 & 3,74 \\
\hline 61,24 & 1564,40 & 159,40 & 14,38 & 11,08 & 9,84 & 8,60 & 7,57 & 6,66 & 5,18 & 4,10 & 2,74 \\
\hline 52,88 & 893,90 & 76,30 & 30,23 & 24,34 & 21,74 & 18,93 & 16,51 & 14,38 & 10,99 & 8,57 & 5,65 \\
\hline 54,52 & 744,80 & 173,00 & 20,86 & 14,23 & 11,75 & 9,53 & 7,88 & 6,58 & 4,73 & 3,60 & 2,39 \\
\hline 59,76 & 1317,20 & 97,80 & 20,75 & 16,57 & 15,03 & 13,36 & 11,91 & 10,60 & 8,40 & 6,73 & 4,54 \\
\hline 30,70 & 221,50 & 150,20 & 448,02 & 25,38 & 17,67 & 12,07 & 9,01 & 7,12 & 4,95 & 3,85 & 2,72 \\
\hline 53,51 & 606,30 & 23,00 & 73,35 & 61,87 & 57,94 & 52,73 & 47,85 & 43,28 & 35,22 & 28,73 & 19,70 \\
\hline 21,68 & 1035,40 & 194,40 & 27,33 & 18,79 & 13,97 & 9,67 & 7,10 & 5,53 & 3,83 & 2,97 & 2,07 \\
\hline 35,17 & 540,80 & 135,30 & 33,68 & 23,06 & 18,25 & 13,68 & 10,54 & 8,36 & 5,73 & 4,34 & 2,98 \\
\hline 59,28 & 1785,10 & 145,50 & 14,56 & 11,55 & 10,41 & 9,20 & 8,15 & 7,22 & 5,67 & 4,52 & 3,03 \\
\hline 46,03 & 1247,00 & 94,10 & 25,48 & 21,08 & 18,80 & 16,20 & 13,95 & 12,00 & 8,97 & 6,89 & 4,49 \\
\hline 29,36 & 1009,10 & 130,70 & 30,44 & 23,13 & 18,84 & 14,34 & 11,08 & 8,77 & 5,97 & 4,50 & 3,07 \\
\hline 38,47 & 1724,30 & 154,80 & 18,76 & 15,24 & 13,24 & 10,96 & 9,07 & 7,54 & 5,37 & 4,02 & 2,64 \\
\hline 80,56 & 1319,60 & 53,50 & 25,42 & 19,40 & 18,12 & 17,00 & 15,92 & 14,90 & 12,99 & 11,30 & 8,56 \\
\hline 49,76 & 895,00 & 94,50 & 27,69 & 21,85 & 19,18 & 16,34 & 13,96 & 11,95 & 8,87 & 6,80 & 4,45 \\
\hline 71,21 & 1064,30 & 60,00 & 27,60 & 21,39 & 19,84 & 18,15 & 16,65 & 15,26 & 12,77 & 10,70 & 7,64 \\
\hline 21,36 & 699,60 & 52,90 & 79,33 & 61,77 & 49,38 & 36,40 & 27,39 & 21,32 & 14,41 & 10,96 & 7,56 \\
\hline 26,23 & 657,60 & 80,30 & 52,27 & 39,55 & 31,72 & 23,64 & 17,98 & 14,10 & 9,57 & 7,26 & 4,99 \\
\hline 70,80 & 1925,50 & 174,70 & 11,59 & 8,74 & 7,87 & 7,00 & 6,29 & 5,66 & 4,57 & 3,73 & 2,57 \\
\hline 33,24 & 812,40 & 186,00 & 24,33 & 16,93 & 13,40 & 10,01 & 7,68 & 6,07 & 4,15 & 3,15 & 2,17 \\
\hline 51,66 & 997,60 & 165,10 & 18,98 & 13,90 & 11,82 & 9,80 & 8,20 & 6,90 & 5,01 & 3,81 & 2,52 \\
\hline 65,66 & 816,40 & 35,00 & 44,68 & 35,65 & 33,49 & 30,86 & 28,42 & 26,11 & 21,93 & 18,42 & 13,17 \\
\hline 30,21 & 1426,30 & 64,30 & 42,50 & 36,71 & 32,28 & 26,85 & 22,21 & 18,42 & 13,00 & 9,68 & 6,32 \\
\hline 84,01 & 737,80 & 125,10 & 20,60 & 13,81 & 11,79 & 10,13 & 8,95 & 7,96 & 6,34 & 5,14 & 3,56 \\
\hline 23,20 & 1506,90 & 38,70 & 73,43 & 64,42 & 56,38 & 46,31 & 37,78 & 30,91 & 21,40 & 15,82 & 10,38 \\
\hline 27,81 & 1031,80 & 30,90 & 82,61 & 73,34 & 65,25 & 54,97 & 45,96 & 38,42 & 27,35 & 20,39 & 13,20 \\
\hline 37,90 & 1491,10 & 144,70 & 20,90 & 16,79 & 14,49 & 11,89 & 9,78 & 8,08 & 5,71 & 4,27 & 2,82 \\
\hline 57,16 & 1957,90 & 41,60 & 32,39 & 26,66 & 25,62 & 24,07 & 22,45 & 20,86 & 17,89 & 15,27 & 11,17 \\
\hline 61,08 & 717,00 & 176,00 & 20,17 & 13,42 & 11,06 & 9,03 & 7,55 & 6,37 & 4,66 & 3,58 & 2,38 \\
\hline 75,45 & 1622,70 & 98,50 & 16,81 & 12,79 & 11,81 & 10,80 & 9,93 & 9,12 & 7,67 & 6,46 & 4,66 \\
\hline 58,17 & 966,50 & 171,20 & 17,85 & 12,75 & 10,83 & 9,05 & 7,67 & 6,54 & 4,84 & 3,72 & 2,46 \\
\hline 83,40 & 1612,20 & 25,60 & 34,99 & 29,50 & 26,97 & 26,08 & 25,25 & 24,25 & 22,20 & 20,25 & 16,69 \\
\hline 85,51 & 1205,00 & 94,20 & 18,44 & 13,37 & 12,13 & 11,01 & 10,11 & 9,30 & 7,85 & 6,66 & 4,85 \\
\hline 58,20 & 681,10 & 192,30 & 20,30 & 13,17 & 10,68 & 8,57 & 7,06 & 5,89 & 4,24 & 3,23 & 2,16 \\
\hline 60,78 & 1323,00 & 119,90 & 18,23 & 14,25 & 12,76 & 11,23 & 9,93 & 8,78 & 6,88 & 5,47 & 3,67 \\
\hline 39,35 & 1160,90 & 156,90 & 21,39 & 16,38 & 13,86 & 11,17 & 9,06 & 7,42 & 5,19 & 3,89 & 2,59 \\
\hline 73,25 & 1408,30 & 96,50 & 18,30 & 13,95 & 12,80 & 11,60 & 10,59 & 9,66 & 8,01 & 6,67 & 4,73 \\
\hline 77,39 & 213,40 & 131,20 & 45,80 & 23,93 & 17,39 & 12,90 & 10,29 & 8,48 & 6,06 & 4,67 & 3,20 \\
\hline 69,82 & 1798,20 & 96,50 & 17,02 & 13,28 & 12,35 & 11,31 & 10,38 & 9,51 & 7,96 & 6,66 & 4,76 \\
\hline 53,37 & 1593,50 & 166,30 & 15,02 & 11,79 & 10,40 & 8,95 & 7,72 & 6,68 & 5,03 & 3,90 & 2,56 \\
\hline 84,67 & 937,30 & 128,90 & 17,81 & 12,26 & 10,67 & 9,32 & 8,33 & 7,48 & 6,07 & 4,98 & 3,48 \\
\hline 78,48 & 997,80 & 122,40 & 18,22 & 12,97 & 11,41 & 10,02 & 8,96 & 8,03 & 6,48 & 5,28 & 3,66 \\
\hline 32,25 & 1148,60 & 40,50 & 58,71 & 52,10 & 46,78 & 40,04 & 34,01 & 28,85 & 21,01 & 15,82 & 10,21 \\
\hline 64,23 & 904,50 & 67,50 & 28,98 & 22,75 & 20,69 & 18,50 & 16,61 & 14,91 & 11,99 & 9,72 & 6,65 \\
\hline 85,87 & 1649,90 & 25,00 & 33,96 & 29,25 & 26,55 & 25,62 & 24,89 & 23,97 & 22,06 & 20,22 & 16,82 \\
\hline 82,74 & 1824,50 & 128,50 & 13,10 & 9,65 & 8,82 & 8,05 & 7,40 & 6,81 & 5,76 & 4,89 & 3,56 \\
\hline 82,58 & 1724,20 & 140,50 & 12,80 & 9,34 & 8,46 & 7,65 & 6,99 & 6,40 & 5,36 & 4,51 & 3,25 \\
\hline 54,96 & 1689,70 & 31,80 & 41,95 & 34,74 & 33,48 & 31,51 & 29,40 & 27,34 & 23,46 & 20,04 & 14,65 \\
\hline 44,21 & 281,80 & 82,10 & 53,66 & 35,38 & 28,23 & 21,77 & 17,22 & 13,91 & 9,65 & 7,29 & 4,95 \\
\hline 43,39 & 1114,00 & 85,10 & 29,48 & 24,43 & 21,67 & 18,51 & 15,78 & 13,46 & 9,92 & 7,55 & 4,92 \\
\hline 76,95 & 1118,30 & 89,80 & 20,54 & 15,29 & 13,89 & 12,52 & 11,39 & 10,37 & 8,59 & 7,15 & 5,07 \\
\hline 89,41 & 853,40 & 106,50 & 20,08 & 13,79 & 12,07 & 10,65 & 9,59 & 8,69 & 7,17 & 5,96 & 4,25 \\
\hline 33,04 & 1902,40 & 188,20 & 17,81 & 14,18 & 12,01 & 9,58 & 7,68 & 6,22 & 4,29 & 3,21 & 2,14 \\
\hline 71,33 & 488,20 & 179,90 & 23,91 & 14,23 & 11,16 & 8,84 & 7,32 & 6,16 & 4,51 & 3,48 & 2,34 \\
\hline 83,49 & 1134,60 & 84,50 & 20,33 & 14,89 & 13,55 & 12,33 & 11,32 & 10,41 & 8,79 & 7,44 & 5,41 \\
\hline 48,65 & 543,90 & 70,60 & 41,09 & 31,50 & 27,20 & 22,77 & 19,16 & 16,19 & 11,80 & 8,97 & 5,89 \\
\hline 59,83 & 1877,20 & 149,10 & 13,98 & 11,10 & 10,03 & 8,88 & 7,89 & 7,00 & 5,52 & 4,41 & 2,97 \\
\hline 62,23 & 507,90 & 25,10 & 67,56 & 54,54 & 50,79 & 46,28 & 42,17 & 38,35 & 31,58 & 26,06 & 18,18 \\
\hline 85,26 & 1290,20 & 49,60 & 25,89 & 19,69 & 18,29 & 17,26 & 16,25 & 15,29 & 13,47 & 11,84 & 9,14 \\
\hline 83,64 & 1229,60 & 83,40 & 19,75 & 14,55 & 13,31 & 12,18 & 11,22 & 10,36 & 8,80 & 7,49 & 5,49 \\
\hline 26,93 & 1935,70 & 183,30 & 20,78 & 16,32 & 13,42 & 10,27 & 7,95 & 6,29 & 4,26 & 3,21 & 2,18 \\
\hline
\end{tabular}




\begin{tabular}{|c|c|c|c|c|c|c|c|c|c|c|c|}
\hline & & & \multicolumn{9}{|c|}{ Deflexões $\left(\times 10^{-4} \mathrm{~cm}\right)$} \\
\hline e1 (cm) & Meq (MPa) & Ms (MPa) & D0 & D25 & D40 & D60 & D80 & D100 & D140 & D180 & D260 \\
\hline 23,40 & 1451,90 & 106,70 & 36,52 & 28,97 & 23,66 & 17,88 & 13,68 & 10,74 & 7,25 & 5,47 & 3,74 \\
\hline 61,91 & 1648,00 & 158,50 & 14,01 & 10,84 & 9,68 & 8,50 & 7,51 & 6,64 & 5,20 & 4,13 & 2,77 \\
\hline 28,61 & 891,70 & 50,10 & 61,37 & 51,52 & 44,38 & 35,90 & 29,00 & 23,59 & 16,30 & 12,11 & 8,02 \\
\hline 70,26 & 245,30 & 98,90 & 46,23 & 26,99 & 20,92 & 16,38 & 13,45 & 11,25 & 8,17 & 6,28 & 4,24 \\
\hline 78,94 & 1998,80 & 188,20 & 10,41 & 7,60 & 6,83 & 6,10 & 5,52 & 5,01 & 4,12 & 3,41 & 2,41 \\
\hline 79,14 & 1087,80 & 157,20 & 15,37 & 10,70 & 9,27 & 8,05 & 7,14 & 6,36 & 5,08 & 4,11 & 2,83 \\
\hline 59,75 & 1876,20 & 72,80 & 21,89 & 17,94 & 16,88 & 15,51 & 14,21 & 12,99 & 10,79 & 8,97 & 6,31 \\
\hline 69,52 & 737,00 & 164,10 & 19,54 & 13,01 & 10,83 & 9,01 & 7,70 & 6,63 & 5,00 & 3,90 & 2,61 \\
\hline 80,06 & 1660,60 & 132,30 & 13,64 & 10,05 & 9,13 & 8,25 & 7,53 & 6,88 & 5,75 & 4,81 & 3,45 \\
\hline 42,88 & 1493,30 & 104,10 & 23,44 & 19,63 & 17,49 & 15,00 & 12,83 & 10,97 & 8,11 & 6,19 & 4,03 \\
\hline 76,55 & 453,10 & 121,50 & 28,52 & 17,99 & 14,65 & 12,05 & 10,26 & 8,84 & 6,70 & 5,25 & 3,54 \\
\hline 59,10 & 414,40 & 170,70 & 28,28 & 16,75 & 12,96 & 10,01 & 8,06 & 6,62 & 4,69 & 3,57 & 2,42 \\
\hline 45,66 & 759,40 & 52,50 & 44,38 & 37,08 & 33,22 & 28,76 & 24,85 & 21,45 & 16,10 & 12,39 & 8,09 \\
\hline 48,89 & 635,90 & 167,10 & 24,06 & 16,13 & 13,10 & 10,36 & 8,37 & 6,86 & 4,82 & 3,65 & 2,45 \\
\hline 76,82 & 1272,00 & 68,30 & 22,86 & 17,40 & 16,16 & 14,90 & 13,77 & 12,72 & 10,82 & 9,21 & 6,73 \\
\hline 31,85 & 510,40 & 148,50 & 34,03 & 22,51 & 17,30 & 12,57 & 9,50 & 7,47 & 5,12 & 3,92 & 2,72 \\
\hline 62,35 & 1023,50 & 50,10 & 33,66 & 27,17 & 25,32 & 23,08 & 21,04 & 19,15 & 15,78 & 13,03 & 9,10 \\
\hline 23,72 & 514,60 & 189,20 & 32,54 & 19,94 & 14,25 & 9,70 & 7,15 & 5,62 & 3,92 & 3,05 & 2,13 \\
\hline 55,72 & 243,20 & 137,00 & 43,23 & 23,70 & 17,52 & 12,96 & 10,16 & 8,20 & 5,72 & 4,37 & 3,00 \\
\hline 73,25 & 1492,60 & 184,90 & 12,47 & 9,02 & 7,93 & 6,94 & 6,16 & 5,48 & 4,36 & 3,51 & 2,40 \\
\hline 65,92 & 905,00 & 61,30 & 30,24 & 23,73 & 21,74 & 19,58 & 17,70 & 15,99 & 13,02 & 10,66 & 7,37 \\
\hline 35,06 & 1641,40 & 88,40 & 29,17 & 25,04 & 22,19 & 18,74 & 15,74 & 13,24 & 9,53 & 7,16 & 4,65 \\
\hline 81,12 & 547,00 & 77,90 & 30,49 & 21,13 & 18,34 & 15,96 & 14,19 & 12,68 & 10,17 & 8,28 & 5,73 \\
\hline 39,55 & 1377,00 & 173,30 & 18,76 & 14,53 & 12,37 & 10,03 & 8,18 & 6,72 & 4,72 & 3,54 & 2,35 \\
\hline 75,01 & 1063,40 & 47,80 & 30,86 & 23,78 & 22,25 & 20,67 & 19,20 & 17,81 & 15,26 & 13,06 & 9,63 \\
\hline$\frac{10,01}{28,52}$ & 991,90 & $\frac{4 r, 00}{67,10}$ & 48,85 & 40,18 & 34,18 & 27,23 & $\begin{array}{l}1 v, 20 \\
21,73\end{array}$ & $\begin{array}{l}1,0 \perp \\
17,53\end{array}$ & $\begin{array}{l}1+, L \\
12,02\end{array}$ & $\begin{array}{c}10,00 \\
8,95\end{array}$ & 5,98 \\
\hline 52,66 & 1993,50 & 76,70 & 22,34 & 18,91 & 17,68 & 16,06 & 14,54 & 13,12 & 10,63 & 8,64 & 5,90 \\
\hline 67,93 & 1878,20 & 120,30 & 14,84 & 11,59 & 10,66 & 9,65 & 8,77 & 7,96 & 6,55 & 5,40 & 3,78 \\
\hline 69,37 & 320,70 & 31,60 & 67,12 & 50,48 & 45,13 & 39,92 & 35,66 & 31,87 & 25,50 & 20,63 & 14,12 \\
\hline 57,92 & 374,00 & $\frac{1,00}{30,90}$ & 69,84 & 55,60 & 50,01 & 44,05 & 38,92 & 34,35 & 26,83 & 21,26 & $\frac{1+,+L}{14,20}$ \\
\hline 58,11 & 673,00 & 36,00 & 50,43 & 41,33 & 38,19 & 34,46 & 31,08 & 27,97 & 22,59 & 18,33 & 12,52 \\
\hline 35,49 & 713,80 & 188,00 & 24,64 & 16,70 & 13,16 & 9,84 & 7,58 & 6,01 & 4,12 & 3,13 & 2,15 \\
\hline 54,74 & 1443,90 & 73,80 & 25,06 & 20,86 & 19,25 & 17,31 & 15,55 & 13,92 & 11,14 & 8,97 & 6,06 \\
\hline 37,32 & 205,10 & 182,30 & 44,51 & 21,51 & 14,56 & 9,90 & 7,43 & 5,89 & 4,09 & 3,17 & 2,25 \\
\hline 33,66 & 1359,30 & 87,40 & 32,44 & 27,26 & 23,80 & 19,70 & 16,26 & 13,47 & 9,51 & 7,10 & 4,65 \\
\hline 58,90 & 1541,00 & 159,00 & 14,80 & 11,46 & 10,16 & 8,85 & 7,74 & 6,78 & 5,23 & 4,11 & 2,73 \\
\hline 82,46 & 674,40 & 79,30 & 26,99 & 19,06 & 16,81 & 14,84 & 13,34 & 12,04 & 9,82 & 8,10 & 5,69 \\
\hline 60,89 & 953,80 & 116,20 & 21,46 & 16,17 & 14,18 & 12,25 & 10,67 & 9,30 & 7,14 & 5,59 & 3,72 \\
\hline 72,55 & 1923,00 & 166,60 & 11,77 & 8,86 & 8,00 & 7,15 & 6,45 & 5,83 & 4,75 & 3,90 & 2,71 \\
\hline 57,83 & 981,30 & 72,60 & 28,43 & 22,87 & 20,72 & 18,36 & 16,31 & 14,46 & 11,39 & 9,07 & 6,08 \\
\hline 66,48 & 1950,10 & 198,40 & 11,07 & 8,39 & 7,47 & 6,58 & 5,84 & 5,19 & 4,11 & 3,29 & 2,23 \\
\hline 49,04 & 915,80 & 105,00 & 26,06 & 20,34 & 17,74 & 15,00 & 12,73 & 10,83 & 7,97 & 6,08 & 3,99 \\
\hline 78,69 & 709,30 & 154,40 & 19,66 & 12,84 & 10,69 & 8,98 & 7,77 & 6,78 & 5,24 & 4,16 & 2,82 \\
\hline 37,68 & 1199,30 & 120,90 & 25,48 & 20,37 & 17,51 & 14,32 & 11,73 & 9,67 & 6,81 & 5,10 & 3,36 \\
\hline 46,28 & 258,50 & 155,80 & 40,83 & 22,21 & 16,18 & 11,67 & 8,95 & 7,13 & 4,92 & 3,77 & 2,63 \\
\hline 23,41 & 1066,80 & 83,90 & 47,40 & 37,32 & 30,31 & 22,78 & 17,38 & 13,62 & 9,20 & 6,95 & 4,77 \\
\hline 76,70 & 848,90 & 33,10 & 41,67 & 32,11 & 30,13 & 28,24 & 26,39 & 24,64 & 21,37 & 18,49 & 13,87 \\
\hline 52,71 & 328,80 & 145,20 & 35,65 & 20,96 & 16,04 & 12,15 & 9,61 & 7,79 & 5,44 & 4,14 & 2,83 \\
\hline 63,53 & 481,10 & 122,70 & 29,12 & 19,12 & 15,69 & 12,81 & 10,74 & 9,09 & 6,68 & 5,14 & 3,43 \\
\hline 58,00 & 911,60 & 168,70 & 18,54 & 13,14 & 11,11 & 9,26 & 7,82 & 6,65 & 4,90 & 3,77 & 2,49 \\
\hline 89,00 & 1784,90 & 115,30 & 13,55 & 9,88 & 9,02 & 8,30 & 7,69 & 7,14 & 6,15 & 5,30 & 3,96 \\
\hline 84,00 & 1004,70 & 137,30 & 16,72 & 11,54 & 10,05 & 8,78 & 7,85 & 7,05 & 5,71 & 4,68 & 3,27 \\
\hline 66,83 & 958,60 & 195,20 & 15,87 & 10,82 & 9,09 & 7,60 & 6,50 & 5,60 & 4,21 & 3,28 & 2,19 \\
\hline 73,29 & 809,50 & 35,30 & 41,88 & 32,47 & 30,45 & 28,28 & 26,25 & 24,33 & 20,81 & 17,77 & 13,06 \\
\hline 84,87 & 256,80 & 36,50 & 63,97 & 43,84 & 38,03 & 33,16 & 29,58 & 26,54 & 21,48 & 17,60 & 12,31 \\
\hline 34,30 & 1550,10 & 49,80 & 44,01 & 39,43 & 35,80 & 31,12 & 26,85 & 23,11 & 17,19 & 13,11 & 8,46 \\
\hline 47,46 & 1743,90 & 60,70 & 29,16 & 25,29 & 23,58 & 21,28 & 19,13 & 17,13 & 13,67 & 10,97 & 7,36 \\
\hline 74,61 & 1426,80 & 110,70 & 16,67 & 12,54 & 11,42 & 10,29 & 9,36 & 8,51 & 7,02 & 5,83 & 4,11 \\
\hline 62,54 & 1093,00 & 106,20 & 20,90 & 16,12 & 14,39 & 12,64 & 11,17 & 9,88 & 7,75 & 6,17 & 4,14 \\
\hline 50,58 & 1268,60 & 138,90 & 18,96 & 14,86 & 13,03 & 11,10 & 9,48 & 8,12 & 6,03 & 4,63 & 3,04 \\
\hline 89,82 & 760,60 & 174,90 & 17,25 & 10,84 & 8,94 & 7,49 & 6,53 & 5,75 & 4,53 & 3,66 & 2,53 \\
\hline 32,45 & 1662,60 & 154,00 & $\begin{array}{l}r, L 5 \\
21,53\end{array}$ & 17,26 & 14,65 & 11,71 & 9,39 & 7,61 & 5,25 & 3,92 & 2,62 \\
\hline 34,04 & 989,60 & 158,40 & 24,69 & $\begin{array}{l}+1,20 \\
18,33\end{array}$ & $\begin{array}{l}1+, 002 \\
15,02\end{array}$ & $\begin{array}{l}1+1,1 \pm \\
11,61\end{array}$ & 9,09 & 7,27 & 4,98 & 3,75 & 2,54 \\
\hline 89,29 & 343,00 & 183,90 & 29,10 & 15,47 & 11,43 & $\begin{array}{c}+\perp, 01 \\
8,66\end{array}$ & 7,05 & 5,91 & 4,34 & 3,39 & 2,32 \\
\hline 71,49 & 888,10 & 65,90 & 28,04 & 21,41 & 19,53 & 17,61 & 15,98 & 14,49 & 11,91 & 9,83 & 6,89 \\
\hline 31,35 & 1499,30 & 24,50 & 77,11 & 71,27 & 66,07 & 58,84 & 51,93 & 45,59 & 35,04 & 27,22 & 17,66 \\
\hline 72,06 & 1385,00 & 73,40 & 21,89 & 16,95 & 15,77 & 14,48 & 13,33 & 12,26 & 10,32 & 8,70 & 6,26 \\
\hline 69,18 & 635,30 & 33,80 & 48,64 & 38,07 & 35,40 & 32,41 & 29,73 & 27,23 & 22,75 & 19,04 & 13,56 \\
\hline 70,97 & 1001,80 & 119,50 & 19,21 & 14,07 & 12,40 & 10,85 & 9,62 & 8,55 & 6,78 & 5,45 & 3,71 \\
\hline 70,06 & 796,70 & 74,50 & 27,69 & 20,88 & 18,75 & 16,65 & 14,92 & 13,38 & 10,77 & 8,75 & 6.02 \\
\hline 50,68 & 522,50 & 158.10 & 26.94 & 17,45 & 13,98 & 10,96 & 8,82 & 7,22 & 5.08 & 3,85 & 2,59 \\
\hline 76,10 & 1717,10 & 27,20 & 36,05 & 29,60 & 27,53 & 26,67 & 25,64 & 24,50 & 22,22 & 20,05 & 16,20 \\
\hline 65,37 & 1634,80 & 184,40 & 12,60 & 9,46 & 8,36 & 7,30 & 6,44 & 5,68 & 4,45 & 3,54 & 2,38 \\
\hline 64,80 & 848,20 & 94,60 & 24,53 & 18,48 & 16,34 & 14,27 & 12,58 & 11,10 & 8,68 & 6,90 & 4,64 \\
\hline 30,74 & 1881,80 & 83,70 & 32,05 & 27,76 & 24,49 & 20,45 & 16,99 & 14,14 & 10,02 & 7,47 & 4,86 \\
\hline 57,41 & 945,70 & 170,20 & 18,21 & 12,99 & 11,01 & 9,18 & 7,76 & 6,60 & 4,87 & 3,73 & 2,47 \\
\hline 39,49 & 1385,90 & 174,90 & 18,63 & 14,43 & 12,27 & 9,95 & 8,11 & 6,66 & 4,68 & 3,51 & 2,33 \\
\hline 33,11 & 565,90 & 51,70 & 62,92 & 50,62 & 43,12 & 34,64 & 27,90 & 22,69 & 15,71 & 11,72 & 7,80 \\
\hline 38,66 & 766,40 & 103,70 & 32,74 & 25,06 & 21,16 & 16,99 & 13,74 & 11,23 & 7,84 & 5,87 & 3,91 \\
\hline 26,93 & 241,30 & 39,70 & 114,10 & 82,84 & 65,14 & 47,69 & 35,98 & 28,16 & 19,19 & 14,63 & 10,11 \\
\hline 47,77 & 1039,20 & 102,20 & 25,49 & 20,38 & 17,92 & 15,26 & 13,01 & 11,11 & 8,22 & 6,28 & 4,11 \\
\hline 21,11 & 847,00 & 194,30 & 29,22 & 19,31 & 14,03 & 9,56 & 7,01 & 5,48 & 3,82 & 2,97 & 2,07 \\
\hline
\end{tabular}




\begin{tabular}{|c|c|c|c|c|c|c|c|c|c|c|c|}
\hline \multirow[b]{2}{*}{ e1 (cm) } & & & & & & & ões (x1 & m) & & & \\
\hline & Meq (MPa) & Ms (MPa) & D0 & D25 & D40 & D60 & D80 & D100 & D140 & D180 & D260 \\
\hline 82,94 & 1375,40 & 36,80 & 30,70 & 24,08 & 22,40 & 21,43 & 20,39 & 19,33 & 17,30 & 15,42 & 12,18 \\
\hline 31,40 & 1406,70 & 172,40 & 21,69 & 16,70 & 13,82 & 10,72 & 8,41 & 6,71 & 4,59 & 3,44 & 2,33 \\
\hline 22,67 & 772,20 & 82,90 & 53,57 & 40,36 & 31,75 & 23,09 & 17,27 & 13,44 & 9,13 & 6,98 & 4,83 \\
\hline 67,31 & 1555,40 & 81,30 & 20,40 & 16,09 & 14,98 & 13,69 & 12,54 & 11,47 & 9,54 & 7,96 & 5,64 \\
\hline 28,10 & 1533,90 & 97,70 & 33,27 & 27,50 & 23,43 & 18,70 & 14,94 & 12,05 & 8,26 & 6,15 & 4,11 \\
\hline 68,20 & 1969,40 & 112,00 & 15,18 & 11,90 & 11,03 & 10,05 & 9,18 & 8,38 & 6,95 & 5,78 & 4,08 \\
\hline 85,05 & 1728,90 & 67,20 & 19,23 & 14,62 & 13,58 & 12,81 & 12,06 & 11,33 & 9,98 & 8,77 & 6,76 \\
\hline 31,42 & 1599,70 & 21,00 & 84,11 & 77,91 & 72,93 & 65,66 & 58,59 & 52,00 & 40,72 & 32,06 & 21,00 \\
\hline 62,81 & 1304,00 & 66,90 & 25,55 & 20,56 & 19,11 & 17,39 & 15,84 & 14,40 & 11,84 & 9,77 & 6,81 \\
\hline 33,41 & 219,20 & 139,50 & 49,53 & 26,73 & 18,91 & 13,08 & 9,79 & 7,73 & 5,36 & 4,15 & 2,92 \\
\hline 89,37 & 1617,30 & 167,80 & 11,61 & 8,12 & 7,22 & 6,45 & 5,86 & 5,35 & 4,47 & 3,76 & 2,71 \\
\hline 86,13 & 1380,00 & 97,30 & 16,97 & 12,38 & 11,29 & 10,32 & 9,51 & 8,79 & 7,48 & 6,38 & 4,70 \\
\hline 75,84 & 1711,50 & 25,40 & 37,73 & 31,23 & 28,98 & 28,10 & 27,08 & 25,90 & 23,55 & 21,31 & 17,28 \\
\hline 25,13 & 1977,80 & 188,70 & 21,23 & 16,50 & 13,39 & 10,07 & 7,70 & 6,05 & 4,09 & 3,09 & 2,12 \\
\hline 45,03 & 1010,80 & 26,60 & 63,03 & 55,36 & 52,07 & 47,35 & 42,82 & 38,56 & 31,08 & 25,11 & 16,97 \\
\hline 61,34 & 362,40 & 190,40 & 29,27 & 16,22 & 12,13 & 9,11 & 7,24 & 5,91 & 4,16 & 3,18 & 2,17 \\
\hline 40,58 & 1075,10 & 147,50 & 22,46 & 17,16 & 14,55 & 11,77 & 9,59 & 7,88 & 5,54 & 4,16 & 2,76 \\
\hline 83,11 & 1005,10 & 130,30 & 17,21 & 11,99 & 10,49 & 9,20 & 8,23 & 7,40 & 6,01 & 4,93 & 3,45 \\
\hline 37,24 & 952,60 & 77,80 & 36,88 & 30,29 & 26,38 & 21,86 & 18,10 & 15,05 & 10,69 & 8,01 & 5,25 \\
\hline 24,69 & 859,10 & 115,50 & 38,86 & 28,76 & 22,61 & 16,49 & 12,38 & 9,66 & 6,57 & 5,02 & 3,47 \\
\hline 75,30 & 1928,40 & 55,10 & 22,56 & 17,65 & 16,65 & 15,81 & 14,91 & 14,02 & 12,35 & 10,83 & 8,30 \\
\hline 63,81 & 808,70 & 180,80 & 18,35 & 12,37 & 10,29 & 8,51 & 7,20 & 6,14 & 4,55 & 3,51 & 2,34 \\
\hline 70,16 & 1658,90 & 151,40 & 13,47 & 10,17 & 9,15 & 8,14 & 7,30 & 6,56 & 5,29 & 4,30 & 2,96 \\
\hline 52,62 & 1716,40 & 137,40 & 16,40 & 13,30 & 11,93 & 10,42 & 9,11 & 7,96 & 6,10 & 4,77 & 3,14 \\
\hline 86,54 & 794,70 & 157,50 & 17,71 & 11,51 & 9,66 & 8,20 & 7,19 & 6,37 & 5,04 & 4,07 & 2,81 \\
\hline 35,27 & 1409,80 & 159,00 & 21,14 & 16,59 & 14,04 & 11,24 & 9,04 & 7,35 & 5,10 & 3,81 & 2,54 \\
\hline 38,23 & 1443,30 & 79,10 & 30,68 & 26,37 & 23,56 & 20,16 & 17,17 & 14,61 & 10,72 & 8,12 & 5,27 \\
\hline 83,86 & 1870,70 & 176,80 & 10,82 & 7,77 & 6,96 & 6,24 & 5,68 & 5,17 & 4,30 & 3,60 & 2,57 \\
\hline 23,59 & 917,20 & 69,50 & 56,29 & 44,56 & 36,36 & 27,46 & 21,02 & 16,49 & 11,14 & 8,40 & 5,75 \\
\hline 77,82 & 1367,50 & 70,00 & 21,74 & 16,53 & 15,37 & 14,22 & 13,18 & 12,21 & 10,44 & 8,92 & 6,57 \\
\hline 35,68 & 855,20 & 90,60 & 35,95 & 28,48 & 24,24 & 19,54 & 15,81 & 12,91 & 8,99 & 6,72 & 4,46 \\
\hline 77,83 & 1428,90 & 148,90 & 13,89 & 10,08 & 8,99 & 7,98 & 7,18 & 6,48 & 5,28 & 4,34 & 3,03 \\
\hline 77,18 & 577,60 & 102,50 & 26,56 & 18,03 & 15,34 & 13,10 & 11,45 & 10,08 & 7,88 & 6,30 & 4,28 \\
\hline 83,97 & 648,80 & 172,30 & 19,48 & 12,10 & 9,84 & 8,12 & 6,97 & 6,07 & 4,67 & 3,71 & 2,53 \\
\hline 62,75 & 976,40 & 181,70 & 16,67 & 11,67 & 9,89 & 8,29 & 7,08 & 6,07 & 4,55 & 3,52 & 2,34 \\
\hline 63,34 & 1657,00 & 192,40 & 12,43 & 9,36 & 8,25 & 7,17 & 6,29 & 5,53 & 4,29 & 3,39 & 2,27 \\
\hline 38,80 & 582,90 & 70,60 & 45,91 & 35,76 & 30,45 & 24,68 & 20,10 & 16,51 & 11,58 & 8,68 & 5,75 \\
\hline 86,61 & 210,30 & 157,00 & 43,87 & 21,76 & 15,29 & 11,00 & 8,64 & 7,07 & 5,03 & 3,89 & 2,69 \\
\hline 21,36 & 310,10 & 52,00 & 99,95 & 69,79 & 52,20 & 36,28 & 26,65 & 20,73 & 14,33 & 11,09 & 7,71 \\
\hline 29,62 & 1083,40 & 26,00 & 86,40 & 78,43 & 71,07 & 61,43 & 52,63 & 44,95 & 33,02 & 24,95 & 16,04 \\
\hline 26,23 & 550,30 & 117,30 & 42,49 & 29,44 & 22,52 & 16,08 & 11,99 & 9,37 & 6,43 & 4,94 & 3,43 \\
\hline 34,67 & 1682,40 & 143,80 & 21,37 & 17,39 & 14,97 & 12,20 & 9,95 & 8,17 & 5,71 & 4,27 & 2,82 \\
\hline 23,95 & 928,10 & 153,70 & 31,60 & 22,56 & 17,32 & 12,34 & 9,17 & 7,14 & 4,89 & 3,76 & 2,61 \\
\hline 78,85 & 385,00 & 32,90 & 57,01 & 41,97 & 37,94 & 34,12 & 31,02 & 28,24 & 23,39 & 19,48 & 13,83 \\
\hline 41,53 & 332,30 & 181,70 & 33,84 & 19,04 & 13,99 & 10,07 & 7,68 & 6,09 & 4,20 & 3,22 & 2,24 \\
\hline 46,35 & 311,30 & 24,10 & 100,11 & 82,57 & 73,57 & 63,38 & 54,54 & 46,92 & 35,05 & 26,92 & 17,57 \\
\hline 40,92 & 495,60 & 155,20 & 30,27 & 19,70 & 15,50 & 11,72 & 9,14 & 7,31 & 5,03 & 3,82 & 2,61 \\
\hline 63,71 & 1069,40 & 52,60 & 31,77 & 25,49 & 23,77 & 21,70 & 19,83 & 18,07 & 14,95 & 12,39 & 8,70 \\
\hline 61,08 & 532,70 & 35,70 & 53,85 & 43,10 & 39,39 & 35,27 & 31,67 & 28,38 & 22,77 & 18,41 & 12,54 \\
\hline 52,95 & 618,10 & 120,10 & 27,84 & 19,75 & 16,58 & 13,60 & 11,32 & 9,49 & 6,86 & 5,22 & 3,46 \\
\hline 34,82 & 1083,90 & 160,90 & 23,32 & 17,55 & 14,52 & 11,34 & 8,96 & 7,19 & 4,94 & 3,71 & 2,51 \\
\hline 74,42 & 1976,50 & 180,30 & 11,00 & 8,18 & 7,37 & 6,58 & 5,93 & 5,36 & 4,37 & 3,59 & 2,51 \\
\hline 34,89 & 1513,80 & 25,60 & 68,57 & 62,79 & 58,77 & 52,97 & 47,35 & 42,12 & 33,13 & 26,20 & 17,25 \\
\hline 76,24 & 251,40 & 96,60 & 45,07 & 26,33 & 20,51 & 16,21 & 13,45 & 11,37 & 8,38 & 6,50 & 4,39 \\
\hline 60,95 & 274,10 & 58,10 & 56,51 & 38,77 & 32,41 & 26,82 & 22,63 & 19,23 & 14,19 & 10,92 & 7,25 \\
\hline 54,24 & 266,70 & 94,40 & 47,99 & 29,76 & 23,46 & 18,26 & 14,70 & 12,04 & 8,49 & 6,45 & 4,36 \\
\hline 80,27 & 940,30 & 33,80 & 38,48 & 29,57 & 27,67 & 26,11 & 24,55 & 23,04 & 20,21 & 17,68 & 13,52 \\
\hline 42,38 & 1547,70 & 167,90 & 17,45 & 13,82 & 11,96 & 9,93 & 8,26 & 6,91 & 4,95 & 3,73 & 2,45 \\
\hline 29,90 & 1462,80 & 33,40 & $\begin{array}{l}65,62 \\
\end{array}$ & 59,78 & 54,35 & 47,19 & 40,61 & 34,82 & 25,74 & 19,52 & 12,54 \\
\hline 32,66 & 1438,40 & 52,20 & 445,55 & 40,37 & 36,25 & 31,03 & 26,38 & 22,39 & 16,31 & 12,29 & 7,93 \\
\hline 48,92 & 1847,70 & 196,20 & 13,51 & 10,67 & 9,35 & 7,95 & 6,77 & 5,78 & 4,27 & 3,27 & 2,14 \\
\hline 22,90 & 1305,80 & 43,90 & 71,24 & 60,93 & 52,35 & 41,99 & 33,56 & 27,04 & 18,45 & 13,66 & 9,10 \\
\hline 35,17 & 495,80 & 96,80 & $\begin{array}{l}42,73 \\
\end{array}$ & 30,69 & 24,84 & 19,01 & 14,82 & 11,82 & 8,10 & 6,11 & 4,16 \\
\hline 71,96 & 1286,60 & 20,70 & 50,16 & 40,72 & 38,27 & 37,01 & 35,43 & 33,72 & 30,36 & 27,20 & 21,65 \\
\hline 23,95 & 461,00 & 172,70 & 35,73 & 21,83 & 15,61 & 10,63 & 7,84 & 6,16 & 4,30 & 3,34 & 2,34 \\
\hline 53,42 & 1411,30 & 156,50 & 16,38 & 12,75 & 11,20 & 9,60 & 8,26 & 7,12 & 5,35 & 4,13 & 2,72 \\
\hline 58,33 & 1828,00 & 117,20 & 16,55 & 13,42 & 12,27 & 10,97 & 9,82 & 8,77 & 6,99 & 5,62 & 3,80 \\
\hline 88,07 & 475,60 & 146,80 & 24,88 & 14,87 & 11,86 & 9,64 & 8,21 & 7,12 & 5,46 & 4,33 & 2,96 \\
\hline 69,50 & 1992,80 & 171,60 & 11,64 & 8,86 & 8,00 & 7,13 & 6,41 & 5,77 & 4,66 & 3,80 & 2,62 \\
\hline 40,59 & 904,80 & 25,50 & 72,15 & 64,46 & 59,85 & 53,62 & 47,73 & 42,30 & 33,12 & 26,14 & 17,23 \\
\hline 32,74 & 794,10 & 149,40 & 28,40 & 20,48 & 16,46 & 12,45 & 9,62 & 7,62 & 5,21 & 3,94 & 2,70 \\
\hline 68,24 & 1233,80 & 72,70 & 23,70 & 18,55 & 17,16 & 15,61 & 14,24 & 12,98 & 10,74 & 8,92 & 6,28 \\
\hline 56,18 & 1988,20 & 109,10 & 17,12 & 14,13 & 13,01 & 11,68 & 10,49 & 9,39 & 7,52 & 6,06 & 4,10 \\
\hline 36,64 & 1927,80 & 182,20 & 16,82 & 13,55 & 11,67 & 9,54 & 7,80 & 6,43 & 4,52 & 3,38 & 2,23 \\
\hline 41,10 & 623,00 & 167,90 & 26,10 & 17,56 & 14,04 & 10,77 & 8,46 & 6,80 & 4,69 & 3,55 & 2,41 \\
\hline 60,46 & 591,70 & 161,20 & 23,42 & 15,25 & 12,42 & 10,04 & 8,33 & 6,99 & 5,07 & 3,88 & 2,59 \\
\hline 78,57 & 790,00 & 197,20 & 16,70 & 10,63 & 8,72 & 7,23 & 6,20 & 5,38 & 4,11 & 3,24 & 2,20 \\
\hline 47,82 & 1902,60 & 156,00 & 15,49 & 12,66 & 11,27 & 9,71 & 8,37 & 7,21 & 5,40 & 4,16 & 2,72 \\
\hline 69,63 & 692,60 & 44,00 & 39,95 & 30,99 & 28,54 & 25,90 & 23,60 & 21,49 & 17,76 & 14,73 & 10,37 \\
\hline 69,82 & 433,90 & 190,60 & 25,40 & 14,53 & 11,14 & 8,63 & 7,03 & 5,85 & 4,22 & 3,25 & 2,20 \\
\hline 20,92 & 1315,90 & 118,90 & 37,58 & 28,52 & 22,37 & 16,17 & 12,04 & 9,34 & 6,35 & 4,86 & 3,36 \\
\hline 52,12 & 498,00 & 65,60 & 42,81 & 32,56 & 28,20 & 23,80 & 20,22 & 17,23 & 12,72 & 9,74 & 6,40 \\
\hline
\end{tabular}




\begin{tabular}{|c|c|c|c|c|c|c|c|c|c|c|c|}
\hline \multirow[b]{2}{*}{ e1 (cm) } & & & & & & & ões (x1 & & & & \\
\hline & Meq (MPa) & Ms (MPa) & D0 & D25 & D40 & D60 & D80 & D100 & D140 & D180 & D260 \\
\hline 48,02 & 1769,40 & 145,10 & 16,61 & 13,57 & 12,08 & 10,42 & 8,98 & 7,74 & 5,80 & 4,47 & 2,92 \\
\hline 56,31 & 766,90 & 143,90 & 22,19 & 15,74 & 13,28 & 11,01 & 9,26 & 7,84 & 5,74 & 4,40 & 2,91 \\
\hline 64,60 & 1213,30 & 175,50 & 15,00 & 10,91 & 9,45 & 8,10 & 7,04 & 6,13 & 4,70 & 3,69 & 2,47 \\
\hline 45,49 & 1668,30 & 152,30 & 17,12 & 13,86 & 12,20 & 10,37 & 8,82 & 7,50 & 5,52 & 4,20 & 2,75 \\
\hline 71,47 & 951,80 & 77,90 & 24,73 & 18,76 & 17,01 & 15,24 & 13,77 & 12,44 & 10,15 & 8,34 & 5,80 \\
\hline 26,80 & 1809,40 & 144,10 & 25,12 & 20,13 & 16,75 & 12,99 & 10,15 & 8,06 & 5,47 & 4,10 & 2,78 \\
\hline 42,02 & 463,80 & 123,40 & 34,97 & 23,58 & 18,92 & 14,59 & 11,51 & 9,27 & 6,41 & 4,84 & 3,29 \\
\hline 56,76 & 775,30 & 138,70 & 22,39 & 16,01 & 13,58 & 11,31 & 9,55 & 8,11 & 5,97 & 4,58 & 3,03 \\
\hline 31,45 & 294,30 & 152,50 & 41,87 & 24,00 & 17,31 & 12,05 & 9,00 & 7,09 & 4,91 & 3,80 & 2,66 \\
\hline 56,94 & 1638,50 & 172,80 & 14,00 & 10,88 & 9,62 & 8,33 & 7,25 & 6,31 & 4,83 & 3,77 & 2,50 \\
\hline 89,38 & 210,80 & 54,70 & 59,52 & 36,66 & 29,83 & 24,70 & 21,33 & 18,67 & 14,57 & 11,67 & 8,03 \\
\hline 49,06 & 1087,20 & 183,00 & 17,73 & 13,00 & 11,01 & 9,04 & 7,50 & 6,27 & 4,51 & 3,41 & 2,26 \\
\hline 88,68 & 466,40 & 45,60 & 41,62 & 29,36 & 26,21 & 23,50 & 21,41 & 19,58 & 16,39 & 13,80 & 9,99 \\
\hline 34,69 & 840,80 & 153,20 & 26,50 & 19,26 & 15,65 & 12,01 & 9,38 & 7,48 & 5,13 & 3,86 & 2,63 \\
\hline 37,02 & 1172,30 & 105,00 & 28,40 & 23,04 & 19,93 & 16,39 & 13,48 & 11,15 & 7,87 & 5,89 & 3,88 \\
\hline 39,30 & 1604,10 & 186,80 & 16,95 & 13,29 & 11,36 & 9,26 & 7,58 & 6,24 & 4,40 & 3,30 & 2,18 \\
\hline 83,17 & 1888,90 & 101,50 & 14,75 & 11,02 & 10,19 & 9,45 & 8,78 & 8,16 & 7,03 & 6,05 & 4,52 \\
\hline 53,63 & 1463,70 & 25,70 & 51,58 & 42,88 & 41,37 & 38,96 & 36,36 & 33,82 & 29,02 & 24,77 & 18,10 \\
\hline 55,42 & 624,90 & 187,80 & 21,88 & 14,08 & 11,32 & 8,98 & 7,32 & 6,06 & 4,31 & 3,28 & 2,20 \\
\hline 21,92 & 1974,90 & 86,70 & 40,57 & 33,60 & 28,14 & 21,85 & 17,02 & 13,48 & 9,09 & 6,79 & 4,60 \\
\hline 53,92 & 1090,80 & 136,90 & 19,69 & 15,04 & 13,09 & 11,14 & 9,53 & 8,18 & 6,10 & 4,70 & 3,09 \\
\hline 63,91 & 1481,90 & 26,80 & 44,38 & 35,78 & 34,25 & 32,75 & 30,95 & 29,15 & 25,69 & 22,51 & 17,21 \\
\hline 83,90 & 1608,40 & 41,50 & 26,58 & 20,93 & 19,42 & 18,61 & 17,75 & 16,85 & 15,12 & 13,52 & 10,75 \\
\hline 26,96 & 284,50 & 162,00 & 42,43 & 23,53 & 16,48 & 11,20 & 8,32 & 6,57 & 4,58 & 3,56 & 2,51 \\
\hline 67,15 & 1249,30 & 69,10 & 24,55 & 19,35 & 17,95 & 16,36 & 14,94 & 13,63 & 11,30 & 9,39 & 6,62 \\
\hline 36,00 & 1197,50 & 32,10 & $\begin{array}{l}61,74 \\
\end{array}$ & 55,83 & 51,36 & 45,42 & 39,87 & 34,85 & 26,62 & 20,62 & 13,39 \\
\hline 73,71 & 1127,40 & 73,10 & 23,53 & 17,96 & 16,52 & 15,04 & 13,76 & 12,58 & 10,49 & 8,77 & 6,25 \\
\hline 50,03 & 619,90 & 102,50 & 31,08 & 22,82 & 19,37 & 15,98 & 13,32 & 11,16 & 8,06 & 6,12 & 4,04 \\
\hline 56,55 & 1354,50 & 118,70 & 18,89 & 15,01 & 13,44 & 11,77 & 10,33 & 9,07 & 7,02 & 5,52 & 3,67 \\
\hline 34,17 & 621,00 & 198,20 & 25,67 & 16,67 & 12,82 & 9,37 & 7,13 & 5,62 & 3,86 & 2,95 & 2,04 \\
\hline 67,52 & 1814,50 & 60,90 & 23,17 & 18,40 & 17,44 & 16,30 & 15,17 & 14,09 & 12,08 & 10,33 & 7,60 \\
\hline 51,48 & 263,90 & 66,40 & 58,00 & 39,10 & 31,98 & 25,56 & 20,85 & 17,23 & 12,23 & 9,26 & 6,20 \\
\hline 70,63 & 1177,30 & 87,10 & 21,31 & 16,33 & 14,90 & 13,42 & 12,17 & 11,03 & 9,04 & 7,45 & 5,21 \\
\hline 74,53 & 999,40 & 163,00 & 16,17 & 11,21 & 9,62 & 8,25 & 7,23 & 6,37 & 4,98 & 3,97 & 2,69 \\
\hline 20,53 & 1329,70 & 82,70 & 49,43 & 39,05 & 31,44 & 23,32 & 17,60 & 13,70 & 9,24 & 7,01 & 4,83 \\
\hline 69,89 & 1123,90 & 60,10 & 27,26 & 21,28 & 19,78 & 18,12 & 16,63 & 15,25 & 12,76 & 10,69 & 7,63 \\
\hline 89,67 & 647,90 & 160,00 & 19,71 & 12,24 & 10,02 & 8,34 & 7,23 & 6,34 & 4,97 & 3,99 & 2,75 \\
\hline 79,64 & 1183,50 & 158,80 & 14,61 & 10,25 & 8,94 & 7,81 & 6,96 & 6,22 & 5,00 & 4,07 & 2,82 \\
\hline 25,99 & 973,20 & 66,70 & 52,94 & 42,98 & 35,97 & 28,04 & 21,97 & 17,49 & 11,87 & 8,87 & 6,00 \\
\hline 69,78 & 1440,40 & 106,50 & 17,53 & 13,48 & 12,29 & 11,07 & 10,02 & 9,07 & 7,42 & 6,10 & 4,25 \\
\hline 58,40 & 1100,90 & 125,90 & 19,66 & 15,05 & 13,24 & 11,43 & 9,94 & 8,65 & 6,61 & 5,16 & 3,42 \\
\hline 45,40 & 536,20 & 168,30 & 26,87 & 17,39 & 13,79 & 10,61 & 8,39 & 6,78 & 4,70 & 3,56 & 2,42 \\
\hline 67,79 & 954,70 & 155,70 & 17,58 & 12,43 & 10,66 & 9,10 & 7,89 & 6,88 & 5,28 & 4,15 & 2,78 \\
\hline 74,08 & 1308,30 & 184,00 & 13,29 & 9,43 & 8,20 & 7,11 & 6,28 & 5,56 & 4,39 & 3,53 & 2,40 \\
\hline 32,21 & 1841,00 & 197,10 & 17,79 & 13,99 & 11,73 & 9,26 & 7,35 & 5,91 & 4,06 & 3,04 & 2,04 \\
\hline 27,09 & 729,70 & 111,90 & 39,45 & 28,98 & 22,95 & 16,92 & 12,81 & 10,03 & 6,83 & 5,20 & 3,59 \\
\hline 88,57 & 567,50 & 23,30 & 55,32 & 41,74 & 38,56 & 36,34 & 34,23 & 32,21 & 28,44 & 25,05 & 19,42 \\
\hline 68,45 & 1197,70 & 141,60 & 16,41 & 12,13 & 10,70 & 9,34 & 8,26 & 7,31 & 5,76 & 4,60 & 3,12 \\
\hline 48,24 & 1282,30 & 59,00 & 32,67 & 27,99 & 25,75 & 22,97 & 20,42 & 18,09 & 14,19 & 11,24 & 7,46 \\
\hline 35,37 & 1023,80 & 119,70 & 28,40 & 22,18 & 18,72 & 14,95 & 12,01 & 9,75 & 6,76 & 5,05 & 3,38 \\
\hline 43,22 & 1353,60 & 93,10 & 25,94 & 21,75 & 19,41 & 16,68 & 14,29 & 12,25 & 9,09 & 6,94 & 4,52 \\
\hline 20,23 & 349,40 & 147,00 & 45,90 & 26,61 & 18,32 & 12,21 & 9,02 & 7,14 & 5,03 & 3,92 & 2,75 \\
\hline 25,02 & 1431,40 & 39,40 & 69,02 & 60,87 & 53,65 & 44,53 & 36,70 & 30,28 & 21,19 & 15,71 & 10,24 \\
\hline 67,72 & 1208,80 & 179,80 & 14,53 & 10,43 & 9,02 & 7,75 & 6,76 & 5,91 & 4,57 & 3,61 & 2,42 \\
\hline 57,94 & 1828,50 & 195,40 & 12,34 & 9,54 & 8,43 & 7,31 & 6,37 & 5,56 & 4,26 & 3,33 & 2,21 \\
\hline 74,57 & 1249,80 & 120,10 & 16,90 & 12,50 & 11,21 & 9,98 & 8,98 & 8,10 & 6,59 & 5,40 & 3,76 \\
\hline 76,40 & 226,80 & 132,30 & 43,80 & 23,20 & 17,00 & 12,71 & 10,18 & 8,41 & 6,03 & 4,64 & 3,17 \\
\hline 21,92 & 263,80 & 23,30 & 184,83 & 141,93 & 112,69 & 82,56 & 61,94 & 48,19 & 32,66 & 24,89 & 17,19 \\
\hline 84,95 & 469,00 & 163,00 & 24,42 & 14,34 & 11,28 & 9,04 & 7,62 & 6,54 & 4,94 & 3,89 & 2,65 \\
\hline 45,21 & 978,60 & 183,40 & 19,40 & 14,00 & 11,68 & 9,40 & 7,65 & 6,29 & 4,44 & 3,34 & 2,23 \\
\hline 70,10 & 1781,20 & 42,20 & 28,90 & 22,93 & 21,79 & 20,75 & 19,59 & 18,43 & 16,22 & 14,21 & 10,87 \\
\hline 71,34 & 433,10 & 95,60 & 33,08 & 21,96 & 18,29 & 15,27 & 13,08 & 11,30 & 8,57 & 6,71 & 4,50 \\
\hline 41,16 & 400,90 & 173,70 & 31,52 & 18,92 & 14,33 & 10,54 & 8,10 & 6,44 & 4,43 & 3,38 & 2,34 \\
\hline 24,96 & 1322,70 & 136,40 & 30,20 & 23,22 & 18,70 & 13,96 & 10,62 & 8,32 & 5,64 & 4,27 & 2,94 \\
\hline 66,10 & 1695,60 & 93,50 & 18,27 & 14,46 & 13,41 & 12,21 & 11,14 & 10,15 & 8,39 & 6,95 & 4,88 \\
\hline 85,28 & 1841,00 & 74,50 & 17,61 & 13,35 & 12,39 & 11,66 & 10,97 & 10,30 & 9,05 & 7,94 & 6,10 \\
\hline 59,86 & 618,80 & 175,10 & 22,09 & 14,29 & 11,59 & 9,32 & 7,70 & 6,44 & 4,66 & 3,56 & 2,38 \\
\hline 54,97 & 1365,40 & 99,20 & 21,27 & 17,29 & 15,64 & 13,80 & 12,20 & 10,76 & 8,39 & 6,63 & 4,42 \\
\hline 29,57 & 1241,00 & 45,50 & 56,99 & 50,05 & 44,40 & 37,31 & 31,15 & 26,02 & 18,52 & 13,82 & 8,96 \\
\hline 43,57 & 1699,20 & 106,70 & 21,73 & 18,38 & 16,50 & 14,28 & 12,31 & 10,61 & 7,94 & 6,09 & 3,97 \\
\hline 22,42 & 282,70 & 121,70 & 54,02 & 31,66 & 22,13 & 14,88 & 10,99 & 8,67 & 6,08 & 4,73 & 3,32 \\
\hline 87,70 & 776,20 & 34,60 & 38,76 & 29,07 & 26,87 & 25,21 & 23,66 & 22,20 & 19,48 & 17,07 & 13,11 \\
\hline 79,91 & 1959,30 & 110,50 & 14,11 & 10,62 & 9,82 & 9,05 & 8,38 & 7,75 & 6,61 & 5,65 & 4,15 \\
\hline 57,71 & 1932,10 & 198,80 & 11,95 & 9,29 & 8,24 & 7,15 & 6,25 & 5,46 & 4,19 & 3,28 & 2,18 \\
\hline 89,33 & 744,50 & 70,20 & 26,48 & 18,70 & 16,73 & 15,04 & 13,73 & 12,58 & 10,58 & 8,93 & 6,49 \\
\hline 20,80 & 958,30 & 40,60 & 89,44 & 73,68 & 61,26 & 47,11 & 36,40 & 28,67 & 19,29 & 14,44 & 9,83 \\
\hline 65,63 & 1309,50 & 182,20 & 14,07 & 10,26 & 8,92 & 7,68 & 6,70 & 5,86 & 4,52 & 3,56 & 2,38 \\
\hline 77,27 & 1267,00 & 198,20 & 12,83 & 8,88 & 7,65 & 6,59 & 5,81 & 5,14 & 4,06 & 3,26 & 2,23 \\
\hline 85,52 & 1203,10 & 33,10 & 33,71 & 26,41 & 24,46 & 23,40 & 22,29 & 21,16 & 18,97 & 16,96 & 13,47 \\
\hline 69,51 & 758,70 & 71,40 & 29,09 & 21,97 & 19,71 & 17,49 & 15,66 & 14,03 & 11,27 & 9,14 & 6,27 \\
\hline 89,52 & 964,80 & 22,80 & 44,01 & 35,43 & 32,42 & 31,14 & 29,91 & 28,57 & 25,93 & 23,46 & 19,05 \\
\hline 68,72 & 1100,30 & 77,50 & 23,81 & 18,43 & 16,86 & 15,20 & 13,78 & 12,48 & 10,21 & 8,40 & 5,86 \\
\hline
\end{tabular}




\begin{tabular}{|c|c|c|c|c|c|c|c|c|c|c|c|}
\hline \multirow[b]{2}{*}{ e1 (cm) } & & & & & & & ões (x1 & m) & & & \\
\hline & Meq (MPa) & Ms (MPa) & D0 & D25 & D40 & D60 & D80 & D100 & D140 & D180 & D260 \\
\hline 49,73 & 1274,10 & 114,00 & 21,43 & 17,28 & 15,33 & 13,21 & 11,39 & 9,82 & 7,38 & 5,69 & 3,73 \\
\hline 75,05 & 1219,70 & 26,70 & 42,26 & 33,57 & 31,60 & 30,32 & 28,83 & 27,31 & 24,36 & 21,63 & 16,96 \\
\hline 76,14 & 431,10 & 150,60 & 27,18 & 16,22 & 12,79 & 10,22 & 8,54 & 7,26 & 5,38 & 4,19 & 2,82 \\
\hline 35,26 & 792,10 & 54,90 & 51,23 & 42,80 & 37,42 & 31,07 & 25,74 & 21,39 & 15,18 & 11,36 & 7,43 \\
\hline 30,11 & 1502,30 & 143,80 & 24,59 & 19,52 & 16,34 & 12,82 & 10,12 & 8,11 & 5,54 & 4,14 & 2,79 \\
\hline 41,44 & 1173,10 & 52,60 & 40,38 & 35,22 & 32,04 & 28,08 & 24,49 & 21,29 & 16,15 & 12,49 & 8,13 \\
\hline 46,05 & 859,40 & 131,50 & 24,48 & 18,31 & 15,56 & 12,76 & 10,54 & 8,77 & 6,27 & 4,73 & 3,13 \\
\hline 53,79 & 381,20 & 34,30 & 68,05 & 54,34 & 48,42 & 42,10 & 36,68 & 31,96 & 24,40 & 19,03 & 12,56 \\
\hline 56,65 & 1930,40 & 20,70 & 53,14 & 43,59 & 41,90 & 40,47 & 38,49 & 36,44 & 32,43 & 28,67 & 22,23 \\
\hline 80,01 & 1362,40 & 138,80 & 14,56 & 10,52 & 9,39 & 8,36 & 7,55 & 6,83 & 5,60 & 4,63 & 3,26 \\
\hline 36,50 & 919,40 & 80,60 & 37,09 & 30,17 & 26,09 & 21,43 & 17,61 & 14,55 & 10,26 & 7,67 & 5,05 \\
\hline 23,83 & 1411,70 & 123,10 & 32,88 & 25,64 & 20,73 & 15,52 & 11,81 & 9,25 & 6,25 & 4,73 & 3,25 \\
\hline 32,50 & 1688,70 & 194,50 & 18,39 & 14,32 & 11,96 & 9,40 & 7,44 & 5,98 & 4,10 & 3,07 & 2,07 \\
\hline 25,57 & 467,70 & 96,10 & 51,96 & 36,12 & 27,58 & 19,64 & 14,62 & 11,41 & 7,83 & 6,02 & 4,18 \\
\hline 58,30 & 491,60 & 68,40 & 39,65 & 29,50 & 25,57 & 21,78 & 18,72 & 16,14 & 12,15 & 9,42 & 6,23 \\
\hline 55,40 & 1164,70 & 28,40 & 50,47 & 42,01 & 40,19 & 37,43 & 34,66 & 31,98 & 27,02 & 22,77 & 16,31 \\
\hline 64,40 & 1791,80 & 70,00 & 21,84 & 17,53 & 16,53 & 15,28 & 14,09 & 12,97 & 10,92 & 9,19 & 6,59 \\
\hline 76,19 & 267,10 & 118,80 & 40,40 & 22,81 & 17,41 & 13,51 & 11,08 & 9,29 & 6,78 & 5,24 & 3,55 \\
\hline 36,21 & 1686,10 & 166,60 & 18,86 & 15,10 & 12,94 & 10,52 & 8,57 & 7,03 & 4,92 & 3,68 & 2,43 \\
\hline 38,65 & 1152,20 & 141,90 & 23,06 & 17,91 & 15,23 & 12,32 & 10,02 & 8,22 & 5,76 & 4,31 & 2,86 \\
\hline 69,85 & 1804,60 & 152,70 & 12,94 & 9,85 & 8,91 & 7,96 & 7,16 & 6,45 & 5,23 & 4,27 & 2,95 \\
\hline 70,81 & 1358,60 & 41,80 & 31,79 & 25,03 & 23,72 & 22,35 & 20,93 & 19,56 & 16,99 & 14,71 & 11,03 \\
\hline 52,88 & 1544,50 & 24,80 & 52,57 & 43,72 & 42,26 & 39,89 & 37,29 & 34,74 & 29,90 & 25,60 & 18,78 \\
\hline 75,28 & 1276,00 & 118,40 & 16,79 & 12,43 & 11,18 & 9,98 & 9,00 & 8,13 & 6,64 & 5,46 & 3,82 \\
\hline 40,78 & 1235,30 & 32,50 & 55,20 & 49,35 & 45,99 & 41,36 & 36,96 & 32,88 & 25,91 & 20,55 & 13,60 \\
\hline 32,07 & 473,00 & 161,60 & 33,17 & 21,17 & 16,03 & 11,52 & 8,68 & 6,82 & 4,69 & 3,60 & 2,50 \\
\hline 41,58 & 691,20 & 107,30 & 32,02 & 23,97 & 20,17 & 16,24 & 13,19 & 10,82 & 7,59 & 5,70 & 3,80 \\
\hline 35,28 & 1314,60 & 157,60 & 21,81 & 16,96 & 14,29 & 11,38 & 9,12 & 7,40 & 5,12 & 3,83 & 2,56 \\
\hline 49,54 & 544,20 & 58,00 & 45,44 & 35,82 & 31,41 & 26,74 & 22,82 & 19,51 & 14,45 & 11,07 & 7,26 \\
\hline 35,64 & 1071,20 & 184,30 & 21,23 & 15,60 & 12,79 & 9,91 & 7,80 & 6,25 & 4,30 & 3,23 & 2,19 \\
\hline 29,30 & 1291,00 & 110,70 & 31,40 & 25,19 & 21,17 & 16,65 & 13,16 & 10,55 & 7,21 & 5,39 & 3,62 \\
\hline 70,98 & 1754,90 & 171,80 & 12,18 & 9,12 & 8,16 & 7,23 & 6,48 & 5,81 & 4,67 & 3,79 & 2,61 \\
\hline 77,29 & 547,00 & 109,20 & 26,61 & 17,71 & 14,89 & 12,59 & 10,94 & 9,57 & 7,42 & 5,90 & 4,00 \\
\hline 43,11 & 430,50 & 118,30 & 36,61 & 24,48 & 19,62 & 15,15 & 11,98 & 9,66 & 6,69 & 5,06 & 3,43 \\
\hline 76,42 & 1846,30 & 37,70 & 28,69 & 22,94 & 21,50 & 20,69 & 19,75 & 18,75 & 16,82 & 15,02 & 11,90 \\
\hline 24,95 & 597,10 & 112,40 & 43,83 & 30,83 & 23,60 & 16,82 & 12,52 & 9,76 & 6,69 & 5,14 & 3,57 \\
\hline 44,75 & 886,60 & 164,80 & 21,62 & 15,64 & 13,04 & 10,48 & 8,52 & 7,01 & 4,93 & 3,72 & 2,48 \\
\hline 26,69 & 1592,80 & 81,70 & 38,63 & 32,46 & 27,83 & 22,34 & 17,91 & 14,48 & 9,94 & 7,38 & 4,91 \\
\hline 73,77 & 1588,00 & 170,40 & 12,59 & 9,25 & 8,22 & 7,26 & 6,50 & 5,82 & 4,69 & 3,81 & 2,63 \\
\hline 70,58 & 1828,10 & 192,00 & 11,29 & 8,40 & 7,48 & 6,60 & 5,88 & 5,25 & 4,20 & 3,39 & 2,32 \\
\hline 31,96 & 1858,20 & 182,00 & 18,78 & 14,93 & 12,59 & 9,99 & 7,96 & 6,42 & 4,42 & 3,30 & 2,21 \\
\hline 69,20 & 203,90 & 165,80 & 44,86 & 22,02 & 15,29 & 10,82 & 8,35 & 6,72 & 4,69 & 3,61 & 2,51 \\
\hline 77,78 & 1174,20 & 26,40 & 41,93 & 33,28 & 31,17 & 29,93 & 28,51 & 27,04 & 24,20 & 21,56 & 17,01 \\
\hline 46,66 & 1716,10 & 90,90 & 22,83 & 19,49 & 17,75 & 15,65 & 13,76 & 12,06 & 9,29 & 7,26 & 4,77 \\
\hline 78,67 & 798,70 & 161,40 & 18,02 & 11,92 & 10,01 & 8,46 & 7,35 & 6,45 & 5,01 & 3,99 & 2,71 \\
\hline 28,27 & 1076,80 & 45,80 & 61,82 & 53,30 & 46,62 & 38,43 & 31,52 & 25,95 & 18,13 & 13,47 & 8,82 \\
\hline 32,60 & 1915,10 & 169,30 & 19,20 & 15,50 & 13,20 & 10,60 & 8,53 & 6,93 & 4,79 & 3,58 & 2,38 \\
\hline 39,42 & 1960,90 & 109,80 & 21,77 & 18,67 & 16,71 & 14,35 & 12,26 & 10,47 & 7,72 & 5,87 & 3,81 \\
\hline 44,13 & 1723,70 & 129,80 & 18,99 & 15,75 & 14,00 & 12,00 & 10,26 & 8,78 & 6,50 & 4,96 & 3,23 \\
\hline 54,52 & 1368,40 & 100,80 & 21,15 & 17,20 & 15,53 & 13,69 & 12,07 & 10,63 & 8,27 & 6,52 & 4,33 \\
\hline 77,01 & 691,80 & 158,90 & 19,85 & 12,89 & 10,68 & 8,92 & 7,67 & 6,67 & 5,11 & 4,04 & 2,73 \\
\hline 73,20 & 1086,10 & 74,70 & 23,69 & 18,06 & 16,56 & 15,01 & 13,69 & 12,49 & 10,36 & 8,63 & 6,11 \\
\hline 51,59 & 910,00 & 45,80 & 41,66 & 35,13 & 32,32 & 28,91 & 25,81 & 22,97 & 18,16 & 14,48 & 9,69 \\
\hline 32,63 & 1615,90 & 85,40 & 31,77 & 27,19 & 23,93 & 19,97 & 16,59 & 13,81 & 9,81 & 7,32 & 4,77 \\
\hline 55,06 & 257,80 & 156,40 & 39,75 & 21,37 & 15,61 & 11,43 & 8,90 & 7,16 & 4,98 & 3,81 & 2,63 \\
\hline 34,53 & 1862,40 & 83,40 & 29,32 & 25,59 & 22,87 & 19,50 & 16,52 & 13,99 & 10,17 & 7,67 & 4,96 \\
\hline 47,62 & 743,20 & 96,50 & 30,44 & 23,37 & 20,15 & 16,82 & 14,11 & 11,88 & 8,62 & 6,54 & 4,30 \\
\hline 68,54 & 696,70 & 71,50 & 30,42 & 22,85 & 20,36 & 17,96 & 15,99 & 14,25 & 11,34 & 9,14 & 6,23 \\
\hline 29,36 & 1546,30 & 193,20 & 20,35 & 15,54 & 12,69 & 9,69 & 7,50 & 5,94 & 4,04 & 3,04 & 2,08 \\
\hline 70,79 & 374,60 & 135,00 & 31,48 & 18,85 & 14,83 & 11,77 & 9,75 & 8,21 & 6,01 & 4,64 & 3,12 \\
\hline 32,99 & 1331,40 & 169,60 & 21,64 & 16,62 & 13,81 & 10,80 & 8,52 & 6,84 & 4,69 & 3,52 & 2,37 \\
\hline 28,91 & 1406,90 & 171,60 & 22,96 & 17,56 & 14,34 & 10,93 & 8,45 & 6,69 & 4,55 & 3,42 & 2,34 \\
\hline 31,42 & 1061,20 & 91,00 & 36,31 & 29,32 & 24,90 & 19,89 & 15,93 & 12,89 & 8,88 & 6,62 & 4,42 \\
\hline 64,63 & 889,70 & 46,40 & 36,52 & 29,14 & 27,09 & 24,70 & 22,54 & 20,53 & 16,96 & 14,05 & 9,85 \\
\hline 46,98 & 1862,60 & 175,50 & 14,74 & 11,86 & 10,45 & 8,90 & 7,59 & 6,48 & 4,79 & 3,66 & 2,39 \\
\hline 64,44 & 1383,10 & 56,20 & 27,58 & 22,13 & 20,83 & 19,22 & 17,70 & 16,27 & 13,67 & 11,47 & 8,20 \\
\hline 65,55 & 1996,00 & 103,90 & 16,16 & 12,85 & 11,95 & 10,90 & 9,96 & 9,09 & 7,53 & 6,25 & 4,40 \\
\hline 89,15 & 1965,40 & 33,30 & 25,87 & 22,13 & 20,03 & 19,29 & 18,72 & 18,02 & 16,58 & 15,19 & 12,64 \\
\hline 20,42 & 904,40 & 137,20 & 37,86 & 26,61 & 19,87 & 13,76 & 10,09 & 7,84 & 5,43 & 4,20 & 2,92 \\
\hline 54,00 & 1244,70 & 194,20 & 15,34 & 11,30 & 9,68 & 8,10 & 6,85 & 5,82 & 4,28 & 3,27 & 2,16 \\
\hline 87,73 & 336,50 & 84,20 & 37,98 & 23,64 & 19,33 & 16,06 & 13,89 & 12,16 & 9,48 & 7,59 & 5,21 \\
\hline 47,33 & 311,10 & 26,10 & 93,97 & 76,65 & 68,05 & 58,48 & 50,24 & 43,17 & 32,21 & 24,73 & 16,16 \\
\hline 31,01 & 849,10 & 25,30 & 91,68 & 82,23 & 74,12 & 63,68 & 54,28 & 46,17 & 33,72 & 25,42 & 16,37 \\
\hline 78,72 & 756,70 & 182,10 & 17,68 & 11,33 & 9,34 & 7,77 & 6,68 & 5,80 & 4,45 & 3,52 & 2,38 \\
\hline 46,90 & 1353,20 & 150,50 & 18,44 & 14,50 & 12,63 & 10,64 & 8,98 & 7,61 & 5,55 & 4,22 & 2,77 \\
\hline 61,92 & 1575,60 & 179,00 & 13,37 & 10,14 & 8,95 & 7,77 & 6,81 & 5,97 & 4,62 & 3,64 & 2,43 \\
\hline 21,52 & 1290,00 & 115,50 & 37,86 & 28,92 & 22,84 & 16,64 & 12,44 & 9,67 & 6,56 & 5,01 & 3,46 \\
\hline 27,46 & 514,80 & 79,90 & 55,03 & 40,42 & 32,05 & 23,68 & 17,96 & 14,08 & 9,58 & 7,29 & 5,02 \\
\hline 73,94 & 1895,30 & 126,30 & 13,76 & 10,48 & 9,62 & 8,75 & 8,00 & 7,31 & 6,09 & 5,08 & 3,62 \\
\hline 21,36 & 1451,30 & 176,20 & 27,08 & 19,85 & 15,26 & 10,84 & 8,01 & 6,22 & 4,26 & 3,27 & 2,27 \\
\hline 84,57 & 1332,80 & 23,70 & 39,31 & 32,66 & 29,91 & 28,89 & 27,89 & 26,74 & 24,42 & 22,20 & 18,20 \\
\hline 33,03 & 364,70 & 172,30 & 35,18 & 20,71 & 15,19 & 10,71 & 8,04 & 6,33 & 4,37 & 3,37 & 2,36 \\
\hline
\end{tabular}




\begin{tabular}{|c|c|c|c|c|c|c|c|c|c|c|c|}
\hline \multirow[b]{2}{*}{ e1 (cm) } & & & & & & $\mathrm{De}$ & ões (x1 & & & & \\
\hline & Meq (MPa) & Ms (MPa) & D0 & D25 & D40 & D60 & D80 & D100 & D140 & D180 & D260 \\
\hline 26,08 & 1322,30 & 57,00 & 53,30 & 45,42 & 39,23 & 31,76 & 25,63 & 20,82 & 14,33 & 10,63 & 7,04 \\
\hline 63,77 & 522,40 & 77,20 & 34,66 & 25,19 & 21,78 & 18,62 & 16,14 & 14,03 & 10,71 & 8,39 & 5,59 \\
\hline 69,04 & 930,40 & 172,60 & 16,85 & 11,61 & 9,85 & 8,32 & 7,18 & 6,23 & 4,76 & 3,73 & 2,50 \\
\hline 71,52 & 1723,10 & 97,00 & 17,03 & 13,18 & 12,23 & 11,19 & 10,27 & 9,42 & 7,89 & 6,61 & 4,73 \\
\hline 64,83 & 1351,90 & 193,10 & 13,52 & 9,85 & 8,54 & 7,33 & 6,38 & 5,56 & 4,27 & 3,36 & 2,24 \\
\hline 46,79 & 1019,00 & 99,40 & 26,47 & 21,21 & 18,64 & 15,83 & 13,47 & 11,47 & 8,45 & 6,44 & 4,21 \\
\hline 32,90 & 380,50 & 70,30 & 59,80 & 43,27 & 34,86 & 26,43 & 20,45 & 16,22 & 11,08 & 8,38 & 5,73 \\
\hline 42,85 & 923,70 & 194,50 & 19,80 & 14,00 & 11,51 & 9,09 & 7,28 & 5,93 & 4,13 & 3,11 & 2,09 \\
\hline 45,00 & 1818,60 & 20,80 & 63,39 & 54,01 & 52,44 & 49,37 & 46,03 & 42,73 & 36,50 & 31,00 & 22,42 \\
\hline 29,63 & 295,80 & 70,80 & 68,75 & 47,15 & 36,49 & 26,51 & 19,99 & 15,69 & 10,74 & 8,21 & 5,69 \\
\hline 52,98 & 1732,90 & 97,00 & 20,11 & 16,77 & 15,37 & 13,71 & 12,21 & 10,85 & 8,56 & 6,82 & 4,56 \\
\hline 33,12 & 1354,10 & 81,00 & 34,56 & 29,23 & 25,58 & 21,22 & 17,54 & 14,55 & 10,28 & 7,68 & 5,02 \\
\hline 32,20 & 386,40 & 75,00 & 57,76 & 41,39 & 33,10 & 24,88 & 19,14 & 15,14 & 10,34 & 7,83 & 5,37 \\
\hline 45,51 & 1144,20 & 117,60 & 23,28 & 18,54 & 16,20 & 13,66 & 11,53 & 9,76 & 7,12 & 5,41 & 3,54 \\
\hline 37,73 & 1935,40 & 117,90 & 21,62 & 18,37 & 16,30 & 13,82 & 11,67 & 9,86 & 7,16 & 5,40 & 3,51 \\
\hline 57,29 & 1989,50 & 137,40 & 14,69 & 11,90 & 10,82 & 9,62 & 8,56 & 7,61 & 6,01 & 4,80 & 3,22 \\
\hline 64,64 & 456,30 & 78,40 & 36,61 & 25,89 & 22,09 & 18,70 & 16,09 & 13,91 & 10,53 & 8,21 & 5,47 \\
\hline 25,13 & 1443,20 & 52,40 & 56,61 & 48,77 & 42,33 & 34,45 & 27,91 & 22,73 & 15,68 & 11,61 & 7,66 \\
\hline 48,81 & 1518,20 & 111,40 & 20,48 & 16,91 & 15,17 & 13,20 & 11,48 & 9,97 & 7,56 & 5,86 & 3,84 \\
\hline 64,50 & 1552,00 & 80,20 & 21,07 & 16,83 & 15,65 & 14,27 & 13,03 & 11,87 & 9,81 & 8,12 & 5,70 \\
\hline 31,92 & 1793,70 & 177,80 & 19,32 & 15,34 & 12,93 & 10,24 & 8,15 & 6,57 & 4,52 & 3,38 & 2,26 \\
\hline 22,09 & 1626,40 & 70,80 & 49,26 & 40,89 & 34,32 & 26,72 & 20,86 & 16,54 & 11,16 & 8,33 & 5,64 \\
\hline 81,02 & 1737,20 & 147,70 & 12,52 & 9,15 & 8,27 & 7,45 & 6,79 & 6,20 & 5,16 & 4,32 & 3,09 \\
\hline 24,53 & 324,80 & 53,40 & 89,47 & 64,18 & 49,54 & 35,52 & 26,47 & 20,62 & 14,11 & 10,83 & 7,51 \\
\hline 86,84 & 1704,80 & 28,10 & 31,10 & 26,45 & 24,04 & 23,19 & 22,48 & 21,63 & 19,86 & 18,16 & 15,06 \\
\hline 84,92 & 1664,30 & 113,70 & 14,42 & 10,58 & 9,67 & 8,85 & 8,16 & 7,54 & 6,42 & 5,47 & 4,02 \\
\hline 75,70 & 1965,10 & 59,80 & 21,20 & 16,53 & 15,58 & 14,76 & 13,90 & 13,05 & 11,46 & 10,02 & 7,66 \\
\hline 65,26 & 778,60 & 68,80 & 30,28 & 23,35 & 21,01 & 18,63 & 16,62 & 14,83 & 11,82 & 9,52 & 6,47 \\
\hline 66,58 & 791,60 & 75,70 & 28,21 & 21,49 & 19,24 & 17,00 & 15,15 & 13,50 & 10,74 & 8,64 & 5,88 \\
\hline 62,95 & 1701,40 & 57,70 & 25,58 & 20,67 & 19,60 & 18,20 & 16,84 & 15,54 & 13,15 & 11,11 & 8,01 \\
\hline 61,19 & 1333,10 & 175,00 & 14,72 & 10,97 & 9,56 & 8,22 & 7,13 & 6,20 & 4,74 & 3,71 & 2,46 \\
\hline 67,65 & 729,50 & 149,30 & 20,70 & 14,07 & 11,81 & 9,89 & 8,46 & 7,29 & 5,50 & 4,29 & 2,87 \\
\hline 63,30 & 1703,80 & 191,40 & 12,31 & 9,31 & 8,22 & 7,16 & 6,30 & 5,54 & 4,31 & 3,41 & 2,29 \\
\hline 36,58 & 1358,10 & 92,80 & 29,32 & 24,58 & 21,60 & 18,07 & 15,08 & 12,61 & 9,02 & 6,77 & 4,42 \\
\hline 37,30 & 778,40 & 34,30 & 66,62 & 58,35 & 52,61 & 45,45 & 39,04 & 33,47 & 24,80 & 18,88 & 12,22 \\
\hline 70,36 & 428,40 & 36,90 & 53,77 & 40,79 & 36,84 & 32,88 & 29,60 & 26,65 & 21,59 & 17,63 & 12,20 \\
\hline 46,04 & 1127,60 & 172,70 & 18,65 & 13,95 & 11,85 & 9,72 & 8,03 & 6,68 & 4,77 & 3,60 & 2,38 \\
\hline 43,47 & 259,10 & 199,10 & 37,11 & 18,79 & 13,12 & 9,15 & 6,92 & 5,49 & 3,79 & 2,93 & 2,06 \\
\hline 72,22 & 1919,30 & 56,30 & 22,92 & 18,00 & 17,05 & 16,12 & 15,14 & 14,19 & 12,40 & 10,79 & 8,17 \\
\hline 63,62 & 1094,50 & 71,40 & 26,07 & 20,69 & 18,97 & 17,08 & 15,41 & 13,89 & 11,26 & 9,18 & 6,32 \\
\hline 79,76 & 1875,70 & 85,50 & 16,76 & 12,74 & 11,88 & 11,07 & 10,32 & 9,62 & 8,31 & 7,18 & 5,37 \\
\hline 62,50 & 1421,10 & 38,40 & 35,79 & 28,95 & 27,64 & 25,91 & 24,15 & 22,44 & 19,25 & 16,45 & 12,07 \\
\hline 24,64 & 1247,60 & 25,50 & 98,00 & 88,32 & 78,89 & 66,67 & 55,82 & 46,68 & 33,22 & 24,71 & 15,95 \\
\hline 82,72 & 1859,90 & 113,30 & 13,96 & 10,38 & 9,55 & 8,78 & 8,12 & 7,52 & 6,42 & 5,49 & 4,05 \\
\hline 79,00 & 1768,40 & 85,70 & 17,22 & 13,08 & 12,18 & 11,31 & 10,51 & 9,77 & 8,40 & 7,22 & 5,36 \\
\hline 20,79 & 1753,50 & 198,50 & 24,00 & 17,66 & 13,58 & 9,63 & 7,11 & 5,52 & 3,78 & 2,91 & 2,02 \\
\hline 73,30 & 1085,70 & 41,90 & 33,71 & 26,22 & 24,68 & 23,07 & 21,50 & 20,01 & 17,24 & 14,82 & 11,00 \\
\hline 48,00 & 1567,40 & 77,30 & 25,66 & 21,92 & 20,08 & 17,84 & 15,79 & 13,94 & 10,86 & 8,56 & 5,66 \\
\hline 64,42 & 1498,90 & 91,00 & 19,76 & 15,69 & 14,46 & 13,08 & 11,85 & 10,73 & 8,76 & 7,19 & 4,99 \\
\hline 84,74 & 1193,20 & 36,70 & 32,06 & 24,83 & 23,06 & 21,97 & 20,84 & 19,71 & 17,56 & 15,59 & 12,24 \\
\hline 64,53 & 1193,50 & 164,00 & 15,66 & 11,48 & 9,98 & 8,59 & 7,49 & 6,54 & 5,03 & 3,96 & 2,64 \\
\hline 41,56 & 1288,90 & 82,60 & 29,26 & 24,74 & 22,09 & 18,95 & 16,21 & 13,86 & 10,24 & 7,80 & 5,07 \\
\hline 47,12 & 1842,90 & 71,30 & 25,86 & 22,40 & 20,75 & 18,63 & 16,65 & 14,82 & 11,72 & 9,33 & 6,22 \\
\hline 73,26 & 350,40 & 174,30 & 29,92 & 16,52 & 12,42 & 9,49 & 7,69 & 6,38 & 4,60 & 3,54 & 2,41 \\
\hline 40,19 & 1941,20 & 142,70 & 18,28 & 15,23 & 13,45 & 11,38 & 9,60 & 8,12 & 5,90 & 4,46 & 2,90 \\
\hline 89,10 & 860,10 & 101,10 & 20,53 & 14,21 & 12,50 & 11,07 & 10,00 & 9,09 & 7,52 & 6,27 & 4,48 \\
\hline 57,49 & 256,30 & 121,20 & 43,59 & 24,98 & 18,96 & 14,37 & 11,43 & 9,31 & 6,54 & 4,99 & 3,40 \\
\hline 81,33 & 206,80 & 85,60 & 52,76 & 30,03 & 23,10 & 18,12 & 15,02 & 12,71 & 9,41 & 7,33 & 4,98 \\
\hline 31,82 & 510,30 & 47,90 & 70,50 & 56,34 & 47,63 & 37,87 & 30,23 & 24,42 & 16,81 & 12,54 & 8,40 \\
\hline 84,11 & 1377,80 & 186,60 & 12,23 & 8,45 & 7,37 & 6,44 & 5,76 & 5,17 & 4,20 & 3,44 & 2,41 \\
\hline 33,18 & 540,40 & 86,00 & 46,06 & 34,19 & 27,93 & 21,47 & 16,76 & 13,36 & 9,14 & 6,88 & 4,68 \\
\hline 44,70 & 1066,60 & 31,00 & 56,03 & 49,28 & 46,10 & 41,70 & 37,51 & 33,60 & 26,83 & 21,52 & 14,42 \\
\hline 37,46 & 1417,90 & 71,70 & 33,40 & 28,91 & 25,89 & 22,20 & 18,93 & 16,13 & 11,84 & 8,98 & 5,81 \\
\hline 54,65 & 1752,00 & 190,10 & 13,19 & 10,27 & 9,04 & 7,78 & 6,73 & 5,82 & 4,40 & 3,41 & 2,25 \\
\hline 26,08 & 700,90 & 100,30 & 44,10 & 32,59 & 25,77 & 18,94 & 14,30 & 11,18 & 7,61 & 5,79 & 4,00 \\
\hline 21,88 & 1558,90 & 155,90 & 28,59 & 21,60 & 16,97 & 12,30 & 9,18 & 7,13 & 4,85 & 3,71 & 2,57 \\
\hline 55,43 & 1516,00 & 185,40 & 14,15 & 10,81 & 9,45 & 8,08 & 6,95 & 5,99 & 4,50 & 3,48 & 2,30 \\
\hline 65,90 & 1661,60 & 97,30 & 17,99 & 14,22 & 13,14 & 11,93 & 10,85 & 9,86 & 8,11 & 6,69 & 4,68 \\
\hline 26,88 & 1579,20 & 139,00 & 26,82 & 21,24 & 17,56 & 13,51 & 10,50 & 8,32 & 5,65 & 4,24 & 2,88 \\
\hline 24,23 & 1938,10 & 99,00 & 34,37 & 28,50 & 24,06 & 18,90 & 14,87 & 11,86 & 8,05 & 5,99 & 4,04 \\
\hline 27,15 & 990,40 & 84,60 & 43,33 & 34,48 & 28,62 & 22,13 & 17,26 & 13,70 & 9,31 & 6,97 & 4,73 \\
\hline 87,24 & 1072,70 & 78,10 & 21,32 & 15,47 & 14,07 & 12,84 & 11,83 & 10,93 & 9,30 & 7,94 & 5,85 \\
\hline 32,21 & 1010,10 & 171,20 & 24,09 & 17,67 & 14,30 & 10,87 & 8,41 & 6,68 & 4,56 & 3,44 & 2,35 \\
\hline 23,12 & 1420,70 & 172,60 & 26,32 & 19,56 & 15,30 & 11,07 & 8,27 & 6,43 & 4,38 & 3,35 & 2,32 \\
\hline 63,35 & 445,80 & 189,00 & 25,57 & 14,92 & 11,51 & 8,90 & 7,21 & 5,95 & 4,25 & 3,25 & 2,20 \\
\hline 34,25 & 1680,50 & 140,30 & 21,91 & 17,87 & 15,38 & 12,53 & 10,21 & 8,38 & 5,85 & 4,37 & 2,89 \\
\hline 55,03 & 1177,50 & 184,00 & 16,05 & 11,80 & 10,11 & 8,48 & 7,19 & 6,12 & 4,51 & 3,46 & 2,28 \\
\hline 53,22 & 752,80 & 79,50 & 31,64 & 24,80 & 21,85 & 18,78 & 16,20 & 13,99 & 10,53 & 8,15 & 5,36 \\
\hline 76,11 & 1157,20 & 52,70 & 27,92 & 21,43 & 20,04 & 18,62 & 17,30 & 16,06 & 13,78 & 11,81 & 8,73 \\
\hline 80,83 & 1067,10 & 24,10 & 44,59 & 35,48 & 33,03 & 31,75 & 30,32 & 28,82 & 25,91 & 23,19 & 18,46 \\
\hline 25,28 & 287,00 & 124,50 & 51,01 & 30,28 & 21,57 & 14,71 & 10,88 & 8,56 & 5,97 & 4,64 & 3,25 \\
\hline 66,57 & 795,80 & 139,50 & 20,53 & 14,39 & 12,26 & 10,39 & 8,96 & 7,76 & 5,90 & 4,62 & 3,08 \\
\hline
\end{tabular}




\begin{tabular}{|c|c|c|c|c|c|c|c|c|c|c|c|}
\hline & & & \multicolumn{9}{|c|}{ Deflexões $\left(\times 10^{-4} \mathrm{~cm}\right)$} \\
\hline e1 (cm) & Meq (MPa) & Ms (MPa) & D0 & D25 & D40 & D60 & D80 & D100 & D140 & D180 & D260 \\
\hline 40,81 & 1174,10 & 99,20 & 27,44 & 22,48 & 19,72 & 16,56 & 13,90 & 11,69 & 8,45 & 6,37 & 4,16 \\
\hline 82,13 & 640,60 & 22,70 & 56,11 & 43,04 & 40,17 & 37,99 & 35,78 & 33,65 & 29,64 & 26,03 & 20,04 \\
\hline 29,81 & 465,40 & 180,60 & 32,00 & 19,76 & 14,61 & 10,27 & 7,67 & 6,02 & 4,16 & 3,21 & 2,24 \\
\hline 37,32 & 822,80 & 32,40 & 67,83 & 59,94 & 54,34 & 47,28 & 40,87 & 35,25 & 26,35 & 20,16 & 13,04 \\
\hline 22,57 & 264,80 & 76,60 & 76,46 & 48,93 & 35,37 & 24,12 & 17,74 & 13,90 & 9,70 & 7,53 & 5,26 \\
\hline 48,09 & 1574,00 & 159,60 & 16,46 & 13,09 & 11,50 & 9,78 & 8,33 & 7,11 & 5,26 & 4,02 & 2,63 \\
\hline 65,37 & 494,50 & 129,90 & 27,70 & 18,00 & 14,73 & 12,02 & 10,09 & 8,56 & 6,31 & 4,86 & 3,25 \\
\hline 31,92 & 1819,20 & 123,60 & 24,38 & 20,27 & 17,52 & 14,29 & 11,64 & 9,54 & 6,66 & 4,96 & 3,27 \\
\hline 27,67 & 1266,50 & 60,40 & 49,57 & 42,16 & 36,51 & 29,71 & 24,10 & 19,66 & 13,60 & 10,10 & 6,67 \\
\hline 83,84 & 1931,10 & 36,30 & 26,54 & 21,79 & 20,03 & 19,33 & 18,63 & 17,82 & 16,22 & 14,70 & 11,98 \\
\hline 75,22 & 1646,20 & 195,50 & 11,43 & 8,26 & 7,28 & 6,40 & 5,70 & 5,10 & 4,09 & 3,32 & 2,29 \\
\hline 66,89 & 1935,80 & 190,00 & 11,35 & 8,61 & 7,70 & 6,79 & 6,05 & 5,38 & 4,28 & 3,44 & 2,34 \\
\hline 39,92 & 1744,70 & 39,10 & 44,34 & 39,82 & 37,31 & 33,73 & 30,28 & 27,06 & 21,49 & 17,14 & 11,40 \\
\hline 21,54 & 1094,10 & 161,80 & 30,93 & 22,06 & 16,71 & 11,73 & 8,64 & 6,71 & 4,62 & 3,57 & 2,48 \\
\hline 77,02 & 204,40 & 168,70 & 44,35 & 21,61 & 14,96 & 10,57 & 8,18 & 6,61 & 4,64 & 3,57 & 2,48 \\
\hline 57,19 & 833,40 & 151,90 & 20,57 & 14,64 & 12,40 & 10,32 & 8,72 & 7,40 & 5,45 & 4,18 & 2,77 \\
\hline 70,63 & 1052,70 & 24,10 & 49,72 & 39,47 & 37,46 & 35,75 & 33,79 & 31,84 & 28,10 & 24,69 & 18,98 \\
\hline 44,00 & 780,10 & 157,80 & 23,65 & 16,84 & 13,93 & 11,08 & 8,94 & 7,31 & 5,12 & 3,85 & 2,58 \\
\hline 78,02 & 379,10 & 173,90 & 28,07 & 15,70 & 11,92 & 9,22 & 7,55 & 6,33 & 4,63 & 3,58 & 2,43 \\
\hline 20,89 & 1699,90 & 58,10 & 58,40 & 49,11 & 41,48 & 32,51 & 25,49 & 20,25 & 13,66 & 10,16 & 6,86 \\
\hline 84,94 & 515,40 & 25,60 & 55,94 & 41,84 & 38,72 & 36,07 & 33,66 & 31,42 & 27,28 & 23,66 & 17,86 \\
\hline 28,92 & 795,20 & 186,10 & 26,27 & 18,07 & 13,95 & 10,10 & 7,60 & 5,96 & 4,08 & 3,12 & 2,16 \\
\hline 48,75 & 350,50 & 70,80 & 50,08 & 35,49 & 29,56 & 23,91 & 19,61 & 16,24 & 11,55 & 8,73 & 5,81 \\
\hline 44,29 & 266,20 & 138,80 & 42,62 & 24,23 & 18,00 & 13,12 & 10,09 & 8,03 & 5,54 & 4,24 & 2,94 \\
\hline 55,33 & 1286,20 & $\frac{100,00}{23,10}$ & 56,62 & 46,76 & 45,10 & $\begin{array}{l}10, \pm L \\
42,56\end{array}$ & 39,79 & 37,08 & 31,94 & 27,38 & 20,14 \\
\hline 25,71 & 1614,00 & 143,20 & 26,94 & 21,20 & 17,37 & 13,22 & 10,19 & 8,03 & 5,44 & 4,09 & 2,80 \\
\hline 39,70 & 936,80 & 30,50 & 64,30 & 57,30 & 52,73 & 46,76 & 41,20 & 36,17 & 27,85 & 21,72 & 14,19 \\
\hline 26,94 & 894,20 & 191,70 & 25,69 & 17,83 & 13,70 & 9,84 & 7,36 & 5,75 & 3,94 & 3,02 & 2,10 \\
\hline$\frac{20,54}{51,12}$ & 745,90 & 112,30 & 26,86 & $\frac{\perp, 00}{20,01}$ & $\frac{10,10}{17,14}$ & $\frac{0,04}{14,29}$ & 12,01 & 10,14 & 7,39 & 5,63 & 3,71 \\
\hline 41,96 & 546,80 & 158,40 & 28,34 & 18,75 & 14,91 & 11,41 & 8,96 & 7,19 & 4,97 & 3,76 & 2,56 \\
\hline 78,72 & 1181,20 & 40,80 & 31,79 & 24,53 & 23,01 & 21,73 & 20,43 & 19,17 & 16,81 & 14,69 & 11,22 \\
\hline 26,26 & 1094,20 & 97,80 & 38,94 & 30,69 & 25,23 & 19,29 & 14,91 & 11,78 & 7,98 & 6,00 & 4,09 \\
\hline 45,58 & 1208,80 & 199,80 & 16,76 & 12,38 & 10,44 & 8,50 & 6,98 & 5,78 & 4,10 & 3,09 & 2,05 \\
\hline 32,53 & 641,50 & 178,20 & 27,61 & 18,46 & 14,30 & 10,47 & 7,95 & 6,26 & 4,29 & 3,27 & 2,26 \\
\hline 22,98 & 1913,10 & 44,70 & 62,15 & 54,87 & 48,20 & 39,79 & 32,60 & 26,76 & 18,60 & 13,75 & 8,99 \\
\hline 20,47 & 217,60 & 69,00 & 90,57 & 55,91 & 39,35 & 26,40 & 19,39 & 15,27 & 10,73 & 8,35 & 5,84 \\
\hline 31,05 & 1045,60 & 66,20 & 45,34 & 37,91 & 32,79 & 26,74 & 21,77 & 17,83 & 12,41 & 9,24 & 6,09 \\
\hline 41,20 & 585,00 & 125,90 & 31,49 & 22,20 & 18,14 & 14,20 & 11,30 & 9,14 & 6,34 & 4,77 & 3,22 \\
\hline 86,83 & 867,00 & 33,10 & 38,27 & 29,08 & 26,95 & 25,46 & 24,02 & 22,62 & 19,99 & 17,63 & 13,68 \\
\hline 21,17 & 1363,70 & 108,90 & 39,36 & 30,39 & 24,14 & 17,68 & 13,25 & 10,30 & 6,97 & 5,31 & 3,67 \\
\hline 29,25 & 710,90 & 52,00 & 63,50 & 51,92 & 44,10 & 35,12 & 28,03 & 22,61 & 15,52 & 11,56 & 7,73 \\
\hline 58,25 & 1291,50 & 37,50 & 39,18 & 32,29 & 30,74 & 28,55 & 26,39 & 24,31 & 20,50 & 17,25 & 12,34 \\
\hline 69,10 & 581,10 & 192,40 & 21,09 & 12,91 & 10,28 & 8,22 & 6,84 & 5,77 & 4,23 & 3,26 & 2,19 \\
\hline 80,06 & 1138,00 & 41,00 & 31,80 & 24,44 & 22,87 & 21,58 & 20,28 & 19,03 & 16,69 & 14,59 & 11,15 \\
\hline 85,84 & 1864,60 & 124,60 & 12,97 & 9,50 & 8,69 & 7,97 & 7,36 & 6,81 & 5,81 & 4,97 & 3,67 \\
\hline 39,65 & 1036,60 & 151,90 & 22,71 & 17,17 & 14,44 & 11,58 & 9,36 & 7,65 & 5,34 & 4,01 & 2,67 \\
\hline 74,97 & 1614,20 & 47,30 & 26,60 & 20,79 & 19,62 & 18,61 & 17,53 & 16,47 & 14,47 & 12,66 & 9,68 \\
\hline 39,90 & 322,40 & 58,60 & 64,09 & 46,68 & 38,61 & 30,46 & 24,34 & 19,74 & 13,70 & 10,30 & 6,92 \\
\hline 65,22 & 1614,40 & 56,80 & 25,76 & 20,62 & 19,53 & 18,16 & 16,83 & 15,56 & 13,22 & 11,21 & 8,13 \\
\hline 63,16 & 1079,30 & 193,50 & 15,31 & 10,78 & 9,16 & 7,71 & 6,60 & 5,68 & 4,27 & 3,31 & 2,20 \\
\hline 47,74 & 577,30 & 58,10 & 45,29 & 36,08 & 31,69 & 26,94 & 22,94 & 19,56 & 14,44 & 11,03 & 7,22 \\
\hline 38,44 & 824,20 & 48,10 & 51,44 & 43,93 & 39,14 & 33,39 & 28,36 & 24,08 & 17,60 & 13,32 & 8,64 \\
\hline 21,86 & 1544,30 & 194,10 & 24,47 & 17,92 & 13,81 & 9,83 & 7,28 & 5,66 & 3,87 & 2,97 & 2,06 \\
\hline 45,69 & 1202,70 & 94,20 & 25,95 & 21,39 & 19,03 & 16,34 & 14,02 & 12,03 & 8,95 & 6,86 & 4,47 \\
\hline 65,32 & 645,90 & 168,90 & 21,26 & 13,83 & 11,32 & 9,24 & 7,76 & 6,58 & 4,85 & 3,74 & 2,50 \\
\hline 60,40 & 1740,70 & 150,70 & 14,27 & 11,22 & 10,08 & 8,89 & 7,87 & 6,97 & 5,47 & 4,36 & 2,92 \\
\hline 24,25 & 406,00 & 141,50 & 42,46 & 26,41 & 19,05 & 13,03 & 9,61 & 7,54 & 5,26 & 4,08 & 2,85 \\
\hline 77,37 & 1613,50 & 64,60 & 21,47 & 16,51 & 15,47 & 14,49 & 13,54 & 12,64 & 10,96 & 9,48 & 7,12 \\
\hline 52,92 & 773,30 & 46,50 & 43,16 & 35,84 & 32,71 & 29,06 & 25,80 & 22,85 & 17,93 & 14,22 & 9,48 \\
\hline 20,81 & 1014,30 & 96,70 & 47,03 & 35,41 & 27,62 & 19,85 & 14,74 & 11,43 & 7,79 & 5,97 & 4,14 \\
\hline 33,96 & 1275,30 & 71,30 & 37,60 & 32,09 & 28,28 & 23,68 & 19,75 & 16,49 & 11,77 & 8,81 & 5,74 \\
\hline 88,15 & 1806,50 & 53,20 & 21,08 & 16,43 & 15,16 & 14,48 & 13,79 & 13,09 & 11,74 & 10,50 & 8,35 \\
\hline 53,19 & 297,60 & 130,40 & 39,42 & 23,20 & $\begin{array}{l}10,+0 \\
17,78\end{array}$ & $\begin{array}{l}13,50 \\
13,50\end{array}$ & 10,69 & 8,67 & 6,06 & 4,61 & 3,15 \\
\hline 56,61 & 459,50 & 80,10 & 38,34 & 27,56 & 23,42 & 19,54 & 16,52 & 14,04 & 10,35 & $\frac{7,01}{7,94}$ & 5,25 \\
\hline 58,17 & 1855,10 & 20,30 & 53,37 & 43,75 & 41,93 & (ד, ד, & 38,63 & 36,62 & 32,68 & 28,97 & 22,58 \\
\hline 82,93 & 1392,90 & 55,30 & 23,95 & 18,23 & 16,98 & 15,97 & 15,00 & 14,07 & 12,33 & 10,78 & 8,24 \\
\hline 32,69 & 1827,40 & 105,00 & 26,55 & 22,53 & 19,74 & 16,38 & 13,54 & 11,23 & 7,94 & 5,92 & 3,87 \\
\hline 41,82 & 208,70 & 64,80 & 71,65 & 46,68 & 36,83 & 27,99 & 21,89 & 17,55 & 12,11 & 9,17 & 6,27 \\
\hline 41,84 & 1085,40 & 153,70 & 21,43 & 16,29 & 13,82 & 11,22 & 9,17 & 7,56 & 5,33 & 4,00 & 2,65 \\
\hline 74,11 & 1279,20 & 88,00 & 19,99 & 15,18 & 13,92 & 12,63 & 11,54 & 10,53 & 8,76 & 7,30 & 5,19 \\
\hline 81.92 & 610,80 & 86.10 & 27,34 & 18.92 & 16,44 & 14,32 & 12.75 & 11,41 & 9,18 & 7,48 & 5,20 \\
\hline 58,78 & 1426,70 & 54,60 & 29,30 & 24,12 & 22,70 & 20,83 & 19,08 & 17,42 & 14,44 & 11,97 & 8,39 \\
\hline 81,74 & 1630,20 & 41,30 & 27,05 & 21,30 & 19,85 & 19,02 & 18,11 & 17,18 & 15,38 & 13,72 & 10,85 \\
\hline 48,72 & 956,40 & 123,60 & 23,41 & 17,95 & 15,51 & 12,99 & 10,94 & 9,24 & 6,74 & 5,12 & 3,37 \\
\hline 47,13 & 731,50 & 197,20 & 20,96 & 14,01 & 11,32 & 8,88 & 7,13 & 5,81 & 4,06 & 3,07 & 2,07 \\
\hline 53,70 & 354,40 & 138,00 & 34,73 & 21,05 & 16,39 & 12,62 & 10,08 & 8,22 & 5,77 & 4,38 & 2,98 \\
\hline 41,76 & 852,90 & 98,20 & 30,86 & 24,23 & 20,86 & 17,20 & 14,23 & 11,83 & 8,43 & 6,34 & 4,17 \\
\hline 85,19 & 1182,10 & 134,40 & 15,46 & 10,86 & 9,60 & 8,51 & 7,68 & 6,95 & 5,72 & 4,75 & 3,37 \\
\hline 82,14 & 1224,40 & 190,30 & 13,02 & 8,89 & 7,65 & 6,62 & 5,86 & 5,22 & 4,17 & 3,39 & 2,34 \\
\hline 80,42 & 1468,50 & 148,00 & 13,56 & 9,79 & 8,74 & 7,79 & 7,04 & 6,38 & 5,24 & 4,34 & 3,06 \\
\hline 74,37 & 529,00 & 70,30 & 33,74 & 24,11 & 21,06 & 18,35 & 16,25 & 14,44 & 11,46 & 9,23 & 6,31 \\
\hline 74,37 & 730,10 & 42,90 & 38,36 & 29,34 & 27,14 & 24,85 & 22,83 & 20,98 & 17,64 & 14,85 & 10,69 \\
\hline
\end{tabular}




\begin{tabular}{|c|c|c|c|c|c|c|c|c|c|c|c|}
\hline \multirow[b]{2}{*}{ e1 (cm) } & & & & & & & ões (x1 & m) & & & \\
\hline & Meq (MPa) & Ms (MPa) & D0 & D25 & D40 & D60 & D80 & D100 & D140 & D180 & D260 \\
\hline 23,74 & 1013,30 & 28,80 & 99,93 & 87,23 & 76,16 & 62,38 & 50,78 & 41,49 & 28,69 & 21,22 & 13,95 \\
\hline 63,95 & 1533,30 & 90,50 & 19,72 & 15,71 & 14,50 & 13,12 & 11,90 & 10,77 & 8,81 & 7,23 & 5,01 \\
\hline 65,64 & 1188,90 & 171,10 & 15,23 & 11,06 & 9,58 & 8,23 & 7,17 & 6,26 & 4,82 & 3,79 & 2,54 \\
\hline 84,68 & 1395,80 & 178,10 & 12,40 & 8,61 & 7,54 & 6,63 & 5,94 & 5,36 & 4,37 & 3,60 & 2,53 \\
\hline 49,75 & 579,30 & 173,00 & 24,62 & 16,02 & 12,84 & 10,06 & 8,08 & 6,60 & 4,64 & 3,51 & 2,37 \\
\hline 39,93 & 1047,40 & 27,80 & 65,71 & 58,91 & 54,77 & 49,11 & 43,75 & 38,80 & 30,40 & 24,01 & 15,83 \\
\hline 47,02 & 1524,90 & 136,10 & 18,58 & 15,05 & 13,31 & 11,38 & 9,73 & 8,33 & 6,18 & 4,73 & 3,09 \\
\hline 45,93 & 749,70 & 41,00 & 51,77 & 44,15 & 40,09 & 35,22 & 30,84 & 26,94 & 20,62 & 16,05 & 10,52 \\
\hline 23,88 & 1603,50 & 169,90 & 25,17 & 19,16 & 15,26 & 11,25 & 8,48 & 6,62 & 4,49 & 3,42 & 2,36 \\
\hline 79,03 & 1829,60 & 51,80 & 23,11 & 18,03 & 16,90 & 16,11 & 15,24 & 14,39 & 12,76 & 11,27 & 8,75 \\
\hline 31,89 & 1094,10 & 100,00 & 33,42 & 26,81 & 22,71 & 18,10 & 14,48 & 11,72 & 8,07 & 6,02 & 4,03 \\
\hline 35,15 & 814,50 & 103,50 & 34,00 & 26,22 & 21,98 & 17,41 & 13,90 & 11,24 & 7,76 & 5,81 & 3,90 \\
\hline 83,26 & 1247,70 & 176,60 & 13,28 & 9,15 & 7,94 & 6,92 & 6,17 & 5,52 & 4,46 & 3,64 & 2,54 \\
\hline 33,55 & 859,00 & 57,30 & 50,29 & 42,07 & 36,64 & 30,22 & 24,88 & 20,56 & 14,48 & 10,81 & 7,09 \\
\hline 31,39 & 1172,10 & 100,20 & 32,96 & 26,63 & 22,62 & 18,06 & 14,47 & 11,71 & 8,07 & 6,02 & 4,02 \\
\hline 21,80 & 1850,20 & 79,00 & 44,37 & 36,82 & 30,87 & 24,00 & 18,71 & 14,82 & 10,00 & 7,46 & 5,05 \\
\hline 75,46 & 1595,30 & 197,50 & 11,53 & 8,28 & 7,28 & 6,38 & 5,67 & 5,07 & 4,05 & 3,28 & 2,26 \\
\hline 44,69 & 368,50 & 114,60 & 39,51 & 25,65 & 20,34 & 15,62 & 12,33 & 9,95 & 6,90 & 5,22 & 3,55 \\
\hline 68,61 & 1617,20 & 117,00 & 15,95 & 12,34 & 11,27 & 10,14 & 9,18 & 8,30 & 6,78 & 5,57 & 3,87 \\
\hline 40,17 & 1868,40 & 25,10 & 59,30 & 52,50 & 50,35 & 46,54 & 42,71 & 39,00 & 32,23 & 26,56 & 18,36 \\
\hline 44,34 & 1688,30 & 28,90 & 51,58 & 45,01 & 43,09 & 39,85 & 36,60 & 33,47 & 27,75 & 22,95 & 15,95 \\
\hline 49,49 & 897,60 & 175,10 & 19,77 & 14,08 & 11,78 & 9,58 & 7,89 & 6,55 & 4,68 & 3,54 & 2,35 \\
\hline 85,61 & 1318,50 & 170,80 & 12,97 & 8,97 & 7,84 & 6,89 & 6,18 & 5,57 & 4,54 & 3,75 & 2,64 \\
\hline 80,27 & 502,00 & 71,00 & 33,48 & 23,28 & 20,23 & 17,61 & 15,64 & 13,97 & 11,19 & 9,10 & 6,29 \\
\hline 33,78 & 1184,80 & 48,30 & 49,85 & 43,83 & 39,27 & 33,56 & 28,49 & 24,16 & 17,59 & 13,26 & 8,57 \\
\hline 75,03 & 1902,60 & 37,70 & 28,80 & 23,05 & 21,65 & 20,85 & 19,88 & 18,88 & 16,92 & 15,10 & 11,93 \\
\hline 77,64 & 398,70 & 100,40 & 33,10 & 21,08 & 17,29 & 14,31 & 12,26 & 10,61 & 8,09 & 6,37 & 4,31 \\
\hline 22,94 & 608,20 & 188,10 & 31,52 & 19,95 & 14,39 & 9,81 & 7,22 & 5,66 & 3,95 & 3,07 & 2,14 \\
\hline 39,34 & 1602,80 & 77,40 & 29,31 & 25,47 & 22,98 & 19,90 & 17,15 & 14,75 & 10,99 & 8,40 & 5,45 \\
\hline 32,30 & 1598,20 & 180,80 & 19,73 & 15,40 & 12,87 & 10,11 & 8,01 & 6,44 & 4,41 & 3,30 & 2,22 \\
\hline 23,48 & 775,80 & 110,10 & 42,69 & 31,11 & 24,09 & 17,29 & 12,87 & 10,02 & 6,84 & 5,25 & 3,64 \\
\hline 35,50 & 1015,50 & 41,80 & 55,50 & 48,85 & 43,97 & 37,85 & 32,38 & 27,65 & 20,36 & 15,44 & 9,97 \\
\hline 54,34 & 1311,10 & 99,80 & 21,69 & 17,60 & 15,86 & 13,94 & 12,27 & 10,79 & 8,36 & 6,58 & 4,37 \\
\hline 49,67 & 997,20 & 134,20 & 21,70 & 16,52 & 14,24 & 11,93 & 10,05 & 8,50 & 6,20 & 4,72 & 3,10 \\
\hline 45,38 & 1731,90 & 192,50 & 14,71 & 11,59 & 10,07 & 8,44 & 7,09 & 5,98 & 4,34 & 3,29 & 2,15 \\
\hline 47,76 & 687,60 & 73,20 & 36,81 & 29,10 & 25,47 & 21,57 & 18,31 & 15,57 & 11,45 & 8,73 & 5,72 \\
\hline 54,37 & 312,00 & 180,20 & 33,52 & 18,28 & 13,46 & 9,90 & 7,73 & 6,23 & 4,33 & 3,31 & 2,28 \\
\hline 87,57 & 1760,80 & 49,10 & 22,41 & 17,57 & 16,21 & 15,51 & 14,79 & 14,05 & 12,63 & 11,31 & 9,02 \\
\hline 24,50 & 500,90 & 126,70 & 42,86 & 28,51 & 21,19 & 14,77 & 10,91 & 8,52 & 5,90 & 4,56 & 3,18 \\
\hline 59,10 & 785,00 & 29,90 & 53,33 & 43,84 & 41,28 & 37,91 & 34,74 & 31,75 & 26,36 & 21,88 & 15,37 \\
\hline 61,40 & 1984,20 & 98,40 & 17,38 & 14,08 & 13,10 & 11,92 & 10,85 & 9,85 & 8,09 & 6,66 & 4,63 \\
\hline 85,03 & 368,80 & 190,20 & 27,51 & 14,83 & 11,04 & 8,41 & 6,86 & 5,75 & 4,21 & 3,27 & 2,23 \\
\hline 25,33 & 1018,60 & 125,10 & 34,37 & 25,87 & 20,59 & 15,21 & 11,51 & 9,00 & 6,11 & 4,65 & 3,20 \\
\hline 82,52 & 1248,40 & 162,40 & 13,87 & 9,68 & 8,46 & 7,42 & 6,64 & 5,96 & 4,83 & 3,96 & 2,77 \\
\hline 31,82 & 1928,80 & 184,40 & 18,44 & 14,70 & 12,42 & 9,86 & 7,86 & 6,34 & 4,36 & 3,26 & 2,18 \\
\hline 26,88 & 1790,90 & 65,20 & 43,03 & 37,40 & 32,78 & 27,05 & 22,20 & 18,27 & 12,76 & 9,46 & 6,19 \\
\hline 84,74 & 445,20 & 116,70 & 28,46 & 17,69 & 14,40 & 11,91 & 10,24 & 8,92 & 6,89 & 5,48 & 3,74 \\
\hline 48,61 & 288,90 & 33,80 & 82,07 & 63,92 & 55,63 & 46,91 & 39,71 & 33,71 & 24,72 & 18,84 & 12,35 \\
\hline 58,66 & 454,30 & 165,20 & 27,20 & 16,62 & 13,08 & 10,23 & 8,30 & 6,85 & 4,87 & 3,71 & 2,50 \\
\hline 74,17 & 1149,80 & 32,90 & 38,18 & 29,92 & 28,26 & 26,81 & 25,25 & 23,73 & 20,84 & 18,23 & 13,93 \\
\hline 26,79 & 1705,40 & 79,60 & 38,32 & 32,52 & 28,07 & 22,72 & 18,33 & 14,90 & 10,27 & 7,62 & 5,04 \\
\hline 37,48 & 670,00 & 95,80 & 36,90 & 27,99 & 23,44 & 18,63 & 14,94 & 12,13 & 8,41 & 6,31 & 4,22 \\
\hline 35,75 & 765,30 & 139,60 & 28,61 & 20,81 & 16,98 & 13,11 & 10,29 & 8,23 & 5,65 & 4,26 & 2,89 \\
\hline 74,13 & 852,00 & 196,20 & 16,30 & 10,65 & 8,83 & 7,36 & 6,31 & 5,46 & 4,16 & 3,27 & 2,20 \\
\hline 80,12 & 1125,50 & 72,60 & 22,68 & 16,93 & 15,56 & 14,24 & 13,11 & 12,08 & 10,22 & 8,67 & 6,31 \\
\hline 68,46 & 1998,90 & 75,50 & 19,32 & 15,27 & 14,42 & 13,41 & 12,45 & 11,53 & 9,84 & 8,38 & 6,12 \\
\hline 57,08 & 1077,00 & 48,70 & 35,42 & 29,32 & 27,31 & 24,80 & 22,49 & 20,34 & 16,57 & 13,53 & 9,31 \\
\hline 33,04 & 805,00 & 170,10 & 25,90 & 18,30 & 14,58 & 10,94 & 8,42 & 6,66 & 4,55 & 3,45 & 2,37 \\
\hline 27,41 & 863,70 & 143,10 & 31,40 & 22,82 & 17,99 & 13,22 & 9,99 & 7,83 & 5,33 & 4,06 & 2,81 \\
\hline 83,12 & 1427,30 & 135,30 & 14,21 & 10,22 & 9,17 & 8,21 & 7,46 & 6,80 & 5,64 & 4,71 & 3,36 \\
\hline 84,42 & 460,20 & 53,80 & 39,30 & 27,60 & 24,34 & 21,52 & 19,38 & 17,53 & 14,38 & 11,89 & 8,40 \\
\hline 53,99 & 659,20 & 186,60 & 21,53 & 14,08 & 11,39 & 9,06 & 7,39 & 6,11 & 4,34 & 3,30 & 2,21 \\
\hline 73,28 & 562,10 & 166,10 & 22,41 & 13,95 & 11,24 & 9,14 & 7,70 & 6,57 & 4,90 & 3,81 & 2,56 \\
\hline 58,86 & 1226,60 & 35,00 & 41,49 & 34,09 & 32,48 & 30,22 & 27,97 & 25,81 & 21,83 & 18,42 & 13,23 \\
\hline 88,55 & 1365,30 & 187,60 & 12,03 & 8,19 & 7,12 & 6,23 & 5,58 & 5,03 & 4,11 & 3,40 & 2,40 \\
\hline 31,78 & 1518,30 & 182,90 & 20,16 & 15,58 & 12,93 & 10,07 & 7,92 & 6,34 & 4,34 & 3,25 & 2,20 \\
\hline 69,48 & 257,20 & 141,40 & 39,82 & 21,57 & 15,99 & 12,02 & 9,62 & 7,91 & 5,63 & 4,32 & 2,95 \\
\hline 31,72 & 885,70 & 164,60 & 26,11 & 18,84 & 15,08 & 11,34 & 8,72 & 6,90 & 4,70 & 3,56 & 2,44 \\
\hline 59,57 & 1217,90 & 110,60 & 20,00 & 15,69 & 14,04 & 12,33 & 10,88 & 9,59 & 7,48 & 5,93 & 3,96 \\
\hline 23,61 & 1662,90 & 68,90 & 47,27 & 39,85 & 33,95 & 26,97 & 21,40 & 17,16 & 11,67 & 8,66 & 5,80 \\
\hline 38,81 & 824,30 & 150,30 & 25,39 & 18,49 & 15,24 & 11,96 & 9,51 & 7,69 & 5,32 & 4,00 & 2,69 \\
\hline 64,17 & 1127,00 & 192,70 & 14,90 & 10,56 & 9,01 & 7,63 & 6,56 & 5,67 & 4,29 & 3,34 & 2,22 \\
\hline 52,88 & 758,60 & 59,00 & 37,63 & 30,59 & 27,49 & 24,07 & 21,09 & 18,46 & 14,20 & 11,12 & 7,34 \\
\hline 70,61 & 1136,70 & 145,10 & 16,39 & 11,91 & 10,44 & 9,09 & 8,03 & 7,11 & 5,60 & 4,48 & 3,04 \\
\hline 76,17 & 1234,90 & 28,20 & 40,15 & 31,81 & 29,89 & 28,66 & 27,25 & 25,80 & 23,01 & 20,43 & 16,02 \\
\hline 42,94 & 1308,80 & 34,80 & 49,90 & 44,24 & 41,41 & 37,44 & 33,66 & 30,12 & 24,00 & 19,21 & 12,84 \\
\hline 69,82 & 956,30 & 131,00 & 18,89 & 13,63 & 11,88 & 10,28 & 9,04 & 7,97 & 6,23 & 4,96 & 3,35 \\
\hline 43,84 & 1735,80 & 35,10 & 44,88 & 39,50 & 37,51 & 34,41 & 31,36 & 28,46 & 23,26 & 19,00 & 13,00 \\
\hline 35,09 & 716,70 & 134,10 & 30,39 & 21,99 & 17,86 & 13,71 & 10,71 & 8,55 & 5,86 & 4,42 & 3,01 \\
\hline 49,27 & 1963,50 & 78,20 & 23,13 & 19,85 & 18,43 & 16,60 & 14,89 & 13,32 & 10,61 & 8,50 & 5,71 \\
\hline 46,63 & 1804,20 & 152,20 & 16,33 & 13,32 & 11,81 & 10,13 & 8,68 & 7,44 & 5,53 & 4,24 & 2,77 \\
\hline 73,45 & 1497,40 & 53,60 & 25,60 & 19,94 & 18,80 & 17,64 & 16,48 & 15,38 & 13,31 & 11,50 & 8,59 \\
\hline
\end{tabular}




\begin{tabular}{|c|c|c|c|c|c|c|c|c|c|c|c|}
\hline \multirow[b]{2}{*}{ e1 (cm) } & & & & & & & ões (x1 & m) & & & \\
\hline & Meq (MPa) & Ms (MPa) & D0 & D25 & D40 & D60 & D80 & D100 & D140 & D180 & D260 \\
\hline 75,85 & 1822,90 & 134,40 & 13,33 & 10,02 & 9,15 & 8,28 & 7,55 & 6,89 & 5,73 & 4,78 & 3,40 \\
\hline 23,04 & 1505,20 & 32,70 & 82,78 & 73,54 & 64,89 & 53,88 & 44,38 & 36,58 & 25,55 & 18,90 & 12,32 \\
\hline 20,27 & 1015,70 & 26,00 & 122,63 & 105,22 & 90,12 & 71,82 & 57,03 & 45,69 & 30,98 & 22,93 & 15,33 \\
\hline 43,85 & 871,00 & 125,00 & 25,76 & 19,52 & 16,61 & 13,58 & 11,17 & 9,26 & 6,58 & 4,95 & 3,28 \\
\hline 63,77 & 1456,80 & 20,20 & 53,90 & 43,82 & 41,76 & 40,33 & 38,42 & 36,42 & 32,52 & 28,87 & 22,58 \\
\hline 77,92 & 409,10 & 179,40 & 26,39 & 14,91 & 11,40 & 8,87 & 7,29 & 6,13 & 4,49 & 3,48 & 2,36 \\
\hline 61,63 & 610,20 & 98,90 & 28,77 & 20,71 & 17,75 & 15,03 & 12,90 & 11,12 & 8,37 & 6,50 & 4,32 \\
\hline 43,63 & 1247,00 & 194,00 & 17,23 & $\begin{array}{l}12,88 \\
\end{array}$ & 10,88 & 8,84 & 7,23 & 5,97 & 4,22 & 3,18 & 2,11 \\
\hline 30,58 & 253,10 & 153,40 & 44,78 & 24,50 & 17,29 & 11,88 & 8,86 & 6,99 & 4,86 & 3,77 & 2,65 \\
\hline 55,30 & 1160,60 & 83,30 & 25,13 & 20,43 & 18,50 & 16,35 & 14,47 & 12,78 & 9,99 & 7,91 & 5,27 \\
\hline 29,56 & 1613,10 & 37,10 & 59,74 & 54,36 & 49,34 & 42,74 & 36,69 & 31,39 & 23,12 & 17,50 & 11,24 \\
\hline 39,27 & 1933,90 & 195,60 & 15,33 & 12,26 & 10,58 & 8,72 & 7,19 & 5,97 & 4,23 & 3,17 & 2,09 \\
\hline 64,53 & 886,50 & 29,90 & 48,51 & 38,96 & 36,94 & 34,38 & 31,88 & 29,49 & 25,08 & 21,29 & 15,45 \\
\hline 21,93 & 563,70 & 45,40 & 92,25 & 71,62 & 57,28 & 42,28 & 31,85 & 24,81 & 16,78 & 12,75 & 8,80 \\
\hline 75,40 & 1570,00 & 76,80 & 19,80 & 15,20 & 14,18 & 13,12 & 12,15 & 11,25 & 9,59 & 8,18 & 6,00 \\
\hline 79,68 & 1948,00 & 197,20 & 10,24 & 7,41 & 6,61 & 5,89 & 5,32 & 4,81 & 3,95 & 3,26 & 2,30 \\
\hline 74,10 & 1321,20 & 148,50 & 14,75 & 10,76 & 9,53 & 8,40 & 7,50 & 6,71 & 5,39 & 4,37 & 3,01 \\
\hline 28,65 & 1100,10 & 55,90 & 53,14 & 45,09 & 39,09 & 31,88 & 25,92 & 21,20 & 14,71 & 10,93 & 7,20 \\
\hline 81,16 & 276,80 & 176,30 & 34,81 & 17,97 & 12,97 & 9,57 & 7,63 & 6,29 & 4,51 & 3,48 & 2,39 \\
\hline 54,59 & 1201,80 & 31,80 & 46,73 & 39,12 & 37,29 & 34,56 & 31,87 & 29,28 & 24,55 & 20,53 & 14,55 \\
\hline 78,33 & 1548,80 & 193,90 & 11,63 & 8,26 & 7,25 & 6,36 & 5,68 & 5,08 & 4,09 & 3,33 & 2,31 \\
\hline 77,16 & 1078,10 & 95,80 & 20,12 & 14,85 & 13,39 & 12,00 & 10,87 & 9,86 & 8,12 & 6,72 & 4,73 \\
\hline 42,17 & 1520,80 & 71,90 & 29,73 & 25,81 & 23,45 & 20,54 & 17,90 & 15,57 & 11,81 & 9,13 & 5,95 \\
\hline 52,60 & 1319,50 & 194,80 & 15,11 & 11,27 & 9,68 & 8,11 & 6,85 & 5,81 & 4,27 & 3,26 & 2,15 \\
\hline 58,82 & 1893,40 & 131,70 & 15,14 & 12,19 & 11,10 & 9,88 & 8,82 & 7,86 & 6,24 & 5,00 & 3,38 \\
\hline 20,34 & 209,70 & 183,10 & 45,19 & 21,56 & 14,21 & 9,51 & 7,15 & 5,71 & 4,01 & 3,14 & 2,23 \\
\hline 46,52 & 478,20 & 132,70 & 31,77 & 21,12 & 17,00 & 13,28 & 10,61 & 8,63 & 6,02 & 4,55 & 3,07 \\
\hline 44,39 & 1370,20 & 132,20 & 20,50 & 16,48 & 14,44 & 12,18 & 10,28 & 8,69 & 6,34 & 4,81 & 3,14 \\
\hline 20,85 & 1895,90 & 167,90 & 26,52 & 20,17 & 15,83 & 11,45 & 8,53 & 6,62 & 4,50 & 3,44 & 2,38 \\
\hline 24,30 & 563,60 & 43,30 & 88,70 & 70,41 & 57,71 & 43,85 & 33,71 & 26,52 & 17,92 & 13,49 & 9,22 \\
\hline 59,15 & 682,40 & 54,60 & 38,54 & 30,64 & 27,65 & 24,45 & 21,69 & 19,22 & 15,11 & 12,04 & 8,08 \\
\hline 80,11 & 1263,70 & 86,60 & 19,52 & 14,52 & 13,30 & 12,13 & 11,14 & 10,24 & 8,64 & 7,30 & 5,29 \\
\hline 35,02 & 240,20 & 137,50 & 47,40 & 26,42 & 19,03 & 13,35 & 10,03 & 7,91 & 5,47 & 4,22 & 2,96 \\
\hline 67,89 & 1839,40 & 50,30 & 26,06 & 20,71 & 19,71 & 18,61 & 17,44 & 16,31 & 14,17 & 12,27 & 9,19 \\
\hline 73,86 & 1452,50 & 130,40 & 15,16 & 11,31 & 10,19 & 9,11 & 8,22 & 7,42 & 6,05 & 4,97 & 3,47 \\
\hline 42,60 & 1422,30 & 89,90 & 26,28 & 22,24 & 19,91 & 17,17 & 14,75 & 12,67 & 9,42 & 7,21 & 4,69 \\
\hline 37,65 & 1184,60 & 171,60 & 20,65 & 15,64 & 13,09 & 10,40 & 8,34 & 6,77 & 4,70 & 3,52 & 2,36 \\
\hline 65,24 & 794,20 & 23,30 & 59,04 & 47,29 & 45,02 & 42,22 & 39,37 & 36,61 & 31,47 & 26,97 & 19,87 \\
\hline 89,27 & 1242,70 & 105,30 & 16,78 & 11,97 & 10,78 & 9,76 & 8,95 & 8,23 & 6,97 & 5,92 & 4,33 \\
\hline 60,10 & 1058,00 & 86,10 & 24,40 & 19,31 & 17,41 & 15,40 & 13,68 & 12,13 & 9,56 & 7,63 & 5,13 \\
\hline 74,48 & 1403,40 & 74,70 & 21,17 & 16,25 & 15,10 & 13,90 & 12,82 & 11,82 & 10,01 & 8,48 & 6,15 \\
\hline 83,08 & 1747,80 & 52,10 & 22,63 & 17,57 & 16,37 & 15,60 & 14,79 & 13,98 & 12,45 & 11,04 & 8,65 \\
\hline 77,98 & 1600,30 & 196,50 & 11,38 & 8,12 & 7,14 & 6,27 & 5,60 & 5,01 & 4,04 & 3,29 & 2,28 \\
\hline 41,44 & 427,10 & 37,00 & 73,46 & 59,98 & 52,59 & 44,21 & 37,14 & 31,27 & 22,62 & 17,08 & 11,15 \\
\hline 60,42 & 1654,00 & 49,20 & 29,45 & 24,04 & 22,89 & 21,30 & 19,73 & 18,23 & 15,45 & 13,06 & 9,42 \\
\hline 63,33 & 837,30 & 27,70 & 52,71 & 42,53 & 40,36 & 37,54 & 34,78 & 32,15 & 27,29 & 23,12 & 16,73 \\
\hline 64,95 & 1104,10 & 30,80 & 44,05 & 35,32 & 33,67 & 31,64 & 29,54 & 27,51 & 23,70 & 20,35 & 15,04 \\
\hline 48,73 & 1130,30 & 79,60 & 28,22 & 23,40 & 21,04 & 18,35 & 15,98 & 13,91 & 10,58 & 8,22 & 5,39 \\
\hline 29,21 & 1341,10 & 105,00 & 32,19 & 26,10 & 22,06 & 17,47 & 13,88 & 11,16 & 7,64 & 5,70 & 3,82 \\
\hline 70,87 & 418,20 & 52,90 & 44,70 & 32,51 & 28,52 & 24,85 & 21,97 & 19,47 & 15,36 & 12,31 & 8,36 \\
\hline 65,77 & 1899,60 & 129,10 & 14,40 & 11,31 & 10,35 & 9,32 & 8,43 & 7,61 & 6,19 & 5,06 & 3,50 \\
\hline 73,33 & 847,60 & 50,90 & 32,86 & 25,20 & 23,29 & 21,28 & 19,52 & 17,89 & 14,99 & 12,57 & 9,00 \\
\hline 41,60 & 1478,80 & 126,20 & 21,37 & 17,49 & 15,35 & 12,93 & 10,88 & 9,17 & 6,65 & 5,02 & 3,28 \\
\hline 78,16 & 1909,50 & 37,50 & 27,90 & 22,45 & 20,93 & 20,18 & 19,32 & 18,39 & 16,57 & 14,87 & 11,88 \\
\hline 69,38 & 866,00 & 161,40 & 18,03 & 12,41 & 10,51 & 8,89 & 7,67 & 6,66 & 5,08 & 3,99 & 2,68 \\
\hline 68,28 & 1326,80 & 197,50 & 13,19 & 9,45 & 8,17 & 7,02 & 6,13 & 5,37 & 4,15 & 3,28 & 2,21 \\
\hline 54,40 & 747,10 & 113,70 & 25,80 & 19,08 & 16,38 & 13,75 & 11,65 & 9,92 & 7,31 & 5,60 & 3,70 \\
\hline 81,14 & 1705,40 & 116,90 & 14,37 & 10,65 & 9,75 & 8,90 & 8,18 & 7,53 & 6,36 & 5,39 & 3,92 \\
\hline 34,11 & 1073,70 & 101,90 & 31,68 & 25,41 & 21,67 & 17,46 & 14,11 & 11,50 & 7,99 & 5,96 & 3,96 \\
\hline 77,16 & 1989,10 & 151,60 & 11,88 & 8,87 & 8,08 & 7,31 & 6,67 & 6,08 & 5,06 & 4,22 & 3,01 \\
\hline 65,22 & 846,60 & 119,80 & 21,64 & 15,76 & 13,68 & 11,76 & 10,24 & 8,95 & 6,88 & 5,42 & 3,62 \\
\hline 40,34 & 1259,80 & 31,20 & 56,88 & 50,97 & 47,59 & 42,86 & 38,36 & 34,17 & 26,99 & 21,44 & 14,21 \\
\hline 71,29 & 477,80 & 159,40 & 25,36 & 15,44 & 12,27 & 9,83 & 8,19 & 6,93 & 5,10 & 3,95 & 2,65 \\
\hline 33,64 & 1387,30 & 183,00 & 20,06 & 15,35 & 12,75 & 9,98 & 7,89 & 6,34 & 4,35 & 3,26 & 2,20 \\
\hline 59,29 & 847,10 & 113,20 & 23,31 & 17,41 & 15,15 & 12,96 & 11,19 & 9,69 & 7,34 & 5,71 & 3,78 \\
\hline 61,97 & 752,70 & 81,40 & 28,75 & 21,94 & 19,42 & 16,93 & 14,87 & 13,07 & 10,15 & 8,02 & 5,37 \\
\hline 54,62 & 1355,60 & 81,20 & 24,19 & 19,98 & 18,28 & 16,29 & 14,52 & 12,91 & 10,20 & 8,14 & 5,46 \\
\hline 85,18 & 417,00 & 33,00 & 53,02 & 38,46 & 34,87 & 31,64 & 29,01 & 26,66 & 22,50 & 19,04 & 13,86 \\
\hline 48,37 & 697,20 & 125,20 & 26,90 & 19,50 & 16,41 & 13,39 & 11,04 & 9,18 & 6,56 & 4,96 & 3,29 \\
\hline 79,92 & 1981,70 & 189,60 & 10,36 & 7,53 & 6,75 & 6,03 & 5,46 & 4,96 & 4,08 & 3,38 & 2,39 \\
\hline 72,51 & 365,70 & 101,50 & 35,41 & 22,38 & 18,17 & 14,85 & 12,56 & 10,74 & 8,04 & 6,25 & 4,20 \\
\hline 82,55 & 689,00 & 183,90 & 18,40 & 11,45 & 9,31 & 7,68 & 6,58 & 5,72 & 4,39 & 3,47 & 2,36 \\
\hline 26,51 & 419,30 & 89,30 & 55,47 & 38,48 & 29,50 & 21,11 & 15,77 & 12,32 & 8,44 & 6,48 & 4,50 \\
\hline 22,15 & 1247,20 & 81,20 & 48,25 & 38,45 & 31,34 & 23,61 & 18,01 & 14,10 & 9,51 & 7,17 & 4,92 \\
\hline 53,88 & 829,10 & 27,70 & 58,22 & 49,05 & 46,25 & 42,37 & 38,67 & 35,18 & 28,94 & 23,82 & 16,51 \\
\hline 50,11 & 250,90 & 127,60 & 44,53 & 25,30 & 18,96 & 14,06 & 10,96 & 8,81 & 6,11 & 4,66 & 3,21 \\
\hline 33,65 & 1208,60 & 126,90 & 26,64 & 21,06 & 17,80 & 14,19 & 11,37 & 9,21 & 6,36 & 4,75 & 3,18 \\
\hline 20,47 & 1585,60 & 65,10 & 55,94 & 46,08 & 38,28 & 29,39 & 22,69 & 17,85 & 12,01 & 8,99 & 6,12 \\
\hline 79,32 & 1439,10 & 67,70 & 21,49 & 16,33 & 15,22 & 14,16 & 13,18 & 12,26 & 10,57 & 9,10 & 6,78 \\
\hline 29,83 & 1305,20 & 87,50 & 36,11 & 29,88 & 25,60 & 20,61 & 16,60 & 13,48 & 9,30 & 6,92 & 4,60 \\
\hline 85,02 & 1139,10 & 61,90 & 24,01 & 17,86 & 16,48 & 15,28 & 14,21 & 13,23 & 11,42 & 9,86 & 7,39 \\
\hline 41,36 & 1601,80 & 149,10 & 18,79 & 15,20 & 13,26 & 11,09 & 9,28 & 7,78 & 5,60 & 4,22 & 2,76 \\
\hline
\end{tabular}




\begin{tabular}{|c|c|c|c|c|c|c|c|c|c|c|c|}
\hline \multirow[b]{2}{*}{ e1 (cm) } & & & & & & & ões (x1 & m) & & & \\
\hline & Meq (MPa) & Ms (MPa) & D0 & D25 & D40 & D60 & D80 & D100 & D140 & D180 & D260 \\
\hline 74,00 & 273,10 & 53,80 & 54,43 & 36,64 & 30,87 & 26,08 & 22,58 & 19,69 & 15,16 & 11,98 & 8,08 \\
\hline 62,01 & 1773,30 & 58,40 & 25,24 & 20,48 & 19,43 & 18,05 & 16,69 & 15,40 & 13,03 & 11,00 & 7,92 \\
\hline 32,70 & 1696,80 & 194,00 & 18,31 & 14,28 & 11,95 & 9,40 & 7,46 & 6,00 & 4,12 & 3,08 & 2,07 \\
\hline 73,01 & 1482,00 & 80,40 & 20,03 & 15,44 & 14,35 & 13,17 & 12,13 & 11,15 & 9,40 & 7,93 & 5,71 \\
\hline 54,62 & 717,10 & 77,80 & 32,24 & 25,10 & 22,10 & 19,02 & 16,44 & 14,23 & 10,75 & 8,34 & 5,50 \\
\hline 74,67 & 1087,60 & 119,50 & 18,07 & 13,19 & 11,71 & 10,33 & 9,24 & 8,29 & 6,67 & 5,43 & 3,75 \\
\hline 54,87 & 1705,80 & 138,00 & 15,99 & 12,87 & 11,56 & 10,14 & 8,91 & 7,82 & 6,05 & 4,75 & 3,15 \\
\hline 85,34 & 1478,40 & 81,00 & 18,37 & 13,65 & 12,58 & 11,67 & 10,85 & 10,10 & 8,72 & 7,53 & 5,65 \\
\hline 44,38 & 746,40 & 22,80 & 77,92 & 68,58 & 63,96 & 57,68 & 51,74 & 46,21 & 36,71 & 29,32 & 19,57 \\
\hline 74,23 & 1419,30 & 139,80 & 14,71 & 10,87 & 9,73 & 8,65 & 7,77 & 7,00 & 5,67 & 4,64 & 3,22 \\
\hline 37,98 & 919,70 & 153,90 & 24,25 & 17,92 & 14,84 & 11,68 & 9,30 & 7,52 & 5,20 & 3,91 & 2,63 \\
\hline 20,77 & 951,50 & 130,00 & 38,53 & 27,61 & 20,88 & 14,61 & 10,74 & 8,34 & 5,75 & 4,44 & 3,08 \\
\hline 86,44 & 457,20 & 141,90 & 25,94 & 15,54 & 12,39 & 10,06 & 8,56 & 7,40 & 5,66 & 4,48 & 3,06 \\
\hline 27,15 & 1209,80 & 62,10 & 50,15 & 42,24 & 36,31 & 29,25 & 23,53 & 19,07 & 13,12 & 9,74 & 6,47 \\
\hline 29,72 & 1749,70 & 47,70 & 48,98 & 44,09 & 39,72 & 34,08 & 29,00 & 24,61 & 17,92 & 13,48 & 8,68 \\
\hline 80,94 & 942,00 & 84,80 & 22,38 & 16,29 & 14,67 & 13,17 & 11,97 & 10,90 & 9,04 & 7,53 & 5,36 \\
\hline 59,73 & 239,00 & 150,30 & 41,87 & 22,16 & 16,10 & 11,79 & 9,22 & 7,46 & 5,21 & 3,98 & 2,75 \\
\hline 73,49 & 1318,00 & 104,40 & 17,95 & 13,55 & 12,31 & 11,08 & 10,05 & 9,11 & 7,49 & 6,19 & 4,35 \\
\hline 49,54 & 1914,20 & 163,30 & 14,70 & 11,92 & 10,61 & 9,16 & 7,92 & 6,84 & 5,15 & 3,98 & 2,61 \\
\hline 43,60 & 468,40 & 65,40 & 48,87 & 37,20 & 31,70 & 25,95 & 21,37 & 17,73 & 12,60 & 9,49 & 6,27 \\
\hline 42,47 & 877,40 & 33,20 & 59,23 & 52,09 & 47,89 & 42,51 & 37,52 & 33,00 & 25,52 & 19,98 & 13,10 \\
\hline 61,78 & 677,10 & 41,60 & 44,43 & 35,64 & 32,76 & 29,51 & 26,63 & 23,98 & 19,41 & 15,80 & 10,84 \\
\hline 21,24 & 537,00 & 60,00 & 78,07 & 57,81 & 44,69 & 31,90 & 23,62 & 18,33 & 12,52 & 9,62 & 6,67 \\
\hline 21,70 & 1309,60 & 73,30 & 51,94 & 41,91 & 34,42 & 26,12 & 20,02 & 15,70 & 10,58 & 7,96 & 5,44 \\
\hline 44,30 & 1213,50 & 24,60 & 63,68 & 55,91 & 53,14 & 48,79 & 44,52 & 40,44 & 33,12 & 27,10 & 18,59 \\
\hline 26,60 & 1298,70 & 156,40 & 26,48 & 20,11 & 16,19 & 12,12 & 9,25 & 7,26 & 4,93 & 3,73 & 2,56 \\
\hline 29,24 & 759,70 & 141,60 & 31,80 & 22,80 & 18,01 & 13,30 & 10,10 & 7,94 & 5,41 & 4,12 & 2,84 \\
\hline 73,65 & 646,70 & 60,20 & 33,41 & 24,87 & 22,35 & 19,92 & 17,94 & 16,17 & 13,15 & 10,77 & 7,49 \\
\hline 70,97 & 1648,30 & 61,80 & 23,05 & 18,07 & 17,05 & 15,91 & 14,81 & 13,76 & 11,82 & 10,12 & 7,47 \\
\hline 41,80 & 1738,40 & 142,00 & 18,61 & 15,31 & 13,48 & 11,39 & 9,62 & 8,13 & 5,92 & 4,48 & 2,92 \\
\hline 20,41 & 1618,70 & 105,00 & 39,55 & 31,07 & 24,90 & 18,38 & 13,82 & 10,75 & 7,26 & 5,51 & 3,80 \\
\hline 28,51 & 543,80 & 83,00 & 51,53 & 38,09 & 30,46 & 22,73 & 17,34 & 13,64 & 9,28 & 7,04 & 4,84 \\
\hline 56,71 & 804,50 & 183,30 & 19,17 & 13,07 & 10,83 & 8,84 & 7,36 & 6,18 & 4,48 & 3,42 & 2,27 \\
\hline 56,63 & 827,40 & 20,20 & 70,08 & 58,00 & 55,52 & 51,81 & 48,06 & 44,43 & 37,70 & 31,88 & 22,97 \\
\hline 76,96 & 1076,30 & 59,40 & 26,56 & 20,18 & 18,72 & 17,23 & 15,92 & 14,69 & 12,48 & 10,60 & 7,74 \\
\hline 67,13 & 201,30 & 130,40 & 48,57 & 25,31 & 18,29 & 13,40 & 10,55 & 8,58 & 6,04 & 4,63 & 3,19 \\
\hline 44,74 & 328,00 & 145,30 & 37,23 & 22,12 & 16,81 & 12,48 & 9,68 & 7,74 & 5,34 & 4,07 & 2,81 \\
\hline 49,25 & 1996,80 & 52,90 & 29,94 & 25,76 & 24,40 & 22,39 & 20,44 & 18,58 & 15,26 & 12,53 & 8,64 \\
\hline 79,98 & 1978,10 & 81,40 & 16,88 & 12,88 & 12,04 & 11,28 & 10,55 & 9,86 & 8,58 & 7,45 & 5,63 \\
\hline 25,44 & 1882,10 & 178,40 & 22,22 & 17,32 & 14,09 & 10,64 & 8,15 & 6,41 & 4,34 & 3,27 & 2,24 \\
\hline 75,53 & 1714,30 & 78,10 & 18,93 & 14,56 & 13,61 & 12,64 & 11,74 & 10,89 & 9,34 & 7,99 & 5,90 \\
\hline 22,77 & 403,10 & 101,90 & 55,16 & 36,30 & 26,59 & 18,28 & 13,45 & 10,51 & 7,31 & 5,66 & 3,95 \\
\hline 51,05 & 1834,60 & 169,20 & 14,38 & 11,52 & 10,22 & 8,82 & 7,62 & 6,58 & 4,96 & 3,84 & 2,52 \\
\hline 44,67 & 1646,20 & 53,60 & 33,66 & 29,55 & 27,49 & 24,73 & 22,13 & 19,73 & 15,62 & 12,44 & 8,28 \\
\hline 64,84 & 382,60 & 103,00 & 35,52 & 22,98 & 18,75 & 15,26 & 12,77 & 10,81 & 7,95 & 6,12 & 4,09 \\
\hline 68,13 & 895,40 & 45,30 & 35,92 & 28,27 & 26,36 & 24,16 & 22,18 & 20,33 & 17,00 & 14,23 & 10,13 \\
\hline 35,78 & 450,90 & 100,80 & 42,89 & 30,03 & 24,07 & 18,28 & 14,20 & 11,30 & 7,75 & 5,86 & 4,00 \\
\hline 54,06 & 1401,70 & 38,20 & 39,48 & 33,16 & 31,56 & 29,19 & 26,86 & 24,63 & 20,57 & 17,14 & 12,09 \\
\hline 89,75 & 1587,10 & 182,00 & 11,23 & 7,78 & 6,85 & 6,08 & 5,50 & 5,01 & 4,16 & 3,47 & 2,49 \\
\hline 88,48 & 1364,30 & 127,70 & 14,56 & 10,32 & 9,24 & 8,31 & 7,58 & 6,95 & 5,83 & 4,92 & 3,57 \\
\hline 76,25 & 1689,40 & 119,80 & 14,66 & 11,03 & 10,09 & 9,16 & 8,37 & 7,65 & 6,38 & 5,34 & 3,81 \\
\hline 81,18 & 1416,20 & 37,80 & 30,34 & 23,77 & 22,19 & 21,22 & 20,16 & 19,09 & 17,03 & 15,14 & 11,90 \\
\hline 28,87 & 1057,60 & 67,30 & 47,29 & 39,21 & 33,55 & 26,94 & 21,63 & 17,52 & 12,06 & 8,97 & 5,97 \\
\hline 26,16 & 1747,80 & 32,10 & 71,27 & 65,16 & 58,93 & 50,70 & 43,19 & 36,68 & 26,69 & 20,05 & 12,86 \\
\hline 42,13 & 339,60 & 178,70 & 33,63 & 19,11 & 14,14 & 10,23 & 7,82 & 6,21 & 4,28 & 3,28 & 2,28 \\
\hline 75,50 & 1866,30 & 188,00 & 10,97 & 8,05 & 7,20 & 6,39 & 5,75 & 5,18 & 4,20 & 3,44 & 2,40 \\
\hline 51,05 & 1163,60 & 75,80 & 27,90 & 23,16 & 20,99 & 18,49 & 16,28 & 14,30 & 11,06 & 8,68 & 5,74 \\
\hline 46,52 & 1022,40 & 195,30 & 18,11 & 13,00 & 10,86 & 8,76 & 7,15 & 5,90 & 4,18 & 3,15 & 2,10 \\
\hline 25,01 & 1398,80 & 168,80 & 25,55 & 19,24 & 15,30 & 11,28 & 8,53 & 6,66 & 4,52 & 3,44 & 2,37 \\
\hline 44,88 & 565,30 & 44,20 & 55,97 & 46,19 & 41,03 & 35,16 & 30,09 & 25,76 & 19,09 & 14,59 & 9,51 \\
\hline 35,30 & 1648,80 & 185,50 & 18,09 & 14,20 & 12,02 & 9,62 & 7,74 & 6,30 & 4,37 & 3,27 & 2,18 \\
\hline 70,74 & 1446,60 & 174,40 & 13,25 & 9,70 & 8,54 & 7,47 & 6,61 & 5,87 & 4,65 & 3,73 & 2,54 \\
\hline 24,72 & 221,30 & 48,00 & 107,54 & 73,71 & 55,63 & 39,20 & 29,04 & 22,66 & 15,61 & 12,03 & 8,37 \\
\hline 20,74 & 1208,90 & 172,80 & 29,34 & 20,88 & 15,72 & 10,97 & 8,06 & 6,26 & 4,32 & 3,34 & 2,32 \\
\hline 27,98 & 1548,00 & 151,50 & 24,74 & 19,43 & 16,05 & 12,36 & 9,61 & 7,63 & 5,18 & 3,89 & 2,64 \\
\hline 60,87 & 1399,40 & 109,50 & 18,75 & 14,85 & 13,43 & 11,92 & 10,62 & 9,46 & 7,49 & 6,00 & 4,05 \\
\hline 37,23 & 554,70 & 188,10 & 26,85 & 17,19 & 13,28 & 9,81 & 7,52 & 5,96 & 4,09 & 3,12 & 2,15 \\
\hline 31,35 & 399,40 & 32,80 & $\begin{array}{l}99,45 \\
\end{array}$ & 80,74 & 68,76 & 55,07 & 44,20 & 35,83 & 24,72 & 18,43 & 12,28 \\
\hline 24,85 & 1201,40 & 52,70 & 60,35 & 50,99 & 43,66 & 34,92 & 27,89 & 22,47 & 15,35 & 11,39 & 7,60 \\
\hline 56,00 & 601,80 & 83,40 & 33,14 & 24,81 & 21,47 & 18,21 & 15,58 & 13,37 & 9,98 & 7,70 & 5,08 \\
\hline 71,60 & 1026,40 & 53,70 & 29,88 & 23,19 & 21,58 & 19,83 & 18,25 & 16,78 & 14,12 & 11,90 & 8,56 \\
\hline 68,42 & 1316,10 & 116,00 & 17,52 & 13,36 & 12,04 & 10,71 & 9,61 & 8,62 & 6,93 & 5,63 & 3,86 \\
\hline 57,78 & 308,40 & 142,80 & 36,49 & 21,01 & 16,00 & 12,16 & 9,69 & 7,91 & 5,56 & 4,24 & 2,89 \\
\hline 46,99 & 1373,60 & 38,70 & 42,99 & 37,42 & 35,21 & 32,07 & 29,05 & 26,21 & 21,22 & 17,20 & 11,68 \\
\hline 30,38 & 1969,40 & 164,70 & 20,39 & 16,47 & 13,94 & 11,07 & 8,83 & 7,12 & 4,89 & 3,65 & 2,44 \\
\hline 85,65 & 651,50 & 164,00 & 19,70 & 12,31 & 10,07 & 8,36 & 7,21 & 6,30 & 4,89 & 3,90 & 2,67 \\
\hline 54,07 & 579,10 & 89,40 & 33,13 & 24,45 & 20,96 & 17,56 & 14,86 & 12,62 & 9,29 & 7,11 & 4,69 \\
\hline 85,62 & 1660,30 & 125,90 & 13,59 & 9,88 & 8,98 & 8,17 & 7,50 & 6,91 & 5,85 & 4,97 & 3,63 \\
\hline 24,68 & 856,70 & 59,40 & 61,99 & 49,90 & 41,34 & 31,80 & 24,66 & 19,49 & 13,18 & 9,88 & 6,72 \\
\hline 60,33 & 967,80 & 152,60 & 18,58 & 13,48 & 11,57 & 9,80 & 8,40 & 7,23 & 5,43 & 4,21 & 2,79 \\
\hline 47,22 & 1443,40 & 132,10 & 19,28 & 15,57 & 13,75 & 11,74 & 10,04 & 8,59 & 6,36 & 4,87 & 3,18 \\
\hline 88,91 & 257,90 & 61,30 & 50,36 & 31,55 & 25,94 & 21,67 & 18,82 & 16,54 & 12,98 & 10,44 & 7,19 \\
\hline
\end{tabular}




\begin{tabular}{|c|c|c|c|c|c|c|c|c|c|c|c|}
\hline \multirow[b]{2}{*}{ e1 (cm) } & & & & & & & ões (x1 & m) & & & \\
\hline & Meq (MPa) & Ms (MPa) & D0 & D25 & D40 & D60 & D80 & D100 & D140 & D180 & D260 \\
\hline 59,56 & 1028,10 & 128,50 & 19,86 & 14,97 & 13,09 & 11,26 & 9,76 & 8,48 & 6,46 & 5,05 & 3,35 \\
\hline 26,49 & 1747,70 & 24,60 & 84,30 & 78,26 & 71,71 & 62,81 & 54,45 & 46,98 & 35,03 & 26,66 & 17,09 \\
\hline 42,93 & 654,50 & 71,30 & 440,83 & 32,31 & 27,99 & 23,29 & 19,41 & 16,25 & 11,67 & 8,81 & 5,78 \\
\hline 52,87 & 1844,10 & 93,80 & 20,10 & 16,86 & 15,53 & 13,92 & 12,45 & 11,11 & 8,83 & 7,07 & 4,75 \\
\hline 55,12 & 946,10 & 150,90 & 19,75 & 14,46 & 12,37 & 10,37 & 8,78 & 7,47 & 5,50 & 4,22 & 2,78 \\
\hline 27,95 & 846,80 & 103,90 & 38,84 & 29,59 & 24,00 & 18,14 & 13,95 & 11,00 & 7,47 & 5,64 & 3,86 \\
\hline 38,21 & 789,60 & 64,30 & 443,76 & 35,99 & 31,42 & 26,17 & 21,77 & 18,17 & 12,98 & 9,74 & 6,37 \\
\hline 56,83 & 1997,80 & 146,70 & 14,17 & 11,44 & 10,36 & 9,17 & 8,13 & 7,20 & 5,65 & 4,49 & 3,00 \\
\hline 76,37 & 1056,60 & 118,80 & 18,19 & 13,17 & 11,67 & 10,30 & 9,22 & 8,27 & 6,68 & 5,45 & 3,78 \\
\hline 36,02 & 579,40 & 76,70 & 45,88 & 35,19 & 29,51 & 23,42 & 18,73 & 15,17 & 10,50 & 7,86 & 5,27 \\
\hline 36,59 & 200,30 & 185,50 & 44,81 & 21,34 & 14,33 & 9,71 & 7,28 & 5,77 & 4,01 & 3,12 & 2,21 \\
\hline 45,05 & 1177,70 & 24,90 & 63,00 & 55,15 & 52,40 & 48,11 & 43,90 & 39,88 & 32,68 & 26,76 & 18,37 \\
\hline 46,02 & 1193,50 & 147,30 & 19,92 & 15,43 & 13,33 & 11,11 & 9,29 & 7,81 & 5,65 & 4,27 & 2,81 \\
\hline 21,80 & 1614,20 & 126,10 & 33,09 & 25,76 & 20,63 & 15,24 & 11,49 & 8,95 & 6,05 & 4,60 & 3,17 \\
\hline 58,04 & 1599,70 & 65,80 & 25,11 & 20,73 & 19,42 & 17,75 & 16,18 & 14,72 & 12,11 & 9,97 & 6,93 \\
\hline 41,86 & 1760,70 & 21,40 & 65,72 & 57,27 & 55,30 & 51,54 & 47,65 & 43,85 & 36,80 & 30,74 & 21,67 \\
\hline 74,59 & 582,50 & 71,70 & 31,83 & 22,94 & 20,18 & 17,67 & 15,72 & 14,02 & 11,20 & 9,06 & 6,22 \\
\hline 62,29 & 1286,50 & 37,50 & 37,65 & 30,50 & 29,06 & 27,14 & 25,22 & 23,38 & 19,94 & 16,97 & 12,35 \\
\hline 62,99 & 643,50 & 29,40 & 55,70 & 44,90 & 42,01 & 38,46 & 35,20 & 32,14 & 26,68 & 22,16 & 15,60 \\
\hline 60,38 & 1680,90 & 139,30 & 15,16 & 11,97 & 10,78 & 9,53 & 8,46 & 7,50 & 5,91 & 4,72 & 3,17 \\
\hline 86,78 & 1880,10 & 108,90 & 13,86 & 10,23 & 9,40 & 8,70 & 8,08 & 7,52 & 6,49 & 5,60 & 4,20 \\
\hline 57,77 & 1887,30 & 173,10 & 13,05 & 10,28 & 9,18 & 8,04 & 7,06 & 6,20 & 4,80 & 3,78 & 2,52 \\
\hline 66,01 & 1971,40 & 60,00 & 23,04 & 18,41 & 17,50 & 16,40 & 15,29 & 14,22 & 12,22 & 10,47 & 7,71 \\
\hline 68,84 & 1126,40 & 59,00 & 27,79 & 21,80 & 20,29 & 18,58 & 17,05 & 15,62 & 13,05 & 10,92 & 7,78 \\
\hline 65,15 & 1233,20 & 92,40 & 21,05 & 16,46 & 14,98 & 13,40 & 12,05 & 10,83 & 8,73 & 7,09 & 4,87 \\
\hline 67,27 & 1835,60 & 186,10 & 11,72 & 8,86 & 7,90 & 6,96 & 6,19 & 5,51 & 4,37 & 3,51 & 2,39 \\
\hline 37,52 & 627,20 & 127,10 & 31,92 & 22,79 & 18,54 & 14,33 & 11,27 & 9,04 & 6,22 & 4,69 & 3,18 \\
\hline 44,89 & 431,70 & 84,10 & 43,19 & 30,96 & 25,72 & 20,60 & 16,71 & 13,71 & 9,65 & 7,27 & 4,85 \\
\hline 45,83 & 379,30 & 50,40 & 60,24 & 46,15 & 39,63 & 32,83 & 27,33 & 22,87 & 16,45 & 12,43 & 8,18 \\
\hline 20,43 & 1330,40 & 25,60 & 113,14 & 99,52 & 86,86 & 70,93 & 57,49 & 46,77 & 32,14 & 23,72 & 15,61 \\
\hline 50,21 & 1668,10 & 59,80 & 28,82 & 24,70 & 23,09 & 20,94 & 18,91 & 17,02 & 13,73 & 11,11 & 7,54 \\
\hline 43,89 & 1654,00 & 77,50 & 26,72 & 23,14 & 21,11 & 18,60 & 16,31 & 14,27 & 10,93 & 8,51 & 5,57 \\
\hline 20,85 & 631,00 & 194,50 & 31,67 & 19,74 & 13,97 & 9,40 & 6,90 & 5,43 & 3,81 & 2,96 & 2,07 \\
\hline 70,83 & 693,20 & 120,20 & 23,11 & 16,04 & 13,68 & 11,65 & 10,12 & 8,84 & 6,81 & 5,38 & 3,62 \\
\hline 54,21 & 596,10 & 24,60 & 70,00 & 58,78 & 54,86 & 49,79 & 45,08 & 40,69 & 33,00 & 26,85 & 18,36 \\
\hline 57,36 & 662,40 & 58,00 & 38,33 & 30,39 & 27,22 & 23,87 & 21,00 & 18,47 & 14,33 & 11,30 & 7,52 \\
\hline 68,29 & 615,80 & 77,90 & 30,84 & 22,61 & 19,82 & 17,23 & 15,18 & 13,39 & 10,49 & 8,35 & 5,64 \\
\hline 60,75 & 958,10 & 128,00 & 20,37 & 15,16 & 13,20 & 11,32 & 9,81 & 8,52 & 6,48 & 5,06 & 3,36 \\
\hline 84,46 & 901,70 & 66,10 & 25,66 & 18,75 & 17,08 & 15,56 & 14,30 & 13,17 & 11,15 & 9,47 & 6,92 \\
\hline 72,69 & 1229,70 & 111,80 & 17,91 & 13,41 & 12,07 & 10,76 & 9,69 & 8,73 & 7,09 & 5,81 & 4,03 \\
\hline 66,89 & 1089,20 & 33,00 & 41,49 & 33,05 & 31,41 & 29,48 & 27,51 & 25,61 & 22,06 & 18,95 & 14,01 \\
\hline 58,69 & 1411,50 & 146,40 & 16,14 & 12,50 & 11,08 & 9,63 & 8,42 & 7,37 & 5,68 & 4,46 & 2,96 \\
\hline 72,23 & 539,70 & 41,20 & 45,14 & 34,31 & 31,25 & 28,14 & 25,53 & 23,16 & 19,02 & 15,71 & 11,01 \\
\hline 66,96 & 1830,90 & 96,80 & 17,26 & 13,63 & 12,67 & 11,58 & 10,59 & 9,68 & 8,04 & 6,69 & 4,73 \\
\hline 77,65 & 497,50 & 23,30 & 63,11 & 48,18 & 44,95 & 41,77 & 38,83 & 36,07 & 31,00 & 26,61 & 19,73 \\
\hline 89,82 & 1036,30 & 98,00 & 18,95 & 13,37 & 11,95 & 10,75 & 9,81 & 8,99 & 7,56 & 6,39 & 4,65 \\
\hline 28,40 & 1866,30 & 109,60 & 28,64 & 23,91 & 20,52 & 16,52 & 13,29 & 10,78 & 7,42 & 5,52 & 3,67 \\
\hline 42,28 & 1509,10 & 101,00 & 24,03 & 20,22 & 18,04 & 15,48 & 13,24 & 11,32 & 8,37 & 6,38 & 4,15 \\
\hline 61,68 & 250,10 & 164,40 & 39,27 & 20,50 & 14,79 & 10,78 & 8,42 & 6,81 & 4,76 & 3,64 & 2,52 \\
\hline 31,80 & 357,90 & 173,30 & 35,70 & 20,86 & 15,19 & 10,63 & 7,95 & 6,26 & 4,33 & 3,34 & 2,34 \\
\hline 62,62 & 1615,70 & 195,90 & 12,52 & 9,40 & 8,25 & 7,15 & 6,25 & 5,47 & 4,22 & 3,32 & 2,22 \\
\hline 65,80 & 1881,90 & 160,30 & 12,74 & 9,84 & 8,88 & 7,89 & 7,06 & 6,32 & 5,05 & 4,08 & 2,79 \\
\hline 51,34 & 843,20 & 199,10 & 18,76 & 12,82 & 10,55 & 8,48 & 6,94 & 5,75 & 4,09 & 3,10 & 2,07 \\
\hline 47,49 & 302,90 & 149,70 & 37,78 & 21,71 & 16,30 & 12,05 & 9,36 & 7,50 & 5,19 & 3,96 & 2,73 \\
\hline 26,36 & 687,90 & 86,30 & 48,90 & 36,89 & 29,55 & 21,99 & 16,73 & 13,12 & 8,90 & 6,75 & 4,65 \\
\hline 48,60 & 1308,20 & 171,40 & 17,01 & 13,02 & 11,24 & 9,40 & 7,90 & 6,67 & 4,86 & 3,69 & 2,43 \\
\hline 49,47 & 1171,00 & 86,40 & 26,23 & 21,62 & 19,41 & 16,91 & 14,73 & 12,81 & 9,75 & 7,57 & 4,97 \\
\hline 44,97 & 642,20 & 68,10 & 41,01 & 32,54 & 28,35 & 23,80 & 20,02 & 16,89 & 12,27 & 9,30 & 6,09 \\
\hline 74,93 & 329,80 & 21,50 & 79,52 & $\begin{array}{l}60,39 \\
\end{array}$ & 55,55 & 50,59 & 46,33 & 42,43 & 35,47 & 29,73 & 21,27 \\
\hline 30,88 & 1572,80 & 107,30 & 28,84 & 23,90 & 20,56 & 16,65 & 13,48 & 10,99 & 7,62 & 5,67 & 3,76 \\
\hline 29,91 & 316,90 & 112,50 & 449,63 & 31,31 & 23,36 & 16,53 & 12,36 & 9,70 & 6,69 & 5,15 & 3,59 \\
\hline 37,50 & 489,70 & 183,00 & 28,73 & 17,96 & 13,73 & 10,08 & 7,71 & 6,10 & 4,19 & 3,20 & 2,22 \\
\hline 48,15 & 400,70 & 195,80 & 28,61 & $\begin{array}{l}16,48 \\
\end{array}$ & 12,40 & 9,19 & 7,16 & 5,74 & 3,97 & 3,03 & 2,09 \\
\hline 78,13 & 571,30 & 56,20 & 35,76 & 26,08 & 23,35 & 20,81 & 18,78 & 16,99 & 13,91 & 11,48 & 8,06 \\
\hline 59,36 & 1914,30 & 54,20 & 26,58 & 21,79 & 20,77 & 19,35 & 17,93 & 16,56 & 14,04 & 11,86 & 8,55 \\
\hline 72,81 & 812,30 & 150,50 & 18,92 & 12,91 & 10,95 & 9,28 & 8,06 & 7,03 & 5,42 & 4,29 & 2,89 \\
\hline 34,76 & 1381,90 & 86,20 & 31,75 & 26,83 & 23,56 & 19,66 & 16,35 & 13,63 & 9,70 & 7,26 & 4,74 \\
\hline 39,65 & 213,40 & 22,10 & 135,99 & 108,39 & 93,52 & 77,03 & 63,55 & 52,73 & 37,41 & 28,08 & 18,47 \\
\hline 51,21 & 1074,30 & 109,30 & 23,17 & 18,33 & 16,15 & 13,85 & 11,91 & 10,25 & 7,67 & 5,91 & 3,88 \\
\hline 27,76 & 1291,80 & 30,90 & 76,69 & 69,26 & 62,30 & 53,25 & 45,12 & 38,15 & 27,59 & 20,68 & 13,31 \\
\hline 25,54 & 1398,80 & 160,30 & 26,13 & 19,88 & 15,94 & 11,86 & 9,01 & 7,06 & 4,79 & 3,63 & 2,50 \\
\hline 81,14 & 840,30 & 72,70 & 25,62 & 18,70 & 16,88 & 15,19 & 13,83 & 12,62 & 10,50 & 8,77 & 6,27 \\
\hline 50,69 & 1114,30 & 181,20 & 17,33 & 12,75 & 10,85 & 8,98 & 7,50 & 6,30 & 4,57 & 3,47 & 2,29 \\
\hline 30,89 & 695,20 & 157,60 & 29,69 & 20,63 & 16,16 & 11,89 & 9,04 & 7,11 & 4,86 & 3,70 & 2,56 \\
\hline 75,59 & 1228,60 & 144,90 & 15,33 & 11,07 & 9,77 & 8,59 & 7,66 & 6,86 & 5,51 & 4,47 & 3,09 \\
\hline 50,63 & 372,60 & 29,90 & 77,22 & 62,92 & 56,28 & 48,93 & 42,55 & 36,98 & 28,10 & 21,82 & 14,34 \\
\hline 25,46 & 678,70 & 138,80 & 36,01 & 25,04 & 19,11 & 13,60 & 10,12 & 7,90 & 5,42 & 4,17 & 2,90 \\
\hline 35,05 & 1342,50 & 56,70 & 41,73 & 36,64 & 32,89 & 28,22 & 24,05 & 20,48 & 15,00 & 11,34 & 7,33 \\
\hline 38,73 & 902,00 & 21,40 & 84,34 & 76,04 & 70,86 & 63,66 & 56,79 & 50,42 & 39,59 & 31,29 & 20,63 \\
\hline 38,71 & 1336,30 & 90,00 & 28,83 & 24,25 & 21,45 & 18,14 & 15,30 & 12,91 & 9,36 & 7,06 & 4,59 \\
\hline 25,63 & 1859,30 & 110,50 & 30,89 & 25,43 & 21,44 & 16,85 & 13,28 & 10,61 & 7,21 & 5,38 & 3,62 \\
\hline 71,20 & 1284,80 & 99,70 & 18,93 & 14,43 & 13,13 & 11,80 & 10,68 & 9,67 & 7,91 & 6,51 & 4,55 \\
\hline
\end{tabular}




\begin{tabular}{|c|c|c|c|c|c|c|c|c|c|c|c|}
\hline \multirow[b]{2}{*}{ e1 (cm) } & & & & & & & ões (x1 & m) & & & \\
\hline & Meq (MPa) & Ms (MPa) & D0 & D25 & D40 & D60 & D80 & D100 & D140 & D180 & D260 \\
\hline 59,13 & 538,10 & 67,20 & 38,10 & 28,76 & 25,15 & 21,61 & 18,73 & 16,26 & 12,37 & 9,65 & 6,40 \\
\hline 56,62 & 415,80 & 39,60 & 58,62 & 46,15 & 41,07 & 35,78 & 31,29 & 27,37 & 21,04 & 16,50 & 10,94 \\
\hline 73,88 & 1099,80 & 33,00 & 38,82 & 30,38 & 28,70 & 27,16 & 25,54 & 23,96 & 20,97 & 18,30 & 13,91 \\
\hline 34,33 & 412,00 & 44,20 & 75,98 & 59,95 & 50,74 & 40,54 & 32,55 & 26,42 & 18,29 & 13,67 & 9,12 \\
\hline 68,67 & 282,50 & 84,90 & 45,13 & 28,27 & 22,77 & 18,40 & 15,39 & 13,04 & 9,61 & 7,42 & 4,97 \\
\hline 20,15 & 1211,30 & 112,20 & 41,10 & 30,86 & 23,95 & 17,12 & 12,67 & 9,82 & 6,70 & 5,14 & 3,57 \\
\hline 26,56 & 269,50 & 178,60 & 40,89 & 21,66 & 14,90 & 10,07 & 7,49 & 5,93 & 4,15 & 3,23 & 2,28 \\
\hline 67,81 & 363,30 & 148,30 & 31,33 & 18,31 & 14,18 & 11,07 & 9,05 & 7,54 & 5,44 & 4,18 & 2,82 \\
\hline 58,98 & 1193,50 & 159,40 & 16,60 & 12,41 & 10,79 & 9,23 & 7,97 & 6,89 & 5,21 & 4,05 & 2,68 \\
\hline 39,37 & 611,50 & 130,80 & 30,93 & 21,85 & 17,79 & 13,81 & 10,91 & 8,79 & 6,07 & 4,57 & 3,10 \\
\hline 29,80 & 1568,60 & 113,10 & 28,64 & 23,49 & 20,03 & 16,03 & 12,85 & 10,40 & 7,16 & 5,33 & 3,55 \\
\hline 58,17 & 592,40 & 122,90 & 26,94 & 18,67 & 15,63 & 12,90 & 10,83 & 9,16 & 6,71 & 5,14 & 3,41 \\
\hline 82,99 & 1727,90 & 129,10 & 13,36 & 9,80 & 8,92 & 8,11 & 7,44 & 6,84 & 5,77 & 4,88 & 3,54 \\
\hline 79,10 & 1197,40 & 145,80 & 15,19 & 10,80 & 9,51 & 8,36 & 7,47 & 6,71 & 5,42 & 4,43 & 3,08 \\
\hline 63,34 & 1776,50 & 69,60 & 22,21 & 17,91 & 16,88 & 15,58 & 14,35 & 13,18 & 11,07 & 9,28 & 6,62 \\
\hline 62,18 & 1344,70 & 82,80 & 22,26 & 17,83 & 16,39 & 14,77 & 13,33 & 12,02 & 9,74 & 7,93 & 5,45 \\
\hline 51,45 & 668,70 & 23,30 & 72,27 & 61,59 & 57,77 & 52,59 & 47,70 & 43,11 & 35,02 & 28,52 & 19,49 \\
\hline 87,58 & 1606,80 & 70,90 & 18,87 & 14,17 & 13,10 & 12,30 & 11,55 & 10,83 & 9,51 & 8,34 & 6,41 \\
\hline 61,17 & 1930,30 & 62,70 & 23,60 & 19,21 & 18,23 & 16,92 & 15,64 & 14,42 & 12,18 & 10,27 & 7,37 \\
\hline 55,35 & 525,20 & 30,80 & 62,73 & 51,73 & 47,41 & 42,37 & 37,86 & 33,74 & 26,78 & 21,44 & 14,42 \\
\hline 45,11 & 703,00 & 67,10 & 39,78 & 32,02 & 28,10 & 23,78 & 20,14 & 17,08 & 12,50 & 9,50 & 6,21 \\
\hline 52,31 & 1660,50 & 109,10 & 19,15 & 15,83 & 14,36 & 12,68 & 11,19 & 9,86 & 7,66 & 6,04 & 4,00 \\
\hline 83,06 & 1349,40 & 193,00 & 12,23 & 8,42 & 7,30 & 6,36 & 5,66 & 5,07 & 4,08 & 3,33 & 2,32 \\
\hline 78,82 & 1466,70 & 192,60 & 11,96 & 8,44 & 7,38 & 6,45 & 5,75 & 5,14 & 4,13 & 3,36 & 2,32 \\
\hline 69,47 & 392,10 & 90,40 & 36,19 & 23,93 & 19,84 & 16,47 & 14,03 & 12,06 & 9,07 & 7,07 & 4,73 \\
\hline 40,94 & 476,40 & 194,90 & 27,35 & 16,67 & 12,72 & 9,39 & 7,23 & 5,75 & 3,96 & 3,02 & 2,09 \\
\hline 74,02 & 795,90 & 101,60 & 22,94 & 16,49 & 14,46 & 12,63 & 11,20 & 9,97 & 7,93 & 6,39 & 4,37 \\
\hline 47,34 & 1670,00 & 28,50 & 50,03 & 42,91 & 41,27 & 38,42 & 35,51 & 32,68 & 27,46 & 22,98 & 16,27 \\
\hline 70,59 & 1439,80 & 52,50 & 26,95 & 21,17 & 19,99 & 18,68 & 17,39 & 16,17 & 13,89 & 11,91 & 8,80 \\
\hline 72,99 & 300,20 & 190,00 & 32,50 & 16,93 & 12,26 & 9,05 & 7,17 & 5,87 & 4,17 & 3,20 & 2,20 \\
\hline 66,36 & 1544,00 & 28,30 & 41,08 & 33,01 & 31,48 & 30,17 & 28,59 & 26,99 & 23,89 & 21,04 & 16,23 \\
\hline 48,04 & 781,10 & 146,70 & 23,52 & 16,92 & 14,17 & 11,50 & 9,45 & 7,84 & 5,58 & 4,22 & 2,80 \\
\hline 53,22 & 1035,00 & 125,70 & 21,29 & 16,36 & 14,27 & 12,15 & 10,40 & 8,92 & 6,65 & 5,12 & 3,37 \\
\hline 49,15 & 1514,50 & 49,60 & 34,21 & 29,48 & 27,64 & 25,11 & 22,72 & 20,48 & 16,55 & 13,41 & 9,11 \\
\hline 41,72 & 1658,00 & 117,10 & 21,36 & 17,88 & 15,88 & 13,55 & 11,53 & 9,82 & 7,21 & 5,48 & 3,56 \\
\hline 40,83 & 1254,40 & 63,80 & 35,22 & 30,45 & 27,48 & 23,86 & 20,62 & 17,78 & 13,31 & 10,21 & 6,63 \\
\hline 37,53 & 454,30 & 100,50 & 41,81 & 29,35 & 23,69 & 18,17 & 14,23 & 11,38 & 7,83 & 5,91 & 4,02 \\
\hline 63,41 & 757,90 & 169,20 & 19,64 & 13,26 & 11,03 & 9,12 & 7,71 & 6,57 & 4,86 & 3,75 & 2,50 \\
\hline 78,96 & 308,70 & 20,60 & 81,65 & 61,06 & 56,04 & 51,15 & 46,98 & 43,17 & 36,37 & 30,70 & 22,22 \\
\hline 67,13 & 427,60 & 85,20 & 35,86 & 24,52 & 20,64 & 17,31 & 14,83 & 12,78 & 9,65 & 7,52 & 5,02 \\
\hline 39,47 & 1362,50 & 152,80 & 20,36 & 16,04 & 13,76 & 11,26 & 9,24 & 7,63 & 5,39 & 4,04 & 2,67 \\
\hline 50,44 & 1301,50 & 140,30 & 18,67 & 14,67 & 12,87 & 10,97 & 9,38 & 8,03 & 5,97 & 4,58 & 3,00 \\
\hline 46,92 & 1808,50 & 58,20 & 29,87 & 26,00 & 24,30 & 22,00 & 19,81 & 17,77 & 14,24 & 11,45 & 7,71 \\
\hline 22,52 & 814,90 & 44,30 & 82,89 & 67,52 & 55,97 & 42,98 & 33,23 & 26,20 & 17,67 & 13,24 & 9,02 \\
\hline 62,92 & 1033,60 & 59,50 & 29,98 & 24,00 & 22,17 & 20,06 & 18,19 & 16,46 & 13,43 & 11,01 & 7,62 \\
\hline 81,90 & 388,80 & 95,20 & 33,78 & 21,41 & 17,59 & 14,63 & 12,60 & 10,98 & 8,47 & 6,73 & 4,58 \\
\hline 54,48 & 475,30 & 135,00 & 29,71 & 19,39 & 15,69 & 12,49 & 10,19 & 8,43 & 6,01 & 4,56 & 3,06 \\
\hline 33,37 & 1331,90 & 179,50 & 20,71 & 15,79 & 13,08 & 10,21 & 8,05 & 6,45 & 4,42 & 3,32 & 2,24 \\
\hline 58,78 & 1687,20 & 137,00 & 15,51 & 12,33 & 11,11 & 9,81 & 8,69 & 7,69 & 6,03 & 4,80 & 3,21 \\
\hline 54,38 & 1116,70 & 193,30 & 16,14 & 11,67 & 9,91 & 8,23 & 6,92 & 5,86 & 4,28 & 3,27 & 2,16 \\
\hline 49,17 & 1959,80 & 175,70 & 14,01 & 11,31 & 10,02 & 8,62 & 7,42 & 6,39 & 4,79 & 3,68 & 2,41 \\
\hline 46,01 & 278,80 & 76,60 & 55,03 & 36,68 & 29,54 & 23,05 & 18,41 & 14,95 & 10,43 & 7,88 & 5,32 \\
\hline 48,46 & 1043,80 & 94,40 & 26,42 & 21,32 & 18,88 & 16,20 & 13,91 & 11,95 & 8,91 & 6,85 & 4,48 \\
\hline 57,29 & 1607,90 & 39,50 & 35,64 & 29,41 & 28,16 & 26,30 & 24,41 & 22,59 & 19,20 & 16,26 & 11,75 \\
\hline 43,05 & 413,10 & 98,00 & 41,36 & 28,55 & 23,22 & 18,16 & 14,47 & 11,73 & 8,15 & 6,15 & 4,15 \\
\hline 51,53 & 1014,10 & 167,00 & 18,75 & 13,75 & 11,69 & 9,69 & 8,11 & 6,83 & 4,96 & 3,77 & 2,49 \\
\hline 41,16 & 1241,20 & 155,90 & 20,32 & 15,74 & 13,45 & 10,99 & 9,02 & 7,46 & 5,28 & 3,96 & 2,62 \\
\hline 59,27 & 277,40 & 140,90 & 38,96 & 21,85 & 16,41 & 12,36 & 9,81 & 7,99 & 5,62 & 4,29 & 2,93 \\
\hline 73,59 & 496,00 & 149,30 & 25,19 & 15,61 & 12,55 & 10,18 & 8,57 & 7,31 & 5,45 & 4,24 & 2,85 \\
\hline 77,61 & 999,90 & 77,70 & 23,32 & 17,36 & 15,79 & 14,27 & 13,01 & 11,87 & 9,87 & 8,24 & 5,87 \\
\hline 36,71 & 1830,70 & 118,60 & 22,44 & 18,93 & 16,69 & 14,03 & 11,75 & 9,86 & 7,08 & 5,32 & 3,46 \\
\hline 80,33 & 397,90 & 94,80 & 33,55 & 21,46 & 17,69 & 14,74 & 12,70 & 11,07 & 8,53 & 6,76 & 4,59 \\
\hline 73,76 & 1783,30 & 87,80 & 17,57 & 13,55 & 12,64 & 11,68 & 10,80 & 9,97 & 8,47 & 7,19 & 5,24 \\
\hline 22,15 & 1159,30 & 184,30 & 27,25 & 19,32 & 14,63 & 10,28 & 7,59 & 5,90 & 4,06 & 3,13 & 2,18 \\
\hline 40,47 & 1034,20 & 34,50 & 56,51 & 50,22 & 46,25 & 41,07 & 36,24 & 31,85 & 24,59 & 19,22 & 12,58 \\
\hline 21,76 & 1099,90 & 118,30 & 38,58 & 28,84 & 22,49 & 16,19 & 12,04 & 9,35 & 6,37 & 4,88 & 3,38 \\
\hline 41,95 & 1518,00 & 36,80 & 46,55 & 41,45 & 38,89 & 35,22 & 31,70 & 28,40 & 22,67 & 18,16 & 12,14 \\
\hline 84,79 & 1567,80 & 30,60 & 31,65 & 25,91 & 23,80 & 22,96 & 22,11 & 21,15 & 19,24 & 17,43 & 14,20 \\
\hline 24,21 & 1689,60 & 158,50 & 25,80 & 19,99 & 16,12 & 12,04 & 9,15 & 7,17 & 4,85 & 3,67 & 2,52 \\
\hline 49,70 & 1437,70 & 89,50 & 23,62 & 19,76 & 17,92 & 15,78 & 13,87 & 12,17 & 9,39 & 7,36 & 4,85 \\
\hline 29,89 & 1547,60 & 117,10 & 28,06 & 22,90 & 19,47 & 15,54 & 12,43 & 10,04 & 6,90 & 5,14 & 3,43 \\
\hline 28,84 & 226,90 & 87,50 & 66,65 & 41,15 & 30,28 & 21,18 & 15,77 & 12,38 & 8,56 & 6,61 & 4,62 \\
\hline 21,83 & 518,90 & 126,30 & 44,92 & 29,55 & 21,52 & 14,72 & 10,80 & 8,45 & 5,88 & 4,57 & 3,19 \\
\hline 21,90 & 621,60 & 50,50 & 83,26 & 64,56 & 51,59 & 38,04 & 28,64 & 22,31 & 15,09 & 11,47 & 7,91 \\
\hline 44,04 & 1809,40 & 141,40 & 17,71 & 14,63 & 12,97 & 11,09 & 9,46 & 8,08 & 5,96 & 4,54 & 2,96 \\
\hline 55,46 & 1271,20 & 157,90 & 16,73 & 12,75 & 11,13 & 9,50 & 8,17 & 7,04 & 5,28 & 4,09 & 2,69 \\
\hline 66,42 & 1682,10 & 51,40 & 26,84 & 21,41 & 20,35 & 19,08 & 17,79 & 16,55 & 14,23 & 12,20 & 9,00 \\
\hline 86,36 & 592,70 & 195,20 & 19,61 & 11,61 & 9,19 & 7,41 & 6,28 & 5,41 & 4,12 & 3,25 & 2,22 \\
\hline 74,64 & 920,70 & 32,90 & 41,26 & 32,05 & 30,19 & 28,36 & 26,53 & 24,78 & 21,51 & 18,62 & 13,98 \\
\hline 60,66 & 401,30 & 153,40 & 29,89 & 17,98 & 14,06 & 10,97 & 8,90 & 7,36 & 5,25 & 4,00 & 2,70 \\
\hline 48,17 & 1658,80 & 91,70 & 22,50 & 19,07 & 17,37 & 15,34 & 13,51 & 11,87 & 9,18 & 7,20 & 4,74 \\
\hline 44,16 & 1904,80 & 20,70 & 63,65 & 54,34 & 52,78 & 49,70 & 46,34 & 43,02 & 36,75 & 31,20 & 22,55 \\
\hline
\end{tabular}




\begin{tabular}{|c|c|c|c|c|c|c|c|c|c|c|c|}
\hline \multirow[b]{2}{*}{ e1 (cm) } & & & & & & & ões (x1 & m) & & & \\
\hline & Meq (MPa) & Ms (MPa) & D0 & D25 & D40 & D60 & D80 & D100 & D140 & D180 & D260 \\
\hline 55,71 & 1649,40 & 94,20 & 20,24 & 16,69 & 15,33 & 13,73 & 12,29 & 10,98 & 8,74 & 7,02 & 4,73 \\
\hline 69,16 & 837,50 & 139,70 & 19,67 & 13,80 & 11,82 & 10,08 & 8,75 & 7,63 & 5,87 & 4,63 & 3,11 \\
\hline 50,13 & 971,30 & 183,80 & 18,44 & 13,21 & 11,08 & 9,05 & 7,48 & 6,23 & 4,47 & 3,39 & 2,24 \\
\hline 52,14 & 593,80 & 53,60 & 44,42 & 35,60 & 31,66 & 27,42 & 23,79 & 20,64 & 15,65 & 12,15 & 7,99 \\
\hline 70,52 & 740,60 & 155,30 & 19,86 & 13,34 & 11,17 & 9,36 & 8,03 & 6,95 & 5,27 & 4,13 & 2,77 \\
\hline 62,63 & 435,10 & 161,70 & 27,64 & 16,69 & 13,10 & 10,28 & 8,39 & 6,97 & 5,00 & 3,82 & 2,57 \\
\hline 49,73 & 1065,20 & 67,50 & 31,53 & 26,33 & 23,85 & 20,99 & 18,43 & 16,16 & 12,45 & 9,75 & 6,43 \\
\hline 64,59 & 1958,40 & 91,70 & 17,76 & 14,21 & 13,29 & 12,18 & 11,16 & 10,21 & 8,50 & 7,08 & 5,00 \\
\hline 82,92 & 700,30 & 39,10 & 38,95 & 29,07 & 26,85 & 24,82 & 23,03 & 21,38 & 18,36 & 15,77 & 11,72 \\
\hline 39,05 & 1076,70 & 61,40 & 39,46 & 33,78 & 30,18 & 25,84 & 22,03 & 18,77 & 13,79 & 10,47 & 6,79 \\
\hline 83,40 & 942,10 & 85,20 & 22,03 & 15,90 & 14,30 & 12,85 & 11,70 & 10,68 & 8,90 & 7,45 & 5,34 \\
\hline 88,99 & 1850,90 & 24,10 & 31,26 & 28,46 & 25,53 & 24,50 & 23,94 & 23,20 & 21,54 & 19,92 & 16,88 \\
\hline 87,83 & 1900,50 & 123,60 & 12,77 & 9,33 & 8,52 & 7,84 & 7,26 & 6,73 & 5,78 & 4,97 & 3,70 \\
\hline 71,42 & 1433,30 & 174,70 & 13,24 & 9,66 & 8,50 & 7,43 & 6,58 & 5,85 & 4,63 & 3,72 & 2,54 \\
\hline 78,45 & 1865,90 & 128,40 & 13,32 & 9,97 & 9,13 & 8,32 & 7,63 & 7,00 & 5,88 & 4,95 & 3,57 \\
\hline 46,83 & 1765,00 & 105,40 & 20,54 & 17,36 & 15,71 & 13,77 & 12,03 & 10,49 & 8,01 & 6,23 & 4,08 \\
\hline 30,31 & 878,50 & 193,90 & 24,14 & 16,84 & 13,18 & 9,68 & 7,34 & 5,77 & 3,94 & 3,01 & 2,08 \\
\hline 89,42 & 650,40 & 116,10 & 22,39 & 14,67 & 12,43 & 10,66 & 9,42 & 8,40 & 6,75 & 5,51 & 3,84 \\
\hline 38,94 & 839,10 & 123,80 & 28,26 & 21,34 & 17,90 & 14,30 & 11,52 & 9,39 & 6,54 & 4,90 & 3,28 \\
\hline 71,60 & 1730,00 & 194,50 & 11,43 & 8,41 & 7,45 & 6,55 & 5,83 & 5,20 & 4,14 & 3,35 & 2,29 \\
\hline 42,41 & 1344,60 & 34,80 & 49,93 & 44,37 & 41,54 & 37,56 & 33,75 & 30,19 & 24,04 & 19,23 & 12,84 \\
\hline 66,39 & 1766,70 & 91,10 & 18,24 & 14,46 & 13,46 & 12,30 & 11,26 & 10,28 & 8,55 & 7,11 & 5,03 \\
\hline 73,51 & 944,10 & 145,20 & 17,69 & 12,42 & 10,71 & 9,23 & 8,10 & 7,14 & 5,59 & 4,46 & 3,03 \\
\hline 83,07 & 672,00 & 187,20 & 18,53 & 11,42 & 9,24 & 7,59 & 6,49 & 5,62 & 4,31 & 3,41 & 2,32 \\
\hline 31,77 & 1029,80 & 188,30 & 22,68 & 16,41 & 13,16 & 9,91 & 7,63 & 6,04 & 4,12 & 3,12 & 2,14 \\
\hline 63,54 & 1238,80 & 154,90 & 15,96 & 11,89 & 10,42 & 9,02 & 7,88 & 6,90 & 5,33 & 4,20 & 2,81 \\
\hline 66,06 & 248,20 & 172,70 & 38,61 & 19,77 & 14,11 & 10,23 & 7,99 & 6,47 & 4,54 & 3,48 & 2,40 \\
\hline 61,26 & 373,70 & 60,90 & 46,99 & 33,81 & 28,96 & 24,50 & 21,01 & 18,09 & 13,60 & 10,55 & 7,00 \\
\hline 67,50 & 1808,10 & 105,50 & 16,37 & 12,86 & 11,89 & 10,82 & 9,86 & 8,98 & 7,43 & 6,16 & 4,33 \\
\hline 40,03 & 734,40 & 21,50 & 87,62 & 78,33 & 72,51 & 64,73 & 57,41 & 50,71 & 39,45 & 31,00 & 20,35 \\
\hline 52,33 & 499,60 & 90,10 & 36,00 & 25,92 & 21,90 & 18,05 & 15,06 & 12,65 & 9,16 & 6,97 & 4,61 \\
\hline 64,10 & 928,90 & 33,10 & 44,89 & 36,11 & 34,17 & 31,70 & 29,33 & 27,07 & 22,91 & 19,37 & 13,97 \\
\hline 25,44 & 605,30 & 55,00 & 71,17 & 55,75 & 45,51 & 34,49 & 26,49 & 20,85 & 14,11 & 10,64 & 7,28 \\
\hline 82,15 & 1333,90 & 172,50 & 13,04 & 9,11 & 7,98 & 6,99 & 6,26 & 5,62 & 4,55 & 3,73 & 2,60 \\
\hline 62,90 & 1204,00 & 77,40 & 24,05 & 19,16 & 17,58 & 15,81 & 14,27 & 12,85 & 10,40 & 8,47 & 5,82 \\
\hline 28,60 & 1527,20 & 136,30 & 26,29 & 20,94 & 17,47 & 13,63 & 10,70 & 8,54 & 5,82 & 4,35 & 2,94 \\
\hline 39,88 & 1295,80 & 114,80 & 24,55 & 19,99 & 17,43 & 14,54 & 12,12 & 10,14 & 7,27 & 5,47 & 3,58 \\
\hline 33,41 & 1612,20 & 71,00 & 35,16 & 30,68 & 27,35 & 23,21 & 19,58 & 16,51 & 11,92 & 8,96 & 5,80 \\
\hline 32,55 & 825,80 & 67,40 & 46,94 & 38,26 & 32,76 & 26,46 & 21,39 & 17,44 & 12,10 & 9,02 & 5,98 \\
\hline 25,32 & 868,80 & 89,10 & 45,70 & 35,24 & 28,46 & 21,33 & 16,27 & 12,76 & 8,65 & 6,54 & 4,49 \\
\hline 81,07 & 816,40 & 73,30 & 25,84 & 18,81 & 16,94 & 15,21 & 13,82 & 12,59 & 10,44 & 8,71 & 6,21 \\
\hline 45,25 & 389,60 & 130,30 & 35,85 & 22,86 & 18,00 & 13,75 & 10,84 & 8,73 & 6,05 & 4,59 & 3,13 \\
\hline 45,41 & 1545,50 & 32,50 & 47,89 & 41,83 & 39,78 & 36,56 & 33,40 & 30,37 & 24,93 & 20,45 & 14,07 \\
\hline 23,40 & 811,00 & 82,20 & 52,08 & 39,74 & 31,63 & 23,28 & 17,54 & 13,68 & 9,28 & 7,06 & 4,87 \\
\hline 67,93 & 1134,30 & 52,40 & 30,05 & 23,73 & 22,22 & 20,46 & 18,84 & 17,31 & 14,56 & 12,24 & 8,77 \\
\hline 67,18 & 1458,80 & 63,10 & 24,53 & 19,45 & 18,27 & 16,86 & 15,55 & 14,31 & 12,06 & 10,16 & 7,30 \\
\hline 72,09 & 405,80 & 65,80 & 40,44 & 28,27 & 24,27 & 20,79 & 18,16 & 15,94 & 12,39 & 9,83 & 6,64 \\
\hline 41,64 & 324,50 & 95,20 & 47,58 & 31,41 & 24,92 & 19,02 & 14,91 & 11,96 & 8,26 & 6,25 & 4,26 \\
\hline 23,02 & 1003,60 & 120,20 & 37,73 & 28,08 & 21,97 & 15,89 & 11,87 & 9,23 & 6,29 & 4,81 & 3,33 \\
\hline 78,24 & 586,00 & 147,20 & 22,48 & 14,31 & 11,73 & 9,72 & 8,33 & 7,22 & 5,51 & 4,35 & 2,94 \\
\hline 57,71 & 1484,80 & 191,60 & 13,74 & 10,36 & 9,03 & 7,72 & 6,66 & 5,76 & 4,35 & 3,37 & 2,23 \\
\hline 74,17 & 1116,50 & 198,40 & 13,93 & 9,54 & 8,12 & 6,92 & 6,03 & 5,28 & 4,10 & 3,26 & 2,20 \\
\hline 84,50 & 1126,10 & 34,00 & 34,44 & 26,72 & 24,83 & 23,66 & 22,46 & 21,25 & 18,94 & 16,83 & 13,23 \\
\hline 40,79 & 233,50 & 40,90 & 89,33 & 65,49 & 54,47 & 43,28 & 34,79 & 28,33 & 19,74 & 14,83 & 9,93 \\
\hline 87,56 & 822,80 & 101,20 & 21,14 & 14,62 & 12,83 & 11,32 & 10,19 & 9,23 & 7,59 & 6,30 & 4,47 \\
\hline 89,26 & 300,00 & 146,70 & 34,10 & 18,50 & 13,85 & 10,64 & 8,73 & 7,37 & 5,46 & 4,27 & 2,92 \\
\hline 26,24 & 918,10 & 189,20 & 26,06 & 18,16 & 13,94 & 9,98 & 7,45 & 5,82 & 3,99 & 3,06 & 2,12 \\
\hline 82,46 & 1822,20 & 64,20 & 19,74 & 15,14 & 14,13 & 13,37 & 12,60 & 11,85 & 10,45 & 9,18 & 7,08 \\
\hline 34,66 & 1872,10 & 68,50 & 33,15 & 29,44 & 26,59 & 22,97 & 19,71 & 16,87 & 12,46 & 9,46 & 6,11 \\
\hline 66,79 & 339,80 & 196,80 & 29,81 & 15,99 & 11,77 & 8,77 & 6,96 & 5,70 & 4,03 & 3,09 & 2,11 \\
\hline 43,82 & 298,80 & 144,10 & 39,47 & 22,94 & 17,21 & 12,63 & 9,73 & 7,76 & 5,35 & 4,09 & 2,83 \\
\hline 40,61 & 864,80 & 34,30 & 60,27 & 53,07 & 48,49 & 42,68 & 37,35 & 32,58 & 24,84 & 19,25 & 12,54 \\
\hline 39,42 & 803,40 & 125,90 & 28,25 & 21,12 & 17,66 & 14,07 & 11,31 & 9,21 & 6,41 & 4,81 & 3,22 \\
\hline 59,91 & 1401,30 & 135,60 & 16,72 & 13,01 & 11,59 & 10,15 & 8,93 & 7,86 & 6,11 & 4,83 & 3,22 \\
\hline 55,69 & 1348,60 & 94,10 & 21,90 & 17,82 & 16,17 & 14,32 & 12,70 & 11,24 & 8,82 & 7,00 & 4,68 \\
\hline 79,35 & 929,40 & 147,40 & 17,20 & 11,81 & 10,15 & 8,76 & 7,73 & 6,85 & 5,43 & 4,38 & 3,01 \\
\hline 41,40 & 1143,00 & 130,10 & 23,32 & 18,34 & 15,79 & 13,01 & 10,76 & 8,94 & 6,36 & 4,78 & 3,15 \\
\hline 56,60 & 1505,20 & 157,20 & 15,38 & 11,97 & 10,59 & 9,17 & 7,98 & 6,95 & 5,31 & 4,14 & 2,74 \\
\hline 20,29 & 705,00 & 77,40 & 62,00 & 45,59 & 34,93 & 24,70 & 18,20 & 14,11 & 9,67 & 7,45 & 5,17 \\
\hline 39,60 & 1536,50 & 101,10 & 25,02 & 21,11 & 18,73 & 15,93 & 13,50 & 11,45 & 8,35 & 6,32 & 4,11 \\
\hline 65,14 & 923,70 & 72,20 & 27,42 & 21,38 & 19,40 & 17,32 & 15,54 & 13,94 & 11,20 & 9,08 & 6,21 \\
\hline 56,82 & 1263,90 & 40,40 & 38,09 & 31,63 & 29,97 & 27,65 & 25,41 & 23,28 & 19,41 & 16,17 & 11,40 \\
\hline 80,38 & 336,40 & 83,60 & 39,02 & 24,75 & 20,31 & 16,85 & 14,49 & 12,59 & 9,67 & 7,66 & 5,20 \\
\hline 30,36 & 1131,60 & 134,70 & 28,10 & 21,67 & 17,87 & 13,80 & 10,77 & 8,58 & 5,85 & 4,39 & 2,98 \\
\hline 70,41 & 574,70 & 89,10 & 29,46 & 20,84 & 17,96 & 15,42 & 13,47 & 11,82 & 9,17 & 7,27 & 4,90 \\
\hline 38,94 & 401,20 & 32,80 & 84,79 & 69,73 & 61,00 & 50,96 & 42,52 & 35,58 & 25,51 & 19,18 & 12,53 \\
\hline 80,49 & 1442,40 & 94,60 & 17,49 & 13,03 & 11,96 & 10,94 & 10,07 & 9,27 & 7,85 & 6,65 & 4,84 \\
\hline 69,14 & 1407,10 & 117,40 & 16,82 & 12,85 & 11,63 & 10,39 & 9,35 & 8,42 & 6,81 & 5,56 & 3,84 \\
\hline 88,73 & 949,20 & 142,90 & 16,58 & 11,15 & 9,60 & 8,35 & 7,45 & 6,69 & 5,43 & 4,47 & 3,14 \\
\hline 23,79 & 1308,00 & 123,10 & 33,65 & 25,98 & 20,88 & 15,52 & 11,76 & 9,20 & 6,23 & 4,72 & 3,25 \\
\hline 74,93 & 1505,50 & 156,60 & 13,41 & 9,84 & 8,77 & 7,77 & 6,97 & 6,27 & 5,07 & 4,14 & 2,87 \\
\hline 28,57 & 1937,80 & 157,60 & 22,07 & 17,77 & 14,93 & 11,73 & 9,26 & 7,41 & 5,06 & 3,78 & 2,54 \\
\hline
\end{tabular}




\begin{tabular}{|c|c|c|c|c|c|c|c|c|c|c|c|}
\hline \multirow[b]{2}{*}{$\mathrm{e} 1(\mathrm{~cm})$} & & & & & & $\mathrm{De}$ & ões (x1 & & & & \\
\hline & Meq (MPa) & Ms (MPa) & D0 & D25 & D40 & D60 & D80 & D100 & D140 & D180 & D260 \\
\hline 65,66 & 1089,20 & 121,70 & 18,97 & 14,25 & 12,60 & 11,02 & 9,72 & 8,59 & 6,74 & 5,37 & 3,62 \\
\hline 84,51 & 710,00 & 183,40 & 17,96 & 11,20 & 9,13 & 7,56 & 6,51 & 5,67 & 4,38 & 3,49 & 2,38 \\
\hline 69,11 & 578,40 & 106,90 & 27,14 & 18,72 & 15,88 & 13,42 & 11,59 & 10,06 & 7,68 & 6,03 & 4,04 \\
\hline 50,39 & 829,30 & 49,90 & 41,45 & 34,69 & 31,55 & 27,88 & 24,60 & 21,65 & 16,80 & 13,21 & 8,74 \\
\hline 46,18 & 1884,30 & 183,00 & 14,47 & 11,61 & 10,19 & 8,65 & 7,34 & 6,24 & 4,59 & 3,49 & 2,28 \\
\hline 68,85 & 1438,70 & 42,20 & 31,53 & 24,97 & 23,72 & 22,35 & 20,92 & 19,54 & 16,95 & 14,64 & 10,95 \\
\hline 33,30 & 1189,20 & 110,80 & 29,44 & 23,63 & 20,12 & 16,16 & 13,01 & 10,58 & 7,33 & 5,47 & 3,64 \\
\hline 30,09 & 1508,70 & 87,10 & 34,24 & 28,82 & 24,97 & 20,37 & 16,59 & 13,58 & 9,45 & 7,02 & 4,63 \\
\hline 51,71 & 1707,20 & 177,60 & 14,31 & 11,27 & 9,93 & 8,51 & 7,32 & 6,30 & 4,72 & 3,64 & 2,39 \\
\hline 72,04 & 569,90 & 51,10 & 39,11 & 29,39 & 26,48 & 23,62 & 21,27 & 19,16 & 15,55 & 12,73 & 8,83 \\
\hline 77,46 & 1704,70 & 119,70 & 14,50 & 10,87 & 9,95 & 9,04 & 8,28 & 7,58 & 6,35 & 5,32 & 3,82 \\
\hline 42,22 & 1453,80 & 170,50 & 17,78 & 13,92 & 11,98 & 9,88 & 8,18 & 6,81 & 4,85 & 3,65 & 2,40 \\
\hline 35,83 & 285,90 & 90,20 & 55,10 & 35,89 & 27,81 & 20,53 & 15,71 & 12,43 & 8,53 & 6,50 & 4,49 \\
\hline 86,86 & 605,20 & 127,30 & 22,67 & 14,58 & 12,15 & 10,27 & 8,97 & 7,92 & 6,25 & 5,04 & 3,47 \\
\hline 42,94 & 1015,30 & 169,00 & 20,55 & 15,19 & 12,75 & 10,26 & 8,34 & 6,85 & 4,82 & 3,62 & 2,41 \\
\hline 31,98 & 1399,80 & 193,40 & 19,92 & 15,09 & 12,40 & 9,57 & 7,48 & 5,96 & 4,07 & 3,06 & 2,08 \\
\hline 85,07 & 1630,00 & 54,80 & 22,22 & 17,08 & 15,86 & 15,06 & 14,25 & 13,45 & 11,93 & 10,56 & 8,24 \\
\hline 20,93 & 349,30 & 35,20 & 130,74 & 97,86 & 76,07 & 54,53 & 40,44 & 31,36 & 21,39 & 16,41 & 11,38 \\
\hline 29,13 & 918,70 & 193,20 & 24,32 & 17,06 & 13,32 & 9,74 & 7,36 & 5,77 & 3,95 & 3,01 & 2,08 \\
\hline 40,48 & 1749,60 & 196,10 & 15,60 & 12,30 & 10,58 & 8,69 & 7,16 & 5,94 & 4,21 & 3,16 & 2,08 \\
\hline 33,53 & 1100,60 & 157,30 & 24,08 & 18,19 & 15,02 & 11,67 & 9,18 & 7,35 & 5,04 & 3,78 & 2,56 \\
\hline 40,38 & 1814,80 & 162,00 & 17,30 & 14,07 & 12,29 & 10,26 & 8,57 & 7,18 & 5,16 & 3,88 & 2,54 \\
\hline 83,02 & 646,20 & 131,00 & 21,86 & 14,29 & 11,98 & 10,14 & 8,85 & 7,79 & 6,12 & 4,91 & 3,36 \\
\hline 56,85 & 1303,60 & 145,20 & 17,09 & 13,19 & 11,61 & 10,02 & 8,69 & 7,55 & 5,74 & 4,48 & 2,96 \\
\hline 42,62 & 721,00 & 47,50 & 50,53 & 42,58 & 38,04 & 32,72 & 28,05 & 24,04 & 17,83 & 13,62 & 8,86 \\
\hline 84,01 & 413,00 & 140,70 & 27,99 & 16,53 & 13,04 & 10,48 & 8,84 & 7,58 & 5,73 & 4,51 & 3,06 \\
\hline 71,06 & 590,80 & 162,30 & 22,15 & 14,07 & 11,45 & 9,36 & 7,90 & 6,75 & 5,03 & 3,91 & 2,62 \\
\hline 22,68 & 1469,90 & 60,70 & 55,35 & 46,38 & 39,25 & 30,89 & 24,32 & 19,39 & 13,13 & 9,77 & 6,57 \\
\hline 25,59 & 1775,40 & 198,50 & 20,92 & 15,97 & 12,84 & 9,58 & 7,29 & 5,71 & 3,87 & 2,94 & 2,02 \\
\hline 53,08 & 1326,10 & 172,60 & 16,02 & 12,18 & 10,57 & 8,95 & 7,63 & 6,52 & 4,83 & 3,71 & 2,44 \\
\hline 73,79 & 227,00 & 42,60 & 66,99 & 45,50 & 38,52 & 32,67 & 28,36 & 24,78 & 19,13 & 15,14 & 10,22 \\
\hline 76,11 & 390,60 & 65,40 & 40,53 & 27,86 & 23,84 & 20,43 & 17,91 & 15,78 & 12,37 & 9,88 & 6,72 \\
\hline 46,80 & 1219,60 & 173,30 & 17,81 & 13,48 & 11,54 & 9,54 & 7,94 & 6,64 & 4,78 & 3,61 & 2,38 \\
\hline 57,99 & 1388,30 & 151,90 & 16,03 & 12,36 & 10,91 & 9,44 & 8,22 & 7,16 & 5,48 & 4,29 & 2,84 \\
\hline 36,65 & 1494,60 & 123,40 & 23,61 & 19,35 & 16,81 & 13,88 & 11,45 & 9,49 & 6,72 & 5,03 & 3,30 \\
\hline 69,13 & 1771,20 & 195,90 & 11,44 & 8,51 & 7,54 & 6,62 & 5,88 & 5,22 & 4,14 & 3,33 & 2,26 \\
\hline 38,22 & 315,60 & 100,70 & 48,34 & 31,38 & 24,47 & 18,26 & 14,09 & 11,20 & 7,69 & 5,85 & 4,02 \\
\hline 84,35 & 337,50 & 189,00 & 29,42 & 15,58 & 11,46 & 8,63 & 6,98 & 5,81 & 4,23 & 3,28 & 2,24 \\
\hline 43,70 & 599,70 & 194,00 & 23,99 & 15,45 & 12,18 & 9,29 & 7,29 & 5,86 & 4,06 & 3,07 & 2,10 \\
\hline 89,02 & 1360,30 & 132,30 & 14,28 & 10,07 & 8,99 & 8,07 & 7,35 & 6,73 & 5,64 & 4,75 & 3,44 \\
\hline 49,55 & 665,10 & 44,10 & 49,25 & 41,00 & 37,04 & 32,49 & 28,46 & 24,88 & 19,09 & 14,91 & 9,81 \\
\hline 69,87 & 479,80 & 104,10 & 30,31 & 20,26 & 16,91 & 14,11 & 12,08 & 10,42 & 7,88 & 6,15 & 4,12 \\
\hline 48,53 & 1879,20 & 79,40 & 23,47 & 20,16 & 18,64 & 16,71 & 14,93 & 13,29 & 10,51 & 8,37 & 5,58 \\
\hline 45,34 & 1418,90 & 107,60 & 22,56 & 18,67 & 16,63 & 14,30 & 12,28 & 10,54 & 7,85 & 6,01 & 3,92 \\
\hline 81,74 & 472,80 & 129,20 & 26,64 & 16,54 & 13,42 & 11,03 & 9,44 & 8,18 & 6,25 & 4,94 & 3,36 \\
\hline 30,50 & 1183,70 & 42,80 & 58,77 & 51,83 & 46,19 & 39,08 & 32,84 & 27,58 & 19,79 & 14,81 & 9,58 \\
\hline 79,61 & 1061,00 & 92,90 & 20,32 & 14,89 & 13,44 & 12,08 & 10,97 & 9,99 & 8,27 & 6,89 & 4,90 \\
\hline 46,77 & 1909,00 & 175,90 & 14,61 & 11,79 & 10,40 & 8,87 & 7,57 & 6,46 & 4,78 & 3,65 & 2,39 \\
\hline 68,75 & 297,40 & 60,60 & 50,59 & 34,32 & 28,83 & 24,17 & 20,73 & 17,91 & 13,56 & 10,59 & 7,09 \\
\hline 59,04 & 1867,80 & 143,80 & 14,42 & 11,51 & 10,41 & 9,22 & 8,19 & 7,27 & 5,73 & 4,57 & 3,07 \\
\hline 25,36 & 1178,60 & 159,20 & 27,77 & 20,62 & 16,29 & 11,95 & 9,00 & 7,03 & 4,78 & 3,65 & 2,52 \\
\hline 34,46 & 1027,10 & 130,10 & 27,38 & 21,10 & 17,65 & 13,93 & 11,09 & 8,94 & 6,16 & 4,61 & 3,10 \\
\hline 69,69 & 1405,80 & 153,90 & 14,44 & 10,73 & 9,52 & 8,37 & 7,44 & 6,62 & 5,26 & 4,24 & 2,89 \\
\hline 38,15 & 1833,40 & 109,20 & 22,94 & 19,55 & 17,39 & 14,79 & 12,53 & 10,62 & 7,74 & 5,85 & 3,80 \\
\hline 81,92 & 607,10 & 48,50 & 36,86 & 26,99 & 24,49 & 22,16 & 20,26 & 18,55 & 15,54 & 13,07 & 9,41 \\
\hline 77,96 & 665,10 & 172,50 & 19,58 & 12,39 & 10,13 & 8,36 & 7,15 & 6,18 & 4,71 & 3,70 & 2,50 \\
\hline 50,18 & 369,00 & 140,10 & 34,42 & 21,12 & 16,46 & 12,60 & 10,00 & 8,11 & 5,66 & 4,29 & 2,92 \\
\hline 78,83 & 1167,40 & 33,90 & 35,76 & 27,86 & 26,13 & 24,87 & 23,52 & 22,18 & 19,63 & 17,31 & 13,42 \\
\hline 24,05 & 1800,40 & 43,90 & 61,68 & 54,64 & 48,21 & 40,05 & 33,01 & 27,24 & 19,06 & 14,11 & 9,19 \\
\hline 20,82 & 659,80 & 86,20 & 57,31 & 41,35 & 31,40 & 22,06 & 16,23 & 12,60 & 8,67 & 6,69 & 4,65 \\
\hline 61,20 & 1304,20 & 185,90 & 14,42 & 10,61 & 9,19 & 7,85 & 6,78 & 5,88 & 4,46 & 3,48 & 2,31 \\
\hline 36,72 & 1109,80 & 149,20 & 23,43 & 17,94 & 15,06 & 11,98 & 9,61 & 7,80 & 5,40 & 4,05 & 2,71 \\
\hline 43,95 & 1984,60 & 90,00 & 22,72 & 19,72 & 18,02 & 15,91 & 13,98 & 12,25 & 9,41 & 7,34 & 4,81 \\
\hline 36,25 & 909,20 & 33,00 & 66,26 & 58,91 & 53,47 & 46,55 & 40,24 & 34,69 & 25,92 & 19,81 & 12,81 \\
\hline 51,21 & 1759,10 & 26,00 & 50,03 & 41,79 & 40,45 & 38,19 & 35,71 & 33,26 & 28,61 & 24,48 & 17,94 \\
\hline 83,83 & 244,20 & 24,60 & 80,08 & 57,18 & 51,02 & 45,55 & 41,29 & 37,54 & 31,07 & 25,89 & 18,44 \\
\hline 52,45 & 1793,90 & 193,30 & 13,24 & 10,36 & 9,11 & 7,81 & 6,71 & 5,78 & 4,33 & 3,34 & 2,20 \\
\hline 20,57 & 656,50 & 122,10 & 44,65 & 30,43 & 22,37 & 15,34 & 11,23 & 8,76 & 6,09 & 4,72 & 3,29 \\
\hline 41,61 & 973,60 & 180,70 & 20,48 & 14,85 & 12,31 & 9,77 & 7,85 & 6,40 & 4,46 & 3,35 & 2,25 \\
\hline 87,42 & 1547,40 & 98,60 & 15,90 & 11,64 & 10,65 & 9,80 & 9,08 & 8,42 & 7,24 & 6,22 & 4,64 \\
\hline 30,73 & 1234,80 & 111,20 & 30,70 & 24,59 & 20,75 & 16,43 & 13,06 & 10,52 & 7,22 & 5,39 & 3,61 \\
\hline 61,34 & 1619,60 & 126,80 & 16,12 & 12,74 & 11,53 & 10,24 & 9,14 & 8,14 & 6,46 & 5,18 & 3,50 \\
\hline 81,57 & 1635,60 & 125,60 & 14,02 & 10,31 & 9,37 & 8,50 & 7,78 & 7,14 & 5,99 & 5,04 & 3,64 \\
\hline 58,39 & 1893,40 & 40,90 & 32,66 & 26,76 & 25,70 & 24,19 & 22,58 & 21,01 & 18,06 & 15,46 & 11,35 \\
\hline 53,93 & 1320,80 & 115,10 & 19,98 & 16,00 & 14,29 & 12,45 & 10,87 & 9,49 & 7,27 & 5,68 & 3,75 \\
\hline 81,39 & 1327,00 & 170,70 & 13,19 & 9,25 & 8,10 & 7,10 & 6,35 & 5,70 & 4,61 & 3,77 & 2,63 \\
\hline 86,01 & 1681,00 & 42,10 & 25,32 & 20,06 & 18,52 & 17,77 & 16,99 & 16,17 & 14,57 & 13,09 & 10,48 \\
\hline 82,02 & 488,40 & 126,60 & 26,29 & 16,48 & 13,45 & 11,12 & 9,55 & 8,30 & 6,38 & 5,05 & 3,44 \\
\hline 89,87 & 1512,70 & 164,70 & 12,08 & 8,41 & 7,44 & 6,63 & 6,01 & 5,48 & 4,57 & 3,83 & 2,76 \\
\hline 20,52 & 332,80 & 64,40 & 85,57 & 57,89 & 42,40 & 29,00 & 21,23 & 16,56 & 11,53 & 8,95 & 6,23 \\
\hline 47,91 & 1536,00 & 122,00 & 19,53 & 16,02 & 14,28 & 12,34 & 10,65 & 9,19 & 6,91 & 5,32 & 3,48 \\
\hline 81,02 & 785,40 & 77,20 & 25,61 & 18,50 & 16,55 & 14,78 & 13,38 & 12,14 & 10,01 & 8,31 & 5,88 \\
\hline
\end{tabular}




\begin{tabular}{|c|c|c|c|c|c|c|c|c|c|c|c|}
\hline \multirow[b]{2}{*}{ e1 (cm) } & & & & & & & ões (x1 & m) & & & \\
\hline & Meq (MPa) & Ms (MPa) & D0 & D25 & D40 & D60 & D80 & D100 & D140 & D180 & D260 \\
\hline 54,68 & 427,30 & 72,30 & 42,57 & 30,89 & 26,28 & 21,90 & 18,46 & 15,64 & 11,47 & 8,77 & 5,79 \\
\hline 59,82 & 1750,10 & 59,10 & 25,70 & 21,06 & 19,95 & 18,44 & 16,99 & 15,61 & 13,10 & 10,97 & 7,81 \\
\hline 82,61 & 1919,20 & 54,10 & 21,39 & 16,69 & 15,55 & 14,85 & 14,10 & 13,35 & 11,91 & 10,58 & 8,32 \\
\hline 55,14 & 1999,20 & 59,50 & 25,72 & 21,52 & 20,42 & 18,85 & 17,32 & 15,86 & 13,21 & 10,99 & 7,74 \\
\hline 56,32 & 551,70 & 36,80 & 54,66 & 44,55 & 40,56 & 36,06 & 32,09 & 28,51 & 22,49 & 17,93 & 12,03 \\
\hline 52,72 & 1914,10 & 51,70 & 29,53 & 24,96 & 23,73 & 21,90 & 20,11 & 18,40 & 15,30 & 12,70 & 8,90 \\
\hline 49,21 & 977,80 & 125,90 & 22,81 & 17,49 & 15,13 & 12,69 & 10,70 & 9,06 & 6,62 & 5,04 & 3,31 \\
\hline 70,19 & 245,40 & 93,00 & 47,29 & 28,01 & 21,90 & 17,28 & 14,25 & 11,96 & 8,71 & 6,71 & 4,52 \\
\hline 65,48 & 504,30 & 138,50 & 26,63 & 17,13 & 13,95 & 11,34 & 9,49 & 8,03 & 5,91 & 4,55 & 3,04 \\
\hline 57,03 & 515,90 & 122,60 & 29,24 & 19,75 & 16,31 & 13,27 & 11,02 & 9,24 & 6,69 & 5,10 & 3,39 \\
\hline 87,26 & 1738,10 & 99,40 & 15,06 & 11,11 & 10,21 & 9,45 & 8,79 & 8,18 & 7,07 & 6,11 & 4,59 \\
\hline 50,28 & 1512,30 & 64,30 & 28,40 & 24,23 & 22,45 & 20,20 & 18,12 & 16,19 & 12,89 & 10,33 & 6,94 \\
\hline 78,88 & 1969,50 & 57,90 & 21,01 & 16,35 & 15,34 & 14,59 & 13,79 & 13,00 & 11,50 & 10,14 & 7,85 \\
\hline 20,63 & 1850,90 & 57,40 & 58,04 & 49,13 & 41,69 & 32,84 & 25,84 & 20,58 & 13,90 & 10,32 & 6,95 \\
\hline 80,87 & 1715,40 & 73,50 & 18,86 & 14,35 & 13,38 & 12,52 & 11,71 & 10,94 & 9,51 & 8,25 & 6,23 \\
\hline 25,03 & 960,90 & 155,00 & 30,31 & 21,87 & 16,98 & 12,25 & 9,15 & 7,14 & 4,88 & 3,74 & 2,59 \\
\hline 52,26 & 1249,30 & 89,10 & 24,24 & 19,90 & 17,97 & 15,79 & 13,88 & 12,18 & 9,40 & 7,38 & 4,88 \\
\hline 50,28 & 214,50 & 172,30 & 43,59 & 21,68 & 15,07 & 10,55 & 8,02 & 6,39 & 4,42 & 3,40 & 2,39 \\
\hline 72,76 & 1847,70 & 45,50 & 26,49 & 20,92 & 19,80 & 18,88 & 17,84 & 16,81 & 14,85 & 13,05 & 10,05 \\
\hline 21,34 & 318,60 & 153,80 & 44,82 & 25,38 & 17,44 & 11,66 & 8,63 & 6,83 & 4,81 & 3,74 & 2,63 \\
\hline 33,35 & 1057,10 & 58,80 & 46,17 & 39,38 & 34,65 & 28,92 & 24,05 & 20,04 & 14,25 & 10,65 & 6,94 \\
\hline 30,32 & 471,00 & 108,40 & 43,79 & 30,30 & 23,63 & 17,30 & 13,10 & 10,29 & 7,04 & 5,37 & 3,71 \\
\hline 46,59 & 1359,80 & 65,90 & 30,50 & 26,19 & 23,96 & 21,23 & 18,74 & 16,49 & 12,78 & 10,03 & 6,61 \\
\hline 61,42 & 938,10 & 100,10 & 23,34 & 17,87 & 15,83 & 13,80 & 12,12 & 10,65 & 8,26 & 6,53 & 4,36 \\
\hline 88,08 & 926,40 & 150,60 & 16,45 & 10,97 & 9,39 & 8,11 & 7,20 & 6,44 & 5,19 & 4,25 & 2,97 \\
\hline 40,63 & 1231,20 & 115,30 & 24,65 & 19,93 & 17,35 & 14,46 & 12,05 & 10,08 & 7,23 & 5,44 & 3,56 \\
\hline 30,32 & 930,20 & 37,20 & 70,27 & 61,39 & 54,37 & 45,63 & 38,06 & 31,77 & 22,61 & 16,87 & 10,95 \\
\hline 22,90 & 1826,60 & 194,40 & 22,64 & 17,11 & 13,50 & 9,85 & 7,38 & 5,74 & 3,90 & 2,98 & 2,06 \\
\hline 22,38 & 1117,70 & 115,10 & 38,47 & 29,07 & 22,89 & 16,65 & 12,45 & 9,68 & 6,58 & 5,03 & 3,48 \\
\hline 47,53 & 1395,20 & 138,20 & 18,97 & 15,15 & 13,32 & 11,33 & 9,65 & 8,23 & 6,08 & 4,64 & 3,04 \\
\hline 66,26 & 1702,10 & 27,70 & 40,28 & 32,51 & 30,94 & 29,79 & 28,32 & 26,81 & 23,87 & 21,14 & 16,47 \\
\hline 48,54 & 1451,80 & 110,90 & 20,97 & 17,25 & 15,43 & 13,39 & 11,61 & 10,05 & 7,60 & 5,87 & 3,85 \\
\hline 76,40 & 750,00 & 123,90 & 21,21 & 14,60 & 12,51 & 10,74 & 9,42 & 8,31 & 6,52 & 5,22 & 3,55 \\
\hline 72,61 & 270,10 & 54,10 & 54,99 & 37,04 & 31,16 & 26,25 & 22,67 & 19,71 & 15,10 & 11,89 & 8,00 \\
\hline 28,44 & 1019,20 & 100,30 & 37,02 & 29,11 & 24,09 & 18,61 & 14,52 & 11,54 & 7,85 & 5,89 & 4,00 \\
\hline 70,65 & 1089,90 & 128,70 & 17,79 & 13,06 & 11,52 & 10,08 & 8,94 & 7,95 & 6,30 & 5,06 & 3,45 \\
\hline 43,93 & 1995,30 & 40,30 & 39,03 & 34,33 & 32,61 & 29,92 & 27,28 & 24,76 & 20,25 & 16,55 & 11,33 \\
\hline 61,15 & 1204,90 & 36,50 & 39,62 & 32,25 & 30,68 & 28,57 & 26,47 & 24,46 & 20,75 & 17,56 & 12,68 \\
\hline 34,89 & 1725,10 & 49,90 & 41,76 & 37,66 & 34,42 & 30,18 & 26,26 & 22,77 & 17,15 & 13,17 & 8,51 \\
\hline 46,22 & 1554,90 & 181,70 & 15,74 & 12,29 & 10,66 & 8,93 & 7,50 & 6,32 & 4,59 & 3,48 & 2,28 \\
\hline 62,46 & 728,30 & 34,00 & 48,70 & 39,34 & 36,74 & 33,58 & 30,68 & 27,97 & 23,13 & 19,16 & 13,44 \\
\hline 68,89 & 1089,70 & 30,60 & 42,77 & 33,89 & 32,22 & 30,41 & 28,51 & 26,66 & 23,18 & 20,08 & 15,07 \\
\hline 56,85 & 1821,80 & 66,00 & 24,28 & 20,17 & 19,00 & 17,43 & 15,94 & 14,54 & 12,02 & 9,94 & 6,94 \\
\hline 50,21 & 1656,30 & 21,60 & 58,83 & 49,14 & 47,66 & 45,14 & 42,29 & 39,47 & 34,10 & 29,29 & 21,58 \\
\hline 30,37 & 893,60 & 102,30 & 36,50 & 28,30 & 23,41 & 18,13 & 14,19 & 11,31 & 7,72 & 5,79 & 3,92 \\
\hline 46,68 & 530,70 & 83,20 & 38,80 & 28,89 & 24,52 & 20,11 & 16,63 & 13,85 & 9,90 & 7,48 & 4,94 \\
\hline 60,06 & 1719,90 & 126,30 & 15,95 & 12,73 & 11,56 & 10,29 & 9,18 & 8,18 & 6,50 & 5,21 & 3,52 \\
\hline 81,24 & 1328,00 & 119,40 & 15,86 & 11,54 & 10,39 & 9,33 & 8,48 & 7,73 & 6,41 & 5,35 & 3,81 \\
\hline 46,96 & 1065,60 & 85,30 & 28,39 & 23,30 & 20,74 & 17,86 & 15,36 & 13,22 & 9,88 & 7,59 & 4,96 \\
\hline 27,17 & 755,90 & 174,80 & 28,74 & 19,70 & 15,06 & 10,77 & 8,05 & 6,29 & 4,32 & 3,32 & 2,30 \\
\hline 82,88 & 772,80 & 72,20 & 26,48 & 19,09 & 17,14 & 15,37 & 13,97 & 12,73 & 10,57 & 8,83 & 6,30 \\
\hline 80,36 & 442,10 & 160,10 & 25,86 & 15,19 & 11,90 & 9,49 & 7,94 & 6,76 & 5,05 & 3,94 & 2,67 \\
\hline 61,01 & 1024,10 & 63,30 & 29,45 & 23,69 & 21,76 & 19,57 & 17,63 & 15,85 & 12,79 & 10,38 & 7,10 \\
\hline 35,55 & 523,20 & 133,90 & 34,17 & 23,29 & 18,41 & 13,81 & 10,65 & 8,45 & 5,79 & 4,39 & 3,02 \\
\hline 60,69 & 397,60 & 88,80 & 38,08 & 25,86 & 21,50 & 17,71 & 14,88 & 12,61 & 9,27 & 7,12 & 4,73 \\
\hline 52,82 & 1107,30 & 178,00 & 17,17 & 12,61 & 10,76 & 8,96 & 7,54 & 6,37 & 4,66 & 3,55 & 2,34 \\
\hline 36,15 & 803,50 & 26,00 & 81,00 & 72,54 & 66,19 & 57,97 & 50,41 & 43,69 & 32,91 & 25,28 & 16,36 \\
\hline 54,00 & 1233,30 & 110,20 & 21,06 & 16,82 & 15,00 & 13,05 & 11,38 & 9,93 & 7,59 & 5,92 & 3,91 \\
\hline 23,39 & 1852,90 & 47,40 & 59,43 & 52,22 & 45,76 & 37,66 & 30,78 & 25,22 & 17,50 & 12,94 & 8,48 \\
\hline 82,26 & 1197,20 & 134,30 & 15,59 & 11,07 & 9,80 & 8,68 & 7,82 & 7,07 & 5,79 & 4,78 & 3,37 \\
\hline 84,13 & 465,20 & 50,70 & 40,32 & 28,54 & 25,32 & 22,49 & 20,32 & 18,42 & 15,17 & 12,59 & 8,93 \\
\hline 37,39 & 969,00 & 100,10 & 31,22 & 24,86 & 21,32 & 17,37 & 14,19 & 11,68 & 8,20 & 6,14 & 4,06 \\
\hline 34,09 & 434,60 & 37,60 & 83,07 & 67,42 & 57,87 & 46,96 & 38,15 & 31,22 & 21,77 & 16,24 & 10,75 \\
\hline 65,88 & 1162,20 & 155,90 & 16,12 & 11,81 & 10,30 & 8,90 & 7,78 & 6,82 & 5,28 & 4,17 & 2,80 \\
\hline 73,03 & 1240,40 & 112,90 & 17,70 & 13,23 & 11,91 & 10,62 & 9,57 & 8,63 & 7,02 & 5,75 & 3,99 \\
\hline 65,43 & 1249,10 & 167,30 & 15,06 & 11,05 & 9,64 & 8,32 & 7,27 & 6,37 & 4,92 & 3,88 & 2,60 \\
\hline 58,34 & 376,40 & 68,70 & 45,08 & 32,00 & 27,10 & 22,61 & 19,14 & 16,29 & 12,04 & 9,25 & 6,13 \\
\hline 68,78 & 1510,90 & 170,40 & 13,31 & 9,88 & 8,74 & 7,66 & 6,79 & 6,03 & 4,77 & 3,83 & 2,60 \\
\hline 82,09 & 1031,40 & 198,80 & 14,04 & 9,28 & 7,82 & 6,65 & 5,81 & 5,13 & 4,03 & 3,24 & 2,22 \\
\hline 56,65 & 1194,70 & 135,00 & 18,53 & 14,28 & 12,55 & 10,82 & 9,37 & 8,13 & 6,18 & 4,81 & 3,18 \\
\hline 39,88 & 1801,30 & 50,30 & 36,96 & 33,10 & 30,70 & 27,46 & 24,39 & 21,58 & 16,84 & 13,26 & 8,72 \\
\hline 23,39 & 1273,40 & 75,20 & 48,60 & 39,49 & 32,77 & 25,22 & 19,54 & 15,44 & 10,42 & 7,81 & 5,31 \\
\hline 71,13 & 322,70 & 124,80 & 35,57 & 20,94 & 16,32 & 12,85 & 10,59 & 8,89 & 6,48 & 5,00 & 3,37 \\
\hline 86,77 & 473,10 & 74,80 & 32,78 & 22,02 & 18,90 & 16,35 & 14,53 & 13,00 & 10,48 & 8,57 & 5,98 \\
\hline 74,23 & 1162,10 & 51,60 & 28,63 & 22,13 & 20,72 & 19,25 & 17,87 & 16,57 & 14,19 & 12,13 & 8,93 \\
\hline 80,75 & 963,00 & 123,60 & 18,25 & 12,83 & 11,24 & 9,85 & 8,80 & 7,90 & 6,38 & 5,22 & 3,63 \\
\hline 77,45 & 1263,90 & 50,70 & 27,35 & 21,02 & 19,70 & 18,45 & 17,24 & 16,09 & 13,95 & 12,07 & 9,06 \\
\hline 23,27 & 514,80 & 92,10 & 54,80 & 38,47 & 29,15 & 20,54 & 15,19 & 11,83 & 8,14 & 6,27 & 4,36 \\
\hline 53,97 & 1880,20 & 30,50 & 42,31 & 35,04 & 33,85 & 32,01 & 29,96 & 27,95 & 24,12 & 20,71 & 15,27 \\
\hline 74,36 & 1834,50 & 140,20 & 13,09 & 9,87 & 8,99 & 8,11 & 7,38 & 6,71 & 5,54 & 4,60 & 3,25 \\
\hline 64,46 & 276,90 & 171,30 & 35,99 & 19,03 & 13,86 & 10,22 & 8,05 & 6,54 & 4,60 & 3,52 & 2,42 \\
\hline 68,22 & 925,40 & 115,70 & 20,66 & 15,18 & 13,32 & 11,59 & 10,21 & 9,01 & 7,06 & 5,63 & 3,80 \\
\hline
\end{tabular}




\begin{tabular}{|c|c|c|c|c|c|c|c|c|c|c|c|}
\hline \multirow[b]{2}{*}{ e1 (cm) } & & & & & & & ões (x1 & m) & & & \\
\hline & Meq (MPa) & Ms (MPa) & D0 & D25 & D40 & D60 & D80 & D100 & D140 & D180 & D260 \\
\hline 86,47 & 1580,70 & 38,10 & 27,40 & 21,84 & 20,12 & 19,33 & 18,51 & 17,63 & 15,93 & 14,34 & 11,54 \\
\hline 66,10 & 1690,40 & 38,60 & 32,53 & 26,03 & 24,85 & 23,60 & 22,20 & 20,83 & 18,21 & 15,85 & 11,98 \\
\hline 22,82 & 1022,80 & 151,50 & 31,95 & 23,02 & 17,66 & 12,55 & 9,30 & 7,23 & 4,96 & 3,81 & 2,65 \\
\hline 28,28 & 1931,70 & 175,00 & 20,74 & 16,47 & 13,70 & 10,64 & 8,33 & 6,64 & 4,52 & 3,38 & 2,29 \\
\hline 37,21 & 545,10 & 90,20 & 41,69 & 30,86 & 25,52 & 20,02 & 15,90 & 12,83 & 8,85 & 6,65 & 4,48 \\
\hline 77,93 & 1756,80 & 113,80 & 14,70 & 11,05 & 10,17 & 9,29 & 8,53 & 7,84 & 6,60 & 5,57 & 4,03 \\
\hline 84,32 & 370,50 & 162,10 & 28,77 & 16,10 & 12,28 & 9,57 & 7,91 & 6,69 & 4,96 & 3,87 & 2,63 \\
\hline 67,68 & 1471,60 & 156,20 & 14,22 & 10,68 & 9,49 & 8,34 & 7,40 & 6,58 & 5,21 & 4,18 & 2,84 \\
\hline 76,80 & 643,30 & 39,00 & 42,06 & 31,85 & 29,40 & 26,93 & 24,78 & 22,80 & 19,24 & 16,26 & 11,77 \\
\hline 37,35 & 1188,60 & 107,20 & 27,72 & 22,48 & 19,45 & 16,01 & 13,19 & 10,92 & 7,72 & 5,78 & 3,80 \\
\hline 37,31 & 910,40 & 31,60 & 66,51 & 59,26 & 54,05 & 47,37 & 41,22 & 35,76 & 26,99 & 20,77 & 13,46 \\
\hline 50,26 & 1630,20 & 42,60 & 36,58 & 31,30 & 29,71 & 27,33 & 25,01 & 22,80 & 18,82 & 15,53 & 10,78 \\
\hline 64,72 & 1897,40 & 65,00 & 22,43 & 18,00 & 17,05 & 15,87 & 14,71 & 13,60 & 11,57 & 9,81 & 7,12 \\
\hline 88,44 & 1239,00 & 174,00 & 13,13 & 8,92 & 7,73 & 6,76 & 6,05 & 5,45 & 4,45 & 3,67 & 2,59 \\
\hline 70,85 & 1894,40 & 59,90 & 22,39 & 17,62 & 16,69 & 15,70 & 14,69 & 13,72 & 11,90 & 10,29 & 7,70 \\
\hline 80,26 & 1485,40 & 167,00 & 12,68 & 9,06 & 8,02 & 7,10 & 6,38 & 5,75 & 4,69 & 3,86 & 2,70 \\
\hline 63,63 & 1842,80 & 108,20 & 16,52 & 13,18 & 12,16 & 11,00 & 9,98 & 9,03 & 7,38 & 6,05 & 4,19 \\
\hline 76,63 & 1194,80 & 119,30 & 17,10 & 12,52 & 11,19 & 9,96 & 8,97 & 8,09 & 6,59 & 5,42 & 3,78 \\
\hline 23,56 & 841,10 & 106,90 & 42,53 & 31,51 & 24,65 & 17,85 & 13,34 & 10,39 & 7,08 & 5,41 & 3,75 \\
\hline 82,02 & 250,20 & 79,20 & 47,65 & 28,70 & 22,87 & 18,52 & 15,67 & 13,48 & 10,20 & 8,02 & 5,44 \\
\hline 37,27 & 1061,60 & 143,00 & 24,24 & 18,56 & 15,61 & 12,45 & 10,01 & 8,14 & 5,65 & 4,23 & 2,83 \\
\hline 88,58 & 1485,00 & 48,70 & 24,02 & 18,51 & 17,09 & 16,26 & 15,43 & 14,61 & 13,05 & 11,62 & 9,17 \\
\hline 61,02 & 204,20 & 160,00 & 45,58 & 22,69 & 15,87 & 11,25 & 8,66 & 6,95 & 4,83 & 3,71 & 2,59 \\
\hline 54,82 & 600,00 & 135,70 & 26,18 & 17,94 & 14,87 & 12,10 & 10,02 & 8,38 & 6,04 & 4,60 & 3,06 \\
\hline 30,62 & 920,80 & 133,20 & 30,20 & 22,65 & $\begin{array}{l}1+, 61 \\
18,42\end{array}$ & $\frac{1 L, \pm 0}{14,02}$ & $\begin{array}{l}10,0< \\
10,85\end{array}$ & 8,60 & 5,86 & 4,42 & 3,02 \\
\hline 40,28 & 470,90 & 71,10 & 48,66 & 36,61 & 30,77 & 24,69 & 19,97 & 16,34 & 11,42 & 8,57 & 5,71 \\
\hline 44,13 & 1674,50 & 31,70 & 48,49 & 42,53 & 40,53 & 37,30 & 34,11 & 31,05 & 25,53 & 20,97 & 14,44 \\
\hline 45,58 & 1080,10 & 100,80 & 26,07 & 21,04 & 18,51 & 15,71 & 13,34 & 11,35 & 8,34 & 6,35 & 4,15 \\
\hline 29,47 & $\frac{1000, \pm 0}{995,50}$ & $\frac{100,00}{73,10}$ & 44,97 & 36,78 & $\begin{array}{l}10,01 \\
31,27\end{array}$ & $\frac{10,1 \pm}{24,94}$ & $\begin{array}{l}10,04 \\
19,92\end{array}$ & $\begin{array}{l} \pm, v 09 \\
16,09\end{array}$ & $\begin{array}{l}0,04 \\
11,05\end{array}$ & 8,23 & 5,50 \\
\hline 38,40 & 1168,20 & 143,00 & 22,92 & 17,82 & 15,14 & 12,24 & 9,95 & 8,15 & 5,71 & 4,28 & 2,84 \\
\hline 66,99 & 1686,70 & 174,80 & 12,63 & 9,53 & 8,48 & 7,46 & 6,63 & 5,89 & 4,66 & 3,74 & 2,54 \\
\hline 53,15 & 729,20 & 162,90 & 21,96 & 15,13 & 12,54 & 10,17 & 8,40 & 7,00 & 5,03 & 3,82 & 2,54 \\
\hline 31,18 & 1190,90 & 72,30 & 40,82 & 34,30 & 29,77 & 24,37 & 19,91 & 16,35 & 11,42 & 8,50 & 5,59 \\
\hline 47,62 & 1320,70 & 98,70 & 23,66 & 19,55 & 17,48 & 15,15 & 13,11 & 11,34 & 8,55 & 6,60 & 4,32 \\
\hline 23,26 & 533,20 & 180,30 & 33,56 & 20,89 & 14,99 & 10,21 & 7,52 & 5,90 & 4,12 & 3,20 & 2,24 \\
\hline 77,34 & 1721,30 & 169,80 & 11,90 & 8,70 & 7,79 & 6,93 & 6,25 & 5,65 & 4,62 & 3,80 & 2,66 \\
\hline 68,72 & 960,00 & 50,20 & 32,68 & 25,64 & 23,87 & 21,86 & 20,06 & 18,37 & 15,35 & 12,85 & 9,15 \\
\hline 22,42 & 725,50 & 106,80 & 45,73 & 32,89 & 25,14 & 17,81 & 13,17 & 10,24 & 7,03 & 5,41 & 3,76 \\
\hline 59,58 & 771,70 & 120,40 & 23,56 & 17,16 & 14,74 & 12,47 & 10,69 & 9,19 & 6,89 & 5,34 & 3,53 \\
\hline 75,53 & 301,20 & 151,70 & 34,50 & 18,94 & 14,20 & 10,84 & 8,79 & 7,31 & 5,29 & 4,08 & 2,77 \\
\hline 44,27 & 740,20 & 186,70 & 22,04 & 15,00 & 12,15 & 9,50 & 7,57 & 6,15 & 4,28 & 3,23 & 2,18 \\
\hline 76,61 & 1439,90 & 193,50 & 12,18 & 8,63 & 7,53 & 6,57 & 5,83 & 5,19 & 4,14 & 3,35 & 2,30 \\
\hline 65,74 & 367,00 & 129,30 & 33,03 & 20,07 & 15,86 & 12,56 & 10,35 & 8,66 & 6,27 & 4,81 & 3,23 \\
\hline 64,84 & 397,10 & 187,60 & 27,46 & 15,56 & 11,81 & 9,03 & 7,27 & 5,99 & 4,26 & 3,26 & 2,22 \\
\hline 43,60 & 705,20 & 135,40 & 27,07 & 19,48 & 16,17 & 12,90 & 10,43 & 8,53 & 5,98 & 4,50 & 3,01 \\
\hline 85,46 & 1210,50 & 61,50 & 23,42 & 17,47 & 16,15 & 15,03 & 14,02 & 13,08 & 11,35 & 9,85 & 7,43 \\
\hline 54,23 & 1626,20 & 68,10 & 25,44 & 21,36 & 19,92 & 18,07 & 16,35 & 14,75 & 11,95 & 9,72 & 6,64 \\
\hline 82,79 & 1096,70 & 96,20 & 19,31 & 14,00 & 12,62 & 11,36 & 10,35 & 9,45 & 7,88 & 6,61 & 4,74 \\
\hline 41,75 & 1456,40 & 133,80 & 20,69 & 16,77 & 14,66 & 12,29 & 10,30 & 8,66 & 6,25 & 4,72 & 3,08 \\
\hline 33,04 & 1356,30 & 199,50 & 19,35 & 14,55 & 11,95 & 9,24 & 7,24 & 5,78 & 3,96 & 2,97 & 2,02 \\
\hline 68,70 & 292,80 & 193,00 & 33,13 & 17,16 & 12,36 & 9,04 & 7,12 & 5,79 & 4,08 & 3,13 & 2,16 \\
\hline 56,48 & 1889,00 & 155,60 & 14,05 & 11,24 & 10,10 & 8,87 & 7,82 & 6,88 & 5,35 & 4,22 & 2,81 \\
\hline 56,97 & 831,20 & 143,70 & 21,21 & 15,26 & 12,98 & 10,84 & 9,18 & 7,81 & 5,77 & 4,43 & 2,93 \\
\hline 42,70 & 1140,40 & 134,50 & 22,43 & 17,54 & 15,11 & 12,48 & 10,35 & 8,62 & 6,16 & 4,64 & 3,05 \\
\hline 87,03 & 1672,30 & 138,00 & 12,79 & 9,20 & 8,31 & 7,53 & 6,90 & 6,34 & 5,35 & 4,54 & 3,31 \\
\hline 23,22 & 1146,90 & 22,00 & 117,41 & 105,46 & 93,78 & 78,69 & 65,43 & 54,37 & 38,35 & 28,43 & 18,41 \\
\hline 74,70 & 712,10 & 92,70 & 25,29 & 18,10 & 15,84 & 13,82 & 12,26 & 10,91 & 8,68 & 7,00 & 4,80 \\
\hline 78,52 & 267,70 & 44,10 & 58,94 & 40,34 & 34,56 & 29,71 & 26,13 & 23,12 & 18,25 & 14,66 & 10,03 \\
\hline 58,29 & 388,30 & 70,90 & 43,71 & 31,04 & 26,29 & 21,93 & 18,56 & 15,80 & 11,67 & 8,97 & 5,94 \\
\hline 84,20 & 1083,00 & 153,40 & 15,23 & 10,46 & 9,08 & 7,92 & 7,06 & 6,33 & 5,12 & 4,19 & 2,92 \\
\hline 51,43 & 684,40 & 44,40 & 47,36 & 39,30 & 35,64 & 31,43 & 27,70 & 24,36 & 18,88 & 14,85 & 9,82 \\
\hline 75,57 & 973,30 & 131,10 & 18,10 & 12,86 & 11,22 & 9,78 & 8,67 & 7,71 & 6,13 & 4,95 & 3,39 \\
\hline 41,98 & 1965,90 & 62,40 & 29,95 & 26,56 & 24,60 & 22,00 & 19,56 & 17,32 & 13,54 & 10,68 & 7,04 \\
\hline 67,57 & 207,20 & 32,30 & 82,96 & 59,13 & 50,93 & 43,58 & 37,90 & 33,09 & 25,46 & 20,05 & 13,44 \\
\hline 71,57 & 1401,50 & 20,30 & 49,31 & 40,41 & 37,86 & 36,71 & 35,24 & 33,61 & 30,39 & 27,33 & 21,91 \\
\hline 34,79 & 1512,90 & 37,80 & 52,70 & 47,87 & 44,03 & 38,90 & 34,11 & 29,77 & 22,68 & 17,54 & 11,37 \\
\hline 88,57 & 456,90 & 74,50 & 33,26 & 22,13 & 18,93 & 16,35 & 14,52 & 13,00 & 10,49 & 8,59 & 6,01 \\
\hline 69,00 & 268,40 & 68,20 & 50,81 & 32,97 & 27,06 & 22,25 & 18,82 & 16,09 & 12,00 & 9,31 & 6,23 \\
\hline 32,09 & 354,70 & 69,80 & 62,47 & 44,65 & 35,64 & 26,74 & 20,55 & 16,24 & 11,09 & 8,40 & 5,77 \\
\hline 68,86 & 1487,50 & 34,90 & 35,26 & 28,05 & 26,69 & 25,40 & 23,94 & 22,51 & 19,77 & 17,28 & 13,17 \\
\hline 51,20 & 1201,90 & 142.20 & 19.02 & 14,73 & 12.85 & 10,90 & 9,29 & 7,94 & 5,88 & 4.51 & 2,96 \\
\hline 38,16 & 1288,20 & 125,30 & 24,04 & 19,31 & 16,67 & 13,70 & 11,27 & 9,33 & 6,59 & 4,94 & 3,25 \\
\hline 65,42 & 218,80 & 24,60 & 94,23 & 70,78 & 62,58 & 54,66 & 48,20 & 42,56 & 33,33 & 26,52 & 17,86 \\
\hline 35,23 & 1041,40 & 162,10 & 23,39 & 17,47 & 14,42 & 11,24 & 8,88 & 7,13 & 4,90 & 3,68 & 2,49 \\
\hline 54,90 & 407,70 & 124,00 & 33,47 & 21,49 & 17,26 & 13,66 & 11,11 & 9,18 & 6,52 & 4,95 & 3,33 \\
\hline 44,03 & 974,70 & 107,90 & 26,71 & 21,08 & 18,28 & 15,25 & 12,75 & 10,70 & 7,72 & 5,83 & 3,83 \\
\hline 75,12 & 1037,70 & 150,10 & 16,44 & 11,58 & 10,04 & 8,70 & 7,68 & 6,80 & 5,38 & 4,32 & 2,95 \\
\hline 60,41 & 952,70 & 20,30 & 64,21 & 52,20 & 50,12 & 47,35 & 44,34 & 41,40 & 35,83 & 30,86 & 22,91 \\
\hline 76,96 & 1760,70 & 192,60 & 11,04 & 8,00 & 7,10 & 6,28 & 5,64 & 5,07 & 4,11 & 3,36 & 2,34 \\
\hline 43,86 & 963,60 & 63,30 & 37,11 & 31,24 & 27,98 & 24,17 & 20,82 & 17,91 & 13,38 & 10,26 & 6,68 \\
\hline 25,56 & 974,50 & 161,40 & 28,98 & 20,89 & 16,25 & 11,75 & 8,80 & 6,87 & 4,69 & 3,59 & 2,49 \\
\hline 80,31 & 814,70 & 91,50 & 23,11 & 16,51 & 14,63 & 12,94 & 11,63 & 10,49 & 8,55 & 7,03 & 4,93 \\
\hline
\end{tabular}




\begin{tabular}{|c|c|c|c|c|c|c|c|c|c|c|c|}
\hline & & & \multicolumn{9}{|c|}{ Deflexões $\left(\times 10^{-4} \mathrm{~cm}\right)$} \\
\hline e1 (cm) & Meq (MPa) & Ms (MPa) & D0 & D25 & D40 & D60 & D80 & D100 & D140 & D180 & D260 \\
\hline 33,60 & 475,20 & 193,80 & 29,23 & 17,89 & 13,37 & 9,56 & 7,20 & 5,67 & 3,91 & 3,00 & 2,09 \\
\hline 27,15 & 1492,20 & 53,40 & 51,79 & 45,15 & 39,66 & 32,84 & 27,03 & 22,30 & 15,62 & 11,59 & 7,57 \\
\hline 86,73 & 1065,10 & 71,00 & 22,61 & 16,53 & 15,11 & 13,86 & 12,81 & 11,86 & 10,15 & 8,69 & 6,44 \\
\hline 47,43 & 260,50 & 158,10 & 40,24 & 21,82 & 15,89 & 11,47 & 8,82 & 7,03 & 4,86 & 3,72 & 2,59 \\
\hline 56,50 & 418,60 & 190,40 & 27,21 & 15,77 & 12,04 & 9,15 & 7,28 & 5,94 & 4,17 & 3,17 & 2,16 \\
\hline 20,78 & 1092,20 & 50,70 & 73,51 & 60,00 & 49,54 & 37,78 & 29,03 & 22,79 & 15,33 & 11,51 & 7,86 \\
\hline 63,23 & 1552,30 & 190,10 & 12,90 & 9,65 & 8,47 & 7,34 & 6,42 & 5,62 & 4,34 & 3,42 & 2,29 \\
\hline 27,74 & 1664,20 & 117,90 & 28,84 & 23,52 & 19,86 & 15,67 & 12,40 & 9,95 & 6,79 & 5,06 & 3,40 \\
\hline 47,56 & 1264,80 & 83,80 & 26,61 & 22,25 & 20,04 & 17,49 & 15,24 & 13,25 & 10,07 & 7,81 & 5,12 \\
\hline 27,54 & 508,40 & 68,50 & 61,25 & 45,97 & 36,91 & 27,59 & 21,06 & 16,56 & 11,25 & 8,52 & 5,85 \\
\hline 55,27 & 1394,70 & 86,40 & 22,87 & 18,80 & 17,17 & 15,30 & 13,63 & 12,12 & 9,58 & 7,64 & 5,13 \\
\hline 64,93 & 261,50 & 133,40 & 40,59 & 22,55 & 16,93 & 12,82 & 10,26 & 8,42 & 5,97 & 4,57 & 3,11 \\
\hline 57,54 & 1948,40 & 107,50 & 17,18 & 14,09 & 12,99 & 11,69 & 10,52 & 9,45 & 7,59 & 6,14 & 4,18 \\
\hline 60,50 & 1843,70 & 63,00 & 24,04 & 19,64 & 18,59 & 17,20 & 15,86 & 14,58 & 12,24 & 10,27 & 7,32 \\
\hline 88,49 & 1001,00 & 183,70 & 14,42 & 9,44 & 7,98 & 6,82 & 6,02 & 5,36 & 4,28 & 3,49 & 2,43 \\
\hline 24,77 & 1356,90 & 72,40 & 46,84 & 38,79 & 32,77 & 25,78 & 20,32 & 16,23 & 11,02 & 8,21 & 5,52 \\
\hline 59,85 & 1138,40 & 143,40 & 17,82 & 13,40 & 11,72 & 10,08 & 8,74 & 7,60 & 5,79 & 4,52 & 3,00 \\
\hline 82,91 & 761,10 & 173,70 & 17,68 & 11,32 & 9,37 & 7,85 & 6,80 & 5,95 & 4,63 & 3,69 & 2,52 \\
\hline 52,14 & 1023,20 & 69,60 & 30,49 & 25,15 & 22,76 & 20,05 & 17,66 & 15,52 & 12,02 & 9,45 & 6,26 \\
\hline 60,89 & 1437,00 & 64,20 & 25,79 & 20,99 & 19,63 & 17,94 & 16,38 & 14,92 & 12,32 & 10,19 & 7,12 \\
\hline 42,68 & 1374,20 & 69,10 & 31,37 & 27,09 & 24,56 & 21,47 & 18,69 & 16,23 & 12,29 & 9,49 & 6,18 \\
\hline 39,97 & 1513,30 & 89,50 & 26,97 & 23,00 & 20,55 & 17,62 & 15,05 & 12,85 & 9,46 & 7,19 & 4,67 \\
\hline 54,27 & 1225,40 & 128,90 & 19,27 & 15,07 & 13,30 & 11,46 & 9,91 & 8,58 & 6,49 & 5,04 & 3,32 \\
\hline 44,06 & 259,80 & 120,40 & 46,19 & 27,14 & 20,48 & 15,10 & 11,66 & 9,31 & 6,42 & 4,90 & 3,38 \\
\hline 71,06 & 1229,20 & 195,70 & 13,55 & 9,53 & 8,19 & 7,02 & 6,13 & 5,38 & 4,17 & 3,31 & 2,23 \\
\hline 37,64 & 636,40 & 147,90 & 28,95 & 20,13 & 16,17 & 12,36 & 9,66 & 7,72 & 5,31 & 4,01 & 2,73 \\
\hline 69,88 & 1420,30 & 70,00 & 22,71 & 17,77 & 16,59 & 15,26 & 14,05 & 12,92 & 10,87 & 9,15 & 6,57 \\
\hline 77,78 & 652,40 & 113,90 & 23,62 & 16,05 & 13,68 & 11,70 & 10,25 & 9,03 & 7,08 & 5,67 & 3,86 \\
\hline 30,14 & 1109,40 & 121,00 & 30,51 & 23,80 & 19,73 & 15,32 & 12,00 & 9,58 & 6,53 & 4,90 & 3,32 \\
\hline 66,36 & 1305,30 & 29,00 & 42,77 & 34,21 & 32,66 & 31,06 & 29,26 & 27,47 & 24,07 & 20,99 & 15,92 \\
\hline 45,36 & 1444,20 & 58,90 & 32,72 & 28,45 & 26,21 & 23,36 & 20,72 & 18,32 & 14,30 & 11,28 & 7,45 \\
\hline 24,10 & 541,10 & 100,10 & 49,91 & 35,03 & 26,67 & 18,89 & 14,01 & 10,91 & 7,50 & 5,77 & 4,01 \\
\hline 58,92 & 1486,40 & 87,30 & 21,36 & 17,37 & 15,98 & 14,36 & 12,92 & 11,60 & 9,33 & 7,55 & 5,14 \\
\hline 69,90 & 556,90 & 132,10 & 25,11 & 16,49 & 13,64 & 11,29 & 9,61 & 8,26 & 6,20 & 4,83 & 3,24 \\
\hline 78,36 & 758,90 & 81,70 & 25,63 & 18,52 & 16,46 & 14,59 & 13,12 & 11,82 & 9,62 & 7,90 & 5,52 \\
\hline 55,19 & 474,80 & 195,40 & 25,13 & 14,98 & 11,59 & 8,89 & 7,10 & 5,80 & 4,07 & 3,10 & 2,11 \\
\hline 34,74 & 1942,20 & 86,00 & 28,19 & 24,64 & 22,05 & 18,83 & 15,99 & 13,56 & 9,88 & 7,45 & 4,82 \\
\hline 68,28 & 1472,10 & 58,10 & 25,54 & 20,19 & 19,03 & 17,67 & 16,37 & 15,13 & 12,87 & 10,93 & 7,95 \\
\hline 62,77 & 1073,20 & 29,40 & 46,91 & 37,90 & 36,18 & 33,92 & 31,60 & 29,37 & 25,19 & 21,54 & 15,80 \\
\hline 23,46 & 211,60 & 55,50 & 100,86 & 66,21 & 48,63 & 33,55 & 24,71 & 19,32 & 13,41 & 10,39 & 7,25 \\
\hline 78,07 & 596,80 & 55,80 & 35,18 & 25,78 & 23,16 & 20,71 & 18,73 & 16,98 & 13,95 & 11,54 & 8,13 \\
\hline 66,24 & 544,40 & 139,80 & 25,29 & 16,48 & 13,52 & 11,07 & 9,32 & 7,93 & 5,86 & 4,53 & 3,03 \\
\hline 69,16 & 731,00 & 70,50 & 29,85 & 22,52 & 20,16 & 17,86 & 15,96 & 14,28 & 11,44 & 9,26 & 6,34 \\
\hline 39,97 & 234,10 & 182,50 & 41,13 & 20,76 & 14,41 & 9,97 & 7,51 & 5,95 & 4,12 & 3,18 & 2,25 \\
\hline 59,45 & 754,00 & 179,00 & 19,68 & 13,24 & 10,94 & 8,94 & 7,46 & 6,29 & 4,59 & 3,51 & 2,34 \\
\hline 29,35 & 1957,00 & 114,40 & 26,69 & 22,38 & 19,30 & 15,65 & 12,67 & 10,33 & 7,15 & 5,32 & 3,52 \\
\hline 26,89 & 1692,20 & 161,40 & 23,69 & 18,58 & 15,26 & 11,67 & 9,03 & 7,14 & 4,84 & 3,64 & 2,48 \\
\hline 44,23 & 745,30 & 57,00 & 43,44 & 35,96 & 31,94 & 27,36 & 23,39 & 20,00 & 14,80 & 11,30 & 7,36 \\
\hline 74,05 & 1475,50 & 73,00 & 21,12 & 16,28 & 15,18 & 14,02 & 12,96 & 11,98 & 10,18 & 8,65 & 6,30 \\
\hline 84,20 & 1961,30 & 199,90 & 9,90 & 7,05 & 6,29 & 5,61 & 5,08 & 4,62 & 3,83 & 3,19 & 2,27 \\
\hline 38,48 & 417,00 & 64,90 & 55,43 & 41,48 & 34,61 & 27,47 & 22,01 & 17,87 & 12,41 & 9,31 & 6,24 \\
\hline 46,63 & 1201,50 & 154,50 & 19,18 & 14,76 & 12,72 & 10,59 & 8,86 & 7,44 & 5,38 & 4,08 & 2,68 \\
\hline 53,86 & 1604,50 & 54,40 & 29,77 & 25,08 & 23,63 & 21,63 & 19,73 & 17,94 & 14,74 & 12,12 & 8,39 \\
\hline 78,04 & 1998,50 & 60,90 & 20,40 & 15,86 & 14,90 & 14,14 & 13,34 & 12,56 & 11,07 & 9,73 & 7,49 \\
\hline 29,61 & 399,00 & 55,30 & 73,18 & 55,08 & 44,70 & 33,89 & 26,14 & 20,67 & 14,07 & 10,62 & 7,26 \\
\hline 51,21 & 1584,90 & 111,40 & 19,52 & 16,10 & 14,52 & 12,75 & 11,18 & 9,79 & 7,53 & 5,90 & 3,89 \\
\hline 88,58 & 685,00 & 45,20 & 34,99 & 25,48 & 23,26 & 21,38 & 19,79 & 18,36 & 15,77 & 13,56 & 10,11 \\
\hline 71,34 & 391,20 & 40,20 & 53,11 & 39,50 & 35,22 & 31,13 & 27,83 & 24,90 & 19,97 & 16,20 & 11,12 \\
\hline 69,22 & 440,60 & 67,10 & 39,03 & 27,79 & 23,98 & 20,59 & 17,98 & 15,75 & 12,20 & 9,65 & 6,49 \\
\hline 23,15 & 920,50 & 169,40 & 30,11 & 21,02 & 15,87 & 11,15 & 8,24 & 6,42 & 4,42 & 3,41 & 2,37 \\
\hline 24,38 & 672,90 & 174,70 & 31,40 & 20,77 & 15,39 & 10,70 & 7,90 & 6,17 & 4,27 & 3,30 & 2,30 \\
\hline 63,94 & 876,10 & 132,30 & 20,42 & 14,78 & 12,75 & 10,89 & 9,43 & 8,19 & 6,25 & 4,89 & 3,26 \\
\hline 69,07 & 671,90 & 141,80 & 22,00 & 14,81 & 12,40 & 10,37 & 8,88 & 7,66 & 5,79 & 4,52 & 3,02 \\
\hline 48,78 & 1357,30 & 69,30 & 28,67 & 24,38 & 22,32 & 19,83 & 17,56 & 15,51 & 12,10 & 9,55 & 6,32 \\
\hline 28,75 & 1329,10 & 40,30 & 61,77 & 54,97 & 49,07 & 41,56 & 34,93 & 29,33 & 21,02 & 15,71 & 10,15 \\
\hline 56,08 & 1926,10 & 163,30 & 13,61 & 10,86 & 9,74 & 8,54 & 7,50 & 6,59 & 5,10 & 4,02 & 2,67 \\
\hline 63,25 & 1519,10 & 122,90 & 16,59 & 12,99 & 11,74 & 10,44 & 9,32 & 8,32 & 6,63 & 5,34 & 3,62 \\
\hline 60,87 & 620,70 & 150,50 & 23,46 & 15,66 & 12,91 & 10,56 & 8,83 & 7,46 & 5,45 & 4,18 & 2,79 \\
\hline 43,30 & 1664,50 & 70,80 & 28,54 & 24,90 & 22,80 & 20,16 & 17,74 & 15,56 & 11,97 & 9,35 & 6,12 \\
\hline 77,91 & 761,70 & 116,50 & 21,50 & 14,90 & 12,85 & 11,11 & 9,80 & 8,70 & 6,89 & 5,55 & 3,80 \\
\hline 44,75 & 399,70 & 51,70 & 58,91 & 45,38 & 38,98 & 32,23 & 26,77 & 22,36 & 16,04 & 12,10 & 7,97 \\
\hline 68,85 & 951,20 & 64,60 & 28,09 & 21,79 & 19,98 & 18,05 & 16,38 & 14,86 & 12,20 & 10,06 & 7,03 \\
\hline 45,99 & 1785,40 & 146,80 & 16,91 & 13,85 & 12,29 & 10,54 & 9,03 & 7,73 & 5,74 & 4,39 & 2,87 \\
\hline 73,26 & 919,90 & 150,10 & 17,68 & 12,30 & 10,56 & 9,05 & 7,91 & 6,96 & 5,42 & 4,31 & 2,92 \\
\hline 74,00 & 1624,80 & 151,00 & 13,28 & 9,88 & 8,88 & 7,91 & 7,13 & 6,43 & 5,23 & 4,29 & 2,99 \\
\hline 59,18 & 1939,80 & 26,70 & 43,16 & 35,17 & 33,81 & 32,47 & 30,76 & 29,03 & 25,66 & 22,55 & 17,31 \\
\hline 63,39 & 1856,60 & 44,60 & 29,41 & 23,70 & 22,67 & 21,40 & 20,04 & 18,71 & 16,21 & 13,97 & 10,40 \\
\hline 61,39 & 1525,50 & 38,20 & 35,51 & 28,82 & 27,58 & 25,91 & 24,17 & 22,48 & 19,31 & 16,53 & 12,15 \\
\hline 28,55 & 1140,40 & 152,30 & 26,86 & 20,26 & 16,38 & 12,36 & 9,49 & 7,49 & 5,09 & 3,84 & 2,63 \\
\hline 66,93 & 1244,40 & 178,10 & 14,47 & 10,47 & 9,08 & 7,82 & 6,82 & 5,97 & 4,62 & 3,64 & 2,44 \\
\hline 56,90 & 1421,40 & 24,40 & 51,91 & 42,58 & 41,06 & 38,93 & 36,53 & 34,16 & 29,65 & 25,59 & 19,05 \\
\hline 77,18 & 1048,90 & 73,10 & 23,72 & 17,80 & 16,31 & 14,83 & 13,57 & 12,43 & 10,40 & 8,73 & 6,26 \\
\hline
\end{tabular}




\begin{tabular}{|c|c|c|c|c|c|c|c|c|c|c|c|}
\hline \multirow[b]{2}{*}{ e1 (cm) } & & & & & & & ões (x1 & m) & & & \\
\hline & Meq (MPa) & Ms (MPa) & D0 & D25 & D40 & $\mathrm{D} 60$ & D80 & D100 & D140 & D180 & D260 \\
\hline 40,29 & 1070,00 & 177,00 & 20,29 & 15,02 & 12,54 & 9,99 & 8,04 & 6,55 & 4,56 & 3,43 & 2,29 \\
\hline 44,12 & 987,10 & 96,40 & 28,38 & 22,79 & 19,93 & 16,79 & 14,15 & 11,95 & 8,69 & 6,59 & 4,31 \\
\hline 51,86 & 1404,70 & 117,60 & 19,69 & 15,93 & 14,23 & 12,38 & 10,77 & 9,37 & 7,14 & 5,55 & 3,66 \\
\hline 33,87 & 1181,30 & 154,90 & 23,55 & 18,04 & 15,01 & 11,77 & 9,32 & 7,50 & 5,15 & 3,86 & 2,60 \\
\hline 31,70 & 805,40 & 37,50 & 70,86 & 61,28 & 54,12 & 45,32 & 37,75 & 31,49 & 22,40 & 16,73 & 10,88 \\
\hline 79,92 & 392,40 & 67,70 & 39,10 & 26,45 & 22,56 & 19,33 & 16,98 & 15,02 & 11,85 & 9,53 & 6,53 \\
\hline 54,34 & 832,30 & 194,70 & 18,63 & 12,69 & 10,48 & 8,49 & 7,01 & 5,85 & 4,20 & 3,19 & 2,13 \\
\hline 36,23 & 803,80 & 162,00 & 25,45 & $\begin{array}{l}18,18 \\
\end{array}$ & 14,73 & 11,31 & 8,85 & 7,07 & 4,86 & 3,66 & 2,49 \\
\hline 26,78 & 321,50 & 166,70 & 39,87 & 22,69 & 16,03 & 10,93 & 8,11 & 6,39 & 4,46 & 3,46 & 2,43 \\
\hline 25,65 & 468,80 & 165,10 & 35,75 & 22,33 & 16,25 & 11,21 & 8,29 & 6,50 & 4,52 & 3,50 & 2,45 \\
\hline 77,11 & 1742,60 & 194,00 & 11,04 & 7,98 & 7,08 & 6,25 & 5,61 & 5,04 & 4,08 & 3,33 & 2,32 \\
\hline 21,02 & 497,90 & 133,20 & 44,44 & 28,52 & 20,45 & 13,84 & 10,15 & 7,96 & 5,57 & 4,33 & 3,02 \\
\hline 87,40 & 1895,00 & 49,20 & 21,72 & 17,17 & 15,82 & 15,17 & 14,50 & 13,80 & 12,44 & 11,17 & 8,96 \\
\hline 45,29 & 1437,80 & 127,20 & 20,30 & 16,49 & 14,55 & 12,38 & 10,54 & 8,98 & 6,61 & 5,04 & 3,29 \\
\hline 89,51 & 1964,50 & 157,50 & 10,92 & 7,81 & 7,06 & 6,41 & 5,90 & 5,44 & 4,62 & 3,94 & 2,90 \\
\hline 63,38 & 1680,10 & 57,40 & 25,68 & 20,72 & 19,64 & 18,24 & 16,88 & 15,59 & 13,21 & 11,17 & 8,06 \\
\hline 88,29 & 538,90 & 112,90 & 25,37 & 16,27 & 13,56 & 11,46 & 10,03 & 8,87 & 7,02 & 5,67 & 3,92 \\
\hline 81,30 & 1327,90 & 28,70 & 36,59 & 29,28 & 27,20 & 26,18 & 25,05 & 23,85 & 21,49 & 19,29 & 15,44 \\
\hline 27,79 & 1442,80 & 104,00 & 32,82 & 26,72 & 22,54 & 17,77 & 14,05 & 11,26 & 7,69 & 5,73 & 3,85 \\
\hline 81,18 & 1359,90 & 171,30 & 13,01 & 9,16 & 8,03 & 7,05 & 6,31 & 5,67 & 4,59 & 3,76 & 2,62 \\
\hline 33,56 & 1203,00 & 145,90 & 24,44 & 18,93 & 15,83 & 12,47 & 9,90 & 7,97 & 5,48 & 4,11 & 2,76 \\
\hline 55,41 & 1149,70 & 193,60 & 15,76 & 11,43 & 9,73 & 8,12 & 6,86 & 5,82 & 4,28 & 3,28 & 2,17 \\
\hline 70,84 & 1767,30 & 115,00 & 15,29 & 11,79 & 10,85 & 9,84 & 8,98 & 8,18 & 6,77 & 5,62 & 3,97 \\
\hline 69,15 & 1320,40 & 126,00 & 16,62 & 12,55 & 11,25 & 9,97 & 8,91 & 7,98 & 6,39 & 5,18 & 3,55 \\
\hline 64,84 & 1828,00 & 69,20 & 21,76 & 17,45 & 16,47 & 15,25 & 14,09 & 12,99 & 10,98 & 9,26 & 6,67 \\
\hline 74,02 & 1151,10 & 171,70 & 14,69 & 10,34 & 8,94 & 7,72 & 6,79 & 6,00 & 4,72 & 3,78 & 2,57 \\
\hline 40,33 & 593,40 & 181,00 & 25,80 & 16,90 & 13,31 & 10,07 & 7,84 & 6,27 & 4,32 & 3,27 & 2,24 \\
\hline 87,21 & 408,90 & 154,40 & 27,12 & 15,59 & 12,11 & 9,62 & 8,07 & 6,90 & 5,20 & 4,09 & 2,79 \\
\hline 82,09 & 1249,60 & 63,90 & 23,12 & 17,38 & 16,11 & 14,96 & 13,91 & 12,94 & 11,16 & 9,62 & 7,18 \\
\hline 22,84 & 1997,90 & 120,60 & 31,05 & 25,07 & 20,68 & 15,79 & 12,17 & 9,58 & 6,46 & 4,85 & 3,31 \\
\hline 22,15 & 460,60 & 156,60 & 39,44 & 24,34 & 17,30 & 11,69 & 8,61 & 6,77 & 4,74 & 3,68 & 2,58 \\
\hline 34,97 & 1973,00 & 157,80 & 18,89 & 15,50 & 13,42 & 11,01 & 9,03 & 7,44 & 5,23 & 3,91 & 2,57 \\
\hline 88,13 & 1600,70 & 184,30 & 11,19 & 7,78 & 6,86 & 6,09 & 5,50 & 4,99 & 4,13 & 3,44 & 2,46 \\
\hline 43,94 & 515,40 & 106,50 & 35,41 & 25,11 & 20,72 & 16,45 & 13,26 & 10,83 & 7,58 & 5,71 & 3,82 \\
\hline 73,67 & 1561,10 & 66,60 & 21,95 & 17,01 & 15,96 & 14,84 & 13,79 & 12,80 & 10,97 & 9,39 & 6,92 \\
\hline 78,10 & 1294,30 & 115,00 & 16,67 & 12,27 & 11,06 & 9,92 & 8,99 & 8,17 & 6,74 & 5,59 & 3,95 \\
\hline 64,94 & 1734,20 & 108,50 & 16,70 & 13,21 & 12,15 & 10,98 & 9,95 & 9,00 & 7,35 & 6,03 & 4,18 \\
\hline 29,06 & 967,90 & 69,40 & 47,46 & 38,86 & 33,02 & 26,30 & 20,99 & 16,93 & 11,61 & 8,65 & 5,78 \\
\hline 81,97 & 617,90 & 155,80 & 21,01 & 13,24 & 10,84 & 8,99 & 7,73 & 6,73 & 5,18 & 4,11 & 2,79 \\
\hline 32,56 & 1902,80 & 79,60 & 31,46 & 27,53 & 24,53 & 20,80 & 17,52 & 14,75 & 10,63 & 7,98 & 5,16 \\
\hline 87,20 & 912,00 & 138,80 & 17,27 & 11,65 & 10,03 & 8,71 & 7,76 & 6,95 & 5,63 & 4,61 & 3,23 \\
\hline 89,84 & 329,10 & 69,30 & 41,26 & 26,32 & 21,92 & 18,52 & 16,22 & 14,35 & 11,39 & 9,23 & 6,40 \\
\hline 41,38 & 649,30 & 168,00 & 25,54 & 17,33 & 13,92 & 10,73 & 8,46 & 6,81 & 4,71 & 3,55 & 2,41 \\
\hline 71,96 & 1780,80 & 31,50 & 34,13 & 27,48 & 25,90 & 24,98 & 23,84 & 22,64 & 20,29 & 18,10 & 14,29 \\
\hline 36,17 & 213,60 & 175,90 & 44,32 & 21,99 & 15,05 & 10,29 & 7,71 & 6,11 & 4,24 & 3,29 & 2,33 \\
\hline 48,52 & 1236,50 & 79,00 & 27,45 & 22,98 & 20,77 & 18,21 & 15,94 & 13,92 & 10,66 & 8,31 & 5,46 \\
\hline 50,04 & 322,10 & 150,30 & 35,99 & 20,94 & 15,88 & 11,89 & 9,32 & 7,50 & 5,21 & 3,97 & 2,72 \\
\hline 32,85 & 1720,20 & 115,60 & 25,39 & 21,19 & 18,40 & 15,10 & 12,38 & 10,20 & 7,15 & 5,33 & 3,50 \\
\hline 67,48 & 400,70 & 77,10 & 38,81 & 26,69 & 22,54 & 18,97 & 16,29 & 14,08 & 10,66 & 8,33 & 5,57 \\
\hline 40,44 & 1456,90 & 40,10 & 45,68 & 40,86 & 37,97 & 34,04 & 30,32 & 26,89 & 21,07 & 16,64 & 10,98 \\
\hline 45,52 & 1554,40 & 33,30 & 46,97 & 41,02 & 38,99 & 35,81 & 32,70 & 29,73 & 24,39 & 19,99 & 13,75 \\
\hline 44,70 & 863,50 & 189,00 & 20,31 & 14,23 & 11,70 & 9,27 & 7,46 & 6,09 & 4,26 & 3,21 & 2,16 \\
\hline 29,54 & 1215,30 & 46,60 & 56,57 & 49,49 & 43,79 & 36,68 & 30,53 & 25,44 & 18,05 & 13,46 & 8,74 \\
\hline 39,94 & 1238,60 & 102,20 & 26,79 & 22,01 & 19,29 & 16,17 & 13,54 & 11,37 & 8,19 & 6,17 & 4,03 \\
\hline 64,18 & 230,00 & 128,70 & 444,80 & 24,33 & 18,01 & 13,46 & 10,68 & 8,72 & 6,15 & 4,71 & 3,22 \\
\hline 42,94 & 1816,10 & 91,20 & 23,65 & 20,42 & 18,52 & 16,21 & 14,12 & 12,27 & 9,31 & 7,20 & 4,69 \\
\hline 29,62 & 1424,30 & 96,50 & 33,02 & 27,27 & 23,33 & 18,74 & 15,06 & 12,21 & 8,42 & 6,26 & 4,17 \\
\hline 83,38 & 213,40 & 122,40 & 46,29 & 24,41 & 17,90 & 13,43 & 10,83 & 9,00 & 6,52 & 5,05 & 3,46 \\
\hline 62,00 & 1055,40 & 185,60 & 15,93 & 11,29 & 9,61 & 8,09 & 6,92 & 5,94 & 4,46 & 3,45 & 2,29 \\
\hline 29,32 & 1538,40 & 89,80 & 34,03 & 28,54 & 24,61 & 19,96 & 16,16 & 13,17 & 9,12 & 6,78 & 4,48 \\
\hline 86,26 & 642,70 & 66,30 & 29,71 & 21,00 & 18,70 & 16,69 & 15,14 & 13,78 & 11,45 & 9,57 & 6,85 \\
\hline 65,75 & 421,20 & 152,20 & 28,50 & $\begin{array}{l}17,22 \\
\end{array}$ & 13,56 & 10,71 & 8,81 & 7,36 & 5,32 & 4,08 & 2,75 \\
\hline 49,82 & 486,50 & 77,30 & 40,57 & 30,01 & 25,56 & 21,14 & 17,65 & 14,81 & 10,71 & 8,13 & 5,36 \\
\hline 22,18 & 864,60 & 21,70 & 135,33 & 118,12 & 102,82 & 83,79 & 67,85 & 55,19 & 37,96 & 28,05 & 18,49 \\
\hline 42,36 & 1331,20 & 159,70 & 19,12 & 14,92 & 12,82 & 10,57 & 8,74 & 7,27 & 5,18 & 3,90 & 2,57 \\
\hline 72,66 & 306,30 & 167,00 & 33,30 & 18,01 & 13,35 & 10,07 & 8,09 & 6,68 & 4,78 & 3,67 & 2,51 \\
\hline 34,00 & 1142,60 & 101,50 & 31,14 & 25,19 & 21,57 & 17,46 & 14,16 & 11,57 & 8,05 & 6,01 & 3,98 \\
\hline 77,14 & 1154,70 & 116,50 & 17,54 & 12,81 & 11,44 & 10,17 & 9,16 & 8,27 & 6,74 & 5,54 & 3,87 \\
\hline 76,58 & 1078,20 & 149,80 & 16,01 & 11,29 & 9,83 & 8,55 & 7,57 & 6,73 & 5,36 & 4,32 & 2,97 \\
\hline 39,79 & 784,50 & 144,00 & 26,21 & 19,06 & 15,74 & 12,41 & 9,90 & 8,03 & 5,57 & 4,18 & 2,81 \\
\hline 34,02 & 1058,70 & 156,30 & 24,30 & 18,28 & 15,08 & 11,72 & 9,23 & 7,39 & 5,07 & 3,81 & 2,58 \\
\hline 89,30 & 741,50 & 62,40 & 28,22 & 20,13 & 18,14 & 16,43 & 15,07 & 13,87 & 11,74 & 9,98 & 7,31 \\
\hline 83,51 & 1701,80 & 38,90 & 27,05 & 21,59 & 19,99 & 19,22 & 18,39 & 17,51 & 15,80 & 14,19 & 11,38 \\
\hline 71,23 & 253,30 & 99,30 & 45,08 & 26,44 & 20,58 & 16,18 & 13,32 & 11,18 & 8,15 & 6,28 & 4,24 \\
\hline 22,62 & 760,00 & 99,20 & 47,37 & 34,73 & 26,87 & 19,24 & 14,29 & 11,11 & 7,59 & 5,83 & 4,04 \\
\hline 44,84 & 274,00 & 107,30 & 47,27 & 29,00 & 22,39 & 16,83 & 13,14 & 10,53 & 7,28 & 5,53 & 3,80 \\
\hline 75,18 & 1196,90 & 189,40 & 13,65 & 9,49 & 8,17 & 7,03 & 6,17 & 5,45 & 4,27 & 3,42 & 2,33 \\
\hline 80,30 & 802,50 & 177,40 & 17,16 & 11,12 & 9,25 & 7,76 & 6,72 & 5,87 & 4,55 & 3,62 & 2,46 \\
\hline 46,35 & 1756,50 & 32,60 & 45,45 & 39,34 & 37,66 & 34,87 & 32,07 & 29,37 & 24,43 & 20,27 & 14,16 \\
\hline 52,20 & 847,50 & 87,00 & 28,88 & 22,77 & 20,08 & 17,25 & 14,87 & 12,82 & 9,63 & 7,44 & 4,89 \\
\hline 66,10 & 1301,60 & 171,30 & 14,51 & 10,66 & 9,31 & 8,05 & 7,05 & 6,19 & 4,80 & 3,80 & 2,55 \\
\hline 76,29 & 567,20 & 192,70 & 20,86 & 12,52 & 9,91 & 7,94 & 6,65 & 5,66 & 4,21 & 3,28 & 2,21 \\
\hline
\end{tabular}




\begin{tabular}{|c|c|c|c|c|c|c|c|c|c|c|c|}
\hline \multirow[b]{2}{*}{ e1 (cm) } & & & & & & & ões (x1 & m) & & & \\
\hline & Meq (MPa) & Ms (MPa) & D0 & D25 & D40 & D60 & D80 & D100 & D140 & D180 & D260 \\
\hline 89,68 & 972,30 & 80,00 & 21,74 & 15,53 & 14,00 & 12,71 & 11,67 & 10,75 & 9,12 & 7,77 & 5,71 \\
\hline 65,58 & 1175,20 & 56,70 & 28,77 & 22,92 & 21,40 & 19,61 & 17,97 & 16,44 & 13,69 & 11,42 & 8,08 \\
\hline 39,37 & 996,40 & 95,20 & 30,76 & 24,79 & 21,49 & 17,78 & 14,73 & 12,25 & 8,72 & 6,55 & 4,30 \\
\hline 38,35 & 371,50 & 130,70 & 38,85 & 24,64 & 19,01 & 14,08 & 10,82 & 8,59 & 5,90 & 4,50 & 3,10 \\
\hline 43,18 & 1878,80 & 107,60 & 20,95 & 17,88 & 16,12 & 14,01 & 12,13 & 10,48 & 7,88 & 6,06 & 3,95 \\
\hline 45,29 & 245,40 & 40,60 & 82,82 & 61,16 & 51,58 & 41,92 & 34,38 & 28,45 & 20,18 & 15,21 & 10,09 \\
\hline 21,86 & 236,40 & 163,80 & 46,64 & 24,02 & 16,14 & 10,78 & 8,05 & 6,40 & 4,50 & 3,51 & 2,49 \\
\hline 71,82 & 401,80 & 30,70 & 60,81 & 46,29 & 42,16 & 37,95 & 34,41 & 31,20 & 25,60 & 21,12 & 14,79 \\
\hline 76,89 & 1272,20 & 151,90 & 14,61 & 10,49 & 9,25 & 8,13 & 7,26 & 6,50 & 5,24 & 4,26 & 2,95 \\
\hline 58,49 & 1851,20 & 80,20 & 20,89 & 17,20 & 16,08 & 14,66 & 13,36 & 12,13 & 9,96 & 8,19 & 5,68 \\
\hline 81,10 & 740,50 & 102,90 & 22,79 & 15,85 & 13,78 & 12,02 & 10,70 & 9,57 & 7,69 & 6,27 & 4,35 \\
\hline 20,03 & 1372,60 & 110,00 & 40,50 & 30,93 & 24,26 & 17,52 & 13,02 & 10,09 & 6,85 & 5,25 & 3,63 \\
\hline 53,27 & 873,20 & 148,30 & 21,06 & 15,31 & 13,01 & 10,80 & 9,07 & 7,65 & 5,58 & 4,26 & 2,81 \\
\hline 84,01 & 866,40 & 189,20 & 15,75 & 10,14 & 8,43 & 7,09 & 6,16 & 5,42 & 4,24 & 3,39 & 2,32 \\
\hline 74,77 & 1376,60 & 73,90 & 21,43 & 16,43 & 15,26 & 14,05 & 12,96 & 11,95 & 10,12 & 8,57 & 6,22 \\
\hline 43,73 & 1052,90 & 63,80 & 35,78 & 30,37 & 27,31 & 23,70 & 20,49 & 17,70 & 13,29 & 10,22 & 6,65 \\
\hline 73,27 & 1091,30 & 39,00 & 35,21 & 27,45 & 25,88 & 24,28 & 22,68 & 21,16 & 18,31 & 15,81 & 11,81 \\
\hline 20,71 & 1759,70 & 159,80 & 28,19 & 21,34 & 16,69 & 12,03 & 8,94 & 6,93 & 4,72 & 3,61 & 2,50 \\
\hline 62,81 & 1113,70 & 31,20 & 44,48 & 35,94 & 34,28 & 32,11 & 29,90 & 27,76 & 23,78 & 20,31 & 14,87 \\
\hline 61,67 & 336,70 & 141,50 & 34,19 & 20,05 & 15,48 & 11,97 & 9,67 & 7,97 & 5,67 & 4,33 & 2,93 \\
\hline 84,62 & 243,30 & 83,20 & 47,38 & 27,93 & 22,01 & 17,68 & 14,91 & 12,80 & 9,68 & 7,62 & 5,18 \\
\hline 30,93 & 1821,60 & 136,80 & 23,35 & 19,14 & 16,36 & 13,16 & 10,59 & 8,60 & 5,94 & 4,43 & 2,94 \\
\hline 55,45 & 1312,20 & 69,60 & 26,73 & 22,15 & 20,42 & 18,35 & 16,47 & 14,75 & 11,80 & 9,51 & 6,43 \\
\hline 77,07 & 1186,50 & 185,20 & 13,73 & 9,51 & 8,19 & 7,06 & 6,22 & 5,51 & 4,35 & 3,49 & 2,39 \\
\hline 77,36 & 912,20 & 36,60 & 37,91 & 29,14 & 27,31 & 25,57 & 23,89 & 22,30 & 19,33 & 16,72 & 12,55 \\
\hline 85,12 & 742,60 & 88,40 & 24,06 & 16,82 & 14,81 & 13,09 & 11,78 & 10,65 & 8,74 & 7,23 & 5,11 \\
\hline 49,30 & 281,90 & 59,60 & 60,46 & 42,41 & 35,21 & 28,41 & 23,27 & 19,26 & 13,69 & 10,36 & 6,90 \\
\hline 54,57 & 1770,60 & 37,40 & 37,08 & 30,87 & 29,65 & 27,75 & 25,79 & 23,88 & 20,31 & 17,22 & 12,44 \\
\hline 35,51 & 1302,40 & 191,10 & 19,31 & 14,57 & 12,10 & 9,49 & 7,53 & 6,07 & 4,18 & 3,13 & 2,11 \\
\hline 43,30 & 1376,50 & 135,90 & 20,46 & 16,41 & 14,33 & 12,02 & 10,09 & 8,50 & 6,15 & 4,65 & 3,04 \\
\hline 63,75 & 747,70 & 185,90 & 18,93 & 12,49 & 10,28 & 8,42 & 7,07 & 5,99 & 4,41 & 3,40 & 2,27 \\
\hline 35,49 & 530,80 & 54,10 & 59,58 & 47,43 & 40,46 & 32,68 & 26,48 & 21,64 & 15,08 & 11,27 & 7,48 \\
\hline 65,51 & 709,50 & 159,50 & 20,66 & 13,86 & 11,52 & 9,55 & 8,09 & 6,92 & 5,16 & 3,99 & 2,66 \\
\hline 59,86 & 484,90 & 20,10 & 80,95 & 66,26 & 62,16 & 56,93 & 52,05 & 47,46 & 39,26 & 32,51 & 22,76 \\
\hline 36,62 & 1488,60 & 128,30 & 23,09 & 18,82 & 16,30 & 13,42 & 11,04 & 9,13 & 6,45 & 4,83 & 3,17 \\
\hline 26,20 & 958,30 & 147,50 & 30,58 & 22,36 & 17,59 & 12,86 & 9,69 & 7,58 & 5,16 & 3,94 & 2,72 \\
\hline 81,42 & 1928,60 & 131,80 & 12,71 & 9,42 & 8,62 & 7,87 & 7,24 & 6,67 & 5,64 & 4,78 & 3,48 \\
\hline 77,90 & 237,80 & 150,60 & 40,75 & 21,13 & 15,28 & 11,28 & 8,98 & 7,38 & 5,28 & 4,07 & 2,79 \\
\hline 41,20 & 780,50 & 23,40 & 79,44 & 70,73 & 65,58 & 58,68 & 52,18 & 46,21 & 36,13 & 28,49 & 18,78 \\
\hline 45,94 & 1022,60 & 198,50 & 18,06 & 12,94 & 10,77 & 8,66 & 7,05 & 5,81 & 4,10 & 3,09 & 2,06 \\
\hline 79,72 & 1285,60 & 126,00 & 15,78 & 11,45 & 10,25 & 9,15 & 8,27 & 7,50 & 6,16 & 5,10 & 3,60 \\
\hline 43,26 & 946,40 & 48,20 & 44,73 & 38,56 & 34,97 & 30,61 & 26,68 & 23,19 & 17,60 & 13,61 & 8,88 \\
\hline 26,74 & 1030,30 & 153,00 & 28,80 & 21,23 & 16,81 & 12,39 & 9,37 & 7,34 & 4,99 & 3,80 & 2,62 \\
\hline 47,44 & 1224,60 & 192,90 & 16,62 & 12,36 & 10,50 & 8,63 & 7,15 & 5,96 & 4,28 & 3,23 & 2,14 \\
\hline 81,54 & 1157,10 & 145,10 & 15,30 & 10,76 & 9,44 & 8,29 & 7,42 & 6,67 & 5,41 & 4,44 & 3,10 \\
\hline 45,19 & 1719,40 & 127,50 & 18,91 & 15,69 & 13,99 & 12,04 & 10,35 & 8,89 & 6,62 & 5,08 & 3,31 \\
\hline 72,38 & 1953,90 & 195,70 & 10,71 & 7,96 & 7,11 & 6,30 & 5,65 & 5,07 & 4,08 & 3,32 & 2,29 \\
\hline 54,51 & 712,50 & 102,40 & 27,85 & 20,79 & 17,93 & 15,12 & 12,86 & 10,97 & 8,13 & 6,24 & 4,11 \\
\hline 34,31 & 1304,70 & 88,00 & 32,31 & 27,03 & 23,59 & 19,53 & 16,13 & 13,37 & 9,45 & 7,06 & 4,62 \\
\hline 72,46 & 1284,40 & 20,70 & 49,90 & 40,54 & 38,05 & 36,81 & 35,25 & 33,56 & 30,25 & 27,12 & 21,62 \\
\hline 39,20 & 1289,60 & 64,20 & 35,82 & 31,05 & 27,96 & 24,16 & 20,77 & 17,83 & 13,24 & 10,11 & 6,55 \\
\hline 83,33 & 1005,50 & 20,80 & 48,54 & 39,24 & 36,23 & 34,92 & 33,52 & 31,99 & 28,97 & 26,14 & 21,11 \\
\hline 65,05 & 1567,20 & 140,60 & 14,94 & 11,52 & 10,35 & 9,16 & 8,17 & 7,28 & 5,79 & 4,66 & 3,16 \\
\hline 78,35 & 1959,60 & 53,20 & 22,28 & 17,43 & 16,36 & 15,61 & 14,78 & 13,96 & 12,39 & 10,95 & 8,52 \\
\hline 41,74 & 1326,00 & 80,60 & 29,30 & 24,90 & 22,31 & 19,22 & 16,50 & 14,15 & 10,51 & 8,03 & 5,22 \\
\hline 40,64 & 1598,40 & 84,40 & 27,10 & 23,36 & 21,03 & 18,21 & 15,69 & 13,50 & 10,07 & 7,70 & 5,00 \\
\hline 33,92 & 1175,40 & 188,10 & 20,83 & 15,47 & 12,67 & 9,78 & 7,66 & 6,12 & 4,19 & 3,15 & 2,14 \\
\hline 25,41 & 349,40 & 66,80 & 73,37 & 51,60 & 39,59 & 28,30 & 21,09 & 16,45 & 11,28 & 8,66 & 6,01 \\
\hline 40,65 & 1514,20 & 27,60 & 58,26 & 52,03 & 49,29 & 45,05 & 40,90 & 36,95 & 29,93 & 24,26 & 16,42 \\
\hline 25,59 & 1354,00 & 42,10 & 65,91 & 57,72 & 50,68 & 41,89 & 34,40 & 28,31 & 19,76 & 14,64 & 9,57 \\
\hline 44,30 & 1197,60 & 24,40 & 64,28 & 56,44 & 53,64 & 49,24 & 44,92 & 40,79 & 33,40 & 27,32 & 18,73 \\
\hline 59,78 & 347,20 & 27,30 & 76,01 & 60,39 & 54,58 & 48,34 & 42,97 & 38,15 & 30,11 & 24,04 & 16,17 \\
\hline 25,83 & 910,00 & 178,40 & 27,45 & 19,26 & 14,80 & 10,60 & 7,91 & 6,17 & 4,23 & 3,25 & 2,25 \\
\hline 57,92 & 1644,00 & 67,70 & 24,46 & 20,20 & 18,93 & 17,29 & 15,76 & 14,33 & 11,78 & 9,70 & 6,74 \\
\hline 80,77 & 1094,30 & 100,40 & 19,09 & 13,88 & 12,49 & 11,19 & 10,16 & 9,25 & 7,65 & 6,37 & 4,53 \\
\hline 39,48 & 1535,80 & 71,80 & 31,13 & 27,12 & 24,51 & 21,29 & 18,38 & 15,85 & 11,85 & 9,07 & 5,88 \\
\hline 42,83 & 675,70 & 39,30 & 58,08 & 49,53 & 44,58 & 38,66 & 33,40 & 28,82 & 21,60 & 16,59 & 10,79 \\
\hline 37,13 & 456,80 & 140,60 & 34,47 & 22,57 & 17,61 & 13,11 & 10,09 & 8,01 & 5,50 & 4,18 & 2,88 \\
\hline 42,00 & 521,10 & 39,80 & 64,48 & 53,48 & 47,31 & 40,20 & 34,10 & 28,95 & 21,18 & 16,07 & 10,46 \\
\hline 84,28 & 748,60 & 181,90 & 17,45 & 11,01 & 9,05 & 7,53 & 6,51 & 5,69 & 4,42 & 3,52 & 2,41 \\
\hline 60,18 & 548,80 & 23,10 & 70,63 & 57,72 & 54,13 & 49,56 & 45,31 & 41,32 & 34,18 & 28,30 & 19,82 \\
\hline 24,57 & 778,50 & 178,40 & 29,52 & 20,02 & 15,02 & 10,53 & 7,79 & 6,08 & 4,20 & 3,24 & 2,26 \\
\hline 29,95 & 1284,30 & 122,90 & 28,89 & 22,91 & 19,17 & 15,02 & 11,84 & 9,48 & 6,48 & 4,85 & 3,27 \\
\hline 85,41 & 267,00 & 57,10 & 51,30 & 33,02 & 27,50 & 23,19 & 20,22 & 17,80 & 13,99 & 11,24 & 7,72 \\
\hline 60,64 & 1528,20 & 99,30 & 19,22 & 15,43 & 14,13 & 12,67 & 11,38 & 10,20 & 8,19 & 6,63 & 4,51 \\
\hline 53,59 & 483,70 & 146,10 & 28,54 & 18,40 & 14,78 & 11,67 & 9,47 & 7,80 & 5,53 & 4,19 & 2,82 \\
\hline 44,74 & 1438,00 & 116,00 & 21,63 & 17,79 & 15,76 & 13,48 & 11,51 & 9,83 & 7,26 & 5,54 & 3,61 \\
\hline 78,40 & 1110,30 & 41,90 & 32,09 & 24,67 & 23,13 & 21,74 & 20,37 & 19,07 & 16,62 & 14,45 & 10,94 \\
\hline 71,75 & 1612,60 & 97,80 & 17,37 & 13,39 & 12,37 & 11,28 & 10,32 & 9,44 & 7,87 & 6,58 & 4,68 \\
\hline 83,52 & 1665,60 & 112,90 & 14,60 & 10,75 & 9,84 & 9,00 & 8,29 & 7,65 & 6,50 & 5,53 & 4,05 \\
\hline 64,06 & 1070,20 & 79,60 & 24,58 & 19,31 & 17,57 & 15,71 & 14,10 & 12,65 & 10,17 & 8,24 & 5,64 \\
\hline 24,71 & 1701,90 & 98,00 & 35,49 & 29,15 & 24,48 & 19,13 & 15,00 & 11,94 & 8,10 & 6,04 & 4,08 \\
\hline
\end{tabular}




\begin{tabular}{|c|c|c|c|c|c|c|c|c|c|c|c|}
\hline & & & \multicolumn{9}{|c|}{ Deflexões $\left(\times 10^{-4} \mathrm{~cm}\right)$} \\
\hline e1 (cm) & Meq (MPa) & Ms (MPa) & D0 & D25 & D40 & D60 & D80 & D100 & D140 & D180 & D260 \\
\hline 71,91 & 1852,40 & 141,00 & 13,21 & 10,05 & 9,16 & 8,25 & 7,48 & 6,78 & 5,57 & 4,60 & 3,22 \\
\hline 61,82 & 1664,80 & 200,00 & 12,29 & 9,26 & 8,13 & 7,04 & 6,15 & 5,38 & 4,14 & 3,26 & 2,17 \\
\hline 34,88 & 442,10 & 170,20 & 32,07 & 19,92 & 15,05 & 10,88 & 8,24 & 6,50 & 4,47 & 3,42 & 2,38 \\
\hline 26,52 & 1735,20 & 53,30 & 50,31 & 44,31 & 39,13 & 32,60 & 26,98 & 22,35 & 15,72 & 11,67 & 7,60 \\
\hline 35,64 & 741,60 & 60,00 & 49,19 & 40,37 & 34,99 & 28,79 & 23,67 & 19,56 & 13,79 & 10,31 & 6,78 \\
\hline 41,88 & 207,60 & 127,80 & 51,21 & 27,81 & 20,09 & 14,30 & 10,87 & 8,62 & 5,95 & 4,57 & 3,20 \\
\hline 53,80 & 349,00 & 69,40 & 48,36 & 34,08 & 28,57 & 23,44 & 19,52 & 16,38 & 11,86 & 9,03 & 5,98 \\
\hline 64,24 & 292,60 & 97,70 & 42,60 & 26,29 & 20,91 & 16,64 & 13,72 & 11,48 & 8,31 & 6,37 & 4,28 \\
\hline 69,57 & 625,30 & 72,70 & 31,48 & 23,23 & 20,51 & 17,96 & 15,91 & 14,13 & 11,17 & 8,96 & 6,09 \\
\hline 82,53 & 1361,20 & 117,20 & 15,73 & 11,43 & 10,32 & 9,30 & 8,48 & 7,75 & 6,47 & 5,42 & 3,89 \\
\hline 38,11 & 1245,40 & 107,50 & 26,81 & 21,88 & 19,03 & 15,77 & 13,07 & 10,87 & 7,74 & 5,80 & 3,80 \\
\hline 76,38 & 842,10 & 106,20 & 21,52 & 15,38 & 13,50 & 11,82 & 10,52 & 9,39 & 7,52 & 6,10 & 4,20 \\
\hline 75,85 & 1808,80 & 110,00 & 15,03 & 11,41 & 10,54 & 9,64 & 8,86 & 8,14 & 6,86 & 5,78 & 4,17 \\
\hline 57,54 & 1136,70 & 114,90 & 20,55 & 16,02 & 14,21 & 12,35 & 10,79 & 9,43 & 7,24 & 5,68 & 3,77 \\
\hline 46,86 & 1197,70 & 143,70 & 19,95 & 15,52 & 13,44 & 11,26 & 9,46 & 7,98 & 5,80 & 4,40 & 2,89 \\
\hline 48,06 & 1958,40 & 40,80 & 36,69 & 31,58 & 30,18 & 27,90 & 25,64 & 23,47 & 19,51 & 16,18 & 11,31 \\
\hline 46,42 & 729,60 & 36,50 & 55,84 & 47,86 & 43,70 & 38,63 & 34,03 & 29,89 & 23,09 & 18,08 & 11,89 \\
\hline 74,84 & 595,30 & 49,60 & 38,29 & 28,64 & 25,94 & 23,30 & 21,11 & 19,15 & 15,74 & 13,01 & 9,14 \\
\hline 64,84 & 896,00 & 65,00 & 29,61 & 23,23 & 21,18 & 18,98 & 17,08 & 15,36 & 12,40 & 10,09 & 6,93 \\
\hline 59,01 & 709,50 & 150,00 & 22,16 & 15,27 & 12,76 & 10,53 & 8,85 & 7,49 & 5,50 & 4,21 & 2,80 \\
\hline 75,52 & 876,50 & 175,50 & 16,72 & 11,17 & 9,40 & 7,93 & 6,88 & 6,00 & 4,63 & 3,67 & 2,48 \\
\hline 49,73 & 1645,60 & 60,20 & 29,00 & 24,89 & 23,23 & 21,03 & 18,96 & 17,03 & 13,68 & 11,04 & 7,46 \\
\hline 88,60 & 853,10 & 134,20 & 18,09 & 12,10 & 10,38 & 9,00 & 8,00 & 7,17 & 5,81 & 4,76 & 3,34 \\
\hline 20,33 & 625,00 & 139,80 & 41,08 & 27,05 & 19,54 & 13,25 & 9,70 & 7,59 & 5,31 & 4,12 & 2,88 \\
\hline 86,28 & 1799,40 & 63,70 & 19,34 & 14,79 & 13,72 & 13,00 & 12,29 & 11,59 & 10,28 & 9,09 & 7,08 \\
\hline 84,49 & 875,40 & 108,90 & 20,02 & 13,96 & 12,25 & 10,78 & 9,68 & 8,73 & 7,13 & 5,88 & 4,14 \\
\hline 40,73 & 374,80 & 70,10 & 53,58 & 38,81 & 32,09 & 25,35 & 20,29 & 16,48 & 11,46 & 8,61 & 5,79 \\
\hline 58,84 & 1721,20 & 76,20 & 22,07 & 18,13 & 16,94 & 15,44 & 14,06 & 12,77 & 10,48 & 8,61 & 5,98 \\
\hline 54,05 & 1312,00 & 156,40 & 16,82 & 12,94 & 11,31 & $\begin{array}{c}10,46 \\
9,66\end{array}$ & $\frac{14,00}{8,29}$ & $\frac{1 L, 11}{7,13}$ & $\frac{10,40}{5,34}$ & $\frac{0,01}{4,12}$ & 2,71 \\
\hline 36,76 & 1714,10 & 189,70 & 17,11 & 13,48 & 11,48 & 9,28 & 7,53 & 6,16 & 4,30 & 3,22 & 2,14 \\
\hline 72,15 & 1275,20 & 89,10 & 20,13 & 15,39 & 14,10 & 12,76 & 11,61 & 10,57 & 8,74 & 7,25 & 5,11 \\
\hline 36,05 & 1527,40 & 174,30 & 19,08 & 14,96 & 12,69 & 10,19 & 8,22 & 6,70 & 4,66 & 3,48 & 2,32 \\
\hline 22,75 & 919,10 & 104,30 & 43,16 & 32,29 & 25,31 & 18,34 & 13,70 & 10,65 & 7,25 & 5,55 & 3,84 \\
\hline 38,27 & 1713,10 & 75,50 & 29,69 & 26,01 & 23,51 & 20,39 & 17,59 & 15,13 & 11,28 & 8,62 & 5,58 \\
\hline 27,28 & 270,00 & 141,90 & 46,86 & 26,60 & 18,81 & 12,85 & 9,54 & 7,52 & 5,24 & 4,07 & 2,86 \\
\hline 60,35 & 1788,50 & 92,60 & 18,95 & 15,40 & 14,28 & 12,95 & 11,74 & 10,63 & 8,67 & 7,09 & 4,90 \\
\hline 69,89 & 212,10 & 172,20 & 43,11 & 21,16 & 14,70 & 10,40 & 8,03 & 6,47 & 4,52 & 3,48 & 2,42 \\
\hline 26,58 & 1194,90 & 53,70 & 56,50 & 48,08 & 41,54 & 33,66 & 27,19 & 22,11 & 15,24 & 11,31 & 7,48 \\
\hline 28,55 & 449,00 & 159,00 & 35,71 & 22,48 & 16,65 & 11,69 & 8,71 & 6,83 & 4,72 & 3,64 & 2,54 \\
\hline 25,97 & 1345,00 & 42,40 & 64,93 & 56,90 & 50,03 & 41,43 & 34,09 & 28,10 & 19,66 & 14,57 & 9,52 \\
\hline 25,67 & 1909,80 & 188,00 & 21,20 & 16,46 & 13,38 & 10,09 & 7,73 & 6,08 & 4,12 & 3,11 & 2,13 \\
\hline 85,98 & 1540,30 & 196,60 & 11,17 & 7,73 & 6,76 & 5,95 & 5,34 & 4,82 & 3,94 & 3,25 & 2,29 \\
\hline 23,27 & 687,00 & 142,40 & 36,94 & 25,29 & 18,93 & 13,21 & 9,75 & 7,60 & 5,25 & 4,06 & 2,82 \\
\hline 45,47 & 249,00 & 194,00 & 38,26 & 19,27 & 13,44 & 9,38 & 7,11 & 5,65 & 3,90 & 3,01 & 2,12 \\
\hline 38,25 & 1469,60 & 47,40 & 42,44 & 37,93 & 34,80 & 30,73 & 26,95 & 23,55 & 17,98 & 13,94 & 9,07 \\
\hline 24,91 & 259,30 & 44,60 & 107,59 & 76,78 & 59,22 & 42,46 & 31,66 & 24,68 & 16,89 & 12,96 & 8,99 \\
\hline 43,62 & 1231,60 & 114,10 & 23,64 & 19,13 & 16,77 & 14,15 & 11,94 & 10,09 & 7,35 & 5,57 & 3,64 \\
\hline 80,01 & 848,10 & 129,80 & 19,11 & 13,15 & 11,35 & 9,81 & 8,68 & 7,72 & 6,15 & 4,97 & 3,42 \\
\hline 54,10 & 1202,00 & 27,50 & 51,93 & 43,43 & 41,61 & 38,77 & 35,90 & 33,12 & 27,99 & 23,58 & 16,87 \\
\hline 65,61 & 1635,00 & 59,70 & 24,75 & 19,78 & 18,71 & 17,37 & 16,09 & 14,86 & 12,61 & 10,69 & 7,74 \\
\hline 35,96 & 465,80 & 174,60 & 30,58 & 19,12 & 14,54 & 10,59 & 8,06 & 6,37 & 4,37 & 3,35 & 2,32 \\
\hline 30,45 & 391,90 & 105,40 & 47,52 & 31,90 & 24,53 & 17,77 & 13,40 & 10,52 & 7,21 & 5,52 & 3,83 \\
\hline 55,14 & 1807,00 & 68,70 & 24,16 & 20,22 & 18,97 & 17,32 & 15,76 & 14,30 & 11,71 & 9,61 & 6,63 \\
\hline 76,68 & 1511,30 & 151,60 & 13,48 & 9,86 & 8,82 & 7,84 & 7,06 & 6,37 & 5,19 & 4,26 & 2,98 \\
\hline 35,99 & 739,00 & 127,10 & 30,61 & 22,50 & 18,47 & 14,35 & 11,31 & 9,07 & 6,24 & 4,69 & 3,18 \\
\hline 21,80 & 725,50 & 22,00 & 143,72 & 123,07 & 105,59 & 84,44 & 67,30 & 54,09 & 36,80 & 27,25 & 18,18 \\
\hline 84,77 & 1861,70 & 172,70 & 10,92 & 7,83 & 7,03 & 6,31 & 5,75 & 5,25 & 4,38 & 3,67 & 2,64 \\
\hline 69,82 & 1899,50 & 182,40 & 11,46 & 8,63 & 7,73 & 6,85 & 6,13 & 5,49 & 4,41 & 3,57 & 2,45 \\
\hline 54,57 & 992,70 & 89,60 & 25,87 & 20,60 & 18,37 & 16,00 & 13,96 & 12,19 & 9,33 & 7,29 & 4,82 \\
\hline 39,28 & 1949,90 & 165,80 & 16,91 & 13,84 & 12,09 & 10,08 & 8,41 & 7,03 & 5,04 & 3,79 & 2,48 \\
\hline 26,91 & 200,90 & 165,30 & 48,17 & 23,79 & 16,01 & 10,76 & 8,05 & 6,39 & 4,47 & 3,48 & 2,47 \\
\hline Le, & 1559,90 & 124,30 & 17,70 & 14,29 & 12,84 & 11,27 & 9,90 & 8,69 & 6,72 & 5,28 & 3,50 \\
\hline 22,19 & 1059,60 & 28,00 & 106,57 & 92,62 & $\begin{array}{l}1 L, 0+ \\
80,38\end{array}$ & $\begin{array}{l}+1+L, 25 \\
65,25\end{array}$ & 52,67 & 42,73 & 29,32 & 21,67 & 14,32 \\
\hline 40,95 & 538,00 & 109,00 & 35,56 & 25,37 & 20,84 & 16,37 & 13,06 & 10,58 & 7,35 & 5,53 & 3,72 \\
\hline 45,90 & 1011,60 & 136,80 & 22,34 & 17,07 & 14,64 & 12,11 & 10,08 & 8,43 & 6,06 & 4,58 & 3,01 \\
\hline 83,95 & 620,00 & 49,30 & 35,79 & 26,05 & 23,62 & 21,41 & 19,61 & 17,99 & 15,14 & 12,78 & 9,27 \\
\hline 31,46 & 1236,80 & 35,10 & 64,22 & 57,85 & 52,35 & 45,22 & 38,75 & 33,11 & 24,36 & 18,43 & 11,87 \\
\hline 48,98 & 541,50 & 157,00 & 26,88 & 17,63 & 14,17 & 11,10 & 8,92 & 7,28 & 5,11 & 3,86 & 2,60 \\
\hline 41,22 & 1394,30 & 145,50 & 20,19 & 16,08 & 13,92 & 11,54 & 9,58 & 7,99 & 5,71 & 4,29 & 2,82 \\
\hline 36,87 & 1056,60 & 116.10 & 27,83 & 21,96 & 18,72 & 15,15 & 12,30 & 10,07 & 7.04 & 5,27 & 3,49 \\
\hline 70,24 & 301,20 & 160,50 & 34,28 & 18,70 & 13,93 & 10,52 & 8,45 & 6.96 & 4.97 & 3,82 & 2,60 \\
\hline 49,82 & 1283,30 & 87,60 & 24,98 & 20,72 & 18,70 & 16,38 & 14,34 & 12,53 & 9,60 & 7,49 & 4,93 \\
\hline 67,60 & 373,00 & 130,90 & 32,32 & 19,59 & 15,48 & 12,29 & 10,15 & 8,52 & 6,20 & 4,77 & 3,21 \\
\hline 32,34 & 544,20 & 191,10 & 28,26 & 17,93 & 13,55 & 9,74 & 7,34 & 5,77 & 3,97 & 3,04 & 2,12 \\
\hline 57,12 & 956,80 & 40,00 & 41,98 & 34,79 & 32,55 & 29,67 & 27,00 & 24,50 & 20,07 & 16,47 & 11,39 \\
\hline 21,58 & 1056,60 & 29,90 & 104,36 & 89,75 & 77,21 & 61,94 & 49,49 & 39,84 & 27,14 & 20,08 & 13,37 \\
\hline 33,72 & 642,30 & 102,90 & 38,24 & 28,38 & 23,23 & 17,91 & 14,01 & 11,19 & 7,66 & 5,76 & 3,91 \\
\hline 83,53 & 577,50 & 90,30 & 27,36 & 18,59 & 15,99 & 13,83 & 12,26 & 10,94 & 8,76 & 7,13 & 4,94 \\
\hline 38,20 & 550,60 & 164,10 & 28,79 & 18,98 & 14,91 & 11,19 & 8,66 & 6,89 & 4,73 & 3,59 & 2,47 \\
\hline 50,76 & 1794,30 & 102,40 & 19,71 & 16,54 & 15,10 & 13,39 & 11,85 & 10,47 & 8,17 & 6,45 & 4,28 \\
\hline 32,95 & 1190,50 & 134,00 & 26,23 & 20,51 & 17,20 & 13,58 & 10,79 & 8,70 & 5,98 & 4,47 & 3,00 \\
\hline 35,82 & 515,00 & 154,10 & 31,55 & 20,79 & 16,20 & 12,01 & 9,21 & 7,29 & 5,00 & 3,81 & 2,62 \\
\hline
\end{tabular}




\begin{tabular}{|c|c|c|c|c|c|c|c|c|c|c|c|}
\hline \multirow[b]{2}{*}{ e1 (cm) } & & & & & & $\mathrm{De}$ & ões (x1 & & & & \\
\hline & Meq (MPa) & Ms (MPa) & D0 & D25 & D40 & D60 & D80 & D100 & D140 & D180 & D260 \\
\hline 89,66 & 1939,40 & 124,00 & 12,50 & 9,10 & 8,31 & 7,66 & 7,10 & 6,60 & 5,69 & 4,91 & 3,68 \\
\hline 31,11 & 806,30 & 147,80 & 29,26 & 21,13 & 16,89 & 12,66 & 9,71 & 7,67 & 5,23 & 3,96 & 2,72 \\
\hline 55,06 & 1656,70 & 140,70 & 15,97 & 12,79 & 11,46 & 10,02 & 8,79 & 7,70 & 5,93 & 4,66 & 3,09 \\
\hline 56,40 & 431,80 & 104,50 & 34,79 & 23,44 & 19,31 & 15,67 & 12,98 & 10,86 & 7,84 & 5,97 & 3,98 \\
\hline 60,65 & 959,40 & 94,60 & 23,99 & 18,59 & 16,55 & 14,49 & 12,75 & 11,23 & 8,74 & 6,92 & 4,62 \\
\hline 34,96 & 1576,10 & 26,00 & 66,99 & 61,32 & 57,48 & 51,88 & 46,45 & 41,37 & 32,63 & 25,86 & 17,06 \\
\hline 87,86 & 1442,80 & 66,90 & 20,38 & 15,24 & 14,07 & 13,18 & 12,35 & 11,58 & 10,14 & 8,87 & 6,79 \\
\hline 34,75 & 576,10 & 75,70 & 47,41 & 36,35 & 30,35 & 23,93 & 19,03 & 15,35 & 10,57 & 7,92 & 5,32 \\
\hline 23,17 & 329,80 & 27,30 & 148,74 & 116,18 & 93,78 & 70,00 & 53,15 & 41,56 & 28,09 & 21,27 & 14,63 \\
\hline 71,44 & 1159,40 & 131,50 & 16,99 & 12,50 & 11,06 & 9,72 & 8,64 & 7,70 & 6,14 & 4,95 & 3,38 \\
\hline 89,02 & 1856,50 & 164,90 & 10,97 & 7,80 & 7,00 & 6,32 & 5,78 & 5,31 & 4,48 & 3,79 & 2,77 \\
\hline 34,99 & 291,00 & 145,00 & 42,15 & 24,45 & 17,93 & 12,71 & 9,57 & 7,55 & 5,21 & 4,01 & 2,80 \\
\hline 60,60 & 785,10 & 197,90 & 18,26 & 12,09 & 9,93 & 8,09 & 6,74 & 5,68 & 4,14 & 3,17 & 2,11 \\
\hline 70,97 & 384,60 & 195,60 & 27,21 & 15,00 & 11,25 & 8,55 & 6,90 & 5,71 & 4,09 & 3,14 & 2,14 \\
\hline 89,82 & 1212,70 & 159,50 & 13,76 & 9,38 & 8,18 & 7,18 & 6,46 & 5,84 & 4,80 & 3,98 & 2,83 \\
\hline 42,76 & 353,60 & 62,60 & 57,07 & 41,71 & 34,81 & 27,86 & 22,55 & 18,47 & 12,94 & 9,74 & 6,50 \\
\hline 34,73 & 310,60 & 77,00 & 59,33 & 40,68 & 32,16 & 24,07 & 18,52 & 14,68 & 10,05 & 7,63 & 5,24 \\
\hline 66,97 & 408,20 & 138,20 & 30,01 & 18,37 & 14,58 & 11,62 & 9,61 & 8,07 & 5,88 & 4,52 & 3,04 \\
\hline 71,66 & 1523,70 & 125,50 & 15,38 & 11,65 & 10,56 & 9,46 & 8,55 & 7,73 & 6,30 & 5,18 & 3,61 \\
\hline 82,72 & 1048,70 & 72,70 & 22,99 & 16,95 & 15,50 & 14,16 & 13,02 & 12,00 & 10,16 & 8,62 & 6,29 \\
\hline 77,53 & 757,00 & 65,40 & 29,04 & 21,46 & 19,39 & 17,41 & 15,80 & 14,35 & 11,84 & 9,83 & 6,95 \\
\hline 67,56 & 1963,90 & 123,00 & 14,43 & 11,29 & 10,40 & 9,42 & 8,57 & 7,78 & 6,40 & 5,29 & 3,70 \\
\hline 46,55 & 1075,80 & 189,30 & 17,99 & 13,12 & 11,03 & 8,96 & 7,36 & 6,09 & 4,33 & 3,27 & 2,17 \\
\hline 65,01 & 829,10 & 55,00 & 33,69 & 26,56 & 24,35 & 21,93 & 19,83 & 17,90 & 14,55 & 11,90 & 8,22 \\
\hline 21,06 & 849,90 & 156,20 & 34,35 & 23,56 & 17,43 & 12,02 & 8,81 & 6,87 & 4,76 & 3,69 & 2,57 \\
\hline $\begin{array}{l}2+, 00 \\
61,86\end{array}$ & 822,20 & $\frac{100, c 0}{147,90}$ & 20,25 & 14,30 & $\begin{array}{l}11,40 \\
12,14\end{array}$ & $\begin{array}{l}1 L, 0< \\
10,20\end{array}$ & $\begin{array}{l}0,01 \\
8,71\end{array}$ & $\begin{array}{l}0,01 \\
7,47\end{array}$ & 5,59 & 4,33 & 2,87 \\
\hline 70,59 & 1842,00 & 100,40 & 16,36 & 12,73 & 11,82 & 10,83 & 9,94 & 9,11 & 7,63 & 6,40 & 4,57 \\
\hline 20,27 & 1770,60 & 64,30 & 55,04 & 45,78 & 38,29 & 29,64 & 23,01 & 18,16 & 12,22 & 9,12 & 6,19 \\
\hline$\frac{L, L 1}{74,62}$ & 964,70 & 156,20 & 16,80 & 11,66 & 10,01 & $\frac{20,04}{8,60}$ & $\begin{array}{c}20,01 \\
7,53\end{array}$ & $\begin{array}{c}10, \pm 0 \\
6,64\end{array}$ & $\begin{array}{c}1\llcorner, L L \\
5,19\end{array}$ & $\frac{0,14}{4,14}$ & 2,81 \\
\hline 37,69 & 1201,90 & 187,00 & 19,48 & 14,57 & 12,13 & 9,59 & 7,66 & 6,20 & 4,29 & 3,22 & 2,16 \\
\hline 63,08 & 1687,20 & 177,80 & 12,89 & 9,83 & 8,73 & 7,63 & 6,73 & 5,93 & 4,63 & 3,68 & 2,47 \\
\hline 75,16 & 528,20 & 77,30 & 32,11 & 22,59 & 19,57 & 16,94 & 14,94 & 13,23 & 10,45 & 8,39 & 5,72 \\
\hline 36,42 & 449,50 & 151,40 & 33,52 & 21,50 & 16,58 & 12,21 & 9,34 & 7,39 & 5,07 & 3,87 & 2,67 \\
\hline 28,03 & 1156,50 & 114,30 & 32,87 & 25,79 & 21,29 & 16,39 & 12,75 & 10,11 & 6,87 & 5,16 & 3,51 \\
\hline 88,11 & 1551,80 & 159,90 & 12,21 & 8,58 & 7,63 & 6,82 & 6,20 & 5,65 & 4,71 & 3,95 & 2,84 \\
\hline 50,63 & 1826,40 & 106,00 & 19,19 & 16,09 & 14,67 & 13,00 & 11,49 & 10,14 & 7,90 & 6,23 & 4,13 \\
\hline 63,57 & 301,80 & 166,20 & 34,37 & 18,76 & 13,92 & 10,42 & 8,28 & 6,76 & 4,77 & 3,65 & 2,49 \\
\hline 57,78 & 682,80 & 102,20 & 27,61 & 20,33 & 17,51 & 14,82 & 12,67 & 10,88 & 8,13 & 6,28 & 4,15 \\
\hline 80,38 & 1382,30 & 158,20 & 13,49 & 9,62 & 8,50 & 7,51 & 6,75 & 6,08 & 4,95 & 4,07 & 2,85 \\
\hline 45,62 & 1400,50 & 172,60 & 17,08 & 13,24 & 11,43 & 9,52 & 7,95 & 6,67 & 4,82 & 3,64 & 2,39 \\
\hline 59,84 & 1547,00 & 89,40 & 20,55 & 16,66 & 15,35 & 13,83 & 12,47 & 11,22 & 9,06 & 7,36 & 5,04 \\
\hline 81,92 & 481,00 & 133,90 & 25,99 & 16,07 & 13,01 & 10,68 & 9,12 & 7,90 & 6,03 & 4,77 & 3,24 \\
\hline 73,44 & 1671,50 & 135,00 & 14,01 & 10,56 & 9,58 & 8,61 & 7,80 & 7,08 & 5,81 & 4,79 & 3,36 \\
\hline 51,59 & 277,00 & 65,10 & 57,12 & 39,07 & 32,18 & 25,89 & 21,22 & 17,58 & 12,53 & 9,49 & 6,33 \\
\hline 75,86 & 1182,10 & 154,80 & 15,09 & 10,75 & 9,41 & 8,21 & 7,29 & 6,50 & 5,18 & 4,19 & 2,88 \\
\hline 62,39 & 1235,70 & 116,10 & 18,86 & 14,60 & 13,06 & 11,50 & 10,18 & 9,01 & 7,08 & 5,64 & 3,80 \\
\hline 62,68 & 602,60 & 32,50 & 53,67 & 43,13 & 39,98 & 36,29 & 32,97 & 29,90 & 24,50 & 20,14 & 13,99 \\
\hline 42,72 & 427,90 & 134,20 & 34,46 & 22,38 & 17,67 & 13,46 & 10,56 & 8,48 & 5,86 & 4,44 & 3,03 \\
\hline 53,53 & 517,90 & 183,30 & 24,81 & 15,40 & 12,14 & 9,44 & 7,58 & 6,20 & 4,37 & 3,32 & 2,24 \\
\hline 41,48 & 1976,90 & 197,60 & 14,56 & 11,66 & 10,13 & 8,43 & 7,03 & 5,88 & 4,22 & 3,17 & 2,08 \\
\hline 63,02 & 211,10 & 144,10 & 45,87 & 23,67 & 16,96 & 12,31 & 9,60 & 7,76 & 5,43 & 4,16 & 2,87 \\
\hline 87,43 & 1222,80 & 150,90 & 14,21 & 9,83 & 8,62 & 7,60 & 6,85 & 6,19 & 5,09 & 4,22 & 3,00 \\
\hline 39,45 & 1197,00 & 91,80 & 29,27 & 24,26 & 21,33 & 17,94 & 15,06 & 12,66 & 9,14 & 6,89 & 4,49 \\
\hline 69,09 & 283,10 & 63,60 & 50,78 & 33,77 & 28,09 & 23,36 & 19,92 & 17,13 & 12,89 & 10,05 & 6,72 \\
\hline 79,25 & 218,60 & 59,80 & 58,07 & 36,25 & 29,43 & 24,18 & 20,62 & 17,81 & 13,55 & 10,67 & 7,22 \\
\hline 77,58 & 1887,80 & 144,10 & 12,48 & 9,30 & 8,47 & 7,66 & 6,99 & 6,38 & 5,31 & 4,44 & 3,17 \\
\hline 29,48 & 1877,30 & 92,80 & 30,99 & 26,46 & 23,07 & 18,96 & 15,53 & 12,77 & 8,92 & 6,63 & 4,35 \\
\hline 40,06 & 738,20 & 67,20 & 42,24 & 34,27 & 29,85 & 24,87 & 20,71 & 17,31 & 12,40 & 9,33 & 6,11 \\
\hline 77,87 & 1837,30 & 157,70 & 11,99 & 8,85 & 8,00 & 7,19 & 6,53 & 5,94 & 4,90 & 4,07 & 2,88 \\
\hline 47,25 & 1229,10 & 45,20 & 39,99 & 34,67 & 32,21 & 28,99 & 25,97 & 23,19 & 18,41 & 14,71 & 9,84 \\
\hline 81,78 & 1662,00 & 181,40 & 11,41 & 8,14 & 7,23 & 6,41 & 5,78 & 5,23 & 4,28 & 3,54 & 2,49 \\
\hline 28,32 & 1964,40 & 121,40 & 26,36 & 21,88 & 18,70 & 14,99 & 12,01 & 9,72 & 6,68 & 4,96 & 3,31 \\
\hline 88,64 & 1526,20 & 139,00 & 13,20 & 9,37 & 8,40 & 7,57 & 6,92 & 6,34 & 5,34 & 4,51 & 3,28 \\
\hline 77,60 & 1282,90 & 122,70 & 16,21 & 11,87 & 10,65 & 9,50 & 8,58 & 7,77 & 6,37 & 5,25 & 3,69 \\
\hline 79,54 & 419,10 & 61,80 & 39,43 & 27,32 & 23,65 & 20,51 & 18,17 & 16,18 & 12,90 & 10,45 & 7,20 \\
\hline 43,06 & 1176,70 & 168,70 & 19,29 & 14,62 & 12,42 & 10,13 & 8,31 & 6,87 & 4,87 & 3,66 & 2,42 \\
\hline 49,88 & 1813,00 & 76,70 & 23,87 & 20,40 & 18,90 & 17,00 & 15,23 & 13,60 & 10,82 & 8,66 & 5,81 \\
\hline 27,37 & 1215,10 & 45,00 & 61,73 & 53,70 & 47,13 & 38,99 & 32,07 & 26,45 & 18,52 & 13,74 & 8,98 \\
\hline 32,61 & 1906,40 & 188,40 & 17,95 & 14,28 & 12,07 & 9,61 & 7,68 & 6,21 & 4,28 & 3,20 & 2,14 \\
\hline 31,54 & 1971,20 & 156,00 & 20,55 & 16,76 & 14,32 & 11,52 & 9,28 & 7,54 & 5,21 & 3,88 & 2,58 \\
\hline 81,20 & 1097,90 & 65,50 & 24,18 & 18,07 & 16,66 & 15,33 & 14,17 & 13,10 & 11,17 & 9,53 & 7,01 \\
\hline 51,65 & 1718,30 & 147,00 & 15,93 & 12,86 & 11,47 & 9,96 & 8,65 & 7,52 & 5,71 & 4,44 & 2,92 \\
\hline 67,82 & 1646,40 & 85,60 & 19,26 & 15,17 & 14,12 & 12,92 & 11,84 & 10,84 & 9,04 & 7,55 & 5,36 \\
\hline 60,72 & 306,50 & 76,00 & 47,06 & 31,27 & 25,73 & 20,98 & 17,52 & 14,77 & 10,79 & 8,27 & 5,51 \\
\hline 56,46 & 809,60 & 48,20 & 39,84 & 32,69 & 29,97 & 26,81 & 23,99 & 21,42 & 17,05 & 13,69 & 9,24 \\
\hline 63,28 & 1428,70 & 85,40 & 21,13 & 16,86 & 15,54 & 14,05 & 12,72 & 11,50 & 9,37 & 7,67 & 5,30 \\
\hline 35,93 & 782,00 & 75,20 & 41,61 & 33,41 & 28,66 & 23,31 & 18,99 & 15,59 & 10,91 & 8,16 & 5,39 \\
\hline 87,85 & 1553,20 & 66,40 & 19,84 & 14,93 & 13,80 & 12,98 & 12,20 & 11,46 & 10,08 & 8,85 & 6,83 \\
\hline 32,06 & 967,70 & 106,90 & 33,27 & 26,03 & 21,78 & 17,12 & 13,55 & 10,89 & 7,47 & 5,59 & 3,76 \\
\hline 28,13 & 341,40 & 141,70 & 42,64 & 25,81 & 18,78 & 13,03 & 9,68 & 7,60 & 5,27 & 4,08 & 2,86 \\
\hline 63,23 & 1524,20 & 155,60 & 14,50 & 11,10 & 9,87 & 8,65 & 7,64 & 6,75 & 5,29 & 4,21 & 2,83 \\
\hline 54,81 & 1078,30 & 28,00 & 52,53 & 43,92 & 41,90 & 38,87 & 35,88 & 33,00 & 27,72 & 23,22 & 16,50 \\
\hline
\end{tabular}




\begin{tabular}{|c|c|c|c|c|c|c|c|c|c|c|c|}
\hline \multirow[b]{2}{*}{ e1 (cm) } & & & & & & & ões (x1 & m) & & & \\
\hline & Meq (MPa) & Ms (MPa) & D0 & D25 & D40 & D60 & D80 & D100 & D140 & D180 & D260 \\
\hline 62,35 & 662,40 & 23,80 & 63,54 & 51,48 & 48,68 & 45,04 & 41,56 & 38,24 & 32,19 & 27,06 & 19,36 \\
\hline 81,79 & 982,80 & 119,70 & 18,26 & 12,87 & 11,32 & 9,97 & 8,94 & 8,05 & 6,54 & 5,38 & 3,76 \\
\hline 30,35 & 1571,90 & 181,90 & 20,61 & 15,96 & 13,19 & 10,20 & 7,98 & 6,36 & 4,34 & 3,25 & 2,21 \\
\hline 89,06 & 633,30 & 138,00 & 21,21 & 13,48 & 11,19 & 9,42 & 8,23 & 7,27 & 5,74 & 4,64 & 3,21 \\
\hline 73,83 & 428,30 & 117,40 & 30,22 & 19,09 & 15,52 & 12,71 & 10,78 & 9,24 & 6,94 & 5,42 & 3,64 \\
\hline 41,75 & 1015,60 & 196,40 & 19,15 & 13,78 & 11,38 & 9,01 & 7,23 & 5,88 & 4,10 & 3,08 & 2,07 \\
\hline 82,59 & 1388,30 & 38,90 & 29,67 & 23,16 & 21,58 & 20,61 & 19,57 & 18,53 & 16,53 & 14,69 & 11,55 \\
\hline 59,24 & 777,90 & 99,30 & 26,02 & 19,57 & 17,09 & 14,67 & 12,70 & 11,02 & 8,37 & 6,52 & 4,32 \\
\hline 80,30 & 1591,70 & 159,00 & 12,58 & 9,09 & 8,13 & 7,24 & 6,55 & 5,93 & 4,88 & 4,04 & 2,85 \\
\hline 72,56 & 291,60 & 175,80 & 33,95 & 17,91 & 13,07 & 9,71 & 7,73 & 6,35 & 4,52 & 3,47 & 2,38 \\
\hline 23,07 & 961,70 & 97,70 & 44,26 & 33,69 & 26,73 & 19,60 & 14,74 & 11,48 & 7,79 & 5,93 & 4,10 \\
\hline 85,74 & 1400,00 & 102,40 & 16,43 & 11,97 & 10,89 & 9,94 & 9,14 & 8,43 & 7,16 & 6,09 & 4,47 \\
\hline 82,16 & 1695,20 & 59,60 & 21,29 & 16,34 & 15,25 & 14,42 & 13,59 & 12,78 & 11,26 & 9,90 & 7,63 \\
\hline 81,92 & 1297,10 & 170,20 & 13,33 & 9,31 & 8,14 & 7,13 & 6,37 & 5,71 & 4,62 & 3,78 & 2,64 \\
\hline 62,33 & 621,20 & 41,60 & 45,73 & 36,42 & 33,32 & 29,89 & 26,90 & 24,16 & 19,47 & 15,79 & 10,80 \\
\hline 25,34 & 1092,90 & 168,60 & 27,30 & 19,87 & 15,52 & 11,26 & 8,44 & 6,59 & 4,50 & 3,44 & 2,38 \\
\hline 68,22 & 819,80 & 180,20 & 17,79 & 11,91 & 9,93 & 8,26 & 7,05 & 6,06 & 4,56 & 3,55 & 2,37 \\
\hline 68,09 & 428,90 & 53,30 & 44,76 & 32,92 & 28,90 & 25,15 & 22,16 & 19,57 & 15,33 & 12,22 & 8,25 \\
\hline 56,80 & 620,90 & 81,60 & 32,80 & 24,71 & 21,49 & 18,33 & 15,76 & 13,58 & 10,21 & 7,90 & 5,22 \\
\hline 34,36 & 283,40 & 164,10 & 40,09 & 22,27 & 15,99 & 11,18 & 8,38 & 6,62 & 4,58 & 3,54 & 2,48 \\
\hline 25,58 & 1305,90 & 68,90 & 47,78 & 39,80 & 33,83 & 26,84 & 21,30 & 17,10 & 11,65 & 8,66 & 5,81 \\
\hline 40,34 & 1632,10 & 147,00 & 19,14 & 15,55 & 13,57 & 11,33 & 9,45 & 7,91 & 5,68 & 4,27 & 2,80 \\
\hline 49,68 & 1081,40 & 185,90 & 17,52 & 12,78 & 10,81 & 8,88 & 7,37 & 6,17 & 4,44 & 3,36 & 2,22 \\
\hline 78,92 & 1024,30 & 115,20 & 18,51 & 13,29 & 11,77 & 10,40 & 9,34 & 8,41 & 6,83 & 5,60 & 3,91 \\
\hline 71,61 & 1613,60 & 155,40 & 13,31 & 9,96 & 8,92 & 7,92 & 7,10 & 6,38 & 5,14 & 4,19 & 2,89 \\
\hline 65,92 & 897,20 & 110,90 & 21,78 & 16,14 & 14,17 & 12,31 & 10,81 & 9,51 & 7,41 & 5,87 & 3,95 \\
\hline 24,56 & 1705,00 & 186,70 & 22,70 & 17,28 & 13,80 & 10,21 & 7,73 & 6,04 & 4,10 & 3,11 & 2,14 \\
\hline 38,56 & 1169,40 & 86,20 & 31,23 & 26,00 & 22,86 & 19,21 & 16,10 & 13,52 & 9,73 & 7,33 & 4,78 \\
\hline 36,63 & 313,40 & 163,30 & 37,79 & 21,63 & 15,84 & 11,26 & 8,50 & 6,72 & 4,63 & 3,56 & 2,49 \\
\hline 44,94 & 1477,60 & 149,20 & 18,36 & 14,67 & 12,82 & 10,80 & 9,11 & 7,70 & 5,61 & 4,26 & 2,78 \\
\hline 22,31 & 1646,40 & 91,80 & 40,58 & 32,92 & 27,19 & 20,78 & 16,01 & 12,60 & 8,49 & 6,38 & 4,35 \\
\hline 20,43 & 586,10 & 86,70 & 59,54 & 42,01 & 31,44 & 21,82 & 16,00 & 12,43 & 8,60 & 6,65 & 4,63 \\
\hline 21,32 & 1186,90 & 161,50 & 30,50 & 21,98 & 16,73 & 11,78 & 8,68 & 6,74 & 4,63 & 3,57 & 2,48 \\
\hline 41,08 & 1593,10 & 133,40 & 20,25 & 16,61 & 14,58 & 12,27 & 10,31 & 8,69 & 6,29 & 4,75 & 3,10 \\
\hline 23,11 & 1784,60 & 136,10 & 29,21 & 23,03 & 18,70 & 14,05 & 10,71 & 8,39 & 5,66 & 4,28 & 2,94 \\
\hline 48,78 & 1225,50 & 30,40 & 51,35 & 44,23 & 41,99 & 38,60 & 35,29 & 32,14 & 26,46 & 21,77 & 15,06 \\
\hline 34,26 & 287,20 & 139,30 & 43,58 & 25,47 & 18,70 & 13,24 & 9,95 & 7,85 & 5,41 & 4,17 & 2,91 \\
\hline 89,65 & 690,30 & 79,90 & 25,71 & 17,79 & 15,67 & 13,89 & 12,57 & 11,43 & 9,47 & 7,92 & 5,67 \\
\hline 42,92 & 1489,00 & 156,70 & 18,32 & 14,56 & 12,65 & 10,55 & 8,81 & 7,39 & 5,32 & 4,01 & 2,63 \\
\hline 43,30 & 312,10 & 191,50 & 33,92 & 18,41 & 13,33 & 9,53 & 7,26 & 5,77 & 3,98 & 3,06 & 2,13 \\
\hline 48,83 & 1241,40 & 142,60 & 19,25 & 15,03 & 13,10 & 11,07 & 9,39 & 7,98 & 5,87 & 4,48 & 2,93 \\
\hline 41,70 & 297,70 & 66,60 & 60,20 & 42,11 & 34,34 & 26,84 & 21,35 & 17,28 & 11,98 & 9,03 & 6,10 \\
\hline 70,09 & 1947,30 & 26,40 & 37,70 & 31,00 & 29,07 & 28,22 & 27,10 & 25,85 & 23,39 & 21,04 & 16,87 \\
\hline 44,63 & 1936,00 & 88,90 & 22,86 & 19,79 & 18,09 & 15,99 & 14,07 & 12,35 & 9,52 & 7,44 & 4,88 \\
\hline 56,39 & 767,40 & 190,10 & 19,36 & 12,98 & 10,67 & 8,63 & 7,14 & 5,97 & 4,30 & 3,28 & 2,18 \\
\hline 51,79 & 1380,10 & 37,90 & 40,92 & 34,77 & 33,00 & 30,37 & 27,83 & 25,40 & 21,02 & 17,38 & 12,11 \\
\hline 59,63 & 522,10 & 124,60 & 28,32 & 19,01 & 15,70 & 12,83 & 10,71 & 9,03 & 6,59 & 5,04 & 3,36 \\
\hline 48,31 & 788,40 & 26,80 & 64,82 & 56,04 & 52,37 & 47,42 & 42,76 & 38,40 & 30,83 & 24,85 & 16,78 \\
\hline 26,47 & 1676,60 & 71,20 & 41,98 & 35,89 & 31,10 & 25,29 & 20,49 & 16,69 & 11,53 & 8,55 & 5,65 \\
\hline 71,97 & 1431,70 & 182,80 & 12,90 & 9,34 & 8,19 & 7,14 & 6,32 & 5,60 & 4,43 & 3,56 & 2,42 \\
\hline 31,73 & 647,90 & 63,20 & 54,30 & 43,18 & 36,40 & 28,83 & 22,95 & 18,51 & 12,72 & 9,50 & 6,37 \\
\hline 43,67 & 1877,60 & 54,80 & 32,27 & 28,50 & 26,60 & 24,00 & 21,52 & 19,22 & 15,27 & 12,19 & 8,13 \\
\hline 29,80 & 1207,20 & 186,00 & 22,46 & 16,64 & 13,40 & 10,09 & 7,75 & 6,12 & 4,17 & 3,15 & 2,16 \\
\hline 69,21 & 1050,10 & 60,00 & 28,17 & 21,99 & 20,37 & 18,58 & 17,00 & 15,53 & 12,92 & 10,76 & 7,63 \\
\hline 58,10 & 1841,30 & 58,40 & 25,91 & 21,39 & 20,29 & 18,76 & 17,28 & 15,87 & 13,30 & 11,13 & 7,89 \\
\hline 75,99 & 1413,20 & 38,20 & 31,67 & 24,82 & 23,38 & 22,27 & 21,06 & 19,85 & 17,54 & 15,45 & 11,93 \\
\hline 28,10 & 1684,00 & 36,50 & 62,22 & 56,64 & 51,26 & 44,19 & 37,74 & 32,14 & 23,49 & 17,70 & 11,37 \\
\hline 53,66 & 1470,50 & 151,30 & 16,36 & 12,86 & 11,35 & 9,78 & 8,46 & 7,32 & 5,53 & 4,29 & 2,82 \\
\hline 25,78 & 760,00 & 151,00 & 32,59 & 22,81 & 17,50 & 12,51 & 9,33 & 7,28 & 4,99 & 3,83 & 2,66 \\
\hline 80,36 & 731,50 & 51,60 & 33,12 & 24,58 & 22,48 & 20,48 & 18,79 & 17,26 & 14,53 & 12,26 & 8,88 \\
\hline 64,59 & 1930,30 & 35,50 & 33,43 & 26,92 & 25,74 & 24,62 & 23,28 & 21,93 & 19,34 & 16,96 & 12,98 \\
\hline 63,06 & 274,80 & 127,10 & 40,21 & 22,97 & 17,49 & 13,39 & 10,76 & 8,85 & 6,29 & 4,80 & 3,26 \\
\hline 31,22 & 1851,00 & 124,90 & 24,47 & 20,32 & 17,52 & 14,24 & 11,56 & 9,45 & 6,56 & 4,89 & 3,23 \\
\hline 29,38 & 1178,70 & 34,50 & 70,06 & 62,66 & 56,19 & 47,89 & 40,49 & 34,18 & 24,69 & 18,51 & 11,93 \\
\hline 52,83 & 1064,20 & 102,80 & 23,65 & 18,77 & 16,63 & 14,36 & 12,44 & 10,77 & 8,15 & 6,32 & 4,16 \\
\hline 21,45 & 1839,00 & 153,70 & 27,98 & 21,54 & 17,10 & 12,51 & 9,38 & 7,29 & 4,94 & 3,77 & 2,60 \\
\hline 75,49 & 1087,40 & 139,80 & 16,59 & 11,86 & 10,39 & 9,08 & 8,07 & 7,19 & 5,74 & 4,64 & 3,18 \\
\hline 37,50 & 497,50 & 120,20 & 36,28 & 25,02 & 20,03 & 15,25 & 11,88 & 9,49 & 6,52 & 4,93 & 3,36 \\
\hline 53,21 & 321,00 & 187,40 & 32,56 & 17,73 & 13,03 & 9,55 & 7,44 & 5,98 & 4,15 & 3,17 & 2,19 \\
\hline 70,77 & 1300,20 & 61,40 & 25,30 & 19,75 & 18,48 & 17,05 & 15,74 & 14,51 & 12,27 & 10,38 & 7,51 \\
\hline 29,33 & 1018,00 & 91,90 & 38,43 & 30,64 & 25,66 & 20,10 & 15,85 & 12,68 & 8,66 & 6,47 & 4,36 \\
\hline 42,53 & 331,80 & 78,40 & 51,88 & 35,85 & 29,13 & 22,74 & 18,09 & 14,64 & 10,17 & 7,67 & 5,18 \\
\hline 45,39 & 389,30 & 105,40 & 39,93 & 26,73 & 21,54 & 16,79 & 13,39 & 10,87 & 7,57 & 5,72 & 3,86 \\
\hline 28,44 & 483,60 & 82,70 & 53,74 & 39,00 & 30,88 & 22,82 & 17,32 & 13,60 & 9,26 & 7,05 & 4,86 \\
\hline 86,32 & 815,30 & 109,50 & 20,56 & 14,12 & 12,31 & 10,78 & 9,66 & 8,70 & 7,09 & 5,84 & 4,11 \\
\hline 68,21 & 518,20 & 164,70 & 24,11 & 14,93 & 11,94 & 9,59 & 7,99 & 6,74 & 4,95 & 3,81 & 2,56 \\
\hline 20,58 & 1556,80 & 73,30 & 51,44 & 41,85 & 34,45 & 26,18 & 20,06 & 15,73 & 10,58 & 7,95 & 5,44 \\
\hline 87,99 & 1957,90 & 52,50 & 20,54 & 16,19 & 14,91 & 14,28 & 13,65 & 12,98 & 11,70 & 10,50 & 8,41 \\
\hline 36,67 & 1784,30 & 187,30 & 17,01 & 13,51 & 11,55 & 9,37 & 7,62 & 6,25 & 4,37 & 3,27 & 2,17 \\
\hline 85,49 & 1764,70 & 41,20 & 25,26 & 20,19 & 18,62 & 17,90 & 17,15 & 16,34 & 14,76 & 13,29 & 10,70 \\
\hline 50,77 & 1018,50 & 151,50 & 19,87 & 14,85 & 12,73 & 10,61 & 8,91 & 7,52 & 5,48 & 4,17 & 2,75 \\
\hline 60,28 & 603,20 & 76,00 & 33,50 & 25,17 & 22,01 & 18,94 & 16,45 & 14,31 & 10,92 & 8,54 & 5,67 \\
\hline
\end{tabular}




\begin{tabular}{|c|c|c|c|c|c|c|c|c|c|c|c|}
\hline \multirow[b]{2}{*}{ e1 (cm) } & & & & & & $\mathrm{De}$ & ões (x1 & & & & \\
\hline & Meq (MPa) & Ms (MPa) & D0 & D25 & D40 & D60 & D80 & D100 & D140 & D180 & D260 \\
\hline 81,54 & 991,70 & 70,60 & 24,13 & 17,83 & 16,29 & 14,84 & 13,62 & 12,52 & 10,56 & 8,93 & 6,48 \\
\hline 76,49 & 1344,00 & 150,60 & 14,32 & 10,37 & 9,19 & 8,11 & 7,26 & 6,52 & 5,27 & 4,30 & 2,98 \\
\hline 21,60 & 1963,90 & 166,10 & 25,85 & 19,90 & 15,80 & 11,57 & 8,68 & 6,75 & 4,57 & 3,48 & 2,41 \\
\hline 29,93 & 1440,40 & 167,10 & 22,67 & 17,52 & 14,44 & 11,14 & 8,69 & 6,91 & 4,71 & 3,54 & 2,40 \\
\hline 64,47 & 499,20 & 138,30 & 26,95 & 17,35 & 14,11 & 11,44 & 9,56 & 8,07 & 5,92 & 4,55 & 3,04 \\
\hline 61,43 & 1614,70 & 141,90 & 15,11 & 11,82 & 10,62 & 9,37 & 8,31 & 7,36 & 5,80 & 4,62 & 3,11 \\
\hline 83,12 & 879,70 & 72,60 & 24,82 & 18,06 & 16,35 & 14,77 & 13,50 & 12,36 & 10,36 & 8,71 & 6,28 \\
\hline 22,41 & 1394,20 & 49,10 & 65,81 & 55,85 & 47,67 & 37,90 & 30,08 & 24,10 & 16,37 & 12,14 & 8,13 \\
\hline 53,06 & 382,60 & 52,90 & 53,74 & 40,49 & 34,97 & 29,48 & 25,04 & 21,33 & 15,75 & 12,07 & 7,95 \\
\hline 88,38 & 952,50 & 170,40 & 15,33 & 10,07 & 8,54 & 7,32 & 6,46 & 5,76 & 4,61 & 3,76 & 2,62 \\
\hline 26,98 & 1199,50 & 72,80 & 45,36 & 37,50 & 31,85 & 25,28 & 20,10 & 16,16 & 11,04 & 8,21 & 5,50 \\
\hline 44,17 & 955,80 & 159,90 & 21,43 & 15,81 & 13,29 & 10,75 & 8,78 & 7,23 & 5,11 & 3,85 & 2,56 \\
\hline 73,92 & 1310,00 & 199,70 & 12,78 & 8,97 & 7,74 & 6,67 & 5,86 & 5,17 & 4,06 & 3,24 & 2,20 \\
\hline 38,05 & 1333,30 & 181,60 & 18,93 & 14,47 & 12,19 & 9,76 & 7,86 & 6,41 & 4,46 & 3,34 & 2,23 \\
\hline 69,76 & 1575,80 & 147,40 & 14,03 & 10,59 & 9,50 & 8,44 & 7,56 & 6,78 & 5,45 & 4,42 & 3,04 \\
\hline 71,10 & 1010,80 & 160,10 & 16,51 & 11,62 & 10,00 & 8,57 & 7,49 & 6,57 & 5,10 & 4,05 & 2,73 \\
\hline 78,25 & 1671,90 & 102,00 & 15,97 & 12,03 & 11,09 & 10,17 & 9,37 & 8,63 & 7,30 & 6,19 & 4,50 \\
\hline 30,71 & 451,00 & 155,80 & 35,13 & 22,33 & 16,78 & 11,96 & 8,96 & 7,04 & 4,84 & 3,73 & 2,59 \\
\hline 47,50 & 1940,40 & 136,60 & 16,72 & 13,91 & 12,48 & 10,85 & 9,42 & 8,17 & 6,18 & 4,78 & 3,13 \\
\hline 68,58 & 1031,30 & 124,40 & 18,84 & 13,89 & 12,22 & 10,66 & 9,42 & 8,33 & 6,55 & 5,24 & 3,54 \\
\hline 81,28 & 1524,00 & 84,90 & 18,11 & 13,58 & 12,56 & 11,60 & 10,74 & 9,96 & 8,53 & 7,30 & 5,40 \\
\hline 73,59 & 1290,90 & 172,80 & 13,84 & 9,90 & 8,65 & 7,53 & 6,66 & 5,91 & 4,67 & 3,76 & 2,56 \\
\hline 28,34 & 1509,50 & 31,90 & 70,01 & 63,87 & 57,92 & 50,07 & 42,89 & 36,62 & 26,87 & 20,29 & 13,03 \\
\hline 47,74 & 335,70 & 130,00 & 38,05 & 23,32 & 18,09 & 13,74 & 10,81 & 8,72 & 6,06 & 4,60 & 3,14 \\
\hline 64,73 & 1405,40 & 160,90 & 14,61 & 10,97 & 9,69 & 8,44 & 7,43 & 6,55 & 5,11 & 4,06 & 2,73 \\
\hline 89,05 & 1909,40 & 31,10 & 27,17 & 23,42 & 21,18 & 20,39 & 19,81 & 19,09 & 17,58 & 16,13 & 13,45 \\
\hline 81,15 & 518,50 & 131,30 & 25,07 & 15,82 & 12,95 & 10,73 & 9,22 & 8,01 & 6,16 & 4,88 & 3,31 \\
\hline 28,22 & 1068,50 & 114,80 & 33,46 & 25,99 & 21,34 & 16,34 & 12,67 & 10,03 & 6,82 & 5,13 & 3,49 \\
\hline 33,36 & 1225,40 & 22,10 & 83,99 & 77,20 & 71,73 & 64,09 & 56,78 & 50,06 & 38,76 & 30,29 & 19,74 \\
\hline 23,67 & 1161,00 & 67,00 & 53,65 & 43,78 & 36,47 & 28,20 & 21,93 & 17,36 & 11,73 & 8,78 & 5,96 \\
\hline 20,23 & 361,40 & 59,50 & 89,66 & 62,09 & 45,94 & 31,62 & 23,14 & 18,01 & 12,50 & 9,69 & 6,75 \\
\hline 82,90 & 848,00 & 53,60 & 29,96 & 22,21 & 20,40 & 18,73 & 17,30 & 15,99 & 13,63 & 11,63 & 8,56 \\
\hline 78,46 & 751,80 & 108,10 & 22,37 & 15,61 & 13,55 & 11,76 & 10,43 & 9,28 & 7,40 & 5,98 & 4,12 \\
\hline 77,89 & 1529,80 & 180,60 & 12,15 & 8,71 & 7,68 & 6,76 & 6,05 & 5,43 & 4,39 & 3,58 & 2,48 \\
\hline 48,24 & 629,80 & 137,90 & 26,84 & 18,72 & 15,47 & 12,41 & 10,11 & 8,33 & 5,89 & 4,45 & 2,97 \\
\hline 30,96 & 546,50 & 72,30 & 53,59 & 40,77 & 33,45 & 25,72 & 20,04 & 15,94 & 10,87 & 8,17 & 5,56 \\
\hline 65,89 & 372,50 & 23,90 & 76,01 & 59,83 & 55,00 & 49,68 & 45,03 & 40,77 & 33,32 & 27,36 & 19,00 \\
\hline 76,21 & 1857,90 & 125,40 & 13,73 & 10,36 & 9,51 & 8,65 & 7,92 & 7,26 & 6,07 & 5,09 & 3,65 \\
\hline 81,77 & 1068,50 & 37,40 & 33,99 & 26,10 & 24,38 & 23,06 & 21,72 & 20,43 & 17,99 & 15,80 & 12,17 \\
\hline 23,70 & 379,60 & 29,80 & 132,29 & 104,39 & 85,01 & 64,10 & 49,00 & 38,45 & 25,97 & 19,60 & 13,43 \\
\hline 78,99 & 1149,20 & 170,10 & 14,40 & 9,99 & 8,64 & 7,49 & 6,63 & 5,90 & 4,70 & 3,80 & 2,61 \\
\hline 44,98 & 1543,40 & 164,00 & 17,04 & 13,52 & 11,78 & 9,89 & 8,32 & 7,01 & 5,09 & 3,86 & 2,53 \\
\hline 21,15 & 816,00 & 103,00 & 47,09 & 34,25 & 26,18 & 18,50 & 13,65 & 10,59 & 7,27 & 5,60 & 3,89 \\
\hline 38,46 & 682,20 & 105,50 & 34,03 & 25,49 & 21,28 & 16,90 & 13,54 & 11,00 & 7,64 & 5,73 & 3,84 \\
\hline 45,18 & 1553,10 & 86,00 & 25,07 & 21,39 & 19,39 & 16,99 & 14,83 & 12,92 & 9,84 & 7,63 & 4,99 \\
\hline 64,82 & 1747,70 & 21,20 & 48,23 & 39,57 & 37,46 & 36,35 & 34,81 & 33,14 & 29,84 & 26,71 & 21,21 \\
\hline 88,38 & 1890,00 & 118,20 & 13,08 & 9,57 & 8,75 & 8,07 & 7,49 & 6,95 & 5,99 & 5,16 & 3,86 \\
\hline 41,16 & 1633,30 & 48,00 & 38,49 & 34,29 & 31,82 & 28,50 & 25,36 & 22,48 & 17,60 & 13,89 & 9,16 \\
\hline 36,83 & 878,40 & 198,30 & 21,57 & 15,08 & 12,12 & 9,25 & 7,21 & 5,76 & 3,95 & 2,99 & 2,04 \\
\hline 82,60 & 1890,30 & 65,90 & 19,13 & 14,68 & 13,70 & 12,96 & 12,22 & 11,51 & 10,15 & 8,93 & 6,89 \\
\hline 42,77 & 1425,40 & 116,50 & 22,33 & 18,36 & 16,20 & 13,75 & 11,65 & 9,88 & 7,22 & 5,48 & 3,57 \\
\hline 78,76 & 461,00 & 32,30 & 53,31 & 39,79 & 36,43 & 33,15 & 30,39 & 27,87 & 23,40 & 19,69 & 14,19 \\
\hline 38,40 & 831,20 & 167,60 & 23,86 & 17,05 & 13,92 & 10,81 & 8,53 & 6,86 & 4,73 & 3,56 & 2,41 \\
\hline 52,70 & 278,50 & 200,00 & 34,81 & 17,87 & 12,68 & 9,04 & 6,94 & 5,55 & 3,84 & 2,95 & 2,06 \\
\hline 49,49 & 1630,70 & 199,50 & 14,03 & 10,84 & 9,41 & 7,93 & 6,72 & 5,70 & 4,19 & 3,19 & 2,10 \\
\hline 58,58 & 559,10 & 187,70 & 22,87 & 14,25 & 11,32 & 8,93 & 7,28 & 6,03 & 4,31 & 3,28 & 2,21 \\
\hline 55,13 & 1314,40 & 187,10 & 15,09 & 11,27 & 9,73 & 8,22 & 7,01 & 5,99 & 4,45 & 3,42 & 2,26 \\
\hline 26,76 & 1931,50 & 82,20 & 36,05 & 30,87 & 26,78 & 21,83 & 17,72 & 14,46 & 10,01 & 7,42 & 4,89 \\
\hline 87,12 & 541,50 & 178,00 & 21,44 & 12,68 & 10,03 & 8,10 & 6,86 & 5,92 & 4,51 & 3,57 & 2,43 \\
\hline 72,56 & 642,90 & 44,80 & 39,89 & 30,45 & 27,90 & 25,26 & 23,01 & 20,96 & 17,35 & 14,41 & 10,18 \\
\hline 72,43 & 865,70 & 166,00 & 17,51 & 11,90 & 10,05 & 8,50 & 7,36 & 6,41 & 4,92 & 3,88 & 2,61 \\
\hline 37,18 & 1910,90 & 168,80 & 17,52 & 14,25 & 12,34 & 10,17 & 8,38 & 6,94 & 4,91 & 3,67 & 2,41 \\
\hline 44,40 & 1939,30 & 104,40 & 20,69 & 17,72 & 16,06 & 14,06 & 12,27 & 10,67 & 8,11 & 6,29 & 4,11 \\
\hline 88,16 & 585,50 & 95,10 & 26,03 & 17,35 & 14,85 & 12,83 & 11,39 & 10,19 & 8,22 & 6,73 & 4,71 \\
\hline 26,60 & 1284,60 & 97,00 & 36,89 & 29,72 & 24,79 & 19,28 & 15,08 & 12,00 & 8,15 & 6,09 & 4,13 \\
\hline 32,25 & 614,90 & 153,80 & 30,87 & 21,08 & 16,48 & 12,14 & 9,24 & 7,28 & 4,98 & 3,80 & 2,62 \\
\hline 51,57 & 1904,80 & 129,10 & 16,53 & 13,66 & 12,36 & 10,88 & 9,57 & 8,40 & 6,49 & 5,10 & 3,37 \\
\hline 77,06 & 204,80 & 157,60 & 45,02 & 22,30 & 15,62 & 11,18 & 8,71 & 7,07 & 4,98 & 3,84 & 2,65 \\
\hline 89,03 & 1007,60 & 136,70 & 16,37 & 11,14 & 9,69 & 8,49 & 7,62 & 6,88 & 5,63 & 4,66 & 3,30 \\
\hline 65,83 & 736,30 & 66,10 & 31,61 & 24,29 & 21,84 & 19,36 & 17,28 & 15,42 & 12,29 & 9,91 & 6,74 \\
\hline 88,83 & 1827,80 & 172,00 & 10,82 & 7,66 & 6,85 & 6,16 & 5,62 & 5,15 & 4,32 & 3,65 & 2,65 \\
\hline 22,63 & 539,20 & 117,60 & 46,01 & 31,07 & 23,02 & 15,93 & 11,72 & 9,15 & 6,34 & 4,91 & 3,42 \\
\hline 25,96 & 279,00 & 79,90 & 68,80 & 44,99 & 33,44 & 23,38 & 17,33 & 13,56 & 9,37 & 7,24 & 5,05 \\
\hline 49,61 & 635,60 & 75,00 & 36,68 & 28,49 & 24,81 & 20,97 & 17,80 & 15,14 & 11,15 & 8,51 & 5,58 \\
\hline 55,77 & 1338,50 & 129,20 & 18,23 & 14,36 & 12,76 & 11,09 & 9,67 & 8,44 & 6,46 & 5,05 & 3,34 \\
\hline 41,95 & 870,10 & 108,90 & 28,71 & 22,25 & 19,05 & 15,63 & 12,87 & 10,67 & 7,57 & 5,69 & 3,76 \\
\hline 57,77 & 1731,90 & 192,60 & 12,76 & 9,82 & 8,66 & 7,48 & 6,51 & 5,66 & 4,32 & 3,38 & 2,24 \\
\hline 63,41 & 374,60 & 52,20 & 49,92 & 36,63 & 31,82 & 27,31 & 23,73 & 20,67 & 15,83 & 12,41 & 8,28 \\
\hline 32,09 & 540,20 & 146,60 & 33,47 & 22,48 & 17,42 & 12,74 & 9,66 & 7,61 & 5,21 & 3,98 & 2,75 \\
\hline 23,89 & 248,70 & 163,50 & 45,31 & 23,89 & 16,26 & 10,91 & 8,12 & 6,44 & 4,52 & 3,52 & 2,49 \\
\hline 85,69 & 360,50 & 191,40 & 27,90 & 14,93 & 11,06 & 8,40 & 6,83 & 5,71 & 4,18 & 3,25 & 2,22 \\
\hline 59,19 & 381,50 & 122,20 & 34,08 & 21,45 & 17,14 & 13,61 & 11,14 & 9,26 & 6,63 & 5,06 & 3,39 \\
\hline
\end{tabular}




\begin{tabular}{|c|c|c|c|c|c|c|c|c|c|c|c|}
\hline \multirow[b]{2}{*}{ e1 (cm) } & & & & & & & ões (x1 & m) & & & \\
\hline & Meq (MPa) & Ms (MPa) & D0 & D25 & D40 & D60 & D80 & D100 & D140 & D180 & D260 \\
\hline 88,40 & 426,40 & 153,10 & 26,36 & $\begin{array}{l}15,28 \\
\end{array}$ & 11,95 & 9,55 & 8,04 & 6,91 & 5,24 & 4,14 & 2,83 \\
\hline 87,76 & 1769,00 & 71,30 & 18,04 & 13,64 & 12,61 & 11,89 & 11,20 & 10,54 & 9,30 & 8,19 & 6,35 \\
\hline 43,19 & 1776,90 & 73,90 & 27,16 & 23,73 & 21,75 & 19,25 & 16,95 & 14,87 & 11,46 & 8,95 & 5,87 \\
\hline 68,98 & 1583,80 & 37,20 & 33,07 & 26,29 & 25,02 & 23,81 & 22,45 & 21,11 & 18,54 & 16,21 & 12,36 \\
\hline 39,42 & 1257,00 & 145,40 & 21,68 & 17,01 & 14,55 & 11,88 & 9,72 & 8,02 & 5,65 & 4,24 & 2,80 \\
\hline 77,73 & 1396,00 & 110,50 & 16,52 & 12,27 & 11,15 & 10,07 & 9,17 & 8,37 & 6,95 & 5,80 & 4,13 \\
\hline 67,74 & 1706,60 & 129,70 & 14,78 & 11,43 & 10,41 & 9,33 & 8,42 & 7,59 & 6,16 & 5,03 & 3,48 \\
\hline 44,10 & 1898,10 & 122,30 & 18,98 & 16,01 & 14,36 & 12,42 & 10,72 & 9,24 & 6,92 & 5,31 & 3,46 \\
\hline 63,24 & 1746,90 & 74,50 & 21,38 & 17,24 & 16,18 & 14,87 & 13,65 & 12,50 & 10,43 & 8,71 & 6,17 \\
\hline 78,09 & 653,30 & 120,50 & 22,99 & 15,47 & 13,11 & 11,16 & 9,75 & 8,58 & 6,70 & 5,35 & 3,65 \\
\hline 28,11 & 1443,30 & 186,20 & 21,94 & 16,61 & 13,43 & 10,12 & 7,77 & 6,12 & 4,16 & 3,14 & 2,15 \\
\hline 26,66 & 464,30 & 144,70 & 38,59 & 24,85 & 18,42 & 12,88 & 9,55 & 7,48 & 5,17 & 4,00 & 2,79 \\
\hline 76,17 & 1873,70 & 130,90 & 13,34 & 10,05 & 9,20 & 8,36 & 7,64 & 6,99 & 5,84 & 4,89 & 3,49 \\
\hline 51,14 & 1338,90 & 176,70 & 16,07 & 12,24 & 10,59 & 8,92 & 7,55 & 6,42 & 4,72 & 3,60 & 2,37 \\
\hline 23,74 & 210,30 & 108,80 & 62,94 & 35,48 & 24,64 & 16,59 & 12,29 & 9,71 & 6,81 & 5,30 & 3,73 \\
\hline 24,19 & 1897,60 & 163,10 & 24,45 & 19,14 & 15,54 & 11,69 & 8,93 & 7,00 & 4,73 & 3,58 & 2,45 \\
\hline 43,43 & 1324,60 & 119,40 & 22,41 & 18,20 & 15,98 & 13,50 & 11,40 & 9,64 & 7,03 & 5,33 & 3,48 \\
\hline 61,93 & 632,00 & 80,70 & 31,32 & 23,38 & 20,44 & 17,62 & 15,33 & 13,38 & 10,26 & 8,05 & 5,36 \\
\hline 20,33 & 1896,80 & 117,50 & 34,99 & 27,60 & 22,19 & 16,42 & 12,37 & 9,63 & 6,49 & 4,93 & 3,40 \\
\hline 78,78 & 1227,50 & 89,40 & 19,57 & 14,57 & 13,31 & 12,08 & 11,06 & 10,13 & 8,48 & 7,12 & 5,12 \\
\hline 69,81 & 1005,20 & 24,90 & 49,98 & 39,63 & 37,66 & 35,79 & 33,73 & 31,69 & 27,81 & 24,30 & 18,50 \\
\hline 79,74 & 1846,40 & 155,60 & 11,92 & 8,75 & 7,92 & 7,13 & 6,49 & 5,92 & 4,92 & 4,11 & 2,93 \\
\hline 49,65 & 1219,50 & 115,70 & 21,65 & 17,33 & 15,32 & 13,14 & 11,30 & 9,71 & 7,26 & 5,58 & 3,66 \\
\hline 24,43 & 1362,00 & 111,50 & 35,00 & 27,60 & 22,54 & 17,06 & 13,08 & 10,28 & 6,95 & 5,24 & 3,59 \\
\hline 34,42 & 435,20 & 71,30 & 54,96 & 40,67 & 33,32 & 25,75 & 20,19 & 16,15 & 11,07 & 8,33 & 5,65 \\
\hline 38,75 & 367,40 & 182,40 & 32,62 & 18,90 & 14,00 & 10,08 & 7,66 & 6,06 & 4,17 & 3,20 & 2,23 \\
\hline 47,15 & 1293,90 & 113,50 & 22,08 & 17,92 & 15,87 & 13,59 & 11,64 & 9,98 & 7,42 & 5,68 & 3,71 \\
\hline 65,56 & 978,10 & 127,90 & 19,46 & 14,32 & 12,52 & 10,82 & 9,47 & 8,31 & 6,44 & 5,09 & 3,41 \\
\hline 64,19 & 1049,80 & 91,80 & 22,79 & 17,66 & 15,90 & 14,08 & 12,55 & 11,18 & 8,89 & 7,14 & 4,85 \\
\hline 84,82 & 823,70 & 109,80 & 20,55 & 14,20 & 12,38 & 10,85 & 9,71 & 8,74 & 7,10 & 5,84 & 4,10 \\
\hline 41,88 & 452,70 & 25,20 & 90,60 & 77,65 & 69,91 & 60,61 & 52,31 & 45,09 & 33,73 & 25,87 & 16,81 \\
\hline 33,65 & 511,90 & 21,10 & 115,08 & 101,09 & 90,49 & 77,23 & 65,49 & 55,48 & 40,34 & 30,39 & 19,64 \\
\hline 80,75 & 1208,10 & 152,50 & 14,66 & 10,33 & 9,06 & 7,95 & 7,11 & 6,38 & 5,17 & 4,23 & 2,94 \\
\hline 73,18 & 318,90 & 143,10 & 34,00 & 19,25 & 14,69 & 11,38 & 9,29 & 7,76 & 5,63 & 4,34 & 2,94 \\
\hline 80,12 & 706,20 & 129,00 & 21,16 & 14,18 & 12,02 & 10,26 & 8,98 & 7,93 & 6,23 & 5,00 & 3,42 \\
\hline 56,36 & 302,60 & 116,40 & 40,34 & 24,42 & 19,07 & 14,77 & 11,88 & 9,74 & 6,88 & 5,23 & 3,54 \\
\hline 20,10 & 1177,40 & 173,70 & 29,98 & 21,08 & 15,72 & 10,88 & 7,96 & 6,19 & 4,29 & 3,32 & 2,31 \\
\hline 26,08 & 611,00 & 199,10 & 28,71 & 18,28 & 13,44 & 9,33 & 6,91 & 5,41 & 3,75 & 2,90 & 2,03 \\
\hline 50,72 & 1250,00 & 75,20 & 27,39 & 22,91 & 20,84 & 18,43 & 16,27 & 14,34 & 11,14 & 8,77 & 5,81 \\
\hline 59,34 & 317,80 & 101,50 & 40,94 & 25,77 & 20,61 & 16,36 & 13,41 & 11,14 & 7,99 & 6,09 & 4,09 \\
\hline 59,20 & 680,00 & 97,90 & 27,95 & 20,64 & 17,85 & 15,18 & 13,06 & 11,26 & 8,48 & 6,58 & 4,36 \\
\hline 77,06 & 313,10 & 23,60 & 76,06 & 56,84 & 51,83 & 46,90 & 42,79 & 39,07 & 32,51 & 27,16 & 19,36 \\
\hline 87,81 & 1265,30 & 119,50 & 15,68 & 11,13 & 9,96 & 8,95 & 8,16 & 7,47 & 6,26 & 5,27 & 3,81 \\
\hline 71,50 & 885,10 & 139,30 & 18,87 & 13,28 & 11,43 & 9,81 & 8,58 & 7,53 & 5,86 & 4,65 & 3,14 \\
\hline 59,43 & 1208,50 & 97,40 & 21,62 & 17,17 & 15,49 & 13,69 & 12,15 & 10,77 & 8,47 & 6,75 & 4,53 \\
\hline 80,28 & 1584,10 & 145,50 & 13,21 & 9,62 & 8,65 & 7,76 & 7,04 & 6,40 & 5,29 & 4,40 & 3,12 \\
\hline 75,41 & 1672,30 & 52,10 & 24,61 & 19,18 & 18,08 & 17,10 & 16,09 & 15,10 & 13,23 & 11,55 & 8,80 \\
\hline 75,19 & 1977,80 & 180,10 & 10,95 & 8,13 & 7,31 & 6,54 & 5,90 & 5,34 & 4,36 & 3,59 & 2,51 \\
\hline 73,06 & 1577,60 & 61,30 & 23,13 & 18,00 & 16,95 & 15,83 & 14,74 & 13,71 & 11,80 & 10,14 & 7,52 \\
\hline 65,19 & 1067,40 & 110,60 & 20,22 & 15,35 & 13,66 & 11,99 & 10,61 & 9,40 & 7,40 & 5,91 & 3,99 \\
\hline 40,15 & 1473,20 & 163,30 & 18,75 & 14,80 & 12,73 & 10,45 & 8,61 & 7,13 & 5,05 & 3,79 & 2,50 \\
\hline 48,43 & 1739,60 & 170,90 & 15,11 & 12,06 & 10,62 & 9,06 & 7,75 & 6,63 & 4,91 & 3,76 & 2,46 \\
\hline 42,13 & 1731,50 & 113,80 & 21,24 & 17,91 & 15,98 & 13,72 & 11,74 & 10,05 & 7,44 & 5,67 & 3,69 \\
\hline 25,01 & 633,70 & 97,10 & 447,66 & 34,67 & 27,02 & 19,56 & 14,65 & 11,42 & 7,79 & 5,96 & 4,13 \\
\hline 67,80 & 1085,40 & 185,80 & 15,11 & 10,60 & 9,05 & 7,69 & 6,66 & 5,79 & 4,43 & 3,47 & 2,33 \\
\hline 46,20 & 1060,10 & 135,80 & 21,90 & 16,87 & 14,54 & 12,09 & 10,10 & 8,48 & 6,12 & 4,63 & 3,04 \\
\hline 50,40 & 905,90 & 109,50 & 25,16 & 19,45 & 16,92 & 14,31 & 12,16 & 10,35 & 7,63 & 5,84 & 3,83 \\
\hline 40,56 & 311,10 & 170,00 & 36,34 & 20,46 & 15,01 & 10,77 & 8,20 & 6,50 & 4,48 & 3,44 & 2,40 \\
\hline 35,77 & 354,70 & 130,80 & 440,61 & 25,49 & 19,42 & 14,15 & 10,76 & 8,50 & 5,84 & 4,47 & 3,10 \\
\hline 77,05 & 1907,60 & 148,10 & 12,27 & 9,15 & 8,33 & 7,53 & 6,86 & 6,25 & 5,19 & 4,33 & 3,08 \\
\hline 61,80 & 494,00 & 77,40 & 36,10 & 26,12 & 22,45 & 19,06 & 16,40 & 14,16 & 10,70 & 8,32 & 5,53 \\
\hline 44,65 & 1183,80 & 105,10 & 24,84 & 20,19 & 17,79 & 15,11 & 12,82 & 10,90 & 8,00 & 6,08 & 3,97 \\
\hline 32,29 & 299,30 & 99,30 & 53,22 & 34,21 & 26,01 & 18,75 & 14,15 & 11,13 & 7,64 & 5,86 & 4,07 \\
\hline 24,97 & 1333,40 & 191,50 & 23,74 & 17,43 & 13,66 & 9,93 & 7,45 & 5,81 & 3,96 & 3,03 & 2,09 \\
\hline 25,46 & 1320,00 & 126,90 & 31,36 & 24,39 & 19,83 & 14,96 & 11,46 & 9,01 & 6,10 & 4,60 & 3,15 \\
\hline 69,25 & 745,10 & 130,70 & 21,57 & 15,01 & 12,79 & 10,86 & 9,41 & 8,19 & 6,28 & 4,94 & 3,31 \\
\hline 41,99 & 1744,20 & 51,30 & 35,53 & 31,57 & 29,35 & 26,35 & 23,51 & 20,89 & 16,43 & 13,02 & 8,61 \\
\hline 32,91 & 1096,90 & 91,50 & 34,59 & 28,14 & 24,10 & 19,47 & 15,75 & 12,85 & 8,92 & 6,65 & 4,41 \\
\hline 48,22 & 590,50 & 63,30 & 42,43 & 33,49 & 29,31 & 24,84 & 21,11 & 17,97 & 13,24 & 10,10 & 6,62 \\
\hline 74,23 & 1566,20 & 107,00 & 16,38 & 12,44 & 11,41 & 10,36 & 9,46 & 8,64 & 7,19 & 6,00 & 4,27 \\
\hline 37,73 & 1379,20 & 31,90 & 57,13 & 51,70 & 48,10 & 43,12 & 38,37 & 33,99 & 26,57 & 20,93 & 13,75 \\
\hline 44,79 & 418,30 & 70,30 & 48,47 & 35,71 & 30,05 & 24,35 & 19,92 & 16,45 & 11,64 & 8,77 & 5,82 \\
\hline 44,53 & 316,30 & 40,00 & 75,64 & 58,47 & 50,28 & 41,62 & 34,59 & 28,90 & 20,73 & 15,65 & 10,29 \\
\hline 26,67 & 1025,90 & 129,00 & 32,48 & 24,53 & 19,69 & 14,69 & 11,19 & 8,79 & 5,96 & 4,52 & 3,11 \\
\hline 60,57 & 1180,70 & 108,70 & 20,28 & 15,83 & 14,17 & 12,45 & 11,00 & 9,71 & 7,60 & 6,03 & 4,04 \\
\hline 72,00 & 446,90 & 100,10 & 31,75 & 20,98 & 17,45 & 14,55 & 12,47 & 10,77 & 8,17 & 6,40 & 4,30 \\
\hline 61,23 & 1460,00 & 160,40 & 14,78 & 11,28 & 9,97 & 8,68 & 7,60 & 6,67 & 5,16 & 4,07 & 2,71 \\
\hline 47,03 & 1098,80 & 61,60 & 34,21 & 29,05 & 26,39 & 23,22 & 20,37 & 17,83 & 13,69 & 10,69 & 7,02 \\
\hline 56,36 & 751,30 & 75,10 & 31,65 & 24,79 & 21,99 & 19,09 & 16,64 & 14,52 & 11,11 & 8,69 & 5,75 \\
\hline 68,66 & 631,70 & 119,60 & 24,64 & 16,94 & 14,33 & 12,09 & 10,42 & 9,03 & 6,87 & 5,38 & 3,60 \\
\hline 70,19 & 1562,00 & 178,20 & 12,67 & 9,36 & 8,27 & 7,26 & 6,44 & 5,73 & 4,55 & 3,66 & 2,49 \\
\hline 71,10 & 1127,40 & 104,30 & 19,55 & 14,70 & 13,21 & 11,75 & 10,56 & 9,49 & 7,66 & 6,24 & 4,31 \\
\hline
\end{tabular}




\begin{tabular}{|c|c|c|c|c|c|c|c|c|c|c|c|}
\hline \multirow[b]{2}{*}{ e1 (cm) } & & & & & & & ões (x1 & m) & & & \\
\hline & Meq (MPa) & Ms (MPa) & D0 & D25 & D40 & D60 & D80 & D100 & D140 & D180 & D260 \\
\hline 32,81 & 351,30 & 29,50 & 107,83 & 87,64 & 75,00 & 60,54 & 48,93 & 39,89 & 27,68 & 20,64 & 13,70 \\
\hline 63,92 & 792,00 & 147,50 & 20,39 & 14,23 & 12,05 & 10,13 & 8,66 & 7,45 & 5,60 & 4,35 & 2,89 \\
\hline 28,60 & 884,80 & 36,80 & 75,61 & 65,41 & 57,37 & 47,48 & 39,09 & 32,26 & 22,63 & 16,82 & 10,99 \\
\hline 47,96 & 1065,50 & 114,00 & 23,62 & 18,66 & 16,32 & 13,83 & 11,74 & 9,99 & 7,35 & 5,61 & 3,67 \\
\hline 56,28 & 1519,70 & 142,30 & 16,25 & 12,83 & 11,43 & 9,96 & 8,71 & 7,62 & 5,86 & 4,59 & 3,04 \\
\hline 75,60 & 389,50 & 164,00 & 28,25 & 16,18 & 12,45 & 9,73 & 8,01 & 6,73 & 4,92 & 3,81 & 2,58 \\
\hline 37,03 & 1798,20 & 92,10 & 26,35 & 22,77 & 20,36 & 17,40 & 14,80 & 12,58 & 9,20 & 6,96 & 4,51 \\
\hline 89,18 & 776,20 & 79,50 & 24,36 & 17,08 & 15,19 & 13,58 & 12,35 & 11,28 & 9,43 & 7,92 & 5,72 \\
\hline 72,56 & 1541,40 & 82,00 & 19,56 & 15,11 & 14,05 & 12,91 & 11,89 & 10,94 & 9,22 & 7,77 & 5,61 \\
\hline 55,75 & 243,20 & 140,90 & 42,77 & 23,26 & 17,12 & 12,62 & 9,87 & 7,96 & 5,55 & 4,24 & 2,92 \\
\hline 81,73 & 585,80 & 24,20 & 56,20 & 42,75 & 39,86 & 37,41 & 35,05 & 32,81 & 28,63 & 24,93 & 18,93 \\
\hline 55,65 & 1415,90 & 125,50 & 18,12 & 14,42 & 12,88 & 11,25 & 9,86 & 8,63 & 6,65 & 5,21 & 3,46 \\
\hline 89,07 & 956,90 & 24,20 & 42,97 & 34,21 & 31,39 & 30,11 & 28,85 & 27,50 & 24,88 & 22,43 & 18,10 \\
\hline 30,89 & 1872,00 & 101,60 & 28,15 & 23,92 & 20,87 & 17,20 & 14,12 & 11,65 & 8,17 & 6,08 & 3,99 \\
\hline 38,39 & 511,10 & 32,30 & 78,99 & 66,90 & 59,34 & 50,34 & 42,55 & 35,98 & 26,15 & 19,75 & 12,83 \\
\hline 48,01 & 625,90 & 120,00 & 29,05 & 20,81 & 17,40 & 14,10 & 11,57 & 9,58 & 6,82 & 5,15 & 3,42 \\
\hline 36,75 & 248,70 & 113,30 & 51,10 & 30,37 & 22,63 & 16,28 & 12,34 & 9,75 & 6,71 & 5,15 & 3,58 \\
\hline 27,71 & 1405,80 & 147,70 & 26,15 & 20,32 & 16,66 & 12,73 & 9,85 & 7,79 & 5,29 & 3,98 & 2,71 \\
\hline 53,19 & 1696,20 & 177,00 & 14,14 & 11,10 & 9,79 & 8,42 & 7,27 & 6,28 & 4,73 & 3,66 & 2,41 \\
\hline 86,49 & 294,20 & 140,70 & 35,15 & 19,23 & 14,46 & 11,14 & 9,15 & 7,71 & 5,70 & 4,45 & 3,03 \\
\hline 41,49 & 1455,40 & 120,00 & 22,21 & 18,25 & 16,06 & 13,55 & 11,42 & 9,64 & 7,00 & 5,29 & 3,45 \\
\hline 75,39 & 1811,60 & 190,00 & 11,07 & 8,10 & 7,21 & 6,39 & 5,73 & 5,16 & 4,17 & 3,41 & 2,37 \\
\hline 28,18 & 1895,80 & 127,70 & 25,88 & 21,27 & 18,06 & 14,36 & 11,44 & 9,21 & 6,31 & 4,69 & 3,14 \\
\hline 44,17 & 981,80 & 91,60 & 29,29 & 23,66 & 20,76 & 17,54 & 14,82 & 12,55 & 9,16 & 6,95 & 4,54 \\
\hline 42,50 & 566,10 & 88,40 & 38,46 & 28,75 & 24,23 & 19,57 & 15,94 & 13,11 & 9,23 & 6,94 & 4,61 \\
\hline 64,93 & 668,70 & 32,00 & 51,16 & 40,87 & 38,18 & 34,96 & 32,03 & 29,28 & 24,36 & 20,29 & 14,34 \\
\hline 36,20 & 1408,00 & 147,30 & 21,79 & 17,30 & 14,77 & 11,95 & 9,70 & 7,94 & 5,55 & 4,15 & 2,75 \\
\hline 85,59 & 1390,40 & 65,80 & 21,22 & 15,90 & 14,72 & 13,75 & 12,86 & 12,03 & 10,48 & 9,12 & 6,93 \\
\hline 37,48 & 1843,30 & 148,10 & 19,17 & 15,78 & 13,76 & 11,43 & 9,49 & 7,90 & 5,63 & 4,22 & 2,76 \\
\hline 39,12 & 1422,80 & 74,70 & 31,44 & 27,13 & 24,35 & 20,96 & 17,96 & 15,38 & 11,37 & 8,66 & 5,61 \\
\hline 55,36 & 860,80 & 137,90 & 21,61 & 15,81 & 13,52 & 11,33 & 9,59 & 8,16 & 6,02 & 4,62 & 3,05 \\
\hline 20,48 & 1005,00 & 64,60 & 63,97 & 50,33 & 40,40 & 29,86 & 22,49 & 17,49 & 11,81 & 8,97 & 6,18 \\
\hline 52,57 & 1867,30 & 137,90 & 15,83 & 12,94 & 11,66 & 10,23 & 8,98 & 7,88 & 6,07 & 4,76 & 3,15 \\
\hline 37,03 & 1746,00 & 33,50 & 52,12 & 47,35 & 44,35 & 40,02 & 35,85 & 31,95 & 25,24 & 20,03 & 13,25 \\
\hline 49,75 & 495,20 & 55,50 & 448,40 & 37,88 & 33,11 & 28,10 & 23,93 & 20,42 & 15,09 & 11,55 & 7,57 \\
\hline 31,90 & 1295,60 & 164,50 & 22,78 & 17,47 & 14,45 & 11,22 & 8,80 & 7,04 & 4,81 & 3,61 & 2,44 \\
\hline 88,30 & 1478,30 & 42,40 & 26,11 & 20,42 & 18,82 & 17,99 & 17,15 & 16,29 & 14,64 & 13,11 & 10,45 \\
\hline 62,40 & 1329,90 & 168,40 & 14,90 & 11,12 & 9,73 & 8,40 & 7,32 & 6,39 & 4,91 & 3,86 & 2,57 \\
\hline 24,97 & 814,00 & 80,10 & 50,71 & 39,23 & 31,71 & 23,77 & 18,12 & 14,21 & 9,62 & 7,28 & 5,00 \\
\hline 66,14 & 1592,40 & 56,40 & 25,79 & 20,57 & 19,47 & 18,12 & 16,81 & 15,56 & 13,25 & 11,26 & 8,19 \\
\hline 74,80 & 1469,20 & 85,20 & 19,16 & 14,64 & 13,55 & 12,42 & 11,43 & 10,51 & 8,85 & 7,47 & 5,39 \\
\hline 86,17 & 760,00 & 94,10 & 22,95 & 15,93 & 13,97 & 12,32 & 11,07 & 10,01 & 8,20 & 6,79 & 4,80 \\
\hline 46,70 & 1913,10 & 175,20 & 14,65 & 11,83 & 10,44 & 8,90 & 7,60 & 6,49 & 4,80 & 3,67 & 2,40 \\
\hline 66,18 & 1336,40 & 152,50 & 15,23 & 11,39 & 10,06 & 8,79 & 7,75 & 6,85 & 5,37 & 4,28 & 2,89 \\
\hline 34,45 & 1887,90 & 175,70 & 18,12 & 14,58 & 12,47 & 10,08 & 8,17 & 6,68 & 4,65 & 3,47 & 2,30 \\
\hline 58,94 & 295,70 & 63,80 & 52,68 & 36,16 & 30,16 & 24,84 & 20,84 & 17,63 & 12,91 & 9,89 & 6,57 \\
\hline 42,29 & 1552,50 & 164,40 & 17,67 & 14,04 & 12,17 & 10,12 & 8,43 & 7,05 & 5,06 & 3,81 & 2,50 \\
\hline 38,49 & 421,80 & 168,00 & 31,94 & 19,64 & 14,95 & 10,96 & 8,38 & 6,64 & 4,57 & 3,49 & 2,42 \\
\hline 48,08 & 566,90 & 28,90 & 69,38 & 59,13 & 54,09 & 47,97 & 42,41 & 37,40 & 29,07 & 22,89 & 15,12 \\
\hline 23,08 & 1756,00 & 195,10 & 22,73 & 17,10 & 13,47 & 9,81 & 7,35 & 5,72 & 3,89 & 2,97 & 2,05 \\
\hline 54,61 & 1377,90 & 177,90 & 15,24 & 11,57 & 10,06 & 8,55 & 7,32 & 6,28 & 4,69 & 3,61 & 2,38 \\
\hline 23,48 & 228,70 & 117,70 & 58,22 & 32,82 & 22,76 & 15,32 & 11,34 & 8,97 & 6,29 & 4,89 & 3,44 \\
\hline 65,30 & 1859,00 & 149,00 & 13,41 & 10,43 & 9,45 & 8,42 & 7,55 & 6,77 & 5,43 & 4,40 & 3,01 \\
\hline 84,84 & 272,10 & 169,30 & 35,48 & 18,35 & 13,28 & 9,84 & 7,88 & 6,52 & 4,70 & 3,64 & 2,50 \\
\hline 47,61 & 899,10 & 112,30 & 25,73 & 19,87 & 17,19 & 14,39 & 12,09 & 10,20 & 7,42 & 5,63 & 3,70 \\
\hline 51,46 & 626,70 & 121,10 & 27,91 & 19,86 & 16,66 & 13,63 & 11,30 & 9,44 & 6,79 & 5,15 & 3,42 \\
\hline 48,87 & 646,30 & 79,90 & 35,46 & 27,38 & 23,74 & 19,96 & 16,86 & 14,28 & 10,45 & 7,96 & 5,22 \\
\hline 42,28 & 1643,40 & 157,80 & 17,71 & 14,26 & 12,44 & 10,42 & 8,73 & 7,34 & 5,29 & 4,00 & 2,61 \\
\hline 21,97 & 1839,40 & 148,70 & 28,17 & 21,87 & 17,49 & 12,91 & 9,73 & 7,58 & 5,13 & 3,90 & 2,69 \\
\hline 78,25 & 556,40 & 69,40 & 32,43 & 23,06 & 20,26 & 17,77 & 15,86 & 14,20 & 11,43 & 9,31 & 6,45 \\
\hline 20,66 & 321,60 & 167,70 & 42,35 & 23,41 & 15,93 & 10,62 & 7,88 & 6,25 & 4,40 & 3,43 & 2,42 \\
\hline 77,27 & 1269,20 & 42,50 & 30,49 & 23,62 & 22,20 & 20,97 & 19,71 & 18,49 & 16,19 & 14,13 & 10,77 \\
\hline 86,67 & 1224,50 & 154,90 & 14,07 & 9,72 & 8,51 & 7,49 & 6,73 & 6,08 & 4,98 & 4,12 & 2,92 \\
\hline 71,12 & 1968,90 & 197,70 & 10,70 & 7,98 & 7,13 & 6,31 & 5,65 & 5,06 & 4,06 & 3,30 & 2,26 \\
\hline 77,09 & 1343,80 & 173,90 & 13,27 & 9,43 & 8,26 & 7,22 & 6,42 & 5,74 & 4,59 & 3,72 & 2,57 \\
\hline 85,91 & 687,40 & 126,40 & 21,19 & 13,95 & 11,81 & 10,09 & 8,88 & 7,88 & 6,27 & 5,08 & 3,51 \\
\hline 89,26 & 988,80 & 125,30 & 17,21 & 11,80 & 10,32 & 9,09 & 8,19 & 7,41 & 6,10 & 5,07 & 3,61 \\
\hline 24,54 & 1216,70 & 23,10 & 105,94 & 95,93 & 85,96 & 72,94 & 61,31 & 51,44 & 36,76 & 27,39 & 17,64 \\
\hline 84,57 & 1213,40 & 164,00 & 13,88 & 9,58 & 8,35 & 7,30 & 6,53 & 5,87 & 4,77 & 3,91 & 2,74 \\
\hline 65,40 & 391,00 & 195,10 & 27,31 & 15,25 & 11,48 & 8,72 & 7,00 & 5,75 & 4,09 & 3,13 & 2,13 \\
\hline 45,58 & 325,80 & 125,20 & 39,91 & 24,57 & 19,04 & 14,37 & 11,25 & 9,04 & 6,25 & 4,75 & 3,25 \\
\hline 36,60 & 491,20 & 58,30 & 57,35 & 44,74 & 37,90 & 30,44 & 24,57 & 20,04 & 13,94 & 10,43 & 6,95 \\
\hline 66,73 & 1295,00 & 189,60 & 13,76 & 9,93 & 8,60 & 7,38 & 6,44 & 5,63 & 4,34 & 3,42 & 2,29 \\
\hline 84,08 & 454,20 & 178,30 & 24,28 & 13,92 & 10,77 & 8,51 & 7,10 & 6,04 & 4,52 & 3,53 & 2,40 \\
\hline 52,65 & 515,40 & 53,00 & 47,20 & 37,17 & 32,79 & 28,19 & 24,32 & 20,99 & 15,80 & 12,22 & 8,03 \\
\hline 55,03 & 1148,00 & 28,00 & 51,42 & 42,88 & 41,01 & 38,17 & 35,32 & 32,57 & 27,49 & 23,14 & 16,54 \\
\hline 40,72 & 671,10 & 123,20 & 30,25 & 21,99 & 18,21 & 14,41 & 11,54 & 9,38 & 6,52 & 4,90 & 3,29 \\
\hline 70,90 & 867,90 & 72,60 & 26,89 & 20,41 & 18,47 & 16,53 & 14,91 & 13,45 & 10,94 & 8,96 & 6,22 \\
\hline 44,18 & 956,10 & 74,00 & 33,64 & 27,82 & 24,69 & 21,13 & 18,05 & 15,42 & 11,40 & 8,70 & 5,67 \\
\hline 41,20 & 1570,20 & 32,00 & 51,50 & 45,95 & 43,38 & 39,52 & 35,76 & 32,21 & 25,95 & 20,94 & 14,11 \\
\hline 86,22 & 652,50 & 97,20 & 24,48 & 16,60 & 14,33 & 12,46 & 11,10 & 9,95 & 8,05 & 6,59 & 4,61 \\
\hline 45,30 & 932,70 & 63,50 & 36,65 & 30,68 & 27,50 & 23,80 & 20,56 & 17,74 & 13,31 & 10,23 & 6,68 \\
\hline
\end{tabular}




\begin{tabular}{|c|c|c|c|c|c|c|c|c|c|c|c|}
\hline \multirow[b]{2}{*}{ e1 (cm) } & & & & & & & ões (x1 & m) & & & \\
\hline & Meq (MPa) & Ms (MPa) & D0 & D25 & D40 & D60 & D80 & D100 & D140 & D180 & D260 \\
\hline 37,04 & 578,60 & 173,10 & 27,69 & 18,25 & 14,28 & 10,65 & 8,20 & 6,51 & 4,47 & 3,40 & 2,34 \\
\hline 76,83 & 1550,30 & 70,80 & 20,69 & 15,85 & 14,81 & 13,77 & 12,80 & 11,89 & 10,22 & 8,77 & 6,50 \\
\hline 61,08 & 757,20 & 79,70 & 29,21 & 22,42 & 19,88 & 17,34 & 15,22 & 13,38 & 10,38 & 8,19 & 5,47 \\
\hline 82,30 & 683,00 & 160,00 & 19,54 & 12,47 & 10,30 & 8,60 & 7,43 & 6,50 & 5,03 & 4,01 & 2,73 \\
\hline 25,46 & 1734,20 & 100,60 & 33,86 & 27,92 & 23,56 & 18,53 & 14,61 & 11,67 & 7,93 & 5,91 & 3,98 \\
\hline 88,48 & 1960,80 & 110,00 & 13,40 & 9,87 & 9,07 & 8,41 & 7,83 & 7,30 & 6,33 & 5,49 & 4,15 \\
\hline 75,51 & 578,60 & 86,70 & 28,92 & 20,25 & 17,50 & 15,13 & 13,33 & 11,80 & 9,31 & 7,47 & 5,09 \\
\hline 55,20 & 1031,40 & 192,30 & 16,71 & 11,89 & 10,04 & 8,31 & 6,97 & 5,89 & 4,30 & 3,28 & 2,17 \\
\hline 86,28 & 1625,80 & 162,70 & 11,93 & 8,46 & 7,55 & 6,75 & 6,13 & 5,59 & 4,65 & 3,90 & 2,79 \\
\hline 57,58 & 978,30 & 150,10 & 19,06 & 13,98 & 12,01 & 10,15 & 8,66 & 7,42 & 5,53 & 4,27 & 2,82 \\
\hline 62,56 & 1226,90 & 93,50 & 21,39 & 16,87 & 15,31 & 13,64 & 12,20 & 10,91 & 8,71 & 7,02 & 4,77 \\
\hline 69,88 & 1404,50 & 101,50 & 18,21 & 14,02 & 12,81 & 11,54 & 10,47 & 9,48 & 7,77 & 6,40 & 4,47 \\
\hline 44,77 & 640,00 & 125,60 & 29,06 & 20,80 & 17,27 & 13,81 & 11,20 & 9,18 & 6,45 & 4,86 & 3,25 \\
\hline 41,71 & 1214,80 & 80,30 & 30,39 & 25,61 & 22,83 & 19,57 & 16,72 & 14,28 & 10,54 & 8,02 & 5,22 \\
\hline 51,45 & 1183,50 & 138,30 & 19,39 & 15,03 & 13,13 & 11,16 & 9,53 & 8,15 & 6,05 & 4,64 & 3,05 \\
\hline 51,84 & 1855,90 & 182,70 & 13,57 & 10,76 & 9,51 & 8,19 & 7,07 & 6,10 & 4,59 & 3,55 & 2,33 \\
\hline 61,28 & 1297,00 & 114,90 & 18,75 & 14,66 & 13,16 & 11,60 & 10,28 & 9,11 & 7,16 & 5,71 & 3,84 \\
\hline 20,61 & 1466,60 & 165,10 & 28,97 & 21,30 & 16,34 & 11,58 & 8,54 & 6,62 & 4,54 & 3,49 & 2,42 \\
\hline 65,19 & 857,00 & 199,20 & 16,88 & 11,25 & 9,33 & 7,70 & 6,51 & 5,55 & 4,12 & 3,19 & 2,13 \\
\hline 36,20 & 532,50 & 147,20 & 31,81 & 21,33 & 16,78 & 12,55 & 9,66 & 7,67 & 5,26 & 3,99 & 2,74 \\
\hline 60,50 & 707,20 & 160,20 & 21,30 & 14,43 & 11,98 & 9,85 & 8,27 & 7,00 & 5,14 & 3,94 & 2,62 \\
\hline 61,93 & 474,40 & 154,10 & 26,86 & 16,76 & 13,38 & 10,65 & 8,76 & 7,31 & 5,27 & 4,03 & 2,70 \\
\hline 72,03 & 997,00 & 100,30 & 20,99 & 15,61 & 13,94 & 12,35 & 11,06 & 9,92 & 7,98 & 6,49 & 4,47 \\
\hline 48,72 & 1673,00 & 55,00 & 31,07 & 26,82 & 25,12 & 22,80 & 20,61 & 18,55 & 14,96 & 12,10 & 8,20 \\
\hline 52,12 & 791,90 & 193,20 & 19,52 & 13,23 & 10,86 & 8,72 & 7,14 & 5,91 & 4,21 & 3,19 & 2,13 \\
\hline 27,80 & 1238,30 & 96,30 & 36,33 & 29,33 & 24,60 & 19,28 & 15,18 & 12,13 & 8,27 & 6,17 & 4,16 \\
\hline 71,17 & 1673,30 & 180,30 & 12,12 & 8,97 & 7,97 & 7,02 & 6,26 & 5,59 & 4,47 & 3,61 & 2,47 \\
\hline 88,40 & 1996,60 & 162,30 & 10,73 & 7,69 & 6,95 & 6,31 & 5,79 & 5,33 & 4,52 & 3,84 & 2,81 \\
\hline 41,57 & 1074,90 & 148,60 & 22,03 & 16,81 & 14,27 & 11,60 & 9,48 & 7,82 & 5,51 & 4,14 & 2,74 \\
\hline 54,64 & 512,70 & 123,30 & 29,76 & 20,15 & 16,59 & 13,42 & 11,07 & 9,23 & 6,63 & 5,04 & 3,36 \\
\hline 24,50 & 513,60 & 54,60 & 77,13 & 58,92 & 47,15 & 34,96 & 26,48 & 20,70 & 14,03 & 10,65 & 7,34 \\
\hline 39,28 & 1283,60 & 61,30 & 36,89 & 32,09 & 28,95 & 25,09 & 21,63 & 18,61 & 13,87 & 10,61 & 6,88 \\
\hline 79,24 & 1137,30 & 136,10 & 16,12 & 11,48 & 10,12 & 8,91 & 7,97 & 7,16 & 5,80 & 4,74 & 3,30 \\
\hline 55,94 & 581,40 & 159,10 & 24,47 & 16,06 & 13,06 & 10,46 & 8,59 & 7,14 & 5,12 & 3,89 & 2,60 \\
\hline 25,33 & 1220,50 & 154,00 & 28,14 & 21,10 & 16,76 & 12,35 & 9,33 & 7,30 & 4,96 & 3,77 & 2,60 \\
\hline 34,45 & 1646,90 & 126,20 & 23,51 & 19,39 & 16,79 & 13,78 & 11,30 & 9,32 & 6,54 & 4,89 & 3,21 \\
\hline 86,90 & 783,30 & 26,70 & 45,20 & 34,69 & 32,13 & 30,51 & 28,89 & 27,29 & 24,27 & 21,52 & 16,86 \\
\hline 36,26 & 1392,10 & 171,60 & 19,88 & 15,42 & 13,01 & 10,40 & 8,36 & 6,80 & 4,72 & 3,53 & 2,36 \\
\hline 48,84 & 910,70 & 157,70 & 20,90 & 15,24 & 12,87 & 10,55 & 8,73 & 7,28 & 5,22 & 3,95 & 2,61 \\
\hline 58,17 & 567,20 & 39,80 & 50,61 & 40,82 & 37,11 & 33,01 & 29,41 & 26,17 & 20,71 & 16,56 & 11,14 \\
\hline 31,63 & 741,00 & 96,80 & 39,29 & 29,99 & 24,71 & 19,11 & 14,95 & 11,93 & 8,15 & 6,12 & 4,15 \\
\hline 88,21 & 683,20 & 41,20 & 36,96 & 27,11 & 24,84 & 22,94 & 21,31 & 19,82 & 17,10 & 14,77 & 11,08 \\
\hline 46,91 & 1260,90 & 136,50 & 20,10 & 15,87 & 13,85 & 11,69 & 9,88 & 8,38 & 6,13 & 4,66 & 3,05 \\
\hline 44,86 & 897,70 & 162,40 & 21,65 & 15,73 & 13,16 & 10,60 & 8,64 & 7,11 & 5,02 & 3,78 & 2,52 \\
\hline 57,43 & 1217,30 & 178,50 & 15,71 & 11,61 & 10,02 & 8,49 & 7,26 & 6,23 & 4,66 & 3,60 & 2,38 \\
\hline 50,42 & 1526,20 & 143,00 & 17,26 & 13,82 & 12,24 & 10,53 & 9,08 & 7,83 & 5,87 & 4,53 & 2,97 \\
\hline 89,44 & 823,00 & 169,80 & 16,66 & 10,67 & 8,91 & 7,54 & 6,61 & 5,86 & 4,65 & 3,77 & 2,61 \\
\hline 49,17 & 1412,00 & 41,30 & 39,58 & 34,10 & 32,15 & 29,36 & 26,69 & 24,17 & 19,70 & 16,07 & 11,00 \\
\hline 43,89 & 1768,40 & 178,00 & 15,61 & 12,48 & 10,89 & 9,15 & 7,69 & 6,48 & 4,70 & 3,56 & 2,33 \\
\hline 26,62 & 1862,60 & 29,30 & 73,20 & 67,63 & 61,71 & 53,76 & 46,36 & 39,81 & 29,46 & 22,32 & 14,31 \\
\hline 57,30 & 1876,20 & 160,60 & 13,72 & 10,91 & 9,78 & 8,59 & 7,56 & 6,66 & 5,17 & 4,08 & 2,72 \\
\hline 39,60 & 746,60 & 65,00 & 43,28 & 35,32 & 30,82 & 25,71 & 21,43 & 17,92 & 12,84 & 9,66 & 6,32 \\
\hline 79,46 & 634,50 & 116,50 & 23,57 & 15,82 & 13,41 & 11,43 & 10,00 & 8,81 & 6,91 & 5,54 & 3,78 \\
\hline 33,48 & 602,20 & 36,50 & 76,35 & 64,53 & 56,51 & 46,92 & 38,83 & 32,23 & 22,81 & 17,04 & 11,14 \\
\hline 64,18 & 389,90 & 79,70 & 39,57 & 27,13 & 22,78 & 19,00 & 16,16 & 13,85 & 10,34 & 8,01 & 5,33 \\
\hline 72,39 & 937,20 & 50,20 & 32,06 & 24,79 & 23,05 & 21,16 & 19,48 & 17,91 & 15,08 & 12,71 & 9,15 \\
\hline 61,29 & 389,00 & 77,20 & 40,98 & 28,45 & 23,94 & 19,93 & 16,89 & 14,41 & 10,69 & 8,24 & 5,47 \\
\hline 42,68 & 544,80 & 60,50 & 48,66 & 38,40 & 33,21 & 27,56 & 22,92 & 19,16 & 13,73 & 10,35 & 6,79 \\
\hline 51,91 & 827,50 & 76,80 & 31,46 & 25,14 & 22,31 & 19,28 & 16,69 & 14,45 & 10,93 & 8,47 & 5,56 \\
\hline 54,48 & 1551,90 & 112,80 & 18,81 & 15,31 & 13,84 & 12,21 & 10,77 & 9,49 & 7,39 & 5,83 & 3,88 \\
\hline 62,62 & 1027,30 & 114,30 & 20,62 & 15,65 & 13,83 & 12,05 & 10,58 & 9,30 & 7,22 & 5,71 & 3,82 \\
\hline 31,81 & 1801,80 & 152,80 & 21,34 & 17,28 & 14,71 & 11,79 & 9,47 & 7,68 & 5,30 & 3,95 & 2,64 \\
\hline 47,86 & 1541,40 & 119,40 & 19,77 & 16,27 & 14,52 & 12,57 & 10,86 & 9,39 & 7,06 & 5,45 & 3,56 \\
\hline 49,92 & 1711,20 & 135,20 & 17,12 & 14,00 & 12,52 & 10,88 & 9,45 & 8,20 & 6,22 & 4,82 & 3,17 \\
\hline 55,87 & 624,60 & 21,60 & 73,86 & 61,65 & 58,15 & 53,37 & 48,83 & 44,53 & 36,81 & 30,43 & 21,23 \\
\hline 73,42 & 890,50 & 37,50 & 38,85 & 30,14 & 28,29 & 26,33 & 24,47 & 22,71 & 19,46 & 16,66 & 12,28 \\
\hline 87,23 & 281,30 & 37,20 & 59,79 & 41,05 & 35,80 & 31,42 & 28,18 & 25,42 & 20,78 & 17,17 & 12,12 \\
\hline 86,87 & 1303,80 & 56,50 & 23,63 & 17,78 & 16,46 & 15,46 & 14,51 & 13,62 & 11,96 & 10,48 & 8,05 \\
\hline 41,56 & 1432,10 & 87,20 & 27,19 & 23,11 & 20,69 & 17,81 & 15,28 & 13,10 & 9,71 & 7,41 & 4,82 \\
\hline 87,62 & 309,60 & 78,00 & 41,18 & 25,60 & 20,92 & 17,37 & 15,01 & 13,14 & 10,24 & 8,19 & 5,62 \\
\hline 43,17 & 1175,90 & 30,60 & 56,20 & 49,78 & 46,67 & 42,27 & 38,06 & 34,11 & 27,26 & 21,87 & 14,65 \\
\hline 80,73 & 1887,30 & 42,60 & 25,27 & 20,11 & 18,72 & 18,00 & 17,19 & 16,34 & 14,69 & 13,15 & 10,47 \\
\hline 63,61 & 1877,40 & 55,10 & 25,38 & 20,45 & 19,48 & 18,22 & 16,96 & 15,74 & 13,47 & 11,50 & 8,41 \\
\hline 87,61 & 522,80 & 97,50 & 27,51 & 18,00 & 15,19 & 12,97 & 11,42 & 10,15 & 8,09 & 6,57 & 4,56 \\
\hline 27,34 & 1942,40 & 116,00 & 28,04 & 23,26 & 19,82 & 15,80 & 12,61 & 10,16 & 6,96 & 5,17 & 3,46 \\
\hline 32,33 & 1276,50 & 99,30 & 31,51 & 25,81 & 22,16 & 17,94 & 14,53 & 11,86 & 8,23 & 6,14 & 4,07 \\
\hline 46,40 & 997,60 & 58,60 & 36,96 & 31,31 & 28,34 & 24,83 & 21,69 & 18,91 & 14,43 & 11,21 & 7,34 \\
\hline 79,40 & 383,00 & 32,40 & 57,41 & 42,21 & 38,18 & 34,37 & 31,28 & 28,50 & 23,65 & 19,72 & 14,04 \\
\hline 81,27 & 1781,20 & 139,20 & 12,77 & 9,39 & 8,53 & 7,73 & 7,07 & 6,47 & 5,42 & 4,56 & 3,28 \\
\hline 77,52 & 1794,80 & 117,10 & 14,37 & 10,81 & 9,94 & 9,07 & 8,33 & 7,65 & 6,44 & 5,42 & 3,91 \\
\hline 47,34 & 1506,80 & 136,70 & 18,54 & 14,98 & 13,24 & 11,32 & 9,68 & 8,29 & 6,15 & 4,71 & 3,08 \\
\hline 31,15 & 1876,70 & 60,60 & 39,23 & 34,99 & 31,43 & 26,89 & 22,83 & 19,35 & 14,07 & 10,58 & 6,82 \\
\hline
\end{tabular}




\begin{tabular}{|c|c|c|c|c|c|c|c|c|c|c|c|}
\hline \multirow[b]{2}{*}{$\mathrm{e} 1(\mathrm{~cm})$} & & & & & & $\mathrm{De}$ & $\overline{\text { ões (x1 }}$ & & & & \\
\hline & Meq (MPa) & Ms (MPa) & D0 & D25 & D40 & D60 & D80 & D100 & D140 & D180 & D260 \\
\hline 71,52 & 1034,20 & 186,50 & 15,15 & 10,42 & 8,86 & 7,52 & 6,53 & 5,69 & 4,38 & 3,46 & 2,33 \\
\hline 25,62 & 1613,20 & 24,50 & 89,55 & 82,66 & 75,23 & 65,26 & 56,03 & 47,92 & 35,22 & 26,58 & 17,02 \\
\hline 41,59 & 1069,60 & 184,20 & 19,47 & 14,32 & 11,94 & 9,54 & 7,70 & 6,29 & 4,39 & 3,30 & 2,21 \\
\hline 34,30 & 305,50 & 58,70 & 71,04 & 51,14 & 41,32 & 31,50 & 24,48 & 19,49 & 13,34 & 10,07 & 6,87 \\
\hline 68,85 & 980,20 & 189,50 & 15,71 & 10,75 & 9,08 & 7,65 & 6,58 & 5,70 & 4,33 & 3,39 & 2,27 \\
\hline 34,41 & 1416,90 & 47,40 & 46,73 & 41,75 & 37,84 & 32,84 & 28,28 & 24,29 & 18,03 & 13,73 & 8,86 \\
\hline 43,61 & 1345,20 & 67,70 & 31,54 & 27,19 & 24,70 & 21,66 & 18,91 & 16,47 & 12,53 & 9,71 & 6,34 \\
\hline 26,83 & 986,70 & 62,70 & 53,71 & 44,16 & 37,36 & 29,52 & 23,37 & 18,74 & 12,78 & 9,52 & 6,39 \\
\hline 70,33 & 572,40 & 128,90 & 24,93 & 16,53 & 13,74 & 11,44 & 9,77 & 8,42 & 6,36 & 4,96 & 3,33 \\
\hline 68,69 & 427,70 & 93,50 & 34,08 & 22,81 & 19,03 & 15,85 & 13,54 & 11,65 & 8,77 & 6,84 & 4,57 \\
\hline 66,95 & 1808,40 & 100,10 & 16,97 & 13,39 & 12,42 & 11,32 & 10,34 & 9,42 & 7,81 & 6,48 & 4,57 \\
\hline 74,53 & 665,30 & 39,10 & 42,03 & 32,12 & 29,71 & 27,21 & 25,01 & 22,97 & 19,32 & 16,28 & 11,72 \\
\hline 20,39 & 1930,90 & 31,90 & 86,80 & 77,27 & 68,00 & 56,16 & 45,98 & 37,70 & 26,13 & 19,28 & 12,60 \\
\hline 48,79 & 314,60 & 102,00 & 43,88 & 28,04 & 22,25 & 17,24 & 13,75 & 11,18 & 7,81 & 5,91 & 4,01 \\
\hline 56,22 & 1607,20 & 199,60 & 13,14 & 10,00 & 8,73 & 7,47 & 6,43 & 5,55 & 4,18 & 3,24 & 2,14 \\
\hline 60,84 & 427,90 & 32,10 & 62,83 & 49,93 & 45,30 & 40,30 & 35,97 & 32,07 & 25,49 & 20,47 & 13,85 \\
\hline 73,79 & 667,70 & 163,30 & 20,31 & 13,14 & 10,82 & 8,96 & 7,65 & 6,60 & 5,00 & 3,91 & 2,63 \\
\hline 44,24 & 995,70 & 155,20 & 21,39 & 15,98 & 13,51 & 10,99 & 9,01 & 7,45 & 5,28 & 3,98 & 2,64 \\
\hline 89,95 & 1503,20 & 33,40 & 29,06 & 23,65 & 21,58 & 20,75 & 19,98 & 19,12 & 17,40 & 15,79 & 12,90 \\
\hline 31,46 & 1735,50 & 46,50 & 47,55 & 43,00 & 39,01 & 33,82 & 29,08 & 24,92 & 18,42 & 13,97 & 8,99 \\
\hline 82,02 & 251,50 & 20,70 & 87,57 & 63,97 & 57,94 & 52,35 & 47,80 & 43,73 & 36,57 & 30,71 & 22,08 \\
\hline 76,83 & 557,40 & 189,40 & 21,19 & 12,70 & 10,05 & 8,06 & 6,75 & 5,75 & 4,28 & 3,33 & 2,25 \\
\hline 82,24 & 879,50 & 90,20 & 22,22 & 15,92 & 14,20 & 12,65 & 11,44 & 10,38 & 8,55 & 7,10 & 5,03 \\
\hline 73,64 & 339,40 & 90,20 & 38,65 & 24,58 & 20,06 & 16,48 & 13,99 & 12,02 & 9,04 & 7,06 & 4,75 \\
\hline 83,89 & 1469,90 & 131,80 & 14,15 & 10,21 & 9,18 & 8,26 & 7,53 & 6,88 & 5,74 & 4,81 & 3,46 \\
\hline 31,82 & 1705,60 & 186,80 & 19,08 & 14,94 & 12,49 & 9,81 & 7,76 & 6,23 & 4,27 & 3,20 & 2,15 \\
\hline 79,32 & 1140,40 & 68,50 & 23,47 & 17,63 & 16,27 & 14,94 & 13,78 & 12,72 & 10,80 & 9,18 & 6,70 \\
\hline 59,94 & 376,80 & 43,60 & 56,31 & 42,87 & 37,72 & 32,63 & 28,45 & 24,83 & 19,05 & 14,94 & 9,93 \\
\hline 46,38 & 892,80 & 47,80 & 43,75 & 37,34 & 33,97 & 29,91 & 26,25 & 22,99 & 17,66 & 13,78 & 9,05 \\
\hline 62,33 & 817,80 & 111,20 & 23,35 & 17,25 & 15,01 & 12,89 & 11,19 & 9,74 & 7,44 & 5,83 & 3,88 \\
\hline 83,74 & 590,10 & 58,40 & 33,48 & 23,95 & 21,40 & 19,13 & 17,35 & 15,79 & 13,08 & 10,91 & 7,78 \\
\hline 56,82 & 1906,10 & 168,90 & 13,30 & 10,55 & 9,44 & 8,26 & 7,25 & 6,37 & 4,93 & 3,88 & 2,58 \\
\hline 58,18 & 1357,80 & 21,10 & 57,31 & 46,77 & 45,07 & 43,00 & 40,54 & 38,08 & 33,35 & 29,05 & 21,94 \\
\hline 30,29 & 1158,10 & 38,20 & 64,17 & 57,00 & 50,99 & 43,35 & 36,58 & 30,84 & 22,23 & 16,66 & 10,76 \\
\hline 57,44 & 576,30 & 127,10 & 27,04 & 18,53 & 15,42 & 12,64 & 10,55 & 8,89 & 6,47 & 4,94 & 3,28 \\
\hline 69,66 & 1812,30 & 152,40 & 12,95 & 9,87 & 8,93 & 7,98 & 7,18 & 6,46 & 5,24 & 4,28 & 2,96 \\
\hline 30,92 & 1505,30 & 64,90 & 40,69 & 35,37 & 31,28 & 26,21 & 21,84 & 18,22 & 12,96 & 9,67 & 6,29 \\
\hline 79,79 & 775,40 & 59,20 & 29,98 & 22,18 & 20,19 & 18,30 & 16,73 & 15,31 & 12,81 & 10,75 & 7,72 \\
\hline 25,78 & 1360,30 & 65,90 & 48,35 & 40,67 & 34,80 & 27,85 & 22,26 & 17,95 & 12,28 & 9,12 & 6,08 \\
\hline 31,12 & 573,50 & 42,10 & 74,93 & 61,62 & 52,81 & 42,60 & 34,38 & 27,98 & 19,36 & 14,42 & 9,57 \\
\hline 44,49 & 1305,80 & 138,40 & 20,32 & 16,13 & 14,04 & 11,77 & 9,88 & 8,33 & 6,03 & 4,57 & 2,99 \\
\hline 85,11 & 372,30 & 139,40 & 30,01 & 17,34 & 13,50 & 10,73 & 8,99 & 7,68 & 5,77 & 4,53 & 3,08 \\
\hline 60,21 & 344,10 & 179,20 & 31,03 & 17,27 & 12,92 & 9,71 & 7,71 & 6,28 & 4,42 & 3,37 & 2,31 \\
\hline 50,57 & 527,70 & 137,50 & 28,72 & 19,24 & 15,67 & 12,45 & 10,11 & 8,32 & 5,89 & 4,46 & 2,99 \\
\hline 57,77 & 244,90 & 98,80 & 48,56 & 28,97 & 22,49 & 17,37 & 13,97 & 11,46 & 8,10 & 6,17 & 4,18 \\
\hline 75,75 & 225,20 & 20,20 & 96,54 & 71,55 & 64,47 & 57,67 & 52,15 & 47,21 & 38,68 & 31,90 & 22,37 \\
\hline 57,11 & 1052,40 & 176,50 & 17,00 & 12,29 & 10,48 & 8,78 & 7,45 & 6,35 & 4,70 & 3,61 & 2,39 \\
\hline 58,01 & 1478,50 & 46,40 & 32,55 & 26,88 & 25,51 & 23,60 & 21,74 & 19,97 & 16,74 & 14,01 & 9,95 \\
\hline 64,43 & 310,80 & 173,90 & 33,14 & 17,99 & 13,31 & 9,95 & 7,90 & 6,46 & 4,56 & 3,49 & 2,39 \\
\hline 27,98 & 912,50 & 171,30 & 26,99 & 19,25 & 15,07 & 11,02 & 8,31 & 6,51 & 4,45 & 3,39 & 2,35 \\
\hline 72,04 & 1113,40 & 147,50 & 16,28 & 11,72 & 10,24 & 8,91 & 7,87 & 6,97 & 5,50 & 4,41 & 3,00 \\
\hline 69,92 & 896,50 & 164,30 & 17,50 & 12,06 & 10,24 & 8,67 & 7,50 & 6,52 & 4,99 & 3,92 & 2,63 \\
\hline 32,46 & 450,20 & 193,50 & 30,25 & 18,26 & 13,51 & 9,57 & 7,18 & 5,65 & 3,90 & 3,00 & 2,09 \\
\hline 23,55 & 1105,40 & 113,70 & 37,63 & 28,69 & 22,84 & 16,82 & 12,67 & 9,89 & 6,70 & 5,10 & 3,52 \\
\hline 28,55 & 1803,60 & 111,10 & 28,59 & 23,77 & 20,35 & 16,34 & 13,12 & 10,62 & 7,31 & 5,43 & 3,62 \\
\hline 54,96 & 557,90 & 43,90 & 49,68 & 40,11 & 36,10 & 31,72 & 27,91 & 24,54 & 19,02 & 14,98 & 9,94 \\
\hline 29,41 & 753,60 & 112,80 & 36,98 & 27,49 & 22,14 & 16,66 & 12,79 & 10,09 & 6,87 & 5,19 & 3,56 \\
\hline 87,82 & 1143,90 & 172,10 & 13,81 & 9,31 & 8,03 & 6,98 & 6,22 & 5,58 & 4,52 & 3,72 & 2,61 \\
\hline 76,16 & 578,70 & 123,80 & 24,53 & 16,18 & 13,51 & 11,34 & 9,80 & 8,54 & 6,57 & 5,19 & 3,51 \\
\hline 22,07 & 526,30 & 144,20 & 40,41 & 26,04 & 18,82 & 12,83 & 9,42 & 7,38 & 5,15 & 4,00 & 2,79 \\
\hline 59,12 & 583,30 & 95,10 & 30,61 & 22,14 & 18,95 & 15,97 & 13,63 & 11,69 & 8,73 & 6,74 & 4,46 \\
\hline 52,37 & 1757,30 & 139,80 & 16,12 & 13,10 & 11,74 & 10,26 & 8,96 & 7,83 & 6,00 & 4,68 & 3,09 \\
\hline 33,09 & 1751,20 & 198,30 & 17,71 & 13,84 & 11,61 & 9,17 & 7,29 & 5,88 & 4,04 & 3,02 & 2,03 \\
\hline 32,41 & 494,10 & 148,50 & 34,19 & 22,48 & 17,27 & 12,55 & 9,50 & 7,48 & 5,13 & 3,92 & 2,72 \\
\hline 86,23 & 1412,10 & 40,20 & 27,97 & 21,84 & 20,21 & 19,32 & 18,39 & 17,45 & 15,64 & 13,97 & 11,08 \\
\hline 85,98 & 1273,00 & 186,00 & 12,67 & 8,62 & 7,46 & 6,49 & 5,79 & 5,19 & 4,20 & 3,45 & 2,41 \\
\hline 55,44 & 1947,80 & 34,20 & 37,95 & 31,31 & 30,20 & 28,53 & 26,70 & 24,90 & 21,49 & 18,45 & 13,61 \\
\hline 47,28 & 576,30 & 46,30 & 52,17 & 42,79 & 38,09 & 32,83 & 28,27 & 24,34 & 18,22 & 14,01 & 9,16 \\
\hline 63,90 & 365,40 & 139,70 & 32,38 & 19,37 & 15,14 & 11,86 & 9,69 & 8,05 & 5,78 & 4,42 & 2,98 \\
\hline 31,02 & 624,60 & 63,70 & 55,54 & 43,82 & 36,69 & 28,82 & 22,79 & 18,29 & 12,52 & 9,36 & 6,31 \\
\hline 61,05 & 1093,30 & 60,70 & 29,46 & 23,81 & 22,01 & 19,91 & 18,02 & 16,28 & 13,24 & 10,81 & 7,45 \\
\hline 60,05 & 1542,00 & 78,40 & 22,30 & 18,16 & 16,86 & 15,29 & 13,87 & 12,55 & 10,24 & 8,39 & 5,79 \\
\hline 73,98 & 1300,60 & 110,50 & 17,44 & 13,07 & 11,82 & 10,60 & 9,58 & 8,68 & 7,11 & 5,86 & 4,10 \\
\hline 43,86 & 1301,80 & 153,30 & 19,33 & 15,12 & 13,05 & 10,83 & 9,02 & 7,54 & 5,42 & 4,09 & 2,69 \\
\hline 46,13 & 1770,60 & 124,90 & 18,67 & 15,55 & 13,93 & 12,06 & 10,42 & 9,00 & 6,76 & 5,21 & 3,40 \\
\hline 55,32 & 761,20 & 46,60 & 42,18 & 34,70 & 31,72 & 28,28 & 25,22 & 22,43 & 17,75 & 14,17 & 9,51 \\
\hline 70,42 & 1402,60 & 198,60 & 12,62 & 9,05 & 7,86 & 6,80 & 5,97 & 5,26 & 4,11 & 3,27 & 2,21 \\
\hline 72,83 & 1687,50 & 164,50 & 12,55 & 9,33 & 8,36 & 7,42 & 6,66 & 5,99 & 4,84 & 3,95 & 2,73 \\
\hline 69,09 & 1859,30 & 125,70 & 14,39 & 11,15 & 10,23 & 9,25 & 8,40 & 7,62 & 6,26 & 5,17 & 3,62 \\
\hline 31,76 & 685,40 & 78,60 & 46,13 & 35,89 & 29,89 & 23,38 & 18,44 & 14,78 & 10,12 & 7,58 & 5,11 \\
\hline 48,83 & 827,40 & 193,20 & 19,65 & 13,52 & 11,11 & 8,87 & 7,21 & 5,94 & 4,20 & 3,17 & 2,12 \\
\hline 62,39 & 1501,20 & 132,60 & 16,08 & 12,53 & 11,26 & 9,94 & 8,83 & 7,84 & 6,19 & 4,95 & 3,34 \\
\hline
\end{tabular}




\begin{tabular}{|c|c|c|c|c|c|c|c|c|c|c|c|}
\hline & & & \multicolumn{9}{|c|}{ Deflexões $\left(\times 10^{-4} \mathrm{~cm}\right)$} \\
\hline e1 (cm) & Meq (MPa) & Ms (MPa) & D0 & D25 & D40 & D60 & D80 & D100 & D140 & D180 & D260 \\
\hline 22,38 & 1902,20 & 103,60 & 35,61 & 28,97 & 23,98 & 18,39 & 14,19 & 11,18 & 7,54 & 5,65 & 3,85 \\
\hline 42,58 & 1416,50 & 118,10 & 22,27 & 18,27 & 16,09 & 13,62 & 11,52 & 9,76 & 7,12 & 5,39 & 3,52 \\
\hline 70,09 & 1480,10 & 153,60 & 14,08 & 10,51 & 9,36 & 8,26 & 7,37 & 6,58 & 5,25 & 4,24 & 2,90 \\
\hline 79,10 & 1717,80 & 138,50 & 13,18 & 9,73 & 8,83 & 7,97 & 7,27 & 6,63 & 5,52 & 4,61 & 3,29 \\
\hline 52,26 & 1558,50 & 194,20 & 14,08 & 10,80 & 9,39 & 7,96 & 6,79 & 5,80 & 4,30 & 3,30 & 2,17 \\
\hline 45,27 & 1350,80 & 169,40 & 17,62 & 13,63 & 11,74 & 9,75 & 8,13 & 6,81 & 4,90 & 3,71 & 2,44 \\
\hline 35,50 & 307,20 & 153,80 & 39,68 & 22,98 & 16,87 & 11,98 & 9,03 & 7,12 & 4,91 & 3,78 & 2,64 \\
\hline 77,45 & 1100,60 & 92,30 & 20,32 & 15,05 & 13,63 & 12,26 & 11,14 & 10,13 & 8,38 & 6,96 & 4,93 \\
\hline 85,77 & 878,50 & 73,10 & 24,41 & 17,61 & 15,91 & 14,40 & 13,18 & 12,09 & 10,18 & 8,60 & 6,25 \\
\hline 65,53 & 577,10 & 44,30 & 44,23 & 34,48 & 31,33 & 28,01 & 25,18 & 22,61 & 18,22 & 14,80 & 10,15 \\
\hline 60,21 & 1758,60 & 87,00 & 19,86 & 16,17 & 15,04 & 13,66 & 12,41 & 11,24 & 9,20 & 7,54 & 5,22 \\
\hline 40,91 & 1186,30 & 147,50 & 21,48 & 16,67 & 14,24 & 11,64 & 9,55 & 7,89 & 5,58 & 4,19 & 2,77 \\
\hline 85,03 & 355,70 & 126,30 & 31,97 & 18,69 & 14,65 & 11,72 & 9,86 & 8,45 & 6,38 & 5,01 & 3,41 \\
\hline 83,44 & 469,00 & 70,90 & 34,24 & 23,37 & 20,17 & 17,49 & 15,53 & 13,88 & 11,15 & 9,08 & 6,31 \\
\hline 81,70 & 239,00 & 47,70 & 59,78 & 39,31 & 33,02 & 27,97 & 24,41 & 21,49 & 16,83 & 13,48 & 9,22 \\
\hline 85,45 & 707,50 & 43,10 & 36,10 & 26,64 & 24,46 & 22,54 & 20,89 & 19,38 & 16,63 & 14,29 & 10,62 \\
\hline 24,07 & 476,70 & 136,60 & 41,58 & 26,93 & 19,73 & 13,61 & 10,03 & 7,85 & 5,45 & 4,22 & 2,95 \\
\hline 88,91 & 1670,20 & 195,50 & 10,60 & 7,34 & 6,47 & 5,73 & 5,17 & 4,70 & 3,89 & 3,24 & 2,32 \\
\hline 81,50 & 1542,60 & 23,60 & 38,27 & 32,24 & 29,55 & 28,60 & 27,68 & 26,57 & 24,32 & 22,16 & 18,22 \\
\hline 38,47 & 1441,50 & 81,70 & 29,93 & 25,64 & 22,88 & 19,55 & 16,64 & 14,15 & 10,37 & 7,85 & 5,09 \\
\hline 70,41 & 986,00 & 50,60 & 31,76 & 24,77 & 23,08 & 21,20 & 19,50 & 17,91 & 15,05 & 12,66 & 9,08 \\
\hline 56,90 & 287,50 & 57,10 & 57,26 & 40,13 & 33,71 & 27,85 & 23,38 & 19,76 & 14,45 & 11,06 & 7,33 \\
\hline 84,75 & 668,10 & 28,30 & 47,46 & 35,87 & 33,30 & 31,28 & 29,35 & 27,52 & 24,11 & 21,07 & 16,12 \\
\hline 43,32 & 233,60 & 39,90 & 87,60 & 64,43 & 54,00 & 43,46 & 35,32 & 29,02 & 20,41 & 15,35 & 10,23 \\
\hline 42,75 & 409,10 & 163,90 & 31,77 & 19,43 & 14,91 & 11,10 & 8,60 & 6,87 & 4,74 & 3,60 & 2,48 \\
\hline 63,07 & 1343,40 & 117,70 & 17,95 & 13,96 & 12,56 & 11,11 & 9,88 & 8,79 & 6,96 & 5,57 & 3,77 \\
\hline 47,29 & 852,80 & 195,40 & 19,54 & 13,52 & 11,11 & 8,85 & 7,17 & 5,88 & 4,14 & 3,13 & 2,09 \\
\hline 48,67 & 1518,90 & 91,40 & 23,15 & 19,47 & 17,66 & 15,54 & 13,65 & 11,96 & 9,21 & 7,20 & 4,74 \\
\hline 61,19 & 554,10 & 50,90 & 43,04 & 33,54 & 30,03 & 26,42 & 23,37 & 20,66 & 16,20 & 12,88 & 8,65 \\
\hline 77,76 & 935,90 & 133,50 & 18,10 & 12,67 & 11,00 & 9,56 & 8,47 & 7,53 & 6,00 & 4,85 & 3,33 \\
\hline 53,59 & 1700,70 & 28,80 & 45,65 & 37,91 & 36,61 & 34,53 & 32,26 & 30,04 & 25,83 & 22,10 & 16,20 \\
\hline 50,80 & 1650,10 & 100,30 & 20,60 & 17,21 & 15,65 & 13,83 & 12,21 & 10,76 & 8,35 & 6,58 & 4,35 \\
\hline 75,88 & 811,90 & 47,20 & 34,36 & 26,15 & 24,20 & 22,19 & 20,44 & 18,81 & 15,89 & 13,43 & 9,72 \\
\hline 45,29 & 970,70 & 110,30 & 25,94 & 20,37 & 17,67 & 14,78 & 12,40 & 10,43 & 7,56 & 5,72 & 3,75 \\
\hline 69,71 & 1023,50 & 27,20 & 46,92 & 37,15 & 35,31 & 33,45 & 31,44 & 29,48 & 25,76 & 22,42 & 16,96 \\
\hline 71,59 & 1131,10 & 125,40 & 17,61 & 12,98 & 11,51 & 10,13 & 9,02 & 8,05 & 6,42 & 5,19 & 3,55 \\
\hline 32,94 & 1401,60 & 81,70 & 34,11 & 28,92 & 25,34 & 21,03 & 17,40 & 14,44 & 10,21 & 7,62 & 4,98 \\
\hline 38,65 & 634,90 & 89,10 & 38,66 & 29,43 & 24,78 & 19,84 & 16,01 & 13,06 & 9,10 & 6,82 & 4,55 \\
\hline 72,35 & 1618,60 & 184,00 & 12,09 & 8,86 & 7,84 & 6,89 & 6,14 & 5,48 & 4,37 & 3,54 & 2,42 \\
\hline 68,35 & 218,00 & 134,20 & 45,45 & 23,96 & 17,46 & 12,90 & 10,21 & 8,34 & 5,89 & 4,52 & 3,10 \\
\hline 38,35 & 918,60 & 162,20 & 23,38 & 17,12 & 14,13 & 11,09 & 8,82 & 7,13 & 4,93 & 3,70 & 2,49 \\
\hline 81,11 & 494,60 & 56,70 & 37,54 & 26,69 & 23,60 & 20,86 & 18,75 & 16,91 & 13,79 & 11,35 & 7,96 \\
\hline 24,10 & 224,80 & 142,30 & 51,30 & 27,37 & 18,71 & 12,57 & 9,34 & 7,41 & 5,19 & 4,05 & 2,86 \\
\hline 28,75 & 490,20 & 136,20 & 38,16 & 25,35 & 19,25 & 13,75 & 10,29 & 8,06 & 5,54 & 4,26 & 2,96 \\
\hline 37,38 & 1525,00 & 162,80 & 19,45 & 15,42 & 13,19 & 10,72 & 8,74 & 7,18 & 5,04 & 3,77 & 2,49 \\
\hline 59,05 & 810,40 & 50,20 & 37,88 & 30,71 & 28,16 & 25,25 & 22,66 & 20,31 & 16,27 & 13,14 & 8,93 \\
\hline 61,70 & 239,50 & 148,10 & 41,84 & 22,20 & 16,17 & 11,89 & 9,34 & 7,57 & 5,30 & 4,06 & 2,79 \\
\hline 66,88 & 1186,10 & 119,40 & 18,27 & 13,83 & 12,34 & 10,87 & 9,66 & 8,60 & 6,82 & 5,48 & 3,72 \\
\hline 47,16 & 695,20 & 181,80 & 22,40 & 15,07 & 12,22 & 9,61 & 7,72 & 6,30 & 4,42 & 3,34 & 2,25 \\
\hline 22,93 & 348,90 & 42,30 & 107,82 & 80,05 & 62,50 & 45,14 & 33,67 & 26,19 & 17,85 & 13,66 & 9,46 \\
\hline 79,23 & 1673,00 & 75,50 & 18,97 & 14,45 & 13,48 & 12,56 & 11,71 & 10,91 & 9,43 & 8,13 & 6,08 \\
\hline 64,82 & 1937,50 & 65,90 & 22,03 & 17,67 & 16,75 & 15,59 & 14,46 & 13,37 & 11,38 & 9,66 & 7,01 \\
\hline 42,32 & 1627,50 & 173,90 & 16,76 & 13,30 & 11,52 & 9,58 & 7,97 & 6,67 & 4,78 & 3,60 & 2,36 \\
\hline 64,58 & 240,20 & 30,60 & 80,83 & 59,89 & 52,41 & 45,35 & 39,67 & 34,78 & 26,91 & 21,24 & 14,22 \\
\hline 58,02 & 584,80 & 148,10 & 24,86 & 16,54 & 13,56 & 10,99 & 9,11 & 7,64 & 5,52 & 4,22 & 2,81 \\
\hline 70,08 & 477,10 & 104,10 & 30,36 & 20,26 & 16,90 & 14,10 & 12,07 & 10,41 & 7,87 & 6,15 & 4,12 \\
\hline 70,42 & 1440,00 & 100,20 & 18,09 & 13,93 & 12,76 & 11,53 & 10,48 & 9,51 & 7,83 & 6,47 & 4,54 \\
\hline 80,24 & 1686,50 & 30,60 & 32,29 & 26,36 & 24,40 & 23,58 & 22,67 & 21,65 & 19,64 & 17,74 & 14,35 \\
\hline 42,29 & 1314,30 & 78,00 & 29,74 & 25,33 & 22,74 & 19,66 & 16,94 & 14,57 & 10,87 & 8,33 & 5,41 \\
\hline 78,15 & 511,30 & 90,10 & 29,96 & 20,31 & 17,29 & 14,78 & 12,94 & 11,41 & 8,95 & 7,16 & 4,88 \\
\hline 37,20 & 1731,90 & 149,20 & 19,63 & 16,02 & 13,90 & 11,47 & 9,47 & 7,85 & 5,56 & 4,16 & 2,73 \\
\hline 45,37 & 1989,10 & 88,40 & 22,46 & 19,45 & 17,84 & 15,83 & 13,98 & 12,31 & 9,55 & 7,50 & 4,93 \\
\hline 63,67 & 1662,70 & 38,60 & 33,49 & 26,96 & 25,80 & 24,40 & 22,88 & 21,39 & 18,57 & 16,05 & 11,99 \\
\hline 53,19 & 1968,40 & 82,70 & 21,23 & 17,90 & 16,67 & 15,09 & 13,63 & 12,26 & 9,89 & 8,02 & 5,45 \\
\hline 41,15 & 764,80 & 197,90 & 21,73 & 14,75 & 11,84 & 9,12 & 7,18 & 5,78 & 3,99 & 3,01 & 2,05 \\
\hline 59,12 & 573,80 & 186,30 & 22,54 & 14,14 & 11,29 & 8,94 & 7,32 & 6,07 & 4,35 & 3,32 & 2,23 \\
\hline 82,22 & 936,90 & 103,20 & 20,10 & 14,30 & 12,68 & 11,25 & 10,14 & 9,17 & 7,52 & 6,21 & 4,38 \\
\hline 85,93 & 1387,80 & 155,50 & 13,22 & 9,28 & 8,21 & 7,28 & 6,58 & 5,97 & 4,93 & 4,10 & 2,91 \\
\hline 36,55 & 1997,40 & 73,60 & 29,64 & 26,32 & 23,89 & 20,80 & 17,99 & 15,51 & 11,60 & 8,87 & 5,74 \\
\hline 84,11 & 1048,50 & 83,40 & 21,14 & 15,38 & 13,95 & 12,64 & 11,58 & 10,63 & 8,95 & 7,55 & 5,48 \\
\hline 68,01 & 1239,10 & 39,20 & 35,13 & 27,87 & 26,45 & 24,81 & 23,15 & 21,55 & 18,57 & 15,95 & 11,81 \\
\hline 59,63 & 1281,30 & 95,00 & 21,38 & 17,08 & 15,50 & 13,77 & 12,27 & 10,92 & 8,65 & 6,93 & 4,67 \\
\hline 27,94 & 1236,20 & 38,10 & 67,39 & 59,72 & 53,09 & 44,67 & 37,32 & 31,17 & 22,17 & 16,52 & 10,70 \\
\hline 58,87 & 517,60 & 25,60 & 68,33 & 55,97 & 51,98 & 47,13 & 42,72 & 38,62 & 31,44 & 25,69 & 17,69 \\
\hline 73,17 & 1426,10 & 138,50 & 14,85 & 11,03 & 9,88 & 8,78 & 7,89 & 7,10 & 5,74 & 4,69 & 3,25 \\
\hline 33,56 & 1687,90 & 48,00 & 44,56 & 40,22 & 36,64 & 31,97 & 27,68 & 23,89 & 17,85 & 13,63 & 8,79 \\
\hline 23,17 & 671,80 & 55,10 & 73,55 & 57,52 & 46,47 & 34,72 & 26,37 & 20,63 & 13,94 & 10,55 & 7,25 \\
\hline 54,52 & 1804,50 & 71,00 & 23,81 & 19,98 & 18,70 & 17,02 & 15,46 & 13,99 & 11,40 & 9,31 & 6,40 \\
\hline 41,43 & 1191,20 & 46,50 & 43,55 & 38,33 & 35,11 & 31,01 & 27,24 & 23,85 & 18,29 & 14,23 & 9,30 \\
\hline 69,33 & 233,50 & 156,40 & 41,32 & 21,30 & 15,30 & 11,17 & 8,78 & 7,15 & 5,04 & 3,86 & 2,66 \\
\hline 77,88 & 1592,70 & 35,40 & 31,10 & 24,71 & 23,13 & 22,22 & 21,18 & 20,09 & 17,99 & 16,04 & 12,67 \\
\hline 35,14 & 588,90 & 89,00 & 42,19 & 31,66 & 26,19 & 20,46 & 16,17 & 13,00 & 8,94 & 6,71 & 4,53 \\
\hline
\end{tabular}




\begin{tabular}{|c|c|c|c|c|c|c|c|c|c|c|c|}
\hline & & & \multicolumn{9}{|c|}{ Deflexões $\left(\times 10^{-4} \mathrm{~cm}\right)$} \\
\hline e1 (cm) & Meq (MPa) & Ms (MPa) & D0 & D25 & D40 & D60 & D80 & D100 & D140 & D180 & D260 \\
\hline 36,14 & 1361,30 & 82,80 & 31,78 & 26,98 & 23,83 & 20,06 & 16,82 & 14,12 & 10,15 & 7,63 & 4,96 \\
\hline 74,60 & 226,10 & 66,00 & 55,68 & 34,66 & 27,97 & 22,77 & 19,24 & 16,46 & 12,33 & 9,62 & 6,47 \\
\hline 75,34 & 1852,20 & 151,90 & 12,38 & 9,26 & 8,40 & 7,55 & 6,85 & 6,22 & 5,13 & 4,25 & 2,99 \\
\hline 73,64 & 1196,20 & 96,40 & 19,58 & 14,75 & 13,39 & 12,04 & 10,91 & 9,89 & 8,13 & 6,71 & 4,71 \\
\hline 55,19 & 1506,30 & 45,50 & 33,79 & 28,26 & 26,81 & 24,73 & 22,71 & 20,79 & 17,30 & 14,39 & 10,11 \\
\hline 80,82 & 906,50 & 147,00 & 17,34 & 11,81 & 10,13 & 8,73 & 7,70 & 6,84 & 5,43 & 4,39 & 3,02 \\
\hline 73,01 & 441,20 & 170,00 & 25,90 & 15,21 & 11,85 & 9,35 & 7,73 & 6,50 & 4,76 & 3,68 & 2,48 \\
\hline 34,55 & 1234,50 & 191,70 & 20,00 & 14,93 & 12,29 & 9,55 & 7,52 & 6,02 & 4,13 & 3,11 & 2,10 \\
\hline 83,10 & 748,60 & 184,10 & 17,44 & 11,01 & 9,04 & 7,52 & 6,48 & 5,65 & 4,37 & 3,48 & 2,37 \\
\hline 52,30 & 872,20 & 126,30 & 23,17 & 17,34 & 14,92 & 12,51 & 10,57 & 8,97 & 6,59 & 5,03 & 3,31 \\
\hline 51,15 & 1508,70 & 193,30 & 14,50 & 11,09 & 9,62 & 8,12 & 6,89 & 5,86 & 4,32 & 3,30 & 2,17 \\
\hline 83,06 & 1945,70 & 120,90 & 13,17 & 9,76 & 8,97 & 8,25 & 7,62 & 7,05 & 6,02 & 5,14 & 3,79 \\
\hline 33,72 & 1699,60 & 120,50 & 24,33 & 20,22 & 17,56 & 14,43 & 11,84 & 9,77 & 6,86 & 5,12 & 3,37 \\
\hline 70,84 & 589,20 & 41,20 & 43,98 & 33,79 & 30,95 & 27,98 & 25,43 & 23,11 & 19,03 & 15,74 & 11,06 \\
\hline 36,86 & 1757,80 & 148,40 & 19,72 & 16,12 & 13,99 & 11,54 & 9,52 & 7,89 & 5,59 & 4,18 & 2,75 \\
\hline 22,04 & 604,70 & 71,80 & 64,77 & 47,89 & 37,14 & 26,61 & 19,76 & 15,35 & 10,48 & 8,04 & 5,58 \\
\hline 88,83 & 1390,70 & 183,90 & 12,01 & 8,21 & 7,15 & 6,28 & 5,64 & 5,10 & 4,18 & 3,46 & 2,46 \\
\hline 75,71 & 1946,20 & 147,30 & 12,30 & 9,24 & 8,42 & 7,61 & 6,93 & 6,32 & 5,24 & 4,36 & 3,10 \\
\hline 84,59 & 1487,30 & 118,40 & 14,86 & 10,79 & 9,78 & 8,87 & 8,13 & 7,46 & 6,29 & 5,31 & 3,86 \\
\hline 22,04 & 1634,20 & 172,70 & 26,09 & 19,60 & 15,35 & 11,10 & 8,27 & 6,43 & 4,38 & 3,35 & 2,32 \\
\hline 64,73 & 1563,50 & 196,80 & 12,49 & 9,26 & 8,12 & 7,03 & 6,16 & 5,40 & 4,18 & 3,31 & 2,22 \\
\hline 36,88 & 377,80 & 36,30 & 84,56 & 67,97 & 58,49 & 47,81 & 39,13 & 32,24 & 22,67 & 16,96 & 11,19 \\
\hline 26,79 & 431,50 & 100,90 & 50,31 & 34,35 & 26,16 & 18,65 & 13,91 & 10,87 & 7,47 & 5,74 & 3,99 \\
\hline 38,20 & 890,10 & 160,70 & 23,86 & 17,40 & 14,33 & 11,22 & 8,90 & 7,18 & 4,96 & 3,73 & 2,52 \\
\hline 48,53 & 786,90 & 89,80 & 30,60 & 23,92 & 20,85 & 17,62 & 14,93 & 12,68 & 9,32 & 7,10 & 4,66 \\
\hline 39,13 & 769,00 & 142,00 & 26,89 & 19,53 & 16,10 & 12,64 & 10,06 & 8,13 & 5,63 & 4,23 & 2,85 \\
\hline 80,65 & 745,50 & 117,10 & 21,41 & 14,66 & 12,61 & 10,89 & 9,63 & 8,56 & 6,81 & 5,51 & 3,79 \\
\hline 57,41 & 1074,60 & 78,60 & 26,25 & 21,16 & 19,18 & 16,99 & 15,09 & 13,38 & 10,53 & 8,38 & 5,62 \\
\hline 50,97 & 1874,80 & 75,30 & 23,56 & 20,07 & 18,68 & 16,87 & 15,19 & 13,63 & 10,94 & 8,81 & 5,96 \\
\hline 34,83 & 1176,20 & 197,30 & 19,90 & 14,68 & 12,02 & 9,30 & 7,29 & 5,84 & 4,00 & 3,01 & 2,04 \\
\hline 42,25 & 1791,00 & 40,70 & 41,08 & 36,52 & 34,38 & 31,25 & 28,23 & 25,39 & 20,40 & 16,43 & 11,05 \\
\hline 60,14 & 1185,70 & 101,10 & 21,19 & 16,69 & 15,01 & 13,24 & 11,73 & 10,39 & 8,16 & 6,50 & 4,36 \\
\hline 69,64 & 888,00 & 80,40 & 25,36 & 19,21 & 17,28 & 15,37 & 13,79 & 12,38 & 9,97 & 8,11 & 5,58 \\
\hline 73,93 & 1044,90 & 138,50 & 17,15 & 12,28 & 10,73 & 9,34 & 8,27 & 7,35 & 5,83 & 4,69 & 3,20 \\
\hline 46,09 & 1356,60 & 105,90 & 22,92 & 18,89 & 16,82 & 14,47 & 12,43 & 10,68 & 7,97 & 6,11 & 3,99 \\
\hline 40,78 & 1202,00 & 119,80 & 24,26 & 19,45 & 16,87 & 14,01 & 11,64 & 9,71 & 6,94 & 5,22 & 3,43 \\
\hline 44,74 & 1665,20 & 153,80 & 17,22 & 13,93 & 12,24 & 10,37 & 8,78 & 7,46 & 5,46 & 4,15 & 2,71 \\
\hline 34,72 & 870,40 & 124,80 & 29,73 & 22,48 & 18,64 & 14,59 & 11,54 & 9,28 & 6,38 & 4,79 & 3,23 \\
\hline 65,52 & 981,20 & 108,00 & 21,24 & 15,99 & 14,16 & 12,39 & 10,94 & 9,67 & 7,59 & 6,05 & 4,08 \\
\hline 89,66 & 1540,80 & 147,90 & 12,66 & 8,92 & 7,97 & 7,16 & 6,53 & 5,98 & 5,02 & 4,24 & 3,08 \\
\hline 30,76 & 394,10 & 93,50 & 50,98 & 35,11 & 27,37 & 20,06 & 15,20 & 11,95 & 8,17 & 6,24 & 4,31 \\
\hline 51,95 & 766,10 & 119,90 & 25,39 & 18,77 & 16,04 & 13,36 & 11,23 & 9,49 & 6,92 & 5,27 & 3,48 \\
\hline 55,44 & 1356,50 & 198,70 & 14,36 & 10,66 & 9,19 & 7,75 & 6,60 & 5,64 & 4,19 & 3,22 & 2,12 \\
\hline 67,47 & 1685,40 & 196,20 & 11,84 & 8,79 & 7,76 & 6,78 & 5,99 & 5,30 & 4,16 & 3,32 & 2,25 \\
\hline 39,47 & 1896,90 & 142,40 & 18,71 & 15,55 & 13,69 & 11,53 & 9,69 & 8,16 & 5,90 & 4,45 & 2,90 \\
\hline 27,28 & 1995,80 & 28,30 & 71,73 & 66,66 & 61,26 & 53,88 & 46,92 & 40,65 & 30,53 & 23,34 & 14,98 \\
\hline 63,92 & 274,80 & 148,00 & 38,01 & 20,85 & 15,53 & 11,66 & 9,28 & 7,59 & 5,36 & 4,10 & 2,80 \\
\hline 56,90 & 309,00 & 50,00 & 59,06 & 42,99 & 36,78 & 30,89 & 26,25 & 22,40 & 16,60 & 12,77 & 8,44 \\
\hline 40,30 & 1539,20 & 106,50 & 23,90 & 20,05 & 17,77 & 15,11 & 12,80 & 10,85 & 7,92 & 6,00 & 3,90 \\
\hline 64,93 & 455,90 & 95,30 & 33,35 & 22,73 & 19,04 & 15,86 & 13,50 & 11,56 & 8,64 & 6,70 & 4,46 \\
\hline 84,04 & 814,80 & 33,80 & 39,55 & 29,96 & 27,85 & 26,17 & 24,56 & 23,03 & 20,17 & 17,63 & 13,47 \\
\hline 84,54 & 492,00 & 147,20 & 24,55 & 14,87 & 11,92 & 9,72 & 8,28 & 7,16 & 5,47 & 4,33 & 2,94 \\
\hline 58,44 & 607,40 & 36,70 & 51,57 & 41,96 & 38,50 & 34,53 & 31,00 & 27,77 & 22,24 & 17,95 & 12,18 \\
\hline 31,05 & 1042,40 & 90,50 & 36,98 & 29,79 & 25,23 & 20,08 & 16,03 & 12,95 & 8,91 & 6,64 & 4,44 \\
\hline 79,72 & 366,80 & 23,10 & 70,80 & 53,00 & 48,78 & 44,69 & 41,17 & 37,95 & 32,15 & 27,27 & 19,87 \\
\hline 25,88 & 1842,50 & 115,70 & 29,80 & 24,41 & 20,54 & 16,11 & 12,68 & 10,12 & 6,88 & 5,13 & 3,46 \\
\hline 53,18 & 1757,60 & 129,50 & 16,71 & 13,65 & 12,31 & 10,82 & 9,51 & 8,35 & 6,46 & 5,07 & 3,36 \\
\hline 21,54 & 216,80 & 101,60 & 67,12 & 38,33 & 26,44 & 17,69 & 13,08 & 10,35 & 7,28 & 5,67 & 3,99 \\
\hline 81,80 & 444,80 & 199,20 & 23,91 & 13,36 & 10,17 & 7,90 & 6,50 & 5,48 & 4,04 & 3,14 & 2,14 \\
\hline 44,28 & 1136,70 & 195,70 & 17,70 & 12,99 & 10,90 & 8,80 & 7,17 & 5,91 & 4,17 & 3,14 & 2,09 \\
\hline 30,09 & 534,20 & 127,20 & 37,92 & 26,06 & 20,23 & 14,75 & 11,15 & 8,75 & 5,99 & 4,57 & 3,17 \\
\hline 51,12 & 927,70 & 178,10 & 18,98 & 13,53 & 11,36 & 9,28 & 7,69 & 6,42 & 4,62 & 3,50 & 2,32 \\
\hline 55,19 & 756,60 & 142,30 & 22,67 & 16,11 & 13,59 & 11,24 & 9,42 & 7,95 & 5,80 & 4,43 & 2,93 \\
\hline 59,36 & 808,00 & 151,10 & 20,60 & 14,52 & 12,28 & 10,24 & 8,68 & 7,40 & 5,47 & 4,21 & 2,79 \\
\hline 28,92 & 497,50 & 37,30 & 89,96 & 73,24 & 62,00 & 49,15 & 39,08 & 31,44 & 21,53 & 16,05 & 10,75 \\
\hline 45,33 & 1862,10 & 35,40 & 42,74 & 37,24 & 35,56 & 32,81 & 30,08 & 27,46 & 22,70 & 18,73 & 12,98 \\
\hline 20,42 & 1531,90 & 38,70 & 81,62 & 70,21 & 60,27 & 48,18 & 38,35 & 30,78 & 20,90 & 15,46 & 10,32 \\
\hline 34,69 & 813,50 & 130,80 & 29,62 & 21,99 & 18,07 & 14,01 & 11,01 & 8,82 & 6,05 & 4,55 & 3,08 \\
\hline 24,12 & 713,60 & 73,70 & 57,24 & 43,78 & 35,01 & 25,92 & 19,61 & 15,32 & 10,38 & 7,89 & 5,43 \\
\hline 56,58 & 1449,00 & 138,40 & 16,80 & 13,22 & 11,77 & 10,25 & 8,96 & 7,83 & 6,02 & 4,72 & 3,13 \\
\hline 30,32 & 896,40 & 97,50 & 37,68 & 29,42 & 24,42 & 18,99 & 14,90 & 11,90 & 8,12 & 6,08 & 4,12 \\
\hline 47,72 & 451,60 & 117,30 & 34,44 & 23,19 & 18,83 & 14,85 & 11,96 & 9,78 & 6,86 & 5,18 & 3,48 \\
\hline 23,72 & 1777,40 & 65,00 & 48,00 & 40,97 & 35,22 & 28,28 & 22,65 & 18,27 & 12,49 & 9,25 & 6,16 \\
\hline 59,64 & 1112,90 & 82,30 & 24,65 & 19,70 & 17,87 & 15,89 & 14,16 & 12,61 & 9,99 & 8,00 & 5,40 \\
\hline 46,54 & 343,70 & 199,60 & 31,17 & 17,13 & 12,55 & 9,10 & 6,99 & 5,58 & 3,85 & 2,95 & 2,05 \\
\hline 82,61 & 1232,80 & 174,80 & 13,47 & 9,29 & 8,07 & 7,03 & 6,26 & 5,60 & 4,51 & 3,68 & 2,56 \\
\hline 81,24 & 312,90 & 23,00 & 75,25 & 55,54 & 50,66 & 46,05 & 42,22 & 38,76 & 32,60 & 27,50 & 19,89 \\
\hline 54,22 & 1139,90 & 66,20 & 29,46 & 24,41 & 22,36 & 19,95 & 17,79 & 15,83 & 12,52 & 9,99 & 6,70 \\
\hline 60,21 & 1264,60 & 147,90 & 16,64 & 12,63 & 11,11 & 9,61 & 8,38 & 7,31 & 5,61 & 4,40 & 2,92 \\
\hline 48,80 & 878,20 & 38,20 & 49,13 & 42,11 & 38,90 & 34,84 & 31,10 & 27,67 & 21,85 & 17,40 & 11,60 \\
\hline 30,85 & 1235,00 & 135,20 & 26,92 & 21,03 & 17,50 & 13,65 & 10,74 & 8,59 & 5,87 & 4,40 & 2,97 \\
\hline 59,97 & 368,40 & 29,10 & 71,37 & 56,65 & 51,20 & 45,36 & 40,32 & 35,81 & 28,27 & 22,58 & 15,20 \\
\hline
\end{tabular}




\begin{tabular}{|c|c|c|c|c|c|c|c|c|c|c|c|}
\hline \multirow[b]{2}{*}{ e1 (cm) } & & & & & & & ões (x1 & m) & & & \\
\hline & Meq (MPa) & Ms (MPa) & D0 & D25 & D40 & D60 & D80 & D100 & D140 & D180 & D260 \\
\hline 77,42 & 1568,60 & 109,00 & 15,86 & 11,90 & 10,90 & 9,91 & 9,08 & 8,32 & 6,96 & 5,85 & 4,20 \\
\hline 40,34 & 342,50 & 143,20 & 37,79 & 22,91 & 17,41 & 12,80 & 9,83 & 7,81 & 5,37 & 4,10 & 2,84 \\
\hline 45,57 & 785,30 & 188,50 & 21,06 & 14,46 & 11,80 & 9,31 & 7,48 & 6,10 & 4,26 & 3,22 & 2,16 \\
\hline 69,84 & 224,70 & 92,10 & 50,25 & 29,23 & 22,62 & 17,67 & 14,48 & 12,09 & 8,76 & 6,74 & 4,55 \\
\hline 45,20 & 1389,40 & 197,10 & 15,98 & 12,12 & 10,34 & 8,51 & 7,04 & 5,86 & 4,19 & 3,16 & 2,09 \\
\hline 53,89 & 209,80 & 62,60 & 66,03 & 42,66 & 34,31 & 27,15 & 22,06 & 18,19 & 12,90 & 9,79 & 6,58 \\
\hline 56,98 & 1323,70 & 130,40 & 18,01 & 14,10 & 12,53 & 10,90 & 9,52 & 8,32 & 6,39 & 5,01 & 3,32 \\
\hline 22,82 & 1566,50 & 175,60 & 25,50 & 19,12 & 15,01 & 10,90 & 8,15 & 6,34 & 4,31 & 3,30 & 2,28 \\
\hline 44,79 & 1732,00 & 45,80 & 36,80 & 32,36 & 30,42 & 27,64 & 24,98 & 22,47 & 18,09 & 14,59 & 9,85 \\
\hline 26,93 & 411,50 & 24,00 & 136,01 & 112,90 & 96,11 & 76,52 & 60,96 & 49,07 & 33,56 & 24,96 & 16,69 \\
\hline 23,53 & 1346,50 & 68,50 & 50,78 & 41,94 & 35,22 & 27,48 & 21,51 & 17,09 & 11,57 & 8,63 & 5,83 \\
\hline 67,96 & 655,40 & 57,90 & 35,26 & 26,93 & 24,26 & 21,57 & 19,33 & 17,32 & 13,92 & 11,28 & 7,74 \\
\hline 30,14 & 442,90 & 194,90 & 31,01 & 18,56 & 13,56 & 9,48 & 7,07 & 5,56 & 3,84 & 2,97 & 2,08 \\
\hline 29,32 & 1139,60 & 32,80 & 73,34 & 65,66 & 58,91 & 50,24 & 42,50 & 35,90 & 25,94 & 19,45 & 12,54 \\
\hline 82,53 & 1164,00 & 55,60 & 25,77 & 19,42 & 18,03 & 16,81 & 15,68 & 14,62 & 12,67 & 10,96 & 8,25 \\
\hline 84,66 & 1793,60 & 69,00 & 18,71 & 14,23 & 13,23 & 12,48 & 11,75 & 11,04 & 9,72 & 8,54 & 6,58 \\
\hline 89,40 & 674,80 & 99,80 & 23,45 & 15,77 & 13,61 & 11,85 & 10,58 & 9,52 & 7,75 & 6,39 & 4,51 \\
\hline 47,36 & 546,90 & 178,80 & 25,41 & 16,24 & 12,86 & 9,91 & 7,87 & 6,38 & 4,44 & 3,36 & 2,28 \\
\hline 46,59 & 1715,80 & 85,50 & 23,76 & 20,37 & 18,61 & 16,46 & 14,51 & 12,76 & 9,87 & 7,73 & 5,09 \\
\hline 88,57 & 1193,30 & 142,20 & 14,74 & 10,20 & 8,97 & 7,93 & 7,16 & 6,49 & 5,36 & 4,47 & 3,19 \\
\hline 67,33 & 1288,60 & 95,70 & 19,91 & 15,45 & 14,08 & 12,64 & 11,40 & 10,28 & 8,35 & 6,83 & 4,72 \\
\hline 23,49 & 692,40 & 38,70 & 92,59 & 75,72 & 63,14 & 48,87 & 38,02 & 30,10 & 20,34 & 15,21 & 10,32 \\
\hline 80,43 & 321,20 & 69,80 & 43,14 & 28,04 & 23,35 & 19,62 & 17,01 & 14,89 & 11,56 & 9,20 & 6,26 \\
\hline 69,59 & 1262,40 & 27,70 & 43,06 & 34,28 & 32,58 & 31,11 & 29,41 & 27,72 & 24,47 & 21,50 & 16,52 \\
\hline 54,12 & 1384,30 & 53,30 & 31,60 & 26,57 & 24,88 & 22,66 & 20,57 & 18,62 & 15,17 & 12,39 & 8,51 \\
\hline 73,62 & 1306,80 & 115,20 & 17,04 & 12,75 & 11,50 & 10,28 & 9,28 & 8,39 & 6,84 & 5,62 & 3,92 \\
\hline 65,37 & 777,90 & 45,70 & 38,52 & 30,51 & 28,18 & 25,56 & 23,23 & 21,09 & 17,31 & 14,27 & 9,95 \\
\hline 73,68 & 1437,00 & 29,60 & 37,78 & 30,12 & 28,39 & 27,28 & 25,95 & 24,59 & 21,95 & 19,50 & 15,29 \\
\hline 25,14 & 1060,30 & 180,50 & 26,38 & 18,89 & 14,61 & 10,51 & 7,84 & 6,12 & 4,18 & 3,21 & 2,22 \\
\hline 80,44 & 402,60 & 76,00 & 36,54 & 24,33 & 20,56 & 17,50 & 15,30 & 13,48 & 10,58 & 8,47 & 5,79 \\
\hline 79,73 & 551,30 & 72,60 & 31,64 & 22,24 & 19,44 & 17,01 & 15,16 & 13,57 & 10,92 & 8,90 & 6,17 \\
\hline 44,24 & 1279,50 & 23,00 & 65,72 & 57,50 & 54,93 & 50,67 & 46,44 & 42,37 & 34,99 & 28,83 & 19,95 \\
\hline 81,79 & 1806,70 & 185,70 & 10,83 & 7,77 & 6,93 & 6,17 & 5,58 & 5,06 & 4,16 & 3,45 & 2,44 \\
\hline 37,82 & 1311,50 & 118,20 & 24,91 & 20,21 & 17,52 & 14,45 & 11,93 & 9,89 & 7,01 & 5,25 & 3,45 \\
\hline 86,41 & 1890,00 & 186,40 & 10,33 & 7,33 & 6,55 & 5,86 & 5,33 & 4,86 & 4,05 & 3,40 & 2,44 \\
\hline 70,81 & 859,60 & 106,90 & 21,93 & 15,99 & 14,04 & 12,25 & 10,84 & 9,61 & 7,59 & 6,09 & 4,14 \\
\hline 55,44 & 447,00 & 42,00 & 55,60 & 43,98 & 39,14 & 34,05 & 29,72 & 25,94 & 19,87 & 15,54 & 10,28 \\
\hline 78,58 & 1759,10 & 29,40 & 33,09 & 27,18 & 25,18 & 24,37 & 23,45 & 22,42 & 20,36 & 18,40 & 14,91 \\
\hline 46,78 & 263,40 & 25,00 & 104,07 & 83,67 & 73,66 & 62,69 & 53,40 & 45,54 & 33,60 & 25,65 & 16,77 \\
\hline 31,01 & 1697,40 & 87,30 & 32,05 & 27,39 & 23,99 & 19,86 & 16,38 & 13,55 & 9,54 & 7,10 & 4,65 \\
\hline 59,73 & 1274,50 & 89,10 & 22,24 & $\begin{array}{l}17,84 \\
\end{array}$ & 16,24 & 14,49 & 12,95 & 11,56 & 9,20 & 7,39 & 5,00 \\
\hline 47,08 & 863,10 & 157,40 & 21,85 & 15,82 & 13,27 & 10,77 & 8,84 & 7,32 & 5,20 & 3,92 & 2,61 \\
\hline 29,69 & 1011,50 & 163,70 & 26,00 & 19,11 & 15,31 & 11,47 & 8,79 & 6,93 & 4,72 & 3,57 & 2,45 \\
\hline 35,63 & 303,50 & 29,00 & 108,18 & 86,89 & 74,49 & 60,51 & 49,24 & 40,38 & 28,23 & 21,10 & 13,96 \\
\hline 59,67 & 1394,30 & 195,30 & 13,78 & 10,21 & 8,85 & 7,55 & 6,51 & 5,63 & 4,25 & 3,31 & 2,19 \\
\hline 45,79 & 442,90 & 194,20 & 27,53 & 16,38 & 12,48 & 9,30 & 7,24 & 5,80 & 4,01 & 3,05 & 2,10 \\
\hline 44,88 & 759,00 & 26,60 & 69,26 & 60,65 & 56,24 & 50,44 & 45,01 & 40,02 & 31,53 & 25,03 & 16,62 \\
\hline 62,64 & 958,30 & 169,80 & 17,41 & 12,30 & 10,46 & 8,81 & 7,54 & 6,48 & 4,87 & 3,78 & 2,51 \\
\hline 57,60 & 1013,60 & 76,30 & 27,31 & 21,94 & 19,85 & 17,57 & 15,59 & 13,81 & 10,85 & 8,63 & 5,78 \\
\hline 30,63 & 542,00 & 46,50 & 72,35 & 58,29 & 49,32 & 39,16 & 31,22 & 25,18 & 17,29 & 12,90 & 8,64 \\
\hline 81,40 & 911,10 & 168,60 & 16,22 & 10,81 & 9,15 & 7,80 & 6,84 & 6,04 & 4,75 & 3,82 & 2,62 \\
\hline 30,47 & 528,10 & 139,70 & 35,63 & 24,00 & 18,49 & 13,41 & 10,11 & 7,94 & 5,44 & 4,16 & 2,89 \\
\hline 26,13 & 1481,30 & 51,30 & 55,08 & 47,91 & 41,94 & 34,54 & 28,28 & 23,23 & 16,18 & 11,99 & 7,86 \\
\hline 50,33 & 1928,00 & 44,80 & 33,50 & 28,58 & 27,27 & 25,21 & 23,18 & 21,23 & 17,67 & 14,68 & 10,29 \\
\hline 56,66 & 1960,60 & 90,20 & 19,33 & 16,02 & 14,90 & 13,51 & 12,24 & 11,05 & 8,97 & 7,31 & 5,02 \\
\hline 45,66 & 1126,80 & 195,10 & 17,51 & 12,82 & 10,78 & 8,74 & 7,16 & 5,92 & 4,19 & 3,16 & 2,10 \\
\hline 36,65 & 1823,90 & 65,00 & 33,10 & 29,46 & 26,79 & 23,38 & 20,27 & 17,51 & 13,14 & 10,07 & 6,51 \\
\hline 54,58 & 1371,40 & 112,60 & 19,78 & 15,92 & 14,28 & 12,51 & 10,97 & 9,62 & 7,42 & 5,82 & 3,86 \\
\hline 22,77 & 841,50 & 179,70 & 29,84 & 20,25 & 15,04 & 10,44 & 7,68 & 5,99 & 4,15 & 3,21 & 2,24 \\
\hline 23,72 & 784,20 & 45,20 & 79,38 & 64,80 & 54,01 & 41,79 & 32,51 & 25,74 & 17,40 & 13,01 & 8,83 \\
\hline 30,76 & 1027,30 & 150,10 & 26,81 & 20,08 & 16,33 & 12,43 & 9,62 & 7,63 & 5,20 & 3,92 & 2,68 \\
\hline 47,55 & 943,60 & 96,20 & 27,57 & 21,93 & 19,24 & 16,33 & 13,89 & 11,83 & 8,72 & 6,65 & 4,35 \\
\hline 59,12 & 1592,50 & 51,00 & 29,46 & 24,21 & 22,97 & 21,26 & 19,61 & 18,03 & 15,15 & 12,70 & 9,05 \\
\hline 30,69 & 427,10 & 194,30 & 31,35 & 18,61 & 13,58 & 9,50 & 7,09 & 5,58 & 3,86 & 2,98 & 2,09 \\
\hline 63,47 & 1039,20 & 117,70 & 20,06 & 15,15 & 13,37 & 11,65 & 10,23 & 9,00 & 7,00 & 5,54 & 3,71 \\
\hline 46,10 & 1618,80 & 199,00 & 14,71 & 11,40 & 9,85 & 8,22 & 6,88 & 5,78 & 4,18 & 3,17 & 2,08 \\
\hline 46,23 & 1047,80 & 192,90 & 18,08 & 13,08 & 10,95 & 8,85 & 7,24 & 5,98 & 4,23 & 3,19 & 2,12 \\
\hline 86,53 & 1821,60 & 156,30 & 11,53 & 8,28 & 7,46 & 6,74 & 6,17 & 5,66 & 4,76 & 4,02 & 2,92 \\
\hline 54,80 & 1119,50 & 191,50 & 16,14 & 11,68 & 9,93 & 8,27 & 6,97 & 5,90 & 4,33 & 3,31 & 2,19 \\
\hline 45,03 & 1246,90 & 169,50 & 18,28 & 13,96 & 11,95 & 9,85 & 8,17 & 6,81 & 4,88 & 3,68 & 2,43 \\
\hline 23,91 & 1117,90 & 103,00 & 39,84 & 30,88 & 24,88 & 18,55 & 14,09 & 11,02 & 7,46 & 5,65 & 3,89 \\
\hline 29,35 & 1005,80 & 88,30 & 39,62 & 31,70 & 26,60 & 20,89 & 16,50 & 13,22 & 9,03 & 6,75 & 4,54 \\
\hline 31,68 & 790,70 & 21,30 & 103,42 & 93,51 & 84,89 & 73,65 & 63,37 & 54,36 & 40,22 & 30,53 & 19,65 \\
\hline 25,82 & 1422,80 & 117,50 & 32,00 & 25,41 & 20,95 & 16,06 & 12,43 & 9,83 & 6,65 & 5,00 & 3,40 \\
\hline 60,55 & 237,20 & 182,30 & 39,49 & 19,78 & 13,88 & 9,87 & 7,61 & 6,11 & 4,24 & 3,26 & 2,27 \\
\hline 26,10 & 477,60 & 96,60 & 50,88 & 35,56 & 27,30 & 19,55 & 14,59 & 11,39 & 7,81 & 5,99 & 4,16 \\
\hline 80,96 & 1333,60 & 58,90 & 23,81 & 18,08 & 16,84 & 15,74 & 14,71 & 13,73 & 11,92 & 10,33 & 7,78 \\
\hline 20,15 & 884,60 & 154,30 & 35,14 & 24,09 & 17,72 & 12,15 & 8,89 & 6,93 & 4,82 & 3,73 & 2,60 \\
\hline 72,21 & 361,40 & 143,20 & 31,39 & 18,34 & 14,24 & 11,19 & 9,22 & 7,74 & 5,65 & 4,36 & 2,94 \\
\hline 54,18 & 399,20 & 89,30 & 39,75 & 27,34 & 22,67 & 18,43 & 15,26 & 12,75 & 9,18 & 6,98 & 4,64 \\
\hline 46,84 & 1241,60 & 196,20 & 16,49 & 12,26 & 10,40 & 8,53 & 7,05 & 5,87 & 4,20 & 3,17 & 2,10 \\
\hline 71,31 & 1273,70 & 81,60 & 21,34 & 16,44 & 15,14 & 13,75 & 12,55 & 11,45 & 9,50 & 7,91 & 5,60 \\
\hline
\end{tabular}




\begin{tabular}{|c|c|c|c|c|c|c|c|c|c|c|c|}
\hline \multirow[b]{2}{*}{ e1 (cm) } & & & & & & & ões (x1 & m) & & & \\
\hline & Meq (MPa) & Ms (MPa) & D0 & D25 & D40 & D60 & D80 & D100 & D140 & D180 & D260 \\
\hline 69,71 & 939,40 & 46,40 & 34,34 & 26,89 & 25,10 & 23,08 & 21,24 & 19,53 & 16,42 & 13,82 & 9,92 \\
\hline 39,60 & 437,10 & 39,60 & 72,08 & 58,50 & 50,92 & 42,34 & 35,21 & 29,39 & 21,01 & 15,79 & 10,34 \\
\hline 68,22 & 1551,60 & 194,00 & 12,32 & 9,05 & 7,94 & 6,91 & 6,09 & 5,38 & 4,21 & 3,36 & 2,27 \\
\hline 89,33 & 877,30 & 153,90 & 16,73 & 10,99 & 9,33 & 8,01 & 7,09 & 6,33 & 5,09 & 4,16 & 2,90 \\
\hline 87,71 & 312,50 & 197,80 & 30,67 & 15,76 & 11,36 & 8,40 & 6,72 & 5,56 & 4,02 & 3,12 & 2,14 \\
\hline 21,07 & 1291,30 & 190,50 & 26,60 & 18,89 & 14,24 & 9,95 & 7,31 & 5,68 & 3,92 & 3,03 & 2,11 \\
\hline 63,14 & 1109,90 & 157,70 & 16,72 & 12,24 & 10,61 & 9,10 & 7,89 & 6,86 & 5,24 & 4,11 & 2,74 \\
\hline 89,19 & 524,00 & 179,40 & 21,75 & 12,71 & 9,99 & 8,03 & 6,79 & 5,86 & 4,47 & 3,54 & 2,42 \\
\hline 85,37 & 902,00 & 109,10 & 19,63 & 13,69 & 12,04 & 10,62 & 9,56 & 8,64 & 7,08 & 5,86 & 4,14 \\
\hline 26,46 & 1167,10 & 127,10 & 31,69 & 24,38 & 19,77 & 14,90 & 11,41 & 8,98 & 6,09 & 4,60 & 3,15 \\
\hline 87,06 & 1800,10 & 53,10 & 21,34 & 16,62 & 15,36 & 14,67 & 13,96 & 13,24 & 11,86 & 10,59 & 8,40 \\
\hline 30,96 & 1241,90 & 74,10 & 39,79 & 33,47 & 29,05 & 23,78 & 19,42 & 15,94 & 11,13 & 8,28 & 5,45 \\
\hline 21,78 & 242,30 & 105,00 & 63,32 & 36,91 & 25,66 & 17,20 & 12,70 & 10,03 & 7,05 & 5,49 & 3,85 \\
\hline 57,65 & 1293,60 & 140,90 & 17,30 & 13,36 & 11,79 & 10,20 & 8,88 & 7,73 & 5,91 & 4,62 & 3,06 \\
\hline 20,24 & 1649,50 & 146,70 & 31,01 & 23,42 & 18,26 & 13,11 & 9,72 & 7,53 & 5,13 & 3,93 & 2,73 \\
\hline 41,74 & 596,30 & 196,20 & 24,32 & 15,63 & 12,25 & 9,26 & 7,22 & 5,78 & 3,98 & 3,02 & 2,07 \\
\hline 62,78 & 1089,90 & 102,40 & 21,31 & 16,48 & 14,75 & 12,99 & 11,51 & 10,19 & 8,02 & 6,40 & 4,31 \\
\hline 30,02 & 1220,70 & 140,40 & 26,84 & 20,78 & 17,15 & 13,24 & 10,34 & 8,23 & 5,61 & 4,21 & 2,86 \\
\hline 38,90 & 414,40 & 177,10 & 31,22 & 18,84 & 14,23 & 10,38 & 7,93 & 6,29 & 4,33 & 3,31 & 2,29 \\
\hline 62,71 & 1392,20 & 162,40 & 14,83 & 11,18 & 9,85 & 8,55 & 7,49 & 6,57 & 5,09 & 4,01 & 2,68 \\
\hline 54,66 & 1128,70 & 40,70 & 40,29 & 33,81 & 31,79 & 29,06 & 26,49 & 24,06 & 19,75 & 16,22 & 11,22 \\
\hline 74,25 & 1486,20 & 143,80 & 14,18 & 10,50 & 9,41 & 8,37 & 7,53 & 6,78 & 5,51 & 4,51 & 3,13 \\
\hline 63,95 & 277,80 & 134,10 & 39,05 & 22,04 & 16,68 & 12,71 & 10,20 & 8,38 & 5,95 & 4,55 & 3,09 \\
\hline 62,21 & 894,40 & 30,50 & 48,86 & 39,62 & 37,54 & 34,82 & 32,18 & 29,66 & 25,05 & 21,12 & 15,17 \\
\hline 54,89 & 936,30 & 31,60 & 50,55 & 42,38 & 39,98 & 36,67 & 33,52 & 30,54 & 25,20 & 20,79 & 14,47 \\
\hline 36,29 & 1516,90 & 117,70 & 24,37 & 20,12 & 17,52 & 14,51 & 12,00 & 9,96 & 7,06 & 5,28 & 3,46 \\
\hline 43,33 & 1875,20 & 92,80 & 22,97 & 19,84 & 18,02 & 15,81 & 13,80 & 12,02 & 9,14 & 7,08 & 4,62 \\
\hline 61,94 & 1816,20 & 115,70 & 16,17 & 12,94 & 11,87 & 10,67 & 9,62 & 8,65 & 6,99 & 5,68 & 3,89 \\
\hline 28,60 & 206,80 & 88,40 & 68,72 & 41,33 & 30,06 & 20,87 & 15,52 & 12,20 & 8,45 & 6,54 & 4,58 \\
\hline 44,85 & 1392,60 & 35,40 & 46,93 & 41,25 & 38,84 & 35,36 & 32,01 & 28,85 & 23,29 & 18,84 & 12,75 \\
\hline 34,14 & 934,10 & 53,80 & 50,11 & 42,65 & 37,54 & 31,40 & 26,16 & 21,83 & 15,56 & 11,65 & 7,59 \\
\hline 29,75 & 992,60 & 38,10 & 68,80 & 60,22 & 53,33 & 44,73 & 37,28 & 31,09 & 22,10 & 16,48 & 10,70 \\
\hline 47,07 & 1647,40 & 126,80 & 18,77 & 15,47 & 13,81 & 11,92 & 10,29 & 8,87 & 6,65 & 5,12 & 3,35 \\
\hline 39,62 & 942,60 & 141,60 & 24,62 & 18,53 & 15,56 & 12,45 & 10,05 & 8,20 & 5,72 & 4,29 & 2,86 \\
\hline 39,30 & 1027,10 & 162,40 & 22,03 & 16,44 & 13,73 & 10,93 & 8,78 & 7,15 & 4,97 & 3,73 & 2,50 \\
\hline 46,74 & 1092,30 & 66,30 & 32,89 & 27,76 & 25,10 & 21,97 & 19,18 & 16,71 & 12,74 & 9,89 & 6,48 \\
\hline 78,14 & 1391,10 & 80,00 & 19,89 & 15,03 & 13,90 & 12,78 & 11,80 & 10,89 & 9,25 & 7,86 & 5,74 \\
\hline 20,94 & 852,30 & 150,20 & 35,45 & 24,46 & 18,14 & 12,52 & 9,18 & 7,15 & 4,96 & 3,84 & 2,67 \\
\hline 29,04 & 820,70 & 149,00 & 30,06 & 21,64 & 17,11 & 12,64 & 9,60 & 7,54 & 5,14 & 3,91 & 2,70 \\
\hline 68,79 & 708,40 & 132,30 & 22,09 & 15,22 & 12,90 & 10,89 & 9,39 & 8,15 & 6,21 & 4,87 & 3,26 \\
\hline 61,66 & 1939,20 & 50,60 & 27,09 & 21,97 & 21,00 & 19,70 & 18,36 & 17,06 & 14,63 & 12,50 & 9,17 \\
\hline 74,91 & 1573,70 & 199,90 & 11,57 & 8,30 & 7,28 & 6,36 & 5,65 & 5,04 & 4,02 & 3,25 & 2,23 \\
\hline 33,37 & 1717,30 & 139,20 & 22,28 & 18,20 & 15,65 & 12,71 & 10,33 & 8,45 & 5,89 & 4,39 & 2,91 \\
\hline 55,03 & 1404,10 & 23,20 & 55,16 & 45,51 & 43,95 & 41,60 & 38,98 & 36,39 & 31,48 & 27,09 & 20,04 \\
\hline 69,05 & 1800,60 & 81,90 & 18,96 & 14,91 & 13,97 & 12,89 & 11,89 & 10,95 & 9,25 & 7,80 & 5,63 \\
\hline 49,83 & 599,30 & 66,90 & 40,03 & 31,33 & 27,40 & 23,26 & 19,82 & 16,91 & 12,51 & 9,57 & 6,28 \\
\hline 52,92 & 659,20 & 141,90 & 24,79 & 17,23 & 14,33 & 11,65 & 9,64 & 8,04 & 5,78 & 4,39 & 2,92 \\
\hline 62,49 & 1035,80 & 154,70 & 17,55 & 12,77 & 11,03 & 9,40 & 8,12 & 7,04 & 5,35 & 4,17 & 2,78 \\
\hline 42,33 & 1687,10 & 56,90 & 33,29 & 29,43 & 27,20 & 24,28 & 21,54 & 19,04 & 14,84 & 11,68 & 7,69 \\
\hline 28,21 & 823,50 & 81,60 & 45,86 & 35,99 & 29,73 & 22,91 & 17,84 & 14,17 & 9,63 & 7,23 & 4,91 \\
\hline 88,57 & 1392,20 & 64,50 & 21,02 & 15,70 & 14,49 & 13,57 & 12,73 & 11,94 & 10,47 & 9,17 & 7,03 \\
\hline 47,33 & 1396,30 & 132,30 & 19,50 & 15,67 & 13,81 & 11,77 & 10,05 & 8,58 & 6,35 & 4,85 & 3,17 \\
\hline 86,80 & 1546,00 & 133,10 & 13,54 & 9,71 & 8,75 & 7,91 & 7,23 & 6,63 & 5,58 & 4,72 & 3,43 \\
\hline 70,57 & 1251,60 & 23,90 & 447,08 & 37,69 & 35,69 & 34,30 & 32,61 & 30,87 & 27,50 & 24,38 & 19,04 \\
\hline 74,41 & 240,80 & 65,80 & 53,72 & 33,92 & 27,59 & 22,61 & 19,19 & 16,47 & 12,39 & 9,68 & 6,51 \\
\hline 38,25 & 1873,60 & 111,20 & 22,47 & 19,15 & 17,04 & 14,50 & 12,30 & 10,43 & 7,60 & 5,75 & 3,73 \\
\hline 54,36 & 1841,50 & 105,50 & 18,36 & 15,22 & 13,95 & 12,46 & 11,12 & 9,90 & 7,84 & 6,27 & 4,21 \\
\hline 33,47 & 439,40 & 60,10 & 62,10 & 47,24 & 39,12 & 30,50 & 24,04 & 19,28 & 13,22 & 9,92 & 6,70 \\
\hline 22,60 & 1499,10 & 76,50 & 446,94 & 38,50 & 32,09 & 24,79 & 19,25 & 15,21 & 10,27 & 7,68 & 5,22 \\
\hline 29,08 & 1285,90 & 112,00 & 31,36 & 25,10 & 21,04 & 16,50 & 13,01 & 10,42 & 7,11 & 5,31 & 3,58 \\
\hline 21,73 & 1912,20 & 143,10 & 28,87 & 22,57 & 18,12 & 13,43 & 10,14 & 7,90 & 5,34 & 4,05 & 2,79 \\
\hline 45,98 & 450,00 & 35,80 & $\begin{array}{l}68,41 \\
\end{array}$ & 56,27 & 50,02 & 42,96 & 36,87 & 31,63 & 23,54 & 18,04 & 11,77 \\
\hline 33,66 & 1910,90 & 177,00 & 18,25 & 14,67 & 12,52 & 10,08 & 8,13 & 6,63 & 4,60 & 3,43 & 2,28 \\
\hline 30,15 & 411,50 & 21,10 & 135,46 & 115,47 & 100,76 & 82,98 & 68,08 & 56,07 & 39,26 & 29,20 & 19,15 \\
\hline 52,09 & 277,70 & 178,10 & 36,43 & 19,34 & 13,99 & 10,12 & 7,82 & 6,26 & 4,34 & 3,32 & 2,31 \\
\hline 37,81 & 836,60 & 151,80 & 25,45 & 18,54 & 15,25 & 11,91 & 9,43 & 7,60 & 5,24 & 3,94 & 2,66 \\
\hline 84,93 & 314,60 & 199,80 & 30,53 & 15,71 & 11,33 & 8,37 & 6,69 & 5,53 & 3,98 & 3,08 & 2,12 \\
\hline 57,44 & 1837,90 & 97,30 & 18,71 & $\begin{array}{l}15,38 \\
\end{array}$ & 14,21 & 12,81 & 11,55 & 10,38 & 8,37 & 6,78 & 4,62 \\
\hline 84,06 & 208,40 & 178,30 & 43,03 & 20,74 & 14,25 & 10,02 & 7,74 & 6,26 & 4,40 & 3,39 & 2,36 \\
\hline 56,37 & 1047,60 & 118,90 & 21,15 & 16,29 & 14,32 & 12,33 & 10,68 & 9,25 & 7,02 & 5,46 & 3,61 \\
\hline 69,69 & 1366,50 & 86,40 & 20,28 & 15,73 & 14,49 & 13,16 & 11,99 & 10,92 & 9,03 & 7,49 & 5,28 \\
\hline 27,58 & 783,30 & 92,40 & 43,50 & 33,27 & 27,01 & 20,42 & 15,69 & 12,37 & 8,40 & 6,34 & 4,34 \\
\hline 43,56 & 1024,30 & 70,70 & 34,02 & 28,51 & 25,45 & 21,89 & 18,78 & 16,10 & 11,96 & 9,15 & 5,96 \\
\hline 33,16 & 749,60 & 44,60 & 62,59 & 52,98 & 46,40 & 38,50 & 31,85 & 26,43 & 18,69 & 13,95 & 9,12 \\
\hline 26,70 & 1298,30 & 66,10 & 47,63 & 40,05 & 34,36 & 27,60 & 22,14 & 17,91 & 12,29 & 9,13 & 6,07 \\
\hline 81,30 & 200,70 & 159,70 & 45,47 & 22,30 & 15,52 & 11,05 & 8,60 & 6,98 & 4,92 & 3,80 & 2,63 \\
\hline 36,60 & 447,50 & 123,80 & 37,67 & 25,26 & 19,89 & 14,90 & 11,50 & 9,13 & 6,26 & 4,76 & 3,27 \\
\hline 63,23 & 1304,20 & 76,20 & 23,48 & 18,76 & 17,32 & 15,67 & 14,20 & 12,85 & 10,49 & 8,59 & 5,95 \\
\hline 86,70 & 1352,70 & 166,00 & 12,92 & 8,96 & 7,87 & 6,94 & 6,24 & 5,65 & 4,64 & 3,84 & 2,72 \\
\hline 58,88 & 327,50 & 189,00 & 31,54 & 17,11 & 12,60 & 9,33 & 7,33 & 5,94 & 4,16 & 3,18 & 2,18 \\
\hline 86,54 & 1633,80 & 142,40 & 12,75 & 9,14 & 8,23 & 7,43 & 6,79 & 6,23 & 5,23 & 4,42 & 3,20 \\
\hline 57,34 & 877,50 & 116,00 & 23,03 & 17,32 & 15,06 & 12,85 & 11,06 & 9,54 & 7,18 & 5,56 & 3,68 \\
\hline
\end{tabular}




\begin{tabular}{|c|c|c|c|c|c|c|c|c|c|c|c|}
\hline \multirow[b]{2}{*}{ e1 (cm) } & & & & & & & ões (x1 & m) & & & \\
\hline & Meq (MPa) & Ms (MPa) & D0 & D25 & D40 & D60 & D80 & D100 & D140 & D180 & D260 \\
\hline 57,72 & 431,60 & 117,50 & 32,66 & 21,39 & 17,41 & 14,01 & 11,55 & 9,64 & 6,94 & 5,29 & 3,53 \\
\hline 45,86 & 1461,90 & 129,30 & 19,80 & 16,08 & 14,20 & 12,11 & 10,33 & 8,81 & 6,51 & 4,97 & 3,24 \\
\hline 20,57 & 1775,10 & 195,30 & 24,37 & 17,97 & 13,81 & 9,79 & 7,23 & 5,60 & 3,84 & 2,95 & 2,05 \\
\hline 49,08 & 934,60 & 155,30 & 20,77 & 15,26 & 12,94 & 10,64 & 8,84 & 7,39 & 5,31 & 4,02 & 2,66 \\
\hline 68,19 & 1013,70 & 90,50 & 22,63 & 17,25 & 15,53 & 13,81 & 12,37 & 11,08 & 8,90 & 7,22 & 4,95 \\
\hline 33,34 & 394,90 & 25,50 & 112,15 & 94,10 & 82,05 & 67,76 & 55,81 & 46,16 & 32,53 & 24,27 & 15,91 \\
\hline 34,41 & 1200,10 & 36,30 & 59,01 & 53,07 & 48,34 & 42,20 & 36,55 & 31,56 & 23,62 & 18,06 & 11,66 \\
\hline 38,25 & 1327,60 & 71,80 & 33,61 & 28,92 & 25,86 & 22,15 & 18,88 & 16,08 & 11,80 & 8,95 & 5,80 \\
\hline 53,86 & 383,80 & 160,70 & 31,06 & 18,48 & 14,25 & 10,89 & 8,66 & 7,05 & 4,94 & 3,75 & 2,56 \\
\hline 76,99 & 1893,20 & 70,80 & 19,15 & 14,77 & 13,87 & 13,03 & 12,20 & 11,40 & 9,92 & 8,61 & 6,49 \\
\hline 79,68 & 820,00 & 124,40 & 19,87 & 13,71 & 11,84 & 10,25 & 9,07 & 8,06 & 6,42 & 5,19 & 3,57 \\
\hline 25,97 & 1437,00 & 67,10 & 46,64 & 39,41 & 33,85 & 27,21 & 21,83 & 17,65 & 12,11 & 8,98 & 5,97 \\
\hline 26,68 & 256,90 & 163,90 & 43,88 & 23,52 & 16,26 & 11,00 & 8,18 & 6,47 & 4,52 & 3,52 & 2,48 \\
\hline 52,62 & 317,00 & 61,20 & 54,64 & 38,82 & 32,60 & 26,74 & 22,24 & 18,64 & 13,46 & 10,23 & 6,78 \\
\hline 40,88 & 1844,80 & 183,40 & 15,80 & 12,67 & 11,00 & 9,13 & 7,59 & 6,34 & 4,54 & 3,41 & 2,24 \\
\hline 54,16 & 1560,00 & 36,60 & 39,30 & 32,88 & 31,47 & 29,30 & 27,11 & 24,99 & 21,09 & 17,74 & 12,67 \\
\hline 45,70 & 417,80 & 102,10 & 39,15 & 26,78 & 21,82 & 17,18 & 13,80 & 11,25 & 7,87 & 5,94 & 3,99 \\
\hline 23,77 & 1430,60 & 107,80 & 36,01 & 28,56 & 23,34 & 17,67 & 13,55 & 10,64 & 7,19 & 5,42 & 3,71 \\
\hline 88,79 & 1604,10 & 152,90 & 12,25 & 8,66 & 7,74 & 6,96 & 6,34 & 5,81 & 4,87 & 4,11 & 2,98 \\
\hline 89,77 & 240,30 & 61,90 & 52,30 & 32,24 & 26,25 & 21,76 & 18,80 & 16,47 & 12,86 & 10,32 & 7,10 \\
\hline 74,58 & 1563,30 & 153,90 & 13,33 & 9,84 & 8,81 & 7,83 & 7,04 & 6,34 & 5,14 & 4,21 & 2,93 \\
\hline 82,57 & 1080,10 & 180,20 & 14,26 & 9,62 & 8,23 & 7,08 & 6,25 & 5,55 & 4,42 & 3,57 & 2,47 \\
\hline 68,65 & 225,00 & 199,70 & 39,74 & 19,08 & 13,04 & 9,09 & 6,95 & 5,57 & 3,87 & 2,98 & 2,08 \\
\hline 28,38 & 1988,30 & 89,00 & 32,24 & 27,67 & 24,14 & 19,84 & 16,23 & 13,33 & 9,30 & 6,91 & 4,53 \\
\hline 80,27 & 1311,60 & 49,20 & 26,89 & 20,61 & 19,28 & 18,15 & 17,04 & 15,98 & 13,98 & 12,21 & 9,30 \\
\hline 48,10 & 477,50 & 145,30 & 29,97 & 19,46 & 15,54 & 12,09 & 9,66 & 7,86 & 5,49 & 4,16 & 2,81 \\
\hline 69,02 & 1631,10 & 179,00 & 12,49 & 9,29 & 8,24 & 7,24 & 6,43 & 5,72 & 4,53 & 3,64 & 2,48 \\
\hline 54,03 & 305,40 & 176,00 & 34,31 & 18,73 & 13,79 & 10,15 & 7,91 & 6,37 & 4,43 & 3,38 & 2,34 \\
\hline 73,83 & 1568,30 & 138,60 & 14,16 & 10,58 & 9,55 & 8,54 & 7,71 & 6,97 & 5,69 & 4,67 & 3,26 \\
\hline 22,77 & 209,30 & 105,20 & 65,18 & 36,84 & 25,49 & 17,11 & 12,67 & 10,02 & 7,03 & 5,48 & 3,85 \\
\hline 65,64 & 574,00 & 79,20 & 32,23 & 23,54 & 20,48 & 17,64 & 15,40 & 13,47 & 10,40 & 8,20 & 5,49 \\
\hline 77,84 & 984,10 & 197,70 & 14,71 & 9,77 & 8,21 & 6,94 & 6,03 & 5,28 & 4,10 & 3,26 & 2,21 \\
\hline 76,99 & 1910,20 & 133,20 & 13,03 & 9,79 & 8,97 & 8,15 & 7,46 & 6,83 & 5,71 & 4,79 & 3,43 \\
\hline 70,30 & 455,40 & 71,40 & 37,00 & 26,14 & 22,51 & 19,30 & 16,85 & 14,77 & 11,45 & 9,07 & 6,11 \\
\hline 44,58 & 969,00 & 39,80 & 49,10 & 42,77 & 39,33 & 34,96 & 30,93 & 27,28 & 21,20 & 16,66 & 10,97 \\
\hline 49,59 & 1887,90 & 51,70 & 30,81 & 26,47 & 25,05 & 22,96 & 20,95 & 19,04 & 15,62 & 12,81 & 8,83 \\
\hline 89,24 & 521,60 & 147,80 & 23,31 & 14,13 & 11,38 & 9,34 & 8,01 & 6,98 & 5,41 & 4,31 & 2,96 \\
\hline 44,54 & 1669,80 & 43,00 & 39,01 & 34,34 & 32,30 & 29,37 & 26,55 & 23,90 & 19,25 & 15,54 & 10,49 \\
\hline 64,55 & 1769,30 & 146,80 & 13,89 & 10,80 & 9,76 & 8,67 & 7,75 & 6,93 & 5,53 & 4,46 & 3,04 \\
\hline 23,25 & 810,20 & 150,80 & 33,85 & 23,61 & 17,83 & 12,53 & 9,25 & 7,21 & 4,96 & 3,83 & 2,66 \\
\hline 29,50 & 477,70 & 150,40 & 35,72 & 23,14 & 17,44 & 12,41 & 9,29 & 7,28 & 5,01 & 3,85 & 2,68 \\
\hline 74,76 & 1908,10 & 59,60 & 21,65 & 16,89 & 15,93 & 15,06 & 14,16 & 13,28 & 11,62 & 10,13 & 7,70 \\
\hline 51,97 & 743,20 & 113,60 & 26,51 & 19,68 & 16,85 & 14,06 & 11,83 & 10,01 & 7,31 & 5,58 & 3,67 \\
\hline 31,20 & 767,10 & 21,20 & 106,22 & 95,82 & 86,74 & 74,96 & 64,25 & 54,91 & 40,40 & 30,57 & 19,68 \\
\hline 40,63 & 497,80 & 197,50 & 26,65 & 16,38 & 12,53 & 9,27 & 7,14 & 5,68 & 3,91 & 2,98 & 2,06 \\
\hline 27,87 & 1143,20 & 159,40 & 26,42 & 19,75 & 15,85 & 11,85 & 9,05 & 7,11 & 4,84 & 3,66 & 2,52 \\
\hline 62,91 & 1007,90 & 108,80 & 21,32 & 16,23 & 14,38 & 12,55 & 11,04 & 9,73 & 7,58 & 6,00 & 4,02 \\
\hline 49,28 & 809,60 & 29,40 & 59,61 & 51,26 & 47,83 & 43,26 & 38,98 & 34,99 & 28,08 & 22,62 & 15,27 \\
\hline 53,77 & 211,10 & 81,90 & 58,39 & 35,41 & 27,59 & 21,25 & 16,98 & 13,85 & 9,73 & 7,39 & 5,01 \\
\hline 42,47 & 1352,20 & 162,10 & 18,80 & 14,67 & 12,61 & 10,40 & 8,60 & 7,16 & 5,10 & 3,84 & 2,53 \\
\hline 87,52 & 1464,50 & 173,20 & 12,11 & 8,41 & 7,40 & 6,55 & 5,91 & 5,36 & 4,42 & 3,67 & 2,61 \\
\hline 50,28 & 1896,80 & 135,20 & 16,36 & 13,50 & 12,16 & 10,64 & 9,30 & 8,12 & 6,22 & 4,85 & 3,19 \\
\hline 34,01 & 282,80 & 117,10 & 48,50 & 29,56 & 22,09 & 15,81 & 11,92 & 9,39 & 6,47 & 4,97 & 3,46 \\
\hline 59,34 & 767,70 & 132,50 & 22,55 & 16,14 & 13,75 & 11,54 & 9,82 & 8,40 & 6,25 & 4,82 & 3,19 \\
\hline 85,77 & 1640,50 & 186,40 & 11,11 & 7,79 & 6,89 & 6,10 & 5,51 & 5,00 & 4,12 & 3,42 & 2,43 \\
\hline 56,86 & 627,00 & 194,80 & 21,30 & 13,56 & 10,87 & 8,62 & 7,04 & 5,83 & 4,16 & 3,16 & 2,12 \\
\hline 42,54 & 791,30 & 106,50 & 29,98 & 22,97 & 19,59 & 16,01 & 13,16 & 10,90 & 7,73 & 5,81 & 3,84 \\
\hline 66,89 & 1481,40 & 40,20 & 32,83 & 26,17 & 24,93 & 23,51 & 22,02 & 20,57 & 17,84 & 15,41 & 11,51 \\
\hline 80,32 & 599,20 & 140,10 & 22,45 & 14,41 & 11,90 & 9,94 & 8,57 & 7,48 & 5,77 & 4,58 & 3,11 \\
\hline 61,80 & 556,90 & 24,70 & $\begin{array}{l}66,30 \\
\end{array}$ & 53,76 & 50,33 & 46,07 & 42,14 & 38,45 & 31,86 & 26,43 & 18,55 \\
\hline 45,07 & 212,50 & 94,30 & 57,31 & 34,01 & 25,85 & 19,21 & 14,90 & 11,92 & 8,23 & 6,27 & 4,32 \\
\hline 76,42 & 249,20 & 102,10 & 444,46 & 25,58 & 19,75 & 15,49 & 12,79 & 10,77 & 7,91 & 6,13 & 4,15 \\
\hline 38,26 & 896,00 & 122,90 & 27,94 & 21,34 & 17,98 & 14,40 & 11,61 & 9,47 & 6,59 & 4,94 & 3,30 \\
\hline 57,30 & 1489,60 & 111,20 & 18,73 & 15,07 & 13,64 & 12,07 & 10,71 & 9,48 & 7,44 & 5,92 & 3,96 \\
\hline 33,15 & 1267,20 & 47,70 & 49,86 & 44,09 & 39,58 & 33,88 & 28,81 & 24,46 & 17,84 & 13,45 & 8,69 \\
\hline 44,89 & 1068,00 & 134,00 & 22,39 & 17,33 & 14,92 & 12,37 & 10,30 & 8,62 & 6,19 & 4,68 & 3,08 \\
\hline 56,73 & 1885,70 & 39,00 & 34,45 & 28,39 & 27,30 & 25,66 & 23,94 & 22,25 & 19,09 & 16,30 & 11,92 \\
\hline 71,46 & 1987,70 & 81,10 & 18,05 & 14,10 & 13,26 & 12,34 & 11,46 & 10,62 & 9,08 & 7,75 & 5,69 \\
\hline 46,59 & 478,90 & 175,60 & 27,59 & 17,16 & 13,39 & 10,19 & 8,02 & 6,46 & 4,48 & 3,40 & 2,32 \\
\hline 36,45 & 1338,10 & 121,80 & 24,90 & 20,15 & 17,38 & 14,23 & 11,66 & 9,62 & 6,77 & 5,06 & 3,34 \\
\hline 34,08 & 1201,80 & 31,10 & 65,79 & 59,68 & 54,69 & 48,09 & 41,94 & 36,44 & 27,54 & 21,18 & 13,69 \\
\hline 28,74 & 1125,90 & 158,40 & 26,15 & 19,59 & 15,79 & 11,88 & 9,11 & 7,18 & 4,88 & 3,69 & 2,53 \\
\hline 69,63 & 208,10 & 172,00 & 43,74 & 21,38 & 14,80 & 10,44 & 8,05 & 6,48 & 4,52 & 3,48 & 2,42 \\
\hline 35,87 & 475,00 & 96,70 & 43,03 & 30,68 & 24,81 & 19,00 & 14,83 & 11,84 & 8,12 & 6,13 & 4,17 \\
\hline 82,16 & 1812,70 & 25,00 & 34,11 & 29,39 & 26,78 & 25,91 & 25,17 & 24,23 & 22,28 & 20,40 & 16,94 \\
\hline 41,35 & 243,20 & 157,70 & 42,77 & 22,87 & 16,38 & 11,58 & 8,78 & 6,96 & 4,80 & 3,70 & 2,59 \\
\hline 54,83 & 996,50 & 23,20 & 61,41 & 51,20 & 49,05 & 45,73 & 42,37 & 39,12 & 33,11 & 27,92 & 20,03 \\
\hline 64,68 & 1954,30 & 92,10 & 17,71 & 14,16 & 13,24 & 12,13 & 11,11 & 10,16 & 8,46 & 7,04 & 4,98 \\
\hline 57,73 & 871,50 & 160,10 & 19,50 & 13,85 & 11,72 & 9,76 & 8,25 & 7,01 & 5,17 & 3,97 & 2,63 \\
\hline 79,44 & 1480,50 & 40,00 & 29,30 & 22,93 & 21,48 & 20,51 & 19,45 & 18,38 & 16,35 & 14,48 & 11,32 \\
\hline 67,84 & 1558,00 & 122,40 & 15,87 & 12,24 & 11,12 & 9,95 & 8,97 & 8,07 & 6,54 & 5,33 & 3,68 \\
\hline 43,99 & 1495,40 & 170,30 & 17,13 & 13,46 & 11,65 & 9,70 & 8,09 & 6,78 & 4,88 & 3,69 & 2,42 \\
\hline
\end{tabular}




\begin{tabular}{|c|c|c|c|c|c|c|c|c|c|c|c|}
\hline \multirow[b]{2}{*}{ e1 (cm) } & & & & & & $\mathrm{De}$ & ões (x1 & & & & \\
\hline & Meq (MPa) & Ms (MPa) & D0 & D25 & D40 & D60 & D80 & D100 & D140 & D180 & D260 \\
\hline 32,80 & 1062,90 & 83,50 & 37,18 & 30,45 & 26,17 & 21,23 & 17,23 & 14,08 & 9,80 & 7,30 & 4,84 \\
\hline 31,89 & 478,60 & 164,40 & 32,74 & 20,87 & 15,78 & 11,32 & 8,52 & 6,70 & 4,61 & 3,54 & 2,46 \\
\hline 58,13 & 272,70 & 163,00 & 37,48 & 20,15 & 14,76 & 10,87 & 8,51 & 6,88 & 4,80 & 3,67 & 2,53 \\
\hline 80,08 & 693,20 & 124,80 & 21,71 & 14,58 & 12,38 & 10,58 & 9,27 & 8,18 & 6,44 & 5,17 & 3,54 \\
\hline 37,14 & 1173,40 & 45,20 & 48,43 & 42,86 & 38,88 & 33,85 & 29,28 & 25,26 & 18,89 & 14,45 & 9,35 \\
\hline 80,63 & 1824,00 & 116,90 & 14,00 & 10,44 & 9,60 & 8,79 & 8,10 & 7,47 & 6,33 & 5,37 & 3,92 \\
\hline 87,63 & 1233,20 & 78,10 & 19,99 & 14,63 & 13,39 & 12,33 & 11,43 & 10,60 & 9,12 & 7,84 & 5,85 \\
\hline 58,99 & 624,70 & 58,10 & 38,65 & 30,29 & 27,05 & 23,70 & 20,86 & 18,35 & 14,26 & 11,27 & 7,52 \\
\hline 50,99 & 1151,30 & 166,30 & 17,82 & 13,38 & 11,49 & 9,61 & 8,09 & 6,84 & 5,00 & 3,81 & 2,51 \\
\hline 71,02 & 1366,30 & 134,40 & 15,60 & 11,67 & 10,44 & 9,25 & 8,28 & 7,42 & 5,97 & 4,85 & 3,33 \\
\hline 44,28 & 1062,00 & 197,00 & 18,17 & 13,15 & 10,97 & 8,80 & 7,14 & 5,86 & 4,12 & 3,10 & 2,07 \\
\hline 76,64 & 1440,00 & 114,10 & 16,11 & 12,02 & 10,92 & 9,85 & 8,97 & 8,17 & 6,77 & 5,63 & 3,99 \\
\hline 43,97 & 1812,70 & 172,90 & 15,70 & 12,65 & 11,08 & 9,34 & 7,88 & 6,66 & 4,85 & 3,67 & 2,40 \\
\hline 55,38 & 371,30 & 110,80 & 36,95 & 23,81 & 19,17 & 15,21 & 12,41 & 10,26 & 7,31 & 5,55 & 3,73 \\
\hline 54,62 & 1681,90 & 61,30 & 26,84 & 22,53 & 21,17 & 19,34 & 17,62 & 16,00 & 13,11 & 10,76 & 7,44 \\
\hline 41,25 & 1285,30 & 174,80 & 18,70 & 14,31 & 12,15 & 9,87 & 8,07 & 6,65 & 4,69 & 3,52 & 2,33 \\
\hline 42,63 & 1300,80 & 57,30 & 36,11 & 31,48 & 28,73 & 25,31 & 22,18 & 19,38 & 14,82 & 11,52 & 7,52 \\
\hline 54,93 & 1538,90 & 66,30 & 26,17 & 21,89 & 20,40 & 18,50 & 16,75 & 15,11 & 12,25 & 9,97 & 6,82 \\
\hline 58,73 & 387,30 & 92,00 & 38,49 & 25,92 & 21,41 & 17,47 & 14,57 & 12,26 & 8,92 & 6,82 & 4,54 \\
\hline 42,35 & 1808,20 & 89,00 & 24,30 & 21,03 & 19,08 & 16,68 & 14,52 & 12,61 & 9,55 & 7,37 & 4,80 \\
\hline 24,60 & 1373,20 & 64,40 & 50,83 & 42,60 & 36,26 & 28,78 & 22,84 & 18,32 & 12,47 & 9,27 & 6,21 \\
\hline 61,26 & 1685,00 & 111,90 & 17,11 & 13,69 & 12,52 & 11,22 & 10,08 & 9,04 & 7,26 & 5,88 & 4,01 \\
\hline 36,18 & 1271,40 & 101,30 & 28,66 & 23,58 & 20,50 & 16,93 & 13,97 & 11,58 & 8,19 & 6,13 & 4,02 \\
\hline 23,39 & 1945,80 & 176,70 & 23,47 & 18,16 & 14,58 & 10,83 & 8,20 & 6,41 & 4,33 & 3,29 & 2,26 \\
\hline 64,46 & 228,80 & 92,10 & 50,60 & 29,85 & 23,18 & 18,07 & 14,71 & 12,20 & 8,75 & 6,70 & 4,52 \\
\hline 83,48 & 595,40 & 184,40 & 20,10 & 12,12 & 9,68 & 7,86 & 6,67 & 5,75 & 4,37 & 3,45 & 2,34 \\
\hline 53,85 & 1999,60 & 38,90 & 35,09 & 29,23 & 28,14 & 26,40 & 24,57 & 22,78 & 19,44 & 16,51 & 11,97 \\
\hline 69,46 & 939,30 & 119,60 & 20,00 & 14,60 & 12,80 & 11,13 & 9,82 & 8,68 & 6,81 & 5,44 & 3,68 \\
\hline 79,76 & 1101,00 & 91,80 & 20,11 & 14,78 & 13,38 & 12,06 & 10,99 & 10,02 & 8,33 & 6,96 & 4,97 \\
\hline 58,04 & 1499,50 & 73,80 & 23,86 & 19,62 & 18,21 & 16,49 & 14,93 & 13,48 & 10,95 & 8,93 & 6,13 \\
\hline 22,64 & 601,10 & 170,10 & 34,19 & 21,99 & 15,93 & 10,88 & 8,00 & 6,27 & 4,37 & 3,39 & 2,37 \\
\hline 29,51 & 1158,30 & 179,20 & 23,48 & 17,37 & 13,96 & 10,48 & 8,04 & 6,34 & 4,32 & 3,27 & 2,24 \\
\hline 52,75 & 1360,70 & 86,00 & 23,82 & 19,73 & 17,95 & 15,90 & 14,07 & 12,43 & 9,71 & 7,68 & 5,10 \\
\hline 36,30 & 324,00 & 39,10 & 86,49 & 67,29 & 56,87 & 45,54 & 36,67 & 29,85 & 20,73 & 15,51 & 10,35 \\
\hline 47,26 & 1742,30 & 70,20 & 26,58 & 22,98 & 21,25 & 19,04 & 16,99 & 15,11 & 11,92 & 9,47 & 6,31 \\
\hline 71,46 & 1197,50 & 55,60 & 27,61 & 21,51 & 20,13 & 18,60 & 17,19 & 15,87 & 13,46 & 11,41 & 8,28 \\
\hline 20,29 & 549,80 & 147,10 & 40,87 & 26,04 & 18,54 & 12,48 & 9,15 & 7,18 & 5,04 & 3,92 & 2,74 \\
\hline 45,12 & 713,00 & 146,00 & 25,39 & 18,02 & 14,91 & 11,90 & 9,63 & 7,90 & 5,55 & 4,18 & 2,80 \\
\hline 21,68 & 1780,00 & 31,00 & 85,88 & 76,90 & 68,08 & 56,73 & 46,84 & 38,69 & 27,06 & 20,01 & 13,00 \\
\hline 49,77 & 1251,40 & 60,90 & 31,66 & 26,91 & 24,74 & 22,09 & 19,66 & 17,44 & 13,72 & 10,89 & 7,25 \\
\hline 42,69 & 449,50 & 102,40 & 39,01 & 27,16 & 22,15 & 17,36 & 13,85 & 11,23 & 7,80 & 5,88 & 3,97 \\
\hline 87,18 & 870,60 & 98,10 & 20,89 & 14,60 & 12,90 & 11,45 & 10,36 & 9,40 & 7,78 & 6,48 & 4,62 \\
\hline 34,29 & 416,50 & 133,50 & 38,12 & 24,73 & 19,02 & 13,91 & 10,58 & 8,35 & 5,73 & 4,37 & 3,03 \\
\hline 52,76 & 1810,20 & 195,80 & 13,05 & 10,20 & 8,97 & 7,69 & 6,62 & 5,70 & 4,28 & 3,30 & 2,17 \\
\hline 28,05 & 691,80 & 145,10 & 33,00 & 23,09 & 17,91 & 12,99 & 9,77 & 7,65 & 5,23 & 4,00 & 2,77 \\
\hline 35,13 & 1750,50 & 86,60 & 28,85 & 24,98 & 22,25 & 18,90 & 15,97 & 13,49 & 9,77 & 7,36 & 4,77 \\
\hline 44,20 & 1077,90 & 46,40 & 43,11 & 37,50 & 34,37 & 30,46 & 26,85 & 23,60 & 18,24 & 14,28 & 9,38 \\
\hline 42,88 & 863,20 & 175,70 & 21,58 & 15,37 & 12,67 & 10,03 & 8,06 & 6,56 & 4,58 & 3,45 & 2,31 \\
\hline 66,78 & 714,90 & 39,00 & 43,38 & 34,25 & 31,79 & 28,99 & 26,48 & 24,16 & 20,02 & 16,63 & 11,72 \\
\hline 35,10 & 1696,90 & 100,00 & 26,62 & 22,64 & 19,97 & 16,76 & 14,01 & 11,73 & 8,40 & 6,30 & 4,10 \\
\hline 58,10 & 1967,60 & 75,60 & 21,35 & 17,63 & 16,58 & 15,20 & 13,90 & 12,67 & 10,48 & 8,67 & 6,06 \\
\hline 20,80 & 1007,30 & 48,50 & 77,66 & 63,17 & 52,03 & 39,57 & 30,35 & 23,80 & 16,01 & 12,03 & 8,23 \\
\hline 60,17 & 519,30 & 196,40 & 23,25 & 14,04 & 10,99 & 8,58 & 6,97 & 5,75 & 4,10 & 3,13 & 2,11 \\
\hline 51,55 & 668,50 & 137,20 & 25,35 & 17,82 & 14,87 & 12,10 & 10,00 & 8,33 & 5,98 & 4,53 & 3,01 \\
\hline 69,53 & 1097,10 & 97,20 & 20,80 & 15,79 & 14,23 & 12,67 & 11,38 & 10,22 & 8,24 & 6,71 & 4,62 \\
\hline 41,23 & 539,50 & 42,80 & 61,63 & 50,88 & 44,83 & 37,89 & 31,97 & 27,01 & 19,63 & 14,85 & 9,68 \\
\hline 38,31 & 216,70 & 64,20 & 73,30 & 48,38 & 38,03 & 28,57 & 22,12 & 17,61 & 12,10 & 9,18 & 6,30 \\
\hline 49,25 & 1144,30 & 133,90 & 20,56 & 16,00 & 13,94 & 11,77 & 9,99 & 8,49 & 6,24 & 4,77 & 3,13 \\
\hline 27,89 & 1187,60 & 197,50 & 22,55 & 16,41 & 12,98 & 9,57 & 7,25 & 5,69 & 3,87 & 2,95 & 2,03 \\
\hline 21,40 & 1149,50 & 81,70 & 50,39 & 39,52 & 31,76 & 23,55 & 17,77 & 13,85 & 9,35 & 7,10 & 4,89 \\
\hline 57,27 & 205,50 & 25,40 & 102,07 & 77,53 & 67,78 & 58,11 & 50,19 & 43,42 & 32,84 & 25,51 & 16,86 \\
\hline 43,09 & 1759,10 & 82,10 & 25,51 & 22,14 & 20,16 & 17,73 & 15,51 & 13,53 & 10,33 & 8,02 & 5,24 \\
\hline 51,13 & 1735,00 & 82,50 & 22,77 & 19,28 & 17,78 & 15,94 & 14,25 & 12,70 & 10,06 & 8,04 & 5,38 \\
\hline 51,05 & 1310,80 & 154,80 & 17,48 & 13,54 & 11,81 & 10,02 & 8,54 & 7,29 & 5,40 & 4,14 & 2,72 \\
\hline 24,86 & 1973,80 & 91,90 & 35,25 & 29,62 & 25,26 & 20,11 & 16,00 & 12,86 & 8,77 & 6,51 & 4,36 \\
\hline 84,56 & 1538,40 & 45,20 & 25,58 & 19,89 & 18,48 & 17,63 & 16,75 & 15,86 & 14,15 & 12,59 & 9,92 \\
\hline 28,89 & 618,10 & 167,00 & 30,77 & 20,56 & 15,67 & 11,22 & 8,41 & 6,59 & 4,52 & 3,47 & 2,41 \\
\hline 66,46 & 982,20 & 65,30 & 28,07 & 22,01 & 20,19 & 18,21 & 16,49 & 14,92 & 12,19 & 10,00 & 6,94 \\
\hline 34,34 & 1874,90 & 47,20 & 42,74 & 38,82 & 35,65 & 31,43 & 27,49 & 23,94 & 18,17 & 14,01 & 9,07 \\
\hline 42,40 & 203,10 & 88,90 & 61,36 & 36,68 & 27,82 & 20,52 & 15,82 & 12,60 & 8,68 & 6,63 & 4,58 \\
\hline 82,07 & 415,30 & 126,40 & 29,12 & 17,68 & 14,16 & 11,51 & 9,77 & 8,42 & 6,40 & 5,04 & 3,42 \\
\hline 22,52 & 1828,00 & 52,10 & 57,86 & 50,08 & 43,36 & 35,10 & 28,27 & 22,90 & 15,70 & 11,61 & 7,69 \\
\hline 75,50 & 276,00 & 48,20 & 56,46 & 38,62 & 32,92 & 28,11 & 24,56 & 21,59 & 16,83 & 13,41 & 9,10 \\
\hline 27,25 & 718,00 & 157,30 & 31,34 & 21,70 & 16,68 & 11,98 & 8,97 & 7,01 & 4,81 & 3,69 & 2,56 \\
\hline 27,07 & 650,50 & 183,70 & 29,23 & 19,25 & 14,44 & 10,19 & 7,58 & 5,93 & 4,09 & 3,15 & 2,19 \\
\hline 53,12 & 1500,10 & 49,20 & 32,85 & 27,78 & 26,19 & 23,98 & 21,87 & 19,88 & 16,33 & 13,42 & 9,28 \\
\hline 34,10 & 482,30 & 173,90 & 30,78 & 19,42 & 14,74 & 10,67 & 8,08 & 6,37 & 4,37 & 3,35 & 2,33 \\
\hline 83,82 & 428,70 & 83,50 & 33,42 & 21,94 & 18,46 & 15,69 & 13,74 & 12,13 & 9,57 & 7,70 & 5,29 \\
\hline 81,84 & 1442,90 & 130,20 & 14,52 & 10,54 & 9,49 & 8,52 & 7,75 & 7,06 & 5,87 & 4,90 & 3,50 \\
\hline 81,92 & 1128,50 & 181,70 & 13,91 & 9,45 & 8,11 & 7,00 & 6,18 & 5,50 & 4,38 & 3,55 & 2,45 \\
\hline 28,55 & 1628,80 & 112,00 & 29,41 & 24,15 & 20,53 & 16,34 & 13,03 & 10,50 & 7,20 & 5,36 & 3,58 \\
\hline 89,83 & 938,10 & 26,90 & 40,59 & 31,81 & 29,23 & 27,95 & 26,68 & 25,36 & 22,83 & 20,49 & 16,41 \\
\hline
\end{tabular}




\begin{tabular}{|c|c|c|c|c|c|c|c|c|c|c|c|}
\hline \multirow[b]{2}{*}{ e1 (cm) } & & & & & & $\mathrm{De}$ & ões (x1 & & & & \\
\hline & Meq (MPa) & Ms (MPa) & D0 & D25 & D40 & D60 & D80 & D100 & D140 & D180 & D260 \\
\hline 56,41 & 344,50 & 165,40 & 32,37 & 18,51 & 14,02 & 10,59 & 8,39 & 6,82 & 4,78 & 3,64 & 2,49 \\
\hline 42,92 & 835,40 & 121,00 & 27,07 & 20,49 & 17,39 & 14,15 & 11,60 & 9,58 & 6,78 & 5,10 & 3,38 \\
\hline 63,49 & 1970,10 & 108,00 & 16,14 & 12,92 & 11,97 & 10,87 & 9,88 & 8,96 & 7,36 & 6,05 & 4,21 \\
\hline 63,94 & 241,30 & 48,10 & 64,75 & 44,63 & 37,55 & 31,37 & 26,72 & 22,91 & 17,13 & 13,27 & 8,83 \\
\hline 57,65 & 1080,40 & 64,90 & 29,36 & 23,97 & 21,99 & 19,70 & 17,67 & 15,81 & 12,63 & 10,17 & 6,89 \\
\hline 72,59 & 635,60 & 150,10 & 21,77 & 14,21 & 11,75 & 9,76 & 8,34 & 7,19 & 5,44 & 4,26 & 2,86 \\
\hline 73,84 & 808,70 & 164,70 & 18,13 & 12,13 & 10,19 & 8,58 & 7,41 & 6,45 & 4,95 & 3,91 & 2,63 \\
\hline 76,65 & 567,50 & 192,80 & 20,82 & 12,49 & 9,88 & 7,93 & 6,64 & 5,65 & 4,21 & 3,28 & 2,21 \\
\hline 65,46 & 1374,30 & 72,90 & 23,22 & 18,46 & 17,15 & 15,64 & 14,28 & 13,01 & 10,76 & 8,92 & 6,27 \\
\hline 48,24 & 1628,50 & 128,00 & 18,45 & 15,15 & 13,52 & 11,70 & 10,12 & 8,74 & 6,58 & 5,08 & 3,32 \\
\hline 45,77 & 1624,40 & 22,40 & 61,38 & 52,58 & 50,83 & 47,58 & 44,16 & 40,82 & 34,57 & 29,13 & 20,81 \\
\hline 51,82 & 1289,50 & 178,70 & 16,13 & 12,17 & 10,50 & 8,82 & 7,47 & 6,34 & 4,66 & 3,56 & 2,34 \\
\hline 60,48 & 938,40 & 190,20 & 16,91 & 11,72 & 9,84 & 8,16 & 6,90 & 5,87 & 4,34 & 3,34 & 2,22 \\
\hline 83,76 & 852,60 & 171,60 & 16,57 & 10,82 & 9,08 & 7,69 & 6,72 & 5,93 & 4,66 & 3,74 & 2,57 \\
\hline 25,20 & 723,80 & 182,40 & 29,35 & 19,61 & 14,67 & 10,28 & 7,61 & 5,94 & 4,10 & 3,17 & 2,21 \\
\hline 88,93 & 454,60 & 60,80 & 36,54 & 24,92 & 21,70 & 19,04 & 17,09 & 15,43 & 12,65 & 10,47 & 7,42 \\
\hline 35,21 & 1606,10 & 144,00 & 21,47 & 17,38 & 14,94 & 12,17 & 9,92 & 8,15 & 5,70 & 4,26 & 2,81 \\
\hline 40,51 & 993,80 & 192,90 & 19,84 & 14,27 & 11,76 & 9,25 & 7,38 & 5,98 & 4,15 & 3,12 & 2,10 \\
\hline 75,16 & 915,10 & 129,30 & 18,85 & 13,32 & 11,58 & 10,05 & 8,88 & 7,88 & 6,23 & 5,01 & 3,43 \\
\hline 48,75 & 1442,00 & 110,00 & 21,08 & 17,34 & 15,52 & 13,47 & 11,68 & 10,13 & 7,66 & 5,93 & 3,88 \\
\hline 28,73 & 1565,30 & 180,30 & 21,53 & 16,60 & 13,60 & 10,40 & 8,05 & 6,38 & 4,34 & 3,26 & 2,22 \\
\hline 28,73 & 834,40 & 113,60 & 36,08 & 27,15 & 21,95 & 16,55 & 12,72 & 10,03 & 6,82 & 5,15 & 3,53 \\
\hline 54,69 & 618,70 & 46,80 & 45,94 & 37,25 & 33,59 & 29,57 & 26,05 & 22,93 & 17,80 & 14,03 & 9,32 \\
\hline 43,20 & 980,40 & 79,50 & 32,39 & 26,65 & 23,55 & 20,02 & 16,99 & 14,44 & 10,59 & 8,04 & 5,24 \\
\hline 53,67 & 1699,10 & 73,90 & 23,90 & 20,09 & 18,68 & 16,90 & 15,25 & 13,72 & 11,06 & 8,96 & 6,09 \\
\hline 58,20 & 1568,60 & 189,20 & 13,43 & 10,21 & 8,95 & 7,70 & 6,67 & 5,79 & 4,40 & 3,43 & 2,27 \\
\hline 67,58 & 773,30 & 197,10 & 17,74 & 11,54 & 9,47 & 7,77 & 6,56 & 5,60 & 4,16 & 3,22 & 2,15 \\
\hline 87,26 & 1669,90 & 123,00 & 13,61 & 9,87 & 8,97 & 8,18 & 7,54 & 6,96 & 5,92 & 5,05 & 3,72 \\
\hline 21,35 & 1452,90 & 93,70 & 42,81 & 33,93 & 27,47 & 20,51 & 15,55 & 12,14 & 8,19 & 6,19 & 4,26 \\
\hline 33,05 & 566,40 & 176,70 & 28,92 & 18,87 & 14,48 & 10,54 & 7,99 & 6,29 & 4,31 & 3,30 & 2,29 \\
\hline 70,33 & 511,80 & 188,50 & 22,89 & 13,65 & 10,71 & 8,48 & 7,01 & 5,89 & 4,30 & 3,31 & 2,23 \\
\hline 40,10 & 1806,80 & 109,20 & 22,23 & 18,92 & 16,89 & 14,47 & 12,35 & 10,54 & 7,76 & 5,89 & 3,83 \\
\hline 82,61 & 557,50 & 96,10 & 27,23 & 18,28 & 15,58 & 13,37 & 11,78 & 10,45 & 8,30 & 6,70 & 4,62 \\
\hline 57,76 & 326,50 & 168,60 & 33,06 & 18,50 & 13,87 & 10,40 & 8,23 & 6,68 & 4,68 & 3,57 & 2,45 \\
\hline 61,28 & 1982,30 & 133,60 & 14,41 & 11,52 & 10,53 & 9,43 & 8,46 & 7,59 & 6,09 & 4,92 & 3,35 \\
\hline 36,56 & 813,20 & 146,70 & 26,78 & 19,52 & 15,99 & 12,42 & 9,78 & 7,85 & 5,40 & 4,06 & 2,75 \\
\hline 27,98 & 904,20 & 71,50 & 48,96 & 39,47 & 33,11 & 25,95 & 20,44 & 16,34 & 11,13 & 8,32 & 5,61 \\
\hline 41,66 & 414,00 & 186,00 & 29,86 & 17,74 & 13,39 & 9,83 & 7,55 & 6,01 & 4,14 & 3,16 & 2,19 \\
\hline 86,91 & 1794,90 & 143,70 & 12,12 & 8,74 & 7,91 & 7,18 & 6,59 & 6,06 & 5,13 & 4,35 & 3,18 \\
\hline 71,78 & 941,00 & 125,50 & 19,23 & 13,84 & 12,09 & 10,51 & 9,27 & 8,21 & 6,47 & 5,18 & 3,52 \\
\hline 85,27 & 1147,30 & 43,50 & 29,36 & 22,35 & 20,76 & 19,61 & 18,47 & 17,38 & 15,33 & 13,49 & 10,43 \\
\hline 78,25 & 1392,90 & 49,00 & 26,75 & 20,64 & 19,37 & 18,27 & 17,16 & 16,08 & 14,07 & 12,28 & 9,35 \\
\hline 25,63 & 1890,90 & 180,00 & 21,94 & 17,10 & 13,93 & 10,53 & 8,08 & 6,36 & 4,31 & 3,25 & 2,22 \\
\hline 21,87 & 1332,20 & 65,90 & 55,39 & 45,33 & 37,62 & 28,91 & 22,35 & 17,61 & 11,87 & 8,89 & 6,05 \\
\hline 33,85 & 1196,90 & 148,50 & 24,08 & 18,60 & 15,55 & 12,25 & 9,72 & 7,83 & 5,39 & 4,04 & 2,71 \\
\hline 42,11 & 715,80 & 123,20 & 28,91 & 21,24 & 17,75 & 14,20 & 11,49 & 9,40 & 6,58 & 4,95 & 3,30 \\
\hline 41,23 & 870,10 & 188,30 & 21,10 & 14,86 & 12,14 & 9,50 & 7,56 & 6,11 & 4,24 & 3,19 & 2,15 \\
\hline 49,04 & 1049,30 & 168,10 & 18,88 & 13,96 & 11,87 & 9,79 & 8,15 & 6,82 & 4,92 & 3,73 & 2,46 \\
\hline 73,26 & 205,50 & 172,30 & 44,04 & 21,41 & 14,78 & 10,41 & 8,03 & 6,47 & 4,52 & 3,48 & 2,42 \\
\hline 29,80 & 585,30 & 198,10 & 27,74 & 17,69 & 13,26 & 9,41 & 7,04 & 5,52 & 3,80 & 2,93 & 2,04 \\
\hline 83,23 & 1636,40 & 83,20 & 17,57 & 13,18 & 12,20 & 11,34 & 10,56 & 9,84 & 8,50 & 7,34 & 5,51 \\
\hline 75,55 & 1363,70 & 39,30 & 31,67 & 24,76 & 23,34 & 22,17 & 20,90 & 19,66 & 17,31 & 15,18 & 11,65 \\
\hline 53,52 & 1407,80 & 83,10 & 23,81 & 19,76 & 18,06 & 16,08 & 14,31 & 12,70 & 10,00 & 7,96 & 5,32 \\
\hline 20,91 & 416,90 & 178,20 & 37,64 & 21,87 & 15,11 & 10,10 & 7,46 & 5,90 & 4,15 & 3,23 & 2,27 \\
\hline 37,48 & 1905,90 & 110,10 & 22,81 & 19,49 & 17,33 & 14,73 & 12,46 & 10,55 & 7,67 & 5,79 & 3,76 \\
\hline 42,73 & 853,20 & 56,40 & 42,52 & 35,81 & 31,99 & 27,52 & 23,60 & 20,22 & 15,01 & 11,46 & 7,46 \\
\hline 61,59 & 1904,40 & 56,90 & 25,19 & 20,46 & 19,48 & 18,16 & 16,85 & 15,58 & 13,25 & 11,23 & 8,14 \\
\hline 29,82 & 1155,00 & 193,00 & 22,23 & 16,26 & 13,01 & 9,73 & 7,45 & 5,87 & 4,00 & 3,03 & 2,08 \\
\hline 22,16 & 1410,20 & 93,50 & 42,09 & 33,47 & 27,25 & 20,49 & 15,62 & 12,22 & 8,24 & 6,22 & 4,27 \\
\hline 74,16 & 1206,90 & 117,40 & 17,43 & 12,90 & 11,56 & 10,28 & 9,24 & 8,32 & 6,75 & 5,53 & 3,84 \\
\hline 30,35 & 1841,30 & 66,90 & 37,78 & 33,29 & 29,64 & 25,05 & 21,02 & 17,63 & 12,63 & 9,45 & 6,12 \\
\hline 49,98 & 408,50 & 87,80 & 41,11 & 28,72 & 23,82 & 19,23 & 15,77 & 13,07 & 9,30 & 7,04 & 4,69 \\
\hline 45,35 & 852,80 & 30,00 & 61,01 & 53,33 & 49,49 & 44,43 & 39,69 & 35,32 & 27,88 & 22,17 & 14,74 \\
\hline 24,77 & 545,00 & 21,40 & 144,01 & 122,92 & 105,95 & 85,45 & 68,69 & 55,61 & 38,14 & 28,26 & 18,76 \\
\hline 45,63 & 353,10 & 198,90 & 30,85 & 17,13 & 12,60 & 9,14 & 7,02 & 5,60 & 3,86 & 2,96 & 2,05 \\
\hline 81,30 & 252,00 & 148,70 & 39,02 & 20,50 & 14,97 & 11,18 & 8,98 & 7,44 & 5,37 & 4,15 & 2,84 \\
\hline 67,93 & 1113,10 & 75,50 & 24,20 & 18,84 & 17,27 & 15,59 & 14,14 & 12,81 & 10,49 & 8,63 & 6,01 \\
\hline 79,08 & 1840,90 & 57,70 & 21,58 & 16,73 & 15,69 & 14,89 & 14,05 & 13,22 & 11,66 & 10,25 & 7,90 \\
\hline 40,45 & 1554,70 & 41,70 & 43,56 & 38,97 & 36,26 & 32,55 & 29,03 & 25,78 & 20,24 & 16,01 & 10,58 \\
\hline 76,52 & 1622,80 & 135,70 & 13,88 & 10,32 & 9,34 & 8,40 & 7,62 & 6,93 & 5,72 & 4,74 & 3,35 \\
\hline 70,76 & 1785,80 & 194,00 & 11,34 & 8,40 & 7,46 & 6,57 & 5,85 & 5,22 & 4,16 & 3,36 & 2,30 \\
\hline 36,85 & 358,10 & 91,20 & 49,25 & 33,60 & 26,70 & 20,17 & 15,64 & 12,45 & 8,54 & 6,47 & 4,43 \\
\hline 40,42 & 1977,80 & 94,90 & 23,36 & 20,30 & 18,36 & 15,98 & 13,83 & 11,95 & 8,96 & 6,88 & 4,47 \\
\hline 81,54 & 669,70 & 84,20 & 26,41 & 18,56 & 16,28 & 14,30 & 12,80 & 11,51 & 9,33 & 7,64 & 5,34 \\
\hline 27,64 & 1068,20 & 187,80 & 24,27 & 17,49 & 13,74 & 10,07 & 7,60 & 5,96 & 4,06 & 3,10 & 2,14 \\
\hline 69,98 & 897,50 & 114,20 & 20,87 & 15,21 & 13,33 & 11,60 & 10,24 & 9,06 & 7,13 & 5,70 & 3,86 \\
\hline 64,68 & 1555,00 & 38,90 & 33,70 & 27,05 & 25,84 & 24,39 & 22,84 & 21,33 & 18,49 & 15,96 & 11,89 \\
\hline 61,41 & 718,80 & 163,70 & 20,78 & 14,03 & 11,65 & 9,59 & 8,06 & 6,83 & 5,03 & 3,86 & 2,57 \\
\hline 36,23 & 579,90 & 123,30 & 34,15 & 24,16 & 19,48 & 14,89 & 11,62 & 9,27 & 6,36 & 4,80 & 3,27 \\
\hline 53,30 & 552,80 & 174,90 & 24,49 & 15,63 & 12,48 & 9,81 & 7,93 & 6,51 & 4,60 & 3,49 & 2,35 \\
\hline 46,99 & 1278,90 & 135,30 & 20,06 & 15,89 & 13,89 & 11,74 & 9,94 & 8,44 & 6,19 & 4,71 & 3,08 \\
\hline 58,84 & 1025,80 & 196,90 & 16,08 & 11,30 & 9,53 & 7,92 & 6,69 & 5,69 & 4,20 & 3,23 & 2,14 \\
\hline
\end{tabular}




\begin{tabular}{|c|c|c|c|c|c|c|c|c|c|c|c|}
\hline & & & \multicolumn{9}{|c|}{ Deflexões $\left(\times 10^{-4} \mathrm{~cm}\right)$} \\
\hline $\mathrm{e} 1(\mathrm{~cm})$ & Meq (MPa) & Ms (MPa) & D0 & D25 & D40 & D60 & D80 & D100 & D140 & D180 & D260 \\
\hline 36,12 & 348,80 & 107,10 & 45,73 & 29,96 & 23,31 & 17,27 & 13,24 & 10,49 & 7,19 & 5,48 & 3,78 \\
\hline 40,03 & 1939,90 & 136,20 & 18,88 & 15,81 & 14,00 & 11,87 & 10,04 & 8,50 & 6,19 & 4,68 & 3,04 \\
\hline 35,74 & 1397,60 & 110,10 & 26,49 & 21,82 & 18,95 & 15,63 & 12,88 & 10,66 & 7,53 & 5,63 & 3,70 \\
\hline 88,55 & 1989,60 & 42,40 & 22,80 & 18,62 & 17,01 & 16,37 & 15,77 & 15,09 & 13,74 & 12,47 & 10,18 \\
\hline 49,44 & 470,40 & 179,70 & 27,04 & 16,58 & 12,91 & 9,86 & 7,80 & 6,32 & 4,40 & 3,34 & 2,27 \\
\hline 35,66 & 340,20 & 151,60 & 38,13 & 22,80 & 16,98 & 12,18 & 9,21 & 7,27 & 5,00 & 3,84 & 2,68 \\
\hline 25,09 & 286,70 & 197,80 & 37,82 & 19,71 & 13,43 & 9,03 & 6,73 & 5,33 & 3,74 & 2,91 & 2,06 \\
\hline 40,96 & 769,10 & 162,70 & 24,26 & 17,16 & 14,04 & 10,99 & 8,75 & 7,08 & 4,91 & 3,70 & 2,49 \\
\hline 37,63 & 1402,90 & 100,30 & 27,02 & 22,56 & 19,82 & 16,62 & 13,90 & 11,65 & 8,36 & 6,28 & 4,10 \\
\hline 86,82 & 465,70 & 77,40 & 32,57 & 21,72 & 18,55 & 15,99 & 14,17 & 12,65 & 10,16 & 8,28 & 5,77 \\
\hline 51,94 & 1407,40 & 117,30 & 19,68 & 15,92 & 14,23 & 12,38 & 10,78 & 9,38 & 7,15 & 5,57 & 3,66 \\
\hline 20,67 & 971,00 & 122,20 & 40,24 & 29,15 & 22,17 & 15,59 & 11,48 & 8,90 & 6,12 & 4,72 & 3,28 \\
\hline 23,48 & 1150,40 & 49,60 & 66,78 & 56,03 & 47,58 & 37,62 & 29,74 & 23,78 & 16,15 & 12,00 & 8,06 \\
\hline 66,28 & 1655,20 & 107,20 & 16,95 & 13,31 & 12,23 & 11,05 & 10,01 & 9,07 & 7,41 & 6,09 & 4,23 \\
\hline 53,96 & 1984,80 & 168,20 & 13,51 & 10,85 & 9,71 & 8,48 & 7,41 & 6,48 & 4,97 & 3,89 & 2,57 \\
\hline 26,57 & 1609,20 & 147,50 & 25,81 & 20,31 & 16,70 & 12,78 & 9,88 & 7,81 & 5,30 & 3,98 & 2,71 \\
\hline 66,64 & 780,20 & 117,90 & 22,49 & 16,15 & 13,95 & 11,95 & 10,39 & 9,07 & 6,98 & 5,49 & 3,68 \\
\hline 77,30 & 627,80 & 104,90 & 25,10 & 17,20 & 14,72 & 12,63 & 11,08 & 9,78 & 7,69 & 6,16 & 4,20 \\
\hline 22,58 & 694,40 & 71,70 & 61,41 & 46,47 & 36,65 & 26,70 & 19,99 & 15,56 & 10,57 & 8,07 & 5,58 \\
\hline 68,02 & 1247,70 & 180,80 & 14,24 & 10,25 & 8,88 & 7,65 & 6,68 & 5,86 & 4,54 & 3,59 & 2,41 \\
\hline 25,67 & 1587,90 & 136,70 & 27,99 & 22,10 & 18,14 & 13,84 & 10,68 & 8,43 & 5,70 & 4,29 & 2,93 \\
\hline 61,10 & 389,10 & 105,80 & 35,51 & 23,11 & 18,83 & 15,23 & 12,66 & 10,63 & 7,73 & 5,92 & 3,95 \\
\hline 64,81 & 1840,90 & 79,10 & 19,92 & 15,95 & 14,98 & 13,78 & 12,68 & 11,63 & 9,75 & 8,16 & 5,82 \\
\hline 79,30 & 1834,20 & 154,00 & 12,05 & 8,87 & 8,03 & 7,23 & 6,58 & 6,00 & 4,98 & 4,15 & 2,96 \\
\hline 33,67 & 648,80 & 175,70 & 27,30 & 18,37 & 14,34 & 10,59 & 8,08 & 6,38 & 4,37 & 3,33 & 2,30 \\
\hline 71,67 & 1565,20 & 119,70 & 15,62 & 11,90 & 10,83 & 9,75 & 8,84 & 8,01 & 6,57 & 5,42 & 3,79 \\
\hline 39,36 & 818,70 & 193,10 & 21,84 & 15,13 & 12,20 & 9,40 & 7,39 & 5,93 & 4,09 & 3,08 & 2,10 \\
\hline 46,47 & 880,80 & 44,50 & 45,98 & 39,39 & 35,95 & 31,78 & 27,98 & 24,57 & 18,97 & 14,86 & 9,77 \\
\hline $\begin{array}{l}66,78 \\
\end{array}$ & 353,20 & 30,00 & 67,45 & 51,91 & 46,87 & 41,71 & 37,38 & 33,49 & 26,89 & 21,78 & 14,91 \\
\hline 67,85 & 1386,10 & 60,50 & 25,52 & 20,18 & 18,94 & 17,49 & 16,14 & 14,86 & 12,54 & 10,58 & 7,62 \\
\hline 42,35 & 1323,50 & 105,20 & 24,63 & 20,33 & 17,95 & 15,23 & 12,91 & 10,95 & 8,00 & 6,07 & 3,96 \\
\hline 44,26 & 1664,80 & 143,30 & 18,10 & 14,77 & 13,03 & 11,07 & 9,41 & 8,00 & 5,87 & 4,46 & 2,91 \\
\hline 27,57 & 1614,50 & 65,40 & 43,48 & 37,54 & 32,82 & 27,01 & 22,12 & 18,18 & 12,68 & 9,41 & 6,17 \\
\hline 50,56 & 1080,00 & 180,00 & 17,67 & 12,95 & 10,99 & 9,07 & 7,57 & 6,35 & 4,59 & 3,49 & 2,30 \\
\hline 77,66 & 647,10 & 84,10 & 27,41 & 19,43 & 17,00 & 14,87 & 13,23 & 11,82 & 9,47 & 7,69 & 5,31 \\
\hline 24,35 & 1103,10 & 45,70 & 69,46 & 58,83 & 50,39 & 40,30 & 32,18 & 25,91 & 17,69 & 13,12 & 8,75 \\
\hline 72,65 & 1806,50 & 144,80 & 13,08 & 9,90 & 8,99 & 8,07 & 7,31 & 6,62 & 5,43 & 4,47 & 3,13 \\
\hline 43,55 & 1841,60 & 187,70 & 14,95 & 11,94 & 10,40 & 8,72 & 7,31 & 6,15 & 4,45 & 3,37 & 2,20 \\
\hline 64,51 & 433,80 & 154,40 & 27,98 & 17,00 & 13,42 & 10,61 & 8,71 & 7,27 & 5,25 & 4,02 & 2,70 \\
\hline 73,14 & 1614,70 & 190,30 & 11,84 & 8,62 & 7,61 & 6,67 & 5,94 & 5,30 & 4,23 & 3,42 & 2,34 \\
\hline 39,27 & 411,20 & 189,40 & 30,17 & 17,84 & 13,36 & 9,70 & 7,40 & 5,86 & 4,04 & 3,09 & 2,15 \\
\hline 38,05 & 1216,10 & 178,80 & 19,81 & 14,96 & 12,52 & 9,96 & 7,99 & 6,50 & 4,51 & 3,38 & 2,26 \\
\hline 51,99 & 672,50 & 70,80 & 35,98 & 28,29 & 24,90 & 21,34 & 18,36 & 15,80 & 11,84 & 9,13 & 6,00 \\
\hline 54,25 & 1747,40 & 170,90 & 14,08 & 11,12 & 9,86 & 8,53 & 7,41 & 6,44 & 4,90 & 3,81 & 2,51 \\
\hline 53,93 & 1594,00 & 178,60 & 14,34 & 11,13 & 9,78 & 8,38 & 7,22 & 6,23 & 4,68 & 3,62 & 2,38 \\
\hline 35,42 & 604,60 & 126,40 & 33,48 & 23,74 & 19,12 & 14,57 & 11,33 & 9,03 & 6,19 & 4,67 & 3,19 \\
\hline 21,80 & 1995,60 & 137,90 & 29,22 & 23,07 & 18,65 & 13,92 & 10,56 & 8,24 & 5,56 & 4,21 & 2,90 \\
\hline 21,45 & 247,40 & 46,50 & 114,90 & 78,82 & 58,44 & 40,37 & 29,63 & 23,09 & 16,01 & 12,39 & 8,63 \\
\hline 43,90 & 991,90 & 167,40 & 20,61 & 15,18 & 12,75 & 10,29 & 8,39 & 6,91 & 4,87 & 3,67 & 2,44 \\
\hline 33,72 & 523,00 & 64,10 & 55,67 & 43,06 & 36,00 & 28,36 & 22,52 & 18,15 & 12,48 & 9,34 & 6,28 \\
\hline 54,46 & 1449,80 & 170,10 & 15,29 & 11,78 & 10,31 & 8,82 & 7,59 & 6,54 & 4,91 & 3,80 & 2,50 \\
\hline 89,61 & 1129,00 & 79,20 & 20,40 & 14,75 & 13,42 & 12,29 & 11,36 & 10,52 & 9,02 & 7,74 & 5,76 \\
\hline 78,16 & 1620,90 & 162,30 & 12,48 & 9,09 & 8,12 & 7,23 & 6,52 & 5,90 & 4,82 & 3,97 & 2,79 \\
\hline 62,08 & 1569,90 & 53,90 & 27,71 & 22,48 & 21,29 & 19,73 & 18,23 & 16,80 & 14,17 & 11,94 & 8,56 \\
\hline 69,26 & 1264,60 & 88,70 & 20,68 & 15,98 & 14,63 & 13,20 & 11,97 & 10,85 & 8,90 & 7,33 & 5,12 \\
\hline 40,34 & 1882,00 & 39,20 & 42,92 & 38,47 & 36,20 & 32,87 & 29,64 & 26,61 & 21,30 & 17,10 & 11,45 \\
\hline 60,95 & 827,70 & 195,20 & 17,81 & 11,95 & 9,89 & 8,10 & 6,79 & 5,74 & 4,21 & 3,23 & 2,15 \\
\hline 46,92 & 964,70 & 61,70 & 35,97 & 30,21 & 27,24 & 23,78 & 20,71 & 18,01 & 13,69 & 10,61 & 6,95 \\
\hline 20,82 & 1279,80 & 144,90 & 32,86 & 24,19 & 18,60 & 13,20 & 9,75 & 7,56 & 5,18 & 3,98 & 2,76 \\
\hline 87,48 & 1714,10 & 103,10 & 14,82 & 10,89 & 9,99 & 9,22 & 8,56 & 7,96 & 6,86 & 5,92 & 4,43 \\
\hline 23,00 & 950,30 & 139,50 & 34,45 & 24,89 & 19,14 & 13,64 & 10,12 & 7,87 & 5,39 & 4,14 & 2,87 \\
\hline 70,58 & 1940,70 & 22,60 & 41,13 & 34,51 & 32,11 & 31,25 & 30,17 & 28,89 & 26,32 & 23,86 & 19,40 \\
\hline 86,91 & 561,00 & 155,30 & 21,99 & 13,46 & 10,88 & 8,95 & 7,68 & 6,68 & 5,16 & 4,11 & 2,81 \\
\hline 74,24 & 409,50 & 112,70 & 31,52 & 19,88 & 16,15 & 13,23 & 11,22 & 9,62 & 7,23 & 5,65 & 3,80 \\
\hline 88,90 & 972,10 & 37,40 & 33,44 & 25,37 & 23,42 & 22,15 & 20,91 & 19,72 & 17,48 & 15,45 & 12,05 \\
\hline 38,23 & 949,40 & 110,00 & 29,25 & 22,93 & 19,56 & 15,87 & 12,92 & 10,61 & 7,44 & 5,57 & 3,69 \\
\hline 58,90 & 296,60 & 121,30 & 39,66 & 23,53 & 18,23 & 14,09 & 11,34 & 9,32 & 6,60 & 5,03 & 3,41 \\
\hline 54,51 & 1940,00 & 21,10 & 54,00 & 44,36 & 42,83 & 41,21 & 39,07 & 36,88 & 32,62 & 28,66 & 21,97 \\
\hline 47,14 & 376,20 & 29,60 & 81,10 & 66,68 & 59,43 & 51,26 & 44,18 & 38,07 & 28,51 & 21,93 & 14,33 \\
\hline 72,39 & 1832,40 & 84,10 & 18,04 & 14,01 & 13,12 & 12,14 & 11,24 & 10,39 & 8,83 & 7,51 & 5,48 \\
\hline 25,55 & 1892,20 & 154,80 & 24,41 & 19,37 & 15,96 & 12,21 & 9,44 & 7,45 & 5,05 & 3,79 & 2,58 \\
\hline 36,86 & 1554,60 & 152,20 & 20,32 & 16,30 & 14,01 & 11,43 & 9,35 & 7,69 & 5,40 & 4,04 & 2,67 \\
\hline 62,33 & 556,20 & 54,20 & 41,09 & 31,70 & 28,29 & 24,84 & 21,95 & 19,40 & 15,20 & 12,09 & 8,12 \\
\hline 49,42 & 1133,60 & 117,10 & 22,24 & 17,61 & 15,48 & 13,20 & 11,28 & 9,65 & 7,16 & 5,49 & 3,60 \\
\hline 39,46 & 1572,50 & 143,20 & 20,04 & 16,25 & 14,14 & 11,74 & 9,76 & 8,14 & 5,81 & 4,37 & 2,86 \\
\hline 47,33 & 439,50 & 141,00 & 31,92 & 20,50 & 16,26 & 12,56 & 9,98 & 8,09 & 5,64 & 4,27 & 2,89 \\
\hline 80,45 & 1981,10 & 198,40 & 10,08 & 7,28 & 6,51 & 5,80 & 5,25 & 4,75 & 3,91 & 3,24 & 2,28 \\
\hline 83,44 & 1661,70 & 160,10 & 12,08 & 8,67 & 7,76 & 6,95 & 6,31 & 5,75 & 4,77 & 3,98 & 2,84 \\
\hline 27,56 & 1781,70 & 164,20 & 22,64 & 17,88 & 14,80 & 11,41 & 8,88 & 7,05 & 4,79 & 3,59 & 2,44 \\
\hline 79,25 & 447,50 & 29,40 & 56,79 & 42,47 & 39,01 & 35,65 & 32,77 & 30,14 & 25,44 & 21,51 & 15,60 \\
\hline 20,45 & 1032,60 & 125,80 & 39,01 & 28,32 & 21,55 & 15,15 & 11,15 & 8,65 & 5,94 & 4,58 & 3,18 \\
\hline 75,57 & 1138,90 & 158,20 & 15,24 & 10,78 & 9,39 & 8,16 & 7,22 & 6,41 & 5,09 & 4,10 & 2,81 \\
\hline
\end{tabular}




\begin{tabular}{|c|c|c|c|c|c|c|c|c|c|c|c|}
\hline & & & \multicolumn{9}{|c|}{ Deflexões $\left(\times 10^{-4} \mathrm{~cm}\right)$} \\
\hline e1 (cm) & Meq (MPa) & Ms (MPa) & D0 & D25 & D40 & D60 & D80 & D100 & D140 & D180 & D260 \\
\hline 28,35 & 701,80 & 78,70 & 49,34 & 38,11 & 31,22 & 23,85 & 18,46 & 14,61 & 9,93 & 7,47 & 5,09 \\
\hline 76,48 & 1171,70 & 95,40 & 19,52 & 14,54 & 13,19 & 11,88 & 10,80 & 9,82 & 8,12 & 6,74 & 4,77 \\
\hline 83,07 & 1855,90 & 106,40 & 14,46 & 10,77 & 9,94 & 9,18 & 8,51 & 7,89 & 6,77 & 5,81 & 4,31 \\
\hline 68,15 & 1735,00 & 95,30 & 17,61 & 13,82 & 12,83 & 11,72 & 10,72 & 9,79 & 8,14 & 6,78 & 4,80 \\
\hline 20,61 & 958,00 & 48,00 & 79,85 & 64,57 & 52,92 & 40,02 & 30,56 & 23,92 & 16,09 & 12,12 & 8,30 \\
\hline 65,52 & 823,50 & 84,80 & 26,25 & 19,92 & 17,73 & 15,58 & 13,80 & 12,24 & 9,65 & 7,71 & 5,21 \\
\hline 46,28 & 1307,30 & 23,50 & 62,55 & 54,08 & 51,84 & 48,05 & 44,24 & 40,55 & 33,80 & 28,09 & 19,67 \\
\hline 52,22 & 1405,90 & 20,60 & 62,30 & 51,80 & 50,14 & 47,46 & 44,45 & 41,49 & 35,84 & 30,78 & 22,70 \\
\hline 51,24 & 308,90 & 43,10 & 67,47 & 50,92 & 43,87 & 36,79 & 31,07 & 26,34 & 19,30 & 14,73 & 9,69 \\
\hline 51,44 & 784,10 & 93,50 & 28,93 & 22,37 & 19,51 & 16,55 & 14,11 & 12,06 & 8,94 & 6,85 & 4,50 \\
\hline 47,99 & 1069,20 & 158,70 & 19,55 & 14,67 & 12,53 & 10,36 & 8,63 & 7,23 & 5,22 & 3,95 & 2,60 \\
\hline 63,25 & 211,50 & 152,90 & 44,98 & 22,85 & 16,21 & 11,66 & 9,06 & 7,30 & 5,10 & 3,91 & 2,71 \\
\hline 27,35 & 1689,00 & 42,80 & 57,23 & 51,39 & 46,02 & 39,09 & 32,92 & 27,69 & 19,87 & 14,85 & 9,57 \\
\hline 45,76 & 1286,80 & 126,00 & 21,22 & 17,01 & 14,92 & 12,63 & 10,70 & 9,08 & 6,66 & 5,06 & 3,31 \\
\hline 30,47 & 1678,60 & 188,40 & 19,64 & 15,27 & 12,66 & 9,83 & 7,71 & 6,15 & 4,20 & 3,15 & 2,13 \\
\hline 24,42 & 466,00 & 38,90 & 100,93 & 79,42 & 64,74 & 48,92 & 37,47 & 29,44 & 19,90 & 15,01 & 10,28 \\
\hline 71,11 & 1994,60 & 197,80 & 10,64 & 7,95 & 7,10 & 6,29 & 5,63 & 5,05 & 4,06 & 3,29 & 2,26 \\
\hline 47,03 & 1440,20 & 22,40 & 62,32 & 53,32 & 51,42 & 48,03 & 44,51 & 41,07 & 34,68 & 29,16 & 20,77 \\
\hline 45,31 & 323,90 & 192,00 & 32,93 & 18,02 & 13,15 & 9,48 & 7,26 & 5,78 & 3,99 & 3,06 & 2,13 \\
\hline 80,19 & 478,80 & 175,50 & 23,79 & 13,94 & 10,91 & 8,68 & 7,26 & 6,18 & 4,61 & 3,60 & 2,44 \\
\hline 59,53 & 1202,70 & 51,90 & 31,90 & 26,14 & 24,47 & 22,35 & 20,40 & 18,56 & 15,29 & 12,62 & 8,80 \\
\hline 43,04 & 1029,90 & 128,50 & 23,91 & 18,54 & 15,91 & 13,11 & 10,85 & 9,02 & 6,44 & 4,85 & 3,19 \\
\hline 29,09 & 641,50 & 56,40 & 62,43 & 49,90 & 41,80 & 32,76 & 25,83 & 20,67 & 14,11 & 10,54 & 7,11 \\
\hline 83,33 & 1678,00 & 198,20 & 10,78 & 7,59 & 6,69 & 5,91 & 5,31 & 4,79 & 3,92 & 3,23 & 2,28 \\
\hline 27,10 & 1534,00 & 87,50 & 36,86 & 30,70 & 26,20 & 20,92 & 16,71 & 13,48 & 9,23 & 6,86 & 4,58 \\
\hline 33,40 & 1039,70 & 56,50 & 47,59 & 40,69 & 35,85 & 29,99 & 24,98 & 20,84 & 14,84 & 11,10 & 7,23 \\
\hline 38,45 & 1202,60 & 186,70 & 19,26 & 14,42 & 12,03 & 9,55 & 7,65 & 6,21 & 4,31 & 3,24 & 2,17 \\
\hline 39,14 & 1311,50 & 49,60 & 42,13 & 37,28 & 34,02 & 29,88 & 26,07 & 22,68 & 17,20 & 13,28 & 8,63 \\
\hline 50,75 & 447,20 & 32,50 & 68,23 & 56,15 & 50,53 & 44,21 & 38,67 & 33,77 & 25,87 & 20,19 & 13,29 \\
\hline 53,85 & 1185,60 & 175,20 & 16,60 & 12,35 & 10,62 & 8,92 & 7,57 & 6,44 & 4,75 & 3,64 & 2,40 \\
\hline 67,90 & 1071,90 & 194,10 & 14,89 & 10,34 & 8,79 & 7,43 & 6,41 & 5,56 & 4,24 & 3,32 & 2,22 \\
\hline 20,63 & 963,40 & 64,70 & 64,33 & 50,44 & 40,41 & 29,82 & 22,43 & 17,45 & 11,78 & 8,95 & 6,18 \\
\hline 65,34 & 1005,20 & 107,30 & 21,11 & 15,96 & 14,17 & 12,41 & 10,98 & 9,71 & 7,63 & 6,09 & 4,11 \\
\hline 26,86 & 350,00 & 34,80 & 111,34 & 86,85 & 71,11 & 54,17 & 41,81 & 33,01 & 22,38 & 16,85 & 11,50 \\
\hline 33,39 & 1236,30 & 99,60 & 31,05 & 25,40 & 21,84 & 17,75 & 14,43 & 11,81 & 8,23 & 6,14 & 4,06 \\
\hline 65,82 & 1512,70 & 31,60 & 38,63 & 30,96 & 29,58 & 28,18 & 26,58 & 24,98 & 21,93 & 19,16 & 14,58 \\
\hline 52,16 & 231,10 & 148,90 & 43,70 & 23,17 & 16,75 & 12,11 & 9,35 & 7,49 & 5,19 & 3,97 & 2,76 \\
\hline 87,83 & 1434,40 & 168,90 & 12,37 & 8,59 & 7,56 & 6,69 & 6,04 & 5,48 & 4,52 & 3,76 & 2,68 \\
\hline 44,10 & 937,70 & 102,50 & 27,94 & 22,08 & 19,17 & 16,01 & 13,40 & 11,26 & 8,13 & 6,15 & 4,03 \\
\hline 59,34 & 1042,50 & 140,10 & 18,88 & 14,09 & 12,25 & 10,48 & 9,05 & 7,83 & 5,93 & 4,61 & 3,06 \\
\hline 27,29 & 561,90 & 32,70 & 98,80 & 82,18 & 70,13 & 56,01 & 44,74 & 36,09 & 24,73 & 18,38 & 12,27 \\
\hline 87,67 & 1018,10 & 89,10 & 20,30 & 14,50 & 13,05 & 11,78 & 10,78 & 9,89 & 8,33 & 7,04 & 5,12 \\
\hline 81,08 & 1759,40 & 192,90 & 10,80 & 7,71 & 6,84 & 6,07 & 5,47 & 4,94 & 4,04 & 3,33 & 2,34 \\
\hline 29,58 & 1696,90 & 177,60 & 20,77 & 16,26 & 13,49 & 10,46 & 8,19 & 6,53 & 4,45 & 3,33 & 2,26 \\
\hline 39,83 & 1101,90 & 75,30 & 33,92 & 28,50 & 25,25 & 21,44 & 18,14 & 15,37 & 11,20 & 8,47 & 5,51 \\
\hline 79,55 & 589,00 & 52,60 & 36,23 & 26,51 & 23,89 & 21,44 & 19,47 & 17,71 & 14,64 & 12,18 & 8,64 \\
\hline 54,16 & 958,10 & 173,40 & 18,42 & 13,21 & 11,17 & 9,25 & 7,75 & 6,54 & 4,77 & 3,64 & 2,40 \\
\hline 84,11 & 1358,70 & 193,20 & 12,12 & 8,32 & 7,22 & 6,30 & 5,61 & 5,03 & 4,06 & 3,33 & 2,32 \\
\hline 49,13 & 382,50 & 179,20 & 30,39 & 17,68 & 13,39 & 10,00 & 7,82 & 6,29 & 4,36 & 3,32 & 2,28 \\
\hline 65,86 & 737,00 & 168,70 & 19,68 & 13,15 & 10,91 & 9,03 & 7,65 & 6,54 & 4,87 & 3,77 & 2,52 \\
\hline 29,03 & 240,50 & 175,70 & 42,74 & 22,02 & 15,12 & 10,25 & 7,64 & 6,05 & 4,22 & 3,28 & 2,32 \\
\hline 57,65 & 693,80 & 58,80 & 37,20 & 29,57 & 26,55 & 23,34 & 20,58 & 18,13 & 14,12 & 11,17 & 7,45 \\
\hline 32,16 & 733,40 & 78,10 & 44,88 & 35,31 & 29,63 & 23,37 & 18,56 & 14,94 & 10,26 & 7,67 & 5,15 \\
\hline 38,77 & 848,30 & 189,10 & 21,94 & 15,38 & 12,45 & 9,60 & 7,55 & 6,06 & 4,18 & 3,15 & 2,14 \\
\hline 52,29 & 812,10 & 187,30 & 19,55 & 13,40 & 11,07 & 8,93 & 7,34 & 6,10 & 4,36 & 3,31 & 2,20 \\
\hline 43,52 & 1116,20 & 139,80 & 21,86 & 16,93 & 14,54 & 12,00 & 9,94 & 8,28 & 5,92 & 4,46 & 2,94 \\
\hline 32,07 & 1162,60 & 152,30 & 24,78 & 18,93 & 15,63 & 12,11 & 9,50 & 7,59 & 5,19 & 3,90 & 2,64 \\
\hline 27,06 & 597,70 & 40,60 & 84,16 & 68,76 & 57,98 & 45,65 & 36,06 & 28,86 & 19,67 & 14,66 & 9,87 \\
\hline 89,45 & 1930,20 & 71,50 & 17,12 & 13,03 & 12,02 & 11,39 & 10,77 & 10,17 & 9,04 & 8,01 & 6,28 \\
\hline 85,83 & 1959,00 & 197,20 & 9,89 & 7,02 & 6,26 & 5,60 & 5,08 & 4,63 & 3,85 & 3,22 & 2,31 \\
\hline 86,92 & 347,70 & 38,30 & 53,00 & 37,16 & 32,91 & 29,25 & 26,47 & 24,06 & 19,91 & 16,61 & 11,86 \\
\hline 21,75 & 1844,40 & 125,80 & 31,97 & 25,26 & 20,44 & 15,27 & 11,58 & 9,04 & 6,10 & 4,62 & 3,17 \\
\hline 73,27 & 806,50 & 79,90 & 25,96 & 19,24 & 17,21 & 15,28 & 13,71 & 12,32 & 9,96 & 8,13 & 5,63 \\
\hline 74,82 & 1564,60 & 139,70 & 14,03 & 10,44 & 9,41 & 8,42 & 7,60 & 6,88 & 5,62 & 4,63 & 3,24 \\
\hline 72,90 & 679,60 & 130,10 & 22,27 & 15,11 & 12,77 & 10,80 & 9,36 & 8,16 & 6,27 & 4,95 & 3,34 \\
\hline 61,96 & 825,60 & 34,50 & 46,42 & 37,65 & 35,35 & 32,47 & 29,77 & 27,23 & 22,67 & 18,88 & 13,32 \\
\hline 23,77 & 314,30 & 103,20 & 57,63 & 36,21 & 26,15 & 17,89 & 13,18 & 10,34 & 7,21 & 5,59 & 3,91 \\
\hline 44,98 & 1652,70 & 39,60 & 41,16 & 36,13 & 34,13 & 31,16 & 28,29 & 25,57 & 20,75 & 16,85 & 11,46 \\
\hline 32,03 & 1330,90 & 68,60 & 39,77 & 34,08 & 29,97 & 24,96 & 20,70 & 17,21 & 12,19 & 9,10 & 5,93 \\
\hline 83,11 & 251,90 & 191,20 & 36,57 & 18,11 & 12,70 & 9,12 & 7,14 & 5,82 & 4,13 & 3,18 & 2,20 \\
\hline 44,33 & 1194,50 & 166,70 & 18,97 & 14,44 & 12,32 & 10,11 & 8,35 & 6,94 & 4,95 & 3,73 & 2,46 \\
\hline 52,28 & 562,90 & 183,00 & 23,91 & 15,18 & 12,08 & 9,44 & 7,60 & 6,22 & 4,38 & 3,32 & 2,24 \\
\hline 89,61 & 1128,10 & 71,30 & 21,63 & 15,76 & 14,40 & 13,28 & 12,32 & 11,45 & 9,88 & 8,53 & 6,40 \\
\hline 74,35 & 1176,80 & 90,00 & 20,40 & 15,38 & 14,01 & 12,64 & 11,49 & 10,45 & 8,63 & 7,16 & 5,05 \\
\hline 44,11 & 1179,40 & 189,00 & 17,81 & 13,24 & 11,17 & 9,06 & 7,42 & 6,12 & 4,33 & 3,26 & 2,16 \\
\hline 21,07 & 1790,30 & 186,10 & 24,81 & 18,52 & 14,38 & 10,30 & 7,64 & 5,92 & 4,04 & 3,10 & 2,15 \\
\hline 60,28 & 337,80 & 37,90 & 63,65 & 48,59 & 42,86 & 37,17 & 32,48 & 28,41 & 21,87 & 17,18 & 11,44 \\
\hline 29,86 & 1021,00 & 158,30 & 26,41 & 19,55 & 15,74 & 11,85 & 9,11 & 7,19 & 4,89 & 3,70 & 2,54 \\
\hline 36,89 & 1758,40 & 73,30 & 30,85 & 27,14 & 24,51 & 21,21 & 18,25 & 15,66 & 11,62 & 8,86 & 5,73 \\
\hline 37,58 & 1500,50 & 106,50 & 25,39 & 21,22 & 18,65 & 15,64 & 13,08 & 10,96 & 7,87 & 5,91 & 3,86 \\
\hline 49,56 & 1396,80 & 100,20 & 22,34 & 18,46 & 16,60 & 14,49 & 12,64 & 11,01 & 8,40 & 6,53 & 4,29 \\
\hline 45,48 & 1485,40 & 25,20 & 57,98 & 50,24 & 48,21 & 44,71 & 41,18 & 37,76 & 31,49 & 26,17 & 18,33 \\
\hline
\end{tabular}




\begin{tabular}{|c|c|c|c|c|c|c|c|c|c|c|c|}
\hline \multirow[b]{2}{*}{ e1 (cm) } & & & & & & & ões (x1 & m) & & & \\
\hline & Meq (MPa) & Ms (MPa) & D0 & D25 & D40 & D60 & D80 & D100 & D140 & D180 & D260 \\
\hline 28,63 & 687,50 & 39,90 & 77,91 & 65,20 & 56,06 & 45,25 & 36,49 & 29,64 & 20,45 & 15,20 & 10,08 \\
\hline 33,39 & 1977,80 & 88,80 & 28,32 & 24,67 & 21,97 & 18,62 & 15,68 & 13,21 & 9,53 & 7,16 & 4,63 \\
\hline 22,50 & 1696,90 & 199,40 & 22,96 & 17,06 & 13,30 & 9,59 & 7,14 & 5,55 & 3,78 & 2,90 & 2,01 \\
\hline 84,04 & 1754,40 & 154,30 & 11,97 & 8,64 & 7,79 & 7,01 & 6,40 & 5,85 & 4,89 & 4,10 & 2,95 \\
\hline 86,04 & 1808,00 & 103,50 & 14,58 & 10,79 & 9,93 & 9,18 & 8,53 & 7,93 & 6,84 & 5,90 & 4,42 \\
\hline 37,74 & 1785,20 & 99,00 & 24,86 & 21,34 & 19,03 & 16,23 & 13,79 & 11,71 & 8,55 & 6,47 & 4,19 \\
\hline 84,14 & 1015,80 & 156,30 & 15,63 & 10,62 & 9,15 & 7,92 & 7,03 & 6,28 & 5,05 & 4,11 & 2,86 \\
\hline 37,47 & 646,60 & 98,70 & 36,76 & 27,59 & 22,99 & 18,18 & 14,52 & 11,76 & 8,14 & 6,10 & 4,10 \\
\hline 82,74 & 809,00 & 178,70 & 16,87 & 10,87 & 9,03 & 7,58 & 6,58 & 5,77 & 4,50 & 3,59 & 2,45 \\
\hline 87,42 & 1038,30 & 48,00 & 28,45 & 21,29 & 19,67 & 18,42 & 17,27 & 16,18 & 14,16 & 12,38 & 9,47 \\
\hline 75,30 & 349,60 & 22,50 & 75,37 & 57,20 & 52,64 & 47,99 & 43,99 & 40,32 & 33,77 & 28,34 & 20,32 \\
\hline 45,69 & 419,80 & 107,30 & 38,05 & 25,78 & 20,90 & 16,40 & 13,13 & 10,69 & 7,46 & 5,64 & 3,80 \\
\hline 39,80 & 1361,80 & 47,60 & 42,17 & 37,44 & 34,35 & 30,36 & 26,67 & 23,34 & 17,88 & 13,90 & 9,06 \\
\hline 61,86 & 450,70 & 126,70 & 30,08 & 19,41 & 15,75 & 12,72 & 10,56 & 8,87 & 6,45 & 4,94 & 3,30 \\
\hline 83,72 & 519,90 & 166,20 & 22,74 & 13,62 & 10,83 & 8,77 & 7,43 & 6,39 & 4,85 & 3,82 & 2,60 \\
\hline 74,71 & 773,60 & 35,80 & 41,75 & 32,17 & 30,08 & 27,89 & 25,87 & 23,97 & 20,49 & 17,49 & 12,85 \\
\hline 82,54 & 1778,30 & 155,40 & 11,94 & 8,67 & 7,82 & 7,04 & 6,41 & 5,86 & 4,88 & 4,09 & 2,93 \\
\hline 65,85 & 754,80 & 146,60 & 20,71 & 14,28 & 12,05 & 10,11 & 8,66 & 7,46 & 5,62 & 4,37 & 2,92 \\
\hline 34,30 & 1667,10 & 90,00 & 29,19 & 25,02 & 22,12 & 18,60 & 15,57 & 13,05 & 9,35 & 7,01 & 4,56 \\
\hline 39,86 & 357,90 & 150,30 & 36,20 & 21,93 & 16,64 & 12,20 & 9,36 & 7,43 & 5,11 & 3,90 & 2,70 \\
\hline 60,99 & 1469,10 & 113,00 & 18,01 & 14,28 & 12,94 & 11,50 & 10,25 & 9,13 & 7,25 & 5,82 & 3,93 \\
\hline 42,62 & 1435,10 & 61,70 & 33,24 & 29,02 & 26,51 & 23,38 & 20,52 & 17,95 & 13,75 & 10,70 & 6,99 \\
\hline 88,00 & 763,80 & 125,80 & 19,85 & 13,21 & 11,29 & 9,74 & 8,64 & 7,73 & 6,22 & 5,09 & 3,56 \\
\hline 85,17 & 1284,90 & 62,90 & 22,59 & 16,90 & 15,64 & 14,58 & 13,62 & 12,72 & 11,06 & 9,60 & 7,26 \\
\hline 74,05 & 1575,70 & 83,50 & 18,97 & 14,59 & 13,56 & 12,48 & 11,51 & 10,61 & 8,98 & 7,60 & 5,51 \\
\hline 29,68 & 731,60 & 168,70 & 28,47 & 19,67 & 15,28 & 11,13 & 8,41 & 6,60 & 4,51 & 3,45 & 2,39 \\
\hline 81,25 & 1758,60 & 101,70 & 15,36 & 11,49 & 10,61 & 9,78 & 9,05 & 8,38 & 7,16 & 6,12 & 4,51 \\
\hline 77,30 & 1401,30 & 109,70 & 16,60 & 12,36 & 11,24 & 10,16 & 9,25 & 8,44 & 7,01 & 5,84 & 4,16 \\
\hline 49,55 & 1978,70 & 120,40 & 17,45 & 14,63 & 13,28 & 11,70 & 10,30 & 9,04 & 6,98 & 5,47 & 3,61 \\
\hline 58,26 & 810,50 & 98,70 & 25,84 & 19,62 & 17,18 & 14,77 & 12,79 & 11,10 & 8,43 & 6,57 & 4,35 \\
\hline 43,49 & 1954,30 & 68,90 & 27,40 & 24,10 & 22,28 & 19,91 & 17,69 & 15,66 & 12,24 & 9,66 & 6,38 \\
\hline 27,10 & 1694,60 & 65,50 & $\begin{array}{l}43,39 \\
\end{array}$ & 37,55 & 32,83 & 27,02 & 22,12 & 18,18 & 12,67 & 9,40 & 6,16 \\
\hline 50,69 & 928,00 & 84,90 & 28,70 & 23,04 & 20,44 & 17,62 & 15,22 & 13,15 & 9,90 & 7,65 & 5,02 \\
\hline 61,92 & 1486,80 & 55,10 & 27,88 & 22,63 & 21,37 & 19,73 & 18,18 & 16,70 & 14,01 & 11,75 & 8,37 \\
\hline 43,46 & 313,10 & 102,90 & 45,66 & 29,30 & 23,04 & 17,53 & 13,74 & 11,04 & 7,63 & 5,78 & 3,95 \\
\hline 84,65 & 728,90 & 170,40 & 18,18 & 11,54 & 9,52 & 7,96 & 6,90 & 6,04 & 4,71 & 3,76 & 2,57 \\
\hline 60,39 & 1721,80 & 124,00 & 16,07 & 12,83 & 11,67 & 10,40 & 9,29 & 8,29 & 6,60 & 5,30 & 3,59 \\
\hline 58,26 & 1832,90 & 31,10 & 39,98 & 32,64 & 31,45 & 29,90 & 28,12 & 26,35 & 22,98 & 19,92 & 14,94 \\
\hline 57,22 & 243,20 & 35,80 & 78,60 & 58,10 & 50,09 & 42,40 & 36,26 & 31,10 & 23,23 & 17,93 & 11,84 \\
\hline 86,97 & 1460,50 & 173,20 & 12,15 & 8,45 & 7,44 & 6,58 & 5,93 & 5,38 & 4,43 & 3,68 & 2,61 \\
\hline 76,05 & 581,10 & 187,60 & 20,75 & 12,60 & 10,04 & 8,09 & 6,80 & 5,80 & 4,33 & 3,37 & 2,27 \\
\hline 52,23 & 1877,30 & 105,20 & 18,71 & 15,65 & 14,33 & 12,76 & 11,35 & 10,06 & 7,91 & 6,29 & 4,19 \\
\hline 33,05 & 270,80 & 107,20 & 52,47 & 32,34 & 24,20 & 17,30 & 13,02 & 10,25 & 7,06 & 5,42 & 3,78 \\
\hline 22,16 & 1190,00 & 39,10 & 81,74 & 69,69 & 59,65 & 47,57 & 37,84 & 30,37 & 20,65 & 15,30 & 10,23 \\
\hline 55,71 & 789,50 & 25,70 & 60,88 & 50,83 & 48,08 & 44,23 & 40,54 & 37,04 & 30,73 & 25,48 & 17,84 \\
\hline 88,46 & 498,40 & 38,30 & 44,27 & 31,89 & 28,90 & 26,32 & 24,22 & 22,34 & 19,00 & 16,20 & 11,93 \\
\hline 58,43 & 1718,60 & 184,80 & 13,02 & 10,05 & 8,88 & 7,70 & 6,72 & 5,87 & 4,50 & 3,53 & 2,34 \\
\hline 72,43 & 1443,00 & 127,10 & 15,56 & 11,69 & 10,55 & 9,42 & 8,49 & 7,66 & 6,23 & 5,11 & 3,55 \\
\hline 26,59 & 257,30 & 148,20 & 46,71 & 25,80 & 18,01 & 12,22 & 9,08 & 7,17 & 5,01 & 3,89 & 2,74 \\
\hline 31,15 & 1512,00 & 42,60 & 53,27 & 47,99 & 43,39 & 37,45 & 32,05 & 27,36 & 20,09 & 15,19 & 9,78 \\
\hline 68,04 & 1838,20 & 48,20 & 26,75 & 21,27 & 20,25 & 19,15 & 17,98 & 16,83 & 14,67 & 12,73 & 9,58 \\
\hline 60,21 & 1550,00 & 60,70 & 26,22 & 21,44 & 20,17 & 18,53 & 16,99 & 15,54 & 12,92 & 10,75 & 7,57 \\
\hline 34,13 & 1061,20 & 91,50 & 34,08 & 27,68 & 23,76 & 19,29 & 15,68 & 12,84 & 8,95 & 6,68 & 4,42 \\
\hline 82,14 & 817,00 & 84,20 & 23,87 & 17,10 & 15,25 & 13,58 & 12,28 & 11,14 & 9,17 & 7,61 & 5,38 \\
\hline 44,18 & 752,70 & 133,60 & 26,31 & 19,20 & 16,07 & 12,93 & 10,52 & 8,65 & 6,09 & 4,59 & 3,05 \\
\hline 29,77 & 1424,40 & 188,40 & 21,08 & 15,98 & 13,03 & 9,93 & 7,68 & 6,09 & 4,14 & 3,12 & 2,13 \\
\hline 27,86 & 422,80 & 50,50 & 79,38 & 60,68 & 49,30 & 37,32 & 28,71 & 22,65 & 15,38 & 11,60 & 7,94 \\
\hline 44,57 & 1689,00 & 102,00 & 22,04 & 18,69 & 16,84 & 14,65 & 12,71 & 11,00 & 8,30 & 6,40 & 4,17 \\
\hline 25,23 & 1660,40 & 82,00 & 39,77 & 33,29 & 28,35 & 22,54 & 17,92 & 14,40 & 9,82 & 7,29 & 4,88 \\
\hline 65,25 & 1349,20 & 63,50 & 25,54 & 20,38 & 19,05 & 17,47 & 16,02 & 14,66 & 12,22 & 10,20 & 7,22 \\
\hline 44,60 & 433,40 & 152,80 & 31,54 & 19,87 & 15,53 & 11,78 & 9,24 & 7,42 & 5,14 & 3,90 & 2,66 \\
\hline 47,94 & 1096,20 & 69,80 & 31,29 & 26,23 & 23,70 & 20,75 & 18,13 & 15,82 & 12,08 & 9,40 & 6,17 \\
\hline 25,26 & 300,30 & 111,10 & 54,26 & 33,45 & 24,17 & 16,59 & 12,26 & 9,63 & 6,70 & 5,19 & 3,64 \\
\hline 51,58 & 1472,90 & 138,40 & 17,61 & 14,06 & 12,46 & 10,75 & 9,30 & 8,04 & 6,06 & 4,69 & 3,08 \\
\hline 64,84 & 1703,40 & 27,90 & 40,79 & 32,93 & 31,43 & 30,21 & 28,67 & 27,10 & 24,05 & 21,23 & 16,43 \\
\hline 55,46 & 1402,90 & 187,70 & 14,56 & 10,98 & 9,52 & 8,09 & 6,93 & 5,94 & 4,44 & 3,42 & 2,26 \\
\hline 77,63 & 1301,90 & 69,90 & 22,21 & 16,86 & 15,65 & 14,44 & 13,35 & 12,35 & 10,52 & 8,97 & 6,57 \\
\hline 63,95 & 696,80 & 115,10 & 24,55 & 17,50 & 14,98 & 12,71 & 10,95 & 9,47 & 7,17 & 5,60 & 3,73 \\
\hline 55,56 & 1729,90 & 198,00 & 12,85 & 9,90 & 8,70 & 7,47 & 6,45 & 5,58 & 4,22 & 3,27 & 2,16 \\
\hline 26,76 & 261,00 & 39,20 & 112,77 & 82,99 & 65,68 & 48,37 & 36,58 & 28,65 & 19,49 & 14,84 & 10,24 \\
\hline 24,48 & 943,20 & 134,20 & 34,18 & 25,06 & 19,58 & 14,18 & 10,61 & 8,27 & 5,64 & 4,32 & 2,99 \\
\hline 60,45 & 530,40 & 189,00 & 23,29 & 14,26 & 11,25 & 8,85 & 7,21 & 5,98 & 4,27 & 3,26 & 2,20 \\
\hline 88,67 & 288,30 & 149,20 & 34,98 & 18,75 & 13,93 & 10,61 & 8,67 & 7,28 & 5,36 & 4,18 & 2,86 \\
\hline 31,28 & 511,20 & 112,80 & 40,82 & 28,53 & 22,44 & 16,60 & 12,64 & 9,96 & 6,80 & 5,18 & 3,57 \\
\hline 50,41 & 1218,10 & 136,00 & 19,56 & 15,30 & 13,39 & 11,38 & 9,71 & 8,30 & 6,16 & 4,72 & 3,10 \\
\hline 32,67 & 1209,30 & 50,90 & 49,14 & 43,00 & 38,32 & 32,48 & 27,37 & 23,05 & 16,62 & 12,47 & 8,07 \\
\hline 26,19 & 1341,70 & 107,00 & 34,41 & 27,49 & 22,78 & 17,57 & 13,66 & 10,83 & 7,34 & 5,50 & 3,74 \\
\hline 78,83 & 1214,20 & 84,00 & 20,36 & 15,20 & 13,92 & 12,68 & 11,63 & 10,67 & 8,97 & 7,55 & 5,45 \\
\hline 62,74 & 1704,20 & 146,90 & 14,32 & 11,17 & 10,05 & 8,90 & 7,92 & 7,04 & 5,57 & 4,47 & 3,02 \\
\hline 83,35 & 1829,80 & 54,30 & 21,62 & 16,80 & 15,64 & 14,91 & 14,14 & 13,38 & 11,91 & 10,57 & 8,29 \\
\hline 41,20 & 1088,80 & 64,00 & 36,80 & 31,40 & 28,14 & 24,25 & 20,82 & 17,85 & 13,25 & 10,11 & 6,57 \\
\hline 73,65 & 1467,40 & 32,20 & 35,57 & 28,25 & 26,66 & 25,56 & 24,27 & 22,95 & 20,42 & 18,09 & 14,11 \\
\hline
\end{tabular}




\begin{tabular}{|c|c|c|c|c|c|c|c|c|c|c|c|}
\hline \multirow[b]{2}{*}{ e1 (cm) } & & & & & & & ões (x1 & m) & & & \\
\hline & Meq (MPa) & Ms (MPa) & D0 & D25 & D40 & D60 & D80 & D100 & D140 & D180 & D260 \\
\hline 55,21 & 1946,00 & 29,70 & 42,06 & 34,61 & 33,45 & 31,78 & 29,86 & 27,95 & 24,31 & 21,02 & 15,68 \\
\hline 33,81 & 785,80 & 32,50 & 74,44 & 65,37 & 58,53 & 49,98 & 42,40 & 35,94 & 26,15 & 19,71 & 12,74 \\
\hline 30,38 & 1084,40 & 168,20 & 24,60 & 18,24 & 14,72 & 11,13 & 8,57 & 6,78 & 4,62 & 3,49 & 2,39 \\
\hline 23,94 & 1817,50 & 79,90 & 41,06 & 34,49 & 29,34 & 23,27 & 18,44 & 14,78 & 10,05 & 7,47 & 5,00 \\
\hline 71,86 & 885,20 & 164,30 & 17,43 & 11,93 & 10,11 & 8,57 & 7,42 & 6,47 & 4,98 & 3,93 & 2,64 \\
\hline 64,87 & 918,60 & 40,70 & 39,13 & 31,31 & 29,36 & 26,99 & 24,79 & 22,73 & 19,01 & 15,90 & 11,30 \\
\hline 40,95 & 326,70 & 22,90 & 110,31 & 92,39 & 81,95 & 69,76 & 59,22 & 50,29 & 36,81 & 27,91 & 18,15 \\
\hline 23,91 & 1235,60 & 56,70 & 58,67 & 49,07 & 41,62 & 32,88 & 25,98 & 20,78 & 14,11 & 10,49 & 7,05 \\
\hline 58,64 & 1748,80 & 174,10 & 13,33 & 10,38 & 9,23 & 8,04 & 7,05 & 6,18 & 4,77 & 3,75 & 2,50 \\
\hline 79,53 & 1403,00 & 149,90 & 13,83 & 9,96 & 8,86 & 7,86 & 7,08 & 6,39 & 5,22 & 4,30 & 3,01 \\
\hline 29,27 & 1025,70 & 48,00 & 59,18 & 50,75 & 44,35 & 36,56 & 30,00 & 24,71 & 17,29 & 12,85 & 8,42 \\
\hline 62,89 & 1919,20 & 93,20 & 17,97 & 14,47 & 13,50 & 12,32 & 11,25 & 10,24 & 8,46 & 7,00 & 4,90 \\
\hline 81,05 & 1048,00 & 155,20 & 15,63 & 10,78 & 9,32 & 8,09 & 7,18 & 6,40 & 5,12 & 4,16 & 2,87 \\
\hline 84,57 & 843,20 & 167,50 & 16,80 & 10,97 & 9,21 & 7,81 & 6,84 & 6,04 & 4,76 & 3,83 & 2,64 \\
\hline 83,89 & 1419,50 & 106,50 & 16,15 & 11,80 & 10,74 & 9,77 & 8,97 & 8,25 & 6,97 & 5,90 & 4,29 \\
\hline 21,38 & 272,60 & 66,10 & 86,58 & 56,77 & 41,18 & 28,06 & 20,58 & 16,10 & 11,23 & 8,72 & 6,08 \\
\hline 53,40 & 791,00 & 127,20 & 23,90 & 17,54 & 14,97 & 12,49 & 10,52 & 8,91 & 6,52 & 4,98 & 3,29 \\
\hline 45,68 & 999,10 & 103,70 & 26,43 & 21,02 & 18,36 & 15,48 & 13,07 & 11,06 & 8,07 & 6,13 & 4,01 \\
\hline 70,14 & 1615,40 & 99,60 & 17,36 & 13,46 & 12,42 & 11,30 & 10,31 & 9,41 & 7,80 & 6,49 & 4,59 \\
\hline 85,96 & 1547,80 & 35,50 & 28,95 & 23,22 & 21,38 & 20,56 & 19,72 & 18,80 & 17,01 & 15,34 & 12,37 \\
\hline 36,70 & 1930,30 & 48,70 & 39,32 & 35,60 & 32,90 & 29,26 & 25,84 & 22,71 & 17,51 & 13,66 & 8,91 \\
\hline 84,94 & 1378,80 & 50,80 & 24,92 & 19,01 & 17,67 & 16,71 & 15,75 & 14,83 & 13,09 & 11,53 & 8,93 \\
\hline 67,06 & 1029,40 & 33,20 & 42,12 & 33,51 & 31,81 & 29,77 & 27,73 & 25,77 & 22,13 & 18,95 & 13,95 \\
\hline 25,38 & 1894,70 & 28,50 & 77,33 & 71,36 & 64,90 & 56,24 & 48,23 & 41,20 & 30,23 & 22,79 & 14,60 \\
\hline 31,17 & 556,30 & 81,60 & 49,00 & 36,71 & 29,90 & 22,83 & 17,71 & 14,06 & 9,59 & 7,22 & 4,93 \\
\hline 68,28 & 1644,70 & 116,90 & 15,89 & 12,32 & 11,26 & 10,14 & 9,18 & 8,31 & 6,79 & 5,57 & 3,88 \\
\hline 47,80 & 375,20 & 170,20 & 31,64 & 18,60 & 14,14 & 10,56 & 8,25 & 6,62 & 4,59 & 3,49 & 2,40 \\
\hline 33,02 & 275,80 & 179,20 & 39,03 & 20,92 & 14,75 & 10,18 & 7,61 & 6,01 & 4,17 & 3,23 & 2,28 \\
\hline 31,58 & 1696,70 & 119,80 & 25,69 & 21,25 & 18,30 & 14,85 & 12,05 & 9,84 & 6,84 & 5,09 & 3,37 \\
\hline 53,99 & 442,80 & 74,00 & 41,60 & 30,29 & 25,78 & 21,47 & 18,08 & 15,30 & 11,20 & 8,56 & 5,65 \\
\hline 84,45 & 1199,70 & 169,30 & 13,76 & 9,45 & 8,20 & 7,15 & 6,38 & 5,72 & 4,63 & 3,79 & 2,65 \\
\hline 75,89 & 1241,00 & 148,90 & 15,02 & 10,82 & 9,53 & 8,37 & 7,47 & 6,68 & 5,36 & 4,35 & 3,00 \\
\hline 65,02 & 905,60 & 47,00 & 35,86 & 28,57 & 26,58 & 24,24 & 22,14 & 20,18 & 16,70 & 13,85 & 9,73 \\
\hline 31,57 & 1315,30 & 55,60 & $\begin{array}{l}46,38 \\
\end{array}$ & 40,47 & 35,91 & 30,25 & 25,33 & 21,22 & 15,18 & 11,35 & 7,36 \\
\hline 83,35 & 1230,70 & 168,40 & 13,67 & 9,46 & 8,24 & 7,20 & 6,42 & 5,76 & 4,66 & 3,82 & 2,66 \\
\hline 49,39 & 1782,80 & 40,10 & 37,52 & 32,14 & 30,67 & 28,34 & 26,04 & 23,83 & 19,81 & 16,44 & 11,50 \\
\hline 79,60 & 1104,30 & 156,60 & 15,25 & 10,62 & 9,23 & 8,03 & 7,13 & 6,36 & 5,08 & 4,13 & 2,85 \\
\hline 51,33 & 870,40 & 146,50 & 21,63 & 15,80 & 13,41 & 11,09 & 9,26 & 7,79 & 5,64 & 4,29 & 2,83 \\
\hline 22,61 & 680,20 & 178,00 & 31,99 & 20,89 & 15,23 & 10,44 & 7,68 & 6,01 & 4,18 & 3,24 & 2,26 \\
\hline 34,47 & 1169,80 & 76,70 & 36,55 & 30,69 & 26,85 & 22,29 & 18,45 & 15,32 & 10,86 & 8,12 & 5,31 \\
\hline 55,92 & 257,30 & 106,00 & 46,20 & 27,50 & 21,28 & 16,34 & 13,08 & 10,68 & 7,52 & 5,72 & 3,88 \\
\hline 29,84 & 1365,00 & 199,70 & 20,54 & 15,35 & 12,41 & 9,39 & 7,23 & 5,72 & 3,89 & 2,94 & 2,01 \\
\hline 28,48 & 1700,60 & 105,10 & 30,32 & 25,19 & 21,55 & 17,29 & 13,87 & 11,23 & 7,72 & 5,74 & 3,82 \\
\hline 32,09 & 1215,60 & 77,00 & 38,01 & 31,86 & 27,68 & 22,72 & 18,61 & 15,32 & 10,73 & 7,99 & 5,25 \\
\hline 61,20 & 1174,30 & 158,70 & 16,46 & 12,21 & 10,62 & 9,11 & 7,90 & 6,86 & 5,23 & 4,08 & 2,71 \\
\hline 39,18 & 958,10 & 55,90 & 43,62 & 37,26 & 33,26 & 28,46 & 24,25 & 20,65 & 15,16 & 11,50 & 7,46 \\
\hline 37,31 & 1752,50 & 134,80 & 20,79 & 17,20 & 15,04 & 12,52 & 10,41 & 8,68 & 6,19 & 4,64 & 3,04 \\
\hline 54,40 & 1391,70 & 188,40 & 14,74 & 11,11 & 9,63 & 8,15 & 6,96 & 5,95 & 4,43 & 3,40 & 2,24 \\
\hline 84,65 & 229,80 & 63,90 & 53,97 & 33,17 & 26,83 & 22,04 & 18,88 & 16,39 & 12,60 & 9,99 & 6,81 \\
\hline 54,65 & 1199,30 & 121,60 & 20,01 & 15,72 & 13,91 & 12,02 & 10,43 & 9,05 & 6,88 & 5,35 & 3,53 \\
\hline 36,91 & 377,40 & 102,60 & 44,95 & 30,26 & 23,89 & 17,96 & 13,88 & 11,04 & 7,57 & 5,74 & 3,94 \\
\hline 43,27 & 790,00 & 159,70 & 23,57 & 16,80 & 13,87 & 11,01 & 8,86 & 7,23 & 5,05 & 3,80 & 2,55 \\
\hline 87,76 & 1979,00 & 26,50 & 29,35 & 26,30 & 23,67 & 22,77 & 22,22 & 21,49 & 19,91 & 18,37 & 15,49 \\
\hline 60,84 & 548,90 & 37,60 & 51,75 & 41,40 & 37,78 & 33,78 & 30,29 & 27,11 & 21,70 & 17,51 & 11,90 \\
\hline 40,90 & 756,40 & 52,10 & 48,23 & 40,48 & 35,94 & 30,62 & 26,02 & 22,11 & 16,20 & 12,29 & 7,99 \\
\hline 78,59 & 1624,80 & 112,50 & 15,23 & 11,38 & 10,43 & 9,49 & 8,70 & 7,98 & 6,71 & 5,64 & 4,07 \\
\hline 46,43 & 1112,50 & 118,20 & 23,18 & 18,36 & 16,03 & 13,53 & 11,43 & 9,69 & 7,08 & 5,38 & 3,52 \\
\hline 61,39 & 230,60 & 61,80 & 60,18 & 39,26 & 32,03 & 25,96 & 21,60 & 18,17 & 13,23 & 10,14 & 6,76 \\
\hline 74,73 & 421,00 & 23,50 & $\begin{array}{l}68,42 \\
\end{array}$ & 52,36 & 48,56 & 44,60 & 41,08 & 37,82 & 31,94 & 26,99 & 19,53 \\
\hline 33,89 & 1317,50 & 52,50 & 45,40 & 40,01 & 35,90 & 30,74 & 26,15 & 22,21 & 16,21 & 12,24 & 7,90 \\
\hline 26,64 & 1422,10 & 62,50 & $\begin{array}{l}48,07 \\
\end{array}$ & 41,01 & 35,49 & 28,82 & 23,33 & 18,99 & 13,11 & 9,72 & 6,43 \\
\hline 39,72 & 1616,50 & 125,40 & 21,42 & 17,73 & 15,59 & 13,11 & 11,01 & 9,27 & 6,69 & 5,04 & 3,29 \\
\hline 20,34 & 938,20 & 91,90 & 50,61 & 37,80 & 29,26 & 20,88 & 15,44 & 11,97 & 8,17 & 6,28 & 4,35 \\
\hline 70,51 & 940,20 & 98,20 & 22,03 & 16,40 & 14,61 & 12,89 & 11,50 & 10,27 & 8,21 & 6,64 & 4,54 \\
\hline 75,14 & 1836,00 & 49,30 & 24,69 & 19,37 & 18,27 & 17,40 & 16,44 & 15,49 & 13,67 & 12,03 & 9,27 \\
\hline 37,45 & 1700,90 & 156,80 & 19,07 & 15,43 & 13,34 & 10,97 & 9,02 & 7,46 & 5,27 & 3,95 & 2,60 \\
\hline 23,77 & 645,60 & 66,60 & 63,95 & 48,81 & 38,92 & 28,72 & 21,67 & 16,92 & 11,47 & 8,72 & 6,01 \\
\hline 57,67 & 661,40 & 96,20 & 28,97 & 21,44 & 18,51 & 15,69 & 13,44 & 11,55 & 8,65 & 6,68 & 4,42 \\
\hline 38,85 & 686,60 & 27,30 & 78,31 & 69,10 & 62,86 & 54,98 & 47,80 & 41,43 & 31,25 & 24,04 & 15,60 \\
\hline 20,23 & 1251,30 & 152,50 & 32,39 & 23,46 & 17,81 & 12,49 & 9,18 & 7,12 & 4,90 & 3,78 & 2,63 \\
\hline 75,92 & 707,10 & 21,80 & 58,38 & 45,49 & 42,86 & 40,58 & 38,20 & 35,88 & 31,49 & 27,54 & 21,04 \\
\hline 67,12 & 773,40 & 134,10 & 21,16 & 14,84 & 12,66 & 10,74 & 9,27 & 8,05 & 6,14 & 4,81 & 3,21 \\
\hline 46,19 & 1027,00 & 176,50 & 19,17 & 14,05 & 11,83 & 9,61 & 7,89 & 6,54 & 4,64 & 3,50 & 2,32 \\
\hline 68,72 & 1045,30 & 156,60 & 16,64 & 11,90 & 10,28 & 8,84 & 7,71 & 6,76 & 5,23 & 4,14 & 2,78 \\
\hline 50,21 & 598,30 & 45,20 & 50,14 & 41,16 & 36,93 & 32,19 & 28,05 & 24,42 & 18,61 & 14,47 & 9,51 \\
\hline 28,81 & 365,10 & 74,90 & 62,56 & 44,06 & 34,41 & 25,14 & 18,99 & 14,89 & 10,17 & 7,77 & 5,37 \\
\hline 29,37 & 1950,00 & 90,80 & 31,13 & 26,72 & 23,37 & 19,28 & 15,84 & 13,05 & 9,14 & 6,80 & 4,45 \\
\hline 54,99 & 1454,50 & 89,80 & 22,03 & 18,14 & 16,57 & 14,76 & 13,14 & 11,68 & 9,22 & 7,35 & 4,93 \\
\hline 77,20 & 485,70 & 143,50 & 25,57 & 15,78 & 12,70 & 10,35 & 8,76 & 7,52 & 5,66 & 4,43 & 2,99 \\
\hline 22,07 & 683,30 & 104,70 & 47,59 & 33,91 & 25,75 & 18,13 & 13,37 & 10,40 & 7,15 & 5,51 & 3,83 \\
\hline 57,67 & 1819,60 & 182,90 & 12,86 & 10,03 & 8,90 & 7,74 & 6,77 & 5,92 & 4,55 & 3,57 & 2,37 \\
\hline 41,36 & 1598,40 & 131,60 & 20,29 & 16,67 & 14,66 & 12,37 & 10,42 & 8,79 & 6,38 & 4,82 & 3,14 \\
\hline
\end{tabular}




\begin{tabular}{|c|c|c|c|c|c|c|c|c|c|c|c|}
\hline & & & \multicolumn{9}{|c|}{ Deflexões $\left(\times 10^{-4} \mathrm{~cm}\right)$} \\
\hline e1 (cm) & Meq (MPa) & Ms (MPa) & D0 & D25 & D40 & D60 & D80 & D100 & D140 & D180 & D260 \\
\hline 20,77 & 704,20 & 46,60 & 88,47 & 69,56 & 55,88 & 41,35 & 31,17 & 24,26 & 16,37 & 12,43 & 8,57 \\
\hline 35,14 & 1774,50 & 92,20 & 27,56 & 23,74 & 21,09 & 17,86 & 15,04 & 12,68 & 9,16 & 6,88 & 4,47 \\
\hline 70,75 & 1967,30 & 164,60 & 11,88 & 9,02 & 8,16 & 7,30 & 6,58 & 5,94 & 4,83 & 3,95 & 2,74 \\
\hline 66,78 & 1422,40 & 153,50 & 14,68 & 11,03 & 9,79 & 8,59 & 7,61 & 6,74 & 5,32 & 4,26 & 2,88 \\
\hline 52,55 & 1919,50 & 74,30 & 23,14 & 19,60 & 18,31 & 16,62 & 15,05 & 13,57 & 10,99 & 8,92 & 6,09 \\
\hline 40,61 & 1138,50 & 88,80 & 29,83 & 24,68 & 21,73 & 18,34 & 15,46 & 13,04 & 9,46 & 7,15 & 4,66 \\
\hline 57,03 & 883,00 & 153,30 & 19,92 & 14,31 & 12,17 & 10,17 & 8,61 & 7,32 & 5,40 & 4,15 & 2,74 \\
\hline 29,13 & 959,60 & 24,70 & 94,26 & 85,05 & 76,65 & 65,77 & 55,95 & 47,48 & 34,54 & 25,98 & 16,71 \\
\hline 38,55 & 643,60 & 103,40 & 35,20 & 26,20 & 21,81 & 17,27 & 13,82 & 11,21 & 7,78 & 5,84 & 3,92 \\
\hline 86,91 & 759,90 & 113,60 & 20,93 & 14,16 & 12,22 & 10,62 & 9,46 & 8,49 & 6,87 & 5,64 & 3,95 \\
\hline 24,30 & 1139,40 & 96,30 & 41,08 & 32,25 & 26,24 & 19,78 & 15,13 & 11,88 & 8,03 & 6,06 & 4,15 \\
\hline 82,67 & 378,00 & 97,50 & 33,96 & 21,27 & 17,37 & 14,37 & 12,35 & 10,74 & 8,27 & 6,56 & 4,46 \\
\hline 43,15 & 1573,20 & 153,70 & 18,06 & 14,51 & 12,67 & 10,63 & 8,92 & 7,51 & 5,44 & 4,11 & 2,69 \\
\hline 58,73 & 1164,50 & 121,10 & 19,53 & 15,12 & 13,40 & 11,65 & 10,19 & 8,91 & 6,86 & 5,39 & 3,58 \\
\hline 30,63 & 949,10 & 151,00 & 27,51 & 20,33 & 16,40 & 12,39 & 9,55 & 7,55 & 5,14 & 3,89 & 2,66 \\
\hline 28,28 & 524,80 & 36,00 & 92,16 & 75,63 & 64,19 & 51,00 & 40,60 & 32,69 & 22,38 & 16,67 & 11,16 \\
\hline 30,86 & 331,10 & 163,50 & 38,46 & 22,33 & 16,16 & 11,25 & 8,40 & 6,61 & 4,58 & 3,54 & 2,48 \\
\hline 60,77 & 620,80 & 163,20 & 22,64 & 14,85 & 12,14 & 9,85 & 8,20 & 6,89 & 5,02 & 3,84 & 2,56 \\
\hline 61,75 & 450,60 & 116,00 & 31,29 & 20,58 & 16,87 & 13,73 & 11,46 & 9,67 & 7,06 & 5,42 & 3,61 \\
\hline 40,15 & 883,50 & 136,10 & 25,67 & 19,25 & 16,15 & 12,93 & 10,44 & 8,53 & 5,95 & 4,47 & 2,98 \\
\hline 68,86 & 1185,20 & 108,90 & 18,95 & 14,37 & 12,92 & 11,47 & 10,27 & 9,20 & 7,39 & 5,99 & 4,11 \\
\hline 40,44 & 894,30 & 24,30 & 75,01 & 67,09 & 62,38 & 55,96 & 49,87 & 44,25 & 34,71 & 27,44 & 18,10 \\
\hline 88,22 & 1440,20 & 28,00 & 33,22 & 27,54 & 25,10 & 24,18 & 23,35 & 22,40 & 20,46 & 18,63 & 15,31 \\
\hline 22,49 & 448,70 & 49,20 & 91,30 & 68,49 & 53,71 & 38,91 & 29,05 & 22,59 & 15,37 & 11,76 & 8,14 \\
\hline 84,00 & 751,10 & 120,80 & 20,72 & 14,00 & 12,01 & 10,36 & 9,18 & 8,18 & 6,55 & 5,32 & 3,69 \\
\hline 71,49 & 1806,10 & 100,10 & 16,40 & 12,71 & 11,80 & 10,80 & 9,92 & 9,10 & 7,63 & 6,40 & 4,58 \\
\hline 45,22 & 228,70 & 167,40 & 42,72 & 21,94 & 15,47 & 10,88 & 8,26 & 6,56 & 4,53 & 3,49 & 2,45 \\
\hline 83,68 & 1087,10 & 162,10 & 14,85 & 10,15 & 8,76 & 7,61 & 6,77 & 6,05 & 4,87 & 3,97 & 2,76 \\
\hline 82,19 & 1727,50 & 155,90 & 12,11 & 8,78 & 7,90 & 7,10 & 6,46 & 5,89 & 4,89 & 4,09 & 2,92 \\
\hline 47,83 & 873,90 & 40,50 & 48,03 & 41,19 & 37,86 & 33,73 & 29,94 & 26,50 & 20,73 & 16,39 & 10,86 \\
\hline 36,50 & 1659,10 & 36,40 & 50,49 & 45,89 & 42,66 & 38,18 & 33,92 & 29,99 & 23,35 & 18,34 & 12,02 \\
\hline 77,16 & 1719,60 & 111,50 & 15,09 & 11,37 & 10,46 & 9,55 & 8,77 & 8,05 & 6,77 & 5,70 & 4,11 \\
\hline 53,94 & 379,50 & 120,40 & 35,49 & 22,60 & 18,05 & 14,20 & 11,50 & 9,46 & 6,69 & 5,08 & 3,42 \\
\hline 75,37 & 1719,60 & 103,80 & 15,92 & 12,12 & 11,19 & 10,24 & 9,41 & 8,64 & 7,27 & 6,13 & 4,42 \\
\hline 29,03 & 1874,40 & 99,10 & 30,07 & 25,45 & 22,05 & 17,98 & 14,62 & 11,96 & 8,30 & 6,17 & 4,07 \\
\hline 70,84 & 1921,40 & 27,30 & 36,72 & 30,10 & 28,23 & 27,38 & 26,27 & 25,05 & 22,64 & 20,35 & 16,30 \\
\hline 57,98 & 1231,70 & 69,40 & 26,70 & 21,84 & 20,12 & 18,10 & 16,29 & 14,62 & 11,75 & 9,51 & 6,47 \\
\hline 87,35 & 1082,00 & 38,20 & 31,91 & 24,40 & 22,59 & 21,42 & 20,26 & 19,13 & 16,99 & 15,05 & 11,77 \\
\hline 37,23 & 1022,40 & 166,00 & 22,47 & 16,69 & 13,83 & 10,86 & 8,64 & 6,97 & 4,82 & 3,62 & 2,43 \\
\hline 40,18 & 303,20 & 164,80 & 37,46 & 21,13 & 15,51 & 11,12 & 8,45 & 6,70 & 4,62 & 3,54 & 2,47 \\
\hline 29,08 & 371,70 & 120,60 & 45,31 & 29,14 & 21,84 & 15,47 & 11,56 & 9,06 & 6,24 & 4,81 & 3,35 \\
\hline 43,47 & 873,40 & 105,70 & 28,52 & 22,21 & 19,13 & 15,82 & 13,13 & 10,96 & 7,84 & 5,91 & 3,89 \\
\hline 23,19 & 234,80 & 168,50 & 45,51 & 23,31 & 15,71 & 10,51 & 7,84 & 6,24 & 4,38 & 3,41 & 2,42 \\
\hline 24,40 & 1903,20 & 21,20 & 97,54 & 91,06 & 83,51 & 73,17 & 63,41 & 54,68 & 40,71 & 30,93 & 19,80 \\
\hline 29,24 & 983,60 & 176,10 & 25,22 & 18,21 & 14,43 & 10,69 & 8,13 & 6,39 & 4,36 & 3,31 & 2,28 \\
\hline 54,15 & 441,00 & 48,20 & 52,43 & 40,81 & 35,90 & 30,84 & 26,62 & 23,00 & 17,34 & 13,42 & 8,84 \\
\hline 76,77 & 1239,30 & 65,40 & 23,73 & 18,08 & 16,80 & 15,50 & 14,34 & 13,26 & 11,29 & 9,61 & 7,04 \\
\hline 78,06 & 298,90 & 168,70 & 33,46 & 17,82 & 13,12 & 9,86 & 7,93 & 6,57 & 4,73 & 3,65 & 2,49 \\
\hline 83,70 & 401,30 & 113,00 & 30,84 & 18,95 & 15,31 & 12,56 & 10,73 & 9,30 & 7,13 & 5,65 & 3,84 \\
\hline 46,66 & 1362,80 & 76,70 & 27,66 & 23,50 & 21,33 & 18,75 & 16,43 & 14,36 & 11,01 & 8,58 & 5,63 \\
\hline 50,15 & 1007,60 & 153,80 & 19,94 & 14,85 & 12,69 & 10,54 & 8,83 & 7,43 & 5,39 & 4,10 & 2,70 \\
\hline 38,93 & 1554,70 & 33,90 & 51,61 & 46,53 & 43,55 & 39,30 & 35,22 & 31,41 & 24,85 & 19,76 & 13,10 \\
\hline 34,01 & 526,80 & 153,90 & 31,97 & 21,17 & 16,42 & 12,08 & 9,21 & 7,27 & 4,98 & 3,80 & 2,62 \\
\hline 83,00 & 501,30 & 174,20 & 22,97 & 13,54 & 10,66 & 8,54 & 7,19 & 6,15 & 4,63 & 3,64 & 2,47 \\
\hline 27,55 & 781,80 & 177,00 & 27,99 & 19,28 & 14,81 & 10,64 & 7,97 & 6,23 & 4,27 & 3,28 & 2,27 \\
\hline 79,96 & 472,40 & 178,70 & 23,87 & 13,89 & 10,83 & 8,58 & 7,16 & 6,08 & 4,52 & 3,52 & 2,39 \\
\hline 38,79 & 1614,80 & 197,80 & 16,47 & 12,81 & 10,90 & 8,83 & 7,18 & 5,90 & 4,13 & 3,10 & 2,05 \\
\hline 51,28 & 1884,10 & 34,40 & 40,16 & 33,81 & 32,57 & 30,48 & 28,31 & 26,19 & 22,24 & 18,81 & 13,53 \\
\hline 86,55 & 1110,20 & 133,90 & 15,89 & 11,04 & 9,71 & 8,58 & 7,72 & 6,99 & 5,74 & 4,76 & 3,38 \\
\hline 20,65 & 572,10 & 135,30 & 42,74 & 27,96 & 20,17 & 13,69 & 10,02 & 7,85 & 5,49 & 4,26 & 2,97 \\
\hline 30,49 & 1814,10 & 145,70 & 22,67 & 18,40 & 15,63 & 12,47 & 9,97 & 8,06 & 5,54 & 4,13 & 2,76 \\
\hline 72,61 & 371,10 & 194,00 & 27,85 & 15,22 & 11,36 & 8,61 & 6,94 & 5,75 & 4,12 & 3,17 & 2,16 \\
\hline 45,17 & 517,60 & 90,70 & 38,09 & 27,84 & 23,36 & 18,89 & 15,44 & 12,74 & 9,01 & 6,79 & 4,51 \\
\hline 47,76 & 1955,10 & 57,10 & 29,17 & 25,30 & 23,80 & 21,67 & 19,64 & 17,73 & 14,36 & 11,66 & 7,93 \\
\hline 79,74 & 409,70 & 91,30 & 33,57 & 21,77 & 18,08 & 15,16 & 13,11 & 11,45 & 8,86 & 7,04 & 4,78 \\
\hline 28,66 & 386,10 & 190,70 & 33,63 & 19,47 & 13,95 & 9,62 & 7,15 & 5,63 & 3,91 & 3,03 & 2,13 \\
\hline 70,86 & 820,80 & 126,00 & 20,67 & 14,63 & 12,62 & 10,85 & 9,49 & 8,33 & 6,48 & 5,14 & 3,47 \\
\hline 66,10 & 458,60 & 147,80 & 27,34 & 16,95 & 13,54 & 10,84 & 8,98 & 7,55 & 5,51 & 4,23 & 2,84 \\
\hline 54,83 & 1292,00 & 116,60 & 19,82 & 15,78 & 14,07 & 12,26 & 10,71 & 9,35 & 7,17 & 5,61 & 3,71 \\
\hline 43,94 & 1538,30 & 134,90 & 19,46 & 15,85 & 13,96 & 11,83 & 10,03 & 8,51 & 6,23 & 4,73 & 3,09 \\
\hline 67,42 & 1713,50 & 152,80 & 13,47 & 10,30 & 9,27 & 8,23 & 7,37 & 6,60 & 5,29 & 4,28 & 2,93 \\
\hline 64,70 & 554,20 & 86,90 & 31,51 & 22,62 & 19,46 & 16,58 & 14,35 & 12,46 & 9,50 & 7,43 & 4,96 \\
\hline 54,52 & 652,00 & 136,20 & 25,10 & 17,50 & 14,61 & 11,96 & 9,95 & 8,34 & 6,04 & 4,60 & 3,05 \\
\hline 70,31 & 1026,50 & 188,70 & 15,23 & 10,48 & 8,89 & 7,53 & 6,51 & 5,67 & 4,34 & 3,42 & 2,29 \\
\hline 41,63 & 1084,60 & 153,60 & 21,51 & 16,35 & 13,86 & 11,24 & 9,18 & 7,56 & 5,33 & 4,00 & 2,65 \\
\hline 73,31 & 996,40 & 57,50 & 28,63 & 22,00 & 20,37 & 18,65 & 17,13 & 15,73 & 13,21 & 11,11 & 7,98 \\
\hline 87,95 & 1207,00 & 50,70 & 25,78 & 19,43 & 17,96 & 16,90 & 15,90 & 14,95 & 13,17 & 11,58 & 8,94 \\
\hline 33,93 & 496,90 & 190,20 & 28,91 & 17,98 & 13,55 & 9,75 & 7,37 & 5,80 & 3,99 & 3,06 & 2,13 \\
\hline 83,91 & 392,20 & 20,70 & 71,41 & 53,35 & 49,32 & 45,77 & 42,58 & 39,63 & 34,23 & 29,54 & 22,12 \\
\hline 85,11 & 1921,60 & 156,90 & 11,31 & 8,19 & 7,41 & 6,71 & 6,14 & 5,64 & 4,75 & 4,01 & 2,91 \\
\hline 33,24 & 1961,10 & 20,50 & 77,41 & 70,77 & 67,30 & 61,60 & 55,93 & 50,49 & 40,79 & 32,94 & 22,14 \\
\hline 41,21 & 1031,10 & 30,80 & 60,23 & 53,62 & 49,73 & 44,50 & 39,58 & 35,05 & 27,42 & 21,63 & 14,25 \\
\hline
\end{tabular}




\begin{tabular}{|c|c|c|c|c|c|c|c|c|c|c|c|}
\hline \multirow[b]{2}{*}{ e1 (cm) } & & & & & & & ões (x1 & m) & & & \\
\hline & Meq (MPa) & Ms (MPa) & D0 & D25 & D40 & D60 & D80 & D100 & D140 & D180 & D260 \\
\hline 57,68 & 1282,80 & 87,90 & 22,81 & 18,46 & 16,80 & 14,95 & 13,33 & 11,86 & 9,38 & 7,50 & 5,05 \\
\hline 32,23 & 1226,40 & 198,40 & 20,43 & 15,10 & 12,27 & 9,36 & 7,26 & 5,77 & 3,94 & 2,97 & 2,03 \\
\hline 24,58 & 1443,70 & 79,70 & 443,25 & 35,65 & 30,00 & 23,50 & 18,46 & 14,70 & 9,97 & 7,43 & 5,02 \\
\hline 77,18 & 706,70 & 97,00 & 24,50 & 17,27 & 15,05 & 13,10 & 11,63 & 10,35 & 8,26 & 6,68 & 4,59 \\
\hline 73,63 & 733,20 & 72,50 & 28,53 & 21,13 & 18,90 & 16,78 & 15,07 & 13,55 & 10,97 & 8,96 & 6,21 \\
\hline 36,03 & 984,50 & 66,70 & 41,13 & 34,50 & 30,27 & 25,27 & 21,04 & 17,57 & 12,54 & 9,40 & 6,13 \\
\hline 48,97 & 281,20 & 129,90 & 41,62 & 24,31 & 18,45 & 13,79 & 10,79 & 8,67 & 6,02 & 4,58 & 3,15 \\
\hline 51,50 & 1410,10 & 89,50 & 23,27 & 19,33 & 17,56 & 15,51 & 13,68 & 12,05 & 9,35 & 7,37 & 4,88 \\
\hline 53,40 & 1073,70 & 147,00 & 19,18 & 14,47 & 12,51 & 10,56 & 8,98 & 7,66 & 5,67 & 4,35 & 2,86 \\
\hline 30,04 & 1722,40 & 124,70 & 25,86 & 21,23 & 18,12 & 14,52 & 11,65 & 9,44 & 6,50 & 4,84 & 3,23 \\
\hline 68,21 & 608,60 & 56,90 & 36,71 & 27,86 & 25,00 & 22,16 & 19,81 & 17,72 & 14,18 & 11,47 & 7,85 \\
\hline 49,25 & 581,90 & 71,60 & 39,30 & 30,35 & 26,34 & 22,17 & 18,75 & 15,91 & 11,66 & 8,89 & 5,83 \\
\hline 28,96 & 1294,20 & 40,60 & 61,69 & 54,80 & 48,88 & 41,36 & 34,74 & 29,15 & 20,88 & 15,60 & 10,08 \\
\hline 85,86 & 247,90 & 40,10 & 62,16 & 41,74 & 35,76 & 30,88 & 27,38 & 24,45 & 19,64 & 16,01 & 11,14 \\
\hline 69,74 & 1928,80 & 54,10 & 24,01 & 18,98 & 18,03 & 17,04 & 15,99 & 14,97 & 13,04 & 11,32 & 8,52 \\
\hline 28,11 & 1125,40 & 130,10 & 30,31 & 23,30 & 19,01 & 14,46 & 11,16 & 8,82 & 5,99 & 4,51 & 3,08 \\
\hline 57,21 & 1778,40 & 130,60 & 15,85 & 12,78 & 11,58 & 10,25 & 9,10 & 8,06 & 6,34 & 5,04 & 3,38 \\
\hline 83,93 & 1221,50 & 24,10 & 40,74 & 33,20 & 30,56 & 29,48 & 28,36 & 27,10 & 24,62 & 22,27 & 18,08 \\
\hline 75,76 & 1608,90 & 76,30 & 19,64 & 15,07 & 14,07 & 13,04 & 12,10 & 11,21 & 9,59 & 8,20 & 6,03 \\
\hline 53,34 & 1481,80 & 147,40 & 16,61 & 13,12 & 11,61 & 10,02 & 8,67 & 7,51 & 5,68 & 4,41 & 2,90 \\
\hline 20,10 & 921,30 & 86,00 & 53,82 & 40,35 & 31,27 & 22,33 & 16,51 & 12,79 & 8,73 & 6,71 & 4,65 \\
\hline 30,75 & 1020,20 & 145,10 & 27,48 & 20,67 & 16,84 & 12,85 & 9,96 & 7,90 & 5,38 & 4,06 & 2,77 \\
\hline 62,81 & 828,30 & 131,70 & 21,22 & 15,27 & 13,11 & 11,14 & 9,60 & 8,30 & 6,28 & 4,89 & 3,25 \\
\hline 22,18 & 1526,00 & 25,30 & 101,42 & 91,46 & 81,44 & 68,41 & 56,91 & 47,31 & 33,36 & 24,72 & 15,99 \\
\hline 22,48 & 1486,80 & 138,40 & 31,00 & 23,75 & 18,88 & 13,85 & 10,41 & 8,11 & 5,50 & 4,18 & 2,89 \\
\hline 43,20 & 218,40 & 48,50 & 80,94 & 56,61 & 46,33 & 36,46 & 29,17 & 23,71 & 16,52 & 12,44 & 8,38 \\
\hline 30,75 & 461,00 & 155,20 & 34,90 & 22,32 & 16,82 & 12,01 & 9,01 & 7,07 & 4,87 & 3,74 & 2,60 \\
\hline 75,11 & 1705,60 & 102,00 & 16,17 & 12,32 & 11,39 & 10,42 & 9,58 & 8,80 & 7,41 & 6,24 & 4,50 \\
\hline 25,83 & 907,50 & 95,50 & 42,41 & 32,67 & 26,44 & 19,87 & 15,19 & 11,93 & 8,08 & 6,11 & 4,19 \\
\hline 56,18 & 1483,40 & 100,70 & 20,14 & 16,40 & 14,91 & 13,24 & 11,77 & 10,44 & 8,22 & 6,55 & 4,39 \\
\hline 47,10 & 1844,20 & 113,80 & 19,19 & 16,16 & 14,61 & 12,79 & 11,16 & 9,73 & 7,42 & 5,77 & 3,78 \\
\hline 66,57 & 671,60 & 198,40 & 19,30 & 12,19 & 9,84 & 7,95 & 6,64 & 5,61 & 4,12 & 3,17 & 2,12 \\
\hline 38,50 & 1172,40 & 40,70 & 50,43 & 44,89 & 41,07 & 36,15 & 31,61 & 27,54 & 20,95 & 16,20 & 10,53 \\
\hline 41,64 & 1240,10 & 179,00 & 18,60 & 14,09 & 11,93 & 9,66 & 7,88 & 6,49 & 4,57 & 3,43 & 2,28 \\
\hline 54,95 & 747,10 & 87,50 & 29,56 & 22,75 & 19,93 & 17,07 & 14,71 & 12,69 & 9,55 & 7,39 & 4,87 \\
\hline 33,90 & 602,50 & 143,40 & 31,72 & 21,92 & 17,34 & 12,95 & 9,95 & 7,88 & 5,39 & 4,09 & 2,81 \\
\hline 25,79 & 1121,90 & 187,50 & 24,89 & 17,93 & 13,96 & 10,11 & 7,58 & 5,92 & 4,04 & 3,09 & 2,14 \\
\hline 38,11 & 608,20 & 23,90 & 90,48 & 79,95 & 72,64 & 63,41 & 55,00 & 47,58 & 35,75 & 27,44 & 17,78 \\
\hline 35,60 & 933,60 & 81,10 & 37,39 & 30,41 & 26,23 & 21,46 & 17,57 & 14,47 & 10,16 & 7,59 & 5,00 \\
\hline 53,73 & 1475,00 & 153,60 & 16,19 & 12,70 & 11,20 & 9,65 & 8,34 & 7,21 & 5,45 & 4,22 & 2,78 \\
\hline 80,68 & 332,90 & 34,00 & 59,30 & 42,72 & 38,11 & 33,94 & 30,66 & 27,77 & 22,81 & 18,87 & 13,31 \\
\hline 52,13 & 1102,70 & 40,80 & 41,71 & 35,41 & 33,15 & 30,13 & 27,29 & 24,64 & 19,98 & 16,25 & 11,09 \\
\hline 78,31 & 1547,40 & 142,60 & 13,66 & 10,01 & 9,00 & 8,06 & 7,30 & 6,62 & 5,45 & 4,51 & 3,18 \\
\hline 48,32 & 1724,60 & 156,30 & 15,99 & 12,91 & 11,42 & 9,79 & 8,40 & 7,22 & 5,38 & 4,13 & 2,70 \\
\hline 89,85 & 1777,30 & 121,70 & 13,12 & 9,50 & 8,65 & 7,93 & 7,34 & 6,81 & 5,85 & 5,03 & 3,75 \\
\hline 67,75 & 1469,80 & 195,50 & 12,64 & 9,22 & 8,05 & 6,97 & 6,12 & 5,38 & 4,19 & 3,33 & 2,24 \\
\hline 38,59 & 1576,80 & 174,60 & 18,00 & 14,20 & 12,17 & 9,92 & 8,12 & 6,69 & 4,71 & 3,53 & 2,33 \\
\hline 69,37 & 1451,20 & 175,70 & 13,30 & 9,77 & 8,60 & 7,51 & 6,64 & 5,88 & 4,63 & 3,71 & 2,51 \\
\hline 65,83 & 1165,10 & 121,10 & 18,41 & 13,94 & 12,40 & 10,89 & 9,65 & 8,56 & 6,75 & 5,40 & 3,65 \\
\hline 69,62 & 1324,20 & 153,30 & 14,89 & 10,99 & 9,71 & 8,50 & 7,54 & 6,69 & 5,30 & 4,25 & 2,89 \\
\hline 58,32 & 653,10 & 41,80 & 46,42 & 37,66 & 34,44 & 30,79 & 27,57 & 24,63 & 19,64 & 15,79 & 10,68 \\
\hline 47,80 & 648,20 & 170,30 & 23,83 & 16,01 & 12,98 & 10,23 & 8,24 & 6,73 & 4,72 & 3,57 & 2,40 \\
\hline 39,40 & 1275,00 & 33,50 & 54,95 & 49,35 & 45,85 & 41,07 & 36,54 & 32,36 & 25,31 & 19,95 & 13,13 \\
\hline 71,77 & 640,00 & 150,30 & 21,75 & 14,25 & 11,79 & 9,79 & 8,36 & 7,20 & 5,44 & 4,25 & 2,86 \\
\hline 45,11 & 547,50 & 181,60 & 25,64 & 16,38 & 12,91 & 9,87 & 7,77 & 6,26 & 4,34 & 3,29 & 2,24 \\
\hline 36,53 & 993,90 & 98,00 & 31,84 & 25,49 & 21,87 & 17,81 & 14,53 & 11,94 & 8,37 & 6,26 & 4,14 \\
\hline 54,11 & 1777,20 & 66,80 & 25,03 & 21,06 & 19,75 & 18,00 & 16,36 & 14,82 & 12,10 & 9,90 & 6,81 \\
\hline 89,69 & 1636,50 & 34,10 & 27,71 & 22,80 & 20,77 & 19,99 & 19,28 & 18,47 & 16,86 & 15,33 & 12,58 \\
\hline 28,71 & 1883,90 & 36,00 & 59,36 & 54,52 & 49,73 & 43,35 & 37,43 & 32,19 & 23,89 & 18,14 & 11,65 \\
\hline 33,59 & 252,10 & 135,50 & 447,15 & 26,77 & 19,36 & 13,57 & 10,17 & 8,02 & 5,54 & 4,28 & 3,00 \\
\hline 79,89 & 911,40 & 159,30 & 16,74 & 11,31 & 9,63 & 8,24 & 7,24 & 6,40 & 5,04 & 4,05 & 2,77 \\
\hline 37,74 & 213,50 & 173,20 & 444,51 & 22,19 & 15,26 & 10,47 & 7,86 & 6,23 & 4,32 & 3,35 & 2,37 \\
\hline 55,60 & 368,40 & 29,80 & 73,52 & 59,07 & 53,10 & 46,64 & 41,05 & 36,09 & 27,98 & 22,05 & 14,65 \\
\hline 77,18 & 1761,40 & 187,50 & 11,18 & 8,12 & 7,22 & 6,40 & 5,75 & 5,18 & 4,21 & 3,45 & 2,40 \\
\hline 27,09 & 612,40 & 95,90 & 46,35 & 33,94 & 26,83 & 19,75 & 14,94 & 11,70 & 7,97 & 6,07 & 4,19 \\
\hline 51,28 & 359,10 & 77,90 & 45,99 & 31,99 & 26,55 & 21,49 & 17,68 & 14,69 & 10,50 & 7,96 & 5,29 \\
\hline 87,14 & 1738,30 & 34,80 & 27,40 & 22,51 & 20,59 & 19,84 & 19,12 & 18,31 & 16,69 & 15,15 & 12,39 \\
\hline 55,63 & 1969,30 & 143,60 & 14,61 & 11,85 & 10,72 & 9,47 & 8,38 & 7,40 & 5,79 & 4,58 & 3,06 \\
\hline 29,21 & 375,00 & 35,90 & 100,58 & 79,57 & 66,29 & 51,64 & 40,54 & 32,36 & 22,06 & 16,51 & 11,17 \\
\hline 34,78 & 1346,90 & 78,10 & 34,11 & 29,04 & 25,61 & 21,48 & 17,95 & 15,02 & 10,74 & 8,05 & 5,24 \\
\hline 22,95 & 1963,10 & 93,50 & 37,19 & 30,79 & 25,86 & 20,17 & 15,78 & 12,53 & 8,47 & 6,32 & 4,27 \\
\hline 78,94 & 446,50 & 140,20 & 27,03 & 16,42 & 13,11 & 10,62 & 8,97 & 7,69 & 5,78 & 4,53 & 3,06 \\
\hline 65,65 & 876,40 & 49,20 & 35,09 & 27,81 & 25,76 & 23,43 & 21,34 & 19,41 & 16,01 & 13,23 & 9,27 \\
\hline 23,36 & 690,10 & 88,00 & 52,00 & 38,46 & 30,02 & 21,70 & 16,20 & 12,61 & 8,59 & 6,58 & 4,55 \\
\hline 68,98 & 1149,50 & 127,20 & 17,65 & 13,13 & 11,63 & 10,21 & 9,06 & 8,06 & 6,38 & 5,13 & 3,49 \\
\hline 48,16 & 206,60 & 192,30 & 43,07 & 20,49 & 13,84 & 9,46 & 7,13 & 5,66 & 3,92 & 3,03 & 2,14 \\
\hline 28,55 & 1279,70 & 135,80 & 27,95 & 21,77 & 17,93 & 13,78 & 10,71 & 8,50 & 5,78 & 4,34 & 2,95 \\
\hline 40,38 & 726,70 & 166,10 & 24,74 & 17,25 & 13,99 & 10,85 & 8,58 & 6,91 & 4,78 & 3,60 & 2,44 \\
\hline 43,94 & 1126,60 & 100,00 & 26,38 & 21,45 & 18,88 & 15,99 & 13,54 & 11,48 & 8,40 & 6,38 & 4,16 \\
\hline 75,33 & 1322,20 & 183,80 & 13,14 & 9,30 & 8,10 & 7,04 & 6,22 & 5,53 & 4,38 & 3,53 & 2,41 \\
\hline 69,27 & 1678,40 & 84,50 & 19,04 & 14,93 & 13,92 & 12,78 & 11,75 & 10,78 & 9,05 & 7,60 & 5,44 \\
\hline 61,29 & 457,80 & 124,80 & 30,11 & 19,57 & 15,94 & 12,90 & 10,72 & 9,01 & 6,55 & 5,02 & 3,35 \\
\hline
\end{tabular}




\begin{tabular}{|c|c|c|c|c|c|c|c|c|c|c|c|}
\hline \multirow[b]{2}{*}{$\mathrm{e} 1(\mathrm{~cm})$} & & & & & & $\mathrm{De}$ & $\overline{\text { ões }(x 1}$ & & & & \\
\hline & Meq (MPa) & Ms (MPa) & D0 & D25 & D40 & D60 & D80 & D100 & D140 & D180 & D260 \\
\hline 21,98 & 1359,60 & 199,80 & 24,71 & 17,71 & 13,48 & 9,51 & 7,02 & 5,45 & 3,75 & 2,89 & 2,01 \\
\hline 53,63 & 1768,40 & 131,20 & 16,46 & 13,41 & 12,09 & 10,64 & 9,36 & 8,22 & 6,37 & 5,01 & 3,32 \\
\hline 77,36 & 1152,40 & 149,90 & 15,41 & 10,93 & 9,57 & 8,36 & 7,44 & 6,65 & 5,32 & 4,32 & 2,98 \\
\hline 73,46 & 1055,30 & 127,20 & 17,87 & 12,96 & 11,42 & 10,00 & 8,89 & 7,93 & 6,32 & 5,11 & 3,50 \\
\hline 25,64 & 1733,80 & 78,70 & 39,82 & 33,68 & 28,92 & 23,24 & 18,63 & 15,06 & 10,32 & 7,66 & 5,09 \\
\hline 49,44 & 728,60 & 96,80 & 30,00 & 22,88 & 19,75 & 16,54 & 13,94 & 11,78 & 8,60 & 6,55 & 4,30 \\
\hline 74,87 & 1064,60 & 58,00 & 27,44 & 21,01 & 19,51 & 17,94 & 16,54 & 15,24 & 12,90 & 10,92 & 7,92 \\
\hline 30,74 & 1398,30 & 36,40 & 61,36 & 55,53 & 50,33 & 43,54 & 37,35 & 31,95 & 23,53 & 17,81 & 11,46 \\
\hline 43,98 & 1423,90 & 46,50 & 39,24 & 34,54 & 32,08 & 28,81 & 25,73 & 22,88 & 18,05 & 14,33 & 9,51 \\
\hline 34,85 & 1951,30 & 162,70 & 18,65 & 15,23 & 13,14 & 10,74 & 8,78 & 7,22 & 5,06 & 3,78 & 2,49 \\
\hline 65,93 & 652,00 & 45,10 & 41,48 & 32,51 & 29,74 & 26,76 & 24,18 & 21,82 & 17,74 & 14,50 & 10,02 \\
\hline 40,79 & 456,10 & 178,20 & 29,29 & 18,06 & 13,85 & 10,27 & 7,92 & 6,30 & 4,34 & 3,30 & 2,28 \\
\hline 27,76 & 1400,90 & 159,80 & 24,78 & 19,05 & 15,53 & 11,79 & 9,08 & 7,17 & 4,87 & 3,67 & 2,51 \\
\hline 64,83 & 893,10 & 161,90 & 18,20 & 12,74 & 10,82 & 9,12 & 7,82 & 6,75 & 5,09 & 3,97 & 2,64 \\
\hline 56,19 & 781,70 & 178,10 & 19,81 & 13,52 & 11,20 & 9,14 & 7,59 & 6,37 & 4,61 & 3,51 & 2,34 \\
\hline 83,49 & 1631,30 & 90,70 & 16,70 & 12,45 & 11,50 & 10,64 & 9,87 & 9,17 & 7,89 & 6,78 & 5,05 \\
\hline 76,13 & 1326,70 & 79,00 & 20,71 & 15,73 & 14,53 & 13,32 & 12,25 & 11,27 & 9,51 & 8,03 & 5,81 \\
\hline 47,55 & 1887,80 & 50,50 & 32,17 & 27,92 & 26,36 & 24,09 & 21,90 & 19,83 & 16,15 & 13,17 & 9,00 \\
\hline 31,43 & 1375,10 & 180,90 & 21,17 & 16,14 & 13,28 & 10,24 & 8,00 & 6,38 & 4,35 & 3,27 & 2,22 \\
\hline 44,54 & 1501,40 & 100,40 & 23,30 & 19,57 & 17,53 & 15,16 & 13,07 & 11,26 & 8,43 & 6,47 & 4,22 \\
\hline 28,94 & 1198,30 & 34,10 & 71,03 & 63,57 & 56,97 & 48,51 & 40,97 & 34,55 & 24,91 & 18,66 & 12,03 \\
\hline 69,06 & 1442,50 & 117,90 & 16,61 & 12,72 & 11,52 & 10,31 & 9,28 & 8,36 & 6,78 & 5,53 & 3,82 \\
\hline 37,30 & 1370,10 & 185,10 & 18,75 & 14,35 & 12,06 & 9,62 & 7,73 & 6,29 & 4,37 & 3,27 & 2,19 \\
\hline 41,35 & 210,90 & 126,20 & 51,16 & 28,03 & 20,32 & 14,49 & 11,01 & 8,73 & 6,02 & 4,63 & 3,23 \\
\hline 70,59 & 538,30 & 54,80 & 39,00 & 29,12 & 25,98 & 22,97 & 20,52 & 18,35 & 14,70 & 11,90 & 8,16 \\
\hline 24,83 & 1701,50 & 95,00 & 36,12 & 29,79 & 25,09 & 19,68 & 15,48 & 12,34 & 8,37 & 6,24 & 4,21 \\
\hline 82,69 & 1634,00 & 153,90 & 12,48 & 9,00 & 8,07 & 7,23 & 6,57 & 5,98 & 4,96 & 4,14 & 2,95 \\
\hline 86,05 & 1151,80 & 153,80 & 14,61 & 10,05 & 8,76 & 7,68 & 6,88 & 6,20 & 5,05 & 4,16 & 2,93 \\
\hline 35,78 & 1968,40 & 52,00 & 38,16 & 34,54 & 31,78 & 28,11 & 24,67 & 21,56 & 16,47 & 12,75 & 8,28 \\
\hline 83,82 & 1687,30 & 80,50 & 17,62 & 13,24 & 12,28 & 11,45 & 10,69 & 9,98 & 8,67 & 7,52 & 5,68 \\
\hline 82,69 & 1568,90 & 77,30 & 18,74 & 14,10 & 13,08 & 12,17 & 11,34 & 10,57 & 9,14 & 7,90 & 5,93 \\
\hline 42,26 & 383,10 & 46,00 & 66,51 & 51,89 & 44,59 & 36,73 & 30,36 & 25,25 & 17,98 & 13,53 & 8,91 \\
\hline 44,65 & 481,50 & 160,70 & 29,17 & 18,62 & 14,65 & 11,18 & 8,79 & 7,07 & 4,90 & 3,71 & 2,53 \\
\hline 55,63 & 1648,10 & 50,10 & 30,59 & 25,54 & 24,23 & 22,36 & 20,54 & 18,82 & 15,68 & 13,05 & 9,19 \\
\hline 80,01 & 694,70 & 144,60 & 20,35 & 13,35 & 11,17 & 9,42 & 8,19 & 7,17 & 5,58 & 4,45 & 3,03 \\
\hline 65,69 & 868,30 & 199,90 & 16,68 & 11,13 & 9,24 & 7,64 & 6,47 & 5,52 & 4,11 & 3,18 & 2,12 \\
\hline 46,77 & 1599,40 & 176,40 & 15,70 & 12,37 & 10,78 & 9,08 & 7,67 & 6,49 & 4,74 & 3,60 & 2,36 \\
\hline 25,72 & 1368,60 & 145,50 & 28,01 & 21,54 & 17,40 & 13,05 & 9,96 & 7,82 & 5,30 & 4,01 & 2,75 \\
\hline 43,60 & 1027,30 & 153,40 & 21,42 & 16,13 & 13,67 & 11,13 & 9,13 & 7,55 & 5,35 & 4,02 & 2,67 \\
\hline 88,22 & 1887,60 & 49,40 & 21,54 & 17,04 & 15,67 & 15,02 & 14,37 & 13,68 & 12,34 & 11,09 & 8,91 \\
\hline 75,72 & 227,80 & 26,80 & 82,73 & 59,72 & 52,71 & 46,35 & 41,37 & 37,03 & 29,75 & 24,18 & 16,69 \\
\hline 40,53 & 386,50 & 145,20 & 35,35 & 22,02 & 16,96 & 12,60 & 9,73 & 7,74 & 5,33 & 4,06 & 2,80 \\
\hline 86,95 & 1343,60 & 42,50 & 27,50 & 21,25 & 19,67 & 18,73 & 17,78 & 16,83 & 15,03 & 13,37 & 10,54 \\
\hline 46,56 & 1413,30 & 71,40 & 28,60 & 24,49 & 22,36 & 19,76 & 17,41 & 15,29 & 11,81 & 9,25 & 6,08 \\
\hline 48,28 & 289,00 & 119,50 & 42,74 & 25,73 & 19,80 & 14,96 & 11,75 & 9,47 & 6,57 & 4,99 & 3,42 \\
\hline 33,29 & 857,90 & 25,00 & 86,81 & 78,22 & 71,12 & 61,90 & 53,45 & 46,00 & 34,24 & 26,09 & 16,82 \\
\hline 79,43 & 1793,40 & 178,70 & 11,23 & 8,14 & 7,28 & 6,49 & 5,86 & 5,31 & 4,35 & 3,60 & 2,53 \\
\hline 35,17 & 762,80 & 162,40 & 26,35 & 18,62 & 14,96 & 11,36 & 8,82 & 7,02 & 4,81 & 3,64 & 2,48 \\
\hline 61,39 & 348,60 & 159,10 & 32,03 & 18,41 & 14,05 & 10,75 & 8,63 & 7,08 & 5,02 & 3,83 & 2,60 \\
\hline 64,23 & 1852,90 & 77,20 & 20,28 & 16,29 & 15,31 & 14,11 & 12,98 & 11,91 & 9,98 & 8,36 & 5,96 \\
\hline 43,57 & 1539,10 & 43,90 & 40,06 & 35,40 & 33,07 & 29,86 & 26,80 & 23,96 & 19,05 & 15,22 & 10,16 \\
\hline 46,58 & 1412,00 & 155,60 & 17,84 & 14,06 & 12,25 & 10,31 & 8,70 & 7,36 & 5,37 & 4,08 & 2,67 \\
\hline 29,17 & 357,40 & 113,50 & 47,70 & 30,83 & 23,17 & 16,44 & 12,29 & 9,63 & 6,63 & 5,11 & 3,56 \\
\hline 40,19 & 1812,50 & 46,90 & 38,48 & 34,48 & 32,12 & 28,86 & 25,76 & 22,89 & 18,00 & 14,25 & 9,42 \\
\hline 23,71 & 1851,20 & 105,20 & 33,99 & 27,79 & 23,19 & 17,96 & 13,99 & 11,08 & 7,49 & 5,60 & 3,80 \\
\hline 26,60 & 280,10 & 165,90 & 42,16 & 23,10 & 16,08 & 10,90 & 8,10 & 6,40 & 4,47 & 3,48 & 2,45 \\
\hline 45,13 & 1725,80 & 89,40 & 23,55 & 20,20 & 18,37 & 16,15 & 14,14 & 12,36 & 9,46 & 7,36 & 4,82 \\
\hline 52,70 & 438,00 & 95,00 & 37,24 & 25,85 & 21,48 & 17,45 & 14,41 & 12,02 & 8,63 & 6,55 & 4,35 \\
\hline 70,61 & 955,10 & 107,80 & 20,79 & 15,34 & 13,58 & 11,93 & 10,60 & 9,44 & 7,50 & 6,04 & 4,12 \\
\hline 80,37 & 1851,00 & 145,10 & 12,33 & 9,09 & 8,26 & 7,48 & 6,83 & 6,25 & 5,23 & 4,38 & 3,15 \\
\hline 76,81 & 794,50 & 73,90 & 26,69 & 19,65 & 17,66 & 15,78 & 14,26 & 12,91 & 10,58 & 8,73 & 6,13 \\
\hline 43,83 & 736,40 & 119,10 & 28,47 & 21,13 & 17,81 & 14,42 & 11,78 & 9,72 & 6,86 & 5,16 & 3,43 \\
\hline 49,09 & 1719,70 & 140,70 & 16,87 & 13,76 & 12,27 & 10,61 & 9,18 & 7,94 & 5,98 & 4,62 & 3,03 \\
\hline 46,64 & 1965,10 & 146,10 & 16,17 & 13,39 & 11,96 & 10,34 & 8,93 & 7,70 & 5,78 & 4,45 & 2,91 \\
\hline 58,20 & 838,90 & 154,80 & 20,14 & 14,28 & 12,08 & 10,07 & 8,51 & 7,24 & 5,34 & 4,11 & 2,72 \\
\hline 54,13 & 568,70 & 139,60 & 26,68 & 18,00 & 14,78 & 11,92 & 9,81 & 8,16 & 5,85 & 4,44 & 2,96 \\
\hline 23,78 & 1030,90 & 65,30 & 56,44 & 45,64 & 37,80 & 29,04 & 22,48 & 17,75 & 11,99 & 8,99 & 6,12 \\
\hline 84,04 & 608,50 & 181,10 & 19,92 & 12,09 & 9,70 & 7,91 & 6,74 & 5,83 & 4,45 & 3,52 & 2,39 \\
\hline 83,65 & 295,00 & 129,40 & 36,15 & 20,24 & 15,43 & 12,02 & 9,93 & 8,40 & 6,22 & 4,85 & 3,30 \\
\hline 83,96 & 1952,40 & 115,40 & 13,43 & 9,97 & 9,17 & 8,46 & 7,84 & 7,27 & 6,24 & 5,35 & 3,97 \\
\hline 37,40 & 731,30 & 35,50 & 66,56 & 57,82 & 51,89 & 44,59 & 38,10 & 32,53 & 23,94 & 18,17 & 11,76 \\
\hline 86,81 & 762,50 & 165,80 & 17,76 & 11,35 & 9,43 & 7,94 & 6,93 & 6,10 & 4,80 & 3,86 & 2,66 \\
\hline 44,32 & 687,30 & 155,50 & 25,16 & 17,51 & 14,34 & 11,31 & 9,08 & 7,40 & 5,17 & 3,89 & 2,62 \\
\hline 73,56 & 929,00 & 194,10 & 15,62 & 10,42 & 8,73 & 7,33 & 6,32 & 5,49 & 4,21 & 3,31 & 2,23 \\
\hline 25,22 & 933,10 & 192,20 & 26,19 & 18,17 & 13,83 & 9,82 & 7,30 & 5,69 & 3,91 & 3,01 & 2,09 \\
\hline 31,85 & 1614,90 & 176,70 & 20,15 & 15,78 & 13,20 & 10,37 & 8,20 & 6,59 & 4,52 & 3,38 & 2,28 \\
\hline 30,90 & 990,80 & 142,70 & 27,98 & 21,01 & 17,11 & 13,06 & 10,13 & 8,03 & 5,48 & 4,13 & 2,82 \\
\hline 26,20 & 975,30 & 69,00 & 51,39 & 41,62 & 34,80 & 27,11 & 21,23 & 16,90 & 11,47 & 8,57 & 5,80 \\
\hline 84,13 & 1439,80 & 68,20 & 20,70 & 15,56 & 14,42 & 13,46 & 12,58 & 11,75 & 10,22 & 8,87 & 6,71 \\
\hline 20,01 & 1041,80 & 67,80 & 62,14 & 48,60 & 38,77 & 28,46 & 21,34 & 16,57 & 11,20 & 8,52 & 5,89 \\
\hline 41,21 & 459,20 & 69,80 & 49,03 & 36,83 & 31,02 & 24,98 & 20,28 & 16,63 & 11,66 & 8,76 & 5,83 \\
\hline 24,69 & 1857,40 & 58,70 & 49,02 & 42,65 & 37,22 & 30,50 & 24,85 & 20,32 & 14,07 & 10,42 & 6,84 \\
\hline
\end{tabular}




\begin{tabular}{|c|c|c|c|c|c|c|c|c|c|c|c|}
\hline \multirow[b]{2}{*}{ e1 (cm) } & & & & & & & ões (x1 & & & & \\
\hline & Meq (MPa) & Ms (MPa) & D0 & D25 & D40 & D60 & D80 & D100 & D140 & D180 & D260 \\
\hline 42,33 & 1648,90 & 148,40 & 18,34 & 14,90 & 13,06 & 10,98 & 9,24 & 7,79 & 5,65 & 4,27 & 2,79 \\
\hline 25,82 & 1277,10 & 196,80 & 23,12 & 16,87 & 13,23 & 9,65 & 7,25 & 5,66 & 3,86 & 2,95 & 2,04 \\
\hline 78,84 & 606,40 & 181,30 & 20,27 & 12,44 & 9,99 & 8,13 & 6,89 & 5,92 & 4,47 & 3,51 & 2,37 \\
\hline 41,97 & 789,40 & 165,30 & 23,48 & 16,64 & 13,66 & 10,75 & 8,59 & 6,97 & 4,85 & 3,65 & 2,46 \\
\hline 57,77 & 1442,60 & 197,10 & 13,71 & 10,24 & 8,89 & 7,57 & 6,51 & 5,61 & 4,22 & 3,27 & 2,16 \\
\hline 36,17 & 395,80 & 140,30 & 37,08 & 23,50 & 18,00 & 13,18 & 10,06 & 7,95 & 5,46 & 4,17 & 2,89 \\
\hline 66,03 & 721,90 & 147,20 & 21,16 & 14,45 & 12,13 & 10,14 & 8,66 & 7,44 & 5,59 & 4,35 & 2,90 \\
\hline 53,07 & 1780,90 & 190,30 & 13,31 & 10,42 & 9,17 & 7,87 & 6,78 & 5,85 & 4,40 & 3,40 & 2,24 \\
\hline 42,41 & 554,70 & 122,10 & 32,33 & 22,67 & 18,54 & 14,55 & 11,62 & 9,43 & 6,55 & 4,94 & 3,33 \\
\hline 85,05 & 633,30 & 126,70 & 22,26 & 14,50 & 12,16 & 10,31 & 9,03 & 7,97 & 6,29 & 5,07 & 3,49 \\
\hline 84,13 & 1186,50 & 194,30 & 13,01 & 8,76 & 7,50 & 6,47 & 5,72 & 5,10 & 4,07 & 3,31 & 2,29 \\
\hline 46,31 & 1732,10 & 63,60 & 28,81 & 25,07 & 23,25 & 20,88 & 18,67 & 16,62 & 13,14 & 10,47 & 6,97 \\
\hline 39,73 & 1088,50 & 126,40 & 24,85 & 19,48 & 16,68 & 13,63 & 11,17 & 9,22 & 6,51 & 4,88 & 3,22 \\
\hline 34,18 & 1939,50 & 105,80 & 24,98 & 21,38 & 18,89 & 15,86 & 13,26 & 11,10 & 7,94 & 5,95 & 3,87 \\
\hline 79,85 & 230,80 & 29,90 & 76,08 & 53,56 & 46,88 & 41,05 & 36,63 & 32,81 & 26,44 & 21,56 & 14,96 \\
\hline 81,52 & 1115,20 & 103,30 & 18,56 & 13,45 & 12,09 & 10,84 & 9,84 & 8,96 & 7,42 & 6,18 & 4,40 \\
\hline 40,52 & 1654,00 & 36,70 & 46,59 & 41,74 & 39,18 & 35,49 & 31,94 & 28,61 & 22,81 & 18,26 & 12,19 \\
\hline 28,70 & 903,40 & 40,70 & 70,00 & 60,12 & 52,52 & 43,23 & 35,44 & 29,15 & 20,37 & 15,13 & 9,92 \\
\hline 87,58 & 356,20 & 185,20 & 28,31 & 15,18 & 11,28 & 8,59 & 7,00 & 5,88 & 4,32 & 3,37 & 2,30 \\
\hline 20,84 & 706,80 & 158,80 & 35,78 & 23,67 & 17,18 & 11,70 & 8,57 & 6,70 & 4,68 & 3,63 & 2,53 \\
\hline 22,68 & 1935,20 & 40,10 & 67,45 & 60,00 & 52,97 & 43,99 & 36,23 & 29,87 & 20,85 & 15,42 & 10,05 \\
\hline 81,48 & 1812,00 & 36,20 & 28,03 & 22,66 & 20,99 & 20,24 & 19,42 & 18,52 & 16,76 & 15,10 & 12,17 \\
\hline 72,16 & 652,40 & 106,60 & 25,06 & 17,49 & 15,01 & 12,85 & 11,22 & 9,85 & 7,65 & 6,07 & 4,10 \\
\hline 65,78 & 974,70 & 174,00 & 16,70 & 11,69 & 9,94 & 8,40 & 7,23 & 6,25 & 4,74 & 3,70 & 2,47 \\
\hline 50,68 & 208,00 & 141,20 & 47,78 & 24,99 & 17,90 & 12,82 & 9,85 & 7,87 & 5,44 & 4,18 & 2,91 \\
\hline 67,32 & 258,80 & 151,50 & 38,96 & 20,83 & 15,30 & 11,39 & 9,04 & 7,39 & 5,23 & 4,01 & 2,74 \\
\hline 75,75 & 958,70 & 49,00 & 31,50 & 24,11 & 22,45 & 20,73 & 19,18 & 17,73 & 15,09 & 12,85 & 9,40 \\
\hline 67,39 & 1543,10 & 184,50 & 12,76 & 9,45 & 8,32 & 7,25 & 6,40 & 5,65 & 4,43 & 3,53 & 2,39 \\
\hline 83,07 & 522,80 & 155,60 & 23,25 & 14,15 & 11,35 & 9,26 & 7,88 & 6,81 & 5,19 & 4,09 & 2,78 \\
\hline 67,18 & 959,10 & 144,60 & 18,26 & 13,10 & 11,31 & 9,70 & 8,45 & 7,38 & 5,69 & 4,48 & 3,00 \\
\hline 51,21 & 1749,20 & 70,30 & 25,16 & 21,42 & 19,94 & 18,02 & 16,23 & 14,57 & 11,70 & 9,44 & 6,38 \\
\hline 43,23 & 1087,50 & 44,60 & 44,79 & 39,16 & 35,91 & 31,81 & 28,04 & 24,63 & 19,00 & 14,86 & 9,74 \\
\hline 76,09 & 897,60 & 27,70 & 45,89 & 35,75 & 33,67 & 31,89 & 30,02 & 28,20 & 24,76 & 21,66 & 16,55 \\
\hline 63,71 & 1516,00 & 133,70 & 15,77 & 12,23 & 11,00 & 9,73 & 8,66 & 7,71 & 6,11 & 4,91 & 3,32 \\
\hline 41,56 & 1597,80 & 31,90 & 51,03 & 45,44 & 42,97 & 39,21 & 35,55 & 32,08 & 25,94 & 20,99 & 14,19 \\
\hline 44,36 & 1996,20 & 43,30 & 36,87 & 32,41 & 30,72 & 28,13 & 25,60 & 23,20 & 18,91 & 15,41 & 10,52 \\
\hline 80,16 & 831,40 & 29,40 & 43,96 & 33,81 & 31,65 & 29,88 & 28,11 & 26,39 & 23,16 & 20,28 & 15,52 \\
\hline 71,72 & 332,70 & 128,10 & 34,50 & 20,30 & 15,83 & 12,48 & 10,30 & 8,65 & 6,32 & 4,87 & 3,29 \\
\hline 78,55 & 394,60 & 113,70 & 31,62 & 19,56 & 15,79 & 12,90 & 10,95 & 9,43 & 7,13 & 5,60 & 3,78 \\
\hline 86,47 & 1051,00 & 195,90 & 13,75 & 9,02 & 7,62 & 6,51 & 5,72 & 5,08 & 4,04 & 3,28 & 2,27 \\
\hline 47,04 & 1966,30 & 183,60 & 14,02 & 11,30 & 9,96 & 8,49 & 7,25 & 6,19 & 4,58 & 3,50 & 2,29 \\
\hline 66,72 & 342,50 & 99,50 & 38,08 & 24,13 & 19,51 & 15,80 & 13,20 & 11,17 & 8,21 & 6,32 & 4,23 \\
\hline 31,34 & 1150,10 & 140,10 & 26,67 & 20,55 & 17,00 & 13,20 & 10,35 & 8,26 & 5,65 & 4,24 & 2,87 \\
\hline 45,32 & 1787,00 & 160,70 & 16,17 & 13,11 & 11,55 & 9,82 & 8,35 & 7,11 & 5,23 & 3,98 & 2,60 \\
\hline 26,75 & 1154,10 & 90,50 & 39,86 & 31,99 & 26,65 & 20,68 & 16,16 & 12,85 & 8,72 & 6,53 & 4,42 \\
\hline 83,25 & 232,20 & 170,30 & 39,99 & 19,96 & 14,07 & 10,16 & 7,99 & 6,53 & 4,64 & 3,58 & 2,47 \\
\hline 83,39 & 1409,30 & 80,50 & 19,05 & 14,18 & 13,08 & 12,08 & 11,20 & 10,40 & 8,93 & 7,66 & 5,69 \\
\hline 72,49 & 975,70 & 186,30 & 15,56 & 10,58 & 8,94 & 7,56 & 6,55 & 5,71 & 4,39 & 3,46 & 2,33 \\
\hline 21,68 & 898,10 & 176,10 & 30,52 & 20,84 & 15,43 & 10,66 & 7,83 & 6,10 & 4,23 & 3,28 & 2,28 \\
\hline 71,47 & 684,50 & 153,90 & 20,75 & 13,72 & 11,41 & 9,50 & 8,14 & 7,02 & 5,32 & 4,16 & 2,79 \\
\hline 39,38 & 1977,10 & 34,70 & 46,91 & 42,12 & 39,86 & 36,37 & 32,95 & 29,70 & 23,97 & 19,35 & 13,04 \\
\hline 65,29 & 1589,40 & 118,10 & 16,39 & 12,82 & 11,67 & 10,45 & 9,40 & 8,45 & 6,82 & 5,54 & 3,81 \\
\hline 84,59 & 1817,00 & 199,40 & 10,27 & 7,25 & 6,43 & 5,71 & 5,16 & 4,68 & 3,86 & 3,20 & 2,27 \\
\hline 65,49 & 1775,40 & 113,20 & 16,05 & 12,66 & 11,64 & 10,51 & 9,52 & 8,62 & 7,04 & 5,77 & 4,01 \\
\hline 72,76 & 1238,90 & 152,30 & 15,13 & 10,97 & 9,65 & 8,44 & 7,49 & 6,67 & 5,30 & 4,27 & 2,92 \\
\hline 52,51 & 1547,70 & 134,90 & 17,32 & 13,92 & 12,41 & 10,79 & 9,38 & 8,16 & 6,21 & 4,84 & 3,18 \\
\hline 37,92 & 358,80 & 133,80 & 39,11 & 24,46 & 18,73 & 13,77 & 10,55 & 8,36 & 5,74 & 4,38 & 3,03 \\
\hline 53,17 & 1480,10 & 59,00 & 29,21 & 24,66 & 23,03 & 20,90 & 18,91 & 17,06 & 13,82 & 11,23 & 7,66 \\
\hline 80,88 & 503,70 & 162,50 & 23,59 & 14,19 & 11,28 & 9,11 & 7,70 & 6,60 & 4,98 & 3,90 & 2,65 \\
\hline 32,92 & 1360,90 & 77,90 & 35,55 & 30,19 & 26,48 & 22,00 & 18,22 & 15,13 & 10,71 & 7,99 & 5,22 \\
\hline 43,31 & 617,90 & 69,10 & 42,34 & 33,37 & 28,88 & 24,01 & 20,02 & 16,76 & 12,04 & 9,08 & 5,96 \\
\hline 62,23 & 915,10 & 142,80 & 19,47 & 14,08 & 12,11 & 10,29 & 8,86 & 7,66 & 5,80 & 4,51 & 3,00 \\
\hline 51,64 & 209,00 & 145,70 & 46,97 & 24,35 & $\begin{array}{l}+L,+\perp \\
17,37\end{array}$ & 12,42 & 9,54 & 7,62 & 5,28 & 4,05 & 2,82 \\
\hline 72,89 & 1897,30 & 178,30 & 11,38 & 8,49 & 7,62 & 6,79 & 6,10 & 5,49 & 4,45 & 3,64 & 2,53 \\
\hline 21,56 & 1879,80 & 85,70 & 42,07 & 34,62 & 28,83 & 22,23 & 17,22 & 13,59 & 9,15 & 6,85 & 4,66 \\
\hline 38,27 & 1946,70 & 94,80 & 24,51 & 21,30 & 19,15 & 16,51 & 14,16 & 12,13 & 8,97 & 6,83 & 4,42 \\
\hline 71,00 & 303,50 & 64,20 & 48,16 & 32,25 & 26,98 & 22,60 & 19,40 & 16,79 & 12,75 & 9,99 & 6,70 \\
\hline 87,09 & 246,40 & 96,60 & 44,50 & 25,38 & 19,62 & 15,51 & 12,97 & 11,07 & 8,32 & 6,54 & 4,45 \\
\hline 52,27 & 1419,00 & 55,60 & 31,17 & 26,42 & 24,67 & 22,37 & 20,22 & 18,21 & 14,72 & 11,94 & 8,12 \\
\hline 21,47 & 1176,70 & 131,80 & 35,32 & 26,20 & 20,30 & 14,52 & 10,77 & 8,36 & 5,71 & 4,38 & 3,04 \\
\hline 61,97 & 1229,80 & 182,30 & 14,90 & 10,87 & 9,39 & 8,01 & 6,91 & 5,99 & 4,54 & 3,54 & 2,35 \\
\hline 74,27 & 1600,00 & 49,70 & 26,03 & 20,33 & 19,19 & 18,14 & 17,04 & 15,98 & 13,97 & 12,18 & 9,24 \\
\hline 82,82 & 1001,40 & 71,20 & 23,72 & 17,46 & 15,94 & 14,54 & 13,36 & 12,30 & 10,40 & 8,82 & 6,42 \\
\hline 83,96 & 1994,20 & 157,50 & 11,17 & 8,13 & 7,38 & 6,69 & 6,13 & 5,63 & 4,74 & 4,00 & 2,90 \\
\hline 69,82 & 1386,60 & 93,30 & 19,25 & 14,88 & 13,66 & 12,36 & 11,24 & 10,21 & 8,41 & 6,95 & 4,88 \\
\hline 30,27 & 1660,50 & 148,20 & 23,22 & 18,60 & 15,66 & 12,37 & 9,81 & 7,89 & 5,41 & 4,04 & 2,71 \\
\hline 29,24 & 772,10 & 181,80 & 26,80 & 18,42 & 14,25 & 10,34 & 7,79 & 6,10 & 4,18 & 3,20 & 2,21 \\
\hline 45,37 & 1066,10 & 154,30 & 20,54 & 15,52 & 13,23 & 10,87 & 8,99 & 7,48 & 5,35 & 4,03 & 2,66 \\
\hline 23,42 & 640,30 & 136,60 & 38,69 & 26,38 & 19,72 & 13,76 & 10,15 & 7,92 & 5,47 & 4,23 & 2,94 \\
\hline 51,06 & 1729,30 & 170,40 & 14,68 & 11,67 & 10,30 & 8,85 & 7,62 & 6,57 & 4,92 & 3,80 & 2,49 \\
\hline 50,40 & 1381,30 & 186,20 & 15,53 & 11,80 & 10,19 & 8,55 & 7,21 & 6,11 & 4,47 & 3,41 & 2,24 \\
\hline 60,13 & 301,20 & 21,60 & 92,18 & 73,69 & 67,00 & 59,69 & 53,33 & 47,57 & 37,84 & 30,40 & 20,56 \\
\hline
\end{tabular}




\begin{tabular}{|c|c|c|c|c|c|c|c|c|c|c|c|}
\hline & & & \multicolumn{9}{|c|}{ Deflexões $\left(\times 10^{-4} \mathrm{~cm}\right)$} \\
\hline e1 (cm) & Meq (MPa) & Ms (MPa) & D0 & D25 & D40 & D60 & D80 & D100 & D140 & D180 & D260 \\
\hline 86,51 & 1163,50 & 172,60 & 13,74 & 9,32 & 8,04 & 7,00 & 6,23 & 5,59 & 4,53 & 3,71 & 2,60 \\
\hline 78,68 & 1170,20 & 55,00 & 26,57 & 20,23 & 18,86 & 17,53 & 16,31 & 15,17 & 13,06 & 11,23 & 8,35 \\
\hline 86,83 & 1356,00 & 81,40 & 18,84 & 13,86 & 12,73 & 11,75 & 10,90 & 10,13 & 8,72 & 7,52 & 5,62 \\
\hline 50,18 & 801,00 & 161,50 & 21,63 & 15,30 & 12,76 & 10,37 & 8,54 & 7,10 & 5,07 & 3,84 & 2,55 \\
\hline 86,31 & 1562,10 & 67,30 & 19,85 & 14,95 & 13,85 & 13,01 & 12,21 & 11,46 & 10,05 & 8,80 & 6,75 \\
\hline 31,89 & 1220,80 & 54,90 & 47,59 & 41,32 & 36,59 & 30,75 & 25,69 & 21,49 & 15,34 & 11,47 & 7,45 \\
\hline 47,02 & 1680,50 & 79,10 & 24,99 & 21,47 & 19,68 & 17,49 & 15,48 & 13,66 & 10,63 & 8,37 & 5,53 \\
\hline 70,18 & 389,30 & 139,70 & 30,41 & 18,24 & 14,37 & 11,41 & 9,44 & 7,95 & 5,81 & 4,48 & 3,02 \\
\hline 60,68 & 370,40 & 28,20 & 72,03 & 57,20 & 51,84 & 46,06 & 41,08 & 36,59 & 29,03 & 23,28 & 15,73 \\
\hline 70,77 & 235,30 & 147,50 & 41,72 & 21,84 & 15,85 & 11,70 & 9,26 & 7,58 & 5,37 & 4,12 & 2,83 \\
\hline 51,06 & 955,90 & 162,40 & 19,66 & 14,34 & 12,16 & 10,04 & 8,38 & 7,03 & 5,09 & 3,87 & 2,55 \\
\hline 85,76 & 1259,90 & 28,30 & 36,01 & 28,93 & 26,65 & 25,64 & 24,59 & 23,46 & 21,24 & 19,16 & 15,47 \\
\hline 65,47 & 777,50 & 113,80 & 23,12 & 16,75 & 14,49 & 12,43 & 10,81 & 9,43 & 7,24 & 5,70 & 3,81 \\
\hline 33,76 & 406,90 & 26,50 & 107,36 & 90,11 & 78,66 & 65,08 & 53,71 & 44,49 & 31,42 & 23,46 & 15,36 \\
\hline 59,58 & 1514,70 & 66,30 & 25,11 & 20,56 & 19,23 & 17,56 & 16,02 & 14,57 & 12,00 & 9,89 & 6,89 \\
\hline 48,42 & 978,30 & 168,70 & 19,59 & 14,31 & 12,08 & 9,89 & 8,17 & 6,81 & 4,88 & 3,69 & 2,44 \\
\hline 87,45 & 942,20 & 65,30 & 24,92 & 18,14 & 16,54 & 15,14 & 13,98 & 12,94 & 11,06 & 9,46 & 7,00 \\
\hline 41,83 & 1216,70 & 26,70 & 62,47 & 55,63 & 52,42 & 47,67 & 43,08 & 38,75 & 31,16 & 25,10 & 16,89 \\
\hline 25,60 & 905,10 & 89,90 & 44,55 & 34,54 & 28,03 & 21,12 & 16,16 & 12,70 & 8,60 & 6,50 & 4,45 \\
\hline 23,08 & 1079,80 & 25,00 & 110,38 & 97,59 & 85,84 & 70,97 & 58,23 & 47,86 & 33,30 & 24,63 & 16,09 \\
\hline 77,08 & 1500,00 & 95,60 & 17,48 & 13,19 & 12,14 & 11,09 & 10,19 & 9,36 & 7,88 & 6,64 & 4,79 \\
\hline 47,00 & 212,90 & 175,80 & 43,67 & 21,58 & 14,91 & 10,35 & 7,84 & 6,23 & 4,30 & 3,32 & 2,34 \\
\hline 80,33 & 1286,70 & 111,40 & 16,80 & 12,29 & 11,10 & 9,98 & 9,08 & 8,28 & 6,87 & 5,74 & 4,09 \\
\hline 60,55 & 590,80 & 199,10 & 21,39 & 13,27 & 10,54 & 8,34 & 6,83 & 5,67 & 4,07 & 3,11 & 2,09 \\
\hline 33,13 & 1955,70 & 195,50 & 17,17 & 13,65 & 11,56 & 9,22 & 7,39 & 5,98 & 4,13 & 3,09 & 2,06 \\
\hline 65,07 & 332,90 & 85,90 & $\begin{array}{l}1 r, \pm r \\
41,52\end{array}$ & 27,10 & $\frac{1 ., 00}{22,21}$ & $\begin{array}{c}0,2 L \\
18,16\end{array}$ & $\begin{array}{r}1,00 \\
15,25\end{array}$ & 12,94 & 9,54 & 7,35 & 4,91 \\
\hline 77,49 & 611,80 & 127,80 & 23,31 & 15,38 & 12,87 & 10,84 & 9,39 & 8,20 & 6,34 & 5,03 & 3,41 \\
\hline 50,06 & 555,00 & 119,00 & 30,26 & 21,14 & 17,54 & 14,17 & 11,62 & 9,63 & 6,86 & 5,19 & 3,46 \\
\hline 84,40 & 1542,50 & $\frac{1 \pm 0,00}{60,40}$ & 21,56 & 16,39 & $\begin{array}{l}1+, 04 \\
15,24\end{array}$ & $\frac{14, \pm 1}{14,36}$ & $\begin{array}{l}1+0< \\
13,51\end{array}$ & 12,69 & 11,16 & $\begin{array}{l}0, \pm 0 \\
9,79\end{array}$ & 7,52 \\
\hline 69,78 & 1486,10 & 164,60 & 13,57 & 10,07 & 8,92 & 7,84 & 6,96 & 6,20 & 4,92 & 3,96 & 2,70 \\
\hline 59,67 & 246,70 & 44,60 & 68,40 & 48,50 & 41,14 & 34,42 & 29,24 & 24,97 & 18,54 & 14,29 & 9,47 \\
\hline 30,10 & 1475,70 & 167,70 & 22,35 & 17,33 & 14,33 & 11,08 & 8,66 & 6,90 & 4,70 & 3,53 & 2,39 \\
\hline 81,28 & 1035,50 & 164,40 & 15,30 & 10,44 & 8,97 & 7,74 & 6,84 & 6,09 & 4,85 & 3,92 & 2,70 \\
\hline 38,42 & 1056,40 & 20,20 & 84,16 & 76,02 & 71,49 & 64,80 & 58,32 & 52,24 & 41,64 & 33,29 & 22,19 \\
\hline 72,98 & 1907,40 & 163,10 & 11,92 & 8,96 & 8,10 & 7,25 & 6,55 & 5,92 & 4,84 & 3,98 & 2,77 \\
\hline 35,59 & 314,30 & 191,30 & 34,98 & 19,13 & 13,69 & 9,57 & 7,19 & 5,68 & 3,93 & 3,03 & 2,13 \\
\hline 46,14 & 1419,00 & 126,60 & 20,22 & 16,40 & 14,48 & 12,35 & 10,53 & 8,99 & 6,64 & 5,07 & 3,31 \\
\hline 83,83 & 319,40 & 116,20 & 35,42 & 20,64 & 16,15 & 12,88 & 10,80 & 9,23 & 6,94 & 5,44 & 3,70 \\
\hline 48,25 & 314,60 & 36,50 & 76,07 & 59,36 & 51,66 & 43,55 & 36,84 & 31,25 & 22,90 & 17,44 & 11,43 \\
\hline 80,75 & 296,70 & 44,90 & 54,70 & 37,63 & 32,48 & 28,13 & 24,92 & 22,19 & 17,71 & 14,36 & 9,91 \\
\hline 32,63 & 917,60 & 75,50 & 41,97 & 34,17 & 29,26 & 23,63 & 19,10 & 15,57 & 10,80 & 8,05 & 5,35 \\
\hline 54,12 & 541,60 & 106,50 & 31,25 & 22,06 & 18,52 & 15,22 & 12,70 & 10,67 & 7,74 & 5,89 & 3,90 \\
\hline 38,45 & 318,80 & 196,70 & 33,79 & 18,39 & 13,21 & 9,31 & 7,03 & 5,56 & 3,84 & 2,96 & 2,07 \\
\hline 52,94 & 1586,70 & 75,50 & 24,35 & 20,47 & 18,93 & 17,03 & 15,28 & 13,67 & 10,92 & 8,78 & 5,92 \\
\hline 35,47 & 373,70 & 124,60 & 40,97 & 26,34 & 20,26 & 14,86 & 11,34 & 8,96 & 6,15 & 4,69 & 3,25 \\
\hline 48,37 & 1329,70 & 184,90 & 16,23 & 12,30 & 10,57 & 8,80 & 7,36 & 6,20 & 4,49 & 3,41 & 2,24 \\
\hline 47,08 & 1677,20 & 74,50 & 25,99 & 22,38 & 20,59 & 18,35 & 16,29 & 14,42 & 11,27 & 8,91 & 5,90 \\
\hline 57,04 & 489,30 & 71,20 & 39,35 & 29,15 & 25,16 & 21,31 & 18,22 & 15,63 & 11,68 & 9,01 & 5,95 \\
\hline 89,56 & 255,40 & 136,30 & 39,12 & 20,81 & 15,39 & 11,67 & 9,51 & 7,97 & 5,86 & 4,57 & 3,13 \\
\hline 33,28 & 1767,00 & 178,30 & 18,83 & 14,96 & 12,66 & 10,10 & 8,10 & 6,56 & 4,53 & 3,38 & 2,26 \\
\hline 49,57 & 1315,50 & 51,40 & 34,79 & 29,84 & 27,74 & 25,02 & 22,49 & 20,14 & 16,09 & 12,92 & 8,69 \\
\hline 53,21 & 1049,50 & 192,80 & 16,84 & 12,06 & 10,18 & 8,40 & 7,01 & 5,90 & 4,28 & 3,26 & 2,16 \\
\hline 81,63 & 626,90 & 66,80 & 30,66 & 21,93 & 19,51 & 17,33 & 15,64 & 14,16 & 11,62 & 9,61 & 6,78 \\
\hline 85,42 & 725,60 & 77,20 & 26,01 & 18,38 & 16,33 & 14,54 & 13,16 & 11,96 & 9,90 & 8,24 & 5,88 \\
\hline 30,83 & 451,40 & 24,00 & 118,52 & 100,89 & 88,12 & 72,70 & 59,76 & 49,31 & 34,60 & 25,76 & 16,88 \\
\hline 86,05 & 1308,40 & 84,10 & 18,86 & 13,85 & 12,68 & 11,65 & 10,78 & 9,99 & 8,55 & 7,33 & 5,44 \\
\hline 70,42 & 627,10 & 78,70 & 30,01 & 21,88 & 19,20 & 16,74 & 14,79 & 13,10 & 10,33 & 8,27 & 5,62 \\
\hline 40,56 & 614,20 & 103,00 & 34,93 & 25,80 & 21,52 & 17,14 & 13,80 & 11,25 & 7,84 & 5,89 & 3,94 \\
\hline 31,77 & 260,50 & 83,80 & 62,71 & 40,57 & 30,86 & 22,24 & 16,76 & 13,18 & 9,05 & 6,94 & 4,82 \\
\hline 83,17 & 717,70 & 193,40 & 17,56 & 10,89 & 8,85 & 7,29 & 6,25 & 5,43 & 4,17 & 3,30 & 2,25 \\
\hline 66,06 & 1624,60 & 58,60 & 25,00 & 19,95 & 18,87 & 17,55 & 16,26 & 15,04 & 12,79 & 10,86 & 7,88 \\
\hline 55,46 & 1629,40 & 30,20 & 43,72 & 36,12 & 34,81 & 32,82 & 30,66 & 28,55 & 24,56 & 21,03 & 15,44 \\
\hline 56,24 & 297,80 & 165,20 & 35,45 & 19,50 & 14,46 & 10,72 & 8,42 & 6,80 & 4,75 & 3,62 & $\frac{1+, 79}{2,49}$ \\
\hline 48,79 & 1710,60 & 39,20 & 38,88 & 33,42 & 31,84 & 29,37 & 26,93 & 24,60 & 20,37 & 16,84 & 11,72 \\
\hline 45,33 & 870,90 & 195,70 & 19,71 & 13,73 & 11,27 & 8,93 & 7,20 & 5,88 & 4,12 & 3,11 & 2,08 \\
\hline 32,78 & 848,60 & 183,00 & 24,36 & 17,14 & 13,61 & 10,18 & 7,82 & 6,18 & 4,22 & 3,20 & 2,20 \\
\hline 45,87 & 247,40 & 171,90 & 40,27 & 21,01 & 14,95 & 10,59 & 8,07 & 6,41 & 4,43 & 3,41 & 2,38 \\
\hline 65,31 & 818,60 & 188,60 & 17,73 & 11,84 & 9,82 & 8,12 & 6,87 & 5,86 & 4,36 & 3,37 & 2,25 \\
\hline 57,71 & 1583,40 & 55,30 & 28,38 & 23,48 & 22,17 & 20,40 & 18,71 & 17,11 & 14,23 & 11,82 & 8,31 \\
\hline 69,65 & 1149,20 & 173,00 & 15,02 & 10,70 & 9,24 & 7,95 & 6,95 & 6,10 & 4.73 & 3,75 & 2,52 \\
\hline 49,48 & 766,60 & 54,90 & 40,79 & 33,72 & 30,32 & 26,47 & 23,08 & 20,11 & 15,33 & 11,93 & 7,83 \\
\hline 47,76 & 1115,60 & 169,40 & 18,55 & 13,87 & 11,83 & 9,76 & 8,11 & 6,79 & 4,88 & 3,69 & 2,44 \\
\hline 38,41 & 1412,60 & 90,80 & 28,25 & 23,89 & 21,17 & 17,94 & 15,15 & 12,80 & 9,29 & 7,01 & 4,56 \\
\hline 44,38 & 1138,80 & 57,40 & 36,73 & 31,62 & 28,75 & 25,26 & 22,11 & 19,30 & 14,74 & 11,46 & 7,49 \\
\hline 73,45 & 1863,20 & 108,00 & 15,26 & 11,71 & 10,85 & 9,93 & 9,12 & 8,37 & 7,03 & 5,91 & 4,25 \\
\hline 26,66 & 1772,30 & 123,30 & 28,24 & 22,97 & 19,28 & 15,10 & 11,88 & 9,48 & 6,45 & 4,81 & 3,25 \\
\hline 33,61 & 566,30 & 179,50 & 28,45 & 18,50 & 14,21 & 10,36 & 7,86 & 6,20 & 4,25 & 3,25 & 2,25 \\
\hline 88,98 & 2000,00 & 151,60 & 11,08 & 7,98 & 7,23 & 6,59 & 6,07 & 5,61 & 4,78 & 4,08 & 3,01 \\
\hline 83,98 & 573,00 & 27,00 & 52,21 & 39,25 & 36,41 & 33,99 & 31,75 & 29,66 & 25,79 & 22,39 & 16,93 \\
\hline 74,28 & 812,60 & 83,90 & 25,04 & 18,42 & 16,43 & 14,55 & 13,05 & 11,73 & 9,48 & 7,73 & 5,35 \\
\hline 37,99 & 1226,90 & 26,30 & 67,39 & 60,98 & 56,97 & 51,31 & 45,87 & 40,81 & 32,15 & 25,47 & 16,82 \\
\hline 20,21 & 1329,10 & 144,70 & 33,18 & 24,41 & 18,70 & 13,22 & 9,74 & 7,55 & 5,17 & 3,99 & 2,77 \\
\hline
\end{tabular}




\begin{tabular}{|c|c|c|c|c|c|c|c|c|c|c|c|}
\hline \multirow[b]{2}{*}{ e1 (cm) } & & & & & & & ões (x1 & m) & & & \\
\hline & Meq (MPa) & Ms (MPa) & D0 & D25 & D40 & $\mathrm{D} 60$ & D80 & D100 & D140 & D180 & D260 \\
\hline 74,35 & 1397,40 & 139,80 & 14,81 & 10,93 & 9,77 & 8,67 & 7,79 & 7,01 & 5,68 & 4,64 & 3,22 \\
\hline 36,60 & 1424,80 & 29,20 & 61,48 & 55,92 & 52,15 & 46,85 & 41,77 & 37,06 & 29,04 & 22,91 & 15,06 \\
\hline 69,15 & 1895,70 & 25,40 & 39,51 & 32,45 & 30,49 & 29,59 & 28,40 & 27,08 & 24,47 & 21,99 & 17,60 \\
\hline 72,70 & 1518,60 & 42,10 & 29,92 & 23,53 & 22,27 & 21,13 & 19,89 & 18,68 & 16,39 & 14,32 & 10,92 \\
\hline 29,37 & 1097,60 & 89,40 & 38,14 & 30,81 & 25,99 & 20,54 & 16,29 & 13,09 & 8,96 & 6,69 & 4,49 \\
\hline 71,22 & 262,60 & 107,30 & 42,87 & 24,91 & 19,27 & 15,08 & 12,38 & 10,36 & 7,53 & 5,80 & 3,92 \\
\hline 69,38 & 713,90 & 179,30 & 19,17 & 12,46 & 10,24 & 8,43 & 7,14 & 6,11 & 4,57 & 3,55 & 2,38 \\
\hline 57,70 & 1265,20 & 190,80 & 14,86 & 10,92 & 9,40 & 7,95 & 6,80 & 5,83 & 4,36 & 3,36 & 2,22 \\
\hline 30,34 & 666,40 & 60,60 & 57,06 & 45,61 & 38,37 & 30,27 & 24,01 & 19,29 & 13,21 & 9,87 & 6,63 \\
\hline 81,89 & 1677,50 & 161,10 & 12,08 & 8,72 & 7,81 & 6,99 & 6,34 & 5,76 & 4,77 & 3,97 & 2,82 \\
\hline 30,18 & 1909,50 & 48,40 & 46,49 & 42,10 & 38,13 & 32,95 & 28,23 & 24,11 & 17,71 & 13,39 & 8,61 \\
\hline 51,95 & 1401,00 & 121,60 & 19,31 & 15,55 & 13,86 & 12,03 & 10,45 & 9,08 & 6,90 & 5,36 & 3,53 \\
\hline 55,18 & 546,50 & 177,00 & 24,23 & 15,32 & 12,21 & 9,61 & 7,80 & 6,42 & 4,56 & 3,46 & 2,33 \\
\hline 39,87 & 1567,90 & 67,90 & 31,81 & 27,87 & 25,31 & 22,11 & 19,21 & 16,64 & 12,54 & 9,65 & 6,27 \\
\hline 48,27 & 908,00 & 156,90 & 21,12 & 15,42 & 13,01 & 10,65 & 8,80 & 7,33 & 5,24 & 3,96 & 2,63 \\
\hline 36,26 & 1518,60 & 181,30 & 18,59 & 14,48 & 12,25 & 9,81 & 7,91 & 6,44 & 4,47 & 3,35 & 2,23 \\
\hline 58,88 & 378,50 & 52,90 & 51,14 & 37,97 & 32,91 & 28,05 & 24,14 & 20,84 & 15,71 & 12,19 & 8,07 \\
\hline 84,11 & 1752,00 & 38,30 & 26,76 & 21,50 & 19,86 & 19,12 & 18,33 & 17,48 & 15,81 & 14,24 & 11,47 \\
\hline 76,41 & 482,50 & 184,60 & 23,50 & 13,74 & 10,70 & 8,46 & 7,03 & 5,94 & 4,38 & 3,40 & 2,30 \\
\hline 28,56 & 1240,80 & 141,80 & 27,41 & 21,14 & 17,31 & 13,22 & 10,24 & 8,11 & 5,51 & 4,15 & 2,83 \\
\hline 59,28 & 223,00 & 190,20 & 40,75 & 19,84 & 13,66 & 9,54 & 7,29 & 5,82 & 4,03 & 3,11 & 2,18 \\
\hline 70,70 & 1550,10 & 91,70 & 18,48 & 14,32 & 13,24 & 12,08 & 11,05 & 10,10 & 8,42 & 7,03 & 4,99 \\
\hline 35,31 & 926,60 & 191,40 & 22,04 & 15,67 & 12,63 & 9,63 & 7,49 & 5,97 & 4,09 & 3,09 & 2,11 \\
\hline 27,47 & 722,30 & 60,50 & 59,72 & 47,71 & 39,73 & 30,86 & 24,14 & 19,22 & 13,06 & 9,78 & 6,62 \\
\hline 86,04 & 918,60 & 178,20 & 15,49 & 10,11 & 8,51 & 7,24 & 6,35 & 5,62 & 4,46 & 3,60 & 2,49 \\
\hline 44,84 & 1434,10 & 144,00 & 19,01 & 15,20 & 13,29 & 11,19 & 9,44 & 7,98 & 5,82 & 4,41 & 2,88 \\
\hline 30,80 & 737,60 & 137,40 & 31,82 & 22,91 & 18,25 & 13,63 & 10,43 & 8,23 & 5,61 & 4,26 & 2,93 \\
\hline 51,64 & 1574,30 & 135,40 & 17,34 & 13,99 & 12,47 & 10,82 & 9,40 & 8,16 & 6,20 & 4,81 & 3,17 \\
\hline 85,49 & 1746,50 & 178,20 & 11,04 & 7,83 & 6,98 & 6,23 & 5,65 & 5,15 & 4,27 & 3,57 & 2,55 \\
\hline 88,49 & 211,50 & 168,70 & 42,96 & 20,99 & 14,58 & 10,38 & 8,10 & 6,59 & 4,67 & 3,61 & 2,50 \\
\hline 29,14 & 452,90 & 135,20 & 39,20 & 25,67 & 19,40 & 13,83 & 10,35 & 8,11 & 5,58 & 4,29 & 2,98 \\
\hline 60,31 & 637,60 & 94,10 & 29,18 & 21,40 & 18,48 & 15,72 & 13,53 & 11,69 & 8,82 & 6,85 & 4,54 \\
\hline 33,24 & 1052,20 & 85,00 & 36,54 & 29,87 & 25,67 & 20,83 & 16,92 & 13,84 & 9,64 & 7,19 & 4,76 \\
\hline 78,25 & 223,00 & 39,10 & 68,79 & 46,65 & 39,72 & 33,97 & 29,76 & 26,25 & 20,60 & 16,49 & 11,25 \\
\hline 53,67 & 605,50 & 36,90 & 54,16 & 44,83 & 40,91 & 36,38 & 32,33 & 28,66 & 22,53 & 17,90 & 11,95 \\
\hline 31,63 & 658,30 & 123,40 & 35,00 & 25,21 & 20,16 & 15,14 & 11,63 & 9,20 & 6,27 & 4,75 & 3,26 \\
\hline 70,29 & 1744,30 & 122,50 & 14,87 & 11,44 & 10,47 & 9,46 & 8,59 & 7,80 & 6,41 & 5,29 & 3,71 \\
\hline 72,46 & 1763,10 & 122,30 & 14,59 & 11,15 & 10,22 & 9,25 & 8,43 & 7,68 & 6,35 & 5,28 & 3,73 \\
\hline 89,82 & 1425,20 & 194,40 & 11,51 & 7,81 & 6,79 & 5,95 & 5,34 & 4,82 & 3,95 & 3,27 & 2,32 \\
\hline 44,48 & 449,20 & 64,10 & 49,70 & 37,68 & 32,11 & 26,32 & 21,72 & 18,04 & 12,86 & 9,69 & 6,40 \\
\hline 60,20 & 1885,50 & 52,90 & 26,93 & 21,99 & 20,97 & 19,57 & 18,16 & 16,80 & 14,28 & 12,11 & 8,76 \\
\hline 73,19 & 1566,30 & 119,60 & 15,46 & 11,71 & 10,67 & 9,61 & 8,73 & 7,93 & 6,53 & 5,40 & 3,80 \\
\hline 61,22 & 556,40 & 21,70 & 72,52 & 59,04 & 55,60 & 51,17 & 47,00 & 43,05 & 35,92 & 29,96 & 21,20 \\
\hline 25,35 & 757,20 & 126,30 & 37,30 & 26,82 & 20,81 & 15,02 & 11,23 & 8,76 & 5,99 & 4,59 & 3,18 \\
\hline 21,04 & 1341,40 & 99,30 & 42,44 & 33,03 & 26,37 & 19,40 & 14,57 & 11,33 & 7,66 & 5,83 & 4,02 \\
\hline 47,90 & 1644,00 & 162,10 & 16,06 & 12,83 & 11,29 & 9,61 & 8,20 & 7,00 & 5,18 & 3,96 & 2,59 \\
\hline 49,73 & 1104,20 & 171,40 & 18,11 & 13,46 & 11,48 & 9,51 & 7,95 & 6,68 & 4,83 & 3,67 & 2,42 \\
\hline 34,95 & 519,70 & 140,60 & 33,53 & 22,59 & 17,72 & 13,19 & 10,12 & 8,01 & 5,49 & 4,17 & 2,87 \\
\hline 79,44 & 673,90 & 154,10 & 20,21 & 13,06 & 10,82 & 9,04 & 7,81 & 6,81 & 5,25 & 4,16 & 2,83 \\
\hline 67,36 & 605,10 & 26,70 & 58,25 & 46,14 & 43,29 & 39,92 & 36,79 & 33,84 & 28,50 & 23,99 & 17,22 \\
\hline 88,40 & 703,70 & 67,70 & 27,84 & 19,69 & 17,59 & 15,79 & 14,39 & 13,17 & 11,03 & 9,29 & 6,72 \\
\hline 67,26 & 534,10 & 50,80 & 41,75 & 31,75 & 28,44 & 25,16 & 22,45 & 20,03 & 15,97 & 12,88 & 8,78 \\
\hline 23,16 & 1815,30 & 178,10 & 23,97 & 18,34 & 14,60 & 10,75 & 8,10 & 6,31 & 4,28 & 3,26 & 2,25 \\
\hline 47,77 & 818,00 & 91,40 & 30,07 & 23,61 & 20,59 & 17,37 & 14,71 & 12,48 & 9,15 & 6,97 & 4,57 \\
\hline 73,67 & 1954,50 & 185,20 & 10,95 & 8,14 & 7,30 & 6,50 & 5,85 & 5,27 & 4,28 & 3,50 & 2,43 \\
\hline 57,46 & 1309,80 & 35,60 & 40,74 & 33,66 & 32,12 & 29,87 & 27,64 & 25,49 & 21,54 & 18,15 & 13,01 \\
\hline 61,08 & 1387,40 & 180,80 & 14,21 & 10,61 & 9,25 & 7,96 & 6,91 & 6,01 & 4,59 & 3,59 & 2,39 \\
\hline 38,17 & 1901,10 & 147,00 & 18,78 & 15,54 & 13,61 & 11,37 & 9,49 & 7,94 & 5,69 & 4,27 & 2,79 \\
\hline 20,29 & 1085,80 & 181,60 & 29,44 & 20,35 & 15,05 & 10,35 & 7,58 & 5,90 & 4,10 & 3,17 & 2,21 \\
\hline 83,61 & 252,30 & 178,10 & 37,13 & 18,68 & 13,25 & 9,63 & 7,60 & 6,23 & 4,44 & 3,43 & 2,36 \\
\hline 82,37 & 1887,30 & 90,80 & 15,83 & 11,93 & 11,07 & 10,32 & 9,62 & 8,97 & 7,76 & 6,71 & 5,04 \\
\hline 83,85 & 1348,00 & 119,60 & 15,52 & 11,20 & 10,09 & 9,08 & 8,28 & 7,57 & 6,32 & 5,30 & 3,81 \\
\hline 27,23 & 808,60 & 69,80 & 52,58 & 41,81 & 34,68 & 26,82 & 20,91 & 16,61 & 11,28 & 8,45 & 5,73 \\
\hline 87,17 & 1201,60 & 28,00 & 36,45 & 29,23 & 26,87 & 25,83 & 24,77 & 23,63 & 21,40 & 19,31 & 15,60 \\
\hline 23,79 & 983,80 & 82,30 & 48,61 & 38,08 & 30,88 & 23,18 & 17,67 & 13,85 & 9,36 & 7,07 & 4,86 \\
\hline 80,39 & 1909,10 & 193,90 & 10,39 & 7,50 & 6,69 & 5,96 & 5,38 & 4,88 & 4,00 & 3,31 & 2,34 \\
\hline 32,47 & 1642,50 & 124,00 & 24,88 & 20,46 & 17,61 & 14,30 & 11,61 & 9,49 & 6,61 & 4,92 & 3,26 \\
\hline 22,29 & 1295,70 & 180,80 & 26,70 & 19,33 & 14,83 & 10,53 & 7,79 & 6,06 & 4,15 & 3,19 & 2,22 \\
\hline 71,82 & 481,10 & 145,00 & 26,13 & 16,25 & 13,07 & 10,59 & 8,89 & 7,57 & 5,62 & 4,36 & 2,93 \\
\hline 25,69 & 1714,50 & 46,30 & 57,05 & 50,58 & 44,79 & 37,43 & 31,03 & 25,75 & 18,14 & 13,47 & 8,75 \\
\hline 80,84 & 1541,90 & 143,70 & 13,43 & 9,75 & 8,76 & 7,84 & 7,12 & 6,47 & 5,35 & 4,45 & 3,16 \\
\hline 39,99 & 862,40 & 46,60 & 50,08 & 43,09 & 38,69 & 33,37 & 28,65 & 24,56 & 18,22 & 13,90 & 9,01 \\
\hline 62,86 & 1732,70 & 31,30 & 38,43 & 31,04 & 29,75 & 28,41 & 26,82 & 25,23 & 22,18 & 19,39 & 14,76 \\
\hline 20,52 & 1949,50 & 179,70 & 25,32 & 19,10 & 14,89 & 10,69 & 7,93 & 6,15 & 4,19 & 3,21 & 2,23 \\
\hline 37,69 & 1936,10 & 121,10 & 21,26 & 18,02 & 15,96 & 13,51 & 11,39 & 9,61 & 6,96 & 5,25 & 3,41 \\
\hline 61,81 & 1284,40 & 100,40 & 20,27 & 16,00 & 14,49 & 12,88 & 11,49 & 10,25 & 8,15 & 6,55 & 4,43 \\
\hline 44,08 & 731,90 & 114,40 & 29,11 & 21,73 & 18,37 & 14,93 & 12,24 & 10,11 & 7,16 & 5,39 & 3,57 \\
\hline 49,80 & 1190,70 & 193,60 & 16,37 & 12,06 & 10,25 & 8,46 & 7,05 & 5,91 & 4,27 & 3,24 & 2,14 \\
\hline 68,32 & 843,60 & 89,10 & 24,77 & 18,56 & 16,51 & 14,52 & 12,91 & 11,48 & 9,12 & 7,33 & 4,98 \\
\hline 31,36 & 1285,30 & 151,30 & 24,40 & 18,89 & 15,67 & 12,20 & 9,59 & 7,67 & 5,24 & 3,93 & 2,66 \\
\hline 35,87 & 1820,20 & 88,30 & 27,63 & 23,98 & 21,43 & 18,29 & 15,53 & 13,17 & 9,60 & 7,25 & 4,69 \\
\hline 56,49 & 783,80 & 142,80 & 22,00 & 15,68 & 13,27 & 11,04 & 9,30 & 7,89 & 5,79 & 4,44 & 2,94 \\
\hline
\end{tabular}




\begin{tabular}{|c|c|c|c|c|c|c|c|c|c|c|c|}
\hline & & & \multicolumn{9}{|c|}{ Deflexões $\left(\times 10^{-4} \mathrm{~cm}\right)$} \\
\hline e1 (cm) & Meq (MPa) & Ms (MPa) & D0 & D25 & D40 & D60 & D80 & D100 & D140 & D180 & D260 \\
\hline 25,97 & 1993,00 & 147,20 & 24,58 & 19,79 & 16,47 & 12,76 & 9,95 & 7,90 & 5,36 & 4,01 & 2,72 \\
\hline 27,39 & 1420,70 & 31,40 & 74,45 & 67,53 & 60,88 & 52,19 & 44,33 & 37,56 & 27,24 & 20,44 & 13,14 \\
\hline 32,78 & 656,10 & 167,90 & 28,31 & 19,26 & 15,06 & 11,11 & 8,47 & 6,68 & 4,57 & 3,48 & 2,40 \\
\hline 26,31 & 587,90 & 61,50 & 64,96 & 50,21 & 40,80 & 30,81 & 23,63 & 18,59 & 12,60 & 9,51 & 6,52 \\
\hline 62,78 & 854,20 & 151,20 & 19,52 & 13,79 & 11,73 & 9,88 & 8,46 & 7,28 & 5,47 & 4,24 & 2,82 \\
\hline 78,66 & 235,30 & 134,50 & 42,32 & 22,46 & 16,50 & 12,38 & 9,95 & 8,24 & 5,94 & 4,58 & 3,13 \\
\hline 49,49 & 1681,50 & 39,10 & 38,83 & 33,27 & 31,71 & 29,27 & 26,87 & 24,56 & 20,38 & 16,88 & 11,78 \\
\hline 24,49 & 974,10 & 180,00 & 27,51 & 19,36 & 14,79 & 10,51 & 7,81 & 6,09 & 4,18 & 3,21 & 2,23 \\
\hline 72,31 & 1211,30 & 110,80 & 18,17 & 13,61 & 12,25 & 10,92 & 9,82 & 8,85 & 7,18 & 5,87 & 4,07 \\
\hline 89,89 & 1352,90 & 95,20 & 16,98 & 12,27 & 11,15 & 10,22 & 9,45 & 8,75 & 7,50 & 6,44 & 4,80 \\
\hline 61,58 & 1398,10 & 92,80 & 20,56 & 16,43 & 15,03 & 13,48 & 12,12 & 10,88 & 8,75 & 7,08 & 4,84 \\
\hline 42,63 & 1424,50 & 152,40 & 19,04 & 15,11 & 13,10 & 10,90 & 9,08 & 7,60 & 5,46 & 4,12 & 2,70 \\
\hline 87,95 & 1619,30 & 112,50 & 14,44 & 10,49 & 9,56 & 8,76 & 8,09 & 7,48 & 6,40 & 5,48 & 4,06 \\
\hline 69,21 & 1696,90 & 144,90 & 13,76 & 10,49 & 9,48 & 8,46 & 7,60 & 6,84 & 5,53 & 4,50 & 3,10 \\
\hline 65,08 & 943,60 & 171,50 & 17,18 & 12,01 & 10,20 & 8,60 & 7,38 & 6,37 & 4,81 & 3,75 & 2,50 \\
\hline 88,50 & 844,00 & 34,90 & 37,04 & 27,93 & 25,80 & 24,31 & 22,89 & 21,54 & 19,00 & 16,73 & 12,96 \\
\hline 72,14 & 1928,00 & 74,60 & 19,13 & 14,93 & 14,06 & 13,12 & 12,22 & 11,35 & 9,76 & 8,37 & 6,18 \\
\hline 86,66 & 1129,00 & 20,20 & 45,03 & 37,66 & 34,34 & 33,13 & 32,04 & 30,75 & 28,14 & 25,64 & 21,12 \\
\hline 71,82 & 1438,90 & 115,20 & 16,53 & 12,54 & 11,39 & 10,22 & 9,25 & 8,37 & 6,85 & 5,63 & 3,93 \\
\hline 49,96 & 932,40 & 116,60 & 24,10 & 18,55 & 16,09 & 13,56 & 11,48 & 9,75 & 7,16 & 5,46 & 3,59 \\
\hline 33,48 & 884,20 & 36,80 & 66,39 & 58,24 & 52,07 & 44,37 & 37,57 & 31,78 & 23,06 & 17,35 & 11,22 \\
\hline 34,60 & 666,00 & 126,70 & 32,61 & 23,52 & 19,04 & 14,55 & 11,33 & 9,03 & 6,18 & 4,67 & 3,18 \\
\hline 27,83 & 1576,90 & 109,60 & 30,76 & 25,15 & 21,27 & 16,82 & 13,34 & 10,71 & 7,32 & 5,45 & 3,66 \\
\hline 67,03 & 740,10 & 78,90 & 28,34 & 21,31 & 18,93 & 16,62 & 14,74 & 13,08 & 10,34 & 8,28 & 5,61 \\
\hline 50,75 & 1856,90 & 73,80 & 24,02 & 20,49 & 19,07 & 17,23 & 15,51 & 13,92 & 11,16 & 9,00 & 6,08 \\
\hline 72,21 & 1071,30 & 163,70 & 15,75 & 11,11 & 9,59 & 8,25 & 7,24 & 6,37 & 4,97 & 3,96 & 2,68 \\
\hline 36,87 & 669,40 & 183,80 & 25,20 & 16,92 & 13,35 & 10,02 & 7,74 & 6,15 & 4,22 & 3,20 & 2,20 \\
\hline 47,94 & 1667,30 & 29,70 & 48,21 & 41,28 & 39,68 & 36,92 & 34,11 & 31,39 & 26,36 & 22,06 & 15,61 \\
\hline 52,86 & 1733,00 & 123,20 & 17,39 & 14,26 & 12,88 & 11,34 & 9,98 & 8,77 & 6,79 & 5,34 & 3,54 \\
\hline 42,62 & 1578,60 & $\frac{1<0, \angle 0}{51,50}$ & 36,24 & 32,04 & $\frac{1 L, 00}{29,68}$ & $\frac{1+, 0}{26,56}$ & 23,62 & 20,93 & 16,39 & 12,94 & 8,54 \\
\hline 57,27 & 425,40 & 187,10 & 27,05 & 15,80 & 12,12 & 9,26 & 7,40 & 6,04 & 4,25 & 3,24 & 2,20 \\
\hline 22,87 & 1886,20 & 42,80 & 64,66 & 57,18 & 50,29 & 41,57 & 34,09 & 28,01 & 19,48 & 14,41 & 9,41 \\
\hline 52,54 & 765,40 & 59,70 & 37,38 & 30,41 & 27,31 & 23,89 & 20,91 & 18,28 & 14,04 & 10,98 & 7,25 \\
\hline 88,43 & 865,40 & 178,50 & 15,90 & 10,21 & 8,53 & 7,22 & 6,32 & 5,60 & 4,44 & 3,59 & 2,48 \\
\hline 26,51 & 1131,50 & 60,20 & 53,32 & 44,60 & 38,10 & 30,45 & 24,33 & 19,62 & 13,43 & 9,98 & 6,66 \\
\hline 40,94 & 1253,50 & 127,30 & 22,93 & 18,33 & 15,89 & 13,18 & 10,95 & 9,13 & 6,53 & 4,91 & 3,22 \\
\hline 52,31 & 961,10 & 141,10 & 20,87 & 15,59 & 13,39 & 11,22 & 9,48 & 8,04 & 5,89 & 4,50 & 2,97 \\
\hline 57,62 & 1605,40 & 151,80 & 15,10 & 11,86 & 10,57 & 9,23 & 8,09 & 7,10 & 5,48 & 4,31 & 2,86 \\
\hline 72,65 & 1884,40 & 101,80 & 15,83 & 12,23 & 11,36 & 10,43 & 9,60 & 8,83 & 7,43 & 6,26 & 4,51 \\
\hline 62,73 & 365,80 & 88,70 & 39,36 & 26,16 & 21,59 & 17,70 & 14,86 & 12,59 & 9,26 & 7,12 & 4,74 \\
\hline 78,42 & 1104,80 & 189,90 & 14,01 & 9,53 & 8,13 & 6,96 & 6,11 & 5,39 & 4,24 & 3,40 & 2,32 \\
\hline 67,54 & 1644,00 & 125,40 & 15,34 & 11,87 & 10,80 & 9,68 & 8,73 & 7,87 & 6,38 & 5,21 & 3,60 \\
\hline 36,46 & 1327,00 & 123,90 & 24,72 & 19,94 & 17,17 & 14,03 & 11,48 & 9,46 & 6,65 & 4,97 & 3,28 \\
\hline 89,02 & 1195,90 & 154,90 & 14,10 & 9,65 & 8,42 & 7,41 & 6,66 & 6,02 & 4,95 & 4,11 & 2,92 \\
\hline 20,59 & 428,40 & 132,70 & 46,72 & 29,02 & 20,48 & 13,76 & 10,10 & 7,95 & 5,58 & 4,34 & 3,04 \\
\hline 64,79 & 615,80 & 94,30 & 28,67 & 20,66 & 17,81 & 15,21 & 13,18 & 11,46 & 8,75 & 6,86 & 4,58 \\
\hline 79,98 & 1433,00 & 80,00 & 19,40 & 14,60 & 13,51 & 12,46 & 11,53 & 10,68 & 9,12 & 7,79 & 5,74 \\
\hline 33,20 & 705,70 & 119,50 & 33,89 & 24,90 & 20,24 & 15,48 & 12,05 & 9,59 & 6,55 & 4,94 & 3,37 \\
\hline 48,46 & 828,70 & 133,30 & 24,01 & 17,76 & 15,08 & 12,41 & 10,31 & 8,62 & 6,19 & 4,69 & 3,10 \\
\hline 65,63 & 1649,80 & 190,90 & 12,29 & 9,19 & 8,11 & 7,07 & 6,23 & 5,50 & 4,30 & 3,42 & 2,30 \\
\hline 54,13 & 1622,10 & 61,20 & 27,34 & 23,00 & 21,56 & 19,65 & 17,86 & 16,18 & 13,20 & 10,80 & 7,43 \\
\hline 29,68 & 1941,70 & 108,80 & 27,43 & 23,13 & 20,03 & 16,34 & 13,29 & 10,87 & 7,56 & 5,62 & 3,70 \\
\hline 28,81 & 1640,70 & 117,00 & 28,31 & 23,17 & 19,67 & 15,65 & 12,47 & 10,05 & 6,89 & 5,13 & 3,43 \\
\hline 69,47 & 1339,80 & 63,20 & 24,83 & 19,48 & 18,22 & 16,79 & 15,48 & 14,24 & 12,01 & 10,12 & 7,29 \\
\hline 88,96 & 930,30 & 24,80 & 42,92 & 33,90 & 31,16 & 29,85 & 28,54 & 27,17 & 24,51 & 22,04 & 17,71 \\
\hline 77,32 & 354,70 & 147,10 & 31,04 & 17,78 & 13,70 & 10,73 & 8,86 & 7,47 & 5,49 & 4,25 & 2,88 \\
\hline 21,59 & 1591,40 & 22,80 & 109,97 & 99,82 & 89,21 & 75,30 & 62,91 & 52,47 & 37,16 & 27,56 & 17,78 \\
\hline 29,31 & 1740,70 & 104,90 & 29,46 & 24,61 & 21,19 & 17,14 & 13,85 & 11,27 & 7,79 & 5,79 & 3,84 \\
\hline 28,93 & 1247,10 & 76,30 & 41,12 & 34,26 & 29,40 & 23,69 & 19,07 & 15,48 & 10,68 & 7,94 & 5,27 \\
\hline 24,27 & 1972,40 & 111,90 & 31,36 & 25,73 & 21,56 & 16,80 & 13,14 & 10,44 & 7,07 & 5,28 & 3,57 \\
\hline 84,05 & 522,00 & 55,70 & 36,34 & 25,79 & 22,91 & 20,38 & 18,43 & 16,72 & 13,79 & 11,46 & 8,14 \\
\hline 31,65 & 464,00 & 122,10 & 39,97 & 27,00 & 20,93 & 15,31 & 11,60 & 9,13 & 6,25 & 4,77 & 3,30 \\
\hline 45,39 & 1715,70 & 83,70 & 24,52 & 21,11 & 19,27 & 17,01 & 14,96 & 13,12 & 10,10 & 7,89 & 5,18 \\
\hline 72,22 & 623,50 & 46,20 & 39,78 & 30,30 & $\begin{array}{l}10,21 \\
27,65\end{array}$ & 24,94 & 22,66 & 20,58 & 16,94 & 14,01 & 9,84 \\
\hline 57,79 & 1576,90 & 43,00 & 33,68 & 27,78 & 26,51 & 24,67 & 22,84 & 21,07 & 17,82 & $15,0 \pm$ & 10,78 \\
\hline 53,46 & 1302,00 & 73,90 & 26,38 & 21,95 & 20,11 & 17,94 & 15,99 & 14,21 & 11,22 & 8,95 & 5,99 \\
\hline 32,91 & 1523,20 & 120,20 & 25,82 & 21,15 & 18,18 & 14,75 & 11,97 & 9,79 & 6,82 & 5,08 & 3,36 \\
\hline 66,97 & 1065,70 & 147,60 & 17,17 & 12,48 & 10,86 & 9,37 & 8,19 & 7,18 & 5,57 & 4,40 & 2,95 \\
\hline 38,54 & 1724,30 & 196,70 & 16,17 & 12,71 & 10,86 & 8,84 & 7,21 & 5,93 & 4,17 & 3,12 & 2,07 \\
\hline 30,45 & 236,20 & 104,80 & 57,68 & 34,46 & 25,19 & 17,62 & 13,15 & 10,34 & 7,15 & 5,53 & 3,87 \\
\hline 48,86 & 1074,00 & 181,80 & 17,94 & 13,14 & 11,12 & 9,12 & 7,56 & $\frac{10,04}{6,31}$ & $\frac{1, \pm 0}{4,53}$ & 3,43 & $\frac{1,27}{2,27}$ \\
\hline 49,60 & 733,00 & 169,90 & 22,11 & 15,22 & 12,52 & 10,03 & 8,18 & 6,75 & 4,78 & 3,62 & 2,42 \\
\hline 37,78 & 1555,30 & 142,00 & 20,86 & 16,89 & 14,63 & 12,06 & 9,94 & 8,24 & 5,83 & 4,37 & 2,87 \\
\hline 38,32 & 1108,40 & 146,40 & 23,10 & 17,75 & 15,00 & 12,05 & 9,74 & 7,96 & 5,55 & 4,16 & 2,77 \\
\hline 63,11 & 891,50 & 182,00 & 17,43 & 11,99 & 10,06 & 8,38 & 7,12 & 6,08 & 4,53 & 3,50 & 2,33 \\
\hline 62,93 & 1406,90 & 30,70 & 41,58 & 33,54 & 32,14 & 30,44 & 28,57 & 26,74 & 23,26 & 20,14 & 15,08 \\
\hline 86,33 & 532,60 & 49,60 & 37,79 & 26,96 & 24,17 & 21,72 & 19,79 & 18,10 & 15,14 & 12,72 & 9,18 \\
\hline 27,99 & 1917,90 & 62,00 & 42,01 & 37,09 & 32,89 & 27,60 & 22,99 & 19,16 & 13,59 & 10,12 & 6,56 \\
\hline 64,20 & 775,50 & 198,40 & 17,98 & 11,78 & 9,66 & 7,90 & 6,63 & 5,62 & 4,13 & 3,18 & 2,12 \\
\hline 89,87 & 1210,00 & 147,80 & 14,28 & 9,82 & 8,61 & 7,61 & 6,86 & 6,23 & 5,15 & 4,29 & 3,06 \\
\hline 84,54 & 490,50 & 50,70 & 39,24 & 27,89 & 24,84 & 22,15 & 20,07 & 18,24 & 15,09 & 12,58 & 8,96 \\
\hline 48,52 & 419,80 & 120,70 & 34,95 & 22,98 & 18,47 & 14,47 & 11,61 & 9,47 & 6,64 & 5,02 & 3,39 \\
\hline
\end{tabular}




\begin{tabular}{|c|c|c|c|c|c|c|c|c|c|c|c|}
\hline \multirow[b]{2}{*}{ e1 (cm) } & & & & & & $\mathrm{De}$ & ões (x1 & & & & \\
\hline & Meq (MPa) & Ms (MPa) & D0 & D25 & D40 & D60 & D80 & D100 & D140 & D180 & D260 \\
\hline 35,53 & 523,80 & 171,20 & 29,56 & 19,10 & 14,73 & 10,82 & 8,26 & 6,53 & 4,48 & 3,42 & 2,36 \\
\hline 78,14 & 422,70 & 64,70 & 38,67 & 26,77 & 23,10 & 19,96 & 17,62 & 15,64 & 12,39 & 9,99 & 6,85 \\
\hline 39,15 & 678,10 & 166,10 & 25,87 & 17,78 & 14,28 & 10,95 & 8,59 & 6,88 & 4,74 & 3,58 & 2,44 \\
\hline 72,91 & 1915,90 & 171,40 & 11,58 & 8,68 & 7,82 & 6,98 & 6,29 & 5,68 & 4,62 & 3,79 & 2,63 \\
\hline 56,79 & 1680,70 & 20,60 & 55,56 & 45,47 & 43,82 & 42,12 & 39,91 & 37,67 & 33,30 & 29,25 & 22,43 \\
\hline 83,03 & 886,20 & 31,60 & 40,10 & 30,71 & 28,63 & 27,08 & 25,52 & 24,01 & 21,17 & 18,61 & 14,36 \\
\hline 74,83 & 1611,80 & 87,50 & 18,17 & 13,92 & 12,93 & 11,89 & 10,96 & 10,11 & 8,55 & 7,24 & 5,25 \\
\hline 25,10 & 599,00 & 195,30 & 29,73 & 18,84 & 13,76 & 9,49 & 7,01 & 5,50 & 3,82 & 2,96 & 2,07 \\
\hline 47,19 & 876,10 & 106,90 & 26,90 & 20,86 & 18,06 & 15,12 & 12,71 & 10,72 & 7,79 & 5,92 & 3,88 \\
\hline 64,79 & 1950,10 & 195,60 & 11,30 & 8,62 & 7,69 & 6,76 & 5,99 & 5,31 & 4,18 & 3,34 & 2,26 \\
\hline 37,64 & 1069,20 & 164,00 & 22,10 & 16,58 & 13,82 & 10,93 & 8,73 & 7,08 & 4,90 & 3,68 & 2,47 \\
\hline 61,65 & 1154,00 & 126,90 & 18,63 & 14,20 & 12,55 & 10,92 & 9,58 & 8,41 & 6,52 & 5,14 & 3,43 \\
\hline 34,73 & 1398,60 & 98,70 & 29,00 & 24,16 & 21,06 & 17,41 & 14,37 & 11,91 & 8,42 & 6,29 & 4,12 \\
\hline 74,27 & 1881,90 & 176,60 & 11,39 & 8,45 & 7,59 & 6,77 & 6,10 & 5,50 & 4,47 & 3,67 & 2,56 \\
\hline 27,44 & 1667,10 & 136,40 & 26,32 & 21,08 & 17,59 & 13,68 & 10,72 & 8,54 & 5,80 & 4,34 & 2,94 \\
\hline 44,60 & 1019,70 & 136,70 & 22,66 & 17,36 & 14,86 & 12,25 & 10,15 & 8,46 & 6,05 & 4,56 & 3,01 \\
\hline 52,38 & 375,40 & 99,40 & 39,49 & 26,29 & 21,40 & 17,07 & 13,92 & 11,50 & 8,16 & 6,19 & 4,14 \\
\hline 66,89 & 1877,10 & 43,20 & 28,89 & 23,07 & 22,01 & 20,91 & 19,69 & 18,48 & 16,18 & 14,10 & 10,68 \\
\hline 67,12 & 941,30 & 115,70 & 20,65 & 15,25 & 13,40 & 11,66 & 10,26 & 9,05 & 7,08 & 5,63 & 3,80 \\
\hline 32,78 & 1784,00 & 42,20 & 48,59 & 44,28 & 40,58 & 35,66 & 31,07 & 26,96 & 20,33 & 15,61 & 10,07 \\
\hline 39,34 & 1426,90 & 108,70 & 24,70 & 20,49 & 18,02 & 15,15 & 12,72 & 10,69 & 7,72 & 5,81 & 3,79 \\
\hline 44,77 & 1201,70 & 136,70 & 21,10 & 16,57 & 14,36 & 11,99 & 10,04 & 8,44 & 6,09 & 4,61 & 3,02 \\
\hline 89,39 & 1976,40 & 179,60 & 10,17 & 7,20 & 6,46 & 5,82 & 5,32 & 4,89 & 4,12 & 3,48 & 2,54 \\
\hline 80,99 & 768,70 & 197,60 & 16,82 & 10,58 & 8,65 & 7,16 & 6,14 & 5,33 & 4,09 & 3,24 & 2,20 \\
\hline 47,22 & 952,60 & 164,60 & 20,36 & 14,89 & 12,55 & 10,23 & 8,43 & 7,00 & 4,99 & 3,77 & 2,50 \\
\hline 22,05 & 484,90 & 68,60 & 71,11 & 51,29 & 39,19 & 27,74 & 20,50 & 15,93 & 10,93 & 8,42 & 5,85 \\
\hline 80,99 & 728,20 & 58,80 & 30,71 & 22,54 & 20,44 & 18,47 & 16,87 & 15,42 & 12,89 & 10,81 & 7,76 \\
\hline 53,37 & 1340,60 & 172,60 & 15,89 & 12,10 & 10,51 & 8,91 & 7,60 & 6,51 & 4,83 & 3,71 & 2,44 \\
\hline 40,94 & 1069,00 & 116,90 & 25,72 & 20,34 & 17,54 & 14,47 & 11,97 & 9,95 & 7,08 & 5,32 & 3,50 \\
\hline 61,92 & 1206,30 & 108,10 & 19,92 & 15,53 & 13,93 & 12,29 & 10,89 & 9,66 & 7,60 & 6,07 & 4,08 \\
\hline 32,13 & 561,00 & 180,50 & 28,99 & 18,76 & 14,30 & 10,33 & 7,79 & 6,13 & 4,21 & 3,22 & 2,24 \\
\hline 74,61 & 343,60 & 92,10 & 37,89 & 24,01 & 19,56 & 16,07 & 13,65 & 11,74 & 8,85 & 6,92 & 4,65 \\
\hline 34,47 & 728,70 & 36,80 & 69,45 & 59,94 & 53,22 & 45,00 & 37,85 & 31,85 & 22,95 & 17,24 & 11,18 \\
\hline 26,27 & 818,80 & 169,00 & 29,17 & 20,33 & 15,60 & 11,17 & 8,34 & 6,51 & 4,46 & 3,43 & 2,38 \\
\hline 69,24 & 1694,70 & 191,10 & 11,83 & 8,77 & 7,76 & 6,81 & 6,04 & 5,37 & 4,25 & 3,41 & 2,32 \\
\hline 37,72 & 730,80 & 99,60 & 34,70 & 26,52 & 22,32 & 17,83 & 14,35 & 11,68 & 8,12 & 6,09 & 4,06 \\
\hline 26,65 & 754,60 & 127,50 & 36,04 & 26,03 & 20,38 & 14,85 & 11,18 & 8,74 & 5,96 & 4,55 & 3,15 \\
\hline 33,80 & 871,50 & 150,90 & 26,79 & 19,63 & 15,96 & 12,24 & 9,54 & 7,60 & 5,20 & 3,92 & 2,67 \\
\hline 31,91 & 764,00 & 172,80 & 26,61 & 18,53 & 14,59 & 10,81 & 8,25 & 6,51 & 4,45 & 3,38 & 2,33 \\
\hline 74,65 & 1962,30 & 183,70 & 10,91 & 8,09 & 7,27 & 6,48 & 5,84 & 5,27 & 4,30 & 3,53 & 2,46 \\
\hline 44,01 & 1979,10 & 192,50 & 14,21 & 11,42 & 9,99 & 8,41 & 7,08 & 5,98 & 4,35 & 3,30 & 2,16 \\
\hline 23,21 & 1316,60 & 117,00 & 35,41 & 27,43 & 22,03 & 16,35 & 12,38 & 9,67 & 6,54 & 4,96 & 3,42 \\
\hline 81,57 & 690,00 & 92,10 & 24,88 & 17,36 & 15,15 & 13,25 & 11,83 & 10,60 & 8,56 & 6,99 & 4,87 \\
\hline 51,90 & 911,40 & 30,10 & 54,63 & 46,46 & 43,73 & 39,93 & 36,33 & 32,93 & 26,91 & 22,01 & 15,13 \\
\hline 28,89 & 989,70 & 44,10 & 64,00 & 55,06 & 48,17 & 39,74 & 32,63 & 26,89 & 18,82 & 13,98 & 9,16 \\
\hline 87,84 & 1319,30 & 122,90 & 15,14 & 10,75 & 9,64 & 8,66 & 7,91 & 7,24 & 6,07 & 5,12 & 3,71 \\
\hline 43,60 & 294,40 & 59,90 & 62,74 & 44,64 & 36,86 & 29,27 & 23,57 & 19,24 & 13,46 & 10,13 & 6,79 \\
\hline 43,07 & 1550,70 & 162,70 & 17,58 & 13,99 & 12,15 & 10,14 & 8,48 & 7,11 & 5,12 & 3,87 & 2,53 \\
\hline 85,92 & 1241,00 & 114,30 & 16,35 & 11,69 & 10,49 & 9,44 & 8,60 & 7,86 & 6,58 & 5,53 & 3,99 \\
\hline 77,20 & 1780,00 & 176,30 & 11,49 & 8,40 & 7,52 & 6,69 & 6,03 & 5,45 & 4,45 & 3,66 & 2,56 \\
\hline 64,48 & 894,70 & 25,30 & 54,18 & 43,51 & 41,48 & 38,92 & 36,31 & 33,78 & 29,05 & 24,90 & 18,35 \\
\hline 65,60 & 724,10 & 124,10 & 22,95 & 16,19 & 13,82 & 11,71 & 10,10 & 8,75 & 6,64 & 5,19 & 3,46 \\
\hline 31,77 & 255,60 & 106,50 & 54,65 & 33,23 & 24,60 & 17,40 & 13,04 & 10,25 & 7,07 & 5,45 & 3,80 \\
\hline 72,15 & 1562,30 & 51,90 & 26,00 & 20,37 & 19,25 & 18,10 & 16,94 & 15,81 & 13,71 & 11,86 & 8,88 \\
\hline 69,67 & 318,80 & 172,00 & 32,30 & 17,58 & 13,07 & 9,85 & 7,90 & 6,50 & 4,64 & 3,56 & 2,43 \\
\hline 76,23 & 532,90 & 70,80 & 33,17 & 23,55 & 20,58 & 17,95 & 15,93 & 14,19 & 11,32 & 9,15 & 6,28 \\
\hline 62,08 & 629,00 & 92,80 & 29,17 & 21,29 & 18,40 & 15,70 & 13,56 & 11,75 & 8,92 & 6,96 & 4,63 \\
\hline 59,67 & 1015,40 & 182,90 & 16,65 & 11,82 & 10,03 & 8,39 & 7,13 & 6,09 & 4,52 & 3,49 & 2,31 \\
\hline 53,88 & 708,40 & 24,90 & 65,86 & 55,49 & 52,19 & 47,70 & 43,46 & 39,46 & 32,34 & 26,54 & 18,33 \\
\hline 30,93 & 310,30 & 82,80 & 59,89 & 40,30 & 31,10 & 22,61 & 17,08 & 13,42 & 9,19 & 7,03 & 4,87 \\
\hline 64,30 & 1006,70 & 193,90 & 15,74 & 10,91 & 9,22 & 7,72 & 6,60 & 5,67 & 4,25 & 3,30 & 2,20 \\
\hline 29,73 & 1997,80 & 42,30 & 50,73 & 46,40 & 42,30 & 36,85 & 31,82 & 27,36 & 20,32 & 15,44 & 9,92 \\
\hline 21,68 & 1183,90 & 114,10 & 38,92 & 29,50 & 23,20 & 16,83 & 12,56 & 9,76 & 6,63 & 5,07 & 3,51 \\
\hline 35,28 & 532,60 & 129,50 & 34,75 & 23,93 & 18,99 & 14,28 & 11,03 & 8,75 & 5,99 & 4,54 & 3,12 \\
\hline 38,26 & 1776,90 & 193,20 & 16,24 & 12,85 & 11,01 & 8,98 & 7,34 & 6,04 & 4,25 & 3,18 & 2,10 \\
\hline 55,75 & 754,70 & 168,40 & 20,79 & 14,27 & 11,84 & 9,67 & 8,03 & 6,74 & 4,88 & 3,72 & 2,47 \\
\hline 58,12 & 867,10 & 26,00 & 57,23 & 47,21 & 44,89 & 41,62 & 38,42 & 35,35 & 29,74 & 24,97 & 17,80 \\
\hline 37,81 & 1910,50 & 92,60 & 25,29 & 21,98 & 19,74 & 17,00 & 14,55 & 12,44 & 9,18 & 6,98 & 4,52 \\
\hline 83,26 & 1172,40 & 49,20 & 27,47 & 20,82 & 19,37 & 18,18 & 17,04 & 15,97 & 13,96 & 12,18 & 9,28 \\
\hline 67,70 & 1716,10 & 87,20 & 18,76 & 14,79 & 13,79 & 12,63 & 11,58 & 10,61 & 8,86 & 7,40 & 5,26 \\
\hline 40,75 & 1179,60 & 31,60 & 57,15 & 51,08 & 47,56 & 42,74 & 38,15 & 33,91 & 26,68 & 21,14 & 13,98 \\
\hline 46,67 & 1809,40 & 188,60 & 14,36 & 11,41 & 9,98 & 8,43 & 7,14 & 6,06 & 4,44 & 3,38 & 2,21 \\
\hline 48,12 & 458,30 & 163,30 & 28,92 & 18,08 & 14,18 & 10,87 & 8,60 & 6,96 & 4,85 & 3,67 & 2,50 \\
\hline 67,35 & 886,50 & 26,80 & 50,80 & 40,40 & 38,39 & 36,05 & 33,66 & 31,36 & 27,05 & 23,25 & 17,23 \\
\hline 60,48 & 1583,50 & 191,10 & 13,04 & 9,85 & 8,64 & 7,46 & 6,50 & 5,67 & 4,34 & 3,40 & 2,26 \\
\hline 69,12 & 1708,60 & 177,30 & 12,28 & 9,19 & 8,19 & 7,22 & 6,43 & 5,73 & 4,57 & 3,68 & 2,51 \\
\hline 46,52 & 399,40 & 189,40 & 29,33 & 17,07 & 12,88 & 9,54 & 7,41 & 5,93 & 4,10 & 3,13 & 2,16 \\
\hline 33,39 & 1072,90 & 180,20 & 22,34 & 16,44 & 13,38 & 10,26 & 7,99 & 6,37 & 4,35 & 3,28 & 2,23 \\
\hline 48,79 & 693,40 & 65,20 & 38,70 & 31,06 & 27,44 & 23,50 & 20,15 & 17,30 & 12,89 & 9,89 & 6,48 \\
\hline 58,57 & 1414,30 & 193,20 & 13,89 & 10,36 & 8,99 & 7,67 & 6,61 & 5,71 & 4,30 & 3,34 & 2,21 \\
\hline 75,47 & 1459,60 & 119,10 & 15,74 & 11,77 & 10,68 & 9,60 & 8,72 & 7,92 & 6,53 & 5,41 & 3,82 \\
\hline 32,25 & 473,00 & 37,40 & 84,34 & 68,96 & 59,11 & 47,77 & 38,63 & 31,50 & 21,85 & 16,28 & 10,80 \\
\hline
\end{tabular}




\begin{tabular}{|c|c|c|c|c|c|c|c|c|c|c|c|}
\hline \multirow[b]{2}{*}{ e1 (cm) } & & & & & & & ões (x1 & m) & & & \\
\hline & Meq (MPa) & Ms (MPa) & D0 & D25 & D40 & $\mathrm{D} 60$ & D80 & D100 & D140 & D180 & D260 \\
\hline 68,25 & 1488,60 & 121,30 & 16,22 & 12,45 & 11,28 & 10,08 & 9,07 & 8,16 & 6,60 & 5,38 & 3,71 \\
\hline 68,49 & 1688,40 & 27,80 & 39,28 & 31,71 & 30,05 & 28,98 & 27,61 & 26,19 & 23,41 & 20,81 & 16,33 \\
\hline 56,21 & 809,10 & 161,20 & 20,43 & 14,33 & 12,03 & 9,92 & 8,31 & 7,01 & 5,12 & 3,91 & 2,59 \\
\hline 80,90 & 240,90 & 98,80 & 45,47 & 25,95 & 20,00 & 15,70 & 13,02 & 11,02 & 8,16 & 6,35 & 4,31 \\
\hline 55,34 & 405,50 & 59,50 & 48,02 & 35,66 & 30,72 & 25,91 & 22,06 & 18,84 & 13,98 & 10,75 & 7,09 \\
\hline 78,85 & 1569,60 & 49,80 & 25,16 & 19,50 & 18,29 & 17,34 & 16,35 & 15,38 & 13,55 & 11,90 & 9,15 \\
\hline 84,32 & 965,30 & 32,60 & 37,67 & 28,95 & 26,93 & 25,56 & 24,16 & 22,79 & 20,19 & 17,84 & 13,88 \\
\hline 80,38 & 976,00 & 44,30 & 32,16 & 24,42 & 22,75 & 21,23 & 19,80 & 18,46 & 15,98 & 13,81 & 10,36 \\
\hline 46,81 & 1442,80 & 162,50 & 17,19 & 13,49 & 11,74 & 9,88 & 8,33 & 7,05 & 5,14 & 3,91 & 2,56 \\
\hline 81,91 & 1677,40 & 190,90 & 11,06 & 7,85 & 6,95 & 6,15 & 5,53 & 4,99 & 4,08 & 3,36 & 2,37 \\
\hline 86,87 & 1156,70 & 75,00 & 21,13 & 15,47 & 14,15 & 13,01 & 12,04 & 11,15 & 9,56 & 8,21 & 6,10 \\
\hline 63,35 & 299,10 & 30,30 & 74,20 & 56,82 & 50,58 & 44,37 & 39,20 & 34,65 & 27,17 & 21,62 & 14,54 \\
\hline 83,98 & 695,50 & 107,40 & 22,80 & 15,50 & 13,34 & 11,56 & 10,25 & 9,16 & 7,35 & 5,99 & 4,16 \\
\hline 57,38 & 493,60 & 168,40 & 25,89 & 16,11 & 12,77 & 10,04 & 8,16 & 6,74 & 4,79 & 3,65 & 2,45 \\
\hline 65,32 & 604,20 & 93,60 & 28,96 & 20,79 & 17,91 & 15,29 & 13,26 & 11,53 & 8,82 & 6,91 & 4,62 \\
\hline 85,86 & 611,30 & 170,00 & 20,21 & 12,39 & 10,01 & 8,23 & 7,05 & 6,13 & 4,73 & 3,76 & 2,56 \\
\hline 86,83 & 1246,50 & 54,90 & 24,48 & 18,40 & 17,03 & 15,98 & 15,00 & 14,07 & 12,34 & 10,80 & 8,28 \\
\hline 25,19 & 1077,30 & 132,60 & 32,57 & 24,48 & 19,47 & 14,36 & 10,85 & 8,49 & 5,76 & 4,38 & 3,02 \\
\hline 50,65 & 1217,20 & 129,10 & 20,10 & 15,83 & 13,90 & 11,87 & 10,17 & 8,72 & 6,49 & 4,99 & 3,27 \\
\hline 35,67 & 1726,60 & 199,80 & 16,86 & 13,19 & 11,15 & 8,93 & 7,19 & 5,85 & 4,06 & 3,03 & 2,02 \\
\hline 41,98 & 1428,50 & 54,70 & 36,39 & 32,02 & 29,39 & 26,03 & 22,92 & 20,12 & 15,50 & 12,10 & 7,92 \\
\hline 43,85 & 998,40 & 56,10 & 39,46 & 33,71 & 30,45 & 26,55 & 23,06 & 19,99 & 15,10 & 11,66 & 7,60 \\
\hline 65,63 & 1827,70 & 107,30 & 16,38 & 12,96 & 11,97 & 10,86 & 9,88 & 8,97 & 7,37 & 6,08 & 4,24 \\
\hline 60,15 & 1320,70 & 155,80 & 15,87 & 12,04 & 10,58 & 9,14 & 7,97 & 6,95 & 5,33 & 4,18 & 2,78 \\
\hline 31,90 & 653,30 & 197,50 & 25,94 & 17,02 & 13,04 & 9,45 & 7,14 & 5,61 & 3,85 & 2,95 & 2,04 \\
\hline 36,18 & 622,80 & 192,90 & 25,46 & 16,65 & 12,94 & 9,59 & 7,35 & 5,82 & 3,99 & 3,04 & 2,10 \\
\hline 50,15 & 1122,00 & 61,00 & 32,75 & 27,62 & 25,26 & 22,43 & 19,88 & 17,57 & 13,72 & 10,84 & 7,19 \\
\hline 25,19 & 1681,20 & 180,00 & 23,01 & 17,63 & 14,18 & 10,57 & 8,04 & 6,30 & 4,27 & 3,24 & 2,22 \\
\hline 89,71 & 1161,60 & 100,70 & 17,70 & 12,58 & 11,31 & 10,23 & 9,37 & 8,62 & 7,29 & 6,19 & 4,53 \\
\hline 21,59 & 1992,70 & 185,30 & 23,79 & 18,10 & 14,26 & 10,37 & 7,74 & 6,02 & 4,09 & 3,12 & 2,16 \\
\hline 65,32 & 897,20 & 160,90 & 18,16 & 12,72 & 10,81 & 9,13 & 7,84 & 6,78 & 5,13 & 4,00 & 2,66 \\
\hline 54,60 & 871,80 & 124,00 & 22,87 & 17,10 & 14,76 & 12,46 & 10,61 & 9,06 & 6,72 & 5,16 & 3,40 \\
\hline 50,70 & 1576,60 & 63,10 & 28,18 & 24,04 & 22,37 & 20,20 & 18,18 & 16,31 & 13,07 & 10,53 & 7,11 \\
\hline 73,20 & 1586,90 & 183,80 & 12,15 & 8,86 & 7,83 & 6,88 & 6,13 & 5,47 & 4,37 & 3,54 & 2,43 \\
\hline 86,98 & 747,80 & 197,10 & 16,80 & 10,38 & 8,44 & 6,97 & 6,00 & 5,24 & 4,06 & 3,24 & 2,22 \\
\hline 24,42 & 1349,00 & 67,00 & 50,06 & 41,68 & 35,29 & 27,84 & 21,98 & 17,57 & 11,94 & 8,88 & 5,97 \\
\hline 25,41 & 565,70 & 166,10 & 33,66 & 21,84 & 16,13 & 11,22 & 8,30 & 6,50 & 4,50 & 3,48 & 2,43 \\
\hline 89,96 & 1571,50 & 155,70 & 12,19 & 8,56 & 7,63 & 6,84 & 6,23 & 5,70 & 4,78 & 4,03 & 2,92 \\
\hline 60,07 & 861,70 & 134,40 & 21,02 & 15,29 & 13,14 & 11,13 & 9,54 & 8,21 & 6,17 & 4,78 & 3,17 \\
\hline 27,85 & 1807,60 & 59,80 & 44,06 & 38,79 & 34,34 & 28,74 & 23,88 & 19,86 & 14,05 & 10,45 & 6,79 \\
\hline 38,26 & 407,10 & 168,00 & 32,53 & 19,82 & 15,01 & 10,96 & 8,37 & 6,63 & 4,56 & 3,48 & 2,42 \\
\hline 60,37 & 1967,90 & 153,70 & 13,40 & 10,63 & 9,62 & 8,53 & 7,60 & 6,75 & 5,34 & 4,28 & 2,88 \\
\hline 56,83 & 979,70 & 121,50 & 21,45 & 16,30 & 14,24 & 12,19 & 10,52 & 9,09 & 6,86 & 5,32 & 3,52 \\
\hline 61,85 & 213,60 & 181,60 & 42,51 & 20,69 & 14,26 & 9,98 & 7,63 & 6,11 & 4,24 & 3,26 & 2,28 \\
\hline 21,11 & 1081,60 & 192,40 & 27,62 & 19,06 & 14,15 & 9,77 & 7,17 & 5,58 & 3,87 & 3,00 & 2,09 \\
\hline 64,59 & 1062,00 & 94,60 & 22,22 & 17,16 & 15,43 & 13,66 & 12,17 & 10,84 & 8,62 & 6,92 & 4,70 \\
\hline 67,12 & 1030,20 & 73,90 & 25,46 & 19,81 & 18,09 & 16,27 & 14,70 & 13,27 & 10,80 & 8,84 & 6,12 \\
\hline 75,79 & 1633,30 & 89,50 & 17,71 & 13,51 & 12,54 & 11,54 & 10,65 & 9,82 & 8,32 & 7,06 & 5,13 \\
\hline 54,87 & 658,40 & 186,00 & 21,45 & 14,01 & 11,34 & 9,04 & 7,39 & 6,12 & 4,36 & 3,32 & 2,22 \\
\hline 47,89 & 481,00 & 183,30 & 26,74 & 16,45 & 12,79 & 9,73 & 7,67 & 6,19 & 4,30 & 3,26 & 2,23 \\
\hline 23,58 & 376,50 & 195,30 & 35,15 & 19,78 & 13,72 & 9,24 & 6,84 & 5,41 & 3,79 & 2,95 & 2,08 \\
\hline 59,51 & 987,30 & 198,30 & 16,26 & 11,31 & 9,50 & 7,88 & 6,65 & 5,65 & 4,16 & 3,20 & 2,12 \\
\hline 87,31 & 1299,90 & 187,80 & 12,41 & 8,42 & 7,29 & 6,35 & 5,67 & 5,10 & 4,14 & 3,41 & 2,39 \\
\hline 82,59 & 277,90 & 25,50 & 74,48 & 53,84 & 48,40 & 43,45 & 39,51 & 36,02 & 29,93 & 25,01 & 17,87 \\
\hline 75,86 & 1211,20 & 153,00 & 15,00 & 10,73 & 9,42 & 8,24 & 7,33 & 6,54 & 5,23 & 4,24 & 2,91 \\
\hline 76,60 & 477,50 & 178,70 & 23,92 & 14,04 & 10,97 & 8,70 & 7,24 & 6,13 & 4,53 & 3,52 & 2,38 \\
\hline 75,41 & 789,40 & 161,70 & 18,39 & 12,24 & 10,27 & 8,65 & 7,49 & 6,53 & 5,03 & 3,98 & 2,69 \\
\hline 35,50 & 1510,50 & 46,40 & 45,23 & 40,64 & 37,10 & 32,50 & 28,27 & 24,50 & 18,45 & 14,16 & 9,16 \\
\hline 32,29 & 1356,70 & 69,50 & 38,92 & 33,40 & 29,40 & 24,54 & 20,39 & 16,97 & 12,05 & 9,00 & 5,86 \\
\hline 32,10 & 719,90 & 113,70 & 35,44 & 26,29 & 21,38 & 16,33 & 12,68 & 10,08 & 6,88 & 5,19 & 3,54 \\
\hline 69,00 & 611,80 & 112,50 & 25,74 & 17,77 & 15,08 & 12,76 & 11,01 & 9,56 & 7,30 & 5,73 & 3,84 \\
\hline 61,77 & 623,20 & 68,80 & 34,37 & 26,18 & 23,14 & 20,13 & 17,66 & 15,50 & 12,01 & 9,48 & 6,33 \\
\hline 44,39 & 1220,90 & 43,10 & 443,20 & 37,89 & 35,09 & 31,42 & 27,99 & 24,84 & 19,51 & 15,45 & 10,24 \\
\hline 53,47 & 1071,70 & 162,00 & 18,21 & 13,51 & 11,59 & 9,72 & 8,22 & 6,98 & 5,13 & 3,93 & 2,59 \\
\hline 31,91 & 236,70 & 35,00 & 112,89 & 84,60 & 69,12 & 53,01 & 41,26 & 32,83 & 22,41 & 16,87 & 11,49 \\
\hline 34,42 & 281,90 & 192,70 & 36,95 & 19,50 & 13,69 & 9,45 & 7,08 & 5,60 & 3,88 & 3,01 & 2,12 \\
\hline 75,79 & 1282,30 & 179,90 & 13,45 & 9,50 & 8,26 & 7,18 & 6,35 & 5,64 & 4,47 & 3,60 & 2,47 \\
\hline 89,50 & 1760,10 & 99,30 & 14,78 & 10,87 & 9,97 & 9,25 & 8,62 & 8,04 & 6,98 & 6,06 & 4,59 \\
\hline 83,26 & 1321,00 & 75,60 & 20,32 & 15,13 & 13,96 & 12,89 & 11,95 & 11,09 & 9,52 & 8,17 & 6,07 \\
\hline 39,40 & 928,50 & 45,20 & 50,26 & 43,65 & 39,36 & 34,09 & 29,37 & 25,25 & 18,81 & 14,38 & 9,32 \\
\hline 89,32 & 799,80 & 59,60 & 27,92 & 20,11 & 18,24 & 16,65 & 15,35 & 14,19 & 12,11 & 10,36 & 7,66 \\
\hline 22,75 & 441,50 & 74,10 & 67,77 & 47,88 & 36,31 & 25,57 & 18,89 & 14,70 & 10,11 & 7,80 & 5,42 \\
\hline 34,05 & 1127,00 & 168,40 & 22,64 & 17,00 & 14,01 & 10,89 & 8,56 & 6,86 & 4,70 & 3,53 & 2,39 \\
\hline 60,53 & 833,30 & 192,90 & 17,89 & 12,07 & 10,00 & 8,20 & 6,88 & 5,82 & 4,26 & 3,27 & 2,18 \\
\hline 20,43 & 1701,80 & 90,20 & 43,49 & 34,92 & 28,44 & 21,36 & 16,24 & 12,68 & 8,53 & 6,44 & 4,42 \\
\hline 45,49 & 525,20 & 32,90 & 68,33 & 57,65 & 51,92 & 45,20 & 39,24 & 34,01 & 25,70 & 19,85 & 12,96 \\
\hline 82,32 & 1239,30 & 80,00 & 20,32 & 15,07 & 13,83 & 12,68 & 11,70 & 10,80 & 9,18 & 7,82 & 5,73 \\
\hline 82,09 & 1444,40 & 60,10 & 22,61 & 17,18 & 16,01 & 15,02 & 14,07 & 13,17 & 11,50 & 10,02 & 7,61 \\
\hline 57,73 & 1756,90 & 90,10 & 19,91 & 16,37 & 15,15 & 13,69 & 12,36 & 11,14 & 9,01 & 7,32 & 5,01 \\
\hline 22,66 & 1310,90 & 145,40 & 30,84 & 23,13 & 18,15 & 13,16 & 9,83 & 7,65 & 5,20 & 3,98 & 2,75 \\
\hline 85,29 & 1344,50 & 73,20 & 20,28 & 15,07 & 13,90 & 12,89 & 11,99 & 11,16 & 9,65 & 8,33 & 6,25 \\
\hline 59,42 & 1575,20 & 63,00 & 25,62 & 21,02 & 19,75 & 18,11 & 16,57 & 15,12 & 12,52 & 10,38 & 7,27 \\
\hline
\end{tabular}




\begin{tabular}{|c|c|c|c|c|c|c|c|c|c|c|c|}
\hline & & & \multicolumn{9}{|c|}{ Deflexões $\left(\times 10^{-4} \mathrm{~cm}\right)$} \\
\hline e1 (cm) & Meq (MPa) & Ms (MPa) & D0 & D25 & D40 & D60 & D80 & D100 & D140 & D180 & D260 \\
\hline 65,14 & 1425,10 & 182,30 & 13,54 & 10,01 & 8,76 & 7,58 & 6,64 & 5,83 & 4,51 & 3,57 & 2,39 \\
\hline 69,52 & 1591,70 & 28,30 & 39,17 & 31,48 & 29,83 & 28,72 & 27,33 & 25,89 & 23,10 & 20,50 & 16,04 \\
\hline 69,70 & 1838,60 & 151,50 & 12,91 & 9,85 & 8,93 & 7,98 & 7,19 & 6,48 & 5,26 & 4,30 & 2,98 \\
\hline 35,62 & 1733,00 & 74,20 & 31,64 & 27,76 & 24,95 & 21,44 & 18,31 & 15,61 & 11,47 & 8,69 & 5,62 \\
\hline 22,69 & 1513,10 & 118,30 & 34,30 & 26,88 & 21,71 & 16,20 & 12,29 & 9,61 & 6,49 & 4,91 & 3,38 \\
\hline 36,80 & 1162,00 & 68,80 & 37,36 & 31,82 & 28,20 & 23,86 & 20,10 & 16,95 & 12,26 & 9,23 & 5,99 \\
\hline 49,06 & 1364,60 & 24,40 & 57,98 & 49,34 & 47,48 & 44,28 & 40,99 & 37,80 & 31,88 & 26,79 & 19,07 \\
\hline 39,78 & 252,20 & 169,00 & 40,87 & 21,66 & 15,40 & 10,81 & 8,17 & 6,46 & 4,47 & 3,44 & 2,42 \\
\hline 84,25 & 507,60 & 57,70 & 36,18 & 25,49 & 22,54 & 19,97 & 18,00 & 16,30 & 13,39 & 11,09 & 7,85 \\
\hline 78,11 & 1544,80 & 129,90 & 14,40 & 10,64 & 9,63 & 8,67 & 7,88 & 7,17 & 5,94 & 4,94 & 3,50 \\
\hline 83,30 & 900,20 & 103,30 & 20,39 & 14,39 & 12,72 & 11,25 & 10,13 & 9,16 & 7,51 & 6,20 & 4,37 \\
\hline 78,99 & 350,40 & 129,70 & 32,50 & 19,05 & 14,89 & 11,84 & 9,88 & 8,39 & 6,24 & 4,86 & 3,29 \\
\hline 26,84 & 1697,40 & 111,80 & 30,45 & 24,94 & 21,04 & 16,58 & 13,10 & 10,49 & 7,15 & 5,33 & 3,58 \\
\hline 24,41 & 1662,10 & 35,70 & 71,74 & 64,33 & 57,25 & 48,12 & 40,10 & 33,40 & 23,63 & 17,55 & 11,35 \\
\hline 74,57 & 238,50 & 145,60 & 41,23 & 21,64 & 15,76 & 11,69 & 9,31 & 7,66 & 5,46 & 4,20 & 2,88 \\
\hline 62,53 & 520,70 & 89,20 & 32,59 & 23,18 & 19,78 & 16,70 & 14,31 & 12,32 & 9,27 & 7,20 & 4,78 \\
\hline 29,61 & 1264,50 & 58,90 & 47,67 & 40,95 & 35,85 & 29,63 & 24,37 & 20,11 & 14,11 & 10,49 & 6,87 \\
\hline 86,01 & 1007,90 & 78,50 & 22,01 & 15,95 & 14,46 & 13,14 & 12,06 & 11,10 & 9,39 & 7,97 & 5,82 \\
\hline 63,83 & 290,90 & 105,00 & 41,61 & 25,24 & 19,88 & 15,68 & 12,85 & 10,70 & 7,71 & 5,90 & 3,97 \\
\hline 77,02 & 271,80 & 71,40 & 47,86 & 30,28 & 24,72 & 20,37 & 17,38 & 15,01 & 11,39 & 8,95 & 6,04 \\
\hline 27,82 & 1789,40 & 109,50 & 29,53 & 24,49 & 20,89 & 16,69 & 13,34 & 10,76 & 7,38 & 5,49 & 3,66 \\
\hline 37,26 & 1059,40 & 190,40 & 20,38 & 14,87 & 12,22 & 9,52 & 7,53 & 6,06 & 4,17 & 3,14 & 2,12 \\
\hline 27,54 & 908,00 & 180,90 & 26,28 & 18,53 & 14,39 & 10,44 & 7,84 & 6,14 & 4,20 & 3,21 & 2,22 \\
\hline 80,33 & 1498,60 & 145,20 & 13,57 & 9,84 & 8,81 & 7,87 & 7,13 & 6,47 & 5,33 & 4,42 & 3,12 \\
\hline 42,63 & 1873,40 & 138,60 & 18,09 & 15,05 & 13,36 & 11,40 & 9,71 & 8,27 & 6,09 & 4,63 & 3,01 \\
\hline 42,10 & 667,40 & 124,80 & 29,57 & 21,41 & 17,76 & 14,12 & 11,36 & 9,26 & 6,47 & 4,86 & 3,26 \\
\hline 58,80 & 1639,40 & 28,50 & 43,62 & 35,56 & 34,25 & 32,56 & 30,61 & 28,69 & 25,01 & 21,69 & 16,27 \\
\hline 56,00 & 1205,60 & 178,30 & 15,99 & 11,84 & 10,20 & 8,61 & 7,34 & 6,28 & 4,66 & 3,59 & 2,37 \\
\hline 89,45 & 1697,60 & 100,30 & 14,94 & 10,95 & 10,03 & 9,28 & 8,63 & 8,04 & 6,96 & 6,03 & 4,55 \\
\hline 52,19 & 874,80 & 100,30 & 26,29 & 20,41 & 17,86 & 15,23 & 13,04 & 11,19 & 8,34 & 6,41 & 4,21 \\
\hline 65,64 & 254,70 & 33,20 & 74,75 & 55,03 & 48,10 & 41,60 & 36,42 & 31,95 & 24,76 & 19,58 & 13,13 \\
\hline 70,07 & 1331,20 & 51,50 & 28,17 & 22,14 & 20,87 & 19,43 & 18,05 & 16,74 & 14,31 & 12,22 & 8,96 \\
\hline 78,82 & 367,80 & 87,30 & 36,57 & 23,49 & 19,38 & 16,15 & 13,90 & 12,08 & 9,28 & 7,34 & 4,97 \\
\hline 26,66 & 791,80 & 167,10 & 29,48 & 20,50 & 15,74 & 11,29 & 8,44 & 6,59 & 4,52 & 3,47 & 2,41 \\
\hline 77,80 & 673,30 & 149,70 & 20,60 & 13,43 & 11,16 & 9,35 & 8,07 & 7,03 & 5,42 & 4,29 & 2,90 \\
\hline 60,82 & 765,80 & 89,70 & 27,31 & 20,69 & 18,20 & 15,75 & 13,75 & 12,01 & 9,24 & 7,25 & 4,83 \\
\hline 58,85 & 545,40 & 123,40 & 27,94 & 19,00 & 15,77 & 12,93 & 10,82 & 9,12 & 6,66 & 5,10 & 3,39 \\
\hline 72,66 & 523,30 & 144,90 & 24,76 & 15,65 & 12,71 & 10,39 & 8,79 & 7,52 & 5,63 & 4,38 & 2,95 \\
\hline 84,98 & 1106,30 & 79,60 & 21,07 & 15,40 & 14,03 & 12,80 & 11,78 & 10,86 & 9,22 & 7,84 & 5,75 \\
\hline 63,88 & 394,70 & 79,10 & 39,52 & 27,22 & 22,89 & 19,12 & 16,28 & 13,95 & 10,42 & 8,07 & 5,37 \\
\hline 82,66 & 1628,00 & 163,00 & 12,13 & 8,70 & 7,77 & 6,94 & 6,28 & 5,71 & 4,71 & 3,92 & 2,78 \\
\hline 53,38 & 1357,00 & 133,90 & 18,21 & 14,40 & 12,74 & 11,01 & 9,53 & 8,26 & 6,26 & 4,85 & 3,20 \\
\hline 21,11 & 528,40 & 194,60 & 33,01 & 19,86 & 13,90 & 9,32 & 6,87 & 5,41 & 3,80 & 2,96 & 2,07 \\
\hline 75,89 & 1369,80 & 109,00 & 16,98 & 12,69 & 11,53 & 10,40 & 9,45 & 8,60 & 7,11 & 5,91 & 4,18 \\
\hline 63,88 & 638,20 & 63,20 & 35,05 & 26,86 & 23,96 & 21,06 & 18,64 & 16,51 & 12,99 & 10,36 & 6,99 \\
\hline 70,26 & 440,30 & 127,80 & 29,16 & 18,35 & 14,83 & 12,04 & 10,12 & 8,61 & 6,39 & 4,95 & 3,32 \\
\hline 28,07 & 722,70 & 35,80 & 83,75 & 71,08 & 61,54 & 50,08 & 40,64 & 33,16 & 22,97 & 17,05 & 11,26 \\
\hline 20,42 & 327,90 & 24,70 & 174,87 & 135,01 & 106,90 & 77,93 & 58,22 & 45,19 & 30,61 & 23,36 & 16,15 \\
\hline 41,35 & 828,70 & 112,00 & 29,05 & 22,25 & 18,92 & 15,38 & 12,58 & 10,37 & 7,32 & 5,49 & 3,64 \\
\hline 43,48 & 1160,60 & 139,30 & 21,57 & 16,82 & 14,49 & 11,99 & 9,96 & 8,31 & 5,95 & 4,49 & 2,95 \\
\hline 58,35 & 1224,60 & 183,10 & 15,33 & 11,27 & 9,71 & 8,23 & 7,05 & 6,06 & 4,54 & 3,51 & 2,32 \\
\hline 57,02 & 793,10 & 182,30 & 19,32 & 13,14 & 10,89 & 8,88 & 7,39 & 6,21 & 4,50 & 3,44 & 2,28 \\
\hline 35,27 & 727,00 & 189,00 & 24,45 & 16,61 & 13,10 & 9,80 & 7,54 & 5,98 & 4,09 & 3,11 & 2,14 \\
\hline 61,58 & 826,90 & 119,60 & 22,50 & 16,50 & 14,28 & 12,19 & 10,53 & 9,13 & 6,93 & 5,40 & 3,59 \\
\hline 75,52 & 686,70 & 91,60 & 25,78 & 18,34 & 16,02 & 13,96 & 12,38 & 11,02 & 8,77 & 7,08 & 4,85 \\
\hline 28,06 & 648,80 & 128,30 & 36,59 & 25,87 & 20,18 & 14,70 & 11,08 & 8,68 & 5,93 & 4,53 & 3,13 \\
\hline 21,02 & 1125,30 & 59,50 & 64,52 & 52,08 & 42,68 & 32,29 & 24,68 & 19,33 & 13,01 & 9,80 & 6,71 \\
\hline 49,47 & 1451,80 & 133,60 & 18,56 & 14,92 & 13,21 & 11,35 & 9,77 & 8,41 & 6,29 & 4,84 & 3,17 \\
\hline 45,68 & 1419,40 & 167,10 & 17,29 & 13,50 & $\begin{array}{l}10,2 \pm \\
11,69\end{array}$ & 9,77 & 8,19 & 6,89 & 4,99 & 3,78 & 2,48 \\
\hline 76,68 & 1860,10 & 24,40 & 36,84 & 31,19 & 28,72 & 27,88 & 26,99 & 25,91 & 23,71 & 21,59 & 17,72 \\
\hline 51,51 & 566,80 & 133,20 & 27,93 & 19,10 & 15,73 & 12,65 & 10,37 & 8,59 & 6,12 & 4,64 & 3,09 \\
\hline 66,98 & 1202,90 & 186,60 & 14,37 & 10,27 & 8,85 & 7,57 & 6,58 & 5,74 & 4,41 & 3,47 & 2,32 \\
\hline 75,66 & 1205,80 & 142,30 & $\begin{array}{l}+7,61 \\
15,61\end{array}$ & 11,27 & 9,94 & 8,74 & 7,80 & 6,98 & $\frac{1,7 \pm}{5,61}$ & 4,56 & 3,14 \\
\hline 68,38 & 274,80 & 96,50 & 43,71 & 26,45 & 20,90 & 16,61 & 13,73 & 11,54 & 8,41 & 6,47 & 4,35 \\
\hline 65,93 & 247,00 & 55,80 & 59,07 & 39,55 & 32,87 & 27,23 & 23,10 & 19,76 & 14,73 & 11,41 & 7,61 \\
\hline 23,73 & 841,70 & 36,40 & 90,28 & 75,85 & 64,51 & 51,12 & 40,49 & 32,42 & 22,04 & 16,37 & 10,98 \\
\hline 83,32 & 1014,80 & 47,10 & 29,87 & 22,50 & 20,89 & 19,51 & 18,23 & 17,02 & 14,80 & 12,84 & 9,70 \\
\hline 26,11 & 1355,20 & 132,70 & 29,64 & 23,08 & 18,82 & 14,26 & 10,96 & 8,64 & 5,85 & 4,41 & 3,02 \\
\hline 37,34 & 241,20 & 168,10 & 42,31 & 22,17 & 15,61 & 10,85 & 8,16 & 6,45 & 4,47 & 3,45 & 2,43 \\
\hline 21,97 & 1426,70 & 127,60 & 33,79 & 25,91 & 20,56 & 15,05 & 11,29 & 8,78 & 5,95 & 4,54 & 3,14 \\
\hline 38.99 & 1950,60 & 133,10 & 19,48 & 16,37 & 14,47 & 12,25 & 10,33 & 8,72 & 6,33 & 4.78 & 3,11 \\
\hline 73,13 & 558,20 & 197,30 & 21,11 & 12,64 & 9,96 & 7,94 & 6,60 & 5,58 & 4,11 & 3,18 & 2,15 \\
\hline 40,69 & 1375,60 & 75,70 & 30,63 & 26,30 & 23,63 & 20,41 & 17,55 & 15,07 & 11,21 & 8,56 & 5,56 \\
\hline 39,28 & 1988,20 & 52,70 & 35,09 & 31,52 & 29,26 & 26,19 & 23,28 & 20,61 & 16,09 & 12,67 & 8,33 \\
\hline 87,58 & 1127,00 & 25,30 & 39,51 & 31,89 & 29,26 & 28,14 & 27,03 & 25,82 & 23,43 & 21,18 & 17,19 \\
\hline 24,12 & 1918,00 & 46,90 & 57,60 & 51,03 & 45,04 & 37,43 & 30,86 & 25,47 & 17,82 & 13,20 & 8,60 \\
\hline 53,89 & 639,60 & 138,80 & 25,24 & 17,48 & 14,53 & 11,84 & 9,81 & 8,20 & 5,91 & 4,49 & 2,99 \\
\hline 57,32 & 1461,40 & 31,40 & 42,98 & 35,36 & 33,97 & 31,92 & 29,76 & 27,65 & 23,71 & 20,24 & 14,79 \\
\hline 79,14 & 1647,20 & 161,40 & 12,36 & 8,98 & 8,04 & 7,17 & 6,48 & 5,87 & 4,82 & 3,99 & 2,81 \\
\hline 85,51 & 1150,00 & 28,20 & 37,65 & 29,89 & 27,61 & 26,51 & 25,35 & 24,13 & 21,75 & 19,54 & 15,66 \\
\hline 44,95 & 1111,60 & 79,60 & 29,98 & 24,98 & 22,31 & 19,23 & 16,54 & 14,22 & 10,61 & 8,14 & 5,31 \\
\hline 83,94 & 820,50 & 43,40 & 34,09 & 25,46 & 23,54 & 21,84 & 20,32 & 18,91 & 16,33 & 14,09 & 10,55 \\
\hline
\end{tabular}




\begin{tabular}{|c|c|c|c|c|c|c|c|c|c|c|c|}
\hline \multirow[b]{2}{*}{ e1 (cm) } & & & & & & & ões (x1 & & & & \\
\hline & Meq (MPa) & Ms (MPa) & D0 & D25 & D40 & D60 & D80 & D100 & D140 & D180 & D260 \\
\hline 71,73 & 424,00 & 37,40 & 53,18 & 40,07 & 36,14 & 32,26 & 29,06 & 26,19 & 21,27 & 17,40 & 12,07 \\
\hline 38,79 & 1245,40 & 76,70 & 32,66 & 27,74 & 24,66 & 20,99 & 17,80 & 15,09 & 11,01 & 8,33 & 5,41 \\
\hline 53,76 & 381,90 & 46,60 & 57,18 & 43,85 & 38,26 & 32,59 & 27,93 & 23,98 & 17,91 & 13,80 & 9,08 \\
\hline 44,45 & 847,40 & 46,20 & 46,97 & 40,19 & 36,40 & 31,85 & 27,77 & 24,15 & 18,35 & 14,21 & 9,28 \\
\hline 52,83 & 305,50 & 22,70 & 96,09 & 78,47 & 70,70 & 62,06 & 54,50 & 47,80 & 36,88 & 28,94 & 19,14 \\
\hline 53,62 & 1300,60 & 74,10 & 26,29 & 21,86 & 20,03 & 17,87 & 15,93 & 14,16 & 11,19 & 8,92 & 5,97 \\
\hline 74,52 & 1484,10 & 28,50 & 37,86 & 30,37 & 28,53 & 27,49 & 26,23 & 24,91 & 22,34 & 19,94 & 15,78 \\
\hline 89,34 & 1803,00 & 93,30 & 15,17 & 11,22 & 10,32 & 9,62 & 8,99 & 8,41 & 7,34 & 6,40 & 4,87 \\
\hline 65,06 & 1033,20 & 44,50 & 35,38 & 28,30 & 26,57 & 24,47 & 22,51 & 20,66 & 17,32 & 14,52 & 10,35 \\
\hline 50,98 & 1811,80 & 26,30 & 49,40 & 41,28 & 39,97 & 37,75 & 35,30 & 32,89 & 28,30 & 24,23 & 17,76 \\
\hline 89,86 & 1066,00 & 140,40 & 15,64 & 10,66 & 9,29 & 8,16 & 7,34 & 6,63 & 5,45 & 4,53 & 3,22 \\
\hline 58,45 & 273,60 & 129,50 & 40,68 & 23,27 & 17,66 & 13,40 & 10,68 & 8,71 & 6,13 & 4,67 & 3,19 \\
\hline 71,77 & 721,90 & 76,70 & 28,20 & 20,87 & 18,56 & 16,38 & 14,63 & 13,08 & 10,48 & 8,49 & 5,83 \\
\hline 71,51 & 1383,00 & 151,90 & 14,48 & 10,69 & 9,48 & 8,35 & 7,44 & 6,64 & 5,30 & 4,29 & 2,93 \\
\hline 82,42 & 1100,40 & 35,80 & 34,33 & 26,48 & 24,71 & 23,46 & 22,17 & 20,90 & 18,50 & 16,33 & 12,67 \\
\hline 52,89 & 1658,60 & 179,20 & 14,23 & 11,12 & 9,78 & 8,39 & 7,22 & 6,22 & 4,67 & 3,61 & 2,37 \\
\hline 49,75 & 471,00 & 144,50 & 29,89 & 19,32 & 15,44 & 12,06 & 9,68 & 7,90 & 5,54 & 4,20 & 2,83 \\
\hline 65,42 & 1258,50 & 71,20 & 24,36 & 19,32 & 17,89 & 16,25 & 14,80 & 13,45 & 11,08 & 9,15 & 6,40 \\
\hline 81,44 & 1257,60 & 29,00 & 37,15 & 29,52 & 27,46 & 26,39 & 25,20 & 23,95 & 21,53 & 19,27 & 15,34 \\
\hline 68,79 & 1910,20 & 135,10 & 13,67 & 10,58 & 9,67 & 8,72 & 7,90 & 7,16 & 5,86 & 4,82 & 3,36 \\
\hline 73,36 & 1207,70 & 176,30 & 14,19 & 10,04 & 8,70 & 7,52 & 6,62 & 5,85 & 4,60 & 3,68 & 2,50 \\
\hline 42,80 & 781,20 & 79,10 & 35,79 & 28,62 & 24,91 & 20,82 & 17,43 & 14,63 & 10,55 & 7,97 & 5,22 \\
\hline 26,92 & 1271,00 & 32,30 & 76,94 & 68,95 & 61,61 & 52,17 & 43,80 & 36,74 & 26,26 & 19,59 & 12,65 \\
\hline 74,26 & 444,10 & 177,60 & 25,30 & 14,70 & 11,39 & 8,95 & 7,39 & 6,22 & 4,55 & 3,52 & 2,38 \\
\hline 31,05 & 1168,90 & 175,20 & 23,04 & 17,20 & 13,97 & 10,64 & 8,24 & 6,53 & 4,45 & 3,36 & 2,29 \\
\hline 83,47 & 459,40 & 126,00 & 27,23 & 16,83 & 13,64 & 11,22 & 9,61 & 8,34 & 6,40 & 5,07 & 3,45 \\
\hline 44,02 & 1473,10 & 195,80 & 15,89 & 12,19 & 10,43 & 8,58 & 7,10 & 5,91 & 4,22 & 3,18 & 2,10 \\
\hline 84,71 & 1368,10 & 63,60 & 21,94 & 16,49 & 15,28 & 14,29 & 13,36 & 12,49 & 10,88 & 9,47 & 7,18 \\
\hline 65,32 & 950,10 & 41,60 & 37,96 & 30,32 & 28,45 & 26,18 & 24,08 & 22,09 & 18,51 & 15,51 & 11,06 \\
\hline 86,59 & 1840,20 & 183,00 & 10,56 & 7,48 & 6,68 & 5,98 & 5,43 & 4,95 & 4,13 & 3,46 & 2,49 \\
\hline 75,19 & 1060,80 & 172,30 & 15,21 & 10,53 & 9,04 & 7,76 & 6,81 & 6,00 & 4,70 & 3,76 & 2,55 \\
\hline 57,31 & 1326,40 & 82,70 & 23,45 & 19,12 & 17,50 & 15,64 & 13,99 & 12,49 & 9,94 & 7,98 & 5,39 \\
\hline 30,43 & 1527,40 & 192,80 & 19,99 & 15,29 & 12,56 & 9,65 & 7,52 & 5,98 & 4,07 & 3,06 & 2,08 \\
\hline 26,60 & 938,50 & 164,80 & 28,26 & 20,27 & 15,81 & 11,49 & 8,63 & 6,75 & 4,61 & 3,52 & 2,44 \\
\hline 77,89 & 872,10 & 28,70 & 44,65 & 34,58 & 32,48 & 30,72 & 28,91 & 27,15 & 23,83 & 20,85 & 15,94 \\
\hline 83,34 & 450,70 & 88,00 & 31,80 & 20,89 & 17,58 & 14,93 & 13,07 & 11,54 & 9,09 & 7,31 & 5,02 \\
\hline 72,12 & 1853,30 & 146,90 & 12,88 & 9,77 & 8,88 & 7,98 & 7,22 & 6,54 & 5,36 & 4,41 & 3,09 \\
\hline 82,51 & 1223,10 & 171,10 & 13,67 & 9,45 & 8,22 & 7,17 & 6,38 & 5,72 & 4,61 & 3,76 & 2,62 \\
\hline 83,17 & 1555,40 & 100,20 & 16,12 & 11,93 & 10,94 & 10,04 & 9,27 & 8,56 & 7,29 & 6,22 & 4,57 \\
\hline 72,53 & 738,60 & 191,60 & 18,02 & 11,55 & 9,45 & 7,78 & 6,61 & 5,67 & 4,26 & 3,32 & 2,23 \\
\hline 58,45 & 545,50 & 89,00 & 32,88 & 23,81 & 20,37 & 17,15 & 14,62 & 12,51 & 9,32 & 7,19 & 4,75 \\
\hline 41,97 & 1291,80 & 21,00 & 72,52 & 64,05 & 61,17 & 56,36 & 51,58 & 46,98 & 38,65 & 31,74 & 21,84 \\
\hline 62,60 & 1813,10 & 158,60 & 13,36 & 10,41 & 9,36 & 8,28 & 7,36 & 6,54 & 5,17 & 4,14 & 2,79 \\
\hline 39,68 & 1449,50 & 25,60 & 63,39 & 56,84 & 53,81 & 49,12 & 44,54 & 40,18 & 32,46 & 26,24 & 17,70 \\
\hline 38,86 & 1415,30 & 34,40 & 52,72 & 47,50 & 44,23 & 39,70 & 35,39 & 31,40 & 24,63 & 19,45 & 12,82 \\
\hline 56,97 & 798,40 & 99,50 & 26,21 & 19,89 & 17,37 & 14,88 & 12,83 & 11,09 & 8,37 & 6,50 & 4,29 \\
\hline 23,17 & 898,80 & 192,00 & 27,68 & 18,84 & 14,05 & 9,78 & 7,21 & 5,62 & 3,89 & 3,01 & 2,09 \\
\hline 87,45 & 698,00 & 197,40 & 17,51 & 10,66 & 8,59 & 7,05 & 6,04 & 5,26 & 4,06 & 3,23 & 2,21 \\
\hline 77,76 & 1969,00 & 168,50 & 11,21 & 8,28 & 7,49 & 6,73 & 6,11 & 5,56 & 4,59 & 3,81 & 2,70 \\
\hline 86,87 & 239,20 & 57,70 & 54,32 & 34,10 & 28,01 & 23,35 & 20,23 & 17,73 & 13,84 & 11,09 & 7,61 \\
\hline 35,49 & 1868,80 & 197,20 & 16,56 & 13,12 & 11,16 & 8,99 & 7,27 & 5,93 & 4,13 & 3,09 & 2,05 \\
\hline 28,99 & 416,90 & 141,70 & 39,25 & 24,97 & 18,62 & 13,14 & 9,81 & 7,69 & 5,30 & 4,09 & 2,85 \\
\hline 68,58 & 1864,30 & 191,50 & 11,35 & 8,53 & 7,60 & 6,70 & 5,97 & 5,32 & 4,23 & 3,41 & 2,32 \\
\hline 71,34 & 1386,40 & 91,00 & 19,32 & 14,86 & 13,67 & 12,40 & 11,31 & 10,31 & 8,54 & 7,09 & 5,01 \\
\hline 82,34 & 611,50 & 126,50 & 22,96 & 14,98 & 12,53 & 10,59 & 9,23 & 8,11 & 6,35 & 5,08 & 3,47 \\
\hline 56,15 & 1210,40 & 136,70 & 18,39 & 14,19 & 12,47 & 10,74 & 9,29 & 8,05 & 6,11 & 4,75 & 3,13 \\
\hline 38,52 & 257,00 & 173,50 & 40,14 & 21,24 & 15,06 & 10,53 & 7,93 & 6,28 & 4,34 & 3,35 & 2,35 \\
\hline 50,57 & 575,00 & 68,80 & 39,78 & 30,79 & 26,82 & 22,70 & 19,31 & 16,46 & 12,15 & 9,30 & 6,10 \\
\hline 45,00 & 436,00 & 71,10 & 47,18 & 34,94 & 29,49 & 23,97 & 19,66 & 16,26 & 11,53 & 8,69 & 5,76 \\
\hline 27,49 & 1514,70 & 176,00 & 22,77 & 17,45 & 14,17 & 10,72 & 8,24 & 6,50 & 4,41 & 3,33 & 2,28 \\
\hline 60,23 & 738,60 & 122,20 & 23,78 & 17,11 & 14,63 & 12,34 & 10,55 & 9,06 & 6,78 & 5,25 & 3,48 \\
\hline 37,10 & 281,60 & 64,10 & 66,69 & 46,55 & 37,42 & 28,57 & 22,30 & 17,81 & 12,23 & 9,24 & 6,30 \\
\hline 38,91 & 1261,70 & 142,60 & 22,09 & 17,38 & 14,88 & 12,13 & 9,93 & 8,18 & 5,76 & 4,32 & 2,85 \\
\hline 34,87 & 1489,60 & 158,20 & 20,94 & 16,56 & 14,06 & 11,28 & 9,09 & 7,39 & 5,13 & 3,83 & 2,55 \\
\hline 34,03 & 1554,70 & 78,00 & 33,01 & 28,48 & 25,26 & 21,32 & 17,90 & 15,04 & 10,81 & 8,11 & 5,26 \\
\hline 66,90 & 1463,80 & 33,20 & 37,37 & 29,85 & 28,48 & 27,08 & 25,50 & 23,95 & 20,98 & 18,30 & 13,88 \\
\hline 89,17 & 1981,50 & 109,20 & 13,33 & 9,83 & 9,02 & 8,38 & 7,81 & 7,29 & 6,34 & 5,51 & 4,17 \\
\hline 34,43 & 440,90 & 156,50 & 33,87 & 21,46 & 16,34 & 11,86 & 8,99 & 7,09 & 4,87 & 3,73 & 2,59 \\
\hline 41,23 & 564,80 & 95,90 & 37,36 & 27,54 & 22,98 & 18,34 & 14,80 & 12,08 & 8,44 & 6,34 & 4,24 \\
\hline 85,22 & 1366,40 & 102,80 & 16,62 & 12,10 & 11,00 & 10,01 & 9,20 & 8,47 & 7,17 & 6,09 & 4,45 \\
\hline 69,36 & 1005,10 & 174,20 & 16,07 & 11,20 & 9,56 & 8,13 & 7,04 & 6,14 & 4,71 & 3,71 & 2,49 \\
\hline 55,37 & 390,10 & 89,30 & 39,86 & 27,23 & 22,54 & 18,34 & 15,21 & 12,73 & 9,19 & 7,00 & 4,65 \\
\hline 89,79 & 1432,50 & 132,30 & 13,88 & 9,81 & 8,78 & 7,91 & 7,23 & 6,63 & 5,59 & 4,73 & 3,44 \\
\hline 67,03 & 1448,40 & 107,80 & 17,72 & 13,77 & 12,54 & 11,25 & 10,15 & 9,15 & 7,42 & 6,06 & 4,18 \\
\hline 39,91 & 808,20 & 25,20 & 76,54 & 68,30 & 63,02 & 56,06 & 49,55 & 43,62 & 33,75 & 26,41 & 17,29 \\
\hline 71,96 & 1869,00 & 132,70 & 13,62 & 10,41 & 9,53 & 8,61 & 7,84 & 7,13 & 5,88 & 4,87 & 3,43 \\
\hline 89,49 & 627,60 & 34,30 & 42,18 & 31,08 & 28,54 & 26,52 & 24,74 & 23,10 & 20,10 & 17,47 & 13,26 \\
\hline 62,67 & 976,80 & 21,00 & 60,75 & 49,05 & 47,01 & 44,55 & 41,83 & 39,15 & 34,06 & 29,50 & 22,10 \\
\hline 61,98 & 1227,80 & 190,40 & 14,58 & 10,56 & 9,09 & 7,73 & 6,65 & 5,75 & 4,35 & 3,39 & 2,25 \\
\hline 77,75 & 973,90 & 158,70 & 16,34 & 11,22 & 9,63 & 8,28 & 7,28 & 6,44 & 5,07 & 4,07 & 2,78 \\
\hline 50,22 & 1956,90 & 155,80 & 14,85 & 12,12 & 10,84 & 9,42 & 8,19 & 7,11 & 5,40 & 4,19 & 2,75 \\
\hline 48,29 & 1511,40 & 28,10 & 51,34 & 43,95 & 42,19 & 39,22 & 36,21 & 33,29 & 27,91 & 23,33 & 16,48 \\
\hline
\end{tabular}




\begin{tabular}{|c|c|c|c|c|c|c|c|c|c|c|c|}
\hline \multirow[b]{2}{*}{ e1 (cm) } & & & & & & $\mathrm{De}$ & ões (x1 & m) & & & \\
\hline & Meq (MPa) & Ms (MPa) & D0 & D25 & D40 & D60 & D80 & D100 & D140 & D180 & D260 \\
\hline 82,73 & 788,90 & 167,30 & 17,59 & 11,42 & 9,53 & 8,03 & 6,99 & 6,14 & 4,80 & 3,84 & 2,63 \\
\hline 26,20 & 1451,80 & 156,30 & 25,85 & 19,90 & 16,12 & 12,13 & 9,28 & 7,30 & 4,95 & 3,74 & 2,56 \\
\hline 55,45 & 222,10 & 196,10 & 40,60 & 19,60 & 13,40 & 9,29 & 7,05 & 5,62 & 3,89 & 3,00 & 2,11 \\
\hline 34,41 & 1857,00 & 21,90 & 72,95 & 66,53 & 63,17 & 57,75 & 52,37 & 47,23 & 38,10 & 30,73 & 20,64 \\
\hline 71,17 & 1060,70 & 117,00 & 18,88 & 13,94 & 12,37 & 10,88 & 9,69 & 8,64 & 6,89 & 5,57 & 3,81 \\
\hline 38,94 & 1289,40 & 109,90 & 25,69 & 21,01 & 18,33 & 15,26 & 12,70 & 10,61 & 7,59 & 5,70 & 3,73 \\
\hline 65,91 & 413,20 & 98,40 & 34,49 & 22,85 & 18,89 & 15,57 & 13,16 & 11,23 & 8,34 & 6,45 & 4,31 \\
\hline 73,10 & 473,30 & 162,30 & 25,17 & 15,18 & 12,01 & 9,60 & 8,01 & 6,78 & 5,01 & 3,88 & 2,61 \\
\hline 71,02 & 1048,10 & 93,10 & 21,51 & 16,24 & 14,64 & 13,05 & 11,74 & 10,57 & 8,56 & 6,99 & 4,83 \\
\hline 22,64 & 1216,20 & 193,80 & 25,60 & 18,22 & 13,86 & 9,79 & 7,23 & 5,63 & 3,87 & 2,98 & 2,07 \\
\hline 62,74 & 1319,50 & 166,70 & 14,99 & 11,18 & 9,79 & 8,45 & 7,37 & 6,44 & 4,96 & 3,90 & 2,60 \\
\hline 52,36 & 1483,90 & 66,20 & 27,33 & 23,09 & 21,41 & 19,29 & 17,35 & 15,55 & 12,44 & 10,02 & 6,77 \\
\hline 77,23 & 205,50 & 123,00 & 47,93 & 25,20 & 18,39 & 13,70 & 10,95 & 9,03 & 6,47 & 4,99 & 3,41 \\
\hline 61,46 & 1883,50 & 108,00 & 16,70 & 13,46 & 12,42 & 11,22 & 10,15 & 9,16 & 7,45 & 6,08 & 4,19 \\
\hline 88,34 & 1653,50 & 92,10 & 15,96 & 11,77 & 10,82 & 10,03 & 9,35 & 8,72 & 7,56 & 6,56 & 4,95 \\
\hline 78,71 & 1389,20 & 181,10 & 12,68 & 8,96 & 7,84 & 6,86 & 6,11 & 5,46 & 4,39 & 3,57 & 2,47 \\
\hline 57,47 & 992,90 & 28,30 & 52,08 & 43,06 & 41,01 & 38,07 & 35,17 & 32,39 & 27,28 & 22,92 & 16,37 \\
\hline 72,25 & 262,20 & 35,40 & 68,36 & 49,07 & 42,81 & 37,18 & 32,81 & 29,05 & 22,89 & 18,34 & 12,47 \\
\hline 54,48 & 1141,30 & 74,30 & 27,34 & 22,46 & 20,44 & 18,14 & 16,10 & 14,26 & 11,19 & 8,88 & 5,93 \\
\hline 88,85 & 1035,60 & 39,50 & 31,52 & 23,92 & 22,09 & 20,89 & 19,74 & 18,61 & 16,50 & 14,59 & 11,39 \\
\hline 35,75 & 1397,40 & 81,60 & 32,04 & 27,30 & 24,14 & 20,34 & 17,06 & 14,33 & 10,31 & 7,74 & 5,03 \\
\hline 68,16 & 1284,00 & 23,70 & 48,10 & 38,59 & 36,69 & 35,22 & 33,43 & 31,60 & 28,06 & 24,80 & 19,24 \\
\hline 32,11 & 1509,30 & 127,80 & 25,34 & 20,53 & 17,51 & 14,06 & 11,31 & 9,19 & 6,35 & 4,74 & 3,15 \\
\hline 46,07 & 669,90 & 172,60 & 23,67 & 16,00 & 12,97 & 10,18 & 8,16 & 6,65 & 4,64 & 3,51 & 2,36 \\
\hline 50,27 & 1449,30 & 191,30 & 14,99 & 11,44 & 9,89 & 8,30 & 7,01 & 5,95 & 4,36 & 3,32 & 2,18 \\
\hline 45,42 & 966,10 & 161,80 & 20,86 & 15,37 & 12,95 & 10,52 & 8,63 & 7,14 & 5,06 & 3,82 & 2,53 \\
\hline 28,69 & 1901,10 & 171,20 & 20,95 & 16,67 & 13,91 & 10,85 & 8,52 & 6,80 & 4,63 & 3,47 & 2,34 \\
\hline 87,25 & 594,40 & 146,60 & 21,65 & 13,52 & 11,08 & 9,22 & 7,97 & 6,99 & 5,45 & 4,36 & 2,99 \\
\hline 40,56 & 927,60 & $\frac{140,00}{192,70}$ & 20,43 & $\frac{10, v<}{14,50}$ & $\begin{array}{l}11,00 \\
11,88\end{array}$ & $\frac{0,2 L}{9,29}$ & 7,39 & 5,98 & 4,14 & 3,12 & 2,10 \\
\hline 75,97 & 1588,50 & 95,20 & 17,24 & 13,10 & 12,10 & 11,08 & 10,19 & 9,37 & 7,90 & 6,67 & 4,82 \\
\hline 84,09 & 954,10 & 173,50 & 15,44 & 10,24 & 8,68 & 7,42 & 6,52 & 5,78 & 4,59 & 3,71 & 2,56 \\
\hline 61,13 & 821,40 & 32,90 & 48,26 & 39,30 & 36,96 & 33,96 & 31,16 & 28,50 & 23,73 & 19,76 & 13,94 \\
\hline 22,71 & 1241,20 & 145,20 & 31,30 & 23,31 & 18,22 & 13,17 & 9,82 & 7,64 & 5,20 & 3,98 & 2,76 \\
\hline 29,74 & 1914,50 & 150,90 & 22,15 & 17,99 & 15,24 & 12,11 & 9,65 & 7,78 & 5,33 & 3,98 & 2,66 \\
\hline 66,61 & 489,50 & 142,10 & 26,67 & 16,91 & 13,68 & 11,07 & 9,25 & 7,83 & 5,75 & 4,43 & 2,97 \\
\hline 50,53 & 483,90 & 57,40 & 47,51 & 36,82 & 32,09 & 27,18 & 23,12 & 19,71 & 14,56 & 11,14 & 7,31 \\
\hline 42,71 & 364,00 & 112,40 & 40,86 & 26,63 & 21,06 & 16,07 & 12,61 & 10,13 & 7,00 & 5,30 & 3,62 \\
\hline 83,99 & 329,60 & 91,20 & 37,77 & 23,27 & 18,84 & 15,48 & 13,26 & 11,51 & 8,84 & 7,00 & 4,77 \\
\hline 75,73 & 957,40 & 178,50 & 15,78 & 10,67 & 9,04 & 7,68 & 6,68 & 5,86 & 4,55 & 3,61 & 2,45 \\
\hline 57,12 & 1235,60 & 122,00 & 19,23 & 15,06 & 13,37 & 11,63 & 10,17 & 8,89 & 6,83 & 5,35 & 3,55 \\
\hline 68,34 & 475,40 & 140,90 & 27,01 & 16,98 & 13,70 & 11,08 & 9,27 & 7,86 & 5,79 & 4,47 & 3,00 \\
\hline 62,09 & 797,30 & 77,80 & 28,70 & 22,15 & 19,76 & 17,34 & 15,32 & 13,53 & 10,59 & 8,42 & 5,65 \\
\hline 65,00 & 376,50 & 162,70 & 29,89 & 17,31 & 13,31 & 10,29 & 8,34 & 6,90 & 4,94 & 3,78 & 2,56 \\
\hline 87,33 & 1369,00 & 176,10 & 12,44 & 8,57 & 7,49 & 6,59 & 5,92 & 5,34 & 4,38 & 3,62 & 2,56 \\
\hline 43,81 & 1674,70 & 87,40 & 24,66 & 21,20 & 19,22 & 16,83 & 14,67 & 12,77 & 9,70 & 7,51 & 4,90 \\
\hline 43,72 & 1669,80 & 179,30 & 15,95 & 12,64 & 10,98 & 9,17 & 7,67 & 6,44 & 4,65 & 3,51 & 2,30 \\
\hline 72,66 & 1965,90 & 24,60 & 37,79 & 31,65 & 29,39 & 28,57 & 27,58 & 26,42 & 24,07 & 21,83 & 17,76 \\
\hline 42,63 & 207,30 & 157,90 & 46,64 & 23,69 & 16,55 & 11,54 & 8,72 & 6,91 & 4,78 & 3,69 & 2,60 \\
\hline 22,97 & 532,30 & 195,10 & 31,90 & 19,47 & 13,84 & 9,38 & 6,91 & 5,44 & 3,80 & 2,96 & 2,07 \\
\hline 63,59 & 1268,70 & 158,90 & 15,56 & 11,59 & 10,16 & 8,79 & 7,68 & 6,73 & 5,20 & 4,10 & 2,74 \\
\hline 48,86 & 1704,80 & 116,50 & 19,03 & 15,82 & 14,25 & 12,46 & 10,87 & 9,48 & 7,23 & 5,63 & 3,69 \\
\hline 53,81 & 1613,20 & 177,50 & 14,34 & 11,16 & 9,81 & 8,42 & 7,26 & 6,26 & 4,71 & 3,65 & 2,40 \\
\hline 35,55 & 1361,70 & 39,60 & 52,01 & 46,87 & 42,91 & 37,72 & 32,91 & 28,60 & 21,64 & 16,67 & 10,79 \\
\hline 87,69 & 333,60 & 51,60 & 46,81 & 31,46 & 27,05 & 23,46 & 20,88 & 18,72 & 15,14 & 12,42 & 8,70 \\
\hline 80,40 & 1746,40 & 74,00 & 18,72 & 14,26 & 13,30 & 12,46 & 11,65 & 10,88 & 9,46 & 8,20 & 6,19 \\
\hline 23,10 & 965,20 & 198,30 & 26,56 & 18,19 & 13,60 & 9,49 & 6,99 & 5,45 & 3,77 & 2,91 & 2,03 \\
\hline 65,38 & 1883,00 & 114,10 & 15,62 & 12,35 & 11,39 & 10,31 & 9,36 & 8,49 & 6,96 & 5,72 & 3,98 \\
\hline 49,60 & 1476,70 & 60,30 & 30,13 & 25,81 & 23,94 & 21,55 & 19,33 & 17,28 & 13,76 & 11,03 & 7,40 \\
\hline 66,84 & 798,10 & 129,70 & 21,19 & 15,03 & 12,90 & 10,99 & 9,53 & 8,29 & 6,34 & 4,98 & 3,33 \\
\hline 69,51 & 1790,70 & 45,00 & 27,83 & 22,07 & 20,98 & 19,92 & 18,75 & 17,60 & 15,42 & 13,46 & 10,22 \\
\hline 20,35 & 907,80 & 160,30 & 33,74 & 23,14 & 17,04 & 11,70 & 8,56 & 6,67 & 4,64 & 3,59 & 2,50 \\
\hline $\begin{array}{l}20,00 \\
61,45\end{array}$ & 978,80 & 174,60 & 17,13 & 12,13 & 10,30 & 8,66 & 7,39 & 6,34 & 4,74 & 3,67 & 2,43 \\
\hline 84,97 & 1341,90 & 187,50 & $\begin{array}{l}1,+10 \\
12,33\end{array}$ & $\begin{array}{l}1+1,46 \\
8,46\end{array}$ & $\begin{array}{c}10,00 \\
7,35\end{array}$ & 6,42 & 5,73 & 5,15 & 4,17 & 3,42 & 2,40 \\
\hline 29,88 & 1210,80 & 171,10 & 23,68 & $\begin{array}{l}0,7,78 \\
17,78\end{array}$ & 14,43 & 10,95 & 8,45 & 6,68 & 4,55 & 3,43 & 2,35 \\
\hline 29,26 & 1766,80 & 21,30 & 85,51 & 79,68 & 74,28 & 66,54 & 59,05 & 52,10 & 40,36 & 31,52 & 20,49 \\
\hline 86,65 & 1996,90 & 191,10 & 9,93 & 7,06 & 6,32 & 5,67 & 5,16 & 4,71 & 3,94 & 3,31 & 2,38 \\
\hline 29,77 & 1058,20 & 197,30 & 22,60 & 16,22 & 12,85 & 9,53 & 7,26 & 5,71 & 3,89 & 2,96 & 2,04 \\
\hline 23,61 & 784,70 & 158,10 & 32,75 & 22,58 & 16,99 & 11,92 & 8,80 & 6,86 & 4,73 & 3,65 & 2,54 \\
\hline 89,25 & 1103,40 & 30,30 & 35,56 & 28,00 & 25,74 & 24,64 & 23,54 & 22,40 & 20,19 & 18,14 & 14,56 \\
\hline 41.70 & 1173,00 & 144,20 & 21.60 & 16.79 & 14,39 & 11,80 & 9,72 & 8,06 & 5,72 & 4,30 & 2,84 \\
\hline 79,81 & 1292,80 & 134,40 & 15,20 & 10,97 & 9,77 & 8,69 & 7,83 & 7,08 & 5,80 & 4,79 & 3,36 \\
\hline 26,07 & 473,60 & 145,80 & 38,50 & 24,80 & 18,33 & 12,77 & 9,46 & 7,41 & 5,13 & 3,96 & 2,77 \\
\hline 27,23 & 815,00 & 139,60 & 32,66 & 23,59 & 18,52 & 13,55 & 10,22 & 8,00 & 5,46 & 4,16 & 2,88 \\
\hline 71,87 & 861,60 & 99,30 & 22,61 & 16,58 & 14,65 & 12,86 & 11,44 & 10,19 & 8,12 & 6,55 & 4,48 \\
\hline 20,22 & 611,10 & 25,00 & 146,85 & 120,74 & 100,07 & 76,63 & 59,01 & 46,37 & 31,17 & 23,36 & 15,94 \\
\hline 77,91 & 1733,80 & 37,80 & 28,92 & 23,02 & 21,54 & 20,70 & 19,74 & 18,74 & 16,80 & 15,00 & 11,87 \\
\hline 86,12 & 1006,70 & 183,60 & 14,50 & 9,56 & 8,09 & 6,92 & 6,10 & 5,41 & 4,31 & 3,50 & 2,42 \\
\hline 53,44 & 861,00 & 39,10 & 45,98 & 38,64 & 35,85 & 32,34 & 29,12 & 26,14 & 20,99 & 16,94 & 11,48 \\
\hline 41,90 & 746,60 & 25,20 & 75,79 & 67,08 & 61,94 & 55,21 & 48,92 & 43,18 & 33,58 & 26,39 & 17,35 \\
\hline 20,66 & 545,30 & 77,10 & 65,74 & 46,81 & 35,25 & 24,59 & 18,06 & 14,03 & 9,68 & 7,48 & 5,20 \\
\hline 48,62 & 500,20 & 172,20 & 26,84 & 16,91 & 13,33 & 10,26 & 8,15 & 6,61 & 4,61 & 3,49 & 2,37 \\
\hline 54,14 & 1298,40 & 129,70 & 18,74 & 14,76 & 13,07 & 11,29 & 9,80 & 8,50 & 6,45 & 5,01 & 3,30 \\
\hline
\end{tabular}




\begin{tabular}{|c|c|c|c|c|c|c|c|c|c|c|c|}
\hline \multirow[b]{2}{*}{ e1 (cm) } & & & & & & & ões (x1 & m) & & & \\
\hline & Meq (MPa) & Ms (MPa) & D0 & D25 & D40 & $\mathrm{D} 60$ & D80 & D100 & D140 & D180 & D260 \\
\hline 34,68 & 1714,10 & 134,10 & 22,19 & 18,25 & 15,80 & 12,97 & 10,63 & 8,76 & 6,16 & 4,60 & 3,03 \\
\hline 35,75 & 563,10 & 112,20 & 36,84 & 26,37 & 21,35 & 16,37 & 12,78 & 10,21 & 7,00 & 5,28 & 3,60 \\
\hline 50,50 & 1788,40 & 194,60 & 13,51 & 10,60 & 9,29 & 7,92 & 6,77 & 5,80 & 4,31 & 3,30 & 2,17 \\
\hline 44,49 & 1279,80 & 166,60 & 18,39 & 14,15 & 12,14 & 10,03 & 8,32 & 6,94 & 4,97 & 3,75 & 2,47 \\
\hline 30,24 & 810,90 & 137,60 & 31,10 & 22,72 & 18,19 & 13,63 & 10,45 & 8,24 & 5,62 & 4,26 & 2,92 \\
\hline 62,51 & 1028,30 & 100,00 & 22,21 & 17,13 & 15,29 & 13,43 & 11,87 & 10,49 & 8,23 & 6,55 & 4,40 \\
\hline 46,35 & 999,20 & 109,80 & 25,33 & 19,97 & 17,39 & 14,63 & 12,34 & 10,44 & 7,61 & 5,78 & 3,79 \\
\hline 84,62 & 1396,80 & 49,20 & 25,31 & 19,38 & 18,03 & 17,07 & 16,12 & 15,19 & 13,44 & 11,85 & 9,20 \\
\hline 63,28 & 856,30 & 136,60 & 20,42 & 14,67 & 12,60 & 10,71 & 9,23 & 7,99 & 6,05 & 4,72 & 3,14 \\
\hline 68,57 & 1028,30 & 168,10 & 16,23 & 11,45 & 9,82 & 8,38 & 7,28 & 6,35 & 4,88 & 3,85 & 2,58 \\
\hline 52,67 & 1985,90 & 131,10 & 15,90 & 13,13 & 11,91 & 10,52 & 9,29 & 8,19 & 6,37 & 5,03 & 3,33 \\
\hline 70,41 & 791,80 & 156,30 & 19,10 & 12,97 & 10,93 & 9,21 & 7,93 & 6,88 & 5,24 & 4,11 & 2,76 \\
\hline 85,78 & 597,50 & 119,80 & 23,51 & 15,28 & 12,81 & 10,86 & 9,51 & 8,40 & 6,64 & 5,36 & 3,69 \\
\hline 86,64 & 204,40 & 125,60 & 47,29 & 24,48 & 17,73 & 13,17 & 10,57 & 8,76 & 6,34 & 4,92 & 3,37 \\
\hline 86,89 & 830,50 & 164,80 & 16,92 & 10,98 & 9,22 & 7,83 & 6,86 & 6,07 & 4,81 & 3,89 & 2,69 \\
\hline 50,58 & 1992,10 & 34,40 & 39,88 & 33,62 & 32,42 & 30,37 & 28,23 & 26,13 & 22,22 & 18,80 & 13,54 \\
\hline 31,59 & 460,20 & 59,20 & 63,99 & 48,95 & 40,38 & 31,25 & 24,47 & 19,53 & 13,34 & 10,01 & 6,79 \\
\hline 46,29 & 707,70 & 118,80 & 28,14 & 20,71 & 17,47 & 14,23 & 11,70 & 9,71 & 6,91 & 5,21 & 3,45 \\
\hline 37,28 & 1908,90 & 112,70 & 22,55 & 19,22 & 17,06 & 14,47 & 12,22 & 10,32 & 7,49 & 5,65 & 3,67 \\
\hline 35,87 & 1027,40 & 60,70 & 43,15 & 36,73 & 32,47 & 27,35 & 22,94 & 19,27 & 13,86 & 10,41 & 6,77 \\
\hline 30,76 & 1793,40 & 98,80 & 29,18 & 24,74 & 21,56 & 17,73 & 14,54 & 11,97 & 8,38 & 6,23 & 4,09 \\
\hline 63,08 & 493,40 & 70,60 & 37,50 & 27,44 & 23,78 & 20,37 & 17,66 & 15,35 & 11,72 & 9,18 & 6,11 \\
\hline 53,93 & 1339,90 & 47,70 & 34,47 & 29,03 & 27,29 & 24,93 & 22,70 & 20,60 & 16,87 & 13,83 & 9,55 \\
\hline 65,74 & 1554,40 & 180,10 & 13,02 & 9,74 & 8,59 & 7,49 & 6,60 & 5,82 & 4,55 & 3,62 & 2,44 \\
\hline 40,88 & 1030,50 & 194,60 & 19,34 & 13,99 & 11,56 & 9,13 & 7,31 & 5,94 & 4,13 & 3,10 & 2,09 \\
\hline 86,70 & 837,80 & 55,10 & 28,97 & 21,20 & 19,38 & 17,80 & 16,46 & 15,24 & 13,05 & 11,19 & 8,30 \\
\hline 50,85 & 1561,30 & 63,40 & 28,12 & 23,97 & 22,29 & 20,12 & 18,10 & 16,23 & 13,00 & 10,47 & 7,06 \\
\hline 81,91 & 864,40 & 133,50 & 18,51 & 12,66 & 10,90 & 9,43 & 8,36 & 7,45 & 5,95 & 4,83 & 3,34 \\
\hline 77,14 & 1262,30 & 20,50 & 47,78 & 39,24 & 36,43 & 35,27 & 33,93 & 32,42 & 29,42 & 26,58 & 21,49 \\
\hline 42,37 & 692,90 & 70,40 & 40,54 & 32,40 & 28,18 & 23,51 & 19,63 & 16,46 & 11,84 & 8,93 & 5,85 \\
\hline 24,87 & 805,10 & 35,10 & 90,42 & 76,46 & 65,50 & 52,43 & 41,90 & 33,77 & 23,08 & 17,13 & 11,42 \\
\hline 82,31 & 1551,70 & 30,20 & 32,93 & 26,77 & 24,73 & 23,86 & 22,93 & 21,90 & 19,86 & 17,94 & 14,51 \\
\hline 55,88 & 1516,00 & 122,70 & 17,80 & 14,29 & 12,85 & 11,29 & 9,94 & 8,74 & 6,79 & 5,35 & 3,56 \\
\hline 71,32 & 960,80 & 82,80 & 23,82 & 18,01 & 16,27 & 14,53 & 13,10 & 11,81 & 9,59 & 7,85 & 5,45 \\
\hline 69,37 & 1248,90 & 130,80 & 16,68 & 12,47 & 11,10 & 9,78 & 8,71 & 7,76 & 6,18 & 4,99 & 3,40 \\
\hline 66,46 & 1313,40 & 84,50 & 21,41 & 16,81 & 15,46 & 13,97 & 12,67 & 11,48 & 9,39 & 7,72 & 5,37 \\
\hline 75,29 & 468,60 & 132,90 & 27,11 & 16,95 & 13,72 & 11,21 & 9,50 & 8,15 & 6,12 & 4,78 & 3,22 \\
\hline 24,72 & 1999,60 & 44,10 & 57,95 & 51,94 & 46,24 & 38,90 & 32,44 & 27,03 & 19,14 & 14,22 & 9,20 \\
\hline 44,78 & 823,80 & 98,10 & 29,97 & 23,37 & 20,20 & 16,81 & 14,03 & 11,77 & 8,48 & 6,41 & 4,21 \\
\hline 64,09 & 911,40 & 45,50 & 36,79 & 29,46 & 27,45 & 25,06 & 22,89 & 20,86 & 17,26 & 14,31 & 10,05 \\
\hline 47,16 & 867,60 & 173,10 & 20,70 & 14,73 & 12,26 & 9,87 & 8,06 & 6,65 & 4,71 & 3,55 & 2,37 \\
\hline 24,09 & 1689,50 & 95,40 & 36,94 & 30,29 & 25,36 & 19,73 & 15,41 & 12,24 & 8,28 & 6,18 & 4,19 \\
\hline 63,35 & 1429,70 & 131,00 & 16,40 & 12,69 & 11,38 & 10,04 & 8,92 & 7,92 & 6,25 & 5,00 & 3,38 \\
\hline 33,38 & 459,70 & 32,40 & 90,94 & 75,55 & 65,53 & 53,78 & 44,07 & 36,30 & 25,47 & 18,99 & 12,49 \\
\hline 29,45 & 1725,70 & 155,30 & 22,66 & 18,08 & 15,15 & 11,88 & 9,38 & 7,51 & 5,13 & 3,83 & 2,58 \\
\hline 20,83 & 1021,80 & 131,90 & 37,35 & 27,00 & 20,53 & 14,44 & 10,63 & 8,25 & 5,67 & 4,37 & 3,04 \\
\hline 69,32 & 693,30 & 82,30 & 28,12 & 20,72 & 18,26 & 15,96 & 14,12 & 12,52 & 9,88 & 7,91 & 5,37 \\
\hline 65,34 & 1779,40 & 26,60 & 41,17 & 33,36 & 31,75 & 30,63 & 29,16 & 27,64 & 24,67 & 21,89 & 17,11 \\
\hline 25,55 & 363,00 & 60,50 & 77,51 & 55,80 & 43,38 & 31,36 & 23,48 & 18,32 & 12,51 & 9,58 & 6,64 \\
\hline 44,36 & 1145,80 & 23,50 & 66,72 & 58,58 & 55,66 & 51,08 & 46,59 & 42,30 & 34,62 & 28,31 & 19,40 \\
\hline 63,32 & 1007,60 & 31,30 & 45,58 & 36,78 & 34,97 & 32,62 & 30,29 & 28,05 & 23,90 & 20,31 & 14,77 \\
\hline 53,58 & 291,40 & 146,10 & 38,02 & 21,58 & 16,23 & 12,13 & 9,54 & 7,71 & 5,37 & 4,10 & 2,81 \\
\hline 49,29 & 1650,20 & 62,50 & 28,44 & 24,44 & 22,75 & 20,54 & 18,47 & 16,55 & 13,24 & 10,64 & 7,17 \\
\hline 87,01 & 1995,10 & 49,20 & 21,32 & 16,97 & 15,62 & 15,00 & 14,36 & 13,68 & 12,35 & 11,12 & 8,94 \\
\hline 37,34 & 1571,00 & 93,00 & 27,32 & 23,28 & 20,67 & 17,53 & 14,80 & 12,51 & 9,07 & 6,84 & 4,44 \\
\hline 53,32 & 1211,10 & 102,70 & 22,28 & 17,93 & 16,03 & 13,98 & 12,20 & 10,65 & 8,15 & 6,36 & 4,20 \\
\hline 50,44 & 1236,90 & 90,60 & 24,63 & 20,26 & 18,22 & 15,92 & 13,91 & 12,13 & 9,27 & 7,23 & 4,75 \\
\hline 70,97 & 1807,10 & 199,70 & 11,09 & 8,19 & 7,26 & 6,39 & 5,69 & 5,07 & 4,04 & 3,26 & 2,23 \\
\hline 23,14 & 1277,80 & 100,60 & 39,86 & 31,32 & 25,38 & 19,02 & 14,48 & 11,33 & 7,65 & 5,79 & 3,97 \\
\hline 83,46 & 1949,80 & 34,00 & 27,50 & 22,83 & 20,94 & 20,23 & 19,53 & 18,72 & 17,08 & 15,52 & 12,71 \\
\hline 67,47 & 1674,80 & 62,70 & 23,40 & 18,57 & 17,54 & 16,31 & 15,12 & 13,99 & 11,91 & 10,13 & 7,37 \\
\hline 76,90 & 964,20 & 29,60 & 42,48 & 33,05 & 31,10 & 29,48 & 27,78 & 26,11 & 22,96 & 20,12 & 15,42 \\
\hline 89,91 & 1261,00 & 57,90 & 23,11 & 17,25 & 15,89 & 14,90 & 13,99 & 13,14 & 11,55 & 10,14 & 7,82 \\
\hline 24,24 & 714,20 & 92,80 & 48,42 & 35,92 & 28,21 & 20,53 & 15,40 & 12,00 & 8,17 & 6,24 & 4,32 \\
\hline 29,24 & 1825,80 & 149,30 & 22,95 & 18,51 & 15,60 & 12,31 & 9,76 & 7,84 & 5,36 & 4,00 & 2,69 \\
\hline 23,16 & 1267,20 & 84,30 & 45,23 & 36,22 & 29,74 & 22,61 & 17,36 & 13,65 & 9,21 & 6,93 & 4,74 \\
\hline 84,07 & 1194,80 & 89,80 & 19,15 & 13,99 & 12,73 & 11,58 & 10,63 & 9,77 & 8,26 & 6,99 & 5,09 \\
\hline 22,56 & 703,00 & 188,70 & 30,41 & 19,75 & 14,37 & 9,83 & 7,23 & 5,66 & 3,94 & 3,06 & 2,13 \\
\hline 61,44 & 1843,70 & 195,60 & 11,91 & 9,13 & 8,09 & 7,05 & 6,20 & 5,45 & 4,23 & 3,34 & 2,23 \\
\hline 47,04 & 1528,10 & 120,00 & 20,01 & 16,46 & 14,66 & 12,65 & 10,90 & 9,39 & 7,03 & 5,40 & 3,53 \\
\hline 52,13 & 1544,00 & 149,30 & 16,42 & 13,05 & 11,55 & 9,96 & 8,61 & 7,45 & 5,62 & 4,35 & 2,86 \\
\hline 46,56 & 1660,40 & 65,50 & 28,55 & 24,76 & 22,90 & 20,50 & 18,28 & 16,24 & 12,78 & 10,15 & 6,74 \\
\hline 39,12 & 406,70 & 172,00 & 31,92 & 19,32 & 14,62 & 10,69 & 8,17 & 6,48 & 4,46 & 3,41 & 2,36 \\
\hline 20,04 & 1926,70 & 129,00 & 32,90 & 25,65 & 20,43 & 14,97 & 11,21 & 8,70 & 5,88 & 4,48 & 3,10 \\
\hline 31,10 & 1916,80 & 70,50 & 35,29 & 31,13 & 27,78 & 23,56 & 19,84 & 16,70 & 12,02 & 9,01 & 5,83 \\
\hline 34,29 & 1456,00 & 195,90 & 18,64 & 14,24 & 11,84 & 9,29 & 7,36 & 5,92 & 4,07 & 3,05 & 2,06 \\
\hline 65,35 & 1712,40 & 130,60 & 14,98 & 11,69 & 10,62 & 9,50 & 8,54 & 7,66 & 6,18 & 5,01 & 3,44 \\
\hline 87,07 & 983,60 & 53,20 & 27,51 & 20,38 & 18,77 & 17,43 & 16,24 & 15,14 & 13,13 & 11,38 & 8,58 \\
\hline 81,86 & 1603,40 & 199,60 & 11,07 & 7,78 & 6,83 & 6,01 & 5,38 & 4,84 & 3,93 & 3,22 & 2,25 \\
\hline 31,13 & 1856,80 & 104,40 & 27,55 & 23,33 & 20,34 & 16,74 & 13,74 & 11,32 & 7,93 & 5,91 & 3,88 \\
\hline 37,92 & 1089,20 & 68,50 & 37,51 & 31,78 & 28,16 & 23,85 & 20,12 & 16,99 & 12,32 & 9,29 & 6,04 \\
\hline 40,24 & 729,00 & 98,60 & 33,58 & 25,72 & 21,81 & 17,65 & 14,37 & 11,80 & 8,29 & 6,22 & 4,13 \\
\hline
\end{tabular}




\begin{tabular}{|c|c|c|c|c|c|c|c|c|c|c|c|}
\hline & & & \multicolumn{9}{|c|}{ Deflexões $\left(\times 10^{-4} \mathrm{~cm}\right)$} \\
\hline e1 (cm) & Meq (MPa) & Ms (MPa) & D0 & D25 & D40 & D60 & D80 & D100 & D140 & D180 & D260 \\
\hline 20,60 & 938,60 & 113,70 & 42,89 & 31,21 & 23,80 & 16,77 & 12,35 & 9,58 & 6,58 & 5,07 & 3,52 \\
\hline 71,80 & 1293,90 & 108,30 & 17,93 & 13,56 & 12,28 & 10,99 & 9,92 & 8,96 & 7,31 & 6,00 & 4,18 \\
\hline 29,72 & 1590,10 & 34,40 & 62,88 & 57,46 & 52,32 & 45,53 & 39,26 & 33,73 & 25,00 & 18,98 & 12,20 \\
\hline 43,49 & 555,60 & 86,20 & 38,81 & 29,02 & 24,52 & 19,90 & 16,28 & 13,43 & 9,49 & 7,14 & 4,74 \\
\hline 45,03 & 1276,50 & 181,40 & 17,41 & 13,20 & 11,26 & 9,25 & 7,65 & 6,37 & 4,55 & 3,43 & 2,26 \\
\hline 86,46 & 1821,80 & 186,20 & 10,52 & 7,44 & 6,63 & 5,92 & 5,38 & 4,90 & 4,07 & 3,41 & 2,44 \\
\hline 45,02 & 1647,30 & 34,10 & 45,71 & 39,99 & 38,03 & 34,95 & 31,91 & 29,01 & 23,81 & 19,51 & 13,41 \\
\hline 66,85 & 1772,50 & 193,70 & 11,69 & 8,77 & 7,78 & 6,82 & 6,03 & 5,35 & 4,22 & 3,37 & 2,28 \\
\hline 20,80 & 1419,20 & 94,40 & 43,70 & 34,35 & 27,59 & 20,42 & 15,39 & 11,98 & 8,09 & 6,14 & 4,23 \\
\hline 48,00 & 466,10 & 78,20 & 41,91 & 30,78 & 26,04 & 21,33 & 17,64 & 14,70 & 10,52 & 7,96 & 5,27 \\
\hline 83,15 & 1360,10 & 83,20 & 19,00 & 14,10 & 12,97 & 11,93 & 11,04 & 10,22 & 8,73 & 7,47 & 5,51 \\
\hline 81,29 & 807,60 & 32,80 & 41,26 & 31,44 & 29,34 & 27,54 & 25,81 & 24,16 & 21,09 & 18,36 & 13,94 \\
\hline 21,19 & 1023,80 & 50,20 & 74,34 & 60,56 & 49,99 & 38,14 & 29,32 & 23,03 & 15,50 & 11,64 & 7,95 \\
\hline 64,39 & 585,10 & 138,30 & 24,65 & 16,41 & 13,58 & 11,18 & 9,43 & 8,03 & 5,94 & 4,59 & 3,06 \\
\hline 52,23 & 1514,50 & 117,30 & 19,03 & 15,51 & 13,93 & 12,18 & 10,66 & 9,31 & 7,15 & 5,58 & 3,68 \\
\hline 47,88 & 307,00 & 112,20 & 42,73 & 26,56 & 20,76 & 15,86 & 12,53 & 10,13 & 7,04 & 5,34 & 3,64 \\
\hline 77,43 & 1180,30 & 171,10 & 14,26 & 9,98 & 8,65 & 7,50 & 6,64 & 5,90 & 4,69 & 3,78 & 2,59 \\
\hline 22,55 & 1984,50 & 28,60 & 84,40 & 77,05 & 69,23 & 58,89 & 49,59 & 41,64 & 29,78 & 22,17 & 14,25 \\
\hline 62,45 & 513,00 & 106,20 & 30,23 & 20,76 & 17,40 & 14,46 & 12,26 & 10,46 & 7,76 & 5,99 & 3,98 \\
\hline 66,20 & 1534,40 & 176,80 & 13,19 & 9,85 & 8,70 & 7,59 & 6,69 & 5,91 & 4,63 & 3,69 & 2,49 \\
\hline 58,16 & 1458,10 & 98,40 & 20,15 & 16,30 & 14,85 & 13,24 & 11,82 & 10,53 & 8,36 & 6,70 & 4,52 \\
\hline 23,07 & 947,90 & 151,90 & 32,37 & 23,09 & 17,63 & 12,50 & 9,25 & 7,20 & 4,94 & 3,80 & 2,64 \\
\hline 44,52 & 307,00 & 88,90 & 49,29 & 32,54 & 26,00 & 20,08 & 15,91 & 12,86 & 8,93 & 6,75 & 4,58 \\
\hline 51,14 & 1909,20 & 107,10 & 18,64 & 15,64 & 14,30 & 12,70 & 11,27 & 9,97 & 7,80 & 6,18 & 4,10 \\
\hline 35,56 & 727,70 & 27,40 & 82,10 & 72,78 & 65,82 & 57,01 & 49,03 & 42,08 & 31,20 & 23,75 & 15,34 \\
\hline 62,90 & 1124,10 & 176,90 & 15,70 & 11,32 & 9,73 & 8,27 & 7,13 & 6,17 & 4,68 & 3,64 & 2,42 \\
\hline 38,65 & 586,70 & 92,30 & 39,05 & 29,17 & 24,33 & 19,31 & 15,47 & 12,57 & 8,73 & 6,55 & 4,39 \\
\hline 39,52 & 1476,00 & 182,50 & 17,70 & 13,75 & 11,71 & 9,51 & 7,76 & 6,39 & 4,49 & 3,37 & 2,23 \\
\hline 67,82 & 1676,80 & 104,40 & 16,92 & 13,24 & 12,20 & 11,06 & 10,06 & 9,15 & 7,53 & 6,22 & 4,36 \\
\hline 28,51 & 608,60 & 174,40 & 30,24 & 19,94 & 15,08 & 10,73 & 8,02 & 6,28 & 4,32 & 3,32 & 2,31 \\
\hline 48,31 & 413,20 & 122,10 & 35,09 & 22,93 & 18,38 & 14,35 & 11,49 & 9,36 & 6,55 & 4,96 & 3,35 \\
\hline 26,11 & 1046,00 & 70,90 & 49,48 & 40,25 & 33,74 & 26,35 & 20,68 & 16,48 & 11,19 & 8,36 & 5,64 \\
\hline 66,31 & 1847,10 & 33,50 & 34,59 & 27,80 & 26,51 & 25,42 & 24,09 & 22,75 & 20,15 & 17,75 & 13,70 \\
\hline 39,65 & 1311,00 & 107,80 & 25,51 & 20,97 & 18,37 & 15,39 & 12,87 & 10,80 & 7,77 & 5,85 & 3,82 \\
\hline 79,00 & 460,30 & 53,80 & 40,37 & 28,85 & 25,47 & 22,46 & 20,12 & 18,09 & 14,66 & 12,00 & 8,36 \\
\hline 37,55 & 1650,60 & 167,90 & 18,45 & 14,73 & 12,65 & 10,33 & 8,45 & 6,96 & 4,90 & 3,67 & 2,42 \\
\hline 40,66 & 610,40 & 166,80 & 26,55 & 17,82 & 14,21 & 10,87 & 8,52 & 6,83 & 4,71 & 3,56 & 2,43 \\
\hline 34,22 & 510,00 & 126,30 & 36,41 & 24,96 & 19,70 & 14,70 & 11,29 & 8,93 & 6,11 & 4,64 & 3,19 \\
\hline 73,52 & 1031,70 & 196,80 & 14,65 & 9,93 & 8,39 & 7,10 & 6,16 & 5,38 & 4,14 & 3,28 & 2,21 \\
\hline 52,15 & 1802,30 & 119,50 & 17,58 & 14,53 & 13,17 & 11,62 & 10,25 & 9,02 & 7,00 & 5,51 & 3,65 \\
\hline 83,82 & 1405,20 & 166,90 & 12,81 & 8,99 & 7,92 & 7,00 & 6,29 & 5,68 & 4,65 & 3,84 & 2,71 \\
\hline 80,19 & 1377,20 & 115,10 & 16,01 & 11,76 & 10,64 & 9,59 & 8,74 & 7,97 & 6,64 & 5,55 & 3,96 \\
\hline 86,09 & 979,80 & 77,50 & 22,45 & 16,24 & 14,72 & 13,36 & 12,26 & 11,28 & 9,53 & 8,08 & 5,90 \\
\hline 48,32 & 1055,70 & 94,00 & 26,41 & 21,36 & 18,92 & 16,24 & 13,95 & 11,99 & 8,95 & 6,88 & 4,50 \\
\hline 25,27 & 1840,70 & 176,60 & 22,63 & 17,59 & 14,28 & 10,76 & 8,23 & 6,46 & 4,38 & 3,30 & 2,27 \\
\hline 76,45 & 325,30 & 125,40 & 34,77 & 20,28 & 15,79 & 12,48 & 10,35 & 8,75 & 6,45 & 5,00 & 3,38 \\
\hline 33,76 & 1943,60 & 191,10 & 17,24 & 13,75 & 11,69 & 9,37 & 7,54 & 6,13 & 4,25 & 3,17 & 2,11 \\
\hline 79,68 & 463,30 & 128,70 & 27,21 & 16,92 & 13,71 & 11,25 & 9,59 & 8,28 & 6,30 & 4,96 & 3,36 \\
\hline 26,15 & 239,10 & 115,30 & 56,52 & 32,75 & 23,22 & 15,83 & 11,73 & 9,24 & 6,45 & 5,01 & 3,52 \\
\hline 57,48 & 1227,60 & 198,00 & 14,82 & 10,78 & 9,22 & 7,76 & 6,60 & 5,64 & 4,19 & 3,23 & 2,13 \\
\hline 81,71 & 427,50 & 167,50 & 25,96 & 14,95 & 11,59 & 9,15 & 7,62 & 6,47 & 4,82 & 3,76 & 2,55 \\
\hline 37,01 & 891,30 & 30,30 & 69,35 & 61,89 & 56,47 & 49,48 & 43,07 & 37,36 & 28,19 & 21,68 & 14,05 \\
\hline 61,01 & 1370,60 & 113,30 & 18,51 & 14,58 & 13,15 & 11,64 & 10,34 & 9,19 & 7,25 & 5,80 & 3,91 \\
\hline 61,91 & 800,70 & 39,50 & 43,01 & 34,78 & 32,38 & 29,49 & 26,87 & 24,42 & 20,09 & 16,56 & 11,54 \\
\hline 68,60 & 1548,70 & 23,80 & 44,63 & 36,19 & 34,22 & 33,08 & 31,59 & 30,01 & 26,91 & 24,01 & 18,96 \\
\hline 37,80 & 320,20 & 151,10 & 38,65 & 22,73 & 16,91 & 12,18 & 9,25 & 7,31 & 5,03 & 3,86 & 2,69 \\
\hline 53,76 & 560,90 & 42,70 & 51,04 & 41,48 & 37,36 & 32,81 & 28,84 & 25,32 & 19,58 & 15,38 & 10,19 \\
\hline 74,37 & 434,60 & 106,90 & 31,05 & 20,03 & 16,48 & 13,65 & 11,66 & 10,06 & 7,63 & 5,98 & 4,02 \\
\hline 32,66 & 1203,70 & 23,30 & 82,75 & 76,02 & 70,26 & 62,37 & 54,90 & 48,09 & 36,82 & 28,55 & 18,50 \\
\hline 72,02 & 268,00 & 54,60 & 55,16 & 37,09 & 31,15 & 26,19 & 22,57 & 19,59 & 14,97 & 11,77 & 7,91 \\
\hline 47,24 & 1919,70 & 164,10 & 15,09 & 12,29 & 10,90 & 9,35 & 8,02 & 6,89 & 5,13 & 3,94 & 2,57 \\
\hline 77,30 & 1338,00 & 93,20 & 18,59 & 13,95 & 12,78 & 11,62 & 10,63 & 9,74 & 8,15 & 6,84 & 4,91 \\
\hline 55,89 & 286,50 & 76,40 & 50,28 & 33,20 & 27,07 & 21,74 & 17,88 & 14,88 & 10,67 & 8,12 & 5,42 \\
\hline 24,49 & 1251,40 & 169,70 & 26,65 & 19,68 & 15,44 & 11,23 & 8,42 & 6,56 & 4,47 & 3,42 & 2,36 \\
\hline 33,37 & 446,30 & 159,40 & 33,72 & 21,32 & 16,16 & 11,66 & 8,81 & 6,94 & 4,77 & 3,65 & 2,54 \\
\hline 26,89 & 923,00 & 92,80 & 41,89 & 32,63 & 26,70 & 20,33 & 15,69 & 12,38 & 8,40 & 6,32 & 4,32 \\
\hline 52,52 & 1568,80 & 27,60 & 48,79 & 40,77 & 39,34 & 36,96 & 34,44 & 31,97 & 27,33 & 23,26 & 16,89 \\
\hline 57,21 & 1483,30 & 106,50 & 19,27 & 15,56 & 14,12 & 12,52 & 11,12 & 9,86 & 7,77 & 6,18 & 4,15 \\
\hline 78,32 & 845,50 & 59,90 & 28,92 & 21,60 & 19,76 & 17,97 & 16,45 & 15,08 & 12,63 & 10,62 & 7,63 \\
\hline 87,33 & 880,80 & 187,40 & 15,48 & 9,92 & 8,26 & 6,97 & 6,09 & 5,37 & 4,24 & 3,42 & 2,36 \\
\hline 35,03 & 1189,80 & 121,90 & 26,73 & 21,25 & 18,09 & 14,57 & 11,77 & 9,60 & 6,68 & 4,99 & 3,32 \\
\hline 87,27 & 1698,60 & 38,40 & 26,20 & 21,11 & 19,39 & 18,64 & 17,90 & 17,09 & 15,50 & 14,01 & 11,35 \\
\hline 75,05 & 1736,20 & 85,80 & 17,83 & 13,69 & 12,77 & 11,81 & 10,93 & 10,11 & 8,61 & 7,33 & 5,36 \\
\hline 27,91 & 324,10 & 152,90 & 41,52 & 24,31 & 17,44 & 12,00 & 8,91 & 7,01 & 4,87 & 3,78 & 2,65 \\
\hline 50,39 & 235,30 & 85,60 & 54,97 & 34,08 & 26,72 & 20,56 & 16,36 & 13,29 & 9,28 & 7,04 & 4,78 \\
\hline 45,12 & 1471,70 & 147,90 & 18,44 & 14,73 & 12,89 & 10,87 & 9,18 & 7,76 & 5,66 & 4,30 & 2,81 \\
\hline 42,43 & 412,80 & 167,90 & 31,31 & 19,08 & 14,60 & 10,85 & 8,39 & 6,69 & 4,61 & 3,51 & 2,42 \\
\hline 87,85 & 821,80 & 157,00 & 17,31 & 11,28 & 9,49 & 8,09 & 7,12 & 6,32 & 5,03 & 4,08 & 2,83 \\
\hline 63,31 & 1748,90 & 98,00 & 17,95 & 14,37 & 13,29 & 12,05 & 10,95 & 9,92 & 8,12 & 6,67 & 4,63 \\
\hline 74,90 & 938,00 & 156,30 & 17,02 & 11,75 & 10,06 & 8,62 & 7,55 & 6,64 & 5,19 & 4,14 & 2,81 \\
\hline 20,16 & 806,60 & 117,20 & 44,18 & 31,17 & 23,29 & 16,13 & 11,82 & 9,19 & 6,35 & 4,92 & 3,42 \\
\hline 40,45 & 1226,80 & 195,70 & 18,03 & 13,44 & 11,25 & 9,00 & 7,26 & 5,93 & 4,14 & 3,11 & 2,07 \\
\hline
\end{tabular}




\begin{tabular}{|c|c|c|c|c|c|c|c|c|c|c|c|}
\hline & & & \multicolumn{9}{|c|}{ Deflexões $\left(\times 10^{-4} \mathrm{~cm}\right)$} \\
\hline e1 (cm) & Meq (MPa) & Ms (MPa) & D0 & D25 & D40 & D60 & D80 & D100 & D140 & D180 & D260 \\
\hline 28,39 & 1829,20 & 35,80 & 60,75 & 55,68 & 50,68 & 44,03 & 37,90 & 32,49 & 24,00 & 18,18 & 11,67 \\
\hline 37,60 & 387,10 & 122,20 & 39,89 & 25,96 & 20,23 & 15,07 & 11,60 & 9,21 & 6,33 & 4,81 & 3,31 \\
\hline 51,74 & 1551,00 & 127,30 & 18,07 & 14,65 & 13,10 & 11,41 & 9,94 & 8,65 & 6,59 & 5,13 & 3,38 \\
\hline 77,61 & 1964,10 & 20,00 & 39,33 & 35,18 & 31,96 & 30,96 & 30,21 & 29,19 & 27,00 & 24,85 & 20,83 \\
\hline 57,36 & 1110,00 & 178,70 & 16,42 & 11,95 & 10,23 & 8,60 & 7,32 & 6,25 & 4,64 & 3,58 & 2,36 \\
\hline 39,21 & 1095,40 & 104,00 & 28,16 & 22,72 & 19,69 & 16,29 & 13,49 & 11,22 & 7,98 & 5,99 & 3,93 \\
\hline 57,71 & 856,10 & 142,90 & 20,84 & 15,06 & 12,86 & 10,79 & 9,17 & 7,83 & 5,81 & 4,47 & 2,95 \\
\hline 85,70 & 1897,80 & 27,90 & 30,07 & 26,06 & 23,63 & 22,80 & 22,17 & 21,36 & 19,68 & 18,05 & 15,05 \\
\hline 55,82 & 1077,10 & 151,80 & 18,39 & 13,73 & 11,87 & 10,05 & 8,59 & 7,36 & 5,48 & 4,23 & 2,79 \\
\hline 44,69 & 844,40 & 99,90 & 29,38 & 22,94 & 19,83 & 16,50 & 13,78 & 11,55 & 8,33 & 6,29 & 4,13 \\
\hline 68,46 & 1005,20 & 121,30 & 19,35 & 14,27 & 12,56 & 10,95 & 9,67 & 8,56 & 6,73 & 5,37 & 3,64 \\
\hline 53,88 & 1093,80 & 85,30 & 25,76 & 20,87 & 18,77 & 16,47 & 14,46 & 12,68 & 9,79 & 7,69 & 5,09 \\
\hline 75,57 & 1033,70 & 122,20 & 18,21 & 13,14 & 11,60 & 10,19 & 9,10 & 8,14 & 6,53 & 5,31 & 3,66 \\
\hline 83,23 & 1092,80 & 148,40 & 15,47 & 10,71 & 9,33 & 8,16 & 7,29 & 6,54 & 5,29 & 4,33 & 3,03 \\
\hline 88,77 & 537,80 & 82,70 & 28,98 & 19,43 & 16,71 & 14,50 & 12,92 & 11,60 & 9,40 & 7,73 & 5,43 \\
\hline 51,19 & 387,40 & 173,30 & 30,31 & 17,79 & 13,59 & 10,25 & 8,07 & 6,52 & 4,54 & 3,45 & 2,36 \\
\hline 73,30 & 1735,10 & 198,00 & 11,19 & 8,17 & 7,23 & 6,36 & 5,67 & 5,06 & 4,05 & 3,28 & 2,25 \\
\hline 86,18 & 1919,70 & 105,60 & 14,04 & 10,41 & 9,59 & 8,89 & 8,28 & 7,71 & 6,67 & 5,76 & 4,33 \\
\hline 23,84 & 1788,70 & 21,00 & 102,38 & 95,21 & 86,91 & 75,64 & 65,12 & 55,80 & 41,12 & 31,06 & 19,87 \\
\hline 89,92 & 1890,40 & 80,90 & 16,04 & 12,05 & 11,10 & 10,45 & 9,84 & 9,26 & 8,17 & 7,20 & 5,58 \\
\hline 45,57 & 1345,90 & 80,70 & 27,36 & 23,18 & 20,93 & 18,27 & 15,90 & 13,82 & 10,48 & 8,11 & 5,30 \\
\hline 29,38 & 1183,90 & 112,10 & 31,98 & 25,35 & 21,16 & 16,52 & 12,99 & 10,38 & 7,08 & 5,30 & 3,58 \\
\hline 80,10 & 1766,10 & 169,80 & 11,58 & 8,41 & 7,53 & 6,73 & 6,10 & 5,53 & 4,56 & 3,78 & 2,67 \\
\hline 20,04 & 1235,90 & 127,70 & 37,29 & 27,57 & 21,18 & 14,99 & 11,05 & 8,56 & 5,86 & 4,52 & 3,13 \\
\hline 26,51 & 1208,40 & 114,30 & 33,69 & 26,41 & 21,65 & 16,51 & 12,75 & 10,07 & 6,82 & 5,13 & 3,50 \\
\hline 33,87 & 1791,30 & 71,90 & 33,23 & 29,26 & 26,25 & 22,46 & 19,09 & 16,21 & 11,83 & 8,92 & 5,76 \\
\hline 51,78 & 1273,60 & 21,40 & 62,70 & 52,49 & 50,69 & 47,65 & 44,41 & 41,24 & 35,27 & 30,02 & 21,81 \\
\hline 71,95 & 1893,70 & 106,50 & 15,45 & 11,95 & 11,08 & 10,14 & 9,31 & 8,54 & 7,16 & 6,01 & 4,31 \\
\hline 61,32 & 445,80 & 78,70 & 37,85 & 26,86 & 22,85 & 19,21 & 16,40 & 14,07 & 10,52 & 8,14 & 5,40 \\
\hline 57,98 & 1132,40 & 190,30 & 15,67 & 11,30 & 9,64 & 8,09 & 6,88 & 5,87 & 4,36 & 3,35 & 2,22 \\
\hline 34,16 & 285,10 & 76,00 & 62,34 & 42,11 & 32,99 & 24,47 & 18,73 & 14,80 & 10,14 & 7,71 & 5,31 \\
\hline 35,51 & 515,50 & 80,60 & 46,90 & 35,01 & 28,92 & 22,58 & 17,84 & 14,34 & 9,87 & 7,41 & 5,00 \\
\hline 58,78 & 1735,30 & 132,80 & 15,61 & 12,48 & 11,29 & 10,00 & 8,89 & 7,88 & 6,21 & 4,95 & 3,33 \\
\hline 88,88 & 1999,30 & 149,00 & 11,20 & 8,07 & 7,33 & 6,69 & 6,16 & 5,69 & 4,85 & 4,15 & 3,07 \\
\hline 78,87 & 1270,80 & 31,20 & 36,38 & 28,68 & 26,85 & 25,72 & 24,46 & 23,17 & 20,68 & 18,39 & 14,46 \\
\hline 33,69 & 1835,60 & 57,70 & 38,23 & 34,29 & 31,10 & 27,00 & 23,26 & 19,98 & 14,83 & 11,28 & 7,27 \\
\hline 29,02 & 1844,70 & 56,40 & 43,90 & 39,08 & 34,92 & 29,61 & 24,91 & 20,94 & 15,03 & 11,24 & 7,26 \\
\hline 69,12 & 263,60 & 118,10 & 41,61 & 23,73 & 18,14 & 14,01 & 11,39 & 9,47 & 6,81 & 5,23 & 3,54 \\
\hline 37,38 & 585,20 & 119,80 & 34,07 & 24,28 & 19,72 & 15,22 & 11,95 & 9,58 & 6,59 & 4,97 & 3,37 \\
\hline 42,19 & 1756,70 & 116,30 & 20,82 & 17,54 & 15,65 & 13,43 & 11,49 & 9,83 & 7,27 & 5,55 & 3,61 \\
\hline 88,29 & 1630,50 & 148,90 & 12,35 & 8,78 & 7,87 & 7,09 & 6,48 & 5,94 & 4,99 & 4,21 & 3,06 \\
\hline 48,07 & 1990,00 & 141,00 & 16,11 & 13,37 & 12,01 & 10,45 & 9,08 & 7,89 & 5,98 & 4,63 & 3,03 \\
\hline 47,49 & 222,30 & 68,10 & 64,47 & 41,84 & 33,36 & 25,89 & 20,64 & 16,76 & 11,70 & 8,85 & 5,99 \\
\hline 69,78 & 595,70 & 138,00 & 23,73 & 15,66 & 12,98 & 10,77 & 9,18 & 7,89 & 5,94 & 4,63 & 3,10 \\
\hline 30,88 & 1335,90 & 102,20 & 31,48 & 25,74 & 21,98 & 17,64 & 14,18 & 11,51 & 7,94 & 5,92 & 3,94 \\
\hline 22,86 & 1397,10 & 147,90 & 29,76 & 22,49 & 17,75 & 12,95 & 9,70 & 7,55 & 5,13 & 3,92 & 2,71 \\
\hline 64,51 & 917,90 & 89,60 & 24,43 & 18,71 & 16,71 & 14,71 & 13,05 & 11,58 & 9,13 & 7,30 & 4,93 \\
\hline 53,66 & 1884,80 & 20,90 & 55,49 & 45,65 & 44,15 & 42,38 & 40,11 & 37,80 & 33,32 & 29,18 & 22,23 \\
\hline 21,35 & 1103,10 & 190,50 & 27,51 & 19,12 & 14,26 & 9,89 & 7,26 & 5,65 & 3,91 & 3,03 & 2,11 \\
\hline 63,18 & 777,40 & 20,10 & 67,01 & 54,04 & 51,64 & 48,57 & 45,37 & 42,25 & 36,41 & 31,26 & 23,08 \\
\hline 54,19 & 275,40 & 37,50 & 74,45 & 56,11 & 48,58 & 41,11 & 35,05 & 29,97 & 22,25 & 17,10 & 11,26 \\
\hline 37,78 & 303,50 & 192,40 & 35,13 & 18,96 & 13,55 & 9,51 & 7,17 & 5,67 & 3,92 & 3,02 & 2,12 \\
\hline 20,46 & 1482,30 & 164,20 & 29,14 & 21,44 & 16,45 & 11,64 & 8,59 & 6,66 & 4,56 & 3,51 & 2,44 \\
\hline 84,55 & 818,60 & 139,10 & 18,51 & 12,39 & 10,57 & 9,08 & 8,02 & 7,14 & 5,70 & 4,62 & 3,20 \\
\hline 25,72 & 1245,80 & 85,10 & 41,80 & 33,90 & 28,33 & 22,03 & 17,23 & 13,70 & 9,29 & 6,95 & 4,70 \\
\hline 81,16 & 591,20 & 64,00 & 32,33 & 23,12 & 20,54 & 18,22 & 16,42 & 14,85 & 12,16 & 10,04 & 7,07 \\
\hline 32,79 & 853,40 & 159,40 & 26,52 & 19,15 & 15,41 & 11,66 & 9,01 & 7,15 & 4,88 & 3,69 & 2,53 \\
\hline 38,32 & 356,80 & 76,40 & 53,73 & 37,96 & 30,81 & 23,80 & 18,72 & 15,03 & 10,35 & 7,80 & 5,30 \\
\hline 50,92 & 1514,00 & 198,90 & 14,29 & 10,89 & 9,43 & 7,93 & 6,72 & 5,71 & 4,19 & 3,20 & 2,10 \\
\hline 74,23 & 698,00 & 162,90 & 19,77 & 12,89 & 10,67 & 8,88 & 7,61 & 6,58 & 5,01 & 3,93 & 2,65 \\
\hline 69,17 & 329,00 & 68,50 & 45,16 & 30,47 & 25,54 & 21,38 & 18,33 & 15,82 & 11,97 & 9,35 & 6,26 \\
\hline 70,02 & 630,50 & 152,50 & 21,98 & 14,38 & 11,86 & 9,80 & 8,34 & 7,15 & 5,37 & 4,18 & 2,80 \\
\hline 71,16 & 975,70 & 53,30 & 30,72 & 23,84 & 22,14 & 20,29 & 18,63 & 17,10 & 14,33 & 12,03 & 8,61 \\
\hline 45,37 & 1869,80 & 128,80 & 18,14 & 15,17 & 13,58 & 11,75 & 10,15 & 8,75 & 6,56 & 5,05 & 3,29 \\
\hline 28,61 & 499,40 & 107,90 & 44,35 & 30,92 & 24,01 & 17,45 & 13,14 & 10,30 & 7,04 & 5,39 & 3,73 \\
\hline 84,57 & 670,90 & 168,90 & 19,19 & 12,02 & 9,84 & 8,16 & 7,04 & 6,14 & 4,76 & 3,79 & 2,59 \\
\hline 28,82 & 1558,90 & 137,90 & 25,77 & 20,56 & 17,19 & 13,44 & 10,57 & 8,45 & 5,76 & 4,31 & 2,91 \\
\hline 88,08 & 1150,10 & 20,90 & 43,16 & 36,21 & 32,94 & 31,75 & 30,72 & 29,50 & 27,03 & 24,67 & 20,37 \\
\hline 24,25 & 1003,00 & 188,80 & 26,51 & 18,57 & 14,13 & 10,01 & 7,43 & 5,79 & 3,98 & 3,06 & 2,13 \\
\hline 33,64 & 1683,10 & 100,00 & 27,60 & 23,39 & 20,52 & 17,08 & 14,16 & 11,78 & 8,35 & 6,24 & 4,08 \\
\hline 85,04 & 1425,00 & 57,20 & 22,91 & 17,37 & 16,13 & 15,19 & 14,29 & 13,42 & 11,79 & 10,34 & 7,95 \\
\hline 39,45 & 1953,40 & 125,90 & 19,99 & 16,90 & 15,01 & 12,77 & 10,83 & 9,19 & 6,71 & 5,08 & 3,30 \\
\hline 23,79 & 329,00 & 180,10 & 38,69 & 21,48 & 14,85 & 9,99 & 7,41 & 5,86 & 4,11 & 3,20 & 2,25 \\
\hline 62,54 & 1646,60 & 138,30 & 15,07 & 11,79 & 10,63 & 9,42 & 8,39 & 7,46 & 5,92 & 4,74 & 3,21 \\
\hline 81,04 & 248,00 & 109,30 & 43,16 & 24,24 & 18,49 & 14,39 & 11,86 & 10,00 & 7,36 & 5,72 & 3,89 \\
\hline 89,49 & 934,00 & 62,30 & 25,38 & 18,43 & 16,80 & 15,44 & 14,30 & 13,26 & 11,40 & 9,81 & 7,33 \\
\hline 20,45 & 1170,40 & 179,40 & 29,01 & 20,36 & 15,20 & 10,52 & 7,71 & 6,00 & 4,15 & 3,21 & 2,24 \\
\hline 35,23 & 1875,70 & 130,60 & 21,58 & 18,02 & 15,75 & 13,07 & 10,82 & 8,99 & 6,38 & 4,77 & 3,12 \\
\hline 78,23 & 1260,70 & 63,30 & 23,78 & 18,08 & 16,82 & 15,58 & 14,46 & 13,41 & 11,49 & 9,83 & 7,26 \\
\hline 55,87 & 692,20 & 76,10 & 32,73 & 25,36 & 22,33 & 19,25 & 16,68 & 14,46 & 10,97 & 8,53 & 5,63 \\
\hline 76,73 & 1901,30 & 115,60 & 14,21 & 10,76 & 9,93 & 9,10 & 8,37 & 7,70 & 6,49 & 5,49 & 3,97 \\
\hline 86,65 & 691,60 & 152,90 & 19,46 & 12,41 & 10,30 & 8,66 & 7,54 & 6,64 & 5,21 & 4,19 & 2,88 \\
\hline
\end{tabular}




\begin{tabular}{|c|c|c|c|c|c|c|c|c|c|c|c|}
\hline \multirow[b]{2}{*}{ e1 (cm) } & & & & & & & ões (x1 & m) & & & \\
\hline & Meq (MPa) & Ms (MPa) & D0 & D25 & D40 & D60 & D80 & D100 & D140 & D180 & D260 \\
\hline 53,50 & 650,60 & 29,70 & 60,65 & 50,96 & 47,26 & 42,64 & 38,39 & 34,45 & 27,66 & 22,33 & 15,13 \\
\hline 74,11 & 827,60 & 173,60 & 17,46 & 11,62 & 9,72 & 8,17 & 7,05 & 6,13 & 4,70 & 3,70 & 2,50 \\
\hline 67,56 & 1736,90 & 184,50 & 12,05 & 9,05 & 8,04 & 7,07 & 6,27 & 5,57 & 4,41 & 3,54 & 2,40 \\
\hline 87,92 & 216,30 & 154,80 & 43,03 & 21,53 & 15,22 & 11,03 & 8,71 & 7,15 & 5,12 & 3,96 & 2,73 \\
\hline 31,65 & 1723,10 & 35,30 & 57,09 & 52,38 & 48,13 & 42,41 & 37,05 & 32,22 & 24,36 & 18,73 & 12,09 \\
\hline 80,69 & 633,30 & 140,70 & 21,66 & 14,02 & 11,65 & 9,77 & 8,46 & 7,40 & 5,74 & 4,57 & 3,11 \\
\hline 76,94 & 1991,60 & 158,30 & 11,61 & 8,65 & 7,86 & 7,09 & 6,45 & 5,88 & 4,87 & 4,06 & 2,88 \\
\hline 74,63 & 1174,60 & 75,50 & 22,57 & 17,17 & 15,80 & 14,40 & 13,19 & 12,08 & 10,11 & 8,47 & 6,06 \\
\hline 85,29 & 1151,60 & 23,70 & 41,60 & 33,83 & 31,10 & 29,97 & 28,82 & 27,54 & 25,02 & 22,64 & 18,38 \\
\hline 78,11 & 828,40 & 147,80 & 18,39 & 12,45 & 10,58 & 9,03 & 7,91 & 6,97 & 5,46 & 4,37 & 2,98 \\
\hline 41,63 & 775,40 & 87,60 & 34,39 & 27,08 & 23,34 & 19,26 & 15,94 & 13,26 & 9,45 & 7,11 & 4,68 \\
\hline 64,66 & 300,80 & 77,60 & 46,08 & 30,11 & 24,68 & 20,16 & 16,92 & 14,35 & 10,57 & 8,14 & 5,43 \\
\hline 71,10 & 1920,30 & 198,50 & 10,80 & 8,04 & 7,16 & 6,33 & 5,65 & 5,06 & 4,05 & 3,28 & 2,25 \\
\hline 23,85 & 1857,00 & 104,10 & 34,04 & 27,89 & 23,32 & 18,11 & 14,13 & 11,21 & 7,58 & 5,66 & 3,84 \\
\hline 80,99 & 577,30 & 122,20 & 24,21 & 15,79 & 13,19 & 11,11 & 9,65 & 8,47 & 6,59 & 5,26 & 3,59 \\
\hline 26,02 & 1647,40 & 152,10 & 25,45 & 19,96 & 16,34 & 12,43 & 9,58 & 7,55 & 5,12 & 3,85 & 2,63 \\
\hline 89,51 & 1032,90 & 112,60 & 17,71 & 12,34 & 10,92 & 9,72 & 8,82 & 8,04 & 6,69 & 5,61 & 4,03 \\
\hline 52,34 & 444,30 & 197,30 & 26,36 & 15,48 & 11,84 & 8,96 & 7,08 & 5,73 & 4,00 & 3,04 & 2,08 \\
\hline 31,90 & 1998,20 & 23,90 & 70,92 & 65,52 & 61,67 & 55,85 & 50,15 & 44,78 & 35,44 & 28,15 & 18,58 \\
\hline 26,41 & 1147,10 & 153,80 & 27,97 & 20,90 & 16,66 & 12,34 & 9,36 & 7,33 & 4,98 & 3,78 & 2,61 \\
\hline 52,30 & 1834,00 & 162,60 & 14,51 & 11,65 & 10,37 & 9,00 & 7,82 & 6,79 & 5,16 & 4,01 & 2,64 \\
\hline 52,39 & 1790,40 & 177,30 & 13,93 & 11,03 & 9,75 & 8,40 & 7,26 & 6,27 & 4,73 & 3,66 & 2,40 \\
\hline 37,50 & 1056,70 & 110,10 & 28,43 & 22,62 & 19,39 & 15,80 & 12,91 & 10,62 & 7,46 & 5,58 & 3,69 \\
\hline 40,90 & 1243,70 & 37,10 & 50,30 & 44,83 & 41,54 & 37,15 & 33,01 & 29,21 & 22,81 & 17,97 & 11,83 \\
\hline 60,79 & 1651,50 & 102,70 & 18,24 & 14,68 & 13,47 & 12,11 & 10,90 & 9,80 & 7,90 & 6,40 & 4,38 \\
\hline 64,59 & 1579,40 & 39,20 & 33,39 & 26,80 & 25,61 & 24,18 & 22,65 & 21,16 & 18,34 & 15,83 & 11,80 \\
\hline 84,72 & 660,60 & 116,60 & 22,54 & 14,99 & 12,74 & 10,92 & 9,63 & 8,55 & 6,81 & 5,51 & 3,81 \\
\hline 37,64 & 1477,90 & 39,90 & 48,13 & 43,39 & 40,08 & 35,65 & 31,48 & 27,68 & 21,36 & 16,67 & 10,88 \\
\hline 49,93 & 731,60 & 160,20 & 22,74 & 15,83 & 13,10 & 10,56 & 8,65 & 7,16 & 5,09 & 3,85 & 2,57 \\
\hline 79,32 & 644,00 & 90,80 & 26,26 & 18,32 & 15,92 & 13,86 & 12,30 & 10,97 & 8,78 & 7,12 & 4,91 \\
\hline 28,60 & 1696,20 & 66,70 & 40,92 & 35,58 & 31,31 & 26,01 & 21,49 & 17,79 & 12,52 & 9,31 & 6,07 \\
\hline 39,94 & 1868,60 & 122,40 & 20,50 & 17,30 & 15,37 & 13,09 & 11,11 & 9,44 & 6,90 & 5,23 & 3,40 \\
\hline 23,48 & 1795,60 & 32,90 & 76,51 & 69,06 & 61,64 & 52,00 & 43,45 & 36,26 & 25,72 & 19,10 & 12,33 \\
\hline 75,90 & 1723,10 & 77,90 & 18,86 & 14,49 & 13,55 & 12,60 & 11,71 & 10,87 & 9,33 & 7,99 & 5,91 \\
\hline 78,79 & 1732,10 & 166,00 & 11,91 & 8,69 & 7,79 & 6,96 & 6,29 & 5,70 & 4,68 & 3,88 & 2,73 \\
\hline 32,97 & 1339,20 & 86,10 & 33,47 & 28,08 & 24,46 & 20,16 & 16,58 & 13,69 & 9,63 & 7,18 & 4,71 \\
\hline 40,55 & 1702,10 & 199,00 & 15,62 & 12,23 & 10,49 & 8,60 & 7,07 & 5,85 & 4,14 & 3,11 & 2,05 \\
\hline 86,03 & 1559,50 & 35,40 & 28,88 & 23,19 & 21,35 & 20,54 & 19,70 & 18,79 & 17,01 & 15,35 & 12,39 \\
\hline 67,52 & 996,80 & 28,80 & 46,56 & 37,02 & 35,22 & 33,15 & 31,00 & 28,93 & 25,03 & 21,59 & 16,08 \\
\hline 58,67 & 1362,10 & 74,40 & 24,45 & 19,97 & 18,44 & 16,63 & 15,01 & 13,51 & 10,91 & 8,86 & 6,06 \\
\hline 59,25 & 995,50 & 195,60 & 16,33 & 11,41 & 9,60 & 7,97 & 6,73 & 5,72 & 4,22 & 3,24 & 2,15 \\
\hline 34,09 & 546,20 & 187,60 & 27,97 & 17,85 & 13,62 & 9,90 & 7,50 & 5,92 & 4,06 & 3,11 & 2,16 \\
\hline 88,64 & 1840,80 & 170,10 & 10,86 & 7,70 & 6,90 & 6,21 & 5,67 & 5,20 & 4,37 & 3,69 & 2,68 \\
\hline 81,38 & 636,30 & 167,10 & 20,12 & 12,60 & 10,27 & 8,48 & 7,27 & 6,31 & 4,84 & 3,83 & 2,60 \\
\hline 82,30 & 1181,50 & 33,80 & 34,56 & 26,93 & 25,11 & 23,96 & 22,74 & 21,51 & 19,16 & 17,01 & 13,34 \\
\hline 74,37 & 744,40 & 34,10 & 43,83 & 33,82 & 31,64 & 29,35 & 27,22 & 25,22 & 21,56 & 18,40 & 13,52 \\
\hline 47,12 & 907,60 & 23,70 & 68,48 & 59,54 & 56,24 & 51,40 & 46,73 & 42,31 & 34,46 & 28,09 & 19,19 \\
\hline 32,89 & 1729,30 & 142,10 & 22,16 & 18,06 & 15,48 & 12,52 & 10,14 & 8,27 & 5,75 & 4,29 & 2,84 \\
\hline 75,21 & 538,50 & 136,00 & 24,71 & 15,82 & 12,98 & 10,73 & 9,16 & 7,90 & 5,99 & 4,70 & 3,17 \\
\hline 55,43 & 610,10 & 52,10 & 43,06 & 34,42 & 30,83 & 26,98 & 23,67 & 20,75 & 16,01 & 12,57 & 8,34 \\
\hline 81,35 & 1657,10 & 125,60 & 13,95 & 10,27 & 9,35 & 8,49 & 7,77 & 7,13 & 5,99 & 5,04 & 3,64 \\
\hline 51,84 & 579,30 & 83,60 & 35,13 & 26,34 & 22,65 & 18,98 & 16,02 & 13,58 & 9,96 & 7,60 & 5,00 \\
\hline 27,82 & 1535,70 & 74,70 & 40,15 & 34,10 & 29,52 & 24,01 & 19,47 & 15,88 & 10,99 & 8,16 & 5,39 \\
\hline 47,60 & 272,90 & 183,30 & 36,84 & 19,38 & 13,89 & 9,91 & 7,58 & 6,04 & 4,17 & 3,20 & 2,24 \\
\hline 53,35 & 1236,90 & 101,70 & 22,22 & 17,94 & 16,07 & 14,04 & 12,28 & 10,73 & 8,23 & 6,44 & 4,25 \\
\hline 54,07 & 1697,50 & 95,10 & 20,26 & 16,83 & 15,45 & 13,81 & 12,33 & 10,98 & 8,70 & 6,96 & 4,67 \\
\hline 29,22 & 1859,80 & 192,70 & 19,24 & 15,06 & 12,48 & 9,66 & 7,55 & 6,01 & 4,09 & 3,07 & 2,08 \\
\hline 60,02 & 1815,60 & 163,20 & 13,44 & 10,54 & 9,44 & 8,30 & 7,33 & 6,48 & 5,06 & 4,02 & 2,69 \\
\hline 78,00 & 1150,20 & 149,40 & 15,40 & 10,91 & 9,55 & 8,35 & 7,44 & 6,65 & 5,33 & 4,33 & 2,99 \\
\hline 46,40 & 1589,90 & 56,20 & 32,15 & 27,99 & 26,02 & 23,41 & 20,97 & 18,71 & 14,85 & 11,85 & 7,91 \\
\hline 68,38 & 384,10 & 160,40 & 29,34 & 17,04 & 13,15 & 10,24 & 8,36 & 6,97 & 5,03 & 3,86 & 2,61 \\
\hline 69,28 & 1927,80 & 173,80 & 11,74 & 8,91 & 8,02 & 7,13 & 6,39 & 5,74 & 4,62 & 3,75 & 2,58 \\
\hline 54,82 & 995,40 & 136,00 & 20,42 & 15,36 & 13,30 & 11,27 & 9,62 & 8,23 & 6,13 & 4,71 & 3,11 \\
\hline 69,47 & 1114,80 & 84,70 & 22,36 & 17,18 & 15,64 & 14,05 & 12,71 & 11,48 & 9,37 & 7,69 & 5,34 \\
\hline 85,28 & 967,80 & 133,70 & 17,17 & 11,79 & 10,25 & 8,96 & 8,01 & 7,20 & 5,84 & 4,80 & 3,36 \\
\hline 67,41 & 1533,30 & 101,20 & 17,93 & 14,01 & 12,86 & 11,62 & 10,54 & 9,55 & 7,82 & 6,44 & 4,49 \\
\hline 49,71 & 1930,50 & 100,40 & 19,68 & 16,67 & 15,27 & 13,58 & 12,05 & 10,66 & 8,33 & 6,59 & 4,37 \\
\hline 65,62 & 704,60 & 77,70 & 29,52 & 22,21 & 19,67 & 17,21 & 15,20 & 13,43 & 10,54 & 8,40 & 5,66 \\
\hline 63,90 & 386,60 & 155,80 & 30,00 & 17,71 & 13,75 & 10,71 & 8,71 & 7,22 & 5,17 & 3,95 & 2,67 \\
\hline 86,85 & 1501,70 & 125,30 & 14,17 & 10,19 & 9,20 & 8,33 & 7,63 & 7,01 & 5,91 & 5,00 & 3,64 \\
\hline 77,30 & 1531,40 & 191,20 & 11,84 & 8,44 & 7,42 & 6,50 & 5,80 & 5,18 & 4,16 & 3,39 & 2,34 \\
\hline 37,03 & 471,70 & 82,20 & 46,82 & 34,35 & 28,27 & 22,07 & 17,46 & 14,05 & 9,68 & 7,28 & 4,92 \\
\hline 51,62 & 1839,20 & 138,40 & 16,06 & 13,15 & 11,82 & 10,34 & 9,05 & 7,90 & 6,06 & 4,74 & 3,12 \\
\hline 24,61 & 373,80 & 195,70 & 34,81 & 19,63 & 13,69 & 9,25 & 6,85 & 5,41 & 3,79 & 2,95 & 2,07 \\
\hline 44,78 & 700,70 & 131,70 & 27,19 & 19,62 & 16,36 & 13,13 & 10,67 & 8,77 & 6,17 & 4,65 & 3,10 \\
\hline 43,47 & 879,80 & 136,30 & 24,53 & 18,35 & 15,51 & 12,59 & 10,29 & 8,50 & 6,00 & 4,52 & 3,00 \\
\hline 20,17 & 435,60 & 183,60 & 36,80 & 21,32 & 14,66 & 9,77 & 7,22 & 5,71 & 4,03 & 3,14 & 2,20 \\
\hline 56,68 & 409,50 & 51,80 & 50,84 & 38,54 & 33,61 & 28,74 & 24,75 & 21,36 & 16,09 & 12,47 & 8,24 \\
\hline 45,35 & 661,60 & 126,30 & 28,36 & 20,39 & 16,99 & 13,65 & 11,11 & 9,14 & 6,44 & 4,85 & 3,24 \\
\hline 42,94 & 1713,20 & 197,80 & 15,06 & 11,82 & 10,20 & 8,45 & 7,02 & 5,86 & 4,19 & 3,16 & 2,08 \\
\hline 74,11 & 1206,10 & 151,60 & 15,24 & 10,98 & 9,64 & 8,43 & 7,48 & 6,66 & 5,30 & 4,28 & 2,93 \\
\hline 80,90 & 1779,70 & 41,20 & 26,35 & 20,92 & 19,48 & 18,71 & 17,86 & 16,97 & 15,24 & 13,63 & 10,83 \\
\hline
\end{tabular}




\begin{tabular}{|c|c|c|c|c|c|c|c|c|c|c|c|}
\hline \multirow[b]{2}{*}{ e1 (cm) } & & & & & & & ões (x1 & m) & & & \\
\hline & Meq (MPa) & Ms (MPa) & D0 & D25 & D40 & D60 & D80 & D100 & D140 & D180 & D260 \\
\hline 31,27 & 460,00 & 33,00 & 94,41 & 77,86 & 66,87 & 54,09 & 43,75 & 35,66 & 24,72 & 18,41 & 12,20 \\
\hline 74,54 & 1361,70 & 151,40 & 14,35 & 10,46 & 9,28 & 8,18 & 7,31 & 6,55 & 5,27 & 4,29 & 2,96 \\
\hline 75,44 & 1782,50 & 162,80 & 12,11 & 8,98 & 8,08 & 7,22 & 6,52 & 5,90 & 4,82 & 3,97 & 2,78 \\
\hline 42,32 & 1172,20 & 99,50 & 26,73 & 21,88 & 19,24 & 16,25 & 13,72 & 11,60 & 8,44 & 6,39 & 4,17 \\
\hline 51,42 & 1698,00 & 35,10 & 40,76 & 34,44 & 33,05 & 30,77 & 28,47 & 26,24 & 22,11 & 18,57 & 13,22 \\
\hline 45,87 & 1924,60 & 110,50 & 19,58 & 16,63 & 15,06 & 13,19 & 11,52 & 10,04 & 7,65 & 5,94 & 3,89 \\
\hline 84,31 & 1336,40 & 42,10 & 28,35 & 21,91 & 20,37 & 19,39 & 18,37 & 17,36 & 15,44 & 13,68 & 10,71 \\
\hline 40,49 & 920,70 & 68,40 & 38,09 & 31,70 & 27,99 & 23,69 & 20,01 & 16,92 & 12,30 & 9,30 & 6,06 \\
\hline 46,24 & 1912,30 & 46,80 & 34,42 & 30,03 & 28,41 & 25,99 & 23,64 & 21,42 & 17,46 & 14,23 & 9,73 \\
\hline 39,28 & 956,00 & 165,60 & 22,42 & 16,47 & 13,66 & 10,78 & 8,62 & 6,99 & 4,85 & 3,64 & 2,45 \\
\hline 51,81 & 927,40 & 135,40 & 21,81 & 16,32 & 14,02 & 11,73 & 9,90 & 8,39 & 6,14 & 4,69 & 3,09 \\
\hline 51,47 & 1340,30 & 166,00 & 16,57 & 12,74 & 11,08 & 9,38 & 7,98 & 6,81 & 5,03 & 3,86 & 2,53 \\
\hline 47,04 & 1323,20 & 143,80 & 19,08 & 15,05 & 13,14 & 11,09 & 9,38 & 7,95 & 5,82 & 4,43 & 2,90 \\
\hline 54,87 & 1229,40 & 114,20 & 20,48 & 16,25 & 14,46 & 12,58 & 10,97 & 9,57 & 7,32 & 5,72 & 3,78 \\
\hline 61,67 & 974,50 & 54,50 & 32,72 & 26,37 & 24,38 & 22,05 & 19,98 & 18,06 & 14,71 & 12,03 & 8,31 \\
\hline 79,64 & 527,10 & 185,90 & 21,93 & 12,97 & 10,20 & 8,16 & 6,83 & 5,83 & 4,35 & 3,40 & 2,30 \\
\hline 82,68 & 1383,30 & 31,40 & 33,66 & 26,85 & 24,90 & 23,94 & 22,90 & 21,79 & 19,64 & 17,63 & 14,10 \\
\hline 30,24 & 504,90 & 148,10 & 34,99 & 23,06 & 17,56 & 12,62 & 9,49 & 7,44 & 5,11 & 3,92 & 2,72 \\
\hline 22,72 & 1604,90 & 92,60 & 40,07 & 32,48 & 26,85 & 20,56 & 15,87 & 12,50 & 8,43 & 6,32 & 4,31 \\
\hline 89,56 & 1433,80 & 90,30 & 17,06 & 12,44 & 11,37 & 10,48 & 9,73 & 9,04 & 7,80 & 6,74 & 5,05 \\
\hline 75,54 & 771,00 & 148,20 & 19,35 & 13,02 & 11,00 & 9,32 & 8,10 & 7,08 & 5,48 & 4,35 & 2,94 \\
\hline 88,63 & 1680,40 & 127,30 & 13,22 & 9,53 & 8,64 & 7,88 & 7,25 & 6,70 & 5,70 & 4,87 & 3,59 \\
\hline 42,77 & 321,70 & 126,20 & 40,82 & 25,09 & 19,30 & 14,40 & 11,17 & 8,92 & 6,15 & 4,68 & 3,22 \\
\hline 38,46 & 774,90 & 185,60 & 23,12 & 15,98 & 12,83 & 9,83 & 7,69 & 6,16 & 4,24 & 3,20 & 2,18 \\
\hline 37,81 & 657,50 & 48,10 & 56,59 & 47,13 & 41,37 & 34,65 & 28,96 & 24,26 & 17,40 & 13,08 & 8,53 \\
\hline 64,85 & 660,80 & 118,10 & 24,77 & 17,38 & 14,78 & 12,47 & 10,71 & 9,25 & 6,99 & 5,44 & 3,63 \\
\hline 64,96 & 974,20 & 135,10 & 19,03 & 13,91 & 12,10 & 10,41 & 9,07 & 7,93 & 6,10 & 4,80 & 3,21 \\
\hline 72,67 & 1815,10 & 62,20 & 21,86 & 17,09 & 16,14 & 15,16 & 14,17 & 13,23 & 11,47 & 9,91 & 7,41 \\
\hline 47,07 & 360,00 & 129,90 & 36,86 & 23,01 & 17,99 & 13,73 & 10,83 & 8,74 & 6,07 & 4,60 & 3,14 \\
\hline 48,37 & 409,50 & 100,60 & 38,86 & 26,46 & 21,62 & 17,17 & 13,90 & 11,41 & 8,04 & 6,07 & 4,07 \\
\hline 26,96 & 846,90 & 52,60 & 63,28 & 52,19 & 44,25 & 35,06 & 27,83 & 22,35 & 15,26 & 11,36 & 7,61 \\
\hline 58,55 & 508,70 & 198,50 & 23,61 & 14,18 & 11,06 & 8,58 & 6,93 & 5,70 & 4,04 & 3,08 & 2,08 \\
\hline 42,50 & 1093,50 & 160,30 & 20,65 & 15,60 & 13,21 & 10,73 & 8,77 & 7,23 & 5,11 & 3,84 & 2,55 \\
\hline 50,66 & 1889,80 & 82,20 & 22,27 & 18,95 & 17,56 & 15,79 & 14,15 & 12,65 & 10,07 & 8,07 & 5,42 \\
\hline 23,19 & 1099,00 & 129,90 & 34,63 & 25,85 & 20,28 & 14,71 & 11,00 & 8,56 & 5,83 & 4,46 & 3,08 \\
\hline 46,24 & 1337,00 & 46,60 & 38,67 & 33,70 & 31,34 & 28,21 & 25,27 & 22,56 & 17,90 & 14,29 & 9,54 \\
\hline 82,92 & 413,70 & 67,40 & 37,59 & 25,43 & 21,79 & 18,79 & 16,61 & 14,78 & 11,79 & 9,56 & 6,61 \\
\hline 23,22 & 630,30 & 186,10 & 31,28 & 20,03 & 14,53 & 9,95 & 7,32 & 5,74 & 4,00 & 3,10 & 2,17 \\
\hline 60,61 & 1390,10 & 35,80 & 38,52 & 31,37 & 29,99 & 28,11 & 26,17 & 24,29 & 20,79 & 17,73 & 12,95 \\
\hline 55,48 & 615,90 & 150,30 & 24,45 & 16,48 & 13,55 & 10,97 & 9,06 & 7,56 & 5,44 & 4,14 & 2,76 \\
\hline 33,32 & 964,00 & 134,60 & 28,00 & 21,23 & 17,54 & 13,64 & 10,73 & 8,59 & 5,89 & 4,42 & 2,99 \\
\hline 25,52 & 1337,30 & 68,10 & 47,92 & 40,05 & 34,10 & 27,12 & 21,56 & 17,33 & 11,82 & 8,78 & 5,88 \\
\hline 20,13 & 1812,80 & 192,00 & 24,89 & 18,36 & 14,08 & 9,96 & 7,34 & 5,69 & 3,90 & 3,00 & 2,08 \\
\hline 55,70 & 1029,70 & 86,70 & 25,66 & 20,53 & 18,41 & 16,13 & 14,17 & 12,44 & 9,62 & 7,57 & 5,02 \\
\hline 69,57 & 246,80 & 152,20 & 40,04 & 21,07 & 15,34 & 11,34 & 8,99 & 7,35 & 5,20 & 3,99 & 2,74 \\
\hline 34,40 & 207,30 & 80,90 & 68,22 & 42,22 & 31,81 & 22,92 & 17,33 & 13,66 & 9,39 & 7,20 & 5,01 \\
\hline 35,41 & 1693,40 & 164,50 & 19,28 & 15,45 & 13,22 & 10,71 & 8,70 & 7,13 & 4,97 & 3,72 & 2,46 \\
\hline 25,37 & 1479,40 & 41,00 & 65,67 & 58,00 & 51,19 & 42,59 & 35,17 & 29,08 & 20,40 & 15,13 & 9,85 \\
\hline 42,54 & 1711,40 & 76,80 & 27,15 & 23,64 & 21,56 & 18,96 & 16,60 & 14,48 & 11,06 & 8,58 & 5,60 \\
\hline 57,12 & 920,90 & 135,10 & 20,81 & 15,40 & 13,28 & 11,24 & 9,61 & 8,24 & 6,16 & 4,75 & 3,14 \\
\hline 36,66 & 1855,60 & 126,20 & 21,49 & 18,03 & 15,85 & 13,27 & 11,08 & 9,27 & 6,64 & 4,98 & 3,25 \\
\hline 67,93 & 1404,80 & 88,00 & 20,11 & 15,72 & 14,48 & 13,13 & 11,94 & 10,85 & 8,94 & 7,39 & 5,18 \\
\hline 53,56 & 1521,00 & 176,00 & 14,83 & 11,47 & 10,04 & 8,58 & 7,37 & 6,34 & 4,75 & 3,67 & 2,41 \\
\hline 58,94 & 1417,40 & 177,70 & 14,46 & 10,91 & 9,54 & 8,19 & 7,10 & 6,16 & 4,68 & 3,65 & 2,42 \\
\hline 47,19 & 1344,90 & 125,50 & 20,48 & 16,49 & 14,54 & 12,41 & 10,59 & 9,05 & 6,70 & 5,12 & 3,35 \\
\hline 29,80 & 483,20 & 57,70 & 66,48 & 51,16 & 42,06 & 32,33 & 25,16 & 19,99 & 13,61 & 10,23 & 6,96 \\
\hline 36,60 & 213,80 & 116,10 & 54,23 & 30,68 & 22,35 & 15,83 & 11,94 & 9,43 & 6,51 & 5,01 & 3,51 \\
\hline 29,64 & 1273,60 & 55,60 & 49,37 & 42,68 & 37,51 & 31,15 & 25,74 & 21,31 & 15,01 & 11,17 & 7,29 \\
\hline 84,61 & 857,90 & 195,10 & 15,62 & 9,97 & 8,25 & 6,91 & 6,00 & 5,26 & 4,11 & 3,29 & 2,25 \\
\hline 40,38 & 1602,30 & 171,30 & 17,55 & 13,93 & 12,02 & 9,91 & 8,18 & 6,80 & 4,83 & 3,63 & 2,39 \\
\hline 43,82 & 538,70 & 49,00 & 54,49 & 44,18 & 38,81 & 32,81 & 27,73 & 23,48 & 17,14 & 13,00 & 8,49 \\
\hline 32,80 & 875,30 & 41,60 & 62,58 & 54,16 & 47,97 & 40,37 & 33,79 & 28,31 & 20,26 & 15,17 & 9,85 \\
\hline 67,11 & 291,40 & 29,30 & 74,29 & 56,20 & 50,15 & 44,20 & 39,31 & 34,99 & 27,77 & 22,32 & 15,16 \\
\hline 56,50 & 1217,00 & 149,00 & 17,44 & 13,29 & 11,62 & 9,95 & 8,58 & 7,42 & 5,60 & 4,34 & 2,87 \\
\hline 83,89 & 1705,60 & 21,30 & 37,24 & 33,14 & 29,97 & 28,92 & 28,20 & 27,25 & 25,21 & 23,21 & 19,49 \\
\hline 44,91 & 1914,70 & 58,40 & 30,14 & 26,47 & 24,72 & 22,32 & 20,05 & 17,93 & 14,29 & 11,43 & 7,65 \\
\hline 82,97 & 1064,70 & 39,70 & 32,51 & 24,83 & 23,15 & 21,84 & 20,56 & 19,32 & 16,99 & 14,90 & 11,45 \\
\hline 28,39 & 601,00 & 62,70 & 60,41 & 47,12 & 38,82 & 29,83 & 23,19 & 18,40 & 12,50 & 9,39 & 6,39 \\
\hline 59,33 & 1092,20 & 136,80 & 18,71 & 14,11 & 12,33 & 10,60 & 9,19 & 7,98 & 6,07 & 4,74 & 3,14 \\
\hline 40,52 & 1925,60 & 117,00 & 20,63 & 17,55 & 15,68 & 13,45 & 11,49 & 9,81 & 7,24 & 5,51 & 3,58 \\
\hline 77,60 & 746,30 & 104,60 & 22,91 & 16,09 & 13,99 & 12,17 & 10,79 & 9,61 & 7,65 & 6,19 & 4,25 \\
\hline 65,32 & 1820,40 & 65,90 & 22,41 & 17,94 & 16,97 & 15,76 & 14,59 & 13,48 & 11,44 & 9,69 & 7,01 \\
\hline 28,96 & 1103,10 & 89,30 & 38,50 & 31,07 & 26,16 & 20,62 & 16,32 & 13,10 & 8,95 & 6,68 & 4,49 \\
\hline 43,84 & 790,80 & 187,90 & 21,40 & 14,76 & 12,02 & 9,42 & 7,53 & 6,12 & 4,26 & 3,21 & 2,16 \\
\hline 85,96 & 1099,40 & 96,90 & 18,89 & 13,56 & 12,20 & 11,00 & 10,05 & 9,21 & 7,72 & 6,51 & 4,71 \\
\hline 63,81 & 1474,50 & 70,00 & 23,54 & 18,90 & 17,65 & 16,15 & 14,77 & 13,49 & 11,19 & 9,30 & 6,55 \\
\hline 37,52 & 589,30 & 138,70 & 31,08 & 21,55 & 17,29 & 13,20 & 10,30 & 8,23 & 5,65 & 4,27 & 2,91 \\
\hline 68,49 & 581,00 & 128,30 & 25,01 & 16,72 & 13,93 & 11,59 & 9,89 & 8,50 & 6,40 & 4,98 & 3,33 \\
\hline 86,30 & 804,40 & 132,80 & 18,95 & 12,67 & 10,83 & 9,34 & 8,27 & 7,38 & 5,93 & 4,83 & 3,36 \\
\hline 62,48 & 1030,30 & 62,20 & 29,33 & 23,48 & 21,62 & 19,51 & 17,64 & 15,92 & 12,93 & 10,55 & 7,27 \\
\hline 66,18 & 578,00 & 154,20 & 23,44 & 15,16 & 12,38 & 10,10 & 8,48 & 7,20 & 5,31 & 4,10 & 2,74 \\
\hline 66,82 & 1311,00 & 174,90 & 14,24 & 10,41 & 9,09 & 7,86 & 6,89 & 6,05 & 4,70 & 3,72 & 2,50 \\
\hline
\end{tabular}




\begin{tabular}{|c|c|c|c|c|c|c|c|c|c|c|c|}
\hline & & & \multicolumn{9}{|c|}{ Deflexões $\left(\times 10^{-4} \mathrm{~cm}\right)$} \\
\hline e1 (cm) & Meq (MPa) & Ms (MPa) & D0 & D25 & D40 & D60 & D80 & D100 & D140 & D180 & D260 \\
\hline 89,56 & 1285,10 & 120,50 & 15,37 & 10,85 & 9,71 & 8,74 & 7,98 & 7,31 & 6,15 & 5,20 & 3,78 \\
\hline 67,31 & 1805,90 & 101,30 & 16,82 & 13,24 & 12,27 & 11,18 & 10,21 & 9,31 & 7,71 & 6,40 & 4,51 \\
\hline 68,55 & 843,10 & 125,80 & 20,69 & 14,81 & 12,80 & 11,00 & 9,61 & 8,42 & 6,52 & 5,15 & 3,46 \\
\hline 87,15 & 1301,70 & 134,40 & 14,60 & 10,30 & 9,16 & 8,18 & 7,43 & 6,77 & 5,63 & 4,71 & 3,38 \\
\hline 23,61 & 282,90 & 32,00 & 137,18 & 103,32 & 81,64 & 59,69 & 44,83 & 34,94 & 23,73 & 18,10 & 12,51 \\
\hline 29,10 & 1322,40 & 149,50 & 25,59 & 19,79 & 16,27 & 12,50 & 9,71 & 7,71 & 5,24 & 3,94 & 2,68 \\
\hline 27,53 & 255,00 & 23,00 & 160,41 & 127,01 & 105,22 & 81,26 & 63,32 & 50,28 & 34,15 & 25,61 & 17,38 \\
\hline 31,37 & 1006,80 & 181,80 & 23,55 & 17,07 & 13,68 & 10,28 & 7,90 & 6,25 & 4,26 & 3,23 & 2,21 \\
\hline 62,11 & 674,70 & 93,10 & 28,14 & 20,76 & 18,04 & 15,47 & 13,41 & 11,66 & 8,90 & 6,96 & 4,63 \\
\hline 51,15 & 277,90 & 166,40 & 37,47 & 20,31 & 14,85 & 10,82 & 8,38 & 6,71 & 4,65 & 3,56 & 2,46 \\
\hline 88,93 & 1481,30 & 105,20 & 15,51 & 11,22 & 10,21 & 9,34 & 8,63 & 7,98 & 6,83 & 5,85 & 4,34 \\
\hline 77,81 & 249,10 & 91,10 & 46,06 & 27,12 & 21,25 & 16,90 & 14,10 & 11,97 & 8,89 & 6,91 & 4,67 \\
\hline 78,85 & 1655,70 & 88,30 & 17,39 & 13,16 & 12,21 & 11,28 & 10,45 & 9,68 & 8,27 & 7,07 & 5,21 \\
\hline 59,58 & 354,80 & 163,00 & 31,60 & 18,18 & 13,86 & 10,57 & 8,46 & 6,92 & 4,89 & 3,73 & 2,53 \\
\hline 51,18 & 1658,30 & 69,00 & 25,96 & 22,08 & 20,51 & 18,51 & 16,65 & 14,92 & 11,95 & 9,62 & 6,49 \\
\hline 42,78 & 1483,60 & 25,40 & 60,11 & 52,93 & 50,53 & 46,55 & 42,60 & 38,81 & 31,94 & 26,24 & 18,07 \\
\hline 40,71 & 1614,10 & 195,60 & 16,08 & 12,53 & 10,72 & 8,77 & 7,20 & 5,95 & 4,21 & 3,16 & 2,09 \\
\hline 22,80 & 339,90 & 58,30 & 86,50 & 60,92 & 46,13 & 32,46 & 23,97 & 18,65 & 12,84 & 9,90 & 6,88 \\
\hline 42,86 & 352,50 & 93,70 & 45,63 & 30,75 & 24,72 & 19,12 & 15,13 & 12,21 & 8,46 & 6,39 & 4,33 \\
\hline 85,12 & 1645,20 & 65,00 & 20,01 & 15,19 & 14,10 & 13,29 & 12,51 & 11,75 & 10,34 & 9,08 & 6,99 \\
\hline 82,75 & 1311,10 & 69,90 & 21,40 & 16,02 & 14,82 & 13,73 & 12,76 & 11,86 & 10,22 & 8,79 & 6,56 \\
\hline 41,95 & 1357,60 & 191,40 & 17,15 & 13,04 & 11,07 & 8,99 & 7,35 & 6,06 & 4,28 & 3,22 & 2,13 \\
\hline 87,30 & 1054,20 & 153,60 & 15,24 & 10,34 & 8,94 & 7,79 & 6,95 & 6,24 & 5,07 & 4,17 & 2,93 \\
\hline 45,63 & 1290,10 & 111,40 & 22,84 & 18,61 & 16,45 & 14,04 & 11,98 & 10,23 & 7,56 & 5,77 & 3,76 \\
\hline 44,27 & 379,10 & 103,80 & 41,19 & 27,54 & 22,12 & 17,16 & 13,63 & 11,02 & 7,66 & 5,79 & 3,92 \\
\hline 60,19 & 1725,60 & 67,00 & 23,68 & 19,37 & 18,24 & 16,76 & 15,37 & 14,06 & 11,70 & 9,73 & 6,86 \\
\hline 60,88 & 867,90 & 172,20 & 18,43 & 12,81 & 10,78 & 8,97 & 7,59 & 6,47 & 4,80 & 3,70 & 2,45 \\
\hline 67,94 & 1495,00 & 188,30 & 12,77 & 9,38 & 8,22 & 7,15 & 6,29 & 5,55 & 4,34 & 3,46 & 2,33 \\
\hline 49,55 & 491,30 & 53,80 & 49,52 & 38,88 & 34,03 & 28,91 & 24,64 & 21,03 & 15,56 & 11,90 & 7,80 \\
\hline 47,11 & 350,10 & 36,40 & 73,94 & 58,71 & 51,40 & 43,52 & 36,92 & 31,38 & 23,05 & 17,56 & 11,49 \\
\hline 33,30 & 589,70 & 28,10 & 91,58 & 79,32 & 70,37 & 59,37 & 49,82 & 41,82 & 30,02 & 22,51 & 14,60 \\
\hline 52,27 & 1903,60 & 113,40 & 17,76 & 14,79 & 13,49 & 11,98 & 10,62 & 9,40 & 7,36 & 5,83 & 3,88 \\
\hline 21,03 & 1920,60 & 179,00 & 25,08 & 18,98 & 14,86 & 10,73 & 7,98 & 6,20 & 4,21 & 3,23 & 2,23 \\
\hline 28,49 & 1345,00 & 189,70 & 21,98 & 16,44 & 13,23 & 9,93 & 7,61 & 5,99 & 4,07 & 3,08 & 2,12 \\
\hline 39,40 & 869,00 & 44,60 & 51,92 & 44,88 & 40,36 & 34,84 & 29,92 & 25,66 & 19,04 & 14,52 & 9,42 \\
\hline 64,50 & 1198,10 & 56,60 & 28,90 & 23,13 & 21,62 & 19,80 & 18,14 & 16,58 & 13,79 & 11,48 & 8,11 \\
\hline 40,72 & 484,60 & 68,50 & 48,84 & 37,14 & 31,42 & 25,39 & 20,66 & 16,96 & 11,91 & 8,94 & 5,94 \\
\hline 36,52 & 1499,70 & 45,50 & 44,90 & 40,34 & 36,95 & 32,53 & 28,42 & 24,75 & 18,78 & 14,50 & 9,40 \\
\hline 42,50 & 260,40 & 44,10 & 79,81 & 58,81 & 49,24 & 39,52 & 32,04 & 26,26 & 18,43 & 13,85 & 9,24 \\
\hline 71,05 & 300,10 & 80,50 & 44,04 & 28,13 & 22,94 & 18,80 & 15,90 & 13,59 & 10,16 & 7,90 & 5,30 \\
\hline 58,55 & 1489,80 & 20,10 & 57,44 & 46,86 & 45,08 & 43,29 & 41,01 & 38,69 & 34,19 & 30,02 & 23,02 \\
\hline 60,47 & 1587,80 & 171,50 & 13,81 & 10,59 & 9,37 & 8,15 & 7,14 & 6,25 & 4,83 & 3,81 & 2,54 \\
\hline 21,89 & 1039,20 & 72,60 & 55,51 & 43,80 & 35,42 & 26,44 & 20,06 & 15,66 & 10,57 & 8,00 & 5,50 \\
\hline 63,43 & 1733,60 & 174,60 & 12,83 & 9,82 & 8,75 & 7,68 & 6,79 & 6,00 & 4,71 & 3,75 & 2,52 \\
\hline 62,77 & 1456,60 & 186,40 & 13,49 & 10,04 & 8,78 & 7,58 & 6,61 & 5,77 & 4,44 & 3,49 & 2,33 \\
\hline 76,61 & 285,40 & 42,80 & 58,30 & 40,68 & 35,17 & 30,41 & 26,83 & 23,79 & 18,81 & 15,13 & 10,35 \\
\hline 47,25 & 1525,20 & 166,50 & 16,46 & 12,97 & 11,32 & 9,56 & 8,09 & 6,86 & 5,02 & 3,82 & 2,50 \\
\hline 67,45 & 1059,10 & 170,60 & 15,98 & 11,33 & 9,73 & 8,31 & 7,21 & 6,28 & 4,82 & 3,79 & 2,54 \\
\hline 71,60 & 1954,50 & 98,60 & 16,05 & 12,47 & 11,62 & 10,70 & 9,86 & 9,08 & 7,66 & 6,47 & 4,67 \\
\hline 78,05 & 1714,60 & 188,00 & 11,26 & 8,12 & 7,21 & 6,38 & 5,73 & 5,16 & 4,19 & 3,44 & 2,40 \\
\hline 62,97 & 1366,50 & 39,80 & 35,24 & 28,47 & 27,12 & 25,36 & 23,59 & 21,88 & 18,71 & 15,94 & 11,64 \\
\hline 54,99 & 441,00 & 144,30 & 29,92 & 18,88 & 15,03 & 11,81 & 9,57 & 7,88 & 5,58 & 4,24 & 2,86 \\
\hline 87,98 & 368,50 & 140,60 & 29,94 & 17,15 & 13,30 & 10,55 & 8,84 & 7,57 & 5,71 & 4,49 & 3,07 \\
\hline 22,95 & 288,00 & 94,20 & 63,96 & 40,02 & 28,72 & 19,54 & 14,39 & 11,29 & 7,89 & 6,12 & 4,28 \\
\hline 21,48 & 1200,50 & 105,80 & 41,21 & 31,53 & 24,93 & 18,17 & 13,59 & 10,56 & 7,17 & 5,47 & 3,78 \\
\hline 74,71 & 1180,00 & 159,90 & 14,96 & 10,65 & 9,29 & 8,08 & 7,15 & 6,36 & 5,04 & 4,06 & 2,77 \\
\hline 83,20 & 404,10 & 105,00 & 31,62 & 19,75 & 16,11 & 13,32 & 11,45 & 9,96 & 7,67 & 6,09 & 4,15 \\
\hline 67,77 & 1525,20 & 184,60 & 12,79 & 9,45 & 8,31 & 7,24 & 6,39 & 5,64 & 4,43 & 3,53 & 2,38 \\
\hline 63,46 & 486,40 & 136,80 & 27,62 & 17,76 & 14,41 & 11,66 & 9,71 & 8,18 & 5,97 & 4,59 & 3,06 \\
\hline 43,40 & 425,70 & 163,20 & 31,07 & 19,20 & 14,83 & 11,12 & 8,65 & 6,92 & 4,78 & 3,63 & 2,49 \\
\hline 28,67 & 1143,70 & 24,40 & 91,01 & 83,05 & 75,38 & 65,27 & 55,99 & 47,87 & 35,21 & 26,61 & 17,09 \\
\hline 34,28 & 775,70 & 108,10 & 34,23 & 26,00 & 21,57 & 16,88 & 13,34 & 10,72 & 7,37 & 5,53 & 3,73 \\
\hline 87,02 & 1829,70 & 44,50 & 23,43 & 18,67 & 17,19 & 16,51 & 15,81 & 15,06 & 13,61 & 12,26 & 9,87 \\
\hline 47,84 & 1110,50 & 160,20 & 19,16 & 14,45 & 12,37 & 10,25 & 8,55 & 7,17 & 5,17 & 3,92 & 2,58 \\
\hline 58,79 & 608,60 & 145,60 & 24,41 & 16,41 & 13,54 & 11,05 & 9,21 & 7,75 & 5,64 & 4,31 & 2,87 \\
\hline 74,76 & 601,70 & 100,10 & 26,57 & 18,35 & 15,72 & 13,47 & 11,79 & 10,37 & 8,10 & 6,46 & 4,38 \\
\hline 79,60 & 816,50 & 174,30 & 17,16 & 11,22 & 9,36 & 7,88 & 6,83 & 5,98 & 4,64 & 3,69 & 2,51 \\
\hline 83,77 & 1631,90 & 175,00 & 11,61 & 8,25 & 7,32 & 6,51 & 5,89 & 5,34 & 4,40 & 3,65 & 2,59 \\
\hline 86,50 & 912,80 & 133,50 & 17,63 & 11,98 & 10,36 & 9,02 & 8,04 & 7,22 & 5,85 & 4,80 & 3,36 \\
\hline 53,11 & 1770,90 & 24,90 & 50,21 & 41,55 & 40,23 & 38,20 & 35,87 & 33,56 & 29,13 & 25,15 & 18,69 \\
\hline 39,34 & 1460,10 & 86,50 & 28,26 & 24,11 & 21,51 & 18,40 & 15,67 & 13,34 & 9,79 & 7,43 & 4,82 \\
\hline 68,04 & 1422,80 & 28,10 & 41,62 & 33,30 & 31,70 & 30,35 & 28,74 & 27,12 & 24,00 & 21,13 & 16,30 \\
\hline 39,19 & 920,00 & 38,10 & 56,51 & 49,70 & 45,16 & 39,45 & 34,26 & 29,68 & 22,36 & 17,19 & 11,15 \\
\hline 46,20 & 753,70 & 90,40 & 32,00 & 24,90 & 21,56 & 18,01 & 15,11 & 12,72 & 9,22 & 6,99 & 4,58 \\
\hline 84,15 & 450,60 & 122,60 & 27,78 & 17,17 & 13,92 & 11,46 & 9,83 & 8,54 & 6,57 & 5,21 & 3,55 \\
\hline 81,02 & 558,90 & 85,40 & 28,88 & 19,82 & 17,10 & 14,80 & 13,11 & 11,67 & 9,31 & 7,55 & 5,21 \\
\hline 71,33 & 1524,60 & 60,70 & 23,91 & 18,70 & 17,60 & 16,39 & 15,23 & 14,13 & 12,10 & 10,34 & 7,60 \\
\hline 86,38 & 664,60 & 89,00 & 25,24 & 17,34 & 15,11 & 13,25 & 11,87 & 10,69 & 8,72 & 7,18 & 5,06 \\
\hline 65,53 & 826,10 & 85,90 & 26,01 & 19,71 & 17,53 & 15,39 & 13,63 & 12,08 & 9,52 & 7,61 & 5,14 \\
\hline 72,47 & 1903,80 & 64,70 & 20,99 & 16,42 & 15,51 & 14,57 & 13,63 & 12,72 & 11,02 & 9,53 & 7,13 \\
\hline 78,58 & 1191,50 & 83,80 & 20,59 & 15,38 & 14,07 & 12,80 & 11,73 & 10,75 & 9,02 & 7,59 & 5,46 \\
\hline 24,89 & 762,60 & 97,60 & 45,09 & 33,65 & 26,61 & 19,51 & 14,69 & 11,47 & 7,80 & 5,94 & 4,10 \\
\hline
\end{tabular}




\begin{tabular}{|c|c|c|c|c|c|c|c|c|c|c|c|}
\hline \multirow[b]{2}{*}{ e1 (cm) } & & & & & & & ões (x1 & m) & & & \\
\hline & Meq (MPa) & Ms (MPa) & D0 & D25 & D40 & D60 & D80 & D100 & D140 & D180 & D260 \\
\hline 63,28 & 458,10 & 177,30 & 25,77 & 15,38 & 12,01 & 9,39 & 7,65 & 6,35 & 4,55 & 3,48 & 2,35 \\
\hline 54,24 & 915,20 & 63,50 & 32,88 & 26,90 & 24,37 & 21,54 & 19,04 & 16,81 & 13,11 & 10,37 & 6,90 \\
\hline 53,21 & 1694,40 & 46,90 & 32,63 & 27,53 & 26,16 & 24,14 & 22,17 & 20,29 & 16,87 & 14,01 & 9,83 \\
\hline 25,62 & 1075,40 & 149,90 & 29,58 & 21,90 & 17,29 & 12,68 & 9,56 & 7,47 & 5,08 & 3,87 & 2,67 \\
\hline 27,42 & 1724,60 & 84,50 & 36,00 & 30,50 & 26,33 & 21,34 & 17,25 & 14,03 & 9,69 & 7,19 & 4,76 \\
\hline 20,95 & 654,80 & 138,30 & 40,32 & 26,99 & 19,72 & 13,48 & 9,87 & 7,71 & 5,37 & 4,17 & 2,91 \\
\hline 65,59 & 1325,80 & 108,00 & 18,58 & 14,41 & 13,04 & 11,62 & 10,42 & 9,33 & 7,49 & 6,06 & 4,14 \\
\hline 81,95 & 719,30 & 80,20 & 26,07 & 18,54 & 16,43 & 14,56 & 13,11 & 11,85 & 9,70 & 8,01 & 5,64 \\
\hline 74,25 & 1039,90 & 26,30 & 45,66 & 35,97 & 33,97 & 32,40 & 30,64 & 28,89 & 25,55 & 22,50 & 17,38 \\
\hline 70,87 & 1870,30 & 108,90 & 15,44 & 11,97 & 11,08 & 10,11 & 9,26 & 8,47 & 7,07 & 5,91 & 4,21 \\
\hline 60,04 & 951,40 & 25,80 & 54,73 & 44,70 & 42,68 & 39,87 & 37,03 & 34,29 & 29,21 & 24,80 & 17,99 \\
\hline 64,64 & 809,50 & 143,20 & 20,34 & 14,31 & 12,18 & 10,28 & 8,83 & 7,63 & 5,76 & 4,49 & 2,99 \\
\hline 82,10 & 435,50 & 85,10 & 33,06 & 21,79 & 18,34 & 15,57 & 13,61 & 12,00 & 9,42 & 7,56 & 5,18 \\
\hline 57,22 & 1743,80 & 78,70 & 21,88 & 18,10 & 16,86 & 15,32 & 13,90 & 12,57 & 10,25 & 8,37 & 5,76 \\
\hline 53,53 & 1540,00 & 147,90 & 16,27 & 12,90 & 11,44 & 9,90 & 8,59 & 7,46 & 5,66 & 4,40 & 2,90 \\
\hline 58,77 & 1694,00 & 30,40 & 41,39 & 33,77 & 32,51 & 30,87 & 29,00 & 27,15 & 23,63 & 20,46 & 15,30 \\
\hline 85,58 & 1770,70 & 165,70 & 11,38 & 8,14 & 7,30 & 6,55 & 5,97 & 5,45 & 4,55 & 3,82 & 2,75 \\
\hline 56,03 & 343,30 & 170,90 & 32,07 & 18,17 & 13,69 & 10,29 & 8,13 & 6,60 & 4,62 & 3,52 & 2,41 \\
\hline 30,59 & 1684,20 & 71,60 & 37,02 & 32,18 & 28,44 & 23,81 & 19,82 & 16,51 & 11,73 & 8,75 & 5,69 \\
\hline 46,58 & 684,80 & 156,50 & 24,53 & 17,00 & 13,96 & 11,09 & 8,97 & 7,34 & 5,16 & 3,89 & 2,61 \\
\hline 77,31 & 1021,50 & 63,60 & 25,98 & 19,61 & 18,08 & 16,54 & 15,21 & 13,99 & 11,80 & 9,97 & 7,21 \\
\hline 85,62 & 1646,00 & 51,40 & 22,87 & 17,69 & 16,41 & 15,63 & 14,83 & 14,03 & 12,51 & 11,11 & 8,74 \\
\hline 51,05 & 1514,90 & 88,90 & 22,86 & 19,13 & 17,44 & 15,45 & 13,67 & 12,07 & 9,41 & 7,43 & 4,93 \\
\hline 45,82 & 304,20 & 136,60 & 39,64 & 23,43 & 17,80 & 13,24 & 10,29 & 8,24 & 5,69 & 4,34 & 2,99 \\
\hline 25,53 & 1218,50 & 130,30 & 31,48 & 24,17 & 19,49 & 14,58 & 11,12 & 8,72 & 5,91 & 4,47 & 3,07 \\
\hline 78,12 & 887,70 & 107,40 & 20,66 & 14,75 & 12,99 & 11,42 & 10,21 & 9,15 & 7,38 & 6,02 & 4,18 \\
\hline 41,60 & 1026,00 & 100,40 & 28,35 & 22,78 & 19,82 & 16,53 & 13,80 & 11,56 & 8,30 & 6,26 & 4,10 \\
\hline 26,06 & 407,90 & 29,00 & 123,04 & 99,54 & 83,12 & 64,64 & 50,57 & 40,21 & 27,29 & 20,40 & 13,81 \\
\hline 44,66 & 405,30 & 182,70 & 29,90 & 17,68 & 13,40 & 9,93 & 7,69 & 6,15 & 4,24 & 3,23 & 2,23 \\
\hline 55,44 & 744,00 & 109,50 & 26,11 & 19,37 & 16,68 & 14,07 & 11,98 & 10,24 & 7,60 & 5,84 & 3,85 \\
\hline 49,79 & 824,00 & 136,40 & 23,43 & 17,20 & 14,60 & 12,04 & 10,02 & 8,39 & 6,06 & 4,59 & 3,03 \\
\hline 88,51 & 979,00 & 71,20 & 23,22 & 16,79 & 15,26 & 13,94 & 12,86 & 11,89 & 10,15 & 8,68 & 6,42 \\
\hline 40,09 & 1859,20 & 99,70 & 23,31 & 20,06 & 18,03 & 15,56 & 13,37 & 11,47 & 8,52 & 6,50 & 4,22 \\
\hline 22,79 & 1616,40 & 43,40 & $\begin{array}{l}67,50 \\
\end{array}$ & 58,84 & 51,22 & 41,77 & 33,86 & 27,56 & 18,98 & 14,03 & 9,25 \\
\hline 50,82 & 573,10 & 74,60 & 37,97 & 29,00 & 25,11 & 21,14 & 17,90 & 15,21 & 11,18 & 8,54 & 5,61 \\
\hline 37,61 & 1934,30 & 111,80 & 22,41 & 19,15 & 17,03 & 14,48 & 12,26 & 10,38 & 7,56 & 5,71 & 3,70 \\
\hline 23,07 & 1150,70 & 170,30 & 28,23 & 20,38 & 15,67 & 11,17 & 8,29 & 6,44 & 4,41 & 3,39 & 2,35 \\
\hline 85,94 & 1315,60 & 32,90 & 32,44 & 25,72 & 23,75 & 22,79 & 21,78 & 20,73 & 18,69 & 16,78 & 13,45 \\
\hline 49,45 & 454,80 & 97,90 & 37,08 & 25,91 & 21,48 & 17,31 & 14,17 & 11,72 & 8,33 & 6,30 & 4,20 \\
\hline 47,96 & 1043,30 & 194,00 & 17,72 & 12,77 & 10,71 & 8,70 & 7,15 & 5,93 & 4,22 & 3,19 & 2,12 \\
\hline 20,31 & 1071,00 & 128,30 & 38,23 & 27,78 & 21,14 & 14,85 & 10,92 & 8,47 & 5,82 & 4,49 & 3,12 \\
\hline 24,98 & 259,10 & 193,80 & 39,82 & 20,23 & 13,67 & 9,18 & 6,85 & 5,44 & 3,81 & 2,97 & 2,11 \\
\hline 34,84 & 1657,80 & 34,40 & 54,43 & 49,73 & 46,12 & 41,16 & 36,43 & 32,09 & 24,82 & 19,39 & 12,65 \\
\hline 78,23 & 1311,10 & 150,30 & 14,37 & 10,32 & 9,12 & 8,05 & 7,22 & 6,49 & 5,25 & 4,30 & 2,99 \\
\hline 84,58 & 1101,50 & 151,20 & 15,17 & 10,45 & 9,09 & 7,95 & 7,10 & 6,38 & 5,17 & 4,24 & 2,97 \\
\hline 88,41 & 1059,20 & 43,60 & 29,62 & 22,35 & 20,65 & 19,46 & 18,32 & 17,24 & 15,21 & 13,40 & 10,38 \\
\hline 55,35 & 1057,60 & 112,80 & 21,90 & 17,06 & 15,05 & 12,98 & 11,25 & 9,76 & 7,41 & 5,76 & 3,80 \\
\hline 74,24 & 1064,60 & 96,70 & 20,50 & 15,26 & 13,74 & 12,27 & 11,07 & 10,00 & 8,16 & 6,70 & 4,67 \\
\hline 89,77 & 639,40 & 50,70 & 33,71 & 24,14 & 21,82 & 19,84 & 18,25 & 16,84 & 14,32 & 12,22 & 9,01 \\
\hline 24,69 & 791,60 & 171,90 & 30,08 & 20,61 & 15,55 & 10,95 & 8,12 & 6,33 & 4,36 & 3,36 & 2,34 \\
\hline 79,82 & 1621,20 & 107,20 & 15,56 & 11,61 & 10,66 & 9,74 & 8,95 & 8,24 & 6,96 & 5,89 & 4,28 \\
\hline 49,46 & 424,00 & 88,70 & 40,36 & 28,37 & 23,57 & 19,05 & 15,62 & 12,94 & 9,21 & 6,97 & 4,64 \\
\hline 53,18 & 852,40 & 63,20 & 34,33 & 28,01 & 25,25 & 22,19 & 19,50 & 17,12 & 13,23 & 10,39 & 6,88 \\
\hline 49,54 & 1973,40 & 73,70 & 23,91 & 20,53 & 19,14 & 17,30 & 15,57 & 13,97 & 11,20 & 9,02 & 6,08 \\
\hline 54,00 & 791,60 & 82,50 & 30,07 & 23,57 & 20,80 & 17,92 & 15,50 & 13,42 & 10,15 & 7,87 & 5,18 \\
\hline 57,45 & 1039,30 & 76,00 & 27,13 & 21,86 & 19,81 & 17,56 & 15,59 & 13,83 & 10,88 & 8,66 & 5,81 \\
\hline 51,05 & 452,60 & 128,10 & 32,04 & 21,06 & 17,00 & 13,43 & 10,87 & 8,92 & 6,30 & 4,77 & 3,20 \\
\hline 88,16 & 657,30 & 24,10 & 51,09 & 38,93 & 35,99 & 34,09 & 32,23 & 30,41 & 26,99 & 23,89 & 18,67 \\
\hline 76,74 & 1556,10 & 187,00 & 11,91 & 8,55 & 7,53 & 6,62 & 5,91 & 5,29 & 4,26 & 3,46 & 2,39 \\
\hline 27,75 & 989,90 & 170,20 & 26,52 & 19,18 & 15,11 & 11,10 & 8,40 & 6,58 & 4,48 & 3,42 & 2,36 \\
\hline 79,55 & 1061,50 & 78,00 & 22,41 & 16,63 & 15,18 & 13,78 & 12,62 & 11,56 & 9,69 & 8,15 & 5,86 \\
\hline 84,73 & 1959,60 & 193,90 & 10,03 & 7,15 & 6,39 & 5,72 & 5,19 & 4,73 & 3,92 & 3,28 & 2,34 \\
\hline 61,44 & 1437,80 & 41,00 & 34,50 & 28,03 & 26,73 & 24,96 & 23,19 & 21,48 & 18,31 & 15,56 & 11,31 \\
\hline 52,20 & 776,20 & 91,50 & 29,17 & 22,56 & 19,70 & 16,76 & 14,33 & 12,28 & 9,14 & 7,02 & 4,61 \\
\hline 51,73 & 1881,70 & 55,50 & 28,60 & 24,33 & 23,01 & 21,11 & 19,29 & 17,55 & 14,45 & 11,89 & 8,24 \\
\hline 79,74 & 228,10 & 31,40 & 74,87 & 52,34 & 45,59 & 39,75 & 35,35 & 31,59 & 25,33 & 20,59 & 14,24 \\
\hline 61,04 & 961,30 & 160,10 & 18,10 & 12,98 & 11,10 & 9,37 & 8,02 & 6,90 & 5,17 & 4,01 & 2,66 \\
\hline 49,90 & 892,80 & 97,10 & 27,25 & 21,41 & 18,76 & 15,96 & 13,62 & 11,64 & 8,63 & 6,61 & 4,33 \\
\hline 58,61 & 1639,00 & 162,70 & 14,25 & 11,10 & 9,87 & 8,61 & 7,54 & 6,61 & 5,11 & 4,02 & 2,67 \\
\hline 30,09 & 1109,20 & 98,90 & 34,93 & 27,97 & 23,53 & 18,56 & 14,71 & 11,82 & 8,09 & 6,04 & 4,06 \\
\hline 22,50 & 1867,30 & 115,60 & 33,01 & 26,52 & 21,77 & 16,53 & 12,68 & 9,96 & 6,71 & 5,05 & 3,46 \\
\hline 77,74 & 1216,90 & 138,40 & 15,59 & 11,22 & 9,93 & 8,76 & 7,85 & 7,06 & 5,71 & 4,67 & 3,25 \\
\hline 48,90 & 581,60 & 142,30 & 27,27 & 18,57 & 15,19 & 12,09 & 9,80 & 8,06 & 5,69 & 4,30 & 2,88 \\
\hline 54,71 & 1290,70 & 64,60 & 28,42 & 23,68 & 21,88 & 19,69 & 17,70 & 15,87 & 12,71 & 10,25 & 6,94 \\
\hline 37,83 & 1409,20 & 101,40 & 26,68 & 22,26 & 19,57 & 16,41 & 13,73 & 11,51 & 8,27 & 6,21 & 4,05 \\
\hline 43,10 & 324,40 & 196,90 & 32,82 & 17,88 & 12,97 & 9,27 & 7,07 & 5,61 & 3,87 & 2,97 & 2,08 \\
\hline 71,58 & 386,10 & 193,70 & 27,18 & 15,02 & 11,28 & 8,60 & 6,95 & 5,76 & 4,14 & 3,18 & 2,16 \\
\hline 56,89 & 1473,30 & 93,90 & 20,91 & 17,06 & 15,58 & 13,90 & 12,41 & 11,06 & 8,77 & 7,02 & 4,73 \\
\hline 28,73 & 1752,30 & 54,40 & 46,17 & 41,00 & 36,56 & 30,91 & 25,94 & 21,75 & 15,56 & 11,62 & 7,51 \\
\hline 73,38 & 1513,70 & 55,60 & 24,93 & 19,41 & 18,29 & 17,14 & 16,00 & 14,92 & 12,89 & 11,12 & 8,29 \\
\hline 65,57 & 1557,00 & 46,40 & 29,73 & 23,79 & 22,64 & 21,22 & 19,79 & 18,40 & 15,82 & 13,55 & 9,99 \\
\hline 81,06 & 484,10 & 149,50 & 24,92 & 15,12 & 12,09 & 9,81 & 8,31 & 7,15 & 5,41 & 4,25 & 2,88 \\
\hline
\end{tabular}




\begin{tabular}{|c|c|c|c|c|c|c|c|c|c|c|c|}
\hline & & & \multicolumn{9}{|c|}{ Deflexões $\left(\times 10^{-4} \mathrm{~cm}\right)$} \\
\hline e1 (cm) & Meq (MPa) & Ms (MPa) & D0 & D25 & D40 & D60 & D80 & D100 & D140 & D180 & D260 \\
\hline 88,94 & 1562,00 & 30,10 & 30,50 & 25,39 & 23,10 & 22,25 & 21,50 & 20,63 & 18,87 & 17,20 & 14,17 \\
\hline 55,74 & 1914,50 & 27,60 & 44,17 & 36,25 & 35,02 & 33,38 & 31,44 & 29,50 & 25,78 & 22,39 & 16,83 \\
\hline 40,60 & 788,80 & 173,30 & 23,26 & 16,33 & 13,31 & 10,37 & 8,22 & 6,64 & 4,59 & 3,46 & 2,34 \\
\hline 40,42 & 1977,80 & 55,80 & 33,11 & 29,60 & 27,47 & 24,60 & 21,88 & 19,38 & 15,16 & 11,96 & 7,88 \\
\hline 63,48 & 1747,20 & 95,60 & 18,21 & 14,58 & 13,51 & 12,27 & 11,15 & 10,12 & 8,31 & 6,84 & 4,76 \\
\hline 88,58 & 750,80 & 40,60 & 35,72 & 26,39 & 24,26 & 22,55 & 21,04 & 19,64 & 17,07 & 14,83 & 11,24 \\
\hline 43,08 & 1371,50 & 111,40 & 23,18 & 19,07 & 16,84 & 14,31 & 12,14 & 10,32 & 7,56 & 5,74 & 3,74 \\
\hline 73,07 & 351,50 & 137,50 & 32,33 & 18,91 & 14,71 & 11,58 & 9,56 & 8,04 & 5,88 & 4,54 & 3,07 \\
\hline 37,72 & 1102,10 & 197,40 & 19,50 & 14,24 & 11,72 & 9,16 & 7,26 & 5,85 & 4,03 & 3,03 & 2,05 \\
\hline 44,05 & 1885,80 & 23,50 & 58,33 & 50,20 & 48,59 & 45,49 & 42,22 & 39,01 & 33,01 & 27,80 & 19,83 \\
\hline 76,70 & 1878,90 & 164,10 & 11,69 & 8,65 & 7,81 & 7,01 & 6,35 & 5,76 & 4,74 & 3,93 & 2,77 \\
\hline 64,62 & 1693,50 & 145,20 & 14,23 & 11,03 & 9,94 & 8,82 & 7,88 & 7,03 & 5,60 & 4,51 & 3,07 \\
\hline 27,27 & 520,30 & 112,70 & 43,55 & 30,22 & 23,25 & 16,72 & 12,52 & 9,79 & 6,71 & 5,14 & 3,57 \\
\hline 31,24 & 1170,40 & 125,00 & 28,63 & 22,46 & 18,76 & 14,70 & 11,61 & 9,31 & 6,37 & 4,77 & 3,22 \\
\hline 89,52 & 1927,40 & 157,80 & 11,00 & 7,86 & 7,10 & 6,44 & 5,91 & 5,45 & 4,62 & 3,94 & 2,89 \\
\hline 77,91 & 1593,60 & 24,70 & 38,45 & 31,85 & 29,46 & 28,54 & 27,52 & 26,34 & 23,97 & 21,72 & 17,66 \\
\hline 68,62 & 906,20 & 120,80 & 20,36 & 14,81 & 12,93 & 11,20 & 9,84 & 8,67 & 6,77 & 5,38 & 3,63 \\
\hline 83,06 & 1832,10 & 128,20 & 13,07 & 9,62 & 8,79 & 8,03 & 7,38 & 6,80 & 5,76 & 4,89 & 3,57 \\
\hline 52,37 & 1018,30 & 40,90 & 42,67 & 36,14 & 33,70 & 30,53 & 27,57 & 24,82 & 20,03 & 16,22 & 11,03 \\
\hline 49,45 & 878,60 & 38,80 & 48,20 & 41,19 & 38,05 & 34,11 & 30,47 & 27,14 & 21,47 & 17,12 & 11,44 \\
\hline 37,93 & 1418,70 & 55,00 & 39,21 & 34,68 & 31,51 & 27,51 & 23,86 & 20,63 & 15,50 & 11,90 & 7,71 \\
\hline 33,04 & 1908,60 & 66,90 & 34,79 & 30,93 & 27,85 & 23,94 & 20,43 & 17,40 & 12,75 & 9,63 & 6,21 \\
\hline 35,63 & 634,20 & 74,60 & 45,44 & 35,45 & 29,95 & 23,94 & 19,24 & 15,64 & 10,85 & 8,11 & 5,41 \\
\hline 82,97 & 1037,30 & 165,60 & 15,12 & 10,26 & 8,81 & 7,61 & 6,73 & 6,00 & 4,79 & 3,89 & 2,69 \\
\hline 81,68 & 1003,10 & $\frac{100,60}{70,60}$ & $\begin{array}{l}10, \pm L \\
23,98\end{array}$ & $\begin{array}{l}10,20 \\
17,72\end{array}$ & $\begin{array}{c}16,20 \\
16,20\end{array}$ & $1,0.77$ & 13,57 & 12,48 & 10,54 & 8,92 & 6,48 \\
\hline 61,63 & 982,00 & 166,10 & 17,51 & 12,51 & 10,68 & 9,01 & 7,72 & 6,64 & 4,98 & 3,86 & 2,57 \\
\hline 66,84 & 252,20 & 191,20 & 37,04 & 18,53 & 13,04 & 9,32 & 7,23 & 5,84 & 4,08 & 3,13 & 2,17 \\
\hline 75,01 & 568,60 & 110,90 & 26,13 & 17,57 & 14,82 & 12,53 & 10,87 & 9,50 & 7,34 & 5,81 & 3,93 \\
\hline$\frac{10,01}{34,44}$ & 707,70 & 185,20 & $\frac{20, \pm 0}{25,30}$ & $\begin{array}{l}1, v 1 \\
17,16\end{array}$ & $\frac{1+4,0<}{13,48}$ & $\frac{1 L, 00}{10,03}$ & $\begin{array}{c}10,01 \\
7,69\end{array}$ & 6,08 & 4,17 & $\frac{0,01}{3,17}$ & 2,18 \\
\hline 29,26 & 1975,90 & 117,90 & 26,16 & 21,88 & 18,84 & 15,24 & 12,32 & 10,03 & 6,93 & 5,15 & 3,41 \\
\hline 25,24 & 231,50 & 178,80 & 43,64 & 21,95 & 14,80 & 9,94 & 7,42 & 5,90 & 4,13 & 3,22 & 2,28 \\
\hline 64,09 & 1634,50 & 82,50 & 20,37 & 16,31 & 15,19 & 13,86 & 12,65 & 11,53 & 9,53 & 7,90 & 5,54 \\
\hline 45,72 & 1812,30 & 69,10 & 27,08 & 23,58 & 21,81 & 19,52 & 17,39 & 15,44 & 12,14 & 9,62 & 6,38 \\
\hline 29,41 & 306,50 & 59,00 & 76,86 & 54,83 & 43,22 & 31,88 & 24,20 & 19,01 & 12,97 & 9,87 & 6,81 \\
\hline 31,03 & 1736,60 & 148,60 & 22,42 & 18,09 & 15,34 & 12,22 & 9,76 & 7,89 & 5,43 & 4,05 & 2,71 \\
\hline 76,94 & 949,70 & 185,60 & 15,49 & 10,36 & 8,73 & 7,39 & 6,43 & 5,63 & 4,37 & 3,47 & 2,35 \\
\hline 86,39 & 791,70 & 78,20 & 24,65 & 17,49 & 15,62 & 13,98 & 12,71 & 11,59 & 9,66 & 8,09 & 5,81 \\
\hline 39,16 & 979,30 & 46,40 & 48,75 & 42,45 & 38,31 & 33,20 & 28,62 & 24,63 & 18,36 & 14,03 & 9,10 \\
\hline 72,68 & 1265,30 & 155,90 & 14,80 & 10,74 & 9,44 & 8,26 & 7,33 & 6,52 & 5,18 & 4,17 & 2,85 \\
\hline 54,72 & 1528,80 & 93,50 & 21,15 & 17,44 & 15,93 & 14,19 & 12,64 & 11,23 & 8,86 & 7,06 & 4,73 \\
\hline 28,91 & 1881,70 & 181,30 & 20,11 & 15,88 & 13,20 & 10,26 & 8,04 & 6,40 & 4,36 & 3,27 & 2,21 \\
\hline 56,86 & 1778,90 & 120,10 & 16,73 & 13,60 & 12,38 & 11,01 & 9,80 & 8,71 & 6,88 & 5,49 & 3,69 \\
\hline 37,64 & 1429,60 & 191,40 & 17,96 & 13,77 & 11,59 & 9,27 & 7,47 & 6,08 & 4,23 & 3,17 & 2,12 \\
\hline 63,05 & 1663,80 & 186,80 & 12,63 & 9,56 & 8,45 & 7,36 & 6,46 & 5,68 & 4,42 & 3,49 & 2,34 \\
\hline 35,51 & 1946,90 & 36,60 & 48,86 & 44,63 & 41,65 & 37,43 & 33,38 & 29,61 & 23,19 & 18,29 & 12,01 \\
\hline 57,24 & 1773,60 & 87,10 & 20,37 & 16,80 & 15,59 & 14,10 & 12,75 & 11,49 & 9,31 & 7,57 & 5,18 \\
\hline 70,66 & 1017,00 & 154,90 & 16,77 & 11,89 & 10,26 & 8,82 & 7,72 & 6,78 & 5,27 & 4,18 & 2,82 \\
\hline 81,37 & 1611,50 & 54,10 & 23,20 & 17,87 & 16,70 & 15,82 & 14,92 & 14,05 & 12,39 & 10,90 & 8,41 \\
\hline 83,31 & 1538,60 & 149,10 & 13,01 & 9,34 & 8,36 & 7,48 & 6,79 & 6,18 & 5,13 & 4,28 & 3,05 \\
\hline 77,67 & 562,10 & 116,10 & 25,48 & 16,84 & 14,11 & 11,89 & 10,31 & 9,02 & 6,98 & 5,54 & 3,76 \\
\hline 61,97 & 1390,20 & 31,90 & 41,11 & 33,27 & 31,88 & 30,09 & 28,17 & 26,29 & 22,75 & 19,59 & 14,55 \\
\hline 28,00 & 1796,60 & 93,00 & 32,75 & 27,66 & 23,87 & 19,35 & 15,65 & 12,74 & 8,80 & 6,53 & 4,32 \\
\hline 56,88 & 1798,00 & 161,70 & 13,98 & 11,06 & 9,89 & 8,65 & 7,59 & 6,66 & 5,15 & 4,05 & 2,69 \\
\hline 72,69 & 668,80 & 36,90 & 44,01 & 33,95 & 31,51 & 28,90 & 26,58 & 24,42 & 20,54 & 17,29 & 12,43 \\
\hline 79,42 & 1781,80 & 169,00 & 11,60 & 8,45 & 7,58 & 6,78 & 6,14 & 5,57 & 4,59 & 3,80 & 2,68 \\
\hline 68,51 & 1234,70 & 23,90 & 48,38 & 38,74 & 36,83 & 35,31 & 33,48 & 31,62 & 28,04 & 24,74 & 19,15 \\
\hline 57,01 & 1710,60 & 107,20 & 18,18 & 14,84 & 13,57 & 12,12 & 10,83 & 9,66 & 7,68 & 6,16 & 4,15 \\
\hline 49,61 & 1887,80 & 163,90 & 14,74 & 11,93 & 10,60 & 9,15 & 7,90 & 6,82 & 5,13 & 3,96 & 2,60 \\
\hline 77,62 & 1970,30 & 93,00 & 15,86 & 12,11 & 11,29 & 10,49 & 9,75 & 9,05 & 7,78 & 6,67 & 4,94 \\
\hline 59,74 & 1407,10 & 179,20 & 14,34 & 10,78 & 9,41 & 8,09 & 7,01 & 6,09 & 4,64 & 3,62 & 2,40 \\
\hline 69,34 & 1491,40 & 173,10 & 13,23 & 9,77 & 8,63 & 7,56 & 6,69 & 5,94 & 4,70 & 3,77 & 2,56 \\
\hline 52,51 & 730,70 & 64,80 & 36,32 & 29,14 & 25,95 & 22,52 & 19,58 & 17,02 & 12,94 & 10,06 & 6,62 \\
\hline 77,01 & 810,90 & 147,50 & 18,72 & 12,67 & 10,75 & 9,16 & 8,00 & $\begin{array}{c}1,0< \\
7,03\end{array}$ & 5,49 & 4,38 & 2,97 \\
\hline 71,52 & 1555,50 & 152,20 & 13,70 & 10,23 & 9,16 & 8,12 & 7,28 & 6,53 & 5,26 & 4,28 & 2,95 \\
\hline 66,86 & 263,10 & 151,40 & 38,58 & 20,73 & 15,27 & 11,39 & 9,05 & 7,40 & 5,24 & 4,01 & 2,75 \\
\hline 73,98 & 742,50 & 86,90 & 25,71 & 18,68 & 16,49 & 14,49 & 12,91 & 11,53 & 9,23 & 7,47 & 5,14 \\
\hline 76,38 & 924,60 & 59,60 & 28,30 & 21,39 & 19,69 & 17,97 & 16,48 & 15,13 & 12,70 & 10,69 & 7,69 \\
\hline 41,67 & 442,40 & 59,70 & 54,20 & 41,52 & 35,33 & 28,77 & 23,56 & 19,45 & 13,74 & 10,32 & 6,83 \\
\hline 44,95 & 670,90 & 55,60 & 45,48 & 37,28 & 33,00 & 28,18 & 24,04 & 20,53 & 15,16 & 11,56 & 7,54 \\
\hline 86,02 & 1990,40 & 170,60 & 10,59 & 7,61 & 6,87 & 6,20 & 5,67 & 5,20 & 4,37 & 3,69 & 2,68 \\
\hline 55,84 & 507,40 & 155,70 & 26.62 & 17.03 & 13,67 & 10,83 & 8.82 & 7,30 & 5,20 & 3,95 & 2,65 \\
\hline 59,44 & 1434,80 & 65,50 & 25,82 & 21,14 & 19,73 & 17,97 & 16,36 & 14,85 & 12,19 & 10,02 & 6,95 \\
\hline 65,46 & 1841,70 & 30,70 & 37,00 & 29,85 & 28,47 & 27,36 & 25,97 & 24,55 & 21,80 & 19,25 & 14,91 \\
\hline 62,13 & 606,70 & 126,50 & 25,53 & 17,52 & 14,68 & 12,18 & 10,31 & 8,79 & 6,52 & 5,03 & 3,34 \\
\hline 76,30 & 1896,70 & 168,40 & 11,50 & 8,52 & 7,68 & 6,88 & 6,23 & 5,65 & 4,64 & 3,83 & 2,69 \\
\hline 38,90 & 219,00 & 193,00 & 41,78 & 20,25 & 13,75 & 9,38 & 7,04 & 5,58 & 3,87 & 3,00 & 2,13 \\
\hline 65,84 & 1345,60 & 139,40 & 15,97 & 12,09 & 10,76 & 9,45 & 8,38 & 7,43 & 5,86 & 4,69 & 3,17 \\
\hline 62,50 & 1273,80 & 36,90 & 38,12 & 30,85 & 29,40 & 27,48 & 25,55 & 23,69 & 20,23 & 17,23 & 12,56 \\
\hline 42,75 & 978,40 & 89,50 & 30,39 & 24,63 & 21,58 & 18,17 & 15,29 & 12,90 & 9,36 & 7,08 & 4,63 \\
\hline 88,75 & 253,70 & 73,30 & 47,65 & 28,82 & 23,15 & 18,96 & 16,24 & 14,13 & 10,92 & 8,70 & 5,96 \\
\hline 56,27 & 1086,90 & 167,30 & 17,33 & 12,74 & 10,94 & 9,21 & 7,84 & 6,70 & 4,97 & 3,82 & 2,52 \\
\hline 28,68 & 1807,00 & 97,30 & 31,12 & 26,25 & 22,68 & 18,42 & 14,93 & 12,17 & 8,43 & 6,26 & 4,14 \\
\hline
\end{tabular}




\begin{tabular}{|c|c|c|c|c|c|c|c|c|c|c|c|}
\hline & & & \multicolumn{9}{|c|}{ Deflexões $\left(\times 10^{-4} \mathrm{~cm}\right)$} \\
\hline e1 (cm) & Meq (MPa) & Ms (MPa) & D0 & D25 & D40 & D60 & D80 & D100 & D140 & D180 & D260 \\
\hline 47,81 & 1429,90 & 33,20 & 46,69 & 40,36 & 38,37 & 35,30 & 32,29 & 29,42 & 24,24 & 19,95 & 13,80 \\
\hline 78,49 & 682,40 & 89,10 & 25,82 & 18,24 & 15,96 & 13,96 & 12,43 & 11,12 & 8,92 & 7,26 & 5,02 \\
\hline 55,64 & 1149,20 & 186,10 & 16,05 & 11,72 & 10,01 & 8,39 & 7,11 & 6,05 & 4,46 & 3,42 & 2,26 \\
\hline 84,11 & 1795,50 & 178,70 & 10,95 & 7,82 & 6,99 & 6,24 & 5,66 & 5,15 & 4,27 & 3,56 & 2,54 \\
\hline 48,12 & 627,40 & 125,50 & 28,30 & 20,11 & 16,75 & 13,53 & 11,08 & 9,16 & 6,51 & 4,92 & 3,27 \\
\hline 81,23 & 598,50 & 175,20 & 20,54 & 12,59 & 10,14 & 8,28 & 7,04 & 6,07 & 4,62 & 3,64 & 2,47 \\
\hline 58,71 & 508,10 & 21,70 & 76,60 & 63,00 & 58,96 & 53,82 & 49,06 & 44,60 & 36,68 & 30,21 & 21,00 \\
\hline 60,87 & 1559,30 & 64,60 & 24,94 & 20,32 & 19,08 & 17,50 & 16,03 & 14,64 & 12,15 & 10,09 & 7,09 \\
\hline 22,91 & 1158,80 & 133,30 & 33,74 & 25,23 & 19,78 & 14,34 & 10,72 & 8,34 & 5,68 & 4,34 & 3,00 \\
\hline 58,51 & 1561,20 & 56,80 & 27,79 & 22,90 & 21,60 & 19,87 & 18,22 & 16,66 & 13,85 & 11,51 & 8,09 \\
\hline 47,45 & 948,60 & 64,60 & 34,94 & 29,14 & 26,21 & 22,83 & 19,85 & 17,23 & 13,07 & 10,12 & 6,63 \\
\hline 20,39 & 606,30 & 126,00 & 44,68 & 29,83 & 21,69 & 14,77 & 10,81 & 8,44 & 5,89 & 4,57 & 3,19 \\
\hline 44,11 & 1092,90 & 168,60 & 19,64 & 14,69 & 12,44 & 10,12 & 8,30 & 6,86 & 4,86 & 3,66 & 2,43 \\
\hline 21,52 & 956,00 & 119,00 & 40,18 & 29,38 & 22,57 & 16,03 & 11,85 & 9,20 & 6,30 & 4,85 & 3,37 \\
\hline 72,33 & 1761,80 & 137,10 & 13,67 & 10,37 & 9,44 & 8,49 & 7,70 & 6,98 & 5,73 & 4,72 & 3,31 \\
\hline 76,77 & 801,40 & 158,50 & 18,28 & 12,20 & 10,27 & 8,69 & 7,54 & 6,60 & 5,12 & 4,06 & 2,75 \\
\hline 43,18 & 1494,30 & 55,10 & 34,96 & 30,73 & 28,33 & 25,23 & 22,35 & 19,72 & 15,34 & 12,06 & 7,94 \\
\hline 49,62 & 1385,60 & 152,50 & 17,50 & 13,74 & 12,02 & 10,21 & 8,70 & 7,43 & 5,49 & 4,20 & 2,76 \\
\hline 32,70 & 419,00 & 176,80 & 32,78 & 19,88 & 14,75 & 10,48 & 7,87 & 6,19 & 4,27 & 3,29 & 2,29 \\
\hline 42,03 & 942,70 & 46,60 & 46,71 & 40,42 & 36,63 & 31,99 & 27,81 & 24,11 & 18,22 & 14,05 & 9,14 \\
\hline 36,75 & 213,00 & 55,90 & 81,44 & 55,22 & 43,73 & 32,94 & 25,49 & 20,27 & 13,91 & 10,54 & 7,23 \\
\hline 20,37 & 1661,10 & 38,50 & 80,07 & 69,35 & 59,83 & 48,12 & 38,51 & 31,02 & 21,13 & 15,61 & 10,38 \\
\hline 26,90 & 216,60 & 41,30 & 114,98 & 81,47 & 63,23 & 45,78 & 34,35 & 26,86 & 18,36 & 14,05 & 9,73 \\
\hline 74,04 & 702,70 & 74,50 & 28,60 & 21,00 & 18,69 & 16,53 & 14,80 & 13,28 & 10,70 & 8,72 & 6,02 \\
\hline 51,67 & 1819,00 & 76,50 & 23,37 & 19,83 & 18,43 & 16,64 & 14,97 & $\begin{array}{l}10,20 \\
13,43\end{array}$ & 10,77 & 8,68 & 5,87 \\
\hline 51,28 & 950,80 & 110,30 & 24,28 & 18,85 & 16,47 & 14,00 & 11,95 & 10,22 & 7,58 & 5,82 & 3,82 \\
\hline 52,97 & 928,40 & 194,70 & 17,83 & 12,45 & 10,38 & 8,46 & 7,01 & 5,86 & 4,22 & 3,20 & 2,13 \\
\hline 36,69 & 1661,20 & 83,90 & 28,98 & 25,08 & 22,41 & 19,15 & 16,28 & 13,83 & 10,10 & 7,64 & 4,95 \\
\hline 72,61 & 753,10 & 49,60 & 35,20 & 26,95 & 24,78 & 22,51 & 20,56 & 18,76 & 15,59 & 12,99 & 9,22 \\
\hline 58,76 & 1095,50 & 31,50 & 46,26 & 38,02 & 36,23 & 33,68 & 31,16 & 28,75 & 24,30 & 20,48 & 14,70 \\
\hline 87,91 & 1737,10 & 144,40 & 12,21 & 8,76 & 7,90 & 7,16 & 6,56 & 6,04 & 5,10 & 4,33 & 3,16 \\
\hline 59,72 & 249,10 & 192,00 & 37,61 & 18,83 & 13,21 & 9,38 & 7,22 & 5,80 & 4,03 & 3,09 & 2,15 \\
\hline 55,67 & 1752,20 & 132,80 & 16,04 & 12,96 & 11,70 & 10,32 & 9,11 & 8,04 & 6,26 & 4,95 & 3,30 \\
\hline 78,08 & 1636,30 & 73,00 & 19,71 & 15,06 & 14,07 & 13,11 & 12,22 & 11,37 & 9,81 & 8,45 & 6,30 \\
\hline 89,23 & 1512,30 & 102,40 & 15,57 & 11,30 & 10,30 & 9,45 & 8,75 & 8,11 & 6,96 & 5,99 & 4,46 \\
\hline 75,18 & 1172,70 & 190,10 & 13,77 & 9,54 & 8,19 & 7,03 & 6,17 & 5,44 & 4,26 & 3,40 & 2,31 \\
\hline 89,09 & 1187,20 & 97,50 & 17,87 & 12,78 & 11,54 & 10,47 & 9,61 & 8,85 & 7,50 & 6,38 & 4,68 \\
\hline 89,83 & 934,70 & 127,70 & 17,53 & 11,90 & 10,34 & 9,06 & 8,13 & 7,34 & 6,01 & 4,98 & 3,53 \\
\hline 61,00 & 1542,80 & 27,90 & 44,07 & 35,73 & 34,33 & 32,70 & 30,80 & 28,91 & 25,30 & 22,02 & 16,63 \\
\hline 60,78 & 1986,40 & 111,30 & 16,17 & 13,08 & 12,08 & 10,92 & 9,88 & 8,91 & 7,24 & 5,91 & 4,06 \\
\hline 59,76 & 459,60 & 40,40 & 53,86 & 42,35 & 37,99 & 33,44 & 29,56 & 26,11 & 20,43 & 16,22 & 10,86 \\
\hline 31,64 & 598,70 & 121,80 & 36,50 & 25,91 & 20,57 & 15,35 & 11,75 & 9,27 & 6,33 & 4,81 & 3,30 \\
\hline 26,90 & 1296,70 & 62,40 & 49,20 & 41,64 & 35,89 & 29,00 & 23,38 & 18,98 & 13,07 & 9,70 & 6,43 \\
\hline 48,65 & 377,60 & 199,80 & 29,27 & 16,48 & 12,26 & 9,02 & 7,00 & 5,61 & 3,88 & 2,96 & 2,05 \\
\hline 41,23 & 1459,00 & 125,10 & 21,73 & 17,77 & 15,58 & 13,10 & 11,00 & 9,26 & 6,70 & 5,05 & 3,30 \\
\hline 63,34 & 1262,50 & 37,40 & 37,58 & 30,31 & 28,86 & 26,98 & 25,09 & 23,28 & 19,90 & 16,96 & 12,39 \\
\hline 59,49 & 1621,10 & 46,30 & 31,16 & 25,53 & 24,33 & 22,65 & 20,99 & 19,39 & 16,43 & 13,88 & 10,00 \\
\hline 43,92 & 1365,90 & 73,90 & 29,52 & 25,30 & 22,90 & 20,02 & 17,43 & 15,14 & 11,48 & 8,87 & 5,79 \\
\hline 83,28 & 820,50 & 139,80 & 18,54 & 12,45 & 10,62 & 9,12 & 8,05 & 7,15 & 5,69 & 4,60 & 3,18 \\
\hline 63,23 & 1149,90 & 113,70 & 19,56 & 15,02 & 13,39 & 11,76 & 10,40 & 9,20 & 7,22 & 5,75 & 3,87 \\
\hline 89,74 & 668,10 & 169,90 & 18,90 & 11,68 & 9,52 & 7,90 & 6,83 & 5,99 & 4,68 & 3,76 & 2,59 \\
\hline 75,26 & 227,90 & 86,30 & 50,11 & 29,42 & 22,96 & 18,17 & 15,08 & 12,74 & 9,38 & 7,27 & 4,91 \\
\hline 64,05 & 724,70 & 161,90 & 20,45 & 13,79 & 11,47 & 9,49 & 8,03 & 6,85 & 5,08 & 3,92 & 2,61 \\
\hline 57,25 & 667,10 & 50,50 & 41,48 & 33,36 & 30,16 & 26,66 & 23,63 & 20,91 & 16,40 & 13,02 & 8,71 \\
\hline 68,40 & 481,50 & 193,40 & 23,73 & 13,91 & 10,80 & 8,45 & 6,92 & 5,78 & 4,18 & 3,21 & 2,17 \\
\hline 85,27 & 778,50 & 85,10 & 23,93 & 16,87 & 14,96 & 13,29 & 12,02 & 10,91 & 9,00 & 7,49 & 5,32 \\
\hline 26,06 & 669,70 & 31,10 & 100,08 & 84,65 & 72,76 & 58,55 & 47,02 & 38,05 & 26,12 & 19,38 & 12,88 \\
\hline 44,89 & 716,50 & 179,90 & 22,68 & 15,44 & 12,53 & 9,82 & 7,85 & 6,38 & 4,45 & 3,36 & 2,26 \\
\hline 47,76 & 1432,20 & 28,00 & 52,62 & 45,26 & 43,34 & 40,15 & 36,96 & 33,89 & 28,25 & 23,49 & 16,47 \\
\hline 50,70 & 246,30 & 151,30 & 41,92 & 22,57 & 16,43 & 11,93 & 9,21 & 7,38 & 5,11 & 3,91 & 2,71 \\
\hline 85,22 & 1616,60 & 199,30 & 10,86 & 7,56 & 6,64 & 5,85 & 5,26 & 4,75 & 3,88 & 3,21 & 2,26 \\
\hline 75,89 & 1730,70 & 167,60 & 12,06 & 8,87 & 7,95 & 7,08 & 6,38 & 5,76 & 4,70 & 3,86 & 2,70 \\
\hline 38,42 & 862,70 & 77,80 & 37,44 & 30,39 & 26,38 & 21,83 & 18,07 & 15,02 & 10,67 & 8,01 & 5,25 \\
\hline 51,93 & 1103,10 & 112,10 & 22,39 & 17,69 & 15,61 & 13,41 & 11,55 & $\begin{array}{c}+0,96 \\
9,96\end{array}$ & 7,48 & 5,78 & 3,79 \\
\hline 54,67 & 1496,70 & 118,40 & 18,50 & 14,94 & 13,44 & $\begin{array}{l}1+, 7 \pm \\
11,79\end{array}$ & 10,37 & 9,11 & 7,05 & 5,54 & 3,68 \\
\hline 87,64 & 611,00 & 197,50 & 19,08 & 11,31 & $\begin{array}{c}10,7+7 \\
8,97\end{array}$ & $\frac{1+, 1}{7,25}$ & $\frac{10,16}{6,16}$ & $\frac{,+1 \pm}{5,32}$ & 4,06 & 3,22 & 2,20 \\
\hline 34,35 & 920,70 & 130,30 & 28,52 & 21,61 & 17,91 & 14,00 & 11,06 & 8,89 & 6,11 & 4,58 & 3,09 \\
\hline 45,33 & 1432,90 & 148,70 & 18,52 & 14,74 & 12,87 & 10,83 & 9,14 & 7,72 & 5,63 & 4,27 & 2,79 \\
\hline 32,18 & 1373,30 & 172,00 & 21,56 & 16,58 & 13,74 & 10,70 & 8,42 & 6,74 & 4,61 & 3,46 & 2,34 \\
\hline 65,83 & 790,40 & 98,20 & 24,67 & 18,27 & 16,03 & 13,91 & 12,22 & 10,75 & 8,36 & 6,63 & 4,45 \\
\hline 88,60 & 1237,10 & 112,30 & 16,31 & 11,58 & 10,39 & 9,36 & 8,56 & 7,85 & 6,60 & 5,58 & 4,06 \\
\hline 71,96 & 1990,90 & 41,10 & 27,72 & 22,10 & 20,90 & 20,05 & 19,04 & 18,01 & 16,03 & 14,19 & 11,06 \\
\hline 30,59 & 1972,70 & 191,80 & 18,33 & 14,54 & 12,19 & 9,58 & 7,58 & 6,08 & 4,16 & 3,11 & 2,09 \\
\hline 89,82 & 1394,20 & 147,60 & 13,30 & 9,28 & 8,23 & 7,35 & 6,67 & 6,09 & 5,08 & 4,27 & 3,08 \\
\hline 70,28 & 334,00 & 199,30 & 29,85 & 15,83 & 11,58 & 8,61 & 6,84 & 5,61 & 3,98 & 3,06 & 2,09 \\
\hline 34,77 & 1334,00 & 174,50 & 20,54 & 15,76 & 13,16 & 10,38 & 8,26 & 6,66 & 4,59 & 3,44 & 2,31 \\
\hline 26,21 & 834,30 & 132,10 & 34,43 & 25,07 & 19,67 & 14,36 & 10,81 & 8,45 & 5,76 & 4,39 & 3,04 \\
\hline 32,15 & 301,70 & 160,10 & 40,07 & 22,82 & 16,46 & 11,47 & 8,58 & 6,76 & 4,68 & 3,62 & 2,54 \\
\hline 65,21 & 837,20 & 190,30 & 17,45 & 11,69 & 9,71 & 8,03 & 6,80 & 5,81 & 4,32 & 3,34 & 2,23 \\
\hline 46,68 & 820,60 & 105,70 & 28,03 & 21,56 & 18,58 & 15,47 & 12,94 & 10,88 & 7,86 & 5,96 & 3,91 \\
\hline 75,15 & 665,90 & 107,60 & 24,30 & 16,84 & 14,46 & 12,42 & 10,90 & 9,61 & 7,53 & 6,02 & 4,09 \\
\hline 39,09 & 665,90 & 186,50 & 24,42 & 16,32 & 12,93 & 9,80 & 7,63 & 6,09 & 4,19 & 3,17 & 2,17 \\
\hline
\end{tabular}




\begin{tabular}{|c|c|c|c|c|c|c|c|c|c|c|c|}
\hline \multirow[b]{2}{*}{ e1 (cm) } & & & & & & & ões (x1 & m) & & & \\
\hline & Meq (MPa) & Ms (MPa) & D0 & D25 & D40 & D60 & D80 & D100 & D140 & D180 & D260 \\
\hline 86,67 & 317,60 & 183,60 & 30,92 & 16,22 & 11,86 & 8,89 & 7,18 & 5,97 & 4,35 & 3,38 & 2,31 \\
\hline 78,43 & 935,20 & 170,80 & 16,10 & 10,84 & 9,20 & 7,84 & 6,86 & 6,04 & 4,72 & 3,78 & 2,57 \\
\hline 61,37 & 1327,60 & 94,00 & 20,87 & $\begin{array}{l}16,62 \\
\end{array}$ & 15,14 & 13,53 & 12,12 & 10,84 & 8,67 & 7,00 & 4,76 \\
\hline 75,65 & 429,50 & 161,20 & 26,64 & 15,66 & 12,24 & 9,69 & 8,05 & 6,81 & 5,02 & 3,89 & 2,63 \\
\hline 86,17 & 435,50 & 138,20 & 27,04 & 16,14 & 12,83 & 10,40 & 8,83 & 7,62 & 5,82 & 4,60 & 3,14 \\
\hline 42,34 & 960,90 & 158,30 & 22,01 & 16,30 & 13,68 & 10,99 & 8,92 & 7,32 & 5,14 & 3,86 & 2,57 \\
\hline 83,93 & 1052,10 & 138,50 & 16,25 & 11,28 & 9,85 & 8,63 & 7,73 & 6,95 & 5,64 & 4,63 & 3,25 \\
\hline 50,57 & 1982,80 & 123,30 & 16,95 & 14,14 & 12,84 & 11,33 & 9,98 & 8,78 & 6,80 & 5,34 & 3,53 \\
\hline 41,63 & 224,60 & 31,80 & 103,91 & 78,99 & 66,96 & 54,32 & 44,36 & 36,53 & 25,75 & 19,34 & 12,83 \\
\hline 39,16 & 1527,10 & 141,60 & 20,51 & 16,60 & 14,41 & 11,94 & 9,90 & 8,24 & 5,87 & 4,40 & 2,89 \\
\hline 87,07 & 316,50 & 178,30 & 31,22 & 16,46 & 12,08 & 9,09 & 7,36 & 6,14 & 4,48 & 3,48 & 2,38 \\
\hline 32,42 & 1389,00 & 66,50 & 39,62 & 34,23 & 30,27 & 25,41 & 21,21 & 17,73 & 12,65 & 9,46 & 6,15 \\
\hline 67,86 & 1682,70 & 124,40 & 15,22 & 11,79 & 10,75 & 9,66 & 8,72 & 7,87 & 6,41 & 5,24 & 3,63 \\
\hline 47,06 & 1194,50 & 131,10 & 21,01 & 16,55 & 14,44 & 12,17 & 10,29 & 8,72 & 6,38 & 4,86 & 3,18 \\
\hline 71,97 & 1078,10 & 126,90 & 17,87 & 13,06 & 11,53 & 10,11 & 8,98 & 8,00 & 6,36 & 5,13 & 3,50 \\
\hline 36,98 & 1510,60 & 88,00 & 28,92 & 24,68 & 21,90 & 18,56 & 15,67 & 13,23 & 9,59 & 7,23 & 4,69 \\
\hline 71,06 & 1333,30 & 138,70 & 15,51 & 11,53 & 10,27 & 9,07 & 8,10 & 7,24 & 5,80 & 4,69 & 3,22 \\
\hline 69,76 & 673,10 & 156,60 & 20,97 & 13,83 & 11,46 & 9,50 & 8,10 & 6,96 & 5,23 & 4,08 & 2,73 \\
\hline 67,25 & 869,40 & 132,80 & 20,00 & 14,32 & 12,35 & 10,58 & 9,21 & 8,04 & 6,19 & 4,88 & 3,27 \\
\hline 47,81 & 1241,90 & 40,30 & 42,75 & 37,06 & 34,69 & 31,44 & 28,37 & 25,50 & 20,50 & 16,54 & 11,17 \\
\hline 22,20 & 655,40 & 124,80 & 42,19 & 29,07 & 21,69 & 15,08 & 11,09 & 8,64 & 5,98 & 4,62 & 3,22 \\
\hline 78,62 & 1875,80 & 79,10 & 17,73 & 13,56 & 12,68 & 11,85 & 11,07 & 10,33 & 8,95 & 7,74 & 5,81 \\
\hline 34,40 & 1788,60 & 22,10 & 73,18 & 66,85 & 63,34 & 57,78 & 52,30 & 47,07 & 37,83 & 30,41 & 20,36 \\
\hline 20,88 & 1228,10 & 158,20 & 31,07 & 22,47 & 17,10 & 12,03 & 8,86 & 6,88 & 4,73 & 3,64 & 2,53 \\
\hline 49,09 & 725,60 & 32,90 & 57,65 & 49,29 & 45,44 & 40,64 & 36,23 & 32,20 & 25,38 & 20,18 & 13,45 \\
\hline 81,39 & 825,00 & 95,30 & 22,39 & 15,89 & 14,04 & 12,41 & 11,15 & 10,06 & 8,20 & 6,75 & 4,73 \\
\hline 23,72 & 1362,30 & 119,30 & 34,07 & 26,53 & 21,43 & 16,01 & 12,17 & 9,53 & 6,44 & 4,88 & 3,35 \\
\hline 86,66 & 1875,30 & 157,70 & 11,31 & 8,13 & 7,34 & 6,64 & 6,08 & 5,58 & 4,70 & 3,98 & 2,89 \\
\hline 56,25 & 1156,40 & 182,00 & 16,10 & 11,79 & 10,10 & 8,49 & 7,22 & 6,16 & 4,56 & 3,51 & 2,32 \\
\hline 78,03 & 1185,60 & 142,10 & 15,55 & 11,12 & 9,80 & 8,62 & 7,70 & 6,91 & 5,58 & 4,55 & 3,16 \\
\hline 33,05 & 1254,30 & 72,40 & 38,25 & 32,48 & 28,48 & 23,67 & 19,61 & 16,28 & 11,53 & 8,61 & 5,62 \\
\hline 41,58 & 1775,30 & 94,60 & 23,85 & 20,52 & 18,51 & 16,07 & 13,88 & 11,98 & 8,98 & 6,89 & 4,48 \\
\hline 79,43 & 863,70 & 63,10 & 27,65 & 20,54 & 18,75 & 17,03 & 15,60 & 14,29 & 11,98 & 10,07 & 7,25 \\
\hline 63,83 & 330,80 & 181,90 & 31,36 & 17,11 & 12,70 & 9,51 & 7,56 & 6,17 & 4,36 & 3,33 & 2,28 \\
\hline 35,97 & 828,10 & 183,80 & 23,39 & 16,40 & 13,17 & 10,01 & 7,79 & 6,20 & 4,25 & 3,22 & 2,20 \\
\hline 60,30 & 1138,50 & 160,80 & 16,71 & 12,34 & 10,69 & 9,13 & 7,88 & 6,82 & 5,16 & 4,02 & 2,66 \\
\hline 20,91 & 670,70 & 25,60 & 136,87 & 113,96 & 95,55 & 74,22 & 57,78 & 45,71 & 30,79 & 22,97 & 15,57 \\
\hline 53,23 & 572,40 & 21,80 & 77,82 & 65,72 & 61,52 & 55,95 & 50,74 & 45,86 & 37,28 & 30,38 & 20,80 \\
\hline 67,76 & 1158,60 & 145,90 & 16,49 & 12,12 & 10,63 & 9,24 & 8,13 & 7,17 & 5,61 & 4,46 & 3,01 \\
\hline 27,27 & 439,60 & 135,20 & 40,74 & 26,37 & 19,65 & 13,81 & 10,26 & 8,04 & 5,55 & 4,28 & 2,98 \\
\hline 55,40 & 853,30 & 113,90 & 23,99 & 18,09 & 15,70 & 13,34 & 11,42 & 9,80 & 7,32 & 5,64 & 3,72 \\
\hline 21,30 & 1746,90 & 66,20 & 52,07 & 43,53 & 36,64 & 28,61 & 22,37 & 17,74 & 11,97 & 8,92 & 6,03 \\
\hline 28,25 & 1834,30 & 107,20 & 29,37 & 24,52 & 21,03 & 16,92 & 13,60 & 11,02 & 7,59 & 5,64 & 3,75 \\
\hline 69,74 & 1918,20 & 108,90 & 15,42 & 12,01 & 11,14 & 10,17 & 9,31 & 8,51 & 7,09 & 5,92 & 4,20 \\
\hline 58,02 & 1358,70 & 169,80 & 15,23 & 11,53 & 10,07 & 8,64 & 7,47 & 6,47 & 4,90 & 3,81 & 2,52 \\
\hline 30,79 & 1838,00 & 66,90 & 37,38 & 32,97 & 29,41 & 24,91 & 20,96 & 17,62 & 12,66 & 9,48 & 6,13 \\
\hline 85,21 & 1132,90 & 150,40 & 14,95 & 10,32 & 9,00 & 7,89 & 7,07 & 6,36 & 5,18 & 4,26 & 2,99 \\
\hline 51,65 & 766,50 & 32,20 & 55,51 & 47,12 & 43,78 & 39,52 & 35,57 & 31,91 & 25,58 & 20,62 & 13,93 \\
\hline 66,49 & 1001,30 & 101,70 & 21,59 & 16,35 & 14,57 & 12,83 & 11,39 & 10,12 & 8,01 & 6,43 & 4,36 \\
\hline 21,50 & 295,50 & 111,00 & 57,81 & 34,74 & 24,36 & 16,36 & 12,05 & 9,50 & 6,67 & 5,19 & 3,64 \\
\hline 36,95 & 1500,20 & 124,10 & 23,36 & 19,15 & 16,65 & 13,76 & 11,37 & 9,44 & 6,69 & 5,01 & 3,29 \\
\hline 89,03 & 457,30 & 125,30 & 26,92 & 16,43 & 13,29 & 10,94 & 9,41 & 8,21 & 6,37 & 5,09 & 3,50 \\
\hline 30,19 & 419,30 & 27,90 & 111,85 & 92,73 & 79,64 & 64,33 & 51,94 & 42,26 & 29,23 & 21,75 & 14,42 \\
\hline 88,43 & 1257,80 & 99,00 & 17,31 & 12,45 & 11,27 & 10,24 & 9,42 & 8,68 & 7,37 & 6,27 & 4,61 \\
\hline 80,22 & 234,70 & 149,10 & 41,13 & 21,26 & 15,36 & 11,34 & 9,04 & 7,44 & 5,33 & 4,12 & 2,82 \\
\hline 31,24 & 1834,30 & 199,90 & 18,02 & 14,10 & 11,76 & 9,20 & 7,26 & 5,82 & 3,98 & 2,98 & 2,01 \\
\hline 61,25 & 440,60 & 21,80 & 78,39 & 63,55 & 59,13 & 53,79 & 48,94 & 44,42 & 36,45 & 29,99 & 20,84 \\
\hline 37,65 & 1336,20 & 83,50 & 30,87 & 26,16 & 23,17 & 19,61 & 16,53 & 13,95 & 10,10 & 7,61 & 4,95 \\
\hline 64,00 & 946,30 & 98,30 & 23,00 & $\begin{array}{l}17,52 \\
\end{array}$ & 15,58 & 13,65 & 12,06 & 10,66 & 8,36 & 6,65 & 4,48 \\
\hline 81,89 & 285,80 & 135,20 & 36,59 & 20,20 & 15,25 & 11,75 & 9,64 & 8,10 & 5,94 & 4,61 & 3,14 \\
\hline 76,51 & 1574,60 & 68,20 & 21,10 & 16,21 & 15,17 & 14,14 & 13,17 & 12,25 & 10,56 & 9,08 & 6,75 \\
\hline 40,45 & 1645,70 & 57,50 & 34,48 & 30,58 & 28,10 & 24,89 & 21,91 & 19,22 & 14,78 & 11,52 & 7,53 \\
\hline 62,79 & 1967,70 & 47,70 & 27,74 & 22,40 & 21,43 & 20,20 & 18,90 & 17,63 & 15,23 & 13,11 & 9,72 \\
\hline 62,25 & 360,80 & 178,50 & 29,96 & 16,85 & 12,71 & 9,64 & 7,70 & 6,31 & 4,46 & 3,41 & 2,32 \\
\hline 45,97 & 1123,00 & 196,20 & 17,42 & 12,73 & 10,70 & 8,68 & 7,11 & 5,88 & 4,17 & 3,15 & 2,09 \\
\hline 36,79 & 840,40 & 143,50 & 26,69 & 19,65 & 16,18 & 12,63 & 10,00 & 8,04 & 5,54 & 4,17 & 2,81 \\
\hline 88,65 & 1914,10 & 46,40 & 22,07 & 17,66 & 16,20 & 15,55 & 14,92 & 14,23 & 12,89 & 11,63 & 9,41 \\
\hline 71,32 & 375,80 & 127,90 & 31,99 & 19,38 & 15,36 & 12,28 & 10,22 & 8,64 & 6,35 & 4,91 & 3,30 \\
\hline 37,71 & 776,40 & 51,90 & 50,83 & 42,76 & 37,73 & 31,79 & 26,70 & 22,46 & 16,19 & 12,19 & 7,93 \\
\hline 74,88 & 1525,60 & 139,40 & 14,20 & 10,54 & 9,49 & 8,48 & 7,65 & 6,91 & 5,65 & 4,64 & 3,24 \\
\hline 70,69 & 1811,10 & 86,90 & 17,99 & 14,04 & 13,13 & 12,10 & 11,16 & 10,28 & 8,68 & 7,34 & 5,30 \\
\hline 50,30 & 1639,60 & 173,40 & 15,01 & 11,83 & 10,39 & 8,86 & 7,58 & 6,50 & 4,83 & 3,71 & 2,43 \\
\hline 43,61 & 648,40 & 30,90 & 67,66 & 58,56 & 53,33 & 46,90 & 41,06 & 35,85 & 27,39 & 21,28 & 13,91 \\
\hline 79,28 & 1705,60 & 200,00 & 10,86 & 7,75 & 6,84 & 6,03 & 5,41 & 4,86 & 3,94 & 3,23 & 2,25 \\
\hline 79,12 & 1226,60 & 180,70 & 13,51 & 9,38 & 8,12 & 7,04 & 6,23 & 5,55 & 4,42 & 3,58 & 2,46 \\
\hline 38,41 & 1896,60 & 169,10 & 17,15 & 13,94 & 12,11 & 10,03 & 8,31 & 6,91 & 4,91 & 3,69 & 2,42 \\
\hline 87,78 & 1556,90 & 118,90 & 14,27 & 10,30 & 9,34 & 8,51 & 7,83 & 7,22 & 6,13 & 5,23 & 3,84 \\
\hline 54,22 & 1849,90 & 175,90 & 13,52 & 10,71 & 9,52 & 8,25 & 7,18 & 6,24 & 4,76 & 3,70 & 2,44 \\
\hline 48,44 & 1961,80 & 137,90 & 16,34 & 13,57 & 12,19 & 10,63 & 9,25 & 8,04 & 6,11 & 4,74 & 3,11 \\
\hline 35,34 & 620,70 & 140,00 & 31,17 & 21,79 & 17,42 & 13,19 & 10,22 & 8,12 & 5,56 & 4,21 & 2,88 \\
\hline 21,66 & 1732,80 & 131,60 & 31,59 & 24,64 & 19,75 & 14,60 & 11,01 & 8,58 & 5,80 & 4,40 & 3,04 \\
\hline 24,12 & 789,30 & 196,30 & 27,73 & 18,47 & 13,70 & 9,53 & 7,04 & 5,50 & 3,80 & 2,94 & 2,05 \\
\hline
\end{tabular}




\begin{tabular}{|c|c|c|c|c|c|c|c|c|c|c|c|}
\hline \multirow[b]{2}{*}{$\mathrm{e} 1(\mathrm{~cm})$} & & & & & & $\mathrm{De}$ & $\overline{\text { ões (x1 }}$ & & & & \\
\hline & Meq (MPa) & Ms (MPa) & D0 & D25 & D40 & D60 & D80 & D100 & D140 & D180 & D260 \\
\hline 76,45 & 419,90 & 37,20 & 52,00 & 38,49 & 34,72 & 31,11 & 28,17 & 25,54 & 20,98 & 17,34 & 12,20 \\
\hline 77,77 & 453,20 & 131,40 & 27,54 & 17,05 & 13,75 & 11,23 & 9,52 & 8,19 & 6,18 & 4,84 & 3,27 \\
\hline 40,17 & 1560,40 & 92,10 & 26,09 & 22,25 & 19,90 & 17,08 & 14,60 & 12,47 & 9,20 & 7,00 & 4,54 \\
\hline 86,79 & 1310,10 & 36,10 & 30,54 & 23,95 & 22,13 & 21,17 & 20,19 & 19,18 & 17,23 & 15,42 & 12,29 \\
\hline 25,38 & 1294,10 & 168,50 & 25,93 & 19,36 & 15,35 & 11,29 & 8,52 & 6,66 & 4,53 & 3,45 & 2,38 \\
\hline 47,42 & 1769,40 & 173,50 & 15,07 & 12,05 & 10,60 & 9,02 & 7,68 & 6,55 & 4,84 & 3,70 & 2,42 \\
\hline 88,43 & 551,60 & 198,50 & 20,36 & 11,79 & 9,22 & 7,36 & 6,20 & 5,33 & 4,04 & 3,19 & 2,18 \\
\hline 35,87 & 377,40 & 79,30 & 53,13 & 37,65 & 30,36 & 23,18 & 18,07 & 14,41 & 9,88 & 7,46 & 5,09 \\
\hline 52,96 & 1375,20 & 70,90 & 26,68 & 22,36 & 20,58 & 18,44 & 16,49 & 14,70 & 11,67 & 9,34 & 6,27 \\
\hline 40,34 & 1449,40 & 126,60 & 21,96 & 17,91 & 15,66 & 13,10 & 10,95 & 9,18 & 6,60 & 4,97 & 3,25 \\
\hline 23,10 & 1477,60 & 173,00 & 26,00 & 19,42 & 15,23 & 11,05 & 8,26 & 6,43 & 4,38 & 3,35 & 2,32 \\
\hline 45,86 & 878,20 & 110,70 & 26,80 & 20,70 & 17,85 & 14,84 & 12,40 & 10,40 & 7,50 & 5,68 & 3,73 \\
\hline 25,75 & 1381,80 & 182,40 & 23,84 & 17,80 & 14,13 & 10,42 & 7,88 & 6,16 & 4,19 & 3,19 & 2,20 \\
\hline 50,95 & 1787,00 & 176,20 & 14,22 & 11,30 & 9,98 & 8,57 & 7,38 & 6,35 & 4,76 & 3,67 & 2,41 \\
\hline 22,31 & 1590,30 & 152,00 & 28,59 & 21,81 & 17,27 & 12,62 & 9,46 & 7,36 & 5,00 & 3,81 & 2,63 \\
\hline 74,02 & 1290,40 & 89,30 & 19,76 & 15,01 & 13,76 & 12,48 & 11,39 & 10,40 & 8,64 & 7,20 & 5,12 \\
\hline 39,28 & 1416,40 & 48,40 & 41,58 & 37,00 & 33,94 & 29,98 & 26,32 & 23,02 & 17,61 & 13,68 & 8,91 \\
\hline 56,95 & 1030,90 & 131,80 & 20,03 & 15,15 & 13,20 & 11,29 & 9,72 & 8,39 & 6,32 & 4,90 & 3,24 \\
\hline 84,27 & 703,20 & 153,30 & 19,40 & 12,48 & 10,38 & 8,73 & 7,60 & 6,67 & 5,22 & 4,19 & 2,87 \\
\hline 73,62 & 751,20 & 192,90 & 17,71 & 11,34 & 9,29 & 7,66 & 6,52 & 5,61 & 4,23 & 3,31 & 2,22 \\
\hline 62,95 & 453,90 & 71,90 & 38,76 & 27,91 & 23,98 & 20,38 & 17,56 & 15,19 & 11,51 & 8,97 & 5,97 \\
\hline 86,00 & 1200,40 & 133,80 & 15,32 & 10,76 & 9,52 & 8,45 & 7,64 & 6,93 & 5,72 & 4,76 & 3,39 \\
\hline 89,68 & 255,70 & 148,60 & 38,21 & 19,96 & 14,56 & 10,91 & 8,81 & 7,35 & 5,37 & 4,18 & 2,86 \\
\hline 21,77 & 512,70 & 178,90 & 34,99 & 21,41 & 15,14 & 10,20 & 7,51 & 5,91 & 4,14 & 3,22 & 2,26 \\
\hline 40,94 & 559,00 & 40,00 & 63,72 & 53,25 & 47,18 & 40,11 & 34,01 & 28,85 & 21,09 & 15,98 & 10,40 \\
\hline 28,37 & 1842,90 & 35,20 & 61,36 & 56,32 & 51,31 & 44,64 & 38,47 & 33,02 & 24,44 & 18,53 & 11,89 \\
\hline 52,38 & 1680,30 & 84,70 & 22,31 & 18,75 & 17,27 & 15,47 & 13,83 & 12,33 & 9,78 & 7,82 & 5,24 \\
\hline 36,93 & 1106,60 & 135,60 & 24,80 & 19,26 & 16,29 & 13,07 & 10,55 & 8,60 & 5,99 & 4,48 & 2,98 \\
\hline 49,30 & 258,40 & 119,00 & 45,28 & 26,46 & 20,10 & 15,04 & 11,77 & 9,48 & 6,58 & 5,01 & 3,44 \\
\hline 65,02 & 261,70 & 167,60 & 37,62 & 19,70 & 14,27 & 10,46 & 8,23 & 6,68 & 4,69 & 3,60 & 2,47 \\
\hline 85,77 & 1755,10 & 96,30 & 15,42 & 11,44 & 10,55 & 9,78 & 9,10 & 8,47 & 7,32 & 6,33 & 4,75 \\
\hline 71,06 & 901,50 & 184,90 & 16,43 & 11,07 & 9,29 & 7,80 & 6,71 & 5,81 & 4,43 & 3,47 & 2,33 \\
\hline 46,15 & 1839,80 & 30,80 & 46,84 & 40,41 & 38,84 & 36,09 & 33,30 & 30,60 & 25,62 & 21,37 & 15,04 \\
\hline 84,85 & 1756,40 & 190,00 & 10,69 & 7,55 & 6,70 & 5,96 & 5,39 & 4,89 & 4,04 & 3,36 & 2,39 \\
\hline 86,55 & 999,00 & 144,90 & 16,17 & 10,99 & 9,51 & 8,29 & 7,40 & 6,64 & 5,38 & 4,42 & 3,10 \\
\hline 33,69 & 502,30 & 197,70 & 28,20 & 17,42 & 13,07 & 9,38 & 7,08 & 5,57 & 3,83 & 2,94 & 2,05 \\
\hline 32,21 & 836,40 & 176,80 & 25,26 & 17,82 & 14,14 & 10,56 & 8,09 & 6,39 & 4,37 & 3,31 & 2,28 \\
\hline 44,13 & 1608,00 & 118,60 & 20,61 & 17,14 & 15,25 & 13,09 & 11,21 & 9,60 & 7,12 & 5,44 & 3,54 \\
\hline 84,44 & 734,20 & 123,30 & 20,75 & 13,92 & 11,88 & 10,23 & 9,04 & 8,04 & 6,42 & 5,21 & 3,61 \\
\hline 54,69 & 489,00 & 100,50 & 33,70 & 23,56 & 19,71 & 16,16 & 13,46 & 11,30 & 8,19 & 6,24 & 4,14 \\
\hline 23,46 & 210,20 & 113,10 & 61,47 & 34,24 & 23,66 & 15,90 & 11,79 & 9,33 & 6,54 & 5,09 & 3,59 \\
\hline 61,93 & 689,80 & 144,60 & 22,42 & 15,38 & 12,87 & 10,68 & 9,03 & 7,70 & 5,70 & 4,39 & 2,92 \\
\hline 31,55 & 374,70 & 145,50 & 38,97 & 24,11 & 17,97 & 12,76 & 9,57 & 7,52 & 5,18 & 3,99 & 2,78 \\
\hline 74,95 & 473,80 & 106,20 & 29,54 & 19,37 & 16,10 & 13,46 & 11,57 & 10,04 & 7,68 & 6,04 & 4,08 \\
\hline 53,18 & 828,20 & 64,00 & 34,48 & 28,03 & 25,20 & 22,09 & 19,37 & 16,97 & 13,08 & 10,25 & 6,78 \\
\hline 58,33 & 558,10 & 173,90 & 23,69 & 15,03 & 12,05 & 9,58 & 7,84 & 6,51 & 4,67 & 3,55 & 2,38 \\
\hline 66,25 & 1734,50 & 196,90 & 11,76 & 8,80 & 7,78 & 6,79 & 6,00 & 5,30 & 4,16 & 3,31 & 2,24 \\
\hline 80,87 & 1908,80 & 79,20 & 17,30 & 13,17 & 12,29 & 11,53 & 10,79 & 10,09 & 8,79 & 7,64 & 5,78 \\
\hline 72,65 & 276,50 & 122,70 & 39,42 & 22,40 & 17,12 & 13,27 & 10,85 & 9,06 & 6,57 & 5,06 & 3,43 \\
\hline 46,82 & 1043,40 & 147,50 & 20,88 & 15,82 & 13,54 & 11,20 & 9,32 & 7,80 & 5,61 & 4,25 & 2,80 \\
\hline 65,93 & 1133,30 & 178,80 & 15,23 & 10,89 & 9,36 & 7,99 & 6,92 & 6,02 & 4,61 & 3,62 & 2,42 \\
\hline 33,78 & 1010,80 & 64,50 & 43,71 & 36,77 & 32,13 & 26,62 & 22,00 & 18,24 & 12,90 & 9,63 & 6,30 \\
\hline 87,61 & 1247,00 & 188,40 & 12,66 & 8,53 & 7,35 & 6,39 & 5,69 & 5,11 & 4,14 & 3,40 & 2,38 \\
\hline 81,60 & 821,60 & 150,80 & 18,04 & 12,03 & 10,19 & 8,70 & 7,63 & 6,74 & 5,31 & 4,27 & 2,93 \\
\hline 21,25 & 732,50 & 198,20 & 29,80 & 19,12 & 13,73 & 9,30 & 6,83 & 5,35 & 3,74 & 2,91 & 2,03 \\
\hline 50,36 & 1202,20 & 88,80 & 25,24 & 20,76 & 18,65 & 16,29 & 14,22 & 12,40 & 9,47 & 7,37 & 4,85 \\
\hline 61,16 & 812,20 & 187,30 & 18,31 & 12,34 & 10,23 & 8,41 & 7,06 & 5,98 & 4,39 & 3,37 & 2,24 \\
\hline 52,45 & 1709,30 & 63,10 & 26,83 & 22,75 & 21,30 & 19,38 & 17,57 & 15,87 & 12,89 & 10,49 & 7,18 \\
\hline 62,76 & 288,70 & 115,10 & 40,51 & 24,03 & 18,68 & 14,55 & 11,82 & 9,78 & 6,99 & 5,34 & 3,61 \\
\hline 75,37 & 1815,60 & 168,80 & 11,78 & 8,72 & 7,84 & 7,00 & 6,31 & 5,71 & 4,66 & 3,83 & 2,68 \\
\hline 46,43 & 819,00 & 46,50 & 45,94 & 39,02 & 35,39 & 31,07 & 27,19 & 23,74 & 18,16 & 14,14 & 9,27 \\
\hline 55,34 & 520,00 & 116,70 & 30,19 & 20,71 & 17,17 & 14,00 & 11,62 & 9,73 & 7,03 & 5,35 & 3,56 \\
\hline 60,66 & 1859,00 & 22,20 & 48,53 & 39,67 & 37,91 & 36,67 & 34,95 & 33,15 & 29,62 & 26,30 & 20,56 \\
\hline 31,16 & 630,20 & 117,60 & 36,98 & 26,63 & 21,26 & 15,92 & 12,20 & 9,63 & 6,57 & 4,98 & 3,42 \\
\hline 79,00 & 1129,00 & 34,30 & 35,88 & 27,87 & 26,14 & 24,83 & 23,45 & 22,09 & 19,51 & 17,17 & 13,26 \\
\hline 80,19 & 1674,70 & 99,60 & 15,98 & 11,98 & 11,05 & 10,16 & 9,39 & 8,67 & 7,38 & 6,29 & 4,61 \\
\hline 55,88 & 954,20 & 180,80 & 17,81 & 12,62 & 10,64 & 8,81 & 7,40 & 6,25 & 4,57 & 3,49 & 2,31 \\
\hline 73,09 & 611,00 & 188,40 & 20,30 & 12,53 & 10,05 & 8,13 & 6,83 & 5,81 & 4,32 & 3,36 & 2,26 \\
\hline 37,46 & 1581,40 & 141,90 & 20,85 & 16,93 & 14,66 & 12,08 & 9,95 & 8,25 & 5,83 & 4,37 & 2,87 \\
\hline 85,80 & 1780,10 & 39,80 & 25,55 & 20,55 & 18,92 & 18,21 & 17,47 & 16,67 & 15,09 & 13,62 & 11,00 \\
\hline 31,31 & 1386,70 & 160,20 & 22,91 & 17,79 & 14,78 & 11,51 & 9,05 & 7,24 & 4,95 & 3,71 & 2,51 \\
\hline 27,94 & 1936,70 & 103,30 & 29,83 & 25,11 & 21,62 & 17,48 & 14,10 & 11,46 & 7,90 & 5,87 & 3,89 \\
\hline 83,96 & 938,20 & 68,00 & 24,90 & 18,24 & 16,63 & 15,16 & 13,94 & 12,84 & 10,87 & 9,22 & 6,73 \\
\hline 22,56 & 1565,60 & 140,10 & 30,22 & 23,28 & 18,58 & 13,69 & 10,31 & 8,04 & 5,44 & 4,14 & 2,85 \\
\hline 41,28 & 1174,40 & 29,80 & 59,02 & 52,69 & 49,24 & 44,43 & 39,82 & 35,54 & 28,17 & 22,44 & 14,92 \\
\hline 24,47 & 1675,90 & 182,70 & 23,23 & 17,68 & 14,11 & 10,44 & 7,90 & 6,17 & 4,18 & 3,18 & 2,19 \\
\hline 72,27 & 623,00 & 66,30 & 32,55 & 24,04 & 21,39 & 18,88 & 16,87 & 15,09 & 12,11 & 9,82 & 6,75 \\
\hline 74,63 & 255,20 & 68,20 & 51,08 & 32,38 & 26,40 & 21,69 & 18,43 & 15,85 & 11,95 & 9,34 & 6,29 \\
\hline 42,48 & 1824,80 & 113,20 & 20,76 & 17,60 & 15,77 & 13,61 & 11,70 & 10,05 & 7,48 & 5,72 & 3,72 \\
\hline 71,12 & 840,70 & 100,60 & 22,84 & 16,71 & 14,73 & 12,89 & 11,43 & 10,16 & 8,05 & 6,47 & 4,41 \\
\hline 55,42 & 1975,90 & 46,40 & 30,55 & 25,40 & 24,34 & 22,70 & 21,05 & 19,45 & 16,48 & 13,92 & 10,00 \\
\hline 77,84 & 1776,00 & 177,30 & 11,43 & 8,33 & 7,45 & 6,63 & 5,98 & 5,40 & 4,42 & 3,64 & 2,55 \\
\hline
\end{tabular}




\begin{tabular}{|c|c|c|c|c|c|c|c|c|c|c|c|}
\hline \multirow[b]{2}{*}{ e1 (cm) } & & & & & & $\mathrm{De}$ & ões (x1 & & & & \\
\hline & Meq (MPa) & Ms (MPa) & D0 & D25 & D40 & D60 & D80 & D100 & D140 & D180 & D260 \\
\hline 33,64 & 1231,50 & 27,30 & 72,08 & 65,85 & 60,69 & 53,71 & 47,15 & 41,20 & 31,43 & 24,32 & 15,75 \\
\hline 82,66 & 1222,20 & 176,80 & 13,45 & 9,26 & 8,02 & 6,98 & 6,21 & 5,55 & 4,47 & 3,64 & 2,53 \\
\hline 48,41 & 602,10 & 23,70 & 76,77 & 66,13 & 61,34 & 55,17 & 49,42 & 44,11 & 35,04 & 28,01 & 18,75 \\
\hline 76,05 & 1103,20 & 67,90 & 24,43 & 18,53 & 17,10 & 15,64 & 14,37 & 13,20 & 11,11 & 9,37 & 6,76 \\
\hline 65,19 & 1055,80 & 29,20 & 46,27 & 37,07 & 35,34 & 33,23 & 31,04 & 28,93 & 24,95 & 21,45 & 15,88 \\
\hline 82,68 & 1570,60 & 145,80 & 13,09 & 9,45 & 8,48 & 7,61 & 6,92 & 6,30 & 5,23 & 4,37 & 3,12 \\
\hline 84,86 & 625,60 & 82,40 & 27,22 & 18,83 & 16,44 & 14,42 & 12,92 & 11,63 & 9,46 & 7,78 & 5,47 \\
\hline 72,97 & 1403,70 & 29,50 & 38,47 & 30,63 & 28,92 & 27,76 & 26,37 & 24,96 & 22,23 & 19,70 & 15,39 \\
\hline 40,30 & 811,00 & 138,60 & 26,25 & 19,33 & 16,09 & 12,78 & 10,27 & 8,35 & 5,82 & 4,37 & 2,93 \\
\hline 84,16 & 1963,80 & 184,10 & 10,33 & 7,42 & 6,65 & 5,97 & 5,43 & 4,95 & 4,12 & 3,45 & 2,47 \\
\hline 67,77 & 223,80 & 173,40 & 41,44 & 20,61 & 14,44 & 10,29 & 7,97 & 6,43 & 4,49 & 3,45 & 2,40 \\
\hline 25,76 & 1667,10 & 110,90 & 31,76 & 25,84 & 21,64 & 16,87 & 13,22 & 10,52 & 7,14 & 5,33 & 3,61 \\
\hline 82,66 & 1656,00 & 117,40 & 14,39 & 10,60 & 9,68 & 8,83 & 8,11 & 7,47 & 6,31 & 5,35 & 3,90 \\
\hline 85,40 & 1772,30 & 133,20 & 12,81 & 9,32 & 8,48 & 7,71 & 7,09 & 6,53 & 5,53 & 4,70 & 3,43 \\
\hline 35,74 & 941,80 & 167,10 & 23,65 & 17,29 & 14,14 & 10,94 & 8,60 & 6,89 & 4,73 & 3,56 & 2,41 \\
\hline 75,57 & 409,00 & 136,30 & 29,19 & 17,62 & 13,99 & 11,23 & 9,41 & 8,01 & 5,96 & 4,63 & 3,12 \\
\hline 65,69 & 631,70 & 96,70 & 27,79 & 19,97 & 17,22 & 14,72 & 12,78 & 11,13 & 8,52 & 6,69 & 4,47 \\
\hline 61,66 & 792,00 & 45,20 & 39,78 & 32,04 & 29,58 & 26,74 & 24,20 & 21,86 & 17,78 & 14,53 & 10,01 \\
\hline 28,80 & 797,40 & 108,30 & 37,78 & 28,45 & 23,01 & 17,37 & 13,35 & 10,53 & 7,16 & 5,41 & 3,71 \\
\hline 75,82 & 904,70 & 177,90 & 16,30 & 10,92 & 9,20 & 7,78 & 6,75 & 5,90 & 4,57 & 3,62 & 2,45 \\
\hline 21,57 & 228,00 & 59,20 & 97,99 & 63,54 & 45,91 & 31,24 & 22,92 & 17,95 & 12,53 & 9,73 & 6,79 \\
\hline 53,91 & 237,80 & 156,00 & 42,00 & 22,11 & 15,94 & 11,53 & 8,92 & 7,15 & 4,96 & 3,80 & 2,64 \\
\hline 72,48 & 1948,00 & 183,50 & 11,10 & 8,29 & 7,44 & 6,62 & 5,95 & 5,36 & 4,34 & 3,54 & 2,45 \\
\hline 39,39 & 632,40 & 188,20 & 24,77 & 16,33 & 12,87 & 9,71 & 7,55 & 6,02 & 4,14 & 3,14 & 2,15 \\
\hline 72,46 & 1696,00 & 103,10 & 16,41 & 12,62 & 11,65 & 10,63 & 9,74 & 8,91 & 7,44 & 6,23 & 4,44 \\
\hline 66,83 & 547,60 & 158,20 & 23,86 & 15,14 & 12,25 & 9,92 & 8,30 & 7,02 & 5,17 & 3,98 & 2,67 \\
\hline 27,82 & 352,80 & 102,70 & 52,20 & 34,25 & 25,75 & 18,22 & 13,58 & 10,63 & 7,32 & 5,64 & 3,93 \\
\hline 78,30 & 1319,30 & 53,60 & 25,85 & 19,81 & 18,55 & 17,37 & 16,24 & 15,16 & 13,16 & 11,40 & 8,57 \\
\hline 64,25 & 578,20 & 138,80 & 24,79 & 16,46 & 13,60 & 11,18 & 9,42 & 8,01 & 5,92 & 4,56 & 3,04 \\
\hline 38,47 & 500,00 & 111,10 & 37,43 & 26,25 & 21,24 & 16,37 & 12,86 & 10,31 & 7,10 & 5,36 & 3,64 \\
\hline 23,22 & 430,70 & 24,20 & 149,73 & 122,17 & 101,62 & 78,41 & 60,85 & 48,10 & 32,48 & 24,31 & 16,52 \\
\hline 67,34 & 1030,40 & 196,00 & 15,19 & 10,47 & 8,85 & 7,45 & 6,41 & 5,54 & 4,20 & 3,28 & 2,19 \\
\hline 40,02 & 756,20 & 167,20 & 24,33 & 17,07 & 13,88 & 10,78 & 8,52 & 6,87 & 4,75 & 3,58 & 2,42 \\
\hline 59,12 & 471,40 & 165,70 & 26,53 & 16,33 & 12,91 & 10,14 & 8,25 & 6,83 & 4,87 & 3,71 & 2,50 \\
\hline 25,63 & 1872,90 & 143,90 & 25,70 & 20,56 & 17,02 & 13,10 & 10,17 & 8,05 & 5,45 & 4,09 & 2,78 \\
\hline 43,76 & 356,30 & 93,40 & 45,08 & 30,44 & 24,54 & 19,07 & 15,15 & 12,26 & 8,52 & 6,43 & 4,35 \\
\hline 63,28 & 1935,70 & 60,00 & 23,80 & 19,21 & 18,27 & 17,04 & 15,82 & 14,65 & 12,49 & 10,62 & 7,72 \\
\hline 53,79 & 1337,60 & 27,20 & 50,90 & 42,48 & 40,85 & 38,24 & 35,53 & 32,90 & 27,99 & 23,71 & 17,12 \\
\hline 71,30 & 1030,30 & 97,60 & 21,09 & 15,81 & 14,19 & 12,60 & 11,31 & 10,15 & 8,19 & 6,67 & 4,60 \\
\hline 82,11 & 327,10 & 81,50 & 39,85 & 25,16 & 20,63 & 17,12 & 14,74 & 12,84 & 9,90 & 7,85 & 5,34 \\
\hline 64,91 & 1071,50 & 137,80 & 18,00 & 13,31 & 11,64 & 10,07 & 8,81 & 7,72 & 5,98 & 4,72 & 3,16 \\
\hline 68,91 & 1752,20 & 183,90 & 11,92 & 8,92 & 7,94 & 6,99 & 6,22 & 5,54 & 4,41 & 3,55 & 2,42 \\
\hline 43,86 & 1418,40 & 150,80 & 18,84 & 14,96 & 13,00 & 10,87 & 9,11 & 7,66 & 5,53 & 4,18 & 2,74 \\
\hline 57,16 & 854,70 & 20,80 & 67,50 & 55,73 & 53,36 & 49,85 & 46,27 & 42,82 & 36,39 & 30,83 & 22,27 \\
\hline 26,60 & 704,90 & 70,50 & 55,44 & 43,16 & 35,26 & 26,79 & 20,63 & 16,28 & 11,03 & 8,31 & 5,68 \\
\hline 76,38 & 757,10 & 103,30 & 23,03 & 16,29 & 14,20 & 12,37 & 10,97 & 9,76 & 7,77 & 6,28 & 4,31 \\
\hline 81,99 & 519,60 & 26,20 & 56,09 & 42,19 & 39,14 & 36,36 & 33,83 & 31,48 & 27,17 & 23,42 & 17,50 \\
\hline 44,21 & 403,00 & 194,30 & 29,21 & 16,97 & 12,74 & 9,36 & 7,22 & 5,76 & 3,97 & 3,03 & 2,10 \\
\hline 62,09 & 423,30 & 117,80 & 32,13 & 20,76 & 16,87 & 13,64 & 11,34 & 9,53 & 6,94 & 5,32 & 3,55 \\
\hline 41,88 & 1678,80 & 138,10 & 19,16 & 15,75 & 13,87 & 11,72 & 9,89 & 8,36 & 6,08 & 4,60 & 3,00 \\
\hline 44,39 & 1899,40 & 176,80 & 15,11 & 12,21 & 10,72 & 9,07 & 7,67 & 6,50 & 4,75 & 3,60 & 2,35 \\
\hline 70,23 & 1263,00 & 140,20 & 15,90 & 11,77 & 10,43 & 9,17 & 8,15 & 7,26 & 5,77 & 4,65 & 3,17 \\
\hline 87,59 & 1317,60 & 160,40 & 13,26 & 9,18 & 8,06 & 7,12 & 6,41 & 5,81 & 4,78 & 3,97 & 2,82 \\
\hline 73,55 & 701,10 & 93,50 & 25,55 & 18,29 & 15,98 & 13,91 & 12,30 & 10,92 & 8,64 & 6,95 & 4,74 \\
\hline 52,10 & 786,80 & 114,30 & 25,69 & 19,23 & 16,53 & 13,85 & 11,70 & 9,92 & 7,28 & 5,56 & 3,66 \\
\hline 42,45 & 764,70 & 93,60 & 32,84 & 25,54 & 21,92 & 18,04 & 14,91 & 12,39 & 8,83 & 6,64 & 4,38 \\
\hline 32,13 & 557,50 & 101,30 & 41,80 & 30,30 & 24,36 & 18,40 & 14,19 & 11,24 & 7,67 & 5,80 & 3,97 \\
\hline 22,04 & 1211,30 & 60,60 & 60,07 & 49,17 & 40,84 & 31,41 & 24,30 & 19,16 & 12,91 & 9,67 & 6,58 \\
\hline 47,61 & 465,90 & 93,60 & 38,22 & 27,15 & 22,59 & 18,22 & 14,89 & 12,29 & 8,71 & 6,58 & 4,38 \\
\hline 31,75 & 745,00 & 40,10 & 69,58 & 59,31 & 51,96 & 43,08 & 35,58 & 29,47 & 20,78 & 15,49 & 10,13 \\
\hline 85,93 & 969,90 & 140,10 & 16,73 & 11,40 & 9,87 & 8,60 & 7,67 & 6,89 & 5,58 & 4,58 & 3,20 \\
\hline 80,26 & 337,20 & 46,00 & 50,73 & 35,45 & 30,89 & 26,96 & 24,00 & 21,47 & 17,25 & 14,04 & 9,73 \\
\hline 23,55 & 555,80 & 103,40 & 49,02 & 34,25 & 25,93 & 18,27 & 13,52 & 10,53 & 7,25 & 5,59 & 3,88 \\
\hline 71,23 & 1646,10 & 59,80 & 23,49 & 18,41 & 17,38 & 16,25 & 15,15 & 14,09 & 12,13 & 10,42 & 7,71 \\
\hline 31,68 & 759,70 & 115,40 & 34,71 & 25,89 & 21,08 & 16,11 & 12,51 & 9,93 & 6,78 & 5,11 & 3,48 \\
\hline 63,89 & 1848,30 & 196,60 & 11,63 & 8,84 & 7,84 & 6,86 & 6,05 & 5,35 & 4,18 & 3,32 & 2,23 \\
\hline 27,60 & 501,40 & 118,70 & 42,32 & 28,91 & 22,12 & 15,85 & 11,86 & 9,27 & 6,36 & 4,88 & 3,39 \\
\hline 32,17 & 1158,40 & 121,10 & 28,75 & 22,67 & 19,05 & 15,05 & 11,97 & 9,64 & 6,62 & 4,95 & 3,32 \\
\hline 55,43 & 1839,40 & 127,50 & 16,16 & 13,17 & 11,95 & 10,59 & 9,39 & 8,31 & 6,51 & 5,17 & 3,45 \\
\hline 52,48 & 1046,30 & 96,70 & 24,77 & 19,77 & 17,57 & 15,20 & 13,19 & 11,44 & 8,67 & 6,73 & 4,43 \\
\hline 73,07 & 1865,30 & 186,80 & 11,17 & 8,28 & 7,40 & 6,56 & 5,88 & 5,28 & 4,27 & 3,48 & 2,40 \\
\hline 44,14 & 637,80 & 78,20 & 38,39 & 29,83 & 25,69 & 21,28 & 17,70 & 14,79 & 10,61 & 8,00 & 5,26 \\
\hline 84,01 & 1259,80 & 145,20 & 14,49 & 10,20 & 9,01 & 7,97 & 7,18 & 6,49 & 5,33 & 4,41 & 3,11 \\
\hline 29,88 & 380,20 & 29,40 & 112,47 & 91,54 & 77,71 & 61,89 & 49,41 & 39,89 & 27,39 & 20,41 & 13,65 \\
\hline 71,50 & 1582,20 & 60,40 & 23,63 & 18,49 & 17,42 & 16,26 & 15,13 & 14,06 & 12,07 & 10,35 & 7,64 \\
\hline 53,18 & 1414,00 & 118,50 & 19,25 & 15,51 & 13,88 & 12,10 & 10,57 & 9,23 & 7,07 & 5,52 & 3,64 \\
\hline 63,23 & 468,70 & 35,50 & 55,93 & 44,03 & 39,99 & 35,68 & 31,97 & 28,62 & 22,92 & 18,51 & 12,61 \\
\hline 37,32 & 680,60 & 54,20 & 52,38 & 43,16 & 37,65 & 31,28 & 25,95 & 21,61 & 15,38 & 11,53 & 7,55 \\
\hline 23,59 & 241,20 & 168,60 & 44,96 & 23,25 & 15,73 & 10,54 & 7,85 & 6,24 & 4,38 & 3,41 & 2,42 \\
\hline 64,46 & 1005,90 & 194,50 & 15,71 & 10,88 & 9,18 & 7,70 & 6,57 & 5,65 & 4,24 & 3,29 & 2,19 \\
\hline 20,16 & 515,60 & 102,60 & 54,62 & 36,65 & 26,67 & 18,16 & 13,29 & 10,38 & 7,24 & 5,62 & 3,92 \\
\hline 67,94 & 1522,70 & 30,10 & 38,88 & 31,11 & 29,62 & 28,35 & 26,85 & 25,33 & 22,41 & 19,72 & 15,20 \\
\hline
\end{tabular}




\begin{tabular}{|c|c|c|c|c|c|c|c|c|c|c|c|}
\hline \multirow[b]{2}{*}{$\mathrm{e} 1(\mathrm{~cm})$} & & & & & & $\mathrm{De}$ & $\overline{\text { ões (x1 }}$ & & & & \\
\hline & Meq (MPa) & Ms (MPa) & D0 & D25 & D40 & D60 & D80 & D100 & D140 & D180 & D260 \\
\hline 72,70 & 461,00 & 180,10 & 24,69 & 14,46 & 11,25 & 8,86 & 7,31 & 6,15 & 4,49 & 3,47 & 2,34 \\
\hline 82,14 & 466,70 & 93,30 & 30,55 & 20,06 & 16,85 & 14,28 & 12,46 & 10,97 & 8,61 & 6,90 & 4,72 \\
\hline 86,76 & 266,10 & 190,30 & 35,02 & 17,53 & 12,40 & 8,99 & 7,10 & 5,82 & 4,16 & 3,22 & 2,22 \\
\hline 77,86 & 688,50 & 79,80 & 27,26 & 19,57 & 17,30 & 15,25 & 13,65 & 12,26 & 9,91 & 8,10 & 5,63 \\
\hline 30,06 & 1117,20 & 78,10 & 40,79 & 33,62 & 28,77 & 23,13 & 18,60 & 15,09 & 10,41 & 7,75 & 5,15 \\
\hline 59,80 & 1285,30 & 103,60 & 20,25 & 16,05 & 14,49 & 12,81 & 11,38 & 10,09 & 7,95 & 6,34 & 4,26 \\
\hline 24,65 & 802,60 & 143,50 & 34,05 & 24,11 & 18,50 & 13,20 & 9,82 & 7,65 & 5,25 & 4,03 & 2,80 \\
\hline 74,71 & 688,90 & 193,90 & 18,54 & 11,62 & 9,42 & 7,70 & 6,52 & 5,59 & 4,20 & 3,28 & 2,21 \\
\hline 24,63 & 1966,00 & 74,50 & 41,03 & 35,10 & 30,29 & 24,46 & 19,69 & 15,95 & 10,95 & 8,11 & 5,38 \\
\hline 78,69 & 892,20 & 23,20 & 50,06 & 39,29 & 36,83 & 35,20 & 33,40 & 31,58 & 28,10 & 24,91 & 19,47 \\
\hline 25,06 & 745,10 & 46,60 & 75,76 & 61,82 & 51,75 & 40,30 & 31,53 & 25,07 & 16,99 & 12,69 & 8,59 \\
\hline 31,38 & 1448,20 & 26,90 & 73,08 & 67,30 & 62,06 & 54,90 & 48,14 & 42,01 & 31,96 & 24,66 & 15,93 \\
\hline 80,11 & 1340,30 & 40,40 & 30,08 & 23,36 & 21,87 & 20,80 & 19,66 & 18,54 & 16,42 & 14,48 & 11,23 \\
\hline 76,37 & 292,30 & 37,70 & 61,37 & 43,73 & 38,31 & 33,49 & 29,78 & 26,57 & 21,24 & 17,21 & 11,84 \\
\hline 87,01 & 755,50 & 75,50 & 25,60 & 18,11 & 16,16 & 14,46 & 13,14 & 11,99 & 9,99 & 8,38 & 6,02 \\
\hline 81,12 & 540,30 & 66,30 & 33,21 & 23,44 & 20,61 & 18,13 & 16,24 & 14,61 & 11,85 & 9,72 & 6,79 \\
\hline 26,61 & 1499,30 & 155,40 & 25,43 & 19,71 & 16,06 & 12,17 & 9,36 & 7,37 & 5,00 & 3,77 & 2,58 \\
\hline 36,87 & 1461,50 & 134,40 & 22,48 & 18,17 & 15,68 & 12,86 & 10,56 & 8,71 & 6,14 & 4,59 & 3,03 \\
\hline 77,70 & 917,20 & 131,60 & 18,42 & 12,89 & 11,19 & 9,71 & 8,60 & 7,65 & 6,09 & 4,92 & 3,38 \\
\hline 62,84 & 1067,50 & 178,40 & 16,06 & 11,46 & 9,80 & 8,29 & 7,12 & 6,15 & 4,64 & 3,61 & 2,40 \\
\hline 52,04 & 398,30 & 111,30 & 36,36 & 23,93 & 19,36 & 15,35 & 12,47 & 10,26 & 7,27 & 5,51 & 3,69 \\
\hline 21,76 & 1814,60 & 23,80 & 101,86 & 93,15 & 83,70 & 71,19 & 59,91 & 50,29 & 35,92 & 26,72 & 17,17 \\
\hline 76,31 & 824,10 & 190,70 & 16,66 & 10,82 & 8,96 & 7,47 & 6,42 & 5,57 & 4,26 & 3,36 & 2,27 \\
\hline 44,43 & 672,80 & 150,80 & 25,81 & 18,00 & 14,75 & 11,66 & 9,36 & 7,63 & 5,33 & 4,02 & 2,70 \\
\hline 69,38 & 1659,20 & 187,40 & 12,06 & 8,94 & 7,91 & 6,93 & 6,15 & 5,47 & 4,33 & 3,48 & 2,37 \\
\hline 85,71 & 782,20 & 99,40 & 22,07 & 15,29 & 13,39 & 11,77 & 10,57 & 9,54 & 7,80 & 6,44 & 4,54 \\
\hline 27,79 & 779,60 & 102,00 & 40,53 & 30,58 & 24,65 & 18,51 & 14,17 & 11,16 & 7,58 & 5,73 & 3,93 \\
\hline 69,19 & 1104,20 & 83,10 & 22,74 & 17,50 & 15,94 & 14,33 & 12,96 & 11,71 & 9,55 & 7,84 & 5,45 \\
\hline 31,23 & 1428,20 & 65,30 & 40,93 & 35,42 & 31,25 & 26,13 & 21,73 & 18,10 & 12,85 & 9,59 & 6,24 \\
\hline 69,02 & 857,80 & 47,60 & 35,17 & 27,51 & 25,52 & 23,31 & 21,34 & 19,52 & 16,26 & 13,56 & 9,63 \\
\hline 52,86 & 431,30 & 109,30 & 34,97 & 23,48 & 19,21 & 15,40 & 12,61 & 10,44 & 7,44 & 5,64 & 3,77 \\
\hline 27,66 & 827,40 & 77,30 & 48,18 & 38,01 & 31,44 & 24,24 & 18,87 & 14,98 & 10,17 & 7,63 & 5,18 \\
\hline 70,48 & 864,90 & 32,70 & 43,86 & 34,44 & 32,48 & 30,29 & 28,17 & 26,16 & 22,42 & 19,18 & 14,12 \\
\hline 75,31 & 459,20 & 180,60 & 24,54 & 14,28 & 11,09 & 8,74 & 7,23 & 6,10 & 4,48 & 3,47 & 2,34 \\
\hline 71,93 & 472,30 & 50,50 & 42,89 & 31,70 & 28,18 & 24,86 & 22,19 & 19,84 & 15,90 & 12,88 & 8,84 \\
\hline 78,56 & 1962,80 & 70,30 & 18,73 & 14,43 & 13,54 & 12,76 & 11,98 & 11,23 & 9,82 & 8,57 & 6,52 \\
\hline 44,07 & 1600,50 & 124,80 & 20,05 & 16,56 & 14,69 & 12,56 & 10,72 & 9,15 & 6,76 & 5,15 & 3,36 \\
\hline 21,69 & 1257,20 & 69,50 & 54,58 & 44,10 & 36,24 & 27,53 & 21,11 & 16,56 & 11,16 & 8,39 & 5,74 \\
\hline 84,60 & 849,40 & 28,60 & 42,78 & 32,88 & 30,58 & 29,02 & 27,44 & 25,89 & 22,95 & 20,29 & 15,81 \\
\hline 44,69 & 1987,50 & 179,20 & 14,65 & 11,88 & 10,46 & 8,87 & 7,53 & 6,40 & 4,69 & 3,57 & 2,33 \\
\hline 77,15 & 758,20 & 57,10 & 31,37 & 23,44 & 21,37 & 19,34 & 17,65 & 16,11 & 13,41 & 11,20 & 7,99 \\
\hline 87,22 & 620,80 & 196,30 & 18,94 & 11,29 & 8,98 & 7,28 & 6,19 & 5,35 & 4,09 & 3,24 & 2,21 \\
\hline 28,89 & 1308,20 & 188,90 & 22,05 & 16,46 & 13,26 & 9,96 & 7,64 & 6,02 & 4,10 & 3,10 & 2,13 \\
\hline 63,40 & 1548,70 & 160,80 & 14,12 & 10,78 & 9,58 & 8,39 & 7,40 & 6,54 & 5,12 & 4,07 & 2,73 \\
\hline 83,75 & 953,90 & 182,60 & 15,13 & 9,96 & 8,40 & 7,15 & 6,27 & 5,54 & 4,37 & 3,52 & 2,42 \\
\hline 68,62 & 1841,50 & 102,50 & 16,40 & 12,84 & 11,91 & 10,87 & 9,95 & 9,09 & 7,56 & 6,30 & 4,47 \\
\hline 68,92 & 1793,90 & 39,80 & 30,32 & 24,14 & 22,97 & 21,91 & 20,70 & 19,49 & 17,17 & 15,06 & 11,53 \\
\hline 82,92 & 698,70 & 108,30 & 22,76 & 15,51 & 13,35 & 11,56 & 10,24 & 9,14 & 7,31 & 5,95 & 4,12 \\
\hline 71,06 & 737,90 & 39,70 & 41,03 & 31,88 & 29,63 & 27,17 & 24,96 & 22,91 & 19,23 & 16,15 & 11,57 \\
\hline 57,23 & 1730,30 & 177,90 & 13,41 & 10,44 & 9,25 & 8,03 & 7,00 & 6,11 & 4,68 & 3,67 & 2,43 \\
\hline 45,64 & 691,30 & 143,90 & 25,81 & 18,25 & 15,09 & 12,05 & 9,76 & 8,01 & 5,63 & 4,25 & 2,84 \\
\hline 31,59 & 927,80 & 71,30 & 44,44 & 36,39 & 31,16 & 25,13 & 20,28 & 16,50 & 11,43 & 8,51 & 5,65 \\
\hline 87,76 & 329,90 & 108,20 & 35,16 & 20,78 & 16,44 & 13,27 & 11,26 & 9,72 & 7,42 & 5,87 & 4,01 \\
\hline 56,70 & 465,80 & 168,10 & 26,88 & 16,51 & 13,00 & 10,15 & 8,20 & 6,75 & 4,78 & 3,64 & 2,45 \\
\hline 23,65 & 1868,70 & 187,60 & 22,59 & 17,29 & 13,80 & 10,19 & 7,70 & 6,01 & 4,07 & 3,09 & 2,13 \\
\hline 31,04 & 1958,90 & 134,10 & 23,01 & 19,07 & 16,41 & 13,31 & 10,78 & 8,80 & 6,10 & 4,54 & 3,01 \\
\hline 64,46 & 1473,00 & 123,80 & 16,57 & 12,87 & 11,62 & 10,32 & 9,22 & 8,23 & 6,57 & 5,29 & 3,60 \\
\hline 29,16 & 981,10 & 144,10 & 28,91 & 21,54 & 17,35 & 13,05 & 10,01 & 7,90 & 5,37 & 4,06 & 2,79 \\
\hline 20,55 & 1314,50 & 52,60 & 68,48 & 56,58 & 47,13 & 36,30 & 28,08 & 22,13 & 14,88 & 11,13 & 7,58 \\
\hline 21,43 & 1353,50 & 168,00 & 28,51 & 20,84 & 16,00 & 11,36 & 8,39 & 6,52 & 4,46 & 3,43 & 2,38 \\
\hline 84,70 & 509,80 & 66,80 & 33,50 & 23,20 & 20,27 & 17,78 & 15,92 & 14,33 & 11,67 & 9,60 & 6,74 \\
\hline 64,88 & 1490,60 & 85,80 & 20,45 & 16,24 & 15,02 & 13,63 & 12,39 & 11,25 & 9,23 & 7,61 & 5,30 \\
\hline 29,24 & 276,00 & 162,50 & 42,13 & 23,22 & 16,36 & 11,21 & 8,34 & 6,58 & 4,58 & 3,55 & 2,50 \\
\hline 79,44 & 745,30 & 102,10 & 22,99 & 16,09 & 14,02 & 12,23 & 10,87 & 9,71 & 7,79 & 6,33 & 4,37 \\
\hline 21,55 & 1199,70 & 113,90 & 38,98 & 29,57 & 23,25 & 16,86 & 12,58 & 9,77 & 6,64 & 5,08 & 3,51 \\
\hline 52,58 & 1298,30 & 131,50 & 18,92 & 14,93 & 13,18 & 11,35 & 9,79 & 8,46 & 6,37 & 4,93 & 3,24 \\
\hline 89,04 & 1736,20 & 126,30 & 13,05 & 9,42 & 8,56 & 7,82 & 7,22 & 6,67 & 5,70 & 4,88 & 3,62 \\
\hline 46,83 & 1295,30 & 158,10 & 18,28 & 14,18 & 12,27 & 10,26 & 8,61 & 7,26 & 5,27 & 4,00 & 2,62 \\
\hline 55,51 & 1665,60 & 69,00 & 24,66 & 20,58 & 19,24 & 17,50 & 15,88 & 14,37 & 11,71 & 9,57 & 6,58 \\
\hline 42,58 & 1185,80 & 40,20 & 47,03 & 41,54 & 38,40 & 34,29 & 30,44 & 26,92 & 21,01 & 16,55 & 10,91 \\
\hline 26,09 & 577,40 & 169,30 & 32,63 & 21,24 & 15,77 & 11,02 & 8,17 & 6,39 & 4,42 & 3,41 & 2,38 \\
\hline 22,49 & 1792,50 & 41,90 & 67,67 & 59,55 & 52,16 & 42,86 & 34,97 & 28,61 & 19,80 & 14,63 & 9,59 \\
\hline 24,81 & 1846,20 & 56,20 & 50,37 & 43,99 & 38,50 & 31,67 & 25,88 & 21,22 & 14,74 & 10,91 & 7,16 \\
\hline 83,56 & 1752,80 & 41,50 & 25,71 & 20,43 & 18,93 & 18,19 & 17,39 & 16,54 & 14,90 & 13,36 & 10,68 \\
\hline 24,44 & 1346,50 & 179,60 & 25,09 & 18,56 & 14,57 & 10,61 & 7,95 & 6,20 & 4,22 & 3,23 & 2,23 \\
\hline 42,28 & 1301,20 & 120,00 & 22,91 & 18,56 & 16,24 & 13,63 & 11,45 & 9,64 & 6,97 & 5,27 & 3,44 \\
\hline 37,05 & 726,30 & 89,80 & 37,51 & 29,10 & 24,61 & 19,75 & 15,94 & 12,99 & 9,04 & 6,77 & 4,51 \\
\hline 33,82 & 344,30 & 172,10 & 35,86 & 20,78 & 15,18 & 10,70 & 8,04 & 6,33 & 4,37 & 3,37 & 2,36 \\
\hline 35,74 & 1221,80 & 58,10 & 41,82 & 36,36 & 32,51 & 27,77 & 23,59 & 20,02 & 14,60 & 11,03 & 7,14 \\
\hline 86,29 & 1681,30 & 123,80 & 13,59 & 9,88 & 8,99 & 8,20 & 7,54 & 6,96 & 5,91 & 5,03 & 3,69 \\
\hline 64,45 & 1726,50 & 157,00 & 13,52 & 10,43 & 9,36 & 8,28 & 7,37 & 6,56 & 5,20 & 4,17 & 2,83 \\
\hline 89,44 & 665,60 & 184,10 & 18,41 & 11,21 & 9,05 & 7,45 & 6,40 & 5,59 & 4,33 & 3,46 & 2,38 \\
\hline
\end{tabular}




\begin{tabular}{|c|c|c|c|c|c|c|c|c|c|c|c|}
\hline & & & \multicolumn{9}{|c|}{ Deflexões $\left(\times 10^{-4} \mathrm{~cm}\right)$} \\
\hline e1 (cm) & Meq (MPa) & Ms (MPa) & D0 & D25 & D40 & D60 & D80 & D100 & D140 & D180 & D260 \\
\hline 30,54 & 1684,00 & 93,70 & 31,06 & 26,29 & 22,87 & 18,77 & 15,36 & 12,62 & 8,82 & 6,56 & 4,31 \\
\hline 34,07 & 535,60 & 111,80 & 38,60 & 27,36 & 21,92 & 16,57 & 12,82 & 10,17 & 6,96 & 5,27 & 3,60 \\
\hline 55,86 & 791,30 & 172,60 & 20,04 & 13,81 & 11,49 & 9,40 & 7,82 & 6,57 & 4,76 & 3,63 & 2,41 \\
\hline 28,27 & 1055,30 & 167,00 & 26,04 & 19,12 & 15,22 & 11,30 & 8,60 & 6,76 & 4,60 & 3,49 & 2,40 \\
\hline 88,32 & 1217,80 & 112,30 & 16,46 & 11,68 & 10,47 & 9,42 & 8,61 & 7,88 & 6,62 & 5,59 & 4,06 \\
\hline 84,42 & 1797,30 & 74,90 & 17,85 & 13,51 & 12,55 & 11,79 & 11,07 & 10,38 & 9,10 & 7,95 & 6,09 \\
\hline 68,16 & 381,80 & 37,20 & 57,22 & 43,27 & 38,70 & 34,22 & 30,53 & 27,25 & 21,75 & 17,55 & 11,98 \\
\hline 45,26 & 756,70 & 142,60 & 25,00 & 18,02 & 15,03 & 12,09 & 9,84 & 8,09 & 5,71 & 4,30 & 2,87 \\
\hline 72,97 & 932,90 & 45,80 & 33,83 & 26,17 & 24,43 & 22,55 & 20,83 & 19,23 & 16,30 & 13,82 & 10,05 \\
\hline 65,54 & 851,90 & 90,00 & 25,01 & 18,92 & 16,81 & 14,74 & 13,05 & 11,55 & 9,09 & 7,26 & 4,90 \\
\hline 50,89 & 1093,40 & 112,40 & 22,71 & 17,95 & 15,80 & 13,53 & 11,62 & 9,98 & 7,46 & 5,74 & 3,77 \\
\hline 74,09 & 1269,90 & 37,00 & 34,21 & 26,79 & 25,31 & 23,99 & 22,58 & 21,21 & 18,61 & 16,26 & 12,40 \\
\hline 38,96 & 304,50 & 110,60 & 46,30 & 29,12 & 22,43 & 16,61 & 12,77 & 10,14 & 6,97 & 5,31 & 3,67 \\
\hline 45,65 & 672,70 & 171,30 & 23,81 & 16,14 & 13,10 & 10,28 & 8,23 & 6,70 & 4,68 & 3,53 & 2,38 \\
\hline 42,02 & 1962,20 & 133,50 & 18,37 & 15,44 & 13,75 & 11,77 & 10,05 & 8,58 & 6,33 & 4,82 & 3,13 \\
\hline 29,70 & 1467,40 & 199,20 & 20,14 & 15,21 & 12,37 & 9,40 & 7,26 & 5,75 & 3,91 & 2,95 & 2,02 \\
\hline 62,13 & 953,60 & 153,30 & 18,42 & 13,26 & 11,37 & 9,64 & 8,29 & 7,16 & 5,40 & 4,20 & 2,79 \\
\hline 82,38 & 368,20 & 90,60 & 35,54 & 22,48 & 18,46 & 15,34 & 13,22 & 11,52 & 8,90 & 7,07 & 4,81 \\
\hline 24,37 & 1500,00 & 189,90 & 23,41 & 17,45 & 13,75 & 10,04 & 7,54 & 5,88 & 4,00 & 3,05 & 2,11 \\
\hline 73,87 & 423,60 & 73,90 & 37,08 & 25,49 & 21,73 & 18,53 & 16,16 & 14,17 & 11,00 & 8,74 & 5,91 \\
\hline 79,81 & 1217,10 & 192,70 & 13,12 & 8,99 & 7,73 & 6,67 & 5,89 & 5,23 & 4,15 & 3,35 & 2,30 \\
\hline 24,76 & 548,60 & 124,10 & 42,11 & 28,65 & 21,55 & 15,15 & 11,22 & 8,76 & 6,04 & 4,66 & 3,24 \\
\hline 20,79 & 872,20 & 160,50 & 33,68 & 23,04 & 17,00 & 11,69 & 8,56 & 6,67 & 4,63 & 3,59 & 2,50 \\
\hline 78,40 & 1448,90 & 30,60 & 35,11 & 28,05 & 26,20 & 25,22 & 24,08 & 22,89 & 20,57 & 18,40 & 14,62 \\
\hline 65,71 & 1961,00 & 192,90 & 11,28 & 8,60 & 7,68 & 6,77 & 6,01 & 5,34 & 4,23 & 3,39 & 2,30 \\
\hline 71,72 & 853,50 & 76,00 & 26,27 & 19,77 & 17,82 & 15,90 & 14,31 & 12,90 & 10,46 & 8,56 & 5,93 \\
\hline 35,22 & 1499,40 & 53,80 & 41,41 & 36,83 & 33,35 & 28,93 & 24,91 & 21,40 & 15,89 & 12,10 & 7,81 \\
\hline 40,44 & 1672,00 & 58,70 & 33,83 & 29,99 & 27,55 & 24,40 & 21,47 & 18,83 & 14,48 & 11,28 & 7,37 \\
\hline 52,37 & 877,20 & 138,20 & 22,01 & 16,24 & 13,88 & 11,56 & 9,73 & 8,22 & 6,01 & 4,58 & 3,02 \\
\hline 38,14 & 1060,60 & 110,70 & 27,96 & 22,25 & 19,11 & 15,62 & 12,80 & 10,56 & 7,44 & 5,57 & 3,68 \\
\hline 49,38 & 464,70 & 105,10 & 35,39 & 24,48 & 20,20 & 16,21 & 13,22 & 10,92 & 7,74 & 5,85 & 3,91 \\
\hline 56,51 & 1895,90 & 180,30 & 12,88 & 10,15 & 9,03 & 7,87 & 6,88 & 6,01 & 4,62 & 3,62 & 2,40 \\
\hline 61,66 & 1224,20 & 63,40 & 27,35 & 22,11 & 20,53 & 18,65 & 16,94 & 15,37 & 12,59 & 10,34 & 7,18 \\
\hline 49,97 & 1356,40 & 62,40 & 30,18 & 25,70 & 23,71 & 21,23 & 18,96 & 16,87 & 13,34 & 10,63 & 7,10 \\
\hline 50,49 & 1198,70 & 154,10 & 18,35 & 14,05 & 12,17 & 10,25 & 8,68 & 7,37 & 5,41 & 4,13 & 2,72 \\
\hline 45,23 & 1574,00 & 49,80 & 35,57 & 31,18 & 29,08 & 26,23 & 23,54 & 21,04 & 16,74 & 13,39 & 8,95 \\
\hline 47,64 & 1369,80 & 129,00 & 19,87 & 15,98 & 14,09 & 12,03 & 10,28 & 8,79 & 6,52 & 4,99 & 3,26 \\
\hline 20,58 & 470,20 & 125,60 & 47,55 & 30,39 & 21,70 & 14,64 & 10,74 & 8,42 & 5,90 & 4,59 & 3,21 \\
\hline 60,07 & 1154,80 & 31,80 & 44,56 & 36,40 & 34,74 & 32,42 & 30,10 & 27,86 & 23,70 & 20,11 & 14,57 \\
\hline 78,43 & 736,20 & 133,40 & 20,53 & 13,84 & 11,75 & 10,02 & 8,77 & 7,72 & 6,05 & 4,84 & 3,30 \\
\hline 37,30 & 833,30 & 121,00 & 29,49 & 22,31 & 18,65 & 14,80 & 11,84 & 9,60 & 6,65 & 4,99 & 3,34 \\
\hline 31,80 & 953,20 & 179,90 & 23,99 & 17,26 & 13,81 & 10,38 & 7,98 & 6,31 & 4,30 & 3,26 & 2,24 \\
\hline 61,63 & 1488,90 & 136,50 & 15,98 & 12,44 & 11,14 & 9,81 & 8,68 & 7,68 & 6,03 & 4,80 & 3,23 \\
\hline 48,47 & 1124,70 & 157,00 & 19,12 & 14,49 & 12,45 & 10,36 & 8,67 & 7,30 & 5,29 & 4,02 & 2,64 \\
\hline 62,98 & 1448,50 & 98,80 & 19,29 & 15,31 & 14,00 & 12,55 & 11,30 & 10,15 & 8,19 & 6,65 & 4,55 \\
\hline 21,19 & 651,30 & 86,00 & 57,05 & 41,24 & 31,42 & 22,15 & 16,32 & 12,67 & 8,71 & 6,71 & 4,66 \\
\hline 45,20 & 1839,50 & 199,00 & 14,11 & 11,16 & 9,71 & 8,15 & 6,85 & 5,78 & 4,20 & 3,18 & 2,08 \\
\hline 54,90 & 833,90 & 138,50 & 21,98 & 15,99 & 13,63 & 11,38 & 9,61 & 8,15 & 5,99 & 4,58 & 3,03 \\
\hline 24,71 & 1298,80 & 86,40 & 42,07 & 34,03 & 28,28 & 21,84 & 16,98 & 13,44 & 9,10 & 6,81 & 4,63 \\
\hline 88,78 & 702,60 & 71,80 & 26,99 & 18,96 & 16,87 & 15,08 & 13,71 & 12,52 & 10,45 & 8,78 & 6,33 \\
\hline 45,34 & 1185,70 & 135,20 & 21,19 & 16,63 & 14,43 & 12,06 & 10,12 & 8,52 & 6,17 & 4,67 & 3,06 \\
\hline 28,47 & 575,50 & 150,40 & 34,00 & 22,85 & 17,42 & 12,47 & 9,34 & 7,31 & 5,02 & 3,86 & 2,68 \\
\hline 45,84 & 1116,40 & 49,10 & 39,99 & 34,60 & 31,77 & 28,24 & 25,00 & 22,05 & 17,15 & 13,50 & 8,90 \\
\hline 27,66 & 1021,30 & 188,10 & 24,59 & 17,58 & 13,76 & 10,05 & 7,57 & 5,93 & 4,05 & 3,09 & 2,14 \\
\hline 81,39 & 1666,10 & 182,10 & 11,40 & 8,14 & 7,22 & 6,41 & 5,77 & 5,22 & 4,27 & 3,53 & 2,48 \\
\hline 31,58 & 1313,70 & 40,40 & 57,17 & 51,21 & 46,19 & 39,73 & 33,91 & 28,87 & 21,13 & 15,95 & 10,28 \\
\hline 66,55 & 598,60 & 114,00 & 26,25 & 18,13 & 15,33 & 12,90 & 11,07 & 9,55 & 7,22 & 5,63 & 3,76 \\
\hline 38,11 & 1503,60 & 63,70 & 34,83 & 30,61 & 27,70 & 24,08 & 20,80 & 17,92 & 13,39 & 10,24 & 6,63 \\
\hline 45,46 & 1421,80 & 112,00 & 21,95 & 18,09 & 16,08 & 13,80 & 11,82 & 10,14 & 7,53 & 5,76 & 3,76 \\
\hline 67,82 & 1411,80 & 25,70 & 44,35 & 35,61 & 33,86 & 32,52 & 30,87 & 29,18 & 25,92 & 22,90 & 17,77 \\
\hline 60,80 & 1643,70 & 63,80 & 24,73 & 20,17 & 18,99 & 17,47 & 16,04 & 14,69 & 12,24 & 10,20 & 7,21 \\
\hline 34,98 & 577,50 & 160,00 & 29,74 & 19,93 & 15,60 & 11,59 & 8,88 & 7,03 & 4,82 & 3,66 & 2,52 \\
\hline 20,38 & 373,70 & 115,60 & 53,82 & 33,36 & 23,50 & 15,77 & 11,58 & 9,12 & 6,40 & 4,98 & 3,49 \\
\hline 22,75 & 549,40 & 195,60 & 31,67 & 19,43 & 13,82 & 9,37 & 6,90 & 5,42 & 3,79 & 2,95 & 2,06 \\
\hline 44,31 & 1639,10 & 133,60 & 18,98 & 15,60 & 13,80 & 11,78 & 10,03 & 8,56 & 6,30 & 4,80 & 3,13 \\
\hline 22,29 & 423,00 & 108,60 & 52,49 & 34,32 & 24,99 & 17,10 & 12,57 & 9,83 & 6,85 & 5,31 & 3,71 \\
\hline 79,20 & 833,90 & 161,60 & 17,53 & 11,67 & 9,84 & 8,34 & 7,28 & 6,39 & 4,99 & 3,99 & 2,72 \\
\hline 72,04 & 1658,20 & 92,90 & 17,68 & 13,66 & 12,67 & 11,61 & 10,66 & 9,78 & 8,21 & 6,89 & 4,94 \\
\hline 88,44 & 514,60 & 37,20 & 44,35 & 32,10 & 29,18 & 26,67 & 24,60 & 22,75 & 19,42 & 16,61 & 12,29 \\
\hline 44,71 & 1925,00 & 138,70 & 17,32 & 14,42 & 12,87 & 11,08 & 9,52 & 8,18 & 6,09 & 4,67 & 3,04 \\
\hline 45,72 & 1581,00 & 157,60 & 17,09 & 13,67 & 11,98 & 10,12 & 8,57 & 7,27 & 5,32 & 4,04 & 2,64 \\
\hline 51,48 & 1356,60 & 55,40 & 32,00 & 27,20 & 25,31 & 22,86 & 20,60 & 18,49 & 14,85 & 11,98 & 8,10 \\
\hline 87,11 & 1338,20 & 147,50 & 13,75 & 9,63 & 8,53 & 7,58 & 6,86 & 6,23 & 5,16 & 4,30 & 3,08 \\
\hline 47,92 & 688,30 & 183,60 & 22,25 & 14,89 & 12,06 & 9,49 & 7,64 & 6,24 & 4,38 & 3,31 & 2,23 \\
\hline 74,23 & 1922,60 & 25,10 & 36,91 & 30,92 & 28,65 & 27,83 & 26,88 & 25,75 & 23,48 & 21,31 & 17,37 \\
\hline 38,21 & 1683,00 & 135,70 & 20,65 & 17,00 & 14,86 & 12,38 & 10,31 & 8,61 & 6,15 & 4,62 & 3,02 \\
\hline 39,27 & 423,00 & 61,80 & 56,06 & 42,40 & 35,64 & 28,53 & 23,03 & 18,79 & 13,11 & 9,83 & 6,56 \\
\hline 89,63 & 327,50 & 79,70 & 39,20 & 24,41 & 20,01 & 16,68 & 14,46 & 12,71 & 9,97 & 8,01 & 5,52 \\
\hline 56,79 & 1266,00 & 170,00 & 15,91 & 11,95 & 10,37 & 8,83 & 7,58 & 6,53 & 4,90 & 3,79 & 2,50 \\
\hline 71,50 & 866,20 & 169,30 & 17,44 & 11,83 & 9,98 & 8,42 & 7,27 & 6,32 & 4,83 & 3,80 & 2,56 \\
\hline 45,46 & 415,40 & 119,10 & 36,31 & 23,99 & 19,22 & 14,91 & 11,85 & 9,60 & 6,68 & 5,05 & 3,42 \\
\hline 21,21 & 544,10 & 110,40 & 49,69 & 33,58 & 24,68 & 16,94 & 12,42 & 9,69 & 6,74 & 5,22 & 3,64 \\
\hline
\end{tabular}




\begin{tabular}{|c|c|c|c|c|c|c|c|c|c|c|c|}
\hline \multirow[b]{2}{*}{ e1 (cm) } & & & & & & & ões (x1 & m) & & & \\
\hline & Meq (MPa) & Ms (MPa) & D0 & D25 & D40 & D60 & D80 & D100 & D140 & D180 & D260 \\
\hline 60,37 & 747,40 & 29,30 & 54,19 & $\begin{array}{l}44,28 \\
\end{array}$ & 41,67 & 38,29 & 35,11 & 32,11 & 26,71 & 22,22 & 15,65 \\
\hline 78,57 & 1628,80 & 108,70 & 15,52 & 11,62 & 10,67 & 9,73 & 8,94 & 8,21 & 6,91 & 5,83 & 4,21 \\
\hline 40,42 & 823,80 & 72,00 & 38,58 & 31,48 & 27,52 & 23,02 & 19,25 & 16,15 & 11,62 & 8,75 & 5,72 \\
\hline 56,89 & 1030,60 & 21,40 & 62,80 & 51,72 & 49,73 & 46,77 & 43,63 & 40,56 & 34,81 & 29,73 & 21,76 \\
\hline 51,95 & 1179,30 & 137,30 & 19,39 & 15,03 & 13,14 & 11,18 & 9,56 & 8,19 & 6,09 & 4,68 & 3,08 \\
\hline 87,29 & 636,30 & 120,70 & 22,47 & 14,68 & 12,37 & 10,55 & 9,28 & 8,23 & 6,55 & 5,31 & 3,68 \\
\hline 33,60 & 641,70 & 48,80 & 61,82 & 50,95 & 44,02 & 35,97 & 29,38 & 24,14 & 16,89 & 12,60 & 8,31 \\
\hline 79,38 & 424,40 & 189,40 & 25,21 & 14,16 & 10,79 & 8,38 & 6,89 & 5,79 & 4,25 & 3,30 & 2,24 \\
\hline 76,68 & 1256,00 & 128,50 & 16,06 & 11,73 & 10,47 & 9,29 & 8,36 & 7,54 & 6,13 & 5,03 & 3,51 \\
\hline 25,71 & 786,90 & 22,20 & 120,47 & 106,42 & 94,00 & 78,31 & 64,76 & 53,61 & 37,67 & 27,94 & 18,18 \\
\hline 76,74 & 1214,70 & 182,00 & 13,69 & 9,55 & 8,26 & 7,14 & 6,30 & 5,59 & 4,42 & 3,56 & 2,43 \\
\hline 68,39 & 349,00 & 77,40 & 41,58 & 27,78 & 23,14 & 19,25 & 16,41 & 14,11 & 10,61 & 8,26 & 5,52 \\
\hline 27,94 & 694,30 & 109,00 & 40,06 & 29,42 & 23,38 & 17,32 & 13,16 & 10,33 & 7,03 & 5,34 & 3,68 \\
\hline 77,86 & 1911,90 & 94,00 & 15,93 & 12,13 & 11,30 & 10,47 & 9,72 & 9,02 & 7,73 & 6,62 & 4,89 \\
\hline 71,62 & 1090,80 & 194,00 & 14,45 & 9,96 & 8,48 & 7,21 & 6,26 & 5,47 & 4,21 & 3,33 & 2,24 \\
\hline 20,75 & 495,20 & 78,60 & 66,27 & 46,41 & 34,65 & 24,02 & 17,61 & 13,70 & 9,48 & 7,33 & 5,10 \\
\hline 89,60 & 641,00 & 140,60 & 20,86 & 13,22 & 10,96 & 9,23 & 8,06 & 7,12 & 5,63 & 4,55 & 3,15 \\
\hline 77,50 & 1909,30 & 69,50 & 19,22 & 14,83 & 13,92 & 13,10 & 12,28 & 11,50 & 10,03 & 8,72 & 6,60 \\
\hline 71,98 & 1170,20 & 179,10 & 14,43 & 10,18 & 8,79 & 7,56 & 6,63 & 5,83 & 4,55 & 3,62 & 2,45 \\
\hline 23,20 & 801,80 & 103,80 & 44,47 & 32,78 & 25,52 & 18,39 & 13,71 & 10,67 & 7,28 & 5,57 & 3,86 \\
\hline 61,86 & 1522,40 & 48,00 & 30,34 & 24,63 & 23,40 & 21,77 & 20,17 & 18,63 & 15,80 & 13,37 & 9,65 \\
\hline 43,49 & 1102,80 & 153,60 & 20,81 & 15,85 & 13,50 & 11,05 & 9,10 & 7,54 & 5,36 & 4,03 & 2,67 \\
\hline 22,58 & 1665,20 & 87,50 & 41,45 & 33,90 & 28,19 & 21,72 & 16,83 & 13,29 & 8,97 & 6,71 & 4,56 \\
\hline 69,14 & 1988,80 & 169,80 & 11,75 & 8,96 & 8,09 & 7,22 & 6,49 & 5,83 & 4,72 & 3,84 & 2,65 \\
\hline 54,04 & 363,40 & 97,50 & 40,04 & 26,50 & 21,57 & 17,25 & 14,11 & 11,69 & 8,34 & 6,33 & 4,23 \\
\hline 64,48 & 1770,50 & 80,60 & 20,01 & 16,03 & 15,01 & 13,77 & 12,63 & 11,56 & 9,64 & 8,04 & 5,69 \\
\hline 73,61 & 909,60 & 125,80 & 19,33 & 13,77 & 11,99 & 10,41 & 9,19 & 8,14 & 6,43 & 5,16 & 3,52 \\
\hline 85,68 & 695,70 & 194,30 & 17,74 & 10,87 & 8,78 & 7,21 & 6,18 & 5,37 & 4,14 & 3,28 & 2,24 \\
\hline 89,83 & 1843,70 & 175,00 & 10,63 & 7,49 & 6,70 & 6,02 & 5,50 & 5,04 & 4,24 & 3,58 & 2,60 \\
\hline 50,35 & 300,40 & 26,70 & 90,51 & 72,94 & 64,80 & 55,94 & 48,34 & 41,77 & 31,47 & 24,31 & 15,95 \\
\hline 46,79 & 1289,20 & 113,80 & 22,19 & 18,00 & 15,92 & 13,62 & 11,65 & 9,97 & 7,39 & 5,66 & 3,70 \\
\hline 77,04 & 460,60 & 67,10 & 36,54 & 25,57 & 22,16 & 19,21 & 16,98 & 15,08 & 11,97 & 9,65 & 6,61 \\
\hline 33,11 & 1731,60 & 102,80 & 27,18 & 23,01 & 20,15 & 16,72 & 13,83 & 11,47 & 8,11 & 6,06 & 3,96 \\
\hline 74,98 & 697,70 & 22,20 & 58,48 & $\begin{array}{l}45,58 \\
\end{array}$ & 42,98 & 40,61 & 38,16 & 35,78 & 31,29 & 27,27 & 20,71 \\
\hline 21,61 & 1934,50 & 76,70 & 44,99 & 37,54 & 31,58 & 24,65 & 19,27 & 15,29 & 10,32 & 7,69 & 5,20 \\
\hline 62,75 & 274,10 & 61,50 & 54,39 & 36,74 & 30,55 & 25,22 & 21,28 & 18,10 & 13,38 & 10,31 & 6,86 \\
\hline 42,92 & 888,90 & 129,40 & 25,36 & 19,18 & 16,27 & 13,24 & 10,84 & 8,96 & 6,34 & 4,77 & 3,16 \\
\hline 89,32 & 341,30 & 67,00 & 41,01 & 26,49 & 22,23 & 18,91 & 16,62 & 14,76 & 11,76 & 9,55 & 6,64 \\
\hline 30,14 & 974,50 & 123,90 & 31,39 & 23,96 & 19,64 & 15,06 & 11,70 & 9,29 & 6,33 & 4,76 & 3,24 \\
\hline 86,13 & 833,30 & 60,10 & 27,76 & 20,22 & 18,41 & 16,81 & 15,48 & 14,29 & 12,15 & 10,35 & 7,61 \\
\hline 73,38 & 277,70 & 127,90 & 38,69 & 21,77 & 16,55 & 12,77 & 10,41 & 8,68 & 6,29 & 4,85 & 3,29 \\
\hline 26,51 & 1553,60 & 34,40 & 69,92 & 63,19 & 56,74 & 48,35 & 40,83 & 34,40 & 24,75 & 18,51 & 11,91 \\
\hline 68,66 & 657,70 & 24,70 & 58,76 & 46,42 & 43,83 & 40,80 & 37,87 & 35,09 & 29,96 & 25,53 & 18,67 \\
\hline 79,75 & 407,90 & 149,40 & 27,96 & 16,40 & 12,83 & 10,21 & 8,54 & 7,26 & 5,41 & 4,22 & 2,86 \\
\hline 40,27 & 533,30 & 172,40 & 27,83 & 17,99 & 14,08 & 10,59 & 8,22 & 6,56 & 4,52 & 3,43 & 2,35 \\
\hline 47,74 & 1884,40 & 177,10 & 14,44 & 11,61 & 10,24 & 8,75 & 7,48 & 6,40 & 4,75 & 3,63 & 2,38 \\
\hline 58,25 & 1733,50 & 63,70 & 24,91 & 20,56 & 19,38 & 17,80 & 16,31 & 14,90 & 12,36 & 10,26 & 7,20 \\
\hline 26,74 & 1859,80 & 21,60 & 89,66 & 83,82 & 77,51 & 68,70 & 60,27 & 52,59 & 39,94 & 30,75 & 19,79 \\
\hline 41,79 & 415,60 & 138,90 & 34,60 & 22,15 & 17,34 & 13,08 & 10,20 & 8,16 & 5,62 & 4,27 & 2,92 \\
\hline 30,40 & 1702,30 & 40,60 & 53,91 & 49,02 & 44,55 & 38,68 & 33,29 & 28,55 & 21,11 & 16,02 & 10,30 \\
\hline 61,73 & 1147,40 & 144,60 & 17,40 & 13,02 & 11,40 & 9,83 & 8,56 & 7,47 & 5,73 & 4,49 & 2,99 \\
\hline 22,98 & 1388,50 & 173,40 & 26,50 & 19,60 & 15,28 & 11,01 & 8,21 & 6,39 & 4,35 & 3,34 & 2,31 \\
\hline 28,48 & 1491,90 & 126,20 & 27,99 & 22,43 & 18,78 & 14,69 & 11,56 & 9,24 & 6,30 & 4,71 & 3,18 \\
\hline 64,28 & 1757,70 & 92,10 & 18,47 & 14,76 & 13,71 & 12,49 & 11,39 & 10,37 & 8,56 & 7,08 & 4,95 \\
\hline 64,31 & 1792,30 & 33,70 & 35,58 & 28,65 & 27,41 & 26,18 & 24,73 & 23,28 & 20,49 & 17,94 & 13,69 \\
\hline 49,93 & 436,50 & 82,70 & 41,10 & 29,43 & 24,69 & 20,14 & 16,64 & 13,86 & 9,93 & 7,52 & 4,99 \\
\hline 67,50 & 513,20 & 120,70 & 27,68 & 18,32 & 15,16 & 12,54 & 10,63 & 9,10 & 6,80 & 5,27 & 3,52 \\
\hline 28,33 & 1578,30 & 57,90 & 46,43 & 40,59 & 35,81 & 29,85 & 24,72 & 20,51 & 14,47 & 10,76 & 7,00 \\
\hline 67,25 & 297,80 & 103,60 & 440,67 & 24,71 & 19,55 & 15,54 & 12,84 & 10,77 & 7,84 & 6,02 & 4,05 \\
\hline 26,96 & 745,80 & 153,50 & 31,65 & 22,14 & 17,07 & 12,30 & 9,21 & 7,20 & 4,93 & 3,78 & 2,62 \\
\hline 41,52 & 940,50 & 105,50 & 28,52 & 22,48 & 19,38 & 15,99 & 13,24 & 11,01 & 7,85 & 5,90 & 3,88 \\
\hline 89,36 & 1208,30 & 121,80 & 15,77 & 11,07 & 9,85 & 8,82 & 8,03 & 7,34 & 6,14 & 5,17 & 3,74 \\
\hline 22,80 & 1677,30 & 103,70 & 36,42 & 29,33 & 24,14 & 18,39 & 14,15 & 11,12 & 7,50 & 5,64 & 3,85 \\
\hline 42,91 & 629,00 & 154,20 & 26,72 & 18,32 & 14,85 & 11,57 & 9,20 & 7,44 & 5,17 & 3,90 & 2,64 \\
\hline 37,10 & 432,40 & 30,80 & 88,84 & 74,18 & 65,11 & 54,46 & 45,45 & 38,02 & 27,21 & 20,43 & 13,33 \\
\hline 70,71 & 792,00 & 156,80 & 19,04 & 12,92 & 10,88 & 9,16 & 7,89 & 6,85 & 5,22 & 4,10 & 2,75 \\
\hline 37,07 & 379,10 & 46,80 & 71,87 & 55,76 & 47,17 & 37,85 & 30,55 & 24,92 & 17,34 & 12,98 & 8,65 \\
\hline 32,54 & 1829,80 & 30,10 & $\begin{array}{ll}61,03 \\
\end{array}$ & 56,27 & 52,36 & 46,84 & 41,54 & 36,65 & 28,41 & 22,21 & 14,48 \\
\hline 64,46 & 856,00 & 95,90 & 24,32 & 18,33 & 16,21 & 14,14 & 12,46 & 10,98 & 8,58 & 6,81 & 4,58 \\
\hline 78,46 & 1734,70 & 93,80 & 16,51 & 12,50 & 11,59 & 10,70 & 9,90 & 9,16 & 7,82 & 6,67 & 4,90 \\
\hline 89,65 & 1973,20 & 195,50 & 9,72 & 6,83 & 6,09 & 5,46 & 4,97 & 4,55 & 3,81 & 3,21 & 2,33 \\
\hline 35,28 & 1299,90 & 106,30 & 28,09 & 23,01 & 19,91 & 16,33 & 13,40 & 11,05 & 7,77 & 5,81 & 3,82 \\
\hline 70,43 & 1733,70 & 54,30 & 24,72 & 19,47 & 18,45 & 17,36 & 16,25 & 15,17 & 13,16 & 11,37 & 8,50 \\
\hline 44,53 & 1958,10 & 187,30 & 14,39 & 11,59 & 10,16 & 8,58 & 7,25 & 6,14 & 4,48 & 3,40 & 2,22 \\
\hline 68,62 & 236,30 & 85,50 & 50,22 & 30,17 & 23,74 & 18,81 & 15,53 & 13,03 & 9,49 & 7,30 & 4,91 \\
\hline 46,16 & 1227,50 & 180,90 & 17,48 & 13,16 & 11,22 & 9,23 & 7,65 & 6,38 & 4,57 & 3,45 & 2,28 \\
\hline 58,58 & 1290,50 & 65,40 & 27,08 & 22,20 & 20,58 & 18,63 & 16,86 & 15,22 & 12,36 & 10,08 & 6,92 \\
\hline 45,00 & 1379,80 & 145,20 & 19,17 & 15,22 & 13,27 & 11,15 & 9,39 & 7,92 & 5,76 & 4,36 & 2,86 \\
\hline 58,68 & 506,40 & 121,20 & 29,35 & 19,74 & 16,29 & 13,29 & 11,07 & 9,31 & 6,77 & 5,18 & 3,45 \\
\hline 45,08 & 1647,50 & 183,60 & 15,51 & 12,21 & 10,61 & 8,88 & 7,45 & 6,27 & 4,54 & 3,44 & 2,25 \\
\hline 86,89 & 755,70 & 85,90 & 23,99 & 16,77 & 14,81 & 13,14 & 11,87 & 10,77 & 8,90 & 7,40 & 5,27 \\
\hline 44,25 & 1078,70 & 148,80 & 21,17 & 16,14 & 13,79 & 11,32 & 9,35 & 7,78 & 5,55 & 4,18 & 2,76 \\
\hline
\end{tabular}




\begin{tabular}{|c|c|c|c|c|c|c|c|c|c|c|c|}
\hline \multirow[b]{2}{*}{ e1 (cm) } & & & & & & $\mathrm{De}$ & ões (x1 & & & & \\
\hline & Meq (MPa) & Ms (MPa) & D0 & D25 & D40 & D60 & D80 & D100 & D140 & D180 & D260 \\
\hline 31,55 & 1378,20 & 191,20 & 20,35 & 15,39 & 12,62 & 9,70 & 7,57 & 6,02 & 4,11 & 3,09 & 2,10 \\
\hline 76,23 & 1425,50 & 130,10 & 15,08 & 11,14 & 10,03 & 8,97 & 8,11 & 7,34 & 6,01 & 4,96 & 3,48 \\
\hline 84,48 & 727,10 & 129,50 & 20,42 & 13,57 & 11,52 & 9,87 & 8,69 & 7,71 & 6,13 & 4,96 & 3,43 \\
\hline 59,49 & 1298,60 & 55,60 & 29,72 & 24,36 & 22,81 & 20,85 & 19,03 & 17,32 & 14,28 & 11,79 & 8,22 \\
\hline 26,58 & 342,20 & 110,40 & 51,23 & 32,74 & 24,18 & 16,86 & 12,50 & 9,79 & 6,78 & 5,24 & 3,66 \\
\hline 36,13 & 1823,10 & 193,00 & 16,73 & 13,26 & 11,31 & 9,14 & 7,41 & 6,06 & 4,23 & 3,16 & 2,10 \\
\hline 59,53 & 1298,10 & 119,90 & 18,58 & 14,55 & 13,01 & 11,41 & 10,06 & 8,86 & 6,90 & 5,46 & 3,65 \\
\hline 77,03 & 844,40 & 180,20 & 16,77 & 11,03 & 9,22 & 7,74 & 6,70 & 5,84 & 4,50 & 3,57 & 2,41 \\
\hline 72,57 & 374,10 & 142,40 & 30,72 & 18,10 & 14,13 & 11,16 & 9,23 & 7,77 & 5,69 & 4,39 & 2,96 \\
\hline 56,83 & 1869,40 & 186,10 & 12,69 & 9,93 & 8,82 & 7,66 & 6,69 & 5,84 & 4,48 & 3,51 & 2,32 \\
\hline 58,72 & 1570,40 & 118,30 & 17,42 & 13,95 & 12,63 & 11,20 & 9,95 & 8,84 & 6,97 & 5,56 & 3,74 \\
\hline 56,00 & 1218,10 & 77,70 & 25,52 & 20,89 & 19,06 & 16,98 & 15,13 & 13,46 & 10,64 & 8,50 & 5,71 \\
\hline 50,28 & 1474,60 & 24,30 & 55,92 & 47,13 & 45,50 & 42,68 & 39,71 & 36,80 & 31,34 & 26,57 & 19,18 \\
\hline 86,05 & 1810,60 & 87,20 & 16,09 & 12,03 & 11,13 & 10,39 & 9,71 & 9,08 & 7,91 & 6,89 & 5,23 \\
\hline 42,86 & 1012,40 & 22,40 & 73,26 & 64,92 & 61,28 & 55,85 & 50,59 & 45,61 & 36,84 & 29,80 & 20,14 \\
\hline 67,31 & 284,30 & 149,00 & 36,77 & 20,22 & 15,11 & 11,42 & 9,15 & 7,52 & 5,35 & 4,10 & 2,79 \\
\hline 20,80 & 449,50 & 115,10 & 51,09 & 32,99 & 23,69 & 16,04 & 11,75 & 9,21 & 6,45 & 5,01 & 3,50 \\
\hline 76,10 & 1279,00 & 149,40 & 14,76 & 10,65 & 9,41 & 8,28 & 7,39 & 6,62 & 5,33 & 4,34 & 3,00 \\
\hline 39,70 & 1057,30 & 101,50 & 28,73 & 23,14 & 20,07 & 16,63 & 13,79 & 11,48 & 8,18 & 6,15 & 4,03 \\
\hline 73,61 & 1293,60 & 104,90 & 18,04 & 13,59 & 12,33 & 11,08 & 10,04 & 9,10 & 7,47 & 6,17 & 4,33 \\
\hline 37,30 & 1663,80 & 69,30 & 32,35 & 28,46 & 25,73 & 22,31 & 19,23 & 16,53 & 12,30 & 9,39 & 6,07 \\
\hline 50,06 & 1832,70 & 92,10 & 21,10 & 17,89 & 16,42 & 14,64 & 13,02 & 11,55 & 9,07 & 7,20 & 4,79 \\
\hline 26,24 & 1207,10 & 137,90 & 29,82 & 22,77 & 18,36 & 13,76 & 10,50 & 8,25 & 5,59 & 4,23 & 2,91 \\
\hline 39,24 & 1664,70 & 32,60 & 51,64 & 46,49 & 43,75 & 39,71 & 35,79 & 32,10 & 25,66 & 20,56 & 13,74 \\
\hline 73,31 & 1613,60 & 60,60 & 23,07 & 17,95 & 16,91 & 15,82 & 14,76 & 13,75 & 11,87 & 10,22 & 7,60 \\
\hline 89,00 & 1145,30 & 150,50 & 14,62 & 9,99 & 8,71 & 7,65 & 6,88 & 6,22 & 5,10 & 4,23 & 3,00 \\
\hline 31,32 & 1010,40 & 123,20 & 30,35 & 23,38 & 19,34 & 15,01 & 11,77 & 9,40 & 6,42 & 4,82 & 3,26 \\
\hline 48,68 & 263,40 & 64,90 & 60,12 & 40,89 & 33,42 & 26,55 & 21,51 & 17,67 & 12,45 & 9,41 & 6,31 \\
\hline 47,02 & 1917,40 & 163,40 & 15,19 & 12,37 & 10,97 & 9,41 & 8,07 & 6,93 & 5,15 & 3,95 & 2,58 \\
\hline 71,24 & 873,50 & 93,70 & 23,26 & 17,22 & 15,31 & 13,49 & 12,03 & 10,75 & 8,59 & 6,95 & 4,76 \\
\hline 83,77 & 1812,70 & 42,70 & 24,86 & 19,78 & 18,32 & 17,60 & 16,83 & 16,01 & 14,43 & 12,95 & 10,36 \\
\hline 60,62 & 911,10 & 145,60 & 19,56 & 14,15 & 12,13 & 10,27 & 8,80 & 7,58 & 5,69 & 4,41 & 2,93 \\
\hline 69,85 & 1062,50 & 189,00 & 14,98 & 10,38 & 8,83 & 7,50 & 6,49 & 5,66 & 4,34 & 3,41 & 2,29 \\
\hline 53,51 & 971,50 & 89,60 & 26,41 & 21,04 & 18,71 & 16,24 & 14,12 & 12,28 & 9,35 & 7,28 & 4,80 \\
\hline 52,37 & 1476,90 & 170,20 & 15,50 & 12,02 & 10,52 & 8,97 & 7,68 & 6,59 & 4,92 & 3,78 & 2,49 \\
\hline 29,02 & 1395,30 & 139,90 & 26,34 & 20,70 & 17,17 & 13,30 & 10,40 & 8,29 & 5,64 & 4,23 & 2,87 \\
\hline 40,80 & 1861,50 & 163,20 & 16,93 & 13,80 & 12,08 & 10,12 & 8,47 & 7,11 & 5,13 & 3,86 & 2,53 \\
\hline 42,16 & 334,00 & 22,20 & 109,12 & 91,87 & 81,94 & 70,30 & 60,13 & 51,42 & 38,01 & 28,98 & 18,84 \\
\hline 70,70 & 1779,40 & 196,40 & 11,28 & 8,35 & 7,40 & 6,51 & 5,79 & 5,16 & 4,11 & 3,32 & 2,27 \\
\hline 25,92 & 1394,20 & 168,50 & 25,02 & 18,93 & 15,16 & 11,27 & 8,56 & 6,71 & 4,55 & 3,46 & 2,38 \\
\hline 60,08 & 1346,10 & 31,30 & 42,96 & 35,00 & 33,56 & 31,57 & 29,47 & 27,43 & 23,59 & 20,20 & 14,86 \\
\hline 58,61 & 1451,20 & 198,20 & 13,53 & 10,09 & 8,76 & 7,48 & 6,44 & 5,56 & 4,20 & 3,26 & 2,16 \\
\hline 49,96 & 1384,40 & 166,10 & 16,61 & 12,87 & 11,19 & 9,46 & 8,03 & 6,83 & 5,03 & 3,84 & 2,52 \\
\hline 56,33 & 691,30 & 162,80 & 22,02 & 14,92 & 12,33 & 10,02 & 8,31 & 6,96 & 5,03 & 3,84 & 2,55 \\
\hline 47,81 & 1239,30 & 130,60 & 20,53 & 16,25 & 14,23 & 12,06 & 10,25 & 8,72 & 6,42 & 4,90 & 3,21 \\
\hline 36,29 & 663,60 & 147,50 & 29,03 & 20,36 & 16,35 & 12,46 & 9,70 & 7,74 & 5,31 & 4,01 & 2,74 \\
\hline 43,48 & 1498,30 & 94,20 & 24,67 & 20,87 & 18,72 & 16,20 & 13,96 & 12,03 & 8,99 & 6,90 & 4,49 \\
\hline 80,30 & 974,80 & 198,60 & 14,61 & 9,61 & 8,06 & 6,81 & 5,93 & 5,20 & 4,06 & 3,24 & 2,21 \\
\hline 51,96 & 1134,20 & 79,40 & 27,10 & 22,30 & 20,15 & 17,71 & 15,57 & 13,66 & 10,55 & 8,28 & 5,47 \\
\hline 87,10 & 1257,70 & 26,80 & 36,64 & 29,79 & 27,31 & 26,29 & 25,29 & 24,18 & 21,98 & 19,91 & 16,20 \\
\hline 23,61 & 1136,80 & 179,20 & 26,95 & 19,35 & 14,87 & 10,60 & 7,87 & 6,13 & 4,20 & 3,23 & 2,24 \\
\hline 30,19 & 1762,40 & 123,50 & 25,72 & 21,20 & 18,15 & 14,60 & 11,75 & 9,54 & 6,58 & 4,90 & 3,26 \\
\hline 37,21 & 515,30 & 155,80 & 30,85 & 20,28 & 15,86 & 11,83 & 9,11 & 7,24 & 4,97 & 3,78 & 2,60 \\
\hline 80,02 & 1515,30 & 52,90 & 24,35 & 18,74 & 17,55 & 16,58 & 15,60 & 14,65 & 12,87 & 11,27 & 8,63 \\
\hline 74,54 & 497,70 & 99,30 & 29,62 & 19,86 & 16,71 & 14,10 & 12,21 & 10,65 & 8,20 & 6,48 & 4,38 \\
\hline 49,46 & 781,20 & 66,40 & 36,14 & 29,33 & 26,10 & 22,55 & 19,48 & 16,83 & 12,67 & 9,78 & 6,41 \\
\hline 73,89 & 1908,50 & 74,10 & 19,01 & 14,76 & 13,89 & 12,98 & 12,11 & 11,27 & 9,72 & 8,36 & 6,22 \\
\hline 46,40 & 1459,00 & 86,00 & 25,21 & 21,35 & 19,32 & 16,92 & 14,78 & 12,88 & 9,83 & 7,63 & 5,00 \\
\hline 23,82 & 696,50 & 195,80 & 28,98 & 18,81 & 13,78 & 9,50 & 7,00 & 5,48 & 3,80 & 2,95 & 2,06 \\
\hline 65,09 & 344,30 & 194,50 & 29,77 & 16,11 & 11,90 & 8,89 & 7,06 & 5,77 & 4,07 & 3,12 & 2,13 \\
\hline 63,72 & 1413,60 & 148,00 & 15,36 & 11,70 & 10,39 & 9,10 & 8,03 & 7,09 & 5,55 & 4,42 & 2,97 \\
\hline 69,26 & 341,40 & 139,40 & 33,18 & 19,34 & 14,98 & 11,70 & 9,58 & 8,00 & 5,79 & 4,45 & 3,01 \\
\hline 23,46 & 1662,60 & 154,40 & 26,99 & 20,83 & 16,71 & 12,39 & 9,38 & 7,32 & 4,96 & 3,76 & 2,59 \\
\hline 66,40 & 466,80 & 198,10 & 24,15 & 14,02 & 10,80 & 8,38 & 6,82 & 5,66 & 4,06 & 3,11 & 2,11 \\
\hline 28,39 & 999,80 & 132,30 & 30,94 & 23,36 & 18,89 & 14,24 & 10,93 & 8,62 & 5,86 & 4,43 & 3,03 \\
\hline 77,34 & 404,20 & 53,40 & 43,60 & 30,87 & 26,99 & 23,57 & 20,95 & 18,69 & 14,95 & 12,12 & 8,35 \\
\hline 72,65 & 1286,80 & 154,20 & 14,77 & 10,75 & 9,47 & 8,30 & 7,38 & 6,57 & 5,23 & 4,22 & 2,88 \\
\hline 59,71 & 1119,30 & 31,30 & 45,64 & 37,35 & 35,62 & 33,21 & 30,80 & 28,47 & 24,18 & 20,47 & 14,79 \\
\hline 87,60 & 1193,80 & 94,30 & 18,29 & 13,18 & 11,93 & 10,84 & 9,96 & 9,17 & 7,77 & 6,61 & 4,84 \\
\hline 26,42 & 1411,90 & 164,00 & 25,09 & 19,13 & 15,43 & 11,56 & 8,83 & 6,93 & 4,70 & 3,56 & 2,44 \\
\hline 78,49 & 1690,10 & 154,30 & 12,55 & 9,20 & 8,28 & 7,42 & 6,72 & 6,10 & 5,02 & 4,16 & 2,94 \\
\hline 72,26 & 1585,40 & 152,10 & 13,52 & 10,09 & 9,05 & 8,04 & 7,22 & 6,49 & 5,24 & 4,28 & 2,96 \\
\hline 65,87 & 1905,20 & 185,10 & 11,68 & 8,91 & 7,96 & 7,02 & 6,25 & 5,56 & 4,40 & 3,53 & 2,40 \\
\hline 76,17 & 1365,00 & 105,60 & 17,28 & 12,93 & 11,77 & 10,63 & 9,68 & 8,82 & 7,31 & 6,08 & 4,32 \\
\hline 74,19 & 1918,80 & 190,40 & 10,84 & 8,01 & 7,16 & 6,36 & 5,72 & 5,14 & 4,17 & 3,41 & 2,36 \\
\hline 35,68 & 1028,30 & 118,80 & 28,32 & 22,15 & 18,74 & 15,01 & 12,08 & 9,83 & 6,82 & 5,10 & 3,40 \\
\hline 68,68 & 404,80 & 30,90 & 61,78 & 47,60 & 43,33 & 38,89 & 35,12 & 31,70 & 25,79 & 21,12 & 14,64 \\
\hline 88,26 & 1749,80 & 170,40 & 11,14 & 7,87 & 7,03 & 6,30 & 5,74 & 5,25 & 4,39 & 3,70 & 2,67 \\
\hline 49,14 & 919,50 & 173,20 & 19,73 & 14,16 & 11,87 & 9,67 & 7,97 & 6,63 & 4,74 & 3,58 & 2,38 \\
\hline 41,24 & 283,70 & 124,30 & 44,27 & 26,49 & 20,05 & 14,72 & 11,31 & 9,00 & 6,20 & 4,73 & 3,27 \\
\hline 32,03 & 1159,60 & 92,10 & 34,44 & 28,12 & 24,07 & 19,41 & 15,68 & 12,76 & 8,84 & 6,59 & 4,38 \\
\hline 69,92 & 986,60 & 40,60 & 36,60 & 28,75 & 27,05 & 25,10 & 23,26 & 21,52 & 18,33 & 15,59 & 11,37 \\
\hline
\end{tabular}




\begin{tabular}{|c|c|c|c|c|c|c|c|c|c|c|c|}
\hline & & & \multicolumn{9}{|c|}{ Deflexões $\left(\times 10^{-4} \mathrm{~cm}\right)$} \\
\hline e1 (cm) & Meq (MPa) & Ms (MPa) & D0 & D25 & D40 & D60 & D80 & D100 & D140 & D180 & D260 \\
\hline 79,65 & 1155,80 & 154,40 & 14,99 & 10,52 & 9,18 & 8,03 & 7,15 & 6,39 & 5,14 & 4,18 & 2,90 \\
\hline 58,58 & 1791,60 & 155,50 & 14,08 & 11,13 & 9,99 & 8,78 & 7,75 & 6,83 & 5,33 & 4,22 & 2,82 \\
\hline 44,00 & 890,00 & 143,70 & 23,53 & 17,47 & 14,73 & 11,94 & 9,76 & 8,05 & 5,69 & 4,29 & 2,84 \\
\hline 26,99 & 1108,60 & 184,40 & 24,62 & 17,85 & 14,02 & 10,26 & 7,74 & 6,06 & 4,13 & 3,15 & 2,18 \\
\hline 22,90 & 1256,70 & 175,90 & 27,02 & 19,65 & 15,15 & 10,83 & 8,04 & 6,25 & 4,28 & 3,28 & 2,28 \\
\hline 34,35 & 980,80 & 149,50 & 25,55 & 19,13 & 15,76 & 12,25 & 9,64 & 7,73 & 5,30 & 3,98 & 2,70 \\
\hline 65,53 & 635,80 & 68,60 & 33,13 & 25,00 & 22,18 & 19,42 & 17,17 & 15,19 & 11,94 & 9,52 & 6,42 \\
\hline 74,76 & 1835,60 & 132,80 & 13,47 & 10,18 & 9,30 & 8,42 & 7,68 & 7,00 & 5,81 & 4,84 & 3,44 \\
\hline 39,66 & 1336,20 & 106,50 & 25,50 & 21,04 & 18,47 & 15,50 & 12,99 & 10,91 & 7,86 & 5,92 & 3,87 \\
\hline 81,55 & 1153,80 & 53,40 & 26,66 & 20,17 & 18,76 & 17,50 & 16,33 & 15,23 & 13,20 & 11,42 & 8,58 \\
\hline 21,08 & 268,60 & 31,20 & 152,38 & 112,05 & 86,20 & 61,24 & 45,25 & 35,11 & 24,03 & 18,49 & 12,83 \\
\hline 58,95 & 884,80 & 67,30 & 30,69 & 24,53 & 22,20 & 19,68 & 17,50 & 15,53 & 12,25 & 9,78 & 6,57 \\
\hline 21,91 & 681,20 & 64,40 & 68,11 & 51,85 & 40,93 & 29,82 & 22,30 & 17,34 & 11,77 & 8,99 & 6,21 \\
\hline 88,37 & 716,30 & 193,20 & 17,32 & 10,62 & 8,60 & 7,09 & 6,10 & 5,33 & 4,14 & 3,30 & 2,27 \\
\hline 26,34 & 292,90 & 54,60 & 87,39 & 62,01 & 48,03 & 34,67 & 25,97 & 20,28 & 13,87 & 10,62 & 7,36 \\
\hline 24,75 & 532,00 & 51,10 & 79,42 & 61,55 & 49,76 & 37,29 & 28,43 & 22,29 & 15,09 & 11,41 & 7,84 \\
\hline 83,58 & 308,90 & 26,80 & 68,61 & 49,66 & 44,79 & 40,36 & 36,82 & 33,67 & 28,14 & 23,63 & 17,00 \\
\hline 59,96 & 1054,70 & 39,20 & 39,96 & 32,72 & 30,86 & 28,42 & 26,10 & 23,90 & 19,93 & 16,61 & 11,73 \\
\hline 81,93 & 601,00 & 188,00 & 19,93 & 12,04 & 9,60 & 7,79 & 6,60 & 5,68 & 4,30 & 3,38 & 2,29 \\
\hline 80,21 & 1563,40 & 42,80 & 27,33 & 21,37 & 19,99 & 19,09 & 18,11 & 17,12 & 15,23 & 13,51 & 10,57 \\
\hline 37,44 & 1401,40 & 114,60 & 24,95 & 20,49 & 17,85 & 14,80 & 12,27 & 10,21 & 7,26 & 5,44 & 3,56 \\
\hline 30,72 & 1975,60 & 98,60 & 28,31 & 24,24 & 21,24 & 17,59 & 14,51 & 12,00 & 8,45 & 6,29 & 4,11 \\
\hline 87,59 & 934,60 & 142,70 & 16,81 & 11,32 & 9,74 & 8,46 & 7,53 & 6,75 & 5,47 & 4,48 & 3,14 \\
\hline 24,37 & 1633,20 & 87,90 & 39,18 & 32,34 & 27,22 & 21,32 & 16,75 & 13,34 & 9,04 & 6,74 & 4,55 \\
\hline 50,28 & 1134,80 & 69,30 & 30,05 & 25,14 & 22,84 & 20,16 & 17,77 & 15,62 & 12,10 & 9,51 & 6,28 \\
\hline 22,87 & 858,20 & 175,20 & 30,16 & 20,65 & 15,41 & 10,73 & 7,91 & 6,16 & 4,26 & 3,29 & 2,29 \\
\hline 32,11 & 1850,30 & 111,80 & 25,75 & 21,71 & 18,91 & 15,58 & 12,80 & 10,56 & 7,42 & 5,53 & 3,63 \\
\hline 55,30 & 248,60 & 92,90 & 50,00 & 30,54 & 23,92 & 18,56 & 14,92 & 12,22 & 8,62 & 6,55 & 4,43 \\
\hline 31,11 & 822,50 & 133,20 & 31,10 & 22,93 & 18,52 & $\begin{array}{l}14,002 \\
14,02\end{array}$ & $\frac{14, v<}{10,82}$ & $\begin{array}{c}+L, L L \\
8,57\end{array}$ & 5,84 & 4,41 & 3,02 \\
\hline 74,07 & 1968,20 & 78,80 & 18,06 & 14,00 & 13,16 & 12,29 & 11,45 & 10,65 & 9,17 & 7,88 & 5,85 \\
\hline 81,47 & 1549,80 & 88,20 & 17,57 & 13,15 & 12,15 & 11,21 & 10,38 & 9,62 & 8,23 & 7,04 & 5,20 \\
\hline 35,22 & 1030,40 & 143,50 & 25,35 & 19,28 & 16,05 & 12,63 & 10,03 & 8,09 & 5,57 & 4,18 & 2,81 \\
\hline 55,33 & 1894,50 & 122,70 & 16,37 & 13,41 & 12,22 & 10,86 & 9,66 & 8,57 & 6,75 & 5,38 & 3,60 \\
\hline 32,49 & 1028,00 & 74,60 & 40,76 & 33,69 & 29,07 & 23,68 & 19,27 & 15,79 & 11,01 & 8,20 & 5,42 \\
\hline 21,91 & 747,40 & 190,70 & 30,08 & 19,63 & 14,25 & 9,73 & 7,14 & 5,59 & 3,90 & 3,02 & 2,11 \\
\hline 71,63 & 1536,40 & 93,60 & 18,20 & 14,04 & 12,96 & 11,81 & 10,81 & 9,88 & 8,23 & 6,88 & 4,89 \\
\hline 85,59 & 421,50 & 37,90 & 48,84 & 35,03 & 31,49 & 28,36 & 25,87 & 23,67 & 19,81 & 16,67 & 12,03 \\
\hline 25,92 & 1053,00 & 20,30 & 115,44 & 105,10 & 94,74 & 81,12 & 68,80 & 58,20 & 42,09 & 31,52 & 20,25 \\
\hline 50,75 & 1861,70 & 58,60 & 28,00 & 23,95 & 22,55 & 20,59 & 18,73 & 16,97 & 13,85 & 11,31 & 7,76 \\
\hline 57,14 & 546,60 & 40,70 & 51,23 & 41,27 & 37,35 & 33,06 & 29,31 & 25,95 & 20,37 & 16,19 & 10,83 \\
\hline 36,61 & 291,20 & 196,10 & 35,72 & 18,93 & 13,38 & 9,31 & 6,99 & 5,53 & 3,83 & 2,96 & 2,08 \\
\hline 56,53 & 993,60 & 73,60 & 28,43 & 22,96 & 20,78 & 18,37 & 16,27 & 14,39 & 11,27 & 8,95 & 5,98 \\
\hline 55,95 & 1356,00 & 98,50 & 21,20 & 17,18 & 15,55 & 13,75 & 12,18 & 10,77 & 8,43 & 6,68 & 4,46 \\
\hline 27,70 & 369,60 & 58,80 & 75,02 & 54,94 & 43,55 & 32,18 & 24,41 & 19,14 & 13,03 & 9,91 & 6,83 \\
\hline 82,98 & 421,00 & 112,90 & 30,01 & 18,65 & 15,15 & 12,49 & 10,71 & 9,30 & 7,14 & 5,66 & 3,85 \\
\hline 22,40 & 415,60 & 74,80 & 68,99 & 48,06 & 36,10 & 25,23 & 18,59 & 14,47 & 9,99 & 7,71 & 5,37 \\
\hline 89,28 & 1204,20 & 66,40 & 21,91 & 16,14 & 14,82 & 13,76 & 12,83 & 11,98 & 10,41 & 9,05 & 6,86 \\
\hline 46,75 & 1877,20 & 105,70 & 20,06 & 17,04 & 15,47 & 13,60 & 11,92 & 10,42 & 7,99 & 6,23 & 4,09 \\
\hline 72,12 & 641,80 & 22,70 & 60,92 & 47,66 & 44,99 & 42,18 & 39,38 & 36,71 & 31,71 & 27,33 & 20,36 \\
\hline 68,29 & 1149,00 & 171,10 & 15,23 & 10,91 & 9,43 & 8,11 & 7,08 & 6,20 & 4,80 & 3,79 & 2,55 \\
\hline 31,36 & 600,90 & 158,90 & 30,90 & 20,84 & 16,13 & 11,77 & 8,91 & 7,00 & 4,80 & 3,66 & 2,54 \\
\hline 68,25 & 1068,60 & 144,90 & 17,16 & 12,46 & 10,86 & 9,40 & 8,25 & 7,25 & 5,65 & 4,49 & 3,02 \\
\hline 85,45 & 600,80 & 93,70 & 26,11 & 17,64 & 15,17 & 13,13 & 11,66 & 10,43 & 8,39 & 6,85 & 4,77 \\
\hline 36,28 & 1695,70 & 126,30 & 22,37 & 18,56 & 16,21 & 13,46 & 11,16 & 9,28 & 6,59 & 4,94 & 3,23 \\
\hline 21,96 & 511,30 & 112,30 & 49,02 & 32,89 & 24,19 & 16,65 & 12,23 & 9,54 & 6,63 & 5,14 & 3,58 \\
\hline 89,49 & 1014,50 & 130,60 & 16,63 & 11,38 & 9,94 & 8,74 & 7,87 & 7,12 & 5,86 & 4,86 & 3,46 \\
\hline 37,52 & 1957,50 & 79,00 & 27,95 & 24,65 & 22,33 & 19,42 & 16,78 & 14,46 & 10,80 & 8,26 & 5,35 \\
\hline 64,10 & 983,20 & 128,70 & 19,55 & 14,45 & 12,62 & 10,89 & 9,51 & 8,32 & 6,41 & 5,05 & 3,38 \\
\hline 49,09 & 985,00 & 75,60 & 30,60 & 25,13 & 22,50 & 19,54 & 16,96 & 14,71 & 11,14 & 8,63 & 5,65 \\
\hline 36,41 & 728,10 & 34,30 & 69,53 & 60,53 & 54,25 & 46,50 & 39,63 & 33,74 & 24,74 & 18,73 & 12,12 \\
\hline 33,88 & 417,50 & 24,70 & 111,02 & 94,19 & 82,73 & 68,97 & 57,30 & 47,71 & 33,91 & 25,35 & 16,54 \\
\hline 22,50 & 1493,40 & 86,40 & $4+1,28$ & 35,02 & 28,89 & 22,06 & 16,99 & 13,37 & 9,01 & 6,77 & 4,62 \\
\hline 80,74 & 1227,80 & 178,00 & 13,50 & 9,34 & 8,09 & 7,03 & 6,25 & 5,57 & 4,46 & 3,62 & 2,51 \\
\hline 24,97 & 510,30 & 80,10 & 58,27 & 42,21 & 32,83 & 23,72 & 17,74 & 13,83 & 9,44 & 7,23 & 5,01 \\
\hline 76,00 & 614,20 & 100,90 & 26,03 & 17,95 & 15,39 & 13,21 & 11,59 & 10,22 & 8,02 & 6,41 & 4,36 \\
\hline 38,66 & 1802,30 & 40,90 & 43,52 & 39,27 & 36,66 & 32,99 & 29,48 & 26,22 & 20,65 & 16,36 & 10,81 \\
\hline 72,22 & 251,50 & 130,50 & 41,22 & 22,57 & 16,87 & 12,80 & 10,32 & 8,54 & 6,13 & 4,71 & 3,21 \\
\hline 38,43 & 469,60 & 194,30 & 28,12 & 17,13 & 12,97 & 9,47 & 7,24 & 5,73 & 3,94 & 3,01 & 2,09 \\
\hline 27,74 & 1800,00 & 140,40 & 24,97 & 20,14 & 16,89 & 13,22 & 10,41 & 8,31 & 5,66 & 4,23 & 2,85 \\
\hline 50,23 & 1345,20 & 174,40 & 16,32 & 12,48 & 10,80 & 9,09 & 7.68 & 6,52 & 4.78 & 3,65 & 2,40 \\
\hline 21,84 & 483,70 & 174.10 & 36,22 & 22,03 & 15,54 & 10,47 & 7.71 & 6.07 & 4.26 & 3,31 & 2,32 \\
\hline 57,86 & 562,60 & 123,00 & 27,73 & 19,02 & 15,84 & 13,00 & 10,88 & 9,17 & 6,69 & 5,12 & 3,40 \\
\hline 23,97 & 1922,00 & 65,40 & 46,23 & 39,78 & 34,41 & 27,86 & 22,46 & 18,21 & 12,50 & 9,26 & 6,13 \\
\hline 48,90 & 1482,20 & 43,90 & 37,55 & 32,40 & 30,51 & 27,84 & 25,28 & 22,87 & 18,60 & 15,15 & 10,35 \\
\hline 41,79 & 1858,60 & 35,50 & 45,09 & 40,06 & 37,98 & 34,75 & 31,58 & 28,57 & 23,21 & 18,85 & 12,80 \\
\hline 40,06 & 390,60 & 161,80 & 33,36 & 20,28 & 15,42 & 11,33 & 8,70 & 6,91 & 4,76 & 3,63 & 2,51 \\
\hline 70,12 & 1659,40 & 25,40 & 41,01 & 33,33 & 31,40 & 30,39 & 29,07 & 27,66 & 24,88 & 22,27 & 17,68 \\
\hline 55,00 & 473,50 & 58,20 & 45,36 & 34,66 & 30,26 & 25,83 & 22,19 & 19,11 & 14,33 & 11,07 & 7,30 \\
\hline 54,79 & 1954,30 & 138,70 & 15,10 & 12,31 & 11,15 & 9,85 & 8,71 & 7,69 & 6,00 & 4,75 & 3,16 \\
\hline 85,22 & 1985,80 & 59,50 & 19,48 & 15,13 & 14,04 & 13,39 & 12,72 & 12,04 & 10,75 & 9,56 & 7,54 \\
\hline 70,02 & 566,30 & 198,90 & 21,08 & 12,72 & 10,04 & 7,99 & 6,62 & 5,58 & 4,08 & 3,15 & 2,12 \\
\hline 75,24 & 1037,80 & 134,00 & 17,37 & 12,42 & 10,88 & 9,50 & 8,44 & 7,52 & 5,99 & 4,84 & 3,32 \\
\hline
\end{tabular}




\begin{tabular}{|c|c|c|c|c|c|c|c|c|c|c|c|}
\hline & & & \multicolumn{9}{|c|}{ Deflexões $\left(\times 10^{-4} \mathrm{~cm}\right)$} \\
\hline e1 (cm) & Meq (MPa) & Ms (MPa) & D0 & D25 & D40 & D60 & D80 & D100 & D140 & D180 & D260 \\
\hline 52,76 & 1196,30 & 169,30 & 17,02 & 12,78 & 11,02 & 9,26 & 7,85 & 6,68 & 4,92 & 3,76 & 2,48 \\
\hline 87,05 & 1817,70 & 25,10 & 31,79 & 28,16 & 25,40 & 24,47 & 23,85 & 23,04 & 21,30 & 19,62 & 16,48 \\
\hline 70,62 & 1883,30 & 35,10 & 31,71 & 25,42 & 24,06 & 23,14 & 22,02 & 20,85 & 18,60 & 16,51 & 12,92 \\
\hline 70,17 & 334,40 & 78,90 & 41,87 & 27,51 & 22,76 & 18,86 & 16,06 & 13,81 & 10,38 & 8,09 & 5,42 \\
\hline 67,45 & 1799,70 & 72,70 & 20,73 & 16,43 & 15,48 & 14,34 & 13,26 & 12,24 & 10,37 & 8,77 & 6,35 \\
\hline 30,47 & 1930,20 & 24,80 & 72,48 & 67,32 & 62,86 & 56,44 & 50,21 & 44,41 & 34,57 & 27,10 & 17,68 \\
\hline 51,71 & 1987,50 & 172,10 & 13,67 & 11,02 & 9,82 & 8,52 & 7,40 & 6,43 & 4,88 & 3,79 & 2,49 \\
\hline 36,68 & 425,80 & 73,20 & 52,55 & 38,64 & 31,79 & 24,79 & 19,60 & 15,76 & 10,86 & 8,16 & 5,51 \\
\hline 32,12 & 1659,30 & 33,90 & 58,69 & 53,84 & 49,56 & 43,77 & 38,32 & 33,40 & 25,36 & 19,55 & 12,63 \\
\hline 39,07 & 401,80 & 42,60 & 71,91 & 57,12 & 49,13 & 40,29 & 33,11 & 27,39 & 19,36 & 14,51 & 9,57 \\
\hline 42,12 & 1607,30 & 76,00 & 28,15 & 24,44 & 22,20 & 19,44 & 16,94 & 14,73 & 11,17 & 8,64 & 5,63 \\
\hline 52,95 & 1879,60 & 194,30 & 12,86 & 10,12 & 8,93 & 7,68 & 6,63 & 5,72 & 4,31 & 3,33 & 2,19 \\
\hline 72,88 & 352,60 & 126,50 & 33,26 & 19,85 & 15,62 & 12,42 & 10,32 & 8,72 & 6,41 & 4,96 & 3,34 \\
\hline 83,47 & 417,00 & 79,60 & 34,69 & 22,87 & 19,29 & 16,42 & 14,39 & 12,72 & 10,04 & 8,08 & 5,56 \\
\hline 54,29 & 1367,80 & 146,90 & 17,05 & 13,30 & 11,72 & 10,08 & 8,71 & 7,54 & 5,69 & 4,41 & 2,91 \\
\hline 21,57 & 1798,70 & 174,60 & 25,57 & 19,34 & 15,18 & 10,99 & 8,20 & 6,37 & 4,33 & 3,31 & 2,29 \\
\hline 69,59 & 1875,40 & 112,10 & 15,30 & 11,91 & 11,00 & 10,02 & 9,15 & 8,35 & 6,93 & 5,77 & 4,08 \\
\hline 45,82 & 273,70 & 41,80 & 77,20 & 57,80 & 49,10 & 40,24 & 33,23 & 27,63 & 19,72 & 14,88 & 9,84 \\
\hline 81,40 & 1789,10 & 151,70 & 12,14 & 8,87 & 8,02 & 7,23 & 6,59 & 6,01 & 5,01 & 4,20 & 3,00 \\
\hline 69,87 & 1982,40 & 58,80 & 22,51 & 17,77 & 16,87 & 15,90 & 14,90 & 13,93 & 12,10 & 10,47 & 7,85 \\
\hline 47,23 & 1799,30 & 49,90 & 33,10 & 28,78 & 27,11 & 24,72 & 22,43 & 20,26 & 16,44 & 13,36 & 9,09 \\
\hline 60,56 & 204,70 & 193,10 & 43,10 & 20,40 & 13,78 & 9,47 & 7,17 & 5,71 & 3,95 & 3,05 & 2,15 \\
\hline 73,77 & 1820,60 & 128,40 & 13,87 & 10,54 & 9,65 & 8,74 & 7,97 & 7,26 & 6,02 & 5,01 & 3,55 \\
\hline 84,71 & 1807,10 & 60,10 & 20,22 & 15,55 & 14,46 & 13,73 & 12,99 & 12,26 & 10,88 & 9,62 & 7,51 \\
\hline 45,94 & 1911,30 & 60,90 & 28,86 & 25,22 & 23,54 & 21,27 & 19,12 & 17,12 & 13,66 & 10,95 & 7,34 \\
\hline$\frac{40,042}{34,72}$ & 247,30 & 64,70 & 72,17 & $\begin{array}{l}20,2 L \\
48,95\end{array}$ & 38,50 & $\begin{array}{l}28, L 1 \\
28,69\end{array}$ & $\frac{\perp v, \pm L}{22,03}$ & $\begin{array}{l}1, \pm L \\
17,44\end{array}$ & $\begin{array}{l}10,00 \\
11,94\end{array}$ & $\begin{array}{c}10,00 \\
9,07\end{array}$ & $\frac{1,04}{6,24}$ \\
\hline 29,54 & 1999,00 & 80,50 & 33,28 & 28,98 & 25,58 & 21,35 & 17,72 & 14,73 & 10,42 & 7,76 & 5,05 \\
\hline 56,99 & 426,20 & 171,90 & 28,00 & 16,73 & 12,98 & 10,01 & 8,04 & 6,59 & 4,65 & 3,54 & 2,40 \\
\hline 44,84 & 1231,60 & $\frac{1}{109,70}$ & 23,75 & $\frac{10,10}{19,30}$ & $\frac{1 L, 00}{17,00}$ & $\frac{10,0 \perp}{14,44}$ & $\begin{array}{l}0,04 \\
12,27\end{array}$ & 10,43 & $\frac{4,05}{7,66}$ & 5,83 & 3,80 \\
\hline 23,00 & 1843,00 & 125,50 & 30,76 & 24,54 & 20,09 & 15,21 & 11,65 & 9,15 & 6,17 & 4,65 & 3,18 \\
\hline 64,58 & 1259,50 & 23,10 & 51,23 & 41,24 & 39,44 & 37,72 & 35,67 & 33,60 & 29,62 & 25,98 & 19,89 \\
\hline 80,32 & 1077,70 & 139,20 & 16,29 & 11,46 & 10,03 & 8,79 & 7,85 & 7,04 & 5,68 & 4,63 & 3,22 \\
\hline 88,52 & 859,00 & 97,00 & 21,02 & 14,63 & 12,92 & 11,47 & 10,38 & 9,44 & 7,82 & 6,53 & 4,68 \\
\hline 89,45 & 235,70 & 36,10 & 66,03 & 44,20 & 38,01 & 33,00 & 29,42 & 26,43 & 21,46 & 17,66 & 12,43 \\
\hline 36,83 & 1550,40 & 194,60 & 17,47 & 13,52 & 11,41 & 9,14 & 7,36 & 5,99 & 4,16 & 3,12 & 2,08 \\
\hline 55,02 & 1736,70 & 104,10 & 18,79 & 15,50 & 14,18 & 12,65 & 11,28 & 10,04 & 7,95 & 6,35 & 4,26 \\
\hline 57,93 & 323,00 & 149,30 & 34,84 & 20,07 & 15,29 & 11,62 & 9,27 & 7,56 & 5,32 & 4,05 & 2,76 \\
\hline 48,78 & 1860,90 & 176,40 & 14,35 & 11,51 & 10,16 & 8,70 & 7,46 & 6,40 & 4,76 & 3,66 & 2,39 \\
\hline 65,02 & 422,10 & 175,50 & 27,04 & 15,81 & 12,22 & 9,49 & 7,72 & 6,40 & 4,59 & 3,51 & 2,37 \\
\hline 27,51 & 1480,60 & 118,40 & 30,04 & 24,14 & 20,18 & 15,74 & 12,35 & 9,85 & 6,70 & 5,01 & 3,38 \\
\hline 65.30 & 1839,10 & 117.60 & 15,49 & 12.22 & 11.23 & 10.14 & 9.18 & 8.31 & 6.78 & 5.56 & 3,85 \\
\hline 80,03 & 1325,50 & 140,70 & 14,65 & 10,54 & 9,38 & 8,32 & 7,50 & 6,78 & 5,54 & 4,57 & 3,21 \\
\hline 60,40 & 1935,00 & 194,90 & 11,78 & 9,11 & 8,10 & 7,08 & 6,22 & 5,47 & 4,25 & 3,35 & 2,24 \\
\hline 70,92 & 259,00 & 85,00 & 47,12 & 28,81 & 22,94 & 18,40 & 15,35 & 12,99 & 9,57 & 7,40 & 4,97 \\
\hline 24,70 & 1423,70 & 82,90 & 42,09 & 34,53 & 28,97 & 22,62 & 17,72 & 14,10 & 9,56 & 7,13 & 4,82 \\
\hline 75,08 & 1773,50 & 51,20 & 24,43 & 19,11 & 18,03 & 17,11 & 16,13 & 15,16 & 13,33 & 11,68 & 8,95 \\
\hline 24,94 & 300,60 & 58,60 & 85,01 & 59,44 & 45,36 & 32,26 & 23,98 & 18,70 & 12,83 & 9,87 & 6,86 \\
\hline 41,87 & 1483,80 & 78,50 & 28,53 & 24,56 & 22,17 & 19,28 & 16,68 & 14,41 & 10,82 & 8,32 & 5,41 \\
\hline 20,01 & 1282,30 & 65,50 & 60,18 & 48,31 & 39,29 & 29,44 & 22,34 & 17,43 & 11,73 & 8,86 & 6,09 \\
\hline 75,75 & 1696,30 & 87,20 & 17,74 & 13,57 & 12,63 & 11,66 & 10,79 & 9,97 & 8,49 & 7,22 & 5,28 \\
\hline 22,91 & 615,30 & 155,20 & 36,09 & 23,78 & 17,44 & 12,01 & 8,83 & 6,91 & 4,80 & 3,72 & 2,59 \\
\hline 47,77 & 1593,10 & 57,80 & 30,93 & 26,77 & 24,92 & 22,47 & 20,17 & 18,04 & 14,38 & 11,52 & 7,73 \\
\hline 85,49 & 210,00 & 199,40 & 41,77 & 19,68 & 13,29 & 9,17 & 7,00 & 5,61 & 3,91 & 3,01 & 2,11 \\
\hline 34,00 & 248,00 & 59,50 & 76,56 & 52,82 & 41,76 & 31,21 & 23,97 & 18,98 & 12,98 & 9,86 & 6,78 \\
\hline 45,86 & 1512,50 & 164,70 & 16,94 & 13,38 & 11,65 & 9,79 & 8,25 & 6,97 & 5,08 & 3,85 & 2,52 \\
\hline 31,65 & 1369,00 & 80,80 & 35,74 & 30,16 & 26,27 & 21,62 & 17,74 & 14,62 & 10,25 & 7,64 & 5,01 \\
\hline 81,66 & 420,50 & 81,30 & 34,45 & 22,78 & 19,20 & 16,31 & 14,26 & 12,57 & 9,87 & 7,92 & 5,42 \\
\hline 41,81 & 311,90 & 123,30 & 42,24 & 25,95 & 19,91 & 14,80 & 11,44 & 9,12 & 6,28 & 4,79 & 3,30 \\
\hline 26,69 & 430,60 & 178,90 & 34,37 & 20,72 & 14,95 & 10,29 & 7,62 & 5,99 & 4,16 & 3,23 & 2,26 \\
\hline 25,03 & 1554,80 & 79,30 & 41,80 & 34,84 & 29,57 & 23,40 & 18,54 & 14,85 & 10,11 & 7,52 & 5,04 \\
\hline 37,82 & 1787,00 & 130,00 & 20,90 & 17,42 & 15,30 & 12,82 & 10,72 & 8,98 & 6,45 & 4,84 & 3,16 \\
\hline 70,05 & 466,80 & 154,40 & 26,16 & 16,00 & 12,73 & 10,20 & 8,49 & 7,17 & 5,27 & 4,07 & 2,73 \\
\hline 22,11 & 291,20 & 35,60 & 131,53 & 96,93 & 75,05 & 53,71 & 39,86 & 30,97 & 21,16 & 16,24 & 11,26 \\
\hline 70,01 & 1265,70 & 87,80 & 20,69 & 15,95 & 14,61 & 13,20 & 11,99 & 10,89 & 8,95 & $\begin{array}{c}1+0,2+ \\
7,39\end{array}$ & 5,18 \\
\hline 26,66 & 1017,40 & 185,80 & 25,34 & 18,06 & 14,05 & 10,18 & 7,64 & 5,97 & 4,08 & 3,12 & 2,16 \\
\hline 88,83 & 708,10 & 159,00 & 18,75 & 11,87 & 9,82 & 8,25 & 7,19 & 6,33 & 4,99 & 4,02 & 2,78 \\
\hline 64,96 & 384,50 & 63,70 & 44,13 & 31,37 & 26,86 & 22,81 & 19,68 & 17,05 & 12,96 & 10,13 & 6,75 \\
\hline 80,36 & 768,00 & 102,60 & 22,48 & 15,74 & 13,74 & 12,01 & 10,71 & 9,58 & 7,71 & 6,29 & 4,36 \\
\hline 37,66 & 1968,10 & 111,10 & 22,34 & 19,13 & 17,04 & 14,52 & 12,31 & 10,44 & 7,61 & 5,76 & 3,73 \\
\hline 31,63 & 1020,20 & 120,80 & 30,44 & 23,57 & 19,57 & 15,25 & 12,00 & 9,60 & 6,57 & 4,92 & 3,33 \\
\hline 27,41 & 252,10 & 80,30 & 69,24 & 44,50 & 33,08 & 23,21 & 17,25 & 13,51 & 9,33 & 7,20 & 5,02 \\
\hline 63,56 & 844,20 & 59,70 & 32,23 & 25,46 & 23,23 & 20,81 & 18,72 & 16,81 & 13,55 & 10,99 & 7,53 \\
\hline 85,55 & 955,30 & 62,50 & 25,66 & 18,84 & 17,25 & 15,83 & 14,63 & 13,54 & 11,57 & 9,90 & 7,32 \\
\hline 60,93 & 546,20 & 120,40 & 27,85 & 18,96 & 15,79 & 13,02 & 10,96 & 9,29 & 6,84 & 5,26 & 3,49 \\
\hline 67,56 & 964,10 & 163,40 & 17,12 & 12,04 & 10,29 & 8,75 & 7,57 & 6,58 & 5,03 & 3,95 & 2,64 \\
\hline 24,85 & 556,90 & 133,10 & 39,85 & 26,85 & 20,11 & 14,10 & 10,44 & 8,15 & 5,62 & 4,34 & 3,02 \\
\hline 22,84 & 969,30 & 186,10 & 27,94 & 19,32 & 14,49 & 10,13 & 7,47 & 5,82 & 4,02 & 3,10 & 2,16 \\
\hline 78,65 & 312,90 & 111,40 & 36,92 & 21,83 & 17,16 & 13,70 & 11,46 & 9,75 & 7,27 & 5,66 & 3,83 \\
\hline 71,28 & 1374,80 & 174,30 & 13,54 & 9,83 & 8,62 & 7,52 & 6,65 & 5,89 & 4,65 & 3,73 & 2,54 \\
\hline 54,01 & 402,50 & 155,10 & 30,67 & 18,63 & 14,53 & 11,21 & 8,96 & 7,32 & 5,14 & 3,91 & 2,65 \\
\hline 20,96 & 1142,40 & 125,00 & 37,58 & 27,83 & 21,49 & 15,31 & 11,33 & 8,79 & 6,01 & 4,62 & 3,20 \\
\hline 36,18 & 351,60 & 134,60 & 39,96 & 24,85 & 18,87 & 13,74 & 10,45 & 8,26 & 5,67 & 4,34 & 3,01 \\
\hline
\end{tabular}




\begin{tabular}{|c|c|c|c|c|c|c|c|c|c|c|c|}
\hline \multirow[b]{2}{*}{ e1 (cm) } & & & & & & Def & ões (x1 & m) & & & \\
\hline & Meq (MPa) & Ms (MPa) & D0 & D25 & D40 & D60 & D80 & D100 & D140 & D180 & D260 \\
\hline 32,16 & 1775,60 & 45,00 & 47,38 & 43,02 & 39,23 & 34,24 & 29,63 & 25,55 & 19,07 & 14,55 & 9,37 \\
\hline 62,47 & 213,30 & 58,00 & 64,29 & 41,73 & 34,00 & 27,57 & 22,97 & 19,35 & 14,12 & 10,83 & 7,23 \\
\hline 79,78 & 1489,50 & 108,60 & 16,02 & 11,88 & 10,85 & 9,86 & 9,03 & 8,28 & 6,95 & 5,85 & 4,21 \\
\hline 89,02 & 277,20 & 87,90 & 42,19 & 25,04 & 19,88 & 16,12 & 13,72 & 11,87 & 9,11 & 7,23 & 4,95 \\
\hline 53,27 & 1946,70 & 147,20 & 14,85 & 12,09 & 10,89 & 9,56 & 8,39 & 7,36 & 5,68 & 4,46 & 2,95 \\
\hline 54,11 & 1506,60 & 92,00 & 21,63 & 17,88 & 16,32 & 14,52 & 12,92 & 11,46 & 9,03 & 7,18 & 4,80 \\
\hline 23,01 & 1504,70 & 178,60 & 25,34 & 18,88 & 14,78 & 10,70 & 7,99 & 6,22 & 4,23 & 3,24 & 2,24 \\
\hline 86,27 & 518,30 & 188,20 & 21,71 & 12,60 & 9,85 & 7,86 & 6,60 & 5,66 & 4,27 & 3,36 & 2,29 \\
\hline 62,25 & 1941,00 & 43,30 & 29,94 & 24,20 & 23,20 & 21,93 & 20,56 & 19,21 & 16,66 & 14,38 & 10,72 \\
\hline 25,20 & 1406,20 & 153,00 & 27,19 & 20,79 & 16,70 & 12,44 & 9,45 & 7,41 & 5,02 & 3,81 & 2,62 \\
\hline 55,31 & 1560,00 & 105,40 & 19,38 & 15,83 & 14,38 & 12,76 & 11,32 & 10,03 & 7,87 & 6,25 & 4,18 \\
\hline 82,87 & 1082,70 & 162,80 & 14,90 & 10,19 & 8,80 & 7,64 & 6,78 & 6,05 & 4,86 & 3,95 & 2,74 \\
\hline 58,05 & 1134,30 & 81,30 & 25,01 & 20,14 & 18,29 & 16,24 & 14,45 & 12,84 & 10,14 & 8,10 & 5,44 \\
\hline 59,41 & 540,40 & 148,90 & 25,67 & 16,71 & 13,59 & 10,95 & 9,06 & 7,58 & 5,48 & 4,19 & 2,80 \\
\hline 80,29 & 1056,10 & 146,50 & 16,06 & 11,19 & 9,74 & 8,49 & 7,55 & 6,75 & 5,42 & 4,40 & 3,05 \\
\hline 89,26 & 873,60 & 66,10 & 25,37 & 18,26 & 16,55 & 15,09 & 13,90 & 12,84 & 10,95 & 9,36 & 6,91 \\
\hline 84,53 & 1268,30 & 111,80 & 16,49 & 11,89 & 10,70 & 9,64 & 8,80 & 8,05 & 6,73 & 5,66 & 4,08 \\
\hline 79,44 & 856,80 & 115,40 & 20,16 & 14,15 & 12,34 & 10,78 & 9,59 & 8,57 & 6,88 & 5,60 & 3,87 \\
\hline 68,27 & 1020,50 & 170,50 & 16,21 & 11,40 & 9,76 & 8,31 & 7,21 & 6,28 & 4,82 & 3,79 & 2,54 \\
\hline 35,18 & 1399,40 & 192,20 & 18,84 & 14,35 & 11,96 & 9,42 & 7,49 & 6,04 & 4,16 & 3,12 & 2,10 \\
\hline 69,68 & 686,00 & 93,60 & 26,41 & 19,08 & 16,63 & 14,40 & 12,66 & 11,16 & 8,72 & 6,95 & 4,69 \\
\hline 29,48 & 836,40 & 146,50 & 29,95 & 21,72 & 17,27 & 12,84 & 9,79 & 7,70 & 5,25 & 3,99 & 2,74 \\
\hline 49,93 & 633,40 & 54,20 & 44,15 & 35,78 & 31,84 & 27,53 & 23,81 & 20,59 & 15,53 & 12,00 & 7,87 \\
\hline 75,84 & 1146,00 & 76,60 & 22,43 & 16,96 & 15,58 & 14,18 & 12,98 & 11,89 & 9,95 & 8,34 & 5,98 \\
\hline 60,57 & 298,70 & 37,90 & 67,25 & 50,44 & 44,09 & 37,95 & 32,96 & 28,68 & 21,90 & 17,13 & 11,38 \\
\hline 43,64 & 1057,80 & 66,10 & 34,98 & 29,60 & 26,57 & 23,00 & 19,85 & 17,11 & 12,81 & 9,83 & 6,40 \\
\hline 47,46 & 835,30 & 126,90 & 24,86 & 18,59 & 15,84 & 13,06 & 10,84 & 9,06 & 6,51 & 4,93 & 3,25 \\
\hline 41,02 & 1720,80 & 86,00 & 25,88 & 22,41 & 20,25 & 17,61 & 15,24 & 13,17 & 9,88 & 7,59 & 4,93 \\
\hline 22,73 & 1517,30 & 93,30 & 40,49 & 32,61 & 26,83 & 20,44 & 15,71 & 12,35 & 8,33 & 6,26 & 4,28 \\
\hline 61,86 & 1868,40 & 124,30 & 15,32 & 12,23 & 11,19 & 10,04 & 9,02 & 8,10 & 6,52 & 5,29 & 3,61 \\
\hline 27,80 & 223,40 & 151,80 & 48,26 & 25,41 & 17,52 & 11,87 & 8,84 & 7,00 & 4,88 & 3,80 & 2,68 \\
\hline 60,35 & 967,00 & 162,80 & 17,99 & 12,90 & 11,01 & 9,28 & 7,93 & 6,80 & 5,09 & 3,94 & 2,61 \\
\hline 89,97 & 243,50 & 184,90 & 37,68 & 18,59 & 13,01 & 9,34 & 7,33 & 6,00 & 4,28 & 3,31 & 2,29 \\
\hline 57,69 & 802,40 & 72,00 & 31,11 & 24,58 & 21,99 & 19,26 & 16,94 & 14,89 & 11,55 & 9,11 & 6,06 \\
\hline 50,80 & 694,20 & 24,40 & 69,58 & 59,46 & 55,69 & 50,60 & 45,81 & 41,32 & 33,45 & 27,15 & 18,49 \\
\hline 59,81 & 821,50 & 146,60 & 20,66 & 14,68 & 12,47 & 10,45 & 8,88 & 7,59 & 5,65 & 4,36 & 2,89 \\
\hline 40,12 & 1191,00 & 34,00 & 54,83 & 49,04 & 45,46 & 40,64 & 36,10 & 31,93 & 24,91 & 19,60 & 12,89 \\
\hline 73,86 & 220,00 & 26,90 & 84,93 & 61,42 & 54,05 & 47,34 & 42,09 & 37,51 & 29,91 & 24,17 & 16,57 \\
\hline 41,17 & 1939,30 & 32,30 & 48,09 & 42,71 & 40,68 & 37,37 & 34,10 & 30,96 & 25,32 & 20,68 & 14,14 \\
\hline 21,83 & 1572,80 & 162,40 & 27,74 & 20,86 & 16,34 & 11,81 & 8,80 & 6,83 & 4,65 & 3,56 & 2,46 \\
\hline 82,13 & 1430,10 & 125,30 & 14,87 & 10,80 & 9,74 & 8,77 & 7,99 & 7,29 & 6,07 & 5,08 & 3,64 \\
\hline 77,91 & 388,50 & 89,50 & 35,17 & 22,78 & 18,86 & 15,75 & 13,57 & 11,81 & 9,07 & 7,17 & 4,86 \\
\hline 67,66 & 264,70 & 96,10 & 44,94 & 27,02 & 21,26 & 16,82 & 13,86 & 11,62 & 8,44 & 6,49 & 4,36 \\
\hline 69,26 & 398,90 & 52,40 & 46,43 & 33,77 & 29,53 & 25,63 & 22,56 & 19,90 & 15,59 & 12,42 & 8,40 \\
\hline 20,56 & 931,60 & 119,00 & 41,59 & 30,03 & 22,78 & 15,99 & 11,75 & 9,12 & 6,28 & 4,84 & 3,37 \\
\hline 71,56 & 738,00 & 182,30 & 18,48 & 11,99 & 9,87 & 8,15 & 6,94 & 5,96 & 4,49 & 3,50 & 2,35 \\
\hline 55,36 & 1803,90 & 56,70 & 27,40 & 22,91 & 21,70 & 19,98 & 18,33 & 16,76 & 13,92 & 11,55 & 8,10 \\
\hline 28,96 & 1193,20 & 119,80 & 30,81 & 24,21 & 20,07 & 15,54 & 12,15 & 9,67 & 6,59 & 4,94 & 3,35 \\
\hline 56,85 & 208,60 & 105,90 & 52,23 & 29,40 & 22,09 & 16,58 & 13,11 & 10,64 & 7,45 & 5,68 & 3,89 \\
\hline 56,78 & 384,50 & 37,80 & 62,13 & 48,70 & 43,26 & 37,62 & 32,86 & 28,70 & 22,03 & 17,25 & 11,43 \\
\hline 53,71 & 1057,60 & 152,80 & 18,86 & 14,09 & 12,13 & 10,21 & 8,66 & 7,38 & 5,45 & 4,17 & 2,75 \\
\hline 31,29 & 980,60 & 84,00 & 39,44 & 31,84 & 27,03 & 21,57 & 17,26 & 13,96 & 9,62 & 7,17 & 4,79 \\
\hline 36,30 & 693,20 & 154,20 & 27,77 & 19,47 & 15,64 & 11,91 & 9,28 & 7,40 & 5,07 & 3,83 & 2,62 \\
\hline 51,23 & 1673,30 & 134,10 & 17,09 & 13,91 & 12,45 & 10,84 & 9,44 & 8,22 & 6,26 & 4,87 & 3,20 \\
\hline 58,70 & 1590,70 & 184,20 & 13,48 & 10,29 & 9,05 & 7,81 & 6,79 & 5,91 & 4,51 & 3,53 & 2,34 \\
\hline 37,81 & 1534,20 & 182,20 & 17,96 & 14,02 & 11,92 & 9,63 & 7,82 & 6,40 & 4,48 & 3,35 & 2,23 \\
\hline 78,21 & 1688,80 & 28,90 & 34,16 & 27,94 & 25,93 & 25,08 & 24,11 & 23,03 & 20,88 & 18,85 & 15,23 \\
\hline 35,97 & 1081,00 & 102,50 & 30,34 & 24,41 & 20,96 & 17,07 & 13,93 & 11,44 & 8,01 & 5,99 & 3,96 \\
\hline 66,26 & 925,40 & 169,70 & 17,32 & 12,05 & 10,23 & 8,63 & 7,42 & 6,41 & 4,86 & 3,79 & 2,53 \\
\hline 78,05 & 655,90 & 171,30 & 19,79 & 12,51 & 10,21 & 8,43 & 7,20 & 6,23 & 4,74 & 3,73 & 2,52 \\
\hline 54,06 & 765,70 & 74,30 & 32,34 & 25,57 & 22,68 & 19,64 & 17,05 & 14,81 & 11,26 & 8,76 & 5,78 \\
\hline 57,02 & 1476,10 & 193,10 & 13,81 & 10,40 & 9,05 & 7,73 & 6,65 & 5,73 & 4,31 & 3,34 & 2,21 \\
\hline 89,02 & 1904,80 & 171,70 & 10,61 & 7,53 & 6,76 & 6,09 & 5,57 & 5,11 & 4,31 & 3,65 & 2,66 \\
\hline 89,88 & 687,60 & 97,20 & 23,45 & 15,84 & 13,72 & 11,99 & 10,74 & 9,69 & 7,92 & 6,55 & 4,64 \\
\hline 44,60 & 1423,10 & 94,30 & 24,69 & 20,75 & 18,60 & 16,09 & 13,89 & 11,97 & 8,97 & 6,89 & 4,49 \\
\hline 44,68 & 1238,10 & 182,00 & 17,68 & 13,34 & 11,34 & 9,29 & 7,65 & 6,35 & 4,52 & 3,41 & 2,25 \\
\hline 33,87 & 255,10 & 60,90 & 74,83 & 51,68 & 40,86 & 30,52 & 23,44 & 18,55 & 12,69 & 9,64 & 6,62 \\
\hline 73,73 & 1681,90 & 46,40 & 26,84 & 21,08 & 19,92 & 18,92 & 17,84 & 16,77 & 14,75 & 12,92 & 9,88 \\
\hline 46,65 & 1123,60 & 25,60 & 61,14 & 53,16 & 50,48 & 46,36 & 42,33 & 38,49 & 31,59 & 25,91 & 17,84 \\
\hline 79,39 & 1856,40 & 158,90 & 11,78 & 8,65 & 7,82 & 7,04 & 6,40 & 5,83 & 4,83 & 4,03 & 2,87 \\
\hline 41,66 & 1637,50 & 156,90 & 17,97 & 14,48 & 12,62 & 10,55 & 8,82 & 7,39 & 5,32 & 4,01 & 2,63 \\
\hline 24,51 & 826,30 & 37,20 & 87,13 & 73,28 & 62,50 & 49,73 & 39,54 & 31,76 & 21,64 & 16,07 & 10,75 \\
\hline 73,10 & 432,70 & 145,00 & 27,77 & 16,83 & 13,36 & 10,71 & 8,94 & 7,58 & 5,61 & 4,34 & 2,92 \\
\hline 28,41 & 1136,10 & 57,40 & 52,03 & 44,13 & 38,23 & 31,14 & 25,29 & 20,65 & 14,32 & 10,63 & 7,02 \\
\hline 64,29 & 1492,70 & 105,90 & 18,08 & 14,24 & 13,00 & 11,65 & 10,49 & 9,43 & 7,62 & 6,19 & 4,25 \\
\hline 30,13 & 1897,00 & 141,10 & 23,01 & 18,83 & 16,05 & 12,84 & 10,30 & 8,33 & 5,74 & 4,27 & 2,85 \\
\hline 75,55 & 1536,00 & 112,90 & 15,87 & 11,94 & 10,91 & 9,87 & 9,00 & 8,21 & 6,82 & 5,69 & 4,04 \\
\hline 66,36 & 1349,80 & 54,80 & 27,81 & 22,14 & 20,85 & 19,28 & 17,81 & 16,41 & 13,86 & 11,69 & 8,42 \\
\hline 82,90 & 1326,60 & 40,10 & 29,61 & 22,97 & 21,40 & 20,39 & 19,32 & 18,26 & 16,23 & 14,39 & 11,25 \\
\hline 85,02 & 500,80 & 121,90 & 26,01 & 16,38 & 13,45 & 11,20 & 9,68 & 8,47 & 6,58 & 5,25 & 3,59 \\
\hline 58,49 & 550,80 & 157,10 & 24,94 & 16,14 & 13,07 & 10,49 & 8,64 & 7,20 & 5,19 & 3,95 & 2,64 \\
\hline 30,45 & 1192,00 & 91,40 & 35,60 & 29,06 & 24,75 & 19,81 & 15,88 & 12,86 & 8,86 & 6,60 & 4,40 \\
\hline
\end{tabular}




\begin{tabular}{|c|c|c|c|c|c|c|c|c|c|c|c|}
\hline \multirow[b]{2}{*}{ e1 (cm) } & & & & & & $\mathrm{De}$ & ões (x1 & & & & \\
\hline & Meq (MPa) & Ms (MPa) & D0 & D25 & D40 & D60 & D80 & D100 & D140 & D180 & D260 \\
\hline 69,08 & 831,80 & 153,50 & 18,89 & 13,03 & 11,05 & 9,35 & 8,07 & 7,00 & 5,35 & 4,20 & 2,81 \\
\hline 77,94 & 408,80 & 105,70 & 31,89 & 20,19 & 16,51 & 13,63 & 11,66 & 10,08 & 7,68 & 6,04 & 4,09 \\
\hline 84,39 & 1273,90 & 90,90 & 18,45 & 13,51 & 12,33 & 11,25 & 10,35 & 9,54 & 8,09 & 6,88 & 5,04 \\
\hline 68,26 & 1451,50 & 183,30 & 13,10 & 9,61 & 8,43 & 7,33 & 6,45 & 5,69 & 4,46 & 3,55 & 2,40 \\
\hline 48,05 & 1093,80 & 63,50 & 33,15 & 28,00 & 25,43 & 22,39 & 19,67 & 17,24 & 13,27 & 10,37 & 6,82 \\
\hline 57,14 & 1842,60 & 118,40 & 16,60 & 13,52 & 12,35 & 11,02 & 9,84 & 8,77 & 6,96 & 5,57 & 3,75 \\
\hline 26,31 & 1370,20 & 132,30 & 29,45 & 23,00 & 18,80 & 14,29 & 11,00 & 8,68 & 5,88 & 4,43 & 3,03 \\
\hline 28,27 & 1874,70 & 153,30 & 22,91 & 18,42 & 15,44 & 12,10 & 9,53 & 7,62 & 5,19 & 3,88 & 2,62 \\
\hline 70,48 & 231,50 & 114,30 & 45,69 & 25,39 & 19,12 & 14,60 & 11,80 & 9,77 & 7,01 & 5,38 & 3,66 \\
\hline 65,98 & 351,70 & 69,50 & 44,06 & 30,26 & 25,49 & 21,37 & 18,28 & 15,73 & 11,84 & 9,21 & 6,14 \\
\hline 26,19 & 243,70 & 27,10 & 150,57 & 115,37 & 93,19 & 69,93 & 53,43 & 41,97 & 28,46 & 21,53 & 14,77 \\
\hline 21,90 & 1753,70 & 81,10 & 44,07 & 36,31 & 30,30 & 23,42 & 18,18 & 14,37 & 9,68 & 7,24 & 4,92 \\
\hline 22,88 & 1066,40 & 31,20 & 96,01 & 83,11 & 72,02 & 58,38 & 47,09 & 38,19 & 26,20 & 19,38 & 12,82 \\
\hline 79,27 & 293,30 & 154,20 & 34,74 & 18,78 & 13,97 & 10,61 & 8,60 & 7,16 & 5,19 & 4,02 & 2,74 \\
\hline 62,22 & 688,60 & 124,50 & 24,06 & 16,96 & 14,39 & 12,09 & 10,33 & 8,86 & 6,64 & 5,14 & 3,42 \\
\hline 29,27 & 896,10 & 36,70 & 74,01 & 64,29 & 56,61 & 47,12 & 39,00 & 32,33 & 22,81 & 16,97 & 11,06 \\
\hline 41,74 & 882,40 & 66,00 & 38,71 & 32,18 & 28,49 & 24,22 & 20,54 & 17,44 & 12,76 & 9,68 & 6,30 \\
\hline 52,98 & 687,60 & 85,20 & 31,77 & 24,35 & 21,21 & 18,02 & 15,39 & 13,18 & 9,80 & 7,54 & 4,96 \\
\hline 55,76 & 674,60 & 59,40 & 38,12 & 30,35 & 27,13 & 23,71 & 20,78 & 18,21 & 14,04 & 11,02 & 7,30 \\
\hline 45,02 & 1085,90 & 108,10 & 25,16 & 20,14 & 17,62 & 14,87 & 12,55 & 10,63 & 7,75 & 5,88 & 3,85 \\
\hline 55,29 & 215,00 & 94,10 & 54,09 & 31,74 & 24,35 & 18,56 & 14,77 & 12,03 & 8,44 & 6,42 & 4,37 \\
\hline 65,60 & 619,30 & 125,70 & 24,78 & 16,95 & 14,24 & 11,91 & 10,16 & 8,73 & 6,55 & 5,09 & 3,39 \\
\hline 21,69 & 1607,30 & 125,40 & 33,38 & 25,96 & 20,77 & 15,33 & 11,54 & 8,99 & 6,08 & 4,62 & 3,19 \\
\hline 77,96 & 949,40 & 35,60 & 37,85 & 29,14 & 27,33 & 25,69 & 24,07 & 22,52 & 19,63 & 17,06 & 12,90 \\
\hline 62,00 & 307,70 & 70,80 & 48,13 & 32,39 & 26,87 & 22,11 & 18,59 & 15,77 & 11,61 & 8,93 & 5,94 \\
\hline 35,28 & 1703,00 & 29,60 & 59,36 & 54,28 & 50,81 & 45,80 & 40,96 & 36,44 & 28,68 & 22,69 & 14,95 \\
\hline 22,03 & 1171,80 & 88,10 & 46,49 & 36,41 & 29,32 & 21,79 & 16,48 & 12,86 & 8,68 & 6,58 & 4,53 \\
\hline 77,43 & 666,30 & 134,10 & 21,76 & 14,45 & 12,14 & 10,26 & 8,91 & 7,80 & 6,05 & 4,80 & 3,26 \\
\hline 63,62 & 1392,90 & 59,70 & 26,65 & 21,45 & 20,13 & 18,50 & 16,99 & 15,57 & 13,00 & 10,86 & 7,70 \\
\hline 48,99 & 308,90 & 36,50 & 75,96 & 59,05 & 51,37 & $\frac{10,00}{43,34}$ & 36,71 & 31,18 & 22,89 & 17,45 & 11,45 \\
\hline 82,84 & 403,40 & 132,30 & 29,12 & 17,38 & 13,78 & 11,12 & 9,39 & 8,07 & 6,10 & 4,80 & 3,26 \\
\hline 68,50 & 812,20 & 161,30 & 18,76 & 12,79 & 10,77 & 9,05 & 7,77 & 6,72 & 5,09 & 3,98 & 2,66 \\
\hline 30,40 & 478,60 & 37,10 & 88,08 & 71,80 & 61,10 & 48,83 & 39,11 & 31,64 & 21,78 & 16,23 & 10,83 \\
\hline 45,65 & 633,70 & 89,00 & 35,01 & 26,58 & 22,72 & 18,73 & 15,53 & 12,96 & 9,28 & 7,01 & 4,62 \\
\hline 83,64 & 272,00 & 105,80 & 40,71 & 23,40 & 18,14 & 14,35 & 11,97 & 10,19 & 7,62 & 5,96 & 4,05 \\
\hline 56,17 & 306,50 & 81,70 & 46,91 & 30,97 & 25,25 & 20,29 & 16,70 & 13,90 & 9,98 & 7,59 & 5,07 \\
\hline 89,06 & 1061,90 & 151,90 & 15,15 & 10,24 & 8,87 & 7,74 & 6,92 & 6,24 & 5,09 & 4,20 & 2,96 \\
\hline 49,15 & 1715,80 & 73,20 & 25,33 & 21,70 & 20,07 & 18,01 & 16,10 & 14,35 & 11,37 & 9,07 & 6,06 \\
\hline 75,60 & 675,70 & 61,30 & 32,05 & 23,75 & 21,38 & 19,12 & 17,27 & 15,63 & 12,79 & 10,54 & 7,39 \\
\hline 84,82 & 852,10 & 49,40 & 30,95 & 22,94 & 21,12 & 19,51 & 18,10 & 16,81 & 14,46 & 12,43 & 9,27 \\
\hline 54,42 & 1588,10 & 57,70 & 28,56 & 23,99 & 22,55 & 20,59 & 18,76 & 17,02 & 13,95 & 11,44 & 7,90 \\
\hline 39,60 & 1224,10 & 160,20 & 20,60 & 15,86 & 13,46 & 10,89 & 8,86 & 7,27 & 5,10 & 3,82 & 2,54 \\
\hline 54,58 & 1661,00 & 136,60 & 16,32 & 13,13 & 11,78 & 10,31 & 9,05 & 7,93 & 6,12 & 4,80 & 3,18 \\
\hline 46,15 & 1122,40 & 123,20 & 22,63 & 17,84 & 15,54 & 13,07 & 11,01 & 9,31 & 6,78 & 5,15 & 3,37 \\
\hline 51,06 & 1589,00 & 20,60 & 60,90 & 50,67 & 49,13 & 46,63 & 43,75 & 40,90 & 35,45 & 30,54 & 22,62 \\
\hline 85,13 & 1926,00 & 147,10 & 11,70 & 8,51 & 7,73 & 7,03 & 6,45 & 5,94 & 5,02 & 4,26 & 3,11 \\
\hline 34,94 & 1864,60 & 58,80 & 36,47 & 32,72 & 29,79 & 26,00 & 22,52 & 19,45 & 14,56 & 11,13 & 7,19 \\
\hline 26,05 & 779,10 & 179,40 & 28,56 & 19,50 & 14,79 & 10,49 & 7,81 & 6,10 & 4,19 & 3,23 & 2,24 \\
\hline 36,81 & 1845,40 & 88,10 & 26,99 & 23,47 & 21,05 & 18,06 & 15,41 & 13,13 & 9,64 & 7,31 & 4,73 \\
\hline 33,76 & 542,00 & 183,00 & 28,58 & 18,32 & 13,99 & 10,16 & 7,70 & 6,07 & 4,16 & 3,19 & 2,21 \\
\hline 46,40 & 561,50 & 71,00 & 41,57 & 32,08 & 27,68 & 23,05 & 19,29 & 16,21 & 11,72 & 8,87 & 5,83 \\
\hline 82,37 & 1914,20 & 38,90 & 26,04 & 21,05 & 19,46 & 18,77 & 18,01 & 17,18 & 15,56 & 14,03 & 11,31 \\
\hline 48,70 & 414,30 & 53,00 & 54,38 & 41,78 & 36,13 & 30,28 & 25,51 & 21,57 & 15,73 & 11,97 & 7,86 \\
\hline 63,04 & 1328,90 & 51,80 & 29,88 & 24,13 & 22,74 & 20,98 & 19,32 & 17,75 & 14,89 & 12,49 & 8,90 \\
\hline 64,49 & 1605,00 & 137,70 & 15,03 & 11,66 & 10,51 & 9,32 & 8,32 & 7,42 & 5,91 & 4,76 & 3,24 \\
\hline 46,24 & 325,10 & 127,60 & 39,43 & 24,13 & 18,66 & 14,08 & 11,03 & 8,87 & 6,14 & 4,67 & 3,20 \\
\hline 42,91 & 1150,70 & 21,70 & 72,19 & 63,73 & 60,60 & 55,62 & 50,73 & 46,05 & 37,66 & 30,77 & 21,05 \\
\hline 20,28 & 794,80 & 171,10 & 33,29 & 22,06 & 15,97 & 10,85 & 7,94 & 6,21 & 4,34 & 3,37 & 2,35 \\
\hline 79,18 & 1265,60 & 115,70 & 16,69 & 12,20 & 10,98 & 9,84 & 8,92 & 8,10 & 6,68 & 5,55 & 3,93 \\
\hline 43,40 & 1081,30 & 185,70 & 18,84 & 13,84 & 11,60 & 9,33 & 7,59 & 6,23 & 4,38 & 3,30 & 2,20 \\
\hline 30,21 & 1382,80 & 135,70 & 26,22 & 20,75 & 17,35 & 13,59 & 10,72 & 8,59 & 5,87 & 4,39 & 2,96 \\
\hline 46,12 & 1532,00 & 145,00 & 18,09 & 14,56 & 12,81 & 10,88 & 9,25 & 7,87 & 5,79 & 4,41 & 2,88 \\
\hline 65,51 & 304,30 & 107,80 & 39,80 & 24,17 & 19,08 & 15,11 & 12,43 & 10,39 & 7,53 & 5,77 & 3,88 \\
\hline 29,21 & 1427,60 & 121,20 & 28,64 & 23,00 & 19,33 & 15,21 & 12,02 & 9,64 & 6,59 & 4,92 & 3,31 \\
\hline 44,41 & 647,60 & 77,00 & 38,35 & 29,93 & 25,85 & 21,48 & 17,91 & 15,01 & 10,80 & 8,15 & 5,36 \\
\hline 29,05 & 884,30 & 184,70 & 25,42 & 17,85 & 13,94 & 10,19 & $\begin{array}{c}+1,0 \pm \\
7,70\end{array}$ & $\begin{array}{c}10,0 \pm \\
6,04\end{array}$ & 4,13 & 3,15 & 2,18 \\
\hline 47,57 & 690,80 & 178,30 & 22,62 & 15,25 & 12,39 & 9,77 & 7,87 & 6,43 & 4,51 & 3,41 & 2,29 \\
\hline 43,97 & 261,80 & 132,20 & 44,05 & 25,28 & 18,85 & 13,78 & 10,60 & 8,44 & 5,82 & 4,45 & 3,08 \\
\hline 55,96 & 1915,00 & 169,90 & 13,35 & 10,61 & 9,48 & 8,29 & 7,27 & 6,37 & 4,91 & 3,85 & 2,56 \\
\hline 88,51 & 847,90 & 130,00 & 18,42 & 12,37 & 10,64 & 9,23 & 8,23 & 7,38 & 5,98 & 4,92 & 3,45 \\
\hline 35,00 & 1982.90 & 104.90 & 24,46 & 21.03 & 18.65 & 15,76 & 13,26 & 11.16 & 8.04 & 6.04 & 3,92 \\
\hline 28,50 & 801,60 & 44,90 & 68,66 & 57,64 & 49,63 & 40,14 & 32,41 & 26,35 & 18,20 & 13,52 & 8,96 \\
\hline 48,18 & 206,00 & 94,40 & 57,27 & 33,56 & 25,49 & 19,03 & 14,87 & 11,94 & 8,28 & 6,30 & 4,33 \\
\hline 30,08 & 1975,80 & 108,20 & 27,08 & 22,93 & 19,92 & 16,32 & 13,33 & 10,94 & 7,63 & 5,67 & 3,73 \\
\hline 83,42 & 986,10 & 167,20 & 15,45 & 10,38 & 8,86 & 7,61 & 6,72 & 5,97 & 4,75 & 3,85 & 2,66 \\
\hline 61,18 & 1623,70 & 124,60 & 16,30 & 12,91 & 11,70 & 10,40 & 9,28 & 8,27 & 6,57 & 5,28 & 3,57 \\
\hline 83,16 & 1053,10 & 66,40 & 24,11 & 17,86 & 16,40 & 15,06 & 13,91 & 12,87 & 10,97 & 9,37 & 6,90 \\
\hline 24,83 & 260,10 & 164,20 & 44,19 & 23,65 & 16,23 & 10,93 & 8,12 & 6,43 & 4,51 & 3,51 & 2,48 \\
\hline 58,52 & 548,80 & 37,50 & 52,93 & 42,72 & 38,92 & 34,68 & 30,96 & 27,59 & 21,91 & 17,56 & 11,85 \\
\hline 41,16 & 1130,20 & 125,30 & 24,04 & 18,98 & 16,37 & 13,50 & 11,16 & 9,28 & 6,61 & 4,97 & 3,27 \\
\hline 37,87 & 1235,60 & 54,20 & 41,66 & 36,51 & 32,97 & 28,57 & 24,60 & 21,15 & 15,73 & 12,01 & 7,77 \\
\hline 81,36 & 567,70 & 103,90 & 26,16 & 17,47 & 14,80 & 12,63 & 11,08 & 9,79 & 7,71 & 6,20 & 4,25 \\
\hline
\end{tabular}




\begin{tabular}{|c|c|c|c|c|c|c|c|c|c|c|c|}
\hline \multirow[b]{2}{*}{ e1 (cm) } & & & & & & $\mathrm{De}$ & ões (x1 & & & & \\
\hline & Meq (MPa) & Ms (MPa) & D0 & D25 & D40 & D60 & D80 & D100 & D140 & D180 & D260 \\
\hline 84,38 & 1270,50 & 153,50 & 14,01 & 9,80 & 8,62 & 7,61 & 6,84 & 6,17 & 5,05 & 4,17 & 2,94 \\
\hline 54,57 & 270,40 & 112,20 & 44,12 & 26,27 & 20,30 & 15,54 & 12,39 & 10,10 & 7,09 & 5,39 & 3,66 \\
\hline 60,95 & 1757,60 & 176,80 & 12,92 & 9,98 & 8,87 & 7,76 & 6,83 & 6,01 & 4,68 & 3,70 & 2,47 \\
\hline 70,15 & 686,90 & 108,70 & 24,45 & 17,26 & 14,85 & 12,72 & 11,10 & 9,72 & 7,53 & 5,96 & 4,01 \\
\hline 54,01 & 724,80 & 43,30 & 45,63 & 37,77 & 34,53 & 30,75 & 27,38 & 24,31 & 19,17 & 15,26 & 10,21 \\
\hline 31,85 & 792,70 & 165,70 & 27,00 & 19,08 & 15,13 & 11,28 & 8,63 & 6,82 & 4,65 & 3,53 & 2,43 \\
\hline 21,12 & 543,50 & 116,80 & 47,77 & 31,93 & 23,33 & 15,96 & 11,70 & 9,14 & 6,36 & 4,94 & 3,44 \\
\hline 28,17 & 1734,90 & 58,80 & 44,72 & 39,34 & 34,83 & 29,16 & 24,25 & 20,18 & 14,29 & 10,63 & 6,91 \\
\hline 21,65 & 1558,90 & 167,30 & 27,36 & 20,44 & 15,93 & 11,45 & 8,51 & 6,61 & 4,51 & 3,45 & 2,39 \\
\hline 49,57 & 813,80 & 136,10 & 23,65 & 17,34 & 14,70 & 12,10 & 10,06 & 8,42 & 6,07 & 4,60 & 3,04 \\
\hline 68,32 & 1361,70 & 35,80 & 35,99 & 28,59 & 27,21 & 25,75 & 24,18 & 22,64 & 19,74 & 17,14 & 12,91 \\
\hline 87,16 & 574,70 & 132,90 & 22,96 & 14,52 & 11,98 & 10,03 & 8,71 & 7,66 & 6,00 & 4,82 & 3,31 \\
\hline 37,53 & 757,10 & 70,90 & 42,36 & 34,19 & 29,53 & 24,26 & 19,95 & 16,50 & 11,65 & 8,72 & 5,74 \\
\hline 37,76 & 820,90 & 31,30 & 68,77 & 60,90 & 55,36 & 48,34 & 41,94 & 36,28 & 27,26 & 20,92 & 13,55 \\
\hline 85,02 & 938,10 & 120,00 & 18,39 & 12,76 & 11,17 & 9,81 & 8,80 & 7,94 & 6,47 & 5,34 & 3,75 \\
\hline 87,25 & 1411,90 & 66,90 & 20,65 & 15,43 & 14,25 & 13,33 & 12,48 & 11,68 & 10,21 & 8,91 & 6,80 \\
\hline 86,98 & 1879,70 & 177,60 & 10,60 & 7,54 & 6,75 & 6,06 & 5,52 & 5,05 & 4,23 & 3,55 & 2,56 \\
\hline 75,13 & 1632,70 & 84,00 & 18,49 & 14,18 & 13,20 & 12,18 & 11,26 & 10,40 & 8,84 & 7,51 & 5,48 \\
\hline 20,75 & 535,50 & 189,80 & 33,71 & 20,39 & 14,27 & 9,56 & 7,03 & 5,55 & 3,90 & 3,04 & 2,13 \\
\hline 76,92 & 670,40 & 160,90 & 20,12 & 12,96 & 10,68 & 8,88 & 7,62 & 6,61 & 5,05 & 3,98 & 2,69 \\
\hline 76,38 & 966,60 & 129,20 & 18,22 & 12,92 & 11,29 & 9,84 & 8,74 & 7,78 & 6,20 & 5,02 & 3,45 \\
\hline 20,10 & 1722,90 & 181,90 & 26,27 & 19,38 & 14,87 & 10,52 & 7,75 & 6,01 & 4,12 & 3,17 & 2,20 \\
\hline 74,12 & 1337,80 & 194,70 & 12,78 & 9,02 & 7,82 & 6,77 & 5,96 & 5,28 & 4,16 & 3,33 & 2,27 \\
\hline 48,44 & 1109,10 & 76,30 & 29,29 & 24,36 & 21,93 & 19,14 & 16,68 & 14,51 & 11,05 & 8,58 & 5,63 \\
\hline 41,60 & 1787,40 & 165,20 & 16,84 & 13,64 & 11,91 & 9,98 & 8,35 & 7,02 & 5,06 & 3,82 & 2,50 \\
\hline 55,39 & 1859,40 & 156,80 & 14,24 & 11,40 & 10,22 & 8,95 & 7,85 & 6,89 & 5,32 & 4,18 & 2,77 \\
\hline 73,43 & 484,20 & 164,30 & 24,67 & 14,90 & 11,80 & 9,45 & 7,89 & 6,69 & 4,94 & 3,83 & 2,58 \\
\hline 88,12 & 254,00 & 104,50 & 42,44 & 23,92 & 18,36 & 14,43 & 12,02 & 10,24 & 7,68 & 6,03 & 4,11 \\
\hline $64,1<2$ & 1609,50 & 33,00 & 37,47 & 30,14 & 28,86 & $\frac{14,40}{27,46}$ & $\frac{1 L, v L}{25,86}$ & $\frac{10,24}{24,27}$ & $\frac{1,00}{21,25}$ & 18,51 & $\frac{4, \pm \perp}{14,01}$ \\
\hline 45,30 & 1656,60 & 111,70 & 20,77 & 17,40 & 15,60 & 13,52 & 11,68 & 10,08 & 7,57 & 5,83 & 3,80 \\
\hline 57,07 & 804,50 & 70,60 & 31,61 & 25,07 & 22,45 & 19,67 & 17,30 & 15,20 & 11,78 & 9,28 & 6,17 \\
\hline 67,46 & 633,80 & 128,90 & 23,92 & 16,29 & 13,68 & 11,46 & 9,81 & 8,45 & 6,38 & 4,97 & 3,32 \\
\hline 35,48 & 1708,50 & 155,30 & 19,90 & 16,09 & 13,83 & 11,27 & 9,19 & 7,55 & 5,29 & 3,95 & 2,61 \\
\hline 74,32 & 1761,20 & 106,70 & 15,62 & 11,93 & 11,02 & 10,07 & 9,25 & 8,48 & 7,12 & 5,98 & 4,30 \\
\hline 67,45 & 1631,40 & 126,80 & 15,29 & 11,82 & 10,74 & 9,62 & 8,66 & 7,80 & 6,32 & 5,15 & 3,55 \\
\hline 62,41 & 647,80 & 112,90 & 26,00 & 18,44 & 15,70 & 13,24 & 11,33 & 9,75 & 7,32 & 5,68 & 3,77 \\
\hline 85,21 & 1008,20 & 142,30 & 16,32 & 11,18 & 9,70 & 8,46 & 7,56 & 6,78 & 5,50 & 4,51 & 3,16 \\
\hline 22,25 & 1202,80 & 188,50 & 26,46 & 18,82 & 14,29 & 10,06 & 7,43 & 5,77 & 3,97 & 3,06 & 2,13 \\
\hline 26,08 & 1821,60 & 112,80 & 30,25 & 24,84 & 20,95 & 16,48 & 13,00 & 10,39 & 7,07 & 5,27 & 3,55 \\
\hline 70,88 & 991,70 & 129,60 & 18,53 & 13,42 & 11,74 & 10,21 & 9,01 & 7,97 & 6,27 & 5,02 & 3,40 \\
\hline 28,04 & 623,20 & 121,00 & 38,58 & 27,37 & 21,37 & 15,59 & 11,76 & 9,21 & 6,29 & 4,80 & 3,32 \\
\hline 24,93 & 1298,70 & 82,50 & 43,15 & 35,12 & 29,34 & 22,79 & 17,79 & 14,13 & 9,57 & 7,15 & 4,85 \\
\hline 68,54 & 1724,80 & 36,60 & 32,60 & 26,01 & 24,75 & 23,64 & 22,36 & 21,06 & 18,59 & 16,33 & 12,54 \\
\hline 38,11 & 1859,90 & 42,50 & 42,41 & 38,34 & 35,73 & 32,09 & 28,61 & 25,39 & 19,92 & 15,73 & 10,36 \\
\hline 45,64 & 1656,00 & 113,20 & 20,50 & 17,15 & 15,37 & 13,32 & 11,51 & 9,94 & 7,47 & 5,75 & 3,75 \\
\hline 40,09 & 974,30 & 20,80 & 81,77 & 73,38 & 68,94 & 62,47 & 56,24 & 50,38 & 40,20 & 32,17 & 21,48 \\
\hline 29,40 & 580,90 & 40,70 & 79,68 & 65,51 & 55,85 & 44,68 & 35,79 & 28,94 & 19,90 & 14,81 & 9,88 \\
\hline 83,27 & 736,80 & 162,60 & 18,49 & 11,90 & 9,89 & 8,31 & 7,21 & 6,33 & 4,94 & 3,95 & 2,70 \\
\hline 77,74 & 1449,90 & 109,10 & 16,37 & 12,20 & 11,13 & 10,07 & 9,20 & 8,40 & 7,01 & 5,86 & 4,19 \\
\hline 29,84 & 370,00 & 23,10 & 133,29 & 111,14 & 95,67 & 77,45 & 62,64 & 51,03 & 35,32 & 26,27 & 17,40 \\
\hline 59,72 & 1986,00 & 84,70 & 19,44 & 15,92 & 14,91 & 13,64 & 12,45 & 11,34 & 9,36 & 7,73 & 5,40 \\
\hline 27,15 & 559,60 & 69,60 & 59,30 & 44,94 & 36,22 & 27,16 & 20,76 & 16,33 & 11,08 & 8,39 & 5,76 \\
\hline 75,27 & 1587,20 & 154,70 & 13,15 & 9,69 & 8,68 & 7,72 & 6,95 & 6,27 & 5,10 & 4,19 & 2,92 \\
\hline 32,59 & 1267,30 & 23,20 & 81,76 & 75,23 & 69,68 & 62,02 & 54,72 & 48,04 & 36,93 & 28,71 & 18,64 \\
\hline 76,25 & 953,50 & 188,30 & 15,41 & 10,30 & 8,68 & 7,34 & 6,37 & 5,57 & 4,31 & 3,42 & 2,32 \\
\hline 85,22 & 740,20 & 89,50 & 23,94 & 16,71 & 14,69 & 12,96 & 11,66 & 10,54 & 8,64 & 7,14 & 5,05 \\
\hline 22,44 & 1321,80 & 122,00 & 35,13 & 26,93 & 21,41 & 15,72 & 11,81 & 9,20 & 6,23 & 4,75 & 3,28 \\
\hline 53,20 & 1345,20 & 43,20 & 37,14 & 31,39 & 29,63 & 27,16 & 24,80 & 22,56 & 18,57 & 15,28 & 10,59 \\
\hline 78,59 & 1407,80 & 134,60 & 14,69 & 10,72 & 9,62 & 8,59 & 7,77 & 7,04 & 5,78 & 4,78 & 3,37 \\
\hline 75,45 & 1148,70 & 140,00 & 16,14 & 11,61 & 10,22 & 8,96 & 7,99 & 7,13 & 5,71 & 4,63 & 3,19 \\
\hline 60,50 & 1635,10 & 76,70 & 22,03 & 17,94 & 16,74 & 15,25 & 13,89 & 12,62 & 10,37 & 8,54 & 5,94 \\
\hline 88,00 & 1181,10 & 60,90 & 23,39 & 17,36 & 15,99 & 14,89 & 13,91 & 13,00 & 11,32 & 9,85 & 7,48 \\
\hline 27,81 & 767,70 & 39,30 & 77,66 & 65,62 & 56,62 & 45,87 & 37,07 & 30,16 & 20,83 & 15,46 & 10,24 \\
\hline 68,01 & 934,80 & 95,60 & 22,79 & 17,16 & 15,29 & 13,48 & 11,99 & 10,68 & 8,49 & $\begin{array}{c}1.0,70 \\
6,83\end{array}$ & $\frac{10,4}{4,65}$ \\
\hline 31,89 & 783,30 & 45,70 & 62,58 & 52,92 & 46,17 & 38,09 & 31,32 & 25,86 & 18,17 & 13,54 & 8,88 \\
\hline 77,86 & 1305,40 & 172,70 & 13,45 & 9,51 & 8,31 & 7,26 & 6,46 & 5,77 & 4,62 & 3,75 & 2,58 \\
\hline 76,11 & 1649,00 & 20,80 & 42,82 & 36,39 & 33,50 & 32,54 & 31,52 & 30,27 & 27,72 & 25,26 & 20,76 \\
\hline 31,99 & 1738,30 & 40,20 & 51,71 & 47,18 & 43,17 & 37,85 & 32,90 & 28,48 & 21,39 & 16,37 & 10,55 \\
\hline 48,19 & 591,70 & 149,10 & 26,58 & 18,00 & 14,67 & 11,62 & 9,39 & 7,69 & 5,41 & 4,09 & 2,74 \\
\hline 75,67 & 328,60 & 65,40 & 44.69 & 29,89 & 25,15 & 21,25 & 18,42 & 16.10 & 12,43 & 9,85 & 6.66 \\
\hline 88,22 & 1783,20 & 182.00 & 10,67 & 7.51 & 6.68 & 5,97 & 5,43 & 4,96 & 4.13 & 3,47 & 2,50 \\
\hline 71,11 & 761,50 & 106,50 & 23,30 & 16,70 & 14,53 & 12,58 & 11,06 & 9,76 & 7,65 & 6,10 & 4,13 \\
\hline 45,47 & 649,20 & 131,70 & 27,92 & 19,84 & 16,45 & 13,15 & 10,67 & 8,76 & 6,16 & 4,64 & 3,10 \\
\hline 81,84 & 513,70 & 27,20 & 55,12 & 41,37 & 38,31 & 35,49 & 32,96 & 30,62 & 26,33 & 22,64 & 16,84 \\
\hline 60,36 & 1312,60 & 164,80 & 15,41 & 11,58 & 10,13 & 8,72 & 7,58 & 6,59 & 5,04 & 3,94 & 2,62 \\
\hline 26,24 & 1571,70 & 85,00 & 38,27 & 31,91 & 27,19 & 21,65 & 17,24 & 13,88 & 9,48 & 7,05 & 4,71 \\
\hline 68,56 & 469,40 & 80,90 & 34,66 & 24,23 & 20,68 & 17,58 & 15,22 & 13,25 & 10,15 & 7,98 & 5,35 \\
\hline 25,49 & 1821,60 & 171,90 & 23,00 & 17,94 & 14,60 & 11,04 & 8,46 & 6,66 & 4,51 & 3,40 & 2,33 \\
\hline 52,50 & 1913,90 & 30,40 & 43,02 & 35,83 & 34,64 & 32,69 & 30,55 & 28,45 & 24,48 & 20,95 & 15,36 \\
\hline 37,52 & 794,40 & 200,00 & 22,17 & 15,16 & 12,09 & 9,17 & 7,13 & 5,69 & 3,91 & 2,96 & 2,02 \\
\hline 25,37 & 1445,10 & 106,10 & 34,63 & 27,81 & 23,06 & 17,77 & 13,80 & 10,93 & 7,40 & 5,55 & 3,77 \\
\hline 81,64 & 216,20 & 119,70 & 46,25 & 24,64 & 18,17 & 13,70 & 11,07 & 9,21 & 6,68 & 5,17 & 3,53 \\
\hline
\end{tabular}




\begin{tabular}{|c|c|c|c|c|c|c|c|c|c|c|c|}
\hline \multirow[b]{2}{*}{$\mathrm{e} 1(\mathrm{~cm})$} & & & & & & $\mathrm{De}$ & $\overline{\text { ões (x1 }}$ & & & & \\
\hline & Meq (MPa) & Ms (MPa) & D0 & D25 & D40 & D60 & D80 & D100 & D140 & D180 & D260 \\
\hline 31,45 & 505,40 & 165,80 & 32,06 & 20,65 & 15,65 & 11,24 & 8,46 & 6,65 & 4,57 & 3,50 & 2,44 \\
\hline 86,52 & 1627,90 & 81,40 & 17,45 & 13,01 & 12,01 & 11,20 & 10,46 & 9,77 & 8,51 & 7,39 & 5,61 \\
\hline 57,17 & 1416,10 & 175,10 & 14,82 & 11,25 & 9,84 & 8,43 & 7,28 & 6,30 & 4,76 & 3,70 & 2,44 \\
\hline 89,15 & 1343,80 & 108,80 & 15,91 & 11,39 & 10,29 & 9,34 & 8,58 & 7,91 & 6,71 & 5,71 & 4,20 \\
\hline 62,08 & 1569,10 & 81,90 & 21,15 & 17,06 & 15,84 & 14,39 & 13,08 & 11,86 & 9,73 & 8,00 & 5,55 \\
\hline 61,00 & 1769,70 & 49,70 & 28,43 & 23,14 & 22,07 & 20,61 & 19,15 & 17,74 & 15,11 & 12,84 & 9,32 \\
\hline 84,79 & 1264,70 & 132,50 & 15,09 & 10,70 & 9,52 & 8,48 & 7,68 & 6,98 & 5,77 & 4,81 & 3,42 \\
\hline 59,70 & 1560,00 & 95,40 & 19,70 & 15,94 & 14,63 & 13,14 & 11,82 & 10,61 & 8,53 & 6,90 & 4,70 \\
\hline 41,08 & 1112,50 & 177,50 & 19,71 & 14,68 & 12,32 & 9,87 & 7,99 & 6,53 & 4,57 & 3,43 & 2,29 \\
\hline 50,58 & 926,70 & 129,50 & 22,64 & 17,10 & 14,72 & 12,33 & 10,39 & 8,79 & 6,42 & 4,90 & 3,22 \\
\hline 25,56 & 1910,20 & 45,90 & 55,62 & 49,75 & 44,29 & 37,28 & 31,11 & 25,95 & 18,41 & 13,69 & 8,86 \\
\hline 26,68 & 1534,90 & 73,60 & 41,95 & 35,49 & 30,55 & 24,65 & 19,85 & 16,10 & 11,07 & 8,22 & 5,45 \\
\hline 35,21 & 1301,40 & 143,50 & 23,25 & 18,30 & 15,51 & 12,43 & 10,01 & 8,14 & 5,65 & 4,22 & 2,82 \\
\hline 20,48 & 1691,50 & 80,50 & 47,16 & 38,29 & 31,46 & 23,86 & 18,25 & 14,30 & 9,62 & 7,23 & 4,95 \\
\hline 82,51 & 811,40 & 132,00 & 19,21 & 13,01 & 11,15 & 9,61 & 8,50 & 7,56 & 6,02 & 4,88 & 3,37 \\
\hline 79,50 & 1439,60 & 48,70 & 26,25 & 20,26 & 18,98 & 17,95 & 16,90 & 15,88 & 13,96 & 12,23 & 9,38 \\
\hline 87,67 & 1109,50 & 65,20 & 23,18 & 17,06 & 15,66 & 14,48 & 13,45 & 12,52 & 10,81 & 9,34 & 7,01 \\
\hline 89,90 & 356,00 & 143,50 & 30,36 & 17,13 & 13,18 & 10,38 & 8,67 & 7,41 & 5,58 & 4,40 & 3,00 \\
\hline 84,92 & 725,60 & 185,40 & 17,63 & 11,00 & 8,99 & 7,45 & 6,42 & 5,60 & 4,33 & 3,45 & 2,36 \\
\hline 34,24 & 776,20 & 162,00 & 26,57 & 18,83 & 15,10 & 11,43 & 8,84 & 7,02 & 4,81 & 3,64 & 2,49 \\
\hline 55,27 & 1189,20 & 25,70 & 53,83 & 44,70 & 42,93 & 40,18 & 37,34 & 34,59 & 29,45 & 24,98 & 18,07 \\
\hline 76,40 & 1237,10 & 181,20 & 13,61 & 9,54 & 8,26 & 7,16 & 6,32 & 5,61 & 4,44 & 3,57 & 2,44 \\
\hline 43,66 & 1727,20 & 92,70 & 23,55 & 20,20 & 18,29 & 15,98 & 13,90 & 12,07 & 9,14 & 7,07 & 4,61 \\
\hline 63,07 & 1716,90 & 129,90 & 15,29 & 12,04 & 10,94 & 9,75 & 8,74 & 7,82 & 6,26 & 5,05 & 3,44 \\
\hline 76,57 & 347,70 & 140,10 & 32,03 & 18,49 & 14,31 & 11,25 & 9,30 & 7,84 & 5,77 & 4,47 & 3,02 \\
\hline 69,91 & 1539,50 & 124,30 & 15,58 & 11,90 & 10,80 & 9,67 & 8,72 & 7,87 & 6,40 & 5,24 & 3,63 \\
\hline 45,46 & 676,30 & 134,90 & 27,04 & 19,28 & 16,00 & 12,82 & 10,40 & 8,54 & 6,01 & 4,53 & 3,03 \\
\hline 29,62 & 882,30 & 56,60 & 55,28 & 45,93 & 39,43 & 31,81 & 25,65 & 20,85 & 14,40 & 10,71 & 7,11 \\
\hline 28,15 & 1931,10 & 28,50 & 70,26 & 65,24 & 60,06 & 52,96 & 46,24 & 40,18 & 30,31 & 23,24 & 14,95 \\
\hline 77,47 & 1527,00 & 85,80 & 18,44 & 13,98 & 12,95 & 11,92 & 11,01 & 10,16 & 8,63 & 7,33 & 5,35 \\
\hline 45,28 & 987,60 & 120,40 & 24,49 & 19,03 & 16,43 & 13,67 & 11,42 & 9,58 & 6,91 & 5,22 & 3,43 \\
\hline 21,79 & 1856,10 & 109,50 & 35,20 & 28,27 & 23,14 & 17,51 & 13,39 & 10,49 & 7,07 & 5,32 & 3,65 \\
\hline 53,03 & 466,90 & 98,30 & 35,37 & 24,68 & 20,57 & 16,77 & 13,89 & 11,60 & 8,35 & 6,34 & 4,21 \\
\hline 34,33 & 1360,70 & 21,70 & 80,47 & 73,83 & 69,17 & 62,38 & 55,81 & 49,66 & 39,10 & 30,94 & 20,38 \\
\hline 22,82 & 543,50 & 57,90 & 76,22 & 57,54 & 45,37 & 33,06 & 24,76 & 19,27 & 13,09 & 10,00 & 6,91 \\
\hline 21,30 & 805,10 & 45,40 & 85,17 & 68,45 & 55,96 & 42,24 & 32,25 & 25,24 & 17,00 & 12,81 & 8,78 \\
\hline 52,94 & 505,70 & 28,00 & 69,38 & 57,91 & 53,09 & 47,38 & 42,22 & 37,53 & 29,63 & 23,61 & 15,80 \\
\hline 62,75 & 420,50 & 195,00 & 26,27 & 15,01 & 11,43 & 8,74 & 7,02 & 5,77 & 4,10 & 3,13 & 2,13 \\
\hline 59,38 & 807,40 & 53,10 & 36,53 & 29,47 & 26,93 & 24,08 & 21,57 & 19,29 & 15,41 & 12,41 & 8,41 \\
\hline 35,03 & 1311,20 & 157,50 & 21,93 & 17,05 & 14,35 & 11,41 & 9,13 & 7,40 & 5,12 & 3,83 & 2,56 \\
\hline 59,90 & 1391,50 & 105,90 & 19,33 & 15,40 & 13,95 & 12,38 & 11,03 & 9,81 & 7,77 & 6,21 & 4,19 \\
\hline 75,88 & 1156,40 & 167,90 & 14,66 & 10,30 & 8,93 & 7,74 & 6,83 & 6,06 & 4,80 & 3,86 & 2,64 \\
\hline 31,96 & 444,50 & 136,30 & 37,76 & 24,70 & 18,90 & 13,68 & 10,33 & 8,13 & 5,58 & 4,27 & 2,96 \\
\hline 27,55 & 987,40 & 190,20 & 24,72 & 17,53 & 13,66 & 9,93 & 7,47 & 5,85 & 3,99 & 3,05 & 2,11 \\
\hline 66,91 & 222,30 & 42,70 & 70,24 & 48,39 & 40,87 & 34,37 & 29,50 & 25,47 & 19,26 & 15,03 & 10,03 \\
\hline 50,64 & 1916,30 & 41,10 & 35,50 & 30,16 & 28,87 & 26,80 & 24,73 & 22,72 & 19,05 & 15,91 & 11,25 \\
\hline 87,37 & 1712,20 & 54,90 & 21,32 & 16,45 & 15,22 & 14,49 & 13,75 & 13,02 & 11,62 & 10,33 & 8,15 \\
\hline 24,29 & 1947,20 & 120,30 & 29,92 & 24,34 & 20,27 & 15,69 & 12,21 & 9,67 & 6,54 & 4,89 & 3,32 \\
\hline 27,65 & 1358,70 & 184,50 & 22,74 & 17,05 & 13,69 & 10,24 & 7,82 & 6,15 & 4,18 & 3,16 & 2,17 \\
\hline 37,93 & 1256,50 & 93,00 & 29,35 & 24,41 & 21,42 & 17,94 & 14,99 & 12,56 & 9,01 & 6,77 & 4,42 \\
\hline 21,96 & 271,20 & 34,80 & 136,76 & 99,95 & 76,95 & 54,78 & 40,57 & 31,51 & 21,57 & 16,58 & 11,51 \\
\hline 71,20 & 1324,00 & 38,80 & 33,58 & 26,44 & 25,06 & 23,68 & 22,22 & 20,81 & 18,14 & 15,76 & 11,89 \\
\hline 39,00 & 1835,40 & 165,30 & 17,43 & 14,15 & 12,30 & 10,21 & 8,47 & 7,06 & 5,03 & 3,78 & 2,48 \\
\hline 48,08 & 633,40 & 87,10 & 34,41 & 26,15 & 22,47 & 18,70 & 15,66 & 13,17 & 9,54 & 7,24 & 4,76 \\
\hline 32,72 & 525,70 & 102,60 & 41,94 & 30,05 & 24,07 & 18,15 & 13,99 & 11,08 & 7,57 & 5,73 & 3,93 \\
\hline 60,72 & 1160,60 & 101,70 & 21,20 & 16,62 & 14,93 & 13,16 & 11,66 & 10,32 & 8,11 & 6,45 & 4,33 \\
\hline 40,31 & 455,80 & 147,70 & 32,50 & 20,99 & 16,43 & 12,36 & 9,60 & 7,66 & 5,27 & 4,00 & 2,75 \\
\hline 34,25 & 434,50 & 114,30 & 41,18 & 27,89 & 21,88 & 16,25 & 12,45 & 9,85 & 6,74 & 5,13 & 3,53 \\
\hline 33,72 & 374,60 & 101,20 & 47,34 & 31,88 & 24,89 & 18,39 & 14,04 & 11,09 & 7,59 & 5,78 & 3,99 \\
\hline 30,40 & 515,80 & 133,50 & 37,02 & 25,04 & 19,32 & 14,03 & 10,59 & 8,31 & 5,69 & 4,36 & 3,02 \\
\hline 80,87 & 1272,70 & 146,10 & 14,59 & 10,38 & 9,18 & 8,11 & 7,29 & 6,57 & 5,36 & 4,41 & 3,09 \\
\hline 35,18 & 258,70 & 37,50 & 98,59 & 74,50 & 61,84 & 48,49 & 38,43 & 30,93 & 21,29 & 15,97 & 10,76 \\
\hline 20,55 & 1910,50 & 197,00 & 23,77 & 17,67 & 13,65 & 9,72 & 7,19 & 5,57 & 3,81 & 2,93 & 2,03 \\
\hline 49,74 & 367,30 & 170,20 & 31,70 & 18,48 & 14,03 & 10,50 & 8,23 & 6,63 & 4,60 & 3,50 & 2,40 \\
\hline 80,86 & 447,90 & 139,00 & 26,90 & 16,31 & 13,03 & 10,57 & 8,95 & 7,70 & 5,82 & 4,57 & 3,10 \\
\hline 28,25 & 897,40 & 50,50 & 61,52 & 51,56 & 44,32 & 35,76 & 28,81 & 23,39 & 16,13 & 11,98 & 7,95 \\
\hline 85,93 & 439,80 & 122,60 & 28,07 & 17,19 & 13,89 & 11,41 & 9,78 & 8,50 & 6,55 & 5,21 & 3,56 \\
\hline 58,57 & 302,10 & 71,40 & 49,51 & 33,38 & 27,59 & 22,52 & 18,78 & 15,80 & 11,50 & 8,79 & 5,85 \\
\hline 70,96 & 1935,00 & 170,30 & 11,72 & 8,86 & 7,99 & 7,13 & 6,41 & 5,77 & 4,68 & 3,82 & 2,65 \\
\hline 33,67 & 1242,50 & 154,90 & 23,21 & 17,91 & 14,95 & 11,76 & 9,32 & 7,51 & 5,16 & 3,86 & 2,60 \\
\hline 52,93 & 547,20 & 194,10 & 23,54 & 14,62 & 11,52 & 8,94 & 7,17 & 5,86 & 4,12 & 3,13 & 2,12 \\
\hline 41,44 & 1317,40 & 66,80 & 33,24 & 28,72 & 25,96 & 22,60 & 19,57 & 16,92 & 12,71 & 9,77 & 6,35 \\
\hline 26,88 & 1201,80 & 100,80 & 36,43 & 29,03 & 24,08 & 18,61 & 14,50 & 11,51 & 7,81 & 5,85 & 3,97 \\
\hline 24,27 & 1684,60 & 173,90 & 24,15 & 18,49 & 14,81 & 10,98 & 8,31 & 6,50 & 4,40 & 3,34 & 2,30 \\
\hline 79,01 & 1271,70 & 183,60 & 13,16 & 9,16 & 7,95 & 6,90 & 6,12 & 5,45 & 4,35 & 3,52 & 2,42 \\
\hline 69,17 & 1773,40 & 165,80 & 12,52 & 9,47 & 8,50 & 7,54 & 6,75 & 6,05 & 4,86 & 3,94 & 2,70 \\
\hline 47,25 & 1090,80 & 36,40 & 48,07 & 41,76 & 38,99 & 35,25 & 31,72 & 28,44 & 22,75 & 18,28 & 12,29 \\
\hline 54,78 & 1227,70 & 80,00 & 25,32 & 20,78 & 18,91 & 16,79 & 14,91 & 13,21 & 10,38 & 8,25 & 5,51 \\
\hline 73,28 & 1532,60 & 174,10 & 12,70 & 9,28 & 8,22 & 7,23 & 6,45 & 5,76 & 4,61 & 3,73 & 2,56 \\
\hline 27,98 & 483,00 & 180,20 & 32,34 & 20,08 & 14,75 & 10,29 & 7,65 & 6,00 & 4,15 & 3,21 & 2,24 \\
\hline 31,31 & 1525,20 & 189,10 & 19,89 & 15,29 & 12,63 & 9,78 & 7,66 & 6,12 & 4,18 & 3,14 & 2,13 \\
\hline 23,38 & 585,20 & 181,00 & 32,50 & 20,63 & 14,93 & 10,21 & 7,52 & 5,89 & 4,11 & 3,19 & 2,23 \\
\hline
\end{tabular}




\begin{tabular}{|c|c|c|c|c|c|c|c|c|c|c|c|}
\hline & & & \multicolumn{9}{|c|}{ Deflexões $\left(\times 10^{-4} \mathrm{~cm}\right)$} \\
\hline $\mathrm{e} 1(\mathrm{~cm})$ & Meq (MPa) & Ms (MPa) & D0 & D25 & D40 & D60 & D80 & D100 & D140 & D180 & D260 \\
\hline 47,82 & 1867,00 & 178,70 & 14,40 & 11,55 & 10,18 & 8,68 & 7,42 & 6,34 & 4,70 & 3,60 & 2,35 \\
\hline 74,87 & 1558,30 & 161,20 & 13,00 & 9,54 & 8,51 & 7,54 & 6,77 & 6,08 & 4,92 & 4,02 & 2,79 \\
\hline 55,41 & 453,30 & 72,90 & 40,92 & 29,91 & 25,58 & 21,43 & 18,15 & 15,44 & 11,39 & 8,73 & 5,76 \\
\hline 23,32 & 749,70 & 191,50 & 29,10 & 19,19 & 14,11 & 9,74 & 7,17 & 5,60 & 3,89 & 3,01 & 2,10 \\
\hline 84,67 & 1468,50 & 41,90 & 27,22 & 21,23 & 19,71 & 18,83 & 17,90 & 16,96 & 15,17 & 13,51 & 10,67 \\
\hline 23,04 & 1105,40 & 86,10 & 46,55 & 36,59 & 29,65 & 22,22 & 16,90 & 13,23 & 8,94 & 6,76 & 4,64 \\
\hline 74,48 & 316,60 & 168,60 & 32,34 & 17,54 & 13,05 & 9,88 & 7,97 & 6,60 & 4,74 & 3,65 & 2,49 \\
\hline 69,74 & 784,80 & 106,80 & 23,10 & 16,69 & 14,55 & 12,60 & 11,08 & 9,77 & 7,64 & 6,08 & 4,11 \\
\hline 35,17 & 968,70 & 59,90 & 45,13 & 38,19 & 33,60 & 28,11 & 23,44 & 19,58 & 13,99 & 10,48 & 6,83 \\
\hline 67,83 & 1693,10 & 42,30 & 30,04 & 23,91 & 22,78 & 21,59 & 20,29 & 19,02 & 16,61 & 14,44 & 10,90 \\
\hline 67,33 & 294,80 & 83,90 & 44,49 & 28,29 & 22,93 & 18,61 & 15,59 & 13,22 & 9,74 & 7,52 & 5,03 \\
\hline 38,26 & 1415,90 & 107,10 & 25,52 & 21,17 & 18,57 & 15,55 & 13,00 & 10,89 & 7,81 & 5,87 & 3,83 \\
\hline 52,68 & 338,50 & 78,50 & 46,62 & 31,92 & 26,34 & 21,28 & 17,50 & 14,55 & 10,41 & 7,90 & 5,26 \\
\hline 50,57 & 844,30 & 97,90 & 27,57 & 21,43 & 18,71 & 15,87 & 13,52 & 11,54 & 8,54 & 6,54 & 4,29 \\
\hline 35,87 & 1389,10 & 73,90 & 34,13 & 29,37 & 26,11 & 22,15 & 18,70 & 15,79 & 11,44 & 8,61 & 5,59 \\
\hline 34,26 & 1787,20 & 124,60 & 23,12 & 19,27 & 16,78 & 13,86 & 11,42 & 9,45 & 6,66 & 4,98 & 3,26 \\
\hline 74,31 & 1534,70 & 84,30 & 19,02 & 14,59 & 13,54 & 12,44 & 11,46 & 10,56 & 8,92 & 7,53 & 5,45 \\
\hline 88,84 & 835,50 & 31,60 & 39,28 & 29,84 & 27,56 & 26,07 & 24,64 & 23,24 & 20,61 & 18,24 & 14,24 \\
\hline 66,23 & 616,10 & 125,60 & 24,77 & 16,91 & 14,20 & 11,87 & 10,14 & 8,72 & 6,56 & 5,10 & 3,40 \\
\hline 30,52 & 1839,80 & 38,70 & 54,14 & 49,59 & 45,35 & 39,69 & 34,42 & 29,73 & 22,24 & 16,97 & 10,92 \\
\hline 72,03 & 1792,80 & 74,20 & 19,74 & 15,39 & 14,46 & 13,45 & 12,49 & 11,58 & 9,91 & 8,47 & 6,22 \\
\hline 21,22 & 1533,40 & 113,30 & 36,96 & 28,82 & 23,05 & 17,00 & 12,79 & 9,95 & 6,73 & 5,11 & 3,53 \\
\hline 21,84 & 1496,60 & 43,50 & 71,53 & 61,49 & 52,91 & 42,47 & 33,95 & 27,34 & 18,64 & 13,79 & 9,18 \\
\hline 69,67 & 1785,10 & 60,90 & 22,87 & 18,03 & 17,07 & 15,98 & 14,90 & 13,87 & 11,94 & 10,25 & 7,59 \\
\hline 25,86 & 1750,20 & 163,60 & 23,86 & 18,66 & 15,25 & 11,57 & 8,90 & 7,01 & 4,75 & 3,58 & 2,45 \\
\hline 82,14 & 645,90 & 34,40 & 443,63 & 32,72 & 30,29 & 28,06 & 26,06 & 24,21 & 20,83 & 17,91 & 13,33 \\
\hline 82,58 & 708,00 & 126,90 & 21,07 & 14,06 & 11,94 & 10,21 & 8,98 & 7,95 & 6,29 & 5,07 & 3,49 \\
\hline 54,68 & 1014,00 & 156,40 & 18,82 & 13,88 & 11,90 & 9,99 & 8,46 & 7,20 & 5,31 & 4,07 & 2,69 \\
\hline 80,51 & 775,90 & 194,10 & 16,87 & 10,68 & 8,76 & 7,26 & 6,24 & 5,42 & 4,17 & 3,30 & 2,24 \\
\hline 76,27 & 1330,20 & 75,20 & 21,28 & 16,19 & 15,00 & 13,78 & 12,71 & 11,72 & 9,92 & 8,41 & 6,11 \\
\hline 42,24 & 1427,90 & 159,40 & 18,63 & 14,70 & 12,69 & 10,51 & 8,73 & 7,28 & 5,21 & 3,92 & 2,58 \\
\hline 45,49 & 675,40 & 65,10 & 40,96 & 32,92 & 28,89 & 24,46 & 20,73 & 17,60 & 12,89 & 9,81 & 6,41 \\
\hline 59,79 & 872,00 & 62,90 & 31,86 & 25,50 & 23,17 & 20,63 & 18,41 & 16,41 & 13,04 & 10,46 & 7,06 \\
\hline 51,44 & 1749,60 & 53,30 & 30,21 & 25,75 & 24,31 & 22,26 & 20,30 & 18,44 & 15,13 & 12,41 & 8,57 \\
\hline 84,55 & 771,80 & 145,50 & 18,76 & 12,36 & 10,43 & 8,89 & 7,81 & 6,91 & 5,47 & 4,42 & 3,04 \\
\hline 30,49 & 1589,40 & 73,20 & 37,31 & 32,18 & 28,30 & 23,54 & 19,49 & 16,16 & 11,41 & 8,50 & 5,55 \\
\hline 47,11 & 1804,10 & 122,50 & 18,49 & 15,44 & 13,88 & 12,08 & 10,49 & 9,10 & 6,89 & 5,33 & 3,49 \\
\hline 73,25 & 680,90 & 175,00 & 19,56 & 12,54 & 10,27 & 8,46 & 7,20 & 6,19 & 4,67 & 3,64 & 2,45 \\
\hline 30,16 & 1339,90 & 103,60 & 31,73 & 25,85 & 21,98 & 17,54 & 14,03 & 11,34 & 7,80 & 5,81 & 3,88 \\
\hline 41,15 & 600,40 & 164,00 & 26,87 & 18,03 & 14,40 & 11,03 & 8,67 & 6,96 & 4,80 & 3,63 & 2,47 \\
\hline 88,93 & 646,60 & 181,50 & 18,88 & 11,47 & 9,25 & 7,60 & 6,52 & 5,68 & 4,40 & 3,51 & 2,41 \\
\hline 86,73 & 1673,30 & 156,40 & 11,99 & 8,54 & 7,65 & 6,88 & 6,27 & 5,73 & 4,80 & 4,03 & 2,91 \\
\hline 88,07 & 1535,90 & 182,60 & 11,49 & 7,96 & 7,00 & 6,20 & 5,59 & 5,07 & 4,18 & 3,48 & 2,48 \\
\hline 23,70 & 518,90 & 30,70 & 117,88 & 95,95 & 79,81 & 61,61 & 47,85 & 37,85 & 25,57 & 19,14 & 13,00 \\
\hline 28,19 & 1419,60 & 193,10 & 21,48 & 16,14 & 13,00 & 9,77 & 7,48 & 5,89 & 4,00 & 3,03 & 2,08 \\
\hline 83,01 & 513,30 & 117,40 & 26,19 & 16,76 & 13,87 & 11,61 & 10,06 & 8,81 & 6,85 & 5,47 & 3,73 \\
\hline 80,68 & 291,70 & 94,80 & 40,65 & 24,41 & 19,40 & 15,66 & 13,21 & 11,33 & 8,53 & 6,69 & 4,53 \\
\hline 63,90 & 342,10 & 112,50 & 36,72 & 22,76 & 18,14 & 14,45 & 11,92 & 9,97 & 7,22 & 5,53 & 3,71 \\
\hline 73,56 & 831,20 & 109,10 & 21,71 & 15,58 & 13,63 & 11,87 & 10,51 & 9,34 & 7,40 & 5,95 & 4,06 \\
\hline 32,04 & 309,80 & 55,10 & 76,39 & 55,57 & 44,73 & 33,82 & 26,11 & 20,68 & 14,11 & 10,67 & 7,30 \\
\hline 78,40 & 1941,80 & 192,40 & 10,46 & 7,62 & 6,81 & 6,07 & 5,48 & 4,96 & 4,06 & 3,35 & 2,35 \\
\hline 51,88 & 1287,30 & 187,80 & 15,70 & 11,75 & 10,09 & 8,45 & 7,13 & 6,04 & 4,43 & 3,38 & 2,22 \\
\hline 56,57 & 840,60 & 156,40 & 20,29 & 14,41 & 12,17 & 10,10 & 8,51 & 7,21 & 5,29 & 4,05 & 2,68 \\
\hline 77,34 & 359,30 & 29,20 & 63,43 & 47,12 & 42,75 & 38,53 & 35,05 & 31,92 & 26,44 & 22,01 & 15,62 \\
\hline 43,40 & 939,30 & 135,10 & 24,01 & 18,19 & 15,46 & 12,61 & 10,36 & 8,58 & 6,08 & 4,58 & 3,03 \\
\hline 21,39 & 1425,90 & 68,60 & 53,72 & 43,91 & 36,37 & 27,86 & 21,48 & 16,90 & 11,38 & 8,53 & 5,82 \\
\hline 45,54 & 936,90 & 159,10 & 21,32 & 15,67 & 13,19 & 10,71 & 8,78 & 7,26 & 5,15 & 3,88 & 2,58 \\
\hline 29,26 & 227,70 & 63,00 & 81,78 & 54,44 & 41,48 & 29,74 & 22,30 & 17,48 & 12,00 & 9,21 & 6,40 \\
\hline 63,27 & 689,20 & 144,70 & 22,23 & 15,20 & 12,72 & 10,57 & 8,97 & 7,66 & 5,69 & 4,40 & 2,93 \\
\hline 39,23 & 1471,20 & 69,60 & 32,43 & 28,24 & 25,49 & 22,10 & 19,06 & 16,40 & 12,23 & 9,35 & 6,06 \\
\hline 58,84 & 1184,10 & 45,40 & 35,26 & 29,02 & 27,31 & 25,06 & 22,95 & 20,95 & 17,37 & 14,40 & 10,10 \\
\hline 36,49 & 687,10 & 116,10 & 33,01 & 24,34 & 20,05 & 15,64 & 12,36 & 9,94 & 6,85 & 5,15 & 3,48 \\
\hline 54,36 & 1958,50 & 36,50 & 36,66 & 30,44 & 29,34 & 27,59 & 25,73 & 23,91 & 20,49 & 17,48 & 12,75 \\
\hline 31,14 & 1898,20 & 62,80 & 38,17 & 33,98 & 30,49 & 26,04 & 22,08 & 18,69 & 13,56 & 10,19 & 6,58 \\
\hline 65,48 & 324,40 & 41,10 & 59,62 & 44,09 & 38,61 & 33,46 & 29,32 & 25,75 & 19,99 & 15,82 & 10,61 \\
\hline 71,21 & 569,00 & 74,50 & 32,21 & 23,29 & 20,38 & 17,72 & 15,65 & 13,85 & 10,91 & 8,73 & 5,93 \\
\hline 27,45 & 977,10 & 80,30 & 44,75 & 35,83 & 29,87 & 23,23 & 18,19 & 14,49 & 9,85 & 7,37 & 4,99 \\
\hline 86,98 & 933,10 & 61,20 & 26,01 & 19,02 & 17,39 & 15,98 & 14,78 & 13,69 & 11,73 & 10,06 & 7,47 \\
\hline 27,07 & 1925,10 & 177,80 & 21,19 & 16,70 & 13,77 & 10,57 & 8,20 & 6,50 & 4,41 & 3,31 & 2,25 \\
\hline 83,13 & 1940,60 & 196,10 & 10,10 & 7,23 & 6,45 & 5,76 & 5,21 & 4,74 & 3,91 & 3,26 & 2,31 \\
\hline 44,16 & 617,90 & 55,00 & 47,87 & 38,91 & 34,24 & 29,02 & 24,59 & 20,87 & 15,28 & 11,60 & 7,57 \\
\hline 56,42 & 1396,90 & 177,90 & 14,88 & 11,28 & 9,83 & 8,39 & 7,22 & 6,23 & 4,68 & 3,63 & 2,39 \\
\hline 86,88 & 558,20 & 170,90 & 21,32 & 12,80 & 10,22 & 8,32 & 7,08 & 6,13 & 4,70 & 3,72 & 2,54 \\
\hline 78,31 & 926,20 & 99,20 & 21,06 & 15,22 & 13,54 & 12,00 & 10,79 & 9,73 & 7,92 & 6,50 & 4,54 \\
\hline 38,52 & 876,70 & 150,30 & 24,87 & 18,31 & 15,16 & 11,94 & 9,51 & 7,70 & 5,33 & 4,00 & 2,69 \\
\hline 54,91 & 1072,40 & 152,60 & 18,54 & 13,85 & 11,95 & 10,10 & 8,60 & 7,35 & 5,46 & 4,20 & 2,77 \\
\hline 55,20 & 1275,80 & 185,20 & 15,37 & 11,44 & 9,86 & 8,32 & 7,09 & 6,06 & 4,49 & 3,45 & 2,28 \\
\hline 41,56 & 1993,60 & 88,20 & 23,92 & 20,88 & 19,01 & 16,68 & 14,56 & 12,68 & 9,63 & 7,45 & 4,86 \\
\hline 56,95 & 1948,60 & 180,80 & 12,66 & 9,98 & 8,90 & 7,77 & 6,81 & 5,97 & 4,61 & 3,62 & 2,40 \\
\hline 45,95 & 1872,70 & 127,10 & 18,12 & 15,16 & 13,60 & 11,80 & 10,21 & 8,83 & 6,65 & 5,13 & 3,35 \\
\hline 63,59 & 985,00 & 81,00 & 25,27 & 19,73 & 17,83 & 15,84 & 14,14 & 12,62 & 10,06 & 8,10 & 5,50 \\
\hline 52,57 & 1564,10 & 150,60 & 16,17 & 12,84 & 11,38 & 9,83 & 8,50 & 7,36 & 5,57 & 4,31 & 2,84 \\
\hline
\end{tabular}




\begin{tabular}{|c|c|c|c|c|c|c|c|c|c|c|c|}
\hline \multirow[b]{2}{*}{ e1 (cm) } & & & & & & $\mathrm{De}$ & ões (x1 & & & & \\
\hline & Meq (MPa) & Ms (MPa) & D0 & D25 & D40 & D60 & D80 & D100 & D140 & D180 & D260 \\
\hline 76,67 & 1383,90 & 41,50 & 30,12 & 23,47 & 22,09 & 20,96 & 19,76 & 18,58 & 16,36 & 14,34 & 11,01 \\
\hline 52,69 & 1214,10 & 97,00 & 23,19 & 18,81 & 16,87 & 14,74 & 12,89 & 11,26 & 8,64 & 6,75 & 4,45 \\
\hline 69,96 & 1361,60 & 95,60 & 19,09 & 14,72 & 13,47 & 12,16 & 11,04 & 10,02 & 8,23 & 6,79 & 4,75 \\
\hline 37,54 & 1848,40 & 99,10 & 24,63 & 21,21 & 18,94 & 16,18 & 13,75 & 11,69 & 8,55 & 6,47 & 4,19 \\
\hline 81,80 & 806,00 & 76,20 & 25,36 & 18,33 & 16,44 & 14,72 & 13,36 & 12,16 & 10,06 & 8,38 & 5,96 \\
\hline 61,47 & 761,70 & 169,00 & 19,84 & 13,47 & 11,21 & 9,25 & 7,79 & 6,61 & 4,87 & 3,75 & 2,49 \\
\hline 28,65 & 1332,10 & 87,80 & 36,90 & 30,45 & 25,97 & 20,76 & 16,60 & 13,42 & 9,21 & 6,85 & 4,57 \\
\hline 50,12 & 1302,00 & 151,20 & 17,96 & 13,97 & 12,19 & 10,33 & 8,79 & 7,49 & 5,53 & 4,23 & 2,78 \\
\hline 64,85 & 1897,80 & 99,70 & 17,00 & 13,55 & 12,60 & 11,48 & 10,48 & 9,54 & 7,89 & 6,53 & 4,58 \\
\hline 79,72 & 712,00 & 105,80 & 23,11 & 16,00 & 13,83 & 11,99 & 10,62 & 9,46 & 7,54 & 6,11 & 4,21 \\
\hline 44,46 & 670,10 & 147,40 & 26,16 & 18,31 & 15,04 & 11,90 & 9,57 & 7,81 & 5,46 & 4,12 & 2,76 \\
\hline 23,63 & 1162,10 & 147,90 & 30,69 & 22,74 & 17,80 & 12,90 & 9,64 & 7,51 & 5,12 & 3,91 & 2,71 \\
\hline 42,94 & 1527,00 & 102,50 & 23,45 & 19,72 & 17,61 & 15,14 & 12,98 & 11,13 & 8,26 & 6,31 & 4,10 \\
\hline 66,55 & 1276,60 & 194,90 & 13,69 & 9,82 & 8,47 & 7,25 & 6,30 & 5,50 & 4,22 & 3,32 & 2,22 \\
\hline 38,79 & 1522,50 & 121,30 & 22,75 & 18,77 & 16,44 & 13,75 & 11,48 & 9,61 & 6,90 & 5,18 & 3,39 \\
\hline 25,14 & 1973,80 & 153,40 & 24,53 & 19,55 & 16,11 & 12,33 & 9,53 & 7,53 & 5,09 & 3,82 & 2,61 \\
\hline 63,31 & 1840,30 & 196,60 & 11,71 & 8,91 & 7,90 & 6,90 & 6,08 & 5,36 & 4,19 & 3,32 & 2,23 \\
\hline 21,69 & 241,30 & 138,80 & 52,06 & 28,24 & 19,21 & 12,83 & 9,53 & 7,57 & 5,32 & 4,15 & 2,93 \\
\hline 81,96 & 1970,20 & 140,10 & 12,12 & 8,95 & 8,17 & 7,45 & 6,84 & 6,29 & 5,31 & 4,50 & 3,27 \\
\hline 88,10 & 1502,90 & 134,50 & 13,56 & 9,66 & 8,67 & 7,82 & 7,15 & 6,56 & 5,52 & 4,66 & 3,39 \\
\hline 41,95 & 1365,60 & 65,40 & 32,98 & 28,61 & 25,97 & 22,72 & 19,77 & 17,17 & 13,00 & 10,04 & 6,53 \\
\hline 65,79 & 663,30 & 48,50 & 39,48 & 30,85 & 28,12 & 25,21 & 22,72 & 20,45 & 16,55 & 13,49 & 9,28 \\
\hline 63,02 & 1743,40 & 41,60 & 31,60 & 25,49 & 24,40 & 23,02 & 21,56 & 20,12 & 17,42 & 15,01 & 11,16 \\
\hline 28,32 & 925,50 & 183,50 & 25,48 & 18,02 & 14,08 & 10,27 & 7,75 & 6,07 & 4,15 & 3,17 & 2,19 \\
\hline 52,22 & 1989,60 & 174,90 & 13,45 & 10,81 & 9,63 & 8,36 & 7,26 & 6,31 & 4,80 & 3,73 & 2,45 \\
\hline 82,33 & 206,90 & 141,80 & 45,66 & 23,15 & 16,51 & 12,05 & 9,54 & 7,83 & 5,59 & 4,32 & 2,97 \\
\hline 44,05 & 1485,00 & 198,80 & 15,69 & 12,02 & 10,28 & 8,46 & 7,00 & 5,82 & 4,15 & 3,13 & 2,06 \\
\hline 38,98 & 1762,40 & 181,80 & 16,71 & 13,32 & 11,48 & 9,43 & 7,76 & 6,42 & 4,54 & 3,41 & 2,24 \\
\hline 31,43 & 371,30 & 128,40 & 42,27 & 26,89 & 20,27 & 14,50 & 10,90 & 8,56 & 5,89 & 4,52 & 3,15 \\
\hline 59,10 & 718,70 & 66,10 & 33,80 & 26,52 & 23,71 & 20,79 & 18,31 & 16,12 & 12,55 & 9,92 & 6,62 \\
\hline 22,40 & 376,00 & 163,10 & 40,42 & 23,65 & 16,51 & 11,10 & 8,20 & 6,47 & 4,54 & 3,53 & 2,48 \\
\hline 41,44 & 778,30 & 92,50 & 33,35 & 26,06 & 22,37 & 18,38 & 15,15 & 12,57 & 8,93 & 6,71 & 4,42 \\
\hline 65,11 & 1032,10 & 155,90 & 17,19 & 12,40 & 10,70 & 9,15 & 7,94 & 6,91 & 5,29 & 4,15 & 2,77 \\
\hline 61,70 & 746,60 & 27,70 & 55,53 & 45,11 & 42,59 & 39,31 & 36,19 & 33,24 & 27,86 & 23,34 & 16,61 \\
\hline 76,88 & 1623,20 & 65,70 & 21,27 & 16,36 & 15,34 & 14,35 & 13,40 & 12,50 & 10,82 & 9,34 & 6,99 \\
\hline 60,11 & 432,40 & 153,10 & 28,69 & 17,60 & 13,90 & 10,93 & 8,91 & 7,38 & 5,28 & 4,02 & 2,71 \\
\hline 41,21 & 297,70 & 73,90 & 57,10 & 39,10 & 31,53 & 24,38 & 19,25 & 15,50 & 10,72 & 8,09 & 5,49 \\
\hline 67,51 & 236,50 & 153,80 & 41,26 & 21,47 & 15,50 & 11,36 & 8,94 & 7,27 & 5,12 & 3,93 & 2,70 \\
\hline 28,09 & 1086,70 & 20,70 & 105,19 & 96,51 & 87,85 & 76,32 & 65,68 & 56,31 & 41,58 & 31,48 & 20,20 \\
\hline 70,07 & 988,90 & 100,30 & 21,34 & 15,96 & 14,25 & 12,59 & 11,24 & 10,05 & 8,04 & 6,50 & 4,45 \\
\hline 61,81 & 1139,20 & 113,20 & 19,93 & 15,37 & 13,69 & 12,00 & 10,58 & 9,33 & 7,29 & 5,78 & 3,88 \\
\hline 61,50 & 1816,00 & 180,70 & 12,52 & 9,67 & 8,61 & 7,54 & 6,64 & 5,86 & 4,57 & 3,62 & 2,43 \\
\hline 22,28 & 698,70 & 155,10 & 35,33 & 23,72 & 17,48 & 12,06 & 8,86 & 6,92 & 4,80 & 3,72 & 2,59 \\
\hline 47,54 & 882,60 & 130,80 & 23,83 & 17,90 & 15,28 & 12,62 & 10,50 & 8,79 & 6,32 & 4,79 & 3,16 \\
\hline 53,38 & 921,80 & 193,30 & 17,89 & 12,49 & 10,41 & 8,50 & 7,05 & 5,89 & 4,25 & 3,23 & 2,14 \\
\hline 25,44 & 1514,40 & 159,80 & 25,62 & 19,70 & 15,89 & 11,89 & 9,06 & 7,11 & 4,82 & 3,65 & 2,50 \\
\hline 53,54 & 1184,80 & 139,60 & 18,85 & 14,54 & 12,71 & 10,85 & 9,31 & 8,01 & 5,99 & 4,62 & 3,04 \\
\hline 84,04 & 1746,80 & 192,30 & 10,69 & 7,56 & 6,70 & 5,95 & 5,37 & 4,87 & 4,01 & 3,32 & 2,36 \\
\hline 51,34 & 779,50 & 161,50 & 21,68 & 15,22 & 12,68 & 10,31 & 8,51 & 7,08 & 5,08 & 3,85 & 2,56 \\
\hline 31,59 & 428,50 & 169,70 & 33,66 & 20,73 & 15,42 & 10,93 & 8,20 & 6,44 & 4,44 & 3,42 & 2,39 \\
\hline 40,47 & 1308,30 & 170,90 & 19,03 & 14,66 & 12,47 & 10,12 & 8,27 & 6,81 & 4,79 & 3,60 & 2,38 \\
\hline 84,95 & 1372,00 & 160,60 & 13,14 & 9,21 & 8,12 & 7,18 & 6,47 & 5,85 & 4,80 & 3,98 & 2,81 \\
\hline 53,54 & 1012,40 & 170,00 & 18,23 & 13,27 & 11,29 & 9,39 & 7,89 & 6,67 & 4,87 & 3,72 & 2,46 \\
\hline 47,03 & 881,90 & 83,70 & 30,98 & 24,90 & 21,92 & 18,67 & 15,92 & 13,59 & 10,04 & 7,67 & 5,01 \\
\hline 85,37 & 787,60 & 96,90 & 22,29 & 15,52 & 13,63 & 12,01 & 10,80 & 9,75 & 7,98 & 6,60 & 4,66 \\
\hline 67,77 & 236,30 & 134,50 & 43,02 & 23,15 & 17,08 & 12,77 & 10,17 & 8,33 & 5,90 & 4,52 & 3,09 \\
\hline 83,46 & 522,00 & 35,60 & 46,40 & 34,17 & 31,26 & 28,58 & 26,33 & 24,28 & 20,62 & 17,54 & 12,84 \\
\hline 65,02 & 577,60 & 91,10 & 30,08 & 21,56 & 18,54 & 15,80 & 13,67 & 11,88 & 9,06 & 7,10 & 4,73 \\
\hline 74,18 & 1664,00 & 62,60 & 22,20 & 17,24 & 16,23 & 15,20 & 14,19 & 13,23 & 11,44 & 9,87 & 7,36 \\
\hline 82,61 & 1048,10 & 96,90 & 19,66 & 14,20 & 12,76 & 11,45 & 10,41 & 9,48 & 7,88 & 6,58 & 4,70 \\
\hline 66,74 & 573,70 & 84,10 & 31,03 & 22,39 & 19,38 & 16,64 & 14,50 & 12,68 & 9,77 & 7,71 & 5,16 \\
\hline 44,32 & 1904,40 & 34,00 & 44,35 & 38,77 & 37,05 & 34,20 & 31,36 & 28,63 & 23,66 & 19,51 & 13,52 \\
\hline 75,91 & 783,30 & 118,00 & 21,26 & 14,86 & 12,84 & 11,10 & 9,78 & 8,66 & 6,83 & 5,49 & 3,75 \\
\hline 76,57 & 202,50 & 135,50 & 47,22 & 24,20 & 17,35 & 12,70 & 10,04 & 8,22 & 5,84 & 4,50 & 3,09 \\
\hline 31,58 & 1835,50 & 155,50 & 21,08 & 17,06 & 14,51 & 11,61 & 9,31 & 7,55 & 5,21 & 3,88 & 2,59 \\
\hline 33,60 & 722,40 & 162,10 & 27,57 & 19,27 & 15,30 & 11,47 & 8,82 & 6,98 & 4,78 & 3,62 & 2,49 \\
\hline 49,78 & 1455,90 & 98,40 & 22,16 & 18,40 & 16,61 & 14,56 & 12,75 & 11,14 & 8,55 & 6,67 & 4,39 \\
\hline 29,39 & 1183,40 & 120,10 & 30,54 & 24,00 & 19,93 & 15,47 & 12,12 & 9,66 & 6,58 & 4,93 & 3,34 \\
\hline 43,74 & 775,10 & 170,40 & 22,81 & 15,98 & 13,11 & 10,35 & 8,30 & 6,76 & 4,72 & 3,55 & 2,39 \\
\hline 76,92 & 640,30 & 108,80 & 24,46 & 16,74 & 14,30 & 12,25 & 10,74 & 9,47 & 7,42 & 5,94 & 4,04 \\
\hline 86,48 & 1990,40 & 107,90 & 13,63 & 10,11 & 9,31 & 8,64 & 8,05 & 7,50 & 6,50 & 5,62 & 4,24 \\
\hline 23,79 & 697,20 & 97,30 & 47,70 & 34,92 & 27,16 & 19,58 & 14,60 & 11,37 & 7,76 & 5,95 & 4,12 \\
\hline 45,06 & 357,60 & 89,90 & 45,35 & 30,86 & 25,04 & 19,63 & 15,70 & 12,77 & 8,91 & 6,72 & 4,53 \\
\hline 51,47 & 331,10 & 188,30 & 32,06 & 17,62 & 12,99 & 9,53 & 7,41 & 5,95 & 4,12 & 3,15 & 2,18 \\
\hline 56,74 & 382,30 & 68,00 & 45,56 & 32,61 & 27,67 & 23,06 & 19,48 & 16,54 & 12,18 & 9,34 & 6,18 \\
\hline 44,68 & 282,40 & 37,00 & 82,79 & 63,62 & 54,58 & 45,07 & 37,40 & 31,21 & 22,36 & 16,87 & 11,11 \\
\hline 25,63 & 968,40 & 110,40 & 37,80 & 28,79 & 23,11 & 17,22 & 13,10 & 10,27 & 6,96 & 5,28 & 3,63 \\
\hline 25,22 & 1865,20 & 88,20 & 36,48 & 30,66 & 26,19 & 20,89 & 16,65 & 13,40 & 9,15 & 6,79 & 4,54 \\
\hline 66,96 & 1500,90 & 92,30 & 19,17 & 15,06 & 13,88 & 12,58 & 11,44 & 10,39 & 8,54 & 7,05 & 4,93 \\
\hline 80,27 & 1772,80 & 48,10 & 24,21 & 18,94 & 17,71 & 16,92 & 16,05 & 15,18 & 13,52 & 11,99 & 9,39 \\
\hline 76,37 & 488,80 & 97,20 & 29,94 & 19,99 & 16,82 & 14,22 & 12,34 & 10,79 & 8,35 & 6,62 & 4,49 \\
\hline 71,55 & 1007,70 & 78,40 & 24,04 & 18,30 & 16,64 & 14,96 & 13,55 & 12,27 & 10,05 & 8,28 & 5,78 \\
\hline
\end{tabular}




\begin{tabular}{|c|c|c|c|c|c|c|c|c|c|c|c|}
\hline & & & \multicolumn{9}{|c|}{ Deflexões $\left(\times 10^{-4} \mathrm{~cm}\right)$} \\
\hline e1 (cm) & Meq (MPa) & Ms (MPa) & D0 & D25 & D40 & D60 & D80 & D100 & D140 & D180 & D260 \\
\hline 36,69 & 1093,20 & 183,10 & 20,80 & 15,36 & 12,67 & 9,90 & 7,84 & 6,31 & 4,35 & 3,27 & 2,21 \\
\hline 36,73 & 786,10 & 116,00 & 31,24 & 23,56 & 19,64 & 15,51 & 12,37 & 10,00 & 6,92 & 5,19 & 3,48 \\
\hline 24,39 & 675,40 & 47,60 & 78,49 & 62,96 & 51,98 & 39,82 & 30,78 & 24,29 & 16,42 & 12,33 & 8,40 \\
\hline 61,24 & 1199,60 & 105,60 & 20,36 & 15,94 & 14,31 & 12,62 & 11,19 & 9,91 & 7,80 & 6,22 & 4,18 \\
\hline 51,97 & 1068,60 & 64,10 & 31,61 & 26,34 & 24,01 & 21,30 & 18,86 & 16,67 & 13,03 & 10,31 & 6,85 \\
\hline 32,75 & 908,40 & 81,50 & 39,98 & 32,22 & 27,44 & 22,02 & 17,72 & 14,40 & 9,97 & 7,43 & 4,95 \\
\hline 84,15 & 668,50 & 169,20 & 19,25 & 12,06 & 9,86 & 8,18 & 7,05 & 6,14 & 4,75 & 3,78 & 2,58 \\
\hline 67,31 & 1134,30 & 182,60 & 14,94 & 10,60 & 9,10 & 7,77 & 6,74 & 5,87 & 4,50 & 3,54 & 2,37 \\
\hline 43,85 & 525,00 & 185,30 & 26,17 & 16,50 & 12,88 & 9,74 & 7,62 & 6,12 & 4,23 & 3,21 & 2,19 \\
\hline 55,50 & 1393,90 & 159,60 & 15,95 & 12,30 & 10,80 & 9,27 & 8,01 & 6,93 & 5,23 & 4,06 & 2,68 \\
\hline 80,51 & 1389,10 & 148,60 & 13,89 & 9,97 & 8,86 & 7,87 & 7,09 & 6,41 & 5,24 & 4,33 & 3,04 \\
\hline 76,10 & 992,90 & 116,30 & 18,98 & 13,69 & 12,09 & 10,64 & 9,50 & 8,51 & 6,85 & 5,57 & 3,85 \\
\hline 75,88 & 1392,20 & 175,70 & 13,05 & 9,34 & 8,20 & 7,17 & 6,38 & 5,70 & 4,56 & 3,69 & 2,54 \\
\hline 26,78 & 1677,20 & 53,40 & 50,37 & 44,29 & 39,08 & 32,54 & 26,91 & 22,29 & 15,68 & 11,64 & 7,58 \\
\hline 30,03 & 1146,50 & 22,60 & 92,02 & 84,52 & 77,37 & 67,80 & 58,86 & 50,89 & 38,10 & 29,10 & 18,72 \\
\hline 86,23 & 1017,70 & 66,20 & 24,07 & 17,65 & 16,15 & 14,84 & 13,72 & 12,71 & 10,88 & 9,32 & 6,91 \\
\hline 54,25 & 1092,00 & 176,80 & 17,11 & 12,52 & 10,69 & 8,93 & 7,54 & 6,39 & 4,69 & 3,59 & 2,37 \\
\hline 85,08 & 257,10 & 199,60 & 35,61 & 17,53 & 12,24 & 8,75 & 6,84 & 5,57 & 3,95 & 3,05 & 2,11 \\
\hline 23,38 & 1824,20 & 117,70 & 31,89 & 25,66 & 21,15 & 16,16 & 12,45 & 9,81 & 6,62 & 4,97 & 3,39 \\
\hline 70,48 & 762,70 & 36,40 & 42,91 & 33,52 & 31,34 & 28,89 & 26,65 & 24,55 & 20,73 & 17,51 & 12,64 \\
\hline 58,63 & 214,40 & 86,50 & 55,24 & 32,90 & 25,54 & 19,76 & 15,91 & 13,08 & 9,26 & 7,05 & 4,78 \\
\hline 45,53 & 1316,10 & 186,60 & 16,80 & 12,73 & 10,88 & 8,96 & 7,42 & 6,19 & 4,43 & 3,34 & 2,20 \\
\hline 65,51 & 1837,40 & 131,50 & 14,47 & 11,34 & 10,35 & 9,29 & 8,37 & 7,54 & 6,11 & 4,98 & 3,43 \\
\hline 35,63 & $\begin{array}{l}798,10 \\
\end{array}$ & 91,70 & 36,65 & 28,70 & 24,29 & 19,45 & 15,66 & 12,74 & 8,84 & 6,61 & 4,41 \\
\hline 89,39 & 1222,20 & 38,30 & 29,76 & 23,06 & 21,24 & 20,25 & 19,26 & 18,27 & 16,37 & 14,62 & 11,61 \\
\hline 46,20 & 415,40 & 108,60 & 37,84 & 25,49 & 20,64 & 16,19 & 12,97 & 10,56 & 7,38 & 5,57 & 3,76 \\
\hline 74,36 & 1733,20 & 37,70 & 30,03 & 23,86 & 22,48 & 21,57 & 20,50 & 19,41 & 17,29 & 15,34 & 12,00 \\
\hline 26,08 & 935,60 & 90,00 & 43,48 & 33,93 & 27,70 & 21,02 & 16,16 & 12,74 & 8,63 & 6,50 & 4,45 \\
\hline 20,19 & 345,10 & 180,30 & 39,63 & 21,82 & 14,80 & 9,85 & 7,31 & 5,81 & 4,09 & 3,19 & 2,25 \\
\hline 72,43 & 1890,90 & 136,40 & 13,30 & 10,14 & 9,27 & 8,38 & 7,62 & 6,93 & 5,72 & 4,74 & 3,34 \\
\hline 79,95 & 1344,40 & 139,00 & 14,65 & 10,57 & 9,42 & 8,38 & 7,56 & 6,84 & 5,60 & 4,63 & 3,25 \\
\hline 83,95 & 1745,30 & 169,10 & 11,43 & 8,19 & 7,33 & 6,56 & 5,96 & 5,43 & 4,51 & 3,76 & 2,69 \\
\hline 83,35 & 851,70 & 97,60 & 21,56 & 15,22 & 13,45 & 11,91 & 10,72 & 9,69 & 7,94 & 6,57 & 4,63 \\
\hline 56,88 & 1909,00 & 25,60 & 45,98 & 37,61 & 36,28 & 34,75 & 32,86 & 30,94 & 27,23 & 23,82 & 18,13 \\
\hline 33,60 & 815,70 & 172,40 & 25,33 & 17,91 & 14,30 & 10,77 & 8,31 & 6,58 & 4,50 & 3,41 & 2,34 \\
\hline 60,51 & 774,80 & 105,50 & 24,99 & 18,55 & 16,12 & 13,80 & 11,94 & 10,35 & 7,87 & 6,13 & 4,07 \\
\hline 66,79 & 1883,60 & 69,00 & 21,21 & 16,87 & 15,95 & 14,83 & 13,75 & 12,72 & 10,83 & 9,20 & 6,69 \\
\hline 50,58 & 683,40 & 50,50 & 44,26 & 36,38 & 32,70 & 28,57 & 24,95 & 21,76 & 16,64 & 12,97 & 8,53 \\
\hline 77,57 & 1847,40 & 23,70 & 37,03 & 31,58 & 29,00 & 28,14 & 27,28 & 26,22 & 24,03 & 21,93 & 18,07 \\
\hline 61,77 & 1938,70 & 174,30 & 12,39 & 9,66 & 8,66 & 7,64 & 6,77 & 6,00 & 4,72 & 3,76 & 2,53 \\
\hline 59,90 & 1745,00 & 50,90 & 28,43 & 23,26 & 22,15 & 20,62 & 19,10 & 17,64 & 14,95 & 12,63 & 9,10 \\
\hline 62,81 & 1390,10 & 192,90 & 13,54 & 9,96 & 8,66 & 7,43 & 6,45 & 5,61 & 4,29 & 3,36 & 2,24 \\
\hline 75,15 & 539,20 & 51,90 & 38,99 & 28,79 & 25,82 & 22,99 & 20,71 & 18,68 & 15,21 & 12,48 & 8,70 \\
\hline 21,23 & 1364,40 & 20,30 & 127,20 & 114,88 & 102,25 & 85,81 & 71,30 & 59,19 & 41,65 & 30,83 & 19,95 \\
\hline 77,52 & 1711,80 & 70,90 & 19,80 & 15,19 & 14,23 & 13,30 & 12,42 & 11,58 & 10,02 & 8,66 & 6,48 \\
\hline 70,75 & 477,60 & 87,00 & 32,78 & 22,57 & 19,16 & 16,25 & 14,07 & 12,26 & 9,41 & 7,41 & 4,98 \\
\hline 74,00 & 245,80 & 198,10 & 37,17 & 18,24 & 12,68 & 9,00 & 6,97 & 5,63 & 3,95 & 3,04 & 2,11 \\
\hline 29,60 & 209,50 & 158,30 & 48,04 & 24,49 & 16,76 & 11,36 & 8,48 & 6,72 & 4,68 & 3,64 & 2,58 \\
\hline 61,12 & 676,90 & 74,60 & 31,86 & 24,32 & 21,49 & 18,69 & 16,37 & 14,36 & 11,10 & 8,75 & 5,84 \\
\hline 65,11 & 1184,40 & 34,90 & 39,52 & 31,67 & 30,15 & 28,26 & 26,34 & 24,49 & 21,04 & 18,02 & 13,26 \\
\hline 67,18 & 781,60 & 151,70 & 19,85 & 13,64 & 11,52 & 9,68 & 8,30 & 7,17 & 5,42 & 4,23 & 2,83 \\
\hline 79,12 & 634,20 & 190,40 & 19,34 & 11,85 & 9,51 & 7,74 & 6,56 & 5,64 & 4,26 & 3,34 & 2,26 \\
\hline 76,91 & 1235,70 & 169,80 & 14,02 & 9,89 & 8,62 & 7,50 & 6,65 & 5,92 & 4,72 & 3,81 & 2,62 \\
\hline 49,84 & 519,90 & 87,40 & 36,80 & 26,95 & 22,85 & 18,82 & 15,65 & 13,10 & 9,45 & 7,16 & 4,73 \\
\hline 43,04 & 1182,70 & 91,00 & 27,80 & 23,02 & 20,40 & 17,39 & 14,80 & 12,60 & 9,27 & 7,05 & 4,59 \\
\hline 65,89 & 1691,00 & 160,90 & 13,31 & 10,17 & 9,11 & 8,04 & 7,16 & 6,37 & 5,06 & 4,07 & 2,76 \\
\hline 25,86 & 791,30 & 57,10 & 63,07 & 50,87 & 42,38 & 32,85 & 25,63 & 20,36 & 13,80 & 10,33 & 7,00 \\
\hline 70,49 & 1292,10 & 86,80 & 20,57 & 15,86 & 14,56 & 13,19 & 12,00 & 10,92 & 9,01 & 7,46 & 5,25 \\
\hline 73,62 & 366,60 & 192,10 & 28,11 & 15,33 & 11,43 & 8,67 & 7,00 & 5,80 & 4,17 & 3,21 & 2,18 \\
\hline 38,54 & 482,90 & 119,60 & 36,36 & 24,94 & 19,98 & 15,26 & 11,93 & 9,54 & 6,56 & 4,96 & 3,38 \\
\hline 24,01 & 1886,50 & 131,90 & 28,57 & 22,89 & 18,85 & 14,39 & 11,10 & 8,75 & 5,91 & 4,44 & 3,03 \\
\hline 41,15 & 1156,40 & 146,50 & 21,70 & 16,80 & 14,34 & 11,71 & 9,61 & 7,94 & 5,61 & 4,22 & 2,79 \\
\hline 30,05 & 1314,10 & 198,80 & 20,78 & 15,45 & 12,48 & 9,43 & 7,26 & 5,74 & 3,91 & 2,95 & 2,02 \\
\hline 72,87 & 1824,90 & 155,80 & 12,48 & 9,39 & 8,49 & 7,60 & 6,86 & 6,20 & 5,07 & 4,16 & 2,90 \\
\hline 75,21 & 653,40 & 95,90 & 25,91 & 18,21 & 15,77 & 13,65 & 12,04 & 10,66 & 8,41 & 6,76 & 4,61 \\
\hline 77,75 & 1657,90 & 95,00 & 16,77 & 12,69 & 11,74 & 10,80 & 9,96 & 9,20 & 7,80 & 6,63 & 4,84 \\
\hline 64,47 & 639,90 & 124,90 & 24,59 & 16,99 & 14,33 & 12,00 & 10,25 & 8,80 & 6,60 & 5,12 & 3,41 \\
\hline 64,94 & 539,80 & 158,50 & 24,26 & 15,40 & 12,44 & 10,04 & 8,36 & 7,05 & 5,15 & 3,96 & 2,65 \\
\hline 56,21 & 695,30 & 136,80 & 23,92 & 16,82 & 14,13 & 11,67 & 9,78 & 8,26 & 6,03 & 4,61 & 3,05 \\
\hline 52,54 & 1503,90 & 149,10 & 16,54 & 13,09 & 11,58 & 9,97 & 8,62 & 7,45 & 5,62 & 4,35 & 2,86 \\
\hline 59,97 & 1758,90 & 123,60 & 16,02 & 12,84 & 11,69 & 10,42 & 9,32 & 8,32 & 6,63 & 5,33 & 3,60 \\
\hline 35,05 & 273,60 & 94,30 & 55,16 & 35,19 & 26,94 & 19,66 & 14,96 & 11,81 & 8,11 & 6,20 & 4,29 \\
\hline 69,98 & 1845,50 & 190,50 & 11,33 & 8,46 & 7,54 & 6,66 & 5,94 & 5,30 & 4,24 & 3,42 & 2,34 \\
\hline 66,62 & 592,50 & 83,60 & 30,66 & 22,26 & 19,33 & 16,64 & 14,53 & 12,73 & 9,83 & 7,76 & 5,21 \\
\hline 34,19 & 1350,50 & 32,30 & 61,66 & 56,14 & 51,64 & 45,63 & 39,99 & 34,90 & 26,57 & 20,53 & 13,30 \\
\hline 89,50 & 959,80 & 23,10 & 43,85 & 35,21 & 32,23 & 30,95 & 29,71 & 28,37 & 25,73 & 23,26 & 18,87 \\
\hline 54,91 & 1217,70 & 184,70 & 15,78 & 11,66 & 10,02 & 8,42 & 7,15 & 6,09 & 4,50 & 3,45 & 2,28 \\
\hline 71,10 & 436,00 & 128,40 & 29,18 & 18,27 & 14,74 & 11,96 & 10,05 & 8,56 & 6,35 & 4,93 & 3,31 \\
\hline 47,60 & 1240,00 & 108,80 & 22,90 & 18,57 & 16,45 & 14,11 & 12,10 & 10,39 & 7,74 & 5,93 & 3,88 \\
\hline 89,39 & 1054,40 & 180,10 & 14,08 & 9,28 & 7,90 & 6,80 & 6,03 & 5,39 & 4,34 & 3,55 & 2,48 \\
\hline 20,82 & 893,10 & 116,20 & 42,50 & 30,68 & 23,31 & 16,38 & 12,06 & 9,36 & 6,44 & 4,96 & 3,45 \\
\hline 46,32 & 1502,20 & 89,30 & 24,37 & 20,63 & 18,66 & 16,33 & 14,25 & 12,42 & 9,46 & 7,34 & 4,81 \\
\hline
\end{tabular}




\begin{tabular}{|c|c|c|c|c|c|c|c|c|c|c|c|}
\hline & & & \multicolumn{9}{|c|}{ Deflexões $\left(\times 10^{-4} \mathrm{~cm}\right)$} \\
\hline e1 (cm) & Meq (MPa) & Ms (MPa) & D0 & D25 & D40 & D60 & D80 & D100 & D140 & D180 & D260 \\
\hline 84,19 & 907,30 & 23,20 & 47,26 & 37,28 & 34,56 & 33,13 & 31,61 & 30,03 & 26,97 & 24,14 & 19,21 \\
\hline 73,73 & 1457,70 & 193,40 & 12,30 & 8,81 & 7,70 & 6,70 & 5,93 & 5,27 & 4,17 & 3,36 & 2,29 \\
\hline 82,28 & 1787,40 & 104,10 & 14,95 & 11,16 & 10,29 & 9,49 & 8,78 & 8,14 & 6,96 & 5,96 & 4,41 \\
\hline 52,96 & 1997,90 & 127,50 & 16,08 & 13,30 & 12,09 & 10,71 & 9,48 & 8,38 & 6,54 & 5,17 & 3,44 \\
\hline 29,82 & 1237,60 & 73,00 & 41,44 & 34,77 & 30,04 & 24,42 & 19,82 & 16,19 & 11,24 & 8,35 & 5,52 \\
\hline 88,00 & 433,50 & 97,10 & 30,75 & 19,50 & 16,15 & 13,56 & 11,81 & 10,41 & 8,19 & 6,60 & 4,55 \\
\hline 47,88 & 1941,00 & 42,40 & 35,87 & 30,95 & 29,51 & 27,22 & 24,96 & 22,79 & 18,87 & 15,59 & 10,84 \\
\hline 74,79 & 439,00 & 150,00 & 27,02 & 16,25 & 12,86 & 10,29 & 8,60 & 7,30 & 5,41 & 4,20 & 2,83 \\
\hline 40,64 & 881,30 & 162,00 & 23,05 & 16,75 & 13,87 & 10,97 & 8,79 & 7,14 & 4,96 & 3,73 & 2,50 \\
\hline 52,32 & 367,90 & 187,90 & 30,04 & 16,99 & 12,74 & 9,48 & 7,43 & 5,99 & 4,17 & 3,18 & 2,18 \\
\hline 45,65 & 744,70 & 89,70 & 32,55 & 25,33 & 21,90 & 18,26 & 15,28 & 12,84 & 9,28 & 7,03 & 4,61 \\
\hline 20,59 & 1276,70 & 198,90 & 26,18 & 18,36 & 13,70 & 9,49 & 6,96 & 5,41 & 3,75 & 2,90 & 2,02 \\
\hline 34,45 & 627,80 & 42,90 & 66,35 & 55,44 & 48,37 & 40,03 & 33,05 & 27,39 & 19,37 & 14,47 & 9,48 \\
\hline 60,45 & 522,90 & 144,50 & 26,33 & 17,10 & 13,90 & 11,22 & 9,30 & 7,80 & 5,65 & 4,32 & 2,89 \\
\hline 42,28 & 658,30 & 108,60 & 32,13 & 23,79 & 19,95 & 16,03 & 13,01 & 10,67 & 7,48 & 5,63 & 3,75 \\
\hline 21,34 & 1915,40 & 135,90 & 30,34 & 23,79 & 19,11 & 14,16 & 10,68 & 8,32 & 5,62 & 4,26 & 2,94 \\
\hline 45,44 & 1155,10 & 62,60 & 34,03 & 29,07 & 26,39 & 23,16 & 20,26 & 17,68 & 13,51 & 10,50 & 6,87 \\
\hline 73,60 & 592,80 & 107,10 & 26,12 & 17,87 & 15,18 & 12,91 & 11,23 & 9,83 & 7,61 & 6,03 & 4,07 \\
\hline 54,75 & 1802,10 & 161,00 & 14,31 & 11,40 & 10,18 & 8,87 & 7,75 & 6,77 & 5,19 & 4,06 & 2,69 \\
\hline 58,63 & 397,10 & 186,00 & 28,12 & 16,12 & 12,26 & 9,32 & 7,43 & 6,07 & 4,27 & 3,26 & 2,22 \\
\hline 80,81 & 838,10 & 164,70 & 17,22 & 11,38 & 9,58 & 8,12 & 7,09 & 6,24 & 4,88 & 3,91 & 2,67 \\
\hline 67,50 & 1139,30 & 27,30 & 46,01 & 36,67 & 34,96 & 33,18 & 31,21 & 29,28 & 25,61 & 22,30 & 16,87 \\
\hline 89,08 & 1111,70 & 188,50 & 13,41 & 8,86 & 7,55 & 6,50 & 5,76 & 5,15 & 4,15 & 3,39 & 2,37 \\
\hline 40,90 & 994,80 & 123,70 & 25,60 & 19,87 & 16,98 & 13,87 & 11,38 & 9,40 & 6,65 & 4,99 & 3,30 \\
\hline 32,10 & 1198,10 & 110,20 & 30,26 & 24,27 & 20,57 & 16,41 & 13,14 & 10,64 & 7,33 & 5,47 & 3,66 \\
\hline 76,33 & 1061,80 & 60,90 & 26,41 & 20,08 & 18,59 & 17,07 & 15,73 & 14,50 & 12,26 & 10,38 & 7,54 \\
\hline 53,57 & 1859,30 & 30,20 & 43,01 & 35,67 & 34,47 & 32,57 & 30,47 & 28,40 & 24,49 & 21,00 & 15,45 \\
\hline 75,97 & 699,20 & 187,50 & 18,52 & 11,70 & 9,53 & 7,83 & 6,67 & 5,74 & 4,34 & 3,40 & 2,29 \\
\hline 66,93 & 1391,10 & 73,50 & 22,72 & 17,95 & 16,69 & 15,25 & 13,95 & 12,75 & 10,59 & 8,82 & 6,23 \\
\hline 56,93 & 1158,90 & 81,70 & 25,00 & 20,25 & 18,38 & 16,31 & 14,50 & 12,86 & 10,13 & 8,07 & 5,41 \\
\hline 29,26 & 1265,20 & 124,30 & 29,27 & 23,09 & 19,20 & 14,93 & 11,71 & 9,34 & 6,37 & 4,77 & 3,23 \\
\hline 44,91 & 978,10 & 140,10 & 22,65 & 17,15 & 14,62 & 12,00 & 9,92 & 8,25 & 5,89 & 4,44 & 2,93 \\
\hline 84,58 & 1546,20 & 158,00 & 12,52 & 8,90 & 7,94 & 7,08 & 6,42 & 5,84 & 4,83 & 4,03 & 2,87 \\
\hline 33,51 & 928,00 & 47,00 & 55,63 & 47,91 & 42,40 & 35,66 & 29,84 & 25,00 & 17,90 & 13,40 & 8,71 \\
\hline 66,68 & 994,40 & 153,30 & 17,48 & 12,51 & 10,78 & 9,23 & 8,02 & 6,99 & 5,37 & 4,22 & 2,83 \\
\hline 82,24 & 1824,80 & 121,00 & 13,60 & 10,07 & 9,23 & 8,45 & 7,78 & 7,18 & 6,09 & 5,18 & 3,79 \\
\hline 52,19 & 1173,40 & 77,00 & 27,16 & 22,46 & 20,38 & 17,99 & 15,87 & 13,98 & 10,86 & 8,55 & 5,67 \\
\hline 22,94 & 1070,80 & 67,80 & 55,85 & 44,90 & 36,93 & 28,13 & 21,63 & 17,01 & 11,47 & 8,62 & 5,89 \\
\hline 27,48 & 1179,60 & 178,30 & 24,44 & 18,03 & 14,33 & 10,61 & 8,05 & 6,32 & 4,30 & 3,27 & 2,25 \\
\hline 84,39 & 1605,30 & 112,70 & 14,77 & 10,83 & 9,89 & 9,03 & 8,32 & 7,67 & 6,51 & 5,54 & 4,06 \\
\hline 32,42 & 433,40 & 150,70 & 35,67 & 22,69 & 17,17 & 12,35 & 9,31 & 7,32 & 5,03 & 3,86 & 2,68 \\
\hline 49,19 & 523,30 & 169,60 & 26,31 & 16,81 & 13,34 & 10,35 & 8,27 & 6,72 & 4,70 & 3,56 & 2,41 \\
\hline 77,86 & 794,80 & 29,80 & 45,26 & 34,85 & 32,69 & 30,73 & 28,79 & 26,94 & 23,47 & 20,40 & 15,42 \\
\hline 87,59 & 387,20 & 173,50 & 27,17 & 15,05 & 11,42 & 8,87 & 7,33 & 6,21 & 4,62 & 3,62 & 2,47 \\
\hline 74,45 & 682,70 & 178,40 & 19,28 & 12,29 & 10,04 & 8,27 & 7,04 & 6,05 & 4,57 & 3,58 & 2,41 \\
\hline 55,98 & 600,10 & 138,60 & 25,67 & 17,48 & 14,47 & 11,77 & 9,77 & 8,18 & 5,92 & 4,51 & 3,00 \\
\hline 50,98 & 1566,40 & 196,30 & 14,16 & 10,88 & 9,45 & 7,98 & 6,77 & 5,77 & 4,25 & 3,25 & 2,14 \\
\hline 26,63 & 1320,20 & 60,80 & 50,23 & 42,66 & 36,81 & 29,79 & 24,04 & 19,53 & 13,45 & 9,98 & 6,61 \\
\hline 59,74 & 1654,30 & 20,80 & 53,26 & 43,46 & 41,67 & 40,18 & 38,20 & 36,14 & 32,14 & 28,40 & 22,02 \\
\hline 37,76 & 1065,30 & 20,10 & 85,29 & 77,26 & 72,56 & 65,69 & 59,03 & 52,78 & 41,95 & 33,46 & 22,23 \\
\hline 58,76 & 1357,50 & 47,90 & 32,52 & 26,78 & 25,30 & 23,30 & 21,40 & 19,60 & 16,34 & 13,61 & 9,61 \\
\hline 46,21 & 399,40 & 67,30 & 49,81 & 36,62 & 30,88 & 25,14 & 20,67 & 17,13 & 12,18 & 9,19 & 6,09 \\
\hline 82,69 & 1430,50 & 98,50 & 16,93 & 12,49 & 11,43 & 10,44 & 9,61 & 8,85 & 7,50 & 6,37 & 4,65 \\
\hline 54,95 & 707,90 & 21,00 & 73,04 & 61,16 & 58,05 & 53,56 & 49,21 & 45,06 & 37,53 & 31,22 & 21,95 \\
\hline 41,89 & 398,30 & 183,60 & 30,61 & 18,05 & 13,59 & 9,95 & 7,65 & 6,08 & 4,19 & 3,20 & 2,22 \\
\hline 29,22 & 1167,60 & 126,60 & 29,73 & 23,14 & 19,10 & 14,74 & 11,49 & 9,13 & 6,22 & 4,67 & 3,17 \\
\hline 59,32 & 1858,70 & 71,70 & 22,26 & 18,28 & 17,21 & 15,80 & 14,47 & 13,22 & 10,97 & 9,11 & 6,40 \\
\hline 81,71 & 1982,90 & 89,50 & 15,73 & 11,91 & 11,08 & 10,35 & 9,67 & 9,03 & 7,84 & 6,79 & 5,12 \\
\hline 67,42 & 239,40 & 173,50 & 39,49 & 19,98 & 14,16 & 10,20 & 7,95 & 6,44 & 4,51 & 3,46 & 2,39 \\
\hline 58,91 & 1591,00 & 127,30 & 16,57 & 13,18 & 11,89 & 10,51 & 9,32 & 8,25 & 6,49 & 5,16 & 3,46 \\
\hline 20,61 & 1503,10 & 137,00 & 33,02 & 24,96 & 19,49 & 14,03 & 10,42 & 8,08 & 5,50 & 4,21 & 2,92 \\
\hline 44,25 & 1130,30 & 105,50 & 25,40 & 20,52 & 18,00 & 15,22 & 12,86 & 10,89 & 7,95 & 6,03 & 3,94 \\
\hline 79,72 & 1838,90 & 58,80 & 21,22 & 16,42 & 15,39 & 14,59 & 13,77 & 12,96 & 11,43 & 10,05 & 7,74 \\
\hline 76,03 & 1025,20 & 150,20 & 16,46 & 11,54 & 10,00 & 8,66 & 7,64 & 6,78 & 5,36 & 4,31 & 2,95 \\
\hline 61,48 & 780,60 & 151,40 & 20,63 & 14,38 & 12,12 & 10,12 & 8,59 & 7,34 & 5,46 & 4,21 & 2,80 \\
\hline 72,29 & 1975,90 & 178,10 & 11,23 & 8,43 & 7,59 & 6,77 & 6,09 & 5,49 & 4,46 & 3,65 & 2,53 \\
\hline 32,01 & 1907,00 & 151,90 & 20,91 & 17,07 & 14,61 & 11,78 & 9,51 & 7,74 & 5,36 & 4,00 & 2,65 \\
\hline 28,80 & 1909,70 & 151,80 & 22,61 & 18,27 & 15,40 & 12,14 & 9,61 & 7,71 & 5,27 & 3,93 & 2,64 \\
\hline 24,87 & 1510,80 & 194,40 & 22,69 & 16,92 & 13,37 & 9,80 & 7,38 & 5,76 & 3,92 & 2,98 & 2,06 \\
\hline 26,42 & 885,70 & 115,90 & 36,83 & 27,62 & 22,06 & 16,37 & 12,43 & 9,74 & 6,62 & 5,02 & 3,46 \\
\hline 83,09 & 667,70 & 43,30 & 37,45 & 27,70 & 25,42 & 23,30 & 21,50 & 19,86 & 16,91 & 14,41 & 10,59 \\
\hline 24,32 & 384,60 & 62,80 & 76,31 & 54,72 & 42,18 & 30,20 & 22,49 & 17,52 & 11,99 & 9,20 & 6,39 \\
\hline 78,94 & 223,40 & 142,60 & 43,23 & 22,35 & 16,13 & 11,90 & 9,47 & 7,79 & 5,57 & 4,29 & 2,95 \\
\hline 38,09 & 226,00 & 52,50 & 81,08 & 56,36 & 45,36 & 34,75 & 27,20 & 21,77 & 14,97 & 11,31 & 7,70 \\
\hline 67,14 & 1512,90 & 113,90 & 16,84 & 13,06 & 11,89 & 10,67 & 9,62 & 8,66 & 7,03 & 5,74 & 3,96 \\
\hline 30,61 & 1597,10 & 58,30 & 43,15 & 38,04 & 33,90 & 28,68 & 24,10 & 20,24 & 14,52 & 10,87 & 7,03 \\
\hline 61,88 & 735,50 & 89,70 & 27,58 & 20,73 & 18,18 & 15,72 & 13,72 & 11,99 & 9,23 & 7,25 & 4,83 \\
\hline 53,64 & 1415,50 & 29,00 & 47,91 & 40,03 & 38,47 & 35,99 & 33,43 & 30,94 & 26,29 & 22,26 & 16,04 \\
\hline 42,05 & 202,90 & 28,10 & 115,84 & 88,38 & 75,12 & 61,15 & 50,09 & 41,35 & 29,22 & 21,96 & 14,54 \\
\hline 26,59 & 1882,90 & 56,10 & 47,23 & 41,73 & 36,92 & 30,85 & 25,59 & 21,24 & 14,98 & 11,13 & 7,23 \\
\hline 51,39 & 933,20 & 29,00 & 55,93 & 47,68 & 44,97 & 41,14 & 37,48 & 34,02 & 27,86 & 22,84 & 15,73 \\
\hline 81,32 & 1204,90 & 74,60 & 21,53 & 16,05 & 14,77 & 13,56 & 12,52 & 11,56 & 9,84 & 8,38 & 6,14 \\
\hline
\end{tabular}




\begin{tabular}{|c|c|c|c|c|c|c|c|c|c|c|c|}
\hline \multirow[b]{2}{*}{ e1 (cm) } & & & & & & & ões (x1 & & & & \\
\hline & Meq (MPa) & Ms (MPa) & D0 & D25 & D40 & D60 & D80 & D100 & D140 & D180 & D260 \\
\hline 88,12 & 1670,30 & 186,50 & 10,89 & 7,60 & 6,72 & 5,97 & 5,40 & 4,91 & 4,07 & 3,40 & 2,43 \\
\hline 81,25 & 364,10 & 156,10 & 29,64 & 16,74 & 12,82 & 10,01 & 8,27 & 6,99 & 5,16 & 4,01 & 2,73 \\
\hline 55,89 & 606,60 & 32,70 & 56,98 & 47,10 & 43,41 & 39,00 & 35,02 & 31,37 & 25,11 & 20,23 & 13,70 \\
\hline 47,75 & 1749,90 & 126,70 & 18,17 & 15,05 & 13,50 & 11,72 & 10,17 & 8,81 & 6,66 & 5,15 & 3,37 \\
\hline 53,30 & 1418,30 & 117,80 & 19,27 & 15,54 & 13,91 & 12,15 & 10,62 & 9,27 & 7,11 & 5,56 & 3,67 \\
\hline 34,68 & 513,80 & 140,30 & 33,85 & 22,75 & 17,81 & 13,22 & 10,13 & 8,02 & 5,49 & 4,18 & 2,88 \\
\hline 47,49 & 551,80 & 120,60 & 30,89 & 21,58 & 17,82 & 14,26 & 11,59 & 9,53 & 6,73 & 5,08 & 3,39 \\
\hline 37,08 & 434,70 & 47,00 & 68,05 & 53,83 & 45,97 & 37,28 & 30,33 & 24,88 & 17,41 & 13,03 & 8,63 \\
\hline 27,14 & 237,20 & 93,20 & 64,37 & 39,40 & 28,66 & 19,84 & 14,71 & 11,55 & 8,01 & 6,20 & 4,34 \\
\hline 87,09 & 750,30 & 62,20 & 28,44 & 20,44 & 18,46 & 16,72 & 15,33 & 14,08 & 11,89 & 10,07 & 7,34 \\
\hline 86,52 & 1282,20 & 161,80 & 13,46 & 9,31 & 8,15 & 7,18 & 6,45 & 5,83 & 4,77 & 3,95 & 2,79 \\
\hline 89,35 & 1813,70 & 187,50 & 10,37 & 7,26 & 6,45 & 5,77 & 5,24 & 4,79 & 4,00 & 3,36 & 2,42 \\
\hline 64,84 & 1470,20 & 108,80 & 17,82 & 13,96 & 12,71 & 11,38 & 10,23 & 9,19 & 7,41 & 6,02 & 4,13 \\
\hline 27,98 & 1115,90 & 190,90 & 23,50 & 17,03 & 13,44 & 9,89 & 7,49 & 5,88 & 4,00 & 3,05 & 2,10 \\
\hline 53,09 & 935,10 & 153,40 & 20,06 & 14,68 & 12,51 & 10,41 & 8,75 & 7,40 & 5,40 & 4,12 & 2,72 \\
\hline 53,36 & 314,40 & 66,90 & 52,08 & 36,24 & 30,17 & 24,59 & 20,37 & 17,03 & 12,26 & 9,32 & 6,19 \\
\hline 88,90 & 206,70 & 187,30 & 42,81 & 20,36 & 13,85 & 9,64 & 7,41 & 5,97 & 4,18 & 3,23 & 2,25 \\
\hline 51,90 & 1325,90 & 151,40 & 17,44 & 13,56 & 11,87 & 10,11 & 8,65 & 7,42 & 5,53 & 4,25 & 2,79 \\
\hline 44,57 & 777,20 & 157,60 & 23,56 & 16,76 & 13,87 & 11,06 & 8,94 & 7,32 & 5,13 & 3,87 & 2,59 \\
\hline 78,67 & 1960,00 & 64,50 & 19,73 & 15,26 & 14,32 & 13,55 & 12,76 & 11,99 & 10,54 & 9,23 & 7,08 \\
\hline 65,68 & 1831,90 & 37,10 & 32,61 & 26,15 & 24,99 & 23,84 & 22,50 & 21,16 & 18,61 & 16,28 & 12,41 \\
\hline 24,13 & 1193,00 & 54,80 & 60,26 & 50,46 & 42,86 & 33,93 & 26,86 & 21,50 & 14,62 & 10,86 & 7,29 \\
\hline 47,43 & 536,90 & 175,70 & 25,85 & 16,52 & 13,07 & 10,08 & 8,01 & 6,49 & 4,52 & 3,42 & 2,32 \\
\hline 40,03 & 1243,20 & 47,80 & 43,21 & 38,15 & 34,86 & 30,67 & 26,83 & 23,39 & 17,81 & 13,79 & 8,98 \\
\hline 47,85 & 765,60 & 133,50 & 25,04 & 18,26 & 15,39 & 12,57 & 10,36 & 8,62 & 6,15 & 4,65 & 3,08 \\
\hline 46,97 & 1464,10 & 182,90 & 15,93 & 12,31 & 10,64 & 8,88 & 7,45 & 6,28 & 4,55 & 3,45 & 2,27 \\
\hline 26,91 & 1028,80 & 23,90 & 100,95 & 91,08 & 81,74 & 69,62 & 58,77 & 49,52 & 35,63 & 26,64 & 17,16 \\
\hline 86,91 & 647,70 & 59,10 & 31,32 & 22,35 & 20,06 & 18,05 & 16,47 & 15,08 & 12,65 & 10,65 & 7,71 \\
\hline 31,66 & 400,30 & 44,50 & 80,82 & 63,14 & 52,69 & 41,28 & 32,60 & 26,15 & 17,91 & 13,41 & 9,04 \\
\hline 77,62 & 264,20 & 161,10 & 37,06 & 19,40 & 14,11 & 10,48 & 8,37 & 6,90 & 4,94 & 3,81 & 2,61 \\
\hline 53,57 & 1586,50 & 159,30 & 15,39 & 12,13 & 10,73 & 9,26 & 8,01 & 6,94 & 5,25 & 4,08 & 2,68 \\
\hline 71,72 & 237,70 & 195,30 & 38,31 & 18,73 & 12,98 & 9,17 & 7,08 & 5,71 & 3,99 & 3,07 & 2,13 \\
\hline 84,64 & 924,20 & 141,20 & 17,20 & 11,68 & 10,07 & 8,73 & 7,75 & 6,93 & 5,58 & 4,55 & 3,17 \\
\hline 75,88 & 1832,50 & 104,60 & 15,39 & 11,72 & 10,86 & 9,97 & 9,19 & 8,46 & 7,15 & 6,05 & 4,39 \\
\hline 63,70 & 712,10 & 56,70 & 35,60 & 27,87 & 25,23 & 22,46 & 20,10 & 17,96 & 14,35 & 11,58 & 7,88 \\
\hline 73,82 & 232,30 & 79,90 & 51,11 & 30,75 & 24,32 & 19,44 & 16,22 & 13,75 & 10,17 & 7,88 & 5,31 \\
\hline 69,34 & 1997,50 & 52,20 & 24,39 & 19,33 & 18,38 & 17,42 & 16,37 & 15,35 & 13,42 & 11,68 & 8,84 \\
\hline 80,08 & 1711,70 & 162,70 & 12,02 & 8,73 & 7,84 & 7,01 & 6,35 & 5,76 & 4,75 & 3,94 & 2,79 \\
\hline 81,44 & 832,60 & 126,00 & 19,44 & 13,35 & 11,52 & 9,99 & 8,85 & 7,89 & 6,31 & 5,12 & 3,54 \\
\hline 75,09 & 507,50 & 177,10 & 23,17 & 13,86 & 10,94 & 8,74 & 7,29 & 6,19 & 4,58 & 3,56 & 2,40 \\
\hline 28,99 & 1495,70 & 112,20 & 29,87 & 24,32 & 20,60 & 16,34 & 12,99 & 10,46 & 7,16 & 5,34 & 3,58 \\
\hline 85,16 & 641,90 & 107,40 & 23,71 & 15,88 & 13,56 & 11,68 & 10,33 & 9,20 & 7,36 & 5,98 & 4,15 \\
\hline 31,00 & 956,10 & 130,80 & 29,94 & 22,66 & 18,55 & 14,23 & 11,07 & 8,79 & 6,00 & 4,51 & 3,07 \\
\hline 55,42 & 1075,40 & 119,00 & 21,08 & 16,33 & 14,37 & 12,37 & 10,70 & 9,27 & 7,02 & 5,45 & 3,59 \\
\hline 62,13 & 1512,80 & 46,50 & 30,95 & 25,09 & 23,86 & 22,23 & 20,62 & 19,07 & 16,21 & 13,74 & 9,95 \\
\hline 20,31 & 738,40 & 95,90 & 52,23 & 37,52 & 28,35 & 19,81 & 14,55 & 11,29 & 7,78 & 6,01 & 4,18 \\
\hline 59,96 & 518,90 & 195,70 & 23,32 & 14,09 & 11,04 & 8,62 & 6,99 & 5,77 & 4,11 & 3,14 & 2,12 \\
\hline 52,00 & 1341,40 & 35,50 & 43,10 & 36,56 & 34,76 & 32,06 & 29,43 & 26,91 & 22,34 & 18,53 & 12,96 \\
\hline 49,33 & 1931,00 & 108,50 & 18,84 & 15,89 & 14,49 & 12,82 & 11,32 & 9,97 & 7,74 & 6,09 & 4,02 \\
\hline 41,40 & 1336,60 & 124,10 & 22,54 & 18,24 & 15,92 & 13,32 & 11,14 & 9,35 & 6,73 & 5,08 & 3,32 \\
\hline 31,81 & 1835,00 & 192,30 & 18,26 & 14,38 & 12,06 & 9,51 & 7,54 & 6,06 & 4,16 & 3,11 & 2,09 \\
\hline 89,39 & 738,80 & 145,20 & 18,93 & 12,23 & 10,26 & 8,72 & 7,67 & 6,81 & 5,43 & 4,41 & 3,06 \\
\hline 30,17 & 1909,50 & 150,10 & 22,01 & 17,90 & 15,20 & 12,12 & 9,68 & 7,82 & 5,38 & 4,01 & 2,68 \\
\hline 76,50 & 682,50 & 189,20 & 18,69 & 11,71 & 9,50 & 7,78 & 6,61 & 5,69 & 4,30 & 3,37 & 2,27 \\
\hline 46,87 & 1904,50 & 172,70 & 14,76 & 11,94 & 10,54 & 9,00 & 7,69 & 6,57 & 4,87 & 3,72 & 2,43 \\
\hline 77,06 & 1274,50 & 100,50 & 18,20 & 13,56 & 12,33 & 11,13 & 10,13 & 9,24 & 7,66 & 6,38 & 4,53 \\
\hline 85,07 & 541,10 & 121,80 & 24,82 & 15,85 & 13,13 & 11,02 & 9,57 & 8,40 & 6,57 & 5,27 & 3,61 \\
\hline 59,58 & 784,00 & 128,90 & 22,58 & 16,29 & 13,94 & 11,75 & 10,03 & 8,61 & 6,43 & 4,97 & 3,29 \\
\hline 33,43 & 1581,40 & 105,10 & 27,45 & 22,97 & 20,00 & 16,49 & 13,57 & 11,21 & 7,89 & 5,89 & 3,86 \\
\hline 61,73 & 1577,10 & 159,10 & 14,28 & 11,00 & 9,79 & 8,57 & 7,55 & 6,65 & 5,19 & 4,11 & 2,75 \\
\hline 85,06 & 749,90 & 120,00 & 20,71 & 13,96 & 11,97 & 10,35 & 9,17 & 8,19 & 6,57 & 5,35 & 3,72 \\
\hline 69,12 & 1523,60 & 96,70 & 18,24 & 14,18 & 13,06 & 11,84 & 10,79 & 9,81 & 8,10 & 6,71 & 4,72 \\
\hline 84,08 & 512,20 & 46,50 & 40,32 & 29,03 & 26,10 & 23,47 & 21,37 & 19,52 & 16,28 & 13,65 & 9,80 \\
\hline 31,08 & 234,00 & 148,50 & 47,06 & 25,40 & 17,85 & 12,26 & 9,15 & 7,22 & 5,02 & 3,89 & 2,74 \\
\hline 37,59 & 1230,60 & 62,70 & 38,17 & 33,02 & 29,57 & 25,35 & 21,62 & 18,42 & 13,53 & 10,26 & 6,64 \\
\hline 71,78 & 1735,70 & 199,70 & 11,24 & 8,25 & 7,29 & 6,40 & 5,69 & 5,07 & 4,04 & 3,26 & 2,23 \\
\hline 33,86 & 1119,20 & 135,60 & 26,14 & 20,26 & 16,96 & 13,38 & 10,64 & 8,58 & 5,91 & 4,42 & 2,97 \\
\hline 50,26 & 400,30 & 41,10 & 62,59 & 49,54 & 43,59 & 37,27 & 31,94 & 27,41 & 20,43 & 15,70 & 10,29 \\
\hline 81,25 & 1089,40 & 67,50 & 23,82 & 17,76 & 16,35 & 15,01 & 13,85 & 12,79 & 10,88 & 9,27 & 6,79 \\
\hline 60,04 & 1409,80 & 44,20 & 33,45 & 27,37 & 26,00 & 24,13 & 22,30 & 20,55 & 17,33 & 14,59 & 10,46 \\
\hline 25,46 & 430,70 & 100,90 & 51,64 & 35,04 & 26,42 & 18,64 & 13,83 & 10,80 & 7,44 & 5,73 & 3,99 \\
\hline 70,35 & 1958,50 & 165,00 & 11,92 & 9,06 & 8,19 & 7,32 & 6,60 & 5,94 & 4,83 & 3,95 & 2,73 \\
\hline 23,55 & 890,30 & 86,70 & 48,57 & 37,29 & 29,81 & 22,05 & 16,66 & 13,01 & 8,81 & 6,69 & 4,61 \\
\hline 29,23 & 1314,80 & 33,70 & 68,84 & 62,15 & 56,05 & 48,14 & 40,98 & 34,81 & 25,36 & 19,08 & 12,27 \\
\hline 70,56 & 1366,40 & 35,50 & 35,34 & 27,95 & 26,53 & 25,18 & 23,71 & 22,26 & 19,51 & 17,03 & 12,95 \\
\hline 33,16 & 1596,80 & 123,50 & 24,80 & 20,37 & 17,55 & 14,29 & 11,63 & 9,53 & 6,65 & 4,95 & 3,27 \\
\hline 33,55 & 680,20 & 31,20 & 80,84 & 70,30 & 62,55 & 52,97 & 44,60 & 37,56 & 27,08 & 20,33 & 13,17 \\
\hline 77,02 & 1747,80 & 45,80 & 25,87 & 20,30 & 19,09 & 18,22 & 17,26 & 16,30 & 14,46 & 12,77 & 9,93 \\
\hline 89,92 & 1390,00 & 129,60 & 14,22 & 10,04 & 8,98 & 8,09 & 7,39 & 6,78 & 5,71 & 4,83 & 3,51 \\
\hline 50,79 & 671,00 & 48,40 & 45,65 & 37,60 & 33,85 & 29,64 & 25,93 & 22,66 & 17,37 & 13,56 & 8,93 \\
\hline 49,04 & 847,40 & 121,70 & 24,82 & 18,70 & 16,04 & 13,34 & 11,17 & 9,40 & 6,82 & 5,18 & 3,41 \\
\hline 65,59 & 818,90 & 173,60 & 18,37 & 12,47 & 10,43 & 8,69 & 7,39 & 6,34 & 4,74 & 3,68 & 2,45 \\
\hline
\end{tabular}




\begin{tabular}{|c|c|c|c|c|c|c|c|c|c|c|c|}
\hline \multirow[b]{2}{*}{ e1 (cm) } & & & & & & $\mathrm{De}$ & ões (x1 & & & & \\
\hline & Meq (MPa) & Ms (MPa) & D0 & D25 & D40 & D60 & D80 & D100 & D140 & D180 & D260 \\
\hline 70,38 & 468,90 & 61,40 & 39,28 & 28,48 & 24,91 & 21,65 & 19,09 & 16,88 & 13,26 & 10,60 & 7,18 \\
\hline 34,80 & 769,70 & 156,80 & 26,97 & 19,21 & 15,47 & 11,77 & 9,14 & 7,28 & 4,98 & 3,76 & 2,57 \\
\hline 71,62 & 1193,10 & 121,10 & 17,50 & 13,02 & 11,62 & 10,28 & 9,20 & 8,24 & 6,62 & 5,38 & 3,70 \\
\hline 45,27 & 1443,70 & 122,80 & 20,70 & 16,91 & 14,95 & 12,76 & 10,88 & 9,29 & 6,85 & 5,23 & 3,41 \\
\hline 53,93 & 821,90 & 97,80 & 26,90 & 20,70 & 18,10 & 15,45 & 13,27 & 11,41 & 8,54 & 6,59 & 4,34 \\
\hline 72,27 & 1627,90 & 89,30 & 18,21 & 14,07 & 13,07 & 11,98 & 11,02 & 10,12 & 8,51 & 7,16 & 5,14 \\
\hline 85,53 & 1325,00 & 85,60 & 18,64 & 13,70 & 12,55 & 11,52 & 10,65 & 9,86 & 8,44 & 7,23 & 5,35 \\
\hline 28,15 & 750,70 & 88,60 & 44,76 & 34,31 & 27,95 & 21,23 & 16,37 & 12,93 & 8,78 & 6,62 & 4,52 \\
\hline 54,13 & 1267,30 & 30,60 & 47,41 & 39,70 & 37,96 & 35,29 & 32,62 & 30,04 & 25,30 & 21,24 & 15,13 \\
\hline 53,24 & 1034,50 & 164,40 & 18,41 & 13,54 & 11,57 & 9,66 & 8,14 & 6,89 & 5,05 & 3,85 & 2,54 \\
\hline 57,31 & 1625,80 & 70,50 & 24,05 & 19,90 & 18,59 & 16,92 & 15,38 & 13,94 & 11,39 & 9,34 & 6,45 \\
\hline 46,36 & 860,10 & 27,20 & 64,10 & 55,93 & 52,28 & 47,29 & 42,57 & 38,16 & 30,53 & 24,53 & 16,49 \\
\hline 43,94 & 1811,40 & 149,30 & 17,16 & 14,09 & 12,45 & 10,60 & 9,01 & 7,67 & 5,64 & 4,29 & 2,80 \\
\hline 31,88 & 1063,80 & 112,80 & 31,20 & 24,54 & 20,57 & 16,20 & 12,84 & 10,33 & 7,09 & 5,30 & 3,56 \\
\hline 81,18 & 1451,70 & 145,90 & 13,68 & 9,86 & 8,80 & 7,85 & 7,10 & 6,44 & 5,30 & 4,39 & 3,11 \\
\hline 34,07 & 264,60 & 134,40 & 46,17 & 26,64 & 19,44 & 13,70 & 10,29 & 8,11 & 5,60 & 4,32 & 3,02 \\
\hline 41,25 & 511,30 & 113,00 & 35,46 & 24,87 & 20,28 & 15,84 & 12,58 & 10,17 & 7,05 & 5,31 & 3,59 \\
\hline 79,85 & 759,50 & 184,20 & 17,49 & 11,16 & 9,18 & 7,64 & 6,57 & 5,72 & 4,39 & 3,48 & 2,36 \\
\hline 39,09 & 572,80 & 143,80 & 30,21 & 20,66 & 16,56 & 12,66 & 9,91 & 7,94 & 5,46 & 4,13 & 2,81 \\
\hline 72,39 & 1370,40 & 130,60 & 15,69 & 11,71 & 10,50 & 9,34 & 8,39 & 7,54 & 6,10 & 4,98 & 3,44 \\
\hline 71,38 & 829,80 & 167,00 & 17,97 & 12,14 & 10,21 & 8,59 & 7,40 & 6,42 & 4,90 & 3,85 & 2,59 \\
\hline 83,70 & 527,60 & 151,80 & 23,27 & 14,24 & 11,47 & 9,39 & 8,02 & 6,94 & 5,31 & 4,20 & 2,86 \\
\hline 78,52 & 365,10 & 113,10 & 33,27 & 20,28 & 16,22 & 13,15 & 11,11 & 9,53 & 7,17 & 5,61 & 3,79 \\
\hline 72,08 & 451,00 & 76,20 & 35,69 & 24,79 & 21,20 & 18,10 & 15,78 & 13,82 & 10,71 & 8,48 & 5,72 \\
\hline 39,09 & 521,70 & 64,00 & 50,65 & 39,38 & 33,52 & 27,19 & 22,15 & 18,20 & 12,78 & 9,58 & 6,35 \\
\hline 62,04 & 1620,30 & 44,60 & 31,17 & 25,26 & 24,11 & 22,57 & 21,01 & 19,50 & 16,69 & 14,23 & 10,40 \\
\hline 21,46 & 238,20 & 192,80 & 41,76 & 20,48 & 13,60 & 9,09 & 6,81 & 5,43 & 3,82 & 2,98 & 2,12 \\
\hline 28,93 & 883,90 & 79,90 & 44,68 & 35,57 & 29,71 & 23,21 & 18,25 & 14,58 & 9,94 & 7,43 & 5,02 \\
\hline 45,56 & 1075,50 & 139,60 & 21,61 & 16,62 & 14,29 & 11,85 & 9,87 & 8,26 & 5,94 & 4,49 & 2,96 \\
\hline 76,22 & 1412,60 & 78,20 & 20,30 & 15,46 & 14,34 & 13,19 & 12,17 & 11,23 & 9,52 & 8,08 & 5,88 \\
\hline 21,56 & 537,50 & 128,80 & 44,12 & 29,04 & 21,12 & 14,42 & 10,58 & 8,27 & 5,77 & 4,48 & 3,12 \\
\hline 27,67 & 1108,90 & 178,00 & 24,86 & 18,17 & 14,39 & 10,62 & 8,05 & 6,31 & 4,30 & 3,27 & 2,26 \\
\hline 46,58 & 1438,30 & 33,40 & 47,26 & 41,12 & 39,02 & 35,80 & 32,67 & 29,68 & 24,32 & 19,93 & 13,69 \\
\hline 62,22 & 1314,30 & 115,10 & 18,48 & 14,42 & 12,96 & 11,45 & 10,17 & 9,03 & 7,13 & 5,70 & 3,84 \\
\hline 44,58 & 1295,20 & 185,70 & 17,17 & 13,01 & 11,08 & 9,08 & 7,50 & 6,23 & 4,44 & 3,34 & 2,21 \\
\hline 47,58 & 805,00 & 87,70 & 31,08 & 24,49 & 21,39 & 18,07 & 15,31 & 13,00 & 9,54 & 7,27 & 4,76 \\
\hline 29,34 & 1979,40 & 150,40 & 22,17 & 18,05 & 15,30 & 12,16 & 9,68 & 7,80 & 5,35 & 3,99 & 2,67 \\
\hline 45,49 & 1573,50 & 168,70 & 16,51 & 13,07 & 11,39 & 9,57 & 8,06 & 6,81 & 4,95 & 3,76 & 2,46 \\
\hline 87,35 & 1197,80 & 63,70 & 22,77 & 16,88 & 15,55 & 14,45 & 13,48 & 12,58 & 10,92 & 9,48 & 7,16 \\
\hline 45,39 & 1807,70 & 69,30 & 27,21 & 23,72 & 21,92 & 19,60 & 17,44 & 15,47 & 12,13 & 9,60 & 6,36 \\
\hline 40,59 & 663,10 & 184,00 & 24,26 & 16,23 & 12,92 & 9,86 & 7,73 & 6,19 & 4,27 & 3,23 & 2,20 \\
\hline 26,95 & 1459,70 & 167,00 & 24,20 & 18,53 & 15,02 & 11,32 & 8,68 & 6,83 & 4,63 & 3,50 & 2,40 \\
\hline 54,70 & 1035,20 & 180,60 & 17,29 & 12,47 & 10,59 & 8,80 & 7,40 & 6,26 & 4,58 & 3,50 & 2,32 \\
\hline 21,05 & 429,20 & 81,10 & 66,64 & 45,50 & 33,58 & 23,11 & 16,94 & 13,21 & 9,17 & 7,11 & 4,95 \\
\hline 44,11 & 807,30 & 136,60 & 25,22 & 18,57 & 15,60 & 12,60 & 10,28 & 8,46 & 5,97 & 4,50 & 2,99 \\
\hline 25,67 & 1625,20 & 199,80 & 21,34 & 16,09 & 12,84 & 9,51 & 7,21 & 5,65 & 3,83 & 2,91 & 2,01 \\
\hline 74,20 & 554,00 & 59,90 & 35,87 & 26,27 & 23,35 & 20,62 & 18,45 & 16,54 & 13,32 & 10,84 & 7,49 \\
\hline 20,62 & 1028,80 & 169,80 & 31,10 & 21,62 & 16,06 & 11,09 & 8,13 & 6,33 & 4,38 & 3,40 & 2,36 \\
\hline 25,27 & 276,00 & 66,70 & 79,13 & 53,33 & 40,04 & 28,15 & 20,86 & 16,29 & 11,23 & 8,67 & 6,03 \\
\hline 79,28 & 1023,40 & 82,10 & 22,16 & 16,37 & 14,86 & 13,42 & 12,24 & 11,17 & 9,30 & 7,78 & 5,56 \\
\hline 65,12 & 1906,40 & 153,80 & 13,04 & 10,14 & 9,18 & 8,18 & 7,33 & 6,57 & 5,27 & 4,26 & 2,91 \\
\hline 47,52 & 203,60 & 169,60 & 45,48 & 22,41 & 15,46 & 10,73 & 8,12 & 6,45 & 4,46 & 3,44 & 2,43 \\
\hline 57,61 & 916,40 & 31,50 & 49,57 & 41,03 & 38,77 & 35,69 & 32,75 & 29,96 & 24,93 & 20,73 & 14,58 \\
\hline 56,75 & 1098,40 & 86,50 & 24,74 & 19,86 & 17,90 & 15,78 & 13,94 & 12,30 & 9,60 & 7,60 & 5,07 \\
\hline 46,13 & 1518,30 & 84,80 & 25,14 & 21,40 & 19,41 & 17,04 & 14,92 & 13,02 & 9,96 & 7,75 & 5,08 \\
\hline 51,03 & 880,70 & 67,90 & 33,32 & 27,24 & 24,44 & 21,32 & 18,60 & 16,21 & 12,38 & 9,64 & 6,34 \\
\hline 20,06 & 892,00 & 43,00 & 90,03 & 72,73 & 59,45 & 44,79 & 34,12 & 26,66 & 17,92 & 13,51 & 9,27 \\
\hline 85,61 & 1577,00 & 164,60 & 12,08 & 8,55 & 7,60 & 6,78 & 6,14 & 5,59 & 4,63 & 3,86 & 2,76 \\
\hline 86,63 & 609,90 & 127,60 & 22,56 & 14,53 & 12,13 & 10,25 & 8,95 & 7,90 & 6,24 & 5,03 & 3,46 \\
\hline 58,24 & 1271,50 & 162,80 & 16,04 & 12,09 & 10,54 & 9,03 & 7,80 & 6,75 & 5,11 & 3,97 & 2,63 \\
\hline 55,45 & 368,80 & 51,40 & 54,20 & 40,58 & 35,10 & 29,73 & 25,39 & 21,75 & 16,20 & 12,48 & 8,23 \\
\hline 88,46 & 603,70 & 53,60 & 33,84 & 24,09 & 21,64 & 19,53 & 17,86 & 16,39 & 13,81 & 11,68 & 8,51 \\
\hline 60,55 & 1323,80 & 64,10 & 26,65 & 21,69 & 20,19 & 18,37 & 16,71 & 15,17 & 12,44 & 10,23 & 7,10 \\
\hline 79,52 & 821,40 & 176,60 & 17,01 & 11,11 & 9,26 & 7,79 & 6,75 & 5,90 & 4,58 & 3,64 & 2,47 \\
\hline 57,96 & 1375,90 & 82,90 & 22,94 & 18,70 & 17,16 & 15,38 & 13,80 & 12,35 & 9,88 & 7,96 & 5,40 \\
\hline 26,81 & 873,90 & 59,70 & 57,74 & 47,09 & 39,62 & 31,12 & 24,53 & 19,61 & 13,35 & 9,96 & 6,71 \\
\hline 39,53 & 1191,80 & 69,30 & 34,89 & 29,81 & 26,63 & 22,82 & 19,47 & 16,61 & 12,22 & 9,28 & 6,02 \\
\hline 68,62 & 1865,40 & 64,20 & 21,96 & 17,37 & 16,45 & 15,37 & 14,32 & 13,30 & 11,42 & 9,78 & 7,20 \\
\hline 80,72 & 1485,00 & 25,70 & 37,48 & 30,85 & 28,47 & 27,53 & 26,52 & 25,37 & 23,08 & 20,90 & 16,99 \\
\hline 64,78 & 1866,60 & 189,40 & 11,74 & 8,94 & 7,97 & 7,00 & 6,20 & 5,49 & 4,32 & 3,45 & 2,33 \\
\hline 66,26 & 578,10 & 42,60 & 44,92 & 35,01 & 31,91 & 28,62 & 25,79 & 23,23 & 18,81 & 15,34 & 10,57 \\
\hline 55,72 & 637,80 & 143,60 & 24,50 & 16,78 & 13,92 & 11,35 & 9,43 & 7,90 & 5,71 & 4,35 & 2,89 \\
\hline 66,38 & 1393,60 & 170,00 & 14,07 & 10,43 & 9,17 & 7,97 & 7,01 & 6,18 & 4,82 & 3,83 & 2,58 \\
\hline 77,21 & 1573,60 & 63,50 & 21,94 & 16,87 & 15,81 & 14,80 & 13,82 & 12,90 & 11,17 & 9,66 & 7,24 \\
\hline 84,82 & 1075,50 & 75,40 & 22,01 & 16,12 & 14,71 & 13,44 & 12,38 & 11,43 & 9,71 & 8,27 & 6,07 \\
\hline 78,13 & 740,70 & 85,90 & 25,30 & 18,15 & 16,04 & 14,14 & 12,66 & 11,38 & 9,20 & 7,53 & 5,23 \\
\hline 57,11 & 1387,80 & 110,20 & 19,41 & 15,55 & 14,02 & 12,36 & 10,92 & 9,64 & 7,53 & 5,96 & 3,98 \\
\hline 55,36 & 1249,70 & 163,40 & 16,57 & 12,53 & 10,89 & 9,27 & 7,94 & 6,82 & 5,10 & 3,94 & 2,60 \\
\hline 35,03 & 989,50 & 182,20 & 22,26 & 16,15 & 13,14 & 10,09 & 7,89 & 6,30 & 4,32 & 3,25 & 2,21 \\
\hline 66,32 & 434,50 & 173,20 & 26,56 & 15,66 & 12,17 & 9,51 & 7,77 & 6,47 & 4,66 & 3,57 & 2,41 \\
\hline 39,53 & 1201,10 & 33,00 & 56,40 & 50,58 & 46,90 & 41,94 & 37,24 & 32,94 & 25,68 & 20,20 & 13,27 \\
\hline 80,06 & 1710,00 & 95,40 & 16,26 & 12,23 & 11,32 & 10,44 & 9,67 & 8,95 & 7,65 & 6,53 & 4,81 \\
\hline
\end{tabular}




\begin{tabular}{|c|c|c|c|c|c|c|c|c|c|c|c|}
\hline & & & \multicolumn{9}{|c|}{ Deflexões $\left(\times 10^{-4} \mathrm{~cm}\right)$} \\
\hline $\mathrm{e} 1(\mathrm{~cm})$ & Meq (MPa) & Ms (MPa) & D0 & D25 & D40 & D60 & D80 & D100 & D140 & D180 & D260 \\
\hline 85,16 & 225,90 & 113,70 & 45,22 & 24,51 & 18,31 & 14,00 & 11,44 & 9,60 & 7,05 & 5,49 & 3,74 \\
\hline 47,93 & 969,20 & 20,80 & 72,71 & 62,68 & 59,81 & 55,22 & 50,68 & 46,32 & 38,40 & 31,77 & 22,13 \\
\hline 70,49 & 1062,70 & 130,40 & 17,90 & 13,09 & 11,51 & 10,05 & 8,89 & 7,88 & 6,23 & 4,99 & 3,39 \\
\hline 69,19 & 759,80 & 74,20 & 28,51 & 21,48 & 19,22 & 17,00 & 15,19 & 13,58 & 10,87 & 8,79 & 6,02 \\
\hline 70,96 & 1704,00 & 46,40 & 27,38 & 21,61 & 20,50 & 19,43 & 18,27 & 17,14 & 15,00 & 13,07 & 9,91 \\
\hline 30,69 & 1973,60 & 187,00 & 18,59 & 14,80 & 12,44 & 9,80 & 7,77 & 6,24 & 4,28 & 3,20 & 2,15 \\
\hline 51,40 & 1508,80 & 85,10 & 23,42 & 19,63 & 17,94 & 15,95 & 14,15 & 12,52 & 9,81 & 7,77 & 5,17 \\
\hline 37,50 & 711,80 & 170,90 & 25,44 & 17,57 & 14,07 & 10,72 & 8,36 & 6,67 & 4,58 & 3,46 & 2,36 \\
\hline 62,54 & 1304,90 & 153,30 & 15,78 & 11,90 & 10,47 & 9,09 & 7,95 & 6,97 & 5,39 & 4,25 & 2,84 \\
\hline 52,18 & 1856,30 & 127,20 & 16,73 & 13,79 & 12,48 & 10,99 & 9,67 & 8,50 & 6,58 & 5,18 & 3,43 \\
\hline 59,31 & 316,60 & 43,70 & 61,34 & 45,58 & 39,56 & 33,77 & 29,12 & 25,17 & 19,02 & 14,78 & 9,79 \\
\hline 75,03 & 1852,50 & 120,00 & 14,21 & 10,79 & 9,93 & 9,05 & 8,29 & 7,59 & 6,35 & 5,33 & 3,81 \\
\hline 57,36 & 832,30 & 180,60 & 18,88 & 12,99 & 10,82 & 8,88 & 7,42 & 6,25 & 4,56 & 3,48 & 2,31 \\
\hline 28,39 & 1315,70 & 144,00 & 26,73 & 20,72 & 17,00 & 13,02 & 10,09 & 8,00 & 5,43 & 4,09 & 2,78 \\
\hline 57,46 & 715,30 & 124,50 & 24,47 & 17,56 & 14,93 & 12,49 & 10,58 & 9,01 & 6,66 & 5,11 & 3,38 \\
\hline 52,36 & 1088,70 & 94,30 & 24,75 & 19,92 & 17,77 & 15,44 & 13,43 & 11,68 & 8,89 & 6,92 & 4,56 \\
\hline 34,52 & 313,70 & 23,00 & 126,67 & 104,99 & 91,22 & 75,12 & 61,78 & 51,05 & 35,96 & 26,85 & 17,64 \\
\hline 77,75 & 573,00 & 21,50 & 62,78 & 48,35 & 45,36 & 42,63 & 39,94 & 37,36 & 32,54 & 28,27 & 21,37 \\
\hline 41,07 & 1728,10 & 34,90 & 47,18 & 42,12 & 39,77 & 36,23 & 32,78 & 29,53 & 23,79 & 19,20 & 12,93 \\
\hline 52,15 & 750,00 & 137,70 & 23,80 & 17,09 & 14,41 & 11,85 & 9,88 & 8,28 & 5,99 & 4,55 & 3,01 \\
\hline 28,12 & 688,20 & 22,70 & 115,00 & 101,39 & 89,88 & 75,37 & 62,76 & 52,28 & 37,07 & 27,60 & 17,91 \\
\hline 29,99 & 1315,80 & 57,70 & 47,20 & 40,84 & 35,94 & 29,91 & 24,76 & 20,53 & 14,49 & 10,79 & 7,04 \\
\hline 86,53 & 1609,90 & 132,50 & 13,34 & 9,61 & 8,68 & 7,87 & 7,21 & 6,62 & 5,59 & 4,73 & 3,45 \\
\hline 74,55 & 305,00 & 191,40 & 31,99 & 16,67 & 12,09 & 8,93 & 7,10 & 5,82 & 4,14 & 3,19 & 2,19 \\
\hline 71,23 & 831,30 & 185,00 & 17,18 & 11,39 & 9,48 & 7,90 & 6,77 & 5,84 & 4,42 & 3,46 & 2,32 \\
\hline 88,65 & 1611,00 & 188,50 & 11,01 & 7,63 & 6,72 & 5,95 & 5,38 & 4,88 & 4,04 & 3,37 & 2,40 \\
\hline 33,10 & 551,40 & 178,10 & 29,07 & 18,82 & 14,39 & 10,45 & 7,91 & 6,23 & 4,28 & 3,27 & 2,27 \\
\hline 86,20 & 1639,60 & 64,40 & 19,99 & 15,16 & 14,06 & 13,26 & 12,49 & 11,75 & 10,36 & 9,11 & 7,04 \\
\hline 69,81 & 1563,60 & 60,20 & 24,12 & 18,98 & 17,90 & 16,66 & 15,48 & 14,35 & 12,27 & 10,47 & 7,67 \\
\hline 22,57 & 1493,70 & 109,30 & 36,56 & 28,84 & 23,39 & 17,53 & 13,33 & 10,43 & 7,04 & 5,32 & 3,66 \\
\hline 46,58 & 1621,30 & 52,20 & 33,48 & 29,18 & 27,26 & 24,65 & 22,19 & 19,89 & 15,90 & 12,78 & 8,58 \\
\hline 45,15 & 1023,00 & 47,10 & 42,83 & 37,03 & 33,88 & 29,99 & 26,43 & 23,22 & 17,94 & 14,04 & 9,23 \\
\hline 58,90 & 1831,40 & 172,50 & 13,10 & 10,26 & 9,16 & 8,01 & 7,05 & 6,20 & 4,81 & 3,80 & 2,53 \\
\hline 35,34 & 1565,40 & 183,00 & 18,58 & 14,51 & 12,25 & 9,78 & 7,85 & 6,38 & 4,42 & 3,30 & 2,21 \\
\hline 80,08 & 1258,80 & 105,30 & 17,52 & 12,87 & 11,64 & 10,50 & 9,56 & 8,72 & 7,26 & 6,06 & 4,33 \\
\hline 35,38 & 1891,70 & 96,00 & 26,11 & 22,55 & 20,08 & 17,04 & 14,40 & 12,16 & 8,81 & 6,63 & 4,30 \\
\hline 83,87 & 1553,20 & 44,90 & 25,75 & 20,05 & 18,64 & 17,80 & 16,90 & 16,00 & 14,28 & 12,70 & 10,00 \\
\hline 78,87 & 1071,10 & 180,00 & 14,57 & 9,93 & 8,49 & 7,28 & 6,40 & 5,66 & 4,46 & 3,59 & 2,45 \\
\hline 43,89 & 1048,20 & 118,30 & 24,61 & 19,37 & 16,77 & 13,96 & 11,66 & 9,77 & 7,04 & 5,31 & 3,49 \\
\hline 77,84 & 671,00 & 198,20 & 18,47 & 11,38 & 9,16 & 7,46 & 6,32 & 5,43 & 4,10 & 3,21 & 2,17 \\
\hline 32,57 & 344,10 & 70,00 & 62,53 & 44,45 & 35,46 & 26,61 & 20,46 & 16,19 & 11,06 & 8,38 & 5,75 \\
\hline 68,91 & 1596,10 & 65,60 & 22,84 & 18,00 & 16,94 & 15,71 & 14,54 & 13,44 & 11,41 & 9,68 & 7,04 \\
\hline 45,58 & 1950,80 & 123,50 & 18,25 & 15,38 & 13,85 & 12,05 & 10,46 & 9,06 & 6,85 & 5,29 & 3,45 \\
\hline 43,54 & 723,40 & 197,20 & 21,79 & 14,59 & 11,71 & 9,07 & 7,18 & 5,80 & 4,02 & 3,04 & 2,06 \\
\hline 30,24 & 777,60 & 171,40 & 27,32 & 19,06 & 14,91 & 10,95 & 8,30 & 6,52 & 4,46 & 3,40 & 2,35 \\
\hline 49,39 & 810,20 & 110,30 & 26,63 & 20,24 & 17,44 & 14,58 & 12,26 & 10,35 & 7,54 & 5,74 & 3,77 \\
\hline 44,69 & 1364,20 & 47,20 & 38,96 & 34,16 & 31,68 & 28,42 & 25,36 & 22,54 & 17,76 & 14,10 & 9,36 \\
\hline 21,07 & 531,60 & 135,70 & 43,05 & 27,88 & 20,08 & 13,62 & 9,99 & 7,82 & 5,47 & 4,25 & 2,97 \\
\hline 33,63 & 601,60 & 108,90 & 37,84 & 27,51 & 22,27 & 16,99 & 13,20 & 10,51 & 7,18 & 5,42 & 3,70 \\
\hline 74,72 & 1952,10 & 33,90 & 30,55 & 24,74 & 23,16 & 22,38 & 21,44 & 20,41 & 18,40 & 16,50 & 13,17 \\
\hline 59,57 & 1980,70 & 77,70 & 20,61 & 16,90 & 15,90 & 14,59 & 13,36 & 12,21 & 10,13 & 8,41 & 5,90 \\
\hline 66,96 & 511,00 & 119,10 & 28,00 & 18,58 & 15,40 & 12,73 & 10,80 & 9,24 & 6,89 & 5,34 & 3,57 \\
\hline 41,97 & 1395,90 & 104,00 & 24,45 & 20,34 & 18,02 & 15,33 & 13,02 & 11,07 & 8,11 & 6,16 & 4,01 \\
\hline 88,44 & 1544,60 & 54,10 & 22,28 & 17,06 & 15,76 & 14,95 & 14,16 & 13,38 & 11,91 & 10,57 & 8,30 \\
\hline 31,11 & 1949,10 & 79,40 & 32,45 & 28,37 & 25,18 & 21,21 & 17,75 & 14,87 & 10,63 & 7,94 & 5,15 \\
\hline 41,47 & 692,20 & 71,30 & 40,83 & 32,58 & 28,25 & 23,46 & 19,51 & 16,30 & 11,67 & 8,78 & 5,76 \\
\hline 37,85 & 1840,90 & 93,40 & 25,47 & 22,04 & 19,76 & 16,96 & 14,49 & 12,36 & 9,10 & 6,90 & 4,47 \\
\hline 35,87 & 1371,00 & 141,80 & 22,69 & 18,04 & 15,39 & 12,45 & 10,09 & 8,26 & 5,76 & 4,30 & 2,86 \\
\hline 79,81 & 1683,90 & 91,90 & 16,76 & 12,63 & 11,70 & 10,81 & 10,01 & 9,27 & 7,93 & 6,78 & 5,00 \\
\hline 28,24 & 1409,90 & 167,10 & 23,72 & 18,18 & 14,81 & 11,26 & 8,68 & 6,86 & 4,66 & 3,51 & 2,40 \\
\hline 32,36 & 514,80 & 198,30 & 28,25 & 17,53 & 13,12 & 9,36 & 7,04 & 5,53 & 3,81 & 2,93 & 2,04 \\
\hline 59,69 & 343,10 & 138,70 & 34,33 & 20,40 & 15,83 & 12,26 & 9,90 & 8,14 & 5,78 & 4,41 & 2,98 \\
\hline 34,45 & 978,60 & 56,60 & 47,38 & 40,33 & 35,54 & 29,76 & 24,83 & 20,75 & 14,81 & 11,09 & 7,23 \\
\hline 49,49 & 293,70 & 171,00 & 36,05 & 19,74 & 14,48 & 10,56 & 8,16 & 6,53 & 4,52 & 3,46 & 2,40 \\
\hline 70,51 & 516,40 & 61,60 & 37,38 & 27,42 & 24,16 & 21,14 & 18,73 & 16,63 & 13,17 & 10,57 & 7,19 \\
\hline 53,98 & 1754,00 & 40,90 & 35,17 & 29,44 & 28,19 & 26,24 & 24,28 & 22,38 & 18,88 & 15,88 & 11,34 \\
\hline 32,07 & 959,50 & 99,50 & 34,96 & 27,59 & 23,19 & 18,32 & 14,56 & 11,73 & 8,06 & 6,02 & 4,04 \\
\hline 39,16 & 1557,70 & 127,20 & 21,75 & 17,88 & 15,65 & 13,09 & 10,93 & 9,16 & 6,57 & 4,94 & 3,23 \\
\hline 32,74 & 1944,40 & 173,80 & 18,72 & 15,09 & 12,85 & 10,32 & 8,31 & 6,75 & 4,67 & 3,48 & 2,32 \\
\hline 44,46 & 1737,00 & 170,50 & 15,99 & 12,83 & 11,22 & 9,46 & 7,98 & 6,74 & 4,91 & 3,72 & 2,44 \\
\hline 30,85 & 746,80 & 159,70 & 28,71 & 20,17 & 15,88 & 11,74 & 8,93 & 7,03 & 4,80 & 3,65 & 2,52 \\
\hline 70,70 & 988,60 & 112,30 & 20,00 & 14,75 & 13,05 & 11,45 & 10,18 & 9,06 & 7,20 & 5,80 & 3,96 \\
\hline 77,96 & 1558,80 & 109,90 & 15,78 & 11,80 & 10,80 & 9,82 & 8,99 & 8,24 & 6,90 & 5,80 & 4,16 \\
\hline 84,51 & 1684,60 & 121,70 & 13,85 & 10,13 & 9,23 & 8,42 & 7,75 & 7,14 & 6,05 & 5,14 & 3,76 \\
\hline 57,72 & 886,70 & 85,20 & 27,06 & 21,21 & 18,89 & 16,48 & 14,44 & 12,65 & 9,76 & 7,67 & 5,10 \\
\hline 87,42 & 783,50 & 161,00 & 17,65 & 11,37 & 9,51 & 8,05 & 7,04 & 6,23 & 4,93 & 3,98 & 2,75 \\
\hline 41,93 & 299,80 & 77,90 & 54,84 & 37,17 & 29,88 & 23,08 & 18,22 & 14,68 & 10,16 & 7,67 & 5,21 \\
\hline 67,72 & 1568,80 & 50,50 & 27,50 & 21,83 & 20,72 & 19,40 & 18,09 & 16,83 & 14,47 & 12,41 & 9,16 \\
\hline 79,62 & 544,30 & 58,60 & 35,48 & 25,52 & 22,68 & 20,11 & 18,11 & 16,34 & 13,34 & 10,98 & 7,70 \\
\hline 44,66 & 1324,20 & 124,00 & 21,51 & 17,36 & 15,24 & 12,90 & 10,91 & 9,25 & 6,77 & 5,14 & 3,36 \\
\hline 67,13 & 1481,90 & 134,00 & 15,48 & 11,84 & 10,64 & 9,44 & 8,44 & 7,55 & 6,04 & 4,88 & 3,33 \\
\hline 49,48 & 987,10 & 191,20 & 18,04 & 12,88 & 10,78 & 8,76 & 7,22 & 6,00 & 4,29 & 3,25 & 2,15 \\
\hline
\end{tabular}




\begin{tabular}{|c|c|c|c|c|c|c|c|c|c|c|c|}
\hline & & & \multicolumn{9}{|c|}{ Deflexões $\left(\times 10^{-4} \mathrm{~cm}\right)$} \\
\hline e1 (cm) & Meq (MPa) & Ms (MPa) & D0 & D25 & D40 & D60 & D80 & D100 & D140 & D180 & D260 \\
\hline 59,47 & 818,10 & 158,20 & 19,99 & 14,01 & 11,81 & 9,82 & 8,31 & 7,07 & 5,22 & 4,02 & 2,66 \\
\hline 45,74 & 1459,20 & 74,20 & 27,94 & 23,96 & 21,84 & 19,26 & 16,91 & 14,82 & 11,39 & 8,90 & 5,84 \\
\hline 35,43 & 866,70 & 166,20 & 24,62 & 17,75 & 14,40 & 11,05 & 8,64 & 6,90 & 4,73 & 3,57 & 2,43 \\
\hline 81,46 & 431,10 & 49,20 & 43,09 & 30,63 & 27,09 & 23,96 & 21,54 & 19,44 & 15,87 & 13,07 & 9,18 \\
\hline 68,43 & 589,60 & 148,90 & 23,26 & 15,14 & 12,43 & 10,22 & 8,65 & 7,39 & 5,50 & 4,27 & 2,85 \\
\hline 40,81 & 1678,80 & 58,50 & 33,65 & 29,83 & 27,43 & 24,33 & 21,45 & 18,84 & 14,52 & 11,34 & 7,42 \\
\hline 82,12 & 796,90 & 95,40 & 22,67 & 16,00 & 14,09 & 12,42 & 11,15 & 10,05 & 8,19 & 6,74 & 4,72 \\
\hline 85,03 & 999,80 & 113,30 & 18,32 & 12,88 & 11,39 & 10,09 & 9,11 & 8,25 & 6,79 & 5,63 & 4,00 \\
\hline 55,64 & 1291,80 & 27,00 & 50,56 & 41,87 & 40,25 & 37,76 & 35,15 & 32,61 & 27,86 & 23,70 & 17,23 \\
\hline 37,31 & 472,30 & 44,00 & 68,46 & 55,29 & 47,74 & 39,20 & 32,22 & 26,63 & 18,79 & 14,07 & 9,26 \\
\hline 47,45 & 1933,60 & 56,30 & 29,70 & 25,80 & 24,26 & 22,08 & 20,00 & 18,04 & 14,60 & 11,84 & 8,04 \\
\hline 38,99 & 1236,90 & 170,70 & 19,94 & 15,22 & 12,84 & 10,31 & 8,34 & 6,82 & 4,76 & 3,57 & 2,38 \\
\hline 86,64 & 282,80 & 52,00 & 51,36 & 33,77 & 28,56 & 24,41 & 21,50 & 19,10 & 15,21 & 12,34 & 8,55 \\
\hline 31,89 & 828,70 & 166,90 & 26,43 & 18,80 & 14,96 & 11,19 & 8,58 & 6,78 & 4,63 & 3,51 & 2,41 \\
\hline 25,69 & 762,40 & 188,10 & 28,02 & 18,85 & 14,17 & 9,98 & 7,41 & 5,79 & 3,99 & 3,07 & 2,14 \\
\hline 56,65 & 1192,10 & 86,40 & 23,98 & 19,39 & 17,57 & 15,56 & 13,80 & 12,22 & 9,59 & 7,62 & 5,10 \\
\hline 78,82 & 1160,80 & 63,30 & 24,49 & 18,52 & 17,16 & 15,84 & 14,66 & 13,57 & 11,58 & 9,88 & 7,26 \\
\hline 35,97 & 1273,90 & 196,20 & 19,01 & 14,23 & 11,79 & 9,24 & 7,33 & 5,90 & 4,07 & 3,05 & 2,06 \\
\hline 22,98 & 652,30 & 138,30 & 38,51 & 26,21 & 19,52 & 13,57 & 10,00 & 7,80 & 5,40 & 4,17 & 2,91 \\
\hline 62,53 & 456,90 & 116,50 & 30,85 & 20,30 & 16,65 & 13,58 & 11,36 & 9,60 & 7,04 & 5,40 & 3,60 \\
\hline 49,65 & 1003,50 & 142,50 & 20,94 & 15,80 & 13,57 & 11,32 & 9,50 & 8,02 & 5,83 & 4,43 & 2,92 \\
\hline 39,57 & 1205,40 & 96,40 & 28,27 & 23,32 & 20,45 & 17,16 & 14,38 & 12,07 & 8,69 & 6,55 & 4,27 \\
\hline 22,26 & 1106,80 & 171,80 & 28,95 & 20,63 & 15,67 & 11,04 & 8,15 & 6,34 & 4,36 & 3,36 & 2,33 \\
\hline 47,02 & 1233,80 & 103,10 & 23,89 & 19,51 & 17,32 & 14,87 & 12,77 & 10,97 & 8,17 & 6,27 & 4,10 \\
\hline 79,11 & 1211,50 & 143,40 & 15,23 & $\begin{array}{l}10,01 \\
10,86\end{array}$ & $\begin{array}{c}1+, 0< \\
9,58\end{array}$ & $\begin{array}{c}+4,44 \\
8,44\end{array}$ & 7,56 & $\begin{array}{c}10,79 \\
6,79\end{array}$ & 5,50 & 4,50 & 3,13 \\
\hline 42,06 & 1144,90 & 102,90 & 26,55 & 21,58 & 18,90 & 15,89 & 13,35 & 11,25 & 8,14 & 6,15 & 4,02 \\
\hline 55,59 & 1918,20 & 144,20 & 14,74 & 11,92 & 10,77 & 9,50 & 8,39 & 7,40 & 5,77 & 4,56 & 3,04 \\
\hline 48,81 & 1574,40 & 183,70 & 15,05 & 11,72 & 10,21 & 8,61 & 7,30 & 6,20 & 4,55 & 3,47 & 2,28 \\
\hline 28,02 & 1560,80 & 189,00 & 21,22 & 16,20 & 13,16 & 9,96 & 7,67 & 6,05 & 4,11 & 3,10 & 2,12 \\
\hline 57,97 & 848,10 & 37,30 & 45,37 & 37,42 & 34,95 & 31,82 & 28,94 & 26,24 & 21,48 & 17,62 & 12,19 \\
\hline 79,03 & 295,90 & 102,00 & 39,44 & 23,47 & 18,52 & 14,84 & 12,45 & 10,62 & 7,94 & 6,20 & 4,19 \\
\hline 29,05 & 978,20 & 117,00 & 33,35 & 25,60 & 20,95 & 16,01 & 12,40 & 9,82 & 6,68 & 5,03 & 3,43 \\
\hline 83,92 & 858,50 & 77,90 & 24,08 & 17,35 & 15,60 & 14,02 & 12,77 & 11,66 & 9,72 & 8,15 & 5,85 \\
\hline 47,78 & 1954,80 & 26,70 & 49,89 & 42,25 & 40,92 & 38,49 & 35,87 & 33,29 & 28,43 & 24,15 & 17,48 \\
\hline 46,46 & 215,60 & 125,70 & 49,62 & 27,25 & 19,95 & 14,45 & 11,10 & 8,85 & 6,12 & 4,68 & 3,25 \\
\hline 43,80 & 1942,60 & 20,90 & 63,19 & 54,03 & 52,48 & 49,39 & 46,03 & 42,72 & 36,45 & 30,93 & 22,32 \\
\hline 27,90 & 601,80 & 137,80 & 35,86 & 24,68 & 18,98 & 13,66 & 10,24 & 8,01 & 5,49 & 4,21 & 2,92 \\
\hline 41,70 & 709,90 & 176,80 & 23,77 & 16,26 & 13,12 & 10,16 & 8,04 & 6,48 & 4,48 & 3,38 & 2,29 \\
\hline 24,12 & 1018,50 & 66,80 & 55,20 & 44,56 & 36,91 & 28,37 & 21,98 & 17,36 & 11,73 & 8,80 & 5,99 \\
\hline 22,70 & 431,20 & 155,30 & 40,04 & 24,50 & 17,41 & 11,78 & 8,68 & 6,83 & 4,78 & 3,71 & 2,60 \\
\hline 73,80 & 1634,20 & 105,10 & 16,31 & 12,44 & 11,46 & 10,43 & 9,55 & 8,74 & 7,29 & 6,10 & 4,35 \\
\hline 36,39 & 988,30 & 26,70 & 73,76 & 66,64 & 61,35 & 54,31 & 47,72 & 41,76 & 31,96 & 24,80 & 16,12 \\
\hline 49,63 & 382,60 & 111,10 & 37,83 & 24,77 & 19,92 & 15,64 & 12,58 & 10,29 & 7,23 & 5,47 & 3,68 \\
\hline 68,73 & 717,50 & 143,90 & 21,12 & 14,37 & 12,09 & 10,15 & 8,71 & 7,53 & 5,71 & 4,46 & 2,99 \\
\hline 21,60 & 1909,80 & 174,00 & 25,19 & 19,21 & 15,16 & 11,04 & 8,25 & 6,41 & 4,35 & 3,32 & 2,30 \\
\hline 40,21 & 1444,20 & 181,10 & 17,74 & 13,75 & 11,72 & 9,54 & 7,80 & 6,43 & 4,53 & 3,40 & 2,25 \\
\hline 66,11 & 1764,70 & 130,30 & 14,72 & 11,48 & 10,46 & 9,38 & 8,45 & 7,61 & 6,16 & 5,02 & 3,46 \\
\hline 59,52 & 1475,50 & 107,90 & 18,73 & 14,99 & 13,61 & 12,10 & 10,79 & 9,61 & 7,62 & 6,10 & 4,11 \\
\hline 22,08 & 220,40 & 163,90 & 47,64 & 24,04 & 16,09 & 10,75 & 8,04 & 6,40 & 4,50 & 3,51 & 2,49 \\
\hline 41,00 & 1955,50 & 32,70 & 47,68 & 42,39 & 40,35 & 37,04 & 33,78 & 30,65 & 25,04 & 20,43 & 13,95 \\
\hline 26,36 & 934,70 & 139,50 & 31,91 & 23,47 & 18,53 & 13,60 & 10,27 & 8,03 & 5,47 & 4,17 & 2,88 \\
\hline 29,77 & 254,20 & 154,20 & 44,78 & 24,48 & 17,22 & 11,80 & 8,79 & 6,94 & 4,83 & 3,75 & 2,64 \\
\hline 68,52 & 425,80 & 46,80 & 47,96 & 35,76 & 31,71 & 27,83 & 24,70 & 21,94 & 17,37 & 13,95 & 9,47 \\
\hline 62,32 & 1231,00 & 72,00 & 25,05 & 20,10 & 18,54 & 16,75 & 15,16 & 13,69 & 11,14 & 9,11 & 6,28 \\
\hline 72,13 & 1422,50 & 69,30 & 22,45 & 17,42 & 16,27 & 15,01 & 13,86 & 12,79 & 10,83 & 9,17 & 6,65 \\
\hline 33,71 & 1915,30 & 56,20 & 38,35 & 34,55 & 31,44 & 27,41 & 23,71 & 20,44 & 15,25 & 11,64 & 7,51 \\
\hline 76,27 & 821,50 & 142,30 & 18,96 & 12,96 & 11,05 & 9,45 & 8,27 & 7,28 & 5,69 & 4,54 & 3,09 \\
\hline 78,81 & 1077,30 & 31,20 & 38,83 & 30,26 & 28,38 & 27,02 & 25,55 & 24,10 & 21,33 & 18,81 & 14,58 \\
\hline 28,86 & 888,00 & 180,00 & 25,90 & 18,28 & 14,30 & 10,46 & 7,91 & 6,20 & 4,23 & 3,23 & 2,23 \\
\hline 48,98 & 550,10 & 62,10 & 43,80 & 34,28 & 29,92 & 25,33 & 21,51 & 18,31 & 13,48 & 10,29 & 6,75 \\
\hline 43,79 & 1453,60 & 96,10 & 24,53 & 20,64 & 18,48 & 15,95 & 13,73 & 11,81 & 8,81 & 6,75 & 4,40 \\
\hline 22,80 & 1773,30 & 146,90 & 27,98 & 21,80 & 17,54 & 13,04 & 9,87 & $\begin{array}{l}+1,01 \\
7,71\end{array}$ & 5,21 & 3,95 & 2,72 \\
\hline 22,36 & 967,80 & 95,90 & 45,71 & 34,71 & 27,42 & 20,00 & 14,97 & 11,65 & $\begin{array}{l}, L 1 \\
7,91\end{array}$ & 6,04 & 4,17 \\
\hline 47,60 & 1168,50 & 85,80 & 27,03 & 22,37 & 20,03 & 17,37 & 15,05 & $\begin{array}{l}1+1,00 \\
13,03\end{array}$ & 9,83 & 7,59 & 4,97 \\
\hline 80,09 & 1314,00 & 111,20 & 16,68 & 12,23 & 11,06 & 9,97 & 9,07 & 8,28 & 6,88 & 5,74 & 4,10 \\
\hline 54,66 & 1417,10 & 168,20 & 15,51 & 11,92 & 10,43 & 8,92 & 7,67 & 6,61 & 4,97 & 3,84 & 2,53 \\
\hline 86,10 & 756,10 & 79,60 & 25,02 & 17,67 & 15,70 & 14,00 & 12,68 & 11,54 & 9,57 & 7,98 & 5,71 \\
\hline 71,93 & 1848,30 & 125,40 & 14,15 & 10,85 & 9,95 & 9,02 & 8,22 & 7,49 & 6,20 & 5,15 & 3,64 \\
\hline 54,96 & 1273,40 & 97,20 & 22,16 & 17,94 & 16,17 & 14,23 & 12,55 & 11,04 & 8,58 & 6,77 & 4,50 \\
\hline 51,47 & 923,10 & 82,50 & 28,96 & 23,27 & 20,70 & 17,91 & 15,52 & 13,45 & 10,17 & 7,88 & 5,18 \\
\hline 38,22 & 979,60 & 128,10 & 26,33 & 20,26 & 17,13 & 13,76 & 11,13 & 9,09 & 6.34 & 4.75 & 3,16 \\
\hline 75,89 & 1825,50 & 24,40 & 37,48 & 31,50 & 29,10 & 28,25 & 27,31 & 26,19 & 23,91 & 21,73 & 17,77 \\
\hline 48,33 & 227,00 & 74,00 & 60,87 & 38,88 & 30,82 & 23,84 & 18,98 & 15,41 & 10,76 & 8,15 & 5,52 \\
\hline 28,14 & 919,00 & 87,10 & 42,44 & 33,49 & 27,75 & 21,45 & 16,74 & 13,31 & 9,05 & 6,78 & 4,60 \\
\hline 26,72 & 523,40 & 26,20 & 119,44 & 100,63 & 86,43 & 69,54 & 55,85 & 45,22 & 31,06 & 23,06 & 15,32 \\
\hline 34,92 & 715,10 & 182,40 & 25,26 & 17,22 & 13,59 & 10,16 & 7,81 & 6,19 & 4,24 & 3,22 & 2,21 \\
\hline 86,10 & 603,70 & 112,30 & 23,99 & 15,77 & 13,32 & 11,37 & 10,00 & 8,88 & 7,06 & 5,72 & 3,96 \\
\hline 89,17 & 626,80 & 129,60 & 21,88 & 14,02 & 11,70 & 9,91 & 8,68 & 7,69 & 6,10 & 4,94 & 3,42 \\
\hline 89,25 & 1724,40 & 23,50 & 32,73 & 29,49 & 26,49 & 25,44 & 24,84 & 24,04 & 22,29 & 20,59 & 17,40 \\
\hline 84,13 & 251,00 & 119,20 & 41,45 & 22,78 & 17,17 & 13,24 & 10,86 & 9,14 & 6,73 & 5,24 & 3,57 \\
\hline 28,36 & 1854,80 & 56,90 & 44,48 & 39,49 & 35,18 & 29,70 & 24,88 & 20,84 & 14,88 & 11,10 & 7,18 \\
\hline 28,71 & 698,50 & 82,00 & 47,67 & 36,64 & 29,97 & 22,88 & 17,70 & 14,02 & 9,53 & 7,17 & 4,89 \\
\hline
\end{tabular}




\begin{tabular}{|c|c|c|c|c|c|c|c|c|c|c|c|}
\hline \multirow[b]{2}{*}{ e1 (cm) } & & & & & & & ões (x1 & m) & & & \\
\hline & Meq (MPa) & Ms (MPa) & D0 & D25 & D40 & D60 & D80 & D100 & D140 & D180 & D260 \\
\hline 68,54 & 1373,50 & 49,30 & 29,03 & 22,96 & 21,71 & 20,25 & 18,82 & 17,46 & 14,95 & 12,77 & 9,37 \\
\hline 87,02 & 932,20 & 108,70 & 19,20 & 13,38 & 11,79 & 10,44 & 9,42 & 8,54 & 7,04 & 5,86 & 4,17 \\
\hline 20,41 & 292,50 & 172,60 & 42,69 & 22,82 & 15,38 & 10,25 & 7,63 & 6,07 & 4,27 & 3,33 & 2,35 \\
\hline 44,78 & 1698,80 & 33,10 & 46,41 & 40,59 & 38,68 & 35,61 & 32,58 & 29,67 & 24,43 & 20,08 & 13,85 \\
\hline 52,17 & 414,10 & 62,70 & 47,72 & 35,47 & 30,40 & 25,40 & 21,40 & 18,12 & 13,26 & 10,11 & 6,66 \\
\hline 28,54 & 1224,60 & 104,10 & 33,94 & 27,18 & 22,76 & 17,81 & 14,02 & 11,21 & 7,64 & 5,71 & 3,85 \\
\hline 33,04 & 1147,20 & 147,20 & 24,98 & 19,17 & 15,92 & 12,45 & 9,82 & 7,88 & 5,40 & 4,05 & 2,73 \\
\hline 23,57 & 659,40 & 142,70 & 37,07 & 25,24 & 18,87 & 13,17 & 9,72 & 7,58 & 5,24 & 4,05 & 2,82 \\
\hline 65,59 & 532,00 & 195,90 & 22,41 & 13,48 & 10,59 & 8,35 & 6,85 & 5,72 & 4,13 & 3,17 & 2,13 \\
\hline 88,95 & 1037,50 & 52,80 & 26,68 & 19,78 & 18,21 & 16,98 & 15,88 & 14,85 & 12,96 & 11,30 & 8,62 \\
\hline 82,96 & 624,20 & 30,90 & 46,89 & 35,23 & 32,67 & 30,40 & 28,33 & 26,40 & 22,85 & 19,75 & 14,83 \\
\hline 86,66 & 1545,60 & 160,10 & 12,31 & 8,69 & 7,73 & 6,90 & 6,26 & 5,70 & 4,74 & 3,96 & 2,84 \\
\hline 43,04 & 462,70 & 37,10 & 69,23 & 57,04 & 50,41 & 42,86 & 36,39 & 30,92 & 22,67 & 17,22 & 11,22 \\
\hline 82,72 & 1284,50 & 103,10 & 17,30 & 12,63 & 11,46 & 10,37 & 9,48 & 8,69 & 7,29 & 6,14 & 4,43 \\
\hline 40,81 & 758,00 & 48,00 & 50,82 & 43,04 & 38,39 & 32,88 & 28,06 & 23,94 & 17,64 & 13,41 & 8,71 \\
\hline 37,03 & 1360,40 & 124,60 & 24,14 & 19,53 & 16,87 & 13,85 & 11,38 & 9,40 & 6,63 & 4,96 & 3,27 \\
\hline 54,61 & 241,30 & 68,50 & 58,48 & 38,17 & 30,88 & 24,59 & 20,08 & 16,62 & 11,84 & 8,99 & 6,02 \\
\hline 37,90 & 1091,80 & 170,70 & 21,31 & 15,93 & 13,27 & 10,49 & 8,38 & 6,79 & 4,71 & 3,53 & 2,37 \\
\hline 54,85 & 1569,70 & 34,60 & 40,45 & 33,67 & 32,31 & 30,20 & 28,03 & 25,93 & 22,02 & 18,63 & 13,43 \\
\hline 42,19 & 707,60 & 48,50 & 50,58 & 42,46 & 37,81 & 32,38 & 27,66 & 23,62 & 17,43 & 13,27 & 8,63 \\
\hline 55,80 & 355,30 & 153,20 & 32,86 & 19,34 & 14,87 & 11,36 & 9,06 & 7,39 & 5,19 & 3,95 & 2,69 \\
\hline 83,21 & 537,90 & 61,60 & 34,16 & 24,13 & 21,33 & 18,87 & 16,99 & 15,36 & 12,58 & 10,40 & 7,33 \\
\hline 70,03 & 1662,40 & 107,80 & 16,39 & 12,68 & 11,66 & 10,58 & 9,63 & 8,77 & 7,25 & 6,01 & 4,23 \\
\hline 80,54 & 1425,70 & 116,10 & 15,66 & 11,50 & 10,43 & 9,42 & 8,59 & 7,85 & 6,55 & 5,49 & 3,93 \\
\hline 71,17 & 993,40 & 69,30 & 26,04 & 19,98 & 18,30 & 16,55 & 15,05 & 13,68 & 11,28 & 9,34 & 6,57 \\
\hline 67,96 & 1130,30 & 161,00 & 15,86 & 11,45 & 9,94 & 8,56 & 7,49 & 6,57 & 5,09 & 4,03 & 2,71 \\
\hline 87,66 & 1076,20 & 139,10 & 15,77 & 10,84 & 9,47 & 8,33 & 7,48 & 6,76 & 5,54 & 4,58 & 3,25 \\
\hline 83,06 & 443,10 & 87,00 & 32,30 & 21,22 & 17,84 & 15,15 & 13,25 & 11,69 & 9,19 & 7,39 & 5,07 \\
\hline 89,20 & 1840,00 & 131,80 & 12,41 & 8,97 & 8,15 & 7,46 & 6,89 & 6,37 & 5,45 & 4,67 & 3,46 \\
\hline 88,73 & 393,20 & 186,30 & 26,27 & 14,36 & 10,80 & 8,33 & 6,86 & 5,80 & 4,30 & 3,36 & 2,30 \\
\hline 59,61 & 1696,80 & 164,50 & 13,83 & 10,77 & 9,59 & 8,39 & 7,38 & 6,49 & 5,04 & 3,98 & 2,66 \\
\hline 66,28 & 583,40 & 23,40 & 64,94 & 51,73 & 48,74 & 45,10 & 41,66 & 38,40 & 32,46 & 27,40 & 19,75 \\
\hline 85,48 & 1997,40 & 39,20 & 24,57 & 20,14 & 18,47 & 17,81 & 17,16 & 16,42 & 14,95 & 13,55 & 11,05 \\
\hline 71,18 & 1302,80 & 132,80 & 16,03 & 11,94 & 10,65 & 9,42 & 8,42 & 7,54 & 6,05 & 4,90 & 3,37 \\
\hline 80,20 & 1405,80 & 143,90 & 14,07 & 10,15 & 9,05 & 8,06 & 7,28 & 6,59 & 5,40 & 4,47 & 3,15 \\
\hline 59,53 & 1934,40 & 99,00 & 17,79 & 14,52 & 13,46 & 12,20 & 11,05 & 9,99 & 8,13 & 6,65 & 4,58 \\
\hline 86,39 & 1952,40 & 151,90 & 11,35 & 8,21 & 7,45 & 6,77 & 6,22 & 5,72 & 4,84 & 4,11 & 3,01 \\
\hline 64,47 & 1755,30 & 183,30 & 12,31 & 9,36 & 8,32 & 7,29 & 6,45 & 5,70 & 4,48 & 3,57 & 2,40 \\
\hline 70,98 & 1652,60 & 126,30 & 14,86 & 11,35 & 10,34 & 9,30 & 8,42 & 7,62 & 6,24 & 5,14 & 3,59 \\
\hline 43,77 & 599,30 & 73,90 & 40,94 & 31,79 & 27,35 & 22,61 & 18,77 & 15,67 & 11,22 & 8,46 & 5,56 \\
\hline 84,38 & 1554,00 & 123,70 & 14,24 & 10,35 & 9,38 & 8,50 & 7,79 & 7,15 & 6,02 & 5,09 & 3,69 \\
\hline 60,70 & 344,50 & 57,20 & 50,72 & 36,44 & 31,15 & 26,29 & 22,50 & 19,33 & 14,49 & 11,22 & 7,44 \\
\hline 86,71 & 930,00 & 55,70 & 27,53 & 20,27 & 18,61 & 17,18 & 15,94 & 14,81 & 12,76 & 10,99 & 8,22 \\
\hline 20,65 & 544,30 & 64,30 & 75,29 & 55,01 & 42,06 & 29,70 & 21,89 & 16,98 & 11,65 & 8,97 & 6,23 \\
\hline 38,27 & 837,40 & 100,30 & 32,48 & 25,34 & 21,56 & 17,45 & 14,19 & 11,64 & 8,15 & 6,10 & 4,05 \\
\hline 31,84 & 694,90 & 186,70 & 26,28 & 17,68 & 13,70 & 10,01 & 7,59 & 5,97 & 4,09 & 3,12 & 2,16 \\
\hline 67,05 & 755,90 & 188,00 & 18,39 & 12,04 & 9,91 & 8,15 & 6,88 & 5,87 & 4,36 & 3,38 & 2,26 \\
\hline 68,27 & 1820,20 & 38,90 & 30,84 & 24,61 & 23,43 & 22,37 & 21,14 & 19,91 & 17,55 & 15,40 & 11,81 \\
\hline 57,12 & 1689,60 & 136,70 & 15,77 & 12,61 & 11,36 & 10,00 & 8,83 & 7,79 & 6,07 & 4,81 & 3,21 \\
\hline 84,40 & 230,50 & 25,80 & 80,15 & 56,53 & 50,04 & 44,38 & 40,04 & 36,28 & 29,84 & 24,74 & 17,53 \\
\hline 57,21 & 397,80 & 141,80 & 31,55 & 19,43 & 15,32 & 11,98 & 9,70 & 8,00 & 5,67 & 4,32 & 2,91 \\
\hline 44,14 & 1033,90 & 137,20 & 22,62 & 17,36 & 14,86 & 12,24 & 10,13 & 8,43 & 6,02 & 4,54 & 2,99 \\
\hline 44,54 & 1360,20 & 126,80 & 21,03 & 16,99 & 14,91 & 12,62 & 10,68 & 9,05 & 6,62 & 5,02 & 3,28 \\
\hline 81,65 & 351,70 & 82,10 & 38,09 & 24,37 & 20,13 & 16,81 & 14,53 & 12,69 & 9,82 & 7,81 & 5,32 \\
\hline 61,26 & 968,20 & 69,60 & 28,37 & 22,59 & 20,55 & 18,34 & 16,42 & 14,68 & 11,72 & 9,44 & 6,41 \\
\hline 64,54 & 1705,20 & 93,30 & 18,49 & 14,74 & 13,67 & 12,42 & 11,31 & 10,29 & 8,47 & 6,99 & 4,88 \\
\hline 39,90 & 1482,70 & 97,90 & 25,72 & 21,69 & 19,26 & 16,39 & 13,91 & 11,80 & 8,62 & 6,53 & 4,24 \\
\hline 48,77 & 1303,10 & 29,00 & 52,11 & 44,77 & 42,70 & 39,43 & 36,20 & 33,10 & 27,47 & 22,75 & 15,87 \\
\hline 68,03 & 451,60 & 115,70 & 30,24 & 19,64 & 16,10 & 13,22 & 11,16 & 9,52 & 7,08 & 5,48 & 3,67 \\
\hline 20,19 & 1603,10 & 35,40 & 86,40 & 75,01 & 64,81 & 52,22 & 41,85 & 33,74 & 23,00 & 16,99 & 11,28 \\
\hline 41,37 & 863,00 & 77,70 & 35,57 & 28,90 & 25,28 & 21,19 & 17,75 & 14,92 & 10,76 & 8,12 & 5,31 \\
\hline 67,94 & 656,80 & 48,70 & 38,89 & 30,10 & 27,44 & 24,65 & 22,26 & 20,10 & 16,35 & 13,38 & 9,27 \\
\hline 87,02 & 455,90 & 24,00 & 60,22 & 44,69 & 41,19 & 38,30 & 35,72 & 33,33 & 28,94 & 25,11 & 18,98 \\
\hline 77,03 & 1658,30 & 68,80 & 20,49 & 15,74 & 14,75 & 13,78 & 12,86 & 11,98 & 10,36 & 8,94 & 6,68 \\
\hline 23,78 & 1349,70 & 198,40 & 23,75 & 17,25 & 13,36 & 9,59 & 7,14 & 5,56 & 3,80 & 2,91 & 2,02 \\
\hline 49,47 & 834,80 & 137,30 & 23,28 & 17,13 & 14,54 & 11,98 & 9,97 & 8,35 & 6,02 & 4,56 & 3,01 \\
\hline 28,79 & 1312,20 & 77,50 & 40,14 & 33,55 & 28,83 & 23,27 & 18,76 & 15,24 & 10,52 & 7,82 & 5,19 \\
\hline 80,76 & 673,90 & 89,60 & 25,62 & 17,93 & 15,66 & 13,70 & 12,21 & 10,94 & 8,82 & 7,19 & 5,00 \\
\hline 67,93 & 645,20 & 39,00 & 44,70 & 35,00 & 32,31 & 29,34 & 26,73 & 24,33 & 20,08 & 16,63 & 11,68 \\
\hline 69,66 & 1797,70 & 80,40 & 19,09 & 14,99 & 14,05 & 12,99 & 11,99 & 11,06 & 9,36 & 7,92 & 5,73 \\
\hline 84,16 & 744,40 & 113,50 & 21,41 & 14,56 & 12,55 & 10,88 & 9,67 & 8,64 & 6,94 & 5,66 & 3,94 \\
\hline 55,51 & 1183,50 & 77,30 & 26,02 & 21,29 & 19,39 & 17,24 & 15,33 & 13,60 & 10,72 & 8,53 & 5,71 \\
\hline 59,83 & 1870,50 & 195,00 & 12,02 & 9,27 & 8,22 & 7,16 & 6,28 & 5,50 & 4,25 & 3,35 & 2,23 \\
\hline 31,32 & 1723,60 & 155,30 & 21,69 & 17,40 & 14,72 & 11,70 & 9,34 & 7,54 & 5,19 & 3,87 & 2,59 \\
\hline 54,57 & 1275,30 & 95,10 & 22,52 & 18,29 & 16,51 & 14,54 & 12,82 & 11,28 & 8,77 & 6,91 & 4,59 \\
\hline 65,56 & 722,10 & 81,00 & 28,57 & 21,46 & 18,98 & 16,58 & 14,63 & 12,92 & 10,13 & 8,06 & 5,43 \\
\hline 74,33 & 501,00 & 134,60 & 26,00 & 16,48 & 13,42 & 11,02 & 9,36 & 8,04 & 6,06 & 4,73 & 3,18 \\
\hline 56,08 & 1178,50 & 58,60 & 30,80 & 25,53 & 23,64 & 21,33 & 19,23 & 17,29 & 13,93 & 11,29 & 7,68 \\
\hline 24,94 & 615,10 & 97,20 & 48,15 & 34,84 & 27,08 & 19,55 & 14,61 & 11,40 & 7,78 & 5,96 & 4,13 \\
\hline 34,18 & 344,20 & 89,40 & 52,41 & 35,59 & 27,95 & 20,77 & 15,92 & 12,59 & 8,62 & 6,55 & 4,51 \\
\hline 51,02 & 865,40 & 160,50 & 20,74 & 14,89 & 12,53 & 10,27 & 8,52 & 7,13 & 5,13 & 3,89 & 2,58 \\
\hline 60,59 & 999,40 & 174,60 & 17,05 & 12,14 & 10,34 & 8,69 & 7,41 & 6,35 & 4,74 & 3,66 & 2,43 \\
\hline
\end{tabular}




\begin{tabular}{|c|c|c|c|c|c|c|c|c|c|c|c|}
\hline & & & \multicolumn{9}{|c|}{ Deflexões $\left(\times 10^{-4} \mathrm{~cm}\right)$} \\
\hline e1 (cm) & Meq (MPa) & Ms (MPa) & D0 & D25 & D40 & D60 & D80 & D100 & D140 & D180 & D260 \\
\hline 61,08 & 333,00 & 35,40 & 66,12 & 50,71 & 44,93 & 39,16 & 34,38 & 30,19 & 23,40 & 18,48 & 12,34 \\
\hline 58,41 & 1724,00 & 84,30 & 20,77 & 17,05 & 15,84 & 14,36 & 13,01 & 11,76 & 9,57 & 7,81 & 5,37 \\
\hline 56,83 & 236,80 & 128,20 & 44,91 & 24,85 & 18,49 & 13,77 & 10,84 & 8,78 & 6,13 & 4,68 & 3,21 \\
\hline 28,76 & 711,20 & 136,00 & 33,69 & 24,02 & 18,87 & 13,86 & 10,49 & 8,23 & 5,62 & 4,28 & 2,96 \\
\hline 22,82 & 764,30 & 135,10 & 37,62 & 26,37 & 19,92 & 13,99 & 10,33 & 8,04 & 5,54 & 4,27 & 2,97 \\
\hline 71,37 & 506,80 & 40,20 & 47,35 & 36,01 & 32,71 & 29,38 & 26,57 & 24,04 & 19,65 & 16,16 & 11,27 \\
\hline 71,15 & 970,90 & 81,10 & 24,03 & 18,22 & 16,50 & 14,76 & 13,32 & 12,02 & 9,79 & 8,02 & 5,57 \\
\hline 89,15 & 1443,40 & 30,60 & 31,34 & 25,67 & 23,43 & 22,54 & 21,73 & 20,80 & 18,96 & 17,22 & 14,10 \\
\hline 69,49 & 1019,20 & 181,50 & 15,64 & 10,84 & 9,23 & 7,83 & 6,78 & 5,90 & 4,52 & 3,55 & 2,38 \\
\hline 74,65 & 1956,20 & 99,10 & 15,64 & 12,02 & 11,19 & 10,33 & 9,55 & 8,82 & 7,50 & 6,37 & 4,64 \\
\hline 31,50 & 1679,00 & 110,30 & 27,27 & 22,73 & 19,66 & 16,03 & 13,06 & 10,70 & 7,46 & 5,55 & 3,66 \\
\hline 48,43 & 1157,60 & 194,90 & 16,77 & 12,30 & 10,41 & 8,53 & 7,07 & 5,89 & 4,23 & 3,20 & 2,12 \\
\hline 42,89 & 1933,60 & 124,60 & 19,01 & 16,05 & 14,36 & 12,38 & 10,64 & 9,13 & 6,80 & 5,20 & 3,38 \\
\hline 28,42 & 1311,50 & 105,80 & 32,92 & 26,52 & 22,27 & 17,49 & 13,80 & 11,04 & 7,53 & 5,63 & 3,79 \\
\hline 20,05 & 806,90 & 123,40 & 42,64 & 29,81 & 22,15 & 15,28 & 11,18 & 8,70 & 6,03 & 4,67 & 3,25 \\
\hline 47,34 & 282,20 & 112,00 & 44,86 & 27,33 & 21,13 & 15,98 & 12,55 & 10,11 & 7,01 & 5,33 & 3,64 \\
\hline 37,86 & 1310,90 & 28,40 & 62,81 & 56,86 & 53,08 & 47,76 & 42,66 & 37,92 & 29,83 & 23,60 & 15,57 \\
\hline 33,98 & 710,70 & 138,60 & 30,40 & 21,82 & 17,58 & 13,36 & 10,36 & 8,24 & 5,63 & 4,26 & 2,91 \\
\hline 21,37 & 1574,30 & 145,90 & 30,40 & 23,09 & 18,16 & 13,17 & 9,82 & 7,63 & 5,18 & 3,96 & 2,74 \\
\hline 42,86 & 201,50 & 42,00 & 91,22 & 64,64 & 53,18 & 42,01 & 33,70 & 27,43 & 19,12 & 14,40 & 9,67 \\
\hline 70,77 & 852,20 & 178,70 & 17,24 & 11,57 & 9,69 & 8,12 & 6,97 & 6,03 & 4,58 & 3,59 & 2,41 \\
\hline 50,36 & 1369,90 & 191,90 & 15,34 & 11,58 & 9,97 & 8,34 & 7,02 & 5,94 & 4,34 & 3,30 & 2,17 \\
\hline 47,16 & 1429,90 & 27,80 & 53,34 & 46,04 & 44,05 & 40,77 & 37,49 & 34,33 & 28,56 & 23,70 & 16,57 \\
\hline 45,44 & 326,70 & 97,90 & 45,14 & 29,53 & 23,54 & 18,19 & 14,42 & 11,67 & 8,11 & 6,13 & 4,16 \\
\hline 59,39 & 973,30 & 113,50 & 21,80 & 16,60 & 14,59 & 12,61 & 10,97 & 9,56 & 7,32 & 5,73 & 3,80 \\
\hline 83,39 & 1071,40 & 155,60 & 15,27 & 10,48 & 9,07 & 7,89 & 7,03 & 6,29 & 5,06 & 4,13 & 2,88 \\
\hline 54,99 & 1062,60 & 164,50 & 17,88 & 13,17 & 11,29 & 9,48 & 8,04 & 6,84 & 5,05 & 3,87 & 2,56 \\
\hline 77,51 & 1210,40 & 163,30 & 14,40 & 10,16 & 8,87 & 7,73 & 6,87 & 6,12 & 4,89 & 3,96 & 2,73 \\
\hline 88,59 & 1466,90 & 177,40 & 11,90 & 8,22 & 7,22 & 6,38 & 5,75 & 5,22 & 4,30 & 3,58 & 2,55 \\
\hline 26,28 & 1831,20 & 24,80 & 83,34 & 77,49 & 71,06 & 62,31 & 54,08 & 46,70 & 34,87 & 26,56 & 17,03 \\
\hline 32,71 & 1455,30 & 108,30 & 28,19 & 23,24 & 20,04 & 16,31 & 13,28 & 10,88 & 7,58 & 5,65 & 3,73 \\
\hline 42,79 & 1734,90 & 189,00 & 15,43 & 12,21 & 10,57 & 8,79 & 7,32 & 6,13 & 4,40 & 3,32 & 2,18 \\
\hline 42,44 & 1379,20 & 196,40 & 16,67 & 12,65 & 10,74 & 8,74 & 7,16 & 5,91 & 4,18 & 3,14 & 2,08 \\
\hline 58,30 & 716,10 & 73,30 & 32,15 & 24,97 & 22,14 & 19,26 & 16,84 & 14,73 & 11,34 & 8,90 & 5,91 \\
\hline 28,84 & 1904,70 & 154,90 & 22,31 & 17,99 & 15,13 & 11,91 & 9,42 & 7,55 & 5,16 & 3,85 & 2,59 \\
\hline 53,23 & 1085,50 & 116,80 & 21,71 & 16,97 & 14,93 & 12,82 & 11,05 & 9,53 & 7,17 & 5,54 & 3,64 \\
\hline 68,18 & 836,40 & 127,00 & 20,73 & 14,81 & 12,78 & 10,97 & 9,56 & 8,37 & 6,46 & 5,10 & 3,43 \\
\hline 75,96 & 428,00 & 54,20 & 42,38 & 30,31 & 26,59 & 23,27 & 20,70 & 18,47 & 14,77 & 11,97 & 8,23 \\
\hline 39,60 & 1817,70 & 81,80 & 26,90 & 23,51 & 21,29 & 18,54 & 16,05 & 13,87 & 10,41 & 7,99 & 5,18 \\
\hline 53,80 & 1349,60 & 62,80 & 28,75 & 24,11 & 22,35 & 20,15 & 18,14 & 16,27 & 13,06 & 10,54 & 7,14 \\
\hline 57,95 & 1409,70 & 53,50 & 30,07 & 24,85 & 23,38 & 21,44 & 19,61 & 17,88 & 14,79 & 12,24 & 8,56 \\
\hline 24,99 & 1131,90 & 187,60 & 25,27 & 18,16 & 14,06 & 10,12 & 7,55 & 5,89 & 4,03 & 3,09 & 2,14 \\
\hline 24,26 & 1796,70 & 118,40 & 31,04 & 25,06 & 20,77 & 15,98 & 12,39 & 9,79 & 6,62 & 4,96 & 3,38 \\
\hline 82,38 & 353,10 & 162,30 & 29,85 & 16,57 & 12,56 & 9,72 & 7,99 & 6,73 & 4,95 & 3,85 & 2,62 \\
\hline 78,72 & 1560,00 & 139,70 & 13,72 & 10,07 & 9,07 & 8,14 & 7,38 & 6,71 & 5,54 & 4,60 & 3,25 \\
\hline 66,09 & 913,20 & 172,00 & 17,35 & 12,02 & 10,17 & 8,56 & 7,35 & 6,34 & 4,79 & 3,73 & 2,49 \\
\hline 58,79 & 1093,80 & 54,50 & 32,22 & 26,40 & 24,50 & 22,21 & 20,12 & 18,18 & 14,79 & 12,08 & 8,31 \\
\hline 40,27 & 1518,30 & 89,10 & 26,87 & 22,94 & 20,52 & 17,62 & 15,08 & 12,89 & 9,52 & 7,24 & 4,70 \\
\hline 28,56 & 633,60 & 38,60 & 82,04 & 68,28 & 58,50 & 47,02 & 37,78 & 30,62 & 21,08 & 15,67 & 10,42 \\
\hline 46,17 & 1250,20 & 69,30 & 30,68 & 26,13 & 23,72 & 20,83 & 18,24 & 15,94 & 12,20 & 9,50 & 6,23 \\
\hline 81,81 & 567,10 & 123,50 & 24,29 & 15,73 & 13,09 & 11,01 & 9,55 & 8,37 & 6,52 & 5,20 & 3,55 \\
\hline 20,42 & 1204,10 & 52,70 & 70,48 & 57,67 & 47,66 & 36,37 & 27,95 & 21,94 & 14,75 & 11,07 & 7,56 \\
\hline 72,85 & 1325,00 & 144,10 & 15,07 & 11,08 & 9,84 & 8,68 & 7,75 & 6,94 & 5,56 & 4,51 & 3,10 \\
\hline 52,61 & 1677,40 & 117,80 & 18,15 & 14,91 & 13,47 & 11,86 & 10,44 & 9,17 & 7,10 & 5,58 & 3,70 \\
\hline 84,98 & 726,80 & 141,20 & 19,64 & 12,86 & 10,82 & 9,20 & 8,07 & 7,13 & 5,64 & 4,55 & 3,14 \\
\hline 46,11 & 1532,40 & 105,30 & 21,92 & 18,32 & 16,43 & 14,25 & 12,33 & 10,66 & 8,02 & 6,19 & 4,04 \\
\hline 88,05 & 356,00 & 146,40 & 30,28 & 17,07 & 13,10 & 10,30 & 8,58 & 7,31 & 5,48 & 4,30 & 2,94 \\
\hline 37,36 & 268,20 & 37,60 & 93,43 & 71,07 & 59,59 & 47,41 & 38,03 & 30,88 & 21,43 & 16,06 & 10,75 \\
\hline 63,62 & 984,70 & 161,50 & 17,47 & 12,48 & 10,70 & 9,07 & 7,81 & 6,76 & 5,12 & 3,99 & 2,65 \\
\hline 27,13 & 273,60 & 135,10 & 48,16 & 27,80 & 19,77 & 13,53 & 10,04 & 7,91 & 5,51 & 4,27 & 3,00 \\
\hline 76,88 & 1166,00 & 75,30 & 22,34 & 16,85 & 15,51 & 14,15 & 12,99 & 11,93 & 10,02 & 8,44 & 6,08 \\
\hline 26,77 & 391,50 & 146,70 & 40,42 & 24,99 & 18,22 & 12,61 & 9,35 & 7,33 & 5,09 & 3,94 & 2,75 \\
\hline 61,24 & 1157,40 & 108,30 & 20,38 & 15,85 & 14,17 & 12,45 & 11,00 & 9,72 & 7,61 & 6,05 & 4,06 \\
\hline 51,81 & 890,50 & 190,90 & 18,57 & 12,94 & 10,75 & 8,73 & 7,20 & 5,99 & 4,29 & 3,25 & 2,16 \\
\hline 48,92 & 756,00 & 49,30 & 44,10 & 36,81 & 33,26 & 29,15 & 25,51 & 22,29 & 17,07 & 13,31 & 8,75 \\
\hline 48,30 & 1740,00 & 161,50 & 15,64 & 12,58 & 11,12 & 9,52 & 8,16 & 6,99 & 5,20 & 3,99 & 2,61 \\
\hline 30,40 & 1690,70 & 109,20 & 28,15 & 23,44 & 20,19 & 16,37 & 13,26 & 10,81 & 7,50 & 5,58 & 3,69 \\
\hline 53,71 & 1710,50 & 169,00 & 14,38 & 11,36 & 10,06 & 8,69 & 7,53 & 6,53 & 4,95 & 3,85 & 2,53 \\
\hline 77,16 & 675,50 & 193,60 & 18,60 & 11,56 & 9,34 & 7,63 & 6,47 & 5,56 & 4,20 & 3,29 & 2,22 \\
\hline 58,57 & 1539,60 & 170,70 & 14,28 & 10,97 & 9,67 & 8,37 & 7,30 & 6,36 & 4,87 & 3,81 & 2,53 \\
\hline 77,72 & 407,50 & 101,30 & 32,53 & 20,76 & 17,05 & 14,13 & 12,11 & 10,49 & 8,01 & 6,31 & 4,27 \\
\hline 72,00 & 1250,50 & 82,00 & 21,34 & 16,38 & 15,06 & 13,68 & 12,48 & 11,39 & 9,45 & 7,87 & 5,57 \\
\hline 40,33 & 1639,10 & 47,20 & 39,49 & 35,29 & 32,72 & 29,26 & 26,00 & 23,00 & 17,96 & 14,14 & 9,30 \\
\hline 29,71 & 1206,30 & 49,80 & 53,99 & 46,93 & 41,39 & 34,53 & 28,64 & 23,79 & 16,82 & 12,53 & 8,16 \\
\hline 41,53 & 698,40 & 141,20 & 27,23 & 19,43 & 15,98 & 12,59 & 10,07 & 8,17 & 5,68 & 4,28 & 2,88 \\
\hline 36,77 & 810,20 & 135,70 & 28,03 & 20,70 & 17,08 & 13,35 & 10,58 & 8,52 & 5,87 & 4,41 & 2,98 \\
\hline 61,26 & 1126,10 & 124,60 & 19,09 & 14,56 & 12,86 & 11,18 & 9,80 & 8,59 & 6,64 & 5,24 & 3,49 \\
\hline 76,42 & 496,70 & 95,70 & 29,88 & 20,06 & 16,93 & 14,35 & 12,48 & 10,93 & 8,48 & 6,74 & 4,57 \\
\hline 39,36 & 524,70 & 90,30 & 40,96 & 30,13 & 25,00 & 19,76 & 15,80 & 12,82 & 8,90 & 6,68 & 4,49 \\
\hline 65,43 & 1874,50 & 97,70 & 17,21 & 13,69 & 12,73 & 11,62 & 10,61 & 9,68 & 8,01 & 6,65 & 4,68 \\
\hline 63,69 & 1334,10 & 45,50 & 32,28 & 26,01 & 24,65 & 22,91 & 21,21 & 19,59 & 16,61 & 14,06 & 10,16 \\
\hline 78,36 & 492,00 & 113,70 & 27,68 & 17,89 & 14,81 & 12,36 & 10,65 & 9,27 & 7,13 & 5,64 & 3,82 \\
\hline
\end{tabular}




\begin{tabular}{|c|c|c|c|c|c|c|c|c|c|c|c|}
\hline \multirow[b]{2}{*}{ e1 (cm) } & & & & & & & $\tilde{\text { ões }(x 1}$ & & & & \\
\hline & Meq (MPa) & Ms (MPa) & D0 & D25 & D40 & D60 & D80 & D100 & D140 & D180 & D260 \\
\hline 54,08 & 1011,30 & 138,40 & 20,23 & 15,24 & 13,19 & 11,15 & 9,50 & 8,12 & 6,02 & 4,63 & 3,05 \\
\hline 70,68 & 1511,20 & 133,80 & 14,98 & 11,33 & 10,21 & 9,10 & 8,19 & 7,37 & 5,96 & 4,87 & 3,36 \\
\hline 52,02 & 1635,00 & 129,50 & 17,44 & 14,18 & 12,72 & 11,10 & 9,70 & 8,46 & 6,48 & 5,05 & 3,33 \\
\hline 24,07 & 1453,40 & 173,50 & 25,38 & 19,04 & 15,04 & 11,00 & 8,27 & 6,45 & 4,38 & 3,34 & 2,31 \\
\hline 45,63 & 1825,30 & 28,80 & 49,66 & 42,85 & 41,24 & 38,38 & 35,45 & 32,61 & 27,35 & 22,85 & 16,12 \\
\hline 34,31 & 818,70 & 149,50 & 27,35 & 19,86 & 16,12 & 12,34 & 9,62 & 7,66 & 5,25 & 3,96 & 2,70 \\
\hline 33,03 & 975,00 & 184,40 & 22,94 & 16,53 & 13,30 & 10,07 & 7,79 & 6,18 & 4,22 & 3,19 & 2,18 \\
\hline 87,61 & 1008,00 & 103,10 & 18,91 & 13,32 & 11,86 & 10,60 & 9,63 & 8,78 & 7,32 & 6,13 & 4,41 \\
\hline 20,74 & 1889,10 & 63,20 & 53,68 & 45,18 & 38,17 & 29,92 & 23,45 & 18,63 & 12,57 & 9,35 & 6,31 \\
\hline 20,56 & 840,80 & 73,20 & 61,11 & 46,43 & 36,38 & 26,26 & 19,53 & 15,14 & 10,30 & 7,88 & 5,46 \\
\hline 80,84 & 556,10 & 96,70 & 27,39 & 18,46 & 15,73 & 13,48 & 11,85 & 10,49 & 8,29 & 6,67 & 4,58 \\
\hline 37,40 & 962,40 & 81,10 & 35,69 & 29,20 & 25,38 & 21,01 & 17,37 & 14,43 & 10,24 & 7,68 & 5,03 \\
\hline 47,25 & 236,90 & 104,20 & 50,97 & 30,23 & 23,06 & 17,26 & 13,48 & 10,82 & 7,49 & 5,70 & 3,92 \\
\hline 58,25 & 619,00 & 158,30 & 23,35 & 15,49 & 12,69 & 10,28 & 8,52 & 7,14 & 5,17 & 3,94 & 2,63 \\
\hline 20,79 & 444,10 & 28,40 & 143,79 & 113,53 & 91,46 & 67,91 & 51,28 & 39,94 & 26,94 & 20,43 & 14,07 \\
\hline 65,56 & 955,00 & 200,00 & 15,84 & 10,78 & 9,03 & 7,52 & 6,41 & 5,50 & 4,12 & 3,19 & 2,13 \\
\hline 24,41 & 1957,00 & 185,60 & 21,98 & 17,03 & 13,74 & 10,27 & 7,82 & 6,12 & 4,14 & 3,14 & 2,16 \\
\hline 46,00 & 511,00 & 158,60 & 28,21 & 18,29 & 14,54 & 11,22 & 8,89 & 7,19 & 5,00 & 3,79 & 2,57 \\
\hline 88,86 & 1264,60 & 136,50 & 14,58 & 10,19 & 9,03 & 8,04 & 7,29 & 6,64 & 5,53 & 4,63 & 3,33 \\
\hline 23,63 & 1188,00 & 171,40 & 27,45 & 19,98 & 15,47 & 11,11 & 8,27 & 6,44 & 4,40 & 3,37 & 2,34 \\
\hline 81,75 & 1555,30 & 66,50 & 20,71 & 15,72 & 14,65 & 13,72 & 12,84 & 12,01 & 10,46 & 9,09 & 6,88 \\
\hline 26,36 & 324,40 & 183,90 & 37,49 & 20,79 & 14,52 & 9,85 & 7,32 & 5,78 & 4,04 & 3,14 & 2,21 \\
\hline 87,51 & 1334,30 & 82,60 & 18,73 & 13,74 & 12,58 & 11,60 & 10,76 & 9,99 & 8,60 & 7,41 & 5,53 \\
\hline 79,53 & 1981,80 & 110,90 & 14,05 & 10,59 & 9,80 & 9,03 & 8,36 & 7,73 & 6,60 & 5,63 & 4,14 \\
\hline 79,29 & 1146,10 & 58,20 & 25,80 & 19,54 & 18,16 & 16,83 & 15,62 & 14,50 & 12,44 & 10,67 & 7,90 \\
\hline 58,75 & 249,20 & 30,60 & 83,34 & 63,12 & 55,26 & 47,52 & 41,19 & 35,76 & 27,20 & 21,21 & 14,05 \\
\hline 58,69 & 495,50 & 64,10 & 40,75 & 30,63 & 26,70 & 22,88 & 19,77 & 17,12 & 12,97 & 10,09 & 6,68 \\
\hline 48,59 & 331,20 & 36,20 & 74,47 & 58,59 & 51,23 & 43,41 & 36,89 & 31,41 & 23,14 & 17,67 & 11,58 \\
\hline 33,62 & 1161,30 & 81,70 & 35,87 & 29,83 & 25,90 & 21,29 & 17,47 & 14,41 & 10,12 & 7,55 & 4,96 \\
\hline 35,50 & 643,70 & 180,50 & 26,32 & 17,60 & 13,79 & 10,26 & 7,88 & 6,24 & 4,28 & 3,25 & 2,24 \\
\hline 79,33 & 660,10 & 110,10 & 23,67 & 16,13 & 13,80 & 11,85 & 10,43 & 9,23 & 7,29 & 5,86 & 4,02 \\
\hline 60,54 & 938,00 & 197,80 & 16,60 & 11,41 & 9,54 & 7,90 & 6,66 & 5,65 & 4,17 & 3,20 & 2,13 \\
\hline 71,89 & 482,00 & 58,10 & 39,49 & 28,79 & 25,36 & 22,19 & 19,69 & 17,51 & 13,91 & 11,19 & 7,64 \\
\hline 83,33 & 217,50 & 32,30 & 74,49 & 50,99 & 44,07 & 38,28 & 34,03 & 30,42 & 24,46 & 19,94 & 13,86 \\
\hline 68,60 & 708,60 & 192,50 & 18,76 & 12,01 & 9,79 & 7,99 & 6,73 & 5,73 & 4,25 & 3,29 & 2,20 \\
\hline 37,28 & 735,60 & 199,50 & 22,99 & 15,48 & 12,24 & 9,22 & 7,14 & 5,68 & 3,90 & 2,96 & 2,03 \\
\hline 23,16 & 1878,60 & 76,30 & 43,08 & 36,27 & 30,84 & 24,43 & 19,33 & 15,47 & 10,50 & 7,80 & 5,23 \\
\hline 22,09 & 1379,50 & 148,40 & 30,45 & 22,83 & 17,86 & 12,90 & 9,62 & 7,47 & 5,09 & 3,89 & 2,70 \\
\hline 30,29 & 1063,90 & 169,10 & 24,72 & 18,25 & 14,70 & 11,08 & 8,52 & 6,73 & 4,58 & 3,47 & 2,38 \\
\hline 47,65 & 720,00 & 144,10 & 24,77 & 17,61 & 14,66 & 11,82 & 9,67 & 7,98 & 5,66 & 4,27 & 2,85 \\
\hline 41,10 & 394,90 & 153,00 & 33,90 & 20,95 & 16,09 & 11,95 & 9,23 & 7,35 & 5,06 & 3,85 & 2,66 \\
\hline 40,02 & 1357,50 & 147,60 & 20,64 & 16,34 & 14,06 & 11,56 & 9,53 & 7,90 & 5,60 & 4,20 & 2,77 \\
\hline 62,81 & 1741,10 & 58,30 & 25,25 & 20,42 & 19,36 & 17,99 & 16,65 & 15,37 & 13,02 & 11,00 & 7,93 \\
\hline 78,00 & 1249,20 & 39,10 & 32,13 & 24,94 & 23,43 & 22,21 & 20,94 & 19,69 & 17,34 & 15,21 & 11,68 \\
\hline 64,43 & 1177,70 & 75,70 & 24,29 & 19,23 & 17,66 & 15,92 & 14,40 & 13,01 & 10,58 & 8,65 & 5,98 \\
\hline 30,98 & 431,30 & 77,70 & 55,44 & 40,16 & 32,12 & 24,08 & 18,48 & 14,59 & 9,95 & 7,54 & 5,18 \\
\hline 54,06 & 1247,60 & 29,20 & 49,30 & 41,26 & 39,50 & 36,77 & 34,02 & 31,36 & 26,46 & 22,26 & 15,89 \\
\hline 51,16 & 1123,20 & 34,30 & 47,13 & 40,22 & 37,95 & 34,73 & 31,65 & 28,74 & 23,54 & 19,30 & 13,30 \\
\hline 31,54 & 777,90 & 123,10 & 33,10 & 24,52 & 19,89 & 15,13 & 11,71 & 9,29 & 6,34 & 4,78 & 3,27 \\
\hline 45,16 & 893,30 & 162,40 & 21,62 & 15,69 & 13,13 & 10,58 & 8,63 & 7,11 & 5,02 & 3,78 & 2,52 \\
\hline 57,43 & 1837,60 & 160,50 & 13,83 & 10,96 & 9,82 & 8,61 & 7,58 & 6,67 & 5,18 & 4,08 & 2,72 \\
\hline 30,63 & 519,70 & 94,90 & 45,91 & 33,15 & 26,44 & 19,75 & 15,12 & 11,93 & 8,13 & 6,17 & 4,24 \\
\hline 31,61 & 1323,20 & 193,90 & 20,43 & 15,32 & 12,51 & 9,58 & 7,45 & 5,92 & 4,04 & 3,04 & 2,07 \\
\hline 44,87 & 442,50 & 67,10 & 48,49 & 36,37 & 30,86 & 25,22 & 20,76 & 17,22 & 12,25 & 9,23 & 6,11 \\
\hline 23,11 & 660,10 & 71,70 & 61,38 & 46,32 & 36,56 & 26,68 & 20,01 & 15,58 & 10,58 & 8,08 & 5,58 \\
\hline 60,88 & 880,10 & 68,90 & 29,81 & 23,60 & 21,36 & 18,96 & 16,89 & 15,03 & 11,92 & 9,55 & 6,45 \\
\hline 79,44 & 1225,60 & 134,50 & 15,62 & 11,22 & 9,96 & 8,82 & 7,93 & 7,15 & 5,83 & 4,79 & 3,35 \\
\hline 40,16 & 1674,10 & 85,80 & 26,60 & 22,99 & 20,71 & 17,93 & 15,45 & 13,29 & 9,91 & 7,58 & 4,92 \\
\hline 39,89 & 1753,90 & 82,20 & 27,02 & 23,54 & 21,29 & 18,51 & 16,01 & 13,82 & 10,36 & 7,94 & 5,15 \\
\hline 47,55 & 1414,10 & 98,90 & 23,02 & 19,15 & 17,20 & 14,96 & 12,99 & 11,27 & 8,53 & 6,60 & 4,32 \\
\hline 50,61 & 397,70 & 133,90 & 33,66 & 21,26 & 16,82 & 13,05 & 10,44 & 8,51 & 5,96 & 4,52 & 3,06 \\
\hline 83,34 & 242,60 & 197,80 & 37,36 & 18,21 & 12,62 & 8,94 & 6,95 & 5,63 & 3,97 & 3,06 & 2,12 \\
\hline 51,64 & 296,90 & 143,40 & 38,20 & 21,96 & 16,59 & 12,42 & 9,74 & 7,86 & 5,47 & 4,17 & 2,86 \\
\hline 79,82 & 960,40 & 173,80 & 15,65 & 10,51 & 8,92 & 7,62 & 6,67 & 5,89 & 4,63 & 3,71 & 2,54 \\
\hline 81,15 & 1977,90 & 41,70 & 24,99 & 20,05 & 18,62 & 17,93 & 17,17 & 16,35 & 14,75 & 13,26 & 10,62 \\
\hline 53,89 & 1634,50 & 161,20 & 15,04 & 11,87 & 10,52 & 9,09 & 7,89 & 6,84 & 5,19 & 4,03 & 2,66 \\
\hline 74,29 & 1330,10 & 59,30 & 24,95 & 19,27 & 18,05 & 16,76 & 15,56 & 14,43 & 12,35 & 10,56 & 7,77 \\
\hline 50,85 & 950,60 & 152,70 & 20,41 & 15,05 & 12,82 & 10,62 & 8,89 & 7,48 & 5,42 & 4,12 & 2,72 \\
\hline 83,49 & 693,60 & 119,50 & 21,80 & 14,60 & 12,44 & 10,68 & 9,42 & 8,36 & 6,65 & 5,38 & 3,72 \\
\hline 40,61 & 1119,70 & 115,50 & 25,57 & 20,40 & 17,65 & 14,60 & 12,10 & 10,07 & 7,18 & 5,40 & 3,55 \\
\hline 30,87 & 1004,40 & 176,30 & 24,27 & 17,65 & 14,14 & 10,62 & 8,15 & 6,44 & 4,39 & 3,32 & 2,28 \\
\hline 68,52 & 745,60 & 180,40 & 18,72 & 12,29 & 10,14 & 8,37 & 7,10 & 6,08 & 4,54 & 3,53 & 2,36 \\
\hline 57,64 & 1581,50 & 185,00 & 13,61 & 10,41 & 9,14 & 7,87 & 6,82 & 5,92 & 4,50 & 3,51 & 2,32 \\
\hline 86,07 & 1664,40 & 72,70 & 18,52 & 13,95 & 12,92 & 12,12 & 11,38 & 10,67 & 9,35 & 8,18 & 6,26 \\
\hline 43,61 & 972,30 & 47,40 & 44,49 & 38,44 & 34,97 & 30,72 & 26,86 & 23,43 & 17,87 & 13,87 & 9,06 \\
\hline 33,91 & 682,80 & 117,40 & 34,28 & 25,15 & 20,48 & 15,72 & 12,26 & 9,78 & 6,69 & 5,04 & 3,43 \\
\hline 72,21 & 1147,50 & 114,90 & 18,26 & 13,58 & 12,13 & 10,75 & 9,63 & 8,64 & 6,96 & 5,66 & 3,90 \\
\hline 24,46 & 1323,60 & 195,90 & 23,70 & 17,28 & 13,45 & 9,71 & 7,26 & 5,66 & 3,86 & 2,96 & 2,05 \\
\hline 29,85 & 417,10 & 32,70 & 101,83 & 82,77 & 70,19 & 55,84 & 44,55 & 35,94 & 24,67 & 18,39 & 12,30 \\
\hline 22,39 & 1095,60 & 169,30 & 29,25 & 20,87 & 15,88 & 11,21 & 8,28 & 6,44 & 4,42 & 3,41 & 2,37 \\
\hline 43,35 & 792,40 & 116,70 & 28,09 & 21,20 & 17,98 & 14,64 & 12,01 & 9,93 & 7,03 & 5,29 & 3,50 \\
\hline 40,34 & 1315,40 & 36,50 & 50,39 & 45,07 & 41,85 & 37,50 & 33,37 & 29,58 & 23,15 & 18,27 & 12,04 \\
\hline
\end{tabular}




\begin{tabular}{|c|c|c|c|c|c|c|c|c|c|c|c|}
\hline \multirow[b]{2}{*}{ e1 (cm) } & & & & & & & ões (x1 & m) & & & \\
\hline & Meq (MPa) & Ms (MPa) & DO & D25 & D40 & D60 & D80 & D100 & D140 & D180 & D260 \\
\hline 40,69 & 1214,20 & 85,70 & 29,71 & 24,87 & 22,04 & 18,74 & 15,88 & 13,47 & 9,84 & 7,46 & 4,85 \\
\hline 61,94 & 1972,70 & 145,90 & 13,62 & 10,79 & 9,81 & 8,75 & 7,83 & 7,00 & 5,59 & 4,51 & 3,06 \\
\hline 50,66 & 1855,10 & 68,70 & 25,22 & 21,56 & 20,13 & 18,25 & 16,48 & 14,83 & 11,95 & 9,67 & 6,56 \\
\hline 69,71 & 620,60 & 39,90 & 44,23 & 34,29 & 31,55 & 28,62 & 26,07 & 23,73 & 19,60 & 16,25 & 11,43 \\
\hline 48,38 & 600,40 & 101,50 & 32,27 & 23,66 & 20,01 & 16,40 & 13,57 & 11,32 & 8,11 & 6,14 & 4,06 \\
\hline 48,28 & 720,30 & 165,60 & 22,87 & 15,79 & 12,99 & 10,37 & 8,43 & 6,93 & 4,89 & 3,70 & 2,47 \\
\hline 69,35 & 793,60 & 184,00 & 17,84 & 11,79 & 9,77 & 8,10 & 6,90 & 5,93 & 4,45 & 3,47 & 2,32 \\
\hline 46,07 & 406,80 & 164,00 & 31,14 & 18,93 & 14,58 & 10,97 & 8,58 & 6,89 & 4,77 & 3,63 & 2,49 \\
\hline 54,54 & 229,00 & 84,00 & 54,93 & 33,74 & 26,49 & 20,55 & 16,51 & 13,52 & 9,53 & 7,24 & 4,90 \\
\hline 24,62 & 1354,30 & 106,70 & 35,96 & 28,52 & 23,39 & 17,80 & 13,69 & 10,78 & 7,29 & 5,49 & 3,75 \\
\hline 28,42 & 1338,80 & 49,10 & 54,65 & 47,79 & 42,19 & 35,19 & 29,17 & 24,21 & 17,09 & 12,71 & 8,27 \\
\hline 38,93 & 1501,20 & 165,40 & 18,85 & 14,89 & 12,77 & 10,44 & 8,55 & 7,06 & 4,98 & 3,73 & 2,46 \\
\hline 59,97 & 366,80 & 59,20 & 48,58 & 35,13 & 30,11 & 25,43 & 21,76 & 18,70 & 14,01 & 10,84 & 7,18 \\
\hline 61,88 & 844,10 & 69,20 & 29,98 & 23,56 & 21,27 & 18,86 & 16,79 & 14,94 & 11,84 & 9,49 & 6,41 \\
\hline 87,11 & 1235,80 & 109,50 & 16,66 & 11,91 & 10,71 & 9,66 & 8,83 & 8,09 & 6,80 & 5,74 & 4,17 \\
\hline 47,72 & 1429,10 & 28,60 & 51,92 & 44,71 & 42,77 & 39,58 & 36,40 & 33,34 & 27,75 & 23,04 & 16,12 \\
\hline 25,88 & 355,80 & 122,10 & 47,77 & 30,04 & 21,95 & 15,18 & 11,24 & 8,81 & 6,11 & 4,73 & 3,31 \\
\hline 81,77 & 1354,80 & 23,00 & 40,97 & 33,94 & 31,22 & 30,19 & 29,13 & 27,90 & 25,43 & 23,08 & 18,84 \\
\hline 48,77 & 620,00 & 38,90 & 55,18 & 46,23 & 41,85 & 36,75 & 32,21 & 28,18 & 21,64 & 16,89 & 11,11 \\
\hline 87,70 & 699,00 & 97,20 & 23,45 & 15,98 & 13,87 & 12,13 & 10,86 & 9,78 & 7,97 & 6,57 & 4,63 \\
\hline 89,91 & 1972,90 & 118,60 & 12,69 & 9,28 & 8,49 & 7,85 & 7,30 & 6,80 & 5,89 & 5,10 & 3,84 \\
\hline 28,62 & 1442,00 & 153,10 & 24,76 & 19,29 & 15,89 & 12,22 & 9,50 & 7,54 & 5,13 & 3,85 & 2,62 \\
\hline 20,86 & 585,80 & 118,20 & 46,74 & 31,51 & 23,08 & 15,80 & 11,58 & 9,03 & 6,29 & 4,88 & 3,40 \\
\hline 76,33 & 1480,50 & 114,30 & 15,93 & 11,92 & 10,85 & 9,80 & 8,92 & 8,13 & 6,75 & 5,62 & 3,99 \\
\hline 45,27 & 435,90 & 96,70 & 39,69 & 27,72 & 22,78 & 18,06 & 14,56 & 11,90 & 8,34 & 6,29 & 4,22 \\
\hline 25,03 & 1644,90 & 188,00 & 22,56 & 17,12 & 13,68 & 10,13 & 7,67 & 6,00 & 4,07 & 3,09 & 2,13 \\
\hline 26,28 & 1923,20 & 160,30 & 23,23 & 18,47 & 15,27 & 11,74 & 9,11 & 7,22 & 4,89 & 3,67 & 2,50 \\
\hline 49,18 & 1993,90 & 99,60 & 19,68 & 16,74 & 15,35 & 13,67 & 12,13 & 10,74 & 8,40 & 6,65 & 4,41 \\
\hline 54,81 & 1967,70 & 85,80 & 20,35 & 17,02 & 15,85 & 14,36 & 12,99 & 11,71 & 9,49 & 7,71 & 5,27 \\
\hline 26,99 & 224,00 & 68,20 & 80,86 & 52,41 & 39,02 & 27,38 & 20,34 & 15,92 & 10,99 & 8,49 & 5,92 \\
\hline 51,16 & 1864,10 & 84,10 & 21,91 & 18,59 & 17,20 & 15,46 & 13,85 & 12,37 & 9,85 & 7,89 & 5,30 \\
\hline 66,86 & 1125,30 & 183,40 & 15,01 & 10,64 & 9,13 & 7,78 & 6,74 & 5,86 & 4,49 & 3,52 & 2,36 \\
\hline 56,13 & 1172,60 & 52,70 & 33,00 & 27,43 & 25,54 & 23,17 & 20,98 & 18,94 & 15,38 & 12,53 & 8,59 \\
\hline 30,93 & 699,80 & 70,30 & 50,16 & 39,65 & 33,21 & 26,10 & 20,65 & 16,57 & 11,35 & 8,48 & 5,71 \\
\hline 30,76 & 345,00 & 137,20 & 42,07 & 25,86 & 19,15 & 13,52 & 10,11 & 7,94 & 5,48 & 4,23 & 2,95 \\
\hline 40,86 & 1240,40 & 114,20 & 24,63 & 19,96 & 17,41 & 14,54 & 12,14 & 10,17 & 7,31 & 5,51 & 3,60 \\
\hline 82,05 & 1377,40 & 38,80 & 29,95 & 23,36 & 21,79 & 20,80 & 19,74 & 18,68 & 16,64 & 14,78 & 11,59 \\
\hline 25,25 & 657,80 & 189,10 & 29,45 & 19,18 & 14,18 & 9,86 & 7,29 & 5,71 & 3,95 & 3,06 & 2,13 \\
\hline 88,54 & 475,60 & 74,80 & 32,47 & 21,72 & 18,64 & 16,15 & 14,37 & 12,88 & 10,42 & 8,55 & 6,00 \\
\hline 63,90 & 1080,00 & 127,50 & 18,81 & 14,11 & 12,42 & 10,80 & 9,47 & 8,32 & 6,46 & 5,11 & 3,42 \\
\hline 77,06 & 332,20 & 136,20 & 33,29 & 19,13 & 14,76 & 11,58 & 9,57 & 8,06 & 5,93 & 4,60 & 3,11 \\
\hline 72,16 & 1492,70 & 128,90 & 15,23 & 11,48 & 10,37 & 9,27 & 8,36 & 7,55 & 6,14 & 5,04 & 3,50 \\
\hline 26,37 & 234,50 & 111,80 & 57,92 & 33,68 & 23,94 & 16,35 & 12,12 & 9,54 & 6,65 & 5,16 & 3,62 \\
\hline 64,11 & 1557,80 & 25,90 & 44,48 & 35,92 & 34,34 & 32,95 & 31,23 & 29,48 & 26,10 & 22,98 & 17,71 \\
\hline 41,25 & 1632,70 & 44,30 & 40,58 & 36,21 & 33,73 & 30,33 & 27,11 & 24,12 & 19,01 & 15,08 & 9,99 \\
\hline 56,81 & 403,90 & 121,20 & 33,59 & 21,56 & 17,35 & 13,81 & 11,29 & 9,37 & 6,69 & 5,09 & 3,41 \\
\hline 24,42 & 1704,10 & 78,50 & 41,70 & 34,98 & 29,76 & 23,62 & 18,74 & 15,03 & 10,23 & 7,60 & 5,09 \\
\hline 77,90 & 1531,40 & 106,30 & 16,21 & 12,14 & 11,12 & 10,12 & 9,27 & 8,50 & 7,12 & 5,99 & 4,30 \\
\hline 41,44 & 439,60 & 116,40 & 37,22 & 25,14 & 20,15 & 15,50 & 12,21 & 9,82 & 6,79 & 5,13 & 3,49 \\
\hline 59,93 & 950,30 & 194,60 & 16,69 & 11,55 & 9,69 & 8,03 & 6,77 & 5,75 & 4,24 & 3,26 & 2,16 \\
\hline 55,62 & 1241,70 & 132,90 & 18,57 & 14,44 & 12,74 & 11,00 & 9,54 & 8,28 & 6,28 & 4,89 & 3,23 \\
\hline 66,13 & 1269,00 & 79,40 & 22,59 & 17,78 & 16,37 & 14,81 & 13,44 & 12,18 & 9,98 & 8,21 & 5,72 \\
\hline 80,85 & 1782,70 & 99,80 & 15,48 & 11,62 & 10,75 & 9,92 & 9,19 & 8,51 & 7,28 & 6,23 & 4,60 \\
\hline 59,95 & 459,30 & 168,60 & 26,64 & 16,21 & 12,74 & 9,98 & 8,11 & 6,71 & 4,78 & 3,65 & 2,46 \\
\hline 68,16 & 1329,40 & 115,00 & 17,57 & 13,43 & 12,12 & 10,79 & 9,68 & 8,69 & 6,99 & 5,68 & 3,90 \\
\hline 55,50 & 1129,20 & 149,40 & 18,20 & 13,73 & 11,93 & 10,14 & 8,69 & 7,46 & 5,58 & 4,30 & 2,84 \\
\hline 35,24 & 1231,60 & 182,70 & 20,38 & 15,34 & 12,71 & 9,95 & 7,88 & 6,34 & 4,36 & 3,27 & 2,21 \\
\hline 50,00 & 1093,10 & 139,30 & 20,33 & 15,60 & 13,52 & 11,37 & 9,62 & 8,17 & 5,99 & 4,57 & 3,00 \\
\hline 56,35 & 427,00 & 107,60 & 34,52 & 23,06 & 18,92 & 15,29 & 12,63 & 10,55 & 7,60 & 5,78 & 3,86 \\
\hline 22,53 & 1814,70 & 193,00 & 23,05 & 17,37 & 13,66 & 9,92 & 7,42 & 5,77 & 3,92 & 3,00 & 2,07 \\
\hline 21,70 & 1423,50 & 151,10 & 30,16 & 22,58 & 17,61 & 12,69 & 9,44 & 7,33 & 4,99 & 3,82 & 2,65 \\
\hline 37,73 & 1742,20 & 166,60 & 18,11 & 14,58 & 12,58 & 10,33 & 8,49 & 7,02 & 4,96 & 3,71 & 2,45 \\
\hline 54,04 & 1330,20 & 28,70 & 48,92 & 40,86 & 39,22 & 36,63 & 33,99 & 31,42 & 26,65 & 22,52 & 16,19 \\
\hline 65,05 & 806,00 & 107,50 & 23,45 & 17,24 & 15,04 & 12,98 & 11,34 & 9,93 & 7,67 & 6,05 & 4,05 \\
\hline 20,66 & 487,30 & 134,00 & 44,82 & 28,52 & 20,33 & 13,71 & 10,06 & 7,89 & 5,53 & 4,30 & 3,01 \\
\hline 45,99 & 1627,00 & 29,00 & 50,77 & 43,95 & 42,13 & 39,04 & 35,93 & 32,93 & 27,42 & 22,78 & 15,94 \\
\hline 23,48 & 739,00 & 131,40 & 38,14 & 26,83 & 20,38 & 14,40 & 10,66 & 8,30 & 5,70 & 4,40 & 3,05 \\
\hline 72,28 & 911,10 & 125,30 & 19,50 & 13,96 & 12,16 & 10,55 & 9,30 & 8,23 & 6,48 & 5,18 & 3,52 \\
\hline 89,34 & 677,30 & 190,00 & 18,01 & 10,94 & 8,82 & 7,24 & 6,22 & 5,42 & 4,20 & 3,36 & 2,30 \\
\hline 52,95 & 729,60 & 194,10 & 20,18 & 13,41 & 10,91 & 8,71 & 7,11 & 5,88 & 4,18 & 3,17 & 2,12 \\
\hline 81,24 & 835,10 & 114,90 & 20,29 & 14,12 & 12,29 & 10,73 & 9,55 & 8,55 & 6,88 & 5,61 & 3,89 \\
\hline 81,00 & 1257,60 & 130,90 & 15,52 & 11,15 & 9,94 & 8,84 & 7,98 & 7,23 & 5,93 & 4,91 & 3,46 \\
\hline 80,34 & 1963,90 & 119,40 & 13,44 & 10,06 & 9,27 & 8,51 & 7,86 & 7,25 & 6,17 & 5,25 & 3,84 \\
\hline 43,73 & 1381,00 & 113,10 & 22,67 & 18,62 & 16,46 & 14,01 & 11,91 & 10,14 & 7,45 & 5,66 & 3,69 \\
\hline 62,74 & 658,10 & 127,20 & 24,30 & 16,89 & 14,26 & 11,92 & 10,15 & 8,69 & 6,49 & 5,02 & 3,34 \\
\hline 22,19 & 706,10 & 140,50 & 37,95 & 25,95 & 19,29 & 13,37 & 9,83 & 7,67 & 5,31 & 4,11 & 2,86 \\
\hline 36,05 & 1397,70 & 52,20 & 42,49 & 37,69 & 34,15 & 29,65 & 25,57 & 22,00 & 16,37 & 12,49 & 8,07 \\
\hline 39,25 & 1632,00 & 124,20 & 21,66 & 17,97 & 15,80 & 13,28 & 11,14 & 9,37 & 6,76 & 5,09 & 3,32 \\
\hline 43,29 & 456,00 & 44,00 & 62,66 & 50,43 & 44,08 & 37,04 & 31,14 & 26,25 & 19,04 & 14,40 & 9,42 \\
\hline 52,33 & 1356,30 & 161,20 & 16,60 & 12,82 & 11,19 & 9,52 & 8,14 & 6,97 & 5,19 & 3,99 & 2,62 \\
\hline 71,34 & 578,60 & 190,40 & 21,04 & 12,85 & 10,23 & 8,20 & 6,84 & 5,79 & 4,27 & 3,30 & 2,22 \\
\hline 83,86 & 1071,60 & 72,00 & 22,76 & 16,76 & 15,34 & 14,04 & 12,95 & 11,95 & 10,17 & 8,66 & 6,36 \\
\hline
\end{tabular}




\begin{tabular}{|c|c|c|c|c|c|c|c|c|c|c|c|}
\hline \multirow[b]{2}{*}{ e1 (cm) } & & & & & & $\mathrm{De}$ & ões (x1 & & & & \\
\hline & Meq (MPa) & Ms (MPa) & D0 & D25 & D40 & D60 & D80 & D100 & D140 & D180 & D260 \\
\hline 39,25 & 1946,90 & 38,70 & 43,67 & 39,32 & 36,98 & 33,54 & 30,21 & 27,08 & 21,62 & 17,31 & 11,56 \\
\hline 89,33 & 874,80 & 61,00 & 26,48 & 19,17 & 17,44 & 15,99 & 14,78 & 13,69 & 11,73 & 10,07 & 7,49 \\
\hline 84,12 & 1483,80 & 111,30 & 15,43 & 11,27 & 10,26 & 9,33 & 8,57 & 7,88 & 6,66 & 5,64 & 4,11 \\
\hline 32,23 & 1945,20 & 79,20 & 31,59 & 27,70 & 24,69 & 20,93 & 17,63 & 14,84 & 10,69 & 8,02 & 5,19 \\
\hline 31,76 & 246,20 & 76,20 & 67,99 & 44,38 & 33,89 & 24,49 & 18,48 & 14,53 & 9,97 & 7,64 & 5,30 \\
\hline 22,60 & 881,20 & 40,60 & 85,79 & 71,09 & 59,67 & 46,50 & 36,33 & 28,82 & 19,47 & 14,52 & 9,83 \\
\hline 74,57 & 1595,30 & 169,50 & 12,54 & 9,19 & 8,18 & 7,23 & 6,48 & 5,82 & 4,70 & 3,83 & 2,65 \\
\hline 72,85 & 380,30 & 61,10 & 43,18 & 30,17 & 25,92 & 22,24 & 19,46 & 17,11 & 13,33 & 10,60 & 7,17 \\
\hline 67,90 & 1846,20 & 31,00 & 35,74 & 28,81 & 27,35 & 26,34 & 25,07 & 23,75 & 21,19 & 18,80 & 14,70 \\
\hline 87,64 & 574,90 & 171,70 & 20,84 & 12,55 & 10,05 & 8,20 & 7,00 & 6,07 & 4,67 & 3,71 & 2,54 \\
\hline 39,76 & 548,00 & 157,00 & 29,09 & 19,33 & 15,31 & 11,61 & 9,05 & 7,24 & 4,98 & 3,77 & 2,58 \\
\hline 59,30 & 273,80 & 165,50 & 37,07 & 19,85 & 14,51 & 10,68 & 8,37 & 6,78 & 4,73 & 3,62 & 2,49 \\
\hline 74,09 & 1976,90 & 164,60 & 11,60 & 8,70 & 7,88 & 7,07 & 6,41 & 5,80 & 4,76 & 3,93 & 2,76 \\
\hline 74,85 & 1865,20 & 128,80 & 13,61 & 10,31 & 9,45 & 8,58 & 7,84 & 7,16 & 5,96 & 4,98 & 3,55 \\
\hline 42,31 & 1073,50 & 125,90 & 24,05 & 18,83 & 16,21 & 13,38 & 11,08 & 9,22 & 6,58 & 4,95 & 3,26 \\
\hline 66,68 & 1807,60 & 167,40 & 12,57 & 9,60 & 8,62 & 7,63 & 6,81 & 6,08 & 4,85 & 3,91 & 2,66 \\
\hline 68,01 & 777,00 & 133,10 & 21,07 & 14,77 & 12,61 & 10,72 & 9,28 & 8,07 & 6,17 & 4,85 & 3,25 \\
\hline 33,54 & 1061,40 & 81,50 & 37,18 & 30,60 & 26,42 & 21,56 & 17,59 & 14,45 & 10,10 & 7,53 & 4,97 \\
\hline 37,34 & 1398,60 & 172,60 & 19,40 & 15,05 & 12,74 & 10,24 & 8,28 & 6,76 & 4,71 & 3,52 & 2,35 \\
\hline 53,71 & 269,00 & 66,50 & 56,37 & 38,00 & 31,18 & 25,10 & 20,63 & 17,14 & 12,26 & 9,31 & 6,21 \\
\hline 45,45 & 756,30 & 49,70 & 46,11 & 38,74 & 34,79 & 30,20 & 26,14 & 22,61 & 17,02 & 13,12 & 8,56 \\
\hline 84,64 & 512,50 & 48,70 & 39,19 & 28,06 & 25,14 & 22,54 & 20,50 & 18,70 & 15,56 & 13,03 & 9,34 \\
\hline 46,41 & 306,40 & 71,10 & 54,48 & 37,64 & 30,85 & 24,47 & 19,75 & 16,16 & 11,35 & 8,56 & 5,74 \\
\hline 84,05 & 1268,70 & 30,10 & 35,31 & 28,09 & 26,00 & 24,98 & 23,89 & 22,73 & 20,48 & 18,39 & 14,72 \\
\hline 82,09 & 480,60 & 138,80 & 25,64 & 15,73 & 12,68 & 10,37 & 8,84 & 7,64 & 5,82 & 4,59 & 3,12 \\
\hline 21,18 & 1439,40 & 186,30 & 26,19 & 18,99 & 14,49 & 10,22 & 7,54 & 5,85 & 4,02 & 3,10 & 2,15 \\
\hline 68,04 & 647,70 & 154,20 & 21,76 & 14,34 & 11,86 & 9,80 & 8,31 & 7,12 & 5,32 & 4,13 & 2,76 \\
\hline 62,50 & 1873,20 & 102,20 & 17,17 & 13,80 & 12,79 & 11,60 & 10,53 & 9,54 & 7,81 & 6,41 & 4,45 \\
\hline 44,82 & 1595,40 & 28,30 & 52,83 & 46,04 & 44,05 & 40,72 & 37,39 & 34,18 & 28,33 & 23,42 & 16,28 \\
\hline 55,10 & 578,40 & 137,40 & 26,45 & 17,94 & 14,79 & 11,99 & 9,91 & 8,27 & 5,95 & 4,53 & 3,02 \\
\hline 60,76 & 846,30 & 28,70 & 52,56 & 42,88 & 40,63 & 37,61 & 34,70 & 31,92 & 26,85 & 22,55 & 16,11 \\
\hline 59,56 & 1485,40 & 189,80 & 13,59 & 10,21 & 8,91 & 7,65 & 6,63 & 5,76 & 4,38 & 3,42 & 2,26 \\
\hline 61,37 & 387,00 & 48,00 & 52,20 & 39,20 & 34,34 & 29,64 & 25,81 & 22,52 & 17,28 & 13,55 & 9,02 \\
\hline 82,03 & 870,90 & 51,40 & 30,51 & 22,76 & 20,98 & 19,33 & 17,88 & 16,55 & 14,15 & 12,10 & 8,92 \\
\hline 50,31 & 1523,90 & 77,90 & 25,01 & 21,16 & 19,42 & 17,31 & 15,39 & 13,65 & 10,72 & 8,50 & 5,66 \\
\hline 24,72 & 1520,80 & 20,80 & 105,22 & 97,39 & 88,67 & 76,95 & 66,07 & 56,49 & 41,50 & 31,30 & 20,03 \\
\hline 49,61 & 1406,60 & 80,30 & 25,51 & 21,49 & 19,58 & 17,32 & 15,29 & 13,47 & 10,45 & 8,22 & 5,44 \\
\hline 31,24 & 1909,60 & 186,50 & 18,61 & 14,77 & 12,42 & 9,81 & 7,78 & 6,26 & 4,30 & 3,21 & 2,16 \\
\hline 72,44 & 649,60 & 64,20 & 32,44 & 24,13 & 21,58 & 19,15 & 17,17 & 15,41 & 12,44 & 10,13 & 6,99 \\
\hline 20,55 & 1133,80 & 62,40 & 63,28 & 50,66 & 41,20 & 30,89 & 23,46 & 18,31 & 12,33 & 9,31 & 6,40 \\
\hline 74,13 & 1898,10 & 118,30 & 14,27 & 10,90 & 10,05 & 9,17 & 8,40 & 7,70 & 6,45 & 5,41 & 3,87 \\
\hline 72,97 & 850,60 & 85,10 & 24,54 & 18,19 & 16,26 & 14,42 & 12,93 & 11,61 & 9,38 & 7,64 & 5,28 \\
\hline 77,39 & 729,20 & 134,90 & 20,63 & 13,90 & 11,78 & 10,02 & 8,75 & 7,69 & 6,00 & 4,78 & 3,25 \\
\hline 37,59 & 621,80 & 177,90 & 26,28 & 17,49 & 13,77 & 10,34 & 7,99 & 6,36 & 4,37 & 3,31 & 2,27 \\
\hline 45,61 & 597,70 & 74,50 & 39,77 & 30,79 & 26,55 & 22,08 & 18,44 & 15,47 & 11,16 & 8,44 & 5,54 \\
\hline 57,21 & 1803,20 & 96,00 & 19,04 & 15,66 & 14,46 & 13,03 & 11,74 & 10,55 & 8,49 & 6,87 & 4,68 \\
\hline 63,29 & 1673,70 & 96,00 & 18,50 & 14,80 & 13,67 & 12,38 & 11,23 & 10,17 & 8,31 & 6,82 & 4,73 \\
\hline 22,72 & 1439,70 & 29,10 & 92,11 & 82,13 & 72,62 & 60,45 & 49,89 & 41,19 & 28,82 & 21,32 & 13,87 \\
\hline 81,35 & 1834,50 & 174,30 & 11,14 & 8,06 & 7,23 & 6,47 & 5,87 & 5,34 & 4,41 & 3,67 & 2,61 \\
\hline 76,60 & 1685,60 & 144,60 & 13,17 & 9,77 & 8,83 & 7,93 & 7,19 & 6,53 & 5,38 & 4,45 & 3,14 \\
\hline 20,21 & 497,20 & 34,80 & 122,65 & 95,32 & 75,77 & 55,43 & 41,48 & 32,20 & 21,79 & 16,61 & 11,47 \\
\hline 57,01 & 1610,80 & 175,30 & 13,99 & 10,82 & 9,54 & 8,25 & 7,17 & 6,24 & 4,75 & 3,71 & 2,45 \\
\hline 40,36 & 1969,60 & 124,80 & 19,70 & 16,69 & 14,87 & 12,71 & 10,83 & 9,22 & 6,78 & 5,15 & 3,34 \\
\hline 28,81 & 1687,70 & 99,00 & 31,35 & 26,23 & 22,55 & 18,22 & 14,69 & 11,94 & 8,24 & 6,13 & 4,06 \\
\hline 54,55 & 993,20 & 173,30 & 18,05 & 13,02 & 11,05 & 9,18 & 7,72 & 6,53 & 4,78 & 3,65 & 2,41 \\
\hline 86,56 & 258,60 & 55,10 & 52,82 & 33,91 & 28,24 & 23,82 & 20,79 & 18,33 & 14,44 & 11,63 & 8,01 \\
\hline 53,31 & 484,90 & 135,20 & 29,62 & 19,45 & 15,76 & 12,54 & 10,21 & 8,43 & 5,99 & 4,55 & 3,05 \\
\hline 71,49 & 908,20 & 68,20 & 27,23 & 20,78 & 18,95 & 17,07 & 15,48 & 14,04 & 11,52 & 9,51 & 6,66 \\
\hline 37,77 & 1147,20 & 60,60 & 39,89 & 34,40 & 30,76 & 26,33 & 22,43 & 19,09 & 14,00 & 10,61 & 6,87 \\
\hline 30,66 & 1733,70 & 77,50 & 34,72 & 30,05 & 26,49 & 22,11 & 18,35 & 15,26 & 10,81 & 8,06 & 5,25 \\
\hline 57,31 & 979,90 & 94,40 & 24,54 & 19,26 & 17,14 & 14,94 & 13,08 & 11,45 & 8,82 & 6,92 & 4,59 \\
\hline 89,57 & 1345,10 & 147,10 & 13,58 & 9,45 & 8,37 & 7,45 & 6,75 & 6,15 & 5,12 & 4,29 & 3,09 \\
\hline 61,41 & 1328,80 & 116,60 & 18,38 & 14,38 & 12,92 & 11,40 & 10,11 & 8,96 & 7,05 & 5,62 & 3,78 \\
\hline 80,59 & 691,00 & 102,20 & 23,77 & 16,42 & 14,20 & 12,32 & 10,93 & 9,74 & 7,79 & 6,32 & 4,36 \\
\hline 21,85 & 685,00 & 38,50 & 98,59 & 79,63 & 65,47 & 49,76 & 38,18 & 29,97 & 20,19 & 15,18 & 10,38 \\
\hline 27,33 & 290,20 & 182,80 & 38,98 & 20,99 & 14,57 & 9,88 & 7,35 & 5,81 & 4,06 & 3,15 & 2,23 \\
\hline 78,99 & 1516,00 & 70,80 & 20,55 & 15,63 & 14,57 & 13,56 & 12,62 & 11,74 & 10,12 & 8,71 & 6,49 \\
\hline 73,90 & 1771,00 & 137,20 & 13,50 & 10,19 & 9,27 & 8,35 & 7,59 & 6,89 & 5,68 & 4,71 & 3,31 \\
\hline 75,81 & 1158,20 & 146,10 & 15,70 & 11,24 & 9,86 & 8,63 & 7,68 & 6,85 & 5,48 & 4,44 & 3,05 \\
\hline 45,92 & 299,10 & 35,70 & 81,17 & 63,24 & 54,74 & 45,72 & 38,32 & 32,24 & 23,35 & 17,68 & 11,60 \\
\hline 44,45 & 1030,00 & 84,00 & 30,14 & 24,76 & 21,92 & 18,71 & 15,95 & 13,60 & 10,03 & 7,65 & 4,99 \\
\hline 41,77 & 965,80 & 83,70 & 32,33 & 26,40 & 23,16 & 19,50 & 16,40 & 13,83 & 10,02 & 7,57 & 4,94 \\
\hline 86,74 & 592,00 & 141,20 & 22,06 & 13,88 & 11,42 & 9,53 & 8,26 & 7,24 & 5,66 & 4,53 & 3,11 \\
\hline 46,97 & 998,40 & 100,10 & 26,52 & 21,16 & 18,57 & 15,75 & 13,39 & 11,39 & 8,38 & 6,39 & 4,18 \\
\hline 73,10 & 1771,60 & 62,70 & 21,86 & 17,05 & 16,09 & 15,09 & 14,11 & 13,16 & 11,39 & 9,84 & 7,35 \\
\hline 49,89 & 1677,30 & 129,90 & 17,69 & 14,50 & 12,98 & 11,29 & 9,82 & 8,53 & 6,48 & 5,03 & 3,30 \\
\hline 35,35 & 233,90 & 97,10 & 57,84 & 35,24 & 26,45 & 19,05 & 14,42 & 11,38 & 7,83 & 6,00 & 4,18 \\
\hline 72,61 & 362,40 & 55,60 & 46,37 & 32,65 & 28,17 & 24,25 & 21,26 & 18,72 & 14,63 & 11,66 & 7,89 \\
\hline 48,29 & 1771,00 & 115,80 & 18,96 & 15,85 & 14,30 & 12,51 & 10,93 & 9,53 & 7,28 & 5,66 & 3,72 \\
\hline 71,08 & 936,40 & 115,80 & 20,16 & 14,69 & 12,91 & 11,27 & 9,98 & 8,85 & 7,00 & 5,62 & 3,82 \\
\hline 40,20 & 1326,90 & 55,20 & 38,35 & 33,68 & 30,67 & 26,89 & 23,44 & 20,37 & 15,43 & 11,91 & 7,75 \\
\hline 39,56 & 1698,60 & 111,80 & 22,64 & 19,09 & 16,94 & 14,40 & 12,20 & 10,35 & 7,55 & 5,71 & 3,71 \\
\hline
\end{tabular}




\begin{tabular}{|c|c|c|c|c|c|c|c|c|c|c|c|}
\hline \multirow[b]{2}{*}{ e1 (cm) } & & & & & & $\mathrm{De}$ & ões (x1 & & & & \\
\hline & Meq (MPa) & Ms (MPa) & D0 & D25 & D40 & D60 & D80 & D100 & D140 & D180 & D260 \\
\hline 54,93 & 1619,10 & 74,50 & 23,85 & 19,91 & 18,49 & 16,72 & 15,09 & 13,58 & 10,96 & 8,88 & 6,05 \\
\hline 65,84 & 1733,00 & 179,30 & 12,41 & 9,40 & 8,36 & 7,35 & 6,51 & 5,78 & 4,56 & 3,65 & 2,47 \\
\hline 74,95 & 1774,20 & 188,60 & 11,25 & 8,23 & 7,33 & 6,48 & 5,81 & 5,22 & 4,21 & 3,44 & 2,38 \\
\hline 71,09 & 1585,70 & 131,10 & 14,80 & 11,24 & 10,18 & 9,11 & 8,23 & 7,43 & 6,05 & 4,96 & 3,45 \\
\hline 66,10 & 1138,50 & 139,60 & 17,21 & 12,76 & 11,21 & 9,74 & 8,56 & 7,54 & 5,88 & 4,67 & 3,14 \\
\hline 43,14 & 1309,30 & 134,00 & 21,11 & 16,85 & 14,67 & 12,26 & 10,27 & 8,63 & 6,23 & 4,70 & 3,08 \\
\hline 41,52 & 663,00 & 192,40 & 23,45 & 15,52 & 12,32 & 9,41 & 7,38 & 5,92 & 4,09 & 3,09 & 2,11 \\
\hline 38,16 & 1978,10 & 104,40 & 22,96 & 19,80 & 17,72 & 15,19 & 12,96 & 11,05 & 8,12 & 6,16 & 3,99 \\
\hline 28,14 & 332,00 & 162,90 & 39,47 & 22,88 & 16,36 & 11,26 & 8,36 & 6,58 & 4,58 & 3,55 & 2,49 \\
\hline 82,36 & 561,40 & 192,10 & 20,65 & 12,23 & 9,64 & 7,74 & 6,52 & 5,58 & 4,20 & 3,30 & 2,24 \\
\hline 50,93 & 1112,00 & 91,90 & 25,34 & 20,57 & 18,37 & 15,95 & 13,86 & 12,04 & 9,14 & 7,10 & 4,66 \\
\hline 62,05 & 1175,80 & 136,20 & 17,72 & 13,40 & 11,81 & 10,25 & 8,97 & 7,86 & 6,07 & 4,79 & 3,20 \\
\hline 55,49 & 224,00 & 180,70 & 41,42 & 20,52 & 14,27 & 10,03 & 7,67 & 6,12 & 4,24 & 3,26 & 2,28 \\
\hline 51,56 & 786,70 & 56,20 & 38,77 & 31,88 & 28,75 & 25,23 & 22,13 & 19,38 & 14,92 & 11,68 & 7,71 \\
\hline 43,41 & 620,30 & 126,70 & 29,79 & 21,18 & 17,48 & 13,87 & 11,16 & 9,10 & 6,36 & 4,79 & 3,21 \\
\hline 73,04 & 1697,30 & 196,40 & 11,38 & 8,30 & 7,34 & 6,45 & 5,74 & 5,12 & 4,09 & 3,31 & 2,27 \\
\hline 22,03 & 848,60 & 117,00 & 41,42 & 29,98 & 22,96 & 16,27 & 12,03 & 9,35 & 6,41 & 4,93 & 3,43 \\
\hline 24,96 & 490,30 & 198,00 & 31,45 & 18,97 & 13,57 & 9,27 & 6,85 & 5,38 & 3,75 & 2,91 & 2,04 \\
\hline 88,45 & 1881,90 & 44,40 & 22,82 & 18,33 & 16,81 & 16,15 & 15,50 & 14,79 & 13,41 & 12,11 & 9,81 \\
\hline 74,28 & 1964,50 & 69,90 & 19,45 & 15,12 & 14,25 & 13,38 & 12,52 & 11,69 & 10,14 & 8,78 & 6,58 \\
\hline 32,79 & 1795,60 & 188,60 & 18,24 & 14,40 & 12,13 & 9,62 & 7,67 & 6,19 & 4,26 & 3,19 & 2,13 \\
\hline 87,17 & 818,50 & 132,90 & 18,70 & 12,50 & 10,70 & 9,24 & 8,20 & 7,33 & 5,90 & 4,82 & 3,37 \\
\hline 72,58 & 822,60 & 108,60 & 22,01 & 15,83 & 13,84 & 12,04 & 10,64 & 9,44 & 7,46 & 5,98 & 4,08 \\
\hline 87,29 & 1781,40 & 139,30 & 12,35 & 8,91 & 8,07 & 7,34 & 6,74 & 6,21 & 5,26 & 4,48 & 3,28 \\
\hline 57,99 & 1320,90 & 112,60 & 19,40 & 15,40 & 13,82 & 12,15 & 10,72 & 9,45 & 7,37 & 5,83 & 3,89 \\
\hline 89,98 & 1480,90 & 28,20 & 31,99 & 26,81 & 24,33 & 23,42 & 22,66 & 21,76 & 19,94 & 18,21 & 15,05 \\
\hline 88,11 & 1947,50 & 122,90 & 12,65 & 9,25 & 8,47 & 7,80 & 7,23 & 6,72 & 5,78 & 4,98 & 3,72 \\
\hline 72,73 & 1400,40 & 156,80 & 14,05 & 10,31 & 9,13 & 8,04 & 7,17 & 6,40 & 5,12 & 4,15 & 2,85 \\
\hline 64,85 & 1879,30 & 54,10 & 25,38 & 20,36 & 19,39 & 18,19 & 16,97 & 15,79 & 13,57 & 11,63 & 8,57 \\
\hline 89,51 & 1557,00 & 98,90 & 15,64 & 11,40 & 10,41 & 9,59 & 8,90 & 8,27 & 7,13 & 6,15 & 4,61 \\
\hline 87,32 & 1589,60 & 71,70 & 18,87 & 14,15 & 13,08 & 12,27 & 11,51 & 10,79 & 9,46 & 8,28 & 6,34 \\
\hline 84,51 & 274,20 & 115,10 & 39,35 & 22,21 & 17,03 & 13,34 & 11,07 & 9,39 & 6,99 & 5,46 & 3,72 \\
\hline 69,78 & 1010,10 & 161,80 & 16,56 & 11,68 & 10,04 & 8,59 & 7,49 & 6,55 & 5,06 & 4,00 & 2,69 \\
\hline 58,23 & 1524,90 & 134,30 & 16,46 & 13,01 & 11,65 & 10,23 & 9,02 & 7,94 & 6,18 & 4,88 & 3,26 \\
\hline 32,69 & 364,70 & 108,00 & 46,59 & 30,74 & 23,68 & 17,26 & 13,09 & 10,31 & 7,06 & 5,40 & 3,74 \\
\hline 85,17 & 1563,00 & 90,50 & 16,85 & 12,48 & 11,49 & 10,61 & 9,85 & 9,15 & 7,88 & 6,78 & 5,06 \\
\hline 41,05 & 1910,60 & 54,50 & 33,64 & 30,00 & 27,87 & 24,99 & 22,26 & 19,75 & 15,49 & 12,24 & 8,08 \\
\hline 52,58 & 1537,60 & 121,80 & 18,42 & 14,96 & 13,42 & 11,73 & 10,26 & 8,97 & 6,88 & 5,38 & 3,55 \\
\hline 29,51 & 1218,20 & 156,60 & 25,26 & 19,22 & 15,68 & 11,95 & 9,25 & 7,33 & 4,98 & 3,76 & 2,56 \\
\hline 57,29 & 956,40 & 105,60 & 23,30 & 17,98 & 15,84 & 13,69 & 11,90 & 10,35 & 7,89 & 6,16 & 4,07 \\
\hline 49,02 & 754,90 & 158,60 & 22,71 & 15,96 & 13,25 & 10,69 & 8,75 & 7,24 & 5,14 & 3,89 & 2,59 \\
\hline 74,14 & 1993,10 & 81,90 & 17,54 & 13,59 & 12,76 & 11,90 & 11,07 & 10,29 & 8,85 & 7,60 & 5,63 \\
\hline 54,48 & 1235,60 & 45,10 & 36,54 & 30,69 & 28,83 & 26,33 & 23,98 & 21,76 & 17,83 & 14,63 & 10,10 \\
\hline 43,19 & 1973,50 & 90,20 & 23,02 & 19,99 & 18,23 & 16,05 & 14,07 & 12,29 & 9,40 & 7,31 & 4,78 \\
\hline 56,00 & 572,90 & 76,80 & 35,44 & 26,66 & 23,14 & 19,68 & 16,86 & 14,49 & 10,84 & 8,37 & 5,52 \\
\hline 64,92 & 618,60 & 198,60 & 20,41 & 12,70 & 10,15 & 8,11 & 6,71 & 5,64 & 4,10 & 3,14 & 2,11 \\
\hline 64,73 & 335,00 & 80,20 & 42,72 & 28,35 & 23,42 & 19,27 & 16,25 & 13,83 & 10,24 & 7,90 & 5,27 \\
\hline 53,73 & 1197,00 & 47,80 & 35,86 & 30,19 & 28,21 & 25,62 & 23,21 & 20,96 & 17,01 & 13,85 & 9,47 \\
\hline 79,70 & 486,50 & 53,10 & 39,40 & 28,30 & 25,12 & 22,26 & 20,03 & 18,07 & 14,74 & 12,13 & 8,50 \\
\hline 20,50 & 1705,00 & 125,20 & 34,19 & 26,50 & 21,05 & 15,39 & 11,52 & 8,95 & 6,06 & 4,62 & 3,19 \\
\hline 56,86 & 1898,20 & 66,40 & 23,87 & 19,83 & 18,71 & 17,19 & 15,75 & 14,38 & 11,92 & 9,88 & 6,92 \\
\hline 53,18 & 1487,70 & 73,40 & 25,30 & 21,22 & 19,59 & 17,59 & 15,77 & 14,10 & 11,24 & 9,02 & 6,08 \\
\hline 42,82 & 296,50 & 29,40 & 95,45 & 76,54 & 66,72 & 55,85 & 46,80 & 39,34 & 28,41 & 21,46 & 14,04 \\
\hline 72,08 & 1103,30 & 170,50 & 15,22 & 10,72 & 9,25 & 7,95 & 6,96 & 6,13 & 4,78 & 3,80 & 2,57 \\
\hline 59,33 & 1167,90 & 101,10 & 21,47 & 16,94 & 15,21 & 13,39 & 11,83 & 10,45 & 8,18 & 6,49 & 4,34 \\
\hline 72,37 & 1367,70 & 37,00 & 33,85 & 26,65 & 25,24 & 23,96 & 22,57 & 21,21 & 18,62 & 16,28 & 12,42 \\
\hline 24,87 & 1962,20 & 116,10 & 30,05 & 24,63 & 20,67 & 16,14 & 12,65 & 10,07 & 6,83 & 5,09 & 3,44 \\
\hline 80,12 & 1810,40 & 114,50 & 14,27 & 10,66 & 9,81 & 8,99 & 8,28 & 7,63 & 6,47 & 5,49 & 4,01 \\
\hline 26,45 & 1462,00 & 185,40 & 22,78 & 17,16 & 13,74 & 10,23 & 7,78 & 6,10 & 4,14 & 3,14 & 2,16 \\
\hline 33,76 & 1840,70 & 21,10 & 76,16 & 69,65 & 66,08 & 60,35 & 54,68 & 49,26 & 39,65 & 31,92 & 21,39 \\
\hline 62,46 & 1699,40 & 109,00 & 17,14 & 13,68 & 12,55 & 11,28 & 10,17 & 9,16 & 7,41 & 6,03 & 4,13 \\
\hline 32,14 & 1418,50 & 178,40 & 20,83 & 16,01 & 13,26 & 10,32 & 8,11 & 6,49 & 4,44 & 3,33 & 2,25 \\
\hline 77,35 & 450,60 & 144,20 & 26,74 & 16,22 & 12,93 & 10,44 & 8,79 & 7,51 & 5,63 & 4,39 & 2,97 \\
\hline 27,36 & 1984,80 & 95,50 & 31,71 & 26,90 & 23,25 & 18,85 & 15,25 & 12,41 & 8,57 & 6,36 & 4,21 \\
\hline 29,00 & 1876,60 & 150,50 & 22,76 & 18,39 & 15,50 & 12,23 & 9,69 & 7,78 & 5,32 & 3,97 & 2,67 \\
\hline 86,52 & 1732,70 & 180,60 & 10,95 & 7,73 & 6,87 & 6,13 & 5,56 & 5,06 & 4,20 & 3,51 & 2,51 \\
\hline 36,04 & 482,00 & 109,20 & 39,65 & 27,70 & 22,19 & 16,86 & 13,10 & 10,43 & 7,15 & 5,41 & 3,70 \\
\hline 56,30 & 798,40 & 28,50 & 56,30 & 46,89 & 44,18 & 40,52 & 37,05 & 33,77 & 27,90 & 23,05 & 16,08 \\
\hline 43,38 & 673,70 & 47,20 & 51,42 & 43,03 & 38,36 & 32,95 & 28,23 & 24,17 & 17,92 & 13,69 & 8,91 \\
\hline 69,34 & 1271,70 & 70,60 & 23,66 & 18,48 & 17,15 & 15,67 & 14,35 & 13,13 & 10,95 & 9,14 & 6,49 \\
\hline 64,13 & 999,00 & 39,40 & 39,04 & 31,38 & 29,57 & 27,31 & 25,17 & 23,15 & 19,47 & 16,36 & 11,70 \\
\hline 72,30 & 1114,20 & 128,70 & 17,42 & 12,75 & 11,27 & 9,90 & 8,81 & 7,85 & 6,26 & 5,06 & 3,46 \\
\hline 75,19 & 456,00 & 156,00 & 25,97 & 15,60 & 12,34 & 9,88 & 8,26 & 7,01 & 5,20 & 4,04 & 2,72 \\
\hline 82,17 & 397,20 & 95,00 & 33,34 & 21,21 & 17,47 & 14,56 & 12,57 & 10,97 & 8,48 & 6,75 & 4,59 \\
\hline 57,92 & 1310,60 & 159,90 & 16,01 & 12,17 & 10,65 & 9,15 & 7,92 & 6,86 & 5,21 & 4,05 & 2,68 \\
\hline 51,75 & 284,80 & 181,40 & 35,64 & 18,97 & 13,73 & 9,94 & 7,68 & 6,15 & 4,26 & 3,26 & 2,26 \\
\hline 83,56 & 713,40 & 29,20 & 45,67 & 34,65 & 32,24 & 30,30 & 28,44 & 26,66 & 23,35 & 20,41 & 15,59 \\
\hline 20,11 & 590,30 & 72,70 & 68,40 & 49,41 & 37,42 & 26,19 & 19,23 & 14,92 & 10,27 & 7,93 & 5,51 \\
\hline 69,60 & 261,70 & 169,10 & 37,24 & 19,37 & 13,99 & 10,27 & 8,11 & 6,61 & 4,67 & 3,58 & 2,46 \\
\hline 79,31 & 1233,00 & 121,00 & 16,47 & 11,97 & 10,71 & 9,56 & 8,64 & 7,82 & 6,42 & 5,31 & 3,74 \\
\hline 74,99 & 1825,00 & 31,20 & 32,87 & 26,68 & 24,94 & 24,12 & 23,11 & 22,02 & 19,87 & 17,84 & 14,27 \\
\hline 26,91 & 247,90 & 85,50 & 67,27 & 42,40 & 31,18 & 21,71 & 16,10 & 12,62 & 8,74 & 6,76 & 4,72 \\
\hline
\end{tabular}




\begin{tabular}{|c|c|c|c|c|c|c|c|c|c|c|c|}
\hline & & & \multicolumn{9}{|c|}{ Deflexões $\left(\times 10^{-4} \mathrm{~cm}\right)$} \\
\hline e1 (cm) & Meq (MPa) & Ms (MPa) & D0 & D25 & D40 & D60 & D80 & D100 & D140 & D180 & D260 \\
\hline 21,38 & 437,00 & 100,10 & 56,35 & 37,34 & 27,21 & 18,60 & 13,64 & 10,66 & 7,43 & 5,76 & 4,02 \\
\hline 45,82 & 1275,00 & 129,70 & 20,92 & 16,68 & 14,60 & 12,33 & 10,42 & 8,83 & 6,46 & 4,91 & 3,21 \\
\hline 46,84 & 1634,80 & 84,60 & 24,25 & 20,72 & 18,90 & 16,70 & 14,70 & 12,91 & 9,97 & 7,80 & 5,13 \\
\hline 42,54 & 515,90 & 129,50 & 32,28 & 22,03 & 17,80 & 13,82 & 10,96 & 8,85 & 6,14 & 4,63 & 3,14 \\
\hline 72,04 & 1161,30 & 154,90 & 15,55 & 11,19 & 9,77 & 8,50 & 7,50 & 6,64 & 5,24 & 4,20 & 2,85 \\
\hline 34,56 & 1782,20 & 21,70 & 74,17 & 67,66 & 64,19 & 58,63 & 53,13 & 47,89 & 38,58 & 31,08 & 20,86 \\
\hline 30,12 & 460,30 & 116,80 & 42,20 & 28,65 & 22,11 & 16,05 & 12,11 & 9,50 & 6,51 & 4,98 & 3,45 \\
\hline 60,85 & 1007,70 & 121,10 & 20,47 & 15,46 & 13,57 & 11,73 & 10,22 & 8,92 & 6,85 & 5,37 & 3,57 \\
\hline 38,73 & 1558,00 & 78,30 & 29,75 & 25,77 & 23,16 & 19,97 & 17,13 & 14,67 & 10,86 & 8,27 & 5,36 \\
\hline 81,99 & 862,70 & 186,10 & 16,02 & 10,39 & 8,65 & 7,28 & 6,33 & 5,55 & 4,32 & 3,45 & 2,36 \\
\hline 58,44 & 1500,90 & 24,80 & 49,59 & 40,46 & 38,98 & 37,11 & 34,94 & 32,78 & 28,63 & 24,87 & 18,71 \\
\hline 63,25 & 1820,20 & 30,00 & 38,71 & 31,29 & 29,95 & 28,72 & 27,20 & 25,66 & 22,69 & 19,95 & 15,33 \\
\hline 47,41 & 970,10 & 199,60 & 18,16 & 12,84 & 10,66 & 8,57 & 6,99 & 5,77 & 4,08 & 3,08 & 2,05 \\
\hline 34,53 & 1653,90 & 172,10 & 19,23 & 15,25 & 12,94 & 10,38 & 8,36 & 6,80 & 4,71 & 3,52 & 2,35 \\
\hline 48,06 & 467,70 & 33,50 & 68,17 & 56,53 & 50,73 & 44,13 & 38,33 & 33,26 & 25,20 & 19,51 & 12,78 \\
\hline 25,28 & 1627,40 & 121,30 & 30,51 & 24,45 & 20,24 & 15,56 & 12,07 & 9,55 & 6,46 & 4,85 & 3,30 \\
\hline 42,22 & 736,60 & 93,00 & 33,59 & 26,00 & 22,26 & 18,26 & 15,05 & 12,48 & 8,87 & 6,67 & 4,40 \\
\hline 83,88 & 586,50 & 40,40 & 41,02 & 30,16 & 27,57 & 25,21 & 23,22 & 21,42 & 18,19 & 15,48 & 11,35 \\
\hline 49,89 & 1256,20 & 117,10 & 21,18 & 16,98 & 15,03 & 12,92 & 11,12 & 9,58 & 7,18 & 5,53 & 3,62 \\
\hline 86,43 & 1098,90 & 90,30 & 19,57 & 14,10 & 12,75 & 11,54 & 10,58 & 9,72 & 8,20 & 6,94 & 5,05 \\
\hline 83,88 & 664,10 & 174,70 & 19,11 & 11,89 & 9,68 & 8,00 & 6,87 & 5,98 & 4,61 & 3,66 & 2,49 \\
\hline 41,13 & 1432,40 & 174,00 & 17,97 & 14,00 & 11,99 & 9,82 & 8,07 & 6,68 & 4,74 & 3,56 & 2,35 \\
\hline 80,39 & 1959,60 & 53,50 & 21,80 & 17,05 & 15,94 & 15,22 & 14,44 & 13,66 & 12,16 & 10,78 & 8,44 \\
\hline 80,99 & 1426,50 & 170,50 & 12,75 & 9,03 & 7,96 & 7,01 & 6,29 & 5,66 & 4,60 & 3,78 & 2,64 \\
\hline 78,86 & 338,30 & 110,10 & 35,23 & 21,23 & 16,88 & 13,61 & 11,47 & 9,81 & 7,36 & 5,75 & 3,89 \\
\hline 47,85 & 1074,30 & 186,80 & 17,87 & 13,04 & 11,00 & 8,98 & 7,41 & 6,16 & 4,40 & 3,33 & 2,20 \\
\hline 71,43 & 800,30 & 97,10 & 23,77 & 17,34 & 15,26 & 13,35 & 11,83 & 10,51 & 8,33 & 6,70 & 4,57 \\
\hline 63,61 & 1150,70 & 166,40 & 15,93 & 11,62 & 10,06 & 8,62 & 7,47 & 6,50 & 4,97 & 3,89 & 2,59 \\
\hline 73,83 & 1401,60 & 92,60 & 18,71 & 14,26 & 13,11 & 11,92 & 10,90 & 9,96 & 8,30 & 6,93 & 4,94 \\
\hline 30,14 & 1763,10 & 152,60 & 22,39 & 17,99 & 15,18 & 12,00 & 9,53 & 7,67 & 5,26 & 3,92 & 2,63 \\
\hline 89,94 & 1764,30 & 126,20 & 12,90 & 9,31 & 8,45 & 7,74 & 7,15 & 6,62 & 5,67 & 4,86 & 3,62 \\
\hline 34,77 & 247,10 & 110,00 & 52,92 & 31,66 & 23,52 & 16,80 & 12,67 & 9,99 & 6,88 & 5,29 & 3,69 \\
\hline 24,85 & 342,40 & 28,00 & 137,49 & 108,70 & 89,05 & 67,68 & 52,05 & 40,99 & 27,72 & 20,86 & 14,26 \\
\hline 49,16 & 1329,20 & 181,20 & 16,26 & 12,36 & 10,64 & 8,89 & 7,47 & 6,31 & 4,59 & 3,49 & 2,29 \\
\hline 60,66 & 314,10 & 48,60 & 57,64 & 41,91 & 36,05 & 30,59 & 26,27 & 22,65 & 17,06 & 13,24 & 8,78 \\
\hline 68,51 & 1685,90 & 43,80 & 29,22 & 23,20 & 22,08 & 20,91 & 19,64 & 18,41 & 16,06 & 13,96 & 10,53 \\
\hline 23,33 & 992,00 & 90,70 & 45,88 & 35,45 & 28,43 & 21,09 & 15,95 & 12,46 & 8,43 & 6,40 & 4,41 \\
\hline 73,56 & 1663,30 & 177,30 & 12,08 & 8,88 & 7,90 & 6,98 & 6,24 & 5,60 & 4,50 & 3,66 & 2,53 \\
\hline 81,57 & 1150,10 & 51,40 & 27,29 & 20,68 & 19,25 & 17,99 & 16,81 & 15,69 & 13,62 & 11,81 & 8,90 \\
\hline 62,56 & 1339,40 & 129,00 & 17,14 & 13,23 & 11,81 & 10,38 & 9,18 & 8,12 & 6,38 & 5,08 & 3,41 \\
\hline 78,48 & 1820,60 & 156,10 & 12,06 & 8,89 & 8,03 & 7,22 & 6,56 & 5,97 & 4,94 & 4,11 & 2,91 \\
\hline 75,99 & 1624,90 & 39,30 & 29,50 & 23,28 & 21,90 & 20,96 & 19,88 & 18,79 & 16,71 & 14,79 & 11,53 \\
\hline 57,81 & 1181,40 & 138,30 & 18,19 & 13,90 & 12,20 & 10,51 & 9,12 & 7,92 & 6,02 & 4,69 & 3,11 \\
\hline 45,79 & 814,60 & 89,70 & 31,26 & 24,65 & 21,45 & 18,01 & 15,16 & 12,80 & 9,31 & 7,06 & 4,63 \\
\hline 60,56 & 930,20 & 176,30 & 17,62 & 12,36 & 10,44 & 8,72 & 7,40 & 6,32 & 4,69 & 3,62 & 2,40 \\
\hline 83,34 & 1192,50 & 145,80 & 14,91 & 10,45 & 9,19 & 8,10 & 7,27 & 6,55 & 5,35 & 4,40 & 3,09 \\
\hline 31,24 & 844,90 & 99,50 & 37,20 & 28,80 & 23,88 & 18,57 & 14,58 & 11,65 & 7,96 & 5,97 & 4,04 \\
\hline 31,46 & 1892,90 & 106,30 & 26,83 & 22,76 & 19,86 & 16,39 & 13,48 & 11,12 & 7,81 & 5,82 & 3,81 \\
\hline 50,34 & 218,90 & 178,90 & 42,45 & 21,01 & 14,56 & 10,17 & 7,73 & 6,15 & 4,25 & 3,28 & 2,30 \\
\hline 24,67 & 1529,20 & 47,80 & 60,06 & 52,30 & 45,67 & 37,45 & 30,52 & 24,97 & 17,30 & 12,81 & 8,41 \\
\hline 27,10 & 706,30 & 119,70 & 38,06 & 27,53 & 21,61 & 15,81 & 11,92 & 9,33 & 6,36 & 4,85 & 3,35 \\
\hline 82,59 & 550,30 & 138,60 & 23,55 & 14,82 & 12,13 & 10,06 & 8,66 & 7,54 & 5,82 & 4,62 & 3,14 \\
\hline 88,11 & 1138,00 & 184,70 & 13,40 & 8,94 & 7,65 & 6,61 & 5,87 & 5,25 & 4,23 & 3,46 & 2,42 \\
\hline 64,70 & 612,90 & 173,00 & 21,75 & 13,93 & 11,31 & 9,16 & 7,64 & 6,45 & 4,73 & 3,63 & 2,43 \\
\hline 27,62 & 1525,10 & 162,20 & 23,95 & 18,58 & 15,21 & 11,60 & 8,96 & 7,08 & 4,81 & 3,62 & 2,47 \\
\hline 55,87 & 1485,20 & 47,90 & 32,56 & 27,17 & 25,71 & 23,67 & 21,71 & 19,85 & 16,49 & 13,69 & 9,60 \\
\hline 49,80 & 900,40 & 158,40 & 20,75 & 15,07 & 12,72 & 10,44 & 8,66 & 7,23 & 5,20 & 3,94 & 2,61 \\
\hline 23,46 & 1281,50 & 144,20 & 30,53 & 22,99 & 18,15 & 13,26 & 9,95 & 7,75 & 5,27 & 4,02 & 2,78 \\
\hline 32,36 & 1121,20 & 184,50 & 22,06 & 16,27 & 13,20 & 10,07 & 7,81 & 6,21 & 4,24 & 3,20 & 2,18 \\
\hline 70,54 & 1070,30 & 24,40 & 49,15 & 39,04 & 37,05 & 35,37 & 33,44 & 31,51 & 27,81 & 24,44 & 18,79 \\
\hline 64,51 & 847,20 & 174,40 & 18,11 & 12,39 & 10,40 & 8,67 & 7,38 & 6,32 & 4,72 & 3,66 & 2,44 \\
\hline 52,93 & 1042,50 & 136,40 & 20,35 & 15,47 & 13,42 & 11,35 & 9,67 & 8,26 & 6,12 & 4,69 & 3,09 \\
\hline 75,85 & 277,40 & 102,10 & 41,50 & 24,49 & 19,19 & 15,24 & 12,68 & 10,74 & 7,93 & 6,16 & 4,16 \\
\hline 58,73 & 854,40 & 108,90 & 23,82 & 17,94 & 15,66 & 13,43 & 11,62 & 10,07 & 7,64 & 5,95 & 3,94 \\
\hline 37,82 & 1404,20 & 92,30 & 28,34 & 23,89 & 21,11 & 17,81 & 14,98 & 12,62 & 9,11 & 6,86 & 4,47 \\
\hline 83,67 & 1617,50 & 164,80 & 12,04 & 8,59 & 7,66 & 6,83 & 6,19 & 5,63 & 4,65 & 3,87 & 2,76 \\
\hline 66,04 & 838,80 & 116,30 & 21,93 & 15,99 & 13,90 & 11,98 & 10,46 & 9,16 & 7,07 & 5,58 & 3,74 \\
\hline 49,05 & 484,00 & 22,60 & 84,84 & 72,44 & 66,67 & 59,54 & 53,00 & 47,04 & 36,98 & 29,35 & 19,53 \\
\hline 43,75 & 1594,50 & 76,50 & 27,36 & 23,66 & 21,55 & 18,96 & 16,60 & 14,49 & 11,08 & 8,61 & 5,63 \\
\hline 46,50 & 843,60 & 64,40 & 37,14 & 30,66 & 27,35 & 23,59 & 20,32 & 17,50 & 13,10 & 10,07 & 6,57 \\
\hline 56,16 & 845,80 & 84,50 & 28,17 & 22,08 & 19,58 & 16,99 & 14,81 & 12,91 & 9,87 & 7,71 & 5,10 \\
\hline 46,98 & 1533,80 & 128,30 & 19,20 & 15,68 & 13,92 & 11,95 & 10,26 & 8,81 & 6,56 & 5,03 & 3,29 \\
\hline 73,00 & 1840,20 & 195,30 & 10,98 & 8,09 & 7,20 & 6,36 & 5,69 & 5,10 & 4,10 & 3,33 & 2,29 \\
\hline 81,27 & 955,10 & 23,00 & 47,82 & 37,84 & 35,24 & 33,82 & 32,24 & 30,61 & 27,46 & 24,53 & 19,45 \\
\hline 20,69 & 1879,70 & 51,50 & 62,10 & 53,16 & 45,50 & 36,23 & 28,76 & 23,04 & 15,62 & 11,57 & 7,74 \\
\hline 73,08 & 583,50 & 121,00 & 25,02 & 16,72 & 14,02 & 11,78 & 10,16 & 8,82 & 6,75 & 5,31 & 3,58 \\
\hline 71,24 & 878,30 & 101,10 & 22,29 & 16,38 & 14,48 & 12,70 & 11,29 & 10,05 & 7,99 & 6,44 & 4,40 \\
\hline 61,25 & 369,70 & 56,50 & 49,04 & 35,67 & 30,72 & 26,11 & 22,47 & 19,41 & 14,66 & 11,40 & 7,56 \\
\hline 28,80 & 1520,60 & 146,20 & 24,99 & 19,73 & 16,39 & 12,73 & 9,96 & 7,94 & 5,41 & 4,05 & 2,74 \\
\hline 68,67 & 273,60 & 119,70 & 40,48 & 23,23 & 17,82 & 13,80 & 11,23 & 9,34 & 6,72 & 5,16 & 3,49 \\
\hline 87,61 & 1710,60 & 169,40 & 11,33 & 8,01 & 7,15 & 6,40 & 5,82 & 5,32 & 4,44 & 3,73 & 2,69 \\
\hline 25,63 & 758,00 & 59,10 & 62,89 & 50,23 & 41,54 & 31,94 & 24,77 & 19,60 & 13,27 & 9,96 & 6,77 \\
\hline
\end{tabular}




\begin{tabular}{|c|c|c|c|c|c|c|c|c|c|c|c|}
\hline & & & \multicolumn{9}{|c|}{ Deflexões $\left(\times 10^{-4} \mathrm{~cm}\right)$} \\
\hline e1 (cm) & Meq (MPa) & Ms (MPa) & D0 & D25 & D40 & D60 & D80 & D100 & D140 & D180 & D260 \\
\hline 27,55 & 1229,60 & 185,30 & 23,46 & 17,31 & 13,77 & 10,21 & 7,75 & 6,08 & 4,14 & 3,14 & 2,17 \\
\hline 34,75 & 713,50 & 112,50 & 34,15 & 25,44 & 20,94 & 16,26 & 12,80 & 10,26 & 7,04 & 5,29 & 3,58 \\
\hline 61,19 & 1820,20 & 100,80 & 17,71 & 14,31 & 13,23 & 11,97 & 10,84 & 9,79 & 7,97 & 6,52 & 4,49 \\
\hline 37,46 & 1857,90 & 93,60 & 25,54 & 22,11 & 19,81 & 16,98 & 14,49 & 12,34 & 9,06 & 6,87 & 4,45 \\
\hline 56,52 & 760,40 & 141,30 & 22,45 & 15,95 & 13,48 & 11,19 & 9,42 & 7,98 & 5,85 & 4,48 & 2,97 \\
\hline 88,96 & 1763,90 & 53,00 & 21,20 & 16,50 & 15,20 & 14,51 & 13,82 & 13,12 & 11,77 & 10,53 & 8,38 \\
\hline 24,14 & 314,80 & 196,50 & 36,97 & 19,81 & 13,56 & 9,11 & 6,77 & 5,37 & 3,76 & 2,93 & 2,07 \\
\hline 25,10 & 1380,40 & 160,60 & 26,49 & 20,06 & 16,02 & 11,86 & 8,98 & 7,02 & 4,76 & 3,62 & 2,49 \\
\hline 20,56 & 1854,00 & 135,40 & 31,52 & 24,46 & 19,45 & 14,24 & 10,67 & 8,29 & 5,61 & 4,27 & 2,95 \\
\hline 42,42 & 594,80 & 178,10 & 25,48 & 16,73 & 13,27 & 10,14 & 7,96 & 6,39 & 4,42 & 3,34 & 2,28 \\
\hline 86,56 & 1447,50 & 66,70 & 20,56 & 15,41 & 14,26 & 13,35 & 12,50 & 11,71 & 10,24 & 8,94 & 6,82 \\
\hline 81,79 & 1294,20 & 157,70 & 13,86 & 9,77 & 8,60 & 7,57 & 6,79 & 6,11 & 4,97 & 4,08 & 2,86 \\
\hline 31,53 & 906,00 & 139,60 & 28,92 & 21,52 & 17,49 & 13,33 & 10,34 & 8,20 & 5,60 & 4,22 & 2,88 \\
\hline 35,46 & 370,70 & 164,10 & 35,18 & 21,07 & 15,70 & 11,26 & 8,51 & 6,71 & 4,62 & 3,55 & 2,47 \\
\hline 63,52 & 308,60 & 64,90 & 49,55 & 33,84 & 28,33 & 23,54 & 19,97 & 17,06 & 12,70 & 9,81 & 6,53 \\
\hline 41,22 & 1349,30 & 88,60 & 27,70 & 23,37 & 20,82 & 17,82 & 15,20 & 12,96 & 9,55 & 7,26 & 4,72 \\
\hline 36,51 & 1070,80 & 69,00 & 38,66 & 32,62 & 28,75 & 24,15 & 20,22 & 16,95 & 12,17 & 9,14 & 5,95 \\
\hline 68,68 & 1180,20 & 163,30 & 15,34 & 11,09 & 9,65 & 8,34 & 7,32 & 6,43 & 5,01 & 3,98 & 2,68 \\
\hline 69,23 & 1872,00 & 190,60 & 11,31 & 8,48 & 7,57 & 6,68 & 5,95 & 5,31 & 4,24 & 3,42 & 2,34 \\
\hline 72,91 & 1909,80 & 165,00 & 11,85 & 8,90 & 8,04 & 7,19 & 6,49 & 5,87 & 4,79 & 3,93 & 2,74 \\
\hline 36,55 & 1169,10 & 113,80 & 27,28 & 21,89 & 18,80 & 15,32 & 12,51 & 10,29 & 7,22 & 5,40 & 3,57 \\
\hline 65,15 & 1364,60 & 32,00 & 39,96 & 32,04 & 30,62 & 29,00 & 27,23 & 25,50 & 22,21 & 19,26 & 14,47 \\
\hline 72,07 & 1183,50 & 96,30 & 19,88 & 15,06 & 13,66 & 12,25 & 11,08 & 10,02 & 8,19 & 6,74 & 4,70 \\
\hline 54,75 & 312,10 & 89,80 & 44,89 & 29,20 & 23,59 & 18,77 & 15,32 & 12,67 & 9,03 & 6,86 & 4,59 \\
\hline 21,19 & 494,50 & 89,00 & 59,74 & 41,18 & 30,56 & 21,11 & 15,49 & 12,06 & 8,36 & 6,47 & 4,51 \\
\hline 45,26 & 665,40 & 141,60 & 26,59 & 18,73 & 15,45 & 12,29 & 9,94 & 8,13 & 5,71 & 4,30 & 2,88 \\
\hline 34,51 & 1228,10 & 144,70 & 23,94 & 18,65 & 15,69 & 12,46 & 9,96 & 8,06 & 5,56 & 4,16 & 2,79 \\
\hline 76,70 & 1195,50 & 158,10 & 14,78 & 10,49 & 9,17 & 8,00 & 7,11 & 6,34 & 5,06 & 4,10 & 2,82 \\
\hline 36,84 & 687,80 & 53,90 & 52,83 & 43,60 & 38,01 & 31,54 & 26,13 & 21,73 & 15,44 & 11,57 & 7,58 \\
\hline 22,14 & 1095,20 & 169,90 & 29,37 & 20,90 & 15,87 & 11,17 & 8,24 & 6,41 & 4,41 & 3,40 & 2,36 \\
\hline 44,85 & 1166,00 & 37,90 & 47,48 & 41,66 & 38,77 & 34,90 & 31,26 & 27,88 & 22,09 & 17,61 & 11,74 \\
\hline 85,18 & 1246,30 & 89,00 & 18,76 & 13,71 & 12,50 & 11,41 & 10,51 & 9,69 & 8,23 & 7,01 & 5,14 \\
\hline 34,82 & 1770,60 & 24,30 & 68,01 & 62,16 & 58,71 & 53,39 & 48,17 & 43,23 & 34,56 & 27,67 & 18,44 \\
\hline 81,94 & 376,70 & 148,90 & 29,36 & 16,87 & 13,06 & 10,30 & 8,57 & 7,28 & 5,42 & 4,23 & 2,87 \\
\hline 77,91 & 1437,70 & 79,00 & 19,79 & 15,00 & 13,90 & 12,82 & 11,85 & 10,95 & 9,32 & 7,94 & 5,81 \\
\hline 44,70 & 821,50 & 159,50 & 22,80 & 16,35 & 13,59 & 10,88 & 8,82 & 7,24 & 5,09 & 3,83 & 2,56 \\
\hline 25,82 & 1409,10 & 127,50 & 30,34 & 23,83 & 19,51 & 14,84 & 11,43 & 9,01 & 6,10 & 4,59 & 3,14 \\
\hline 28,11 & 1104,50 & 177,40 & 24,71 & 18,10 & 14,37 & 10,64 & 8,09 & 6,35 & 4,32 & 3,29 & 2,26 \\
\hline 29,02 & 979,60 & 170,50 & 25,91 & 18,79 & 14,90 & 11,05 & 8,41 & 6,61 & 4,50 & 3,42 & 2,36 \\
\hline 43,04 & 910,50 & 146,30 & 23,35 & 17,37 & 14,62 & 11,81 & 9,62 & 7,92 & 5,58 & 4,20 & 2,79 \\
\hline 43,50 & 1761,20 & 47,50 & 36,42 & 32,20 & 30,16 & 27,30 & 24,56 & 22,00 & 17,56 & 14,08 & 9,43 \\
\hline 74,39 & 1674,70 & 40,70 & 29,02 & 22,90 & 21,62 & 20,65 & 19,56 & 18,47 & 16,37 & 14,44 & 11,20 \\
\hline 21,08 & 1505,20 & 25,90 & 104,97 & 93,65 & 82,63 & 68,51 & 56,30 & 46,31 & 32,22 & 23,80 & 15,51 \\
\hline 87,84 & 766,20 & 90,90 & 23,07 & 16,00 & 14,08 & 12,45 & 11,24 & 10,19 & 8,40 & 6,99 & 4,98 \\
\hline 22,63 & 1172,50 & 123,60 & 35,81 & 27,03 & 21,30 & 15,50 & 11,60 & 9,03 & 6,13 & 4,68 & 3,24 \\
\hline 21,77 & 1316,90 & 152,80 & 30,49 & 22,56 & 17,48 & 12,52 & 9,29 & 7,21 & 4,92 & 3,78 & 2,62 \\
\hline 56,40 & 1729,10 & 106,20 & 18,32 & 15,01 & 13,74 & 12,27 & 10,96 & 9,77 & 7,76 & 6,22 & 4,19 \\
\hline 34,17 & 746,10 & 42,20 & 63,43 & 54,08 & 47,67 & 39,92 & 33,30 & 27,82 & 19,86 & 14,87 & 9,68 \\
\hline 31,41 & 541,70 & 194,70 & 28,29 & 17,83 & 13,39 & 9,55 & 7,17 & 5,63 & 3,88 & 2,98 & 2,08 \\
\hline 84,55 & 1528,20 & 192,90 & 11,39 & 7,93 & 6,95 & 6,11 & 5,48 & 4,94 & 4,03 & 3,32 & 2,34 \\
\hline 84,70 & 940,40 & 58,50 & 26,96 & 19,90 & 18,27 & 16,81 & 15,56 & 14,41 & 12,34 & 10,57 & 7,83 \\
\hline 55,51 & 1202,90 & 21,00 & 61,74 & 50,92 & 49,13 & 46,44 & 43,47 & 40,55 & 35,02 & 30,09 & 22,21 \\
\hline 64,58 & 1612,00 & 21,00 & 50,18 & 40,97 & 38,89 & 37,66 & 35,98 & 34,19 & 30,67 & 27,35 & 21,57 \\
\hline 63,15 & 797,60 & 169,40 & 19,13 & 13,05 & 10,91 & 9,06 & 7,67 & 6,55 & 4,86 & 3,76 & 2,50 \\
\hline 66,24 & 1839,00 & 117,70 & 15,37 & 12,08 & 11,11 & 10,04 & 9,10 & 8,25 & 6,75 & 5,55 & 3,86 \\
\hline 31,27 & 985,30 & 161,50 & 25,68 & 18,91 & 15,27 & 11,56 & 8,92 & 7,07 & 4,82 & 3,64 & 2,49 \\
\hline 62,50 & 1628,00 & 36,40 & 35,55 & 28,72 & 27,52 & 26,02 & 24,40 & 22,81 & 19,79 & 17,09 & 12,75 \\
\hline 75,11 & 1435,50 & 158,40 & 13,62 & 9,93 & 8,81 & 7,77 & 6,96 & 6,24 & 5,03 & 4,10 & 2,83 \\
\hline 63,24 & 1225,90 & 115,60 & 18,84 & 14,54 & 13,01 & 11,46 & 10,16 & 9,01 & 7,10 & 5,67 & 3,82 \\
\hline 21,02 & 1834,40 & 183,90 & 24,91 & 18,67 & 14,53 & 10,43 & 7,74 & 6,01 & 4,09 & 3,14 & 2,18 \\
\hline 77,19 & 1097,80 & 101,70 & 19,32 & 14,21 & 12,78 & 11,42 & 10,33 & 9,35 & 7,67 & 6,34 & 4,46 \\
\hline 28,24 & 1704,90 & 155,30 & 23,44 & 18,59 & 15,46 & 12,00 & 9,39 & 7,48 & 5,09 & 3,81 & 2,58 \\
\hline 33,23 & 719,90 & 161,20 & 27,85 & 19,47 & 15,44 & 11,55 & 8,87 & 7,02 & 4,80 & 3,64 & 2,50 \\
\hline 41,95 & 1395,50 & 119,00 & 22,52 & 18,43 & 16,19 & 13,65 & 11,50 & 9,71 & 7,05 & 5,33 & 3,48 \\
\hline 64,00 & 974,50 & 32,00 & 45,19 & 36,37 & 34,52 & 32,15 & 29,82 & 27,59 & 23,47 & 19,92 & 14,47 \\
\hline 48,83 & 636,10 & 34,50 & 58,90 & 49,90 & 45,54 & 40,33 & 35,62 & 31,38 & 24,37 & 19,18 & 12,67 \\
\hline 42,78 & 787,90 & 125,90 & 27,17 & 20,22 & 17,02 & 13,74 & 11,19 & 9,20 & 6,48 & 4,87 & 3,24 \\
\hline 60,76 & 500,70 & 29,90 & 61,68 & 49,75 & 45,78 & 41,23 & 37,18 & 33,47 & 27,05 & 21,99 & 15,06 \\
\hline 60,97 & 794,20 & 38,80 & 44,00 & 35,73 & 33,26 & 30,27 & 27,54 & 25,00 & 20,52 & 16,88 & 11,73 \\
\hline 84,20 & 1488,70 & 165,40 & 12,48 & 8,81 & 7,81 & 6,93 & 6,25 & 5,66 & 4,66 & 3,86 & 2,74 \\
\hline 24,62 & 1593,40 & 161,90 & 25,56 & 19,65 & 15,80 & 11,77 & 8,94 & 7,00 & 4,74 & 3,59 & 2,47 \\
\hline 75,92 & 654,80 & 98,90 & 25,41 & 17,75 & 15,34 & 13,25 & 11,68 & 10,34 & 8,16 & 6,55 & 4,47 \\
\hline 58,33 & 577,10 & 109,70 & 28,82 & 20,31 & 17,14 & 14,25 & 12,03 & 10,22 & 7,53 & 5,78 & 3,83 \\
\hline 54,81 & 1852,70 & 115,70 & 17,21 & 14,16 & 12,93 & 11,50 & 10,23 & 9,09 & 7,16 & 5,70 & 3,82 \\
\hline 82,83 & 508,10 & 85,80 & 30,12 & 20,27 & 17,31 & 14,88 & 13,13 & 11,66 & 9,28 & 7,51 & 5,18 \\
\hline 51,28 & 1674,00 & 81,40 & 23,22 & 19,63 & 18,09 & 16,20 & 14,47 & 12,89 & 10,20 & 8,14 & 5,45 \\
\hline 77,03 & 1413,80 & 150,10 & 13,96 & 10,14 & 9,03 & 8,00 & 7,19 & 6,47 & 5,26 & 4,31 & 3,00 \\
\hline 60,78 & 1072,60 & 197,50 & 15,47 & 10,90 & 9,24 & 7,73 & 6,58 & 5,63 & 4,19 & 3,23 & 2,14 \\
\hline 67,22 & 1450,20 & 30,20 & 39,80 & 31,83 & 30,35 & 28,97 & 27,36 & 25,76 & 22,69 & 19,89 & 15,22 \\
\hline 69,45 & 787,00 & 87,40 & 25,65 & 19,04 & 16,87 & 14,81 & 13,15 & 11,70 & 9,28 & 7,46 & 5,08 \\
\hline 61,06 & 266,20 & 32,30 & 76,95 & 58,00 & 50,89 & 43,96 & 38,31 & 33,44 & 25,66 & 20,13 & 13,40 \\
\hline 30,61 & 889,40 & 87,90 & 40,19 & 31,80 & 26,63 & 20,91 & 16,52 & 13,25 & 9,07 & 6,78 & 4,57 \\
\hline
\end{tabular}




\begin{tabular}{|c|c|c|c|c|c|c|c|c|c|c|c|}
\hline & & & \multicolumn{9}{|c|}{ Deflexões $\left(\times 10^{-4} \mathrm{~cm}\right)$} \\
\hline e1 (cm) & Meq (MPa) & Ms (MPa) & D0 & D25 & D40 & D60 & D80 & D100 & D140 & D180 & D260 \\
\hline 74,38 & 1690,60 & 168,50 & 12,26 & 9,05 & 8,09 & 7,19 & 6,46 & 5,81 & 4,71 & 3,85 & 2,67 \\
\hline 60,67 & 1892,40 & 50,00 & 27,80 & 22,64 & 21,63 & 20,25 & 18,84 & 17,47 & 14,93 & 12,72 & 9,27 \\
\hline 62,55 & 1624,60 & 61,70 & 24,95 & 20,20 & 19,06 & 17,59 & 16,20 & 14,89 & 12,49 & 10,48 & 7,47 \\
\hline 66,42 & 1372,60 & 83,60 & 21,18 & 16,68 & 15,38 & 13,94 & 12,67 & 11,50 & 9,45 & 7,79 & 5,44 \\
\hline 62,89 & 1764,30 & 108,00 & 16,92 & 13,52 & 12,44 & 11,22 & 10,14 & 9,16 & 7,44 & 6,08 & 4,19 \\
\hline 52,48 & 1079,20 & 76,00 & 28,21 & 23,17 & 20,94 & 18,42 & 16,21 & 14,24 & 11,01 & 8,65 & 5,73 \\
\hline 24,64 & 1621,30 & 40,40 & 66,05 & 58,61 & 51,83 & 43,20 & 35,72 & 29,56 & 20,75 & 15,38 & 10,00 \\
\hline 59,94 & 1502,90 & 82,10 & 21,89 & 17,79 & 16,44 & 14,86 & 13,43 & 12,12 & 9,83 & 8,02 & 5,51 \\
\hline 26,23 & 719,20 & 73,60 & 54,03 & 41,86 & 34,05 & 25,74 & 19,75 & 15,55 & 10,54 & 7,95 & 5,44 \\
\hline 82,95 & 609,40 & 158,80 & 20,96 & 13,10 & 10,68 & 8,83 & 7,58 & 6,59 & 5,08 & 4,03 & 2,74 \\
\hline 62,50 & 1953,80 & 83,00 & 19,30 & 15,61 & 14,66 & 13,46 & 12,34 & 11,29 & 9,40 & 7,83 & 5,53 \\
\hline 75,42 & 1452,00 & 145,90 & 14,12 & 10,38 & 9,27 & 8,24 & 7,41 & 6,67 & 5,42 & 4,44 & 3,09 \\
\hline 42,92 & 621,10 & 127,70 & 29,81 & 21,18 & 17,45 & 13,81 & 11,08 & 9,03 & 6,30 & 4,74 & 3,18 \\
\hline 36,19 & 279,60 & 110,30 & 49,42 & 30,50 & 23,08 & 16,76 & 12,74 & 10,06 & 6,92 & 5,30 & 3,68 \\
\hline 72,81 & 1696,60 & 105,80 & 16,11 & 12,36 & 11,40 & 10,39 & 9,51 & 8,70 & 7,26 & 6,07 & 4,33 \\
\hline 70,55 & 1097,70 & 175,20 & 15,20 & 10,70 & 9,20 & 7,88 & 6,88 & 6,03 & 4,67 & 3,70 & 2,49 \\
\hline 60,97 & 997,70 & 190,90 & 16,30 & 11,40 & 9,63 & 8,04 & 6,82 & 5,83 & 4,33 & 3,34 & 2,22 \\
\hline 85,06 & 685,10 & 142,70 & 20,23 & 13,09 & 10,94 & 9,24 & 8,07 & 7,11 & 5,60 & 4,50 & 3,09 \\
\hline 52,94 & 895,90 & 65,80 & 32,93 & 26,91 & 24,27 & 21,32 & 18,74 & 16,45 & 12,71 & 9,98 & 6,60 \\
\hline 38,40 & 299,30 & 195,90 & 34,99 & 18,69 & 13,31 & 9,33 & 7,03 & 5,56 & 3,85 & 2,97 & 2,08 \\
\hline 41,67 & 1931,50 & 35,40 & 44,73 & 39,73 & 37,72 & 34,56 & 31,45 & 28,49 & 23,20 & 18,88 & 12,85 \\
\hline 73,03 & 1364,80 & 25,00 & 43,09 & 34,64 & 32,60 & 31,43 & 30,00 & 28,49 & 25,54 & 22,79 & 18,01 \\
\hline 81,85 & 459,60 & 109,20 & 28,93 & 18,44 & 15,20 & 12,68 & 10,94 & 9,55 & 7,39 & 5,87 & 4,00 \\
\hline 89,85 & 551,90 & 125,00 & 23,91 & 15,07 & 12,45 & 10,45 & 9,11 & 8,03 & 6,34 & 5,12 & 3,54 \\
\hline 40,70 & 1082,00 & 38,00 & 52,01 & 46,09 & 42,36 & 37,54 & 33,07 & 29,02 & 22,34 & 17,43 & 11,40 \\
\hline 46,16 & 1207,80 & 120,50 & 22,23 & 17,77 & 15,58 & 13,19 & 11,18 & 9,49 & 6,96 & 5,30 & 3,46 \\
\hline 80,40 & 1860,20 & 156,00 & 11,82 & 8,67 & 7,84 & 7,07 & 6,44 & 5,88 & 4,89 & 4,09 & 2,92 \\
\hline 33,49 & 795,60 & 116,20 & 32,87 & 24,75 & 20,39 & 15,81 & 12,42 & 9,94 & 6,81 & 5,11 & 3,46 \\
\hline 51,01 & 741,00 & 173,40 & 21,50 & 14,73 & 12,13 & 9,75 & 7,97 & 6,60 & 4,69 & 3,56 & 2,37 \\
\hline 41,39 & 1875,10 & 159,00 & 16,98 & 13,90 & 12,20 & 10,27 & 8,64 & 7,28 & 5,27 & 3,98 & 2,60 \\
\hline 54,47 & 1150,60 & 60,60 & 30,95 & 25,76 & 23,73 & 21,29 & 19,09 & 17,06 & 13,60 & 10,93 & 7,37 \\
\hline 43,63 & 518,40 & 98,40 & 37,04 & 26,70 & 22,19 & 17,72 & 14,33 & 11,73 & 8,23 & 6,19 & 4,14 \\
\hline 68,80 & 729,50 & 187,50 & 18,63 & 12,07 & 9,89 & 8,12 & 6,87 & 5,86 & 4,37 & 3,39 & 2,27 \\
\hline 25,21 & 475,50 & 168,40 & 35,34 & 22,00 & 15,96 & 10,97 & 8,11 & 6,36 & 4,42 & 3,43 & 2,40 \\
\hline 55,32 & 1332,80 & 62,50 & 28,49 & 23,73 & 22,03 & 19,91 & 17,97 & 16,17 & 13,05 & 10,58 & 7,21 \\
\hline 71,75 & 793,70 & 36,60 & 41,71 & 32,47 & 30,39 & 28,10 & 25,99 & 24,00 & 20,38 & 17,29 & 12,58 \\
\hline 64,65 & 537,60 & 112,60 & 28,29 & 19,28 & 16,15 & 13,45 & 11,43 & 9,79 & 7,31 & 5,66 & 3,77 \\
\hline 82,60 & 677,30 & 156,80 & 19,78 & 12,64 & 10,45 & 8,74 & 7,56 & 6,61 & 5,13 & 4,09 & 2,79 \\
\hline 47,63 & 282,30 & 81,80 & 52,15 & 34,27 & 27,51 & 21,47 & 17,18 & 13,98 & 9,77 & 7,39 & 4,99 \\
\hline 73,90 & 999,30 & 51,60 & 30,40 & 23,40 & 21,79 & 20,08 & 18,53 & 17,09 & 14,48 & 12,27 & 8,91 \\
\hline 86,69 & 209,50 & 37,50 & 70,08 & 46,24 & 39,21 & 33,58 & 29,62 & 26,35 & 21,03 & 17,09 & 11,85 \\
\hline 86,46 & 992,80 & 128,60 & 17,17 & 11,84 & 10,35 & 9,09 & 8,16 & 7,36 & 6,02 & 4,97 & 3,51 \\
\hline 68,46 & 801,30 & 30,50 & 47,94 & 37,90 & 35,76 & 33,26 & 30,86 & 28,57 & 24,36 & 20,74 & 15,14 \\
\hline 42,46 & 516,70 & 90,60 & 39,44 & 28,88 & 24,10 & 19,29 & 15,60 & 12,77 & 8,95 & 6,73 & 4,49 \\
\hline 55,53 & 1923,40 & 174,80 & 13,16 & 10,45 & 9,32 & 8,13 & 7,11 & 6,21 & 4,77 & 3,74 & 2,48 \\
\hline 36,25 & 1175,20 & 37,20 & 56,04 & 50,24 & 45,90 & 40,27 & 35,07 & 30,44 & 22,98 & 17,68 & 11,45 \\
\hline 31,34 & 1431,30 & 164,10 & 22,30 & 17,33 & 14,40 & 11,23 & 8,84 & 7,07 & 4,84 & 3,62 & 2,45 \\
\hline 25,75 & 758,20 & 96,30 & 44,64 & 33,51 & 26,69 & 19,74 & 14,95 & 11,70 & 7,95 & 6,04 & 4,16 \\
\hline 45,69 & 1083,60 & 136,30 & 21,80 & 16,85 & 14,52 & 12,07 & 10,08 & 8,45 & 6,09 & 4,61 & 3,03 \\
\hline 39,63 & 584,70 & 25,20 & 86,00 & 75,41 & 68,46 & 59,77 & 51,89 & 44,93 & 33,84 & 26,02 & 16,89 \\
\hline 55,98 & 1544,90 & 95,00 & 20,58 & 16,88 & 15,44 & 13,78 & 12,30 & 10,96 & 8,69 & 6,95 & 4,67 \\
\hline 23,79 & 568,00 & 142,00 & 38,65 & 25,67 & 18,98 & 13,16 & 9,71 & 7,58 & 5,25 & 4,07 & 2,83 \\
\hline 43,12 & 1532,50 & 65,90 & 30,86 & 26,92 & 24,62 & 21,75 & 19,11 & 16,74 & 12,86 & 10,03 & 6,56 \\
\hline 42,34 & 1443,90 & 35,50 & 48,22 & 42,87 & 40,23 & 36,45 & 32,82 & 29,42 & 23,52 & 18,86 & 12,63 \\
\hline 52,52 & 1904,80 & 24,10 & 50,71 & 41,93 & 40,63 & 38,71 & 36,43 & 34,16 & 29,78 & 25,81 & 19,31 \\
\hline 53,58 & 1438,60 & 125,70 & 18,38 & 14,73 & 13,15 & 11,45 & 9,99 & 8,71 & 6,66 & 5,20 & 3,43 \\
\hline 47,19 & 472,40 & 146,60 & 30,22 & 19,56 & 15,57 & 12,06 & 9,60 & 7,78 & 5,43 & 4,11 & 2,78 \\
\hline 69,26 & 751,50 & 169,50 & 19,08 & 12,68 & 10,54 & 8,76 & 7,48 & 6,43 & 4,84 & 3,77 & 2,52 \\
\hline 83,69 & 721,20 & 71,80 & 27,32 & 19,53 & 17,45 & 15,59 & 14,14 & 12,86 & 10,65 & 8,88 & 6,33 \\
\hline 70,77 & 1536,30 & 50,10 & 27,09 & 21,30 & 20,17 & 18,95 & 17,71 & 16,53 & 14,30 & 12,34 & 9,21 \\
\hline 29,36 & 646,50 & 34,60 & 85,73 & 72,56 & 62,93 & 51,39 & 41,85 & 34,26 & 23,82 & 17,70 & 11,67 \\
\hline 73,40 & 1204,90 & 53,70 & 27,72 & 21,47 & 20,12 & 18,66 & 17,31 & 16,04 & 13,70 & 11,69 & 8,57 \\
\hline 76,76 & 214,50 & 117,00 & 47,20 & 25,38 & 18,80 & 14,19 & 11,44 & 9,49 & 6,84 & 5,27 & 3,59 \\
\hline 55,64 & 1354,60 & 52,50 & 31,64 & 26,42 & 24,78 & 22,61 & 20,59 & 18,68 & 15,31 & 12,56 & 8,68 \\
\hline 64,44 & 551,00 & 159,60 & 23,97 & 15,27 & 12,36 & 9,98 & 8,31 & 7,00 & 5,12 & 3,93 & 2,63 \\
\hline 23,55 & 1789,60 & 135,10 & 28,95 & 22,92 & 18,70 & 14,12 & 10,81 & 8,48 & 5,73 & 4,32 & 2,96 \\
\hline 34,03 & 1773,50 & 190,10 & 17,78 & 14,03 & 11,86 & 9,46 & 7,58 & 6,15 & 4,25 & 3,18 & 2,12 \\
\hline 27,23 & 1539,40 & 21,40 & 94,37 & 87,76 & 80,70 & 71,04 & 61,90 & 53,68 & 40,35 & 30,87 & 19,82 \\
\hline 60,25 & 749,60 & 197,40 & 18,79 & 12,33 & 10,08 & 8,17 & 6,79 & 5,70 & 4,14 & 3,17 & 2,12 \\
\hline 80,14 & 842,20 & 156,50 & 17,61 & 11,77 & 9,96 & 8,49 & 7,43 & 6,55 & 5,14 & 4,12 & 2,81 \\
\hline 78,94 & 1791,30 & 22,50 & 37,96 & 32,77 & 29,95 & 29,04 & 28,21 & 27,16 & 24,96 & 22,84 & 18,93 \\
\hline 28,54 & 1392,00 & 191,20 & 21,59 & 16,22 & 13,08 & 9,85 & 7,55 & 5,95 & 4,05 & 3,06 & 2,10 \\
\hline 51,59 & 511,80 & 94,90 & 34,88 & 25,02 & 21,06 & 17,29 & 14,37 & 12,04 & 8,68 & 6,59 & 4,36 \\
\hline 46,56 & 760,80 & 158,70 & 23,19 & 16,37 & 13,56 & 10,86 & 8,83 & 7,26 & 5,12 & 3,86 & 2,58 \\
\hline 36,34 & 977,70 & 44,60 & 52,99 & 46,27 & 41,53 & 35,66 & 30,45 & 25,96 & 19,07 & 14,45 & 9,35 \\
\hline 46,93 & 671,20 & 42,40 & 52,07 & 43,78 & 39,51 & 34,52 & 30,08 & 26,17 & 19,91 & 15,44 & 10,11 \\
\hline 22,00 & 333,60 & 124,60 & 50,99 & 30,79 & 21,69 & 14,61 & 10,76 & 8,48 & 5,95 & 4,62 & 3,24 \\
\hline 26,42 & 1537,70 & 85,10 & 38,32 & 31,91 & 27,18 & 21,64 & 17,23 & 13,86 & 9,47 & 7,04 & 4,71 \\
\hline 57,43 & 459,20 & 24,50 & 74,57 & 61,29 & 56,61 & 51,02 & 45,98 & 41,33 & 33,29 & 26,97 & 18,38 \\
\hline 64,46 & 1519,40 & 122,20 & 16,48 & 12,85 & 11,63 & 10,36 & 9,27 & 8,30 & 6,64 & 5,36 & 3,66 \\
\hline 50,36 & 809,60 & 47,30 & 43,27 & 36,30 & 33,07 & 29,27 & 25,86 & 22,79 & 17,72 & 13,96 & 9,24 \\
\hline 77,78 & 537,20 & 28,80 & 53,79 & 40,82 & 37,88 & 34,96 & 32,34 & 29,92 & 25,50 & 21,73 & 15,94 \\
\hline
\end{tabular}




\begin{tabular}{|c|c|c|c|c|c|c|c|c|c|c|c|}
\hline & & & \multicolumn{9}{|c|}{ Deflexões $\left(\times 10^{-4} \mathrm{~cm}\right)$} \\
\hline e1 (cm) & Meq (MPa) & Ms (MPa) & D0 & D25 & D40 & D60 & D80 & D100 & D140 & D180 & D260 \\
\hline 41,92 & 1006,90 & 22,30 & 74,87 & 66,65 & 62,78 & 57,09 & 51,58 & 46,39 & 37,29 & 30,04 & 20,20 \\
\hline 85,93 & 692,40 & 139,40 & 20,24 & 13,14 & 11,01 & 9,34 & 8,17 & 7,22 & 5,71 & 4,60 & 3,17 \\
\hline 42,58 & 1976,50 & 66,80 & 28,29 & 24,99 & 23,10 & 20,63 & 18,32 & 16,20 & 12,65 & 9,97 & 6,57 \\
\hline 72,02 & 1119,60 & 79,80 & 22,68 & 17,33 & 15,85 & 14,33 & 13,03 & 11,85 & 9,78 & 8,10 & 5,70 \\
\hline 87,77 & 1242,60 & 188,00 & 12,68 & 8,55 & 7,36 & 6,40 & 5,70 & 5,12 & 4,15 & 3,40 & 2,39 \\
\hline 52,07 & 1256,10 & 185,80 & 15,94 & 11,90 & 10,21 & 8,54 & 7,21 & 6,11 & 4,47 & 3,41 & 2,25 \\
\hline 48,82 & 1635,60 & 120,00 & 19,00 & 15,69 & 14,08 & 12,25 & 10,65 & 9,25 & 7,02 & 5,44 & 3,57 \\
\hline 47,88 & 1440,30 & 110,10 & 21,32 & 17,56 & 15,70 & 13,59 & 11,76 & 10,17 & 7,66 & 5,91 & 3,87 \\
\hline 64,05 & 1887,20 & 114,80 & 15,72 & 12,50 & 11,52 & 10,41 & 9,43 & 8,53 & 6,96 & 5,70 & 3,95 \\
\hline 34,12 & 1473,60 & 194,30 & 18,72 & 14,33 & 11,93 & 9,37 & 7,42 & 5,97 & 4,11 & 3,08 & 2,07 \\
\hline 62,27 & 1368,20 & 29,10 & 43,83 & 35,43 & 33,97 & 32,18 & 30,21 & 28,27 & 24,59 & 21,28 & 15,93 \\
\hline 73,08 & 1682,10 & 30,30 & 35,27 & 28,39 & 26,71 & 25,76 & 24,60 & 23,37 & 20,97 & 18,73 & 14,82 \\
\hline 66,60 & 1025,40 & 131,60 & 18,60 & 13,69 & 11,98 & 10,38 & 9,11 & 8,02 & 6,24 & 4,95 & 3,33 \\
\hline 67,53 & 813,20 & 197,00 & 17,25 & 11,34 & 9,36 & 7,72 & 6,54 & 5,59 & 4,16 & 3,23 & 2,16 \\
\hline 20,81 & 1616,50 & 85,90 & 45,05 & 36,28 & 29,66 & 22,37 & 17,06 & 13,34 & 8,98 & 6,77 & 4,64 \\
\hline 60,02 & 235,10 & 93,10 & 50,45 & 30,12 & 23,44 & 18,20 & 14,72 & 12,13 & 8,63 & 6,58 & 4,45 \\
\hline 40,29 & 1201,90 & 90,20 & 29,09 & 24,18 & 21,33 & 18,03 & 15,20 & 12,84 & 9,32 & 7,04 & 4,59 \\
\hline 53,55 & 286,30 & 97,20 & 45,71 & 28,67 & 22,71 & 17,72 & 14,28 & 11,70 & 8,25 & 6,26 & 4,23 \\
\hline 45,93 & 1840,30 & 174,10 & 15,10 & 12,16 & 10,69 & 9,08 & 7,71 & 6,56 & 4,82 & 3,68 & 2,40 \\
\hline 29,07 & 1740,00 & 26,80 & 73,63 & 68,28 & 62,95 & 55,64 & 48,71 & 42,43 & 32,15 & 24,73 & 15,94 \\
\hline 26,15 & 545,30 & 93,10 & 50,05 & 36,00 & 28,05 & 20,35 & 15,27 & 11,93 & 8,14 & 6,23 & 4,31 \\
\hline 46,73 & 1871,40 & 54,70 & 30,89 & 26,93 & 25,28 & 22,97 & 20,77 & 18,70 & 15,07 & 12,18 & 8,24 \\
\hline 30,56 & 1172,80 & 195,30 & 21,64 & 15,86 & 12,74 & 9,59 & 7,37 & 5,82 & 3,97 & 3,00 & 2,06 \\
\hline 32,06 & 202,10 & 185,10 & 44,79 & 21,39 & 14,32 & 9,66 & 7,23 & 5,74 & 4,00 & 3,12 & 2,22 \\
\hline 45,53 & 1257,30 & 104,70 & 23,98 & 19,63 & 17,39 & 14,87 & 12,71 & 10,87 & 8,04 & 6,14 & 4,01 \\
\hline 48,65 & 647,30 & 91,70 & 32,88 & 24,85 & 21,32 & 17,73 & 14,85 & 12,49 & 9,05 & 6,87 & 4,52 \\
\hline 66,32 & 1065,20 & 85,30 & 23,23 & 18,00 & 16,31 & 14,56 & 13,08 & 11,74 & 9,45 & 7,68 & 5,26 \\
\hline 71,62 & 1687,50 & 80,30 & 19,27 & 14,99 & 14,02 & 12,94 & 11,95 & 11,02 & 9,34 & 7,91 & 5,73 \\
\hline 41,06 & 888,00 & 111,10 & 28,51 & 22,10 & 18,88 & 15,43 & 12,66 & 10,47 & 7,40 & 5,56 & 3,67 \\
\hline 52,69 & 1727,70 & 187,30 & 13,66 & 10,68 & 9,39 & 8,05 & 6,92 & 5,96 & 4,47 & 3,45 & 2,27 \\
\hline 44,41 & 867,40 & 185,40 & 20,54 & 14,47 & 11,91 & 9,45 & 7,61 & 6,22 & 4,35 & 3,28 & 2,20 \\
\hline 63,05 & 1401,00 & 163,40 & 14,70 & 11,07 & 9,75 & 8,47 & 7,43 & 6,52 & 5,05 & 3,99 & 2,67 \\
\hline 58,09 & 1630,10 & 52,50 & 28,97 & 23,92 & 22,68 & 20,95 & 19,29 & 17,70 & 14,82 & 12,38 & 8,78 \\
\hline 20,32 & 1743,90 & 45,00 & 70,85 & 60,77 & 52,05 & 41,48 & 32,93 & 26,38 & 17,89 & 13,24 & 8,85 \\
\hline 52,72 & 320,30 & 91,80 & 44,44 & 29,04 & 23,44 & 18,57 & 15,08 & 12,42 & 8,80 & 6,67 & 4,48 \\
\hline 24,00 & 1494,80 & 59,30 & 53,48 & 45,38 & 38,89 & 31,11 & 24,84 & 20,00 & 13,65 & 10,12 & 6,75 \\
\hline 73,84 & 1866,30 & 184,00 & 11,21 & 8,30 & 7,42 & 6,59 & 5,92 & 5,33 & 4,32 & 3,53 & 2,45 \\
\hline 73,34 & 1681,30 & 110,70 & 15,68 & 11,97 & 11,01 & 10,01 & 9,14 & 8,35 & 6,95 & 5,80 & 4,13 \\
\hline 28,32 & 1883,20 & 95,30 & 31,44 & 26,65 & 23,07 & 18,78 & 15,24 & 12,44 & 8,62 & 6,40 & 4,23 \\
\hline 75,89 & 1068,20 & 39,90 & 34,23 & 26,47 & 24,88 & 23,35 & 21,84 & 20,39 & 17,70 & 15,33 & 11,51 \\
\hline 71,86 & 830,30 & 33,40 & 43,43 & 33,90 & 31,89 & 29,70 & 27,60 & 25,61 & 21,94 & 18,76 & 13,81 \\
\hline 60,90 & 405,70 & 158,20 & 29,30 & 17,53 & 13,67 & 10,65 & 8,64 & 7,13 & 5,09 & 3,88 & 2,62 \\
\hline 23,94 & 618,60 & 186,80 & 30,96 & 19,82 & 14,44 & 9,92 & 7,32 & 5,73 & 3,98 & 3,09 & 2,16 \\
\hline 68,20 & 1441,40 & 135,60 & 15,45 & 11,72 & 10,51 & 9,32 & 8,33 & 7,44 & 5,96 & 4,82 & 3,29 \\
\hline 49,44 & 447,30 & 159,40 & 29,37 & 18,33 & 14,39 & 11,07 & 8,80 & 7,14 & 4,98 & 3,78 & 2,57 \\
\hline 62,36 & 377,90 & 27,30 & 71,81 & 56,91 & 51,81 & 46,29 & 41,51 & 37,17 & 29,78 & 24,06 & 16,39 \\
\hline 77,55 & 630,50 & 190,50 & 19,51 & 11,98 & 9,62 & 7,81 & 6,61 & 5,67 & 4,26 & 3,33 & 2,25 \\
\hline 40,50 & 1118,50 & 46,80 & 45,04 & 39,53 & 36,01 & 31,59 & 27,55 & 23,96 & 18,18 & 14,04 & 9,14 \\
\hline 39,82 & 343,30 & 197,80 & 32,23 & 17,88 & 13,00 & 9,26 & 7,02 & 5,56 & 3,84 & 2,95 & 2,06 \\
\hline 62,28 & 1367,70 & 51,30 & 29,95 & 24,27 & 22,91 & 21,15 & 19,48 & 17,90 & 15,02 & 12,60 & 8,98 \\
\hline 74,79 & 842,30 & 136,70 & 19,20 & 13,32 & 11,43 & 9,81 & 8,60 & 7,58 & 5,93 & 4,73 & 3,22 \\
\hline 74,12 & 922,90 & 100,70 & 21,43 & 15,69 & 13,93 & 12,29 & 10,99 & 9,85 & 7,93 & 6,45 & 4,45 \\
\hline 89,28 & 1010,70 & 112,50 & 17,94 & 12,47 & 11,02 & 9,80 & 8,88 & 8,08 & 6,72 & 5,62 & 4,04 \\
\hline 66,55 & 261,20 & 96,80 & 45,37 & 27,20 & 21,35 & 16,83 & 13,83 & 11,56 & 8,37 & 6,42 & 4,32 \\
\hline 65,92 & 1459,30 & 196,40 & 12,82 & 9,39 & 8,18 & 7,06 & 6,18 & 5,41 & 4,19 & 3,31 & 2,22 \\
\hline 29,71 & 515,50 & 188,40 & 30,03 & 18,81 & 13,98 & 9,86 & 7,37 & 5,78 & 3,99 & 3,08 & 2,15 \\
\hline 84,47 & 1181,10 & 109,20 & 17,27 & 12,40 & 11,13 & 10,00 & 9,10 & 8,31 & 6,93 & 5,81 & 4,17 \\
\hline 37,87 & 1376,50 & 187,60 & 18,38 & 14,05 & 11,83 & 9,46 & 7,62 & 6,21 & 4,32 & 3,23 & 2,16 \\
\hline 61,73 & 1308,50 & 48,60 & 31,67 & 25,73 & 24,29 & 22,42 & 20,64 & 18,96 & 15,89 & 13,31 & 9,48 \\
\hline 22,14 & 1808,50 & 80,50 & 43,54 & 36,08 & 30,24 & 23,52 & 18,34 & 14,53 & 9,81 & 7,32 & 4,96 \\
\hline 88,68 & 1646,00 & 186,00 & 10,96 & 7,62 & 6,73 & 5,98 & 5,41 & 4,92 & 4,08 & 3,41 & 2,44 \\
\hline 72,45 & 753,90 & 53,10 & 33,81 & 25,80 & 23,62 & 21,37 & 19,46 & 17,71 & 14,64 & 12,15 & 8,57 \\
\hline 24,56 & 460,80 & 137,50 & 41,47 & 26,70 & 19,57 & 13,52 & 9,98 & 7,81 & 5,42 & 4,20 & 2,93 \\
\hline 37,13 & 1795,50 & 91,60 & 26,41 & 22,84 & 20,43 & 17,48 & 14,88 & 12,65 & 9,26 & 7,01 & 4,54 \\
\hline 85,59 & 1536,50 & 35,20 & 29,29 & 23,47 & 21,64 & 20,81 & 19,95 & 19,02 & 17,20 & 15,50 & 12,49 \\
\hline 55,65 & 1049,10 & 146,60 & 19,00 & 14,21 & 12,29 & 10,41 & 8,90 & 7,62 & 5,68 & 4,38 & 2,89 \\
\hline 84,70 & 1810,70 & 118,70 & 13,59 & 10,00 & 9,16 & 8,40 & 7,76 & 7,18 & 6,12 & 5,23 & 3,86 \\
\hline 47,93 & 1087,90 & 54,30 & 36,74 & 31,37 & 28,72 & 25,49 & 22,55 & 19,90 & 15,49 & 12,20 & 8,06 \\
\hline 43,69 & 1694,30 & 182,40 & 15,70 & 12,44 & 10,80 & 9,02 & 7,55 & 6,34 & 4,57 & 3,45 & 2,26 \\
\hline 75,92 & 667,30 & 179,20 & 19,40 & 12,25 & 9,98 & 8,20 & 6,98 & 6,01 & 4,54 & 3,56 & 2,40 \\
\hline 36,33 & 1301,70 & 137,00 & 23,43 & 18,59 & 15,87 & 12,84 & 10,43 & 8,54 & 5,96 & 4,46 & 2,96 \\
\hline 57,89 & 575,80 & 20,00 & 78,16 & 64,61 & 61,04 & 56,19 & 51,57 & 47,18 & 39,26 & 32,65 & 22,98 \\
\hline 31,50 & 1356,20 & 33,60 & 64,10 & 58,25 & 53,05 & 46,22 & 39,92 & 34,36 & 25,56 & 19,46 & 12,52 \\
\hline 44,00 & 574,20 & 176,90 & 25,63 & 16,69 & 13,23 & 10,15 & 8,00 & 6,44 & 4,46 & 3,38 & 2,30 \\
\hline 51,72 & 1392,00 & 128,60 & 18,79 & 15,03 & 13,34 & 11,53 & 9,98 & 8,64 & 6,53 & 5,05 & 3,32 \\
\hline 49,06 & 884,40 & 128,70 & 23,61 & 17,75 & 15,21 & 12,64 & 10,58 & 8,90 & 6,45 & 4,90 & 3,22 \\
\hline 77,21 & 635,60 & 154,60 & 21,08 & 13,53 & 11,14 & 9,25 & 7,94 & 6,88 & 5,26 & 4,14 & 2,80 \\
\hline 57,30 & 333,80 & 151,60 & 34,03 & 19,71 & 15,05 & 11,46 & 9,14 & 7,45 & 5,24 & 3,99 & 2,72 \\
\hline 74,90 & 504,30 & 189,80 & 22,72 & 13,36 & 10,44 & 8,27 & 6,86 & 5,79 & 4,27 & 3,30 & 2,23 \\
\hline 83,36 & 468,40 & 94,70 & 30,15 & 19,69 & 16,51 & 13,98 & 12,21 & 10,76 & 8,45 & 6,78 & 4,65 \\
\hline 35,52 & 1681,20 & 30,90 & 57,57 & 52,59 & 49,14 & 44,22 & 39,47 & 35,06 & 27,52 & 21,73 & 14,30 \\
\hline 89,12 & 1431,10 & 40,70 & 26,91 & 21,09 & 19,40 & 18,55 & 17,71 & 16,83 & 15,14 & 13,58 & 10,86 \\
\hline
\end{tabular}




\begin{tabular}{|c|c|c|c|c|c|c|c|c|c|c|c|}
\hline & & & \multicolumn{9}{|c|}{ Deflexões $\left(\times 10^{-4} \mathrm{~cm}\right)$} \\
\hline e1 (cm) & Meq (MPa) & Ms (MPa) & D0 & D25 & D40 & D60 & D80 & D100 & D140 & D180 & D260 \\
\hline 53,66 & 1963,00 & 107,10 & 17,89 & 14,91 & 13,69 & 12,25 & 10,94 & 9,75 & 7,73 & 6,18 & 4,15 \\
\hline 42,67 & 1965,10 & 133,60 & 18,15 & 15,25 & 13,60 & 11,67 & 9,99 & 8,55 & 6,33 & 4,83 & 3,14 \\
\hline 88,28 & 564,40 & 110,40 & 24,92 & 16,16 & 13,57 & 11,54 & 10,14 & 8,99 & 7,16 & 5,80 & 4,02 \\
\hline 23,31 & 1276,30 & 33,20 & 85,58 & 75,06 & 65,69 & 53,96 & 44,02 & 36,02 & 24,95 & 18,45 & 12,10 \\
\hline 61,20 & 349,20 & 34,60 & 65,42 & 50,56 & 45,03 & 39,43 & 34,74 & 30,61 & 23,86 & 18,90 & 12,65 \\
\hline 74,21 & 316,20 & 165,20 & 32,59 & 17,77 & 13,26 & 10,06 & 8,12 & 6,73 & 4,85 & 3,73 & 2,54 \\
\hline 62,76 & 265,30 & 188,80 & 36,05 & 18,40 & 13,09 & 9,44 & 7,34 & 5,92 & 4,13 & 3,17 & 2,19 \\
\hline 43,90 & 457,80 & 44,70 & 61,34 & 49,25 & 43,07 & 36,23 & 30,51 & 25,75 & 18,71 & 14,17 & 9,26 \\
\hline 47,33 & 1764,90 & 119,70 & 18,85 & 15,74 & 14,15 & 12,32 & 10,71 & 9,30 & 7,05 & 5,46 & 3,57 \\
\hline 44,87 & 1260,40 & 87,60 & 26,96 & 22,53 & 20,15 & 17,40 & 14,99 & 12,90 & 9,64 & 7,40 & 4,83 \\
\hline 85,78 & 1358,80 & 162,00 & 13,10 & 9,14 & 8,04 & 7,11 & 6,40 & 5,79 & 4,76 & 3,94 & 2,79 \\
\hline 47,61 & 1298,80 & 107,30 & 22,65 & 18,50 & 16,45 & 14,17 & 12,19 & 10,49 & 7,85 & 6,03 & 3,94 \\
\hline 76,01 & 997,10 & 64,20 & 26,31 & 19,92 & 18,33 & 16,72 & 15,34 & 14,07 & 11,80 & 9,92 & 7,13 \\
\hline 84,90 & 475,90 & 155,10 & 24,60 & 14,64 & 11,61 & 9,38 & 7,94 & 6,84 & 5,19 & 4,09 & 2,79 \\
\hline 31,04 & 866,90 & 81,20 & 42,31 & 33,76 & 28,44 & 22,49 & 17,88 & 14,40 & 9,88 & 7,38 & 4,95 \\
\hline 31,68 & 511,80 & 61,70 & 59,89 & 46,25 & 38,36 & 29,86 & 23,48 & 18,78 & 12,84 & 9,63 & 6,51 \\
\hline 52,82 & 978,20 & 57,00 & 34,82 & 28,99 & 26,50 & 23,58 & 20,96 & 18,58 & 14,61 & 11,60 & 7,74 \\
\hline 72,28 & 329,40 & 107,70 & 36,92 & 22,53 & 17,94 & 14,41 & 12,04 & 10,21 & 7,55 & 5,85 & 3,93 \\
\hline 75,52 & 1039,30 & 125,40 & 17,92 & 12,91 & 11,37 & 9,98 & 8,90 & 7,95 & 6,38 & 5,17 & 3,56 \\
\hline 60,94 & 990,90 & 105,50 & 22,22 & 17,04 & 15,10 & 13,15 & 11,54 & 10,13 & 7,85 & 6,19 & 4,13 \\
\hline 80,67 & 361,80 & 145,60 & 30,48 & 17,48 & 13,50 & 10,63 & 8,82 & 7,47 & 5,54 & 4,32 & 2,93 \\
\hline 21,03 & 1429,00 & 72,70 & 52,17 & 42,28 & 34,75 & 26,38 & 20,21 & 15,84 & 10,66 & 8,02 & 5,49 \\
\hline 27,39 & 1055,30 & 120,50 & 33,15 & 25,45 & 20,69 & 15,65 & 12,03 & 9,49 & 6,44 & 4,86 & 3,32 \\
\hline 42,18 & 1395,50 & 146,80 & 19,77 & 15,73 & 13,64 & 11,34 & 9,45 & 7,90 & 5,67 & 4,27 & 2,80 \\
\hline 57,58 & 1135,90 & 137,50 & 18,61 & 14,17 & 12,40 & 10,66 & 9,22 & 7,99 & 6,06 & 4,71 & 3,12 \\
\hline 43,91 & 1939,10 & 25,70 & 54,32 & 46,96 & 45,35 & 42,33 & 39,20 & 36,13 & 30,43 & 25,51 & 18,08 \\
\hline 27,40 & 1079,30 & 42,90 & 66,26 & 57,27 & 50,07 & 41,22 & 33,76 & 27,75 & 19,35 & 14,36 & 9,41 \\
\hline 38,49 & 1037,50 & 109,40 & 28,23 & 22,43 & 19,27 & 15,77 & 12,93 & 10,67 & 7,53 & 5,64 & 3,72 \\
\hline 35,91 & 1227,50 & 150,80 & 22,73 & 17,63 & 14,86 & 11,86 & 9,52 & 7,73 & 5,36 & 4,01 & 2,68 \\
\hline 64,21 & 586,40 & 186,50 & 21,68 & 13,54 & 10,83 & 8,66 & 7,17 & 6,01 & 4,36 & 3,35 & 2,24 \\
\hline 89,38 & 1224,80 & 114,70 & 16,15 & 11,41 & 10,21 & 9,19 & 8,39 & 7,69 & 6,47 & 5,46 & 3,97 \\
\hline 40,65 & 1246,00 & 131,50 & 22,65 & 18,01 & 15,56 & 12,85 & 10,64 & 8,85 & 6,30 & 4,74 & 3,11 \\
\hline 84,43 & 1699,80 & 167,40 & 11,61 & 8,29 & 7,41 & 6,63 & 6,02 & 5,48 & 4,55 & 3,80 & 2,72 \\
\hline 60,06 & 485,00 & 119,90 & 29,92 & 19,92 & 16,39 & 13,36 & 11,14 & 9,38 & 6,84 & 5,24 & 3,49 \\
\hline 78,06 & 1684,30 & 94,80 & 16,64 & 12,59 & 11,66 & 10,73 & 9,92 & 9,16 & 7,79 & 6,62 & 4,84 \\
\hline 48,22 & 1239,10 & 28,30 & 54,28 & 46,80 & 44,56 & 41,06 & 37,62 & 34,33 & 28,37 & 23,41 & 16,26 \\
\hline 25,49 & 509,70 & 150,60 & 37,14 & 24,08 & 17,79 & 12,37 & 9,16 & 7,16 & 4,96 & 3,84 & 2,68 \\
\hline 25,20 & 886,50 & 113,90 & 38,39 & 28,69 & 22,73 & 16,71 & 12,61 & 9,85 & 6,70 & 5,10 & 3,52 \\
\hline 25,83 & 1765,90 & 194,10 & 21,15 & 16,20 & 13,07 & 9,78 & 7,46 & 5,86 & 3,97 & 3,01 & 2,06 \\
\hline 81,16 & 224,40 & 124,10 & 44,60 & 23,78 & 17,54 & 13,23 & 10,69 & 8,89 & 6,44 & 4,98 & 3,40 \\
\hline 31,06 & 932,20 & 154,40 & 27,06 & 19,88 & 16,02 & 12,10 & 9,33 & 7,38 & 5,03 & 3,80 & 2,60 \\
\hline 30,05 & 1853,60 & 93,40 & 30,53 & 26,06 & 22,76 & 18,76 & 15,40 & 12,69 & 8,89 & 6,61 & 4,33 \\
\hline 50,89 & 1741,10 & 26,20 & 50,18 & 42,01 & 40,65 & 38,33 & 35,80 & 33,31 & 28,60 & 24,42 & 17,83 \\
\hline 63,04 & 954,70 & 129,20 & 19,95 & 14,72 & 12,81 & 11,02 & 9,58 & 8,35 & 6,40 & 5,02 & 3,35 \\
\hline 49,12 & 1126,30 & 48,90 & 38,17 & 32,68 & 30,20 & 27,08 & 24,19 & 21,54 & 17,04 & 13,58 & 9,07 \\
\hline 21,50 & 354,70 & 192,30 & 36,99 & 20,36 & 13,89 & 9,28 & 6,88 & 5,46 & 3,84 & 2,99 & 2,11 \\
\hline 42,19 & 692,30 & 193,50 & 22,77 & 15,18 & 12,12 & 9,31 & 7,33 & 5,90 & 4,08 & 3,08 & 2,10 \\
\hline 58,56 & 1194,60 & 139,10 & 17,91 & 13,68 & 12,02 & 10,37 & 9,01 & 7,84 & 5,98 & 4,67 & 3,10 \\
\hline 85,84 & 1399,10 & 179,40 & 12,27 & 8,49 & 7,43 & 6,53 & 5,86 & 5,29 & 4,32 & 3,57 & 2,51 \\
\hline 24,44 & 520,10 & 114,10 & 45,68 & 31,19 & 23,46 & 16,48 & 12,20 & 9,52 & 6,56 & 5,06 & 3,52 \\
\hline 63,32 & 848,40 & 192,30 & 17,43 & 11,73 & 9,75 & 8,05 & 6,79 & 5,78 & 4,28 & 3,30 & 2,20 \\
\hline 51,59 & 687,00 & 199,10 & 20,78 & 13,57 & 10,93 & 8,63 & 6,98 & 5,73 & 4,05 & 3,07 & 2,06 \\
\hline 89,84 & 1855,70 & 34,90 & 25,76 & 21,63 & 19,63 & 18,89 & 18,29 & 17,57 & 16,11 & 14,71 & 12,17 \\
\hline 73,24 & 362,80 & 148,90 & 30,79 & 17,81 & 13,76 & 10,77 & 8,86 & 7,44 & 5,43 & 4,19 & 2,83 \\
\hline 65,16 & 691,20 & 83,20 & 28,83 & 21,49 & 18,90 & 16,43 & 14,43 & 12,70 & 9,88 & 7,83 & 5,26 \\
\hline 53,84 & 1801,40 & 43,60 & 33,43 & 28,03 & 26,80 & 24,90 & 23,00 & 21,17 & 17,81 & 14,94 & 10,63 \\
\hline 89,87 & 409,20 & 198,80 & 25,03 & 13,58 & 10,18 & 7,82 & 6,43 & 5,43 & 4,03 & 3,15 & 2,15 \\
\hline 20,13 & 1265,90 & 83,00 & 50,66 & 39,63 & 31,64 & 23,25 & 17,44 & 13,55 & 9,15 & 6,97 & 4,81 \\
\hline 33,13 & 1951,50 & 115,20 & 24,18 & 20,48 & 17,94 & 14,89 & 12,32 & 10,23 & 7,24 & 5,40 & 3,53 \\
\hline 50,02 & 918,10 & 66,50 & 33,59 & 27,70 & 24,91 & 21,76 & 18,99 & 16,56 & 12,65 & 9,85 & 6,47 \\
\hline 33,99 & 1470,90 & 82,60 & 32,47 & 27,70 & 24,41 & 20,44 & 17,04 & 14,23 & 10,15 & 7,60 & 4,95 \\
\hline 34,85 & 719,60 & 83,60 & 40,97 & 32,00 & 26,98 & 21,49 & 17,22 & 13,96 & 9,66 & 7,22 & 4,83 \\
\hline 25,48 & 1555,20 & 37,70 & 68,16 & 60,90 & 54,17 & 45,55 & 37,97 & 31,64 & 22,42 & 16,66 & 10,79 \\
\hline 65,49 & 1068,30 & 51,50 & 31,71 & 25,26 & 23,59 & 21,61 & 19,81 & 18,12 & 15,09 & 12,58 & 8,90 \\
\hline 37,09 & 352,60 & 30,40 & 96,61 & 78,79 & 68,34 & 56,37 & 46,49 & 38,53 & 27,27 & 20,42 & 13,41 \\
\hline 66,33 & 1923,30 & 136,90 & 13,78 & 10,76 & 9,83 & 8,83 & 7,98 & 7,19 & 5,84 & 4,77 & 3,30 \\
\hline 47,72 & 1169,00 & 42,30 & 42,23 & 36,56 & 34,03 & 30,68 & 27,54 & 24,63 & 19,63 & 15,73 & 10,55 \\
\hline 33,26 & 932,90 & 89,30 & 36,92 & 29,54 & 25,09 & 20,10 & 16,16 & 13,12 & 9,08 & 6,78 & 4,52 \\
\hline 45,39 & 1447,70 & 194,40 & 15,78 & 12,07 & 10,35 & 8,55 & 7,11 & 5,94 & 4,26 & 3,22 & 2,12 \\
\hline 35,22 & 800,40 & 181,80 & 24,12 & 16,83 & 13,45 & 10,16 & 7,87 & 6,25 & 4,28 & 3,24 & 2,22 \\
\hline 75,03 & 1991,60 & 136,80 & 12,77 & 9,67 & 8,87 & 8,05 & 7,36 & 6,73 & 5,61 & 4,69 & 3,34 \\
\hline 52,92 & 788,70 & 91,50 & 28,75 & 22,25 & 19,47 & 16,62 & 14,25 & 12,24 & 9,14 & 7,04 & 4,63 \\
\hline 66,49 & 510,10 & 78,20 & 34,20 & 24,52 & 21,14 & 18,09 & 15,72 & 13,71 & 10,53 & 8,28 & 5,54 \\
\hline 53,99 & 1053,80 & 30,70 & 50,19 & 42,21 & 40,06 & 36,93 & 33,89 & 31,00 & 25,76 & 21,38 & 14,99 \\
\hline 42,15 & 1251,20 & 186,20 & 17,98 & 13,55 & 11,46 & 9,28 & 7,57 & 6,23 & 4,39 & 3,30 & 2,19 \\
\hline 20,87 & 1288,10 & 155,00 & 31,16 & 22,75 & 17,41 & 12,31 & 9,08 & 7,04 & 4,83 & 3,72 & 2,58 \\
\hline 66,50 & 1001,20 & 21,60 & 56,75 & 45,41 & 43,34 & 41,27 & 38,92 & 36,58 & 32,11 & 28,05 & 21,34 \\
\hline 82,02 & 1774,80 & 163,00 & 11,69 & 8,46 & 7,61 & 6,83 & 6,20 & 5,65 & 4,69 & 3,91 & 2,79 \\
\hline 89,63 & 596,60 & 93,00 & 25,88 & 17,28 & 14,84 & 12,87 & 11,46 & 10,29 & 8,35 & 6,87 & 4,83 \\
\hline 80,22 & 965,90 & 100,00 & 20,34 & 14,66 & 13,07 & 11,62 & 10,49 & 9,49 & 7,78 & 6,43 & 4,52 \\
\hline 89,90 & 260,50 & 104,60 & 41,54 & 23,46 & 18,06 & 14,23 & 11,89 & 10,16 & 7,66 & 6,03 & 4,12 \\
\hline 36,81 & 1702,20 & 70,20 & 32,14 & 28,30 & 25,57 & 22,14 & 19,05 & 16,35 & 12,14 & 9,25 & 5,98 \\
\hline
\end{tabular}




\begin{tabular}{|c|c|c|c|c|c|c|c|c|c|c|c|}
\hline \multirow[b]{2}{*}{$\mathrm{e} 1(\mathrm{~cm})$} & & & & & & $\mathrm{De}$ & $\overline{\text { ões (x1 }}$ & m) & & & \\
\hline & Meq (MPa) & Ms (MPa) & D0 & D25 & D40 & D60 & D80 & D100 & D140 & D180 & D260 \\
\hline 79,75 & 268,60 & 43,50 & 58,86 & 40,23 & 34,52 & 29,73 & 26,21 & 23,25 & 18,42 & 14,85 & 10,19 \\
\hline 48,85 & 344,30 & 152,60 & 34,65 & 20,47 & 15,62 & 11,73 & 9,19 & 7,40 & 5,14 & 3,91 & 2,68 \\
\hline 50,98 & 590,60 & 44,90 & 50,12 & 41,04 & 36,85 & 32,17 & 28,08 & 24,49 & 18,71 & 14,58 & 9,60 \\
\hline 41,92 & 479,70 & 118,80 & 35,21 & 24,11 & 19,48 & 15,11 & 11,96 & 9,65 & 6,68 & 5,04 & 3,42 \\
\hline 30,94 & 722,50 & 51,20 & 61,14 & 50,45 & 43,30 & 34,98 & 28,27 & 23,02 & 15,94 & 11,87 & 7,87 \\
\hline 67,50 & 491,20 & 53,40 & 42,10 & 31,54 & 27,97 & 24,54 & 21,76 & 19,31 & 15,25 & 12,22 & 8,28 \\
\hline 34,48 & 1031,50 & 107,00 & 30,92 & 24,52 & 20,82 & 16,69 & 13,44 & 10,93 & 7,58 & 5,66 & 3,77 \\
\hline 51,88 & 204,20 & 143,50 & 47,91 & 24,78 & 17,65 & 12,61 & 9,68 & 7,74 & 5,36 & 4,11 & 2,87 \\
\hline 20,46 & 1749,20 & 70,40 & 51,43 & 42,45 & 35,31 & 27,15 & 20,98 & 16,52 & 11,11 & 8,31 & 5,66 \\
\hline 74,52 & 1853,80 & 33,90 & 31,24 & 25,17 & 23,61 & 22,78 & 21,77 & 20,70 & 18,61 & 16,65 & 13,23 \\
\hline 62,86 & 641,10 & 104,50 & 27,07 & 19,40 & 16,63 & 14,10 & 12,13 & 10,48 & 7,92 & 6,16 & 4,10 \\
\hline 52,20 & 889,00 & 50,50 & 39,21 & 32,76 & 29,97 & 26,67 & 23,70 & 21,01 & 16,50 & 13,10 & 8,73 \\
\hline 66,86 & 1872,70 & 158,90 & 12,73 & 9,79 & 8,84 & 7,87 & 7,06 & 6,32 & 5,08 & 4,12 & 2,82 \\
\hline 46,20 & 1802,30 & 131,20 & 17,97 & 14,92 & 13,34 & 11,53 & 9,95 & 8,58 & 6,43 & 4,95 & 3,23 \\
\hline 48,79 & 958,70 & 49,00 & 40,58 & 34,51 & 31,60 & 28,07 & 24,86 & 21,96 & 17,13 & 13,51 & 8,95 \\
\hline 65,89 & 928,80 & 66,50 & 28,53 & 22,31 & 20,37 & 18,29 & 16,49 & 14,86 & 12,05 & 9,83 & 6,78 \\
\hline 61,98 & 1388,40 & 90,10 & 20,92 & 16,72 & 15,32 & 13,76 & 12,39 & 11,14 & 8,99 & 7,30 & 4,99 \\
\hline 39,60 & 1943,80 & 74,70 & 27,87 & 24,63 & 22,48 & 19,75 & 17,25 & 15,02 & 11,41 & 8,82 & 5,73 \\
\hline 33,77 & 1061,60 & 32,70 & 66,85 & 60,04 & 54,53 & 47,41 & 40,90 & 35,18 & 26,17 & 19,93 & 12,86 \\
\hline 64,85 & 1943,70 & 132,80 & 14,13 & 11,13 & 10,19 & 9,16 & 8,27 & 7,45 & 6,04 & 4,93 & 3,40 \\
\hline 51,33 & 549,60 & 74,10 & 38,63 & 29,31 & 25,32 & 21,30 & 18,03 & 15,31 & 11,25 & 8,59 & 5,65 \\
\hline 22,70 & 1058,70 & 60,90 & 60,91 & 49,39 & 40,83 & 31,27 & 24,13 & 19,01 & 12,82 & 9,62 & 6,56 \\
\hline 48,27 & 1762,50 & 59,50 & 29,14 & 25,20 & 23,55 & 21,33 & 19,24 & 17,28 & 13,88 & 11,19 & 7,55 \\
\hline 56,18 & 1898,70 & 145,70 & 14,62 & 11,79 & 10,64 & 9,38 & 8,29 & 7,31 & 5,70 & 4,51 & 3,01 \\
\hline 68,01 & 1606,80 & 123,60 & 15,56 & 12,01 & 10,92 & 9,79 & 8,83 & 7,96 & 6,46 & 5,28 & 3,65 \\
\hline 56,12 & 470,00 & 154,10 & 27,86 & 17,54 & 13,97 & 11,00 & 8,93 & 7,37 & 5,24 & 3,98 & 2,68 \\
\hline 25,09 & 1571,80 & 82,80 & 40,38 & 33,55 & 28,42 & 22,45 & 17,76 & 14,21 & 9,67 & 7,19 & 4,83 \\
\hline 76,70 & 520,00 & 50,90 & 39,71 & 29,12 & 26,08 & 23,22 & 20,94 & 18,91 & 15,44 & 12,70 & 8,88 \\
\hline 47,92 & 951,20 & 81,30 & 30,19 & 24,55 & 21,80 & 18,74 & 16,12 & 13,86 & 10,36 & 7,96 & 5,21 \\
\hline 62,14 & 639,30 & 182,30 & 21,05 & 13,52 & 10,96 & 8,84 & 7,34 & 6,16 & 4,48 & 3,43 & 2,29 \\
\hline 73,94 & 1269,20 & 167,30 & 14,16 & 10,14 & 8,87 & 7,73 & 6,84 & 6,08 & 4,82 & 3,88 & 2,65 \\
\hline 38,99 & 1730,60 & 154,60 & 18,58 & 15,11 & 13,14 & 10,91 & 9,06 & 7,55 & 5,38 & 4,04 & 2,65 \\
\hline 31,01 & 1068,10 & 165,90 & 24,66 & 18,30 & 14,83 & 11,25 & 8,70 & 6,89 & 4,70 & 3,55 & 2,42 \\
\hline 35,19 & 1134,50 & 21,80 & 83,24 & 76,09 & 70,88 & 63,57 & 56,56 & 50,07 & 39,07 & 30,71 & 20,13 \\
\hline 79,27 & 1107,70 & 34,80 & 35,76 & 27,72 & 25,99 & 24,66 & 23,27 & 21,90 & 19,32 & 16,98 & 13,09 \\
\hline 49,79 & 855,20 & 179,90 & 19,89 & 13,95 & 11,59 & 9,37 & 7,69 & 6,37 & 4,54 & 3,44 & 2,29 \\
\hline 45,04 & 457,10 & 186,80 & 27,72 & 16,82 & 12,92 & 9,68 & 7,54 & 6,04 & 4,18 & 3,18 & 2,18 \\
\hline 31,83 & 1642,10 & 31,70 & 62,10 & 57,10 & 52,64 & 46,57 & 40,84 & 35,65 & 27,13 & 20,95 & 13,54 \\
\hline 72,49 & 498,50 & 132,80 & 26,41 & 16,84 & 13,74 & 11,27 & 9,56 & 8,19 & 6,15 & 4,79 & 3,22 \\
\hline 62,22 & 1278,90 & 56,20 & 28,92 & 23,41 & 21,93 & 20,09 & 18,40 & 16,80 & 13,95 & 11,59 & 8,16 \\
\hline 28,94 & 215,50 & 114,30 & 57,55 & 32,68 & 23,27 & 16,00 & 11,90 & 9,38 & 6,52 & 5,05 & 3,55 \\
\hline 31,80 & 1458,50 & 43,70 & 52,12 & 46,80 & 42,29 & 36,48 & 31,22 & 26,65 & 19,58 & 14,81 & 9,54 \\
\hline 31,49 & 1705,80 & 66,70 & 37,70 & 33,11 & 29,50 & 24,97 & 21,00 & 17,65 & 12,69 & 9,50 & 6,15 \\
\hline 85,75 & 1389,90 & 100,80 & 16,63 & 12,12 & 11,04 & 10,07 & 9,27 & 8,55 & 7,26 & 6,18 & 4,54 \\
\hline 69,67 & 1448,30 & 193,10 & 12,66 & 9,17 & 8,01 & 6,95 & 6,11 & 5,40 & 4,23 & 3,37 & 2,28 \\
\hline 81,73 & 408,60 & 29,70 & 57,78 & 42,60 & 38,87 & 35,37 & 32,45 & 29,82 & 25,12 & 21,22 & 15,39 \\
\hline 75,26 & 765,90 & 103,40 & 23,02 & 16,36 & 14,28 & 12,43 & 11,01 & 9,79 & 7,78 & 6,27 & 4,29 \\
\hline 53,26 & 1438,10 & 61,10 & 28,82 & 24,28 & 22,60 & 20,45 & 18,46 & 16,61 & 13,40 & 10,85 & 7,37 \\
\hline 77,45 & 356,10 & 28,20 & 64,83 & 48,22 & 43,82 & 39,55 & 36,02 & 32,84 & 27,26 & 22,72 & 16,16 \\
\hline 47,01 & 1797,40 & 88,60 & 22,70 & 19,44 & 17,79 & 15,76 & 13,92 & 12,25 & 9,50 & 7,47 & 4,92 \\
\hline 71,05 & 1356,50 & 41,80 & 31,76 & 24,99 & 23,68 & 22,31 & 20,91 & 19,54 & 16,98 & 14,71 & 11,04 \\
\hline 79,88 & 457,70 & 112,30 & 28,88 & 18,38 & 15,11 & 12,55 & 10,79 & 9,38 & 7,21 & 5,70 & 3,87 \\
\hline 42,33 & 762,60 & 43,80 & 52,29 & 44,67 & 40,18 & 34,82 & 30,05 & 25,90 & 19,37 & 14,86 & 9,66 \\
\hline 24,05 & 452,40 & 115,10 & 47,70 & 31,62 & 23,40 & 16,25 & 11,99 & 9,37 & 6,49 & 5,02 & 3,50 \\
\hline 62,75 & 1188,50 & 199,70 & 14,39 & 10,26 & 8,77 & 7,42 & 6,37 & 5,49 & 4,14 & 3,22 & 2,14 \\
\hline 79,05 & 1453,50 & 64,00 & 22,20 & 16,93 & 15,81 & 14,75 & 13,76 & 12,83 & 11,10 & 9,58 & 7,17 \\
\hline 27,64 & 934,40 & 103,50 & 37,99 & 29,32 & 23,93 & 18,19 & 14,03 & 11,08 & 7,52 & 5,67 & 3,87 \\
\hline 53,17 & 1419,20 & 160,30 & 16,17 & 12,56 & 11,01 & 9,42 & 8,10 & 6,97 & 5,22 & 4,03 & 2,65 \\
\hline 40,45 & 548,40 & 155,50 & 29,03 & 19,33 & 15,35 & 11,69 & 9,14 & 7,32 & 5,05 & 3,82 & 2,61 \\
\hline 81,50 & 1775,80 & 184,30 & 10,98 & 7,88 & 7,02 & 6,25 & 5,64 & 5,11 & 4,20 & 3,48 & 2,46 \\
\hline 84,21 & 704,80 & 32,90 & 42,58 & 32,01 & 29,69 & 27,73 & 25,92 & 24,22 & 21,08 & 18,32 & 13,87 \\
\hline 80,70 & 1961,40 & 133,90 & 12,56 & 9,33 & 8,55 & 7,80 & 7,17 & 6,59 & 5,57 & 4,71 & 3,42 \\
\hline 57,26 & 863,90 & 68,50 & 31,17 & 24,97 & 22,51 & 19,85 & 17,55 & 15,50 & 12,11 & 9,60 & 6,41 \\
\hline 38,36 & 893,60 & 120,80 & 28,22 & 21,61 & 18,23 & 14,62 & 11,80 & 9,64 & 6,72 & 5,03 & 3,36 \\
\hline 45,41 & 915,00 & 104,70 & 27,37 & 21,47 & 18,63 & 15,58 & 13,06 & 11,00 & 7,97 & 6,03 & 3,96 \\
\hline 83,36 & 1561,80 & 84,90 & 17,70 & 13,21 & 12,21 & 11,31 & 10,51 & 9,76 & 8,41 & 7,24 & 5,40 \\
\hline 71,63 & 655,20 & 153,10 & 21,30 & 13,97 & 11,57 & 9,61 & 8,20 & 7,07 & 5,34 & 4,17 & 2,80 \\
\hline 79,01 & 383,20 & 108,00 & 32,79 & 20,36 & 16,47 & 13,49 & 11,48 & 9,90 & 7,51 & 5,90 & 3,99 \\
\hline 39,84 & 607,50 & 88,40 & 38,82 & 29,38 & 24,75 & 19,87 & 16,08 & 13,15 & 9,20 & 6,90 & 4,60 \\
\hline 78,42 & 1098,70 & 122,80 & 17,36 & 12,49 & 11,07 & 9,78 & 8,78 & 7,90 & 6,42 & 5,26 & 3,67 \\
\hline 30,78 & 332,00 & 78,20 & 60,78 & 41,92 & 32,70 & 23,98 & 18,18 & 14,29 & 9,77 & 7,46 & 5,15 \\
\hline 46,01 & 629,90 & 136,20 & 27,63 & 19,38 & 15,98 & 12,74 & 10,31 & 8,45 & 5,94 & 4,48 & 3,00 \\
\hline 89,39 & 1904,90 & 187,30 & 10,12 & 7,12 & 6,35 & 5,70 & 5,19 & 4,75 & 3,98 & 3,35 & 2,43 \\
\hline 84,29 & 1985,90 & 191,00 & 10,07 & 7,21 & 6,46 & 5,78 & 5,25 & 4,79 & 3,98 & 3,33 & 2,38 \\
\hline 52,52 & 1542,80 & 148,20 & 16,42 & 13,05 & 11,56 & 9,98 & 8,64 & 7,48 & 5,66 & 4,38 & 2,88 \\
\hline 24,03 & 1551,40 & 168,90 & 25,42 & 19,29 & 15,35 & 11,31 & 8,53 & 6,66 & 4,52 & 3,44 & 2,37 \\
\hline 69,04 & 1209,50 & 59,90 & 26,76 & 21,00 & 19,60 & 18,01 & 16,56 & 15,21 & 12,77 & 10,72 & 7,68 \\
\hline 34,67 & 434,30 & 178,50 & 31,52 & 19,25 & 14,43 & 10,37 & 7,84 & 6,18 & 4,25 & 3,26 & 2,27 \\
\hline 41,11 & 653,30 & 71,70 & 41,87 & 33,10 & 28,55 & 23,57 & 19,50 & 16,21 & 11,55 & 8,68 & 5,71 \\
\hline 64,19 & 507,10 & 143,20 & 26,35 & 16,90 & 13,71 & 11,10 & 9,25 & 7,80 & 5,71 & 4,39 & 2,93 \\
\hline 89,87 & 1770,90 & 24,20 & 31,53 & 28,49 & 25,56 & 24,53 & 23,96 & 23,20 & 21,52 & 19,89 & 16,82 \\
\hline 77,71 & 1763,80 & 182,70 & 11,29 & 8,21 & 7,32 & 6,50 & 5,85 & 5,28 & 4,30 & 3,53 & 2,47 \\
\hline
\end{tabular}




\begin{tabular}{|c|c|c|c|c|c|c|c|c|c|c|c|}
\hline \multirow[b]{2}{*}{ e1 (cm) } & & & & & & & ões (x1 & m) & & & \\
\hline & Meq (MPa) & Ms (MPa) & D0 & D25 & D40 & D60 & D80 & D100 & D140 & D180 & D260 \\
\hline 63,28 & 636,20 & 197,20 & 20,29 & 12,77 & 10,25 & 8,21 & 6,79 & 5,69 & 4,13 & 3,16 & 2,12 \\
\hline 69,58 & 509,10 & 22,00 & 68,93 & 54,16 & 50,85 & 47,07 & 43,53 & 40,19 & 34,08 & 28,88 & 20,95 \\
\hline 37,56 & 331,60 & 31,50 & 95,81 & 77,19 & 66,61 & 54,68 & 44,93 & 37,14 & 26,21 & 19,63 & 12,92 \\
\hline 80,75 & 365,90 & 140,20 & 30,62 & 17,75 & 13,81 & 10,93 & 9,11 & 7,74 & 5,76 & 4,49 & 3,05 \\
\hline 73,20 & 324,90 & 68,40 & 44,62 & 29,74 & 24,89 & 20,89 & 18,00 & 15,62 & 11,94 & 9,40 & 6,33 \\
\hline 22,99 & 560,80 & 56,30 & 76,73 & 58,46 & 46,39 & 34,03 & 25,58 & 19,93 & 13,52 & 10,30 & 7,11 \\
\hline 72,93 & 1095,80 & 112,00 & 18,83 & 13,93 & 12,43 & 11,01 & 9,86 & 8,85 & 7,13 & 5,80 & 4,01 \\
\hline 87,14 & 219,70 & 95,70 & 48,32 & 26,94 & 20,53 & 16,01 & 13,27 & 11,26 & 8,39 & 6,57 & 4,48 \\
\hline 24,67 & 608,60 & 83,20 & 54,23 & 40,04 & 31,43 & 22,88 & 17,17 & 13,39 & 9,12 & 6,96 & 4,82 \\
\hline 33,90 & 560,00 & 35,30 & 79,31 & 66,81 & 58,46 & 48,52 & 40,14 & 33,32 & 23,59 & 17,62 & 11,53 \\
\hline 69,21 & 430,30 & 148,20 & 28,04 & 17,02 & 13,47 & 10,74 & 8,90 & 7,50 & 5,48 & 4,23 & 2,84 \\
\hline 50,10 & 1664,90 & 188,50 & 14,25 & 11,13 & 9,73 & 8,26 & 7,03 & 6,00 & 4,44 & 3,40 & 2,23 \\
\hline 67,35 & 578,80 & 57,40 & 37,59 & 28,45 & 25,41 & 22,42 & 19,96 & 17,78 & 14,14 & 11,38 & 7,74 \\
\hline 63,13 & 1894,10 & 166,20 & 12,71 & 9,89 & 8,89 & 7,86 & 6,99 & 6,22 & 4,92 & 3,95 & 2,67 \\
\hline 86,85 & 1714,30 & 33,50 & 28,25 & 23,27 & 21,28 & 20,51 & 19,79 & 18,95 & 17,28 & 15,70 & 12,86 \\
\hline 24,82 & 1237,30 & 174,60 & 25,99 & 19,12 & 14,99 & 10,90 & 8,17 & 6,38 & 4,34 & 3,32 & 2,30 \\
\hline 57,29 & 1860,80 & 138,20 & 15,04 & 12,11 & 10,97 & 9,71 & 8,61 & 7,63 & 5,99 & 4,76 & 3,19 \\
\hline 49,01 & 2000,00 & 106,80 & 18,86 & 15,98 & 14,60 & 12,95 & 11,45 & 10,10 & 7,86 & 6,19 & 4,09 \\
\hline 28,67 & 999,40 & 132,70 & 30,69 & 23,18 & 18,77 & 14,18 & 10,90 & 8,60 & 5,85 & 4,42 & 3,02 \\
\hline 41,98 & 1434,40 & 28,40 & 56,71 & 50,38 & 47,70 & 43,59 & 39,58 & 35,77 & 29,00 & 23,52 & 15,95 \\
\hline 48,53 & 594,90 & 188,20 & 23,53 & 15,13 & 12,04 & 9,35 & 7,46 & 6,06 & 4,24 & 3,21 & 2,17 \\
\hline 55,34 & 1961,10 & 185,80 & 12,63 & 9,98 & 8,88 & 7,72 & 6,73 & 5,87 & 4,49 & 3,51 & 2,32 \\
\hline 69,18 & 1536,80 & 58,40 & 24,89 & 19,63 & 18,52 & 17,24 & 16,01 & 14,84 & 12,68 & 10,81 & 7,92 \\
\hline 25,91 & 600,50 & 99,00 & 46,82 & 33,83 & 26,39 & 19,16 & 14,37 & 11,22 & 7,66 & 5,86 & 4,05 \\
\hline 23,71 & 1689,20 & 30,70 & 81,20 & 73,45 & 65,67 & 55,54 & 46,53 & 38,92 & 27,68 & 20,58 & 13,27 \\
\hline 79,38 & 204,10 & 41,50 & 70,09 & 46,23 & 38,78 & 32,77 & 28,49 & 24,98 & 19,44 & 15,49 & 10,55 \\
\hline 26,14 & 923,00 & 121,70 & 35,39 & 26,47 & 21,09 & 15,60 & 11,82 & 9,26 & 6,29 & 4,78 & 3,29 \\
\hline 73,68 & 213,80 & 192,20 & 41,62 & 19,90 & 13,57 & 9,44 & 7,23 & 5,80 & 4,04 & 3,11 & 2,17 \\
\hline 37,62 & 385,60 & 77,10 & 52,26 & 37,41 & 30,48 & 23,59 & 18,57 & 14,91 & 10,27 & 7,73 & 5,24 \\
\hline 30,49 & 1081,70 & 79,10 & 40,43 & 33,19 & 28,37 & 22,79 & 18,33 & 14,87 & 10,26 & 7,64 & 5,08 \\
\hline 47,17 & 1050,30 & 65,80 & 33,33 & 28,04 & 25,32 & 22,15 & 19,32 & 16,83 & 12,83 & 9,96 & 6,53 \\
\hline 22,56 & 1497,50 & 94,50 & 40,52 & 32,50 & 26,65 & 20,22 & 15,50 & 12,17 & 8,20 & 6,17 & 4,22 \\
\hline 20,17 & 1818,60 & 189,40 & 25,09 & 18,55 & 14,26 & 10,11 & 7,45 & 5,78 & 3,95 & 3,04 & 2,11 \\
\hline 43,71 & 298,50 & 145,10 & 39,39 & 22,85 & 17,13 & 12,55 & 9,67 & 7,70 & 5,31 & 4,06 & 2,81 \\
\hline 71,63 & 1424,10 & 82,40 & 20,25 & 15,65 & 14,49 & 13,25 & 12,14 & 11,13 & 9,30 & 7,79 & 5,56 \\
\hline 36,90 & 624,70 & 28,50 & 81,88 & 71,51 & 64,28 & 55,33 & 47,35 & 40,46 & 29,82 & 22,64 & 14,65 \\
\hline 60,50 & 657,40 & 39,30 & 47,05 & 37,98 & 34,94 & 31,46 & 28,36 & 25,51 & 20,60 & 16,73 & 11,45 \\
\hline 21,37 & 901,90 & 70,90 & 59,76 & 46,31 & 36,91 & 27,12 & 20,37 & 15,85 & 10,72 & 8,16 & 5,63 \\
\hline 28,17 & 378,50 & 170,10 & 36,56 & 21,69 & 15,66 & 10,82 & 8,04 & 6,32 & 4,39 & 3,40 & 2,38 \\
\hline 59,07 & 1222,20 & 190,80 & 14,94 & 10,89 & 9,35 & 7,91 & 6,76 & 5,81 & 4,35 & 3,36 & 2,23 \\
\hline 62,17 & 847,00 & 120,30 & 22,07 & 16,21 & 14,05 & 12,02 & 10,41 & 9,04 & 6,88 & 5,38 & 3,58 \\
\hline 36,59 & 1550,00 & 137,60 & 21,78 & 17,69 & 15,29 & 12,55 & 10,31 & 8,52 & 6,00 & 4,49 & 2,96 \\
\hline 32,48 & 1718,10 & 166,50 & 20,22 & 16,12 & 13,64 & 10,86 & 8,69 & 7,03 & 4,84 & 3,62 & 2,42 \\
\hline 29,59 & 1456,20 & 33,10 & 66,59 & 60,64 & 55,07 & 47,74 & 41,01 & 35,12 & 25,90 & 19,61 & 12,60 \\
\hline 27,40 & 339,00 & 160,90 & 39,76 & 23,21 & 16,60 & 11,39 & 8,45 & 6,65 & 4,63 & 3,59 & 2,52 \\
\hline 83,30 & 1998,00 & 62,30 & 19,23 & 14,88 & 13,86 & 13,19 & 12,49 & 11,79 & 10,48 & 9,28 & 7,25 \\
\hline 52,58 & 1146,70 & 56,10 & 33,24 & 27,96 & 25,80 & 23,15 & 20,74 & 18,52 & 14,74 & 11,81 & 7,94 \\
\hline 47,45 & 1526,30 & 29,30 & 50,26 & 43,29 & 41,46 & 38,42 & 35,37 & 32,42 & 27,03 & 22,48 & 15,76 \\
\hline 76,76 & 285,60 & 145,70 & 36,16 & 19,76 & 14,78 & 11,26 & 9,14 & 7,60 & 5,50 & 4,25 & 2,89 \\
\hline 79,31 & 1925,00 & 198,80 & 10,27 & 7,43 & 6,62 & 5,89 & 5,31 & 4,80 & 3,93 & 3,24 & 2,27 \\
\hline 85,83 & 1784,90 & 24,40 & 33,12 & 29,21 & 26,40 & 25,46 & 24,80 & 23,95 & 22,13 & 20,36 & 17,07 \\
\hline 47,85 & 978,30 & 178,40 & 19,12 & 13,83 & 11,61 & 9,45 & 7,77 & 6,45 & 4,59 & 3,47 & 2,30 \\
\hline 27,60 & 1335,00 & 103,50 & 33,94 & 27,38 & 22,94 & 17,95 & 14,12 & 11,28 & 7,68 & 5,73 & 3,87 \\
\hline 35,11 & 1755,60 & 163,40 & 19,22 & 15,48 & 13,27 & 10,77 & 8,76 & 7,18 & 5,01 & 3,74 & 2,48 \\
\hline 80,66 & 1523,70 & 23,30 & 39,11 & 32,81 & 30,14 & 29,18 & 28,22 & 27,07 & 24,74 & 22,51 & 18,47 \\
\hline 39,06 & 587,00 & 28,50 & 80,15 & 69,64 & 62,74 & 54,28 & 46,70 & 40,12 & 29,83 & 22,77 & 14,76 \\
\hline 71,93 & 833,90 & 128,70 & 20,18 & 14,22 & 12,26 & 10,55 & 9,24 & 8,12 & 6,33 & 5,04 & 3,41 \\
\hline 37,98 & 1569,90 & 159,60 & 19,26 & 15,38 & 13,22 & 10,82 & 8,87 & 7,32 & 5,16 & 3,87 & 2,55 \\
\hline 74,74 & 419,00 & 71,60 & 37,68 & 25,92 & 22,14 & 18,93 & 16,54 & 14,54 & 11,33 & 9,02 & 6,12 \\
\hline 43,66 & 996,60 & 94,60 & 28,77 & 23,19 & 20,31 & 17,11 & 14,42 & 12,18 & 8,85 & 6,71 & 4,38 \\
\hline 48,37 & 589,60 & 168,90 & 24,96 & 16,43 & 13,21 & 10,35 & 8,30 & 6,77 & 4,75 & 3,59 & 2,42 \\
\hline 26,89 & 1802,50 & 164,10 & 22,96 & 18,11 & 14,93 & 11,46 & 8,89 & 7,04 & 4,77 & 3,58 & 2,44 \\
\hline 29,37 & 244,80 & 70,20 & 74,20 & 49,04 & 37,26 & 26,67 & 19,99 & 15,67 & 10,76 & 8,27 & 5,75 \\
\hline 82,87 & 1525,50 & 117,80 & 14,87 & 10,88 & 9,89 & 8,97 & 8,22 & 7,55 & 6,35 & 5,36 & 3,88 \\
\hline 63,13 & 1890,20 & 175,10 & 12,35 & 9,56 & 8,56 & 7,55 & 6,70 & 5,94 & 4,68 & 3,74 & 2,52 \\
\hline 67,66 & 732,00 & 123,00 & 22,62 & 15,92 & 13,62 & 11,59 & 10,04 & 8,73 & 6,68 & 5,25 & 3,51 \\
\hline 66,58 & 463,00 & 175,30 & 25,39 & 15,15 & 11,85 & 9,32 & 7,65 & 6,39 & 4,62 & 3,54 & 2,39 \\
\hline 49,39 & 1684,30 & 94,00 & 21,68 & 18,30 & 16,69 & 14,77 & 13,05 & 11,50 & 8,93 & 7,03 & 4,65 \\
\hline 72,44 & 670,10 & 83,40 & 27,86 & 20,20 & 17,75 & 15,51 & 13,75 & 12,22 & 9,69 & 7,80 & 5,32 \\
\hline 69,36 & 1670,10 & 65,40 & 22,42 & 17,66 & 16,64 & 15,47 & 14,36 & 13,30 & 11,34 & 9,66 & 7,06 \\
\hline 20,76 & 1144,50 & 123,80 & 38,05 & 28,16 & 21,72 & 15,46 & 11,42 & 8,86 & 6,06 & 4,66 & 3,23 \\
\hline 42,85 & 1802,60 & 23,00 & 61,04 & 53,00 & 51,17 & 47,72 & 44,14 & 40,65 & 34,16 & 28,58 & 20,19 \\
\hline 63,95 & 905,20 & 47,10 & 36,12 & 28,91 & 26,87 & 24,47 & 22,31 & 20,30 & 16,74 & 13,84 & 9,68 \\
\hline 53,04 & 466,30 & 48,70 & 51,48 & 40,42 & 35,63 & 30,63 & 26,42 & 22,81 & 17,18 & 13,29 & 8,74 \\
\hline 89,42 & 1536,50 & 95,60 & 16,04 & 11,71 & 10,70 & 9,87 & 9,17 & 8,52 & 7,36 & 6,35 & 4,77 \\
\hline 74,80 & 809,10 & 149,70 & 18,82 & 12,78 & 10,83 & 9,20 & 8,01 & 7,01 & 5,43 & 4,31 & 2,92 \\
\hline 39,82 & 489,90 & 179,80 & 28,41 & 17,81 & 13,73 & 10,19 & 7,86 & 6,25 & 4,30 & 3,27 & 2,26 \\
\hline 30,22 & 1189,70 & 193,40 & 21,81 & 16,04 & 12,89 & 9,69 & 7,44 & 5,88 & 4,00 & 3,03 & 2,08 \\
\hline 26,14 & 494,80 & 98,80 & 49,52 & 34,70 & 26,67 & 19,13 & 14,28 & 11,15 & 7,64 & 5,86 & 4,07 \\
\hline 59,30 & 1121,50 & 164,70 & 16,76 & 12,33 & 10,65 & 9,05 & 7,78 & 6,70 & 5,04 & 3,91 & 2,59 \\
\hline 72,77 & 1503,40 & 102,30 & 17,27 & 13,19 & 12,10 & 10,98 & 10,01 & 9,13 & 7,57 & 6,30 & 4,46 \\
\hline 87,81 & 463,90 & 108,60 & 28,25 & 17,79 & 14,66 & 12,26 & 10,65 & 9,36 & 7,34 & 5,89 & 4,05 \\
\hline
\end{tabular}




\begin{tabular}{|c|c|c|c|c|c|c|c|c|c|c|c|}
\hline & & & \multicolumn{9}{|c|}{ Deflexões $\left(\times 10^{-4} \mathrm{~cm}\right)$} \\
\hline e1 (cm) & Meq (MPa) & Ms (MPa) & D0 & D25 & D40 & D60 & D80 & D100 & D140 & D180 & D260 \\
\hline 67,75 & 1117,00 & 32,40 & 41,30 & 32,82 & 31,21 & 29,37 & 27,48 & 25,64 & 22,19 & 19,14 & 14,26 \\
\hline 83,57 & 697,00 & 155,30 & 19,45 & 12,49 & 10,36 & 8,70 & 7,55 & 6,62 & 5,17 & 4,13 & 2,83 \\
\hline 78,53 & 1298,70 & 34,70 & 33,91 & 26,57 & 24,92 & 23,79 & 22,55 & 21,31 & 18,93 & 16,76 & 13,06 \\
\hline 87,82 & 1336,40 & 103,90 & 16,46 & 11,87 & 10,75 & 9,78 & 8,99 & 8,29 & 7,03 & 5,99 & 4,40 \\
\hline 65,47 & 790,90 & 78,60 & 27,88 & 21,24 & 18,95 & 16,68 & 14,81 & 13,15 & 10,39 & 8,32 & 5,63 \\
\hline 59,03 & 1823,00 & 37,10 & 35,10 & 28,66 & 27,55 & 26,02 & 24,36 & 22,73 & 19,64 & 16,90 & 12,51 \\
\hline 64,43 & 429,60 & 41,60 & 52,50 & 40,25 & 35,97 & 31,68 & 28,11 & 24,95 & 19,69 & 15,75 & 10,64 \\
\hline 39,25 & 1695,20 & 149,10 & 19,06 & 15,53 & 13,53 & 11,26 & 9,37 & 7,82 & 5,59 & 4,20 & 2,75 \\
\hline 29,42 & 1514,20 & 60,40 & 44,35 & 38,63 & 34,09 & 28,45 & 23,61 & 19,62 & 13,87 & 10,33 & 6,72 \\
\hline 77,07 & 1709,70 & 176,80 & 11,70 & 8,52 & 7,60 & 6,75 & 6,07 & 5,47 & 4,45 & 3,66 & 2,55 \\
\hline 48,05 & 918,40 & 67,50 & 34,16 & 28,25 & 25,31 & 21,98 & 19,07 & 16,53 & 12,49 & 9,66 & 6,33 \\
\hline 28,61 & 1292,80 & 25,70 & 84,45 & 77,37 & 70,43 & 61,21 & 52,69 & 45,20 & 33,41 & 25,32 & 16,25 \\
\hline 42,10 & 1370,70 & 144,70 & 20,12 & 16,00 & 13,86 & 11,52 & 9,59 & 8,02 & 5,75 & 4,33 & 2,84 \\
\hline 23,13 & 496,10 & 57,60 & 77,79 & 58,18 & 45,67 & 33,16 & 24,81 & 19,31 & 13,14 & 10,04 & 6,95 \\
\hline 44,38 & 742,40 & 158,30 & 24,04 & 16,93 & 13,95 & 11,06 & 8,91 & 7,28 & 5,09 & 3,84 & 2,57 \\
\hline 29,24 & 826,60 & 67,40 & 50,81 & 41,01 & 34,57 & 27,29 & 21,64 & 17,38 & 11,89 & 8,87 & 5,96 \\
\hline 64,56 & 1608,70 & 181,20 & 12,89 & 9,71 & 8,58 & 7,48 & 6,59 & 5,81 & 4,54 & 3,60 & 2,42 \\
\hline 86,90 & 1181,10 & 114,10 & 16,68 & 11,84 & 10,59 & 9,49 & 8,64 & 7,89 & 6,59 & 5,54 & 3,99 \\
\hline 33,10 & 1429,80 & 76,30 & 35,26 & 30,18 & 26,59 & 22,23 & 18,51 & 15,43 & 10,98 & 8,21 & 5,35 \\
\hline 87,06 & 511,50 & 45,70 & 40,11 & 28,66 & 25,76 & 23,22 & 21,21 & 19,44 & 16,33 & 13,78 & 9,99 \\
\hline 55,85 & 1747,00 & 186,00 & 13,20 & 10,27 & 9,07 & 7,83 & 6,80 & 5,90 & 4,49 & 3,49 & 2,31 \\
\hline 35,27 & 1813,20 & 23,20 & 69,22 & 63,00 & 59,76 & 54,59 & 49,48 & 44,61 & 35,96 & 28,99 & 19,47 \\
\hline 53,74 & 778,30 & 166,00 & 20,95 & 14,56 & 12,12 & 9,89 & 8,20 & 6,86 & 4,94 & 3,76 & 2,50 \\
\hline 42,69 & 979,00 & 167,00 & 21,08 & 15,51 & 12,98 & 10,42 & 8,45 & 6,93 & 4,86 & 3,66 & 2,44 \\
\hline 60,24 & 1173,90 & 129,40 & 18,50 & 14,16 & 12,51 & 10,86 & 9,50 & 8,31 & 6,41 & 5,04 & 3,35 \\
\hline 87,91 & 1362,60 & 140,00 & 13,94 & 9,81 & 8,73 & 7,80 & 7,09 & 6,46 & 5,39 & 4,52 & 3,25 \\
\hline 73,01 & 1796,10 & 63,00 & 21,70 & 16,94 & 15,98 & 15,00 & 14,02 & 13,08 & 11,33 & 9,79 & 7,32 \\
\hline 73,20 & 1619,10 & 82,70 & 18,99 & 14,66 & 13,66 & 12,58 & 11,61 & 10,71 & 9,06 & 7,67 & 5,56 \\
\hline 24,89 & 1926,30 & 179,30 & 22,32 & 17,38 & 14,10 & 10,61 & 8,11 & 6,36 & 4,31 & 3,25 & 2,23 \\
\hline 53,63 & 1080,50 & 103,00 & 23,26 & 18,45 & 16,38 & 14,18 & 12,31 & 10,69 & 8,13 & 6,32 & 4,16 \\
\hline 86,31 & 514,10 & 92,50 & 28,55 & 18,85 & 15,98 & 13,68 & 12,06 & 10,72 & 8,55 & 6,94 & 4,81 \\
\hline 42,82 & 939,20 & 74,00 & 34,62 & 28,59 & 25,28 & 21,51 & 18,26 & 15,52 & 11,38 & 8,64 & 5,63 \\
\hline 29,91 & 388,30 & 47,20 & 81,49 & 62,56 & 51,38 & 39,46 & 30,70 & 24,39 & 16,61 & 12,49 & 8,50 \\
\hline 52,18 & 1779,20 & 41,40 & 35,46 & 29,96 & 28,64 & 26,58 & 24,52 & 22,53 & 18,89 & 15,79 & 11,18 \\
\hline 20,74 & 1559,70 & 107,30 & 38,87 & 30,42 & 24,35 & 17,96 & 13,50 & 10,50 & 7,10 & 5,39 & 3,72 \\
\hline 23,01 & 1554,40 & 188,60 & 24,15 & 17,94 & 14,02 & 10,13 & 7,56 & 5,88 & 4,01 & 3,07 & 2,12 \\
\hline 39,01 & 1187,10 & 141,30 & 22,71 & 17,74 & 15,13 & 12,30 & 10,03 & 8,25 & 5,80 & 4,35 & 2,88 \\
\hline 41,04 & 733,90 & 129,90 & 28,14 & 20,59 & 17,12 & 13,60 & 10,94 & 8,91 & 6,21 & 4,67 & 3,13 \\
\hline 65,19 & 1516,80 & 132,20 & 15,68 & 12,11 & 10,91 & 9,68 & 8,64 & 7,71 & 6,15 & 4,96 & 3,37 \\
\hline 54,61 & 654,50 & 37,40 & 51,55 & 42,69 & 39,15 & 34,99 & 31,25 & 27,84 & 22,07 & 17,65 & 11,86 \\
\hline 71,00 & 700,30 & 187,00 & 18,91 & 12,09 & 9,86 & 8,08 & 6,84 & 5,85 & 4,37 & 3,40 & 2,28 \\
\hline 24,08 & 782,20 & 151,50 & 33,43 & 23,28 & 17,65 & 12,46 & 9,23 & 7,19 & 4,95 & 3,81 & 2,65 \\
\hline 68,08 & 890,80 & 58,50 & 30,79 & 24,00 & 22,05 & 19,94 & 18,11 & 16,43 & 13,49 & 11,12 & 7,77 \\
\hline 79,51 & 1774,30 & 138,70 & 12,95 & 9,57 & 8,70 & 7,87 & 7,19 & 6,57 & 5,49 & 4,60 & 3,29 \\
\hline 75,96 & 1345,20 & 107,90 & 17,19 & 12,85 & 11,67 & 10,51 & 9,55 & 8,69 & 7,18 & 5,96 & 4,22 \\
\hline 78,82 & 1504,70 & 99,50 & 16,87 & 12,63 & 11,60 & 10,59 & 9,73 & 8,94 & 7,54 & 6,36 & 4,61 \\
\hline 52,75 & 687,10 & 184,60 & 21,36 & 14,16 & 11,51 & 9,18 & 7,48 & 6,18 & 4,39 & 3,33 & 2,23 \\
\hline 26,12 & 1391,80 & 57,10 & 52,32 & 44,80 & 38,83 & 31,56 & 25,56 & 20,82 & 14,37 & 10,65 & 7,04 \\
\hline 36,20 & 1689,30 & 45,70 & 43,36 & 39,18 & 36,05 & 31,90 & 28,01 & 24,49 & 18,72 & 14,51 & 9,43 \\
\hline 30,38 & 817,80 & 40,40 & 69,47 & 59,48 & 52,08 & 43,07 & 35,47 & 29,31 & 20,59 & 15,33 & 10,03 \\
\hline 26,51 & 1490,20 & 81,90 & 39,62 & 33,02 & 28,16 & 22,44 & 17,89 & 14,41 & 9,85 & 7,32 & 4,89 \\
\hline 36,58 & 1343,10 & 162,30 & 20,74 & 16,14 & 13,65 & 10,95 & 8,83 & 7,19 & 5,00 & 3,74 & 2,49 \\
\hline 70,67 & 1577,80 & 105,40 & 16,88 & 13,01 & 11,95 & 10,82 & 9,85 & 8,97 & 7,41 & 6,14 & 4,32 \\
\hline 30,90 & 1799,90 & 186,40 & 19,13 & 15,06 & 12,59 & 9,87 & 7,79 & 6,24 & 4,27 & 3,20 & 2,15 \\
\hline 53,06 & 1127,30 & 123,80 & 20,70 & 16,15 & 14,19 & 12,16 & 10,46 & 9,01 & 6,76 & 5,22 & 3,43 \\
\hline 67,34 & 319,50 & 134,90 & 35,25 & 20,45 & 15,77 & 12,25 & 9,98 & 8,30 & 5,97 & 4,58 & 3,10 \\
\hline 46,97 & 1106,60 & 26,80 & 59,33 & 51,56 & 48,86 & 44,79 & 40,84 & 37,07 & 30,34 & 24,83 & 17,05 \\
\hline 79,54 & 829,20 & 135,20 & 19,02 & 13,00 & 11,14 & 9,59 & 8,45 & 7,49 & 5,93 & 4,78 & 3,28 \\
\hline 47,24 & 1177,50 & 128,60 & 21,32 & 16,80 & 14,67 & 12,38 & 10,47 & 8,89 & 6,51 & 4,95 & 3,24 \\
\hline 39,89 & 1506,50 & 67,00 & 32,53 & 28,45 & 25,80 & 22,51 & 19,53 & 16,90 & 12,71 & 9,77 & 6,34 \\
\hline 34,46 & 1314,20 & 110,30 & 27,79 & 22,66 & 19,52 & 15,91 & 12,97 & 10,65 & 7,45 & 5,56 & 3,67 \\
\hline 79,06 & 985,30 & 186,50 & 15,00 & 10,03 & 8,47 & 7,20 & 6,29 & 5,53 & 4,32 & 3,46 & 2,36 \\
\hline 75,98 & 909,10 & 190,20 & 15,78 & 10,45 & 8,75 & 7,36 & 6,37 & 5,55 & 4,27 & 3,38 & 2,29 \\
\hline 64,77 & 788,40 & 65,80 & 31,02 & 24,08 & 21,75 & 19,34 & 17,29 & 15,45 & 12,34 & 9,96 & 6,78 \\
\hline 37,53 & 767,80 & 196,10 & 22,74 & 15,50 & 12,34 & 9,36 & 7,27 & 5,80 & 3,98 & 3,01 & 2,06 \\
\hline 87,86 & 587,60 & 171,60 & 20,55 & 12,42 & 9,97 & 8,15 & 6,98 & 6,06 & 4,67 & 3,71 & 2,54 \\
\hline 31,44 & 878,50 & 183,80 & 24,51 & 17,31 & 13,70 & 10,18 & 7,78 & 6,13 & 4,19 & 3,18 & 2,19 \\
\hline 80,34 & 340,80 & 154,50 & 31,19 & 17,42 & 13,24 & 10,26 & 8,43 & 7,09 & 5,21 & 4,04 & 2,75 \\
\hline 20,14 & 1025,20 & 153,50 & 34,00 & 23,87 & 17,79 & 12,30 & 9,00 & 7,00 & 4,85 & 3,75 & 2,61 \\
\hline 52,19 & 964,90 & 90,70 & 26,68 & 21,27 & 18,87 & 16,30 & 14,12 & 12,22 & 9,24 & 7,16 & 4,71 \\
\hline 22,44 & 1250,80 & 125,00 & 35,06 & 26,61 & 21,02 & 15,33 & 11,48 & 8,94 & 6,07 & 4,63 & 3,20 \\
\hline 30,53 & 590,40 & 145,20 & 33,36 & 22,81 & 17,69 & 12,91 & 9,76 & 7,67 & 5,25 & 4,01 & 2,77 \\
\hline 61,41 & 455,60 & 22,60 & 75,62 & 61,26 & 57,00 & 51,86 & 47,20 & 42,85 & 35,17 & 28,95 & 20,13 \\
\hline 74,91 & 805,50 & 92,70 & 23,77 & 17,25 & 15,26 & 13,43 & 11,99 & 10,73 & 8,62 & 7,00 & 4,83 \\
\hline 33,67 & 1134,80 & 157,50 & 23,72 & 18,01 & 14,91 & 11,62 & 9,16 & 7,35 & 5,04 & 3,78 & 2,56 \\
\hline 55,05 & 1016,90 & 178,30 & 17,50 & 12,60 & 10,69 & 8,89 & 7,49 & 6,34 & 4,64 & 3,55 & 2,35 \\
\hline 30,58 & 818,40 & 109,60 & 35,77 & 27,14 & 22,20 & 17,00 & 13,21 & 10,49 & 7,15 & 5,38 & 3,66 \\
\hline 73,77 & 1359,70 & 149,50 & 14,52 & 10,63 & 9,43 & 8,32 & 7,43 & 6,66 & 5,35 & 4,34 & 2,99 \\
\hline 60,11 & 932,00 & 167,30 & 18,11 & 12,85 & 10,91 & 9,14 & 7,77 & 6,65 & 4,95 & 3,82 & 2,53 \\
\hline 33,73 & 926,80 & 51,00 & 52,57 & 44,92 & 39,60 & 33,15 & 27,64 & 23,08 & 16,46 & 12,32 & 8,02 \\
\hline 89,01 & 1258,60 & 113,80 & 16,03 & 11,38 & 10,21 & 9,20 & 8,42 & 7,72 & 6,50 & 5,50 & 4,01 \\
\hline 31,15 & 1260,20 & 23,60 & 83,98 & 77,32 & 71,21 & 62,91 & 55,07 & 47,99 & 36,41 & 28,05 & 18,11 \\
\hline
\end{tabular}




\begin{tabular}{|c|c|c|c|c|c|c|c|c|c|c|c|}
\hline & & & \multicolumn{9}{|c|}{ Deflexões $\left(\times 10^{-4} \mathrm{~cm}\right)$} \\
\hline e1 (cm) & Meq (MPa) & Ms (MPa) & D0 & D25 & D40 & D60 & D80 & D100 & D140 & D180 & D260 \\
\hline 85,99 & 1939,90 & 185,60 & 10,25 & 7,30 & 6,54 & 5,86 & 5,34 & 4,87 & 4,07 & 3,41 & 2,45 \\
\hline 41,96 & 860,00 & 71,40 & 37,15 & 30,50 & 26,85 & 22,68 & 19,14 & 16,18 & 11,77 & 8,91 & 5,81 \\
\hline 75,23 & 862,80 & 199,10 & 16,00 & 10,43 & 8,64 & 7,20 & 6,18 & 5,36 & 4,09 & 3,22 & 2,17 \\
\hline 52,76 & 933,70 & 126,00 & 22,38 & 16,93 & 14,65 & 12,36 & 10,51 & 8,95 & 6,62 & 5,07 & 3,34 \\
\hline 60,90 & 588,20 & 32,80 & 54,74 & 44,27 & 40,90 & 36,98 & 33,46 & 30,21 & 24,56 & 20,05 & 13,80 \\
\hline 55,86 & 1182,40 & 60,90 & 30,06 & 24,90 & 23,00 & 20,71 & 18,64 & 16,72 & 13,43 & 10,85 & 7,36 \\
\hline 38,27 & 895,20 & 138,30 & 26,02 & 19,49 & 16,27 & 12,90 & 10,33 & 8,39 & 5,82 & 4,37 & 2,93 \\
\hline 74,85 & 818,70 & 27,20 & 48,47 & 37,73 & 35,57 & 33,53 & 31,45 & 29,45 & 25,68 & 22,32 & 16,88 \\
\hline 39,20 & 1837,40 & 198,60 & 15,51 & 12,29 & 10,56 & 8,65 & 7,11 & 5,88 & 4,15 & 3,11 & 2,05 \\
\hline 85,45 & 1315,80 & 99,40 & 17,20 & 12,51 & 11,37 & 10,35 & 9,51 & 8,75 & 7,41 & 6,29 & 4,60 \\
\hline 86,89 & 748,50 & 25,70 & 47,10 & 36,12 & 33,45 & 31,76 & 30,06 & 28,39 & 25,24 & 22,37 & 17,51 \\
\hline 31,49 & 1762,70 & 40,30 & 52,06 & 47,52 & 43,43 & 38,01 & 32,98 & 28,50 & 21,34 & 16,30 & 10,50 \\
\hline 81,49 & 822,20 & 138,00 & 18,77 & 12,69 & 10,85 & 9,33 & 8,22 & 7,29 & 5,79 & 4,67 & 3,21 \\
\hline 44,09 & 1264,90 & 117,40 & 22,83 & 18,46 & 16,20 & 13,69 & 11,57 & 9,80 & 7,15 & 5,42 & 3,54 \\
\hline 85,99 & 1555,00 & 58,60 & 21,62 & 16,45 & 15,26 & 14,43 & 13,60 & 12,81 & 11,31 & 9,97 & 7,72 \\
\hline 33,09 & 988,30 & 186,20 & 22,67 & 16,35 & 13,16 & 9,97 & 7,72 & 6,12 & 4,18 & 3,16 & 2,16 \\
\hline 35,73 & 1401,60 & 88,90 & 30,33 & 25,62 & 22,54 & 18,88 & 15,77 & 13,19 & 9,43 & 7,07 & 4,61 \\
\hline 26,79 & 912,70 & 141,20 & 31,56 & 23,12 & 18,26 & 13,42 & 10,14 & 7,94 & 5,40 & 4,12 & 2,84 \\
\hline 60,61 & 1808,60 & 24,90 & 45,45 & 36,98 & 35,46 & 34,13 & 32,39 & 30,61 & 27,16 & 23,95 & 18,49 \\
\hline 53,82 & 1633,10 & 85,40 & 22,06 & 18,41 & 16,95 & 15,20 & 13,61 & 12,15 & 9,67 & 7,75 & 5,22 \\
\hline 71,32 & 248,20 & 103,40 & 45,03 & 26,03 & 20,08 & 15,68 & 12,85 & 10,75 & 7,80 & 6,01 & 4,06 \\
\hline 83,76 & 490,00 & 49,70 & 39,82 & 28,42 & 25,35 & 22,63 & 20,50 & 18,64 & 15,42 & 12,84 & 9,14 \\
\hline 29,82 & 893,20 & 103,30 & 36,72 & 28,39 & 23,40 & 18,03 & 14,06 & 11,18 & 7,62 & 5,72 & 3,89 \\
\hline 35,45 & 1968,60 & 134,40 & 20,72 & 17,35 & 15,19 & 12,64 & 10,49 & 8,73 & 6,21 & 4,65 & 3,04 \\
\hline 40,79 & 1453,90 & $\frac{10,+70}{191,10}$ & 16,98 & $\begin{array}{l}11,06 \\
13,06\end{array}$ & 11,12 & $\begin{array}{c}+L, 04 \\
9,04\end{array}$ & $\begin{array}{c}10,+7 \\
7,39\end{array}$ & 6,09 & 4,29 & 3,22 & 2,13 \\
\hline 34,03 & 327,90 & 121,40 & 44,62 & 27,97 & 21,17 & 15,29 & 11,56 & 9,11 & 6,26 & 4,80 & 3,33 \\
\hline 85,98 & 1746,10 & 97,40 & 15,33 & 11,36 & 10,46 & 9,69 & 9,02 & 8,39 & 7,25 & 6,26 & 4,70 \\
\hline 61,59 & 1375,80 & 180,20 & 14,23 & 10,60 & 9,24 & 7,95 & 6,91 & 6,01 & 4,60 & 3,60 & 2,39 \\
\hline 60,56 & 1295,90 & $\frac{100, c 0}{53,90}$ & $\frac{14,20}{30,05}$ & 24,52 & 23,01 & 21,09 & $\frac{0,0}{19,30}$ & $\frac{1,0 \perp}{17,62}$ & 14,61 & $\frac{,, 00}{12,12}$ & 8,51 \\
\hline 66,51 & 854,70 & 132,00 & 20,33 & 14,56 & 12,54 & 10,73 & 9,32 & 8,12 & 6,23 & 4,90 & 3,28 \\
\hline 47,60 & 1022,30 & 59,00 & 35,83 & 30,32 & 27,52 & 24,22 & 21,25 & 18,60 & 14,29 & 11,16 & 7,34 \\
\hline 39,37 & 973,90 & 119,20 & 27,05 & 21,04 & 17,93 & 14,56 & 11,88 & 9,77 & 6,87 & 5,15 & 3,41 \\
\hline 84,71 & 221,40 & 193,30 & 40,32 & 19,35 & 13,25 & 9,28 & 7,15 & 5,77 & 4,05 & 3,13 & 2,17 \\
\hline 66,95 & 1496,70 & 125,40 & 16,03 & 12,34 & 11,16 & 9,94 & 8,92 & 8,00 & 6,43 & 5,22 & 3,58 \\
\hline 49,23 & 669,00 & 80,80 & 34,56 & 26,77 & 23,26 & 19,61 & 16,60 & 14,09 & 10,34 & 7,89 & 5,17 \\
\hline 57,42 & 1560,60 & 121,10 & 17,44 & 13,99 & 12,63 & 11,16 & 9,88 & 8,73 & 6,84 & 5,43 & 3,63 \\
\hline 34,05 & 1256,70 & 31,40 & 64,49 & 58,61 & 53,79 & 47,38 & 41,40 & 36,03 & 27,30 & 21,03 & 13,60 \\
\hline 50,02 & 356,00 & 183,60 & 31,20 & 17,66 & 13,20 & 9,77 & 7,62 & 6,12 & 4,24 & 3,24 & 2,23 \\
\hline 45,33 & 1088,50 & 20,60 & 73,43 & 63,96 & 61,10 & 56,39 & 51,72 & 47,22 & 39,05 & 32,23 & 22,35 \\
\hline 71,61 & 1579,50 & 50,50 & 26,49 & 20,79 & 19,68 & 18,52 & 17,34 & 16,20 & 14,07 & 12,17 & 9,13 \\
\hline 38,56 & 1962,30 & 44,70 & 39,99 & 36,10 & 33,69 & 30,30 & 27,07 & 24,07 & 18,94 & 14,99 & 9,90 \\
\hline 70,19 & 1807,40 & 157,50 & 12,69 & 9,62 & 8,68 & 7,74 & 6,97 & 6,27 & 5,07 & 4,14 & 2,86 \\
\hline 72,89 & 1202,80 & 69,40 & 23,80 & 18,32 & 16,97 & 15,53 & 14,26 & 13,08 & 10,98 & 9,22 & 6,61 \\
\hline 25,41 & 267,50 & 140,40 & 48,18 & 27,22 & 19,06 & 12,92 & 9,58 & 7,56 & 5,28 & 4,11 & 2,89 \\
\hline 33,27 & 1567,70 & 165,00 & 20,66 & 16,32 & 13,77 & 10,95 & 8,75 & 7,08 & 4,88 & 3,65 & 2,44 \\
\hline 64,34 & 1673,20 & 118,80 & 16,11 & 12,68 & 11,58 & 10,38 & 9,34 & 8,40 & 6,78 & 5,52 & 3,79 \\
\hline 20,45 & 727,70 & 194,40 & 30,81 & 19,66 & 14,02 & 9,45 & 6,93 & 5,44 & 3,81 & 2,96 & 2,07 \\
\hline 63,35 & 1880,20 & 44,90 & 29,19 & 23,52 & 22,50 & 21,25 & 19,90 & 18,58 & 16,10 & 13,88 & 10,33 \\
\hline 57,83 & 593,40 & 120,80 & 27,21 & 18,94 & 15,88 & 13,11 & 11,01 & 9,32 & 6,83 & 5,23 & 3,47 \\
\hline 30,24 & 1069,10 & 93,80 & 36,51 & 29,30 & 24,70 & 19,53 & 15,51 & 12,48 & 8,55 & 6,38 & 4,28 \\
\hline 89,45 & 1211,80 & 62,60 & 22,57 & 16,70 & 15,36 & 14,32 & 13,38 & 12,52 & 10,93 & 9,53 & 7,26 \\
\hline 78,43 & 1228,80 & 138,40 & 15,46 & 11,11 & 9,84 & 8,69 & 7,80 & 7,02 & 5,69 & 4,67 & 3,25 \\
\hline 43,75 & 1965,60 & 99,30 & 21,48 & 18,51 & 16,81 & 14,74 & 12,87 & 11,21 & 8,54 & 6,62 & 4,32 \\
\hline 26,12 & 1893,30 & 137,30 & 26,09 & 21,07 & 17,57 & 13,65 & 10,67 & 8,48 & 5,75 & 4,30 & 2,91 \\
\hline 44,46 & 380,00 & 39,90 & 70,24 & 55,83 & 48,63 & 40,79 & 34,27 & 28,88 & 20,94 & 15,85 & 10,38 \\
\hline 48,93 & 1666,60 & 44,00 & 36,12 & 31,13 & 29,48 & 27,03 & 24,66 & 22,41 & 18,38 & 15,08 & 10,39 \\
\hline 42,83 & 778,50 & 160,10 & 23,81 & 16,92 & 13,94 & 11,02 & 8,85 & 7,20 & 5,03 & 3,78 & 2,54 \\
\hline 29,98 & 1067,40 & 25,50 & 87,04 & 79,10 & 71,78 & 62,18 & 53,39 & 45,69 & 33,68 & 25,50 & 16,39 \\
\hline 86,37 & 1443,80 & 189,30 & 11,74 & 8,09 & 7,06 & 6,20 & 5,56 & 5,01 & 4,09 & 3,38 & 2,38 \\
\hline 44,34 & 357,50 & 28,40 & 88,34 & 72,81 & 64,54 & 55,16 & 47,07 & 40,19 & 29,68 & 22,63 & 14,75 \\
\hline 30,46 & 907,70 & 40,00 & 67,32 & 58,31 & 51,40 & 42,88 & 35,58 & 29,58 & 20,94 & 15,61 & 10,16 \\
\hline 30,74 & 1334,20 & 100,20 & 32,02 & 26,23 & 22,40 & 17,99 & 14,47 & 11,74 & 8,10 & $\frac{10,01}{6,04}$ & 4,02 \\
\hline 23,80 & 474,10 & 162,20 & 37,10 & 23,11 & 16,64 & 11,36 & $\begin{array}{c}1+7,7 \\
8,37\end{array}$ & $\begin{array}{c}1+, 1+ \\
6,57\end{array}$ & 4,58 & 3,56 & 2,49 \\
\hline 26,57 & 739,60 & 137,60 & 34,47 & 24,49 & 19,00 & $1+13,74$ & 10,31 & 8,05 & 5,50 & 4,21 & 2,92 \\
\hline 83,42 & 1435,60 & 142,20 & 13,78 & 9,86 & 8,82 & 7,88 & 7,14 & 6,50 & 5,38 & 4,48 & 3,19 \\
\hline 34,01 & 1025,70 & 27,10 & 76,27 & 69,13 & 63,28 & 55,57 & 48,41 & 42,01 & 31,68 & 24,34 & 15,72 \\
\hline 62,18 & 822,60 & 22,50 & 61,50 & 49,80 & 47,54 & 44,53 & 41,46 & 38,49 & 32,96 & 28,13 & 20,58 \\
\hline 38,49 & 1490,20 & 99,30 & 26,14 & 22,01 & 19,47 & 16,46 & 13,87 & 11,71 & 8,48 & 6,40 & 4,16 \\
\hline 37,96 & 306,90 & 32,30 & 96,41 & 76,60 & 65,71 & 53,63 & 43,88 & 36,15 & 25,43 & 19,04 & 12,58 \\
\hline 78,47 & 694,80 & 199,40 & 17,99 & 11.14 & 9,00 & 7,35 & 6,25 & 5,38 & 4.07 & 3,19 & 2,16 \\
\hline 38,09 & 1710,90 & 27,10 & 59,69 & 53,83 & 51,00 & 46,56 & 42,21 & 38,06 & 30,72 & 24,81 & 16,71 \\
\hline 71,34 & 828,60 & 136,00 & 19,78 & 13,83 & 11,86 & 10,15 & 8,85 & 7,75 & 6,01 & 4,76 & 3,21 \\
\hline 86,30 & 900,10 & 58,40 & 27,24 & 19,97 & 18,28 & 16,80 & 15,54 & 14,39 & 12,32 & 10,56 & 7,83 \\
\hline 75,90 & 769,10 & 28,00 & 48,38 & 37,45 & 35,22 & 33,09 & 30,98 & 28,96 & 25,18 & 21,83 & 16,44 \\
\hline 84,32 & 1764,60 & 64,00 & 19,74 & 15,09 & 14,03 & 13,27 & 12,52 & 11,78 & 10,40 & 9,16 & 7,08 \\
\hline 36,31 & 967,00 & 38,90 & 58,17 & 51,32 & 46,36 & 40,12 & 34,49 & 29,59 & 21,94 & 16,70 & 10,80 \\
\hline 24,89 & 1564,00 & 151,80 & 26,70 & 20,68 & 16,73 & 12,54 & 9,56 & 7,50 & 5,08 & 3,84 & 2,64 \\
\hline 69,73 & 1144,90 & 141,00 & 16,67 & 12,21 & 10,73 & 9,36 & 8,27 & 7,32 & 5,77 & 4,62 & 3,13 \\
\hline 42,07 & 1263,70 & 168,00 & 19,04 & 14,62 & 12,46 & 10,18 & 8,36 & 6,91 & 4,89 & 3,68 & 2,43 \\
\hline 85,51 & 1048,80 & 39,90 & 32,01 & 24,36 & 22,61 & 21,36 & 20,13 & 18,94 & 16,71 & 14,70 & 11,37 \\
\hline 77,30 & 1780,80 & 171,60 & 11,65 & 8,54 & 7,65 & 6,83 & 6,16 & 5,57 & 4,56 & 3,76 & 2,64 \\
\hline 59,86 & 1997,50 & 77,30 & 20,57 & 16,85 & 15,86 & 14,57 & 13,36 & 12,21 & 10,15 & 8,44 & 5,94 \\
\hline
\end{tabular}




\begin{tabular}{|c|c|c|c|c|c|c|c|c|c|c|c|}
\hline & & & \multicolumn{9}{|c|}{ Deflexões $\left(\times 10^{-4} \mathrm{~cm}\right)$} \\
\hline e1 (cm) & Meq (MPa) & Ms (MPa) & D0 & D25 & D40 & D60 & D80 & D100 & D140 & D180 & D260 \\
\hline 85,60 & 266,30 & 184,80 & 35,27 & 17,79 & 12,65 & 9,21 & 7,29 & 5,99 & 4,29 & 3,32 & 2,28 \\
\hline 68,33 & 1901,90 & 120,60 & 14,70 & 11,47 & 10,56 & 9,57 & 8,71 & 7,91 & 6,52 & 5,39 & 3,78 \\
\hline 68,09 & 726,20 & 127,60 & 22,26 & 15,53 & 13,23 & 11,23 & 9,70 & 8,43 & 6,44 & 5,05 & 3,38 \\
\hline 88,87 & 1828,90 & 188,80 & 10,31 & 7,23 & 6,43 & 5,75 & 5,22 & 4,77 & 3,98 & 3,34 & 2,41 \\
\hline 61,95 & 1815,60 & 105,30 & 17,14 & 13,78 & 12,71 & 11,48 & 10,39 & 9,38 & 7,63 & 6,23 & 4,30 \\
\hline 77,93 & 1181,80 & 177,00 & 13,99 & 9,73 & 8,41 & 7,28 & 6,43 & 5,71 & 4,53 & 3,65 & 2,51 \\
\hline 75,60 & 1706,60 & 165,30 & 12,24 & 9,02 & 8,08 & 7,20 & 6,49 & 5,85 & 4,77 & 3,91 & 2,73 \\
\hline 69,04 & 1084,70 & 51,80 & 30,54 & 23,99 & 22,43 & 20,64 & 19,01 & 17,48 & 14,71 & 12,38 & 8,89 \\
\hline 38,23 & 1160,30 & 117,40 & 26,01 & 20,79 & 17,90 & 14,67 & 12,05 & 9,95 & 7,02 & 5,26 & 3,47 \\
\hline 82,88 & 983,90 & 151,40 & 16,22 & 11,07 & 9,53 & 8,26 & 7,32 & 6,53 & 5,23 & 4,25 & 2,95 \\
\hline 23,77 & 1327,30 & 154,30 & 28,56 & 21,45 & 16,94 & 12,38 & 9,29 & 7,25 & 4,92 & 3,76 & 2,60 \\
\hline 66,16 & 377,40 & 124,50 & 32,91 & 20,30 & 16,17 & 12,91 & 10,69 & 8,97 & 6,53 & 5,02 & 3,37 \\
\hline 84,25 & 291,40 & 192,70 & 32,65 & 16,66 & 11,94 & 8,77 & 6,97 & 5,74 & 4,12 & 3,19 & 2,19 \\
\hline 73,16 & 1943,70 & 40,80 & 27,76 & 22,11 & 20,87 & 20,03 & 19,04 & 18,02 & 16,05 & 14,24 & 11,13 \\
\hline 45,77 & 1222,00 & 105,30 & 24,09 & 19,63 & 17,36 & 14,82 & 12,65 & 10,81 & 7,99 & 6,10 & 3,98 \\
\hline 40,41 & 668,30 & 86,60 & 37,48 & 28,90 & 24,59 & 19,98 & 16,32 & 13,44 & 9,46 & 7,10 & 4,70 \\
\hline 27,25 & 1294,70 & 117,30 & 31,76 & 25,11 & 20,76 & 15,99 & 12,44 & 9,86 & 6,69 & 5,02 & 3,41 \\
\hline 36,87 & 234,00 & 53,20 & 80,56 & 56,24 & 45,18 & 34,46 & 26,86 & 21,44 & 14,72 & 11,12 & 7,59 \\
\hline 40,61 & 833,80 & 45,00 & 51,23 & 44,07 & 39,63 & 34,26 & 29,48 & 25,33 & 18,86 & 14,41 & 9,36 \\
\hline 47,25 & 1781,50 & 49,30 & 33,43 & 29,06 & 27,38 & 24,97 & 22,65 & 20,46 & 16,60 & 13,49 & 9,19 \\
\hline 24,75 & 1061,10 & 20,60 & 118,98 & 107,71 & 96,52 & 81,93 & 68,89 & 57,82 & 41,34 & 30,81 & 19,85 \\
\hline 68,64 & 335,50 & 98,40 & 38,39 & 24,18 & 19,53 & 15,82 & 13,26 & 11,24 & 8,30 & 6,41 & 4,30 \\
\hline 55,31 & 1393,70 & 84,70 & 23,15 & 19,05 & 17,42 & 15,54 & 13,86 & 12,34 & 9,76 & 7,80 & 5,24 \\
\hline 68,72 & 501,60 & 132,50 & 26,79 & 17,26 & 14,10 & 11,55 & 9,74 & 8,31 & 6,18 & 4,78 & 3,20 \\
\hline 67,59 & 1339,90 & 159,70 & 14,69 & 10,88 & 9,58 & 8,36 & 7,38 & 6,52 & 5,12 & 4,08 & 2,76 \\
\hline 21,23 & 978,20 & 119,30 & 40,19 & 29,40 & 22,56 & 16,00 & 11,82 & 9,17 & 6,28 & 4,84 & 3,36 \\
\hline 80,38 & 1495,30 & 180,60 & 12,14 & 8,60 & 7,57 & 6,67 & 5,97 & 5,37 & 4,36 & 3,57 & 2,49 \\
\hline 35,78 & 478,50 & 183,40 & 29,45 & 18,31 & 13,89 & 10,09 & 7,66 & 6,05 & 4,16 & 3,18 & 2,21 \\
\hline 76,92 & 1301,80 & 61,80 & 24,05 & 18,39 & 17,16 & 15,92 & 14,79 & 13,72 & 11,76 & 10,08 & 7,44 \\
\hline 68,74 & 883,70 & 128,80 & 19,95 & 14,32 & 12,41 & 10,69 & 9,35 & 8,20 & 6,36 & 5,04 & 3,39 \\
\hline 65,70 & 1868,70 & 77,30 & 19,95 & 15,92 & 14,98 & 13,83 & 12,75 & 11,73 & 9,88 & 8,31 & 5,96 \\
\hline 57,86 & 1483,90 & 138,80 & 16,40 & 12,89 & 11,50 & 10,05 & 8,82 & 7,74 & 5,99 & 4,72 & 3,14 \\
\hline 38,81 & 1824,00 & 96,60 & 24,52 & 21,14 & 18,95 & 16,29 & 13,93 & 11,91 & 8,78 & 6,68 & 4,33 \\
\hline 66,37 & 540,80 & 20,10 & 73,36 & 58,46 & 55,23 & 51,29 & 47,51 & 43,90 & 37,29 & 31,62 & 22,93 \\
\hline 26,18 & 1553,70 & 36,80 & 67,65 & 60,76 & 54,30 & 45,96 & 38,57 & 32,32 & 23,08 & 17,20 & 11,10 \\
\hline 37,26 & 1624,10 & 83,80 & 28,90 & 24,97 & 22,33 & 19,10 & 16,26 & 13,83 & 10,12 & 7,66 & 4,96 \\
\hline 88,11 & 1517,70 & 50,80 & 23,32 & 17,92 & 16,56 & 15,75 & 14,93 & 14,12 & 12,59 & 11,19 & 8,81 \\
\hline 28,63 & 945,60 & 62,00 & 52,20 & 43,11 & 36,77 & 29,40 & 23,52 & 19,01 & 13,05 & 9,71 & 6,48 \\
\hline 34,83 & 820,60 & 172,00 & 24,84 & 17,61 & 14,14 & 10,74 & 8,33 & 6,63 & 4,54 & 3,43 & 2,34 \\
\hline 53,54 & 1335,30 & 160,10 & 16,56 & 12,74 & 11,13 & 9,49 & 8,13 & 6,98 & 5,22 & 4,02 & 2,65 \\
\hline 51,37 & 1376,40 & 93,60 & 22,90 & 18,93 & 17,11 & 15,05 & 13,23 & 11,61 & 8,96 & 7,03 & 4,64 \\
\hline 76,03 & 1321,70 & 121,70 & 16,21 & 11,98 & 10,78 & 9,63 & 8,70 & 7,87 & 6,44 & 5,31 & 3,72 \\
\hline 52,67 & 1582,00 & 139,10 & 16,82 & 13,51 & 12,04 & 10,46 & 9,10 & 7,91 & 6,02 & 4,69 & 3,09 \\
\hline 61,06 & 454,10 & 169,40 & 26,63 & 16,11 & 12,63 & 9,89 & 8,05 & 6,66 & 4,76 & 3,63 & 2,45 \\
\hline 36,84 & 294,20 & 105,30 & 49,29 & 31,16 & 23,89 & 17,54 & 13,41 & 10,61 & 7,29 & 5,56 & 3,85 \\
\hline 40,94 & 611,70 & 129,80 & 30,46 & 21,54 & 17,62 & 13,79 & 10,97 & 8,87 & 6,15 & 4,63 & 3,13 \\
\hline 46,25 & 1802,50 & 30,90 & 46,91 & 40,49 & 38,89 & 36,11 & 33,30 & 30,57 & 25,56 & 21,30 & 14,97 \\
\hline 85,86 & 389,40 & 161,30 & 27,74 & 15,67 & 12,03 & 9,44 & 7,85 & 6,67 & 4,98 & 3,90 & 2,66 \\
\hline 79,03 & 717,10 & 133,30 & 20,78 & 13,93 & 11,80 & 10,04 & 8,78 & 7,73 & 6,05 & 4,84 & 3,30 \\
\hline 33,11 & 1361,80 & 180,70 & 20,56 & 15,70 & 13,01 & 10,15 & 8,00 & 6,41 & 4,39 & 3,30 & 2,23 \\
\hline 61,51 & 1318,60 & 31,60 & 42,32 & 34,32 & 32,87 & 30,94 & 28,91 & 26,93 & 23,21 & 19,93 & 14,71 \\
\hline 24,32 & 1516,10 & 84,00 & 41,41 & 34,08 & 28,61 & 22,35 & 17,51 & 13,93 & 9,44 & 7,04 & 4,76 \\
\hline 45,68 & 1301,30 & 178,00 & 17,30 & 13,20 & 11,30 & 9,34 & 7,76 & 6,48 & 4,65 & 3,51 & 2,31 \\
\hline 67,08 & 983,80 & 76,70 & 25,39 & 19,65 & 17,85 & 15,97 & 14,38 & 12,94 & 10,46 & 8,52 & 5,87 \\
\hline 20,91 & 1440,70 & 30,40 & 96,27 & 84,41 & 73,55 & 59,95 & 48,53 & 39,45 & 27,09 & 20,00 & 13,18 \\
\hline 78,80 & 1019,50 & 102,30 & 19,75 & 14,34 & 12,82 & 11,42 & 10,30 & 9,32 & 7,63 & 6,30 & 4,42 \\
\hline 51,82 & 1906,40 & 29,90 & 43,89 & 36,64 & 35,43 & 33,41 & 31,21 & 29,04 & 24,94 & 21,31 & 15,58 \\
\hline 28,85 & 821,90 & 169,70 & 27,65 & 19,45 & 15,19 & 11,10 & 8,38 & 6,57 & 4,49 & 3,43 & 2,37 \\
\hline 48,35 & 962,60 & 155,20 & 20,67 & 15,28 & 12,98 & 10,67 & 8,86 & 7,40 & 5,32 & 4,03 & 2,66 \\
\hline 86,89 & 1376,20 & 96,50 & 17,01 & 12,38 & 11,29 & 10,33 & 9,53 & 8,81 & 7,51 & 6,42 & 4,74 \\
\hline 20,60 & 374,40 & 132,20 & 48,48 & 29,31 & 20,49 & 13,72 & 10,10 & 7,96 & 5,60 & 4,36 & 3,05 \\
\hline 35,02 & 1064,80 & 191,30 & 21,00 & 15,31 & 12,47 & 9,60 & 7,51 & 6,00 & 4,12 & 3,10 & 2,11 \\
\hline 75,47 & 1086,90 & 179,80 & 14,70 & 10,14 & 8,69 & 7,45 & 6,53 & 5,76 & 4,51 & 3,60 & 2,45 \\
\hline 42,71 & 1035,60 & 48,50 & 43,52 & 37,78 & 34,38 & 30,18 & 26,37 & 22,98 & 17,50 & 13,56 & 8,85 \\
\hline 84,44 & 1435,80 & 66,60 & 20,96 & 15,76 & 14,62 & 13,66 & 12,78 & 11,94 & 10,40 & 9,05 & 6,86 \\
\hline 31,93 & 1585,80 & 113,40 & 27,04 & 22,35 & 19,26 & 15,65 & 12,71 & 10,39 & 7,23 & 5,39 & 3,56 \\
\hline 47,22 & 855,10 & 20,50 & 76,88 & 66,72 & 63,28 & 58,05 & 52,97 & 48,13 & 39,46 & 32,34 & 22,24 \\
\hline 50,48 & 340,80 & 60,10 & 54,36 & 39,42 & 33,30 & 27,37 & 22,74 & 19,03 & 13,71 & 10,40 & 6,88 \\
\hline 85,30 & 1072,90 & 164,50 & 14,75 & 9,99 & 8,60 & 7,46 & 6,63 & 5,93 & 4,78 & 3,90 & 2,72 \\
\hline 88,16 & 234,70 & 81,40 & 48,46 & 28,29 & 22,22 & 17,83 & 15,06 & 12,96 & 9,85 & 7,79 & 5,32 \\
\hline 37,56 & 1513,80 & 70,60 & 32,88 & 28,67 & 25,79 & 22,23 & 19,06 & 16,31 & 12,05 & 9,17 & 5,93 \\
\hline 84,02 & 756,80 & 20,90 & 54,25 & 42,45 & 39,43 & 37,70 & 35,87 & 34,00 & 30,42 & 27,12 & 21,45 \\
\hline 72,44 & 577,80 & 81,90 & 30,27 & 21,57 & 18,74 & 16,22 & 14,29 & 12,62 & 9,92 & 7,93 & 5,38 \\
\hline 24,61 & 1251,90 & 170,40 & 26,49 & 19,56 & 15,35 & 11,17 & 8,38 & 6,54 & 4,45 & 3,40 & 2,35 \\
\hline 73,61 & 403,40 & 48,30 & 46,87 & 34,01 & 29,97 & 26,28 & 23,38 & 20,85 & 16,64 & 13,45 & 9,22 \\
\hline 63,80 & 1680,60 & 184,40 & 12,59 & 9,53 & 8,44 & 7,37 & 6,49 & 5,72 & 4,46 & 3,54 & 2,38 \\
\hline 59,28 & 931,70 & 165,20 & 18,34 & 13,07 & 11,10 & 9,30 & 7,90 & 6,75 & 5,01 & 3,86 & 2,56 \\
\hline 44,33 & 402,10 & 156,00 & 32,48 & 19,99 & 15,44 & 11,59 & 9,04 & 7,24 & 5,00 & 3,80 & 2,61 \\
\hline 83,36 & 852,00 & 117,70 & 19,66 & 13,59 & 11,82 & 10,32 & 9,21 & 8,26 & 6,68 & 5,46 & 3,81 \\
\hline 60,56 & 1045,20 & 84,60 & 24,68 & 19,51 & 17,61 & 15,59 & 13,86 & 12,31 & 9,72 & 7,77 & 5,23 \\
\hline 23,92 & 1007,80 & 61,80 & 58,78 & 47,73 & 39,66 & 30,59 & 23,75 & 18,79 & 12,70 & 9,51 & 6,46 \\
\hline 31,30 & 362,60 & 169,60 & 36,12 & 21,30 & 15,53 & 10,88 & 8,13 & 6,40 & 4,42 & 3,42 & 2,39 \\
\hline
\end{tabular}




\begin{tabular}{|c|c|c|c|c|c|c|c|c|c|c|c|}
\hline \multirow[b]{2}{*}{ e1 (cm) } & \multirow[b]{2}{*}{ Meq (MPa) } & \multirow[b]{2}{*}{ Ms (MPa) } & \multicolumn{9}{|c|}{ Deflexões $\left(\times 10^{-4} \mathrm{~cm}\right)$} \\
\hline & & & D0 & D25 & D40 & D60 & D80 & D100 & D140 & D180 & D260 \\
\hline 81,20 & 863,30 & 186,50 & 16,04 & 10,42 & 8,68 & 7,30 & 6,34 & 5,55 & 4,32 & 3,44 & 2,35 \\
\hline 70,30 & 301,50 & 191,70 & 32,44 & 16,93 & 12,26 & 9,03 & 7,14 & 5,83 & 4,12 & 3,17 & 2,17 \\
\hline 88,13 & 1042,90 & 114,20 & 17,61 & 12,31 & 10,90 & 9,70 & 8,78 & 7,99 & 6,63 & 5,55 & 3,97 \\
\hline 83,84 & 417,50 & 102,00 & 31,28 & 19,74 & 16,21 & 13,49 & 11,64 & 10,17 & 7,88 & 6,28 & 4,29 \\
\hline 32,87 & 697,00 & 71,00 & 47,84 & 37,92 & 32,02 & 25,47 & 20,35 & 16,46 & 11,34 & 8,47 & 5,67 \\
\hline 30,96 & 1245,80 & 46,80 & 53,76 & 47,32 & 42,16 & 35,68 & 29,99 & 25,19 & 18,09 & 13,54 & 8,76 \\
\hline 46,67 & 1390,60 & 103,50 & 22,83 & 18,90 & 16,88 & 14,59 & 12,60 & 10,87 & 8,16 & 6,28 & 4,10 \\
\hline 69,76 & 1177,60 & 109,00 & 18,88 & 14,26 & 12,81 & 11,38 & 10,20 & 9,15 & 7,36 & 5,98 & 4,11 \\
\hline 83,07 & 1194,60 & 195,20 & 12,99 & 8,78 & 7,52 & 6,48 & 5,73 & 5,10 & 4,07 & 3,30 & 2,28 \\
\hline 21,55 & 648,90 & 154,70 & 36,70 & 24,18 & 17,59 & 12,01 & 8,81 & 6,89 & 4,80 & 3,73 & 2,60 \\
\hline 23,09 & 1778,60 & 193,40 & 22,78 & 17,18 & 13,56 & 9,89 & 7,42 & 5,78 & 3,92 & 2,99 & 2,07 \\
\hline 67,10 & 512,20 & 129,10 & 26,98 & 17,61 & 14,47 & 11,88 & 10,03 & 8,55 & 6,35 & 4,91 & 3,28 \\
\hline 57,12 & 435,70 & 42,00 & 55,32 & 43,43 & 38,64 & 33,67 & 29,46 & 25,78 & 19,85 & 15,57 & 10,33 \\
\hline 56,78 & 978,50 & 37,10 & 43,89 & 36,47 & 34,28 & 31,37 & 28,64 & 26,07 & 21,48 & 17,71 & 12,32 \\
\hline 38,65 & 975,80 & 106,30 & 29,35 & 23,22 & 19,91 & 16,26 & 13,32 & 10,99 & 7,74 & 5,80 & 3,83 \\
\hline 23,69 & 1671,40 & 27,20 & 88,48 & 80,65 & 72,49 & 61,76 & 52,08 & 43,82 & 31,42 & 23,43 & 15,06 \\
\hline 53,65 & 1013,30 & 86,80 & 26,38 & 21,19 & 18,94 & 16,51 & 14,42 & 12,59 & 9,64 & 7,53 & 4,97 \\
\hline 53,23 & 1483,70 & 198,50 & 14,08 & 10,66 & 9,23 & 7,81 & 6,64 & 5,67 & 4,20 & 3,22 & 2,12 \\
\hline 20,48 & 1656,10 & 83,40 & 46,29 & 37,37 & 30,58 & 23,08 & 17,60 & 13,77 & 9,26 & 6,98 & 4,78 \\
\hline 85,14 & 508,00 & 195,00 & 21,81 & 12,54 & 9,73 & 7,71 & 6,45 & 5,50 & 4,13 & 3,24 & 2,20 \\
\hline 49,48 & 901,60 & 171,30 & 19,96 & 14,29 & 11,98 & 9,76 & 8,05 & 6,70 & 4,79 & 3,63 & 2,41 \\
\hline 79,60 & 1029,80 & 124,60 & 17,67 & 12,55 & 11,05 & 9,73 & 8,71 & 7,82 & 6,33 & 5,18 & 3,60 \\
\hline 75,77 & 1302,10 & 30,50 & 37,66 & 29,77 & 28,02 & 26,83 & 25,48 & 24,10 & 21,45 & 19,01 & 14,86 \\
\hline 48,43 & 1221,40 & 105,90 & 23,15 & 18,78 & 16,67 & 14,34 & 12,34 & 10,62 & 7,95 & 6,11 & 4,00 \\
\hline 84,59 & 1418,30 & 86,60 & 18,08 & 13,37 & 12,28 & 11,31 & 10,47 & 9,71 & 8,32 & 7,13 & 5,29 \\
\hline 89,11 & 505,40 & 101,20 & 27,48 & 17,71 & 14,83 & 12,59 & 11,05 & 9,80 & 7,79 & 6,32 & 4,39 \\
\hline 76,30 & 1242,30 & 80,50 & 21,01 & 15,88 & 14,61 & 13,33 & 12,23 & 11,22 & 9,41 & 7,92 & 5,69 \\
\hline 61,56 & 608,30 & 127,70 & 25,47 & 17,48 & 14,63 & 12,13 & 10,25 & 8,72 & 6,45 & 4,97 & 3,30 \\
\hline 54,05 & 1526,70 & 83,10 & 22,94 & 19,09 & 17,54 & $\frac{1 L,+0}{15,70}$ & 14,04 & 12,52 & 9,94 & 7,96 & 5,35 \\
\hline 74,80 & 529,20 & 67,10 & 34,47 & 24,74 & 21,70 & 18,97 & 16,85 & 15,02 & 11,97 & 9,67 & 6,64 \\
\hline 86,80 & 331,90 & 100,10 & 36,06 & 21,71 & 17,37 & 14,15 & 12,07 & 10,46 & 8,02 & 6,36 & 4,34 \\
\hline 34,48 & 1739,50 & 94,20 & 27,79 & 23,82 & 21,06 & 17,72 & 14,85 & 12,45 & 8,93 & 6,69 & 4,35 \\
\hline 25,39 & 1348,20 & 194,60 & 23,16 & 17,03 & 13,39 & 9,77 & 7,34 & 5,74 & 3,91 & 2,98 & 2,06 \\
\hline 50,07 & 695,80 & 172,30 & 22,43 & 15,21 & 12,44 & 9,92 & 8,07 & 6,65 & 4,70 & 3,56 & 2,38 \\
\hline 49,87 & 1881,50 & 117,50 & 17,97 & 15,02 & 13,63 & 12,00 & 10,55 & 9,26 & 7,15 & 5,60 & 3,70 \\
\hline 22,51 & 398,90 & 174,00 & 37,89 & 22,15 & 15,48 & 10,41 & 7,69 & 6,07 & 4,26 & 3,31 & 2,33 \\
\hline 70,18 & 1048,10 & 191,30 & 14,97 & 10,32 & 8,76 & 7,42 & 6,42 & 5,59 & 4,28 & 3,37 & 2,26 \\
\hline 49,50 & 438,00 & 44,30 & 58,20 & 46,21 & 40,67 & 34,73 & 29,73 & 25,47 & 18,94 & 14,53 & 9,52 \\
\hline 68,49 & 1823,70 & 49,20 & 26,34 & 20,91 & 19,89 & 18,80 & 17,64 & 16,51 & 14,38 & 12,47 & 9,38 \\
\hline 76,35 & 1900,20 & 175,40 & 11,24 & 8,29 & 7,46 & 6,67 & 6,02 & 5,45 & 4,46 & 3,68 & 2,58 \\
\hline 38,69 & 1996,70 & 142,50 & 18,61 & 15,55 & 13,71 & 11,55 & 9,70 & 8,16 & 5,90 & 4,44 & 2,89 \\
\hline 73,17 & 608,00 & 75,20 & 30,65 & 22,18 & 19,50 & 17,05 & 15,14 & 13,47 & 10,71 & 8,64 & 5,91 \\
\hline 61,29 & 853,90 & 179,70 & 18,16 & 12,47 & 10,43 & 8,64 & 7,30 & 6,21 & 4,59 & 3,53 & 2,35 \\
\hline 26,27 & 1777,00 & 195,20 & 20,79 & 15,96 & 12,92 & 9,71 & 7,43 & 5,84 & 3,96 & 2,99 & 2,05 \\
\hline 67,24 & 671,00 & 87,40 & 28,09 & 20,58 & 18,00 & 15,60 & 13,69 & 12,05 & 9,38 & 7,45 & 5,01 \\
\hline 60,10 & 1738,60 & 66,70 & 23,72 & 19,40 & 18,28 & 16,81 & 15,42 & 14,11 & 11,74 & 9,77 & 6,89 \\
\hline 81,47 & 1774,70 & 162,40 & 11,74 & 8,52 & 7,66 & 6,88 & 6,25 & 5,69 & 4,72 & 3,93 & 2,80 \\
\hline 70,09 & 699,50 & 182,00 & 19,21 & 12,38 & 10,13 & 8,32 & 7,04 & 6,02 & 4,49 & 3,49 & 2,34 \\
\hline 71,46 & 1032,90 & 76,50 & 24,13 & 18,43 & 16,82 & 15,16 & 13,76 & 12,48 & 10,26 & 8,47 & 5,93 \\
\hline 61,96 & 1011,10 & 88,70 & 24,06 & 18,79 & 16,88 & 14,91 & 13,24 & 11,74 & 9,26 & 7,40 & 4,99 \\
\hline 28,25 & 1358,40 & 153,50 & 25,41 & 19,60 & 16,04 & 12,23 & 9,46 & 7,48 & 5,08 & 3,83 & 2,61 \\
\hline 57,87 & 1323,70 & 194,30 & 14,38 & 10,62 & 9,16 & 7,77 & 6,65 & 5,72 & 4,28 & 3,31 & 2,19 \\
\hline 44,70 & 376,90 & 176,00 & 31,61 & 18,51 & 13,97 & 10,31 & 7,98 & 6,37 & 4,40 & 3,35 & 2,32 \\
\hline 22,08 & 1313,40 & 112,30 & 37,77 & 29,15 & 23,24 & $\frac{10,010}{17,10}$ & 12,86 & 10,02 & 6,78 & 5,16 & 3,56 \\
\hline 61,45 & 1322,30 & 74,80 & 24,01 & 19,36 & 17,88 & 16,17 & 14,63 & 13,22 & 10,75 & 8,78 & 6,05 \\
\hline 35,45 & 386,40 & 123,50 & 40,63 & 26,38 & 20,39 & 15,00 & 11,46 & $\frac{10, L 6}{9,06}$ & 6,21 & 4,74 & 3,27 \\
\hline 33,25 & 698,80 & 170,70 & 27,17 & 18,67 & 14,69 & 10,91 & 8,35 & 6,60 & 4,51 & 3,43 & 2,36 \\
\hline 86,58 & 1882,60 & 97,90 & 14,75 & 10,97 & 10,12 & 9,41 & 8,78 & 8,19 & 7,11 & 6,17 & 4,67 \\
\hline 63,68 & 837,30 & 126,90 & 21,37 & 15,47 & $\frac{10,+L}{13,34}$ & 11,39 & 9,85 & 8,55 & 6,51 & 5,09 & 3,39 \\
\hline 37,35 & 639,60 & 67,30 & 46,82 & 37,19 & 31,85 & 25,92 & 21,15 & 17,38 & 12,20 & 9,13 & 6,04 \\
\hline 27,41 & 1865,50 & 64,70 & 41,95 & 36,71 & 32,35 & 26,90 & 22,22 & 18,39 & 12,93 & 9,60 & 6,26 \\
\hline 60,03 & 1248,50 & 121,00 & 18,72 & 14,56 & 12,98 & 11,36 & 9,99 & 8,80 & 6,84 & 5,41 & 3,61 \\
\hline
\end{tabular}


ANEXO F - Erro na retroanálise do subleito utilizando-se a Teoria do Ponto Inerte. 


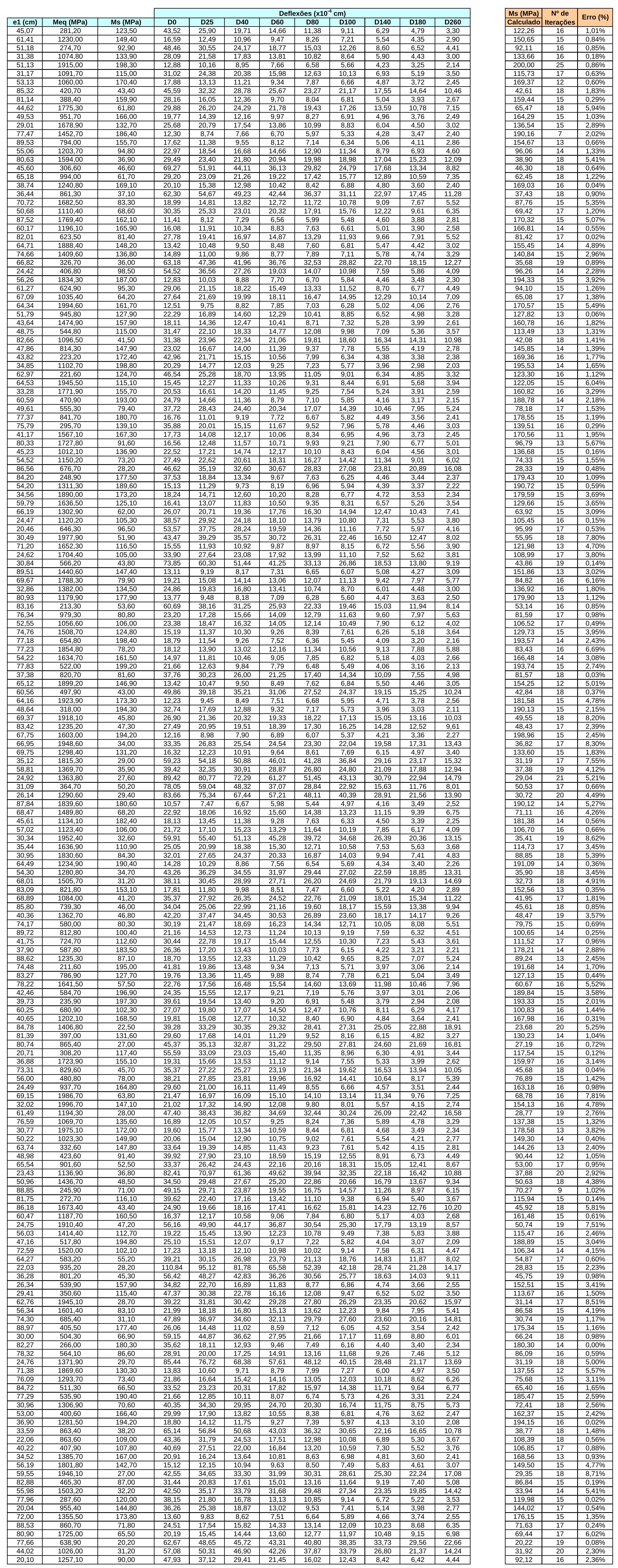




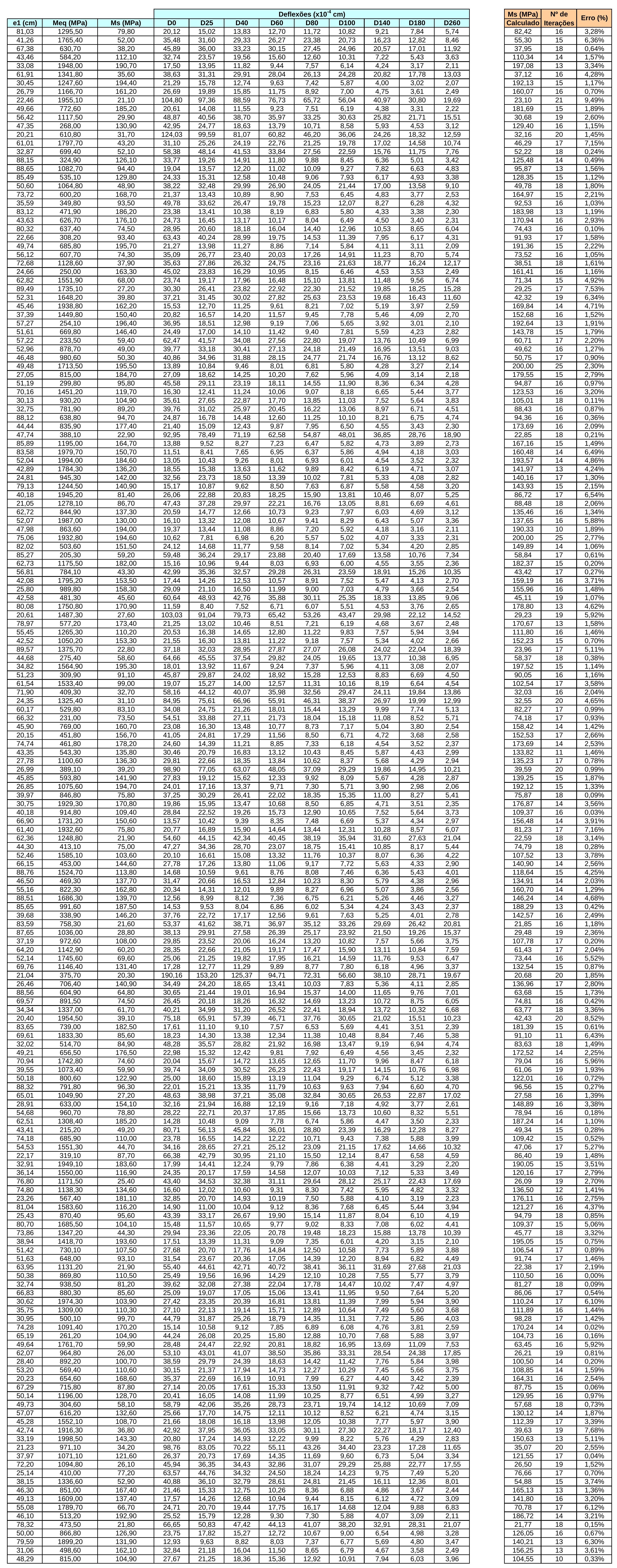




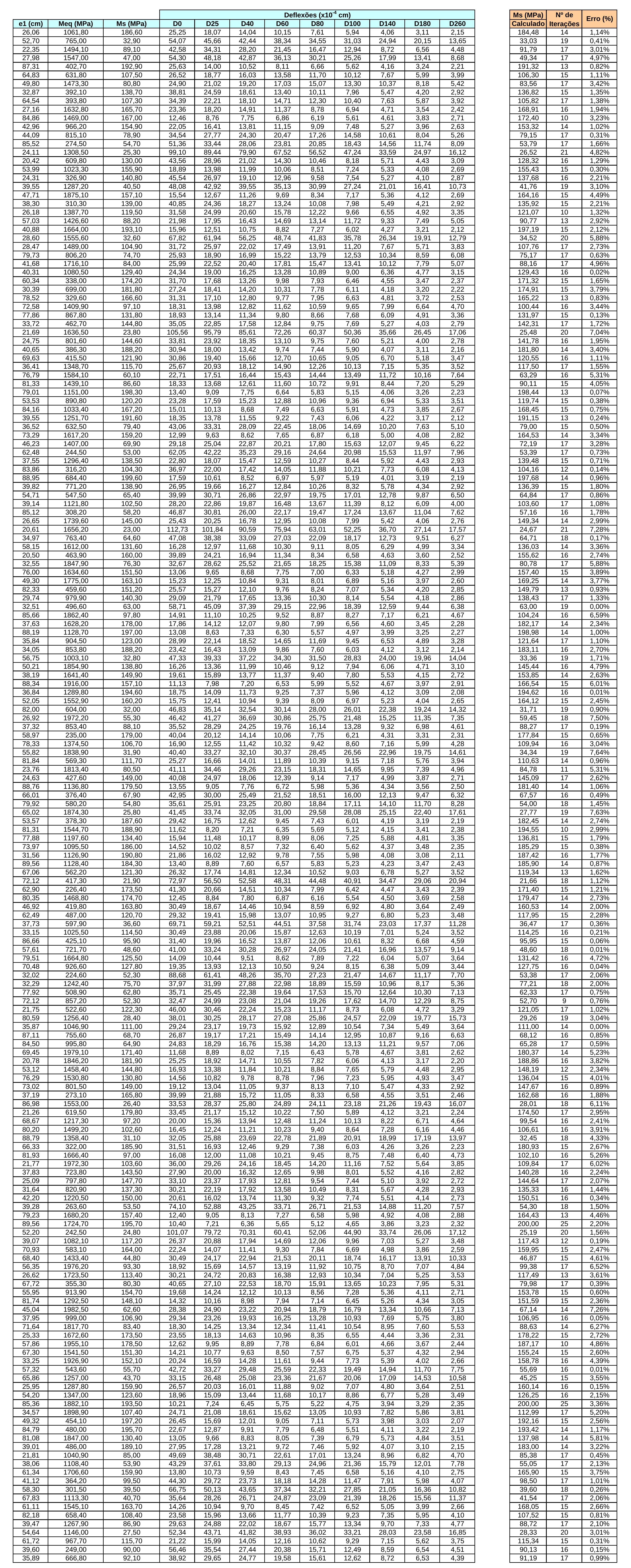




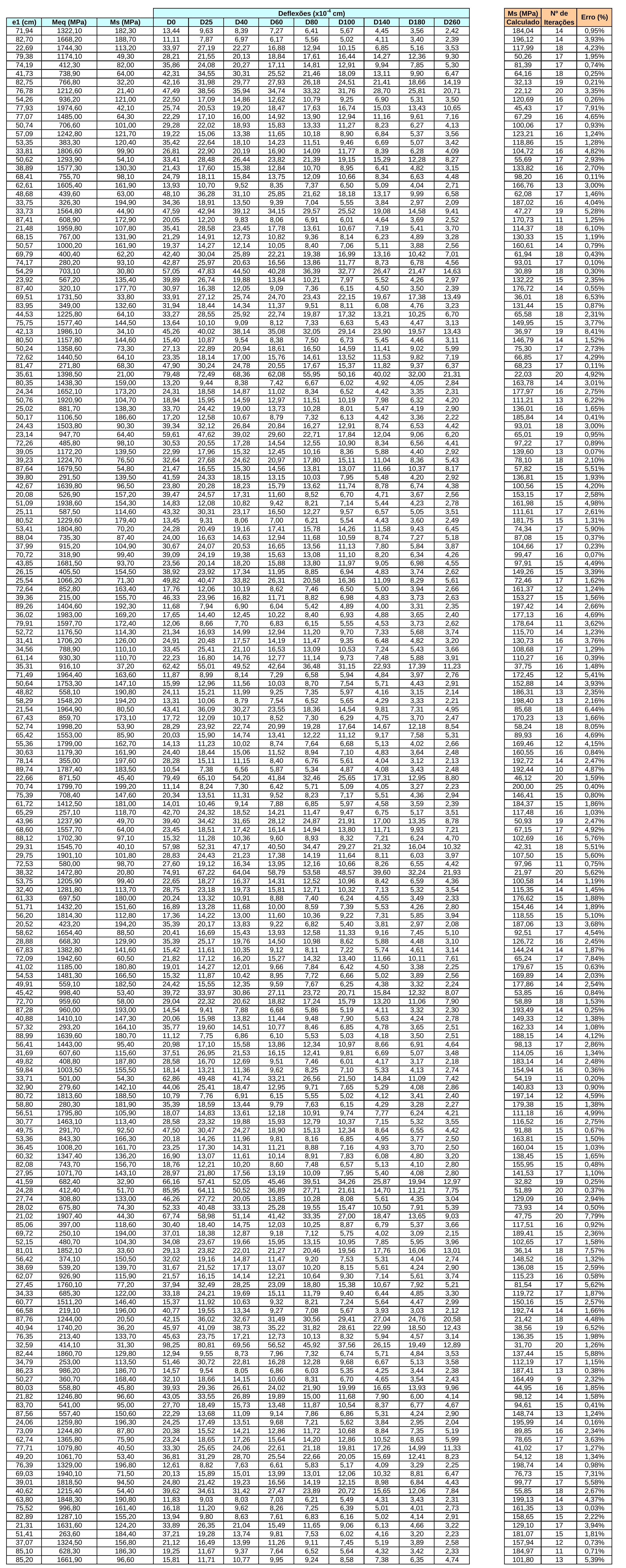




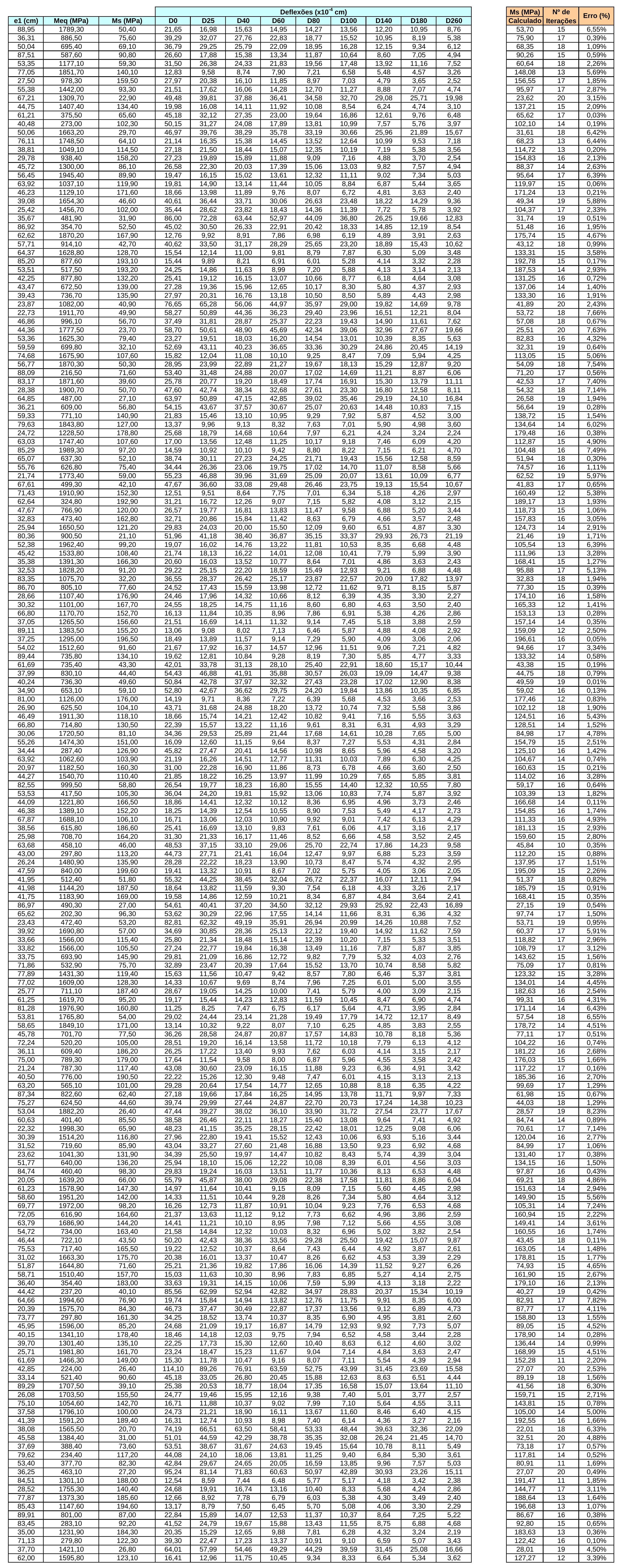




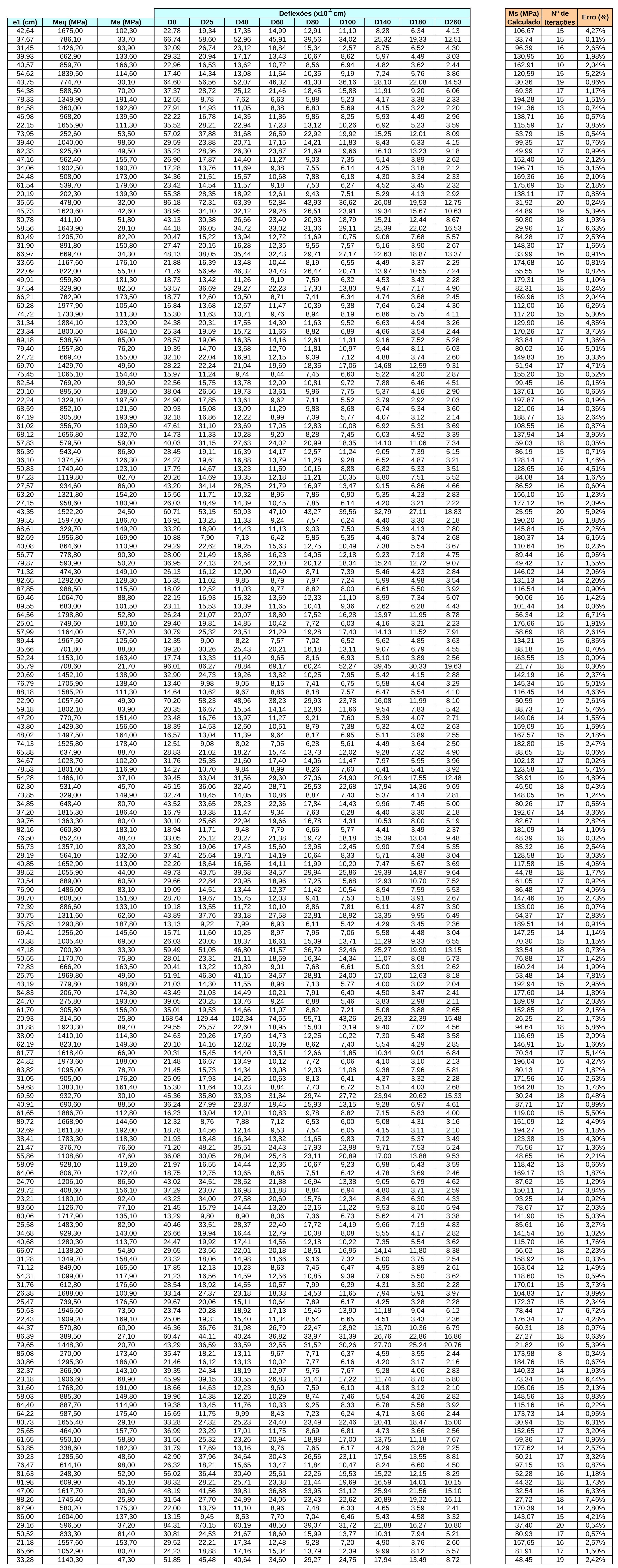




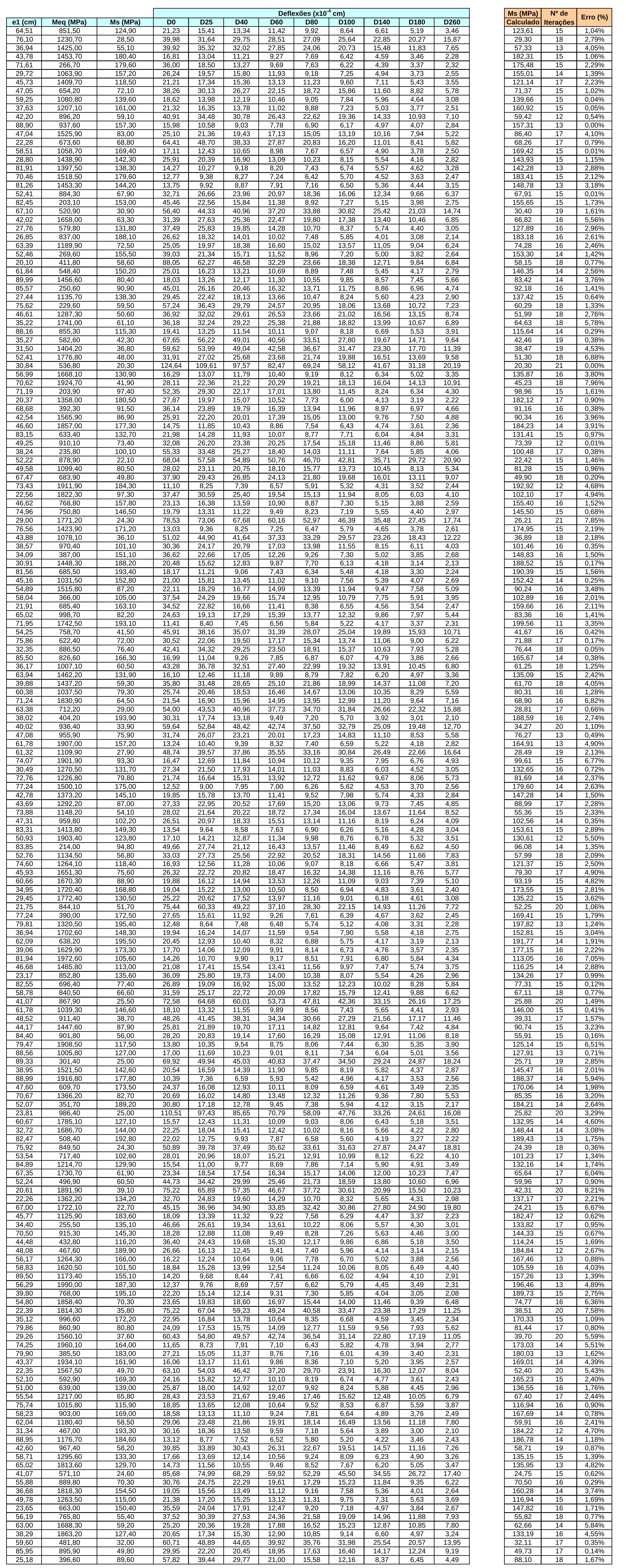




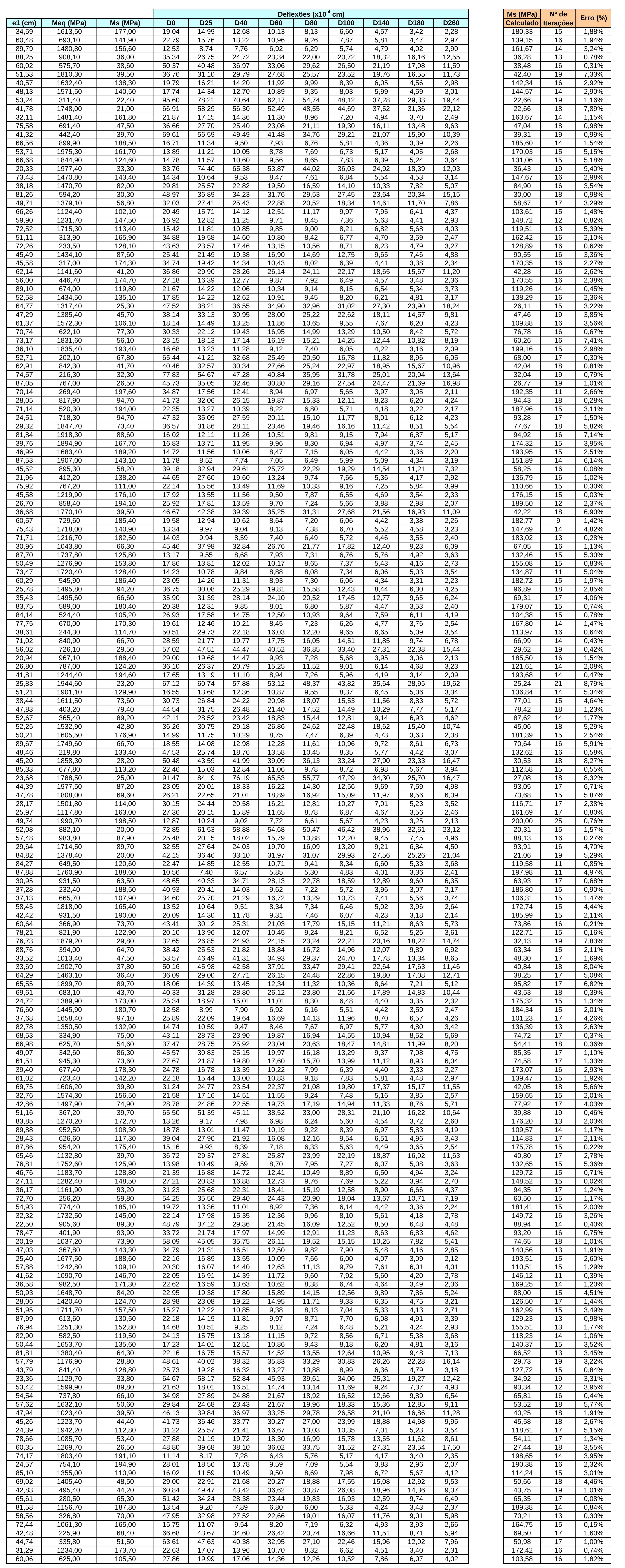




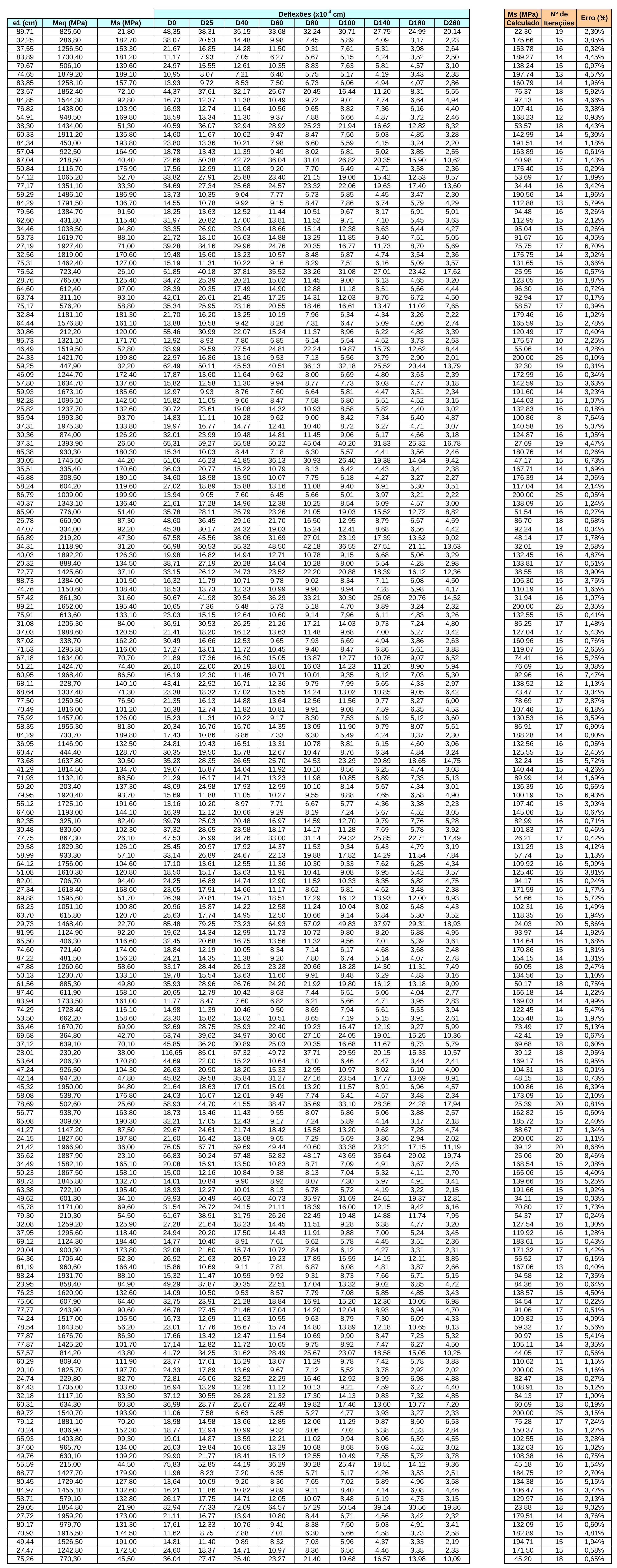




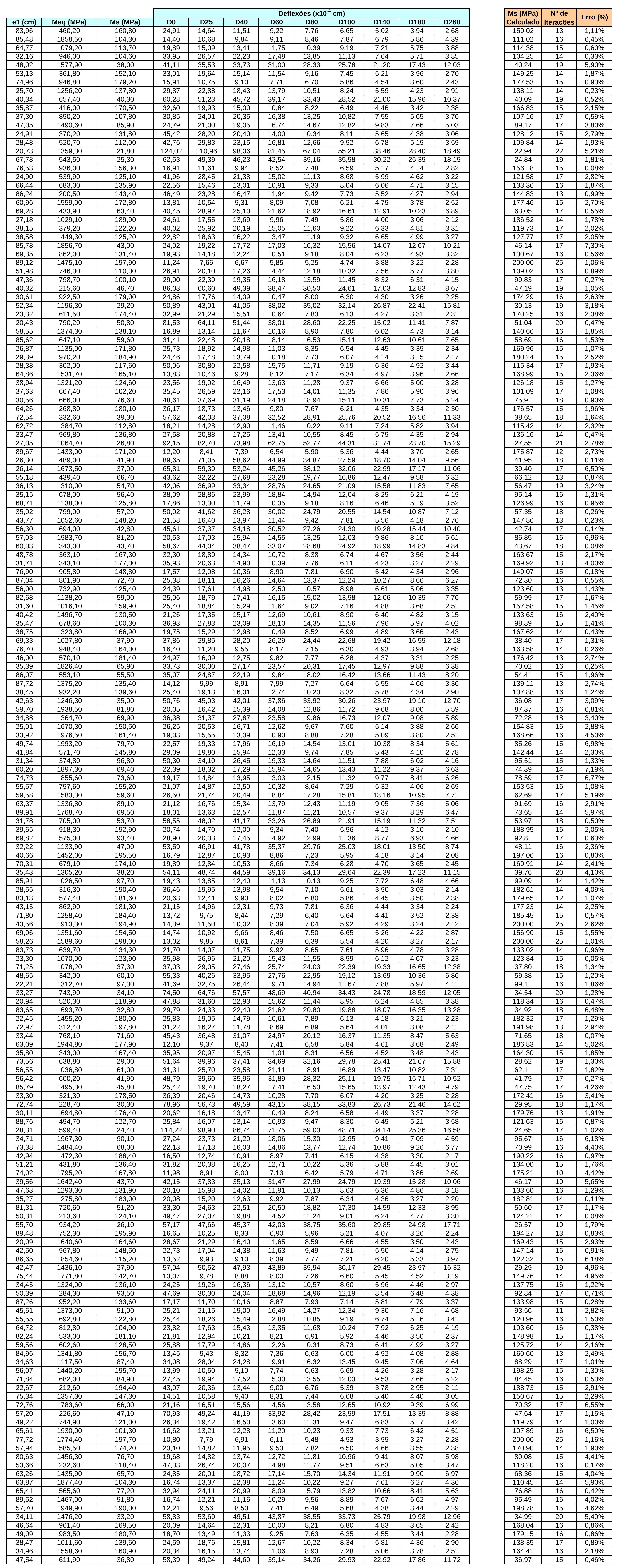




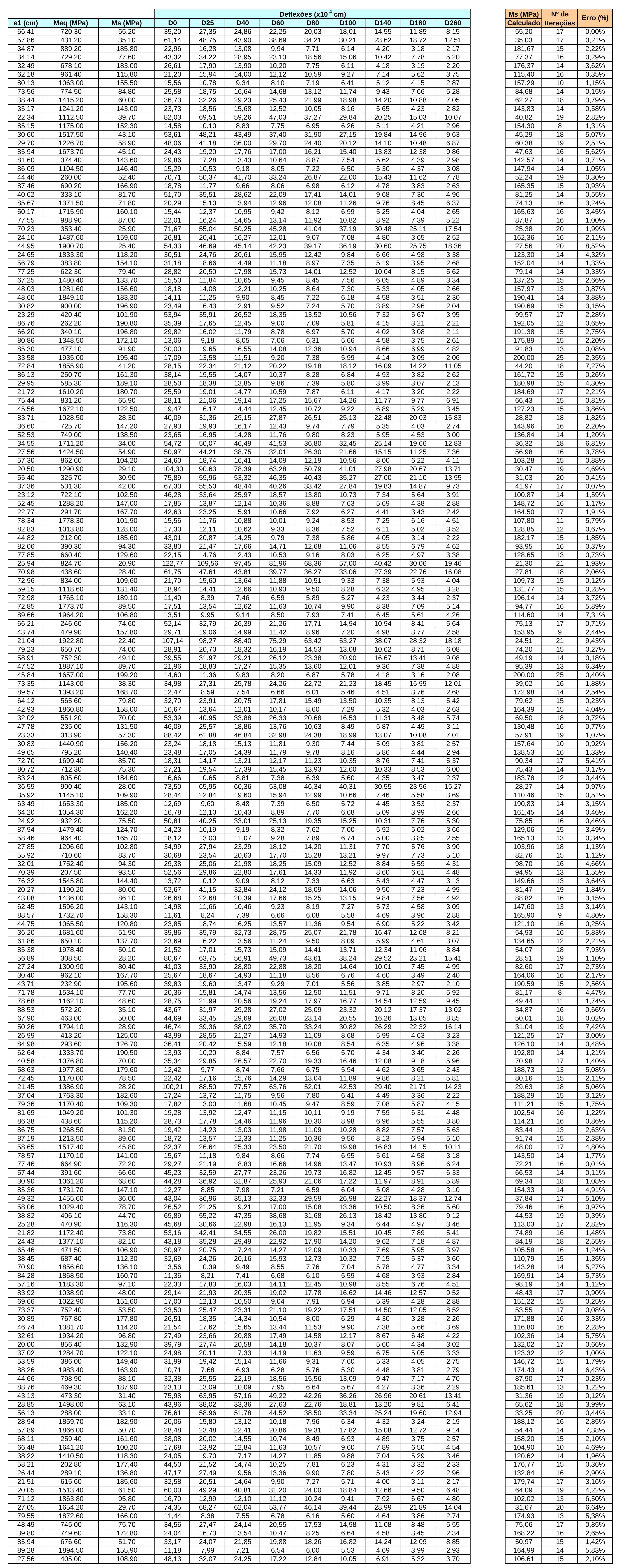




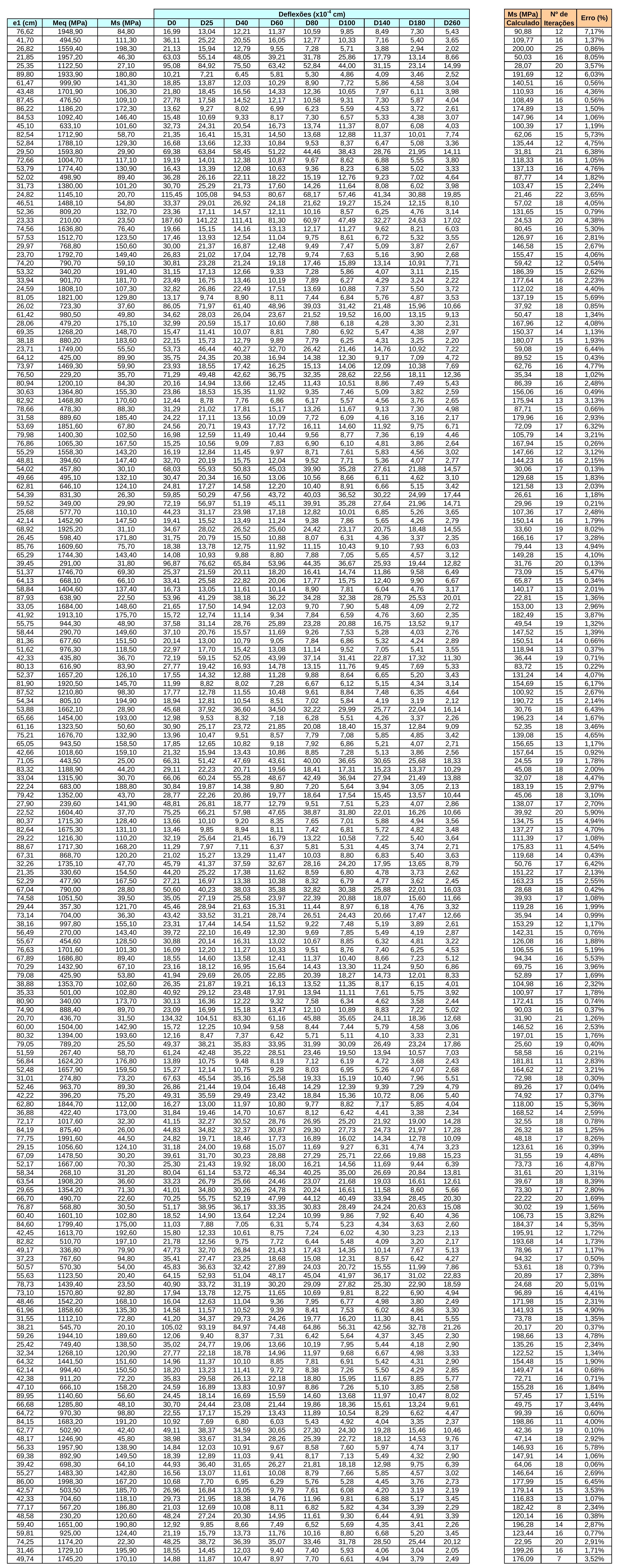




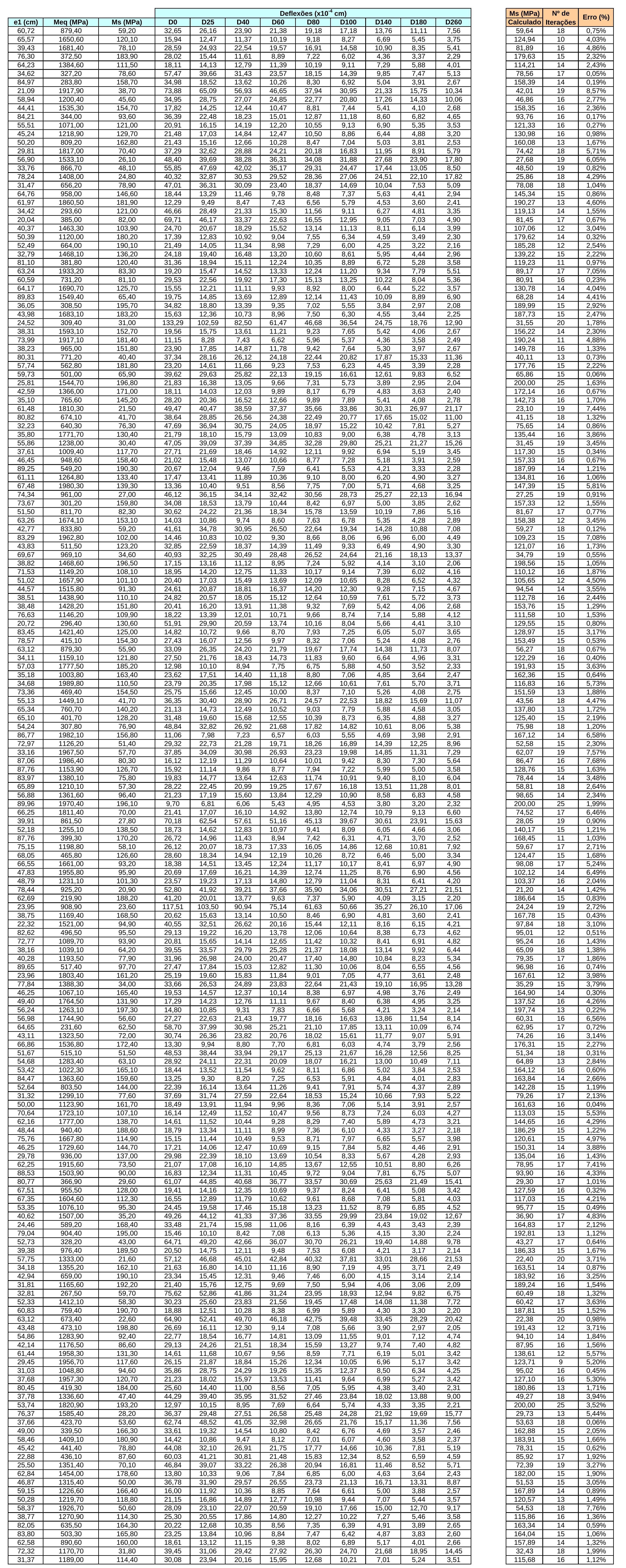




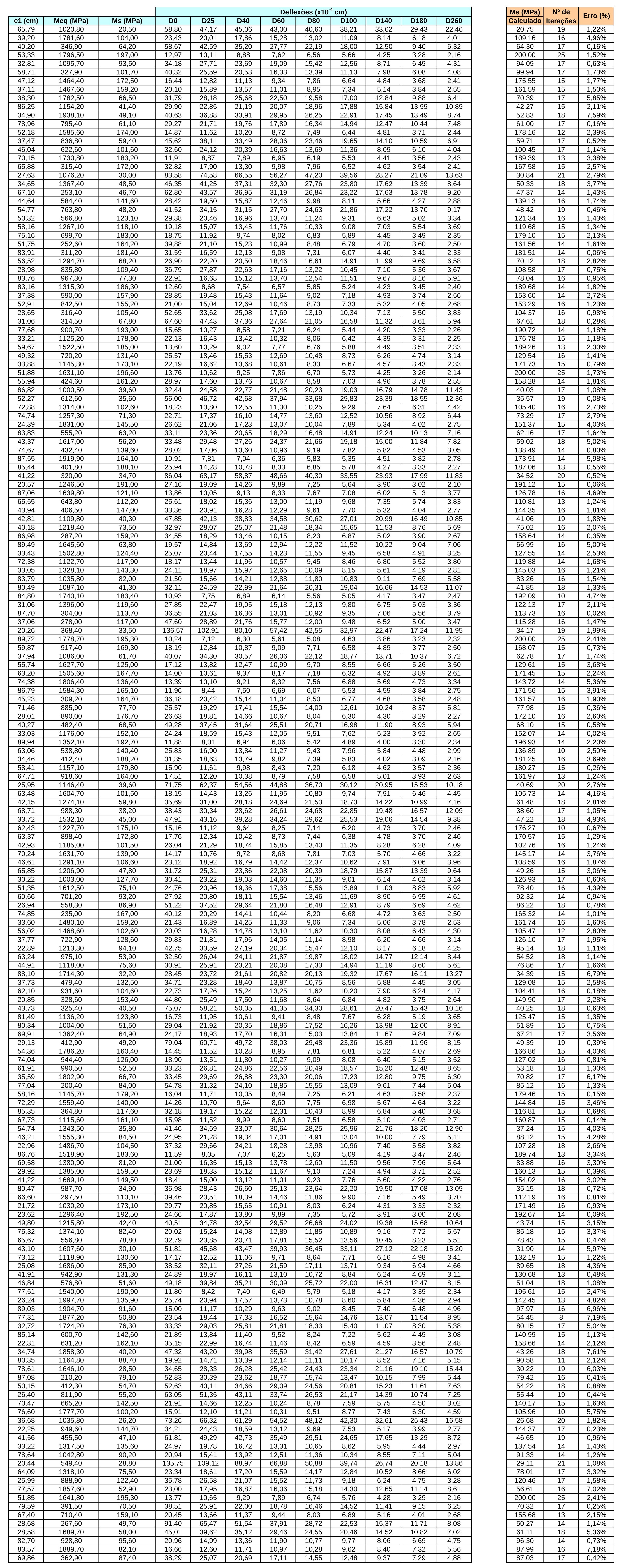




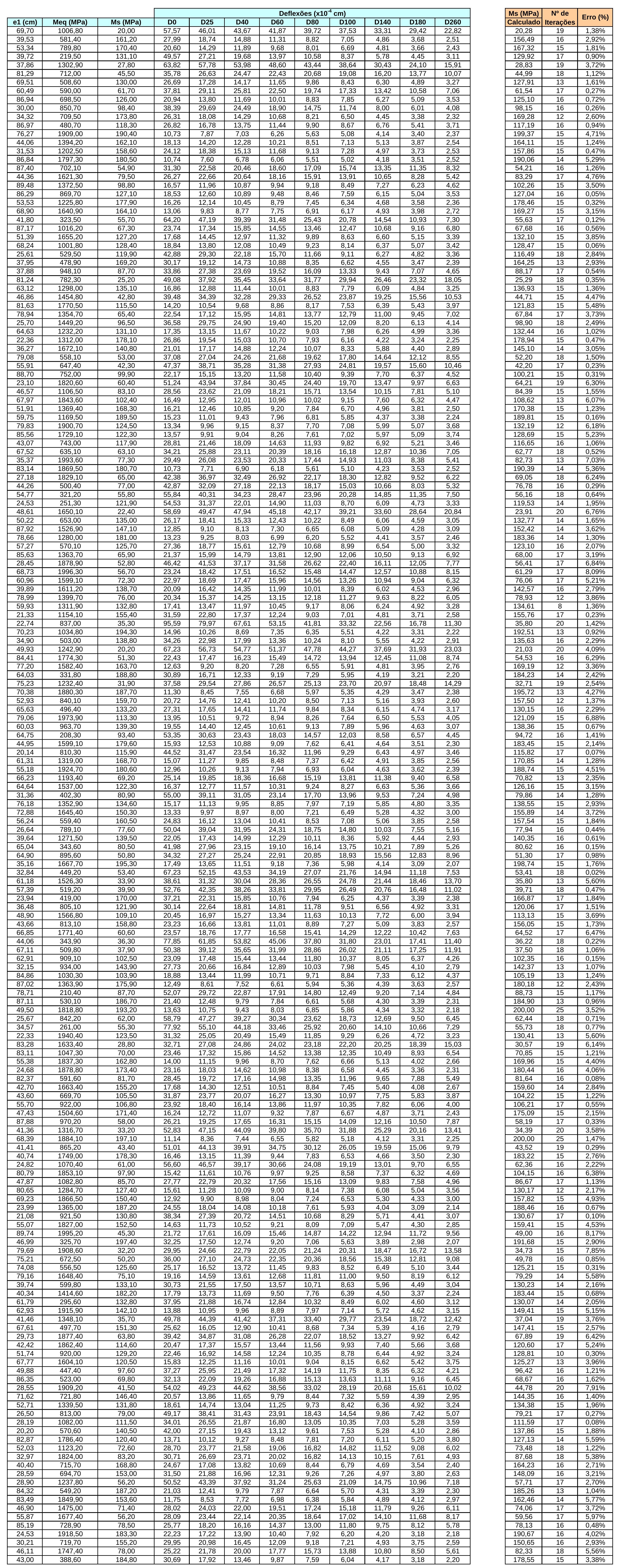




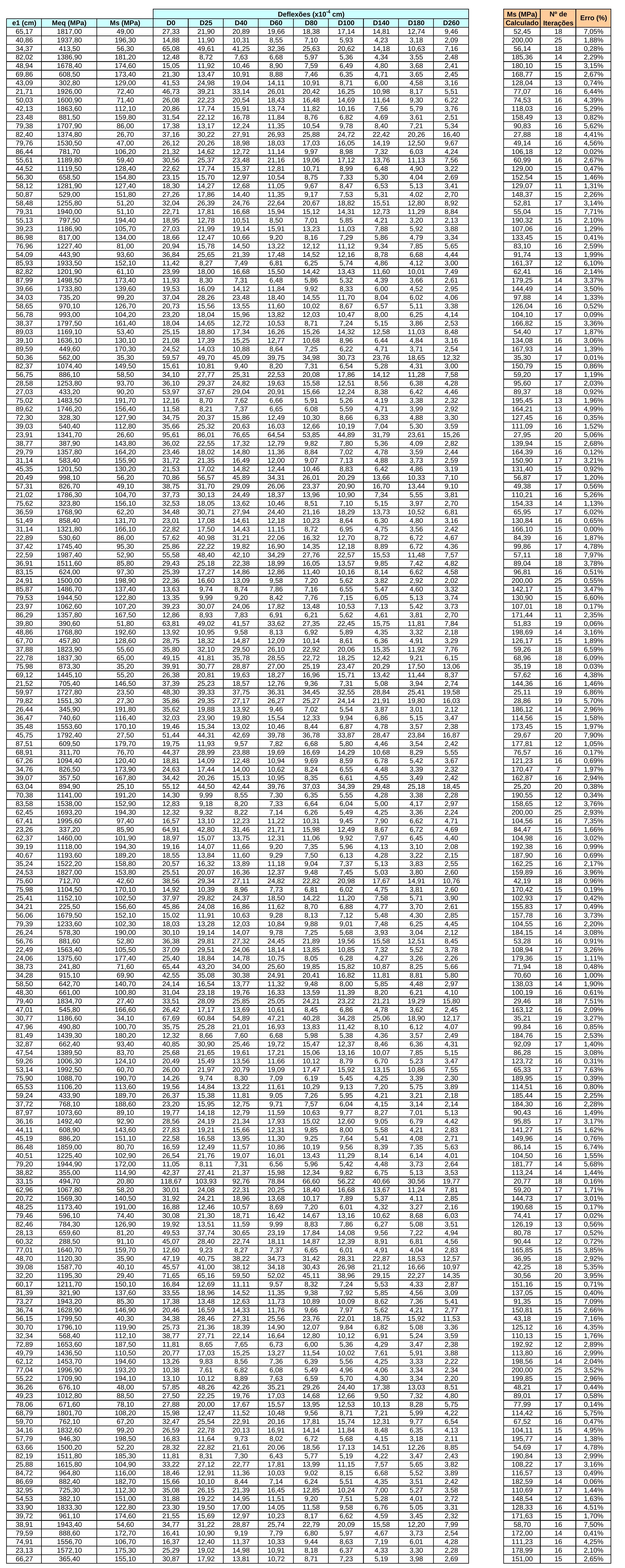




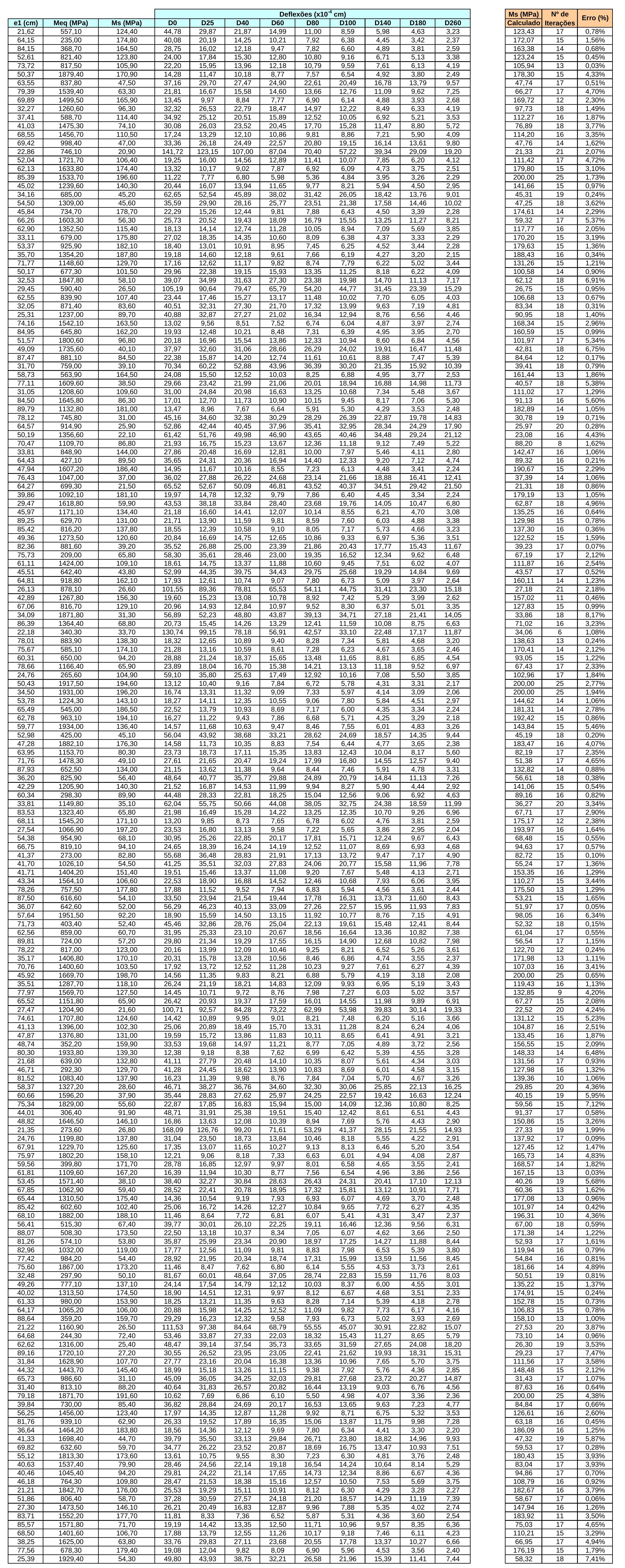




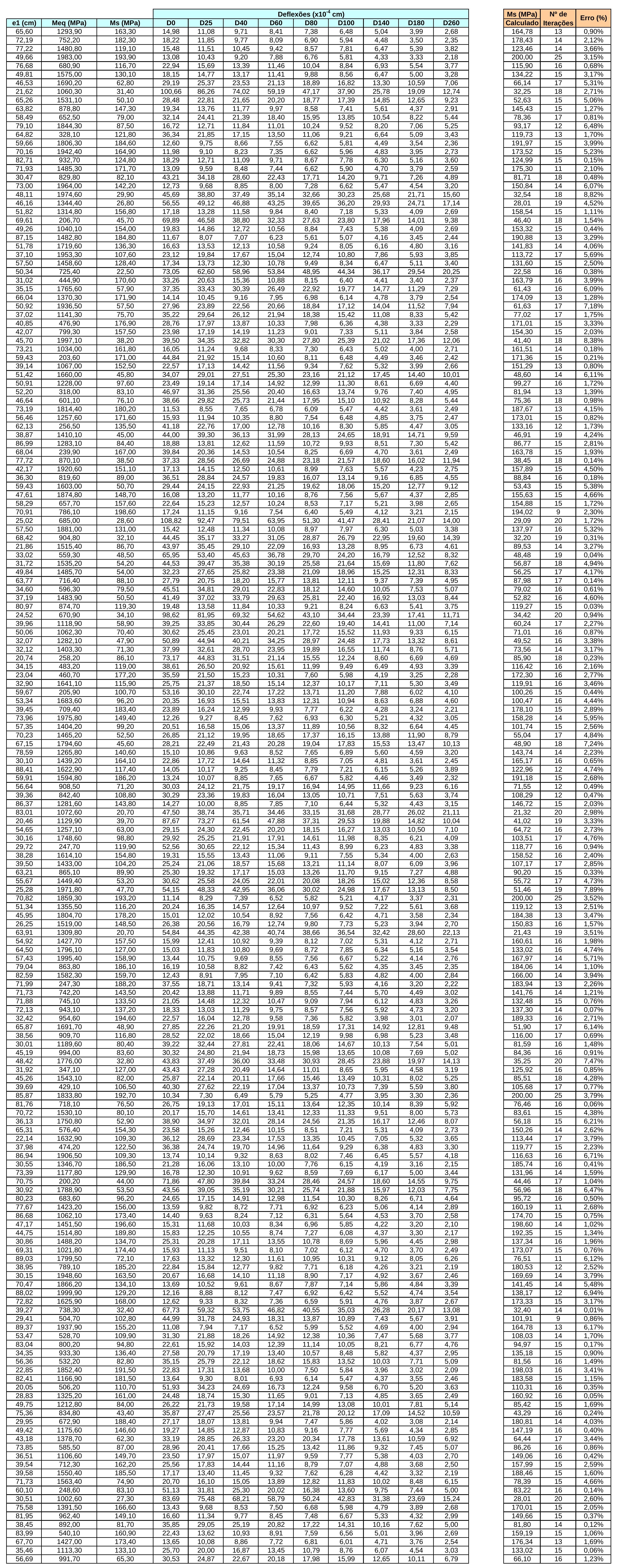




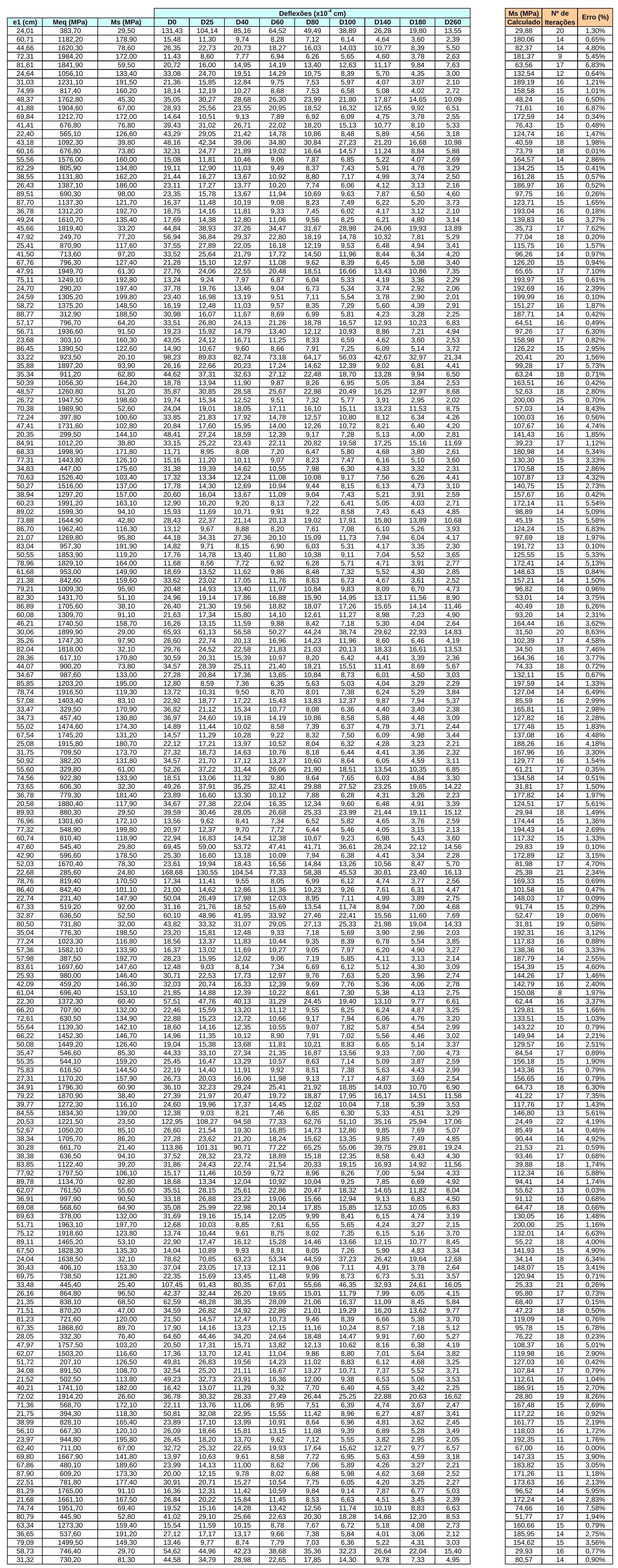




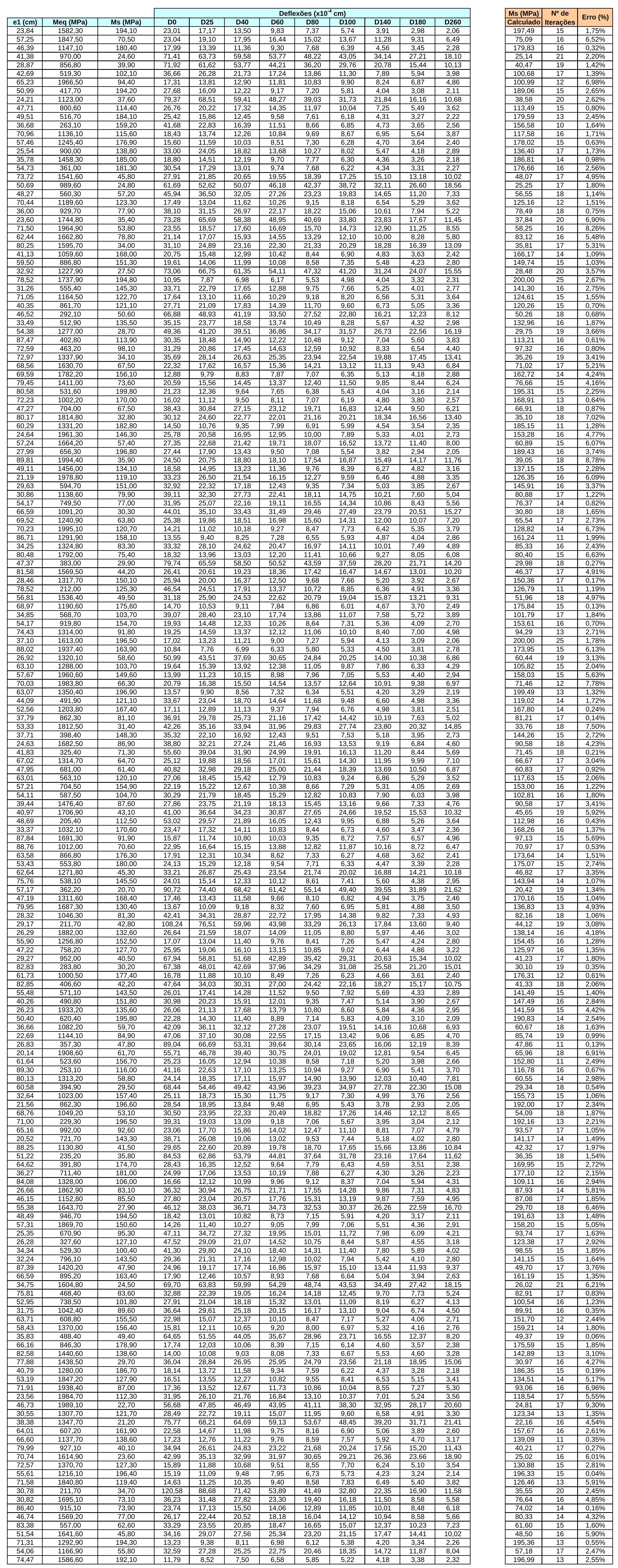




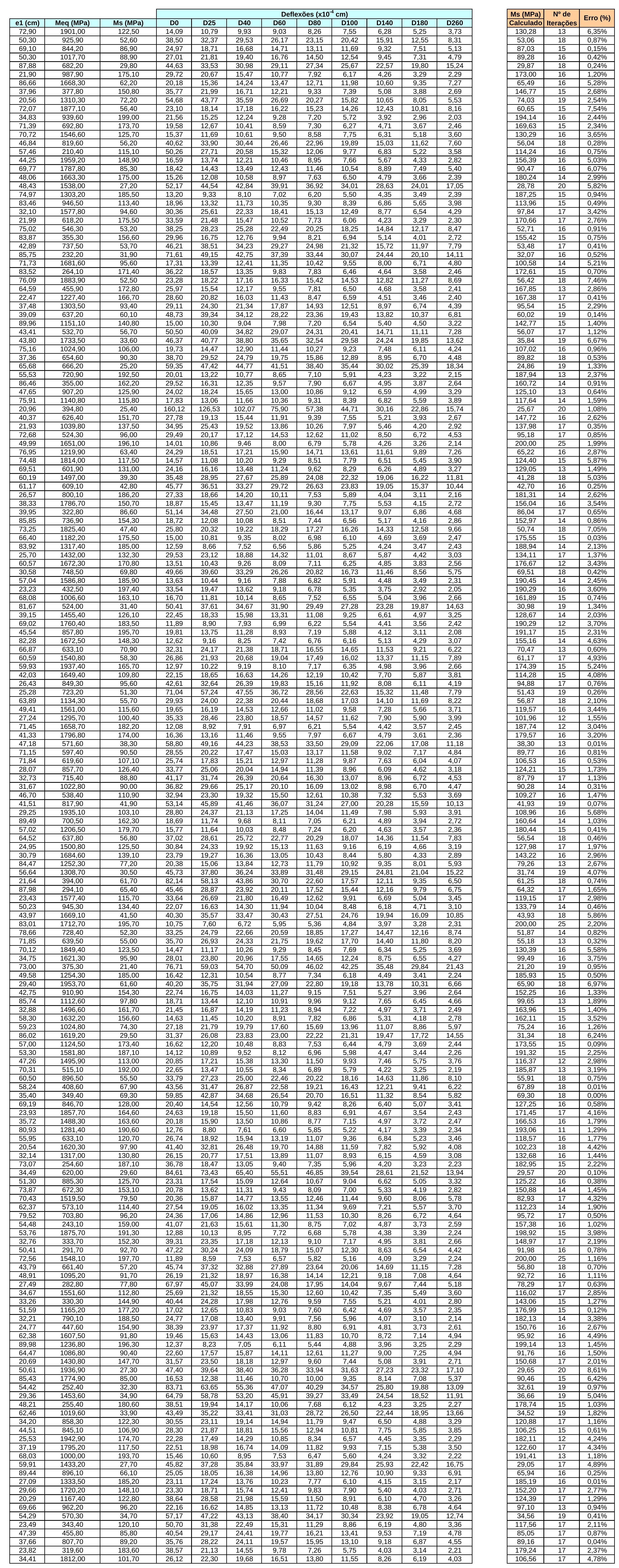




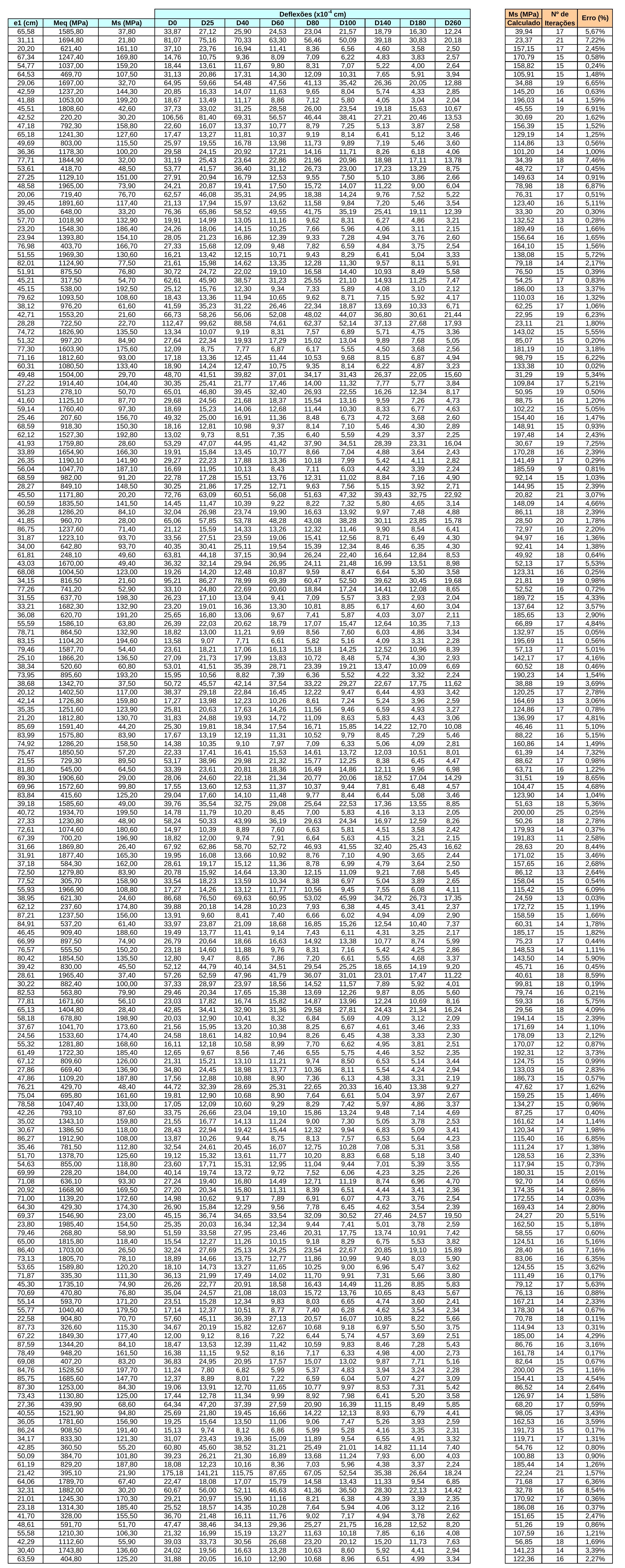




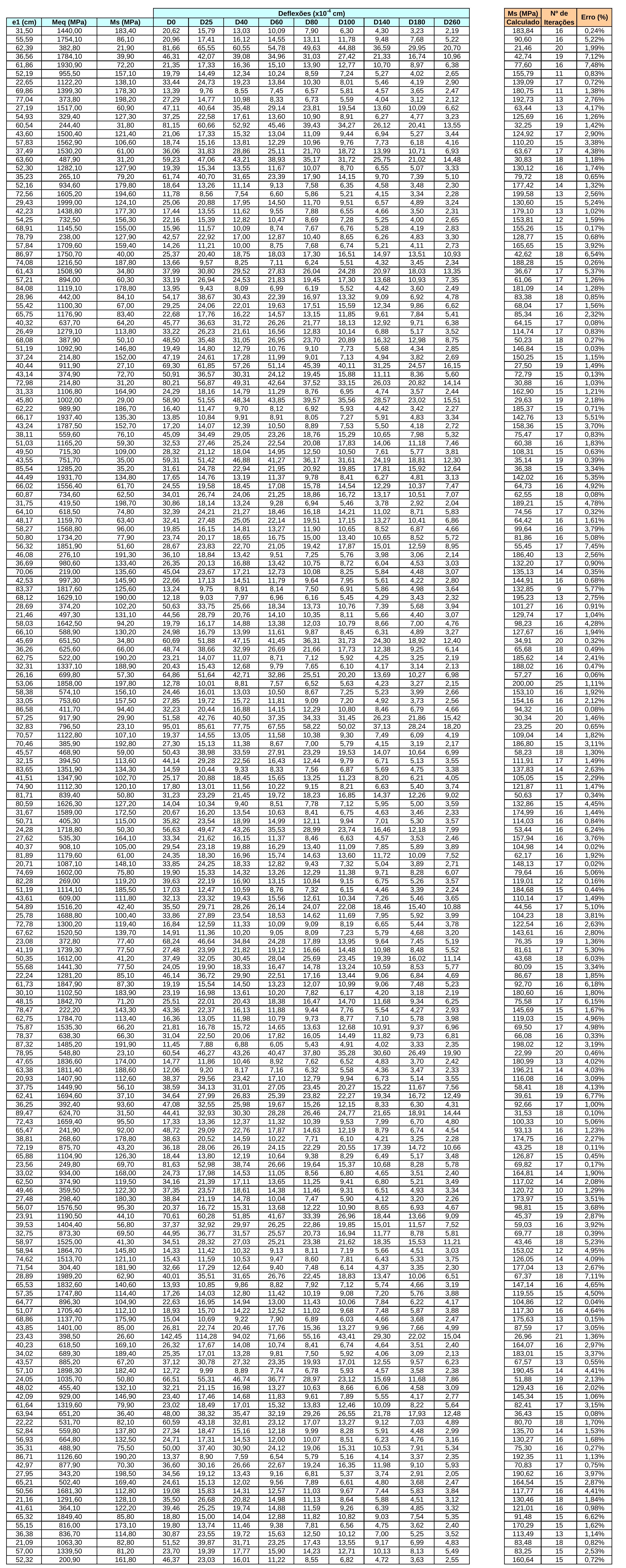




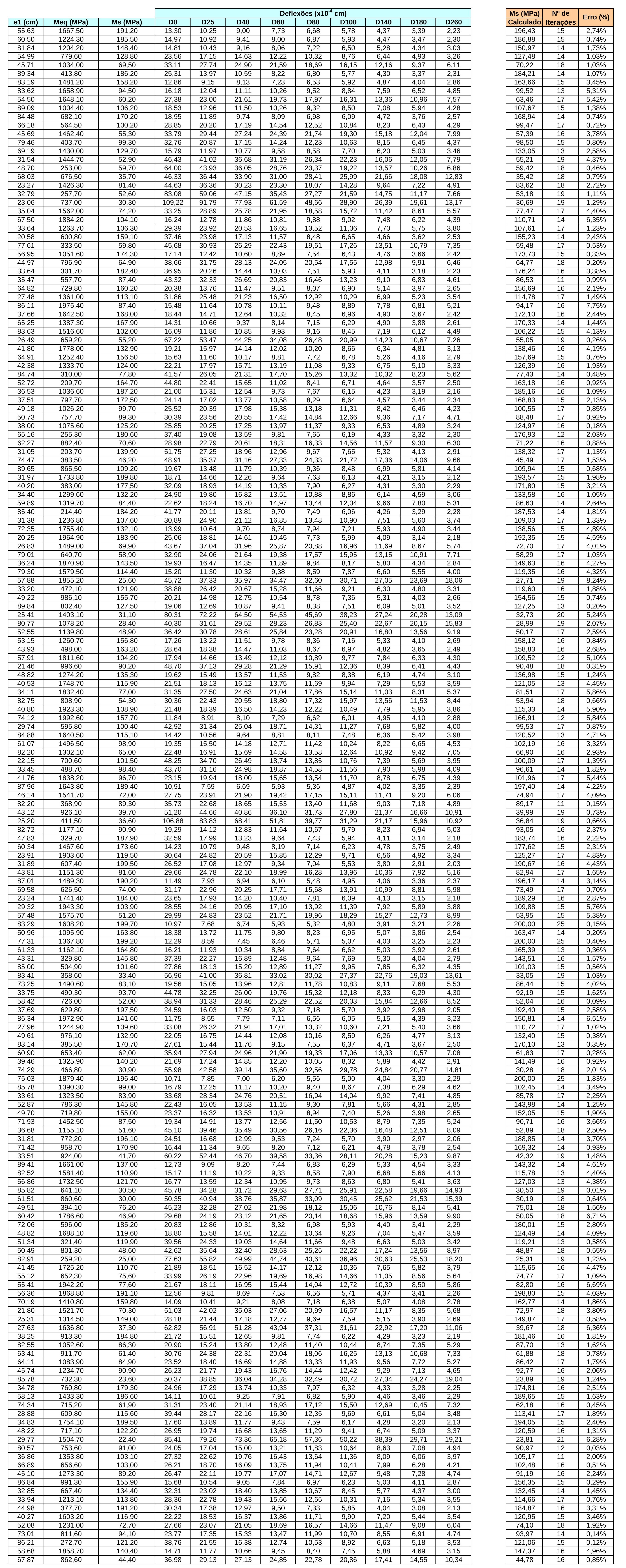




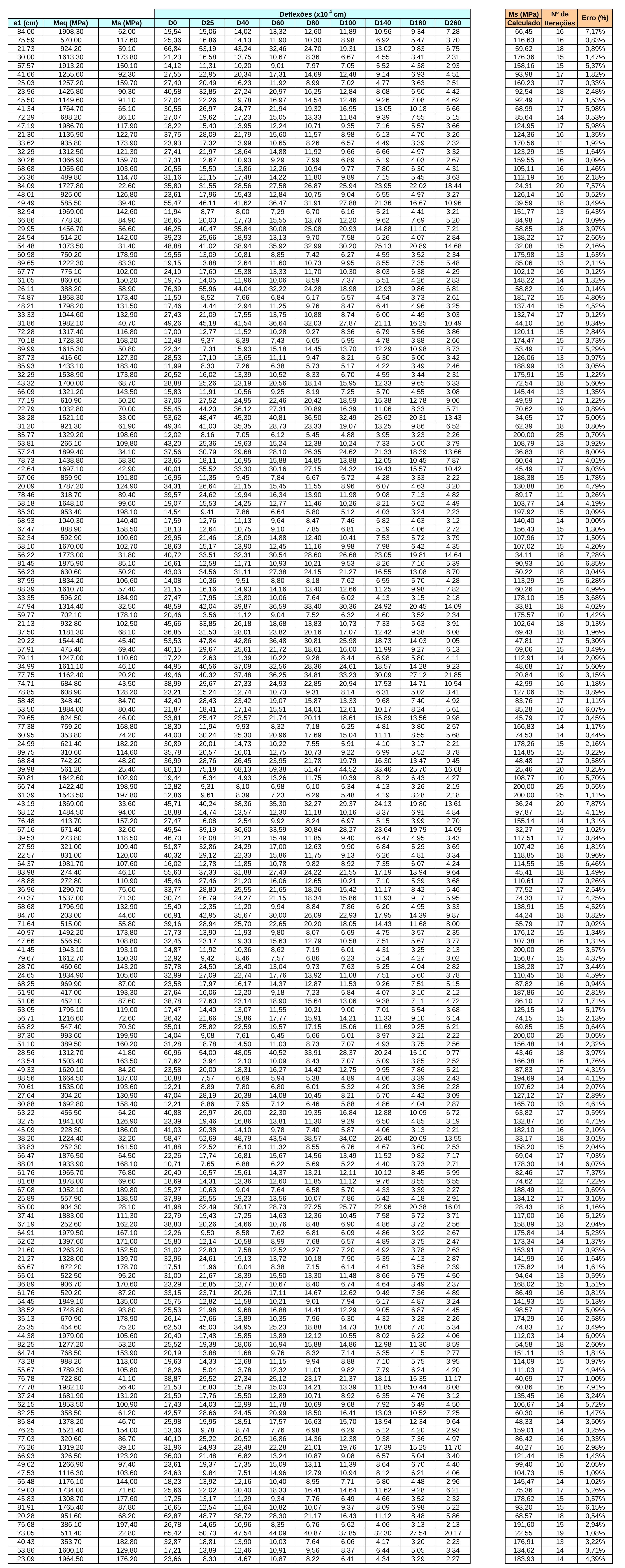




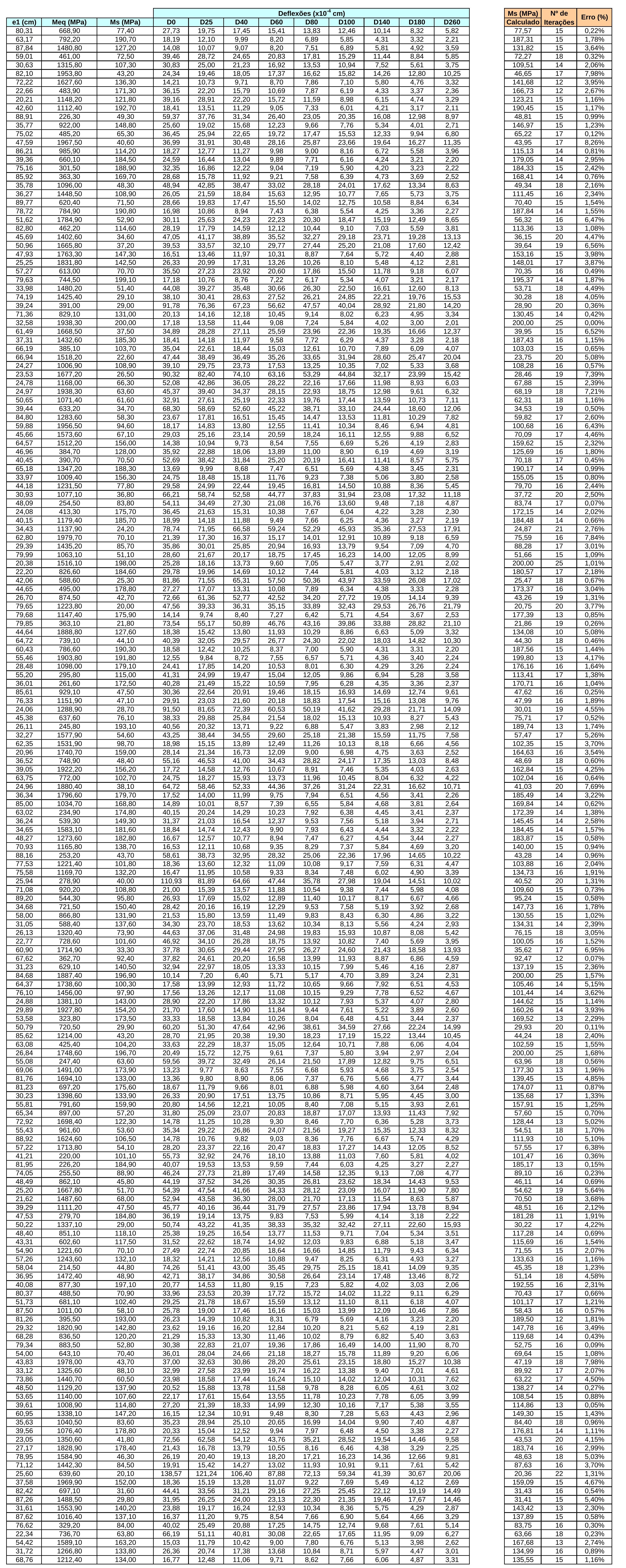




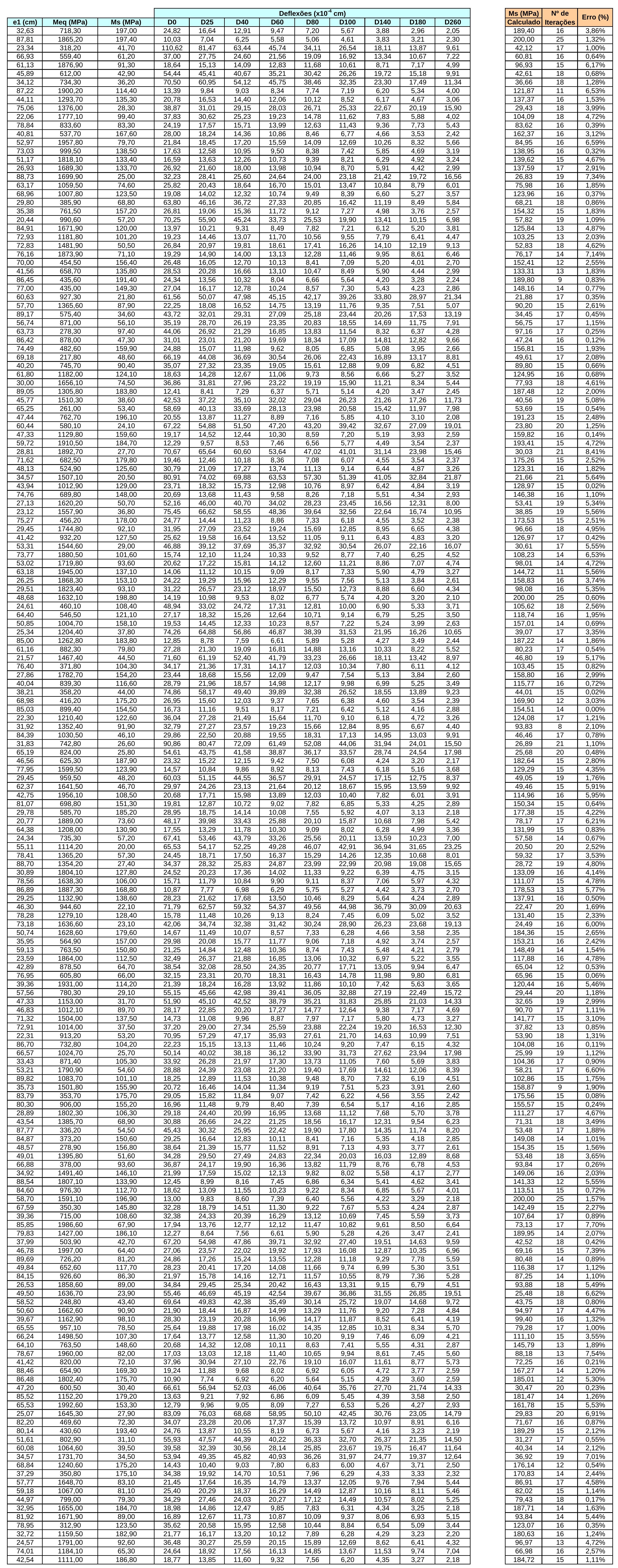




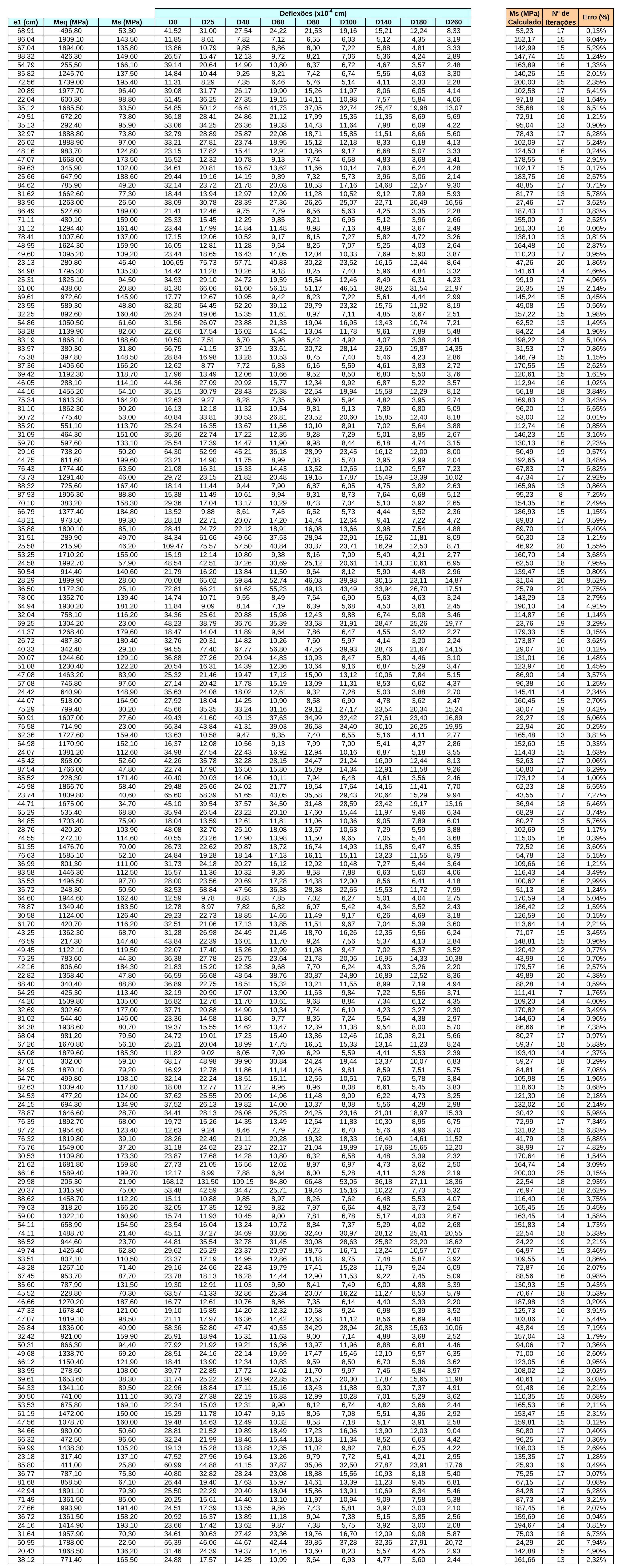




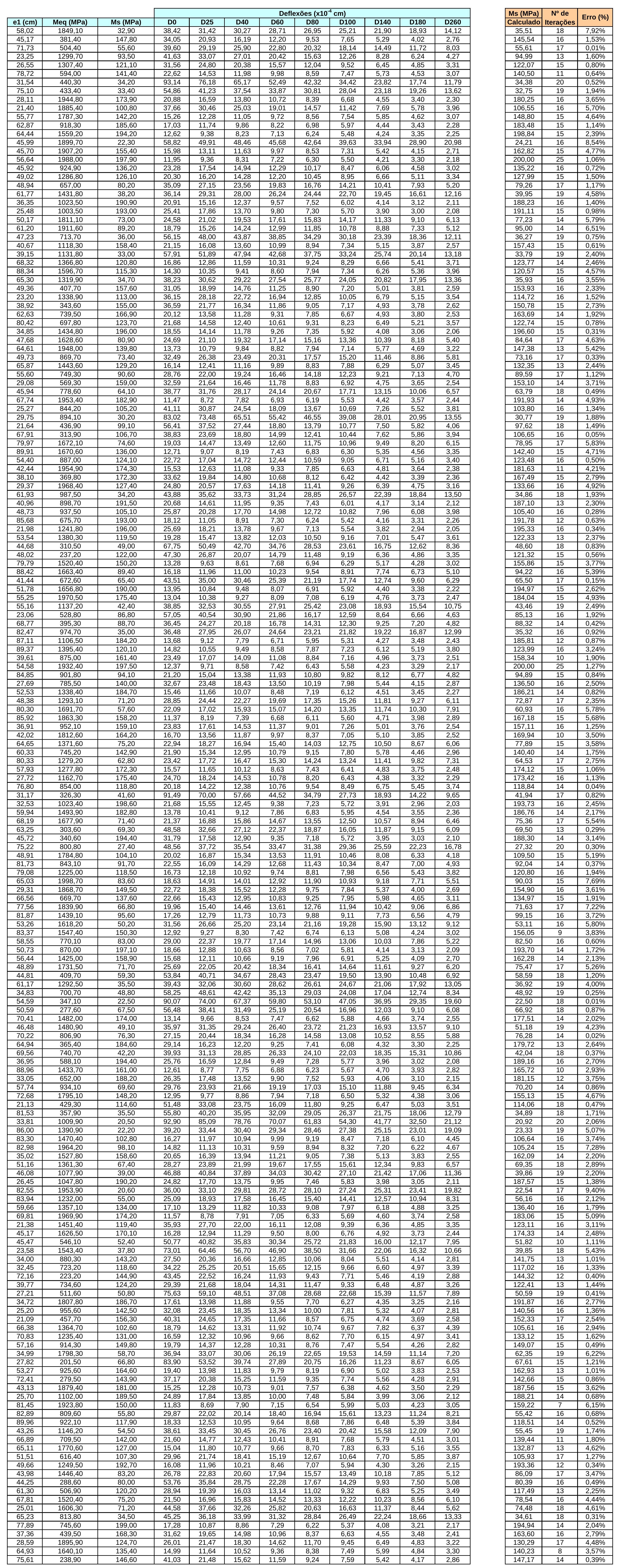




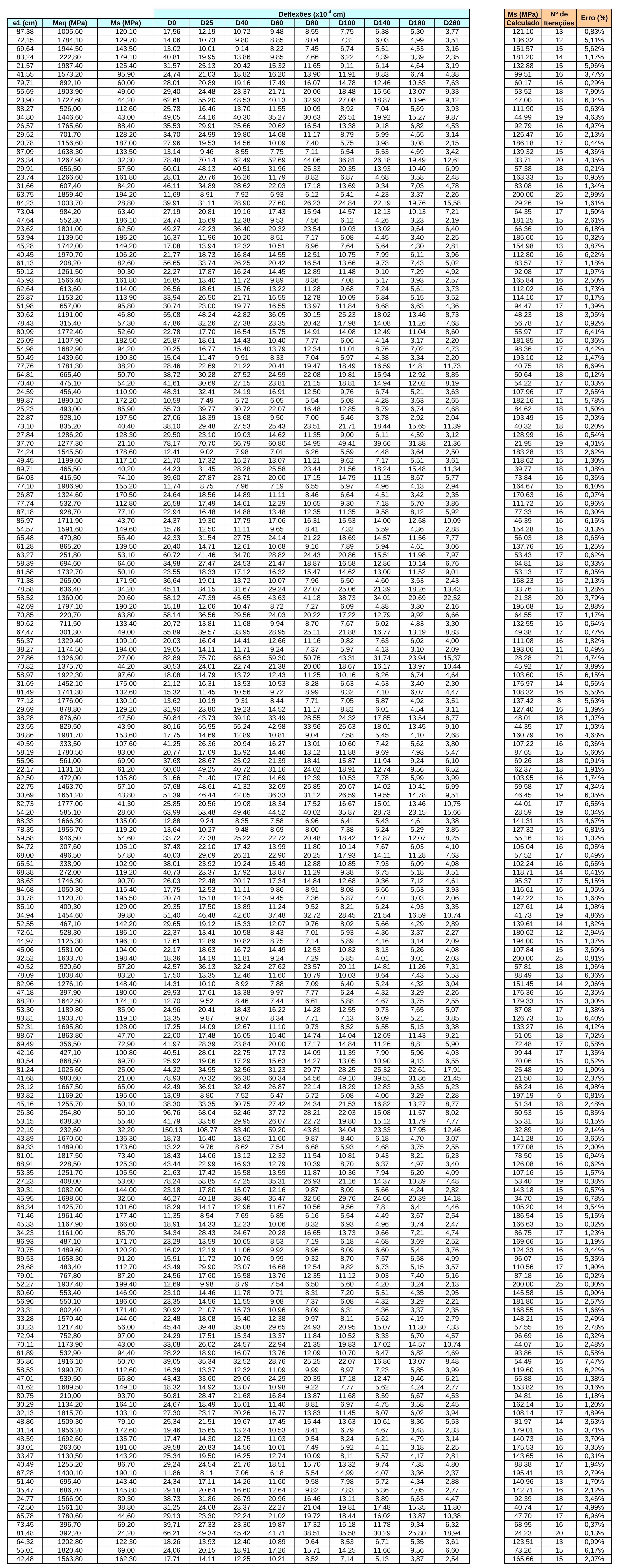




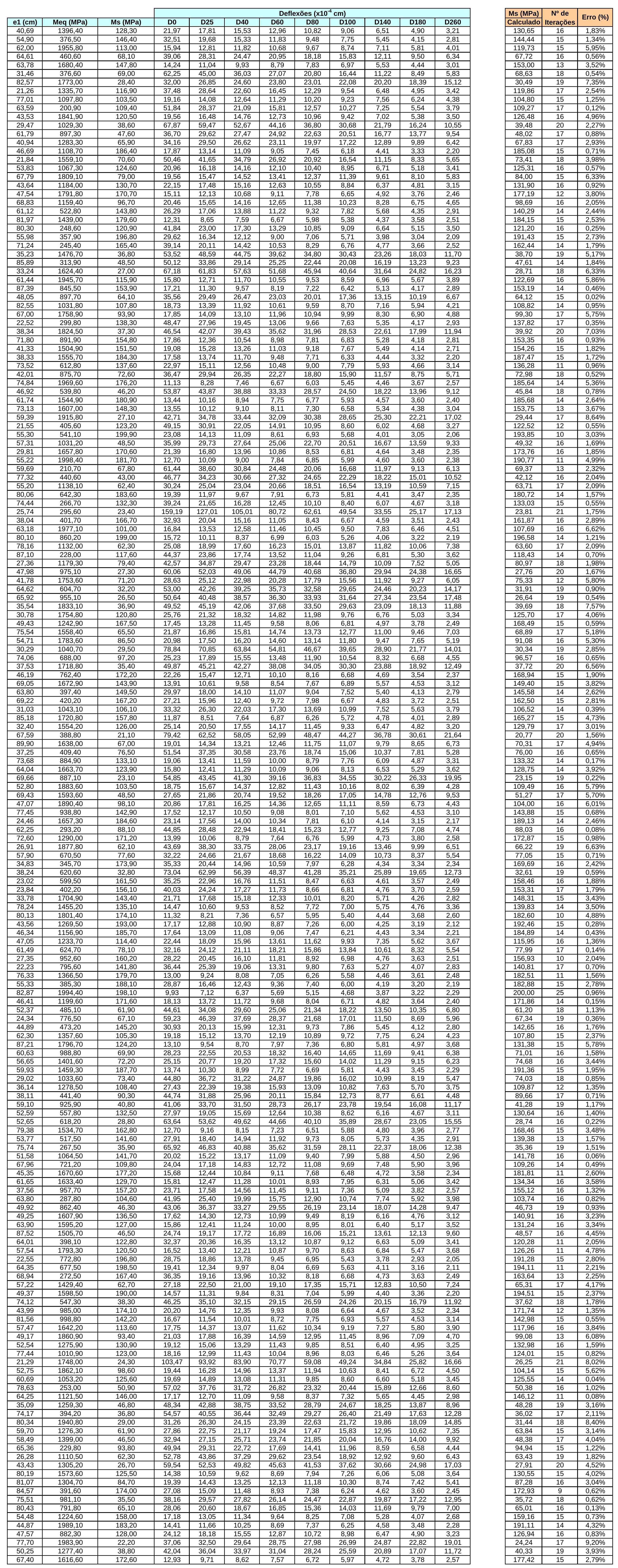




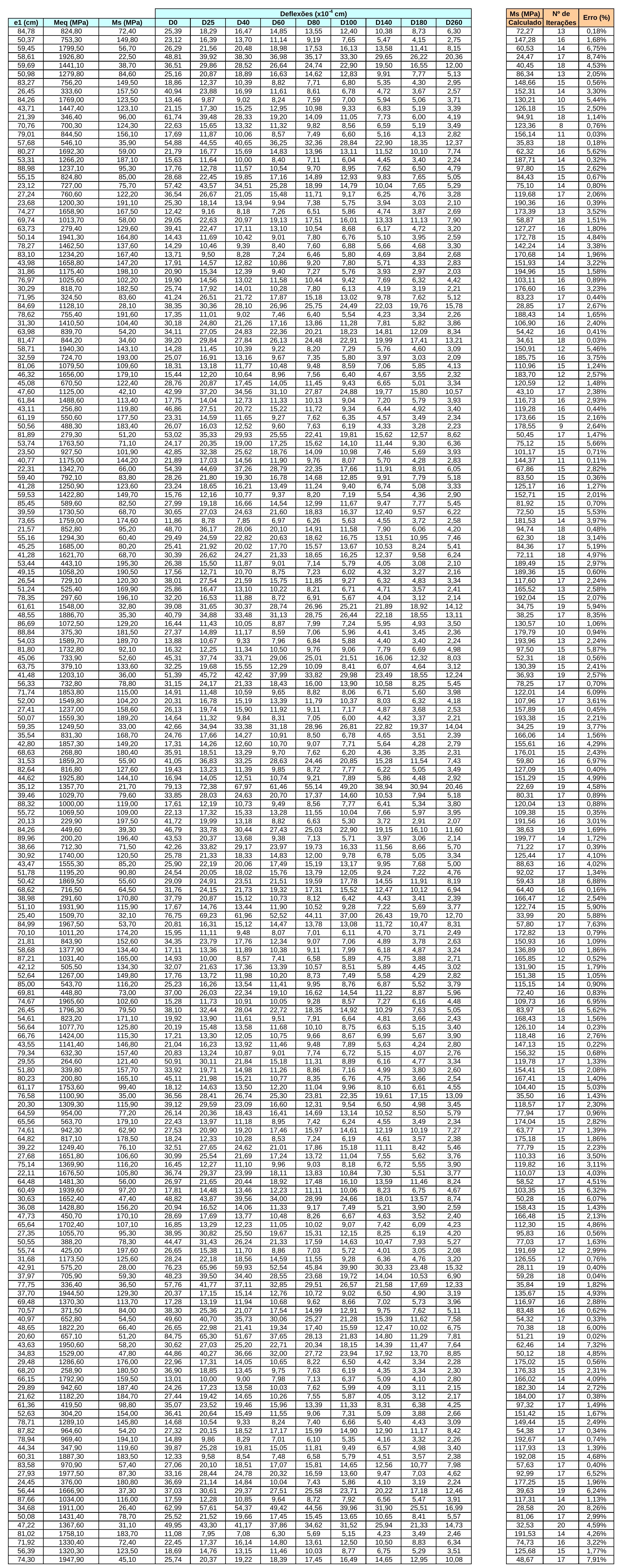




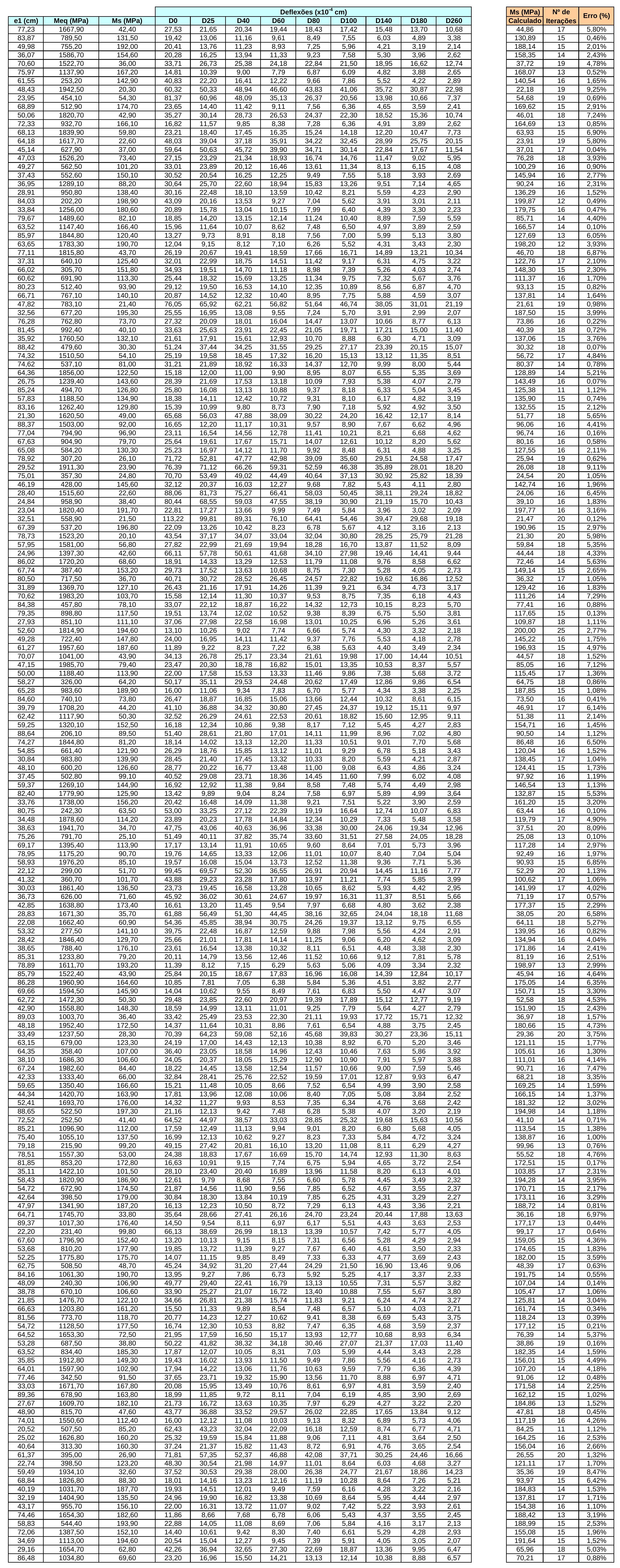




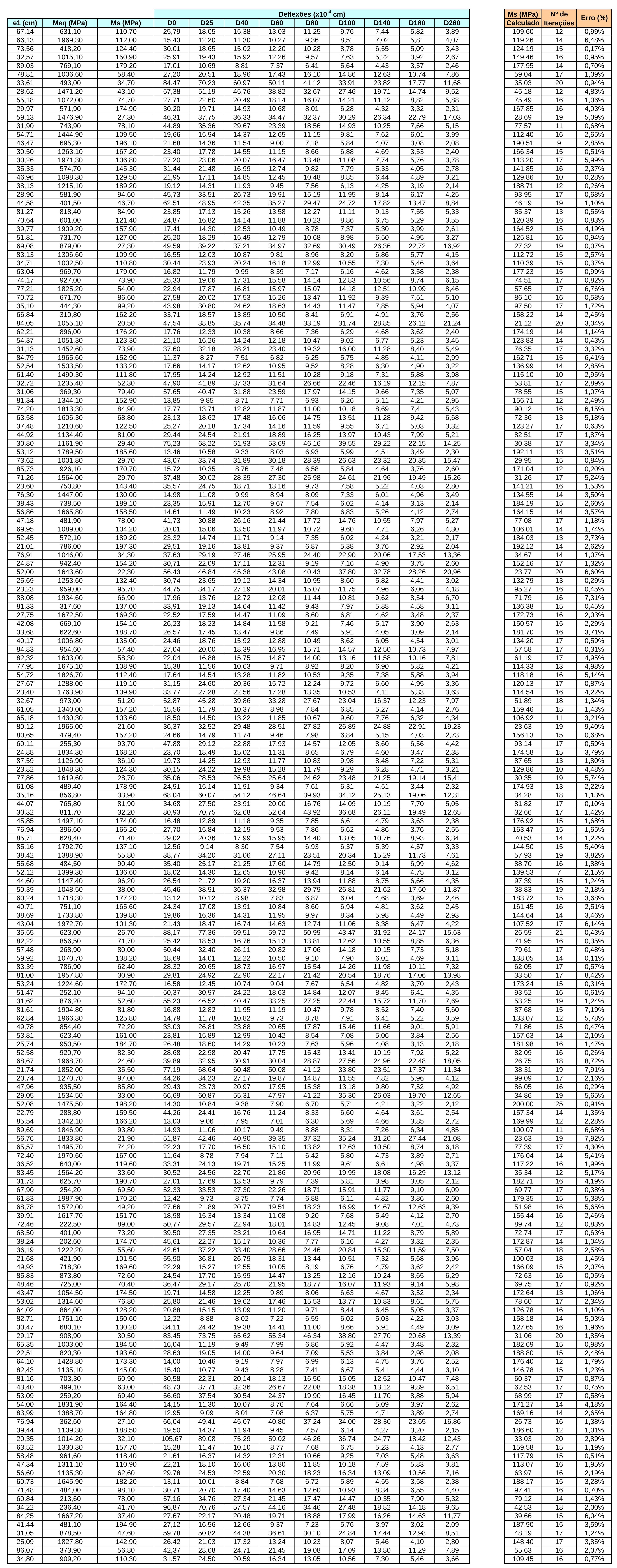




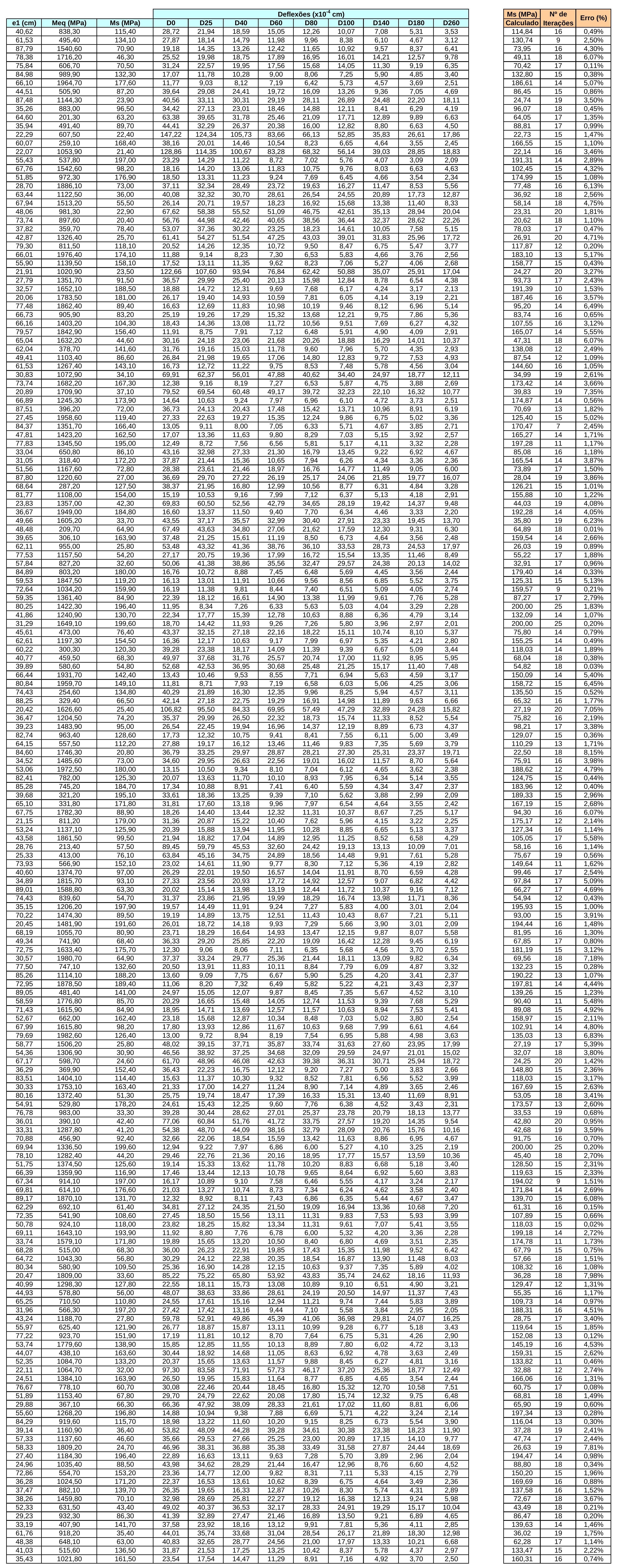




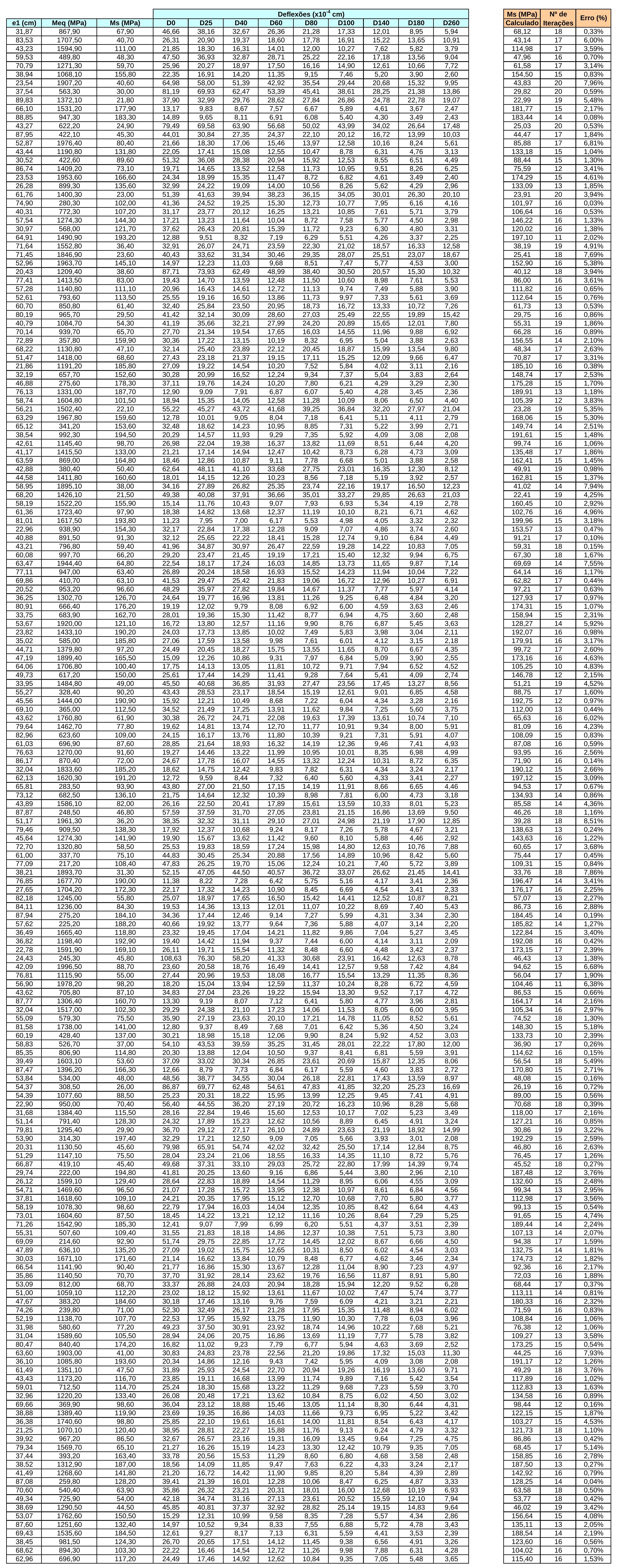




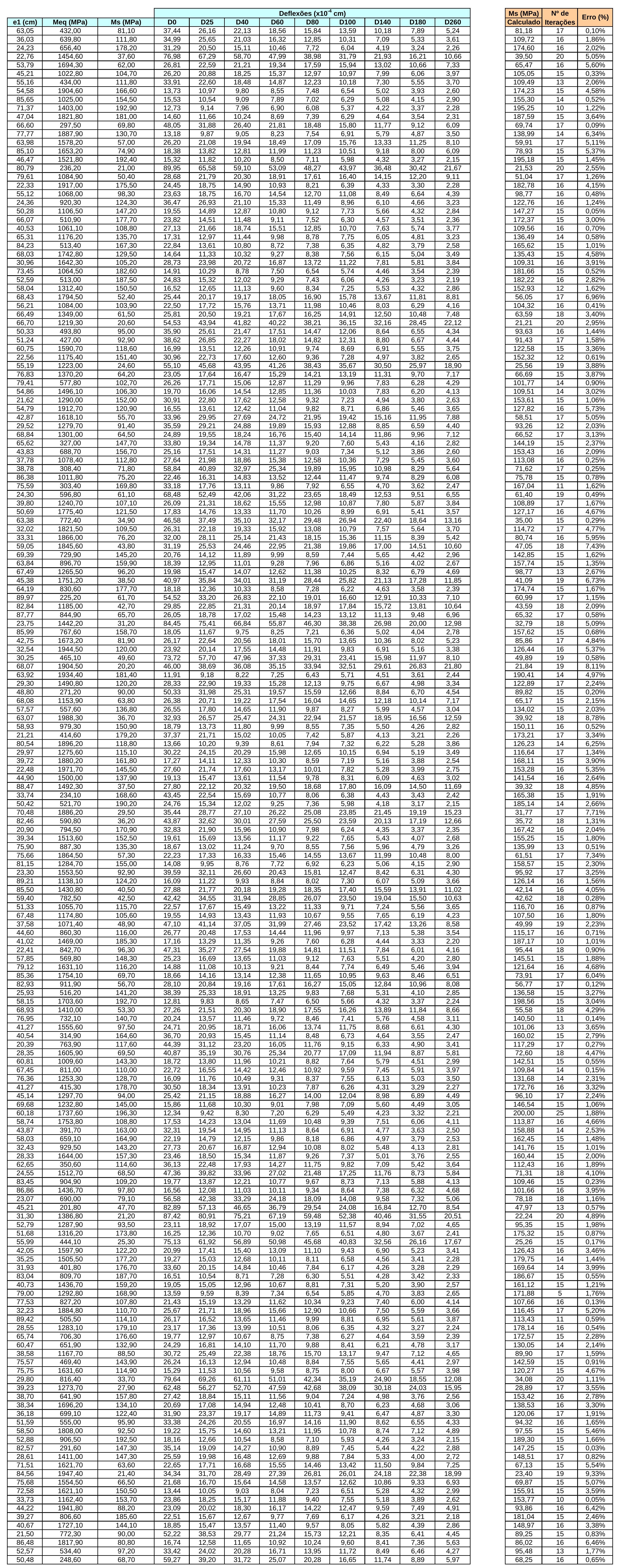




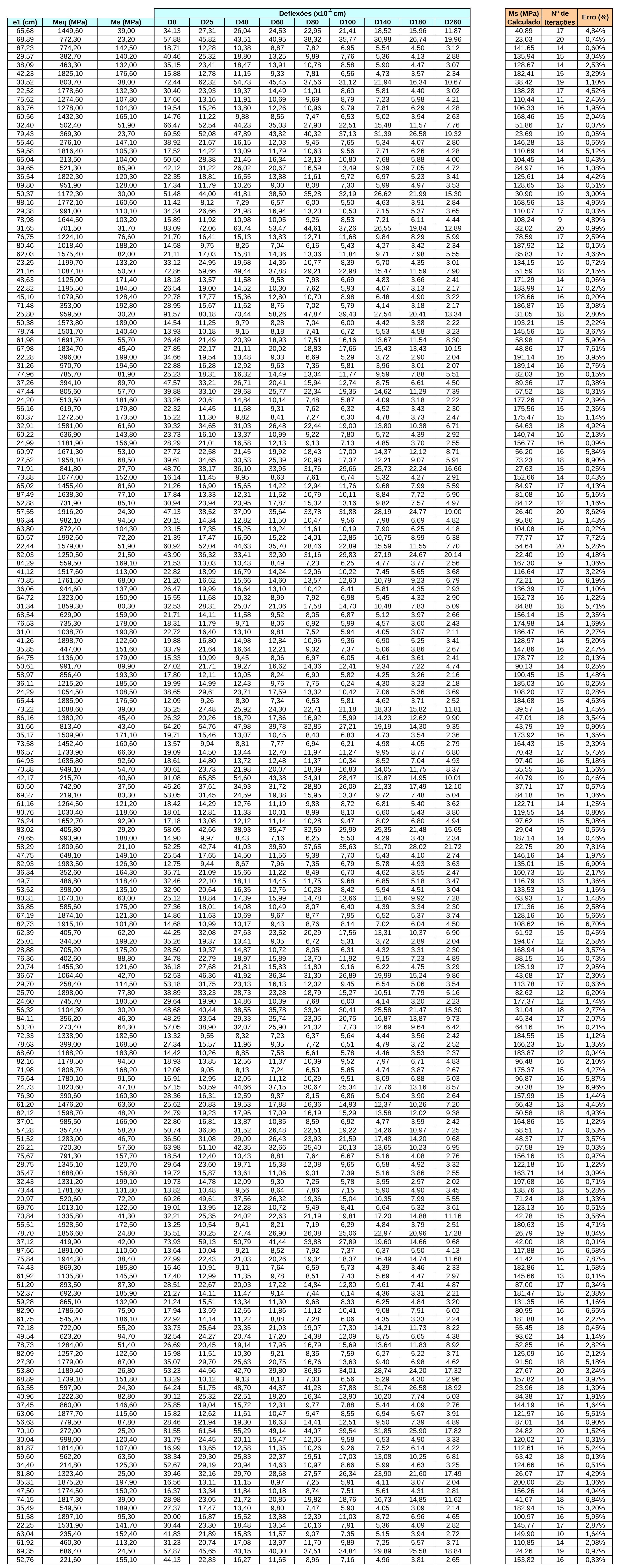




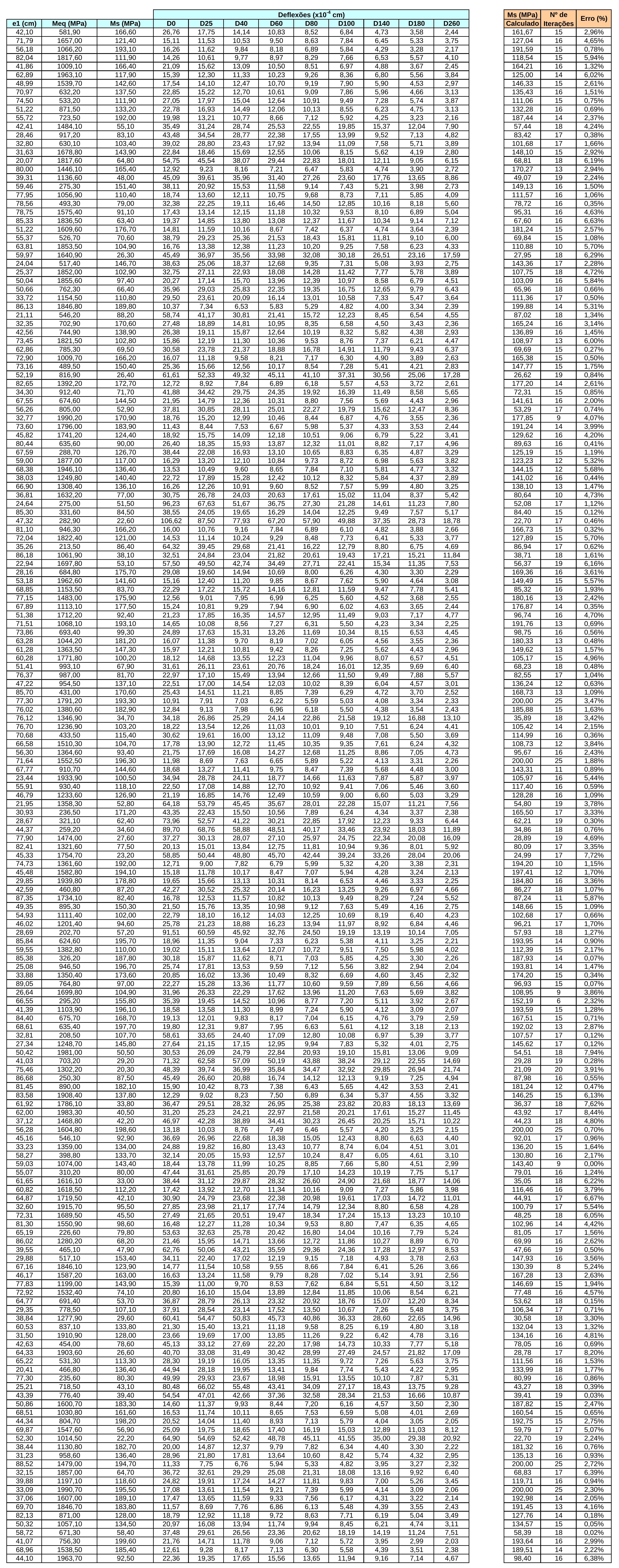




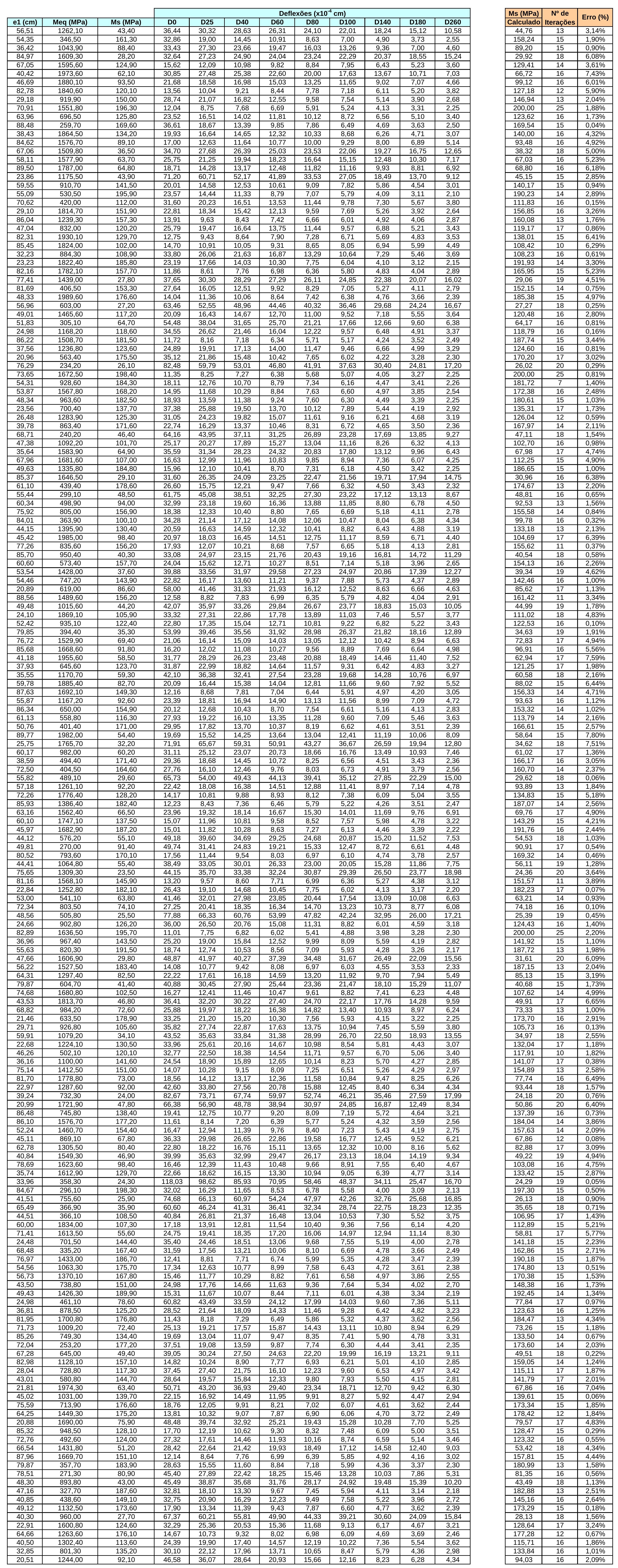




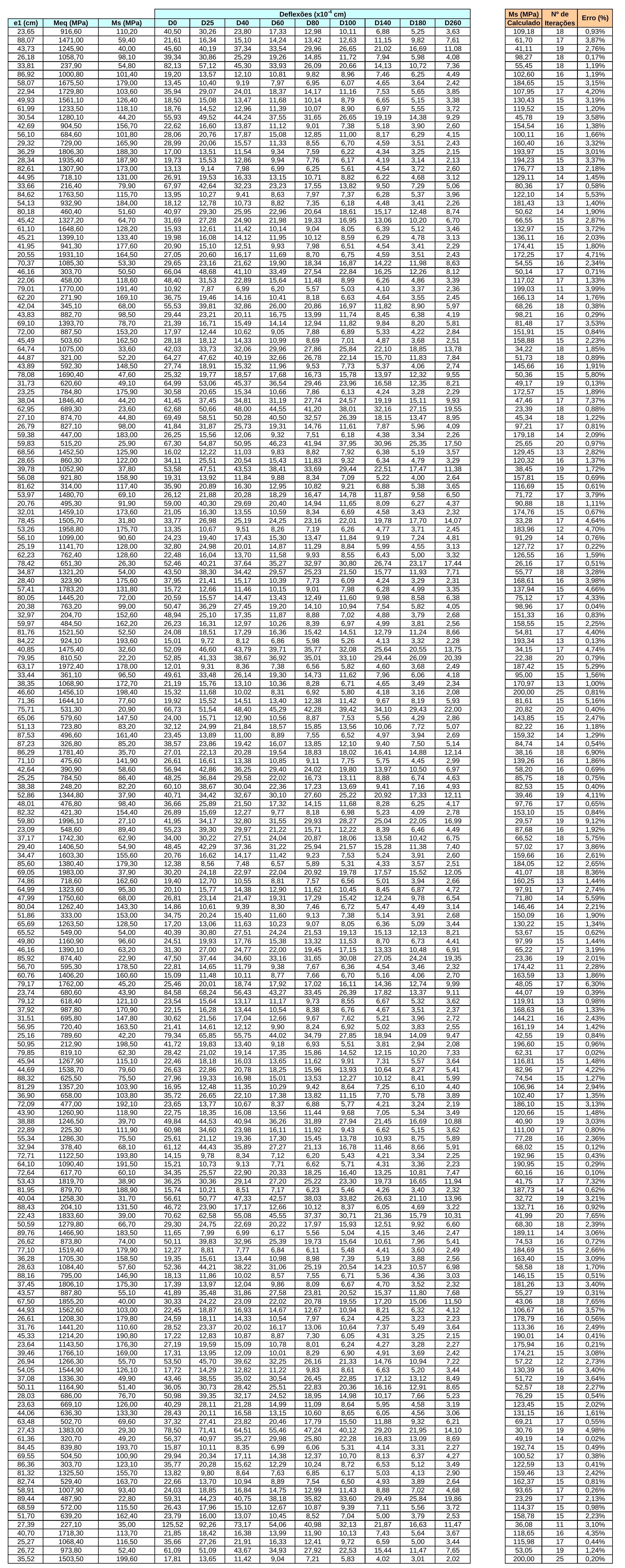




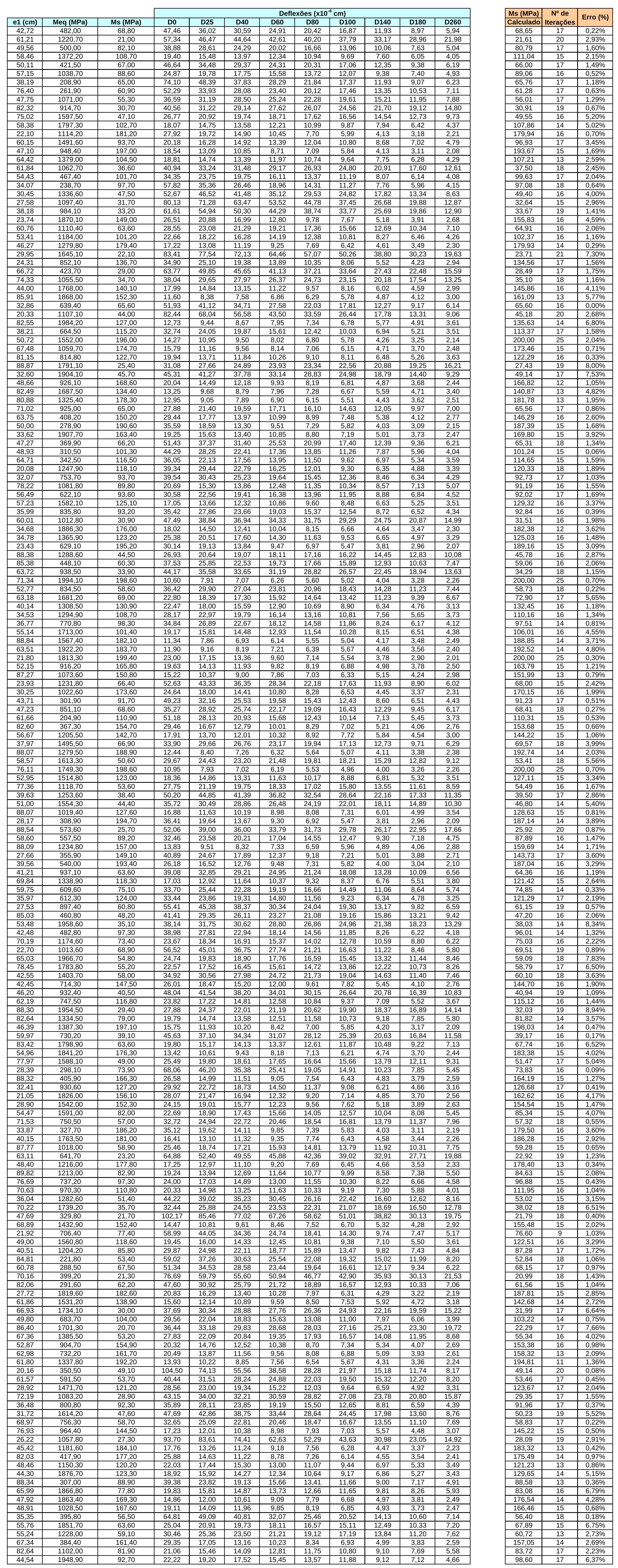




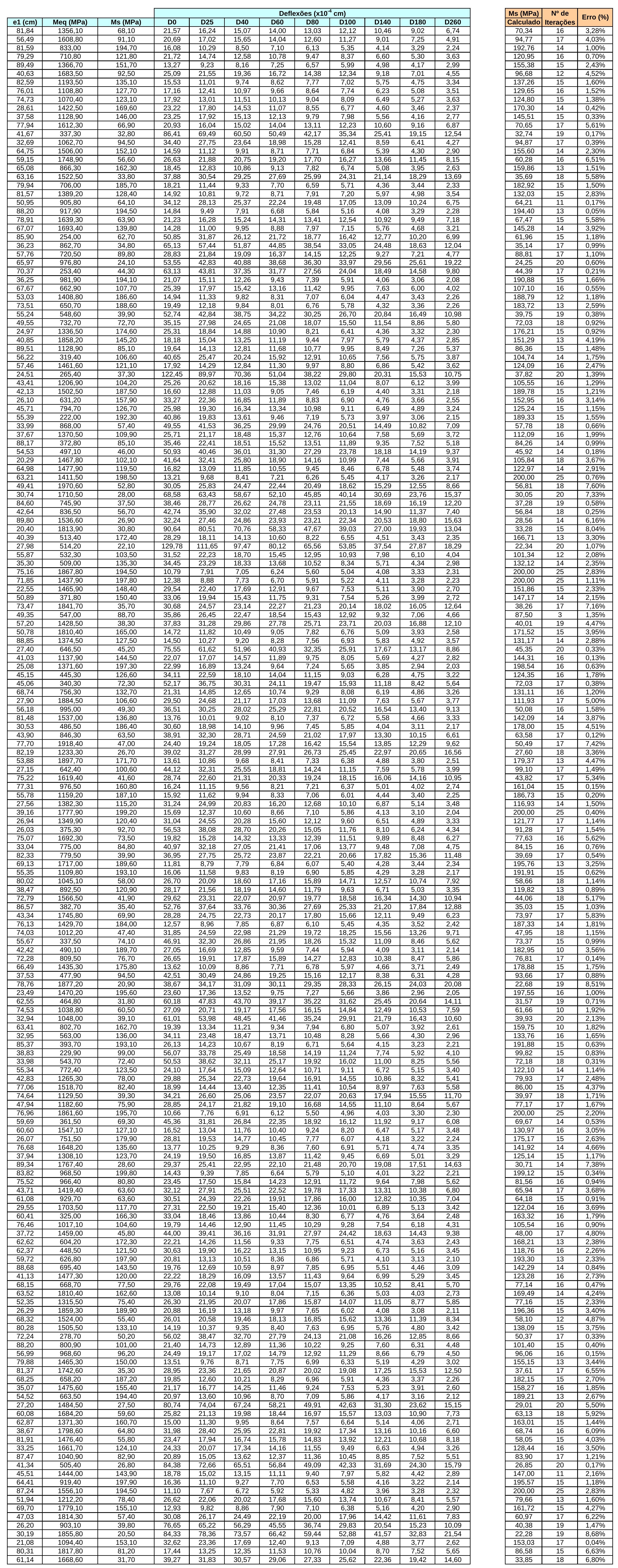




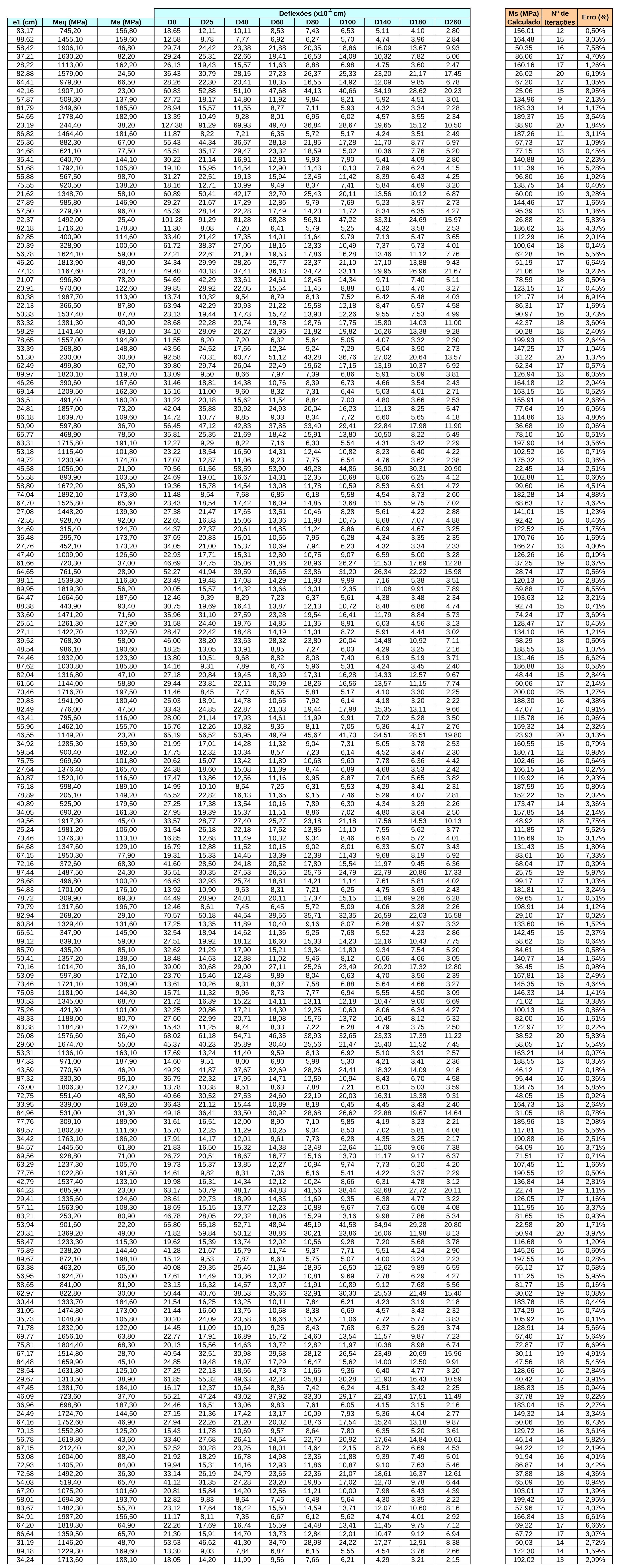




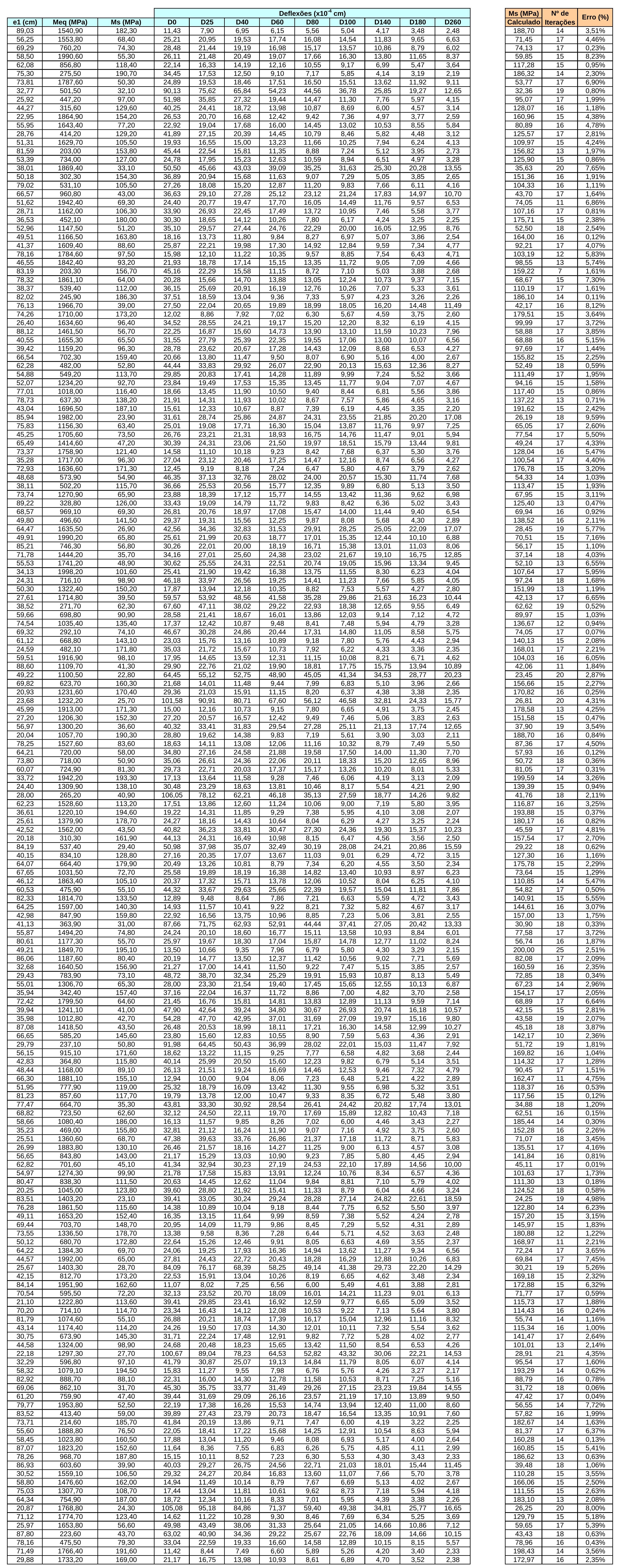




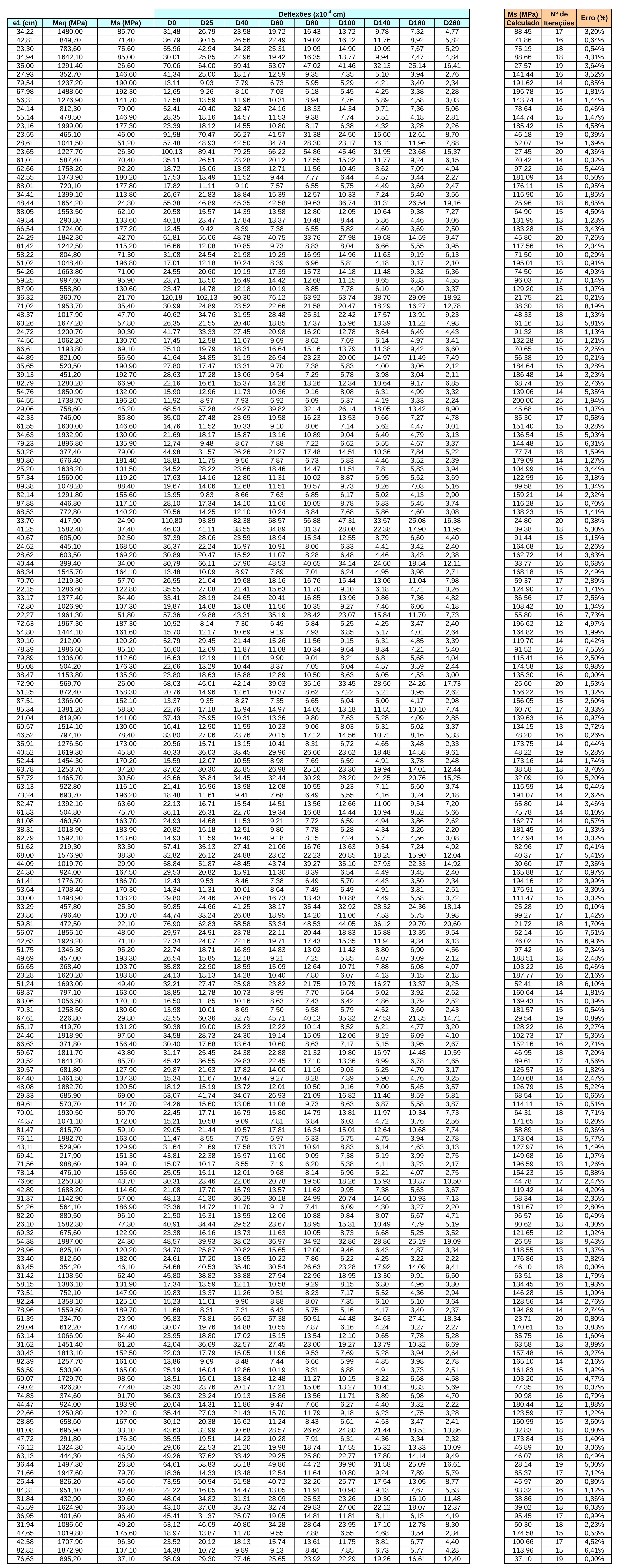




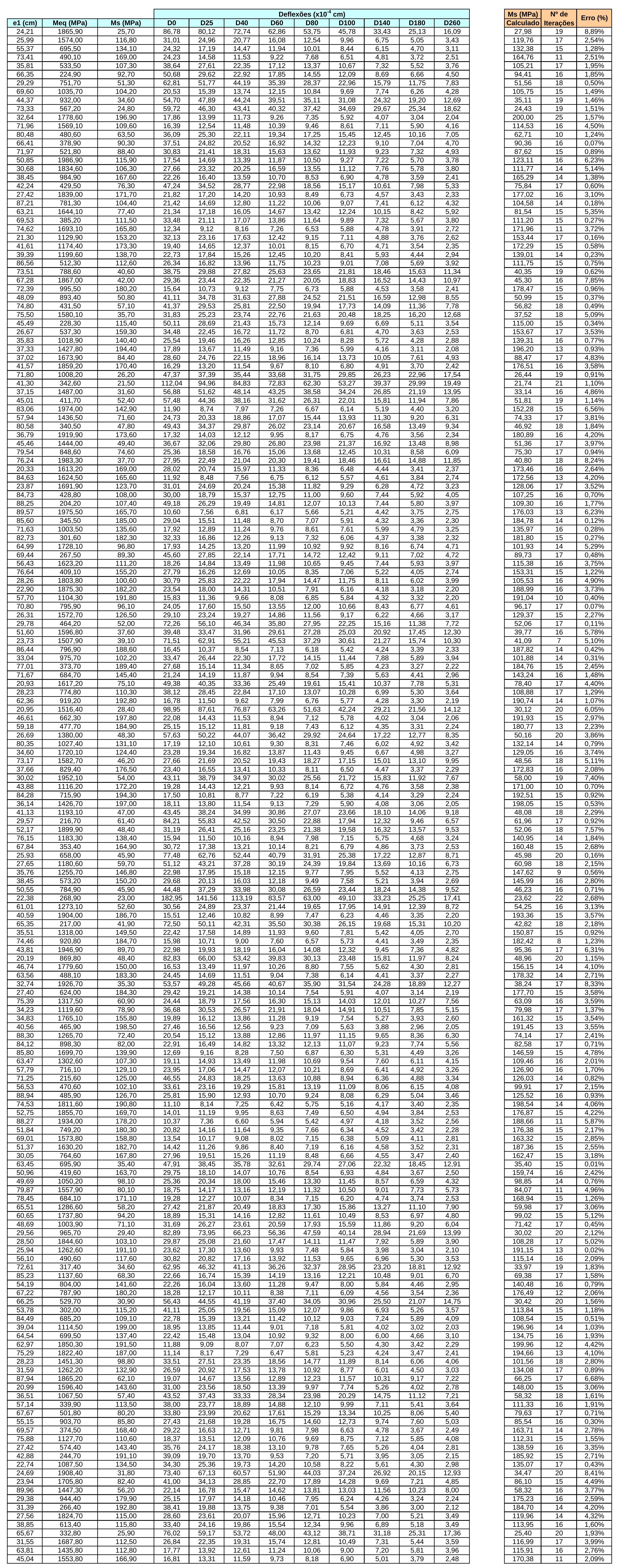




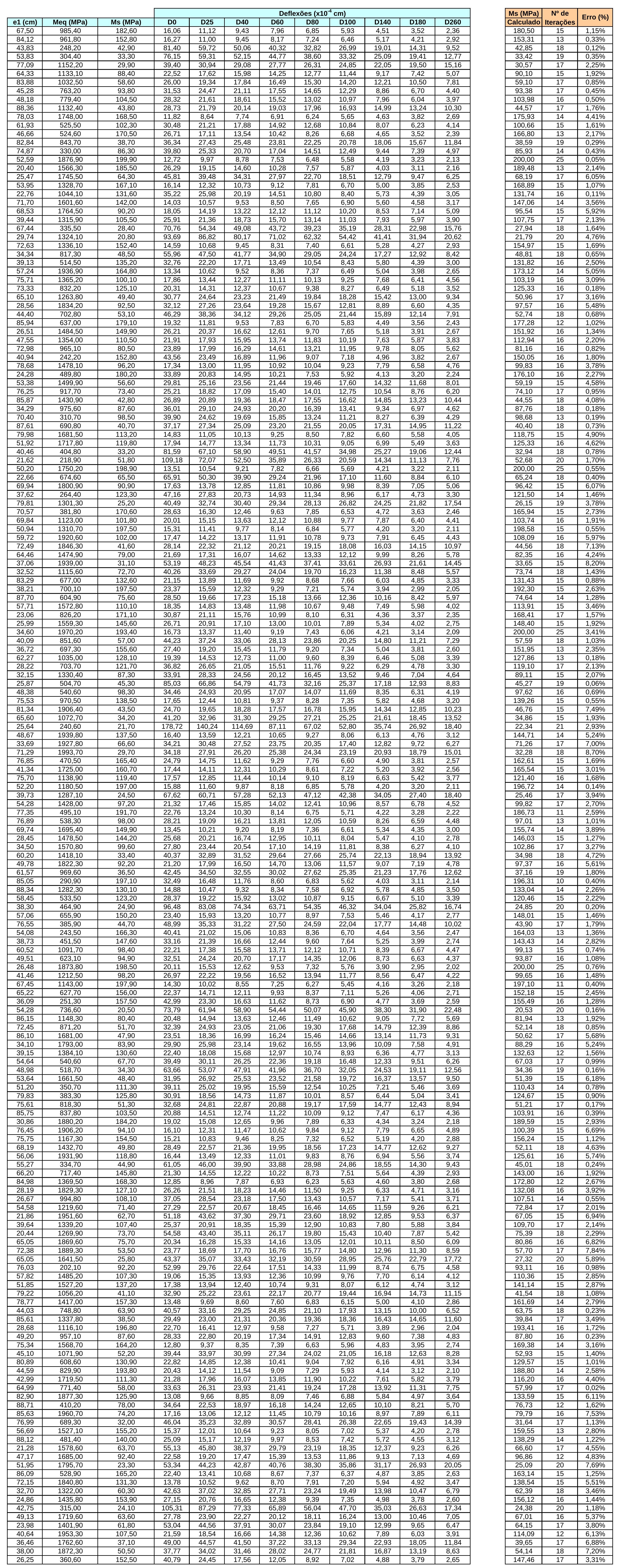




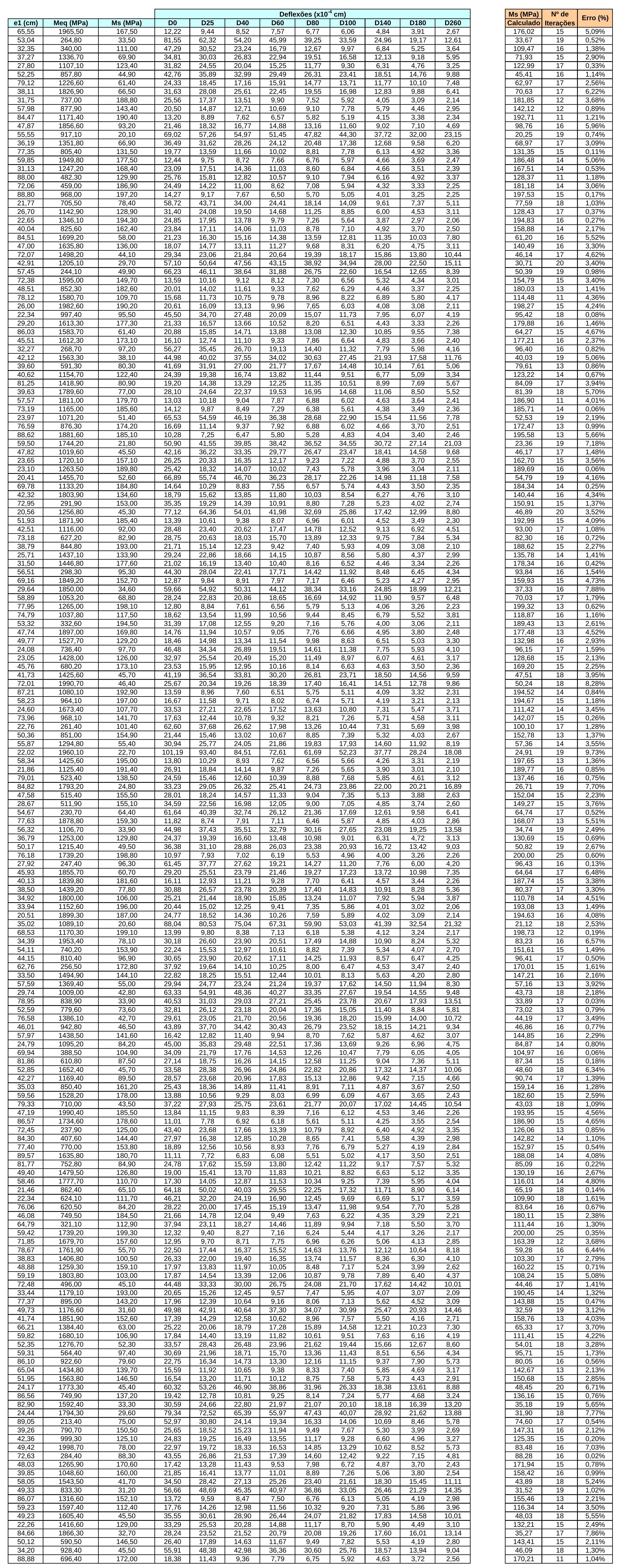




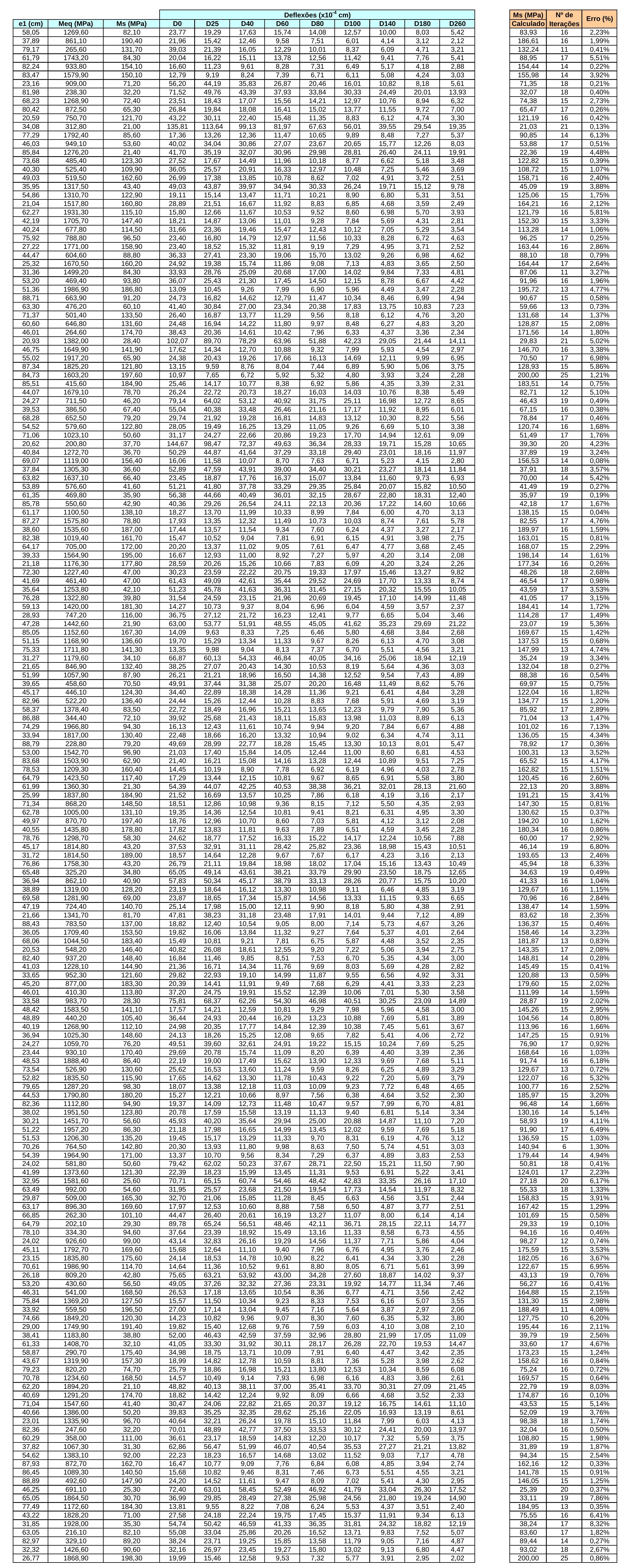




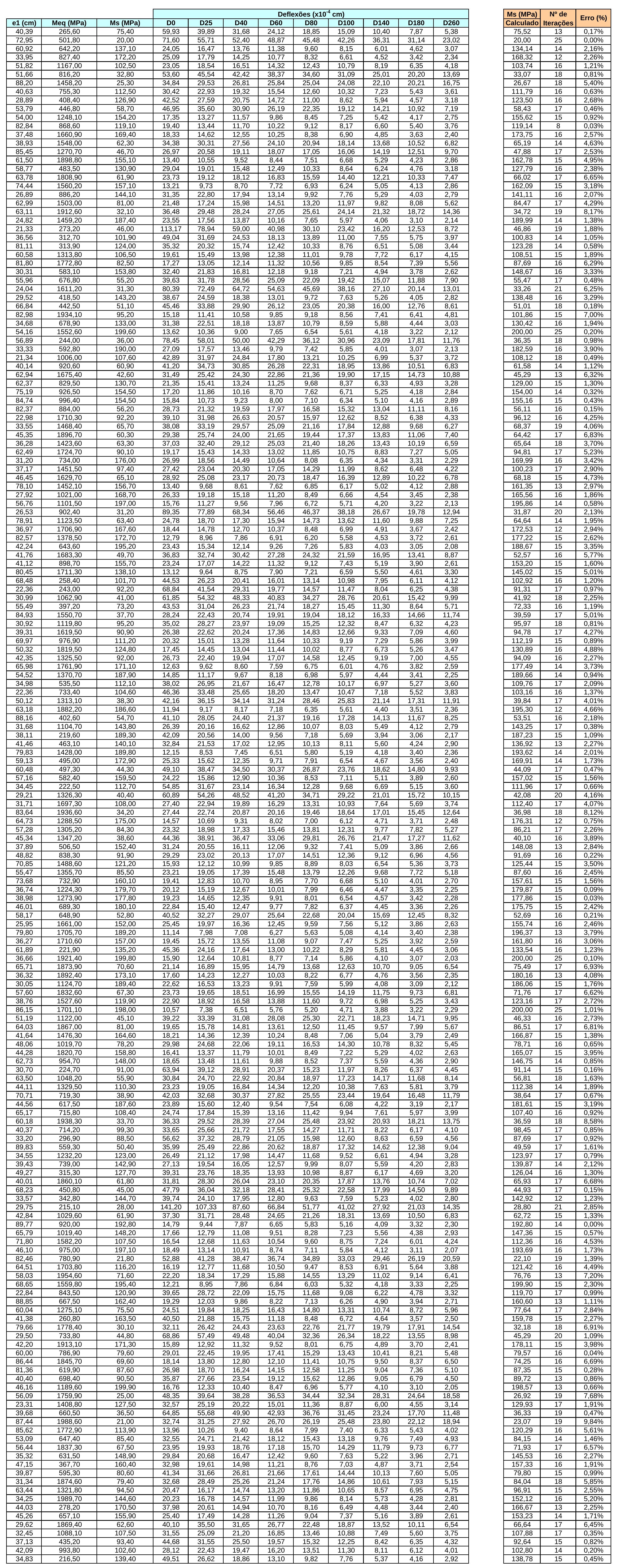




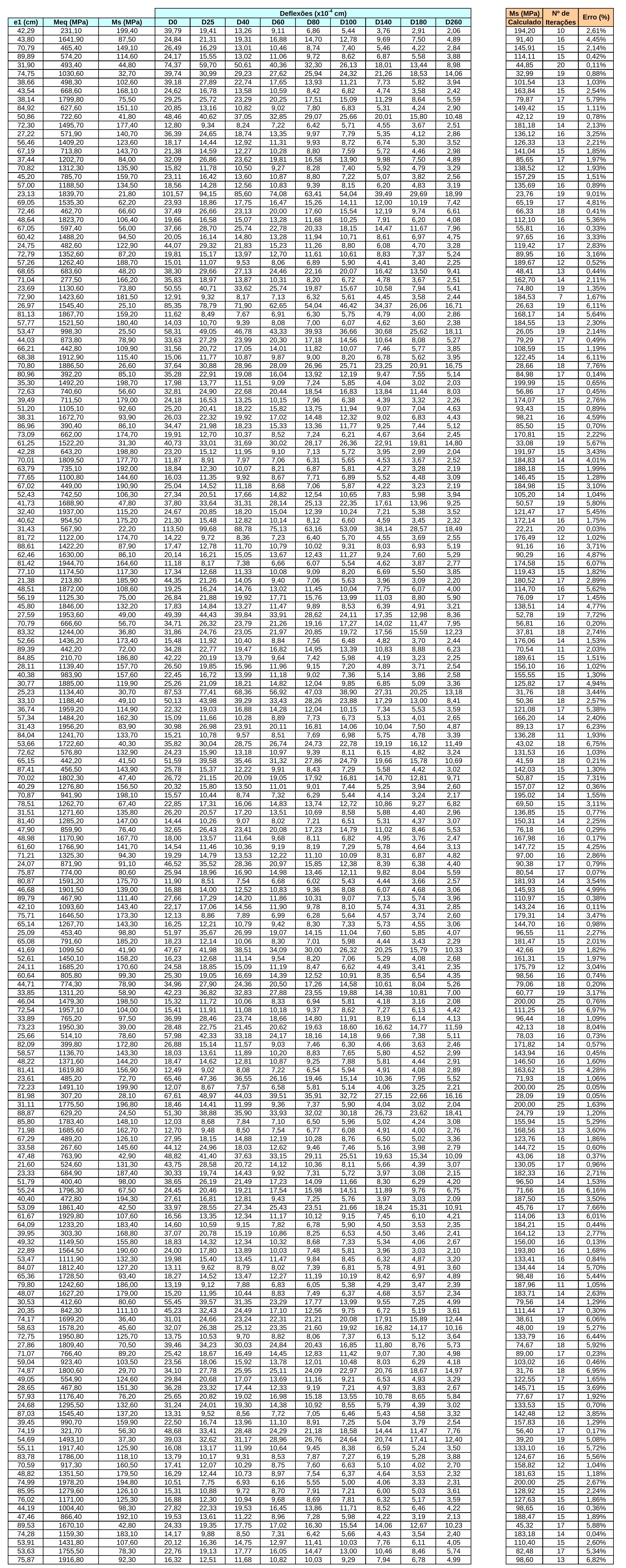




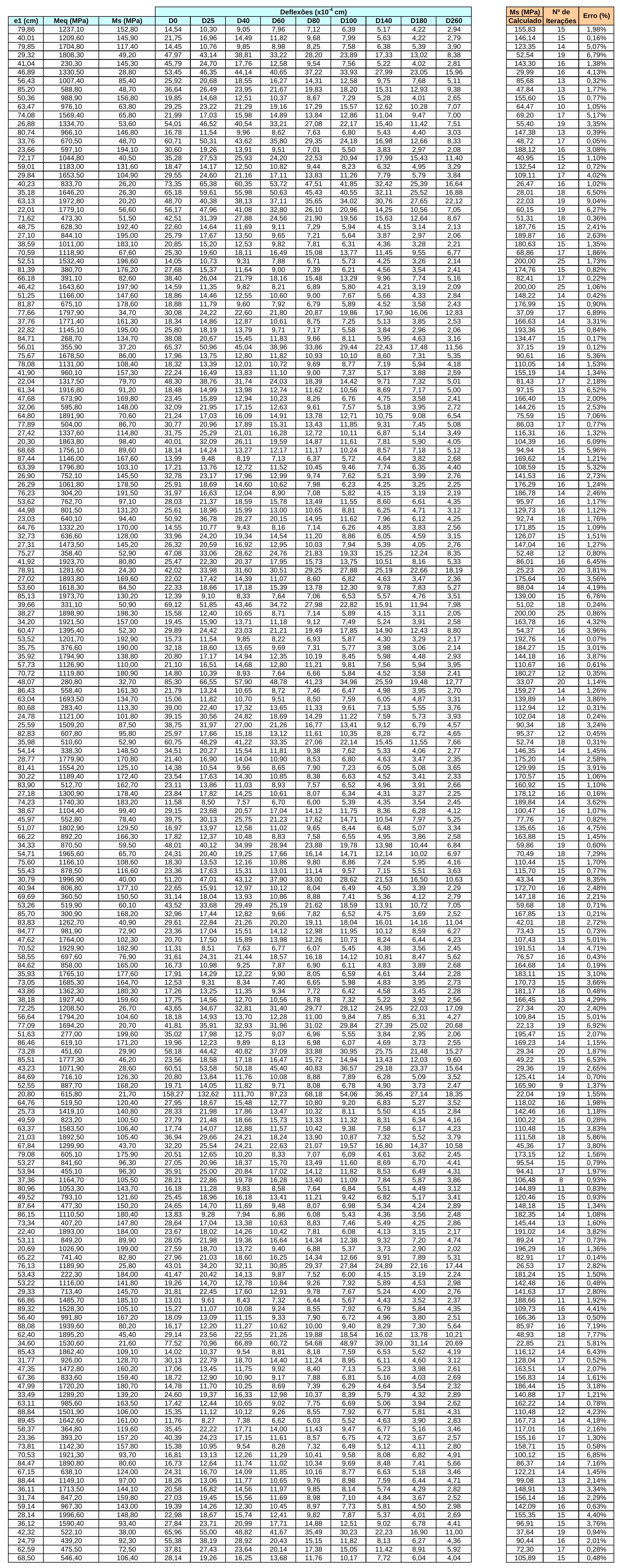




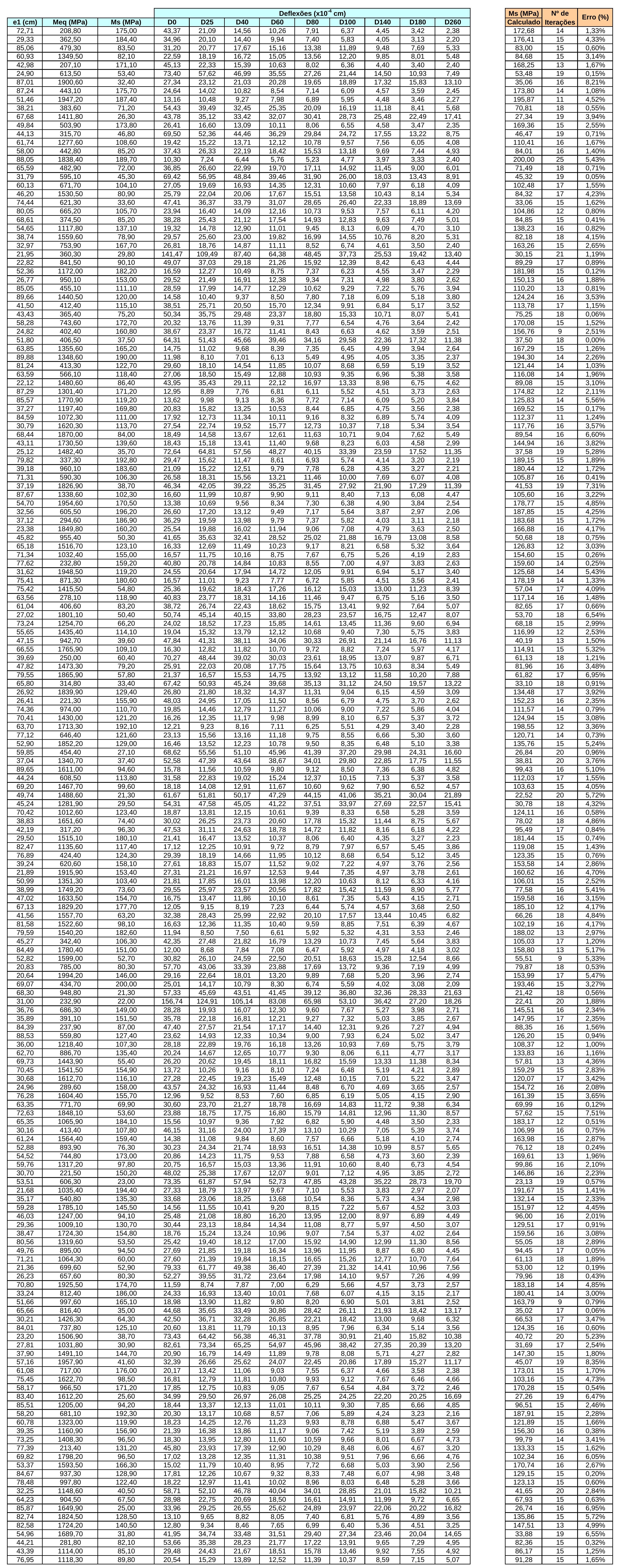




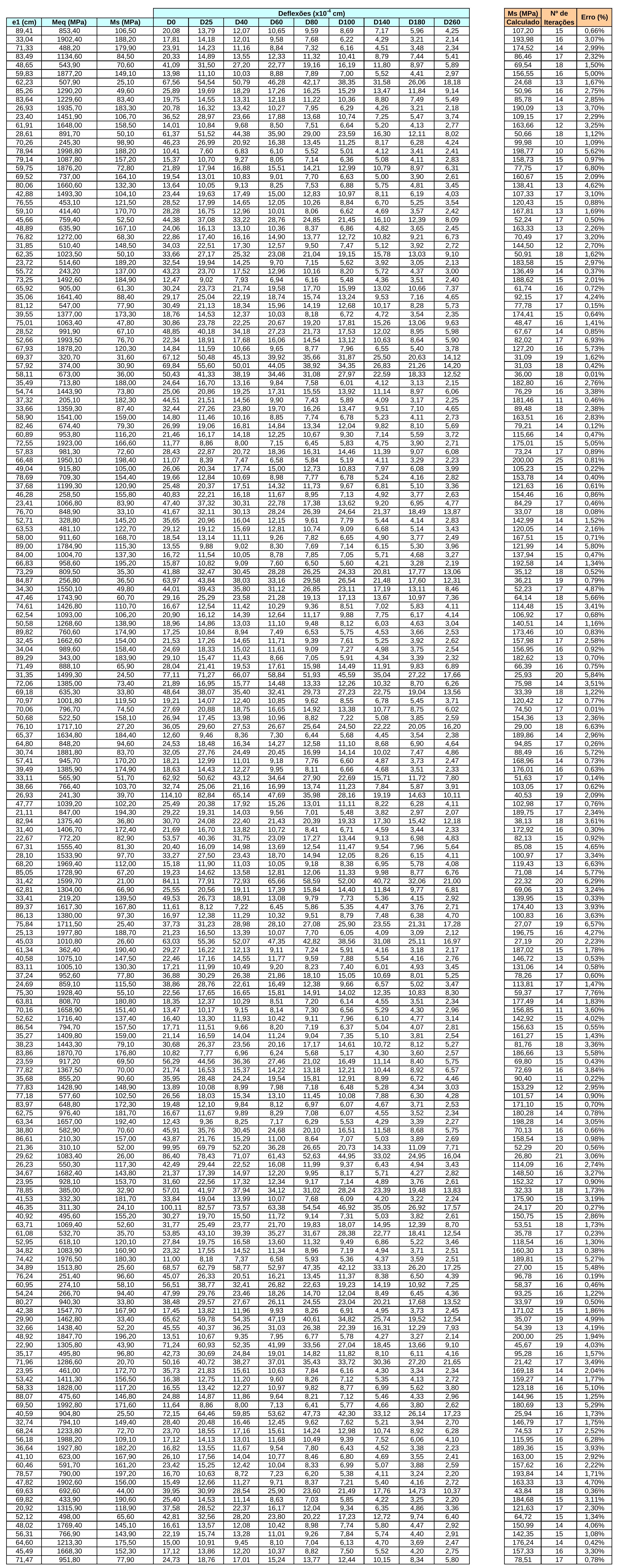




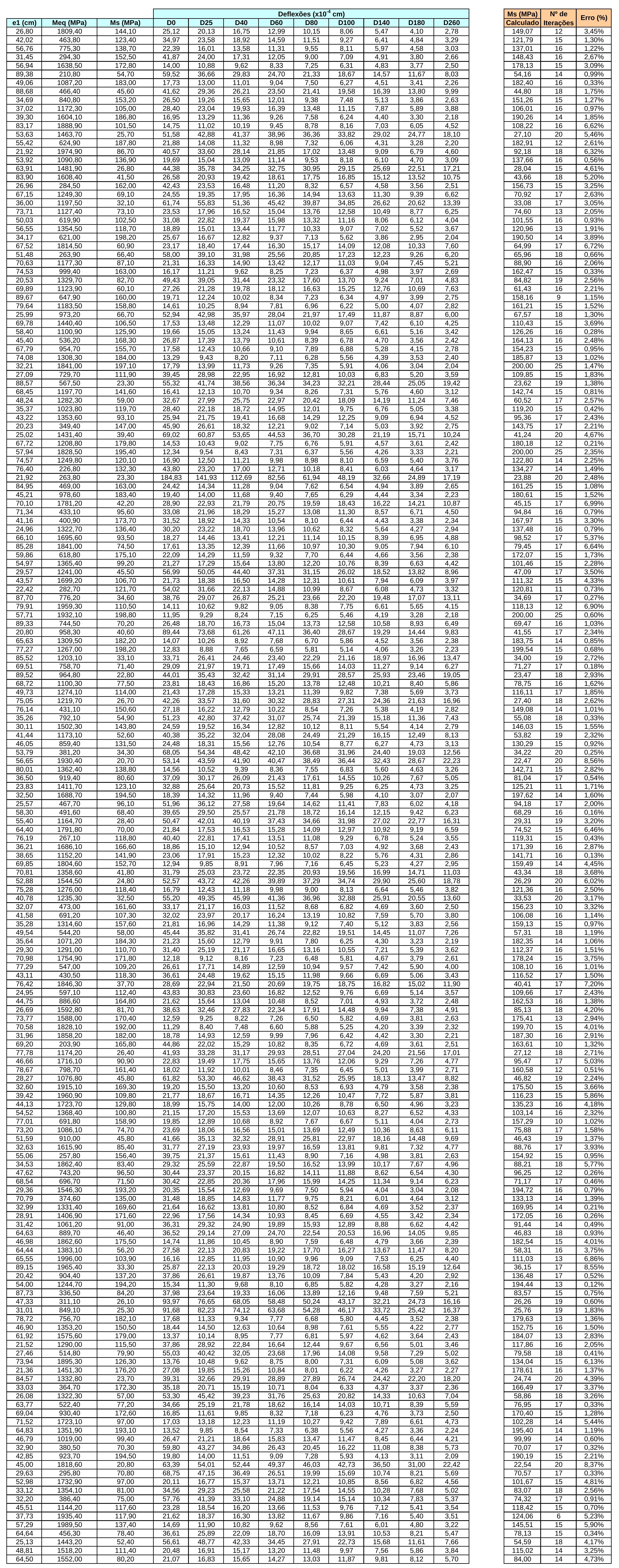




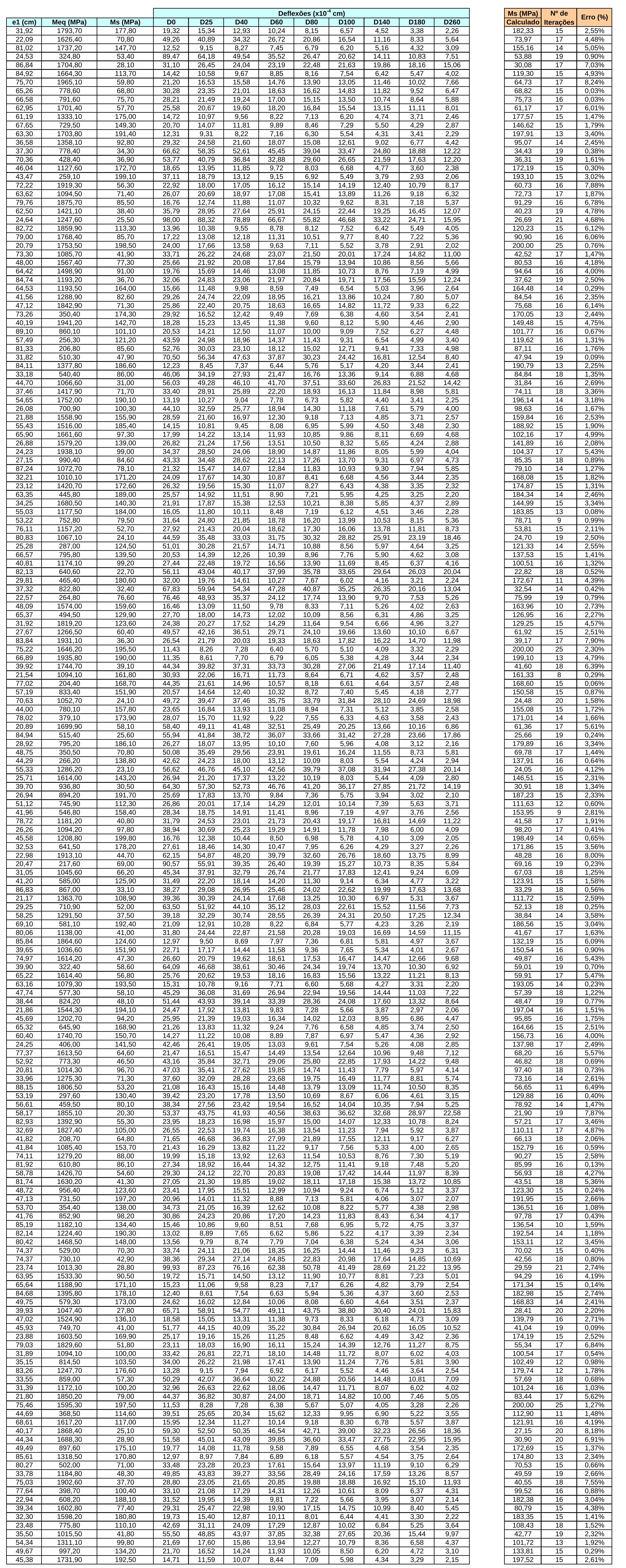




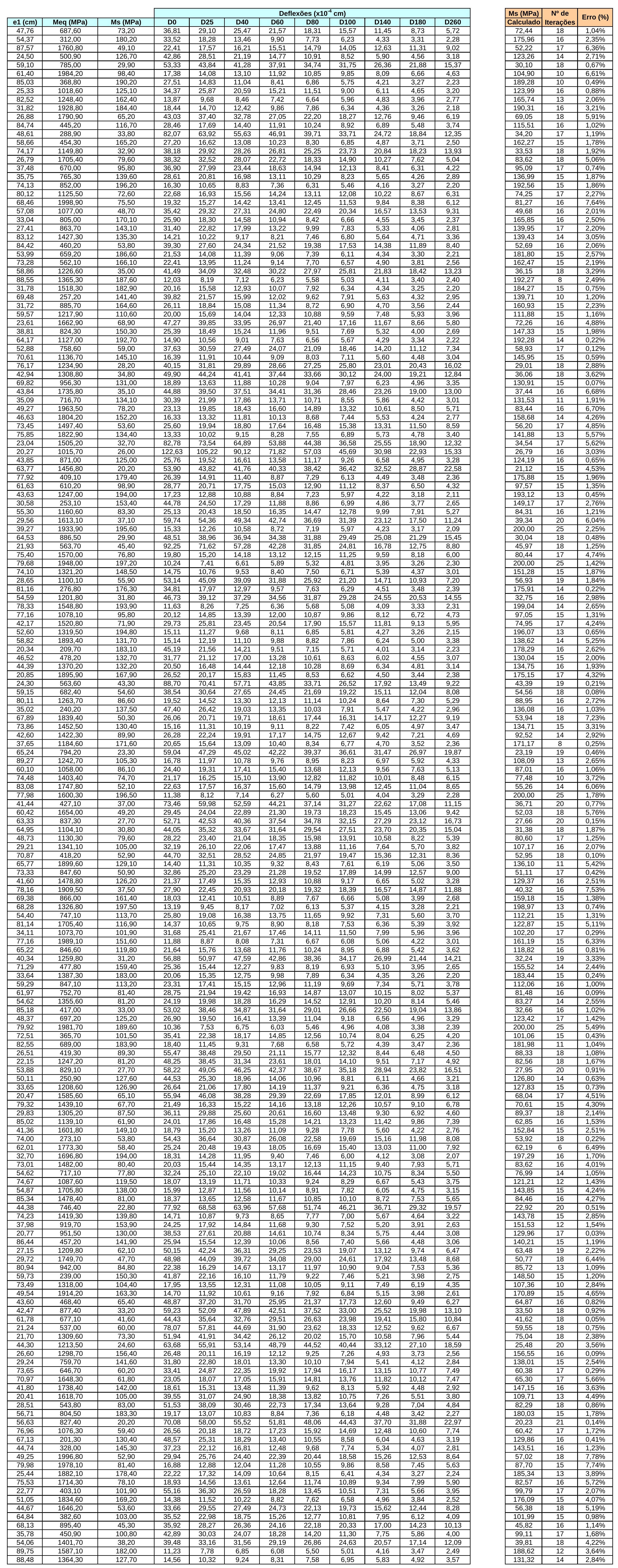




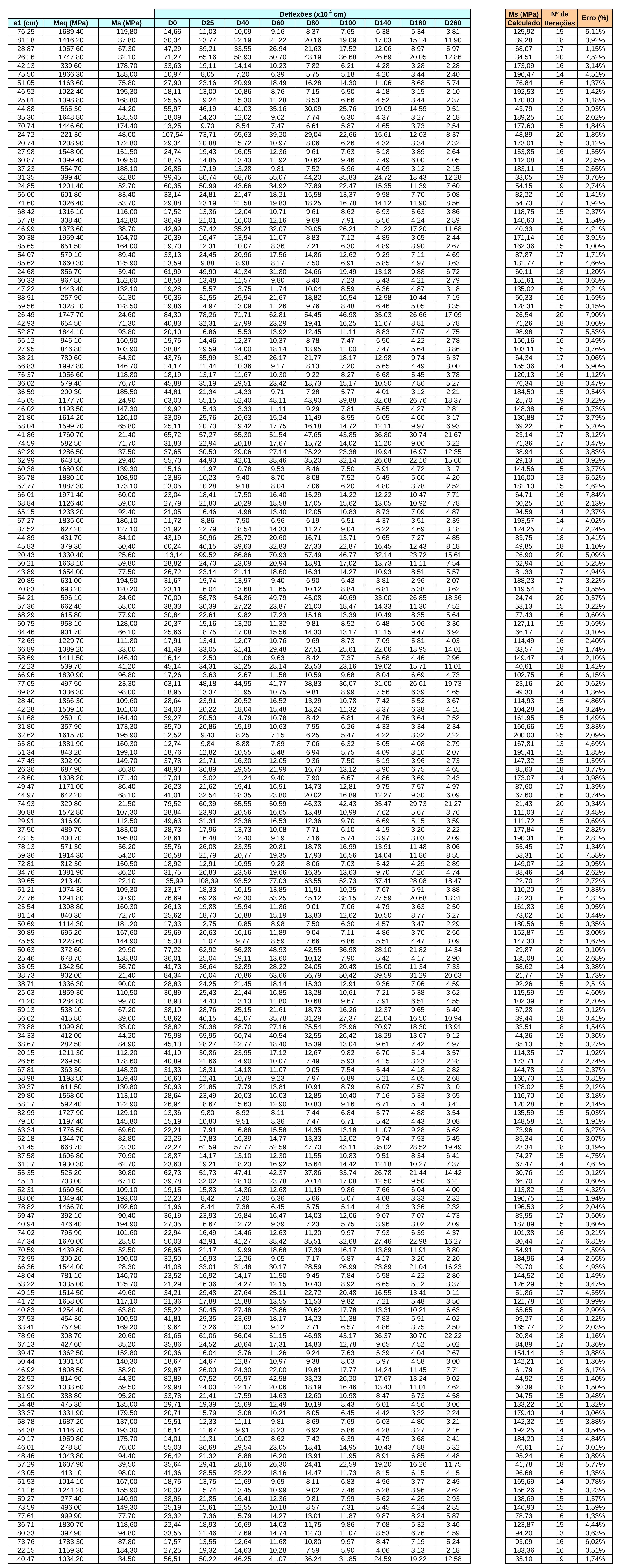




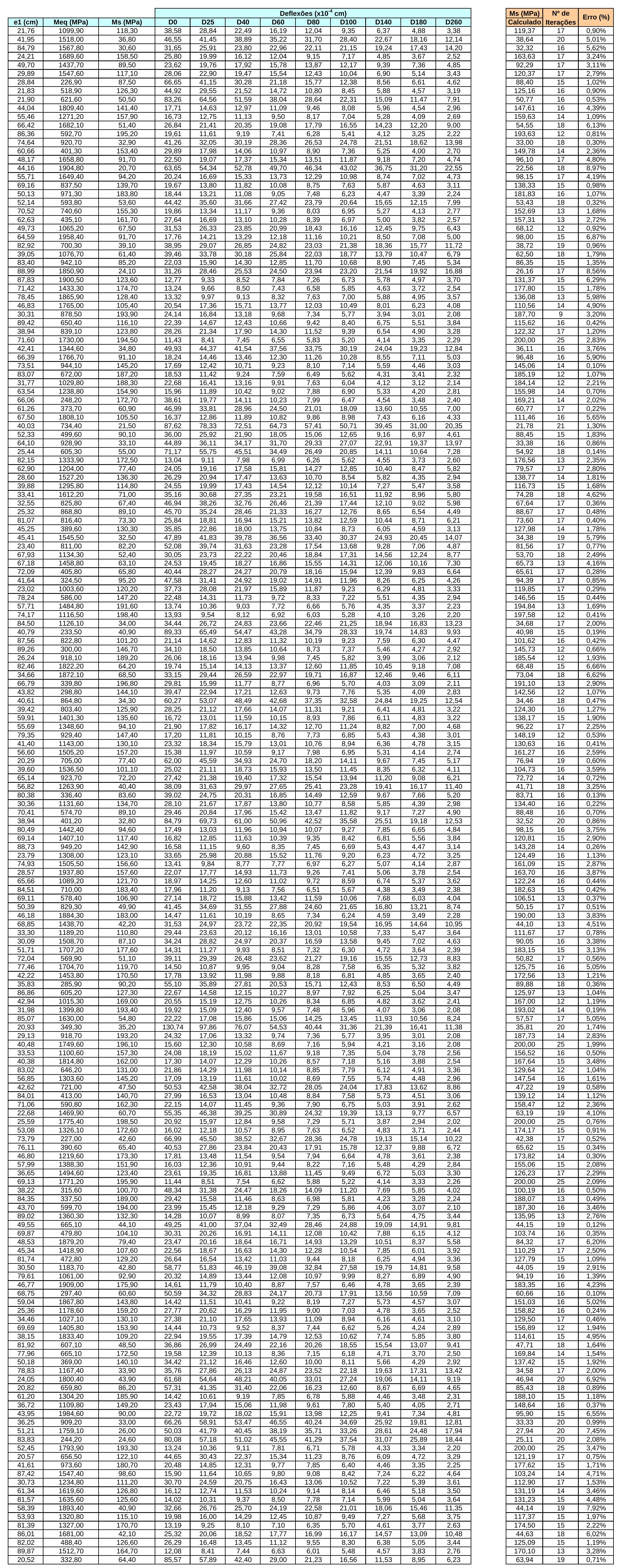




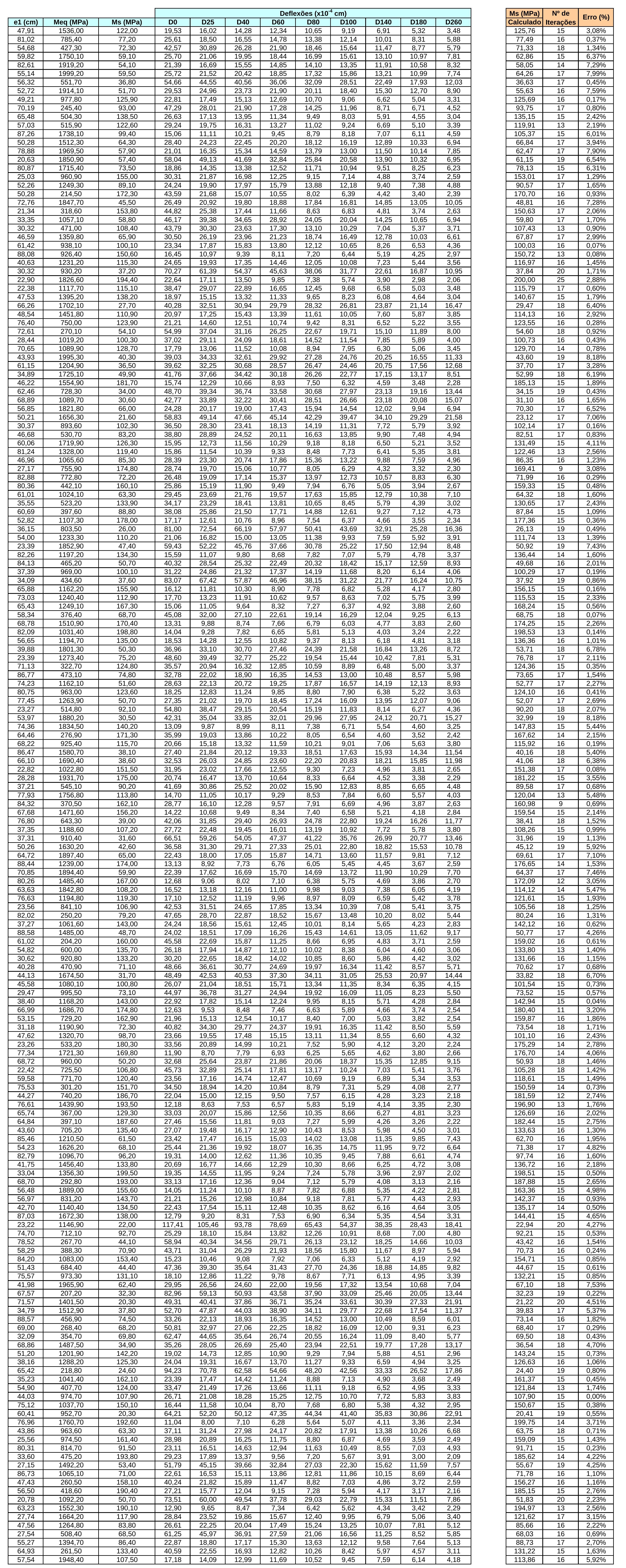




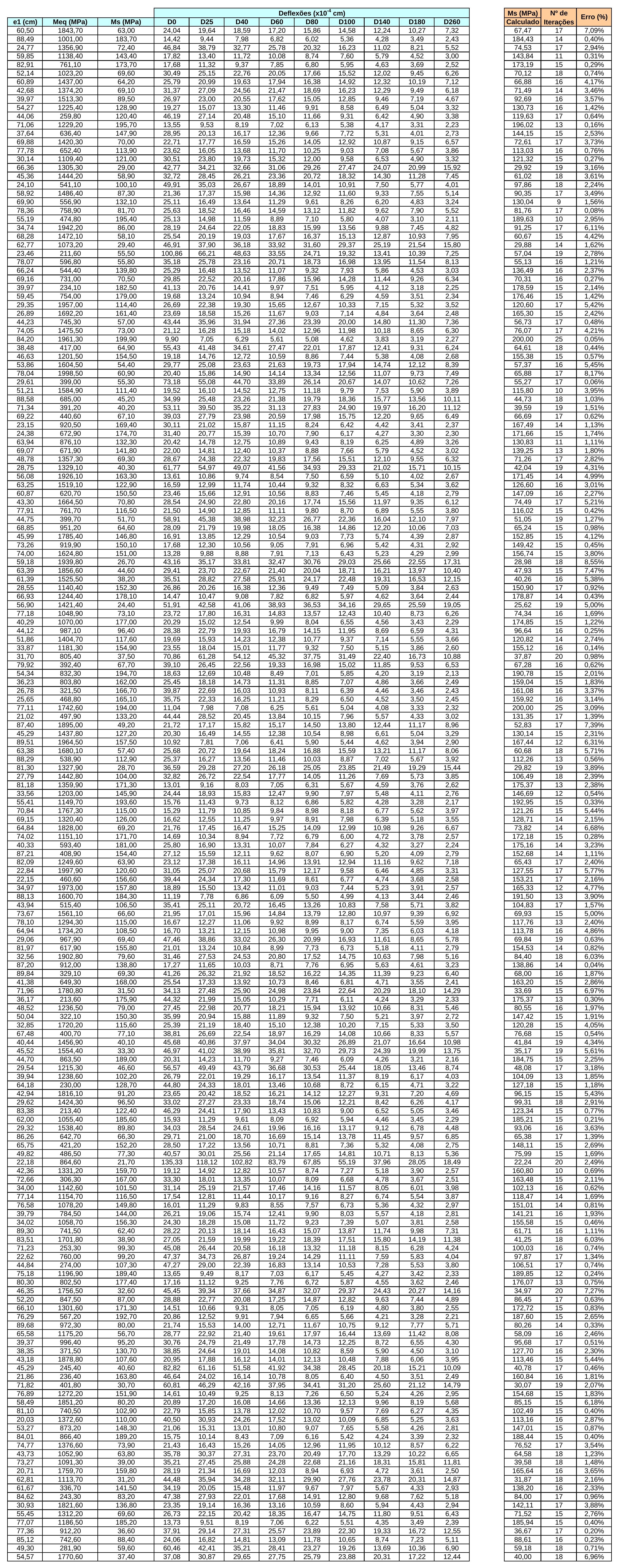




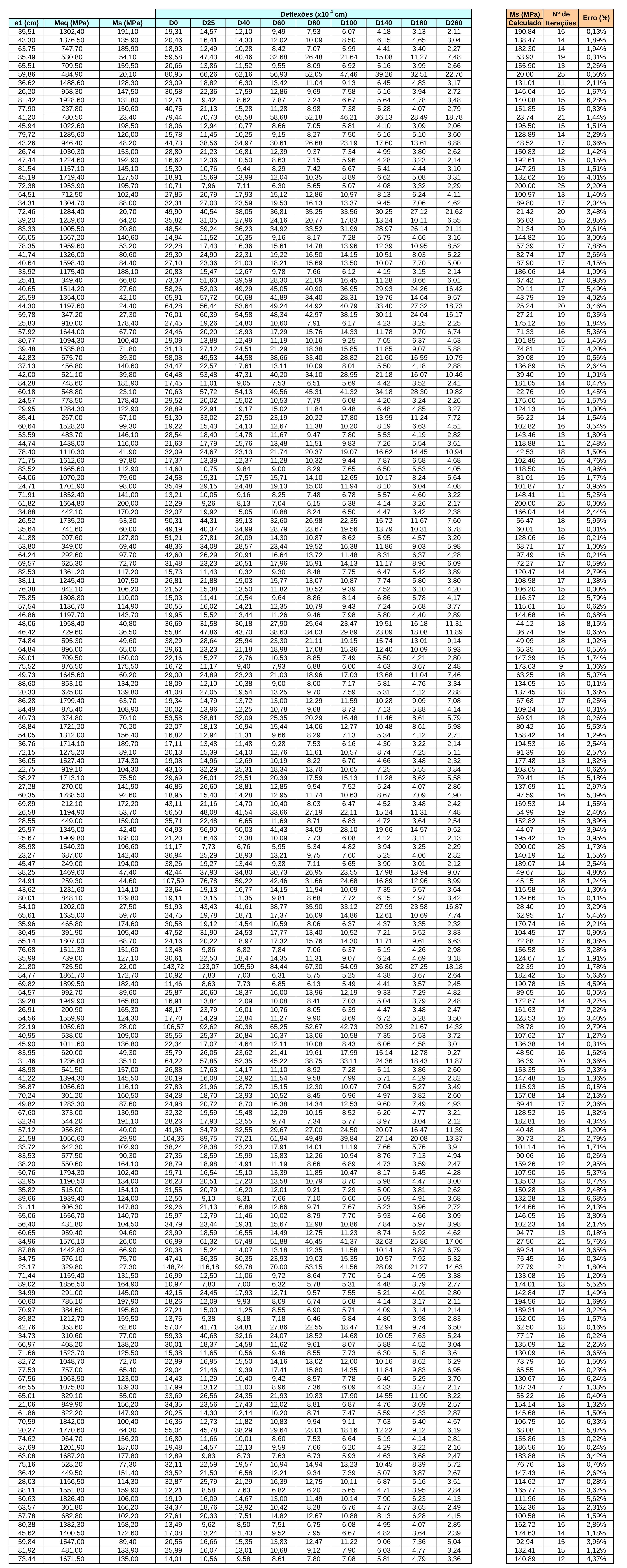




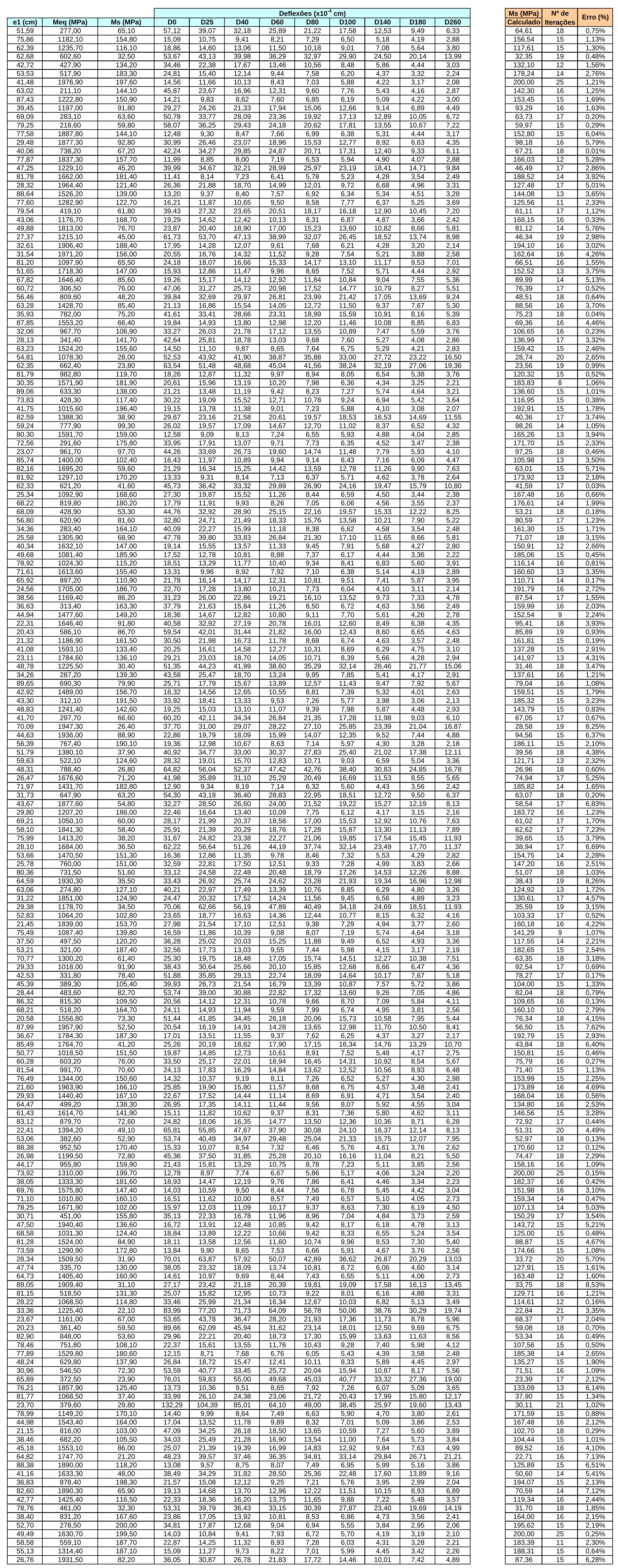




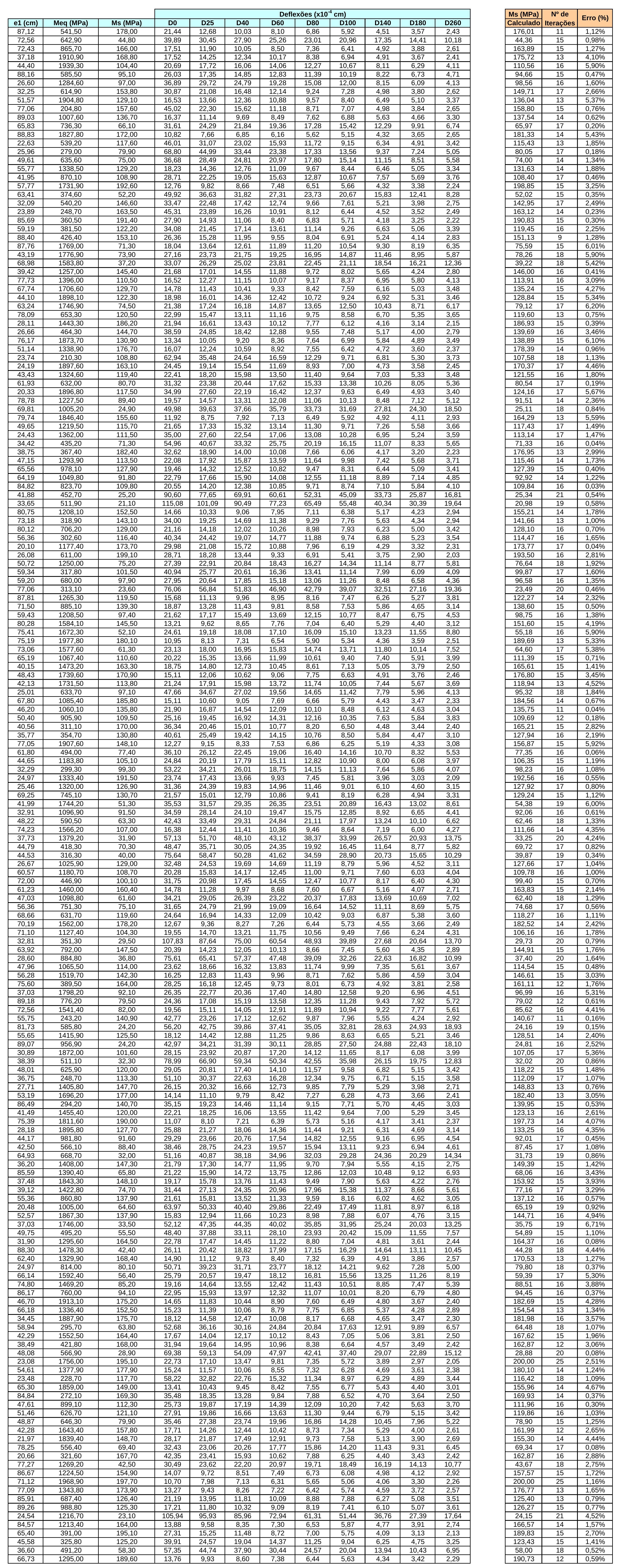




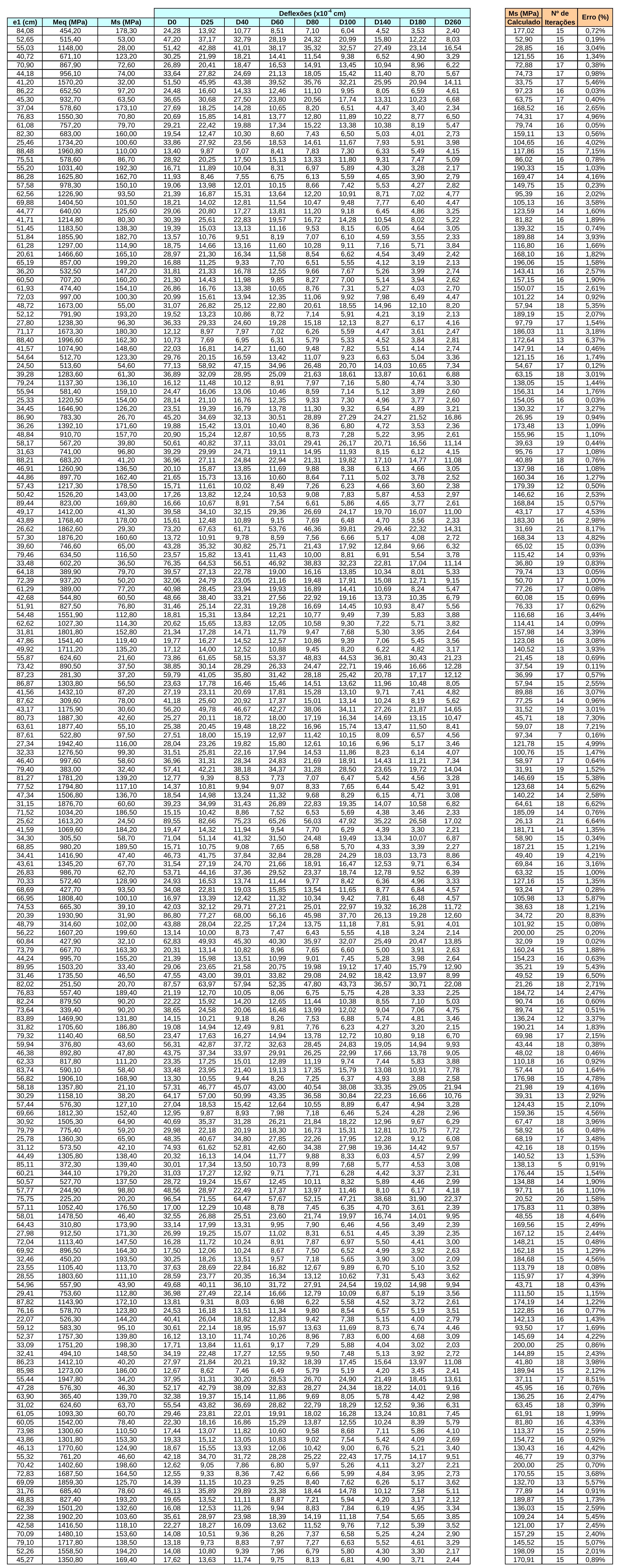




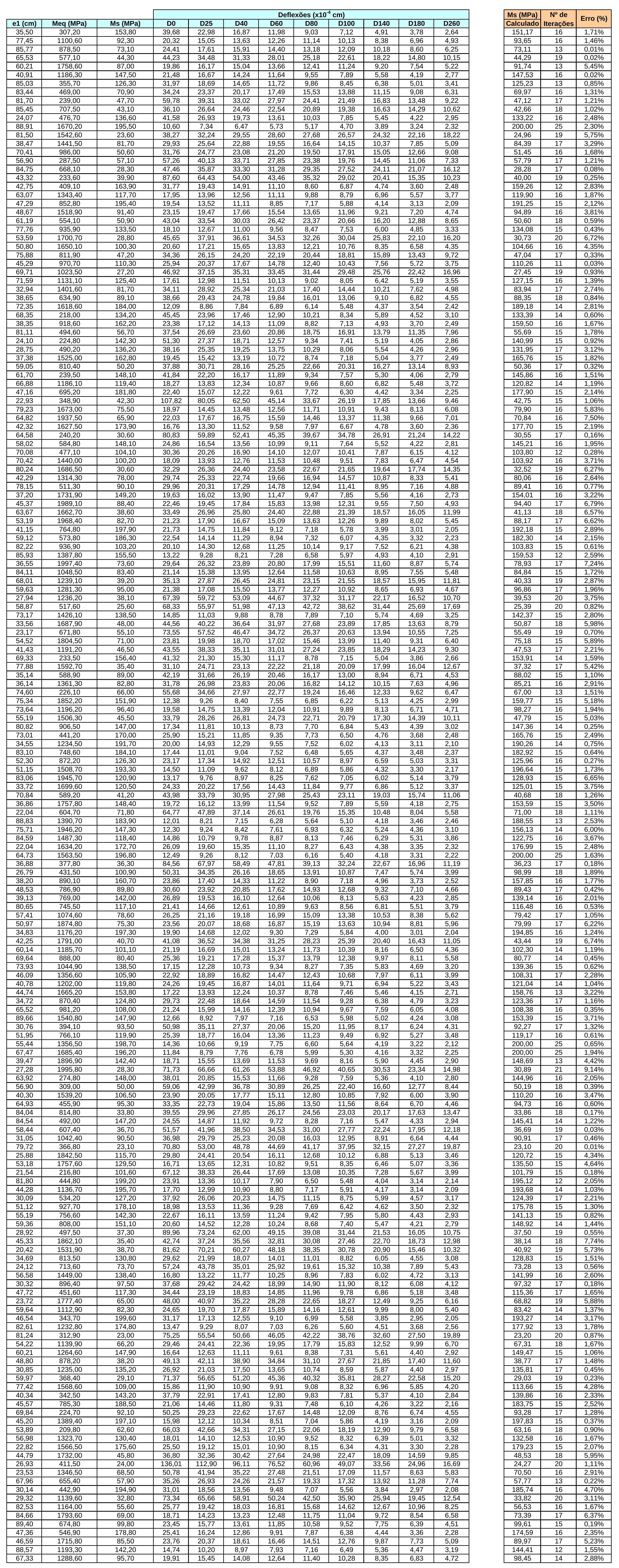




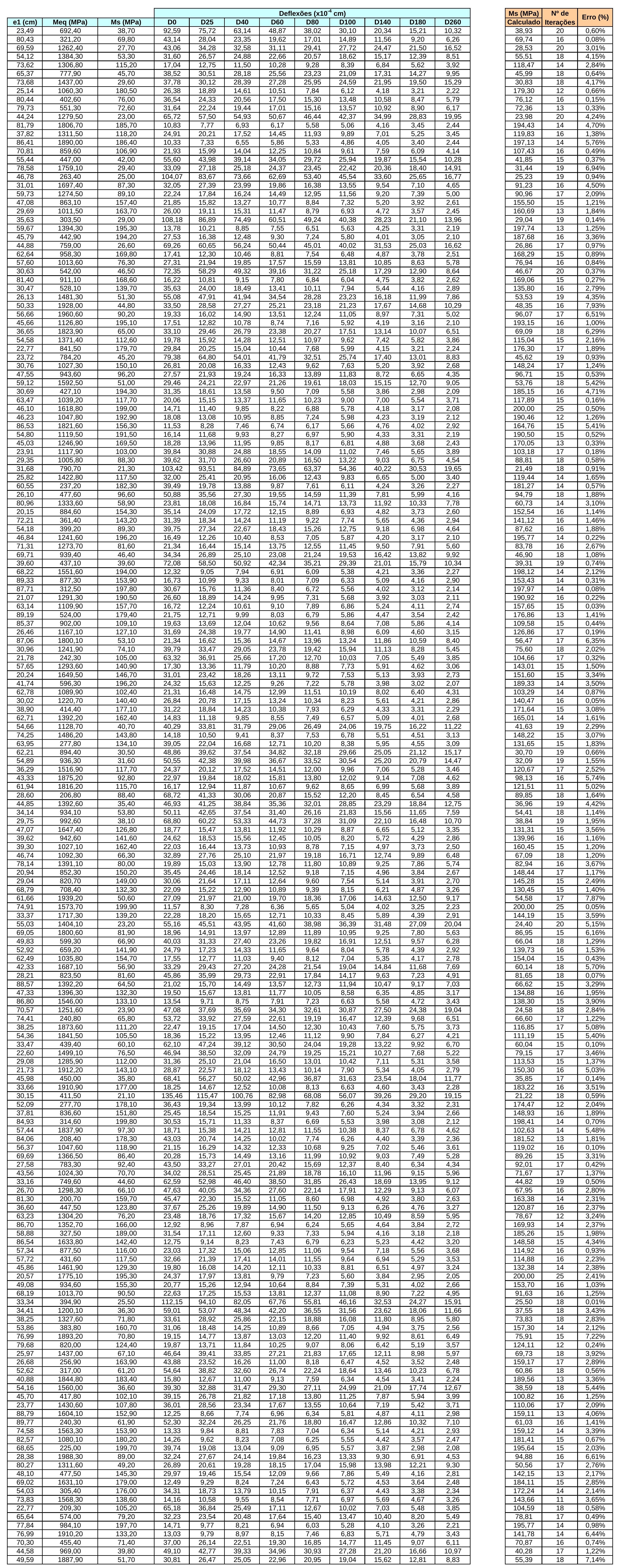




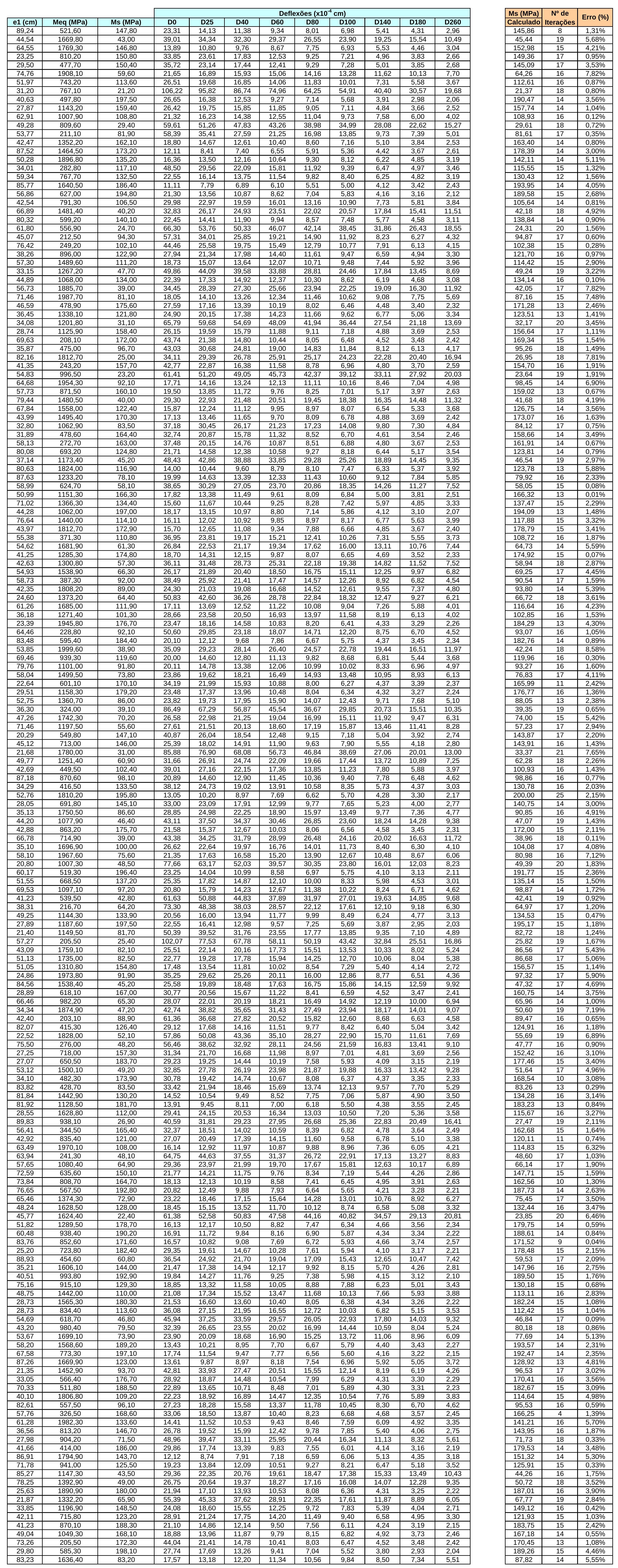




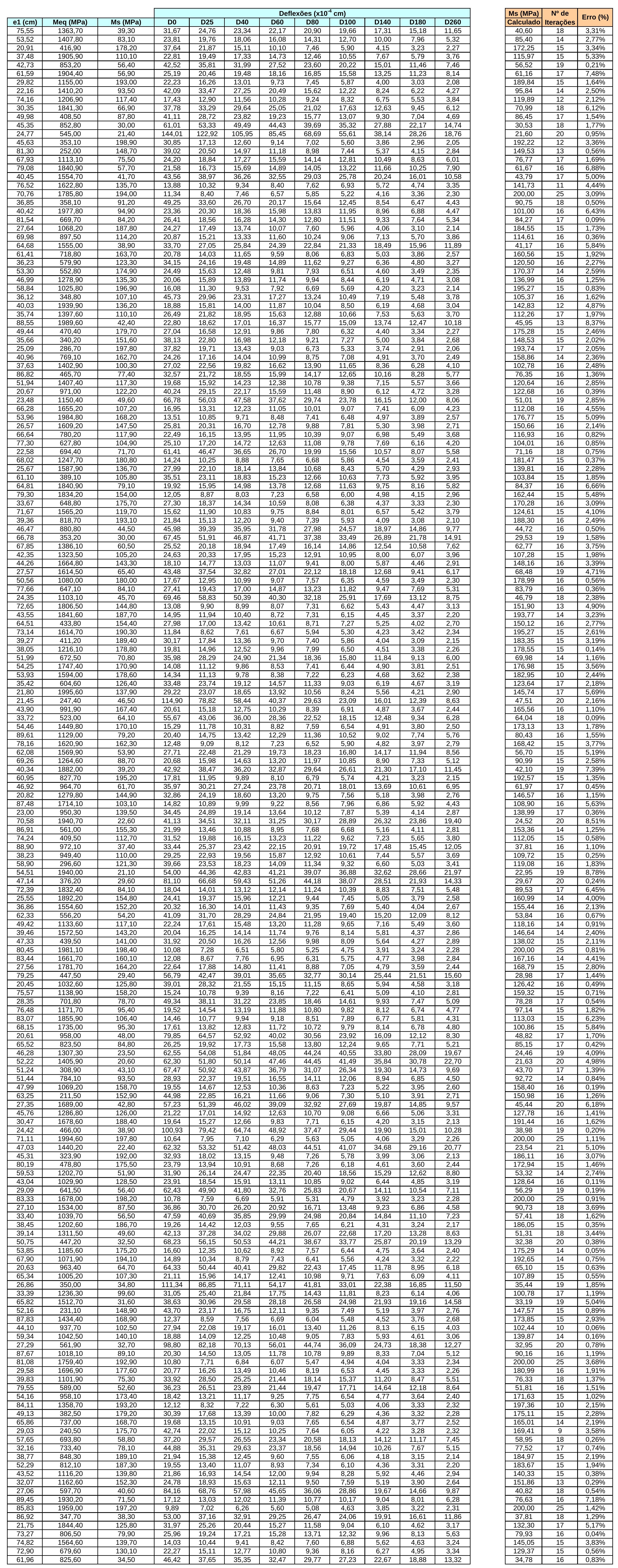




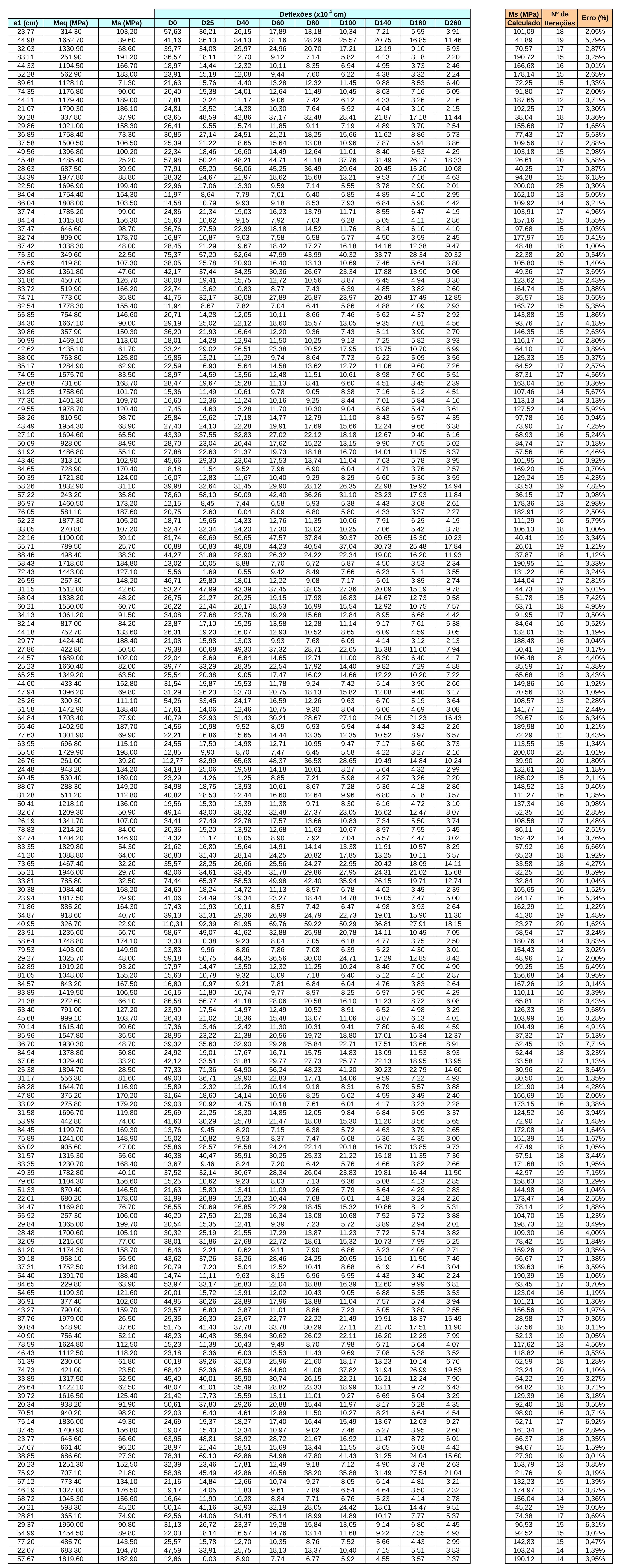




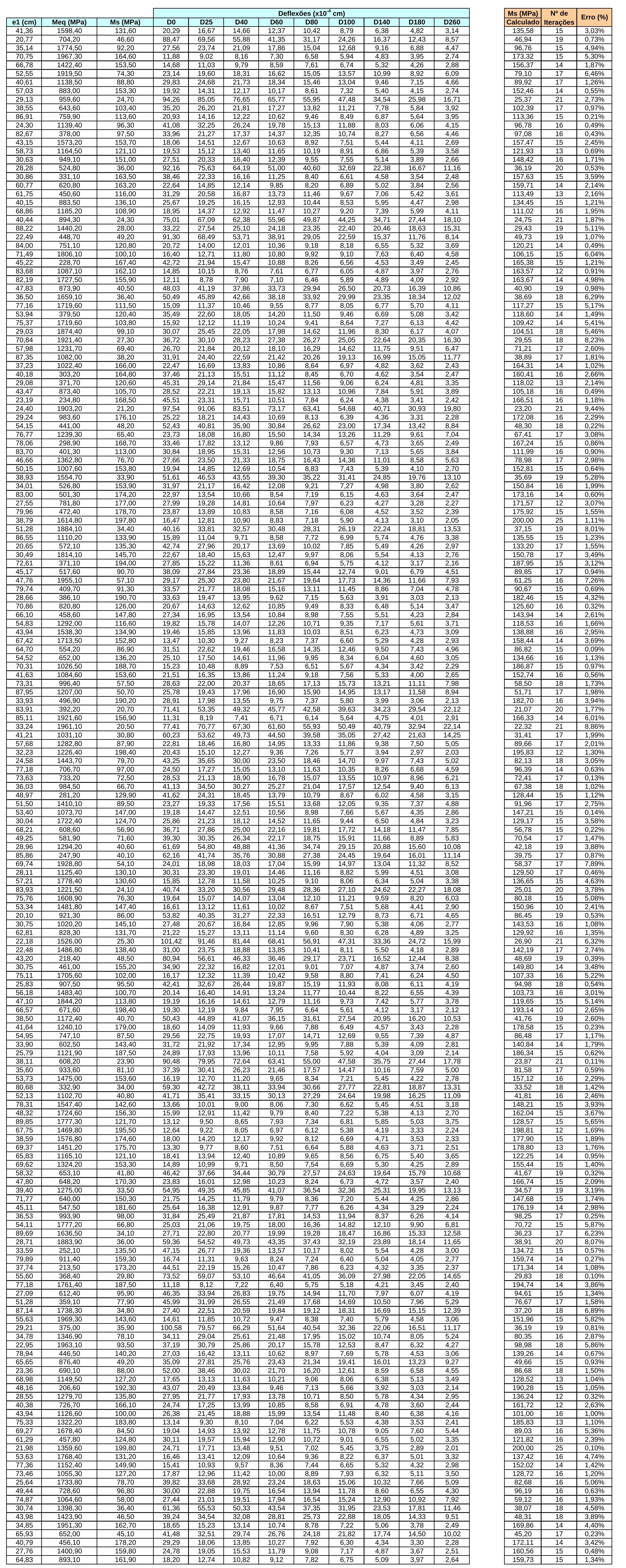




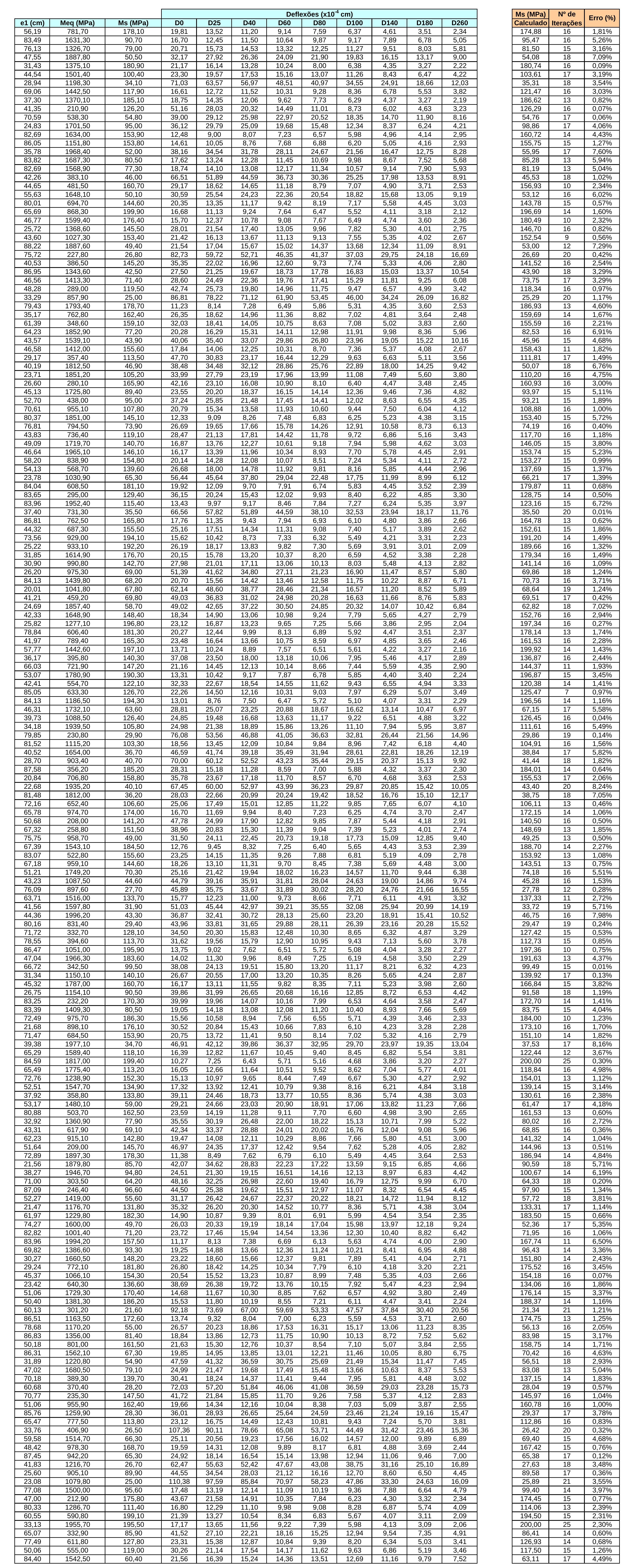




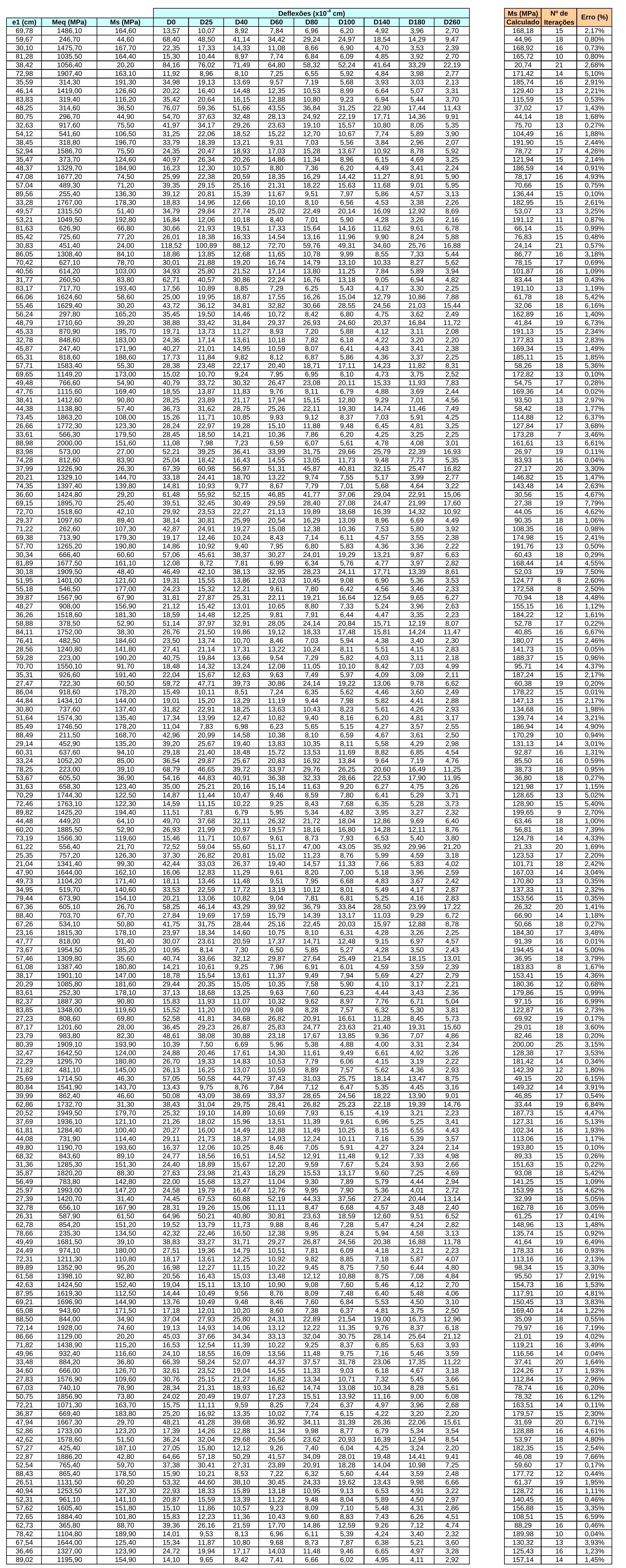




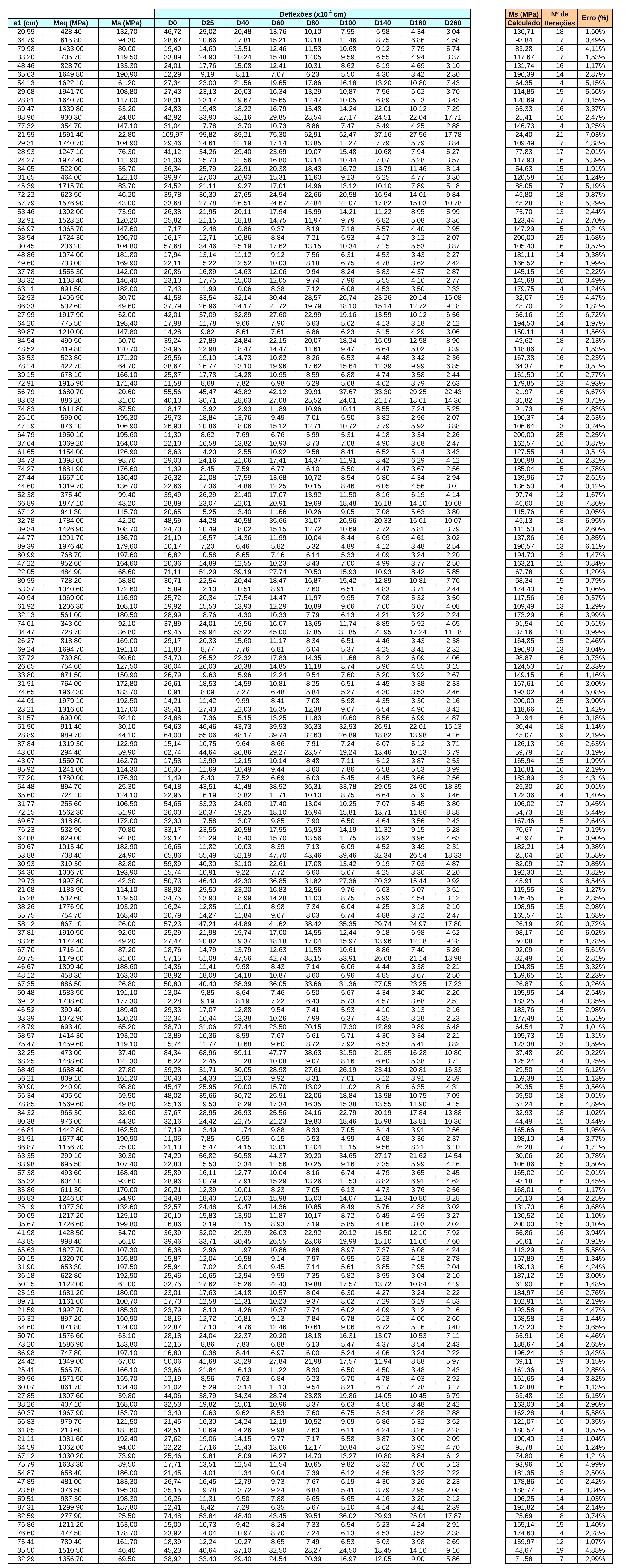




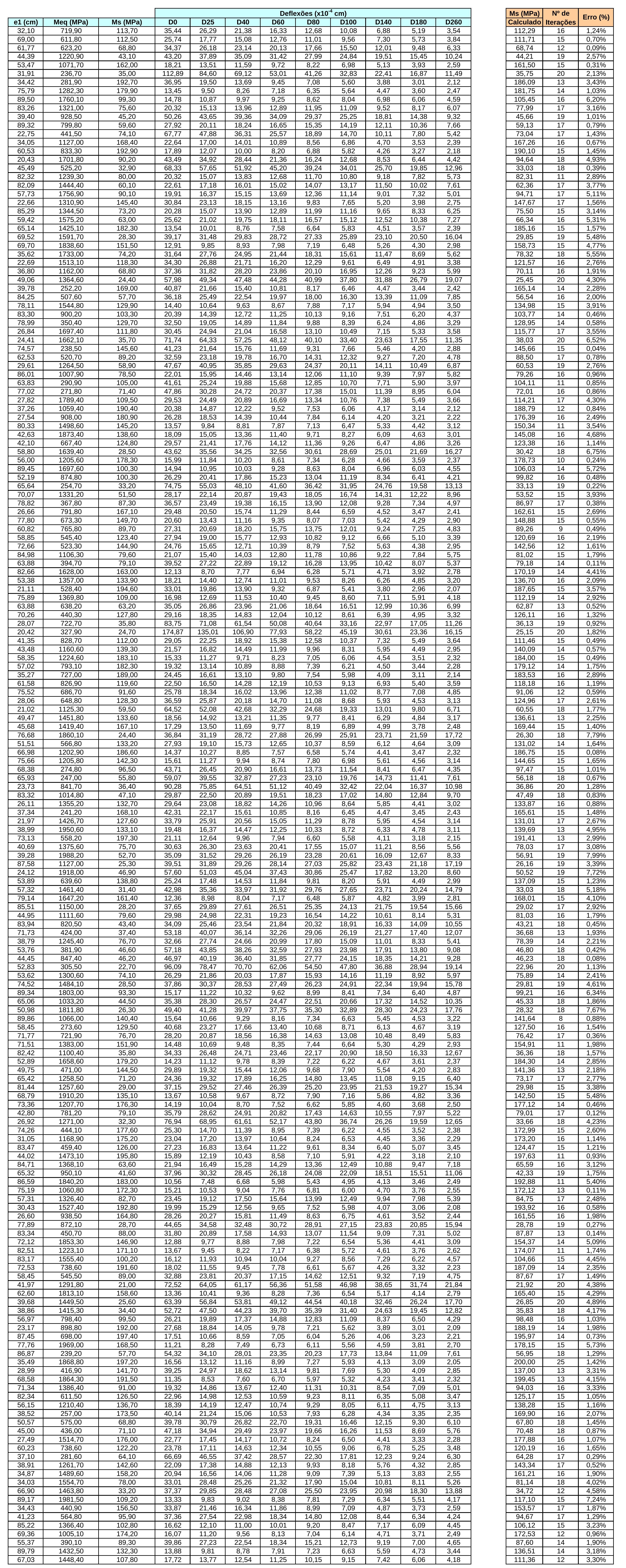




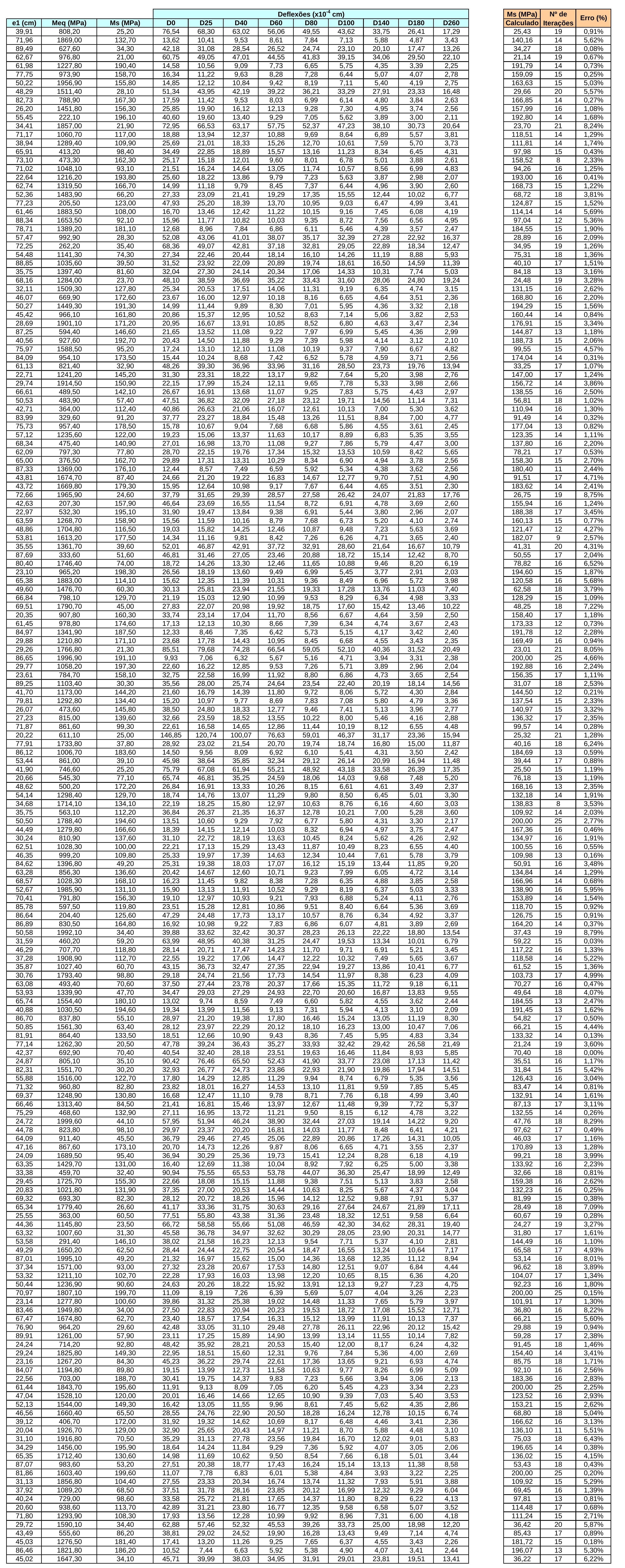




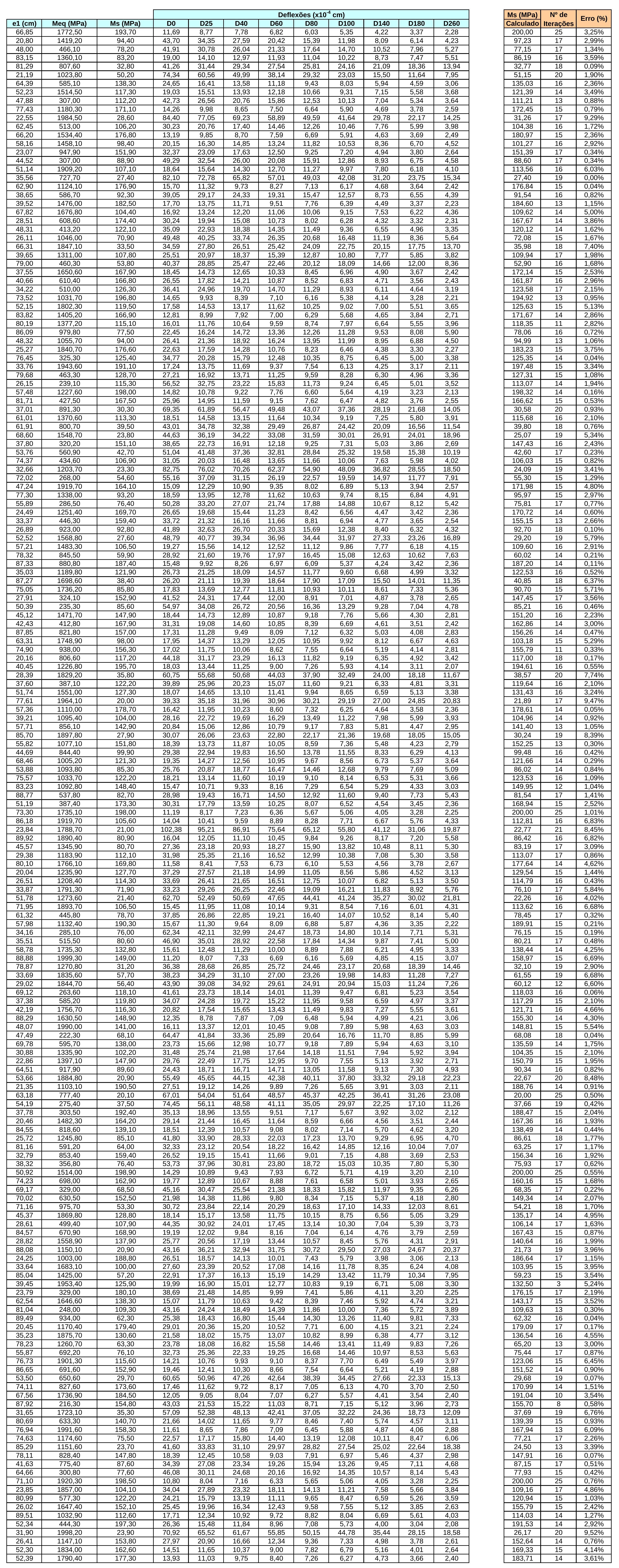




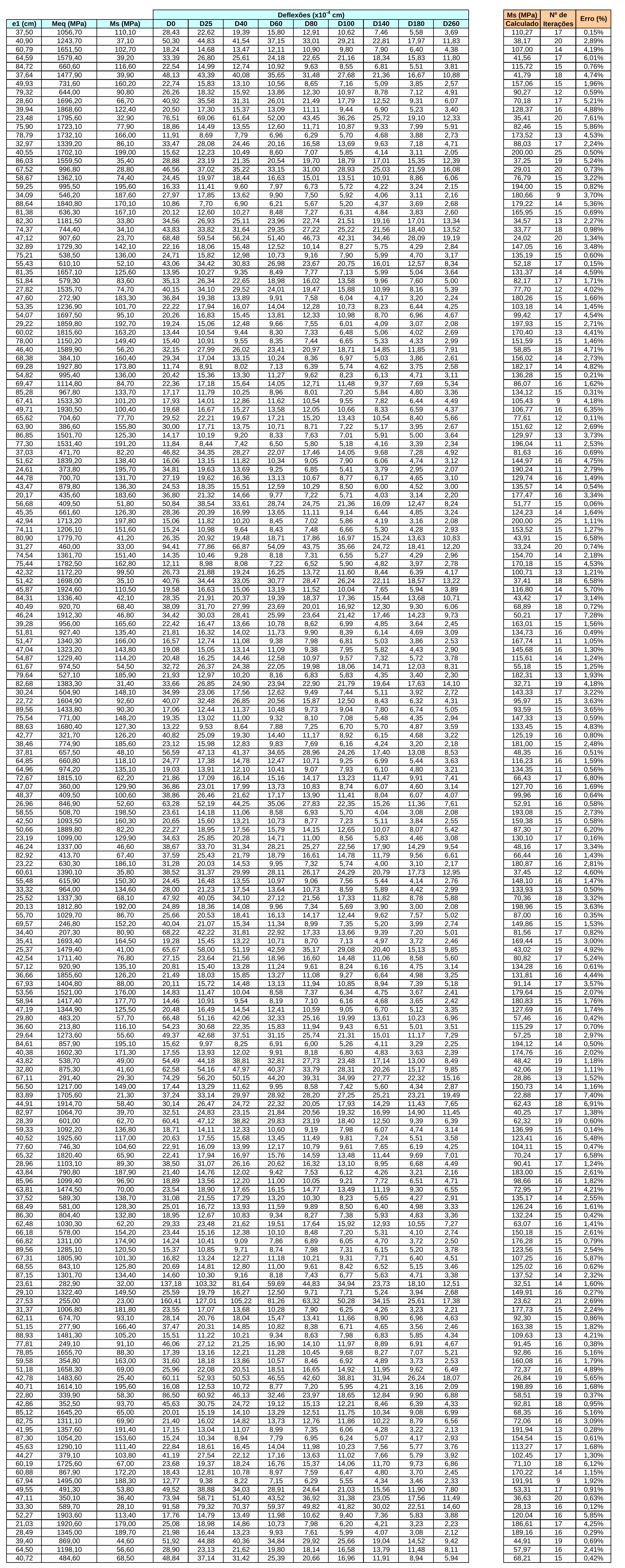




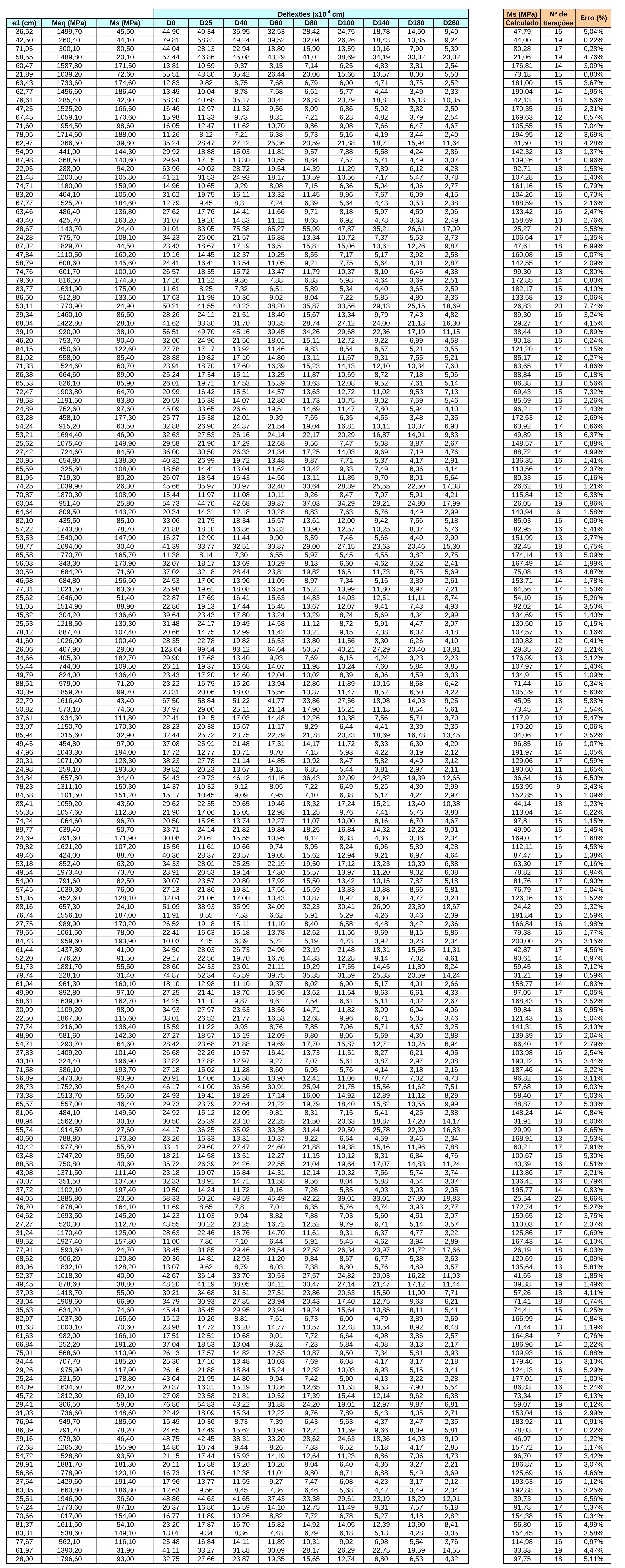




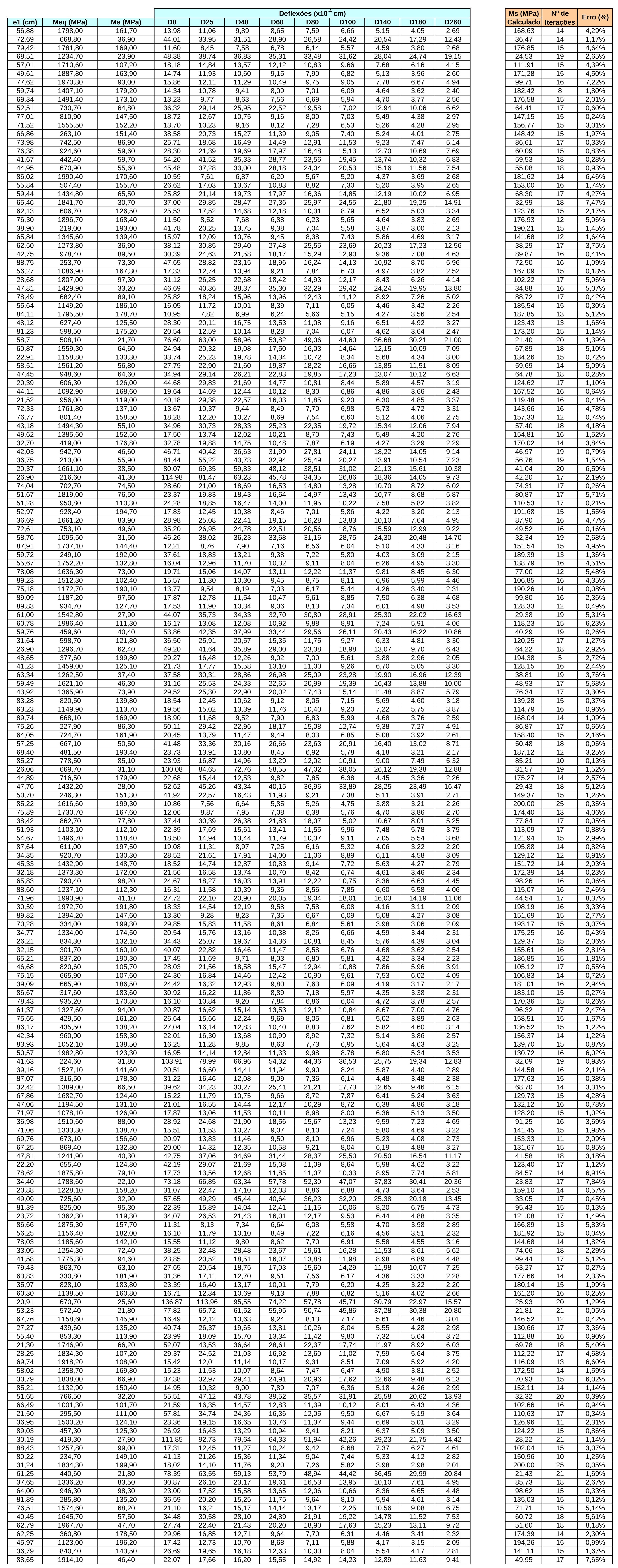




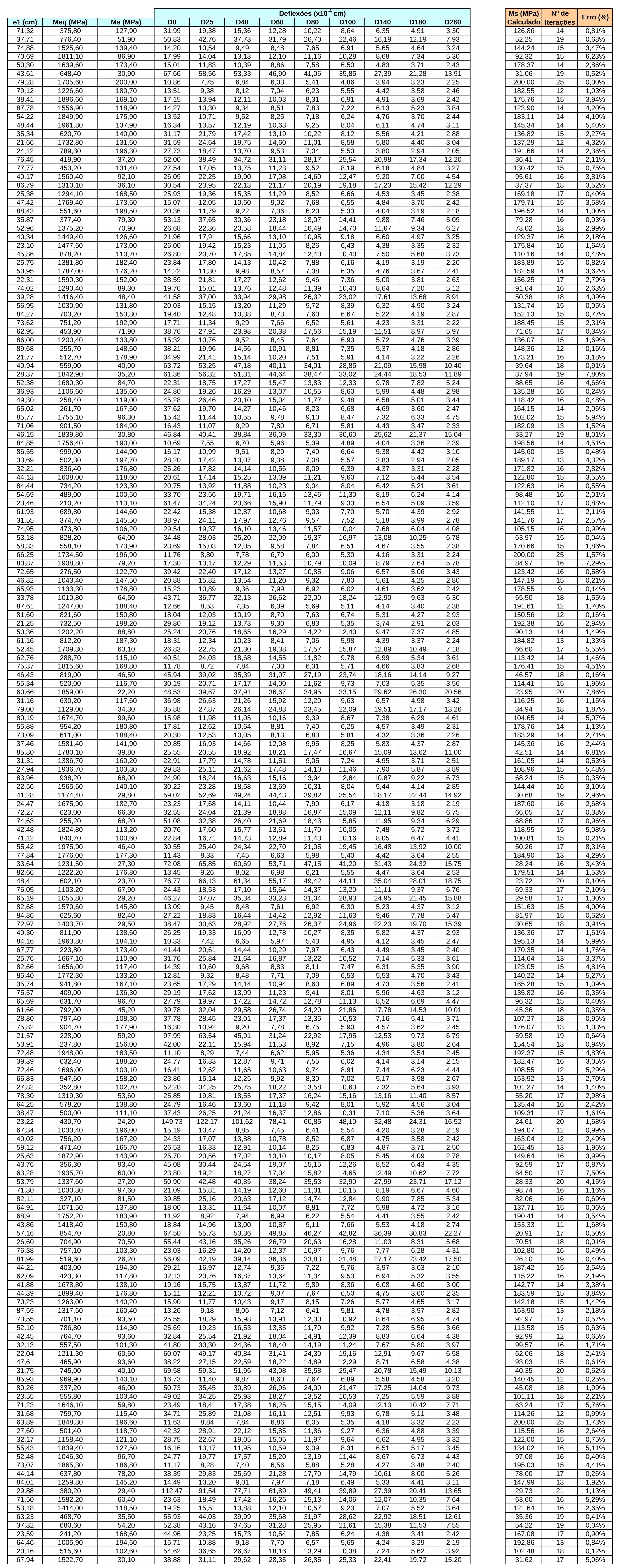




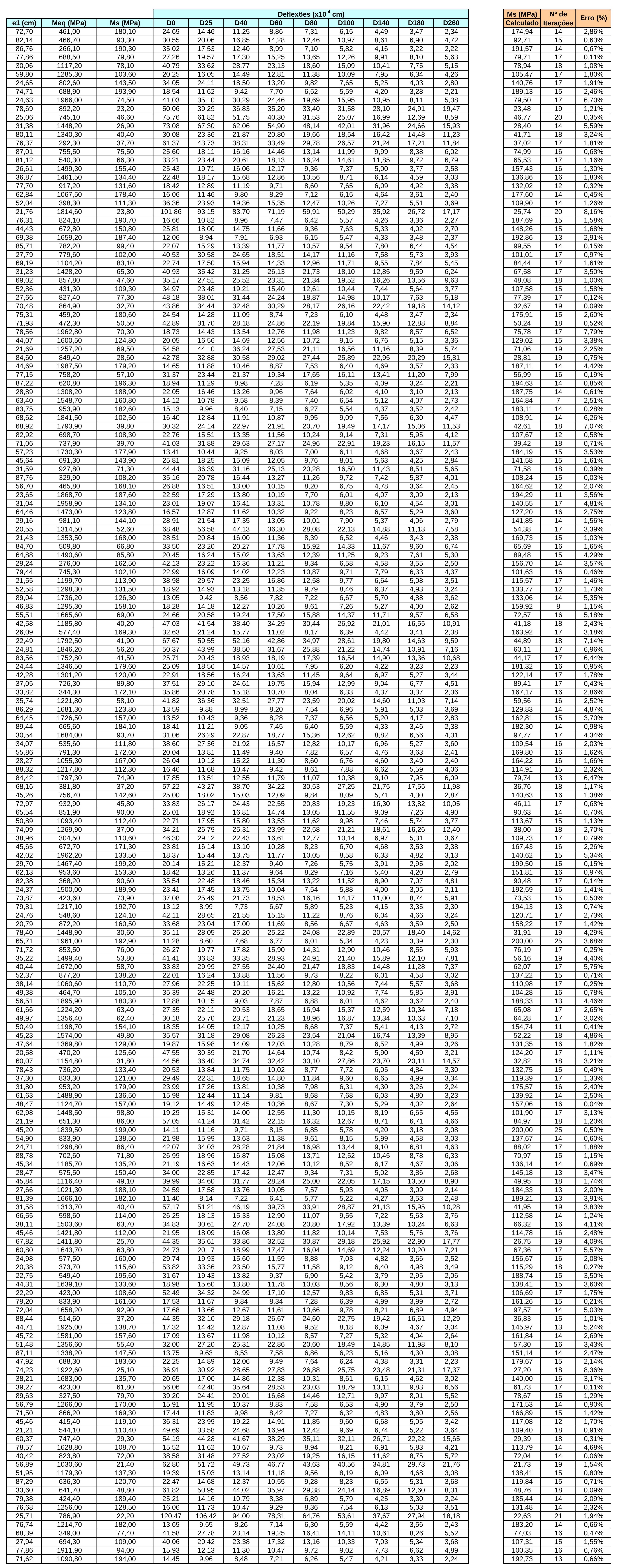




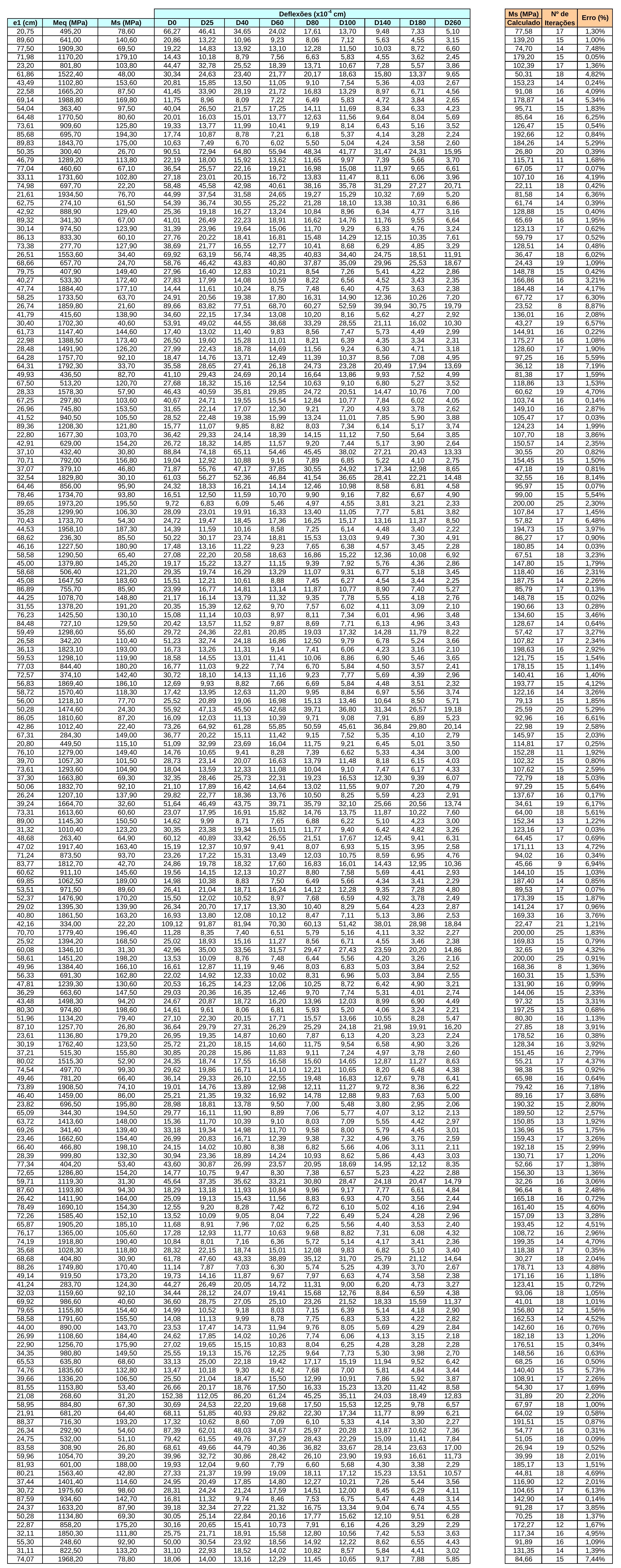




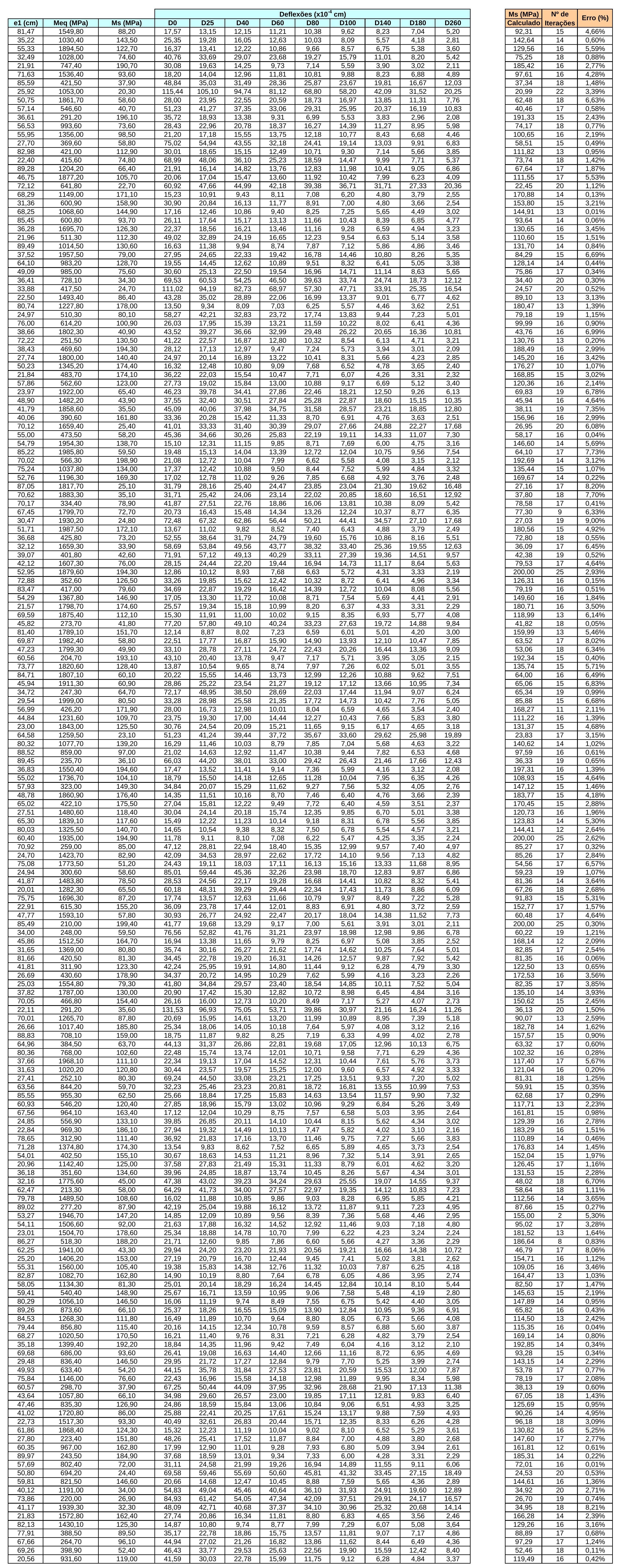




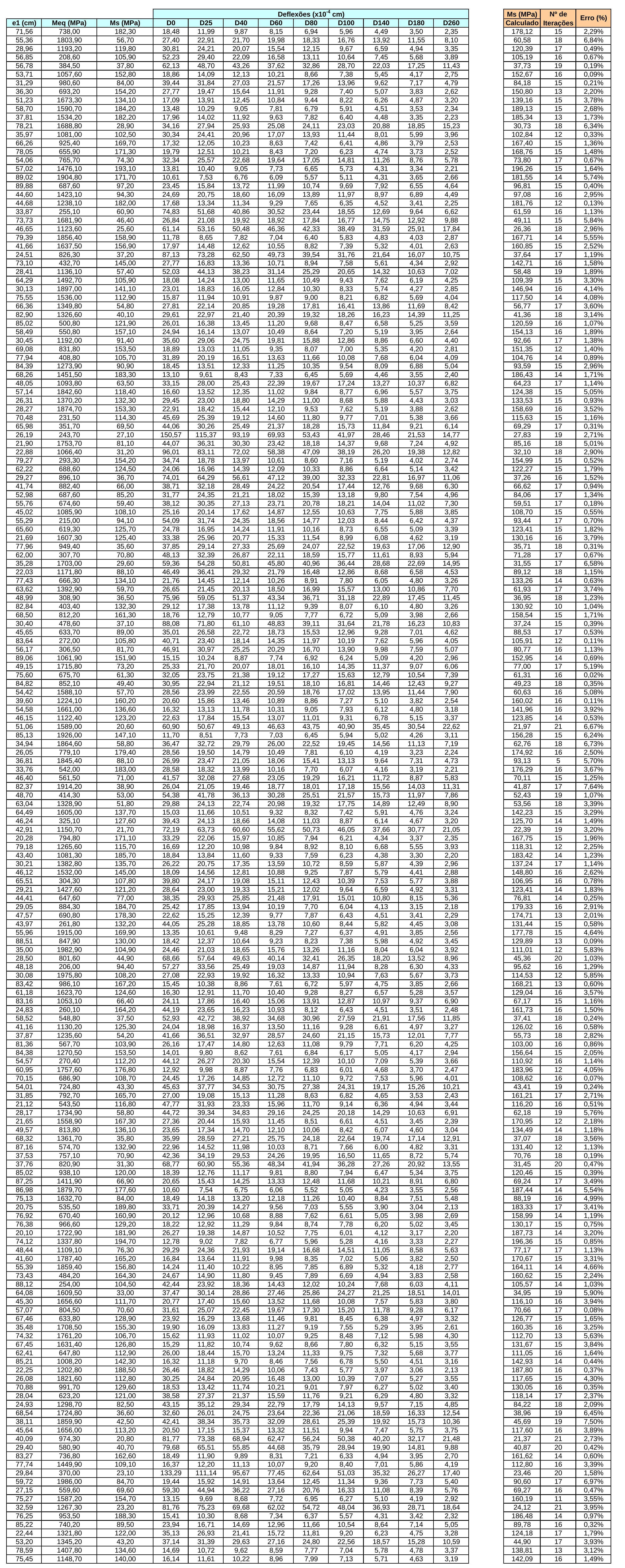




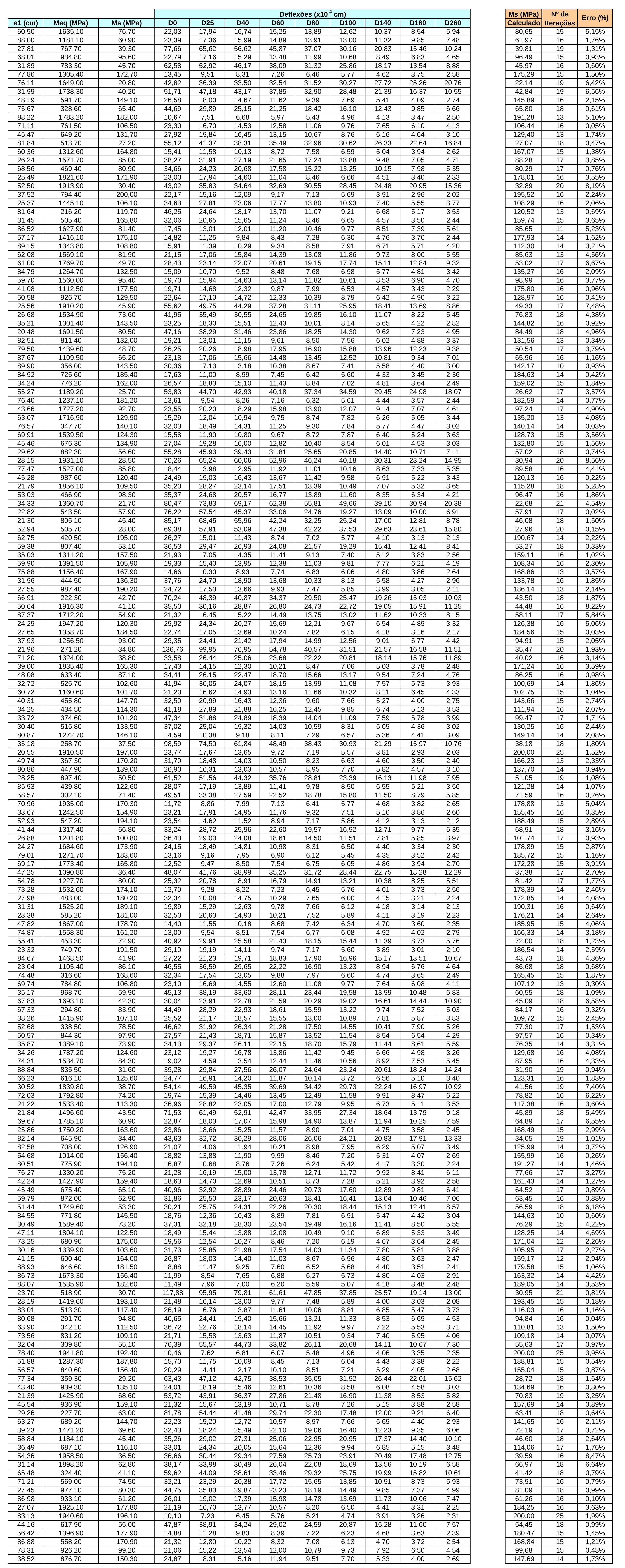




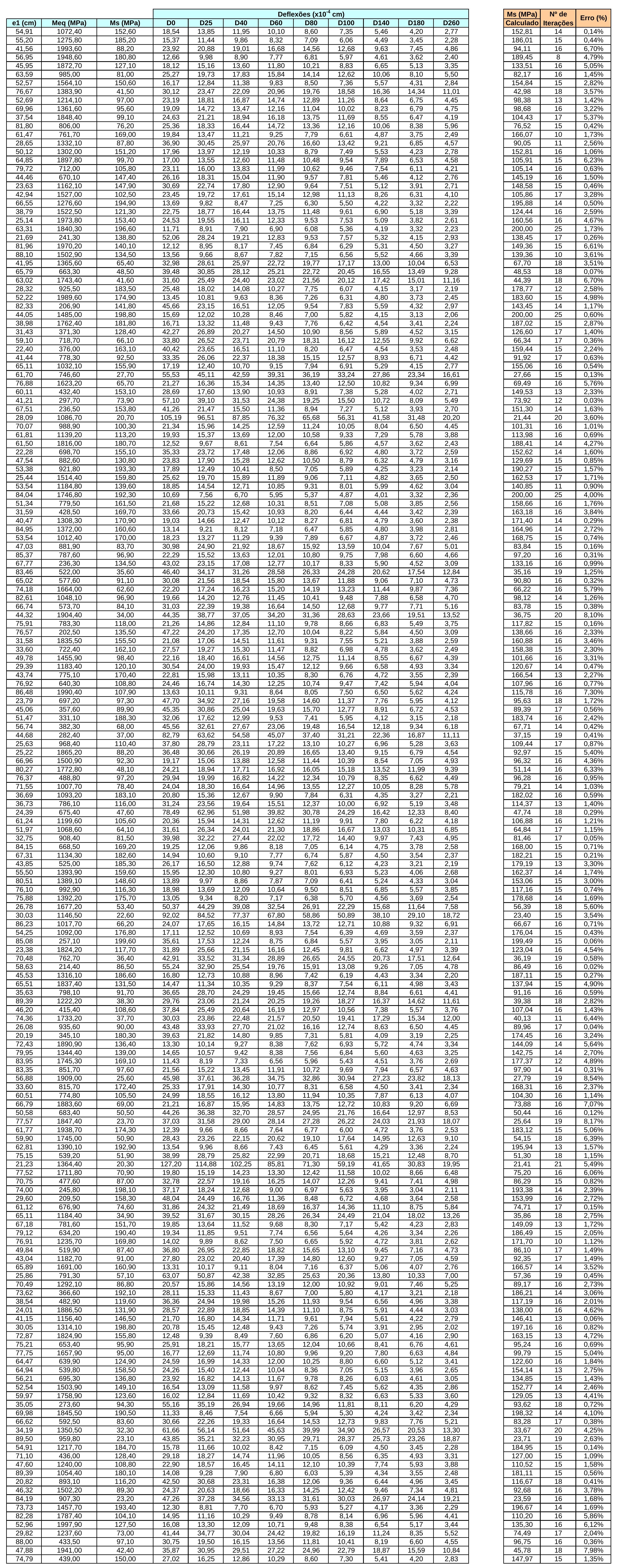




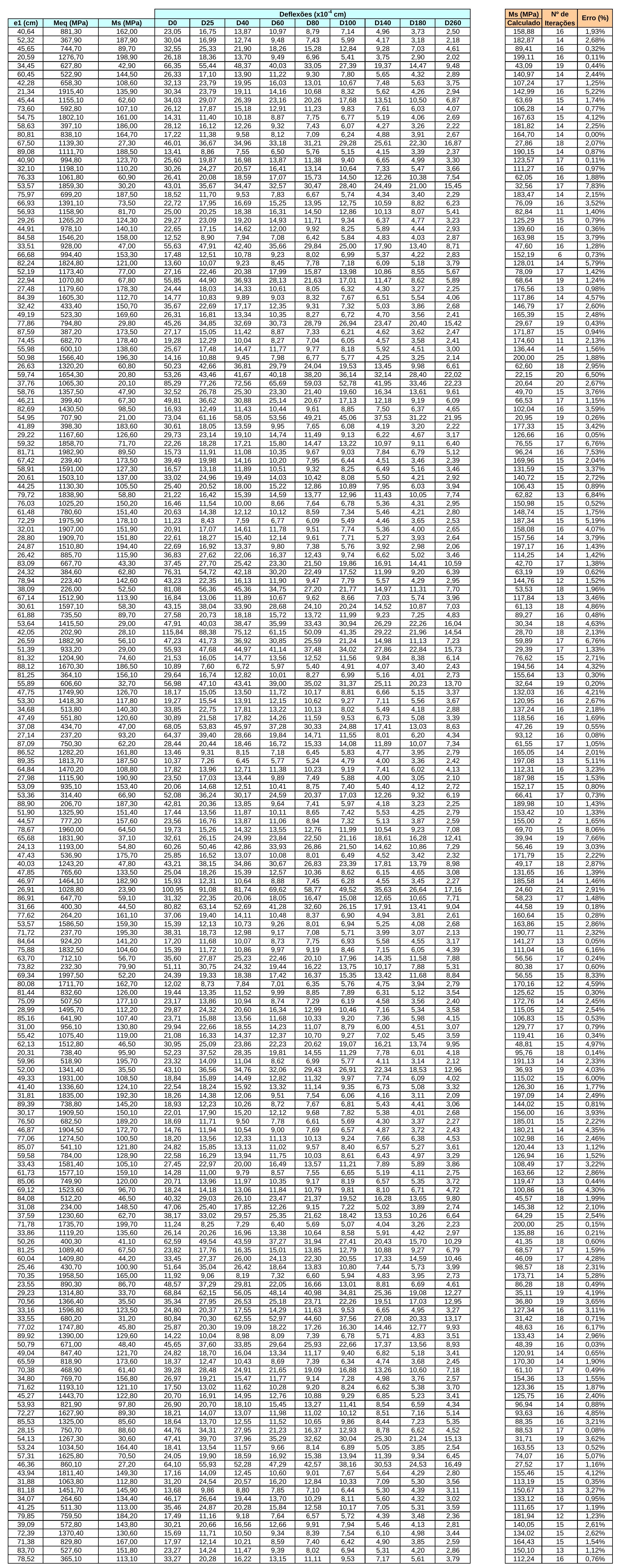




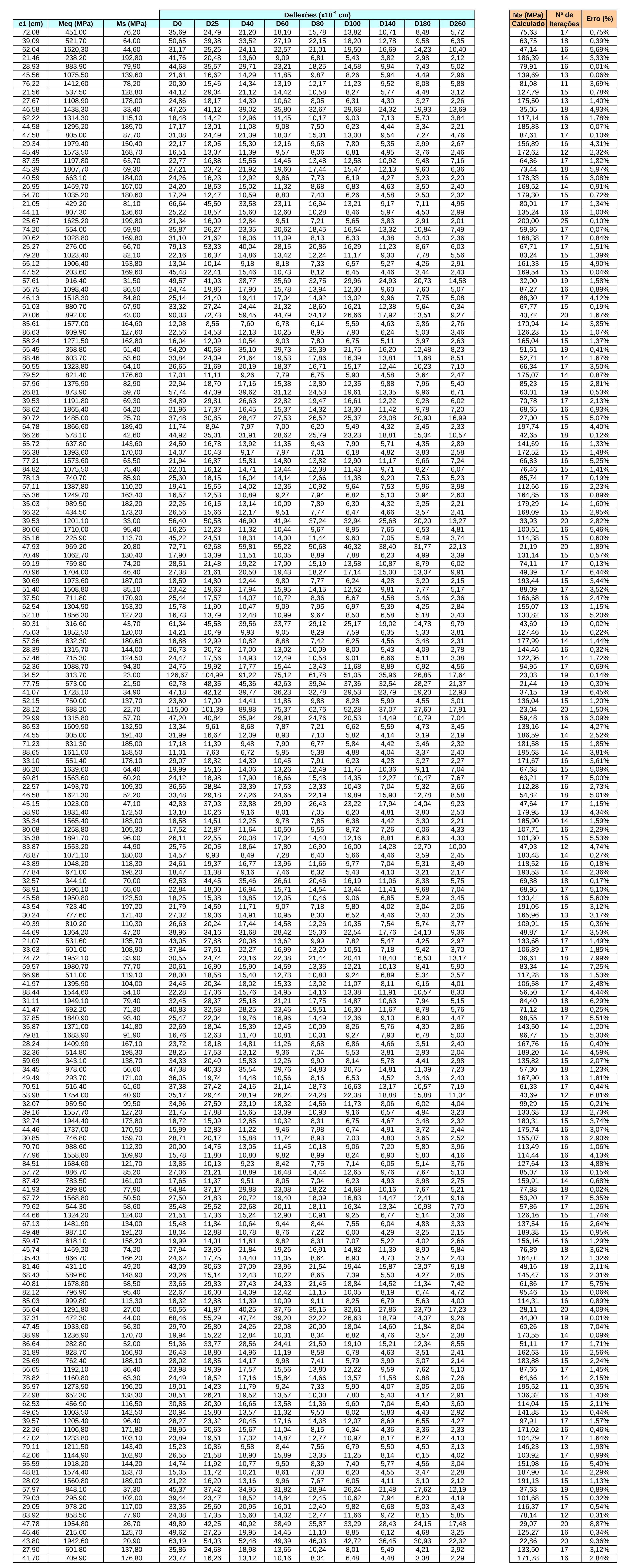




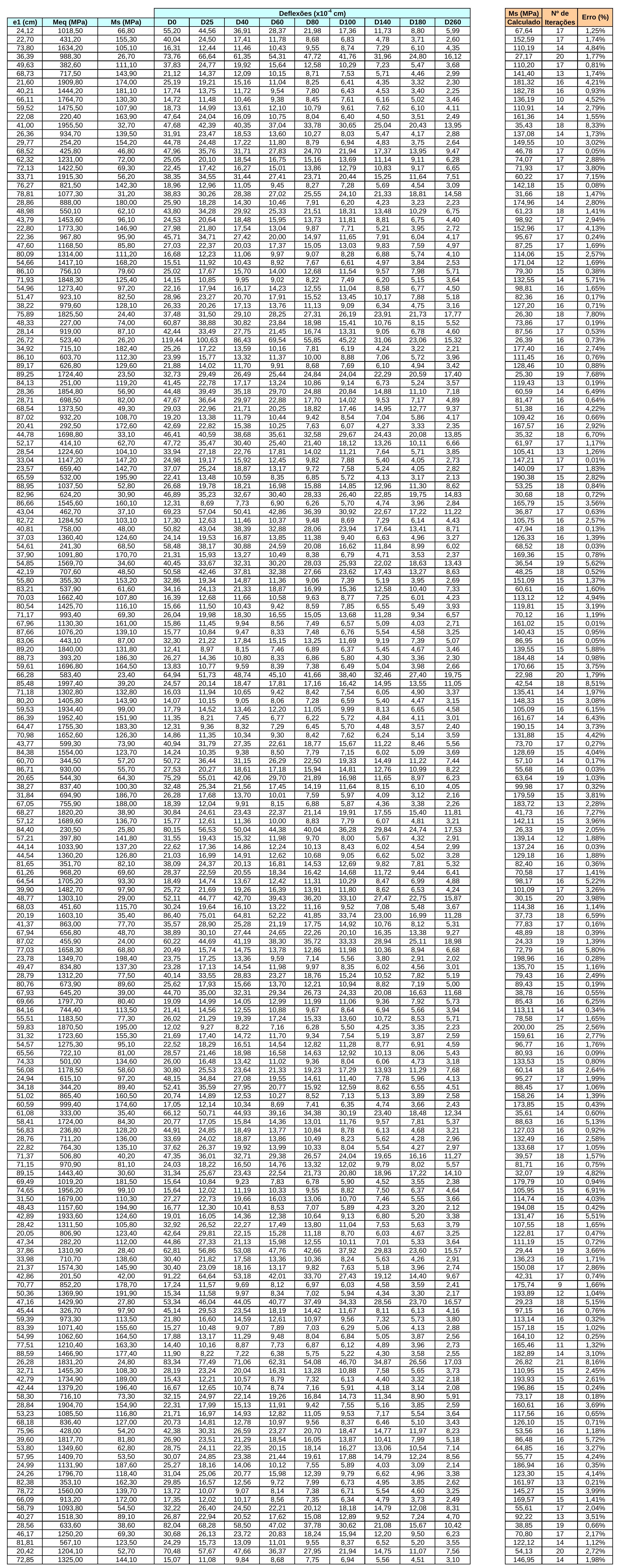




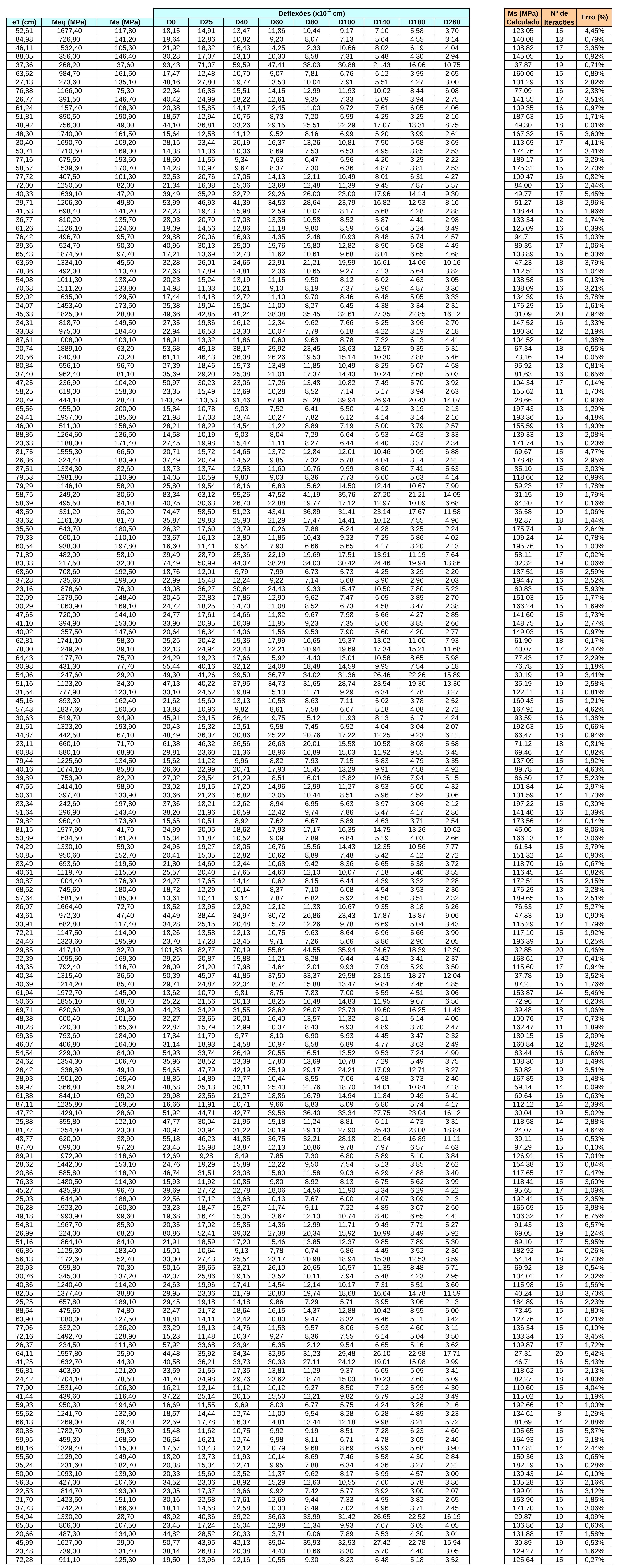




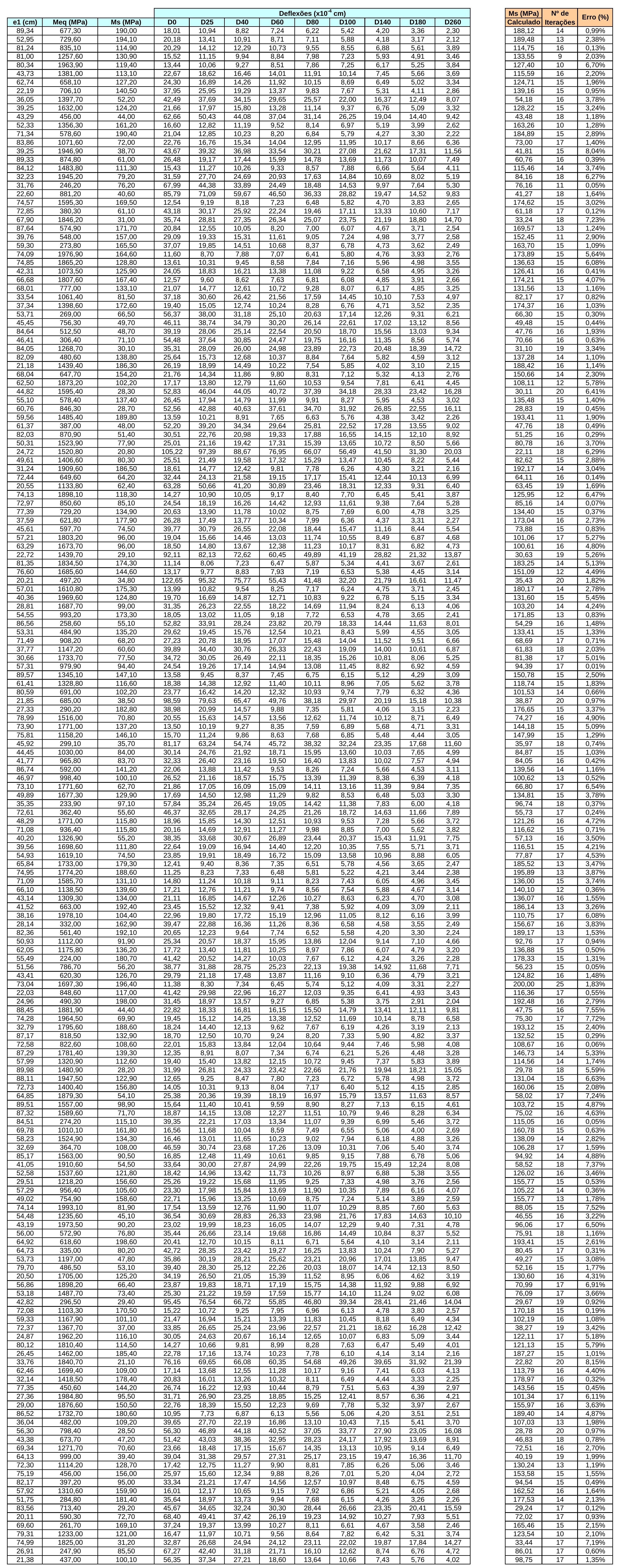




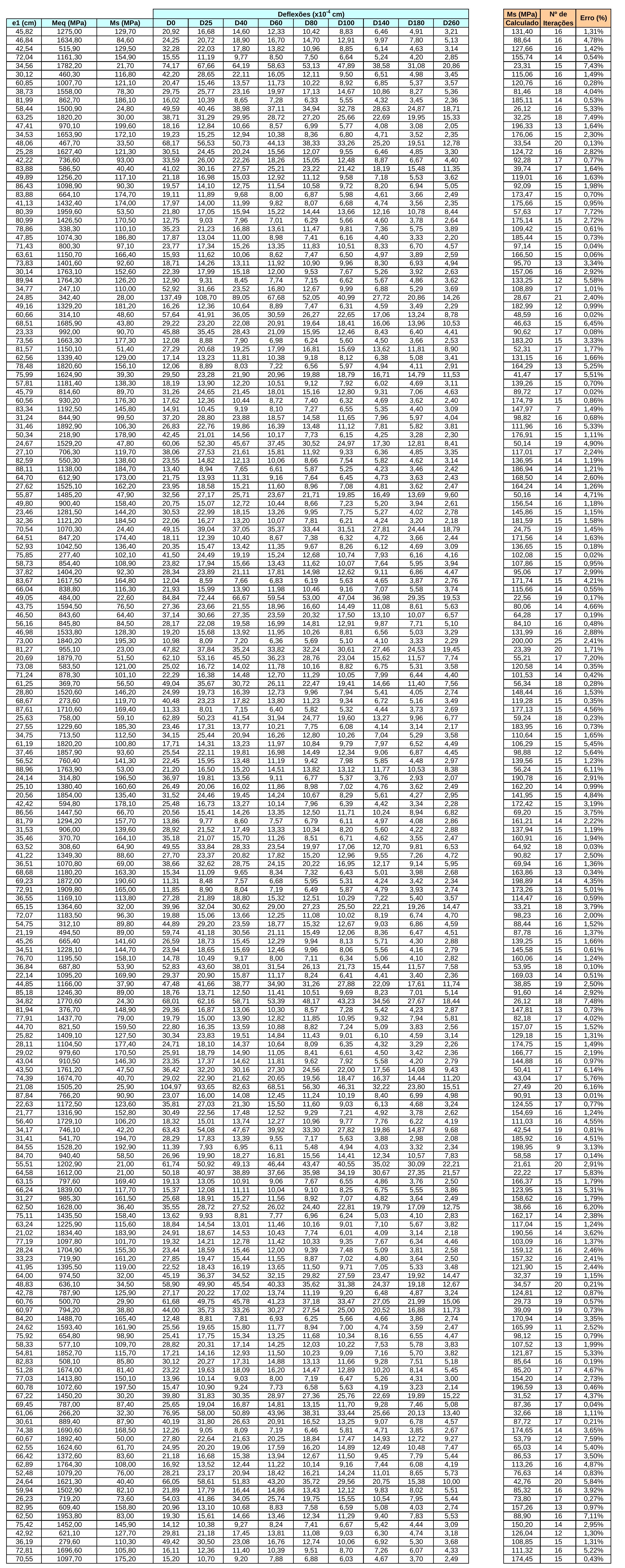




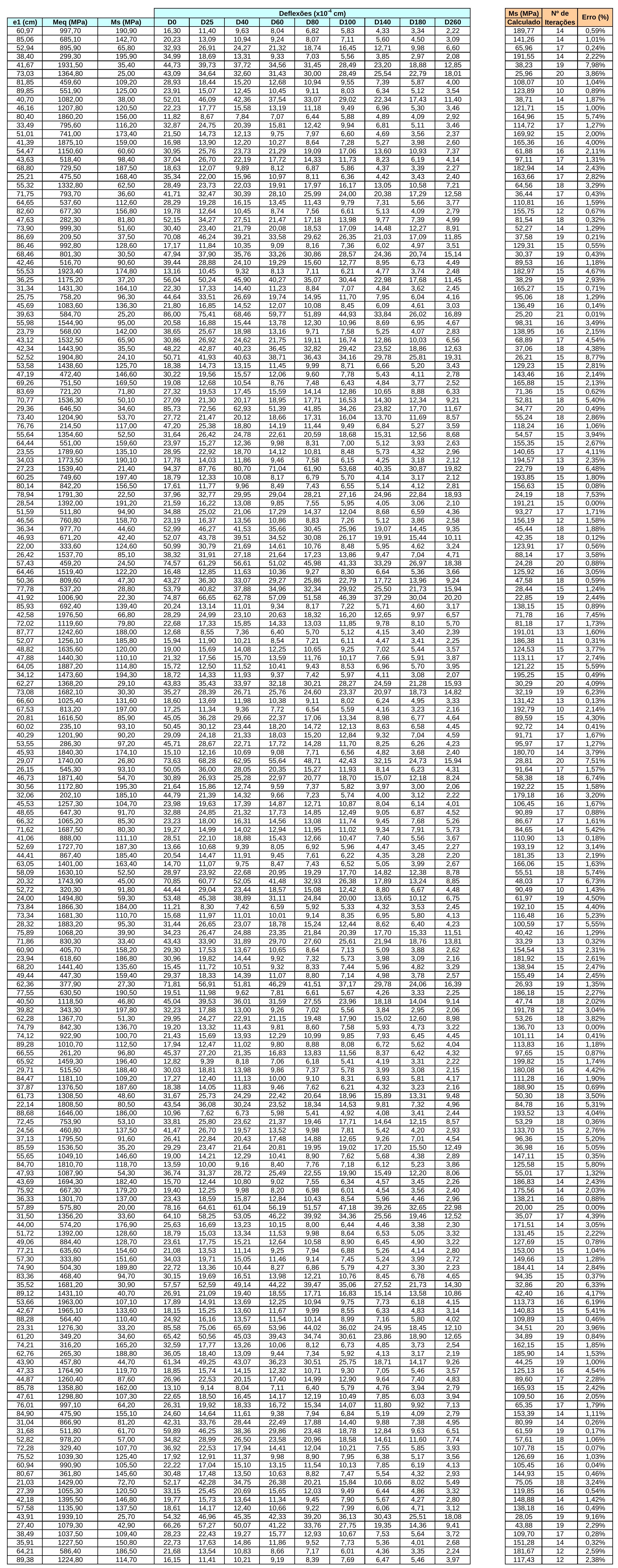




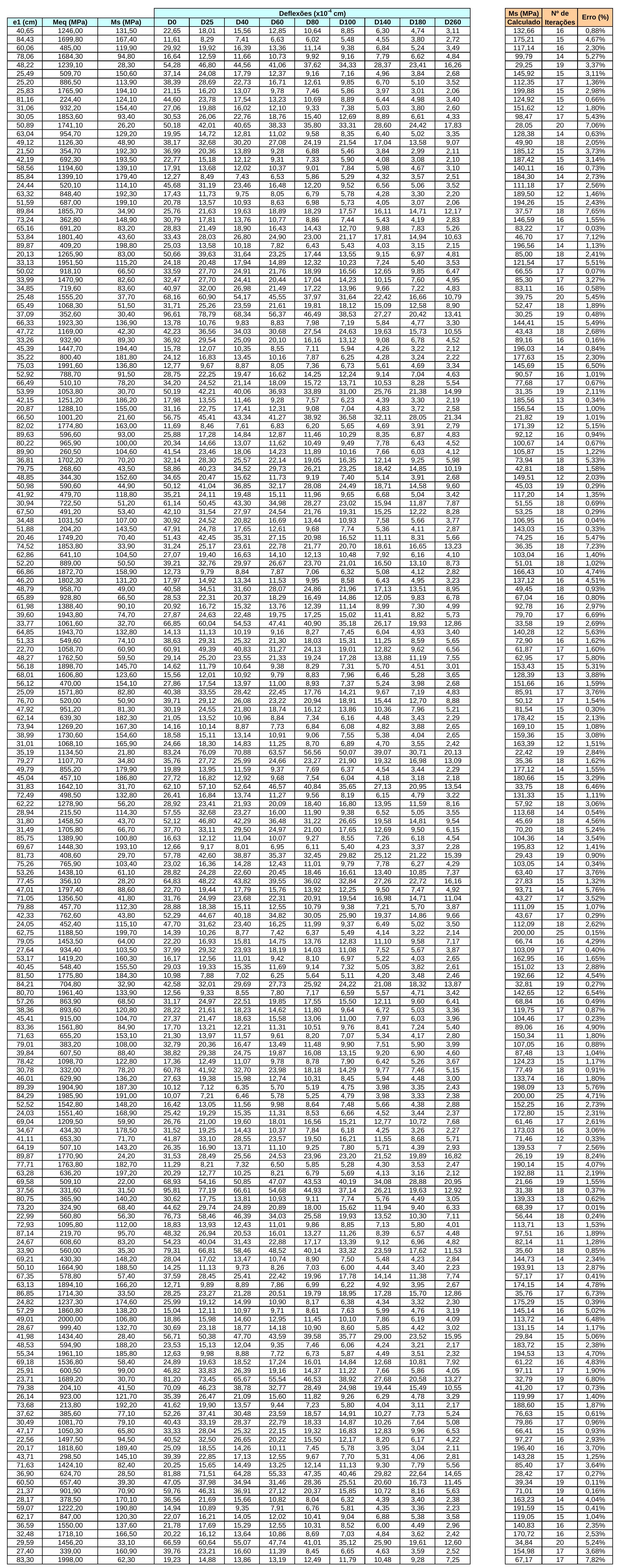




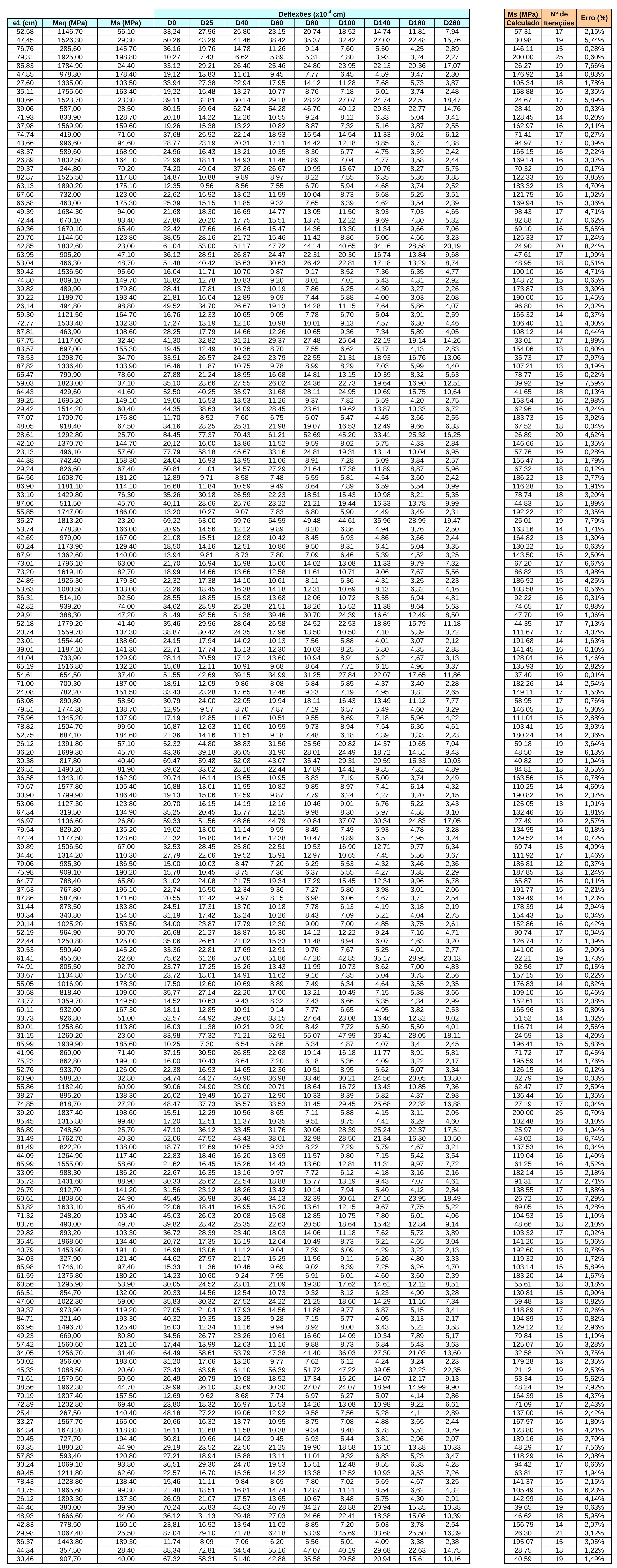



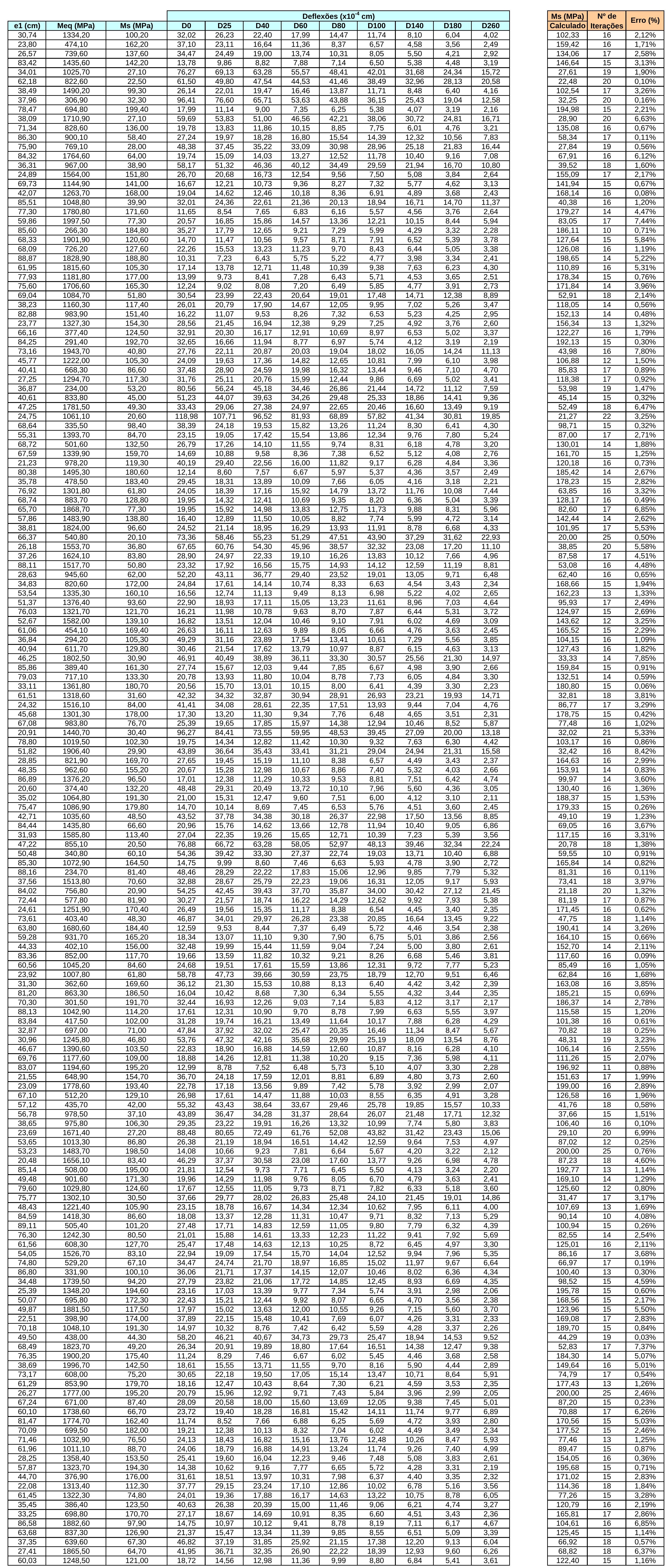
ANEXO G - Erro na retroanálise da Camada Equivalente. 


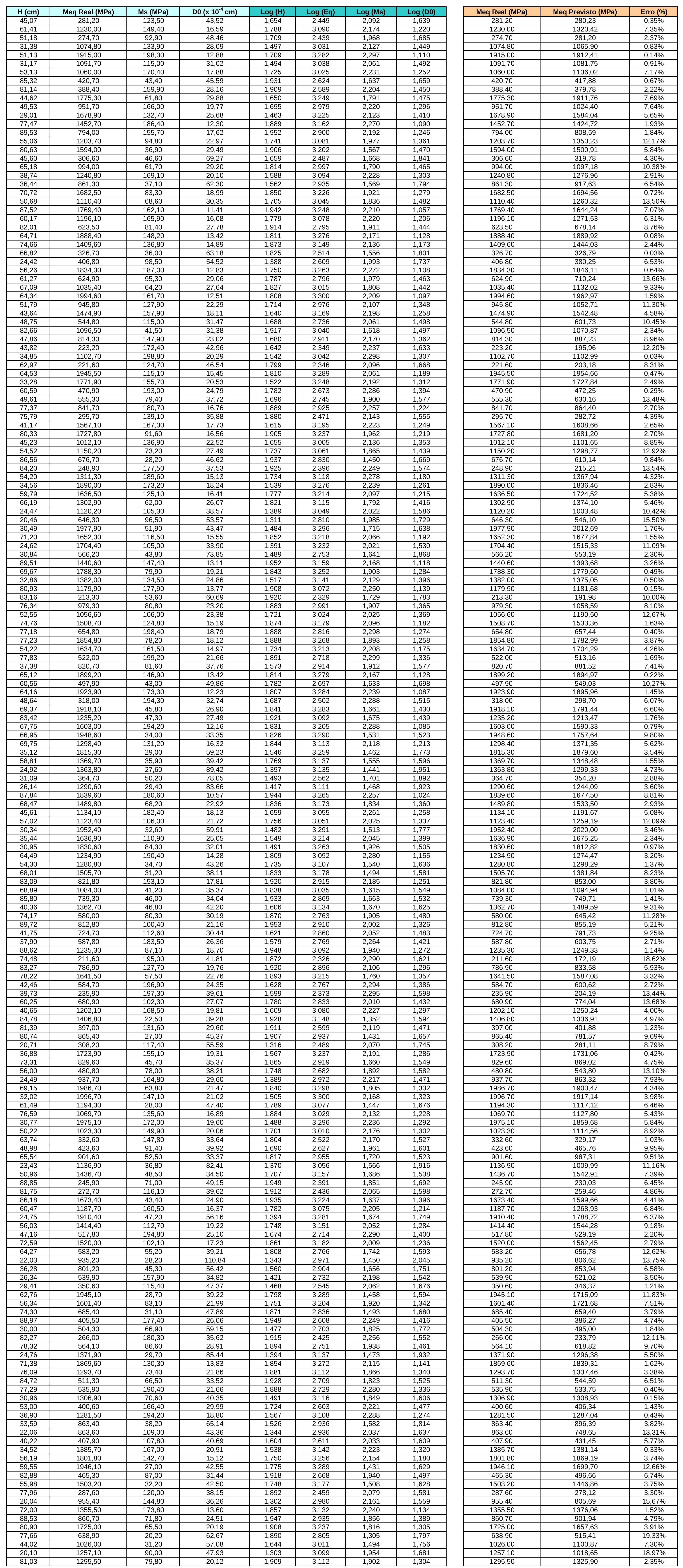




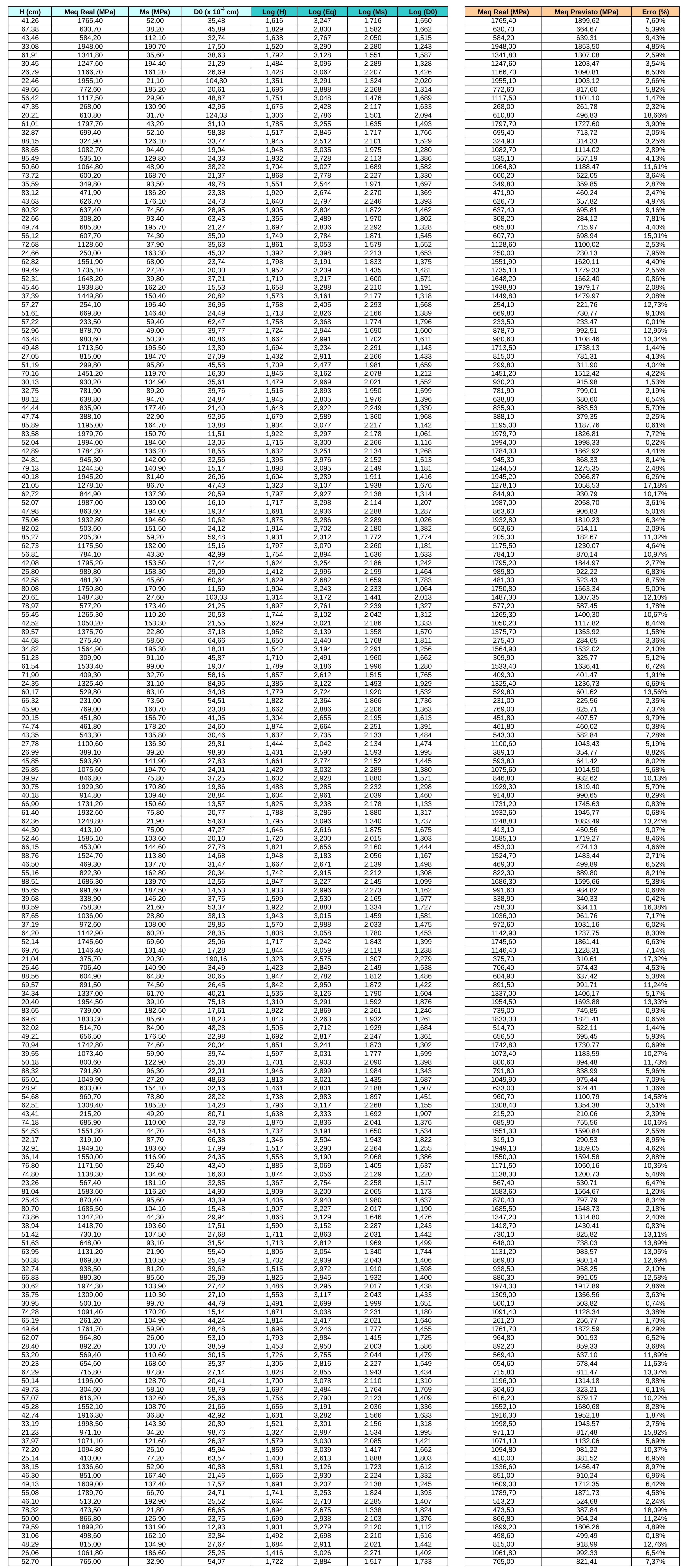




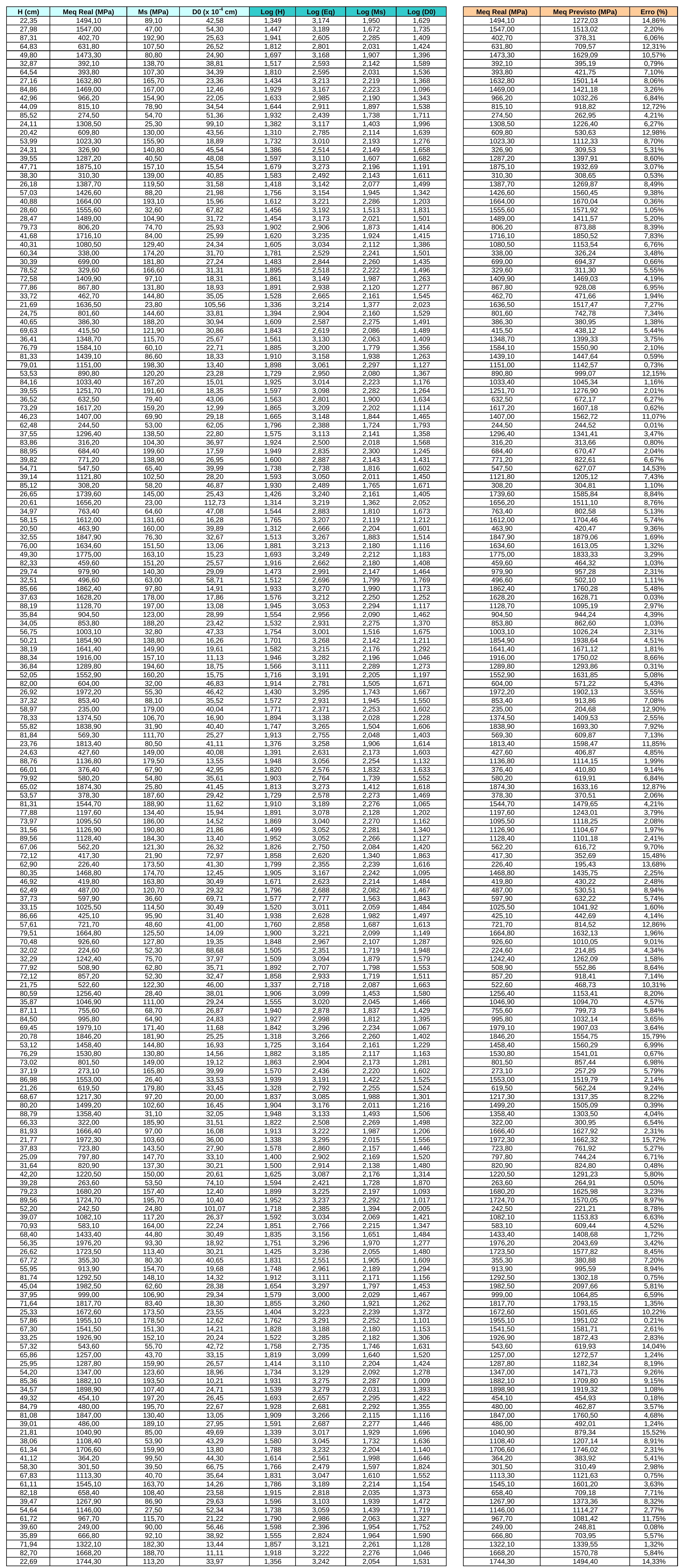




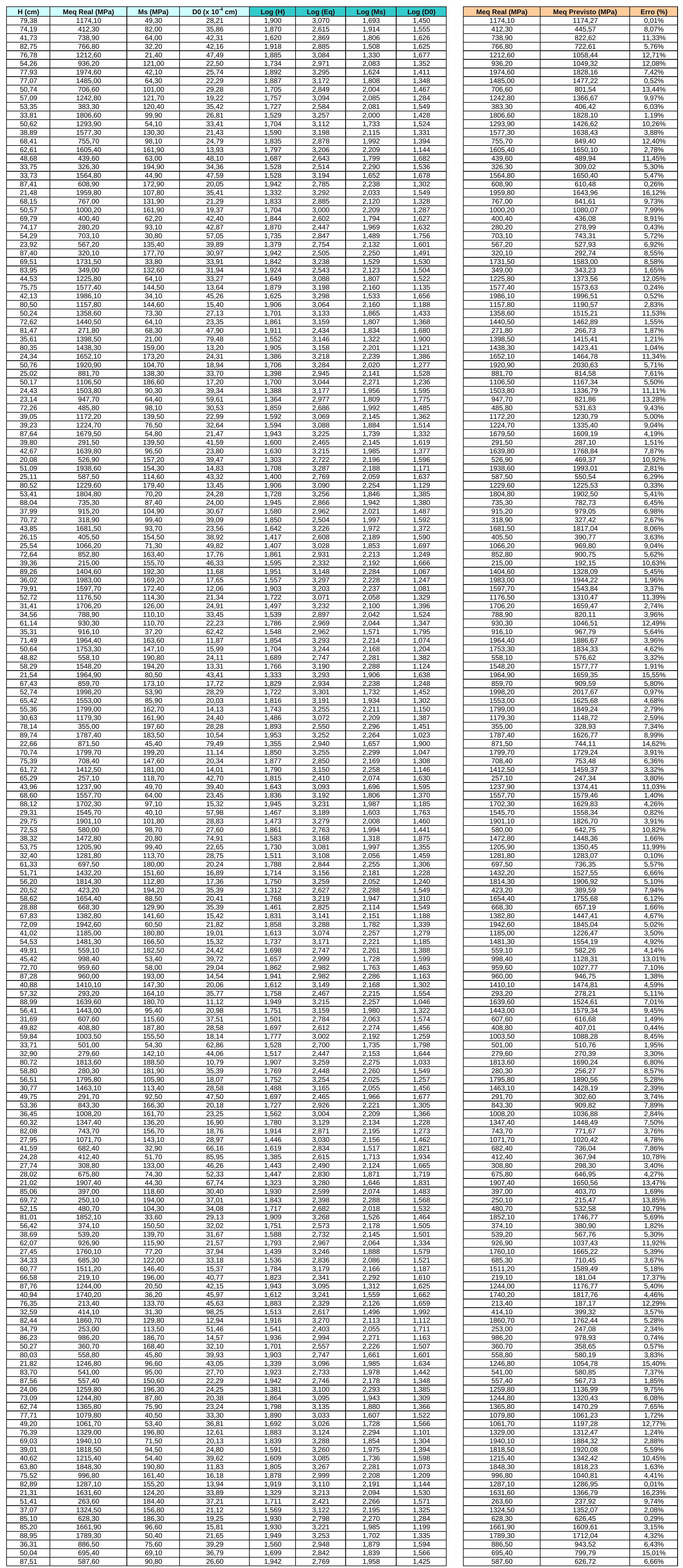




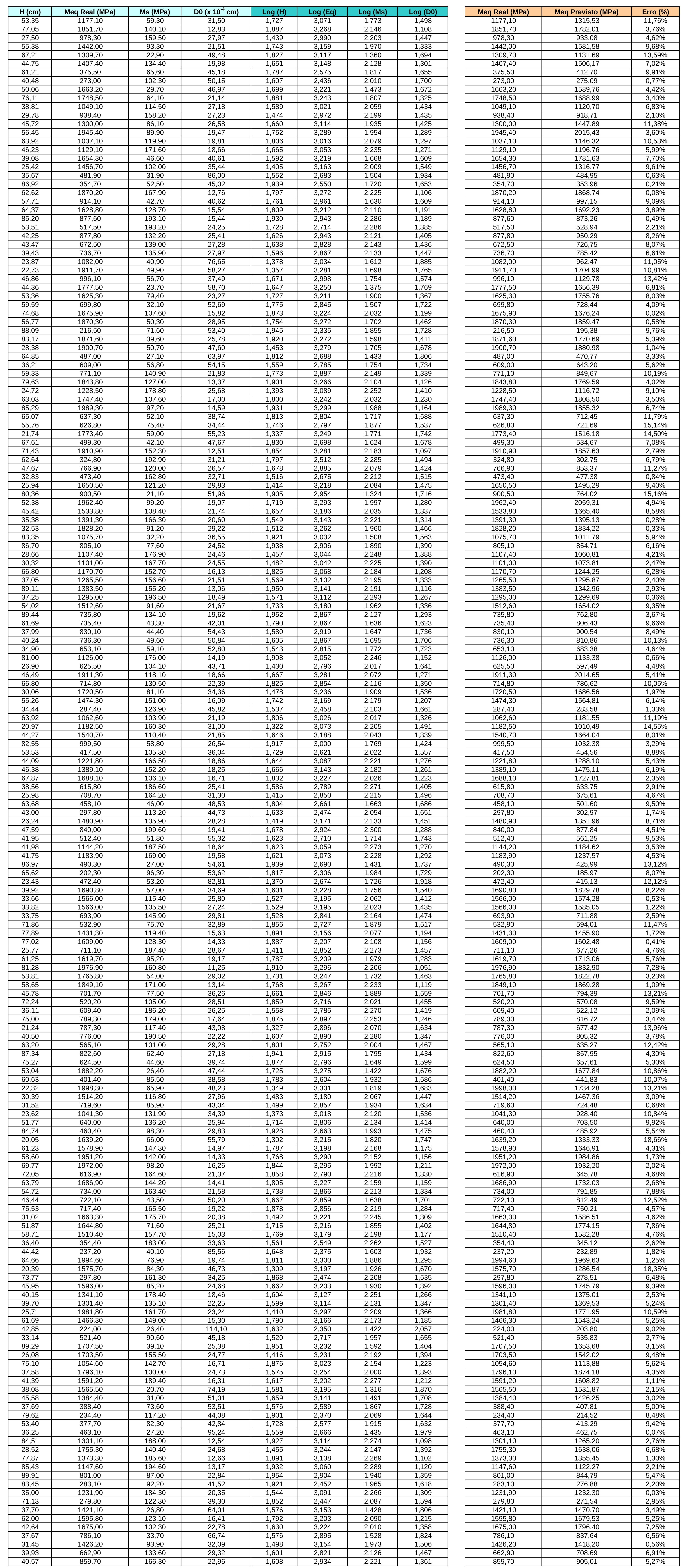




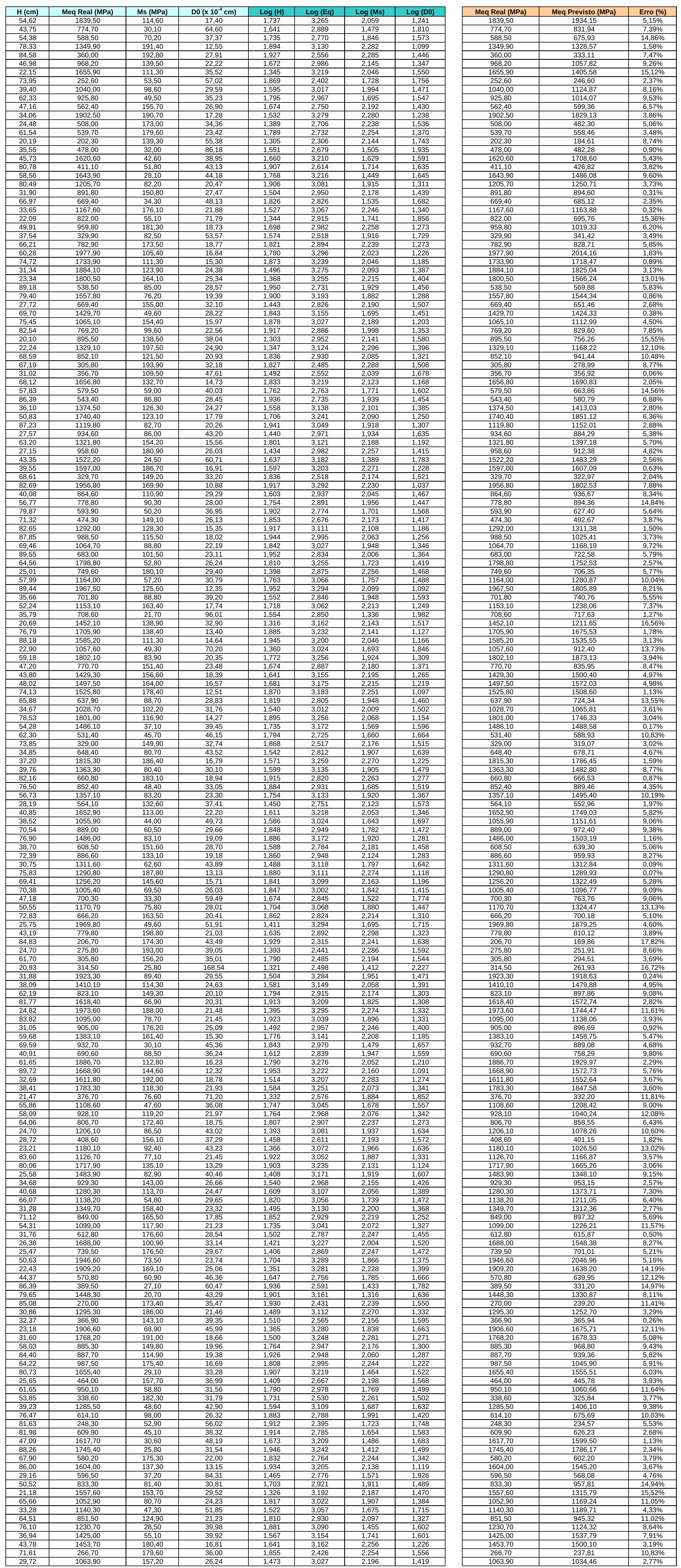




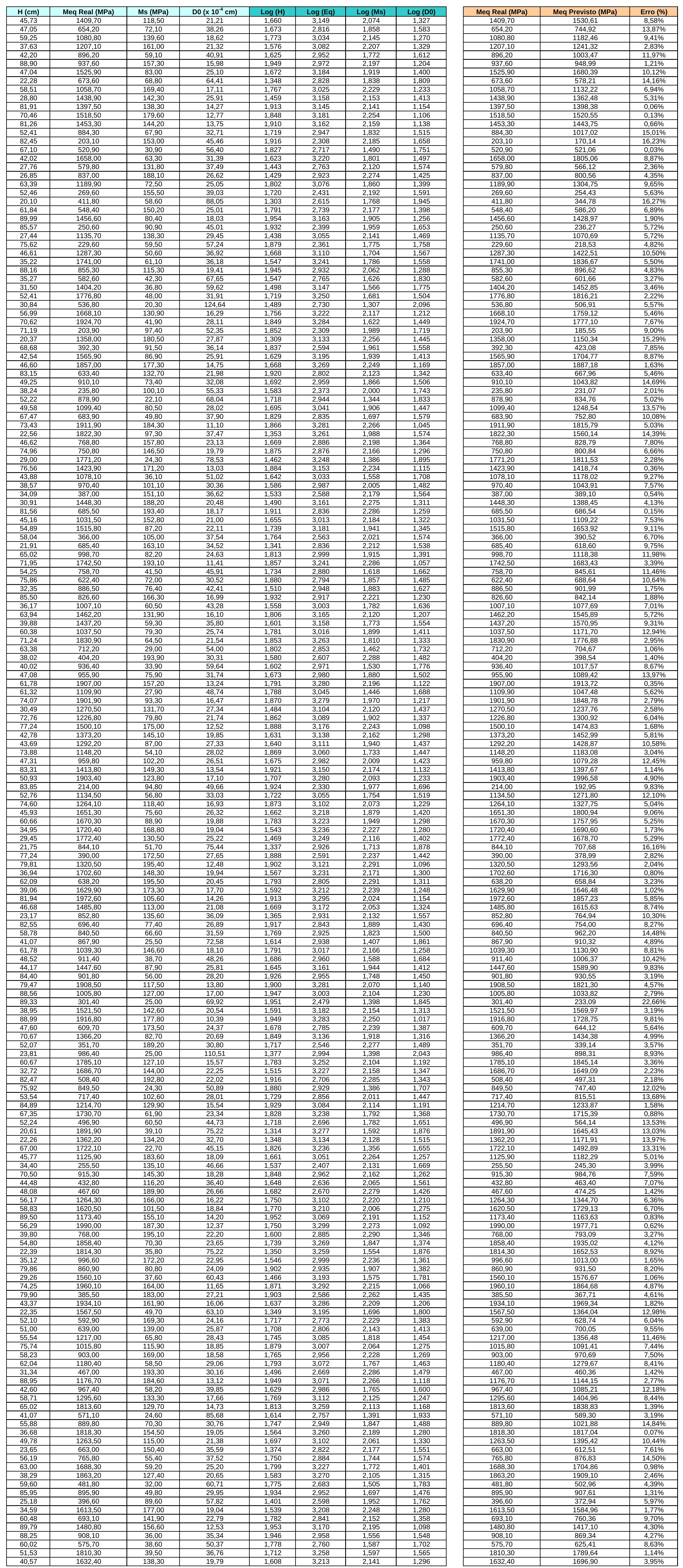




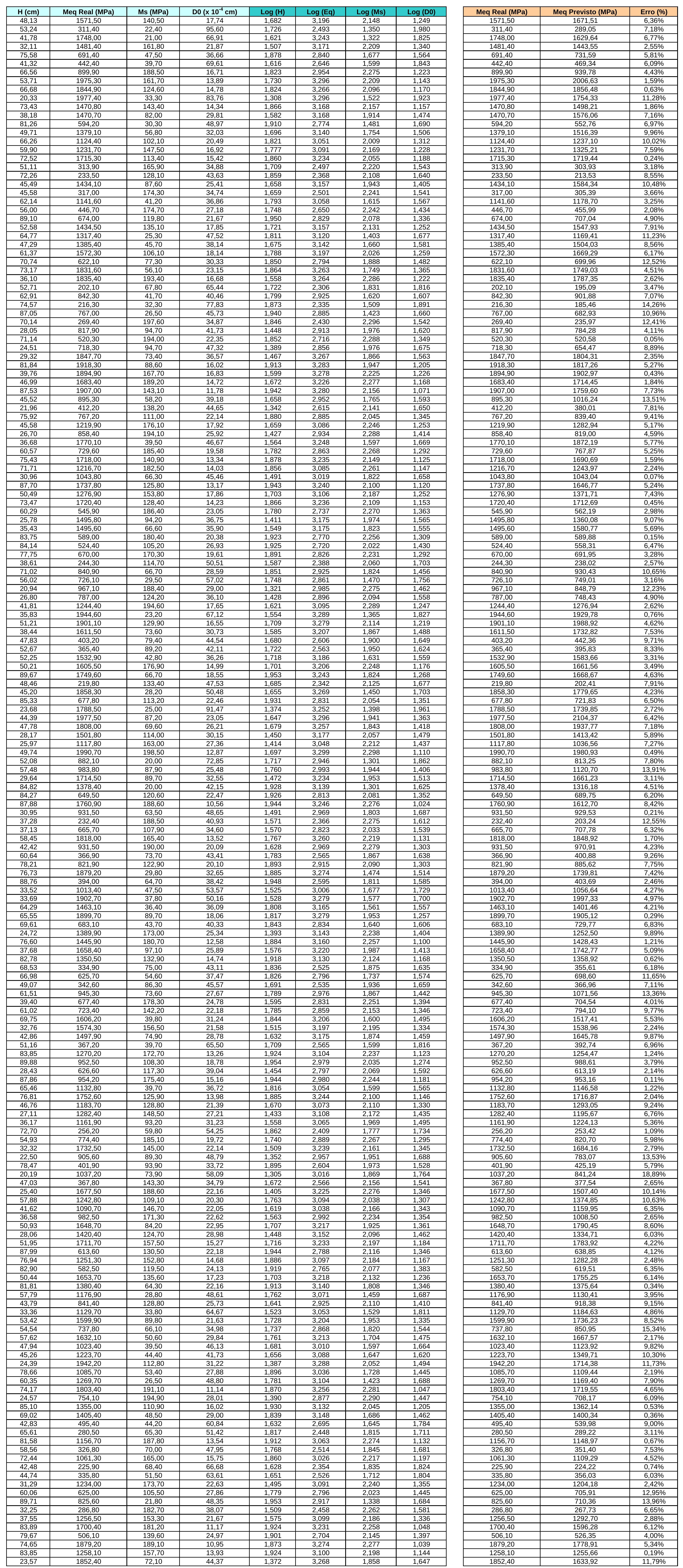




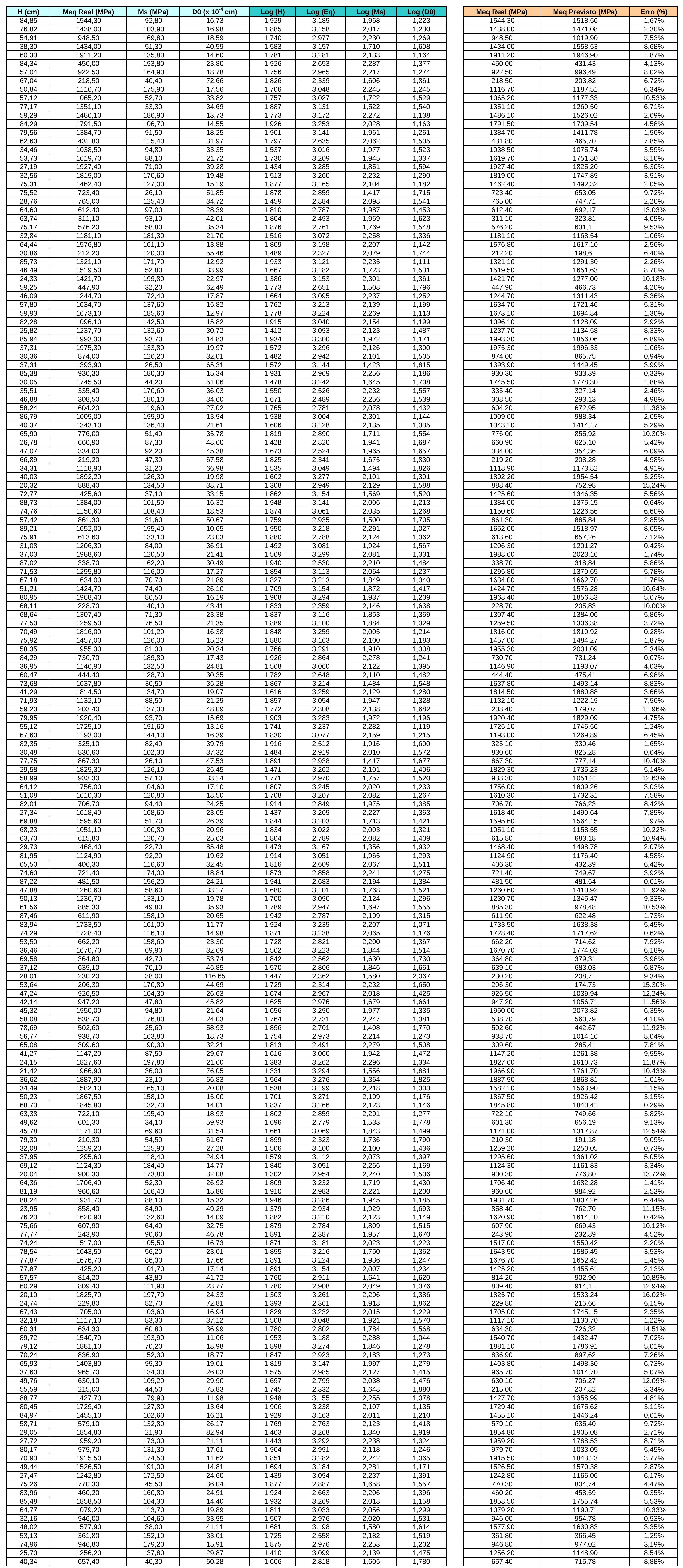




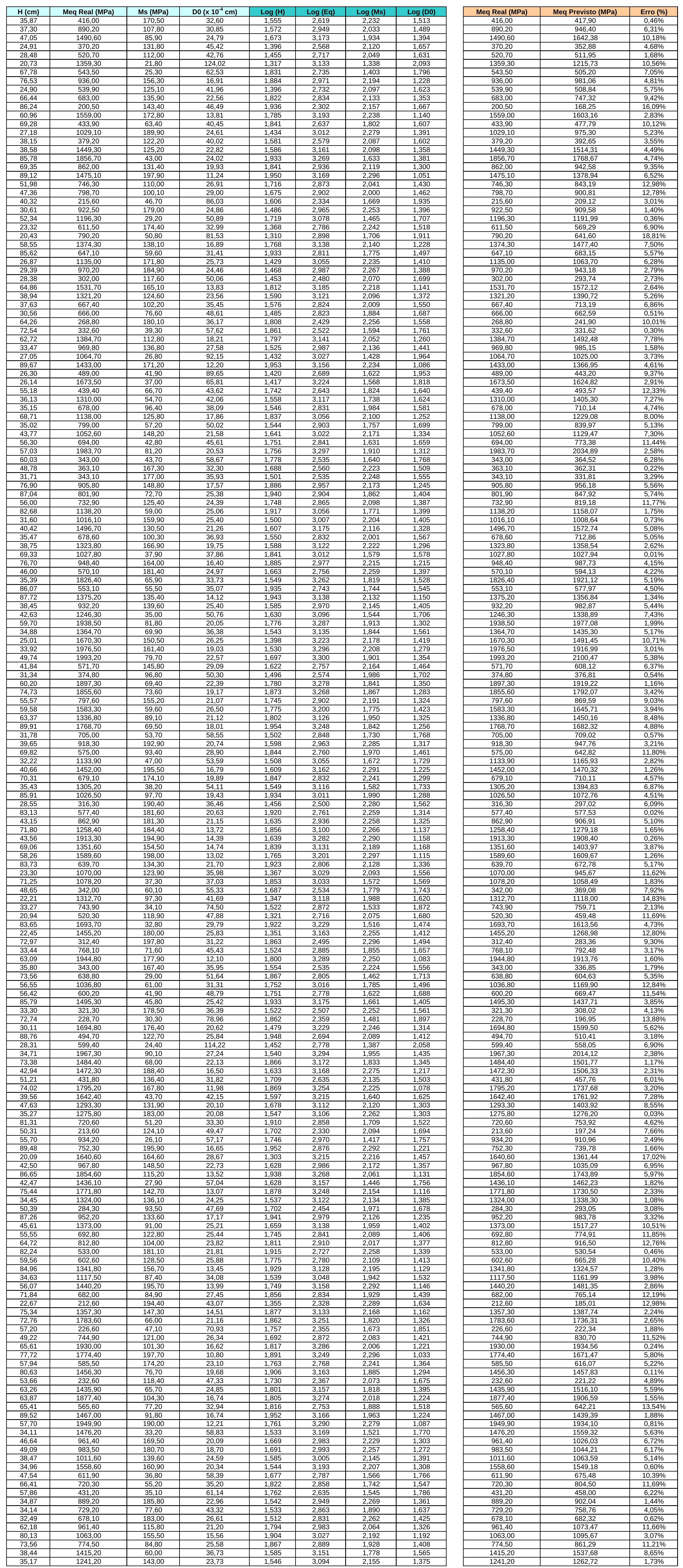




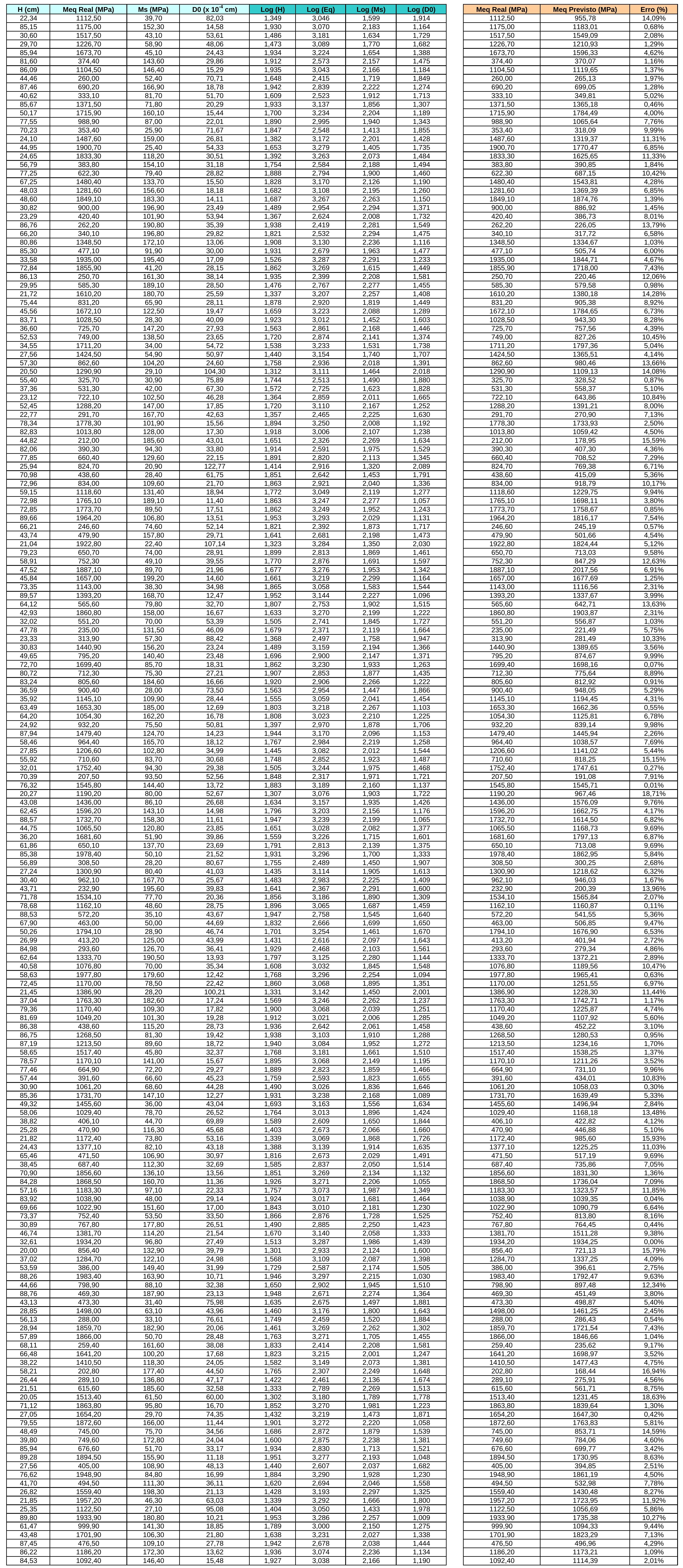




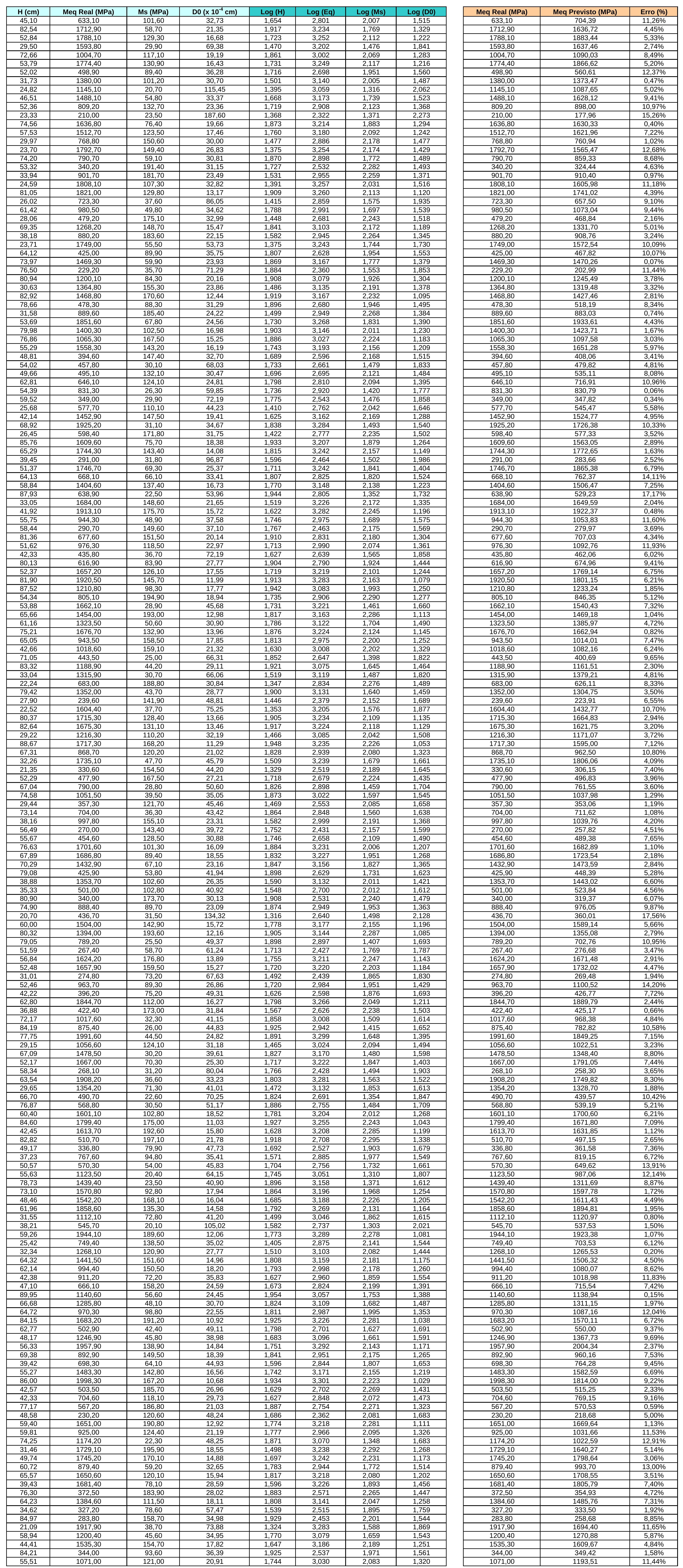




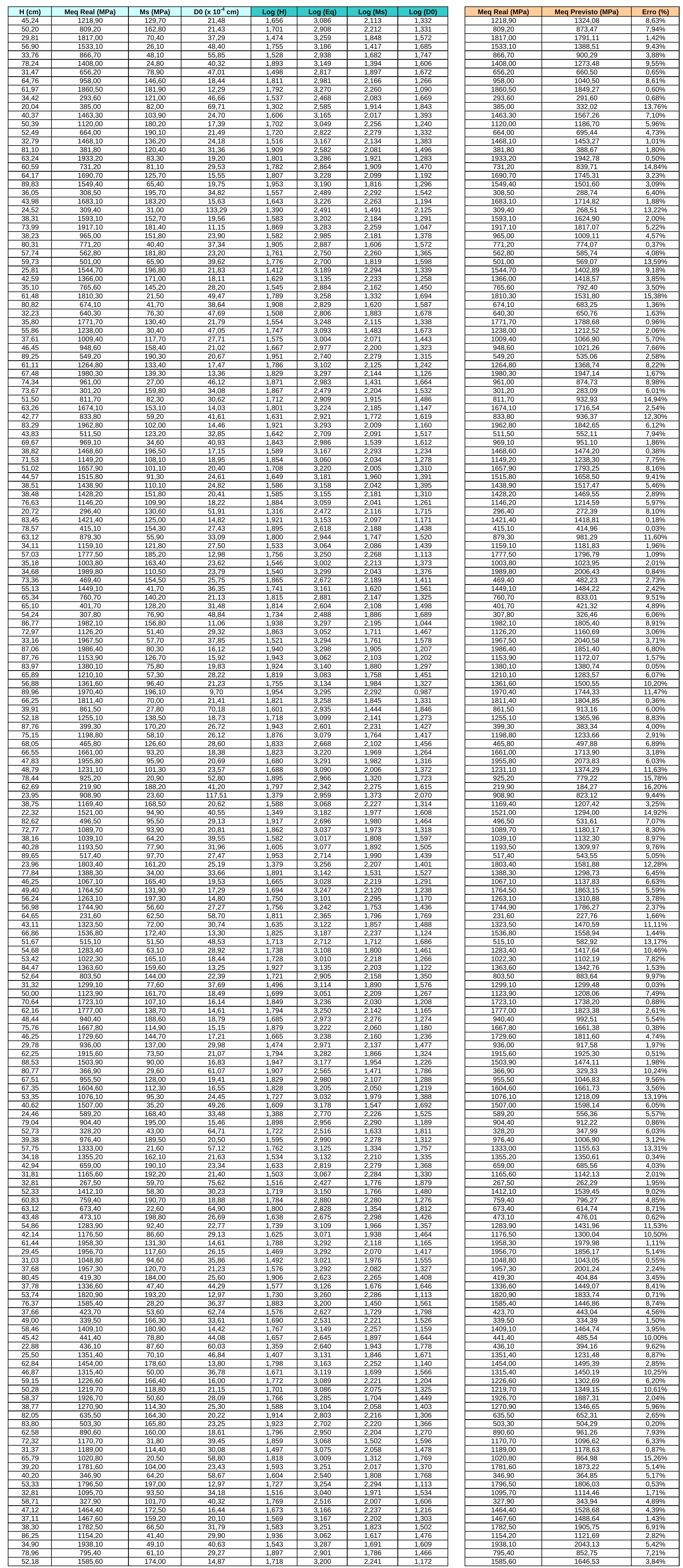




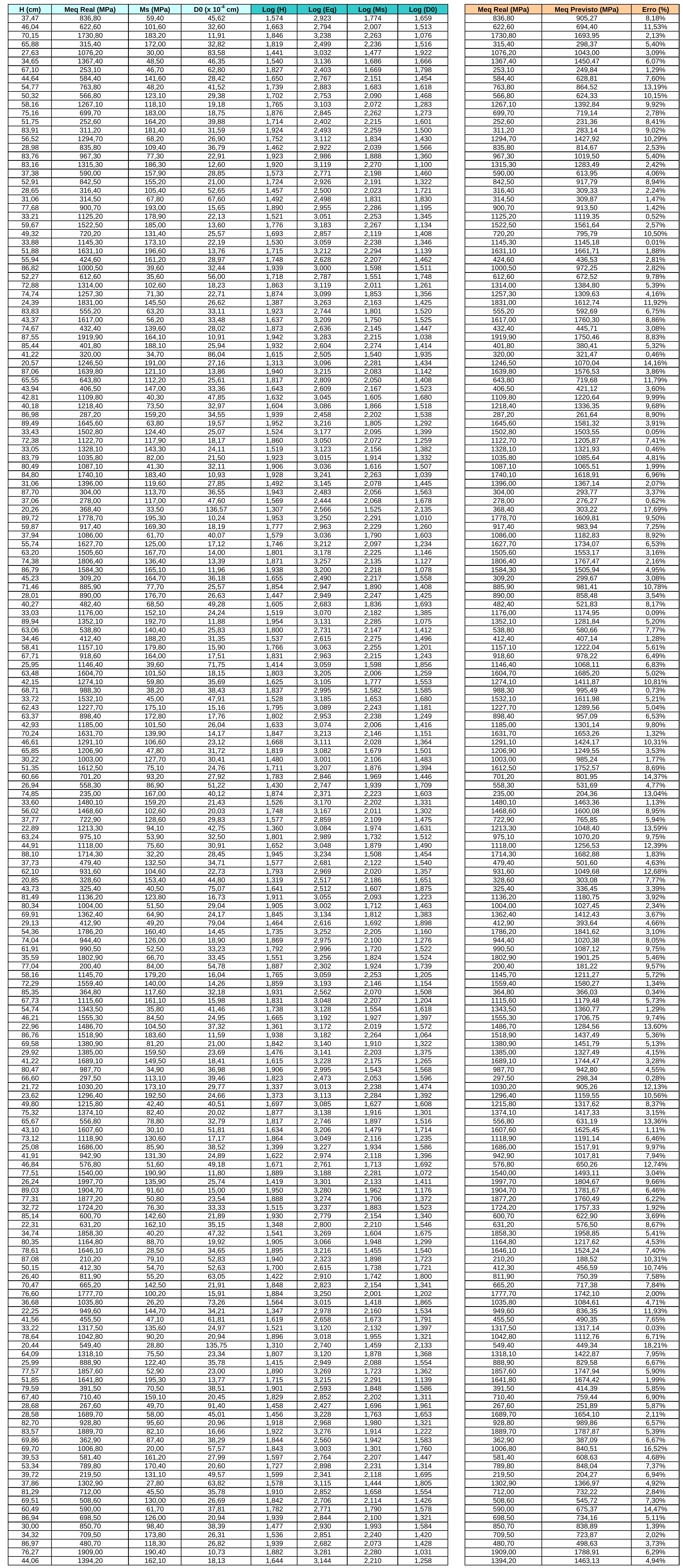




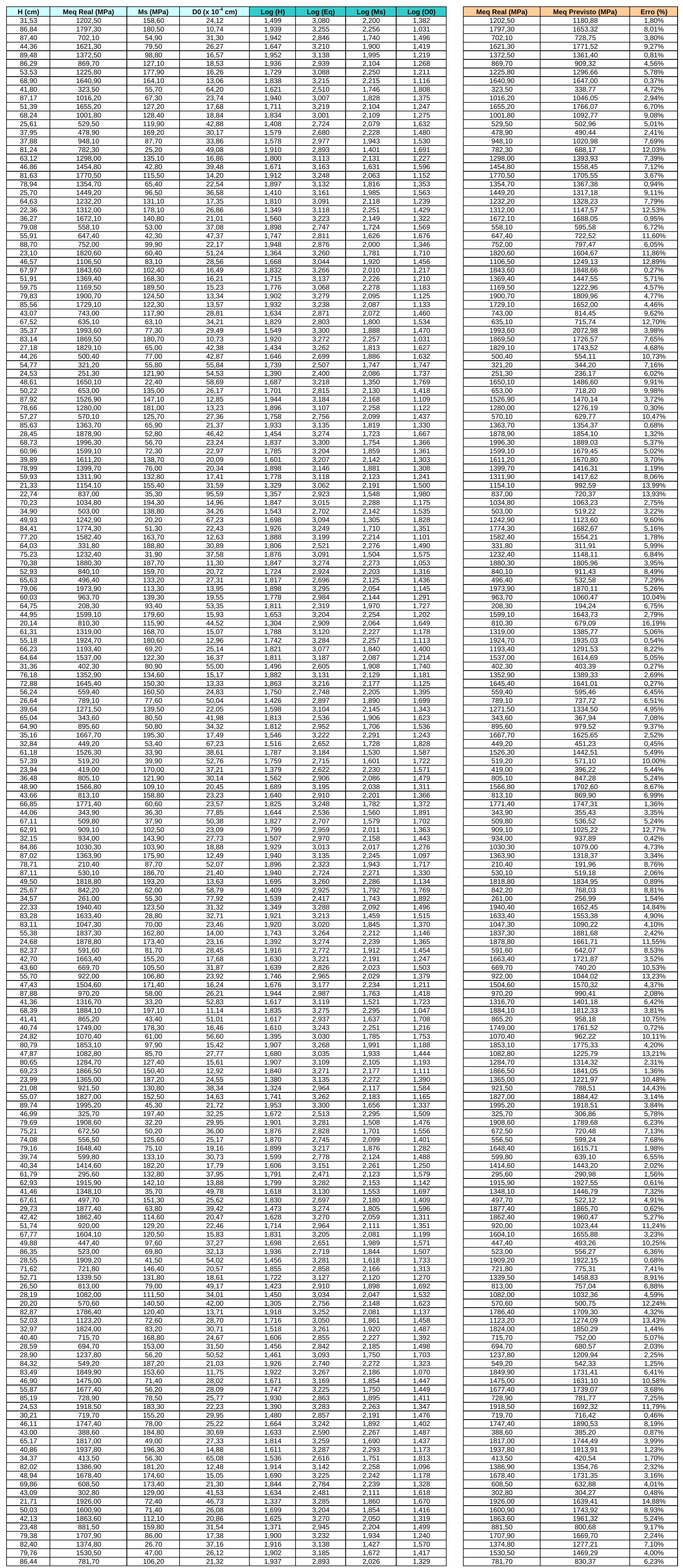




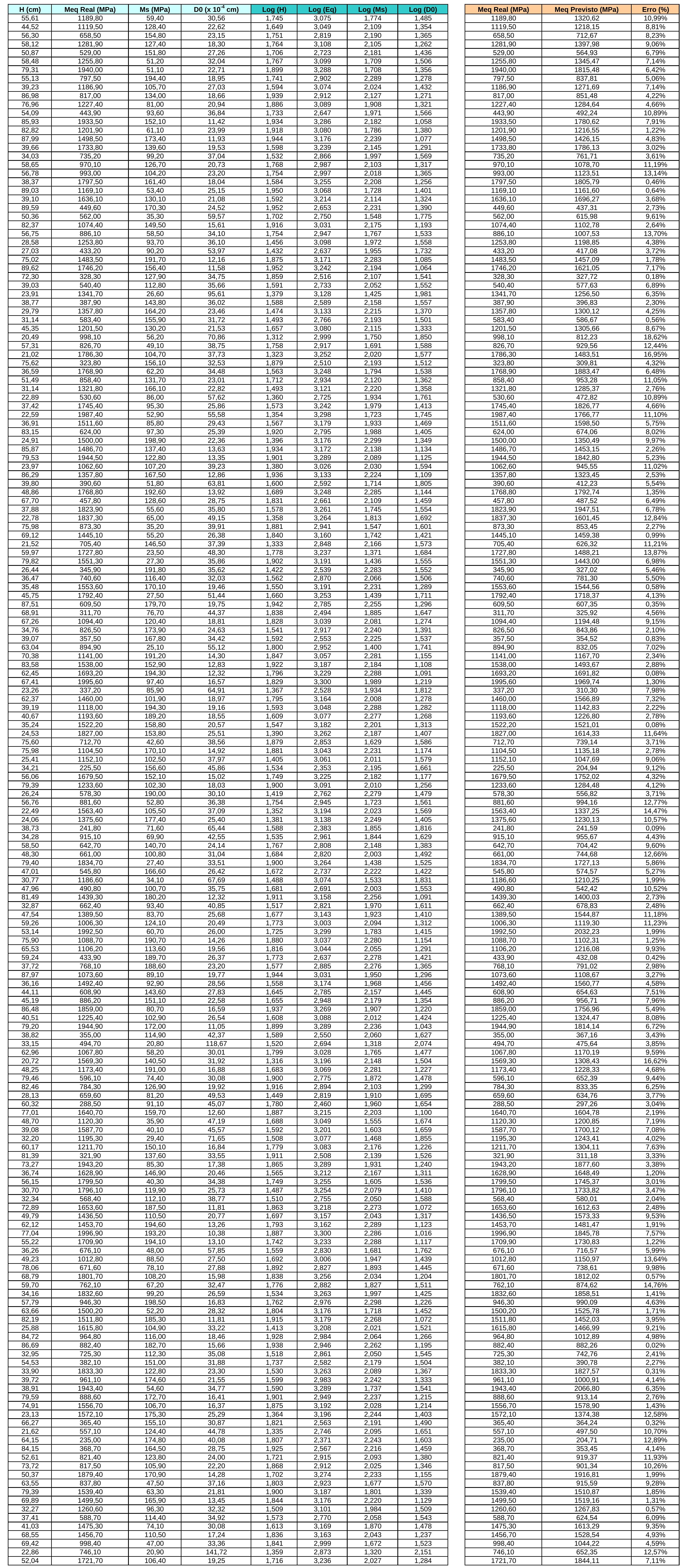




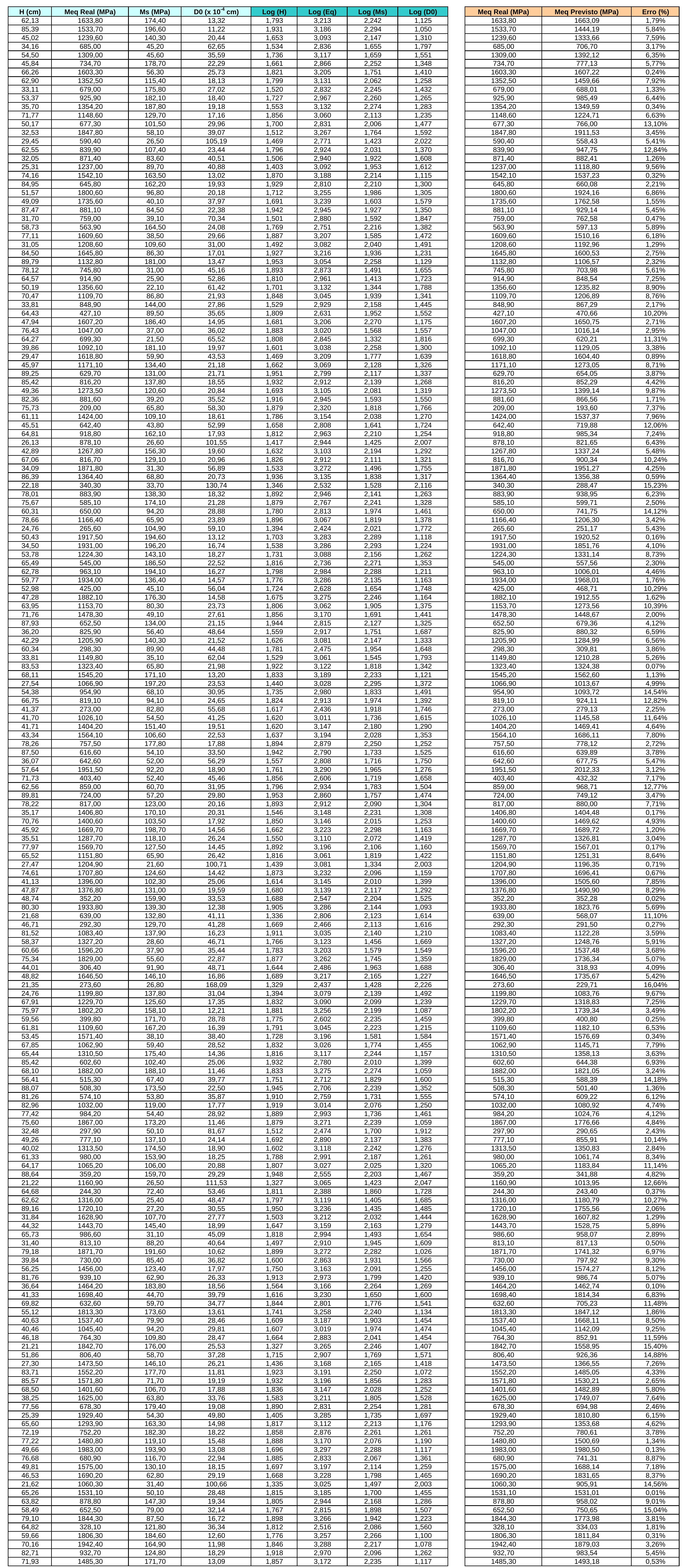




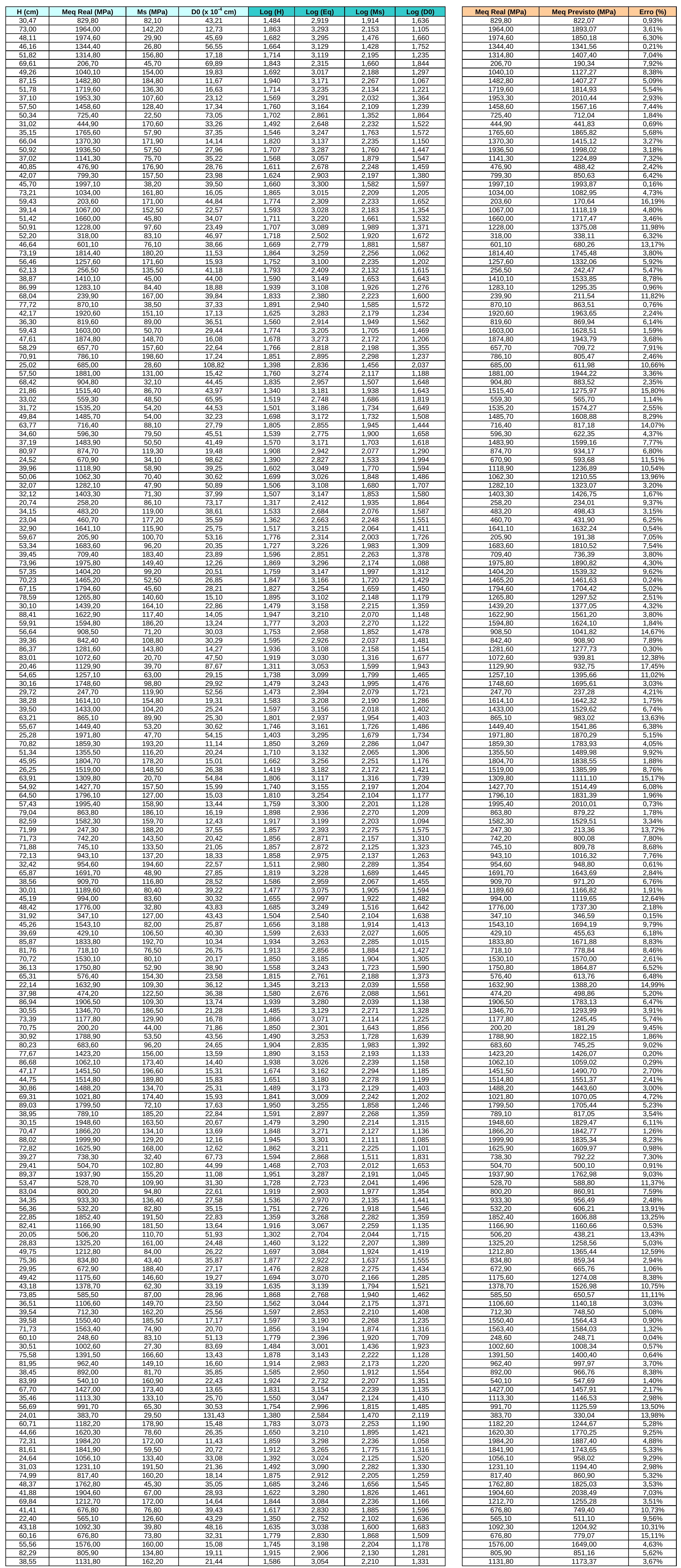




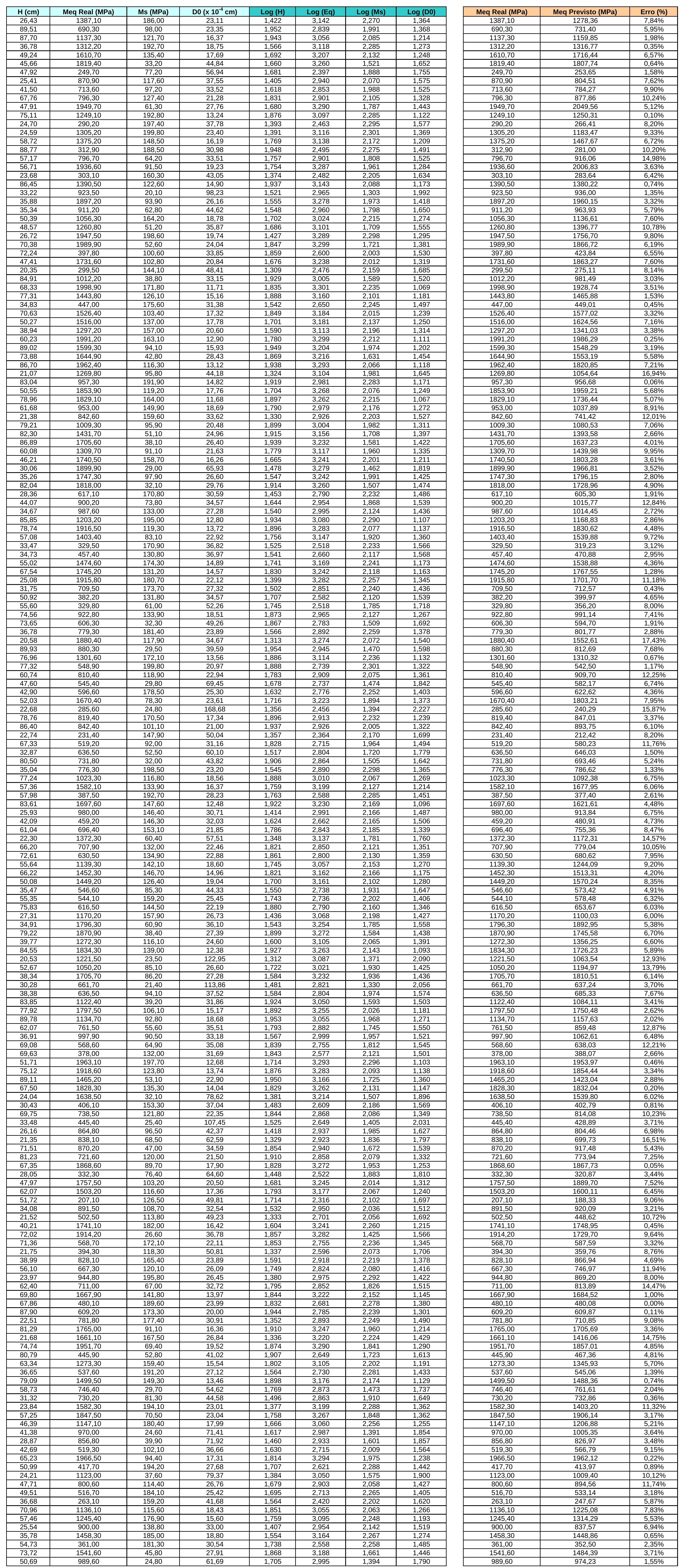




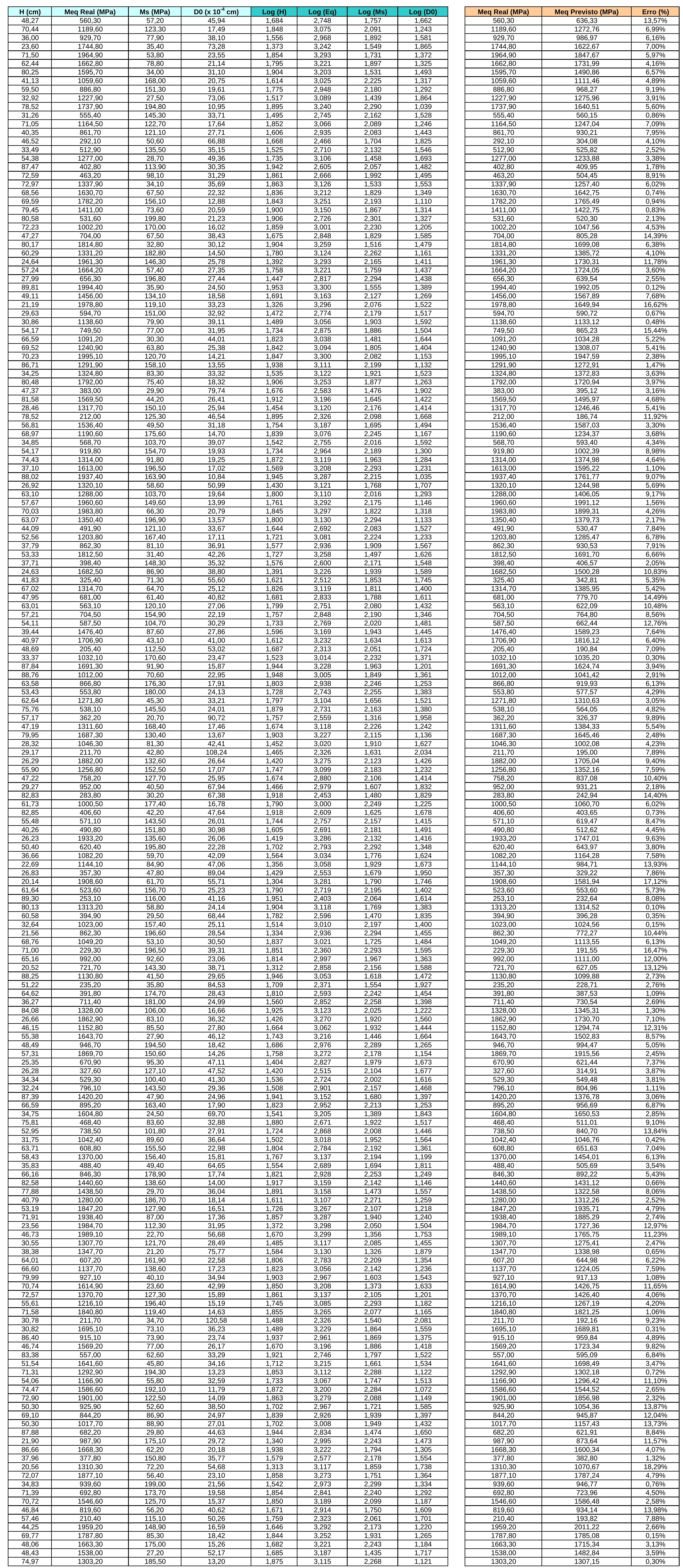




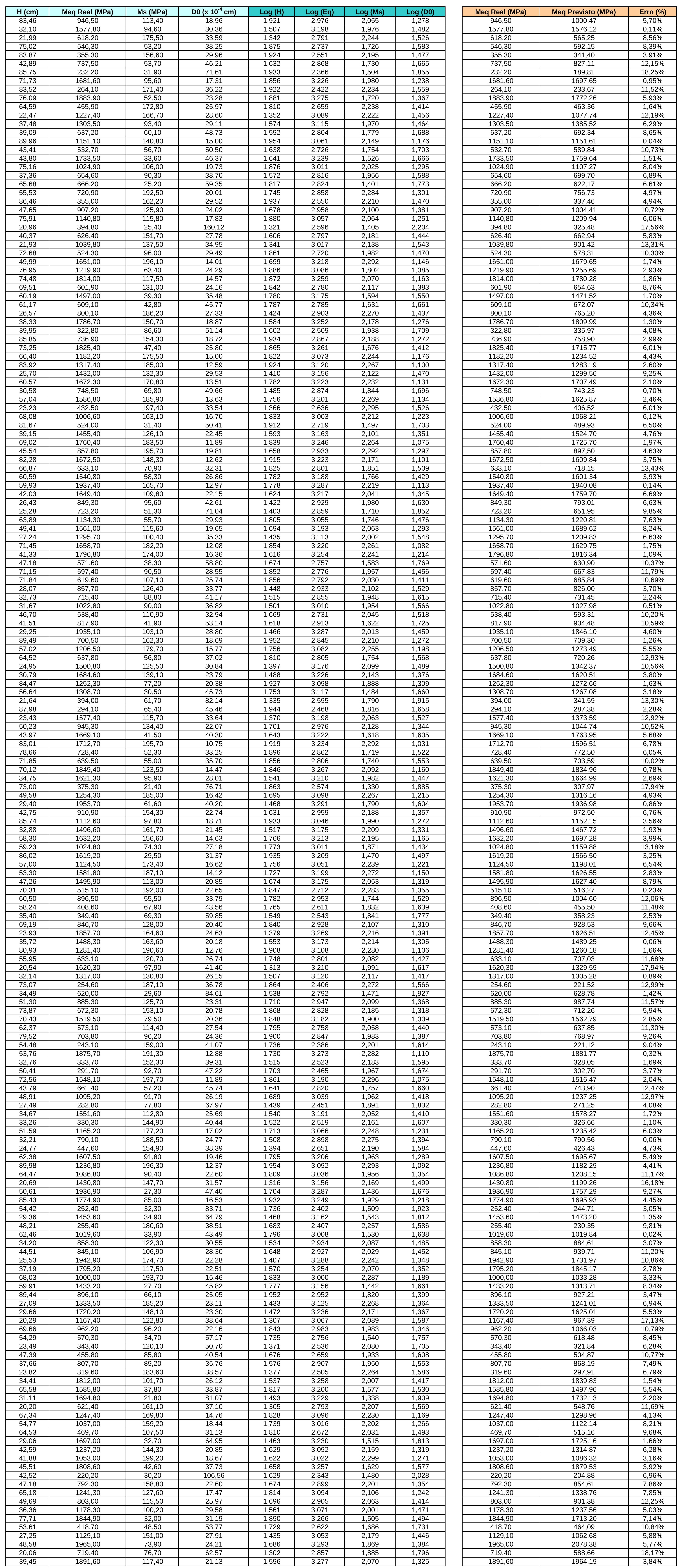




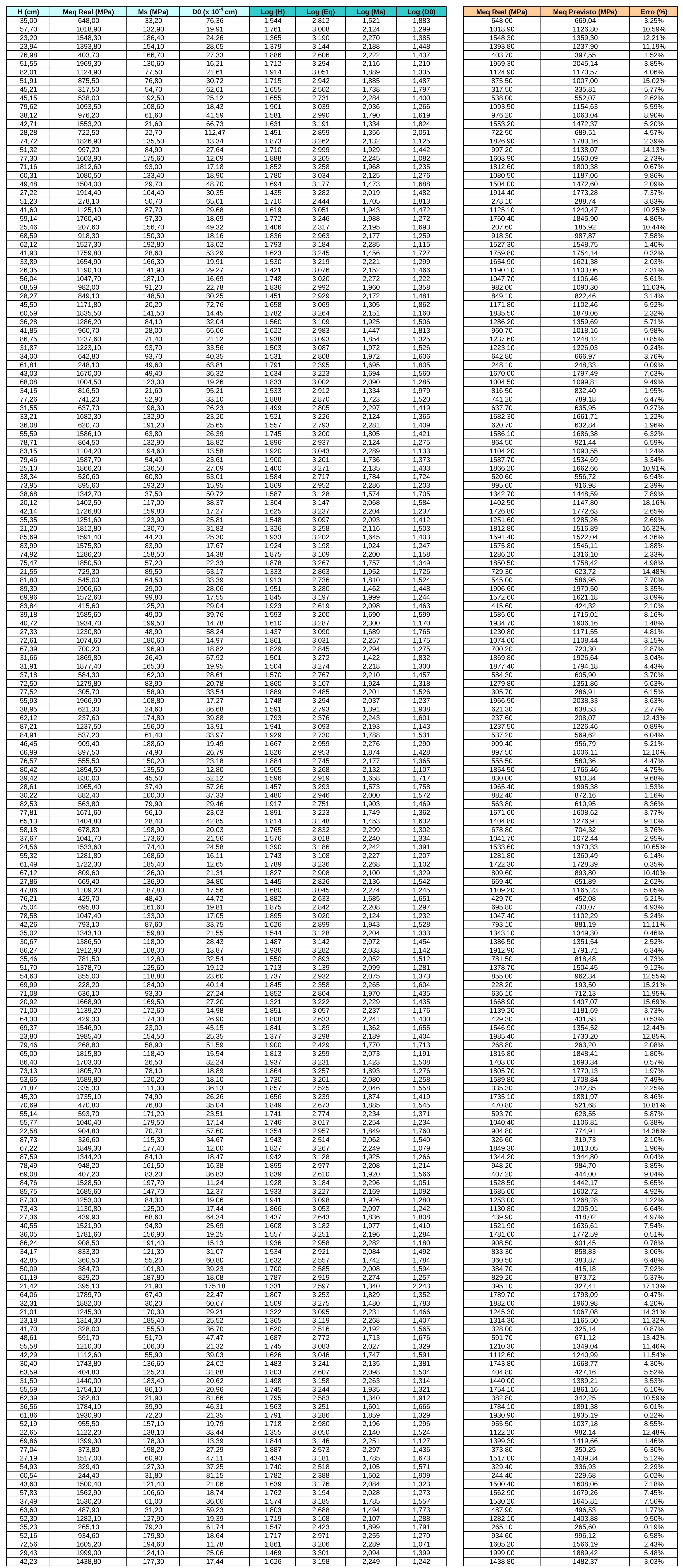




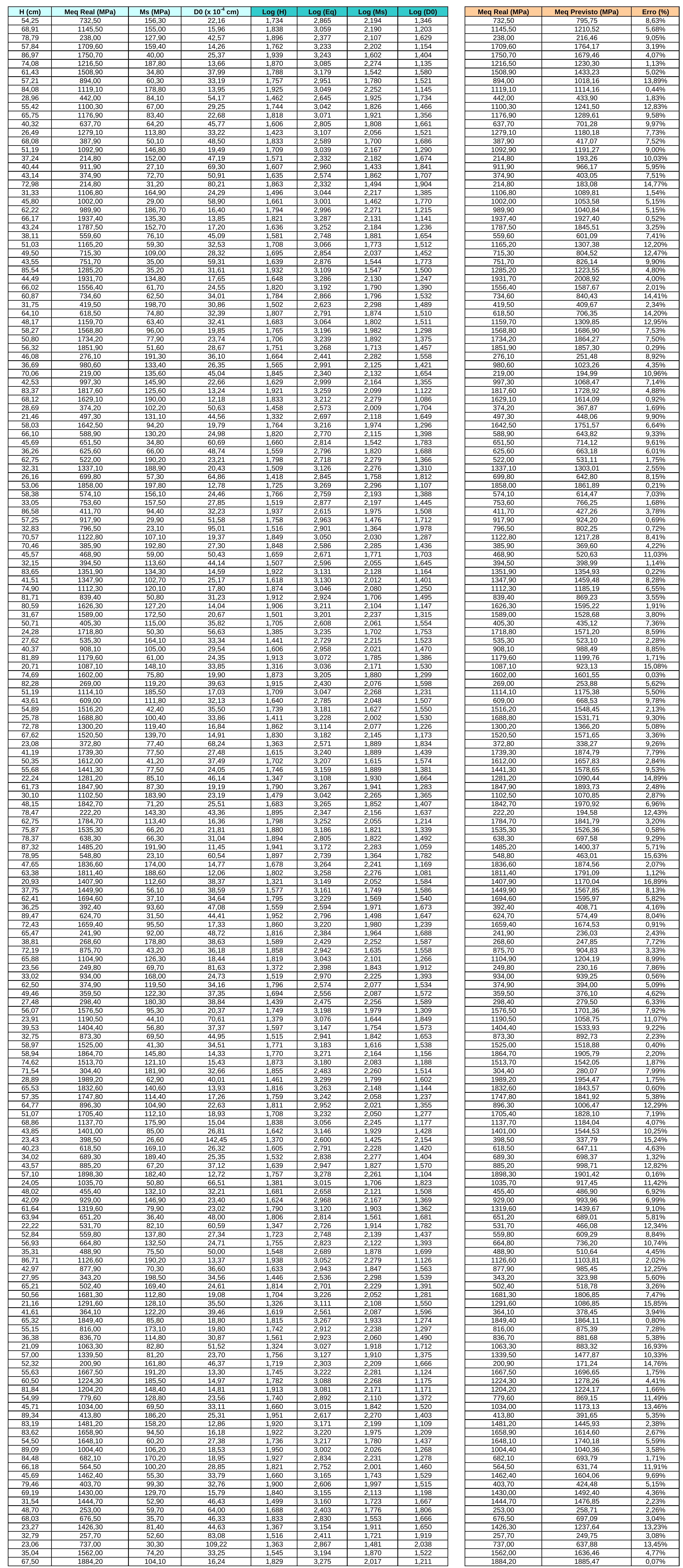




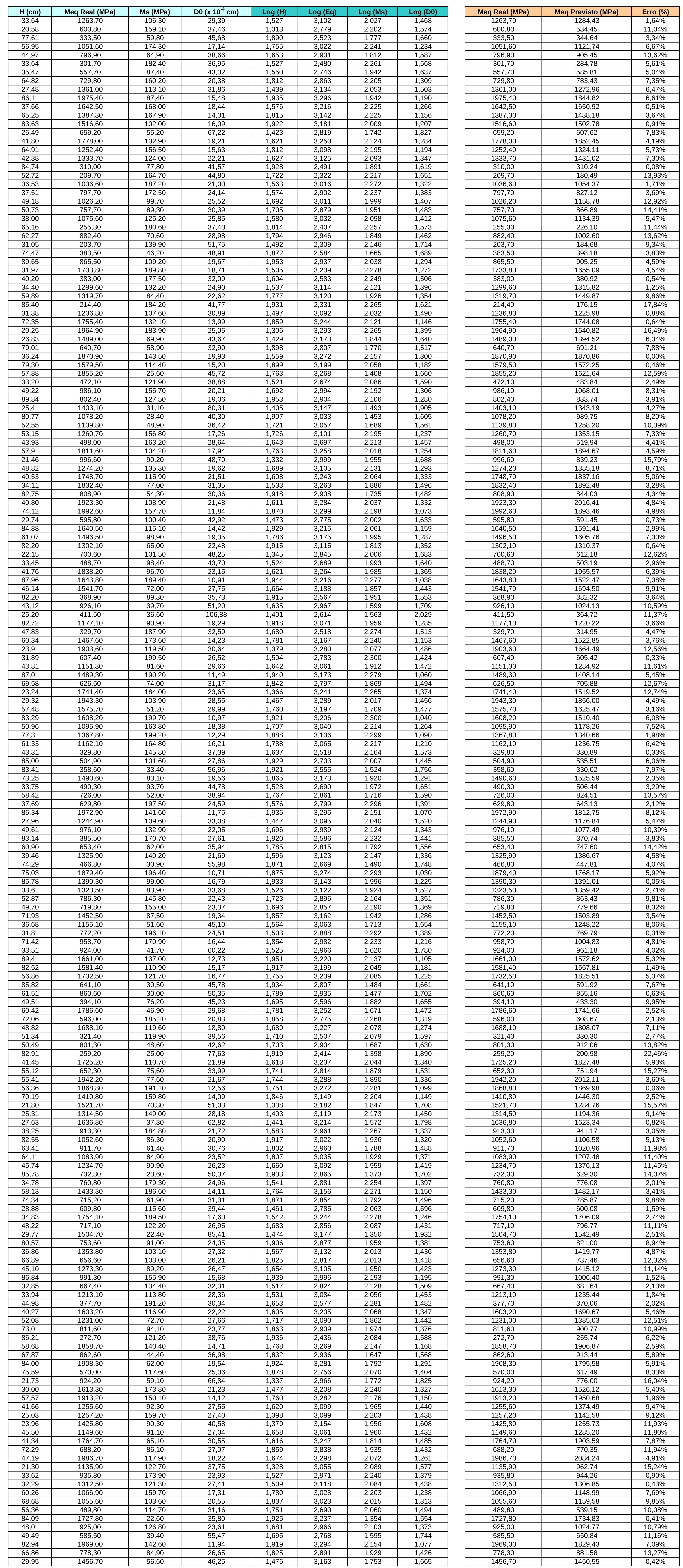




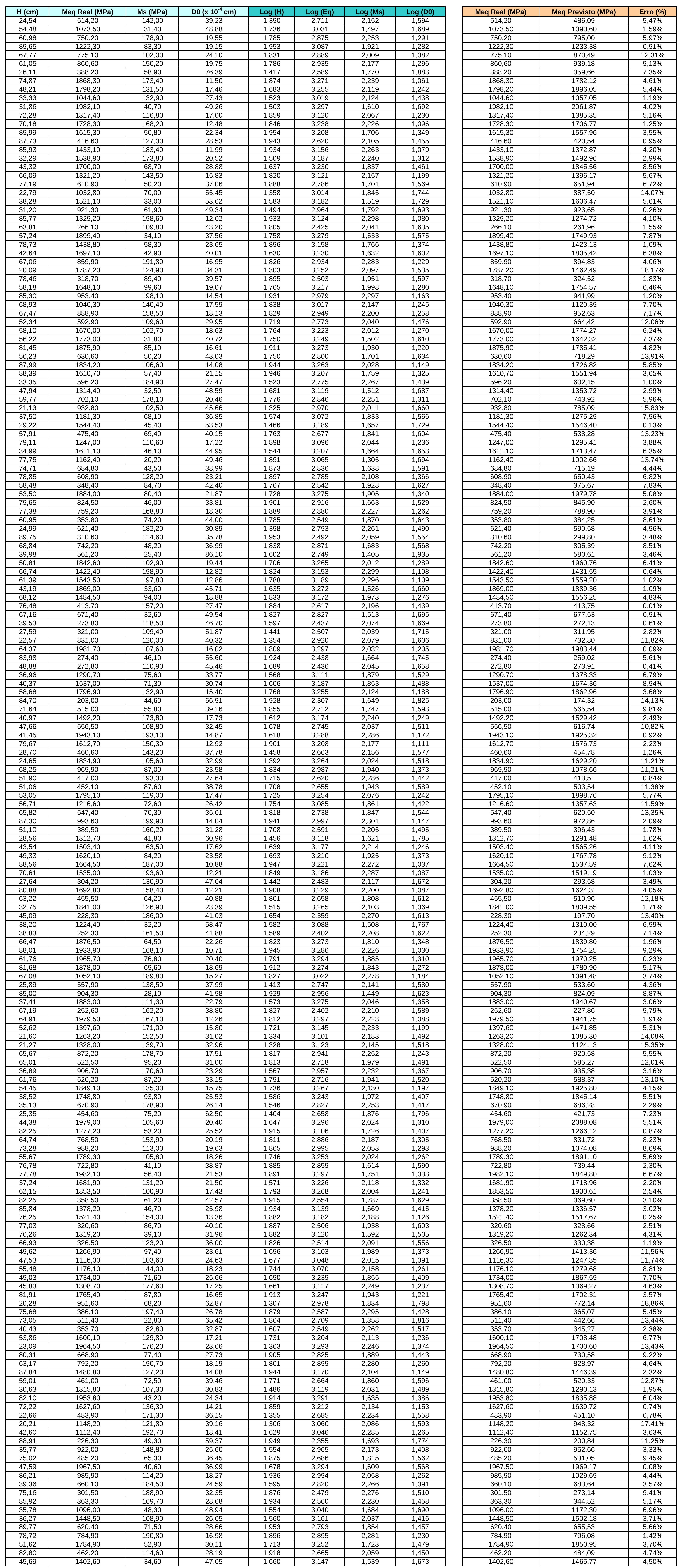




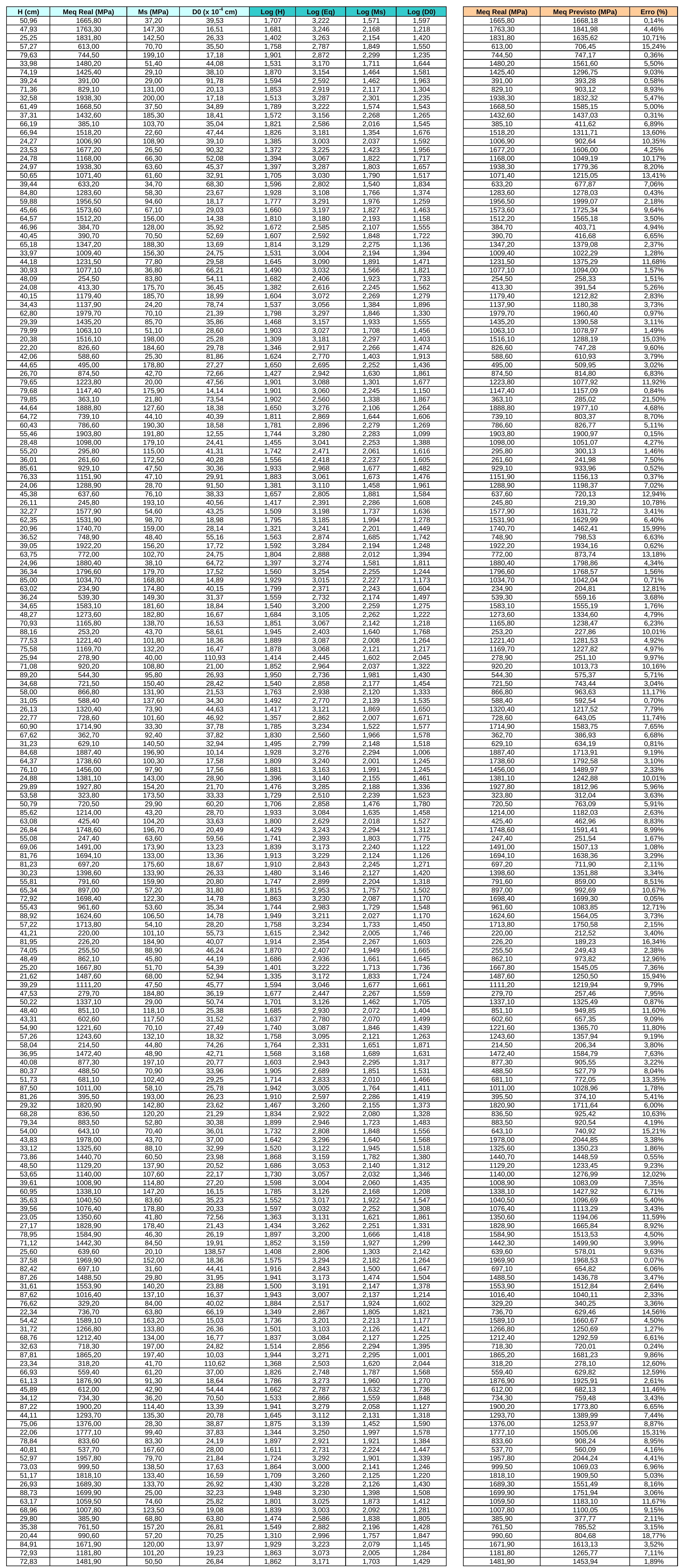




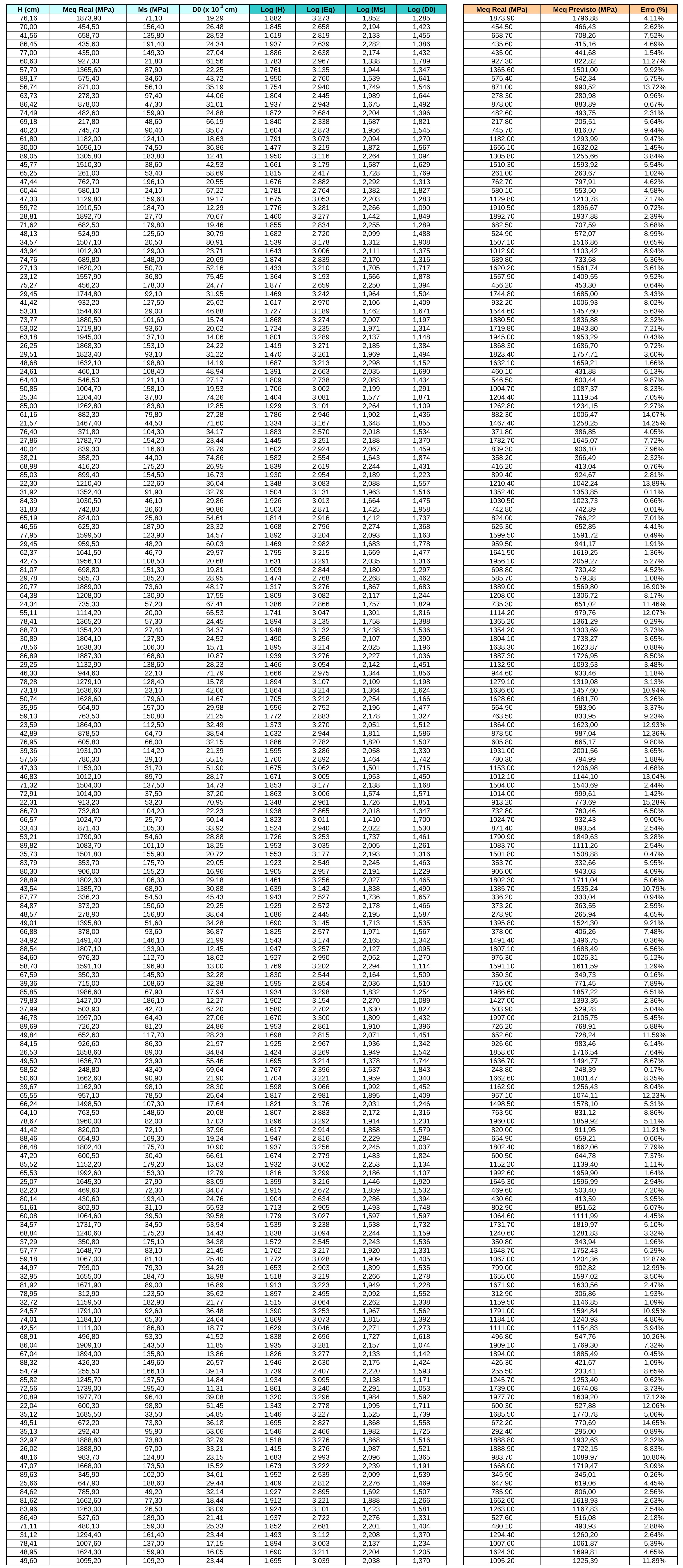




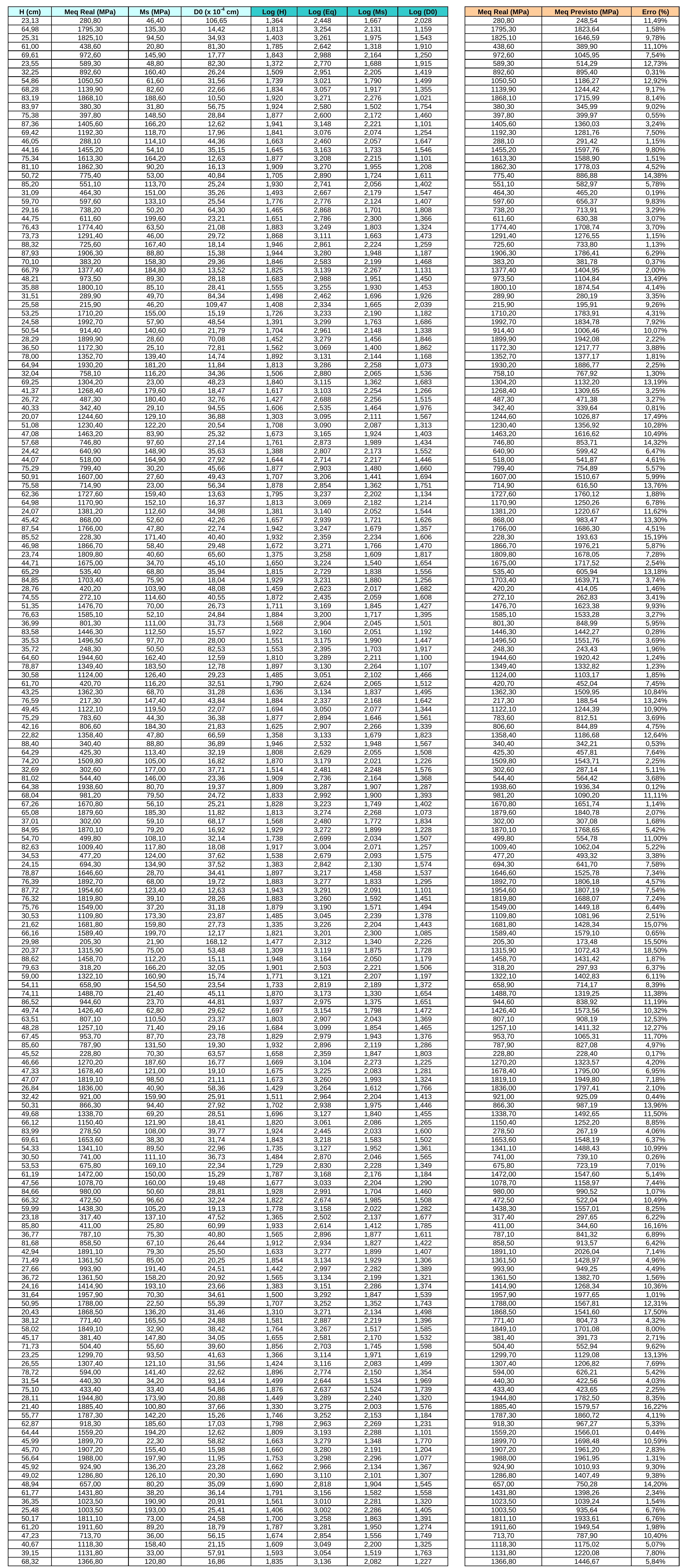




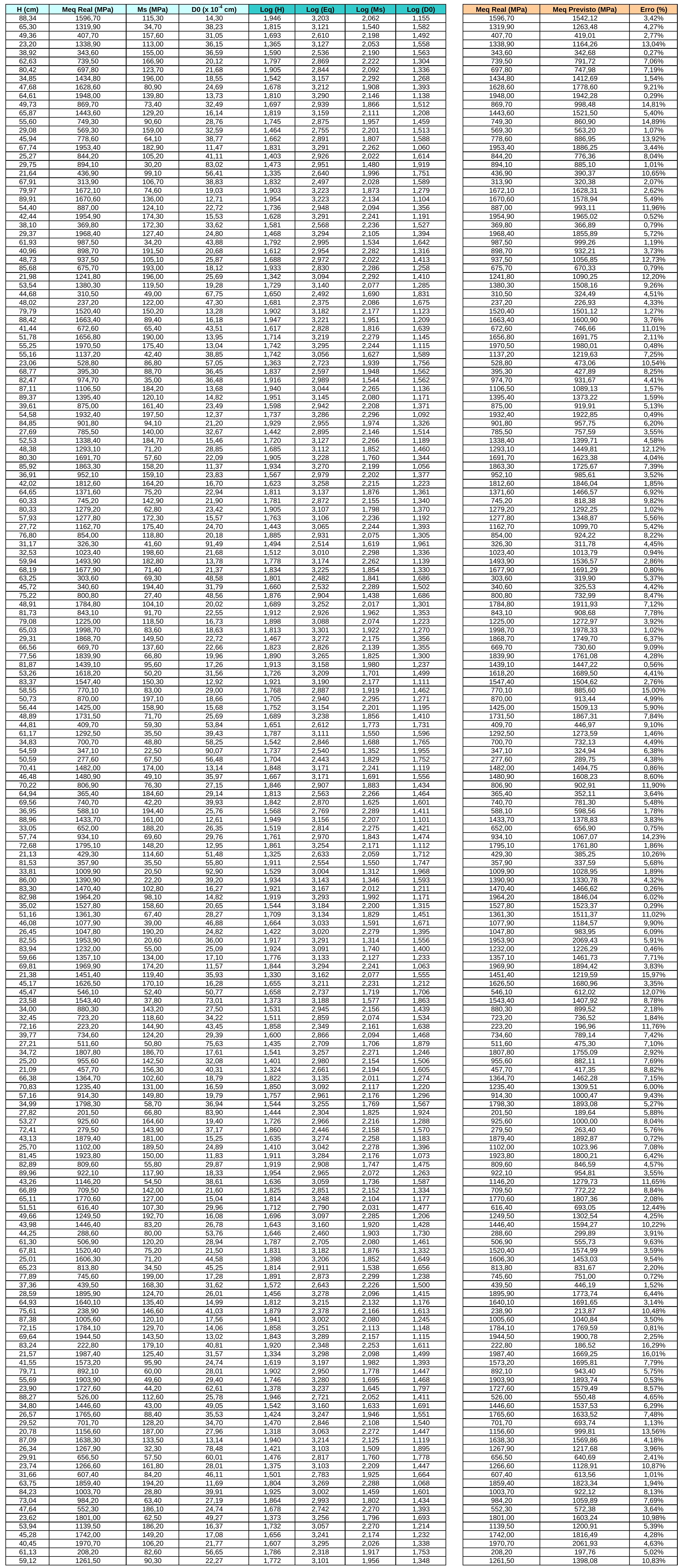




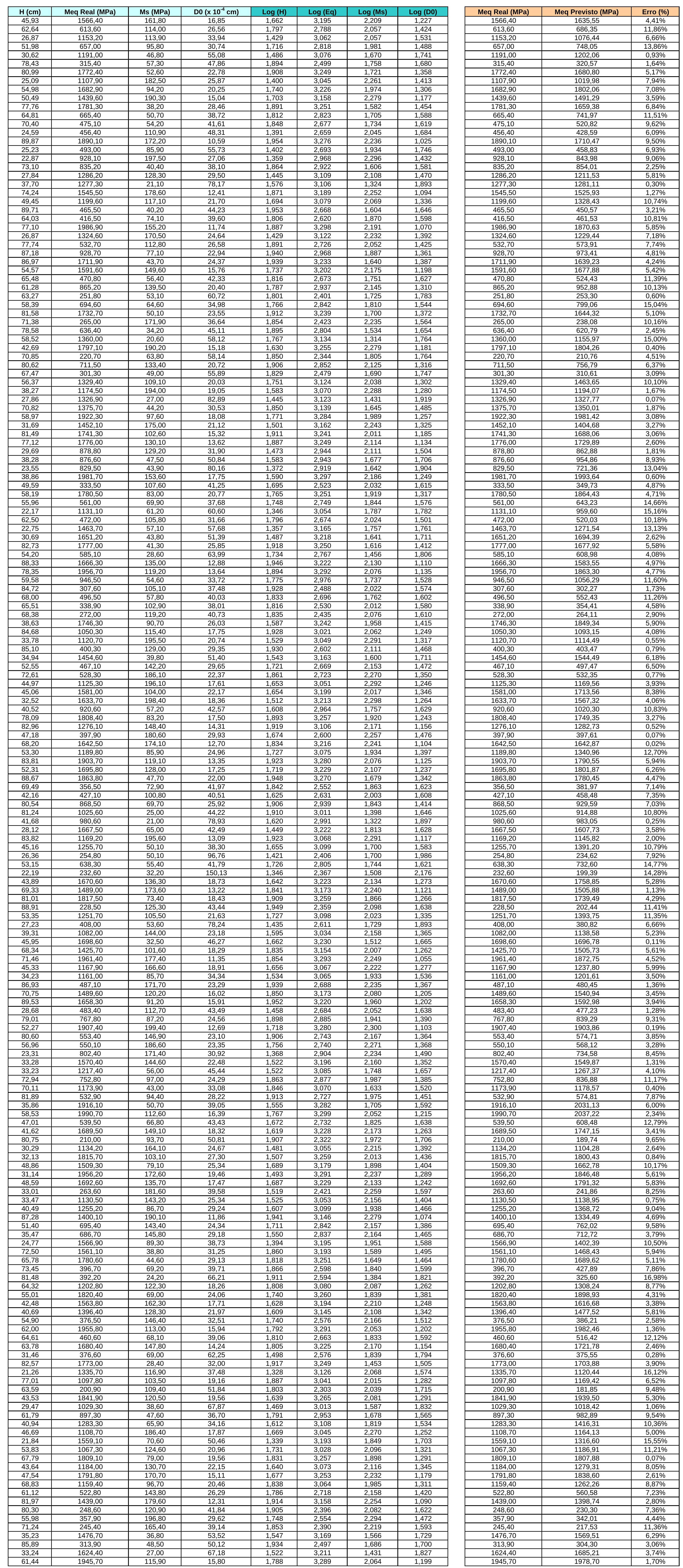




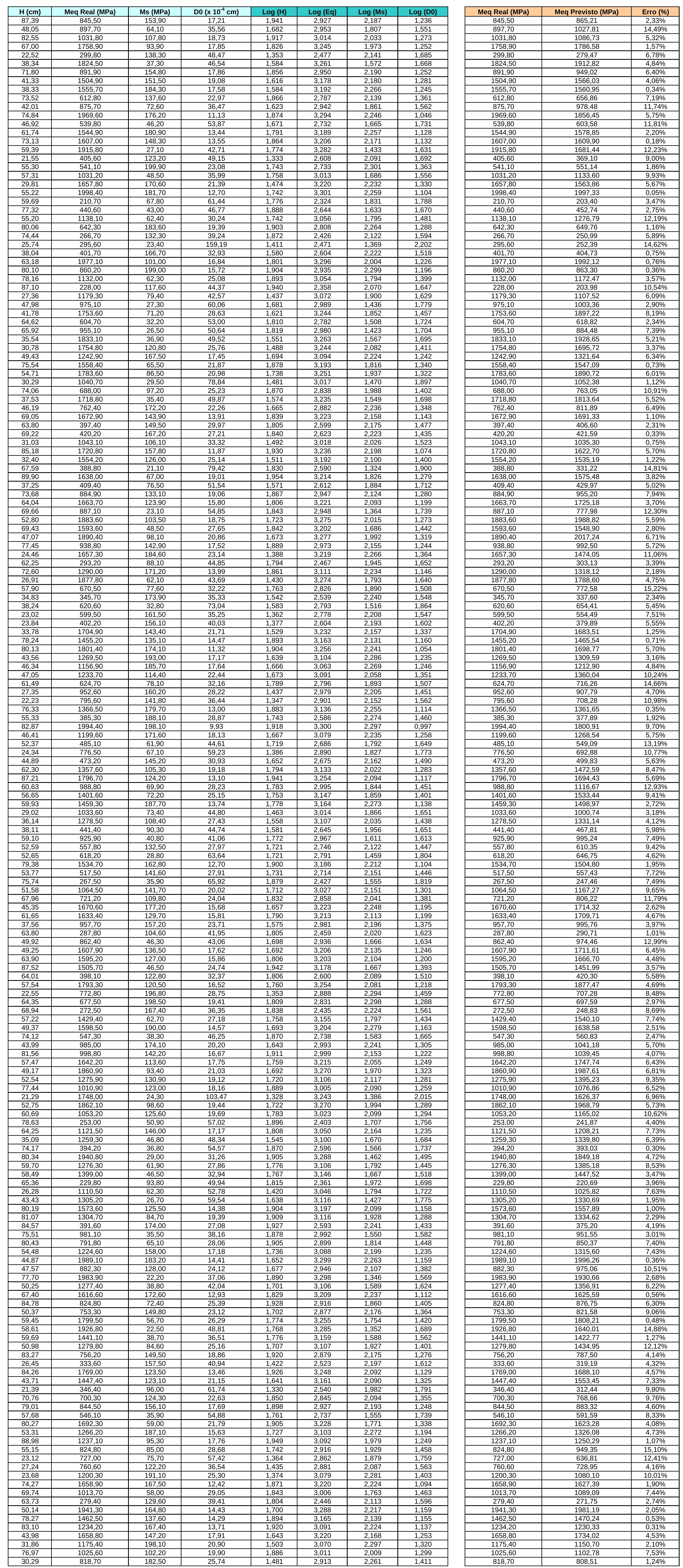




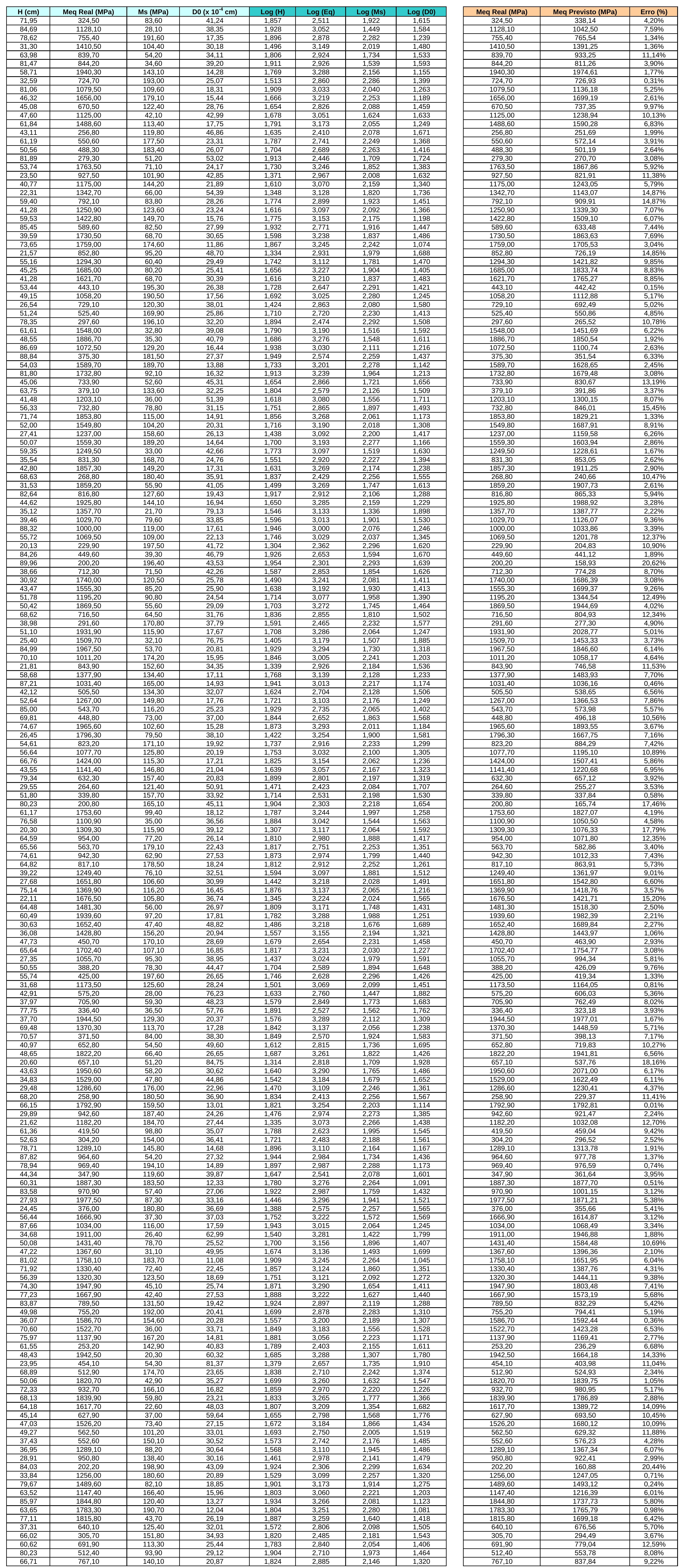




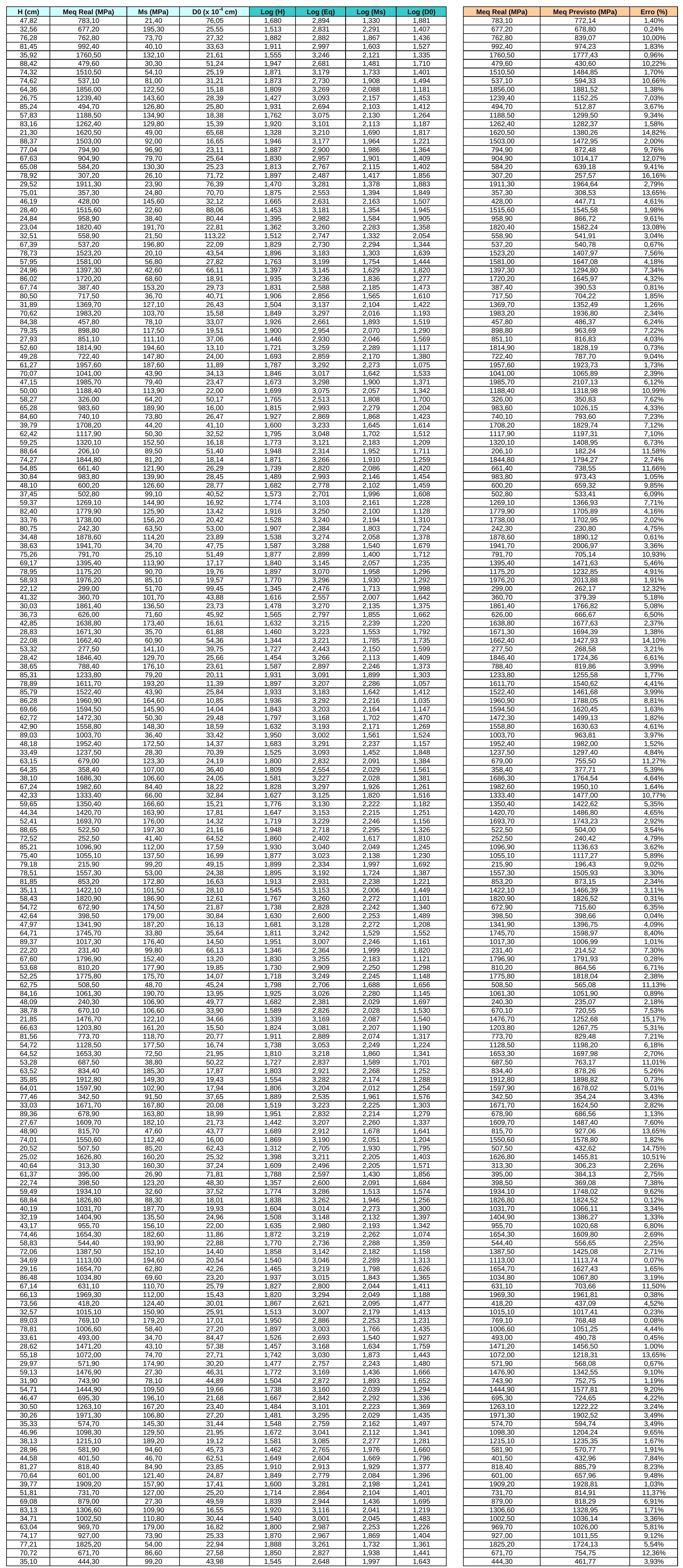




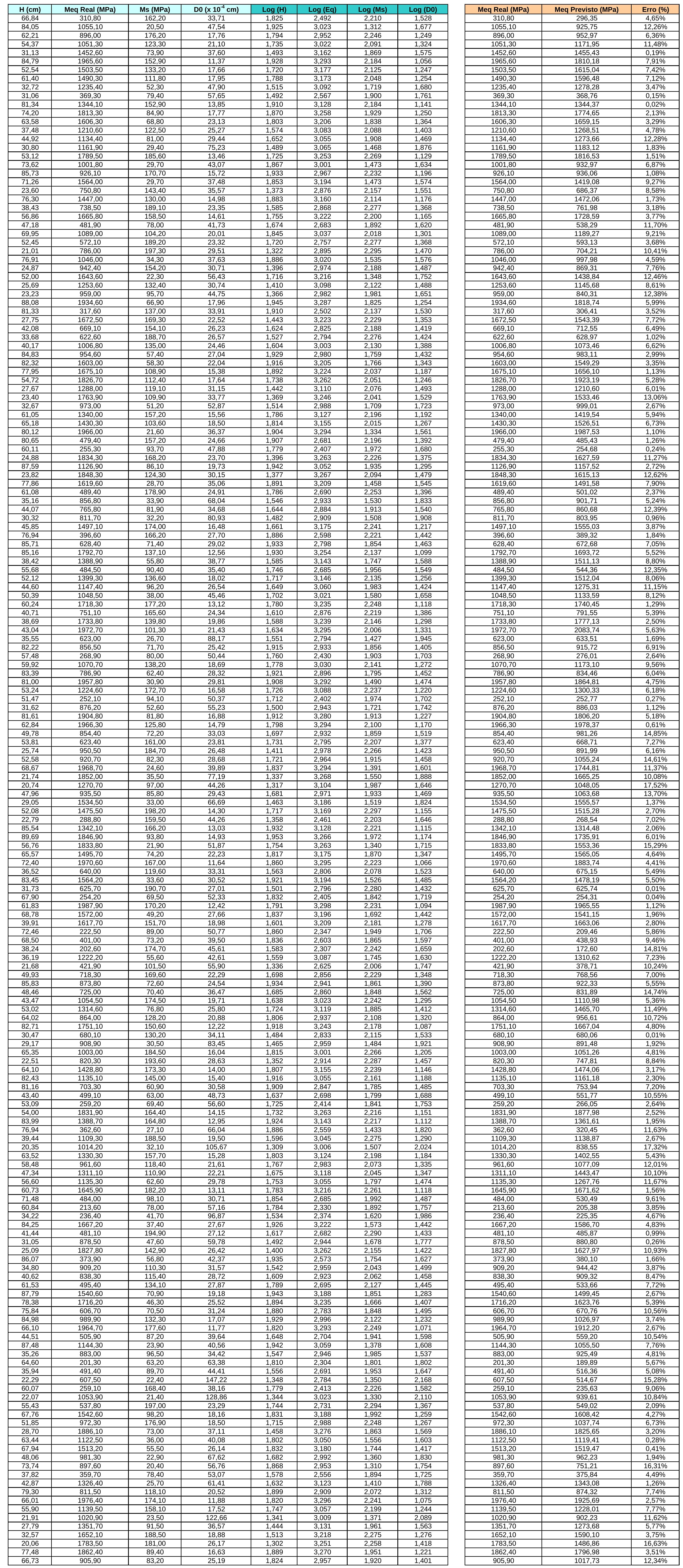




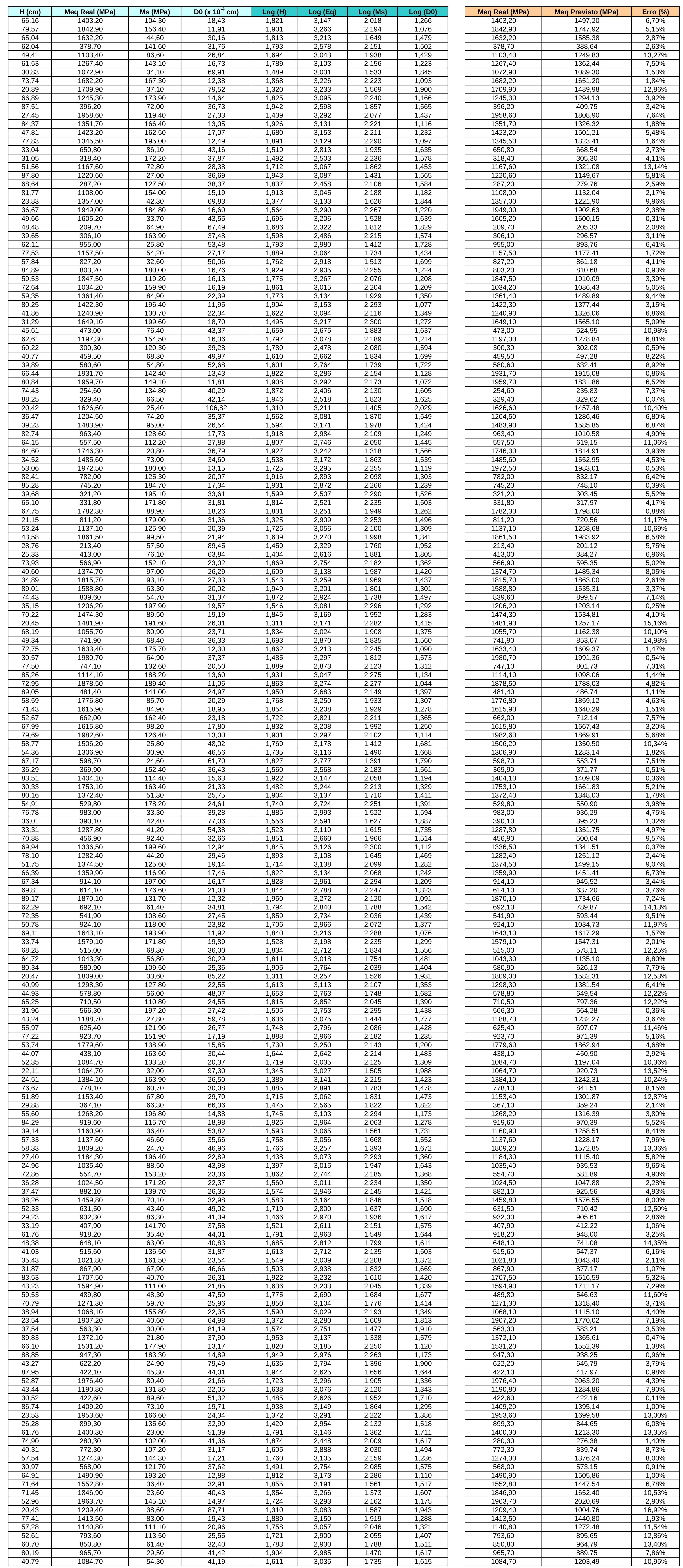




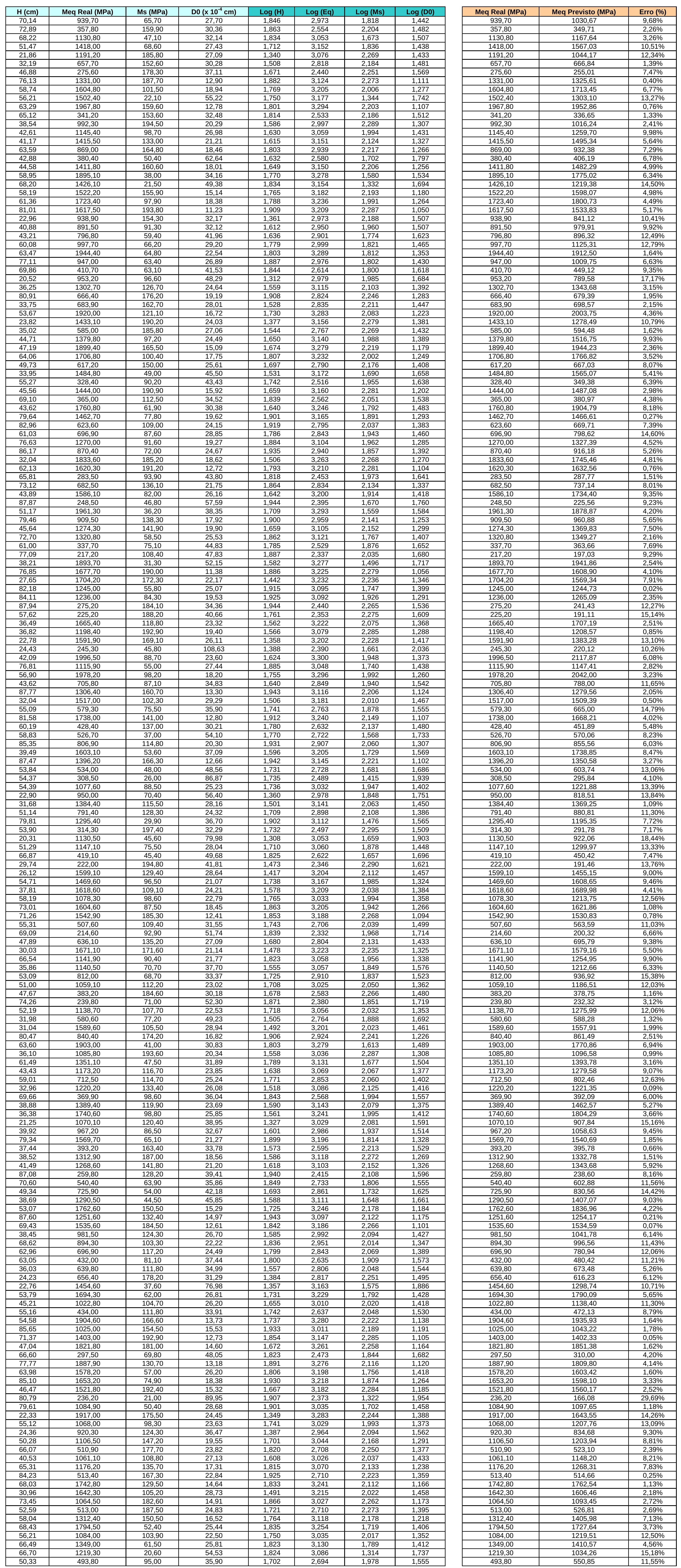




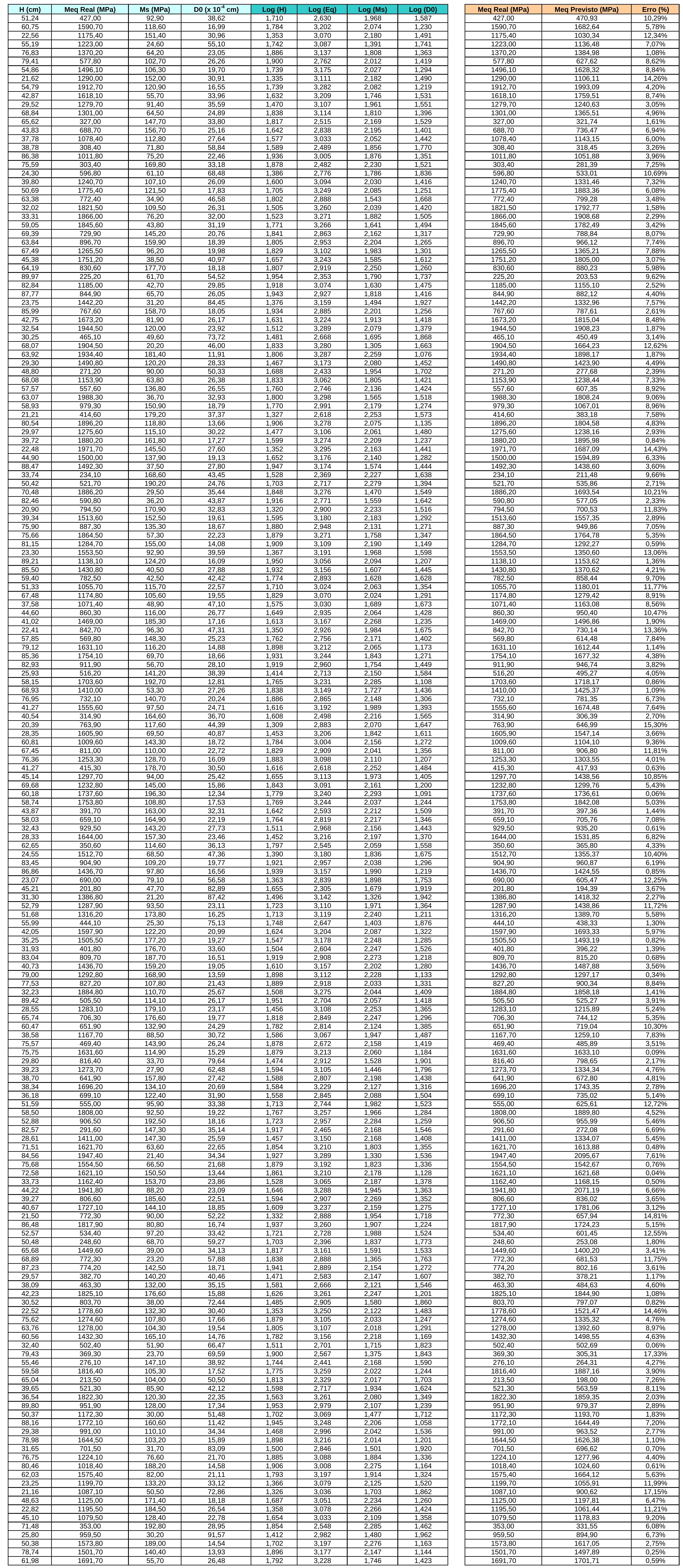




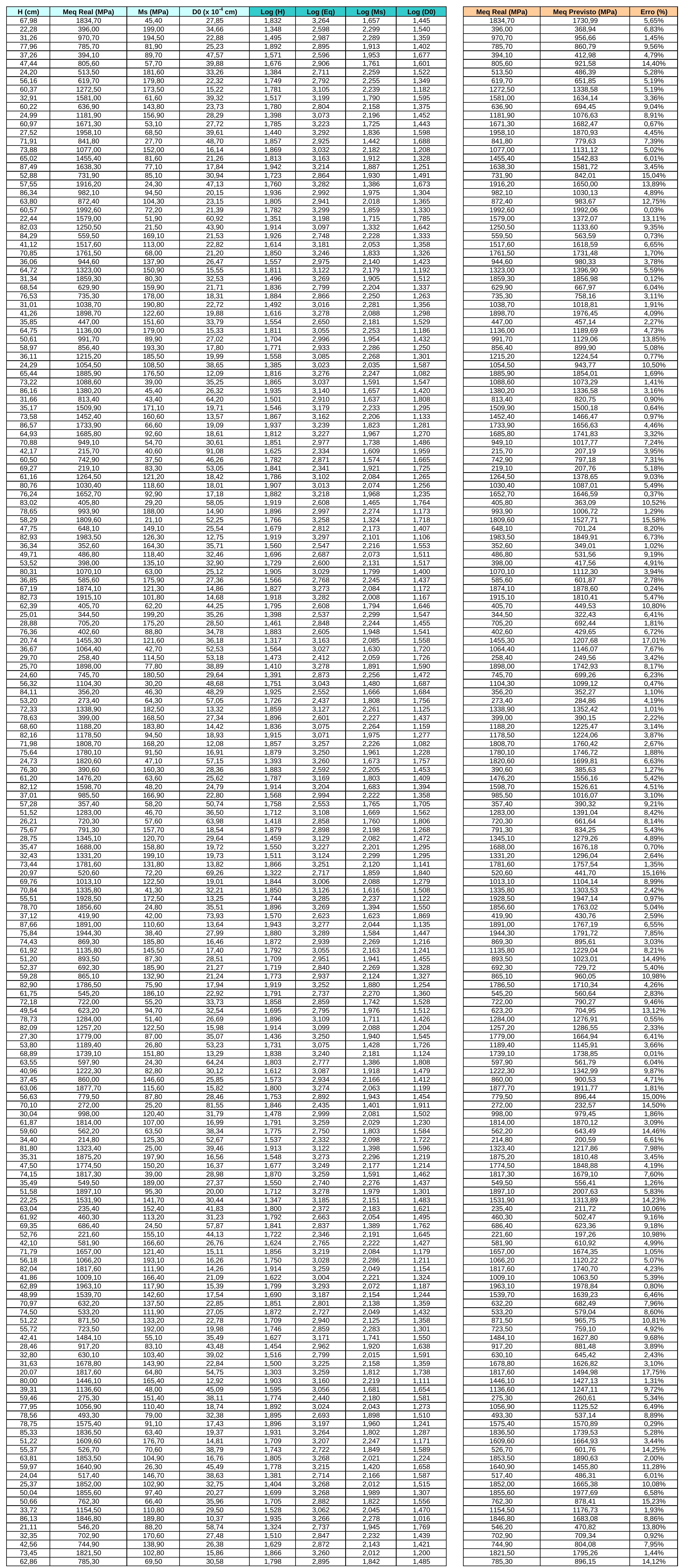




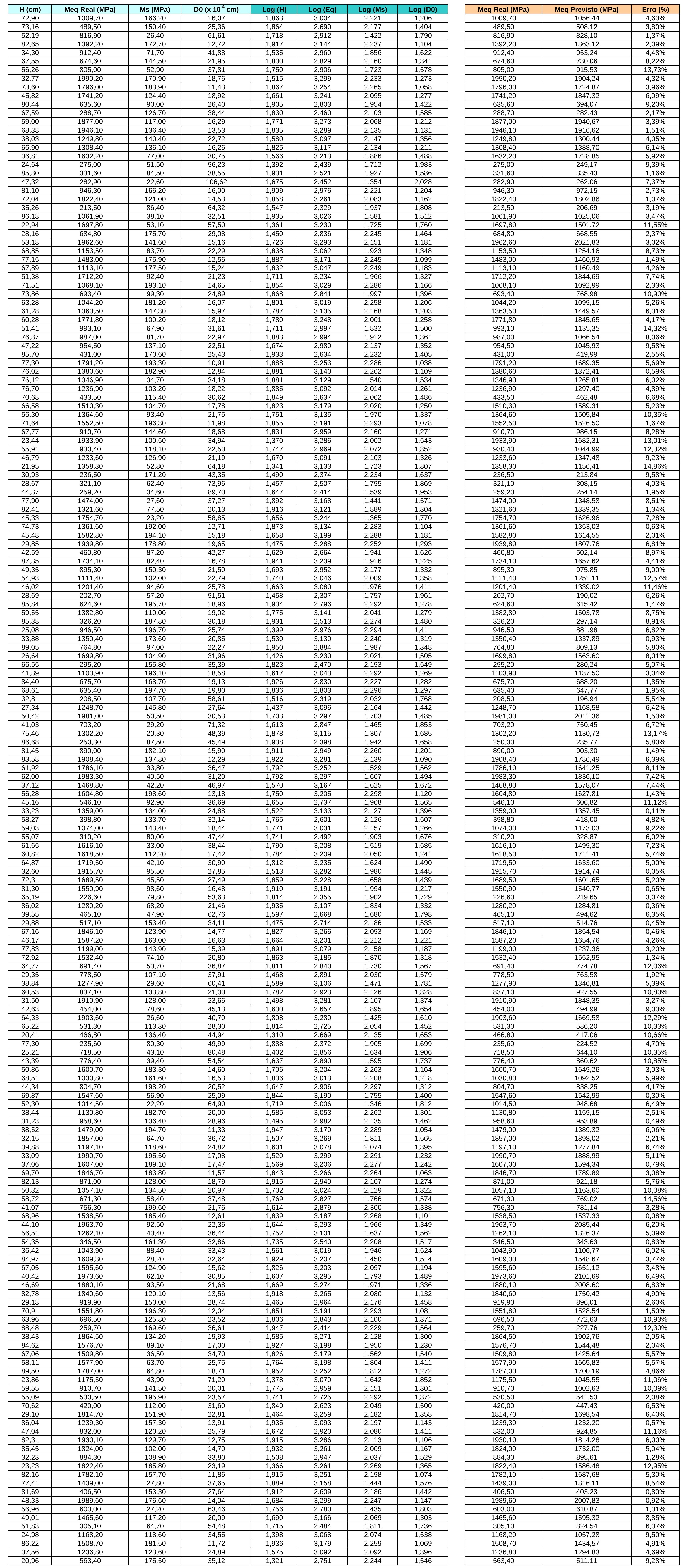




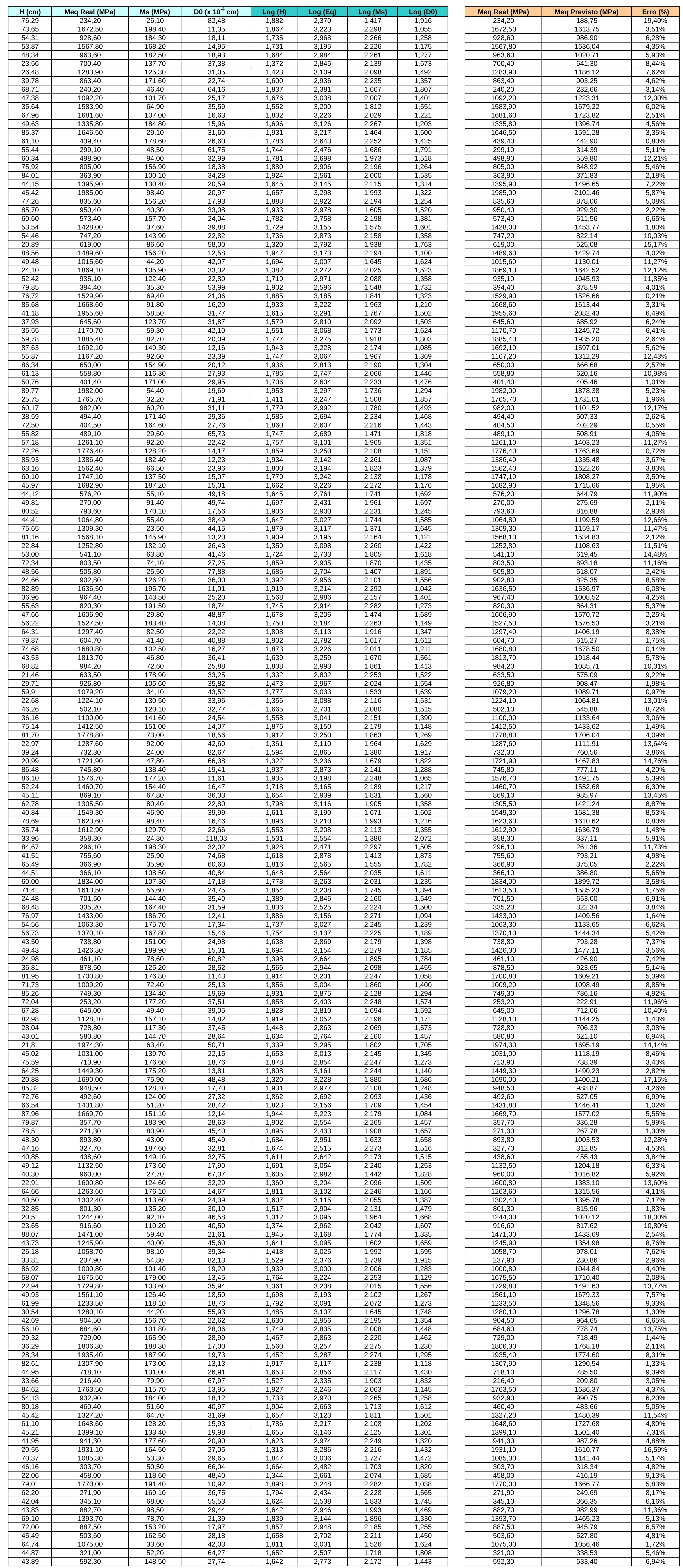




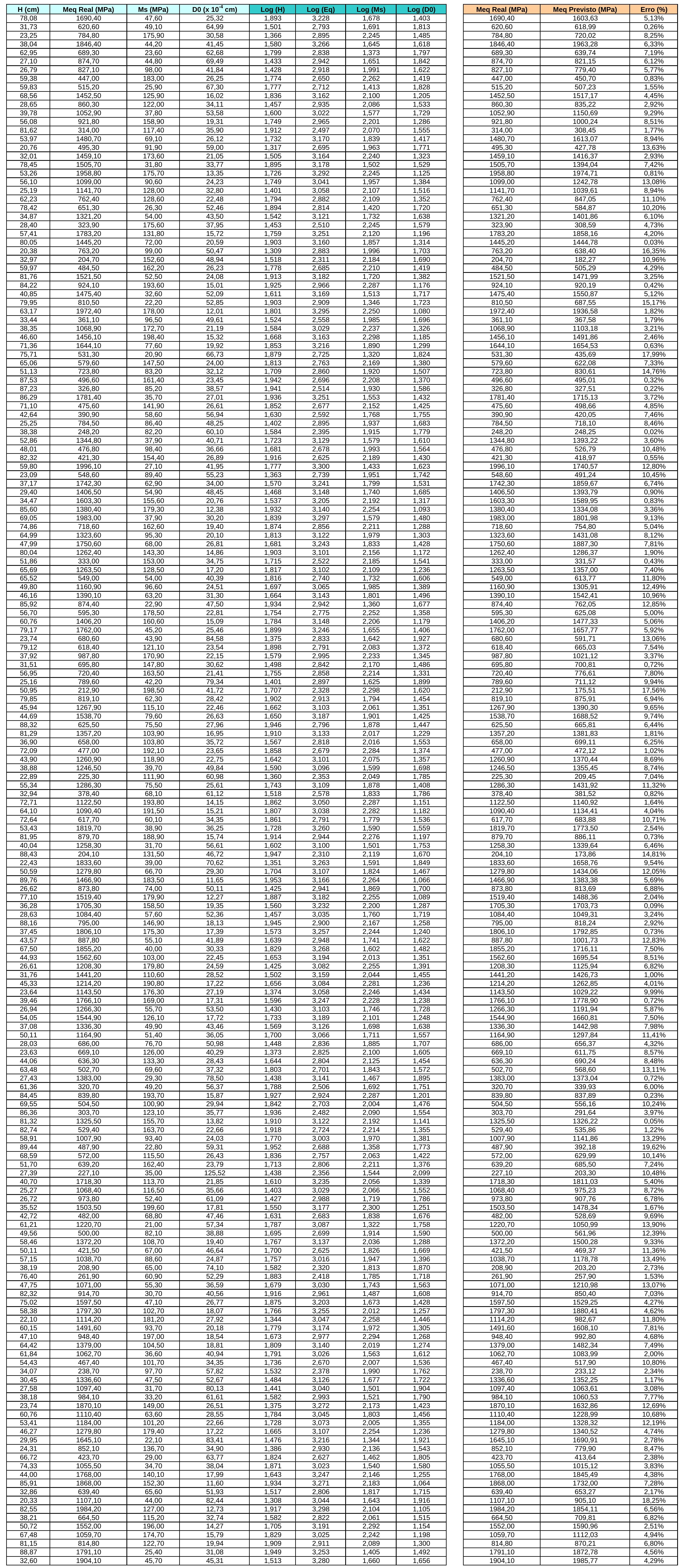




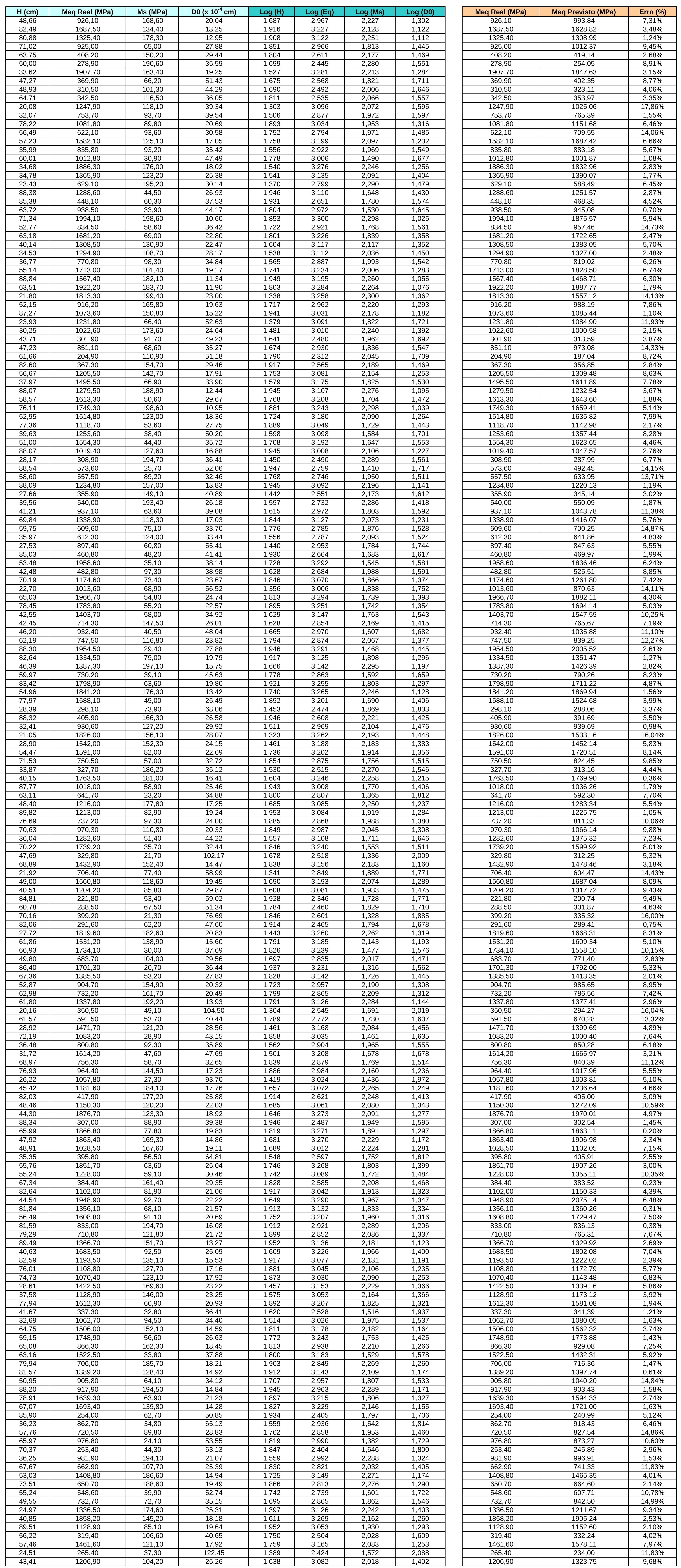




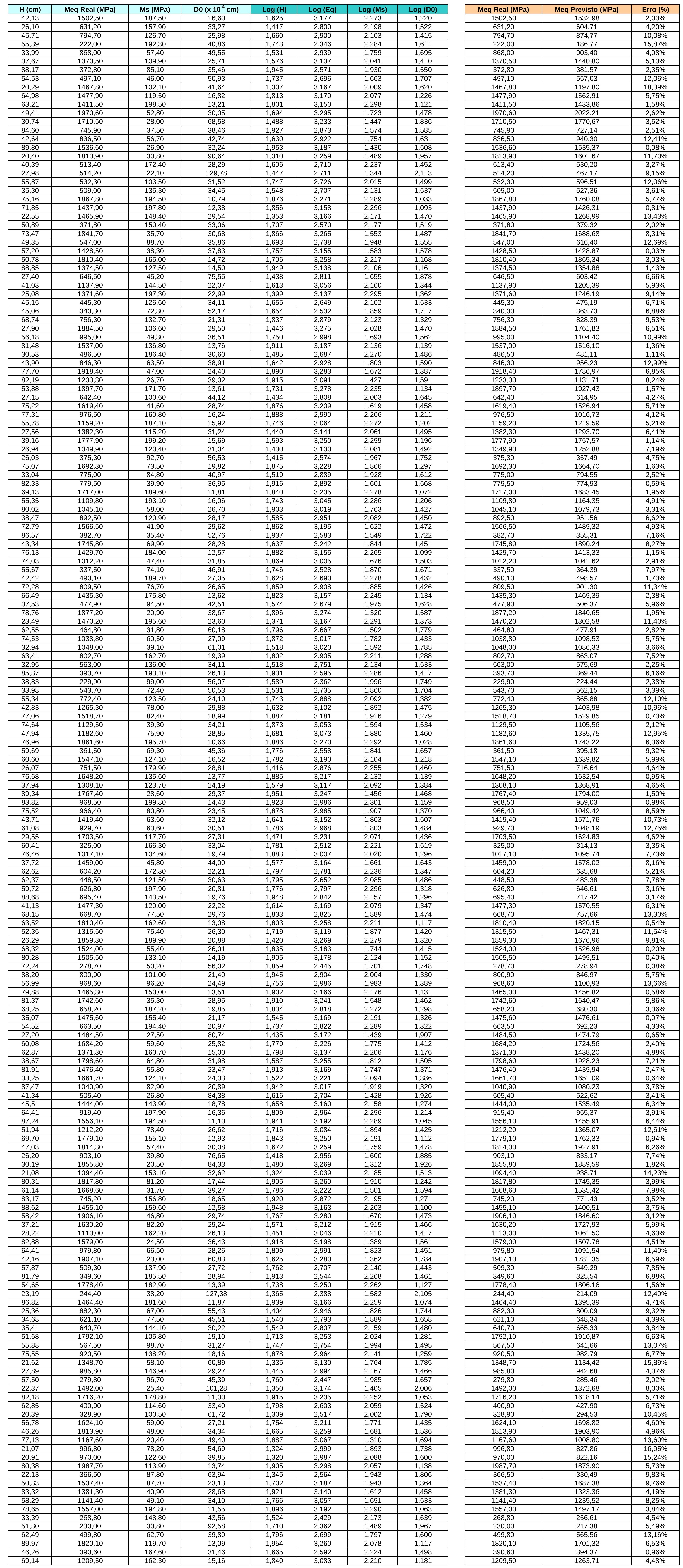




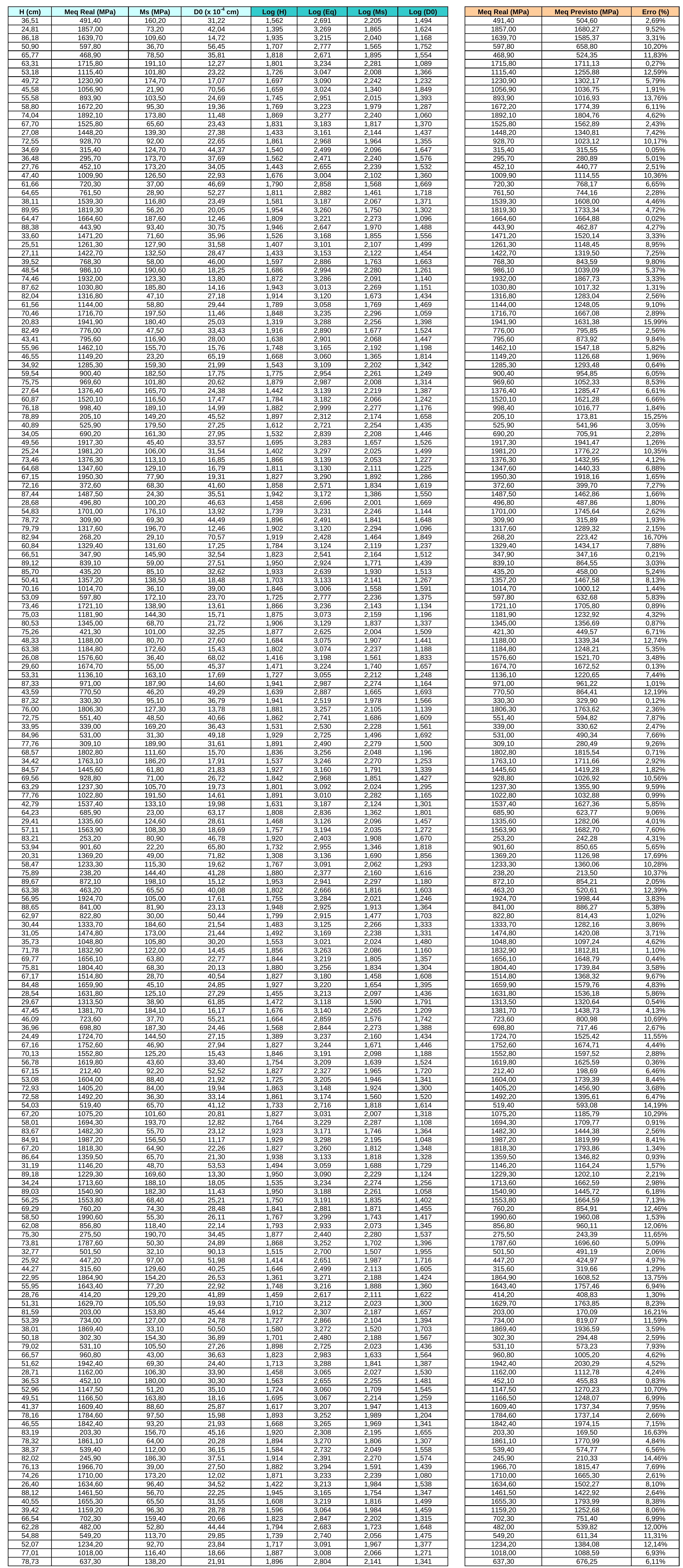




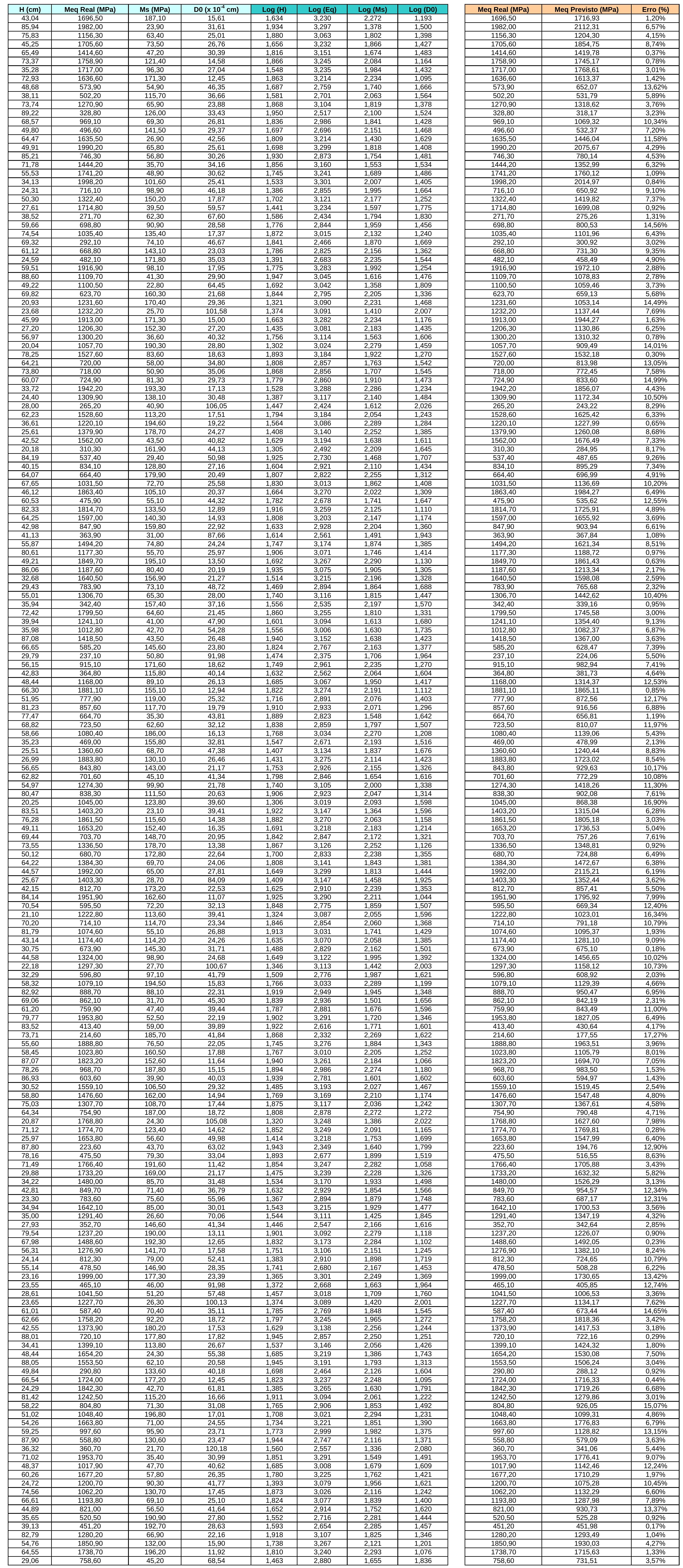




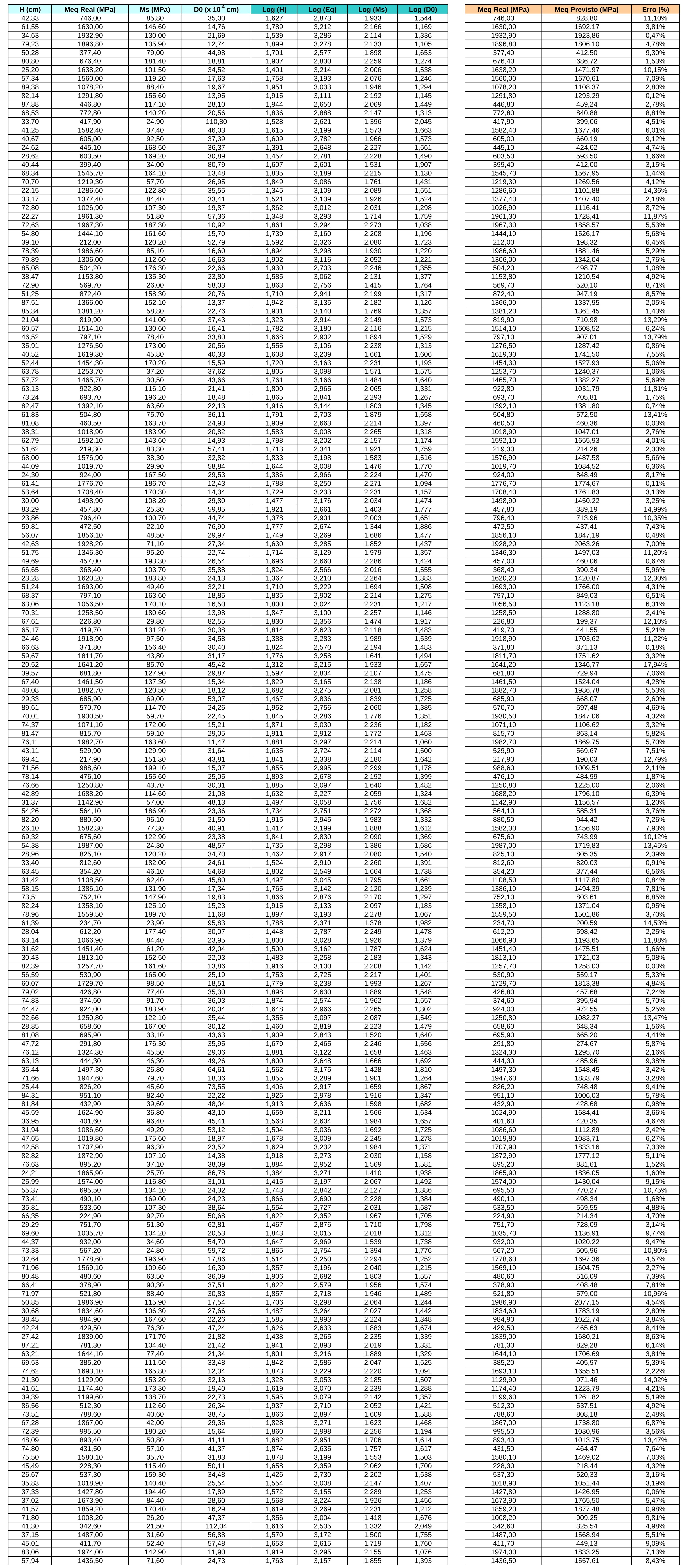




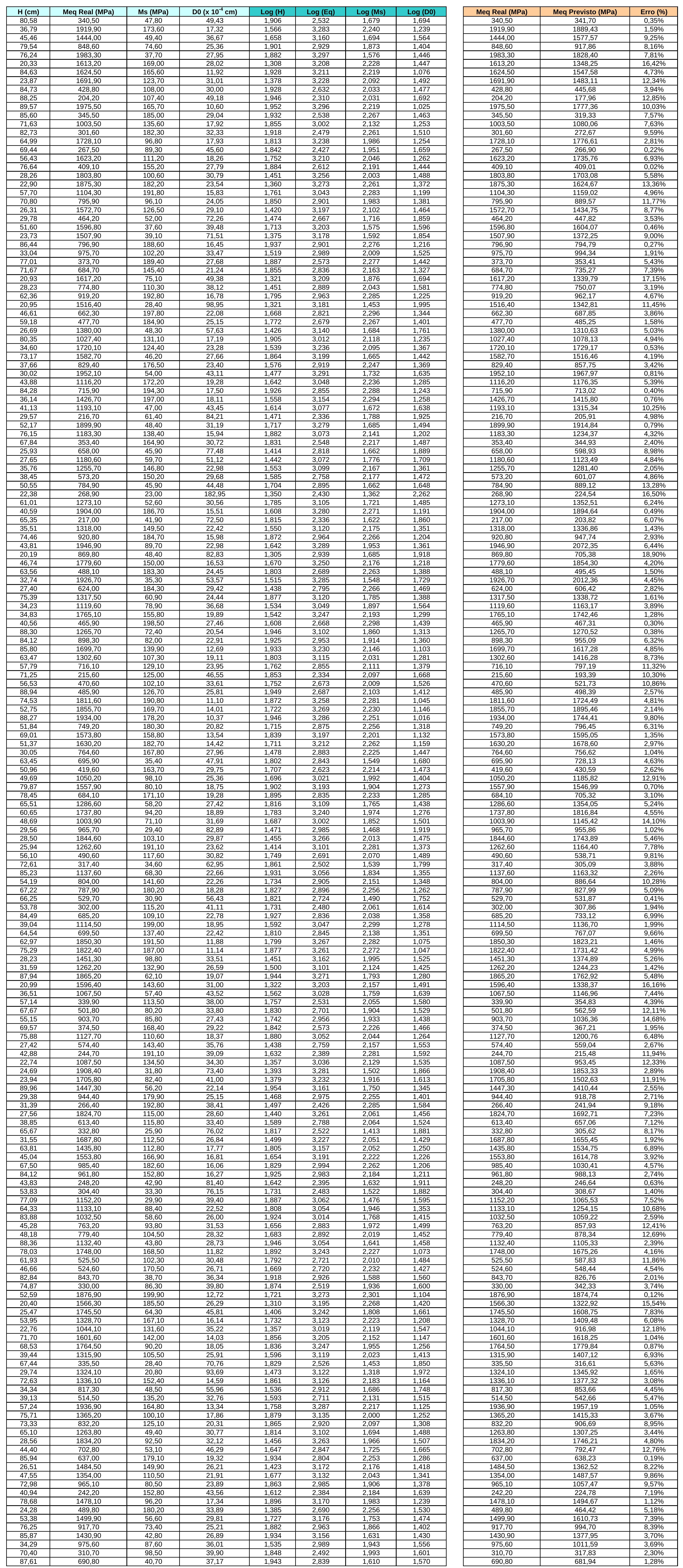




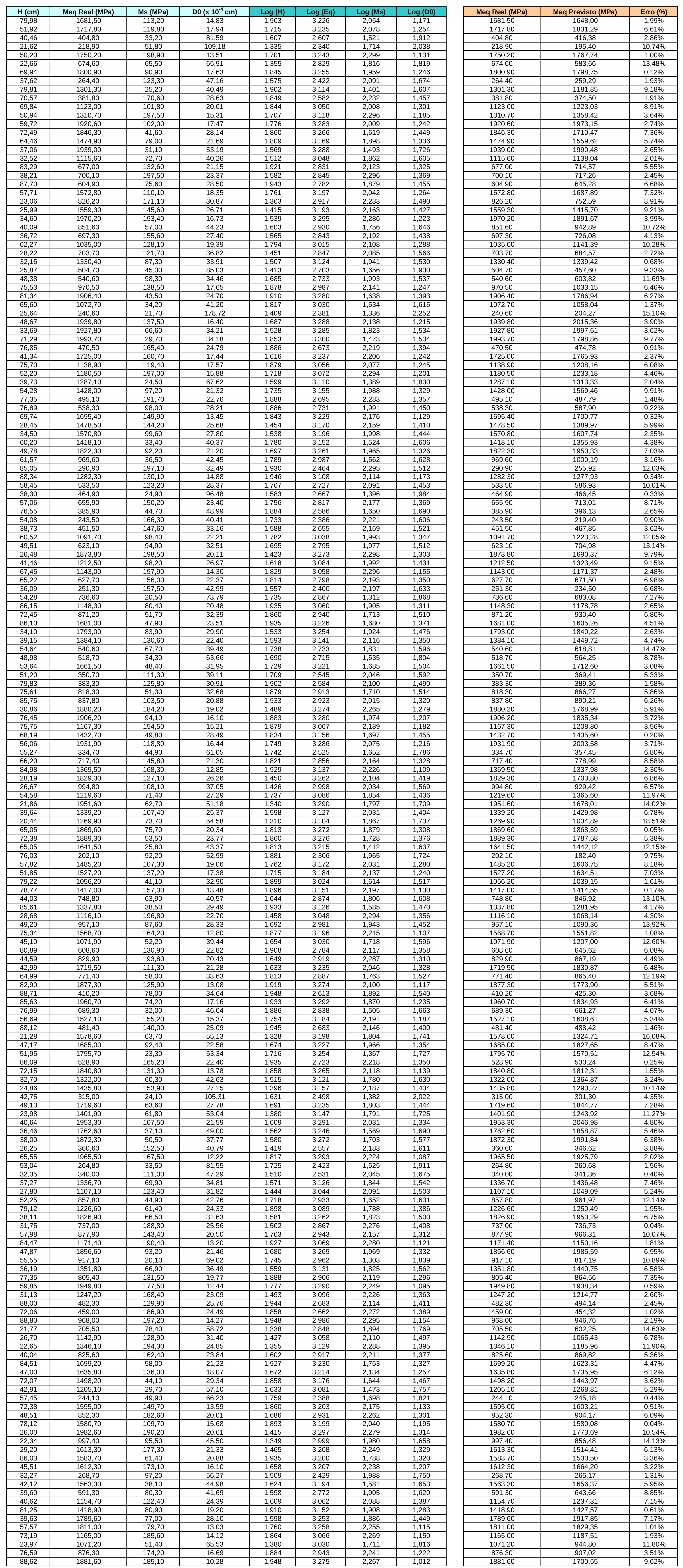




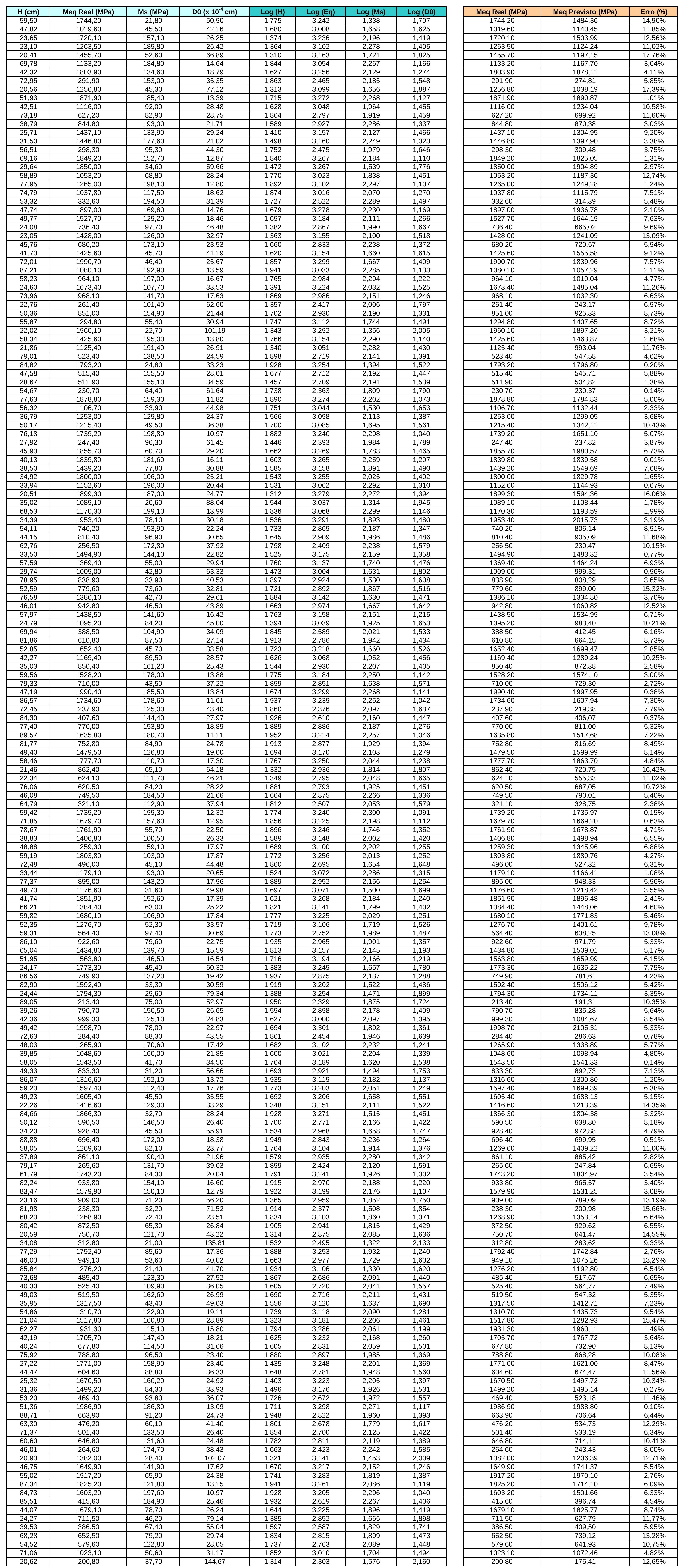




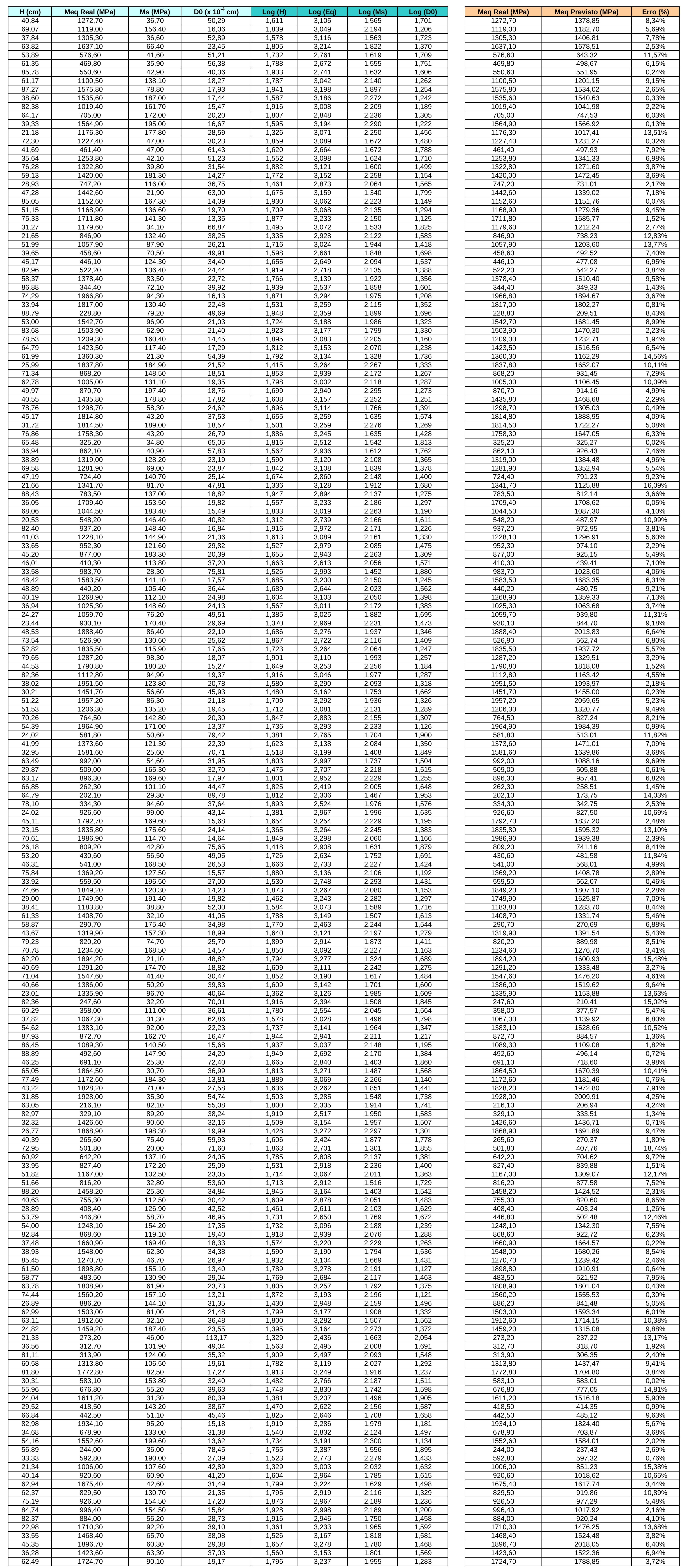




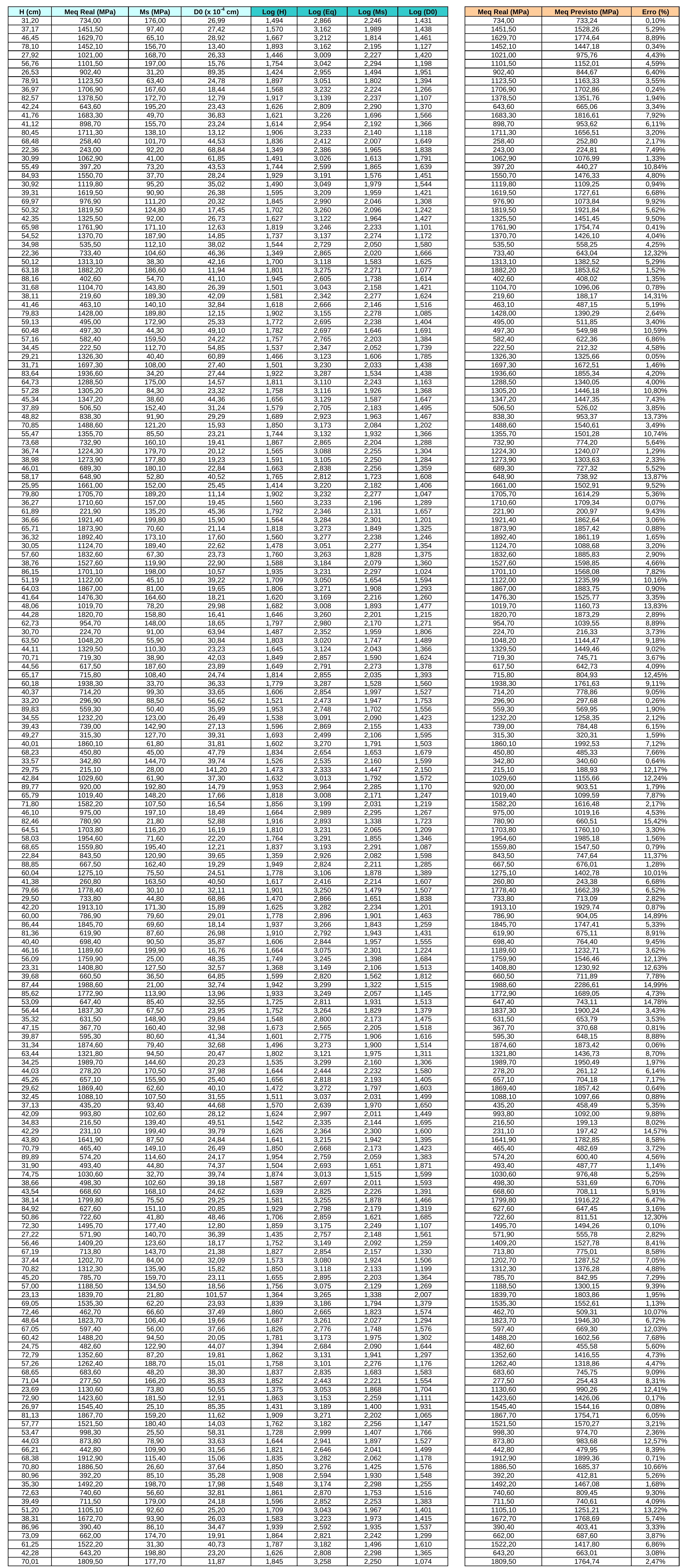




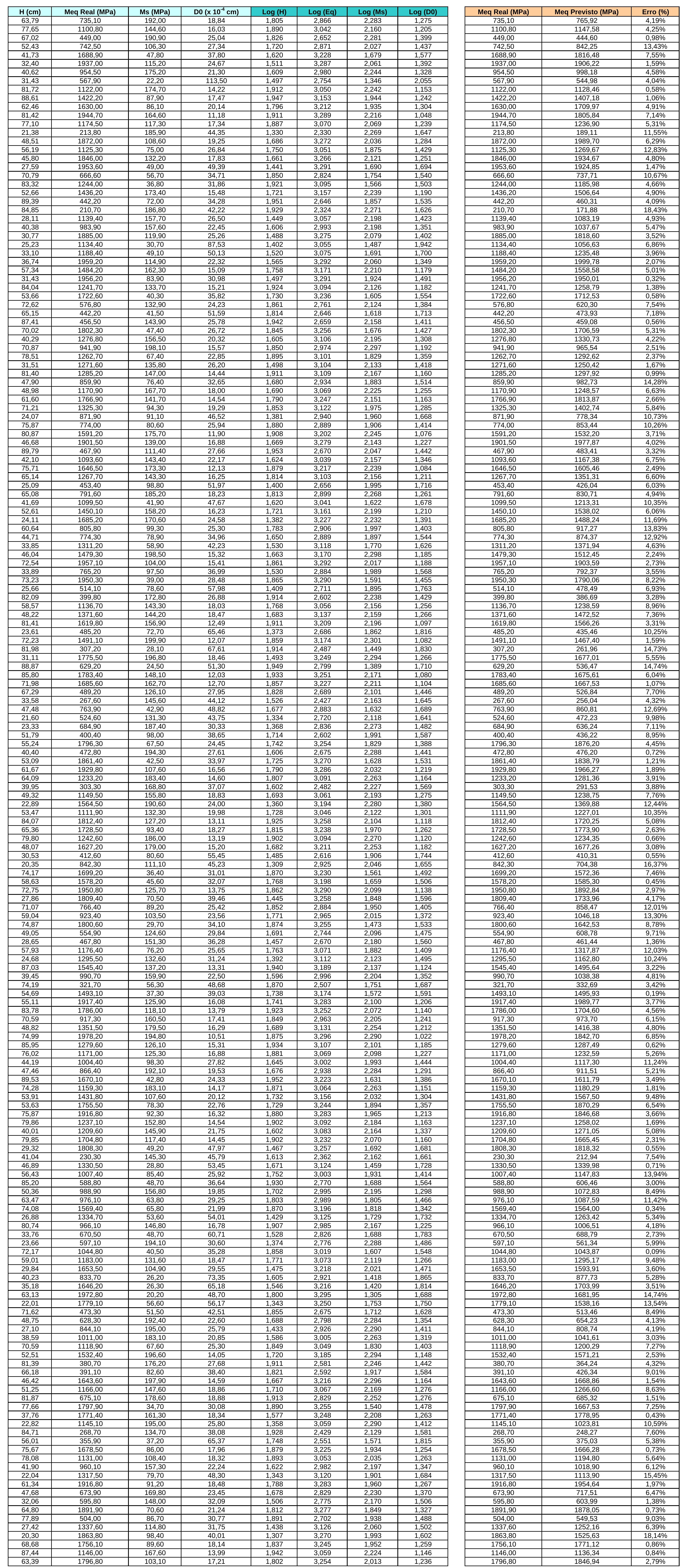




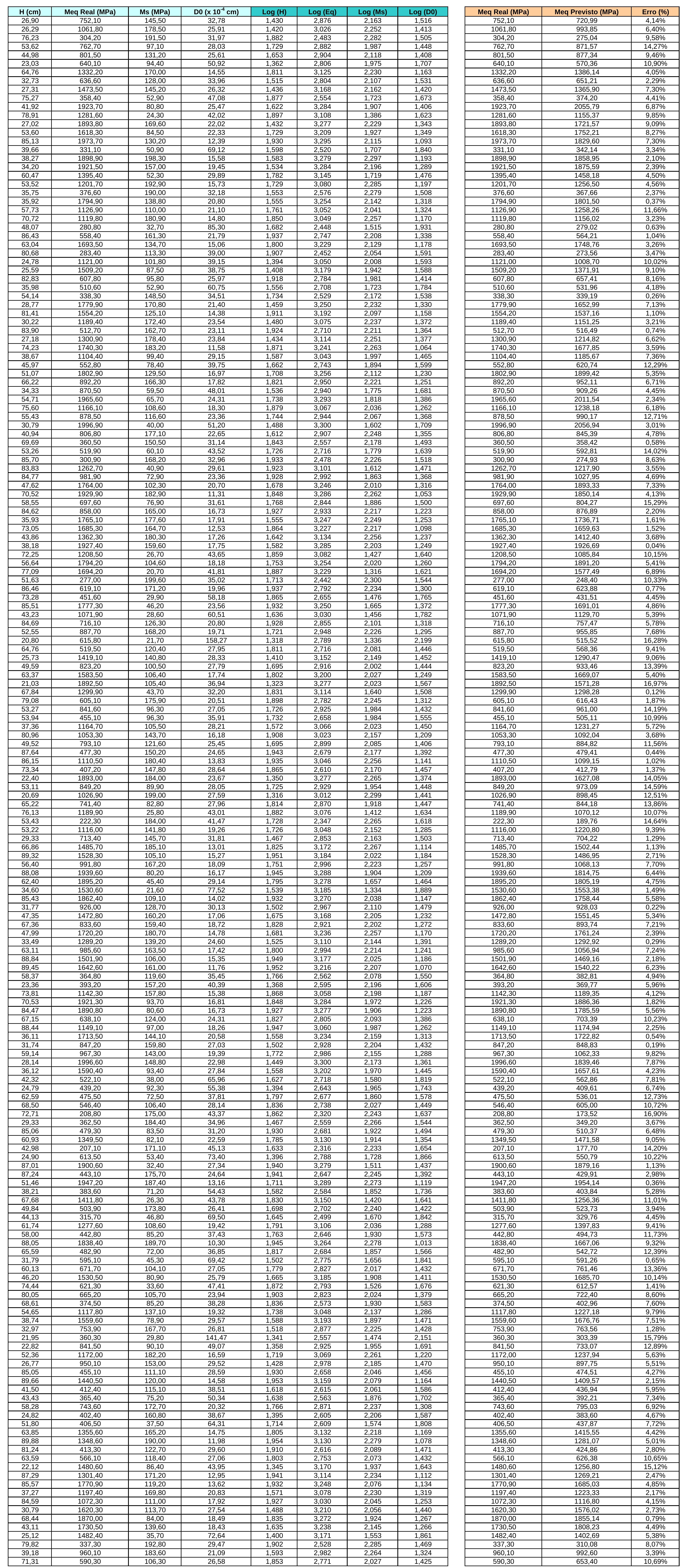




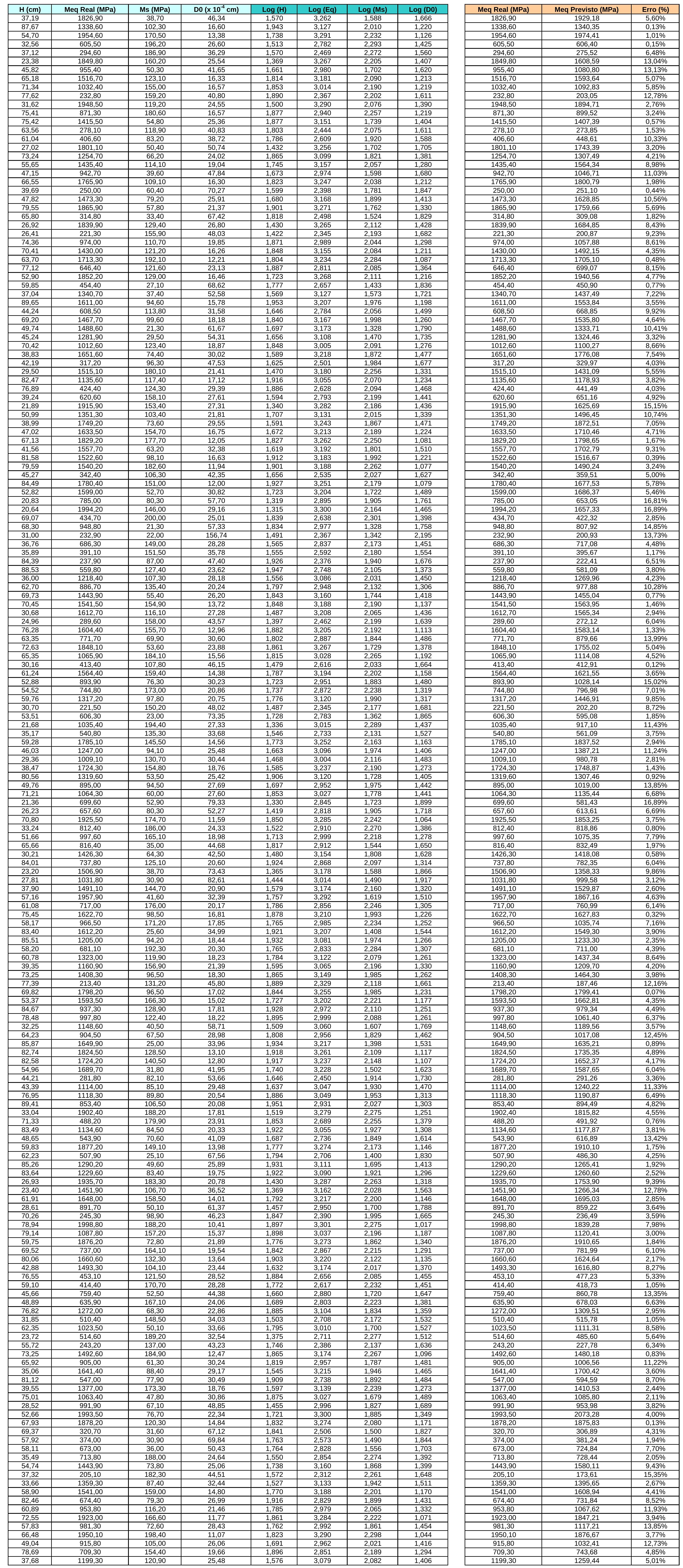




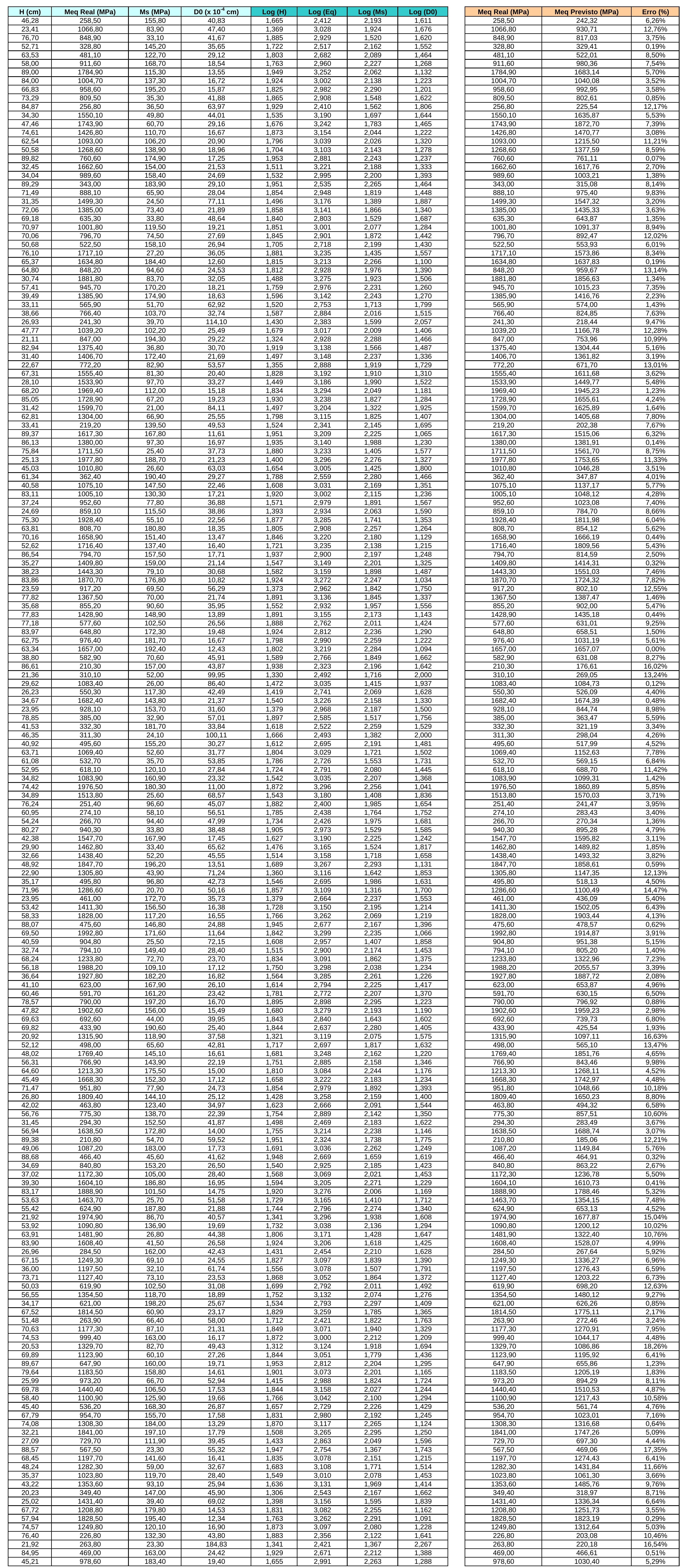




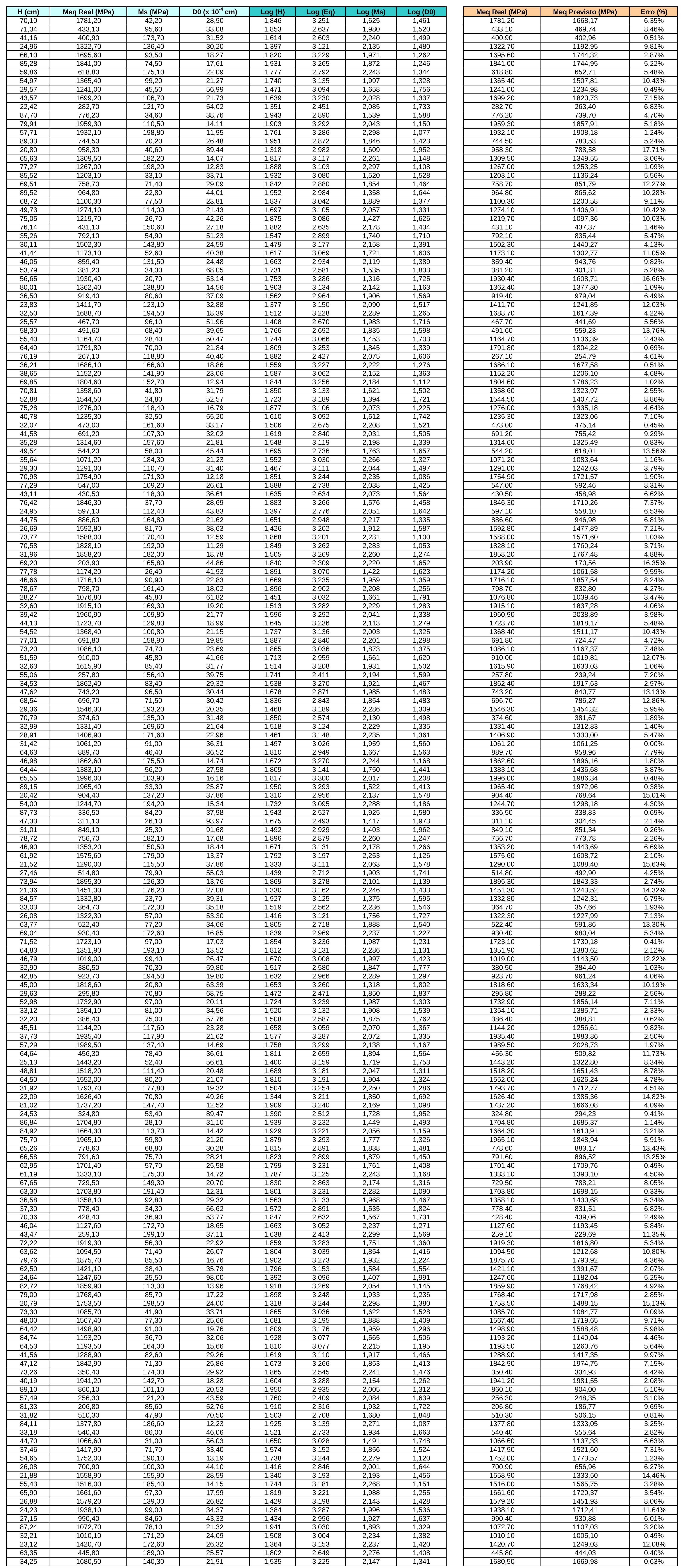




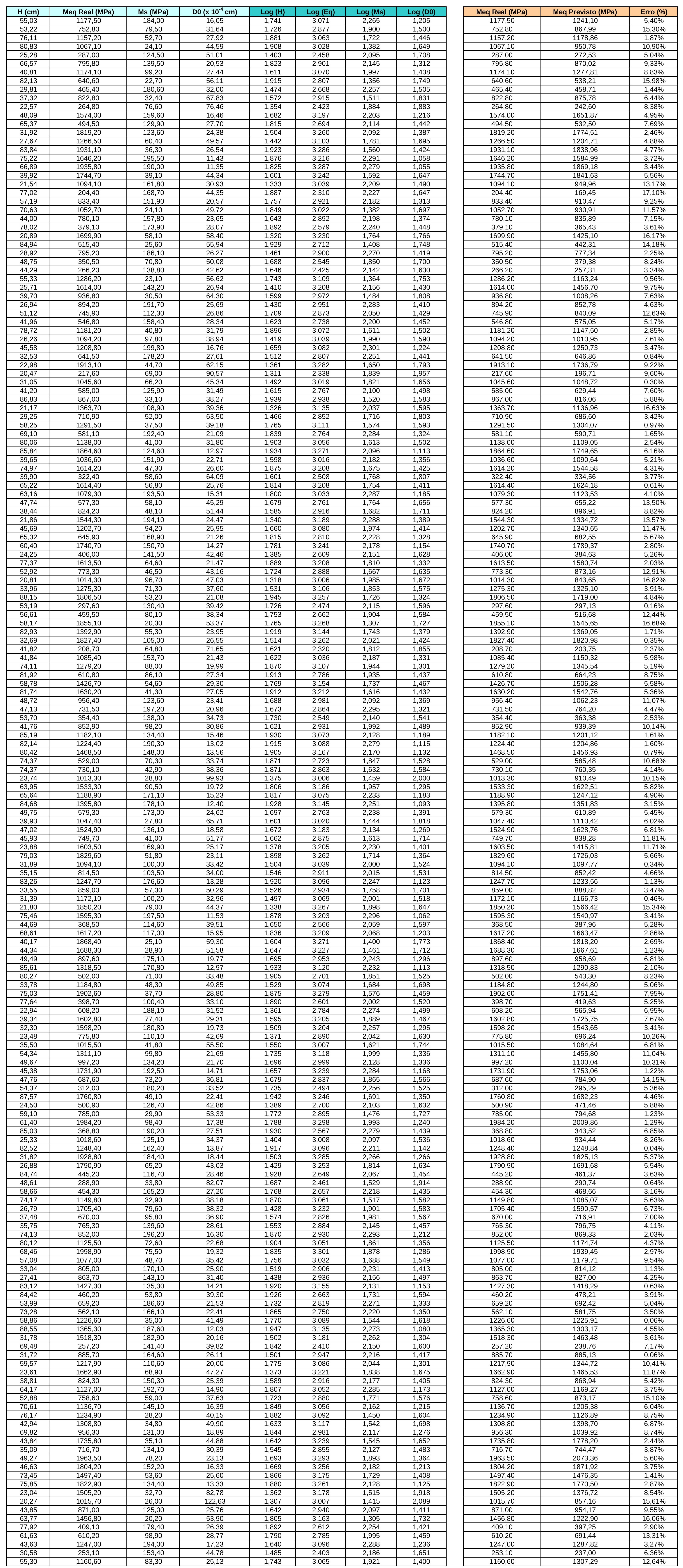




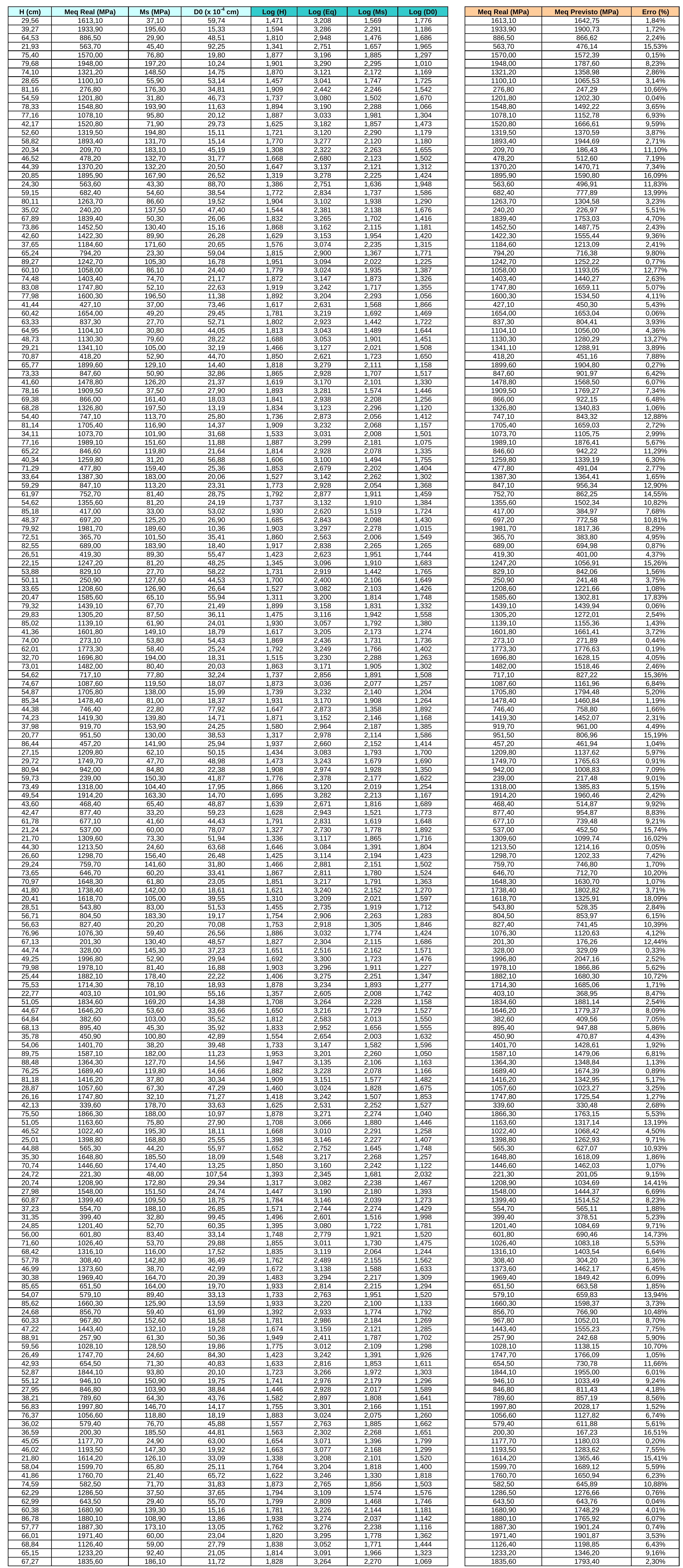




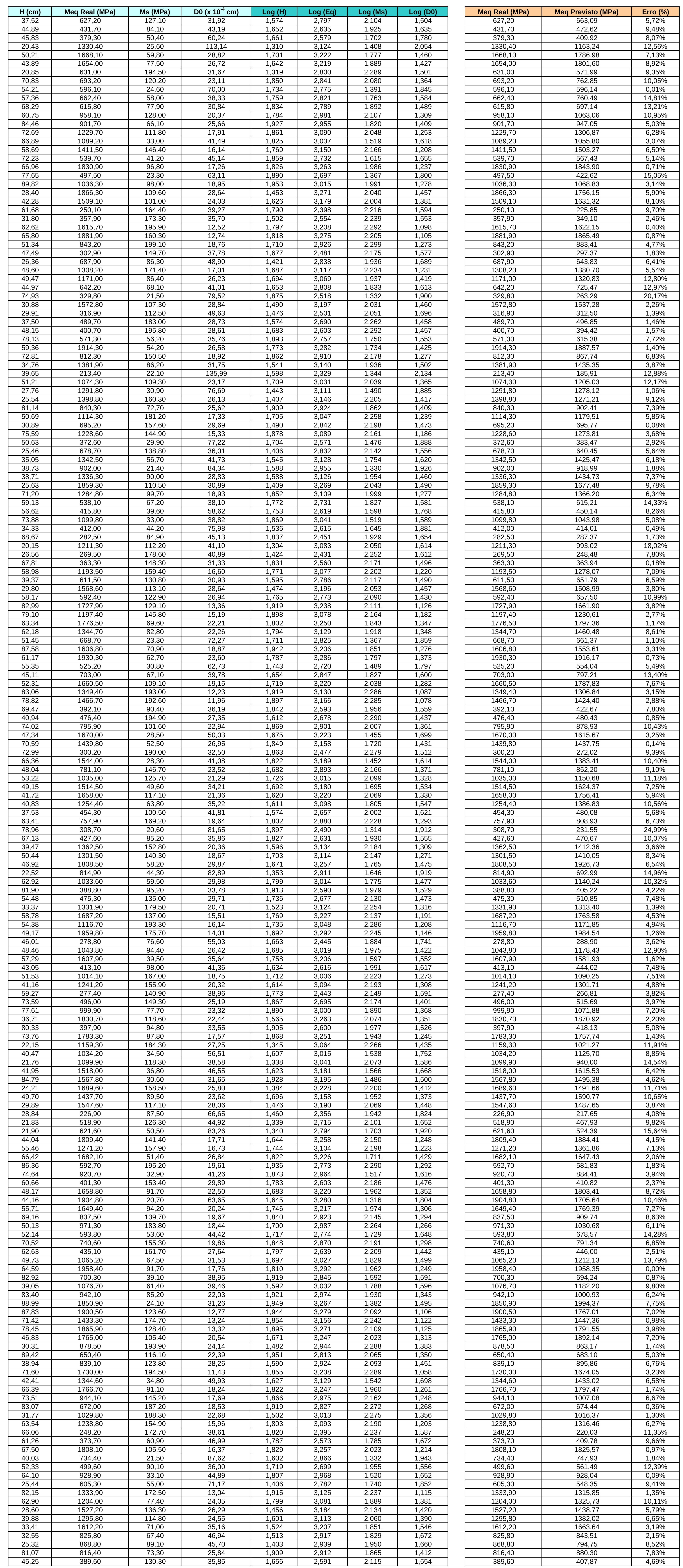




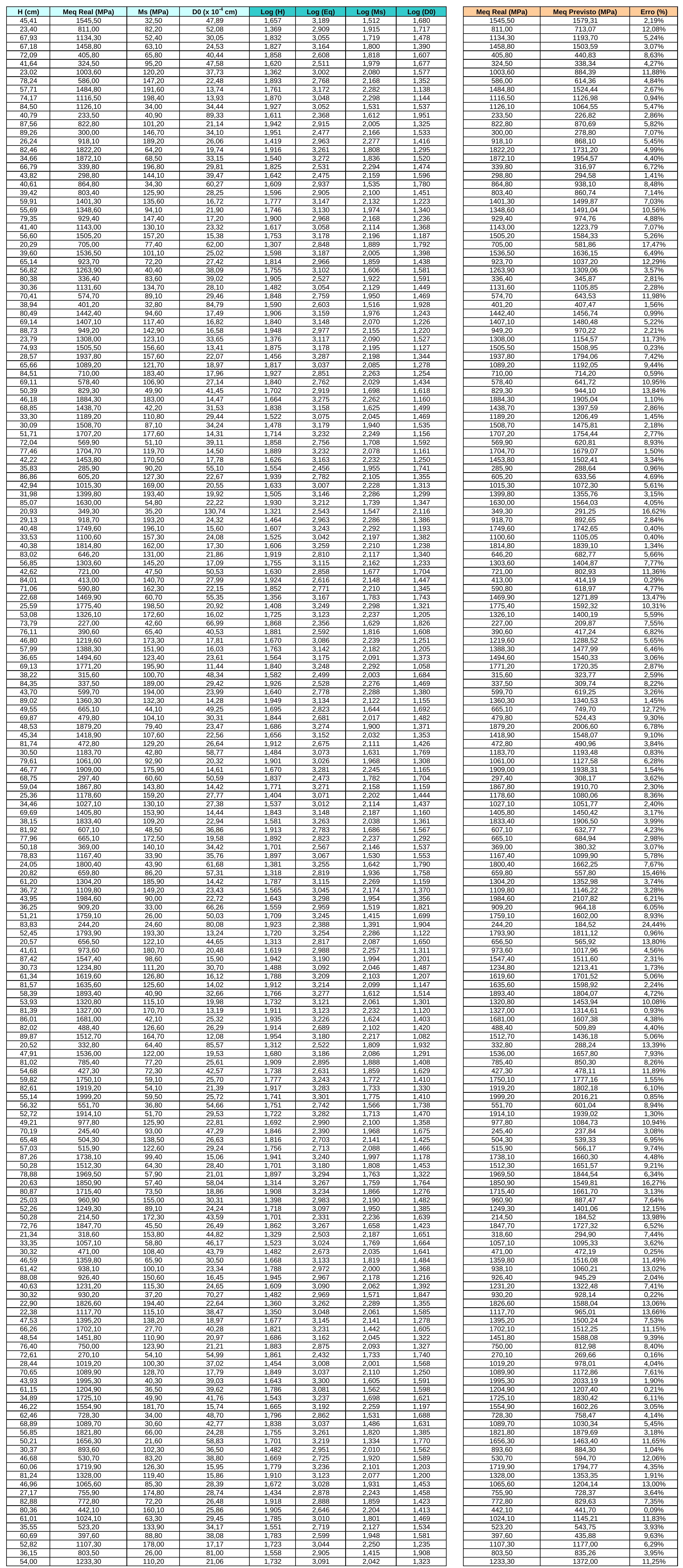




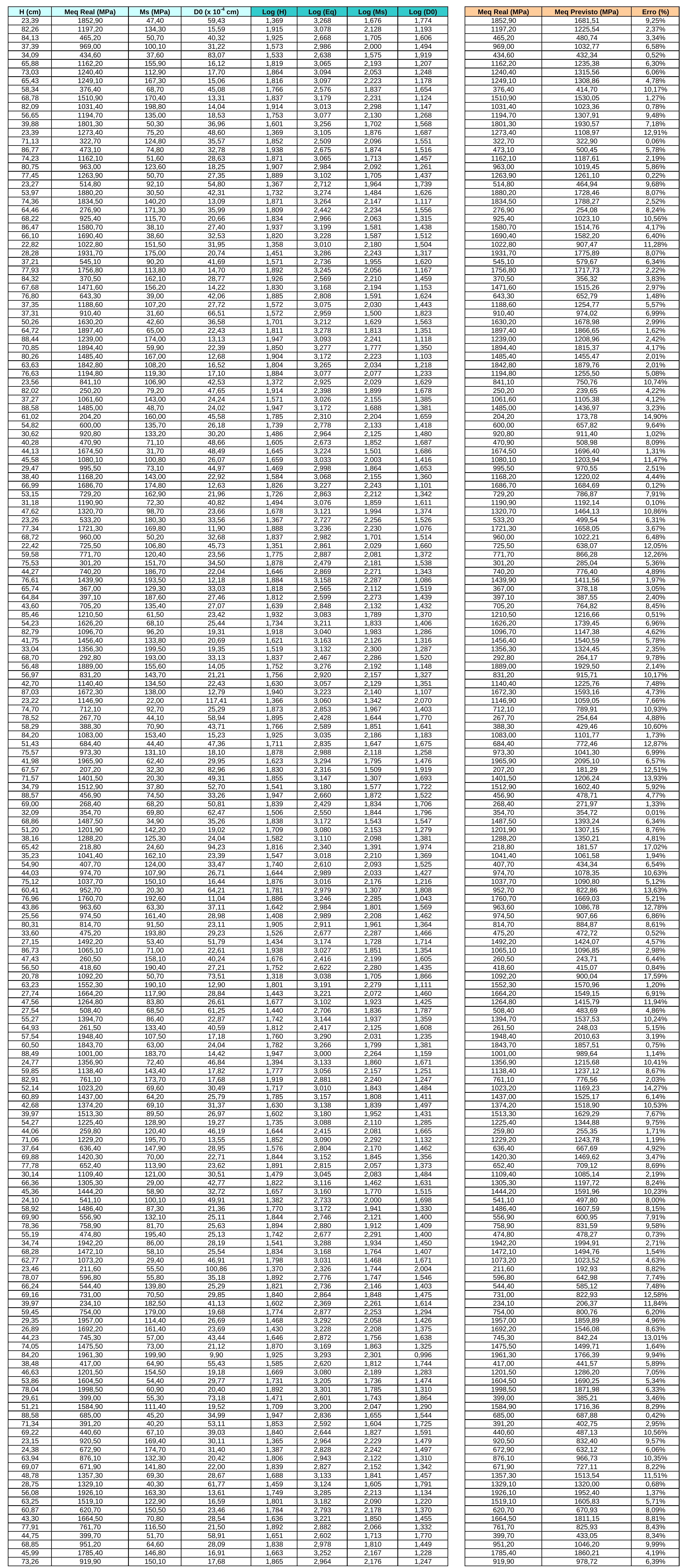




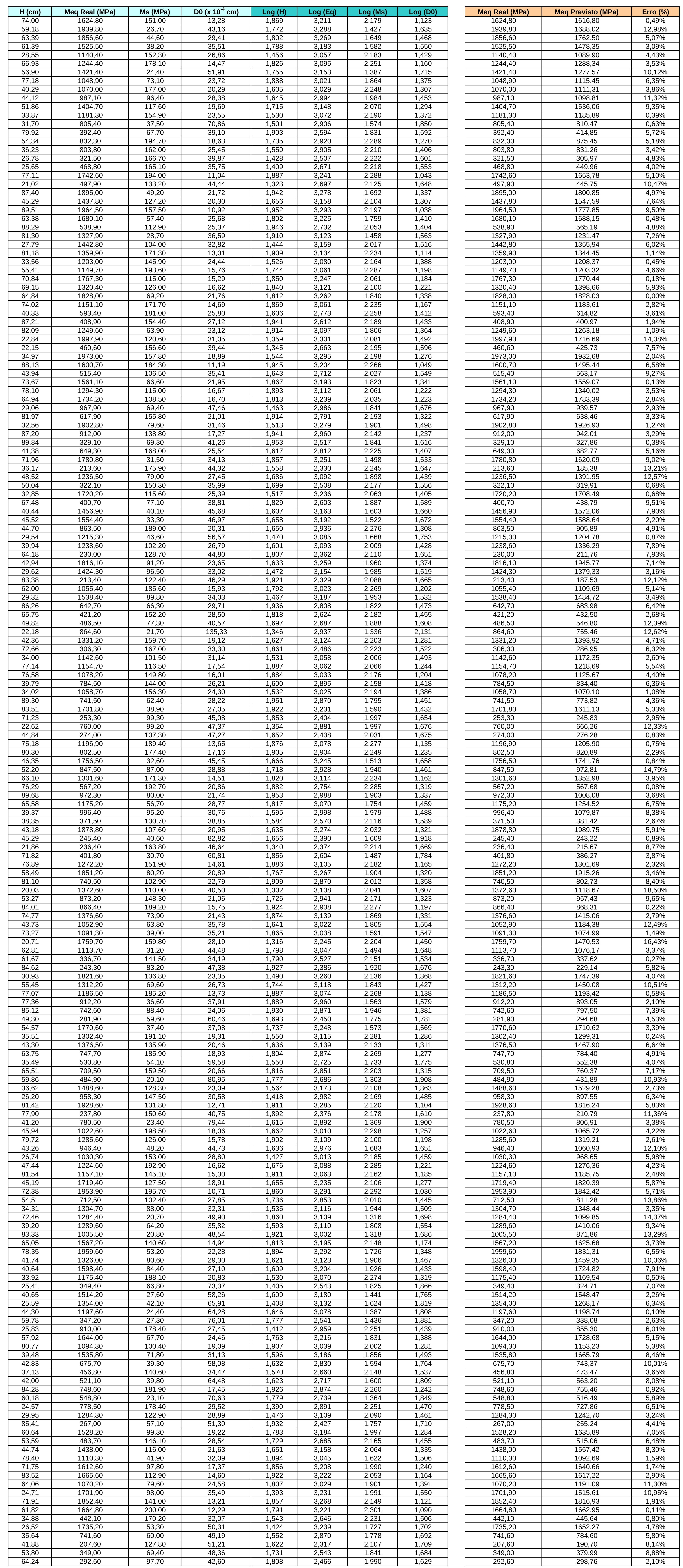




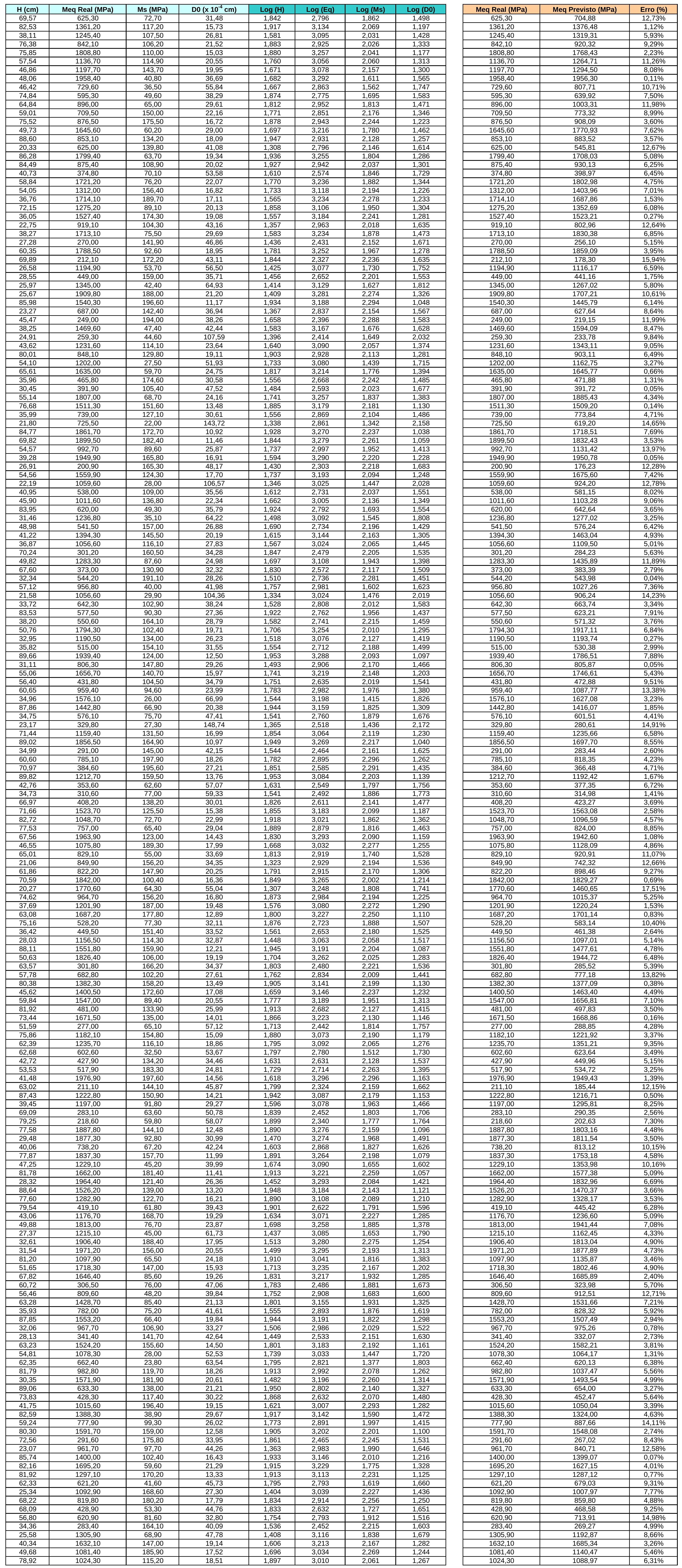




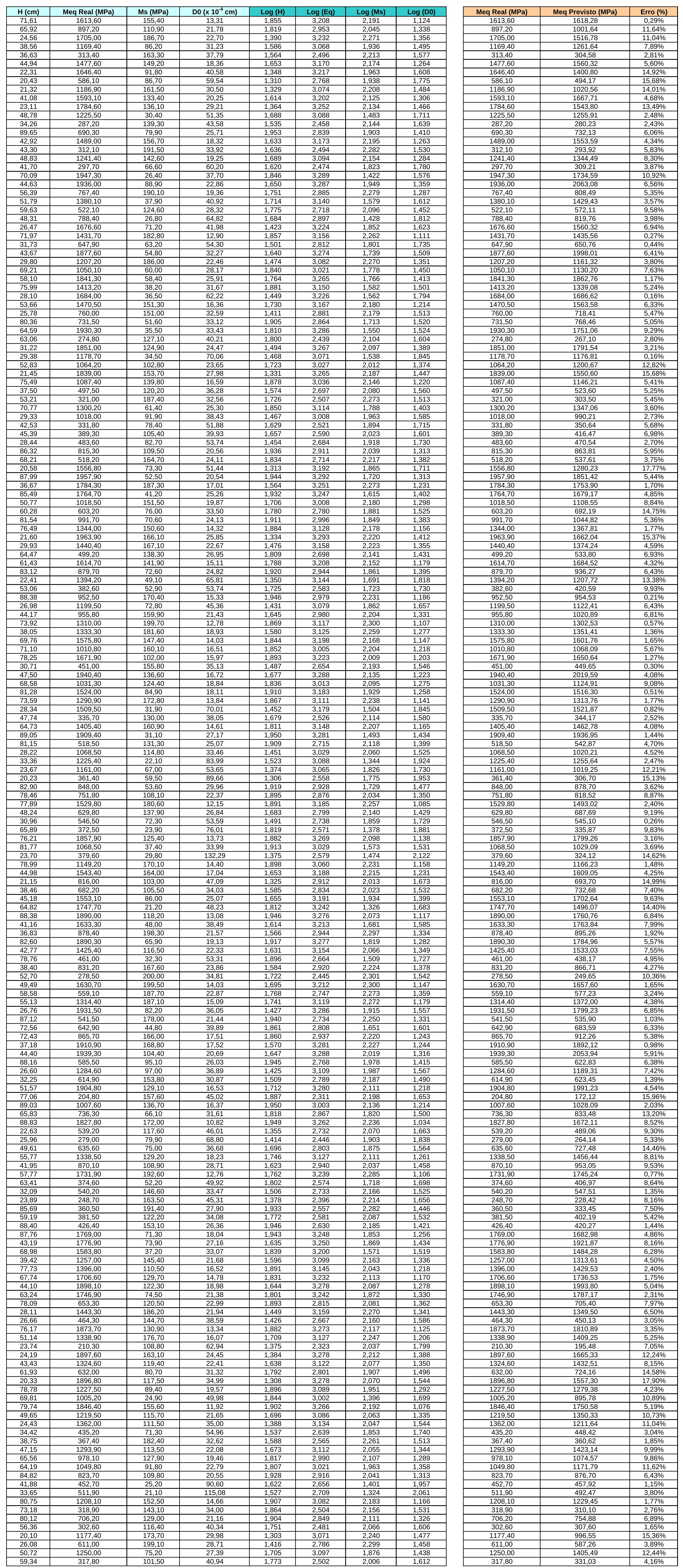




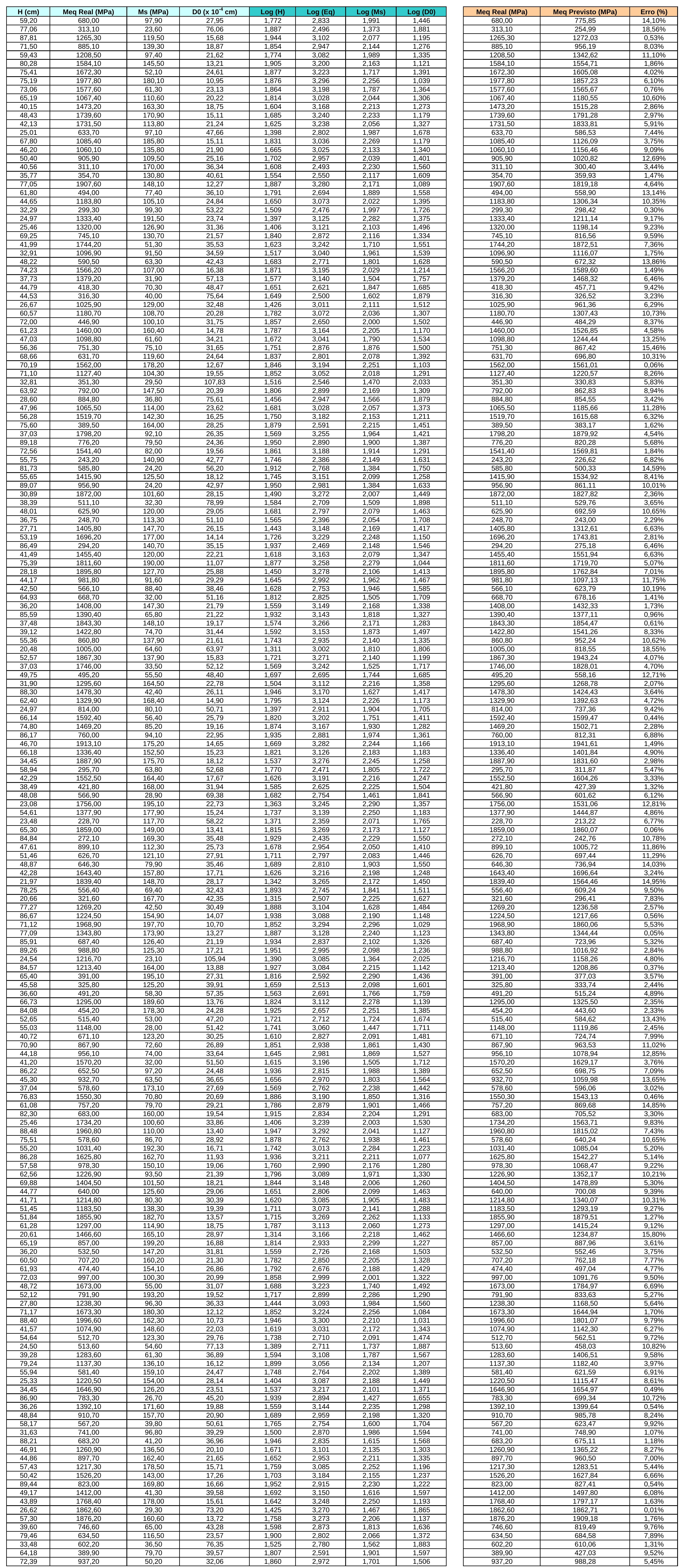




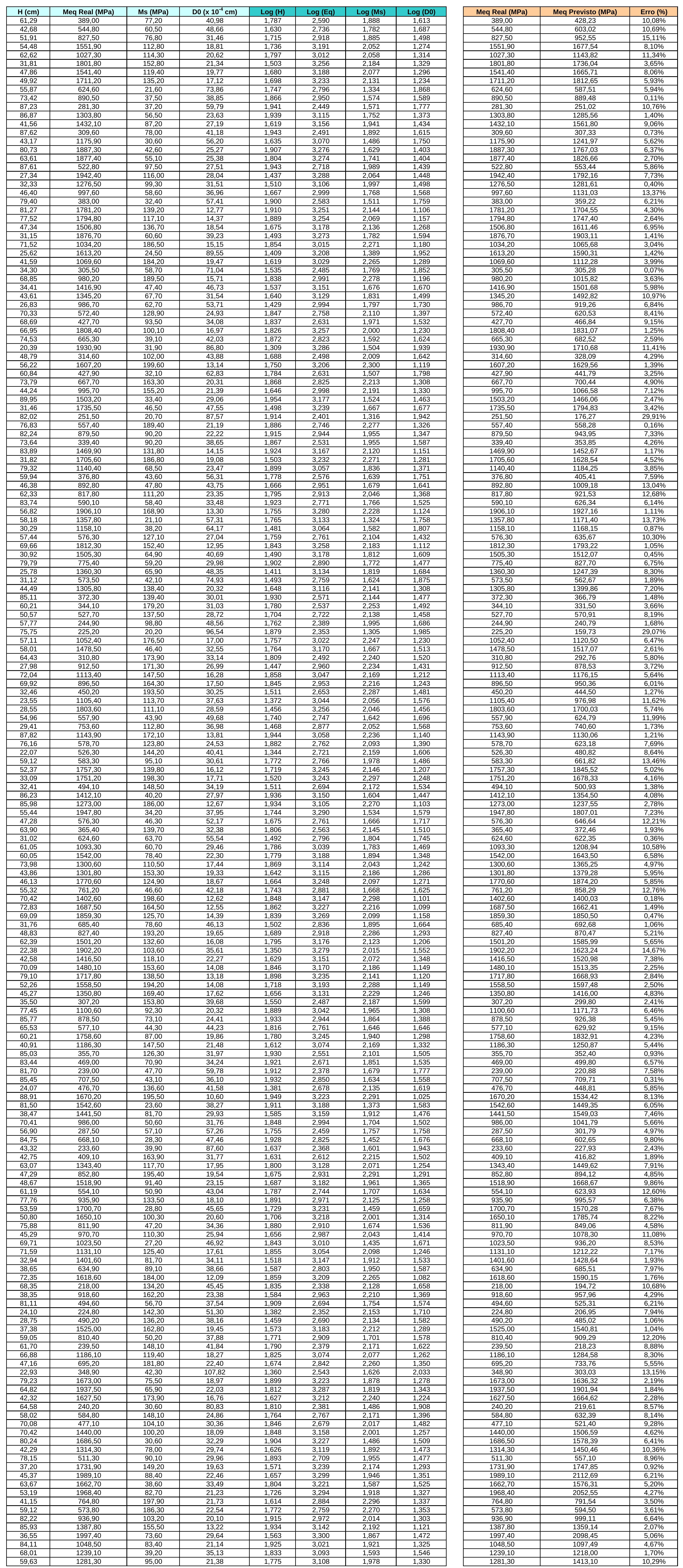




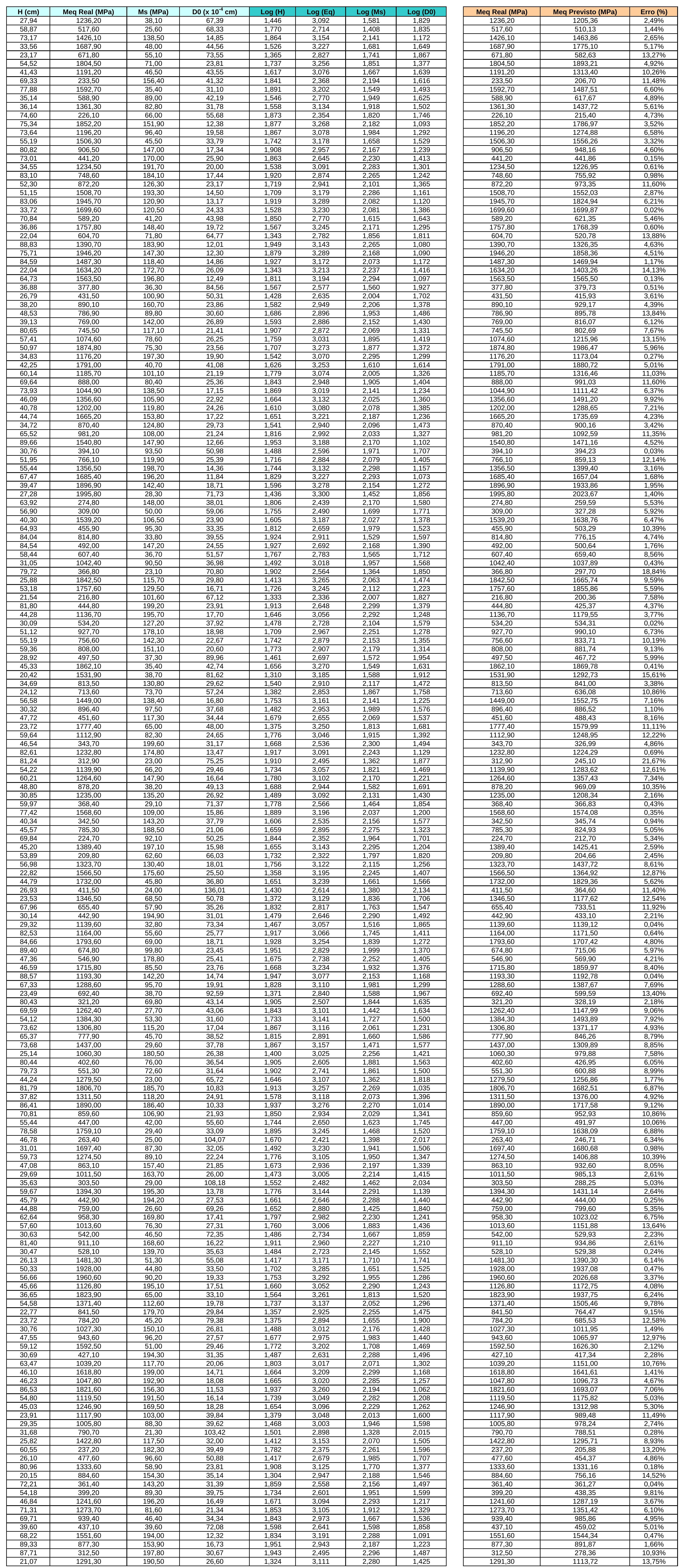




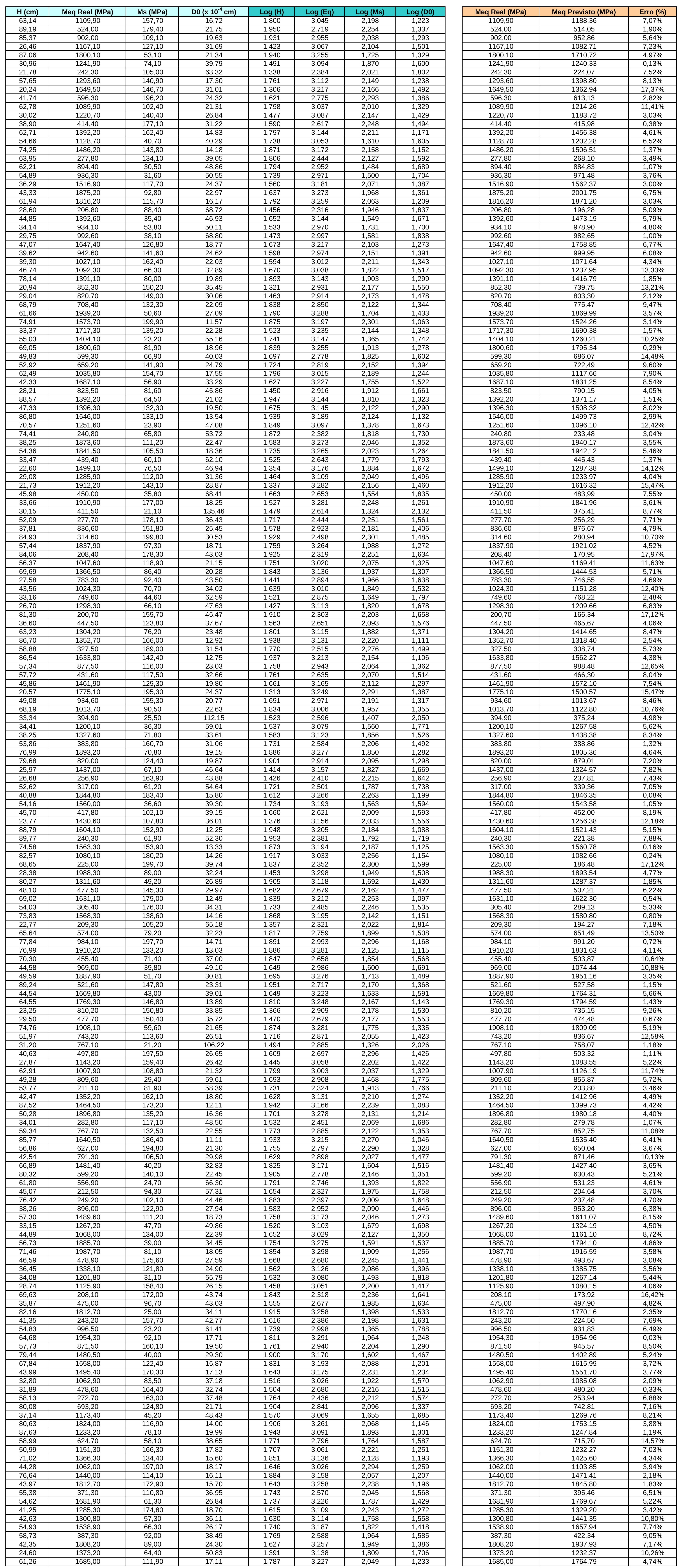




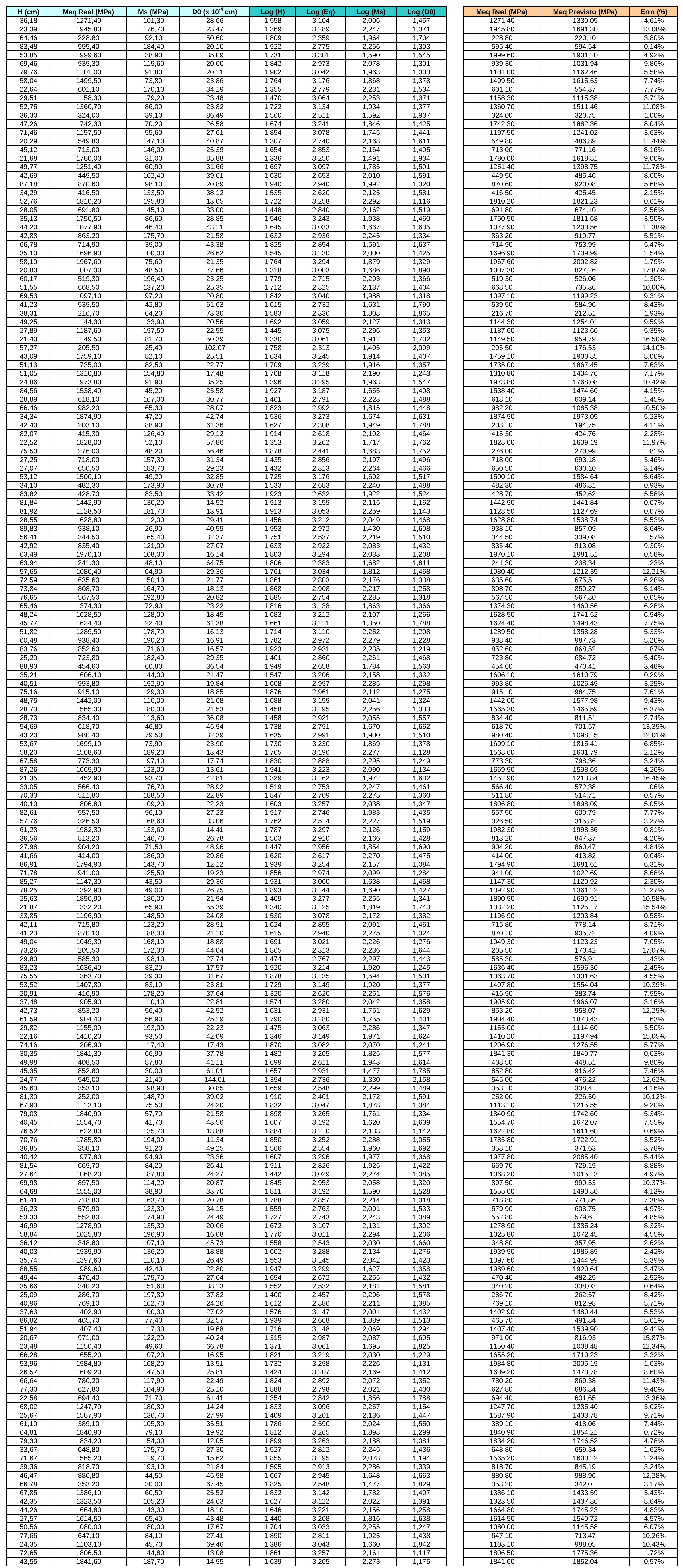




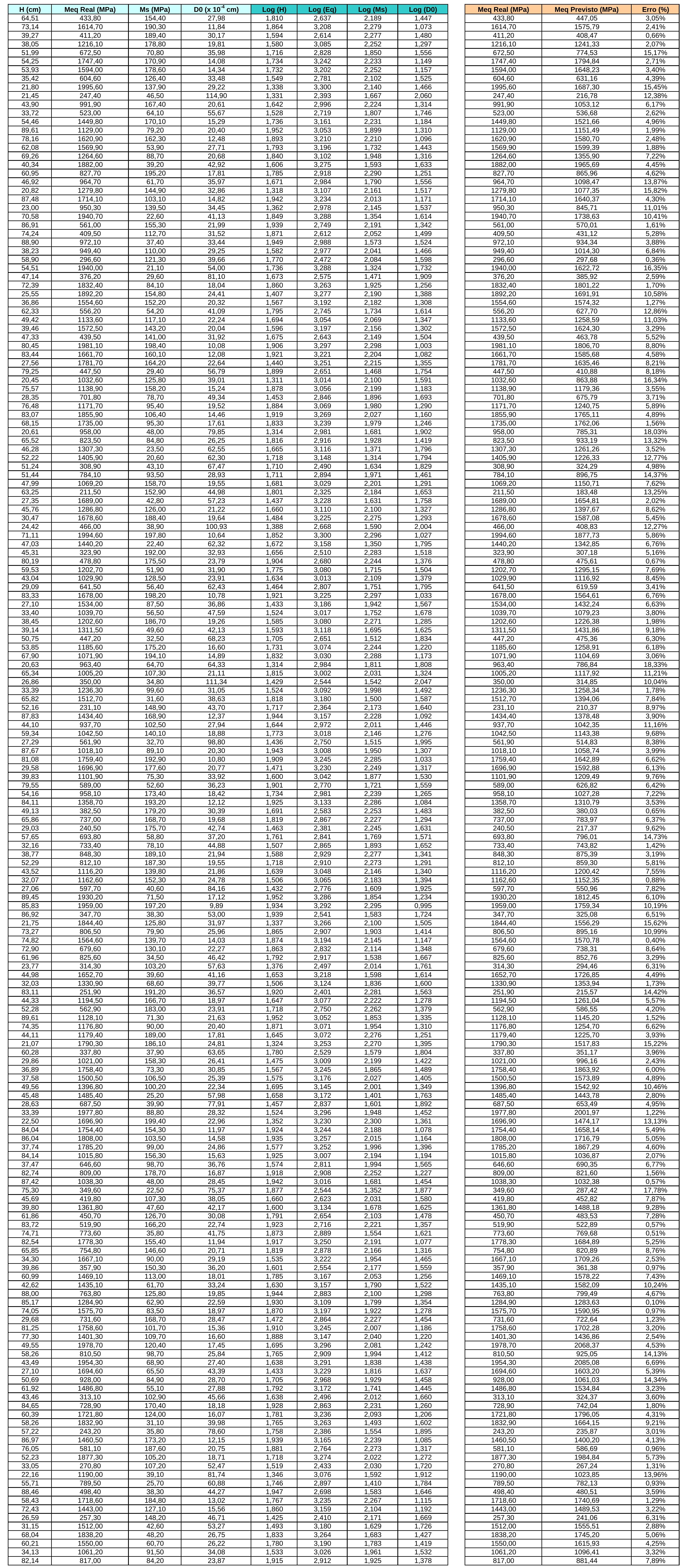




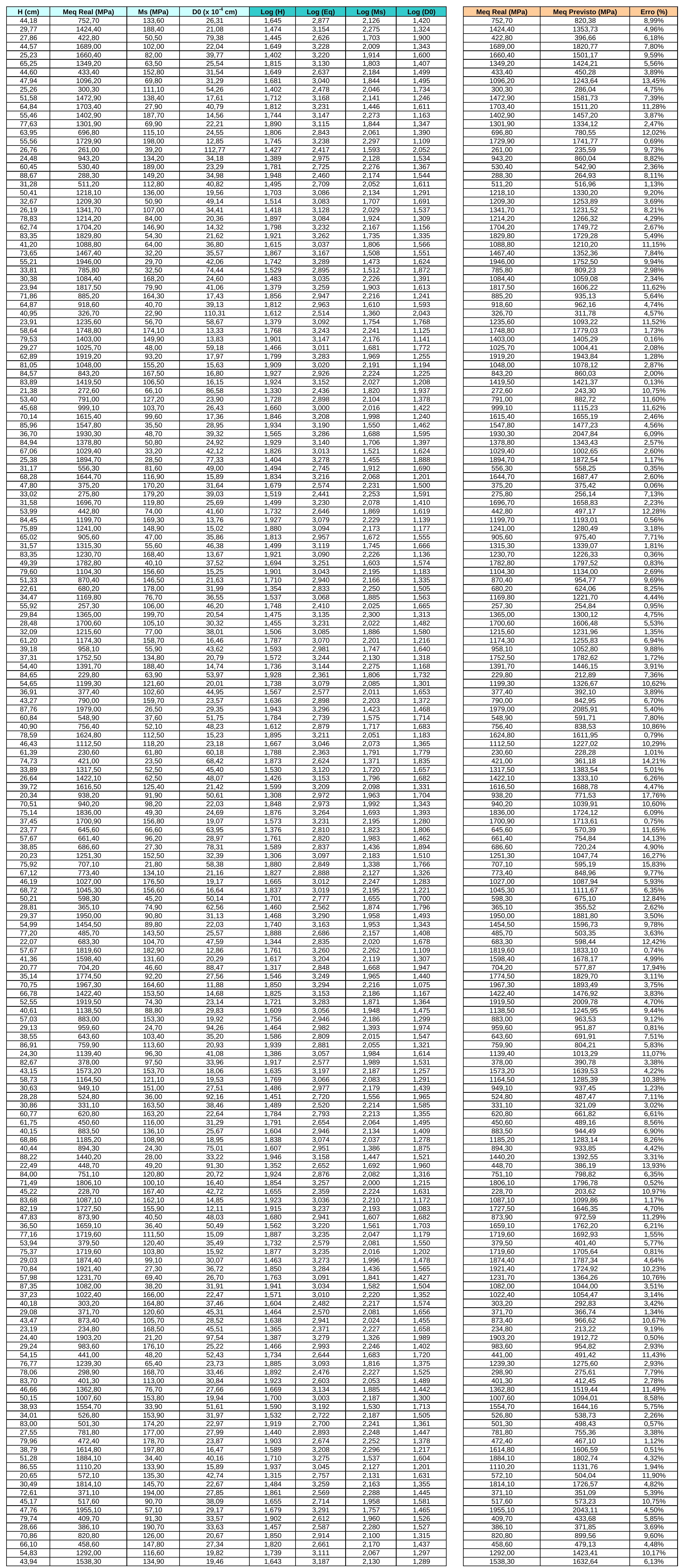




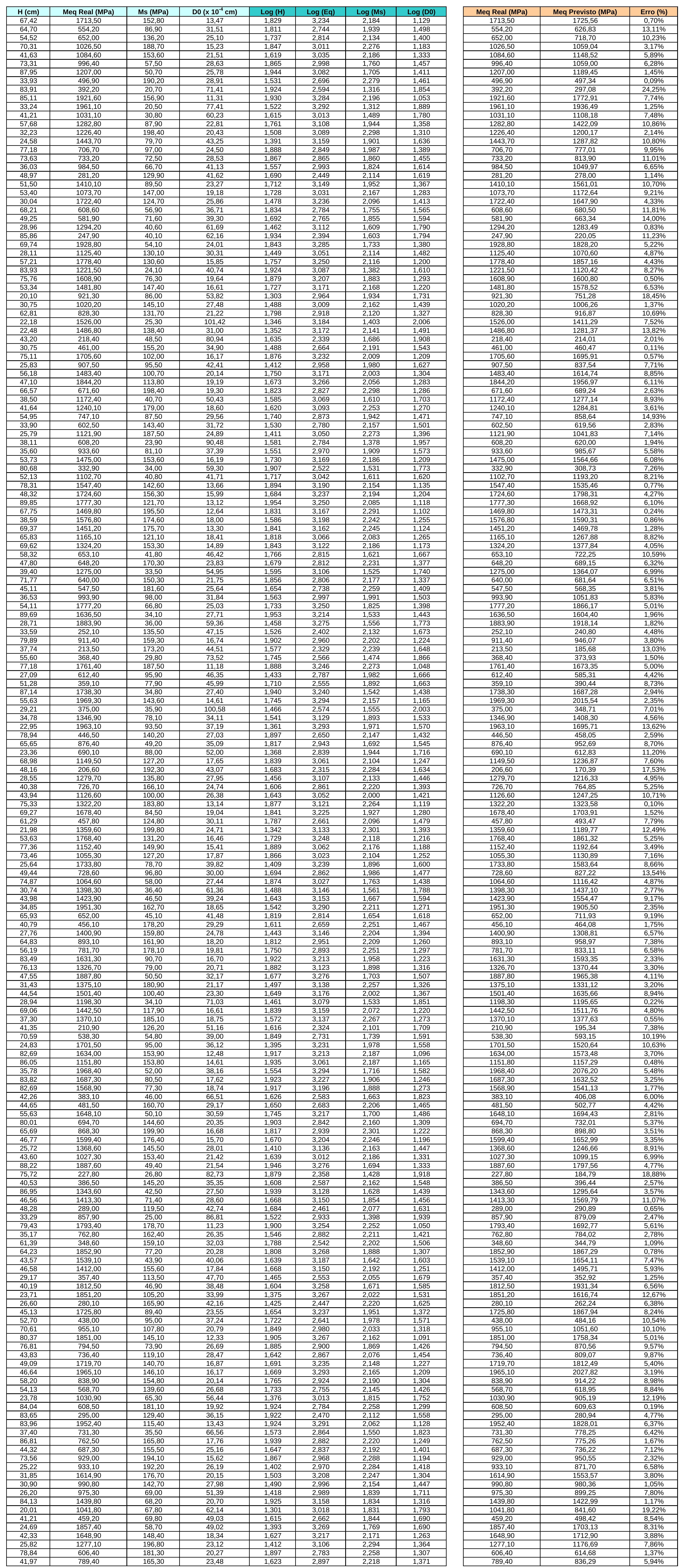




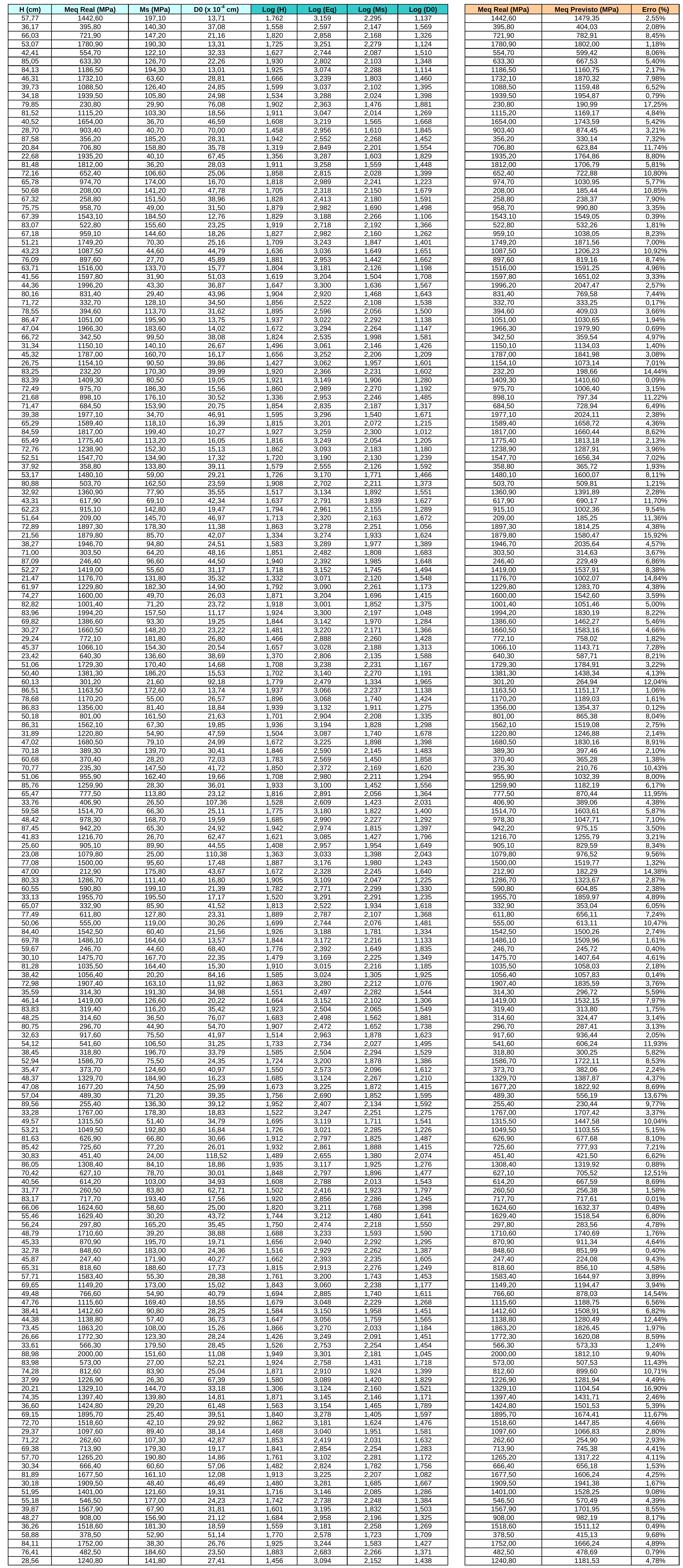




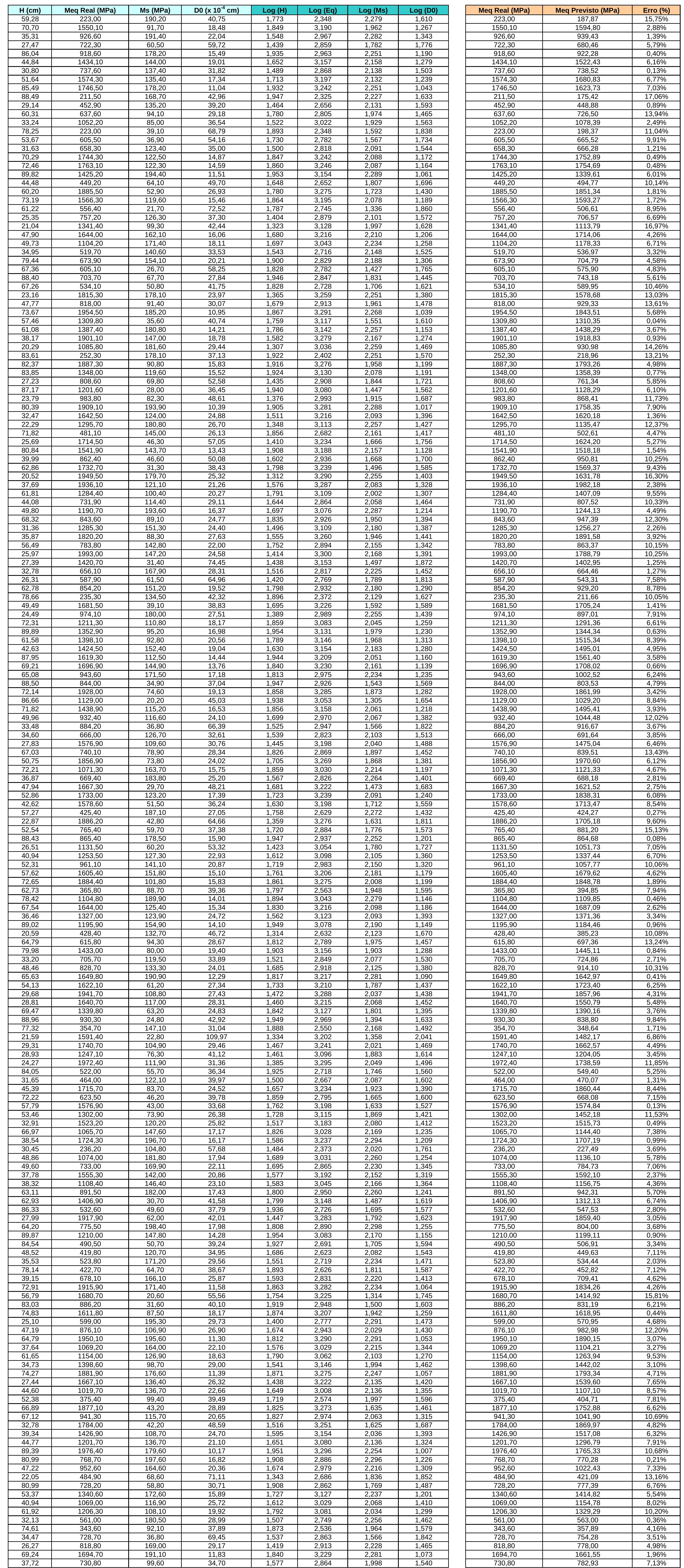




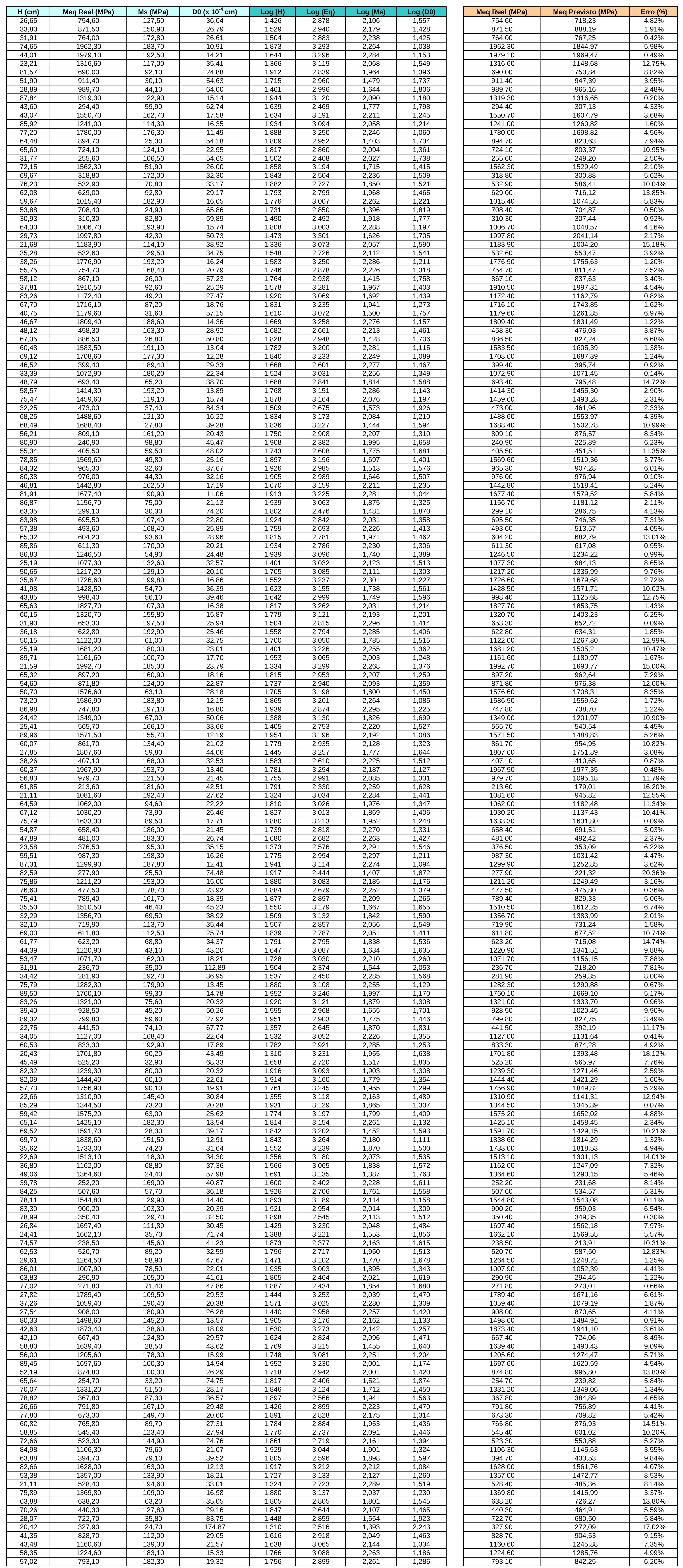




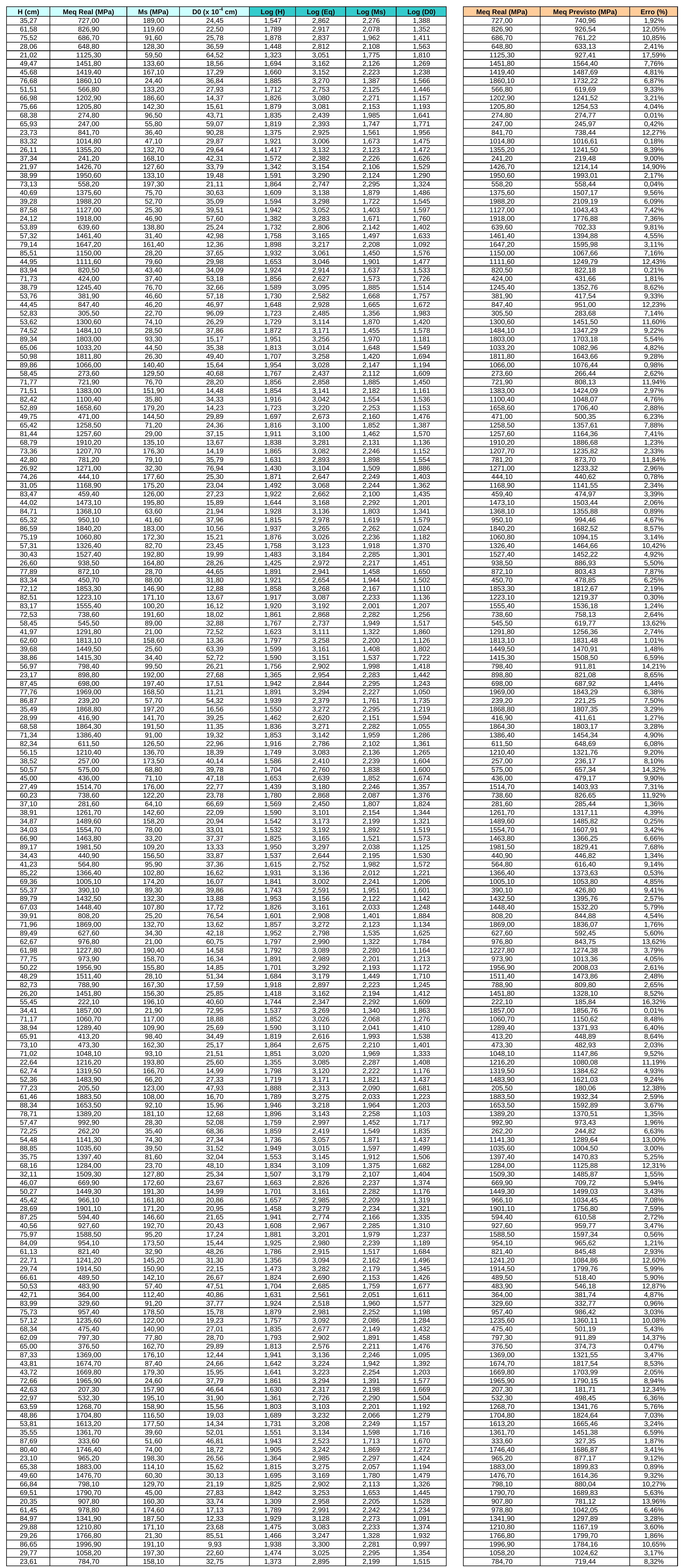




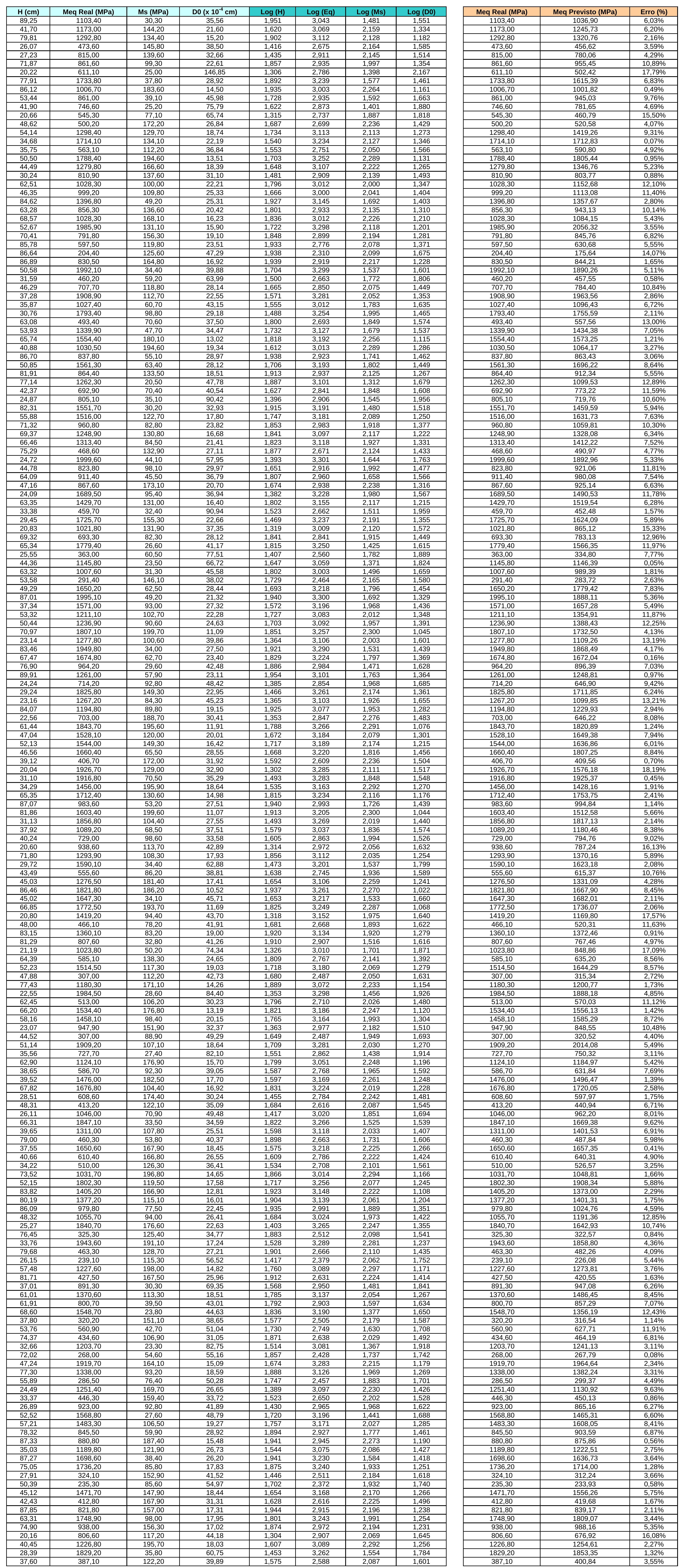




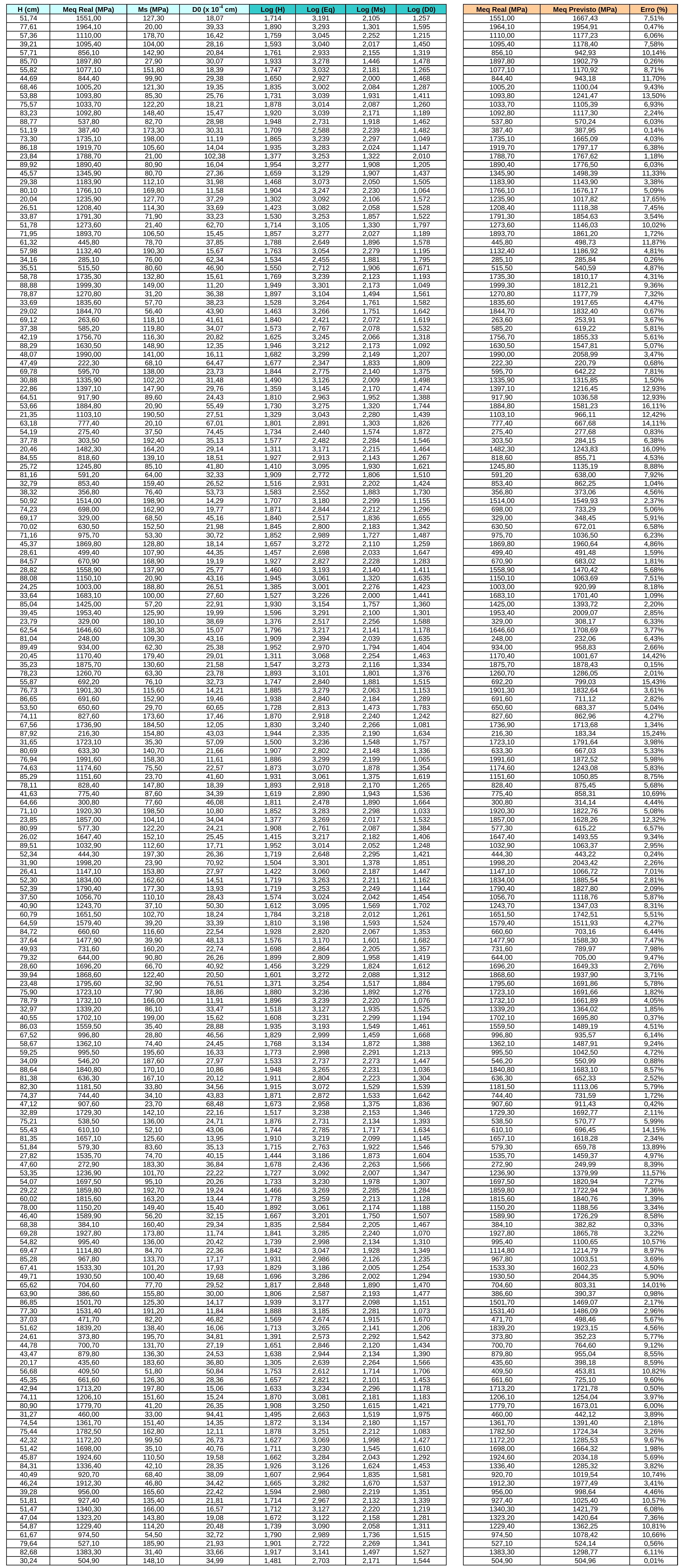




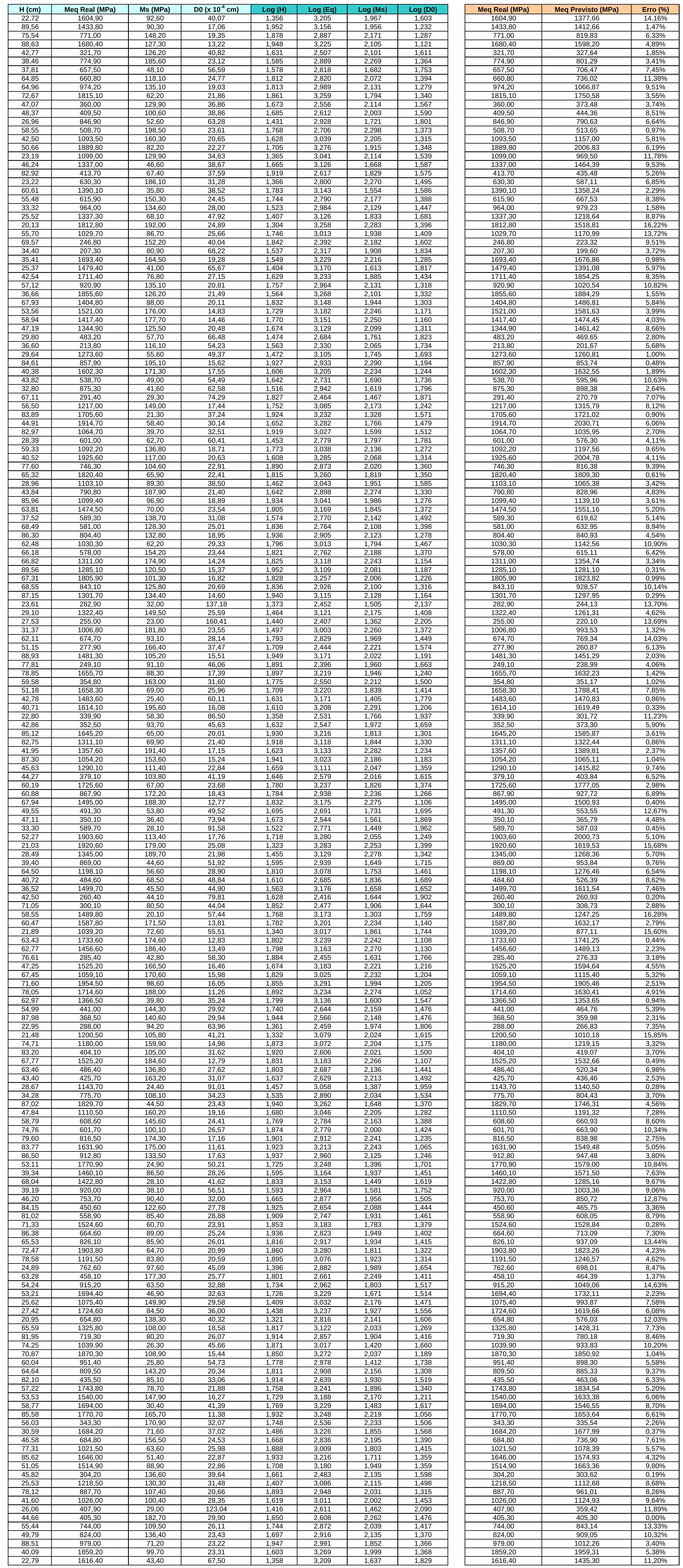




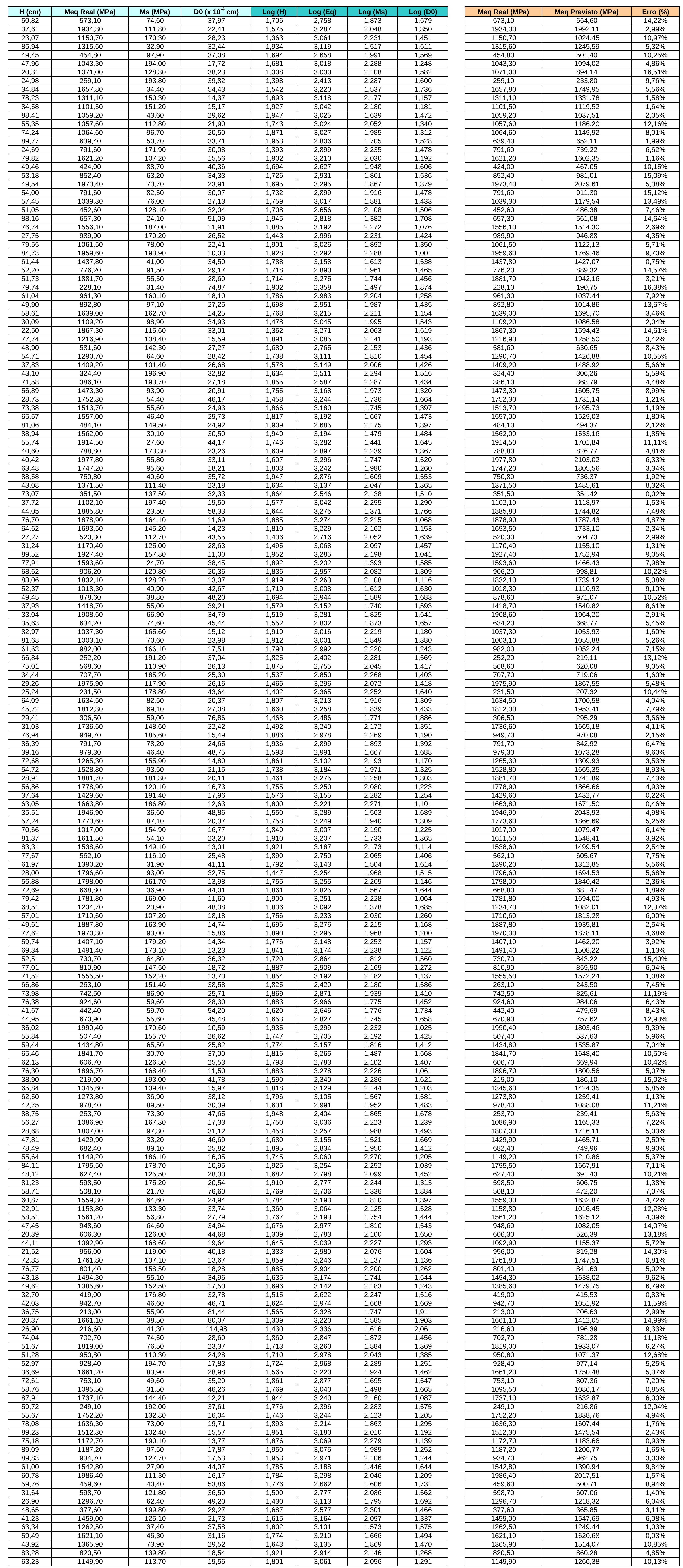




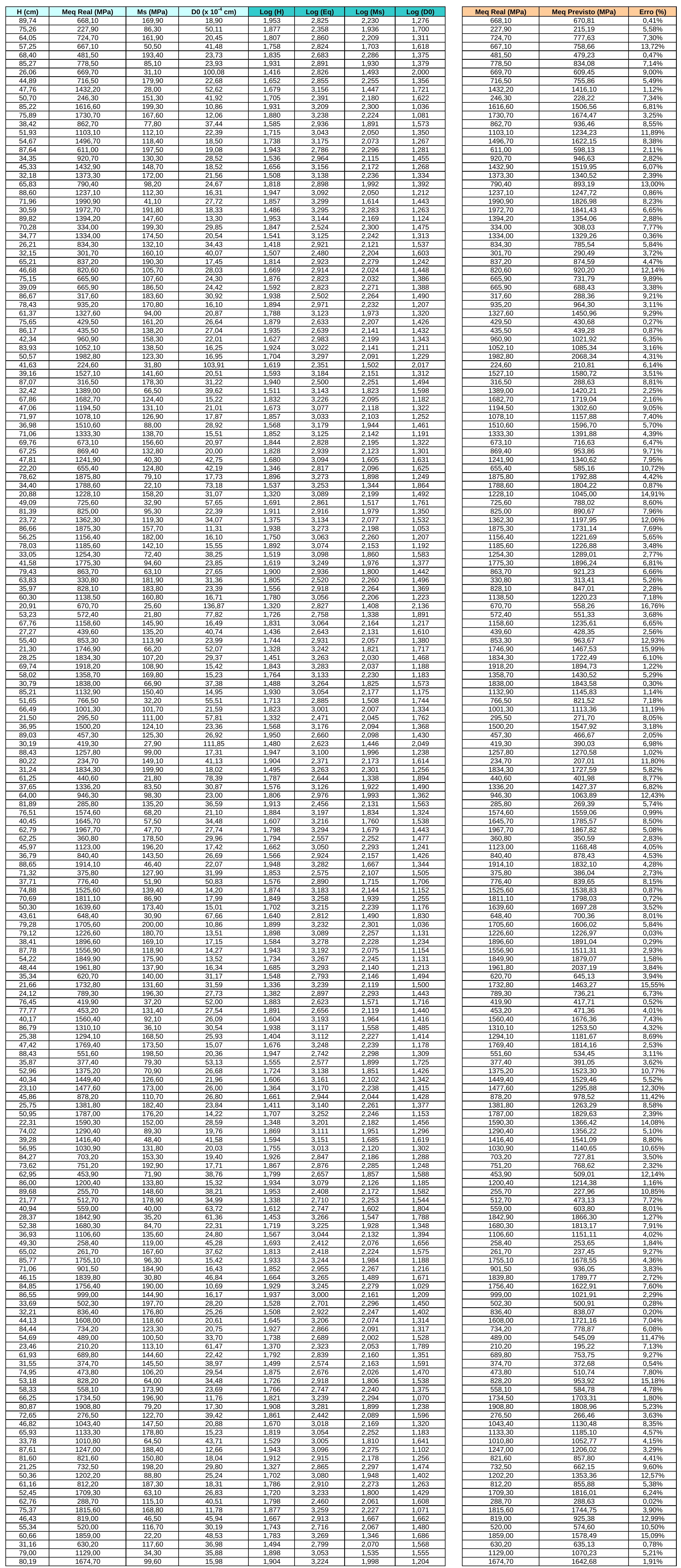




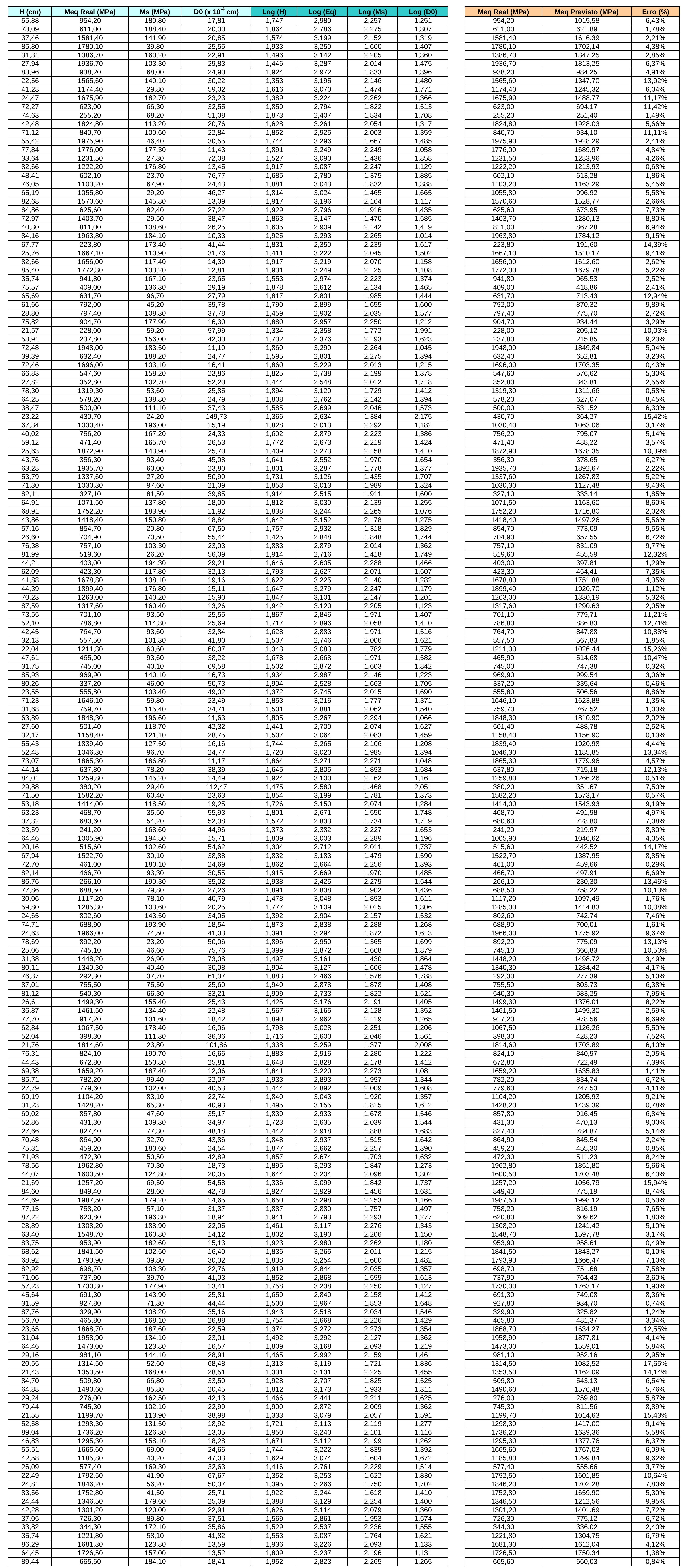




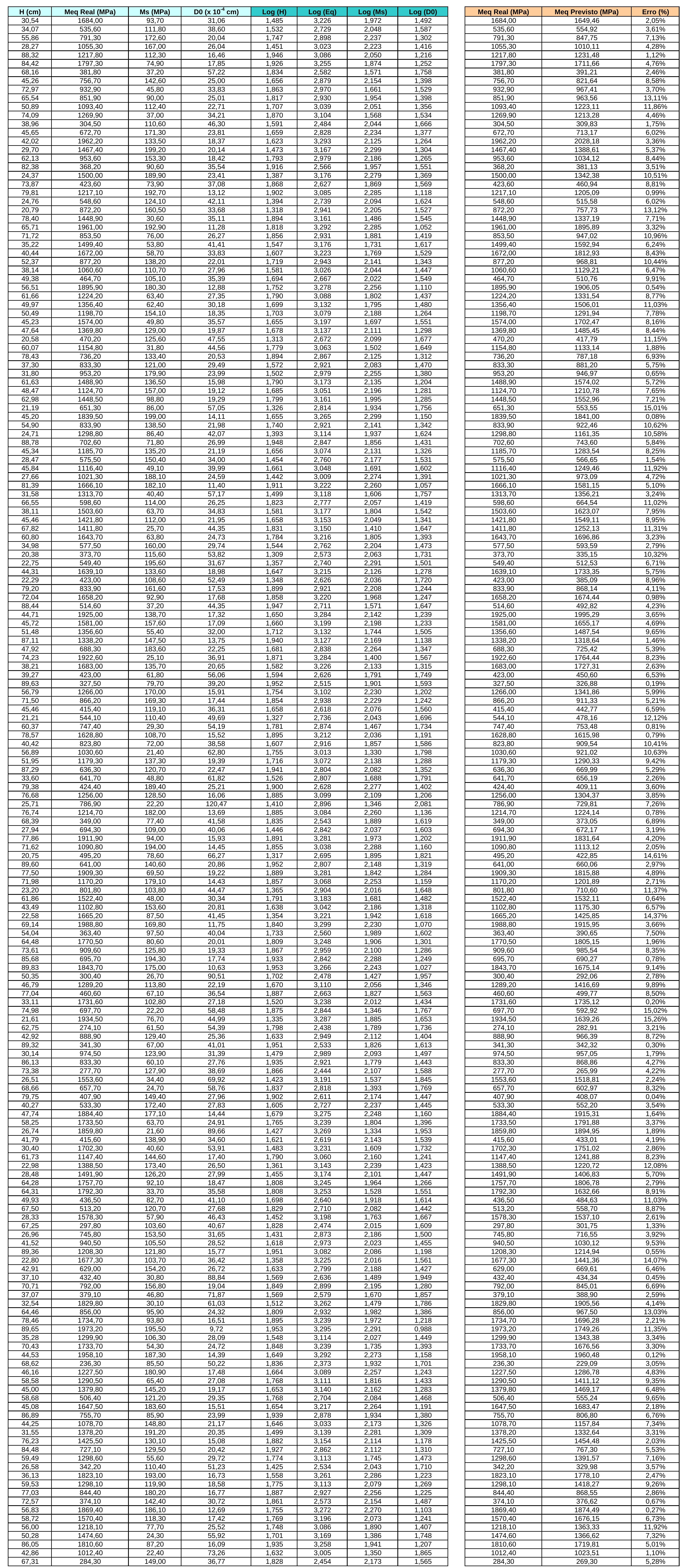




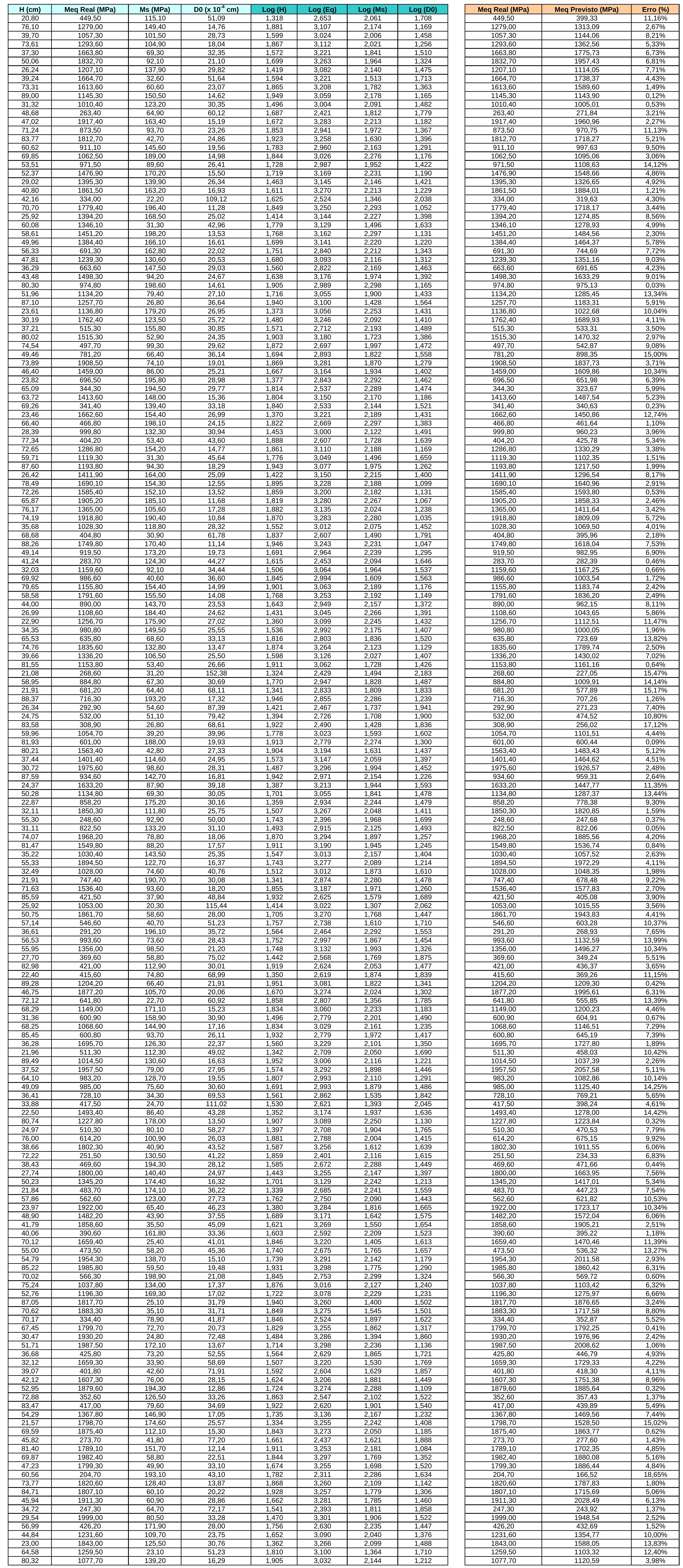




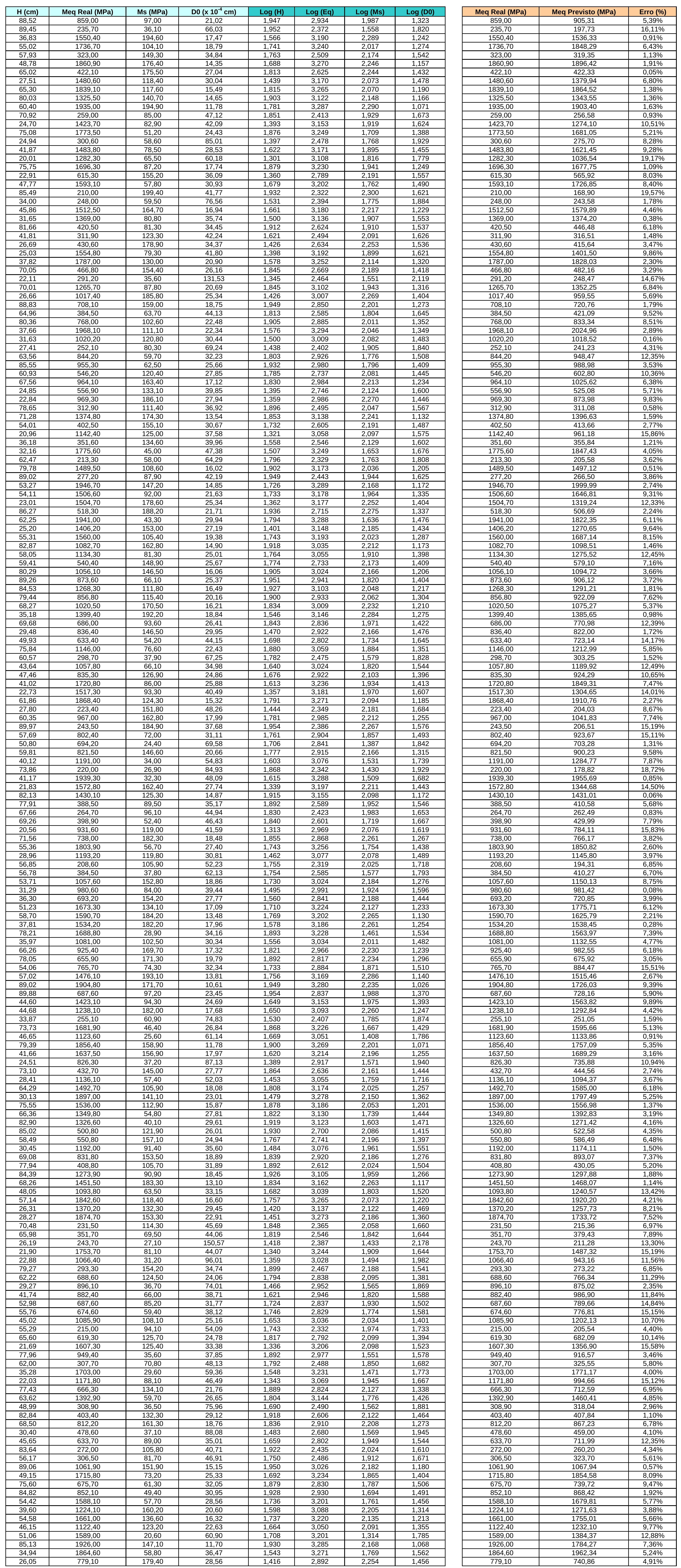




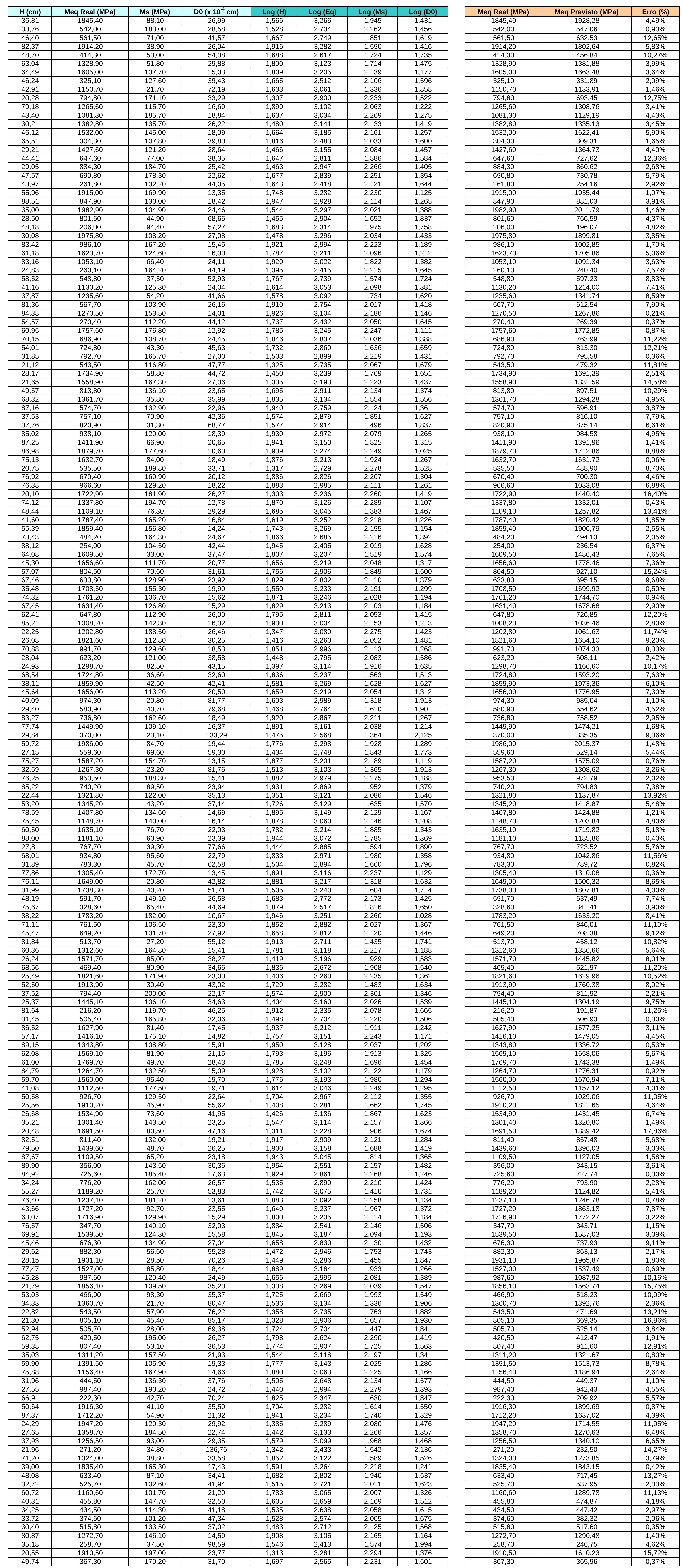




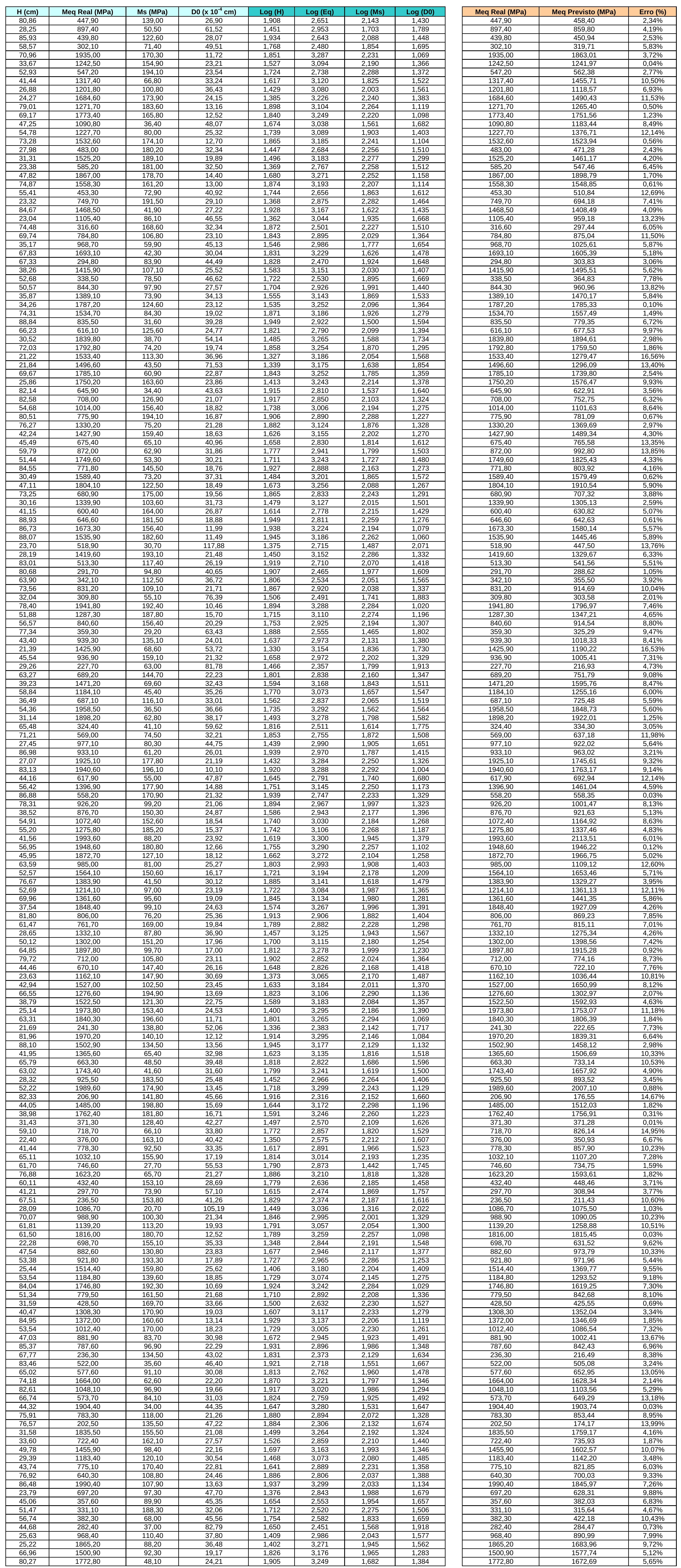




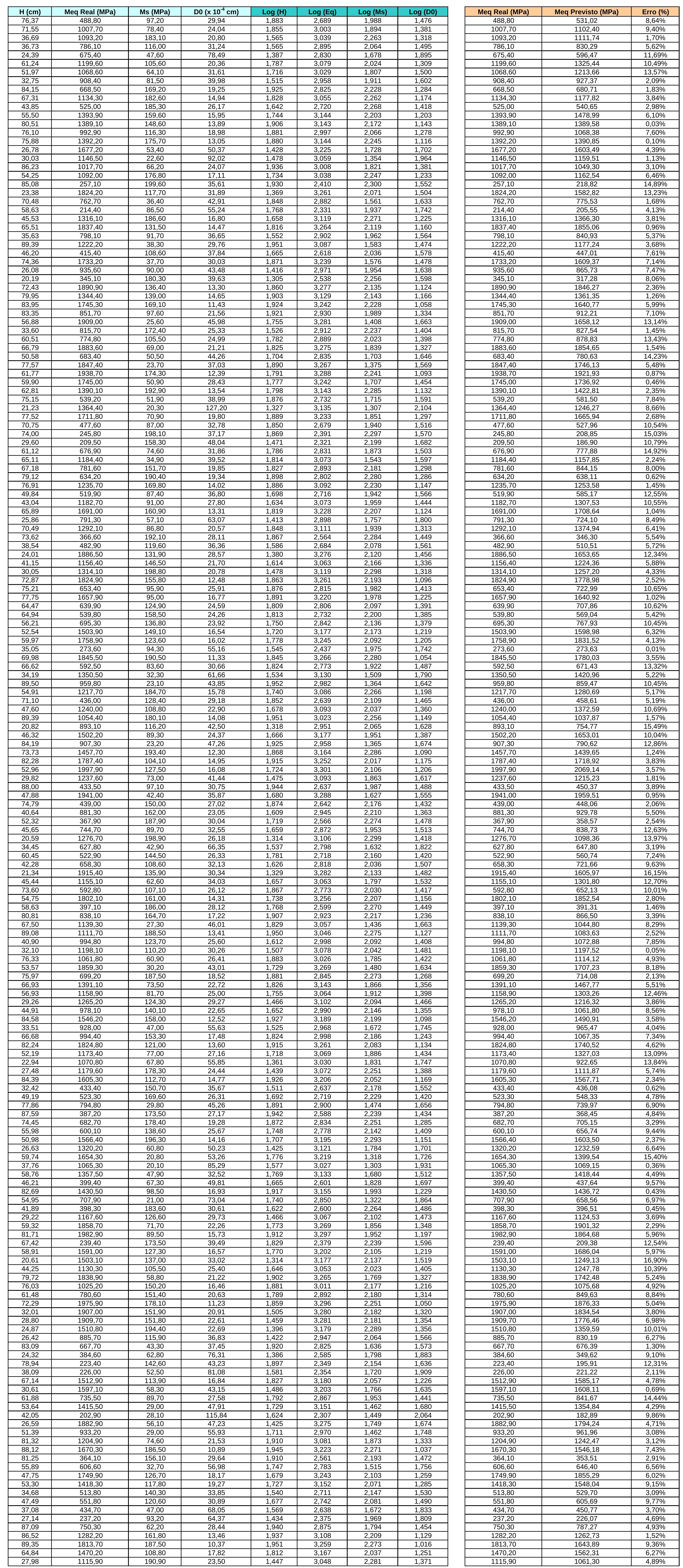




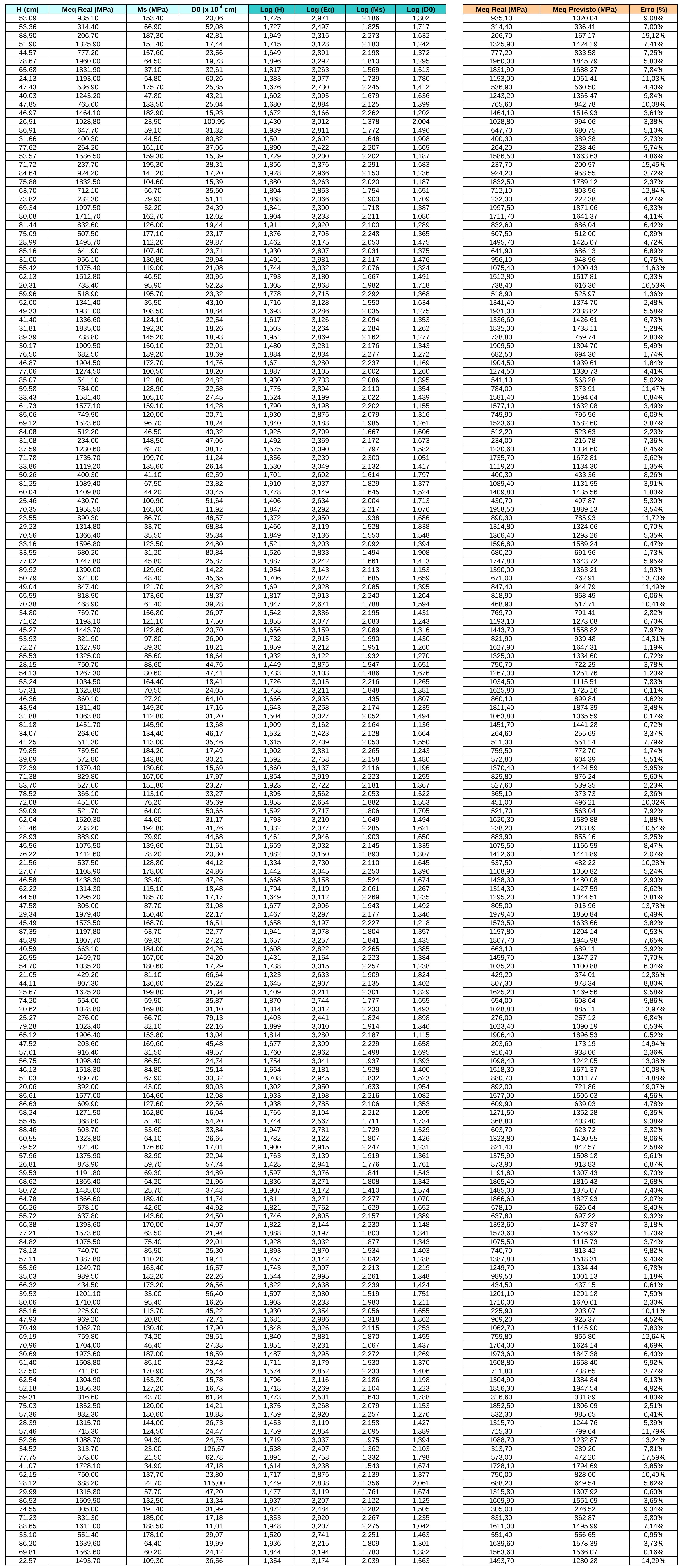




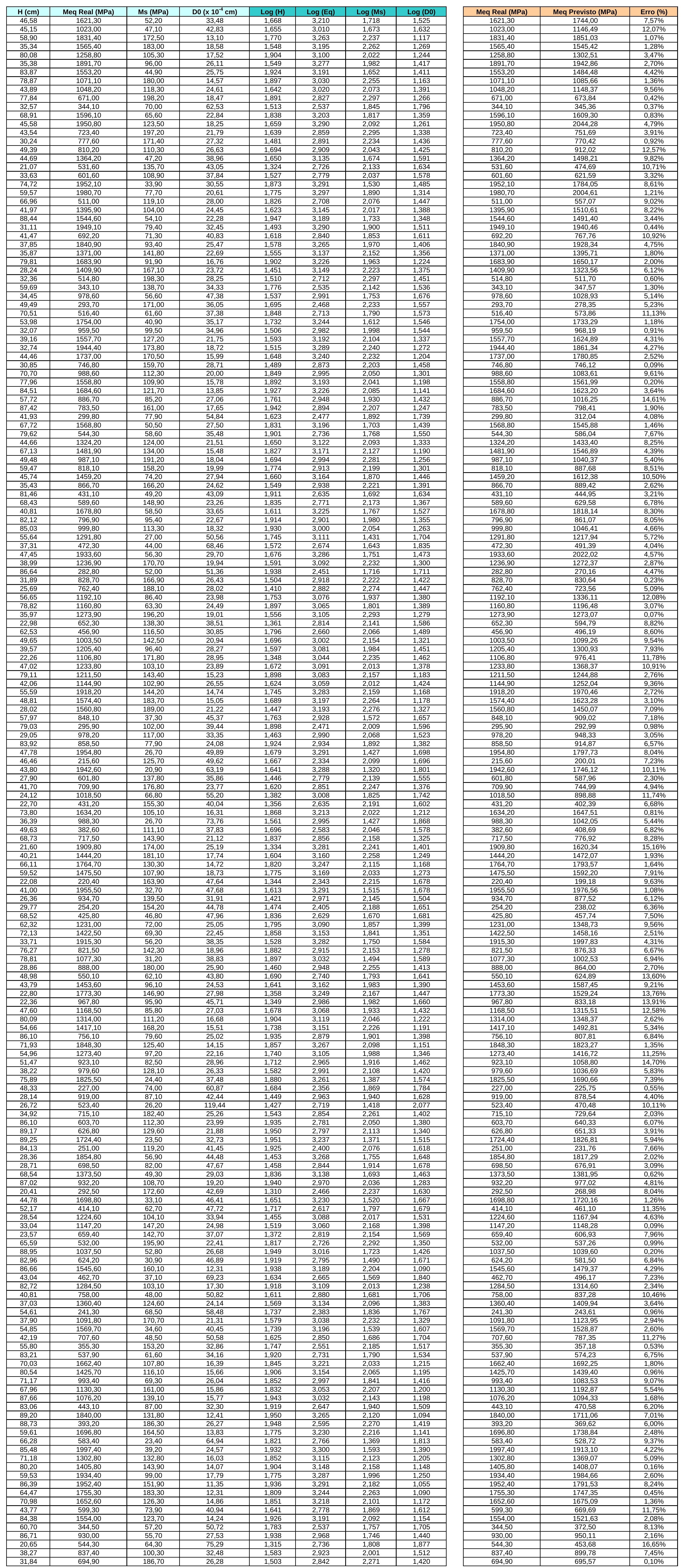




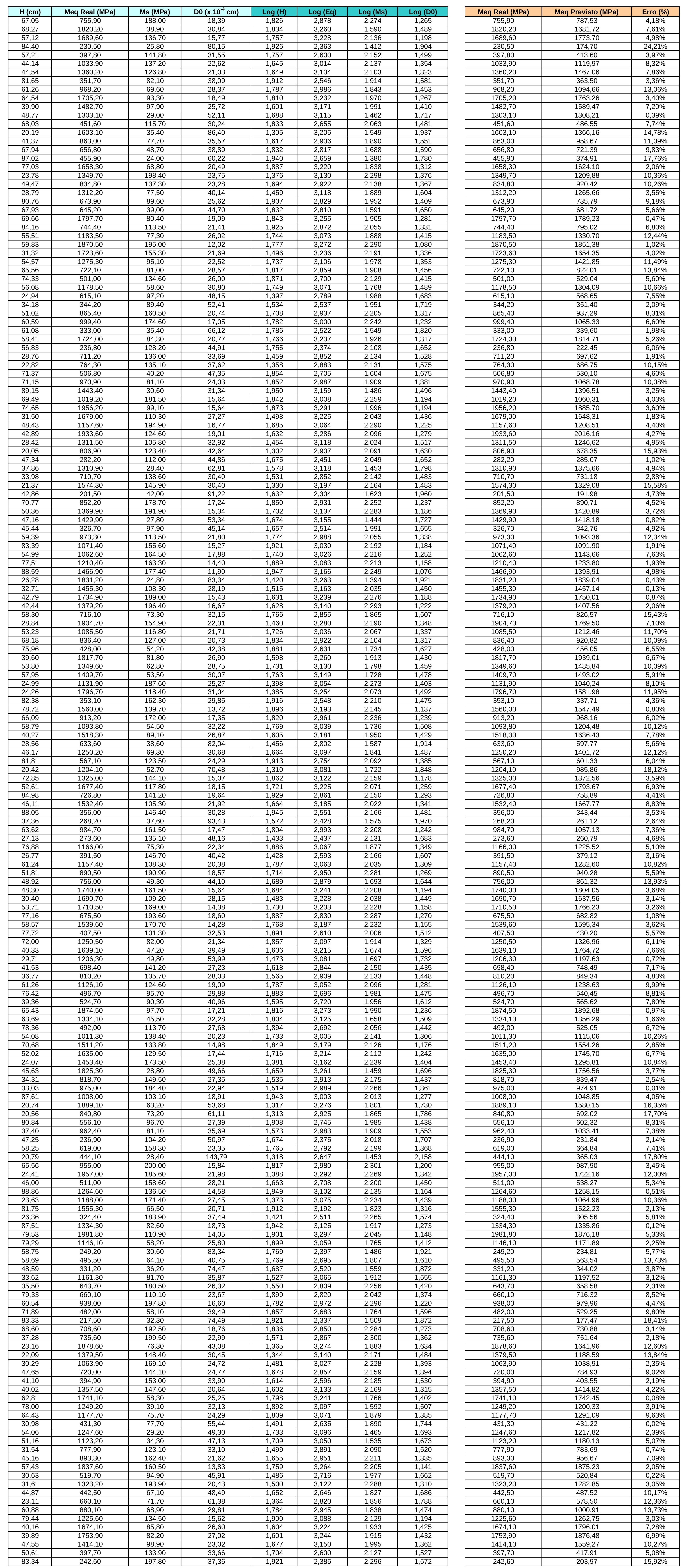




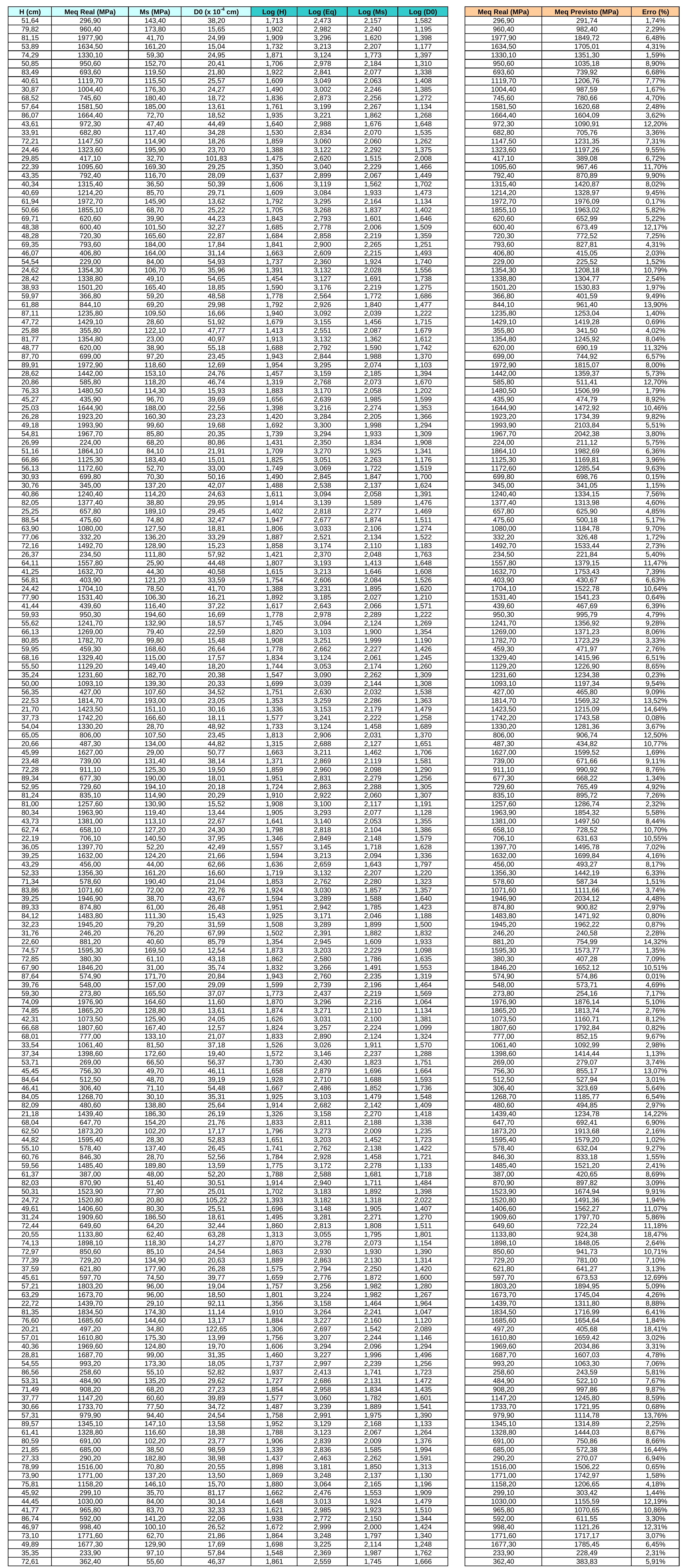




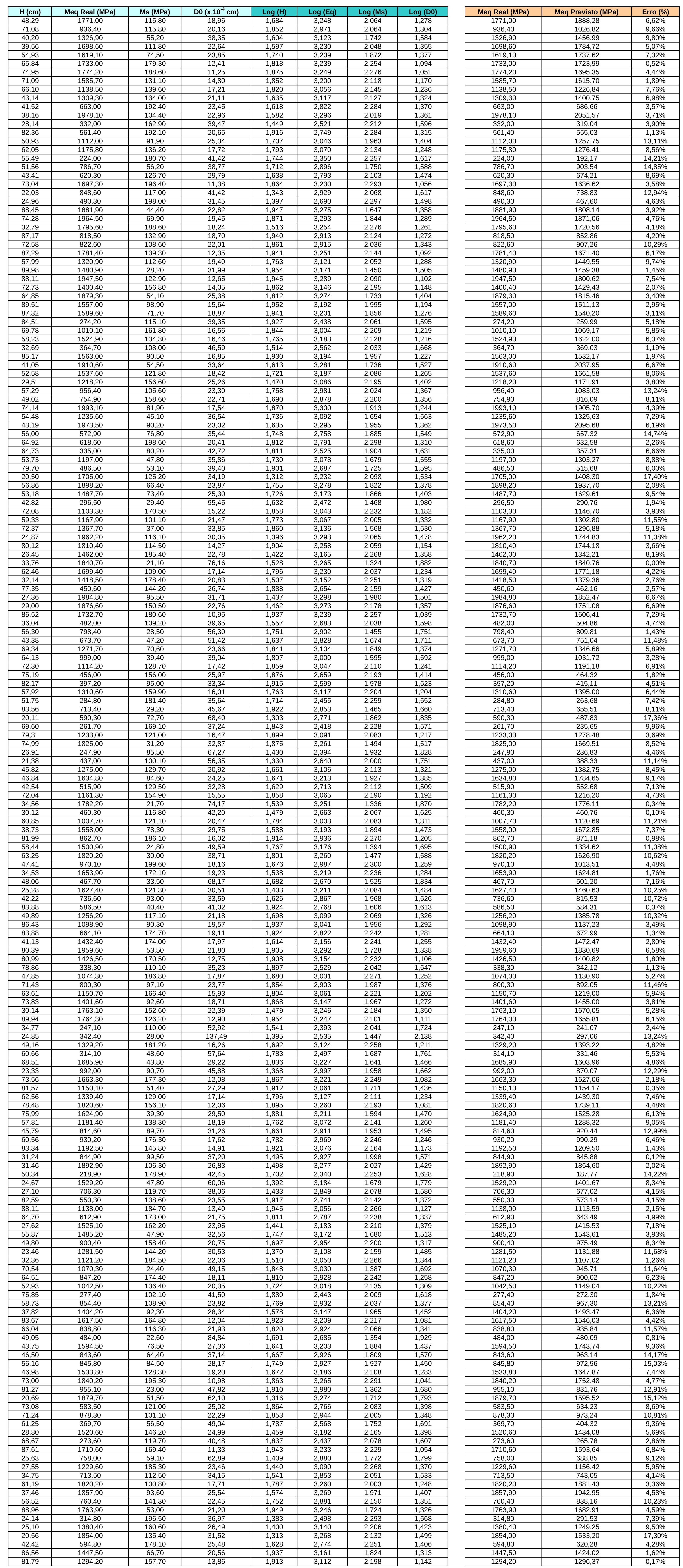




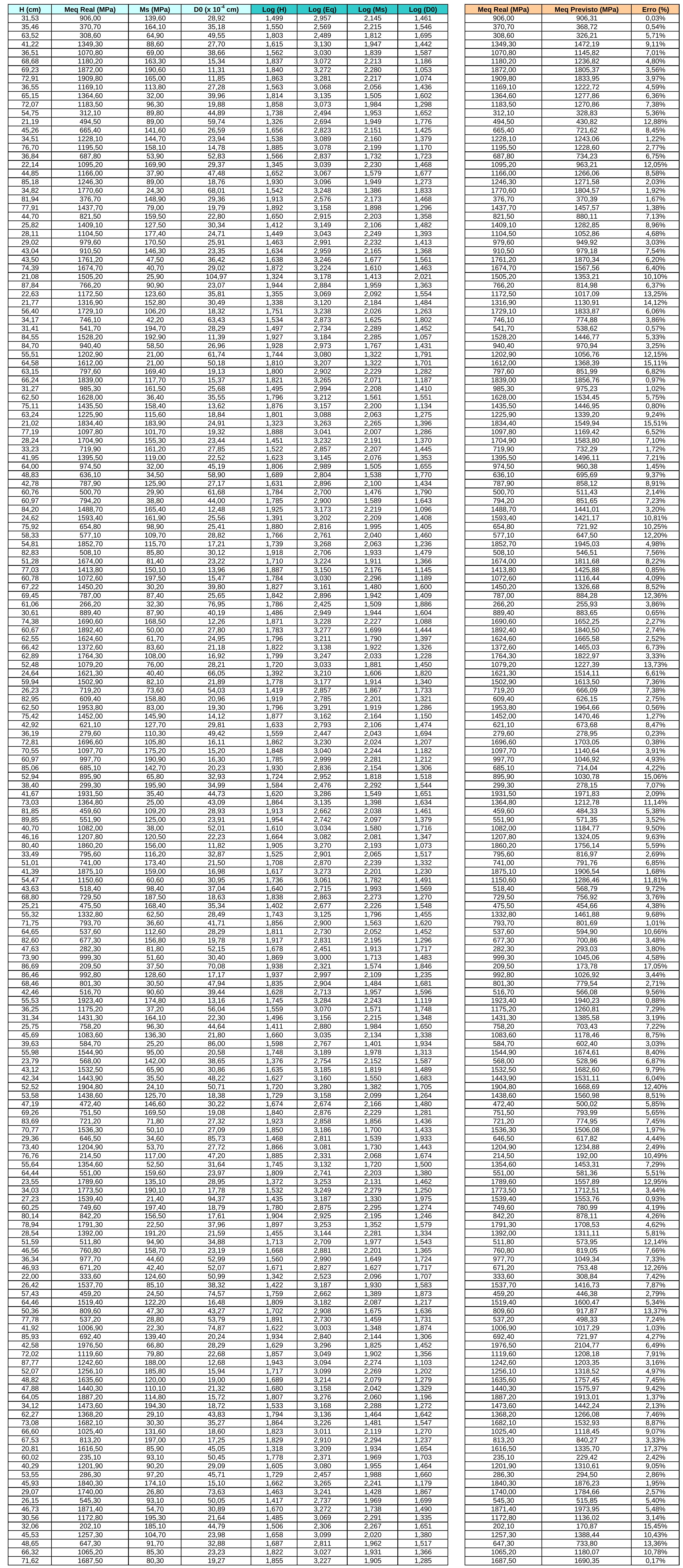




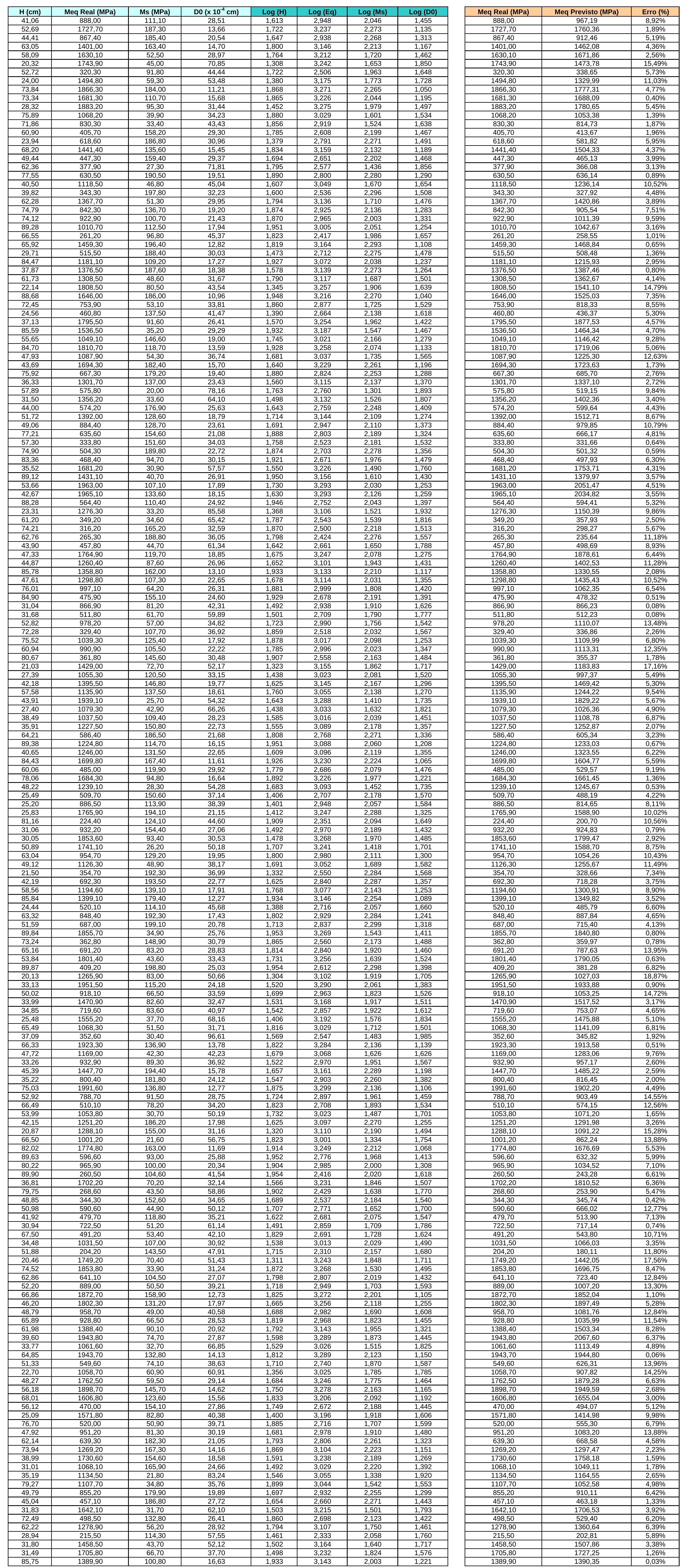




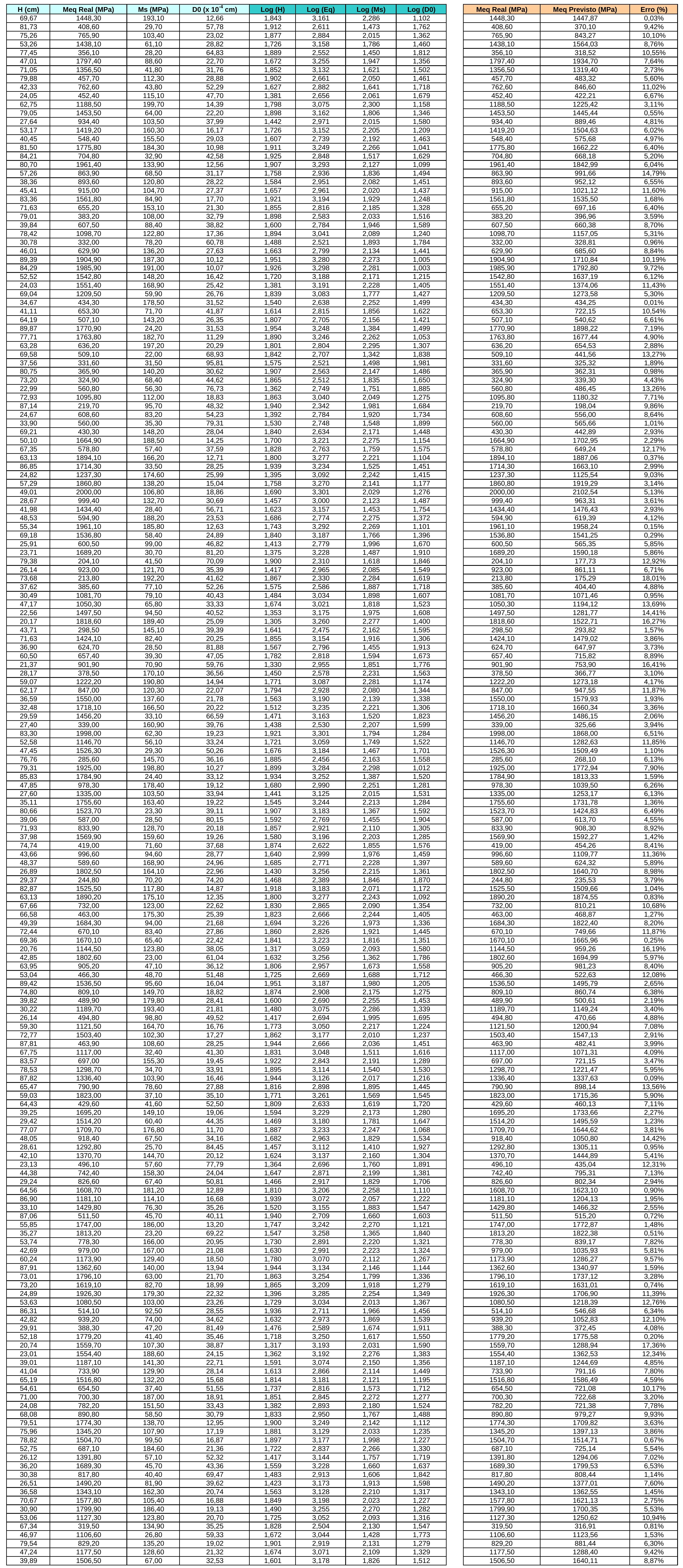




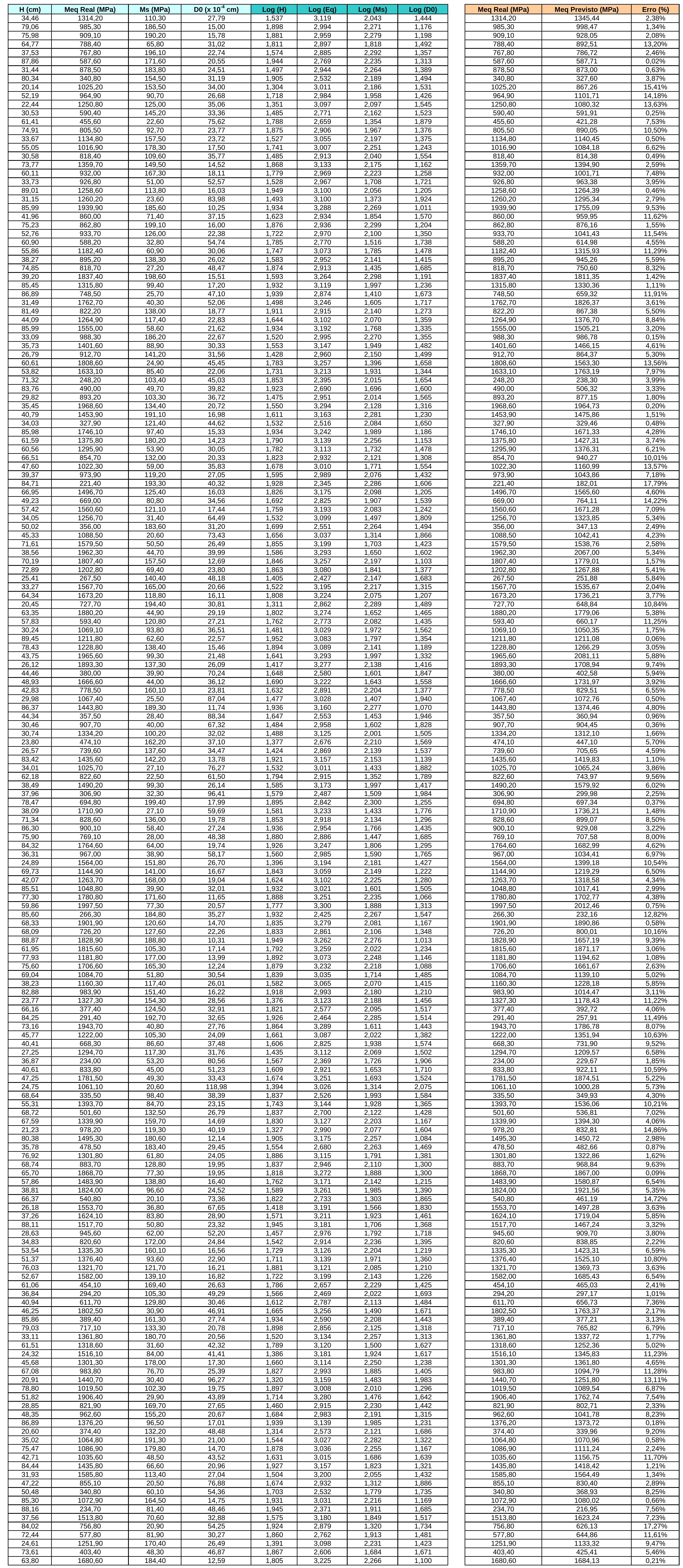



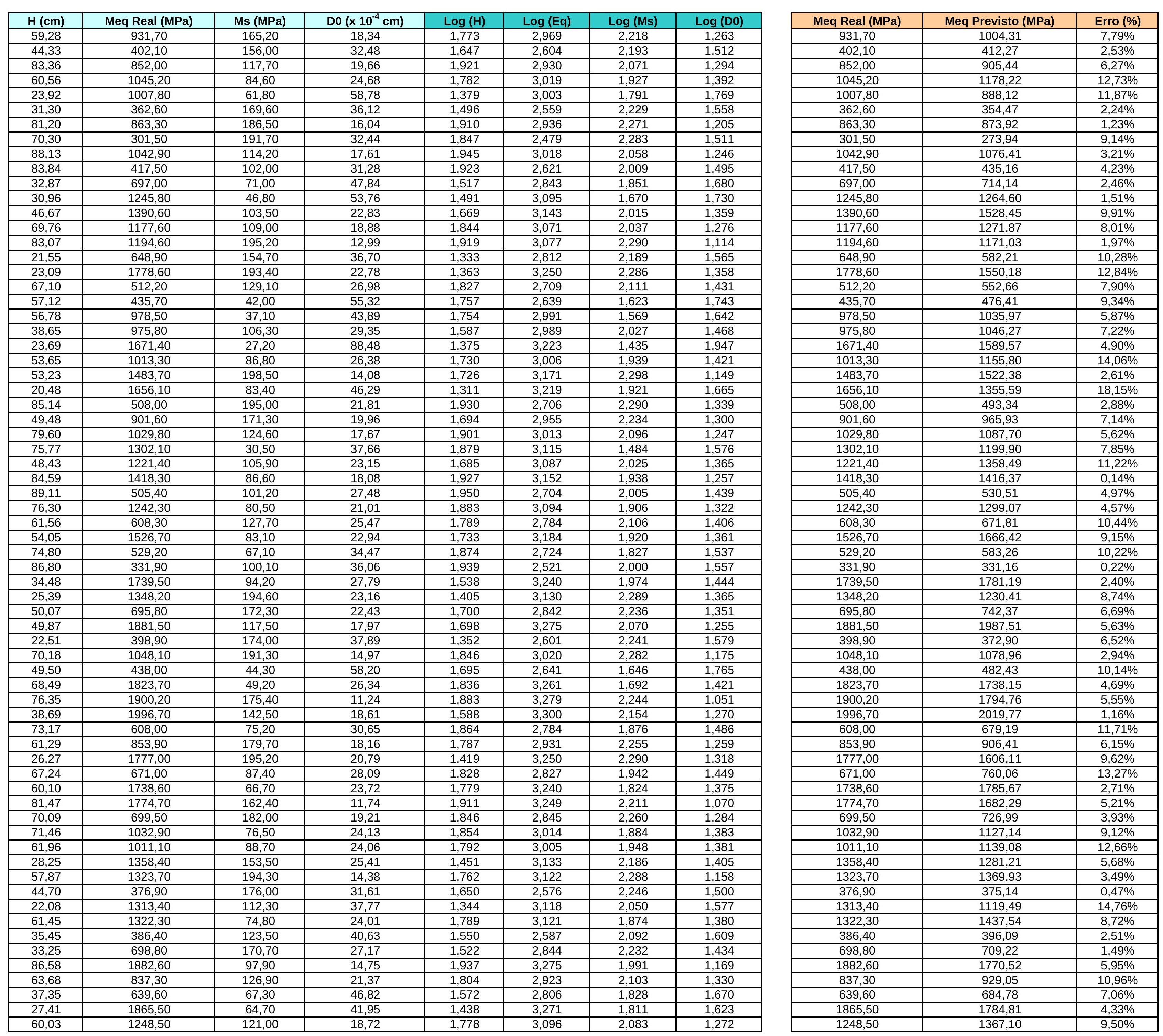
ANEXO I - Ábacos para retroanálise do subleito. 
Retroanálise do subleito (20 a $80 \mathrm{MPa}$ )

$\mathrm{Rc}(\mathrm{cm})$

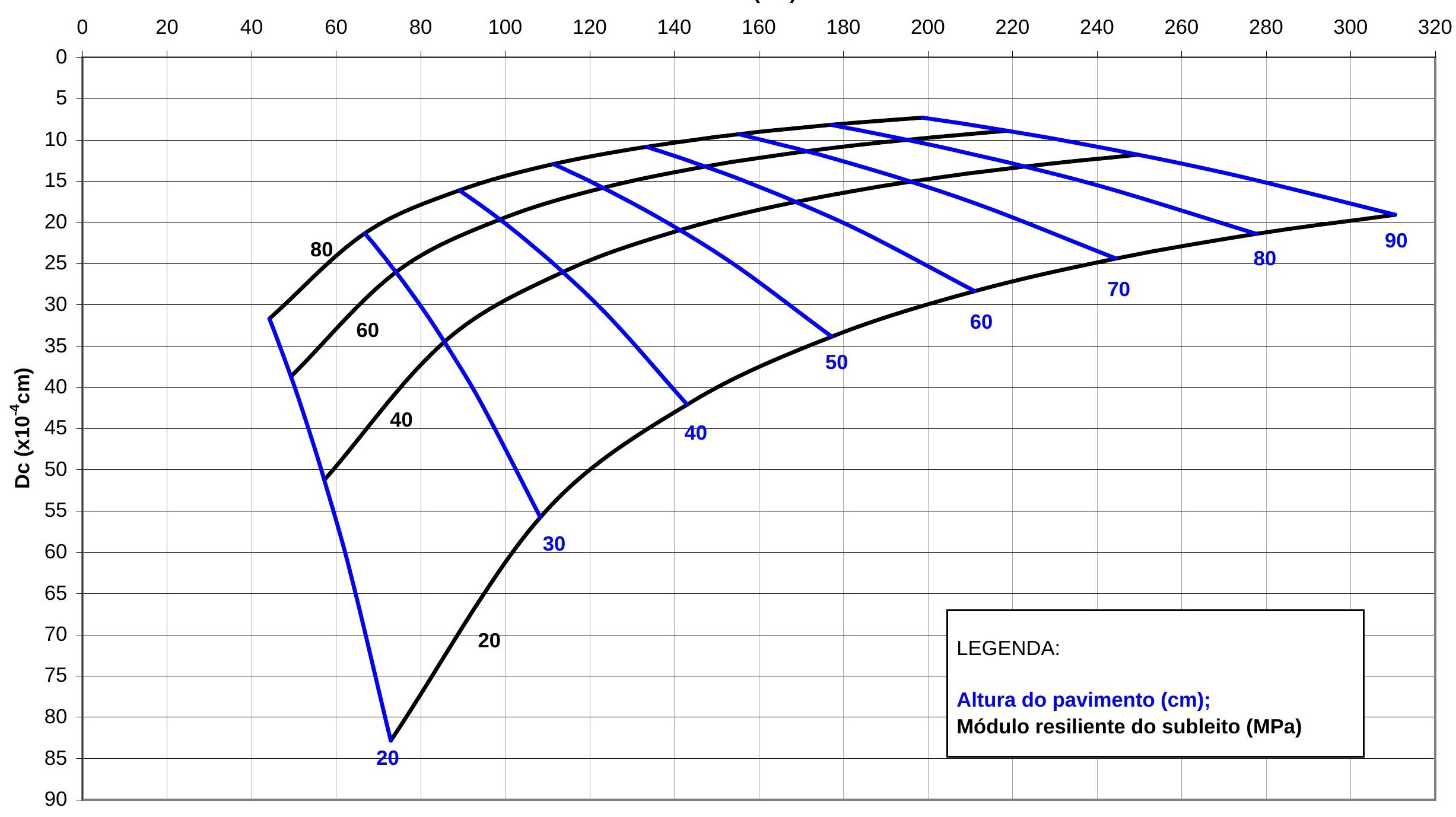


Retroanálise do subleito (80 a $140 \mathrm{MPa}$ )

Rc (cm)

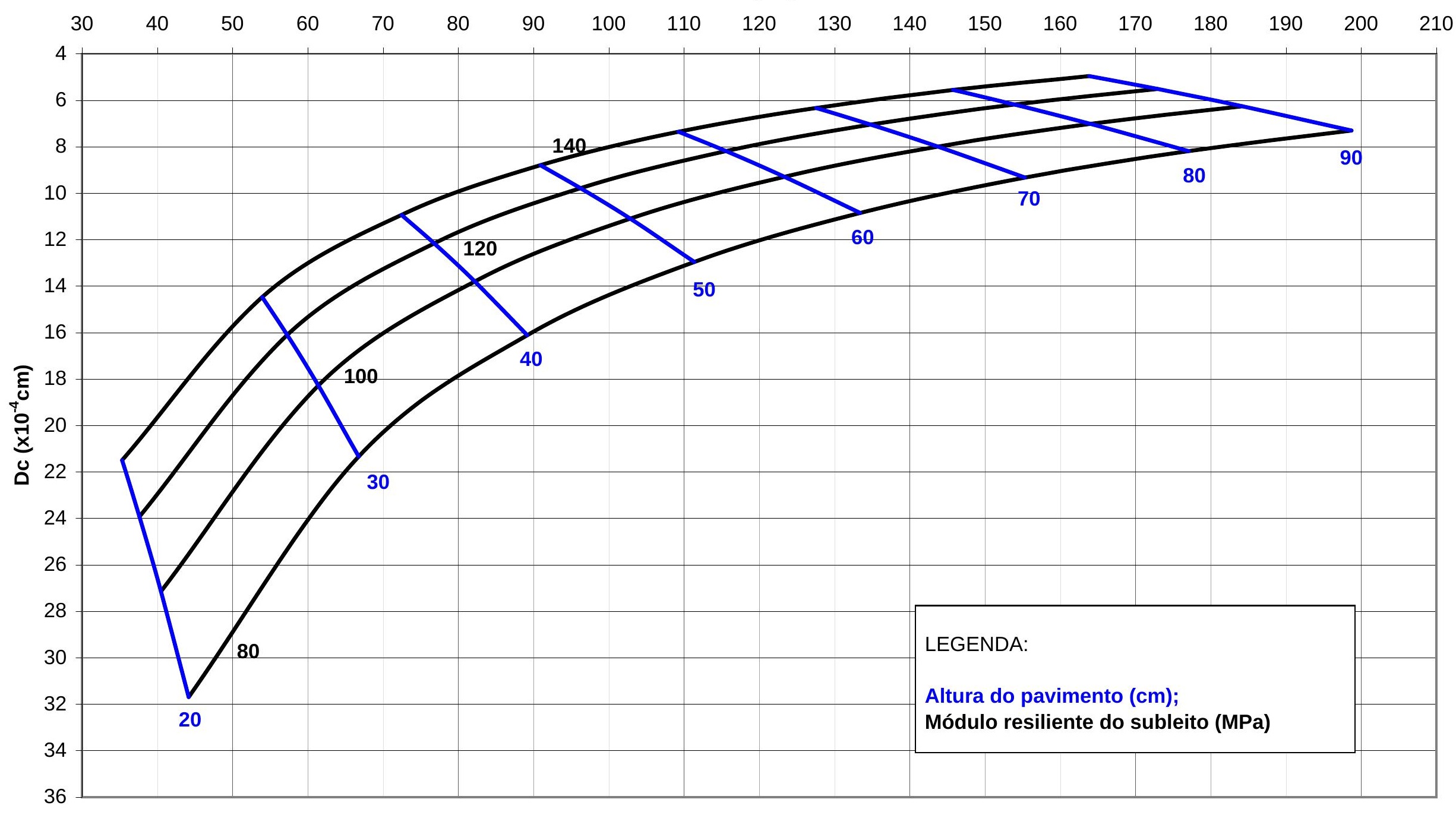




\section{Retroanálise do subleito (140 a $200 \mathrm{MPa}$ )}

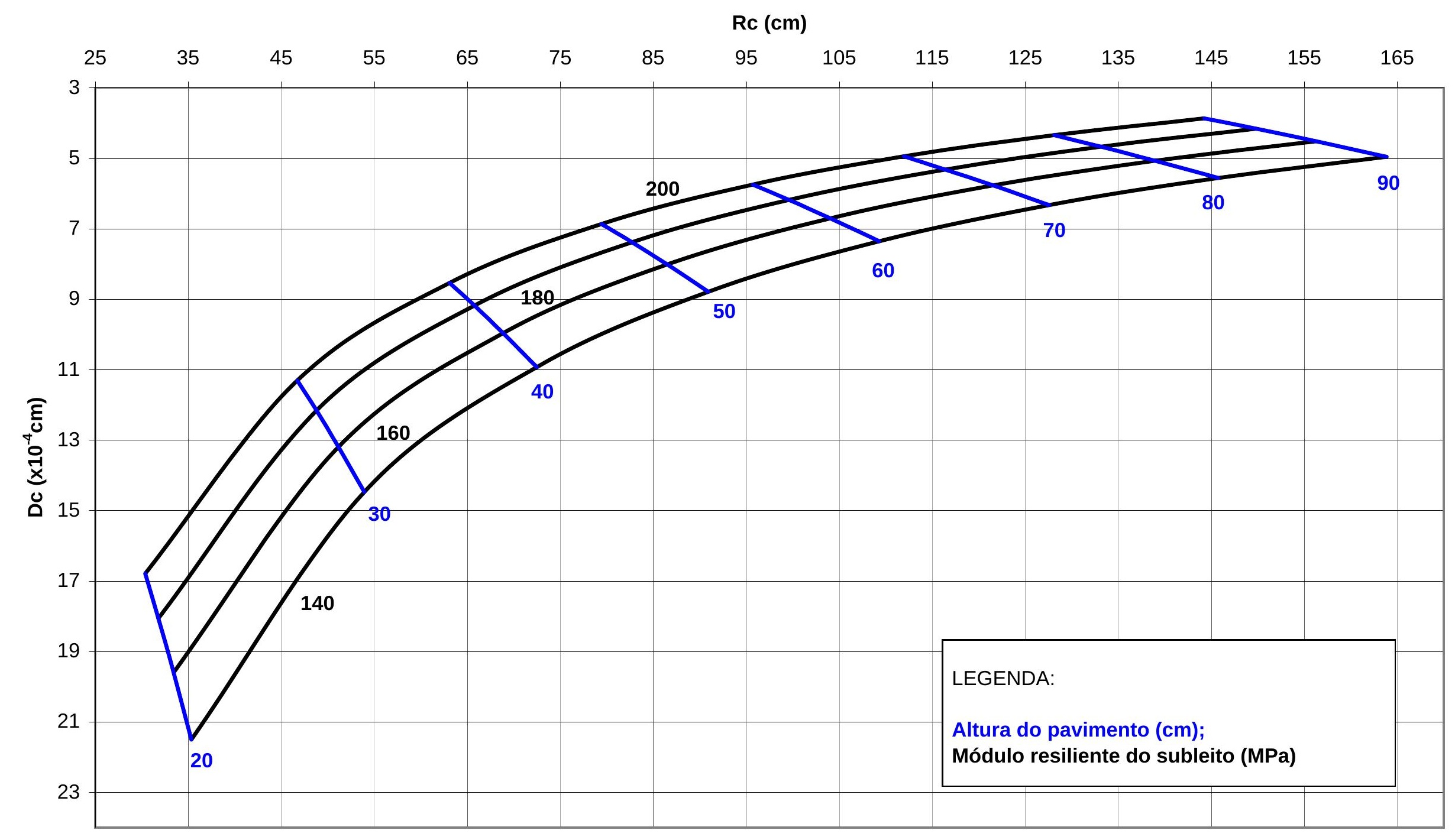

